\title{
DICTIONARY OF
}

\section{ALASKA PLAGE NAMES}

By Donald J. Orth

GEOLOGIGAL SURVEY PROFESSIONAL PAPER 567

The principal names listed conform with nomenclature established through decisions of the U.S. Board on Geographic Names or are recognized by the Board as standard names for use on Federal maps and other publications

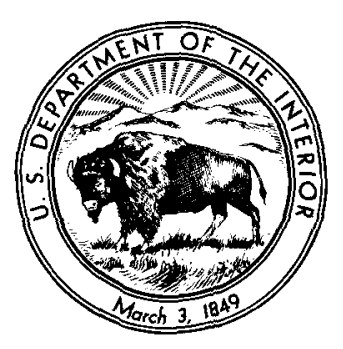

REPRINTED 1971

WITH MINOR REVISIONS 


\section{United States Department of the Interior}

ROGERS C. B. MORTON, Secretary

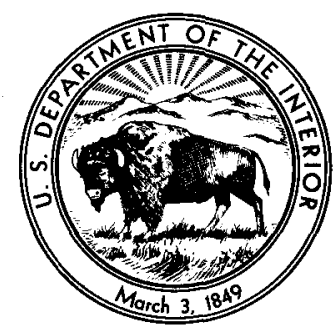

\section{Geological Survey}

William T. Pecora, Director 
Foreword

At 3:30 in the afternoon of October 18, 1867, on the parade ground near Baranov's Castle in Sitka, an area of about 580,000 square miles of Russian territory was formally transferred to the United States; 92 years later this territory, Alaska, became the 49 th State of the Union. Alaska extends over an area one-fifth as large as that of the conterminous United States and is unbelievably rich in landscape and other natural resources, but it has comparatively few inhabitants. This, the largest State, also contains other extremes in geography; the highest point (Mount McKinley -20,320 ft.), the northernmost point (Point Barrow -71 ${ }^{\circ} 23^{\prime}$ $\mathrm{N})$, and relative to the Greenwich meridian, the westernmost point (Amatignak Island -179 $10^{\prime} \mathrm{W}$ ), and the easternmost point (Pochnoi Point -179 $46^{\prime}$ E) in the United States.

The discovery of gold in Alaska in the 1890's caused the Geological Survey to undertake geographical exploration and geological and mineral-resource investigations in that remote territory. As the work progressed, the need was recognized for a names dictionary as an aid in preparing and publishing maps and reports on Alaska. In June 1900 Marcus Baker undertook the completimon of a dictionary begun in 1892 by the Board on Geographic Names. The first "Geographic Dictionary of Alaska" was pub-

$$
\begin{gathered}
\text { Amatignach Is }= \\
\text { Southernmost pt. } \\
\left(51.16^{\circ} \mathrm{N}\right)
\end{gathered}
$$

listed in 1902 as Geological Survey Bulletin 187. A second editon, prepared by James McCormick, was published in 1906 as Bulletin 299.

Six decades have passed since the geographic names dictionaries of Baker and McCormick were published. Alaska has now been completely mapped at the scale of $1: 250,000$ and extensively mapped at the scale of $1: 63,360$. These maps provide a wealth of geographic-names information. Names in current use, as well as many names formerly in use, have been assembled by Donald J. Orth and his colleagues into a new and greatly enlarged edition of the geographic names dictionary.

V 


\section{Contents}

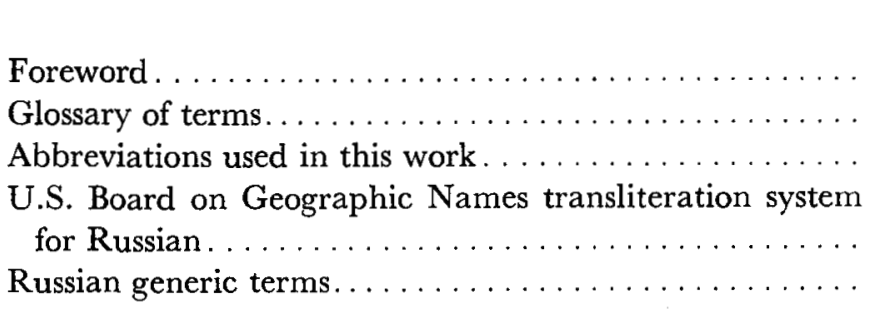

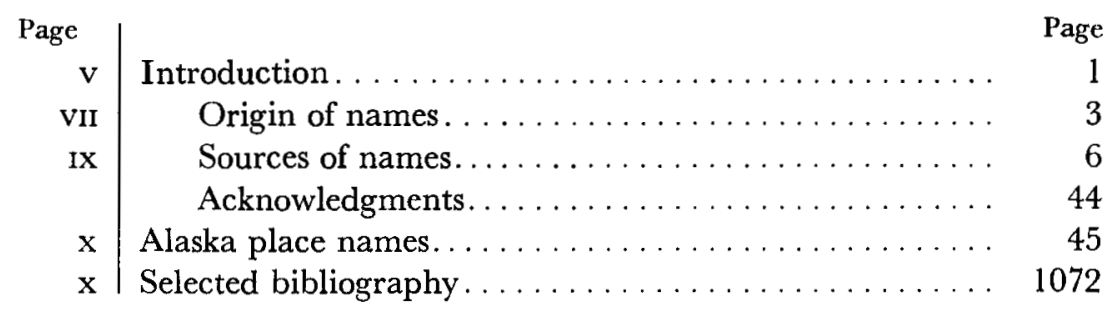

\section{Illustrations}

Frontrspiece. Shishaldin Volcano on Unimak Island in the Aleutians.

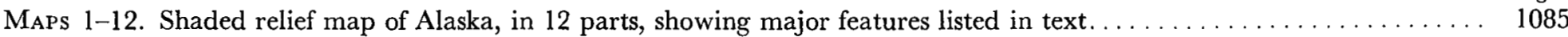

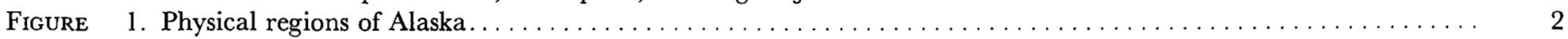

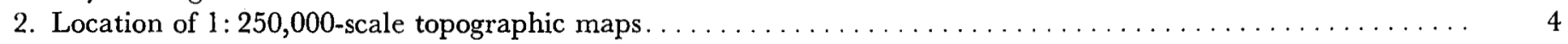

3. Indian, Eskimo, and Aleut linguistic areas of Alaska in $1890 \ldots \ldots \ldots \ldots \ldots$

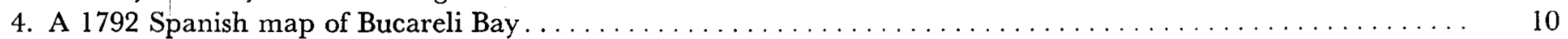

5. Part of the Plan du Port des Français (Lituya Bay); engraved map 19 in La Pérouse atlas, Paris, 1797. . . . . 18

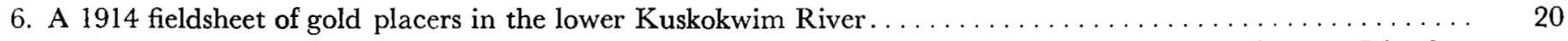

7. Part of a 1901-2 manuscript map of the crest of the Brooks Range between Fort Yukon and Flaxman Island... 21

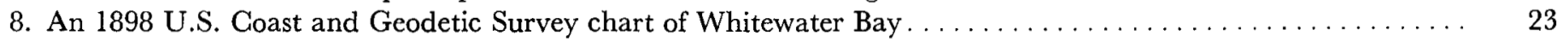

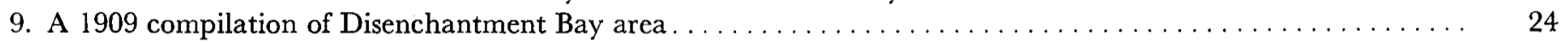

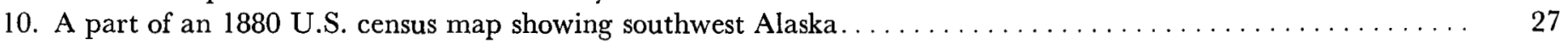

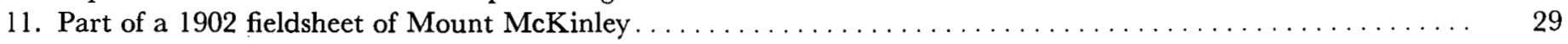

12. Part of Russian Hydrographic Department Chart 1378, dated 1847, showing Cook Inlet area .......... 30

13. A part of a Russian chart of St. Paul Harbor and Kodiak from an 1826 atlas . . . . . . . . . . . . . . . 31

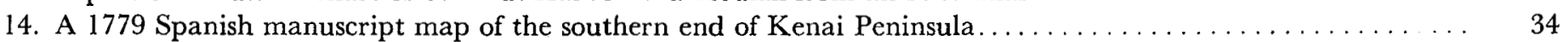

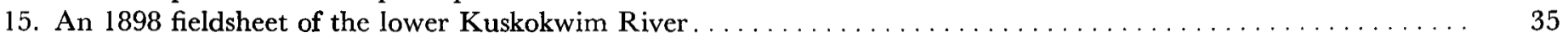

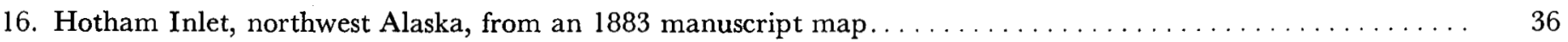

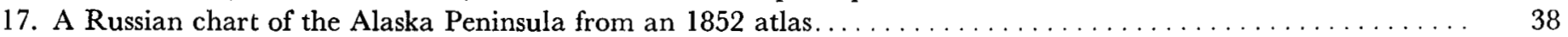

18. Part of the 1800 French edition of Capt. George Vancouver's map of the "Northwest Coast of America" showing

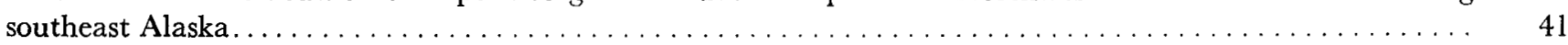

19. An 1898 manuscript map of Haines Mission and surrounding country $\ldots \ldots \ldots \ldots$

\section{Glossary of Terms}

The following words or combinations of words are used to designate the geographic features of Alaska. Each designator is defined as it is used in this publication.

Airfield-area of land cleared and maintained for the operation of aircraft.
Anabranci (modifier of stream) - a diverging branch of a stream which reenters the original stream or a tributary to it.

Anchorage - a protected area of water where ships anchor safely. Area-part of a larger tract of land, especially applicable to parts of cities. 
Aufeis (modifier of area) - a sheet of ice on a river flood plain; formed in winter when shoals in the river freeze solid or are otherwise dammed so that water spreads over the flood plain and freezes.

Bank - the land rising along the side of a stream.

Bar-an accumulation in a stream of sand, gravel, or alluvium, which forms an obstruction to navigation.

Barrier beach - a ridge of sand extending above high tide, parallel to the coastline and separated from it by a lagoon or other body of water.

Barrier island-a detached part of a barrier beach between two inlets; an island between an area of sheltered water and the open sea.

Basin-a low area enclosed by higher land.

Bay-a large indentation of a sea or lake into the land. A bay is as long or longer than it is wide; its width is at least 1 mile, as opposed to the width of a cove. See also bight.

Beach-a gently sloping part of a shore that is washed by waves or tides and is generally covered by sand or pebbles.

Bench-a steplike strip of relatively level land with a sharp rise on one side and a sharp drop on the other.

$B c n d-a$ sharp curve in the course of a stream and the land enclosed therein.

Bight - a wide gentle curve or indentation of a coast, commonly between two headlands; unlike a bay or cove, the length across its mouth is greater than the length of the indentation into the coast.

Bluff - a high broad-faced bank or cliff cut by lateral erosion of a stream.

Canal-a manmade watercourse constructed and maintained primarily for navigation.

Canyon-a large steep-walled chasm, gorge, or ravine cut into the earth's surface by water.

Channel-a deep part of a bay, stream, or strait frequently used as a route for ships.

Cirque-a steep-walled rock basin of glacial origin.

City - a place having more than 5,000 inhabitants.

Cliff-a high steep rock face or precipice.

Coast-the area along the contact between the land and sea, including offshore islands.

Cove-a small bay or indentation along the edge of a larger body of water. Like a bay, it is as long or longer than it is wide; its width is less than 1 mile, as opposed to the width of a bay.

Crater-a bowl-shaped depression at the vent of a volcano.

Crossing-a short stretch of a stream where a boat, following a channel, crosses from one side of the stream to the other. This term is common on the Yukon and Tanana Rivers.

Delta-low-lying alluvial deposits at the mouth of a stream over which distributaries of the main stream often flow.

Distributary (modifier of stream) - a branch of a stream flowing away from the original stream and not rejoining it; generatly on a delta.

Ditch-a manmade watercourse constructed primarily for drainage, irrigation, or placer mining.

Drainage divide-the line of separation between drainage basins.

Dune-a ridge or hill of drifted sand.
Embankment - a natural or manmade ridge along the course of a stream or along the coast; designed to hold back water or carry a roadway.

Escarpment-a nearly continuous line of cliffs or steep slopes facing in one general direction.

Estuary-the lower course of a stream or former glacier which has been drowned by a relative rise in sea level and within which the tide ebbs and flows; an inlet or arm of the sea where the tide meets the current at the mouth of a stream.

Fish camp-a site occupied by natives during the fishing season.

Flat-a notably level area within a region of relief.

Ford-a place where a road or trail crosses a shallow stream or body of water without a bridge or ferry.

Gap - a notch or opening between hills or mountains or in a ridge or mountain range.

Glacier - a stream of ice moving outward and downslope from an area of accumulation.

Gulf-a very large indentation of the sea into the land-much larger than a bay.

Hill-a prominent elevation of less than 1,000 feet.

Hummock-a small area of land slightly above the general level of a swamp or marsh.

Icefall-a steep part of a glacier characterized by numerous crevasses which are formed by movement down the steep gradient.

Icefield-extensive area of permanent ice.

Interfluve-the neck of land between two parallel or converging streams.

Intermontane valley-a valley or depression enclosed by mountains; the drainage is generally internal but may have an outlet.

Island -an area of dry or normally dry land entirely surrounded by water.

Island chain-a group of islands in fairly close proximity to each other and extending along a line.

Lagoon-a body of water cut off from a larger body of water by a barrier beach or reef.

Lake-any standing body of inland water.

Landing strip - a small area of land cleared for the limited use of aircraft.

Locality - a place or location with past or present cultural associations.

Marsh-wet land along the coast, frequently covered with salt water.

Meadow - an expanse of low or level grassland.

Military reservation-a tract of land designated and administered for military purposes.

Moraine-a mass of undifferentiated material deposited by a glacier.

Mountain-a prominent elevation rising more than 1,000 feet above the level of the surrounding country.

Mountain range - a chain of mountains or one complex mountain much longer than it is broad.

Natural bridge - a natural rock arch.

Nunatak-an isolated hill or peak projecting above the surface of a glacier.

Open area-an area devoid of standing trees in a woodland.

Pass-a relatively low gap or opening in a mountain range or ridge which serves as a route of travel. 
Peak-the pointed top of a mountain or a hill.

Peninsula - a fairly narrow body of land nearly surrounded by water and connected on one side to a larger body of land.

Pingo-a relatively large mound raised by frost action above the permafrost; generally persists for more than a single season.

Pinnacle - a high spire-shaped pillar of rock.

Plateau - an elevated plain or flat-topped region of considerable extent.

Point of land-a protuberance of land along the shore of a lake, river, or sea or along the side of a hill, mountain, or ridge, or glacier; a projecting or tapering piece of land.

Portage - an overland route of travel between navigable bodies of water.

Promontory--a projection, headland, or cliff protruding into the sea, commonly with offshore rocks.

Rapids - a fast-flowing section of a stream, generally with exposed rock or boulders.

Ravine-a rather small steep-walled valley; a gulch.

Reach-any section of a stream which is unique from the sections above and below it.

Reef-a line of rocks or a ridge of sand lying at or near the surface of the water.

Ridge-an elevation with a narrow elongated crest.

Roadhouse - an inn or trading post along a road or a trail.

Rock $(s)$ - a mass of rock, visible or exposed at low tide along the coast or in rivers and lakes.

Rookery - a natural breeding ground of seals.

$R R$ station - an established stop along a railroad.

Sea-large open body of saline water.

Settlement-a place inhabited by several persons, normally less than 10.

Shoal - a shallow area in a sea, river, or lake.
Shore-the strip of land constituting the border between the land and sea, lake, or lagoon.

Slope-an inclined face of any part of the earth's surface.

Spit-a long, narrow accumulation of sand or gravel attached to the land and projecting into a sea or a bay.

Spring-a place where water issues naturally from the surface of the earth.

Stream-a body of water flowing overland; it includes anabranch, creek, distributary, pup, river, run, slough.

$S u b u r b$-an unincorporated cluster of population near an urban center.

Swamp-wet land, partially inundated with fresh water.

Tidal flat- a flat area of sand or mud, inundated at high tide:

Town-a place having 1,000 to 5,000 inhabitants.

Trail-a designated path or line of travel.

Valley-a linear depression in the earth's surface, generally produced by erosion and drained by a stream.

Village - a place having 1 to 1,000 inhabitants.

Volcano-a mountain with a recent history of volcanic activity.

Watercourse-a natural or manmade channel through which water flows.

Waterfall-a perpendicular or nearly perpendicular cascade along a stream.

Water gap-a pass or gap through which a stream flows.

Water passage-a coastal waterway connecting bodies of open water or other passages; it includes inlets to lagoons and channels between islands.

Whirlpool - a violent circular eddy in a body of water.

Winter crossing - a place where a person may cross a major stream during the freezeup.

Wooded area-an area covered with trees, in contrast to the surrounding area.

\section{Abbreviations Used in This Work}

Adm.-Admiral

AEC-Atomic Energy Commission

AMS-Army Map Service

ARC-Alaska Road Commission

Arch.-archipelago

BAE-Bureau of American Ethnology

BGN-Board on Geographic Names

BIA-Bureau of Indian Affairs

BLM-Bureau of Land Management

Brig. Gen.-brigadier general

Brit.-British

Brit. Adm.-British Admiralty

Capt.-captain
Capt. Lt.-captain lieutenant

cnna-complete name not available

Comdr.-commander

CPCGN-Canadian Permanent Committee on Geographical Names

GRREL-Cold Regions Research and Engineering Laboratory

Dept.-department

E-east

elev.-elevation

ENE-east-northeast

Ens.-ensign

ESE-east-southeast

Esq.--esquire

ft. - feet
Gen.--general

GLO-General Land Office

High.--highland

H.M.S.-His (Her) Majesty's

Ship

Hydrog.-hydrographic

I. - island

IBC-International Boundary Commission

IRN-Imperial Russian Navy

Is.-islands

junc.-junction

Low.-lowland

Lt._lieutenant

Maj-_major

mi.-mile

Mtn.-mountain

Mts.-mountains
$\mathrm{N}$-north

NE-northeast

NNE-north-northeast

NNW - north-northwest

NPS-National Park Service

NW-northwest

O.S. - Old Style calendar

Penin.-peninsula

Plat.-plateau

pop.-population

Pvt.-private

Ra.-range

Rear Adm.-rear admiral

Rev--reverend

RN-Royal Navy

RR.-railroad

S-south

SE-southeast 
Sgt.-sergeant

SS-steamship

SSE-south-southeast

SSW-south-southwest

SW-southwest

Univ.-university

USA-U.S. Army

USAAF-U.S. Army Air Force
USAF_U.S. Air Force

USBF-U.S. Bureau of Fisheries

USCG-U.S. Coast Guard

USC\&GS-U.S. Coast and

Geodetic Survey

USDA-U.S. Department of Agriculture
USFS-U.S. Forest Service

USF\&WS-U.S. F is h and

Wildlife Service

USGS-U.S. Geological Survey

USN-U.S. Navy

USRCS-U.S. Revenue-Cutter

Service
U.S.S.-United States Ship

Var.-variant

W-west

WNW-west-northwest

WSW-west-southwest

yd.-yard

\section{U.S. Board on Geographic Names Transliteration System For Russian}

\begin{tabular}{|c|c|c|c|c|c|c|c|c|c|c|c|}
\hline Russian & Roman & Russian & Roman & Russian & Roman & Russian & Roman & Russian & Roman & Russian & Roman \\
\hline $\begin{array}{ll}\mathrm{A}, & \mathbf{a} \\
\mathrm{B}, & \text { б } \\
\mathrm{B}, & \mathbf{B} \\
\Gamma, & \Gamma \\
\text { Д, } & \text { д } \\
\mathrm{E}, & \mathrm{e}\end{array}$ & $\begin{array}{l}a \\
b \\
v \\
g \\
d \\
e, y e^{3}\end{array}$ & 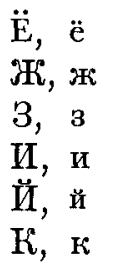 & $\begin{array}{c}\text { ë, yë }{ }^{1} \\
\text { zh } \\
z \\
\mathrm{i} \\
\mathrm{y}^{2} \\
\mathrm{k}\end{array}$ & $\begin{array}{l}\text { Д, л } \\
\mathrm{M}, \mathrm{M} \\
\mathrm{H}, \mathrm{н} \\
\mathrm{O}, \mathrm{o} \\
\Pi, \mathrm{\Pi} \\
\mathrm{P}, \mathrm{p}\end{array}$ & $\begin{array}{l}1 \\
\mathrm{~m} \\
\mathrm{n} \\
\mathrm{o} \\
\mathrm{p} \\
\mathrm{r}\end{array}$ & $\begin{array}{l}\mathrm{C}, \mathrm{c} \\
\mathrm{T}, \mathrm{T} \\
\mathrm{У}, \mathrm{y} \\
\Phi, \text { Ф } \\
\mathrm{X}, \mathrm{x} \\
\text { Щ, ц }\end{array}$ & $\begin{array}{l}\mathrm{s} \\
\mathrm{t} \\
\mathrm{u} \\
\mathrm{f} \\
\mathrm{kh} \\
\mathrm{ts}^{4}\end{array}$ & $\begin{array}{l}\text { ч, ч } \\
\text { III, யI } \\
\text { Щ, щ } \\
\text { Ђ, ъ } \\
\text { Ы, ы } \\
\text { b, ь }\end{array}$ & $\begin{array}{l}\text { ch } \\
\text { sh } \\
\text { shch } \\
" \Rightarrow \\
y^{2}\end{array}$ & $\begin{array}{ll}Э, & \text { э } \\
\mathrm{I}, & \text { юо } \\
\mathcal{G}, & \text { я }\end{array}$ & $\begin{array}{l}\text { e } \\
\text { yu } \\
\text { ya }\end{array}$ \\
\hline
\end{tabular}

1 The letter $\ddot{e}$ is not considered a separate letter of the alphabet, and the ë is often omitted. When printed in Russian as ë, it is transliterated as yë initially, after vowels, and after $\mathbf{z}$ and $\mathrm{b}$; elsewhere as $\ddot{\mathrm{e}}$.

2 Both and the likelihood of confusion is slight; the second part of diphthongs, while the s occurs before other vowels or between consonants.
${ }^{3}$ The Russian letter $\mathrm{e}$ is transliterated as ye initially, after vowels, and after $\mathrm{B}$ and $\mathrm{s}$; elsewhere as $\mathrm{e}$.

4 This system provides no means of distinguishing between the transliterations of the Russian letter $\mu$ and the Tc letter combination; however, the latter occurs rarely.

\section{Russian Generic Terms}

This Russian-English glossary lists in transliterated form a few of the more common terms and name generics found on 18th and 19th century Russian maps. The masculine, feminine, and neuter nominative singular inflections of adjectives are given; other parts of speech have not been distinguished.

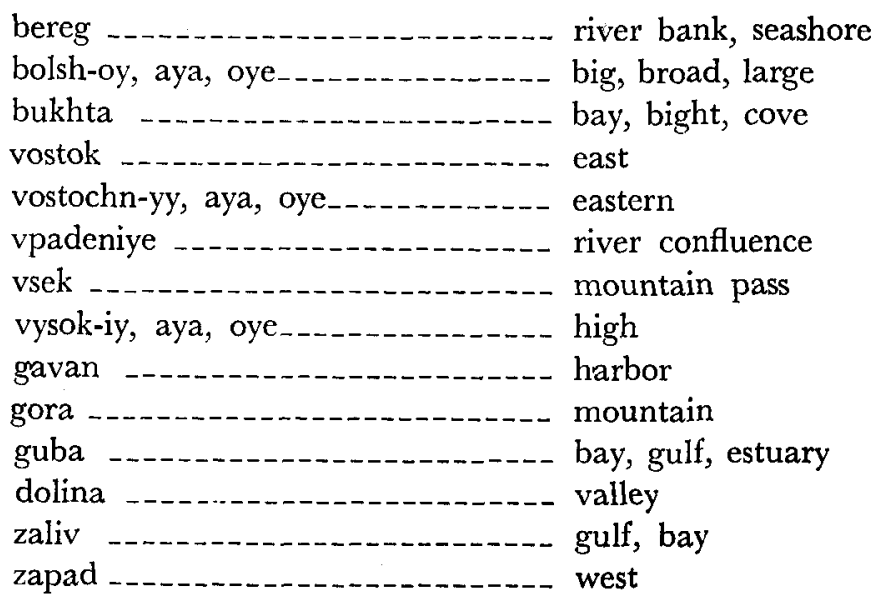

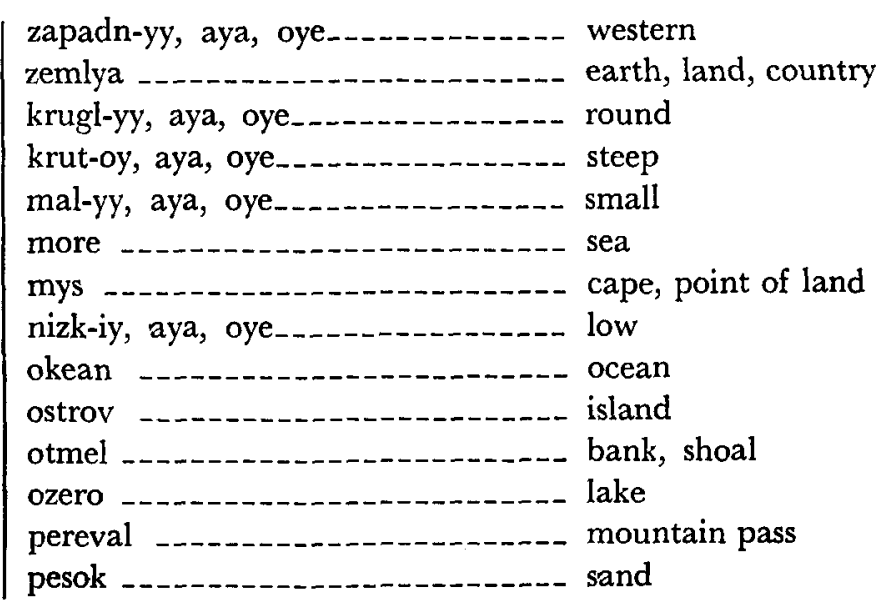


poluostrov _-

proliv _._-_._. strait, sound, channel

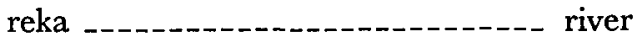

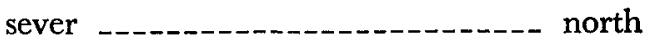

severn-yy, aya, oye..............- northern

seleniye -..-_- village, settlement selo

village with a church

sopka _-_._-_. peak, mud volcano

utës -...-_...- rock, crag, cliff

yug - -

yuzhn-yy, aya, oye..._._._... southern 


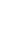




\title{
DICTIONARY OF ALASKA PLACE NAMES
}

\author{
By Donald J. ORth \\ INTRODUCTION
}

This work is an alphabetical list of the geographic names that are now applied and have been applied to places and features of the Alaska landscape. Principal names, compiled from modern maps and charts and printed in boldface type, generally reflect present-day local usage. They conform to the principles of the U.S. Board on Geographic Names for establishing standard names for use on Government maps and in other Government publications. Each name entry gives the present-day spelling along with variant spellings and names; identifies the feature named; presents the origin and history of the name; and, where possible, gives the meaning of an Eskimo, Aleut, Indian, or foreign name. Variant, obsolete, and doubtful names are alphabetically listed and are cross referenced, where necessary, to the principal entries.

Each name entry consists of two paragraphs. The first gives its application and location and presents variant forms. The second paragraph presents the history and meaning of the name.

The order of information in the first paragraph of a name entry is as follows:

Name.-The recommended name, normally conforming to present-day local and map usage in spelling and form.

Designation.-A standardized geographic term identifying the kind of feature named. See glossary of terms.

Population or elevation.-Expressed numerically. Population is determined from the 1960 census or from an earlier census indicated by a date in parentheses after the population number. Elevations are normally given for the summits of mountains, peaks, hills, and passes. For a named mountain range, group of hills, or ridges, the highest elevation is given unless it is more appropriate to express the average summit elevation. Elevations are determined from the most recent maps of the area.

Description.-The application of the name to the feature and its location relative to other and more distinctive features, such as well-known mountains, lakes, or towns. The last part of the description is the name of the physical region in which the feature occurs. (See fig. 1.)

Geographical coordinates.-Latitude and longitude for mouths of streams, canyons, and ravines; for terminal ends of glaciers; for centers of bays, lakes, mountain and hill groups, ridges, and populated places; for summits of mountains, hills, peaks, and passes; and for the extremities of points of land and of some linear features requiring identification of both ends.
Board on Geographic Names decisions.-If the Board has taken action on the name or its application, the year of the most recent decision is given.

Map number.-This number, shown in parentheses, indicates the U.S. Geological Survey 1:250,000-scale quadrangle map on which the named feature or place is shown. (See fig. 2.)

Variant names.-All known variant spellings and other names that have at any time been applied to the entry feature are listed alphabetically.

In the second paragraph of the entries, certain stereotyped phrasing used in the entries should be explained. The phrases "named by" and "name given by" refer to the act of a person or agency applying a new or different name to a feature. The expression "reported by" only means that the name was documented or reported outside the named feature's locality. The name may have been in use many years before the documentation. The phrase "prospectors' name" implies that the name giving was associated with the need for locating and filing a mining claim. Prospectors' names were given arbitrarily and of ten borrowed from other mining areas.

A Federal agency is referred to by its present official designation, abbreviation, or acronym even though it may have had a different designation at the time mentioned in the Dictionary entry. Exceptions to this rule involve obsolete agencies and those combined with others due to reorganization. The military title of a person refers to the rank he possessed on the date mentioned in the entry.

Where a published reference is not given for historical and quoted information, the information has been obtained from the Alaskan files and records of the U.S. Geological Survey, which date back to 1884 . The reasons for giving a new name or changing an old one have been carefully recorded in the entry, in the exact words written by the person or agency responsible. This wording is shown in quotation marks.

Russian names are spelled according to the transliteration system recommended by the Board on Geographic Names. Meanings are given but may not be precise inasmuch as many of the Russian names used words or terms which were peculiar to the Kamchatka area of Siberia more than a hundred years ago, and present-day dictionaries may not give accurate connotations. Russian personal names, however, are given according to the present-day conventional spelling. 


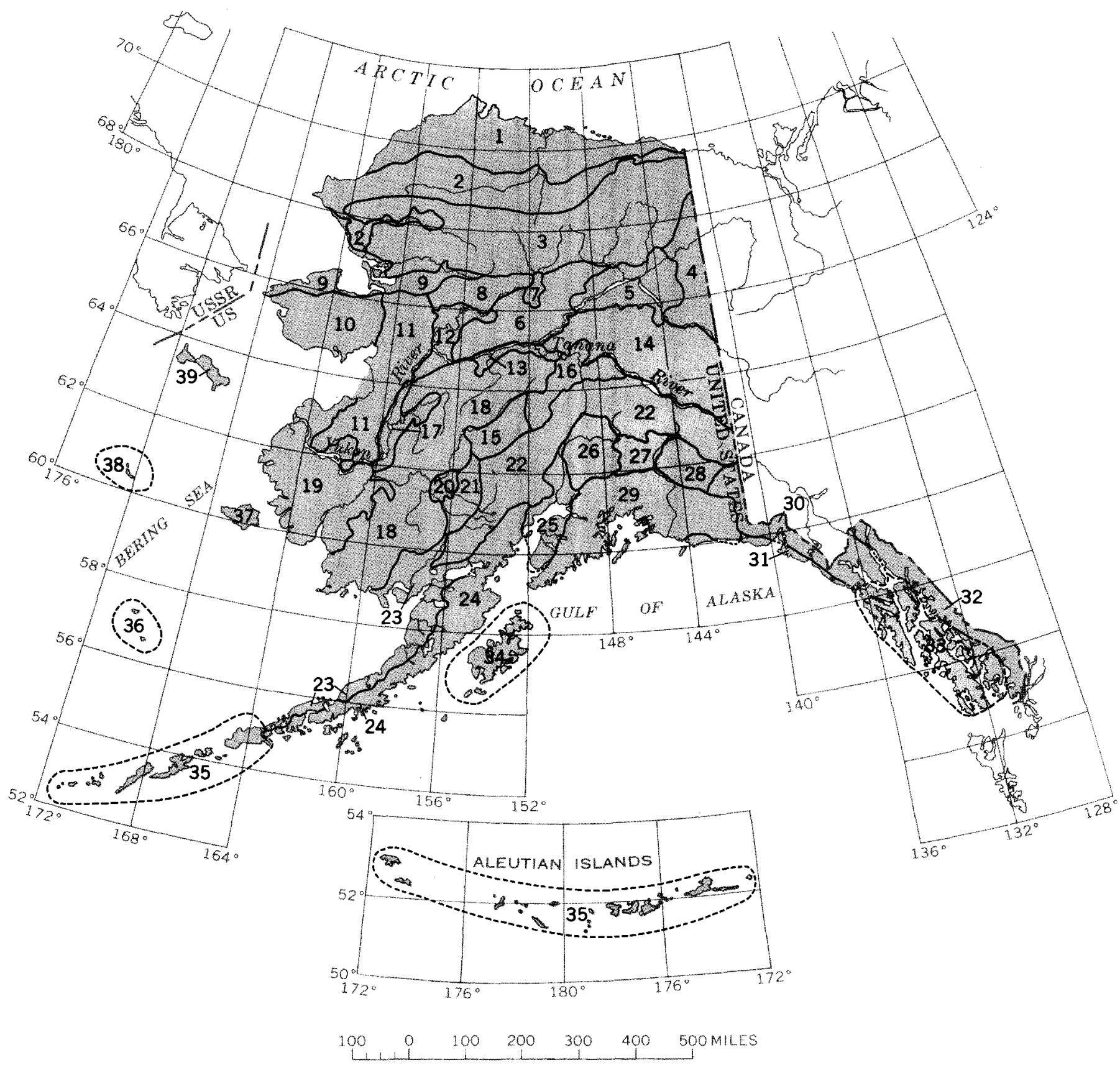

FIGURE 1.-Physical regions of Alaska. For another classification, see "Physiographic Divisions of Alaska," by Wahrhaftig (1965).

Native names presented the largest problem in compiling this dictionary. The native languages do not have established written forms, and the transcription of names from Eskimo, Aleut, or Indian into our Roman alphabet (some by way of the Russian Cyrillic alphabet), by nonlinguists, is extremely varied. The only choice was to present the names and their meanings as documented. Wherever possible, spellings based on the orthography recommended by the Board on Geographic Names have been added in brackets. This orthography, simply stated, is that consonants are pronounced except in a few diphthongs. Care should be taken in accepting the meaning of a native name listed in this dictionary. Often the meaning reported by a fieldman may express the reason for giving the name instead of the denotation of the word or words constituting the name. A real understanding requires knowledge of both the reason for giving a name and the meaning of the name, along with the relationship between the two. 
EXPLANATION OF FIGURE 1

NORThern ALAska

1. Arctic Plain

4. Porcupine Plateau

5. Yukon Flats

6. Kokrines-Hodzana Highlands

7. Kanuti Flats

8. Hogatza Highlands

9. Kotzebue-Kobuk Lowland

22. Alaska Rangc

23. Bristol Bay Lowland

24. Aleutian Range

25. Cook Inlet Lowland

34. Kodiak Island

35. Aleutian Islands
2. Arctic Slope

Central Alaska

10. Seward Peninsula Highlands

11. Nulato Hills

12. Koyukuk Lowland

13. Nowitna Lowland

14. Yukon-Tanana Highlands

15. Kuskokwim Lowland

Southern Alaska

26. Talkeetna Mountains

27. Copper River Basin

28. Wrangell Mountains

29. Chugach Mountains

INSULAR ALASKa

36. Pribilof Islands

37. Nunivak Island
3. Brooks Range

16. Tanana Lowland

17. Innoko Lowland

18. Kilbuck-Kuskokwim Mountains

19. Yukon-Kuskokwim Delta

20. Stony River Lowland

21. Lime Hills

30. St. Elias Mountains

31. Malaspina Coastal Plain

32. Coast Mountains

33. Alexander Archipelago

38. St. Matthew Island

39. St. Lawrence Island

\section{Origin of Names}

The second paragraph of a name entry gives the available information concerning the origin (or derivation), history, and meaning of the name. The circumstances involved in the naming of some places are not known. Alaskan geographic names, however, are comparatively new, few being so old or so corrupt that their origins or meanings are wholly concealed. They are derived almost exclusively from six general sources, as follows:

Russian names.-Vitus Bering, sent by Empress Anne of Russia, made landfall on the coast near Mount St. Elias on July 16, 1741, and thus is officially recognized as the discoverer of Alaska. There is evidence, however, that a Russian party landed on the Seward Peninsula as early as 1732 . After Bering's discovery, Russian interest centered on the lucrative fur trade, which began with the visits of hunting parties, the promyshlenniki, and evolved into the powerful Russian American Company. The first permanent Russian settlement was established on Three Saints Bay, Kodiak Island, in 1784 and was later moved to St. Paul Harbor in 1792. The first Russian post in southeast Alaska, founded by Alexander Baranov in 1799, was near present-day Sitka. Russian explorations of Alaska, which continued until the purchase by the United States in 1867, was primarily confined to the Aleutians and the southern coastal areas, with some expansion up the Yukon and Kuskokwim Rivers. Thus, the major period of application of Russian names lasted about 125 years. Although many Russian names were translated after the American purchase, several hundred are still applied to Alaskan features.

Spanish names.- Spanish exploration of Alaska was competitive with the Russian exploration. The expeditions sent out by Spain (or Mexico) were limited for the most part to the south coast, from the southern boundary of Alaska to Prince William Sound. One expedition traveled as far west as Unalaska and named a few points along that coast. In general, names of Spanish origin in Alaska are few and were given between 1774 and 1780; they originated mainly in 1775 and 1779 with the expeditions of Lt. Ignacio Arteaga and Bodega y Quadra. Many Spanish names once applied to the Alaskan landscape have never been widely used because of tardy and obscure publication.

British names.-British naming activity in Alaska began with the 1778 expedition of Capt. James Cook. From time to time during the subsequent 80 years, English traders and naval officers contributed to the knowledge of Alaskan geography, and most of the names of major coastal features can be attributed to them. Noteworthy contributions in the 18 th century were made by Captains G. Dixon, J. Meares, and N. Portlock; British fur traders; and especially Capt. George Vancouver, RN, during his extensive exploration and survey of the coast from Kodiak eastward and southward to Dixon Entrance from 1792 to 1794 . Vancouver named many features, and because those features were fully described and mapped and the results published, most of the names remain unchanged today. During the 19th century, major contributions were made by Capt. F. Beechey, RN, 1826-27 ; Sir John Franklin, 1826; Sir Edward Belcher, RN, 1836-42; P. Dease and T. Simpson, factors of the Hudson Bay Company, 1837; and most especially the so-called Franklin search expeditions, 1848-54. 


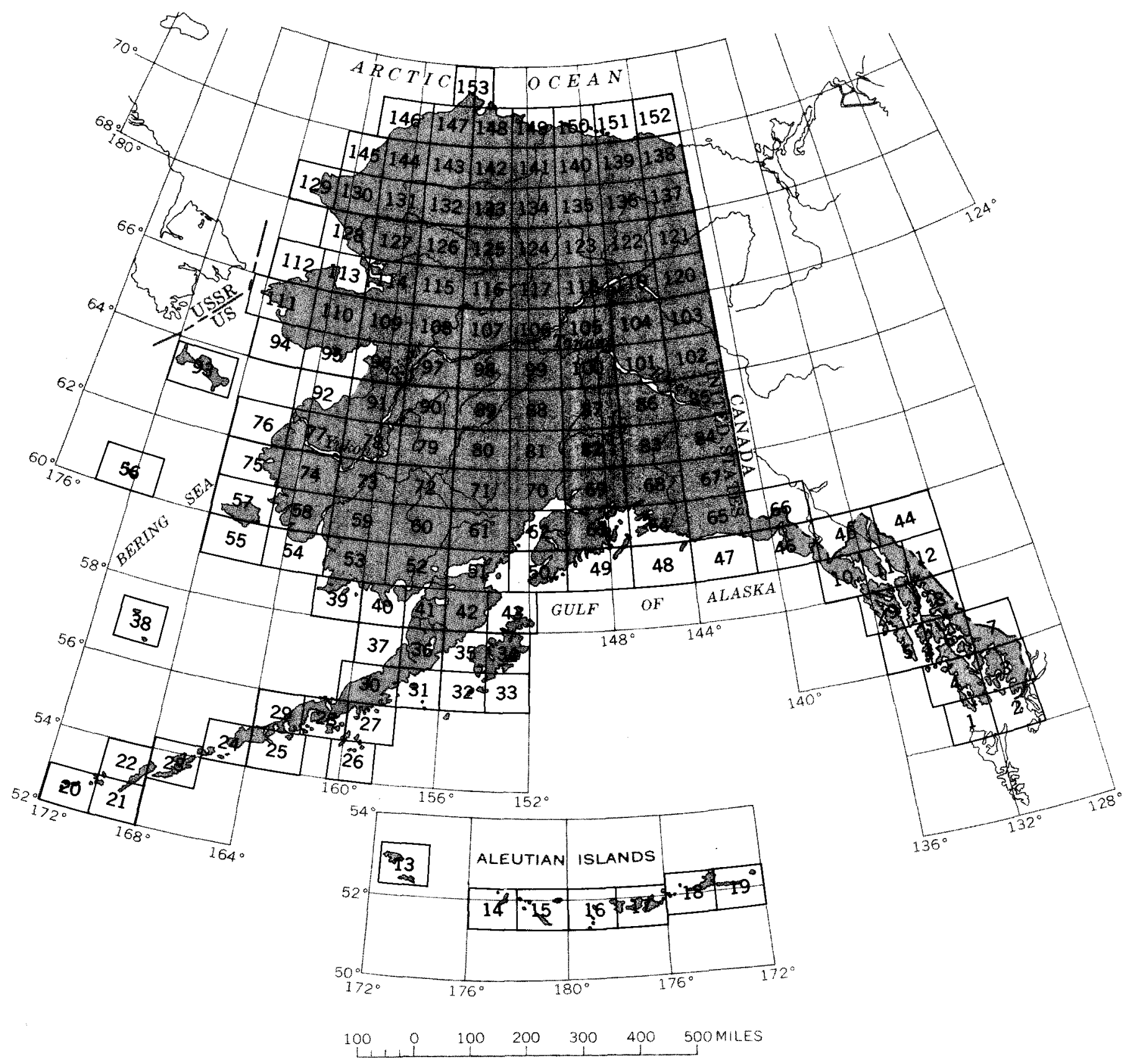

FIGURE 2.-Location of 1:250,000-scale topographic maps.

French names.-The explorations of the French were wholly confined to southeastern Alaska. The ill-fated La Pérouse expedition in 1786 was the only French voyage that contributed names to Alaskan features.

American names.-American whalers first entered the Arctic Ocean through Bering Strait in 1848 and thus began the American contribution to Alaska geographic names which has continued to the present day. The earliest large contribution was made by the U.S. Navy's North Pacific Exploring Expedition of 1855, chiefly in the Aleutian Islands and Bering Sea. Since the purchase of Alaska in 1867, many official expeditions have explored, surveyed, mapped, and named Alaskan features. The earliest work fell to the U.S. Coast and Geodetic Survey (then Coast Survey), which directed its effort primarily to the Gulf of Alaska littoral. Systematic official exploration of the interior of Alaska began with Lt. F. Schwatka, USA, who made a reconnaissance of the Yukon River from source to mouth in 1883. The Revenue Marine Service, Navy, Army, Bureau of the Census, and several other Federal agencies all contributed significantly throughout Alaska. 


\section{EXPLANATION OF FIGURE 2}

\begin{aligned} \multicolumn{1}{c}{ Map } & \multicolumn{1}{c}{ Name } \\ 1 & Dixon Entrance \\ 2 & Prince Rupert \\ 3 & Ketchikan \\ 4 & Craig \\ 5 & Port Alexander \\ 6 & Petersburg \\ 7 & Bradfield Canal \\ 8 & Sumdum \\ 9 & Sitka \\ 10 & Mt. Fairweather \\ 11 & Juneau \\ 12 & Taku River \\ 13 & Attu \\ 14 & Kiska \\ 15 & Rat Islands \\ 16 & Gareloi Island \\ 17 & Adak \\ 18 & Atka \\ 19 & Seguam \\ 20 & Amukta \\ 21 & Samalga Island \\ 22 & Umnak \\ 23 & Unalaska \\ 24 & Unimak \\ 25 & False Pass \\ 26 & Simeonof Island \\ 27 & Stepovak Bay \\ 28 & Port Moler \\ 29 & Cold Bay \\ 30 & Ghignik \\ 31 & Sutwik Island \end{aligned}

\begin{tabular}{cl} 
Map & \multicolumn{1}{c}{ Name } \\
32 & Trinity Islands \\
33 & Kaguyak \\
34 & Kodiak \\
35 & Karluk \\
36 & Ugashik \\
37 & Bristol Bay \\
38 & Pribilof Islands \\
39 & Hagemeister Island \\
40 & Nushagak Bay \\
41 & Naknek \\
42 & Mt. Katmai \\
43 & Afognak \\
44 & Atlin \\
45 & Skagway \\
46 & Yakutat \\
47 & Icy Bay \\
48 & Middleton Island \\
49 & Blying Sound \\
50 & Seldovia \\
51 & Iliamna \\
52 & Dillingham \\
53 & Goodnews \\
54 & Kuskokwim Bay \\
55 & Cape Mendenhall \\
56 & St. Matthew \\
57 & Nunivak Island \\
58 & Baird Inlet \\
59 & Bethel \\
60 & Taylor Mts. \\
61 & Lake Clark \\
62 & Kenai \\
&
\end{tabular}

\begin{tabular}{cl} 
Map & \multicolumn{1}{c}{ Name } \\
63 & Seward \\
64 & Cordova \\
65 & Bering Glacier \\
66 & Mt. St. Elias \\
67 & McCarthy \\
68 & Valdez \\
69 & Anchorage \\
70 & Tyonek \\
71 & Lime Hills \\
72 & Sleetmute \\
73 & Russian Mission \\
74 & Marshall \\
75 & Hooper Bay \\
76 & Black \\
77 & Kwiguk \\
78 & Holy Gross \\
79 & Iditarod \\
80 & McGrath \\
81 & Talkeetna \\
82 & Talkeetna Mts. \\
83 & Gulkana \\
84 & Nabesna \\
85 & Tanacross \\
86 & Mt. Hayes \\
87 & Healy \\
88 & Mt. McKinley \\
89 & Medfra \\
90 & Ophir \\
91 & Unalakleet \\
92 & St. Michael \\
93 & St. Lawrence
\end{tabular}

\begin{aligned} & Map \multicolumn{1}{c}{ Name } \\ & 94 Nome \\ & 95 Solomon \\ & 96 Norton Bay \\ & 97 Nulato \\ & 98 Ruby \\ & 99 Kantishna River \\ & 100 Fairbanks \\ & 101 Big Delta \\ & 102 Eagle \\ & 103 Charley River \\ & 104 Circle \\ & 105 Livengood \\ & 106 Tanana \\ & 107 Melozitna \\ & 108 Kateel River \\ & 109 Candle \\ & 110 Bendeleben \\ & 111 Teller \\ & 112 Shishmaref \\ & 113 Kotzebue \\ & 114 Selawik \\ & 115 Shungnak \\ & 116 Hughes \\ & 117 Bettles \\ & 118 Beaver \\ & 119 Fort Yukon \\ & 120 Black River \\ & 121 Coleen \\ & 122 Christian \\ & 123 Chandalar \\ & 124 Wiseman \\ & \\ & \hline\end{aligned}

\begin{tabular}{ll} 
Map & \multicolumn{1}{c}{ Name } \\
125 & Survey Pass \\
126 & Ambler River \\
127 & Baird Mts. \\
128 & Noatak \\
129 & Point Hope \\
130 & De Long Mts. \\
131 & Misheguk Mtn. \\
132 & Howard Pass \\
133 & Killik River \\
134 & Chandler Lake \\
135 & Philip Smith Mts. \\
136 & Arctic \\
137 & Table Mtn. \\
138 & Demarcation Point \\
139 & Mt. Michelson \\
140 & Sagavanirktok \\
141 & Umiat \\
142 & Ikpikpuk River \\
143 & Lookout Ridge \\
144 & Utukok River \\
145 & Point Lay \\
146 & Wainwright \\
147 & Meade River \\
148 & Teshekpuk \\
149 & Harrison Bay \\
150 & Beechey Point \\
151 & Flaxman Island \\
152 & Barter Island \\
153 & Barrow \\
&
\end{tabular}

Some of the densest concentrations of names in Alaska can be traced directly to the search for and mining of gold. The closing years of the 19 th century brought large numbers of prospectors to the northern frontier, and their primary need was for maps and information to guide them through the country. To fulfill this need, the U.S. Geological Survey began a program of exploration and mapping in 1898, and through its topographic and geological work has since become a major force in establishing and documenting Alaskan names.

Native names.-A major contributor of geographic names has been the indigenous people of Alaska. In this work the native peoples have been divided into three linguistic groups-Indian, Eskimo, and Aleut. These divisions are not uniform because Aleut is considered a divergent branch of the Eskimo linguistic stock; however, the grouping is one of historical and geographic convenience. (See fig. 3.) A high percentage of Aleut names was obtained and first recorded by the Russians. The Eskimo occupied most of the Alaskan coast from Kayak Island, near the mouth of the Copper River, to the Canadian boundary on the Arctic coast, except the upper end of Cook Inlet and that part of the Alaska Peninsula which, with the Aleutian Islands, was occupied by the Aleut. The Indian occupied most of the interior and southeastern Alaska; most of the languages are, or are thought to be related to, Athapascan. The Tsimshiam of Annette Island have migrated from the Skeena River area of British Columbia since 1887. See distribution map of Eskimo, Aleut, and Indian linguistic areas in 1890 (fig. 3).

Eskimo, Aleut, and Indian names, like those of the Europeans, are generally commonplace and descriptive. Native naming habits, however, have two characteristic differences. The natives tend to name many small, even minute, landmark features and ignore those that are large. Few mountains were named unless they stood alone and had some peculiar characteristic. For foot, boat, or sled travel, there was no need to name large and vague features. In addition, the natives commonly applied several names to one feature, based on the characteristics of its particular parts. Many streams, even short ones, had various names along their lengths. Many of the native names now appearing on published maps are long and unpronounceable by the average English-speaking person.

Geographic names evolve historically, their origins and forms being closely associated with the languages of the peoples who successively occupy the area. Thus, many native names are changed or altered in form as a result of adjusting to the new languageEnglish. This is a universal process. However altered, many of these names have become or will become firmly established as part of the native heritage of the Alaska landscape. 


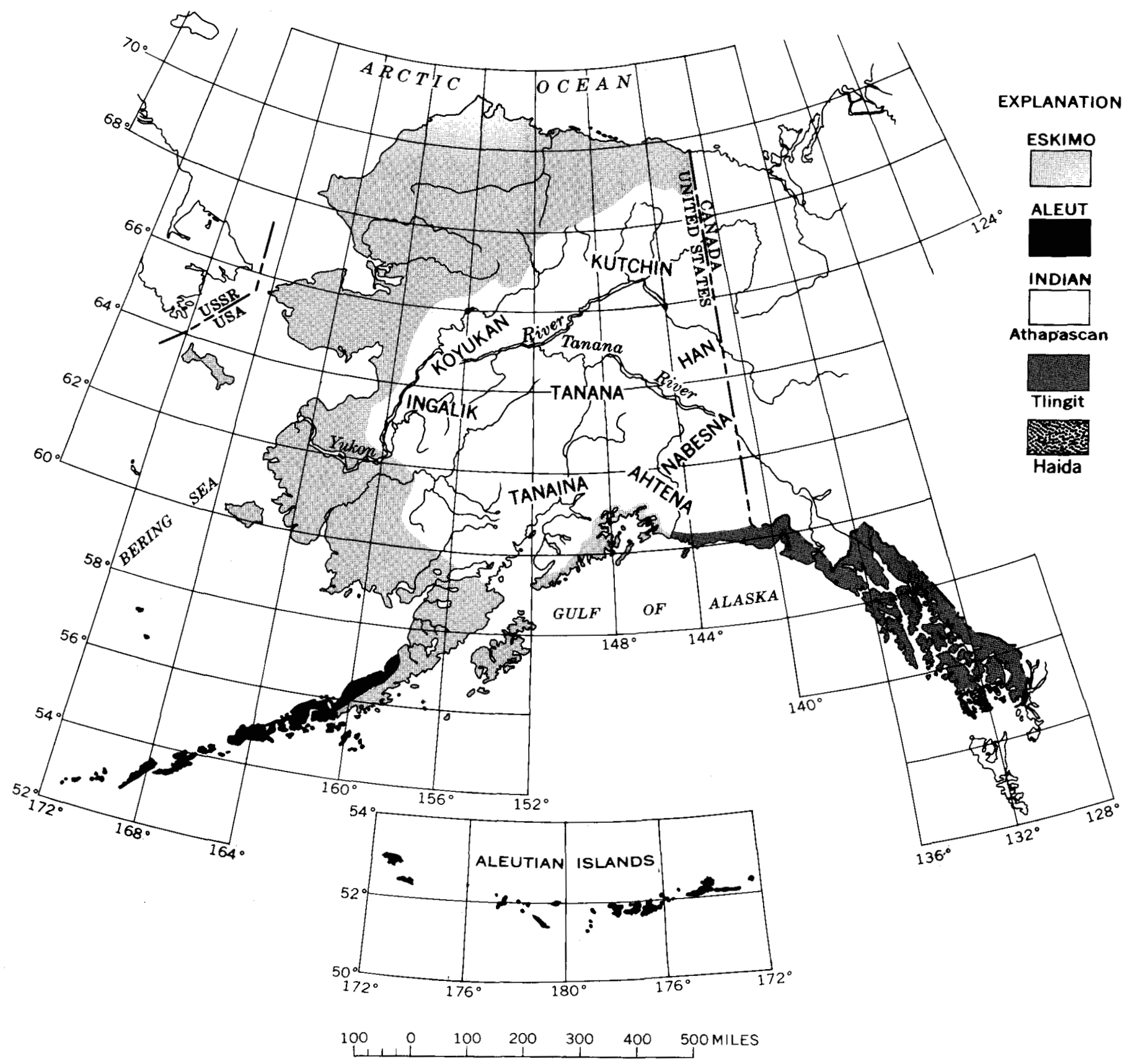

Figure 3.-Indian, Eskimo, and Aleut linguistic areas of Alaska in 1890.

\section{Sources of Names}

Many published maps, charts, manuscripi maps, fieldsheets, name records, books, letters, and persons were consulted in preparing this work. Each entry in this dictionary aims to give reference to the source of the listed name. Source is herein defined as the first documentation of the name and its application. This section lists alphabetically many of the principal sources used in the dictionary. Dates in the boldface headings refer to the time spent on Alaskan or Russian American affairs.

Dates following a person's name in the discussion refer to birth and death years. The source information should be used in conjunction with the "Selected bibliography" given in the dictionary.

\section{Abercrombie, William Ralph: 1884-19?}

Capt. William Ralph Abercrombie, 1857-19?, USA, an aide of Gen. N. A. Miles, was selected in 1884 to lead an exploring expedition up the Copper River and across the Alaska Range to 
the Yukon River. His attempt to ascend the Copper River was unsuccessful although he was able to survey the Copper River Delta and a portage route to Port Valdez.

Abercrombie returned to Alaska in the spring of 1898 with more than 20 men. The expedition was divided into two parties: one, led by F. C. Schrader, USGS, assisted by Emil Mahlo, topographer, made reconnaissance surveys of the Prince William Sound and Copper River districts, and the other, led by Lt. P. G. Lowe, USA, traversed the trail from Valdez to Mentasta Pass, then to the Yukon via the Fortymile and Sixtymile Rivers. Abercrombie's report was published with that of Capt. E. F. Glenn.

Abercrombie returned to Alaska the following year with instructions to construct a military road from Valdez to Fort Egbert on the Yukon. Accompanying Abercrombie was Oscar Rohn, who made a geologic reconnaissance and topographic survey in the Wrangell Mountains and adjacent areas and provided a report of a route for reaching the interior goldfields of Alaska and Canada. Rohn's report was published in 1900 in the Twentyfirst Annual Report of the Geological Survey. Abercrombie's report was published by the U.S. Congress in "Compilation of Narratives of Explorations in Alaska." Abercrombie Mountain in the Valdez area was named for him.

\section{Alaska Road Commission: 1905-56}

The Alaska Road Commission was established by the U.S. War Department (later called the U.S. Department of Defense) in 1905 to survey and develop roads, trails, and mail routes between the coast and the mining areas. In 1932 the Alaska Road Commission was transferred to the U.S. Department of the Interior, where it remained until 1956 when its functions were assumed by the Bureau of Public Roads of the U.S. Department of Commerce. A survey of a land route for a mail and pack trail from Fairbanks to Council City on the Seward Peninsula was made during the summer of 1906 under Major Wilds P. Richardson, 1861-1929, USA, president of the Alaska Road Commission.

By 1917 the Alaska Road Commission had made 980 miles of wagon roads, 549 miles of sled roads, and 2,291 miles of trail. The principal wagon road was the Fairbanks-Valdez Road, now known as the Richardson Highway, named for Maj. Richardson. The 371-mile road connected the interior of Alaska with the Pacific Ocean.

In the early 1920's compilation of a series of 13 maps of the region south of Brooks Range was begun. In addition to wagon roads, sled roads, pack trails, and physical features, the maps showed the towns and villages with the latest census population and locations of shelter cabins along the trails. In addition, several reports have been made by the Alaska Road Commission that provide cartographic and toponymic material on Alaska.

\section{Allen, Henry Tureman: 1885}

Lt. (later Gen.) Henry Tureman Allen, 1859-1930, USA, graduated from West Point in 1882 and in 1884 was assigned to Sitka as an aide to Gen. Nelson A. Miles. In the summer of 1885 he made a remarkable journey of 1,500 miles with a complement of four men: Pvt. Frederick W. Fickett and Sgt. Cady Robertson, of the Army, and two prospectors, Peder Johnson, who was recruited at Nuchek, and John Bremner, who joined the group at Taral. On March 29 they ascended the Copper River, made a side trip up the Chitina, and proceeded to the head of the Chitistone. They resumed the voyage up the Copper, then up the Slana and down the Tetlin and Tanana to the Yukon. From there Allen and Fickett portaged to the Kanuti and traveled thence to the Koyukuk, where they proceeded upstream. They returned down the Koyukuk to the Yukon, then portaged to the Unalakleet and traveled down it to St. Michael. Allen named a considerable number of features, and his journey was subsequently praised as one of the greater explorations in the history of North America. The results were published in 1887. Allen Glacier and Mount Allen, near the head of the Tanana River, were named for this distinguished explorer.

\section{Archimandritov: 1848-50}

Capt. Archimandritov (cnna) made surveys in the Kenai Peninsula and Kodiak Island areas about 1850 while in command of a Russian American Company(?) vessel. Some of his results were probably used in Tebenkov's atlas; copies of his manuscript maps and charts were used by the Russian American Company. His survey of Port Graham, Cook Inlet, was published as a harbor chart in 1869 by the U.S. Coast and Geodetic Survey. See Tebenkov.

Arey, H. T.: 1901-3. See Marsh.

Arteaga, Don Ignacio: 1779. See Spanish Expeditions.

\section{Bagley, James Warren: 1907-16}

James Warren Bagley, 1881-1947, USGS topographer from 1905 to 1918, began his Alaskan career in 1907 in the YukonTanana region. This work continued until 1911 when he began topographic surveys in south-central Alaska, which continued for 5 years. During this period, Bagley experimented with the use of panoramic cameras for mapping.

\section{Baker, Marcus: 1873-80}

Marcus Baker, 1849-1903, USC\&GS from 1873 to 1886 and USGS from 1886 to 1903 . Baker surveyed the Aleutian Islands and the Alaskan coast from Dixon Entrance to Point Belcher on the Arctic coast in 1873,1874 , and 1880 in the party of $\mathbf{W} . \mathbf{H}$. Dall. In May 1880, through the courtesy of Capt. L. A. Beardslee, USN, he made a boat journey from Sitka to Chilkat and returned to Sitka. The names given by himself and the U.S. Coast and Geodetic Survey personnel during this period of 7 years are recorded in the 1883 Coast Pilot, which he and W. H. Dall prepared. When working for the U.S. Geological Survey, Baker prepared the first listing of Alaskan names, published in the Twenty-first Annual Report of the U.S. Geological Survey in 1900. This work led directly to the first "Geographic Dictionary of Alaska," published as Bulletin 187 in 1902. Baker began preparation of a second edition but died before its completion. James McCormick, USGS, continued the work, which resulted in the 1906 "Geographic Dictionary of Alaska," published as Bulletin 299.

\section{Barnard, Edward Chester: 1898-1900}

Edward Chester Barnard, 1863-1921, USGS, topographer, surveyed the Fortymile River mining area in the summer of 1898 and made surveys on the Seward Peninsula in the summer of 1900. His work in the Fortymile district was published in $\mathbf{1 8 9 9}$ on pages 174-177 of Public Resolution 25, U.S. 55th Congress, 
second session, titled "Maps and Descriptions of Routes of Exploration in Alaska in 1898," and was also published in 1901 as an atlas sheet of the U.S. Geological Survey titled "Reconnaissances of the Cape Nome and Norton Bay Regions, Alaska, in 1900." His fieldsheets are the sources of over 200 prospectors' names listed in the present dictionary.

\section{Beardslee, Lester Anthony: 1879-80}

Capt. (later Rear Adm.) Lester Anthony Beardslee, 1836-1903, USN, in command of the U.S.S. Jamestown, was sent to Sitka in 1879 because of the threat of an Indian uprising. Capt. Beardslee attempted to organize the local government, negotiated with the Indians to open Chilkoot Pass, and policed the illegal manufacture of liquor. Among the officers were Lt. (later Rear Adm.) Frederick Martin Symonds, 1846-1926, and Lt. (later Comdr.) Gustavus C. Hanus, 1848-1931, both of whom had worked for the U.S. Coast and Geodetic Survey and were enthusiastic surveyors. The personnel of the Jamestown examined much of Alexander Archipelago, and their work increased the geographic knowledge of that area and included the reporting of many new geographic names. A map of Sitka Harbor was made, and was published by the Coast and Geodetic Survey. Beardslee's report was published in 1882. Beardslee's name has been given to a group of islands, a passage, and a river. A bay, island, point of land, and reef have been named for Hanus. A bay and point of land were named for Symonds.

\section{Becker, George Ferdinand: 1895}

George Ferdinand Becker, 1847-1919, USGS geologist, accompanied by W. H. Dall and C. W. Purington, visited Alaska in 1895 for the purpose of examining and reporting on its coal and gold resources. Their examination was confined to the south coast from Sitka to Unalaska. It included several localities in the Alexander Archipelago, in the Kodiak and Cook Inlet areas, and along the Alaska Peninsula. The trip ended with a visit to Bogoslof Island.

\section{Beechey, Frederick William: 1826-27}

Capt. (later Rear Adm.) Frederick William Beechey, 17961856, RN, in command of H.M.S. Blossom, was sent from the Pacific Ocean through the Bering Strait to join Sir John Franklin, who was approaching Point Barrow from the east. Capt. Beechey arrived at Kotzebue Sound on July 22, 1826. Sailing north he made surveys along the coast to Point Barrow, the later part of the journey being accomplished by the ship's Mate, Thomas Elson, in an open boat. Beechey left Kotzebue Sound October 13 and passing through Unimak Strait, reached San Francisco on November 7 .

He returned to Kotzebue Sound on August 5, 1827, and the remainder of the season was spent in surveys about the Seward Peninsula. He left Alaskan waters in October.

\section{Bering, Ivan Ivanovich: 1728-41}

Capt. Comdr. Ivan Ivanovich (Vitus) Bering, 1680-1741, a Dane who entered the Imperial Russian Navy in 1704, is generally credited with the discovery of the American continent in the area now called Alaska. He was originally sent to the east by Peter the Great of Russia in 1728 to determine whether Asia and North America were a continuous landmass. He sailed the
St. Gabriel, and it was on this trip that probably the first nonnative name was applied to what is now a part of Alaska, when Bering sighted and named St. Lawrence Island in August 1728. It appears, however, that he did not see any part of the American continent.

In 1741 Bering made his famous voyage of discovery. After a long and involved overland expedition from St. Petersburg, he sailed from Petropavlovsk, Avacha Bay, on June 4 (O.S.), commanding the St. Peter, with a crew of 75, accompanied by Capt. Lt. Alexei (Alexsei) Ilich Chirikov (?-1748) commanding the St. Paul, with 76 men. With Bering was Georg Wilhelm Steller, 1709-46, naturalist, and sailing with Chirikov was Prof. Delisle (Louis de l'Isle) de la Croyère (?-1741). Both ships sailed eastward together, but on the 20th (O.S.) they were separated by a storm and did not meet again. Bering made landfall, sighting Mount St. Elias on July 16 (O.S.). A few days later he landed Steller on Kayak Island for a few hours and then turned back, touching the Shumagin Islands and sighting several of the Aleutian Islands. He was driven ashore on Bering Island (U.S.S.R.), where he died of scurvy in December, sailing master Sven Waxel assuming command.

Chirikov, after the separation, continued to sail eastward, sighting land in the Alexander Archipelago, probably in the Sitka area, on July 15 (O.S.). On July 18 (O.S.) the first of two boats were sent ashore, the crews of both disappearing without a trace. After several days of waiting, Chirikov was forced to leave, his return taking him near the south end of Kenai Peninsula, near Kodiak Island, and along the Aleutian Islands; he returned to Petropavlovsk in October.

Several features in and adjacent to Alaska are named for Bering and Steller. Chirikov is commemorated by Chirikof Island and Waxel by Waxell Ridge in the Bering Glacier area.

\section{Billings, Joseph: 1790-92}

Capt. (later Commodore) Joseph Billings, 1761?-1806, IRN, commanded a Russian exploring and surveying expedition to Alaska in 1790-92. He began his naval career in the Royal Navy and served on the Discovery during the expedition of Capt. James Cook, RN, in 1776-79. In 1783, he was assigned to the Imperial Russian Navy, and shortly afterward, in 1784, preparations for his expedition began. Empress Catherine of Russia issued an edict in 1785, officially appointing Billings to command "A Secret Astronomical and Geographical Expedition for navigating the Frozen Sea, describing its Coasts, and ascertaining the Situation of the Islands in the Seas between the two Continents of Asia and America" (Bancroft, 1886, p. 282). Billings' first attempt in 1787 was unsuccessful. He sailed again in 1790 commanding the Slava Rossiy (Glory of Russia) and visited the Aleutian Islands and Kodiak Island before returning. In 1791 he visited the Near Islands, Tanaga, Pribilof, and St. Lawrence Islands, and the Aleutian Islands from Atka to Unalaska.

Blake, Eugene: 1899-1901. See Cantwell.

Blake, William P.: 1863. See Rynda Expedition.

Bodega y Quadra, Don Juan Francisco de la: 1775-79. See Spanish Expeditions. 


\section{British Admiralty}

The British Admiralty published many charts relating to the early explorations of Alaska. Most of these were compilations from, or reproductions of, other maps previously made under the direction of Captains Cook, Beechey, and Vancouver, Sir John Franklin, and the officers of the Franklin searching expedition, and many were from published Russian charts. Some names on British Admiralty charts have not been traced to any other source, and for such names reference is simply made to the British Admiralty.

\section{Brooks, Alfred Hulse: 1898-1912}

Alfred Hulse Brooks, 1871-1924, USGS geologist from 1898 to 1923 , first came to Alaska in 1898 as a geologist in the party of W. J. Peters, making geologic studies in the Tanana and White River basins. Again in 1899, with Peter's party, he made a reconnaissance from Pyramid Harbor at the head of Lynn Canal to Eagle on the Yukon River. He spent the summer season of 1900 on Seward Peninsula, his assistants being George Burr Richardson, 1872-1949, USGS geologist, and A. J. Collier. In 1901 he made a geologic examination of the Ketchikan mining district, southeastern Alaska, and a more hasty reconnaissance of the northern belt of southeastern Alaska.

In 1902 Brooks conducted an exploring expedition, including seven men and 20 pack horses, from the head of Cook Inlet to Rampart, on the Yukon, with D. L. Reaburn, topographer, and L. M. Prindle, geologic assistant. From Tyonek, on Cook Inlet, the route lay northwest across the Skwentna River to the Kitchatna, up this stream and through Rainy Pass, down the Kuskokwim River a short distance, and then northeast 200 miles along the northwest base of the Alaska Range to the Kantishna River drainage. From there they traveled northwest, then north along the 149th meridian across the Tanana and Tolovana Rivers, to Rampart, on the Yukon.

In 1903 Brooks was placed in charge of the U.S. Geological Survey division of Alaskan mineral resources and later became Chief Alaskan Geologist. For reports on his work, see bibliography. His early work was published in the Twentieth Annual Report of the Geological Survey (Pt. 7, p. 425-494) and in the Twenty-first Annual Report (Pt. 2, p. 331-391). The report on the work of 1900 on Seward Peninsula was in a separate publication of the Geological Survey (1901, p. 1-180), titled "Reconnaissances of the Cape Nome and Norton Bay Regions, Alaska, in 1900." The report for 1901 was published as Geological Survey Professional Paper 1 (1902). The report on the 1902 expedition may be found in the Twenty-second Annual Report of the Geological Survey (Pt. 3, p. 515-571).

Brooks was vice chairman of the Alaska Railroad Commission in 1911-12 and chief geologist of the American Expeditionary Force during World War I. Brooks is commemorated in Alaska by the Brooks Range and Mount Brooks in the Alaska Range.

Broughton, William Robert: 1792-94. See Vancouver.

Bucareli, Antonio Maria: 1775-79. See Spanish Expeditions.

Butirkin (ccna): 1863. See Rynda Expedition.

\section{Caamaño, Don Jacinto: 1792}

Lt. Don Jacinto Caamaño was sent in 1792 by the Viceroy of Mexico, Count de Revilla Gigedo, in the corvette Aranzazu, to explore the northwest coast of North America from the Strait of Juan de Fuca northward. He left Mexico March 20, 1792, arrived in Bucareli Bay July 12, surveyed southward along the coasts of Alaska and British Columbia, and returned to Mexico February 6, 1793. Capt. George Vancouver, RN, met Caamaño in the field and apparently obtained copies of some of his maps, especially of places north of Dixon Entrance, which were incorporated in Vancouver's work. (See fig. 4.)

Camden, B. H.: 1899-1901. See Cantwell.

\section{Cantwell, John C.: 1884-1901}

Lt. John C. Cantwell, USRCS, was taken to Cape Krusenstern in 1884 by Capt. Michael A. Healy, USN, commander of the revenue cutter Corwin. Cantwell, preceding by a few days the naval expedition of Lt. G. M. Stoney, ascended the Kobuk River about 185 miles. On his return he explored Selawik Lake and vicinity. Cantwell repeated his journey in 1885, traveling up the Kobuk to Walker Lake, which he named. Also disembarking from the Corwin in the summer of 1885 was 2d Asst. Eng. S. B. McLenegan, USRCS, who with one man explored about 250 miles up the Noatak. Reports of Cantwell's and McLenegan's 1885 explorations were published in 1889 and 1887 , respectively, unde: the authorship of Capt. Healy.

In the summers of 1899, 1900, and 1901, Cantwell commanded the revenue steamer Nunivak on the Yukon River, and he wintered at the mouth of the Dall River during these years. From information gathered while on this duty, including a reconnaissance of the Dall River-Koyukuk Trail by 3d Lt. Eugene Blake, USRCS, and a reconnaissance of the Koyukuk River by $2 d$ Lt. B. H. Camden, USRCS, sketch charts of the Yukon and Koyukuk Rivers were constructed but were not published. Cantwell's report of the cruises of the Nunivak was published in 1902.

\section{Capps, Stephan Reid: 1908-36}

Stephan Reid Capps, 1881-1949, USGS geologist from 1907 to 1945, began his geological surveys in Alaska in 1908 and continued his Alaskan studies throughout the southern part of the State until 1936.

Carter, F. G.: 1901-3. See Marsh.

Chapin, Theodore Sheffield: 1910-19?

Theodore Sheffield Chapin, 1876-19?, USGS geologist from 1910 to 1920 , did geological surveys in the southeast quarter of the State, including the Yukon-Tanana, Nelchina-Susitna, Bremner, Seward Peninsula, and Ketchikan regions.

\section{Chernov, Ivan: 1832-38}

Ivan Chernov, ?-1877, was a Russian American Company pilot who made various surveys in the Aleutian Islands in the early 1830's. These surveys were primarily at Amlia Island in the Andreanof group, and in the Rat Island group. Chernov, a creole, was given by the Indians to the Russians in 1804 as a hostage and was returned in 1805. During this year he was sent to the Russian navigation school at Sitka, after which he began a long period of service with the Russian American Company. 


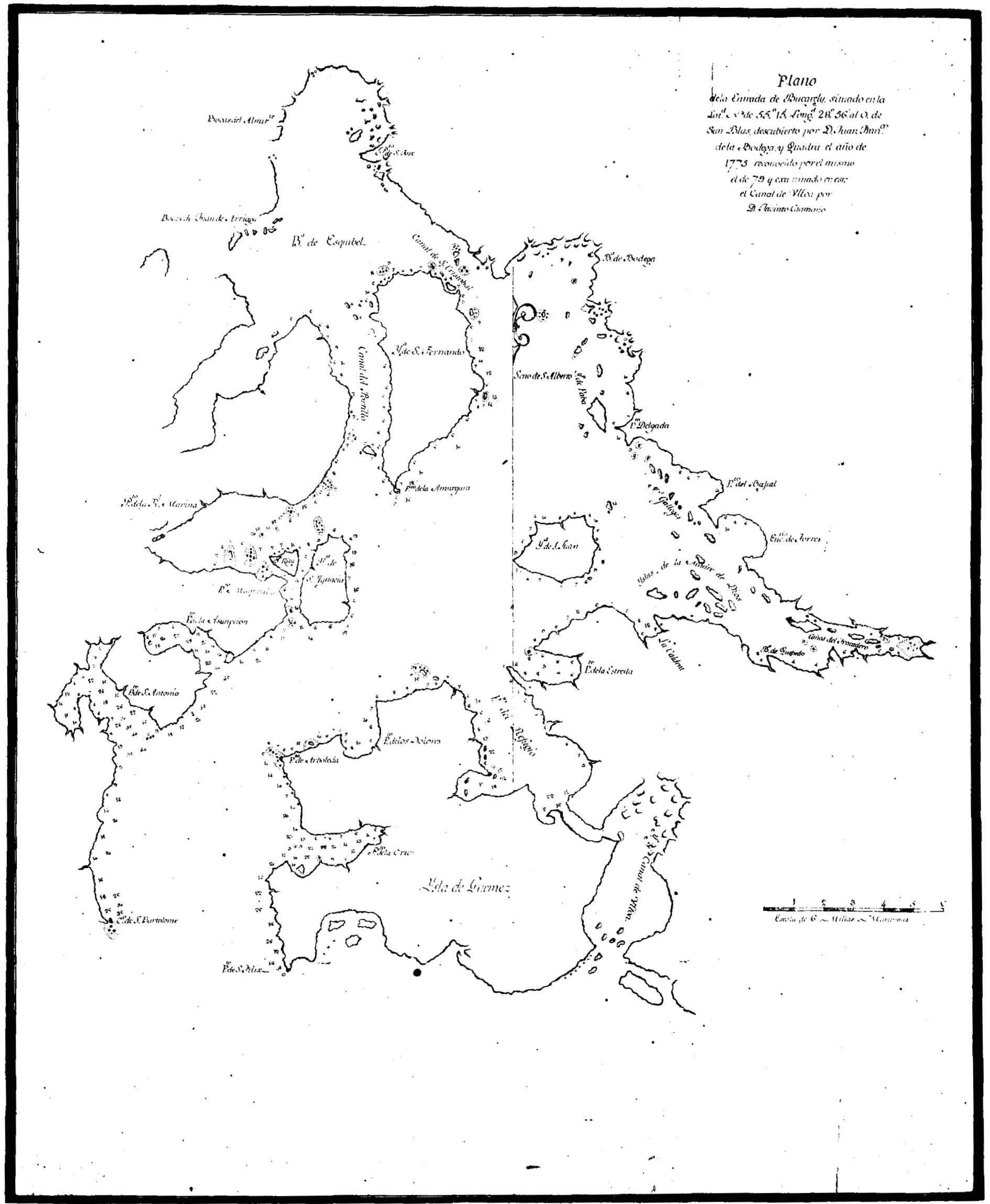

FIGURE 4.--A 1792 Spanish map of Bucareli Bay, by Don Jacin:o Caamaño. Courtesy of Library of Congress. 
Some of the results of his surveys were incorporated in Russian Hydrographic Department Charts 1378 and 1400. Chernof Cape, on the north coast of Kodiak Island, was named for this navigator.

Chirikov, Alexei Ilich: 1741-42. See Bering.

Clerke, Charles: 1778. See Cook.

Clover, Richardson: 1885

Lt. Comdr. (later Rear Adm.) Richardson Clover, 1846-1919, USN, commanding the U.S. Coast and Geodetic Survey steamer Patterson, made surveys in the south end of the Alexander Archipelago in the summer of 1885 . Extracts from his reports were published in the Coast and Geodetic Survey Annual Report for 1886. A bay, an island, a passage, and a point of land have been named for Clover.

\section{Coghlan, Joseph Bullock: 1884}

Comdr. (later Rear Adm.) Joseph Bullock Coghlan, 1844 . 1908, USN, commanded the U.S.S. Adams in southeast Alaska in the summer of 1884. He surveyed the interior passages north and east from Sitka Sound, through Peril Strait to Chatham Strait, and in and about Barlow Cove at the south end of Lynn Canal. The results of this work were incorporated on U.S. Coast and Geodetic Survey Charts 727 and 728, published in 1885. An island in the Alexander Archipelago was named for Coghlan in 1885.

\section{Collier, Arthur James: 1900-1904}

Arthur James Collier, 1866-1939, USGS geologist, began his Alaskan work as assistant to A. H. Brooks in the Cape Nome region, Seward Peninsula, in 1900. An account of this work was published as a U.S. Geological Survey special report, "Reconnaissance of the Cape Nome and Norton Bay Regions, Alaska, 1900." The notes on climate and vegetation in that report were written by Collier.

He returned to the Seward Peninsula in 1901 as geologist with T. G. Gerdine's party. In 1902 Collier, with two assistants, made an examination of the coal deposits along the Yukon River from Dawson to the delta. Collier's fieldsheets along the Yukon River were the source of numerous names for the present dictionary.

In 1903 Collier, with F. L. Hess as assistant, returned to the Seward Peninsula in order to continue mineral-resource investigations and visited nearly all placer-mining camps on the peninsula. He also examined the tin deposits in the York region. In 1904 he spent 46 days making supplementary observations on the gold and tin deposits of the Seward Peninsula, and he then spent a month making a reconnaissance of the Cape Lisburne coal deposits. Collier also made a geologic and topographic survey along the coast and several miles inland, from Cape Beaufort to Cape Thompson, a distance of 140 miles. An account of these operations may be found in the Twenty-sixth Annual Report of the Geological Survey, 1905. Collier's fieldsheets of the reconnaissance were the source of some Eskimo geographic names.

Colnett, James: 1789. See Meares.

\section{Cook, James: 1778}

Capt. James Cook, RN, 1728-79, went to sea as an apprenticed seaman and entered the Royal Navy at the age of 27 . He rose in rank by merit and was sent on two scientific expeditions-the first to the South Pacific in 1768-71 and the second to Antarctica in 1772-75.

In July 1776 the British Admiralty instructed Capt. Cook to proceed with Capt. Charles Clerke, RN, to the northwest coast of North America and from there north in an attempt to find a passage by sea from the Pacific to the Atlantic. Cook commanded the Resolution and Clerke the Discovery. The ships sailed from Plymouth to Cape of Good Hope, New Zealand, Tahiti, the Hawaiian Islands, and Nootka Sound in Vancouver Island, arriving March 30, 1778. From then until October 3, 1778, Cook cruised northward and westward along the North American coast to Icy Cape, in the Arctic Ocean, and sketched the chief outlines of this coast, heretofore practically unknown. During this trip Cook applied names to numerous features that were discovered. Leaving Unalaska on October 27, 1778, he returned to the $\mathrm{Ha}$ waiian Islands where he was killed by the natives on February 14, 1779. The two vessels later returned to the northwest coast of North America for additional exploration but, being unable to find a northwest passage, turned south and sailed for England, arriving there on October 4, 1780. The British Admiralty published in 1784-85 an account of this voyage in three volumes and a large atlas. Cook is commemorated in Alaska by Cook Inlet and Mount Cook.

\section{Coxe, William: 1780}

William Coxe (later Reverend, Archdeacon of Wilts), an English scholar, visited the Russian court in St. Petersburg and was given permission by Empress Gatherine to search the archives and study the records of the early Russian discoveries made between Asia and America from 1741 to 1780 . The result of his research was published in 1780 under the title "Account of the Russian Discoveries between Asia and America." The third edition of this work, published in London in 1787, was frequently used in the preparation of this dictionary in connection with early naming in the Aleutian Islands, Alaska Peninsula, and Kodiak Island.

Croyère, Louis de l'Isle de la: 1741. See Bering.

\section{Dall, William Healey: 1865-99}

William Healey Dall, 1845-1927, first went to Alaska in 1865 in the employment of the Western Union Telegraph Expedition. In 1867 Dall succeeded Robert Kennicott as director of the scientific corps of the Western Union Expedition. He returned to the United States in 1868 and wrote "Alaska and its Resources," which was published in 1870 .

In 1871 Dall was appointed Acting Assistant of the U.S. Coast Survey (later U.S. Coast and Geodetic Survey). Aboard the Humboldt in 1871 and 1872 and the Yukon in 1873 and 1874, Dall made reconnaissance surveys along the coast from Sitka westward to Attu at the end of the Aleutians and northward in the Bering Sea as far as Nunivak and the Pribilof Islands. Mark Walrod Harrington assisted Dall in 1871-72. Dall returned to Washington, D.C., at the end of 1874 in order to write the 1879 Coast Pilot and its appendix, with the assistance of Marcus Baker. In 1880 Dall again returned to Alaska aboard the Yukon and cruised along the coast from Sitka to Unalaska and northward 
nearly to Point Barrow. The result of this trip was a series of some 50 charts and plans published by the Coast and Geodetic Survey as well as the 1883 Coast Pilot and its appendix.

In 1884 Dall resigned from the Coast and Geodetic Survey and began work with the U.S. Geological Survey as a paleontologist detailed to the U.S. National Museum where he was curator of the Division of Mollusks and Tertiary Fossils until his death. In 1895 he returned to Alaska accompanied by G. F. Becker and C. W. Purington for the purpose of studying and reporting on coal and gold resources. In 1899 he returned to Alaska with the Harriman Expedition.

Dall reported a large number of names in Alaska in his early publications and is also credited with giving a considerable number of names. In commemoration of this distinguished person, Mount Dall in the Alaska Range and Dall Island in southeastern Alaska, as well as several other features in Alaska, were named for him.

\section{Davidov, Gavril Ivanovich: 1803}

Two Russian naval officers, Gavril Ivanovich Davidov, 1784 1809, IRN, and Lt. Nikolai Alexandrovich Khwostov, 1776-1809, IRN, traveled from St. Petersburg to Sitka in 1802-4 for the purpose of scientific research along the Aleutian Islands and Kodiak Island and in the Cook Inlet area. This voyage was undertaken with their Government's permission under the auspices of the Russian American Company. Davidov wrote an account of the journey, including descriptions of the places visited, which was published in two volumes in St. Petersburg in 1810 and 1812.

\section{Davidson, George: 1867-69}

Assistant George Davidson, 1825-1911, went to Alaska prior to its purchase by the United States aboard the revenue cutter Lincoln. He did reconnaissance work off the coast while the final negotiations were underway, making observations at Sitka, Chilkat, Kodiak, and Unalaska. His report was published in the U.S. Coast and Geodetic Survey Annual Report for 1867 and separately as "Coast Pilot of Alaska, First Part, from Southern Boundary to Cook's Inlet." Davidson also provided material for charts of Sitka, St. Paul Harbor, Kodiak, and Captains Bay on Unalaska Island, which were published by the Coast and Geodetic Survey in 1869.

Davidson returned to Alaska in 1869 to do further reconnaissance surveying in the Alexander Archipelago. While in the Chilkat River valley, he observed the total solar eclipse on August 7, 1869. Subsequently, he returned to the United States where he worked with G. R. Putnam and others until his separation from the Coast and Geodetic Survey in 1895. Several features in Alaska were named for this scientist.

Dease, Peter Warren: 1837. See Simpson.

Delisle de la Croyère, Louis: 1741. See Bering.

Dickins, Edmund Finlay: 1899-1905

Assistant Edmund Finlay Dickins, USC\&GS, was in command of the U.S. Coast and Geodetic Survey steamer Gedney from 1899 to 1905 . In 1899 he connected the triangulation surveys of Chatham and Sumner Straits. In 1901-2, Dickins joined J. F. Pratt in making hydrographic and topographic surveys in the Alexander Archipelago from Chatham Strait to Inian Islands, and in 1903-4 he did survey work in the Davidson Inlet and Iphigenia Bay area. The surveys extended from Moira Sound to bays on Prince of Wales Island. His reports were published by the Coast and Geodetic Survey in its annual reports in 1900 and $1902-4$ and incorporated onto the charts.

Dixon, George: 1786-87. See Portlock.

\section{Doroshin, Peter P.: 1848}

Peter P. Doroshin, mining engineer of the Russian American Company, was sent to its American possessions in 1847 to examine the gold resources. He traveled in the ship Atka to Baranof Island and Cook Inlet. His results were published in the Russian Mining Journal for 1866.

Douglas, William: 1788. See Meares.

\section{Duffield, Will Ward: 1897}

In April 1897 Assistant Will Ward Duffield, 1841-?, USC\&GS, was directed to conduct a topographical survey of the Pribilof Islands and the seal rookeries. Assisting in this survey were Fremont Morse, G. R. Putnam, and G. L. Flower. Complete topographical surveys were made of St. Paul, St. George, Walrus, and Otter Islands. Results of these surveys were published on U.S. Coast and Geodetic Survey charts in 1898.

\section{Eakin, Henry Miner: 1907-21}

Henry Miner Eakin, 1883-1936, USGS geologist, did geological surveys for 11 years in Alaska.

\section{Eldridge, George Homans: 1898}

George Homans Eldridge, 1854-1905, USGS geologist, with Robert Muldrow, 1864-1946, USGS topographer from 1887 to 1928, made a reconnaissance of the Susitna River basin in the summer of 1898. Their explorations extended from the head of Cook Inlet up the Susitna to about the north boundary of present Mount McKinley National Park. Both men are commemorated by features such as Mount Eldridge and Miuldrow Glacier, in the Mount McKinley region.

\section{Elliott: Henry Wood: 1872-76}

Henry Wood Elliott, 1846-1930, a naturalist, was chosen as a member of the scientific corps of the 1865-67 Western Union Telegraphic Expedition but served solely in Canada. In 1872 he was appointed assistant agent of the U.S. Treasury Department for the Pribilof Islands. He remained in this position the following year. In 1874, aboard the revenue cutter Reliance, under command of Capt. Baker (cnna), Elliott and Lt. Washburn Maynard, USN, visited the Pribilof Islands and the islands of Sitka, Kodiak, Unalaska, St. Matthew, and St. Lawrence. His reports were published in 1875 and 1876 . He also wrote a monograph on the Pribilof Islands, which was published in the 10th Census, in 1880, and as separate editions in 1881 and 1882. Included in the monograph were two maps of Pribilof Islands made in 1874 by Elliott and Maynard. Many names were obtained from these maps and text for the present dictionary.

\section{Erickson Hjalmar: 1900-1902}

First Lt. Hjalmar Erickson, USA, was "selected for the duty of exploring and locating the most feasible route for a military road from Camp Rampart [Rampart], or some point in the 
vicinity, to Fort Egbert [Eagle], Alaska, southward of the Yukon Flats * **." Following this official order Erickson, assisted by William Yanert, a civilian employee of the U.S. Army Signal Corps, left St. Michael in August 1900 and spent several months exploring and mapping the area between Rampart and Eagle on the south side of the Yukon River. The sketch maps made by the expedition furnished many new prospectors' names. Erickson recommended against a road and recommended the construction of a telegraph line instead.

\section{Etolin, Adolph Karlovich: 1818-45}

Capt. Adolph Karlovich Etolin, IRN, was governor of the Russian American colonies from 1841 to 1845 . In 1822-24 Etolin, with Kromchenko (cnna), IRN, participated in one of the principal expeditions of the Russian American Company, exploring and surveying the Bering Sea coast. During this expedition detailed surveys of the coast, from Bristol Bay to the mouth of the Kuskokwim River, and of Norton Sound, were made. Tamgas Harbor and Kaigani Strait were surveyed by Etolin in 1833, and the results were published in 1848 on Russian Hydrographic Department Chart 1396. In $1839 \mathrm{Etolin}$, in command of the Russian American Company ship Nikolai, sailed from Russia to the colonies, assuming the duties of governor in 1841. He is commemorated in Alaska by Etolin Island in southeast Alaska and by Etolin Strait in the Bering Sea.

\section{Faris, Robert Lee: 1898-1901}

Assistant Robert Lee Faris, 1868-1932, USC\&GS, accompanied Assistant J. F. Pratt, USC\&GS, in 1898-1900. During this period Faris, in charge of a subparty, made surveys in the vicinity of the Yukon River Delta, the results of which were incorporated in U.S. Coast and Geodetic Survey Charts 9370 and 9373 . In 1901 Faris accompanied Assistant Ferdinand Westdahl, USC\&GS, during the survey of the Sannak Islands off the south end of the Alaska Peninsula.

\section{Fassett, Henry Clifford: 1900-1919}

Henry Clifford Fassett, USBF, worked in Alaska from 1900 until 1919. While on the U.S. Fish Commission steamer Albatross, under command of Lt. Comdr. Moser, USN, in 1900-01, he made studies of the southern coast of Alaska from Dixon Entrance to Nushagak Bay. In 1903, Fassett continued his research on the Albatross under the command of Lt. F. Swift, USN. In his reports he described the early canning industry at Karluk and dredging operations at several places along the Alaskan coast. He also sketched several maps, on which he reported native names in the areas he visited. Fassett Glacier and Fassett Point were named for him.

\section{FitzGerald, Gerald: 1921-30}

Gerald FitzGerald, 1898-

, USGS topographer from 1917 to 1957 , did his first work in Alaska in 1921 in the Iniskin oil field on Cook Inlet. He spent four seasons, from 1923 to 1926, as topographer with field parties exploring the newly established Naval Petroleum Reserve 4 in northwestern Alaska. FitzGerald's fieldsheets represent the first documentation of some Eskimo names and new names given by the field parties. He also did topographic surveys in southwest Alaska. He was Chief Alaskan
Topographer, 1938-42, and Chief Topographic Engineer, 194757 , for the U.S. Geological Survey.

\section{Flemer, John Adolph: 1898-1905}

Assistant John Adolph Flemer, USC\&GS, went to Alaska with Assistant John Nelson, USC\&GS, in 1898 to make a topographic reconnaissance survey of the region near Lynn Canal. While there, in 1898-99, he cooperated with the Canadians in taking terrestrial photos from high places and utilizing them in surveys along the boundary. His reports appeared in the U.S. Coast and Geodetic Survey Annual Report for 1899, and the information provided by the surveys was applied to the charts of the area.

Flemer also participated in the boundary surveys in southeastern Alaska in 1903-05 under the Alaska Boundary Tribunal.

\section{Franklin, Sir John: 1826}

Sir John Franklin, 1786-1847, RN, English Arctic explorer, made explorations along the Arctic coast of Alaska in July and August 1826. He planned to meet Capt. F. W. Beechey, RN, at or near Point Barrow and thus complete the exploration of the coast of northwest North America. After wintering at Fort Franklin (in Canada), Sir John descended the Mackenzie River to its mouth and traveled by small boat westward along the coast into Alaska as far as Beechey Point, where he turned back owing to the lateness of the season. Franklin and his crew disappeared on an expedition in northern Canada in 1847. The search for the missing expedition motivated intense exploration of the northern Alaskan coastline. See Franklin Searching Expeditions.

\section{Franklin Searching Expeditions: 1849-54}

Numerous Arctic expeditions were sent out by the British Government in search of Sir John Franklin's party. The first began July 25, 1849, when Lt. W. J. Pullen, RN, accompanied by Lt. W. H. Hooper, RN, led a party of four boats and 25 men from Comdr. T. E. L. Moore's, RN, ship Plover on a traverse of the Arctic coast from Wainwright Inlet to Fort Simpson on the Mackenzie River; they reached Fort Simpson October 3. Both Pullen and Hooper's accounts were published.

Several other expeditions followed. In the summer of 1850 Moore made a boat journey from a locality south of Point Barrow to Cape Simpson. He is credited with the naming of the eastem four of the Plover Islands after his ship and the naming of several other islands for his officers. Capt. Robert McClure, RN, in command of the Investigator, passed Point Barrow on August 5,1850 , and Flaxman Island on the 18th, but was lost in fog and snow until the 21 st, when the ship approached the Mackenzie River.

Capt. Richard Collinson, RN, commander of the Enterprise, passed Point Barrow in July 1851 and made observations along the coast, wintered 2 years in British territory, started his return trip in September 1853, and on the 26th was frozen in for the winter. Collinson and his men made several attempts to explore the region. On July 10, 1854, Lt. Jago left the Enterprise in a whaleboat for Point Barrow, where he arrived July 24. The Enterprise broke free July 16 , but because of the ice was not able to reach Point Barrow until August 8.

Comdr. Rochfort Maguire, RN, of the Plover, wintered in Moore Harbor, Elson Lagoon, between 1852 and 1854 and made several trips yielding geographical information which was incor- 
porated in the charts made by Master Thomas Hull. Maguire and his ship's surgeon, John Simpson, are credited with naming and reporting Eskimo names for a number of Arctic features. Simpson recorded considerable information about the Eskimo of northern Alaska and was responsible for drawing a map of the north coast between Point Barrow and Humphreys Point on the basis of information given by Eskimos.

Accounts of these expeditions were published in the 1850's in various publications. The reports and papers published by Great Britain were used in the compilation of the present dictionary.

General Land Office: 1899-

The General Land Office was established in 1812 as part of the U.S. Treasury Department. It was transferred in 1849 to the newly created U.S. Department of the Interior. In 1946, the General Land Office, the Grazing Service, and the Surveyor General's Office were combined to form the U.S. Bureau of Land Management.

The General Land Office first worked in Alaska in 1897 when the office of Surveyor General of the District of Alaska was created. The first Surveyor General was William L. Distin, who served until 1914. The establishment of the Copper River meridian and base line in 1905 was the beginning of the rectangular system of surveys in Alaska.

In 1910 , Congress appropriated $\$ 100,000$ for subdivision surveys of public lands in Alaska. With the cooperation of the U.S. Geological Survey, the General Land Office initiated work in the vicinity of Fairbanks under the direction of R. H. Sargent, USGS. The U.S. Coast and Geodetic Survey provided precise astronomical observations for latitude, longitude, and azimuth at Fairbanks, Tanana, and Copper Center. In 1915, 15 field parties were organized to extend the cadastral surveys to the Bering River, Matanuska, and Nenana coal fields, opened in 1914. At the same time the rectangular surveys were extended to the widely separated areas in the Cook Inlet district, along The Alaska Railroad, and to Haines. The townsites of Douglas, Eska, Fairbanks, Haines, and Sitka were surveyed during this period.

By 1922, 1,550,000 acres were surveyed in Alaska. During the next two decades surveys were expanded on the Alaska and Kenai Peninsulas, and the survey of Mount McKinley National Park was completed; thus, 2,500,000 acres had been surveyed by 1940 .

At the close of World War II and after the conflict in Korea, surveying activity greatly increased with the influx of homesteaders. The achievement of statehood in 1959 and the subsequent transfer of public lands to the State of Alaska, as well as the discovery of oil, have led to increased surveying. By 1966, 11,440,000 acres in Alaska had been surveyed by the Bureau of Land Management. Over the years the surveyors have reported names when they found them and have given names where needed.

\section{Geoghegan, Richard Henry: 1902-43}

Richard Henry Geoghegan, 1866-1943, linguist and master of many languages including Gaelic, Greek, and Chinese, was born in Ireland, studied at Oxford University in England, and came to Alaska as a court reporter under James Wickersham, who was then U.S. district judge. Geoghegan became interested in Alaskan native languages and is primarily known for his translations, from Russian, of Father Ioann Veniaminov's Aleut and Tlingit vocabu- laries. Both he and his brother, James T. Geoghegan, who also came to Alaska, collected word lists of various Indian tribes that included geographic names. Most of his manuscript material is at the University of Alaska and at the State Historical Library.

\section{Gerdine, Thomas Golding: 1899-1907}

Thomas Golding Gerdine, 1872-1930, USGS topographer, worked in 1899 in F. C. Schrader's party on the Chandalar and Koyukuk Rivers. Gerdine was in general charge of all topographic surveys in Alaska from 1902 until 1907, under A. H. Brooks, Chief Alaskan Geologist. In 1908 he became Pacific Region Engineer for the U.S. Geological Survey. Gerdine is commemorated in Alaska by Mount Gerdine.

Gibson, William: 1854-55. See North Pacific Exploring Expedition.

\section{Gilbert, John Jacob: 1900-1901}

Assistant John Jacob Gilbert, USC\&GS, commanded the U.S. Coast and Geodetic Survey steamer Pathfinder in 1900-1901. In 1900 he surveyed the shore of Norton Sound from St. Michael Harbor to Golovnin Bay. The following year he surveyed the Fox Islands and the passes between the eastern Aleutian Islands between Unalaska and Unimak Islands. These surveys were included in new charts published by the Coast and Geodetic Survey for the Norton Sound and Fox Island areas. Gilbert's reports were published by the Coast and Geodetic Survey in 1901 and 1902.

\section{Glass, Henry: 1881}

Comdr. (later Rear Adm.) Henry Glass, 1844-1908, USN, in command of the U.S.S. Wachusett, succeeded Capt. L. A. Beardslee at the Sitka station in 1881 . The surveying done by Symonds and Hanus under Beardslee was continued under Glass and was published by the U.S. Coast and Geodetic Survey. A peninsula and point of land were named for Glass.

\section{Glenn, Edwin Forbes: 1898-99}

Capt. (later Maj. Gen.) Edwin Forbes Glenn, 1857-1926, USA, was ordered in 1898 to establish a camp at Port Wells, Prince William Sound, and explore for routes to the Copper and Susitna Rivers. He was then to proceed to Cook Inlet and explore for routes to the Tanana. Accompanying Glenn was W. C. Mendenhall, USGS, who made geologic and topographic reconnaisance from Resurrection Bay to the Tanana. Also in the party were Lt. J. C. Castner, USA, who reached the Yukon via Lake Louise and the Delta and Tanana Rivers, and Sgt. William Yanert, USA, who explored the headwaters of the Susitna. The results of this series of ventures was published with those of Capt. W. R. Abercrombie, USA. In 1899 Glenn returned to continue his explorations of the previous year. Mount Glenn in the Chugach Mountains was named for him.

\section{Glotov, Stephen: 1763-66}

Stephen Glotov, Russian fur trader, was the first to visit and trade peacefully with the natives of Umnak and Unalaska Islands during his voyage of 1758-62 on the ship Yulian, which he commanded. His second voyage, in command of the Andreian $i$ Natalia, in $1762-65$ was one of the most important of the early 
expeditions to the Aleutian Islands in that it marked the turning point of the free lance customs of the Promyshleniki (fur hunters). Glotov traveled as far east as Kodiak Island, landing on September 8,1763 , and probably was the first European to visit this island. For a further account of his travels, see Bancroft (1886) and Coxe (1787).

\section{Grant, Ulysses Sherman: 1905-10}

Ulysses Sherman Grant, 1867-1932, USGS geologist from 1904 to 1925 , did geological investigations in the Prince William Sound and Kenai Peninsula area. He is credited with the naming and reporting of many names in that area.

\section{Grewingk, Constantin: 1850}

In 1850 Dr. Constantin Grewingk, 1819-87, published a "Contribution to the Knowledge of the Orography and Geography of the Northwest Coast of America and Neighboring Islands" in German. In this article Grewingk reported many names which have been used in this dictionary. Grewingk Glacier, on the Kenai Peninsula, was named for this writer.

\section{Griggs, Robert Fiske: 1915-30}

Robert Fiske Griggs, 1881-1962, botanist, was chosen director of six National Geographic Society Mount Katmai expeditions in 1915-19 and 1930, during which he named nearly 50 geographic features in the Katmai region. $\mathrm{He}$ was commemorated by the naming of Mount Griggs in Katmai National Monument.

\section{Hamilton, Ernest G.: 1904-5}

Ernest G. Hamilton, USGS topographer, worked with F. H Moffit, geologist, on the Kenai Peninsula in 1904 and with G. C. Martin, geologist, mapping the Controller Bay area in 1905.

Hanus, Gustavus C. See Beardslee.

\section{Harriman Alaska Expedition: 1899}

In the summer of 1899 Edward Henry Harriman, 1848-1909, of New York, chartered the steamer George W. Elder and, inviting about 30 scientific men, sailed to Alaska. Many of the guests did some exploration, carried out surveys, collected specimens, and took photographs. The Harriman Alaska Expedition cruised 9,000 miles with about 50 stops; it left Seattle on July 1 and returned August 31. The results of the expedition were published in 12 volumes. The expedition named several geographic features, including Harriman Fiord and Harriman Glacier in the Chugach Mountains region.

\section{Hayes, Charles Willard: 1891}

Charles Willard Hayes, 1859-1916, USGS geologist from 1887 to 1911 , was detailed to accompany an expedition led by Lt. Frederick Schwatka, organized by a syndicate of newspapers, to explore the region lying between Lynn Canal and the Copper River. The route followed up Taku Inlet, down the Teslin and Lewes, up the White, over Skolai Pass, and down the Chitina and Copper. Several new names were added to Alaskan maps by this expedition. Hayes made the first classification of Alaskan physiographic provinces. Several features in Alaska are named for him.

HeIm, James M.: 1886. See Snow.

\section{Herron, Joseph Sutherland: 1899}

The most notable part of Capt. E. F. Glenn's 1899 exploration was that conducted by Lt. Joseph Sutherland Herron, 1869-19?, USA.

He explored the portage between Passage Canal and Prince William Sound and the area around Turnagain Arm on Cook Inlet and joined Glenn at Tyonek. Herron then proceeded up the Kichatna River, across the Alaska Range to the headwaters of the Kuskokwim drainage, then to the Cosna, Tanana, and Yukon Rivers.

\section{Hess, Frank Lee: 1903-5}

Frank Lee Hess, 1871-1955, USGS geologist from 1903 to 1925, began his Alaska work as assistant to A. J. Collier on the Seward Peninsula in 1903. In 1904, as assistant to L. M. Prindle, he made a geological reconnaissance from Eagle to Rampart via Fairbanks. In 1905, assisting F. H. Moffit, Hess helped make a detailed geological survey of the area adjacent to Cape Nome on the Seward Peninsula.

\section{Hooper, Calvin Leighton: 1880-99}

Capt. Calvin Leighton Hooper, 1842-1900, USRCS, spent a number of years in Alaska during the period of early exploration and in later years was Commander of the Bering Sea fleet. His annual reports to the U.S. Treasury Department contributed many geographical facts. Hooper Bay in the Yukon River Delta was named for him.

Howard, William Lauriston: 1885-86. See Stoney.

Ilin, Peter Ivanovich: 1818-42

Staff Capt. Peter Ivanovich Ilin, IRN, of the Pilot Corps, first sailed to the Russian American colonies in 1817 with Capt. Vasili M. Golovnin, IRN, on the Kamchatka. On an unknown date Ilin is believed to have surveyed a bay on the western side of Chichagof Island, and his sketch of the bay was published in the 1826 Sarichev atlas on map 28. He died in 1842 in Okhotsk (or Kamchatka). Ilin Bay, on the west side of Chichagof Island, was named for this navigator by his countrymen.

\section{Ingenstrem: 1829-32}

Ingenstrem (cnna) was a Russian American Company pilot who made various surveys on Atka and Amlia Islands in the Andreanof group of Aleutian Islands in the late 1820's. In 183032, with Ivan Chernov, he made surveys in the Prince William Sound area and at the mouth of the Kenai River, Cook Inlet. His results were used in 1836 by Capt. F. P. Lutke, IRN; in 1852 by Capt. M. D. Tebenkov, IRN; and in 1848 by the Russian Hydrographic Department on Chart 1400 . The Ingenstrem Rocks, in the western Aleutians, were named for this navigator by his countrymen.

\section{International Boundary Commission}

In 1903 the Alaska Boundary Tribunal, established between Great Britain and the United States, negotiated the AlaskaCanada boundary southeast of longitude $141^{\circ} \mathrm{W}$. On the basis of these negotiations, the International Boundary Commission was established by treaties between Great Britain and the United States in 1906, 1908, 1909, and 1925. Pursuant to the Tribunal 
decision, surveying and monumenting of the boundary southeast of Mount St. Elias was begun in 1904. The survey of this area was completed in 1920 and resulted in 13 maps. The maps were individually published upon their completion and were collectively published in 1951 by the International Boundary Commission, U.S. Department of State, under the title "Joint Maps of the International Boundary between the United States and Canada, from Cape Muzon to Mount St. Elias." The surveying and monumenting of the boundary along long. $141^{\circ} \mathrm{W}$. between 1907 and 1913 resulted in 38 maps. The first 32 sheets were published individually in 1914 ; sheets $33-38$ were published in 1918. The International Boundary Commission collectively published the maps in 1918 under the title "Atlas of the International Boundary between the United States and Canada, Arctic Ocean to Mount St. Elias." Many local names were reported by personnel of the survey parties. They also gave names in commemoration of persons, events, or conditions.

\section{Jackson, Sheldon: 1877-1906}

Rev. Sheldon Jackson, 1834-1909, Presbyterian missionary, first visited Alaska in 1877 in the interests of schools and missions. Because he had repeatedly visited Alaska, had established missionary schools there, and had written a book on Alaska, Jackson in 1885 was appointed U.S. general agent for education in Alaska. Thereafter he made annual visits to Alaska, traveling extensively in various areas on inspection tours. In 1891 he began the importation of reindeer into Alaska from Siberia as a means of improving native conditions. Jackson remained general agent until 1906, when he was recalled. Reports by Jackson and his subordinates were published annually from 1890 to 1906 .

Jarvis, David Henry: 1897-98

In the winter of $1897-98$, Lt. (later Capt.) David Henry Jarvis, 1852-19?, USRCS, conducted an overland expedition for the relief of the whaling fleet imprisoned by the ice in the vicinity of Point Barrow. On December 16, 1897, he and three companions were landed on Nunivak Island by the revenue cutter Bear.

From Nunivak Island the expedition traveled by dog teams across the delta and lake country to Andreafski, on the Yukon, thence down the Yukon and along the coast to St. Michael. From St. Michael the route lay along the coast of Norton Sound to Cape York, by one section, and across the base of Seward Peninsula to Kotzebue Sound, by another. From the various stations on the shore of Norton Sound, a herd of 448 reindeer was collected and driven across Kotzebue Sound on the ice and thence along the Arctic coast to Point Barrow, which was reached on March 29, 1898.

This expedition was more remarkable for the feat than its contributions to geographic knowledge. A detailed account was published in 1899 in the report of the Bear, under the authorship of the U.S. Revenue-Cutter Service.

A mountain, stream, and village have been named in commemoration of Jarvis, who in 1902 was appointed collector of customs for Alaska.

\section{Jones, Ernest Lester : 1913-1929}

Ernest Lester Jones, ?-1929, veterinary surgeon, served as Deputy Commissioner of the U.S. Bureau of Fisheries (later in- cluded in the U.S. Fish and Wildlife Service), from 1913 to 1915 , during which period he named many features in Alaska. He also wrote "Report of Alaska Investigations in 1914," published by the Bureau of Fisheries in 1915.

In 1915, President Woodrow Wilson appointed him Superin. tendent of the U.S. Coast and Geodetic Survey, an office he retained until his death in 1929. While in office he reorganized the Coast and Geodetic Survey and included added emphasis on Alaskan surveys. During his administration he named several new features in Alaska.

Kadin (cnna): 1963. See Rynda Expedition.

Kennicott, Robert: 1860-62, 1865-66. See Western Union Telegraph Expedition.

Kennon, Beverley: 1854-55. See North Pacific Exploring Expedition.

Khwostov, Nikolai Alexandrovich: 1803. See Davidov.

Kilbuck, John Henry: 1885-1922. See Spurr.

\section{Kotzebue, O+to von: 1816-17}

Lt. Otto von Kotzebue, 1787-1846, IRN, in command of the brig Rurik, sailed on an exploratory mission to America in 1816 with the hope of finding a northwest passage. He landed on Saint Lawrence Island on July 27, crossed Bering Strait on July 31 , and entered the sound which he named for himself on August 3, 1816. Kotzebue explored and mapped these areas and in 1821 published an account of his travels; the account was translated in London by H. E. Lloyd in the same year.

\section{Krause, Arthur: 1882}

Two brothers, Arthur Krause, 1851-?, and Aurel Krause, 1848-?, were sent in 1881 by the Bremen Geographical Society to the Chukotsk Peninsula in Siberia. After completing their studies there, they traveled to the Chilkat Inlet where they mapped the area and made intensive studies of the Tlingit Indians. Aurel returned to Germany in the spring of 1882 , and Arthur made two journeys into Canada. Results of their journeys were published in German in 1883 and 1885. The English translation by Edna Gunther of their study of the Tlingit Indians was published in 1956.

Krause, Aurel: 1882. See Krause, Arthur.

\section{Krenitzin, Peter Kuzmich: 1768-69}

Capt. Peter Kuzmich Krenitzin, ?-1770, IRN, in command of the galiot St. Catherine, and his assistant, Lt. Michael Levashev, IRN, in command of the hooker St. Paul, cruised through the eastern Aleutian Islands in 1768-69. This expedition was organized and conducted as a mission of observation, physical and cultural, of the regions visited, under the auspices of the Imperial Russian Government. The first account of this voyage, with a track chart, was published in 1780 by Coxe (1787). Port Levashev, on the north coast of Unalaska Island, and the Krenitzin Islands, also in the eastern Aleutians, were named for these two men. See Bancroft (1886).

\section{Krusenstern, Adam Johann von: 1804-5}

Lt. Comdr. (later Adm.) Adam Johann von Krusenstern, 1770 1846, IRN, was appointed in 1802 by Alexander I of Russia to 
lead an expedition for "exploring the Russian Pacific shores and of developing diplomatic and trade relations with Japan and China." This expedition, 1803-6, commanded by Krusenstern on the Nadezhda, accompanied by Capt. U. T. Lisianski, IRN, on the Neva, resulted in the first circumnavigation of the world by the Russians. The first part of the journey was concerned with the delivery of supplies to the Russian American Company and was followed by an exploration of the Siberian coast and a diplomatic mission to Japan. Many surveys were carried out on this voyage, Krusenstern later being responsible for many publications on the North Pacific including an atlas of the Pacific Ocean published in 1827, although he never set foot on the northwest coast of America. Several maps of this atlas were used in the preparation of this dictionary. Krusenstern is commemorated by Cape Krusenstern, in northwest Alaska.

\section{Kuritzien: 1849}

Full Pilot Kuritzien (cnna), IRN, made a survey of Umnak Island in the Aleutian Islands about 1849. His map was published as an inset on map 25 of the 1852 Tebenkov atlas.

\section{Langsdorff, Georg Heinrich von: 1804-5}

Georg Heinrich von Langsdorff, 1774-1852, a member of the Russian embassy to Japan headed by Ambassador Nikolai Rezanov, sailed with Lt. Comdr. A. J. von Krusenstern, IRN, on the Nadezhda in 1803. In 1805 he left Krusenstern's company in Siberia and, with Rezanov, he then traveled to the Pribilof Islands, Unalaska and Kodiak Islands, Sitka, and California before returning to Russia. An account of his travels was published in London in 1813-14.

\section{La Pérouse, Jean Francois de Galaup de: 1786}

In 1785 Louis XVI of France placed Jean Francois de Galaup (Comte?) de La Pérouse, 1741-88, in charge of a scientific exploring expedition to search for a northwest passage and to establish a valid claim in northwest North America. La Pérouse, in command of the vessel La Boussole, was accompanied by Capt. de Langle, in command of the L'Astrolabe. Sailing from France in 1785, via Cape Horn and Hawaii, they sighted the coast of Alaska in the vicinity of Yakutat on June 24, 1786. La Pérouse landed at Lituya Bay, made a detailed examination, and took formal possession. They then sailed south, surveying the coast to Monterey, Calif. The expedition was last heard from in 1788 off the coast of Australia. La Pérouse had sent his interpreter Jean, Baron de Lesseps, back to France along an overland route with maps and records of the expedition. The results of the expedition were published in 1797 by the French Government. (See fig. 5.) English editions were published the following year. La Pérouse Glacier and Mountain, in the southern part of the St. Elias Range, were

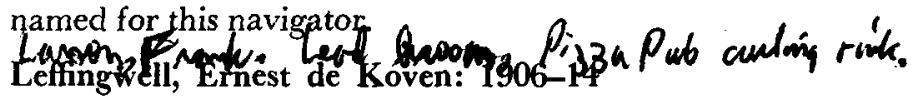

Ernest de Koven Leffingwell, 1876first went to Alaska in 1906 with Capt. Ejnar Mikkelsen in the schooner Duchess of Bedford on the Anglo-American Polar Expedition. They sailed north, around Point Barrow to Flaxman Island on the Arctic coast. Although Mikkelsen returned home the following year and published his narrative, Leffingwell lived with the Eskimos another year.
He returned to the Flaxman Island base in 1909 and remained 3 years doing geological and geographical studies of the Canning River region; during this time, he compiled the first accurate maps of a part of the north coast of Alaska. Another year was spent in the area in 1913-14. The results of this work, done mostly without assistance and at Leffingwell's own expense, were published as a U.S. Geological Survey professional paper. Leffingwell had an interest in geographical nomenclature, and his work contains a list of names on the Arctic coast of Alaska which were applied by explorers, obtained from the Eskimos, or given by himself.

\section{Leslie Expedition: 1890-91}

In the spring of 1890 Frank Leslie's Illustrated Newspaper sent an expedition to Alaska. Early in May E. J. Glave, executive officer and artist, E. Hazard Wells, chief of operations, and Alfred B. Schanz, astronomer and historian, accompanied by Frank Price and John Dalton, guide, ascended the Chilkat River. The party split at Lake Kusawa in Canada.

Though an extensive endeavor, actual geographic contributions of the expedition were limited to Glave's descent of the Alsek River, Well's examination of the area near the upper Tanana and Tok Rivers, and Schanz's survey of the region which placed Lake Clark definitely on the maps. Schanz's chapter on the Nushagak district was published in the 11 th Census, in 1890 (1893, p. 91-97).

Leslie Glacier and Pass, at the head of the Chilkat River, were named by the expedition, but these names have not survived. Mount Glave in Canada near the headwaters of the Klehini River was named for the leader of the expedition.

Levashev, Michael: 1768-69. See Krenitzin.

\section{Lindenberg: 1838}

In 1838 a survey and chart was made of the head of Lynn Canal and the lower end of the Chilkat River by Lindenberg (cnna). This chart was published in 1848 as an inset on Russian Hydrographic Department Chart 1396. The Lindenberg Peninsula, on the eastern side of Kupreanof Island, was named for this navigator by his countrymen.

\section{Lisianski, Urey Theodorovich: 1804-5}

Capt. Urey Theodorovich Lisianski, 1773-1837, IRN, in command of the Neva, accompanied by Adm. A. J. von Krusenstern, IRN, on the Nadezhda, made the first Russian circumnavigation of the world in 1803-6. Lisianski parted company with Krusenstern near the Hawaiian Islands and sailed for Kodiak while Krusenstern continued to the Far East. When Lisianski arrived at Kodiak on July 14, 1804, he learned that the Indians had destroyed the Russian settlement at Sitka. Lisianski then sailed to Sitka, after making minor repairs to his ship and unloading some supplies. He arrived at Sitka on August 20, helped Alexander A. Baranov, governor of the Russian American colonies, repel the Indians and build a new settlement. Lisianski went back to Kodiak for the winter but returned to Sitka in June 1805 and remained until September 1, when he sailed to China and then returned to Russia. Lisianski contributed to the naming of Alaskan features in the Kodiak Island and southeast areas, including the naming of Baranof Island for the governor in 1805. In 1814 an account of his journey, translated from the Russian, was published in London. Lisianski Point and Strait in southeastern Alaska were named for this Russian explorer. 


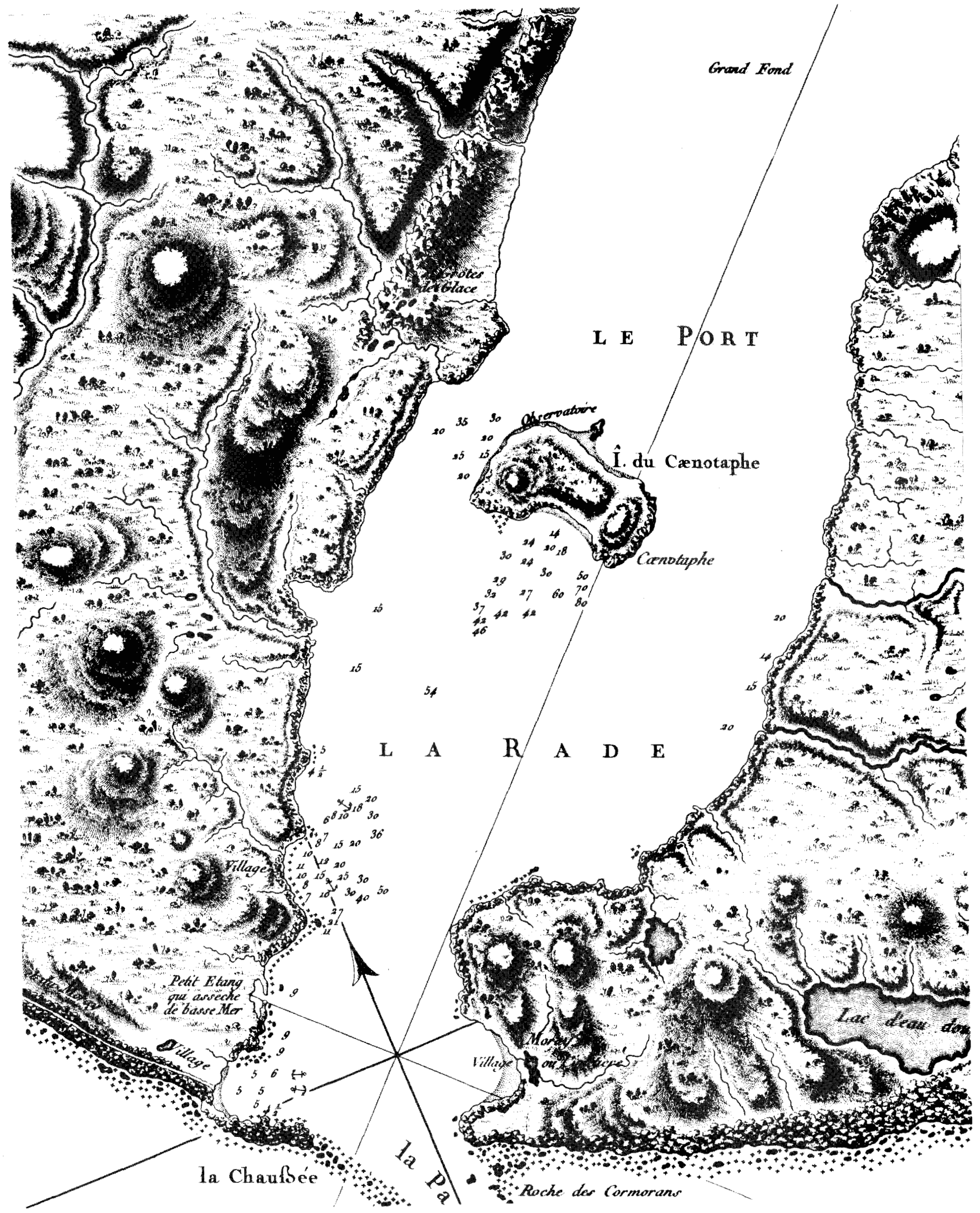

Figure. 5.--Part of the Plan du Port des Français (Lituya Bay) : 'nşaved map 19 in the La Pérouse atlas, Paris, 1797. 
Lutke, Feodor Petrovich: 1827-28

In 1826 Capt. Feodor Petrovich Lutke, 1797-1882, IRN, in command of the corvette Seniavine, accompanied by Capt. M. N. Staniukovich, IRN, in command of the sloop Moller, was sent by the Russian Government on an exploring expedition around the world which lasted until 1829. Lutke and Staniukovich arrived at Sitka on June 24, 1827. On July 31, they sailed to Unalaska where they stayed for 8 days after their arrival on August 22. They then cruised north and west in the Bering Sea from the Alaska Peninsula to the Pribilof Islands, St. Matthew Island, and Kamchatka, from where they returned home. An account of this expedition was published in 1836 under the title "Voyage around the World ***" and includes an atlas and a separate volume called "Nautical Part." This work contains hydrographic and geographic information mainly concerning the above-mentioned areas and is considered to be an important reference in the evolution of our geographic knowledge in Alaska. Lutke was responsible for naming many major features on the northern side of the Alaska Peninsula. An index to the "Nautical Part" was written by W. H. Dall, USC\&GS, and was published in the 1883 Coast Pilot (p. 320-324). Cape Lutke, on the south coast of Unimak Island in the western Aleutians, was named for this navigator and explorer.

McCormick, James. See Baker.

McGrath, John Edward: 1899-92. See Turner, John Henry.

McLenegan, S. B.: 1885. See Cantwell.

\section{Maddren, Alfred Geddes: 1906-17}

Alfred Geddes Maddren, USGS geologist, began his Alaskan investigations as assistant to F. H. Moffit in the Kotsina-Chitina River drainage area in 1906 . In subsequent years he worked in various mining areas of Alaska and produced topographic fieldsheets which were the sources of many prospectors' names. (See fig. 6.)

\section{Malaspina, Alessandro: 1791}

Capt. Alessandro (Alejandro) Malaspina, an Italian navigator in the service of Spain, in command of the Descubierta, with Jose de Bustemante in command of the Atrevida, sailed from Mexico on May 1, 1791, by commission to attempt to find the water passage which Ferrer Lorenzo Maldonaldo claimed connected the Pacific with the Atlantic. Sighting land near Sitka on May 1, 1791, the two ships sailed to Yakutat Bay, which they carefully explored. Malaspina then went to Prince William Sound, surveying the coast for the nonexistent passage. $\mathrm{He}$ is commemorated in Alaska by the Malaspina Glacier.

\section{Mansfield, Henry Buckingham: 1889-91}

Succeeding Lt. Comdr. C. M. Thomas, USN, on the U.S. Coast and Geodetic Survey steamer Patterson in 1889 was Lt. Comdr. (later Rear Adm.) Henry Buckingham Mansfield, 18461918, USN, who made surveys in the Alexander Archipelago in 1889, 1890, and 1891 before being relieved by Lt. W. I. Moore, USN, on February 2, 1892. Mansfield is credited with the naming of several features in the southeastern part of Alaska. An account of his work was published in the Coast and Geodetic Survey Annual Reports for 1890, and his surveys were reflected in Coast and Geodetic Survey Charts 8075, 8170, 8216, 8218, 8224, 8235, and 8302. Mansfield is commemorated by the naming of Mansfield Peninsula on the northern part of Admiralty Island.

\section{Marsh, S. J.: 1901-3}

Two prospectors, S. J. Marsh and F. G. Carter, arrived at Collinson Point in Camden Bay in September 1901. They wintered on the beach, explored some of the inland streams, and reported three large rivers between the Canning and the Colville Rivers.

In April 1902 Marsh moved provisions inland to Cache Creek and explored its headwaters. He met Carter and H. T. "Ned" Arey 25 miles from this stream's junction with the Canning River, and the three men wintered in the mountains.

In February 1903 Carter ascended the Marsh Fork Canning River and crossed the divide into the Yukon drainage. Marsh followed him in April and remained with him until the Chandalar River was navigable. (See fig. 7)

Arey sledded to the Canning from Point Barrow in 1901 and spent 11 years in this area. He was the first to explore the mouths of the Canning, Julahula, Jago, and Okpilak Rivers and to gain detailed knowledge of the coastline. He gave Marsh the native maps of the Kuparuk, Sagavanirktok, and Shaviovik Rivers, and these maps were eventually incorporated in the U.S. Geological Survey maps of 1903 .

Carter Creek east of Collinson Point, Marsh Fork Canning River, and Arey Island west of Barter Island commemorate these early prospectors.

\section{Marshall, Robert: 1929-39}

As a forester, Robert Marshall, 1901-39, made several journeys into the upper reaches of the Koyukuk River in the Brooks Range to study tree growth at the northern timberline as well as to know the pleasure of wilderness exploration. Marshall made a reconnaissance map of the northern Koyukuk region after his 1931 trip. This map displayed 137 names never before published. Many of these names had been in use for many years but were unknown outside the immediate area. A great number of the names were given by Marshall. All names were approved by the U.S. Board on Geographic Names in 1932. His 1938 and 1939 trips to the same area produced more names and refinements in his map.

\section{Martin, George Curtis: 1903-21}

George Curtis Martin, 1875-1943, USGS geologist from 1903 to 1924 , spent 17 years participating in Alaskan fieldwork and for several years had administrative responsibility for the conduct of U.S. Geological Survey Alaskan work. He was Executive Secretary of the U.S. Board on Geographic Names from 1935 to 1943. Mount Martin on the Alaska Peninsula is named for him.

\section{Martin, Lawrence: 1904-13}

Lawrence Martin, 1880-1955, geologist and geographer, participated in six expeditions to Alaska in 1904-13, including the Yakutat and Glacier Bays excursion of the 12th International Geological Congress in 1913. He was a member of the U.S. Board on Geographic Names from 1921 to 1944. See National Geographic Society Expeditions. 
Maurelle, Francisco Antonio: 1775-79. See Spanish Expeditions. Meade, Richard Worsam: 1868-69

Comdr. (later Rear Adm.) Richard Worsam Meade, 18701933, USN, in command of the U.S.S. Saginaw, cruised through the Alexander Archipelago in southeast Alaska during the winter of 1868-69 and made reconnaissance sketches of various places en route. An account of the cruise was published by the U.S. Navy Department as "Hydrographic Notice No. 13 of 1869," and Meade's maps were incorporated in U.S. Navy Hydrographic Chart 225, published in 1869. Meade Glacier, near Lynn Canal, and Meade Point, on the northwest coast of Kuiu Island in southeast Alaska, were named for him.

\section{Meares, John: 1786-89}

Capt. John Meares, 1756?-1809, on the Nootka, and Lt. William Tipping, RN, in command of the Sea Otter, sailed from Bengal, India, in March 1786 on a trading venture to the Malay Peninsula and northwest North America. Mears reached the Aleutian Islands in August 1786, but nothing was ever heard again of Lt. Tipping or the Sea Otter.

Meares then cruised eastward through the Aleutian Islands to Unalaska Island, the Shumagin and Kodiak Islands, Cook Inlet, and Prince William Sound where he wintered. In 1787 he proceeded to Sitka and sailed from there to the Hawaiian Islands and then on to China, arriving there in October 1787.

In 1788 Meares again set out for northwest North America with two new ships, the Felice and Iphigenia. Capt. William Douglas was placed in command of the Iphigenia. Meares reached Vancouver Island in May 1788, and Douglas arrived in Cook Inlet in June. From Cook Inlet Douglas voyaged east and south and joined Meares at Nootka Sound in August. They wintered in Hawaii, returned to North America for additional fur trading, and then sailed for China in 1789. That same year Meares sent out another trading expedition to North America under Capt. James Colnett, who commanded two vessels, the Princess Royal and the Argonaut. Meares is commemorated by several features in Alaska.

\section{Mendenhall, Walter Curran: 1898-1902}

Walter Curran Mendenhall, 1871-1957, USGS geologist from 1894 to 1943 and Director of the USGS from 1930 to 1943, was attached to an Alaskan military exploring expedition, under the command of Capt. E. F. Glenn, which in the summer of 1898 explored east of Cook Inlet and northeastward up the Matanuska River and across the Alaska Range to the Tanana River. Mendenhall worked in the east part of the Seward Peninsula with W. J. Peters, topographer, in 1900. In 1901, with D. L. Reaburn, topographer, he made a topographic and geologic reconnaissance from Fort Hamlin on the Yukon, by way of the Dall, Kanuti, Alatna, and Kobuk Rivers, to Kotzebue Sound. Mendenhall in 1902 was geologist to a party led by T. G. Gerdine, topographer, in the Copper River area.

Mertie, John Beaver, Jr.: 1911-42

John Beaver Mertie, Jr., 1888- ， USGS geologist, began his Alaskan work in 1911 assisting L. M. Prindle in the study of gold placers on the upper Yukon River. In following seasons he did geological investigations in various areas from the Circle and Fairbanks districts south.

Mikkelsen, Ejnar: 1906. See Leffingwell.

\section{Moore, Edwin King: 1895-98}

Lt. Comdr. Edwin King Moore, 1847-1931, USN, succeeded Lt. W. I. Moore, USN, in command of the U.S. Coast and Geodetic Survey steamer Patterson on March 15, 1895, and made surveys in the Alexander Archipelago until being recalled in the spring of 1898 to participate in the Spanish-American War. An account of his work was published in the Coast and Geodetic Survey Annual Report for 1895, and his work was also reflected in Coast and Geodetic Survey Charts 8170, 8281, and 8283. (See fig. 8.) The Moore Mountains on the southern end of Chichagof Island in southeast Alaska were named for him and for Lt. W. I. Moore, USN.

\section{Moore, William Irwin: 1892-95}

Lt. William Irwin Moore, USN, succeeded Lt. Comdr. H. B. Mansfield, USN, in command of the U.S. Coast and Geodetic Survey steamer Patterson, on February 2, 1892, and made surveys in southeast Alaska until being relieved by Lt. Comdr. E. K. Moore, USN, on March 15, 1895. An account of his work was published in the U.S. Coast and Geodetic Survey Annual Reports for 1893, 1894, and 1895. Results of his surveys were also included in Coast and Geodetic Survey Charts 8075, 8214, 8240, and 8283 .

\section{Moser, Jefferson Franklin: 1897-1901}

Lt. Comdr. (later Rear Adm.) Jefferson Franklin Moser, 1848-1934, USN, commanded the U.S. Bureau of Fisheries (later the U.S. Fish and Wildlife Service) steamer Albatross during cruises in Alaskan waters in the sum.ners of 1897 and $1898 . \quad A$ report of this work was published in 1899 . The hydrographic notes and sketches of harbors and anchorages made on the 1897 cruise were published by the U.S. Coast and Geodetic Survey in 1899.

In 1900-1901 Moser, on the Albatross, visited most of the canneries and important salmon streams on the Alaskan coast from Dixon Entrance to the Nushagak River on Bristol Bay. He made sketch maps of the streams with their tributary lakes, added to Lt. Comdr. Z. L. Tanner's 1890 chart of Bristol Bay, and made reconnaissance charts of Alitak Bay, the southwestern coast of Kodiak Island, and Afognak Bay. He also made a topographic reconnaissance of the coast between Alsek River Delta and Yakutat Bay. Reports of these trips were published in 1902. Moser is credited with having reported as well as given a large number of names in Alaska. A number of features have been named for Moser.

\section{Muir, John: 1879-99}

John Muir, 1838-1914, naturalist and travel writer, first visited Alaska in 1879; in the company of Samuel Hall Young, 18471927, Presbyterian missionary, he canoed through the Alexander Archipelago and was the first to systematically explore Glacier Bay and Muir Glacier. This journey was recorded and published by Young. They made a chart of Glacier Bay and enumerated the Tlingit Indians, the results being incorporated by Ivan Petroff in the 10th Census in 1880. 


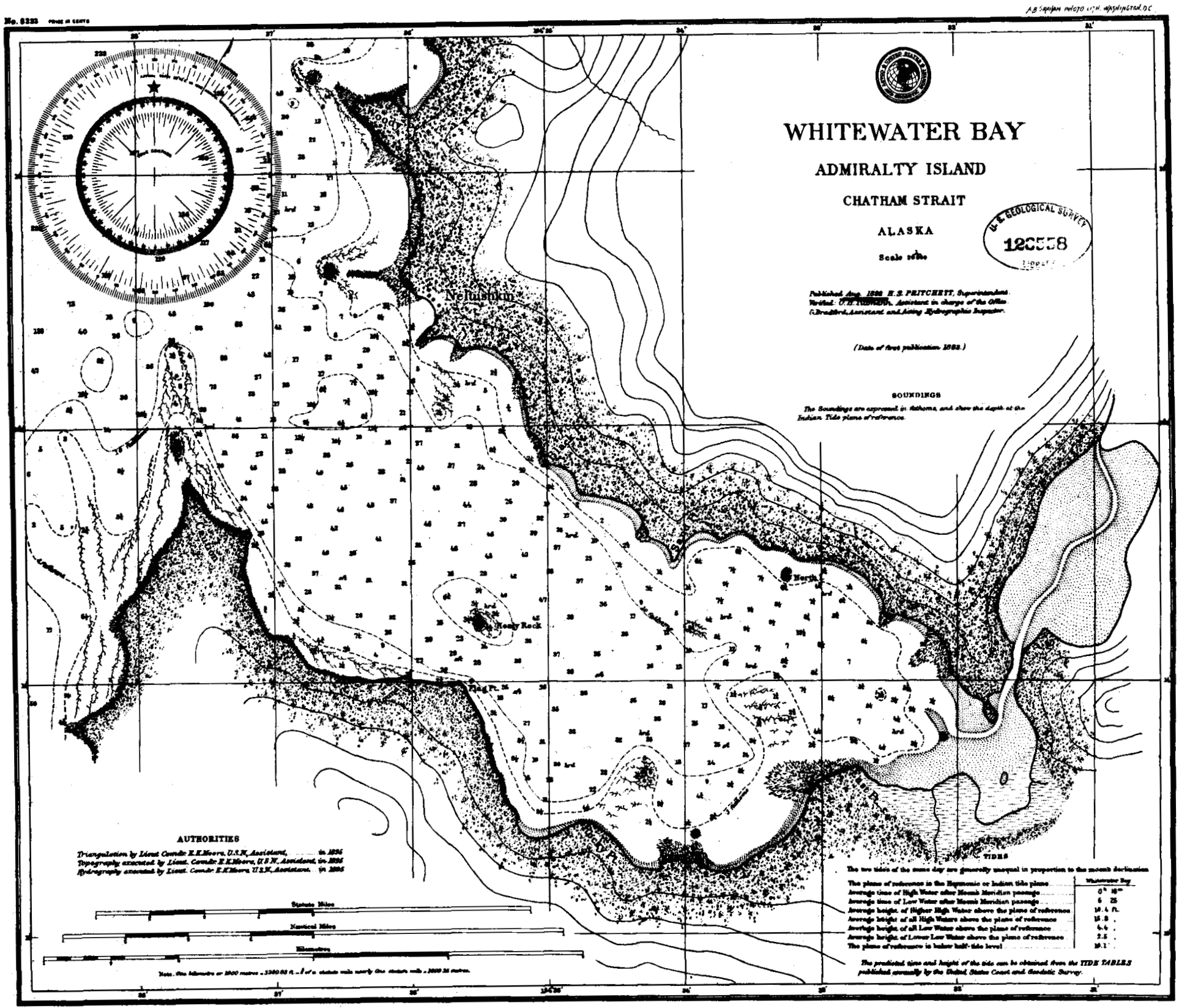

Figure 8.-An 1898 U.S. Coast and Geodetic Survey chart of Whitewater Bay, by Lt. Comdr. E. K. Moore, USN.

In 1881 Muir joined E. W. Nelson on the revenue cutter Corwin on a cruise in the Bering Sea and Arctic Ocean. Muir, as an authority on glaciers, returned to Alaska in 1899 as a member of the Harriman Alaska Expedition. Muir Inlet and Muir Glacier, in the Glacier Bay area, were named for him.

Muldrow, Robert: 1898. See Eldridge.

Murashev, Mikhail: 1839-40

Sub-Lt. Mikhail Murashev, IRN, sailed to the Russian American colonies with Capt. M. D. Tebenkov, IRN, on the Russian American Company's ship Elena in 1835-36. Murashev made some excellent surveys between Afognak and Kodiak Islands in 1839-40. The results of these surveys were published in 1849 on Russian Hydrographic Department Chart 1425.
Murdoch, John: 1881-83. See Ray.

National Geographic Society Expeditions: 1890-1963

The National Geographic Society has sponsored several expeditions or series of studies in Alaska, beginning with the Mount St. Elias Expedition of 1890-91, led by I. C. Russell. In 1909-11 and 1913, R. S. Tarr and Laurence Martin carried out glacier studies in southeast Alaska (see fig. 9). After the Mount Katmai eruption in 1912, G. C. Martin made a reconnaissance survey of the region, while R. F. Griggs led six expeditions to the Mount Katmai area from 1915 to 1919 and in 1930. Other expeditions sponsored by the society included T. A. Jaggar's study of Pavlof Volcano in 1928 and Father B. R. Hubbard's trip to the Alaska Peninsula and the Aleutian Islands in 1934. In 1936 two expeditions were sent to Alaska: the Smithsonian 


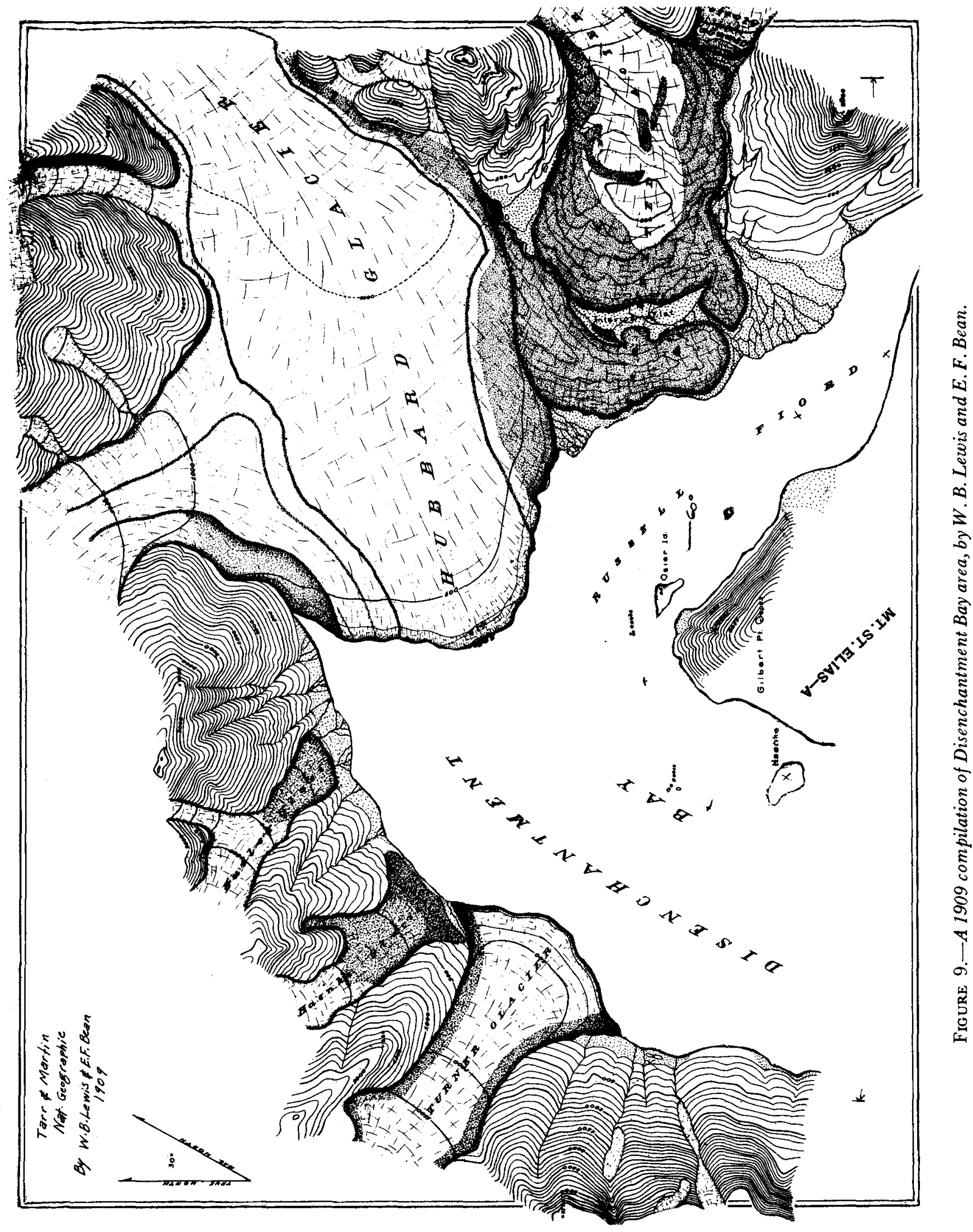


Institution Bering Strait, Alaska, Archeological Expedition, led by H. B. Collins, Jr., and the Bradford Washburn Mount McKinley aerial photographic survey. A Mount St. Elias-Mount Logan aerial survey was also made by Washburn in 1938 . Research on North American birds was carried out in Alaska in 1948 by A. A. Allen, of Cornell University; that same year the society sponsored an extensive study of the May 8-9 solar eclipse, establishing stations in the Aleutian Islands. In 1961 a party led by M. M. Miller revisited areas covered by the 1909-11 Alaskan glacier studies. The society also took part in the study of the August 1963 solar eclipse, which passed across central Alaska.

\section{Nelson, Edward William: 1877-81}

Edward William Nelson, 1855-1934, spent the years 1877-81 at St. Michael conducting meteorological observations for the Service (U.S. Army Signal Corps). Nelson replaced Lucien McShan Turner, who had been there since 1874; Turner in 1877 went to the Aleutians where he trained voluntary observers and collected specimens until 1881. Both men were naturalists and devoted much of their time to study of the local population and collecting material and information for the Smithsonian Institution. Nelson made sledge journeys throughout the vicinity, including one journey of about 1,200 miles through the Yukon Delta from December 1878 to March 1879. Much of his knowledge of that area was incorporated by Ivan Petroff into the 10th Census, in 1880 , and he is credited in this dictionary with reporting numerous Eskimo names. In 1881 Nelson joined John Muir on the revenue cutter Corwin on a cruise in the Bering Sea and Arctic Ocean. Nelson went on to become Chief of the U.S. Bureau of the Biological Survey (later included in the U.S. Fish and Wildlife Service) from 1916 to 1927 . Nelson Island in the Yukon-Kuskokwim Delta was named for him.

\section{Nichols, Henry E.: 1881-84}

Lt. Comdr. Henry Ezra Nichols, 1843-99, USN, was in command of the U.S. Coast and Geodetic Survey steamer Hassler from 1881 to 1883 . In this capacity he made surveys in Kaigani and Wrangell Straits in 1881 . In 1882 he worked in the Revillagigedo Channel area and north to Wrangell, and in 1883 he surveyed several coves and harbors just north of Dixon Entrance. Relieved of his command in 1884 by Lt. Comdr. A. S. Snow, USN, Nichols took command of the U.S.S. Pinta and through September of that year was responsible for the maintenance of order in Alaska.

Nichols was again employed by the Coast and Geodetic Survey in $1888-90$ to revise the 1883 Coast Pilot. The revised Coast Pilot was published in 1891 and is sometimes referred to as the Nichols Coast Pilot. Accounts of Nichols' activities were published in Coast and Geodetic Survey annual reports. Nichols' name has been given to a bay, a group of islands, a mountain, and a passage in the Alexander Archipelago as well as to a group of hills at the mouth of the Nushagak River.

\section{North Pacific Exploring Expedition: 1854-55}

In 1854-55, explorations and surveys were made in the North Pacific, Aleutian Islands, Bering Sea, and Siberian coast by the U.S. Navy. This expedition is referred to as the North Pacific
Exploring Expedition and was begun under the command of Capt. Cadwalader Ringgold, USN. Owing to the stress of illness, Ringgold relinquished command to Capt. John Rodgers, USN, of the U.S.S. Vincennes. Also on the Expedition were Lts. William Gibson and Beverley Kennon, USN, on the schooner Fenimore Cooper. During the summer of 1855 Gibson, in command of the Fenimore Cooper, cruised through the Aleutian Islands and with the help of Kennon, corrected charts and surveyed harbors, concentrating his efforts at Attu and Adak Islands. Kennon Island, in the entrance to Chichagof Harbor on Attu Island, was named by Gibson for his fellow officer, and nearby Gibson Island was named by members of the expedition for Lt. Gibson. The resulting maps and charts of the entire expedition were published by the U.S. Navy Hydrographic Office as Charts $8,54,55,60$, and 68 .

\section{Osgood, Wilfred Husdon: 1899-1914}

In 1899 Wilfred Hudson Osgood, 1875-1947, conducted a biological reconnaissance for the U.S. Bureau of the Biological Survey (later included in the U.S. Fish and Wildlife Service) along a route from Skagway, over White Pass, to the headwaters of the Yukon River and along the course of the Yukon to its delta. The results of this study, including a general account of the region, were published by the U.S. Department of Agriculture in 1900. Osgood next went to the Cook inlet region in 1900 for a biological investigation of the flora and fauna of this region.

$\mathrm{He}$ continued his investigation in the Cook Inlet region in 1902 by conducting an overland journey across the upper Alaska Peninsula. He and his party embarked from Iliamna Bay in July and proceeded over the mountains to Lake Iliamna and Lake Clark. They continued by way of the Chulitna and Nushagak Rivers to Bristol Bay, and from there to the head of the southern arm of Becharof Lake. Here they crossed the moun: tains and proceeded to Portage Bay on Shelikof Strait; they finally arrived at Cold Bay in October. A report, including a map of the region constructed from sketches and notes by Osgood, was published by the U.S. Department of Agriculture in 1904. Osgood continued his biological studies in Alaska in the summer of 1903 by conducting surveys between Eagle and Circle on the Yukon River, and in the area of Glacier Mountain.

In addition to his Alaska mainland studies, he did extensive research and fieldwork on the fur seals and other life on the Pribilof Islands. The results of this work were published in 1915 by the U.S. Fish Commission.

\section{Pender, David: 1868}

Staff Comdr. David Pender, RN, made a survey of Portland Canal and vicinity in 1868. The resulting map was published in 1882 as a flyleaf attached to British Admiralty Chart 2431. Pender named several features in southeast Alaska.

Perez, Juan: 1774. See Spanish Expeditions.

\section{Peters, William John: 1898-1902}

William John Peters, 1863-1942, USGS topographer, began his Alaskan work in the summer of 1898 by leading a reconnaissance party, with A. H. Brooks as geologist, to the White and Tanana Rivers in eastern Alaska. In 1899 the same party continued explorations from the head of Lynn Canal to Eagle on the 
Yukon. In 1900, with W. C. Mendenhall as geologist, a reconnaissance was made in the Norton Bay area of southeast Seward Peninsula. Peters led a party in 1901 on a reconnaissance of northern Alaska with F. C. Schrader as geologist. This trip crossed the Brooks Range at Anaktuvuk Pass to the Arctic, and proceeded along the coast to Cape Lisburne. In 1902 Peters made a topographic map of the Juneau area. His fieldsheets of these expeditions were the source of many new names in Alaska. $\mathrm{He}$ is commemorated in northern Alaska by Lake Peters and by Peters Glacier on Mount McKinley.

\section{Petroff, Ivan: 1866-92}

Born in St. Petersburg, Russia, in 1842, Ivan Petroff came to America in 1861 and fought in the Union Army. He worked in the Kenai and Kodiak areas from 1866 to 1870 . In 1874 he was employed collecting, examining, and translating Russian sources for H. H. Bancroft's "History of Alaska," published in 1866.

Petroff was appointed special agent to conduct the Alaska part of the 10th Census, in 1880. (See fig. 10.) As an agent he spent the summer of 1880 and 1881 traveling between Kodiak, the Shumigans, Sannak, Belkofski, Unalaska, Unimak, Atka, Pribilof Islands, and St. Michael, and he made journeys of considerable distance up the Yukon and Kuskokwim Rivers. Petroff's report included not only population information but also history, geography, and resources. An enumeration of the people of the Arctic coast down to Kings Island in the Bering Sea was conducted by Capt. E. E. Smith, a whaling master, who spoke the Eskimo language and sailed with the Thomas Corwin on her Arctic cruise in 1880 in the capacity of ice pilot. An enumeration of the people from Kings Island to the mouth of the Kuskokwim River, including the people on the Yukon Delta, was reported by E. W. Nelson, U.S. Signal Service. Petroff was unable to visit southeast Alaska as he was shipwrecked on his way south. A preliminary report of the 10th Census was published in 1881 and the final report in 1884. Numerous maps and sketches added to this detailed survey. Petroff was assigned the same position for the 11 th Census in 1890.

\section{Portlock, Nathaniel: 1786-87}

Capt. Nathaniel Portlock of the King George and Capt. George Dixon, 1755-1800, of the Queen Charlotte sailed from England in 1785 for the northwest coast of North America on a commercial trading expedition. These two vessels were owned by the King George's Sound Company, a partnership set up for trade between the Pacific Northwest and China. They went by way of Cape Horn, touched the Hawaiian Islands, and on July 16, 1786, arrived at Cook Inlet. Portlock and Dixon traded with the natives of Cook Inlet and Prince William Sound and gave names to many of the features they discovered. Leaving this area the two ships cruised eastward and southward along the coast as far as Nootka Sound on Vancouver Island. They then sailed for the Hawaiian Islands where they wintered, and returned again in the spring to Prince William Sound.

As the native villages around the sound were small, it was decided that only Portlock would stay to trade while Dixon proceeded down the coast. Dixon visited Yakutat Bay, Sitka Sound, and Dixon Entrance. Portlock did some additional trading and exploring down the southeast coast of Alaska. Both vessels then proceeded separately back to England via Hawaii and China. Both Portlock and Dixon wrote accounts of their voyages which were published in London in 1789. Dixon Entrance was named by Portlock for Dixon, and there are several features named for Portlock.

Post, William Schuyler: 1898. See Spurr.

Pratt, John Francis: 1898-1904

Assistant John Francis Pratt, USC\&GS, commanded the Coast and Geodetic Survey steamer Patterson in Alaskan waters during 1899-1904. In 1898-99 Pratt had general supervision of all Coast and Geodetic Survey parties on the Bering Sea, and a party under his immediate direction made a reconnaissance of the passes of the Yukon River and surveyed St. Michael Harbor. In 1900 he commanded a party that performed a hydrographic study in Norton Sound and made a detailed survey in Port Clarence. He continued his survey work in southeast Alaska during the summer of 1901. In 1902 Pratt, commanding the Patterson, did survey work and took soundings in the Bering Sea in the vicinity of St. Lawrence Island. The following year was spent taking soundings in the Pacific Ocean from the entrance of Juan de Fuca Strait to Cape St. Elias preparatory to laying a deep-sea cable. Pratt also did additional survey work in the Controller Bay region. In 1904 Pratt was in charge of a survey in the Kiska Island region.

\section{Pribilov, Gerassim Gavrilovich: 1786}

A master in the Imperial Russian Navy, Gerassim Gavrilovich Pribilov entered the employ of the Lebedev-Lastochkin Company, a competitor of the Shelikov Company (later, Russian American Company) in 1778. In 1786 Pribilov discovered the fur seals' breeding place, a group of islands in the Bering Sea which were subsequently named for him. Pribilov died in Sitka in 1796.

\section{Prindle, Louis Marcus: 1902-11}

Louis Marcus Prindle, 1865-1956, USGS geologist from 1902 to 1935 , began his Alaskan work in 1902 as assistant to A. H. Brooks in the exploration of the Mount McKinley region. He spent each season until 1911 in the Yukon-Tanana area and in parts of the Alaska Range. Mount Prindle in the White Mountains and Prindle Volcano near the head of Fortymile River were named for him.

\section{Prospectors and miners}

Ever since its purchase in 1867 , prospectors and miners have been giving names to the streams and gulches of Alaska either for their own reference or for the purpose of identifying mining claims. Various parts of the State have experienced gold rushes, and each of these areas consequently has a high density of stream names. The names exist today because government explorers and surveyors obtained them from prospectors' stakes, or by word of mouth. Such names, if determined, have been credited to the prospectors and miners. A few prospectors made fairly good sketch maps of previously unmapped areas and, if known, have been given credit in this dictionary for the name reporting.

Purington, Chester Wells: 1895. See Becker. 


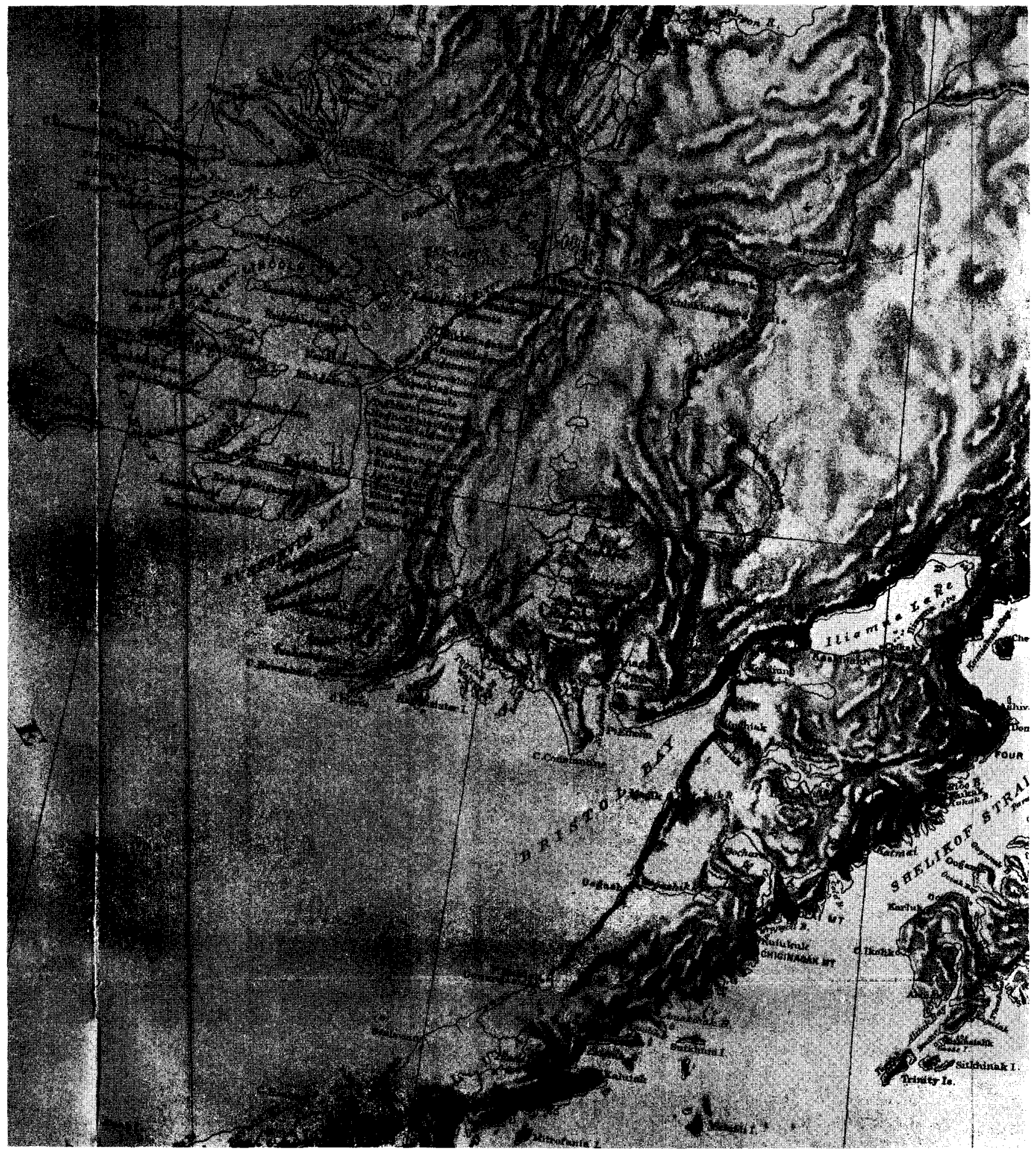

Figure 10.-A part of an 1880 U.S. census map (Petroff, 1884) showing southwest Alaska.

Putnam, George Rockwell: 1897-1899

Assistant George Rockwell Putnam, 1865-?, USC\&GS, was a member of Duffield's 1897 survey party on the Pribilof Islands. While he was there, he collected a list of "Native Names for Localities on Saint George Island, Bering Sea," which was published in the U.S. Coast and Geodetic Survey Annual Report for 1903. While Faris and Pratt surveyed the Yukon River Delta in 1898-99, Putnam, with a subparty, made topographic and hydrographic surveys of the coast north from Scammon Bay to the Apoon River, including several of the principal river channels. The material he acquired was published on several new Coast and Geodetic Survey charts, and his reports of the operation were included in the Coast and Geodetic Survey Annual Reports for 1899 and 1900. 
Ray, Patrick Henry: 1881-83

Capt. Patrick Henry Ray, 1842-1911, USA, was chosen to head the Point Barrow meteorological station during the first international polar year. In 1883 Capt. Ray made a sledge journey into the interior and published a map showing the results of his exploration. At the Barrow station with Ray was Sgt. John Murdoch, 1852-1925, naturalist, who contributed the natural-history part of Capt. Ray's report. Murdoch also studied the Eskimos, acquired some knowledge of their language, and published in 1892 the ethnological results of the expedition. The Ray Mountains in central Alaska were named for Ray.

\section{Raymond, Charles Walker: 1869}

In 1869 the U.S. Army sent Capt. (later Brig. Gen.) Charles Walker Raymond, 1842-1913, to Fort Yukon to establish its longitude to determine whether the Hudson's Bay Company's trading station was in Alaska as was believed. Raymond was a member of the U.S. Army Corps of Engineers (sometimes referred to as the U.S. Engineers). He was authorized to represent the U.S. Treasury Department so that he could order the Hudson's Bay Company to vacate Fort Yukon if the determination was favorable to the United States. He went upriver on the Alaska Commercial Co. river steamer Yukon and returned on a raft he designated Eclipse. His reports were published in 1871, and the sketch maps of the Yukon River showed many native names for tributary streams.

\section{Reaburn, Dewitt Lee: 1900-1903}

Dewitt Lee Reaburn, 1871-?, USGS topographer, began work in Alaska with E. C. Barnard in 1900. In 1901, with W. C. Mendenhall, Reaburn made a reconnaissance topographic survey from Fort Hamlin on the Yukon, by way of the Dall, Kanuti, Alatna, and Kobuk Rivers, to Kotzebue Sound. In 1902, with A. H. Brooks, Reaburn carried a continuous planetable survey over $\mathbf{8 0 0}$ miles from Cook Inlet to the Yukon River along the west flank of the Alaska Range. (See fig. 11.) He temporarily transferred to the U.S. Department of State in 1903, where he participated in United States-Canada boundary work.

\section{Reid, Henry Fielding: 1890-92}

Henry Fielding Reid, 1859-1944, professor of mathematics, physics, geology, and geography at the Case School of Applied Sciences and at Johns Hopkins University, visited Muir Glacier area in 1890 and 1892, and the results of his glaciological studies were published in 1896 in the Sixteenth Annual Report of the U.S. Geological Survey (Pt. 1, p. 415-461). He was an advisor on glaciology and earthquakes to the U.S. Geological Survey from 1902 to 1914.

Richardson, George Burr: 1900. See Brooks.

Ringgold, Cadwalader: 1854. See North Pacific Exploring Expedition.

Ringgold and Rodgers Exploring Expedition: 1854-55. See North Pacific Exploring Expedition.

\section{Ritter, Homer Peter: 1898-1904}

Assistant Homer Peter Ritter, USC\&GS, was in charge of a survey party on the U.S. Coast and Geodetic Survey steamer Taku from 1898 to 1903 and surveyed the Copper River Delta and the east part of Prince William Sound to Port Valdez. In 1904, he was in command of the steamer McArthur and with Assistant Pratt, USC\&GS, surveyed Kiska Harbor in the western Aleutian Islands. These surveys resulted in several new charts for the Coast and Geodetic Survey and the U.S. Navy. Ritter's reports were published in Coast and Geodetic Survey Annual Reports for 1899-1905.

Rodgers, John: 1854-55. See North Pacific Exploring Expedition.

Romig, Dr. Joseph H.: 1896-1905. See Spurr.

Russell, Israel Cook: 1889-91

Israel Cook Russell, 1852-1906, USGS geologist, traveled the Yukon River in 1889. In 1890-91, under the joint auspices of the National Geographic Society and U.S. Geological Survey, Russell explored Malaspina Glacier, Yakutat Bay, and the Mount St. Elias region. Mark Keer accompanied Russell as a topographer, and the party topographically mapped more the 1,000 square miles. Russell was commemorated by the naming of Mount Russell, in the Alaska Range, as well as Russell Fiord, in southeastern Alaska.

\section{Russian American Company: 1799-1867}

In the summer of 1799 under an authorization by the Imperial Government, the Russian American Company was chartered for a period of 20 years and was authorized to act as the official Russian representative in the northwest part of North America. The charter was periodically renewed until the 1867 purchase of Alaska by the United States. During the company's existence much geographic information was gathered and published, including the naming of many features, by its officers. This work was done primarily in the areas of the Alaska Peninsula and Baranof, Kodiak, and Afognak islands. After the Russian sale of Alaska, the majority of the company's material holdings were sold to a private group of Americans under the name of the Alaska Commercial Co.

\section{Russian Hydrographic Department: 1844-54}

Between 1844 and 1854 several charts of northwest North America, Bering Sea, and the Arctic were issued as part of a $\mathbf{P a}$ cific Ocean series by the Russian Hydrographic Department; many of these charts were used extensively in the preparation of this dictionary. (See fig. 12.) The principal charts in this series, listed by their dates of publication, current numbers, and the old Pacific Ocean series numbers, are as follows:

\begin{tabular}{l|r|r|r|r|r}
\hline Date & Number & $\begin{array}{c}\text { Old } \\
\text { number }\end{array}$ & Date & Number & $\begin{array}{c}\text { Old } \\
\text { number }\end{array}$ \\
\hline 1844 & 1345 & & 1849 & 1427 & 5 \\
1847 & 1378 & 9 & 1850 & 1441 & $10 \mathrm{~b}$ \\
1847 & 1379 & 8 & 1851 & 1454 & 4 \\
1848 & 1396 & 10 & 1852 & 1455 & 6 \\
1848 & 1397 & 10 & 1852 & 1493 & $10 \mathrm{~d}$ \\
1848 & 1400 & 7 & 1853 & 1494 & $10 \mathrm{c}$ \\
1849 & 1425 & 9 & 1854 & 1495 & 13 \\
\hline
\end{tabular}

See Chernov, Etolin, Ingenstrem, Lindenberg, Murashev, Woronkofski, and Zarembo. 


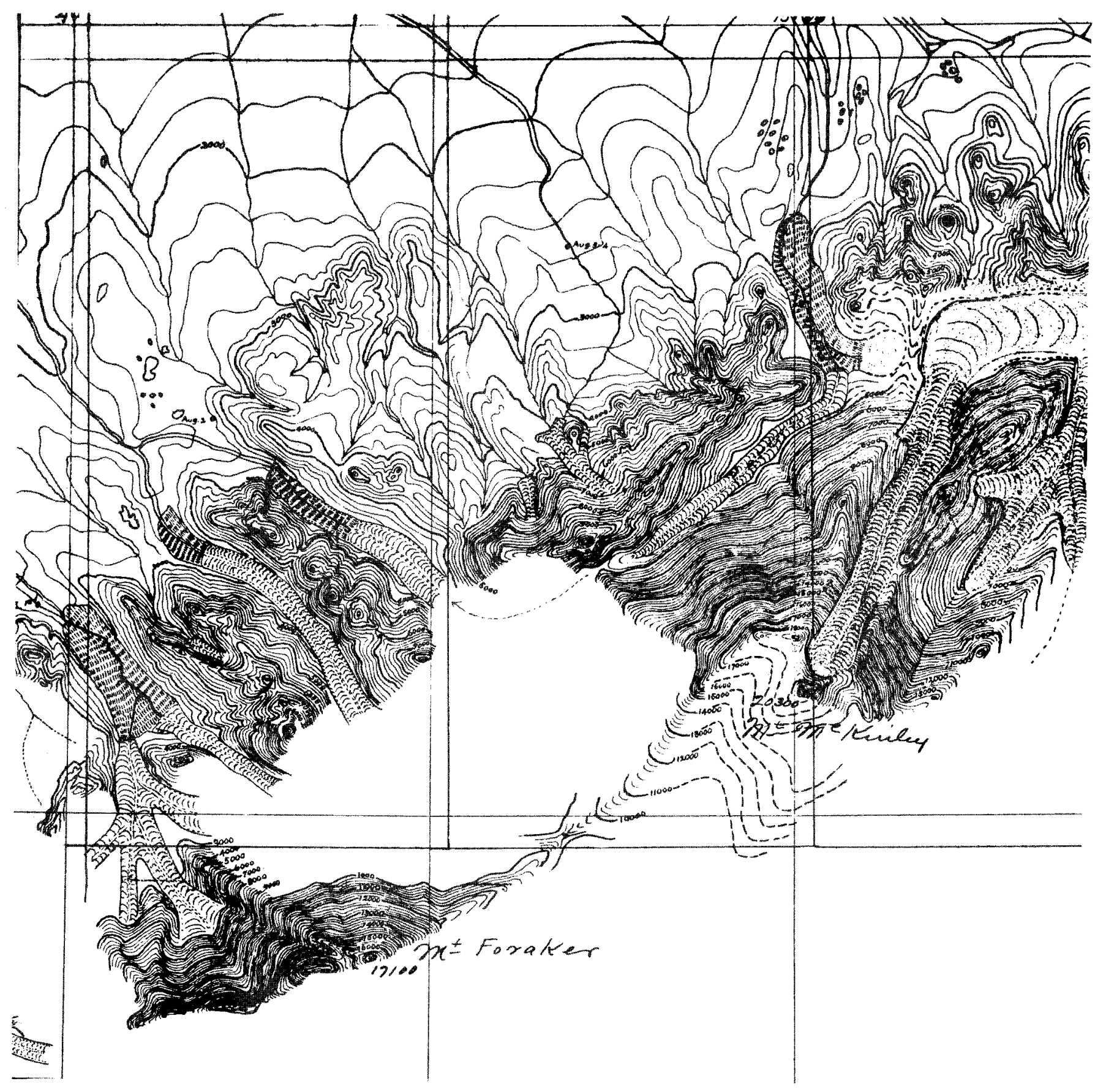

Figure 11.-Part of a 1902 fieldsheet of Mount McKinley, by D. L. Reaburn, USGS.

\section{Rynda Expedition: 1863}

Two Russian naval officers, Butirkin (cnna) and Kadin (cnna), IRN, under the command of Comdr. Bassárguine (cnna), IRN, on the corvette Rynda, made a survey of the lower 65 miles of the Stikine River in 1863. Another member of the party, William P. Blake, of New Haven, published in 1867 an account of the work done and the results obtained. In the same year the Russian Hydrographic Department published a chart resulting from this survey. Several names were contributed to the Stikine River area by members of this expedition.

\section{Sargent, Rufus Harvey: 1906-37}

Rufus Harvey Sargent, 1875-1951, USGS topographer from 1898 to 1947 , began his Alaskan work in 1906 assisting T. G. Gerdine, USGS, in the Cook Inlet area. In subsequent seasons he worked throughout the south half of Alaska, excluding the Aleutians, and his fieldsheets give a wealth of geographicname information.

Sarichev, Gavrila Andreevich: 1790-92

Lt. (later Vice Adm. and Hydrographer) Gavrila Andreevich Sarichev, IRN, sailed on the Slava Rossiy under the command of 


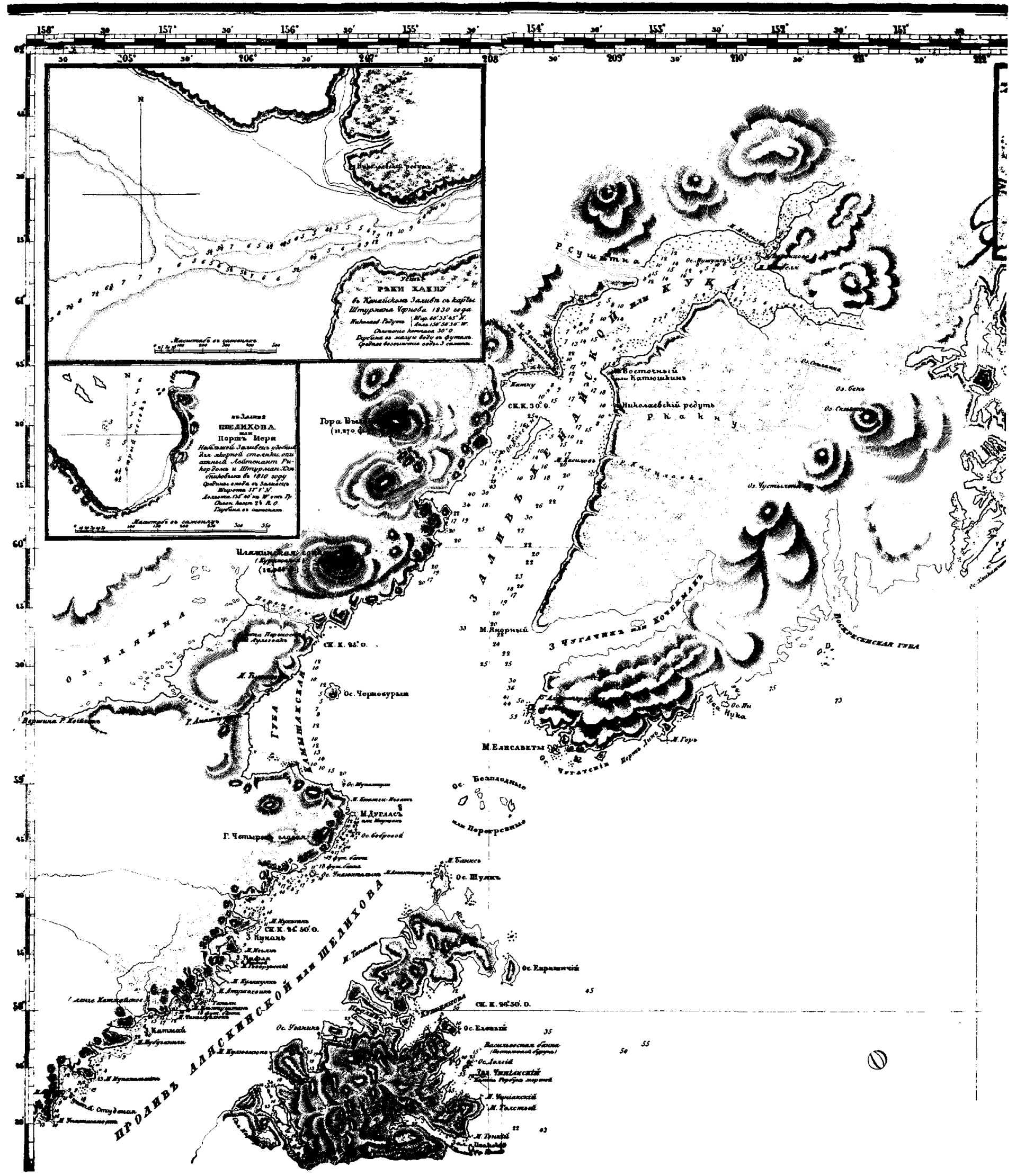

Figure 12.-Part of Russian Hydrographic Department Chart 1378, dated 1847, showing Cook Inlet area. Courtesy of Library of Congress. 
Capt. J. Billings, IRN, during the latter's exploring expedition in 1790-92. During this voyage, Sarichev explored the Aleutian Islands and made several surveys there, the most notable in the vicinity of and at Unalaska Island. In 1826 the Russian Hydrographic Office published an "Atlas of the Northern Part of the Pacific Ocean," compiled under the direction of Vice Adm. and Hydrographer Sarichev; many of his earlier surveys appear in this atlas. This work was often used in the preparation of the present dictionary. (See fig. 13.) Cape Sarichef, on the western end of Unimak Island in the eastern Aleutians, was named for this distinguished contributor to the geographic knowledge of Alaska.

Sauer, Martin: 1790-92

Martin Sauer accompanied Capt. J. Billings, IRN, on the Slava Rossiy (Glory of Russia) as the official secretary and translator during Billings' exploring expedition in 1790-92. In 1802 Sauer's record of the expedition was published in London. Many names of features in the eastern Aleutian Islands can be attributed to his meticulous recording of places and events. See Bancroft (1886).

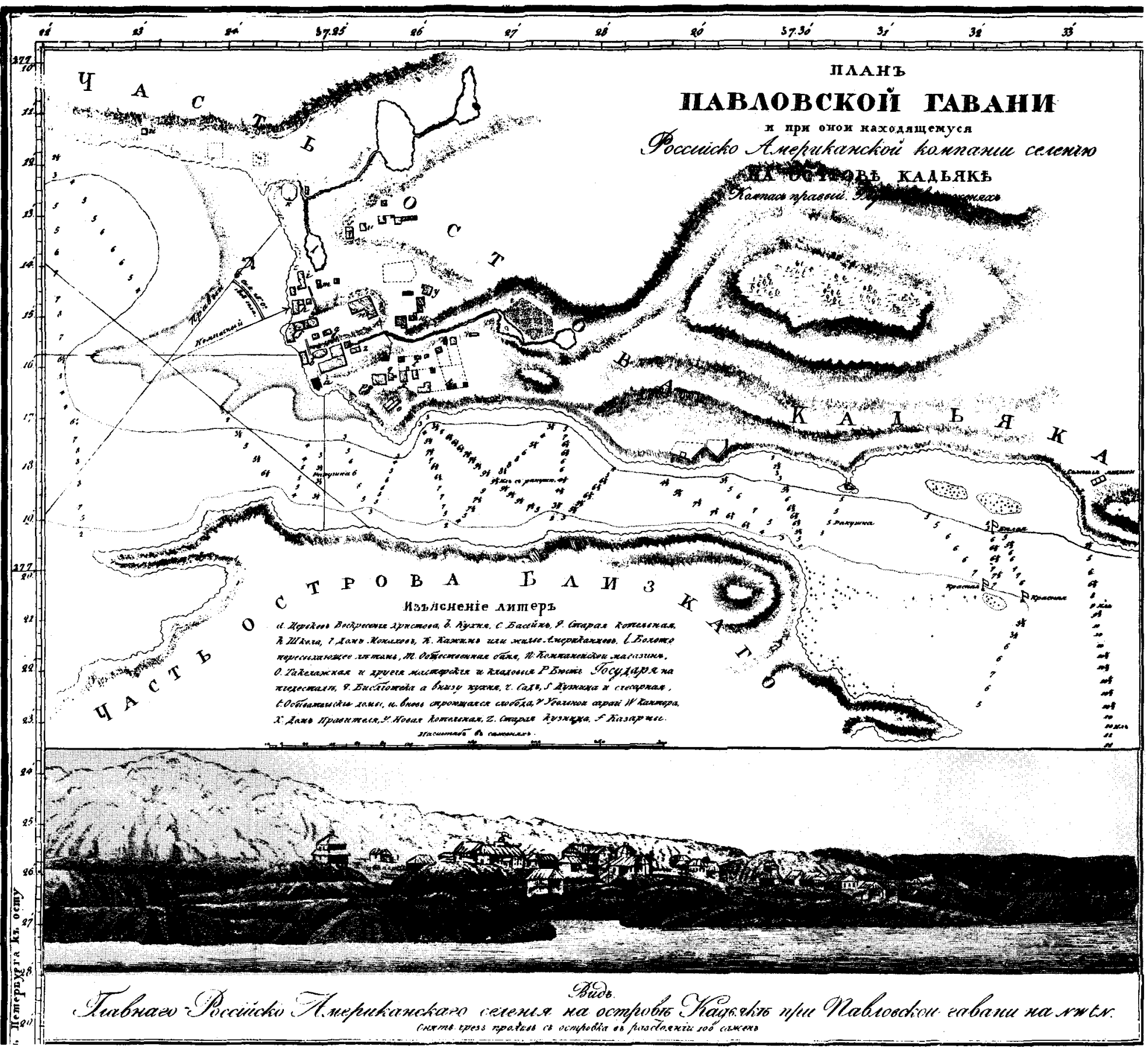

FIgURE 13.-A part of a Russian chart of St. Paul Harbor and Kodiak from Lt. G. A. Sarichev's 1826 atlas, map 16 dated 1808-10. Courtesy of Library of Congress. 
Schrader, Frank Charles: 1896-1902

Frank Charles Schrader, 1860-1944, USGS geologist from 1896 to 1944 , spent six seasons in Alaska beginning in 1896 when he accompanied J. E. Spurr and H. B. Goodrich on a geological reconnaissance from the head of Lynn Canal over Chilkoot Pass to the Yukon River and down the Yukon to St. Michael. In 1898 Schrader was attached to a military exploring expedition, under the command of Capt. W. R. Abercrombie, USA, which made explorations from Valdez northeast to and along the Copper River.

In 1899 he was in charge of a party, including T. G. Gerdine and D. C. Witherspoon, that made explorations along the Chandalar and Koyukuk Rivers. In 1900 he returned to the Copper River area assisted by A. S. Spencer, geologist, with Gerdine and Witherspoon doing the topographic work. In 1901 he was geologist attached to the party led by W. J. Peters on a reconnaissance in northern Alaska; in 1902, with Witherspoon as topographic assistant, he worked again in the upper Copper River basin. Lake Schrader in northern Alaska was named for him.

\section{Schwatka, Frederick: 1883-86}

Lt. Frederick Schwatka, 1849-92, USA, graduated from West Point in 1871 and achieved a reputation as an Arctic explorer when in 1879-80 he led a search in the Canadian Arctic for clues to the lost Sir John Franklin expedition. In 1883 he made a military reconnaissance on his raft Resolute down the Yukon River from its source to its mouth. The results were published in 1885 in official form and in popular form. In 1886 he returned to Alaska with William Libbey and Heywood W. SetonKarr under the auspices of the New York Times. This expedition explored and mapped the Mount St. Elias region. Schwatka named a number of features, but his greatest contribution appears to have been the popularization of the State. Schwatka Mountain, on the south side of the Yukon River, and the Schwatka Mountains in northwest Alaska were named for him.

Shishmarev, Glieb Semenovich: 1816-21

Capt. Lt. Glieb Semenovich Shishmarev, IRN, sailed on the brig Rurik under the command of Lt. O. von Kotzebue, IRN, during the latter's exploring expedition in 1816-17. While on this expedition, Shishmarev made surveys in Kotzebue Sound and at St. Lawrence Island. In August 1816 Kotzebue named Shishmaref Inlet on the north shore of the Seward Peninsula in his honor. In 1819 Shishmarev left Russia for the colonies in command of the Blagonamerennyy (Good Intent), accompanied by Capt. Lt. M. N. Vasiliev, IRN, commanding the Otkrytiye (Discovery). When they reached the North Pacific they separated, Vasiliev continuing to Siberia and Shishmarev sailing for Unalaska, where he arrived on June 4, 1820. Afterward he cruised through the Aleutian Islands to Amchitka, Semisopochnoi, Gareloi, and Bogoslof Islands. He then cruised north along the coast and met Vasiliev at Kotzebue Sound. Together, they explored the Arctic coast as far east as Icy Cape and returned via St. Lawrence Island, where Shishmarev completed a survey of the shoreline, partly done by the Kotzebue expedition in 1817. They continued to the Pribilof Islands and explored the Bering Sea coast from Norton Sound to Cape Newenham before arriving at
Unalaska on August 19, 1820. Shishmarev returned to Russia from Unalaska. See Vasiliev, Mikhail Nikolaievich.

\section{Simpson, Thomas: 1837}

Thomas Simpson, 1808-40, and Peter Warren Dease, 1783-18?, officers of the Hudson's Bay Company, were placed in charge of an exploring expedition with instructions to complete the gap left in 1826 between the explorations made by Capt. F. W. Beechey and Sir John Franklin, RN.

On June 1, 1837, the party of 14 men started down the Mackenzie River in two open boats and reached Demarcation Point on July 15th and Franklin's Point Beechey July 24th. The bearings and distances between points were found to differ from Franklin's records, but charts were made and names placed on the nearest feasible feature.

From this point their exploration was along an unexplored coast, and they attached names-many commemorating officers of the company, members of their party, and historical personalities, and a few being descriptive-to conspicuous geographic features on their map.

On July 31, further progress of the boats was prevented by ice. Simpson, accompanied by five of the party, proceeded on foot, by means of canvas canoe, and in umiaks borrowed from the Eskimos to Point Barrow, which was reached August 3d. After some hours of communication with the Eskimos at the village, they returned to rejoin Dease and the remainder of the party August 6th. Simpson's journal was published by his brother, Alexander Simpson. Dease Inlet was named by Thomas Simpson for his colleague, and Simpson Lagoon was named by Ernest de Koven Leffingwell for Thomas Simpson.

\section{Smith, Philip Sidney: 1906-46}

Philip Sidney Smith, 1877-1949, USGS geologist and Chief Alaskan Geologist from 1924 to 1946 , began his Alaskan work on the Seward Peninsula in 1906. In 1910 Smith, accompanied by H. M. Eakin, geologist, made a geological survey from the Koyukuk River drainage to the upper Kobuk River and then decended that stream to its mouth. The following year, accompanied by C. E. Giffin, topographer, he made a reconnaissance of the Alatna River and found a pass to the head of the Noatak River, traversing that stream to its mouth. Smith was on the 1924-26 expeditions to investigate Naval Petroleum Reserve 4. $\mathrm{He}$ also worked in the Lake Clark, Iditarod, and Fairbanks area. In 1933-34 he was in Alaska to supervise Public Works Administration programs. The Philip Smith Mountains in the Brooks Range were named for him.

\section{Snow, Albert Sydney: 1886}

Lt. Comdr. (later Rear Adm.) Albert Sydney Snow, 1845-1932, USN, in command of the U.S. Coast and Geodetic Survey steamer Patterson, and Lt. (later Rear Adm.) James Meredith Helm, 1855-1927, USN, in command of the McArthur, made surveys and charted southeastern Alaska between Wrangell Harbor and Port Simpson. Charts of this area, incorporating the results of their reports, were published by the Coast and Geodetic Survey.

\section{Spanish Expeditions: 1775-79}

Spanish exploration of the northwest coast of America north of California began in 1774 with an expedition, led by Juan Perez, 
which reached the Queen Charlotte Islands, Canada, before turning back. Not satisfied with the results of Perez' expedition, the Mexican Viceroy, Antonio Maria Bucareli, sent two ships in 1775 to explore northward. Owing to scurvy among the crew, the Santiago, under the command of Bruno Heceta, turned back before reaching Alaskan waters. The smaller ship Sonora, commanded by Don Juan Francisco de la Bodega y Quadra, continued northward to about the area of present-day Sitka, where Bodega $y$ Quadra landed and took possession in the name of the King of Spain. The account of this expedition was recorded by pilot Francisco Antonio Maurelle (Mourelle), second in command on the Sonora. On this voyage they discovered and named Bucareli Bay.

On February 11, 1779, another expedition sailed from Mexico; it consisted of La Princesa, commanded by Don Ignacio Arteaga, and La Favorita, under Bodega y Quadra, with Maurelle as pilot.

The two vessels reached Bucareli Bay early in May, after which they explored the area for 2 months and named many features. (See fig. 14.) About July 1 they sailed north and west along the coast to Prince William Sound, Cook Inlet, and the Alaska Peninsula before turning back on August 7.

\section{Spencer, Arthur Coe: 1900-1916}

Arthur Coe Spencer, 1871-1964, USGS geologist from 1896 to 1939, worked with F. C. Schrader in the Copper River region in 1900. In 1903, assisted by C. W. Wright, geologist, he made a detailed study of the geology and mineral resources in the Juneau area and a reconnaissance of the mining camps of the mainland part of southeast Alaska from Windham Bay to and including the Porcupine Creek placer district. He was again in the Juneau area in 1916 working with H. M. Eakin.

\section{Spurr, Josiah Edward: 1896-98}

Josiah Edward Spurr, 1870-1950, USGS geologist intermittently from 1895 to 1906 , made a geological reconnaissance in the summer of 1896 from the head of Lynn Canal, over Chilkoot Pass, to the Yukon, and then down that river to St. Michael. He was assisted on this trip by H. B. Goodrich and F. C. Schrader; the group did special investigations in the Fortymile, Birch Creek, Eagle, and Rampart districts and thereby reported some of the first prospectors' place names from those areas. See the U.S. Geological Survey Eighteenth Annual Report for 1896-97 (Pt. 3, p. 87-392).

In the summer of 1898 Spurr made a reconnaissance of southwestern Alaska accompanied by William Schuyler Post, topographer. They began at Cook Inlet, crossed the Alaska Range, descended the Kuskokwim River, crossed from its mouth to Nushagak, and then traveled across the Alaska Peninsula to Katmai. On the lower Kuskokwim, Spurr and Post obtained Eskimo names from John Henry Kilbuck, 1861-1922, and Dr. Joseph Herman Romig, Moravian missionaries stationed in the area, and most of these names are recorded on Post's fieldsheets which cover the entire route of the expedition. (See fig. 15.) An account of the expedition was published by the Geological Survey in its Twentieth Annual Report (Pt. 7, p. 31-264). Mount Spurr in the Alaska Range, the Post River in the Kuskokwim drainage, and Kilbuck Mountains commemorate the above men.

\section{Staniukovich, Mikhail Nikolaievich: 1827-28}

Capt. Mikhail Nikolaievich Staniukovich, IRN, in command of the sloop Moller, accompanied Capt. F. P. Lutke, IRN, on the latter's voyage around the world in 1826-29. Staniukovich made a survey of the north shore of the Alaska Peninsula, the results of which were incorporated in Lutke's "Voyage around the World *** Nautical Part."

\section{Stanley-Brown, Joseph: 1891}

Joseph Stanley-Brown, 1858-1941, USGS geologist, was detailed in April 1891 as special agent for the U.S. Treasury Department to study the seal of the Pribilof Islands. Between June 10 and September 22 he also made contour maps of St. Paul and St. George Islands and detailed maps, not contoured, of the various seal rookeries. These maps were published in the Proceedings of the Fur Seal Arbitration Tribunal of 1893. From 1894 to 1899 Stanley-Brown served as Superintendent of the North America Commercial Co.

Steller, Georg Wilhelm: See Bering.

\section{Stockton, Charles Herbert: 1889}

Lt. Comdr. (later Rear Adm.) Charles Herbert Stockton, 18451923, USN, in command of the U.S.S. Thetis, was assigned the duty of looking after whaling interests in Alaskan water. The cruise of the Thetis covered the coast of Alaska from Dixon Entrance, through the Aleutians at Unalaska Island, along the west coast, and east from Point Barrow to the Mackenzie River.

Stockton published an account of this voyage in 1890 in the National Geographic Magazine, and his nomenclature and geographic results were recorded the same year on U.S. Navy Hydrographic Chart 1189. Stockton named the Thetis Islands after his ship, and Stockton Islands were named by Ernest de Koven Leffingwell to commemorate this naval officer's contribution to the geography of the Arctic coast.

\section{Stoney, George Morse: 1883-86}

In 1883 Lt. (later Comdr.) George Morse Stoney, 1852-1905, USN, was sent to St. Lawrence Bay, Siberia, to carry presents to the natives who had been very kind to the officers and men of the Naval ship Rodgers, which had burned in winter quarters while in search for the Jeannette. Stoney, who had been on the Rodgers, traveled to St. Lawrence Bay aboard the U.S. revenue cutter Corwin, under command of Capt. Michael A. Healy, USN. Healy then proceeded to Kotzebue Sound where Stoney borrowed a boat and some men and explored Hotham Inlet and the lower course of the Kobuk River.

Stoney returned in 1884 aboard the schooner Ounalaska. He explored about 300 miles up the Kobuk but had been preceded in this journey by Lt. J. C. Cantwell, USRCS, by a few days. He returned again in 1885 aboard the schooner Viking and was again preceded upriver by Cantwell. Stoney wintered at Fort Cosmos, which he built and named. During this time a system of triangulation was extended over the valleys of the Kobuk, Noatak, and Selawik Rivers, and this region as well as the upper Alatna and Colville Rivers and Chandler Lake were explored and mapped. During the winter Ens. (later Rear Adm.) Abraham Vanhoy Zane, 1850-1919, traveled overland to St. Michael 


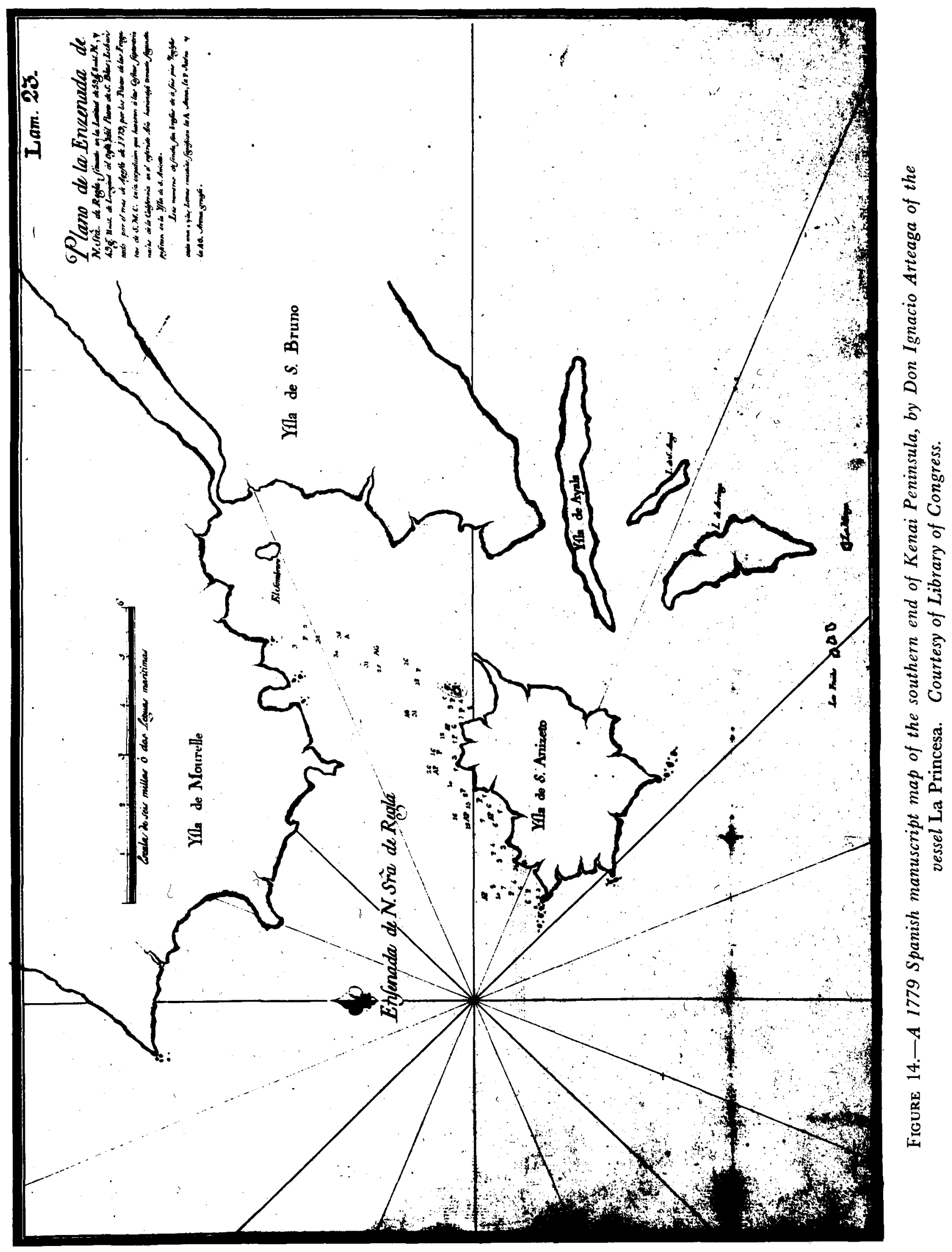




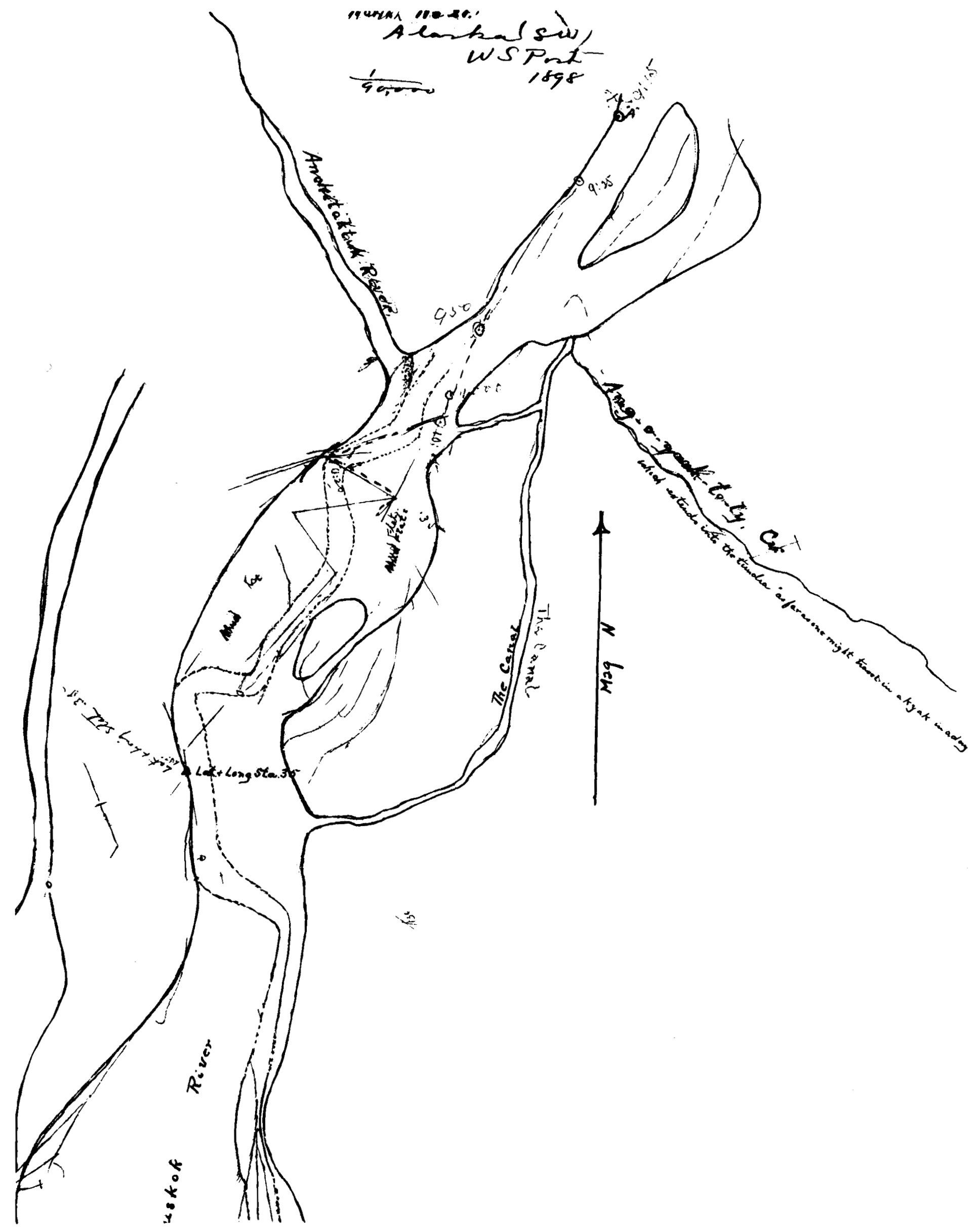

FIGURE 15.-An 1898 fieldsheet of the lower Kuskokwim River, by W. S. Post, USGS. 


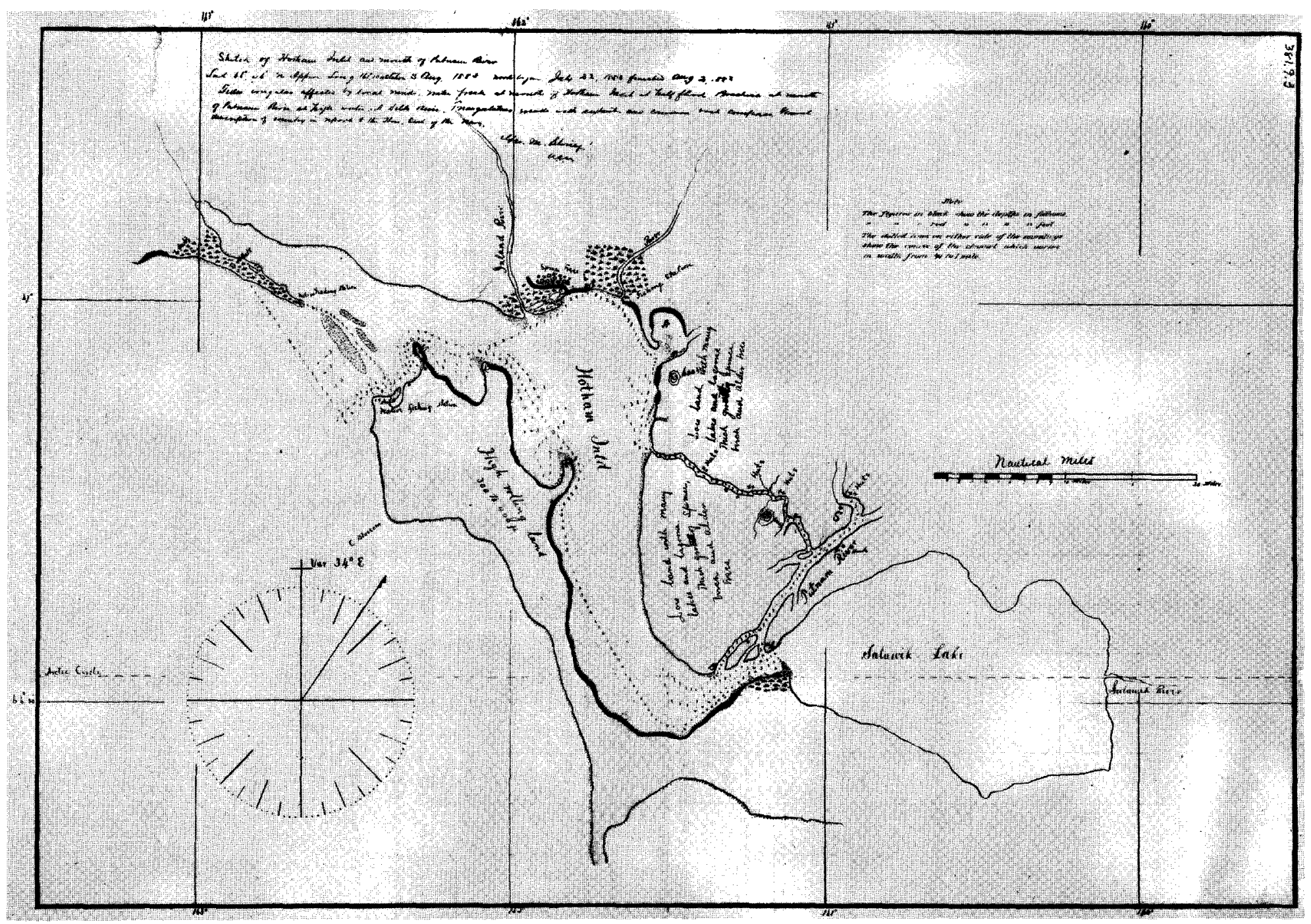

Figure 16.-Hotham Inlet, northwest Alaska, from an 1883 manuscript map by G. M. Stoney, USN. Courtesy of National Archives.

and returned. He has been commemorated by Zane Hills and Zane Pass. In the following spring and summer Ens. (later Rear Adm.) William Lauriston Howard, 1860-1930, made a trip from Fort Cosmos to the upper Noatak and thence via the upper Colville and Chipp Rivers to the Arctic coast and finally to Point Barrow. Here Howard embarked on the revenue cutter Bear and returned to Kotzebue Sound. Howard's name has been applied to a pass and a point of land.

Stoney's original report was never published and appears to have been lost. An abbreviated report of his explorations was published in 1900. Some of Stoney's maps survived and are in the National Archives. (See fig. 16.)

Stuck, Hudson: 1903-20

Archdeacon of the Alaskan missions of the Episcopal Church, Hudson Stuck, 1863-1920, traveled more than 20,000 miles by dogsled throughout central and northern Alaska and more than 30,000 miles aboard the launch Pelican, on the Yukon River and its tributaries. In 1913 he was a member of the first party (recorded) to have successfully climbed Mount McKinley.
His books, recording accounts of his journeys, were filled with descriptions of physical features, for many of which he supplied the Eskimo or Indian names, and historic notes of the origin of names with valuable information concerning the personalities for whom the features were named.

Symonds, Frederick Martin. See Beardslee.

Tanner, Zera Luther: 1888-93

Lt. Comdr. Zera Luther Tanner, 1835-1906, USN, was commander of the U.S. Bureau of Fisheries (later included in the U.S. Fish and Wildlife Service) steamer Albatross. Each season from 1888 to 1893 he cruised in Alaskan waters, making investigations of the fisheries and fishing grounds. His reports were published annually in the "Report of the Commissioner of Fish and Fisheries." Of special note are the reports and accompanying maps of his 1888 and 1890 investigations. A considerable number of names in southwest Alaska and Bristol Bay were reported on these maps, which were published in Fish Commission Bulletins for 1888 and 1889. 
Tarr, Ralph Stockman: 1909-11

Ralph Stockman Tarr, 1864-1912, geologist and glaciologist, accompanied Lawrence Martin on the 1909-11 National Geographic Society Expedition to Alaska. He was author of several articles on Alaskan glaciology and on the Alaskan earthquake of 1899.

\section{Tebenkov, Mikhail Dmitrievich: 1831-50}

Capt. Mikhail Dmitrievich Tebenkov, IRN, was director of the Russian American Company and governor of the Russian American colonies from 1845-50. His first voyage to northwest North America in the early 1830's took him to the Norton Sound area where he made several surveys. In 1835, he sailed from Russia in command of the Russian American Company's ship Elena and arrived in Sitka on April 16, 1836. He remained in the colonies until 1850, when, at the close of his term as director and governor, he returned to Russia. During his stay in the colonies, Tebenkov was active in surveying Alaskan coastal waters and was responsible for the improvement of charts in the interest of the Russian American Company.

Between 1848 and 1850, 39 maps were compiled at Nev: Archangel (now Sitka) under the direction of Capt. Tebenkov. These maps were later put together and published in Russia in 1852 under the title "Atlas of the Northwest Coast of America." The atlas plates were originally engraved at New Archangel by a creole named Kozima Terentiev. (See fig. 17.)

Terentiev, Kozima. See Tebenkov.

\section{Thomas, Charles Mitchell: 1887-88}

Lt. Comdr. (later Rear Adm.) Charles Mitchell Thomas, 1846-1908, USN, in command of the U.S. Coast and Geodetic Survey steamer Patterson, surveyed and mapped extensively in the Alexander Archipelago. In 1888 surveys of the Portland Canal area were made for the U.S. Department of State. An account of his work was pubiished in the Coast and Geodetic Survey Annual Reports for 1888 and 1889, and his nomenclature was incorporated on Coast and Geodetic Survey Charts 704, 733, and 8227.

Tikhmeniev, P.: 1861-63

P. Tikhmeniev (cnna) is considered by many to be the chief historian of the Russian American Company. He published, in Russian, two volumes, dated 1861 and 1863, titled "Historical Review of the Russian American Company." He is also credited with the authorship of several Russian American Company maps of southeast Alaska which incorporate geographical data known to about 1861, including the explorations of Lt. L. A. Zagoskin, IRN.

Tipping, William: 1786-87. See Meares.

\section{Topham, Harold W.: 1888}

In 1888 Harold W. Topham, 1957-1915, his brother Edwin, and George Broke, all of London, and William Williams, of New York, attempted to climb Mount St. Elias. They reached an altitude of 11,460 feet and then turned back. Topham read an account of this trip before the Royal Geographical Society on April 8, 1889. Various accounts of the journey were published in 1889 and 1890 .

\section{Turner, John Henry: 1889-91}

Assistant John Henry Turner, ?-1893, USC\&GS, participated in the Alaskan boundary survey from June 1889 to July 1891 . He ascended the Yukon River with John E. McGrath to Fort Yukon, where they separated and Turner continued up the Porcupine River to the Canadian boundary. He established a camp, named Camp Colonna, for his party in August 1889. On March 22, 1890, Turner traveled by sled to the Arctic Ocean, where he arrived on April 8. He began his return the next day and was at Camp Colonna on April 17. He descended the Porcupine and Yukon Rivers to St. Michael, where he remained until July 1891. Turner returned to Alaska in 1892 to continue boundary work but had to leave because of illness.

While in Alaska, Turner collected bird and animal skins at his own expense and gave them to the University of California. Reports of his surveys were published in the U.S. Coast and Geodetic Survey Annual Report for 1891, and an account of his work was published in 1893 in the National Geographic Magazine.

Turner, Lucien McShan: 1874-81. See Nelson.

\section{U.S. Bureau of Fisheries: 1880-1940}

The U.S. Fish Commission was established in 1871. In 1880 it became known as the U.S. Fish and Fisheries Commission and in 1903 the Agency was placed under the U.S. Department of Commerce, and the name was changed to U.S. Bureau of Fisheries. In 1939 the Bureau was transferred to the U.S. Department of the Interior. The following year it was merged with the U.S. Bureau of the Biological Survey to form the U.S. Fish and Wildlife Service.

In the 1880's and 1890's this Agency made numerous investigations in Alaskan waters, primarily aboard the steamer Albatross, under Lt. Comdr. J. F. Moser and Lt. Comdr. Z. L. Tanner. In this dictionary USBF has been used to refer to personnel working for the agency prior to 1940 and USF\&WS for personnel employed since that time. A bibliography of the Bureau of Fisheries publications was compiled in 1920 by Rose M. E. MacDonald. A listing of subsequent Bureau publications was published in 1955 by the Fish and Wildlife Service.

\section{U.S. Bureau of Land Management: 1946-} Land Office.

\section{U.S. Coast and Geodetic Survey: 1867-}

In 1816 the U.S. Survey of the Coast was established within the U.S. Treasury Department. In 1834 the Agency was transferred to the U.S. Navy Department but was returned to the Treasury Department 2 years later and assigned the name U.S. Coast Survey. In 1878 Congresss changed the name to U.S. Coast and Geodetic Survey. The Coast and Geodetic Survey was transferred to the newly created U.S. Department of Commerce in 1903. Within this publication, USC\&GS has been used to refer to personnel of both the Coast Survey and the Coast and Geodetic Survey.

Since 1867, the Coast and Geodetic Survey has conducted extensive hydrographic and topographic studies in Alaska, from which it has derived material used in its numerous publications, including coast charts, coast pilots, annual reports, and special 


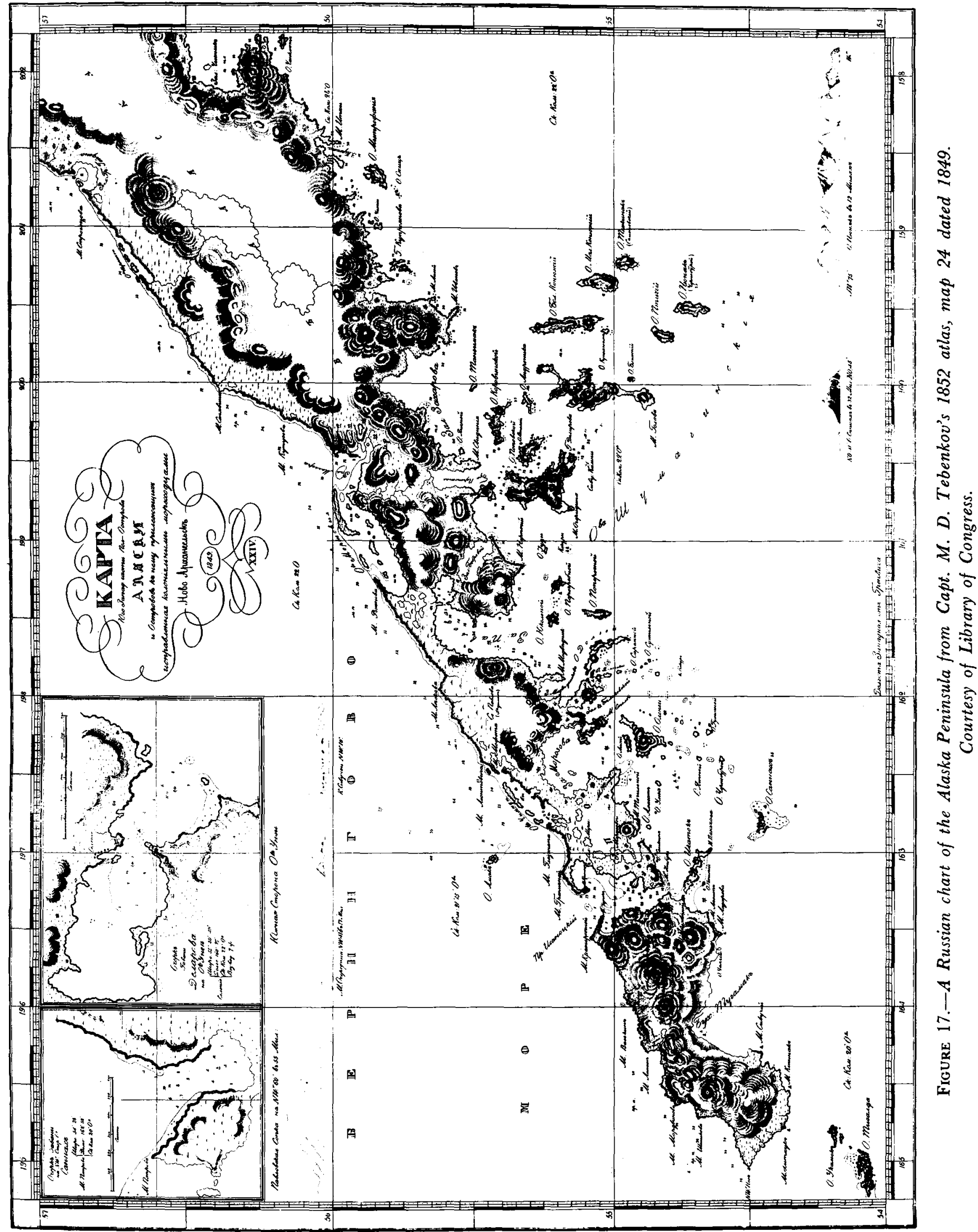


reports. All these publications have been widely used in the preparation of this dictionary.

Many of the earlier charts were of minor value, but as new information was gathered these charts were modernized and greater detail was achieved by producing them on a larger scale. The Agency has published charts of various scales covering the entire coast of Alaska, but particular attention has been paid to harbors of populated areas and to navigation channels. The charts are continually revised to keep them current.

Concurrently with the publication of the coast charts, the Coast and Geodetic Survey has produced a series of coast pilots. These books contain descriptions of harbors and channels, sailing instructions, and aids to navigation. The first Alaskan coast pilot was produced in 1869 under the direction of George Davidson. Information covering the coastline from Dixon Entrance to Cook Inlet was contained in this volume.

There followed a series of coast pilots entitled "Coast Pilot of Alaska, Part I." The first, published in 1883, was a survey of the coast from Dixon Entrance to Yakutat Bay prepared by W. H. Dall and Marcus Baker. It has been a valuable source of reference in the preparation of this dictionary. A later edition covering the same region was prepared by $H$. E. Nichols and published in 1891. A revised edition was done by Herbert C. Graves, E. H. Francis, and John Ross in 1901. Coast pilots and their supplements for this region have been published intermittently since this date.

In 1908 the Coast and Geodetic Survey published two books entitled "Coast Pilot Notes." One covered the Alaskan coast from Yakutat Bay to Cook Inlet, and the other covered the Bering Sea and Arctic Ocean. Another one followed in 1910 which dealt with Yakutat Bay to Gook Inlet and Shelikof Strait. The first complete coast pilot covering Alaska from Yakutat Bay to the Arctic Ocean came out in 1916. Revised editions and their supplements continue to be published.

Throughout the years there have been special geographic-name field investigations, especially along the coast of Alaska and in the Yukon-Kuskokwim Delta area. These investigations resulted in numerous special reports which for the most part were unpublished. These reports, made available through the courtesy of the Coast and Geodetic Survey, have contributed information for over 300 entries in the present dictionary, especially Eskimo and Aleut names.

The Agency was directly involved in establishing the international boundary between Alaska and Canada. Much of the fieldwork for the project was carried out from 1889 to 1914, particularly by J. H. Turner and J. E. McGrath, USC\&GS.

Each year the Coast and Geodetic Survey publishes a report of their operations. Since 1867 these annual reports have given coverage to the operations which took place in Alaska. Names of vessels, personnel involved, and the areas under study were mentioned. Some of the vessels which were active in Alaskan waters were the steamers Patterson, Pathfinder, McArthur, Gedney, Taku, Yukon, Explorer, Wendonah, and Pioneer. The names of the commanders of these vessels appear quite frequently in the discussions of Alaskan activities. Many of them, such as H. E. Nichols, C. M. Thomas, W. S. Moore, E. K. Moore, J. F.
Pratt, J. J. Gilbert, Ferdinand Westdahl, H. P. Ritter, E. F. Dickins, R. B. Derickson, G. T. Rude, F. H. Hardy, and W. C. Dibrell, appear with some frequency in this dictionary. In many entries they are referred to as the individual who recorded the name of a feature and in others as the person who applied the name.

The Coast and Geodetic Survey has been one of the leading agencies in naming features and recording local names.

\section{U.S. Coast Guard: 1915- See U.S
U.S. Fish and Wildlife Service: 1940-}

In 1940 the U.S. Bureau of Fisheries was merged with the U.S. Bureau of the Biological Survey to form the U.S. Fish and Wildlife Service. Personnel of this Agency have given many names to features in Alaska for clarification in administering the wildlife reservations.

\section{U.S. Forest Service}

In 1907 President Theodore Roosevelt established forest reserves in Alaska under the names of Chugach National Forest and Tongass National Forest. The original limits of the forests have been altered many times. Over the years U.S. Forest Service personnel have reported names in local use and have occasionally proposed names to meet a need or to commemorate worthwhile persons or deeds.

\section{U.S. Geological Survey: 1889-}

The U.S. Geological Survey is considered by many to have begun its work in Alaska in 1889 when I. C. Russell accompanied J. E. McGrath, USC\&GS, to the upper Yukon River to determine the position of the Alaska-Canada boundary. Russell then conducted geological investigations in the Mount St. Elias area the following 2 years. The Geological Survey published the results of H. F. Reid's Alaskan glaciological studies, and C. W. Hayes, of the Survey, performed important work with the 1891 Frederick Schwatka expedition.

In 1895 the Geological Survey sent its first independent party to Alaska-W. H. Dall, G. F. Becker, and C. W. Purington made coal and gold surveys along the coast from Sitka to Unalaska. The Klondike gold discoveries in Canada and the great influx of prospectors to Alaska caused the Survey to increase its Alaskan work in 1898, and systematic topographical mapping became an integral part of its Alaskan mineral resources program.

The first years of this survey work were devoted to exploration of main river valleys, then the principal routes of travel. In 1898 the Kuskokwim, Susitna, Nenana, Tanana, and White Rivers were explored and mapped. In the interest of economy, most Geological Survey expeditions consisted of a combined topographical and geological party.

With increased prospecting and mining activity, topographical and geological mapping soon became more localized. Exploratory surveys evolved into more or less detailed mapping of the mining districts. From 1902 to 1907, T. G. Gerdine directed topographical mapping in Alaska with A. H. Brooks, Chief Alaskan Geologist. R. H. Sargent supervised topographical mapping operations after 1907, and each year there were increased demands for more detailed mapping. During this period hundreds 
of new names, mostly given by prospectors, were reported by USGS geologists and topographers.

P. S. Smith became Chief Alaskan Geologist in 1924 and directed geological and topographical work in Alaska. Mapping of Naval Petroleum Reserve 4 began in 1923 and continued through the 1926 field season. This work not only filled a geological and topographical void on the map, but also added numerous geographical names in northwestern Alaska.

In the last half of the 1920's aerial photogrammetric work was begun in Alaska as an aid to mapping. With the increased use of this new method, the pattern of Geological Survey work changed. It was no longer necessary for the geologist and topographer to work together. With photogrammetric mapping topographic work developed into control surveys and geographical name investigation became a part of these surveys.

In 1935 Gerald FitzGerald took charge of topographical work in Alaska. Mapping became increasingly detailed, most of it being published at 1:250,000 scale (the older reconnaissance mapping being at 1:500,000 scale). During World War II trimetrogon mapping was developed, and by 1953 Alaska was completely covered by reconnaissance maps at $1: 250,000$ scale. The proliferation of mapping and geological activities in the last 20 years required special efforts in the field to investigate geographical names. The 1956 Brooks Range control surveys used two men to do name research, and several hundred new local names appeared on the resulting maps. Geological investigations associated with the Naval Petroleum Reserve 4 since World War II also contributed many names in the Alaskan arctic.

\section{U.S. Navy Survey Expedition: 1933-36}

From 1933 to 1936 the U.S. Navy conducted hydrographic and coastal surveys in the Aleutian Islands. These expeditions gave many names to unnamed features and reported a large number of names used locally.

\section{U.S. Revenue-Cutter Service: 1865-}

The predecessor of the U.S. Revenue-Cutter Service was organized within the U.S. Treasury Department in 1790. From 1843 to 1880 it was known as the U.S. Revenue-Marine Bureau and from 1881 as the U.S. Revenue-Marine Service. In 1897 the name was changed to the Revenue-Cutter Service. In 1915 the Revenue-Gutter Service was merged with the U.S. Life-Saving Service to form the U.S. Coast Guard.

The Revenue-Cutter Service first became involved in Alaska in 1865 when one of its cutters, the Shubrick, was chosen as flagship for the Western Union Telegraph Expedition. In 1867, just prior to the purchase of Alaska, the revenue cutter Lincoln under Sr. Capt. W. H. Howard carried George Davidson, USC\&GS, and four other scientists on a cruise in southern Alaskan waters between Sitka and Unalaska. The following year the Wayanda under Capt. J. M. White cruised in the Gulf of Alaska, Bering Sea, and Cook Inlet.

The Revenue-Cutter Service and subsequently the Coast Guard have been active in the Bering Sea and Arctic Ocean every year since 1868. The revenue cutters have transported scientists and explorers from all agencies, including Sheldon Jackson on his annual journeys. The Bear carried the first reindeer from Siberia.
The Revenue-Cutter Service often provided medical aid, performed rescues, delivered mail, collected customs, and policed traffic in arms and liquor. Capt. E. E. Smith, aboard the Corwin, enumerated the Arctic Eskimo for the 10th Census, in 1880, reporting many place names. A surveillance of salmon fisheries was conducted in 1889. The Revenue-Cutter Service was also charged with policing the activities in respect to fur seals in the Pribilof Islands.

A number of revenue cutters plied Alaska's waters over the years. Early ships were the Rush, the Reliance, which carried W. H. Elliott on his 1874 cruise, and the Corwin, under Capt. Michael A. Healy, which carried G. M. Stoney, USN, to the Kobuk in 1883 and was responsible for bringing Lt. J. C. Cantwell, USRCS, to the same river in 1884 and 1885 . Other cutters were the Grant, Perry, Wolcott, and the Bear. It was from the Bear that Lt. D. H. Jarvis, USRCS, embarked on his 1897-98 rescue mission to the whaling fleet at Point Barrow.

\section{Vancouver, George: 1792-94}

Capt. George Vancouver, 1757-98, RN, in command of the sloop Discovery, accompanied by Lt. William R. Broughton, RN, in command of the tender Chatham, made an exploring and surveying voyage from England to southeastern Alaska and around the world from 1790 to 1795 .

In July 1793 the ships reached the entrance to Portland Inlet, from which explorations were made northward past Cape Caamaño, the northernmost point of Spanish discovery. Vancouver, having thus established that the continent extended from the Columbia River to beyond the northern extreme of Prince of Wales Island, retired southward on September 21, 1793, to winter in Hawaii.

In April 1794 the Discovery was joined by the Chatham at the head of Cook Inlet, and Vancouver's explorations continued eastward to complete the surveys to the line of the preceeding season and disprove any claim for a northwest passage within the limits of his explorations. During this expedition Lt. James Whidbey, RN, was often sent out in a launch by Vancouver to explore the coast in greater detail. Whidbey discovered several features in southeast Alaska which he or Vancouver named. The two ships left Port Conclusion in August 1794 and reached England in September 1795.

Vancouver devoted his remaining years to the compilation of his journal and charts, which were completed after his death by his brother, John Vancouver, and published in 1798 by the British Government in three volumes accompanied by a folio atlas. (See fig. 18.)

Vancouver's expedition is credited with adding a wealth of knowledge and names to the previously ill-defined coastal features of southeastern Alaska. He respected the names applied by traders and foreign officials, and the nomenclature of his charts has been generally accepted.

Cape Vancouver, on the Bering Sea coast northeast of Nunivak Island, and Vancouver Mountain, in the St. Elias Mountains, were named for this navigator.

\section{Vasiliev: 1831-32}

Ens. Vasiliev (cnna), IRN, surveyed and mapped a part of the Alaska Peninsula from Cook Inlet west nearly to Chignik 


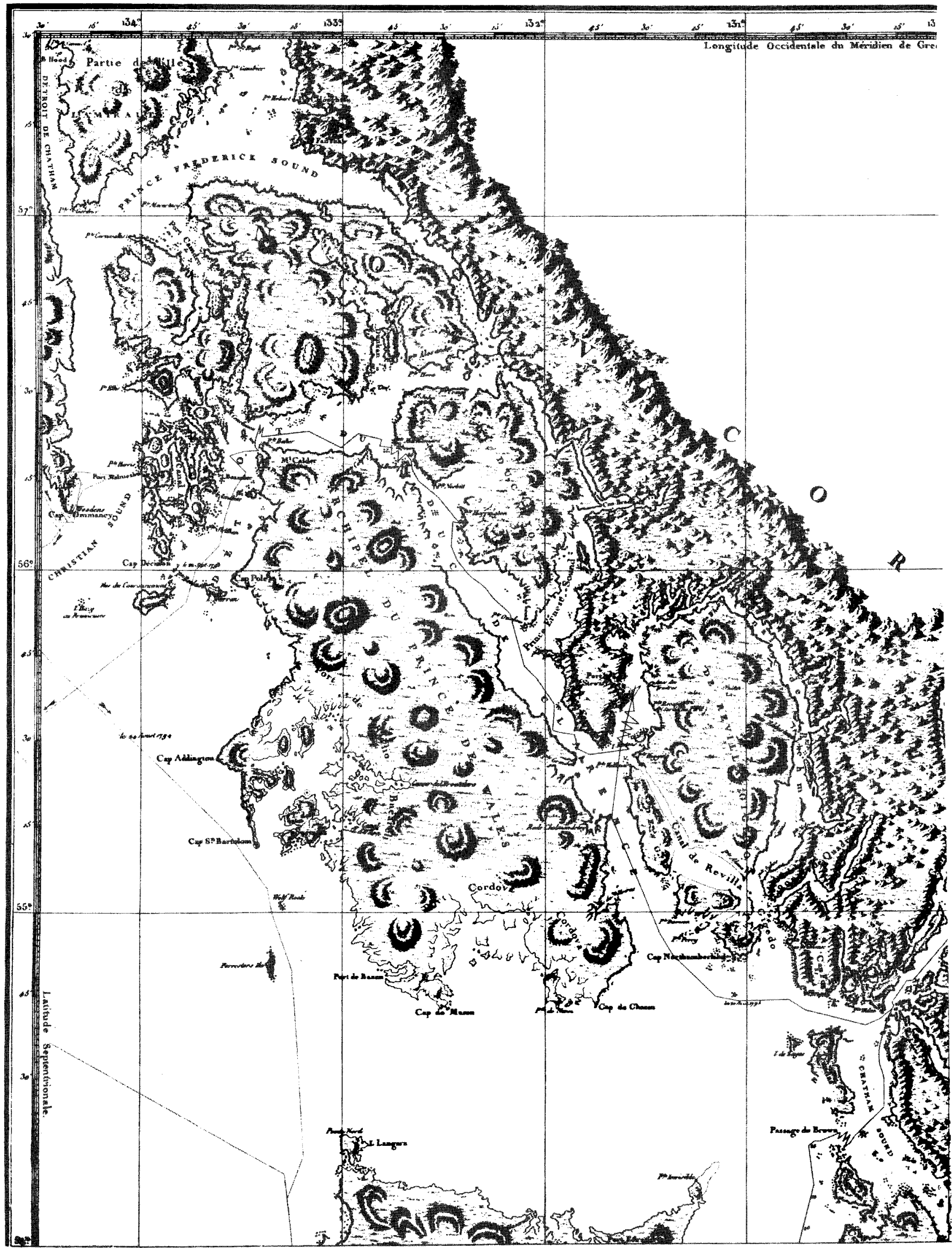

FIGURE 18.-Part of the 1800 French edition of Capt. George Vancouver's map of the "Northwest Coast of America" showing southeast Alaska. 
Bay. His map was published by Capt. Lutke in his "Voyage around the world *** Nautical Part" (1836, p. 274). Vasilief Bay, on the southern coast of Atka Island in the middle Aleutians, was named by Lutke for this navigator, who contributed several names to the area himself.

Vasiliev, Ivan: 1809

Ivan Vasiliev the first, IRN, accompanied Capt. L. V. Hagemeister, IRN, to the Russian American colonies on the ship Neva in 1806. He remained in southeastern Alaska and in 1809 surveyed the western coast of Baranof Island. His results were incorporated in the Sarichev atlas. Vasilief Bank, Reef, Rock, and Shoal, in southeast Alaska, were probably named for this navigator, who contributed several names to the southeastern part of Alaska.

\section{Vasiliev, Mikhail Nikolaievich: 1819-21}

In 1819 Capt. Lt. Mikhail Nikolaievich Vasiliev, IRN, in command of the Otkrytiye (Discovery), with Capt. Lt. G. S. Shishmarev, IRN, on the Blagonamerennyy (Good Intent), sailed for the Russian American colonies. In the North Pacific he left Shishmarev and continued to Petropavlovsk, Kamchatka, where he arrived on June 4, 1820. From here, he sailed across the Bering Sea and met Shishmarev at Kotzebue Sound. They cruised along the Arctic coast to Icy Cape and returned via the St. Lawrence and Pribilof Islands to Unalaska, where they arrived on August 19, 1820. Shishmarev left Unalaska for Russia, and Vasiliev continued to Sitka, San Francisco, and the Hawaiian Islands and was back in Sitka on April 7, 1821. He returned to Russia via Unalaska in 1821.

\section{Veniaminov, Ioann: 1824-42}

Father Ioann Veniaminov (later Bishop of Alaska and Kamchatka and Metropolitan Archbishop of Moscow), 1797-1879, was sent as a missionary by his church to Unalaska Island, where he arrived on July 29, 1824. From 1824 to 1834 he lived at Unalaska, where he wrote a grammar and dictionary of the Aleut language, published in 1846 in St. Petersburg under the title "Essay toward a Grammar and Dictionary of the Aleutian-Fox Language." This work was translated in 1906 by R. H. Geoghegan. In 1834 Veniaminov was transferred to Sitka where he wrote a brief description of the Tlingit Indian language published in 1840 in St. Petersburg with his "Notes of the Islands of the Unalaska District." Veniaminov went back to Russia in 1838 and was consecrated as Bishop of Alaska on December 15, 1840. He returned to Sitka on September 27, 1841. On May 4, 1842, he left for an inspection tour through his diocese, which eventually took him back to Russia via Kamchatka. Some of Veniaminov's work, translated and interpreted by Geoghegan, proved useful in substantiating meanings of certain Aleut and Tlingit Indian names which appear in this dictionary. Mount Veniaminof on the Alaska Peninsula was named for him.

Waxel, Sven: 1741. See Bering.

\section{Westdahl, Ferdinand, 1900-1902}

Assistant Ferdinand Westdahl, USC\&GS, in command of the steamer McArthur, was engaged in surveying along the coast of Alaska from the south coast of Unimak Island and the Samnak
Islands east to Montague Island and Prince William Sound. His accounts were published in the U.S. Coast and Geodetic Survey Annual Reports for 1901, 1902, and 1903, and the results were incorporated on Coast and Geodetic Survey Charts 8520, 8841, 8860 and 8881 .

Westdahl was earlier employed by the Western Union Telegraph Expedition of 1865-67 and by the Alaska Commercial Co. in 1880 , but little information pertinent to his earlier work has been found. Westdahl Peak on Unimak Island was named for him.

\section{Western Union Telegraph Expedition: 1865-67}

After the failure of the second Atlantic telegraphic cable, the Western Union Telegraph Co., believing that an ocean cable could not succeed, undertook to construct an overland telegraph to Asia and Europe via Bering Strait. For this purpose preparations were made on a large scale, and parties worked, explored, and built some line in British Columbia, Alaska, and Siberia in 1865 and 1866. The Alaska section was under the leadership of the explorer and naturalist Robert Kennicott, 1835-66. Kennicott organized a scientific corps of six naturalists, including W. H. Dall, to accompany the Expedition. Frederick Whymper, an English artist, also traveled with the Alaska section. The expedition in Alaska was divided into two groups, one to explore the Yukon east of Nulato, the other to explore between Nulato and the Bering Strait. When in 1866 the Atlantic cable proved to be a success, the enterprise was abandoned and the geographic information was scattered. No inclusive account of the venture was published although several manuscript maps were made and a manuscript newspaper entitled "The Esquimaux" was assembled by the group at Teller. The newspapers were later printed in San Francisco as a memento of the expedition.

Whidbey, James: 1792-94. See Vancouver.

Whymper, Frederick, 1865-67. See Western Union Telegraph Expedition.

\section{Woronkofski: 1836}

In 1836 Lt. Woronkofski (cnna), IRN, was in the employ of the Russian American Company, under whose directive he surveyed the southern coast of the Alaska Peninsula while in command of the transport Kadiak. His survey extended from the vicinity of Chignik Bay where Ens. Vasiliev's work ended in 1832, west to Unimak Pass, connecting with Capt. M. N. Staniukovich's survey of the northern coast in 1828. In 1837 Woronkofski also made surveys in the Shumagin Islands. The results of his work were published in 1847 on Russian Hydrographic Department Chart 1379. Woronkofski Island and Point in the Alexander Archipelago were named for this navigator.

\section{Wosnesenski, Ilia G.: 1842-43}

In 1839 Ilia G. Wosnesenski was sent to Alaska by the Imperial Academy of Sciences of St. Petersburg to make scientific collections. He spent the years of 1840-41 in California and was in the Aleutian Islands and western Alaska in 1842-43 where he explored, collected, and made observations. Wosnesenski Glacier, on the Kenai Peninsula, and Wosnesenski Island, off the south coast of the Alaska Peninsula, were named for this scientist. 


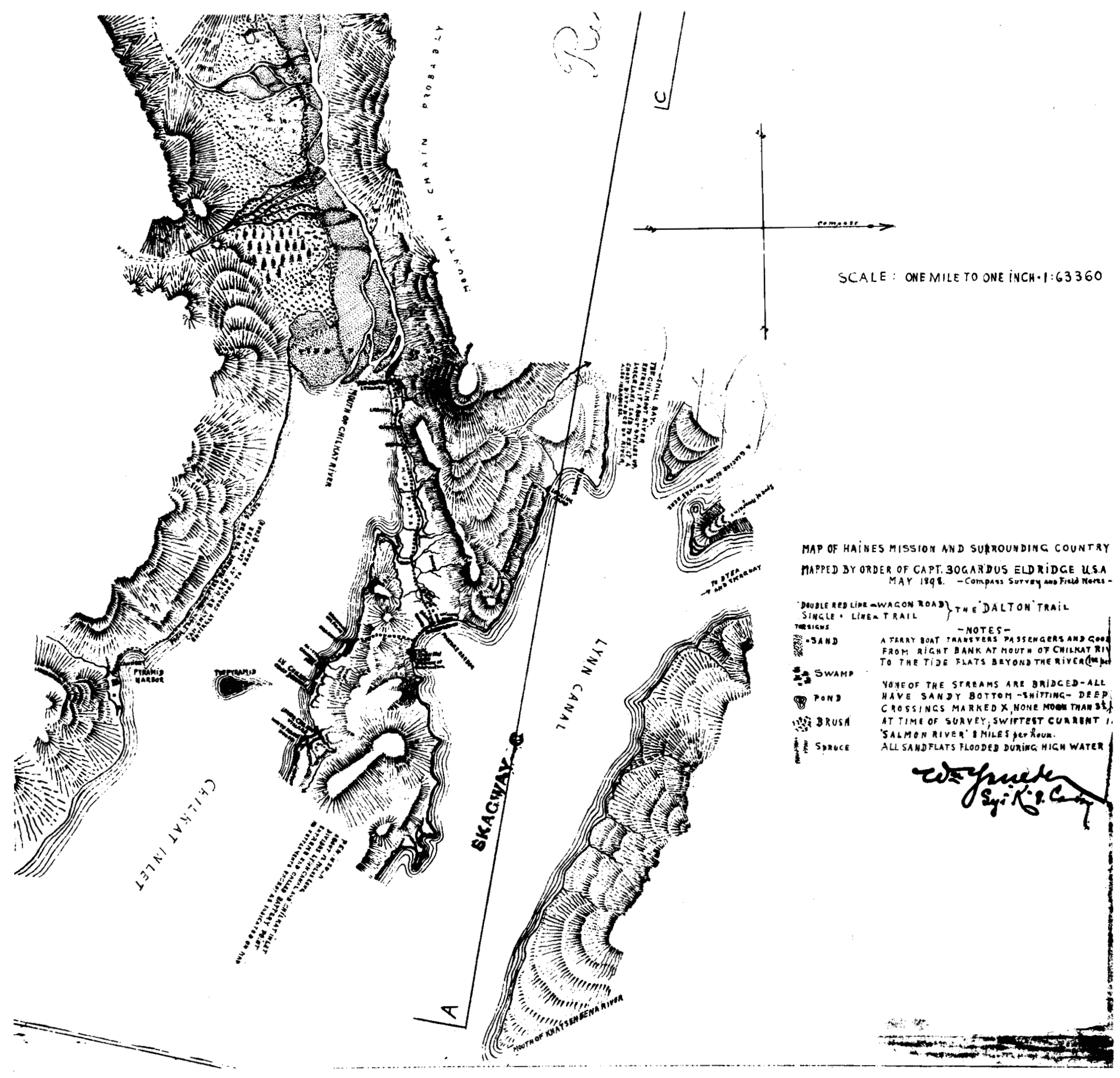

FIgURE 19.--An 1898 manuscript map of Haines Mission and surrounding country, by William Yanert, USA.

Yanert, William: 1897-1952

Sgt. William Yanert, 1864-1952, USA, came to Alaska in 1897 to report on the trail from Skagway to Lake Bennett. (See fig. 19.) After working under Capt. E. F. Glenn, USA, with the Alaska military expedition of 1898 , Yanert, in a civilian capacity, went to St. Michael and accompanied Lt. Hjalmar Erickson, USA, in 1900-1901 on a search for a military road route between Rampart and Eagle. Yanert settled in the Yukon Flats at a place he called Purgatory. He made a compass survey map of the
Yukon Flats around Purgatory in 1916, and it was published by Hudson Stuck in the following year.

Young, Samuel Hall. See Muir.

\section{Zagoskin, Laurenti Alexief: 1842-45}

From 1842 to 1845 , while in the employ of the Russian American Company, Lt. Laurenti Alexief Zagoskin, 1808-90, IRN, made explorations and surveys on the lower Yukon River, on the Kuskokwim River, and in the Norton Sound area. An account of his work, including some maps of the areas he covered, was 
published in 1847 in St. Petersburg. These maps proved to be extremely useful in substantiating early Eskimo names of streams and settlements in the Yukon-Kuskokwim Delta and Norton Sound areas. Ilis surveys extended from the junction of the Kateel and Koyukuk Rivers, in March 1843, to a point on the Yukon River below the mouth of the Tozitna River in June 1843, and to the junction of the Takotna and Kuskokwim Rivers in June 1844

Zane, $\Lambda$ braham Vanhoy: 1885-86. See Stoney.

\section{Zarembo, Dionysius Fedorovich: 1834-39}

Ciapt. Lt. Dionysius Fedorovich Zarembo, IRN, in command of the brig Chichagof, surveyed Wrangell Harbor, in southeast Alaska, in 1834. The same year he founded the present town of Wrangell and built a stockade here which was named for him. In 1838 he surveyed and named Woewodski Harbor on the south side of Admiralty Island in the Alexander Archipelago. Zarembo's maps were published in 1848 as insets on Russian Hydrographic Department Chart 1396.

\section{Acknowledgments}

Compilation of this dictionary required the time and effort of many persons in the U.S. Geological Survey. Special recognition is given James R. Carter whose helpful advice and supervisory assistance contributed greatly toward the book's format and completion. Noteworthy research and compilation contri- butions were made by Jerold Gettleman, who did most of the Russian transliteration, Susan A. Aldrich, Ellen J. Davis, Ernest M. Harwood, Donald A. Johnson, Arthur S. Knox, Margaret O. Miller, Paul J. Sorvo, and Louise G. Van Winkle. 


\section{ALASKA PLACE NAMES}

[Names in bold type indicate present-day usage; names in standard type ind icate historical names or names which cannot be applied to an exact feature]

\section{A}

A, Peak: peak, see University Peak.

Aaats Bay: bay, see Aats Bay.

Aalalik River: stream, see Arolik River.

Aamak Isle: island, see Amak Island.

Aantlen, Reka: stream, see Antlen River.

Aantlen River: stream, see Ahrnklin River.

Aaron Creek: stream, heads N of Mount Waters,

flows SE $19 \mathrm{mi}$. to Blake Channel, $14 \mathrm{mi}$. N of Bradfield Canal, Coast Mts.; $56^{\circ} 21^{\prime}$ N, $131^{\circ} 59^{\prime}$ W; BGN 1929; (map 7). Var. Aaron's Creek, Oerns Creek.

Local name reported in 1929 by USGS.

Aaron Island: island, $0.4 \mathrm{mi}$. long, in Favorite Channel, $1.2 \mathrm{mi}$. NW of Point Stephens and $17 \mathrm{mi}$. NW of Juneau, Coast Mts.; $58^{\circ} 26^{\prime} 25^{\prime \prime}$ $\mathrm{N}, 134^{\circ} 49^{\prime} 15^{\prime \prime} \mathrm{W}$; (map 11).

Named in 1880 by Capt. L. A. Beardslee, USN, for a relative of $\mathrm{O}$. J. Vanderbilt, a local miner.

Aaron's Creek: stream, see Aaron Creek.

Aatsakizaaq: hummock, see Atsakirak Mound.

Aats Bay: bay, 1.5 mi. wide, $\mathrm{N}$ coast of Coronation I., Alex. Arch.; $55^{\circ} 55^{\prime} \mathrm{N}, 134^{\circ} 15^{\prime} \mathrm{W}$; (map 4). Var. Aaats Bay.

"Thlinkit [Tlingit] Indian name" reported in 1886 by Lt. Comdr. A. S. Snow, USN.

Aats Point: point of land, $\mathrm{N}$ tip of Coronation I., Alex. Arch.; 55 $55^{\prime} 45^{\prime \prime} \mathrm{N}, 134^{\circ} 16^{\prime} 00^{\prime \prime} \mathrm{W}$; (map 4).

"Thlinkit [Tlingit] Indian name" reported in 1886 by Lt. Comdr. A. S. Snow, USN.

Aavn Alaska: island, see Unalaska Island.

Abala River: stream, see Anisak River.

Abalone Island: island, $0.1 \mathrm{mi}$. long, $1.2 \mathrm{mi}$. S of Point Webster, on SW coast of Prince of Wales I., Alex. Arch.; 54 $57^{\prime} 15^{\prime \prime} \mathrm{N}, 132^{\circ} 36^{\prime} 00^{\prime \prime} \mathrm{W}$; (map 1).

Local name reported in 1951 by USGS.

Abaramiut: locality, $40 \mathrm{mi}$. NW of Cape Mendenhall, on $\mathrm{N}$ coast of Nunivak I.; $60^{\circ} 19^{\prime} 30^{\prime \prime}$ $\mathrm{N}, 166^{\circ} 42^{\prime} 30^{\prime \prime} \mathrm{W}$; (map 57).

Camp used during fishing and sealing season, reported in 1949 by USC\&GS

Abbe, Mount: mountain, 8,200 ft., in Glacier Bay National Monument, $2.3 \mathrm{mi}$. SE of terminus of John Hopkins Glacier, $75 \mathrm{mi}$. NW of Hoonah, St. Elias Mts. ; $58^{\circ} 47^{\prime} 45^{\prime \prime}$ N, $137^{\circ} 04^{\prime}$ 35" W; BGN 1937; (map 10).

Named in 1936 by W. O. Field and W. S. Cooper, American Geographical Society, for
Cleveland Abbe, Jr., 1872-1934, physiographer and climatologist.

Abbe Gulch: ravine, trends SE $1 \mathrm{mi}$. to Glacier Creek, $9 \mathrm{mi}$. N of Nome, Seward Penin. High.; $64^{\circ} 38^{\prime} 15^{\prime \prime} \mathrm{N}, 165^{\circ} 21^{\prime} 25^{\prime \prime} \mathrm{W}$; (map 94). Var. Abby Gulch.

Prospectors' name shown as "Abby Gul." on the 1902 "Map of the Nome and Snake River Country" by J. M. Davidson.

Abbess Island: island, $0.9 \mathrm{mi}$. long, between San Alberto Bay and Shinaku Inlet, W of Wadleigh I., Alex. Arch.; $55^{\circ} 33^{\prime} 30^{\prime \prime} \mathrm{N}, 133^{\circ} 10^{\prime}$ $30^{\prime \prime} \mathrm{W}$; BGN 1928; (map 4).

Named in 1927 by USFS, "After a boat named Abbess, property of Robert Scott, former fox farmer on the island."

Abbie Creek: stream, see Myrtle Creek.

Abby Creek: stream, flows W to Anikovik River, about $15 \mathrm{mi}$. SE of Cape Prince of Wales, Seward Penin. High.; (map 111).

Prospectors' name shown on the 1900 "Map of Nome Peninsula" by J. M. Davidson and B. D. Blakeslee. This feature cannot be precisely identified on current maps.

Abby Gulch: ravine, see Abbe Gulch.

Abdallah, Mount: mountain, 4,430 ft., $3.3 \mathrm{mi} . \mathrm{N}$ of Russell I., in Glacier Bay National Monument, $80 \mathrm{mi}$. NW of Hoonah, St. Elias Mts.; $58^{\circ} 59^{\prime} 45^{\prime \prime} \mathrm{N}, 136^{\circ} 51^{\prime} 30^{\prime \prime} \mathrm{W}$; (map 10).

Named in 1892 by Reid (1896, pl. 86 and p. 431), USGS.

Abercombie: locality, on Copper River and Northwestern RR. near Abercrombie Rapids, Chugach Mts.; $60^{\circ} 40^{\prime} \mathrm{N}, 144^{\circ} 37^{\prime} \mathrm{W}$; (map 64).

Former RR. station listed in the 1911 RR. guide; it was established in 1911 and was still in use in 1922.

Abercrombie, Mount: mountain, see Frederika Mountain.

Abercrombie Creek: stream, flows SE $1.2 \mathrm{mi}$. to Miles Lake, $35 \mathrm{mi}$. $\mathrm{N}$ of Katalla, Chugach Mts. ; $60^{\circ} 42^{\prime} \mathrm{N}, 144^{\circ} 43^{\prime} \mathrm{W}$; (map 64).

Name published in 1959 by USGS; probably named for Capt. William R. Abercrombie, USA.

Abercrombie Gulch: ravine, trends N-S $3 \mathrm{mi}$. on a tributary of Lowe River, $2.5 \mathrm{mi}$. S of Valdez, Chugach Mts.; $61^{\circ} 03^{\prime} 00^{\prime \prime} \mathrm{N}, 146^{\circ} 14^{\prime} 40^{\prime \prime} \mathrm{W}$; (map 68).

Named in 1911 by J. W. Bagley, and C. E. Giffn, USGS, for Capt. William R. Abercrombie, USA, who explored this area in 1884 and 1898-99.
Abercrombie Lake: lake, see Klutina Lake.

Abercrombie Mountain: mountain, near headwater of White River, St. Elias Mts.; $61^{\circ} 30^{\prime}$ N, $142^{\circ} 00^{\prime} \mathrm{W}$; BGN 1960; (map 67.) Var. Frederika Mountain.

Named by Rohn (1899, p. 791), USGS; "This I have named Mt. Abercrombie." The location of this mountain is uncertain; it may be equivalent to Frederika Mountain, reported by USGS.

Abercrombie Rapids: rapids, on Copper River, at $\mathrm{N}$ entrance to Miles Lake, $37 \mathrm{mi}$. $\mathrm{N}$ of Katalla, Chugach Mts.; $60^{\circ} 43^{\prime} 30^{\prime \prime}$ N, $144^{\circ}$ $34^{\prime} 00^{\prime \prime} \mathrm{W}$; (map 64).

Named by W. C. Mendenhall and F. C. Schrader, USGS, in 1903. This feature is synonymous with Abercrombie Canyon and Copper River rapids. The term "canyon," as used by Lt. H. T. Allen, USA, is a misnomer as there presently is no canyon here. The name "Abercrombie" was retained by applying it to the rapids.

Aberdeen Rock: rock, between Sitkalidak I. and SE coast of Kodiak I.; $57^{\circ} 12^{\prime} 40^{\prime \prime} \mathrm{N}, 153^{\circ}$ 11'30" W; BGN 1930; (map 34).

Name published in the 1929 Alaska Coast Pilot (p. 32). "Probably *** from the whaling ship Aberdeen."

Abermabby Creek: stream, see Abernathy Creek. Abermathy Creek: stream, see Abernathy Creek. Abernathy Creek: stream, on Kenai Penin., flows NE $3.5 \mathrm{mi}$. to Resurrection Creek, $17 \mathrm{mi}$. S of Hope, Chugach Mts.; $60^{\circ} 41^{\prime} 15^{\prime \prime} \mathrm{N}, 149^{\circ} 45^{\prime}$ $36^{\prime \prime}$ W; BGN 1942; (map 63). Var. Abermabby Creek, Abermathy Creek.

Local name published in 1936 by USFS. The name was reported in 1904 as Abermathy Creek by USGS.

Abkhun Protoka: stream, see Apoon Pass. Abkun Mouth: stream mouth, see Apoon Mouth. Abkun Pass: stream, see Apoon Pass.

AB Mountain: mountain, 5,000 ft., $2 \mathrm{mi}$. W of Clifton and $4 \mathrm{mi}$. $\mathrm{N}$ of Skagway, Coast Mts.; $59^{\circ} 31^{\prime} 45^{\prime \prime} \mathrm{N}, 135^{\circ} 17^{\prime} 00^{\prime \prime} \mathrm{W}$; (map 45). Var. Mount Clifford.

Named by E. C. Robertson and published in 1952 by USGS. The name refers to the rough outline of the letters " $A$ " and " $B$ " formed by the late snow on the flat face of the mountain.

Aboud Creek: stream, heads in Weston Mts., flows SW $1.5 \mathrm{mi}$. to Temnac Bay, on $\mathrm{S}$ coast of Attu I., Aleutian Is. ; $52^{\circ} 48^{\prime} 00^{\prime \prime} \mathrm{N}, 173^{\circ} 06^{\prime}$ $22^{\prime \prime} \mathrm{E}$; (map 13). 
Named by the U.S. Army during World War II; published in 1948 by AMS.

Abraham Bay: bay, $5.5 \mathrm{mi}$. across, on SW coast of Attu I., Aleutian Is.; $52^{\circ} 50^{\prime} 30^{\prime \prime} \mathrm{N}, 172^{\circ}$ $43^{\prime} 00^{\prime \prime} \mathrm{E}$; BGN 1938; Var. Deep Bay.

Local name reported by AMS in 1943; called "Deep Bay" in the 1944 Aleutian Coast Pilot. It is said the name "Abraham Bay" was derived from "St. Abraham," the name supposedly given to the island in 1741 by Capt. Comdr. Vitus Bering, IRN. See Attu Island.

Abraham Islands: islands, extend $0.7 \mathrm{mi}$. in Clarence Strait, $1 \mathrm{mi}$. W of Etolin I., Alex. Arch.; $56^{\circ} 03^{\prime} 45^{\prime \prime} \mathrm{N}, 132^{\circ} 40^{\prime} 50^{\prime \prime} \mathrm{W}$; (map 6).

Named in 1891 by Lt. Comdr. A. S. Snow, USN, for Abraham Lincoln, 1809-65, the 16th President of the United States.

Abraham Lake: lake, $1 \mathrm{mi}$. across, between Gamble Slough and Pat Creek, $13 \mathrm{mi}$. NE of Stevens Village, Yukon Flats; $66^{\circ} 09^{\prime} 45^{\prime \prime} \mathrm{N}$, $148^{\circ} 55^{\prime} 00^{\prime \prime} \mathrm{W}$; (map 118).

Local name obtained in 1956 by USGS.

Abraham Lake: lake, $0.9 \mathrm{mi}$. long, $0.7 \mathrm{mi}$. W of Ninemile Lake, $22 \mathrm{mi}$. SE of Beaver, Yukon Flats; $66^{\circ} 11^{\prime} 30^{\prime \prime} \mathrm{N}, 146^{\circ} 43^{\prime} 30^{\prime \prime} \mathrm{W}$; (map 119).

Local name reported in 1956 by T. E. Taylor, USGS.

Abraham River: stream, flows W 4.5 mi. to Abraham Bay, on SW coast of Attu I., Aleutian Is.; $52^{\circ} 53^{\prime} 05^{\prime \prime} \mathrm{N}, 172^{\circ} 48^{\prime} 00^{\prime \prime} \mathrm{E}$; (map 13).

Name derived from Abraham Bay; published in 1948 by AMS.

Abraham-Temnac Pass: pass, between Abraham and Temnac Rivers, on Attu I., Aleutian 1s.; $52^{\circ} 52^{\prime} 37^{\prime \prime} \mathrm{N}, 172^{\circ} 54^{\prime} 15^{\prime \prime} \mathrm{E}$; (map 13).

Name published in 1948 by AMS.

Abraham Valley: valley, $4.5 \mathrm{mi}$. long, formed by Abraham River, on Attu I., Aleutian Is.; $52^{\circ} 53^{\prime} 10^{\prime \prime} \mathrm{N}, 172^{\circ} 48^{\prime} 10^{\prime \prime} \mathrm{E}$; (map 13).

Name derived from Abraham Bay; published in 1948 by AMS.

Abre-el-ojo: rocks, see Abrejo Rocks.

Abrejo Rocks: rocks, two, extend $500 \mathrm{ft}$., between the Gulf of Esquibel and Portillo Channel, W of San Fernando I., Alex. Arch.; $55^{\circ} 32^{\prime} 00^{\prime \prime} \mathrm{N}$, $133^{\circ} 28^{\prime} 40^{\prime \prime} \mathrm{W}$; (map 4). Var. Abre-el-ojo, Abreojo Rocks, Eye Opener Islet.

Spanish name given in $1775-79$ by Don Juan de la Bodega y Quadra and Francisco Antonio Maurelle as "Abre-el-ojo," meaning "open the eye"; published as "Eye Opener Islet" by Baker (1906, p. 249) and "Abreojo Rocks" in 1923 by.USC\&GS.

Abreojo Rocks: rocks, see Abrejo Rocks.

Abyss Lake: lake, 2 mi. long, in Glacier Bay National Monument, $1 \mathrm{mi}$. $\mathrm{S}$ of Threesome Mtn., 50 mi. NW of Hoonah, St. Elias Mts.; $58^{\circ} 31^{\prime} 00^{\prime \prime} \mathrm{N}, 136^{\circ} 35^{\prime} 45^{\prime \prime} \mathrm{W}$.

Local name reported in 1951 by USGS.

Acalolik: stream, see Akalolik Creek.

Ace Creek: stream, flows NE $2 \mathrm{mi}$. to Saint Patrick Creek, $6 \mathrm{mi}$. NW of Fairbanks, YukonTanana High.; 64 $52^{\prime} \mathrm{N}, 147^{\circ} 54^{\prime} \mathrm{W}$; (map $100)$.
Prospectors' name published by USGS (Brooks and others, 1914, pl. 15). The name was applied earlier to a stream near the head of Saint Patrick Greek as published by USGS (Prindle, 1913, pl. 2), but the present usage has subsequently become established.

Ace Creek: stream, flows NE $0.5 \mathrm{mi}$. to Saint Patrick Creek, 7 mi. NW of Fairbanks, YukonTanana High.; $64^{\circ} 52^{\prime} \mathrm{N}, 147^{\circ} 57^{\prime} \mathrm{W}$; (map 100).

Local name published by USGS in 1913. The name was later applied to a longer stream nearer the mouth of Saint Patrick Creek (Brooks and others, 1914, pl. 15). The later usage has become established.

Ace Lake: lake, $0.3 \mathrm{mi}$. long, on Ace Creek, 6.3 mi. NW of Fairbanks, Yukon-Tanana High.; $64^{\circ} 51^{\prime} 45^{\prime \prime} \mathrm{N}, 147^{\circ} 56^{\prime} 00^{\prime \prime} \mathrm{W}$; (map 100).

Local name published on a 1955 USGS map.

Achaiak: island, see Aghiyuk Island.

Achakoo Island: island, see Middleton Island.

Acharon Channel: water passage, channel at mouth of Yukon River, extends S $14 \mathrm{mi}$. from Kwikluak Channel to Bering Sea, between off-shore mud flats and mainland, $18 \mathrm{mi}$. SW of Kwiguk, Yukon-Kuskokwim Delta; $62^{\circ} 30^{\prime}$ $\mathrm{N}, 165^{\circ} 11^{\prime} \mathrm{W}$; (map 76)

Eskimo name, "may be derived from the word for slough"; reported in 1898 by USC\&GS.

Achek Island: island, see Middleton Island.

Achenchik: lake, see Chandalar Lake.

Achenchik River: stream, see Chandalar River. Acheredin Bay: bay, $4 \mathrm{mi}$. across, on $S$ coast of Unga I., in Shumagin Is., Aleutian Ra.; $55^{\circ}$ $10^{\prime} \mathrm{N}, 160^{\circ} 04^{\prime} \mathrm{W}$; (map 28).

Probably named for Acheredin Point; published by USC\&GS in the 1916 Coast Pilot (p. 180).

Acheredin Point: point of land, SW tip of Unga I., in Shumagin Is., Aleutian Ra.; 55 $07^{\prime} 45^{\prime \prime}$ N, $160^{\circ} 48^{\prime} 30^{\prime \prime}$ W; (map 28). Var. Mys Otcheredin, Mys Otcheredinskiy, Point Atcheridina.

Word meaning "turn" or "turning"; probably named for "mate Ath. [?] Atcheredin, a Russian fur trader who wintered at Kodiak in 1779." Published in 1847 as "M[ys] Otcheredinskiy" on Russian Hydrog. Dept. Chart 1379 , and as "M[ys] Otcheredin" by Capt. Tebenkov (1852, map 24), IRN. An 1890 USBF map shows "Point Atcheridina"; USC\&GS, in the 1916 Coast Pilot (p. 180), lists "Acheredin Point."

Acherk Harbor: harbor, see Sanak Harbor.

Acherun: watercourse, see Azacharum.

Achilles Mountain: mountain, 3,014 ft., on Revillagigedo I. on W shore of George Inlet, $3.5 \mathrm{mi}$. E of Ketchikan, Alex. Arch.; 55 21 $1^{\prime} 15^{\prime \prime}$ $\mathrm{N}, 131^{\circ} 32^{\prime} 40^{\prime \prime} \mathrm{W}$; (map 3 ).

This is one of several names given in 1883 by Lt. Comdr. H. E. Nichols, USN, which were suggested by classical mythology.

Achirun Slough: watercourse, see Azacharum Slough.

Achteedeedung : stream, see Portage Creek.
Achulik Island: island, see Ayakulik Island.

Ackanungta: point of land, see Dalnoi Point. Ackerman Lake: lake, $3 \mathrm{mi}$. long, drains $\mathrm{W}$ to Middle Fork Chandalar River, $24 \mathrm{mi}$. E of Chandalar, Brooks Ra.; 67 $32^{\prime}$ N, $147^{\circ} 32^{\prime}$ W ; (map 123).

Local name reported in 1956 by T. F. Taylor, USGS.

Ackiagmute: village, see Akiak

Aclek Cape: point of land, see Aklek, Cape.

Acma Crcek: stream, see Acme Creek.

Acme Creek: stream, heads on Brower Ridge and fows $\mathrm{S} 1 \mathrm{mi}$. to a marsh on Gulf of Alaska, $3.6 \mathrm{mi}$. E of Cape Yakataga, St. Elias Mts.; $60^{\circ} 03^{\prime} 55^{\prime \prime} \mathrm{N}, 142^{\circ} 19^{\prime} 45^{\prime \prime} \mathrm{W}$; (map 65)

Local name published by USGS in 1951 .

Acme Creek: stream, flows NE $11 \mathrm{mi}$. to Birch Creek, $54 \mathrm{mi}$. SW of Circle, Yukon-Tanana High.; $65^{\circ} 15^{\prime} 35^{\prime \prime} \mathrm{N}, 145^{\circ} 24^{\prime} 00^{\prime \prime} \mathrm{W}$; (map 104). Var. Acma Creek.

Named by prospectors; reported in 1911 by USGS (Prindle, 1913, pl. 1).

Acoctan: island, see Akutan Island.

Acootan Bay: bay, see Akutan Bay.

Acorn Peak: peak, 1,864 ft., between Igushik and Weary Rivers, $18 \mathrm{mi}$. SW of Dillingham, Kilbuck-Kuskokwim Mts.; 58 59'30' N, $158^{\circ} 57^{\prime} 30^{\prime \prime} \mathrm{W}$; (map 40).

Named in 1890 by USBF.

Acorn Rock: rock, off N coast of Adak I., at $\mathrm{W}$ entrance to Andrew Bay, Aleutian Is.; $51^{\circ} 58^{\prime} 30^{\prime \prime} \mathrm{N}, 176^{\circ} 43^{\prime} 00^{\prime} \mathrm{W}$; (map 17).

Name published in 1957 by USC\&GS or Chart 9193

Acouan: island, see Akun Island.

Acoulogack, Lac: lake, see Naknek Lake.

Acpalliut: locality, see Akpaliut.

AC Point: point of land, on left bank of Iliamn: Bay, $1.3 \mathrm{mi}$. E of Diamond Point and $23 \mathrm{mi}$ $\mathrm{N}$ of Augustine I., Aleutian Ra.; 59 $39^{\prime} 10^{\prime \prime}$ $\mathrm{N}, 153^{\circ} 35^{\prime} 10^{\prime \prime} \mathrm{W}$; (map 51 ).

Local name published in 1907 on USC\&GS Chart 8665 .

Acutan: island, see Akutan Island.

Ada, Mount: mountain, 4,528 ft., between Gut and Patterson Bays, on E coast of Baranof I., $30 \mathrm{mi}$. N of Port Alexander, Alex. Arch.; $56^{\circ} 40^{\prime} 45^{\prime \prime} \mathrm{N}, 134^{\circ} 41^{\prime} 30^{\prime \prime} \mathrm{W} ; B G N$ 1918; (map 5).

Named in 1917 by USC\&GS for Ada Lester Jones, mother of E. Lester Jones, superintendent of USC\&GS

Adachdach, Cape: point of land, see Adagdak, Cape.

Adach Island: island, see Adak Island.

Adagdak, Cape: point of land on $\mathrm{N}$ coast of Adak I., Aleutian Is.; $52^{\circ} 00^{\prime} 10^{\prime \prime} \mathrm{N}, 176^{\circ} 34^{\prime}-$ 45" W; BGN 1936; (map 17). Var. Cape Adachdach, Mys Adagdakh.

Aleut name published as "M[ys] Adagdakh," or "Cape Adagdakh," by Capt. Tebenkov (1852, map 28), IRN.

Adagdak, Mount: mountain, 2,115 ft., on $\mathrm{N}$ coast of Adak I., Aleutian Is.; $51^{\circ} 59^{\prime} 28^{\prime \prime} \mathrm{N}$, $176^{\circ} 35^{\prime} 00^{\prime \prime} \mathrm{W}$; BGN 1948; (map 17).

Name derived from Cape Adagdak in 1948 by USGS. 
Adagdakh, Mys: point of land, see Adagdak, Cape.

Adair, Mount: mountain, 5,181 ft ${ }_{\bullet}$ in Kenai Mts., $2 \mathrm{mi}$. S of Sleeping Sister Mtn., $17 \mathrm{mi}$. N of Seward, Chugach Mts.; $60^{\circ} 21^{\prime} 20^{\prime \prime} \mathrm{N}, 1^{\circ} 9^{\circ}$ $27^{\prime} 45^{\prime \prime} \mathrm{W}$; (map 63).

Local name reported in 1951 by USGS.

Adak: locality, at head of Kuluk Bay, on NE coast of Adak I., Aleutian Is. ; $51^{\circ} 52^{\prime} \mathrm{N}, 176^{\circ}$ $39^{\prime} \mathrm{W}$; (map 17).

Name derived from Adak Island; published in 1951 by USGS.

Adak Bight: cove, $0.5 \mathrm{mi}$. across, on $\mathrm{E}$ coast of Adak I., Aleutian Is.; $51^{\circ} 46^{\prime} 20^{\prime \prime} \mathrm{N}, 176^{\circ} 25^{\prime}$ $30^{\prime \prime} \mathrm{W}$; BGN 1936; (map 17).

Name derived from Adak Island in 1934 by members of the U.S. Navy Aleutian Island Survey Expedition.

Adakh, Ostrov: island, see Adak Island.

Adak Island: island, $28 \mathrm{mi}$. long, one of Andreanof Is., Aleutian Is.; $51^{\circ} 45^{\prime} \mathrm{N}, 176^{\circ} 45^{\prime} \mathrm{W}$; $B G N$ 1944; (map 17). Var. Adach Island, Ajaga Island, Ayagh Island, Ayasgh, Kayaku Island, Kejachu Island, Ostrov Adakh.

Aleut name reported as "Ayasgh" or "Kayaku" by Maxim Lazerov in 1761 (Coxe, 1787, p. 81). This island was called "Os[trov] Adakh" by Lt. Sarichev (1826, map 3), IRN, and Capt. Tebenkov (1852, map 28), IRN. The name may be from the Aleut word "adaq" which R. H. Geoghegan translates as "father."

Adak Strait: water passage, between Adak and Kanaga Is., Aleutian Is.; $51^{\circ} 47^{\prime} \mathrm{N}, 177^{\circ} 00^{\prime}$ W.

Name derived from Adak Island; published in 1896 by USC\&GS on Chart 9100 .

Adam, Point: point of land, NW point of entrance to Koyuktolik Bay, on SW end of Kenai Penin., $16 \mathrm{mi}$. SW of Seldovia, Chugach Mts.; $59^{\circ} 15^{\prime} 20^{\prime \prime} \mathrm{N}, 1^{\circ} 59^{\circ} 30^{\prime \prime} \mathrm{W}$; BGN 1908; (map 50). Var. Cabo Gaston, Cape Bede.

Named in 1908 by USC\&GS. This appears to be the "Cape Bede" of Capt. James Cook, RN; name now applied farther north. See Bede, Point. Salvador Fidalgo called this point of land "Cabo Gaston" in 1790

Adamagan: bay, see Morzhovoi Bay.

Adam Creek: stream, see Adams Creek.

Adam Lake: lake, $1 \mathrm{mi}$. long, just $\mathrm{N}$ of Nelson Lake, $14 \mathrm{mi}$. NW of Beaver, Yukon Flats; $66^{\circ} 31^{\prime} \mathrm{N}, 147^{\circ} 44^{\prime} \mathrm{W}$; (map 118).

Local name obtained in 1956 by USGS.

Adam Mountains: mountain range, elev. 4,500 ft., extends E-W $8 \mathrm{mi}$, at head of Wilson River, 5 mi. W of Halleck Ra., Coast Mts.; $55^{\circ} 39^{\prime} \mathrm{N}, 130^{\circ} 27^{\prime} \mathrm{W}$; (map 3). Var. Adams Mountains.

Named "Adams Mountains" in 1868 by David Pender, Staff Comdr. RN; published on Brit. Adm. Chart 2431.

Adams Anchorage: bay, $0.5 \mathrm{mi}$. across, on $\mathrm{S}$ end of Shelter I. in Stephens Passage, $3 \mathrm{mi}$. W of Point Louisa and $15 \mathrm{mi}$. NW of Juneau, Alex. Arch.; $58^{\circ} 22^{\prime} 20^{\prime \prime} \mathrm{N}, 134^{\circ} 49^{\prime} 00^{\prime \prime} \mathrm{W}$; (map 11).

Named by Comdr. J. B. Coghlan, USN, in 1884 after the U.S.S. Adams, which he commanded and which anchored there that year.
Adams Channel: water passage, in Peril Strait, 0.5 mi. E of Rapids Point, between Big Rose I. and NW coast of Baranof I., $29 \mathrm{mi}$. N of Sitka, Alex. Arch.; $57^{\circ} 27^{\prime} 30^{\prime \prime}$ N, $135^{\circ} 32^{\prime} 00^{\prime \prime}$ W; (map 9)

Named in 1884 by Comdr. J. B. Coghlan, USN, for the U.S.S. Adams, which he commanded while making surveys in this area. The name was published by USC\&GS in the 1891 Coast Pilot (p. 183).

Adams Creek: stream, flows SE $2 \mathrm{mi}$. to Shovel Creek, $10 \mathrm{mi}$. N of Solomon, Seward Penin. High.; $64^{\circ} 42^{\prime} \mathrm{N}, 164^{\circ} 26^{\prime} \mathrm{W}$; (map 95). Var. Adam Creek.

Prospectors' name reported in 1900 by E. C. Barnard (in Brooks, 1901, pl. 17), USGS.

Adams Creek: stream, flows $\mathrm{S}$ to Middle Fork Koyukuk River, Brooks Ra.; $67^{\circ} 35^{\prime}$ N, $151^{\circ}$. $00^{\prime} \mathrm{W}$; (map 124).

Prospector's name given by miners in 1899 ; published by Maddren (1913, pl. 1), USGS. Location is uncertain.

Adams Creek: stream, see Vi Creek.

Adams Glacier: glacier, in Glacier Bay National Monument, $40 \mathrm{mi}$. SW of Skagway, St. Elias Mts.; $59^{\circ} 10^{\prime} \mathrm{N}, 136^{\circ} 15^{\prime} \mathrm{W}$; (map 45), Var. Southeast Tributary Muir Glacier.

Named in 1896 by H. F. Reid, USGS, for C. A. Adams, a member of his party in 1892 . It was also called "Southeast Tributary Muir Glacier" (Reid, 1892, map)

Adams Inlet: estuary, trends W $7 \mathrm{mi}$. to Muir Inlet, in Glacier Bay National Monument, $\mathrm{S}$ of Point George, $55 \mathrm{mi}$. NW of Hoonah, St. Elias Mts.; $58^{\circ} 50^{\prime} 45^{\prime \prime} \mathrm{N}, 136^{\circ} 03^{\prime} 00^{\prime \prime} \mathrm{W}$; BGN 1937; (map 10).

Named in 1936 by W. O. Field, Jr., and W. S. Cooper, for Adams Glacier, which formerly occupied the inlet. See Adams Glacier.

Adams Island: island, $2.3 \mathrm{mi}$. long, in Yukon River, $6 \mathrm{mi}$. NE of Stevens Village, Yukon Flats; $66^{\circ} 03^{\prime} 40^{\prime \prime} \mathrm{N}, 148^{\circ} 55^{\prime} 00^{\prime \prime} \mathrm{W}$; (map 118 ).

Local name obtained in 1956 by USGS.

Adams Mountains: mountain range, see Adam Mountains.

Adamson, Cape: point of land, see Bartolome, Cape.

Adams Peak: peak, 2,814 ft., on right bank of Yukon River, $12.5 \mathrm{mi}$. N of Eagle, Porcupine Plat.; $64^{\circ} 58^{\prime} 18^{\prime \prime} \mathrm{N}, 141^{\circ} 11^{\prime} 00^{\prime \prime} \mathrm{W}$; $B G N$ 1965; (map 102)

Named by USGS for William Adams, local resident and hunter who died in 1964; the name was published in 1966 by USGS.

Adams Peak: mountain, see Sunrise Peak.

Adams Point: point of land, $\mathrm{N}$ point of entrance to Moira Sound, on SE coast of Prince of Wales I., Alex. Arch.; 55 01'45" N, 131 $59^{\circ}$ $45^{\prime \prime} \mathrm{W}$; (map 3 ).

Named in 1891 by USC\&GS

Adams Point: point of land, on $\mathrm{N}$ shore of $\mathrm{Ka}$ saan Bay, on $\mathbf{E}$ coast of Prince of Wales I., Alex. Arch.; 55 $33^{\prime} \mathrm{N}, 132^{\circ} 26^{\prime} \mathrm{W}$; BGN 1966; (map 4). Var. Point Adams.

Local name recorded in 1949 by USGS.
Adanac Creek: stream, heads in Reverdy Mts., flows W $1.5 \mathrm{mi}$. to Fish Creek, $4.5 \mathrm{mi}$. N of Hyder, Coast Mts.; 55 $59^{\prime} \mathrm{N}, 130^{\circ} 03^{\prime} \mathrm{W}$; (map 3).

Local name reported in 1955 by USGS.

Adanarayak: stream, see Boss Creek.

Addington, Cape: point of land, SW tip of Noyes I., Alex. Arch.; $55^{\circ} 26^{\prime} 15^{\prime \prime} \mathrm{N}, 133^{\circ} 24^{\prime} 15^{\prime \prime} \mathrm{W}$; (map 4). Var. Cape Barnett, Mys Adington, Mys Eddington.

Named on August 24, 1794, by Capt. George Vancouver, RN, for Henry Addington, 17571844, Speaker of the House of Commons (Wagner, 1937, p. 371); named "Cape Barnett" by Capt. John Meares in 1788 (U.S. Coast and Geodetic Survey, 1883, p. 98). Russian transliterations of this name were published by Capt. Tebenkov (1852, map 9), IRN, as "Mys Adington," and by the Russian Hydrog. Dept. in 1853 on Chart 1493 as "Mys Eddington."

Addison Creek: stream, heads $2 \mathrm{mi}$. NE of Attu Mtn., flows E, through Addison Valley, 6.5 mi. to West Arm Holtz Bay, Attu I., Aleutian Is.; $52^{\circ} 55^{\prime} 25^{\prime \prime} \mathrm{N}, 173^{\circ} 07^{\prime} 25^{\prime \prime} \mathrm{E}$; (map 13).

Named by the U.S. Army during World War II ; published in 1948 by AMS.

Addison Glacier: glacier, $2 \mathrm{mi}$. long, $2 \mathrm{mi}$. $\mathrm{N}$ of Pederson Glacier, $19 \mathrm{mi}$. SW of Seward, Chugach Mts.; $59^{\circ} 56^{\prime} \mathrm{N}, 149^{\circ} 46^{\prime} \mathrm{W}$; $B G N$ 1910; (map 49).

Named in 1911 by U. S. Grant, USGS, "after my son."

Addison Valley: valley, of Addison Creek, 2.5 mi. long, on NE coast of Attu I., Aleutian Is.; $52^{\circ} 55^{\prime} 25^{\prime \prime} \mathrm{N}, 173^{\circ} 07^{\prime} 25^{\prime \prime} \mathrm{E}$; (map 13).

Named by the U.S. Army during World War II; published in 1948 by AMS.

Adington, Mys: point of land, see Addington, Cape.

Admiral Creek: stream, flows S $4 \mathrm{mi}$. to Tubutulik River, $28 \mathrm{mi}$. N of Elim and $48 \mathrm{mi}$. SE of Imuruk Lake, Seward Penin. High.; $65^{\circ} 02^{\prime}$ N, $162^{\circ} 09^{\prime} \mathrm{W}$; (map 110$)$.

Prospectors' name reported in 1900 by W. J. Peters (in Mendenhall, 1901, pl. 20), USGS.

Admiral Range: mountain range, $\mathrm{E}$ of Thomas Bay, Coast Mts. ; $57^{\circ} 00^{\prime} \mathrm{N}, 132^{\circ} 30^{\prime} \mathrm{W}$; (map 8).

Named in 1887 by Lt. Comdr. C. $M$ Thomas, USN; published on USC\&GS Chart 705

Admiralty Bay: bay, $11 \mathrm{mi}$. across, at head of Dease Inlet, $30 \mathrm{mi}$. SE of Barrow; Arctic Plain; 70 53' N, $155^{\circ} 43^{\prime} \mathrm{W}$; (map 148).

Named in 1856 by and for the British Admiralty.

Admiralty Bay: bay, see Yakutat Bay.

Admiralty Cove: cove, $0.8 \mathrm{mi}$. across, in Young Bay, $\mathrm{N}$ coast of Admiralty I., $0.5 \mathrm{mi}$. SW of Point Young and $10 \mathrm{mi}$. SW of Juneau, Alex. Arch.; 58 $11^{\prime} 15^{\prime \prime} \mathrm{N}, 134^{\circ} 34^{\prime} 30^{\prime \prime} \mathrm{W}$; BGN 1917; (map 11). Var. Van Auke Bay, Auke Cove.

Named "Auke Bay" by Comdr. R. W. Meade, USN, in 1868 after a subdivision of 
the Tlingit Indians living there. Because of another Auke Bay $12 \mathrm{mi}$. to the north, BGN changed the name to Admiralty Cove in 1917. Admiralty Greek: stream, $6.6 \mathrm{mi}$. long, flows NW to Admiralty Cove, $10 \mathrm{mi}$. SW of Juneau, Alex. Arch.; 58 $10^{\prime} 30^{\prime \prime} \mathrm{N}, 134^{\circ} 33^{\prime} 30^{\prime \prime} \mathrm{W}$ $B G N$ 1917; (map 11). Var. Auke Creek.

Locally named Auke Cove and reported by A. C. Spencer and C. W. Wright in 1903. This name was changed to Admiralty Creek by BGN in 1917 as a result of the change in name of Auke Cove to Admiralty Cove.

Admiralty Island: island, $96 \mathrm{mi}$. long, from Point Gardner on Frederick Sound to Point Retreat on Lynn Canal, $9 \mathrm{mi}$. S of Juneau, Alex. Arch.; $57^{\circ} 40^{\prime} \mathrm{N}, 134^{\circ} 20^{\prime} \mathrm{W}$; (map 8). Var. Khutsnoi Island.

Named in 1794 by Capt. Vancouver (1798, v. 3, p. 276), RN. Capt. Tebenkov (1852, map 8), IRN, published the Russian name "O[strov] Kutsnoi" meaning "fear island."

Adolph Point: point of land, see Adolphus, Point.

Adolphus, Point: point of land, at $\mathrm{N}$ end of Chichagof I., in Icy Strait, $50 \mathrm{mi}$. W of Juneau, Alex. Arch.; 58 $17^{\prime} 15^{\prime \prime} \mathrm{N}, 135^{\circ} 47^{\prime} 00^{\prime \prime} \mathrm{W}$; (map 11). Var. Adolph Point, Point Adolph.

Discovered in 1794 by Joseph Whidbey and named by Capt. Vancouver $(1798$, v. 3, p. 259), RN, in honor of Adolphus Frederick, seventh son of George III, King of England. Adougakh: island, see Adugak Island.

Adrian Cove: bay, $0.4 \mathrm{mi}$. wide, on NE coast of Suemez I., Alex. Arch.; 55 $20^{\prime}$ N, $133^{\circ} 19^{\prime}$ W; (map 4).

Named in 1914 by USC\&GS; derived from nearby San Adrian Islets.

Adrigigon Creek: stream, flows E 8 mi. to Kaolak River, $40 \mathrm{mi}$. S of Wainwright, Arctic Plain; $70^{\circ} 04^{\prime} 50^{\prime \prime} \mathrm{N}, 159^{\circ} 42^{\prime} 00^{\prime \prime} \mathrm{W}$; (map 146).

Eskimo name reported in 1926 by USGS

Adugak Island: island, $1.2 \mathrm{mi}$. across, $6 \mathrm{mi}$. N of Cape Sagak at SW tip of Umnak I., Aleutian Is.; $52^{\circ} 54^{\prime} 30^{\prime \prime} \mathrm{N}, 169^{\circ} 09^{\prime} 40^{\prime \prime} \mathrm{W}$; (map 21). Var. Adougakh.

Name reported in 1840 by Father Ioann Veniaminov which may possibly be from the Aleut word "adudak" which, according to R. H. Geoghegan, means "somewhat long."

Adventure Creek: stream, heads in DeLong Mts. and flows $\mathrm{N} 16 \mathrm{mi}$. to Utukok River, $43 \mathrm{mi}$. $\mathrm{N}$ of Misheguk Mtn., Arctic Slope; $68^{\circ} 51^{\prime} \mathrm{N}$, $161^{\circ} 09^{\prime} \mathrm{W}$; BGN 1926; (map 131).

So named in 1925 by Gerald FitzGerald, USGS, whose party went astray on this creek.

Adventuress Creek: stream, flows SW $0.7 \mathrm{mi}$. to Telegram Creek, between Oversight and Penny Creeks, in Pilgrim River basin, $21 \mathrm{mi}$. $\mathrm{N}$ of Solomon, Seward Penin. High.; 64 $51^{\circ}$ '$55^{\prime \prime} \mathrm{N}, 164^{\circ} 34^{\prime} 30^{\prime \prime} \mathrm{W}$; (map 95).

Prospectors' name reported in 1908 by P. S. Smith (in Brooks and others, 1909, pl. 10), USGS.

A. E. Co. Camp: locality, see Kings Slough Village.

Aektok: island, see Aiktak Island.

Aektok: water passage, see Rootok Strait.

Aektok, Ostrov: island, see Rootok Island.
Aeolian Hills: hills, $250 \mathrm{ft}$., extend S $4 \mathrm{mi}$. on W bank of Tanana River $3.5 \mathrm{mi}$. $\mathrm{S}$ of its junc. with Yukon River, Nowitna Low.; $65^{\circ} 05^{\prime} \mathrm{N}, 151^{\circ} 52^{\prime} \mathrm{W}$; (map 106).

Local name reported in 1952 by USGS.

Aeolus Mountain: mountain, 1,452 ft., on $\mathrm{W}$ shore of Togiak Bay $16 \mathrm{mi}$. SW of Togiak, Kilbuck-Kuskokwim Mts. ; $58^{\circ} 55^{\prime} \mathrm{N}, 160^{\circ} 45^{\prime}$ W; (map 39).

Local name published in 1948 by USGS.

Aetna River: stream, see Copper River.

Afagnack Island: island, see Afognak Island.

Afagnak Island: island, see Afognak Island.

Afanasa Creek: stream, on Kenai Penin., flows $\mathrm{N} 3 \mathrm{mi}$. to Abernathy Creek, $18 \mathrm{mi}$. SSW of Hope, Chugach Mts. ; $60^{\circ} 40^{\prime} 15^{\prime \prime}$ N, $149^{\circ} 46^{\prime}$ $00^{\prime \prime} \mathrm{W}$; (map 63).

Local name reported as "Afanasi" in 1933 by R. H. Sargent, USGS.

Affleck Canal: estuary, on Kuiu I., extends S 20 mi. to Sumner Strait, 30 mi. SE of Port Alexander, Alex. Arch.; $56^{\circ} 05^{\prime} \mathrm{N}, 134^{\circ} 03^{\prime} \mathrm{W}$ (map 5). Var. Afflecks Canal, Affleck's Channel.

Named by Capt. George Vancouver, RN, on September 11, 1793, for Adm. Philip Affleck, RN (Wagner, 1937, p. 371).

Afflecks Canal: estuary, see Affleck Canal.

Affleck's Channel: estuary, see Affleck Canal. Afgonak Island: island, see Afognak Island.

Afognak: locality, on $\mathbf{S}$ coast of Afognak I., $\mathbf{N}$ of Kodiak I.; $58^{\circ} 00^{\prime} 30^{\prime \prime} \mathrm{N}, 152^{\circ} 46^{\prime} 00^{\prime \prime} \mathrm{W}$; $B G N$ 1966; (map 43). Var. Afognac, Litnik, Ratkovsky, Rubertz, Rubtsovskaya, Rubtzovskaia, Rubyets, Rutkovsky.

Name derived from Afognak Island and reported in the 11 th Census of 1890 (1893, p. 73-74) as "*** Afognak Village [Afognak ${ }^{*} * *$ really consists of a series of settlements lining the long, curving beach *** the creole village of Afognak, extending in a single row of dwellings, somewhat widely scattered, about three-fourths of a mile along the beach. This settlement was founded during the first quarter of the present [19th] century under the name of Rutkovsky village by superannuated and pensioned employees of the Russian American Company * * *. Proceeding northward a few hundred yards $* * *$ we find the native village of Afognak [Aleut Village], inhabited by Kadiak Eskimos ***. To the northward, across the bays of Afognak we find 2 small settlements $* * *$ inhabited by creoles [Little Afognak] ***."

The Russian Hydrog. Dept. published the name for this settlement on Chart 1425 in 1849. This name was reported by Sub-Lt. Mikhail Murashev in 1839 or 1840 as "S[eleniye] Volnyk Promyshlen," meaning "village of free industry." This name was probably given because the Russian government allowed these retiring settlers to do as they pleased and released them from obligations to pay taxes for the first year of settlement. The descriptive name "Odinoch[ka] Rubyets," meaning "one part of a ridge" was published for this village by Capt. Tebenkov (1852, map 23), IRN. The Russian name "Litnik," a combi- nation of the words "Iytniy" meaning "summer" and "domik" meaning "house," has erroneously been applied to Afognak. Litnik is a separate village located at the head of Afognak Bay, 5 miles north of Afognak. A post office has been maintained intermittently from 1888 to 1958 (Ricks, 1965, p. 2). On March 27,1964 , a tidal wave resulting from an earthquake destroyed most of Afognak. A new community was built on the northeast coast of Kodiak Island and the residents of Afognak moved there in December 1964. See Port Lions.

Afognaka, Mys: point of land, see Afognak Point. Afognaka, Mys: point of land, see Lighthouse Point.

Afognak Bay: estuary, $\mathbf{N}$ of Afognak, extends SSE $3.5 \mathrm{mi}$. at mouth of Afognak River, on S coast of Afognak I., Kodiak I.; $58^{\circ} 02^{\prime} 30^{\prime \prime} \mathrm{N}$, $152^{\circ} 45^{\prime} 00^{\prime \prime} \mathrm{W}$; (map 43). Var. Litnik Bay, Zaliv Afognak.

Name derived from Afognak Island; published by Capt. Tebenkov (1852, map 23), IRN, as "Z[aliv] Afognak," or "Afognak Bay." The Russian name "Litnik" was reported in 1900 by Lt. Comdr. J. F. Moser, USN. See Litnik, locality.

Afognak Island: island, $50 \mathrm{mi}$. across, $\mathrm{N}$ of Kodiak I.; $58^{\circ} 15^{\prime} \mathrm{N}, 152^{\circ} 30^{\prime} \mathrm{W}$; (map 43). Var. Afagnack Island, Afagnak Island, Afgonak Island, Aphoknak Island, Appoknak Island, Fogniak, Kodiac Island, Ostrov Afognak.

Native name published by Rev. Coxe (1780, p. 289) as "Afagnack." Capt. George Vancouver $(1798$, v. 3, p. 175$)$ referred to this island in 1794 as that "which the Russians call Fogniak * * *." It was called "Afognack" by Capt Lisianski (1814, p. 186), IRN, and "Ostrov Afognak" or "Afognak Island" by Lt. Sarichev (1826, map 5), IRN, and Capt. Tebenkov (1852), map 22), IRN. Capt. Cook $(1785$, v. 2, p. 404), IRN, suspected that this feature might be an island, but referred to it as a part of the Alaska Peninsula. See Marmot Island.

Afognak Lake: lake, $5.5 \mathrm{mi}$. long, on Afognak I., $8 \mathrm{mi}$. NW of Afognak, Kodiak I.; $58^{\circ} 06^{\prime} 30^{\prime \prime}$ $\mathrm{N}, 152^{\circ} 55^{\prime} 00^{\prime \prime} \mathrm{W}$; (map 43). Var. Litnik Lake.

Name derived from Afognak Island; published in 1910 by USC\&GS. The Russian name "Litnik" was reported in 1900 by Lt. Comdr. J. F. Moser, USN, See Litnik, locality.

Afognak Mountain: mountain, 2,256 ft., on Afognak I., 9 mi. NW of Afognak, Kodiak I.; $58^{\circ} 07^{\prime} 25^{\prime \prime} \mathrm{N}, 152^{\circ} 53^{\prime} 00^{\prime \prime} \mathrm{W}$; (map 43).

Name derived from Afognak Island; published in 1910 by USC\&GS.

Afognak Point: point of land, $1.5 \mathrm{mi}$. S of Afog. nak, on $\mathrm{S}$ coast of Afognak I., $\mathrm{N}$ of Kodiak I.; $57^{\circ} 59^{\prime} 30^{\prime \prime} \mathrm{N}, 152^{\circ} 47^{\prime} 30^{\prime \prime} \mathrm{W}$; (map 34). Var. Mys Afognaka.

Name derived from Afognak Island; given in 1839 or 1840 by Sub-Lt. Mikhail Murashev, IRN, as "M[ys] Afognaka" or "Cape Afognak." 
Afognak River: stream, on $\mathbf{S}$ coast of Afognak I., heads at Afognak Lake, flows SE $3.2 \mathrm{mi}$. to Afognak Bay, Kodiak I.; $58^{\circ} 04^{\prime} 15^{\prime \prime}$ N, $152^{\circ}$ $46^{\prime} 40^{\prime \prime}$ W; (map 43). Var. Litnik River, Reka Afognak.

Name derived from Afognak Island. Reported in 1839 or 1840 as "R[eka] Afognak," or "Afognak River," by Sub-Lt. Mikhail Murashev, IRN; published in 1849 on Russian Hydrog. Dept. Chart 1425. The Russian name "Litnik" was reported in 1900 by Lt. Comdr. J. F. Moser, USN. See Litnik, locality.

Afognakskaya Odinochka: village, see Aleut Village.

Afognak Strait: water passage, $5.5 \mathrm{mi}$. long, between Whale and Afognak Is., $\mathrm{N}$ of Kodiak I.; $57^{\circ} 59^{\prime} \mathrm{N}, 152^{\circ} 48^{\prime} \mathrm{W}$; (map 34).

Name derived from Afognak Island and given in 1897 by Lt. Comdr. Moser, USN, of the USBF steamer Albatross.

Afonasi Lake: lake, $1.2 \mathrm{mi}$. long, westernmost of Seven Lakes, on Kenai Penin. in course of East Fork Moose River, $25 \mathrm{mi}$. E of Kenai, Cook Inlet Low.; $60^{\circ} 33^{\prime} 30^{\prime \prime} \mathrm{N}, 150^{\circ} 30^{\prime} 00^{\prime \prime} \mathrm{W}$; (map 62).

Named about 1963 by officials of Kenai National Moose Range, for administrative purposes.

Afroon River: stream, see Aphrewn River.

Afrun River: stream, see Aphrewn River.

Afternoon Creek: stream, flows SW $3.3 \mathrm{mi}$. to

Tagoomenik River, $21 \mathrm{mi}$. SW of Christmas Mtn., Nulato Hills; $64^{\circ} 18^{\prime} \mathrm{N}, 160^{\circ} 53^{\prime} \mathrm{W}$; (map 96).

Local name reported about 1954 by U.S. Army Corps of Engineers.

Agaak Creek: stream, flows NE $8 \mathrm{mi}$. to Easter Creek $6.4 \mathrm{mi}$. SE of that stream's junc. with Killik River, Brooks Ra.; 68 $05^{\circ}$ N, 153 $59^{\prime}$ W; (map 133).

Eskimo name "A-gah-ak"; obtained at Anuktuvuk Pass in 1956 by Orth.

Agachuk Island: island, see Aguchik Island.

Aga Cove: cove, $0.5 \mathrm{mi}$. across, $\mathrm{S}$ of McDonald Point, on E coast of Ágattu I., Aleutian Is. $52^{\circ} 25^{\prime} 30^{\prime \prime} \mathrm{N}, 173^{\circ} 42^{\prime} 30^{\prime \prime} \mathrm{E}$; (map 13).

Derived from the first three letters of Agattu I.; may have been given by the U.S. Army during World War II.

Agadak Island: island, see Rat Island.

Agaerruich Hills: mountains, see Tahinichok Mountains.

Agagrak Creek: stream, heads in Tahinichok Mts. at SW end of Mulgrave Hills, flows W $7 \mathrm{mi}$. to Chukchi Sea, $27 \mathrm{mi}$. W of Noatak, Kotzebue-Kobuk Low.; 67 $31^{\prime} 30^{\prime \prime} \mathrm{N}, 163^{\circ}$ $59^{\prime} 30^{\prime \prime}$ W ; (map 128). Var. Agagruak Creek, Agagruk River.

Eskimo name reported in 1950 by USC\&GS.

Agagrak Mountains: mountains, see Tachinichok Mountains.

Agagruak Creek: stream, see Agagrak Creek. Agagruk Mountains: mountains, see Tahinichok Mountains.

Agagruk River: stream, see Agagrak Creek.

A-gahk-la-rok: point of land, see Tin Can Point.
Agaiak Island: island, "in Krestof sound, north of Sitka sound, Alexander archipelago."

"Apparently an Aleut name, first applied by Vasiliev in 1833. "Has also been written Agayak and Agiak" (Baker, 1906, p. 82).

Agaiouchack, Ile: island, see Ugaiushak Island. Agajedan: mountain, see Shishaldin Volcano.

Agak Creek: stream, see Agiak Creek.

Agakhlyak: locality, see Techek.

Agak Lake: lake, see Agiak Lake.

Agaklarok: locality, on Tin Can Point, Yukon Delta, $13 \mathrm{mi}$. SW of Kwiguk, Yukon-Kuskokwim Delta; $62^{\circ} 36^{\prime} 30^{\prime \prime} \mathrm{N}, 164^{\circ} 46^{\prime} 45^{\prime \prime} \mathrm{W}$; (map 77).

Eskimo name spelled "Ageklarokamiut," meaning "Ageklarok people," by G. R. Putnam, USC\&GS, in 1899.

Agaklarok : point of land, see Tin Can Point.

Agaligamute: locality, see Arolik.

Agalitnak River: stream, see Hoholitna River.

Agamgik Bay: bay, $1 \mathrm{mi}$. across, in Beaver Inlet, on NE coast of Unalaska I., Aleutian Is. $53^{\circ} 52^{\prime} 30^{\prime \prime} \mathrm{N}, 166^{\circ} 20^{\prime} 30^{\prime \prime} \mathrm{W} ; B G N$ 1904; (map 23). Var. Food Bay, Muscle Cove, Mussel Cove, Zaliv Agamgik.

Aleut name reported by John Henry Fox in 1791 (Wagner, 1937, p. 356), which, according to R. H. Geoghegan, is derived from "agamaq" and means "hoarfrost." This feature was called "Food Bay" by USBF in 1888.

Agamsik, Cape: point of land, on $\mathrm{N}$ shore of Tanaga Bay, Tanaga I., Aleutian Is.; $51^{\circ}$. $47^{\prime} 00^{\prime \prime} \mathrm{N}, 178^{\circ} 02^{\prime} 15^{\prime \prime}$ W; (map 16). Var. Cape Agamsikh.

Aleut name published by Capt. Tebenkov (1852, map 28), IRN, as "M[ys] Agamsik." Agamsikh, Cape: point of land, see Agamsik, Cape.

Agarak Creek: stream, flows W 1 mi. to Chukchi Sea, $2 \mathrm{mi}$. N of Cape Thompson, Arctic Slope; $68^{\circ} 10^{\prime} 20^{\prime \prime} \mathrm{N}, 166^{\circ} 00^{\prime} 05^{\prime \prime} \mathrm{W}$; BGN 1963; (map 129). Var. Agaraq Creek, Ahgahruk Creek.

Eskimo name reported to mean "mother-inlaw [akaroaq]"; translated in 1950 by USC\&GS which spelled it "Ah-gah-ruk."

Agaraq Creek: stream, see Agarak Creek.

Agaschagoch Island: island, see Bogoslof Island. Agashashok River: stream, heads in Baird Mts. at $67^{\circ} 37^{\prime} \mathrm{N}, 161^{\circ} 14^{\prime} \mathrm{W}$, flows SW $50 \mathrm{mi}$. to Noatak River, $23 \mathrm{mi}$. SE of Noatak, Arctic Slope; $67^{\circ} 16^{\prime} \mathrm{N}, 162^{\circ} 38^{\prime} \mathrm{W} ; B G N \quad 1962$ (map 128).

Eskimo name reported in 1911 by P. S. Smith, USGS.

Agashogok Island: island, see Bogoslof Island. Agassiz, Point: point of land, on mainland, 8.5 mi. NE of Petersburg, Coast Mts.; $56^{\circ} 55^{\prime} 20^{\prime \prime}$ $\mathrm{N}, 132^{\circ} 53^{\prime} 00^{\prime \prime} \mathrm{W}$; (map 6).

Named in 1877 by W. H. Dall, USC\&GS, for Louis Agassiz, 1807-73, famous SwissAmerican naturalist, who taught at Harvard University, 1848-73.

Agassiz Glacier: glacier, heads at Newton Glacier, in Canada, trends S $15 \mathrm{mi}$. to Malaspina Glacier, $55 \mathrm{mi}$. NW of Yakutat, St. Elias Mts. : $60^{\circ} 05^{\prime} \mathrm{N}, 140^{\circ} 50^{\prime} \mathrm{W}$; (map 66).
Named by William Libbey, Jr., of the New York Times Expedition of 1886, for Louis Agassiz, 1807-73. See Agassiz, Point.

Agassiz Lakes: lakes, extend NNE $4 \mathrm{mi}$. along 1951 terminus of Libbey and Agassiz Glaciers, $10 \mathrm{mi}$. SSW of Mount St. Elias and $61 \mathrm{mi}$. NW of Yakutat, St. Elias Mts.; $60^{\circ} 09^{\prime} \mathrm{N}, 141^{\circ} 00^{\prime}$ W; (map 66).

Name published in 1959 by USGS.

Agassiz Mountain: mountain, 2,323 ft., on Annette I., highest point of Bald Ridge, $4.2 \mathrm{mi}$. $\mathrm{SE}$ of Metlakatla, Alex. Arch.; $55^{\circ} 05^{\prime} 00^{\prime \prime} \mathrm{N}$ $131^{\circ} 29^{\prime} 45^{\prime \prime}$ W; (map 3). Var. Aggassiz Mountain.

Named in 1883 by Lt. Comdr. H. E. Nichols, USN.

Agassiz Peak: peak, 5,913 ft., $20 \mathrm{mi}$. NW of Mount Burkett and $100 \mathrm{mi}$. E of Sitka, Coast Mts. ; $57^{\circ} 12^{\prime} 50^{\prime \prime} \mathrm{N}, 132^{\circ} 48^{\prime} 10^{\prime \prime} \mathrm{W}$; (map 8).

Named in 1887 by Lt. Comdr. C. M. Thomas, USN, for Louis Agassiz, 1807-73. See Agassiz, Point.

Agataku Island: island, see Agattu Island.

Agate Fork: stream, see Susulatna River.

Agate Fork Susulatna River: stream, flows NW $11 \mathrm{mi}$. to Susulatna River, $46 \mathrm{mi}$. NW of Medfra, Kilbuck-Kuskokwim Mts,; 63ำ $\mathrm{N}, 155^{\circ} 49^{\prime} \mathrm{W}$; (map 89).

Local name reported in 1954 by USGS.

Agate Rock: cliff, $625 \mathrm{ft}$., on Chukchi Sea coast, $1.2 \mathrm{mi}$. SE of Cape Thompson, Arctic Slope; $68^{\circ} 07^{\prime} 55^{\prime \prime} \mathrm{N}, 165^{\circ} 56^{\prime} 50^{\prime \prime} \mathrm{W}$; $B G N$ 1963; (map 129).

So named in 1906 by A. J. Collier, USGS, "because its varicolored anticlinal beds give the appearance of half a bulls-eye agate."

Agatha Island: island, see Ringgold Island.

Agatha Lake: lake, see Ringgold, Lake.

Agatha Sound: water passage, see Ringgold Sound.

Agattu Island: island, $20 \mathrm{mi}$. long, southernmost of Near Is., $30 \mathrm{mi}$. SE of Attu I., Aleutian Is.; $52^{\circ} 26^{\prime} \mathrm{N}, 173^{\circ} 36^{\prime} \mathrm{E} ; B C N 1890$; (map 13). Var. Krugloi Island, Agataku Island, Agatu Island, Agattou Island, St. Etienne Island, St. Abraham Island.

Aleut name published as "Agataku" by Rev. Coxe (1787, p. 50). The early Russians called the island "Ostrov Kruglyy," meaning "round island." The island probably was discovered September 21, 1741 (O.S.), by the crew of the St. Paul, under the command of Capt. A. I. Chirikov (Golder, 1922, v. 1, p. 307). Marcus Baker (1906, p. 82) indicates that Agattu may have been the island named "St. Abraham" by Vitus Bering, October 29, 1741 (O.S.), but Golder (1922, v. 1, p. 202) attributes that distinction to Shemya Island.

Agattu Roadstead: anchorage, $10 \mathrm{mi}$. across, between Cape Sabak and Krugloi Point, on E coast of Agattu I., Aleutian Is.; 52 $26^{\prime} \mathrm{N}$, $173^{\circ} 43^{\prime} \mathrm{E}$; (map 13 ).

Name listed in the 1946 supplement to the USC\&GS Coast Pilot published in 1944.

Agattu Strait: water passage, between Attu and Agattu Is., Aleutian Is.; $52^{\circ} 35^{\prime} \mathrm{N}, 173^{\circ} 25^{\prime}$ E; (map 13).

Name derived from Agattu Island. 
Agayak: island, see Aghiyuk Island. Agayuquaq Creek: stream, see Angayukak Creek. Ageagh, Ile: island, see Aghik Island. Ageakh, Ostrov: island, see Aghik Island. Ageapuk River: stream, see Agiapuk River. Agee-ee-puk River: stream, see Agiapuk River. Ageeopak River: stream, see Agiapuk River. Ageepuk River: stream, see Agiapuk River. Ageklarok: locality, "Eskimo village, Yukon delta, on the right bank of Kwikluak pass at its mouth, near latitude $62^{\circ} 37^{\prime}$, longitude $164^{\circ} 45^{\prime} . "$

"Native name obtained by Putnam, 1899 and written Ageklarokamint-i.e., Ageklarok folks" (Baker, 1906, p. 82).

Ageklekak: locality, on S bank of Kewanak Pass, $18 \mathrm{mi}$. N of Kwiguk, Yukon-Kuskokwim Delta; $63^{\circ} 02^{\prime} \mathrm{N}, 164^{\circ} 32^{\prime} \mathrm{W}$; (map 92$)$.

Eskimo campsite which a 1950 USC\&GS field report states "is seldom now used."

Agenuk Mountain: mountain, 2,638 ft., $6 \mathrm{mi}$. S of Tikchik Lake and $58 \mathrm{mi}, \mathrm{N}$ of Dillingham, Kilbuck-Kuskokwim Mts.; $59^{\circ} 52^{\prime} \mathrm{N}, 158^{\circ} 29^{\prime}$ W; BGN 1931; (map 52).

Eskimo name obtained about 1931 from F. H. Waskey and Beverley Polley, local residents, by Gerald FitzGerald, USGS.

Ageopuk River: stream, see Agiapuk River.

Aggassiz Mountain: mountain, sec Agassiz Mountain.

Aggie Creek: stream, flows NW $3.6 \mathrm{mi}$. to Fish River, $15 \mathrm{mi}$. E of Council and $46 \mathrm{mi}$. NE of Solomon, Seward Penin. High, ; $64^{\circ} 56^{\prime}$ N, $163^{\circ} 10^{\prime} \mathrm{W}$; (map 95).

Prospectors' name published on the 1908 "Map of Seward Peninsula" by Arthur Gibson.

Aggie Creek: stream, flows SW $10 \mathrm{mi}$. to Washington Creek, $25 \mathrm{mi}$. NW of Fairbanks, Yukon-Tanana High.; $65^{\circ} 07^{\prime} \mathrm{N}, 148^{\circ} 18^{\prime} \mathrm{W}$; (map 105).

Named by prospectors; reported in 1908 by USGS (Covert and Ellsworth, 1909, pl. 2)

Aghaluk Creek: stream, flows NW $3.3 \mathrm{mi}$. to Kuskokwim River $5 \mathrm{mi}$. NE of its junc. with Holokuk River, $8 \mathrm{mi}$. NE of Little Mountain Village, Kilbuck-Kuskokwim Mts.; $61^{\circ} 34^{\prime} 30^{\prime \prime}$ N, $158^{\circ} 27^{\prime} 30^{\prime \prime} \mathrm{W}$; (map 72).

Name taken from that of the nearby mountain; reported in 1954 by USGS.

Aghaluk Mountain: mountain, 2,913 ft., in Kuskokwim Mts. on E bank of Veahna Creek $13 \mathrm{mi}$. E of Napaimiut, Kilbuck-Kuskokwim Mts.; 61 ${ }^{\circ} 32^{\prime} \mathrm{N}, 158^{\circ} 15^{\prime} \mathrm{W}$; BGN 1948; (map 72)

Eskimo name obtained in 1945 by USGS.

Aghik Island: island, $0.2 \mathrm{mi}$. across, in the Semidi Is., $1 \mathrm{mi}$. E of Aghiyuk I., Aleutian Ra.; $56^{\circ} 12^{\prime} \mathrm{N}, 156^{\circ} 45^{\prime} \mathrm{W}$; (map 31). Var. Ile Ageagh, Ostrov Ageakh.

Native name shown as "I[le] Ageagh" by Adm. von Krusenstern (1827, map 20) IRN; published in 1847 by "O[strov] Ageakh" on Russian Hydrog. Dept. Chart 1379. Aghik Island is shown on an 1888 USBF chart.

Aghileen Pinnacles: peaks, 4,800 ft., $24 \mathrm{mi}$. NE of village of Cold Bay, on SW end of Alaska
Penin., Aleutian Ra.; $55^{\circ} 09^{\prime} \mathrm{N}, 162^{\circ} 13^{\prime} \mathrm{W}$; (map 29).

Eskimo name reported in 1880 by $\mathrm{W}$. $\mathrm{H}$. Dall, USC\&GS

Aghiyukh: island, see Aghiyuk Island.

Aghiyuk Island: island, $6 \mathrm{mi}$. long, northernmost of Semidi Is., Aleutian Ra.; $56^{\circ} 10^{\prime} \mathrm{N}, 156^{\circ}$ $47^{\prime} \mathrm{W}$; (map 31). Var. Achaiak, Agayak, Aghiyukh, North Semidi, Semidin, Simidin.

Name first published as "I[le] Simidin" by Adm. von Krusenstern (1827, map 20), IRN, and as "Semidin" by Lt. Sarichev (1826, p. 32), IRN. The name "Aghiyuk Island" appears on an 1890 USBF chart. "Achaiak" is said to be the Aleut word for the cormorant.

Aghnaghak Lagoon: lagoon, extends NW $5 \mathrm{mi}$ from mouth of Kangik River to Bering Sea, $10 \mathrm{mi}$. SE of Gambell, St. Lawrence I.; $63^{\circ}$ $40^{\prime} \mathrm{N}, 171^{\circ} 33^{\prime} \mathrm{W}$; (map 93). Var. Akhanam Naiva, Two Girl Lagoon.

Eskimo name, more correctly transliterated "Akhnakhak," which refers to "two women"; recommended to USGS in 1949 by the Gambell village council. The name was originally used for the inlet or mouth of the lagoon and refers to two young Eskimo women who lost their lives here. The lagoon is reported to be called "Akhanam Naiva," meaning "women's lagoon," by the Eskimo.

Aghnuk River: stream, flows N $10 \mathrm{mi}$. to Aghnaghak Lagoon, $17 \mathrm{mi}$. S of Gambell, St. Lawrence I.; $63^{\circ} 36^{\prime} \mathrm{N}, 171^{\circ} 39^{\prime} \mathrm{W}$; (map $93)$.

Eskimo name, more correctly transliterated as "Akhnak," in the dual form, meaning "two women"; recommended to USGS in 1949 by the Gambell village council.

Aghsit Cape: point of land, see Aghsit Point.

Aghsit Point: point of land, on $\mathrm{W}$ coast of St. Lawrence I., S of Upapak Point, $11 \mathrm{mi}$. $\mathrm{S}$ of Gambell ; $63^{\circ} 38^{\prime} \mathrm{N}, 171^{\circ} 48^{\prime} \mathrm{W} ; B G N$ 1951; (map 93). Var. Aghsit Cape, Cape Aghsit, Cape Calghsit, Ogsit Cape.

Eskimo name recorded in 1965 by Orth as "Okhsit," meaning "animal resting place," and refers specifically to seals. The name appears to have been first recorded during the Bun nell-Geist Expedition of 1927, 1928, or 1929.

Agiagiak Creek: stream, flows NW $3.5 \mathrm{mi}$., joins Sulugiak Creek to form Okokmilaga River, $26 \mathrm{mi}$. E of junc. of Easter Creek and Killik River, Brooks Ra.; $68^{\circ} 07^{\prime} \mathrm{N}, 153^{\circ} 08^{\prime} \mathrm{W}$ (map 133).

Eskimo name, said to mean "route to Agiak [Creek or Lake]"; reported in 1956 by T. E Taylor, USGS.

Agiak Creek: stream, flows S $27 \mathrm{mi}$. from Agiak Lake, joins Kevuk Creek to form Hunt Fork of John River, $6.5 \mathrm{mi}$. N of Sillyasheen Mtn. and $73 \mathrm{mi}$. NW of Wiseman, Brooks Ra. $67^{\circ} 51^{\prime} 30^{\prime \prime} \mathrm{N}, 152^{\circ} 38^{\prime} 00^{\prime \prime} \mathrm{W} ;$ BGN 1959; (map 124). Var. Agak Creek.

Eskimo word, said to mean "file"; reported about 1930 by Marshall (1956, p. 102).

Agiak Lagoon: lagoon, on Chukchi Sea coast, E of Cape Sabine and W of mouth of Mutaktuk
Creek, 38 mi. NW of Mount Kelly, Arctic Slope; $68^{\circ} 55^{\prime} \mathrm{N}, 164^{\circ} 30^{\prime} \mathrm{W}$; (map 130).

Eskimo name meaning "to file (or rub)" obtained at Point Lay and reported in 1956 by Orth; so called because the shoreward side of the offshore bar is serrated and resembles teeth of a file (Chapman and Sable, 1960, p. 52).

Agiak Lake: lake, $1.5 \mathrm{mi}$. long, at head of Agiak Creek, $9 \mathrm{mi}$. S of Chandler Lake and $31 \mathrm{mi}$. W of Anaktuvuk Pass, Brooks Ra.; $68^{\circ} 04^{\prime} 30^{\prime \prime}$ N, 152 58'00' W; BGN 1959; (map 134). Var. Agak Lake.

Eskimo name, meaning "file," reported in 1945 by USGS.

Agiak Point: point of land, between Alatakrok and Kuk Rivers, $11 \mathrm{mi}$. S of Wainwright Arctic Plain; $70^{\circ} 29^{\prime} 05^{\prime \prime} \mathrm{N}, 159^{\circ} 54^{\prime} 15^{\prime \prime} \mathrm{W}$; (map 146).

Eskimo name reported in 1926 by USGS Agiapuk River: stream, heads $8 \mathrm{mi}$. NE of Black $\mathrm{Mtn}$. and flows SE $60 \mathrm{mi}$. to Imuruk Basin, $21 \mathrm{mi}$. SE of Teller, Seward Penin. High.; $65^{\circ} 10^{\prime} \mathrm{N}, 165^{\circ} 41^{\prime} \mathrm{W}$; (map 111). Var Ageapuk River, Agee-ee-puk River, Ageeopak River, Ageepuk River, Ageopuk River, Agiopuk River, Ahgeeapuk River.

Eskimo name reported in 1827 as "Ageeee-puk" by Capt. F. W. Beechey, RN (Baker, 1906 , p. 83).

Agiopuk River: stream, see Agiapuk River.

Agisåm-koverushka': hill, $542 \mathrm{ft}$., between High and First Bluffs, on $N$ coast of Saint George I., in Pribilof Is.; $56^{\circ} 36^{\prime} 10^{\prime \prime} \mathrm{N}, 169^{\circ} 37^{\prime} 10^{\prime \prime} \mathrm{W}$; (map 38).

Aleut-Russian name reported by Putnam (1903, p. 1013), USC\&GS, meaning "watch place hill."

Agis-chucka: depression, on bluff line $\mathbf{E}$ of High Bluff, on $\mathrm{N}$ coast of Saint George $\mathrm{I}$., in Pribilof Is.; $56^{\circ} 36^{\prime} 00^{\prime \prime} \mathrm{N}, 169^{\circ} 38^{\prime} 30^{\prime \prime} \mathrm{W}$; (map 38)

Aleut name reported by Putnam (1903, p. 1013), USC\&GS, meaning "hollow near the watch place.'

Agisógh: bluff, overlooking Zapadni Rookery, on Zapadni Bay, on SW coast of Saint George $\mathrm{I}$., in Pribilof Is.; $56^{\circ} 33^{\prime} 20^{\prime \prime} \mathrm{N}, 169^{\circ} 39^{\prime} 50^{\prime \prime}$ W; (map 38).

Aleut name reported by Putnam (1903, p. 1013), USC\&GS, meaning "the watch place." Agisogh Bluff: bluff, "on the west side and overlooking Staraya Artil rookery, north shore of St. George island, Bering sea, near longitude $169^{\circ} 36^{\prime}$. ."

"Aleut name, the watch place, reported by Putnam in 1897" (Baker, 1906, p. 83).

Agitator Creek: stream, flows SE $3 \mathrm{mi}$. to Middle

Fork Chandalar River, $14 \mathrm{mi}$. SSE of Chandalar, Brooks Ra.; $67^{\circ} 19^{\prime} 00^{\prime \prime} \mathrm{N}, 148^{\circ} 15^{\prime} 30^{\prime \prime} \mathrm{W}$ (map 123).

Prospectors' name obtained in 1909 by A. G. Maddren (in Brooks and others, 1910, pl. 7), USGS.

Agiukchugamute: locality, see Agiukchuk.

Agiukchuk: locality, on left bank of Kolovinerak River, $95 \mathrm{mi}$. WSW of Bethel, Yukon-Kuskokwim Delta; $60^{\circ} 29^{\prime} \mathrm{N}, 164^{\circ} 27^{\prime} \mathrm{W}$; (map 58). 
Var. Agiukchugamute, Aguikchuk, Monrak, Monroke.

Eskimo village visited in December 1878 by E. W. Nelson, U.S. Signal Service; name reported by him was "Agiukchugamute," that is, "pcople of Agiukchuk." The 10th Census in 1880 listed the name from Nelson, pertaining to a village of 35 inhabitants. USC\&GS reported in 1949 that the village was abandoned and the site, of ten used for a fish camp, is now called "Monrak" or "Monroke." The 1940 Census listed the place as Aguikchuk with 65 people, but this may refer to those who were at the fish camp or in the vicinity.

Agivarik: locality, on right bank of Mulchatna River, $96 \mathrm{mi}$. NE of Dillingham, Bristol Bay Low.; $59^{\circ} 59^{\prime} \mathrm{N}, 156^{\circ} 27^{\prime} \mathrm{W}$; (map 52 ).

Eskimo village or camp published on a 1917 map by the Alaska Steamship Co. The place is no longer occupied.

Agivarik: locality, see Agivavik.

A'givavik: locality, right bank of Ugashik River, Bristol Bay Low.; (map 36). Var. Agivarik.

Former Eskimo village listed in the 1880 Census with a population of $52 ; 30$ in 1890 . Aglidakh: island, see Agligadak Island.

Agligadak Island: island, $0.2 \mathrm{mi}$. across, in Andreanof Is., $3 \mathrm{mi}$. E of Amlia I., Aleutian Is.; $52^{\circ} 06^{\prime} 30^{\prime \prime} \mathrm{N}, 172^{\circ} 53^{\prime} 30^{\prime \prime} \mathrm{W}$; (map 19). Var. Aglidakh, Ostrov Agligadak.

Published as "O[strov] Agligadak," by Capt. Tebenkov (1852, map 27), IRN; from the Aleut word "agligaq," meaning "albatross" (Geoghegan, 1944, p. 99).

Agligadak Reefs: reefs, extend E $3 \mathrm{mi}$. from E tip of Amlia I., Aleutian Is.; $52^{\circ} 06^{\prime} 15^{\prime \prime} \mathrm{N}$, $172^{\circ} 55^{\prime} 00^{\prime \prime} \mathrm{W}$; (map 19).

Named for Agligadak Island; published by USC\&GS in the 1944 Aleutian Coast Pilot (p. 89).

Aglungak Hills: hills, $1,200 \mathrm{ft}$., NE of junc. of Noatak and Nimiuktuk Rivers, Brooks Ra.; $68^{\circ} 08^{\prime} \mathrm{N}, 159^{\circ} 52^{\prime} \mathrm{W}$; (map 131).

Eskimo name referring to "hole in the top of the tent"; obtained at Noatak in 1956 by Orth.

Agnak Rocks: rocks, see Aiugnak Columns.

Agnayaghit Cape: point of land, see Agnayaghit Point.

Agnayaghit Point: point of land, on NE coast of St. Lawrence I., $23 \mathrm{mi}$. SE of Savoonga; $63^{\circ} 28^{\prime} 30^{\prime \prime} \mathrm{N}, 169^{\circ} 57^{\prime} 30^{\prime \prime} \mathrm{W}$; BGN 1951; (map 93). Var. Agnayaghit Cape, Akhnakhyakhit Point, Arnaryarit Point.

Eskimo name recommended by the Savoonga village council; reported in 1949 by Maj. H. B. Allen, USAF.

Agnes Beach: locality, on South Channel of Unalaska Bay, $0.3 \mathrm{mi}$. SW of Unalaska, NE coast of Unalaska I., Aleutian Is.; $53^{\circ} 52^{\prime} 20^{\prime \prime}$ $\mathrm{N}, 166^{\circ} 32^{\prime} 30^{\prime \prime} \mathrm{W}$; (map 23). 9008.

Published in 1965 by USC\&GS on Chart

Agnes Cove: cove, $1 \mathrm{mi}$. wide, on $\mathrm{E}$ coast of Aialik Penin., $25 \mathrm{mi}$. S of Seward, Chugach Mts.; $59^{\circ} 47^{\prime} \mathrm{N}, 149^{\circ} 34^{\prime} \mathrm{W}$; $B G N$ 1910; ( map 49).
Named in 1910 by U. S. Grant, USGS, "after our launch Agnes."

Agnes Creek: stream, flows SE $8 \mathrm{mi}$. to Cross Creek, $1.8 \mathrm{mi}$. $\mathrm{N}$ of that stream's junc. with Ambler River and $22 \mathrm{mi}$. $\mathbf{N}$ of Shungnak, Brooks Ra.; $67^{\circ} 13^{\prime} \mathrm{N}, 157^{\circ} 24^{\prime} \mathrm{W}$; (map 126)

Local name reported in 1956 by USGS.

Agnes Creek: stream, flows SW $3.5 \mathrm{mi}$. to Flat Creek, $6 \mathrm{mi}$. E of Wild Lake and $33 \mathrm{mi}$. W of Wiseman, Brooks Ra.; 67 $29^{\prime} 30^{\prime \prime} \mathrm{N}, 151^{\circ}$ $21^{\prime} 00^{\prime \prime} \mathrm{W} ; B G N$ 1932; (map 124).

Local name; reported in 1932 by Robert Marshall.

Ago Bay: bight, see Hallo Bay.

Agomekelenanak: locality, "nin the Kuskokwim district." Var. Ahgomekhelanaghamiut.

Former Eskimo camp or village listed as "Ahgomekhelanaghamiut" with a population of 15 in the 1890 Census.

Agony Point: point of land, on SE coast of Little Tanaga I., Aleutian Is.; $51^{\circ} 47^{\prime} 45^{\prime \prime} \mathrm{N}, 176^{\circ}$ 05'40" W; BGN 1936; (map 17). Var. Cape Nazan

Named in 1934 by members of the U.S. Navy Aleutian Island Survey Expedition. Agoo: lake, see Aropuk Lake.

Agoocharuk: stream, see Agucharuk River.

Agoocharuk River: stream, see Agucharuk River. Agookauchuk: locality, see Bluff.

Agoulouikatuk: lake, see Aleknagik, Lake.

Agouloukpak: lake, see Nerka, Lake.

Agouyak: village, see Egegik.

Agouyak River: stream, see Egegik River.

Agphtapuk Cape: point of land, see Agtapuk Point.

Agphtapuk Point: point of land, see Agtapuk Point.

Agre Creek: stream, flows SW $5.8 \mathrm{mi}$. to Bering Sea, $42 \mathrm{mi}$. NW of Nome, Seward Penin. High.; 64 ${ }^{\circ} 55^{\prime} \mathrm{N}, 166^{\circ} 27^{\prime} \mathrm{W}$; (map 94).

Prospectors' name reported in 1900 by E. C. Barnard (in Brooks, 1901, pl. 17), USGS.

Agrepin Bay: bay, see Agripina Bay.

Agriktagvik Bank: bank, on right side of Kangnirvik Creek, $24 \mathrm{mi}$. NE of Kivalina, Brooks Ra.; $68^{\circ} 02^{\prime} \mathrm{N}, 164^{\circ} 02^{\prime} \mathrm{W}$; (map 130).

Eskimo name meaning "rolling down place." According to E. S. Burch, who reported this name in 1966 , it is so called because a man once slipped and rolled down the bank into the water.

Agriktagvik Creek: stream, flows $\mathrm{S} 5 \mathrm{mi}$. to Kangnirvik Creek, $24 \mathrm{mi}$. NE of Kivalina, Brooks Ra.; $68^{\circ} 02^{\prime} \mathrm{N}, 164^{\circ} 02^{\prime} \mathrm{W}$; (map 130). Var. Agriktagvik Koogoranga, Agriqtagwik Kuugauzanga.

Eskimo name reported in 1966 by E. S. Burch.

Agriktagvik Koogoranga: stream, see Agriktagvik Creek.

Agripina Bay: bay, $9 \mathrm{mi}$. NE of Cape Providence, extends $\mathrm{E} 2.8 \mathrm{mi}$, off $\mathrm{S}$ coast Alaska Penin., 43 mi. NE of Sutwik I., Aleutian Ra.; $57^{\circ} 06^{\prime} \mathrm{N}, 156^{\circ} 25^{\prime} \mathrm{W}$; (map 36). Var. Agrepin Bay, Agripin Bay, Agrippina Bay, Agrippine Baie, Zaliv Agripinni.
Named in 1832 by Ens. Vasiliev and published as "Agrippine baie" by Capt. Lutke (1836, p. 277), IRN.

Agripin Bay: bay, see Agripina Bay.

Agrippina Bay: bay, see Agripina Bay.

Agrippine Baie : bay, see Agripina Bay.

Agripinni, Zaliv: bay, see Agripina Bay.

Agriqtagwik Kuugauzanga: stream, see Agriktagviк Creek.

Agsinoralak Beach: beach, on Chukchi Sea coast S of Point Barrow, Arctic Plain; $71^{\circ} 22^{\prime}$ N, $156^{\circ} 31^{\prime} \mathrm{W}$; (map 153).

Eskimo name recorded at Barrow in 1965 by Orth. The beach on the Elson Lagoon side is "Arigilivik."

Agtapuk Point: point of land, on $\mathrm{N}$ coast of St. Lawrence I., $4.5 \mathrm{mi}$. SE of Gambell; $63^{\circ} 44^{\prime}$ $\mathrm{N}, 171^{\circ} 39^{\prime} \mathrm{W}$; BGN 1951; (map 93). Var. Agphtapuk Cape, Agphtapuk Point, Cape Noovookiak, Noovookiak Cape, Nuvurarak Point.

Eskimo name reported in 1949 by Maj. $\mathrm{H}$. B. Allen, USAF. According to Orth, in 1965, the people of Gambell called this point of land "Nuvurarak" meaning "pointed place." Aguada, Rio de la: stream, flows N $1.5 \mathrm{mi}$. to Aguada Cove, on $W$ coast of Suemez I., Alex. Arch.; 55 $16^{\prime} 10^{\prime \prime} \mathrm{N}, 133^{\circ} 25^{\prime} 45^{\prime \prime} \mathrm{W}$; (map 4).

Spanish name meaning "river of the watering place," given in 1779 by Francisco Antonio Maurelle, "probably where Arteaga took water in 1779" (Wagner, 1937, p. 1371).

Aguada Cove: bight, $1 \mathrm{mi}$. across, on $\mathrm{S}$ shore of Port Santa Cruz, on W coast of Suemez I., Alex. Arch.; $55^{\circ} 16^{\prime} 15^{\prime \prime} \mathrm{N}, 133^{\circ} 25^{\prime} 45^{\prime \prime} \mathrm{W}$; $B G N$ 1923; (map 4). Var. Aquada Cove.

Spanish name meaning "watering place" given in 1923 by USC\&GS; derived from the name "Rio de la Aguada." See Aguada, Rio de la.

Agua Dulce, Riachuelo de: stream, flows NNW $5 \mathrm{mi}$. to Disenchantment Bay, $2 \mathrm{mi}$. $\mathrm{E}$ of point Latouche; $59^{\circ} 54^{\prime} \mathrm{N}, 139^{\circ} 35^{\prime} \mathrm{W}$; (map 46).

Spanish name, meaning "little stream of fresh water," published by Capt. Alessandro Malaspina on a 1791 "plano."

Agucharuk River: stream, "an affluent of Naniwuknuk lake or of Lake Agnu," about $61^{\circ} \mathrm{N}$, $164^{\circ} \mathrm{W}$. Var. Agoocharuk.

Eskimo name reported in 1897 by Lt. D. H. Jarvis, USRCS, as "Agoocharuk."

Aguchik, Ostrov: island, see Aguchik Island.

Aguchik Island: island, $1.2 \mathrm{mi}$. long, in Kukak Bay, on S coast of Alaska Penin., in Katmai National Monument, $25 \mathrm{mi}$. E of Mount Katmai, Aleutian Ra.; $58^{\circ} 17^{\prime} 30^{\prime \prime} \mathrm{N}, 154^{\circ} 16^{\prime} 45^{\prime \prime}$ W; BGN 1924; (map 42). Var. Agachuk Island, Aguvhik Island, Ostrov Aguchik.

Aleut name reported in 1831 by Ens. Vasiliev, IRN, and published in 1847 as "Ostrov Aguchik," or "Aguvhik Island," on Russian Hydrog. Dept. Chart 1378.

Agueda Point: point of land, NE tip of San Juan Bautista I., Alex. Arch.; 55 $27^{\prime} 05^{\prime \prime} \mathrm{N}$, $133^{\circ} 14^{\prime} 30^{\prime \prime}$ W; (map 4). Var. Aqueda Point, Mys San Ageda, Punta de Santa Agueda, San Ageda Point. 
Name given in $1775-79$ by Don Juan de la. Bodega y Quadra and Francisco Antonio Maurelle as "Punta de Santa Agueda," meaning "Point of Saint Agueda."

Agughum udda: bay, see Northwest Harbor. Aguirre: point of land, see Steele, Point.

Aguirre, Point: point of land, on NW coast of San Fernando I., Alex. Arch.; 55 $33^{\prime} 20^{\prime \prime}$ N, $133^{\circ} 26^{\prime} 55^{\prime \prime}$ W; (map 4). Var. Punta de Aguirre.

Spanish name given in $1775-79$ by Don Juan de la Bodega y Quadra and Francisco Antonio Maurelle as "Punta de Aguirre," or "Point of Aguirre," "probably after one of the pilots of the 1779 expedition, Juan Bautista Aguirre * * *" (Wagner, 1937, p. 371).

Aguirre Bay: bight, $0.7 \mathrm{mi}$. across, on NW coast of San Fernando I., Alex. Arch.; 55 $33^{\prime}$ N, $133^{\circ} 27^{\prime} \mathrm{W}$; BGN 1923; (map 4).

Spanish name given in 1923 by USC\&GS; derived from Point Aguirre.

Agu Lake: lake, sce Aropuk Lake.

Agulakpak: locality, "near Kuskokwim River." Var. Ahgulakhpaghamiut.

Former Eskimo camp or village listed as "Ahgulakhpaghamiut" with a population of 19 in the 1890 Census.

Aguliagamiut: locality, see Arolik.

Aguliak: locality, see Arolik.

Aguliak Islands: islands, extend N-S $0.7 \mathrm{mi}$., off $W$ coast of Knight I., on E side of Knight Island Passage, $9 \mathrm{mi}$. NE of Chenega, Chugach Mts.; $60^{\circ} 22^{\prime} 00^{\prime \prime} \mathrm{N}, 147^{\circ} 52^{\prime} 15^{\prime \prime} \mathrm{W}$; (map 63). V'ar. Aguliak Island.

Eskimo name published in 1917 by USC\&GS.

Aguligak, Ostrov: island, see Aguligik Island.

Aguligamute: locality, see Arolik.

Aguligat Island: island, see Aguligik Island.

Aguligik Island: island, $1 \mathrm{mi}$. long, in Kukak Bay, W of Kukak, on S coast of Alaska Penin., in Katmai National Monument, 28 mi. ENE of Mount Katmai, Aleutian Ra.; $58^{\circ} 19^{\prime} \mathrm{N}$, $154^{\circ} 12^{\prime} \mathrm{W}$; (map 42). Var. Aguligat Island, Ostrov Aguligak, Uguligik Island.

Aleut name meaning "hawk" reported as "Aguligak" in 1831 by the Russian navigator Ens. Vasiliev.

Aguliuk Point: point of land, on NW coast of Umnak I., Aleutian Is.; $53^{\circ} 28^{\prime} 45^{\prime \prime} \mathrm{N}, 168^{\circ}$ 20'15" W; (map 22). Var. Chidak, Mys Agulyuk, Mys Chidakh.

Aleut name published by Capt. Tebenkov (1852, map 25), IRN, as "M[ys] Agulyuk," or "Cape Agulyuk," and "M[ys] Chidakh," or "Cape Chidakh." According to R. H. Geoghegan, these names are from the Aleut "aguliq," meaning "sparrow-hawk," and "cidaq," meaning "young birds."

Agulogak Lake: lake, see Naknek Lake.

Agulogak River: stream, see Naknek River.

Agulok: locality, on Unalaska I.; exact location unknown.

Former Aleut village or camp cited by Hodge (1907, p. 28), BAE, as reported by Coxe $(1787$, p. 159$)$.

Agulowak River: stream, flows SW, from River Bay of Lake Nerka, $4 \mathrm{mi}$. to Lake Aleknagik,
$30 \mathrm{mi}$. NW of Dillingham, Kilbuck-Kuskokwim Mts.; $59^{\circ} 24^{\prime} \mathrm{N}, 158^{\circ} 54^{\prime} \mathrm{W}$; BGN 19.31; (map 52). Var. Ahguhlerok.

Eskimo name, "Ahguhlerok," said to mean "many rapids": reported in 1910 by H. C. Fassett, and published in 1929 as "Agulowak River" by USBF.

Agulukok: lake see Nerka, Lake.

Agulukpak: locality, probably on Agulukpak River between Lakes Nerka and Beverley; $59^{\circ} 35^{\prime} \mathrm{N}, 158^{\circ} 30^{\prime} \mathrm{W}$; (map 52). Var. Agulukpuk, Agulukpukmiut.

Former Eskimo camp or settlement area listed in the 1890 Census as "Agulukpukmiut," i.e. "Agulukpak people," with a population of 22.

Agulukpak: lake, see Nerka, Lake.

Agulukpak River: stream, heads in Lake Beverley, flows S 2 mi. to Lake Nerka, $40 \mathrm{mi}$. N of Dillingham, Kilbuck-Kuskokwim Mts.; $59^{\circ} 38^{\prime}$ N., $158^{\circ} 32^{\prime \prime}$ W; BGN 1931; (map 52).

Eskimo name; published in 1929 by USBF. Agulukpok Lake: lake, see Nerka, Lake. Agulukpuk: locality, see Akuliukpak. Agulukpukmiut: locality, see Akuliukpak.

$\Lambda$ gulyuk, Mys: point of land, see Aguliuk Point. Agumak: locality, "in the Kuskokwim district"

Former Eskimo village or camp listed with a population of 41 in the 1890 Census.

Agumsadak, Cape: point of land, on SE coast of Umak I., Aleutian Is.; $51^{\circ} 51^{\prime} 00^{\prime \prime} \mathrm{N}, 175^{\circ}$ 57'45"' W; BGN 1936; (map 18). Var. Cape Agumsadakh.

Aleut name recorded by members of the North Pacific Exploring Expedition of 1855. Agumsadakh, Cape: point of land, see Agumsadak, Cape.

Agunalaksha: island, see Unalaska Island.

Agusta, Mount: mountain, see Augusta, Mount. Agusta Glacier: glacier, see Augusta Glacier.

Agutiroak Creek: stream, flows NE $10 \mathrm{mi}$, to Meade River S of Pikroka Creek, $17 \mathrm{mi}$. SE of village of Meade River, Arctic Plain; 70 14'$30^{\prime \prime} \mathrm{N}, 15^{\circ} 09^{\prime} 00^{\prime \prime} \mathrm{W}$; (map 147).

Eskimo name reported in 1956 by T. E. Taylor, USGS.

Agutka, Cape: point of land, see Ayutka, Cape. Agutukpok River: stream, see Kokwok River.

Aguvhik Island: island, see Aguchik Island.

Agvignak Creek: stream, flows $\mathrm{S} 1 \mathrm{mi}$. to Wulik River, $12 \mathrm{mi}$. NE of Kivalina, Kotzebue-

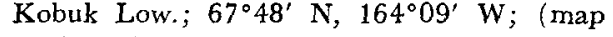
128). Var. Agwignam Kuugauzanga, Avignam Koogowranga.

Eskimo name spelled "Avenak" in 1950 by USC\&GS

Agvignak Hill: hill, $703 \mathrm{ft} ., 12 \mathrm{mi}$. NE of Kivalina, Arctic Slope; $67^{\circ} 49^{\prime} \mathrm{N}, 164^{\circ} 10^{\prime} \mathrm{W}$; (map 128).

Eskimo name meaning "like a whale" reported in 1966 by E. S. Burch.

Agvik: village, see Platimum.

Agwignam Kuugauzanga: stream, see Agvignak Creek.

Ahagateyeit Lake: lake, $0.5 \mathrm{mi}$. long, on $\mathrm{S}$ bank of Kanuti River, $20 \mathrm{mi}$. SE of Allakaket, Kanuti Flats; $68^{\circ} 17^{\prime} 45^{\prime \prime} \mathrm{N}, 152^{\circ} 23^{\prime} 30^{\prime \prime} \mathrm{W}$; (map 117).
Koyukan Indian name obtained in 1956 at Allakaket by T. E. Taylor, USGS.

Ahaliknak Creek: stream, heads in Maiyumerak Mts. of the Baird Mts., flows SW $12 \mathrm{mi}$. to Eli River, 28 mi. NE of Noatak, Brooks Ra.; $67^{\circ} 43^{\prime} \mathrm{N}, 161^{\circ} 59^{\prime} \mathrm{W}$; ( $\operatorname{map} 127$ ).

Eskimo name obtained in 1955 by the U.S. Army Corps of Engineers.

Ahaliorak Lake: lake, $1.7 \mathrm{mi}$. long, between Tuluga and Anaktuvuk Rivers, $18 \mathrm{mi}$. NE of Gunsight Mtn. and $54 \mathrm{mi}$. NE of Anaktuvuk Pass, Arctic Slope; 68 $54^{\prime} \mathrm{N}, 151^{\circ} 19^{\prime} \mathrm{W}$; $B G N$ 1960; (map 134). Var. Heart Lake.

Eskimo name reported in 1956 by USGS to mean "old woman."

Ahchakeerock: hummock, see Atsakirak Mound. Ahding-Ingria: hill, see Ahding Ingrid Mountain.

Ahding Ingrid Mountain: hill, $640 \mathrm{ft}$., $26 \mathrm{mi}$. SW of Cape Etolin, on Nunivak I.; $60^{\circ} 08^{\prime} \mathrm{N}$, $166^{\circ} 35^{\prime} \mathrm{W}$; (map 57). Var. Ahding-Ingria.

Eskimo name meaning "Ahding [river] Ingria [mountain]" reported in 1949 by USC\&GS. The " $d$ " ending appears to have originated from a typographical error.

Ahdingmiut: locality, on left bank of Ahding River, 24 mi. SW of Cape Etolin, near $\mathrm{N}$ coast of Nunivak I.; $60^{\circ} 16^{\prime} 31^{\prime \prime} \mathrm{N}, 166^{\circ} 47^{\prime} 00^{\prime \prime} \mathrm{W}$; (map 57).

Eskimo summer camp reported in 1949 by USC\&GS.

Ahding River: stream, flows NW $24 \mathrm{mi}$. to Bering Sea, $24 \mathrm{mi}$. SW of Cape Etolin, on $\mathrm{N}$ coast of Nunivak I.; $60^{\circ} 17^{\prime} 40^{\prime \prime} \mathrm{N}, 166^{\circ} 46^{\prime} 45^{\prime \prime} \mathrm{W}$; (map 57).

Eskimo name obtained in 1949 by USC\&GS.

Ahduck Bay: bay, $1.5 \mathrm{mi}$. across, on NE coast of Khantaak I., on SE side of Yakutat Bay, 4.4 mi. N of Yakutat, Malaspina Coastal Plain; $59^{\circ} 36^{\prime} 45^{\prime \prime} \mathrm{N}, 139^{\circ} 43^{\prime} 30^{\prime \prime} \mathrm{W}$; ( $\left.\operatorname{map} 46\right)$.

Tlingit Indian name published by the USGS in 1959.

Ahgahruk Creek: stream, see Agarak Creek.

Ahgahyoukuk Greek: stream, see Angayukak Creek.

Ahgahyoukuk Mountain: hill, see Angayukak Hill.

Ahgecapuk River: stream, see Agiapuk River.

Ahgeyagrock: mountains, see Tahinichok Mountains.

Ahgomekhelanaghamiut: locality, see Agomekelenanak.

Ah-Gude-Le-Rock: locality, on spit on Chukchi Sea coast, 16 mi. NE of Cape Prince of Wales, at $\mathrm{W}$ end of Seward Penin., Kotzebue-Kobuk Low.; $65^{\circ} 47^{\prime} \mathrm{N}, 167^{\circ} 44^{\prime} \mathrm{W}$; (map 111).

Site of an Eskimo campground; the name was recorded on the 1908 "Map of Seward Peninsula" by Arthur Gibson.

Ah-guh-le-rok: locality, on right bank of mouth of Agulowak River, $30 \mathrm{mi}$. NW of Dillingham, Kilbuck-Kuskokwim Mts.; $59^{\circ} 24^{\prime}$ N, $158^{\circ} 54^{\prime}$ W; (map 52).

Eskimo name used by H. C. Fassett, USBF, in 1910. The locality took its name from the stream.

Ahguhlerok: stream, see Agulowak River. 
Ahguhlerok Creek: stream, flows SE $6 \mathrm{mi}$. to Nuyakok Lake, $64 \mathrm{mi}$. N of Dillingham, Kilbuck-Kuskokwim Mts. ; $59^{\circ} 57^{\prime} \mathrm{N}, 158^{\circ} 50^{\prime} \mathrm{W}$; (map 52).

Eskimo name shown as "Ah-guh-le-rok" on a 1910 manuscript map by H. C. Fassett, USBF.

Ahguhlerok Creek: stream, flows $\mathrm{S} 3 \mathrm{mi}$. to Okstukuk Lake, $35 \mathrm{mi}$. N of Dillingham, Bristol Bay Low.; $59^{\circ} 33^{\prime} \mathrm{N}, 158^{\circ} 18^{\prime} \mathrm{W}$; (map 52).

Eskimo name shown as "Ah-guh-le-rok" on a 1910 manuscript map by H. C. Fassett, USBF.

Ah-guh-lok-puk: locality, see Akuliukpak.

Ahgulakhpaghamiut: locality, see Akuliukpak. Ahguliagamiut: locality, see Aklut.

Ah-kah-loo-gen: stream, see Alkalugen Creek.

Ah-kah-nuk-lin-uk Slough: stream, see Akanuklinuk Slough.

Ahkaloograak Pahnga: locality, see Akalugrak Panga.

Ahkaloograhm Koonga: stream, see Akalugram Creek.

Ahkalurak: locality, see Akalurak.

Ahkalurak: stream, see Akalolik Creek.

Ahkalurak Creek : stream, see Alkalugen Creek.

Ahkaluruk: locality, see Akalurak.

Ahkaluruk: stream, see Akalolik Creek.

Ahkaluruk River: stream, see Alkalugen Creek.

Ahkargichek Mountain: mountain, see Akargichek Mountain.

Ahkiok: village, see Akhiok.

Ahkitook: locality, at mouth of Anluk Creek, $12 \mathrm{mi}$. SW of Cape Etolin, on $\mathbf{N}$ coast of Nunivak I.; $60^{\circ} 22^{\prime} 45^{\prime \prime} \mathrm{N}, 166^{\circ} 29^{\prime} 30^{\prime \prime} \mathrm{W}$; (map 57). Var. Aqituk.

Eskimo seal camp used in the fall; reported in 1949 by USC\&GS.

Ahkiuiksnuk Lake: lake, see Ahkiulksnuk Lake. Ahkiulksnuk Lake: lake, $0.1 \mathrm{mi}$. across, $2.5 \mathrm{mi}$. E of Roberts Mtn. and $15 \mathrm{mi}$. N of Cape Mendenhall, on Nunivak I.; $60^{\circ} 01^{\prime} 45^{\prime \prime} \mathrm{N}$, $166^{\circ} 11^{\prime} 30^{\prime \prime} \mathrm{W}$; (map 57). Var. Ahkiuiksnuk Lake, Ahkiwixnux, Akiwikhnakh.

Eskimo name for a small lake in a crater; reported in 1949 by USC\&GS as "Ahkiwixnux." The present spelling is from the U.S. Army Corps of Engineers in 1952.

Ahkiwixnux: lake, see Ahkiulksnuk Lake.

Ahklun Mountains: mountains, elev. 1,000$3,000 \mathrm{ft}$, in group $80 \mathrm{mi}$. long and $30 \mathrm{mi}$. wide, extend SW from Kanektok River and Narogurum River to Hagemeister Strait and Kuskokwim Bay, Kilbuck-Kuskokwim Mts. $59^{\circ} 45^{\prime} \mathrm{N}, 160^{\circ} 00^{\prime} \mathrm{W}$ [NE end], 58 $52^{\prime} \mathrm{N}$, $161^{\circ} 40^{\prime} \mathrm{W}$ [SW end]; (map 53). Var. Oklune Mountains.

Eskimo name reported in 1898 as "Oklune" by J. E. Spurr and W. S. Post, USGS.

Ahkolikotak Head: promontory, on $\mathrm{S}$ shore of Nash Harbor, $29 \mathrm{mi}$. SW of Cape Etolin, on Nunivak I.; $60^{\circ} 13^{\prime} 00^{\prime \prime} \mathrm{N}, 166^{\circ} 52^{\prime} 30^{\prime \prime} \mathrm{W}$; (map 57). Var. Akolikotak Head.

Eskimo name obtained in 1949 by USG\&GS. Ahkooleerak: locality, see Akulirak.

Ahkooleerak: portage, see Akulirak.

Ahkoolik River: stream, see Akulik River.
Ahkoorock: bluff, see Akurak Bluff.

Ahkootahgrock: hills, see Akutagrak Hills.

Ah-ko-se-a-ge-wick: stream, see Beaver Creek.

Ahk-tung-ha-mut: locality, on $\mathrm{W}$ shore Nushagak Bay, on W bank at mouth of Igushik River, Bristol Bay Low.; (map 40). Var. Ahk-twngha-mut.

Former Eskimo camp or settlement reported in 1910 by H. C. Fassett, USBF,

Ahk-twng-ha-mut: locality, see Ahk-tung-hamut.

Ah-kúh-puk: locality, see Akokpak.

Ahkvaystkie: locality, see Akvetskoe.

Ah-lai-luk-ah: locality, see Elilakok.

Ah-lash-ok: stream, see Alatna River.

Ah-lek-nug-uk: village, see Dillingham.

Ah-lek-nüg-uk: village, see Wood River.

Ahleknuguki: village, see Aleknagik.

Ahleknuguk Lake: lake, see Aleknagik, Lake.

Ahleknuguk River: stream, see Wood River.

Ahlik River: stream, flows NW 7 mi. to Bering Sea, $1 \mathrm{mi}$. E. of Mikisagimiut and $41 \mathrm{mi}$. SW of Cape Etolin, on Nunivak $\mathrm{l}$.; $60^{\circ} 13^{\prime} \mathrm{N}$, $167^{\circ} 15^{\prime} \mathrm{W}$; (map 57). Var. Alikh River.

Eskimo name reported in 1949 by USC\&GS to mean "stream."

Ahliktongnak Lake: lake, see Aliktongnak Lake.

Ahlolúkroq: locality, see Alolukrok.

Ahlucheyak Hill: hill, see Ulakaia Hill.

Ah-lue-ga-wik: spring, see Reed River Hot Spring.

Ahmikdoligamiut: locality, $26 \mathrm{mi}$. SE of Cape Etolin, on W shore of Etolin Strait, on Nunivak I. ; $60^{\circ} 08^{\prime} 15^{\prime \prime} \mathrm{N}, 165^{\circ} 41^{\prime} 20^{\prime \prime} \mathrm{W}$; (map 57). Var. Amiqdoligamiut.

Eskimo fish camp reported in 1949 by USC\&GS.

Ahmocktoosuk: promontory, see Crowbill Point. Ahneeyahk: locality, see Aniyak.

Ahneeyahm Koonga: water passage, see Tukrok River.

Ahneéyouyahktuvik Creek: stream, see Aniyuyaktuvik Creek.

Ahnevik Creek: stream, see Anivik Creek.

Ahnewetut Creek: stream, heads in Great Kobuk Sand Dunes, flows N 14 mi. to Kobuk River, Brooks Ra.; $67^{\circ} 10^{\prime} \mathrm{N}, 158^{\circ} 47^{\prime} \mathrm{W}$; (map 126).

Eskimo name reported in 1956 by USGS

Ahnewetut Lake: lake, $2 \mathrm{mi}$. long, drains $\mathrm{W}$ to Ahnewetut Creek, $3 \mathrm{mi} \mathrm{SE}$ of that stream's junc. with Kobuk River, Brooks Ra.; 67 $09^{\prime}$ N, $158^{\circ} 39^{\prime} \mathrm{W}$; (map 126).

Eskimo name reported in 1956 by USGS.

Ahneyiyuk: mountain, see Bendeleben, Mount.

Ahnowiksat Rocks: rocks, $16 \mathrm{mi}$. SW of Cape Etolin, in Bering Sea, off $\mathrm{N}$ coast of Nunivak I. ; $60^{\circ} 21^{\prime} 20^{\prime \prime} \mathrm{N}, 166^{\circ} 34^{\prime} 40^{\prime \prime} \mathrm{W}$; (map 57). Var. Anoikhat Rocks.

Eskimo name obtained in 1949 by USC\&GS. Ahnowtahlooram Koogowranga: stream, see Anotalurak Creek.

Ah-nu-zuk-a-nuk Pass: water course, see Anuzukanuk Pass.

Aho Bay: bight, see Hallo Bay.

Aho Glacier: glacier, trends NW 2 mi. to its 1958 terminus, $1 \mathrm{mi}$. E of Lake Clark Pass, $50 \mathrm{mi}$. WNW of Kenai, Aleutian Ra.; 60 $49^{\circ} 30^{\prime \prime} \mathrm{N}$, $152^{\circ} 39^{\prime} 30^{\prime \prime} \mathrm{W}$; (map 62).
A Finnish surname meaning "meadow" reported in 1958 by USGS. See Aho Lake.

Aho Lake: lake, $1,700 \mathrm{ft}$. long, $\mathrm{N}$ of Friday Creek, $46 \mathrm{mi}$. NW of Tyonek, Alaska Ra.; $61^{\circ} 42^{\prime} 15^{\prime \prime} \mathrm{N}, 151^{\circ} 34^{\prime} 52^{\prime \prime} \mathrm{W}$; (map 70).

Local name reported in 1954 by USGS. Named for a Finnish bush pilot, Mr. Aho (cnna), who crashed near here.

Ahpokagamiut: locality, see Apokak.

Ahpuiak Creek: stream, see Snowbank Creek. Ah-quay River: stream, see Akwe River.

Ahrayuksookwit Bluff: promontory, $10 \mathrm{mi}$. SW of Cape Etolin, extends $2 \mathrm{mi}$. along $\mathrm{N}$ coast of Nunivak I.; $60^{\circ} 22^{\prime} 45^{\prime \prime} \mathrm{N}, 166^{\circ} 26^{\prime} 30^{\prime \prime} \mathrm{W}$; (map 57). Var. Ahrayuxsoowit, Areakhsukhwit.

Eskimo name spelled "Ahrayuxsooxwit" in 1949 by USC\&GS.

Ahrayuxsooxwit: promontory, see Ahrayuksookwit Bluff.

Ahrnklin River: stream, heads on S side of Slate Peak and flows $S$ and $W 15 \mathrm{mi}$. to Gulf of Alaska at Situk, $10 \mathrm{mi}$. SE of Yakutat, Malaspina Coastal Plain; 59 $25^{\prime} 45^{\prime \prime} \mathrm{N}, 139^{\circ} 32^{\prime} 20^{\prime \prime}$ W; (map 46). Var. Aantlen River, Ahrnklin River, Antlen River, Arn Klane River.

Tlingit Indian name published as " $R$ [eka] Aantlen," or "Aantlen River," by Capt. Tebenkov (1852, map 7), IRN. Lt. Comdr. Moser (1901, pl. 43), USN, spelled the name "AhrnKlin," later to be combined to its present form. Tebenkov's name "Antlen" [sic] is shown on present-day maps as a tributary, although it appears as if both names were derived from the same Indian name.

Ahrn Klin River: stream, see Antlen River. Ahsiglirahgim: stream, see New Heart Creek. Ahsiglirahngik: hill, see Asiglirangik Hill. Ahsik Mountain: mountain, see Asik Mountain. Ah-tah-ai-ak: mountain, see Atayak Mountain.

Ahtell Creek: stream, flows SE $16 \mathrm{mi}$. to Slana

River, $1 \mathrm{mi}$. E of the village of Slana, Alaska Ra.; $62^{\circ} 42^{\prime} 30^{\prime \prime} \mathrm{N}, 143^{\circ} 57^{\prime} 00^{\prime \prime} \mathrm{W}$; (map 84). Var. Atel Creek.

Indian name reported in 1903 by W. C. Mendenhall and F. C. Schrader, USGS.

Ahtenmuk: locality see Atanik.

Ahteut: locality, near Kobuk River, about 50 mi. NE of Selawik, Brooks Ra.; near $67^{\circ} 00^{\prime}$, N, $159^{\circ} 00^{\prime} \mathbf{W}$; (map 126 ).

Archeological site reported by Giddings (1964, p. 29).

Ahtoo: island, see Attu Island.

Ahtosik Lagoon: lagoon, see Atosik Lagoon.

Ahtun Point: point of land, on $\mathrm{W}$ coast of Prince of Wales I., in Tuxekan Passage, $22 \mathrm{mi}$. $\mathrm{N}$ of Craig, Alex. Arch.; 55 $47^{\prime} 25^{\prime \prime} \mathrm{N}, 133^{\circ}$ $13^{\prime} 00^{\prime \prime} \mathrm{W}$; (map 4).

Indian name published in 1964 by USC\&GS

Ahues Bay: bay, see Porcupine Bay.

Ahushi Island: island, see Akusha Island.

Ahvak Bay: bay, see Avak Bay.

Ahvak Bay: estuary, see Iko Bay.

Ahvak Creek: stream, see Avak Creek.

Ahvak River: stream, see Avak Creek.

Ahvenuk Mountain: hill, see Avenak Mountain. 
Ahviknuk Lagoon: lagoon, see Akoviknak Lagoon.

Ahviknuk Mountain: hill, see Akoviknak Mountain.

Ahvunmun Creek: stream, see Avgunum Creek.

Ahyak: locality, see Ayak.

Ahyoksekawik: locality, see Aiacheruk.

Ahzwiryuk Bluff: bluff, on S shore of Nash Harbor, 1 mi. E of village of Nash Harbor and $31 \mathrm{mi}$. SW of Cape Etolin, on Nunivak I.; $60^{\circ} 12^{\prime} 15^{\prime \prime} \mathrm{N}, 166^{\circ} 55^{\prime} 00^{\prime \prime} \mathrm{W}$; (map 57). Var. Azwiryak Bluff.

Eskimo name obtained in 1949 by USC\&GS.

Aiachagiuk: locality, on right bank of Yukon River near the head of its delta, YukonKuskokwim Delta; (map 77). Var. Ayachaghayuk.

Former Eskimo village reported in 1898 as "Ayachaghayuk" by USC\&GS.

Aiacheruk: locality, on $\mathrm{N}$ coast of Norton Sound, $W$ of Cape Nome, Seward Penin. High.; $64^{\circ} 26^{\prime} \mathrm{N}, 165^{\circ} 02^{\prime} \mathrm{W}$; (map 94). Var. Ahyoksekawik, Ayacheruk.

Site of an Eskimo village reported by Ivan Petroff as "Ayacheruk," with a population of 60 , in the 10th Census, in 1880 . Reported as "Ahyoksekawik" in the 11th Census, in 1890. Aiahutak Lagoon: lagoon, see Aiautak Lagoon. Aiaialgutak: island, see Avatanak Island.

Aiaiepta : island, see Rootok Island.

Aiak, Cape: point of land, on E shore of Surveyor Bay, on SW coast of Unalaska I., Aleutian Is.; $53^{\circ} 15^{\prime} 35^{\prime \prime} \mathrm{N}, 167^{\circ} 30^{\prime} 00^{\prime \prime} \mathrm{W}$; (map 23). Var. Lake Point, Mys Ayak.

Capt. Tebenkov (1852, map 26), IRN, referred to this cape as "M[ys] Ayak," meaning "Cape Ayak." Named "Lake Point" in 1888 by USBF.

Aiaktak: island, see Rootok Island.

Aiaktalik: locality, on NW coast of Aiaktalik I., Kodiak I.; $56^{\circ} 42^{\prime} 15^{\prime \prime} \mathrm{N}, 154^{\circ} 06^{\prime} 40^{\prime \prime} \mathrm{W}$; (map 32). Var. Aiekhtalik, Ayakhtalik, Goose Island.

Reported in the 10th Census, in 1880 , by Petroff $(1884$, p. 29$)$ as the village of "Ayakhtalik" (now abandoned)

Aiaktalik Cove: bay, $1.5 \mathrm{mi}$. across, on NW coast of Aiaktalik I., Kodiak I.; $56^{\circ} 42^{\prime} 30^{\prime \prime} \mathrm{N}, 154^{\circ}$ 06'00" W; (map 32).

Name derived from Aiaktalik Island; published in 1943 by USC\&GS.

Aiaktalik Island: island, $4 \mathrm{mi}$. long, between Kodiak and Sitkinak Is., Kodiak I.; $56^{\circ} 42^{\prime} \mathrm{N}$, $154^{\circ} 03^{\prime} \mathrm{W}$; (map 32). Var. Ajanahtack, Anaiaktak Island, Anaiaktalik Island, Anayachtalak Island, Anayakhtakh, Geese Islands, Goose Island.

Native name published as "Anayachtalak Island" by Sauer (1802, p. 169); as "Anayakhtakh" by Lt. Sarichev (1826, map 3), IRN; as "Ajanahtack" by Adm. von Krusenstern (1827, map 17), IRN ; as "Anayakhtakh" (Anayakhtalik) by the Russian American Company in 1849; and as "Goose Island" by Petroff (1884, p. 31) in the 10th Census, in 1880

Aialik Bay: bay, $5 \mathrm{mi}$. wide, extends S $22 \mathrm{mi}$. from Aialik Glacier to Gulf of Alaska, 33 mi. S of Seward, Chugach Mts.; $59^{\circ} 40^{\prime} \mathrm{N}$, $149^{\circ} 34^{\prime}$ W; (map 49). Var. Aialikskaia Bay, Ajalik Bay, Ayalik Bay, Bukhta Ayalikskaya.

Eskimo name obtained by the Russians and recorded as "Bukh [ta] Ayalikskaya."

Aialik Cape: point of land, on S tip of Aialik Penin., $30 \mathrm{mi}$. S of Seward, Chugach Mts.; $59^{\circ} 42^{\prime} 25^{\prime \prime} \mathrm{N}, 149^{\circ} 31^{\prime} 30^{\prime \prime} \mathrm{W}$; BGN 1910; (map 49).

Named in 1908 by U. S. Grant, USGS, "after the bay."

Aialik Glacier: glacier, trends SE $4 \mathrm{mi}$. from Harding Icefield to Aialik Bay, $17 \mathrm{mi}$. SW of Seward, Chugach Mts.; $59^{\circ} 57^{\prime} \mathrm{N}, 149^{\circ} 44^{\prime}$ W; (map 49).

Named in 1909 by U. S. Grant and D. F. Higgins, USGS.

Aialik Peninsula: peninsula, extends S $20 \mathrm{mi}$ from Bear Glacier to Aialik Cape, $30 \mathrm{mi}$. S of Seward, Chugach Mts.; 59 $45^{\prime} \mathrm{N}, 149^{\circ} 35^{\prime}$ W; BGN 1930; (map 49).

Named in 1929 by USC\&GS "after the cape."

Aialikskaia Bay: $b a y$, see Aialik Bay.

Aialki Islands: islands, see Chiswell Islands.

Aiaugatak Lagoon: lagoon, see Aiautak Lagoon.

Aiaugatak Lagoon: lagoon, see Ayugatak Lagoon.

Aiaugatak River: stream, see Ayugatak Creek.

Aiautak Lagoon: lagoon, $11 \mathrm{mi}$. long, on Chukchi Sea coast, $10 \mathrm{mi}$. SE of Point Hope, Arctic Slope; 68 $17^{\prime} \mathrm{N}, 166^{\circ} 18^{\prime} \mathrm{W} ; B G N$ 1963; (map 129). Var. Aiahutak Lagoon, Aiaugatak Lagoon, Eyeautuk Lagoon.

Eskimo name obtained in 1956 at Point Hope by Orth.

Aiautaq Lagoon: lagoon, see Ayugatak Lagoon. Aichilik River: stream, heads in Romanzof Mts. at $69^{\circ} 03^{\prime} \mathrm{N}, 143^{\circ} 26^{\prime} \mathrm{W}$, flows NE $75 \mathrm{mi}$. to Beaufort Lagoon W of Egaksrak River, 22 mi. NW of Demarcation Point, Arctic Plain; $69^{\circ} 51^{\prime} \mathrm{N}, 142^{\circ} 08^{\prime} \mathrm{W}$; BGN 1959; (map 138). Var. Aichillik River, Aitshillik River, Angnun River, Angun River, Atchelik River, George River.

Eskimo name, "Aichillik," recorded in 1918 by Leffingwell (1919, p. 93) who wrote, "spelled Aitshillik by Jenness."

Aichilik River: stream, see Egaksrak River. Aichilik River: stream, see Ekaluakat River.

Aichillik River: stream, see Aichilik River. Aichillik River: stream, see Egaksrak River. Aichillik River: stream, see Ekaluakat River. Aiekhtalik: village, see Aiaktalik.

Aievak: village, "18 miles southwest of Cape Douglas, Shelikof strait."

"Native name so given to Martin in 1904 by Nikolai Kalmakof, of Katmai. (May be the same as Ashivak of Petrof, which see.) Called Douglas village by the whites" (Baker, 1906, p. 85).

Aigagin: volcano, see Makushin Volcano.

Aiken Cove: estuary, extends $\mathrm{W} 1.2 \mathrm{mi}$. off Clarno Cove, at head of North Arm Moira Sound, on SE coast of Prince of Wales I., Alex.

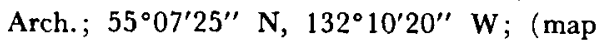
4). Var. Clara Marie Bay.
Local name reported in 1904 by $\mathrm{H}$. C. Fassett, USBF; named Clara Marie Bay in 1901 by A. H. Brooks, USGS, after his launch (Brooks, 1902, fig. 5).

Aikens Rock: rock, E of Elghi I., between Prince of Wales and Tuxekan Is., Alex. Arch.; $55^{\circ} 54^{\prime} 00^{\prime \prime} \mathrm{N}, 133^{\circ} 15^{\prime} 35^{\prime \prime} \mathrm{W}$; (map 4).

Local name published in 1964 by USC\&GS. Aikhak: island, see Rootok Island.

Aikhwunat: point of land, see Iwoonut Point.

Aiktak Island: island, $1.3 \mathrm{mi}$. long, in Krenitzin Is., $38 \mathrm{mi}$. E of Akutan, Fox Is., Aleutian Is.; $54^{\circ} 11^{\prime} 10^{\prime \prime} \mathrm{N}, 164^{\circ} 50^{\prime} 00^{\prime \prime} \mathrm{W}$; (map 24). Var. Aektok, Ashmiahk, Ostrovi Ayaktak, Ostrovi Goloy, Ouektock, Rootok Island.

Aleut name transcribed by Capt. Tebenkov (1852, map 26), IRN, as "O[strov] Aikhtak." R. H. Geoghegan suggests that this name is "aikhaq," meaning "travel" or "going on a voyage."

Aimgiagmiut: locality, in Yukon River delta, on right bank of Apoon Pass, Yukon-Kuskokwim Deita; (map 77). Var. Aimgiagmyut.

Former Eskimo camp or settlement reported in 1842-44 as "Aimgiagmyut" by Lt. L. A. Zagoskin, IRN.

Aimgiagmyut: locality, see Aimgiagmiut.

Aimgua: locality, near the mouth of Yukon River; (map 77).

Former Eskimo village or camp recorded on an 1850 map by Lt. L. A. Zagoskin, IRN (Hodge, 1907, p. 31).

Ainslie Gulch: ravine, trends $\mathrm{W} 1 \mathrm{mi}$. to New Eldorado Greek, $12 \mathrm{mi}$. NE of Nome, Seward Penin. High.; $64^{\circ} 39^{\prime} \mathrm{N}, 165^{\circ} 10^{\prime} \mathrm{W}$; (map 94).

Prospectors' name reported in 1904 by T. G. Gerdine, USGS.

Aiou Porte: bight, see Hallo Bay.

Air Mountain: mountain, see Ear Mountain.

Airplane Flats: beach, $0.8 \mathrm{mi}$. long, on $\mathrm{W}$ coast of Unimak I., Aleutian Is.; $54^{\circ} 37^{\prime} 15^{\prime \prime} \mathrm{N}$, $164^{\circ} 51^{\prime} 25^{\prime \prime} \mathrm{W}$; (map 24).

Name published in 1943 on an AMS map. So named by U.S. Army during World War II "because planes landed there on the beach." Airport Heights: area, in Anchorage, SE of Merrill Field Airport, Cook Inlet Low. ; 61 ${ }^{\circ} 12^{\prime} 20^{\prime \prime}$ $\mathrm{N}, 149^{\circ} 49^{\prime} 25^{\prime \prime} \mathrm{W}$; (map 69).

Local name reported in 1954 by the city engineer of Anchorage.

Airs Hill: mountain, 3,390 ft., $4 \mathrm{mi}$. SW of point where Alaska Highway crosses Alaska-Canada boundary, Alaska Ra.; $62^{\circ} 35^{\prime} \mathrm{N}, 141^{\circ} 06^{\prime} \mathrm{W}$; (map 84).

Named in 1898 by W. J. Peters and A. H. Brooks, USGS, for A. R. Airs, a member of their field party.

Aitshillik River: stream, see Aichilik River.

Aiu Bay: bay, see Hallo Bay.

Aiugnak, Kameny: islands, see Aiugnak Columns.

Aiugnak Columns: islands, group of 5, maximum elev. $85 \mathrm{ft}$., $6 \mathrm{mi}$. across, $6 \mathrm{mi}$. S of Cape Providence, in Pacific Ocean, Aleutian Ra.; 56 ${ }^{\circ} 3^{\prime}$ N, $156^{\circ} 34^{\prime}$ W; (map 31). Var. Agnak Rocks, Augnak Rocks, Kameny Aiugnak. 
Shown as "K[ameny] Aiugnak," or "Aiugnak Rocks," by Capt. Tebenkov (1852, map 22) and as "Augnak Rocks" on an 1849 manuscript map of Kodiak. The name "Aiugnak Columns" appears on an 1888 USBF chart. $\mathrm{Ai}$-u-wath-lok: stream, see Iowithla River.

Aiuwathlok Kagati: lake, at head of Iowithla River, in Muklung Hills, $24 \mathrm{mi}$. NE of Dillingham, Kilbuck-Kuskokwim Mts.; 59 $24^{\prime}$ N, $158^{\circ} 17^{\prime} \mathrm{W}$; ( map 52).

Name applied in 1910 by H. C. Fassett, USBF, to a lake at the head of the Iowithla River, which (lake) is not shown on presentday maps.

Aivichtik River: stream, flows SE $15 \mathrm{mi}$. to Bering Sea at Camp Iveetok, $56 \mathrm{mi}$. SE of Gambell, NE coast of St. Lawrence I.; 63․ $29^{\prime} 30^{\prime \prime} \mathrm{N}, 170^{\circ} 03^{\prime} 00^{\prime \prime} \mathrm{W}$; BGN 1951; (map 93). Var. Aivikhtak, Iveetok.

Eskimo name of ten recorded as "Aivikhtak" or "Iveetok."

Aivikan Mountain: mountain, see Ivekan Mountain.

Aivik Creek: stream, flows $1.2 \mathrm{mi}$. SW to Chukchi Sea, $4 \mathrm{mi}$. N of Cape Dyer, Arctic Slope; $68^{\circ} 42^{\prime} 30^{\prime \prime} \mathrm{N}, 166^{\circ} 11^{\prime} 50^{\prime \prime} \mathrm{W}$; (map 129).

Eskimo name meaning "walrus" reported in 1950 by USC\&GS; so called because "a rock in the sea near the creek's mouth is frequented by walrus."

Aivikhtak: stream, see Aivichtik River.

Aiyagin: volcano, see Makushin Volcano.

Aja Bay: bight, see Hallo Bay.

Ajaga Island: island, see Adak Island.

Ajagisch: volcano, see Makushin Volcano.

Ajak Island: island, see Sledge Island.

Ajalik Bay: bay, see Aialik Bay.

Ajaliki Islands: islands, see Chiswell Islands.

Ajanahtack: island, see Aiaktalik Island.

Ajax Reef: reef, extends 0.2 mi. in Felice Strait, $0.8 \mathrm{mi}$. S of Annette I., Alex. Arch.; $55^{\circ} 00^{\prime} 05^{\prime \prime}$ $\mathrm{N}, 131^{\circ} 27^{\prime} 40^{\prime \prime} \mathrm{W}$; (map 3$)$.

This is one of several names given in 1883 by Lt. Comdr. H. E. Nichols, USN, which were suggested by classical mythology.

Ajugadach Island: island, see Rat Island.

Akachaga Head: point of land, see Murder Point.

Akachagamut: village, see Akiachak.

Akagowik Pass: water passage, see Kawokhawik Pass.

Akahamut: locality, on N bank of Yukon River, $14 \mathrm{mi}$. SW of Russian Mission, Yukon-Kuskokwim Delta; $61^{\circ} 37^{\prime} 30^{\prime \prime} \mathrm{N}, 161^{\circ} 39^{\prime} 20^{\prime \prime} \mathrm{W}$; (map 73). Var. Ikuagmiut, Ikuak, Ingahame, Ingahameh, Ohogamiut, Okhnagamiut, Selo Ikogmiut, Selo Ikuagmyut, Yukagamut, Yukamut.

Eskimo name "Okhnagamiut," meaning "village [people] on other side [of river];" recorded on a 1916 fieldsheet by $R$. H. Sargent, USGS. This name and place may be the same as that shown on Tikhmeniev's 1861 map as "S[elo] Ikogmiut" or "Ikuagmyut"; presumably derived from information received from Lt. L. A. Zagoskin (1842-44), IRN. Written as "Yukagamut" by Capt. Raymond (1871, p. 25), USA; shown as "Ingahameh" and "Ingahame" by Petroff in the 10th (1884) Census. There are several names similar to "Akahamut" spelled variously, in western Alaska, which probably represent an Eskimo response to the question, "What is that place?", or a reference to "the people on the other side." Because these villages of ten change from one side of the river to the other, this name, "Akahamut" may refer to a similar situation.

Akak: locality, "in the Nushagak district." Var. Akakhpuk.

Former Eskimo village or camp listed as "Akakhpuk" with a population of 9 in the 1890 Census.

Aka Lake: lake, most westerly of Summit Lakes, $0.8 \mathrm{mi}$. long, on Phipps Penin. $2.8 \mathrm{mi}$. SW of Yakutat, Malaspina Coastal Plain; 59 $47^{\prime} 00^{\prime \prime}$ $\mathrm{N}, 139^{\circ} 47^{\prime} 50^{\prime \prime} \mathrm{W}$; (map 46).

Tlingit Indian name reported in 1964 (de Laguna and others, 1964, map 4, p. 24).

Akalok: locality, "Eskimo village on the Arctic coast, 25 miles north of Hotham Inlet."

"This may be the same as Tikizat or Sheshalek or Anyok; most likely another spelling of the latter name. Eskimo name taken from Reindeer Rept. 1900, p. 137" (Baker, 1906, p. 85).

Akalolik Creek: stream, heads in Lisburne Hills, flows SW $20 \mathrm{mi}$. to Chukchi Sea, $17 \mathrm{mi}$. NE of Point Hope, Arctic Slope; $68^{\circ} 29^{\prime} \mathrm{N}, 166^{\circ} 18^{\prime}$ W; (map 129). Var. Acalolik, Ahkalurak, Ahkaluruk, Akaloolick, Akaloolik Creek, Akalolik River, Akalulik River.

Eskimo name recorded in 1918 as "Ahka-lú-rak" by Archdeacon Stuck (1920, p. 155-156). According to USC\&GS in 1950, the name "A-ka-loo-lick" means "fishing place."

Akalolik River: stream, see Akalolik Creek.

Akaloolick: stream, see Akalolik Creek.

Akaloolik Creek: stream, see Akalolik Creek.

Akalugrak Panga: locality, at mouth of Akalugram Creek, 6 mi. NE of Kivalina, KotzebueKobuk Low.; $67^{\circ} 47^{\prime} \mathrm{N}, 164^{\circ} 22^{\prime} \mathrm{W}$; (map 128). Var. Ahkaloograak Pahnga, Aqalug. zaam Kuunga.

Eskimo name meaning "salmon [river] mouth" reported in 1966 by E. S. Burch.

Akalugram Creek: stream, an anabranch of Wulik River, flows SW 2 mi. to Akalugrak Creek, $6 \mathrm{mi}$. NE of Kivalina, Kotzebue-Kobuk Low.; $67^{\circ} 47^{\prime} \mathrm{N}, 164^{\circ} 22^{\prime} \mathrm{W}$; (map 128). Var. Ahkaloograhm Koonga.

Eskimo name meaning "salmon"; reported in 1966 by E. S. Burch.

Akalulik River: stream, see Akalolik Creek.

Akaluovik Lakes: lakes, group, extends $\mathrm{W} 1 \mathrm{mi}$., NW of junc. of Noatak and Miniuktuk Rivers, Brooks Ra. ; $68^{\circ} 08^{\prime} \mathrm{N}, 160^{\circ} 00^{\prime} \mathrm{W}$; (map 131).

Eskimo name reported in 1956 by USGS.

Akalura Creek: stream, heads at Akalura Lake, flows $\mathrm{S} 1 \mathrm{mi}$. to Cannery Cove in Olga Bay, $30 \mathrm{mi}$. SE of Karluk, in SW part of Kodiak I.; $B G N$ 1939; (map 35). Var. Cannery Creek, Home Stream, North Olga Stream.

Named in 1939 by USC\&GS which also reported the name Cannery Creek for this fea- ture in 1930. The names North Olga Stream and Home Stream were reported in 1901.

Akalurak: locality, site of an Eskimo camp on Chukchi Sea coast at mouth of Akalolik Creek, $17 \mathrm{mi}$. NE of Point Hope, Arctic Slope; $68^{\circ} 29^{\prime}$ N, $166^{\circ} 18^{\prime} \mathrm{W}$; (map 129). Var. Ahkalurak, Ahkaluruk.

Shelter and camp reported in 1918 as "Ahkalurak" by Archdeacon Stuck (1920, p. 156). See Akalolik Creek.

Akalura Lake: lake, $2.5 \mathrm{mi}$. across, $3 \mathrm{mi}$. N of Olga Bay and $28 \mathrm{mi}$. SE of Karluk, in SW part of Kodiak I.; $57^{\circ} 11^{\prime} \mathrm{N}, 154^{\circ} 13^{\prime} \mathrm{W}$; $B G N$ 1934; (map 35). Var. North Olga Lake.

Named in 1934 by USC\&GS for "the salmon found in these waters." The name North Olga Lake was reported in 1900.

Akamok: island, see Chirikof Island.

Akan: island, see Akun Island.

Akanuklinuk Slough: stream, flows $\mathrm{W} 3 \mathrm{mi}$. to Kwiguk Pass, 6.2 mi. W of Kwiguk, YukonKuskokwim Delta; $62^{\circ} 47^{\prime} \mathrm{N}, 164^{\circ} 41^{\prime} \mathrm{W}$; (map 77). Var. Ah-kah-nuk-lin-uk Slough.

Eskimo name reported in 1952 by USC\&GS to mean "all women."

Akargichek Mountain: mountain, 1,147 ft., in Igichuk Hills, $12 \mathrm{mi}$. NE of Cape Krusenstern, Arctic Slope; $67^{\circ} 10^{\prime} 30^{\prime \prime} \mathrm{N}, 163^{\circ} 18^{\prime} 30^{\prime \prime} \mathrm{W}$; $B G N$ 1962; (map 128). Var. Ahkargichek Mountain.

Eskimo name reported to mean "young ptarmigan" by USG\&GS in 1950.

Akava.t: locality, see Akvat.

Akeftapak: locality, site of village or camp, 6 mi. SE of Gambell, on $\mathrm{N}$ coast of St. Lawrence I.; $63^{\circ} 42^{\prime} \mathrm{N}, 171^{\circ} 39^{\prime} \mathrm{W}$; (map 93). Var. Akiftapohak, Akiftapphak.

According to Orth, in 1965, this Eskimo name refers to a kind of bag.

Akeftapak Bay: bight, $6 \mathrm{mi}$. across, $7 \mathrm{mi}$. SE of Gambell, on $\mathrm{N}$ coast of St. Lawrence $1 . ; 6^{\circ}$ $41^{\prime} \mathrm{N}, 171^{\circ} 38^{\prime} \mathrm{W}$; BGN 1951; (map 93). Var. Akiftapphak, Akiptappak Bay.

Named for the locality.

Akeit: point of land, see Aksit, Cape.

Akeku Point: point of land, S point of entrance to Edward Passage, on $\mathrm{W}$ shore of Pearse Canal, Coast Mts.; $54^{\circ} 50^{\prime} 00^{\prime \prime} \mathrm{N}, 130^{\circ} 29^{\prime} 45^{\prime \prime}$ W; BGN 1937; (map 2).

Local name reported in 1936 by USC\&GS. Akelk, Cape: point of land, $\mathrm{W}$ point of entrance to Puale Bay, on SE coast of Alaska Penin., 42 mi. NW of Karluk, Aleutian Ra.; $57^{\circ} 40^{\prime} 45^{\prime \prime}$ $\mathrm{N}, 155^{\circ} 34^{\prime} 35^{\prime \prime} \mathrm{W}$; (map 35 ).

Local name reported in 1951 by USGS.

Akeonik: locality, site of Eskimo reindeer camp on Chukchi Sea coast, on point of mainland 4 mi. S of Icy Cape, Arctic Plain; $70^{\circ} 16^{\prime} 30^{\prime \prime} \mathrm{N}$, $161^{\circ} 56^{\prime} 50^{\prime \prime} \mathrm{W}$; (map 146).

Eskimo name reported in 1924 by USGS (in Smith and Mertie, 1930, p. 104).

Akfayegak Creek: stream, heads in lake, flows NE $4 \mathrm{mi}$. to Niyrakpak Lagoon, $13 \mathrm{mi}$. SE of Gambell, St. Lawrence I.; $63^{\circ} 37^{\prime} \mathrm{N}, 171^{\circ}$ 32' W; BGN 1951; (map 93). Var. Akfayegak River. 
Eskimo name recommended by the Gambell village council; reported in 1949 by Maj. H. B. Allen, USAF.

Akfayegak River: stream, see Akfayegak Creek.

Akgulurigiglak: locality, "in the Nushagak district."

Former Eskimo camp or village listed with a population of 61 in the 1890 Census.

Akha Lake: lake, see Chilkoot Lake.

Akhanam Naiva: lagoon, see Aghnaghak Lagoon. Akheit, Mys: point of land, see Aksit, Cape.

Akhiok: village, on Akhiok Bay, $\mathrm{W}$ of Alitak Bay, at $\mathrm{S}$ end of Kodiak I.; $56^{\circ} 56^{\prime} 40^{\prime \prime} \mathrm{N}$,

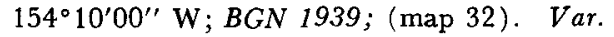
Ahkiok, Alitak, Oohaiack.

Native name reported by Petroff (1881, p. 30 ) in the 10th Census, in 1880. This village may be the same as "Oohaiack" reported by Capt. Lisianski (1814, p. 169), IRN. The U.S. Post Office Department established the Alitak post office in 1933; discontinued in 1945 (Ricks, 1965, p. 3 ).

Akhiok Bay: bay, 2 mi. across, W of Alitak Bay, at $\mathrm{S}$ end of Kodiak I.; $56^{\circ} 56^{\prime} \mathrm{N}, 154^{\circ} 10^{\prime} \mathrm{W}$; (map 32).

Name derived from Akhiok village by USC\&GS in the early 1930's.

Akhiok Island: island, $1.6 \mathrm{mi}$. across, on W shore of Alitak Bay, at $\mathrm{S}$ end of Kodiak I.; $56^{\circ} 55^{\prime}$ $20^{\prime \prime} \mathrm{N}, 154^{\circ} 11^{\prime} 00^{\prime \prime} \mathrm{W}$; $B G N$ 1934; (map 32). Var. Round Island.

Named in 1934 for Akhiok Bay and village by USC\&GS. It was previously called "Round Island" by USC\&GS.

Akhiok Reef: reef, $0.2 \mathrm{mi}$. long, on W shore of Alitak Bay, at $\mathrm{S}$ end of Kodiak I.; 56 $6^{\circ} 55^{\prime} 00^{\prime \prime}$ $\mathrm{N}, 154^{\circ} 08^{\prime} 30^{\prime \prime} \mathrm{W}$; ( $\operatorname{map} 32$ ).

Name derived from Akhiok village; published in 1943 by USC\&GS.

Akhnakhyakhit Point: point of land, see Agnayaghit Point.

Akhotóruk: bluff, see Augutaurak.

Akhotoruk Creek : stream, see Ogotoruk Creek.

Akhoviknuk Lagoon: lagoon, see Akoviknak Lagoon.

Akhoviknuk Mountain: hill, see Akoviknak Mountain.

Akhsit, Mys: point of land, see Aksit, Cape.

Akhtididung: stream, see Portage Creek.

Akhtidung: stream, see Portage Creek.

Akhun: island, see Akun Island.

Akiachagamut: village, see Akiachak.

Akiachak: village, pop. 229, on right bank of Kuskokwim River, $13 \mathrm{mi}$. NE of Bethel, Yukon-Kuskokwim Delta; $60^{\circ} 54^{\prime} 30^{\prime \prime} \mathrm{N}, 161^{\circ}$ 25'45' W; (map 59). Var. Akachagamut, Akiachagamut, Akiachok, Akiachuak, Akiachuck, Akiakchagmiut, Akiakchak, Akiatshágamut.

Eskimo village shown on an 1898 fieldsheet by W. S. Post, USGS, who obtained the name "Akiatshágamut," meaning "Akiachak people," from J. H. Kilbuck, Moravian missionary. This is undoubtedly the same village listed in the 11 th Census, in 1890, as "Akiakchagamiut" with a population of 43 ; the village had a population of 165 in 1900,156 in
1939 , and 179 in 1950. A post office named "Akiachak" was established there in 1934. Akiachok: village, see Akiachak.

Akiachuak: village, see Akiachak.

Akiachuck: village, see Akiachak.

Akiagamiut: village, see Akiak.

Akiagamute: village, see Akiak.

Akiagmut: village, see Akiak.

Akiak: village, pop. 187, on right bank of Kuskokwim River, $20 \mathrm{mi}$. NE of Bethel, YukonKuskokwim Delta; 60 $0^{\circ} 5^{\prime} \mathrm{N}, 1^{\circ} 1^{\circ} 13^{\prime} \mathrm{W}$; (map 59). Var. Ackiagmute, Akiagamuit, Akiagamute, Akiagmut, Akkiagamute, Akkiagmute.

Eskimo village listed by Ivan Petroff in the 10th Census, in 1880, as "Ackiagmute" and "Akkiagmute," meaning "Akiak people." G. L. Harrington, USGS, said in 1919 that the name means " 'crossing over' *** the natives cross to the Yukon in winter from this village." The village population was 175 in 1880,97 in 1890 (Akiagamiut), 150 in 1920 (Akiak), 228 in 1930, 209 in 1939, and 168 in 1950. The Akiak post office was established in 1916.

Akiakchagmiut: village, see Akiachak.

Akiakchak: village, see Akiachak.

Akiak Creek: stream, flows SE $20 \mathrm{mi}$. to Hunt River $11 \mathrm{mi}$. $\mathrm{N}$ of that stream's junc. with Kobuk River, $52 \mathrm{mi}$. NW of Shungnak, Brooks Ra.; $67^{\circ} 22^{\prime} \mathrm{N}, 158^{\circ} 37^{\prime} \mathrm{W}$; (map 126).

Eskimo name meaning "its opposite (equivalent )," or in another sense "fork of the Hunt River"; obtained at Shungnak in 1956 by Orth.

Akiak Mountains: ridge, elev. 2,000-4,040 ft., in Baird Mts., extends NNW $16 \mathrm{mi}$. from junc. of Akiak Creek and Hunt River, Brooks Ra.; $67^{\circ} 30^{\prime} \mathrm{N}, 158^{\circ} 43^{\prime} \mathrm{W}$; (map 126).

Eskimo name obtained at Shungnak in 1956 by Orth. See Akiak Creek.

Akiatshágamut: village, sec Akiachak.

Akiftapohak: locality, see Akeftapak.

Akiftapphak: locality, see Akeftapak.

Akiftapphak: $b a y$, see Akef tapak Bay.

Akiknaak Peaks: ridge, elev. 2,880 ft., extends 4 $\mathrm{mi}$. on $\mathrm{S}$ side of Noatak River valley, $33 \mathrm{mi}$. SW of Howard Pass, Brooks Ra.; 67 $48^{\prime} \mathrm{N}$, $157^{\circ} 38^{\prime} \mathrm{W}$; (map 126).

Eskimo name meaning "against (along side)"; obtained in 1956 at Shungnak, Noatak, and Kobuk by Orth. So named because these separate peaks "stand against the other mountains."

Akikukchiak Creek: stream, in Baird Mts., flows N $22 \mathrm{mi}$. to Noatak River, $3 \mathrm{mi}$. NW of junc. of Kaluktavik River and $56 \mathrm{mi}$. NE of Noatak, Brooks Ra.; 67 $56^{\prime}$ N, $161^{\circ} 06^{\prime} \mathrm{W}$; (map 127).

Eskimo name meaning "going to the new (other) side"; obtained at Noatak in 1956 by Orth.

Akillik River: stream, heads in lake, flows SW $35 \mathrm{mi}$. to Hunt River, $2.8 \mathrm{mi}$. NE of that stream's junc. with Kobuk River and $44 \mathrm{mi}$. NW of Shungnak, Brooks Ra.; $67^{\circ} 13^{\prime} \mathrm{N}, 158^{\circ}$ $32^{\prime} \mathrm{W}$; (map 126).
Eskimo name meaning "something on the other side" or "across"; obtained at Shungnak in 1956 by Orth.

Akilloaq: locality, on Ghukchi Sea coast $6 \mathrm{mi}$. SW of Barrow, Arctic Plain; $71^{\circ} 12^{\prime} \mathrm{N}, 156^{\circ}$ $58^{\prime}$ W; (map 153). Var. Nakedrixo, Nakeduxo.

Eskimo camp name published by R. F. Spencer (1959, map 2), BAE. Lt. P. H. Ray (1885, p. 55), USA, lists "Nakedrixo" as the second camp below the village at Cape Smyth, which is in the same general area.

Akillyik Creek: stream, flows S 7 mi. to Redstone River, $16 \mathrm{mi}$. NE of Ambler, Brooks Ra.; $67^{\circ} 18^{\prime} \mathrm{N}, 157^{\circ} 36^{\prime} \mathrm{W}$; (map 126).

Eskimo name reported in 1965 by Wilfried Zibell.

Akillyik Mountain: mountain, 1,740 ft., $14 \mathrm{mi}$. NE of Ambler, Brooks Ra.; $67^{\circ} 15^{\prime} \mathrm{N}, 157^{\circ} 33^{\prime}$ W; (map 126).

Eskimo name reported in 1965 by Wilfried Zibell.

Akiptappak Bay: bay, see Akeftapak Bay.

Akishdak-kosh-kunno: locality, see Akshadak.

Akituk Creek: stream, flows N 2 mi. to Bering Sea, $10 \mathrm{mi}$. SW of Cape Etolin, on $\mathrm{N}$ coast of Nunivak 1.; $60^{\circ} 22^{\prime} 15^{\prime \prime} \mathrm{N}, 166^{\circ} 25^{\prime} 40^{\prime \prime} \mathrm{W}$; (map 57).

Eskimo name reported in 1937 by USAAF.

Akjemguiga Cove: cove, at head of Alaska Penin., extends W 1.4 mi. off Kamishak Bay, at mouth of Paint River, Aleutian Ra.; 59 $10^{\prime}$ $\mathrm{N}, 154^{\circ} 12^{\prime} \mathrm{W}$; (map 51$)$.

Eskimo name reported in 1923 by $K$. F. Mather (in Brooks and others, 1925, pl. 3), USGS.

Akka: locality, see Makak.

Akkiagamute: village, see Akiak.

Aklek, Cape: point of land, the SW point of entrance to Puale Bay, on the $\mathrm{W}$ side of Shelikof Strait, Aleutian Ra.; $57^{\circ} 40^{\prime} 30^{\prime \prime} \mathrm{N}, 1^{\circ} 5^{\circ}$ 05'00" W; (map 35). Var. Aclek Cape, Alek Cape, Ialek, Mys Yaklak, Taklek, Yaklek.

Probably an Aleut name, reported in 1831 by the Russian navigator Ens. Vasiliev.

Aklukwagamut: locality, see Aklut.

Aklumayuak Creek: stream, in Baird Mts., flows W 42 mi. to Noatak River at $\mathrm{E}$ end of its Grand Canyon, Brooks Ra.; 67 $7^{\circ} 5^{\prime} \mathrm{N}, 160^{\circ}$ $20^{\prime} \mathrm{W}$; (map 127). Var. Aklummayuak Creek.

Eskimo name meaning "bear slope (climb) ;" obtained at Noatak in 1956 by Orth.

Aklut: locality, at mouth of Eek River on Eek Point, $45 \mathrm{mi}$. SW of Bethel, Yukon-Kuskokwim Delta; $60^{\circ} 12^{\prime} \mathrm{N}, 162^{\circ} 15^{\prime} \mathrm{W}$; (map 58). Var. Ahguliagamiut, Akooligamute, Aklukwagamut, Akulik, Eek Fish Camp.

Eskimo village reported in December 1878 by E. W. Nelson, U.S. Signal Service; listed in the 10th Census, in 1880, as "Akooligamute" (pop. 162); in the 11th Census, in 1890, as "Ahguliagamiut" (pop. 106). W. S. Post, USGS, spelled it "Aklukwagamut" on an 1898 fieldsheet. J. H. Kilbuck, Moravian missionary, said the name was from "Akklut," meaning "ammunition" or "pro- 
visions." The place was abandoned before 1949. It is the site of Eek (village) fish camp. Akmagolik Creek: stream, flows NE $13 \mathrm{mi}$. to Anaktuvuk River, $3 \mathrm{mi}$. E of Nasaurak Mtn. and $15 \mathrm{mi}$. NE of Anaktuvuk Pass, Brooks Ra.; $68^{\circ} 20^{\prime} \mathrm{N}, 151^{\circ} 28^{\prime} \mathrm{W}$; (map 134).

Eskimo name obtained at Anaktuvuk Pass in 1956 by T. E. Taylor, USGS.

Akmaktaksrak Bluff: bluff, $200 \mathrm{ft}$. high, on E bank of Okokmilaga River, 12 mi. SE of its junc. with Killik River, Brooks Ra.; 68 $38^{\prime} \mathrm{N}$, $153^{\circ} 14^{\prime} \mathrm{W}$; (map 133).

Eskimo name meaning "supplied with flint"; reported in 1956 by T. E. Taylor, USGS.

Akmalik Creek: stream, flows NE $14 \mathrm{mi}$. to Killik River, $14 \mathrm{mi}$. E of Kurupa Lake, Brooks Ra.; 68 $24^{\prime}$ N, $154^{\circ} 04^{\prime}$ W ; (map 133).

Eskimo name meaning "flint boulders"; obtained at Anaktuvuk Pass in 1956 by Orth.

Akmiut: locality, on left bank of Kuskokwim River near mouth of Holokuk River, KilbuckKuskokwim Mts.; 61 ${ }^{\circ} 31^{\prime} \mathrm{N}, 158^{\circ} 35^{\prime} \mathrm{W}$; (map 72). Var. Akmute.

Former Eskimo village listed as "Akmute" on the 1880 Census map. J. E. Spurr and W. S. Post, USGS, who passed the site in 1898 did not mention it.

Akmute: locality, see Akmiut.

Aknasuk Creek: stream, see Arrow Creek.

Aknerkochik River: stream, see Anerkochik River.

Aknokivik Slough: stream, flows W $3.3 \mathrm{mi}$. to Kwiguk Pass, $7 \mathrm{mi}$. NW of Kwiguk, YukonKuskokwim Delta; $62^{\circ} 47^{\prime} 40^{\prime \prime} \mathrm{N}, 164^{\circ} 42^{\prime} 30^{\prime \prime}$ W; (map 77).

Eskimo name obtained in 1952 by U.S. Army Corps of Engineers.

Akoalaakat Pass: water passage, see Akoliakatat Pass.

Akoblak Creek: stream, see Knapp Creek.

Akoblooiek River: stream, see Millichetah Creek.

Akoblueik: stream, see Nahtuk River.

Akogpak Slough: stream, flows W $5.2 \mathrm{mi}$. to Akularak Pass, $10 \mathrm{mi}$. SW of Kwiguk, YukonKuskokwim Delta; $62^{\circ} 39^{\prime} 30^{\prime \prime} \mathrm{N}, 164^{\circ} 16^{\prime} 00^{\prime \prime}$ W; (map 77).

Eskimo name obtained in 1899 by G. R. Putnam, USC\&GS; published in 1899 on Chart 9372.

Akoi River: stream, see Akwe River.

Akokpak: locality, on right bank of Nushagak River at mouth of Mulchatna River, $65 \mathrm{mi}$. NE of Dillingham, Bristol Bay Low.; $59^{\circ} 40^{\prime}$ $\mathrm{N}, 157^{\circ} 07^{\prime} \mathrm{W}$; BGN 1931; (map 52). Var. Ah-kúh-puk, Akupuk.

Eskimo name reported by USBF in 1910.

Akoliakatat Pass: water passage, in barrier bar between Chukchi Sea and Kasegaluk Lagoon, $13 \mathrm{mi}$. E of Icy Cape, Arctic 'Plain; $70^{\circ} 18^{\prime} \mathrm{N}$, $161^{\circ} 18^{\prime} \mathrm{W}$; (map 146). Var. Akoalaakat Pass.

Eskimo name, meaning "entrance between," referring to a mound on the barrier bars on each side of the pass. Reported by USGS in 1925.

Akoliakruich Hills: hills, extend N $15 \mathrm{mi}$. from Junc. of Reed and Kobuk Rivers, $60 \mathrm{mi}$. NNW of Hughes, Brooks Ra.; $66^{\circ} 52^{\prime}$ N., $154^{\circ} 45^{\prime}$ W ; (map 116).

Eskimo name recorded at Hughes in 1956 by Orth; refers in meaning to the fact that the hills "divide or are split" by the Reed River.

Akolikotak Head: promontory, see Ahkolikotak Head.

Akolorachok: settlement, see Akulurak.

Akomilinak Creek: stream, flows S $10 \mathrm{mi}$. to Black Slough, $4 \mathrm{mi}$. E of Dillingham, Bristol Bay Low.; 59 $04^{\prime} \mathrm{N}, 158^{\circ} 22^{\prime} \mathrm{W}$; (map 52).

Eskimo name written "A-kom-y-li-nuk" by H. C. Fassett, USBF, in 1910; it may mean "one who sits."

Akoo lakok Point: point of land, see Akoolokok Point.

Akooligamute: locality, see Aklut.

Akoolokok Cape: point of land, see Akoolokok Point.

Akoolokok Point: point of land, on NE coast of Saint Lawrence I., $32 \mathrm{mi}$. SE of Savoonga; $63^{\circ} 26^{\prime} \mathrm{N}, 169^{\circ} 39^{\prime} \mathrm{W}$; BGN 1951; (map 93). Var. Akoo lakok Point, Akoolokok Cape, Akulokok Point, Cape Akoolokok.

Eskimo name reported in 1932 by Otto $W$. Geist, Univ. of Alaska.

A-koo-loo-ik River: stream, see Millichetah Creek.

Akooloorok Pass: watercourse, see Akularak Pass.

Akoonik Pass: water passage, see Akunik Pass. Akootchook Creek: stream, see Turner River.

Akoou: island, see Akun Island.

Akoswift Creek: stream, flows NW $8 \mathrm{mi}$. to Crooked Creek, $67 \mathrm{mi}$. SE of Bethel, KilbuckKuskokwim Mts.; $60^{\circ} 17^{\prime} \mathrm{N}, 1^{\circ} 59^{\circ} 51^{\prime} \mathrm{W}$; (map 59).

Eskimo-English name reported in 1955 by J. M. Hoare, USGS.

Akoun: island, see Akun Island.

Akouna: island, see Akun Island.

Akoutan: island, see Akutan Island.

Akoutan Harbor: bay, see Akutan Harbor.

Akoutan Pass: water passage, see Akutan Pass.

Akoutanskoi Pass: water passage, see Akutan Pass.

Akoviknak Lagoon: lagoon, $2 \mathrm{mi}$. long, on Chuckchi Sea coast, $3.1 \mathrm{mi}$. NW of Cape Thompson, Arctic Slope; $68^{\circ} 12^{\prime} \mathrm{N}, 166^{\circ} 02^{\prime}$ W; BGN 1963; (map 129). Var. Ahviknuk Lagoon, Akhoviknuk Lagoon, Isuk Lagoon. Named for nearby Akoviknak Mountain in 1962 by Project Chariot personnel.

Akoviknak Mountain: hill, $435 \mathrm{ft}$., E of Akoviknak Lagoon, $3.5 \mathrm{mi}$. N of Cape Thompson, Arctic Slope; $68^{\circ} 12^{\prime} 05^{\prime \prime} \mathrm{N}, 165^{\circ} 59^{\prime} 45^{\prime \prime} \mathrm{W}$; BGN 1963; (map 129). Var. Ahviknuk Mountain, Akhoviknuk Mountain, Angoviknak Mountain.

Eskimo name meaning "resembles a Right Whale." The name alludes to the "bumps on its [whale's] head, represented by large boulders on the ridge," according to $W$. $O$. Pruitt, Univ. of Alaska, in 1962. Project Chariot personnel reported the name as "Ahviknuk" in 1962.
Akpaliut: locality, on Norton Sound W of Golovnin Bay, Seward Penin. High.; 64 $30^{\prime} \mathrm{N}$, $163^{\circ} 20^{\prime} \mathrm{W}$; (map 95). Var. Acpalliut.

Former Eskimo village or camp shown as "Acpalliut" on The Western Union Telegraph Expedition map of 1867 . It appears to be near or at Chiukak.

Akpelik Greek: stream, heads in Angayucham Mts., flows S $13 \mathrm{mi}$, to Kobuk River, $57 \mathrm{mi}$. NNW of Hughes, Kotzebue-Kobuk Low.; $66^{\circ}$. $45^{\prime} \mathrm{N}, 155^{\circ} 21^{\prime} \mathrm{W}$; (map 116).

Eskimo personal name recorded at Kobuk in 1956 by Orth.

Akporvik Hill: hill, $600 \mathrm{ft}$., S of Agiak Lagoon, near Chukchi Sea coast, between Mutaktuk Creek and Pitmegea River, $36 \mathrm{mi}$. NW of Mount Kelly, Arctic Slope ; $68^{\circ} 54^{\prime} \mathrm{N}, 164^{\circ} 27^{\prime}$ W; (map 130).

Eskimo name reported to mean "place where travel is easy" by Chapman and Sable (1960, p. 52), USGS.

Akshadak: locality, "near head of Buckland River," Nulato Hills; (map 109). Var. Akishdak-kosh-kunno, Akshadak Kunno, Talnik Zhilye.

Former Eskimo camp or settlement reported in 1842-44 as "Akshadak 'Talnik' Kunno 'Zhilye'," i.e. "willow dwellings," by Lt. L. A. Zagoskin, IRN. Zagoskin added the Russian equivalent (Talnik Zhilye) to the Eskimo.

Akshadak Kunno: locality, see Akshadak.

Aksit, Cape: point of land, on SE coast of Unimak I., 14 mi. S of village of False Pass, Aleutian Is.; $54^{\circ} 39^{\prime} 35^{\prime \prime} \mathrm{N}, 163^{\circ} 25^{\prime} 30^{\prime \prime} \mathrm{W}$; (map 25). Var. Akeit, Mys Akhsit, West Cape Lazaref, Mys Akheit.

Name published by Capt. Tebenkov (1852, map 24), IRN, as "M[ys] Akhsit," or "Cape Akhsit." Father Veniaminov (1840, v. 1, p. 210) says that the ship Okenna "was wrecked near here." Baker (1906, p. 87) states that the name is derived from the word "Akeit" which may "have been an attempted rendering of the name of the ship."

Akuaine: point of land, see Akuyan, Cape.

Akuasrakuvik Creek: stream, see Old Woman Creek.

Akuchin Rocks: rocks, on SE coast of Attu I., Aleutian Is.; $52^{\circ} 42^{\prime} \mathrm{N}, 173^{\circ} 30^{\prime} \mathrm{E}$; (map 13).

Recorded on a manuscript map drawn by L. M. Turner in the 1880's; this feature has not been positively identified.

Akulakutuk River: stream, see Akulikutak River. Akula Lake: lake, $0.8 \mathrm{mi}$. long, on Kenai Penin., $1.5 \mathrm{mi}$. NW of Beaver Lake and $10 \mathrm{mi}$. NE of Kenai, Cook Inlet Low.; $60^{\circ} 41^{\prime}$ N, $151^{\circ} 02^{\prime}$ $\mathrm{W}$; (map 62)

Named about 1963 by officials of Kenai National Moose Range, for administrative purposes.

Akularak Pass: watercourse, in Yukon Delta, extends NE $40 \mathrm{mi}$. from Kwemeluk Pass to Kwikluak Pass, 21 mi. S of Kwiguk, KukonKuskokwim Delta; $62^{\circ} 27^{\prime} \mathrm{N}, 164^{\circ} 35^{\prime} \mathrm{W}$; (map 77). Var. Akooloorok Pass. 
Eskimo name that means "the one between" or "connecting"; obtained in 1899 by G. R Putnam, USC\&GS.

Akuliakhpuk: locality, see Akuliukpak.

Akuliak Lake: lake, $1.5 \mathrm{mi}$. long, in Howard Pass $2 \mathrm{mi}$. NE of Nigtun Lake, Brooks Ra. $68^{\circ} 15^{\prime} \mathrm{N}, 156^{\circ} 47^{\prime} \mathrm{W}$; (map 132).

Eskimo name meaning "bridge of nose"; obtained at Noatak in 1956 by Orth.

Akulik: locality, see Aklut.

Akulik Creek: stream, flows NW $11 \mathrm{mi}$. to Chukchi Sea, $36 \mathrm{mi}$. NNW of Mount Kelly, Arctic Slope; $68^{\circ} 58^{\prime} \mathrm{N}, 164^{\circ} 04^{\prime} \mathrm{W}$; (map 130).

Eskimo name reported to mean "fancy trimming" by Chapman and Sable $(1960$, p. 52$)$, USGS.

Akulik River: stream, flows SW about $30 \mathrm{mi}$. to NE side of Norton Bay, between Koyuk and Inglutalik Rivers, Seward Penin. High.; $64^{\circ}$ $50^{\prime} 50^{\prime \prime}$ N, $160^{\circ} 59^{\prime} 50^{\prime \prime} \mathrm{W}$; (map 96). Var. Ahkoolik River, Kuingak, Kvyguk.

Eskimo name reported in 1842-44 as "Kvyguk" by Lt. L. A. Zagoskin, IRN. The name "Ahkoolik" was reported for this stream in 1900 by W. J. Peters, USGS.

Akulikutak River: stream, heads at $60^{\circ} 30^{\circ} \mathrm{N}$, $160^{\circ} 32^{\prime} \mathrm{W}$, flows NW $40 \mathrm{mi}$. to Kushluk River, $20 \mathrm{mi}$. SE of Bethel, Yukon-Kuskokwim Delta; $60^{\circ} 44^{\prime} 45^{\prime \prime} \mathrm{N}, 161^{\circ} 15^{\prime} 15^{\prime \prime} \mathrm{W}$; BGN 1960; (map 59). Var. Akulakutuk River.

Eskimo name meaning "the one between," reported in 1948 by USC\&GS.

Akulikutak River: stream, see Kushluk River

Akulirak: portage, between Sapumik Creek and Shorty River, $30 \mathrm{mi}$. NE of Kivalina, Arctic Slope; $68^{\circ} 02^{\prime} \mathrm{N}, 164^{\circ} 09^{\prime} \mathrm{W}$; (map 130). Var. Ahkooleerak, Akuliraq.

Eskimo name reported in 1966 by E. S. Burch.

Akuliraq: portage, see Akulirak.

Akuliukhpak Lake: lake, see Nerka, Lake.

Akuliukpak: locality, on Agulukpak River, 40 mi. $\mathbf{N}$ of Dillingham, Kilbuck-Kuskokwim Mts.; $59^{\circ} 38^{\prime} \mathrm{N}, 158^{\circ} 32^{\prime} \mathrm{W}$; (map 52). Var. Ah-guh-lok-puk.

Former Eskimo village listed as "Akuliakhpuk" with a population of 83 in the 1880 Census.

Akulivikchuk: locality, "on Nushagak River." Var. Akulvikchuk.

Former Eskimo camp or settlement listed as "Akulvikchuk" with a population of 72 by Ivan Petroff in the 1880 Census.

Akulogak: lake, see Naknek.

Akulokok Point: point of land, see Akoolokok Point.

Akuluik: stream, see Nahtuk River.

Akuluktok Peak: peak, 3,800 ft., $6 \mathrm{mi}$. $\mathrm{N}$ of Elbow Point, between Lake Nerka and Lake Beverley, $45 \mathrm{mi}$. NW of Dillingham, KilbuckKuskokwim Mts.; 59 $38^{\prime}$ N, 158 $59^{\circ} \mathrm{W}$; $B G N 1933$; (map 52 ).

Eskimo name, meaning "the one between," recorded in 1933 by Gerald FitzGerald, USGS.
Akulurak: locality, on W bank of Akularak Pass, $14 \mathrm{mi}$. S of Kwiguk, Yukon-Kuskowim Delta; $62^{\circ} 33^{\prime} 15^{\prime \prime} \mathrm{N}, 164^{\circ} 33^{\prime} 10^{\prime \prime} \mathrm{W}$; (map 77).

Eskimo village, former location of a Roman Catholic mission, which, due to inundation from Akulurak Pass, has been generally abandoned. It had a post office from 1924 to 1951 (Ricks, 1965, p. 2).

Akulurak: locality, see Akumsuk.

Akulurak: settlement, on left bank of Kuskokwim River, $2.5 \mathrm{mi}$. NE of Helmick Point and 43 mi. SW of Bethel, Yukon-Kuskokwim Delta; $60^{\circ} 17^{\prime} \mathrm{N}, 162^{\circ} 26^{\prime} \mathrm{W}$; (map 58). Var. Akolorachok.

Eskimo village or camp. Name means "that in between" according to a 1949 USC\&GS field report. The place had a population of 15 in 1940.

Akulvikchuk: locality, see Akulivikchuk.

Akumsuk: locality, on $\mathrm{N}$ bank of Lamont Slough, 2 mi. S of Kwiguk, Yukon-Kuskokwim Delta; $62^{\circ} 43^{\prime} 25^{\prime \prime} \mathrm{N}, 164^{\circ} 28^{\prime} 05^{\prime \prime} \mathrm{W}$; (map 77). Var. Akulurak, Mumsuk.

Eskimo camp reported in 1952 by U.S. Army Corps of Engineers. The same year USC\&GS reported the name as "Mumsuk."

Akumwake: locality, on left bank of Kolovinerak River at Akumwaken Slough, $100 \mathrm{mi}$. SW of Bethel, Yukon-Kuskokwim Delta; 60 $22^{\prime} \mathrm{N}$, $164^{\circ} 33^{\prime} \mathrm{W}$; (map 58). Var. Akumwoke.

Eskimo name reported in 1948 by USC\&GS as "a small settlement"; however, a 1951 USC\&GS field party remarks that "the place is now abandoned." It may be a fish camp. Akumwake Slough: stream, flows NNW $5 \mathrm{mi}$. to Kolovinerak River, $25 \mathrm{mi}$. SW of Baird Inlet, Yukon-Kuskokwim Delta; $60^{\circ} 22^{\prime} \mathrm{N}, 164^{\circ} 33^{\prime}$ W; (map 58). Var. Akumwoke Slough.

Eskimo name reported in 1949 by USC\&GS.

Akumwarvik Bay: bay, on $\mathrm{N}$ coast of Alaska Penin., extends SSW 5 mi. off Kamishak Bay, Aleutian Ra.; $59^{\circ} 06^{\prime} \mathrm{N}, 154^{\circ} 09^{\prime} \mathrm{W}$; (map 51). Var. Kamishak Bay.

Eskimo name reported in 1923 by K. F Mather (in brooks and others, 1925, pl. 3), USGS.

Akumwoke: locality, see Akumwake.

Akumwoke Slough: stream, see Akumwake Slough.

Akun Bay: bay, $5.5 \mathrm{mi}$. across, on NE coast of Akun I., Krenitzin Is., Aleutian Is.; $54^{\circ} 15^{\prime} \mathrm{N}$, $165^{\circ} 30^{\prime} \mathrm{W}$; (map 24). Var. Akun Cove, Riecheshnoi, Zaliv Recheshnoy.

Named in 1888 by USBF for the island. Capt. Tebenkov (1852, map 26), IRN, published the name " $\mathrm{Z}$ [aliv] Recheshnoy," meaning "little river bay."

Akun Cove: bay, see Akun Bay.

Akun Head: promontory, on N coast of Akun I., Aleutian Is.; $54^{\circ} 17^{\prime} 35^{\prime \prime} \mathrm{N}, 165^{\circ} 37^{\prime} 35^{\prime \prime} \mathrm{W}$; (map 24). Var. Mys Syvernoy, Sievernoi.

Named about 1900 by USC\&GS. It was called "M[ys] Syvernoy," meaning "North Cape," by Capt. Tebenkov (1852, map 26), IRN.

Akunik Pass: water passage, in barrier bar between Chukchi Sea and Kasegaluk Lagoon, $10 \mathrm{mi}$. NE of Point Lay, Arctic Plain; 69 53'- $45^{\prime \prime} \mathrm{N}, 162^{\circ} 49^{\prime} 30^{\prime \prime} \mathrm{W}$; (map 145). Var Akoonik Pass, Kokolik Pass.

Eskimo name (akuniq) meaning "the middle part"; obtained at Point Lay in 1956 by Orth

Akun Island: island, $10 \mathrm{mi}$ across, one of Kre nitzin Is., Aleutian Is.; $54^{\circ} 11^{\prime} \mathrm{N}, 165^{\circ} 32^{\prime} \mathrm{W}$; $B G N$ 1890; (map 24). Var. Acouan, Akan, Akhun, Akoou, Akoun, Akouna.

Aleut name recorded in 1768 by Capt. Lt. P. K. Krenitzin, IRN (Coxe, 1787, map facing p. 205). R. H. Geoghegan gives the meaning of the Aleut name [hakún] as "that, over there."

Akun Strait: water passage, between Akun and Akutan Is., Krenitzin Is., Aleutian Is.; $54^{\circ} 08^{\prime}$ N., $165^{\circ} 39^{\prime} \mathrm{W}$; (map 24).

Name reported about 1830 by Father Ioann Veniaminov and Capt. F. P. Lutke, IRN; named because of its relationship to Akun Island.

Akuogak: lake, see Naknek Lake.

Akupuk: locality, see Akokpak.

Akupukmiut: locality, see Akokpak.

Akupukmute: locality, see Akokpak.

Akurak Bluff: bluff, $1.5 \mathrm{mi}$. long, on left bank of Wulik River, $22 \mathrm{mi}$. NE of Kivalina, Arctic Slope; $67^{\circ} 49^{\prime} \mathrm{N}, 163^{\circ} 58^{\prime} \mathrm{W}$; (map 128). Var. Ahkoorock, Akuzzaaq.

Eskimo name reported in 1966 by E. S. Burch.

Akurekvik Creek: stream, see Beaver Creek.

Akurekvik Pass: pass, $850 \mathrm{ft}$., in Schwatka Mts. at head of Beaver Creek, $12 \mathrm{mi}$. W of head of Walker Lake, Brooks Ra.; $67^{\circ} 13^{\prime} \mathrm{N}, 1^{155^{\circ} 01^{\prime}}$ W; (map 125).

"Akurekvik" is the Eskimo name for Beaver Creek and literally means "place where beaver is hunted"; recorded at Kobuk in 1956 by Orth.

Akusha Island: island, $0.5 \mathrm{mi}$. across, largest of The Five Fingers, in Stephens Passage, $70 \mathrm{mi}$. NE of Sitka, Coast Mts.; $57^{\circ} 18^{\prime} 15^{\prime \prime} \mathrm{N}, 133^{\circ}$. $39^{\prime} 15^{\prime \prime}$ W; BGN 1923; (map 8). Var. Ahushi Island, Northwest Fivefinger, Thumb Island, Ukushe Island.

Tlingit Indian name, reported to mean "thumb," published in 1923 by USC\&GS ; so called because the island occupies the position of the thumb in The Five Fingers.

Akutagrak Hills: hills, $5 \mathrm{mi}$. NW of Mount Sapumik and $32 \mathrm{mi}$. NE of Kivalina, Brooks Ra.; 68 $12^{\prime} \mathrm{N}, 164^{\circ} 02^{\prime} \mathrm{W}$; (map 130). Var. Ahkootahgrock, Akuttaagzaaq.

Eskimo name reported by E. S. Burch, in 1966, to mean "old scrub-willow."

Akutan: village, pop. 107, on $\mathrm{N}$ shore of Akutan Harbor, on $\mathrm{E}$ coast of Akutan I., Krenitzin Is., Aleutian Is.; $54^{\circ} 08^{\prime} 05^{\prime \prime} \mathrm{N}$, $165^{\circ} 46^{\prime} 20^{\prime \prime} \mathrm{W}$; BGN 1890; (map 24).

Name derived from Akutan Island and published in 1869 by George Davidson, USC\&GS. A post office was established in 1914 (Ricks, 1965, p. 2).

Akutan Bay: bay, $10 \mathrm{mi}$. across, between Akutan and Akun Is., Krenitzin Is., Aleutian Is.; $54^{\circ}$. $11^{\prime} \mathrm{N}, 165^{\circ} 43^{\prime} \mathrm{W} ; B G N$ 1890; (map 24). Var. Acootan Bay. 
So named in 1888 by USBF because of its relationship to Akutan Island.

Akutan Harbor: bay, $4 \mathrm{mi}$. long, part of Akutan Bay, E coast of Akutan I., Krenitzin Is., Aleutian Is.; $54^{\circ} 07^{\prime} 45^{\prime \prime} \mathrm{N}, 165^{\circ} 45^{\prime} 00^{\prime \prime} \mathrm{W}$; $B G N$ 1890; (map 24). Var. Akoutan Harbor, Chinchan Bay.

Named "Akoutan" in 1888 by USBF. Capt. Tebenkov (1852, map 26), IRN, published the name " $Z[$ aliv] Chinchan."

Akutan Island: island, $18 \mathrm{mi}$. long in Krenitzin Is., Aleutian Is.; $54^{\circ} 07^{\prime} \mathrm{N}, 165^{\circ} 55^{\prime} \mathrm{W}$; $B G N$ 1890; (maps 23, 24). Var. Acootan, Acutan, Akoutan.

Aleut name reported by Capt. Lt. P. K. Krenitzin and Lt. Michael Levashev in 1768 (Coxe, 1787, p. 205) and spelled "Acootan" by Capt. Cook (1785, v. 2, p. 425), RN. This name may be from the Aleut word "hakuta" which, according to R. H. Geoghegan, means "I made a mistake."

Akutan Pass: water passage, between Unalaska and Akutan Is., Aleutian Is.; $54^{\circ} 01^{\prime} 30^{\prime \prime} \mathrm{N}$, $166^{\circ} 03^{\prime} 00^{\prime \prime} \mathrm{W} ; B G N$ 1890; (map 23). Var. Akoutan Pass, Akoutanskoi Pass, Akutan Strait, Paso de Sanganoac, Proliv Akutanskiy, Proliv Akutanskoy.

Name published by Capt. Lutke (1836, p. $289,304,305$ ), IRN, as "Le detroit d'Akoutan" and as "Le detroit Akoutanskoi." Capt. Tebenkov (1852, map 56), IRN, published the name as "P[roliv] Akutanskiy," meaning "Akutan Strait." Baker (1906, p. 88) suggests that this feature may possibly be the same as "Paso de Sanganoac" recorded by Galiano (1802, map 3). According to R. H. Geoghegan, the name may be from the Aleut word "hakuta," meaning "I made a mistake."

Akutan Peak: volcano, 4,275 ft., on Akutan I., Krenitzin Is., Aleutian Is.; $54^{\circ} 08^{\prime} \mathrm{N}, 165^{\circ}$. $59^{\prime} \mathrm{W} ; B G N$ 1890; (map 24).

Name reported in 1873 by USC\&GS and presumably named by that agency.

Akutan Point: point of land, on N shore of Akutan Harbor, E coast of Akutan I., Krenitzin Is., Aleutian Is.; $54^{\circ} 08^{\prime} 45^{\prime \prime} \mathrm{N}, 165^{\circ} 43^{\prime} 45^{\prime \prime} \mathrm{W}$; (map 24).

Local name derived from Akutan Island; published in 1951 on a USGS map.

Akutanskiy, Proliv: water passage, see Akutan Pass.

Akutanskoy, Proliv: zeater passage, see Akutan Pass.

Akutan Strait: zeater passage, see Akutan Pass.

Akutoktak River: stream, heads in Romanzof Mts., $9.5 \mathrm{mi}$. NE of Mount Michelson, flows NE $33 \mathrm{mi}$. to Okpilak River, $18 \mathrm{mi}$. S of Barter I., Arctic Plain; $69^{\circ} 50^{\prime} \mathrm{N}, 143^{\circ} 45^{\prime} \mathrm{W}$; (map 138). Var. Akootoaktuk River.

Eskimo name reported in 1948 by USC\&GS. The name refers to a mixture of seal oil, caribou fat, and snow.

Akutsok Creek: stream, see Turner River.

Akuttaagzaaq : hills, see Akutagrak Hills.

Akuyan, Cape: point of land, on $\mathrm{W}$ coast of Great Sitkin I., Aleutian Is.; 52 $03^{\prime} 50^{\prime \prime} \mathrm{N}$, 176'12'35" W; BGN 1936; (map 17). Var. Akuaine, Mys Akuyan.
Aleut name published as "M[ys] Akuyan," or "Cape Akuyan," by Capt. Tebenkov (1852, map 28), IRN. This name may come from the Aleut words "hakuya" or "haquyan" which, according to R. H. Geoghegan, mean "standing at a distance" and "river otters," respectively.

Akuyan Creek: stream, flows W 2 mi. to Cape Akuyan, on W coast of Great Sitkin I., Aleutian Is. ; $52^{\circ} 03^{\prime} 30^{\prime \prime} \mathrm{N}, 176^{\circ} 12^{\prime} 15^{\prime \prime} \mathrm{W}$; (map 17).

Local name derived from Cape Akuyan; published in 1951 by USGS.

Akuzzaaq: bluff, see Akurak Bluff.

Akvakniakvik Lagoon: lagoon, see Kaktovik Lagoon.

Akvalutak Creek: stream, flows NW $5.5 \mathrm{mi}$. from Mount Stuver to Anaktuvuk River, 9 mi. NE of Anaktuvuk Pass, Brooks Ra.; 68 ${ }^{\circ} 14^{\prime} 15^{\prime \prime} \mathrm{N}$, $151^{\circ} 33^{\prime} 00^{\prime \prime} \mathrm{W}$; (map 134). Var. Akvalutuk Creek.

Eskimo name published by Rausch (1951, p. 150).

Akvalutuk Creek: stream, see Akvalutak Creek.

Akvat: locality, on Chukchi Sea coast, $8 \mathrm{mi}$. NE of Wainwright, Arctic Plain; $70^{\circ} 43^{\prime} 50^{\prime \prime} \mathrm{N}$, $159^{\circ} 47^{\prime} 45^{\prime \prime}$ W; (map 146). Var. Akavat.

An Eskimo camp on the coastal trail; name published in 1958 by AMS.

Akve River: stream, see Akwe River.

Akvetskoe: locality, on Lituya Bay; (map 10). Var. Ahkvaystkie, Akwetz.

Tlingit Indian summer camp, with a population of 200 in 1835, reported as "Ahkvaystkie" by Father Ioann Veniaminov in 1840 (Hodge, 1907, p. 34). The name is reported to mean "lake town."

Akwe Lake: lake, $1.8 \mathrm{mi}$. long, at head of Akwe River $2 \mathrm{mi}$. NW of Ustay Lake and $37 \mathrm{mi}$. SE of Yakutat, St. Elias Mts.; $59^{\circ} 19^{\prime} 45^{\prime \prime} \mathrm{N}$, $138^{\circ} 46^{\prime} 50^{\prime \prime} \mathrm{W}$; BGN 1962; (map 46).

Local name derived from Akwe River for which the lake is the source. The name was published by USGS in 1959.

Akwe River: stream, heads at Akwe Lake and flows SW $20 \mathrm{mi}$. to Gulf of Alaska, $35 \mathrm{mi}$. SE of Yakutat Bay, Malaspina Coastal Plain; $59^{\circ} 17^{\prime} \mathrm{N}, 139^{\circ} 03^{\prime} \mathrm{W}$; BGN 1962; (map 46). Var. Ah-quay River, Akoi River, Akve River, Akwi River, Ar Quay River, Ustay River.

Tlingit Indian name first reported by Capt. Tebenkov (1852, map 7), IRN, as "R[eka] Akve," or "Akve River," and since recorded with various spellings. The name was evidently applied originally to the whole drainage system between the Italio River and the Alsek Delta area. The name has been restricted in its application, however, since 1901 .

Akwe River: stream, see Ustay River.

Akwetz: locality, see Akvetskoe.

Akwi River: stream, see Akwe River.

Alabama Creek: stream, flows S $2.1 \mathrm{mi}$. to Hutlinana Creek, $4.2 \mathrm{mi}$. E of Eureka and $23 \mathrm{mi}$. $\mathrm{S}$ of Rampart, Yukon-Tanana High.; $65^{\circ} 10^{\prime}$ $33^{\prime \prime} \mathrm{N}, 150^{\circ} 04^{\prime} 20^{\prime \prime} \mathrm{W}$; BGN 1965; (map 106).

Prospectors' name reported in 1963 by Bond Taber, USGS.
Alabam Creek: stream, flows SW $4 \mathrm{mi}$. to Goldstream Creek, $6 \mathrm{mi}$. NE of Livengood, YukonTanana High.; $65^{\circ} 34^{\prime} 25^{\prime \prime} \mathrm{N}, 148^{\circ} 23^{\prime} 15^{\prime \prime} \mathrm{W}$; (map 105).

Named by prospectors for Charles ("Alabam") Laboyteaux; reported in 1915 by Brooks (in Brooks and others, 1916, pl. 9).

Alachschak: peninsula, see Alaska Peninsula.

Alaeksu: peninsula, see Alaska Peninsula.

Alaganak: locality, see Alaganik.

Alakanik: locality, in Copper River Delta, 20 mi. SE of Cordova, Malaspina Coastal Plain; $60^{\circ} 26^{\prime} 45^{\prime \prime} \mathrm{N}, 147^{\circ} 13^{\prime} 00^{\prime \prime} \mathrm{W}$; (map 64). Var. Alaganak, Alaganok, Alaganu, Alaganuk, Alagnak, Anahanuk, Lookta-ek, Sákhalis, Skatalis.

Former Eskimo and Ahtena Indian village visited in 1848 by Serebrenikov, who reported the name as "Alagnak." In $1885 \mathrm{Lt}$. H. T. Allen, USA, discovered that the village had moved to a new site called "Skatalis." Its population (including Eyak) was 117 in 1880; 48 in 1890 . The name is now applied to a locality along the Copper River Highway.

Alaganik Slough: stream, $15 \mathrm{mi}$. long, distributary of Copper River, 12 mi. SE of Cordova, Malaspina Coastal Plain; $60^{\circ} 25^{\prime} \mathrm{N}, 145^{\circ} 30^{\prime}$ W; (map 64). Var. Algonek River.

Eskimo name derived from the nearby Eskimo village of Alaganik; reported as "Algonek River" in 1899 by Lt. Comdr. J. F. Moser, USN, and "Alaganik River" in 1900 by F. C. Schrader and T. G. Gerdine, USGS. Alaganok: locality, see Alaganik.

Alaganu: locality, see Alaganik.

Alaganuk: locality, see Alaganik.

Alagnak: locality, see Alaganik.

Alagnak River: stream, heads at Kukaklek Lake and flows SW $64 \mathrm{mi}$. to Kvichak River, 58 mi. E of Dillingham, Bristol Bay Low.; $59^{\circ}$ $00^{\prime} \mathrm{N}, 156^{\circ} 53^{\prime} \mathrm{W}$; (map 52). Var. Aliknuk, Lockenuck.

Eskimo name shown as "Alagnak" by Capt. Tebenkov (1852, map 4), IRN, and is said by R. H. Geoghegan to mean "wild raspberry." Alagogshak Creek: stream, on S coast of Alaska Penin., in Katmai National Monument, flows SE $18 \mathrm{mi}$. to Katmai Bay, $17 \mathrm{mi}$. SW of Mount Katmai, Aleutian Ra.; $58^{\circ} 01^{\prime} 00^{\prime \prime} \mathrm{N}, 1^{\circ} 5^{\circ}$ 02'15' W; (map 42). Var. Alagogshuk Creek.

Eskimo name published by Griggs (1922, map, p. 68), National Geographic Society, as "Alagogshuk Creek."

Alagogshuk Creek: stream, see Alagogshak Creek.

Alai, Mount: peak, 2,850 ft., near $\mathrm{W}$ end of Wide Bay, on S coast of Alaska Penin., 33 mi. $\mathrm{SE}$ of Ugashik, Aleutian Ra.; $57^{\circ} 18^{\prime} 20^{\prime \prime} \mathrm{N}$, $156^{\circ} 38^{\prime} 15^{\prime \prime} \mathrm{W}$; (map 36). Var. Gora Alay, Gora Olai, Mount Alay, Mount Olai, Mount Otai, Olav Mountain.

Apparently a native name given in 1831-32 by Ens. Vasiliev as "Gora Alai" and published in 1847 as "Gora Alay" on Russian Hydrog. Dept. Chart 1379.

Alai Creek: stream, flows SE $3.2 \mathrm{mi}$. to Wide Bay, $\mathbf{N}$ of Kialagvik Creek, on $\mathbf{E}$ coast of 
Alaska Penin., $36 \mathrm{mi}$. SE of Ugashik, Aleutian Ra.; $57^{\circ} 18^{\prime} 45^{\prime} \mathrm{N}, 156^{\circ} 32^{\prime} 25^{\prime} \mathrm{W}$; (map 36 ).

Name published in 1956 by USGS; probably derived from Mount Alai.

Alaid Head: promontory, $600 \mathrm{ft}$., at NW tip of Alaid I., in Semichi Is., Aleutian Is.; 52 ${ }^{\circ} 6^{\prime}$ 25" N, 17352'00" E, BGN 1938; (map 13). Var. West Head.

Name derived from Alaid Island.

Alaid Island: island, $3.1 \mathrm{mi}$. long, westernmost of Semichi Islands, Aleutian Is.; 52 $2^{\circ} 5^{\prime} 50^{\prime \prime}$ N, $173^{\circ} 54^{\prime} 00^{\prime \prime}$ E; (map 13). Var. Alida Island, Little Alaid Island, Alaidskaya Pupka.

Named by the Russians from its resemblance to Alaid Island, one of the Kuril Islands in Russia, "sometimes called Little Alaid, presumably to distinguish it from that island. American whalers called it Alida ( $\mathrm{Al}^{\prime} \mathrm{ida}$ ). Constantin Grewingk stated that Alaid meant "heart rock." Capt. Tebenkov (1852, map 30), , IRN, called it "Alaidskaya Pupka," meaning "navel of Alaid."

Alaidskaya Pupka: island, see Alaid Island.

Alakaket: village, see Allakaket.

Alakanuk: village, pop. 278 , at $\mathbf{E}$ entrance to Alakanuk Pass, $6 \mathrm{mi}$. SW of Kwiguk, YukonKuskokwim Delta ; $62^{\circ} 41^{\prime} 20^{\prime \prime} \mathrm{N}, 164^{\circ} 37^{\prime} 00^{\prime \prime}$ W; (map 77)

Eskimo village reported in 1899 by G. R. Putnam, USC\&GS. Its population was 61 in 1939 and 140 in 1950. A post office was established here in 1946 (Ricks, 1965, p. 3).

Alakanuk Pass: watercourse, in distributary system of Yukon River, trends W $11 \mathrm{mi}$. from Kwikluak Pass to Norton Sound, $11 \mathrm{mi}$. W of Kwiguk, Yukon-Kuskokwim Delta ; 62 ${ }^{\circ} 43^{\prime} 30^{\prime \prime}$ $\mathrm{N}, 164^{\circ} 52^{\prime} 00^{\prime \prime} \mathrm{W}$; (map 77). Var. Alakanuk Slough.

Eskimo name obtained in 1899 by G. R. Putnam, USC\&GS. According to a USC\&GS report in 1950, it means "wrong way" or "mistakes."

Alakanuk Slough: watercourse, see Alakanuk Pass.

Alakhskhak: peninsula, see Alaska Peninsula. Alaknakik: village, see Aleknagik.

Alaknakik Lake: lake, see Aleknagik, Lake.

Alaksa: peninsula, see Alaska Peninsula.

Alakshak: peninsula, see Alaska Peninsula.

Alaksu: peninsula, see Alaska Peninsula.

Alaktak: locality, on E shore of Alaktak River, between Admiralty and Smith Bays, $19 \mathrm{mi}$. SW of Cape Simpson and $53 \mathrm{mi}$. SE of Barrow, Arctic Plain; $70^{\circ} 46^{\prime} \mathrm{N}, 1^{\circ} 5^{\circ} 02^{\prime} \mathrm{W}$; (map 148). Var. Alaktak Ranch, Half Moon Three Ranch.

This was once a reindeer camp with a herd "of a few thousand," sometimes referred to as Half Moon Three (Ranch), a name derived from the call letters of the radio station maintained there in the 1940's because of its strategic location for emergency landings and weather reporting. The present name is derived from the stream.

Alaktak Ranch: $l \cdot$ ality, see Alaktak.

Alaktak River: $s t \quad m$, distributary of Ikpikpuk River, heads at $70^{\circ} 27^{\prime} 10^{\prime \prime} \mathrm{N}, 154^{\circ} 53^{\prime} 30^{\prime \prime} \mathrm{W}$, flows NW 50 mi. to Pittalukruak Lake, S of
Dease Inlet, $47 \mathrm{mi}$. SE of Barrow, Arctic Plain; $70^{\circ} 49^{\prime} \mathrm{N}, 155^{\circ} 19^{\prime} \mathrm{W}$; (map 148).

Eskimo name reported in the 1940's by USGS, and refers in meaning to the stream's "meandering."

Alakuchak River: stream, flows SW $6 \mathrm{mi}$. to Kangirlvar Bay, $12 \mathrm{mi}$. E of Cape Vancouver, Yukon-Kuskokwim Delta; $60^{\circ} 33^{\prime} \mathrm{N}, 1^{\circ} 5^{\circ} 04^{\prime}$ W; (map 57).

Eskimo name meaning "elder sister," obtained at Tanunak in 1949 by USC\&GS.

Alameda Creek: stream, flows NE $4 \mathrm{mi}$. to Koyuk River, $10 \mathrm{mi}$. SE of Haycock, Seward Penin. High.; $65^{\circ} 05^{\prime} \mathrm{N}, 160^{\circ} 58^{\prime} \mathrm{W}$; BGN 1910; (map 109). Var. Wilson Creek.

Prospectors' name reported in 1909 by P. S. Smith, USGS.

Alameda Creek: stream, flows S $1.2 \mathrm{mi}$. to Kentucky Creek $1.1 \mathrm{mi}$. N of that stream's junc. with Hutlinana Creek, $23 \mathrm{mi}$. S of Rampart, Yukon-Tanana High.; $65^{\circ} 10^{\prime} 00^{\prime \prime}$ N, $150^{\circ} 10^{\prime}$ $30^{\prime \prime} \mathrm{W}$; (map 106).

Prospectors' name reported in 1931 by J. B. Mertie, Jr., USGS

Alanzo, Mys de: point of land, see Alonzo Point. Alapah Creek: stream, flows N $25 \mathrm{mi}$. from Alapah Mtn. through Shainin Lake to Kanayut River, $30 \mathrm{mi}$. NE of Anaktuvuk Pass, Brooks Ra.; $68^{\circ} 28^{\prime}$ N, $150^{\circ} 59^{\prime}$ W; $B G N$ 1960; (map 134).

Named by USGS geologists, in 1950, after the mountain on which it heads.

Alapah Mountain: mountain, 7,000 ft., at heads of Nanushuk and Anaktuvuk Rivers, $W$ of Cockedhat Mtn., 23 mi. E of Anaktuvuk Pass, Brooks Ra.; $68^{\circ} 08^{\prime} \mathrm{N}, 150^{\circ} 50^{\prime} \mathrm{W}$; $B G N$ 1932; (map 134)

Named by Marshall (1956, p. 20) who wrote "and determined instead to climb directly to the top of a great tabletop mountain *** We later named this mountain Alapah, meaning cold in Eskimo."

Alapak Hill: hill, $400 \mathrm{ft}$., in Igichuk Hills, on E bank of Noatak River, $20 \mathrm{mi}$. N of KotzebueKobuk Low.; Arctic Slope; $67^{\circ} 11^{\prime} 30^{\prime \prime} \mathrm{N}$, $162^{\circ} 28^{\prime} 30^{\prime \prime} \mathrm{W}$; (map 128). Var. Elapuk Hill.

Eskimo name reported to mean "poor man" in 1956 by Orth.

Alargate Alla: islands, see Alargate Rocks.

Alargate Rocks: islands, two, extend 1,100 ft. in Portillo Channel, on NW coast of San Fernando I., Alex. Arch.; 55 $31^{\prime} 00^{\prime \prime}$ N, $133^{\circ} 26^{\prime}$ $30^{\prime \prime} \mathrm{W}$; BGN 1923; (map 4). Var. Alargate Alla, Sheer-off-there Rock.

Named in 1923 by USC\&GS. The word "alargate" is from the Spanish "alagar," meaning "to sheer off"; Baker (1906, p. 568) published the name "Sheer-off-there Rock." The notation "Alargate Alla," meaning "give this a wide berth," was published next to this feature on maps of the 1779 expedition of Ignacio Arteaga (Wagner, 1937, p. 373). This notation was probably made by the navigator Francisco Antonio Maurelle.

Alasca: peninsula, see Alaska Peninsula. Alaschka: peninsula, see Alaska Peninsula. Alashka: peninsula, see Alaska Peninsula.
Alashuk: village, see Alatna.

Alaska: state, pop. 226,167, largest in area in the United States. Purchased from Russia in 1867; organized as a territory in 1912; became the 49th State in 1959 . Capital is Juneau. Total area 586,400 sq. miles. Its population was 33,426 in $1880 ; 32,052$ in $1890 ; 63,592$ in $1900 ; 64,356$ in $1910 ; 55,036$ in $1920 ; 59,278$ in $1930 ; 72,524$ in 1939 ; and 128,643 in 1950 .

It is bounded on the $\mathrm{N}$ by the Arctic Ocean, on the $E$ by Canada, on the $S$ by the Gulf of Alaska (Pacific Ocean), and on the $W$ by Bering Sea, Bering Strait, and Chukchi Sea. Var. Russian America, Sewards Folly, Territory of Alexander, Walrussia.

The name "Alaska" seems to have been gradually established by local use; vaguely applied at first to a supposed island, later found to be the southwestern end of the Alaska Peninsula. The application of the name gradually developed from this beginning to include the whole area (Stewart, 1956, p. 203). The Russians officially designated it "Russian America" prior to its 1867 purchase by the United States. The name "Alaska" was pro. posed in 1867 for official acceptance by W. H. Seward, U.S. Secretary of State, the Honorable Charles Sumner, Senator and chairman of the Committee on Foreign Relations, and by Maj. General H. W. Halleck, Commander of the Military Division of the Pacific. There is some controversy over which of these three men proposed the name first (ibid., p. 198-203). For a comprehensive analysis of the origin of the name, see Stewart (1956, p. 193-204). See Alaska Peninsula.

Alaska, Gulf of: gulf, bounded on $\mathrm{N}$ by the $\mathrm{S}$ coast of Alaska, and on $S$ by a line running ESE from $S$ end of Kodiak I. to $S$ end of Dall I. in Alex. Arch.; 58 $8^{\circ} \mathrm{N}, 145^{\circ} \mathrm{W}$; BGN 1965.

Name derived from the Territory of Alaska and published by Baker (1906, p. 89) who wrote, "This name has for the last two or three decades been applied to that part of the North Pacific Ocean lying approximately to the north of a line from Sitka to Kodiak."

Alaska, Presquile D': peninsula, see Alaska Peninsula.

Alaska, Sea of : sea, see Bering Sea.

Alaska Cape: point of land, see Kabuch Point.

Alaska Chief Falls: falls, on Icy Gulch, $2.5 \mathrm{mi}$. $\mathrm{E}$ of Juneau, Coast Mts.; $58^{\circ} 18^{\prime} 18^{\prime \prime} \mathrm{N}$, $134^{\circ} 20^{\prime} 24^{\prime \prime} \mathrm{W}$; (map 11).

Name derived from the Alaska Chief lode claim staked there by Joe Juneau and Richard Harris in 1880 . Juneau and Harris called the canoe, in which they came from Sitka, the "Alaska Chief" (DeArmond, 1957, p. 5). Alaska City: city, see Anchorage.

Alaska Creek: stream, flows S $1.6 \mathrm{mi}$. to Healy Creek, $5 \mathrm{mi}$. E of Healy, Alaska Ra.; $63^{\circ}$ $51^{\prime} 30^{\prime \prime} \mathrm{N}, 148^{\circ} 48^{\prime} 00^{\prime \prime} \mathrm{W}$; BGN 1945; (map 87).

Local name reported in 1944 by USGS

Alaska Gulch: valley, in Bonnifield region, extends $S$ to Healy Creek about $18 \mathrm{mi}$. E of 
Healy, Alaska Ra.; $63^{\circ} 52^{\prime} \mathrm{N}, 148^{\circ} 06^{\prime} \mathrm{W}$; (map 87).

Reported in 1917 by R. M. Overbeck and A. G. Maddren (in Brooks and others, 1918, pl. 15), USGS.

Alaska Island: barrier island, $3 \mathrm{mi}$. long, on Beaufort Sea coast, in Maguire Is., $7 \mathrm{mi}$. W of Flaxman I., Arctic Plain; $70^{\circ} 14^{\prime}$ N, $146^{\circ} 33^{\prime}$ W; (map 151).

Named about 1913 by Leffingwell (1919, p. 93), "After the schooner Alaska of the $\mathrm{Ca}$ nadian Arctic Expedition."

Alaskan Mountains: mountain range, see Alaska Range.

Alaskan Range: mountain range, see Alaska Range.

Alaska Peak: mountain, 2,600 ft., $2.5 \mathrm{mi}$. W of North Arm in Farragut Bay, $77 \mathrm{mi}$. E of Sitka, Coast Mts. ; $57^{\circ} 08^{\prime} 35^{\prime \prime} \mathrm{N}, 133^{\circ} 18^{\prime} 55^{\prime \prime}$ W; (map 8).

Named in 1887 by Lt. Comdr. C. M. Thomas, USN.

Alaska Peninsula: peninsula, extends SW about $475 \mathrm{mi}$. from Iliamna Lake to Unimak I.; $59^{\circ} 30^{\prime} \mathrm{N}, 155^{\circ} 30^{\prime} \mathrm{W}$ [NE end], $54^{\circ} 50^{\prime} \mathrm{N}$, $163^{\circ} 24^{\prime}$ W [SW end]; BGN 1901; Var. Alachschak, Aleaksu, Alakhskhak, Alaksa, Alakshak, Alaksu, Alasca, Alaschka, Alashka, Alayeksa, Alaxa, Alaxsu, Aliaksa, Aliakshka, Aliaska, Aljaska, Mys Alyaksa, Poluostrov Alyaska, Presquile D'Alaska.

Authoritative sources generally agree that the name "Alaska" is derived from "an Aleut root meaning 'a great country or continent' ***” or '*** 'mainland' ***" (Stewart, 1956, p. 193-203).

In 1762, Bechevin (cnna), a merchant of Irkutsk, Siberia, wintered in Isanotski Strait between Unimak Island and the Alaska Peninsula. He regarded the western end of the peninsula as an island, reportedly called "Alaksu" or "Alakshak" (Bancroft, 1886, p. 122-124 and 165). Capt. Lt. P. K. Krenitzin and Lt. Michael Levashev, IRN, in 1768, also referred to a large island called "Alaxa" northeast of Unimak Island (Coxe, 1787, map facing p. 205).

The first to correctly apply the name was Capt. James Cook (1785, v. 2, p. 504), RN, in 1778, who said "I have already observed that the American continent is here called by the Russians, as well as the islanders, Alaschka, which name, though it properly belongs only to the country adjoining to Oonemak [Unimak Island], is used by them when speaking of the American continent in general, which they know perfectly well to be a great land."

After the publication of Cook's work, the name was generally applied (with various spellings) to the peninsula ; $L t$. Sarichev (1826, map 3), IRN, used "Mys Alyaksa" or "Alyaksa Cape [headland]" on a 1791 map and Capt. Lutke (1836, p. 257), IRN, reported it as "Presquile D'Alaska" meaning "Alaska Peninsula." The Aleut name "Alakhskhak" was recorded by Father Veniaminov (1840, v. 1, p. 220) and Capt. Tebenkov
(1852, map 24), IRN, applied the name "Poloustrov Alyaska" or "Alaska Peninsula."

The name and its application to the State and peninsula was well established in the late 1880 's when W. H. Dall (1870, p. 129-30) wrote: "*** This name, now applied to the whole of our new territory, is a corruption, very far removed from the original word. * * *alled by the natives Al-ák-shak or Al-áy-ek-sa ***. From Aláyeksa the name became, ** * Aláksa, Aláshka, Aliáska, and finally Aláska ***. We have, then Alaska for the territory, Aliaska for the peninsula ***."

Alaska Range: mountain range, extends in an arc $650 \mathrm{mi}$. from Iliamna Lake at $\mathrm{SW}$ end to White River in Canada at SE end; highest point is Mount McKinley at $20,320 \mathrm{ft}$.; $62^{\circ} 00^{\prime}$ $\mathrm{N}, 141^{\circ} 00^{\prime} \mathrm{W}$ [SE end], $59^{\circ} 45^{\prime} \mathrm{N}, 156^{\circ} 00^{\prime}$ [SW end]. Var. Alaskan Mountains, Alaskan Range, Beaver Mountains, Chigmit Mountains, Khrebet Chigmit, Tschigmit Mountains.

The name "Alaskan Range" appears to be first applied to these mountains in 1869 by Dall (1870, p. 286). The name eventually became "Alaska Range" through local use. In 1849 Constantin Grewingk applied the name "Tschigmit" to this mountain range. "A map made by the United States Land Office, 1869 , calls the southwestern part of the Alaska Range Chigmit mountains and the northeastern part Beaver mountains" (Baker, 1906, p. 176). See Alaska and Alaska Peninsula.

Alasuk: stream, see Alatna River.

Alataktok River: stream, heads in lake, flows NE $16 \mathrm{mi}$. to Kuk River, $9 \mathrm{mi}$. S of Wainwright, Arctic Plain; $70^{\circ} 30^{\prime} \mathrm{N}, 159^{\circ} 55^{\prime} \mathrm{W}$; BGN 1925; (map 146). Var. Aulatakroak River. Eskimo name reported in 1924 by USGS.

Alatna: village, pop. 16, on $\mathrm{N}$ bank of Koyukuk River, W of Allakaket, Kanuti Flats; $66^{\circ}-$ $34^{\prime} 00^{\prime \prime} \mathrm{N}, 152^{\circ} 40^{\prime} 00^{\prime \prime} \mathrm{W}$; BGN 1952; (map 117). Var. Alashuk, Aletna, Marsan, Alatna Landing.

Eskimo village established by Archdeacon Stuck $(1914$, p. 70$)$ at an old trading post called Marsan. See Allakaket.

Alatna: village, see Allakaket.

Alatna Hills: hills, extend $50 \mathrm{mi}$. long and 20 mi. wide, $1 \mathrm{mi}$. $W$ of Bettles, bounded on the SW by the Alatna River and on the $\mathrm{E}$ by the John and Koyukuk Rivers, Hogatza High.; $66^{\circ} 50^{\prime}$ N. $151^{\circ} 43^{\prime} \mathrm{W}$ [E end], $66^{\circ} 50^{\prime} \mathrm{N}$, $153^{\circ} 30^{\prime} \mathrm{W}$ [W end]; $B G N$ 1966; (map 125, $124,116,117)$.

Named in 1965 for the Alatna River by W. W. Patton, Jr., USGS.

Alatna Landing: village, see Alatna.

Alatna River: stream, flows SE $145 \mathrm{mi}$. to Koyukuk River at Allakaket, Kanuti Flats; $66^{\circ} 34^{\prime} 00^{\prime \prime}$ N, $152^{\circ} 37^{\prime} 30^{\prime \prime}$ W; (map 117). Var. Ah-lash-ok, Alasuk, Allakaket, Al-lashook, Allatna River, Allenkakat, Allenkaket, Allenkkat, Allen River, Oklashok.

Koyukan Indian name reported in 1885 by Lt. Allen (1887, p. 98), USA, as "Allenkakat," or "mouth of the Allen." We do not know if this was an attempt by Allen to commemorate himself or whether it was an unintentional corruption of "Allakaket," or "mouth of Ala." Archdeacon Stuck (1917, p. 341 ) thinks the latter is true, and that all white men (in 1917) corrupted "Allakaket" to "Allenkaket" because the pronunciation was easier for those speaking English. The present spelling appears to have been obtained in 1899 by F. C. Schrader and T. G. Gerdine, USGS, although the latter still showed "Allenkakat River" on his fieldsheet. The Eskimo name for this stream is "Alasuk," spelled in 1886 by Lt. Stoney (1900, map), USN, "Al-lash-ook" and in 1885 by Lt. Cantwell, USRCS, "Ah-lash-ok" (Healy, 1887, p. 39). W. C. Mendenhall and D. L. Reaburn's 1901 USGS expedition showed the "Alatna" and "Alasuk," which since 1885 had been represented as different streams, to be the same. The present Indian name came to be the most commonly accepted name.

Alava, Point: point of land, $\mathrm{S}$ tip of Revillagigedo I., Alex. Arch.; 55 $11^{\prime} 30^{\prime \prime} \mathrm{N}, 131^{\circ}$ $11^{\prime} 00^{\prime \prime} \mathrm{W}$; (map 3$)$.

Named by Capt. George Vancouver, "August 7, 1793, no doubt in honor of José Manuel de Alava, who succeeded Bodega as commissioner and as commandant of San Blas * **” (Wagner, 1937, p. 372).

Alava Bay: bay, $2 \mathrm{mi}$. across, on $\mathrm{S}$ coast of Revillagigedo I.; $2.3 \mathrm{mi}$. NE of Point Alava, Alex. Arch.; $55^{\circ} 13^{\prime} 30^{\prime \prime} \mathrm{N}, 1^{\circ} 01^{\circ} 30^{\prime \prime} \mathrm{W}$; (map 3).

Local navigators' name obtained in 1904 by H. C. Fassett, USBF.

Alava Ridge: ridge, on S coast of Revillagigedc I., extends $2.5 \mathrm{mi}$. NW of Alava Bay, Alex. Arch.; $55^{\circ} 14^{\prime} 45^{\prime \prime} \mathrm{N}, 131^{\circ} 10^{\prime} 00^{\prime \prime} \mathrm{W}$; (map 3).

Named in 1883 by Lt. Comdr. H. E. Nichols, USN.

Alaxa: peninsula, see Alaska Peninsula. Alaxsu: peninsula, see Alaska Peninsula. Alay, Gora: peak, see Alai, Mount.

Alayeksa : peninsula, see Alaska Peninsula.

Albatross Anchorage: anchorage, $0.6 \mathrm{mi}$. across, at SW end of Alaska Penin., in NE arm of Balboa Bay, $13 \mathrm{mi}$. N of Unga I., Aleutian Ra.; 5535' N, $160^{\circ} 36^{\prime}$ W; (map 28).

Surveyed and named in September 1893 by officers of the USBF steamer Albatross.

Albatross Bank: shoal, $50 \mathrm{mi}$. long, $50 \mathrm{mi}$. SE of Kodiak I.; $56^{\circ} 30^{\prime} \mathrm{N}, 152^{\circ} 30^{\prime} \mathrm{W}$; (map 33 ).

Named in 1888 by USBF for the USBF steamer Albatross, which was used for making investigations and surveys in this area.

Albert Channel: channel, at mouth of Kvichak River, extends SW $7 \mathrm{mi}$. from Telephone Point, between Salmon Flats and N shore of Kvichak Bay, $8 \mathrm{mi}$. NW of Naknek, Bristol Bay Low.; $58^{\circ} 50^{\prime} \mathrm{N}, 157^{\circ} 10^{\prime} \mathrm{W}$; (map 41).

Local name reported in 1952 by USGS.

Albert Creek: stream, on Alaska Penin., flows W 10 mi. to East Fork, 2 mi. E of that stream's junc. with Kejulik River, $32 \mathrm{mi}$. SW of Mount Katmai, Aleutian Ra.; 57 $54^{\prime} 05^{\prime \prime} \mathrm{N}, 155^{\circ}$ $32^{\prime} 50^{\prime \prime} \mathrm{W}$; (map 35). 
Local name obtained from J. L. McPherson of Iliamna; published by W. R. Smith and A. A. Baker (in Brooks and others, 1924, pl. 9), USGS.

Albert Creek: stream, heads in Horn Mts., flows E $3.5 \mathrm{mi}$. to Crooked Creek, $8 \mathrm{mi}$. N of Tahneta Pass, Talkeetna Mts. ; $62^{\circ} 00^{\prime} 20^{\prime \prime} \mathrm{N}, 147^{\circ}$ $17^{\prime} 30^{\prime \prime} \mathrm{W}$; (map 82).

Prospectors' name published by G. C. Martin and J. B. Mertie, Jr. (in Brooks and others, 1914, pl. 11), USGS.

Albert Creek: stream, flows SE $24 \mathrm{mi}$. to Crooked Creek, $22 \mathrm{mi}$. SW of Circle, Yukon-Tanana High.; $65^{\circ} 34^{\prime} 45^{\prime \prime} \mathrm{N}, 144^{\circ} 30^{\prime} 00^{\prime \prime} \mathrm{W}$; (map 104).

Named by prospectors; reported in 1896 by USGS (Prindle, 1905, pl. 13).

Albert Creek: stream, flows NE to Pargon River, about $15 \mathrm{mi}$. NE of Council, Seward Penin. High.; (map 110).

Prospectors' name reported on the 1900 "Map of Nome Peninsula" by J. M. Davidson and B. D. Blakeslee. This stream cannot be precisely located on current maps.

Albert Johnson Creek: stream, on Alaska Penin., flows $\mathrm{E} 7 \mathrm{mi}$. to Aniakchak River, $21 \mathrm{mi}$. W of Cape Kunmik, Aleutian Ra.; $56^{\circ} 47^{\prime}$ N, $157^{\circ}$ $45^{\prime} \mathrm{W}$; (map 31 ).

Locally named for an "old trapper" and reported in 1923 by R. H. Sargent, USGS.

Albert Lake: lake, $0.6 \mathrm{mi}$. long, $\mathrm{SW}$ of Burnt Lake and $22 \mathrm{mi}$. SW of junc. of Herron and Foraker Rivers, Kuskokwim Low.; 63 $22^{\prime} 30^{\prime \prime}$ N, $152^{\circ} 30^{\prime} 40^{\prime \prime} \mathrm{W}$; (map 88).

Local name reported in 1954 by USGS.

Albert Lake: lake, $1.3 \mathrm{mi}$. long, $0.5 \mathrm{mi}$. SE of Bullrush Lake and $25 \mathrm{mi}$. SW of Beaver, Yukon Flats; $66^{\circ} 15^{\prime} 40^{\prime \prime} \mathrm{N}, 148^{\circ} 15^{\prime} 00^{\prime \prime} \mathrm{W}$; (map 118).

Probably named by William Yanert who showed it on a 1916 manuscript map of the Yukon Flats (Stuck, 1917, map facing p. 122).

Alberto Islands: islands, group extends $2 \mathrm{mi}$. W of Wadleigh I., in San Alberto Bay, Alex. Arch.; $55^{\circ} 32^{\prime} \mathrm{N}, 133^{\circ} 10^{\prime} \mathrm{W}$; $B G N$ 1908; (map 4).

Named in 1897 by Lt. Comdr. J. F. Moser, USN.

Alberto Reef: rock, in San Alberto Bay, W of Alberto I., Alex. Arch.; $55^{\circ} 31^{\prime} 40^{\prime \prime} \mathrm{N}, 133^{\circ}$ $11^{\prime} 55^{\prime \prime} \mathrm{W}$; BGN 1908; (map 4).

Local name reported in 1907 by E. F. Dickins, USC\&GS.

Albert Ridge: ridge, trends SE $2.5 \mathrm{mi}$ : from Alaska-Canada boundary monument 44 , between Lava Fork and West Fork Blue River, Coast Mts.; $56^{\circ} 23^{\prime} \mathrm{N}, 130^{\circ} 55^{\prime} \mathrm{W}$; (map 7).

Local name reported in 1955 by USGS.

Albion Creek: stream, flows SW $0.6 \mathrm{mi}$. to Rock Creek, $8 \mathrm{mi}$. N of Nome, Seward Penin. High.; $64^{\circ} 37^{\prime} 15^{\prime \prime} \mathrm{N}, 165^{\circ} 24^{\prime} 30^{\prime \prime} \mathrm{W}$; (map 94).

Prospectors' name reported on the 1903 Campion Mining and Trading Co. map by George M. Ashford.

Albion Creek: stream, flows NE $1 \mathrm{mi}$. to Crooked Creek which flows to Ophir Creek, $9 \mathrm{mi}$. N of Council and $42 \mathrm{mi}$. SW of Imuruk Lake,
Seward Penin. High.; $65^{\circ} 01^{\prime} 30^{\prime \prime} \mathrm{N}, 163^{\circ} 41^{\prime}$ 50" W; (map 110).

Prospectors' name reported on a map of Cape Nome gold fields by David Fox, Jr., dated 1901.

Albion Creek: stream, flows SW to Nome River, about $36 \mathrm{mi}$. NE of Nome, Seward Penin. High.; (map 94).

Prospectors' name reported on the 1900 "Map of Nome Peninsula" by J. M. Davidson and B. D. Blakeslee; this feature has not been positively identified.

Alcan Cove: harbor, see Alcan Harbor.

Alcan Harbor: harbor, $0.7 \mathrm{mi}$. across, in Semichi Is., on NW coast of Shemya I., Aleutian Is. ; $52^{\circ} 43^{\prime} 45^{\prime \prime} \mathrm{N}, 174^{\circ} 04^{\prime} 30^{\prime \prime} \mathrm{E}$; (map 13). Var. Alcan Gove.

Listed as "Alcan Cove" in the 1944 Aleutian Coast Pilot, and as "Alcan Harbor" in its supplement published in 1946. The name may have been suggested by the Alaska-Canada [Alcan] highway.

Alcha Island: island, see Atka Island.

Alchichna: stream, see John River.

Alder Cove: cove, $0.3 \mathrm{mi}$. across, on SE shore of Hetta Inlet, on SW coast of Prince of Wales I., Alex. Arch.; $55^{\circ} 06^{\prime} 10^{\prime \prime}$ N, $132^{\circ} 37^{\prime}$ $40^{\prime \prime} \mathrm{W}$; (map 4).

Local name recorded in 1951 by USGS.

Alder Creek: stream, flows to North Fork Koyukuk River.

Prospectors' name published in 1902 by $\mathrm{Lt}$. J. C. Cantwell, USRCS; however, not found on any map.

Alder Creek: stream, flows $S$ to Quartz Creek, $13 \mathrm{mi}$. SE of Long and $32 \mathrm{mi}$. SE of Ruby, Kilbuck-Kuskokwim Mts.; $64^{\circ} 18^{\prime} \mathrm{N}, 155^{\circ} 08^{\prime}$ W; (map 98).

Prospectors' name reported in 1913 by Eakin (1914, pl. 3), USGS. The stream's exact application is in doubt.

Alder Creek: stream, flows NW $7 \mathrm{mi}$. to Sumner Strait, $3.5 \mathrm{mi}$. E of village of Point Baker, on $\mathrm{N}$ coast of Prince of Wales I., Alexander

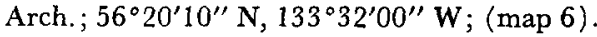

Local name recorded in 1949 by USGS.

Alder Creek: stream, flows W $2 \mathrm{mi}$. to Karluk Lake, $21 \mathrm{mi}$. SE of Karluk, Kodiak I. ; $57^{\circ} 22^{\prime}$ $45^{\prime \prime} \mathrm{N}, 154^{\circ} 01^{\prime} 25^{\prime \prime} \mathrm{W}$; (map 35).

Local name reported in 1952 by USGS.

Alder Creek: stream, on Kenai Penin., flows NE $5 \mathrm{mi}$. to Sixmile Creek, $4.7 \mathrm{mi}$. S of Sunrise, Chugach Mts. ; $60^{\circ} 49^{\prime} 05^{\prime \prime} \mathrm{N}, 149^{\circ} 25^{\prime} 40^{\prime \prime} \mathrm{W}$; (map 63).

Local name reported in 1904 by Moffit (1906, pl. 2), USGS.

Alder Creek: stream, flows SE $2.7 \mathrm{mi}$. to Friday Creek, $46 \mathrm{mi}$. NW of Tyonek, Alaska Ra.; $61^{\circ} 41^{\prime} 45^{\prime \prime} \mathrm{N}, 151^{\circ} 36^{\prime} 30^{\prime \prime} \mathrm{W}$; (map 70).

Local name reported in 1954 by USGS.

Alder Creek: stream, flows to Chavolda Creek, Alaska Ra.; $62^{\circ} 30^{\prime} \mathrm{N}, 142^{\circ} 10^{\prime} \mathrm{W}$; (map 84).

Name reported by USGS (in Brooks and others, 1914, pl. 14).

Alder Creek: stream, in Innoko region, flows into Otter Creek, tributary of Iditarod River, Kilbuck-Kuskokwim Mts.; $62^{\circ} 32^{\prime}$ N, $157^{\circ} 44^{\prime}$ W; (map 79).
Name reported by Eakin (1914, pl. 2), USGS.

Alder Creek: stream, heads at glacier E of Ruth Glacier, flows SE $16 \mathrm{mi}$. to Tokositna River $1.5 \mathrm{mi}$. W of its junc. with Chulitna River, 25 mi. NW of Talkeetna, Cook Inlet Low.; $62^{\circ} 49^{\prime} 30^{\prime \prime} \mathrm{N}, 150^{\circ} 20^{\prime} 10^{\prime \prime} \mathrm{W}$; (map 81).

Local name published in 1940 by USGS.

Alder Creek: stream, flows NW $4 \mathrm{mi}$. to Boulder Creek, $20 \mathrm{mi}$. N of Medfra, Kilbuck-Kuskokwim Mts.; $63^{\circ} 23^{\prime} \mathrm{N}, 154^{\circ} 38^{\prime} \mathrm{W}$; (map 89).

Local name reported in 1910 by A. G. Maddren (in Brooks and others, 1911, pl. 14), USGS.

Alder Creek: stream, in Kantishna Hills, flows SSW $3.6 \mathrm{mi}$. to Toklat River, $2 \mathrm{mi}$. WSW of junc. of that stream's East Fork, Alaska Ra.; $63^{\circ} 53^{\prime} 30^{\prime \prime} \mathrm{N}, 150^{\circ} 12^{\prime} 30^{\prime \prime} \mathrm{W}$; (map 88).

Local name shown on a 1916 fieldsheet by C. E.. Giffin, USGS.

Alder Creek: stream, flows NE $2 \mathrm{mi}$. to South Fork Fortymile River, $50 \mathrm{mi}$. SW of Eagle, Yukon-Tanana High.; $64^{\circ} 08^{\prime} 20^{\prime \prime} \mathrm{N}, 141^{\circ} 46^{\prime} 20^{\prime \prime}$ W; (map 102).

Prospectors' name obtained in 1898 by E. C. Barnard, USGS.

AIder Creek: stream, flows SE $15 \mathrm{mi}$. to O'Brien Creek, $31 \mathrm{mi}$. SW of Eagle, Yukon-Tanana High.; $64^{\circ} 21^{\prime} 30^{\prime \prime} \mathrm{N}, 141^{\circ} 24^{\prime} 40^{\prime \prime} \mathrm{W}$; (map 102).

Prospectors' name obtained in 1898 by E. C. Barnard, USGS.

Alder Creek: stream, flows to Ungalik River E of Norton Bay, Norton Sound, Nulato Hills; $64^{\circ}$ $45^{\prime} \mathrm{N}, 160^{\circ} 30^{\prime} \mathrm{W}$; (map 96).

Name reported in 1909 by P. S. Smith, USGS.

Alder Creek: stream, flows NE $6 \mathrm{mi}$. to Cripple Creek, $9 \mathrm{mi}$. W of Fairbanks, Yukon-Tanana High.; $64^{\circ} 49^{\prime} 30^{\prime \prime} \mathrm{N}, 148^{\circ} 00^{\prime} 40^{\prime \prime} \mathrm{W}$; (map 100 ).

Local name published in 1905 on a manuscript map by C. W. Joint.

Alder Creek: locality, on right bank of Alder Creek, $1 \mathrm{mi}$. S of Seventymile River, $38 \mathrm{mi}$. NW of Eagle, Yukon-Tanana High.; 64.58'$45^{\prime \prime} \mathrm{N}, 142^{\circ} 19^{\prime} 30^{\prime \prime} \mathrm{W}$; BGN 1944; (map 102).

Mining camp reported in 1925 by ARC.

Alder Creek: stream, flows NE $7 \mathrm{mi}$. to Seventymile River, $38 \mathrm{mi}$. NW of Eagle, YukonTanana High.; 64 $59^{\prime} \mathrm{N}, 142^{\circ} 19^{\prime} \mathrm{W}$; (map 102).

Named by prospectors and shown on a 1905 manuscript map by Maj. W. A. Glassford, U.S. Army Signal Corps.

Alder Creek: stream, flows SW $3 \mathrm{mi}$. to Gold Run which flows to Bluestone River, $15 \mathrm{mi}$. SE of Teller, Seward Penin. High.; $65^{\circ} 04^{\prime}$ N, $166^{\circ} 12^{\prime} \mathrm{W}$; (map 111$)$.

Local name reported in 1900 by E. C. Barnard (in Brooks, 1901, pl. 17), USGS.

Alder Creek: stream, flows SE $1.5 \mathrm{mi}$. to Fair. banks Creek, 21 mi. NE of Fairbanks, YukonTanana High.; $65^{\circ} 04^{\prime} 45^{\prime \prime} \mathrm{N}, 147^{\circ} 12^{\prime} 20^{\prime \prime} \mathrm{W}$; (map 105). 
Named by prospectors; reported in 1903 by T. G. Gerdine (in Prindle, 1905, pl. 13), USGS.

Alder Creek: stream, flows N $4.5 \mathrm{mi}$. to Kokomo Creek, 25 mi. NE of Fairbanks, Yukon-Tanana High.; $65^{\circ} 10^{\prime} 25^{\prime \prime} \mathrm{N}, 147^{\circ} 16^{\prime} 40^{\prime \prime} \mathrm{W}$; (map 105). Var. Rusty Gold Creek.

Named by prospectors; reported in 1903 by T. G. Gerdine, USGS; as Rusty Gold Creek; the present name was published in 1908 by USGS.

Alder Creek: stream, flows NE $8 \mathrm{mi}$. to Webber Creek, $27 \mathrm{mi}$. SW of junc. of Charley and Yukon Rivers, Yukon-Tanana High.; $65^{\circ} 17^{\prime}$ $30^{\prime \prime} \mathrm{N}, 143^{\circ} 42^{\prime} 00^{\prime \prime} \mathrm{W}$; (map 103).

Name reported in 1938 by Mertie (1942, p. 250), USGS.

Alder Creek: stream, flows SW $3.2 \mathrm{mi}$. to North Fork Kougarok River, $2 \mathrm{mi}$. E of Harris Dome and $37 \mathrm{mi}$. NW of Imuruk Lake, Seward Penin. High.; $65^{\circ} 37^{\prime} \mathrm{N}, 164^{\circ} 29^{\prime} \mathrm{W}$; (map 110).

Prospectors' name reported in 1901 by $\mathrm{T}$. G. Gerdine (in Collier, 1902, pl. 12), USGS.

Alder Creek: stream, flows $\mathrm{N} 9 \mathrm{mi}$. to Yukon River, 12 mi. NE of Rampart, Yukon-Tanana High.; $65^{\circ} 37^{\prime} 30^{\prime \prime} \mathrm{N}, 149^{\circ} 52^{\prime} 45^{\prime \prime} \mathrm{W}$; (map 105).

Named by prospectors; reported in 1902 by Lt. Hjalmar Erickson, USA.

Alder Creek: stream, on Seward Penin., flows NE $4 \mathrm{mi}$. to Willow Bay, $15 \mathrm{mi}$. SE of Deering, Kotzebue-Kobuk Low.; $66^{\circ} 03^{\prime} \mathrm{N}, 162^{\circ} 12^{\prime} \mathrm{W}$; (map 113).

Prospectors' name obtained in 1903 by D. C.

Witherspoon (Moffit, 1905, pl. 2), USGS.

Alder Creek: stream, flows SW $10 \mathrm{mi}$. to North Fork Koyukuk River, $3 \mathrm{mi}$. E of mouth of Florence Creek and $26 \mathrm{mi}$. SW of Wiseman, Brooks Ra.; $67^{\circ} 08^{\prime} 30^{\prime \prime} \mathrm{N}, 150^{\circ} 48^{\prime} 00^{\prime \prime} \mathrm{W}$; (map 124).

Local name reported in $1930-31$ by Marshall (1956, map).

Alder Creek: ravine, see Alder Gulch.

Alder Creek : stream, see Rusty Gold Creek.

Alder Creek : stream, see Teddys Fork.

Alder Creek Camp: locality, on left bank of Fairbanks Creek, W of mouth of Walnut Creek, $21 \mathrm{mi}$. NE of Fairbanks, Yukon-Tanana High.; $65^{\circ} 04^{\prime} 45^{\prime \prime} \mathrm{N}, 147^{\circ} 11^{\prime} 35^{\prime \prime} \mathrm{W}$; (map 105).

Mining camp name derived from Alder Creek. Mine tailings have altered the course of the drainage so that Alder Creek now flows 0.4 mile to the west.

Alder Creek Camp: locality, see Meehan.

Alder Gulch: ravine, in Nutzotin Mts., extends SE $1.2 \mathrm{mi} ., 6 \mathrm{mi}$. NW of Beaver Lake, Alaska Ra.; $62^{\circ} 04^{\prime} 50^{\prime \prime} \mathrm{N}, 141^{\circ} 57^{\prime} 30^{\prime \prime} \mathrm{W}$; (map 84).

Local name reported in 1941 by S. R. Capps (in Brooks and others, 1915, p. 222), USGS. Alder Gulch: ravine, trends $0.7 \mathrm{mi}$. NW to Livengood Creek, $0.8 \mathrm{mi}$. NE of Livengood, Yukon-Tanana High.; $65^{\circ} 31^{\prime} 50^{\prime \prime} \mathrm{N}, 148^{\circ} 31^{\prime}$ 26" (map 105). Var. Alder Creek.

Name reported in 1915 as Alder Creek by Brooks and J. B. Mertie, Jr. (in Brooks and others, 1916, pl. 9), USGS. Mertie reported the present name in 1916 (in Brooks and others, 1918, pl. 13), USGS.

Alder Lake: lake, $0.5 \mathrm{mi}$. long, $\mathrm{S}$ of Gakona Glacier terminus, $11 \mathrm{mi}$. NE of Paxson, Alaska Ra.; $63^{\circ} 05^{\prime} 40^{\prime \prime} \mathrm{N}, 145^{\circ} 10^{\prime} 55^{\prime \prime} \mathrm{W}$; (map 86).

Local name reported in 1949 by T. L. Péwé, USGS.

Alder Lakes: lakes, four, extend $0.8 \mathrm{mi}$. in Alder Gulch, in Nutzotin Mts., 7 mi. NE of Euchre Mtn., Alaska Ra.; $62^{\circ} 05^{\prime} \mathrm{N}, 141^{\circ} 58^{\prime} \mathrm{W}$; (map 84).

Local name derived from Alder Gulch; published in 1961 by USGS.

Alder Point: point of land, on Prince of Wales I., near head of Kasaan Bay, $0.8 \mathrm{mi}$. S of village of Salt Chuck, Alex. Arch.; $55^{\circ} 36^{\prime} 50^{\prime \prime}$ $\mathrm{N}, 132^{\circ} 33^{\prime} 15^{\prime \prime} \mathrm{W}$; (map 4).

Local name published in 1961 by USC\&GS.

Alder Rock: rock, awash at half tide, in Palma Bay $0.4 \mathrm{mi}$. SW of Boussole Head, in Glacier Bay National Monument, $57 \mathrm{mi}$. WNW of Hoonah, St. Elias Mts.; $58^{\circ} 22^{\prime} 25^{\prime \prime} \mathrm{N}, 136^{\circ} 55^{\prime}$ 45" W; BGN 1930; (map 10).

Named in 1926 by USC\&GS, for the lighthouse tender Alder which struck this rock.

Alder Stream: stream, heads at terminus of Malaspina Glacier, flows S $3 \mathrm{mi}$. to Gulf of Alaska, $4 \mathrm{mi}$. W of Point Manby and $26 \mathrm{mi}$. NW of Yakutat, Malaspina Coastal Plain; $59^{\circ} 41^{\prime} 50^{\prime \prime} \mathrm{N}, 140^{\circ} 24^{\prime} 10^{\prime \prime} \mathrm{W}$; (map 46).

Local name published by the USGS in 1951.

Alecks Creek: stream, flows $\mathrm{S} 4 \mathrm{mi}$. to Elena Bay, on NE shore of Tebenkof Bay, on $W$ coast of Kuiu I., Alex. Arch.; 56 $30^{\prime} 15^{\prime \prime}$ N, 134 ${ }^{\circ}$ $02^{\prime} 40^{\prime \prime}$ W; (map 5). Var. Kuiu Stream.

Local name reported in 1900 by Lt. Comdr. J. F. Moser, USN, commander of USBF steamer Albatross.

Alecks Lake: lake, $1 \mathrm{mi}$. long, on NE shore of Tebenkof Bay, on $W$ coast of Kuiu I., Alex. Arch.; $56^{\circ} 31^{\prime} 30^{\prime \prime} \mathrm{N}, 134^{\circ} 01^{\prime} 00^{\prime \prime} \mathrm{W}$; (map 5). Var. Kuiu Lake.

Local name reported in 1900 by Lt. Comdr. J. F. Moser, USN, commander of USBF steamer Albatross.

Alecktonuk Lake: lake, see Aliktongnak Lake. Alec River: stream, flows W 9 mi. to Black Lake, $23 \mathrm{mi}$. NW of Chignik, Aleutian Ra.; $56^{\circ} 28^{\prime}$ N, $158^{\circ} 56^{\prime}$ W; (map 30). Var. Alee River.

Reported as "Alee" in 1923 by R. H. Sargent, USGS; probably represents a native name changed to its present spelling by a typographical error.

Aleek River: stream, see Stink Creek.

Alee River: stream, see Alec River.

Alek Cape: point of land, see Aklek, Cape.

Aleknagek, Reka: stream, see Wood River.

Aleknagik: village, pop. 223 , on SE shore of Lake Aleknagik, $17 \mathrm{mi}$. N of Dillingham, Kilbuck-Kuskokwim Mts.; $59^{\circ} 17^{\prime} \mathrm{N}, 158^{\circ} 36^{\prime} \mathrm{W}$; (map 52). Var. Abaknakik, Agoulouikatuk, Ahleknuguk, Alaknakik, Aleknagik Lake, Aleknagik Mission, Aliaknagik, Imiak, Seleniye Imyak.

Eskimo village recorded as "Sel[eniye] Imyak" by Capt. Tebenkov (1852, map 4), IRN. According to H. C. Fassett, USBF, in 1910 there were two villages, both named for the lake, the other being at the head of Lake Aleknagik. All indications of this latter village have disappeared. Fassett spelled the name "Ah-lek-nug-uk."

Aleknagik, Lake: lake, $20 \mathrm{mi}$. long, at head of Wood River, $20 \mathrm{mi}$. NW of Dillingham, Kilbuck-Kuskokwim Mts. ; $59^{\circ} 17^{\prime} \mathrm{N}, 158^{\circ} 37^{\prime} \mathrm{W}$; (map 11). Var. Agoulouikatuk, Ahleknuguk Lake, Alaknakik Lake, Aliaknagik, Alyaknagik.

Eskimo name published by Lt. Sarichev (1826, map 3), IRN, as "Alyaknagik." The present spelling of the name is a transliteration from Capt. Tebenkov (1852, map 4), IRN. Jackson (1886, p. 57) stated that the name "Alaknakik" means "well studded with beautiful pine-covered islands" which seems a bit fanciful but may carry the general meaning. From a trader named Mittendorf, J. E. Spurr and W. S. Post, USGS, recorded the name as "Agoulouikatuk," meaning "testicle." Aleknagik Lake: village, see Aleknagik.

Aleknagik Mission: village, see Aleknagik.

Aleknagik River: stream, see Wood River.

Aleksandr, Mys: point of land, see Alexander, Point.

Aleksandra, Mys: point of land, see Alexander, Point.

Aleksandrovskiy: locality, see Nushagak.

Aleksashkina: locality, at Icehouse Point, on W coast of Woody I., 2 mi. E of Kodiak, Kodiak I.; 57 $46^{\prime} 50^{\prime \prime} \mathrm{N}, 52^{\circ} 21^{\prime} 29^{\prime \prime} \mathrm{W}$; (map 34). Var. Aleksashkino, Aleutskoye Aleksashkino Zhilo, Seleniye Chiniak.

Name published by Capt. Tebenkov (1852, map 23), IRN, as "Sel[eniye] Chiniak (Aleksashkina)," or "Chiniak Settlement (Aleksashkina)." Lt. Sarichev (1826, map 16), IRN, published the name "Aleutskoye Aleksashkino Zhilo," or "the Aleut dwellings of Aleksashkino," but applied this name 2 miles to the southeast, at Lake Una. This is probably the village referred to by Ameigh and Chaffin (1962, p. 53) who said, "the 157 natives living on Woody Island in a little village of approximately fifteen log cabins, made their living during the summer months as sea otter hunters * * *." See Woody Island.

Aleksashkino: locality, see Aleksashkina.

Aleks Rock: rock, in Pacific Ocean, $16 \mathrm{mi}$. SW of Sanak I., on NE end of Davidson Bank; $54^{\circ} 28^{\prime} \mathrm{N}, 163^{\circ} 10^{\prime} \mathrm{W}$; (map 25$)$.

Named in 1890 by Capt. William Patterson, commander of the schooner Alexander, from which he took the name.

Alektonak Lake: lake, see Aliktongnak Lake. Alentkina Bay: bay, see Aleutkina Bay. Aleotskia Isles: islands, see Aleutian Islands. Aléoutienne, Mer d': sea, see Bering Sea. Aleoutiennes: islands, see Aleutian Islands. Alert Creek : stream, see Lower Willow Creek. Alert Creek: stream, see Moonlight Creek.

Aletna: village, see Alatna.

Aletna: village, see Allakaket.

Aleutian Islands: islands, chain separating Bering Sea from Pacific Ocean, extending in an arc from Alaska Penin. WSW 1,100 mi. to Attu I. ; $54^{\circ} 51^{\prime} \mathrm{N}, 163^{\circ} 24^{\prime} \mathrm{W}$ [E end], $52^{\circ} 55^{\prime}$ 
$\mathrm{N}, 172^{\circ} 28^{\prime} \mathrm{E}[\mathrm{W}$ end]; $B G N$ 1963. Var. Aleotskia Isles, Aleoutiennes, Aleutian Isles, Billy Mitchell Islands, Catherina Archipelago, Catherine Archipelago, Fox Islands, Katerina Archipelago.

The name "Aleutian," used to designate the natives living on these islands, was first applied by Adm. von Krusenstern (1827, v. 2, p. 78), IRN, to the entire chain which is comprised of five major groups: Andreanof Islands, Fox Islands, Islands of Four Mountains, Near Islands, and Rat Islands. The name "Aleutian Islands" was previously applied to only the westernmost group, the Near Islands (Coxe, 1787, p. 25 ). There are several hypotheses concerning the linguistic origin and meaning of the name. See: Kotzebue, 1821, v. 3, p. 312 ; Veniaminov, 1840 , จ. 2, p. 2; Bancroft, 1886, p. 106; and Hrdlixka, 1945, p. 19-23. The Russians also called the chain "Katerina" in honor of Catherine the Great. See Andreanof Islands; Four Mountains, Islands of ; Fox Islands; Near Islands; Rat Islands.

Aleutian Islands: islands, see Near Islands.

Aleutian Isles: islands, see Aleutian Islands.

Aleutian Mountains: mountain range, see Aleutian Range.

Aleutian Range: mountain range, extends SW $600 \mathrm{mi}$. along SE side of Alaska Penin. from Chakachamna Lake, $80 \mathrm{mi}$. W of Anchorage to Unimak I.; the Aleutian Is. are a continuation of the Aleutian Ra.; $61^{\circ} 10^{\prime} \mathrm{N}, 152^{\circ}$ $20^{\prime} \mathrm{W}$ [NE end], $55^{\circ} 00^{\prime} \mathrm{N}, 163^{\circ} 10^{\prime} \mathrm{W}$ [SW end]. Var. Aleutian Mountains.

Spurr (1900, p. 238), USGS, wrote: "The mountains of the Alaska Peninsula the writer proposes to call also the Aleutian Mountains."

Aleutian Rock: rock, $0.3 \mathrm{mi}$. S of Amook I., in Uyak Bay, Kodiak I.; $57^{\circ} 25^{\prime} 30^{\prime \prime} \mathrm{N}, 153^{\circ}$ $50^{\prime} 30^{\prime \prime} \mathrm{W}$; (map 34).

Local name published in 1943 by USC\&GS. Aleutian Sea: sea, see Bering Sea.

Aleutkina Bay: bay, $2.5 \mathrm{mi}$. across, on $\mathrm{W}$ coast of Baranof I., 4 mi. SE of Sitka, Alex. Arch.; $57^{\circ} 00^{\prime} \mathrm{N}, 135^{\circ} 17^{\prime} \mathrm{W}$; (map 5). Var. Alentkina Bay, Guba Aleutkina, Leesia Bay, Leesoffskaia Bay, Bukhta Lisyaskaya.

A colloquial Russian term used in reference to an Aleut woman; applied in 1809 to this feature by Ivan Vasiliev the first, IRN; published by Lt. Sarichev (1826, map 19), IRN, as "Guba Aleutkina." The name "Bukhta Lisyaskaya," meaning "Fox Bay," was published by Capt. Tebenkov (1852, map 38), IRN, and referred to the Aleuts that inhabit the Fox Islands in the eastern Aleutians.

Aleut Point: point of land, $\mathrm{W}$ tip of Amchitka I., Rat Is., Aleutian Is. ; $51^{\circ} 38^{\prime} 30^{\prime \prime} \mathrm{N}, 178^{\circ}-$ 37'30" E; BGN 1937; (map 15).

Reported by personnel of U.S.S. Oglala of the 1935 U.S. Navy Survey Expedition.

Aleutski Island: island, $0.1 \mathrm{mi}$. across, in Eastern Channel, Sitka Sound, $0.4 \mathrm{mi}$. S of Sitka, Alex. Arch.; $57^{\circ} 02^{\prime} 44^{\prime \prime} \mathrm{N}, 135^{\circ} 20^{\prime} 20^{\prime \prime} \mathrm{W}$; (map 9). Var. Ball Island.

Named about 1850 by the Russians; called Ball Island in 1880 by Capt. L. A. Beardslee, USN.
Aleutskoye Aleksashkino Zhilo: locality, see Aleksashkina.

Aleutskoye Seleniye Kattagmyut: village, see Aleut Village.

Aleutsk Selen Kaniyagmyut: village, see Kaguyak.

Aleut Village: village, $0.6 \mathrm{mi}$. $\mathrm{N}$ of Afognak, on $S$ coast of Afognak I., Kodiak I.; $58^{\circ} 01^{\prime} 00^{\prime \prime}$ $\mathrm{N}, 152^{\circ} 45^{\prime} 40^{\prime \prime} \mathrm{W}$; (map 43). Var. Afognakskaya Odinochka, Aleutskoye Seleniye Kattagmyut, Kattag.

Published in 1943 by USG\&GS. In 1849 the Russian American Company called this "Aleutskoye Sel[eniye] Kattagmyu," or "Aleut village of Kattag" [the ending "myut" is Eskimo for "people"]. The same year, on Chart 1425, the Russian Hydrog. Dept. published the name "Afognakskaya Odinochka," meaning "a separate part of Afognak." See Afognak.

Alexai Beach: beach, $0.8 \mathrm{mi}$. long, on SE coast of Attu I., E shore of Massacre Bay, Aleutian Is.; $52^{\circ} 49^{\prime} 30^{\prime \prime} \mathrm{N}, 173^{\circ} 17^{\prime} 55^{\prime \prime} \mathrm{E}$; $B G N$ 1938; (map 13).

Name reported in 1938 by USC\&GS; derived from nearby Alexai Point.

Alexai Creek: stream, on SE coast of Attu I., flows SW and SE $2.4 \mathrm{mi}$. to Bedard Cove, Aleutian Is.; $52^{\circ} 49^{\prime} 45^{\prime \prime} \mathrm{N}, 173^{\circ} 18^{\prime} 38^{\prime \prime} \mathrm{E}$; (map 13).

Name derived from Alexai Point; published in 1948 by AMS.

Alexai Pass: pass, $800 \mathrm{ft}$., on Attu I., at SE end of Gilbert Ridge, Aleutian Is. ; 52 $51^{\prime} 10^{\prime \prime} \mathrm{N}$, $173^{\circ} 18^{\prime} 50^{\prime \prime} \mathrm{E}$; (map 13).

Name derived from Alexai Point; published in 1948 by AMS.

Alexai Point: point of land, at $\mathrm{E}$ entrance to Massacre Bay and SW end of Bedard Cove, on SE coast of Attu I., Aleutian Is. ; $52^{\circ} 48^{\prime} 45^{\prime \prime}$ $\mathrm{N}, 173^{\circ} 18^{\prime} 30^{\prime \prime} \mathrm{E} ; B G N$ 1938; (map 13). Var. Big Mike Point, Nanikakaya Point.

Name published in 1943 on an AMS map and is shown as "Alexai (Big Mike) Point" in the 1944 Aleutian Coast Pilot (p. 133).

Alexander: locality, see Nushagak.

Alexander: village, on Susitna River delta, near mouth of Alexander Creek, $27 \mathrm{mi}$. NW of Anchorage, Cook Inlet Low.; $61^{\circ} 25^{\prime} 00^{\prime \prime} \mathrm{N}$, $150^{\circ} 35^{\prime} 35^{\prime \prime} \mathrm{W}$; (map 70).

This small Indian village was reported in 1898 by Eldridge (1900, map 3), USGS

Alexander: village, see English Bay.

Alexander: point of land, "the southeastern point of entrance to Wrangell strait, Alexander archipelago.'

"So named by Lindenberg, 1838" (Baker, 1906, p. 92).

Alexander, Cape: point of land, see Yanaliuk, Cape.

Alexander, Lake: lake, $1.5 \mathrm{mi}$. long, $3 \mathrm{mi}$. W of Mole Harbor, on $\mathrm{E}$ coast of Admiralty I., 61 mi. NE of Sitka, Alex. Arch.; 57 $40^{\prime} \mathrm{N}, 134^{\circ}$ 10' W; BGN 1928; (map 9).

Named in 1907 by "the University of California Alexander Alaska Expedition" for Annie M. Alexander, founder of the expedition.
Alexander, Mount: mountain, 3,805 ft., $2.6 \mathrm{mi}$. SW of Marble Point, on Russell Fiord, 27 mi. NE of Yakutat, St. Elias Mts.; 59 $54^{\prime} 45^{\prime \prime}$ N, $139^{\circ} 26^{\prime} 55^{\prime \prime} \mathrm{W}$; (map 46)

Named in 1905 by Tarr and Martin (1906, map), USGS, probably after Beno Alexander, one of the Duke of Abruzzi's porters on the Duke's expedition of 1897.

Alexander, Point: point of land, SW tip of Mitkof I., $21 \mathrm{mi}$. S of Petersburg, Alex. Arch.; $56^{\circ} 30^{\prime} 35^{\prime \prime} \mathrm{N}, 132^{\circ} 56^{\prime} 55^{\prime \prime} \mathrm{W}$; (map 6). Var. Mys Aleksandr.

"Discovered by James Johnstone August 29, 1793, and named by Capt. George Vancouver, RN, for Daniel Asher Alexander, architect and engineer at his time" (Wagner, 1937, p. 372).

Alexander, Port: bay, $0.2 \mathrm{mi}$. across, $5 \mathrm{mi}$. NE of Cape Ommaney, on $\mathrm{S}$ coast of Baranof $\mathrm{I}$., Alex. Arch.; $56^{\circ} 14^{\prime} 30^{\prime \prime} \mathrm{N}, 134^{\circ} 38^{\prime} 50^{\prime \prime} \mathrm{W}$; (map 5).

Name published in 1849 by Capt M. D. Tebenkov, IRN.

Alexander Archipelago: islands, group in SE Alaska, extends S $280 \mathrm{mi}$. from Cross Sound and Icy Strait to Dixon Entrance; $58^{\circ} 20^{\prime} \mathrm{N}$, $136^{\circ} 00^{\prime} \mathrm{W}$ [N end], $54^{\circ} 45^{\prime} \mathrm{N}, 132^{\circ} 10^{\prime} \mathrm{W}$ [S end]; BGN 1919. Var. Indian Arkipelagan, Indianischen Archipel, Kaloschen Archipel.

Named in 1867 by USC\&GS for Tsar Alexander of Russia. See King George the Third Archipelago.

Alexander Creek: stream, heads in Alexander Lake, flows SE $35 \mathrm{mi}$. to Susitna River at Alexander, $27 \mathrm{mi}$. NW of Anchorage, Cook Inlet Low.; $61^{\circ} 24^{\prime} 45^{\prime \prime} \mathrm{N}, 150^{\circ} 35^{\prime} 40^{\prime \prime} \mathrm{W}$; (map 70). Var. Taguntna Creek.

Name reported in 1898 by Eldridge (1900, p. 10), USGS.

Alexander Glacier: glacier, heads $0.2 \mathrm{mi}$. W of summit of Mount McCarty, trends N $1.9 \mathrm{mi}$. to its 1961 terminus, $1.2 \mathrm{mi}$. E of Mount Alexander and $28 \mathrm{mi}$. NE of Yakutat, St. Elias Mts.; $59^{\circ} 54^{\prime} 30^{\prime \prime} \mathrm{N}, 139^{\circ} 24^{\prime} 55^{\prime \prime} \mathrm{W}$; (map 46).

Named in 1905 by Tarr and Martin (1906, map), USGS, probably after Beno Alexander, one of the Duke of Abruzzi's porters on the Duke's expedition of 1897 .

Alexander Island: island, $0.2 \mathrm{mi}$. long, in Marmot Bay, 4.2 mi. NE of Afognak, Kodiak I.; $58^{\circ} 02^{\prime} 10^{\prime \prime} \mathrm{N}, 152^{\circ} 39^{\prime} 50^{\prime \prime} \mathrm{W}$; (map 43).

Local name reported in 1900 by Lt. Comdr. J. F. Moser, USN, commander of the USBF steamer Albatross.

Alexander Island: island, see Kochu Island.

Alexander Lake: lake, $2.5 \mathrm{mi}$. long, at head of Alexander Creek, $46 \mathrm{mi}$. $\mathrm{N}$ of Tyonek, Cook Inlet Low.; $61^{\circ} 44^{\prime} 40^{\prime \prime} \mathrm{N}, 150^{\circ} 54^{\prime} 00^{\prime \prime} \mathrm{W}$; $(\operatorname{map} 70)$.

Reported in 1926 by Capps (1935, pl. 1), USGS. Probably derived from Alexander Creek which drains the lake.

Alexander Point: point of land, E entrance point to Ivanof Bay, on S coast of Alaska Penin., 9 mi. E of Stepovak Bay, Aleutian Ra.; $55^{\circ} 47^{\prime}$ $40^{\prime \prime} \mathrm{N}, 159^{\circ} 25^{\prime} 00^{\prime \prime} \mathrm{W}$; BGN 1939; (map 27). 
Var. Alexander's Cape, Alexandra Point, Mys Aleksandra, Reynolds Point.

Named "M[ys] Aleksandra," or "Alexander's Cape," by Lt. Woronkofski in 1836; published in 1847 on Russian Hydrog. Dept. Chart 1379. Published in 1888 as "Alexander Point" by USBF.

Alexander Rock: rock, in Eastern Channel, Sitka Sound, 0.5 mi. S of Sitka, Alex. Arch.; $57^{\circ} 02^{\prime}$ $34^{\prime \prime} \mathrm{N}, 135^{\circ} 20^{\prime} 12^{\prime \prime} \mathrm{W}$; (map 9).

Name published in 1881 by USC\&GS on Chart 725.

Alexander's Cape: point of land, see Alexander Point.

Alexanders Village: locality, $0.4 \mathrm{mi}$. W of Shovun Lake and $17 \mathrm{mi}$. NW of Fort Yukon, Yukon Flats; $66^{\circ} 47^{\prime} 25^{\prime \prime} \mathrm{N}, 145^{\circ} 26^{\prime} 00^{\prime \prime} \mathrm{W}$; (map 119).

Local name obtained in 1956 by USGS.

Alexandra : locality, see Nudhagak.

Alexandra Point: point of land, see Alexander Point.

Alexandro: village, see English Bay.

Alexandroffsk : locality, see Nushagak.

Alexandrovek: village, see English Bay.

Alexandrovsk: locality, see Nushagak.

Alexandrovsk: village, see English Bay.

Alexandrovski : locality, see Nushagak.

Alexcy Lake: lake, $1.5 \mathrm{mi}$. long, $\mathrm{N}$ of Iliamna Lake, WNW of Roadhouse Mtn. and $9 \mathrm{mi}$. NNE of Iliamna, Aleutian Ra.; 59 $53^{\prime} \mathrm{N}$, $154^{\circ} 47^{\prime} \mathrm{W}$; (map 51). Var. Alexey Lake.

Name published in 1954 by USGS.

Alexeief: locality, see Alexeiev.

Alexeief's: locality, see Alexeiev.

Alexeief's Trading Post: locality, see Alexeiev. Alexeiev: locality, on Yukon delta; $62^{\circ} 30^{\prime} \mathrm{N}$, $163^{\circ} 30^{\prime} \mathrm{W}$; (map 77). Var. Alexeief, Alexeief's, Alexeief's Trading Post, Odinotchka.

Small Eskimo settlement and trading post, now abandoned, mentioned by Ivan Petroff in the 10th Census, in 1880. E. W. Nelson, U.S. Signal Service, passed through it in December 1878.

Alexinoy: island, see Aliksemit Island.

Alfalfa Ridge: ridge, elev. 1200-1300 ft., extends SE $1.5 \mathrm{mi}$. from Mattress Hill to Mission Hill, $1.5 \mathrm{mi}$. NW of Hatchet Point, central Kiska I., Aleutian Is.; $51^{\circ} 56^{\prime} 30^{\prime \prime} \mathrm{N}, 177^{\circ} 31^{\prime} 30^{\prime \prime} \mathrm{E}$; (map 14).

This is one of the plant names given to features in 1943 by USAAF for tactical purposes during World War II.

Alfield Creek: stream, flows W $1.7 \mathrm{mi}$, joins Monte Cristo Creek to form Sulphur Creek, 23 mi. NE of Nome, Seward Penin. High.; $64^{\circ}$ $49^{\prime} 00^{\prime \prime} \mathrm{N}, 165^{\circ} 11^{\prime} 40^{\prime \prime} \mathrm{W}$; (map 94). Var. Alphield Creek.

Prospectors' name shown on a 1900 "Map of Nome Peninsula" by J. M. Davidson and B. D. Blakeslee.

Alf Island: island, $0.7 \mathrm{mi}$. long, $1.5 \mathrm{mi}$. S of Amook I., in Uyak Bay, on NW coast of Kodiak I.; $57^{\circ} 24^{\prime} 35^{\prime \prime} \mathrm{N}, 153^{\circ} 50^{\prime} 10^{\prime \prime} \mathrm{W}$; $B G N$ 1910; (map 34)

Named in 1908 by H. C. Denson, USC\&GS. Alfred Creek: stream, flows E $7 \mathrm{mi}$. to Chignik
Bay, 7 mi. NW of Chignik, Aleutian Ra.; $56^{\circ}$ $22^{\prime} \mathrm{N}, 158^{\circ} 30^{\prime} \mathrm{W}$; (map 30).

Named by R. H. Sargent, USGS, and recorded on a 1926 fieldsheet.

Alfred Creek: stream, flows SW $12 \mathrm{mi}$. to Caribou Creek, $54 \mathrm{mi}$. NE of Palmer, Talkeetna Mts. ; $61^{\circ} 55^{\prime} 00^{\prime \prime} \mathrm{N}, 147^{\circ} 36^{\prime} 45^{\prime \prime} \mathrm{W}$; (map 69).

Name used by local prospectors; reported in 1906 by T. G. Gerdine and R. H. Sargent, USGS.

Alfred Creek: stream, flows NW $34 \mathrm{mi}$. to Yukon River, $14 \mathrm{mi}$. NE of Stevens Village, Yukon Flats; $66^{\circ} 05^{\prime} 45^{\prime \prime} \mathrm{N}, 148^{\circ} 41^{\prime} 00^{\prime \prime} \mathrm{W}$; (map 118).

Local name obtained in 1956 by USGS.

Alfred Creek: stream, heads at $65^{\circ} 50^{\prime} \mathrm{N}, 148^{\circ}$ $10^{\prime} \mathrm{W}$, flows NW $28 \mathrm{mi}$. to Rogers Creek, $41 \mathrm{mi}$. SW of Beaver, Yukon Flats; $66^{\circ} 06^{\prime} \mathrm{N}$ $148^{\circ} 40^{\prime} \mathrm{W}$; (map 118 ).

Local name reported in 1917 by USGS. Alga-anatorol'og: rookery, see North Rookery.

Äl'gän-ūdä: cove, $0.2 \mathrm{mi}$. across, in front of Zapadni Rookery, part of Zapadni Bay, on SW coast of Saint George I., in Pribolof Is. $56^{\circ} 34^{\prime} 50^{\prime \prime} \mathrm{N}, 169^{\circ} 39^{\prime} 45^{\prime \prime} \mathrm{W}$; (map 38).

Aleut name, meaning "seal bay," reported by Putnam (1903, p. 1014), USC\&GS.

Alger Peak: peak, 7,500 ft., in Tordrillo Mts. NW of Cook Inlet, $75 \mathrm{mi}$. NW of Tyonek, Alaska Ra.; $61^{\circ} 54^{\prime}$ N, $152^{\circ} 40^{\prime}$ W ; (map 70).

Named in 1898 by J. E. Spurr and W. S. Post, USGS.

Algives, Isla : rock, see Wolf Rock.

Algonek River: stream, see Alaganik Slough.

Algonquin, Cape: promontory, SW point of entrance to Nash Harbor, $32 \mathrm{mi}$. SW of Cape Etolin, on Nunivak I. ; $60^{\circ} 13^{\prime} 30^{\prime \prime} \mathrm{N}, 166^{\circ} 56^{\prime}$. $30^{\prime \prime} \mathrm{W}$; (map 57).

Name reported about 1908 by USC\&GS.

Alhamblar Mountain: mountain, 6,000 ft., $5 \mathrm{mi}$. $\mathrm{N}$ of Apoon $\mathrm{Mtn}$. and $38 \mathrm{mi}$. N of Wiseman Brooks Ra.; $67^{\circ} 58^{\prime} 30^{\prime \prime} \mathrm{N}, 150^{\circ} 15^{\prime} 00^{\prime \prime} \mathrm{W}$ (map 124).

Named in 1931 by Marshall (1956, p. 162), who explained the name: "Because the waters rising on this peak flowed into the three drainages of Alinement Creek, Hammond River and Blarney Creek, we gave it the compound name of Alhamblar Mountain."

Alhodoruk Creek: stream, see Ogotoruk Creek. Aliaga, Punta de: point of land, see Montague Point.

Aliagnagik River: stream, see Wood River.

Aliaknagik: lake, see Aleknagik, Lake.

Aliaksa: peninsula, see Alaska Peninsula.

Aliakshka: peninsula, see Alaska Peninsula.

Aliaksin, Cape: peninsula, on $\mathrm{S}$ coast of Alaska Penin., between Beaver and Balboa Bays, Aleutian Ra.; $55^{\circ} 30^{\prime} \mathrm{N}, 160^{\circ} 45^{\prime} \mathrm{W}$; (map 28). Var. Aliaksinskie, Cap Aliakska, Mys Alksin, Mys Alyaksinskiy.

Published as "Cap Aliakska" by Capt. Lutke (1836, p. 257), IRN.

Aliaksin, Point: point of land, on Cape Aliaksin at SW end of Alaska Penin., Aleutian Ra.; $55^{\circ} 28^{\prime} 20^{\prime \prime} \mathrm{N}, 160^{\circ} 49^{\prime} 30^{\prime \prime} \mathrm{W}$; (map 28).

Named for Cape Aliaksin.

Aliaksinskie: peninsula, see Aliaksin, Cape.
Aliakska, Cap: peninsula, see Aliaksin, Cape. Aliaska: peninsula, see Alaska Peninsula.

Aliaska, Mer d': sea, see Bering Sea.

Aliaskinskoi: water passage, see Shelikof Strait.

Alice, Port: bay, $2.5 \mathrm{mi}$. long, NW coast of Heceta I., Alex. Arch.; 55 $50^{\prime}$ N, 133 ${ }^{\circ} 36^{\prime}$ W; (map 4).

Named in 1903 or 1904 by E. F. Dickins, USC\&GS, who wrote "named by our party, has no local name."

Alice Cove: cove, $0.2 \mathrm{mi}$. across, on $\mathrm{N}$ shore of Orca Bay, $9 \mathrm{mi}$. NW of Cordova, Chugach Mts.; $60^{\circ} 37^{\prime} 30^{\prime \prime} \mathrm{N}, 145^{\circ} 57^{\prime} 30^{\prime \prime} \mathrm{W}$; (map 64). Published by USGS in 1950 .

Alice Creek: stream, flows NW $0.5 \mathrm{mi}$. to Casadepaga River, $3 \mathrm{mi}$. NE of Casadepaga and $19 \mathrm{mi}$. NE of Solomon, Seward Penin. High.; $64^{\circ} 50^{\prime} \mathrm{N}, 164^{\circ} 19^{\prime} \mathrm{W}$; (map 95).

Prospectors' name reported in 1907 by

USGS geologists (Smith, P. S., 1910, pl. 4).

Alice Creek: stream, flows NE $2.8 \mathrm{mi}$, to Niukluk River, $31 \mathrm{mi}$. NE of Solomon, Seward Penin. High.; $64^{\circ} 57^{\prime} \mathrm{N}, 163^{\circ} 58^{\prime} \mathrm{W}$; (map 95).

Prospectors' name reported on a 1902 prospectors' manuscript map.

Alice Creek: stream, flows N $35 \mathrm{mi}$. to Wolf Creek, $30 \mathrm{mi}$. NE of head of Ikpikpuk River, Arctic Plain; $69^{\circ} 40^{\prime} 30^{\prime \prime} \mathrm{N}, 153^{\circ} 51^{\prime} 30^{\prime \prime} \mathrm{W}$; (map 142)

According to USGS, this stream was named in the 1950's "for Alice Buchanan of Dumbarton, Scotland."

Alice Gulch: ravine, trends NE $0.6 \mathrm{mi}$. to Mineral Creek, $4.5 \mathrm{mi}$. SSW of junc. of Woodchopper Creek and Yukon River and $42 \mathrm{mi}$. SSE of Gircle, Yukon-Tanana High.; 65 ${ }^{\circ} 17^{\prime}$ $20^{\prime \prime} \mathrm{N}, 143^{\circ} 22^{\prime} 00^{\prime \prime} \mathrm{W}$; (map 103).

Prospectors' name reported by A. H. Brooks (in Brooks and others, 1907, p. 203), USGS.

Alice Island: island, $0.1 \mathrm{mi}$. across, tied to Japonski I., $0.5 \mathrm{mi}$. SW of Sitka, Alex. Arch.; $57^{\circ} 02^{\prime} 50^{\prime \prime} \mathrm{N}, 1^{\circ} 20^{\circ} 50^{\prime \prime} \mathrm{W}$; (map 9).

Named in 1880 by the U.S. Navy and published by USC\&GS in the 1883 Coast Pilot (p. 142).

Alice Island: island, $3.3 \mathrm{mi}$. long, in Yukon River, $4 \mathrm{mi}$. SW of Blackburn 1. and $52 \mathrm{mi}$. SE of Unalakleet, Innoko Low.; $63^{\circ} 18^{\prime} \mathrm{N}$, $159^{\circ} 39^{\prime} \mathrm{W}$; (map 91).

Steamboat pilots' name shown on a 1901 manuscript chart of the Yukon River; reportedly named for the steamboat Alice, built in 1895 at Saint Michael.

Alice Lake: lake, $0.3 \mathrm{mi}$. wide, $2.3 \mathrm{mi}$. $\mathrm{N}$ of Port Houghton, $4 \mathrm{mi}$. N of Walter I. and 84 mi. ENE of Sitka, Coast Mts.; $57^{\circ} 22^{\prime} 00^{\prime \prime} \mathrm{N}$, $133^{\circ} 17^{\prime} 30^{\prime \prime} \mathrm{W}$; (map 8).

Local name reported in 1955 by USGS.

Alice Peak: mountain, 3,550 ft., $4 \mathrm{mi}$. NE of Anita Bay, on Etolin I., Alex. Arch.; 56 $14^{\prime}$. $30^{\prime \prime} \mathrm{N}, 132^{\circ} 33^{\prime} 00^{\prime \prime} \mathrm{W}$; (map 6).

Named in 1886 by Lt. Comdr. A. S. Snow, USN; name published in 1887 on USC\&GS Chart 706.

Alice Peak: peak, 6,438 ft., $4 \mathrm{mi}$. NW of Ivan Mtn. and $80 \mathrm{mi}$. NE of Valdez, Wrangell Mts.; $61^{\circ} 40^{\prime} 05^{\prime \prime} \mathrm{N}, 144^{\circ} 07^{\prime} 05^{\prime \prime} \mathrm{W}$; (map 68). 
Local name reported in 1912 by D. C. Witherspoon, USGS.

Alice Rocks: rocks, widely scattered over $2 \mathrm{mi}$. area, in Iphigenia Bay, $2 \mathrm{mi}$. $\mathrm{S}$ of Boot Point, S coast of Warre I., Alex. Arch.; $55^{\circ} 49^{\prime} \mathrm{N}$, $133^{\circ} 56^{\prime \prime} \mathrm{W}$; BGN 1961; (map 4). Var. Cay Rocks.

Named by USG\&GS in 1960; "based on the wreck in this immediate vicinity of the vessel Alice, in 1914 * * *." The local name "Cay Rocks" was reported by the commander of the USC\&GS steamer Hodgson, who surveyed this area in 1960; triangulation station Cay is located on the most prominent rock.

Alida Island: island, see Alaid Island.

Aligo Point: point of land, $\mathrm{S}$ tip of Harris Penin., $36 \mathrm{mi}$. SW of Seward, Chugach Mts.; $59^{\circ} 38^{\prime} 20^{\prime \prime} \mathrm{N}, 149^{\circ} 44^{\prime} 35^{\prime \prime} \mathrm{W}$; BGN 1930; (map 49).

Named in 1929 by USC\&GS; derived from "the native word said to mean quartz, referring to the geological formation at the point."

Alihack, Cape: point of land, see Alitak, Cape. Alikh River: stream, see Ahlik River.

Alikhsemit: island, see Aliksemit Island.

Aliknuk: stream, see Alagnak River.

Aliknuk Lake: lake, see Kukaklek Lake.

Aliksemit Island: island, $0.3 \mathrm{mi}$. across, $1 \mathrm{mi}$. SE of Chowiet I., in Semidi Is., Aleutian Ra.; $56^{\circ} 00^{\prime} \mathrm{N}, 156^{\circ} 40^{\prime} \mathrm{W}$; (map 31). Var. Alexinoy, Alikhsemit.

Native name shown as "I[le] Alexinoy" by Adm. von Krusenstern (1827, map 20), IRN; shown as "Alikhsemit Island" on an 1888 USBF chart.

Aliktongnak Lake: lake, $2 \mathrm{mi}$. across, $8 \mathrm{mi}$. E of junc. of Eli and Noatak Rivers, $13 \mathrm{mi}$. SE of Noatak, Arctic Slope; $67^{\circ} 24^{\prime} \mathrm{N}, 162^{\circ} 41^{\prime}$ W; BGN 1962; (map 128). Var. Ahliktongnak Lake, Alecktonuk Lake, Alektonak Lake.

Eskimo name meaning "big pickerel" obtained at Kotzebue in 1956 by Orth.

Alikula Bay: estuary, $1 \mathrm{mi}$. long, E of Egg Harbor on NW coast of Coronation I., Alex. Arch.; 55 $55^{\prime} 20^{\prime \prime} \mathrm{N}, 134^{\circ} 18^{\prime} 00^{\prime \prime} \mathrm{W}$; BGN 1925; (map 4).

Haida Indian word meaning "night"; name given in 1924 by USC\&GS "because this Bay is so clear it may be readily entered at night." Alilok: bay, see Alitak.

Alimuda Bay: bay, $1.6 \mathrm{mi}$. across, on NW coast of Unalaska I., Aleutian Is.; $53^{\circ} 26^{\prime} \mathrm{N}, 167^{\circ}$. $21^{\prime}$ W; BGN 1938; (map 23). Var. Middle Bay, Srednaia Bay, Srednaya Bay, Ungay Bay, Ungaymilud Bay, Zaliv Alimuda.

Aleut name reported in 1792 as "Z[aliv] Alimuda," or "Alimuda Bay," by Lt. Sarichev (1826, map 14), IRN. According to R. H. Geoghegan the name comes from the Aleut words "alim" and "uddha" meaning "old man's bay." Called "Srednaya" meaning "middle" by Father Veniaminov (1840, v. 1, p. 166); named "Middle Bay" by the USBF in 1888 .

Alimuda Bay: bay, see Kismaliuk Bay.

Alimvoak Bay: bay, see Malina Bay.

Alinak Lake: lake, see Coville, Lake.

Alinak Lake: lake, see Grosvenor, Lake.
Alinchak Bay: bight, $5 \mathrm{mi}$. across, on $\mathrm{E}$ coast of Alaska Penin., $33 \mathrm{mi}$. NW of Karluk, Aleutian Ra.; $57^{\circ} 47^{\prime}$ N, $155^{\circ} 16^{\prime} \mathrm{W}$; (map 35).

Native name obtained in 1904 from Nikolai Kalmakov of Katmai; published by G. C. Martin (1921, pl. 9), USGS.

Alinement Greek: stream, flows SW $8 \mathrm{mi}$. to North Fork Koyukuk River, $8 \mathrm{mi}$. NW of Apoon Mtn. and $42 \mathrm{mi}$. N of Wiseman, Brooks Ra.; $67^{\circ} 59^{\prime} 30^{\prime \prime} \mathrm{N}, 150^{\circ} 30^{\prime} 00^{\prime \prime} \mathrm{W}$; BGN 1932; (map 124).

Named in 1930 by Marshall (1956, p. 49) who wrote, " *** the north divide consisted of the unusual group of almost equally high peaks in perfect alinement ***."

Alinnak: locality, "on Alaska Penin.", Aleutian Ra.; (map 42). Var. Allinnak.

Former Eskimo camp or settlement reported in 1852 on Russian Hydrog. Dept. Chart 1455. Alitack, Cape: point of land, see Alitak, Cape. Alitak: village, see Akhiok.

Alitak, Cape: point of land, on Tanner Head, at SW tip of Kodiak I.; $56^{\circ} 50^{\prime} 40^{\prime \prime} \mathrm{N}, 154^{\circ}$ $18^{\prime} 00^{\prime \prime} \mathrm{W}$; (map 32). Var. Gape Alihack, Cape Alitack, Cape Alitok, Cape Alutak.

Eskimo name published by Lt. Sarichev (1826, map 3), IRN, as "M[ys] Alitok" or "Cape Alitok."

Alitak Bay: $b a y, 7$ mi. across, at S end of Kodiak I., $56^{\circ} 50^{\prime} \mathrm{N}, 154^{\circ} 10^{\prime} \mathrm{W}$; (map 32-33). Var. Alilok, Aluta Bay, Alutak Bay, Kaniat, Yagekhtalyk, Yagektaliek.

Native name published in 1869 by USC\&GS. This bay was called "Yagekhtalyk" by Lt. Sarichev (1826, map 3), IRN, and was published as "Kaniat" (Alitak) by Bancroft (1886, p. 145).

Alitak Lagoon: lagoon, $4 \mathrm{mi}$. long, $3 \mathrm{mi}$. W of Alitak Bay, at S end of Kodiak I.; $56^{\circ} 53^{\prime} 00^{\prime \prime}$ $\mathrm{N}, 154^{\circ} 17^{\prime} 30^{\prime \prime} \mathrm{W}$; (map 32 ).

Name derived from Cape Alitak; published in 1934 by USC\&GS.

Alitak Shoal: shoal, $2.5 \mathrm{mi}$. long, at mouth of Alitak Bay, at $\mathrm{S}$ end of Kodiak I.; $56^{\circ} 50^{\prime} \mathrm{N}$, $14^{\circ} 17^{\prime}$ W; BGN 1934; (map 32).

Named in 1934 by USC\&GS for Cape Alitak.

Alitok, Cape: point of land, see Alitak, Cape.

Alituya Bay: bay, see Lituya Bay.

Aliuksuk: $b a y$, see Pumicestone Bay.

Aliulik: point of land, see Trinity, Cape.

Aliulik Peninsula: peninsula, $25 \mathrm{mi}$. long, on $\mathrm{E}$ shore of Aliulik Bay, SW coast of Kodiak I. $56^{\circ} 50^{\prime} \mathrm{N}, 153^{\circ} 55^{\prime} \mathrm{W}$; BGN 1934; (map 32).

Aleut name given by USC\&GS in 1934, "from the native name of Cape Trinity." The name is derived from the word "aluluk," meaning "thimble," according to R. H. Geoghegan.

Aliutik: point of land, see Trinity.

Aljaska : peninsula, see Alaska.

Alkali Creek: stream, flows S $8 \mathrm{mi}$. to Unakserak River, $15 \mathrm{mi}$. S of Survey Pass, Brooks Ra.; $67^{\circ} 37^{\prime} 30^{\prime \prime} \mathrm{N}, 154^{\circ} 04^{\prime} 00^{\prime \prime} \mathrm{W} ; B G N$ 1932; (map 125).

So named by Robert Marshall in 1931, because of the extreme alkalinity of the water.
Alkalugen Creek: stream, flows SW $3 \mathrm{mi}$. to Chukchi Sea, $7 \mathrm{mi}$. S of Cape Lisburne, Arctic Slope; $68^{\circ} 47^{\prime} \mathrm{N}, 166^{\circ} 11^{\prime} \mathrm{W}$; (map 129). Var. Ah-kah-loo-gen, Ahkalurak Creek, Ahkaluruk River.

Eskimo name reported in 1950 by USC\&\&S ; spelled "Ah-kah-loo-gen."

Alksin, Mys : peninsula, see Aliaksin, Cape.

Allakakat: village, see Allakaket.

Allakaket: village, pop. 115, on S bank of Koyukuk River SW of its junc. with Alatna River, Kanuti Flats; $66^{\circ} 34^{\prime} 00^{\prime \prime} \mathrm{N}, 152^{\circ} 38^{\prime} 30^{\prime \prime} \mathrm{W}$; $B G N$ 1952; (map 117). Var. Alakaket, Alatna, Aletna, Allakakat, Allakakset.

Koyukuk Indian name meaning "mouth of the Alatna [River]," borrowed in 1906 by Archdeacon Stuck (1914, p. 70). He wrote: "I was again impressed with the eligibility of that spot as a mission site. It was but ten miles above the present native village [Moses Village], and, with church and school established, the whole population would sooner or later move to it. Moreover, the Alatna River is the highway between the Kobuk and the Koyukuk ***. I foresaw two villages, *** one clustered about the church [Allakaket; Indian] $* * *$ the other lower down on the opposite side of the river. [Alatna; Eskimo] $* * *$ so I staked a mission site $* *$ almost opposite the mouth of the Alatna, which, in the native tongue, is 'Allakaket' or 'Allachaket'." A post office was originally established in 1925 as Alatna, but it was changed to Allakaket in 1938 (Ricks 1965, p. 3).

Allakaket: stream, see Alatna River.

Allakakset: village, see Allakaket.

Allan Point: point of land, NE tip of Halleck I., $13 \mathrm{mi}$. N of Sitka, Alex. Arch.; $57^{\circ} 14^{\prime} 30^{\prime \prime}$ $\mathrm{N}, 135^{\circ} 23^{\prime} 30^{\prime \prime} \mathrm{W}$; (map 9).

Named in 1897 by Lt. Comdr. E. K. Moore, USN, for W. S. Allan, a member of his party.

Allard Creek: stream, flows NW $25 \mathrm{mi}$. to Kanuti Kilolitna River, $40 \mathrm{mi}$. NW of Rampart and $59 \mathrm{mi}$. NE of Tanana, Kokrines-Hodzana High.; $65^{\circ} 55^{\prime} 30^{\prime \prime} \mathrm{N}, 151^{\circ} 09^{\prime} 00^{\prime \prime} \mathrm{W}$; (map 106).

Prospectors' name reported in 1956 by Orth; named for "Mike" Allard, a prospector who crossed the head of the Ray River about 20 years ago.

Al-lash-ook: stream, see Alatna River.

Allatna River: stream, see Alatna River.

Allen Mount; mountain, see Stoney Mountain.

Allen Creek: stream, heads at $62^{\circ} 25^{\prime}$ N., $163^{\circ} 20^{\prime}$

W, flows NE $25 \mathrm{mi}$. to Andreafsky River, 59 mi. SE of Kwiguk, Nulato Hills; $62^{\circ} 29^{\prime} \mathrm{N}$, $162^{\circ} 44^{\prime} \mathrm{W}$; (map 77).

Local name obtained in 1948 by USC\&GS.

Allen Creek: stream, flows SE $1.5 \mathrm{mi}$. to Topkok River, $4.3 \mathrm{mi}$. NE of Topok on Norton Sound and $17 \mathrm{mi}$. NE of Solomon, Seward Penin. High.; $64^{\circ} 37^{\prime} 20^{\prime \prime} \mathrm{N}, 163^{\circ} 53^{\prime} 20^{\prime \prime} \mathrm{W}$; (map 95). Var. Surprise Creek.

Prospectors' name reported in 1900 by E. C. Barnard (in Brooks, 1901, pl. 17), USGS.

Allen Creek: stream, flows NW $3.7 \mathrm{mi}$. to Goldstream Creek, 17 mi. W of Fairbanks, Yukon- 
Tanana High.; $64^{\circ} 50^{\prime} 45^{\prime \prime}$ N, $148^{\circ} 17^{\prime} 00^{\prime \prime} \mathrm{W}$; (map 100).

Local name published on a 1906 USGS map.

Allen Creek: stream, flows SW $7.8 \mathrm{mi}$. to New York Creek, $24 \mathrm{mi}$. SSW of Rampart, YukonTanana High.; $65^{\circ} 10^{\prime} 45^{\prime \prime} \mathrm{N}, 150^{\circ} 28^{\prime} 45^{\prime \prime} \mathrm{W}$; (map 106).

Prospectors' name reported in 1906 by USGS (Prindle, 1908, pl. 5).

Allen Creek: stream, "on the north bank of Tanana river, near longitude $147^{\circ} . "$

"So named in 1902 by Lieut. George S. Gibbs, U.S.A., probably after Brig. Gen. Henry Tureman Allen, U.S.A." (Baker, 1906, p. 93). This may be the Allen Creek that flows to Goldstream Creek.

Allen Creek: stream, see California Creek.

Allen Creek: stream, see Surprise Creek.

Allene Creek: stream, flows NE $7 \mathrm{mi}$. to North Creek which flows to Agiapuk River, $11 \mathrm{mi}$. NE of Teller, Seward Penin. High.; $65^{\circ} 23^{\prime}$ N, $165^{\circ} 59^{\prime} \mathrm{W}$; (map 111).

Prospectors' name reported in 1901 by T. G. Gerdine (in Collier, 1902, pl. 12), USGS.

Allen Glacier: glacier, trends E $15 \mathrm{mi}$. to its terminus at Allen River, $1 \mathrm{mi}$. W of Copper River and $40 \mathrm{mi}$. N of Katalla, Chugach Mts.; $60^{\circ} 47^{\prime} \mathrm{N}, 144^{\circ} 37^{\prime} \mathrm{W}$; BGN 1910; (map 64). Var. Baird Glacier.

Named by Lawrence Martin for Lt. Henry Tureman Allen, USA, 1859-1930, who did extensive exploration in central Alaska. Leaving Nuchek on March 20, 1885 Allen ascended the Copper River, crossed to and descended the Tanana River to its mouth. From there he traveled north to the Koyukuk, ascended it some distance, then descended to its mouth and arrived at St. Michael on August 29. $\mathrm{He}$ then returned to San Francisco. Allen travelled approximately 1,500 miles of wilderness and his maps remained for a dozen years the only source of topographical information on the regions he investigated.

Allen Glacier: glacier, see Stoney Glacier.

Allenkakat: stream, see Alatna River.

Allenkaket: stream, see Alatna River.

Allenkkat: stream, see Alatna River.

Allen River: stream, heads at Chikuminuk Lake, ffows SE $3.6 \mathrm{mi}$. to Lake Chauekuktuli, 125 mi. SW of Sleetmute, Kilbuck-Kuskokwim Mts.; $60^{\circ} 04^{\prime} \mathrm{N}, 158^{\circ} 37^{\prime} \mathrm{W}$; $B G N$ 1932; (map 60).

Locally named for "Byron Allen, who with a partner was lost in the river about 1900"; reported in 1931 by USGS.

Allen River: stream, flows S $38 \mathrm{mi}$. to John River, $8 \mathrm{mi}$. S of Gunsight Mtn. and $51 \mathrm{mi}$. W of Wiseman, Brooks Ra. ; $67^{\circ} 22^{\prime} \mathrm{N}, 152^{\circ} 02^{\prime}$ W; BGN 1932; (map 124).

Named in 1930 by Robert Marshall for Lt. Gen. Henry Tureman Allen (1859-1930), USA, "the first white man to penetrate north of the Arctic Circle in the Koyukuk drainage. This [the stream chosen] would seem an especially appropriate feature $* * *$ because his most northerly point $* * *$ reached was on the drainage of the John River less than thirty miles below the mouth of the proposed Allen River."

Allen River: stream, see Alatna River.

All Gold Creek: stream, flows SW $2 \mathrm{mi}$, to join Dexter Creek to form Totatlanika River, 20

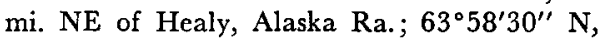
$148^{\circ} 23^{\prime} 30^{\prime \prime} \mathrm{W}$; (map 87).

Prospectors' name shown on a 1910 fieldsheet by J. W. Bagley, USGS; published by Capps (1912, pl. 1), USGS.

All Gold Creek: stream, flows NW $1.5 \mathrm{mi}$. to Fish Creek, $22 \mathrm{mi}$. NE of Fairbanks, YukonTanana High.; $65^{\circ} 02^{\prime} 30^{\prime \prime} \mathrm{N}, 147^{\circ} 08^{\prime} 00^{\prime \prime} \mathrm{W}$; (map 105).

Named by prospectors; published in 1908 by USGS.

Allgold Creek: stream, flows SE $1.3 \mathrm{mi}$. to Canyon Creek which flows to Casadepaga River, $21 \mathrm{mi}$. N of Solomon, Seward Penin. High.; $64^{\circ} 52^{\prime} \mathrm{N}, 164^{\circ} 28^{\prime} \mathrm{W}$; (map 95).

Prospectors' name reported in 1905 by $\mathrm{T}$. G. Gerdine, USGS.

All Hand Help Lake: lake, $1 \mathrm{mi}$. long, $5 \mathrm{mi}$. E of Minto and $39 \mathrm{mi}$. W of Fairbanks, Tanana

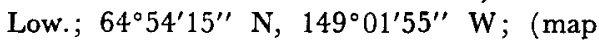
100 ).

Local name published on a 1950 USGS map.

Alligator Island: island, $0.2 \mathrm{mi}$. across, in Shelikof Strait, $33 \mathrm{mi}$. N of Afognak, Kodiak I.; $58^{\circ} 28^{\prime} 30^{\prime \prime} \mathrm{N}, 152^{\circ} 47^{\prime} 10^{\prime \prime} \mathrm{W}$; (map 43).

So named in 1926 by USC\&GS, "from the [island's] resemblance [to an alligator] from certain directions."

Allinnak: locality, see Alinnak.

Allison Creek, stream, heads in lake, flows N 2 mi. to Port Valdez, $3.7 \mathrm{mi}$. SW of Valdez, Chugach Mts. ; $61^{\circ} 05^{\prime} 10^{\prime \prime} \mathrm{N}, 146^{\circ} 21^{\prime} 05^{\prime \prime} \mathrm{W}$; (map 68).

Local name reported in 1917 by B. L. Johnson, USGS.

Allman Lake: lake, $0.8 \mathrm{mi}$. across, $\mathrm{N}$ of Nageethluk River, $29 \mathrm{mi}$. NE of Marshall, YukonKuskokwim Delta; $62^{\circ} 16^{\prime} \mathrm{N}, 161^{\circ} 42^{\prime} \mathrm{W}$; (map 78).

Local name obtained in 1952 by USGS.

Allook: mountain, see South Aluk Hill.

Allowluraux: locality, see Alolukrok.

Al-lue-ga-wick: spring, see Reed River Hot Spring.

Alma Creek: stream, heads in Canada, flows NW $3.5 \mathrm{mi}$. to Moose Creek, $36 \mathrm{mi}$. SE of Eagle, Yukon-Tanana High.; $64^{\circ} 17^{\prime}$ N, $141^{\circ}$ 01' W; (map 102).

Prospectors' name shown on a 1898 manuscript map by C. A. Woodruff, Fort Cudahy, Canada.

Alma Creek: stream, flows NW $1.2 \mathrm{mi}$. to $\mathrm{Au}$ burn Creek which flows to Birch Creek, $19 \mathrm{mi}$. $\mathrm{NE}$ of Solomon, Seward Penin. High.; 64 ${ }^{\circ}$ $48^{\prime} \mathrm{N}, 164^{\circ} 11^{\prime} \mathrm{W}$; (map 95).

Prospectors' name reported on a 1902 prospectors' manuscript map.

Alma Creek: stream, flows NE $4 \mathrm{mi}$. to Yankee River which flows to Mint River, $37 \mathrm{mi}$. NW of Teller, Seward Penin. High.; 65 $40^{\prime} \mathrm{N}$, $167^{\circ} 13^{\prime} \mathrm{W}$; (map 111).
Prospectors' name reported on the 1908 "map of Seward Peninsula" by Arthur Gibson. Alma Gulch: ravine, trends SW $0.8 \mathrm{mi}$. to Norton Sound, $10 \mathrm{mi}$. SE of Nome, Seward Penin. High.; $64^{\circ} 26^{\prime} 55^{\prime \prime} \mathrm{N}, 165^{\circ} 04^{\prime} 45^{\prime \prime} \mathrm{W}$; (map 94).

Prospectors' name reported in 1904 by T. G. Gerdine, USGS.

Almejas, Punta: point of land, see Fern Point. Almguist Rock: rock, in North Arm Moira Sound, on SE coast of Prince of Wales I., Alex. Arch.; 55 $06^{\prime} 05^{\prime \prime} \mathrm{N}, 132^{\circ} 05^{\prime} 55^{\prime \prime} \mathrm{W}$; (map 4).

Local name recorded in 1948 by USGS.

Almiralty, Bahia: bay, see Yakutat Bay.

Almirantazgo: bay, see Yakutat Bay.

Almirante, Bocas de: bay, or channel, in $\mathrm{N}$ part of San Alberto Bay, Prince of Wales I., Alex. Arch.

Named by Francisco Antonio Maurelle about May 24, 1779. Don Juan de la Bodega y Quadra was the almirante of this expedition but this feature probably was not named for him (Wagner, 1937, p. 425). No inlets or openings show on present charts.

Almos, Punta de los: point of land, on $\mathbf{E}$ side of San Juan Bautista I., Bucareli Bay, Alex. Arch.; $55^{\circ} 26^{\prime} \mathrm{N}, 133^{\circ} 14^{\prime} \mathrm{W}$; (map 4).

Spanish name, meaning "point of the cottonwood trees," given by the 1779 Don Ignacio Arteaga expedition.

Alngeeyak Cape: point of land, see Alngeeyak Point.

Alngeeyak Point: point of land, on NE coast of Saint Lawrence I., $35 \mathrm{mi}$. SE of Savoonga; $63^{\circ} 24^{\prime} \mathrm{N}, 169^{\circ} 35^{\prime} \mathrm{W}$; BGN 1951; (map 93). Var. Alngeeyak Cape, Alngegyak Cape, Alngiyak Point, Cape Alngeeyak.

Eskimo name reported in 1932 by Otto W. Geist, Univ, of Alaska.

Alngegyak Cape: point of land, see Alngeeyak Point.

Alngiyak Point: point of land, see Alngeeyak Point.

Alōgh'-kōverūshkä': hill, see North Sealion Hill.

Aloha Creek: stream, heads on Elephant Mtn., flows SW and W 3 mi. to Minook Creek, $17 \mathrm{mi}$. $\mathrm{S}$ of Rampart, Yukon-Tanana High.; $65^{\circ} 15^{\prime}$ $40^{\prime \prime} \mathrm{N}, 150^{\circ} 08^{\prime} 30^{\prime \prime} \mathrm{W}$; (map 106).

Prospectors' name reported in 1906 by USGS.

Aloha Creek: stream, heads in Zane Hills, flows E $13 \mathrm{mi}$. to Clear Creek $2 \mathrm{mi}$. W of its junc. with Hogatza River, $38 \mathrm{mi}$. WNW of Hughes, Hogatza High.; $66^{\circ} 13^{\prime} \mathrm{N}, 155^{\circ} 34^{\prime} \mathrm{W}$; (map 116).

Mining engineers' name applied in 1955; reported in 1956 by Orth.

Aloktorak Basin: basin, $18 \mathrm{mi}$. long, on Kokolik and Tingmerkpuk Rivers, in DeLong Mts., Brooks Ra.; $68^{\circ} 45^{\prime} \mathrm{N}, 162^{\circ} 10^{\prime} \mathrm{W}$; (map 130).

Eskimo name reported in 1956 to mean "very cold" by USGS.

Alokut Point: point of land, on Chukchi Sea coast, $0.8 \mathrm{mi}$. S of Cape Lisburne, Arctic Slope; $68^{\circ} 52^{\prime} 30^{\prime \prime} \mathrm{N}, 166^{\circ} 13^{\prime} 30^{\prime \prime} \mathrm{W}$; (map 129). Var. Ak-loe-gook. 
Eskimo name reported to mean "jaw" by USC\&GS in 1950; spelled "Ak-loe-gook." Its present spelling was reported in 1955 by the U.S. Army Corps of Engineers.

Alolukrok: locality, site of an Eskimo village, in a meander of Kukpuk River, $19 \mathrm{mi}$. E of Cape Thompson, Arctic Slope; 68 $07^{\prime} 30^{\prime \prime} \mathrm{N}$, $165^{\circ} 16^{\prime} 00^{\prime \prime} \mathrm{W}$; BGN 1963; (map 129). Var. Ahlolúkroq, Allowluraux, Alowlookroak.

Eskimo name reported as Allowluraux in 1960 by D. C. Foote, in connection with Project Chariot studies.

Alonzo Point: point of land, on NE coast of Baker I., in Port Asumcion, Alex. Arch.; $55^{\circ} 22^{\prime} 20^{\prime \prime} \mathrm{N}, 133^{\circ} 31^{\prime} 15^{\prime \prime} \mathrm{W}$; (map 4). Var. Mys de Alanzo, Punta de Alonzo.

Name given in 1775-79 by Don Juan de la Bodega y Quadra and Francisco Antonio Maurelle as "Punta de Alonzo."

Alookuk: loçality, see Ulukuk.

Alowas Camp: locality, see Sooghmeghat.

Alowlookroak: locality, see Alolukrok.

Alpha Creek: stream, flows SE $1 \mathrm{mi}$. to Snake River, $8 \mathrm{mi}$. NW of Nome, Seward Penin. High.; $64^{\circ} 37^{\prime} \mathrm{N}, 165^{\circ} 29^{\prime} \mathrm{W}$; (map 94).

Prospectors' name reported in 1899 by $D$. C. Witherspoon (in Schrader and Brooks, 1900, map 2), USGS.

Alpha Creek: stream, flows SW $0.8 \mathrm{mi}$. to Omega Creek, $3.5 \mathrm{mi}$. W of Eureka and $23 \mathrm{mi}$. SSW of Rampart, Yukon-Tanana High.; $65^{\circ} 10^{\prime} 45^{\prime \prime}$ N, $150^{\circ} 20^{\prime} 20^{\prime \prime} \mathrm{W}$; (map 106).

Prospectors' name reported in 1904 by Prindle and Hess (1906, pl. 3), USGS.

Alpha Creek: stream, see Omega Creek.

Alpha Ridge: ridge, elev. 3,420 ft., in Kantishna Hills, extends SW $1.5 \mathrm{mi}$. from Moose Creek, $4 \mathrm{mi}$. WNW of Wonder Lake, Alaska Ra.; $63^{\circ} 31^{\prime} 30^{\prime \prime} \mathrm{N}, 151^{\circ} 01^{\prime} 00^{\prime \prime} \mathrm{W}$; (map 88).

Local name reported in 1925 by $S . R$. Capps, USGS.

Alphield Creek: stream, see Alfield Creek.

Alpine Cove: bay, extends E $1.6 \mathrm{mi}$. at head of Deadman Bay, on S coast of Kodiak I ; $57^{\circ} 08^{\prime}$ -

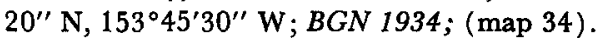

Descriptive name given in 1931 by USC\&GS "because of Alpine aspect of adjacent rugged, snow-covered mountains * * *."

Alpine Creek: stream, flows SW $4 \mathrm{mi}$. to Raft

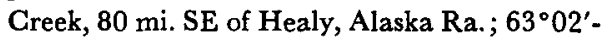
$15^{\prime \prime}$ N, $147^{\circ} 16^{\prime} 15^{\prime \prime}$ W; BGN 1959; (map 87).

Named in 1954 by USGS geologists because "the valley being similar to those in the Swiss Alps, with steep, sharp-crested walls, broad floor, U-shape, and lakes."

Alpine Lake: lake, $0.4 \mathrm{mi}$. across, on Kenai Penin. SE of Twin Lakes, $45 \mathrm{mi}$. SE of Kenai, Chugach Mts.; $60^{\circ} 15^{\prime} 50^{\prime \prime} \mathrm{N}, 150^{\circ} 07^{\prime} 10^{\prime \prime} \mathrm{W}$; (map 62).

So named about 1963 by officials of Kenai National Moose Range, because of its high elevation.

Alseck River: stream, see Alsek River.

Alsek Glacier: glacier, heads at $59^{\circ} 15^{\prime} \mathrm{N}$, $137^{\circ} 55^{\prime} \mathrm{W}$, trends $\mathrm{S}$ and $\mathrm{W} 11 \mathrm{mi}$. to its 1961 terminus on Alsek River, $1 \mathrm{mi}$. E of Gateway Knob and $61 \mathrm{mi}$. SE of Yakutat; $59^{\circ} 12^{\prime} \mathrm{N}$, $138^{\circ} 08^{\prime} \mathrm{W}$; (map 46$)$.
Named by Lt. Comdr. J. F. Moser (1901, pl. 43 and p. 388), USN.

Alsekh River: stream, see Alsek River.

Alsek Lake: lake, $6 \mathrm{mi}$. long, on Alsek River at 1961 terminus of Alsek Glacier, $61 \mathrm{mi}$. SE of Yakutat, St. Elias Mts. ; $59^{\circ} 10^{\prime} 30^{\prime \prime}$ N, $138^{\circ} 12^{\prime}$ $00^{\prime \prime} \mathrm{W}$; (map 46).

Name derived from the Alsek River, annotated by Eliot Blackwelder and G. C. Martin, USGS, on a manuscript map dated 1907.

Alsek River: stream, heads in Canada and flows S 240 mi. to Gulf of Alaska at Dry Bay, $49 \mathrm{mi}$. SE of Yakutat, St. Elias Mts.; $59^{\circ} 03^{\prime} \mathrm{N}$, 13834' W; BGN 1953; (map 46). Var. Alseck River, Alsekh River, Altsek River, Altsekh River, Alzech River, Harrison River, Jones River, Riviere de Behring.

Native name reported by Capt. Tebenkov (1852, map 7), IRN, as "R[eka] Alsekh," or "Alsekh River." It was called "Riviere de Behring" by La Perouse in 1786, "Jones River" by the New York Times Expedition in 1886, and "Harrison River" by USC\&GS in 1890 . The name "Alsek River" was originally adopted by the United States and Canada in 1891.

Alsentia: village, see Kaguyak.

Alsentia Bay: bay, see Kaguyak Bay.

Als Mountain: mountain, 6,900 ft., between Ernie Greek and North Fork Koyukuk River, $27 \mathrm{mi}$. E of Anaktuvuk Pass, Brooks Ra. $68^{\circ} 02^{\prime} 45^{\prime \prime} \mathrm{N}, 150^{\circ} 45^{\prime} 13^{\prime \prime} \mathrm{W}$; (map 134).

Named in 1930 by Marshall (1956, p. 122) for his companion, Al Retzlaf, who shot two Dall sheep on this mountain.

Alta Creek: stream, flows $1.5 \mathrm{mi}$. to California Creek which flows to Bonanza River, $10 \mathrm{mi}$. NW of Solomon, Seward Penin. High.; 64으. $41^{\prime} 20^{\prime \prime} \mathrm{N}, 164^{\circ} 36^{\prime} 55^{\prime \prime} \mathrm{W}$; (map 95).

Prospectors' name reported on the 1900 "Map of Nome Peninsula" by J. M. Davidson and B. D. Blakeslee.

Althorp, Mount: mountain, 2,933 ft., on Althorp Penin., on $\mathrm{N}$ coast of Chichagof I., $34 \mathrm{mi}$. WNW of Hoonah, Alex. Arch.; 58 $04^{\prime} 45^{\prime \prime} \mathrm{N}$, $136^{\circ} 21^{\prime} 10^{\prime \prime}$ W; BGN 1960; (map 10).

Named in 1955 by USGS, for Port Althorp. Althorp, Port: bay, on $\mathrm{N}$ coast of Chichagof $\mathrm{I}$., extends SE $7.5 \mathrm{mi}$. from George Is., $34 \mathrm{mi}$. WNW of Hoonah, Alex. Arch.; 58 $8^{\circ} 11^{\prime} 30^{\prime \prime} \mathrm{N}$, $136^{\circ} 23^{\prime} 00^{\prime \prime}$ W; (map 10). Var. Apthorp Port, Port Altorp.

Named in 1794 by Capt. George Vancouver, RN, for Althorp, the eldest son of Earl G. J. Spencer, 1758-1834, of England (Wagner, 1937, p. 372). Earl Spencer was made First Lord of the Admiralty in 1794. Vancouver was anchored here July 10-28, 1794.

Althorp Peninsula: peninsula, $5 \mathrm{mi}$. long, on $\mathrm{N}$ coast of Chichagof I., between Lisianski Inlet and Port Althorp, $34 \mathrm{mi}$. WNW of Hoonah, Alex. Arch., $58^{\circ} 06^{\prime} \mathrm{N}, 136^{\circ} 22^{\prime} \mathrm{W}$; BGN 1960; (map 10).

Named in 1955 by USGS for Port Althorp. Althorp Rock: rock, on $\mathrm{N}$ coast of Chichagof $\mathrm{I}$, in Port Althorp, $1 \mathrm{mi}$. $\mathrm{N}$ of Point Lucan and $34 \mathrm{mi}$. WNW of Hoonah, Alex. Arch.; 58 $10^{\prime} 00^{\prime \prime} \mathrm{N}, 136^{\circ} 21^{\prime} 30^{\prime \prime} \mathrm{W}$; (map 10).
Named for Port Althorp in 1901 by J. F. Pratt, USC\&GS.

Althouse Point: point of land, E tip of Cat I., in Twelvemile Arm, near center of Prince of Wales I., Alex. Arch.; $55^{\circ} 28^{\prime} 25^{\prime \prime} \mathrm{N}, 1^{\circ} 2^{\circ}$ $38^{\prime} 35^{\prime \prime} \mathrm{W}$; (map 4).

Local name reported in 1905 by E. F. Dickins, USC\&GS.

Altona Bay: bay, see Lituya Bay.

Altorp Port: bay, see Althorp, Port.

Altsekh River: stream, see Alsek River.

Altsek River: stream, see Alsek River.

Altuya Bay: bay, see Lituya Bay.

Alukeyak Hill: hill, see Ulakaia Hill.

Aluklik Bay: cove, $0.5 \mathrm{mi}$. across, on $\mathrm{SW}$ end of Evans I., SE side of Prince of Wales Passage, $18 \mathrm{mi}$. S of Chenega, Chugach Mts.; $60^{\circ}$ $01^{\prime} 30^{\prime \prime} \mathrm{N}, 148^{\circ} 07^{\prime} 45^{\prime \prime} \mathrm{W}$; (map 63).

Local name reported in 1951 by USGS. Alukuk: locality, see Ulukuk.

Aluta Bay: bay, see Alitak Bay.

Alutak, Cape: point of land, see Alitak, Cape.

Alutak Bay: bay, see Alitak Bay.

Alverstone, Mount: peak, 14,500 ft., on AlaskaCanada boundary, $2 \mathrm{mi}$. N of Mount Hubbard and $61 \mathrm{mi}$. NE of Yakutat, St. Elias Mts.; $60^{\circ} 21^{\prime} \mathrm{N}, 1^{\circ} 9^{\circ} 04^{\prime} \mathrm{W}$; BGN 1924; (map 66). Var. Alverstone Peak, Boundary Peak 180.

Named in 1908 for Lord Richard Everard Webster Alverstone, 1842-1915, Lord Chief Justice of England, 1900-13, and Boundary Commissioner in 1903. He served on various arbitration commissions including the one dealing with the Bering Sea Fur-Seal controversy. In the Alaska boundary dispute in 1903 , his vote was the deciding one against Canadian claims.

Alverstone Peak: mountain, see Alverstone, Mount.

Alvides, Cabo de: point of land, on Alaska Penin. or some outlying island, about $163^{\circ} \mathrm{W}$.

Name used in López de Haro's account of the 1788 expedition. See Wagner (1937, p. 425).

Alvin Bay: bay, extends E 4 mi. to Sumner Strait, $12 \mathrm{mi}$. NW of Point Baker, on E coast of Kuiu I., Alex. Arch.; $56^{\circ} 26^{\prime} \mathrm{N}, 133^{\circ} 53^{\prime} \mathrm{W}$; (map 6).

Local navigators' name reported in 1904 by H. C. Fassett, USBF.

Alyagnagik, Reka: stream, see Wood River. Alyagnagik River: stream, see Wood River. Alyaknagik: lake, see Aleknagik, Lake. Alyaksa, Mys: peninsula, see Alaska Peninsula. Alyaksinskiy, Mys: peninsula, see Aliaksin, Cape. Alyaska, Poluostrov: peninsula, see Alaska Peninsula.

Alyeska, Mount: mountain, 3,939 ft., in SW end of Chugach Mts. between Winner Creek and Turnagain Arm, Chugach Mts.; 60 57'$30^{\prime \prime} \mathrm{N}, 149^{\circ} 03^{\prime} 30^{\prime \prime} \mathrm{W}$; BGN 1961; (map 63).

Named by USFS in 1959 "after the Alyeska Ski Area which has been improved with a lift and buildings by the Alyeska Ski Corporation, immediately to the west of this mountain." Alyukhsyuk: bay, see Pumicestone Bay.

Alzáne: island, see Talsani Island.

Alzech River: stream, see Alsek River. 
Amaagtut: promontory, see Crowbill Point. Amadedori Creek: stream, see Amakdedori Creek.

Amadens Creek: stream, flows W $22 \mathrm{mi}$. to Kolovinerak River, $8 \mathrm{mi}$. SW of Baird Inlet and $90 \mathrm{mi}$. W of Bethel, Yukon-Kuskokwim Delta; 60 $36^{\prime} \mathrm{N}, 164^{\circ} 20^{\prime} \mathrm{W}$; (map 58). Var. Amadeus Creek, Kinarak Creek, Kinaruk Creek.

This stream was named for Frank Amadeus, trapper, prospector, and "long-time resident of the area." The Amadens spelling is a typographical error that has been perpetuated. USC\&GS reported in 1949 the Eskimo name as "Kinarak," meaing "something to look through."

Amadeus Creek: stream, see Amadens Creek. Amagadak Island: island, see Amagat Island.

Amagalik, Cape: point of land, on SW coast of Tanaga I., Aleutian Is.; $51^{\circ} 41^{\prime} \mathrm{N}, 178^{\circ} 06^{\prime} \mathrm{W}$; (map 16). Var. Cape Amagalikh.

Aleut name published by Capt. Tebenkov (1852, map 28) as "M[ys] Amagalik." $\mathbf{R}$. $H$. Geoghegan thought this name to be derived from "hamaghalik," meaning "has come to be."

Amagalikh, Cape: point of land, see Amagalik, Cape.

Amagat Island: island, $1 \mathrm{mi}$. long, near $\mathrm{S}$ coast of Alaska Penin. $21 \mathrm{mi}$. E of village of False Pass, near mouth of Morzhovoi Bay, Aleutian Ra.; 54 $54^{\prime} \mathrm{N}, 162^{\circ} 53^{\prime} \mathrm{W}$; (map 25). Var. Amagadak Island, Ostrov Amagat.

Aleut name published as "O[strov] Amagat," or "Amagat Island," by Capt. Tebenkov (1852, map 24), IRN; called "Amagadak" by Capt. Lutke (1836, p. 272), IRN.

Amagat Peak: mountain, 1,065 ft., on Amagat I. near S coast of Alaska Penin., 21 mi. E of village of False Pass, Aleutian Ra.; 54 53'52" N, $162^{\circ} 52^{\prime} 45^{\prime \prime} \mathrm{W}$; (map 25).

Name published in 1957 by AMS.

Amagaulik: hill, see Amulik Hill.

Amagoalik Creek: stream, flows SE $4.5 \mathrm{mi}$. to Kungok River, $14 \mathrm{mi}$. SE of Wainwright, Arctic Plain; $70^{\circ} 30^{\prime} 30^{\prime \prime} \mathrm{N}, 159^{\circ} 35^{\prime} 45^{\prime \prime} \mathrm{W}$; (map 146).

Eskimo name transcribed in 1956 by Orth; reported by the people at Wainwright to mean "wolf pups."

Amagta: island, see Chuginadak Island.

Amagul Creek: stream, see Amugul Creek.

Amah-chack, Baie: bay, see Aniakchak Bay.

Amahktoosook Mountain: ridge, see Amatusuk Hills.

Amakagagvak: lake, "near to and connected with Nushagak lake."

"Native name, from Tebenkof, 1849" (Baker 1906, p. 95).

Amakaktuli: point of land, see Eagle Cape.

Amakatatee Creek: stream, flows SE $6 \mathrm{mi}$. to Kanektok River, $70 \mathrm{mi}$. NE of Goodnews, Kilbuck-Kuskokwim Mts.; $59^{\circ} 53^{\prime} 30^{\prime \prime} \mathrm{N}, 160^{\circ} 23^{\prime}$ 15" W; (map 53). Var. Baichron River, Baikron Creek, Bychron River.

Eskimo name shown as "Baichron" on an 1898 field sheet by W. S. Post, USGS; published as "Baikron" (Spurr, 1900, map 10).
Present-day maps show the Eskimo name "Amakatatee Creek" for this stream.

Amakdedori: locality, site of a village, on $W$ shore of Kamashik Bay, $\mathrm{N}$ of mouth of Amakdedori Creek and $26 \mathrm{mi}$. SW of Augustine I., Aleutian Ra.; $59^{\circ} 16^{\prime} 40^{\prime \prime} \mathrm{N}, 154^{\circ} 07^{\prime} 30^{\prime \prime} \mathrm{W}$; (map 51).

Native name obtained in 1923 by members of R. H. Sargent's party, USGS, and published by K. F. Mather (in Brooks and others, 1925, pl. 3), USGS.

Amakdedori Creek: stream, flows SE $10 \mathrm{mi}$. to Kamishak Bay, $26 \mathrm{mi}$. SW of Augustine I. Aleutian Ra.; 59 $16^{\prime} 40^{\prime \prime} \mathrm{N}, 154^{\circ} 07^{\prime} 30^{\prime \prime} \mathrm{W}$; (map 51). Var. Amadedori Creek.

Native name obtained in 1923 by members of R. H. Sargent's party, USGS, and published by K. F. Mather (in Brooks and others, 1925, pl. 3), USGS.

Amakdedulia Cove: cove, $2 \mathrm{mi}$. across, on W shore of Kamishak Bay $27 \mathrm{mi}$. SE of Kakhonak, Aleutian Ra.; $59^{\circ} 11^{\prime} \mathrm{N}, 154^{\circ} 09^{\prime} \mathrm{W}$; (map 51).

Eskimo name reported in 1923 by K. F. Mather (in Brooks and others, 1925, pl. 3), USGS.

Amakhnak: island, see Amaknak Island.

Amak Island: island, $3 \mathrm{mi}$. across, in Bering Sea, $20 \mathrm{mi}$. NW of village of Cold Bay, Bristol Bay Low.; $55^{\circ} 25^{\prime} \mathrm{N}, 163^{\circ} 08^{\prime} \mathrm{W}$; (map 29). Var. Aamak Isle, Ostrov Amak, Walrus Island.

Aleut name published as "O[strov] Amak" or "Amak Island," by Capt. Tebenkov (1852, map 24), IRN. According to R. H. Geoghegan, this native name comes from the word "amaq" which means "blood".

Amaknak Cave: cave, under Cave Rock, on SW coast of Amaknak I., in Unalaska Bay, $1 \mathrm{mi}$. W of Unalaska village, Fox Is., Aleutian Is.; $53^{\circ}$ $53^{\prime} 10^{\prime \prime} \mathrm{N}, 166^{\circ} 33^{\prime} 12^{\prime \prime} \mathrm{W}$; (map 23).

Name probably derived from Amaknak Island. This cave was an old Aleutian burial place (Baker, 1906, p. 95). According to R. H. Geoghegan the name means "burial place" from amiknaq (place of impurity).

Amaknakh, Ostrov: island, see Amaknak Island. Amaknak Island: island, $4.3 \mathrm{mi}$. long, in Fox Is., in Unalaska Bay, on NE coast of Unalaska I., Aleutian Is. ; $53^{\circ} 54^{\prime} 30^{\prime \prime} \mathrm{N}, 166^{\circ} 32^{\prime} 00^{\prime \prime} \mathrm{W}$; BGN 1931; (map 23). Var. Amakhnak, Amaknax, Amoknak, Ostrov Amaknakh.

Aleut name published by Lt. Sarichev (1826, maps 14-15), IRN, as "Ostr[ov] Amaknakh", meaning "Amaknak Island." Spelled "Amakhnak" by Capt. Lutke (1836, p. 281), IRN; "Amaknak" by USBF in 1888 . According to $R$. $H$. Geoghegan, the name means "burial place," from "amaiknag" meaning "place of impurity".

Amaknax: island, see Amaknak Island.

Amakomanak Creek: stream, flows NW $20 \mathrm{mi}$. to Imelyak River, $36 \mathrm{mi}$. SW of Howard Pass, Brooks Ra.; 67 $45^{\prime}$ N, $156^{\circ} 36^{\prime}$ W; (map 126).

Eskimo name meaning "wolf dung"; obtained at Shungnak and Noatak in 1956 by Orth.
Amaktusak Creek: stream, flows $S 0.6 \mathrm{mi}$. to Chukchi Sea, $0.4 \mathrm{mi}$. NW of Crowbill Point and $5 \mathrm{mi}$. SE of Cape Thompson, Arctic Slope; $68^{\circ} 06^{\prime} 15^{\prime \prime} \mathrm{N}, 165^{\circ} 49^{\prime} 00^{\prime \prime} \mathrm{W}$; BGN 1963; (map 129). Var. Amatusuk Creek.

Eskimo name reported in 1962 by Project Chariot personnel.

Amaktuvik Pass: pass, $1,820 \mathrm{ft}$., in DeLong Mts. between Tumit and Kukukpilak Creeks, $21 \mathrm{mi}$. E of Misheguk Mtn., Brooks Ra.; $68^{\circ}$ $19^{\prime} \mathrm{N}, 160^{\circ} 16^{\prime} \mathrm{W}$; (map 131).

Eskimo name meaning "place where pack is used"; obtained at Noatak in 1956 by Orth. Amakuk Arm: estuary, $8 \mathrm{mi}$. long, at NW end of Lake Nerka, $45 \mathrm{mi}$. NW of Dillingham, Kilbuck-Kuskokwim Mts.; $59^{\circ} 35^{\prime} \mathrm{N}, 159^{\circ} 03^{\prime}$ W; BGN 1931; (map 53).

Eskimo name reported in 1929 by USBF.

Amalga: locality, site of former settlement and post office at the Eagle River Mine, about 4 mi. NE of mouth of Eagle River and $22 \mathrm{mi}$. NW of Juneau, Coast Mts.; $58^{\circ} 44^{\prime} 30^{\prime \prime} \mathrm{N}$, $134^{\circ} 46^{\prime} 00^{\prime \prime} \mathrm{W}$; (map 11).

A miner's name apparently derived from the word "amalgam." This mining settlement at the Eagle River mine was established about 1902 and the post office in 1905 . The settlement was abandoned about 1927 (DeArmond, 1957). The same year the post office was discontinued (Ricks, 1965, p. 3).

Amalga Harbor: harbor, $0.2 \mathrm{mi}$. across, on $\mathrm{W}$ shore of Favorite Channel, $1 \mathrm{mi}$. $\mathrm{N}$ of Pearl Harbor and $19 \mathrm{mi}$. NW of Juneau, Coast Mts.; $58^{\circ} 29^{\prime} 30^{\prime \prime} \mathrm{N}, 134^{\circ} 47^{\prime} 20^{\prime \prime} \mathrm{W}$; (map 11).

Local name derived from the former settlement of Amalga at the Eagle River mine 5.5 $\mathrm{mi}$. to the north. The mining company had a wharf and warehouse here about 1905 (DeArmond, 1957).

Amalga Landing: locality, site of wharf and warehouse of Eagle River mine, on Amalga Harbor, $19 \mathrm{mi}$. NW of Juneau, Coast Mts.; $58^{\circ} 29^{\prime} 30^{\prime \prime} \mathrm{N}, 134^{\circ} 47^{\prime} 05^{\prime \prime} \mathrm{W}$; (map 11).

Locally named from the settlement of Amalga at the Eagle River mine which was in operation from 1902 to 1927 (DeArmond, 1957).

Amalik Bay: bay, extends N 6 mi. from Cape Ilktugitak, on S coast of Alaska Penin., in Katmai National Monument, $19 \mathrm{mi}$. SE of Mount Katmai, Aleutian Ra. ; 58 $04^{\circ} \mathrm{N}, 154^{\circ}$ $29^{\prime} \mathrm{W}$; (map 42).

Eskimo name reported in 1895 by W. H. Dall, USC\&GS.

Amandliktok Island: barrier island, see Thetis Island.

Amanka Lake: lake, $8 \mathrm{mi}$. long, extends $\mathrm{W}$ to Iqushik River, $30 \mathrm{mi}$. W of Dillingham, Kilbuck-Kuskokwim Mts. ; $59^{\circ} 03^{\prime} \mathrm{N}, 159^{\circ} 16^{\prime} \mathrm{W}$; (map 53). Var. Pogakhluk Lake.

Eskimo name reported in 1898 by J. E. Spurr and W. S. Post, USGS; Ivan Petroff reported its name as "Pogakhluk Lake" in the 10 th Census, in 1880.

Amaouk Creek: stream, flows SW $13 \mathrm{mi}$. to Ekichuk Lake, $47 \mathrm{mi}$. NW of Selawik, Kotze- 
bue-Kobuk Low.; $66^{\circ} 58^{\prime}$ N, 161 ${ }^{\circ} 29^{\prime} \quad \mathrm{W}$; (map 114).

Eskimo name obtained in 1955 by U.S. Army Corps of Engineers.

Amargura, Point: point of land, $\mathrm{S}$ tip of San Fernando I., Alex. Arch.; 55 $27^{\prime} 00^{\prime \prime} \mathrm{N}, 133^{\circ}$ 21'30" W; (map 4). Var. Cabo Amargura, Mys de la Amargura, Point Amatgura, Punta de la Amargura.

Name given by Francisco Antonio Maurelle as "Punta de la Amargura," meaning "point of bitterness," on "either May 21, 1779, when he first anchored there or May 27, when he returned to the same point. He was obliged to remain in the bay west of the point until the 30th, hence, perhaps the name" (Wagner, 1937, p. 372).

Amarilla Point: point of land, between Fortaleza Bay and Thimble Cove, on SE coast of Baker 1., Alex. Arch.; 55 $18^{\prime} 35^{\prime \prime}$ N, $133^{\circ} 34^{\prime}$ $45^{\prime \prime}$ W; BGN 1923; (map 4).

Spanish name meaning "yellow," given in 1923 by USC\&GS, "for the triangulation station Yellow."

Amatgura, Point: point of land, see Amargura, Point.

Amatiegnak: island, see Amatignak Island.

Amatignake: island, see Amatignak Island.

Amatignak Island: island, $6 \mathrm{mi}$. long, in Delarof Is., southernmost of Aleutian Is.; $51^{\circ} 16^{\prime} \mathrm{N}$, $179^{\circ} 06^{\prime} \mathrm{W}$; $B G N$ 1890; (map 16). Var. Amatiegnak, Amatignake, Amatignas, Amatygnak.

Aleut name reported by Commodore Joseph Billings about 1792, as "Amatignas." Capt. Tebenkov (1852, map 29), IRN, shows "O[strov] Amatignak." Capt. Lutke (1836, p. 323), IRN, gave "Amatignak and Amatygnak 'qui en Aleoute signifie copeau [wood chip]'."

Amatignas: island, see Amatignak Island.

Amatosuk Hills: ridge, see Amatusuk Hills.

Amatuli Cove: cove, $0.6 \mathrm{mi}$. across in Barren

Is., on NW coast of East Amatuli I., in Gulf of Alaska ; $58^{\circ} 55^{\prime} 10^{\prime \prime} \mathrm{N}, 152^{\circ} 00^{\prime} 15^{\prime \prime} \mathrm{W}$; (map 43).

Named by USGS in 1908.

Amatuli Island: island, see East Amatuli Island. Amatuli Island: island, see West Amatuli Island. Amatusak Hills: ridge, see Amatusuk Hills.

Amatusuk Creek: stream, flows $\mathrm{N} 7 \mathrm{mi}$. to Chukchi Sea, $48 \mathrm{mi}$. SW of Point Lay, Arctic Plain $69^{\circ} 05^{\prime} 45^{\prime \prime} \mathrm{N}, 163^{\circ} 38^{\prime} 45^{\prime \prime} \mathrm{W}$; (map 145).

Named for the Amatusuk Hills.

Amatusuk Creek: stream, see Amaktusak Creek. Amatusuk Hills: ridge, elev. 1,550 ft., extend NE $45 \mathrm{mi}$. from Cape Beaufort, on coast of Chukchi Sea, $45 \mathrm{mi}$. S of Point Lay; Arctic Slope ; $69^{\circ} 07^{\prime} \mathrm{N}, 162^{\circ} 56^{\prime} \mathrm{W}$; (map 145). Var. Amahtooscok Mountain, Amatosuk Hills, Amatusak Hills. Amooktoosuk Hills.

Eskimo name published by Archdeacon Stuck (1920, p. 177), who wrote, "The last mountain, 'Amahk-too-sook,' rose beside us at this encamprient * * *."

Amatygnak: island, see Amatignak Island.

Amaudliktok Island: barrier island, see Thetis Island.
Amawak: promontory, "on the south side of Alaska Penin."

"Native name from [G. H. von] Langsdorft, 1805, who wrote it 'Amawack'" (Baker, 1906, p. 95).

Amawk Creek: stream, flows W $5 \mathrm{mi}$. from Amawk Mtn. to North Fork Koyukuk River, $40 \mathrm{mi}$. NW of Wiseman, Brooks Ra.; $67^{\circ} 57^{\prime} \mathrm{N}$, $150^{\circ} 32^{\prime} \mathrm{W}$; BGN 1932; (map 124).

Marshall (1956, p. 48) wrote, "a * * * stream * * * which I later named 'Amawk Creek,' meaning [in Eskimo] wolf creek."

Amawk Mountain: mountain, 5,770 ft., $3 \mathrm{mi}$. $\mathrm{NW}$ of Apoon Mtn. and $37 \mathrm{mi}$. N of Wiseman, Brooks Ra.; 67 $56^{\prime} 00^{\prime \prime} \mathrm{N}, 1^{\circ} 50^{\circ} 23^{\prime} 30^{\prime \prime} \mathrm{W}$; (map 124).

Named about 1930 by Marshall (1956, p. 156) who reported "*** judging by the wolf sign which was lying there. We named the peak Amawk Mouıtain-Amawk meaning wolf in Eskimo."

Amazon Greek: stream, in Amazon Gulch, flows SW $1.2 \mathrm{mi}$. to Root Glacier near its junc. with Kennicott Glacier, $6 \mathrm{mi}$. N of McCarthy, Wrangell Mts.; $61^{\circ} 30^{\prime} 12^{\prime \prime} \mathrm{N}, 142^{\circ} 54^{\prime} 02^{\prime \prime} \mathrm{W}$; $B G N$ 1964; (map 67). Var. Jumbo Creek. Local name reported in 1908 by D. C. Witherspoon (in Moffit and Capps, 1911, pl. 2), USGS.

Amazon Gulch: ravine, trends SW $2.6 \mathrm{mi}$. to Root Glacier, $6 \mathrm{mi}$. $\mathrm{N}$ of McCarthy, Wrangell Mts. ; $61^{\circ} 30^{\prime} 45^{\prime \prime} \mathrm{N}, 142^{\circ} 54^{\prime} 00^{\prime \prime} \mathrm{W} ; B G N$ 1964; (map 67).

Name used by miners; reported in 1962 by E. M. MacKevett, Jr., USGS. See Amazon Creek.

Amber Bay: bay, $5 \mathrm{mi}$. wide, on SW shore of Cape Kunmik, on S shore of Alaska Penin., Aleutian Ra.; $56^{\circ} 45^{\prime} \mathrm{N}, 157^{\circ} 17^{\prime} \mathrm{W}$; (map 31).Var. Bernstein Bucht, Zaliv Yantarniy. Named by Dall (1870, p. 476), USC\&GS, who translated Grewingk's "Bernstein Bucht" as "Amber Bay."

Amber Creek: stream, flows $W$ to Nushagak River near Etolin Point; Var. Reka Yantar.

Name reported in 1852 as "R[eka] Yantar," i.e. "Amber River" on Russian Hydrog. Dept. Chart 1455.

Amber Lake: lake, $1.4 \mathrm{mi}$. long, flows $\mathrm{W}$ to Kroto Creek, $17 \mathrm{mi}$. SW of Talkeetna, Cook Inlet Low.; $62^{\circ} 10^{\prime} \mathrm{N}, 150^{\circ} 32^{\prime} \mathrm{W}$; (map 81).

Local descriptive name reported in 1958 by USGS.

Amber Lake: lake, on Unalaska I., Aleutian Is.; (map 23).

Father Veniaminov (1840, v. 1, p. 171), from information given by the natives, wrote "There is near Mikrovski bay, between the mountains above, a lake, which has an islet in the middle, on the eastern precipitous shore of which excellent amber occurs." This name was published by Baker (1906, p. 96); this feature has not been positively identified.

Amber Lake: lake, see January Lake.

Ambler: village, pop. 70 , on right bank near mouth of Ambler River, Kotzebue-Kobuk Low.; $67^{\circ} 05^{\prime} \mathrm{N}, 157^{\circ} 52^{\prime} \mathrm{W}$; (map 126).
Eskimo village, named for the river, founded in the late 1950's. The Ambler post office was established in 1963 (Rick's, 1965, p. 3).

Ambler Lowland: valley, extends E-W $35 \mathrm{mi}$., includes parts of valleys of Ambler, Shungnak, and Kogoluktuk Rivers, Brooks Ra.; $67^{\circ} 07^{\prime}$ $\mathrm{N}, 157^{\circ} 00^{\prime} \mathrm{W}$; (map 126$)$.

Name published in 1959 by USGS.

Ambler Peak: mountain, 3,035 ft., in Missionary Ra., $14 \mathrm{mi}$. NW of Petersburg, on Lindenberg Penin., Kupreanof I., Alex. Arch.; $56^{\circ} 58^{\prime} 00^{\prime \prime}$ $\mathrm{N}, 133^{\circ} 12^{\prime} 30^{\prime \prime} \mathrm{W}$; (map 6).

Named in 1887 by Lt. Comdr. C. M. Thomas, USN, for "Dr. James M. Ambler, surgeon of the ill-fated Arctic expedition under De Long in 1879-1880."

Ambler River: stream, heads in Schwatka Mts. at Nakmaktuak Pass, flows SW $75 \mathrm{mi}$. to Kobuk River, Brooks Ra.; $67^{\circ} 06^{\prime}$ N, $157^{\circ} 48^{\prime}$ W; (map 126). Var. Nakmaktuak, Nuckvuck-to-ark, Nut-vuck-to-wo-ark, Pack River.

Named in 1890 by Lt. G. M. Stoney, USN, for Dr. James M. Ambler, USN, surgeon of the U.S.S. Jeannette, who perished in 1881 in the Lena River delta while with the Arctic expedition under the command of Lt. Comdr. G. W. De Long. The Eskimo name "Nakmaktuak," meaning "backpacking place," as obtained in 1956 by Orth, was spelled "Nutvuck-to-woark" in 1885 by Stoney (1900, p. 50), and "Nuck-vuck-to-ark" by Lt. J. C. Cantwell, USRCS.

Ambre Jaoune, Baie d': estuary, see Yantarni Bay.

Ambresvajun Lake: lake, $0.5 \mathrm{mi}$. long, in Sheenjek River valley at head of $E$ tributary to Sheenjek River, $17 \mathrm{mi}$. NW of Table Mtn. and $56 \mathrm{mi}$. NE of Arctic Village, Brooks Ra.; $68^{\circ}$. $36^{\prime} \mathrm{N}, 143^{\circ} 45^{\prime} \mathrm{W}$; (map 137). Var. Last Lake.

Kutchin Indian name obtained in 1956 by T. E. Taylor, USGS.

Amchik Point: point of land, see Eagle Point.

Amchitka Island: island, $35 \mathrm{mi}$. long and about $3 \mathrm{mi}$. wide, one of Rat Is., Aleutian Is.; $51^{\circ}$. $32^{\prime} \mathrm{N}, 179^{\circ} 00^{\prime} \mathrm{E} ; B G N$ 1890; (map 15). Var. Amtatka Island, Amtchitka Island, Amtschitka Island, Saint Makarius, Saint Markiana.

Aleut name reported by early Russians as "Ostrov Amchitka." Baker (1906, p. 96), USGS, indicates that this may be the island named "St. Makarius (St. Markiana)" by Vitus Bering on October 25, 1741 (O.S.). Golder (1922, p. 199-200), however, was of the opinion that Amchitka is too low to have been seen by Bering, and thus it is more probable that Kiska was the island so named.

Amchitka Pass: water passage, $50 \mathrm{mi}$. wide, between Rat Is. and Delarof Is., Aleutian Is.; $51^{\circ} 35^{\prime} \mathrm{N}, 180^{\circ} 00^{\prime} \mathrm{E}$; $B G N$ 1931; (maps 15, 16).

Named for Amchitka Is. and listed in 1944 Aleutian Coast Pilot (p. 123).

Amee Bay: $b a y$, extends SW 2 mi., off Sitkalidak Strait, on $\mathrm{N}$ coast of Sitkalidak I., SE of Kodiak I.; $57^{\circ} 12^{\prime} 30^{\prime \prime} \mathrm{N}, 153^{\circ} 11^{\prime} 30^{\prime \prime} \mathrm{W}$; (map 34). 
Named in early 1900's by USC\&GS and published in the 1947 Alaska Coast Pilot (p. 222).

Amee Island: island, $0.4 \mathrm{mi}$. long, between Sitkalidak I. and SE coast of Kodiak I.; $57^{\circ} 12^{\prime} 10^{\prime \prime}$ N., $153^{\circ} 11^{\prime} 10^{\prime \prime} \mathrm{W}$; BGN 1930; (map 34).

Named in 1930 by USC\&GS for Amee Bay. Amelia, Point: point of land, NW entrance to Gilmer Bay, on W coast of Kruzof I., $28 \mathrm{mi}$. NW of Sitka, Alex. Arch.; 57 $13^{\prime} 30^{\prime \prime}$ N, $135^{\circ} 52^{\prime} 30^{\prime \prime} \mathrm{W}$; (map 9).

Named by Capt. George Vancouver, RN, July 30,1794 , for the youngest daughter of King George III of England (Wagner, 1937, p. 372).

Amelius, Point: point of land, $9 \mathrm{mi}$. NE of 'Point St. Albans, on SE coast of Kuiu I., Alex. Arch.; $56^{\circ} 12^{\prime} 00^{\prime \prime} \mathrm{N}, 133^{\circ} 54^{\prime} 15^{\prime \prime} \mathrm{W}$; (map 6).

Discovered by Joseph Whidbey September 11, 1793 and named by Capt. George Vancouver, RN, for Amelius Beauclerk (Wagner, 1937, p. 372). See Beauclerk, Port.

Amelius Island: island, $0.2 \mathrm{mi}$. long, $8 \mathrm{mi}$. NE of Point St. Albans, on SE coast of Kuiu I., Alex. Arch.; $56^{\circ} 10^{\prime} 40^{\prime \prime} \mathrm{N}, 133^{\circ} 52^{\prime} 30^{\prime \prime} \mathrm{W}$; (map 6).

Local name recorded in 1948 by USGS.

American Bay: bay, extends W $1.8 \mathrm{mi}$., off Kaigani Strait, on E coast of Dall 1., Alex. Arch.; 54 51' N, $132^{\circ} 48^{\prime} \mathrm{W}$; (map 1). Var. Amerikanskaia, Amyerikanskaya Bukhta.

This is a translation by USC\&GS of "Amyerikanskaya Bukhta," given in 1833 by A. K. Etolin and published in 1848 on Russian Hydrog. Dept. Chart 1396.

American Bay: bay, $3 \mathrm{mi}$. across, on $\mathbf{S}$ coast of Aleutian Penin. between Blunt and Elephant Points, Aleutian Ra.; 55 $42^{\prime} \mathrm{N}, 160^{\circ} 08^{\prime} \mathrm{W}$; (map 28). Var. Mobile Bay.

Local name. Called "Mobile Bay" by USC\&GS in the 1916 Coast Pilot (v. 2, p. 165).

American Creek: stream, $50 \mathrm{mi}$. long, flows NW, through Murray and Hammersly Lakes, then $\mathrm{S}$ to Lake Coville, in Katmai National Monument, on Alaska Penin., $45 \mathrm{mi}$. NW of Mount Katmai, Aleutian Ra.; $58^{\circ} 48^{\prime} 30^{\prime \prime} \mathrm{N}, 155^{\circ} 39^{\prime}$ $30^{\prime \prime} \mathrm{W}$; (map 42).

Named in 1950 by Bill Hammersly of King Salmon.

American Creek: stream, on Kenai Penin., flows NE $4.5 \mathrm{mi}$. to Resurrection Creek, $17 \mathrm{mi}$. SSW of Hope, Chugach Mts.; $60^{\circ} 41^{\prime} 15^{\prime \prime} \mathrm{N}$, $149^{\circ} 45^{\prime} 35^{\prime \prime} \mathrm{W}$; (map 63 )

Local prospectors' name; reported in 1904 by Moffit (1906, pl. 2), USGS.

American Creek: stream, flows NE and SE 6 mi. to Iditarod River, $\mathrm{S}$ of Mosquito Mtn., $26 \mathrm{mi}$. NW of village of Crooked Creek and $32 \mathrm{mi}$. SE of Holy Cross, Kilbuck-Kuskokwim Mts.; $62^{\circ} 01^{\prime} \mathrm{N}, 158^{\circ} 51^{\prime} \mathrm{W}$; (map 79).

Prospectors' name obtained in 1913 by Eakin (1914, pl. 1), USGS.

American Creek: stream, flows NW $5.5 \mathrm{mi}$. to Crooked Creek $13 \mathrm{mi}$. NW of its junc. with Kuskokwim River, $43 \mathrm{mi}$. NW of Sleetmute,
Kilbuck-Kuskokwim Mts.; $62^{\circ} 02^{\prime} 40^{\prime \prime} \mathrm{N}$, $158^{\circ} 15^{\prime} 20^{\prime \prime} \mathrm{W}$; BGN 1944; (map 79).

Prospectors' name obtained in 1913 by Eakin (1914, pl. 1), USGS.

American Creek: stream, flows NE $10 \mathrm{mi}$. to Innoko River, $8 \mathrm{mi}$. NW of Ophir and $39 \mathrm{mi}$. NW of McGrath, Kilbuck-Kuskokwim Mts.; $63^{\circ} 14^{\prime} \mathrm{N}, 156^{\circ} 41^{\prime} \mathrm{W}$; (map 90).

Prospectors' name obtained in 1908 by Maddren (1910, pl, 1), USGS.

American Creek: stream, flows E $8.4 \mathrm{mi}$. to Telsitna River, $39 \mathrm{mi}$. SE of Monzonite Hills, Kilbuck-Kuskokwim Mts.; $64^{\circ} 08^{\prime} \mathrm{N}, 153^{\circ} 32^{\prime}$ W; (map 98).

Local name reported 1915 by H. M. Eakin (in Brooks and others, 1916, pl. 10), USGS. American Creek: stream, flows SW $3 \mathrm{mi}$. to Snake River, about $5 \mathrm{mi}$. NW of Nome, Seward Penin. High.; $64^{\circ} 32^{\prime} 30^{\prime \prime}$ N, $165^{\circ} 31^{\prime}$. $30^{\prime \prime} \mathrm{W}$; (map 94).

Prospectors' name shown on the 1904 "Map of Cape Nome Precinct" by Arthur Gibson. This stream cannot be identified on current maps.

American Creek: stream, heads near Banner Peak, flows SW $2 \mathrm{mi}$. to Snake River, $4 \mathrm{mi}$. NW of Nome, Seward Penin. High.; $64^{\circ} 33^{\prime}$ $\mathrm{N}, 165^{\circ} 00^{\prime} \mathrm{W}$; (map 94).

Prospectors' name reported in 1899 by D. C. Witherspoon (in Schrader and Brooks, 1900, map 2), USGS. This may be the "Crystal Creek" or "Golden Gulch" shown on recent maps.

American Creek: stream, flows SE $8 \mathrm{mi}$. to Sinuk River, $22 \mathrm{mi}$. NW of Nome, Seward Penin. High.; $64^{\circ} 47^{\prime} \mathrm{N}, 165^{\circ} 48^{\prime} \mathrm{W}$; (map 94).

Prospectors' name reported in 1900 by E. C. Barnard (in Brooks, 1901, pl. 17), USGS.

American Creek: stream, flows $\mathrm{N} 9 \mathrm{mi}$. to Mission Creek, $1 \mathrm{mi}$. NW of Eagle, Yukon-Tanana High.; $64^{\circ} 48^{\prime} \mathrm{N}, 141^{\circ} 14^{\prime} \mathrm{W}$; (map 102)

Named by prospectors and reported in 1896 by Spurr (1898, pl. 38), USGS.

American Creek: stream, flows NE $20 \mathrm{mi}$. to Niukluk River, $32 \mathrm{mi}$. NE of Solomon, Seward Penin. High.; $65^{\circ} 00^{\prime} \mathrm{N}, 164^{\circ} 10^{\prime} \mathrm{W}$; (map 95).

Prospectors' name reported in 1900 by E. C. Barnard (in Brooks, 1901, pl. 17), USGS.

American Creek: stream, heads at $W$ end of Serpentine Ridge, flows SW $8.5 \mathrm{mi}$. to Fish Lake, $23 \mathrm{mi}$. ESE of Tanana, Yukon-Tanana High.; $65^{\circ} 03^{\prime} 30^{\prime \prime} \mathrm{N}, 151^{\circ} 20^{\prime} 00^{\prime \prime} \mathrm{W}$; (map 106). Var. Camp Creek.

Prospectors' name reported in 1911 by H. M. Eakin, USGS.

American Creek: stream, heads E of Eureka Dome, flows SSE $1.4 \mathrm{mi}$. to Eureka Creek, 20 mi. S of Rampart, Yukon-Tanana High.; $65^{\circ} 12^{\prime} 30^{\prime \prime} \mathrm{N}, 150^{\circ} 11^{\prime} 57^{\prime \prime} \mathrm{W}$; (map 106).

Prospectors' name reported in 1931 by J. B. Mertie, USGS.

American Creek: stream, flows SSE $0.9 \mathrm{mi}$. to Lynx Creek, $1.5 \mathrm{mi}$. E of Lynx Dome and 26 mi. WNW of Tanana, Kokrines-Hodzana High.; $65^{\circ} 16^{\prime} 05^{\prime \prime} \mathrm{N}, 152^{\circ} 56^{\prime} 30^{\prime \prime} \mathrm{W}$; (map 106).
Prospectors' name reported in 1956 by R. M. Chapman, USGS.

American Creek: stream, flows NE $11 \mathrm{mi}$. to Preacher Creek, $65 \mathrm{mi}$. SW of Circle, YukonTanana High.; $65^{\circ} 31^{\prime} 00^{\prime \prime} \mathrm{N}, 146^{\circ} 10^{\prime} 05^{\prime \prime} \mathrm{W}$; (map 104).

Named by prospectors; reported in 1903 by T. G. Gerdine (in Prindle, 1905, pl. 13), USGS.

American Creek: stream, flows NE $6 \mathrm{mi}$. to Old Glory Creek, in Inmachuk River basin, 16 mi. N of Imuruk Lake, Seward Penin. High.; $65^{\circ} 51^{\prime} \mathrm{N}, 163^{\circ} 08^{\prime} \mathrm{W}$; BGN 1952; (map 110).

Prospectors' name reported in 1903 by D. C. Witherspoon (in Moffit, 1905, pl. 2), USGS.

American Creek: stream, see Crystal Creek.

American Gulch: ravine, trends $\mathrm{W} 0.6 \mathrm{mi}$. to Bear Creek, $4 \mathrm{mi}$. NE of Nome, Seward Penin.

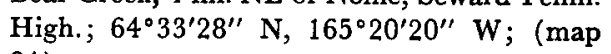
94).

Prospectors' name reported in 1904 by T. G. Gerdine, USGS.

American Mouth : stream, see Kwikluak Pass.

American Pass: pass, 2,750 ft., in Kenai Mts., $3 \mathrm{mi}$. N of Swan Lake, $20 \mathrm{mi}$. SW of Hope, Chugach Mts.; $60^{\circ} 40^{\prime} 10^{\prime \prime} \mathrm{N}, 149^{\circ} 51^{\prime} 45^{\prime \prime} \mathrm{W}$; (map 63).

Local name reported in 1951 by USGS.

American Range: mountain range, $\mathrm{N}$ of Farragut Bay, Coast Mts. (map 8 ).

Named in 1887 by Lt. Comdr. C. M. Thomas USN; published on USG\&GS Chart 705.

American River: stream, flows NE $10 \mathrm{mi}$. to Little Cove at head of Middle Bay, $11 \mathrm{mi}$. SW of Kodiak, Kodiak I.; $57^{\circ} 39^{\prime} 00^{\prime \prime}$ N, $152^{\circ} 30^{\prime}$ $30^{\prime \prime}$ W; BGN 1966; (map 34).

Local name reported in 1952 by USGS.

American River: stream, flows NE $15 \mathrm{mi}$., then S $35 \mathrm{mi}$., to Agiapuk River, $20 \mathrm{mi}$. NE of Teller, Seward Penin. High.; $65^{\circ} 25^{\prime} \mathrm{N}, 165^{\circ}$ 47' W; (map 111).

Prospectors' name reported in 1900 by Messrs. Kemp and David Fox (in Brooks, 1901, pl. 11).

American Station: village, see Anvik.

Amerikanskaia : bay, see American Bay.

Amerk Point: point of land, on SE coast of Bainbridge I., W side of Prince of Wales Passage, $18 \mathrm{mi}$. S of Chenega, Chugach Mts.; $60^{\circ} 02^{\prime} 45^{\prime \prime} \mathrm{N}, 148^{\circ} 08^{\prime} 15^{\prime \prime} \mathrm{W}$; (map 63).

Local name reported in 1951 by USGS.

Amherst Glacier: glacier, trends NW $4 \mathrm{mi}$. to a lake, $5.5 \mathrm{mi}$. NE of Point Pakenham and $52 \mathrm{mi}$. SW of Valdez, Chugach Mts. ; $61^{\circ} 02^{\prime} \mathrm{N}, 147^{\circ}$. $53^{\prime}$ W; BGN 1943; (map 69).

Named in 1899 by members of the Harri. man Alaska Expedition for Amherst College, Amherst, Massachusetts.

Amherst Peak: peak, 5,479 ft., at head of Southwest Branch Taku Glacier, $0.2 \mathrm{mi}$. NW of Echo Pass and $14 \mathrm{mi}$. N of Juneau, Coast Mts.; $58^{\circ} 30^{\prime} 05^{\prime \prime} \mathrm{N}, 134^{\circ} 22^{\prime} 25^{\prime \prime} \mathrm{W}$; (map 11).

Local name published by USGS in 1960 . Amielkinok Creek: stream, "flows to Talbiksok River, near Yukon-Kuskokwim Portage," Kilbuck-Kuskokwim Mts. 
Eskimo name reported in $1842-44$ by Lt. L. A. Zagoskin, IRN.

Amik Island: island, $0.4 \mathrm{mi}$. across, at mouth of Moser Bay, in Alitak Bay, $\mathbf{S}$ end of Kodiak I.; $56^{\circ} 58^{\prime} 00^{\prime \prime} \mathrm{N}, 154^{\circ} 07^{\prime} 15^{\prime \prime} \mathrm{W}$; BGN 1934; (map 32). Var. Turn Island.

Name derived from an Eskimo word meaning "gate" or "door"; given by USC\&GS in 1934.

Amikpak Lake: lake, see Imikpuk Lake.

Amikpuk Lake: lake, see Imikpuk Lake.

Amiloyak Lake: lake, $1.7 \mathrm{mi}$. long, in headwaters of Chandler River, $6 \mathrm{mi}$. SW of Chandler Lake and $28 \mathrm{mi}$. W of Anaktuvuk Pass, Brooks Ra.; $68^{\circ} 06^{\prime} 30^{\prime \prime} \mathrm{N}, 152^{\circ} 52^{\prime} 30^{\prime \prime} \mathrm{W}$; (map 134).

Eskimo name obtained at Anaktuvuk Pass in 1956 by T. E. Taylor, USGS.

Amilrhoen: point of land, see Drew Point.

Amilrokmuit: locality, on spit between Bering Sea and Port Clarence, $10 \mathrm{mi}$. S of Point Spencer and $18 \mathrm{mi}$. SW of Teller, Seward Penin. High.; (map 111).

Eskimo village or camp reported in 1867 by a Western Union Telegraph exploration party. Subsequent publications have not mentioned this village.

Amiqdoligamiut: locality, see Ahmikdoligamiut. Amirante Bay: bay, see Yakutat Bay.

Amitchiak, Lake: lake, $2.5 \mathrm{mi}$. long, $23 \mathrm{mi}$. SE of Howard Pass, Brooks Ra.; 67 $59^{\prime} \mathrm{N}, 156^{\circ}$ 15' W; (map 126).

Eskimo name meaning "narrow"; obtained at Noatak in 1956 by Orth.

Amlag Island: island, see Amlia Island.

Amlä Island: island, see Amlia Island.

Amlak Island: island, see Amlia Island.

Amlia Island: island, $45 \mathrm{mi}$. long, $8 \mathrm{mi}$. wide, in Andreanof Is., Aleutian Is.; 52 $04^{\prime} \mathrm{N}$, $173^{\circ} 30^{\prime} \mathrm{W}$; (maps 18, 19). Var. Amlä Island, Amlag Island, Amlak Island, Amli Island, Amlja Island, Amlya Island, Amluk Island.

Aleut name reported in 1761 as "Amlak" by Capt. Tolstyk of the ship Andreian i $\mathrm{Na}$ talia, according to Ivan Petroff (Bancroft, 1886, p. 168). The name "Amlia" was published in Lt. Sarichev's atlas (1826, map 3), IRN. The southern part of Atka Island has been called "Amlia Peninsula."

Amlia Pass: water passage, in Andreanof Is., $1.2 \mathrm{mi}$. across, between Amlia and Atka Is., Aleutian Is.; $52^{\circ} 07^{\prime} 30^{\prime \prime} \mathrm{N}, 174^{\circ} 04^{\prime} 00^{\prime \prime} \mathrm{W}$; (map 18).

Published by USC\&GS in the 1944 Aleutian Coast Pilot (p. 90).

Amlia Peninsula: peninsula, extends SE $2.5 \mathrm{mi}$., terminates at Gape Utalug, on SE coast of Atka I., Aleutian Is.; $52^{\circ} 06^{\prime} 20^{\prime \prime} \mathrm{N}, 1^{\circ} 4^{\circ} 05^{\prime}$ 50" W; (map 18). Var. Amlinskoi Peninsula. Published as "Amlinskoi Peninsula" by Capt. Lutke (1836, p. 311), IRN.

Amli Island: island, see Amlia Island.

Amlinskoi Peninsula : peninsula, see Amlia Peninsula.

Amlja Island: island, see Amlia Island.

Amluk Island: island, see Amlia Island.

Amlya Island: island, see Amlia Island.
Ammak, Mys: point of land, see Aspid Cape.

Ammak Point: point of land, see Aspid Cape.

Ammerman Creek: stream, heads in Yukon, Canada, flows SW $15 \mathrm{mi}$. across Alaska-Canada boundary to Old Crow River, SW of Ammerman Mtn., Porcupine Plat.; $68^{\circ} 20^{\prime} 30^{\prime \prime} \mathrm{N}$, $141^{\circ} 13^{\prime} 30^{\prime \prime} \mathrm{W}$; BGN 1912; (map 137).

Local name reported in 1911 by IBC field survey crew.

Ammerman Mountain: ridge, elev. 3,000 ft., extends E-W 7 mi., centered on Alaska-Canada boundary, $11 \mathrm{mi}$. N of Crow River, Porcupine Plat.; $68^{\circ} 23^{\prime} \mathrm{N}, 141^{\circ} 00^{\prime} \mathrm{W}$; BGN 1954; (map 137).

Local name reported in 1911 by IBC field survey crew.

Am-mok-a-look-tok: stream, see Black River.

Ammonite Creek: stream, flows NW $1 \mathrm{mi}$. to Limestone Gulch, $15 \mathrm{mi}$. NW of Tahneta Pass, Talkeetna Mts.; $62^{\circ} 02^{\prime} 20^{\prime \prime} \mathrm{N}, 147^{\circ} 40^{\prime} 03^{\prime \prime} \mathrm{W}$; $B G N 1965$; (map 82).

Named in 1964 by USGS because "an important ammonite (fossil mollusk) locality lies at the head of this creek."

Amna Bay: bay, $1 \mathrm{mi}$. across, on W tip of Attu I., S of Cape Wrangell, Aleutian Is. ; 52 ${ }^{\circ} 5^{\prime} 00^{\prime \prime}$ N, $172^{\circ} 27^{\prime} 30^{\prime \prime} \mathrm{E}$; (map 13 ).

Recorded on a manuscript map drafted by L. M. Turner in the 1880's.

Amnak Island: island, see Bogoslof Island.

Amnak Island: island, see Umnak Island.

Amnuk Island: island, see Bogoslof Island.

Amnuk Island: island, see Umnak Island .

Amo Creek: stream, heads in lake $\mathrm{N}$ of Meat Mtn., flows NE $18 \mathrm{mi}$. to Colville River, $13 \mathrm{mi}$. NW of Noluck Lake, Arctic Slope; $68^{\circ} 57^{\prime} \mathrm{N}$, $160^{\circ} 12^{\prime} \mathrm{W}$; (map 131).

So named by geologists in 1950 "from an Eskimo name for wolf [amaguk], because several wolves were seen in this vicinity" (Chapman and Sable, 1960, p. 52), USGS.

Amoghta Island: island, see Amukta Island.

Amogla, Isla : island, see Chuginadak Island.

Amok Island: island, see Amook Island.

Amoknak: island, see Amaknak Island.

Amook Island: island, $8.5 \mathrm{mi}$. long, in Uyak Bay, on NW coast of Kodiak I.; $57^{\circ} 30^{\prime} \mathrm{N}, 153^{\circ} 51^{\prime}$ W; BGN 1910; (map 34). Var. Amok Island, Amuk Island.

Eskimo name "Amok Island" published in 1908 by USC\&GS and changed to its present spelling in 1910.

Amooktoosuk Hills: ridge, see Amatusuk Hills.

Amortak Canyon: canyon, see Lower Noatak Canyon.

Amortuk Canyon: canyon, see Lower Noatak Canyon.

Amos Bay: bay, $1 \mathrm{mi}$. across, on $\mathrm{SE}$ coast of Umnak I., Aleutian Is.; $53^{\circ} 02^{\prime} 30^{\prime \prime} \mathrm{N}, 168^{\circ}$. $30^{\prime} 00^{\prime \prime} \mathrm{W}$; (map 22).

Name published by USC\&GS in the 1944 Aleutian Coast Pilot (p. 70).

Amos Cove: cove, $0.3 \mathrm{mi}$. across, $\mathrm{W}$ of Harpoon Point, on SE coast of Kiska I., Aleutian Is. $51^{\circ} 55^{\prime} 40^{\prime \prime} \mathrm{N}, 177^{\circ} 35^{\prime} 35^{\prime \prime} \mathrm{E}$; (map 14).

One of many arbitrary names applied to features on Kiska I. by USAF for tactical purposes during World War II.
Amos Cove: cove, see Andy Cove.

Amos Lakes: lakes, between Tonzona River and Red Paint Creek, $23 \mathrm{mi}$. NW of Mount Russell, Alaska Ra.; $62^{\circ} 51^{\prime} 40^{\prime \prime} \mathrm{N}, 152^{\circ} 36^{\prime} 45^{\prime \prime}$ W; (map 81).

Local name reported in 1958 by USGS.

Amotoloriasak River: stream, see Sawpit Creek. Amotoloriasak River: stream, see Swift Creek. Amoughta Island: island, see Amukta Island.

Amoughta Pass: water passage, see Amukta Pass. Amoukhta, Detroit d': water passage, see Amukta Pass.

Amoukhta Island: island, see Amukta Island.

Amphitheater Knob: peak, 2,490 ft., $5.8 \mathrm{mi}$. W of Bancas Point and $28 \mathrm{mi}$. N of Yakutat, St. Elias Mts.; $59^{\circ} 56^{\prime} 50^{\prime \prime} \mathrm{N}, 1^{\circ} 39^{\circ} 47^{\prime} 00^{\prime \prime} \mathrm{W}$; (map 46).

Descriptive name given in 1905 by Tarr and Martin (1906, map), USGS.

Amphitheater Mountains: mountain range, 5,500 ft., extends SE $35 \mathrm{mi}$. from Maclaren River to Paxson Lake, crossed by Denali Highway, $6 \mathrm{mi}$. NW of Paxson, Alaska Ra. ; $63^{\circ} 08^{\prime}$ $30^{\prime \prime} \mathrm{N}, 145^{\circ} 59^{\prime} 30^{\prime \prime} \mathrm{W}$; (map 86).

So named in 1955 by T. L. Péwé, USGS, because "the many well-developed cirques give the appearance of many amphitheaters."

Amphitheatre Creek: stream, flows E $2.2 \mathrm{mi}$. to Nizina Glacier, $17 \mathrm{mi}$. NE of McCarthy, Wrangell Mts.; $61^{\circ} 36^{\prime} 38^{\prime \prime} \mathrm{N}, 142^{\circ} 29^{\prime} 30^{\prime \prime}$ W; BGN 1964; (map 67).

So named in 1962 by E. M. Mackevett, Jr., and D. L. Jones, USGS, "because the stream heads in a spectacular basinlike feature * * termed 'The Amphitheatre' by USGS geologists * * *."

Amphitheatre Mountain: mountain, 3,400 ft., 17 mi. SSW of Tingmerkput Mtn., $53 \mathrm{mi}$. N of Noatak, Brooks Ra.; $68^{\circ} 19^{\prime} 00^{\prime \prime} \mathrm{N}, 162^{\circ}$ $34^{\prime} 30^{\prime \prime} \mathrm{W}$; BGN 1965; (map 130).

Name proposed in 1965 by geologists of the B. P. Exploration Co. Inc., "because the mountain has a natural amphitheatre on its side."

Amtagis Islands: islands, $0.5 \mathrm{mi}$. across, in mouth of Kobakof Bay, on $S$ coast of Atka I., Aleutian Is.; $52^{\circ} 01^{\prime} 00^{\prime \prime} \mathrm{N}, 174^{\circ} 25^{\prime} 30^{\prime \prime} \mathrm{W}$; (map 18). Var. Ostrova Amtagis.

Aleut name published as "O[strova] Amtagis" by Capt. Tebenkov (1852, map 27), IRN.

Amtatka Island: island, see Amchitka Island.

Amtchik Peninsula: point of land, see Eagle Point.

Amtchitka Island: island, see Amchitka Island. Amtschitka Island: island, see Amchitka Island. Amuckta Island: island, see Amukta Island.

Amugul Bay: bay, $1 \mathrm{mi}$. across, on $\mathrm{S}$ side of Beaver Inlet on NE coast of Unalaska I., Aleutian Is.; $53^{\circ} 45^{\prime} \mathrm{N}, 166^{\circ} 23^{\prime} \mathrm{W}$; (map 23). Var. Amugulik, Fourth of July Bay.

Aleut name shown as "Zal[iv] Amugul," meaning "Amugul Bay," by Lt. Sarichev (1826, maps 14, 15), IRN. It was recorded as "Amugulik" by Father Veniaminov (1840, v. 1 , p. 162), possibly from the Aleut word "amuk" meaning "lightning." 
Amugul Creek: stream, on E coast of Unalaska I., flows to Amugul Bay, on $\mathrm{S}$ shore of Beaver Inlet, Aleutian Is.; $53^{\circ} 45^{\prime} \mathrm{N}, 166^{\circ} 23^{\prime} \mathrm{W}$; (map 23). Var. Amagul Creek.

Reported by von Langsdorff (1813-14, v. 2, p. 28) as "Amagul" in 1805 .

Amukhta, Ostrov: island, see Amukta Island.

Amukhta Pass: water passage, see Amukta Pass.

Amukhtenskiy, Proliv: water passage, see Amukta Pass.

Amuk Island: island, see Amook Island.

Amukta Island: island, $5 \mathrm{mi}$. across, westernmost of Islands of Four Mts., Aleutian Is.; $52^{\circ} 30^{\prime} \mathrm{N}, 171^{\circ} 16^{\prime} \mathrm{W}$; BGN 1890; (map 20). Var. Amoghta Island, Amoughta Island, Amoukhta Island, Amuckta Island, Amukhta, Ostrov, Anoghta Island.

Aleut name reported in 1768 by Capt. Lt. P. K. Krenitzin and Lt. M. Levashev (in Coxe, 1787, map, p. 205), IRN.

Amukta Pass: water passage, $43 \mathrm{mi}$. across, between Andreanof and Fox Is., Aleutian Is.; $52^{\circ} 15^{\prime} \mathrm{N}, 172^{\circ} 00^{\prime} \mathrm{W}$; BGN Sixth Report; (maps 19, 20). Var. Amoughta Pass, Amukhta Pass, d'Amoukhta, Detroit, Hundred Seventy-two Degree Pass, Proliv Amukhtenskiy, Seventy-Second Pass, Seventy-two Pass. Aleut name derived from Amukta Islands; published in 1847 as "Proliv Amukhtenskiy" meaning "Amukhten Strait," on Russian Hydrog. Dept. Chart 1379. Known to the whalers as "Seventy-Second Pass" because it is located near $172^{\circ} \mathrm{W}$.

Amulik Hill: hill, $812 \mathrm{ft}$., on E bank of Nilik River $6 \mathrm{mi}$. $\mathrm{N}$ of its junc. with Ipewik River, $29 \mathrm{mi}$. E of Cape Dyer, Arctic Slope; 68.36'$30^{\prime \prime} \mathrm{N}, 165^{\circ} 04^{\prime} 50^{\prime \prime} \mathrm{W}$; (map 129). Var. Amagaulik.

Eskimo name spelled "Amagaulik," meaning "wolf cubs," by Orth in 1956. Name shortened by USGS when published.

Amungna: locality, on Chukchi Sea coast $\mathrm{S}$ of Barrow, Arctic Plain; $71^{\circ} 17^{\prime} \mathrm{N}, 156^{\circ} 49^{\prime} \mathrm{W}$; (map 153). Var. Ukuksik, Uquksiq.

Eskimo name published by Lt. P. H. Ray (1885, p. 55), USA. "Uquksiq" is shown on a map published by R. F. Spencer (1959, map 2), BAE.

Amy Creek: mining camp, on left bank of Livengood Creek, E of Amy Creek, 3 mi. NE of Livengood, Yukon-Tanana High.; 65 $32^{\prime} 30^{\prime \prime}$ N, 148 $26^{\prime} 15^{\prime \prime} \mathrm{W}$; (map 105).

Local name for a temporary mining camp; published by USGS (Mertie, 1937, pl. 1).

Amy Creek: stream, flows $W$ and SW $8 \mathrm{mi}$. to North Fork Bremner River, $8.5 \mathrm{mi}$. NW of 1950 terminus of Bremner Glacier and $78 \mathrm{mi}$. NE of Cordova, Chugach Mts.; 60 $0^{\circ} 59^{\prime} \mathrm{N}$, $143^{\circ} 42^{\prime} \mathrm{W}$; (map 65).

Local name published by Moffit (1914, pl. 1), USGS.

Amy Creek: stream, flows NW $0.6 \mathrm{mi}$. from glacier terminus to Kotsina River, $37 \mathrm{mi}$. NW of McCarthy, Wrangell Mts.; $61^{\circ} 43^{\prime} 00^{\prime \prime} \mathrm{N}$, $143^{\circ} 51^{\prime} 20^{\prime \prime} \mathrm{W}$; (map 67).

Reported in 1914 by F. H. Moffit (in Brooks and others, pl. 5, 1915), USGS.
Amy Creek: stream, flows NW $2.5 \mathrm{mi}$, to Livengood Creek, $3 \mathrm{mi}$. NE of Livengood, YukonTanana High.; $65^{\circ} 32^{\prime} 30^{\prime \prime} \mathrm{N}, 148^{\circ} 26^{\prime} 45^{\prime \prime} \mathrm{W}$; (map 105).

Named by prospectors; reported in 1915 by A. H. Brooks (in Brooks and others, 1916, pl. 9), USGS

Amy Dome: mountain, 2,317 ft., $4 \mathrm{mi}$. SE of Livengood and $50 \mathrm{mi}$. NW of Fairbanks, Yukon-Tanana High.; $65^{\circ} 30^{\prime} \mathrm{N}, 148^{\circ} 25^{\prime} \mathrm{W}$; (map 105).

Local name derived from Amy Creek; published on recent maps by USGS.

Amyerikanskaya Bukhta: bay, see American Bay. Amy Landing: locality, "place on Klutina river about 6 miles below the outlet of Klutina lake where the river enters The Gorge."

"So named by Abercrombie in 1898, after W. S. Amy, of Copper Center"' (Baker, 1906, p. 97).

Anachlik Island: island, $4 \mathrm{mi}$. long, on Beaufort Sea coast, in Colville River Delta, Arctic Plain; $70^{\circ} 25^{\prime} 32^{\prime \prime} \mathrm{N}, 150^{\circ} 25^{\prime} 28^{\prime \prime} \mathrm{W}$; (map 149).

Eskimo name meaning "white fish;" reported in 1951 by USC\&GS.

Anaconda Creek: stream, flows W $5.3 \mathrm{mi}$. to Crooked Creek $11 \mathrm{mi}$. NW of its junc. with Kuskokwim River, $41 \mathrm{mi}$. NW of Sleetmute, Kilbuck-Kuskokwim Mts. ; $62^{\circ} 00^{\prime} 05^{\prime \prime} \mathrm{N}, 158^{\circ}$ 15'30' W; BGN 1944; (map 79).

Prospectors' name obtained in 1913 by Eakin (1914, pl. 1), USGS.

Anaconda Creek: stream, in Nutzotin Mts., flows NE $6.7 \mathrm{mi}$. to anabranch of Beaver Creek, 1 mi. E of Alaska-Canada boundary and $7 \mathrm{mi}$. $\mathrm{SE}$ of Carden Hills, Alaska Ra.; $62^{\circ} 13^{\prime} \mathrm{N}$, $141^{\circ} 02^{\prime} \mathrm{W}$; (map 84).

Local name published by USGS (Brooks and others 1909, pl. 7).

Anaconda Creek: stream, flows SE $2 \mathrm{mi}$. to Hutchinson Creek, $48 \mathrm{mi}$. SW of Eagle, YukonTanana High.; $64^{\circ} 23^{\prime} \mathrm{N}, 142^{\circ} 15^{\prime} \mathrm{W}$; (map 102).

Prospectors' name shown on an 1898 manuscript map by C. A. Woodruff, Fort Cudahy, Canada.

Anaconda Creek: stream, flows SW $17 \mathrm{mi}$. to Little Chena River, $23 \mathrm{mi}$. NE of Fairbanks, Yukon-Tanana High.; $64^{\circ} 58^{\prime} \mathrm{N}, 147^{\circ} 03^{\prime} \mathrm{W}$; (map 100).

Local name published on recent USGS maps.

Anaconda Creek: stream, see Bullion Creek.

Anaconda Creek: stream, see Duncan Creek.

Anaconda Creek: stream, see Pargon River.

Anagakhsikh Island: island, see Anagaksik Island.

Anagaksik Island: island, $1 \mathrm{mi}$. across, in Andreanof Is., $4 \mathrm{mi}$. E of Umak I., Aleutian Is.; $51^{\circ} 51^{\prime} 10^{\prime \prime} \mathrm{N}, 175^{\circ} 53,00^{\prime \prime} \mathrm{W}$; BGN 1936; (map 18). Var. Anagakhsikh Island, Ostrov Anagaksik.

Aleut name published as "O[strov] Anagaksik" by Capt. Tebenkov (1852, map 28), IRN.

Än'ägchŭchnŭn'ŭm-älgärā'lógrāy： rookery, see Great East Rookery.
Änagchŭcknūn'a : bluff, overlooking Great East Rookery, on NE coast of Saint George I., in Pribilof Is.; $56^{\circ} 35^{\prime} 50^{\prime \prime} \mathrm{N}, 169^{\circ} 29^{\prime} 00^{\prime \prime} \mathrm{W}$; (map 38).

Aleut name reported by Putnam (1903, p. 1014), USC\&GS, and means "'difficult trail,' * * * so called because it is very difficult to ascend this bluff."

Än'ägchŭcknŭn'am-än'yi: lake, 50 yd. across, at Great East Rookery, on NE coast of Saint George I., in Pribilof Is. ; $56^{\circ} 36^{\prime} 15^{\prime \prime}$ N, $169^{\circ}$. $29^{\prime} 30^{\prime \prime}$ W ; (map 38).

Aleut name reported by Putnam (1903, p. 1014), USC\&GS, and means "lake near Anagchucknuna [difficult trail]."

Anagnak Creek: stream, "flowing southwest to the Wood River in the Dillingham Area"; (map 52).

Eskimo name reported in a letter dated 1882 from the Committee on the Census.

Anagnak: locality, see Anugnak.

Anagok: locality, see Anogok.

Anahanuk: locality, see Alaganik.

Anaiaktak Island: island, see Aiaktalik Island.

Anaiaktalik Island: island, see Aiaktalik Island.

Anaiuliak Island: island, see Ananiuliak Island.

Anajuk Point: point of land, formed by junc. of Colville and Kachemach Rivers, $11 \mathrm{mi}$. SW of Harrison Bay, Arctic Plain; $70^{\circ} 20^{\prime} 40^{\prime \prime} \mathrm{N}$, $150^{\circ} 40^{\prime} 10^{\prime \prime} \mathrm{W}$; (map 149 ).

Eskimo name reported in 1951 by USC\&GS. Anak Creek: stream, flows S $11 \mathrm{mi}$. to Maybe Creek, $21 \mathrm{mi}$. E of head of Ikpikpuk River, Arctic Slope; $69^{\circ} 15^{\prime} \mathrm{N}, 153^{\circ} 52^{\prime} \mathrm{W}$; BGN 1960; (map 142).

Eskimo name [anaq] meaning "excrement," and generally referring to animal dung as a sign for hunting purposes. The name was reported in 1956 by T. E. Taylor, USGS.

Anakeksik Creek: stream, flows NW $15 \mathrm{mi}$. to Shaktoolik River, $11 \mathrm{mi}$. S of Christmas Mtn. Nula to Hills; $64^{\circ} 24^{\prime} \mathrm{N}, 160^{\circ} 36^{\prime} \mathrm{W}$; (map 96). Var. Andeksik Creek.

Eskimo name reported about 1954 by U.S. Army Corps of Engineers.

Anakink: locality, see Anaktuk.

Anaknak: locality, see Anugnak.

Anakovik River: stream, see Anikovik River.

Anakruak: locality, on SE shore of Smith Bay, 70 mi. SE of Barrow, Arctic Plain; $70^{\circ} 48^{\prime} \mathrm{N}$, $154^{\circ} 03^{\prime} \mathrm{W}$; (map 148).

Eskimo name meaning "old dung;" reported by AMS in 1955.

Anakshek Pass: stream, flows W $35 \mathrm{mi}$. to Black River, $37 \mathrm{mi}$. SW of Kwiguk, Yukon-Kuskokwim Delta; 62 $16^{\prime} 30^{\prime \prime} \mathrm{N}, 164^{\circ} 59^{\prime} 00^{\prime \prime} \mathrm{W}$; $(\operatorname{map} 77)$.

Eskimo name obtained in 1899 by G. R. Putnam, USC\&GS. Published in 1901 on Chart 9372.

Anaktok Creek: stream, in Baird Mts., flows NE and SE $15 \mathrm{mi}$. to Salmon River, $49 \mathrm{mi}$. NE of Kiana, Brooks Ra.; 67 $38^{\prime} \mathrm{N}, 159^{\circ} 48^{\prime} \mathrm{W}$; (map 127).

Eskimo name obtained in 1955 by U.S. Army Corps of Engineers.

Anaktook : locality, see Anaktuk. 
Anaktuk: locality, on E bank of Kuk River, 31 mi. S of Wainwright, Arctic Plain; $70^{\circ} 11^{\prime} \mathrm{N}$, $159^{\circ} 45^{\prime}$ W; (map 146). Var. Anakink, Anaktook.

Eskimo name "Anaktook" reported in 1923 by Sidney Paige, USGS ; may refer in meaning to "excrement [anaqtoq]." This may have been one of the "Killaimute" villages mentioned in the 10th Census, in 1880 (1881, p. 4).

Anaktuvak Pass: pass, see Anaktuvuk Pass.

Anaktuvuk Plateau: plateau, between Brooks Ra. and Arctic Plain, extends from Canada on E to Cape Lisburne on W.

Named in 1901 by W. J. Peters and F. C. Schrader, USGS, after the river of the same name. This is the feature referred to as Arctic Slope in this dictionary and as Arctic Foothills by Wahrhaftig (1965, pl. 1), USGS.

Anaktuvuk Pass: village, pop. 35, at Anaktuvuk Pass, Brooks Ra.; 68 $08^{\circ}$ N, $151^{\circ} 45^{\prime}$ W; (map 134).

The name for this Nunamiut Eskimo village is derived from the name of the pass. Although the village is presently permanent, the people were once scminomadic, and the settlement periodically was moved about the valleys near the heads of the John and Anaktuvuk Rivers. They call themselves the "Tulugagmiut," "raven people" or "the people living in the vicinity of Tulugak Lake." The present village is now comprised of Eskimos from the Killik and Chandler Rivers. A post office was established in 1951. (Ricks, 1965, p. 3.)

Anaktuvuk Pass: pass, 2,200 ft., between headwaters of Anaktuvuk and John Rivers, SE of Soakpak Mtn., Brooks Ra.; $68^{\circ} 08^{\prime} \mathrm{N}, 151^{\circ}$ $45^{\prime} \mathrm{W}$; (map 134). Var. Anaktuvak Pass.

Named by W. J. Peters, USGS, in 1901. He wrote, "being satisfied that the mountains could be crossed through this pass, which I called Anaktuvuk, from the northward-flowing river that it leads to ***" (Schrader, 1904, p. 2).

Anaktuvuk River: stream, heads at glacier, in Endicott Mts., $68^{\circ} 09^{\prime} \mathrm{N}, 150^{\circ} 54^{\prime} \mathrm{W}$., flows N $135 \mathrm{mi}$. to Colville River $7 \mathrm{mi}$. $\mathrm{N}$ of its junc. with Chandler River, Arctic Slope; 69 $34^{\prime}$ N, $151^{\circ} 28^{\prime}$ W; $B G N$ 1948; (map 141). Var. Anukturuk River.

Eskimo name reported in 1901 by W. C. Mendenhall, USGS, as "Anukturuk" and corrected to its present spelling by W. J. Peters and F. C. Schrader, USGS, the same year. This may be the stream referred to as " $\mathrm{A}$ '-naktok" by Surgeon John Simpson, RN, in the 1850 's.

Analak Creek: stream, heads in Poktovik Mts., flows NE and SW 12 mi. to Kaluktavik River, $12 \mathrm{mi}$. SE of Misheguk Mtn., Brooks Ra.; $68^{\circ}$ $06^{\prime} \mathrm{N}, 160^{\circ} 46^{\prime} \mathrm{W}$; (map 131).

Eskimo name obtained at Noatak in 1956 by Orth.

Ananakeik: island, see Dolgoi Island.

Anan Bay: bay, $1 \mathrm{mi}$. across, in Bradfield Canal $3 \mathrm{mi}$. E of its mouth at Ernest Sound, Alex. Arch.; $56^{\circ} 11^{\prime} 10^{\prime \prime} \mathrm{N}, 131^{\circ} 53^{\prime} 30^{\prime \prime} \mathrm{W} ; B G N$
1959; (map 7). Var. An-An Bay, Humpback Bay.

Named in 1886 by Lt. Comdr. A. S. Snow, USN. This feature was called "Humpback Bay" in 1904 by H. C. Fassett, USBF.

Anan Creek: stream, heads in Anan Lake, flows N $2.5 \mathrm{mi}$. to Anan Lagoon, $3 \mathrm{mi}$. $\mathbf{E}$ of mouth of Bradfield Canal, at Ernest Sound, Alex. Arch.; $56^{\circ} 10^{\prime} 50^{\prime \prime} \mathrm{N}, 131^{\circ} 53^{\prime} 05^{\prime \prime} \mathrm{W}$; $B G N$ 1966; (map 7).

Name derived from Anan Bay and reported in 1897 by Lt. Comdr. J. F. Moser, USN.

Anangouliak Island: island, see Ananiuliak Island.

Anangusik Island : island, see Gareloi Island.

Ananiuliak Island: island, $1.5 \mathrm{mi}$. long, one of Fox Is. 2 mi. $N$ of Nikolski Bay, $W$ of Umnak I., Aleutian Is.; $53^{\circ} 00^{\prime} \mathrm{N}, 168^{\circ} 54^{\prime} \mathrm{W}$; (map 21, 22). Var. Anaiuliak Island, Anangouliak Island, Ananulyak, Anayulyakh Island.

Aleut name reported by Capt. Lutke (1836, p. 299) as "Anangouliak" and by Father Veniaminov (1840, v. 1, p. 156) as "Ananulyak." This island was called "O[strov] Anayulyakh," or "Anayulyakh Island," by Capt. Tebenkov (1852, map 25), IRN.

Anan Lagoon: lagoon, $0.2 \mathrm{mi}$. across, at mouth of Anan Creek, empties into Anan Bay, $3 \mathrm{mi}$. $E$ of mouth of Bradfield Canal, at Ernest Sound, Alex. Arch.; $56^{\circ} 10^{\prime} 55^{\prime \prime} \mathrm{N}, 131^{\circ} 53^{\prime} 10^{\prime \prime}$ W; (map 7).

Name derived from Anan Bay; published in 1924 by USC\&GS.

Anan Lake: lake, $2.5 \mathrm{mi}$. long, $4 \mathrm{mi}$. SE of Point Ward, at mouth of Bradfield Canal, Alex. Arch.; $56^{\circ} 09^{\prime} \mathrm{N}, 131^{\circ} 53^{\prime} \mathrm{W}$; $B G N$ 1923; (map 7).

Name derived from Anan Bay; given in 1923 by USFS

Anăn'ŏng-ūtc'ha: bluff, see Ananongutka.

Ananongutka: bluf, $1 \mathrm{mi}$. E of Suskaralogh Point, on NW coast of Saint George I., in Pribilof Is.; $56^{\circ} 36^{\prime} 35^{\prime \prime} \mathrm{N}, 1^{\circ} 49^{\circ} 43^{\prime} 10^{\prime \prime} \mathrm{W}$; (map 38). Var. Ananong-utcha.

An Aleut name, meaning "Ananong's shelf," spelled "Ananong-utcha" by Putnam (1903, p. 1014), USC\&GS. A native by that name is said to have gathered eggs here and by local custom had the right to the place.

Ananulyak : island, see Ananiuliak Island.

Anatusuk Hills: hills, "between Kokolik and Kukpowruk Rivers."

Eskimo name reported in 1929 by $P$. S Smith and J. B. Mertie, Jr., USGS.

Anautaaluuzam Kuugauzanga: stream, see Anotalurak Creek.

Anavinguk River : stream, see Ongivinuck River. Anayachtalak Island: island, see Aiaktalik Island.

Anayakhtakh: island, see Aiaktalik Island.

Anayaknaurak Creek: stream, flows NNE $15 \mathrm{mi}$ to Anaktuvuk River, $33 \mathrm{mi}$. NNE of Anaktuvuk Pass, Arctic Slope; $68^{\circ} 34^{\prime} 15^{\prime \prime} \mathrm{N}, 151^{\circ}$. $18^{\prime} 00^{\prime \prime} \mathrm{W}$; (map 134).

Eskimo name obtained at Anaktuvuk Pass in 1956 by T. E. Taylor, USGS.

Anayulyakh Island: island, see Ananiuliak Island.
Ancau, Estero del: estuary, see Ankau, The.

Anchitaktuk River: stream, see Johnson River.

Anchorage: city, pop. 44,237, on Knik Arm, Cook Inlet, $75 \mathrm{mi}$. NW of Seward, Cook Inlet Low.; 61 $13^{\prime} 05^{\prime \prime} \mathrm{N}, 1^{\circ} 53^{\prime} 30^{\prime \prime} \mathrm{W}$; $B G N$ 1944; (map 69). Var. Alaska City, Brownville, Ship Creek, Port Woodrow, Woodrow.

Alaska's largest city, established in 1913 as the construction camp and headquarters of The Alaska RR. to be built from Seward to Fairbanks. A post office was established the following year (Ricks, 1965, p. 3-4). It was early referred to as "Ship Creek" and "Woodrow," but with the establishment of the Anchorage post office in 1914-15 the present name soon became firmly established. The name was derived from that of Knik Anchorage immediately off shore from the new camp. Its population was estimated to be 6,000 in 1917 , but in 1920 it was officially 1,856 . In 1930 it was 2,$277 ; 3,495$ in 1939 , and 11,254 in 1950 .

Anchorage Bay: $b a y$, on E coast of Alaska Penin,, extends SSW $6 \mathrm{mi}$. off Chignik Bay W of Chignik, Aleutian Ra.; $56^{\circ} 19^{\prime} \mathrm{N}, 158^{\circ} 23^{\prime} \mathrm{W}$; (map 30).

Local name reported by Lt. Comdr. Moser, USN, commander of the USBF steamer Albatross; published in 1899 by USC\&GS.

Anchorage Cove: cove, 1,200 ft. across, indents $\mathrm{N}$ shore of American Bay, on $\mathrm{E}$ coast of Dall I., Alex. Arch.; 54 $51^{\prime} 00^{\prime \prime} \mathrm{N}, 132^{\circ} 49^{\prime} 40^{\prime \prime}$ W; (map 1$)$.

Named in 1882 by W. H. Dall, USC\&GS.

Anchorage Cove: cove, $0.4 \mathrm{mi}$. across, on Gulf of Alaska at mouth of Lituya Bay, in Glacier Bay National Monument, $16 \mathrm{mi}$. SE of Cape Fairweather, Malaspina Coastal Plain; $58^{\circ} 37^{\prime}$ $20^{\prime \prime} \mathrm{N}, 137^{\circ} 39^{\prime} 45^{\prime \prime} \mathrm{W}$; (map 10).

Named by W. H. Dall USC\&GS, and published in the 1883 Coast Pilot (p. 203).

Anchorage Pass: water passage, see Anchor Pass. Anchorage Point: point of land, "on Hamilton island in Shakan bay, Sumner strait, Alexander archipelago."

"Local name, published in the Coast Pilot, 1883." (Baker, 1906, p. 98).

Anchorage Point: point of land, at $\mathrm{S}$ entrance to Pyramid Harbor, on W shore of Chilkat Inlet, $3.2 \mathrm{mi}$. NNW of mouth of Ludaseska Creek, $20 \mathrm{mi}$. SSW of Skagway, St. Elias Mts.; $59^{\circ}$ $10^{\prime} 30^{\prime \prime} \mathrm{N}, 135^{\circ} 28^{\prime} 10^{\prime \prime} \mathrm{W}$; (map 45). Var. Sandy Point, Mys Yakorniy, Yakorni Point.

Called by the Russians "M[ys] Yakorniy," meaning "anchor cape" on Russian Hydrog. Dept. Chart 1396 (1848). It was called Sand Point in 1868 by Comdr. R. W. Meade, USN, because "it is the bed of an old glacier, low and composed of broken stones which from a distance appear like sand" (1883 Coast Pilot, p. 197).

Anchor Cove: cove, "on Admiralty Island near $\mathrm{N}$ end of Stephens Passage."

Named in 1884 by Comdr. J. B. Coghlan, USN; published by USC\&GS on Chart 728 . Anchor Cove: cove, $0.4 \mathrm{mi}$. across, on SE shore of Olga Bay, $34 \mathrm{mi}$. SE of Karluk, on SW coast 
of Kodiak I.; $57^{\circ} 07^{\prime} \mathrm{N}, 154^{\circ} 08^{\prime} \mathrm{W}$; (map 35 ).

Local name reported in 1900 by Lt. Comdr. Moser, USN, commander of the USBF steamer Albatross.

Anchor Cove: cove, $0.7 \mathrm{mi}$. across, at $\mathrm{E}$ shore of Day Harbor, on Kenai Pe in., $15 \mathrm{mi}$. SE of Seward, Ghugach Mts.; $60^{\circ} 00^{\prime} \mathrm{N}, 149^{\circ} 06^{\prime}$ W; BGN 1910; (map 49). Var. Timber Cove.

So named in 1909 by U. S. Grant and D. F. Higgins, USGS, "because we lost a boat's anchor there and because it is the first safe anchorage in this harbor."

Anchor Island: island, $400 \mathrm{ft}$. across, between Cordova and Tah Bays, on SW coast of Prince of Wales I., Alex. Arch.; 54 $49^{\prime} 50^{\prime \prime} \mathrm{N}, 132^{\circ}$ $20^{\prime} 20^{\prime \prime} \mathrm{W}$; (map 1 ).

Local name reported in 1951 by USGS.

Anchor Mountain: mountain, "near Nass River, Portland Inlet."

Name published on Brit. Adm. Chart 2431 (Baker, 1906, p. 98).

Anchor Pass: water passage, extends $3 \mathrm{mi}$., connects Bell Arm to Behm Canal, E of Bell I., Alex. Arch.; $55^{\circ} 59^{\prime} \mathrm{N}, 131^{\circ} 24^{\prime} \mathrm{W}$; $B G N$ 1900; (map 3). Var. Anchorage Pass.

Name published in 1894 by USC\&GS.

Anchor Point: village, pop. 171, on Kenai Penin., at junc. of Anchor River and its North Fork, $14 \mathrm{mi}$. NW of Homer, Cook Inlet Low.; $59^{\circ}$ $46^{\prime} 45^{\prime \prime} \mathrm{N}, 151^{\circ} 49^{\prime} 50^{\prime \prime} \mathrm{W}$; (map 50).

Name probably derived from nearby Anchor Point. A post office was established here in 1949 (Ricks, 1965, p. 3).

Anchor Point: point of land, "on W end of Alaska Peninsula on E shore of Isanotski Strait, $\mathrm{N}$ shore of Traders Cove, $0.5 \mathrm{mi}$. SE of Boulder Point."

Named in 1894 by USBF; published in 1912 by USC\&GS on Chart 8822 .

Anchor Point: point of land, on $\mathrm{W}$ coast of Mitkof I. in Wrangell Narrows, $12 \mathrm{mi}$. S of Petersburg, Alex. Arch.; 56 $38^{\prime} 15^{\prime \prime} \mathrm{N}, 132^{\circ}$ 55'35" W; (map 6).

Named in 1869 by Comdr. R. W. Meade, USN.

Anchor Point: spit, on W coast of Kenai Penin., $15 \mathrm{mi}$. NW of Homer, Cook Inlet Low.; 59 ${ }^{\circ}$ $46^{\prime} 30^{\prime \prime} \mathrm{N}, 151^{\circ} 51^{\prime} 45^{\prime \prime} \mathrm{W}$; (map 50). Var. Jakorny, Kasnatchin, Laidernoj.

So named by Capt. Cook (1785, v. 2, p. 353), RN, because he lost an anchor off a point when he was exploring the area in 1778 . This name appears to have originally been applied by Cook to a point of land farther north.

Anchor River: stream, on Kenai Penin., flows W $30 \mathrm{mi}$. to a lagoon on $\mathrm{E}$ shore of Cook Inlet, $14 \mathrm{mi}$. NW of Homer, Cook Inlet Low.; $59^{\circ} 46^{\prime} 30^{\prime \prime} \mathrm{N}, 151^{\circ} 51^{\prime} 30^{\prime \prime} \mathrm{W}$; (map 50).

Anchor Terrace: area, in southern part of Anchorage, $1.2 \mathrm{mi}$. S of the City Hall, Cook Inlet Low.; $61^{\circ} 12^{\prime} 10^{\prime \prime} \mathrm{N}, 149^{\circ} 53^{\prime} 40^{\prime \prime} \mathrm{W}$; (map 69).

Residential district in the city of Anchorage, reported in 1954 by the office of the city engineer of Anchorage.
Ancon, Point: point of land, on $\mathrm{W}$ coast of Woronkofski I., Alex. Arch.; $56^{\circ} 24^{\prime} 15^{\prime \prime} \mathrm{N}$, $132^{\circ} 33^{\prime} 00^{\prime \prime} \mathrm{W}$; BGN 1923; (map 6). Var. Ancon Point, High Point.

Named in 1923 by USC\&GS; derived from Ancon Peak. "High Point" was reported as a local name for this feature in 1904 by H. C. Fassett, USBF.

Ancon Peak: mountain, $2,750 \mathrm{ft}$. on $\mathrm{W}$ coast of Woronkofski I., Alex. Arch.; 56 $23^{\prime} 25^{\prime \prime} \mathrm{N}$, $132^{\circ} 32^{\prime} 00^{\prime \prime} \mathrm{W}$; $B G N$ 1923; (map 6). Var. West Peak.

Local name reported by USC\&GS in 1923; descriptively called "West Peak" by USC\&GS in 1916 "before local name was known." The name "Ancon" was applied to what is now called "Mount Woronkofski," two miles to the east, by Lt. Comdr. A. S. Snow, USN, in 1886. See Mount Woronkofski.

Ancon Peak: mountain, see Berg Mountain.

Ancon Peak: mountain, see Woronkofski, Mount.

Ancon Rock: rock, in Glacier Bay National Monument, in Icy Strait, $0.4 \mathrm{mi}$. SW of Point Gustavus and $55 \mathrm{mi}$. NW of Juneau, St. Elias Mts. ; $58^{\circ} 22^{\prime} 35^{\prime \prime} \mathrm{N}, 135^{\circ} 55^{\prime} 30^{\prime \prime} \mathrm{W}$; (map 11).

Named in 1891 or earlier for the SS Ancon (Baker, 1906, p. 99).

Andeksik Creek: stream, see Anakeksik Creek.

Andersen Creek: stream, near center of Prince of Wales I., flows NE $7 \mathrm{mi}$. to Salmon Lake, 15 mi. E of Klawock, Alex. Arch.; 55 $34^{\prime} 32^{\prime \prime}$ $\mathrm{N}, 132^{\circ} 42^{\prime} 20^{\prime \prime} \mathrm{W}$; (map 4).

Local name recorded in 1949 by USGS.

Andersen Island: island, $0.3 \mathrm{mi}$. across, in Appleton Cove, on NE coast of Baranof I., 30 mi. $\mathrm{N}$ of Sitka, Alex. Arch.; $57^{\circ} 28^{\prime} \mathrm{N}, 135^{\circ}$. $17^{\prime} \mathrm{W}$; (map 9).

Local name reported in 1951 by USGS.

Anderson: village, pop. 200, $5 \mathrm{mi}$. NW of Glear, $12 \mathrm{mi}$. SW of Nenana, Tanana Low.; $64^{\circ} 25^{\prime}$ $\mathrm{N}, 149^{\circ} 15^{\prime} \mathrm{W}$; (map 100).

Village reported in 1962 by USGS; named "for Arthur Anderson, who subdivided his homestead into quarter-acre lots and was elected one of the first councilmen" (Alaska Sportsman, Sept. 1962, p. 12).

Anderson, Cape: point of land, see Northeast Cape.

Anderson, Mount: mountain, 2,800 ft., on Douglas Island, $5 \mathrm{mi}$. WNW of Juneau, Alex. Arch.; $58^{\circ} 19^{\prime} 30^{\prime \prime} \mathrm{N}, 134^{\circ} 31^{\prime} 00^{\prime \prime} \mathrm{W}$; BGN 1957; (map 11).

Named in 1954 by the Juneau Botanical Club for Jacob Peter Anderson who did extensive botanical research in the area; author of "Flora of Alaska."

Anderson, Mount: mountain, 10,770 ft., $W$ of Anderson Glacier, 2 mi. W of Alaska-Canada boundary, St. Elias Mts.; $61^{\circ} 09^{\prime} 45^{\prime \prime} \mathrm{N}, 141^{\circ}$ 03'30" W; BGN 1917; (map 67).

Named by the Alaska-Canada boundary surveyors for Chandler Parsons Anderson, 1866-1936, of New York, a lawyer and one of the counsels for the United States before the Alaskar Boundary Tribunal in 1903.

Anderson Bay: bay, on W coast of Unalaska I., extends $3 \mathrm{mi}$. SSE off Makushin Bay, Aleutian
Is.; $53^{\circ} 42^{\prime} \mathrm{N}, 166^{\circ} 51^{\prime} \mathrm{W}$; (map 23). Var. Iksiaktak.

Published as "Iksiaktak" by Father Veniaminov (1840, v. 1, p. 164), possibly from the Aleutian word, "igdagax," meaning "stick for making fire" or "fire-mill." Published in 1888 as "Anderson Bay" by USBF.

Anderson Bay: bay, $1 \mathrm{mi}$. across, on $\mathrm{S}$ shore of Port Valdez, $9.6 \mathrm{mi}$. SW of Valdez, Chugach Mts.; $61^{\circ} 05^{\prime} \mathrm{N}, 146^{\circ} 33^{\prime} \mathrm{W}$; (map 68).

Local name reported in 1905 by U. S. Grant, USGS.

Anderson Bay: estuary, extends NE $1.5 \mathrm{mi}$. on $\mathrm{N}$ coast of Hinchinbrook I., at mouths of Eagle and Anderson Creeks, $28 \mathrm{mi}$. WSW of Cordova, Chugach Mts.; $60^{\circ} 28^{\prime} \mathrm{N}, 146^{\circ} 32^{\prime} \mathrm{W}$; (map 64).

Local name published in 1943 by USC\&GS. Anderson Camp: locality, "on Kasaan Bay, 30 mi. NW of Ketchikan." Var. Anderson's Camp.

Former settlement reported in . .16 in Polk's Gazetteer.

Anderson Creek: stream, on Hinchinbrook I., flows NE $4 \mathrm{mi}$. to Anderson Bay, $28 \mathrm{mi}$. WSW of Cordova, Chugach Mts.; $60^{\circ} 27^{\prime} \mathrm{N}, 146^{\circ} 30^{\prime}$ W; (map 64).

Published in 1950 by USGS.

Anderson Creek: stream, heads on Trail Ridge, flows S $7.7 \mathrm{mi}$. to Susitna River, SW of Susitna, $31 \mathrm{mi}$. NW of Anchorage, Cook Inlet Low.; $61^{\circ} 31^{\prime} 45^{\prime \prime} \mathrm{N}, 150^{\circ} 34^{\prime} 00^{\prime \prime} \mathrm{W}$; (map 70).

Local name reported in 1958 by USGS.

Anderson Creek: stream, flows SW $5.5 \mathrm{mi}$. to Munson Creek, $49 \mathrm{mi}$. N of Big Delta, YukonTanana High.; $64^{\circ} 51^{\prime}$ N, $145^{\circ} 52^{\prime}$ W; (map 101).

Named by prospectors; reported in 1910 by USGS (Prindle, 1913b, pl. 1).

Anderson Creek: stream, flows NE $8 \mathrm{mi}$. to Don River which flows to Breving Lagoon, $25 \mathrm{mi}$. NW of Teller, Seward Penin. High.; 65 $32^{\prime}$ N, $166^{\circ} 53^{\prime} \mathrm{W}$; (map 111).

Prospectors' name shown on the 1900 "Map of Nome Peninsula" by J. M. Davidson and B. D. Blakeslee.

Anderson Treek: stream, flows S $4.5 \mathrm{mi}$. to Baby Creek, $8.5 \mathrm{mi}$. NNW of Chandalar, Brooks Ra.; $67^{\circ} 36^{\prime} 30^{\prime \prime} \mathrm{N}, 148^{\circ} 35^{\prime} 00^{\prime \prime} \mathrm{W}$; (map 123).

Local name reported in 1956 by T. E. Taylor, USGS.

Anderson Creek : stream, see Warm Creek.

Anderson Glacier: glacier, heads in Yukon, Canada, trends SW across Alaska-Canada boundary $20 \mathrm{mi}$. to Chitina Glacier, $70 \mathrm{mi}$. $\mathrm{SE}$ of McCarthy, St. Elias Mts.; $61^{\circ} 02^{\prime} \mathrm{N}$, $141^{\circ} 09^{\prime} \mathrm{W}$; BGN 1954; (map 67).

Named in 1912-13 by the Alaska-Canada boundarv surveyors for Chandler Parsons Anderson. See Anderson, Mount.

Anderson Gulch: ravine, trends S $1.4 \mathrm{mi}$, to Windy Creek which flows to Kougarok River, $48 \mathrm{mi}$. SW of Imuruk Lake, Seward Penin. High.; $65^{\circ} 27^{\prime} \mathrm{N}, 164^{\circ} 47^{\prime} \mathrm{W}$; (map 110).

Prospectors' name reported in 1906 by A. H. Bro is (in Collier and others. 1908. p. 321), USGS 
Anderson Gulch: ravine, trends $W 1 \mathrm{mi}$. to Kougarok River, $17 \mathrm{mi}$. SW of Midnight Mtn. and $45 \mathrm{mi}$. W of Imuruk Lake, Seward Penin. High.; $65^{\circ} 37^{\prime} \mathrm{N}, 164^{\circ} 45^{\prime} \mathrm{W}$; (map 110).

Prospectors' name reported on the 1908 "Map of Seward Peninsula" by Arthur Gibson

Anderson Island: island, see Saint Lawrence Island.

Anderson Pass: pass, on $\mathrm{N}$ side of Anderson Glacier, $2 \mathrm{mi}$. E of Lake Number One and 15 mi. W of Valdez, Chugach Mts.; $61^{\circ} 08^{\prime} 40^{\prime \prime}$ $\mathrm{N}, 146^{\circ} 43^{\prime} 30^{\prime \prime} \mathrm{W}$; (map 68).

Local name reported in 1905 by U. S. Grant, USGS.

Anderson Pass: pass, 5,300 ft., in Mount McKinley National Park, between Muldnow and West Fork Glaciers, $10 \mathrm{mi}$. S of Eielson Visitor Center, Alaska Ra.; $63^{\circ} 17^{\prime} 30^{\prime \prime} \mathrm{N}$, 150'14'00" W; BGN 1947; (map 88).

Local name shown on a 1920 fieldsheet by J. R. Aiken, USGS.

Anderson Point: point of land, on $\mathrm{W}$ coast of Unalaska I., in Makushin Bay between Anderson and Cannery Bays, Aleutian Is.; 53 $42^{\prime} 05^{\prime \prime} \mathrm{N}, 166^{\circ} 49^{\prime} 40^{\prime \prime} \mathrm{W}$; (map 23).

Published in 1951 by USGS.

Anderson Point: point of land, $\mathrm{S}$ point of entrance to Clover Bay, on $\mathbf{E}$ coast of Prince of Wales I., $\mathbf{N}$ of Cholmondeley Sound, Alex. Arch.; $55^{\circ} 18^{\prime} 00^{\prime \prime} \mathrm{N}, 132^{\circ} 07^{\prime} 40^{\prime \prime} \mathrm{W}$; (map 4).

Navigator's name reported in 1904 by H. C. Fassett, USBF.

Anderson Point: point of land, on Beaufort Sea coast, on $\mathbf{E}$ shore of Camden Bay, Arctic Plain; $70^{\circ} 01^{\prime} 30^{\prime \prime} \mathrm{N}, 144^{\circ} 27^{\prime} 45^{\prime \prime} \mathrm{W}$; (map 151).

Named in 1914 by Leffingwell (1919, p. 93) for Dr. Rudolph Martin Anderson, of the Canadian Arctic Expedition, to whom Leffingwell was "indebted for transportation from Nome to Flaxman Island * * *."

Anderson: rock, "reported in 1883 and still uncharted about 25 miles south of Sannak island, near latitude $54^{\circ} 03^{\prime}$, longitude $162^{\circ} 45^{\prime}$."

"So called by the Fish Commission in 1888" (Baker, 1906, p. 99).

Anderson's Camp: locality, see Anderson Camp.

Andesite Creek: stream, heads in Lava Lake, flows SW $6 \mathrm{mi}$. to Noxapaga River, $25 \mathrm{mi}$. W of Imuruk Lake, Seward Penin. High.; $65^{\circ} 34^{\prime} \mathrm{N}, 164^{\circ} 06^{\prime} \mathrm{W}$; (map 110).

Reported in 1950 by D. M. Hopkins, USGS; so named because "the south bank consists of an andesite flow throughout most of the length of the stream." Andesite is a specific type of lava.

Andreafski: locality, see Old Andreafsky.

Andreafski : village, see Andreafsky.

Andreafski Hills: ridge, see Andreafsky Hills.

Andreafski Mountain: hill, see Andreafsky Mountain.

Andreafski Redoubt: locality, see Old Andreafsky.

Andreafski River: stream, see Andreafsky River.

Andreafsky: village, pop. 220, on $\mathrm{N}$ bank of Andreafsky River, $3.5 \mathrm{mi}$. NE of Pitkas Point, and $37 \mathrm{mi}$. NW of Marshall, Yukon-Kuskokwim Delta ; $62^{\circ} 03^{\prime} \mathrm{N}, 163^{\circ} 10^{\prime} \mathrm{W}$; BGN 1931; (map 77). Var. Andreafski, New Andreafski, New Andreafsky, Saint Marys.

Andreafsky was established about 1898 or 1899 as a supply depot and winter quarters for the Northern Commercial Company's riverboat fleet. It is difficult to determine now whether the village received its name from the Andreafsky River or whether the village name was instrumental in changing the river name which was earlier called "Clear River." One report says, however, that the "place received its name from the 'Andrea' family who settled here in the early days and built the Russian church." The village's post office name was changed in 1955 to "Saint Marys," after the Roman Catholic Mission here. See Old Andreafski.

Andreafsky: locality, see Old Andreafsky.

Andreafsky Hills: ridge, highest elev. $868 \mathrm{ft}$., trends NE $14 \mathrm{mi}$. from Pitkas Point along Andreafsky River, $36 \mathrm{mi}$. NW of Marshall, Nulato Hills; $62^{\circ} 07^{\prime} \mathrm{N}, 163^{\circ} 07^{\prime} \mathrm{W}$; (map 77). Var. Andreafski Hills.

Local name shown on a 1916 fieldsheet by R. H. Sargent, USGS.

Andreafsky Mountain: hill, $600 \mathrm{ft}$., $\mathrm{N}$ of Pitkas Point, at SW end of Andreafsky Hills, $40 \mathrm{mi}$. NW of Marshall, Nulato Hills; $62^{\circ} 02^{\prime} 30^{\prime \prime} \mathrm{N}$, $163^{\circ} 16^{\prime} 30^{\prime \prime} . \mathrm{W}$; (map 77). Var. Andreafski Mountain.

Local name reported in 1899 by G. R. Putnam, USC\&GS, who spelled it "Andreafski." Andreafsky River: stream, heads at $63^{\circ} 07^{\prime} \mathrm{N}$, $161^{\circ} 46^{\prime} \mathrm{W}$, flows SW $120 \mathrm{mi}$. to Yukon River at Pitkas Point, $39 \mathrm{mi}$. NW of Marshall, Yukon-Kuskokwim Delta ; $62^{\circ} 01^{\prime} 45^{\prime \prime} \mathrm{N}, 163^{\circ}$. $15^{\prime} 00^{\prime \prime}$ W; (map 77). Var. Andreafski River, Clear River, Konnekova River, Niegieklik, Nygyklik, Reka Nuggyklik.

Name reported in 1898 by USC\&GS ; probably derived from the name of the nearby village. The Russians called this stream "R[eka] Nuggyklik," an Eskimo name. Capt. C. W. Raymond, U.S. Army Corps of Engineers, reported the name in 1869 as "Konnekova" or "Clear." See Andreafsky.

Andreaivsky: locality, see Old Andreafsky.

Andreanoffsky Islands: islands, see Andreanof Islands.

Andreanof Islands: islands, chain in Aleutian Is., between Is. of Four Mts. to the east, and Rat Is. to the west, extend from Amukta Pass westward about $310 \mathrm{mi}$. to Amchitka Pass; they include Seguam, Amilia, Atka, Great Sitkin, Little Tanaga, Umak, Igitkin, Chugul, Tagalak, Kagalaska, Adak, Kanaga, Tanaga, Gareloi, Amatiknak, Ulak, Unalga, Kavalga, and Ogliuga Islands and other smaller islands, $52^{\circ} 21^{\prime} \mathrm{N}, 172^{\circ} 17^{\prime} \mathrm{W}$ [E end], $51^{\circ} 15^{\prime} \mathrm{N}, 179^{\circ}$ $09^{\prime} \mathrm{W}$ [W end]; $B G N$ 1963. Var. Andreanoffsky Island, Andreanowsky Islands, Andreianofsky Islands, Andreianovski Islands, Fox Islands, Islands of Saint Andrean.

These islands were first explored by Andreian Tolstyk with Peter Vasiutkin and Maxim Lazaref in 1761. The merchant
Tolstyk owned the vessel Andreian and $\mathrm{Na}$ talia, named after himself and his wife, which was used in this expedition. Rev. Coxe (1787, p. 183-184) wrote, "The first certain account was brought by this vesseel, the St. Andrean and Natalia, from whence they were called the Andreanofskie Ostrova, or the Islands of St. Andrean." Petroff (in Bancroft, 1886, p. 169) wrote, "*** After a stay on these islands, subsequently named after him the Andreianovski, *** Tolstykh collected quite a valuable cargo of furs * * ." See Aleutian Islands.

Andreanof Islands: islands, see Fox Islands.

Andreanowsky Islands: islands, see Andreanof Islands.

Andreavski Redut: locality, see Old Andreafsky. Andreianofski Islands: islands, see Andreanof Islands.

Andreianovski Islands: islands, see Andreanof Islands.

Andreievsky: locality, see Old Andreafsky.

Andreon Bay: bay, $0.7 \mathrm{mi}$. across, $\mathrm{N}$ of Afognak I. on SE coast of Shuyak I., Kodiak I.; $58^{\circ} 30^{\prime}$ $30^{\prime \prime} \mathrm{N}, 152^{\circ} 24^{\prime} 30^{\prime \prime} \mathrm{W}$; (map 43).

Local name published in 1927 by USC\&GS on Chart 8555.

Andrew, Mount: mountain, 1,500 ft., on Kasaan Penin., on E coast of Prince of Wales I., Alex. Arch.; $55^{\circ} 31^{\prime} \mathrm{N}, 132^{\circ} 18^{\prime} \mathrm{W}$; BGN 1966; (map 4). Var. Mount Andrews.

Local name published by Brooks (1902, p. 13), USGS. Named for the Mount Andrew Mine. Andrew was the name of the mining company operating the mine.

Andrew Bay: bay, $3 \mathrm{mi}$. across, on $\mathrm{N}$ coast of Adak I., Aleutian Is.; $51^{\circ} 57^{\prime} 30^{\prime \prime} \mathrm{N}, 176^{\circ} 39^{\prime}$ $30^{\prime \prime}$ W; BGN 1936; (map 17). Var. Lidrejana Bay, Zaliv Andreyana.

Translation of name published by Capt. Tebenkov (1852, map 28), IRN, as " $Z$ [aliv] Andreyana," meaning "Andrew Bay," possibly given for Andrean (Andrew) Tolstyk, a merchant who, according to Rev. Coxe (1787, p. 79), was one of the first explorers of Adak Island, in 1761.

Andrew Creek: stream, flows NW $9 \mathrm{mi}$. to Stikine River, $14 \mathrm{mi}$. NE of Wrangell, Coast Mts.; $56^{\circ} 40^{\prime} 10^{\prime \prime} \mathrm{N}, 132^{\circ} 15^{\prime} 00^{\prime \prime} \mathrm{W}$; (map 6).

Local name recorded in 1953 by USGS. Andrew Creek: stream, flows SW $14 \mathrm{mi}$. to Yukon River, $8 \mathrm{mi}$. NW of mouth of Charley River, Porcupine Plat.; $65^{\circ} 22^{\prime \prime} \mathrm{N}, 1^{\circ} 3^{\circ} 01^{\prime}$ W; (map 103).

Local name published in 1951 by USGS.

Andrew Island: island, $3.4 \mathrm{mi}$. long, in Stikine River, $15 \mathrm{mi}$. NE of Wrangell, Coast Mts.; $56^{\circ} 41^{\prime} \mathrm{N}, 132^{\circ} 13^{\prime} \mathrm{W}$; (map 6).

Local name recorded in 1953 by USGS. Andrew Lagoon: lagoon, see Andrew Lake.

Andrew Lake: lagoon, $2.5 \mathrm{mi}$. across, on $\mathrm{N}$ end of Adak I., Aleutian Is., $51^{\circ} 56^{\prime} 30^{\prime \prime}$ N. $176^{\circ}$ $38^{\prime} 00^{\prime \prime}$ W; BGN 1959; (map 17). Var. Andrew Lagoon.

Name derived from Andrew Bay in 1934 by members of the U.S. Navy Aleutian Island Survey Expedition. 
Andrew Lake: lake, $0.5 \mathrm{mi}$. long, between Moose Creek and Nabesna Slough, $1.6 \mathrm{mi}$. S of Northway, Alaska Ra.; $62^{\circ} 56^{\prime} \mathrm{N}, 141^{\prime} 56^{\prime} \mathrm{W}$; (map 84).

Local name reported in 1954 by USGS. Andrew River: stream, see Willow Creek.

Andrew: stream, "Learnard, of Glenn's expedition, 1898, gives this as the name of a river coming into the Susitna from the left but the exact location is uncertain" (Baker, 1906, p. 100).

Andrews, Mount: mountain, see Andrew, Mount.

Andrews, Port: bight, see Blying Sound.

Andrews, Port : estuary, see Resurrection Bay.

Andrews, Port: sound, see Blying Sound.

Andrews Glacier: glacier, in Glacier Bay National Monument, trends W 2 mi. to Plateau Glacier, $70 \mathrm{mi}$. NW of Hoonah, St. Elias Mts.; $58^{\circ} 54^{\prime}-$ $45^{\prime \prime} \mathrm{N}, 136^{\circ} 20^{\prime} 30^{\prime \prime} \mathrm{W}$; (map 10).

Named by members of the American Geographical Society's Glacier Bay Expedition of 1941, for Clarence Leroy Andrews, 18621948 , who visited Muir Inlet in 1892, 1903, and 1913 and published reports of his observations. He is also the author of many publications dealing largely with Alaskan history.

Andrew Slough: stream, anabranch of Stikine River, separates Andrew I. from mainland, flows SE $4 \mathrm{mi}$. to Andrew Creek, $14 \mathrm{mi}$. NE of Wrangell, Coast Mts. ; $56^{\circ} 40^{\prime} 10^{\prime \prime} \mathrm{N}, 132^{\circ} 15^{\prime}$ $00^{\prime \prime} \mathrm{W}$; (map 6).

Local name recorded in 1953 by USGS.

Andrews River: stream, see Douglas River.

Andrews Slough: channel, $5 \mathrm{mi}$. long, on southern part of Koyukuk I., in Yukon River, $16 \mathrm{mi}$. NE of Nulato, Koyukuk Low.; 64.52' N, $157^{\circ} 41^{\prime} \mathrm{W}$; (map 97).

Riverboat pilots' name shown on a 1940 "Navigation Chart of the Tanana-Yukon Rivers" published by the U.S. Dept. of the Interior.

Andreyana, Zaliv: bay, see Andrew Bay.

Andromeda Cone: hill, 1,134 ft., $3 \mathrm{mi}$. SW of Hoodoo Hill and $7 \mathrm{mi}$. W of Imuruk Lake, Seward Penin. High.; $65^{\circ} 35^{\prime} \mathrm{N}, 163^{\circ} 30^{\prime} \mathrm{W}$; $B G N 1952$; (map 110).

Reported in 1950 by D. M. Hopkins, USGS; one of "Four conspicuous volcanic cones * * * named for wild flowers which are common on the slopes of all four cones."

Andronica Island: island, $3.5 \mathrm{mi}$. long, in Shumagin Is.; Aleutian Ra.; $55^{\circ} 20^{\prime} \mathrm{N}, 160^{\circ} 05^{\prime}$ W; (map 28). Var. Foggy Island, Ostrov Apostol Andrenika, Yasni Island.

Named "O[strov] Ap[ostol] Andrenika" in 1847 on Russian Hydrog. Dept. Chart 1379, for the apostle Andrew. W. H. Dall lists "Yasni" [clear], and "Foggy Island" as variant names in the USC\&GS Report for 1872 (p. 195).

Andrus Peak: mountain, 8,145 ft., $3.5 \mathrm{mi}$. SW of Pyramid Peak, $19 \mathrm{mi}$. SE of McCarthy, St. Elias Mts. ; $61^{\circ} 17^{\prime} \mathrm{N}, 142^{\circ} 26^{\prime} \mathrm{W}$; (map 67).

Local name reported in 1908 by $D$. C. Witherspoon, USGS.

Andy Cove: cove, $0.4 \mathrm{mi}$. across, $\mathbf{E}$ of Hammer Point, on SE coast of Kiska I., Aleutian Is.; $51^{\circ} 55^{\prime} 40^{\prime \prime} \mathrm{N}, 177^{\circ} 35^{\prime} 00^{\prime \prime} \mathrm{E}$; (map 14). Var. Amos Cove.

One of many arbitrary names applied to features on Kiska I. by USAF for tactical purposes during World War II.

Andy Simons Mountain: mountain, 6,210 ft., on Kenai Penin., between Ptarmigan Lake and Victor Creek, $20 \mathrm{mi}$. NE of Seward, Chugach Mts. ; $60^{\circ} 22^{\prime} \mathrm{N}, 149^{\circ} 15^{\prime} \mathrm{W}$; BGN 1963; (map 63).

Named in 1963 by the Seward Chamber of Commerce for Andrew Adrian Simons, 18821962, early Alaska settler, guide, and conservationist.

Andys Slough: stream, anabranch, heads at Yukon River, flows SW $2.2 \mathrm{mi}$. to Pilot Mountain Slough, $25 \mathrm{mi}$. NE of Nulato, Koyukuk Low; $64^{\circ} 46^{\prime} \mathrm{N}, 157^{\circ} 15^{\prime} \mathrm{W}$; (map 97).

Riverboat pilots' name shown on a 1940 "Navigation Chart of the Tanana-Yukon Rivers" published by the U.S. Dept. of the Interior.

Anechlangamute : locality, on left bank of Kanektok River, $W$ of Takshilik Creek, $50 \mathrm{mi}$. NE of Goodnews, Kilbuck-Kuskokwim Mts.; $59^{\circ} 44^{\prime} \mathrm{N}, 161^{\circ} 01^{\prime} \mathrm{W}$; (map 53 ).

Eskimo village or camp reported in 1898 by W. S. Post, USGS. It is now abandoned. Aneeaktovik Creek: stream, see Aniyuyaktuvik Creek.

Aneeaxtovik Creek: stream, see Aniyuyaktuvik Creek.

Aneegulgit: snowfield, $20 \mathrm{mi}$. long, very narrow, on S slope of Kookooligit Mts., $42 \mathrm{mi}$. SE of Gambell, St. Lawrence I.; $63^{\circ} 32^{\prime}$ N, $170^{\circ} 26^{\prime}$ W; (map 93). Var. Anigulgit.

Eskimo name often recorded as "Anigulgit," meaning "perpetual snow"; published by the Univ. of Alaska in 1932. The prevailing north wind has drifted snow into a bank often reaching more than $150 \mathrm{ft}$ high along a south-facing cliff. This permanent snowbank furnishes fresh water to several south-flowing streams. Anegadizos, Los: stream(?).

Spanish name meaning "the flooded one"; located about $59^{\circ} 09^{\prime} \mathrm{N}$, used by Capt. Alessandro Malaspina on a 1791 "plano."

Anelagaggerack: stream, see Reed River.

Anelo: locality, on Port Clarence, Seward Penin. High.; (map 111).

Former Eskimo camp or settlement listed in the 1890 Census.

Anemuk: locality, on left bank of Anvik River about $30 \mathrm{mi}$. above is junc. with Yukon River; (map 91).

Eskimo camp or small settlement listed by Hodge (1907, p. 57), BAE ; first reported in 1869 by Capt. C. W. Raymond, U.S. Army Corps of Engineers.

Anepangwagavigamiut: settlement, see Owl Village.

Anepoungwagavik: settlement, see Owl Village.

Anerkochik River: stream, heads in lake, flows SW $35 \mathrm{mi}$. to Hazen Bay $\mathrm{N}$ of Azun River, Yukon-Kuskokwim Delta; $61^{\circ} 06^{\prime} \mathrm{N}, 165^{\circ} 09^{\prime}$ W; (map 75). Var. Aknerkochik River, Oknakuchak River.
Eskimo name meaning "a small hurt"; reported in 1951 by USC\&GS.

Anertz Lake: lake, $0.5 \mathrm{mi}$. long, on Kenai Penin. $\mathrm{N}$ of Dolly Varden Lake, $20 \mathrm{mi}$. NE of Kenai, Cook Inlet Low.; $60^{\circ} 43^{\prime} \mathrm{N}, 150^{\circ} 47^{\prime} \mathrm{W}$; (map 62).

Named about 1963 by officials of Kenai National Moose Range, for administrative purposes.

Aneskett Point: point of land, on NE coast of Kosciusko I., Alex. Arch.; 56 $08^{\circ} 50^{\prime \prime}$ N, $133^{\circ}$ $16^{\prime} 10^{\prime \prime} \mathrm{W}$; (map 6).

Indian name reported in 1904 by $E$. $F$. Dickins, USC\&GS.

Aneyeukuk Greek: stream, see Angayukak Creek.

Angahyoukuk Creek: stream, see Angayukak Creek.

Angahyoukuk Mountain: hill, see Angayukak Hill.

Angayucham Mountains: $m$ o $u$ n $t$ a in $s, 1,000$ $4,765 \mathrm{ft}$., extend E $18 \mathrm{mi}$. from Narvak Lake, $40 \mathrm{mi}$. E of Kobuk, Brooks Ra.; $66^{\circ} 55^{\prime} \mathrm{N}$, $155^{\circ} 20^{\prime} \mathrm{W}$; (map 116). Var. Angyuchaminri.

"Angyuchaminri" is the full Eskimo name, reported to mean "old man mountains"; recorded at Kobuk in 1956 by Orth.

Angayu Creek: stream, heads in Angunelechak Pass, flows N $14 \mathrm{mi}$. to Noatak River, $36 \mathrm{mi}$. SW of Survey Pass, Brooks Ra.; $67^{\circ} 33^{\prime} \mathrm{N}$, $155^{\circ} 12^{\prime} \mathrm{W}$; (map 125). Var. Twelvemile Greek.

Eskimo name generally meaning "older brother" or "old one," but, in this case, in 1956 , Orth reported that it is the name of a dance.

Angayukachak Creek: stream, heads in Angayucham Mts., flows SW $12 \mathrm{mi}$. to Selby River, 32 mi. ESE of Kobuk, Kotzebue-Kobuk Low.; $66^{\circ} 49^{\prime} \mathrm{N}, 155^{\circ} 43^{\prime} \mathrm{W}$; (map 116).

Eskimo name reported to mean "old man," obtained at Kobuk in 1956 by Orth.

Angayukak Creek: stream, flows N and E $6 \mathrm{mi}$. to Akoviknak Lagoon, $5 \mathrm{mi}$. $\mathrm{N}$ of Cape Thompson, Arctic Slope; $68^{\circ} 12^{\prime} 43^{\prime \prime} \mathrm{N}, 166^{\circ}$. 03'45" W; BGN 1963; (map 129). Var. Agayuquaq Creek, Ahgahyoukuk Creek, Aneyeukuk Creek, Angahyoukuk Creek.

Eskimo name reported in 1950 by USC\&GS as "Ah-gah-you-kuk," meaning "old man." The stream may be named for Angayukak Hill. See Inukpak Rock.

Angayukak Hill: hill, $290 \mathrm{ft}$., $\mathrm{N}$ end of Akoviknak Mtn., $4.8 \mathrm{mi}$. N of Cape Thompson, Arctic Slope; $68^{\circ} 12^{\prime} 48^{\prime \prime} \mathrm{N}, 166^{\circ} 00^{\prime} 35^{\prime \prime} \mathrm{W}$; $B G N$ 1963; (map 129). Var. Ahgahyoukuk Mountain, Angahyoukuk Mountain.

Eskimo name reported in 1950 by USC\&GS ; the name means "old man."

Angayukalik Hills: ridge, elev. 2,000 ft., in Baird Mts. S of Noatak River, extends 10 mi. on S bank of Sapun Creek, Brooks Ra.; $67^{\circ} 50^{\prime} \mathrm{N}, 160^{\circ} 30^{\prime} \mathrm{W}$; (map 127).

Eskimo name meaning "oldest brother" [angayuk-klig]; obtained at Noatak in 1956 by Orth. 
Angayukasrakvik Creek: stream, see Old Man Creek.

Angayutak Mountain: mountain, 1,116 ft., on $\mathrm{N}$ bank of Kapaloak Creek, $2 \mathrm{mi}$. $\mathrm{E}$ of Cape Dyer, Arctic Slope ; $68^{\circ} 38^{\prime} 50^{\prime \prime} \mathrm{N}, 166^{\circ} 08^{\prime} 00^{\prime \prime}$ W; (map 129).

Eskimo name reported in 1955 by the U.S. Army Corps of Engineers. It probably means "old man's [mountain]."

Angel Cove: cove, $0.4 \mathrm{mi}$. across, $1.8 \mathrm{mi}$. SW of Lief Cove, on W coast of Kiska I., Aleutian Is.; $51^{\circ} 55^{\prime} 25^{\prime \prime} \mathrm{N}, 177^{\circ} 17^{\prime} 15^{\prime \prime} \mathrm{E}$; (map 14).

One of many arbitrary names applied to features on Kiska Island by USAF for tactical purposes during World War II.

Angel Creek: stream, flows S $1.3 \mathrm{~m}$. to Peaceful River, on SE coast of Attu I., Aleutian Is. $52^{\circ} 50^{\prime} 25^{\prime \prime} \mathrm{N}, 173^{\circ} 07^{\prime} 55^{\prime \prime} \mathrm{E}$; (map 13).

Named by the U.S. Army during World War II ; published in 1948 by AMS.

Angel Creek: stream, flows E $11 \mathrm{mi}$. to Chena River, $5 \mathrm{mi}$. SW of Chena Hot Springs and $85 \mathrm{mi}$. SW of Circle, Yukon-Tanana High.; $65^{\circ} 01^{\prime} 15^{\prime \prime} \mathrm{N}, 146^{\circ} 12^{\prime} 30^{\prime \prime} \mathrm{W}$; (map 104).

Prospectors' name reported in 1954 or 1955 by USGS topographers.

Angel Creek: stream, see Angle Creek.

Angeles Creek: stream, flows S $3.5 \mathrm{mi}$. to Garfield Creek which flows to Kuzitrin River, $40 \mathrm{mi}$. SW of Imuruk Lake, Seward Penin. High.; $65^{\circ} 27^{\prime} \mathrm{N}, 164^{\circ} 30^{\prime} \mathrm{W}$; (map 110).

Prospectors' name reported in 1901 by T. G. Gerdine (in Collier, 1902, pl. 12), USGS.

Angel Lake: lake, $1.3 \mathrm{mi}$. Iong, in course of Goose Creek, on Prince of Wales I., W of Thorne Bay, Alex. Arch.; 55 40 $15^{\prime \prime} \mathrm{N}, 132^{\circ}$ 38'10" W; BGN 1960; (map 4).

Local descriptive name reported in 1956 by C. L. Sainsbury, USGS, who stated, "This name is in local use by residents of the village of Salt Chuck, and the name is suggested by the shape of the lake."

Angeyukangak: mountains, see Parents Mountains.

Angiaak Pass: pass, 3,650 ft., in Schwatka Mts., $5 \mathrm{mi}$. NW of Mount Igikpak, Brooks Ra. $67^{\circ} 37^{\prime} \mathrm{N}, 155^{\circ} 07^{\prime} \mathrm{W}$; (map 125).

Eskimo name meaning "stone scraper"; recorded in Kobuk in 1956 by Orth.

Angilya, Ostrov: island, see Anguilla Island.

Angle Creek: stream, heads at glacier terminus on Mount Mageik, flows W $25 \mathrm{mi}$. to Takayofo Creek, on Alaska Penin., in Katmai National Monument, $33 \mathrm{mi}$. WSW of Mount Katmai, Aleutian Ra.; $58^{\circ} 10^{\prime} 15^{\prime \prime} \mathrm{N}, 155^{\circ}$ $52^{\prime} 30^{\prime \prime} \mathrm{W}$; (map 42). Var. Angel Creek.

So named in 1923 by a USGS field party, "because it is at the southwestern angle of the Katmai National Monument."

Angle Point: point of land, SW tip of Bold I. in Revillagigedo Channel, off SW coast of Revillagigedo I., Alex. Arch.; 55 $14^{\prime} 20^{\prime \prime} \mathrm{N}, 131^{\circ}$ $25^{\prime} 30^{\prime \prime} \mathrm{W}$; (map 3).

Named in 1886 by USC\&GS

Angler Lake: lake, $0.9 \mathrm{mi}$. long, on Kenai Penin. SW of Bird Lake, $5.5 \mathrm{mi}$. SW of Point Possession and $41 \mathrm{mi}$. NE of Kenai, Cook Inlet Low.; $69^{\circ} 58^{\prime} 00^{\prime \prime} \mathrm{N}, 150^{\circ} 26^{\prime} 30^{\prime \prime} \mathrm{W}$; (map 62).
Named by officials of Kenai National Moose Range, about 1963, for administrative purposes.

Anglicé Island: islands, see Martin Islands.

Anglice Islands: islands, see Fox Islands.

Angmakrog Creek: stream, see Angmakrok Creek.

Angmakrog Mountain: mountain, see Angmakrok Mountain.

Angmakrok Creek: stream, flows SW $5.5 \mathrm{mi}$. to Kukpuk River, $13 \mathrm{mi}$. NE of Cape Thompson, Arctic Slope; $68^{\circ} 17^{\prime} 30^{\prime \prime} \mathrm{N}, 1^{\circ} 65^{\circ} 40^{\prime} 35^{\prime \prime}$ W; BGN 1963; (map 129). Var. Angmakrog Creek, Angamakroq Creek, Angmarok Creek, Angmarox Creek, Angmorak Creek.

Eskimo name reported in 1962 as "Angmarok" by personnel of Project Chariot. See Angmakrok Mountain.

Angmakrok Mountain: mountain, 1,563 ft., $\mathrm{N}$ of Kukpuk River, $14 \mathrm{mi}$. NE of Cape Thompson, Arctic Slope; $68^{\circ} 17^{\prime} 30^{\prime \prime} \mathrm{N}, 1^{\circ} 35^{\circ} 32^{\prime} 25^{\prime \prime}$ W; BGN 1963; (map 129). Var. Angmakrog Mountain, Angmakroq Mountain, Angmarok Mountain, Angmarox Mountain, Angmorak Mountain, Ukmaggruk Mountain.

Eskimo name meaning "old flint" reported in 1956 by Orth.

Angmakroq Creek: stream, see Angmakrok Creek.

Angmakroq Mountain: mountain, see Angmakrok Mountain.

Angmarok Creek: stream, see Angmakrok Creek. Angmarok Mountain: mountain, see Angmakrok Mountain.

Angmarox Creek: stream, see Angmakrok Creek. Angmarox Mountain: mountain, see Angmakrok Mountain.

Angmorak Creek: stream, see Angmakrok Creek. Angmorak Mountain: mountain, see Angmakrok Mountain.

Angnovchak: locality, "in the Nushagak district." Var. Angnovchamiut.

Former Eskimo camp or settlement listed as "Angnovchamiut" with a population of 16 in the 1890 Census.

Angnovchamiut: locality, see Angnovchak. Angnun: locality, see Angun.

Angnun Lagoon: lagoon, see Angun Lagoon. Angnun Point: point of land, see Angun Point. Angnun River: stream, see Aichilik River. Angnun River: stream, see Angun River.

Angolik Creek: stream, flows NW $2 \mathrm{mi}$. to Chukchi Sea, $1.8 \mathrm{mi}$. S of Cape Dyer, Arctic Slope; $68^{\circ} 37^{\prime} 30^{\prime \prime} \mathrm{N}, 166^{\circ} 13^{\prime} 30^{\prime \prime} \mathrm{W}$; (map 129). Var. Angowlik Creek.

Eskimo name reported in 1950 by USC\&GS. Angoon: village, pop. 395, on $\mathrm{W}$ coast of $\mathrm{Ad}$ miralty I., $41 \mathrm{mi}$. NE of Sitka, Alex. Arch.; $57^{\circ} 30^{\prime} \mathrm{N}, 134^{\circ} 35^{\prime} \mathrm{W}$; (map 9). Var. Angun, Augoon

Tlingit Indian village listed as "Augoon" with a population of 420 in the 10th Census, in 1880. The village lost much of its population in the late 1880's when Killisnoo was established with a fish reducing plant. Angoon's population was 114 in $1920 ; 319$ in 1930 ; 342 in 1939; and 429 in 1950 . The Angoon post office was established in 1928.
Angora Point: point of land, on SE coast of Kanaga I., on N shore of Kanaga Bay, Aleutian Is. ; $51^{\circ} 43^{\prime} 30^{\prime \prime} \mathrm{N}, 1^{\circ} 7^{\circ} 12^{\prime} 05^{\prime \prime} \mathrm{W}$; (map 17).

Name published in 1957 by AMS.

Angoviknak Mountain: hill, see Akoviknak Mountain.

Angowlik Creek: stream, see Angolik Creek.

Angoyachtoly Creek: stream, flows WSW $20 \mathrm{mi}$. to Kuskokwim River, $14 \mathrm{mi}$. SW of Bethel, Yukon-Kuskokwim Delta; $60^{\circ} 38^{\prime} \mathrm{N}, 162^{\circ} 02^{\prime}$ W; (map 58). Var. Angoyaktoli.

Eskimo name obtained by W. S. Post, USGS, from J. H. Kilbuck, Moravian missionary, and shown on Post's 1898 fieldsheet with the note "which extends into the tundra "as far as one might travel in a kyak in a day." "

Angoyaktoli: stream, see Angoyachtoly Creek.

Angoyakvik Pass: pass, $900 \mathrm{ft}$., $\mathrm{E}$ of Knifeblade Ridge, $15 \mathrm{mi}$. SE of head of Ikpikpuk River, Arctic Slope; $69^{\circ} 07^{\prime} 30^{\prime \prime} \mathrm{N}, 154^{\circ} 29^{\prime} 30^{\prime \prime} \mathrm{W}$; (map 142).

Eskimo name originally applied to a hill at the head of September Creek but now applied to the pass just west of the hill. This name was reported to mean "place where the enemy is," but it may also mean "hunting place."

Anguilla Bay: bay, 2 mi. long, between Anguilla and Esquibel Is., in Maurelle Is., Alex. Arch.; $55^{\circ} 39^{\prime} 30^{\prime \prime} \mathrm{N}, 133^{\circ} 35^{\prime} 00^{\prime \prime} \mathrm{W}$; BGN 1924; (map 4).

Spanish word meaning "eel," given in 1924 by USC\&GS ; "from name of island, of which this is the principal indentation."

Anguilla Island: island, $3 \mathrm{mi}$. long, largest of Maurelle Is., Alex. Arch; $55^{\circ} 40^{\prime} \mathrm{N}, 133^{\circ} 35^{\prime}$ W; BGN 1908; (map 4). Var. Isla Anguilla, Ostrov Angilya.

Spanish name given in $1775-1779$ by Don Juan de la Bodega y Quadra and Francisco Antonio Maurelle as "Isla Anguilla," meaning "Eel Island."

Anguk Island: island, $0.3 \mathrm{mi}$. across, near S shore of Spiridon Bay, on NW coast of Kodiak I. $57^{\circ} 38^{\prime} 45^{\prime \prime} \mathrm{N}, 153^{\circ} 42^{\prime} 00^{\prime \prime} \mathrm{W}$; BGN 1931; (map 34). Var. Big Island.

Name derived from the the Aleut word "angunaq," meaning "big"; given in 1931 by USC\&GS.

Angun: locality, site of Eskimo village, on Beaufort Sea coast at Angun Point, $31 \mathrm{mi}$. NW of Demarcation Point, Arctic Plain; 69 $55^{\prime} 30^{\prime \prime}$ N, $142^{\circ} 24^{\prime} 00^{\prime \prime}$ W; (map 138). Var. Angnun.

Archdeacon Stuck (1920, p. 307) mentions spending a night in 1918 at Angun, a village of several igloos, about $35 \mathrm{mi}$. SE of Barter Island.

Angun: village, see Angoon.

Angunelechek Pass: pass, 4,050 ft., in Schwatka Mts., $10 \mathrm{mi}$. SW of Mount Igikpak, Brooks Ra.; $67^{\circ} 20^{\prime} \mathrm{N}, 155^{\circ} 16^{\prime} \mathrm{W}$; (map 125 ).

Eskimo name meaning "for use by the man who does not hunt"; reported in 1956 by USGS.

Angun Lagoon: lagoon, $4 \mathrm{mi}$. long, on Beaufort Sea coast between Angun and Humphrey 
Points, $33 \mathrm{mi}$. NW of Demarcation Point, Arctic Plain; $69^{\circ} 57^{\prime} \mathrm{N}, 142^{\circ} 27^{\prime} \mathrm{W} ; B G N$ 1962; (map 138). Var. Angnun Lagoon.

This lagoon was originally a part of Sir John Franklin's Beaufort Bay, which Leffingwell (1919, p. 88) described as extending "from the western end of Icy Reef to Humphreys Point."

See Angun Point.

Angun Point: point of land, on Beaufort Sea coast between Angun and Beaufort Lagoons, $33 \mathrm{mi}$. NW of Demarcation Point, Arctic Plain; $69^{\circ} 56^{\prime} \mathrm{N}, 142^{\circ} 23^{\prime} \mathrm{W}$; $B G N$ 1962; (map 138). Var. Angun Point.

Named for the Eskimo village of Angun, which is believed to have been located on this point.

Angun River: stream, flows NE $30 \mathrm{mi}$. to Angun Lagoon W of Angun Point, $34 \mathrm{mi}$. NW of Demarcation Point, Arctic Plain; $69^{\circ} 56^{\prime} \mathrm{N}$, $142^{\circ} 24^{\prime}$ W; BGN 1962; (map 138). Var. Angnun River

See Angun Point.

Angun River: stream, see Aichilik River.

Angutikada Peak: peak, 4,130 ft., in Lockwood Hills, $25 \mathrm{mi}$. SE of Shungnak, Hogatza High.; $66^{\circ} 39^{\prime} \mathrm{N}, 156^{\circ} 30^{\prime} \mathrm{W}$; (map 115). Var. Ounalima.

Eskimo name reported in 1901 by Mendenhall (1902, map), USGS. Lt. G. M. Stoney, USN, placed a station on this peak which he called "Ounalima."

Anguvik Island: island, $1,000 \mathrm{ft}$. long, on E coast of Alaska Penin. in Chignik Bay, $11 \mathrm{mi}$. NE of Chignik, Aleutian Ra.; $56^{\circ} 26^{\prime} \mathrm{N}, 158^{\circ} 17^{\prime}$ W; (map 30). Var. Anguvik Islet, Ostrov Anyuvik.

Published in 1847 as "O[strov] Anguvik," or "Anguvik Island," on Russian Hydrog. Dept. Chart 1379.

Anguvik Islet: island, see Ankuvik Island.

Angyoyaravak Bay: bay, $8 \mathrm{mi}$. across, on coast of Bering Sea, at mouth of Kashunuk River, $18 \mathrm{mi}$. S of village of Hooper Bay, YukonKuskokwim Delta; $61^{\circ} 16^{\prime} \mathrm{N}, 1^{\circ} 5^{\circ} 44^{\prime} \mathrm{W}$; (map 75).

Eskimo name reported in 1951 by USG\&GS.

Angyuchaminri: mountains, see Angayucham Mountains.

Aniak: village, pop. 308, on S bank of Kuskokwim River at head of Aniak Slough, $59 \mathrm{mi}$. SW of Russian Mission, Yukon-Kuskokwim Delta; $61^{\circ} 34^{\prime} 40^{\prime \prime} \mathrm{N}, 159^{\circ} 31^{\prime} 45^{\prime \prime} \mathrm{W}$; BGN 1944; (map 134). Var. Aniyak.

Founded about 1910 when a trading store was located here to supply the mining operations at the heads of Tuluksak and Aniak Rivers. A post office was established in 1914 (Ricks, 1965, p. 4).

Aniakchak: locality, "on Alaska Penin." Former Eskimo camp or settlement reported in 1925 by USGS as "occupied only by a trapper's cabin."

Aniakchak Bay: bay, $8 \mathrm{mi}$. wide, faces ESE from mouth of Aniakchak River, on $\mathbf{S}$ shore of Alaska Penin., $8 \mathrm{mi}$. SW of Cape Kunmik,
Aleutian Ra.; 56 $42^{\prime} \mathrm{N}, 157^{\circ} 22^{\prime}$ W; (map 31). Var. Baie Amah-chack, Zaliv Aniakshak. Shown as "Baie Amah-chack" by Adm. von Krusenstern (1827, map 20), IRN. The Russian Hydrog. Dept. shows this native name as "Zal[iv] Aniakshak" in 1847 on Chart 1379; "Aniakchak Bay" appears on an 1890 USBF chart.

Aniakchak Crater: crater, $6 \mathrm{mi}$. in diameter, on Alaska Penin., $41 \mathrm{mi}$. NNE of Chignik, Aleutian Ra.; $56^{\circ} 53^{\prime} \mathrm{N}, 158^{\circ} 09^{\prime} \mathrm{W}$; (map 30). Var. Vent Mountain.

Discovered and named in 1922 by R. H. Sargent and W. R. Smith, USGS; name probably derived from Aniakchak Bay.

Aniakchak River: stream, on Alaska Penin., heads in Surprise Lake, in Aniakchak Crater, flows SE $27 \mathrm{mi}$. to Aniakchak Bay, $11.5 \mathrm{mi}$. W of Cape Kunmik, Aleutian Ra.; $56^{\circ} 46^{\prime} \mathrm{N}$, $157^{\circ} 30^{\prime} \mathrm{W}$; (map 31).

Local name reported by $W$. R. Smith and A. A. Baker (1924, p. 155), USGS. They referred to the river as "the largest stream on the [Alaska] peninsula flowing toward the $\mathrm{Pa}$ cific Ocean."

Aniak Lake: lake, $3.5 \mathrm{mi}$. long, on Aniak River, $90 \mathrm{mi}$. SE of Bethel, $8 \mathrm{mi}$. W of Nishlik Lake, Kilbuck-Kuskokwim Mts.; $60^{\circ} 28^{\prime} \mathrm{N}, 159^{\circ}$ $10^{\prime} \mathrm{W}$; (map 59 ).

Local name reported in 1955 by $\mathrm{J}$. M. Hoare, USGS

Aniak River: stream, heads at $60^{\circ} 21^{\prime} \mathrm{N}, 159^{\circ}$ 13' W, flows N 95 mi. to Kuskokwim River, $1 \mathrm{mi}$. E of Aniak, Yukon-Kuskokwim Delta; $61^{\circ} 34^{\prime} 40^{\prime \prime} \mathrm{N}, 159^{\circ} 29^{\prime} 10^{\prime \prime} \mathrm{W}$; BGN 1947; (map 73). Var. Anjak River, Reka Aniak, Reka Anniak, Anyaguk River.

Eskimo name reported in 1842-44 as "R[eka] Aniak" and "R[eka] Anniak" by Lt. L. A. Zagoskin, IRN. On his 1898 fieldsheet W. S. Post, USGS, recorded "Anyaguk River." Aniakshak Zaliv: bay, see Aniakchak Bay.

Aniak Slough: watercourse, anabranch of Kuskokwim River, heads at Aniak and flows W 16 mi.; Yukon-Kuskokwim Delta; 61 ' $34^{\prime} 15^{\prime \prime}$ $\mathrm{N}, 159^{\circ} 33^{\prime} 10^{\prime \prime} \mathrm{W}$; (map 73)

Local name reported in 1942 by USGS.

Aniakvik Creek: stream, flows W $8.5 \mathrm{mi}$. to Killik River $9.4 \mathrm{mi}$. N of junc. of Easter Creek, Brooks Ra.; $68^{\circ} 16^{\prime} \mathrm{N}, 154^{\circ} 03^{\prime} \mathrm{W}$; (map 133).

Eskimo name meaning "place where one goes out"; obtained at Anaktuvuk Pass in 1956 by Orth.

Anian, Strets de: water passage, see Bering Strait.

Anigulgit: snowfield, see Aneegulgit.

Anihitsk: locality, see Onihitsk.

Anikovik River: stream, heads in York Mts., flows SW $11 \mathrm{mi}$. to Bering Sea, $41 \mathrm{mi}$. NW of Teller, Seward Penin. High.; $65^{\circ} 30^{\prime}$ N, $167^{\circ}$. 41' W; (map 111). Var. Anakovik River, Onokoruk River, Onokovuk River, Up-nut, Youp-nut.

Eskimo name reported in 1900 as "Anakovik" by Brooks (1901, pl. 13 and p. 134), USGS. Schrader and Brooks in 1900 (map 3) spelled the name "Onokovuk," and in the same year USC\&GS showed "Onokuruk" on Chart 9380.

Aniktum Island: island, $3.5 \mathrm{mi}$. long, between Kokechik Bay and Bering Sea, $3 \mathrm{mi}$. S of Cape Romanzof, Yukon-Kuskokwim Delta; $61^{\circ} 46^{\prime} \mathrm{N}, 166^{\circ} 08^{\prime} \mathrm{W}$; (map 75).

Eskimo name obtained at Hooper Bay; reported in 1951 by USC\&GS.

Aniluk: locality, see Atnuk.

Anilukhlukh-kat: village, see Holy Cross.

Anilukhtak-kak: village, see Holy Cross.

Anilukhtakpak: village, see Holy Cross.

Anilyak: island, see Atniliak Island.

Animak: island, see Atniliak Island.

Animak Island: island, see Deer Island.

Än'ìm-äl'gerā: lake, see Seal Lake.

Animas, Point: point of land, on NW coast of San Fernando I., Alex. Arch.; $55^{\circ} 32^{\prime} \mathrm{N}, 133^{\circ}$. 27' W; (map 4). Var. Punta Animas, Punta de las Animas.

Spanish name given in $1775-79$ by Don Juan de la Bodega y Quadra and Francisco Antonio Maurelle as "Punta Animas," meaning "point of souls."

Animas Island: islands, two, extend $750 \mathrm{ft}$., on NW coast of San Fernando I., Alex. Arch.; $55^{\circ} 32^{\prime} 20^{\prime \prime} \mathrm{N}, 133^{\circ} 27^{\prime} 30^{\prime \prime} \mathrm{W}$; (map 4). Var. Isla Animas, Ysla de las Animas.

Spanish name given in $1775-79$ by Don Juan de la Bodega y Quadra and Francisco Antonio Maurelle as "Isla Animas," meaning "island of souls."

Animatchoutchkok: point of land, see Tachilni, Cape.

Animok Island: island, see Deer Island.

Anipaunorovik: settlement, see Owl Village.

Anirak, Lake: lake, $1.5 \mathrm{mi}$. across, in Ambler Lowland, $20 \mathrm{mi}$. N of Shungnak, Brooks Ra.; $67^{\circ} 11^{\prime} \mathrm{N}, 157^{\circ} 11^{\prime} \mathrm{W}$; (map 126).

Eskimo name meaning "place to go out"; obtained at Shungnak in 1956 by Orth.

Aniralik Lake: lake, $2 \mathrm{mi}$. long, $6 \mathrm{mi}$. NE of junc. of Noatak and Nimiuktuk Rivers, Brooks Ra.; $68^{\circ} 12^{\prime} \mathrm{N}, 159^{\circ} 50^{\prime} \mathrm{W}$; (map 131).

Eskimo name obtained at Noatak in 1956 by Orth.

Anisak River: stream, heads in De Long Mts. at $68^{\circ} 36^{\prime} \mathrm{N}, 159^{\circ} 11^{\prime} \mathrm{W}$, flows $\mathrm{SE} 60 \mathrm{mi}$. to Noatak River, $54 \mathrm{mi}$. WSW of Howard Pass, Brooks Ra.; $68^{\circ} 02^{\prime} \mathrm{N}, 1^{\circ} 8^{\circ} 57^{\prime} \mathrm{W}$; BGN 1960; (map 132). Var. Abala River.

Eskimo name reported to mean "place to go out or pass route" [anizrak]; obtained at Noatak in 1956 by Orth.

Anisom Point: point of land, on Kenai Penin., $\mathrm{N}$ point of entrance to Eldred Passage, on SE shore of Kachemak Bay, $8 \mathrm{mi}$. SE of Homer, Chugach Mts.; $59^{\circ} 32^{\prime} \mathrm{N}, 151^{\circ} 27^{\prime} \mathrm{W}$; (map 50).

Local name published by USGS in 1961 . This point probably derived its name from an Eskimo named Anisim [sic], who had a cabin in the area. Reported by de Laguna (1934, p. 20), BAE.

Anita Bay: bay, extends SW $6.5 \mathrm{mi}$. off Zimovia Strait, on NE coast of Etolin I., Alex. Arch.; $56^{\circ} 14^{\prime} \mathrm{N}, 132^{\circ} 23^{\prime} \mathrm{W}$; (map 6). 
Named in 1886 by Lt. Comdr. A. S. Snow, USN; published in 1887 on USC\&GS Chart 706.

Anita Creek: stream, flows NW $1.4 \mathrm{mi}$. to Salmon River, $25 \mathrm{mi}$. NE of Cape Newenham, Kilbuck-Kuskokwim Mts. ; 58 54 $00^{\prime \prime} \mathrm{N}, 161^{\circ}$ $43^{\prime} 30^{\prime \prime}$ W; BGN 1940; (map 39).

Local name reported in 1938 by USGS.

Anita Creek: stream, flows E $1.8 \mathrm{mi}$. to Kougarok River $17 \mathrm{mi}$. N of its junc. with Kuzitrin River, $45 \mathrm{mi}$. SW of Imuruk Lake, Seward Penin. High.; $65^{\circ} 29^{\prime} \mathrm{N}, 164^{\circ} 43^{\prime} \mathrm{W}$; (map 110). Var. Oneita Creek.

Prospectors' name reported in 1900 by Brooks (1901, pl. 11), USGS.

Anita Creek: stream, see Premier Creek.

Anita Gulch: ravine, trends SE $0.6 \mathrm{mi}$. to Osborn Creek, $11 \mathrm{mi}$. NE of Nome, Seward Penin. High.; $64^{\circ} 34^{\prime} 25^{\prime \prime} \mathrm{N}, 165^{\circ} 06^{\prime} 00^{\prime \prime} \mathrm{W}$; (map 94).

Prospectors' name shown on the 1902 "Map of the Nome and Snake River Country" by J. M. Davidson.

Anita Point: point of land, $\mathrm{S}$ entrance to Anita Bay, on NE coast of Etolin I., Alex. Arch.; 56 ${ }^{\circ}-$ $13^{\prime} 30^{\prime \prime} \mathrm{N}, 132^{\circ} 22^{\prime} 00^{\prime \prime} \mathrm{W}$; BGN 1923; (map 6).

Named in 1923 by USC\&GS.

Aniuk: village, "on the upper Noatak river, northwestern Alaska. Latitude $68^{\circ}$, longitude $157^{\circ} . "$

"Visited by Howard of Stoney's expedition in spring, 1886, and written An-e-yuk" (Baker, 1906, p. 101).

Aniuk River: stream, heads on $\mathrm{S}$ slope of Kavaksurak Mtn., flows SW 45 mi. to Noatak River, Brooks Ra.; 67 $59^{\prime} \mathrm{N}, 157^{\circ} 56^{\prime} \mathrm{W}$; (map 132).

Eskimo name recorded on a 1910 fieldsheet by C. E. Giffin; probably related in origin to a local Eskimo village called "An-eyuk," reported by Ens. Howard (In Stoney, 1900 , p. 67), USN. The name may mean "he goes out" or "he passes," referring to the trail through the mountains at Howard Pass.

Anivik Creek: stream, flows NW $3.5 \mathrm{mi}$., from $\mathrm{N}$ side of Napaktualuit Mtn. to Anaktuvuk River $7 \mathrm{mi}$. NE of Anaktuvuk Pass, Brooks Ra.; $68^{\circ} 13^{\prime} 00^{\prime \prime} \mathrm{N}, 151^{\circ} 34^{\prime} 30^{\prime \prime} \mathrm{W}$; (map 134). Var. Ahnevik Creek.

Eskimo name, meaning "village place," published by Rausch (1951, p. 150).

Anivik Lake: lake, $0.8 \mathrm{mi}$. long, at NW base of Napaktualuit Mtn., 6 mi. NE of Anaktuvuk Pass, Brooks Ra.; $68^{\circ} 11^{\prime} 30^{\prime \prime} \mathrm{N}, 151^{\circ} 34^{\prime} 00^{\prime \prime}$ W; (map 134).

Eskimo name obtained at Anaktuvuk Pass in 1956 by T. E. Taylor, USGS.

Aniyaaq: locality, see Aniyak.

Aniyak: locality, on $\mathbf{N}$ shore of Kotzebue Sound at mouth of Tukrok River, Kotzebue-Kobuk Low.; 67 $04^{\prime} \mathrm{N}, 163^{\circ} 18^{\prime} \mathrm{W}$; (map 128). Var. Ahneeyahk, Aneyok, Aniyaaq, Aniyakh, Anlyak, Anyok.

Former Eskimo village recorded as "Aniyakh," population 25 , in the 10th Census, in 1880. Visited and reported in 1898 as "Anyok," by Lt. D. H. Jarvis, USRCS. The name is said to mean "place where one goes out," referring to the river mouth.

Aniyak: village, see Aniak.

Aniyuyaktuvik Creek: stream, flows SW $3.5 \mathrm{mi}$., between Angmakrok and Kayaksak Mts. to Kukpuk River, $15 \mathrm{mi}$. NE of Cape Thompson, Arctic Slope; $68^{\circ} 16^{\prime} 35^{\prime \prime} \mathrm{N}, 165^{\circ} 30^{\prime} 15^{\prime \prime} \mathrm{W}$ BGN 1963; (map 129.) Var. Ahneéyouyahktuvik Creek, Aneeaktovik Creek, Aneeaxtovik Creek.

Eskimo name reported in 1962 by W. O. Pruitt, Univ, of Alaska, as "Ahneéyouyahktuvik," meaning "place where wind has hardened snow so that a snow house can be built."

Anjak River: stream, śee Aniak River.

Ankachagamuk: locality, see Ankachak.

Ankachak: locality, on right bank of Yukon River near Pilot Station; (map 73). Var. Anakachagamuk, Ankahchagmiut, Ankatchagmiout, Ankatschagmiut, Ankochagamut, Kenunimik.

Former Eskimo camp or village reported as "Ankatchag-miout," i.e. "Ankachak people," by Lt. L. A. Zagoskin, IRN, on an 1850 map. This may be the same place reported in 1902 as "Kenunimik" by USC\&GS. The 11 th Census, in 1890, listed it as "Ankahchagmiut" with a population of 103 .

Ankahchagmiut: locality, see Ankachak.

Ankatchag-miout: locality, see Ankachak.

Ankatschagmiut: locality, see Ankachak.

Ankau, The: estuary, $0.6 \mathrm{mi}$. long, on $\mathrm{W}$ end of Phipps Penin., flows from Ankau Saltchucks E to Monti Bay, $2.6 \mathrm{mi}$. W of Yakutat, Malaspina Coastal Plain; 59 $32^{\prime} 50^{\prime \prime} \mathrm{N}, 139^{\circ} 48^{\prime} 20^{\prime \prime}$ W; BGN 1962; (map 46). Var. Ankau Creek, Ankau Inlet, Ankau River, Aukon, Estero del Ancau, Tawah.

Named "Estero del Ancau" by Capt. Alessandro Malaspina in 1791 after a Tlingit chief named Ancau (Galiano, 1802, map 8). According to Dixon $(1789$, p. 172) "Ancau" means "chief" or "friend." Marcus Baker reversed the two names "Tawah" and "Ankau" in his Geographic Dictionary.

Ankau Creek: estuary, see Ankau, The.

Ankau Creek: stream, see Tawah Creek.

Ankau Head: point of land, on S shore of Monti Bay, $1.4 \mathrm{mi}$. SE of Point Carrew and $2.7 \mathrm{mi}$. $W$ of Yakutat, Malaspina Coastal Plain; $59^{\circ}$. $32^{\prime} 45^{\prime \prime}$ N, $139^{\circ} 48^{\prime} 30^{\prime \prime}$ W; (map 46). Var. Punta Gorda.

Name derived from The Ankau and published by USC\&GS in 1898. Capt. Alessandro Malaspina, in 1791, called it "Punta Gorda," i.e. "massive point."

Ankau Inlet: estuary, see Ankau, The.

Ankau Inlet: stream, see Tawah Creek.

Ankau River: estuary, see Ankau, The.

Ankau River: stream, see Tawah Creek.

Ankau Saltchucks: tidal flats, $1.2 \mathrm{mi}$. across, on $\mathrm{W}$ end of Phipps Penin., $1 \mathrm{mi}$. $\mathrm{S}$ of Point Carrew and $3.4 \mathrm{mi}$. W of Yakutat, Malaspina Coastal Plain; $59^{\circ} 32^{\prime} 15^{\prime \prime} \mathrm{N}, 139^{\circ} 50^{\prime} 00^{\prime \prime} \mathrm{W}$; (map 46). Var. Ankau Inlet.

Name derived from The Ankau and published by USGS in 1959.

Ankitaktuk Creek: stream, see Kvichavak River.
Ankochagamut: locality, see Ankachak.

Ankorage Cove: cove, see Nunatak Cove.

Anlik: locality, "on shore of Golovnin Bay," Seward Penin. High; (map 95). Var. Anlygmjuten.

Former Eskimo camp or village reported in 1855 by H. J. Holmberg (Hodge, 1907, p. 58 ).

Anluk Creek: stream, heads at Ingriruk Hill, flows $\mathrm{N} 7 \mathrm{mi}$. to Bering Sea at Ahkitook, $12 \mathrm{mi}$. SW of Gape Etolin, on N coast of Nunivak I.; $60^{\circ} 23^{\prime} 00^{\prime \prime} \mathrm{N}, 166^{\circ} 29^{\prime} 30^{\prime \prime} \mathrm{W}$; (map 57).

Eskimo name reported in 1937 by USAAF. Anlygmjuten: locality, see Anlik.

Anman Creek: stream, heads in glacier, on $\mathbf{N}$ side of Chunekukleik Mtn., flows NE $2.2 \mathrm{mi}$. to Chilkat Lake, $23 \mathrm{mi}$. SW of Skagway, St. Elias Mts.; $59^{\circ} 19^{\prime} 40^{\prime \prime} \mathrm{N}, 135^{\circ} 54^{\prime} 15^{\prime \prime} \mathrm{W}$; (map 45).

Tlingit Indian name reported by Aurel and Arthur Krause (1883, map).

Anmer, Point: point of land, on $\mathrm{W}$ coast of Snettisham Penin., in Stephens Passage, $33 \mathrm{mi}$. SE of Juneau, Coast Mts.; $57^{\circ} 56^{\prime} 10^{\prime \prime} \mathrm{N}$, $50^{\circ} 00^{\prime} 50^{\prime \prime} \mathrm{W}$; (map 8).

Named by Capt. George Vancouver, RN, when it was discovered on August 12, 1794, by Lt. Joseph Whidbey, RN (Wagner, 1937, p. 373).

Anna, Lake: lake, $3 \mathrm{mi}$. long, $2.5 \mathrm{mi}$. SE of Chichagof, on W coast of Chichagof I., $49 \mathrm{mi}$. NW of Sitka, Alex. Arch.; $57^{\circ} 38^{\prime}$ N, 136 $06^{\circ}$ W; BGN 1908; (map 9).

Named in 1908 by Capt. E. F. Dickins USC\&GS, and published in 1910 on Chart 8250.

Annahootz Mountain: mountain, 4,301 ft., on north-central Baranof I., $16 \mathrm{mi}$. N of Sitka, Alex. Arch.; 57 $17^{\prime} 20^{\prime \prime} \mathrm{N}, 135^{\circ} 18^{\prime} 40^{\prime \prime} \mathrm{W}$; BGN 1929; (map 9).

Named in 1929 by USFS for Sitka Chief Annahootz, of the Kock-won-ton, a subtribe of the Tlingit Indians, who protected the white settlers from the Indians under Katlian, a rival chief. Annahootz was appointed policeman of an Indian village by Capt. L. A. Beardslee, USN, in 1880 , which office he held for many years.

Annette: village, pop. 337, on Annette I., 1 mi. NNE of Annette Island Airport on the W shore of Tamgas Harbor, Alex. Arch.; $55^{\circ}$. $03^{\prime} 45^{\prime \prime} \mathrm{N}, 131^{\circ} 32^{\prime} 30^{\prime \prime} \mathrm{W}$ (map 3).

This place was probably established during World War II; now home for Coast Guard, Weather Bureau, Federal Aviation Agency, and airline personnel and their families. The community has a school (Alaska Sportsman, 1962 , no. 12, p. 26$)$; it obtained a post office in 1947 (Ricks, 1965, p. 4)

Annette Bay: estuary, extends SE $3.8 \mathrm{mi}$., on N coast of Annette I., Alex. Arch.; 55 $16^{\prime} 45^{\prime \prime} \mathrm{N}$, $131^{\circ} 34^{\prime} 45^{\prime \prime} \mathrm{W}$; (map 3$)$.

Named in 1879 by W. H. Dall, USC\&GS; published in the 1883 Coast Pilot (p. 79).

Annette Island: island, $20 \mathrm{mi}$. long and $10 \mathrm{mi}$. wide, S of Revillagigedo I., Alex. Arch.; $55^{\circ} 09^{\prime} \mathrm{N}, 131^{\circ} 28^{\prime} \mathrm{W}$; (map 3 ).

Named in 1879 by W. H. Dall, USC\&GS, for his wife, Annette Whitney Dall. This 
island was reserved for the Tsimshian Indians by a Federal act on March 3, 1891.

Annette Point: point of land, SE tip of Annette I., Alex. Arch.; $55^{\circ} 00^{\prime} 45^{\prime \prime} \mathrm{N}, 131^{\circ} 23^{\prime} 00^{\prime \prime} \mathrm{W}$; (map 3).

Named in 1883 by Lt. Comdr. H. E. Nichols, USN.

Annex Creek: stream, flows $5 \mathrm{mi}$. SE to Taku Inlet, $0.4 \mathrm{mi}$. NE of Sunny Cove and $10 \mathrm{mi}$. E of Juneau, Coast Mts.; $58^{\circ} 18^{\prime} 45^{\prime \prime} \mathrm{N}, 134^{\circ} 06^{\prime}$ $15^{\prime \prime} \mathrm{W} ; B$ B 1930 ; (map 11).

Local name published by USGS in 1916 (Brooks, pl. 4). Name submitted by USFS in 1929 and approved by BGN in 1930 .

Annex Lakes: lakes, one $2 \mathrm{mi}$. long and other $0.4 \mathrm{mi}$. long, on Annex Creek, $0.8 \mathrm{mi}$. NW of Taku Inlet and $11 \mathrm{mi}$. $\mathrm{E}$ of Juneau, Coast Mts.; $58^{\circ} 19^{\prime} 15^{\prime \prime} \mathrm{N}, 134^{\circ} 07^{\prime} 05^{\prime \prime} \mathrm{W}$; $B G N$ 1930; (map 11).

Local name reported by USFS in 1923.

Annex Peak: peak, 4,170 ft., $3 \mathrm{mi}$. W of Scow Cove and $11 \mathrm{mi}$. NE of Juneau, Coast Mts.; $58^{\circ} 21^{\prime} 45^{\prime \prime} \mathrm{N}, 134^{\circ} 08^{\prime} 50^{\prime \prime} \mathrm{W}$; (map 11).

Local name reported in 1965 by D. A. Brew and A. B. Ford, USGS.

Annex Ridge: ridge, $2 \mathrm{mi}$. long, extends $\mathrm{W}$ from Annex Pass to Carlson Creek, $9 \mathrm{mi}$. NE of Juneau, Coast Mts. ; 58 $21^{\prime} 15^{\prime \prime} \mathrm{N}, 134^{\circ} 12^{\prime} 30^{\prime \prime}$ W; $(\operatorname{map} 11)$.

Local name reported in 1965 by D. A. Brew and A. B. Ford, USGS.

Anniak Reka: stream, see Aniak River.

Annie Lake: lake, $1.5 \mathrm{mi}$. long, $2.5 \mathrm{mi}$. NE of Beaver, Yukon Flats; $66^{\circ} 23^{\prime} 30^{\prime \prime} \mathrm{N}, 147^{\circ} 17^{\prime}$. $00^{\prime \prime} \mathrm{W}$; (map 118).

Local name obtained in 1956 by USGS.

Annin Glacier: glacier, $0.5 \mathrm{mi}$. long, $2 \mathrm{mi}$. NE of Mount Thomas and $13.5 \mathrm{mi}$. W of Valdez, Chugach Mts.; $61^{\circ} 06^{\prime} 35^{\prime \prime} \mathrm{N}, 146^{\circ} 40^{\prime} 30^{\prime \prime} \mathrm{W}$; (map 68).

Named in 1898 by Capt. W. R. Abercrombie, USA.

Anniok River: stream, see Aniak River.

An-nock-seck: stream, see Annoksek Creek.

Annoksek Creek: stream, in Glacier Bay National Monument, flows S $2.5 \mathrm{mi}$. to Murk Bay, on Gulf of Alaska, $49 \mathrm{mi}$. NW of Hoonah, St. Elias Mts.; $58^{\circ} 18^{\prime} 30^{\prime \prime} \mathrm{N}, 136^{\circ} 43^{\prime} 40^{\prime \prime} \mathrm{W}$; (map 10). Var. An-nock-seck.

Tlingit Indian name; reported in 1901 as "An-nock-seck" by Lt. Comdr. Moser (1902, p. 381) USN.

Annovokhamiut: locality, see Anovok.

Annoy Rock: rock, in Andreanof Is. between Tanaga and Kanaga Is., Aleutian Is. ; 51 ${ }^{\circ} 42^{\prime}$ $30^{\prime \prime} \mathrm{N}, 177^{\circ} 46^{\prime} 00^{\prime \prime} \mathrm{W}$; (map 17).

Name published by USC\&GS in the 1944 Aleutian Coast Pilot (p. 116).

Annugamok: locality, "near the Nushagak River," Bristol Bay Low. Var. Annugannok, Annuganok, Anookamok.

Former Eskimo camp or settlement listed as "Annugannok" with a population of 214 by Ivan Petroff in the 10th Census, in 1880 . Annugannok: locality, see Annugamok.

Annuganok: locality, see Annugamok.

Annuk: locality, see Atnuk.

Anoghta Island: island, see Amukta Island.
Anogogmute: locality, see Anogok.

Anogok: locality, on NW shore of Kuskokwim Bay, $12 \mathrm{mi}$. SE of Kinak Bay, $8 \mathrm{mi}$. S of Kipnuk, Yukon-Kuskokwim Delta; 59 $50^{\prime} \mathrm{N}$, $164^{\circ} 02^{\prime}$ W; BGN 1966; (map 54). Var. Anagok, Anogogmute.

Name of an Eskimo summer camp first reported as "Anogogmute," meaning "Anogok people," by E. W. Nelson (1882, map), U.S. Signal Service, who visited it in December 1878.

Anoikhat Rocks: rocks, see Ahnowiksat Rocks.

Anookamok: locality, see Annugamok.

Anook River: stream, see Anuk River.

Anorat Creek: stream, flows SW $10 \mathrm{mi}$. to Noatak River, $38 \mathrm{mi}$. SW of Survey Pass, Brooks Ra.; $67^{\circ} 40^{\prime} \mathrm{N}, 155^{\circ} 28^{\prime} \mathrm{W}$; (map 125).

Eskimo name [Anruak] reported to mean "amulet" or "charm;" recorded at Kobuk in 1956 by Orth.

Anotalurak Creek: stream, flows S $8 \mathrm{mi}$. to Wulik River, $20 \mathrm{mi}$. NE of Kivalina, Arctic Slope; $67^{\circ} 51^{\prime} \mathrm{N}, 163^{\circ} 52^{\prime} \mathrm{W}$; (map 128). Var. Ahnowtahlooram Koogowranga, Anautaaluuzam Kuugauzanga.

Eskimo name reported in 1966 by E. S. Burch.

Another River: stream, heads in lake, $1.7 \mathrm{mi} . \mathrm{N}$ of Merrill Pass, flows SE $13 \mathrm{mi}$. to Igitna River, $1 \mathrm{mi}$. NW of Kenibuna Lake and 63 mi. NW of Tyonek, Alaska Ra. ; 61 ${ }^{\circ} 11^{\prime} 15^{\prime \prime} \mathrm{N}$, $153^{\circ} 00^{\prime} 40^{\prime \prime} \mathrm{W}$; BGN 1930; (map 71).

So named by S. R. Capps and R. H. Sargent, USGS, in 1927, "because of the many new rivers discovered in this area."

Anotleneega Mountain: mountain, $2.356 \mathrm{ft}$., at head of Dulbi River, $2 \mathrm{mi}$. S of Hochandochtla Mtn. and $47 \mathrm{mi}$. NW of Birches, KokrinesHodzana High.; $65^{\circ} 30^{\prime} 10^{\prime \prime} \mathrm{N}, 154^{\circ} 55^{\prime} 30^{\prime \prime}$ W; (map 107).

Koyukan Indian name obtained at Huslia in 1956 by Orth.

Anovok: locality, "on a small river $\mathrm{N}$ of Kuskokwim Bay." Var. Annovokhamiut.

Former Eskimo camp or settlement listed as "Annovokhamiut" with a population of 15 in the 1890 Census.

Anowik Island: island, $1.5 \mathrm{mi}$. long, $2 \mathrm{mi}$. NE of $\mathrm{N}$ end of Chowiet I., in Semidi Is., in Pacific Ocean.; Aleutian Ra.; 56 $06^{\prime} \mathrm{N}, 156^{\circ} 40^{\prime} \mathrm{W}$; (Map 31).

Eskimo name published in 1888 by USBF. Ansley Island: island, $2.2 \mathrm{mi}$. long, off $\mathrm{N}$ shore of Icy Strait, $2.4 \mathrm{mi}$. NW of Point Couverden, at mouth of Lynn Canal and $25 \mathrm{mi}$. SW of Juneau, St. Elias Mts.; $58^{\circ} 12^{\prime} 30^{\prime \prime} \mathrm{N}, 135^{\circ} 07^{\prime}$ $10^{\prime \prime} \mathrm{W} ; B G N$ 1900; (map 11). Var. Astley Island.

Probably named by Comdr. R. W. Meade, USN, in 1868 and published on the first edition of Hydrog. Chart 225 as "Astley," but on subsequent charts as "Ansley." BGN established the latter spelling.

Answer Creek: stream, heads on Bald Mtn., flows SW $11.5 \mathrm{mi}$. to Question Creek, $8 \mathrm{mi}$. $S$ of Talkeetna, Cook Inlet Low.; 62 $12^{\prime} 10^{\prime \prime}$ $\mathrm{N}, 150^{\circ} 04^{\prime} 45^{\prime \prime} \mathrm{W}$; (map 81 ).
Local name shown on a 1917 blue print of The Alaska Railroad.

Antcgaltsu: locality, see Auke.

Antelope Creek: stream, flows S $0.5 \mathrm{mi}$. to Quartz Creek, $14 \mathrm{mi}$. SE of Long and $33 \mathrm{mi}$. SE of Ruby, Kilbuck-Kuskokwim Mts.; 64․ $17^{\prime} \mathrm{N}$, $155^{\circ} 07^{\prime} \mathrm{W}$; (map 98).

Prospectors' name reported in 1913 by Eakin (1914, pl. 3), USGS. The stream's exact lecation is in doubt.

Anthony Gulch: ravine, trends NE $1 \mathrm{mi}$. to Montana Creek, $50 \mathrm{mi}$. SW of Eagle, YukonTanana High.; $64^{\circ} 19^{\prime} \mathrm{N}, 142^{\circ} 22^{\prime} \mathrm{W}$; (map 102).

Prospectors' name shown on an 1898 manuscript map by C. A. Woodruff, Fort Cudahy, Canada.

Anthony Island: island, at head of Bartlett Cove on $\mathrm{E}$ side of entrance to Glacier Bay, St. Elias Mts.; $58^{\circ} 27^{\prime} 35^{\prime \prime} \mathrm{N}, 135^{\circ} 52^{\prime} 06^{\prime \prime} \mathrm{W}$; $B G N$ 1943; (map 11). Var. Terminal Island.

Named in 1939 by USC\&GS for Capt. Lester Anthony Beardslee, USN, who is supposed to have been the first to apply the name Glacier Bay.

Anthracite Ridge: ridge, elev. 6,000 ft., extends E $10 \mathrm{mi}$. from Boulder Creek, $\mathrm{N}$ of Glenn Highway, $35 \mathrm{mi}$. NE of Palmer, Talkeetna Mts. ; $61^{\circ} 50^{\prime} 45^{\prime \prime} \mathrm{N}, 148^{\circ} 04^{\prime} 00^{\prime \prime} \mathrm{W}$; (map 69). Local name reported in 1905 by G. C. Martin, USGS.

Antimony Creek: stream, flows NW $3.4 \mathrm{mi}$. to East Fork Chulitna River $0.7 \mathrm{mi}$. E of its mouth and $47 \mathrm{mi}$. SSW of McKinley Park, Alaska Ra.; $63^{\circ} 06^{\prime} 45^{\prime \prime} \mathrm{N}, 149^{\circ} 31^{\prime} 00^{\prime \prime} \mathrm{W}$; (map 87).

Prospectors' name obtained in 1913 by J. W. Bagley, USGS ; published by S. R. Capps (in Martin, 1919, pl. 5), USGS.

Antimony Creek: stream, flows NW $3 \mathrm{mi}$. to Tibbs Creek $6.7 \mathrm{mi}$. S of that stream's junc. with Goodpaster River and $50 \mathrm{mi}$. ENE of Big Delta, Yukon-Tanana High.; $64^{\circ} 22^{\prime} \mathrm{N}$, $144^{\circ} 16^{\prime} \mathrm{W}$; (map 101)

Named by prospectors; published in 1956 by USGS.

Antingmiut Creek: stream, flows NW $9 \mathrm{mi}$. to Dachirowruk Cove, $25 \mathrm{mi}$. SW of Cape Etolin, on Nunivak I.; $60^{\circ} 13^{\prime} 25^{\prime \prime} \mathrm{N}, 166^{\circ} 48^{\prime} 20^{\prime \prime} \mathrm{W}$; (map 57).

Eskimo name reported in 1937 by USAAF.

Antipatr Lake: lake, $0.7 \mathrm{mi}$. across, $18 \mathrm{mi}$. NW of village of Port Alexander, on $\mathrm{S}$ coast of Baranof I., Alex. Arch.; $56^{\circ} 29^{\prime} 30^{\prime \prime}$ N, $134^{\circ}$ $50^{\prime} 30^{\prime \prime}$ W; BGN 1933; (map 5).

Named in 1933 by USFS "for a son of Governor Baranof." See Baranof Island.

Antitonnie Creek: stream, on Iniskin Penin., flows W $1.5 \mathrm{mi}$. to Portage Creek, $2 \mathrm{mi}$. SE of Mount Eleanor, Aleutian Ra.; 59 $45^{\prime} 45^{\prime \prime} \mathrm{N}$, $153^{\circ} 19^{\prime} 00^{\prime \prime} \mathrm{W}$; BGN 1962; (map 51).

Local name published in 1958 by USGS. Antlen River: stream, flows S $6 \mathrm{mi}$. to Ahrnklin River, $7 \mathrm{mi}$. W of Harlequin Lake and $20 \mathrm{mi}$. SE of Yakutat, Malaspina Coastal Plain; $59^{\circ} 27^{\prime} 00^{\prime \prime} \mathrm{N}, 139^{\circ} 12^{\prime} 00^{\prime \prime} \mathrm{W}$; (map 46). Var. Aantlen River, Ahrn-Klin River, Arn Klane, Reka Antlen. 
A Tlingit Indian name reported as " $R$ [eka] Aantlen," or "Antlen River," by Capt. Tebenkov (1852, map 7), IRN, who applied the name to the entire length of what is now the Ahrnklin River. Called "Arn Klane" by E. J. Glave in 1890; "Ahrn-Klin" by Lt. Comdr. Moser (1902, pl. 43), USN.

Antlen River: stream, see Ahrnklin River.

Antler Creek: stream, on N coast of Umnak I., heads on Okmok Volcano, flows NE $7.5 \mathrm{mi}$. to Bering Sea, Aleutian Is.; $53^{\circ} 31^{\prime} 30^{\prime \prime} \mathrm{N}, 167^{\circ}$. $56^{\prime} 00^{\prime \prime} \mathrm{W}$; (map 23).

Published by Byers (1959, pl. 41), USGS.

Antler Creek: stream, in Nutzotin Mts., flows E $9 \mathrm{mi}$. to Stuver Creek, $13 \mathrm{mi}$. NE of Cooper Pass, Alaska Ra.; $62^{\circ} 22^{\prime} \mathrm{N}, 142^{\circ} 11^{\prime} \mathrm{W}$; $B G N$ 1941; (map 84).

Name proposed in 1940 by P. S. Smith, USGS, because a pair of interlocked moose antlers was found near this stream.

Antler Creek: stream, flows NE 2 mi. to Nenana River, $6 \mathrm{mi}$. $\mathbf{N}$ of village of McKinley Park, Alaska Ra.; $63^{\circ} 49^{\prime} 08^{\prime \prime} \mathrm{N}, 148^{\circ} 57^{\prime} 30^{\prime \prime} \mathrm{W}$; $B G N 1965$; (map 87).

Named in 1965 by Alaska Dept. of Highways because "moose antlers are found in the area." See Iceworm Gulch.

Antler Creek: stream, flows SW 2 mi. to Tributary Creek which flows to Big Hurrah Creek, $9 \mathrm{mi}$. NE of Solomon, Seward Penin. High.; $64^{\circ} 39^{\prime} \mathrm{N}, 164^{\circ} 12^{\prime} \mathrm{W}$; (map 95).

Prospectors' name shown on Arthur Gibson's "Map of Cape Nome Precinct" dated 1904.

Antler Glacier: glacier, heads at $58^{\circ} 41^{\prime} \mathrm{N}$, $134^{\circ} 35^{\prime} \mathrm{W}$, trends W $3.5 \mathrm{mi}$. to its 1948 terminus on lake at head of Antler River, 11 $\mathrm{mi}$. E of Berners Bay and $33 \mathrm{mi}$. NW of Juneau, Coast Mts.; $58^{\circ} 50^{\prime} 45^{\prime \prime} \mathrm{N}, 134^{\circ} 40^{\prime} 45^{\prime \prime}$ W; $(\operatorname{map} 11)$.

Name derived from the river of the same name and published by USGS in 1960 .

Antler Lake: lake, $0.8 \mathrm{mi}$. long, on Kenai Penin. $\mathrm{N}$ of Buteo Lake, $33 \mathrm{mi}$. NE of Kenai, Cook Inlet Low.; $60^{\circ} 45^{\prime} 45^{\prime \prime} \mathrm{N}, 150^{\circ} 24^{\prime} 00^{\prime \prime} \mathrm{W}$; (map 62).

Named about 1963 by officials of Kenai National Moose Range, for administrative purposes.

Antler Peaks: peaks, on a ridge, trend NW-SE $2 \mathrm{mi}$., $6 \mathrm{mi}$. N of Twin Glacier Lake, $30 \mathrm{mi}$. $\mathrm{NE}$ of Juneau, Coast Mts.; $58^{\circ} 38^{\prime} 00^{\prime \prime} \mathrm{N}, 133^{\circ}$ $52^{\prime} 00^{\prime \prime} \mathrm{W}$; BGN 1965; (map 12).

Local name reported in 1960 by USGS

Antler Point: point of land, SW of Fort Glenn, on NE coast of Umnak I., Aleutian Is. ; $53^{\circ}$ $21^{\prime} 30^{\prime \prime} \mathrm{N}, 167^{\circ} 54^{\prime} 15^{\prime \prime} \mathrm{W}$; (map 23).

Reported in 1942 by U.S. Army Corps of Engineers.

Antler River: stream, heads in lake at 1962 terminus of Antler Glacier and flows SW $11 \mathrm{mi}$. to Berners Bay, $40 \mathrm{mi}$. NW of Juneau, Coast Mts.; $58^{\circ} 48^{\prime} 30^{\prime \prime} \mathrm{N}, 134^{\circ} 57^{\prime} 30^{\prime \prime} \mathrm{W}$; $B G N$ 1930 ; (map 11).

Name published in 1924 by USC\&GS on Chart 8302.

Antler Valley Creek: stream, flows NW $7 \mathrm{mi}$. to Anaktuvuk River, $7.5 \mathrm{mi}$. SW of Table Top and $32 \mathrm{mi}$. NE of Anaktuvuk Pass, Arctic Slope; $68^{\circ} 33^{\prime} 40^{\prime \prime} \mathrm{N}, 151^{\circ} 17^{\prime} 30^{\prime \prime} \mathrm{W}$; (map 134)

Named by R. E. Fellows, USGS, about 1945. Antone Lake: lake, see Antones Lake.

Antones Lake: lake, on SW coast of Saint Paul $\mathrm{I}$, in Pribilof Is.; $57^{\circ} 09^{\prime} 10^{\prime \prime} \mathrm{N}, 170^{\circ} 20^{\prime} 40^{\prime \prime}$ W; (map 38), Var. Antone Lake.

Local name reported in 1891 by Joseph Stanley-Brown, USGS.

Anton Larsen Bay: bay, extends $54 \mathrm{mi}$. off Kizhuyak Bay, $10 \mathrm{mi}$. NW of Kodiak, Kodiak I. ; $57^{\circ} 52^{\prime} \mathrm{N}, 152^{\circ} 38^{\prime} \mathrm{W}$; BGN 1939; (map 34). Var. Anton Larson Bay.

Named in 1933 by USC\&GS "for the Norwegian, Anton Larsen."

Anton Larson Bay: bay, see Anton Larsen Bay. Antoski Creek: stream, flows E $6.3 \mathrm{mi}$. to Sulatna River, $12 \mathrm{mi}$. NE of Sulatna Crossing and 18 mi. SW of Monzonite Hills, Kilbuck-Kuskokwim Mts. ; 64 $14^{\prime} \mathrm{N}, 155^{\circ} 04^{\prime} \mathrm{W}$; (map 98).

Prospectors' name reported in 1913 by Eakin (1914, pl. 3), USGS.

Änŭckäsēl'ogh: lake, N of Ulakaia Hill, on eastcentral Saint George I., in Pribilof Is.; $56^{\circ}$ $35^{\prime} 15^{\prime \prime} \mathrm{N}, 169^{\circ} 34^{\prime} 35^{\prime \prime} \mathrm{W}$; (map 38). Var. Anukasilokh.

Aleut name reported by Putnam (1903, p. 1014), USC\&GS

Anugamuk: locality, on left bank of Togiak River, $5 \mathrm{mi}$. S of Togiak Lake and $68 \mathrm{mi}$. NE of Goodnews, Kilbuck-Kuskokwim Mts. $59^{\circ} 29^{\prime} \mathrm{N}, 159^{\circ} 46^{\prime} \mathrm{W}$; (map 53).

Name of an Eskimo village or camp reported by Ivan Petroff in the 10th Census, in 1880. An Indian camp was marked at this location on an 1898 fieldsheet by W. S. Post, USGS. The place is no longer occupied.

Anugnak: locality, on left bank of Wood River, $7 \mathrm{mi}$. N of Dillingham, Bristol Bay Low, ; $59^{\circ}$. $08^{\prime} \mathrm{N}, 158^{\circ} 30^{\prime} \mathrm{W}$; (map 52). Var. Anagnak, Anaknak.

Former Eskimo village recorded as "Anaknak," population 87 , by Ivan Petroff in the 10th Census, in 1880.

Anukasilokh: lake, see Anuckasel'ogh.

Anuk Creek: stream, flows NE $16 \mathrm{mi}$. to Kuna River, $15 \mathrm{mi}$. ESE of Liberator Lake, Brooks Ra.; $68^{\circ} 49^{\prime} 30^{\prime \prime} \mathrm{N}, 1^{\circ} 7^{\circ} 45^{\prime} 00^{\prime \prime} \mathrm{W}$; (map 132)

Probably from the Eskimo word "anaq," meaning "dung" or "excrement"; reported in 1950 by USGS geologists. See Anak Creek.

Anuk River: stream, "heads near Alaska-Canada boundary, flows $W$ to Stikine River at $S$ end of Frederick Sound." Var. Anook River.

Name published in 1888 by USC\&GS on Chart 8200.

Anuk River: stream, flows W $12 \mathrm{mi}$. to Yukon River, $37 \mathrm{mi}$. SW of Kwiguk, Yukon-Kuskokwim Delta; $62^{\circ} 19^{\prime} \mathrm{N}, 163^{\circ} 51^{\prime} \mathrm{W}$; (map 77).

Eskimo name obtained in 1899 by G. R. Putnam, USC\&GS; published in 1901 on Chart 9370.

Anukturuk River: stream, see Anaktuvuk River. Anuzukanuk Pass: watercourse, $6.5 \mathrm{mi}$. long, in Yukon Delta, $5 \mathrm{mi}$. W of Kwiguk, Yukon-
Kuskokwim Delta; $62^{\circ} 45^{\prime} \mathrm{N}, 164^{\circ} 40^{\prime} \mathrm{W}$; (map 77). Var. Ah-nu-zuk-a-nuk Pass.

Eskimo name obtained in 1948 by USC\&GS. Anvaniek River: stream, see Ongivinuck River. Anvanyk, Reka: stream, see Ongivinuck River. Anvic: village, see Anvik.

Anvick: village, see Anvik.

Anvig: village, see Anvik.

Anvig, Reka: stream, see Anvik River.

Anvik: village, pop. 120, on right bank of Yukon River at mouth of Anvik River, $34 \mathrm{mi}$. N of Holy Cross, Nulato Hills; $62^{\circ} 39^{\prime} 15^{\prime \prime} \mathrm{N}, 160^{\circ}$ $12^{\prime} 30^{\prime \prime} \mathrm{W}$; (map 78). Var. American Station, Anvic, Anvick, Anvig, Anwig.

Ingalik Indian village where Andreï Glazanov found several hundred people when he visited there in January 1834. Recorded by the Russians as "Anvig" or "Anvik." A post office, first called "Anvick," was established here in 1897.

Anvik Mountains: mountains, trend N-S about $80 \mathrm{mi}$., at $S$ end of Nulato Hills.

So shown by Ivan Petroff in the 10th Census, in 1880 .

Anvik River: stream, heads at $63^{\circ} 39^{\prime} \mathrm{N}, 160^{\circ} 08^{\prime}$ W, flows SE $140 \mathrm{mi}$. to Yukon River, $1.5 \mathrm{mi}$ $\mathrm{N}$ of Anvik and $36 \mathrm{mi}$. N of Holy Cross, Nulato Hills; $62^{\circ} 41^{\prime} \mathrm{N}, 160^{\circ} 12^{\prime} \mathrm{W}$; (map 78). Var. Reka Anvig.

Andreï Glazanov traveled down this stream in January 1834 ; written in $1842-44$ by Lt. $\mathrm{L}$. A. Zagoskin, IRN, as "R[eka] Anvig."

Anvik River: stream, see Ynveeghik River.

Anvil Bay: bay, in Lake Nerka, $\mathbf{N}$ of Frog Mts., $38 \mathrm{mi}$. NW of Dillingham, Kilbuck-Kuskokwim Mts.; $59^{\circ} 34^{\prime} \mathrm{N}, 1^{\circ} 8^{\circ} 48^{\prime} \mathrm{W}$; $B G N 1931$; (map 52).

Local name; published in 1929 by USBF.

Anvil City: town, see Nome.

Anvil Creek: stream, $6 \mathrm{mi}$. long, flows NW to Quicksilver Creek, $7 \mathrm{mi}$. SE of Mount Romig and $74 \mathrm{mi}$. SE of Bethel, Kilbuck-Kuskokwim Mts. ; $60^{\circ} 31^{\prime} 30^{\prime \prime} \mathrm{N}, 159^{\circ} 39^{\prime} 00^{\prime \prime} \mathrm{W}$; (map $59)$.

Local name reported in 1955 by J. M. Hoare, USGS.

Anvil Greek: stream, flows NE $1.8 \mathrm{mi}$. to Innoko River, $0.8 \mathrm{mi}$. SE of Ophir and $31 \mathrm{mi}$. NW of McGrath, Kilbuck-Kuskokwim Mts.; $63^{\circ} 08^{\prime}$ N, $156^{\circ} 30^{\prime} \mathrm{W} ; B G N 1936$; (map 90).

Prospectors' name obtained in 1933 by J. B. Mertie, Jr. (in Smith, P. S., 1936, pl. 4), USGS.

Anvil Creek: stream, flows SW $7 \mathrm{mi}$. to Little Creek, $2.5 \mathrm{mi}$. NW of Nome, Seward Penin. High. $\left\{64^{\circ} 32^{\prime} \mathrm{N}, 165^{\circ} 29^{\prime} \mathrm{W}\right.$; (map 94).

Prospectors' name reported in 1899 by D. C. Witherspoon (in Schrader and Brooks, 1900, map 2), USGS. A rock at summit of Anvil Mountain, near head of this stream, is shaped like an anvil

Anvil Creek: stream, flows NW $10 \mathrm{mi}$. to Clums Fork Birch Creek, $54 \mathrm{mi}$. SW of Circle, YukonTanana High.; $65^{\circ} 14^{\prime} \mathrm{N}, 145^{\circ} 17^{\prime} \mathrm{W}$; (map 104).

Named by prospectors and reported in 1911 by USGS (Prindle, 1913, pl. 1). 
Anvil Creek: stream, flows $\mathbf{N}$ to Cripple River, about $24 \mathrm{mi}$. NW of Imuruk Lake, Seward Penin. High.; (map 110).

Prospectors' name reported on a precinct map of Seward Peninsula by Monroe and Hutchins corrected to June 1903 by Arthur Gibson. This stream cannot be precisely located on current maps.

Anvil Head: mountain, see Anvil Mountain.

Anvil Lakes: lakes, $\mathrm{N}$ of Vega Point, on $\mathrm{S}$ tip of Kiska I., Aleutian Is.; $51^{\circ} 50^{\prime} 15^{\prime \prime} \mathrm{N}, 177^{\circ}$ $18^{\prime} 30^{\prime \prime}$ E.; (map 14).

An arbitrary name beginning with " $\mathrm{A}$ " to correspond to "A" grid used by the U.S. Army for tactical purposes during World War II; published by AMS in 1953.

Anvil Mountain: mountain, 1,530 ft., $20 \mathrm{mi}$. SW of Karluk, on W coast of Kodiak I.; 57 $17^{\prime}$ $15^{\prime \prime} \mathrm{N}, 154^{\circ} 35^{\prime} 20^{\prime \prime} \mathrm{W}$; (map 35).

Local name published in 1943 by USC\&GS.

Anvil Mountain: mountain, 1,800 ft., on Annette I., $1.5 \mathrm{mi}$. SW of Walden Point, Alex. Arch.; $55^{\circ} 00^{\prime} 18^{\prime \prime} \mathrm{N}, 131^{\circ} 34^{\prime} 10^{\prime \prime} \mathrm{W}$; (map 3). Var. Anvil Head.

Descriptive name given in 1883 by Lt. Comdr. H. E. Nichols, USN. Because of its promontory-like appearance, it was called "Anvil Head" in the 1883 Coast Pilot (p. 80).

Anvil Mountain: mountain, $1,134 \mathrm{ft} ., 4 \mathrm{mi}$. N of Nome, Seward Penin. High.; 64 $34^{\prime} \mathrm{N}$, $165^{\circ} 22^{\prime}$ W; (map 94). Var. Anvil Peak.

Local descriptive name reported in 1899 by D. G. Witherspoon (in Schrader and Brooks, 1900, map 2), USGS. So named because of anvil-shaped rock formation on mountain's flank.

Anvil Peak: volcano, 4,007 ft., on Semisopochnoi I., Rat Is., Aleutian Is.; $51^{\circ} 59^{\prime} 20^{\prime \prime}$ N, $179^{\circ}$ $35^{\prime} 15^{\prime \prime}$ E; BGN 1952; (map 15).

Name published in 1951 on a USGS map. "So called because of the flat area north of the summit."

Anvil Peak: mountain, see Anvil Mountain.

Anvil Peak: mountain, see King Mountain.

Anwig: village, see Anvik.

Anxiety Point: point of land, $\mathrm{E}$ tip and highest point of Howe I., in Sagavanirktok River Delta, Arctic Plain; $70^{\circ} 18^{\prime} 55^{\prime \prime} \mathrm{N}, 147^{\circ} 57^{\prime} 25^{\prime \prime}$ W; (map 150). Var. Point Anxiety.

Named "Point Anxiety" August 16, 1826, by Sir John Franklin (1828, p. 158); described as "the point we had so often attempted to reach."

Anyaguk River: stream, see Aniak River.

Anyaka Island: island, $1.3 \mathrm{mi}$. long, in Chilkat Is. in Lynn Canal, $1.5 \mathrm{mi}$. SSE of Seduction Point and 27 mi. S of Skagway, Coast Mts.; $59^{\circ} 03^{\prime} 15^{\prime \prime} \mathrm{N}, 135^{\circ} 16^{\prime} 45^{\prime \prime} \mathrm{W}$; (map 45). Var. Schikossean.

Tlingit Indian name reported in 1922 by IBC. Arthur and Aurel Krause (1883, map) reported another Indian name, "Schikossean."

Any Creek: stream, flows NW $2.5 \mathrm{mi}$. to Our Creek, $13 \mathrm{mi}$. NW of Fairbanks, Yukon-Tanana High.; $65^{\circ} 00^{\prime} 55^{\prime \prime} \mathrm{N}, 147^{\circ} 52^{\prime} 45^{\prime \prime} \mathrm{W}$; (map 105).

Named by prospectors; published in 1908 by USGS.
Anyok: locality, see Aniyak.

Anzac Creek: stream, flows SE $3.5 \mathrm{mi}$. to Peace River, $13 \mathrm{mi}$. N of Haycock, Seward Penin. High.; $65^{\circ} 23^{\prime} \mathrm{N}, 161^{\circ} 02^{\prime} \mathrm{W}$; (map 109). Var. Farmer Creek.

Prospectors' name reported in 1917 by G. L. Harrington, USGS.

Anzac Creek: stream, see Boulder Creek.

Apahiachak: locality, "in the Kuskokwim district." Var. Apahiachamiut.

Former Eskimo camp or village listed as "Apahiachamiut," i.e. "Apahiach people," with a population of 91 in the 1890 Census. See Hodge (1907, p. 67).

Apahiachamiut: locality, see Apahiachak.

Apakshau Slough: watercourse, in Yukon Delta, flows E $2.7 \mathrm{mi}$. to Apoon Pass, $1.4 \mathrm{mi}$. NE of Pieneluk I. and $30 \mathrm{mi}$. NE of Kwiguk, YukonKuskokwim Delta; 63 $02^{\prime} \mathrm{N}, 163^{\circ} 45^{\prime} \mathrm{W}$; (map 92).

Eskimo name obtained in 1899 by R. L. Faris, USC\&GS; published in 1901 on Chart 9372.

Apapak, Cape: point of land, see Upapak Point. Apapok Cape: point of land, see Upapak Point. Apatiki Camp: locality, on Taphook Point on $\mathrm{N}$ coast of St. Lawrence I., $19 \mathrm{mi}$. SE of Gambel; $63^{\circ} 37^{\prime} \mathrm{N}, 171^{\circ} 15^{\prime} \mathrm{W}$; BGN 1951; (map 93). Var. Taphook, Tapok Camp, Tapphook. Named for an Eskimo family at Gambell, which frequently camps on this point. The Eskimo name "Taphook" is derived from "taphak," meaning "barrier bar."

Apavawook Cape: point of land, on S part of the barrier reef forming Kiloknak Lagoon, 12 mi. SW of Northeast Cape, on $E$ coast of Saint Lawrence I.; $63^{\circ} 08^{\prime} \mathrm{N}, 168^{\circ} 53^{\prime} \mathrm{W}$; $B G N$ 1951; (map 93). Var. Apavwook Cape, Appavawooka, Appavawook Cape, East Cape.

Eskimo name reported in 1948 by USC\&GS.

Apavwook Cape: point of land, see Apavawook Cape.

Ape Point: point of land, E point of entrance to Alava Bay, on SE coast of Revillagigedo I., Alex. Arch.; $55^{\circ} 14^{\prime} 00^{\prime \prime} \mathrm{N}, 131^{\circ} 06^{\prime} 10^{\prime \prime} \mathrm{W}$; (map 3). Var. Cone Island Point.

Named in 1891 by USC\&GS; published as "Cone Island Point" on Brit. Adm. Chart 2431.

Apex El Nido: locality, "on W shore of Lisianski Inlet, Chichagof I., at mouth of Cann Creek."

Former mining camp and mail stop named for the Apex lode mine discovered in 1919. According to R. N. DeArmond the camp was active from 1920 to about 1941 .

Apex Mountain: mountain, 3,200 ft., on Chichagof $1 ., 3 \mathrm{mi}$. SW of Pelican, $28 \mathrm{mi}$. SW of Hoonah, Alex. Arch.; 57 ${ }^{\circ} 56^{\prime} 20^{\prime \prime} \mathrm{N}, 136^{\circ} 18^{\prime}-$ $30^{\prime \prime} \mathrm{W} ; B G N 1960$; (map 9).

Named in 1955 by USGS; published by D. L. Rossman (1959b, map). It is named for the Apex Mine on northern flank of the mountain.

Aphoknak Island: island, see Afognak Island.

Aphoon: locality, see Apoon.

Aphoon Mouth: stream mouth, see Apoon Mouth.
Aphoon Pass: stream, see Apoon Pass.

Aphrewn River: stream, distributary of Kashunuk River, heads at $61^{\circ} 24^{\prime} \mathrm{N}, 165^{\circ} 11^{\prime} \mathrm{W}$, flows S $25 \mathrm{mi}$. to Hazen Bay, Yukon-Kuskokwim Delta; $61^{\circ} 10^{\prime} \mathrm{N}, 165^{\circ} 18^{\prime} \mathrm{W}$; (map 75). Var. Afroon River, Afrun River, Aphroon River.

Eskimo name; reported in 1919 by R. H. Sargent, USGS.

Aphroon River: stream, see Aphrewn River.

Apiktalluk: locality, see Opiktulik.

Apikuguruak Creek: stream, flows N and E 15 mi. to Ivisaruk River, $21 \mathrm{mi}$. S. of Wainwright, Arctic Plain; $70^{\circ} 20^{\prime} 25^{\prime \prime} \mathrm{N}, 160^{\circ} 06^{\prime}$ $40^{\prime \prime} \mathrm{W}$; (map 146). Var. Apkogarek Creek.

Eskimo name transcribed in 1956 by Orth; reported by the people at Wainwright to mean "many berries."

Apkhun, Reka: stream, see Apoon Pass.

Apkogarek Creek: stream, see Apikuguruak Creek.

Apodaca, Bocas de: bays, entrances of Moira and Cholmondeley Sounds on east coast of Prince of Wales I., Alex. Arch.

Named by Lt. Don Jacinto Caamaño who saw them July 23, 1792, when in the middle of Clarence Strait. "Sebastian Ruiz de Apodaca was one of the most eminent naval officers of Spain of the day; later he was Viceroy of New Spain" (Wagner, 1937, p. 427).

Apoga River: stream, see Apokak Slough.

Apokachamute: locality, see Apokak.

Apokagamut: locality, see Apokak.

Apokagamute: locality, see Apokak.

Apokak: locality, at mouth of Apokak Slough, on Eek Channel of Kuskokwim River, $48 \mathrm{mi}$. SW of Bethel, Yukon-Kuskokwim Delta; $60^{\circ} 08^{\prime} \mathrm{N}, 162^{\circ} 12^{\prime} \mathrm{W}$; (map 58). Var. Ahpokagamiut, Apokagamut, Apokagamute.

Eskimo name for village obtained in December 1878 by E. W. Nelson, U.S. Signal Service, and listed in the 10th Census, in 1880 , as "Apokagamute," i.e. "Apokak people," with 94 people. The 1890 Census listed it as "Ahpokagamiut" with 210 people USC\&GS reported in 1949 that "the village has been abandoned for many years. Two dilapidated cabins remain."

Apokak Slough: stream, flows SW $8 \mathrm{mi}$. to Eek Channel of Kuskokwim River at Apokak, 48 mi. SW of Bethel, Yukon-Kuskokwim Delta; $60^{\circ} 08^{\prime}$ N, $162^{\circ} 12^{\prime} \mathrm{W}$; (map 58). Var. Apoga River, Apoka River, Apokok Creek.

Eskimo name shown on an 1898 fieldsheet by W. S. Post, USGS, as "Apoga River"; obtained from J. H. Kilbuck, Moravian missionary.

Apoka River: stream, see Apokak Slough.

Apokok Creek: stream, see Apokak Slough.

Apollo: locality, on Acheredin Bay, on $\mathrm{S}$ coast of Unga I., in Shumagin Is., Aleutian Ra.; $55^{\circ} 12^{\prime} \mathrm{N}, 160^{\circ} 44^{\prime} \mathrm{W}$; (map 28).

A post office was maintained here from February 1899 to November 1906, possibly in connection with the Apollo Mine on Delarof Harbor, eight miles to the east. 
Apollo Mountain: mountain, 1,630 ft., on S part of Unga I., in Shumagin Is., Aleutian Ra.; $55^{\circ} 11^{\prime} 20^{\prime \prime} \mathrm{N}, 160^{\circ} 36^{\prime} 30^{\prime \prime} \mathrm{W}$; (map 28).

Named for the Apollo Mine, two miles east, at head of Delarof Harbor; reported in 1908 by W. W. Atwood, USGS; published in 1917 on USC\&GS Chart 8700.

Apoon: locality, on Apoon Pass, a distributary of Yukon River, S of Pastol Bay, about $50 \mathrm{mi}$. SW of Saint Michael, Yukon-Kuskokwim Delta; $63^{\circ} 02^{\prime} \mathrm{N}, 163^{\circ} 20^{\prime} \mathrm{W}$; (map 92). $V$ ar. Aphoon.

Small Eskimo settlement or camp and trading post mentioned by Hodge (1907, p. 70) . The Eskimo name "Aphoon" is reported to mean "thumb," which refers to the position of the locality on the Yukon River Delta. See Apoon Pass.

Apoon Mountain: mountain, 7,020 ft., $3 \mathrm{mi}$. N of Harvey Mtn. and $35 \mathrm{mi}$. N of Wiseman, Brooks Ra.; $67^{\circ} 54^{\prime} 30^{\prime \prime} \mathrm{N}, 150^{\circ} 17^{\prime} 00^{\prime \prime} \mathrm{W}$; BGN 1932; (map 124).

Eskimo word meaning "snow" (apun); given in 1931 by Marshall (1956, p. 74).

Apoon Mouth: stream mouth, in Yukon Delta, at $S$ end of Pastol Bay at mouth of Apoon Pass, 41 mi. NE of Kwiguk, Yukon-Kuskokwim

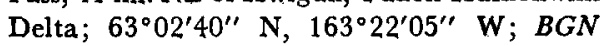
1901; (map 92). Var. Abkun Mouth, Aphoon Mouth, Aproon Mouth, Uphoon Mouth.

Eskimo name published by Capt. Tebenkov (1852, map 2), IRN. See Apoon Pass.

Apoon Pass: stream, water passage in Yukon Delta, flows NE $30 \mathrm{mi}$. from Kwikpak Pass to Pastol Bay, $41 \mathrm{mi}$. NE of Kwiguk, YukonKuskokwim Delta; $63^{\circ} 03^{\prime} \mathrm{N}, 163^{\circ} 22^{\prime} \mathrm{W}$; $B G N$ 1901; (map 92). Var. Abkun Pass, Aphoon Pass, Aproon Pass, Protoka Abkhun, Reka Apkhun, Uphoon Pass.

Eskimo name published by Capt. Tebenkov (1852, map 2), IRN, as "Prot[oka] Abkhun," or "Abkhun Watercourse." According to William Hamilton, U.S. Bureau of Education, "The natives compared the delta of the Yukon with its mouths to a human hand and have given the name 'Aphoon' (thumb) to its northernmost channel" (Baker, 1906, p. 103).

Apostle Matthei, Island: island, see Saint Matthew Island.

Apostol Andrenika, Ostrov: island, see Andronica Island.

Appavawook: locality, on S coast of Saint Lawrence $I$., at $W$ end of Kiloknak Lagoon, $12 \mathrm{mi}$. SW of Northeast Cape; $63^{\circ} 10^{\prime} \mathrm{N}, 168^{\circ} 57^{\prime} \mathrm{W}$; (map 93).

Eskimo name reported in 1932 by Otto W. Geist, Univ, of Alaska.

Appavawooka: point of land, see Apavawook Cape.

Appavawook Cape: point of land, see Apavawook Cape.

Appel Mountain: mountain, 1,569 ft., $25 \mathrm{mi}$. SW of Medfra, Kilbuck-Kuskokwim Mts.; $63^{\circ} 01^{\prime} \mathrm{N}, 155^{\circ} 30^{\prime} \mathrm{W}$; (map 89). Var. Apple Mountain.
Local name reported in 1910 as "Apple Mountain" by A. G. Maddren, USGS, and shown as "Appel Mountain" by J. B. Mertie, Jr. (in Smith, P. S., and others, 1936, pl. 4), USGS.

Applegate Cove: bay, $4.5 \mathrm{mi}$. across, $5 \mathrm{mi}$. WNW of village of Cold Bay, at SW end of Alaska Penin., Bristol Bay Low.; 55 $13^{\prime}$ N, $162^{\circ} 52^{\prime}$ W; BGN 1965; (map 29).

Named in 1888 by USBF for Samuel Applegate, USC\&GS, who commanded the schooner Nellie Juan during a survey of this area in the 1880's.

Applegate Cove: bight, $2.5 \mathrm{mi}$. across, on $\mathrm{N}$ coast of Chuginadak I., Aleutian Is.; 52 ${ }^{\circ} 1^{\prime}$ $30^{\prime \prime} \mathrm{N}, 169^{\circ} 53^{\prime} 00^{\prime \prime} \mathrm{W}$; (map 21 ).

Published in 1943 on USC\&GS Chart 8802; named for Samuel Applegate, USC\&GS, who commanded the schooner Nellie Juan during a survey of this area in the 1880's.

Applegate Creek: stream, flows SW $12 \mathrm{mi}$. to Hutlinana Creek, $62 \mathrm{mi}$. E of Tanana, YukonTanana High.; $65^{\circ} 11^{\prime} \mathrm{N}, 150^{\circ} 01^{\prime} \mathrm{W}$; (map 106).

Prospectors' name reported in 1906 by USGS.

Applegate Glacier: glacier, on E side of Kenai Penin., trends NW $1 \mathrm{mi}$. to its terminus $1.5 \mathrm{mi}$. E of Kings Point, $23 \mathrm{mi}$. S of Whittier, Chugach Mts.; $60^{\circ} 27^{\prime} 45^{\prime \prime} \mathrm{N}, 148^{\circ} 36^{\prime} 50^{\prime \prime} \mathrm{W}$; $B G N 1911$; (map 63).

Named in 1908 by U. S. Grant, USGS, for Samuel Applegate who explored the region in the schooner Nellie Juan.

Applegate Island: island, $0.7 \mathrm{mi}$. across, off S tip of Culross I., in NE end of Port Nellie Juan, $22 \mathrm{mi}$. SE of Whittier, Chugach Mts.; $60^{\circ} 37^{\prime} 30^{\prime \prime} \mathrm{N}, 148^{\circ} 09^{\prime} 00^{\prime \prime} \mathrm{W}$; $B G N$ 1910; (map 63).

Named in 1910 by USGS for Samuel Applegate who discovered and mapped Port Nellie Juan in 1887. His report, "The third or Unalaska district," appears in the 1890 Census (1893, p. 81 to 90$)$.

Applegate Rock: rock, in Prince William Sound, between Seal I. and Green I., $24 \mathrm{mi}$. NE of Chenega, Chugach Mts.; $60^{\circ} 21^{\prime} 20^{\prime \prime} \mathrm{N}, 147^{\circ}$. 23'30' W; (map 63).

Local name published on recent USGS maps. Probably named for Samuel Applegate who explored the area in 1887.

Apple Islands: islands, $0.5 \mathrm{mi}$. across, in Sitka Sound, $3 \mathrm{mi}$. NW of Sitka, Alex. Arch.; $57^{\circ} 04^{\prime} 00^{\prime \prime} \mathrm{N}, 135^{\circ} 24^{\prime} 30^{\prime \prime} \mathrm{W}$; BGN 1901; (map 9). Var. Iablosh Island, Middle Island, Sredni Island.

Named in Russian "O[strova] Sryednyye," meaning "middle islands," in 1890 by Ivan Vasiliev the first, IRN. They were called "Os[trova] Yabloshnyye," meaning "apple islands," in 1848 by the Russian Hydrog. Dept. on Chart 1397.

Apple Islands: islands, see Kasiana Islands.

Apple Mountain: mountain, see Appel Mountain.

Appleton Cove: cove, 1 mi. across, in Rodman Bay, on Baranof I., 29 mi. N of Sitka, Alex. Arch.; $57^{\circ} 28^{\prime} 30^{\prime \prime} \mathrm{N}, 135^{\circ} 16^{\prime} 30^{\prime \prime} \mathrm{W}$; (map $9)$.
Named in 1895 by Lt. Comdr. E. K. Moore, USN, "for W. G. Appleton, a member of his party."

Applevun Lake: lake, 2 mi. long, oxbow $\mathrm{S}$ of Black River, $34 \mathrm{mi}$. NE of Fort Yukon, Yukon Flats; $66^{\circ} 38^{\prime} 30^{\prime \prime} \mathrm{N}, 144^{\circ} 02^{\prime} 00^{\prime \prime} \mathrm{W}$; (map 119).

Kutchin Indian name obtained in 1956 by T. E. Taylor, USGS.

Appoknak Island: island, see Afognak Island.

Approach Hill: hill, $500 \mathrm{ft}$., $4.5 \mathrm{mi}$. E of Fairbanks, Tanana Low.; $64^{\circ} 50^{\prime} 15^{\prime \prime} \mathrm{N}, 147^{\circ}$. $34^{\prime} 00^{\prime \prime}$ W; (map 100).

Locally named because the hill is in the line of approach for airplanes to an airfield; the name was published on a 1955 USGS map.

Approach Point: point of land, E tip of Grindall I., between Glarence Strait and Kasaan Bay, Alex. Arch.; $55^{\circ} 26^{\prime} 30^{\prime \prime} \mathrm{N}, 132^{\circ} 06^{\prime} 30^{\prime \prime} \mathrm{W}$; (map 4).

Named by local fishermen and reported in 1904 by H. C. Fassett, USBF.

April Creek: stream, heads at Kutuk Pass, flows NW $20 \mathrm{mi}$. to Killik River $11 \mathrm{mi}$. SW of its junc. with Easter Creek, Brooks Ra.; $68^{\circ} 02^{\prime} \mathrm{N}, 154^{\circ} 30^{\prime} \mathrm{W}$; BGN 1925; (map 133).

So named by the 1924 USGS expedition, because they descended this stream in April; shown on fieldsheet by Gerald FitzGerald.

April Inlet: cove, $200 \mathrm{yds}$. across, SW coast of Kiska I. on W shore of Spring Cove, $3.3 \mathrm{mi}$. NW of Vega Point, Aleutian Is.; 51 ${ }^{\circ} 51^{\prime} 43^{\prime \prime}$ $N, 177^{\circ} 15^{\prime} 45^{\prime} \mathrm{E}$; (map 14).

One of many arbitrary names applied to features on Kiska Island by USAAF for tactical purposes during World War II.

Aproka Pass: watercourse, in distributary system of Yukon River, trends $\mathrm{N} 15 \mathrm{mi}$. from Kwikluak Pass to Kwikpak Pass, $12 \mathrm{mi}$. NE of Kwiguk, Yukon-Kuskokwim Delta; $62^{\circ} 53^{\prime}$ $\mathrm{N}, 164^{\circ} 07^{\prime} \mathrm{W}$; (map 77). Var. Apruka.

Eskimo name meaning "little trail (or passage)," written "ăprūkă" by R. L. Faris, USC\&GS, in 1899.

Aproon Mouth: stream mouth, see Apoon Mouth.

Aproon Pass: stream, see Apoon Pass.

Aprothluk River: stream, flows SE $18 \mathrm{mi}$. to Hazen Bay, Yukon-Kuskokwim Delta; $61^{\circ}$. $08^{\prime} \mathrm{N}, 165^{\circ} 21^{\prime} \mathrm{W}$; (map 75).

Eskimo name; reported in 1951 by USC\&GS.

Apruka: watercourse, see Aproka Pass.

Apthorp Port: bay, see Althorp, Port.

Aqalugzaam Kuunga: locality, see Akalugrak Panga.

Aqituk: locality, see Ahkitook.

Aquada Cove: bight, see Aguada Cove.

Aquadulce Creek: stream, heads in a glacier, flows NW 4 mi. to Disenchantment Bay, 1,2 mi. NE of Point Latouche and $26 \mathrm{mi}$. NE of Yakutat, St. Elias Mts.; $59^{\circ} 54^{\prime} 30^{\prime \prime} \mathrm{N}, 139^{\circ}$ $35^{\prime} 20^{\prime \prime} \mathrm{W}$; (map 46).

Local name published in 1959 by USGS. Aquadulce is a Spanish word referring to the 
clearness of the water. Many glacial streams are turbid or milky.

Aqueda Point: point of land, see Agueda Point. Araga, Mount: mountain, see Kingak Mountain. Aragon, Entrada de: bay, see Lituya Bay.

Arastra Creek: stream, tributary of Mendenhall River, about $10 \mathrm{mi}$. NW of Juneau, Coast Mts.; $58^{\circ} 23^{\prime} \mathrm{N}, 134^{\circ} 35^{\prime} \mathrm{W}$; (map 11).

Local name used because a group of miners built an arastra (arrastra) near the creek about 1890 (DeArmond, 1957, p. 32). An "arrastra" is a rude drag-stone mill for crushing ore. Arathlatuluk, Mount: mountain, 2,995 ft., in Darby Mts., $10 \mathrm{mi}$. NE of Mount Kachauik and $58 \mathrm{mi}$. NE of Solomon, Seward Penin. High.; $64^{\circ} 49^{\prime} \mathrm{N}, 162^{\circ} 33^{\prime} \mathrm{W}$; (map 95).

Local name published in 1956 by USGS.

Arathlatuluk Creek: stream, see Rathlatulik River.

Arboleda, Point: point of land, NW tip of Sue-

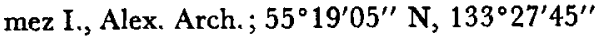
W; (map 4). Var. Mys Arboleda, Punta Arboleda, Punta de Arboleda.

Name given by Francisco Antonio Maurelle as "Punta de Arboleda," meaning "wooded point," on or "about June 5, 1779" (Wagner, 1937, p. 373).

Arboles Island: island, in Portillo Channel, on E coast of Lulu I., Alex. Arch.; $55^{\circ} 29^{\prime} 20^{\prime \prime} \mathrm{N}$, $133^{\circ} 25^{\prime} 45^{\prime \prime} \mathrm{W}$; (map 4). Var. Ysla de los Arboles.

Name given in $1775-79$ by Don Juan de la Bodega y Quadra and Francisco Antonio Maurelle as "Ysla de los Arboles," meaning "island of the trees."

Arbor Island: island, $5 \mathrm{mi}$. long, between Wilson Creek Slough and Yukon River, $\mathbf{S}$ of Marshall, Yukon-Kuskokwim Delta; $61^{\circ} 51^{\prime} \mathrm{N}, 162^{\circ} 04^{\prime}$ W; (map 74). Var. Poltes Island.

Riverboat pilots' name from a manuscript chart of the Yukon River dated 1899.

Arcada Rock: rock, $200 \mathrm{ft}$. long, on W coast of Baker I., S of Outer Point, Alex. Arch.; $55^{\circ} 22^{\prime} 15^{\prime \prime} \mathrm{N}, 133^{\circ} 40^{\prime} 20^{\prime \prime} \mathrm{W}$; BGN 1923; (map 4).

Spanish name meaning "arcade lor row of arches];" given in 1923 by USC\&GS.

Arcadio, Punta de: point of land, see Hinchinbrook, Cape.

Arcana Creek: stream, heads on Marsh Mtn., flows $\mathrm{S} 5 \mathrm{mi}$. to Wood River, $13 \mathrm{mi}$. N of Dillingham, Bristol Bay Low.; $59^{\circ} 14^{\prime} \mathrm{N}, 158^{\circ} 32^{\prime}$ W; (map 52).

Name used in 1910 by H. C. Fassett, USBF.

Archangel Creek: stream, flows SE $3.8 \mathrm{mi}$. to Little Susitna River, $13 \mathrm{mi}$. NW of Palmer, Talkeetna Mts.; $61^{\circ} 46^{\prime} 50^{\prime \prime} \mathrm{N}, 149^{\circ} 11^{\prime} 10^{\prime \prime} \mathrm{W}$; (map 69).

Local name reported in 1913 by USGS (in Brooks and others, 1914, pl. 2).

Archangel Gabriel, Fort: locality, see Fort Saint Michael.

Archangel Michael: locality, see Fort Saint Michael.

Archdeacons Tower: peak, 19,650 ft. in Mount McKinley National Park, at head of Harper Glacier, $0.5 \mathrm{mi}$. NW of summit of Mount
McKinley, Alaska Ra.; $63^{\circ} 04^{\prime} 30^{\prime \prime} \mathrm{N}, 151^{\circ}$ $01^{\prime} 00^{\prime \prime} \mathrm{W}$; $B G N 1947$; (map 88).

Named in 1942 by the U.S. Army Alaskan Test Expedition, for Hudson Stuck, 18631920, Archdeacon of the Yukon, who with Henry Karstens, Walter Harper, and Robert Tatum made the first ascent of Mount McKinley (South Peak) June 7, 1913.

Archer: stream, see Tonsina.

Archimandritof Islands: islands, see Geese Islands.

Archimandritoff Rocks: shoal, see Archimandritof Shoals.

Archimandritof Shoals: shoal, SW of Home Spit, in Kachemak Bay, on Kenai Penin., 4 mi. $\mathrm{SE}$ of Homer, Gook Inlet Low.; 59 $36^{\prime} \mathrm{N}$, $151^{\circ} 27^{\prime} \mathrm{W}$; (map 50). Var. Archimandritoff Rocks.

Named in 1880 by W. H. Dall, USC\&GS, for Capt. Archimandritov of the Russian American Co.

Archimedes Ridge: ridge, extends $30 \mathrm{mi}$. between Kokolik and Utukok Rivers, Arctic Slope $69^{\circ} 10^{\prime} 30^{\prime \prime} \mathrm{N}, 161^{\circ} 16^{\prime} 30^{\prime \prime} \mathrm{W}$; (map 144).

So named by USGS geologists in 1947 because the ridge "gives the impression on vertical photographs of an Archimedes screw owing to the effect of snow and shadows" (Chapman and Sable, 1960, p. 52).

Arch Point: point of land, $2 \mathrm{mi}$. SW of Promontory Hill, on the S coast of Unimak 1., Aleutian Is.; $54^{\circ} 24^{\prime} 30^{\prime \prime} \mathrm{N}, 164^{\circ} 33^{\prime} 45^{\prime \prime} \mathrm{W}$; (map 24).

So named in 1901 by Ferdinand Westdahl, USC\&GS, because the point consists of "A rocky projection, 40 feet high, with an arch through the extremity of the point."

Arch Point: point of land, $\mathrm{N}$ point of entrance to Volcano Bay, $3 \mathrm{mi}$. N of Dolgoi I., Alaska Penin., Aleutian Ra.; 55 $12^{\prime} 30^{\prime \prime}$ N, 161 ${ }^{\circ} 54^{\prime}$ 20" W; (map 28). Var. Bear Cape.

Published by USC\&GS in 1916 Coast Pilot (v. 2, p. 183); shown as "Bear Cape" on an 1890 USBF chart.

Arch Rock: rock, on $\mathrm{N}$ coast of Unalaska $\mathrm{I}$. between Captains and Unalaska Bays, $1.8 \mathrm{mi}$. W of Unalaska, Aleutian Is.; $53^{\circ} 52^{\prime} 40^{\prime \prime} \mathrm{N}$, $166^{\circ} 33^{\prime} 50^{\prime \prime} \mathrm{W}$; (map 23).

Descriptive name given in 1871 by $W . H$. Dall, USC\&GS. Baker (1906, p. 104) incorrectly located this rock near Amaknak I., $0.5 \mathrm{mi}$. to the east.

Arch Rock: rock, in Popoff Strait near Sand Point on $W$ coast of Popof $I$., in Shumagin Is., Aleutian Ra.; $55^{\circ} 19^{\prime} \mathrm{N}, 160^{\circ} 31^{\prime} \mathrm{W}$; (map 28).

Descriptive name given by $W . H$. Dall in 1871, and published on USC\&GS Chart 814. Arch Rock: rock, at Gore Point, on S coast of Kenai Penin., $32 \mathrm{mi}$. SE of Seldovia, Chugach Mts.; $59^{\circ} 12^{\prime} 00^{\prime \prime} \mathrm{N}, 150^{\circ} 57^{\prime} 30^{\prime \prime} \mathrm{W}$; (map $50)$.

Local name published in 1939 on USC\&GS Ghart 8530

Archuelinguk River: stream, heads at $62^{\circ} 23^{\prime} \mathrm{N}$, $163^{\circ} 14^{\prime} \mathrm{W}$, flows SW $35 \mathrm{mi}$. to Yukon River, $51 \mathrm{mi}$. SE of Kwiguk, Yukon-Kuskokwim Delta ; $62^{\circ} 07^{\prime} \mathrm{N}, 163^{\circ} 48^{\prime} \mathrm{W}$; (map 77).
Eskimo name reported in 1952 by U.S. Army Corps of Engineers. It appears to be the same name as "Atchuelinguk [River]."

Arc Mountain: mountain, 2,600 ft., $7 \mathrm{mi}$. SE of the confluence of May Creek and Nanushuk River, $14 \mathrm{mi}$. E of Table Top and $47 \mathrm{mi}$. NE of Anaktuvuk Pass, Arctic Slope; 68 $39^{\prime} \mathrm{N}$, $150^{\circ} 30^{\prime} \mathrm{W}$; (map 134).

Named by USGS geologists during the exploration of Naval Petroleum Reserve No. 4; name given in 1944 .

Arctic: village, see Arctic Village.

Arctic Circle Hot Springs: settlement, see Circle Hot Springs.

Arctic City: locality, site of Indian village, on right bank of Koyukuk River, opposite mouth of Kanuti River; $66^{\circ} 27^{\prime} \mathrm{N}, 153^{\circ} 00^{\prime} \mathrm{W}$; (map 117). Var. Moses Village.

This was once one of the largest Koyukun Indian villages on the river. It was named "Moses Village" for the Indian chief "Moses" by prospectors about 1897. Archdeacon Stuck (1917, p. 328) wrote: "a road-house and a store turned it from 'Moses Village' to 'Arctic City' when the mail trail from Tanana reached the Koyukuk at that point, but store and road-house and Indian are alike gone some twelve miles up [to Allakaket]."

Arctic Creek: stream, flows SW $5 \mathrm{mi}$. to Cripple River, $13 \mathrm{mi}$. NW of Nome, Seward Penin. High.; 64 $36^{\prime} \mathrm{N}, 165^{\circ} 49^{\prime} \mathrm{W}$; (map 94). Var. Artic Creek.

Prospectors' name reported in 1899 by D. C. Witherspoon (in Schrader and Brooks, 1900, map 2), USGS.

Arctic Creek: stream, flows E $6 \mathrm{mi}$., then SW $11 \mathrm{mi}$., to Agiapuk River, $14 \mathrm{mi}$. N of Teller, Seward Penin. High.; $65^{\circ} 27^{\prime} \mathrm{N}, 166^{\circ} 24^{\prime} \mathrm{W}$; (map 111).

Prospectors' name reported on a map of Cape Nome goldfields by David Fox, Jr., dated 1901

Arctic Creek: stream, flows SW $2.6 \mathrm{mi}$. to Kougarok River, $12 \mathrm{mi}$. SW of Midnight Mtn. and $46 \mathrm{mi}$. W of Imuruk Lake, Seward Penin. High.; $65^{\circ} 38^{\prime} \mathrm{N}, 164^{\circ} 47^{\prime} \mathrm{W}$; (map 110). Var. Goldrun Greek.

Prospectors' name reported on the 1908 "Map of Seward Peninsula" by Arthur Gibson. This appears to be the stream shown as "Goldrun Creek" by T. G. Gerdine (in Collier, 1902, pl. 12), USGS

Arctic Creek: stream, flows N $9 \mathrm{mi}$. to Sadlerochit River, between Kingak Cliff and Kingak Hill, 22 mi. N of Mount Michelson, Brooks Ra.; $69^{\circ} 37^{\prime} \mathrm{N}, 144^{\circ} 27^{\prime} \mathrm{W}$; (map 139). Var. Arctic River.

Named in the 1950's by USGS geologists.

Arctic Creek: stream, "eastern Alaska, on south bank of Seventymile creek, near Arctic Dome and tributary to Flume creek, about latitude $64^{\circ} 55^{\prime}$, longitude $142^{\circ} 40^{\prime}$."

"Prospectors' name from sketch map compiled by Major Glassford, Signal Corps, U.S.A., 1905" (Baker, 1906, p. 104).

Arctic Dome: mountain, 5,335 ft., $12 \mathrm{mi}$. SE of Mount Sorenson and $43 \mathrm{mi}$. NW of Eagle, 
Yukon-Tanana High.; 64 ${ }^{\circ} 55^{\prime} \mathrm{N}, 142^{\circ} 36^{\prime} \mathrm{W}$; (map 102).

Prospectors' name obtained in 1905 by D. C. Witherspoon, USGS.

Arctic Gulch: ravine, tributary to Gold Creek, $2 \mathrm{mi}$. W of Juneau, Coast Mts.; $58^{\circ} 18^{\prime} \mathrm{N}$, $134^{\circ} 20^{\prime} \mathrm{W}$; (map 11).

Miners' name for a gulch subsequently destroyed by mining operations (DeArmond, 1957 , p. 22).

Arctic Island: island, $1 \mathrm{mi}$. long, in Yukon River SW of Johnson I., $4.4 \mathrm{mi}$. N of Russian Mission, Yukon-Kuskokwim Delta; 61 ${ }^{\circ} 1^{\prime} 25^{\prime \prime}$ $\mathrm{N}, 161^{\circ} 19^{\prime} 10^{\prime \prime} \mathrm{W}$; (map 73).

Named about 1900 by pilots, for the riverboat Arctic, which wintered several times in Kako Creek, behind the island (Curtin, 1938 , p. 278). Recorded on a 1916 fieldsheet by R. H. Sargent, USGS.

Arctic Lagoon: lagoon, on Chukchi Sea coast, $37 \mathrm{mi}$. SW of Shishmaref Inlet, KotzebueKobuk Low.; $66^{\circ} 12^{\prime} \mathrm{N}, 166^{\circ} 09^{\prime} \mathrm{W}$; (map 112).

Name reported in 1950 by USGS.

Arctic Lake: lake, $1 \mathrm{mi}$. across, on Kenai Penin. $\mathrm{N}$. of Tustumena Glacier, $45 \mathrm{mi}$. SE of Kenai, Chugach Mts.; $60^{\circ} 02^{\prime} 30^{\prime \prime} \mathrm{N}, 150^{\circ} 27^{\prime} 30^{\prime \prime} \mathrm{W}$; (map 62).

So named about 1963 by officials of Kenai National Moose Range, because of the lake's association with Tustumena Glacier.

Arctic Mountains: mountain range, see Brooks Range.

Arctic River: stream, heads in lake, flows NE $33 \mathrm{mi}$. to Shishmaref Inlet, $15 \mathrm{mi}$. SE of Shishmaref, Kotzebue-Kobuk Low.; $66^{\circ} 06^{\prime} \mathrm{N}$, $165^{\circ} 41^{\prime} \mathrm{W}$; (map 112).

Prospectors' name reported in 1901 by T. G. Gerdine, USGS.

Arctic River: stream, see Arctic Greek.

Arctic Village: village, pop. 110, on E bank of East Fork Chandalar River, $6 \mathrm{mi}$. SW of junc. of Junjik River, Brooks Ra.; $68^{\circ} 08^{\prime}$ N, $145^{\circ}$. 32' W; BGN 1944; (map 136). Var. Arctic.

Indian village reported in 1926 by $\mathrm{J} . \mathrm{B}$. Mertie, Jr. (in Smith and others, 1930a, pl. 1), USGS. Its population in 1930 was 40 ; the village had a post office in 1909-10 named "Arctic" and a new one in 1959 under the present name.

Arcy Creek: stream, see Carex Creek.

Arden, Point: point of land, in Stephens Passage, on $\mathrm{N}$ coast of Glass Penin., $2 \mathrm{mi}$. $\mathrm{N}$ of Cove Point and $13 \mathrm{mi}$. SE of Juneau, Alex. Arch.; $58^{\circ} 09^{\prime} 30^{\prime \prime} \mathrm{N}, 134^{\circ} 10^{\prime} 30^{\prime \prime} \mathrm{W}$; (map 11) Var. Arden Point.

Discovered by Joseph Whidbey August 8, 1794, and named by Capt. Vancouver (1798, v. 3, p. 275) in honor of Richard P. Arden, Lord Chief Justice of Common Pleas, and a friend of Pitt (Wagner, 1937, p. 373).

Ardiguen: rookery, on Reef Point, on $\mathrm{S}$ coast of Saint Paul I., in Pribilof Is.; $57^{\circ} 06^{\prime} 30^{\prime \prime} \mathrm{N}$, $170^{\circ} 17^{\prime} 30^{\prime \prime} \mathrm{W}$; (map 38).

This seal-rookery was reported in 1897 by W. W. Duffield, USC\&GS, and is probably the same as, or part of, Reef Rookery.
Areakhsukhwit: promontory, see Ahrayuksookwit Bluff.

Arecite, Punta del: point of land, see Reef Point. Arena Cove: cove, extends N $0.8 \mathrm{mi}$. off Pacific Ocean on S coast of Suemez I., Alex. Arch.; $55^{\circ} 13^{\prime} \mathrm{N}, 133^{\circ} 23^{\prime} \mathrm{W}$; BGN 1923; (map 4). Var. Sandy Cove.

Spanish name meaning "sand," given in 1923 by USC\&GS, because it is "shaped like an arena (Eng.), and fringed by beaches of sand * * ." The name "Sandy Cove" was applied to this feature by members of the USC\&GS steamer Lydonia, who sounded it in 1921. However, the name was changed because of duplication.

Arey Island: barrier island, $7 \mathrm{mi}$. long, $W$ of Barter I., between Arey Lagoon and Beaufort Sea, Arctic Plain; $70^{\circ} 07^{\prime}$ N, $143^{\circ} 54^{\prime}$ W ; (map 152). Var. Arie Island, Barter Island, Nalageavik.

Originally named "Barter Island" August 4, 1826, by Sir John Franklin (1828, p. 147). Local usage applied Barter Island to the large island $E$ of this. In July 1907 Leffingwell $(1919$, p. 13, 93) mapped and renamed the above location for the prospector $H$. T. ("Ned") Arey, originally from Cape Cod, Mass., who lived in the neighborhood several years, and assisted him in explorations on the Okpilak River. The Eskimo name of the island is "Nalageavik," reported in 1948 by USC\&GS

Arey Lagoon: lagoon, 7 mi. across, on Beaufort Sea coast, between Arey I. and mainland, Arctic Plain; $70^{\circ} 06^{\prime} \mathrm{N}, 143^{\circ} 53^{\prime} \mathrm{W}$; (map 152).

Named in 1948 by USC\&GS, "based on the established name of the island enclosing the lagoon [Arey Island]."

Argo Bill Lake: lake, $0.6 \mathrm{mi}$. long, $2 \mathrm{mi}$. NE of Beaver, Yukon Flats; $66^{\circ} 23^{\prime} \mathrm{N}, 147^{\circ} 19^{\prime} \mathrm{W}$; (map 118).

Local name obtained in 1956 by USGS.

Argogak: point of land, see Brant Point.

Argo Gulch: ravine, extends SW $0.9 \mathrm{mi}$. to Yukon River, $\mathrm{E}$ of Minook I., $3 \mathrm{mi}$. NNE of Rampart, Yukon-Tanana High.; $65^{\circ} 32^{\prime} \mathrm{N}$, $150^{\circ} 07^{\prime} \mathrm{W}$; (map 106).

Prospectors' name shown on a manuscript map dated 1906; reported in 1956 by Orth.

Argo Island: barrier island, $0.7 \mathrm{mi}$. long, on Beaufort Sea coast, $\mathrm{E}$ island of Midway Is., Arctic Plain; $70^{\circ} 28^{\prime} \mathrm{N}, 148^{\circ} 15^{\prime} \mathrm{W}$; (map 150).

Named by Leffingwell $(1919$, p. 15, 93) for his yawl Argo. The yawl left Seattle for Flaxman Island in May 1909, and "was turned over to Samuel McIntyre for payment of his wages * *," in August 1912

Argonaut: mining camp, "Now deserted, established in 1899, and called Argonaut City, on the Right Bank of the Koyukuk, 15 miles above Huggins island, near latitude $66^{\circ} 10^{\prime}$, longitude $154^{\circ} 20^{\prime} . "$

"Reported by Cantwell, 1900" (Baker, 1906, p. 105).
Argonne Channel: water passage, in Bay of Islands, on Adak I., Aleutian Is.; 51 $49^{\prime} 10^{\prime \prime}$ N, $176^{\circ} 49^{\prime} 40^{\prime \prime} \mathrm{W}$; BGN 1936; (map 17).

Named in 1933 by members of the U.S. Navy Aleutian Island Survey Expedition, for the U.S.S. Argonne.

Argonne Island: island, $0.7 \mathrm{mi}$. long, on Adak I. in Bay of Islands, between Staten and Dora Is., Aleutian Is.; $51^{\circ} 48^{\prime} 20^{\prime \prime} \mathrm{N}, 176^{\circ} 47^{\prime} 10^{\prime \prime} \mathrm{W}$; $B G N$ 1936; (map 17).

Named in 1933 by members of the U.S. Navy Aleutian Island Survey Expedition, for the U.S.S. Argonne.

Argonne Point: point of land, on $\mathrm{W}$ coast of Adak I., Aleutian Is.; $51^{\circ} 47^{\prime} 30^{\prime \prime} \mathrm{N}, 176^{\circ} 54^{\prime}$ 45" W; BGN 1936; (map 17). Var. Oglala Point.

Named in 1933 by members of the U.S. Navy Aleutian Island Survey Expedition, for the U.S.S. Argonne.

Argo Shoals: shoals, SE of Argo I., in Midway Is., Beaufort Sea coast, Arctic Plain; (map 150).

So named by Leffingwell (1919, p. 93) after his yawl Argo.

Arguello Island: island, $0.2 \mathrm{mi}$. long, at head of Silver Bay, $8.5 \mathrm{mi}$. SE of Sitka, on central Baranof I., Alex. Arch.; $56^{\circ} 59^{\prime} 10^{\prime \prime} \mathrm{N}, 135^{\circ}$ 08'20" W; BGN 1935; (map 5).

Named in 1935 by USFS "for Doña Concepción de Arguello, whom Nicholas Rezanof courted while he was endeavoring to establish trade relations between the Spanish of California and his people at Sitka."

Arhymot Lake: lake, $8 \mathrm{mi}$. long, in the YukonKuskokwim Portage, $4 \mathrm{mi}$. N of Kalskag and $24 \mathrm{mi}$. W of Aniak, Yukon-Kuskokwim Delta; $61^{\circ} 38^{\prime} \mathrm{N}, 160^{\circ} 20^{\prime} \mathrm{W}$; (map 73).

Eskimo name presumably reported about 1952 by the U.S. Army Corps of Engineers.

Ariadne Cove: cove, $0.5 \mathrm{mi}$. across, on $\mathrm{S}$ coast of Kenai Penin. at $S$ entrance to Surprise Bay, $47 \mathrm{mi}$. E of Seldovia, Chugach Mts.; $59^{\circ} 28^{\prime} 45^{\prime \prime} \mathrm{N}, 150^{\circ} 32^{\prime} 00^{\prime \prime} \mathrm{W}$; BGN 1929: (map 50).

Named in 1927 by USC\&GS.

Ariadne Island: island, $0.3 \mathrm{mi}$. across, on SE coast of Kenai Penin., between W arm Nuka and Surprise Bays, $47 \mathrm{mi}$. E of Seldovia, Chugach Mts.; $59^{\circ} 29^{\prime} \mathrm{N}, 150^{\circ} 31^{\prime} \mathrm{W}$; BGN 1929; (map 50).

Named in 1927 by USC\&GS.

Ariarigayarak Slough: stream, see Church Slough.

Arie Cape: point of land, see Inner Right Cape. Arie Island: barrier island, see Arey Island.

Aries, Point: point of land, $3 \mathrm{mi}, \mathrm{N}$ of $\mathrm{Hot}$ Springs Bay, on NE coast of Tanaga I., Aleutian Is.; $51^{\circ} 50^{\prime} 30^{\prime \prime} \mathrm{N}, 177^{\circ} 47^{\prime} 20^{\prime \prime} \mathrm{W}$; (map 17).

Published in 1956 by USC\&GS on Chart 9145.

Arigilivik Beach: beach, on Elson Lagoon S of Point Barrow, Arctic Plain; $71^{\circ} 22^{\prime} \mathrm{N}, 156^{\circ}$. $31^{\prime} \mathrm{W}$; (map 153).

Eskimo name recorded at Barrow in 1965 by Orth. The beach on the Chukchi Sea side is "Agsinoralak." 
Ariswaniski: locality, on right bank of Yukon River near Pilot Station; (map 74).

Former Eskimo camp or settlement; name published by USC\&GS in 1899 on Chart 9370 .

Ariy, Mys: point of land, see Inner Right Cape. Arizona Creek: stream, flows NE $6 \mathrm{mi}$. to Kougarok River, $7 \mathrm{mi}$. SW of Midnight Mtn. and $46 \mathrm{mi}$. W of Imuruk Lake, Seward Penin. High.; $65^{\circ} 37^{\prime} \mathrm{N}, 164^{\circ} 47^{\prime} \mathrm{W}$; (map 110).

Prospectors' name reported in 1901 by $\mathrm{T}$. G. Gerdine (in Collier, 1902, pl. 12), USGS.

Arizona Creek: stream, flows SW $1.8 \mathrm{mi}$. to Taylor Creek which flows to Kougarok River, $7 \mathrm{mi}$. SW of Midnight Mtn. and $46 \mathrm{mi}$. NW of Imuruk Lake, Seward Penin. High.; $65^{\circ}$ $41^{\prime} \mathrm{N}, 164^{\circ} 45^{\prime} \mathrm{W}$; (map 110).

Prospectors' name reported on a precinct map of Seward Peninsula by Monroe and Hutchins; corrected to June 1903 by Arthur Gibson.

Arizona Creek: stream, flows NW $5 \mathrm{mi}$. to Inmachuk River, $19 \mathrm{mi}$. NE of Imuruk Lake, Seward Penin. High.; $65^{\circ} 54^{\prime} \mathrm{N}, 163^{\circ} 01^{\prime} \mathrm{W}$; (map 110).

Prospectors' name reported in 1901 by USGS (Collier, 1902, pl. 12).

Arkansas Creek: stream, flows NW $3 \mathrm{mi}$. to join Woods Creek to form Canyon Creek, $48 \mathrm{mi}$. S of Eagle, Yukon-Tanana High.; 64 $06^{\circ} 40^{\prime \prime} \mathrm{N}$, $141^{\circ} 06^{\prime} 40^{\prime \prime}$ W; (map 102). Var. Camp Creek.

Local name reported in 1966 by USGS; the stream, formerly known as "Camp Creek," was reported in 1898 by E. C. Barnard, USGS.

Arkansas Creek: stream, flows SE $2 \mathrm{mi}$. to Champion Creek, $20 \mathrm{mi}$. SW of Eagle, YukonTanana High.; $64^{\circ} 34^{\prime} \mathrm{N}, 141^{\circ} 36^{\prime} \mathrm{W}$; (map 102).

Named by prospectors and shown on an 1898 manuscript map by E. F. Ball, prospector. Arkansas Creek: stream, see Champion Creek.

Arkose Ridge: ridge, 5,000 ft., extends NE $8 \mathrm{mi}$., between Little Susitna River and Moose Creek, $10 \mathrm{mi}$. N of Palmer, Talkeetna Mts.; 61 ${ }^{\circ} 45^{\prime}$ N, $149^{\circ} 07^{\prime} \mathrm{W}$; (map 69).

Local name reported in 1962 by USGS. Arko-sher-wak: stream, see Beaver Creek. Ark-o-sherwik: stream, see Beaver Creek.

Armeria Bay: bight, $3.5 \mathrm{mi}$. across, on NW coast of Agattu I., Aleutian Is.; 52 $27^{\prime}$ N, $173^{\circ} 30^{\prime}$ E; (map 13).

Listed in the 1946 supplement to the 1944 Aleutian Coast Pilot.

Armeria Point: point of land, on NW coast of Agattu I., $6 \mathrm{mi}$. NE of Gillon Point, Aleutian Is.; $52^{\circ} 27^{\prime} 00^{\prime \prime} \mathrm{N}, 173^{\circ} 26^{\prime} 45^{\prime \prime} \mathrm{E}$; BGN 1938; (map 13).

This point was named for an early lighthouse tender, the U.S.S. Armeria; proposed in 1938 by U.S. Navy Hydrog. Office.

Arm Mountain: mountain, 2,173 ft., at $S$ end of Peninsula Ridge, between Harry Bay and $\mathrm{Na}$ kat Inlet, Coast Mts.; $54^{\circ} 50^{\prime} 50^{\prime \prime} \mathrm{N}, 130^{\circ}$ $46^{\prime} 30^{\prime \prime} \mathrm{W}$; (map 2).

Named in 1883 by Lt. Comdr. Nichols, USN. Armour, Mount: mountain, 8,770 ft., on AlaskaCanada boundary, $3.4 \mathrm{mi}$. SE of Mount Ayles- worth and $44 \mathrm{mi}$. NE of Yakutat, St. Elias Mts.; $59^{\circ} 54^{\prime} 30^{\prime \prime} \mathrm{N}, 138^{\circ} 42^{\prime} 00^{\prime \prime} \mathrm{W}$; $B G N$ 1923; (map 46). Var. Boundary Peak 175.

Named jointly by BGN and CPCGN in 1923 for John D. Armour, Judge of the Supreme Court of Canada and one of the original British members of the Alaskan Boundary Tribunal in 1903. Name was proposed by Lawrence Martin of the U.S. State Department.

Armour, Mount: mountain, see Aylesworth, Mount.

Armstrong, Port: estuary, $1 \mathrm{mi}$. long, on E coast of Baranof I., $4 \mathrm{mi}$. N of Port Alexander, Alex. Arch.; 56 $17^{\circ} 50^{\prime \prime} \mathrm{N}, 134^{\circ} 38^{\prime} 45^{\prime \prime} \mathrm{W}$; (map 5).

Named by Capt. George Vancouver, RN, "during his stay in Port Conclusion between August 1 and August 22, 1794" (Wagner, 1937, p. 373).

Armstrong Point: point of land, at $\mathrm{S}$ point of entrance to Port Lucy, $5.6 \mathrm{mi}$. N of village of Port Alexander, on S coast of Baranof I., Alex. Arch.; 56 $19^{\prime} 50^{\prime \prime} \mathrm{N}, 134^{\circ} 38^{\prime} 30^{\prime \prime} \mathrm{W}$; (map 5).

Local name used by fishermen; derived from Port Armstrong and published in 1910 by USGS.

Army Peak: hill, $612 \mathrm{ft}, 7 \mathrm{mi}$. NE of Nome, Seward Penin. High.; $64^{\circ} 32^{\prime} \mathrm{N}, 165^{\circ} 11^{\prime} \mathrm{W}$; (map 94). Var. Nelson Butte.

Local name reported in 1900 by J. F. Pratt, USC\&GS. Probably so named because in 1900 the U.S. Army established Fort Davis at Nome.

Arnaryarit Point: point of land, see Agnayaghit Point.

Arnkil Island: island, $0.1 \mathrm{mi}$. across, in Afognak Bay, on S coast of Afognak I., $3.2 \mathrm{mi}$. $\mathrm{N}$ of Afognak, Kodiak I. ; $58^{\circ} 03^{\prime} 10^{\prime \prime} \mathrm{N}, 152^{\circ} 45^{\prime} 00^{\prime \prime}$ W; (map 43).

Local name reported in 1900 by Lt. Comdr. J. F. Moser, USN, commandar of the USBF steamer Albatross.

Arn Klane: stream, see Antlen River.

Arn Klane River: stream, see Ahrnklin River. Arolic: locality, see Arolik.

Arolic Creek: stream, see Arolik River.

Arolic Gap: pass, see Arolik Gap.

Arolic River: stream, see Arolik River.

Arolik: locality, on shore of Kuskokwim Bay, at North mouth of Arolik River, $43 \mathrm{mi}$. N of Goodnews, Yukon-Kuskokwim Delta; 59 $42^{\prime}$ N, 161 $53^{\prime}$ W; BGN 1939; (map 53). Var. Agaligamute, Aguliagamiut, Aguliagamute, Aguliak, Aguligamute, Arolic.

Eskimo village, now abandoned, published as "Arolic" in 1913 by USC\&GS on Chart $\mathrm{T}-3399$. This Eskimo name is reported to mean "moon." The place is no longer permanently inhabited. This may be the site of the burnt village reported to be at the north mouth of Arolik River. The Eskimo name of the river is "Aalalik," meaning "ashes," and refers to ashes of the village at its mouth. An Eskimo village or camp called "Aguliagamute" was reported by Ivan Petroff in the 1880 Census at or near this location. At that time the population was 120 , in 1890 it was 94 . It is not shown on the 1898 map of J. E. Spurr and W. S. Post, USGS.

Arolik Gap: pass, $4 \mathrm{mi}$. long, traversed by the Arolik River, $3 \mathrm{mi}$. NE of Yukon Hill and 35 mi. N of Goodnews, Kilbuck-Kuskokwim Mts.; $59^{\circ} 36^{\prime}$ N, $161^{\circ} 32^{\prime}$ W; (map 53). Var. Arolic Gap.

Name derived from Arolik River; published in 1916 by USC\&GS on Chart 9103 as "Arolic Gap."

Arolik Lake: lake, extends NW 2.5 mi. to headwaters of East Fork Arolik River, $31 \mathrm{mi}$. NE of Goodnews, Kilbuck-Kuskokwim Mts.; $59^{\circ} 29^{\prime} \mathrm{N}, 161^{\circ} 06^{\prime} \mathrm{W}$; (map 53).

Name derived from the Arolik River; published in 1951 by USGS.

Arolik River: stream, heads at confluence of East and South Forks Arolik River, flows NW 14 mi. to North and South Mouths Arolik River, $36 \mathrm{mi}$. $\mathrm{N}$ of Goodnews, Yukon-Kuskokwim Delta; 59³8' N, 161 ${ }^{\circ} 36^{\prime}$ W; BGN 1939; (map 53). Var. Aalalik River, Arolic Creek, Arolic River, Kwiyadik Creek.

The name of this stream was originally reported in 1898 as "Kwiyadik," an Eskimo name, by J. E. Spurr and W. S. Post (in Spurr, 1900, map 10), USGS, and it included what is now the North Mouth. In 1913 USC\&GS published the name "Arolic Creek" on Chart T-3399; it is an Eskimo name reported to mean "moon." The Eskimos also called the stream "Aalalik," meaning "ashes," which refers to the "ashes of a burnt village at the mouth of north fork."

Aropuk Lake: lake, $15 \mathrm{mi}$. long, $15 \mathrm{mi}$. N of Baird Inlet, Yukon-Kuskokwim Delta; $61^{\circ} 10^{\prime}$ N, $163^{\circ} 46^{\prime} \mathrm{W}$; (map 74). Var. Agoo, Agu Lake.

Eskimo name obtained at Bethel by USC\& GS in 1948. This appears to be the same lake, for which, in 1897, Lt. D. H. Jarvis, USRCS, recorded the Eskimo name "Agoo."

Arotak Creek: stream, heads in Kingasivik Mts., flows SE $6 \mathrm{mi}$. to Noatak River, $27 \mathrm{mi}$. ESE of Misheguk Mtn., Brooks Ra.; $68^{\circ} 07^{\prime} \mathrm{N}$, $160^{\circ} 03^{\prime} \mathrm{W}$; (map 131).

Eskimo name referring to the stretch of Noatak River near this stream's mouth which is "windy and cold" [argoag]; obtained at Noatak in 1956 by Orth.

Arovirchagk: locality, on left bank of Kanelik Pass, $18 \mathrm{mi}$. S of Kwiguk, Yukon-Kuskokwim Delta; 62 $30^{\prime} 15^{\prime \prime}$ N, 164 $37^{\circ} 10^{\prime \prime}$ W; (map 77).

Eskimo name obtained in 1952 by U.S. Army Corps of Engineers.

Ar Quay River: stream, see Akwe River.

Arrecife, Punta del: point of land, see Reef Point.

Arrecife Islands: islands, extend $0.5 \mathrm{mi}$., $\mathbf{E}$ of Arrecife Point, on SE coast of Lulu I., Alex. Arch.; $55^{\circ} 27^{\prime} \mathrm{N}, 133^{\circ} 25^{\prime} \mathrm{W}$; BGN 1923; (map 4). Var. El Arrecife.

The descriptive term "El Arrecife," meaning "the reefs," was applied to these islands in $1775-79$ by Don Juan de la Bodega y Quadra and Francisco Antonio Maurelle. 
The islands were formally named "Arrecife Islands" in 1923 by USC\&GS.

Arrecife Point: point of land, SE tip of Lulu I., Alex. Arch.; $55^{\circ} 27^{\prime} 10^{\prime \prime}$ N, $133^{\circ} 25^{\prime} 35^{\prime \prime} \mathrm{W}$; $B G N$ 1966; (map 4). Var. Point Arrecife, Punta Arrecife, Punta del Arrecife.

Name given in $1775-79$ by Don Juan de la Bodega y Quadra and Francisco Antonio Maurelle as "Punta del Arrecife," meaning "reef point."

Arrecifes, Punta de: point of land, see Arrecifes Point.

Arrecifes Point: point of land, extends into Yakutat Roads, $1 \mathrm{mi}$. NW of Yakutat, Malaspina Coastal Plain; $59^{\circ} 33^{\prime} 40^{\prime \prime} \mathrm{N}, 139^{\circ}$. $45^{\prime} 00^{\prime \prime}$ W; (map 46). Var. Punta de Arrecifes.

Capt. Alessandro Malaspina in 1791 named it "Punta de Arrescifes," meaning "point of reefs" (Galiano, 1802, map 8).

Arre Rocks: rocks, in Bering Sea, $2 \mathrm{mi}$. W of Hall I., $8 \mathrm{mi}$. NW of Glory of Russia Cape, Saint Matthew I.; $60^{\circ} 38^{\prime} \mathrm{N}, 173^{\circ} 10^{\prime} \mathrm{W}$; (map 56).

"Apparently so named by [H. W.] Elliott in 1874, who says Arrie, a sea bird, the Murre, was so named by the Russians from its harsh cry Arra-arra" (Baker, 1906, p. 105).

Arresife, Mys del: point of land, see Reef Point. Arriaga, Bokas: water passage, see Arriaga Passage.

Arriaga, Isla de: island, see Perl Island.

Arriaga Passage: water passage, extends $5 \mathrm{mi}$. W, from Gulf of Esquibel, between Noyes and Saint Joseph Is., Alex. Arch.; $55^{\circ} 34^{\prime} \mathrm{N}, 133^{\circ}$ $40^{\prime} \mathrm{W}$; (map 4). Var. Bocas de Arriaga, Bokas Arriaga.

Named "Bocas de Arriaga," or "Arriaga Passage" by Francisco Antonio Maurelle "about August 22 or 23, 1779, no doubt in honor of Juan Pantoja y Arriaga, one of his pilots" (Wagner, 1937, p. 373).

Arriaga Passage: water passage, see Sonora Passage.

Arrigetch Creek: stream, heads on Arrigetch Peaks, flows NE $10 \mathrm{mi}$. to Alatna River, 25 mi. S of Survey Pass, Brooks Ra.; 67 $30^{\prime} \mathrm{N}$, $153^{\circ} 5^{\prime}$ W; BGN 1932; (map 125).

Local name reported in 1931 by Robert Marshall.

Arrigetch Peaks: peaks, 6,000-7,200 ft., group extends NE-SW $7 \mathrm{mi}$., $30 \mathrm{mi}$. S of Survey Pass, Brooks Ra.; 67 $26^{\prime} \mathrm{N}, 154^{\circ} 10^{\prime} \mathrm{W}$; BGN 1932; (map 125).

Eskimo name said" to mean "fingers extended"; reported in 1931 by Robert Marshall.

Arrow Creek: stream, heads on Panoramic Peak of Granite Mtn., flows NE $8 \mathrm{mi}$. to Sawmill Creek, S of Alaska Highway, $14 \mathrm{mi}$. SE of Delta Junction, Tanana Low.; 63 ${ }^{\circ} 53^{\prime} 45^{\prime \prime}$ $\mathrm{N}, 145^{\circ} 14^{\prime} 00^{\prime \prime} \mathrm{W}$; (map 86).

Local name reported in 1949 by $T$. L. Péwé, USGS

Arrow Creek: stream, flows NW $4 \mathrm{mi}$. to Chukchi Sea, $24 \mathrm{mi}$. E of Cape Lisburne, Arctic Slope; 68 $51^{\prime} 55^{\prime \prime} \mathrm{N}, 165^{\circ} 14^{\prime} 05^{\prime \prime} \mathrm{W}$; (map 129). Var. Aknasuk Creek.

Name reported about 1901 by USC\&GS.
Arrowhead Peak: mountain, 3,200 ft., on $W$ coast of Baranof I., $4.5 \mathrm{mi}$. NE of Sitka, Alex. Arch.; 57 $04^{\prime} 10^{\prime \prime} \mathrm{N}, 135^{\circ} 12^{\prime} 50^{\prime \prime} \mathrm{W}$; (map 9). Var. Mount Verstovia.

Local name reported in 1951 by USGS.

Arrow Lake: lake, $0.5 \mathrm{mi}$. long, on Kenai Penin., $5 \mathrm{mi}$. NE of Swan Lake and $30 \mathrm{mi}$. NE of Kenai, Cook Inlet Low.; $60^{\circ} 45^{\prime} 15^{\prime \prime} \mathrm{N}, 150^{\circ}$ $29^{\prime} 30^{\prime \prime} \mathrm{W}$; (map 62).

Named about 1963 by officials of Kenai National Moose Range, for administrative purposes.

Arrow Lake: lake, $0.25 \mathrm{mi}$. across, near $\mathrm{S}$ tip of Kiska I., Aleutian Is.; 51 ${ }^{\circ} 50^{\prime} 50^{\prime \prime} \mathrm{N}, 177^{\circ}$ 18'45" E; (map 14).

An arbitrary name beginning with " $A$ " to correspond to " $A$ " grid used by the U.S. Army for tactical purposes during World War II; published by AMS in 1953.

Arsenic Creek: stream, $3 \mathrm{mi}$. long, flows SW to Rainy Creek, $12 \mathrm{mi}$. SE of junc. of Kapon Creek and Eek River, $79 \mathrm{mi}$. SE of Bethel, Kilbuck-Kuskokwim Mts.; $60^{\circ} 00^{\prime}$ N, $160^{\circ}$ $09^{\prime} \mathrm{W}$; (map 59).

Local name reported in 1955 by J. M. Hoare, USGS.

Artaylnovskoi: locality, see Artelnov.

Arteegotrot: promontory, see Artigotrat.

Arteljnowskoje: locality, see Artelnov.

Artelnof : locality, see Artelnov.

Artelnov: locality, on rocky SW coast of Akun I., Aleutian Is.; (map 24). Var. Artaylnovskoi, Artelnof, Artelnovskoe, Arteljnowskoje.

Former Aleut village and Russian post reported as "Artelnovskoe" by Father Veniaminov $(1840$, v. 1, p. 196). Its population was 32 in 1834 (Hodge, 1907, p. 96).

Artelnovskoe: locality, see Artelnov.

Arthur Glacier: glacier, on N slope of Takhinsha Mts., trends N $5 \mathrm{mi}$. to its 1964 terminus, 1 mi. S of Takhin River and $24 \mathrm{mi}$. SW of Skagway, St. Elias Mts.; $59^{\circ} 14^{\prime} \mathrm{N}, 135^{\circ} 50^{\prime}$ W; (map 45).

Named by USC\&GS for Arthur Krause, biologist and geographer who, with his brother Aurel, mapped this area in 1881 ; the name was published in the 1883 Alaska Coast Pilot (pl. 1819). In 1881 Arthur and Aurel Krause were sent by the Bremen Geographic Society to make ethnographic and geographic studies in Alaska. They visited Bering Strait and the district at the head of the Lynn Canal. The results of their investigations were published in various journals.

Arthur Island: island, $0.1 \mathrm{mi}$. across, $1 \mathrm{mi}$. NE of Deep Bay, in Peril Strait, $29 \mathrm{mi}$. N of Sitka, Alex. Arch.; $57^{\circ} 26^{\prime} 55^{\prime \prime} \mathrm{N}, 1^{\circ} 5^{\circ} 34^{\prime} 40^{\prime \prime} \mathrm{W}$; (map 9).

Named in 1895 by Lt. Comdr. E. K. Moore, USN, and published in 1900 by USC\&GS on Chart 8282.

Arthur Peak: mountain, $3,650 \mathrm{ft} ., 1.3 \mathrm{mi}$. N of head of Limestone Inlet and $25 \mathrm{mi}$. SE of Juneau, Coast Mts. ; 58 $03^{\prime} 10^{\prime \prime} \mathrm{N}, 133^{\circ} 58^{\prime} 30^{\prime \prime}$ W; (map 12).

Named in 1888 by Lt. Comdr. C. M. Thomas, USN.
Arthur Point: point of land, in Peril Strait, 1 mi. NE of Deep Bay, on Chichagof I., $29 \mathrm{mi}$. $\mathrm{N}$ of Sitka, Alex. Arch.; $57^{\circ} 27^{\prime} \mathrm{N}, 135^{\circ} 35^{\prime}$ W; (map 9)

Named in 1884 by Comdr. J. B. Coghlan, USN, and published by USC\&GS in the 1891 Coast Pilot (p. 183).

Artic Creek: stream, see Arctic Creek.

Artic Hot Springs: locality, see Serpentine Hot Springs.

Artigotrat: promontory, elev. $550 \mathrm{ft}$., on Chukchi Sea coast, $3.2 \mathrm{mi}$. SE of Cape Thompson, Arctic Slope; $68^{\circ} 07^{\prime} \mathrm{N}$; $165^{\circ} 53^{\prime} \mathrm{W}$; $B G N$ 1963; (map 129). Var. Arteegotrot.

Eskimo name meaning "resembling hands," reported in 1962 by W. O. Pruit, Univ. of Alaska, and spelled by him "Arteegotrot."

Artist Creek: stream, flows SW $1.4 \mathrm{mi}$. to Pacific Ocean, $1.5 \mathrm{mi}$. NW of Vega Point, on SW coast of Kiska I., Aleutian Is. ; $51^{\circ} 50^{\prime} 45^{\prime \prime} \mathrm{N}$, $177^{\circ} 17^{\prime} 35^{\prime \prime} \mathrm{E}$; (map 14).

An arbitrary name beginning with " $\mathrm{A}$ " to correspond to "A" grid used by the U.S. Army for tactical purposes during World War II; published by AMS in 1953 .

Art Lewis Glacier: glacier, heads near AlaskaCanada boundary, $4 \mathrm{mi}$. E of Mount Jette, trends SE $15 \mathrm{mi}$. to East Nunatak Glacier, 3 mi. $E$ of head of Nunatak Fiord and $37 \mathrm{mi}$. NE of Yakutat, St. Elias Mts.; 59 $48^{\prime} 30^{\prime \prime} \mathrm{N}$, $138^{\circ} 47^{\prime} 30^{\prime \prime} \mathrm{W}$; BGN 1953; (map 46). Var. Artlewis Glacier.

Named in 1922 jointly by BGN and CPCGN for Art Lewis, a member of Canadian surveying parties in 1912 and 1914. Lewis was killed in France while serving in the Canadian Expeditionary Force with the 72d Highlanders in WW I. The name was published by IBC in 1928 as "Art Lewis Glacier."

Arucenas, Mys: point of land, see Aruncenas Point.

Arucenas, Punta de: point of land, see Aruncenas, Point.

Aruncenas, Point: point of land, $\mathrm{N}$ of Port Dolores, on NW coast of Suemez I., Alex. Arch.; $55^{\circ} 20^{\prime} 30^{\prime \prime} \mathrm{N}, 133^{\circ} 24^{\prime} 00^{\prime \prime} \mathrm{W}$; (map 4). Var. Mys Arucenas, Punta de Arucenas. Name given in 1775-79 by Don Juan de la Bodega y Quadra and Francisco Antonio Maurelle as "Punta de Arucenas," or "Point Arucenas."

Arvesta Creek: stream, flows SW $1 \mathrm{mi}$. to Katalla Slough, $2.8 \mathrm{mi}$. SE of Katalla, Malaspina Coastal Plain; $60^{\circ} 11^{\prime} \mathrm{N}, 144^{\circ} 26^{\prime} \mathrm{W}$; (map 64).

Local name reported in 1904 by G. C. Martin, USGS.

Arvesta Creek: stream, flows NE $26 \mathrm{mi}$. to Kateel River, $71 \mathrm{mi}$. SW of Roundabout Mtn., Nulato Hills; $65^{\circ} 09^{\prime} \mathrm{N}, 158^{\circ} 47^{\prime} \mathrm{W}$; (map 108).

Name published on a manuscript map dated 1906. This is probably a form of a Koyukun Indian name unless a typographical error changed an " $r$ " to a " $v$," in which case it may refer to a primitive ore mill often spelled arrestra, arestra, and arrastra.

Arvesta Creek: stream, see Porcupine Creek. 
Arwirnuk Rock: rock, in Bering Sea, $12 \mathrm{mi}$. SW of Cape Etolin and $1 \mathrm{mi}$. NW of Ahrayuksookwit Bluff, off $\mathrm{N}$ coast of Nunivak I.; $60^{\circ} 23^{\prime} 30^{\prime \prime}$ $\mathrm{N}, 166^{\circ} 29^{\prime} 40^{\prime \prime} \mathrm{W}$; (map 57).

Eskimo name reported in 1937 by USAAF. Asagpa Hill: hill, see Asikpak Mountain.

Asagpam Kunga: stream, see Asikpak River.

Asahkpa: hill, see Asikpak.

Asahkpam Koonga : stream, see Asikpak River.

Asakpa : hill, see Asikpak.

Asaqpa: hill, see Asikpak.

Asbestos Creek: stream, in Ray Mts., flows NE $7.5 \mathrm{mi}$. to Dreamland Creek $3.5 \mathrm{mi}$. S of that stream's junc. with Big Salt River, $24 \mathrm{mi}$. NNW of Rampart and $65 \mathrm{mi}$. NE of Tanana, Kokrines-Hodzana High. ; $65^{\circ} 49^{\prime} 30^{\prime \prime} \mathrm{N}, 150^{\circ}$ $30^{\prime} 00^{\prime \prime} \mathrm{W}$; (map 106).

Prospectors' name reported in 1956 by Orth; so named because asbestos deposits were located here.

Asbestos Mountain: mountain, 2,640 ft., $3 \mathrm{mi}$. E of Inerevuk Mtn. and $11 \mathrm{mi}$. NE of Shungnak, Brooks Ra.; $67^{\circ} 00^{\prime} \mathrm{N}, 156^{\circ} 49^{\prime} \mathrm{W}$; (map 115). 1940.

Prospectors' name reported by USGS after

Asbestos Mountain: mountain, 2,980 ft., $13 \mathrm{mi}$. NE of Shungnak, Brooks Ra.; $67^{\circ} 01^{\prime} \mathrm{N}, 156^{\circ}$ 47' W; (map 126).

Prospectors' name reported in 1956 by USGS.

Ascheeshna: stream, see John River.

Ashby Mountains: mountain range, 5,200-5,500

ft., "E of Portland Canal," Alex. Arch.

Named in 1868 by Staff Comdr. David Pender, RN; published on Brit. Adm. Chart 2431.

Ash Creek: stream, on Alaska Penin., flows WNW $4 \mathrm{mi}$. to Crater Creek, $5 \mathrm{mi}$. N of Black Lake and $30 \mathrm{mi}$. NW of Chignik, Aleutian Ra.; $56^{\circ} 34^{\prime} \mathrm{N}, 158^{\circ} 56^{\prime} \mathrm{W}$; (map 30).

Descriptive name, "for the volcanic ash all about," recorded on a 1923 fieldsheet by R. H. Sargent, USGS.

Ash Creek: stream, flows SE $2 \mathrm{mi}$. to Tozimoran Creek, $3 \mathrm{mi}$. E of Moran Dome and $25 \mathrm{mi}$. NW of Tanana, Kokrines-Hodzana High,; $65^{\circ}$ $22^{\prime} 30^{\prime \prime} \mathrm{N}, 152^{\circ} 49^{\prime} 00^{\prime \prime} \mathrm{W}$; (map 106).

Prospectors' name reported in 1956 by R. M. Chapman, USGS.

Ashiganok: mountains, see Jade Mountains.

Ashiiak Island: island, $0.4 \mathrm{mi}$. long, in Pacific Ocean, $S$ of Agripina Bay, on SE coast of Alaska Penin., 42 mi. NE of Sutwik I., Aleutian Ra.; $57^{\circ} 04^{\prime} 30^{\prime \prime} \mathrm{N}, 156^{\circ} 24^{\prime} 30^{\prime \prime} \mathrm{W}$; (map 36).

Native name published as " $\mathrm{O}$ [strov] Ashiiak" by the Russian Hydrog. Dept. on Chart 1379 in 1847.

Ashington: mountain range, "between Portland canal and Observatory inlet."

"So named by Pender, 1868" (Baker, 1906, p. 106).

Ashishikh, Mys: point of land, see Ashishik Point.

Ashishik Point: point of land, on NW coast of Umnak I., Aleutian Is.; $53^{\circ} 33^{\prime} 45^{\prime \prime}$ N, $168^{\circ}$ 04'55" W; (map 22). Var. Mys Ashishikh.
Aleut name published by Capt. Tebenkov (1852, map 25), IRN, as "M[ys] Ashishikh," or "Cape Ashishikh."

Ashivak: locality, $13 \mathrm{mi}$. NW of Cape Douglas on Kamishak Bay, Aleutian Ra.; $58^{\circ} 59^{\prime} \mathrm{N}$, $153^{\circ} 30^{\prime} \mathrm{W}$; (map 43).

Former Eskimo camp or village listed in the 1880 Census with a population of 46 .

Ashivak: locality, site of Eskimo village, on $\mathrm{N}$ coast of Alaska Penin., on $\mathrm{E}$ shore of Akumwarvik Bay, Aleutian Ra.; $59^{\circ} 02^{\prime} \mathrm{N}, 154^{\circ} 07^{\prime}$ W; (map 51).

Eskimo village with a population of 46 , reported by Petroff (1881, p. 28) in the 1880 Census.

Ashland Creek: stream, flows W $1.2 \mathrm{mi}$. to Washington Creek, $19 \mathrm{mi}$. NW of Nome, Seward Penin. High.; $64^{\circ} 44^{\prime} \mathrm{N}, 165^{\circ} 48^{\prime} \mathrm{W}$; (map 94).

Prospectors' name reported on Arthur Gibson's "Map of Cape Nome Precinct" dated 1904.

Ashlar Point: point of land, "on $\mathbf{E}$ shore of Suemez Island," Alex. Arch.

Named in 1923 by Comdr. Rochford Maguire, RN.

Ashmiahk: island, see Aiktak Island.

Ashmun, Mount: mountain, 6,500 ft., on AlaskaCanada boundary, $2.6 \mathrm{mi}$. NW of Hiteshitak Mtn. and $33 \mathrm{mi}$. NW of Skagway, St. Elias Mts.; BGN 1927; $59^{\circ} 38^{\prime} 25^{\prime \prime} \mathrm{N}, 136^{\circ} 11^{\prime} 15^{\prime \prime}$ W; (map 45).

Named by the United States and Canada in 1927 for R. N. Ashmun, employed by U.S. section of IBC.

Asiak Island: island, see Sledge Island.

Asiatchak Point: point of land, see Romanof Point.

Asi Cape: point of land, see Bunnell Cape.

Asickpun Lagoon: lagoon, see Asikpak Lagoon. Asickpun Mountain: hill, see Asikpak Mountain. Asickpun River: stream, see Asikpak River.

Asigiyukpak Spit: spit, see Asigyukpak Spit.

Asigliraangig: hill, see Asiglirangik Hill.

Asiglirangik Hill: hill, $377 \mathrm{ft}$, $4 \mathrm{mi}$. E of Eppiahvik Lagoon and $16 \mathrm{mi}$. SE of Kivalina, Kotzebue-Kobuk Low.; $67^{\circ} 37^{\prime}$ N, $164^{\circ} 00^{\prime}$ W; (map 128). Var. Ahsiglirahngik, Asigliraangig, Asikraraxnik Hill.

Eskimo name reported by USC\&GS in 1950 .

Asigyulkpak Spit: spit, extends NE $3.5 \mathrm{mi}$. into Hagemeister Strait from mainland $E$ of Norseman Lake, $11 \mathrm{mi}$. W of Hagemeister I., Kilbuck-Kuskokwim Mts.; $58^{\circ} 41^{\prime}$ N, $161^{\circ}$. 18' W; (map 39). Var. Asigiyukpak Spit, Sasseen.

Eskimo name obtained in 1948 by USGS. The spit is also known as "Sasseen."

Asik Mountain: mountain, 2,246 ft., on W bank of Agashashok River, $17 \mathrm{mi}$. SE of Noatak, Brooks Ra. ; $67^{\circ} 28^{\prime} \mathrm{N}, 162^{\circ} 22^{\prime} \mathrm{W}$; (map 128). Var. Ahsik Mountain, Asiq Hill.

Eskimo name meaning "coat sleeve," according to USC\&GS in 1950.

Asikpak Creek: stream, see Asikpak River.

Asikpak Lagoon: lagoon, $2.3 \mathrm{mi}$. long on Chukchi Sea coast, at mouth of Asikpak River, 11 mi. NW of Kivalina, Kotzebue-Kobuk Low.; $67^{\circ} 51^{\prime} \mathrm{N}, 164^{\circ} 50^{\prime} \mathrm{W}$; BGN 1963; (map 128). Var. Asickpun Lagoon, Asikpan Lagoon.

Eskimo name, derived from that of the stream, reported in 1950 by USC\&GS.

Asikpak Mountain: hill, $300 \mathrm{ft}$., between Asikpak River and $\mathbf{N}$ end of Kivalina Lagoon, 10 mi. NW of Kivalina, Arctic Slope; $67^{\circ} 52^{\prime} \mathrm{N}$, $164^{\circ} 43^{\prime} \mathrm{W}$; (map 128). Var. Asagpa Hill, Asickpun Mountain, Asikpan Mountain.

Name, derived from that of the river, reported as "Asickpun" in 1950 by USC\&GS. E. S. Burch, 1966, placed this hill north of the Asikpak River and spelled it "Asagpa." See Asikpak River.

Asikpak River: stream, flows SW $17 \mathrm{mi}$. to Asikpak Lagoon, $11 \mathrm{mi}$. NW of Kivalina, Kotzebue-Kobuk Low.; $67^{\circ} 51^{\prime} \mathrm{N}, 164^{\circ} 51^{\prime} \mathrm{W}$; $B G N$ 1963; (map 128). Var. Asagpam Kunga, Asahkpam Koonga, Asickpun River, Asikpak Creek, Asikpan Creek, Asikpan River, Seevolookruk Creek.

Eskimo name meaning "big sleeve [asigpak]" according to USC\&GS in 1950 . E. S. Burch records the name as "Asaqpam Kunga" meaning "Asaqpa River," "Asaqpa" being the name of the 590 foot hill north of the stream's mouth. See Asikpak Mountain.

Asikpan Creek: stream, see Asikpak River.

Asikpan Lagoon: lagoon, see Asikpak Lagoon.

Asikpan Mountain: hill, see Asikpak Mountain.

Asikpan River: stream, see Asikpak River.

Asikraraxnik Hill : hill, see Asiglirangik Hill.

Asiksat Hills: mountains, see Lockwood Hills.

Asimsion, Gavan Nuyesta Sensora de la: bay, see Asumcion, Port.

Asiniak Point: point of land, on $\mathrm{W}$ shore of Peard Bay, 9 mi. SW of Point Franklin, Arctic Plain; $70^{\circ} 52^{\prime} \mathrm{N}, 159^{\circ} 10^{\prime} \mathrm{W}$; (map 146).

Eskimo name obtained by Orth in 1956.

Asiq Hill: mountain, see Asik Mountain.

Askomute: village, see Holy Cross.

Askinaghamiut: village, see Hooper Bay.

Askinak: village, see Hooper Bay.

Askinuk : village, see Hooper Bay.

Askinuk Mountains: mountains, 2,342 ft., $10 \mathrm{mi}$. wide, extending E $32 \mathrm{mi}$. from Cape Romanzof, Yukon-Kuskokwim Delta; $61^{\circ} 48^{\prime} \mathrm{N}$, $165^{\circ} 33^{\prime} \mathrm{W}$; (map 75). Var. Igiak Mountains.

Eskimo name obtained in $1878-79$ by Nelson (1882, p. 666), U.S. Signal Service.

Askinuk River: river, "in the Yukon delta, debouching into Hooper Bay."

"Native name, from Nelson, who crossed it December 15, 1878." (Baker, 1906, p. 106). Asko: village, see Holy Cross.

Aslik, Cape: point of land, on W coast of Umnak I., Aleutian Is.; $53^{\circ} 25^{\prime} \mathrm{N}, 168^{\circ} 24^{\prime} \mathrm{W}$; (map 22).

Aleut name published by Capt. Tebenkov (1852, map 25), IRN, as "M[ys] Aslik" or "Cape Aslik."

Asowalak Cove: bay, see Tiflighak Bay.

Aspen Creek: stream, heads at glacier, flows NW $12 \mathrm{mi}$. to Talkeetna River, $11 \mathrm{mi}$. $\mathrm{N}$ of Talkeetna Glacier and $52 \mathrm{mi}$. $\mathrm{E}$ of Talkeetna, 
Talkeetna Mts.; $62^{\circ} 20^{\prime} 45^{\prime \prime} \mathrm{N}, 148^{\circ} 29^{\prime} 20^{\prime \prime}$ W; (map 82).

Local name reported in 1951 by USGS.

Aspen Creek: stream, heads in British Mts. NW of Park Peak and flows SE 23 mi., across Alaska-Canada boundary, to Joe Creek, SW of its junc. with Firth River, Yukon Canada; $69^{\circ} 01^{\prime} \mathrm{N}, 140^{\circ} 31^{\prime} \mathrm{W}$; (map 138).

Name reported by the 1911 IBC Survey crew.

Aspen Lake: lake, $0.8 \mathrm{mi}$. long, on Kenai Penin., $1.3 \mathrm{mi}$. S of Mull Lake and $28 \mathrm{mi}$. SW of Anchorage, Cook Inlet Low.; $60^{\circ} 52^{\prime} 45^{\prime \prime} \mathrm{N}$, $150^{\circ} 21^{\prime} 00^{\prime \prime} \mathrm{W}$; (map 62).

Named about 1963 by officials of Kenai National Moose Range, for administrative purposes.

Aspero Peak: mountain, 9,831 ft., between Meares and Yale Glaciers, $35 \mathrm{mi}$. NW of Valdez, Chugach Mts. ; $61^{\circ} 17^{\prime} 40^{\prime \prime} \mathrm{N}, 147^{\circ} 15^{\prime} 15^{\prime \prime}$ W; BGN 1965; (map 69).

"Aspero" is a Spanish word meaning "rough," given about 1957 by members of the Chugach Mountains Expedition, sponsored by the Arctic Institute of North America (Nielsen, 1963, p. 135).

Aspid, Mount: mountain, 2,145 ft., on SW coast of Unalaska I., Aleutian Is.; $53^{\circ} 29^{\prime} 30^{\prime \prime}$ $\mathrm{N}, 167^{\circ} 33^{\prime} 00^{\prime \prime} \mathrm{W}$; (map 23).

Name derived from Cape Aspid; published in 1951 by USGS.

Aspid, Ostrov: islands, see Slate Islets.

Aspid Bay: bay, $1 \mathrm{mi}$. across, on SW coast of Unalaska I., $18 \mathrm{mi}$. NE of Fort Glenn, Aleutian Is.; $53^{\circ} 26^{\prime} \mathrm{N}, 167^{\circ} 24^{\prime} \mathrm{W}$; BGN 1938; (map 23). Var. Nellie Juan Bay.

Name reported in 1840 by Father Veniaminov. Named "Nellie Juan Bay" by USC\&GS, probably in the 1920 's, for "Nellie Juan Cape," which is now "Cape Aspid." See Aspid, Cape.

Aspid Cape: point of land, on SW coast of Unalaska I., $16 \mathrm{mi}$. E of Fort Glenn, Aleutian Is.; $53^{\circ} 26^{\prime} 45^{\prime \prime} \mathrm{N}, 167^{\circ} 28^{\prime} 00^{\prime \prime} \mathrm{W}$; $B G N$ 1938; (map 23). Var. Ammak Point, Aspidnoi Cape, Mys Ammak, Mys Aspidney, Mys Aspidskiy, Nellie Juan Cape, Salty Cape.

Recorded in 1792 as "M[ys] Ammak," probably from "ammak," the Aleut word for "night", by Lt. Sarichev (1826, map 14), IRN. According to R. H. Geoghegan, the name "Mys Aspidskiy" was published in 1850 by Father Veniaminov, derived from the derogatory name "Aspid," meaning "asp", given by the Russians to an unpopular local Aleut chief. Published as "M[ys] Aspidney" by Capt. Tebenkov (1852, map 25), IRN. In 1888 USBF published "Nellie Juan Cape", "presumably after the schooner Nellie Juan, belonging to Mr. Samuel Applegate" (Baker, 1906, p. 107); Applegate contributed to the 1890 Census taken in the Prince William Sound area.

Aspid Cape: point of land, on W coast of Baranof I., $26 \mathrm{mi}$. SE of Sitka, Alex. Arch.; 56 ${ }^{\circ}$ 41'15' N, $135^{\circ} 13^{\prime} 30^{\prime \prime}$ W; (map 5).

Russian name meaning "slate" given in 1926 by USC\&GS.
Aspid Islets: islands, see Slate Islets.

Aspidney, Mys : point of land, see Aspid Cape.

Aspidnoi Cape: point of land, see Aspid Cape.

Aspidskiy, Mys: point of land, see Aspid Cape.

Asses Ears: peaks, two, extend 200 feet above bench, elev. of $W$ peak $1,995 \mathrm{ft}$., $2 \mathrm{mi}$. SE of Black Butte and $8 \mathrm{mi}$. N of Imuruk Lake, Seward Penin. High.; $65^{\circ} 44^{\prime} 45^{\prime \prime}$ N, $163^{\circ}$ $11^{\prime} 00^{\prime \prime}$ W; (map 110).

So named August 11, 1816, by Lt. Otto von Kotzebue (1821, p. 223), IRN, because "its summit is in the form of two asses' ears" (Baker, 1906, p. 107). Examined and described in 1903 by Moffit (1905, pl. 5 and p. 27-28), USGS.

Asses Ears Mountain: mountain, see Black Butte. Asses Head: point of land, near Chernofski village, on SW coast of Unalaska I., Aleutian Is.; (map 23).

Written in pencil as a memorandum on a 1792 chart drafted by Lt. Sarichev, IRN (Baker, 1906, p. 107). This feature has not been positively identified.

Asshiak Island: island, see Sledge Island.

Assumcion, Puerto de mostra Señora de la: bay, see Asumcion, Port.

Assumption, Port: bay, see Asumcion, Port.

Astley, Point: point of land, $\mathrm{S}$ point of entrance to Holkham Bay, $3 \mathrm{mi}$. W of Wood Spit and $49 \mathrm{mi}$. SE of Juneau, Coast Mts.; $57^{\circ} 43^{\prime} \mathrm{N}$, $133^{\circ} 39^{\prime} \mathrm{W}$; (map 8).

Named by Capt. Vancouver (1798, v. 3, p. 280), RN, when it was discovered on August 13,1794 , by Lt. J. Whidbey, RN.

Astley Island: island, see Ansley Island.

Aston Island: island, $0.8 \mathrm{mi}$. long, on NW coast of Long I., between Kaigani and Tlevak Straits, Alex. Arch.; 54 $56^{\prime} 20^{\prime \prime} \mathrm{N}, 132^{\circ} 50^{\prime} 15^{\prime \prime}$ W; (map 1). Var. Wright Island.

Named in 1881 by Lt. Comdr. H. E. Nichols, USN, for Ralph Aston, 1841-1904, USN, a member of his party. This island was called "Wright Island" by Sheldon Jackson (1880, map facing p. 376).

Astrolabe Bay: bay, $1.2 \mathrm{mi}$. across, between Astrolabe Penin. and Boussole Head, in Glacier Bay National Monument, $57 \mathrm{mi}$. WNW of Hoonah, St. Elias Mts.; $58^{\circ} 22^{\prime} 30^{\prime \prime}$ N, $136^{\circ}$ 54'30" W; BGN 1930; (map 10).

Named in 1883 by George Davidson, USC\&GS, for L'Astrolabe, one of the two ships of the French scientific expedition under the command of La Perouse, which explored this region in 1786 .

Astrolabe Peninsula: peninsula, $3 \mathrm{mi}$. long, between Astrolabe Bay and Dixon Harbor, in Glacier Bay National Monument, $56 \mathrm{mi}$. WNW of Hoonah, St. Elias Mts.; $58^{\circ} 22^{\prime} \mathrm{N}$, $136^{\circ} 53^{\prime} \mathrm{W}$; BGN 1930; (map 10).

Named by USC\&GS in 1929 for Astrolabe Point.

Astrolabe Point: point of land, SW end of Astrolabe Penin. in Glacier Bay National Monument, $55 \mathrm{mi}$. WNW of Hoonah, St. Elias Mts.; $58^{\circ} 20^{\prime} 40^{\prime \prime} \mathrm{N}, 136^{\circ} 54^{\prime} 20^{\prime \prime} \mathrm{W}$; (map 10).

Named by USC\&GS in 1883 for L'Astrolabe. See Astrolabe Bay.
Astrolabe Rocks: rocks, at $\mathrm{S}$ end of Astrolabe Penin., in Glacier Bay National Monument, $56 \mathrm{mi}$. WNW of Hoonah, St. Elias Mts.; $58^{\circ}$ $20^{\prime} 30^{\prime \prime} \mathrm{N}, 136^{\circ} 54^{\prime} 20^{\prime \prime} \mathrm{W}$; BGN 1930; (map 10).

Named in 1926 by USC\&GS for nearby Astrolabe Point.

Astronomical Point: point of land, $\mathrm{N}$ point of entrance to Halibut Bay off Portland Canal, Coast Mts.; $55^{\circ} 13^{\prime} 15^{\prime \prime} \mathrm{N}, 130^{\circ} 05^{\prime} 00^{\prime \prime} \mathrm{W}$; (map 3).

Named in 1891 by USC\&GS.

Asukak Island: island, $1 \mathrm{mi}$. long, in Andreanof Is. between Great Sitkin and Umak Is., Aleutian Is.; $51^{\circ} 56^{\prime} \mathrm{N}, 176^{\circ} 06^{\prime} \mathrm{W}$; $B G N$ 1936; (map 17). Var. Agugsiak Island, Ostrov Asukhsakh.

Aleut name published as "O[strov] Asukhsakh," or "Asukhsakh Island," by Capt. Tebenkov (1852, map 28), IRN. This name may possibly come from the Aleut word "asux" which, according to R. H. Geoghegan, means "clay pot" or "boiler."

Asukhsakh, Ostrov: island, see Asukak Island.

Asuksak Pass: water passage, in Andreanof Is. between Umak and Asuksak Is., Aleutian Is.; $51^{\circ} 55^{\prime} \mathrm{N}, 176^{\circ} 04^{\prime} \mathrm{W}$; BGN 1936; (map 17).

Name derived from Asuksak Island in 1934 by members of the U.S. Navy Aleutian Island Survey Expedition.

Asumcion, Port: bay, extends NW 3 mi., off Bucareli Bay, on NE coast of Baker I., Alex. Arch.; $55^{\circ} 21^{\prime} 45^{\prime \prime} \mathrm{N}, 133^{\circ} 30^{\prime} 00^{\prime \prime} \mathrm{W}$; (map 4). Var. Gavan Nuyesta Sensora de la Asimsion, Port Assumption, Puerto de la Assumpcion, Puerto de nostra Señora de la Asumcion.

Name given on May 19, 1779, by Francisco Antonio Maurelle as "Puerto de la Assumpcion," meaning "Port of the Assumption."

Asumpcion, Puerto de la: bay, see Asumcion, Port.

At: island, see Attu Island.

Ata-ai-ach Mountain: mountain, 2,000 ft., at $E$ end of Pegati Lake, $75 \mathrm{mi}$. NE of Goodnews, Kilbuck-Kuskokwim Mts.; $59^{\circ} 51^{\prime}$ N, $160^{\circ} 04^{\prime}$ W; (map 53). Var. Atayak Mountain.

Eskimo name reported in 1898 by J. E. Spurr and W. S. Post, USGS.

Ataaiach Mountain: mountain, see Atayak Mountain.

Ataaiak Mountain: mountain, see Atayak Mountain.

Atakas Camp: locality, $12 \mathrm{mi}$. SE of Savoonga, $1 \mathrm{mi}$. W of Singikpo Cape, on $\mathrm{N}$ coast of Saint Lawrence I.; $63^{\circ} 37^{\prime} \mathrm{N}, 170^{\circ} 07^{\prime} \mathrm{W}$; (map 93). Var. Taphaparak.

This is a personal name. The place is also called "Taphaparak" according to Orth, 1965.

Atago Point: point of land, see Atahgo Point.

Atahgo Point: point of land, extends NE 2.5 mi. into Etolin Strait, $25 \mathrm{mi}$. NE of Cape Mendenhall, on Nunivak I.; $59^{\circ} 58^{\prime} 40^{\prime \prime} \mathrm{N}, 165^{\circ}$ $33^{\prime} 20^{\prime \prime} \mathrm{W}$; (map 55). Var. Atago Point.

Eskimo name reported in 1937 by USAAF. Atahgo Point: promontory, see Corwin Cape.

Atak: lake, see Atuk Lake.

Ataka: island, see Attu Island.

Atako: island, see Attu Island. 
Atakon: island, see Attu Island.

Atakou Island: island, see Attu Island.

Ataku Island: island, $0.4 \mathrm{mi}$. across, in Necker Is., on $W$ coast of Baranof $I ., 17 \mathrm{mi}$. SW of Sitka, Alex. Arch.; $56^{\circ} 49^{\prime} 45^{\prime \prime} \mathrm{N}, 135^{\circ} 29^{\prime} 00^{\prime \prime}$ W; (map 5). Var. Atakou Island, Ostrov Ataku.

Tlingit Indian name reported in 1809 by Ivan Vasiliev the first, IRN; published by Lt. Sarichev (1826, map 19), IRN, as "O[strov] Ataku," or "Ataku Island."

Ataniek: locality, see Atanik.

Atanik: locality, on Chukchi Sea coast, $7 \mathrm{mi}$. $\mathrm{NE}$ of Point Belcher and $20 \mathrm{mi}$. NE of Wainwright, Arctic Plain; $70^{\circ} 50^{\prime} \mathrm{N}, 159^{\circ} 21^{\prime} \mathrm{W}$; (map 146). Var. Ahtenmuk, Ataniek, Atnik, Attanak, Atune.

Former Eskimo village recorded on Brit. Adm. Chart 593 (1827-55), as "Attanak." Lt. L. A. Zagoskin, IRN, reported the name as "Atinikq" in 1847. Its population was given as 34 in the 1890 U.S. Census. The name may mean "straight."

Atayak Mountain: mountain, 3,000 ft., $3.5 \mathrm{mi}$. $E$ of Kagati Lake and $80 \mathrm{mi}$. NE of Goodnews, Kilbuck-Kuskokwim Mts.; $59^{\circ} 52^{\prime} \mathrm{N}$, $159^{\circ} 57^{\prime}$ W; (map 53). Var. Ataaiach Mountain, Ataaiak Mountain, Ah-tah-ai-ak.

Eskimo name reported in 1898 by J. E. Spurr and W. S. Post, USGS.

Atayak Mountain: mountain, see Ata-ai-ach Mountain.

Atcha Island: island, see Atka Island.

Atchaka Island: island, see Middleton Island. Atchalugumiut: locality, see Atchaluk.

Atchaluk: locality, "in the Kuskokwim district." Var. Atchalugumiut.

Former Eskimo camp or village listed as "Atchalugumiut" with a population of 39 in the 1880 Census.

Atchelik River: stream, see Aichilik River.

Atcheredina, Point: point of land, see Acheredin Point.

Atchka Island: island, see Atka Island.

Ätchō'-kōverūshkä': hill, see Gull Hill.

Atchueelingak Slough: stream, see Atchuelinguk River.

Atchuelinguk River: stream, heads at $63^{\circ} 02^{\prime} \mathrm{N}$, $161^{\circ} 27^{\prime} \mathrm{W}$, flows SW $165 \mathrm{mi}$. to Yukon River, $25 \mathrm{mi}$. W. of Marshall, Yukon-Kuskokwim Delta; $61^{\circ} 57^{\prime} 30^{\prime \prime} \mathrm{N}, 162^{\circ} 50^{\prime} 00^{\prime \prime} \mathrm{W}$; (map 74). Var. Chuilnak River, Chuilanuk River, Five Day Slough, Atchueelingak Slough.

Eskimo name first appearing as "Chuilanuk" on a fieldsheet by R. H. Sargent, USGS, dated 1916. Sargent notes that it is the "lower end of 5 day Si[ough]. It takes 5 days to row through this slough because it is so sinuous." The spelling has been modified to "Atchuelinguk" on recent maps to conform more closely with pronunciation. It refers in meaning to "water that isn't roily."

Atchu Island : island, see Atka Island.

Atel Creek : stream, see Ahtell Creek.

Atghka Island: island, see Atka Island.

Atherton Mountain: mountain, "( 1,700 feet high) on south shore of Wrangell island, Arctic ocean."
"So named by the British Admiralty, 1884." (Baker, 1906, p. 107).

Atigaru Point: point of land, on coast of Beaufort Sea, extends E into Harrison Bay, Arctic Plain; $70^{\circ} 33^{\prime} \mathrm{N}, 151^{\circ} 42^{\prime} \mathrm{W}$; (map 149). Var. At-ligga-ru, Attigaru.

Eskimo name published on Maguire's map (Great Britain, 1854, facing p. 186) as "Attigaru," and on Surgeon John Simpson's map of about the same date as "At-ligga-ru." Orth was told by an Anaktuvuk Pass Eskimo in 1956 that it may mean "old coat" (atigaruak).

Atigun River: stream, in Endicott Mts., heads at glacier terminus, flows NE $45 \mathrm{mi}$. to Sagavanirktok River $20 \mathrm{mi}$. S of its junc. with Rib-

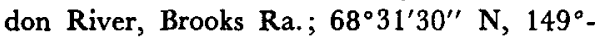
$01^{\prime} 00^{\prime \prime} \mathrm{W}$; (map 135).

Eskimo name reported in 1956 by USGS.

Atik: lake, see Atuk Lake.

Atileegówrak: water passage, see Atiligorak Inlet.

Atiligaurak Inlet: water passage, see Atiligorak Inlet.

Atiligauzaq: water passage, see Atiligorak Inlet.

Atiligorak Inlet: water passage, between a lagoon and Chukchi Sea, $8.3 \mathrm{mi}$. N of Cape Krusenstern, Kotzebue-Kobuk Low.; 67 ${ }^{\circ} 14^{\prime}$ $\mathrm{N}, 163^{\circ} 45^{\prime} \mathrm{W}$; (map 128). Var. Atileegówrak, Atiligaurak Inlet, Atiligauzaq.

Eskimo name meaning "little outlet," reported in 1966 by E. S. Burch.

Atinaaq: locality, see Atinak.

Atinahk: locality, see Atinak.

Atinak: locality, neck of land between Ipiavik and Imigrook Lagoons, $10 \mathrm{mi}$. SE of Kivalina, Kotzebue-Kobuk Low. ; $67^{\circ} 38^{\prime}$ N, $164^{\circ} 12^{\prime}$ W (map 128). Var. Atinaaq, Atinahk.

Eskimo name reported in 1966 by $E$. S. Burch.

Atka: village, pop. 119 , on Nazan Bay, on $\mathrm{E}$ coast of Atka I., Aleutian Is.; $52^{\circ} 12^{\prime} \mathrm{N}, 174^{\circ}$ $12^{\prime} \mathrm{W}$; BGN 1945; (map 18). Var. Atkha, Nazan.

Named for Atka Island. Reported as "Atkha" by Schwatka (1885, p. 115), USA. Recorded in 1880 as "Nazan," with a population of 236 , in the 1880 Census by Petroff (1884, p. 16). Atka post office was maintained 1938-57 (Ricks, 1965, p. 5).

Atka Island: island, $55 \mathrm{mi}$. long, largest of Andreanof Is., Aleutian Is.; $52^{\circ} 07^{\prime} \mathrm{N}, 174^{\circ} 30^{\prime}$ W; BGN 1890; (map 18). Var. Alcha Island, Atcha Island, Atchka Island, Atchu Island, Atghka Island, Atkha Isle, Ostrov Atka.

Aleut name reported by early Russian traders; published as "Atchu Island" by Rev. Coxe (1780, p. 156) ; "Atghka" by Capt. Cook (1785, v. 2, p. 503), RN; "Atkha Ile," by Capt. Lutke (1836, p. 307); IRN; "O[strov] Atka" or "Atka Island," on the 1848 Russian Hydrog. Dept. Chart 1400, and by Capt. Tebenkov (1852, map 27), IRN.

Atka Lake: lake, $0.1 \mathrm{mi}$. across, on west-central Saint George I., in Pribilof Is.; $56^{\circ} 34^{\prime} 45^{\prime \prime} \mathrm{N}$, $169^{\circ} 39^{\prime} 25^{\prime \prime} \mathrm{W}$; (map 38). Var. Naro'aman'yi.

This name is a translation of the Aleut name, "Naro'am-an'yi," recorded by Putnam
(1903, p. 1015), USC\&GS, and "so called by Atka [island in the Aleutians] natives having lived in the vicinity." The name was published in 1898 by USC\&GS.

Atka Pass: water passage, $5 \mathrm{mi}$. across, in Andreanof Is. between Atka and Oglodak Is. Aleutian Is.; $52^{\circ} 00^{\prime} \mathrm{N}, 175^{\circ} 22^{\prime} \mathrm{W}$; $B G N$ 1936; (map 18).

Named for Atka I. by members of the U.S. Navy Aleutian Island Survey Expedition of 1934; published by the USC\&GS in the 1944 Aleutian Coast Pilot (p. 104).

Atkasak: village, see Meade River.

Atkasuk: village, see Meade River.

Atkha: village, see Atka.

Atkha Island: island, see Atka Island.

Atkin Island : island, see Atkins Island.

Atkins Island: island, $2 \mathrm{mi}$. long, in Shumagin Is. NE of Little Koniuji I., Aleutian Ra.; $55^{\circ} 03^{\prime} 30^{\prime \prime} \mathrm{N}, 159^{\circ} 18^{\prime} 30^{\prime \prime} \mathrm{W}$; (map 27). Var. Atkin Island.

Named about 1880 by W. H. Dall, USC\&GS, for the fishing schooner Minnie $G$. Atkins.

Atkoulick, Île: island, see Atkulik Island.

Atkritoi: rocks, see Discovery Rocks.

Atkritoi Bay: bay, see Otkriti Bay.

Atkroiglaza: rock, see Eye Opener, The.

Atkulik : locality, on Agattu I., Near Is., Aleutian Is. ; (map 13).

Former Aleut settlement or camp listed by Hodge (1907, p. 111), BAE.

Atkulik Island: island, elev. $725 \mathrm{ft}$., $1 \mathrm{mi}$. across, $4 \mathrm{mi}$. SE of Nakchamik I. and $26 \mathrm{mi}$. E. of Chignik, in Pacific Ocean, Aleutian Ra.; $56^{\circ} 16^{\prime} \mathrm{N}, 157^{\circ} 44^{\prime} \mathrm{W}$; (map 31). Var. Atkunk, Ile Atkoulick, Ostrov Atkulik.

Native name, shown as "I[le] Atkoulick" by von Krusenstern (1827, map 20) and as "[Ostrov] Atkulik" by the Russian Hydrog. Dept. (1847, Chart 1379).

Atkulik, Ostrov: island, see Atkulik Island.

Atkunk : island, see Atkulik Island.

Atla Creek: stream, heads in Indian Mts., flows W $12 \mathrm{mi}$. to Koyukuk River, $6 \mathrm{mi}$. NNE of Hughes, Kokrines-Hodzana High.; $66^{\circ} 08^{\prime} \mathrm{N}$, $154^{\circ} 10^{\prime} \mathrm{W}$; (map 116).

Indian family name recorded at Hughes in 1956 by Orth. Archdeacon Stuck (1914b, p. 170-171) mentioned an Indian called "Old Atler," who lived in this area in 1909.

Atlas Creek: stream, flows SE $2 \mathrm{mi}$. to Quartz Creek which flows to Kougarok River, $48 \mathrm{mi}$. SW of Imuruk Lake, Seward Penin. High.; $65^{\circ} 22^{\prime} \mathrm{N}, 164^{\circ} 45^{\prime} \mathrm{W}$; (map 110).

Prospectors' name reported in 1906 by A. H. Brooks (in Collier and others, 1908, pl. 9), USGS.

Atlasta Creek: stream, flows S $3.2 \mathrm{mi}$. to Lost Cabin Lake, $\mathrm{S}$ of Glenn Highway, $21 \mathrm{mi}$. W of Glennallen, Cooper River Basin ; 62 ${ }^{\circ} 04^{\prime} 30^{\prime \prime}$ $\mathrm{N}, 146^{\circ} 11^{\prime} 00^{\prime \prime} \mathrm{W}$; (map 83).

Name derived from a roadhouse which was named from a chance remark of the owner's wife on completion of the first building, "At last a house."

At-ligga-ru: point of land, see Atigaru Point. Atliggaru: point of land, see Halkett, Cape. 
Atlik Hill: hill, 1,630 ft., on right bank of Colville River, $29 \mathrm{mi}$. E of Liberator Lake, Arctic Slope; 68 $51^{\prime} \mathrm{N}, 157^{\circ} 12^{\prime} \mathrm{W}$; (map 132).

Eskimo name meaning "lower" or "beneath," reported in 1956 by T. E. Taylor, USGS.

Atlin, Mount: nunatak, 7,550 ft., in the Chilkoot Range, on the Alaska-Canada boundary $8 \mathrm{mi}$. SE of Mount Poletica, Coast Mts.; 59 $02^{\prime} \mathrm{N}$, $134^{\circ} 23^{\prime}$ W; (map 44). Var. Boundary Peak 100.

Named by Lawrence Martin, U.S. Department of State, in 1923 "because glimpses of Atlin Lake in Canada can be seen from this point."

Atmo Mountain: mountain, 2,661 ft., on E coast of Alaska Penin. in Katmai National Monument, $19 \mathrm{mi}$. SW of Mount Katmai, Aleutian

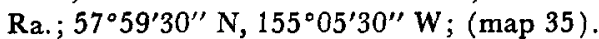
Named in 1919 by Griggs (1922, map), NGS.

Atmugiak Creek: stream, flows SW $6 \mathrm{mi}$. to Kagati Lake, $75 \mathrm{mi}$. NE of Goodnews, Kilbuck-Kuskokwim Mts.; $59^{\circ} 52^{\prime} \mathrm{N}, 160^{\circ} 03^{\prime} \mathrm{W}$; (map 53).

Eskimo name reported in 1898 by J. E. Spurr and W. S. Post, USGS.

Atna Peaks: peaks, two, 13,860 and $13,600 \mathrm{ft}$., $6 \mathrm{mi}$. E of Mount Blackburn and $24 \mathrm{mi}$. NW of McCarthy, Wrangell Mts.; $61^{\circ} 45^{\prime} 00^{\prime \prime} \mathrm{N}$, 143 $13^{\prime} 40^{\prime \prime}$ W; BGN 1966; (map 67).

So named in 1965 by the Mountaineering Club of Alaska, because the "peaks are at the edge of the Copper River drainage and the old Indian name for that river was Atna."

Atna River: stream, see Copper River.

Atneerich Creek: stream, in De Long Mts., flows $7 \mathrm{mi}$. to Kelly River, $23 \mathrm{mi}$. NW of Misheguk Mt., Brooks, Ra., $68^{\circ} 22^{\prime} \mathrm{N}, 162^{\circ} 00^{\prime} \mathrm{W}$; (map 131).

Eskimo name reported about 1955 by U.S. Army Corps of Engineers.

Atnick: locality, see Atnuk.

Atnick-miut: locality, see Atnuk.

Atnik: locality, see Atanik.

Atnikmioute: locality, see Atnuk.

Atnikmut: locality, see Atnuk.

Atniliak Ile: island, see Atniliak Island.

Atniliak Island: island, one of smaller Shumagin Is., Aleutian Ra.; $55^{\circ} \mathrm{N}, 160^{\prime} \mathrm{W}$; (map 27). Var. Anilyak, Animak, Atniliak Ile.

Aleut name, published as "Atniliak Ile" by Capt. Lutke (1836, p. 267), IRN. Described by Father Veniaminov (1836, p. 255) as oblong and low, with a long cape and a lake. The exact location of this island is unknown. Atnuk: locality, on NW shore of Norton Bay, $10 \mathrm{mi}$. NE of Cape Darby, Seward Penin.

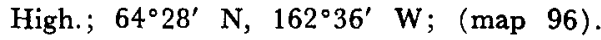
Var. Aniluk, Annuk, Atnick, Atnick-miut, Atnikmioute, Atnikmut, Att-nagha-mute.

Site of an Eskimo village reported as "Atnick-myut" in 1842-44 by Lt. L. A. Zagoskin, IRN. Personnel of the Western Union Telegraph Expedition of 1865-67 quartered at Teller reported the name as "Att-naghamute." Ivan Petroff reported "Atnuk" with a population of 20 in the 1880 Census.
The 11 th Census in 1890 listed "Aniluk" as having a population of 34 . About 1900, USC\&GS and USGS showed the village of "Atnuk" here as well as a village named "Annuk," located between here and Cape Darby. See Portage Roadhouse.

Atnuk River: stream, "on the northern shore of Norton bay, Norton sound."

"Tebenkov, 1849, calls the river Atnick, and Tikhmenief, in 1861, calls the settlement Atniek-miut. Petroff, 1880, writes it Atnuk. Erroneously Annuk" (Baker, 1906, p. 108). Atongarak Creek: stream, heads in lake, flows SW $15 \mathrm{mi}$, to Noatak River, $24 \mathrm{mi}$. ENE of junc. of Cutler River, Brooks Ra.; $67^{\circ} 56^{\prime} \mathrm{N}$, $157^{\circ} 27^{\prime} \mathrm{W}$; (map 126).

Eskimo name meaning "been used before;" obtained at Noatak in 1956 by Orth.

Atonisuk River: stream, "tributary to the Yukon from the north, about 50 miles above Rampart."

"Native name, from Raymond, 1869, who wrote it Atonisonik. Petroff, 1880, wrote it Ahtonisuk. This may be identical with Ray River of Allen, 1885, and of recent maps. See Ray" (Baker, 1906, p. 108).

Atoo: island, see Attu Island.

Atosik Lagoon: lagoon, $0.4 \mathrm{mi}$. long, on Chukchi Sea coast, S of Kisimilok Mtn., $15 \mathrm{mi}$. SE of Cape Thompson, Arctic Slope; 68 $8^{\circ} 03^{\prime} 05^{\prime \prime}$ N, $165^{\circ} 26^{\prime} 20^{\prime \prime} \mathrm{W}$; $B G N$ 1963; (map 129). Var. Ahtosik Lagoon.

Eskimo name reported to mean "one" by Project Chariot personnel in 1962.

Atouchagvik, Cap: point of land, see Atushagvik, Cape.

Atrevida Glacier: glacier, heads at about $60^{\circ} 01^{\prime}$ $\mathrm{N}, 138^{\circ} 43^{\prime} \mathrm{W}$; trends $6 \mathrm{mi}$. SW to Lucia Glacier, $W$ of Amphitheater Knob, $29 \mathrm{mi}$. N of Yakutat, St. Elias Mts.; 59 $56^{\prime} 30^{\prime \prime} \mathrm{N}$, $139^{\circ} 50^{\prime} 00^{\prime \prime} \mathrm{W}$; (map 46).

Named in 1890 by Russell (1891, p. 92), USGS, for one of the two vessels of Capt. Malaspina, an Italian who, in the service of Spain, explored the Alaskan coast in 1791.

At River: stream, see Copper River.

Atrnak Point: point of land, on SW coast of Nelson I., $7 \mathrm{mi}$. SE of Cape Vancouver, Yukon-Kuskokwim Delta; $60^{\circ} 29^{\prime} \mathrm{N}, 165^{\circ} 16^{\prime}$ W; (map 57).

Eskimo name obtained at Tanunak in 1949 by USC\&GS.

Atroic: village, see Stebbins.

Atroik : village, see Stebbins.

Atsakirak Mound: $h u m m o c k$, on barrier beach of Kivalina Lagoon, $6 \mathrm{mi}$. NW of Kivalina, Kotzebue-Kobuk Low.; $67^{\circ} 47^{\prime} \mathrm{N}, 164^{\circ} 42^{\prime} \mathrm{W}$; (map 128). Var. Aatsakizaaq, Ahchakeerock. Eskimo name reported in 1966 by E. S. Burch.

Atsaksovluk Creek: stream, flows SW $20 \mathrm{mi}$. to Aniak River, $93 \mathrm{mi}$. NE of Bethel, KilbuckKuskokwim Mts.; $60^{\circ} 57^{\prime}$ N, $159^{\circ} 04^{\prime}$ W; BGN 1948; (map 59). Var. East Fork, East Fork Aniak River, Waterboot Creek.

Eskimo name reported in 1945 by USGS to mean "place to get berries."
Atshichlut Mountain: mountain, 4,000 ft., 4 mi. SW of Nenevok Lake, $74 \mathrm{mi}$. NE of Goodnews, Kilbuck-Kuskokwim Mts.; $59^{\circ} 44^{\prime}$ N, 159 $52^{\prime}$ W; (map 53).

Eskimo name reported in 1898 by W. S. Post, USGS.

Attak: island, see Attu Island.

Attanak: locality, see Atanik.

Attemut: locality, see Atten.

Atten: locality, "near the head of the Buckland

River, northwestern Alaska." (map 109). Var. Attenmut, Attemut.

Former Eskimo village spelled "Attenmut" in 1869 by Dall (1870, p. 284), USC\&GS.

Attenmut: locality, see Atten.

Attenok: locality, on Seahorse Is. between Peard Bay and Chukchi Sea, Arctic Coastal Plain; (map 148). Var. Attenokamiut.

Former Eskimo village reported as "Attenokamiut" in the 11 th Census of 1890.

Attenokamiut: locality, see Attenok.

Attigaru: point of land, see Atigaru Point.

Attiunik Channel: stream, distributary of Kobuk River, heads at Nazuruk Channel, Kobuk River, flows SE $6 \mathrm{mi}$. to Hotham Inlet, 34 mi. NW of Selawik, Kotzebue-Kobuk Low.; $66^{\circ} 32^{\prime} \mathrm{N}, 161^{\circ} 14^{\prime} \mathrm{W}$; (map 114).

Eskimo name obtained in 1955 by U.S. Army Corps of Engineers.

Attiunik Point: point of land, at outlet of Selawik Lake, $32 \mathrm{mi}$. WSW of Selawik, KotzebueKobuk Low.; 66 $32^{\prime} \mathrm{N}, 161^{\circ} 10^{\prime} \mathrm{W}$; (map 114).

Eskimo name reported by Lt. G. M. Stoney, USN, on a manuscript map made about 1885 . Att-nagha-mute: locality, see Atnuk.

Atto: island, see Attu Island.

Attonock Mountain: mountain, 3,220 ft., $4.5 \mathrm{mi}$. SSW of Stone Mtn., $50 \mathrm{mi}$., NE of Medfra, Kilbuck-Kuskokwim Mts.; $63^{\circ} 39^{\prime} \mathrm{N}, 153^{\circ} 55^{\prime}$ W; (map 89).

Named by the U.S. Army Corps of Engineers about 1951, "for an area or district in India."

Attou Island: island, see Attu Island.

Attu: locality, on NW shore of Chichagof Harbor, on NE coast of Attu I., Aleutian Is.; $52^{\circ} 56^{\prime} 25^{\prime \prime} \mathrm{N}, 173^{\circ} 15^{\prime} 00^{\prime \prime} \mathrm{E}$; (map 13). Var. Attoo, Chichagof, Chichagov.

Aleut village listed in the 1880 Census with 107 people; 101 in 1890; 29 in 1930; and 44 in 1940. The 1944 Aleutian Coast Pilot relates that this village was mostly destroyed in 1943 in connection with U.S. military operations against the Japanese. The U.S. military forces referred to the village as "Chichagof" at that time.

Attu Island: island, $37 \mathrm{mi}$. long, the westernmost of Near Islands, the farthest $W$ of Aleutian Islands; $52^{\circ} 55^{\prime} \mathrm{N}, 172^{\circ} 55^{\prime} \mathrm{E}$; BGN 1890; (map 13). Var. Ahtoo, At, Ataka, Atako, Atakon, Atoo, Attak, Attoo, Attou Island, Otma, Saint Abraham Island, Saint Etienne Island, Saint Theodore Island.

Attu, although possibly seen by one or both of the 1741 expedition ships from a great distance, was officially discovered and called "Saint Theodore" by Capt. A. I. Chirikov in 
the spring of 1742 (Bancroft, 1886, p. 93). The first landing on the island appears to have been in 1745 by a party of promyshlenniki led by Mikhail Nevodchikov. The Aleut name of the island was early transcribed by the Russians as "Ostrov Attu"; spelled "Atakou" by Capt. Cook (1785, v. 2, p. 502), RN.

Attu Mountain: mountain, 3,000 ft., on central Attu I., Aleutian Is., $52^{\circ} 54^{\prime} 45^{\prime \prime} \mathrm{N}, 172^{\circ} 56^{\prime} 00^{\prime \prime}$ E; (map 13).

Name derived from Attu Island; published in 1948 by AMS.

Atuk Lake: lake, $0.5 \mathrm{mi}$. long, in crater of Atuk Mtn., 42 mi. SE of Gambell, St. Lawrence I.; $63^{\circ} 36^{\prime} \mathrm{N}, 170^{\circ} 26^{\prime} \mathrm{W}$; BGN 1951; (map 93). Var. Atak, Atik.

Eskimo name. See Atuk Mountain.

Atuk Mountain: mountain, 2,010 ft., in Kookooligit Mts. $7 \mathrm{mi}$. S of Savoonga, St. Lawrence I.; $63^{\circ} 36^{\prime} \mathrm{N}, 170^{\circ} 26^{\prime} \mathrm{W}$; BGN 1951; (map $93)$.

Eskimo name sometimes written "Atak" or "Atik," meaning "name;" recommended to USGS in 1947 by the Savoonga village council.

Atune: locality, see Atanik.

Atushagvik, Cape: point of land, on S coast of Alaska Penin., in Katmai National Monument, extends SE between Kinak and Missak Bays, $22 \mathrm{mi}$. SE of Mount Katmai, Aleutian Ra.; $58^{\circ} 05^{\prime} \mathrm{N}, 154^{\circ} 19^{\prime} \mathrm{W}$; (map 42). Var. Cap Atouchagvik, Mys Atushagvik.

Name published by Capt. F. P. Lutke (1836, p. 275), IRN, as "Cap Atouchagvik."

Atushagvik, Mys: point of land, see Atushagvik, Cape.

Atutsakalakushchargut: stream, see Atutsak River.

Atutsak River: stream, flows N $18 \mathrm{mi}$. to Yukon River, S of Little Joker I., $18 \mathrm{mi}$. WSW of Tanana, Nowitna Low.; $65^{\circ} 09^{\prime} \mathrm{N}, 152^{\circ} 41^{\prime}$ W; (map 106). Var. Atutsakalakushchargut, Atutsakulakushakakat, Atutsakulakushehakat, Atutzehhuilcusten.

Indian name reported in 1869 as "Atutsakalakushchargut" by Capt. Raymond (1871, p. 23), U.S. Army Corps of Engineers. In 1885, Lt. Allen, USA, spelled it "Atutsakulakushakakat"; USC\&GS published it as "Atutzehhuilcusten." The name has been shortened for obvious reasons.

Atutsakulakushakakat: strcam, see Atutsak River.

Atutsakulakushehakat: stream, see Atutsak River.

Atutzehhuilcusten: stream, see Atutsak River.

Atwater Creek: stream, flows N $5.5 \mathrm{mi}$. to South

Fork Fortymile River, $55 \mathrm{mi}$. SW of Eagle, Yukon-Tanana High.; $64^{\circ} 03^{\prime} 00^{\prime \prime} \mathrm{N}, 141^{\circ}$ 47'30' W; (map 102).

Prospectors' name obtained in 1898 by E. C. Barnard, USGS.

Auan Alaska: island, see Unalaska Island.

Auburn Cove: cove, $1 \mathrm{mi}$. across, part of Steller Cove, on $\mathrm{N}$ coast of Attu I., Aleutian Is. ; $52^{\circ}$ $58^{\prime} 45^{\prime \prime} \mathrm{N}, 172^{\circ} 55^{\prime} 00^{\prime \prime} \mathrm{E}$; (map 13).

Named by the U.S. Army during World War II. This name, along with Brunette and Blonde Coves, so-called "pin-up" names, may have been suggested by Red Head, a nearby promontory.

Auburn Creek: stream, flows NE $1 \mathrm{mi}$. to Birch Creek which flows to Big Four Creek, $19 \mathrm{mi}$. NE of Solomon, Seward Penin. High.; $64^{\circ}$. $49^{\prime} \mathrm{N}, 164^{\circ} 11^{\prime} \mathrm{W}$; (map 95). Var. Auburn Ravine Creek.

Prospectors' name reported on a 1902 prospectors' manuscript map.

Auburn Creek: stream, flows NW $4 \mathrm{mi}$. to American Creek which flows to Niukluk River, 26 mi. NW of Solomon, Seward Penin. High.; $64^{\circ} 55^{\prime} \mathrm{N}, 164^{\circ} 32^{\prime} \mathrm{W}$; (map 95). Var. Auburn Ravine Creek.

Prospectors' name reported as "Auburn Ravine" on a 1901 map of Cape Nome gold fields by David Fox, Jr.

Auburn Creek: stream, see Game Creek.

Auburn Ravine Creek: stream, see Auburn Greek.

Aucella Creek: stream, flows NW 4 mi. to Kiruktagiak River, $8 \mathrm{mi}$. SSW of Castle Mtn., 35 mi. NW of Anaktuvuk Pass, Arctic Slope ; $68^{\circ}-$ $28^{\prime} \mathrm{N}, 152^{\circ} 45^{\prime} \mathrm{W}$; BGN 1959; (map 134).

So named in 1950 by W. W. Patton, USGS, because of the abundance of species of Aucella, fossil clams, found in the outcrops on the creek.

Audrey, Port: estuary, on W coast of Knight I., trends $\mathrm{S} 1 \mathrm{mi}$. to head of Drier Bay, $12 \mathrm{mi}$. $\mathrm{NE}$ of Chenega, Chugach Mts.; $60^{\circ} 20^{\prime} 05^{\prime \prime} \mathrm{N}$, $147^{\circ} 45^{\prime} 30^{\prime \prime} \mathrm{W}$; (map 63).

Name published in 1943 by USC\&GS.

Audrey Passage: water passage, see Windy Passage.

Audubon Mountain: mountain, 8,400 ft., $4 \mathrm{mi}$. $\mathrm{NE}$ of Mount Powder Top and $30 \mathrm{mi}$. NW of Valdez, Chugach Mts.; $61^{\circ} 28^{\prime} 17^{\prime \prime} \mathrm{N}, 146^{\circ}$. $47^{\prime} 43^{\prime \prime} \mathrm{W}$; BGN 1965; (map 68).

Named about 1957 by L. E. Nielsen for John James Audubon, 1785-1851, American ornithologist and artist.

Aueruk: stream, "Tributary to Norton Bay from the northwest, between the Tabutulik and Kwiniuk Rivers, Seward Peninsula."

"Native name, from the Davidson Blakeslee map of 1900 , where it is spelled 'Oweruk' " (Baker, 1906, p. 109).

Augnak Rocks: islands, see Aiugnak Columns.

Augusta, Mount: peak, 14,070 ft., on AlaskaCanada boundary, $16 \mathrm{mi}$. E of Mount St. Elias and $58 \mathrm{mi}$. NNW of Yukutat, St. Elias Mts.; $60^{\circ} 18^{\prime} 30^{\prime \prime} \mathrm{N}, 140^{\circ} 27^{\prime} 20^{\prime \prime} \mathrm{W}$; (map 66). Var. Boundary Peak 183, Mount Agusta.

Named in 1891 by I. C. Russell, USGS, for his wife J. Augusta Olmsted Russell. It was first climbed July 4, 1952 (Farquhar, 1959, p. 213).

Augusta, Point: point of land, on NE coast of Chicagof I., on Chatham Strait, $4 \mathrm{mi}$. N of False Bay and $26 \mathrm{mi}$. SW of Juneau, Alex. Arch.; $58^{\circ} 02^{\prime} 25^{\prime \prime} \mathrm{N}, 134^{\circ} 57^{\prime} 00^{\prime \prime} \mathrm{W}$; (map 11).

Discovered by Joseph Whidbey July 24, 1794, and named by Capt. George Vancouver (1798, v. 3, p. 259), RN, for Augusta Sophia, daughter of George III of England (Wagner, 1937, p. 374).

Augusta Glacier: glacier, heads in Canada, between Mounts Augusta and Eaton, trends W and $S 3 \mathrm{mi}$. to Seward Glacier, $54 \mathrm{mi}$. NNW of Yakutat, St. Elias Mts.; $60^{\circ} 14^{\prime} \mathrm{N}, 140^{\circ} 25^{\prime}$ W; (map 66). Var. Agusta Glacier.

Named in 1891 by I. C. Russell, USGS, "for Mt. Augusta," and presumably for his wife J. Augusta Olmsted Russell.

August Creek: stream, flows NE to Auburn Creek which flows to American Creek, $0.7 \mathrm{mi}$. $\mathrm{S}$ of Jack Wade Greek and $22 \mathrm{mi}$. $\mathrm{N}$ of Solomon, Seward Penin. High.; 64 $4^{\circ} 53^{\prime} 10^{\prime \prime}$ N,

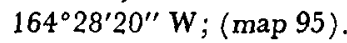

Prospectors' name reported in 1907 by USGS geologists (Smith, P. S., 1910, pl. 4).

August Hill: hill, 1,170 ft., on W shore of Cook Inlet, S of Slope Mtn., $62 \mathrm{mi}$. SW of Kenai, Aleutian Ra.; $60^{\circ} 01^{\prime} \mathrm{N}, 152^{\circ} 40^{\prime} \mathrm{W}$; (map 62).

Local name reported in 1958 by USGS.

Augustin Peak: peak, "in the McKinley range, near latitude $62^{\circ} 10^{\prime}$, longitude $153^{\circ}$. "

"So named by Herron, 1899" (Baker, 1906, p. 109).

Augustine, Cape: point of land, between Augustine and Waterfall Bays, on $W$ coast of Dall I., Alex. Arch.; $54^{\circ} 57^{\prime} \mathrm{N}, 133^{\circ} 10^{\prime} \mathrm{W}$; $B G N$ 1923; (map 1). Var. Cabo de San Augustin, Cape Saint Augustine.

Named "Cabo de San Augustine" or "Cape of Saint Augustine" by Francisco Antonio Maurelle in 1775; published in its present form by USC\&GS in 1883 .

Augustine Bay: estuary, extends E $1 \mathrm{mi}$., on W coast of Dall I., $N$ of Cape Augustine, Alex.

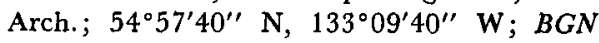
1923; (map 1). Var. Saint Augustine Bay.

Named by W. H. Dall, USC\&GS, in 1883; derived from nearby Cape Augustine.

Augustine Island: island, elev. 4,025 ft., $7.5 \mathrm{mi}$. across, in Kamishak Bay, $70 \mathrm{mi}$. SW of Homer, Aleutian Ra.; $59^{\circ} 22^{\prime} \mathrm{N}, 153^{\circ} 26^{\prime} \mathrm{W}$; $B G N$ 1910; (map 51). Var. Blackbrown Island, Chernoburii Island, Mount Saint Augustin, Mount Saint Augustine, Ostrov Chernoburoy, Saint Augustine Island, Saint Augustin Island.

Formed by Augustine Volcano, it was discovered and named "Saint Augustine Island" in 1778 by Capt. James Cook, RN. Capt. Tebenkov (1852, map 5), IRN, called it "O[strov] Chernoburoy," which was derived from the Russian words "chernyy," meaning "black," and "buryy," meaning "brown." Reported in 1867 as "Blackbrown Island" by USC\&GS.

Augustine Rocks: rocks, in Cook Inlet, $10 \mathrm{mi}$. $\mathrm{S}$ of Augustine I., Aleutian Ra.; $59^{\circ} 03^{\prime} \mathrm{N}$, $153^{\circ} 21^{\prime}$ W; BGN 1910; (map 51). Var. Sea Otter Rocks.

Named "Sea Otter Rocks" by W. H. Dall (1896, pl. 50), USGS, but renamed in 1910 because of their proximity to Augustine Island.

Augustine Volcano: mountain, 4,025 ft., former volcano, which formed Augustine I., in $\mathrm{Ka}$ mishak Bay, $70 \mathrm{mi}$. SW of Homer, Aleutian 
Ra.; 59 $22^{\prime}$ N, $153^{\circ} 26^{\prime}$ W; (map 51). Var. Mount Chinabora, Mount Saint Augustin, Mount Saint Augustine, Mount San Augustine, Pan de Azucar, Pilon de Azucar.

The mountain was named "Mount San Augustine" in an 1867 USC\&GS report, and "Mount Chinabora" on a 1928 U.S. Post Route map. In the larger sense one may credit Capt. James Cook with the naming for it appears as if the name he gave to the island also applied to the mountain. See Augustine Island. It was called "Pan de Azucar," i.e. "sugar loaf" by Don Ignacio Arteaga in 1779.

Augustin Peak: peak, 8,600 ft., in Cathedral Spires of Kichatna Mts., $81 \mathrm{mi}$. W of Talkeetna, Alaska Ra.; $62^{\circ} 25^{\prime} 10^{\prime \prime} \mathrm{N}, 152^{\circ} 37^{\prime} 15^{\prime \prime}$ W; (map 81).

Named in 1899 by Lt. J. S. Herron, USA.

Augutaurak: bluff, on Saligvik Ridge, $1 \mathrm{mi}$. NW of mouth of Ogotoruk Creek and $5.5 \mathrm{mi}$. SE of Cape Thompson, Arctic Slope; 68 $06^{\prime} \mathrm{N}$, $165^{\circ} 47^{\prime} \mathrm{W}$; (map 129). Var. Augutauzaq, Owgootowruk, Akhotóruk.

Eskimo name meaning "little food bag (poke)" or "seal's stomach" which the bluff resembles; reported as "Akhotóruk" in 1962 by W. O. Pruitt, Jr. of Univ. of Alaska.

Augutauzaq: bluff, see Augutaurak.

Augutorux Creek: stream, see Ogotork Creek.

Aukamunuk Creek: stream, heads at Tshachaling-Atachtoli Lake, flows NW $8 \mathrm{mi}$. to Kagati Lake, $75 \mathrm{mi}$. NE of Goodnews, KilbuckKuskokwim Mts. ; 59 51' N, 160 03' W ; (map 53).

Eskimo name reported in 1898 by W. S. Post, USGS.

Aukan: locality, see Auke.

Auk Bay: bay, on E coast of Kenai Penin., 2 mi. long, on Port Bainbridge, $22 \mathrm{mi}$. SW of Chenega, Chugach Mts.; $60^{\circ} 01^{\prime} 15^{\prime \prime} \mathrm{N}, 148^{\circ}$ 24'15" W; BGN 1929; (map 63).

Named in 1929 by USC\&GS "for the Auk subdivision of the Tlingit Indians."

Auk Bay: bay, see Auke Bay.

Auk Creek: stream, see Eagle Creek.

Auke: locality, just E of Point Louisa adjacent to Glacier Bay Highway and $13 \mathrm{mi}$. NW of Juneau, Coast Mts. ; $58^{\circ} 22^{\prime} 30^{\prime \prime} \mathrm{N}, 134^{\circ} 43^{\prime} 30^{\prime \prime}$ W; (map 11). Var. Antcgaltsu, Anchguhlsu, Aukan, Old Auk Village, Akan.

Former Tlingit Indian village of the Auk tribe. The name "Ak an" means "lake town" according to J. R. Swanton in 1904. The name "Anchguhlsu (or Antcgaltsu)" is reported by Swanton to mean "town they abandoned," a name obviously applied after abandonment about 1902.

Auke Bay: village, pop. 500, on Auke Bay, 1 mi. W of Auke Lake and $10.5 \mathrm{mi}$. NW of Juneau, Coast Mts. ; $58^{\circ} 23^{\prime} 00^{\prime \prime} \mathrm{N}, 134^{\circ} 39^{\prime} 30^{\prime \prime}$ W; (map 11).

Name derived from the bay of the same name. It was settled soon after Glacier Highway reached there in 1918 (DeArmond, 1957, p. 6). A post office was established in 1946 (Ricks, 1965, p. 5).

Auke Bay: bay, $3 \mathrm{mi}$. across, off $\mathrm{W}$ coast of Mendenhall Penin., just NE of Coglan I., 10 mi. NW of Juneau, Coast Mts.; $58^{\circ} 21^{\prime} \mathrm{N}$, $134^{\circ} 41^{\prime}$ W; $B G N$ 1917; (map 11), Var. Auk Bay, Auke Cove.

Narne reported by Spencer and Wright (1906, pl. 37), USGS. The name is from the Auk Tlingit Indians, who occupied the north end of Admiralty Island, Douglas Island, and the mainland from Juneau, north to Berners Bay. It is said the Indians derived their name from the word "AK! $u$ " meaning "little lake." It was one of the few Indian names in this area retained by the miners (DeArmond, 1957, p. 6).

Auke Bay: bight, about $14 \mathrm{mi}$. W of Point Arden on Admiralty I. and $10 \mathrm{mi}$. S of Juneau, Coast Mts.; 58 $11^{\prime} \mathrm{N}, 134^{\circ} 34^{\prime} \mathrm{W}$; (map 11). Var. Auke Cove.

Named in 1869 by Comdr. R. W. Meade, USN, for the Auk Indians, a subdivision of the Tlingits. They had a village near the bay, according to 1883 Coast Pilot (p. 172 and map 182). The exact position of this bay as described by Meade is uncertain. It is called "Auke Cove" by Baker (1906, p. 109), USGS. On recent maps the name has been applied to a bay 11 miles northwest of Juneau. See other Auke Bay.

Auke Cape: peninsula, $0.4 \mathrm{mi}$. long, in Auke Bay, $0.2 \mathrm{mi}$. $E$ of Fairhaven and $11 \mathrm{mi}$. NW of Juneau, Coast Mts. ; $58^{\circ} 22^{\prime} 45^{\prime \prime} \mathrm{N}, 134^{\circ} 41^{\prime} 30^{\prime \prime}$ W; BGN 1937; (map 11).

Local name derived from the bay of the same name, and reported by USFS in 1937.

Auke Cove: bay, see Auke Bay.

Auke Cove: bight, see Auke Bay.

Auke Cove: cove, see Admiralty Cove.

Auke Creek: stream, flows $0.3 \mathrm{mi}$. SW from Auke Lake to Auke Bay, on $\mathrm{N}$ end of Mendenhall Penin., $1 \mathrm{mi}$. W of Juneau Airport and $9 \mathrm{mi}$. NW of Juneau, Coast Mts.; $58^{\circ} 22^{\prime} 55^{\prime \prime} \mathrm{N}$, $134^{\circ} 38^{\prime} 30^{\prime \prime} \mathrm{W}$; (map 11). Var. Aylward Creek, Auke River.

The miners called this Aylward Creek from the lake of the same name, which is its source. The name was probably changed to Auke Creek about 1902, when the name of the lake was changed to Auke Lake. This name was reported in 1903 by Wright (1906, fig. 39), USGS.

Auke Creek: stream, see Admiralty Creek.

Auke Glacier: glacier, see Mendenhall Glacier. Auke Lake: lake, $0.8 \mathrm{mi}$. across, $1 \mathrm{mi}$. $\mathrm{E}$ of village of Auke Bay and $12 \mathrm{mi}$. NW of Juneau, Coast Mts. ; $58^{\circ} 23^{\prime} \mathrm{N}, 134^{\circ} 38^{\prime} \mathrm{W}$; BGN 1929; (map 11). Var. Aylward Lake.

Originally called Aylward Lake by early miners for Edward Aylward who, in 1884, located mining claims in the vicinity. The present name is derived from the name of the Auks, a subdivision of the Tlingit Indians, who lived in this area (DeArmond, 1957, p. 6). The name was published by USGS (Knopf, 1912a, pl. 1).

Auke Mountain: mountain, $1,870 \mathrm{ft} ., 1 \mathrm{mi}$. N of Fairhaven on Auke Bay and $12 \mathrm{mi}$. NW of Juneau, Coast Mts.; $58^{\circ} 23^{\prime} 30^{\prime \prime} \mathrm{N}, 134^{\circ}$. 42'45" W; BGN 1929; (map 11).
Local name derived from the name of the Auk subdivision of the Tlingit Indians who once occupied this area; published by USGS (Knopf, 1912a, pl, 2).

Auke Nu Cove: cove, $1 \mathrm{mi}$. across, on $\mathrm{N}$ shore of Auke Bay, $\mathrm{N}$ of Auke Cape and $12 \mathrm{mi}$. NW of Juneau, Coast Mts.; $58^{\circ} 22^{\prime} 50^{\prime \prime} \mathrm{N}$, $134^{\circ} 41^{\prime} 30^{\prime \prime} \mathrm{W}$; (map 11).

Tlingit Indian name "Auk Nu," meaning "Auk Fort"; published by USGS in 1962. Auke Nu Creek: stream, flows SE 2.3 mi. to Auke Bay, $0.2 \mathrm{mi}$. W of village of Auke Bay and $11 \mathrm{mi}$. NW of Juneau, Coast Mts.; 58 ${ }^{\circ} 3^{\prime}$ $\mathrm{N}, 134^{\circ} 40^{\prime} \mathrm{W}$; (map 11 ).

Tlingit Indian name "Auk Nu," meaning "Auk Fort"; published by USGS in 1962. Auke Village: locality, see Auke.

Auk Glacier: glacier, see Eagle Glacier.

Aukon: estuary, see Ankau, The.

Aukoolak Lagoon: lagoon, see Aukulak Lagoon.

Aukulak Lagoon: lagoon, $2.5 \mathrm{mi}$. long, on $\mathrm{N}$ shore of Kotzebue Sound, $13 \mathrm{mi}$. SE of Cape Krusenstern, Kotzebue-Kobuk Low.; 67 ${ }^{\circ} 04^{\prime}$ $N, 163^{\circ} 15^{\prime} \mathrm{W}$; (map 128). Var. Aukoolak Lagoon, Okulak Lagcon.

Eskimo name for a "strip of land between two bodies of water" which exists between the lagoon and the sound; reported in 1950 by USC\&GS.

Aulatakroak River: stream, see Alataktok River. Aulatauruk River: stream, flows NE $3 \mathrm{mi}$ to lagoon on $W$ shore of Kuk River, $7 \mathrm{mi}$. S of Wainwright, Arctic Plain; $70^{\circ} 32^{\prime} 15^{\prime \prime} \mathrm{N}$, $159^{\circ} 54^{\prime} 00^{\prime \prime} \mathrm{W}$; (map 146)

Eskimo name published in 1958 by AMS ; it may mean "many fishing lines."

Aumalik Creek: stream, see Omalik Creek.

Aumalik Creek: stream, see Omalik River.

Aumalik Lagoon: lagoon, see Omalik Lagoon.

Aumalik River: stream, see Omalik River.

Aunak: locality, see Onak.

Aunaq: locality, see Onak.

Aungua-mut: village, see Hamilton.

Aupak Creek: stream, see Aupuk Creek.

Aupilatuk Hills: hills, E of Kivalina River, 23 mi. NE of Kivalina, Brooks Ra.; $68^{\circ} 01^{\prime} \mathrm{N}$, $164^{\circ} 05^{\prime} \mathrm{W}$; (map 130). Var. Ohpeelatuk.

Eskimo name reported in 1966 by E. S. Burch.

Aupuck Creek: stream, see Aupuk Creek.

Aupuk Creek: stream, flows NE $25 \mathrm{mi}$. to Colville River $21 \mathrm{mi}$. SE of head of Ikpikpuk River, Arctic Slope; $69^{\circ} 04^{\prime} \mathrm{N}, 154^{\circ} 18^{\prime} \mathrm{W}$; $B G N$ 1925; (map 142). Var. Aupak Creek, Aupuck Creek, Oupuk Creek, Owpuk Creek.

Named by USGS in 1924 for one of Ensign W. L. Howard's Eskimo guides on his trip from the Kobuk River to Point Barrow in the spring of 1886 . The name is spelled "Owpuk" in the text (Stoney, 1900, p. 67).

Aurel, Lake: lake, $0.3 \mathrm{mi}$. Iong, drains $\mathrm{S}$ to Russian Creek, 10 mi. SW of Kodiak, Kodiak I.; $57^{\circ} 42^{\prime} 00^{\prime \prime} \mathrm{N}, 152^{\circ} 37^{\prime} 20^{\prime \prime} \mathrm{W}$; (map 34).

Local name reported in 1949 by USGS.

Aurel Glacier: glacier, in Takhinsha Mts., trends $\mathrm{N} 2 \mathrm{mi}$. to 1964 terminus, $2 \mathrm{mi}$. S of Takhin River and $28 \mathrm{mi}$. SW of Skagway, St. Elias 
Mts.; $59^{\circ} 14^{\prime} 15^{\prime \prime} \mathrm{N}, 135^{\circ} 57^{\prime} 00^{\prime \prime} \mathrm{W}$; (map 45).

Named by USC\&GS for Aurel Krause. See Arthur Glacier.

Aurora: locality, at junc. of Eldorado Creek and Noxapaga River, $26 \mathrm{mi}$. WNW of Imuruk Lake, Seward Penin. High.; $65^{\circ} 40^{\prime} \mathrm{N}, 164^{\circ}$ $04^{\prime} \mathrm{W}$; (map 110).

Site of a mining camp reported about 1940 by USC\&GS and published on Chart 9302 .

Aurora: locality, site of mining camp, on Kenai Penin., on SE short of Kachemak Bay, $28 \mathrm{mi}$. NE of Seldovia, Chugach Mts.; 59 $41^{\prime} \mathrm{N}$, $151^{\circ} 06^{\prime} \mathrm{W}$; (map 50).

Established about 1900 , this village received its name from a nearby coal mine. A post office was established here in 1902 and discontinued in 1904 (Ricks, 1965, p. 5). The place was probably abandoned before 1910 .

Aurora: village, pop. 293, residential suburb on Garden I., $1.5 \mathrm{mi}$. NW of center of Fairbanks, Tanana Low.; $64^{\circ} 51^{\prime} 30^{\prime \prime} \mathrm{N}, 147^{\circ} 46^{\prime} 00^{\prime \prime} \mathrm{W}$; (map 100). Var. Aurora Subdivision.

Local name reported in 1950 by USGS topographers.

Aurora Creek: stream, flows NW $2.7 \mathrm{mi}$. to Cripple River, $17 \mathrm{mi}$. NW of Nome, Seward Penin. High.; $64^{\circ} 44^{\prime} \mathrm{N}, 165^{\circ} 39^{\prime} \mathrm{W}$; (map 94).

Prospectors' name reported on a 1901 map of Cape Nome goldfields by David Fox, Jr.

Aurora Creek: stream, flows SE $1.5 \mathrm{mi}$. to Eldorado River, $22 \mathrm{mi}$. NW of Solomon, Seward Penin. High.; $64^{\circ} 47^{\prime}$ N, $164^{\circ} 59^{\prime}$ W; (map 95).

Prospectors' name published on the 1908 "Map of Seward Peninsula" by Arthur Gibson.

Aurora Creek: stream, flows SW $3 \mathrm{mi}$. to Fox Creek, $13 \mathrm{mi}$. NW of Eagle, Yukon-Tanana High.; 64 $55^{\prime} 15^{\prime \prime} \mathrm{N}, 141^{\circ} 32^{\prime} 00^{\prime \prime} \mathrm{W}$; (map 102).

Local name published in 1956 by USGS.

Aurora Creek: stream, flows NE $7 \mathrm{mi}$. to Noxapaga River, $24 \mathrm{mi}$. W of Imuruk Lake, Seward Penin. High.; $65^{\circ} 39^{\prime} \mathrm{N}, 164^{\circ} 07^{\prime} \mathrm{W}$; BGN 1952; (map 110).

Prospectors' name reported in 1901 by T. G. Gerdine (in Collier, 1902, pl. 12), USGS.

Aurora Glacier: glacier, in Glacier Bay National Monument, heads E of July Fourth Mountain, trends NW $4 \mathrm{mi}$. to icefield between heads of Reid and Brady Glaciers, $61 \mathrm{mi}$. NW of Hoonah, St. Elias Mts. ; $58^{\circ} 41^{\prime} \mathrm{N}, 136^{\circ} 44^{\prime} \mathrm{W}$; (map 10).

Published in 1947 by USC\&GS

Aurora Lagoon: lagoon, $0.5 \mathrm{mi}$. across on $\mathrm{E}$ shore of Kachemak Bay, on Kenai Penin., $16 \mathrm{mi}$. NE of Homer, Chugach Mts.; $59^{\circ}$ $42^{\prime} 00^{\prime \prime} \mathrm{N}, 151^{\circ} 06^{\prime} 30^{\prime \prime} \mathrm{W}$; (map 50).

Local name published by USGS in 1951; probably named for the village of Aurora, formerly located in the area.

Aurora Lodge: settlement, pop. 5, along the Richardson Highway at junction of Salcha and Tanana Rivers, $40 \mathrm{mi}$. NW of Big Delta, Tanana Low.; 64 $29^{\prime} \mathrm{N}, 146^{\circ} 59^{\prime} \mathrm{W}$; (map 101). Var. Munsons, Salchaket, Salchakaket, Salcha.
Established in 1902 when the U.S. Army Signal Corps located the Salcha telegraph station about three miles from the mouth of the Salcha River. The Salchaket post office (from the Indian name "Salchakaket" i.e. "mouth of the Salcha") was located at the mouth of the Salcha in 1909; discontinued in 1926 (Ricks, 1965 , p. 55). The trading post and roadhouse are shown on maps as "Munsons" and recently "Aurora."

Aurora Mountain: mountain, 2,100 ft., on SW side of Aurora Creek, $17 \mathrm{mi}$. NW of Nome, Seward Penin. High.; $64^{\circ} 43^{\prime} \mathrm{N}, 165^{\circ} 38^{\prime} \mathrm{W}$; (map 94).

Local name reported on a 1901 map of Cape Nome goldfields by David Fox, Jr.

Aurora Mountain: mountain, 2,250 ft., $12 \mathrm{mi}$. N of Shungnak, Brooks Ra.; $67^{\circ} 03^{\prime} \mathrm{N}, 157^{\circ} 04^{\prime}$ W; (map 126).

In 1910 P. S. Smith and H. M. Eakin wrote, "A low limestone hill, locally known as Aurora Mountain, is the center around which the [copper] prospects are grouped." (in Brooks and others, 1911, p. 300), USGS.

Aurora Peak: peak, 10,065 ft., near head of Trident Glacier, $8.6 \mathrm{mi}$. SE of Mount Hayes, Alaska Ra.; $63^{\circ} 31^{\prime} 18^{\prime \prime} \mathrm{N}, 146^{\circ} 32^{\prime} 40^{\prime \prime} \mathrm{W}$; (map 86).

Name published on relatively recent maps.

Aurora Point: point of land, extends $\mathrm{S}$ from Dall I., between Liscome Bay and Wolk Harbor, Alex. Arch.; 54 $41^{\prime} 15^{\prime \prime}$ N, $132^{\circ} 47^{\prime} 50^{\prime \prime}$ W; BGN 1929; (map 1). Var. Leonard Wood Point.

Named in 1928 by USC\&GS

Aurora Spit: spit, on Kenai Penin., on $\mathbf{E}$ shore of Kachemak Bay, $16 \mathrm{mi}$. NE of Homer, Chugach Mts.; $59^{\circ} 42^{\prime} 15^{\prime \prime} \mathrm{N}, 151^{\circ} 06^{\prime} 30^{\prime \prime} \mathrm{W}$; (map 50).

Local name reported by de Laguna (1934, p. 24), BAE; probably named for the village of Aurora formerly located in the area.

Aurora Subdivision: village, see Aurora.

Ausana: stream, see Beaver Slough.

Austin Beach: beach, $1 \mathrm{mi}$. long, at head of Austin Cove, on $\mathrm{N}$ coast of Attu I., Aleutian Is.; $52^{\circ} 59^{\prime} 08^{\prime \prime} \mathrm{N}, 173^{\circ} 04^{\prime} 25^{\prime \prime} \mathrm{E}$; (map 13).

Named by the U.S. Army during World War II ; published in 1948 by AMS.

Austin Cove: cove, $1.5 \mathrm{mi}$. across, at mouth of Ballentine Creek, on $\mathrm{N}$ coast of Attu I., Aleutian Is.; $52^{\circ} 59^{\prime} 03^{\prime \prime} \mathrm{N}, 173^{\circ} 04^{\prime} 30^{\prime \prime} \mathrm{E}$; (map 13).

Listed in the 1946 supplement to the 1944 Aleutian Coast Pilot.

Austin Creek: stream, flows S $1 \mathrm{mi}$. to Wade Creek, $47 \mathrm{mi}$. SW of Eagle, Yukon-Tanana High.; $64^{\circ} 09^{\prime} \mathrm{N}, 141^{\circ} 27^{\prime} \mathrm{W}$; (map 102).

Local name published in 1956 by USGS.

Austin Pass: pass, between Addison and Ballentine Creeks, on N central Attu I., Aleutian Is.; $52^{\circ} 55^{\prime} 55^{\prime \prime} \mathrm{N}, 173^{\circ} 02^{\prime} 45^{\prime \prime} \mathrm{E}$; (map 13).

Named by the U.S. Army during World War II ; published in 1948 by AMS.

Autokakat: stream, see Bear Creek.

Autokokakat: stream, see Bear Creek.

Automatic Creek: stream, heads in Teocalli Mts., flows NW $8 \mathrm{mi}$. to South Fork Kuskokwim
River $3 \mathrm{mi}$. $\mathrm{N}$ of its junc. with Post River, $77 \mathrm{mi}$. SE of McGrath, Alaska Ra.; $62^{\circ} 27^{\prime}$ $\mathrm{N}, 153^{\circ} 29^{\prime} \mathrm{W}$; (map 80).

Local name obtained in 1958 by USGS.

Auto River: stream, see Bear Creek.

Autumn Bight: bight, $0.2 \mathrm{mi}$. across, NE of Corvie Bay, on S coast of Kiska I., Aleutian Is. ; $51^{\circ} 55^{\prime} 10^{\prime \prime} \mathrm{N}, 177^{\circ} 22^{\prime} 15^{\prime \prime} \mathrm{E}$; (map 14).

One of many arbitrary names applied to features on Kiska Island by USAF for tactical purposes during World War II.

Autumn Creek: stream, flows NE $22 \mathrm{mi}$. to Siksikpuk River at Gunsight $M$ tn. and $S$ end of Gunsight Pass, $41 \mathrm{mi}$. N of Anaktuvuk Pass, Arctic Slope; $68^{\circ} 43^{\prime} \mathrm{N}, 151^{\circ} 54^{\prime} \mathrm{W}$; (map 134).

So named in 1950 by W. W. Patton, Jr., USGS, "because our field party camped along the stream during autumn season."

Auvaum Creek: stream, see Auvom Creek.

Auvom Creek: stream, flows S $10 \mathrm{mi}$. to Asikpak River, $14 \mathrm{mi}$. N of Kivalina, Arctic Slope; $67^{\circ} 55^{\prime} \mathrm{N}, 164^{\circ} 37^{\prime} \mathrm{W}$; (map 128). Var. Auvaum Creek, Awwaum Kuunga, Uhvowm Koonga.

Eskimo name taken from the name of two hills (Awak) between which the stream flows; reported in 1966 by E. S. Burch.

Avachiak Point: point of land, see Scott Point.

Avak Bay: bay, $0.8 \mathrm{mi}$. across, indents NW shore of Iko Bay, $15 \mathrm{mi}$. SE of Point Barrow, Arctic Plain; $71^{\circ} 13^{\prime} 40^{\prime \prime} \mathrm{N}, 156^{\circ} 04^{\prime} 50^{\prime \prime} \mathrm{W}$; (map 153). Var. Ahvak Bay.

Eskimo name meaning "divide" or "cut in half"; recorded at Barrow in 1951 by USC\&GS.

Avak Creek: stream, heads in Ikroavik Lake, flows E $25 \mathrm{mi}$. to Iko Bay, $15 \mathrm{mi}$. SE of Point Barrow, Arctic Plain; $71^{\circ} 10^{\prime} 14^{\prime \prime} \mathrm{N}, 156^{\circ}$. 05'15" W; BGN 1964; (map 153). Var. Ahvak Greek, Ahvak River, Kuaruaipa.

Eskimo name recorded at Barrow in 1951 by USC\&GS. See Avak Bay.

Avak Inlet: estuary, extends SW $11 \mathrm{mi}$. from Kasegaluk Lagoon at mouth of Avak River, 8 mi. SE of Icy Cape, Arctic Plain; $70^{\circ} 15^{\prime} \mathrm{N}$, $161^{\circ} 38^{\prime} \mathrm{W}$; ( $\left.\operatorname{map} 146\right)$.

Eskimo name reported in 1923 by Sidney Paige, USGS. It is said to mean "the back part" or "the farther one."

Avak River: stream, heads at $69^{\circ} 50^{\prime} \mathrm{N}, 160^{\circ} 56^{\prime}$ W, flows NW $50 \mathrm{mi}$. to Avak Inlet, $12 \mathrm{mi}$. S of Icy Cape, Artcic Plain; $70^{\circ} 10^{\prime} \mathrm{N}, 162^{\circ} 02^{\prime}$ W; (map 146).

Eskimo name reported in 1923 by Sidney Paige, USGS.

Avalanche Canyon: valley, heads at $58^{\circ} 46^{\prime} \mathrm{N}$, $134^{\circ} 16^{\prime} \mathrm{W}$, trends W $6.5 \mathrm{mi}$. to Gilkey Glacier, $9 \mathrm{mi}$. SW of Mount Ogilvie and $34 \mathrm{mi}$. N of Juneau, Coast Mts. ; $58^{\circ} 46^{\prime} 45^{\prime \prime} \mathrm{N}, 134^{\circ} 26^{\prime} 45^{\prime \prime}$ W; BGN 1965; (map 11 ).

Named in 1964 by members of the Juneau Icefield Research Project.

Avalik River: stream, heads on Shaningarok Ridge, at $69^{\circ} 42^{\prime} \mathrm{N}, 157^{\circ} 53^{\prime} \mathrm{W}$, flows NW 85 mi., joins Kaolak River to form Kuk River, 37 mi. SE of Wainwright, Arctic Plain; $70^{\circ} 07^{\prime}$ 
N, 159 $41^{\prime}$ W; BGN 1966; (map 146). Var. Ketik River.

Eskimo name reported in 1924 by W. T. Foran, USGS

Avalik River Valley: valley, $35 \mathrm{mi}$. SE of Wainwright, Arctic Plain; $70^{\circ} 07^{\prime} 30^{\prime \prime} \mathrm{N}, 159^{\circ}$ $36^{\prime} 00^{\prime \prime}$ W; (map 146). Var. Avalik Valley.

Named in 1926 by Gerald FitzGerald and P. S. Smith, USGS.

Avalik Valley: valley, see Avalik River Valley.

Avalitkok Creek: stream, flows W $30 \mathrm{mi}$. to Avalik River, $44 \mathrm{mi}$. SE of Wainwright, Arctic Plain; $70^{\circ} 05^{\prime} \mathrm{N}, 159^{\circ} 07^{\prime} \mathrm{W}$; (map 146).

Eskimo name recorded in 1956 by Orth reported to mean "the farther stream."

Avanmun: stream, see Avgunum Creek.

Avaraart Lake: lake, $2 \mathrm{mi}$. long, in Mauneluk River valley, $5 \mathrm{mi}$. NW of Narvak Lake, Brooks Ra.; $67^{\circ} 02^{\prime} \mathrm{N}, 1^{\circ} 5^{\circ} 45^{\prime} \mathrm{W}$; (map 125). Var. Avaterat Lake.

Eskimo name referring to "calling" or "shouting"; reported in 1956 by USGS.

Avatanak Bight: bight, $1.5 \mathrm{mi}$. across, on SE coast of Avatanak I., Aleutian Is. ; $54^{\circ} 03^{\prime} 15^{\prime \prime}$ $\mathrm{N}, 165^{\circ} 16^{\prime} 00^{\prime \prime} \mathrm{W}$; BGN 1936; (map 24).

Named in 1935 for Avatanak Island by USC\&GS.

Avatanak Bight: bight, $9 \mathrm{mi}$. across, on Beaufort Sea coast $\mathbf{E}$ of Smith Bay, between Point McLeod and Pitt Point, Arctic Plain; $70^{\circ} 54^{\prime} \mathrm{N}$, $153^{\circ} 27^{\prime} \mathrm{W}$; (map 148).

Eskimo name reported in 1951 by USC\&GS.

Avatanak Island: island, $10 \mathrm{mi}$. long, in Krenitzin Is., Aleutian Is.; $54^{\circ} 05^{\prime} 45^{\prime \prime} \mathrm{N}, 165^{\circ} 20^{\prime} 00^{\prime \prime}$ W; (map 24). Var. Aiaialgutak, Avatanak, Avatanakskoi, Avatanok, Avatanouskoe, Awatanok.

Aleut name transcribed by the Russians into various spellings and apparently identical with "Aiaialgutak" of Capt. Lt. P. K. Krenitzin and Lt. Michael Levashev, 1768 (Coxe, 1787, map p. 205). The name Avatanak was published by Father Veniaminov in 1840 (v. 1, p. 198) and Capt. Tebenkov (1852, map 26), IRN, where as Capt. Lutke (1836, p. 290), IRN, and the Russian Hydrog. Dept. used the spelling "Avatanok."

Avatanak Point: point of land, on S coast of Avatanak I., Krenitzin Is., Aleutian Is.; $54^{\circ}$ $02^{\prime} 30^{\prime \prime} \mathrm{N}, 165^{\circ} 17^{\prime} 30^{\prime \prime} \mathrm{W}$; BGN 1936; (map 24).

Named in 1935 by USG\&GS.

Avatanak Strait: water passage, between Avatanak and Akun Is., in Krenitzin Is., Aleutian Is.; $54^{\circ} 06^{\prime} 30^{\prime \prime} \mathrm{N}, 165^{\circ} 30^{\prime} 00^{\prime \prime} \mathrm{W}$; (map 24) Var. Pathfinder Channel.

Named for the island and so called by Father Veniaminov (1840, v. 1, p. 17) and Capt. Lutke (1836, p. 306), IRN. It was called Pathfinder Channel by USC\&GS in 1902 presumably for the ship.

Avatanok: island, see Avatanak Island.

Avaterat Lake: lake, see Avaraart Lake.

Avenak Mountain: hill, $700 \mathrm{ft}$., on $\mathrm{N}$ bank of Wulik River, $11 \mathrm{mi}$. NE of Kivalina, Arctic Slope; $67^{\circ} 49^{\prime} \mathrm{N}, 164^{\circ} 10^{\prime} \mathrm{W}$; (map 128). Var. Ahvenuk Mountain.
Eskimo name meaning "black whale," according to a report by USC\&GS in 1950.

Avery River: stream, heads between Crescent Glacier and Cap Glacier, flows NW $5.5 \mathrm{mi}$. to Port Wells, $28 \mathrm{mi}$. NE of Whittier, Chugach Mts.; $60^{\circ} 59^{\prime} 45^{\prime \prime} \mathrm{N}, 147^{\circ} 57^{\prime} 45^{\prime \prime} \mathrm{W}$; $B G N$ 1910; (map 63).

Named in 1908 by Grant and Higgins (1910, pls. 1, 2), USGS.

Avgun: stream, see Barnum Creek.

Avgunum Creek: stream, flows NE $6 \mathrm{mi}$. to Kugrua River, $18 \mathrm{mi}$. NE of Wainwright, Arctic Plain; $70^{\circ} 44^{\prime} \mathrm{N}, 159^{\circ} 18^{\prime} \mathrm{W}$; (map 146). Var. Avanmun, Ahvunmun Creek.

Eskimo name, "Avanmun," reported in 1956 by USGS to mean "in opposite directions."

Avignam Koogowranga: stream, see Agvignak Creek.

A-vi-lu-legorack: stream, see Cosmos Creek.

Avingak Creek: stream, flows W $28 \mathrm{mi}$. to Kokolik River, $15 \mathrm{mi}$. N of Archimedes Ridge, Arctic Slope; $69^{\circ} 25^{\prime} \mathrm{N}, 161^{\circ} 21^{\prime} \mathrm{W}$; (map 144).

Named by Chapman and Sable (1960, p. 52), USGS. "Avingak" is the Eskimo word for the lemming. The stream was so named because these animals were abundant here during the 1949 field season.

Avingoriak Peak: hill, $700 \mathrm{ft}$., in Igichuk Hills, $W$ of Noatak River, $20 \mathrm{mi}$. $\mathrm{N}$ of Kotzebue, Arctic Slope; $67^{\circ} 12^{\prime} \mathrm{N}, 162^{\circ} 39^{\prime} \mathrm{W}$; (map 128).

Eskimo name obtained at Kotzebue in 1956 by Orth.

Avingyak Hills: hills, 2,000-2,478 ft., extend NNW $17 \mathrm{mi}$. from junc. of Makpik Creek with Noatak River, $40 \mathrm{mi}$. W of Howard Pass, Brooks Ra.; 68 $12^{\prime} \mathrm{N}, 158^{\circ} 45^{\prime} \mathrm{W}$ (map 132).

Eskimo family name, reported to mean "mouse"; obtained at Noatak in 1956 by Orth.

Avinof, Cape: point of land, $4 \mathrm{mi}$. of Anogok, 8 mi. S of Kipnuk, Yukon-Kuskokwin Delta; $59^{\circ} 50^{\prime} \mathrm{N}, 164^{\circ} 05^{\prime} \mathrm{W}$; (map 54). Var. Cape Avinoff, Mys Avinova.

Named in 1821 by Capt. Lt. M. N. Vasiliev, IRN, for Lt. Alexander Avinov, IRN, a member of his party; published as "M[ys] Avinova," or "Cape Avinov," by Lt. Sarichev (1826, map 4), IRN.

Avinoff, Cape: point of land, see Avinof Cape. Avinova, Mys: point of land, see Cape Avinof. Avis Glacier: glacier, see Yalik Glacier.

Avnuligmiut: locality, see Avnulik.

Avnulik : locality, "in the Yukon district." Var. Avnuligmiut.

Eskimo camp or settlement listed as "Avnuligmiut," that is, "Avnulik people," with a population of 30 in the 1890 Census.

Avnulu Creek: stream, heads in lake, flows S 2.4 mi. to Kaiugnak Bay, on SE coast of Kodiak I.; $57^{\circ} 05^{\prime} 35^{\prime \prime} \mathrm{N}, 153^{\circ} 34^{\prime} 30^{\prime \prime} \mathrm{W}$; (map 34). Native name published in 1943 by USC\&GS

Avogon Island: island, $2.7 \mathrm{mi}$. long, among islands W of Yukon Delta, at mouth of Kwikluak Pass, Yukon-Kuskokwin Delta; 62 $37^{\prime}$
N, $164^{\circ} 53^{\prime}$ W; (map 77). Var. Kukitiyak Island.

Name shown on an 1899 manuscript map; probably named for the channel. See Avogon Pass.

Avogon Pass: water passage, $2.8 \mathrm{mi}$. long, in Yukon Delta, E of Avogon I., $15 \mathrm{mi}$. SW of Kwiguk, Yukon-Kuskokwim Delta; $62^{\circ} 37^{\prime} \mathrm{N}$, $164^{\circ} 52^{\prime} \mathrm{W}$; (map 77)

Eskimo name obtained in 1899 by G. R. Putnam, USC\&GS. Published in 1901 on Chart 9372.

Avon Island: island, $0.2 \mathrm{mi}$. across in McHenry Anchorage on SW coast of Etolin I, Alex. Arch.; 55 $58^{\prime} 30^{\prime \prime} \mathrm{N}, 132^{\circ} 27^{\prime} 30^{\prime \prime} \mathrm{W}$; (map 4). Var. Avon Islet.

Published as "Avon Islet" in the 1891 Coast Pilot (p. 109).

Avon Islet: island, see Avon Island.

Avoss Lake: lake, $1.7 \mathrm{mi}$. across, $5 \mathrm{mi}$. NE of Whale Bay, on $\mathrm{S}$ central Baranof I., Alex. Arch.; $56^{\circ} 41^{\prime} 30^{\prime \prime} \mathrm{N}, 134^{\circ} 55^{\prime} 45^{\prime \prime} \mathrm{W}$; $B G N$ 19.35; (map 5).

Named in 1935 by USFS "for the first ship to be built in the Sitka Shipyard, 1806."

Avriotmut: locality, see Barnum.

Avriotmute: locality, see Barnum.

Awak Hills: hills, two, in the Saitut Hills, 21 mi. N of Kivalina, Arctic Slope; (map 128). Var. Uhvak, Awwaq.

Eskimo name reported by E. S. Burch, in 1966 , to mean "half."

Awatanok: island, see Avatanak Island.

Aw-aw Creek: stream, see Thoms Creek.

Aw-aw Lake: lake, see Thoms Lake.

Awayak Greek: stream, heads at Awayak Lake, flows S $10 \mathrm{mi}$. to Goodnews River, $41 \mathrm{mi}$. NE of Goodnews, Kilbuck-Kuskokwim Mts.; $59^{\circ} 28^{\prime} \mathrm{N}, 160^{\circ} 42^{\prime} \mathrm{W}$; (map 53).

Eskimo name reported to mean "branch" or "tributary"; published in 1951 by USGS.

Awayak Lake: lake, $1 \mathrm{mi}$. long, $8 \mathrm{mi}$. NW of Goodnews Lake and $44 \mathrm{mi}$. NE of Goodnews, Kilbuck-Kuskokwim Mts. ; $59^{\circ} 34^{\prime} \mathrm{N}, 160^{\circ} 42^{\prime}$ W; (map 53).

Name derived from Awayak Creek of which the lake is the source; name published in 1951 by USGS.

Awizrayak: hill, see Beluga Hill.

Awlinyak Creek: stream, flows NE $18 \mathrm{mi}$. to Alatna River, $21 \mathrm{mi}$. S of Survey Pass, Brooks

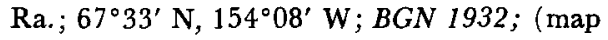
125).

Eskimo name, said to mean "exit"; reported in 1931 by Robert Marshall.

Awomanak River: stream, see Urumangnak River.

Awuna River: stream, heads in swamp at $69^{\circ} 20^{\prime}$ $\mathrm{N}, 158^{\circ} 45^{\prime} \mathrm{W}$, flows E $200 \mathrm{mi}$. to Colville River $28 \mathrm{mi}$. SW of head of Ikpikpuk River, Arctic Slope; $69^{\circ} 03^{\prime} \mathrm{N}, 155^{\circ} 28^{\prime} \mathrm{W}$; $B G N$ 1925; (map 142). Var. Sagvailuk River, Sakvailak River, Sakvailuk River.

Eskimo name; shown on a fieldsheet by R. K. Lynt and was reported in 1924 by P. S. Smith, USGS. The name is reported to mean "westward" [Uwanmun]; the present-day Eskimo name is Sakvailak. 
Awwaum Kuunga: stream, see Auvom Creek. Awwaq: hills, see Awak Hills.

Axel Lind Island: island, $1.3 \mathrm{mi}$. long, in Prince William Sound, $2.5 \mathrm{mi}$. S of Eaglek Bay and $33 \mathrm{mi}$. E of Whittier, Chugach Mts. ; $60^{\circ} 47^{\prime}$ $30^{\prime \prime} \mathrm{N}, 147^{\circ} 43^{\prime} 30^{\prime \prime} \mathrm{W}$; BGN 1918; (map 63). Var. Bald Head, Chris Island, Lind Island, Pond Island.

Named for Axel W. Lind, a resident of the island; reported in 1908 by U. S. Grant and D. F. Higgins (in Brooks and others, 1909, pl. 4), USGS.

Ayachaghayuk: locality, see Aiachagiuk.

Ayacheruk: locality, see Aiacheruk.

Ayagh Island: island, see Adak Island.

Ayagish: volcano, see Makushin Volcano.

Ayak: locality, on Sledge I. in Bering Sea, $5 \mathrm{mi}$. off $S$ coast of Seward Penin.; 64 ${ }^{\circ} 29^{\prime} \mathrm{N}, 166^{\circ}$ 13' W; (map 94). Var. Ahyak.

Former Eskimo village reported as "Ahyak" in the 1890 Census. See Aziak and Sledge Island.

Ayak, Mys: point of land, see Aiak, Cape.

Ayakalak Creek: stream, flows SE $13 \mathrm{mi}$. to Kil-

lik River $7.5 \mathrm{mi}$. SW of its junc. with Easter

Greek, Brooks Ra.; 68 $05^{\circ} \mathrm{N}, 154^{\circ} 23^{\prime} \mathrm{W}$; (map 133).

Eskimo name for "joint of the neck-bone," reported in 1956 by T. E. Taylor, USGS.

Ayakhtalik: locality, see Aiaktalik.

Ayak Island: island, see Sledge Island.

Ayaktak, Ostrovi: island, see Aiktak Island.

Ayakulih River: stream, see Ayakulik River.

Ayakulik: locality, at mouth of Ayakulik River, on W coast of Kodiak I., $26 \mathrm{mi}$. SW of Karluk; $57^{\circ} 12^{\prime} \mathrm{N}, 154^{\circ} 32^{\prime} \mathrm{W}$; (map 35).

Ayakulik, Reka: stream, see Ayakulik River.

Ayakulik Island: island, $0.2 \mathrm{mi}$. across, $2.3 \mathrm{mi}$. NW of mouth of Ayakulik River and $25 \mathrm{mi}$. SW of Karluk, on W coast of Kodiak I. $57^{\circ} 13^{\prime} \mathrm{N}, 154^{\circ} 35^{\prime} \mathrm{W}$; (map 35). Var. Achulik Island, Ostrov Ayakulik.

Aleut [?] name; published as "O[strov] Ayakulik," or "Ayakulik Island," by Capt. Tebenkov (1852, map 22), IRN.

Ayakulik River: stream, heads in lake $11 \mathrm{mi}$. SSW of Karluk, flows S 28 mi. to Pacific Ocean 2 mi. SE of Ayakulik I., on W coast of Kodiak I. ; $57^{\circ} 12^{\prime} \mathrm{N}, 154^{\circ} 32^{\prime} \mathrm{W}$; BGN 1939; (map 35). Var. Ayakulih River, Old Red River, Red River, Reka Ayakulik.

Aleut [?] name; published as " $R$ [eka] Ayakulik," or "Ayakulik River," by Capt. Tebenkov (1852, map 22), IRN. Baker (1906, p. 110) wrote, "among the local cannery men it is known as 'Red River' * * *." The name "R[eka] Krasnaya," meaning "Red River," was applied to a stream six miles NW of the mouth of the Ayakulik River, by Capt. Tebenkov (1852, map 22), IRN. See Red River.

Ayala, Ysla de: coast line, of $\mathrm{S}$ end of Kenai Penin.; (map 50).

Named by Don Ignacio Arteaga about August 1, 1779, who thought it to be an island. Named for Juan Manuel de Ayala, the Spanish naval officer who explored San Francisrn Bay. California, in 1775.

Ayalik Bay: bay, see Aialik Bay.
Ayaliki, Ostrova: islands, see Chiswell Islands.

Ayalikskaya, Bukhta: bay, see Aialik Bay.

Ayasgh Island: island, see Adak Island.

Ayiyak Mesa: mountain, 1,545 ft., $4 \mathrm{mi}$. long, $4 \mathrm{mi}$. NW of junc. of Ayiyak and Chandler Rivers, $54 \mathrm{mi}$. NW of Anaktuvuk Pass, Arctic Slope; $68^{\circ} 54^{\prime} \mathrm{N}, 152^{\circ} 03^{\prime} \mathrm{W}$; BGN 1949; (map 134).

Eskimo name used by USGS geologists during the exploration of Naval Petroleum Reserve No. 4; name given in 1944.

Ayiyak River: stream, heads $2 \mathrm{mi}$. W of Little Chandler Lake, flows NE $58 \mathrm{mi}$. to Chandler River, $4 \mathrm{mi}$. SE of Ayiyak Mesa and $51 \mathrm{mi}$. $\mathrm{N}$ of Anaktuvak Pass, Arctic Slope; $68^{\circ} 51^{\prime}$ $30^{\prime \prime} \mathrm{N}, 151^{\circ} 56^{\prime} 00^{\prime \prime} \mathrm{W}$; BGN 1949; (map 134).

Eskimo name used by USGS geologists during the exploration of Naval Petroleum Reserve No. 4 ; name given in 1944.

Aylesworth, Mount: mountain, 9,310 ft., on Alaska-Canada boundary, $3.5 \mathrm{mi}$. NW of Mount Armour and $42 \mathrm{mi}$. NE of Yakutat, St. Elias Mts.; $59^{\circ} 55^{\prime} 30^{\prime \prime} \mathrm{N}, 138^{\circ} 47^{\prime} 45^{\prime \prime} \mathrm{W}$; $B G N$ 1953; (map 46). Var. Boundary Peak 176, Mount Armour, Peak 8900.

Named by USC\&GS in 1903 for the Hon. Sir Allen Bristol Aylesworth, IBC Commissioner. The name was published on USC\&GS Chart 8000 in 1908; feature called "Peak 8900 " in USC\&GS triangulation records of 1906.

Aylward: lake, see Auke Lake.

Ayo, Zaliv: bight, see Hallo Bay.

Ayougadakh Island: island, see Rat Island.

Ayuatak Hills: hills, 1,000 ft., extend $7 \mathrm{mi}$. on Chukchi Sea coast, $\mathrm{S}$ of Ayugatak Lagoon, 12 mi. E of Cape Lisburne, Arctic Slope ; $68^{\circ} 50^{\prime}$ N, $165^{\circ} 36^{\prime} \mathrm{W}$; (map 129).

Eskimo name derived from that of the nearby stream; reported in 1955 by U.S. Army Corps of Engineers. See Ayugatak Creek. Ayugadak Island : island, see Rat Island.

Ayugadak Islands: islands, see Rat Islands.

Ayugadak Point: point of land, SE tip of Rat I., Aleutian Is.; $51^{\circ} 46^{\prime} \mathrm{N}, 178^{\circ} 23^{\prime} \mathrm{E}$; $B G N$ 1937; (map 15).

Reported by personnel of U.S.S. Oglala of the 1935 U.S. Navy Survey Expedition. Aleut name meaning "rat" formerly applied to the whole island.

Ayugatak Creek: stream, heads in Lisburne Hills, flows NE and NW $14 \mathrm{mi}$. to Chukchi Sea, 11 mi. E of Cape Lisburne, Arctic Slope; $68^{\circ} 48^{\prime}$ $45^{\prime \prime} \mathrm{N}, 165^{\circ} 45^{\prime} 50^{\prime \prime}$ W; (map 129). Var. Aiaugatak River, Iyagatak River, Iyaggatak River.

Eskimo name published by Archdeacon Stuck (1920, p. 156) as "Iyagatak." The present spelling appears to be based on that shown as "Aiaugatak" by D. C. Foote, of Project Chariot. The name is reported to refer to a "T-pole."

Ayugatak Lagoon: lagoon, $4.5 \mathrm{mi}$. long, on Chukchi Sea coast, $12 \mathrm{mi}$. E of Cape Lisburne, Arctic Slope; $68^{\circ} 49^{\prime} \mathrm{N}, 165^{\circ} 40^{\prime} \mathrm{W}$; (map 129). Var. Aiaugatak Lagoon, Aiautaq Lagoon, Eyeautuk Lagoon.

Eskimo name reported as "Aiaugatak" by
D. C. Foote, of Project Chariot. See Ayugatak Creek.

Ayutka, Cape: point of land, extends SE between Amber Bay and Aniakchak Bay on S shore of Alaska Penin., 8 mi. W. of Cape Kunmik, Aleutian Ra.; $56^{\circ} 46^{\prime} \mathrm{N}, 157^{\circ} 24^{\prime} \mathrm{W} ; B G N$ Sixth Report; (map 31). Var. Cape Agutka.

Aleut name published in 1900 by USC\&GS. Ayyagyh: volcano, see Makushin Volcano.

Azachagvyak, Mys: point of land, see Romanof Point.

Azachagyamut: locality, see Nokrot.

Azacharak: locality, "on left bank of Yukon River," Yukon-Kuskokwim Delta; (map 77).

Former Eskimo camp or settlement reported in 1899 by G. R. Putnam, USG\&GS.

Azacharum Slough: watercourse, extends $17 \mathrm{mi}$. $\mathrm{N}$ between Archuelinguk and Yukon Rivers, $41 \mathrm{mi}$. SE of Kwiguk, Yukon-Kuskokwim Delta; $62^{\circ} 14^{\prime} \mathrm{N}, 163^{\circ} 52^{\prime} \mathrm{W}$; (map 77). Var. Acherun, Achirun Slough.

Eskimo name reported to mean "slough," recorded in 1899 by G. R. Putnam, USC\&GS

Azachorok Hill: hill, $517 \mathrm{ft}$., on right bank of Yukon River, E of Archuelinguk River, 52 mi. SE of Kwiguk, Yukon-Kuskokwin Delta; $62^{\circ} 05^{\prime} 30^{\prime \prime} \mathrm{N}, 163^{\circ} 45^{\prime} 00^{\prime \prime} \mathrm{W}$; (map 77).

Eskimo name obtained in 1948 by USC\&GS. Azaik Island: island, see Aziak Island.

Azamis, Cape: point of land, $\mathrm{E}$ tip of Little Tanaga I., Aleutian Is.; $51^{\circ} 48^{\prime} 20^{\prime \prime} \mathrm{N}, 176^{\circ}$ $00^{\prime} 00^{\prime \prime}$ W; BGN 1936; (map 18). Var. Cape Azimis.

Published as "M[ys] Azamis," or "Cape Azamis," by Capt. Tebenkov (1852, map 28), IRN.

Azamis Cove: cove, $1 \mathrm{mi}$. across, on $\mathrm{SE}$ coast of Little Tanaga I., Aleutian Is.; $51^{\circ} 49^{\prime} \mathrm{N}$, $176^{\circ} 05^{\prime} \mathrm{W}$; BGN 1936; (map 17).

Name derived from Cape Azamis in 1934 by members of the U.S. Navy Aleutian Island Survey Expedition.

Azeegurglik Ikpick: bluff, see Azigurglik Ikpik.

Azeviuk: locality, "at mouth of Azeviuk River, Bristol Bay."

Former Eskimo village or camp meaning "walrus" reported in 1919 by G. L. Harrington, USGS.

Azeviuk River: stream, "on $\mathrm{N}$ shore of Hagemeister Strait, Bristol Bay."

Eskimo name meaning "walrus" reported in 1919 by G. L. Harrington, USGS.

Aziachak, Mys: point of land, see Romanof Point.

Aziak: locality, on Sledge I. in Bering Sea, $5 \mathrm{mi}$. off $\mathrm{S}$ coast of Seward Penin., $25 \mathrm{mi}$. W of Nome; $64^{\circ} 29^{\prime} \mathrm{N}, 166^{\circ} 13^{\prime} \mathrm{W}$; (map 94).

Former Eskimo village reported with a population of 50 by Ivan Petroff in the 1880 Census. See Ayak and Sledge Island.

Aziak Island: island, $1 \mathrm{mi}$. long, in Andreanof Is. between Great Sitkin and Umak Is., Aleutian Is.; $51^{\circ} 57^{\prime} 15^{\prime \prime} \mathrm{N}, 176^{\circ} 09^{\prime} 20^{\prime \prime} \mathrm{W}$; $B G N$ 1936; (map 17). Var. Azaik Island, Azik Island, Azki Island, Ostrov Azik, Ostrov Azyak.

Aleut name published in 1852 as "O[strov] Azyak," or "Azyak Island," by Capt. Teben- 
kov (map 28), IRN, and in 1848 as "O[strov] Azik," or "Azik Island," on Russian Hydrog. Dept. Ghart 1400.

Aziak Island: island, see Sledge Island.

Aziavigamut: locality, see Aziavik.

Aziavigamute: locality, see Aziavik.

Aziavigiokhamiut: locality, see Aziavik.

Aziavik: locality, on Osviak River near its mouth at Bristol Bay; Kilbuck-Kuskokwim Mts.; $58^{\circ} 47^{\prime} \mathrm{N}, 161^{\circ} 15^{\prime} \mathrm{W}$; Var. Aziavigamut, Aziavigamute, Aziavigiokhamiut, Osvackamute, Osviak.

Former Eskimo village listed in the 1880 Census with a population of 132 by Ivan Petroff as "Aziavigmute," or "Aziavik people."

Aziavik: stream, see Osviak River.

Azigurglik Ikpik: bluff, on right bank of Wulik River, $24 \mathrm{mi}$. NE of Kivalina, Arctic Slope; $67^{\circ} 52^{\prime} \mathrm{N}, 163^{\circ} 44^{\prime} \mathrm{W}$; (map 128). Var. Azeegurglik Ikpick.

Eskimo name meaning "more distant riverbank," reported in 1966 by E. S. Burch. See Kinguaglik Ikpik.

Azik, Ostrov: island, see Aziak Island.

Azimis, Cape: point of land, see Azamis, Cape. Azimuth Point: point of land, "on the eastern shore of Portland canal."

"So named by the Coast Survey" (Baker, 1906, p. 111).

Azimuth Point: point of land, $5.3 \mathrm{mi}$. N of Kodiak, on NE coast of Kodiak I. ; $57^{\circ} 52^{\prime} 00^{\prime \prime}$ $\mathrm{N}, 152^{\circ} 25^{\prime} 15^{\prime \prime} \mathrm{W}$; (map 34). Var. Bearing Point, Mys Pelenga, Pelenga.

Translation of "M[ys] Pelenga," the name given in 1839 or 1840 by Sub-Lt. Mikhail Murashev, IRN, and published in 1849 on Russian Hydrog. Dept. Chart 1425.

Azjiak Island: island, see Sledge Island.

Aski Island: island, see Aziak Island.

Azoon River: stream, see Azun River.

Azucar, Pilon de: mountain, see Augustine Volcano.

Azun River: stream, distributary of Manokinak River, heads at $61^{\circ} 19^{\prime} \mathrm{N}, 164^{\circ} 38^{\prime} \mathrm{W}$, flows $\mathrm{S} 40 \mathrm{mi}$. to Hazen Bay, Yukon-Kuskokwim Delta; $61^{\circ} 02^{\prime} \mathrm{N}, 165^{\circ} 06^{\prime} \mathrm{W}$; BGN 1960; (map 75). Var. Azoon River.

Eskimo name recorded as "Azoon" in December 1878 by E. W. Nelson (1882, p. 667),

U.S. Signal Service.

Azvichviak: stream, see Osviak River.

Azvichvyak: stream, see Osviak River.

Azvyak, Ostrov: island, see Sledge Island.

Azwiryak Bluff : bluff, see Ahzwiryuk Bluff.

Azyachagyak, Mys: point of land, see Romanof Point.

Azyak, Ostrov: island, see Aziak Island.

Azzhiak, Ostrov: island, see Sledge Island.

\section{B}

Baathbakdizuni Creek: stream, heads in Isahultila Mts., flows NE $15 \mathrm{mi}$. to Hughes Creek, $11 \mathrm{mi}$. NW of Hughes, Hogatza High.; $66^{\circ} 07^{\prime}$ N, $154^{\circ} 32^{\prime} \mathrm{W}$; (map 116).

Indian name "Ba-ath-bak-dizu-ni," reported to mean "spruce trees for good bows," recorded at Hughes in 1956 by Orth.
Babantaltlin Creek: stream, heads in Babantaltlin Hills, flows NNW $10 \mathrm{mi}$. to Hogatza River, 38 mi. NW of Hughes, Hogatza High.; $66^{\circ} 20^{\prime} \mathrm{N}$, $155^{\circ} 24^{\prime} \mathrm{W}$; (map 116).

Indian name recorded at Hughes in 1956 by Orth.

Babantaltlin Hills: hills, 1,760 ft., extends NW from Bakatigikh Mtn. 17 mi. to Hogatza River, $25 \mathrm{mi}$. WNW of Hughes, Hogatza High.; $66^{\circ} 10^{\prime} \mathrm{N}, 155^{\circ} 15^{\prime} \mathrm{W}$; (map 116).

Indian name recorded at Hughes in 1956 by Orth.

Babbler Point: point of land, on E shore of Eastern Passage, $4 \mathrm{mi}$. E of Wrangell, Coast Mts.; $56^{\circ} 29^{\prime} 10^{\prime \prime} \mathrm{N}, 132^{\circ} 17^{\prime} 10^{\prime \prime} \mathrm{W}$; (map 6).

Local name reported in 1904 by H. C. Fassett, USBF; so named for "a Mr. Babbler (cnna)," superintendent of the cannery at Wrangell.

Babbling Brook: stream, "northern shore Olga bay, Kodiak, tributary to North Olga stream, from the left. Local name, reported by Moser, 1900" (Baker, 1906, p. 111).

Babcock Creek: stream, on Kenai Penin., flows S 2 mi. to Palisade Lagoon, $38 \mathrm{mi}$. ESE of Homer, Chugach Mts.; $59^{\circ} 31^{\prime} 45^{\prime} \mathrm{N}, 150^{\circ}$. $28^{\prime} 30^{\prime \prime} \mathrm{W}$; (map 50).

Local name reported by USGS in 1951.

Babe Creek: stream, flows $\mathrm{N} 1 \mathrm{mi}$. to Vault Creek, $12 \mathrm{mi}$. NE of Fairbanks, Yukon-Tanana High.; $65^{\circ} 00^{\prime} 35^{\prime \prime} \mathrm{N}, 1^{\circ} 7^{\circ} 39^{\prime} 55^{\prime \prime} \mathrm{W}$; (map 105).

Named by prospectors; published in 1908 by USGS.

Babe Island: islands, see Babe Islands.

Babe Islands: islands, group, extend $1.3 \mathrm{mi}$. in Cholmondeley Sound, on SE coast of Prince

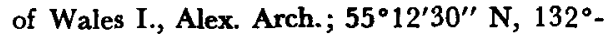
07'50". W; BGN 1966; (map 4). Var. Babe Island.

Local name reported in 1904 by H. C. Fassett, USBF.

Babel River: stream, flows SW $25 \mathrm{mi}$. to North Fork Swift River $13 \mathrm{mi}$. NE of that stream's junc. with Swift River and $100 \mathrm{mi}$. SE of McGrath, Lime Hills; 61 $37^{\circ} 15^{\prime \prime} \mathrm{N}, 154^{\circ} 42^{\prime} 00^{\prime \prime}$ W; $(\operatorname{map} 71)$.

So named in 1956 by Orth, "because of the 'confusion of tongues' by authorities with respect to the name of this stream."

Babia Bay: bay, see Womens Bay.

Babs Creek: stream, flows NE $2.8 \mathrm{mi}$. to Iron Creek which flows to Pilgrim River, $26 \mathrm{mi}$. NW of Solomon, Seward Penin. High.; $64^{\circ} 55^{\prime}$ N, $164^{\circ} 41^{\prime}$ W; (map 95). Var. Bobs Creek.

Prospectors' name published on the 1908 "Map of Seward Peninsula" by Arthur Gibson. Babya Bay: bay, see Womens Bay.

Babybasket Hill: ridge, 1,455 ft., extends NESW $8 \mathrm{mi}$., $27 \mathrm{mi}$. E of Medfra, Kuskokwim Low.; $63^{\circ} 06^{\prime} \mathrm{N}, 153^{\circ} 49^{\prime} \mathrm{W}$; (map 89).

Local name reported in 1958 by USGS.

Baby Bear Bay: bay, $0.8 \mathrm{mi}$. across, on NW coast of Baranof I., $28 \mathrm{mi}$. N of Sitka, Alex. Arch.; $57^{\circ} 26^{\prime} 00^{\prime \prime} \mathrm{N}, 135^{\circ} 33^{\prime} 30^{\prime \prime} \mathrm{W}$; (map 9).

Name published in 1962 by USC\&GS on Chart 8248.
Baby Creek: stream, flows NE $4 \mathrm{mi}$. to $\mathrm{Kal}$ Creek, $46 \mathrm{mi}$. $\mathrm{S}$ of Eagle, Yukon-Tanana High.; $64^{\circ} 08^{\prime} 45^{\prime \prime} \mathrm{N}, 141^{\circ} 10^{\prime} 20^{\prime \prime} \mathrm{W}$; (map 102).

Prospectors' name obtained in 1898 by E. C. Barnard, USGS.

Baby Creek: stream, flows NE $12 \mathrm{mi}$. to North Fork Chandalar River, $6.5 \mathrm{mi}$. N of Chandalar, Brooks Ra.; 67 $35^{\prime} 30^{\prime \prime}$ N, $148^{\circ} 27^{\prime} 00^{\prime \prime} \mathrm{W}$; (map 123).

Prospectors' name shown on an 1899 fieldsheet by T. G. Gerdine, USGS.

Baby Creek: stream, flows S $8 \mathrm{mi}$. to Maybe Creek, $14 \mathrm{mi}$. E of head of Ikpikuk River, Arctic Slope; $69^{\circ} 16^{\prime} \mathrm{N}, 154^{\circ} 07^{\prime} \mathrm{W}$; $B G N$ 1960; (map 142).

Name published in 1956 by USGS; originally used by geologists working on the Naval Petroleum Reserve No. 4 explorations.

Baby Glacier: glacier, heads at Dartmouth Glacier, trends SE $1.5 \mathrm{mi}$. to its terminus at head of a stream which drains into Unakwik Inlet, $44 \mathrm{mi}$. W of Valdez, Chugach Mts. ; $61^{\circ} 09^{\prime} \mathrm{N}$, $147^{\circ} 36^{\prime}$ W; BGN 1910; (map 69).

Descriptive name given in 1910 by USGS.

Baby Islands: islands, in Fox Is., group, extends $2 \mathrm{mi}$. in Akutan Pass, Aleutian Is.; 53 59'30" N, 166 $04^{\prime} 00^{\prime \prime} \mathrm{W}$; BGN 1910; (map 23). Var. Chaichi Islands, Chaiki Islands, Gull Islands, Gull Rocks, Ostrova Chayachi, Sea Gull Islands, Seagull Islets.

Local name reported by J. J. Gilbert, USC\& GS, commander of the steamer Pathfinder during 1900-01. Marcus Baker (1906) published both "Baby Islands" and "Seagull Islets," and notes (p. 556) that they are "locally known as Chaiki (gull) rocks." The islands were named "O[strova] Chayachi," or "Chayachi Islands," by Capt. Tebenkov (1852, map 26), IRN. In 1871 they were called "Gull Rocks" by W. H. Dall, USC\&GS, who "established a tide gage upon one of them."

Baby Pass: water passage, $1 \mathrm{mi}$. across, in Fox Is., between Unalga I. and Baby Is., Aleutian Is. ; $53^{\circ} 59^{\prime} \mathrm{N}, 166^{\circ} 05^{\prime} \mathrm{W}$; (map 23).

Local name recorded by J. J. Gilbert, commander of the USC\&GS steamer Pathfinder during 1900-01.

Bachatna Creek: stream, distributary of North Fork Big River, flows SE $15 \mathrm{mi}$. to Johnson Slough, $29 \mathrm{mi}$. NW of Kenai, Cook Inlet Low.; $60^{\circ} 44^{\prime} 15^{\prime \prime} \mathrm{N}, 151^{\circ} 59^{\prime} 00^{\prime \prime} \mathrm{W}$; (map 62).

Tanaina Indian name reported in 1958 by USGS.

Bachatna Flats: flats, $8 \mathrm{mi}$. across, between Kustatan and Big Rivers, $30 \mathrm{mi}$. NW of Kenai, Cook Inlet Low.; $60^{\circ} 45^{\prime} \mathrm{N}, 152^{\circ} 00^{\prime}$ $\mathrm{W}$; (map 62).

Tanaina Indian name reported in 1958 by USGS.

Bache Island: island, see Evans Island.

Bachelor Creek: stream, flows NE $8 \mathrm{mi}$. to Preacher Creek, $64 \mathrm{mi}$. SW of Circle, YukonTanana High.; 65 $31^{\circ} 30^{\prime \prime} \mathrm{N}, 146^{\circ} 03^{\prime} 45^{\prime \prime} \mathrm{W}$; (map 104). 
Named by prospectors; reported in 1903 by T. G. Gerdine (in Prindle, 1905, pl. 13), USGS.

Back Bay: bay, on S coast of Afognak I., extends $\mathrm{N} 1 \mathrm{mi}$. at head of Afognak Bay, $5 \mathrm{mi}$. $\mathrm{N}$ of Afognak, Kodiak I.; $58^{\circ} 04^{\prime} 40^{\prime \prime} \mathrm{N}, 152^{\circ} 45^{\prime}$. $50^{\prime \prime} \mathrm{W}$; (map 43).

Local name reported in 1900 by Lt. Comdr. J. F. Moser, USN, commander of the USBF steamer Albatross.

Backbone Mountain: mountain, 2,269 ft., $\mathrm{N}$ of Sykes Lake, $4.4 \mathrm{mi}$. SE of Point Sykes, Coast Mts. ; $55^{\circ} 10^{\prime} 25^{\prime \prime} \mathrm{N}, 130^{\circ} 59^{\prime} 10^{\prime \prime} \mathrm{W}$; (map 3).

Named in 1885 by Lt. Comdr. H. E. Nichhols, USN.

Back Island: island, $0.6 \mathrm{mi}$. long, in Behm Canal, between Betton and Grand Is., Alex. Arch.; $55^{\circ} 32^{\prime} 20^{\prime \prime} \mathrm{N}, 131^{\circ} 45^{\prime} 30^{\prime \prime} \mathrm{W}$; (map 3$)$.

Named in 1886 by USC\&GS.

Backman Creek: stream, flows NW $2.3 \mathrm{mi}$. to Chatanika River, 16 mi. N of Fairbanks, Yukon-Tanana High.; $65^{\circ} 04^{\prime} 28^{\prime \prime} \mathrm{N}, 147^{\circ} 45^{\prime} 00^{\prime \prime}$ W; (map 105). Var. Beckman Creek.

Named by prospectors. Name published in 1908 by USGS as "Beckman Creek"; local usage has been adopted for the present spelling.

Back Point: point of land, on Beaufort Sea coast, W point of entrance to Gwydyr Bay, $3 \mathrm{mi}$. SE of Beechey Point, Arctic Plain; 70 $27^{\prime} 52^{\prime \prime} \mathrm{N}$, $149^{\circ} 03^{\prime} 40^{\prime \prime}$ W; (map 150). Var. Point Back.

Sir John Franklin (1828, p. 166) wrote on August 16,1826, "We had *** the gratification of being able to trace the land round Gwydyr Bay to its outer point, *** which I have named after my excellent companion, Lieut. [later Capt.] George Back, * * *"

Back Range: mountain range, trends $\mathrm{S} 7 \mathrm{mi}$. along W shore of Iniskin Bay to Knoll Head, $44 \mathrm{mi}$. N of Augustine I., Aleutian Ra.; 59. $40^{\prime} \mathrm{N}, 153^{\circ} 29^{\prime} \mathrm{W} ; B G N$ 1916; (map 51).

Name published in 1914 on USC\&GS Chart 3421.

Back Range Head: promontory, see Knoll Head.

Back Yukon Slough: stream, anabranch of $\mathrm{Yu}$ kon River, flows SW $10 \mathrm{mi}$., $13 \mathrm{mi}$. NW of Fort Yukon, Yukon Flats; 66 $35^{\prime} 50^{\prime \prime} \mathrm{N}, 145^{\circ} 53^{\prime}$ $00^{\prime \prime} \mathrm{W}$; (map 119).

Local descriptive name obtained in 1956 by USGS.

Backus Creek: stream, flows NW to Dome Greek which flows to American River, about $30 \mathrm{mi}$. NE of Teller, Seward Penin. High.; (map 111).

Prospectors' name shown on a map of Cape Nome gold fields by David Fox, Jr., dated 1901. This feature cannot be precisely identified on current maps.

Bacon Creek: stream, heads at terminus of Bacon Glacier, trends E $9 \mathrm{mi}$. to Thallsaykway River, in British Columbia, $41 \mathrm{mi}$. NE of Juneau, Coast Mts. ; $58^{\circ} 45^{\prime} \mathrm{N}, 134^{\circ} 33^{\prime} \mathrm{W}$; (map 12).

Local name reported in 1960 by USGS.

Bacon Creek: stream, flows S $7 \mathrm{mi}$. to Melozitna River, $33 \mathrm{mi}$. N of Birches, Kokrines-Hodzana High. ; $65^{\circ} 36^{\prime} 45^{\prime \prime} \mathrm{N}, 153^{\circ} 39^{\prime} 00^{\prime \prime} \mathrm{W}$; (map 107).
Prospectors' name reported by USGS in the 1940 's, but probably was used much earlier.

Bacon Glacier: glacier, trends SE $3.5 \mathrm{mi}$. to its 1948 terminus at Bacon Creek, $8 \mathrm{mi}$. NE of Twin Glacier Lake and $33 \mathrm{mi}$. NE of Juneau, Coast Mts.; $58^{\circ} 38^{\prime} 45^{\prime \prime} \mathrm{N}, 133^{\circ} 47^{\prime} 15^{\prime \prime} \mathrm{W}$; BGN 1965; (map 12).

Local name reported in 1960 by USGS.

Bactrian Point: point of land, between Marten Arm and Boca de Quadra, Coast Mts.; $55^{\circ}$ $07^{\prime} 15^{\prime \prime} \mathrm{N}, 130^{\circ} 42^{\prime} 30^{\prime \prime} \mathrm{W}$; BGN 1929; (map $3)$.

Descriptive name given in 1929 by J. M. Wyckoff, USFS, because the point "has a striking resemblance to a two-hump camel." The camel referred to is the Bactrian or Asian camel.

Badger: railroad station, on Fairbanks-Eielson section of The Alaska Railroad, $8 \mathrm{mi}$. SE of Fairbanks, Tanana Low.; $64^{\circ} 48^{\prime} \mathrm{N}, 147^{\circ} 32^{\prime}$ W; BGN 1949; (map 100).

Named by personnel of The Alaska Railroad in 1949; "so called because it is in the vicinity of the Old Badger Road."

Badger Bay: estuary, extends N 3.7 mi. off Boca de Quadra, $2.2 \mathrm{mi}$. NE of Orca Point, Coast Mts.; $55^{\circ} 08^{\prime} 38^{\prime \prime}$ N, $130^{\circ} 49^{\prime} 00^{\prime \prime}$ W ; (map 3).

One of many arbitrary names applied to features in this area in 1891 by USC\&GS.

Badger Creek: stream, flows $\mathbf{N}$ to Paystreak Creek which flows to Pilgrim River, $12 \mathrm{mi}$. NE of Salmon Lake and $23 \mathrm{mi}$. W of Mount Bendeleben, Seward Penin. High.; $65^{\circ} 06^{\prime}$ N, $164^{\circ} 54^{\prime} \mathrm{W}$; (map 110).

Prospectors' name reported on a map of Cape Nome gold fields by David Fox, Jr., dated 1901. This stream cannot be precisely located on current maps.

Badger Hill: mountain, $1.852 \mathrm{ft}$, on SE coast of Kenai Penin. between Chugach and Windy Bays, $18 \mathrm{mi}$. SE of Seldovia, Chugach Mts.; $59^{\circ} 13^{\prime} \mathrm{N}, 151^{\circ} 32^{\prime} \mathrm{W}$; (map 50).

Local name published by USC\&GS in 1939 on Chart 8531.

Badger Lake: lake, 2 mi. long, between Boca de Quadra and Smeaton Bay, $8 \mathrm{mi}$. E of Behm Mtn., Coast Mts.; $55^{\circ} 13^{\prime} \mathrm{N}, 130^{\circ} 46^{\prime} \mathrm{W}$; (map 3).

Local name reported in 1955 by USGS; derived from Badger Bay.

Bagial, Port: cove, extends N $1 \mathrm{mi}$. off Bucareli Bay, on $W$ coast of Prince of Wales I., SE of

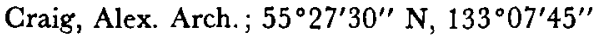
W; (map 4), Var. Bagial Cove, Bajial Cove, Cape Bagial, Mys Bagial, Puerto Bagial, Puerto Bayeal.

Name given in 1779 by Francisco Antonio Maurelle as "Puerto Bagial [from Baquial]" meaning "port of shoals"; Maurelle was in this port on May 30 and 31, 1779, and according to his account of the expedition, it was named "Bayeal" (Wagner, 1937, p. 374). Bagial Cove: cove, see Bagial, Port.

Bagley Icefield: icefield, in Chugach and St. Elias Mts., extends from head of Steller Glacier $80 \mathrm{mi}$. E to head of Columbus Glacier; $60^{\circ} 33^{\prime} \mathrm{N}, 142^{\circ} 30^{\prime} \mathrm{W}$; (map 65).
Named by USGS in 1951 for Col. James Warren Bagley, 1881-1947, USGS topographer.

Bagot, Mount: mountain, 7,155 ft., in Coast Mts., on Alaska-Canada boundary, $5 \mathrm{mi}$. NW of Snow Top and $13 \mathrm{mi}$. SE of Skagway; $B G N$ 1923 ; $59^{\circ} 20^{\prime} 55^{\prime \prime} \mathrm{N}, 135^{\circ} 01^{\prime} 45^{\prime \prime} \mathrm{W}$; (map $45)$.

Named jointly by United States and Canada for Sir Charles Bagot, 1781-1843, British Ambassador to Russia and Plenipotentiary at St. Petersburg in 1822 in negotiations regarding the Alaska boundary. $\mathrm{He}$ was British Minister to the United States, 1815-20, and negotiated the Rush-Bagot Convention in 1817 limiting armaments on the Great Lakes. He served as Governor General of Canada from 1841 to 1843.

Bahovec Peak: mountain, 2,265 ft., on E coast of Baranof I., $1.6 \mathrm{mi}$. SE of Baranof and $20 \mathrm{mi}$ $\mathrm{E}$ of Sitka, Alex. Arch.; $57^{\circ} 04^{\prime} 10^{\prime \prime} \mathrm{N}, 134^{\circ}$. $08^{\prime} 30^{\prime \prime} \mathrm{W}$; (map 9).

Local name reported in 1951 by USGS.

Baht Harbor: bight, $4 \mathrm{mi}$. across, on $\mathrm{N}$ coast of Zarembo I., Alex. Arch.; $56^{\circ} 27^{\prime} \mathrm{N}, 132^{\circ} 49^{\prime}$ W; (map 6). Var. Bath Harbor, Gavan Bat.

Published in 1853 on Russian Hydrog. Dept. Chart 1493 as "Gav[an] Bat," or "Bat Harbor." It was named for engineer Baht (cnna) of the steamer Alexander.

Baichron River: stream, see Amakatatee Creek. Baikron Creek: stream, see Amakatatee Creek. Bailey Bay: estuary, extends N $3.4 \mathrm{mi}$. off Behm Canal at mouth of Bell Arm, Alex. Arch.; 55 $56^{\prime} 15^{\prime \prime} \mathrm{N}, 131^{\circ} 37^{\prime} 15^{\prime \prime} \mathrm{W}$; (map 3). Var. Baily Bay.

Named in 1879 by W. H. Dall, USC\&GS; published in the 1883 Coast Pilot (p. 73 ).

Bailey Bay Hot Springs: locality, on Cleveland Penin. N of Bailey Bay, on W shore of Lake Shelokum, Alex. Arch.; 55 $59^{\prime} 00^{\prime \prime} \mathrm{N}, 131^{\circ}$. $39^{\prime} 30^{\prime \prime} \mathrm{W}$; (map 3$)$.

Local name published by Waring (1917, p. 20), USGS.

Bailey Creek: stream, flows SW $6 \mathrm{mi}$. to Boulder Creek, $2 \mathrm{mi}$. $\mathrm{N}$ of Fish Lake and $21 \mathrm{mi}$ ESE of Tanana, Yukon-Tanana High.; $65^{\circ} 07^{\prime} 00^{\prime \prime} \mathrm{N}$, $151^{\circ} 22^{\prime} 30^{\prime \prime} \mathrm{W}$; (map 106).

Local name reported in 1952 by USGS.

Bailey Creek: stream, see Gimlet Creek.

Bailey Harbor: cove, see Captain Harbor.

Bailey Ledge: reef, in Fox Is., on $\mathbf{N}$ coast of Unalaska I. in Captains Bay, Aleutian Is.; $53^{\circ} 51^{\prime} 48^{\prime \prime}$ N., $166^{\circ} 33^{\prime} 26^{\prime \prime} \mathrm{W}$; (map 23).

Reef shown, but not named, on early charts. Rediscovered in 1872 by Sylvanus Bailey, for whom it was named, second mate of the USC\&GS schooner Humboldt.

Bailey Rock: rock, in Nichols Passage, $1.3 \mathrm{mi}$. $\mathrm{SW}$ of Walden Point on Annette I., Alex. Arch.; $55^{\circ} 15^{\prime} 20^{\prime \prime} \mathrm{N}, 131^{\circ} 35^{\prime} 50^{\prime \prime} \mathrm{W}$; (map $3)$.

Local name recorded in 1954 by USGS.

Baily Bay: estuary, see Bailey Bay.

Bainbridge, Port: estuary, off E coast of Kenai Penin., trends S $20 \mathrm{mi}$. to Gulf of Alaska, 26 mi. SW of Chenega Mts.; $59^{\circ} 57^{\prime} \mathrm{N}, 148^{\circ} 21^{\prime}$ W; BGN 1910; (map 63). 
Named by Capt. Vancouver, RN, "after an examination by Joseph Whidbey about June 1, 1794, very likely in honor of John Bainbridge, an astronomer of the seventeenth century" (Wagner, 1937, p. 374).

Bainbridge Glacier: glacier, heads on Pinnacle Mtn., Kenai Penin., trends E $12 \mathrm{mi}$. to Port Bainbridge, $16 \mathrm{mi}$. SW of Chenega, Chugach Mts.; $60^{\circ} 06^{\prime} 45^{\prime \prime} \mathrm{N}, 148^{\circ} 22^{\prime} 30^{\prime \prime} \mathrm{W}$; (map 63).

Named for nearby Port Bainbridge; reported in 1905 by U.S. Grant, USGS.

Bainbridge Island: island, trends NE-SW $16 \mathrm{mi}$. from Knight Island Passage to $\mathrm{S}$ end of Port Bainbridge, off $E$ coast of Kenai Penin., Chugach Mts.; $60^{\circ} 06^{\prime} \mathrm{N}, 148^{\circ} 09^{\prime} \mathrm{W} ; B G N$ 1910; (map 63). Var. Flemming Island

Named for nearby Port Bainbridge; reported in 1900 by USC\&GS.

Bainbridge Passage: water passage, trends SW 14 mi. from Knight Island Passage to Port Bainbridge, between Kenai Penin. and Bainbridge 1., Chugach Mts.; $60^{\circ} 08^{\prime} 30^{\prime \prime} \mathrm{N}, 148^{\circ} 10^{\prime} \mathrm{no}$ " W; (map 63).

Named for nearby Port Bainbridge; reported in 1905 by U.S. Grant, USGS.

Bainbridge Peak: peak, 3,545 ft., $1.3 \mathrm{mi}$. E of head of Thomas Bay, $103 \mathrm{mi}$. E of Sitka, Coast Mts. ; $57^{\circ} 06^{\prime} 00^{\prime \prime} \mathrm{N}, 132^{\circ} 46^{\prime} 30^{\prime \prime} \mathrm{W}$; (map 8).

Named in 1887 by Lt. Comdr. C. M. Thomas, USN, presumably for Commodore W. Bainbridge, USN. The name was published in 1888 by USC\&GS on Chart 705.

Bainbridge Point: point of land, on NE tip of Bainbridge I., in Knight Island Passage, $6 \mathrm{mi}$. $\mathrm{S}$ of Chenega, Chugach Mts.; $60^{\circ} 12^{\prime} \mathrm{N}, 148^{\circ}$. 03' W; BGN 1929; (map 63).

Named in 1929 by USC\&GS; derived from the name of the island.

Bain Creek: locality, see Windy.

Bain Creek: stream, flows E 5 mi. to Nenana River, $28 \mathrm{mi}$. S of Healy, Alaska Ra.; $63^{\circ}$ $28^{\prime} \mathrm{N}, 148^{\circ} 49^{\prime} \mathrm{W}$; (map 87).

Local name shown on a 1923 manuscript map by The Alaska RR.

Bains Cove: cove, $1 \mathrm{mi}$. long, on $\mathrm{E}$ side of Kupreanof I., $15 \mathrm{mi}$. SW of Petersbung, Alex. Arch.; $56^{\circ} 38^{\prime} 10^{\prime \prime} \mathrm{N}, 133^{\circ} 10^{\prime} 50^{\prime \prime} \mathrm{W}$; BGN 1966; (map 6). Var. Basin Cove, Brailand Slough.

Local name reported in 1961 by USGS.

Baird Bank: locality, "off the northern shore of Alaska peninsula. Named by Tanner, 1890 , after Prof. Spencer F. Baird, of the Smithsonian Institution" (Baker, 1906, p. 112).

Baird Canyon: canyon, along course of Copper River, trends SW $4 \mathrm{mi}$. to Miles Lake, 38 mi. N of Katalla, Chugach Mts.; $60^{\circ} 44^{\prime} \mathrm{N}$, $144^{\circ} 33^{\prime} \mathrm{W}$; (map 64).

Named in 1885 by Lt. Allen (1887, p. 43), USA, for Spencer Fullerton Baird, 1823-87. See Baird Glacier.

Baird Creek: stream, flows W to Sinuk River, about $33 \mathrm{mi}$. NW of Nome, Seward Penin. High.; ( map 94).

Prospectors' name reported on the 1900 "Map of Nome Peninsula" by J. M. Davidson and B. D. Blakeslee; this feature has not been positively identified.

Baird Glacier: glacier, heads near Alaska-Canada boundary, at $57^{\circ} 15^{\prime} \mathrm{N}, 132^{\circ} 15^{\prime} \mathrm{W}$, trends SW $22 \mathrm{mi}$, to its 1961 terminus, $1.5 \mathrm{mi}$. $\mathrm{N}$ of Thomas Bay and $100 \mathrm{mi}$. E of Sitka, Coast Mts. ; $57^{\circ} 07^{\prime} \mathrm{N}, 132^{\circ} 48^{\prime} \mathrm{W}$; (map 8).

Named in 1887 by Lt. Comdr. C. M. Thomas, USN, for Spencer Fullerton Baird, 1823-87, pioneer American naturalist noted for his studies of North American birds while Secretary of the Smithsonian Institution, 1850-87, and U.S. Commissioner of Fish and Fisheries, 1871-87.

Baird Glacier: glacier, see Allen Glacier.

Baird Inlet: lake, $35 \mathrm{mi}$. long, borders NE Nelson I., drained primarily by Ningaluk and Kolovinerak Rivers, Yukon-Kuskokwim Delta ; $60^{\circ} 45^{\prime} \mathrm{N}, 164^{\circ} 00^{\prime} \mathrm{W}$; (map 48). Var. Nunavarok, Nunavaroke, Nunvarok.

Named in 1880 by Ivan Petroff for Spencer Fullerton Baird, 1823-87. See Baird Glacier. The Eskimo name is "Nunavarok" according to a 1949 USC\&GS report.

Baird Island: island, $0.6 \mathrm{mi}$. long, on $\mathrm{W}$ coast of Chichagof I., $8 \mathrm{mi}$. SE of Chichagof, $37 \mathrm{mi}$. NW of Sitka, Alex. Arch.; $57^{\circ} 33^{\prime} 00^{\prime \prime} \mathrm{N}, 136^{\circ}$. $02^{\prime} 30^{\prime \prime} \mathrm{W}$; (map 9)

Named by USC\&GS and published on Chart 8280 in 1928.

Baird Lake: lake, 1,300 ft. across, in Matanuska Valley, $2.8 \mathrm{mi}$. SW of Palmer, Cook Inlet Low.; 61 $34^{\prime} 30^{\prime \prime} \mathrm{N}, 149^{\circ} 11^{\prime} 00^{\prime \prime} \mathrm{W}$; $B G N$ 1957; (map 69). Var. Bairds Lake, Bear Lake.

Local name reported in 1950 by Fred Machetanz of Palmer, Alaska; named for Mr. Baird (cnna), who was an early homesteader in the area.

Baird Mountain: mountain, "near Mount Augusta, St. Elias Range, southeastern Alaska. So named by Russell, 1890, after Prof. Spencer F. Baird, Secretary of the Smithsonian Institution" (Baker, 1906, p. 113).

Baird Mountains: mountain range, extends E-W $120 \mathrm{mi}$. at SW end of Brooks Ra., separated from Schwatka Mts. on $\mathrm{E}$ by Amakomanak Creek and Redstone River and bounded on $\mathrm{W}$ by valley of Noatak River; $67^{\circ} 25^{\prime} \mathrm{N}, 157^{\circ}$ $30^{\prime} \mathrm{W}$ [E end], $67^{\circ} 35^{\prime} \mathrm{N}, 162^{\circ} 15^{\prime} \mathrm{W}$ [W end]; (map 127).

Named in 1886 by Lt. G. M. Stoney, USN, for Spencer Fullerton Baird. See Baird Glacier.

Baird Peak: mountain, 3,064 ft., NE coast of Prince of Wales I., Alex Arch.; 55 $54^{\prime} 45^{\prime \prime}$ $N, 132^{\circ} 42^{\prime} 00^{\prime \prime} \mathrm{W}$; (map 4).

Named in 1886 by Lt. Comdr. A. S. Snow, USN.

Bairds Lake: lake, see Baird Lake.

Bairds Lake: lake, see High Ridge Lake.

Bairo Creek: stream, flows $\mathrm{N} 12 \mathrm{mi}$. to Chukowan River, $80 \mathrm{mi}$. SW of Sleetmute, KilbuckKuskokwim Mts. ; $60^{\circ} 46^{\prime} \mathrm{N}, 158^{\circ} 28^{\prime} \mathrm{W}$; BGN 1948; (map 60).

Eskimo name [Pairoq] that refers to a "meeting place [at river mouth]"; reported in 1945 by USGS.
Baituk Creek: stream, flows SW 6 mi. to Bering Sea, $10 \mathrm{mi}$. SE of Cape Prince of Wales and $45 \mathrm{mi}$. NW of Teller, Seward Penin. High.; $65^{\circ} 31^{\prime} \mathrm{N}, 167^{\circ} 47^{\prime} \mathrm{W}$; (map 111). Var Beetuk Creek, Bituk Creek, Botuk Creek.

Eskimo name published in 1900 as "Botuk" on USC\&GS Chart 9380, and as "Bituk" by Schrader and Brooks (map 3), USGS. Reported the same year as "Baituk" by Brooks (1901, pl. 13 and p. 135), USGS.

Bakatigikh Mountain: mountain, 1,650 ft., 18 mi. WNW of Hughes, Hogatza High.; $66^{\circ} 06^{\prime}$ N, $154^{\circ} 52^{\prime} \mathrm{W}$; (map 116).

Indian name "Bakatigikhdalitani," reported to mean "dry weed hill," recorded in 1956 by Orth. The name was shortened for cartographic acceptability.

Bakbuk Creek: stream, flows SE $20 \mathrm{mi}$. to Holitna River, $49 \mathrm{mi}$. SW of Sleetmute, Kilbuck-Kuskokwim Mts.; $61^{\circ} 02^{\prime} \mathrm{N}, 157^{\circ} 42^{\prime}$ W; BGN 1948; (map 72).

Eskimo name said to mean "stream with a big mouth"; reported in 1945 by USGS

Baked Creek: stream, see Baker Creek.

Baked Mountain: mountain, 3,695 ft., on Alaska Penin, in Katmai National Monument, $9 \mathrm{mi}$. W. of Mount Katmai, Aleutian Ra.; $58^{\circ}$. $16^{\prime} 55^{\prime \prime} \mathrm{N}, 155^{\circ} 11^{\prime} 25^{\prime \prime} \mathrm{W}$; BGN 1924; (map 42).

Descriptive name given in 1919 by $\mathbf{R}$. F. Griggs (1921, p. 227), of the National Geographic Society, "because of the big fumaroles at the foot."

Baker: locality, on right bank of Tanana River at mouth of Baker Creek, Yukon-Tanana High.; $64^{\circ} 58^{\prime} 30^{\prime \prime} \mathrm{N}, 150^{\circ} 27^{\prime} 30^{\prime \prime}$ ' W ; (map 99)

Telegraph station established in 1903 by the U.S. Army Signal Corps. It was later a sawmill and riverboat landing.

Baker, Mount: mountain, 2,250 ft., on W coast of Chichagof I., $11.5 \mathrm{mi}$. NW of Chichagof, Alex. Arch.; $57^{\circ} 49^{\prime} 00^{\prime \prime} \mathrm{N}, 136^{\circ} 14^{\prime} 10^{\prime \prime} \mathrm{W}$; (map 9).

Local name published by R. M. Overbeck (in Martin and others, 1919, pl. 2), USGS.

Baker, Point: point of land, northwesternmost tip of Prince of Wales I., extends into Sumner Strait, Alex. Arch.; 56 $21^{\prime} 32^{\prime \prime}$ N, 133 $37^{\prime} 15^{\prime \prime}$ W; (map 6). Var. North Point Baker.

Named on September 8, 1793, by Capt. George Vancouver, RN, for Lt. Joseph Baker, who drew the maps in Vancouver's atlas (Wagner, 1937, p. 374).

Baker Cove: cove, $0.5 \mathrm{mi}$. long, on $\mathrm{W}$ coast of Chichagof I., in Goulding Harbor, $10 \mathrm{mi}$. NW of Chichagof, Alex. Arch.; $57^{\circ} 47^{\prime} \mathrm{N}, 136^{\circ} 15^{\prime}$ W; (map 9).

Local name published in 1925 by USC\&GS, probably for Mount Baker, 1.5 miles as to the north.

Baker Creek: stream, flows NW $2 \mathrm{mi}$. to Merrifield Bay, $1 \mathrm{mi}$. $\mathbf{E}$ of village of Point Baker, on $\mathrm{N}$ coast of Prince of Wales I., Alex. Arch.; $56^{\circ} 20^{\prime} 50^{\prime \prime} \mathrm{N}, 133^{\circ} 35^{\prime} 05^{\prime \prime} \mathrm{W}$; BGN 1923; (map 6).

Named in 1923 by USFS. 
Baker Creek: stream, heads on S slope of Mount Hurst, flows SW $5 \mathrm{mi}$. to Tolstoi Creek, 17 mi. W of Ophir and $47 \mathrm{mi}$. NW of McGrath, Kilbuck-Kuskokwim Mts.; $63^{\circ} 10^{\prime} \mathrm{N}, 157^{\circ} 03^{\prime}$ W; $(\operatorname{map} 90)$.

Local name published in 1921 by USGS.

Baker Creek: stream, flows SW $7 \mathrm{mi}$-to Eden Creek, $49 \mathrm{mi}$. NE of Medfra, Kilbuck-Kuskokwim Mts.; $63^{\circ} 38^{\prime} \mathrm{N}, 153^{\circ} 42^{\prime} \mathrm{W}$; (map 89).

Local name reported in 1958 by USGS.

Baker Creek: stream, flows E $4.4 \mathrm{mi}$. to Sethkokna River, $34 \mathrm{mi}$. SW of Bitzshtini Mts., Kilbuck-Kuskokwim Mts. ; $64^{\circ} 15^{\prime} \mathrm{N}, 152^{\circ} 59^{\prime}$ W; (map 99).

Local name reported in 1952 by USGS.

Baker Creek: stream, flows SE $1 \mathrm{mi}$. to Fox River, $26 \mathrm{mi}$. NE of Solomon, Seward Penin. High.; $64^{\circ} 48^{\prime} \mathrm{N}, 163^{\circ} 45^{\prime} \mathrm{W}$; (map 95). Var. Baked Creek.

Reported as "Baked" on the 1900 "Map of Nome Peninsula" by J. M. Davidson and B. D. Blakeslee. Shown as "Baker" on a map of Cape Nome gold fields by David Fox, Jr., dated 1901.

Baker Creek: stream, flows E, then SW, $28 \mathrm{mi}$ to Tanana River, $57 \mathrm{mi}$. NE of Bitzshtini Mts., Tanana Low.; $64^{\circ} 58^{\prime} \mathrm{N}, 150^{\circ} 28^{\prime} \mathrm{W}$; (map 99). Var. Saklekageta.

Name reported in 1885 by Lt. H. T. Allen USA.

Baker Creek: stream, flows NW $1 \mathrm{mi}$. to Duncan Creek $0.2 \mathrm{mi}$. S of its junc. with Bullion Creek in Pargon River basin, $12 \mathrm{mi}$. NE of Council and $22 \mathrm{mi}$. SE of Mount Bendeleben Seward Penin. High.; $65^{\circ} 01^{\prime} \mathrm{N}, 163^{\circ} 25^{\prime} \mathrm{W}$; (map 110).

Prospectors' name reported on a map of Cape Nome gold fields by David Fox, Jr., dated 1901.

Baker Creek: stream, heads in Bendeleben Mts. flows SE $13 \mathrm{mi}$. to Boston Creek which flows to Fish River, $30 \mathrm{mi}$. S of Imuruk Lake, Seward Penin. High.; $65^{\circ} 08^{\prime} \mathrm{N}, 163^{\circ} 16^{\prime} \mathrm{W}$; (map 110).

Prospectors' name reported in 1909 by Smith and Eakin (1911, pl. 1), USGS.

Baker Creek: stream, flows $S$ to Fish River, between Pargon River and Bourne Creek, about $46 \mathrm{mi}$. NE of Solomon, Seward Penin. High.; (map 95).

Prospectors' name reported on the 1900 "Map of Nome Peninsula" by J. M. Davidson and B. D. Blakeslee. This stream cannot be precisely located on current maps.

Baker Creek: stream, "tributary to Middle fork Koyukuk river. See Hammond" (Baker, 1906, p. 113).

Baker Glacier: glacier, trends S $2 \mathrm{mi}$. to its terminus at head of stream which drains into Surprise Inlet, $6.5 \mathrm{mi}$. W of Point Doran and $52 \mathrm{mi}$. SE of Anchorage, Chugach Mts.; $61^{\circ} 04^{\prime} \mathrm{N}, 148^{\circ} 21^{\prime} \mathrm{W}$; BGN 1910; (map 69).

Named in 1910 by U. S. Grant, USGS, for Marcus Baker, 1849-1903, cartographer with USC\&GS and USGS and author of the "Dictionary of Alaska."

Baker Gulch: ravine, trends NE $1 \mathrm{mi}$. to Mastodon Greek, 2 mi. NNE of Mastodon Dome and $42 \mathrm{mi}$. SW of Circle, Yukon-Tanana High.; $65^{\circ} 28^{\prime} 40^{\prime \prime} \mathrm{N}, 145^{\circ} 17^{\prime} 36^{\prime \prime} \mathrm{W}$; (map 104). Var. Bakers Gulch.

Named by prospectors and reported in 1936 as "Bakers Gulch" by Mertie (1938a, p. 207), USGS.

Bakers Gulch: ravine, see Baker Gulch.

Baker Hot Springs: village, see Manley Hot Springs.

Baker Inlet: bay, "in Kasaan bay, Prince of Wales island, Alexander archipelago. This name was given by Dall, in 1880 , to a supposed inlet identing the southern shore of Kasaan bay. When Clover surveyed Kasaan bay, in 1885, and found the inlet did not exist he applied the name to a point near by" (Baker, 1906, p. 113).

Baker Island: island, 15 mi. long, between Bucareli Bay and Pacific Ocean, Alex. Arch.; $55^{\circ} 22^{\prime} \mathrm{N}, 133^{\circ} 36^{\prime} \mathrm{W}$; (map 4).

Named in 1879 by W. H. Dall, USC\&GS, "after Marcus Baker, 1849-1903." See Baker Glacier. Baker (1906, p. 113) says "Professor [George] Davidson identifies this island as the landfall of Chirikof, July 15, 1741."

Baker Island: island, see Rugged Island.

Baker Lake: lake, $1.2 \mathrm{mi}$. long, at head of Hot Springs Slough, $7 \mathrm{mi}$. ENE of village of Manley Hot Springs and $50 \mathrm{mi}$. ESE of Tanana, Yukon-Tanana High.; $65^{\circ} 02^{\prime} \mathrm{N}, 150^{\circ} 23^{\prime} \mathrm{W}$; (map 106).

Prospectors' name reported in 1906 by USGS (Prindle, 1908, pl. 5).

Baker Mountain: mountain, "on west bank of White river, near latitude $63^{\circ}$. So named, 1898, by Peters and Brooks, after H. B. Baker, a member of their party" (Baker, 1906, p. 113 ).

Baker Point: point of land, on $\mathbf{E}$ coast of Prince of Wales I., in Kasaan Bay, $1.3 \mathrm{mi}$. NW of Kasaan I., Alex. Arch.; 55 $30^{\circ} 50^{\prime \prime}$ N, $132^{\circ}$ 24'30' W; (map 4).

Named in 1885 by Lt. Comdr. R. C. Clover, USN, for Marcus Baker, 1849-1903. See Baker Glacier.

Bakewell Arm: estuary, flows E 3 mi., joins Wilson Arm to form Smeaton Bay, Coast Mts. $55^{\circ} 19^{\prime} \mathrm{N}, 130^{\circ} 42^{\prime} \mathrm{W}$; (map 3$)$.

Local navigators' name obtained in 1904 by H. C. Fassett, USBF.

Bakewell Arm Lake: lake, see Bakewell Lake.

Bakewell Lake: lake, $4.3 \mathrm{mi}$. long, drains $\mathrm{N}$ into Bakewell Arm, $1.7 \mathrm{mi}$. E of Smeaton Bay, Coast Mts. ; $55^{\circ} 16^{\prime} \mathrm{N}, 130^{\circ} 40^{\prime} \mathrm{W}$; BGN 1966; (map 3). Var. Bakewell Arm Lake.

Local name published in 1960 by USFS.

Balaena Rocks: islands, see Ballena Islands.

Balandra Island: island, 1,100 ft. long, between Bucareli and San Alberto Bays, NE of San Juan Bautista I., 3 mi. SW of Craig, Alex. Arch.; $55^{\circ} 27^{\prime} 10^{\prime \prime} \mathrm{N}, 133^{\circ} 13^{\prime} 10^{\prime \prime} \mathrm{W}$; (map 4).

Spanish name meaning "sloop" given in 1775 by Francisco Antonio Maurelle and Don Juan de la Bodega y Quadra. See Fish Egg Island.

Balandra Shoal: shoal, extends $0.8 \mathrm{mi}$. in San Alberto Bay, $3 \mathrm{mi}$. W of Craig, Alex. Arch.; $55^{\circ} 28^{\prime} 30^{\prime \prime} \mathrm{N}, 133^{\circ} 14^{\prime} 15^{\prime \prime} \mathrm{W}$; (map 4).
Named in 1897 by Lt. Comdr. J. F. Moser, USN; derived from Balandra Island.

Balboa Bay: bay, on S coast of Alaska Penin,, extends $\mathrm{N} 7 \mathrm{mi}$., $\mathrm{E}$ of Cape Aliaksin, Aleutian Ra., 55 $30^{\prime} \mathrm{N}, 161^{\circ} 35^{\prime} \mathrm{W}$; BGN 1907; (map 28). Var. Bukhta Perenosnaya, Bukhta Perenosnoi, Perenosnaia Bay, Portage Bay.

Named "Bukhta Perenosnoi," or "Portage Bay," in 1847 by the Russian Hydrog. Dept., for the portage across the peninsula from the head of this bay to Herendeen Bay. Published as "Bukh[ta] Perenosnaya," by Capt. Tebenkov (1852, map 24), IRN. "Balboa Bay" was proposed in 1907 by S. S. Philbrick and adopted by BGN, but this feature is known locally as "Portage Bay."

Bald Cape : point of land, see Ghacon, Cape.

Bald Head: island, see Axel Lind Island.

Bald Head: island, see Deuce Island.

Bald Head: promontory, on $\mathrm{N}$ shore of Norton Bay, 35 mi. NE of Elim, Seward Penin. High.; $64^{\circ} 45^{\prime}$ N, $161^{\circ} 32^{\prime}$ W; (map 96). Var. Point Ennis, Point Inglestat, Point Issacs.

Named September 1778 by Gapt. James Cook, RN. It has been called Point Inglestat, and also Isaacs Point, by the miners and prospectors. Some part of it was also called Point Ennis by the Western Union Telegraph expedition of 1867 .

Bald Head Chris Island: island, $1 \mathrm{mi}$. long, in Prince William Sound, at NE end of Wells Passage, $28 \mathrm{mi}$. E of Whittier, Chugach Mts.; $60^{\circ} 47^{\prime} 30^{\prime \prime} \mathrm{N}, 147^{\circ} 50^{\prime} 45^{\prime \prime} \mathrm{W} ; B G N$ 1918; (map 63).

Local name reported in 1908 by U. S. Grant, USGS. Named for Chris Christensen who operated a fox farm on the island at the end of the 19 th century.

Bald Headed Cove: cove, $0.4 \mathrm{mi}$, across, on $\mathrm{E}$ coast of Pennock I., 2 mi. SE of Ketchikan, Alex. Arch.; $55^{\circ} 19^{\prime} 00^{\prime \prime} \mathrm{N}, 131^{\circ} 36^{\prime} 30^{\prime \prime} \mathrm{W}$; (map 3).

Local name reported in 1954 by USGS.

Baldhead Mountain: peak, 1,676 ft., in Ilivit Mts. on $\mathrm{N}$ bank of Yukon River, $15 \mathrm{mi}$. NE of Russian Mission, Nulato Hills; 61 ${ }^{\circ} 56^{\prime} \mathrm{N}$, $161^{\circ} 59^{\prime} \mathrm{W}$; (map 73).

Descriptive name, used by early riverbost pilots; published by AMS in 1952.

Bald Hill: mountain, 2,130 ft., $1 \mathrm{mi}$. E of Oil Bay and $21 \mathrm{mi}$. NE of Augustine I., Aleutian Ra.; $59^{\circ} 39^{\prime} 15^{\prime \prime} \mathrm{N}, 153^{\circ} 14^{\prime} 15^{\prime \prime} \mathrm{W}$; $B G N$ 1916; (map 51).

Descriptive name published in 1913 on USC\&GS Chart 3420 .

Bald Mountain: hill, 3,600 ft., $2.5 \mathrm{mi}$. long, 4.5 mi. S of junc. of Sheep and Talkeetna Rivers and $11 \mathrm{mi}$. E of Talkeetna, Talkeetna Mts.; $62^{\circ} 18^{\prime} 30^{\prime \prime} \mathrm{N}, 149^{\circ} 44^{\prime} 00^{\prime \prime} \mathrm{W}$; (map 82).

Local name recorded in 1949 by USGS.

Bald Mountain: mountain, 2,700 ft., near SW end of Heceta I., Alex. Arch.; $55^{\circ} 43^{\prime} 20^{\prime \prime} \mathrm{N}$, $133^{\circ} 33^{\prime} 30^{\prime \prime} \mathrm{W}$; (map 4).

Local descriptive name given in 1904 by E. F. Dickins, USC\&GS.

Bald Mountain: mountain, 2,630 ft., on Cleveland Penin. $\mathrm{E}$ of Lake McDonald, Alex. Arch.; $55^{\circ} 59^{\prime} \mathrm{N}, 131^{\circ} 49^{\prime} \mathrm{W}$; (map 3). 
Descriptive name published in 1910 by USC\&GS.

Bald Mountain: mountain, 3,851 ft., in Glacier Bay National Monument, between Crillon Lake and Lituya Bay, $21 \mathrm{mi}$. SE of Cape Fairweather, St. Elias Mts.; $58^{\circ} 37^{\prime} 10^{\prime \prime} \mathrm{N}, 137^{\circ}-$ $28^{\prime} 10^{\prime \prime}$ W; (map 10).

Descriptive name published by members of the Harvard-Dartmouth Expedition, 193334.

Bald Mountain: mountain, 1,961 ft,, on Kenai Penin., $11 \mathrm{mi}$. NE of Homer, Cook Inlet Low.; $59^{\circ} 46^{\prime} \mathrm{N}, 151^{\circ} 20^{\prime} \mathrm{W}$; (map 50).

Local name reported and published by USGS in the 1950's.

Bald Mountain: peak, 5,285 ft., in Mount McKinley National Park, SE of junc. of Sunrise Creek and Thorofare River, $4.2 \mathrm{mi}$. SE of Eielson Visitor Center, Alaska Ra.; $63^{\circ} 23^{\prime} \mathrm{N}$, $150^{\circ} 14^{\prime} \mathrm{W}$; BGN 1932; (map 88).

Prospectors' name reported in 1931 by J. C. Reed, Sr., and S. N. Stoner, USGS.

Bald Mountain: mountain, see Juneau, Mount.

Bald Mountain Ridge: ridge, elev. 4,700 ft., extends W $7 \mathrm{mi}$. from Little Susitna River, 11 mi. NW of Palmer, Talkeetna Mts. ; $61^{\circ} 44^{\prime} \mathrm{N}$, $149^{\circ} 21^{\prime} \mathrm{W}$; (map 69 ).

Local descriptive name reported in 1911 by USGS (in Brooks and others, 1914, pl. 2).

Bald Mountains: mountains, "near Taku river. Probably so called by the exploring parties of the Western Union Telegraph Company in 1865" (Baker, 1906, p. 114)

Bald Peak: mountain, 2,212 ft., SW Warren I., Alex. Arch.; $55^{\circ} 52^{\prime} 25^{\prime \prime} \mathrm{N}, 133^{\circ} 54^{\prime} 00^{\prime \prime} \mathrm{W}$; $(\operatorname{map} 4)$.

Descriptive name published in 1906 by USC\&GS.

Bald Ridge: ridge, extends E $2.7 \mathrm{mi}$. from Tamgas Harbor, S of Purple Lake, on Annette I., Alex. Arch.; $55^{\circ} 05^{\prime} \mathrm{N}, 131^{\circ} 30^{\prime} \mathrm{W}$; (map 3).

Descriptive name given in 1883 by Lt. Comdr. H. E. Nichols, USN, "because of an absence of vegetation."

Baldry Creek: stream, flows NW 3.5 mi. to Goldstream Creek, 16 mi. NW of Fairbanks, Yukon-Tanana High.; $64^{\circ} 52^{\prime} 10^{\prime \prime} \mathrm{N}, 148^{\circ} 14^{\prime} 45^{\prime \prime}$ W; (map 100)

Name given by prospectors; published on a 1906 USGS map.

Baldry Mountain: mountain, 3,846 ft., $14 \mathrm{mi}$. SSW of Rampart, Yukon-Tanana High.; $65^{\circ}$ $18^{\prime} 30^{\prime \prime} \mathrm{N}, 150^{\circ} 18^{\prime} 00^{\prime \prime} \mathrm{W}$; (map 106).

Prospectors' name reported in 1906 by USGS (Prindle, 1908, pl. 5)

Baldwin: locality, on $\mathrm{N}$ shore of North Arm Moira Sound, Prince of Wales I., Alex. Arch.; $55^{\circ} 10^{\prime} \mathrm{N}, 132^{\circ} 10^{\prime} \mathrm{W}$; (map 4 ).

The Baldwin post office was maintained here from 1905 to 1907 (Ricks, 1965, p. 5).

Baldwin: village, see Elephant Point.

Baldwin Creek: stream, flows NW $3 \mathrm{mi}$. to Fish River, $10 \mathrm{mi}$. E of Council and $40 \mathrm{mi}$. NE of Solomon, Seward Penin, High.; 64 $52^{\prime} \mathrm{N}$, $163^{\circ} 18^{\prime} \mathrm{W}$; (map 95)

Local name reported in 1900 by W. J. Peters (in Mendenhall, 1901, pl. 20), USGS. Baldwin Greek: stream, flows NW to Anikovik
River, about $15 \mathrm{mi}$. ESE of Cape Prince of Wales, Seward Penin High.; (map 111).

Prospectors' name shown on a map of Cape Nome gold fields by David Fox, Jr., dated 1901. This feature cannot be precisely identified on current maps.

Baldwin Glacier: glacier, in Glacier Bay $\mathrm{Na}-$ tional Monument, trends NE $2 \mathrm{mi}$. to Plateau Glacier, $5 \mathrm{mi}$. SE of head of Queen Inlet, $68 \mathrm{mi}$. NW of Hoonah, St. Elias Mts.; $58^{\circ}$. $55^{\prime} 30^{\prime \prime} \mathrm{N}, 136^{\circ} 23^{\prime} 00^{\prime \prime} \mathrm{W}$; (map 10).

Named by members of the American Geographical Society Glacier Expedition of 1941 for Samuel Baldwin, born in 1868, a practicing lawyer interested in geology, geography, and natural history. In 1886 he visited Muir Glacier and published two papers concerning his observations.

Baldwin Glacier: glacier, heads at $60^{\circ} 43^{\prime} \mathrm{N}$ $141^{\circ} 21^{\prime} \mathrm{W}$, trends $\mathrm{N} 14 \mathrm{mi}$. to Logan Glacier, $14 \mathrm{mi}$. SW of Mount George and $109 \mathrm{mi}$. NW of Yakutat, St. Elias Mts.; $60^{\circ} 54^{\prime} \mathrm{N}, 140^{\circ}$. $18^{\prime} \mathrm{W}$; (map 65$)$.

Local name published in 1942 by USGS.

Baldwin Peninsula: peninsula, extends NW 75 mi. from $W$ coast of Alaska, bounded on NE by Hotham Inlet and Selawik Lake and on SW by Kotzebue Sound, Kotzebue-Kobuk Low.; $66^{\circ} 45^{\prime} \mathrm{N}, 162^{\circ} 20^{\prime} \mathrm{W}$; BGN 1933; (map $113)$.

Named in 1933 by Carl J. Lomen of the Lomen Reindeer Corporation "for Leonard D. Baldwin, 1867-1933, philanthropist, who added to the economic development of Alaska ***, and who was outstanding for his activities in the protection of wild life throughout North America."

Baldy Bay: bay, $2.5 \mathrm{mi}$. across, off Tlevak Strait, on $\mathrm{E}$ coast of Dall I., Alex. Arch.; $55^{\circ} 02^{\prime} \mathrm{N}$, $132^{\circ} 58^{\prime} \mathrm{W}$; BGN 1908; (map 4).

Local name reported in 1907 by $E$. F. Dickins, USC\&GS

Baldy Creek: stream, flows N $3.6 \mathrm{mi}$. to North Fork Kougarok River, $\mathrm{S}$ of Harris Dome and $40 \mathrm{mi}$. W of Imuruk Lake, Seward Penin. High.; $65^{\circ} 37^{\prime} \mathrm{N}, 164^{\circ} 33^{\prime} \mathrm{W}$; (map 110).

Prospectors' name reported in 1901 by T. G. Gerdine (in Collier, 1902, pl. 12), USGS.

Baldy Lake: lake, $0.5 \mathrm{mi}$. long, between Birch and Montana Creeks, $8 \mathrm{mi}$. SW of Bald Mtn. and $8.5 \mathrm{mi}$. SE of Talkeetna, Talkeetna Mts.; $62^{\circ} 14^{\prime} 20^{\prime \prime} \mathrm{N}, 149^{\circ} 55^{\prime} 20^{\prime \prime} \mathrm{W}$; (map 82 ).

Local name recorded in 1963 by USGS.

Baldy Mountain: mountain, $1,720 \mathrm{ft}$., $5 \mathrm{mi}$. S of Harris Dome and $38 \mathrm{mi}$. W of Imuruk Lake, Seward Penin. High.; $65^{\circ} 33^{\prime} \mathrm{N}, 164^{\circ} 34^{\prime} \mathrm{W}$ (map 110).

Local name reported in 1900 by Brooks (1901, pl. 11), USGS.

Baleful Peak: mountain, 7,900 ft., $8 \mathrm{mi}$. W of Inner Lake George and $24 \mathrm{mi}$. SE of Palmer, Chugach Mts.; $61^{\circ} 17^{\prime} \mathrm{N}, 148^{\circ} 50^{\prime} \mathrm{W}$; $B G N$ 1964; (map 69)

So named in 1963 by members of the Mountaineering Club of Alaska, because "of its rugged and sinister appearance."

Balena Islands: islands, see Ballena Islands. Bales Creek: stream, see Kinegnak River.
Bales Landing: anchorage, on S coast of Alaska Penin., on Ramsey Bay, at head of Stepovak Bay, Aleutian Ra.; $55^{\circ} 51^{\prime} 30^{\prime \prime} \mathrm{N}, 159^{\circ} 49^{\prime} 00^{\prime \prime}$ W; (map 27).

Local name published by USC\&GS in 1916 Alaska Coast Pilot.

Balika Basin: lagoon, $0.5 \mathrm{mi}$. across, on $\mathrm{N}$ coast of Spruce I., NE of Kodiak I.; 57 $56^{\prime} 20^{\prime \prime} \mathrm{N}$, $152^{\circ} 26^{\prime} 30^{\prime \prime}$ W; (Map 34).

Name published in 1943 by USC\&GS; possibly derived from the Russian word "balka," meaning "valley" or "ravine."

Balika Cove: cove, extends NW $0.4 \mathrm{mi}$., off Knee Bay, on NE coast of Spruce I., NE of Kodiak I.; $57^{\circ} 56^{\prime} 10^{\prime \prime} \mathrm{N}, 152^{\circ} 25^{\prime} 40^{\prime \prime} \mathrm{W}$; (map 34).

Name published in 1943 by USC\&GS. See Balika Basin.

Ballaine Lake: lake, $0.1 \mathrm{mi}$. across, $3.6 \mathrm{mi}$. NW of Fairbanks, Yukon-Tanana High.; 645' $15^{\prime \prime} \mathrm{N}, 147^{\circ} 47^{\prime} 30^{\prime \prime} \mathrm{W}$; (map 100).

Local name published on a 1955 USGS map.

Ballarat Creek: stream, "Seward peninsula, tributary from the south to Humboldt creek, which is a tributary to Goodhope river. Latitude $65^{\circ} 50^{\prime}$, longitude $164^{\circ} 10^{\prime}$. Local name, from Gerdine, 1901" (Baker, 1906, p. 114).

Ballarat Creek: stream, flows NW $11 \mathrm{mi}$. to Humboldt Creek, $13 \mathrm{mi}$. NE of Midnight Mtn. and $37 \mathrm{mi}$. NW of Imuruk Lake, Seward Penin. High.; $65^{\circ} 55^{\prime} \mathrm{N}, 164^{\circ} 18^{\prime} \mathrm{W}$; (map 110).

Prospectors' name reported in 1901 by USGS (in Collier, 1902, pl. 12).

Ballast Island: island, "in Portage bay, Alaska peninsula. So named by the Fish Commission in 1893" (Baker, 1906, p. 114).

Ballast Island: rock, in Albatross Anchorage of Balboa Bay, on $\mathrm{S}$ coast of Alaska Penin., Aleutian Ra.; 55 $35^{\prime} 15^{\prime \prime} \mathrm{N}, 160^{\circ} 35^{\prime} 35^{\prime \prime} \mathrm{W}$; (map 28).

Named by USBF in 1893.

Ball Creek: stream, flows W $0.7 \mathrm{mi}$. to Shovel Creek, $0.3 \mathrm{mi}$. S of Harlem Creek and $11 \mathrm{mi}$. $\mathrm{N}$ of Solomon, Seward Penin., High.; 64 $43^{\circ}$ '$10^{\prime \prime} \mathrm{N}, 164^{\circ} 26^{\prime} 00^{\prime \prime} \mathrm{W}$; (map 95).

Local name reported on a 1902 prospectors manuscript map.

Ballena, La: island, see Fish Egg Island.

Ballena Islands: islands, two, extend $0.8 \mathrm{mi}$, between Bucareli and San Alberto Bays, $1.4 \mathrm{mi}$. SW of Craig, Alex. Arch.; 55 $28^{\prime} 10^{\prime \prime} \mathrm{N}$, $133^{\circ} 11^{\prime} 30^{\prime \prime}$ W; (map 4). Var. Balaena Rocks, Balena Islands, Los Mondragones.

Spanish word meaning "whale" applied in 1897 as "Balena" by Lt. Comdr. J. F. Moser, USN. Named "los Mondragones" in 1799 by Don Juan de la Bodega y Quadra and Francisco Antonio Maurelle. "Mondragon is a [Spanish] family name * * *" (Wagner, 1937, p. 473). They were called "Balaena Rocks" and included in the "Fish Egg Islets" of Lt. Comdr. H. E. Nichols (U.S. Coast and Geodetic Survey, 1891, p. 121), USN. See Fish Egg Island.

Ballena Island Shoal: shoal, extends $1,500 \mathrm{ft}$., in San Alberto Bay, $2.4 \mathrm{mi}$. W of Craig, Alex. Arch.; $55^{\circ} 28^{\prime} 15^{\prime \prime} \mathrm{N}, 133^{\circ} 13^{\prime} 05^{\prime \prime} \mathrm{W}$; (map 4). 
Name published in 1925 Coast Pilot ( $p$. 143) ; derived from Ballena Islands.

Ballentine Creek: stream, on N coast of Attu I., heads at Brannon Ridge, flows $\mathrm{N} 4 \mathrm{mi}$. to Austin Cove, Aleutian Is.; 52 $59^{\prime} 10^{\prime \prime} \mathrm{N}$, $173^{\circ} 04^{\prime} 00^{\prime \prime} \mathrm{E}$; (map 13 ).

Named by the U.S. Army during World War II; published in 1948 by AMS.

Ball Islets: island, "forming eastern part of the Galankin group, Sitka sound, Alexander archipelago. So named by United States naval officers, 1879, after Col. Mottrom Dulany Ball, at that time collector of customs at Sitka" (Baker, 1906, p. 114).

Ball Island: island, see Aleutski Island.

Balls Pass: pass, "between the headwaters of Fortymile creek and the Tanana river on the west side of Sixtymile butte, near latitude $63^{\circ} 50^{\prime}$, longitude $142^{\circ} 30^{\prime}$. Probably named after E. F. Ball, a prospector, and written Ball's on a manuscript map made by him in 1898 and deposited in the Coast Survey archives" (Baker, 1906, p. 114).

Ballyhoo, Mount: mountain, 1,589 ft., on Amaknak I., in Unalaska Bay on NE coast of Unalaska I., Aleutian Is.; $53^{\circ} 54^{\prime} 41^{\prime \prime} \mathrm{N}$, $166^{\circ} 32^{\prime} 08^{\prime \prime} \mathrm{W}$; (map 23).

Published by USC\&GS in 1965 on Chart 9008.

Balm Gulch: ravine, see Balm of Gilead Gulch. Balmof Gulch: ravine, see Balm of Gilead Gulch.

Balm of Gilead Gulch: ravine, trends NE $1 \mathrm{mi}$. to Crooked Creek which flows to Ophir Creek, $8 \mathrm{mi}$. N of Council and $16 \mathrm{mi}$. SE of Mount Bendeleben, Seward Penin. High.; $65^{\circ} 01^{\prime} 15^{\prime \prime}$ $\mathrm{N}, 163^{\circ} 41^{\prime} 30^{\prime \prime} \mathrm{W}$; (map 110). Var. Balm Gulch, Balmof Gulch.

Prospectors' name reported in 1906 by USGS geologists (in Collier and others, 1908, p. 254), USGS. Reported as "Balm" on a map of Cape Nome gold fields 'yy David Fox, Jr., dated 1901.

Baltimore Glacier: glacier, trends SE 3 mi., near head of Harvard Arm College Fiord, $50 \mathrm{mi}$. SE of Palmer, Chugach Mts.; $61^{\circ} 17^{\prime} 30^{\prime \prime} \mathrm{N}$, $147^{\circ} 44^{\prime} 00^{\prime \prime}$ W; BGN 1910; (map 69).

Named in 1908 by U. S. Grant and D. F. Higgins, USGS, for "the Woman's College of Baltimore, now Goucher College."

Balto Creek: stream, flows SW $1 \mathrm{mi}$. to Snake River, $9 \mathrm{mi}$. NW of Nome, Seward Penin. High.; $64^{\circ} 38^{\prime} \mathrm{N}, 165^{\circ} 28^{\prime} \mathrm{W}$; (map 94). Var. Batto Creek.

Prospectors' name reported on a map by S. E. King dated 1900 .

Baluka Hill: hill, see Beluga Hill.

Balween Mountain: mountain, "Annette island, Alexander archipelago, on north shore Tamgas lake, west shore Tamgas harbor, $11 / 2$ miles north of Davison mountain, near latitude $55^{\circ}$ 04'. Name from Moser, 1901" (Baker, 1906, p. 115).

Bamboo Bay: bight, $1.5 \mathrm{mi}$. across, facing Bering Sea, W of West Kiska Lake on NW coast of Kiska I., Aleutian Is.; $52^{\circ} 04^{\prime} \mathrm{N}, 177^{\circ} 31^{\prime} \mathrm{E}$; (map 14).

This is one of the plant names arbitrarily applied to features on Kiska Island in 1943 by
USAAF for tactical purposes during World War II.

Bamdoroshinyy, Ostrov : island, see Bamdoroshni Island.

Bamdoroshni Island: island, $0.3 \mathrm{mi}$. across, in Galankin Is., off W coast of Baranof I., $1.7 \mathrm{mi}$ $\mathrm{S}$ of Sitka, Alex. Arch.; $57^{\circ} 01^{\prime} 35^{\prime \prime} \mathrm{N}, 135^{\circ}$. 20'00" W; (map 9). Var. Bamdorotchnoi Island, Ostrov Bamdoroshinyy, Ostrov Bamdoroshnoy, Russian Island.

Named in 1809 by the Russian navigator Ivan Vasiliev the first; published by Lt. Sarichev (1826, map 19), IRN, as "O[strov] Bamdoroshnoy" or "Bamdoroshnoy Island." According to George Kostrometinoff, U.S. court interpreter of Sitka in 1900, this name is derived from "podorozhnyy," meaning "on the road" or "journey."

Bamdoroshnoy, Ostrov: island, see Bamdoroshni Island.

Bamdorotchnoi Island: island, see Bamdoroshni Island.

Bancas, Bahia de las: bay, see Disenchantment Bay.

Bancas, Punta de las: point of land, see Bancas Point.

Bancas Point: point of land, on W shore of Disenchantment Bay, $1.8 \mathrm{mi}$. $\mathrm{E}$ of 1961 terminus of Black Glacier, 28 mi. NNE of Yakutat, St. Elias Mts.; $59^{\circ} 56^{\prime} 45^{\prime \prime} \mathrm{N}, 1^{\circ} 39^{\circ} 36^{\prime} 55^{\prime \prime} \mathrm{W}$; (map 46). Var. Punta de las Bancas.

Named "Punta de las Bancas" meaning "point of the banks (shoals)" in 1791 by Capt Alessandro Malaspina (Galiano, 1802, map 9).

Bandana Creek: stream, see Deer Creek.

Band Cove: bay, $0.4 \mathrm{mi}$. across, just W of Security Bay, on N Coast of Kuiu I., Alex. Arch.; $56^{\circ} 46^{\prime} 40^{\prime \prime} \mathrm{N}, 134^{\circ} 23^{\prime} 00^{\prime \prime} \mathrm{W}$; (map 5).

Named in 1881 by Comdr. Henry Glass, USN.

Banddana Creek: stream, heads in Ray Mts., flows SW $21 \mathrm{mi}$. to Dagislakhna Creek $2.5 \mathrm{mi}$. $\mathrm{N}$ of that stream's junc. with Tozitna River, $27 \mathrm{mi}$. N of Tanana, Kokrines-Hodzana High.; $65^{\circ} 33^{\prime} \mathrm{N}, 152^{\circ} 14^{\prime} \mathrm{W}$; BGN 1960; (map 106). Var. Middle Fork of the West Fork Tozitna River, Middle Fork Tozitna River.

Indian name meaning "duck river," obtained in 1956 at Tanana by Orth.

Banded Mountain: mountain, 5,676 ft., between Chickamin and Through Glaciers, 16 mi. NW of Hyder, Coast Mits.; $56^{\circ} 01^{\prime} 30^{\prime \prime} \mathrm{N}$, $130^{\circ} 22^{\prime} 50^{\prime \prime} \mathrm{W}$; (map 7 ).

Local name reported in 1924 by USGS.

Banded Mountain: mountain, 2,693 ft., between Terrace Creek and Anaktuvuk River, $8.5 \mathrm{mi}$. W of Table Top and $37 \mathrm{mi}$. NNE of Anaktuvuk Pass, Arctic Slope; 68 $39^{\prime} 45^{\prime \prime}$ N, $151^{\circ}$. 22'00" W; BGN 1960; (map 134).

So named in 1950 by R. E. Fellows, USGS, "because the strata on the mountain forms bands."

Bander Bay: bay, see Banner Bay.

Baner Bay: bay, see Banner Bay.

Bangookbit Dunes: sand dunes, trend NW $3 \mathrm{mi}$. along Bering Sea, $5 \mathrm{mi}$. NW of Cape Mendenhall, on SW coast of Nunivak I.; $59^{\circ} 50^{\prime} \mathrm{N}$, $166^{\circ} 21^{\prime}$ W; (map 55). Var. Bangooxthleet Dunes, Bangukhthleet Dunes.

Eskimo name spelled "Bangooxthleet" in 1949 by USC\&GS.

Bankookthleet Dunes: sand dunes, trend NW 5 mi. from Cape Mendenhall along Bering Sea, on SW coast of Nunivak I.; $59^{\circ} 48^{\prime} \mathrm{N}, 166^{\circ} 15^{\prime}$ W; (map 55). Var. Bangukthlik Dunes.

Eskimo name reported in 1937 by USAAF.

Bangooxthleet Dunes: sand dunes, see Bangookbit Dunes.

Bangor Creek: stream, flows SE $3.7 \mathrm{mi}$. to Snake River, $12 \mathrm{mi}$. N of Nome, Seward Penin. High.; $64^{\circ} 40^{\prime} \mathrm{N}, 165^{\circ} 26^{\prime} \mathrm{W}$; (map 94).

Prospectors' name reported in 1900 by E. C. Barnard (in Brooks, 1901, pl. 17), USGS.

Bangukhthleet Dunes: sand dunes, see Bangookbit Dunes.

Bangukthlik Dunes: sand dunes, see Bangookthleet Dunes.

Ban Island: island, $6.5 \mathrm{mi}$. long, on $\mathrm{W}$ coast of Afognak I., $27 \mathrm{mi}$. N of Afognak, Kodiak I.; $58^{\circ} 19^{\prime} \mathrm{N}, 152^{\circ} 53^{\prime} \mathrm{W}$; (map 43). Var. Bok Island, Ostrov Ban.

Transliteration by USC\&GS in 1868 of "O[strov] Ban," possibly from the word "banya" meaning "bathhouse"; published by Capt. Tebenkov (1852, map 22), IRN. The Russian American Company in 1849 called this island "Bok" meaning "side" or "flank."

Banks, Point: point of land, on NE coast of Shuyak I., 51 mi. N of Kodiak I.; $58^{\circ} 37^{\prime} 50^{\prime \prime}$ N, $152^{\circ} 19^{\prime} 00^{\prime \prime}$ W; (map 43). Var. Cape Benkes, Mys Benks.

Discovered by Capt. Cook (1785, v. 2, p. 385), RN, on May 25, 1778, and named for Sir Joseph Banks, 1743-1820, English naturalist (Wagner, 1937, p. 375). The Russian Hydrog. Dept. transliterated the name in 1847 and published it as "M[ys] Banks" on Chart 1378. The Russian American Company did likewise in 1849 and Capt. Tebenkov (1852, map 22), IRN, published the name " $M$ [ys] Benks."

Banks, Port: bay, $0.7 \mathrm{mi}$. across, S part of Whale Bay, on SE coast of Baranof I., Alex. Arch.; $56^{\circ} 35^{\prime} 45^{\prime \prime} \mathrm{N}, 135^{\circ} 00^{\prime} 30^{\prime \prime} \mathrm{W}$; (map 5). Var. Closed Bay, Zakritoi Bay, Zaliv Zakritoy.

Named on June 23, 1787, "by Capt. George Dixon for Sir Joseph Banks, president of the Royal Society" (Wagner, 1937, p. 375). Capt. Tebenkov (1852, map 8), IRN, published the name "Z[aliv] Zakrytoy," meaning "closed bay," for this feature.

Banks, Port: bay, see Whale Bay.

Bannard Pup: stream, flows SW $1 \mathrm{mi}$. to Ruby Creek, $10 \mathrm{mi}$. NW of Medfra, Kilbuck-Kuskokwim Mts.; $63^{\circ} 14^{\prime} \mathrm{N}, 154^{\circ} 48^{\prime} \mathrm{W}$; (map 89).

Local name reported in 1920 by G. C. Martin (in Brooks and others, 1922, fig. 5), USGS.

Banner: locality, on Seward Penin. RR., on NW side of Anvil Mt., $4.8 \mathrm{mi}$. N of Nome, Seward Penin. High.; $64^{\circ} 34^{\prime} \mathrm{N}, 165^{\circ} 24^{\prime} \mathrm{W}$; (map 94). Var. Banner Station.

Site of a mining camp and RR. station. In 1901 the Wild Goose RR. (later Seward Pe- 
nin. RR.) extended from Nome to Banner (Cole, 1953, p. 14).

Banner Bay: bay, extends $\mathrm{E} 4.3 \mathrm{mi}$., on $\mathrm{N}$ coast of Atka I., Aleutian Is.; $52^{\circ} 08^{\prime} 40^{\prime \prime} \mathrm{N}, 174^{\circ}$ $34^{\prime} 10^{\prime \prime}$ W; (map 18). Var. Bander Bay, Baner Bay, Bannerskaia Baie, Bukhta Gloubokaia, Glubokoi Bay.

Named for Ivan Ivanovich Banner, Danishborn Russian American Company agent at Kodiak (1804-16) ; published as "Bannerskaia baie" by Capt. Lutke (1836, p. 314), IRN. Lutke also described it as an arm of "Bukhta Gloubokaia," meaning "Deep Bay." This name was published in 1848 on Russian $\mathrm{Hy}$ drog. Dept. Chart 1400, while, on the same chart, "Gav[an] Banera," or "Baner Harbor," was applied to a smaller bay, $3.5 \mathrm{mi}$. to the southwest.

Banner Creek: locality, see Warren.

Banner Creek: stream, flows NE $3 \mathrm{mi}$. to Moore Creek, $3.5 \mathrm{mi}$. W of Sugarloaf Mtn. and 32 mi. E of Flat, Kilbuck-Kuskokwim Mts,; $62^{\circ} 32^{\prime} \mathrm{N}, 157^{\circ} 01^{\prime} \mathrm{W}$; (map 79).

Prospectors' name obtained in 1952 by USGS topographers.

Banner Creek: stream, flows NE $3.8 \mathrm{mi}$. to Sulatna River, $3.5 \mathrm{mi}$. NW of Sulatna Crossing and $36 \mathrm{mi}$. S of Ruby, Kilbuck-Kusko-

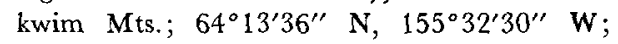
(map 98). Var. Spangle Creek.

Prospectors' name published by Mertie and Harrington (1924, p. 95), USGS.

Banner Creek: stream, flows SW $7 \mathrm{mi}$. to Tanana River W of Richardson, $18 \mathrm{mi}$. NW of Big Delta, Tanana Low.; $64^{\circ} 17^{\prime} 15^{\prime \prime} \mathrm{N}$, $146^{\circ} 20^{\prime} 30^{\prime \prime} \mathrm{W}$; (map 101).

Named by prospectors; reported in 1905 by Prindle (in Brooks and others, 1906, p. 124), USGS.

Banner Creek: stream, flows SE $2.5 \mathrm{mi}$, to Nome River, $9 \mathrm{mi}$. NE of Nome, Seward Penin. High.; 64 $38^{\prime} \mathrm{N}, 165^{\circ} 18^{\prime} \mathrm{W}$; (map 94).

Local name published in 1900 on USC\&GS Chart 9380.

Banner Creek: stream, flows NW $2 \mathrm{mi}$. to Casadepaga River, $18 \mathrm{mi}$. NE of Solomon, Seward Penin. High.; $64^{\circ} 49^{\prime} 30^{\prime \prime} \mathrm{N}, 164^{\circ} 19^{\prime} 30^{\prime \prime} \mathrm{W}$; (map 95).

Prospectors' name reported in 1900 by E. C. Barnard (in Brooks, 1901, pl. 17), USGS.

Banner Creek: stream, flows SW $5 \mathrm{mi}$. to Anikovik River, $14 \mathrm{mi}$. SE of Cape Prince of Wales and $40 \mathrm{mi}$. NW of Teller, Seward Penin. High.; $65^{\circ} 31^{\prime} \mathrm{N}, 167^{\circ} 38^{\prime} \mathrm{W}$; (map 111).

Local name reported in 1900 by Brooks (1901, p. 135), USGS.

Banner Creek: stream, flows $W$ to Belt Creek which flows to Kuzitrin River, about $8 \mathrm{mi}$. NW of Mount Bendeleben, Seward Penin. High.; (map 110).

Prospectors' name shown on a map of Cape Nome gold fields by David Fox, Jr., dated 1901. This stream cannot be precisely located on current maps.

Banner Creek: stream, flows SW to Big Hurrah Creek near its head, about $9 \mathrm{mi}$. NE of Solomon, Seward Penin. High.; (map 95).
Prospectors' name reported on a prospector's manuscript map dated 1902. This stream cannot be precisely located on current maps.

Banner Creek: stream, see Bonnie Creek.

Banner Lake: lake, $1 \mathrm{mi}$. long, empties into Patterson Bay, on SE coast of Baranof I., Alex Arch.; $56^{\circ} 34^{\prime} 20^{\prime \prime} \mathrm{N}, 134^{\circ} 41^{\prime} 30^{\prime \prime} \mathrm{W} ; B G N$ 1933; (map 5).

Named in 1933 by USFS "for Ivan Ivanovich Banner, one of Governor Baranof's assistants at the time of the re-establishment of the settlement of Sitka," about 1804-16. See Baranof Island.

Banner Peak: hill, $720 \mathrm{ft}$, $0.5 \mathrm{mi}$. N of Perkinsville and $5 \mathrm{mi}$. N of Nome, Seward Penin. High.; $64^{\circ} 34^{\prime} \mathrm{N}, 165^{\circ} 26^{\prime} \mathrm{W}$; (map 94).

Local name published in 1956 by USGS.

Banner Point: point of land, NE point of entrance to Banner Bay, on $\mathrm{N}$ coast of Atka I., Aleutian Is.; $52^{\circ} 10^{\prime} 40^{\prime \prime} \mathrm{N}, 174^{\circ} 33^{\prime} 10^{\prime \prime} \mathrm{W}$; (map 18).

Named for Banner Bay; published by the USC\&GS in the 1944 Aleutian Coast Pilot (p. 94).

Bannerskaia Baie: bay, see Banner Bay.

Banner Station: locality, see Banner.

Banshee Creek: stream, flows SE $5 \mathrm{mi}$. to Maybe Greek, $11 \mathrm{mi}$. E of head of Ikpikpuk River Arctic Slope; $69^{\circ} 17^{\prime} 30^{\prime \prime} \mathrm{N}, 154^{\circ} 13^{\prime} 30^{\prime \prime} \mathrm{W}$; $B G N 1960$; (map 142).

Name published in 1956 by USGS.

Banzer Creek: stream, flows SW $0.5 \mathrm{mi}$. to Landlocked Bay, $35 \mathrm{mi}$. NW of Cordova, Chugach Mts.; $60^{\circ} 49^{\prime} \mathrm{N}, 146^{\circ} 33^{\prime} \mathrm{W}$; (map 64).

Named for L. E. Banzer, local prospector; reported in 1912 by R. H. Sargent and C. E. Giffin, USGS.

Baptist Bay: bay, see Saint John Baptist Bay.

Barabara Cove: bight, $0.5 \mathrm{mi}$. across, on W shore of Kizhuyak Bay, $18 \mathrm{mi}$. W of Kodiak, Kodiak I.; $57^{\circ} 49^{\prime} 15^{\prime \prime} \mathrm{N}, 152^{\circ} 54^{\prime} 00^{\prime \prime} \mathrm{W}$; BGN 1936; (map 34$)$.

Named in 1935 by USC\&GS "from a Kamchatkan [Siberian] word brought to Alaska by the Russians and applied to the native huts or 'Kozarmie,' one of which was found at this cove by one of our field parties."

Barabara Creek: stream, on Alaska Penin., heads on W slope of Aniakchak Crater, flows W 25 $\mathrm{mi}$. to Port Heiden, Bristol Bay Low.; 56 $53^{\prime}$ $N, 158^{\circ} 40^{\prime} \mathrm{W}$; (map 30 ).

Recorded on a 1923 fieldsheet by R. H. Sargent, USGS.

Barabara Creek: stream, heads near Burls Pass, flows W $1.6 \mathrm{mi}$. to Blue Creek $1 \mathrm{mi}$. NE of its junc. with Ugashik Creek, on Alaska Penin., $41 \mathrm{mi}$. NE of Ugashik, Aleutian Ra.; $57^{\circ} 40^{\prime}$ $15^{\prime \prime}$ N., $156^{\circ} 18^{\prime} 40^{\prime \prime} \mathrm{W}$; (map 36).

Local name reported in 1921 by Capps (1923, pl. 2), USGS.

Barabara Creek: stream, on Kenai Penin., flows NW 9 mi. to Kachemak Bay, $15 \mathrm{mi}$. NE of Seldovia, Chugach Mts.; $59^{\circ} 29^{\prime} \mathrm{N}, 151^{\circ} 39^{\prime}$ W; (map 50). Var. Fish Greek.

Local name published by USGS in 1951. The name is probably derived from the point of land located at the mouth of the stream.

Barabara Lake: lake, $4 \mathrm{mi}$. long, on Kenai Penin., $13 \mathrm{mi}$. SSE of Point Possession and $27 \mathrm{mi}$.
SSW of Anchorage, Cook Inlet Low.; $60^{\circ} 51^{\prime}$ $\mathrm{N}, 150^{\circ} 14^{\prime} \mathrm{W}$; (map 62).

Named about 1963 by officials of Kenai National Moose Range.

Barabara Point: point of land, on Kenai Penin., $4 \mathrm{mi}$. NE of Seldovia, Chugach Mts.; 59 $29^{\prime}$ $10^{\prime \prime} \mathrm{N}, 151^{\circ} 38^{\prime} 30^{\prime \prime} \mathrm{W}$; (map 50).

Local name reported in 1918 by A. C. Gill, Cornell Univ. (in Martin and others, 1920, p. 127). "This is a Russian term for a large native hut."

Barada, Placer de las: beach, on Yakutat Bay near Point Carrew; (map 46).

Named by Capt. Alessandro Malaspina in 1791.

Baralof Bay: village, see Squaw Harbor.

Baralof Bay: bay, in Shumagin Is., extends W 3 mi. off Popof Strait, on E coast of Unga I., Aleutian Ra.; 55 $14^{\prime} \mathrm{N}, 160^{\circ} 32^{\prime} \mathrm{W}$; (map 28). Var. Baraloff Bay, Baralof Harbor, Barloff Harbor, New Harbor, Squaw Harbor; Vavilofskaia Gavan.

Apparently a corruption of "Vavilof," as the bay was named "Vavilofskaia Gavan" by Father Veniaminov (1840, v. 1, p. 258). In 1872 W. H. Dall, USC\&GS called it "New Harbor"; Atwood (1911, p. 21), USGS, wrote of "Baralof" or "Squaw Harbor."

Baraloff Bay: bay, see Baralof Bay.

Baralof Harbor: $b a y$, see Baralof Bay.

Baraney, Ostrov: island, see Sheep Island.

Baranie Island: island, see Sheep Island.

Barani Island: island, see Sheep Island.

Baranof: village, pop. 15, at head of Warm Spring Bay, on E coast of Baranof I., $19 \mathrm{mi}$. E of Sitka, Alex. Arch.; $57^{\circ} 05^{\prime} 10^{\prime \prime} \mathrm{N}, 134^{\circ} 50^{\prime}$ $20^{\prime \prime} \mathrm{W}$; (map 9). Var. Baranoff.

A post office named "Baranoff" was established here in 1907 and was discontinued in 1912. It was reestablished in 1917; name changed to Baranof in 1930. The town was probably named for Baranof Island.

Baranof Archipelago: group of islands, Baranof I. and adjoining islands, extend SE $105 \mathrm{mi}$. from Peril Strait to Christian Sound, Alex. Arch.; $56^{\circ} 45^{\prime} \mathrm{N}, 135^{\circ} 10^{\prime} \mathrm{W}$; (map 9).

Name published by USC\&GS in 1883 Coast Pilot (p. 122). Name was derived from Baranof Island, the largest of the group.

Baranoff: village, see Baranof.

Baranoff Island: island, see Baranof Island.

Baranoffs Island: island, see Baranof Island.

Baranof Island: island, $105 \mathrm{mi}$. long between Alex. Arch. and Chatham Strait, extends SE from Peril Strait to Christian Sound, Alex. Arch.; $56^{\circ} 45^{\prime} \mathrm{N}, 135^{\circ} 10^{\prime} \mathrm{W} ; B G N 1890$ (map 9). Var. Baranoffs Island, Baranov Island, Baranow Island, Baronoff Island, Ostrov Sitkha (Baranov), Shi, Sitka Island.

Named in 1805 by Capt. U. F. Lisianski, IRN, for Alexander Andreievich Baranov, first Governor of the Russian American colonies. Baranov was in charge of building the first headquarters of the Russian American Company (then the Shelikov Company) at Kodiak (St. Paul) in 1792, and moved it in 17991800 to Sitka (New Archangel). 
Hodge (1910, p. 582) lists "Sitka (probably meaning 'on Shi,' the native name of Baranof id.)."

Baranof Lake: lake, $2.5 \mathrm{mi}$. long, $\mathrm{W}$ of Baranof, on E coast of Baranof I., $18 \mathrm{mi}$. W of Sitka, Alex. Arch.; $57^{\circ} 05^{\prime} \mathrm{N}, 134^{\circ} 51^{\prime} \mathrm{W}$; (map 9).

Name reported in 1916 by G. H. Canfield, USGS, and published in 1919 by USC\&GS on Chart 8250 . Name was probably derived from the nearby village of Baranof.

Baranof River: stream, flows NE $9 \mathrm{mi}$. to Baranof Lake, $2.5 \mathrm{mi}$. W of Baranof, $16 \mathrm{mi}$. E of Sitka, Alex. Arch.; $57^{\circ} 04^{\prime} 10^{\prime \prime} \mathrm{N}, 134^{\circ} 54^{\prime} 00^{\prime \prime} \mathrm{W}$; $B G N$ 1959; (map 9). Var. Baranov River.

Local name reported in 1947 by USFS.

Baranovichs: locality, site of salmon fishery, on shore of Baronovichs Bay, near head of Kasaan Bay, on E coast of Prince of Wales I. Alex. Arch.; (map 4). Var. Baronovich Fishery.

Named for Philip Baronovich who established a fishing station here; name published by USC\&GS (1869, p. 79).

Barbarossa Island: island, see East San Lorenzo Island.

Baronovichs Bay: cove, extends S $0.7 \mathrm{mi}$., off Kasaan Bay, at mouth of Karta Bay, on E coast of Princeof Wales I. Alex. Arch.; 55 $34^{\prime} \mathrm{N}, 132^{\circ} 34^{\prime} \mathrm{W}$; (map 4).

Name published by USC\&GS $(1869$, p. 79 1891, p. 89).

Baranov Island: island, see Baranof Island.

Baranov River: stream, see Baranof River.

Baranow Island: island, see Baranof Island.

Barbara, Lake: lake, $700 \mathrm{ft}$. across, E of Eklutna River, $13 \mathrm{mi}$. S of Palmer, Chugach Mts.; $61^{\circ}$ $25^{\prime} 40^{\prime \prime} \mathrm{N}, 149^{\circ} 12^{\prime} 30^{\prime \prime} \mathrm{W}$; (map 69).

Local name reported in 1951 by USGS.

Barbara Island: island, in Andreanof Is., $3 \mathrm{mi}$. NNE of Trunk Point on $E$ coast of Tanaga $I$., Aleutian Is.; $51^{\circ} 48^{\prime} 25^{\prime \prime} \mathrm{N}, 177^{\circ} 44^{\prime} 30^{\prime \prime} \mathrm{W}$; (map 17).

Local name published in 1956 by USC\&GS on Chart 9145.

Barbara Point: point of land, in Pyramid Cove on SE coast of Attu I., Aleutian Is.; $52^{\circ} 49^{\prime}$. $35^{\prime \prime} \mathrm{N}, 173^{\circ} 11^{\prime} 15^{\prime \prime} \mathrm{E}$; (map 13).

Named by USA during its occupation of the island during World War II; shown on an AMS map published in 1948. "Barbara" is derived from a Russian name; see Barabara Cove, Kodiak

Barbara Point: point of land, on S shore of Karluk Lake, $25 \mathrm{mi}$. SE of Karluk, Kodiak I.; $57^{\circ} 17^{\prime} 30^{\prime \prime} \mathrm{N}, 154^{\circ} 00^{\prime} 20^{\prime \prime} \mathrm{W}$; (map 35).

Local name reported in 1952 by USGS.

Barbara Rock: rock, $400 \mathrm{ft}$. long, in Cordova Bay, S of Shipwreck Point, on SW coast of Prince of Wales I., Alex. Arch.; 54 $53^{\prime} 35^{\prime \prime} \mathrm{N}$, $132^{\circ} 29^{\prime} 35^{\prime \prime} \mathrm{W}$; (map 1).

Local name reported in 1951 by USGS.

Barber, Point: point of land, on Hinchinbrook I., at entrance to Port Etches, $35 \mathrm{mi}$. SW of Cordova, Chugach Mts.; $60^{\circ} 20^{\prime} \mathrm{N}, 146^{\circ} 39^{\prime}$ W; (map 64).

Named by Capt. Nathaniel Portlock, RN, while he was there in May, 1787.

Barca, Punta: point of land, see Barca Point.
Barca Point: point of land, "on the western shore of Port Refugio Bucareli bay, Prince of Wales archipelago. Named Punta de la Barca (boat point) by Maurelle and Quadra in 1775-1779" (Baker, 1906, p. 116).

Bar Creek: stream, flows SW 6 mi. along $E$ and $\mathrm{S}$ sides of Gunsight Mtn. to John River, $5 \mathrm{mi}$. $\mathrm{N}$. of confluence of Allen and John Rivers and 52 mi. W of Wiseman, Brooks Ra.; $67^{\circ} 26^{\prime} 30^{\prime \prime}$ $\mathrm{N}, 152^{\circ} 04^{\prime} 00^{\prime \prime} \mathrm{W}$; (map 124). Var. Cabin Creek.

Local descriptive name obtained in 1956 by USGS topographers.

Bar Creek: stream, see Barr Creek.

Bareface Bluff: bluff, $250 \mathrm{ft}$., on $\mathrm{W}$ bank of Yukon River $4 \mathrm{mi}$. N of Russian Mission, Yukon-Kuskokwim Delta; $61^{\circ} 50^{\prime} 45^{\prime \prime} \mathrm{N}, 161^{\circ}$ $19^{\prime} 10^{\prime \prime} \mathrm{W}$; (map 73).

Riverboat pilots' descriptive name; recorded on a 1916 fieldsheet by R. H. Sargent, USGS.

Bare Gulch: ravine, trends E $0.5 \mathrm{mi}$. to Glacier Creek, 8 mi. NE of Nome, Seward Penin. High.; $64^{\circ} 37^{\prime} 25^{\prime \prime} \mathrm{N}, 165^{\circ} 20^{\prime} 25^{\prime \prime} \mathrm{W}$; (map 94).

Prospectors' name shown on the 1902 "Map of the Nome and Snake River Country" by J. M. Davidson.

Bare Island: island, $0.1 \mathrm{mi}$. across, in Port Krestof, off E coast of Kruzof I., $11 \mathrm{mi}$. NW of Sitka, Alex. Arch.; 57 $08^{\prime} 55^{\prime \prime} \mathrm{N}, 135^{\circ} 35^{\prime}$ $30^{\prime \prime} \mathrm{W}$; (map 9). Var. Ostrov Goloy.

This is an 1882 translation by USC\&GS of the name given in 1809 by the Russian navigator Ivan Vasiliev the first; reported by Lt. Sarichev (1826, map 19) IRN, as "Os[trov] Goloy."

Bare Island: island, $1 \mathrm{mi}$. long, in Kupreanof Strait at mouth of Dry Spruce Bay, $N$ of Kodiak I. ; $57^{\circ} 57^{\prime} 15^{\prime \prime} \mathrm{N}, 153^{\circ} 04^{\prime} 30^{\prime \prime} \mathrm{W}$; (map 34). Var. Goloi, Ostrov Goloy.

Translation of the name "Os[trov] Goloy," given in 1839 or 1840 by Sub-Lt. Mikhail Murashev, IRN, and published in 1849 on Russian Hydrog. Dept. Chart 1425.

Bare Island: island, $0.1 \mathrm{mi}$. across, in Funter Bay $0.4 \mathrm{mi}$. NE of Clear Point and $18 \mathrm{mi}$. SW of Juneau, Alex. Arch.; $58^{\circ} 14^{\prime} 45^{\prime \prime} \mathrm{N}, 134^{\circ} 54^{\prime}$ $15^{\prime \prime} \mathrm{W}$; (map 11).

Descriptive name given by $\mathrm{Lt}$. Comdr. $\mathrm{H}$. B. Mansfield, USN, in 1890 .

Bare Islet: island, "in Wrangell strait, Alexander archipelago. Either this or an islet near it was named Goloi (bare) by Lindenberg in 1838. There seems to be confusion of names here'" (Baker, 1906, p. 116).

Bare Mountain: mountain, "on the mainland of Alaska, east of Admiralty island. So named by the British admiralty in or about 1865 " (Baker, 1906, p. 116).

Bare Point: point of land, "on the eastern side of McClellan flats, at mouth of Chilkat river, southeastern Alaska. Named Goloi (bare) by Lindenberg in 1838" (Baker, 1906, p. 116).

Bare Point: point of land, "north shore Afognak bay, Afognak island, Kodiak group, near latitude $58^{\circ} 01^{\prime}$, longitude $152^{\circ} 46^{\prime}$. Descrip- tive name, from Moser, 1900" (Baker, 1906, p. 116)

Bare Point: point of land, see Settlement Point. Bare Rock: rock, in Sitka Sound, $3 \mathrm{mi}$. W of Sitka, Alex. Arch.; $57^{\circ} 03^{\prime \prime} 00^{\prime \prime} \mathrm{N}, 135^{\circ} 25^{\prime} 20^{\prime \prime}$ W; (map 9).

Name apparently derived from the descriptive phrase "golya Kamyennya ostrovski," meaning "bare rocky islets," applied in 1809 by Ivan Vasiliev the first, IRN.

Bare Rock: rock, "in Hawk inlet, Chatham strait, Alexander archipelago. So named by the Coast Survey in 1891" (Baker, 1906, p. 116).

Barge Slough: stream, cutoff meander of Holitna River, flows NE $2.5 \mathrm{mi}$., $6.7 \mathrm{mi}$. SE of Sleetmute, Kilbuck-Kuskokwim Mts.; 61 '37'15" N, 157 03'40" W; BGN 1948; (map 72).

"Local name given because the slough serves as a protection for barges against ice before the freeze and after the break-up"; reported in 1945 by USGS.

Barigon Cape: point of land, "on the western shore of Port Dolores, Bucareli bay, Prince of Wales archipelago. On La Perouse's copy (1798) of the Spanish map by Maurelle and Quadra, 1775-1779, it bears the designation El Barigon" (Baker, 1906, p. 117).

Barkley Lake: lake, $2.3 \mathrm{mi}$. long, on $\mathrm{E}$ side of Tana Glacier, at end of Granite Creek, 109 mi. E of Cordova, Chugach Mts.; 60 $43^{\prime} 48^{\prime \prime}$ $\mathrm{N}, 141^{\circ} 34^{\prime} 00^{\prime \prime} \mathrm{W}$; (map 65).

Name published by F. H. Moffit (1918, pl. 6 ), USGS. Presumably named for a prospector, called locally, "Jimmy the Bear" Barkley. See Barkley Ridge.

Barkley Ridge: ridge, elev. 4,000-11,000 ft., in Robinson Mts. S of Bagley Icefield, extends W $36 \mathrm{mi}$. from head of Bering Glacier, St. Elias Mts.; $60^{\circ} 27^{\prime} \mathrm{N}, 142^{\circ} 10^{\prime} \mathrm{W}$; (map 65). Var. Bartley Ridge.

Local name published as "Bartley Ridge" by A. G. Maddren (in Brooks and others, 1914, pl. 4), USGS. USGS changed the spelling to "Barkley," and reported that it was named for a local prospector called "Jimmy the Bear" Barkley, who crossed this area in 1905 or 1906 and again in 1907 (Moffit, 1918, p. 77).

Barley Cove: cove, $0.5 \mathrm{mi}$. across, NE of Conquer Point, on west-central coast of Kiska I., Aleutian Is.; $52^{\circ} 00^{\prime} 45^{\prime \prime} \mathrm{N}, 177^{\circ} 30^{\prime} 00^{\prime \prime} \mathrm{E}$; (map 14).

This is one of the plant names arbitrarily applied to features on Kiska Island in 1943 by USAAF for tactical purposes duirng World War II.

Barling Bay: bay, extends NE $2.8 \mathrm{mi}$. off Sitkalidak Strait, on SE coast of Kodiak I. $57^{\circ} 11^{\prime} \mathrm{N}, 153^{\circ} 21^{\prime} \mathrm{W}$; BGN 1937; (map 34). Var. Lisianski Bay, Old Harbor.

Local name published in 1929 by USC\&GS In 1930 the name "Old Harbor" was er roneously published on USC\&GS Chart 8502 probably because of its proximity to the village of Old Harbor, 2 miles northeast. In 1888 the bay was called "Lisianski Bay" by USBF. 
Barloff Harbor: bay, see Baralof Bay.

Barlou, Guba: bay, see Barlow Cove.

Barlow Cove: bay, 4 mi. long, trends N-S on $\mathrm{N}$ end of Mansfield Penin., W of Saginaw Channel and $19 \mathrm{mi}$. NW of Juneau, Alex. Arch.; $58^{\circ} 24^{\prime} \mathrm{N}, 134^{\circ} 55^{\prime} \mathrm{W}$; (map 11). Var. Barlows Cove, Burlow Cove, Guba Barlou.

This cove was explored and named about July 18, 1794, by Joseph Whidbey (Vancouver, 1798, p. 277).

Barlow Islands: islands, group of 3 small islands, off $\mathrm{N}$ end of Mansfield Penin. $0.5 \mathrm{mi}$. NW of Barlow Point and $18 \mathrm{mi}$. NW of Juneau, Alex. Arch.; $58^{\circ} 23^{\prime} 30^{\prime \prime} \mathrm{N}, 134^{\circ} 54^{\prime} 00^{\prime \prime} \mathrm{W}$; (map 11). Var. Barlow Islets.

Described in the 1883 USC\&GS Coast Pilot as "small rock islets ***" and also given its present name in the 1883 Coast Pilot. The name is derived from Barlow Cove.

Barlow Islets: islands, see Barlow Islands.

Barlow Mountain: mountain, see Lone Moun. tain.

Barlow Point: point of land, on end of Mansfield Penin., in Saginaw Channel, $3 \mathrm{mi}$. SE of Point Retreat and $18 \mathrm{mi}$. NW of Juneau, Alex. Arch.; $58^{\circ} 22^{\prime} 45^{\prime \prime} \mathrm{N}, 134^{\circ} 53^{\prime} 30^{\prime \prime} \mathrm{W}$; (map 11).

Named by W. H. Dall, USC\&GS, and published in the 1883 Coast Pilot. The name is derived from nearby Barlow Cove.

Barlows Cove: bay, see Barlow Cove.

Barnaba Point: point of land, see Barnabas, Cape.

Barnabas, Cape: point of land, E tip of Sitkalidak I., SE of Kodiak I.; $53^{\circ} 09^{\prime} \mathrm{N}, 152^{\circ} 53^{\prime} \mathrm{W}$; (map 34). Var. Barnaba Point, Cape Saint Barnabas, Mys Barnabas.

Named on June 12, 1778, by Capt. Cook (1785, v. 2, p. 406), RN, who reported "an elevated point, which obtained the name of "Cape Barnabas," lying in the latitude of $57^{\circ}$ $13^{\prime}$ * **." The Russian American Company published [a transliteration of] the name in 1849 as "M[ys] Barnabas." Named in honor of Saint Barnabas whose day is June 11.

Barnabas Rock: rock, $3 \mathrm{mi}$. N of Cape Barnabas, off $E$ coast of Sitkalidak $I$., on SE coast of Kodiak I. ; $57^{\circ} 11^{\prime} 35^{\prime \prime}$ N, $152^{\circ} 53^{\prime} 30^{\prime \prime} \mathrm{W}$; $B G N 1930$; (map 34).

Name given in 1929 by USC\&GS; derived from Cape Barnabas.

Barnacle Point: point of land, on $\mathrm{E}$ coast of Kiska I., on SW shore of Kiska Harbor, Aleutian Is.; $51^{\circ} 57^{\prime} 40^{\prime \prime} \mathrm{N}, 177^{\circ} 32^{\prime} 30^{\prime \prime} \mathrm{E}$; (map 14).

One of many arbitrary names applied to features on Kiska Island by USAF for tactical purposes during World War II.

Barnacle Rock: rock, in Lake Bay, on NE coast of Prince of Wales I., Alex. Arch.; 56 $02^{\circ} 45^{\prime \prime}$ $\mathrm{N}, 132^{\circ} 52^{\prime} 40^{\prime \prime} \mathrm{W}$; (map 6).

Descriptive name published in 1907 by USC\&GS.

Barnard, Mount: mountain, 8,214 ft., in Glacier Bay National Monument, on Alaska-Canada boundary, $3.5 \mathrm{mi}$. NE of head of Tarr Inlet and $64 \mathrm{mi}$. WSW of Skagway, St. Elias Mts.;
$B G N$ 1923; $59^{\circ} 06^{\prime} 05^{\prime \prime} \mathrm{N}, 136^{\circ} 58^{\prime} 00^{\prime \prime} \mathrm{W}$; (map 45).

Named by the IBC in 1923 for Edward Chester Barnard, 1863-1921, U.S. Boundary Commissioner from 1915 to 1921 . He was born in New York and graduated from Columbia Univ. in 1884. He was a topographer with USGS from 1884 to 1907 and was in charge of a party which mapped the FortyMile District and Nome District in Alaska in 1898 and 1900 . He was chief topographer of the United States and Canada boundary survey from 1903 to 1915 .

Barnard Glacier: glacier, trends SW $33 \mathrm{mi}$. to Chitina River $\mathrm{E}$ of Hawkins Glacier, $40 \mathrm{mi}$. SE of McCarthy, St. Elias Mts.; 61 ${ }^{\circ} 06^{\prime} \mathrm{N}$, $141^{\circ} 55^{\prime} \mathrm{W}$; (map 67).

Named for Edward Chester Barnard, 18631921 ; see Barnard, Mount.

Barnard Point: point of land, on the S coast of Adak I., $11 \mathrm{mi}$. NE of Turret Point and $5 \mathrm{mi}$. $\mathrm{SE}$ of Boot Point, Aleutian Is.: $51^{\circ} 41^{\prime} \mathrm{N}$, $176^{\circ} 37^{\prime} \mathrm{W}$; (map 17).

This feature appears to have been named by USAAF during World War II. A note in BGN files states it was named for George Grey Barnard, 1863-1938, American sculptor.

Barnard Glacier: glacier, trends E $2.2 \mathrm{mi}$. on W shore of College Fiord, S of Wellesley Glacier, $66 \mathrm{mi}$. E of Anchorage, Chugach Mts. ; $61^{\circ} 10^{\prime} \mathrm{N}, 147^{\circ} 55^{\prime} \mathrm{W}$; BGN 1910; (map 69).

Name reported in 1910 by U. S. Grant, USGS; presumably named for Barnard College, part of Columbia University, New York, N.Y.

Barnes, Point: point of land, NW point of entrance to Lake Bay, on Stevenson I., NE ccast of Prince of Wales I., Alex. Arch.; 56 $06^{\circ} 35^{\prime \prime}$ $\mathrm{N}, 132^{\circ} 55^{\prime} 50^{\prime \prime} \mathrm{W}$; (map 6$)$.

Local name published in 1904 by USC\&GS. See Barnes Lake.

Barnes Cove: estuary, on W coast of Knight I., trends NW $0.5 \mathrm{mi}$. to Drier Bay, $11 \mathrm{mi}$. NE of Chenega, Chugach Mts.; $60^{\circ} 19^{\prime} 00^{\prime \prime} \mathrm{N}$, $147^{\circ} 46^{\prime} 20^{\prime \prime} \mathrm{W}$; (map 63).

Local name published in 1908 on USC\&GS charts.

Barnes Creek: stream, flows SE 3 mi., joins Pearl Creek to form Fish Creek, $2.5 \mathrm{mi}$. NE of Gilmore Dome, $16 \mathrm{mi}$. NE of Fairbanks, Yukon-Tanana High.; $65^{\circ} 01^{\prime} \mathrm{N}, 147^{\circ} 18^{\prime} \mathrm{W}$; (map 105).

Named by prospectors; published in 1908 by USGS.

Barnes Lake: cove, $1 \mathrm{mi}$. across, between Stevenson I. and NE coast of Prince of Wales I., Alex. Arch.; $56^{\circ} 01^{\prime} \mathrm{N}, 132^{\circ} 58^{\prime} \mathrm{W}$; $B G N$ 1915; (map 6).

Local name reported in 1914 by E. Lester Jones, USBF ; named for F. C. Barnes, owner of a local salmon cannery.

Barnes Lake: lake, $0.6 \mathrm{mi}$. across, $2 \mathrm{mi}$. W of Alaska-Canada boundary and $2 \mathrm{mi}$. $\mathrm{N}$ of Stikine River, Coast Mts.; $56^{\circ} 40^{\prime} 30^{\prime \prime} \mathrm{N}$, $131^{\circ} 54^{\prime} 00^{\prime \prime} \mathrm{W}$; ( $\operatorname{map} 7$ ).

Local name reported in 1955 by USGS.
Barnes Mountain: mountain, 3,820 ft., $4.5 \mathrm{mi}$. SE of Moraine Pass and $29 \mathrm{mi}$. SE of $\mathrm{An}$ chorage, Chugach Mts.; $61^{\circ} 02^{\prime} 40^{\prime \prime} \mathrm{N}, 149^{\circ}$ $06^{\prime} 10^{\prime \prime} \mathrm{W} ; B G N$ 1932; (map 69).

Local name reported in 1932 by USGS.

Barnes Point: point of land, $3 \mathrm{mi}$. S of Cape Sudak, on E coast of Tanaga I., Aleutian Is.; $51^{\circ} 49^{\prime} 15^{\prime \prime} \mathrm{N}, 177^{\circ} 39^{\prime} 00^{\prime \prime} \mathrm{W}$; (map 17).

Published by USC\&GS in the 1944 Aleutian Coast Pilot (p. 118).

Barness, Mount: mountain, 2,000 ft., on $\mathrm{W}$ coast of Chichagof I., $12 \mathrm{mi}$. NW of Chichagof, Alex. Arch.; 57 $48^{\prime} 45^{\prime \prime} \mathrm{N}, 136^{\circ} 15^{\prime} 50^{\prime \prime} \mathrm{W}$; (map 9).

Local name published in 1928 by USC\&GS. Barnett, Cape: point of land, see Addington, Cape.

Barnette Creek: stream, flows W $10 \mathrm{mi}$. to Nelchina River, $6 \mathrm{mi}$. $\mathrm{N}$ of Nelchina Glacier, $100 \mathrm{mi}$. NE of Anchorage, Chugach Mts.; $61^{\circ} 49^{\prime} \mathrm{N}, 147^{\circ} 01^{\prime} \mathrm{W}$; (map 68).

Named for Paul Barnet, prospector whose home was on this stream; name reported in 1947 by USGS.

Barnettes Cache : city, see Fairbanks.

Barney Creek: stream, flows NE $1 \mathrm{mi}$. to Iron Creek which flows to Pilgrim River, $0.5 \mathrm{mi}$. N of Babs Creek and $27 \mathrm{mi}$. NW of Solomon, Seward Penin. High.; 64 ${ }^{\circ} 55^{\prime} 55^{\prime \prime}$ N, $164^{\circ} 41^{\prime} 00^{\prime \prime}$ W; (map 95). Var. Bunny Creek.

Reported in 1906 as "Bunny" by P. S. Smith (in Brooks and others, 1907, fig. 8).

Barney Creek: stream, flows SW $3 \mathrm{mi}$. to Seventymile River, $26 \mathrm{mi}$. NW of Eagle, YukonTanana High.; $64^{\circ} 58^{\prime} 40^{\prime \prime}$ N, $141^{\circ} 58^{\prime} 20^{\prime \prime}$ W; (map 102).

Prospectors' name shown on a 1902 manuscript map by E. J. Chamberlain, U.S. Deputy Surveyor.

Barnhard Creek: stream, flows S $10 \mathrm{mi}$. to Michigan Creek, $24 \mathrm{mi}$. SE of Flat, Kilbuck-Kuskokwim Mts.; $62^{\circ} 15^{\prime} 40^{\prime \prime} \mathrm{N}, 157^{\circ} 23^{\prime} 00^{\prime \prime} \mathrm{W}$; (map 79).

Local name obtained in 1945 by USGS topographers.

Barns, The: locality, on Valdez trail which is now Richardson Highway, near present location of Tiekel Cache, $1.7 \mathrm{mi}$. NE of mouth of Squaw Creek and $40 \mathrm{mi}$. NE of Valdez, Chugach Mts.; $61^{\circ} 22^{\prime} \mathrm{N}, 145^{\circ} 15^{\prime} \mathrm{W}$; (map 68).

This was "Telegraph Station No. 4" locally called "The Barns--the Ioveliest spot on the line." Name published in the 1903 "Alaska Prospector."

Barnum: locality, on right bank of Goodnews River, at mouth of Barnum Creek, $12 \mathrm{mi}$. NE of Goodnews, Kilbuck-Kuskokwim Mts. ; $59^{\circ}$ $15^{\prime} \mathrm{N}, 161^{\circ} 23^{\prime} \mathrm{W}$; (map 53). Var. Avriotmut, Avriotmute.

Site of abandoned Eskimo village called "Avriotmut." The name Barnum was reported in 1920 by G. L. Harrington (in Brooks and others, 1921, pl. 7), USGS. In 1921 there were two cabins here and in 1940 the population was 27 .

Barnum Creek: stream, flows SE $13 \mathrm{mi}$. to Goodnews River, $13 \mathrm{mi}$. NE of $\mathrm{G}$ rodnews, Kilbuck- 
Kuskokwim Mts.; $59^{\circ} 15^{\prime} \mathrm{N}, 161^{\circ} 23^{\prime}$ W; (map 53). Var. Avgun.

Name reported in 1919 by G. L. Harrington (in Brooks and others, 1921, pl. 7), USGS. Its Eskimo name is "Avgun," meaning "dividing," and is similar to "Avan" found in the north.

Barometer Mountain: mountain, 2,488 ft., $6 \mathrm{mi}$. SW of Kodiak, on NE coast of Kodiak I.; $57^{\circ} 45^{\prime} 20^{\prime \prime} \mathrm{N}, 152^{\circ} 32^{\prime} 45^{\prime \prime} \mathrm{W}$; (map 34). Var. Gora Ostraya, Ostraia Mountain, Skotnik.

Descriptive name given in 1867 by USC\&GS as "the behavior of fog and clouds on the mountain is said to foretell the weather." This feature was called in Russian "Gora Ostraya," meaning "pointed mountain," by Lt. Sarichev (1826, map 16), IRN, and "Skotnik" meaning "cow-keeper" by Capt. Tebenkov (1852, map 23), IRN.

Barometer Mountain: mountain, 2,434 ft., in Kuskokwim Mts., $5 \mathrm{mi}$. W of Sleetmute, Kilbuck-Kuskokwim Mts.; $61^{\circ} 43^{\prime} \mathrm{N}, 157^{\circ} 21^{\prime} \mathrm{W}$; (map 72). Var. Yklyk.

Named in 1898 by W. S. Post and J. E. Spurr (U.S. Geological Survey, 1899, map 4).

Baronoff Island: island, see Baranof Island.

Baronovich Fishery: locality, see Baranovichs.

Baron Stroganoff Cap du: point of land, see Strogonof Point.

Bar Point: point of land, on SW coast of Revillagigedo I., $0.8 \mathrm{mi}$. NW of Ketchikan Harbor, Alex. Arch.; $55^{\circ} 21^{\prime} 00^{\prime \prime} \mathrm{N}, 131^{\circ} 40^{\prime} 30^{\prime \prime} \mathrm{W}$; (map 3).

Named about 1880 by W. E. George, a local pilot.

Bar Point: flat, "mostly bare at low water, extending $1 \frac{1}{2}$ miles alcing the northwest shore of Tongas narrows at Bar point above. So described in the Coast Pilot of 1901" (Baker 1906, p. 117).

Barter Island: islınd, see Kaktovik.

Barrabora: locality, on left bank of Nonvalnuk River, $11 \mathrm{mi}$. SW of St. Michael, YukonKuskokwim Delta; $63^{\circ} 23^{\prime} \mathrm{N}, 162^{\circ} 20^{\prime} \mathrm{W}$; (map 92). Var. Barraboras.

Eskinno village, now abandoned, mentioned in 1902 by USGS. It may be an altered form of "barrabara," meaning "house." A 1950 USC\&GS field report stated that the place is a landmark in the flat country and consists of "several hulks of abandoned riverboat ruins."

Barraboras: locality, see Barrabora.

Barracks: village, see Latouche.

Barrancas, Ensenada de: cove, "on the east side of Yakutat Bay, $59^{\circ} 45^{\prime}$ N."

This is a doubtful name mentioned by Capt. Alessandro Malaspina. See Wagner (1937, p. 431).

Barr Creek: stream, flows E $0.8 \mathrm{mi}$. to Nome River, $0.2 \mathrm{mi}$. upstream from Basin Creek and $12 \mathrm{mi}$. N of Nome, Seward Penin. High.: $64^{\circ} 41^{\prime} \mathrm{N}, 165^{\circ} 19^{\prime} \mathrm{W}$; (map 94). Var. Bar Creek, Burr Creek.
Prospectors' name reported on the 1900 "Map of Nome Peninsula" by J. M. Davidson and B. D. Blakeslee.

Barrel Island: island, $750 \mathrm{ft}$. long, at mouth of Susitna River, $22 \mathrm{mi}$. NE of Tyonek, Cook Inlet Low.; $61^{\circ} 17^{\prime} 10^{\prime \prime} \mathrm{N}, 150^{\circ} 38^{\prime} 00^{\prime \prime} \mathrm{W}$; (map $70)$.

Local name reported by USGS (Martin and others, 1915, pl. 1).

Barren Greek: stream, in Mount McKinley National Park, flows $\mathrm{N} 7 \mathrm{mi}$., joins Somber Creek to form Highpower Creek, $30 \mathrm{mi}$. W of Mount McKinley, Alaska Ra. ; $63^{\circ} 05^{\prime} 10^{\prime \prime} \mathrm{N}, 151^{\circ} 57^{\prime}$ $10^{\prime \prime} \mathrm{W}$; (map 88).

Local name reported in 1925 by $S$. R. Capps, USGS.

Barren Island: rock, elev. $30 \mathrm{ft}$., 1,500 ft. long, in Dixon Entrance, $8 \mathrm{mi}$. S of Duke I., Alex. Arch.; 54 $44^{\prime} 45^{\prime \prime}$ N, $131^{\circ} 20^{\prime} 30^{\prime \prime}$ W; (map 2). Var. Barren Rock.

Named "Barren Rock" in 1883 by W. H. Dall ; published as "Barren Island" in 1886 by USC\&GS.

Barren Island: island, see Long Island.

Barren Islands: islands, $15 \mathrm{mi}$. across, in Gulf of Alaska between Kenai Peninsula and Shuyak I., $68 \mathrm{mi}$. NE of Afognak, Chugach Mts.; $67^{\circ} 48^{\prime} \mathrm{N}, 152^{\circ} 15^{\prime} \mathrm{W}$; (map 43). Var. Barren Isles, Islas de Langara; Islas Esteriles, Bezpodnie Bareninseln, Peregrebni.

Named on May 25, 1778 by Capt. James Cook (1785, v. 2, p. 385), RN, who wrote, "They obtained the name of Barren Isles from their very naked appearance * * *" The names, "Islas Esteriles," published by Don D. A. Galiano (1802, map 3) and "O[stro]va Bezplodnyya," published by Capt. M. D. Tebenkov (1852, map 22), IRN, are Spanish and Russian translations of the English name.

Barren Isles: islands, See Barren Islands.

Barren Lake: lake, $0.1 \mathrm{mi}$. across, $5.5 \mathrm{mi}$. NE of Haines Lake and $51 \mathrm{mi}$. W of Mount McKinley, Kuskokwim Low.; $63^{\circ} 04^{\prime} 05^{\prime \prime} \mathrm{N}, 152^{\circ} 38^{\prime}$ $00^{\prime \prime} \mathrm{W}$; (map 88).

Local name reported in 1954 by USGS.

Barrenland Creek: stream, flows SE $6 \mathrm{mi}$. from Als Mtn. around S side of Inclined Mtn. to North Fork Koyukuk River, $43 \mathrm{mi}$. NW of Wiseman, Brooks Ra.; $68^{\circ} 00^{\prime} 30^{\prime \prime} \mathrm{N}, 150^{\circ}$. $30^{\prime} 30^{\prime \prime} \mathrm{W}$; (map 134).

Named in 1939 by Marshall (1956, p. 154). About it he wrote, "It was fascinating in its barrenness, so we called the drainage 'Barrenland Creek.' "'

Barren Mountain: mountain, 3,335 ft., $\mathrm{N}$ of Cholmondeley Sound, near center of Prince of Wales I., Alex. Arch.; $55^{\circ} 16^{\prime} 55^{\prime \prime} \mathrm{N}, 132^{\circ}$ $24^{\prime} 20^{\prime \prime} \mathrm{W}$; (map 4).

Local name recorded in 1935 by USFS

Barren Rock: rock, "20 feet high, in Dixon entrance, 7 miles south of Cape Northumberland. Called Barren rock by Dall in the Coast Pilot, 1883. Also called Barren Island" (Baker, 1906, p. 117).

Barren Rock: rock, see Barren Island.

Barrett Creek: stream, flows S $1 \mathrm{mi}$. to Burls Creek, $8 \mathrm{mi}$. E of Katalla, Malaspina Coastal
Plain; $60^{\circ} 12^{\prime} \mathrm{N}, 144^{\circ} 18^{\prime} \mathrm{W}$; BGN 1946; (map 64).

Local name, reported in 1915 on GLO (BLM) survey map.

Barrie, Point: point of land, SW tip of Kupreanof I., Alex Arch.; 56 $26^{\prime} 10^{\prime \prime}$ N, $133^{\circ} 39^{\prime} 00^{\prime \prime}$ $W ;(\operatorname{map} 6)$.

Named by Capt. George Vancouver, RN, on "September 11, 1793, after Robert Barrie, one of the master's mates on the Discovery * * *" (Wagner, 1937, p. 375).

Barrie Island: island, $0.1 \mathrm{mi}$. long, $1 \mathrm{mi}$. SE of Point Barrie, in Sumner Strait on S coast of Kupreanof I., Alex. Arch.; $56^{\circ} 25^{\prime} 35^{\prime \prime} \mathrm{N}$, $133^{\circ} 38^{\prime} 00^{\prime \prime} \mathrm{W}$; (map 6). Var. Barrie Islet.

Named by USC\&GS for charting purposes; name published in 1932 Coast Pilot (p. 256) as "Barrie Islet."

Barrie Island: island, see Strait Island.

Barrie Islet: island, see Barrie Island.

Barrie Lake: lake, $0.5 \mathrm{mi}$. long, $3 \mathrm{mi}$. NE of Point of Barrie, on S coast of Kupreanof I., Alexander Arch.; 56 $28^{\prime} 00^{\prime \prime}$ N, $133^{\circ} 35^{\prime} 30^{\prime \prime}$ $W_{i}$ (map 6).

Local name recorded in 1960 by USC\&GS. Barrientos, Punta: point of land. This may be Point Manby but its exact identity is in doubt. Named by Capt. Alessandro Malaspina about July 7, 1791.

Barrie Point: point of land, "the southwestern point of Kupreanof island, Sumner Strait, Alexander archipelago. So named by Vancouver, in 1793, after Mr. Barrie, a member of his party" (Baker, 1906, p. 117).

Barrier Creek: stream, flows NW $10 \mathrm{mi}$. to South Fork Chickamin River, $7 \mathrm{mi}$. N of Walker Lake, Coast Mts.; 55 $51^{\prime} 15^{\prime \prime} \mathrm{N}, 130^{\circ} 37^{\prime} 50^{\prime \prime}$ W; BGN 1962; (map 3).

Local name reported in 1961 by USFS.

Barrier Glacier: glacier, heads on Mount Spurr, trends $S 9 \mathrm{mi}$. to its terminus at $E$ end of Chakachamna Lake, $41 \mathrm{mi}$. NW of Tyonek, Alaska Ra.; $61^{\circ} 13^{\prime} \mathrm{N}, 152^{\circ} 11^{\prime} \mathrm{W}$; BGN 1930; (map 70).

So named in 1927 by S. R. Capps and R. H. Sargent (in Smith and others, 1930, pl. 1, 2), USGS, because "the moraine lay across their route."

Barrier Islands: islands, group extends W $5 \mathrm{mi}$, off SW coast of Prince of Wales I., Alex. Arch.; $54^{\circ} 48^{\prime} \mathrm{N}, 132^{\circ} 25^{\prime} \mathrm{W}$; (map 1$)$.

Descriptive name given in 1899 by USC\&GS.

Barrier Island: islands, $2 \mathrm{mi}$. long, at $\mathrm{N}$ point of entrance to Shakan Bay, on NW coast of Prince of Wales I., Alex. Arch.; 56 ${ }^{\circ} 13^{\prime} \mathrm{N}$, $133^{\circ} 40^{\prime} \mathrm{W}$; $(\operatorname{map} 6)$.

Descriptive name given by W. H. Dall, USC\&GS, who reported, "a number of rocks and two large islands connected by a reef, covered at high water, giving the appearance of two islands" (U.S. Coast and Geodetic Survey, 1883, p. 102).

Barrier Mountain: mountain range, see Barrier Range.

Barrier Range: mountain range, 3,500 ft., extends NE 15 mi., between Katmai River and Soluka Creek, near S coast of Alaska Penin., 
in Katmai National Monument, $5 \mathrm{mi}$. SE of Mount Katmai, Aleutian Ra. ; $58^{\circ} 12^{\prime} \mathrm{N}, 154^{\circ}$ 54' W; $B G N$ 1924; (map 42). Var. Barrier Mountain.

Named in 1915 by R. F. Griggs of the National Geographic Society "because the range blocked the view of Mount Katmai from Soluka Creek valley."

Barrigon, El: point of land, "in Port Etches on Hinchinbrook Island."

Name found on an anonymous 1779 Spanish map. See Wagner (1937, p. 431). The name means "big belly" in Spanish.

Barrigon, Point: point of land, on NW coast of Suemez I., in Port Dolores, Alex. Arch.; 55. $19^{\prime} 45^{\prime \prime} \mathrm{W} ; 133^{\circ} 25^{\prime} 00^{\prime \prime} \mathrm{N}$; (map 4).

Spanish name meaning "potbelly" published in 1932 Coast Pilot (p. 209).

Barrille, Mount: peak, 7,650 ft., $\mathrm{S}$ of Ruth Amphitheater, $13 \mathrm{mi}$. SE of Denali Pass in Mount McKinley National Park, Alaska Ra.; $62^{\circ} 58^{\prime} \mathrm{N}, 150^{\circ} 43^{\prime} \mathrm{W}$; (map 81). Var. Pittock Peaks.

Named in 1906 by F. A. Cook for Edward Barrill, his companion in their "reported" ascent of Mount McKinley.

Barrow: town, pop. 1,314, on Chukchi Sea coast, $10 \mathrm{mi}$. SW of Point Barrow, Arctic Plain; $71^{\circ} 17^{\prime} 30^{\prime \prime} \mathrm{N}, 156^{\circ} 47^{\prime} 15^{\prime \prime} \mathrm{W} ; B G N$ 1944; (map 153). Var. Barrow Point, Government Station, Ooglaamie, Ooglamie, Ootivakh, Ootiwakh, Ootkaiowik, Ootkeavie, Ootkeawie, Ootkiavie, Ot-ke-a-vik, Otkiawik, Ot-ki-a-wing, Otkiovik, Otkiwik, Uglaamie, Utkeakhvik, Utkeagvik, Utkeavic, Utkiavi, Utkiaving, Utkiavwīn, Utkiawǐn.

Name derived from Point Barrow, and was originally a general designation, because "white" residents found it easier to pronounce than the Eskimo name. A post office established in 1901 helped the name "Barrow" to become dominant. The Eskimo name, best rendered "Utkiakvik," refers in meaning to a "high place for viewing," so named because it was situated on relatively high ( $30 \mathrm{ft}$.) land at Cape Smyth. Although Capt. Beechey's party (1831, p. 307$), \mathrm{RN}$, mentions a village at Cape Smyth in 1826, the name was first recorded in 1853 as "Ot-ki-a-wing" by Comdr. Rockfort Maguire, RN (Great Britain, 1854, map facing p. 186). John Simpson's native map dated 1855, records the name "Otkiawik," which was printed on the subsequent Brit. Adm. Chart as "Otkiovik." Lt. P. H. Ray's party established a station located onehalf mile northeast of the native village for meteorologic and magnetic observations in 1881. They called the station "Ooglaamie" or "Uglaamie," a name that was later often transferred to the village (Murdoch, 1892, p. 26), USA. See Cape Smyth and Browerville.

Barrow, Point: point of land, between Beaufort and Chukchi Seas, northernmost point in United States, Arctic Plain; $71^{\circ} 23^{\prime} 29^{\prime \prime} \mathrm{N}$, $156^{\circ} 28^{\prime} 30^{\prime \prime}$ W; $B G N$ 1944; (map 153). Var. Barrow Spit, Cape North, Noowooh, Noowook, Nowuk, Numuk, Nuvuk, Nuwuk. Named by Capt. Beechey (1831, p. 302),
RN, in Sept. 1826 for Sir John Barrow "to mark the progress of northern discovery *** advocated by that distinguished member of our naval administration." The point was discovered by Thomas Elson, William Smyth, and the crew whom Beechey sent in an open boat to explore northward when his ship, the HMS Blossom, was unable to proceed farther The Eskimo name for the point is "Nuwak" meaning "point of land." The name "Cape North," originally applied by Thomas Simpson, had some use on early charts before the present name became established.

Barrow Point: town, see Barrow.

Barrow Spit: point of land, see Barrow Point. Barry Arm Port Wells: estuary, extends S 9 mi. from Barry Glacier to Point Pakenham, $58 \mathrm{mi}$. $\mathrm{SE}$ of Anchorage, Chugach Mts.; $61^{\circ} 00^{\prime} \mathrm{N}$, $148^{\circ} 08^{\prime} \mathrm{W}$; (map 69).

Named in 1898 by Capt. E. F. Glenn, USA, for Col. Thomas Henry Barry, Assistant Adjutant General, USA.

Barry Glacier: glacier, trends SW $16 \mathrm{mi}$. to Barry Arm Port Wells, $58 \mathrm{mi}$. E of Anchorage, Chugach Mts.; 61 ${ }^{\circ} 07^{\prime} \mathrm{N}, 148^{\circ} 09^{\prime} \mathrm{W}$; (map 69). Var. Washington Glacier.

Named in 1898 by Capt. E. F. Glenn, USA. See Barry Arm Port Wells.

Barry Lagoon: lake, $1 \mathrm{mi}$. long, $1.3 \mathrm{mi}$. $\mathrm{N}$ of Narrow Cape and Kodiak, on $E$ coast of Kodiak I.; $57^{\circ} 27^{\prime} \mathrm{N}, 152^{\circ} 20^{\prime} \mathrm{W}$; (map 34). Local name reported in 1951 by USGS.

Bartel Creek: stream, see Bartell Creek.

Bartell Creek: stream, in Mentasta Mts., flows S $7 \mathrm{mi}$. to Station Creek $2 \mathrm{mi}$. E of Mentasta Pass, and $34 \mathrm{mi}$. SW of Tok, Alaska Ra.; $62^{\circ} 55^{\prime}$ N, $143^{\circ} 34^{\prime}$ W; (map 84). Var. Bartel Creek.

Local name reported in 1951 by USGS.

Barter Island: island, $4 \mathrm{mi}$. across, on coast of Beaufort Sea, between Arey and Kaktovick Lagoons, $62 \mathrm{mi}$. NW of Demarcation Point, Arctic Plain; $70^{\circ} 07^{\prime} \mathrm{N}, 143^{\circ} 40^{\prime} \mathrm{W} ; B G N$ 1952; (map 152). Var. Barter Islands, Kaaktovik Island, Kaktoavik Island, Noobooa, Point Manning, Tungak Island, Nuwuak.

On August 4, 1826, Sir John Franklin (1828, p. 146), assuming it part of the mainland, applied the name "Point Manning" to the $\mathbf{E}$ point of this island. Franklin's original "Barter Island" was renamed "Arey Island" by Leffingwell (1919, p. 93), because local usage had applied the name Barter Island to the above location. John Simpson's native map, dated 1855, shows "Tungak Island," and on what appears to be present-day Manning Point the Eskimo name "Nu-wu-ak Point" is shown with the note "the place of barter." This is probably the source of the name Barter Island. Leffingwell gives the Eskimo name for the island as "Kaktoavik" meaning "seining place." Vilhjalmur Stefansson spells this name "Kaaktovik." See Arey Island, Kaktovik Lagoon, and Manning Point.

Barter Island: barrier island, see Arey Island. Barter Islands: island, see Barter Island.

Barter River: stream, see Sadlerochit River.
Bartholf Creek: stream, heads at glacier terminus, flows $\mathrm{N} 7 \mathrm{mi}$. to Kashwitna River, $24 \mathrm{mi}$. $\mathrm{N}$ of Palmer, Talkeetna Mts.; $61^{\circ} 57^{\prime} \mathrm{N}, 149^{\circ}$ $10^{\prime} \mathrm{W} ; B G N$ 1935; (map 69).

Local name reported in 1935 by P. S. Smith, USGS. Named "in honor of Frank Bartholf, pioneer prospector in this district who did much toward the opening and developing of the surrounding country."

Bartholomew Creek: stream, flows SW $5.5 \mathrm{mi}$. to Smeaton Bay, $33 \mathrm{mi}$. E of Ketchikan, Coast Mts.; $55^{\circ} 18^{\prime} 45^{\prime \prime} \mathrm{N}, 130^{\circ} 47^{\prime} 00^{\prime \prime} \mathrm{W}$; $B G N$ 1962; (map 3).

Local name reported in 1961 by USFS.

Bart Island: rock, near $\mathrm{W}$ end of Nakwasina Passage, off NW coast of Halleck I., $15 \mathrm{mi}$. NW of Sitka, Alex. Arch.; 57 $14^{\prime} 48^{\prime \prime} \mathrm{N}$, $135^{\circ} 30^{\prime} 13^{\prime \prime}$ W; (map 9). Var. Bart Rock.

Named in 1896 by Lt. Comdr. E. K. Moore, USN, and published in 1900 by USC\&GS on Chart 8281.

Bart Lake: lake (elev. $986 \mathrm{ft}$ ) , $0.8 \mathrm{mi}$. across, at head of Dorothy Creek, $1.3 \mathrm{mi}$. E of mouth on Taku Inlet and $16 \mathrm{mi}$. SE of Juneau, Coast Mts.; 58 $13^{\prime} 45^{\prime \prime} \mathrm{N}, 134^{\circ} 01^{\prime} 30^{\prime \prime} \mathrm{W}$; $B G N$ 1954; (map 11). Var. Lake Mary, Mary Lake.

Name published in 1951 by USGS.

Bartlett: locality, $4 \mathrm{mi}$. E of Dome Spur and 10 mi. NW of Fairbanks, Yukon-Tanana High.; $64^{\circ} 48^{\prime} 30^{\prime \prime} \mathrm{N}, 148^{\circ} 00^{\prime} 30^{\prime \prime} \mathrm{W}$; (map 100).

This was a railroad station established in 1922 and discontinued the following year. The name was published in a 1922 railway guide.

Bartlett Cove: village, pop. 20, on Bartlett Cove, $5 \mathrm{mi}$. N of Gustavus $50 \mathrm{mi}$. NW of Juneau, St. Elias Mts. ; $58^{\circ} 27^{\prime} \mathrm{N}, 135^{\circ} 55^{\prime} \mathrm{W}$; (map 11). Village reported in 1961 by USGS.

Bartlett Cove: bay, extends N $5 \mathrm{mi}$. from Point Gustavus, in Glacier Bay National Monument, on $\mathrm{E}$ shore of Glacier Bay $\mathrm{S}$ of Lester I., St. Elias Mts.; $58^{\circ} 27^{\prime} \mathrm{N}, 1^{135^{\circ}} 55^{\prime} \mathrm{W}$; (map 11).

Named about 1881 by Capt. W. E. George, local pilot, probably for Charles C. Bartlett, who bought "fishing property and claim on Bartlett Bay" in 1884. A saltery was operated here in the 1880's which was replaced by a cannery in 1889 .

Bartlett Glacier: glacier, heads in Kenai Mts., between Spencer and Trail Glaciers, trends NW $4 \mathrm{mi}$. to its terminus, $4 \mathrm{mi}$. S of Placer River Valley, $40 \mathrm{mi}$. NE of Seward, Chugach Mts.; $60^{\circ} 38^{\prime} 30^{\prime \prime} \mathrm{N}, 149^{\circ} 01^{\prime} 30^{\prime \prime} \mathrm{W}$; $B G N$ 1910; (map 63).

Named in 1907 for Frank Bartlett, Alaska Central RR. civil engineer; reported by U. S. Grant and D. F. Higgins (in Brooks and others, 1909, pls. 1, 2), USGS.

Bartlett Lake: lake, $0.6 \mathrm{mi}$. across, in Glacier Bay National Monument, $3 \mathrm{mi}$. NE of Bartlett Cove and $52 \mathrm{mi}$. NW of Juneau, St. Elias Mts.; $58^{\circ} 30^{\prime} 10^{\prime \prime} \mathrm{N}, 1^{\circ} 45^{\circ} 45^{\prime \prime} \mathrm{W}$; (map 11).

Name published in 1962 by USGS. Probably derived from the cove and river of the same name. 
Bartlett Point: point of land, on an unnamed island, on $\mathbf{S}$ tip of Admiralty I., $29 \mathrm{mi}$. $\mathbf{E}$ of Sitka, Alex. Arch.; $57^{\circ} 01^{\prime} 00^{\prime \prime} \mathrm{N}, 134^{\circ} 34^{\prime} 10^{\prime \prime}$ W; (map 9).

Name published by USC\&GS in the 1891 Coast Pilot (p. 141).

Bartlett Point: point of land, on $\mathrm{W}$ coast of Whitney I., S of Bill Point, $70 \mathrm{mi}$. E of Sitka, Coast Mts.; $57^{\circ} 14^{\prime} 30^{\prime \prime} \mathrm{N}, 133^{\circ} 32^{\prime} 45^{\prime \prime} \mathrm{W}$; (map 8).

Named by Lt. Comdr. H. B. Mansfield, USN, and published in 1891 by USC\&GS.

Bartlett River: stream, in Glacier Bay National Monument, flows SW $14 \mathrm{mi}$. where it divides into two courses: one SW $1 \mathrm{mi}$. to Bartlett Cove, the other $4 \mathrm{mi}$. $\mathrm{N}$ to Hutchins Bay, $53 \mathrm{mi}$. NW of Juneau, St. Elias Mts.; $58^{\circ} 28^{\prime} 30^{\prime \prime} \mathrm{N}, 135^{\circ} 50^{\prime} 45^{\prime \prime} \mathrm{W}$; BGN 1963; (map 11)

Name reported by USFS in 1929 for the cove at stream mouth.

Bartley Ridge: ridge, see Barkley Ridge.

Bartolome, Cape: point of land, $\mathrm{S}$ tip of Baker I., includes chain of off-shore islands, Alex. Arch.; $55^{\circ} 14^{\prime} \mathrm{N}, 133^{\circ} 37^{\prime} \mathrm{W}$; (map 4). Var. Cabo del Saint Bartolom, Cabo de San Bartolome, Cape Adamson, Cape Cheericoff, Cape Saint Bartolom, Point Chirikoff.

Name given in 1775 by Francisco Antonio Maurelle as "Cabo de San Bartolome," or "Cape of Saint Bartolomew," probably for Saint Bartholomew whose day is August 24. Named "Cape Adamson" by Capt. Meares (1790, p. 326), RN, and "Cape Cheericoff" by Capt. Lisianski (1814, map facing p. 221), IRN.

Bart Rock: rock, see Bart Island.

Barwell Island: island, $0.3 \mathrm{mi}$. across, in Blying Sound, $1 \mathrm{mi}$. SE of Cap Resurrection, $20 \mathrm{mi}$. SE of Seward, Chugach Mts.; $59^{\circ} 51^{\prime} 35^{\prime \prime} \mathrm{N}$, $149^{\circ} 16^{\prime} 45^{\prime \prime} \mathrm{W}$; BGN 1906; (map 49). Var. Cape Island.

Named in 1906 by BGN, on account of proximity to Cape Resurrection which was called "Barwell" by Capt. Nathaniel Portlock in 1787 .

Barwell, Point: point of land, see Resurrection, Cape.

Basalt Knob: hill, $310 \mathrm{ft}$., on NW coast of its Chichagof I., on NE shore of Lisianski Inlet, $34 \mathrm{mi}$. SW of Hoonah, Alex. Arch.; $58^{\circ} 01^{\prime} 47^{\prime \prime}$ N, 136 19'50" W; BGN 1960; (map 10).

Descriptive name given by USGS in 1955 , "because the hill is composed of basaltic rock and is the only significant body of this rock type found on the NW part of Chichagof Island."

Basalt Lake: lake, $0.7 \mathrm{mi}$. long, near $W$ end of Amphitheater Mts., $28 \mathrm{mi}$. NW of Paxson, Alaska Ra.; $63^{\circ} 09^{\prime} 20^{\prime \prime}$ N, $146^{\circ} 20^{\prime} 20^{\prime \prime}$ W; (map 86).

So named in 1955 by T. L. Péwé, USGS, because the lake "is flanked by towering basalt cliffs."

Basalt Rock: rock, in Avatanak Strait, 1 mi. N of Avatanak I., Aleutian Is.; $54^{\circ} 06^{\prime} 30^{\prime \prime} \mathrm{N}$, $165^{\circ} 22^{\prime} 25^{\prime \prime} \mathrm{W}$; (map 24).
Descriptive name reported in 1901 by J. J. Gilbert, USC\&GS.

Basargin, Mount: mountain, 2,276 ft., $\mathbf{N}$ of Stikine River, $19 \mathrm{~m}$. NE of Wrangell, Coast Mts.; $56^{\circ} 44^{\prime} 00^{\prime \prime} \mathrm{N}, 132^{\circ} 13^{\prime} 30^{\prime \prime} \mathrm{W}$; (map 6). Var. Mount Bassarguine.

Named in 1877 by Joseph Hunter, Canadian engineer and surveyor, who spelled it "Bassarguine." Named for Lt. Vladimir Basargin, IRN, who commanded the corvette Rynda, during an exploration and survey of this vicinity in 1863. See Rynda Island.

Basco Island: island, $1 \mathrm{mi}$. long, in Yukon River, $3 \mathrm{mi}$. W of Tozitna I. and $14 \mathrm{mi}$. WSW of Tanana, Nowitna Low.; $65^{\circ} 08^{\prime} \mathrm{N}, 152^{\circ} 34^{\prime}$ W; (map 106).

Riverbook pilots' name shown on Navigation Chart of the Tanana-Yukon Rivers, dated 1940.

Base Island: island, $4 \mathrm{mi}$. long, in Yukon River $\mathrm{E}$ of Pearl I., $23 \mathrm{mi}$. NE of Russian Mission, Yukon-Kuskokwim Delta ; $61^{\circ} 56^{\prime} \mathrm{N}, 160^{\circ} 40^{\prime}$ W ; $(\operatorname{map} 73)$

So named in 1916 by W. S. Post, USGS, because "a triangulation check base was established on this island."

Basher: settlement, pop. 8, near Anchorage, Cook Inlet Low.

Name of a suburb of Anchorage obtained in 1961 by USGS; the village was incorporated in 1958 (Rand McNally, 1961, p. 57).

Bashful Peak: mountain, 8,005 ft., $9.2 \mathrm{mi}$. W of Inner Lake George and $22 \mathrm{mi}$. SE of Palmer, Chugach Mts.; $61^{\circ} 18^{\prime} 30^{\prime \prime} \mathrm{N}, 148^{\circ} 52^{\prime} 00^{\prime \prime} \mathrm{W}$; $B G N$ 1964; (map 69).

So named in 1958 by members of the Mountaineering Club of Alaska because "it is often hidden by other peaks, ridges, or clouds."

Bashmakoff Rocks: rocks, off SE coast of Attu I., Aleutian Is.; $52^{\circ} 45^{\prime} \mathrm{N}, 173^{\circ} 19^{\prime} \mathrm{E}$; (map 13).

Recorded on a manuscript map drafted by L. M. Turner in the 1880 's; this feature has not been positively identified.

Basic Creek: stream, heads in Dutch Hills, flows NW $1.7 \mathrm{mi}$. between Siwash and Stony Creeks to Dutch Creek, $35 \mathrm{mi}$. NW of Talkeetna, Alaska Ra.; $62^{\circ} 33^{\prime} 55^{\prime \prime} \mathrm{N}, 151^{\circ} 05^{\prime} 10^{\prime \prime} \mathrm{W}$; (map 81).

Prospectors' name reported in the 1930's by USGS

Basin, The: bay, $1.5 \mathrm{mi}$. across, $\mathrm{S}$ part of Kelp Bay, on Baranof I., $21 \mathrm{mi}$. NE of Sitka, Alex. Arch.; $57^{\circ} 17^{\prime} \mathrm{N}, 134^{\circ} 55^{\prime} \mathrm{W}$; (map 9).

Descriptive name given in 1895 by $L t$. Comdr. E. K. Moore, USN, and published by USC\&GS in the 1901 Coast Pilot (p. 159) Basin Cove: cove, see Bains Cove.

Basin Creek: stream, flows N $1.5 \mathrm{mi}$. to Bering Lake, $8 \mathrm{mi}$. NE of Katalla, Chugach Mts. $60^{\circ} 17^{\prime} \mathrm{N}, 144^{\circ} 20^{\prime} \mathrm{W} ; B G N$ 1945; (map 64)

Local descriptive name; published in 1951 by USGS.

Basin Creek: stream, heads in Brown Bear Basin, flows NW $3.5 \mathrm{mi}$. to Canyon Creek, $15 \mathrm{mi}$ NW of Mount Russcll, Alaska Ra. ; 62 ${ }^{\circ} 55^{\prime} 10^{\prime \prime}$ $\mathrm{N}, 152^{\circ} 17^{\prime} 45^{\prime \prime} \mathrm{W}$; (map 81$)$
Local name reported in 1954 by USGS.

Basin Creek: stream, flows NW $4 \mathrm{mi}$. to Tolstoi Creek S of Ledge Creek, $20 \mathrm{mi}$. NW of Ophir and $50 \mathrm{mi}$. NW of McGrath, Kilbuck-Kuskokwim Mts.; $63^{\circ} 17^{\prime} \mathrm{N}, 157^{\circ} 05^{\prime} \mathrm{W}$; (map 90).

Prospectors' name published in 1921 by USGS.

Basin Creek: stream, flows SW $10 \mathrm{mi}$. to Long Creek, $6 \mathrm{mi}$. SW of Long and $28 \mathrm{mi}$. SW of Ruby, Kilbuck-Kuskokwim Mts.; 64' 20'36"

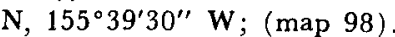

Prospectors' name reported in 1913 by Eakin (1914, pl. 3), USGS.

Basin Creek: stream, flows W $1.2 \mathrm{mi}$. to Eldorado Creek which flows to Norton Sound, $21 \mathrm{mi}$. $\mathrm{E}$ of Solomon, Seward Penin. High.; 64 ${ }^{\circ} 35^{\prime}$ N, $163^{\circ} 45^{\prime} \mathrm{W}$; (map 95).

Prospectors' name shown on Arthur Gibson's "Map of Cape Nome Precinct" dated 1904.

Basin Creek: stream, flows NW 4 mi, to Klokerblok River, $21 \mathrm{mi}$. NE of Solomon, Seward Penin. High.; 64 $40^{\prime} \mathrm{N}, 163^{\circ} 48^{\prime} \mathrm{W}$; (map 95)

Prospectors' name reported in 1900 by $\mathrm{E}$. C. Barnard (in Brooks, 1901, pl. 17), USGS.

Basin Creek: stream, flows SW $3.2 \mathrm{mi}$. to Nome River, $13 \mathrm{mi}$. N of Nome, Seward Penin. High. $64^{\circ} 41^{\prime} \mathrm{N}, 165^{\circ} 19^{\prime} \mathrm{W}$; (map 94)

Prospectors' name published by Schrader and Brooks (1900, map 3), USGS.

Basin Creek: stream, flows SW $4.2 \mathrm{mi}$. to Melsing Creek, $34 \mathrm{mi}$. NE of Solomon, Seward Penin. High.; $64^{\circ} 54^{\prime} \mathrm{N}, 163^{\circ} 38^{\prime} \mathrm{W}$; (map 95).

Prospectors' name reported in 1900 by E. C. Barnard (in Brooks, 1901, pl. 17), USGS.

Basin Creek: stream, see Secret Creek.

Basin Gulch: ravine, "at the headwaters of Chititu creek. Prospectors' name, first appears on map by George M. Esterly, of Valdez, 1902'" (Baker, 1906, p. 119).

Basin Lake: lake, $1.4 \mathrm{mi}$. long, on Revillagigedo I., near head of Thorne Arm, $\mathbf{E}$ of Big Lake, Alex. Arch.; $55^{\circ} 25^{\prime} 00^{\prime \prime} \mathrm{N}, 131^{\circ} 09^{\prime} 45^{\prime \prime} \mathrm{W}$; (map 3).

Local name recorded in 1915 by G. H. Canfield (in Brooks and others, 1922, p. 83) USGS

Basket Bay, bay, $0.5 \mathrm{mi}$. across, $8 \mathrm{mi}$. S of mouth of Tanakee Inlet, on Chichagof I., $45 \mathrm{mi}$. NE of Sitka, Alex. Arch.; $57^{\circ} 39^{\prime} 30^{\prime \prime}$ N, 134 54' $00^{\prime \prime}$ W; (map 9). Var. Kakagin Inlet, Kook Bay.

Named by the employees of the Alaska Oil and Guano Company at Killisnoo about 1900. The Tlingit Indian name "Kook Bay" was published in 1899 by USC\&GS on Chart 8050 . It was called Kakagin Inlet in the 1883 Coast Pilot (p 178).

Basket Creek: stream, heads in a lake, flows SW and NW $45 \mathrm{mi}$. to Holitna River, $7 \mathrm{mi}$. SE of its junc. with Kuskokwim River, $8 \mathrm{mi}$. SE of Sleetmute, Stony River Low.; 61 ${ }^{\circ} 37^{\prime} \mathrm{N}$, $157^{\circ} 00^{\prime} \mathrm{W}$; (map 72 ).

Local name obtained in 1952 by USGS 
Basket Lake: lake, $0.7 \mathrm{mi}$. across, $10 \mathrm{mi}$. S of mouth of Tenakee Inlet, on SE coast of Chichagof I., $59 \mathrm{mi}$. NE of Sitka, Alex. Arch.; $57^{\circ} 37^{\prime} 50^{\prime \prime} \mathrm{N}, 1^{\circ} 4^{\circ} 55^{\prime} 00^{\prime \prime} \mathrm{W} ; B G N \quad 1935$; (map 9).

Named in 1935 by USGS for Little Basket Bay into which it drains. It was important in the fish-stocking program in southeastern Alaska at that time.

Basnuná: stream, tributary of Alatna River near its head, Brooks Ra.

Koyukun Indian name obtained in 1885 by Lt. Allen (1887, p. 98), USA, who wrote "an old man *** had, as he said, been more than once over the mountains [Brooks Range], in which this tributary [Alatna River] heads, to a rather small river, 'Basnuná,' then down it to a large river, the 'Holöatná'."

Bassarguine, Mount: mountain, see Basargin, Mount.

Bassett Creek: stream, on E end of Attu I., heads on Robinson Ridge, flows E, through Siddens Valley, $2.3 \mathrm{mi}$. to Lake Nicholas, Aleutian Is. $52^{\circ} 53^{\prime} 00^{\prime \prime} \mathrm{N}, 173^{\circ} 13^{\prime} 15^{\prime \prime} \mathrm{E}$; (map 13).

Named by the U.S. Army during World War II; published in 1948 by AMS.

Bassett Island: island, $300 \mathrm{ft}$. across, in Albatross Anchorage on $\mathrm{S}$ coast of Alaska Penin., $9 \mathrm{mi}$ NNW of Swedania Point, Aleutian Ra.; $55^{\circ}$. $35^{\prime} 35^{\prime \prime} \mathrm{N}, 160^{\circ} 36^{\prime} 40^{\prime \prime} \mathrm{W}$; (map 28). Var. Fassett Island.

Named "Fassett Island" in 1893 by USBF, for H. C. Fasset of that agency; published as "Bassett Island" in 1912 by USC\&GS.

Bass Harbor: bay, on S side of Naked I., extends $\mathrm{S} 2 \mathrm{mi}$. to Prince William Sound, $34 \mathrm{mi}$. NE of Chenega, Chugach Mts.; $60^{\circ} 37^{\prime} 30^{\prime \prime} \mathrm{N}$, $147^{\circ} 24^{\prime} 30^{\prime \prime} \mathrm{W}$; (map 63 )

Local name reported in 1952 by USGS.

Bassie, Mount: mountain, 4,423 ft., on Baranof I., $11 \mathrm{mi}$. E of Sitka and $4 \mathrm{mi}$. W of Baranof Lake, Alex. Arch.; 57 $03^{\prime} 30^{\prime \prime}$ N, $135^{\circ} 02^{\prime} 30^{\prime \prime}$ W; $(\operatorname{map} 9)$

Local name reported in 1951 by USGS.

Bass Point: point of land, on $\mathrm{N}$ shore of Alava Bay, on SE coast of Revillagigedo I., Alex. Arch. ; 55 $13^{\prime} 45^{\prime \prime} \mathrm{N}, 131^{\circ} 08^{\prime} 40^{\prime \prime} \mathrm{W}$; (map 3 ).

One of many arbitrary names applied to features in this area in 1891 by USC\&GS.

Bastille, Mount: peak, 4,440 ft., in DeLong Mts., 17 mi. NNE of Misheguk Mtn., Brooks Ra.; $68^{\circ} 28^{\prime} \mathrm{N}, 160^{\circ} 52^{\prime} \mathrm{W}$; BGN 1961; (map 131).

So named by USGS geologists in 1951 "because the name reflects the massive appearance of the mountain and, also, it was first climbed on Bastille Day [July 14], 1951."

Bat, Gavan: bight, see Baht Harbor.

Bat, The: hill, 1,699 ft., $3 \mathrm{mi}$. W of Kuzitrin Lake and $13 \mathrm{mi}$. S of Imuruk Lake, Seward Penin. High.; $65^{\circ} 24^{\prime} \mathrm{N}, 163^{\circ} 22^{\prime} \mathrm{W}$; BGN 1954; (map 110)

Reported in 1953 by D. M. Hopkins, USGS so named because the "silhouette of the peaks when seen from Kuzitrin Lake suggests the profile of a bat with folded wings.'

Batan, Point: point of land, W point of entrance to Port Caldera, on $W$ coast of Prince of
Wales I., $6.5 \mathrm{mi}$. S of Craig, Alex. Arch.; $55^{\circ} 22^{\prime} 55^{\prime \prime} \mathrm{N}, 133^{\circ} 11^{\prime} 00^{\prime \prime} \mathrm{W}$; (map 4). Var. Mys Botan, Punta Batan, Punta de Batan.

Spanish name given in 1775-79 by Don Juan de la Bodega y Quadra and Francisco Antonio Maurelle as "Punta de Batan" or "Point Batan."

Batareinoi Island: island, see Battery Island. Bates Creek: stream, flows NE $2.3 \mathrm{mi}$. to Thursday Creek, $5 \mathrm{mi}$. NW of Hiline Lake and 51 mi. NW of Tyonek, Cook Inlet Low.; $61^{\circ} 47^{\prime}$ $45^{\prime \prime} \mathrm{N}, 151^{\circ} 28^{\prime} 45^{\prime \prime} \mathrm{W}$; (map 70).

Local name published in 1954 by USGS.

Bates Creek: stream, flows SW 3 mi. to Ptarmigan Creek, $50 \mathrm{mi}$. SW of Circle, Yukon-Tanana High.; $65^{\circ} 27^{\prime} 18^{\prime \prime} \mathrm{N}, 145^{\circ} 30^{\prime} 10^{\prime \prime} \mathrm{W}$; (map 104).

Named by prospectors; reported in 1903 by USGS (Prindle, 1905, pl. 13).

Bates Pass: pass, "over Valdez glacier, so named by Abercrombie, 1898" (Baker, 1906, p. 119). Bates Rapid: rapids, see Bates Rapids.

Bates Rapids: rapids, in Tanana River extends $\mathrm{W}$ from Big Delta, Tanana Low.; $64^{\circ} 14^{\prime} \mathrm{N}$, $146^{\circ} 00^{\prime} \mathrm{W}$; (map 101). Var. Bates Rapid.

Named in 1885 by Lt. H. T. Allen (1887, p. 84), USA, for a "Mr. Bates *** an Englishman who is reported to have descended the Tanana River."

Bath Harbor: bight, see Baht Harbor.

Bat Point: point of land, on Revillagigedo I., near head of George Inlet, Alex. Arch.; 55 $30^{\prime} 10^{\prime \prime} \cdot \mathrm{N}, 131^{\circ} 29^{\prime} 45^{\prime \prime} \mathrm{W}$; (map 3 ).

Arbitrary name given in 1891 by USC\&GS.

Battery Creek: stream, flows NE $5.5 \mathrm{mi}$. to Kukpuk River, E of Sigrikpak Ridge, $17 \mathrm{mi}$. NE of Cape Thompson, Arctic Slope; $68^{\circ}$ $12^{\prime} 18^{\prime \prime} \mathrm{N}, 165^{\circ} 19^{\prime} 30^{\prime \prime} \mathrm{W}$; BGN 1963; (map 129).

Named in 1960 by Project Chariot personnel.

Battery Island: island, $0.1 \mathrm{mi}$. across, $1.5 \mathrm{mi}$. W of Sitka, in Sitka Sound, Alex. Arch.; 57 $03^{\prime}$ $35^{\prime \prime} \mathrm{N}, 135^{\circ} 22^{\prime} 50^{\prime \prime} \mathrm{W}$; (map 9). Var. Batareinoi Island.

Name published in 1883 by USC\&GS. It was called "O[strov] Bataryeynyy" meaning "battery island" by the Russians in 1809, (U.S. Coast and Geodetic Survey, 1883, p. 141).

Battery Islets: islands, $0.3 \mathrm{mi}$. long, in Wrangell Narrows between Mitkof and Woewodski Is., 16 mi. S of Petersburg, Alex. Arch.; 56 $34^{\circ} 30^{\prime \prime}$ $\mathrm{N}, 132^{\circ} 58^{\prime} 15^{\prime \prime} \mathrm{W}$; (map 6). Var. Clear lslets.

Name published by USC\&GS in 1883 Coast Pilot (p. 113); taken from Russian name "Batareynyy," given in 1838 by G. Lindenberg. The name "Clear Islets" was aplied to this feature in 1869 by Cmdr. R. W. Meade, USN.

Battery Lake: lake, $0.5 \mathrm{mi}$. across, in Ipnavik River Valley, on N slope of Brooks Ra., $32 \mathrm{mi}$. $\mathrm{N}$ of Howard Pass; $68^{\circ} 41^{\prime} \mathrm{N}, 156^{\circ} 57^{\prime} \mathrm{W}$; (map 132).

Named by B. H. Kent and I. L. Tailleur, USGS, in 1950, "for a weasel [type of vehicle] battery that was left behind there."
Battery Point: point of land, on $\mathrm{S}$ coast of Akutan I., Krenitzin Is., Aleutian Is.; 54 ${ }^{\circ} 02^{\prime}$ $15^{\prime \prime}$ N, $165^{\circ} 53^{\prime} 06^{\prime \prime} \mathrm{W}$; BGN 1904; (map 24). Var. Cape Kaianak, Liberty Cap, Mys Kayanak, South Head.

A translation of the descriptive name given by Father Veniaminov (1840, v. 1, p. 193). So named because the booming waves on this point sounded like a battery of guns. Capt. Tebenkov (1852, map 26), IRN, shows " $M$ [ys] Kayanak." USBF called it "South Head" in 1888 , in contradistinction to North Head. USC\&GS in 1901 proposed the name "Liberty Cap," undoubtedly suggested by Scotch Cap on Unimak Island .

Battery Point: point of land, in Chilkook Inlet, on $\mathrm{E}$ coast of Chilkat Penin., $0.2 \mathrm{mi}$. $\mathrm{S}$ of Kelgaya Bay and $17 \mathrm{mi}$. SSW of Skagway, Coast Mts.; $59^{\circ} 12^{\prime} 30^{\prime \prime} \mathrm{N}, 1^{\circ} 5^{\circ} 21^{\prime} 40^{\prime \prime} \mathrm{W}$ (map 45). Var. KetIrachta.

So named by USC\&GS in 1891 because of its resemblance to an earthwork fortification (U.S. Coast and Geodetic Survey, 1891, p. 203). Arthur and Aurel Krause (1883, map) reported its native name as "Ketlrachta." In 1901 the point was reserved for use as a lighthouse

Battle Creek: stream, flows SE $1.6 \mathrm{mi}$. to Pine Creek, $4 \mathrm{mi}$. NE of Solomon, Seward Penin. High.; $64^{\circ} 35^{\prime} \mathrm{N}, 164^{\circ} 19^{\prime} \mathrm{W}$; (map 95).

Prospectors' name shown on Arthur Gibson's "Map of Nome Precinct" dated 1904.

Battle Creek: stream, on Kenai Penin., flows NW $6.5 \mathrm{mi}$. to Kachemak Bay, $22 \mathrm{mi}$. NE of Homer, Chugach Mts. ; $59^{\circ} 46^{\prime} \mathrm{N}, 150^{\circ} 59^{\prime} \mathrm{W}$; (map 50).

Local name reported by USGS in 1961.

Battle Glacier: glacier, heads in West Branch of Taku Glacier, $0.8 \mathrm{mi}$. W of Camp 15 Peak, trends $5 \mathrm{mi}$. $\mathrm{N}$ to Gilkey Glacier, $23 \mathrm{mi}$. NW of Juneau, Coast Mts.; 58 $45^{\prime} 40^{\prime \prime}$ N, $134^{\circ} 34^{\prime} 00^{\prime \prime}$ W; BGN 1962; (map 11).

Named in 1962 by M. M. Miller, Michigan State University, for W. R. B. Battle, glaciologist, who was killed on an expedition to Baffin Island, Canada.

Battle Glacier: glacier, heads in Alaska $10 \mathrm{mi}$. $\mathrm{SE}$ of Mount Herbert, trends E $12 \mathrm{mi}$. across Alaska-Canada boundary to Alsek River, St. Elias Mts.; $59^{\circ} 39^{\prime} \mathrm{N}, 138^{\circ} 18^{\prime} \mathrm{W}$; BGN 1954; (map 46). Var. Flanner Glacier.

Named in 1922 by IBC for Arthur Battle who was head of the Canadian Expeditionary Force in France during World War I.

Battle Lake: lake, $9 \mathrm{mi}$. long, at head of Alaska Penin. SE of Kukaklek Lake, $25 \mathrm{mi}$. SSW of Kakhonak, Aleutian Ra.; 59 $04^{\prime} \mathrm{N}, 154^{\circ} 55^{\prime}$ W; (map 51)

Local translation of an Eskimo name re. ported by K. F. Mather (in Brooks and others, 1925 , pl. 3 ), USGS.

Battleship Island: island, $0.1 \mathrm{mi}$. across, in Auke Bay, $1.6 \mathrm{mi}$. S of village of Auke Bay and $9.9 \mathrm{mi}$. NW of Juneau, Coast Mts. ; 58 $21^{\prime} 30^{\prime \prime}$ N, $134^{\circ} 39^{\prime} 45^{\prime \prime}$ W; (map 11).

A local, possibly descriptive, name reported by DeArmond (1957, p. 7). 
Battleship Reef: reef, at $\mathrm{N}$ end of Fritz Cove, $0.2 \mathrm{mi}$. $W$ of $S$ end of Mendenhall Penin. and $9 \mathrm{mi}$. NW of Juneau, Coast Mts. ; 58 $20^{\prime} 30^{\prime \prime}$ $\mathrm{N}, 134^{\circ} 38^{\prime} 50^{\prime \prime} \mathrm{W}$; (map 11).

Name published in 1962 by USGS.

Batto Creek: stream, flows W $1.7 \mathrm{mi}$. to Wilson Creek Slough, $3.5 \mathrm{mi}$. S of Marshall, YukonKuskokwim Delta; $61^{\circ} 49^{\prime} 45^{\prime \prime} \mathrm{N}, 162^{\circ} 50^{\prime} 00^{\prime \prime}$ W; (map 74).

Local miners' name reported in 1916 by Harrington (1918, map), USGS.

Batto Creek: stream, see Balto Creek.

Baturin Lake: lake, $1 \mathrm{mi}$. across, $13 \mathrm{mi}$. NW of Port Alexander, on $\mathrm{S}$ coast of Baranof I., Alex. Arch.; $56^{\circ} 24^{\prime} 45^{\prime \prime} \mathrm{N}, 134^{\circ} 50^{\prime} 00^{\prime \prime} \mathrm{W}$; BGN 1933; (map 5).

Named in 1933 by USFS, for Colonel Baturin (cnna), "one of the survivors of the historic massacre at the first site of Sitka," in 1802.

Batzakakat River: stream, see Batza River.

Batza Mountains: mountains, in central Alaska, probably those behind or near the Batza River; (map 116).

Name reported by Lt. H. T. Allen, USA, in 1885 , undoubtedly named for the stream by Allen himself.

Batza River: stream, flows SE 10 mi. to Koyukuk River across from $\mathrm{N}$ end of Huggins I., $\mathrm{E}$ of Isahultila Mts., $31 \mathrm{mi}$. NNE of Hochandochtla Mtn., Kokrines-Hodzana High.; 65 ${ }^{\circ} 57^{\prime} 00^{\prime \prime} \mathrm{N}$, $154^{\circ} 24^{\prime} 50^{\prime \prime} \mathrm{W}$; (map 107). Var. Batzakakat River.

Koyukan Indian name reported in 1885 as "Batzakakat River," applied to a stream nearer the Hogatza River, by Lt. Allen (1887, map), USA. It appears as if the name originally applied to a slough on the left bank of the Koyukuk near Huggins Island.

Batza Slough: stream, anabranch of Koyukuk River, flows S $10.5 \mathrm{mi}$. on S side of Deniktaw Ridge, $23 \mathrm{mi}$. NNW of Hochandochtla Mtn., Kokrines-Hodzana High.; $65^{\circ} 51^{\prime} \mathrm{N}, 155^{\circ} 04^{\prime}$ W; (map 107).

Local name shown on a 1932 sketch map of the area; author unknown.

Batztoa Lake: lake, $2 \mathrm{mi}$. long, in Koyukuk River valley, $10 \mathrm{mi}$. NNE of Hughes, KokrinesHodzana High.; $66^{\circ} 10^{\prime} \mathrm{N}, 154^{\circ} 06^{\prime} \mathrm{W}$; (map 116).

Indian name recorded at Hughes in 1956 by Orth.

Batzulnatos: locality, see Batzulnetas.

Batzulneta: locality, see Batzulnetas.

Batzulnetas: locality, site of Indian village, on $\mathrm{N}$ bank of Tanada Creek $0.9 \mathrm{mi}$. SE of its junc. with Copper River, Copper River Basin; $62^{\circ} 37^{\prime}$ N, $143^{\circ} 46^{\prime}$ W; (map 84). Var. Batzulnatos, Batzulneta, Batzulnetos.

From unpublished manuscript by Walter James Hoffman (ca. 1895), Batzulnetas was an Ahtena Indian village near the upper Copper River where the trail to Tanana River began. Name is derived from that of a chieftain of the Ahtena, who lived on the Copper River near the mouth of the Slana River. Lt. Allen (1887, p. 67), USA, wrote, on June 2, 1885, that Batzulneta "was six feet four inches high, and clad in a blouse of scarlet flannel *** pair of native trousers *** a black woolen hat with strips of red flannel, completed his costume. His hair hung down his back in a tangled roll three feet long."

Batzulnetos: locality, see Batzulnetas.

Baultoff Creek: stream, heads at glacier terminus, in Nutzotin Mts., flows SE and NE 15 mi. across Alaska-Canada boundary to Beaver Creek in Yukon Canada ; 62 $09^{\circ} \mathrm{N}, 140^{\circ} 59^{\prime}$ W; BGN 1954; (map 84). Var. Bautoff Creek.

Local name published in 1914 on IBC Sheet 31 (1918 atlas).

Baultoff Lakes: lakes, group, extends N-S 1.2 mi., $2.5 \mathrm{mi}$. SW of junc. of Nizina River and Young Creek and $8 \mathrm{mi}$. SE of McCarthy, Copper River Basin; $61^{\circ} 20^{\prime} \mathrm{N}, 142^{\circ} 47^{\prime} \mathrm{W}$; (map 67).

Local name published in 1959 by USGS.

Baum Cape: point of land, "near Belkofski, Alaska peninsula, west of the north end of Dolgoi island. Named by the traders after one of the employees of the Alaska Commercial Company. The name has also been applied to the northwesternmost point of Dolgoi island" (Baker, 1906, p. 120).

Bautista Peak: mountain, 2,040 ft., on San Juan Bautista I., $6.4 \mathrm{mi}$. SW of Craig, Alex. Arch.; $55^{\circ} 25^{\prime} \mathrm{N}, 133^{\circ} 17^{\prime} \mathrm{W}$; BGN 1923; (map 4).

Spanish name meaning "baptist," given in 1923 by J. W. McGuire, USG\&GS.

Bautoff Creek: stream, see Baultoff Creek.

Bay: anchorage, see Ray.

Bayard, Mount: mountain, 6,547 ft., on AlaskaCanada boundary, $14.5 \mathrm{mi}$. NW of Hyder, Coast Mts.; $56^{\circ} 07^{\prime} 25^{\prime \prime} \mathrm{N}, 130^{\circ} 06^{\prime} 10^{\prime \prime} \mathrm{W}$; BGN 1924; (map 7). Var. Mount Johnson.

Name reported in 1917 by USGS; named for Thomas F. Bayard, 1828-98, American statesman and diplomat.

Bay City: village, see John Fitzgerald Kennedy City.

Bay Creek: stream, flows $0.5 \mathrm{mi}$. SE to $\mathrm{N}$ end of Auke Bay, $0.4 \mathrm{mi}$. NE of Spaulding Point and $10 \mathrm{mi}$. NW of Juneau, Coast Mts.; $58^{\circ} 23^{\prime} 15^{\prime \prime} \mathrm{N}, 134^{\circ} 38^{\prime} 55^{\prime \prime} \mathrm{W}$; (map 11).

Local name published in 1962 by USGS.

Bay Creek: stream, on $\mathrm{N}$ end of Kenai Penin., flows NW $1.5 \mathrm{mi}$. to Turnagain Arm, 4.5 mi. NW of Sunrise, Chugach Mits.; $60^{\circ} 56^{\prime} \mathrm{N}$, $149^{\circ} 32^{\prime} \mathrm{W}$; ( $\operatorname{map} 63$ )

Local name reported in 1952 by USGS

Bay Creek: stream, flows SW $4 \mathrm{mi}$. to Grantley Harbor, $4 \mathrm{mi}$. $\mathrm{N}$ of Teller, Seward Penin. High.; $65^{\circ} 19^{\prime} \mathrm{N}, 166^{\circ} 20^{\prime} \mathrm{W}$; (map 111). Var. Boy Creek.

Local name reported in 1900 by E. C. Barnard (in Brooks, 1901, pl. 17), USGS.

Bayeal, Puerto: cove, see Bagial, Pnrt.

Bay Island: island, "in Koyukuk river, near longitude $157^{\circ}$. So named by Allen, 1885" (Baker, 1906, p. 120).

Bay Islands: islands, two, extend $900 \mathrm{ft}$. in American Bay, on $\mathbf{E}$ coast of Dall I., Alex. Arch.; 5451' N, $132^{\circ} 49^{\prime} \mathrm{W}$; (map 1).

Named in 1881 by Lt. Comdr. H. E. Nichols, USN.
Bay Islet: island, "on eastern shore of Portland canal. So named by Pender, 1868" (Baker, 1906 , p. 120).

Bay Lake: lake, $0.8 \mathrm{mi}$. long, on Kenai Penin., $6 \mathrm{mi}$. $\mathrm{N}$ of Caribou I. in Tustumena Lake, 17 mi. SE of Kenai, Cook Inlet Low.; $60^{\circ} 20^{\prime} 00^{\prime \prime}$ N, $151^{\circ} 01^{\prime} 30^{\prime \prime} \mathrm{W}$; (map 62).

Named about 1963 by officials of Kenai National Moose Range for administrative purposes.

Baylio Bazan, Puerto del: bay, see Bazan, Port. Baylio Bucareli, Puerto del: water passage, see Bucareli Bay.

Bayou Point: point of land, on Lindenberg Penin., Kupreanof I., at West Petersburg, Alex. Arch.; $56^{\circ} 48^{\prime} 40^{\prime \prime} \mathrm{N}, 132^{\circ} 59^{\prime} 30^{\prime \prime} \mathrm{W}$; (map 6).

Named by USC\&GS for charting purposes; name published in 1883 Coast Pilot (p. 115).

Bay Peak: peak, 5,780 ft., in Glacier Bay National Monument, $2 \mathrm{mi}$. $\mathrm{N}$ of head of Lituya Bay and $84 \mathrm{mi}$. NW of Hoonah, St. Elias Mts.; $58^{\circ} 42^{\prime} \mathrm{N}, 138^{\circ} 27^{\prime} \mathrm{W}$; (map 10).

Name published by members of the Harvard-Dartmouth Expedition, 1933-34 (Washburn and Goldthwait, 1936, map)

Bay Point: point of land, on $\mathrm{W}$ coast of Unga I., in Shumagin Is., Aleutian Ra.; $55^{\circ} 19^{\prime} 15^{\prime \prime}$ N, 160 $51^{\prime} 45^{\prime \prime} \mathrm{W}$; (map 28). Var. Cap Tonkoi, Mys Zaliva, Tonkoi Point, Zaliva Point.

Published in 1847 as "M[ys] Zaliva," or "bay point," on Russian Hydrog. Dept. Chart 1379; listed as "Cap Tonkoi," or "narrow," by Capt. Lutke (1836, p. 267), IRN. Shown as "Bay Point" on an 1888 USC\&GS chart.

Bay Point: point of land, at SE point of Heceta I., Alex. Arch.; $55^{\circ} 42^{\prime} 20^{\prime \prime} \mathrm{N}, 133^{\circ} 29^{\prime} 30^{\prime \prime} \mathrm{W}$; (map 4).

Local name recorded in 1951 by USGS.

Bay Point: port of land, $17 \mathrm{mi}$. $\mathrm{E}$ of village of Point Baker, on $\mathrm{N}$ coast of Prince of Wales I., Alex. Arch.; $56^{\circ} 19^{\prime} 40^{\prime \prime} \mathrm{N}, 133^{\circ} 10^{\prime} 30^{\prime \prime} \mathrm{W}$; (map 6).

Local navigators' name reported in 1904 by H. C. Fassett, USBF.

Bay Point: point of land, on $\mathrm{N}$ shore off Frederick Sound at $W$ point of Farragut Bay, 79 mi. E of Sitka, Coast Mts.; 57 $06^{\prime} 30^{\prime \prime} \mathrm{N}$, $133^{\circ} 19^{\prime} 00^{\prime \prime} \mathrm{W}$; (map 8 ).

Named in 1879 by W. H. Dall, USC\&GS ; published in the 1883 Coast Pilot (p. 126).

Bay Point Knoll: mountain, 2,018 ft., $2 \mathrm{mi}$. NE of Bay Point, on N shore of Frederick Sound, $80 \mathrm{mi}$. E of Sitka, Coast Mts.; $57^{\circ} 07^{\prime} 45^{\prime \prime} \mathrm{N}$, $133^{\circ} 17^{\prime} 30^{\prime \prime} \mathrm{W}$; (map 8).

Named in 1887 by Lt. Comdr. C. M Thomas, USN, for nearby Bay Point.

Bazan, Point: point of land, $\mathrm{S}$ point of entrance to Port Bazan, on SW coast of Dall I., Alex Arch.; 54 $48^{\prime} 20^{\prime \prime} \mathrm{N}, 132^{\circ} 58^{\prime} 30^{\prime \prime} \mathrm{W}$; (map 1). Var. Mys. Bazan.

This is a transliteration published in 1865 on Brit. Adm. Chart 2431 from the Russian "M[ys] Bazan," meaning "Cape Bazan." The name was published by Capt. Tebenkov (1852, map 9), IRN, who derived it from Port Bazan. 
Bazan, Port: bay, extends NE $3.5 \mathrm{mi}$. on SW coast of Dall I., Alex. Arch.; $54^{\circ} 49^{\prime} \mathrm{N}, 132^{\circ}$ $59^{\prime} \mathrm{W}$; (map 1). Var. Bazan Bay, Distress Cove, Port Meares, Puerto del Baylio Bazan. Named "Puerto del Baylio [Baile] Bazan," meaning "port of Judge [?] Bazan" by Lt. Don Jacinto Caamaño on July 18, 1792, for Antonio Valdez y Bazan, Spanish naval commander and Minister of Marine and Admiral (Wagner, 1937, p. 375); published as "Port Bazan" in 1853 on Russian Hydrog. Dept Chart 1493.

Bazan Bay: bay, see Bazan, Port.

Bazhi: locality, "on left bank of Yukon River, at mouth of Innoko River," Innoko Low.; (map 78). Var. Seleniye Bazhigagat.

Former Eskimo camp or settlement reported in 1861 as "Seleniye Bazhigagat," or "Bazhigagat Village," by P. Tikhmeniev.

Bazhigagat, Seleniye: locality, see Bazhi.

Bazil, Point: point of land, at $\mathrm{N}$ limit of Hanning Bay, on NW coast of Montague I., $63 \mathrm{mi}$. SE of Seward, Chugach Mts.; 59 $59^{\prime} \mathrm{N}$, $147^{\circ} 42^{\prime} \mathrm{W}$; ( $\left.\operatorname{map} 49\right)$.

Named by Capt. George Vancouver, RN, in 1794 when Hanning Bay was examined (Wagner, 1937 , p. 375 ).

Bazil, Port: bay, see Hanning Bay.

Beach Cove: cove, $0.5 \mathrm{mi}$. across, $0.7 \mathrm{mi}$. S of Conquer Point on W coast of Kiska I., Aleutian Is. ; $51^{\circ} 59^{\prime} 45^{\prime \prime} \mathrm{N}, 177^{\circ} 29^{\prime} 20^{\prime \prime} \mathrm{E}$; (map 14).

One of many arbitrary names applied to features on Kiska Island by USAF for tactical purposes during World War II.

Beachey Point: locality, see Beechey Point.

Beachey Point: point of land, see Beechey Point.

Beach Lake: lake, $0.5 \mathrm{mi}$. long, $\mathrm{W}$ of Birchwood, on SE bank of Knik Arm Cook Inlet, $17 \mathrm{mi}$. NE of Anchorage, Cook Inlet Low.; 61 ${ }^{\circ} 24^{\prime}$ $15^{\prime \prime} \mathrm{N}, 149^{\circ} 33^{\prime 2} 5^{\prime \prime} \mathrm{W}$; (map 69).

Local name reported in 1951 by USGS.

Beach River: stream, on E coast of Montague I., flows $S 1 \mathrm{mi}$. to Gulf of Alaska, $22 \mathrm{mi}$. SW of Montague Peak, Chugach Mts. ; 60000'02' N, 147 $23^{\prime} 02^{\prime \prime}$ W; (map 63).

Local name reported in 1951 by USGS.

Beachy Point: locality, see Beechey Point.

Beachy Point: point of land, see Beechey Point. Beacon Group: islands, see Eckholms, The.

Beacon Island: island, $0.1 \mathrm{mi}$. long, in Rocky Pass, Keku Strait, between Kupreanof and Kuiu Is., 16 mi. SE of Kake, Alex. Arch.; $56^{\circ} 46^{\prime} 45^{\prime \prime} \mathrm{N}, 133^{\circ} 43^{\prime} 00^{\prime \prime} \mathrm{W}$; (map 6).

Descriptive name given for charting purposes by USC\&GS in 1932 Coast Pilot (p. 258).

Beacon Point: point of land, on $\mathbf{E}$ coast of Lindenberg Penin., Kupreanof I., $8.5 \mathrm{mi}$. N of Petersburg, Alex. Arch.; 56 $56^{\prime} 15^{\prime \prime}$ N, $132^{\circ} 59^{\prime} 30^{\prime \prime} \mathrm{W}$; (map 6).

Descriptive name given for charting purposes by USC\&GS in 1925 Coast Pilot ( $p$. 211).

Beacon Point: point of land, on left bank of Kuskokwim River at Eek Channel, $52 \mathrm{mi}$. SW of Bethel, Yukon-Kuskokwim Delta; $60^{\circ} 05^{\prime}$ N, $162^{\circ} 14^{\prime}$ W; (map 58). Var. Weber Point.

This feature was called "Weber Point" on an 1898 fieldsheet by W. S. Post, USGS. Named Beacon Point in 1914 by USC\&GS

Beacon Rock: rock, at mouth of Mole Harbor, on $\mathrm{E}$ coast of Admiralty I., $62 \mathrm{mi}$. NE of Sitka Alex. Arch.; $57^{\circ} 40^{\prime} \mathrm{N}, 134^{\circ} 02^{\prime} \mathrm{W}$; (map 9).

Named in 1889 by Lt. Comdr. H. B. Mansfield, USN, and published by USC\&GS in the 1891 Coast Pilot (p. 171).

Beacon Rock: rock, see Makhnati Rock.

Beaded Creek: stream, heads in Dry Lake, flows N $4.5 \mathrm{mi}$. to Middle Salt Lagoon, $2 \mathrm{mi}$. NE of Barrow, Arctic Plain; $71^{\circ} 18^{\prime} 30^{\prime \prime} \mathrm{N}, 156^{\circ} 41^{\prime}$ 15" W; (map 153).

Descriptive name first used by CRREL in 1964 for scientific purposes. It is so named because along the stream are a series of ponds like beads on a string.

Beak Point: point of land, S point of entrance to Gold Harbor, on W coast of Dall I., Alex. Arch.; 54 $54^{\prime} 30^{\prime \prime} \mathrm{N}, 1^{\circ} 3^{\circ} 05^{\prime} 15^{\prime \prime} \mathrm{W}$; BGN 1928; (map 1).

Descriptive name given in 1927 by USC\&GS because "the shape of the point *** resembles a fowl's head with an open beak."

Bean Creek: stream, on Kenai Penin., flows SE $3 \mathrm{mi}$. to Kenai River, $32 \mathrm{mi}$. SSW of Hope, Chugach Mts. ; $60^{\circ} 20^{\prime} 39^{\prime \prime} \mathrm{N}, 149^{\circ} 50^{\prime} 00^{\prime \prime} \mathrm{W}$; (map 63)

Local name reported in 1951 by USGS.

Bean Creek: stream, flows NW to Candle Creek about $10 \mathrm{mi}$. SW of Candle and $33 \mathrm{mi}$. NE of Imuruk Lake, Seward Penin. High.; (map 110)

Prospectors' name reported in 1903 by $\mathrm{D}$. C. Witherspoon (in Moffit, 1905, pl. 2), USGS. This stream cannot be precisely located on current maps.

Bean Island: island, $1.5 \mathrm{mi}$. long, in mouth of Nichols Bay on $S$ coast of Prince of Wales $I$., Alex. Arch.; $54^{\circ} 41^{\prime} 30^{\prime \prime} \mathrm{N}, 132^{\circ} 06^{\prime} 00^{\prime \prime} \mathrm{W}$; (map 1).

Named in 1880 by W. H. Dall for Tarleton Hoffman Bean of the Fish Commission.

Bean Lake: lake, $0.5 \mathrm{mi}$. long, in Mentasta Mts., drains $\mathrm{E}$ to Tetlin River, $43 \mathrm{mi}$. S of Tok, Alaska Ra.; $62^{\circ} 43^{\prime} \mathrm{N}, 142^{\circ} 57^{\prime} \mathrm{W}$; (map 84).

Local name reported by USGS in 1960 .

Bean Ridge: ridge, 1,300 to $2,700 \mathrm{ft}$., extends NE-SW $30 \mathrm{mi}$. between Yukon and Tanana Rivers, $5 \mathrm{mi}$. NW of Manley Hot Springs, Tanana Low.; $65^{\circ} 00^{\prime} \mathrm{N}, 150^{\circ} 50^{\prime} \mathrm{W}$; (map 106).

Named in 1898 by W. J. Peters and A. H Brooks, USGS, for the first trader to establish a post on the Tanana. The post was at Harper Bend, where Mrs. Bean was murdered by the Indians. See Harper Bend.

Bear, Mount: peak, 14,831 ft., at head of Anderson Glacier, $9 \mathrm{mi}$. N of Mount Anderson and $60 \mathrm{mi}$. E of McCarthy, St. Elias Mts.; 61 ${ }^{\circ} 17^{\prime}$ N, $141^{\circ} 09^{\prime} \mathrm{W}$; BGN 1917; (map 67).

Named by Alaska-Canada boundary surveyors in 1912-13 and published on IBC Sheet 34 (1918 atlas).
Bear Bay: bay, on S coast of Alaska Penin., extends W $3 \mathrm{mi}, 28 \mathrm{mi}$. E of village of Cold Bay, Aleutian Ra.; 55 $10^{\prime} 30^{\prime \prime} \mathrm{N}, 162^{\circ} 00^{\prime} 00^{\prime \prime} \mathrm{W}$; (map 29, 28). Var. Medvednikova, Zaliv Medvydnikova.

Translation of " $Z$ [aliv] Medvydnikova," published by Capt. Tebenkov (1852, map 24), IRN. Descriptive name probably given because of the abundance of brown bears in the vicinity.

Bear Bay: bay, $0.2 \mathrm{mi}$. across, in Peril Strait, 3 mi. N of Fish Bay, on Baranof I., $28 \mathrm{mi}$. N of Sitka, Alex. Arch.; $57^{\circ} 25^{\prime} 15^{\prime \prime} \mathrm{N}, 135^{\circ} 34^{\prime} 45^{\prime \prime}$ W; (map 9).

Named in 1884 by Comdr. J. B. Coghlan, USN, and published by USC\&GS in the 1891 Coast Pilot (p. 182)

Bear Bay: cove, see Bear Cove

Bear Bay: estuary, see Bruin Bay.

Bear Bay Island: island, $0.5 \mathrm{mi}$. across, in Peril Strait, 3 mi. N of Fish Bay, on Baranof I., 28 mi. N of Sitka, Alex. Arch.; $57^{\circ} 25^{\prime} 30^{\prime \prime} \mathrm{N}$, $135^{\circ} 34^{\prime} 30^{\prime \prime} \mathrm{W}$; (map 9).

Named in 1884 by Comdr. J. B. Coghlan, USN.

Bear Blanket Slough: stream, flows NE $10 \mathrm{mi}$. to Eightmile Slough, $8 \mathrm{mi}$. NE of Fort Yukon, Yukon Flats; $66^{\circ} 36^{\prime} 20^{\prime \prime} \mathrm{N}, 144^{\circ} 59^{\prime} 00^{\prime \prime} \mathrm{W}$; (map 119)

Local descriptive name obtained in 1956 by USGS

Bear Bluff: bluff, on right bank of Yukon River, $44 \mathrm{mi}$. E of Nulato, Koyukuk Low.; 64 $44^{\circ}$ $\mathrm{N}, 156^{\circ} 37^{\prime} \mathrm{W}$; (map 97).

Local name reported in 1954 by USGS.

Bear Canyon: canyon, $1 \mathrm{mi}$. long, on Kenai Penin., 3 mi. NE of Homer, Cook Inlet Low.; $59^{\circ} 40^{\prime} 30^{\prime \prime} \mathrm{N}, 151^{\circ} 28^{\prime} 00^{\prime \prime} \mathrm{W}$; (map 50).

Local name reported by USGS in 1951.

Bear Cape: point of land, $\mathrm{N}$ point of entrance to Bear Bay, on S side of Alaska Penin., NE of Belkofski, Aleutian Ra.; $55^{\circ} 11^{\prime} \mathrm{N}, 162^{\circ} 00^{\prime}$ W; (map 28). Var. Middle Point, Mys Medvydnik.

Translation by USC\&GS in the 1880's of "Mys Medvydnik" reported by Capt. Tebenkov (1852, map 24), IRN. The name "Middle Point" was published for this feature in the 1880's by USC\&GS

Bear Cape: point of land, $\mathrm{N}$ point of entrance to Port Etches, on SW end of Hinchinbrook I., $35 \mathrm{mi}$. SW of Cordova, Chugach Mts.; $60^{\circ} 12^{\prime} \mathrm{N}, 146^{\circ} 43^{\prime} \mathrm{W}$; (map 64). Var. Mys Medvyzhiy.

Named "Mys Medvyzhiy," i.e. "Bear Cape," in 1830 by Ivan Chernov; published as such on Chart 1378 by Russian Hydrog. Dept. in 1847. It was translated by USG\&GS in 1869 . Bear Cape: point of land, see Arch Point.

Bear Cove: bay, see Ursus Cove.

Bear Cove: cove, $0.4 \mathrm{mi}$. across, on $\mathrm{E}$ shore of Silver Bay, $7 \mathrm{mi}$. SE of Sitka, on $W$ coast of Baranof I., Alex. Arch.; $57^{\circ} 00^{\prime} 50^{\prime \prime}$ N, $135^{\circ}$. $09^{\prime} 30^{\prime \prime}$ W; (map 9). Var. Bear Bay.

Name published by Knopf (1912, p. 26), USGS, as "Bear Bay."

Bear Cove: cove, on Kenai Penin., extend E 1.8 mi. off Kachemak Bay, $18 \mathrm{mi}$. NE of Homer, 
Chugach Mts.; $59^{\circ} 44^{\prime} \mathrm{N}, 151^{\circ} 03^{\prime} \mathrm{W}$; (map $50)$.

Local name recorded on a 1912 fieldsheet by D. F. Higgins and R. H. Sargent, USGS.

Bear Cove: cove, $0.8 \mathrm{mi}$. wide, on $\mathrm{W}$ coast of Aialik Penin., $1.5 \mathrm{mi}$. N of Three Hole Bay and $24 \mathrm{mi}$. SW of Seward, Chugach Mts.; $59^{\circ}$ $47^{\prime} \mathrm{N}, 149^{\circ} 39^{\prime} \mathrm{W}$; (map 49).

Local name reported in the early 1950 's by USC\&GS.

Bear Creek: locality, see Woodrow

Bear Creek: stream, flows W $1 \mathrm{mi}$. to Karluk Lake $20 \mathrm{mi}$. SE of Karluk, Kodiak I.; $57^{\circ} 23^{\prime}$ $35^{\prime \prime} \mathrm{N}, 154^{\circ} 02^{\prime} 00^{\prime \prime} \mathrm{W}$; (map 35).

Local name published in 1957 by AMS.

Bear Creek: stream, on Admiralty I., flows SE $8 \mathrm{mi}$. to Seymour Canal, $2 \mathrm{mi}$. N of Mole Harbor and $23 \mathrm{mi}$. NE of Angoon, Alex. Arch.; 57 $41^{\prime} 40^{\prime \prime} \mathrm{N}, 134^{\circ} 04^{\prime} 00^{\prime \prime} \mathrm{W}$; (map 9).

Local name reported in 1951 by USGS.

Bear Creek: stream, flows NW $4 \mathrm{mi}$. to Becharof Lake, on Alaska Penin., 53 mi. NE of Ugashik, Aleutian Ra.; $57^{\circ} 41^{\prime} 50^{\prime \prime} \mathrm{N}, 156^{\circ} 02^{\prime} 35^{\prime \prime} \mathrm{W}$; (map 36).

Named in 1901 by prospectors; reported in 1904 by G. C. Martin, USGS.

Bear Creek: stream, flows S $3 \mathrm{mi}$. to Buskin River, $4.5 \mathrm{mi}$. W of Kodiak, Kodiak I.; $57^{\circ}$ $46^{\prime} 35^{\prime \prime} \mathrm{N}, 152^{\circ} 31^{\prime} 15^{\prime \prime} \mathrm{W}$; (map 34).

Local name reported in 1949 by USGS.

Bear Creek: stream, on Douglas I., flows $1.5 \mathrm{mi}$. $\mathrm{NE}$ to Gastineau Channel at Douglas, $0.7 \mathrm{mi}$. SE of Juneau, Coast Mts. ; $58^{\circ} 16^{\prime} 45^{\prime \prime} \mathrm{N}, 134^{\circ}$ $23^{\prime} 35^{\prime \prime}$ W ; (map 11). Var. Mission Creek.

The first record of this name appears in 1882 in a water claim for mining use. In early years it was also sometimes called Mission Creek because of its proximity to a Quaker mission in Douglas (DeArmond, 1957).

Bear Creek: stream, on Mansfield Penin., flows E $4 \mathrm{mi}$. to Stephens Passage, $1.8 \mathrm{mi}$. NW of Colt I. and $13 \mathrm{mi}$. W of Juneau, Alex. Arch.; $58^{\circ} 16^{\prime} 55^{\prime \prime} \mathrm{N}, 134^{\circ} 46^{\prime} 30^{\prime \prime} \mathrm{W}$; (map 11).

Local name published in 1951 by USGS.

Bear Creek: stream, former tributary of Gold Creek, about $2 \mathrm{mi}$. W of Juneau, Coast Mts.; $58^{\circ} 18^{\prime} \mathrm{N}, 134^{\circ} 20^{\prime} \mathrm{W}$; (map 11$)$.

Miners' name for a stream subsequently destroyed by mining operations (DeArmond, 1957, p. 22).

Bear Creek: stream, flows SSE $26 \mathrm{mi}$. to Kvichak River, $57 \mathrm{mi}$. E of Dillingham, Bristol Bay Low.; $59^{\circ} 00^{\prime} 30^{\prime \prime} \mathrm{N}, 156^{\circ} 54^{\prime} 00^{\prime \prime} \mathrm{W}$; (map 52).

Local name published in 1951 by USGS.

Bear Creek: stream, "on the south bank of the Yukon, 20 miles above Rampart (City), and just below Alder Creek. Prospectors' name, reported by Lieutenant Erickson, U.S.A., 1902" (Baker, 1906, p. 122).

Bear Creek: stream, flows NE $3 \mathrm{mi}$. to Canyon Creek, $28 \mathrm{mi}$. NE of Goodnews, Kilbuck-Kuskokwim Mts.; $59^{\circ} 26^{\prime} \mathrm{N}, 161^{\circ} 07^{\prime} \mathrm{W}$; (map 53).

Prospectors' name reported in 1916 by USGS (Brooks and others, 1918, p. 61). Gold claims for placer mining were staked along this stream in 1917 , although gold may have been found here as early as 1900 or 1901 .

Bear Creek: stream, heads in lake $\mathrm{N}$ of Iliamna Lake, flows W 3 mi. to Newhalen River, 5 mi. NNW of Iliamna, Aleutian Ra.; $59^{\circ} 49^{\prime} \mathrm{N}$, $154^{\circ} 54^{\prime} \mathrm{W}$; (map 51 ).

Local name published in 1952 by USGS.

Bear Creek: stream, heads on SW slope of Watson Peak, flows SW $1.7 \mathrm{mi}$. to Cape Yakataga, $100 \mathrm{mi}$. NW of Yakutat, St. Elias Mts.; $60^{\circ} 03^{\prime} 04^{\prime \prime} \mathrm{N}, 142^{\circ} 26^{\prime} 00^{\prime \prime} \mathrm{W}$; (map 65).

Named by pioneers in 1897 ; the name was obtained by G. C. Martin, USGS, in 1904.

Bear Greek: stream, flows NE $5 \mathrm{mi}$. to Tuxedni Channel, $58 \mathrm{mi}$. SW of Kenai, Aleutian Ra.; $60^{\circ} 08^{\prime} \mathrm{N}, 152^{\circ} 41^{\prime} \mathrm{W}$; (map 62 ).

Local name reported about 1921 by Moffit (1927, pl. 1), USGS.

Bear Creek: stream, heads at Bear Lake, on Kenai Penin., flows S $0.5 \mathrm{mi}$. to Salmon Creek, $5.5 \mathrm{mi}$. NE of Seward, Chugach Mts. ; $60^{\circ} 11^{\prime}$ N, $149^{\circ} 22^{\prime} W$; ( $\left.\operatorname{map} 63\right)$.

Local name published by D. H. Sleem on his map of Central Alaska dated 1910; derived from Bear Lake, the source of the stream. Bear Creek: stream, heads in Kenai Mts., on Kenai Penin., flows W $15 \mathrm{mi}$. to Tustumena Lake, $29 \mathrm{mi}$. SE of Kenai, Chugach Mts. $60^{\circ} 13^{\prime} \mathrm{N}, 150^{\circ} 48^{\prime} \mathrm{W}$; (map 62).

Local name reported in 1904 by Moffit (1906, pl. 2), USGS.

Bear Creek: stream, flows SW $1 \mathrm{mi}$. to Trout Creek, $23 \mathrm{mi}$. NE of Katalla, Chugach Mts.; $60^{\circ} 25^{\prime} \mathrm{N}, 144^{\circ} 04^{\prime} \mathrm{W}$; (map 64).

Prospectors' name reported in 1905 by G. C. Martin, USGS.

Bear Creek: stream, on Hinchinbrook I., flows $\mathrm{NE} 1.7 \mathrm{mi}$. to Double Bay, $25 \mathrm{mi}$. SW of Cordova, Chugach Mts.; $60^{\circ} 27^{\prime} \mathrm{N}, 146^{\circ} 29^{\prime}$ W; (map 64).

\section{Published in 1950 by USGS.}

Bear Creek: stream, on Kenai Penin., flows NW $6.5 \mathrm{mi}$. to Turnagain Arm, at Hope, Chugach Mts. ; $60^{\circ} 55^{\prime} 30^{\prime \prime} \mathrm{N}, 149^{\circ} 38^{\prime} 10^{\prime \prime} \mathrm{W}$; (map 63).

Local prospectors' name published in 1895 by USGS.

Bear Creek: stream, flows SW $20 \mathrm{mi}$. to Tuluksak River, $0.7 \mathrm{mi}$. NE of Nyac and $40 \mathrm{mi}$. SW of Aniak, Kilbuck-Kuskokwim Mts.; $61^{\circ} 00^{\prime} 45^{\prime \prime} \mathrm{N}, 159^{\circ} 55^{\prime} 20^{\prime \prime} \mathrm{W}$; (map 73).

Prospectors' name reported in 1914 by A. G. Maddren, USGS. William Fisher and party discovered gold on this stream in 190708.

Bear Creek: stream, heads at terminus of Keystone Glacier, flows SE $1.5 \mathrm{mi}$. to Lowe River, $1.6 \mathrm{mi}$. SW of Wortmanns and $13 \mathrm{mi}$. $\mathrm{E}$ of Valdez, Chugach Mts. ; $61^{\circ} 05^{\prime} 50^{\prime \prime} \mathrm{N}, 1^{\circ} 5^{\circ} 51^{\prime}$ $30^{\prime \prime} \mathrm{W}$; (map 68)

Local name recorded in 1953 by USGS.

Bear Creek: stream, heads in Fourth of July Pass, flows SW $2.3 \mathrm{mi}$. to Fohlin Creek, 12 mi. NW of McCarthy, Wrangell Mts. ; 61 ${ }^{\circ} 29^{\prime}$ $\mathrm{N}, 143^{\circ} 15^{\prime} \mathrm{W}$; (map 67$)$.

Local name reported in 1907 by F. H. Moffit (in Brooks and others, 1908, pl. 3), USGS.
Bear Creek: stream, flows N $4.5 \mathrm{mi}$. to Quartz Creek, $4 \mathrm{mi}$. E of Tonsina Lake and $39 \mathrm{mi}$. NE of Valdez, Chugach Mts.; $61^{\circ} 29^{\prime} 45^{\prime \prime} \mathrm{N}$, $145^{\circ} 24^{\prime} 15^{\prime \prime} \mathrm{W}$; (map 68).

Prospectors' name reported in 1899 by Oscar Rohn.

Bear Creek: stream, flows SE $4 \mathrm{mi}$. to Sue Creek $3.4 \mathrm{mi}$. NW of its junc. with Kuskokwim River, 33 mi. E of Aniak, Kilbuck-Kuskokwim Mts.; $61^{\circ} 37^{\prime} 20^{\prime \prime} \mathrm{N}, 158^{\circ} 31^{\prime} 00^{\prime \prime} \mathrm{W}$; (map 72). Local name obtained in 1952 by USGS.

Bear Creek: stream, heads on Beluga Mtn., flows $\mathrm{NE} 14 \mathrm{mi}$. to Alexander Lake, $46 \mathrm{mi}$. NE of Tyonek, Cook Inlet Low.; $61^{\circ} 43^{\prime} 45^{\prime \prime} \mathrm{N}, 150^{\circ}$. 53'00" W; (map 70).

Local name reported in 1954 by USGS.

Bear Creek: stream, heads $\mathrm{N}$ of Little Peter Hills, flows SW $18 \mathrm{mi}$. to Kahiltna River, 26 mi SW of Talkeetna, Alaska Ra.; $62^{\circ} 12^{\prime} 00^{\prime \prime}$ $\mathrm{N}, 150^{\circ} 53^{\prime} 15^{\prime \prime} \mathrm{W}$; (map 81).

Local name obtained in 1911 by S. R. Capps (in Brooks, 1912, pl. 9), USGS.

Bear Creek: stream, flows SE $2.4 \mathrm{mi}$. to Gulkana River, $11 \mathrm{mi}$. N of Glennallen, Copper River Basin; 62 $2^{\circ} 15^{\prime} \mathrm{N}, 145^{\circ} 24^{\prime} \mathrm{W}$; (map 83).

Local name reported in 1950 by USGS.

Bear Creek: stream, flows NW $6.5 \mathrm{mi}$. to South Fork Kuskokwim River, 2 mi. $S$ of junc. of Tatina River and $87 \mathrm{mi}$. SE of McGrath, Alaska Ra.; $62^{\circ} 16^{\prime} \mathrm{N}, 153^{\circ} 22^{\prime} \mathrm{W}$; (map 80). Local name reported in 1931 by USGS.

Bear Creek: stream, heads in Dutch Hills, flows NE $7 \mathrm{mi}$. to Tokositna River, $32 \mathrm{mi}$. NW of Talkeetna, Alaska Ra.; $62^{\circ} 39^{\prime} 45^{\prime \prime} \mathrm{N}, 150^{\circ} 49^{\prime}$ 05" W; (map 81).

Prospectors' name reported in 1906 by R. W. Porter, USGS.

Bear Creek: stream, flows NW $40 \mathrm{mi}$. to Pitka Fork Kuskokwim River, $3 \mathrm{mi}$. S of junc. of Salmon River and $35 \mathrm{mi}$. SE of McGrath, Kuskokwim Low.; $62^{\circ} 51^{\prime} \mathrm{N}, 1^{\circ} 54^{\circ} 33^{\prime} \mathrm{W}$; (map 80).

Local name reported in 1912 by USGS.

Bear Creek: stream, flows $\mathrm{N} 15 \mathrm{mi}$. to Tetlin Lake, in Mentasta Mts., $20 \mathrm{mi}$. S of Tok, Alaska Ra.; $63^{\circ} 03^{\prime} \mathrm{N}, 142^{\circ} 44^{\prime} \mathrm{W}$; (map 85).

Named in 1902 by F. G. Schrader, USGS, because he saw four large bears at the stream's head.

Bear Creek: stream, heads at glacier terminus, flows NW $6.6 \mathrm{mi}$. to a ditch between Delta River and Richardson Highway, $30 \mathrm{mi}$. $\mathrm{S}$ of Delta Junction, Alaska Ra.; $63^{\circ} 36^{\prime} 30^{\prime \prime} \mathrm{N}$, $145^{\circ} 53^{\prime} 20^{\prime \prime} \mathrm{W}$; (map 86).

Locally named "from the fact that a hunter named Henry Stock was mauled by a bear there about 1905" (Davies, 1965, p. 22).

Bear Creek: stream, flows NW $6 \mathrm{mi}$. to a ditch parallel to Delta River, $5 \mathrm{mi}$. S of Donnelly and $42 \mathrm{mi}$. $\mathrm{N}$ of Paxson, Alaska Ra.; $63^{\circ} 36^{\prime} 45^{\prime \prime} \mathrm{N}, 145^{\circ} 53^{\prime} 20^{\prime \prime} \mathrm{W}$; (map 86).

Local name reported in 1949 by USGS

Bear Creek: stream, flows NE $4.5 \mathrm{mi}$. to Graham Creek, $33 \mathrm{mi}$. NE of Ophir and $45 \mathrm{mi} \mathrm{NW}$ of McGrath, Kilbuck-Kuskokwim Mts.; 63⒊' $30^{\prime \prime} \mathrm{N}, 156^{\circ} 09^{\prime} 00^{\prime \prime} \mathrm{W}$; (map 90)

Prospectors' name reported in 1933 by USGS. 
Bear Creek: stream, flows SE $30 \mathrm{mi}$. to Yukon River, $1 \mathrm{mi}$. N of Eagle I. and $45 \mathrm{mi}$. SE of Unalakleet, Nulato Hills; $63^{\circ} 38^{\prime} 30^{\prime \prime} \mathrm{N}, 159^{\circ}$ 24'05" W; (map 91). Var. Auto River, Autokakat, Autokokakat, Kozikakat River.

Local name reported in 1949 by USC\&GS. Published as "Autokakat" and "Autokokakat" by Lt. Allen, USA, in 1887; listed as "Auto River" by Baker (1906, p. 110).

Bear Creek: stream, flows NE $21 \mathrm{mi}$. to Tanana River, $27 \mathrm{mi}$. NW of Tanacross, YukonTanana High.; $63^{\circ} 39^{\prime} 35^{\prime \prime} \mathrm{N}, 143^{\circ} 57^{\prime} 00^{\prime \prime} \mathrm{W}$; BGN 1961; (map 85). Var. Chief Creek.

Local name reported in 1955 by USGS.

Bear Creek: stream, heads on Brooker Mtn., at $\mathrm{S}$ end of Kantishna Hills, flows $\mathrm{N} 40 \mathrm{mi}$. to Bearpaw River, $21 \mathrm{mi}$. WNW of junc. of Toklat River and its East Fork, Tanana Low.; $63^{\circ} 58^{\prime} 50^{\prime \prime} \mathrm{N}, 150^{\circ} 49^{\prime} 40^{\prime \prime} \mathrm{W}$; (map 88).

Name shown on a 1905 manuscript map of the "Kantishna Gold Fields" by A. Friedrich, prospector.

Bear Creek: stream, heads on SE side of Anvil Peak, flows SE $3 \mathrm{mi}$. to Dry Creek, $3 \mathrm{mi}$. NE of Nome, Seward Penin. High.; 64 $31^{\circ} 40^{\prime \prime} \mathrm{N}$, $165^{\circ} 20^{\prime} 00^{\prime \prime} \mathrm{W}$; (map 94).

Prospectors' name reported in 1904 by T. G. Gerdine, USGS.

Bear Creek: stream, flows SW $13 \mathrm{mi}$. to Champion Creek, $30 \mathrm{mi}$. SW of Eagle, YukonTanana High.; $64^{\circ} 33^{\prime} 30^{\prime \prime} \mathrm{N}, 142^{\circ} 02^{\prime} 00^{\prime \prime} \mathrm{W}$; (map 102)

Prospectors' name obtained in 1898 by E. C. Barnard, USGS.

Bear Creek: stream, flows S $0.4 \mathrm{mi}$ to Minnesota Creek which flows to Penny Creek, $9 \mathrm{mi}$. N of Solomon, Seward Penin. High.; 64 ${ }^{\circ} 40^{\prime} 42^{\prime \prime}$ $\mathrm{N}, 164^{\circ} 20^{\prime} 50^{\prime \prime} \mathrm{W}$; (map 95).

Prospectors' name reported in 1907 by USGS geologists (Smith, P. S., 1910, pl. 3).

Bear Creek: stream, flows WNW $4 \mathrm{mi}$. to North Fork Salcha River, $42 \mathrm{mi}$. NNE of Big Delta, Yukon-Tanana High.; $64^{\circ} 42^{\prime} \mathrm{N}, 145^{\circ} 18^{\prime} \mathrm{W}$; (map 101).

Local name reported in 1958 by USGS.

Bear Creek : stream, flows NE to Kwiniuk River, 12 mi. N of Elim, Seward Penin. High.; $64^{\circ}$. $47^{\prime} \mathrm{N}, 162^{\circ} 10^{\prime} \mathrm{W}$; (map 95)

Prospectors' name shown on a precinct map of Seward Peninsula by Monroe and Hutchins, corrected up to June 1903 by Arthur Gibson. This feature cannot be precisely identified on current maps.

Bear Creek: stream, flows NW $50 \mathrm{mi}$. to Yukon River, $30 \mathrm{mi}$. NE of Nulato, Koyukuk Low. $64^{\circ} 49^{\prime} \mathrm{N}, 157^{\circ} 06^{\prime} \mathrm{W}$; (map 97)

Riverboat pilots' name shown on a 1940 "Navigation Chart of the Tanana-Yukon Rivers" published by U.S. Dept. of Interior.

Bear Creek: stream, flows S $1 \mathrm{mi}$. to Little Washington Creek, $22 \mathrm{mi}$. NW of Eagle, Yukon-

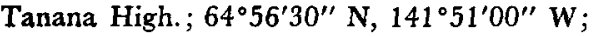
(map 102).

Prospectors' name shown on a 1902 manuscript map by E. J. Chamberlain, U.S. Deputy Surveyor.

Bear Creek: stream, flows E $8 \mathrm{mi}$. to Fish Creek, $21 \mathrm{mi}$. NE of Fairbanks, Yukon-Tanana High.; $65^{\circ} 02^{\prime} 30^{\prime \prime} \mathrm{N}, 147^{\circ} 08^{\prime} 45^{\prime \prime} \mathrm{W}$; (map 105).

Local name reported in 1903 by T. G Gerdine (in Prindle, 1905, pl. 13), USGS.

Bear Creek: stream, flows NE $4 \mathrm{mi}$. to Charley River, $17 \mathrm{mi}$. SW of that stream's junc. with Yukon River, Yukon-Tanana High.; $65^{\circ} 07^{\circ}$ N, 1430.' W; (map 103).

Prospectors' name from an unpublished map by E. J. Chamberlain, dated 1902.

Bear Creek: stream, in Rampart Mts., flows SW $16 \mathrm{mi}$. to Yukon River, $4 \mathrm{mi}$. NE of junc. of Tozitna River, $5 \mathrm{mi}$. W of Tanana, KokrinesHodzana High.; $65^{\circ} 10^{\prime} \mathrm{N}, 152^{\circ} 17^{\prime} \mathrm{W}$; (map 106). Var. Deer Creek.

Local name reported in 1899 by Lt. J. S. Herron, USA.

Bear Creek: stream, heads at confluence of California and Cash Creeks, flows NW $8 \mathrm{mi}$. to Clums Fork Birch Creek, Yukon-Tanana High.; $65^{\circ} 12^{\prime} \mathrm{N}, 145^{\circ} 23^{\prime} \mathrm{W}$; (map 104).

Named by prospectors and reported in 1911 by USGS (Prindle, 1913, pl. 1).

Bear Creek: stream, flows NW $2.3 \mathrm{mi}$. to Hutlinana Creek, $18 \mathrm{mi}$. SE of Rampart, YukonTanana High.; $65^{\circ} 18^{\prime} \mathrm{N}, 149^{\circ} 50^{\prime} \mathrm{W}$; (map 105).

Local name published by USGS (Prindle and others, 1913, pl. 1).

Bear Creek: stream, flows SE $2 \mathrm{mi}$. to Sourdough Creek, $9 \mathrm{mi}$. S of Mount Prindle and $76 \mathrm{mi}$. SW of Circle, Yukon-Tanana High.; $65^{\circ} 19^{\prime}$ $45^{\prime \prime} \mathrm{N}, 146^{\circ} 28^{\prime} 50^{\prime \prime} \mathrm{W}$; (map 104).

Prospectors' name reported in 1954 or 1955 by USGS topographers.

Bear Creek: stream, flows N $3 \mathrm{mi}$. to Yukon River, $7 \mathrm{mi}$. NW of junc. of Charley River Yukon-Tanana High.; $65^{\circ} 20^{\prime} 35^{\prime \prime} \mathrm{N}, 143^{\circ} 00^{\prime}$ 50 " W; (map 103)

Local name published in 1956 by USGS.

Bear Creek: stream, in Rampart Mts., flows ESE $17 \mathrm{mi}$. to Yukon River, $34 \mathrm{mi}$. ENE of Tanana, Kokrines-Hodzana High. ; $65^{\circ} 21^{\prime} 30^{\prime \prime} \mathrm{N}, 151^{\circ}$ $00^{\prime} 00^{\prime \prime} \mathrm{W}$; (map 106).

Name reported in 1894 by Cantwell (1902, p. 277), USRCS

Bear Creek: stream, flows S 6 mi. to Birch Creek, $52 \mathrm{mi}$. SW of Circle, Yukon-Tanana High.; $65^{\circ} 24^{\prime} 30^{\prime \prime} \mathrm{N}, 145^{\circ} 37^{\prime} 40^{\prime \prime} \mathrm{W}$; (map 104).

Named by prospectors; reported in 1909 by C. E. Ellsworth (in Brooks and others, 1910, p. 264), USGS.

Bear Creek: stream, flows SW $21 \mathrm{mi}$., joins Champion Creek to form Beaver Creek, $52 \mathrm{mi}$. NE of Fairbanks, Yukon-Tanana High.; $65^{\circ}$. $25^{\prime} \mathrm{N}, 146^{\circ} 59^{\prime} \mathrm{W}$; (map 104).

Named by prospectors; reported in 1909 by L. M. Prindle (in Brooks and others, 1910, pl. 6), USGS.

Bear Creek: stream, flows SE $16 \mathrm{mi}$. to West Fork Buckland River, $24 \mathrm{mi}$. NE of Haycock, Seward Penin. High.; $65^{\circ} 32^{\prime} \mathrm{N}, 160^{\circ} 50^{\prime} \mathrm{W}$; (map 109).

Local name shown on a 1903 fieldsheet by D. C. Witherspoon, USGS.

Bear Creek: stream, flows NE $7 \mathrm{mi}$., joins Westover Greek to form Rock Creek, $12 \mathrm{mi}$. NNE of Porcupine Dome and $36 \mathrm{mi}$. WSW of Circle, Yukon-Tanana High.; $65^{\circ} 40^{\prime} 15^{\prime \prime} \mathrm{N}, 145^{\circ}$. $17^{\prime} 00^{\prime \prime} \mathrm{W}$; (map 104).

Prospectors' name reported in 1954 or 1955 by USGS topographers.

Bear Creek: stream, flows SW $26 \mathrm{mi}$. to North Fork Hess Creek, $15 \mathrm{mi}$. $\mathrm{N}$ of Livengood, Yukon-Tanana High.; $65^{\circ} 43^{\prime} 10^{\prime \prime} \mathrm{N}, 148^{\circ} 19^{\prime} 50^{\prime \prime}$ W; (map 105). Var. East Fork Hess Creek.

Local name reported in 1902 by Lt. Hjalmar Erickson, USA, and published by USGS (Prindle, 1905, pl. 16). In 1902 it is shown joining Grouse Creek to form East Fork Hess Creek. However, in 1916, it is shown on a USGS map flowing to North Fork Hess Creek. Bear Creek: stream, heads on Caribou Mtn., in Zane Hills, fows SE $10 \mathrm{mi}$. to Caribou Creek $3 \mathrm{mi}$. WSW of that stream's junc. with Hogatza River, $37 \mathrm{mi}$. WNW of Hughes, Hogatza High.; $66^{\circ} 10^{\prime} \mathrm{N}, 155^{\circ} 33^{\prime} \mathrm{W}$; (map 116).

Named about 1955 by mining engineers; reported in 1956 by Orth.

Bear Creek: stream, flows W $3 \mathrm{mi}$. to Beaver Creek, $13 \mathrm{mi}$. SW of Beaver, Yukon Flats; $66^{\circ} 12^{\prime} 40^{\prime \prime} \mathrm{N}, 147^{\circ} 40^{\prime} 40^{\prime \prime} \mathrm{W}$; (map 118). Local name obtained in 1956 by USGS.

Bear Creek: stream, flows NW $2.5 \mathrm{mi}$. to South Fork Koyukuk River, NE of Davis Creek, 35 mi. NE of Bettles, Kokrines-Hodzana High.; $67^{\circ} 00^{\prime} 30^{\prime \prime} \mathrm{N}, 150^{\circ} 26^{\prime} 00^{\prime \prime} \mathrm{W}$; (map 124). Var. Cripple Creek.

Local name originally applied to a nearby stream; reported in 1899 by T. G. Gerdin: (in Schrader, 1900, pl. 60), USGS.

Bear Creek: stream, heads in Kallarichuk Hills of Baird Mts., flows SW $6.5 \mathrm{mi}$. to Klery Creek, $4.6 \mathrm{mi}$. NE of that stream's junc. with Squirrel River and $10 \mathrm{mi}$. N of Kiana, Brooks Ra.; $67^{\circ} 08^{\prime} \mathrm{N}, 160^{\circ} 27^{\prime} \mathrm{W}$; (map 127).

Prospectors' name reported in 1910 by $P$. S. Smith (in Brooks and others, 1911, pl. 13), USGS.

Bear Creek: stream, flows SE to Anikovik River, about $15 \mathrm{mi}$. SE of Cape Prince of Wales, Seward Penin. High.; (map 111).

Prospectors' name shown on the 1900 "Map of Nome Peninsula" by J. M. Davidson and B. D. Blakeslee. This feature cannot be precisely identified on current maps.

Bear Creek: stream, flows SW to Nucksack Creek which flows to Kuzitrin River near its head, about $20 \mathrm{mi}$. SW of Imuruk Lake, Seward Penin. High.; (map 110).

Prospectors' name shown on a map of Cape Nome gold fields by David Fox, Jr., dated 1901. This stream cannot be precisely located on current maps.

Bear Creek: stream, "tributary to Chilkat river from the west, near latitude $59^{\circ} 30^{\prime}$, longitude $136^{\circ} 10^{\prime}$. Local name, obtained by Wright in 1903. Its Indian name, written Jelchitni by Krause brothers in 1882, was written Yelchthini by Flemer in 1898" (Baker, 1906, p. 121).

Bear Creek: stream, see Davidson Creek.

Bear Creek: stream, see Eagle Creek.

Bear Creek: stream, see Kelsall River.

Bear Creek: stream, see Otter Creek.

Bear Creek: stream, see Roy Creek. 
Bear Creek : stream, see Tetlin River.

Bear Draw: ravine, in Mount McKinley National Park, extends ENE $0.9 \mathrm{mi}$. to Sheldon Creek, $1 \mathrm{mi}$. WSW of that stream's junc. with

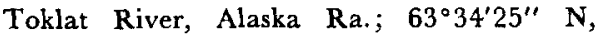
$150^{\circ} 04^{\prime} 20^{\prime \prime} \mathrm{W}$; (map 88).

Local name reported in 1954 by USGS.

Beardslee Entrance: water passage, in Glacier Bay National Monument, $1.5 \mathrm{mi}$. across, near $S$ entrance to Glacier Bay, between Young and Strawberry Is., $58 \mathrm{mi}$. NW of Juneau, St. Elias Mts. ; $58^{\circ} 30^{\prime} \mathrm{N}, 136^{\circ} 00^{\prime} \mathrm{W}$; BGN 1942; (map 11). Var. Strawberry Passage.

Name proposed by USC\&GS in 1938 for Rear Adm. Lester Anthony Beardslee, 18361903, USN, who explored and named Glacier Bay in 1880 . The name Strawberry Passage was used by USC\&GS prior to BGN approval of the name Beardslee Entrance.

Beardslee Island: island, see Kayak Island.

Beardslee Islands: islands, $0.2 \mathrm{mi}$. across, $1 \mathrm{mi}$. S of Sitka, in Galankin Is., Sitka Sound, Alex. Arch.; 57 $02^{\prime} 05^{\prime \prime}$ N, $135^{\circ} 20^{\prime} 30^{\prime \prime}$ W; (map 9). Var. Sand Islands.

Named in 1880 by the U.S. Navy for Capt. (later Rear Adm.) Lester Anthony Beardslee, 1836-1903, USN. Beardslee commanded the U.S.S. Jamestown, 1879-90 in Alaska waters; he discovered, surveyed, and named Glacier Bay.

Beardslee Islands: islands, group $9.5 \mathrm{mi}$. long, in Glacier Bay National Monument, off E shore of Glacier Bay, $5 \mathrm{mi}$. $\mathrm{N}$ of Point Gustavus and $55 \mathrm{mi}$. NW of Juneau, St. Elias Mts.; $58^{\circ} 32^{\prime}$ $\mathrm{N}, 135^{\circ} 55^{\prime} \mathrm{W}$; (map 11). Var. Beardsley Islands, Sand Islands.

Named by officers of the U.S. Navy in 1880 for Capt. Lester Anthony Beardslee, 18361903, USN.

Beardslee River: stream, "on the mainland, tributary to William Henry bay, Lynn canal, Alexander archipelago. So named by United States naval officers, 1880, after Rear-Admiral Beardslee" (Baker, 1906, p. 123).

Beardsley Islands: islands, see Beardslee Islands.

Beare Glacier: glacier, heads on $\mathrm{S}$ slope of Robinson Mts., trends SE $4 \mathrm{mi}$. to its 1951 terminus at head of Big River, $75 \mathrm{mi}$. WNW of Yakutat, St. Elias Mts.; $60^{\circ} 00^{\prime} 10^{\prime \prime} \mathrm{N}$, $141^{\circ} 40^{\prime} 55^{\prime \prime}$ W; (map 65).

Reported by A. G. Maddren, USGS, in 1913 and published by G. C. Martin (1921, pl. 6), USGS.

Bear Fort: locality, see Kootznahoo.

Bear Glacier Point: point of land, at $\mathrm{E}$ end of Bulldog Cove, on E coast of Aialik Penin., $16 \mathrm{mi}$. SW of Seward, Chugach Mts.; $59^{\circ} 53^{\prime}$ $40^{\prime \prime} \mathrm{N}, 149^{\circ} 33^{\prime} 15^{\prime \prime} \mathrm{W}$; (map 49).

Local name reported in the 1940's by USC\&GS.

Bear Glacier: glacier, trends SE $21 \mathrm{mi}$. to its terminus in Resurrection Bay, $15 \mathrm{mi}$. $\mathrm{S}$ of Seward, Chugach Mts.; $59^{\circ} 55^{\prime} 30^{\prime \prime} \mathrm{N}, 149^{\circ} 31^{\prime}$ 30" W; BGN 1910; (map 49).

Local name reported in 1909 by U. S. Grant and D. F. Higgins, USGS.
Bear Gulch: ravine, trends S 5 mi. to Sundown Lake, 22 mi. W of Beaver, Yukon Flats; $66^{\circ} 21^{\prime \prime}$ $\mathrm{N}, 148^{\circ} 11^{\prime} \mathrm{W}$; (map 118$)$.

Local name obtained in 1956 by USGS.

Bear Gulch: ravine, trends SW $3 \mathrm{mi}$. to Long Creek at Long, $23 \mathrm{mi}$. S of Ruby, KilbuckKuskokwim Mts.; $64^{\circ} 24^{\prime} 12^{\prime \prime} \mathrm{N}, 155^{\circ} 30^{\prime} 00^{\prime \prime}$ W; (map 98). Var. Bear Pup.

Prospectors" name reported in 1911 as "Bear Pup" by A. G. Maddren, USGS.

Bear Gulch : gulch, "at the headwaters of Chititu creek.

"Prospectors' name; first appears on map of Nizina mining district by George M. Esterly, of Valdez, 1902" (Baker, 1906, p. 122).

Bear Harbor: estuary, $0.5 \mathrm{mi}$. across, $15 \mathrm{mi}$. NE of Cape Decision, Affleck Canal, on $S$ coast of Kuiu 1., Alex. Arch.; $56^{\circ} 06^{\prime} 00^{\prime \prime}$ N, $134^{\circ}$. $13^{\prime} 14^{\prime \prime} \mathrm{W}$; (map 5)

Named in 1886 by Lt. J. M. Helm, USN, for charting purposes and published in 1887 by USC\&GS on Chart 706.

Bear Head: promontory, see Ursus Head.

Bear Hill: hill, $428 \mathrm{ft}$, $0.5 \mathrm{mi}$. E of Little Kiska Beach, on west-central Little Kiska I., Aleutian Is.; $51^{\circ} 57^{\prime} 30^{\prime \prime} \mathrm{N}, 177^{\circ} 37^{\prime} 50^{\prime \prime} \mathbf{E}$; (map 14). Var. Ridge Hill.

This is an arbitrary name shown on a 1943 USAAF map. Variant derived from triangulation station Ridge on hill.

Bearhole Creek: stream, flows NE $8 \mathrm{mi}$. to Kiagna River, $33 \mathrm{mi}$. SE of McCarthy, St. Elias Mts. ; $61^{\circ} 02^{\prime} \mathrm{N}, 142^{\circ} 23^{\prime} \mathrm{W}$; (map 67).

Named in 1915 by F. H. Moffit, USGS.

Bearing point: point of land, see Azimuth Point.

Bear Island: island, $0.4 \mathrm{mi}$. across, on NW coast of Kodiak I., $17 \mathrm{mi}$. NE of Karluk; 57 $39^{\prime} 40^{\prime \prime}$ $\mathrm{N}, 154^{\circ} 02^{\prime} 00^{\prime \prime} \mathrm{W}$; (map 35).

Named in 1897 by Lt. Comdr. J. F. Moser, USN, commander of the USBF steamer Albatross.

Bear Island: island, $0.8 \mathrm{mi}$. across, on $\mathrm{N}$ coast of Afognak I. in Bluefox Bay, Kodiak I.; $58^{\circ}$ $26^{\prime} 40^{\prime \prime} \mathrm{N}, 152^{\circ} 41^{\prime} 30^{\prime \prime} \mathrm{W}$; (map 43).

Local name published in 1928 on USC\&GS Chart 8573.

Bear Island: hill, $215 \mathrm{ft} ., 0.6 \mathrm{mi}$. across, in Dry Bay, $53 \mathrm{mi}$. SE of Yakutat, St. Elias Mts.; $59^{\circ}$ $09^{\prime} 00^{\prime \prime} \mathrm{N}, 138^{\circ} 26^{\prime} 30^{\prime \prime} \mathrm{W}$; (map 46). Var. Delta Island.

Local name published by USGS in 1959. This hill was called Delta Island on a USGS manuscript map dated 1907.

Bear Island: island, $0.5 \mathrm{mi}$. long, on Kenai Penin., on E shore of Kachemak Bay, $18 \mathrm{mi}$. $\mathrm{NE}$ of Homer, Chugach Mts.; $59^{\circ} 43^{\prime} 45^{\prime \prime} \mathrm{N}$, $151^{\circ} 04^{\prime} 00^{\prime \prime} \mathrm{W}$; (map 50).

Named for Bear Cove and published by USGS in 1951.,

Bear Island: island, in Chitina River, $10 \mathrm{mi} . \mathrm{W}$. of Gibraltar Hill, $28 \mathrm{mi}$. SE of McCarthy, St. Elias Mts.; $61^{\circ} 06^{\prime} \mathrm{N}, 142^{\circ} 26^{\prime} \mathrm{W}$; (map 67).

So named in 1915 by F. H. Moffit, USGS, "because a bear was seen on its shore."

Bear Island: island, see Woewodski.

Bear Lake: lake, $0.7 \mathrm{mi}$. long, on $\mathrm{SW}$ end of Cleveland Penin., $5 \mathrm{mi}$. SE of Union Bay,
Alex. Arch.; 55 $41^{\prime} 00^{\prime \prime} \mathrm{N}, 132^{\circ} 06^{\prime} 15^{\prime \prime} \mathrm{W}$; (map 4).

Local name recorded in 1951 by USGS.

Bear Lake: lake, $7.5 \mathrm{mi}$. long, on Alaska Penin., in course of Bear River, $13 \mathrm{mi}$. ENE of Port Moller, Bristol Bay Low.; 56 $03^{\prime} \mathrm{N}, 160^{\circ} 17^{\prime}$ W; (map 30).

Reported by Maddren (1919, fig. 12), USGS.

Bear Lake: lake, $0.1 \mathrm{mi}$. across, just $\mathrm{W}$ of Saint George, on $\mathrm{N}$ coast of Saint George $\mathrm{I}$., in Pribilof Is.; $56^{\circ} 36^{\prime} 00^{\prime \prime}$ N, $169^{\circ} 34^{\prime} 30^{\prime \prime}$ W; (map 38). Var. Tenra'rum-any'i.

A translation of the Aleut name, "Tenra'rum'any'i," reported in 1897 by Putnam (1903. p. 1016), USC\&GS, and so named because "a polar bear was once driven here by the natives, and became mired in the bog which surrounds the lake."

Bear Lake: lake, $0.4 \mathrm{mi}$. across, $7.5 \mathrm{mi}$. SE of Sitka, on W coast of Baranof I., Alex. Arch.; $57^{\circ} 02^{\prime} \mathrm{N}, 135^{\circ} 08^{\prime} \mathrm{W}$; (map 9).

Name recorded by Knopf (1912, fig. 4), USGS.

Bear Lake: lake, $0.6 \mathrm{mi}$. long, $1 \mathrm{mi}$. NW of Bear Glacier Point, on Aialik Penin., $16 \mathrm{mi}$. SW of Seward, Chugach Mts. ; $59^{\circ} 54^{\prime} \mathrm{N}, 149^{\circ} 35^{\prime} \mathrm{W}$; (map 49).

Local name reported in the 1940's by USC\&GS.

Bear Lake: lake, on Kenai Penin., 2 mi. long, $6 \mathrm{mi}$. NE of Seward, Chugach Mts. ; $60^{\circ} 17^{\prime} \mathrm{N}$, $149^{\circ} 21^{\prime}$ W ; BGN 1912; (map 63). Var. Salmon Lake.

Local name published by D. H. Sleem on his map of Central Alaska dated 1910.

Bear Lake: lake, $1.2 \mathrm{mi}$. long, $4.5 \mathrm{mi}$. WNW of Harriet Point and $39 \mathrm{mi}$. WSW of Kenai, Aleutian Ra.; $60^{\circ} 25^{\prime} \mathrm{N}, 152^{\circ} 22^{\prime} \mathrm{W}$; (map 62).

Local name reported in 1958 by USGS.

Bear Lake: lake, $0.5 \mathrm{mi}$. long, on Kenai Penin. in course of Moose River, $31 \mathrm{mi}$. NE of Kenai, Cook Inlet Low.; $60^{\circ} 39^{\prime} 45^{\prime \prime} \mathrm{N}, 150^{\circ} 22^{\prime} 30^{\prime \prime}$ W; (map 62).

Named about 1963 by officials of Kenai National Moose Range, for administrative purposes.

Bear Lake: lake, $0.5 \mathrm{mi}$. long, $\mathrm{N}$ of Slide Mtn., $38 \mathrm{mi}$. W of Glennallen, Copper River Basin; $62^{\circ} 06^{\prime} \mathrm{N}, 146^{\circ} 51^{\prime} \mathrm{W}$; (map 83$)$.

Local name reported in 1949 by USGS.

Bear Lake: lake, in Mentasta Mts., drains into headwaters of Tetlin River, $41 \mathrm{mi}$. S of Tok, Alaska Ra.; $62^{\circ} 45^{\prime} \mathrm{N}, 143^{\circ} 00^{\prime} \mathrm{W}$; (map 84). Local name reported in 1951 by USGS.

Bear Lake: lake, $1.3 \mathrm{mi}$. across, $1.5 \mathrm{mi}$. NW of Zitziana River and $41 \mathrm{mi}$. NE of Bitzshtini Mts., Tanana Low.; 64 $47^{\prime} \mathrm{N}, 150^{\circ} 49^{\prime} \mathrm{W}$; (map 99).

Local name reported in 1937 by USGS.

Bear Lake: lake, $1 \mathrm{mi}$. long, $2 \mathrm{mi}$. W of Hodzana Slough and $17 \mathrm{mi}$. SW of Beaver, Yukon Flats; $66^{\circ} 16^{\prime} 45^{\prime \prime} \mathrm{N}, 147^{\circ} 58^{\prime} 00^{\prime \prime} \mathrm{W}$; (map 118).

Probably named by William Yanert who showed it on a 1916 manuscript map of the Yukon Flats (Stuck, 1917, map facing p. 122). Bear Lake: lake, see Baird Lake. 
Bear Lake: lake, see High Ridge Lake.

Bear Lake: lake, see Medvejie Lake.

Bear Lake : lake, see Mirror Lake.

Bear Lake Glacier: glacier, on Kenai Penin., trends NW $3.5 \mathrm{mi}$. to its terminus at head of Salmon Creek, $7 \mathrm{mi}$. NE of Seward, Chugach Mts.; $60^{\circ} 11^{\prime} 00^{\prime \prime} \mathrm{N}, 149^{\circ} 18^{\prime} 25^{\prime \prime} \mathrm{W}$; $B G N$ 1959; (map 63),

Local name published on recent USGS maps; derived from nearby Bear Lake.

Bearman Lake: lake, $2 \mathrm{mi}$. long, $13 \mathrm{mi}$. SE of Cache Lake, $26 \mathrm{mi}$. NW of Fort Yukon, Yukon

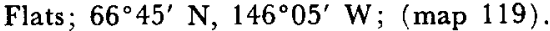

Local descriptive name obtained in 1956 by USGS.

Bear Mountain: mountain, 2,780 ft., SE of Cone Mtn., on W coast of Dall I., Alex. Arch.; $55^{\circ} 05^{\prime} 20^{\prime \prime} \mathrm{N}, 133^{\circ} 12^{\prime} 00^{\prime \prime} \mathrm{W}$; (map 4).

Published in 1924 by USC\&GS.

Bear Mountain: mountain, 4,200 ft., $6 \mathrm{mi}$. E of Sitka, on $W$ coast of Baranof I., Alex. Arch.; $57^{\circ} 02^{\prime} 35^{\prime \prime} \mathrm{N}, 135^{\circ} 09^{\prime} 55^{\prime \prime} \mathrm{W}$; (map 9). Var. Harlampy's Hill, Harlampy's Mountain.

Local name reported in 1954 by $R$. N. DeArmond. It was also locally known as $\mathrm{Har}$ lampy's Hill or Mountain because, about 1890, Harlampy Sokoloff started a rockslide on the side of the mountain which was still plainly visible in 1954. The slide was known as Harlampy's slide, which gave the mountain this name.

Bear Mountain: mountain, "on right bank of Tanana river, near latitude $62^{\circ}$. So named by Peters, 1898" (Baker, 1906, p. 122).

Bear Moutain: mountain, "on right bank of upper Anvik river, western Alaska, near latitude $63^{\circ} 20^{\prime}$, longitude $160^{\circ} 20^{\prime}$. Prospectors' name, published in 1900" (Baker, 1906, p. 122).

Bear Mountain: mountain, "about 40 or 50 miles north, by compass, from Mount St. Elias. So named by Russell, 1891, after the U.S. revenue cutter Bear" (Baker, 1906, p. 122).

Bear Mountain: mountain, on Kenai Penin., between Lowell and Spruce Creeks, $2 \mathrm{mi}$. SW of Seward, Chugach Mts.; $60^{\circ} 04^{\prime} 55^{\prime \prime} \mathrm{N}$, $149^{\circ} 29^{\prime} 55^{\prime \prime} \mathrm{W}$; (map 63).

Local name reported in 1951 by USGS.

Bear Mountain: mountain, 3,314 ft., Kenai Penin., in Kenai Mts., E of Skilak Lake, $40 \mathrm{mi}$. ESE of Kenai, Chugach Mts.; $60^{\circ} 26^{\prime} 15^{\prime \prime}$ N, $150^{\circ} 05^{\prime} 45^{\prime \prime} \mathrm{W}$; (map 62).

Local name reported by USGS in 1958 .

Bear Mountain: mountain, $11 \mathrm{mi}$. NW of Haycock, Seward Penin. High.; $65^{\circ} 20^{\prime} \mathrm{N}, 161^{\circ} 24^{\prime}$ W; (map 109).

Local name published on maps after 1950 .

Bear Mountain: mountain, 1,310 ft., on left bank of Koyukuk River, $21 \mathrm{mi}$. NW of Hochandochtla Mtn., Kokrines-Hodzana High.; $65^{\circ} 47^{\prime} 45^{\prime \prime} \mathrm{N}, 155^{\circ} 16^{\prime} 00^{\prime \prime} \mathrm{W}$; (map 107).

Local name shown on a 1932 sketch map of the area; author unknown.

Bear Mountain: mountain, $2,856 \mathrm{ft}$., $42 \mathrm{mi}$. W of Midnight Hill, Porcupine Plat.; $66^{\circ} 03^{\prime} \mathrm{N}$, $142^{\circ} 35^{\prime} \mathrm{W}$; (map 120).
Local name reported in 1956 by T. E. Taylor, USGS. It may be a form of translation of an Indian name.

Bear Mountain: mountain, 5,254 ft., in Davidson Mts., on $\mathrm{E}$ bank of Coleen River, $39 \mathrm{mi}$. $\mathrm{E}$ of Table Mtn., Brooks Ra.; $68^{\circ} 2^{\prime} 5^{\prime} \mathrm{N}, 1^{2} 2^{\circ}$ 07' W; (map 137).

Local name reported in 1956 by USGS.

Bear Mountain Creek: stream, heads at $65^{\circ} 57^{\prime}$ $\mathrm{N}, 142^{\circ} 54^{\prime} \mathrm{W}$, and flows E $25 \mathrm{mi}$. to Black River, $52 \mathrm{mi}$. NE of junc. of Charley and Yukon Rivers, Porcupine Plat.; 65 $59^{\prime} 30^{\prime \prime} \mathrm{N}$, $142^{\circ} 09^{\prime} 00^{\prime \prime} \mathrm{W}$; (map 103).

Local name published on the 1951 USGS map. Named for nearby Bear Mountain.

Bear Mountain Lake: lake, $1 \mathrm{mi}$. long, $8 \mathrm{mi}$. NE of Bear Mtn. and $40 \mathrm{mi}$. W of Midnight Hill, Porcupine Plat.; $66^{\circ} 08^{\prime} \mathrm{N}, 142^{\circ} 21^{\prime} \mathrm{W}$; (map 120).

Local name obtained in 1956 by T. E. Taylor and R. C. Foley, USGS.

Bearnose Hill: hill, $850 \mathrm{ft}$., $15 \mathrm{mi}$. SE of Chalkyitsik, Porcupine Plat.; $66^{\circ} 28^{\prime} \mathrm{N}, 143^{\circ}$. $26^{\prime} \mathrm{W}$; (map 120).

Local name reported in 1956 by T. E. Taylor, USGS. It may be a form of translation of an Indian name.

Bear Pass Mountain: mountain, 3,853 ft., on Admiralty I., $2.6 \mathrm{mi}$. S of Soapberry Mtn., and $45 \mathrm{mi}$. NE of Sitka, Alex. Arch.; $57^{\circ} 18^{\prime}$ 45" N, 134'15'00' W; BGN 1962; (map 9).

Local name reported in 1961 by USFS; so called because "a migrating bear trail is located on the flank of this mountain."

Bearpaw: locality, on right bank of Bearpaw River, $48 \mathrm{mi}$. SE of Bitzshtini Mts., Tanana Low.; $64^{\circ} 05^{\prime} \mathrm{N}, 150^{\circ} 41^{\prime} \mathrm{W}$; (map 99). Var. Bear Paw City.

This was a mining camp, established in 1905 and called "Bear Paw City" by prospectors; reported in 1905 by $\mathbf{L}$. M. Prindle, USGS.

Bear Paw City: locality, see Bearpaw.

Bearpaw Creek: stream, "a right or east branch of Kantishna river, 120 miles above its mouth, near latitude $64^{\circ}$, longitude $150^{\circ}$. Prospectors' name, reported by Prindle, 1905" (Baker, 1906, p. 123).

Bearpaw Creek: stream, flows SE $4 \mathrm{mi}$. to Colville River, $2 \mathrm{mi}$. NE of Umiat, Arctic Slope ; $69^{\circ} 23^{\prime} 10^{\prime \prime} \mathrm{N}, 152^{\circ} 03^{\prime} 20^{\prime \prime} \mathrm{W}$; (map 141).

Named about 1945 by USGS geologists of the Naval Petroleum Reserve No. 4

Bearpaw Creek: stream, see Bearpaw River.

Bearpaw Mountain: mountain, 2,026 ft., $9.2 \mathrm{mi}$. $\mathrm{NW}$ of Bearpaw and $39 \mathrm{mi}$. SE of Bitzshtini Mts., Tanana Low.; $64^{\circ} 06^{\prime} \mathrm{N}, 150^{\circ} 59^{\prime} \mathrm{W}$; (map 99).

Local name reported in 1937 by USGS.

Bearpaw River: stream, flows NE $55 \mathrm{mi}$. to Kantishna River, $47 \mathrm{~m}$. SE of Bitzshtini Mts. Tanana Low.; $64^{\circ} 06^{\prime} \mathrm{N}, 150^{\circ} 42^{\prime} \mathrm{W}$; (map 99). Var. Bearpaw Creek.

Prospectors' name reported in 1905 by L. M. Prindle, USGS.

Bear Point: point of land, on NE shore of Karluk Lake, $20 \mathrm{mi}$. SE of Karluk, Kodiak I.; $57^{\circ} 23^{\prime} 30^{\prime \prime} \mathrm{N}, 154^{\circ} 02^{\prime} 00^{\prime \prime} \mathrm{W}$; (map 35).

Local name reported in 1952 by USGS.
Bear Point: point of land, on SE coast of Kenai Penin., at $W$ entrance of Paguna Arm, $50 \mathrm{mi}$. $\mathrm{E}$ of Homer, Chugach Mts.; $59^{\circ} 36^{\prime} 15^{\prime \prime} \mathrm{N}$, $150^{\circ} 06^{\prime} 30^{\prime \prime} \mathrm{W}$; ( $\left.\operatorname{map} 50\right)$.

Local name published by USGS in 1953.

Bear Pup: ravine, see Bear Gulch.

Bear River: stream, "tributary to the head of Portland canal. Apparently so named by Pender, 1868" (Baker, 1906, p. 122).

Bear River: stream, on W coast of Alaska Penin., flows NW, through Bear Lake, 16 mi. to Bristol Bay, $14 \mathrm{mi}$. NE of Port Moller, Bristol Bay Low.; $56^{\circ} 10^{\prime} \mathrm{N}, 160^{\circ} 26^{\prime} \mathrm{W}$; (map 30).

Local name reported in 1951 by USGS.

Bear River: stream, flows NE $15 \mathrm{mi}$. to Niukluk River, $32 \mathrm{mi}$. NE of Solomon, Seward Penin. High.; 64 $52^{\prime} \mathrm{N}, 163^{\circ} 38^{\prime} \mathrm{W}$; (map 95). Var. Lime Creek.

This appears to be the stream reported in 1899 as "Lime Creek" by Schrader and Brooks (1900, map 3), USGS.

Bear River Ridge: mountains, see Reverdy Mountains.

Bear Rock: rock, in Cold Bay, $14 \mathrm{mi}$. SE of village of Cold Bay, at SW end of Alaska Penin., Aleutian Ra.; $55^{\circ} 02^{\prime} 55^{\prime \prime} \mathrm{N}, 162^{\circ} 28^{\prime} 20^{\prime \prime} \mathrm{W}$; (map 29).

Local name published in 1925 by USC\&GS.

Bear Rock: rock, in Deadman Bay, off $\mathbf{S}$ coast of Kodiak I.; $57^{\circ} 04^{\prime} 20^{\prime \prime} \mathrm{N}, 153^{\circ} 57^{\prime} 00^{\prime \prime} \mathrm{W}$; (map 34).

Local name reported in 1954 by USGS.

Bearskin Gulch: ravine, trends $\mathrm{N}$ and $\mathrm{E} 12 \mathrm{mi}$. to Chignik River, $2 \mathrm{mi}$. N of Chignik Lake, Aleutian Ra.; $56^{\circ} 19^{\prime} \mathrm{N}, 158^{\circ} 56^{\prime} \mathrm{W}$; (map $30)$.

Local name reported in 1923 by $R$. $H$. Sargent, USGS.

Bear Slough: slough, "on the eastern shore of Kvichak bay, Bristol bay, southwestern Alaska, 6 miles below Koggiung, near latitude $58^{\circ} 50^{\prime}$. So called by the fisheries, and reported by Moser, 1900" (Baker, 1906, p. 122).

Bears River: stream, see Berners River.

Beartrack Cove: bay, $1.6 \mathrm{mi}$. across, in Glacier Bay, in Glacier Bay National Mounment, $1 \mathrm{mi}$. $\mathrm{N}$ of Hutchins Bay and $57 \mathrm{mi}$. NW of Juneau, St. Elias Mts.; $58^{\circ} 36^{\prime} \mathrm{N}, 135^{\circ} 55^{\prime} \mathrm{W}$; $B G N$ 1923; (map 11).

Named by W. S. Cooper, Univ. of Minnesota, in 1923.

Beartrack Creek: stream, flows NW $7 \mathrm{mi}$. down W slope of Pogromni Volcano to Bering Sea, 1 mi. $E$ of Raven Point on $W$ coast of Unimak I., Aleutian Is.; $54^{\circ} 38^{\prime} 00^{\prime \prime} \mathrm{N}, 164^{\circ} 49^{\prime} 30^{\prime \prime} \mathrm{W}$; BGN 1939; (map 24). Var. Red River.

This name was suggested by a 1937 USC\&GS field report that states, "some of the largest bears in Alaska are supposed to be on this (Unimak) Island. Although seldom seen along the coast, their tracks are of ten found in this locality. One such track measured 17 inches long and 11 inches wide." The name was submitted in 1938 by USC\&GS to BGN.

Beartrack Island: island, $0.1 \mathrm{mi}$. across, in Beartrack Cove, $\mathbf{N}$ of Beardslee Is., in Glacier Bay, Glacier Bay National Monument, $57 \mathrm{mi}$. NW 
of Juneau, St. Elias Mts. ; $58^{\circ} 36^{\prime} 10^{\prime \prime} \mathrm{N}, 135^{\circ}$ 51'55" W; BGN 1948; (map 11).

Name published in 1962 by USGS.

Beartrack River: stream, in Glacier Bay National Monument, heads in glacier, flows $15 \mathrm{mi}$. $\mathrm{S}$ to Beartrack Cove on Glacier Bay, $1.3 \mathrm{mi}$. E of Heartrack I. and $55 \mathrm{mi}$. NW of Juneau, St. Elias Mts.; $58^{\circ} 36^{\prime} 15^{\prime \prime} \mathrm{N}, 135^{\circ} 49^{\prime} 50^{\prime \prime} \mathrm{W}$; $B G N 1948$; (map 11).

Named in 1939 by a USC\&GS field party; derived from the cove of the same name.

Beartrail Creek: stream, flows $\mathrm{S} 3 \mathrm{mi}$. to Ibeck Creek, $7.5 \mathrm{mi}$. E of Cordova, Chugach Mts.; $60^{\circ} 33^{\prime} \mathrm{N}, 145^{\circ} 32^{\prime} \mathrm{W}$; (map 64).

Local name reported in 1908 by U. S. Grant and D. F. Higgins (in Brooks and others, 1909, pl. 4), USGS.

Beartrap Bay: estuary, extends E $3 \mathrm{mi}$. off Port Gravina, $18 \mathrm{mi}$. NW of Cordova, Chugach Mts.; $60^{\circ} 45^{\prime} 15^{\prime \prime} \mathrm{N}, 1^{\circ} 46^{\circ} 03^{\prime} 30^{\prime \prime} \mathrm{W}$; $B G N$ 1910; (map 64).

Local name reported in 1910 by USGS.

Bear Valley: valley, on Kenai Penin., extends NE $3 \mathrm{mi}$. from Portage Lake, $4.5 \mathrm{mi}$. NW of Whittier, Chugach Mts.; $60^{\circ} 48^{\prime} \mathrm{N}, 148^{\circ} 48^{\prime}$ W; (map 63)

Local name reported in 1951 by USGS.

Beasley Creek: stream, heads in lake at terminus of Fourth Glacier, flows SW and NW $6 \mathrm{mi}$. to Russell Fiord, 3 mi. SW of Mount Pinta and $18 \mathrm{mi}$. NE of Yakutat, St. Elias Mts.; $59^{\circ} 36^{\prime}$ $05^{\prime \prime} \mathrm{N}, 139^{\circ} 13^{\prime} 45^{\prime \prime} \mathrm{W}$; (map 46).

Name appears on a 1906 map of Fourth Glacier by the Canadian section of IBC, published by Tarr and Martin (1914, fig. 15). The name was probably derived from Beasley Glacier, the name given Fourth Glacier by Eliot Blackwelder, USGS, in 1906.

Beasley Glacier: glacier, see Fourth Glacier.

Beaton Creek: stream, flows SE $1.8 \mathrm{mi}$. to Cache Creek which flows to Norton Sound, $9 \mathrm{mi}$. NE of Solomon, Seward Penin. High.; 64 $36^{\circ}$ N, $164^{\circ} 09^{\prime} \mathrm{W}$; (map 95).

Prospectors' name shown on Arthur Gibson's "Map of Cape Nome Precinct" dated 1904.

Beaton Island: island, see Betton Island.

Beaton Pup: stream, flows ESE $1.5 \mathrm{mi}$. to Coal Creek, $3.5 \mathrm{mi}$. SE of that stream's junc. with Yukon River and $44 \mathrm{mi}$. SE of Circle, YukonTanana High.; $65^{\circ} 18^{\prime} 30^{\prime \prime} \mathrm{N}, 143^{\circ} 09^{\prime} 00^{\prime \prime} \mathrm{W}$; (map 103).

Local name reported in 1936 by Mertie (1938a, pl. 5), USGS.

Beatons Island: island, see Betton Island.

Beatson: village, see Latouche.

Beatson, Mount: mountain, 2,065 ft., on $\mathrm{N}$ end of Latouche I., $20 \mathrm{mi}$. SE of Chenega, Chugach Mts.; $60^{\circ} 02^{\prime} 20^{\prime \prime} \mathrm{N}, 147^{\circ} 52^{\prime} 35^{\prime \prime} \mathrm{W}$; (map 63).

Local name reported in 1909 by Grant and Higgins (1910, pl. 12), USGS.

Beatsons Wharf: village, see Latouche. Beattle Creek: stream, see Holyoke Creek.

Beauchamp Island: island, $1.5 \mathrm{mi}$. across, one of Rakof Is., $10 \mathrm{mi}$. SE of Goddard, on SW coast of Baranof I., Alex. Arch.; $56^{\circ} 43^{\prime}$ N, $134^{\circ} 14^{\prime}$ W; (map 5). Var. Beauchamp Islets.
Name published in 1943 by USC\&GS. Beauchamp Islets : island, see Beauchamp Island. Beauclerc, Port: bay, extends SE $7 \mathrm{mi}$. to Sumner Strait, 12 mi. SW of Point Baker, on $\mathrm{E}$ coast of Kuiu I., Alex. Arch.; 56 $16^{\prime} \mathrm{N}, 133^{\circ} 53^{\prime} \mathrm{W}$; (map 6). Var. Port Beauclere.

Named on September 11, 1793, by Capt. George Vancouver, RN, "after Amelius Beauclerk who served under Commander Gardner * * * in the West Indies where no doubt Vancouver knew him" (Wagner, 1937, p. 375)

Beauclerc Island: island, $0.2 \mathrm{mi}$. long, at entrance to Port Beauclerc, $11 \mathrm{mi}$. SW of Point Baker, on $\mathrm{E}$ coast of Kuiu I., Alex. Arch.; $56^{\circ} 15^{\prime} 30^{\prime \prime}$ $\mathrm{N}, 133^{\circ} 51^{\prime} 20^{\prime \prime} \mathrm{W}$; (map 6). Var. Beauclere Island.

Named in 1879 by W. H. Dall, USC\&GS. Beauclerc Peak: mountain, 2,500 ft., $14 \mathrm{mi}$. SW of Point Baker, at $S$ point of entrance to Port Beauclerc, on E coast of Kuiu I., Alex. Arch. $56^{\circ} 15^{\prime} 40^{\prime \prime} \mathrm{N}, 133^{\circ} 56^{\prime} 00^{\prime \prime} \mathrm{W}$; ( $\left.\operatorname{map} 6\right)$.

Named in 1886 by Lt. J. M. Helm, USN, for charting purposes; name published in 1887 on USC\&GS Chart 706

Beauclere, Port: bay, see Beauclerc, Port.

Beauclere Island: island, see Beauclerc Island. Beauford Bay: lagoon, see Beaufort Lagoon.

Beauford Bay: bay, see Demarcation Bay.

Beaufort, Cape: point of land, on coast of Chukchi Sea, $54 \mathrm{mi}$. SW of Point Lay, Arctic Plain; $69^{\circ} 02^{\prime} \mathrm{N}, 163^{\circ} 50^{\prime} \mathrm{W}$; (map 145). Var. Cape Bophor, Kukeatak.

Named August 9, 1826, by Capt. Beechey (1831, v. 1, p. 269), RN, who wrote, "a small cape, which I named Cape Beaufort, in compliment to Captain Beaufort [later Adm. Sir Francis, 1774-18571, the present hydrographer to the Admiralty." Beaufort is best known for his scale of wind velocities.

Beaufort, Mer de: sea, see Beaufort Sea.

Beaufort Basin: valley, $2.5 \mathrm{mi}$. across, on Kukpowruk River, $21 \mathrm{mi}$. E of Cape Beaufort and $50 \mathrm{mi}$. S of Point Lay, Arctic Slope; $69^{\circ} 02^{\prime} \mathrm{N}$, $162^{\circ} 58^{\prime} \mathrm{W}$; ( $\left.\operatorname{map} 145\right)$.

Named about 1950 by USGS geologists. This basin is formed by the Beaufort syncline. Beaufort Bay: bay, see Demarcation Bay.

Beaufort Bay: lagoon, see Beaufort Lagoon.

Beaufort Bay: sea, see Beaufort Sea.

Beaufort Lagoon: lagoon, on Beaufort Sea coast, extends $14 \mathrm{mi}$. between Angun and Siku Points, $17 \mathrm{mi}$. NW of Demarcation Point, Arctic Plain; 69 $52^{\prime} \mathrm{N}, 142^{\circ} 12^{\prime} \mathrm{W}$; BGN 1962; (map 138). Var. Beauford Bay, Beaufort Bay.

On August 3, 1826, Sir John Franklin $(1828$, p. 144) wrote: "we reached the eastern part of the bay, which I have had the pleasure of naming after my friend Captain Beaufort, RN." Leffingwell (1919, p. 88) wrote: "Beaufort Bay, which extends from the western end of Icy Reef to Humphreys Point, is locally called a lagoon, so the name of Beaufort Lagoon has been adopted on the writer's map."

See Beaufort Cape.
Beaufort Sea: sea, on S side of Arctic Ocean on $\mathrm{N}$ coast of Alaska and NW coast of Canada it is defined by Prince Patrick I., Canada, at $\mathrm{NE}$ end, and Point Barrow, Alaska, at $\mathrm{W}$ end; $70^{\circ} \mathrm{N}, 135^{\circ} \mathrm{W} ; B G N$ 1954. Var. Beaufort Bay, Mer de Beaufort.

Named in 1826 by Sir John Franklin, RN, for his friend Capt. (later Adm.) Sir Francis Beaufort, hydrographer to the British Admiralty.

Beautemps, Cape de: point of land, see Fairweather, Cape.

Beautemps, Mount: mountain, see Fairweather, Mount.

Beautems, Cape: point of land, see Fairweather, Cape.

Beautiful Isle: island, $0.2 \mathrm{mi}$. long, in entrance to Quartz Bay, on SE coast of Kenai Penin., $36 \mathrm{mi}$. ESE of Homer, Chugach Mts. ; $59^{\circ} 30^{\prime}$. $45^{\prime \prime} \mathrm{N}, 150^{\circ} 33^{\prime} 30^{\prime \prime} \mathrm{W}$; BGN 1929; (map 50). Descriptive name given by USC\&GS in 1927.

Beauty Bay: $b a y$, on SE coast of Kenai Penin., extends NW $2.5 \mathrm{mi}$. off West Arm Nuka Bay, $32 \mathrm{mi}$. ESE of Homer, Chugach Mts.; $59^{\circ} 32^{\prime}$ N, $150^{\circ} 37^{\prime} \mathrm{W}$; (map 50$)$.

Local name reported in 1951 by USGS.

Beauty Creek: stream, in Kantishna Hills, flows W 3 mi. to Bearpaw River, $15 \mathrm{mi}$. N of Wonder Lake, Alaska Ra.; $63^{\circ} 42^{\prime} 45^{\prime \prime} \mathrm{N}, 150^{\circ} 54^{\prime} 30^{\prime \prime}$ W; (map 88).

Local name shown on a 1916 fieldsheet by C. E. Giffin, USGS

Beaver: village, pop. 101, on $\mathrm{N}$ bank of Yukon River, $17 \mathrm{mi}$. NE of mouth of Beaver Creek and $60 \mathrm{mi}$. SW of Fort Yukon, Yukon Flats $66^{\circ} 21^{\prime} 30^{\prime \prime} \mathrm{N}, 147^{\circ} 23^{\prime} 30^{\prime \prime} \mathrm{W}$; BGN 1954 (map 118). Var. Beaver City.

Eskimo and Indian village originally established about 1906 as a river landing. About 1911 ARC built a trail from the "Chandalar diggings" to the Yukon River here. With the expectation of much travel and town growth a town site was staked and many cabins built. The "Chandalar quartz" did not prove productive and the place reverted to a "native village" with a post office, established in 1913 , and trading post to serve the Yukon in that area. Its population was 103 in 1930; 88 in 1939 ; and 101 in 1950.

Beaver: locality, site of Eskimo village on NE coast of Unalaska I., near N entrance of Beaver Bay; Aleutian Is.; (map 23). Var. Selo Bobrova, Selo Bobrovo, Uguiúg, Uguyug.

Published as "Sel[o] Bobrova," or "sea otter village," by Lt. Sarichev (1826, map 14), IRN Father Veniaminov (1840, v. 1, p. 185) called it "Uguyug." Baker (1906, p. 124) wrote, "In about 1830 it [Beaver] consisted of 4 huts (yourts) and 41 people. Its native name is Uguiúg."

Beaver Bay: bay, on S coast of Atka I., extends N 3 mi., E of Cape Tadluk, Aleutian Is.; $52^{\circ} 02^{\prime} \mathrm{N}, 174^{\circ} 40^{\prime} \mathrm{W}$; BGN 1961; (map 18). Var. Bobrovaia baie, Bukhta Bobrovaia, Otter Bay, Sea Otter Bay.

Published as "Bobrovaia baie," or "Sea Otter Bay," by Capt. Lutke (1836, p. 317), 
IRN, and as "Bukh[ta] Bobrovaia" in 1848 on Russian Hydrog. Dept. Chart 1400. Baker (1906, p. 123) published "Beaver Bay."

Beaver Bay: bay, on S coast of Alaska Penin., extends $\mathrm{N} 5 \mathrm{mi}$., $\mathrm{W}$ of Cape Aliaksin, Aleutian Ra.; $55^{\circ} 30^{\prime} \mathrm{N}, 160^{\circ} 53^{\prime} \mathrm{W}$; (map 28). Var. Bobrovaia Baie, Zaliv Bobrovoi.

Translated from the Russian "Zal[iv] Bobrovoi," shown by Capt. Tebenkov (1852, map 24), IRN, and published as "Bobrovaia Baie" by Capt. Lutke (1836, p. 269), IRN.

Beaver Bay: bay, see Otter Bay.

Beaver City: locality, on Alatna River at mouth of Helpmejack Creek, $66 \mathrm{mi}$. NNE of Hughes, Brooks Ra. ; $66^{\circ} 56^{\prime} \mathrm{N}, 153^{\circ} 26^{\prime} \mathrm{W}$; (map 116).

A small mining camp established for a short period-probably over winter-about 1898 . Mentioned by Mendenhall (1902, p. 39), USGS.

Beaver City; village, see Beaver.

Beaver Cove: cove, "just north of Cape Providence, in Port Wrangell, Alaska peninsula. So called by the Russians, before 1831 , because parties of sea otter hunters from Katmai usually stopped there. Lutke calls it Port Bobrovoi (des loutres)" (Baker, 1906, p. 123).

Beaver Creek: locality, on the Alaska Highway, at head of Tanana River, $3.5 \mathrm{mi}$. N of Northway Junction, Yukon-Tanana High.; 630. $03^{\prime}$ $\mathrm{N}, 141^{\circ} 51^{\prime} \mathrm{W}$; (map 85).

This is an abandoned roadhouse.

Beaver Creek: stream, heads in a lake on Mary I., flows $1 \mathrm{mi}$. W to Felice Strait, Alex. Arch.; $55^{\circ} 04^{\prime} 50^{\prime \prime} \mathrm{N}, 131^{\circ} 14^{\prime} 30^{\prime \prime} \mathrm{W}$; (map 3).

Named in 1883 by Lt. Comdr. H. E. Nichols, USN.

Beaver Creek: stream, flows NW and SE $7 \mathrm{mi}$. to Sulzer Passage, on Prince of Wales I., near head of Hetta Inlet, Alex. Arch.; 55 $17^{\prime} 15^{\prime \prime}$ N, $132^{\circ} 37^{\prime} 20^{\prime \prime} \mathrm{W}_{\text {; ( }}$ (map 4).

Local name reported in 1908 by C. W'. Wright (in Brooks and others, 1909, pl. 3), USGS.

Beaver Creek: stream, flows N 3 mi. to an estuary off Behm Canal, on $\mathbf{N}$ coast of Revillagigedo I., Alex Arch.; 55 $55^{\prime} 55^{\prime \prime} \mathrm{N}, 131^{\circ} 26^{\prime} 05^{\prime \prime} \mathrm{W}$; BGN 1962; (map 3).

Local name reported in 1961 by USFS.

Beaver Greek: stream, on Alaska Penin,, flows NE $1.4 \mathrm{mi}$. to Oil Creek, $5.5 \mathrm{mi}$. W of Cape Aklek and $48 \mathrm{mi}$. NW of Karluk, Aleutian Ra. ; $57^{\circ} 41^{\prime} 40^{\prime \prime} \mathrm{N}, 155^{\circ} 44^{\prime} 35^{\prime \prime} \mathrm{W}$; (map 35).

Local name obtained from J. L. McPherson of Iliamna; published by G. C. Martin (1921, pl. 10), USGS.

Beaver Creek: stream, on Kenai Penin., flows W $11 \mathrm{mi}$. to Anchor River, $8 \mathrm{mi}$. N of Homer, Gook Inlet Low.; $59^{\circ} 45^{\prime} 15^{\prime \prime} \mathrm{N}, 151^{\circ} 30^{\prime} 30^{\prime \prime}$ W; (map 50).

Local name reported in 1951 by USGS.

Beaver Creek: stream, in Chigmit Mts., flows SE $3.8 \mathrm{mi}$. to Dam Creek, N of Chinitna Bay, Aleutian Ra.; 59 $52^{\prime} 25^{\prime \prime} \mathrm{N}, 153^{\circ} 12^{\prime} 00^{\prime \prime} \mathrm{W}$; (map 51).

Local name published in 1958 by USGS.

Beaver Creek: stream, on Kenai Penin,, heads at Beaver Lake, flows SW $11 \mathrm{mi}$. to Kenai
River, $4 \mathrm{mi}$. E of Kenai, Cook Inlet Low.; $60^{\circ} 32^{\prime} 30^{\prime \prime} \mathrm{N}, 151^{\circ} 08^{\prime} 40^{\prime \prime} \mathrm{W}$; (map 62).

Local name reported in 1951 by USGS.

Beaver Creek: stream, flows NE $7 \mathrm{mi}$. to Gemuk River, $84 \mathrm{mi}$. SW of Sleetmute, KilbuckKuskokwim Mts. ; $60^{\circ} 47^{\prime} \mathrm{N}, 158^{\circ} 42^{\prime} \mathrm{W} ; B G N$ 1948; (map 60).

Prospectors' name reported in 1945 by USGS.

Beaver Creek: stream, on Kenai Penin., flows NE $1 \mathrm{mi}$. to Sixmile Creek, $5 \mathrm{mi}$. S of Sunrise, Chugach Mts.; $60^{\circ} 48^{\prime} 50^{\prime \prime} \mathrm{N}, 149^{\circ} 25^{\prime} 50^{\prime \prime} \mathrm{W}$; (map 63). Var. Beaver Dam Creek.

Local name reported in 1952 by USGS.

Beaver Creek: stream, in Nutzotin Mts., flows $\mathrm{SE}$, through Beaver Lake, and NE $85 \mathrm{mi}$., across Alaska-Canada boundary, to White River in Yukon, Canada, Alaska Ra.; $62^{\circ} 02^{\prime}$ N, $141^{\circ} 47^{\prime} \mathrm{W}$; (map 84$)$.

Local name used before 1902; published by USGS (Brooks and others, 1909, p. 176). Beaver Creek: stream, flows NE $3 \mathrm{mi}$. to Kahiltna River, $30 \mathrm{mi}$. SW of Talkeetna, Cook Inlet Low.; $62^{\circ} 03^{\prime} 35^{\prime \prime} \mathrm{N}, 150^{\circ} 51^{\prime} 00^{\prime \prime} \mathrm{W}$; (map 81).

Local name reported in 1958 by USGS.

Beaver Creek: stream, flows SE $19 \mathrm{mi}$. to George River, 27 mi. SE of Flat, Kilbuck-Kuskokwim Mts. ; $62^{\circ} 20^{\prime} 20^{\prime \prime} \mathrm{N}, 157^{\circ} 11^{\prime} 00^{\prime \prime} \mathrm{W}$; (map 79).

Local name obtained in 1952 by USGS topographers.

Beaver Creek: stream, flows E $40 \mathrm{mi}$. to Kuskokwim River, W of Vinsale Mtn., $18 \mathrm{mi}$. S of McGrath, Kilbuck-Kuskokwim Mts.; $62^{\circ} 37^{\prime}$ N, $155^{\circ} 44^{\prime} \mathrm{W}$; (map 80).

Local name obtained in 1954 by USGS.

Beaver Creek: stream, flows SE $30 \mathrm{mi}$. to Anvik River, $20 \mathrm{mi}$. NW of Anvik and $53 \mathrm{mi}$. NW of Holy Cross, Nulato Hills; $62^{\circ} 50^{\prime} 30^{\prime \prime} \mathrm{N}$, $160^{\circ} 43^{\prime} 00^{\prime \prime} \mathrm{W}$; (map 78). Var. Long Portage Creek.

Prospectors' name reported in 1916 by G. L. Harrington (in Brooks, 1918, pl. 16), USGS.

Beaver Creek: stream, heads on Cheneathda Hill, flows SW $8 \mathrm{mi}$. to head of Tanana River, $3 \mathrm{mi}$. $\mathrm{N}$ of Northway Junction, Yukon-Tanana High.; $63^{\circ} 03^{\prime} \mathrm{N}, 141^{\circ} 52^{\prime} \mathrm{W}$; BGN 1961; (map 85). Var. Chethakne Creek.

Local name reported in 1960 by T. E. Taylor, USGS.

Beaver Creek: stream, heads in Beaver Mts., flows $\mathrm{N} 40 \mathrm{mi}$. to Innoko River, $5 \mathrm{mi}$. W of Ophir and $36 \mathrm{mi}$. NW of McGrath, KilbuckKuskokwim Mts. ; $63^{\circ} 09^{\prime} 40^{\prime \prime} \mathrm{N}, 156^{\circ} 40^{\prime} 45^{\prime \prime}$ W; (map 90)

Prospectors' name obtained in 1908 by Maddren (1910, pl. 1), USGS.

Beaver Greek: stream, flows SE $13 \mathrm{mi}$. to North Fork Kuskokwim River, 34 mi. NE of Medfra, Kilbuck-Kuskokwim Mts.; $63^{\circ} 23^{\prime}$ N, $153^{\circ}$ 49' W; (map 89).

Local name reported in 1958 by USGS.

Beaver Creek: stream, flows SE $6 \mathrm{mi}$. to Poorman Creek, $4.5 \mathrm{mi}$. SW of Poorman and $48 \mathrm{mi}$. SW of Ruby, Kilbuck-Kuskokwim Mts.; $64^{\circ}$. $04^{\prime} 00^{\prime \prime} \mathrm{N}, 155^{\circ} 40^{\prime} 30^{\prime \prime} \mathrm{W}$; BGN 1936; (map $98)$.
Prospectors' name reported in 1935 by USGS.

Beaver Creek: stream, flows SW $11 \mathrm{mi}$. to Eldorado River, $15 \mathrm{mi}$. W of Sclomon, Seward Penin. High.; 64 $33^{\prime}$ N, $164^{\circ} 55^{\prime}$ W; (map 95).

Prospectors' name reported in 1900 by E. C. Barnard (in Brooks, 1901, pl. 17), USGS.

Beaver Creek: stream, flows E $22 \mathrm{mi}$. to Big Creek, $18 \mathrm{mi}$. SE of Ruby, Nowitna Low.; $64^{\circ} 38^{\prime} 20^{\prime \prime} \mathrm{N}, 154^{\circ} 56^{\prime} 30^{\prime \prime} \mathrm{W}$; (map 98).

Prospectors' name reported in 1913 by $\mathrm{H}$. M. Eakin, USGS.

Beaver Creek: stream, flows SW 4.2 mi. to Yukon River, $40 \mathrm{mi}$. E of Nulato, Koyukuk Low.; $64^{\circ} 43^{\prime} \mathrm{N}, 156^{\circ} 45^{\prime} \mathrm{W}$; (map 97).

Local name reported by USGS in 1909.

Beaver Creek: stream, flows W $12 \mathrm{mi}$. to South Fork Chena River, $47 \mathrm{mi}$. NW of Big Delta, Yukon-Tanana High.; $64^{\circ} 45^{\prime} 45^{\prime \prime} \mathrm{N}, 146^{\circ} 28^{\prime}$ $00^{\prime \prime} \mathrm{W}$; (map 101).

Named by prospectors; reported in 1908 by J. W. Bagley, USGS.

Beaver Creek: stream, flows NE $13 \mathrm{mi}$. to Yukon River, $12 \mathrm{mi}$. SW of Tanana, Nowitna Low.: $65^{\circ} 06^{\prime} 30^{\prime \prime} \mathrm{N}, 152^{\circ} 27^{\prime} 30^{\prime \prime} \mathrm{W}$; (map 106).

Local name reported in 1952 by USGS

Beaver Creek: stream, heads at junc. of Bear and Champion Creeks at $65^{\circ} 25^{\prime} \mathrm{N}, 146^{\circ} 59^{\prime} \mathrm{W}$, flows NW $180 \mathrm{mi}$. to Beaver Creek Slough, Yukon River, $9 \mathrm{mi}$. SW of Beaver, Yukon Flats; $66^{\circ} 14^{\prime} \mathrm{N}, 147^{\circ} 32^{\prime} \mathrm{W}$; (map 118). Var. Nocotocargut.

Local name published in 1867 by USC\&GS ; this stream probably is the "Nocotocargut," meaning "mouth of the Nokot," reported in 1867 by the Western Union Telegraph Expedition.

Beaver Creek: stream, heads at Akurekvik Pass, flows S $37 \mathrm{mi}$. to Kobuk River, $50 \mathrm{mi}$. ESE of Kobuk, Brooks Ra.; $66^{\circ} 49^{\prime} \mathrm{N}, 155^{\circ} 03^{\prime} \mathrm{W}$; (map 116). Var. Ah-ko-se-a-ge-wick, Akurekvik Creek, Ark-sher-wak, Ark-o-sherwik, Beaver River.

Recorded on a 1901 fieldsheet by D. L. Reaburn, USGS ; may represent a modified translation of the Eskimo name published by Lt. Stoney (1900, map), USN, as "Ah-ko-se-a-gewick," and recorded in 1956 as "Akurekvik," by Orth. See Akurekvik Pass. Lt. J. C. Cantwell (in Healy, 1887, p. 33), USRCS, reported this stream as "Arko-sher-wak, Arko-sherwik, or Beaver River."

Beaver Creek: stream, flows SW to Cripple River, about $17 \mathrm{mi}$. NW of Nome, Seward Penin. High.; (map 94).

Prospectors' name reported on the 1900 "Map of Nome Peninsula" by J. M. Davidson and B. D. Blakeslee; this feature has not been positively identified.

Beaver Creek: stream, see Iowithla River.

Beaver Creek: stream, see Iyouktug Creek.

Beaver Creek Flats: flats, 2 mi. long, on Kenai Penin., $2 \mathrm{mi}$. N of Lookout Mtn. and $8 \mathrm{mi}$. $\mathrm{NE}$ of Homer, Cook Inlet Low.; 59 $44^{\prime} 30^{\prime \prime} \mathrm{N}$, $151^{\circ} 26^{\prime} 00^{\prime \prime} \mathrm{W}$; (map 50$)$. 
Local name published by USGS in 1961; derived from Beaver Creek which flows through the flats.

Beaver Creek Range: mountains, "indefinite, south of the Yukon flats, near Beaver creek. So named on Edwards' Track Chart of the Yukon, 1899. See also Beaver mountains" (Baker, 1906, p. 124).

Beaver Dam Creek: stream, see Beaver Creek.

Beaver Dam Lake: lake, $1 \mathrm{mi}$. long, $6 \mathrm{mi}$. E of Minto and $38 \mathrm{mi}$. NW of Fairbanks, Tanana Low. ; $64^{\circ} 54^{\prime} 15^{\prime \prime} \mathrm{N}, 148^{\circ} 58^{\prime} 45^{\prime \prime} \mathrm{W}$; (map 100).

Local name published on a 1952 USGS map.

Beaverdam Lake: lake, $1 \mathrm{mi}$. long, in course of Nolitna Creek, $16 \mathrm{mi}$. SW of Beaver, Yukon Flats; $66^{\circ} 10^{\prime} \mathrm{N}, 147^{\circ} 43^{\prime} \mathrm{W}$; (map 118).

Probably named by William Yanert who showed it on a 1916 manuscript map of the Yukon Flats (Stuck, 1917, map facing p. 122).

Beaver Falls: settlement, pop. 5, on Revillagigedo I., on $W$ bank of George Inlet, at mouth of Beaver Falls Creek, Alex. Arch.; 55 ${ }^{\circ} 3^{\prime}$ N, $131^{\circ} 28^{\prime} \mathrm{W}$; (map 3 ).

This site is a cannery.

Beaver Falls: waterfall, on Revillagigedo I., 5.3 mi. NE of Ketchikan, between Upper and Lower Silvis Lakes, in course of Beaver Falls Creek, Alex. Arch.; $55^{\circ} 22^{\prime} 50^{\prime \prime}$ N, $131^{\circ} 31^{\prime} 07^{\prime \prime}$ W; (map 3).

Local name reported in 1915 by G. H. Canfield (in Brooks and others, 1916, p. 107), USGS.

Beaver Falls Greek: stream, on Revillagigedo I., heads in a lake, flows $\mathrm{E}$, through Upper and Lower Silvis Lakes, $4 \mathrm{mi}$. to George Inlet, Alex. Arch.; $55^{\circ} 22^{\prime} 55^{\prime \prime} \mathrm{N}, 131^{\circ} 28^{\prime} 10^{\prime \prime} \mathrm{W}$; (map 3).

Local name reported in 1915 by G. H. Canfield (in Brooks and others, 1922, p. 80), USGS.

Beaverhouse Hill: hill, $288 \mathrm{ft}$., on $\mathrm{N}$ bank of Holitna River $1.4 \mathrm{mi}$. W of its junc. with Hoholitna River, $13 \mathrm{mi}$. SE of Sleetmute, Stony River Low.; $61^{\circ} 30^{\prime} 45^{\prime \prime} \mathrm{N}, 157^{\circ} 01^{\prime} 20^{\prime \prime}$ W; BCN 1948; (map 72).

Local descriptive name reported in 1945 by USGS.

Beaverhouse Lake: lake, $0.3 \mathrm{mi}$. across, one of Beaver Lakes, $25 \mathrm{mi}$. N of Anchorage, Cook Inlet Low.; $61^{\circ} 34^{\prime} 30^{\prime \prime} \mathrm{N}, 149^{\circ} 51^{\prime} 45^{\prime \prime} \mathrm{W}$; $B G N 1963$; (map 69).

So named in 1963 by Viola F. McMillen of Wasilla, Alaska, so the name will "go along with the general naming of the group."

Beaver Inlet: bay, $18 \mathrm{mi}$. long and $5 \mathrm{mi}$. wide, on NE coast of Unalaska I., Aleutian Is.; $5^{\circ}$ $50^{\prime} \mathrm{N}, 166^{\circ} 15^{\prime} \mathrm{W}$; (map 23). Var. Bay of Otters, Bobrovoi Guba, Bobrovoy Guba, SeaOtter Bay, Sea Otters Bay.

Published by USBF in 1888 . Sauer (1802, p. 154) referred to the inlet as "Bobrovoy Guba," or the "bay of otters"; von Langsdorff (1813-14, v. 2, p. 28) translated the Russian name as "Sea Otters Bay."
Beaver Inlet: cove, $0.1 \mathrm{mi}$. across, at mouth of Nazi Creek, on $\mathbf{S}$ coast of Little Kiska I., Aleutian Is.; $51^{\circ} 56^{\prime} 50^{\prime \prime} \mathrm{N}, 177^{\circ} 40^{\prime} 25^{\prime \prime} \mathrm{E}$; (map 14).

This is one of the animal names arbitrarily applied to features in this area in 1943 by USAAF for tactical purposes during World War II.

Beaver Island: island, see Bobrof Island.

Beaver Island: island, see Sea Otter Island.

Beaver Island: island, see Sedanka Island.

Beaver Islet: island, see Bobrof Island.

Beaver Lake: lake, "between the headwaters of Unalaklik and Yukon rivers, draining into the latter. 'An open tundra known as Beaver lake, as it is covered with water in the spring.' Local name from Dall, 1866" (Baker, 1906, p. 124).

Beaver Lake: lake, 1,200 ft. long, on Revillagigedo 1 ., on NE shore of Thorne Arm, Alex. Arch.; 55 $22^{\prime} 40^{\prime \prime} \mathrm{N}, 131^{\circ} 11^{\prime} 00^{\prime \prime} \mathrm{W}$; (map $3)$.

Local name reported in 1901 by A. H. Brooks (1902b, pl. 2), USGS.

Beaver Lake: lake, $0.4 \mathrm{mi}$. long, $5 \mathrm{mi}$. E of Sitka, on W coast of Baranof I., Alex. Arch.; 57 . $03^{\prime} 30^{\prime \prime} \mathrm{N}, 135^{\circ} 11^{\prime} 30^{\prime \prime} \mathrm{W}$; BGN 1928; (map 9).

Local name reported in 1927 by USFS.

Beaver Lake: lake, $1 \mathrm{mi}$. long, $4 \mathrm{mi}$. E of Mole Harbor, on $\mathrm{E}$ coast of Admiralty I., $61 \mathrm{mi}$. NE of Sitka, Alex. Arch.; $57^{\circ} 40^{\prime} 30^{\prime \prime} \mathrm{N}, 134^{\circ} 12^{\prime}$ $00^{\prime \prime} \mathrm{W} ;$ BGN 1928; (map 9).

Named by members of the Alexander Alaska Expedition, 1907 (Grinnell, 1909, p. 174), who found a new species of beaver at this locality.

Beaver Lake: lake, $0.2 \mathrm{mi}$. long, $1.5 \mathrm{mi}$. NE of Kodiak, on NE coast of Kodiak I.; $57^{\circ} 48^{\prime}$ $30^{\prime \prime} \mathrm{N}, 152^{\circ} 22^{\prime} 40^{\prime \prime} \mathrm{W}$; (map 34). Var. Ozero Verkhui.

Name published in 1943 by USC\&GS. The descriptive name "Oz[ero] Verkhui," meaning "upper lake," was published for this feature by Capt. Tebenkov (1852, map 23), IRN.

Beaver Lake: lake, $0.8 \mathrm{mi}$. long, on Alaska Penin., $1 \mathrm{mi}$. E of Lookout Mtn. and $22 \mathrm{mi}$. $\mathrm{SE}$ of Iliamna, Aleutian Ra.; $59^{\circ} 29^{\prime} 30^{\prime \prime} \mathrm{N}$, $154^{\circ} 35^{\prime} 00^{\prime \prime} \mathrm{W}$; (map 51$)$

Name published in 1951 by USGS

Beaver Lake: lake, $0.3 \mathrm{mi}$. long, $2.5 \mathrm{mi}$. W of terminus of Sheridan Glacier and $10 \mathrm{mi}$. E of Cordova, Chugach Mts.; $60^{\circ} 32^{\prime} \mathrm{N}, 145^{\circ}$ $27^{\prime} \mathrm{W}$; (map 64).

Published in 1950 by USGS

Beaver Lake: lake, $2.5 \mathrm{mi}$. long, on Kenai Penin. at head of Beaver Creek, $11 \mathrm{mi}$. NW of Sterling and $10 \mathrm{mi}$. NE of Kenai, Cook Inlet Low.; $60^{\circ} 39^{\prime} 30^{\prime \prime} \mathrm{N}, 150^{\circ} 59^{\prime} 30^{\prime \prime} \mathrm{W}$; (map 62).

Named by officials of Kenai National Moose Range, about 1963, for administrative purposes.

Beaver Lake: lake, $1.9 \mathrm{mi}$. long, $\mathrm{E}$ of Susitna River, $21 \mathrm{mi}$. NW of Anchorage, Cook Inlet Low.; $61^{\circ} 22^{\prime} \mathrm{N}, 150^{\circ} 28^{\prime} \mathrm{W}$; (map 70).

Local name reported in 1958 by USGS.
Beaver Lake: lake, $2 \mathrm{mi}$. long, in course of Beaver Creek, in Nutzotin Mts., $11 \mathrm{mi}$. E of Euchre Mtn., Alaska Ra.; $62^{\circ} 02^{\prime} \mathrm{N}, 141^{\circ} 49^{\prime} \mathrm{W}$; (map 84).

Local name reported by Brooks (in Brooks and others, 1915, pl. 9), USGS.

Beaver Lake: lake, $0.5 \mathrm{mi}$. long, $4.4 \mathrm{mi}$. SSW of Doghouse Lake and $7 \mathrm{mi}$. S of Lake Snohomish, Tanana Low.; $63^{\circ} 38^{\prime} 30^{\prime \prime} \mathrm{N}, 152^{\circ} 31^{\prime}$ $30^{\prime \prime} \mathrm{W}$; (map 88).

Local name reported in 1954 by USGS.

Beaver Lake: lake, $0.5 \mathrm{mi}$. long, on $\mathrm{S}$ bank of Melozitna River between Dome and Wolf Creeks, $29 \mathrm{mi}$. NNW of Birches, KokrinesHodzana High.; $65^{\circ} 29^{\prime} 00^{\prime \prime} \mathrm{N}, 154^{\circ} 04^{\prime} 30^{\prime \prime}$ W; (map 107).

Local name obtained in 1954 by USGS topographers.

Beaver Lake: lake, $0.6 \mathrm{mi}$. across, $\mathrm{S}$ of Sweeney Lake, $20 \mathrm{mi}$. SW of Beaver, Yukon Flats; $66^{\circ}$ $06^{\prime} 30^{\prime \prime} \mathrm{N}, 147^{\circ} 45^{\prime} 00^{\prime \prime} \mathrm{W}$; (map 118).

Local name obtained in 1956 by USGS.

Beaver Lake: lake, $0.8 \mathrm{mi}$. long, $\mathrm{E}$ of Tincan Lake and $18 \mathrm{mi}$. SW of Beaver, Yukon Flats; $66^{\circ} 09^{\prime} 50^{\prime \prime} \mathrm{N}, 147^{\circ} 51^{\prime} 00^{\prime \prime} \mathrm{W}$; (map 118). Var. Hill Lake.

Local name reported in 1956 by T. E. Taylor; shown in 1916 as "Hill Lake" by William Yanert (Stuck, 1917, p. 122).

Beaver Lake: lake, $0.6 \mathrm{mi}$. long, $0.5 \mathrm{mi}$. $\mathrm{S}$ of Olaf Lake and $19 \mathrm{mi}$. SE of Beaver, Yukon Flats; $66^{\circ} 11^{\prime} 20^{\prime \prime} \mathrm{N}, 146^{\circ} 51^{\prime} 00^{\prime \prime} \mathrm{W}$; (map 119).

Local descriptive name obtained in 1956 by USGS.

Beaver Lake: lake, $0.9 \mathrm{mi}$. long, $12 \mathrm{mi}$. SE of Beaver, Yukon Flats; $66^{\circ} 13^{\prime} 15^{\prime \prime} \mathrm{N}, 147^{\circ} 06^{\prime}$ $00^{\prime \prime} \mathrm{W}$; (map 118).

Local name obtained in 1956 by USGS.

Beaver Lakes: lakes, $\mathrm{N}$ of Big Lake, extend E-W $3.2 \mathrm{mi}$., $25 \mathrm{mi}$. $\mathrm{N}$ of Anchorage, Cook Inlet Low.; $61^{\circ} 35^{\prime} 20^{\prime \prime} \mathrm{N}, 149^{\circ} 51^{\prime} 00^{\prime \prime} \mathrm{W}$; (map 69).

Local name reported in 1950 by USGS.

Beaver Mountain: mountain, 3,000 ft., near center of Prince of Wales Island, $\mathbf{N}$ of Portage Creek, $\mathbf{E}$ of head of Hetta Inlet, Alex. Arch.; $55^{\circ} 17^{\prime} 15^{\prime \prime} \mathrm{N}, 132^{\circ} 30^{\prime} 50^{\prime \prime} \mathrm{W}$; (map 4).

Local name reported in 1908 by C. W. Wright (in Brooks and others, 1909, pl. 3), USGS.

Beaver Mountain: peak, on Unalaska I. near Beaver Inlet, Aleutian Is.; (map 23). Var. Bobrovskoi.

Published as "Bobrovskoi," meaning "sea otter," by Capt. Lutke (1836, p. 280), IRN; this feature has not been positively identified.

Beaver Mountains: mountain range, $3,500 \mathrm{ft}$., in Kuskokwim Mts., extends NW-SE $14 \mathrm{mi}$. between Tolstoi Creek and Takotna River, 40 mi. W of McGrath, Kilbuck-Kuskokwim Mts., $62^{\circ} 54^{\prime} \mathrm{N}, 156^{\circ} 58^{\prime} \mathrm{W}$; (map 79).

Prospectors' name obtained in 1913 by Eakin (1914, pl. 1), USGS.

Beaver Mountains: mountains, part of Alaska Ra., in central Alaska.

This name was published on a map of Alaska by British Parliament in 1855 and was 
also used on a GLO map in 1869 (Baker 1906, p. 124)

Beaver Mountains: mountain range, see Alaska Range.

Beaver Peak: mountain, $8,800 \mathrm{ft}$., in Nutzotin Mts. E of Lime Glacier, $48 \mathrm{mi}$. NE of McCarthy, Alaska Ra.; $61^{\circ} 50^{\prime} \mathrm{N}, 141^{\circ} 58^{\prime} \mathrm{W}$ (map 67).

Local name reported by Capps (1916, pl. 1), USGS

Beaver Point: point of land, $\mathrm{S}$ entrance to Shelikof Bay, on W coast of Kruzof I., $19 \mathrm{mi}$. W of Sitka, Alex. Arch, ; $57^{\circ} 05^{\prime} 30^{\prime \prime} \mathrm{N}, 135^{\circ} 50^{\prime} 30^{\prime \prime}$ W; (map 9). Var. Bobrovie, Mys Böbrovyy.

This is an 1880 USC\&GS translation of the name "Mys Bobrovyy," meaning "sea otter cape"; probably given in 1810 by Lt. Rikord (cnna).

Beaver Point: point of land, on right bank of Yukon River, opposite Weir I., $57 \mathrm{mi}$. SSW of Nulato, Innoko Low.; $63^{\circ} 58^{\prime} 00^{\prime \prime} \mathrm{N}, 158^{\circ}$. $56^{\prime} 40^{\prime \prime} \mathrm{W}$; (map 90).

Riverboat pilots' name shown on 1940 "Navigation Chart of the Tanana-Yukon Rivers," by the U.S. Dept. of Interior.

Beaver Pond Lake: lake, $0.4 \mathrm{mi}$. long, on Kenai Penin., $1.5 \mathrm{mi}$. NW of junc. of West Fork with Moose River, $20 \mathrm{mi}$. NE of Kenai, Cook Inlet Low.; $60^{\circ} 36^{\prime} 25^{\prime \prime} \mathrm{N}, 150^{\circ} 41^{\prime} 00^{\prime \prime} \mathrm{W}$; (map 62).

Named about 1963 by officials of Kenai National Moose Range, for administrative purposes.

Beaver Reef: reef, see Douglas Reef.

Beaver River: stream, on $\mathrm{S}$ coast of Alaska Penin., flows $\mathrm{S} 10 \mathrm{mi}$. to Beaver Bay, Aleutian Ra, $55^{\circ} 31^{\prime} 30^{\prime \prime} \mathrm{N}, 160^{\circ} 55^{\prime} 00^{\prime \prime} \mathrm{W}$; ( $\operatorname{map} 28$ ).

Reported in 1929 by USGS.

Beaver River: stream, see Beaver Creek.

Beaver Slough: stream, anabranch of Yukon River, flows SW $9 \mathrm{mi}$., $10 \mathrm{mi}$. SW of Beaver, Yukon Flats; $66^{\circ} 14^{\prime} 40^{\prime \prime} \mathrm{N}, 147^{\circ} 35^{\prime} 30^{\prime \prime} \mathrm{W}$; (map 118). Var. Ausana, She Beaver.

This appears to be a partial translation of the Indian name which in complete form would be "female beaver creek." The name was first published on Edwards Track Chart of the Yukon, 1899, as "She Beaver (Ausana)." See Hodzana River. The simple form "Beaver" was published by Mendenhall (1902, pl. 4), USGS.

Beavertail Island: island, $0.5 \mathrm{mi}$. long, at $\mathrm{E}$ point of entrance to Redfish Bay, $8.8 \mathrm{mi}$. NW of village of Port Alexander, on S coast of Baranof I., Alex. Arch.; 56 $18^{\prime} 25^{\prime \prime}$ N, 134 $51^{\circ} 00^{\prime \prime}$ W; (map 5).

Named in 1897 by Lt. Comdr. J. F. Moser, USN, commander of USBF steamer Albatross.

Beaver Trail Lake: lake, $0.3 \mathrm{mi}$. long, one of Beaver Lakes, $26 \mathrm{mi}$. $\mathrm{N}$ of Anchorage, Cook Inlet Low.; $61^{\circ} 35^{\prime} 40^{\prime \prime} \mathrm{N}, 1^{\circ} 59^{\circ} 51^{\prime} 15^{\prime \prime} \mathrm{W}$; (map 69).

Local name reported in 1950 by USGS.

Becharof : locality, on NW coast of Alaska Penin. on NE shore of Egegik Bay, $7 \mathrm{mi}$. NW of Egegik, Bristol Bay Low.; $58^{\circ} 17^{\prime} \mathrm{N}, 157^{\circ} 28^{\prime}$ W; (map 41).

Reported in 1923 on an ARC map.
Becharof, Mount: peak, 3,100 ft., S of Kanatak, between Kanatak Lagoon and Portage Bay, on $\mathbf{S}$ coast of Alaska Penin., Aleutian Ra.; $57^{\circ}$ $32^{\prime} 10^{\prime \prime} \mathrm{N}, 156^{\circ} 04^{\prime} 40^{\prime \prime} \mathrm{W}$; (map 36). Var. Mount Becharoff, Mount Botcharoff, Mount Betchareff.

Name published in the 1880 's by USC\&GS as "Mount Becharoff" and "Mount Botcharoff"; derived from Becharof Lake.

Becharof Creek: stream, on Alaska Penin., flows NW $15 \mathrm{mi}$. to Becharof Lake, S of Severson Penin., 49 mi. SW of Mount Katmai, Aleutian Ra.; 57 $47^{\circ} 25^{\prime \prime}$ N, $155^{\circ} 57^{\prime} 45^{\prime \prime}$ W; (map 35).

Named in 1903 by J. L. McPherson of Iliamna and reported in 1904 by G. C. Martin, USGS.

Becharoff, Mount: peak, see Becharof, Mount.

Becharoff Lake: lake, see Becharof Lake.

Becharof Lake: lake, $37 \mathrm{mi}$. long, on Alaska Penin., 23 mi. SE of Egegik, Aleutian Ra.; $57^{\circ} 56^{\prime} \mathrm{N}, 156^{\circ} 23^{\prime} \mathrm{W}$; (map 36). Var. Becharoff Lake, Betchareff Lake, Bocharof Lake, Botcharoff Lake, Igiagiuk, Tugat, Lac Nanouan Toughat, Lake Bochonoff, Lake Ugiagwik, Niniua-Tugat, Ozero Ugashek, Rochanoff Lake.

Named in 1868 by W. H. Dall, USC\&GS, for the navigator "Bocharov," IRN, who was at Kodiak in 1788. The Russian Hydrog. Dept. published the name "Oz[ero] Ugashek" on Chart 1455 in 1852

Becher Creek: stream, heads on King Mtn., flows E $1 \mathrm{mi}$. to Nome River, $7 \mathrm{mi}$. NNE of Nome, Seward Penin. High.; $64^{\circ} 36^{\prime}$ N, $165^{\circ} 17^{\prime}$ W; (map 94).

Prospectors' name published on the 1900 "Map of Nome Peninsula" by J. M. Davidson and B. D. Blakeslee.

Becher Point: point of land, see Beechey Point.

Bechevin Bay: bay, on $\mathrm{N}$ coast, near $\mathrm{W}$ end of Atka I., extends SW $5 \mathrm{mi}$. from Bechevin Point, Aleutian Is.; $52^{\circ} 03^{\prime} \mathrm{N}, 175^{\circ} 06^{\prime} \mathrm{W}$; (map 18). Var. Betshevinskoi, Betchevinskoi, Bichevina.

According to Sauer (1802, chart), named "Betchevinskoi" by Commodore Joseph Billings, IRN, after "Bechevin, who sent the ship Gavril to the Aleutian Islands in 1760 . See below.

Bechevin Bay: bay, $8 \mathrm{mi}$, across, between Unimak I. and Alaska Penin., at SW end of Aleutian Ra.; 55 $00^{\prime} \mathrm{N}, 163^{\circ} 23^{\prime} \mathrm{W}$; BGN 1906; (map 25, 29). Var. Bitchevinskoi, Isanotski Bay, Issannakh Bay, Port Betchevinskoi, Proliv Isannakhskiy.

Named "Betchevinskoi" by Capt. Lutke (1836, p. 296), IRN, for the merchant, Bechevin, of Irkutsk, Siberia, who "dispatched in 1760 the largest vessel hitherto sent to the Aleutian Islands * * *," the Gavril (Bancroft, 1886, p. 122). The Russian Hydrog. Dept. included this feature in its application of the name "Pr[oliv] Isannakhskiy" (Isanotski Strait), published in 1847 on Chart 1379. In 1882 the USC\&GS published the name "Bitchevinskoi"."
Bechevin Cape: point of land, see Bechevin Point.

Bechevin Point: point of land, on $\mathrm{N}$ coast of Atka I., Aleutian Is.; $52^{\circ} 04^{\prime} 20^{\prime \prime} \mathrm{N}, 175^{\circ}$. 01'00" W; (map 18). Var. Bechevin Cape, Betchevinskoi cap.

Published as "Betchevinskoi cap" by Capt. Lutke (1836, p. 315), probably obtained from the Russian American Company pilot, Ingenstrem (cnna), who surveyed Atka and Amlia about 1829. Named "Bechevin Cape" by Baker (1906, p. 125); "Bechevin Point" was published by the USG\&GS in the 1944 Aleutian Coast Pilot (p. 97)

Beckett Ridge: ridge, trends NW-SE $6 \mathrm{mi}$., 23 mi. S of Cape Sabine, $56 \mathrm{mi}$. E of Point Hope, Arctic Slope; $68^{\circ} 36^{\prime} 30^{\prime \prime} \mathrm{N}, 164^{\circ} 47^{\prime} 00^{\prime \prime} \mathrm{W}$. [NW end], $68^{\circ} 32^{\prime} 15^{\prime \prime} \mathrm{N}, 164^{\circ} 40^{\prime} 00^{\prime \prime} \mathrm{W}$. [SE end]; BGN 1965; (map 130).

So named for Thomas à Beckett, 1118-70, English Royal Chancellor, Archbishop of Canterbury, and martyr, because the date of his death corresponds with the elevation of the highest point on the ridge. Named in 1965 by a geologist of the B. P. Exploration Co., Inc.

Beck Hills: hills, see Becks Hills.

Beck Island: island, $200 \mathrm{ft}$. long, at SE end of Kashevarof Passage, on NE coast of Prince of Wales I., Alex. Arch.; $56^{\circ} 02^{\prime} 50^{\prime \prime} \mathrm{N}, 132^{\circ}$ $51^{\prime} 45^{\prime \prime} \mathrm{W}$; (map 6).

Local name used by fishermen and published in 1907 by USC\&GS.

Beck Island: island, $0.1 \mathrm{mi}$. long, in Rocky Pass, Keku Strait, $21 \mathrm{mi}$. N of Point Baker, Alex. Arch.; $56^{\circ} 39^{\prime} 30^{\prime \prime} \mathrm{N}, 133^{\circ} 43^{\prime} 00^{\prime \prime} \mathrm{W}$; (map 6).

Local name published by USC\&GS in 1932 Coast Pilot (p. 258)

Beckman Creek: stream, see Backman Creek.

Beck Mountains: hills, see Becks Hills.

Beck Rock: rock, in North Arm Moira Sound, on SE coast of Prince of Wales I., Alex. Arch.; $55^{\circ} 06^{\prime} 35^{\prime \prime} \mathrm{N}, 132^{\circ} 06^{\prime} 55^{\prime \prime} \mathrm{W}$; (map 4).

Local name reported in 1905 by E. F. Dickins, USC\&GS.

Becks Hills: hills, 2,700 ft., extend W $25 \mathrm{mi}$. from Koyukuk River at Bettles to West Fork Henshaw Creek, Brooks Ra.; $66^{\circ} 53^{\prime} \mathrm{N}, 152^{\circ}$ $15^{\prime} \mathrm{W}$; (map 117). Var. Beck Hills, Beck Mountains.

Named in 1885 by Lt. Allen (1887, p. 100), USA, "in honor of Senator James B. Beck of Kentucky.'

Bedard Cove: bight, $1.2 \mathrm{mi}$. across, on SE coast of Attu I. NE of Alexai Point, Aleutian Is.; $52^{\circ} 49^{\prime} 15^{\prime \prime} \mathrm{N}, 173^{\circ} 19^{\prime} 00^{\prime \prime} \mathrm{E}$; (map 13). Var. Lastova Bay.

Recorded as "Lastova Bay" by Jochelson (1925, p. 24); published in 1948 as "Bedard Cove" by AMS.

Bede, Cape: point of land, see Adam, Point. Bede, Mount: mountain, 3,255 ft., on SW end of Kenai Penin. in Kenai Mts., $12 \mathrm{mi}$. SW of Seldovia, Chugach Mts.; $59^{\circ} 18^{\prime} 30^{\prime \prime} \mathrm{N}, 151^{\circ}$. 55'20" W; BGN 1911; (map 50).

Local name derived from Bede Point; reported in 1911 by U. S. Grant, USGS. 
Bede, Point: point of land, on SW coast of Kenai Penin., 13 mi. SW of Seldovia, Chugach Mts.; $59^{\circ} 18^{\prime} 50^{\prime \prime} \mathrm{N}, 151^{\circ} 58^{\prime} 15^{\prime \prime} \mathrm{W}$; (map 50).

Named on May 26, 1778 by Capt. Cook (1785, v. 2, p. 387), RN, for Saint Bede whose day is May 27. Cook's "Cape Bede" was about five miles south of the present point of land, on what is now called Point Adam.

Bedlam Creek: stream, on Kenai Penin., heads in Mull Lake of the Bedlam Lakes, flows $\mathbf{E}$ $5 \mathrm{mi}$. to Chickaloon Bay, $22 \mathrm{mi}$. SW of Anchorage, Cook Inlet Low.; $60^{\circ} 56^{\prime} 00^{\prime \prime} \mathrm{N}, 150^{\circ}$ $13^{\prime} 45^{\prime \prime} \mathrm{W}$; (map 62).

Local name reported in 1950 by USGS

Bedlam Lake: lake, $1.2 \mathrm{mi}$. long, one of the Bedlam Lakes on Kenai Penin. in course of Bedlam Creek, $40 \mathrm{mi}$. NE of Kenai, Cook Inlet Low.; $60^{\circ} 55^{\prime} 30^{\prime \prime} \mathrm{N}, 150^{\circ} 20^{\prime} 40^{\prime \prime} \mathrm{W}$; (map 62).

Named about 1963 by officials of Kenai National Moose Range, for administrative purposes.

Bedlam Lakes: lakes, on Kenai Penin., W of Chickaloon Bay, at head of Bedlam Creek, $25 \mathrm{mi}$. SW of Anchorage, Cook Inlet Low.; $60^{\circ} 55^{\prime} \mathrm{N}, 150^{\circ} 20^{\prime} \mathrm{W}$; (map 62).

Local name reported in 1958 by USGS. Name derived from the creek.

Bedrock Creek: stream, on Kenai Penin., flows E $3.5 \mathrm{mi}$. to Resurrection Creek, $3.5 \mathrm{mi}$. S of Hope, Chugach Mts. ; 60 $52^{\prime} 15^{\prime \prime} \mathrm{N}, 149^{\circ}$ $37^{\prime} 45^{\prime \prime} \mathrm{W}$; (map 63).

Local prospectors' name reported in 1904 by Moffit (1906, pl. 2), USGS.

Bedrock Creek: stream, flows SE $1 \mathrm{mi}$. to Middle Fork Chistochina River, $28 \mathrm{mi}$. NE of Paxson, Alaska Ra.; $63^{\circ} 08^{\prime} 25^{\prime \prime} \mathrm{N}, 144^{\circ} 37^{\prime} 30^{\prime \prime} \mathrm{W}$; (map 86).

Name published on relatively recent maps.

Bedrock Creek: stream, flows SE across AlaskaCanada boundary, 6.2 mi. to Sixty Mile River in Yukon, Canada, $11 \mathrm{mi}$. NE of point where river crosses boundary, Yukon-Tanana High.; $63^{\circ} 58^{\prime} \mathrm{N}, 140^{\circ} 52^{\prime} \mathrm{W}$; (map 85).

Descriptive name reported about 1914 by IBC.

Bedrock Creek: stream, flows $\mathrm{N} 1 \mathrm{mi}$. to Cleary Creek, $17 \mathrm{mi}$. NE of Fairbanks, Yukon-Tanana High.; $65^{\circ} 04^{\prime} \mathrm{N}, 147^{\circ} 26^{\prime} \mathrm{W}$; (map 105 ).

Named by prospectors; shown on a manuscript map by C. W. Joynt dated 1905 .

Bedrock Creek: stream, flows NE $6 \mathrm{mi}$. to Crooked Creek, $35 \mathrm{mi}$. SW of Circle, TananaYukon Highlands; $65^{\circ} 33^{\prime} 45^{\prime \prime} \mathrm{N}, 1^{\circ} 5^{\circ} 05^{\prime} 40^{\prime \prime}$ W; BGN 1938; (map 104)

Named by prospectors and reported in 1896 by USGS (Spurr, 1898, pl. 50).

Bedrock Creek: stream, flows SW $12 \mathrm{mi}$, $\mathrm{N}$ of Heart and Deadman Mts., to Malamute Fork Alatna River, $73 \mathrm{mi}$. SW of Wiseman, Brooks Ra.; $67^{\circ} 06^{\prime} 20^{\prime \prime} \mathrm{N}, 152^{\circ} 44^{\prime} 00^{\prime \prime}$ W; (map 124).

Local descriptive name obtained in 1956 by USGS topographers.

Bedzin Point: point of land, on Alaska Peninsula.

Russian name mentioned by W. H. Dall, USGS, in a letter to BGN dated 1891. Its exact application and origin are unknown.
Beebe, Lake: lake, $800 \mathrm{ft}$. across, $0.2 \mathrm{mi}$. $\mathrm{N}$ of Sixmile Lake and $6.1 \mathrm{mi}$. NE of Anchorage, Cook Inlet Low.; $61^{\circ} 17^{\prime} 45^{\prime \prime} \mathrm{N}, 1^{\circ} 49^{\circ} 47^{\prime} 45^{\prime \prime}$ W; (map 69). Var. Beebe Lake.

Local name reported in 1953 by USGS named for Herb Beebe, a retired Alaska RR. engineer and homesteader.

Beecher Pass: water passage, extends W $3 \mathrm{mi}$. from Wrangell Narrows to Duncan Canal, 15 mi. S of Petersburg, Alex. Arch.; $56^{\circ} 36^{\prime} \mathrm{N}$, $133^{\circ} 00^{\prime} \mathrm{W}$; (map 6). Var. Duncan Passage.

Named in 1887 by Lt. Comdr. C. M. Thomas, USN, for Ens. Albert Morrison Beecher, USN, died 1903, a member of his party. Named "Duncan Passage" in 1869 by Comdr. R. W. Meade, USN.

Beecher Point: point of land, see Beechey Point. Beechery Point: point of land, see Beechey Point. Beechey Mound: pingo, elev. $56 \mathrm{ft}$., on Beaufort Sea coast, $3.5 \mathrm{mi}$. SW of Beechey Point, Arctic Plain; $70^{\circ} 26^{\prime} 30^{\prime \prime} \mathrm{N}, 149^{\circ} 14^{\prime} 15^{\prime \prime} \mathrm{W}$; (map 150)

Named in 1911 for Beechey Point and used as a triangulation station by Leffingwell (1919 p. 41).

Beechey Point: locality, on Beaufort Sea coast, $25 \mathrm{mi}$. E of mouth of Colville River, Arctic Plain; $70^{\circ} 29^{\prime} \mathrm{N}, 1^{\circ} 9^{\circ} 09^{\prime} \mathrm{W}$; (map 150). Var. Beachey Point, Beachy Point.

Shown as Beachy Point on 1941 Kroll map of Alaska. Named for adjacent point of land.

Beechey Point: point of land, on Beaufort Sea coast, on S shore of Simpson Lagoon, $25 \mathrm{mi}$. E of month of Colville River, Arctic Plain; $70^{\circ}$ $29^{\prime} 20^{\prime \prime} \mathrm{N}, 149^{\circ} 09^{\prime} 30^{\prime \prime} \mathrm{W}$; BGN 1916; (map 150). Var. Beachey Point, Beachy Point, Becher Point, Beecher Point, Beechery Point, Point Beechey, Point Beechy.

Named "Point Beechey" on August 17 1826, by Sir John Franklin (1828, p. 166), who wrote, "a more westerly hummock, * * * that has been distinguished by the name of my friend Capt. [Frederick William] Beechey, [RN], at which point ***our discoveries terminated."

Beechey Point: point of land, see Oliktok Point. Beechy, Point: point of land, see Beechey Point. Beehive, The: hill, $430 \mathrm{ft}$., on S coast of Golf I., $4 \mathrm{mi}$. S of Goddard, off W coast of Baranof I., Alex. Arch.; $56^{\circ} 46^{\prime} 50^{\prime \prime} \mathrm{N}, 135^{\circ} 24^{\prime} 00^{\prime \prime} \mathrm{W}$; (map 5).

Descriptive name published in 1927 by USC\&GS.

Beehive Creek: stream, flows SW to Budd Creek which flows to American River, about $10 \mathrm{mi}$. SW of Kougarok Mtn. and $35 \mathrm{mi}$. NE of Teller, Seward Penin. High.; (map 111).

Prospectors' name reported in 1900 by Messrs. Kemp and David Fox (in Brooks, 1901, pl. 11), USGS. This stream cannot be precisely defined on current maps.

Beehive Island: island, $0.2 \mathrm{mi}$. across, at mouth of Nakwasina Sound, $9.5 \mathrm{mi}$. N of Sitka, Alex. Arch.; $57^{\circ} 11^{\prime} 10^{\prime \prime} \mathrm{N}, 1^{\circ} 5^{\circ} 26^{\prime} 00^{\prime \prime} \mathrm{W}$; (map 9)

Descriptive name given in 1880, by Marcus Baker, USC\&GS, because of "its resemblance, as seen from the west, to the shape of a con- ventional straw beehive." The name was published in the 1883 Coast Pilot (p. 152).

Beehive Island: island, $0.3 \mathrm{mi}$. across, $\mathrm{E}$ of $\mathrm{Ma}$ tushka I., one of Chiswell Is., $36 \mathrm{mi}$. SW of Seward, Chugach Mts.; 59 $37^{\prime} 10^{\prime \prime} \mathrm{N}, 149^{\circ}$ $36^{\prime} 45^{\prime \prime}$ W; BGN 1911; (map 49). Var. The Beehive.

Named "The Beehive" in 1910 by U. S. Grant, USGS; "suggestive of its shape."

Beelzebub, Mount: mountain, 7,280 ft., $10 \mathrm{mi}$. S of Eklutna Lake and $29 \mathrm{mi}$. E of Anchorage, Chugach Mts.; $61^{\circ} 11^{\prime} 25^{\prime \prime} \mathrm{N}, 149^{\circ} 01^{\prime} 20^{\prime \prime} \mathrm{W}$; $B G N$ 1966; (map 69).

Named by Art Davidson, Mike Judd, Dave Myers, and Nick Parker, of the Mountaineering Club of Alaska, who were in the first ascent party on this mountain on August 22, 1965. They felt that "this name for the devil was considered appropriate."

Beemguiga Creek: stream, flows W $3.6 \mathrm{mi}$. to Holokuk River, N of Holokuk Mtn., $14 \mathrm{mi}$. SE of Little Mountain Village and $43 \mathrm{mi}$. SW of Sleetmute, Kilbuck-Kuskokwim Mts.; $61^{\circ}$ $24^{\prime} \mathrm{N}, 158^{\circ} 20^{\prime} \mathrm{W}$; BGN 1948; (map 72).

Name is simplification of native word, "Holokukbeemguiga," meaning "stream flowing alongside stone knife (Holokuk) mountain"; reported in 1945 by USGS.

Beerings Bay: delta, see Dry Bay.

Beerings Strait: water passage, see Bering Strait. Bee Rocks: rocks, include East Bee Rock and West Bee Rock, $1.3 \mathrm{mi}$. apart, in Clarence Strait, $4 \mathrm{mi}$. SW of Duke I., Alex. Arch.; $54^{\circ} 53^{\prime} \mathrm{N}, 131^{\circ} 33^{\prime} \mathrm{W}$; (map 2).

Named in 1883 by Lt. Comdr. H. E. Nichols, USN.

Beeson Slough: lagoon, extends NW-SE $8 \mathrm{mi}$. along Norton Sound, $24 \mathrm{mi}$. SW of Christmas Mtn., Nulato Hills; $64^{\circ} 15^{\prime} \mathrm{N}, 161^{\circ} 00^{\prime} \mathrm{W}$; (map 96).

Local name reported about 1954 by U.S. Army Corps of Engineers.

Beetuk Creek: stream, see Baituk Creek.

Behm Canal: water passage, between Revillagigedo $I$. and mainland, from $W$ entrance at Clarence Strait at $55^{\circ} 28^{\prime} \mathrm{N}, 131^{\circ} 55^{\prime} \mathrm{W}$ it extends N $33 \mathrm{mi}$. then NE $15 \mathrm{mi}$. through Behm Narrows to Point Whaley and then $S$ $60 \mathrm{mi}$. to its $\mathrm{E}$ entrance at Revillagigedo Channel, $55^{\circ} 10^{\prime} \mathrm{N}, 131^{\circ} 08^{\prime} \mathrm{W}$; Alex. Arch.; (map 3).

Named by Capt. George Vancouver, RN, "in 1793 after Major Magnus Carl von Behm, commandant of Kamchatka in 1779" (Wagner, 1937, p. 375).

Behm Mountain: mountain, 2,744 ft., on mainland near $E$ entrance to Behm Canal, Coast Mts.; $55^{\circ} 11^{\prime} 45^{\prime \prime} \mathrm{N}, 131^{\circ} 00^{\prime} 30^{\prime \prime} \mathrm{W}$; (map 3).

Named in 1883 by Lt. Comdr. H. E. Nichols, USN.

Behm Narrows: water passage, $4 \mathrm{mi}$. long, in Behm Canal, between Bell and Revillagigedo Is., Alex. Arch.; 55 55' N, 131 $30^{\prime} \mathrm{W}$; (map 3).

Arbitrary name given in 1891 by USC\&GS. 
Behring, Bahia de: bay, "in about $59^{\circ} 30^{\prime} \mathrm{N}$, apparently taken from [Capt. James] Cook's map." See Wagner (1937, p. 432).

Behring, Riviere de: stream, "a name given by La Pérouse to a river where there was no bay, in the latitude assigned by Capt. [James] Cook to a bay which he called Behrings Bay [Bahia de Behring]"' (Wagner, 1937, p. 432). Behring, Riviere de: stream, see Alsek River. Behring Bay: bay, see Yakutat Bay.

Behring Glacier: glacier, see Bering Glacier. Behring Sea : sea, see Bering Sea.

Behring Strait: water passage, see Bering Strait. Behrings River: delta, see Dry Bay.

Bajial Cove: cove, see Bagial, Port.

Belanger Pass: pass, 4,300 ft., at $\mathrm{E}$ end of Syncline Mtn., $62 \mathrm{mi}$. NE of Palmer, Talkeetna Mts.; $61^{\circ} 56^{\prime} 45^{\prime \prime} \mathrm{N}, 147^{\circ} 21^{\prime} 35^{\prime \prime} \mathrm{W}$; $B G N$ 1960; (map 69).

Local name reported in 1956 by USGS. Named "for George Belanger, a placer gold miner who lived in this area over forty years."

Belcaro: locality, "(established in August 1899), about 50 miles north of Valdez, Prince William sound. It was discontinued in 1900" (Baker, 1906, p. 126). A post office was maintained from 1899 to 1900 (Ricks, 1965, p. 6).

Belcher, Point: point of land, on Chukchi Sea coast, $13 \mathrm{mi}$. NE of Wainwright, Arctic Plain; $70^{\circ} 47^{\prime} 40^{\prime \prime} \mathrm{N}, 159^{\circ} 39^{\prime} 02^{\prime \prime} \mathrm{W}$; (map 146).

Named in September 1826 by Capt. F. W. Beechey, RN, for Lt. (later Sir Edward) Belcher, RN, Supernumerary, Assistant Surveyor, and contributor to its journal on geological research. The following year he was responsible for the loss of the Blossom's barge and the lives of three of Beechey's men off Choris Peninsula.

Belieka Peak: hill, see Beluga Hill.

Belinda Creek: stream, flows NW $10 \mathrm{mi}$. to Iliamna Lake, $1 \mathrm{mi}$. W. of Reindeer Bay and $31 \mathrm{mi}$. SW of Iliamna, Bristol Bay Low.; 59 $22^{\prime} 30^{\prime \prime} \mathrm{N}, 155^{\circ} 22^{\prime} 30^{\prime \prime} \mathrm{W}$; (map 51).

Local name published in 1951 by USGS.

Belknap Islands: islands, $0.2 \mathrm{mi}$. across, $\mathrm{S}$ of Eastern Channel, Sitka Sound, $3 \mathrm{mi}$. S of Sitka, Alex. Arch.; $57^{\circ} 00^{\prime} 30^{\prime \prime} \mathrm{N}, 135^{\circ} 21^{\prime} 10^{\prime \prime} \mathrm{W}$; (map 9).

Named in 1880 by U.S. Naval Officers for Capt. (later Rear Adm.) George E. Belknap, USN.

Belkoffski: village, see Belkofski.

Belkoffski : bay, see Belkofski Bay.

Belkoffsky: village, see Belkofski.

Belkoffsky: bay, see Belkofski Bay.

Belkofski: village, pop. 57 , on S coast of Alaska Penin., $27 \mathrm{mi}$. E of village of Cold Bay, Aleutian Ra.; 55 $05^{\prime} 10^{\prime \prime} \mathrm{N}, 162^{\circ} 02^{\prime} 00^{\prime \prime} \mathrm{W}$; BGN 1899; (map 29). Var. Belkoffski, Belkoffsky, Belkoftski, Belkovsky, Selo Belkovskoe.

Aleut village reported in 1847 on Russian Hydrog. Dept. Chart 1379 as "S[elo] Belkovskoe" from "belka," meaning "squirrel." Its population was 102 in $1833 ; 268$ in 1880 ; 185 in $1890 ; 147$ in $1900 ; 129$ in $1920 ; 123$ in $1930 ; 140$ in 1939 ; and 119 in 1950 . The
Belkofsky post office was established in 1888 ; discontinued in 1951.

Belkofski Bay: bay, on S. coast of Alaska Penin., extends N $10 \mathrm{mi}$. from Bold Cape, $23 \mathrm{mi}$. SE of village of Cold Bay, Aleutian Ra. ; $55^{\circ} 05^{\prime} \mathrm{N}$, $162^{\circ} 09^{\prime}$ W; BGN 1899; (map 29). Var. Belkoffski, Belkoffsky, Belkoftski, Belkovskaia, Belkovsky.

Published by Capt. Lutke (1836, p. 271), IRN, as "Belkovskaia."

Belkofski Point: point of land, at E entrance to Belkofski Bay, on SW end of the Alaska Penin., Aleutian Ra.; $55^{\circ} 54^{\prime} 30^{\prime \prime} \mathrm{N}, 162^{\circ} 03^{\prime} 00^{\prime \prime} \mathrm{W}$; $B G N 1899$; (map 29).

Russian name published in 1899 by USC\&GS.

Belkof tski: village, see Belkofski.

Belkoftski: bay, see Belkofski Bay.

Belkovskaia: bay, see Belkofski Bay.

Belkovskoe, Selo: village, see Belkofski.

Belkovsky: village, see Belkofski.

Belkovsky: bay, see Belkofski Bay.

Bella Creek: stream, flows NE $5.5 \mathrm{mi}$. to Schlitz Creek which flows to Serpentine River, $8 \mathrm{mi}$. NW of Midnight Mtn. and $51 \mathrm{mi}$. NW of Imuruk Lake, Seward Penin. High. ; $65^{\circ} 50^{\prime} \mathrm{N}$, $164^{\circ} 51^{\prime} \mathrm{W}$; (map 110).

Prospectors' name reported in 1901 by T. G. Gerdine (in Collier, 1902, pl. 12), USGS.

Bell Arm: water passage, extends $9.5 \mathrm{mi}$. from Behm Canal to head of Anchor Pass, between Bell I. and mainland, Alex. Arch.; 55 ${ }^{\circ} 58^{\prime} 15^{\prime \prime}$ $\mathrm{N}, 131^{\circ} 31^{\prime} 00^{\prime \prime} \mathrm{W}$; (map 3$)$.

Named in 1883 by USC\&GS.

Bell Creek: stream, flows NW $8 \mathrm{mi}$. to Cripple Creek, $76 \mathrm{mi}$. E of Bethel, Kilbuck-Kuskokwim Mts.; $60^{\circ} 47^{\prime} \mathrm{N}, 159^{\circ} 32^{\prime} \mathrm{W}$; (map 59).

Prospectors' name reported in 1914 by A. G. Maddren (in Brooks, 1915, pl. 11), USGS.

Bell Creek: stream, flows SE and SW $18 \mathrm{mi}$. to Crooked Creek $3 \mathrm{mi}$. NW of its junc. with Kuskokwim River, $3 \mathrm{mi}$. NW of village of Crooked Creek, Kilbuck-Kuskokwim Mts.; $61^{\circ} 54^{\prime} 20^{\prime \prime} \mathrm{N}, 158^{\circ} 10^{\prime} 20^{\prime \prime} \mathrm{W}$; (map 72).

Local name reported in 1916 by $P$. S. Smith (1917, pl. 5), USGS.

Bell Creek: stream, flows SE $1.5 \mathrm{mi}$. to Pilgrim River between Crater and Grouse Greeks, 29 mi. NW of Solomon, Seward Penin. High.; $64^{\circ} 56^{\prime} \mathrm{N}, 164^{\circ} 49^{\prime} \mathrm{W}$; (map 95).

Prospectors' name reported on a map of Cape Nome gold fields by David Fox, Jr. dated 1901

Belle Bay: bay, "on the eastern shore of Portland canal. So called by the Coast Survey" (Baker, 1906, p. 126)

Belle Creek: stream, flows SE $3 \mathrm{mi}$. to Iditarod River, $8.5 \mathrm{mi}$. NW of Flat, Kilbuck-Kuskokwim Mts.; $62^{\circ} 34^{\prime} \mathrm{N}, 158^{\circ} 08^{\prime} \mathrm{W}$; (map 79).

Prospectors' name obtained in 1952 by USGS topographers.

Belle Creek: stream, flows SE $10 \mathrm{mi}$. to Chatanika River, $28 \mathrm{mi}$. NE of Fairbanks, YukonTanana High.; $65^{\circ} 12^{\prime} 30^{\prime \prime} \mathrm{N}, 147^{\circ} 11^{\prime} 10^{\prime \prime} \mathrm{W}$; (map 105).

Named by prospectors; published in 1907 by USGS.
Belle Isle: village, see Eagle.

Belle Lake: lake, $0.8 \mathrm{mi}$. long, $18 \mathrm{mi}$. $\mathrm{N}$ of Chalkyitsik, Yukon Flats; $66^{\circ} 54^{\prime} \mathrm{N}, 143^{\circ} 47^{\prime}$ W; (map 120).

Local name obtained in 1956 by T. E. Taylor and R. C. Foley, USGS.

Bellen Lakes: lakes, 3 lakes, extend NW-SE 2 mi., $51 \mathrm{mi}$. NE of Medfra, Kuskokwim Low.; $63^{\circ} 38^{\prime} \mathrm{N}, 153^{\circ} 26^{\prime} \mathrm{W}$; (map 89).

Local name reported in 1958 by USGS.

Bellevue Beach: beach, $1.5 \mathrm{mi}$. long, on W coast of Kanaga Island, $9 \mathrm{mi}$. S of Cape Miga, Aleutian Is.; $51^{\circ} 48^{\prime} 30^{\prime \prime} \mathrm{N}, 177^{\circ} 12^{\prime} 45^{\prime \prime} \mathrm{W}$; (map 17).

Published in 1957 by USC\&GS on Chart 9193.

Belle Vue River: stream, see Mayoeak River.

Bell Flats: meadow, $0.5 \mathrm{mi}$. across, at head of Womens Bay, $8 \mathrm{mi}$. SW of Kodiak, Kodiak I.; $57^{\circ} 43^{\prime} \mathrm{N}, 152^{\circ} 34^{\prime} \mathrm{W}$; (map 34). Var. Bell's Flats.

Local name published in 1965 by USC\&GS. This feature is reported to be named for "Mr. Bell, who owned and operated a dairy farm [here]. Mr. and Mrs. Bell now live in the state of Washington."

Bellicose Peak: mountain, 7,640 ft., W of Eklutna Glacier, $29 \mathrm{mi}$. E of Anchorage, Chugach Mts.; $61^{\circ} 14^{\prime} 30^{\prime \prime} \mathrm{N}, 1^{\circ} 9^{\circ} 02^{\prime} 00^{\prime \prime} \mathrm{W}$; $B G N 1964$; (map 69).

John Bousman and his brother, William, made the first ascent of this peak on August 21, 1963. They named it "Bellicose Peak" since "the mountain peak in a personified sense, appears belligerent because of difficulty encountered while climbing it."

Bellim Bay: bight, $2.5 \mathrm{mi}$. across, on $\mathrm{E}$ shore of Becharof Lake, $\mathrm{S}$ of Seal Point, on Alaska Penin., 9.5 mi. N of Kanatak, Aleutian Ra.; $57^{\circ} 43^{\prime} \mathrm{N}, 156^{\circ} 02^{\prime} \mathrm{W}$; (map 36).

Name reported in 1902 by J. L. McPherson, Deputy Mineral Surveyor.

Bell Island: village, see Bell Island Hot Springs.

Bell Island: island, $8.7 \mathrm{mi}$. long, in Behm Canal, $\mathrm{N}$ of Revillagigedo I., Alex. Arch.; 55 $57^{\prime}$ N, $131^{\circ} 30^{\prime} \mathrm{W}$; (map 3). Var. Bells Island. Named in 1793 by Capt. George Vancouver, RN, for Midshipman Bell (cnna), a member of his crew; discovered by Joseph Whidbey in August 1793 (Wagner, 1937, p. 375).

Bell Island: island, $1 \mathrm{mi}$. long, at mouth of Red Bay, on $\mathrm{N}$ coast of Prince of Wales I., Alex. Arch.; $56^{\circ} 19^{\prime} 10^{\prime \prime} \mathrm{N}, 133^{\circ} 18^{\prime} 00^{\prime \prime} \mathrm{W}$; (map 6). Var. Bells Island.

Named in 1886 by Lt. J. M. Helm, USN, for Ens. John Arthur Bell, USN, a member of his party.

Bell Island: island, $0.1 \mathrm{mi}$. across, near the head of Port Frederick, 15 mi. SW of Hoonah, on N central Chichagof I., Alex. Arch.; 57 $59^{\prime} 30^{\prime \prime}$ $\mathrm{N}, 135^{\circ} 46^{\prime} 10^{\prime \prime} \mathrm{W}$; (map 9).

Name published by USG\&GS in the 1925 Coast Pilot (p. 345).

Bell Island: island, $5 \mathrm{mi}$. long, in Susitna River delta, $23 \mathrm{mi}$. NW of Anchorage, Cook Inlet Low.; $61^{\circ} 25^{\prime} 45^{\prime \prime} \mathrm{N}, 150^{\circ} 30^{\prime} 40^{\prime \prime} \mathrm{W}$; (map $70)$. 
Local name reported in 1958 by USGS.

Bell Island Hot Springs: village, summer pop. 15, on $\mathrm{N}$ bank of Behm Canal at SW end of Bell I., Alex. Arch.; 55 $56^{\prime} \mathrm{N}, 131^{\circ} 34^{\prime} \mathrm{W}$; (map 3). Var. Bell Island.

Hot springs resort probably named by George Roe who took this property as a homestead in 1902 and "erected a bathhouse and a number of cabins along a boardwalk extending to a landing place opposite the boat anchorage and developed the springs as a resort for the medicinal use of the water. On his death in 1914 the management of the place was continued by his two brothers" (Waring, 1917 , p. 19). The Bell Island post office was established here in 1932; discontinued in 1954 (Ricks, 1965, p. 6).

Bell Island Lakes: lakes, extend $2 \mathrm{mi}$., in course of a stream on Bell I., Alex. Arch.; 55 56 $45^{\prime \prime}$ $\mathrm{N}, 131^{\circ} 31^{\prime} 30^{\prime \prime} \mathrm{W}$; (map 3).

Local name recorded in 1952 by USGS.

Bellkat: locality, on right bank of Yukon River, $2 \mathrm{mi}$. downstream from Dogfish Village and $10 \mathrm{mi}$. NE of Russian Mission, Yukon-Kuskokwim Delta;61 ${ }^{\circ} 54^{\prime} \mathrm{N}, 161^{\circ} 07^{\prime} \mathrm{W}$; (map 73). Var. Pogoreshapka.

This probably is an old village site, possibly the "Pogoreshapka" (Russian for "burned hat"?), listed by Ivan Petroff in the 1880 Census as having 121 inhabitants. It is diffcult to correlate these village and camp names from one small-scale map to the next.

Bell Lake: lake, $2 \mathrm{mi}$. long, $6 \mathrm{mi}$. N of Lake Louise and $38 \mathrm{mi}$. NW of Glennallen, Copper River Basin; $62^{\circ} 27^{\prime} \mathrm{N}, 146^{\circ} 29^{\prime} \mathrm{W}$; (map 83). Local name reported in 1951 by USGS.

Bellows Creek: stream, flows SE 1 mi. to Bear Creek, $18 \mathrm{mi}$. NE of Fairbanks, Yukon-Tanana High.; $65^{\circ} 02^{\prime} 45^{\prime \prime} \mathrm{N}, 147^{\circ} 20^{\prime} 45^{\prime \prime} \mathrm{W}$; (map 105).

Named by prospectors; published in 1908 by USGS.

Bell River: stream, "tributary to Gwydyr bay, Arctic coast of Alaska, named Bell's by Dease and Simpson, 1837"' (Baker, 1906, p. 126).

Bells Butte: peak, 2,675 ft., at head of Boulder Bay, $2.7 \mathrm{mi}$. ENE of Tatitlek and $38 \mathrm{mi}$. NW of Cordova, Chugach Mts. ; $60^{\circ} 53^{\prime} \mathrm{N}, 146^{\circ} 37^{\prime}$ W; (map 64).

Reported in 1911 by R. H. Sargent and C. E. Giffin, USGS.

Bell's Flats: meadow, see Bell Flats.

Bells Island: island, see Bell Island.

Belltown: village, see Hoonah.

Belmezok: village, on barrier beach, on Bering Strait, $1.5 \mathrm{mi}$. N of Cape Prince of Wales, at W end of Seward Penin., Kotzebue-Kobuk Low.; $65^{\circ} 37^{\prime} \mathrm{N}, 168^{\circ} 06^{\prime} \mathrm{W}$; (map 111).

This appears to be an Eskimo village closely associated with the village of Wales, 1 mile southeast. Shown on a 1952 USGS map on the Lopp Lagoon side of the spit and as above on a 1956 map.

Belmont Creek: stream, flows $\mathrm{N}$ to Cripple River, about $25 \mathrm{mi}$. NW of Imuruk Lake, Seward Penin. High.; (map 110).

Prospectors' name reported on a precinct map of Seward Peninsula by Monroe and
Hutchins; corrected to June 1903 by Arthur Gibson. This stream cannot be precisely located on current maps.

Beloi Rock: rock, see Bieli.

Beloit Glacier: glacier, on Kenai Penin., trends NE $2 \mathrm{mi}$. to Blackstone Bay, $8 \mathrm{mi}$. S of Whittier, Chugach Mts.; $60^{\circ} 39^{\prime} 40^{\prime \prime} \mathrm{N}, 148^{\circ} 41^{\prime} 00^{\prime \prime}$ W; BGN 1930; (map 63$)$.

Named in 1910 by Lawrence Martin, USGS, for Beloit College, Beloit, Wis.

Below Tree Lake: lake, $1.3 \mathrm{mi}$. long, drains SW to East Fork Chandalar River, $15 \mathrm{mi}$. NE of Arctic Village, Brooks Ra.; $68^{\circ} 20^{\prime} \mathrm{N}, 145^{\circ} 15^{\prime}$ W; (map 136).

Translation of a Kutchin Indian name reported in 1956 by T. E. Taylor, USGS.

Belt Creek: stream, flows NE $6 \mathrm{mi}$. to Wood River, $9 \mathrm{mi}$. N of Dillingham, Bristol Bay Low.; $59^{\circ} 10^{\prime} 15^{\prime \prime} \mathrm{N}, 158^{\circ} 32^{\prime} 15^{\prime \prime} \mathrm{W}$; (map 52).

Local name published in 1951 by USGS.

Belt Creek: stream, heads N of Mount Bendeleben, flows NW $17 \mathrm{mi}$. to Kuzitrin River, 45 mi. SW of Imuruk Lake, Seward Penin. High.; $65^{\circ} 16^{\prime} \mathrm{N}, 164^{\circ} 31^{\prime} \mathrm{W}$; (map 110).

Prospectors' name reported in 1900 by Brooks (1901, pl. 11), USGS.

Belt Creek: stream, flows $5 \mathrm{mi}$. NW to Bear Creek, $20 \mathrm{mi}$. NE of Livengood, YukonTanana High.; $65^{\circ} 43^{\prime} 28^{\prime \prime} \mathrm{N}, 148^{\circ} 01^{\prime} 50^{\prime \prime} \mathrm{W}$; (map 105).

Named in 1916 by prospectors; reported by J. B. Mertie, Jr. (in Brooks and others, 1918, pl. 13), USGS.

Beluga: village, at Cottonwood Beach on NW shore of Cook Inlet, $8 \mathrm{mi}$. NE of Tyonek, Cook Inlet Low.; $61^{\circ} 10^{\prime} 45^{\prime \prime} \mathrm{N}, 151^{\circ} 01^{\prime} 25^{\prime \prime} \mathrm{W}$; (map 70).

Name of a Tanaina Indian village reported at the present site in 1958 by USGS. A map indicates a site with four or five buildings. An earlier USGS map, dated 1933, placed the village five miles NE of the present Beluga along the Beluga River. See Beluga River. Beluga: village, see Tyonek.

Beluga Hill: hill, $924 \mathrm{ft}$., on $\mathrm{N}$ shore of Goodnews Bay, $6 \mathrm{mi}$. W of Goodnews, KilbuckKuskokwim Mts.; $59^{\circ} 06^{\prime} 45^{\prime \prime} \mathrm{N}, 161^{\circ} 45^{\prime} 00^{\prime \prime}$ W; BGN 1939; (map 53). Var. Awizrayak, Baluka Hill, Belieka Peak, Beluga Peak, Beluka Peak, Beluka.

Local name published in 1911 by USC\&GS on Chart T-3227. The Eskimo name of the hill is reported to be "Awizrayak," meaning "place to get away," where "soldiers got away from enemy."

Beluga Lake: lake, $1.5 \mathrm{mi}$. long, on Kenai Penin., $0.5 \mathrm{mi}$. SE of Homer, Cook Inlet Low.; $59^{\circ} 38^{\prime} 30^{\prime \prime} \mathrm{N}, 151^{\circ} 31^{\prime} 00^{\prime} \mathrm{W}$; (map 50 ). Var. Bieluga.

A transliterated Russian name meaning "white whale" reported in 1904 by $R$. W. Stone, USGS.

Beluga Lake: lake, $7 \mathrm{mi}$. long and $3 \mathrm{mi}$. wide, at head of Beluga River, $25 \mathrm{mi}$. NW of Tyonek, Cook Inlet Low.; $61^{\circ} 24^{\prime} \mathrm{N}, 151^{\circ} 35^{\prime} \mathrm{W}$; (map 70).
Local name reported in 1904 by USGS; derived from the Beluga River which drains the lake.

Beluga Mountain: mountain, 3,699 ft., $11 \mathrm{mi}$. long, $40 \mathrm{mi} . \mathrm{N}$ of Tyonek, Alaska Ra.; $61^{\circ}$. $42^{\prime} 30^{\prime \prime}$ N, $151^{\circ} 11^{\prime} 00^{\prime} \mathrm{W}$; (map 70). Var. Snee-dee Mountain, Snidi Mountain.

Local name reported in 1898 by Eldridge (1900, map 3), USGS.

Beluga Peak: hill, see Beluga Hill.

Beluga River: stream, heads at Beluga Lake, and flows SE $35 \mathrm{mi}$. to Cook Inlet, $11 \mathrm{mi}$. NE of Tyonek, Cook Inlet Low.; $61^{\circ} 12^{\prime} \mathrm{N}, 150^{\circ} 56^{\prime}$ W; (map 70).

Local name reported in 1898 by Eldridge (1900, map 3), USGS. The word "beluga" or "byeluga" in Russian refers to the "white whale."

Beluga Slough: stream, trends NE-SW $2.8 \mathrm{mi}$., between Ivan River and mouth of Susitna River, $22 \mathrm{mi}$. NE of Tyonek, Cook Inlet Low.; $61^{\circ} 18^{\prime} 15^{\prime \prime} \mathrm{N}, 150^{\circ} 42^{\prime} 15^{\prime \prime} \mathrm{W}$; (map 70).

Local name published in 1958 by USGS; derived from the nearby Beluga River.

Beluka: hill, see Beluga Hill.

Beluka Peak: hill, see Beluga Hill.

Belvedere Island: barrier island, $1 \mathrm{mi}$. long, in Stockton Is., on Beaufort Sea coast, $17 \mathrm{mi}$. NW of Flaxman I., Arctic Plain ; 70 $17^{\prime} 30^{\prime \prime} \mathrm{N}$, $146^{\circ} 54^{\prime} 45^{\prime \prime} \mathrm{W}$; (map 151).

Named by Leffingwell (1919, p. 94) after the whale ship Belvedere, upon which he returned from Point Barrow to San Francisco in the fall of 1912.

Bence Mountain: mountain, 5,500 ft., $3 \mathrm{mi}$. ESE of head of Klutina Lake, $35 \mathrm{mi}$. NNE of Valdez, Chugach Mts.; 61 $35^{\prime} 15^{\prime \prime} \mathrm{N}, 145^{\circ}$ $52^{\prime} 30^{\prime \prime} \mathrm{W}$; (map 68).

Named in 1898 by Capt. W. R. Abercrombie, USA, for "Private Bence" (cnna) of his party.

Ben Creek: stream, "eastern Alaska, at the head of Slate creek, tributary from the west to North fork Fortymile creek, near latitude $64^{\circ} 40^{\prime}$, longitude $142^{\circ} 45^{\prime} . "$

"Prospectors' name, from sketch map compiled by Maj. W. A. Glassford, Signal Corps, U.S.A., 1905." (Baker, 1906, p. 127.)

Bench Creek: stream, leads at Bench Lake, flows $\mathrm{N} 8.5 \mathrm{mi}$. to Center Creek, $13 \mathrm{mi}$. SSE of Sunrise and $22 \mathrm{mi}$. SW of Whittier, Chugach Mts. ; $60^{\circ} 43^{\prime} 00^{\prime \prime} \mathrm{N}, 149^{\circ} 17^{\prime} 00^{\prime \prime} \mathrm{W}$; (map 63).

Name used by local prospectors; reported in 1898 by Mendenhall (1900, map 16), USGS.

Bench Creek: stream, heads at terminus of Bench Glacier, flows NW $3.5 \mathrm{mi}$. to Lowe River, 2.2 mi. E of Wortmanns and $17 \mathrm{mi}$. E of Valdez, Chugach Mts.; 61 $06^{\prime} 25^{\prime \prime} \mathrm{N}, 145^{\circ} 45^{\prime} 15^{\prime \prime} \mathrm{W}$; BGN 1964; (map 68).

Named in 1963 by A. S. Post, USGS, "because the stream crosses a bench in the Lowe River valley."

Bench Creek: stream, heads in Horn Mts., flows $\mathrm{S} 1.4 \mathrm{mi}$. to Alfred Creek, $57 \mathrm{mi}$. NE of Palmer, Talkeetna Mts.; $61^{\circ} 57^{\prime} 05^{\prime \prime} \mathrm{N}, 147^{\circ}$. $31^{\prime 2} 5^{\prime \prime} \mathrm{W}$; (map 69).

Local name reported in 1952 by USGS. 
Bench Glacier: glacier, heads $11 \mathrm{mi}$. NE of Meteorite Mtn., trends NW $5 \mathrm{mi}$. to its terminus (1953) at head of Bench Creek, $4.8 \mathrm{mi}$. SE of Wortmanns and $18 \mathrm{mi}$. SE of Valdez, Chugach Mts.; $61^{\circ} 03^{\prime} 50^{\prime \prime} \mathrm{N}, 145^{\circ} 42^{\prime} 50^{\prime \prime} \mathrm{W}$; BGN 1964; (map 68).

Named in 1963 by A. S. Post, USGS, "because the glacier terminates at the head of a bench."

Bench Lake: lake, $1 \mathrm{mi}$. long, at head of Bench Creek, $0.5 \mathrm{mi}$. NE of Johnson Lake and 22 mi. SE of Sunrise, Chugach Mts.; $60^{\circ} 37^{\prime} 15^{\prime \prime}$ N, $149^{\circ} 14^{\prime} 00^{\prime \prime} \mathrm{W}$; (map 63).

Local name reported by Grant and Higgins (1913, pl. 1), USGS; derived from Bench Creek which drains the lake.

Bench Lake: lake, $0.4 \mathrm{mi}$. long, $\mathrm{N}$ of Little Susitna River, $19 \mathrm{mi}$. NW of Palmer, Cook Inlet Low.; $61^{\circ} 39^{\prime} 25^{\prime \prime} \mathrm{N}, 149^{\circ} 40^{\prime} 30^{\prime \prime} \mathrm{W}$; (map 69).

Local name reported in 1950 by USGS.

Bench Lake: lake, $0.6 \mathrm{mi}$. long, between Lake Creek and Matanuska River, $41 \mathrm{mi}$. NE of Palmer, Chugach Mts.; $61^{\circ} 46^{\prime} 45^{\prime \prime} \mathrm{N}, 147^{\circ}$. $55^{\prime} 25^{\prime \prime} \mathrm{W}$; (map 69).

Local name reported in 1952 by USGS.

Ben Creek: stream, flows E 6 mi. to Slate Creek, $45 \mathrm{mi}$. W of Eagle, Yukon-Tanana High.; $64^{\circ} 40^{\prime} \mathrm{N}, 142^{\circ} 45^{\prime} \mathrm{W}$; (map 102).

Prospectors' name shown on a 1902 manuscript map by E. J. Chamberlain, U.S. Deputy Surveyor.

Ben Creek: stream, flows SE $4 \mathrm{mi}$. to Sam Creek, $4.5 \mathrm{mi}$. SW of that stream's junc. with Yukon River and $49 \mathrm{mi}$. SE of Circle, Yukon-Tanana High.; $65^{\circ} 16^{\prime} \mathrm{N}, 142^{\circ} 59^{\prime} \mathrm{W}$; (map 103).

Local name reported by Mertie (1942, p. 250), USGS.

Bend, The : bend, see Devils Elbow.

Bendel, Cape: point of land, on NW tip of Kupreanof I., 50 mi. E of Sitka, Alex. Arch.; $57^{\circ} 03^{\prime} 50^{\prime \prime} \mathrm{N}, 134^{\circ} 01^{\prime} 40^{\prime \prime} \mathrm{W}$; (map 9).

Named in 1877 by W. H. Dall, USC\&GS, for Bernhard Bendel, born in Germany, who was an Alaska pioneer and who helped USC\&GS parties with his hospitality and valuable information (U.S. Coast and Geodetic Survey, 1883, p. 124).

Bendeleben, Mount: mountain, $3,730 \mathrm{ft}$., in Bendeleben Mts., 37 mi. SW of Inuruk Lake, Seward Penin. High.; $65^{\circ} 10^{\prime} \mathrm{N}, 164^{\circ} 05^{\prime} \mathrm{W}$; BGN Sixth Report; (map 110). Var. Ahneyiyuk, Bendelson Mount, Mount Berdeleben.

Named in 1866 by members of the Western Union Telegraph exploring expedition for the leader of the expedition, Baron Otto von Bendeleben. A. H. Brooks, USGS, reported in 1921 the native name as "Ahneyiyuk," meaning "looks like a big one."

Bendeleben Mountains: mountain range, extends E $50 \mathrm{mi}$. from head of Niukluk River, $7 \mathrm{mi}$. $W$ of Mount Bendeleben to Death Valley and Windy Creek at $\mathrm{N}$ end of Darby Mts., Seward Penin. High.; $65^{\circ} 15^{\prime} \mathrm{N}, 163^{\circ} 30^{\prime} \mathrm{W}$; (map 110). Var. Green Horn Mountain Range, Greenhorn Mountains.

Local name reported in 1900 by Brooks (1901, p. 17), USGS. Named for Mount
Bendeleben, the highest peak in the range. Schrader (1900c, p. 16), USGS, applied the name "Green Horn Mt. Range."

Bendel Island: island, $3 \mathrm{mi}$. across, in Shumagin Is. between Big Koniuji and Nagai Is., Aleutian Ra.; $55^{\circ} 05^{\prime} \mathrm{N}, 159^{\circ} 48^{\prime} \mathrm{W}$; BGN 1901; (map 27). Var. Morse Island, Turner Island.

Named in 1872 by W. H. Dall, USC\&GS, for Bernhard Bendel, a trader in Alaska in 1871-72; published in 1888 on a USC\&GS chart and in a USBF report. "Morse Island" was shown on an 1891 USC\&GS chart.

Bendelson Mount: mountain, see Bendeleben, Mount.

Bender Pup: stream, flows NW $1.6 \mathrm{mi}$. to Boulder Creek, $10 \mathrm{mi}$. SW of Central and $38 \mathrm{mi}$. SW of Circle, Yukon-Tanana High.; $65^{\circ} 28^{\prime}$ $45^{\prime \prime} \mathrm{N}, 145^{\circ} 03^{\prime} 20^{\prime \prime} \mathrm{W}$; (map 104).

Prospectors' name reported in 1954 or 1955 by USGS topographers.

Bend Mountain: mountain, 1,535 ft., on $\mathrm{N}$ bank of Yukon River $11 \mathrm{mi}$. SW of Russian Mission, Yukon-Kuskokwim Delta, 61 ${ }^{\circ} 39^{\prime} 30^{\prime \prime} N$, $161^{\circ}$ $33^{\prime} 30^{\prime \prime} \mathrm{W}$; (map 73).

Riverboat pilots' name, so called "because it indicated the approach, when going downstream, to the sharp bend at Devils Elbow."

Bend Mountan: mountain, 4,420 ft., between Your Creek and North Fork Chandalar River, $23 \mathrm{mi}$. N of Chandalar, Brooks Ra.; $67^{\circ} 49^{\prime} 15^{\prime \prime}$ N, $148^{\circ} 24^{\prime} 30^{\prime \prime} \mathrm{W}$; (map 123).

Descriptive name reported on an 1899 fieldsheet by T. G. Gerdine, USGS, So named "because of a bend in the river near the mountains."

Benedum Landing: locality, on right bank of Yukon River, $7 \mathrm{mi}$. SW of Nulato, Nulato Hills; $64^{\circ} 39^{\prime} \mathrm{N}, 158^{\circ} 16^{\prime} \mathrm{W}$; (map 97).

Riverboat pilots' name shown on a 1940 "Navigation Chart of the Tanana-Yukon Rivers" published by U.S. Dept. of Interior. Benelaracher: hill, see Koyukuk Mountain.

Be-ne-le-rah-cher: hill, see Koyukuk Mountain. Ben Gulch: ravine, trends SE $2 \mathrm{mi}$. to Bonanza Creek which flows to Casadepaga River, 28 mi. NE of Solomon, Seward Penin. High.; $64^{\circ} 58^{\prime} \mathrm{N}, 164^{\circ} 14^{\prime} \mathrm{W}$; (map 95).

Prospectors' name reported in 1907 by USGS geologists (Smith, P. S., 1910, pl. 4).

Benham, Point: point of land, between Rodman Bay and Saook Bay, on Baranof I., $29 \mathrm{mi}$. $\mathrm{N}$ of Sitka, Alex. Arch.; 57 $28^{\prime} 45^{\prime \prime}$ N, $135^{\circ} 11^{\prime} 15^{\prime \prime}$ W; (map 9).

Named in 1895 by Lt. Comdr. E. K. Moore, USN, for Ens. Henry Kennedy Benham, USN, a member of his party.

Benign Peak: peak, 7,200 ft., $5 \mathrm{mi}$. S of Eklutna Lake and $28 \mathrm{mi}$. NE of Anchorage, Chugach Mts.; $61^{\circ} 16^{\prime} 25^{\prime \prime} \mathrm{N}, 149^{\circ} 01^{\prime} 20^{\prime \prime} \mathrm{W}$; $B G N$ 1966; (map 69).

So named in 1965 by the Mountaineering Club of Alaska because "nearby Bellicose Peak was a much harder climb, while this one's nature was quite benign."

Benikakakat River: stream, see Tatalina River. Benikakat River: stream, see Washington Creek.
Benito Creek: stream, flows SW and NW $2.4 \mathrm{mi}$. to Loraine Creek, $1.9 \mathrm{mi}$. NE of its mouth on Kotsina River and $77 \mathrm{mi}$. NE of Valdez, Wrangell Mts.; $61^{\circ} 37^{\prime} 00^{\prime \prime} \mathrm{N}, 144^{\circ} 08^{\prime} 15^{\prime \prime} \mathrm{W}$; (map 68).

Local name recorded in 1951 by USGS.

Benjamin Creek: stream, on Kenai Penin., flows SW $12 \mathrm{mi}$. to Killey River, $38 \mathrm{mi}$. SE of Kenai, Chugach Mts.; $60^{\circ} 15^{\prime} 20^{\prime \prime} \mathrm{N}, 150^{\circ} 21^{\prime} 20^{\prime \prime} \mathrm{W}$; (map 62).

Local name reported about 1911 by USGS (Martin, G. C., and others, 1915, pl. 2).

Benjamin Creek: stream, flows W $1 \mathrm{mi}$. to Norton Sound, $1.4 \mathrm{mi}$. E. of Tolstoi Point and 18 mi. SW of Unalakleet, Nulato Hills; $63^{\circ}$. $37^{\prime} 10^{\prime \prime} \mathrm{N}, 160^{\circ} 58^{\prime} 00^{\prime \prime} \mathrm{W}$; (map 91).

Local name reported in 1952 by USC\&GS; "named by sled runners."

Benjamin Island: island, $1.5 \mathrm{mi}$. long, off $\mathrm{E}$ shore of Favorite Channel, $25 \mathrm{mi}$. NW of Juneau, Coast Mts. ; $58^{\circ} 33^{\prime} 45^{\prime \prime} \mathrm{N}, 134^{\circ} 54^{\prime} 15^{\prime \prime}$ W; (map 11). Var. Benjamin Islet.

Named in 1880 by Capt. L. A. Beardslee, USN, who visited the area that year.

Benjamin Islet: island, see Benjamin Island.

Benka Lake: lake, $3,500 \mathrm{ft}$. across, $9.5 \mathrm{mi}$. SE of Talkeetna, Cook Inlet Low.; 62 $11^{\prime} 15^{\prime \prime} \mathrm{N}$, $150^{\circ} 00^{\prime} 05^{\prime \prime} \mathrm{W}$; BGN 1965; (map 81). Var. Big Lake, Question Lake.

Tanaina Indian expression reported to mean "big lake," given to this feature by R. E. Bell in 1964 in order to eliminate duplication of the common English name "Big Lake."

Benkes, Cape: point of land, see Banks, Point. Ben Lake: lake, see Cooper Lake.

Benner Creek: stream, see Isabell Creek.

Benner Gulch: stream, see Isabell Creek.

Bennett Creek: stream, flows NE $1.3 \mathrm{mi}$. to Niukluk River, $6.5 \mathrm{mi}$. NW of Council and 30 mi. NE of Solomon, Seward Penin. High.; $64^{\circ}$. $55^{\prime} \mathrm{N}, 163^{\circ} 53^{\prime} \mathrm{W}$; (map 95). Var. Bonnet Greek, Lane Creek.

Prospectors' name reported in 1900 by $\mathrm{E}$. C. Barnard (in Brooks, 1901, pl. 17), USGS.

Bennett Island: island, "in the Arctic ocean, north of the New Siberian islands."

"Discovered by De Long, 1881, and named by him, after Mr. James Gordon Bennett" (Baker, 1906, p. 127).

Bennett Rock Cabin: locality, on left bank of Martin River Slough, $2 \mathrm{mi}$. NW of Katalla, Malaspina Coastal Plain; $60^{\circ} 17^{\prime} \mathrm{N}, 144^{\circ} 39^{\prime}$ $\mathrm{W}$; (map 64).

Name of a shelter cabin; published in 1950 by USGS.

Bennetts: locality, see Toklik.

Benson Creek: stream, see Kingsley Creek.

Bent Cape: point of land, on SW coast of Deer I., 24 mi. SSE of village of Gold Bay, Aleutian Ra.; $54^{\circ} 53^{\prime} 30^{\prime \prime} \mathrm{N}, 162^{\circ} 25^{\prime} 00^{\prime \prime} \mathrm{W}$; $B G N$ 1942; (map 25).

Descriptive name given in 1941 by USC\&GS.

Benson Creek: stream, flows W $1.2 \mathrm{mi}$. to Iron Creek, 26 mi. NW of Solomon, Seward Penin. High.; 64 $54^{\prime} 50^{\prime \prime} \mathrm{N}, 164^{\circ} 41^{\prime} 30^{\prime \prime} \mathrm{W}$; (map 95). Var. Lulu Creek, Sulu Creek. 
Prospectors" name reported as "Benson or Lulu" on a map of Cape Nome gold fields by David Fox, Jr., dated 1901.

Bent Cove: cove, $1.5 \mathrm{mi}$. long, on $\mathrm{SW}$ coast of Deer Island, between Bent and Paw Capes, Aleutian Ra.; 54 $52^{\prime} 30^{\prime \prime} \mathrm{N}, 162^{\circ} 24^{\prime} 05^{\prime \prime} \mathrm{W}$; $B G N 1942$; ( $\operatorname{map} 25)$.

Named in 1941 by USC\&GS.

Bentura, Isla de : island, see Ventura, La.

Bentura Island: island, see Ventura, La.

Bentinck, Point: point of land, NE tip of Hinchinbrook I., $15 \mathrm{mi}$. SW of Cordova, Chugach Mts.; $60^{\circ} 24^{\prime} \mathrm{N}, 146^{\circ} 00^{\prime} \mathrm{W}$; (map 64).

In 1794 this name was applied to a point 4 miles SW of the present location, by Capt. George Vancouver, RN, who named it for William Henry Cavendish Bentinck, third Duke of Portland (Wagner, 1937, p. 376). Since Capt. Nathaniel Portlock, RN, in 1787, had named that feature "Point Steele," the name "Point Bentinck" was transferred to its present location.

Bentinck, Point: point of land, see Steele, Point.

Bentley Creek: stream, flows NW $1 \mathrm{mi}$. to Discovery Creek which flows to Dome Creek, 23 mi. NW of Solomon, Seward Penin. High.; $64^{\circ} 52^{\prime} \mathrm{N}, 164^{\circ} 42^{\prime} \mathrm{W}$; (map 95).

Prospectors' name reported in 1908 by $P$. S. Smith (in Brooks and others, 1909, pl. 10), USGS.

Bentley's Island: island, $0.8 \mathrm{mi}$ long, in Chena River, part of residential area of Fairbanks, Tanana Low.; $64^{\circ} 50^{\prime} 15^{\prime \prime} \mathrm{N}, 147^{\circ} 41^{\prime} 45^{\prime \prime} \mathrm{W}$; (map 100).

Local name published on a 1955 USGS map. Named for Henry T. Bentley who established a farm on the island in 1912 ; published locally in 1947.

Benzeman Lake: lake, $5 \mathrm{mi}$. long, at head of Necker Bay, on central Baranof I., Alex. Arch.; $56^{\circ} 48^{\prime} \mathrm{N}, 1^{\circ} 5^{\circ} 58^{\prime} \mathrm{W}$; BGN 1933; (map 5).

Named in 1933 by USFS "for Christopher M. Benzeman, master of various trading ships of the Russian American Company between 1808 and 1828."

Berdeleben, Mount: mountain, see Bendeleben Mount.

Berens, Point: point of land, see Oliktok Point. Berens Point: point of land, see Beechey Point. Berezhnoi Island: island, see Caution Island. Berezhnoy, Ostrov: island, see Caution Island. Berezovaia Cove: cove, see Birch Cove.

Berg: locality, former site of railroad station, 12 mi. NE of Nenana, Tanana Low.; 64 $42^{\prime} \mathrm{N}$, $148^{\circ} 52^{\prime} \mathrm{W}$; (map 100). Var. Little Goldstream.

This name, shown on a 1922 timetable, was applied to a railroad station on The Alaska RR. The name has been reapplied to a station 6 miles southwest.

Berg: RR. station, mile 420.4 on The Alaska RR., $6 \mathrm{mi}$. NE of Nenana, Tanana Low.; $64^{\circ} 38^{\prime} 25^{\prime \prime} \mathrm{N}, 149^{\circ} 02^{\prime} 10^{\prime \prime} \mathrm{W}$; (map 100). Var. Little Goldstream.

Originally named Little Goldstream whereas another station just north of Little Goldstream Creek was called Berg. Subsequently, the other station was discontinued, and the present station received the name Berg. The name was published on a 1952 USGS map at its present location.

Berg Basin: valley, $1 \mathrm{mi}$. long, near head of Berg Creek, $14 \mathrm{mi}$. E of Wrangell, Coast Mts.; $56^{\circ} 26^{\prime} 30^{\prime \prime} \mathrm{N}, 132^{\circ} 02^{\prime} 00^{\prime \prime} \mathrm{W}$; (map 6).

Local name recorded in 1955 by USGS.

Berg Bay: bay, $0.3 \mathrm{mi}$. across, on NE shore of Blake Channel, $\mathbf{E}$ of Wrangell I., Coast Mts.; $56^{\circ} 21^{\prime} 30^{\prime \prime} \mathrm{N}, 132^{\circ} 00^{\prime} 20^{\prime \prime} \mathrm{W}$; (map 6). Var. Berg Cove.

Local name used by fishermen and published in 1917 by USC\&GS. Named for Berg Mine and camp.

Berg Bay: bay, in Glacier Bay National Monument, extends W $4 \mathrm{mi}$. off Sitakaday Narrows near mouth of Glacier Bay, $38 \mathrm{mi}$. NW of Hoonah, St. Elias Mts. ; $58^{\circ} 32^{\prime} \mathrm{N}, 136^{\circ} 09^{\prime} \mathrm{W}$; Var. Berg Inlet.

Published as "Berg Inlet" by USC\&GS in the 1883 Coast Pilot (p. 189).

Berg Cove: bay, see Berg Bay.

Berg Creek: stream, heads in Berg Basin, flows SE $5 \mathrm{mi}$. to Aaron Creek, $17.5 \mathrm{mi}$. SE of Wrangell, Coast Mts.; $56^{\circ} 23^{\prime} 30^{\prime \prime} \mathrm{N}, 131^{\circ}$ $56^{\prime} 45^{\prime \prime} \mathrm{W}$; (map 7).

Local name reported in 1955 by USGS.

Berg Creek: stream, in Glacier Bay National Monument, heads in glacier, flows $8 \mathrm{mi}$. SW to head of Adams Inlet, $64 \mathrm{mi}$. NW of Juneau, St. Elias Mts. ; $58^{\circ} 54^{\prime} 10^{\prime \prime} \mathrm{N}, 135^{\circ} 50^{\prime} 05^{\prime \prime} \mathrm{W}$; (map 11).

Name published in 1962 by the USGS, probably from the mountain of the same name located just to the north.

Berg Creek: stream, flows NW $2.8 \mathrm{mi}$. to MacDougall Creek, 1 mi. NE of that stream's junc. with Kuskulana River and $32 \mathrm{mi}$. NW of McCarthy, Wrangell Mts. ; $61^{\circ} 34^{\prime} \mathrm{N}, 143^{\circ} 48^{\prime}$ W; (map 67).

Local name reported in 1912 by USGS.

Berg Creek: stream, see Borg Creek.

Berger Bay: bay, on SE coast of Kenai Penin., extends E $1.6 \mathrm{mi}$. off Nuka Passage on W coast of Nuka I., $35 \mathrm{mi}$. ESE of Seldovia, Chugach Mts.; $59^{\circ} 20^{\prime} 30^{\prime \prime} \mathrm{N}, 150^{\circ} 44^{\prime} 30^{\prime \prime} \mathrm{W}$; BGN 1931; (map 50). Var. Berger Cove.

Name derived in 1931 from nearby Berger Island by USC\&GS.

Berger Cove: bay, see Berger Bay.

Berger Island: island, $600 \mathrm{ft}$. long, on SE coast of Kenai Penin., between Berger Bay and Nuka Passage, $34 \mathrm{mi}$. SE of Seldovia, Chugach Mts. ; $59^{\circ} 20^{\prime} 30^{\prime \prime} \mathrm{N}, 150^{\circ} 44^{\prime} 30^{\prime \prime} \mathrm{W}$; (map 50 ).

Local name reported by USC\&GS in 1938.

Bergh Lake: lake, $0.4 \mathrm{mi}$. long, in Mount McKinley National Park, in course of Stony Creek, $4.2 \mathrm{mi}$. NE of Eielson Visitor Center, Alaska Ra.; $63^{\circ} 28^{\prime} 20^{\prime \prime} \mathrm{N}, 150^{\circ} 12^{\prime} 30^{\prime \prime} \mathrm{W}$; (map 88).

Local name reported in 1954 by USGS.

Berg Inlet: bay, see Berg Bay.

Berg Lake: lake, $3 \mathrm{mi}$. long, at mouth of Berg Greek in Glacier Bay National Monument, 64 mi. NW of Juneau, St. Elias Mts.; 58 $55^{\prime} \mathrm{N}$, $135^{\circ} 45^{\prime} \mathrm{W}$; (map 11).
So named in 1890 by Reid (1892, pl. 14) because of the large number of icebergs floating on the lake. Reid's map shows the lake at the edge of Muir Glacier. Since 1890 the glacier has retreated $6 \mathrm{mi}$., a condition which has resulted in the lake's disappearance.

Berg Lake: lake, $0.8 \mathrm{mi}$. long, on Kenai Penin. between Kasilof River and Tustumena Lake, $21 \mathrm{mi}$. S of Kenai, Cook Inlet Low.; $60^{\circ} 15^{\prime} 00^{\prime \prime}$ $\mathrm{N}, 151^{\circ} 09^{\prime} 30^{\prime \prime} \mathrm{W}$; (map 62).

Named about 1963 by officials of Kenai National Moose Range, for administrative purposes.

Berg Lake: lake, $2.8 \mathrm{mi}$. across, at 1961 terminus of Steller Glacier, $1 \mathrm{mi}$. SE of Doughton Peak and $66 \mathrm{mi}$. E of Cordova, Chugach Mts.; $60^{\circ} 25^{\prime} \mathrm{N}, 143^{\circ} 51^{\prime} \mathrm{W}$; (map 65). Var. First Berg Lake, Second Berk Lake, Second Lake, Third Berg Lake, Third Lake.

The local name First Berg Lake was reported in 1905 by G. C. Martin (1908, pl. 2), USGS. It applied originally to the largest and most western of the Berg Lakes. The recent retreat of the Steller and Bering Glaciers caused First Berg Lake to join with Second Berg and Third Berg Lakes to form one lake now called Berg Lake. See also Fifth Lake.

Berg Lakes: two lakes, each about $3 \mathrm{mi}$. across, at 1961 terminus of Steller Glacier, S of Carbon Mtn. and $66 \mathrm{mi}$. E of Cordova, Chugach Mts. ; $60^{\circ} 25^{\prime} \mathrm{N}, 143^{\circ} 51^{\prime} \mathrm{W}$; (map 65).

Descriptive collective name used by prospec. tors and reported by G. C. Martin, USGS, in 1905. Originally there were five lakes locally called First, Second, Third, Fourth, and Fifth Lakes, as shown on a 1908 USGS map by E. C. Hamilton. A 1961 USGS map shows only two lakes, Berg Lake and Fifth Lake, as a result of the recent retreat of the Steller and Bering Glaciers and the enlargement and joining of the original five lakes.

Bergman: locality, site of village on $\mathrm{N}$ bank of Koyukuk River NE of its junc. with Kanuti River, $7.5 \mathrm{mi}$. SE of Allakaket, Hogatza High.; $66^{\circ} 30^{\prime} \mathrm{N}, 152^{\circ} 53^{\prime} \mathrm{W}$; (map 117). Var. Burgeman.

Named by prospectors for the operator of the trading post; reported in 1899 by T.' G. Gerdine (in Schrader, 1900, pl. 60), USGS. The locality maintained some prominence during the height of the Koyukuk gold rush because it was a transfer point for supplies and was situated near the head of navigation for the larger riverboats on the Koyukuk. Bergman is shown as abandoned on a 1913 map.

Bergman Creek: stream, flows SE $10 \mathrm{mi}$. to Koyukuk River $5 \mathrm{mi}$. NE of its junc. with Kanuti River, $7.4 \mathrm{mi}$. SW of Allakaket, Hogatza High.; $66^{\circ} 30^{\prime} \mathrm{N}, 152^{\circ} 52^{\prime} \mathrm{W}$; $B G N$ 1944; (map 117). Var. Pickarts Creek.

Local name obtained at Hughes and Allakaket by Orth in 1956; named for the settlement of Bergman that formerly existed at the stream's mouth. It was earlier known as "Pickarts Creek," as shown on an 1899 fieldsheet by T. G. Gerdine, USGS. Pickarts (Frank?) was one member of the firm of 
Pickarts, Bettles, and Pickarts, owners of the trading post at Bergman in 1899.

Berg Mountain: mountain, 3,930 ft., $16 \mathrm{mi}$. E of Wrangell and $18 \mathrm{mi}$. N of Bradfield Canal, Coast Mts.; $56^{\circ} 27^{\prime} 10^{\prime \prime} \mathrm{N}, 131^{\circ} 59^{\prime} 40^{\prime \prime} \mathrm{W}$; (map 7).

Local name reported in 1955 by USGS.

Berg Mountain: mountain, 5,633 ft., in Glacier Bay National Monument, $0.2 \mathrm{mi}$. NW of head of Girdled Glacier and $66 \mathrm{mi}$. NW of Juneau, St. Elias Mts.; $58^{\circ} 57^{\prime} 30^{\prime \prime} \mathrm{N}, 135^{\circ} 43^{\prime} 25^{\prime \prime} \mathrm{W}$; (map 11). Var. Ancon Peak.

Local name published by USGS in 1951 .

Bergstrom Gulch: ravine, trends SW $1 \mathrm{mi}$. to Glacier Creek, $6 \mathrm{mi}$. N of Nome, Seward Penin. High.; $64^{\circ} 35^{\prime} 45^{\prime \prime} \mathrm{N}, 165^{\circ} 25^{\prime} 35^{\prime \prime} \mathrm{W}$; (map 94).

Prospectors' name reported in 1904 by T. G. Gerdine, USGS.

Berie Island: island, $0.2 \mathrm{mi}$. across, in Porcupine Is., $14.5 \mathrm{mi}$. NW of Chichagof, on Chichagof I., Alex. Arch.; 57 $48^{\prime} 10^{\prime \prime} \mathrm{N}, 1^{\circ} 6^{\circ} 23^{\prime} 30^{\prime \prime} \mathrm{W}$; (map 9).

Name published by USC\&GS in the 1947 Coast Pilot (p. 393).

Bering: locality, at mouth of Bering Creek, on Port Clarence, $5 \mathrm{mi}$. SW of Teller, Seward Penin. High.; $65^{\circ} 12^{\prime} \mathrm{N}, 166^{\circ} 28^{\prime} \mathrm{W}$; (map 111). Var. Bering City.

Harbor town established about 1899 or 1900 to serve the placer mines along the Bluestone River. Brooks (1901, p. 68), USGS, noted that by fall of 1900 it had a population of 200 and as a harbor, "has some advantage over Teller, inasmuch as vessels can easily approach much nearer the shore and have more protections from easterly and northeasterly winds." Teller, however, dominated and drew most of the people from Bering (Collier and others, 1908, p. 270). See Teller.

Beringa, Proliv: water passage, see Bering Strait. Bering City: locality, see Bering.

Bering Bay: bay, see Yakutat Bay.

Bering Creek: stream, flows NW $31 \mathrm{mi}$. to Bering Slough, channel in Yukon River, $17 \mathrm{mi}$. E of Kokrines and $43 \mathrm{mi}$. NE of Ruby, Nowitna Low. ; $64^{\circ} 58^{\prime} \mathrm{N}, 154^{\circ} 08^{\prime} \mathrm{W}$; (map 98).

Riverboat pilots' name shown on 1940 "Navigation Chart, Tanana-Yukon Rivers" of the River Boat Service, U.S. Dept of Interior.

Bering Creek: stream, flows $\mathrm{N} 1 \mathrm{mi}$. to Eagle Creek which flows to Right Fork Bluestone River, $12 \mathrm{mi}$. S of Teller, Seward Penin. High.; $65^{\circ} 05^{\prime} \mathrm{N}, 166^{\circ} 23^{\prime} \mathrm{W}$; (map 111).

Prospectors' name reported on the 1908 "Map of Seward Peninsula" by Arthur Gibson.

Bering Creek: stream, flows SW $1 \mathrm{mi}$. to Willow Creek which flows to Port Clarence, $5 \mathrm{mi}$. SW of Teller, Seward Penin. High.; 65 $12^{\prime} \mathrm{N}$, $166^{\circ} 28^{\prime} \mathrm{W}$; (map 111).

Prospectors' name reported on the 1908 "Map of Seward Peninsula" by Arthur Gibson.

Bering Glacier: glacier, heads in Bagley Ice Field at $60^{\circ} 32^{\prime} \mathrm{N}, 142^{\circ} 35^{\prime} \mathrm{W}$, trends SW $48 \mathrm{mi}$. to its 1950 terminus, $66 \mathrm{mi}$. ESE of Cordova, Malaspina Coastal Plain; $60^{\circ} 10^{\prime} \mathrm{N}, 143^{\circ} 50^{\prime}$
W; BGN 1932; (mæp 65). Var. Behring Glacier.

Named by USC\&GS in 1880 to commemorate Capt. Comdr. Ivan Ivanovich (Vitus) Bering, a Dane in the naval service of Peter the Great, and as leader of an official voyage of exploration, credited with the discovery of Alaska. His first landfall was made in this area in July 1741 .

Bering Haven: bay, see Controller Bay.

Bering Lake: lake, $5.5 \mathrm{mi}$. long, drains $\mathrm{E}$ to Bering River, $50 \mathrm{mi}$. ESE of Cordova, Chugach Mts.; $60^{\circ} 18^{\prime} \mathrm{N}, 144^{\circ} 18^{\prime} \mathrm{W}$; (map 64).

Local name reported in 1903 by G. C. Martin (1905, pl. 3), USGS.

Bering Point: point of land, western tip of Kathaleen I.; in Yukon River, $40 \mathrm{mi}$. NE of Ruby, Nowitna Low.; $64^{\circ} 57^{\prime} \mathrm{N}, 154^{\circ} 12^{\prime} \mathrm{W}$; (map 98).

Riverboat pilots' name shown on 1940 "Navigation Chart, Tanana-Yukon Rivers" of the River Boat Service, U.S. Dept. of Interior.

Bering River: stream, heads at Bering Glacier terminus, flows SW $20 \mathrm{mi}$. to Controller Bay, $57 \mathrm{mi}$. ESE of Cordova, Malaspina Coastal Plain ; $60^{\circ} 11^{\prime} \mathrm{N}, 144^{\circ} 15^{\prime} \mathrm{W}$; (map 64). Var. Chilcat River, Chilkaht River, Chilkat River, Rio de Lagartos.

Local name reported in 1903 by G. C. Martin, USGS. Named "Rio de Lagartos" in July, 1779 , by Don Ignacio Arteaga. "Arteaga, however, did not reach the river, so the name must have had some other source than any knowledge he had that there were lagartos, 'lizards' in it," (Wagner, 1937, p. 466). George Davidson, USC\&GS, called it "Chilkaht" in the 1869 Coast Pilot (p. 146), for the Chilkat subdivision of Tlingit Indians.

Bering Sea: sea, $\mathrm{N}$ part of Pacific Ocean, between Siberia on $W$ and Alaska on $E$, enclosed by Aleutian Is. on $\mathbf{S}$ and Komandorski Is. on SW, and connected by Bering Strait with Chukchi Sea on $\mathrm{N} ; 60^{\circ} \mathrm{N}, 175^{\circ} \mathrm{E} ; B G N$ 1951; Var. Aleutian Sea, Behring Sea, Eastern Ocean, Kamchatka Sea, Mer d'Aléoutienne, Mer d'Aliaska, Mer d'Ormante, Sea of Alaska, Sea of Kamchatka, Sea of Otters (Bobrovoi), Sleepy Sea.

Named in 1822 by Capt. V. M. Golovnin, IRN, for Comdr. Ivan Ivanovich (Vitus) Bering, IRN, who was selected by Peter the Great, Tsar of Russia "for the work of exploring eastern Asia and western America ***. Before 1822 it was for the most part called the Sea of Kamchatka ***. On a very old map it is called the Mer d'Ormante and on another the Sleepy sea ***"' (Baker, 1906, p. 129).

Bering Slough: channel, in Yukon River, flows SW $5.1 \mathrm{mi}$. around SE side of Kathaleen I., 40 mi. NE of Ruby, Nowitna Low.; 64ำ $57^{\prime} \mathrm{N}$, $154^{\circ} 12^{\prime} \mathrm{W}$; (map 98).

Riverboat pilots' name shown on 1940 "Navigation Chart, Tanana-Yukon River" of the River Boat Service, U.S. Dept. of Interior.

Bering Strait: water passage, $55 \mathrm{mi}$. wide, connecting Arctic Ocean and Bering Sea and separating Asia and North America; $66^{\circ} \mathrm{N}$, $169^{\circ} \mathrm{W}$; BGN 1951; Var. Beerings Strait, Behring Strait, Bherings Straits, Proliv Beringa, Strets de Anian.

Named in 1778 by Capt. James Cook, RN. The name "Strets de Anian" is shown for this feature on a map dated 1572 .

Berkley Canyon: ravine, trends SE $1 \mathrm{mi}$. to its junc. with Canine Gulch at head of Francisco Creek which flows to Stewart River, $20 \mathrm{mi}$. N of Nome, Seward Penin. High., 64 $49^{\prime} 20^{\prime \prime} \mathrm{N}$, $165^{\circ} 29^{\prime} 30^{\prime \prime} \mathrm{W}$; (map 94).

Prospectors" name shown on the 1904 "Map of Cape Nome Precinct" by Arthur Gibson.

Bermudez Bluff: mountain, $1,731 \mathrm{ft}$., $6 \mathrm{mi}$. E of Mount Dixon and $27 \mathrm{mi}$. NE of Solomon, Seward Penin. High. ; $64^{\circ} 55^{\prime} \mathrm{N}, 164^{\circ} 03^{\prime} \mathrm{W}$; (map 95).

Local name published in 1956 by USGS.

Bernard Creek: stream, flows NW $17 \mathrm{mi}$. to Tonsina River, $0.5 \mathrm{mi}$. NE of Tonsina and 52 mi. NE of Valdez, Chugach Mts.; $61^{\circ} 39^{\prime} 45^{\prime \prime}$ $\mathrm{N}, 145^{\circ} 10^{\prime} 05^{\prime \prime} \mathrm{W}$; (map 68).

Local name reported in 1900 by T. G. Gerdine, USGS.

Bernard Harbor: harbor, on Beaufort Sea coast, extends $2.6 \mathrm{mi}$., off Jago Lagoon S of Bernard Spit, Arctic Plain; $70^{\circ} 07^{\prime} 40^{\prime \prime} \mathrm{N}, 143^{\circ} 30^{\prime} 01^{\prime \prime}$ W; BGN 1961; (map 152). Var. Teddy Bear Harbor

Named by Leffingwell (1919, p. 94) June 1912, "After Capt. Joe Bernard of the schooner Teddy Bear, which wintered there in 1909-10.'

Bernard Spit: spit, 5 mi. long, on Beaufort Sea coast NE of Barter I., Arctic Plain; $70^{\circ} 08^{\prime} \mathbf{N}$, $143^{\circ} 30^{\prime} \mathrm{W}$; (map 152)

Local name reported in 1948 by USC\&GS. Bern Creek: stream, see Drifting Snow Creek. Berners Bay: bay, $3 \mathrm{mi}$. across, on $\mathrm{E}$ shore of Lynn Canal, $16 \mathrm{mi}$. NW of Dotsons Landing and $34 \mathrm{mi}$. NW of Juneau, Coast Mts.; $58^{\circ} 43^{\prime}$ $\mathrm{N}, 135^{\circ} 00^{\prime} \mathrm{W}$; (map 11).

Discovered by Joseph Whidbey in 1794 and named by Capt. Vancouver (1801, v. 5. p. 435). Name is probably from "Berners," his mother's family name (Wagner, 1937, p. 376). Berncrs Bay Peaks: ridge, see Berners Peaks.

Berners Peaks: ridge, elev. 5,500-6,700 ft., trends N $2.5 \mathrm{mi}$., $4.5 \mathrm{mi}$. W of Echo Mtn. and $24 \mathrm{mi}$. $\mathrm{NW}$ of Juneau, Coast Mts.; $58^{\circ} 42^{\prime} 30^{\prime \prime} \mathrm{N}$, $134^{\circ} 30^{\prime} 15^{\prime \prime} \mathrm{W}$; BGN 1965; (map 11). Var. Berners Bay Peaks.

The name "Berners Bay Peaks" was suggested by the Juneau Icefield Research Project in 1964. The shortened name, "Berners Peaks," was approved by BGN.

Berners River: stream, heads in glacier in Kakuhan Ra., flows SE $15 \mathrm{mi}$. to Berners Bay, 43 mi. NW of Juneau, Coast Mts.; 58 $50^{\prime} \mathrm{N}$, $134^{\circ} 59^{\prime}$ W; BGN 1929; (map 11). Var. Bears River.

Local name reported by USGS in 1906 and published in 1908 . Name derived from the bay into which it flows.

Bernice Lake: lake, $1 \mathrm{mi}$. long, on $\mathrm{W}$ coast of Kenai Penin., $10 \mathrm{mi}$. NW of Kenai, Cook Inlet Low.; $60^{\circ} 41^{\prime} 30^{\prime \prime} \mathrm{N}, 151^{\circ} 21^{\prime} 30^{\prime \prime} \mathrm{W}$; (map 62). 
Local name reported in 1950 by USGS.

Bernirk: locality, in area between Chukchi Sea, North Salt Lagoon, and Elson Lagoon, $4 \mathrm{mi}$. SW of Point Barrow, Arctic Plain; 71 $20^{\prime} 50^{\prime \prime}$ $N$, $156^{\circ} 36^{\prime} 00^{\prime \prime}$ W; (map 153). Var. Birnirk, Hunting Beach, Perginik, Pergniak, Perignak, Perignax, Perigniak, Pernyu.

Archaeological excavation indicates that this strategic location has been the site of human occupancy since prehistoric time. The locality's name was also given to an ancient whaling culture. "Bernirk" is derived from an Eskimo name more closely rendered "Pirginik," which was shown as "Pergniak" on Brit. Adm. Chart 2164, compiled by Master Thomas Hull in 1853. Lt. P. H. Ray (1885, p. 55), USA, spells the name "Perignax" and "Pernyu."

Bernstein Bucht: bay, see Amber Bay.

Berry: locality, at the trail junc. $1 \mathrm{mi}$. E of Ester, $8 \mathrm{mi}$. W of Fairbanks, Yukon-Tanana High.; $64^{\circ} 51^{\prime} \mathrm{N}, 147^{\circ} 59^{\prime} \mathrm{W}$; (map 100).

Named "for the Berry Brothers who settled there in 1906, at the time the village was setthed." Subsequently, the population dwindled and the Berry Post Office was moved to Ester.

Berry: village, see Ester.

Berry Arm: bay, "of Port Frederick, Chichagof island, Alexander archipelago. So called in the Coast Pilot of 1883, p. 192"' (Baker, 1906, p. 130).

Berry Camp: locality, on S bank of Eagle Creek, $2 \mathrm{mi}$. NW of Mastodon Dome and $47 \mathrm{mi}$. SW of Circle, Yukon-Tanana High.; $65^{\circ} 27^{\prime} \mathrm{N}$, $145^{\circ} 26^{\prime}$ W; (map 104). Var. Eagle Creek.

A highway camp originally named "Eagle Creek" in 1924 by the ARC. The name has been changed locally to "Berry Camp."

Berry Creek: stream, heads at glacier SE of Macomb Plat., flows NE $19 \mathrm{mi}$. to Johnson Slough $7 \mathrm{mi}$. E of junc. of Johnson and Tanana Rivers, $47 \mathrm{mi}$. SE of Delta Junction, Alaska Ra.; $63^{\circ} 42^{\prime} 10^{\prime \prime} \mathrm{N}, 144^{\circ} 23^{\prime} 20^{\prime \prime} \mathrm{W}$; $B G N$ 1937; (map 86).

Local name shown on a 1927 manuscript map of the "Endicott and Haley Hunting Expedition."

Berry Creek: stream, flows $\mathrm{N} 4.5 \mathrm{mi}$. to Chatanika River, $40 \mathrm{mi}$. NE of Fairbanks, YukonTanana High.; $65^{\circ} 13^{\prime} 40^{\prime \prime} \mathrm{N}, 146^{\circ} 55^{\prime} 00^{\prime \prime} \mathrm{W}$; (map 104).

Named by prospectors; published by USGS (Prindle, 1908, pl. 4).

Berry Creek: stream, flows SW $15 \mathrm{mi}$. to Noxapaga River, $21 \mathrm{mi}$. W of Imuruk Lake, Seward Penin. High.; $65^{\circ} 40^{\prime} \mathrm{N}, 163^{\circ} 59^{\prime} \mathrm{W}$; BGN 1952; (map 110). Var. Pioneer Creek.

Prospectors' name reported in 1903 by D. C. Witherspoon (in Moffit, 1905, pl. 2), USGS. This stream appears to be the Pioneer Creek shown on a map of Cape Nome gold fields by David Fox, Jr., dated 1901.

Berry Island: island, $1,100 \mathrm{ft}$. long, in Kasaan Bay, on E coast of Prince of Wales I., NW of Kasaan I., Alex. Arch.; $55^{\circ} 30^{\prime} 25^{\prime \prime}$ N, $132^{\circ}$ $23^{\prime} 20^{\prime \prime} \mathrm{W}$; (map 4).
Named in 1886 by Lt. Comdr. R. C. Clover, USN.

Berry Island: island, $0.1 \mathrm{mi}$. long, in Keku Strait, SW of Horseshoe I., 15 mi. SE of Kake, Alex. Arch.; $56^{\circ} 47^{\prime} 05^{\prime \prime} \mathrm{N}, 133^{\circ} 45^{\prime} 05^{\prime \prime} \mathrm{W}$; (map 6).

Local name published by USC\&GS in 1925 Coast Pilot (p. 110).

Berry Island: island, $0.2 \mathrm{mi}$. across, in Kutchuma Is., 3 mi. S of Sitka, off $W$ coast of Baranof $I$., Alex. Arch.; $57^{\circ} 00^{\prime} 20^{\prime \prime} \mathrm{N}, 135^{\circ} 18^{\prime} 20^{\prime \prime} \mathrm{W}$; (map 9). Var. Johnson Island.

Named "O[strov] Yagodnyy," meaning "berry island," by Ivan Vasiliev the first in 1809 (U.S. Coast and Geodetic Survey, 1883, p. 144).

Berry Knoll: hill, $816 \mathrm{ft}$., on Annette I., between Bald Ridge and Tamgas Lake, Alex. Arch.; $55^{\circ} 04^{\prime} 10^{\prime \prime} \mathrm{N}, 131^{\circ} 30^{\prime} 10^{\prime \prime} \mathrm{W}$; (map 3). Named in 1883 by Lt. Comdr. H. E. Nichols, USN.

Berry Lake: lake, 0.5 mi. long, on Kenai Penin. $\mathrm{N}$ of Leaf Lake, $31 \mathrm{mi}$. NE of Kenai, Cook Inlet Low.; $60^{\circ} 48^{\prime} 20^{\prime \prime} \mathrm{N}, 150^{\circ} 33^{\prime} 30^{\prime \prime} \mathrm{W}$; (map 62).

Named about 1963 by officials of Kenai National Moose Range, for administrative purposes.

Berry Lake: lake, $0.4 \mathrm{mi}$. across, $21 \mathrm{mi}$. NE of Medfra, Kilbuck-Kuskokwim Mis.; $63^{\circ} 16^{\prime} \mathrm{N}$, $154^{\circ} 08^{\prime} \mathrm{W}$; (map 89).

Local name reported in 1955 by USGS.

Berry Passage: estuary, see Tenakee Inlet.

Berrys Landing: village, see Medfra.

Bertha, Mount: peak, 10,204 ft., in Glacier Bay National Monument, in Fairweather Ra., 22 mi. N of Icy Point and $70 \mathrm{mi}$. NW of Hoonah, St. Elias Mts.; 58 $41^{\prime} 15^{\prime \prime} \mathrm{N}, 137^{\circ} 01^{\prime} 30^{\prime \prime} \mathrm{W}$; (map 10).

Published in 1910 by USC\&GS on Chart 8306.

Bertha Bay: bay, $0.8 \mathrm{mi}$. across, $14 \mathrm{mi}$. NW of Chichagof, on W coast of Chichagof I., Alex. Arch.; $57^{\circ} 48^{\prime} \mathrm{N}, 136^{\circ} 21^{\prime} \mathrm{W}$; (map 9).

Name published by R. M. Overbeck (in Martin and others, 1919, pl. 2), USGS.

Bertha Creek: stream, on Kenai Penin., flows NW $2 \mathrm{mi}$. to Granite Creek, $11 \mathrm{mi}$. SE of Sunrise and $20 \mathrm{mi}$. W of Whittier, Chugach Mts.; $60^{\circ} 45^{\prime} \mathrm{N}, 149^{\circ} 15^{\prime} \mathrm{W}$; (map 63).

Local name reported by Grant and Higgins (1913, pl. 1), USGS.

Bertha Creek: stream, flows SW $0.4 \mathrm{mi}$. to Iron Creek, $28 \mathrm{mi}$. NW of Solomon, Seward Penin. High.; 64. $56^{\prime} 30^{\prime \prime} \mathrm{N}, 164^{\circ} 40^{\prime} 50^{\prime \prime} \mathrm{W}$; (map 95). Var. Grape Creek.

Prospectors' name reported on a map of Cape Nome gold fields by David Fox, Jr., dated 1901.

Bertha Glacier: glacier, heads on N slope of Takhinsha Mts., trends N $6.5 \mathrm{mi}$. to its terminus, $0.6 \mathrm{mi}$. S of Takhin River and $23 \mathrm{mi}$. SW of Skagway, St. Elias Mts.; $59^{\circ} 14^{\prime} 15^{\prime \prime} \mathrm{N}$, $135^{\circ} 47^{\prime} 30^{\prime \prime} \mathrm{W}$; (map 45).

Named by the U.S. Navy in 1880 and published by USC\&GS in the 1883 Coast Pilot (p. 198).

Bert Millar Cutoff: water passage, $0.8 \mathrm{mi}$. long, between Bean I. and S coast of Prince of Wales I., near mouth of Nichols Bay, Alex. Arch.; 54 $41^{\prime} 30^{\prime \prime} \mathrm{N}, 132^{\circ} 06^{\prime} 45^{\prime \prime} \mathrm{W}$; (map 1). Var. Bert Miller Cutoff.

Named for a local sea captain; reported by H. C. Fassett, USBF, in 1904.

Bert Miller Cutoff: water passage, see Bert Millar Cutoff.

Bertoncini Island: barrier island, $0.5 \mathrm{mi}$. long, in Jones Is., on Beaufort Sea Coast, $4.5 \mathrm{mi}$. NW of Beechey Point, Arctic Plain; 70 32' $10^{\prime \prime}$ N, 149 $17^{\prime} 45^{\prime \prime} \mathrm{W}$; (map 150).

Named by Leffingwell (1919, p. 14, 94) after Capt. John Bertoncini, "known as 'Johnny the Painter'." Capt. Bertoncini commanded the whaleship Jeannette, on which Leffingwell returned to San Francisco in the fall of 1914.

Bert Point: point of land, in Portage Bay, near head of Alitak Bay, at S end of Kodiak I.; $56^{\circ} 58^{\prime} \mathrm{N}, 153^{\circ} 51^{\prime} \mathrm{W}$; BGN 1934; (map 33).

Named in 1934 by USC\&GS "for the triangulation station, 'Bert,' on the point."

Besboro Island: island, $1,042 \mathrm{ft}$. long, in Norton Sound, $11 \mathrm{mi}$. W of the mainland and $38 \mathrm{mi}$. SW of Christmas Mtn., Nulato Hills; $64^{\circ} 07^{\prime}$ $45^{\prime \prime} \mathrm{N}, 161^{\circ} 18^{\prime} 30^{\prime \prime} \mathrm{W}$; BGN Sixth Report; (map 96). Var. Besborough Island.

Named on September 12, 1778, by Capt. James Cook $(1785$, v. 2, p. 479$), \mathrm{RN}$, who published it as "Besborough Island."

Besborough Island: island, see Besboro Island.

Beshta Bay: bight, $6.4 \mathrm{mi}$. across, on NW shore of Cook Inlet, between Granite Point and North Foreland, $6 \mathrm{mi}$. SW of Tyonek, Cook Inlet Low.; $61^{\circ} 01^{\prime} 45^{\prime \prime} \mathrm{N}, 151^{\circ} 11^{\prime} 00^{\prime \prime} \mathrm{W}$; $B G N 1916$; (map 70).

Tanana Indian name meaning "coal" published in 1916 by USC\&GS.

Bess, Lake: lake, $0.8 \mathrm{mi}$. long, on Cleveland Penin., $N$ of Bailey Bay, Alex. Arch.; 55 $59^{\prime}$ $50^{\prime \prime} \mathrm{N}, 131^{\circ} 37^{\prime} 20^{\prime \prime} \mathrm{W}$; (map 3).

Local name published in 1943 by USC\&GS.

Bessie Creek: stream, flows W $3 \mathrm{mi}$. to Yankee Cove, on E shore of Favorite Channel, $26 \mathrm{mi}$. NW of Juneau, Coast Mts.; $58^{\circ} 35^{\prime} 30^{\prime \prime} \mathrm{N}$, $134^{\circ} 54^{\prime} 00^{\prime \prime} \mathrm{W}$; (map 11).

Name published in 1912 by USGS (Knopf, $1912 \mathrm{a}$, pl. 5), and probably derived from the Bessie Mine located near this stream.

Bessie Creek: stream, flows NW $24 \mathrm{mi}$. to North Mouth Arolik River, $43 \mathrm{mi}$. N of Goodnews, Yukon-Kuskokwim Delta; $59^{\circ} 38^{\prime} \mathrm{N}, 161^{\circ} 45^{\prime}$ W; (map 53).

Name published in 1921 by USGS.

Bessie No. 5 Dredge Camp: village, pop. 54 (1950), at junc. of Osborn Creek and St. Michaels Creek, $8 \mathrm{mi}$. NE of Nome, Seward Penin. High.; 64 $33^{\prime}$ N, $165^{\circ} 09^{\prime}$ W ; (map 94).

Site of a mining camp; name published in 1956 by USGS.

Bessie Peak: mountain, 3,915 ft. on Etolin I., Alex. Arch.; $56^{\circ} 16^{\prime} 00^{\prime \prime} \mathrm{N}, 132^{\circ} 29^{\prime} 45^{\prime \prime} \mathrm{W}$; (map 6).

Named in 1886 by Lt. Comdr. A. S. Snow, USN; name published in 1887 on USC\&GS Chart 706. 
Bessy Slough: stream, anabranch, heads at Louden Slough, flows NW $1.6 \mathrm{mi}$. to Yukon River, $40 \mathrm{mi}$. E of Nulato, Koyukuk Low.; $64^{\circ} 40^{\prime}$ $\mathrm{N}, 156^{\circ} 45^{\prime} \mathrm{W}$; (map 97).

Local name reported in 1954 by USGS.

Besziviit Lake: lake, $1.1 \mathrm{mi}$. across, $\mathrm{S}$ of Nayuko River, $19 \mathrm{mi}$. NW of Hochandochtla Mtn., Kokrines-Hodzana High.; $65^{\circ} 39^{\prime} 10^{\prime \prime} \mathrm{N}$, $155^{\circ} 28^{\prime} 20^{\prime \prime} \mathrm{W}$; (map 107).

Koyukan Indian name obtained at Huslia in 1956 by Orth.

Beta Rock: rock, $400 \mathrm{ft}$. long, between Gulf of Esquibel and Sonora Passage, near $\mathrm{S}$ end of Maurelle Is., Alex. Arch.; 55 $36^{\prime} 50^{\prime \prime} \mathrm{N}$, $133^{\circ} 37^{\prime} 15^{\prime \prime} \mathrm{W}$; (map 4).

Named in 1925 by USC\&GS; derived "from the second letter of the Greek alphabet."

Betchareff, Mount: peak, see Becharof, Mount. Betchareff Lake: lake, see Becharof Lake.

Betchevinskoi Cap: point of land, see Bechevin Point.

Betchevinskoi, Port: $b a y$, see Bechevin Bay.

Beth, Lake: lake, $0.4 \mathrm{mi}$. across, $15 \mathrm{mi}$. $\mathrm{N}$ of Anchorage, between Fish and Goose Creeks, Cook Inlet Low.; $61^{\circ} 26^{\prime} \mathrm{N}, 149^{\circ} 49^{\prime} \mathrm{W}$; (map 69).

Local name reported in 1952 by USGS.

Bethel: town, pop. 1,258, on right bank of Kuskokwim River, $90 \mathrm{mi}$. SW of Aniak and $83 \mathrm{mi}$. $E$ of Nelson I., Yukon-Kuskokwim Delta; $60^{\circ} 47^{\prime} 30^{\prime \prime} \mathrm{N}, 161^{\circ} 45^{\prime} 00^{\prime \prime} \mathrm{W}$; (map 59). Var. Mumtreckhlagamute, Mumtrekhlagamute, Mumtrekkhlogamute, Mumtrelega, Mumtrelegamut, Mamtrelich.

Bethel was originally the site of an Eskimo village and trading post of the Alaska Commercial Company, listed as "Mumtrekhlogamute" with 41 people by Ivan Petroff in the 10th Census, in 1880. The name is reported to mean "smokehouse people" because here a peculiar house for smoking fish was erected. In 1884, the Moravian church sent Henry Hartmann and W. H. Weinland to Alaska to locate a site for a mission, which they placed at the village of Mumtrekhlogamute. The mission was established a year later by Weinland and J. $\mathrm{H}$. Kilbuck. The name given to the mission is derived from the biblical passage "And God said unto Jacob, Arise, and go up to Bethel, and dwell there; and make there an altar unto God ***" (Gen. 35:1). The scriptural Bethel was 22 mi. $\mathrm{N}$ of Jerusalem and means "house of God" in Hebrew.

The Alaskan Bethel had a population of 33 in 1890, 110 in 1910, 221 in 1920, 278 in 1930,376 in 1940 , and 651 in 1950 . The Bethel post office was established in 1905.

Betrug, Cape: point of land, see Deceit, Cape. Betshevinskoi: bay, see Bechevin Bay.

Betsy Creek: stream, flows NE to Ivanhoe Creek which flows to Big Four Creek, about $18 \mathrm{mi}$. NE of Solomon, Seward Penin. High.; $64^{\circ} 46^{\prime}$ N, $164^{\circ} 04^{\prime} \mathrm{W}$; (map 95$)$.

Prospector's name reported on a prospector's manuscript map dated 1902. This stream cannot be precisely located on current maps.
Bettels Bay: estuary, see Bettles Bay.

Bettels Glacier: glacier, see Bettles Glacier.

Bettles: village, pop. 77, on W bank of Koyukuk River $1 \mathrm{mi}$. SW of its junc. with John River, Kanuti Flats; $66^{\circ} 54^{\prime} 30^{\prime \prime} \mathrm{N}, 151^{\circ} 41^{\prime} 30^{\prime \prime} \mathrm{W}$; (map 117).

Named "for Gordon C. Bettles, printer for the Fort Adams Press in 1893; the village grew up around a trading post he established in 1899; Pickarts, Bettles, and Pickarts" (Kitchener, 1954, p. 156). A post office was established in 1901 and continued intermittently until 1956 (Ricks, 1965, p. 7). The construction of an airfield in 1945, at Bettles Field, five miles up river has attracted people away from this village. See Evansville.

Bettles Bay: estuary, $3.5 \mathrm{mi}$. long, on $\mathrm{W}$ side of Port Wells, $18 \mathrm{mi}$. NE of Whittier, Chugach Mts.; $60^{\circ} 55^{\prime} 30^{\prime \prime} \mathrm{N}, 148^{\circ} 15^{\prime} 05^{\prime \prime}$ W; BGN 1910; (map 63). Var. Bettels Bay.

Named in 1910 for Capt. James Bettles of Valdez by Grant and Higgins (1913, pls. 1, 2), USGS. See Bettles Glacier.

Bettles Field: village, see Evansville.

Bettles Glacier: glacier, trends NE $2.5 \mathrm{mi}$. to its 1951 terminus, $2 \mathrm{mi}$. SW of head of Bettles Bay and $15 \mathrm{mi}$. NE of Whittier, Ghugach Mts.; $60^{\circ} 56^{\prime} 20^{\prime \prime} \mathrm{N}, 148^{\circ} 22^{\prime} 30^{\prime \prime} \mathrm{W}$; $B G N$ 1910; (map 63). Var. Bettels Glacier.

Named in 1910 for Capt. James Bettles of Valdez by Grant and Higgins (1913, pls. 1, 2), USGS. The name for the glacier was originally erroneously spelled "Bettels."

Bettles Island: island, $0.7 \mathrm{mi}$. long, at $\mathrm{N}$ end of Elrington Passage, off E coast of Evans I., 18 mi. SSE of Chenega, Chugach Mts.; $60^{\circ} 03^{\prime}$ $00^{\prime \prime} \mathrm{N}, 147^{\circ} 59^{\prime} 30^{\prime \prime} \mathrm{W}$; BGN 1908; (map 63). Var. James Island.

Local name reported in 1908 by U. S. Grant, USGS. Probably named for Capt. James Bettles of Valdez.

Bettles River: stream, heads at junc, of Robert and Phoebe Creeks, flows W $17 \mathrm{mi}$. to join Dietrich River to form the Middle Fork Koyukuk River, $40 \mathrm{mi}$. WNW of Chandalar, Brooks Ra.; $67^{\circ} 38^{\prime} 40^{\prime \prime}$ N, $149^{\circ} 45^{\prime} 00^{\prime \prime}$ W; (map 123).

Named in 1899 by miners in the area for Gordon C. Bettles of the firm Pickarts, Bettles, and Pickarts, owners of the trading post at Bergman.

Betton Cape: mountain, see Betton Head.

Betton Head: mountain, 1,138 ft., on W coast of Betton I., $14 \mathrm{mi}$. NW of Ketchikan, Alex. Arch.; $55^{\circ} 30^{\prime} 45^{\prime \prime} \mathrm{N}, 131^{\circ} 49^{\prime} 35^{\prime \prime}$ W; (map 3). Var. Betton Cape.

Named in 1886 by USG\&GS; published as "Betton Cape."

Betton Island: island, $4.3 \mathrm{mi}$. long, at $\mathrm{W}$ entrance to Behm Canal, Alex. Arch.; $55^{\circ} 31^{\prime} \mathrm{N}$, $131^{\circ} 48^{\prime} \mathrm{W}$; (map 3). Var. Beaton Island, Beatons Island, Bettons Island.

Named in 1793 by Capt. George Vancouver, RN, "after Roderick Betton, a sailor who was badly wounded in a fight with the Indians August 12, 1793" (Wagner, 1937, p. 431). This name was erroneously published as "Beatons" on Capt. Vancouver's chart.
Betton Point: point of land, on NW coast of Betton I., near W entrance to Behm Canal, Alex. Arch.; 55 $32^{\prime} 30^{\prime \prime} \mathrm{N}, 131^{\circ} 48^{\prime} 00^{\prime \prime} \mathrm{W}$; (map 3).

Local name published in the 1925 Coast Pilot (p. 68).

Bettons Island: island, see Betton Island.

Betty, Lake: lake, $1.5 \mathrm{mi}$. long, $4 \mathrm{mi}$. $\mathrm{S}$ of junc. of Nigu and Etivluk Rivers, $20 \mathrm{mi}$. NNE of Howard Pass, Arctic Slope; 68 $29^{\prime}$ N, $156^{\circ} 30^{\prime} \mathrm{W}$; (map 132).

Recorded on a 1925 fieldsheet by Gerald FitzGerald, USGS.

Betty Island: island, 2 mi. long, in Yukon River $\mathrm{N}$ of Fox Point I., Innoko Low.; $63^{\circ} 03^{\prime} \mathrm{N}$, $159^{\circ} 48^{\prime} \mathrm{W}$; (map 91 ).

Riverboat pilots' name shown on a 1940 "Navigation Chart of the Tanana-Yukon Rivers" published by the U.S. Dept. of Interior.

Betty Lake: lake, $1.4 \mathrm{mi}$. long, on Baranof I., $3.5 \mathrm{mi}$. NW of Port Alexander, Alex. Arch.; $56^{\circ} 17^{\prime} 30^{\prime \prime} \mathrm{N}, 134^{\circ} 42^{\prime} 00^{\prime \prime} \mathrm{W}$; (map 5).

Local name recorded in 1951 by USGS.

Between Mountain: mountain, 1,495 $\mathrm{ft}$., on Annette I., $\mathbf{N}$ of Tamgas Lake, Alex. Arch.; $55^{\circ} 04^{\prime} 15^{\prime \prime} \mathrm{N}, 131^{\circ} 28^{\prime} 00^{\prime \prime} \mathrm{W}$; (map 3 ).

Named in 1886 by USC\&GS.

Beulah Island: island, $0.1 \mathrm{mi}$. long, on Norton Sound, $1 \mathrm{mi}$. N of St. Michael, YukonKuskokwim Delta; 63⒉ $9^{\prime} 50^{\prime \prime} \mathrm{N}, 162^{\circ} 00^{\prime} 45^{\prime \prime}$ W; (map 92).

Named in $1898-1900$ by USG\&GS.

Beverley, Lake: lake, one of Wood River Lakes, extends NW-SE $20 \mathrm{mi}$. between Lake Nerka and Lake Kulik, $45 \mathrm{mi}$. $\mathrm{N}$ of Dillingham, Kilbuck-Kuskokwim Mts.; $59^{\circ} 40^{\prime} \mathrm{N}, 158^{\circ} 45^{\prime}$ W; BGN 1931; (map 52). Var. Beverly Lake, Cho-kwok-stchu-luk, Lake Nushagak.

Named for Beverley N. Polley, a prospector in the area in 1909-10; published in 1912 by USGS. This seems to be the same lake reported in 1910 by H. C. Fassett, USBF, to have the Eskimo name "Cho-kwok-stchu-luk," which he reported to mean "pike here." It may be the Lake Nushagak of Ivan Petroff in the 1880 Census. See Tikchik Lake.

Beverley Cove: cove, $0.4 \mathrm{mi}$. across, on $\mathrm{W}$ coast of Adak I., $E$ end of Expedition Harbor in Bay of Islands, Aleutian Is.; $51^{\circ} 47^{\prime} 50^{\prime \prime} \mathrm{N}$, $176^{\circ} 43^{\prime} 20^{\prime \prime}$ W; (map 17). Var. Blattman Cove.

Named in 1936 by the U.S. Navy Hydrog. Office, for Lt. Beverley Kinnon, USN. See Beverley Point.

Beverley Point: point of land, on W coast of Adak I., E point of entrance to Expedition Harbor in Bay of Islands, Aleutian Is.; $51^{\circ} 47^{\prime} 35^{\prime \prime} \mathrm{N}$, $176^{\circ} 43^{\prime} 20^{\prime \prime}$ W; (map 17). Var. Blattman Point.

Named in 1936 by the U.S. Navy Hydrog. Office, for Lt. Beverley Kinnon, USN, one of the officers of the schooner Fenimore Cooper during the North Pacific Exploring Expedition in 1855 .

Beverly Creek: stream, heads at $65^{\circ} 04^{\prime} \mathrm{N}$, $143^{\circ} 54^{\prime}$ W, flows SE $16 \mathrm{mi}$. to Charley River, 
$10 \mathrm{mi}$. NW of Eagle, Yukon-Tanana High.; $64^{\circ} 58^{\prime} \mathrm{N}, 143^{\circ} 30^{\prime} \mathrm{W}$; (map 102).

Prospectors' name reported in 1905 by

D. C. Witherspoon, USGS.

Beverly Lake: lake, see Beverley, Lake.

Beyer Bay: bight, $2.5 \mathrm{mi}$. across, on $\mathrm{S}$ coast of Adak I., N of Cape Kagigikak, Aleutian Is.; $51^{\circ} 40^{\prime} 00^{\prime \prime} \mathrm{N}, 176^{\circ} 42^{\prime} 30^{\prime \prime} \mathrm{W}$; BGN 1936; (map 17). Var. Naros Bay.

Named in 1934 by members of the U.S. Navy Aleutian Island Survey Expedition, "after a motor boat [Beyer] which brought supplies to the Aleutian Islands."

Bezdonnoye, Ozero: lake, see Bottomless Lake. Beziemiannoi Island: island, see Nameless Island. Bezpodnie: islands, see Barren Islands.

Bezymyannoy, Ostrov: island, see Nameless Island.

Bherings Straits : water passage, see Bering Strait Biali Rock: rock, $0.2 \mathrm{mi}$. across, $8.8 \mathrm{mi}$. S of Goddard, off SW coast of Baranof I., Alex. Arch.; $56^{\circ} 42^{\prime} 40^{\prime \prime} \mathrm{N}, 135^{\circ} 21^{\prime} 30^{\prime \prime} \mathrm{W}$; (map 5$)$.

Named by USC\&GS for charting purposes; name published in the 1925 Coast Pilot (p. 284).

Bibb Shoal: shoal, $0.2 \mathrm{mi}$. long, at mouth of Security Bay, on $\mathrm{N}$ coast of Kuiu I., Alex. Arch.; $56^{\circ} 52^{\prime} 05^{\prime \prime} \mathrm{N}, 134^{\circ} 23^{\prime} 00^{\prime \prime} \mathrm{W}$; (map 5).

Named in 1881 by Comdr. H. Glass, USN, "perhaps for one of the Coast Survey vessels."

Bibora Island: island, $200 \mathrm{ft}$. long, in Ursua Channel, on $\mathrm{N}$ coast of Saint Ignace $\mathrm{I}$., $11 \mathrm{mi}$. SW of Craig, Alex. Arch.; 55 $25^{\prime} 35^{\prime} \mathrm{N}, 133^{\circ}$ $25^{\prime} 05^{\prime \prime}$ W; (map 4). Var. Bibora Reef

Named "Bibora Reef" in 1775-79 by Francisco Antonio Maurelle and Don Juan de la Bodega y Quadra.

Bibora Reef: island, see Bibora Island.

Bichevina: bay, see Bechevin Bay.

Bidarka Point: point of land, on $\mathbf{N}$ shore of Port Fidalgo, $36 \mathrm{mi}$. NW of Cordova, Chugach Mts.; $60^{\circ} 49^{\prime} \mathrm{N}, 146^{\circ} 37^{\prime} \mathrm{W}$; BGN 1914; (map 64). Var. Copper Mountain Point.

Local name derived from the Russian word for a skin-covered boat similar to the kayak; reported in 1905 by U. S. Grant, USGS. Called "Copper Mountain Point" by Capt. W. R. Abercrombie, USA, who explored the Copper River region in 1898.

Bidark Creek: stream, on Kenai Penin., flows S $1 \mathrm{mi}$. to Kachemak Bay, $1.5 \mathrm{mi}$. W of Homer, Cook Inlet Low.; $59^{\circ} 38^{\prime} 45^{\prime \prime} \mathrm{N}, 151^{\circ} 35^{\prime} 30^{\prime \prime}$ W; (map 50).

Local name published by USGS in 1961

Biederman Bluff: bluff, elev. 2,485 ft., extends $8 \mathrm{mi}$. on $\mathrm{N}$ bank of Yukon River, $6 \mathrm{mi}$. NE of junc. of Charley River, Porcupine Plat.; $65^{\circ} 23^{\prime} 15^{\prime \prime} \mathrm{N}, 142^{\circ} 39^{\prime} 30^{\prime \prime} \mathrm{W}$; BGN 1965; (map 103).

Named in 1965 by USGS for Adolph Biederman, who carried mail to miners along the Yukon River by dog sled between 1910 and 1938.

Biedermans Camp: locality, on S bank of Yukon River, opposite mouth of Kandik River, Yukon-Tanana High.; $65^{\circ} 24^{\prime} \mathrm{N}, 142^{\circ} 34^{\prime} \mathrm{W}$; (map 103).
Name published in 1946 by USGS. See Biederman Bluff.

Bielie Rock: rocks, see Bieli Rocks.

Bieli Rock: rocks, see Bieli Rocks.

Bieli Rocks: rocks, in Sitka Sound, $6.5 \mathrm{mi}$. NW of Sitka, Alex. Arch.; 57 05'25' N, $135^{\circ} 29^{\prime} 53^{\prime \prime}$ W; BGN 1966; (map 9). Var. Bieli Rock, Bielie Rock, Kamen Bylyy, White Rock, Beloi rock.

Shown on an 1950 Russian American Co. map as "K[amen] Bylyy," meaning "White Rock."

Bieluga: lake, see Beluga Lake.

Bier Spale Creek: stream, flows $\mathbf{S}$ to Bering Sea, about $29 \mathrm{mi}$. NE of Nome, Seward Penin. High.; (map 94).

Prospectors' name reported on the 1900 "Map of Nome Peninsula" by J. M. Davidson and B. D. Blakeslee; this feature has not been positively identified.

Big Bar Creek: stream, flows SE $18 \mathrm{mi}$. to Koyuk River, $10 \mathrm{mi}$. SE of Kiwalik Mtn. and $35 \mathrm{mi}$. SE of Imuruk Lake, Seward Penin. High.; $65^{\circ} 21^{\prime} \mathrm{N}, 162^{\circ} 06^{\prime} \mathrm{W}$; (map 110$)$.

Prospectors' name reported in 1903 by D. C. Witherspoon (in Moffit, 1905, pl. 2), USGS.

Big Bay: bay, $0.2 \mathrm{mi}$. across and $2 \mathrm{mi}$. long, 1.5 mi. SE of Goddard, on W coast of Baranof I., Alex. Arch.; $56^{\circ} 49^{\prime} \mathrm{N}, 135^{\circ} 21^{\prime} \mathrm{W}$; (map 5).

Local name used by fishermen and published in 1929 by USC\&GS.

Big Bay: bay, on W coast of Shuyak I., extends NE $3 \mathrm{mi}$. from Eagle Cape, $45 \mathrm{mi}$. $N$ of Kodiak I. ; 58 $33^{\prime}$ N, $152^{\circ} 39^{\prime}$ W ; BGN 1933; (map 43).

Local name published in 1927 by USC\&GS on Chart 8555.

Big Bay: bay, see Kadashan Bay.

Big Bay: bight, $1 \mathrm{mi}$. across, on Kenai Penin. on S shore of Tustumena Lake, $32 \mathrm{mi}$. SSE of Kenai, Cook Inlet Low.; $60^{\circ} 09^{\prime} 20^{\prime \prime} \mathrm{N}, 150^{\circ}$. $51^{\prime} 00^{\prime \prime} \mathrm{W}$; (map 62).

Local descriptive name reported in 1954 by Barnes and Cobb (1959, pl. 17), USGS.

Big Bay: cove, see Steller Cove.

Big Bear Creek: stream, flows to Inglutalik River about $30 \mathrm{mi}$. above its mouth, Nulato Hills; $65^{\circ} 00^{\prime} \mathrm{N}, 160^{\circ} 30^{\prime} \mathrm{W}$; (map 109).

Prospectors' name reported in 1910 by A. H. Brooks, USGS. This feature cannot be identified on current maps.

Big Beaver Creek: stream, flows SW $10 \mathrm{mi}$. to Nixon Fork, $21.5 \mathrm{mi}$. N of Medfra, KilbuckKuskokwim Mts. ; $63^{\circ} 25^{\prime} \mathrm{N}, 154^{\circ} 33^{\prime} \mathrm{W}$; (map 89).

Local name reported in 1910 by A. G. Maddren (in Brooks and others, 1911, pl. 14), USGS.

Big Beaver Lake: lake, $1 \mathrm{mi}$. long, largest of Beaver Lakes, $25 \mathrm{mi}$. $\mathrm{N}$ of Anchorage, Cook Inlet Low.; $61^{\circ} 35^{\prime} 00^{\prime \prime} \mathrm{N}, 149^{\circ} 49^{\prime} 30^{\prime \prime} \mathrm{W}$; (map 69).

Local name reported in 1950 by USGS.

Big Bend: bend, "in Koyukuk river near latitude $65^{\circ} 25^{\prime}$, longitude $157^{\circ}$. Descriptive name, from Schrader, 1899" (Baker, 1906, p. 132).

Big Bend: bend, on Nushagak River, $90 \mathrm{mi}$. S of Sleetmute, Kilbuck-Kuskokwim Mts.; $60^{\circ} 25^{\prime}$
$\mathrm{N}, 156^{\circ} 43^{\prime} \mathrm{W} ;(\operatorname{map} 60)$.

Local name reported in 1952 by USC\&GS.

Big Bend: bend, on left bank of Yukon River, $31 \mathrm{mi}$. NE of Ruby, Nowitna Low.; $64^{\circ} 55^{\prime} \mathrm{N}$, $154^{\circ} 30^{\prime} \mathrm{W}$; (map 98).

Riverboat pilots' name shown on 1940 "Navigation Chart, Tanana-Yukon Rivers" of the River Boat Service, U.S. Dept. of Interior.

Big Bend: bend, in Chandler River, $19 \mathrm{mi}$. SE of Umiat, Arctic Slope; $69^{\circ} 05^{\prime} \mathrm{N}, 151^{\circ} 54^{\prime} \mathrm{W}$; $B G N$ 1960; (map 141).

Name proposed in 1957 by USGS for use in geologic purposes.

Big Bend Creek: stream, see Bronx Creek.

Big Bend Lakes: lakes, on Young and Canyon Creeks divide, drain $\mathrm{E}$ to Canyon Creek, $5 \mathrm{mi}$ $\mathrm{N}$ of its junc. with Chitina River and $27 \mathrm{mi}$ SE of McCarthy, St. Elias Mts.; $61^{\circ} 12^{\prime} \mathrm{N}$ $142^{\circ} 23^{\prime} \mathrm{W}$; (map 67)

Local name reported in 1959 by USGS

Big Bend Slough: stream, $9.5 \mathrm{mi}$. long, anabranch of Yukon River, W of Horse I., $12 \mathrm{mi}$. SW of Holy Cross, Innoko Low.; $62^{\circ} 03^{\prime} \mathrm{N}$, $160^{\circ} 00^{\prime} \mathrm{W}$; (map 78).

Local descriptive name obtained in 1952 by USGS.

Big Black River: stream, see Black River.

Big Black River: stream, see Little Black River.

Big Bonanza Creek: stream, flows W $20 \mathrm{mi}$. to Mulchatna River, $48 \mathrm{mi}$. NW of Nondalton, Lime Hills ; $60^{\circ} 39^{\prime} \mathrm{N}, 155^{\circ} 19^{\prime} \mathrm{W}$; (map 61). Var. Bonanza Creek.

Local name reported in 1914 as Bonanza Creek by R. H. Sargent, USGS; obtained from Thomas Hanmore, U.S. commissioner at Iliamna. The name was published, however, by USGS, as Big Bonanza Creek.

Big Bonanza Creek: stream, see Bonanza Creek.

Big Bones Ridge: ridge, 3,900 ft., extends N-S $6 \mathrm{mi}$., $3 \mathrm{mi}$. $\mathrm{E}$ of the junc. of Little Ophetna and Oshetna Rivers, and $15 \mathrm{mi}$. S of Susitna River, Talkeetna Mts. ; $62^{\circ} 22^{\prime} \mathrm{N}, 147^{\circ} 24^{\prime} \mathrm{W}$; $B G N$ 1960; (map 82).

Named in 1956 by USGS for the large fossil mammoth or mastodon bones found on its top.

Big Boulder Creek: stream, heads on $\mathbf{S}$ slope of Mount Seltat, flows SE $10 \mathrm{mi}$. to Klehini River, $1.5 \mathrm{mi}$. NE of Porcupine, and $31 \mathrm{mi}$. W of Skagway, St. Elias Mts.; $59^{\circ} 25^{\prime} 40^{\prime \prime} \mathrm{N}$, 136 $11^{\prime} 30^{\prime \prime} \mathrm{W}$; BGN 1967; (map 45). Var. Boulder Creek, Jockeach Creek, Yokeak Creek.

Tlingit Indian name reported by Aurel and Arthur Krause (1883, map) as "Jockeach". The prospectors' name was "Boulder Creek", reported by Brooks (1900, pl. 49), USGS.

Big Boulder Creek: stream, heads on Fairview Mtn., flows SE $1 \mathrm{mi}$. to join Little Boulder Creek to form Twin Creek, $46 \mathrm{mi}$. W of Talkeetna, Alaska Ra.; $62^{\circ} 20^{\prime} 45^{\prime \prime} \mathrm{N}, 151^{\circ} 33^{\prime}$ 20" W; (map 81).

Local descriptive name reported in 1911 by USGS.

Big Boulder Creek: stream, flows S $4 \mathrm{mi}$. to Seventymile River, $10 \mathrm{mi}$. NW of Eagle, Yukon-Tanana High.; $64^{\circ} 53^{\prime} 45^{\prime \prime}$ N, $141^{\circ} 26^{\prime}$ 45" W; (map 102).

Local name published in 1956 by USGS.

Big Bowlder: rock, "near Danger point in Wran- 
gell Narrows, Alexander archipelago." $56^{\circ} 40^{\prime}$ $\mathrm{N}, 132^{\circ} 55^{\prime} \mathrm{W}$.

So called by Lt. Comdr. H. E. Nichols, USN, in 1881.

Big Branch Bay: bay, $0.5 \mathrm{mi}$. across, empties into Branch Bay, 9 mi. NW of village of Port Alexander, on $S$ coast of Baranof I., Alex. Arch.; $56^{\circ} 20^{\prime} \mathrm{N}, 134^{\circ} 50^{\prime} \mathrm{W}$; (map 5). Var. Bolshoi Rukav, Bolshoi Strelka, Bolshoy Rukav, Great Strelki Bay.

Name published by USC\&GS in 1883 Coast Pilot (p. 133) ; derived from "Bolshoy Rukav," meaning "big sleeve"; published in 1850 by the Russian American Company.

Big Branch Rock: rock, $0.1 \mathrm{mi}$. across, in Branch Bay, $8 \mathrm{mi}$. NW of Port Alexander, on $\mathrm{S}$ coast of Baranof I., Alex. Arch.; 56 $6^{\circ} 16^{\prime} 48^{\prime \prime} \mathrm{N}, 134^{\circ}$ $50^{\prime} 50^{\prime \prime} \mathrm{W}$; (map 5).

Named in 1897 by Lt. Comdr. J. F. Moser, USN, commander of USBF steamer Albatross.

Big Canoe Creek: stream, flows SW to Sinuk River, about $30 \mathrm{mi}$. NW of Nome, Seward Penin. High.; (map 94).

Prospectors' name reported on the 1900 "Map of Nome Peninsula" by J. M. Davidson and B. D. Blakeslee; this feature has not been positively identified.

Big Castle Island: island, $1 \mathrm{mi}$. long, one of Castle Is., in Duncan Canal, $13 \mathrm{mi}$. SW of Petersburg, on SW coast of Kupreanof I., Alex. Arch.; 56 $39^{\prime} 40^{\prime \prime} \mathrm{N}, 133^{\circ} 10^{\prime} 00^{\prime \prime} \mathrm{W}$; $B G N$ 1933; (map 6).

Local name reported in 1933 by $R$. H. Sargent, USGS; so named because it is the largest of the Castle Islands.

Big Champion Creek: stream, see Champion Creek.

Big Chena River: stream, see Chena River.

Big Chief Mountain: mountain, 3,060 ft., $12 \mathrm{mi}$. $\mathrm{N}$ of Chichagof, on $\mathrm{W}$ coast of Chichagof I., Alex. Arch.; 57 $50^{\prime} \mathrm{N}, 136^{\circ} 11^{\prime} \mathrm{W}$; (map 9).

Name published in 1928 by USC\&GS on Chart 8258.

Big Chutes: water passage, in Iliamna Lake, extends W 2 mi. between Pile and Pedro Bays, $\mathrm{N}$ of Porcupine I., Aleutian Ra.; 59 $45^{\prime} 45^{\prime \prime}$ $\mathrm{N}, 154^{\circ} 06^{\prime} 00^{\prime \prime} \mathrm{W}$; $(\operatorname{map} 51)$.

Local name published in 1954 by USGS.

Big Creek: stream, flows NE $4 \mathrm{mi}$. to Red Bay, $12 \mathrm{mi}$. SE of village of Point Baker, on $\mathrm{N}$ coast of Prince of Wales I., Alex. Arch.; $56^{\circ}$ $15^{\prime} 50^{\prime \prime} \mathrm{N}, 133^{\circ} 20^{\prime} 30^{\prime \prime} \mathrm{W}$; (map 6).

Named in 1886 by Lt. J. M. Helm, USN, for charting purposes; name published in 1887 by USC\&GS on Chart 706.

Big Creek: stream, flows NE $7 \mathrm{mi}$. to Frederick Sound, on E coast of Mitkof I., $12 \mathrm{mi}$. SE of Petersburg, Alex. Arch.; $56^{\circ} 42^{\prime} 00^{\prime \prime} \mathrm{N}, 132^{\circ}$ $42^{\prime} 36^{\prime \prime} \mathrm{W}$; (map 6).

Local descriptive name obtained in 1953 by USGS.

Big Creek: stream, flows SE $10 \mathrm{mi}$. to Wide Bay, $\boldsymbol{N}$ of Coal Point, on $\mathbf{S}$ coast of Alaska Penin., 16 mi. SW of Kanatak, Aleutian Ra.; $57^{\circ} 28^{\prime}$ $30^{\prime \prime} \mathrm{N}, 156^{\circ} 12^{\prime} 30^{\prime \prime} \mathrm{W}$; (map 36).

Local name reported in 1921 by $\mathbf{S}$. $\mathbf{R}$. Capps, USGS
Big Creek: stream, heads in lake, flows SW, through several lakes, $40 \mathrm{mi}$. to Egegik Bay on $\mathrm{N}$ coast of Alaska Penin., $\mathrm{S}$ of Cape Chichagof and $35 \mathrm{mi}$. SW of Naknek, Bristol Bay Low.; 58 $17^{\prime} 25^{\prime \prime} \mathrm{N}, 1^{\circ} 7^{\circ} 32^{\prime} 30^{\prime \prime} \mathrm{W}$; (map 41).

Local name published in 1958 by USGS.

Big Creek: stream, heads at Westbrook Glacier, flows NE $1.5 \mathrm{mi}$. to edge of Shoup Glacier, 2.4 mi. NW of Shoup Bay and $14 \mathrm{mi}$. W of Valdez, Chugach Mts.; $61^{\circ} 08^{\prime} 45^{\prime \prime} \mathrm{N}, 146^{\circ} 40^{\prime} 10^{\prime \prime} \mathrm{W}$; (map 68).

Local name reported in 1912 by J. W. Bagley and C. E. Giffin, USGS.

Big Creek: stream, heads in Peters Hills, flows SE $3.6 \mathrm{mi}$. to Martin Creek, $24 \mathrm{mi}$. NW of Talkeetna, Alaska Ra.; $62^{\circ} 27^{\prime} 35^{\prime \prime} \mathrm{N}, 150^{\circ}$ $47^{\prime} 20^{\prime \prime} \mathrm{W}$; (map 81).

Local descriptive name reported by $S . R$. Capps (1913, p. 52), USGS.

Big Creek stream, heads on Black Mtn., flows NW $19 \mathrm{mi}$. to Takotna River $2.6 \mathrm{mi}$. N of junc. of Big Waldren Fork, $35 \mathrm{mi}$. SW of McGrath, Kilbuck-Kuskokwim Mts.; 62 ${ }^{\circ} 40^{\prime} 15^{\prime \prime}$ N, 156 $32^{\prime} 30^{\prime \prime} \mathrm{W}$; (map 79).

Prospectors' name reported in 1933 by J. B. Mertie, Jr., USGS.

Big Creek stream, flows SE $11 \mathrm{mi}$. to Takotna River, $3 \mathrm{mi}$. W of Mount Joaquin and $24 \mathrm{mi}$. SW of McGrath, Kilbuck-Kuskokwim Mts. $62^{\circ} 50^{\prime} 40^{\prime \prime} \mathrm{N}, 156^{\circ} 19^{\prime} 30^{\prime \prime} \mathrm{W}$; (map 79).

Prospectors' name reported in 1908 by A. G. Maddren, USGS.

Big Creek: stream, flows NE $11 \mathrm{mi}$. to Teklanika River, $22 \mathrm{mi}$. SW of Healy, Alaska Ra.; $63^{\circ} 42^{\prime} 15^{\prime \prime} \mathrm{N}, 149^{\circ} 34^{\prime} 30^{\prime \prime} \mathrm{W}$; (map 87).

Local name shown on a 1916 fieldsheet by C. E. Griffin, USGS.

Big Creek: stream, heads on $\mathrm{N}$ slope of Boston Dome, flows SE-NW $48 \mathrm{mi}$. to Yukon River, 6 mi. NE of Ruby, Nowitna Low.; 64. $48^{\prime} \mathrm{N}$, $155^{\circ} 19^{\prime} \mathrm{W}$; (map 98).

Prospectors' name reported in 1908 by $A$. G. Maddren (in Brooks and others, 1909, p. 230), USGS.

Big Creek: stream, flows SE $6.5 \mathrm{mi}$. to Grouse Creek, $0.1 \mathrm{mi}$. $\mathrm{N}$ of Pilgrim River, $29 \mathrm{mi}$. NW of Solomon, Seward Penin. High.; $64^{\circ} 57^{\prime} \mathrm{N}$, $164^{\circ} 44^{\prime} \mathrm{W}$; (map 95).

Prospectors' name reported in 1900 by $\mathrm{E}$. C. Barnard (in Brooks, 1901, pl. 17), USGS.

Big Creek: stream, heads in Darby Mts., flows NE $8.3 \mathrm{mi}$. to Tubutulik River, $43 \mathrm{mi}$. SE of Imuruk Lake, Seward Penin. High.; $65^{\circ} 04^{\prime} \mathrm{N}$, $162^{\circ} 17^{\prime} \mathrm{W}$; (map 110).

Prospectors' name published on the 1908 "Map of Seward Peninsula" by Arthur Gibson.

Big Creek: stream, flows SW $14 \mathrm{mi}$. to Melozitna River, $35 \mathrm{mi}$. WNW of Birches, KokrinesHodzana High.; $65^{\circ} 15^{\prime} 15^{\prime \prime} \mathrm{N}, 154^{\circ} 44^{\prime} 30^{\prime \prime}$ W; (map 107).

Local name obtained in 1952 by USGS topographers.

Big Creek: stream, heads at $65^{\circ} 49^{\prime} \mathrm{N}, 144^{\circ} 59^{\prime}$ W, flows ENE $26 \mathrm{mi}$. to Birch Creek, $7 \mathrm{mi}$. NW of Circle, Yukon Flats; $65^{\circ} 51^{\prime} 30^{\prime \prime} \mathrm{N}$, $144^{\circ} 17^{\prime} 00^{\prime \prime} \mathrm{W}$; (map 104).
Prospectors' name reported in 1954 or 1955 by USGS topographers.

Big Creek: stream, flows NNE $17 \mathrm{mi}$. to Indian River, $57 \mathrm{mi}$. $N$ of Birches, Kokrines-Hodzana High.; $65^{\circ} 57^{\prime} 15^{\prime \prime} \mathrm{N}, 153^{\circ} 26^{\prime} 00^{\prime \prime} \mathrm{W}$; (map 107).

Local name obtained in 1952 by USGS topographers.

Big Creek: stream, flows NE $30 \mathrm{mi}$. to Beaver Creek, $42 \mathrm{mi}$. SW of Fort Yukon, Yukon Flats ; $66^{\circ} 15^{\prime} 20^{\prime \prime} \mathrm{N}, 146^{\circ} 33^{\prime} 40^{\prime \prime} \mathrm{W}$; (map 119).

Local name published in 1951 by USGS.

Big Creek: stream, heads at $65^{\circ} 47^{\prime} \mathrm{N}, 143^{\circ} 33^{\prime}$ $\mathrm{W}$, flows $46 \mathrm{mi}$. $\mathrm{N}$ to Little Black River, $16 \mathrm{mi}$. S. of Chalkyitsik, Yukon Flats; $66^{\circ} 25^{\prime} 30^{\prime \prime} \mathrm{N}$, $143^{\circ} 47^{\prime} 00^{\prime \prime} \mathrm{W}$; (map 120).

Local descriptive name reported in 1956 by R. C. Foley, USGS.

Big Creek: stream, flows SW $28 \mathrm{mi}$. to North Fork Chandalar River, $7 \mathrm{mi}$. NW of that stream's junc. with Middle Fork Chandalar River and $19 \mathrm{mi}$. S of Chandalar, Brooks Ra.; $67^{\circ} 28^{\prime} 30^{\prime \prime} \mathrm{N}, 148^{\circ} 32^{\prime} 00^{\prime \prime} \mathrm{W}$; (map 123).

Prospectors' name reported in 1899 by Schrader (1900b, pl. 60), USGS.

Big Delta: village, pop. 50, at junc. of Delta and Tanana Rivers, $73 \mathrm{mi}$. SW of Fairbanks; $64^{\circ} 09^{\prime} 30^{\prime \prime} \mathrm{N}, 145^{\circ} 50^{\prime} 30^{\prime \prime} \mathrm{W}$; (map 101). Var. Big Delta Roadhouse, Grundler, McCarthy, McCarty, McCarthy Telegraph Station, McCarty Roadhouse, McGarty Telegraph Station, Tanana Ferry, Washburn.

Village established in 1904 by the U.S. Army Signal Corps as the McCarthy (or McCarty) Telegraph Station. The Washburn post office was established here, or near here, and operated from 1905 to 1913 . The $\mathrm{Big}$ Delta post office operated from 1925 to 1959 , from which the village received its present name. Its population was 155 in 1950 .

Big Delta Junction: village, see Delta Junction. Big Delta River: stream, see Delta River.

Big Delta Roadhouse: village, see Big Delta.

Big Denver Creek: stream, heads on Manley Hot Springs Dome, flows W $7.5 \mathrm{mi}$. to Patterson Greek, $33 \mathrm{mi}$. SE of Tanana, Yukon-Tanana High.; $65^{\circ} 06^{\prime} 30^{\prime \prime} \mathrm{N}, 150^{\circ} 59^{\prime} 40^{\prime \prime} \mathrm{W}$; (map 106).

Prospectors' name reported in 1931 by J. B. Mertie, Jr., USGS.

Big Duck Lake: lake, $0.5 \mathrm{mi}$. across, $8 \mathrm{mi}$. NE of Bear Mtn. and $40 \mathrm{mi}$. W of Midnight Hill, Porcupine Plat.; $66^{\circ} 07^{\prime} \mathrm{N}, 142^{\circ} 21^{\prime} \mathrm{W}$; (map 120).

Local name reported in 1956 by T. E. Taylor, USGS. It may be a form of translation of an Indian name.

Big Eightmile Island: island, in Yukon River, 44 mi. SW of Nulato, Koyukuk Low.; $64^{\circ} 08^{\prime} \mathrm{N}$. $158^{\circ} 40^{\prime} \mathrm{W}$; ( $\operatorname{map} 97$ ).

Local descriptive name reported in 1954 by USGS.

Big Eldorado Creek: stream, in Nutzotin Mts., flows NW $2.2 \mathrm{mi}$. to Chavolda Creek $6 \mathrm{mi}$. $\mathrm{SE}$ of that stream's junc. with Chisana River, Alaska Ra.; $62^{\circ} 08^{\prime} \mathrm{N}, 141^{\circ} 57^{\prime} \mathrm{W}$; (map 84).

Prospectors' name reported by Brooks (in Brooks and others, 1915, p. 204), USGS. 
Big Eldorado Creek: stream, flows SW $8 \mathrm{mi}$. to Goldstream Creek, $6 \mathrm{mi}$. NW of Fairbanks, Yukon-Tanana High.; $64^{\circ} 55^{\prime} 00^{\prime \prime} \mathrm{N}, 147^{\circ}$ $49^{\prime} 30^{\prime \prime} \mathrm{W}$; (map 100).

Named by prospectors; reported in 1903 by T. G. Gerdine and R. B. Oliver (in Prindle, 1905, pl. 16), USGS.

Big Eldorado Greek: stream, see Last Chance Creek.

Big Eldorado Creek: stream, see Little Eldorado Creek.

Big Falls: falls, see Ebner Falls.

Big Fish Lake: lake, $2 \mathrm{mi}$. long, $10 \mathrm{mi}$. $\mathrm{N}$ of Helmet Mtn. and $50 \mathrm{mi}$. NE of Christian, Brooks Ra.; $67^{\circ} 56^{\prime}$ N, $144^{\circ} 06^{\prime}$ W ; (map 122).

Local name reported in 1956 by T. E. Taylor, USGS.

Big Flash Lake: lake, $450 \mathrm{ft}$. across, on southern Kiska I., Aleutian Is.; $51^{\circ} 52^{\prime} 50^{\prime \prime} \mathrm{N}$, $177^{\circ} 18^{\prime} 18^{\prime \prime} \mathrm{E}$; (map 14).

An arbitrary name beginning with " $B$ " to correspond to " $B$ " grid used by the U.S. Army for tactical purposes during World War II; published in 1953 by AMS.

Big Flat: tidal flat, $1.7 \mathrm{mi}$. wide, extends S $20 \mathrm{mi}$. from mouth of Naknek River, on $\mathrm{N}$ coast of Alaska Penin., Bristol Bay Low.; 58 $37^{\prime} \mathrm{N}$, $157^{\circ} 17^{\prime} \mathrm{W}$; (map 41)

Descriptive name given by USGS in 1963, because of "the extensive tide flats $* * *$ off the east shore of Kvichak Bay."

Big Fort Channel: water passage, between Shuyak and Big Fort Is., $41 \mathrm{mi}$. N of Kodiak I.; $58^{\circ} 29^{\prime} 30^{\prime \prime} \mathrm{N}, 152^{\circ} 26^{\prime} 30^{\prime \prime} \mathrm{W}$; (map 43).

Name derived from Big Fort Island; published in 1943 by USC\&GS.

Big Fort Island: island, $2 \mathrm{mi}$. long, on SE coast of Shuyak I., $42 \mathrm{mi}$. N of Kodiak I.; $58^{\circ} 30^{\prime}$ N, $152^{\circ} 25^{\prime \prime}$ W; (map 43). Var. Bolshoi Krieposti, Ostrov Bolshoy Krypost.

Translation of the name "Os[trov] Bol[shoy] Krypost"; published in 1849 by the Russian American Company.

Big Four Creek: stream, flows NW $11 \mathrm{mi}$. to Casadepaga River, $25 \mathrm{mi}$. NE of Solomon, Seward Penin. High.; $64^{\circ} 55^{\prime} \mathrm{N}, 164^{\circ} 10^{\prime} \mathrm{W}$; (map 95).

Prospectors' name reported in 1900 by E. C. Barnard (in Brooks, 1901, pl. 17), USGS.

Big Fox Creek: stream, see Fox Creek.

Big Fritz: locality, $\mathrm{N}$ of Pikmiktalik River, $34 \mathrm{mi}$. $S$ of Russian Mission, Yukon-Kuskokwim Delta; $61^{\circ} 17^{\prime} 45^{\prime \prime} \mathrm{N}, 161^{\circ} 25^{\prime} 30^{\prime \prime} \mathrm{W}$; (map 73)

This was a cabin on the trail between the Kuskokwim and Yukon Rivers.

Big Gavanski Island: island, $0.8 \mathrm{mi}$. across, in Gavanski Is., $6.5 \mathrm{mi}$. NW of Sitka, Alex. Arch.; $57^{\circ} 08^{\prime} 00^{\prime \prime} \mathrm{N}, 135^{\circ} 25^{\prime} 30^{\prime \prime} \mathrm{W}$; (map 9). Var. Big Island, Gavanski Island, Ostrov Gavanskoy Bolshoy.

USC\&GS derived this name about 1882 from translation of part of "Ostrov Gavanskoy Bolshoy," meaning "big harbor island"; published by Lt. Sarichev (1826, map 19), IRN; given in 1809 by the navigator Ivan Vasiliev the first, IRN.

Big Glacier: glacier, see Ruth Glacier.
Big Glacier Slough: stream, heads at Johnson Slough, flows SE $1 \mathrm{mi}$. to Gulf of Alaska, 10 mi. SE of Cordova, Malaspina Coastal Plain; $60^{\circ} 27^{\prime} \mathrm{N}, 145^{\circ} 33^{\prime} \mathrm{W}$; (map 64).

Local descriptive name published in 1951 by USGS.

Big Goat Lake: lake, $2.4 \mathrm{mi}$. long, on mainland, W of Wilson Lake, Coast Mts.; 55 $32^{\prime} \mathrm{N}$, $130^{\circ} 35^{\prime}$ W ; BGN 1962; (map 3). Var. Goat Lake.

Local name reported in 1961 by USFS.

Big Goose Island: island, see Goose Island.

Big Granite Creek: stream, flows. W $8 \mathrm{mi}$. to North Fork Salcha River, $43 \mathrm{mi}$. NNE of Big Delta, Yukon-Tanana High.; $64^{\circ} 43^{\prime} \mathrm{N}$, $145^{\circ} 18^{\prime} \mathrm{W}$; (map 101).

Local name reported in 1958 by USGS.

Big Grass Lake: lake, $2.1 \mathrm{mi}$. long, $1 \mathrm{mi}$. W of Elbow Lake and $15 \mathrm{mi}$. W of Beaver, Yukon Flats; $66^{\circ} 18^{\prime} 30^{\prime \prime} \mathrm{N}, 147^{\circ} 57^{\prime} 00^{\prime \prime} \mathrm{W}$; (map 118). Var. Grass Lake.

Probably named by William Yanert who showed it on a 1916 manuscript map of the Yukon Flats (Stuck, 1917, map facing p. 122).

Big Grayling Lake: lake, $1 \mathrm{mi}$. across, drains into Chalk Creek in Mentasta Mts., 9 mi. NW of Devils Mtn., Alaska Ra.; 62 $32^{\prime} \mathrm{N}, 143^{\circ} 05^{\prime}$ W; (map 84).

Local name reported in 1951 by USGS.

Big Grizzly Creek: stream, flows NW $9 \mathrm{mi}$. to Wood River, $33 \mathrm{mi}$. SE of Healy, Alaska Ra.; $63^{\circ} 45^{\prime} \mathrm{N}, 147^{\circ} 53^{\prime} \mathrm{W}$; (map 87).

Prospectors' name shown on a 1910 fieldsheet by J. W. Bagley, USGS; published by Capps (1912, pl. 1), USGS.

Biggs Creek: stream, see Willow Creek.

Big Gulch: ravine, extends SW $2 \mathrm{mi}$. to Blind Slough, on W coast of Mitkof I., $12 \mathrm{mi}$. $\mathrm{S}$ of Petersburg, Alex. Arch.; $56^{\circ} 38^{\prime} 20^{\prime \prime} \mathrm{N}$, $132^{\circ} 54^{\prime} 00^{\prime \prime} \mathrm{W}$; (map 6).

Local descriptive name obtained in 1953 by USGS.

Big Harbor: bay, see Trocadero Bay

Big Hazy Islet: island, $0.2 \mathrm{mi}$. long, one of Hazy Is., $9 \mathrm{mi}$. W of Coronation I., Alex. Arch.; 55 $53^{\prime} 15^{\prime \prime} \mathrm{N}, 134^{\circ} 36^{\prime} 15^{\prime \prime} \mathrm{W}$; (map 4).

Local descriptive name published in 1925 Coast Pilot (p. 192).

Big Hill: mountain, $3,843 \mathrm{ft} ., 4.5 \mathrm{mi}$. NW of mouth of Bruin Bay and $24 \mathrm{mi}$. W of Augustine I., Aleutian Ra.; $59^{\circ} 25^{\prime} 45^{\prime \prime} \mathrm{N}$,

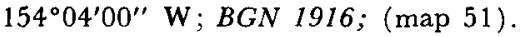

Descriptive name published in 1914 by USC\&GS.

Big Hill: point of land, on $\mathrm{N}$ coast of Alaska Penin., on SW shore of Nelson Lagoon, $25 \mathrm{mi}$. W of village of Port Moller, Bristol Bay Low.; $55^{\circ} 57^{\prime} 30^{\prime \prime} \mathrm{N}, 161^{\circ} 10^{\prime} 45^{\prime \prime} \mathrm{W}$; (map 28).

Published in 1963 on USC\&GS Chart 8833.

Big Horn: locality, along Richardson Highway, $14 \mathrm{mi}$. SE of Fairbanks, Tanana Low.; $64^{\circ} 43^{\prime} 30^{\prime \prime} \mathrm{N}, 147^{\circ} 18^{\prime} 30^{\prime \prime} \mathrm{W}$; (map 100).

Local name published on a 1952 USGS map.

Big Hurrah Greek: stream, flows NW 6 mi. to Solomon River, $7 \mathrm{mi}$. NE of Solomon, Seward Penin. High.; 64 $39^{\prime}$ N, $164^{\circ} 19^{\prime}$ W; (map 95).
Prospectors' name reported in 1900 by E. C. Barnard (in Brooks, 1901, pl. 17), USGS. Big Iliazhek: island, see Outer Iliasik Island. Big Ilyamna Lake: lake, see Iliamna Lake.

Big Indian Creek: stream, on $\mathbf{N}$ end of Kenai Penin., flows NW $18 \mathrm{mi}$. to Chickaloon Bay, $12 \mathrm{mi}$. W. of Hope, Cook Inlet Low.; $60^{\circ} 55^{\prime} 30^{\prime \prime} \mathrm{N}, 149^{\circ} 59^{\prime} 45^{\prime \prime} \mathrm{W}$; (map 63). Var. Big Indian River, Indian Creek.

Local name reported by G. C. Martin, B. L. Johnson, and U. S. Grant (1915, pl. 2), USGS. Originally called Indian Creek in 1895 by Becker (1898, p. 82), USGS.

Big Indian River: stream, see Big Indian Creek. Big Island: island, $0.7 \mathrm{mi}$. across, at mouth of Deep Bay, in Peril Strait, off Chichagof I., 29 mi. N of Sitka, Alex. Arch.; $57^{\circ} 26^{\prime} 15^{\prime \prime} \mathrm{N}$, $135^{\circ} 35^{\prime} 30^{\prime \prime}$ W; (map 9). Var. Ostrov Bolshoy.

This is a translation by USC\&GS about 1882 of the name given by the Russian pilot Ens. Vasiliev; published in 1848 on Russian Hydrog. Dept. Chart 1397 as "O[strov] Bolshoy."

Big Island: island, $1.5 \mathrm{mi}$. long, in Iliamna Lake, $1.3 \mathrm{mi}$. NW of Reindeer Bay and $30 \mathrm{mi}$. SW of Iliamna, Bristol Bay Low.; 59 24' N, $155^{\circ} 21^{\prime} \mathrm{W}$; (map 51). Var. Chekok Island.

Local name reported in 1956 by $R$. $L$. Detterman and B. L. Reed, USGS; recorded as "Chekok Island" on a 1923 ARC map.

Big Island: island, $6.3 \mathrm{mi}$. long in Susitna River delta, $23 \mathrm{mi}$. NW of Anchorage, Cook Inlet Low.; $61^{\circ} 19^{\prime} \mathrm{N}, 150^{\circ} 37^{\prime} \mathrm{W}$; (map 70).

Local descriptive name reported in 1958 by USGS.

Big Island: island, $16 \mathrm{mi}$. long, in Yukon River, $62 \mathrm{mi}$. E of Nulato, Kilbuck-Kuskokwim Mts.; $64^{\circ} 42^{\prime} \mathrm{N}, 156^{\circ} 00^{\prime} \mathrm{W}$; (map 97).

Local descriptive name reported in 1954 by USGS.

Big Island: island, $3 \mathrm{mi}$. long, in Yukon River, $5 \mathrm{mi}$. NE of Nulato, Koyukuk Low.; $64^{\circ} 45^{\prime}$ N, $157^{\circ} 59^{\prime} \mathrm{W}$; (map 97).

Local descriptive name reported in 1954 by USGS.

Big Island: island, see Anguk Island.

Big Island: island, see Big Gavanski Island.

Big Jim Creek: stream, flows WSW $2.7 \mathrm{mi}$. to S lake of Twin Lakes, $15 \mathrm{mi}$. W of Chandalar, Brooks Ra.; $67^{\circ} 31^{\prime} 40^{\prime \prime} \mathrm{N}, 1^{\circ} 49^{\circ} 03^{\prime} 40^{\prime \prime} \mathrm{W}$; $B G N$ 1932; (map 123).

Local name reported in 1956 by T. $E$. Taylor, USGS.

Big Jim Creek: stream, flows SE $6 \mathrm{mi}$. to Dietrich River, $13 \mathrm{mi}$. N of head of Koyukuk River, $42 \mathrm{mi}$. NW of Chandalar, Brooks Ra.; $67^{\circ} 49^{\prime}$ $15^{\prime \prime} \mathrm{N}, 149^{\circ} 50^{\prime} 00^{\prime \prime} \mathrm{W}$; BGN 1939; (map 123). Var. Bigjim Creek.

Named by Robert Marshall about 1930 "for a well-known Eskimo hunter, his neighbor in Wiseman"; shown by Marshall as both "Bigjim" and "Big Jim."

Big Joe Creek: stream, flows SE $4 \mathrm{mi}$. to Beaver Creek, $11 \mathrm{mi}$. SE of Ruby, Kilbuck-Kuskokwim Mts.; $64^{\circ} 35^{\prime} 30^{\prime \prime} \mathrm{N}, 155^{\circ} 19^{\prime} 00^{\prime \prime} \mathrm{W}$; (map 98).

Local name reported in 1933 by USGS. 
Big Joe Creek: stream, flows S 3 mi. to Big Creek, $7 \mathrm{mi}$. SSE of Chandalar, Brooks Ra.; $67^{\circ} 25^{\prime}$ $\mathrm{N}, 148^{\circ} 20^{\prime} \mathrm{W}$; (map 123 ).

Prospectors' name obtained in 1909 by A. G. Maddren (in Brooks and others, 1910, pl. 7), USGS.

Big John Bay: bay, extends S $4 \mathrm{mi}$. to Keku Strait, $14 \mathrm{mi}$. SE of Kake, on W coast of Kupreanof I., Alex. Arch.; $56^{\circ} 48^{\prime} \mathrm{N}, 133^{\circ} 43^{\prime}$ W; (map 6).

Local name published by USC\&GS in 1932 Coast Pilot (p. 259).

Big John Creek: stream, flows W $5 \mathrm{mi}$. to Big John Bay, $15 \mathrm{mi}$. SE of Kake, on W coast of Kupreanof I., Alex. Arch.; 56 $48^{\prime} 50^{\prime \prime}$ N, $133^{\circ}$ $41^{\prime} 00^{\prime \prime} \mathrm{W}$; (map 6).

Local name published in 1943 by USC\&GS.

Big John Hill: hill, between Big John Lake and Kalutna River, $14 \mathrm{mi}$. WNW of Northway Junction, Yukon-Tanana High.; 63 $04^{\prime} \mathrm{N}$, $142^{\circ} 11^{\prime} \mathrm{W}$; (map 85$)$.

Local name reported by USGS in 1963.

Big John Lake: lake, $1.5 \mathrm{mi}$. long, $\mathrm{E}$ of Big John Hill, $13 \mathrm{mi}$. WNW of Northway Junction, Yukon-Tanana High.; $63^{\circ} 04^{\prime} \mathrm{N}, 142^{\circ} 10^{\prime} \mathrm{W}$; (map 85).

Local name reported by USGS in 1963.

Big Kiska Island: island, see Kiska Island.

Big Kitoi Lake: lake, $1.5 \mathrm{mi}$. long, at head of Kitoi Bay on SE coast of Afognak I., $19 \mathrm{mi}$. NE of Afognak, Kodiak I., $58^{\circ} 11^{\prime} 00^{\prime \prime} \mathrm{N}, 152^{\circ}$ $24^{\prime} 00^{\prime \prime} \mathrm{W}$; (map 43).

Local descriptive name reported in 1952 by USGS; derived from Kitoi Bay.

Big Koniuji Island: island, $15 \mathrm{mi}$. long, in Shumagin Is., Aleutian Ra.; 55 $06^{\prime} \mathrm{N}, 159^{\circ} 33^{\prime}$ W; (map 27). Var. Big Koniushi Island, Bolshoi Koniuzhi, Kiuniuiu Tannai, Konioujii, Koniugi, Koniuzhka, Kunuliuk Tanani, Kunujutanany, Kunuyu-tanan.

Aleut name "Kiuniuiu Tanani" or "Kunujutanany," meaning "big-crested auk," reported in 1790-92 by Lt. Sarichev (1802, v. 2, p. 31), IRN. The Russians translated this name to "O[strov] Bolshoi Koniuzhi," from "Koniuzhka," meaning "the crested auk," published by Capt. Tebenkov (1852, map 24), IRN. "Big Koniushi Island" was shown on several USC\&GS charts in 1872.

Big Koniushi Island: island, see Big Koniuji Island.

Big Lagoon: lagoon, $4 \mathrm{mi}$. long, on $\mathrm{W}$ side of Morzhovoi Bay, at SW end of Alaska Penin., Bristol Bay Low.; $55^{\circ} 07^{\prime} \mathrm{N}, 163^{\circ} 10^{\prime} \mathrm{W}$; (map 29).

Local descriptive name published in 1925 on a USGS map.

Big Lake: area, "a region of flat country abounding in lakes, between the lower Yukon and the Kuskokwim rivers, was, as early as 1878 and probably earlier, known to the fur traders as the Big Lake country" (Baker, 1906, p. 132).

Big Lake: locality, on W shore of Big Lake, 25 mi. W of Chandalar, Brooks Ra.; $67^{\circ} 30^{\prime} 00^{\prime \prime}$ N, $149^{\circ} 26^{\prime} 30^{\prime \prime} \mathrm{W}$; (map 123).

Local name reported in 1956 by T. E. Taylor, USGS.
Big Lake: village, pop. 74, on shore of Big Lake, $13 \mathrm{mi}$. WSW of Wasilla and $18 \mathrm{mi} . \mathrm{N}$ of Anchorage, Chugach Mts. ; $61^{\circ} 33^{\prime} \mathrm{N}, 149^{\circ} 52^{\prime}$ W; (map 69). Var. Gronwoldt.

Name obtained in 1958 by USGS; established in the late 1950's.

Big Lake: lake, $1.2 \mathrm{mi}$. long, on Revillagigedo I. near head of Thorne Arm, in course of Fish

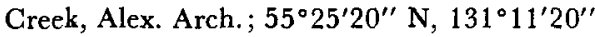
W; (map 3 ).

Local name recorded in 1915 by G. H. Canfield (in Brooks and others, 1916, p. 111), USGS.

Big Lake: lake, $1 \mathrm{mi}$. long, on course of Ratz Creek, Prince of Wales I., Alex. Arch.; 55 52' N, $132^{\circ} 38^{\prime} \mathrm{W} ; B G N$ 1963; (map 4).

Local descriptive name reported in 1962 by USGS

Big Lake: lake, $1.5 \mathrm{mi}$. across, on NE coast of Saint Paul I., Pribilof Is. ; $57^{\circ} 12^{\prime} 30^{\prime \prime}$ N, $170^{\circ}$. $10^{\prime} 00^{\prime \prime} \mathrm{W}$; (map 38). Var. Great Lake, Mee-sulk-mah-nee.

This lake was descriptively called "Great Lake" by Elliott (1881, Saint Paul map); he says the Aleut call it "Mee-sulk-mah-nee," meaning "very shallow" (p. 16).

Big Lake: lake, $0.5 \mathrm{mi}$. long, between Beaver and Potatopatch Lakes, $1 \mathrm{mi}$. NE of Kodiak, Kodiak I.; $57^{\circ} 48^{\prime} 10^{\prime \prime} \mathrm{N}, 152^{\circ} 22^{\prime} 50^{\prime \prime} \mathrm{W}$; (map 34)

Local descriptive name reported in 1949 by USFS.

Big Lake: lake, $4.5 \mathrm{mi}$. long, $21 \mathrm{mi}$. $\mathrm{N}$ of Anchorage, Cook Inlet Low.; $61^{\circ} 32^{\prime} \mathrm{N}, 149^{\circ} 54^{\prime} \mathrm{W}$ BGN 1961; (map 69). Var. Fish Lake.

Local name reported in 1960 by USGS.

Big Lake: lake, $2 \mathrm{mi}$. long, SE of Deadman Lake and $35 \mathrm{mi}$. SE of Cantwell, Talkeetna Mts. $63^{\circ} 00^{\prime} \mathrm{N}, 148^{\circ} 12^{\prime} \mathrm{W}$; (map 82).

Local name reported in 1931 by USGS.

Big Lake: lake, $1.5 \mathrm{mi}$. long, between Tanana River and Alaska Highway, $19 \mathrm{mi}$. SE of Tok, Yukon-Tanana High; $63^{\circ} 13^{\prime} \mathrm{N}, 142^{\circ} 24^{\prime} \mathrm{W}$; (map 85)

Local descriptive name reported in 1963 by USGS.

Big Lake: lake, $1.6 \mathrm{mi}$. long, $\mathrm{SE}$ of Otter Lake and $25 \mathrm{mi}$. SSW of village of Lake Minchu-

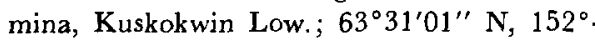
$31^{\prime} 30^{\prime \prime} \mathrm{W}$; (map 88).

Local name reported in 1954 by USGS.

Big Lake: lake, $3 \mathrm{mi}$. long, on $\mathrm{S}$ bank of Innoko River, at mouth of Taft Creek, $S$ of Rennies Landing, $36 \mathrm{mi}$. NW of Ophir and $62 \mathrm{mi}$. NW of McGrath, Innoko Low.; $63^{\circ} 36^{\prime} \mathrm{N}, 157^{\circ} 04^{\prime}$ W; (map 90).

Local name obtained in 1954 by $R$. E. Isto, USGS.

Big Lake: lake, $0.5 \mathrm{mi}$. across, between Delta River and Richardson Highway, $14 \mathrm{mi}$. SW of Delta Junction, Alaska Ra.; 63 $51^{\circ} 20^{\prime \prime} \mathrm{N}$, $145^{\circ} 52^{\prime} 30^{\prime \prime} \mathrm{W}$; (map 86).

Name published on relatively recent maps.

Big Lake: lake, $2.5 \mathrm{mi}$. long, $5 \mathrm{mi}$. $\mathrm{E}$ of Minto and $40 \mathrm{mi}$. W of Fairbanks, Tanana Low. $64^{\circ} 52^{\prime} 30^{\prime \prime} \mathrm{N}, 149^{\circ} 02^{\prime} 30^{\prime \prime} \mathrm{W}$; (map 100).

Local descriptive name published on a 1952 USGS map.
Big Lake: lake, 1 mi. long, $\mathrm{W}$ of Sundown Lake and $21 \mathrm{mi}$. SW of Beaver, Yukon Flats ; 66 ${ }^{\circ} 11^{\prime}$ $\mathrm{N}, 148^{\circ} 00^{\prime} \mathrm{W}$; (map 118$)$.

Local descriptive name obtained in 1956 by USGS.

Big Lake: lake, $1 \mathrm{mi}$. long, $2 \mathrm{mi}$. $\mathrm{N}$ of Marten I. and $19 \mathrm{mi}$. SW of Beaver, Yukon Flats; $66^{\circ} 16^{\prime} 40^{\prime \prime} \mathrm{N}, 148^{\circ} 03^{\prime} 00^{\prime \prime} \mathrm{W}$; (map 118).

Probably named by William Yanert who showed it on a 1916 manuscript map of the Yukon Flats (Stuck, 1917, map facing p. 122).

Big Lake: lake, $3 \mathrm{mi}$. long, $4.5 \mathrm{mi}$. NW of Beaver, Yukon Flats; $66^{\circ} 23^{\prime} 30^{\prime \prime} \mathrm{N}, 147^{\circ} 36^{\prime} 00^{\prime \prime} \mathrm{W}$; (map 118).

Local descriptive name obtained in 1956 by USGS.

Big Lake: lake, $2 \mathrm{mi}$. long, $3 \mathrm{mi}$. SE of Vundik Lake and $27 \mathrm{mi}$. NW of Coleen Mtn., Yukon Flats; $67^{\circ} 18^{\prime} \mathrm{N}, 143^{\circ} 39^{\prime} \mathrm{W}$; (map 121).

Local name reported in 1956 by T. E. Taylor, USGS.

Big Lake: lake, $5 \mathrm{mi}$. long, between Bettles and South Fork Koyukuk Rivers, drains $\mathrm{N}$ into Bettles River, $22 \mathrm{mi}$. W of Chandalar, Brooks Ra.; $67^{\circ} 30^{\prime} \mathrm{N}, 14^{\circ} 24^{\prime} \mathrm{W}$; (map 123 ).

Prospectors' name obtained in 1909 by A. G. Maddren (in Brooks and others, 1910, pl. 7), USGS

Big Lake: lake, see Benka Lake.

Big Lake: lake, see Long Lake.

Big Lake: lake, see Nanvakfak Lake.

Big Lake: lake, see Nunavakpak Lake.

Big Lake: lake, see Tsolmund Lake.

Big Level Island: island, $1.5 \mathrm{mi}$. long, one of Level Is., in Sumner Strait, SE coast of Kupreanof I., Alex. Arch.; $56^{\circ} 28^{\prime} \mathrm{N}, 133^{\circ} 04^{\prime}$ W; (map 6).

Local descriptive name reported in 1949 by USGS.

Big Long Lake: lake, $1.5 \mathrm{mi}$. long, $3 \mathrm{mi}$. SSW of Spectacle Lake and $25 \mathrm{mi}$. SSW of village of Lake Minchumina, Tanana Low.; 63 $31^{\prime} 25^{\prime \prime}$ $\mathrm{N}, 152^{\circ} 27^{\prime} 00^{\prime \prime} \mathrm{W}$; (map 88).

Local name reported in 1954 by USGS.

Big Loss Creek: stream, see Mishap Creek.

Big Martin Lake: lake, see Martin Lake.

Big Meadow: flat, $13 \mathrm{mi}$. SE of Beaver, Yukon Flats; $66^{\circ} 12^{\prime} 30^{\prime \prime} \mathrm{N}, 147^{\circ} 07^{\prime} 00^{\prime \prime} \mathrm{W}$; (map 118 ).

Local descriptive name obtained in 1956 by USGS.

Big Merganser Lake: lake, $0.5 \mathrm{mi}$. long, on Kenai Penin., $3 \mathrm{mi}$. NW of Swan Lake and $25 \mathrm{mi}$. $\mathrm{NE}$ of Kenai, Cook Inlet Low.; $60^{\circ} 43^{\prime} 00^{\prime \prime} \mathrm{N}$, $150^{\circ} 36^{\prime} 30^{\prime \prime} \mathrm{W}$; (map 62).

Named about 1963 by officials of Kenai National Moose Range, probably for the American Merganser or Pond Shelldrake (Mergus americanus), a large freshwater duck which breeds in southern Alaska.

Big Mike Beach: beach, $1 \mathrm{mi}$. long, on Attu I., on W shore of Bedard Cove, Aleutian Is. ; $52^{\circ}$ $49^{\prime} 20^{\prime \prime} \mathrm{N}, 173^{\circ} 18^{\prime} 10^{\prime \prime} \mathrm{E}$; (map 13).

Named by the U.S. Army during World War II; published in 1948 by AMS.

Big Mike Point: point of land, see Alexai Point. Big Mink Lake: lake, $0.7 \mathrm{mi}$. long, on Kenai Penin. $\mathrm{N}$ of Camp Island Lake, $20 \mathrm{mi}$. NE of 
Kenai, Cook Inlet Low.; $60^{\circ} 39^{\prime} 15^{\prime \prime} \mathrm{N}, 150^{\circ}$ $43^{\prime} 15^{\prime \prime} \mathrm{W}$; (map 62).

Named about 1963 by officials of Kenai National Moose Range, for administrative purposes.

Big Moose Creek: stream, see Moose Creek.

Big Mosquito Creek: stream, flows SE $5 \mathrm{mi}$. to Crooked Creek, $5 \mathrm{mi}$. N of Medicine Lake and $21 \mathrm{mi}$. SW of Circle, Yukon-Tanana High.; $65^{\circ} 35^{\prime} \mathrm{N}, 144^{\circ} 30^{\prime} \mathrm{W}$; (map 104).

Prospectors' name reported in 1954 or 1955 by USGS topographers.

Big Mountain: mountain, " $(8,750$ feet high $)$, on the mainland, east of Stikine river and near the international boundary. So called on recent Coast Survey charts" (Baker, 1906, p. 131).

Big Mountain: mountain, 2,161 ft., on $\mathrm{S}$ shore of Iliamna Lake, $28 \mathrm{mi}$. SW of Iliamna, Aleutian Ra.; $59^{\circ} 23^{\prime} 30^{\prime \prime} \mathrm{N}, 155^{\circ} 13^{\prime} 30^{\prime \prime} \mathrm{W}$; (map 51).

Reported in 1909 on a USGS manuscript map.

Big Mountain: mountain, 2,333 ft., $28 \mathrm{mi}$. NW of Midnight Hill, Porcupine Plat.; $66^{\circ} 24^{\prime}$ N, $141^{\circ} 36^{\prime} \mathrm{W}$; (map 120).

Local descriptive name reported in 1956 by R. C. Foley, USGS.

Big Mud River: stream, flows SW $43 \mathrm{mi}$. to Nowitna River $7 \mathrm{mi}$. $\mathbf{N}$ of its junc. with Titna River, $31 \mathrm{mi}$. NE of Monzonite Hills, KilbuckKuskokwim Mts.; $64^{\circ} 30^{\prime} \mathrm{N}, 153^{\circ} 38^{\prime} \mathrm{W}$; (map 98).

Local name reported in 1924 by USGS.

Big Naked Island: island, see Naked Island.

Big Point: point of land, on SE shore of Orca Inlet, $6 \mathrm{mi}$. SW of Cordova, Chugach Mts.; $60^{\circ} 29^{\prime} \mathrm{N}, 145^{\circ} 55^{\prime} \mathrm{W}$; (map 64).

Local descriptive name published in 1943 by USC\&GS.

Big Pond: lagoon, see Shishkof Pond.

Big Port Walter: locality, at head of Port Walter, $9.5 \mathrm{mi}$. NW of village of Port Alexander, on $\mathbf{S}$ coast of Baranof I., Alex. Arch.; $56^{\circ} 22^{\prime} 40^{\prime \prime} \mathrm{N}$, $134^{\circ} 44^{\prime} 00^{\prime \prime}$ W; (map 5). Var. Port Walter.

Former cannery village and harbor. The Port Walter post office was established in 1918; discontinued in 1921 (Ricks, 1965, p. 53). Its population was 21 in 1940.

Big Port Walter: bay, $1.5 \mathrm{mi}$. long, at head of Port Walter, $9.5 \mathrm{mi}$. N of village of Port Alexander, on S coast of Baranof I., Alex. Arch.; $56^{\circ} 23^{\prime} \mathrm{N}, 134^{\circ} 43^{\prime} \mathrm{W}$; (map 5).

Local name used by fishermen; published in 1925 by USC\&GS.

Big Potato Mountain: peak, 1,400 ft., on S side of Potato Mtn., $15 \mathrm{mi}$. NE of Cape Prince of Wales, Seward Penin. High.; $65^{\circ} 29^{\prime} 00^{\prime \prime}$ N, $167^{\circ} 34^{\prime} 30^{\prime \prime} \mathrm{W}$; (map 111).

Local name reported in 1918 by Steidtmann and Cathcart (1922, fig. 14), USGS.

Big Ptarmigan Creek: stream, flows S $8.5 \mathrm{mi}$. to Kuzitrin River, $19 \mathrm{mi}$. N of Salmon Lake and $24 \mathrm{mi}$. NW of Mount Bendeleben, Seward Penin. High.; $65^{\circ} 11^{\prime} \mathrm{N}, 164^{\circ} 56^{\prime} \mathrm{W}$; (map 110). Var. Ptarmigan Creek.
Prospectors' name reported as "Ptarmigan Creek" in 1901 by T. G. Gerdine (in Collier, 1902, pl. 12), USGS.

Big Ptarmigan Creek: stream, see Ptarmigan Creek.

Big Rat Lake: lake, 1,500 ft. long, between Devils and Lower Horseshoe Lakes, $23 \mathrm{mi}$. SW of Beaver, Yukon Flats; $66^{\circ} 15^{\prime} 20^{\prime \prime} \mathrm{N}$, $148^{\circ} 11^{\prime} 00^{\prime \prime} \mathrm{W}$; (map 118).

Probably named by William Yanert who showed it on a 1916 manuscript map of the Yukon Flats (Stuck, 1917, map facing p. 122).

Big Rat Lake: lake, $1.5 \mathrm{mi}$. long, $3.5 \mathrm{mi}$. NW of Graphite Lake and $22 \mathrm{mi}$. W of Coleen Mtn., Yukon Flats; $67^{\circ} 08^{\prime} \mathrm{N}, 143^{\circ} 36^{\prime} \mathrm{W}$; (map 121).

Local name reported in 1956 by T. E. Taylor, USGS.

Big River: stream, flows SW $4.7 \mathrm{mi}$. to Unimak Pass, 2 mi. NW of Scotch Cap, on SW coast of Unimak I., Aleutian Is.; $54^{\circ} 25^{\prime} 14^{\prime \prime} \mathrm{N}$, $164^{\circ} 50^{\prime} 43^{\prime \prime} \mathrm{W}$; (map 24).

Descriptive name published in 1943 by AMS.

Big River: river, flows $\mathrm{S} 7 \mathrm{mi}$. to Stepovak Bay, on $\mathrm{S}$ coast of Alaska Penin., Aleutian Ra.; $55^{\circ} 51^{\prime} \mathrm{N}, 159^{\circ} 45^{\prime} \mathrm{W}$; (map 27).

Name published by USC\&GS in 1916 Alaska Coast Pilot.

Big River: stream, heads $7.4 \mathrm{mi}$. W of Kaguyak Volcano, in Katmai National Monument, on NE coast of Alaska Penin., flows E $20 \mathrm{mi}$. to Shelikof Strait, $46 \mathrm{mi}$. NE of Mount Katmai, Aleutian Ra.; $58^{\circ} 36^{\prime} 30^{\prime \prime} \mathrm{N}, 153^{\circ} 53^{\prime} 30^{\prime \prime} \mathrm{W}$; (map 43).

Local descriptive name reported in 1951 by USGS.

Big River: stream, heads at Beare Glacier terminus and flows SW $7.5 \mathrm{mi}$. to Gulf of Alaska, $2 \mathrm{mi}$. NW of Icy Cape and $76 \mathrm{mi}$. NW of Yakutat, Malaspina Coastal Plain; 59 $58^{\prime}$ $\mathrm{N}, 141^{\circ} 46^{\prime} \mathrm{W}$; (map 47).

Local descriptive name reported in 1913 by A. G. Maddren, USGS.

Big River: stream, flows NE and SE through Big River Lakes $23 \mathrm{mi}$. to Redoubt Bay, Cook Inlet, $28 \mathrm{mi}$. WNW of Kenai, Cook Inlet Low.; $60^{\circ} 39^{\prime} 30^{\prime \prime} \mathrm{N}, 152^{\circ} 02^{\prime} 30^{\prime \prime} \mathrm{W}$; (map 62). Var. Katnu River.

Local descriptive name reported by USGS in 1958.

Big River: stream, flows $\mathrm{NW}$ and $\mathrm{S} 20 \mathrm{mi}$. to Kashunuk River, $44 \mathrm{mi}$. W of Marshall, Yukon-Kuskokwim Delta ; $61^{\circ} 48^{\prime} 30^{\prime \prime} \mathrm{N}, 163^{\circ}$ 25'15" W; (map 74).

Local name obtained in 1951 from G. A. Sheppard at Mountain Village by USC\&GS.

Big River: stream, heads at a glacier at $61^{\circ} 45^{\prime}$ $\mathrm{N}, 154^{\circ} 00^{\prime} \mathrm{W}$, flows NW $130 \mathrm{mi}$. to Middle Fork Kuskokwim River $3.3 \mathrm{mi}$. SE of its junc. with Kuskokwim River, $24 \mathrm{mi}$. E of McGrath, Kuskokwim Low.; 62 $58^{\prime}$ N, $154^{\circ} 53^{\prime} \mathrm{W}$; $B G N$ 1966; (map 80). Var. Kwikpukna River, Kwikpuk River, West Fork, West Fork Kuskokwim River.

Local descriptive name reported in 1909 by Maddren (1910, pl. 1), USGS. The name is a translation of the Eskimo name "Kwikpak."
Big River: stream, see Mishap Creek.

Big River: stream, see Tlikakila River.

Big River Lakes: lakes, in course of Big River, $40 \mathrm{mi}$. WNW of Kenai, Aleutian Ra.; $60^{\circ} 47^{\prime}$ $\mathrm{N}, 152^{\circ} 19^{\prime} \mathrm{W}$; (map 62).

Local name reported in 1958 by USGS.

Big River Lobe Double Glacier: glacier, extends E $4 \mathrm{mi}$. from Double Glacier to its 1958 terminus, at head of South Fork Big River, $40 \mathrm{mi}$. WNW of Kenai, Aleutian Ra.; $60^{\circ} 41^{\prime} \mathrm{N}$, $152^{\circ} 23^{\prime} \mathrm{W}$; (map 62).

Local name reported in 1958 by USGS.

Big Rock: rock, in Marmot Bay, $3.7 \mathrm{mi}$. E of Afognak, Kodiak I.; $58^{\circ} 01^{\prime} 08^{\prime \prime} \mathrm{N}, 152^{\circ} 40^{\prime} 00^{\prime \prime}$ W; (map 43). Var. Bolshoi Rock, Kamen Bolshoy.

Translation of "K[amen] Bolshoy," given by Sub-Lt. Mikhail Murashev, IRN, in 1839 or 1840, published in 1849 on Russian Hydrog. Dept. Chart 1425.

Big Rock: rock, in Cook Inlet, $1 \mathrm{mi}$. SE of Pomeroy $I$. and $18 \mathrm{mi}$. $\mathrm{N}$ of Augustine I., Aleutian Ra.; $59^{\circ} 36^{\prime} 45^{\prime \prime} \mathrm{N}, 153^{\circ} 20^{\prime} 40^{\prime \prime} \mathrm{W}$; (map 51 ).

Descriptive name published in 1913 by USC\&GS.

Big Rock Mountain: mountain, 3,073 ft., 5 mi. $\mathrm{N}$ of Little Rock Mtn. and $34 \mathrm{mi}$. NW of Christian, Brooks Ra.; 67 $42^{\prime} \mathrm{N}, 146^{\circ} 09^{\prime}$ W; (map 122).

Local name reported in 1956 by T. E. Taylor, USGS.

Big Rose Island: island, $0.3 \mathrm{mi}$. across, in Peril Strait, $0.4 \mathrm{mi}$. NE of Rapids Point, $29 \mathrm{mi}$. N of Sitka, Alex. Arch.; $57^{\circ} 27^{\prime} 20^{\prime \prime}$ N, $135^{\circ} 32^{\prime}$ $30^{\prime \prime} \mathrm{W}$; (map 9).

Named in 1884 by Comdr. J. B. Coghlan, USN, probably for the U.S.S. Rose.

Big Rusty Creek: stream, flows NW $2 \mathrm{mi}$. to White Creek, $70 \mathrm{mi}$. SE of Healy, Alaska Ra.; $63^{\circ} 11^{\prime} \mathrm{N}, 147^{\circ} 18^{\prime} \mathrm{W}$; (map 87).

Named relative to neighboring Rusty Creek; published in 1960 by USGS.

Big Saint Michael Canal: water course, see Saint Michael Canal.

Big Salmon Fork: stream, heads at a glacier at $62^{\circ} 35^{\prime} \mathrm{N}, 152^{\circ} 59^{\prime} \mathrm{W}$, flows NW $55 \mathrm{mi}$. to Little Tonzona River, 7.4 mi. E of McGrath, Kuskokwim Low.; 62 $57^{\prime} 20^{\prime \prime} \mathrm{N}, 1^{\circ} 3^{\circ} 55^{\prime} 30^{\prime \prime}$ W; BGN 1964; (map 80). Var. Big Salmon Fork Tonzona River.

Local name reported in 1961 by USGS.

Big Salmon Fork Tonzona River: stream, see Big Salmon Fork.

Big Salmon River: stream, see Tsirku River.

Big Salt Creek: stream, see Big Salt River.

Big Saltery Island: island, $0.7 \mathrm{mi}$. long, $15 \mathrm{mi}$. SW of Petersburg, between Woewodski I. and Lindenberg Penin., Kupreanof I., Alex. Arch.; $56^{\circ} 36^{\prime} \mathrm{N}, 1^{\circ} 03^{\circ} 01^{\prime} \mathrm{W}$; BGN 1933 (map 6).

Local name reported in 1933 by $R$. $H$. Sargent, USGS; name obtained from G. J. Hilderbrand of Pearl Island.

Big Salt Lake: estuary, extends NE $8 \mathrm{mi}$., off Klawak and Shinaku Inlets, on W coast of Prince of Wales I., 2 mi. NE of Klawock, Alex. Arch.; 55 $37^{\prime} 45^{\prime \prime} \mathrm{N}, 133^{\circ} 00^{\prime} 15^{\prime \prime} \mathrm{W}$; (map 4). Var. Klawak Inlet. 
Name published in 1932 Coast Pilot (p. 213) ; considered part of Klawak Inlet in 1925 Coast Pilot (p. 141). See Klawak Inlet.

Big Salt River: stream, heads at $65^{\circ} 42^{\prime} \mathrm{N}$, $150^{\circ} 51^{\prime} \mathrm{W}$, flows NE $40 \mathrm{mi}$. to Yukon River, $30 \mathrm{mi}$. NE of Rampart, Kokrines-Hodzana High.; $65^{\circ} 51^{\prime} \mathrm{N}, 149^{\circ} 54^{\prime} \mathrm{W}$; (map 105). Var. Big Salt Creek.

Local name published by USGS in the 1950's.

Big Sands: shoal, $3 \mathrm{mi}$. long, in Nushagak Bay between its Middle and West Channels, $22 \mathrm{mi}$. SW of Dillingham, Bristol Bay Low.; $58^{\circ} 42^{\prime}$ $30^{\prime \prime} \mathrm{N}, 158^{\circ} 33^{\prime} 45^{\prime \prime} \mathrm{W}$; (map 40).

Local name reported in 1950 by USC\&GS. Nushagak Bay shoals are subject to constant change in location and depth.

Big Sandy Creek: stream, heads in Robinson Mts. and flows SW $2 \mathrm{mi}$. to Gulf of Alaska, $4 \mathrm{mi}$. NW of Icy Cape, Malaspina Coastal

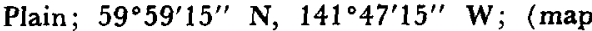
47).

Local descriptive name published in 1948 by USGS.

Big Sandy Island: island, see Let Island.

Big Scotty Creek: stream, see Scottie Creek.

Big Sitdown Creek: stream, heads in Canada, flows NW across Alaska-Canada boundary 25 mi. to Kandik River, $47 \mathrm{mi}$. NE of that stream's junc. with Yukon River, Porcupine Plat.; $65^{\circ} 44^{\prime} \mathrm{N}, 141^{\circ} 18^{\prime} \mathrm{W}$; (map 103). Var. Sitdown Creek.

Named in 1910 by IBC survey.

Big Skookum Creek: stream, flows S $0.9 \mathrm{mi}$. to Mills Creek, $45 \mathrm{mi}$. W of Talkeetna, Alaska Ra.; $62^{\circ} 21^{\prime} 30^{\prime \prime} \mathrm{N}, 151^{\circ} 30^{\prime} 45^{\prime \prime} \mathrm{W}$; (map 81).

Local name reported by S. R. Capps (1911, pl. 7), USGS.

Big Spruce Creek: stream, flows S $15 \mathrm{mi}$. to Bettles River $1.5 \mathrm{mi}$. W of that stream's head and $22 \mathrm{mi}$. WNW of Chandalar, Brooks Ra. $67^{\circ} 35^{\prime} 00^{\prime \prime} \mathrm{N}, 149^{\circ} 17^{\prime} 30^{\prime \prime} \mathrm{W}$; (map 123). Var. Mule Creek.

Prospectors' name obtained in 1909 by A. G. Maddren (in Brooks and others, 1910, pl. 7), USGS.

Big Squaw Creek: stream, see Squaw Greek.

Big Swede Creek: stream, flows SE $10 \mathrm{mi}$. to South Fork Goodpaster River, $34 \mathrm{mi}$. E of Big Delta, Yukon-Tanana High.; 64 $11^{\prime} 30^{\prime \prime}$ N, $144^{\circ} 44^{\prime} 44^{\prime \prime}$ W; (map 101).

Named by prospectors; reported in 1907 by D. C. Witherspoon, USGS.

Big Swift River: stream, see Chukowan River Big Tetling Lake: lake, see Tetlin Lake.

Big Timber: locality, at junc. of Glenn and Richardson Highways, $1.5 \mathrm{mi}$. NE of Gulkana, Copper River Basin; 62 $2^{\circ} 17^{\prime} \mathrm{N}, 145^{\circ} 21^{\prime} \mathrm{W}$; (map 83). Var. Big Timber Junction, Gakona Junction, North Junction.

Local name reported in 1951 by USGS; probably the name of a road construction camp.

Big Timber Creek: stream, heads at a glacier W of Knik Glacier, flows N $2.5 \mathrm{mi}$. to Knik River, 19 mi. SE of Palmer, Chugach Mts. $61^{\circ} 25^{\prime} 20^{\prime \prime} \mathrm{N}, 148^{\circ} 39^{\prime} 40^{\prime \prime} \mathrm{W}$; (map 69).

Local name reported in 1960 by USGS.
Big Timber Creek: stream, flows W $13 \mathrm{mi}$. to Dennison Fork, $9 \mathrm{mi}$. $\mathbf{N}$ of junc. of that stream's East Fork, Yukon-Tanana High.; $63^{\circ} 45^{\prime} \mathrm{N}, 141^{\circ} 58^{\prime} \mathrm{W}$; (map 85).

Local name reported by USGS in 1950.

Big Timber Junction: locality, see Big Timber.

Big Timber Lake: lake, $1.5 \mathrm{mi}$. long, $3.5 \mathrm{mi}$. S of Chalkyitsik, Yukon Flats; $66^{\circ} 38^{\prime} \mathrm{N}, 143^{\circ} 50^{\prime}$ W; (map 120)

Local descriptive name reported in 1956 by R. C. Foley, USGS.

Big Tokio River: stream, see Dry Tok Creek.

Big Waldren Fork Takotna River: stream, flows N $40 \mathrm{mi}$. to Takotna River, $37 \mathrm{mi}$. SW of McGrath, Kilbuck-Kuskokwim Mts.; $62^{\circ} 38^{\prime} 15^{\prime \prime} \mathrm{N}, 156^{\circ} 35^{\prime} 00^{\prime \prime} \mathrm{W}$; (map 79).

Local name obtained in 1952 by USGS topographers.

Big Waterfall Bay: bay, extends SW $1.3 \mathrm{mi}$ off Perenosa Bay, on $\mathbf{N}$ coast of Afognak I., Kodiak I.; $58^{\circ} 25^{\prime} \mathrm{N}, 152^{\circ} 30 \mathrm{~W}$; (map 43). Var. West Arm Perenosa Bay.

Local descriptive name reported in 1952 by USGS. This feature was named "West Arm Perenosa Bay" by USFS in 1925.

Big Whitefish Island: island, "in Yukon river, at the Palisades. Called Big White Fish island by the Coast Survey in 1898" (Baker, 1906, p. 133)

Big Windy Creek: stream, flows NE $18 \mathrm{mi}$. to South Fork Birch Creek, $40 \mathrm{mi}$. SW of Circle, Yukon-Tanana High.; $65^{\circ} 18^{\prime} 15^{\prime \prime} \mathrm{N}, 144^{\circ}$ $25^{\prime} 50^{\prime \prime} \mathrm{W}$; (map 104).

Named by prospectors; reported in 1904 by D. C. Witherspoon, USGS.

Big Wrangell Island: island, see Wrangell Island.

Big Yetna River: stream, flows NE $70 \mathrm{mi}$. to join Little Yetna River to form Yetna River, 32 mi. E of Holikachuck and $32 \mathrm{mi}$. NW of Flat, Innoko Low.; 62 $51^{\prime} 30^{\prime \prime} \mathrm{N}, 158^{\circ} 30^{\prime} 00^{\prime \prime}$ W; (map 79).

Local name obtained in 1952 by USGS topographers.

Bilge Creek: stream, flows NW $7 \mathrm{mi}$. to Goodhope River, $15 \mathrm{mi}$. NW of Imuruk Lake, Seward Penin. High.; $65^{\circ} 47^{\prime}$ N, $163^{\circ} 36^{\prime}$ W; $B G N$ 1952; (map 110). Var. Bilgewater Creek.

So named in 1951 by D. M. Hopkins, USGS, because "throughout the upper course of the creek the current is sluggish and the water is foul-tasting and coffee-brown in color, suggestive of bilgewater in a ship's hold."

Bilgewater Creek: stream, see Bilge Creek.

Bill Creek: stream, flows SE $1 \mathrm{mi}$. to Dahl Creek, in Kougarok River basin, $9 \mathrm{mi}$. NW of junc. of Kougarok and Kuzitrin Rivers, Seward Penin. High.; $65^{\circ} 20^{\prime} \mathrm{N}, 164^{\circ} 49^{\prime} \mathrm{W}$; (map 110).

Prospectors' name shown on a map of Cape Nome gold fields by David Fox, Jr., dated 1901.

Billie Mountain: mountain, 3,194 ft., $1.8 \mathrm{mi}$. SE of Gould I., near center of Prince of Wales I., Alex. Arch.; $55^{\circ} 15^{\prime} 20^{\prime \prime} \mathrm{N}, 132^{\circ} 34^{\prime} 20^{\prime \prime} \mathrm{W}$; (map 4).
Local name reported in 1908 by C. W. Wright (in Brooks and others, 1909, pl. 3), USGS.

Billings Creek: stream, heads at terminus of Billings Glacier, flows SW $2.5 \mathrm{mi}$. to Passage Canal, 3.5 mi. NE of Whittier, Chugach Mts.; $60^{\circ} 48^{\prime} 55^{\prime \prime} \mathrm{N}, 148^{\circ} 37^{\prime} 10^{\prime \prime} \mathrm{W}$; (map 63).

Local name published in 1951 by USGS. See Billings Glacier.

Billings Glacier: glacier, trends SE $5 \mathrm{mi}$. to head of Billings Creek, $5.5 \mathrm{mi}$. NE of Whittier, Chugach Mts.; $60^{\circ} 50^{\prime} 30^{\prime \prime} \mathrm{N}, 148^{\circ} 35^{\prime} 45^{\prime \prime} \mathrm{W}$; $B G N$ 1910; (map 63)

Named in 1908 by Grant and Higgins (1910, pls. 1, 2), USGS, for Commodore Joseph Billings, IRN, an Englishman, who commanded a Russian exploring and surveying expedition in the Bering Sea and North Pacific Ocean in 1791-92.

Billings Head: promontory, on NE coast of Akun I., Krenitzin Is., Aleutian Is.; $54^{\circ} 17^{\prime} 30^{\prime \prime} \mathrm{N}$, 165'28'40" W; BGN 1939; (map 24).

Named in 1938 by USC\&GS for Commodore Joseph Billings, IRN.

Billings Point: point of land, easternmost point of Perry I., on W side of Lone Passage in Prince William Sound, $30 \mathrm{mi}$. NE of Chenega, Chugach Mts.; $60^{\circ} 41^{\prime} 30^{\prime \prime} \mathrm{N}, 147^{\circ} 50^{\prime} 35^{\prime \prime} \mathrm{W}$; (map 63).

Local name reported in 1952 by USGS.

Billion Slough: stream, distributary of Talkeetna River, flows SW $0.6 \mathrm{mi}$. to Susitna River, $1 \mathrm{mi}$. NW of Talkeetna, Cook Inlet Low.; $62^{\circ} 20^{\prime} \mathrm{N}, 150^{\circ} 08^{\prime} \mathrm{W}$; (map 81).

Local name reported in 1958 by USGS.

Bill Island : island, see Junction Island.

Bill Moore Slough: settlement, see Bill Moores.

Bill Moores: settlement, on left bank of Apoon Pass, $26 \mathrm{mi}$. NE of Kwiguk, Yukon-Kuskokwim Delta; $62^{\circ} 57^{\prime} \mathrm{N}, 163^{\circ} 46^{\prime} \mathrm{W}$; (map 77). Var. Bill Moore Slough, Bill Moors, Konog. kelyokamiut.

This was a landing and riverboat woodyard reported in 1899 by R. L. Faris, USC\&GS. He also gave the Eskimo name, "Konogkelyokamiut," for this locality, implying the existence of an Eskimo camp or village here. Reported as "Bill Moore Slough" with a population of 32 in 1961; 4 in 1963 (Klein, 1966, p. 320 ).

Bill Moors: settlement, see Bill Moores.

Bill Point: point of land, $\mathrm{N}$ tip of Whitney $\mathrm{I}$. $0.6 \mathrm{mi}$. SW of McNairy Point and $70 \mathrm{mi}$. E of Sitka, Coast Mts.; $57^{\circ} 15^{\prime} 10^{\prime \prime} \mathrm{N}, 133^{\circ} 32^{\prime} 30^{\prime \prime}$ W; (map 8).

Named in 1891 by USC\&GS

Billy Creek: stream, flows E and SW $11 \mathrm{mi}$. to Caribou Creek, $51 \mathrm{mi}$. NE of Palmer, Talkeetna Mts.; $61^{\circ} 57^{\prime} 55^{\prime \prime} \mathrm{N}, 147^{\circ} 46^{\prime} 00^{\prime \prime} \mathrm{W}$; (map 69).

Named in 1898 by Capt. E. F. Glenn, USA, for his Indian guide "Billy."

Billy Creek: stream, flows SW $23 \mathrm{mi}$. to Tanana River, $42 \mathrm{mi}$. NW of Tok, Yukon-Tanana High.; $63^{\circ} 43^{\prime} 25^{\prime \prime} \mathrm{N}, 144^{\circ} 02^{\prime} 30^{\prime \prime} \mathrm{W}$; $B G N$ 1961 ; (map 86). Var. George Creek.

Local name reported in 1958 by R. E. Isto, USGS. See George Creek. 
Billy Creek: stream, flows SW $3 \mathrm{mi}$. to Sweepstakes Creek, 7 mi. N of Haycock, Seward Penin. High.; $65^{\circ} 18^{\prime} \mathrm{N}, 161^{\circ} 10^{\prime} \mathrm{W}$; (map 109).

Prospectors' name reported in 1917 by G. L. Harrington, USGS.

Billy Glen Creek: stream, flows S $1.7 \mathrm{mi}$. to Big Lake, $23 \mathrm{mi}$. W of Chandalar, Brooks Ra.; $67^{\circ} 30^{\prime} \mathrm{N}, 149^{\circ} 23^{\prime} \mathrm{W}$; (map 123).

Local name reported in 1956 by T. E. Taylor, USGS.

Billy Goat Creek: stream, heads in a small lake and flows NW $3 \mathrm{mi}$. to Humpback Lake, Coast Mts.; $55^{\circ} 01^{\prime} 12^{\prime \prime} \mathrm{N}, 130^{\circ} 32^{\prime} 30^{\prime \prime} \mathrm{W} ; B G N$ 1963; (map 3).

So named in 1961 by USFS "because of numerous goats found in headwaters."

Billy Goat Creek: stream, heads in Beaver Mts., flows W $18 \mathrm{mi}$. to join Moose Creek to form California Creek, $35 \mathrm{mi}$. NE of Flat, KilbuckKuskokwim Mts.; $62^{\circ} 50^{\prime} 50^{\prime \prime} \mathrm{N}, 157^{\circ} 19^{\prime} 50^{\prime \prime}$ W; (map 79).

Local name obtained in 1952 by USGS topographers.

Billygoat Mountain: peak, 2,231 ft., N of Port Fidalgo, $33 \mathrm{mi}$. NW of Cordova, Chugach Mts.; $60^{\circ} 50^{\prime} \mathrm{N}, 146^{\circ} 31^{\prime} \mathrm{W}$; (map 64). Var. Billy Goat Mountain.

Local name reported in 1912 by R. H. Sargent, USGS

Billy Hawk Creek: stream, heads on Purcell Mtn., flows SE to Huslia River, $27 \mathrm{mi}$. N of Roundabout Mtn., Koyukuk Low.; $65^{\circ} 57^{\prime} \mathrm{N}$ $156^{\circ} 40^{\prime}$ W ; (map 108). Var. Hawk Creek, North Fork Huslia River.

Local name obtained at Huslia in 1954-55 by USGS.

Billy Hurleys: village, see Ekwok.

Billy Lake: lake, $1 \mathrm{mi}$. long, $7 \mathrm{mi}$. NE of junc. of Chitina and Tebay Rivers, $32 \mathrm{mi}$. W of McCarthy, Copper River Basin; 61 ${ }^{\circ} 27^{\prime} 15^{\prime \prime} \mathrm{N}$ $143^{\circ} 53^{\prime} 00^{\prime \prime} \mathrm{W}$; (map 67).

Local name published on a 1909 blueprint map of the Copper River and Northwestern Railway, Chitina Branch Line.

Billy Lake: lake, $0.5 \mathrm{mi}$. long, one of the Yokneda Lakes, $5.5 \mathrm{mi}$. S of Chistochina, Copper River Basin; $62^{\circ} 29^{\prime} \mathrm{N}, 144^{\circ} 43^{\prime} \mathrm{W}$; (map 83).

Local name reported by F. C. Schrader (in Mendenhall and Schrader, 1903, p. 31), USGS.

Billy Mitchell Islands: islands, see Aleutian Islands.

Billys Hole Lake: lake, $3.4 \mathrm{mi}$. long, $\mathrm{S}$ of First Branch Columbia Glacier, $30 \mathrm{mi}$. W of Valdez, Chugach Mts.; $61^{\circ} 06^{\prime} \mathrm{N}, 147^{\circ} 12^{\prime} \mathrm{W}$; (map 69)

Named by USBF and reported in 1897 by Lt. Comdr. J. F. Moser, USN.

Bilwaddy Creek: stream, heads at $\mathrm{E}$ end of Davidson Mts., flows NE $20 \mathrm{mi}$. across AlaskaCanada boundary to Old Crow River in Yukon, Canada, Porcupine Plat.; $68^{\circ} 10^{\prime} \mathrm{N}$, $140^{\circ} 55^{\prime} \mathrm{W}$; (map 137).

Name reported in 1911 by IBC field survey crew.

Bimahyook Creek: stream, flows NE $6 \mathrm{mi}$. to Antingmiut Creek, above Dachirowruk Cove,
25 mi. SW of Cape Etolin, on Nunivak I.; $60^{\circ} 13^{\prime} 20^{\prime \prime} \mathrm{N}, 166^{\circ} 48^{\prime} 19^{\prime \prime} \mathrm{W}$; (map 57). Var. Bimayuk Creek.

Eskimo name obtained in 1949 by USC\&GS.

Bimayuk Creek: stream, see Bimahyook Creek.

Bimiut: locality, $15 \mathrm{mi}$. NE of Cape Mendenhall, on SE Nunivak I.; $59^{\circ} 55^{\prime} \mathrm{N}, 165^{\circ} 46^{\prime} \mathrm{W}$; (map 55). Var. Bimute.

Former Eskimo village reported in 1949 by USC\&GS.

Bimiut: locality, site of an Eskimo village or camp, on Bering Sea coast, $13 \mathrm{mi}$. SW of Black, Yukon-Kuskokwim Delta; $62^{\circ} 11^{\prime} 00^{\prime \prime}$ N, 165 $35^{\prime} 20^{\prime \prime} \mathrm{W}$; (map 76). Var. Bismut, Paimiut.

Eskimo name obtained in 1899 by G. R. Putnam, USC\&GS ; may be the same name as "Paimiut" meaning "river mouth people."

Bimute: locality, see Bimiut.

Binachoakhmiut: locality, see Binajoaksmiut.

Binajoaksmiut: locality, on left bank of mouth of Binajoaksmiut River, $12 \mathrm{mi}$. NW of Cape Mendenhall, Ninivak 1.; $59^{\circ} 51^{\prime} 00^{\prime \prime} \mathrm{N}$, $166^{\circ} 30^{\prime} 30^{\prime \prime} \mathrm{W}$; (map 55). Var. Binachoakhmiut, Binajoaxmiut, Bingwakamute, Pinnaichwakamiut.

Eskimo fishing village, now abandoned; reported in 1932 by USC\&GS

Binajoaksmiut-Koweerat River: stream, see Binajoaksmiut River.

Binajoaksmiut River: stream, flows S $15 \mathrm{mi}$. to Bering Sea, $12 \mathrm{mi}$. NW of Cape Mendenhall, on Nunivak I.; $59^{\circ} 51^{\prime} \mathrm{N}, 166^{\circ} 31^{\prime} \mathrm{W}$; (map 55). Var. Binajoaksmiut-Koweerat River, Bingwakamute River.

Eskimo name reported in 1937 by USAAF. Binajoaxmiut: locality, see Binajoaksmiut. Binakhbakh Bluff: bluff, see Binaksbak Bluff. Binakhslit Bluff: bluff, see Binakslit Bluff.

Binaksbak Bluff: bluff, extends S $9 \mathrm{mi}$. from Cape Mohican to Datheekook Point, along W coast of Nunivak I.; $60^{\circ} 08^{\prime} 00^{\prime \prime} \mathrm{N}, 167^{\circ} 20^{\prime} 50^{\prime \prime}$ W; (map 57). Var. Binakhbakh Bluff, Binaxbax Bluff.

Eskimo name meaning "big bluff" reported in 1949 by USC\&GS.

Binakslit Bluff: bluff, $W$ of Cape Algonquin and $32 \mathrm{mi}$. SW of Cape Etolin, on $\mathrm{N}$ coast of Nunivak I.; $60^{\circ} 13^{\prime} 20^{\prime \prime} \mathrm{N}, 166^{\circ} 56^{\prime} 30^{\prime \prime} \mathrm{W}$; (map 57). Var. Binakhslit Bluff, Binaxlit Bluff.

Eskimo name meaning "steep bluff" according to USC\&GS in 1949.

Binalik Crater: volcanic crater, $0.3 \mathrm{mi}$. across, $2 \mathrm{mi}$. SE of Roberts Mtn. and $15 \mathrm{mi}$. N of Cape Mendenhall, Nunivak I.; $60^{\circ} 01^{\prime} 35^{\prime \prime} \mathrm{N}, 166^{\circ}$ $12^{\prime} 00^{\prime \prime} \mathrm{W}$; (map 57)

Eskimo name reported in 1937 by USAAF.

Binat-Ingrat Hill: hill, $927 \mathrm{ft}$., $20 \mathrm{mi}$. NW of Cape Mendenhall, Nunivak I.; $59^{\circ} 59^{\prime} \mathrm{N}$, $166^{\circ} 34^{\prime} \mathrm{W}$; (map 55 ).

Eskimo name reported in 1949 to mean "bluff mountain" according to USC\&GS

Binaxbax Bluff : bluff, see Binaksbak Bluff.

Binaxlit Bluff: bluff, see Binakslit Bluff.

Bingham, Cape: point of land, on $\mathrm{N}$ coast of Yakobi I., $0.6 \mathrm{mi}$. SW of Soapstone Point and $40 \mathrm{mi}$. W of Hoonah, Alex. Arch.; $58^{\circ} 05^{\prime}$ $30^{\prime \prime} \mathrm{N}, 136^{\circ} 31^{\prime} 00^{\prime \prime}$ W; (map 10). Var Cape Cross, Mys Bingkhem, Mys Takhanys, Point Bingham.

Named about July 25, 1794 by Capt. George Vancouver, RN, for Margaret Bingham, Countess of Lucan, an English amateur painter (Wagner, 1937, p. 376).

Bingham Cove: cove, $0.6 \mathrm{mi}$. across, on NW coast of Yakobi I., $2 \mathrm{mi}$. S. of Soapstone Point $41 \mathrm{mi}$. W of Hoonah, Alex. Arc.; 58 $05^{\prime} 15^{\prime \prime}$ N, 136 $32^{\prime} 45^{\prime \prime} \mathrm{W}$; BGN 1928; (map 10).

Named by USC\&GS in 1928 for Cape Bingham

Bingham Peak: peak, 2,172 ft., on Yakobi I., 1 mi. N of Surge Lake and $39 \mathrm{Mi}$. WSW of Hoonah, Alex. Arch.; $58^{\circ} 01^{\prime} 45^{\prime \prime} \mathrm{N}, 136^{\circ} 29^{\prime}$ $50^{\prime \prime} \mathrm{W}$; BGN 1928; (map 10).

Named by USC\&GS in 1928 for Cape Bingham, "because the peak appears from the South to rise from the cape beyond."

Bingkhem, Mys: point of land, see Bingham, Cape.

Bingo Mountain: mountain, 2,015 ft., on Annette I., S of Nubbins Mtn., $7 \mathrm{mi}$. $\mathrm{N}$ of Metlakatla Alex. Arch.; 55 $13^{\prime} 48^{\prime \prime}$ N, $131^{\circ} 33^{\prime} 00^{\prime \prime} \mathrm{W}$; (map 3).

Named in 1883 by Lt. Comdr. H. E. Nichols, USN

Bingwakamute: locality, see Binajoaksmiut.

Bingwakamute River: stream, see Binajoaksmiut River.

Binkleys Slough: stream, flows SW $1.3 \mathrm{mi}$. to mouth of Stikine River on $S$ coast of Farm $I$., $9 \mathrm{mi}$. N of Wrangell, Coast Mts.; $56^{\circ} 36^{\prime} 25^{\prime \prime}$ $\mathrm{N}, 132^{\circ} 26^{\prime} 35^{\prime \prime} \mathrm{W}$; (map 6)

Local name recorded in 1948 by USGS.

Binnacle Bay: bay, extends S $2 \mathrm{mi}$. from Patricia Point, on $\mathrm{N}$ coast of Agattu I., Aleutian Is. $52^{\circ} 28^{\prime} 40^{\prime \prime} \mathrm{N}, 173^{\circ} 35^{\prime} 30^{\prime \prime} \mathrm{E}$; (map 13).

Listed in 1944 Aleutian Coast Pilot. A binnacle is a case, box, or stand containing a ship's compass and a lamp.

Binnyanaktuk Creek: stream, flows S $3.5 \mathrm{mi}$. from Midnight Mtn. to Clear River, $30 \mathrm{mi}$. NW of Wiseman, Brooks Ra.; $67^{\circ} 49^{\prime} 30^{\prime \prime} \mathrm{N}$, $150^{\circ} 31^{\prime} 30^{\prime \prime}$ W; (map 124). Var. Pinnyanaktuk.

Described by Marshall (1956, p. 72) as "the gorge surrounded by the fabulous series of needled pinnacles, we called 'Pinnyanaktuk', the Eskimo word synonymous with 'absolute perfection of beauty'." Erroneously published by USGS as "Binnyanaktuk Creek."

Binowarat: sand dunes, $11 \mathrm{mi}$. SE of Cape Etolin, on NE coast of Nunivak I.; $60^{\circ} 20^{\prime} 15^{\prime \prime}$ N, $165^{\circ} 53^{\prime} 45^{\prime \prime}$ W.; (map 57).

Eskimo name obtained in 1949 by USC\&GS. Biorka: village, pop. 20, on $\mathrm{N}$ coast of Sedanka I., in Fox Is., $13 \mathrm{mi}$. SE of Unalaska village, Aleutian Is.; $53^{\circ} 49^{\prime} 50^{\prime \prime} \mathrm{N}, 166^{\circ} 12^{\prime} 30^{\prime \prime} \mathrm{W}$; (map 23). Var. Borka, Burka, Sedanka, Sedanki, Sidankin, Ugiú-ug, Uguyug.

In 1790 Martin Sauer recorded the Aleut name "Sidankin"; in 1826 Lt. Sarichev (map 14 dated 1792), IRN, published "S[elo] Sedanka" or "Sedanka Village"; Father Veniaminov (1840, v. 1, p. 185) wrote the Aleut name "Uguyug." In 1888 USBF recorded 
"Burka," which Baker (1906, p. 133) published "Biorka," from the Norwegian Bjerk Ö or Swedish Björk Ö, meaning "Birch Island."

Biorka Cape: point of land, see Cape Sedanka.

Biorka Channel: water passage, main pass through Necker Is., just SE of Biorka I., off W coast of Baranof I., Alex. Arch.; $56^{\circ} 50^{\prime} \mathrm{N}$, 135 30' W; BGN 1926; (map 5). Var. Dangerous Channel.

Named in 1926 by USC\&GS after the island. This is probably the feature named "Dangerous Channel" by United States naval officers in 1879-80.

Biorka Island: island, $2.5 \mathrm{mi}$. across, $15 \mathrm{mi}$. SW of Sitka, in Necker Is., off W coast of Baranof I., Alex. Arch.; $56^{\circ} 51^{\prime} \mathrm{N}, 135^{\circ} 32^{\prime} \mathrm{W}$; BGN 1921; (map 5). Var. South Island, Wadzis.

Named in 1809 by the Russian navigator, Ivan Vasiliev the first, IRN; published by Lt. Sarichev (1826, map 19), IRN, as "Ostrov Biorka" or "Biorka Island." In 1805 it was called "South Island" by Capt. U. T. Lisianski, IRN.

Biorka Island: island, see Sedanka Island.

Biorka Reef: reef, extends NW 2 mi. off NW coast of Biorka $I$., on $W$ coast of Baranof $I$. Alex. Arch.; $56^{\circ} 52^{\prime} \mathrm{N}, 135^{\circ} 36^{\prime} \mathrm{W} ; B G N$ 1897; (map 5). Var. Biorka Rock.

Named by W. H. Dall, USC\&GS ; published in 1883 Coast Pilot (p. 148) as "Biorka Rock."

Biorka Rock: reef, see Biorka Reef.

Birch, Lake: lake, see Dathlalmund Lake.

Birch Beach: beach, $0.5 \mathrm{mi}$. long, on $\mathrm{N}$ coast of Attu I., at mouth of Diehm Creek in Blonde Cove, Aleutian Is.; $52^{\circ} 58^{\prime} 40^{\prime \prime} \mathrm{N}, 172^{\circ} 58^{\prime} 15^{\prime \prime}$ E; (map 13).

Named by the U.S. Army during World War II ; published in 1948 by AMS.

Birch Creek: village, pop. 32, on right bank of Lower Mouth Birch Creek, $26 \mathrm{mi}$. SW of Fort Yukon, Yukon Flats; $66^{\circ} 15^{\prime} 40^{\prime \prime} \mathrm{N}, 145^{\circ} 48^{\prime}$ $45^{\prime \prime} \mathrm{W}$; (map 119).

Local name published in 1951 by USGS.

Birch Creek: stream, "Kenai peninsula, tributary to Tustumena Lake from the northwest, near longitude $150^{\circ} 40^{\prime}$. Local name, from Moffit, 1904" (Baker, 1906, p. 134).

Birch Creek: stream, flows SW, through Fish Lake, $10 \mathrm{mi}$. to Birch Creek Slough, $6 \mathrm{mi}$. S of Talkeetna, Cook Inlet Low.; $62^{\circ} 14^{\prime} 00^{\prime \prime} \mathrm{N}$, $150^{\circ} 06^{\prime} 30^{\prime \prime} \mathrm{W}$; (map 81).

Local name shown on a RR. location blueprint map compiled in 1915 .

Birch Creek: stream, heads at glacier terminus in Mount McKinley National Park, flows N 65 mi., joins McKinley River to form Kantishna River, $23 \mathrm{mi}$. E of village of Lake Minchumina, Tanana Low.; $63^{\circ} 52^{\prime} 00^{\prime \prime} \mathrm{N}, 151^{\circ} 33^{\prime}$ $20^{\prime \prime} \mathrm{W}$; (map 88). Var. Nutchitalichaket.

Local name reported in 1910 by A. H. Brooks, USGS. In 1907, Gordon (1917, p. 80) obtained the Tanana Indian name "Nutchitalichaket."

Birch Creek: stream, flows SE $6 \mathrm{mi}$. to Flint Creek, $20 \mathrm{mi}$. SE of Ruby, Nowitna Low.; $64^{\circ} 27^{\prime} 40^{\prime \prime}$ N, $155^{\circ} 17^{\prime} 00^{\prime \prime}$ W; (map 98). Var. Dry Birch Creek.
Prospectors' name reported in 1911 by A. G. Maddren (in Brooks and others, 1912, p. 294296), USGS.

Birch Creek: stream, flows NE $4.5 \mathrm{mi}$. to Big Four Creek which flows to Casadepaga River, $22 \mathrm{mi}$. NE of Solomon, Seward Penin. High.; $64^{\circ} 51^{\prime} \mathrm{N}, 164^{\circ} 07^{\prime} \mathrm{W}$; (map 95).

Prospectors' name reported in 1900 by E. C. Barnard (in Brooks, 1901, pl. 17), USGS.

Birch Creek: stream, flows NE $20 \mathrm{mi}$. to Tanana River, $7.5 \mathrm{mi}$. SE of Tanana, Nowitna Low.; $65^{\circ} 05^{\prime} 45^{\prime \prime} \mathrm{N}, 151^{\circ} 49^{\prime} 50^{\prime \prime} \mathrm{W}$; (map 106).

Local name reported in 1952 by USGS

Birch Creek: stream, flows N 2 mi. to Chatanika River, $45 \mathrm{mi}$. NE of Fairbanks, Yukon-Tanana High.; $65^{\circ} 15^{\prime} 30^{\prime \prime} \mathrm{N}, 146^{\circ} 44^{\prime} 10^{\prime \prime} \mathrm{W}$; (map 104).

Named by prospectors; published by USGS (Prindle, 1908, pl. 4).

Birch Creek: stream, heads in Bendeleben Mts. flows NW $17 \mathrm{mi}$. to Kuzitrin River, $39 \mathrm{mi}$ SW of Imuruk Lake, Seward Penin. High.; $65^{\circ} 20^{\prime} \mathrm{N}, 164^{\circ} 21^{\prime} \mathrm{W}$; (map 110).

Prospectors' name reported in 1901 by T. G. Gerdine (in Collier, 1902, pl. 12), USGS.

Birch Creek: stream, heads at junction of Ptarmigan and Bates Creeks and flows N $150 \mathrm{mi}$. to divide into Lower and Upper Mouths Birch Creek, its distributaries, before entering the Yukon River SW of Fort Yukon, Yukon-Flats ; $66^{\circ} 16^{\prime} 30^{\prime \prime} \mathrm{N}, 145^{\circ} 30^{\prime} 20^{\prime \prime} \mathrm{W}$; (map 119). Var. Noctocargut, Tohwun-nukakat.

Named by traders of the Hudson's Bay Company at Fort Yukon in the mid 1800's. Its Indian name, applied to its Upper Mouth, was reported to be "Tohwun-nukakat," and the "Nocotocargut" reported by the Western Union Telegraph expedition in 1867 probably applies to its Lower Mouth. Gold was discovered on this stream in 1891.

Birch Creek: stream, heads in lake, in Hogatza Flats, flows W 6 mi. to Hogatza River, $24 \mathrm{mi}$. NW of Hughes, Hogatza High.; $66^{\circ} 18^{\prime} \mathrm{N}$, $154^{\circ} 49^{\prime} \mathrm{W}$; (map 116).

Partial translation of an Indian name, "K'yikh-J'teteth-gran-in," reported to mean "stream among the birch"; recorded at Hughes in 1956 by Orth. This name is also used for the next stream south and seems to function more as a descriptive term.

Birch Creek: stream, flows W $4 \mathrm{mi}$. to Flat Creek, $6 \mathrm{mi}$. SE of Wild Lake, and $34 \mathrm{mi}$. W of Wiseman, Brooks Ra.; $67^{\circ} 27^{\prime} \mathrm{N}, 151^{\circ} 23^{\prime}$ W; BGN 1932; (map 124).

Local name in general use since 1904 ; reported by Robert Marshall in 1932.

Birch Creek: stream, see Bullion Creek.

Birch Creek: stream, see Ptarmigan Creek.

Birch Creek Slough: stream, anabranch of Susitna River, flows S $5 \mathrm{mi}$., $3 \mathrm{mi}$. S of Talkeetna, Cook Inlet Low.; $62^{\circ} 13^{\prime} 30^{\prime \prime} \mathrm{N}, 150^{\circ} 06^{\prime} 30^{\prime \prime}$ W; (map 81).

Local name reported in 1958 by USGS.

Birches: locality, on $\mathbf{N}$ shore of Yukon River, W of mouth of Montana Creek, $7 \mathrm{mi}$. SE of Gold Mtn. and $15 \mathrm{mi}$. WSW of Kallands, Kokrines-Hodzana High.; $65^{\circ} 08^{\prime} 10^{\prime \prime} \mathrm{N}, 153^{\circ}$ $33^{\prime} 30^{\prime \prime} \mathrm{W}$; (map 107)
Telegraph station, now abandoned, established in 1903 by the U.S. Army Signal Corps. Named for nearby Birches Creek.

Birches Creek: stream, flows SSE 5 mi. to Yukon River, 1 mi. W of locality of Birches and 16 mi. WSW of Kallands, Kokrines-Hodzana High.; $65^{\circ} 07^{\prime} 30^{\prime \prime} \mathrm{N}, 153^{\circ} 35^{\prime} 00^{\prime \prime} \mathrm{W}$; (map 107).

Local name published as "Birch Creek" in 1898 by USC\&GS

Birch Gulch: ravine, extends $\mathrm{N} 0.5 \mathrm{mi}$. from Hidden Greek, $1.2 \mathrm{mi}$. NW of Greens Head and $7.5 \mathrm{mi}$. N of Medfra, Kilbuck-Kuskokwim Mts. ; $63^{\circ} 13^{\prime} \mathrm{N}, 154^{\circ} 46^{\prime} \mathrm{W}$; (map 89)

Local name reported in 1920 by G. C. Martin (in Brooks and others, 1922, fig. 5), USGS.

Birch Hill: hill, $100 \mathrm{ft}$., on NW coast of Kenai Penin., $39 \mathrm{mi}$. NE of Kenai, Cook Inlet Low.; $60^{\circ} 55^{\prime} \mathrm{N}, 150^{\circ} 45^{\prime} \mathrm{W}$; (map 62).

Local name reported in 1950 by USGS.

Birch Hill: hill, 1,050 ft., $2.7 \mathrm{mi}$. NE of Fairbanks, Yukon-Tanana High.; BGN 1939; $64^{\circ} 51^{\prime} 50^{\prime \prime} \mathrm{N}, 147^{\circ} 38^{\prime} 25^{\prime \prime} \mathrm{W}$; (map 100).

Local name reported in 1939 by P. S. Smith, USGS. The crest of the hill is the location of the initial point of the Fairbanks meridian.

Birch Hill: hill, $283 \mathrm{ft}$., on $\mathrm{N}$ bank of Kuzitrin River, between Big Ptarmigan and Little Ptarmigan Creeks, $23 \mathrm{mi}$. W of Mount Bendeleben, Seward Penin. High.; $65^{\circ} 13^{\prime} \mathrm{N}$, $164^{\circ} 53^{\prime} \mathrm{W}$; (map 110 ).

Local name reported in 1901 by T. G. Gerdine (in Collier, 1902, pl. 12), USGS.

Birch Hill: hill, 1,010 ft., on E bank of Koyukuk River, $7 \mathrm{mi}$. NE of Bettles, Kanuti Flats; $66^{\circ} 57^{\prime} \mathrm{N}, 151^{\circ} 27^{\prime} \mathrm{W}$; (map 117).

Local name reported in 1956 by $T$. $E$. Taylor, USGS.

Birch Hill: mountain, 1,202 ft., $2 \mathrm{mi}$. W of Yukon River and $30 \mathrm{mi}$. SW of Nulato, Nulato Hills; $64^{\circ} 32^{\prime} \mathrm{N}, 158^{\circ} 14^{\prime} \mathrm{W}$; (map 97).

Riverboat pilots' name shown on a 1940 "Navigation Chart of the Tanana-Yukon Rivers" published by U.S. Dept. of Interior.

Birch Hill Lake: lake, $1 \mathrm{mi}$. long, $1.5 \mathrm{mi}$. SE of Birch Hill and $7.5 \mathrm{mi}$. E of Bettles, Kanuti Flats; $66^{\circ} 55^{\prime} 30^{\prime \prime} \mathrm{N}, 151^{\circ} 24^{\prime} 00^{\prime \prime} \mathrm{W}$; (map 117)

Local name reported in 1956 by T. E. Taylor, USGS.

Birch Hills: hills, 1400-1665 ft., $5 \mathrm{mi}$. apart, each hill about $3 \mathrm{mi}$. long, $\mathrm{S}$ and $\mathrm{W}$ of Tonzona River, $45 \mathrm{mi}$. SE of Medfra and 73 mi. E of McGrath, Kuskokwim Low.; $62^{\circ}$ $58^{\prime} 41^{\prime \prime} \mathrm{N}, 153^{\circ} 02^{\prime} 30^{\prime \prime} \mathrm{W}$; (map 80)

Local name obtained in 1958 by USGS

Birch Lake: lake, $1 \mathrm{mi}$. long, on Kenai Penin., $2.5 \mathrm{mi}$. $\mathrm{N}$ of Swan Lake and $28 \mathrm{mi}$. NE of Kenai, Cook Inlet Low.; $60^{\circ} 43^{\prime} 30^{\prime \prime} \mathrm{N}, 150^{\circ}$ $31^{\prime} 30^{\prime \prime} \mathrm{W}$; (map 62).

Named about 1963 by officials of Kenai National Moose Range, for administrative purposes.

Birch Lake: lake, $600 \mathrm{ft}$. across, $5.2 \mathrm{mi}$. SW of Anchorage, Cook Inlet Low.; $61^{\circ} 08^{\prime} 45^{\prime \prime} \mathrm{N}$, $149^{\circ} 56^{\prime} 05^{\prime \prime} \mathrm{W}$; (map 69).

Local name reported in 1962 by USGS 
Birch Lake: lake, $1.2 \mathrm{mi}$. across, $3.5 \mathrm{mi}$. $\mathrm{E}$ of Ewan Lake and $22 \mathrm{mi}$. $\mathrm{N}$ of Glennallen, Copper River Basin; $62^{\circ} 25^{\prime} \mathrm{N}, 145^{\circ} 36^{\prime} \mathrm{W}$; (map 83).

Named in 1898 by Lt. P. G. Lowe, USA, under the command of Capt. W. R. Abercrombie, for Stephen Birch, a civilian member of his party.

Birch Lake: lake, $0.9 \mathrm{mi}$. long, $1.2 \mathrm{mi}$. SW of Dog Lake and $7.3 \mathrm{mi}$. SE of Northway, Alaska Ra.; $62^{\circ} 52^{\prime} \mathrm{N}, 141^{\circ} 47^{\prime} \mathrm{W}$; (map 84).

Local name reported in 1954 by USGS.

Birch Lake: lake, $1.7 \mathrm{mi}$. across, $28 \mathrm{mi}$. NW of Big Delta, $\mathrm{E}$ of Tanana River, Yukon-Tanana High.; $64^{\circ} 20^{\prime} \mathrm{N}, 147^{\circ} 10^{\prime} \mathrm{W}$; (map 101).

Named by prospectors; reported in 1910 by USGS (Capps, 1912, pl. 1).

Birch Lake: lake, 2 mi. $\mathrm{S}$ of Coffee Can Lake and $22 \mathrm{mi}$. SW of Roundabout Mtn., Koyukuk Low.; $65^{\circ} 16^{\prime} \mathrm{N}, 156^{\circ} 56^{\prime} \mathrm{W}$; (map 108).

Local name obtained at Huslia in 1954-55 by USGS.

Birch Lake: lake, $1.5 \mathrm{mi}$. long, between Bear and Lily Lakes, $16 \mathrm{mi}$. SW of Beaver, Yukon Flats; $66^{\circ} 17^{\prime} 20^{\prime \prime} \mathrm{N}, 147^{\circ} 56^{\prime} 15^{\prime \prime} \mathrm{W}$; (map 118).

Probably named by William Yanert who showed it on a 1916 manuscript map of the Yukon Flats (Stuck, 1917, map facing p. 122).

Birch Lake: lake, $1.5 \mathrm{mi}$. long, $15 \mathrm{mi}$. S of Salmon Village and $37 \mathrm{mi}$. SE of Chalkyitsik, Porcupine Plat.; $66^{\circ} 22^{\prime} \mathrm{N}, 142^{\circ} 37^{\prime} \mathrm{W}$; (map 120).

Local name obtained in 1956 by T. E. Taylor and R. C. Foley, USGS.

Birch Lakes: lakes, two, in Nulitna River flat, extend NE-SW $2 \mathrm{mi}$., $26 \mathrm{mi}$. NW of Roundabout Mtn. Koyukuk Low.; $65^{\circ} 47^{\prime}$ N, $157^{\circ} 09^{\prime}$ W; (map 108).

Local name obtained at Huslia in 1954-55 by USGS.

Birch Lakes: lake, see Tontethaimund Lake.

Birch Slough: stream, flows NW $14 \mathrm{mi}$. to Tuluksak River, $12 \mathrm{mi}$. E of Tuluksak and $50 \mathrm{mi}$. SW of Aniak, Yukon-Kuskokwim Delta; $61^{\circ} 04^{\prime} \mathrm{N}, 160^{\circ} 37^{\prime} \mathrm{W}$; (map 73).

Local name reported by USGS in 1947.

Birch Tree Lake: lake, $1 \mathrm{mi}$. long, on Kenai Penin., one of Swanson Lakes, $1 \mathrm{mi}$. NE of Pepper Lake and $36 \mathrm{mi}$. NE of Kenai, Cook Inlet Low.; $60^{\circ} 51^{\prime} 45^{\prime \prime} \mathrm{N}, 150^{\circ} 24^{\prime} 00^{\prime \prime} \mathrm{W}$; (map 62).

Named about 1963 by officials of Kenai National Moose Range, for administrative purposes.

Birchwood: village, pop. 534, mile 136.3 on The Alaska RR., $19 \mathrm{mi}$. NE of Anchorage, Cook Inlet Low.; $61^{\circ} 24^{\prime} 30^{\prime \prime} \mathrm{N}, 149^{\circ} 28^{\prime} 50^{\prime \prime} \mathrm{W}$; (map 69).

Name of a suburb of Anchorage reported in 1939 by USGS.

Bird: village, pop. 25 , mile 81.7 on The Alaska RR., along Seward Highway on $\mathbf{N}$ shore of Turnagain Arm, $3.5 \mathrm{mi}$. NE of Sunrise and $26 \mathrm{mi}$. NW of Whittier, Chugach Mts. ; $60^{\circ}$ $55^{\prime} 50^{\prime \prime} \mathrm{N}, 149^{\circ} 21^{\prime} 30^{\prime \prime} \mathrm{W}$; (map 63).
Stop on The Alaska RR. reported in 1940 by USGS. Name derived from nearby Bird Point.

Bird Cape: point of land, on NW coast of Amfichitka I., Rat Is., Aleutian Is.; $51^{\circ} 39^{\prime} 45^{\prime \prime} \mathrm{N}$, $178^{\circ} 39^{\prime} 30^{\prime \prime}$ E; BGN 1937; (map 15). Var. Cape Ptichi, Pitchie, Ptitsa, Satanna.

This name appears to be an English translation of a Russian translation of an Aleut name meaning "bird" or "of the birds." The Russian name was "M[ys] Ptichiy" [from Ptitsa]; published on the 1848 Russian Hydro. Dept. Chart 1400, and the Aleut name, reported by Capt. Lutke (1836, p. 324), IRN, was "Satanna," meaning "des oiseaux."

Bird Cape: point of land, see Bird Point.

Bird Creek: stream, heads in SE end of Chugach Mts., flows SW $16 \mathrm{mi}$. to Turnagain Arm, 5.5 mi. NW of Sunrise, Chugach Mts. ; $60^{\circ} 58^{\prime} 25^{\prime \prime}$ $\mathrm{N}, 149^{\circ} 28^{\prime} 10^{\prime \prime} \mathrm{W}$; (map 63).

Name used by local miners; reported by Mendenhall (1900a, p. 320), USGS.

Bird Creek: stream, heads in Dutch Hills, flows SE $3.5 \mathrm{mi}$. to Peters Creek, $30 \mathrm{mi}$. NW of Talkeetna, Alaska Ra.; $62^{\circ} 34^{\prime} 25^{\prime \prime}$ N, $150^{\circ} 53^{\prime}$ $10^{\prime \prime} \mathrm{W}$; (map 81).

Prospectors' name published by Capps (1913, pl. 2), USGS.

Bird Creek: stream, flows SE $0.7 \mathrm{mi}$. to Little Derby Creek, on shore of Norton Sound, $6 \mathrm{mi}$. SE of Nome, Seward Penin. High.; 64' $28^{\prime} 12^{\prime \prime}$ $\mathrm{N}, 165^{\circ} 12^{\prime} 15^{\prime \prime} \mathrm{W}$; (map 94).

Prospectors' name reported in 1904 by T. G. Gerdine, USGS.

Bird Creek: stream, flows W $2 \mathrm{mi}$. to Niyiklik Creek, $\mathrm{N}$ of its junc. with Ogotoruk, $8.5 \mathrm{mi}$. $\mathrm{E}$ of Cape Thompson, Arctic Slope ; 68 $10^{\prime} 05^{\prime \prime}$ N, 165'39'35" W; BGN 1963; ( $\operatorname{map} 129$ ).

Named in 1962 by Project Chariot personnel.

Bird Creek Pass: pass, 2,100 ft., on a $\mathrm{N}$ tributary of Bird Creek, $5 \mathrm{mi}$. W of Moraine Pass and $20 \mathrm{mi}$. SE of Anchorage, Chugach Mts.; $61^{\circ}$ $05^{\prime} 40^{\prime \prime} \mathrm{N}, 149^{\circ} 20^{\prime} 30^{\prime \prime} \mathrm{W}$; BGN 1932 ; (map $69)$.

Local name reported in 1932 by USGS.

Bird Glacier: glacier, trends NW $0.7 \mathrm{mi}$., on N slope of Bird Peak, $24 \mathrm{mi}$. SE of Anchorage, Chugach Mts.; $61^{\circ} 00^{\prime} 45^{\prime \prime} \mathrm{N},{ }^{\prime} 149^{\circ} 17^{\prime} 30^{\prime \prime} \mathrm{W}$; (map 69).

Local name reported in 1960 by USGS.

Bird Island: island, $0.7 \mathrm{mi}$. long, on SE coast of Unimak I. S of Ikatan Penin., Aleutian Is. $54^{\circ} 40^{\prime} 00^{\prime \prime} \mathrm{N}, 163^{\circ} 17^{\prime} 20^{\prime \prime} \mathrm{W}$; (map 25). Var. Ptichie Island, Ostrov Ptichiy.

Translation of "O[strov] Ptichiy," reported by Capt. Tebenkov (1852, map 24), IRN.

Bird Island: island, $5 \mathrm{mi}$. long, in Shumagin Is., Aleutian Ra.; $54^{\circ} 49^{\prime} \mathrm{N}, 159^{\circ} 46^{\prime}{ }^{\circ} \mathrm{W}$; (map 26). Var. Petitski, Ptichnie, Ptichnoi, Ptitchny.

Translation of the Russian name $\mathrm{O}$ [strov] Ptichnoi. Published in 1872 by W. H. Dall, USC\&GS.

Bird Island: island, $250 \mathrm{ft}$., long, between Felice Strait and Revillagigedo Channel, $0.5 \mathrm{mi}$. E.

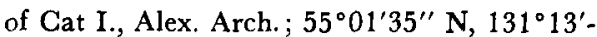
$30^{\prime \prime} \mathrm{W}$; (map 3 )
Local name published in the 1932 Coast Pilot (p. 95).

Bird Island: island, $0.1 \mathrm{mi}$. across, $1.2 \mathrm{mi}$. E. of Kodiak, on NE coast of Kodiak I.; $57^{\circ} 47^{\prime} 05^{\prime \prime}$ N, 152 22'05" W; (map 34). Var. Ostrov Ptichey, Ptichi Island.

Translation of the name "O[strov] Ptichey," published by Sarichev (1826, map 16), IRN.

Bird Island: island, $0.1 \mathrm{mi}$. across, in Favorite Channel, $2.4 \mathrm{mi}$. NW of Pearl Harbor and 20 mi. NW of Juneau, Coast Mts.; $58^{\circ} 29^{\prime} \mathrm{N}$, $134^{\circ} 51^{\prime} \mathrm{W}$; (map 11). Var. Bird Islet.

Named by Capt. L. A. Beardslee, USN, in 1880 and published in 1883 on USC\&GS Chart 728.

Bird Islet: island, see Bird Island.

Bird Lake: lake, $1.1 \mathrm{mi}$. long, on Kenai Penin., $4 \mathrm{mi}$. S of Point Possession and $43 \mathrm{mi} \mathrm{NE}$ of Kenai, Cook Inlet Low.; $60^{\circ} 48^{\prime} 40^{\prime \prime} \mathrm{N}, 150^{\circ}$ $24^{\prime} 30^{\prime \prime} \mathrm{W}$; (map 62).

Named about 1963 by officials of Kenai National Moose Range, for administrative purposes.

Bird Peak: mountain, 5,505 ft., $5 \mathrm{mi}$. NW of Girdwood and $25 \mathrm{mi}$. SE of Anchorage, Chugach Mts.; $61^{\circ} 00^{\prime} 15^{\prime \prime} \mathrm{N}, 149^{\circ} 17^{\prime} 00^{\prime \prime} \mathrm{W}$; BGN 1964; (map 69).

Named in 1963 by members of the Mountaineering Club of Alaska. Name "derived from Bird Creek which makes a half-circle around this mountain."

Bird Point: point of land, on $\mathrm{S}$ coast of Whale I., $\mathrm{N}$ of Kodiak I. ; $57^{\circ} 55^{\prime} 20^{\prime \prime} \mathrm{N}, 152^{\circ} 47^{\prime} 25^{\prime \prime} \mathrm{W}$; map 34). Var. Mys Ptichiy, Bird Cape.

Translation of the name "M[ys] Ptichiy," given in 1839 or 1840 by Sub-Lt. Mikhail Murashev, IRN, and published in 1849 on Russian Hydrog. Dept. Chart 1425.

Bird Point: point of land, on $\mathrm{N}$ side of Turnagain Arm, $0.5 \mathrm{mi}$. SW of Bird, $3 \mathrm{mi}$. NE of Sunrise, Chugach Mts.; $60^{\circ} 55^{\prime} 45^{\prime \prime} \mathrm{N}, 149^{\circ} 21^{\prime} 45^{\prime \prime} \mathrm{W}$; (map 63). Var. Hunters Point.

Local name reported in 1898 by Capt. Glenn (in Glenn and Abercrombie, 1899, map), USA

Bird Reef: reef, in $\mathrm{N}$ entrance to Port Graham, on SW coast of Kenai Penin., $8 \mathrm{mi}$. SW of Seldovia, Chugach Mts.; 59 23'15" N, $151^{\circ} 55^{\prime} 00^{\prime \prime} \mathrm{W}$; (map 50).

Named in 1910 by USC\&GS.

Bird Rock: island, $0.4 \mathrm{mi}$. across, $1 \mathrm{mi}$. W of Bird Cape, in Bering Sea, off NW Amchitka I., Rat Is., Aleutian Is.; $51^{\circ} 39^{\prime} 55^{\prime \prime} \mathrm{N}, 178^{\circ}$ $38^{\prime} 00^{\prime \prime}$ E.; BGN 1937; map 15). Var. Bird Rocks.

Name shown on recent maps and charts of Amchitka Island. The name "Bird Rocks" was reported by 1935 U.S. Navy Survey Expedition.

Bird Rock: island, $0.3 \mathrm{mi}$. across, $2.5 \mathrm{mi}$. NE of tip of Cape Newenham, in Kuskokwim Bay, 7 mi. W of Castle Rock, Kilbuck-Kuskokwim Mts.; $58^{\circ} 40^{\prime} \mathrm{N}, 162^{\circ} 08^{\prime} \mathrm{W}$; (map 39). Var. Seal Rock.

Local name reported in 1948 by USGS. The name "Seal Rock" was published by USC\&GS on Chart 9103 
Bird Rock: rock, in Bechevin Bay, at SW end of Alaska Penin., Aleutian Ra.; $54^{\circ} 52^{\prime} 30^{\prime \prime} \mathrm{N}$, $163^{\circ} 20^{\prime} 50^{\prime \prime} \mathrm{W}$; (map 29).

Name published in 1912 by USC\&GS.

Bird Rock: rock, at SW end of Storm Is., in Stephens Passage, $1.5 \mathrm{mi}$. NW of Cape Fanshaw and $68 \mathrm{mi}$. NE of Sitka, Coast Mts.; $57^{\circ} 12^{\prime} 30^{\prime \prime} \mathrm{N}, 133^{\circ} 35^{\prime} 30^{\prime \prime} \mathrm{W}$; (map 8).

Named by USC\&GS and published in the 1891 Coast Pilot (p. 146).

Bird Rock: rock, between Spiridon and Uyak Bays, $4 \mathrm{mi}$. NE of Harvester I., on NW coast on Kodiak I.; $57^{\circ} 41^{\prime} 40^{\prime \prime} \mathrm{N}, 153^{\circ} 54^{\prime} 30^{\prime \prime} \mathrm{W}$; (map 34).

Local name reported in 1954 by USGS

Bird Rocks: rocks, extend 1,000 ft. in Cordova Bay near entrance to Klakas Inlet, on SW coast of Prince of Wales I., Alex. Arch.; $54^{\circ} 53^{\prime} \mathrm{N}, 132^{\circ} 27^{\prime} \mathrm{W}$; (map 1 ).

Local name published in 1943 by USC\&GS.

Bird Rocks : rocks, see Porpoise Rocks.

Birdsnest Bay: bay, 0.2 mi. across, on $\mathrm{W}$ coast of Baranof I., between No Thorofare and Camp Coogan Bays, 4.5 mi. SE of Sitka, Alex. Arch.; $57^{\circ} 00^{\prime} 45^{\prime \prime} \mathrm{N}, 135^{\circ} 14^{\prime} 15^{\prime \prime} \mathrm{W}$; (map 9). Var. Kaditskaya Bay.

Local name reported in 1951 by USGS. It was called "Kaditskaya Bay" by Samuel Milletich in 1879; according to $R$. N. DeArmond this is "said to be a Russian family name."

Birnirk: locality, see Bernirk.

Birthday Creek: stream, on W coast of Alaska Penin., flows W $17 \mathrm{mi}$. to Port Heiden, Bristol Bay Low.; $56^{\circ} 52^{\prime} \mathrm{N}, 158^{\circ} 40^{\prime} \mathrm{W}$; (map 30 ). Local name reported in 1923 by USGS.

Birthday Creek: stream, heads near Birthday Pass, flows S $10 \mathrm{mi}$. to Awuna River, $130 \mathrm{mi}$. SE of Wainwright, Arctic Slope; $69^{\circ} 08^{\prime} \mathrm{N}$, $156^{\circ} 39^{\prime} \mathrm{W} ; B G N$ 1925; (map 143).

So named by members of the 1924 USGS Expedition, "because two men of our field party had birthdays on the day of our portage over pass at head."

Birthday Gulch: ravine, trends SE $0.8 \mathrm{mi}$. to St. Michaels Creek, $7 \mathrm{mi}$. NE of Nome, Seward Penin. High.; $64^{\circ} 31^{\prime} 20^{\prime \prime}$ N, $165^{\circ} 08^{\prime}$ $30^{\prime \prime} \mathrm{W}$; (map 94).

Prospectors' name reported in 1904 by T. G. Gerdine, USGS.

Birthday Pass: pass, 1,200 ft., on ridge between Awuna and Kigalik Rivers, $125 \mathrm{mi}$. SE of Wainwright, Arctic Slope; $69^{\circ} 15^{\prime} \mathrm{N}, 156^{\circ} 36^{\prime}$ W; BGN 1925; (map 143).

Named by members of the 1924 USGS Expedition; recorded on a 1924 fieldsheet by R. K, Lynt. See Birthday Creek.

Biscuit Knob: hill, $848 \mathrm{ft}$, near Biscuit Lagoon, on SW coast of Prince of Wales I., Alex Arch.; $54^{\circ} 53^{\prime} 45^{\prime \prime} \mathrm{N}, 132^{\circ} 19^{\prime} 45^{\prime \prime} \mathrm{W}$; BGN 1922; (map 1)

Recorded on a 1911 manuscript map by USFS; published in 1922 by USC\&GS.

Biscuit Lagoon: estuary, extends NE $2.5 \mathrm{mi}$. off Hunter Bay, on SW coast of Prince of Wales I., Alex. Arch.; 54 $53^{\prime} \mathrm{N}, 132^{\circ} 19^{\prime} \mathrm{W}$; (map 1).
Name derived from "Biscuit Knob"; published by USGS in 1948.

Bishop Creek: stream, on $S$ coast of Alaska Penin., flows SE $2 \mathrm{mi}$. to Albatross Anchorage in Balboa Bay, Aleutian Ra.; $55^{\circ} 36^{\prime} 00^{\prime \prime} \mathrm{N}$, $160^{\circ} 36^{\prime} 30^{\prime \prime} \mathrm{W}$; (map 28).

Named in 1914 by E. L. Jones, USBF.

Bishop Creek: stream, heads in lake, flows SW $3.2 \mathrm{mi}$. to Egegik Bay, $4.5 \mathrm{mi}$. NW of Egegik, on $\mathrm{N}$ coast of Alaska Penin., $38 \mathrm{mi}$. SW of Naknek, Bristol Bay Low.; 58 $14^{\prime} 30^{\prime \prime} \mathrm{N}, 157^{\circ}$ $29^{\prime} 40^{\prime \prime} \mathrm{W}$; (map 41).

Local name reported in 1952 by USGS.

Bishop Creek: stream, on Kenai Penin., flows NE $15 \mathrm{mi}$. to Number Three Bay, $17 \mathrm{mi}$. NNE of Kenai, Cook Inlet Low.; $60^{\circ} 47^{\prime} 10^{\prime \prime} \mathrm{N}$, $151^{\circ} 04^{\prime} 30^{\prime \prime} \mathrm{W}$; (map 62).

Local name reported in 1950 by USGS

Bishop Creek: stream, flows NE $18 \mathrm{mi}$. to Beluga River, $18 \mathrm{mi}$. NW of Tyonek, Cook Inlet Low.; $61^{\circ} 19^{\prime} \mathrm{N}, 151^{\circ} 19^{\prime} \mathrm{W}$; $B G N$ 1964; (map 70).

Named in 1962 by USGS; derived from nearby Bishop Lake.

Bishop Creek: stream, flows NW $35 \mathrm{mi}$. to Pilot Mtn. Slough, $24 \mathrm{mi}$. E of Nulato, Koyukuk Low; $64^{\circ} 45^{\prime} \mathrm{N}, 157^{\circ} 18^{\prime} \mathrm{W}$; (map 97).

Local name reported in 1948 by USGS; named after Bishop Rock.

Bishop Lake: lake, 2,800 ft. long, $\mathrm{S}$ of Bishop Creek, $19 \mathrm{mi}$. NW of Tyonek, Cook Inlet Low.; $61^{\circ} 18^{\prime} 50^{\prime \prime} \mathrm{N}, 151^{\circ} 25^{\prime} 15^{\prime \prime} \mathrm{W}$; (map 70).

Local name reported in 1954 by USGS.

Bishop Point: point of land, on NW coast of Unalaska I., $19 \mathrm{mi}$. NW of Unalaska, Aleutian Is. ; $53^{\circ} 58^{\prime} 25^{\prime \prime} \mathrm{N}, 166^{\circ} 57^{\prime} 00^{\prime \prime} \mathrm{W}$; $B G N 1938$; (map 23).

Named by USG\&GS in 1938 for Father Ioann Veniaminov who served as a priest on Unalaska Island and made weather observations there from 1825-34. He published a geography of the district in 1840 and was made Bishop of Russian America that same year.

Bishop Point: point of land, at $\mathrm{S}$ end of Taku Inlet, on Stephens Passage, $4.8 \mathrm{mi}$. SE of Dupont and $12 \mathrm{mi}$. SE of Juneau, Coast Mts.; $58^{\circ} 12^{\prime} 10^{\prime \prime} \mathrm{N}, 134^{\circ} 08^{\prime} 45^{\prime \prime} \mathrm{W}$; (map 11). Var. Point Salisbury.

This point of land was named "Point Salisbury" in 1794 by Capt. Vancouver (1798, v. 3, p. 278), RN, for the Bishop of Salisbury. W. H. Dall, changed the name to Bishop Point in 1883 because the name "Point Salisbury" was accidently transferred on Vancouver's chart to another point 3 miles to the west. Capt. Tebenkov (1852, map 8), IRN, located the point in the right place, but all other charts took the location from the Vancouver chart.

Bishop Rock: hill, $300 \mathrm{ft}$., on right bank of Yukon River, $23 \mathrm{mi}$. NE of Nulato, Koyukuk

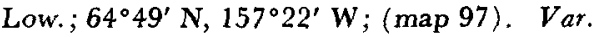
Bishops Mountain, Seagher Bluff.

Local name reported in 1902 by A. J. Collier, USGS. So called because Roman Gatholic Archbishop Seagher of Oregon was murdered near here in 1885 "by a half-breed attendant, when engaged upon a missionary prospecting journey in the winter. A memorial cross was erected by the Jesuit Fathers of Nulato * * *" on this hill (Stuck, 1917 p. 164).

Bishop Rock: rock, in Latouche Pass, off NE coast of Evans I., $14 \mathrm{mi}$. SE of Chenega Chugach Mts. ; $60^{\circ} 06^{\prime} 15^{\prime \prime} \mathrm{N}, 147^{\circ} 53^{\prime} 15^{\prime \prime} \mathrm{W}$; (map 63).

Local name reported in 1908 by U. S. Grant (in Brooks and others, 1909, pl. 4) USGS.

Bishop Rock Island: island, in Yukon River, 1.2 mi. SW of Bishop Rock, $21 \mathrm{mi}$. NE of Nulato, Koyukuk Low.; 64. $50^{\prime} \mathrm{N}, 157^{\circ} 27^{\prime} \mathrm{W}$; (map 97).

Riverboat pilots' name shown on a 1940 "Navigation Chart of the Tanana-Yukon Rivers" published by the U.S. Dept. of Interior.

Bishops Cap: promontory, NE entrance to Agamgik Bay off Beaver Inlet, Unalaska I., Aleutian Is.; $53^{\circ} 52^{\prime} \mathrm{N}, 166^{\circ} 20^{\prime} \mathrm{W}$; (map 23).

Name reported by John Henry Fox and published in 1791 by Alexander Dalrymple (Wagner, 1937, p. 356).

Bishops Mountain: hill, see Bishop Rock.

Bismarck Creek: stream, flows $S 6$ mi. to Willow Creek, $3.3 \mathrm{mi}$. E of its junc. with George River, $31 \mathrm{mi}$. SE of Flat, Kilbuck-Kuskokwim Mts. ; $62^{\circ} 20^{\prime} 45^{\prime \prime} \mathrm{N}, 157^{\circ} 03^{\prime} 30^{\prime \prime} \mathrm{W}$; (map 79). Prospectors' name obtained in 1952 by USGS topographers.

Bismark Creek: stream, flows NW $1.6 \mathrm{mi}$. to Star Creek which flows to South Fork Serpentine River, $5 \mathrm{mi}$. $\mathrm{N}$ of Kougarok Mtn. and $30 \mathrm{mi}$. SE of Ear Mtn. ; Seward Penin. High.; $65^{\circ} 45^{\prime}$ $\mathrm{N}, 165^{\circ} 16^{\prime} \mathrm{W}$; (map 111 )

Prospectors' name reported on the 1908 "Map of Seward Peninsula" by Arthur Gibson.

Bismark Mountain: mountain, 2,610 ft., $13 \mathrm{mi}$. N of Shungnak, Brooks Ra.; $67^{\circ} 04^{\prime}$ N., $157^{\circ}$ $16^{\prime} \mathrm{W}$; (map 126).

Prospectors' name reported in 1919 by USGS.

Bismut: locality, see Bimiut.

Bison Gulch: ravine, heads in Mount McKinley National Park, trends NE $1.5 \mathrm{mi}$. to Nenana River, $5.3 \mathrm{mi}$. NW of village of McKinley Park, Alaska Ra.; 63⒋ $8^{\prime} 28^{\prime \prime} \mathrm{N}, 148^{\circ} 56^{\prime} 30^{\prime \prime}$ W; BGN 1965; (map 87).

Named in 1965 by Alaska Dept. of Highways because "bison are being domesticated at nearby Lignite." See Iceworm Gulch.

Bison Hill: mountain, see Faint Mountain.

Bitchevinskoi : bay, see Bechevin Bay.

Bitsishtena: mountains, see Bitzshtini Mountains.

Bitter Creek: stream, heads on Sheep Mtn., flows NW $3 \mathrm{mi}$. to Caribou Creek, $53 \mathrm{mi}$. NE of Palmer, Talkeetna Mts.; 61 ${ }^{\circ} 51^{\prime} 55^{\prime \prime} \mathrm{N}, 147^{\circ}$. 35'45" W; BGN 1960; (map 69).

So named in 1956 by USGS because its waters are bitter from mineralization.

Bitters Creek: stream, flows NW and SW $6.2 \mathrm{mi}$. to Tanana River, $14 \mathrm{mi}$. NW of Northway Junction, Yukon-Tanana High.; 63 $09^{\prime} \mathrm{N}$, $142^{\circ} 06^{\prime} \mathrm{W}$; (map 85$)$.

Local name reported in 1958 by USGS. 
Bituk Creek: stream, see Baituk Creek.

Bitzla River: stream, flows SW $6.5 \mathrm{mi}$. to Koyukuk River, $35 \mathrm{mi}$. SW of Roundabout Mtn., Koyukuk Low.; $65^{\circ} 17^{\prime} \mathrm{N}, 157^{\circ} 35^{\prime} \mathrm{W}$; (map 108). Var. Bitzlatoilóeta, Bitzlatoilocta.

This is a shortened form of an Indian name published by Lt. Allen (1887, p. 106), USA, as "Bitzlatoilóeta" and "Bitzlatoilocta" (ibid., map)

Bitzlatoilocta: stream, see Bitzla River.

Bitzlatoilóeta: stream, see Bitzla River.

Bitz-ish-ti-nee: mountains, see Bitzshtini Mountains.

Bitzshtini Mountains: mountains, 3,186 ft., $9 \mathrm{mi}$. SE of Chitanatala Mts., and $33 \mathrm{mi}$. SW of Mooseheart Mtn., Kilbuck-Kuskokwim Mts.; $64^{\circ} 28^{\prime} \mathrm{N}, 151^{\circ} 58^{\prime} \mathrm{W}$; (map 99). Var. Bitsishtena, Bitz-ish-ti-nee.

Tanana Indian name reported in 1899 by Lt. J. S. Herron, USA, as "Bitz-ish-ti-nee" possibly referring to "caribou" in its meaning.

Biugam Island: island, see Bushy Island.

Black: locality, site of Eskimo village, on $\mathrm{S}$ bank of Black River, $1.5 \mathrm{mi}$. $\mathrm{S}$ of its mouth and 39 mi. SW of Kwiguk, Yukon-Kuskokwim Delta ; $62^{\circ} 20^{\prime} \mathrm{N}, 165^{\circ} 20^{\prime} \mathrm{W}$.; BGN 1906; (map 76). Var. Kipniak, Kipniuk.

Little is left of this village which was reported about 1896 by USC\&GS as "Kipniak." It is primarily used as a fishing camp by Eskimo living on the Black River.

Black, Mount: mountain, 4,900 ft., in Glacier Bay National Monument, $3 \mathrm{mi}$. NW of head of Muir Inlet and $41 \mathrm{mi}$. SW of Skagway, St. Elias Mts.; $59^{\circ} 06^{\prime} 30^{\prime \prime} \mathrm{N}, 136^{\circ} 15^{\prime} 30^{\prime \prime} \mathrm{W}$; (map 45).

Descriptive name given in 1882 by John Muir. The name was published by Reid (1892, map, p. 52), USGS.

Black, Point: point of land, $\mathrm{E}$ point of entrance to Chichagof Harbor, on NE coast of Attu I., Aleutian Ra.; $52^{\circ} 55^{\prime} 55^{\prime \prime} \mathrm{N}, 173^{\circ} 16^{\prime} 50^{\prime \prime} \mathrm{E}$; (map 13).

Descriptive name given by U.S. Army during World War II; published in 1948 by AMS.

Black and Tan Creek: stream, flows NW $7 \mathrm{mi}$. to Skwentna River, $7 \mathrm{mi}$. SE of Mount Estelle and $73 \mathrm{mi}$. NW of, Tyonek, Alaska Ra.; $61^{\circ} 49^{\prime} 35^{\prime \prime} \mathrm{N}, 152^{\circ} 43^{\prime} 30^{\prime \prime} \mathrm{W}$; (map 70).

Local name published in 1958 by USGS.

Black and Tan Glacier: glacier, in Tordrillo Mts., trends $\mathrm{N} 10 \mathrm{mi}$. to its terminus at Black and Tan Creek, $70 \mathrm{mi}$. NW of Tyonek, Alaska Ra.; $61^{\circ} 48^{\prime} 15^{\prime \prime} \mathrm{N}, 152^{\circ} 39^{\prime} 00^{\prime \prime} \mathrm{W}$; (map 70).

Local name published in 1958 by USGS.

Black Bay: $b a y, 1.5 \mathrm{mi}$. long, $3.5 \mathrm{mi}$. NNW of Chichagof, on W coast of Chichagof I., Alex. Arch.; $57^{\circ} 42^{\prime} 30^{\prime \prime} \mathrm{N}, 136^{\circ} 08^{\prime} 00^{\prime \prime} \mathrm{W}$; (map 9).

Local name reported in 1917 by USGS.

Black Bay: bay, extends N $3 \mathrm{mi}$., W of Black Mts., on SE coast of Kenai Penin., 46 mi. ESE of Homer, Chugach Mts.; $59^{\circ} 31^{\prime} \mathrm{N}, 150^{\circ} 13^{\prime}$ W; $(\operatorname{map} 50)$.

Local name published by USGS in 1951. Black Bay: bay, see Bluefox Bay.

Black Bear Creek: stream, probably near head of Gold Creek valley in vicinity of Icy Gulch,
$2.5 \mathrm{mi}$. E of Juneau, Coast Mts., $58^{\circ} 18^{\prime} \mathrm{N}$, $134^{\circ} 20^{\prime} \mathrm{W}$; (map 11).

Named after a claim for water from this stream filed in 1882 by Michael Powers. The stream has been subsequently destroyed by mining operation (DeArmond, 1957, p. 22).

Black Bear Creek: stream, heads in Bear Lake, flows NW 6 mi. to Union Bay, on SW coast of Gleveland Penin., Alex. Arch.; 55 $44^{\prime} 20^{\prime \prime} \mathrm{N}$, 132 11'45" W; BGN 1915; (map 4).

Descriptive name published in 1911 by USC\&GS and recorded in 1914 by E. L. Jones, USBF, who "observed here a heavy destruction of salmon by black bear."

Black Bear Creek: stream, flows WNW $7 \mathrm{mi}$, to Ricks Creek $1.2 \mathrm{mi}$. E of that stream's junc. with North Fork Salcha River and $51 \mathrm{mi}$. NNE of Big Delta, Yukon-Tanana High.; $64^{\circ} 49^{\prime} \mathrm{N}$, $145^{\circ} 10^{\prime} \mathrm{W}$; (map 101).

Local name reported in 1958 by USGS.

Black Bear Lake: lake, $1.4 \mathrm{mi}$. long, $8.5 \mathrm{mi}$. $\mathrm{E}$ of Klawock, on Prince of Wales I., Alex. Arch.; $55^{\circ} 33^{\prime} \mathrm{N}, 132^{\circ} 52^{\prime} \mathrm{W}$; (map 4).

Name derived from Black Bear Creek and given in 1935 by USGS.

Blackbird Island: island, $0.2 \mathrm{mi}$. across, in Necker Is., W of Baranof I., $15 \mathrm{mi}$. S of Sitka, Alex. Arch.; 56 $50^{\prime} 20^{\prime \prime} \mathrm{N}, 135^{\circ} 26^{\prime} 00^{\prime \prime} \mathrm{W}$; (map 5). Var. Drozdof Island, Ostrov Drozdov.

This is a translation by USC\&GS of the name given in 1809 by the navigator Ivan Vasiliev the first, IRN. Lt. Sarichev (1826, map 19), IRN, published it as "O[strov] Drozdov."

Blackbird Point: point of land, see Wolf Point.

Black Blufts: cliff, $40 \mathrm{ft}$. high, on $\mathrm{S}$ coast of Saint Paul I., in Pribilof Is. ; $57^{\circ} 07^{\prime} 20^{\prime \prime} \mathrm{N}, 170^{\circ} 16^{\prime}$ $00^{\prime \prime} \mathrm{W}$; (map 38).

Local descriptive name reported in 1875 by USC\&GS: "A symmetrical remnant of a cinder cone mostly dissected away by erosion or the waves."

Blackbrown Island: island, see Augustine Island.

Blackburn: locality, on W bank of Yukon River, W of Blackburn I. and $50 \mathrm{mi}$. SE of Unalakleet, Nulato Hills; $63^{\circ} 22^{\prime} 40^{\prime \prime} \mathrm{N}, 159^{\circ} 34^{\prime} 00^{\prime \prime}$ W; (map 91). Var. Blackburn Landing.

Steamboat landing and trading post reported in 1899 by Lt. Cantwell (1902, p. 277), USRCS

Blackburn, Mount: mountain, $16,390 \mathrm{ft}$, at head of Kennicott Glacier, $26 \mathrm{mi}$. NW of McCarthy, Wrangell Mts.; BGN $1913 ; 61^{\circ} 44^{\prime} \mathrm{N}$, $143^{\circ} 26^{\prime} \mathrm{W}$; (map 67). Var. Mount Blackburne.

Named in 1885 by Lt. Allen (1887, pl. 59), USA, for Joseph Clay Stiles Blackburn, 18381918, State and U.S. Congressman and U.S. Senator from Kentucky. Its first ascent was by Dora Keen and G. W. Handy on May 19, 1912 (Farquhar, 1959, p. 213).

Blackburn Creek: stream, flows $E 18 \mathrm{mi}$. to Yukon River, W of Blackburn I. and $50 \mathrm{mi}$. SE of Unalakleet, Nulato Hills; $63^{\circ} 22^{\prime} 30^{\prime \prime}$ N, 159 $34^{\circ} 00^{\prime \prime}$ W; (map 91).

Named after "Val" Blackburn, a trapper; reported about 1916 .
Blackburne, Mount: peak, see Blackburn, Mount Blackburn Island: island, $5.5 \mathrm{mi}$. long, in Yukon River, $50 \mathrm{mi}$. SE of Unalakleet, Innoko Low.; $63^{\circ} 23^{\prime} \mathrm{N}, 159^{\circ} 28^{\prime} \mathrm{W}$; (map 91). Var. Louise Island.

Named after nearby Blackburn; reported about 1916. The earlier name "Louise Island" was named after the steamboat Louise, built in Unalaska in 1898.

Blackburn Island: island, see Eagle Island.

Blackburn Landing: locality, see Blackburn.

Black Butte: mountain, 2,073 ft., $2 \mathrm{mi}$. NW of Asses Ears and $10 \mathrm{mi}$. $\mathrm{N}$ of Imuruk Lake, Seward Penin. High.; $65^{\circ} 45^{\prime} 45^{\prime \prime} \mathrm{N}, 163^{\circ}$ $14^{\prime} 30^{\prime \prime}$ W; BGN 1952; (map 110). Var. Asses Ears Mountain.

Reported in 1950 by D. M. Hopkins, USGS; so named because "The hill lies on the crest of a ridge underlain by marble; the hill itself, however consists of granite. A heavy cover of lichens gives the granite rubble a black color which contrasts sharply with the surrounding marble when seen from a distance."

Black Cap: peak, $9,800 \mathrm{ft}$., between Castner and Gerstle Glaciers, $29 \mathrm{mi}$. N of Paxson, Alaska Ra.; $63^{\circ} 27^{\prime} 15^{\prime \prime} \mathrm{N}, 145^{\circ} 25^{\prime} 20^{\prime \prime} \mathrm{W}$; (map 86).

Name published on relatively recent maps.

Black Cap Mountain: mountain, 3,321 ft., in Glacier Bay National Monument, on $\mathbf{N}$ shore of Glacier Bay N of Tidal Inlet, $62 \mathrm{mi}$. NW of Hoonah, St. Elias Mts.; $58^{\circ} 51^{\prime} 05^{\prime \prime} \mathrm{N}, 136^{\circ}$. $24^{\prime} 40^{\prime \prime}$ W; BGN 1960; (map 10).

Descriptive name given by USGS in 1956 "because the peak is composed of black limestone and the contrast with the color of the flanks of the mountain makes it visible for many miles."

Black Cape: point of land, on E shore of Traders Cove, $S$ coast of Umnak I., Aleutian Is.; $52^{\circ} 57^{\prime} 15^{\prime \prime} \mathrm{N}, 168^{\circ} 41^{\prime} 00^{\prime \prime} \mathrm{W}$; (map 21). Var. Chornoi, Mys Chornoy.

Translation of the name "M[ys] Chornoy"; published by Capt. Tebenkov (1852, map 25), IRN.

Black Cape: point of land, on NW coast of Afognak I., $28 \mathrm{mi}$. NW of Afognak, Kodiak I.; $58^{\circ} 24^{\prime} 30^{\prime \prime}$ N, $152^{\circ} 53^{\prime} 00^{\prime \prime}$ W; (map 43). Var. Cape Chernoi, Cape Chornoi, Cape Torno, Mys Chernoy.

Translation by USC\&GS in 1868 of the name of "M[ys] Chernoy" published in 1849 by the Russian American Company.

Black Channel: water passage, see Blake Channel.

Black Chief Gulch: ravine, trends W $0.7 \mathrm{mi}$. to Daniels Creek, $0.5 \mathrm{mi}$. NE of village of Bluff on Norton Sound and $21 \mathrm{mi}$. E of Solomon, Seward Penin. High; $64^{\circ} 34^{\prime} \mathrm{N}, 163^{\circ} 45^{\prime} \mathrm{W}$; (map 95).

Prospectors' name shown on Arthur Gibson's "Map of Cape Nome Precinct" dated 1904.

Blackcliff Mountain: mountain, 10,270 ft., near head of Columbia Glacier, $32 \mathrm{mi}$. NW of Valdez, Chugach Mts. ; 61 ${ }^{\circ} 23^{\prime} 15^{\prime \prime} \mathrm{N}, 147^{\circ} 03^{\prime}$ $40^{\prime \prime}$ W; BGN 1695; (map 69). Var. Black Cliff Mountain. 
Named about 1957 by members of the Chugach Mountains Expedition, sponsored by the Arctic Institute of North America, "for the prominent blackish cliff on its east face" (Nielsen, 1963, p. 135).

Black Cove: $b a y, 1.6 \mathrm{mi}$. across, off Norton Sound, $6 \mathrm{mi}$. SW of Tolstoi Point and $25 \mathrm{mi}$. SW of Unalakleet, Nulato Hills; $63^{\circ} 32^{\prime} \mathrm{N}$, $161^{\circ} 07^{\prime} \mathrm{W}$.

So named "because of its nearness to Black Point." Reported in 1952 by USC\&GS.

Black Crag: mountain, 5,880 ft., $4 \mathrm{mi}$. S of Alaska-Canada boundary, $27 \mathrm{mi}$. NE of Wrangell, Coast Mts. ; $56^{\circ} 32^{\prime} 50^{\prime \prime} \mathrm{N}, 131^{\circ} 42^{\prime}$ 45" W; (map 7).

Descriptive name published in 1895 by USC\&GS.

Black Creek: stream, flows $7.5 \mathrm{mi}$. SW to Bering Sea, on SW coast of Umnak I., Aleutian Is.; $53^{\circ} 03^{\prime} 55^{\prime \prime} \mathrm{N}, 168^{\circ} 46^{\prime} 00^{\prime \prime} \mathrm{W}$; (map 22).

Name published in 1951 on a USGS map.

Black Creek: stream, flows W $4 \mathrm{mi}$. to Blue Violet Creek, $24 \mathrm{mi}$. NE of Chignik, Aleutian Ra.; $56^{\circ} 37^{\prime} \mathrm{N}, 158^{\circ} 17^{\prime} \mathrm{W}$; (map 30).

Local descriptive name recorded on a 1923 fieldsheet by R. H. Sargent, USGS.

Black Creek: stream, on Alaska Penin., flows E $6 \mathrm{mi}$. to a lagoon at head of Aniakchak Bay, $16 \mathrm{mi}$. WSW of Cape Kunmik, Aleutian Ra.; $56^{\circ} 43^{\prime} \mathrm{N}, 157^{\circ} 36^{\prime} \mathrm{W}$; (map 31 ).

Local name reported in 1951 by USGS.

Black Creek: stream, heads near Sids Pass, flows NW $18 \mathrm{mi}$. to Lower Ugashik Lake, $25 \mathrm{mi}$. SE of Ugashik, Aleutian Ra.; $57^{\circ} 29^{\prime} \mathrm{N}, 156^{\circ}$ 45' $\mathrm{W}$; (map 36).

Descriptive name given in 1922 by $R . H$. Sargent, USGS, because of "the black walls of the canyon at its head."

Black Creek: stream, flows SE $15 \mathrm{mi}$. to Koksetna River $32 \mathrm{mi}$. NW of Nondalton, Alaska Ra.; $60^{\circ} 16^{\prime} 30^{\prime \prime} \mathrm{N}, 155^{\circ} 07^{\prime} 00^{\prime \prime} \dot{\mathrm{W}}$; (map 61). Var. Black River.

Local descriptive name reported on a 1912 blueprint of the Alaska Short Line Railway.

Black Creek: stream, on Kenai Penin., flows W $1.5 \mathrm{mi}$. to Sixmile Creek, $4.5 \mathrm{mi}$. S of Sunrise and $10 \mathrm{mi}$. SE of Hope, Chugach Mts.; $60^{\circ}$. $49^{\prime} 15^{\prime \prime} \mathrm{N}, 149^{\circ} 25^{\prime} 30^{\prime \prime} \mathrm{W}$; (map 63).

Local name reported in 1914 by USGS.

Black Creek: stream, flows W $1.5 \mathrm{mi}$. to Valdez Arm, Prince William Sound, $42 \mathrm{mi}$. NW of Cordova, Chugach Mts. ; $60^{\circ} 54^{\prime} 45^{\prime \prime} \mathrm{N}, 146^{\circ}$. $43^{\prime} 30^{\prime \prime}$ W; (map 64).

Local name reported by USGS (in Brooks and others, 1913, pl. 4). Name probably derived from nearby Black Point.

Black Creek: stream, heads in lake, flows NE 6 mi. to Stony River $5 \mathrm{mi}$. NW of its junc. with Stink River, $33 \mathrm{mi}$. SE of Sleetmute, Stony River Low.; $61^{\circ} 33^{\prime} 50^{\prime \prime} \mathrm{N}, 156^{\circ} 13^{\prime} 00^{\prime \prime} \mathrm{W}$; (map 72).

Local descriptive name reported in 1952 by USGS.

Black Creek: stream, flows E $7 \mathrm{mi}$. to Martin Creek, 21 mi. W of Talkeetna, Alaska Ra.; $62^{\circ} 22^{\prime} 50^{\prime \prime} \mathrm{N}, 150^{\circ} 46^{\prime} 00^{\prime \prime} \mathrm{W}$; (map 81).

Prospectors' name published by Capps (1913, fig, 5), USGS.
Black Creek: stream, flows NE $2.4 \mathrm{mi}$. to Otter Creek $9.5 \mathrm{mi}$. E of its junc. with Iditarod River, $2 \mathrm{mi}$. E of Flat and $58 \mathrm{mi}$. NW of Sleetmute, Kilbuck-Kuskokwim Mts.; $62^{\circ} 27^{\prime} \mathrm{N}$, $157^{\circ} 56^{\prime} \mathrm{W}$; (map 79).

Name shown on a 1910 manuscript map of "Iditarod Placer Fields."

Black Creek: stream, flows SE $15 \mathrm{mi}$. to North Fork Kuskokwim River, 49 mi. NE of Medfra, Kilbuck-Kuskokwim Mts.; $63^{\circ} 33^{\prime} \mathrm{N}, 153^{\circ} 32^{\prime}$ W; (map 89).

Local name reported in 1958 by USGS.

Black Creek: stream, flows SE $1 \mathrm{mi}$, to Anikovik River, $14 \mathrm{mi}$. SE of Cape Prince of Wales and $41 \mathrm{mi}$. NW of Teller, Seward Penin. High.; $65^{\circ} 30^{\prime} \mathrm{N}, 167^{\circ} 40^{\prime} \mathrm{W}$; (map 111).

Prospectors' name shown on the 1900 "Map of Nome Peninsula" by J. M. Davidson and B. D. Blakeslee.

Black Creek: stream, flows S $0.5 \mathrm{mi}$., to Noxapaga River, $0.5 \mathrm{mi}$. W of Buzzard Creek and $28 \mathrm{mi}$. SW of Imuruk Lake, Seward Penin. High. $65^{\circ} 31^{\prime} \mathrm{N}, 164^{\circ} 12^{\prime} \mathrm{W}$; (map 110). Var. Black Gulch.

Prospectors' name reported as "Black Gulch" in 1901 by T. G. Gerdine (in Collier, 1902, pl. 12), USGS.

Black Creek: stream, in Indian Mts., flows NE $1.7 \mathrm{mi}$. to Indian River, $12 \mathrm{mi}$. ENE of Hughes, Kokrines-Hodzana High.; $66^{\circ} 05^{\prime} \mathrm{N}$, $153^{\circ} 50^{\prime} \mathrm{W}$; (map 116).

Local name obtained in 1915 by Eakin (1916, pl. 1), USGS.

Black Creek : stream, see Highpower Creek.

Black Crook Creek: stream, flows SW $4.5 \mathrm{mi}$. to Igloo Creek which flows to American River, 27 mi. NE of Teller, Seward Penin. High.; $65^{\circ} 26^{\prime} \mathrm{N}, 165^{\circ} 32^{\prime} \mathrm{W}$; (map 111). Var. Blackcrook Creek.

Prospectors' name reported in 1900 by Messrs. Kemp and David Fox (in Brooks, 1901, pl. 11).

Black Currant Lake: lake, $4.1 \mathrm{mi}$. long, $2 \mathrm{mi}$. S of Natrahazuivun Lake and $22 \mathrm{mi}$. NE of Fort Yukon, Yukon Flats; $66^{\circ} 36^{\prime}$ N., $144^{\circ} 28^{\prime}$ $\mathrm{W}$; (map 119).

Local name obtained in 1956 by USGS.

Black Diamond Creek: stream, flows NE $4 \mathrm{mi}$. to Mission Creek, $11 \mathrm{mi}$. SW of Eagle, YukonTanana High.; 64 $44^{\circ} \mathrm{N}, 141^{\circ} 33^{\prime} \mathrm{W}$; (map 102).

Prospectors' name obtained in 1898 by $\mathrm{E}$. C. Barnard, USGS.

Black Dog Creek: stream, heads in Sadlerochit Mts., $6 \mathrm{mi}$. SW of Mount Weller, flows S $4 \mathrm{mi}$, to Fire Creek $2.4 \mathrm{mi}$. W of its junc. with Sadlerochit River, $25 \mathrm{mi}$. NW of Mount Michelson, Brooks Ra.; $69^{\circ} 32^{\prime} \mathrm{N}, 145^{\circ} 03^{\prime} \mathrm{W}$ (map 139).

So named by USGS geologists in 1948 , "because a black wolf came so close to a working geologist, he thought it was going to attack." Since "wolf" is a common name in Alaska, "dog" was used instead.

Black Duck Bay: bay, $1 \mathrm{mi}$. across, W of Dolgoi I., $4 \mathrm{mi}$. $\mathrm{N}$ of Yakutat, Malaspina Coastal Plain; $59^{\circ} 36^{\prime} 00^{\prime \prime} \mathrm{N}, 139^{\circ} 41^{\prime} 00^{\prime \prime} \mathrm{W}$; (map 46).
Local name published in 1964 (de Laguna and others, map 4 ).

Blackerby Ridge: ridge, extends $3 \mathrm{mi}$. E-W, 3.6 mi. N. of Juneau, Coast Mts.; $58^{\circ} 21^{\prime} 30^{\prime \prime} \mathrm{N}$, $134^{\circ} 24^{\prime} 30^{\prime \prime} \mathrm{W}$; BGN 1961; (map 11).

Named by USFS in 1960 for Alva W. Blackerby, who served 16 years with USFS in the Juneau area. He was killed in an airplane accident in Idaho in 1960 while fighting a forest fire.

Blackface Mountain: mountain, 5,000 ft., SSW of junc. of Kenunga and Ernie Creeks, $23 \mathrm{mi}$. $\mathrm{E}$ of Anaktuvuk Pass, Brooks Ra.; 68 $02^{\prime} 30^{\prime \prime}$ N, $150^{\circ} 52^{\prime} 00^{\prime \prime} \mathrm{W}$; BGN 1932; (map 134).

"So named by local trappers because of 3,000 feet sheer blackface of conglomerate rock." Reported by Robert Marshall in 1932.

Blackface Point: point of land, on $\mathrm{W}$ coast of Tanaga I., Aleutian Is.; $51^{\circ} 48^{\prime} 10^{\prime \prime} \mathrm{N}, 178^{\circ}$ 05'00" W; (map 16).

Descriptive name reported as a "prominent headland with black rock cliffs" in the 1954 Coast Pilot (p. 454) and published the same year on a USGS map.

Blackfish Lake: lake, $1.3 \mathrm{mi}$. long, $2 \mathrm{mi}$. NE of Sprucefish Lake, $21 \mathrm{mi}$. SSW of village of Lake Minchumina, Tanana Low.; 63 $36^{\prime} 30^{\prime \prime}$ N, $152^{\circ} 39^{\prime} 45^{\prime \prime}$ W ; (map 88). Var. Khozreghimená.

This may be a translation of the Tanana Indian name reported in 1954 as "Khozreghimená" by USGS.

Blackfish Lake: lake, $1.7 \mathrm{mi}$. long, W of Swan Mtn. and $7.5 \mathrm{mi}$. NE of Arctic Village, Brooks Ra.; $68^{\circ} 11^{\prime} \mathrm{N}, 145^{\circ} 18^{\prime} \mathrm{W}$; (map 136).

Translation of a Kutchin Indian name reported in 1956 by T. E. Taylor, USGS.

Black Flats Creek: stream, flows W to Sunday Creek which flows to Anikovik River, about 16 mi. SE of Cape Prince of Wales, Seward Penin. High.; (map 111).

Prospectors' name shown on the 1900 "Map of Nome Peninsula" by J. M. Davidson and B. D. Blakeslee. This feature cannot be precisely identified on current maps.

Black Glacier: glacier, heads $3 \mathrm{mi}$. NW of Bancas Point, trends S $2.2 \mathrm{mi}$. to its 1961 terminus, 1 mi. NE of terminus of Galiano Glacier and $28 \mathrm{mi}$. N of Yakutat, St. Elias Mts. ; $59^{\circ} 56^{\prime} 45^{\prime \prime}$ N, $139^{\circ} 40^{\prime} 15^{\prime \prime} \mathrm{W}$; (map 46).

Descriptive name given by Russell (1891, p. $101)$ because of its dark appearance, a result of the earth and stone almost completely covering it.

Black Gulch: stream, see Black Creek.

Black Head: point of land, $\mathrm{N}$ point of entrance to Kurgorak Bay, $37 \mathrm{mi}$. SE of Barrow, Arctic Plain; $71^{\circ} 04^{\prime} \mathrm{N}, 155^{\circ} 16^{\prime} \mathrm{W}$; (map 153). Var. Black Rock Point.

Originally named "Black Rock Point" on Thomas Simpson's map. On August 2, 1837 he wrote, "an angular mass of dark-colored granite lay off the point * * *." "Black Head" was published on Capt. F. W. Beechey's "Point Rodney to Point Barrow" chart, dated 1826-54.

Black Hill: hill, 5,160 ft., in Nutzotin Mts. E of Flat Creek Flats, 17 mi. NW of Rock Lake, 
Alaska Ra.; $61^{\circ} 59^{\prime} 00^{\prime \prime} \mathrm{N}, 1^{\circ} 31^{\circ} 37^{\prime} 30^{\prime \prime} \mathrm{W}$; (map 67).

Local descriptive name; reported in 1959 by USGS.

Black Hill: mountain, 1,480 ft., on $\mathrm{W}$ part of Unimak I., Aleutian Is.; $54^{\circ} 45^{\prime} 50^{\prime \prime} \mathrm{N}$, 164'32'35" W; BGN .1942; (map 24).

So named by USC\&GS in 1939 , "** * because it usually appears quite dark in color when viewed off shore."

Black Hill: hills, see Black Hills.

Black Hills: hills, $1,000 \mathrm{ft}$, , on $\mathrm{N}$ coast of Alaska Penin., $44 \mathrm{mi}$. NE of village of Cold Bay, Bristol Bay Low.; $55^{\circ} 41^{\prime} \mathrm{N}, 162^{\circ} 05^{\prime} \mathrm{W}$; (map 29). Var. Black Hill.

Local descriptive name published in 1943 by USGS.

Black Hills: mountain range, elev. $3,000 \mathrm{ft}$, northern range of Nutzatin Mts., extends SE $23 \mathrm{mi}$. from confluence of Cheslina and Nabesna Rivers, $12 \mathrm{mi}$. S of Northway, Alaska Ra.; $62^{\circ} 40^{\prime} \mathrm{N}, 141^{\circ} 45^{\prime} \mathrm{W}$; (map 84 ).

Local name reported in 1954 by USGS.

Black Island: island, $0.1 \mathrm{mi}$. long, in Bay of Islands $\mathrm{N}$ of Ringgold I., on W coast of Adak I., Aleutian Is.; $51^{\circ} 48^{\prime} 30^{\prime \prime} \mathrm{N}, 176^{\circ} 48^{\prime} 54^{\prime \prime}$ W; (map 17).

Descriptive name published in 1960 by USC\&GS on Chart 9120.

Black Island: island, $700 \mathrm{ft}$. long, near E shore of Revillagigedo Channel, $3.5 \mathrm{mi}$. N of Boca de Quadra, Coast Mts.; $55^{\circ} 08^{\prime} \mathrm{N}, 131^{\circ} 05^{\prime}$ W; (map 3). Var. Black Islet.

Named "Black Islet" in 1883 by Lt. Comdr. H. E. Nichols, USN.

Black Island: island, $3 \mathrm{mi}$. long, in Behm Canal, NW of Hassler I., off NW end of Revillagigedo I., Alex. Arch.; 55 $54^{\prime} \mathrm{N}, 131^{\circ} 40^{\prime} \mathrm{W}$; (map 3).

Named in 1891 by USC\&GS.

Black Island: island, $0.1 \mathrm{mi}$. across, $6 \mathrm{mi}$. SW of Chichagof, on W coast of Chichagof I., Alex. Arch.; $57^{\circ} 36^{\prime} 05^{\prime \prime} \mathrm{N}, 136^{\circ} 13^{\prime} 10^{\prime \prime} \mathrm{W}$; (map 9).

Descriptive name given in 1897 by Lt. Comdr. E. K. Moore, USN.

Black Island: island, $0.2 \mathrm{mi}$. long, in Canning River, $4.7 \mathrm{mi}$. W of Mount Copleston and $47 \mathrm{mi}$. S of Flaxman I., Arctic Slope ; $69^{\circ} 31^{\prime}$ $10^{\prime \prime} \mathrm{N}, 146^{\circ} 17^{\prime} 20^{\prime \prime} \mathrm{W}$; (map 139).

Leffingwell did not list this as a geographic name but wrote $(1919$, p. 119), "A small outcrop of black shale was observed *** at a small island called Black Island, in Canning River, opposite Mount Copleston."

Black Islet: island, see Black Island.

Black Lake: lake, $1 \mathrm{mi}$. long, $6.5 \mathrm{mi}$. E of Klawock, on Prince of Wales I., Alex. Arch.; $55^{\circ} 34^{\prime} 45^{\prime \prime} \mathrm{N}, 132^{\circ} 55^{\prime} 00^{\prime \prime} \mathrm{W}$; (map 4).

Local name recorded in 1949 by USGS.

Black Lake: lake, $6.5 \mathrm{mi}$. long, at head of Chignik River, $23 \mathrm{mi}$. NE of Mount Veniaminof, Bristol Bay Low.; $56^{\circ} 25^{\prime} \mathrm{N}, 158^{\circ} 57^{\prime} \mathrm{W}$; (map 30). Var. Upper Chiknik Lake, Upper Lake.

Named by Ivan Petroff in the 1880 Census. In 1923 this lake was locally called "Upper
Lake" or "Upper Chignik Lake," according to R. H. Sargent, USGS.

Black Lake: lake, $0.6 \mathrm{mi}$. across, on Chichagof I., $1 \mathrm{mi}$. $\mathrm{N}$ of Freeburn Mtn., $2 \mathrm{mi}$. $\mathrm{N}$ of Chichagof, Alex. Arch.; 57 $41^{\prime} 30^{\prime \prime} \mathrm{N}, 136^{\circ}$ 01'00' W; BGN 1935; (map 9).

Local name reported in 1935 by USFS.

Black Lake: lake, 1,700 ft. long, in Matanuska Valley, $7.5 \mathrm{mi}$. SW of Palmer, Cook Inlet Low.; $61^{\circ} 34^{\prime} 20^{\prime \prime} \mathrm{N}, 149^{\circ} 20^{\prime} 15^{\prime \prime} \mathrm{W}$; (map 69).

Local descriptive name reported in 1950 by USGS.

Black Lake: lake, $0.9 \mathrm{mi}$. long, in course of Black River, $40 \mathrm{mi}$. NW of Tahneta Pass and $80 \mathrm{mi}$. W of Gulkana, Talkeetna Mts.; $62^{\circ}$ $24^{\prime} 15^{\prime \prime}$ N, $147^{\circ} 53^{\prime} 10^{\prime \prime} \mathrm{W}$; (map 82).

Local name reported in 1931 by USGS.

Black Lake: lake, $2.5 \mathrm{mi}$. long, NW of Lake George, $35 \mathrm{mi}$. SE of Delta Junction, Tanana, Low.; 63⒋ $48^{\prime} 35^{\prime \prime} \mathrm{N}, 1^{\circ} 44^{\circ} 41^{\prime} 00^{\prime \prime} \mathrm{W}$; (map 86).

Name published on relatively recent maps.

Black Lake: lake, $4.5 \mathrm{mi}$. NE of Coffee Can Lake and $17 \mathrm{mi}$. SW of Roundabout Mtn., Koyukuk Low.; $65^{\circ} 19^{\prime} \mathrm{N}, 156^{\circ} 43^{\prime} \mathrm{W}$; (map 108).

Local name obtained at Huslia in 1954 or 1955 by USGS.

Black Lake: lake, $0.3 \mathrm{mi}$. across, $0.4 \mathrm{mi}$. NE of Fox Lake and $18 \mathrm{mi}$. W of Beaver, Yukon Flats; $66^{\circ} 19^{\prime} 40^{\prime \prime} \mathrm{N}, 148^{\circ} 03^{\prime} 00^{\prime \prime} \mathrm{W}$; (map 118)

Probably named by William Yanert who showed it on a 1916 manuscript map of the Yukon Flats (Stuck, 1917, map facing p. 122).

Black Mountain: mountain, $1,630 \mathrm{ft}$., on eastcentral Attu I. N of Henderson Ridge, Aleutian Is.; 52 $52^{\prime} 53^{\prime \prime} \mathrm{N}, 173^{\circ} 07^{\prime} 30^{\prime \prime} \mathrm{E}$; (map 13).

Descriptive name given by U.S. Army during World War II; published in 1948 by AMS.

Black Mountain: mountain, 2,058 ft., on $\mathrm{S}$ coast of Revillagigedo I., between Carroll Inlet and Thorne Arm, Alex. Arch.; 55 $16^{\circ} 50^{\prime \prime} \mathrm{N}$, $131^{\circ} 23^{\prime} 55^{\prime \prime} \mathrm{W}$; (map 3). Var. Black Mountains.

Descriptive name given in 1883 by Lt. Comdr. H. E. Nichols, USN.

Black Mountain: mountain, 2,028 ft., on SE coast of Kenai Penin., at $S$ entrance to Thunder Bay, $48 \mathrm{mi}$. ESE of Homer, Chugach Mts.; $59^{\circ} 32^{\prime} \mathrm{N}, 150^{\circ} 12^{\prime} \mathrm{W}$; (map 50).

Descriptive name given by U. S. Grant (in Martin and others, 1915, pl. 2), USGS.

Black Mountain: mountain, 2,213 ft., in Kenai Mts., $3 \mathrm{mi}$. NE of Mount Adair, $19 \mathrm{mi}$. $\mathrm{N}$ of Seward, Chugach Mts.; $60^{\circ} 23^{\prime} 15^{\prime \prime} \mathrm{N}$, $149^{\circ} 24^{\prime} 10^{\prime \prime} \mathrm{W}$; (map 63).

Local name reported in 1951 by USGS.

Black Mountain: mountain, 5,600 ft., $3.4 \mathrm{mi}$. NE of Camp Mtn., and $26 \mathrm{mi}$. NE of Valdez, Chugach Mts.; $61^{\circ} 28^{\prime} \mathrm{N}, 145^{\circ} 56^{\prime} \mathrm{W}$; (map 68).

Descriptive name given in 1898 by Capt. W. R. Abercrombie, USA.
Black Mountain: mountain, 5,080 ft., $50 \mathrm{mi}$. ENE of Big Delta, Yukon-Tanana High.; $64^{\circ} 20^{\prime} \mathrm{N}, 144^{\circ} 12^{\prime} \mathrm{W}$; (map 101).

Local name reported in 1958 by USGS.

Black Mountain: mountain, $1,850 \mathrm{ft} ., 19 \mathrm{mi}$. NW of 'Teller, Seward Penin. High.; 65 $60^{\circ} \mathrm{N}$, $166^{\circ} 40^{\prime} \mathrm{W}$; (map 111).

Local name reported in 1918 by Steidtmann and Cathcart (1922, pl. 12), USGS.

Black Mountain: mountain, $3,700 \mathrm{ft}$., $10 \mathrm{mi}$. SE of Table Mtn., Brooks Ra.; 68 $14^{\prime}$ N, $143^{\circ} 24^{\prime}$ W; (map 137).

Local descriptive name reported by J. B. Mertie, Jr., USGS, in 1926.

Black Mountain: mountain, 4,915 ft., in De Long Mts., $29 \mathrm{mi}$. NE of Misheguk Mtn., Brooks Ra.; $68^{\circ} 33^{\prime} 45^{\prime \prime} \mathrm{N}, 160^{\circ} 19^{\prime} 00^{\prime \prime} \mathrm{W}$; BGN 1966; (map 131).

So named in 1965 by the B. P. Exploration Co., because of "the very dark appearance of the mountain."

Black Mountain: ridge, 1,710 ft., in Kuskokwim Mts., extends NE-SW $5 \mathrm{mi}$. at head of Black River, $40 \mathrm{mi}$. SW of McGrath, Kilbuck-Kuskokwim Mts.; $62^{\circ} 30^{\prime} \mathrm{N}, 156^{\circ} 24^{\prime} \mathrm{W}$; (map 79).

Local descriptive name published in 1956 by USGS.

Black Mountains: mountains, $1,820 \mathrm{ft}$., extend NW 10 mi. from Kuskokwim River to head of Nunsatuk River, $32 \mathrm{mi}$. NE of Sleetmute and $54 \mathrm{mi}$. SE of Flat, Kilbuck-Kuskokwim Mts.; $62^{\circ} 03^{\prime} \mathrm{N}, 156^{\circ} 26^{\prime} \mathrm{W}$; (map 79).

Local name published in 1954 by USGS.

Black Mountains: mountain, see Black Mountain.

Black Pass: pass, 1,600 ft., in Kuskokwim Mts., $2 \mathrm{mi}$. W of Camelback Mtn. and $20 \mathrm{mi}$. NE of Flat, Kilbuck-Kuskokwim Mts.; 62 $33^{\prime} 15^{\prime \prime} \mathrm{N}$, 157 24: $30^{\prime \prime} \mathrm{W}$; (map 79).

Prospectors' name reported in 1923 by J. B. Mertie, Jr., and G. L. Harrington, USGS.

Black Peak: mountain, $1,525 \mathrm{ft}$., on SE coast of Chuginadak I., Aleutian Is.; $52^{\circ} 48^{\prime} 30^{\prime \prime} \cdot \mathrm{N}$, $169^{\circ} 45^{\prime} 30^{\prime \prime} \mathrm{W}$; (map 21).

Descriptive name published by USC\&GS in 1944 Aleutian Coast Pilot (p. 75); the mountain is described as "the remnant of a large crater, the west rim of which is a distinctive black crag ***."

Black Peak: mountain, 3,200 ft., on Aleutian Penin., $24 \mathrm{mi}$. NW of Chignik, Aleutian Ra.; $56^{\circ} 34^{\prime} \mathrm{N}, 158^{\circ} 47^{\prime} \mathrm{W}$; (map 30). Var. Black Volcano, Sopka Chornaia.

Translation of the Russian name "So[pka] Chornaia" published by Capt. Tebenkov (1852, map 24), IRN.

Black Peak: mountain, 6,385 ft., $6 \mathrm{mi}$. NW of Big River Lakes and $45 \mathrm{mi}$. NW of Kenai, Aleutian Ra.; $60^{\circ} 51^{\prime} 15^{\prime \prime} \mathrm{N}, 152^{\circ} 25^{\prime} 15^{\prime \prime} \mathrm{W}$; (map 62).

Local descriptive name published in 1912 by USC:\&S.

Black Peak: peak, 2,700 ft., a spur of Zane Hills, $49 \mathrm{mi}$. WNW of Hughes, Hogatza High.; $66^{\circ} 16^{\prime} \mathrm{N}, 155^{\circ} 51^{\prime} \mathrm{W}$; (map 116).

Named about 1940 by mining engineers. 
Black Point: point of land, on NW coast of Kagalaska I., Aleutian Is.; $51^{\circ} 51^{\prime} 45^{\prime \prime} \mathrm{N}$, $176^{\circ} 24^{\prime} 40^{\prime \prime}$ W; BGN 1936; (map 17).

Descriptive name given in 1934 by members of the U.S. Navy Aleutian Island Survey Expedition.

Black Point: point of land, on SE coast of Prince of Wales I., between Moira Sound and Niblack Anchorage, Alex. Arch.; 55 $02^{\prime} 15^{\prime \prime} \mathrm{N}$, $132^{\circ} 05^{\prime} 00^{\prime \prime} \mathrm{W}$; (map 4).

Named by local fishermen and reported in 1904 by H. C. Fassett, USBF.

Black Point: point of land, W. point of entrance to Pavlof Bay, on SW coast of Alaska Penin., Aleutian Ra.; $55^{\circ} 24^{\prime} 40^{\prime \prime} \mathrm{N}, 161^{\circ} 41^{\prime} 30^{\prime \prime} \mathrm{W}$; (map 28).

So named in 1925 by USC\&GS, "because it is composed of black cinders and ashes."

Black Point: point of land, on Alaska Penin. SW of village of Port Moller, between Herendeen and Mud Bays, Bristol Bay Low.; 55 $53^{\prime}$ N, $160^{\circ} 56^{\prime} \mathrm{W}$; (map 28).

Published in 1963 on USC\&GS Chart 8833.

Black Point: point of land, on SW coast of Sitkalidak I., on SE coast of Kodiak I. ; $57^{\circ} 00^{\prime}$ N, $153^{\circ} 18^{\prime} \mathrm{W}$; (map 33). Var. Miesof, Miesofski, Mizofek Point, Mys Mysovskoy, Point du Cap.

Descriptive name given in 1888 by $L t$. Comdr. Tanner, USN, commander of the USBF steamer Albatross from 1888 to 1893 , while making investigations of fisheries and fishing grounds in the area. This name was published by von Krusenstern (1827, map 17) as "Point du Cap," or "Cape Point," and by Capt. Tebenkov (1852, map 22) as "M[ys] Mysovskoy" or "Cape Promontory."

Black Point: point of land, on $\mathrm{N}$ shore of Whitewater Bay, on SW coast of Admiralty I., 31 mi. NE of Sitka, Alex. Arch.; 57 $14^{\prime} 55^{\prime \prime} \mathrm{N}$, $134^{\circ} 35^{\prime} 30^{\prime \prime} \mathrm{W}$; BGN 1908; (map 9).

Named in 1881 by Comdr. Henry Glass, USN.

Black Point: point of land, on $\mathrm{W}$ coast of Spruce I., NE of Kodiak I. ; $57^{\circ} 54^{\prime} 50^{\prime \prime} \mathrm{N}, 152^{\circ} 29^{\prime} 00^{\prime \prime}$ W; (map 34). Var. Chernie, Mys Chernyi.

Translation of the name "M[ys] Chernyi," given in 1839 or 1840 by Sub-Lt. Mikhail Murashev, IRN, and published in 1849 by the Russian Hydrog. Dept.

Black Point: point of land, on $\mathrm{N}$ bank of Nushagak River, $19 \mathrm{mi}$. SE of Dillingham, Bristol, Bay Low.; 58 $54^{\prime} \mathrm{N}, 158^{\circ} 01^{\prime} \mathrm{W}$; BGN 1931; $(\operatorname{map} 40)$.

Local name reported in 1925 by USBF.

Black Point: point of land, at NE base of Black Mtn., on Kenai Lake, $20 \mathrm{mi}$. N of Seward, Chugach Mts.; $60^{\circ} 23^{\prime} 45^{\prime \prime} \mathrm{N}, 149^{\circ} 23^{\prime} 00^{\prime \prime} \mathrm{W}$; (map 63).

Local name reported in 1951 by USGS.

Black Point: point of land, on SE shore of Valdez Arm Prince William Sound, $43 \mathrm{mi}$. NW of Cordova, Chugach Mts.; $60^{\circ} 54^{\prime} 45^{\prime \prime} \mathrm{N}, 146^{\circ}$ 48'00" W; (map 64).

Local name published by Capps and Johnson (1915, pl, 1), USGS.

Black Point: point of land, between Black Cove and Norton Sound, $5.2 \mathrm{mi}$. SW of Tolstoi
Point and $25 \mathrm{mi}$. SW of Unalakleet, Nulato Hills; $63^{\circ} 33^{\prime} \mathrm{N}, 161^{\circ} 07^{\prime} \mathrm{W}$; (map 91). Var. Niegvielnuk, Nigvilnak.

Descriptive name reported in 1902 by USGS. Its Eskimo name was reported in $1842-44$ as "Niegvielnuk" by Lt. L. A. Zagoskin, IRN.

Black Rapids: rapids, in course of Delta River, $36 \mathrm{mi}$. S of Delta Junction, Alaska Ra.; $63^{\circ}$ $31^{\prime} 40^{\prime \prime} \mathrm{N}, 145^{\circ} 51^{\prime} 40^{\prime \prime} \mathrm{W}$; (map 86). Var. The Rapids.

Local name shown on a 1910 fieldsheet by C. E. Giffin, USGS.

Black Rapids Glacier: glacier, trends NW and E $29 \mathrm{mi}$. to its 1950 terminus near Black Rapids of Delta River, $37 \mathrm{mi}$. S of Delta Junction, Alaska Ra.; $63^{\circ} 30^{\prime} 30^{\prime \prime} \mathrm{N}, 145^{\circ} 53^{\prime} 00^{\prime \prime}$ W; BGN 1939; (map 86). Var. Galloping Glacier, Rapids Glacier.

Local name reported in 1938 by USGS; at that time the glacier was receiving considerable publicity from the press, because of the speed of its movement and was nicknamed "Galloping Glacier."

Black Reef: reef, in Cook Inlet, $1.2 \mathrm{mi}$. E of North Head and $18 \mathrm{mi}$. N of Augustine I., Aleutian Ra.; $59^{\circ} 37^{\prime} 30^{\prime \prime} \mathrm{N}, 153^{\circ} 31^{\prime} 30^{\prime \prime} \mathrm{W}$; BGN 1916; (map 11).

Descriptive name published on 1915 USC\& GS Chart 8554.

Black River: stream, flows W $10 \mathrm{mi}$. to Black Bay, $2 \mathrm{mi}$. $\mathrm{N}$ of Chichagof, on $\mathrm{W}$ coast of Chichagof I., Alex. Arch.; 57 $42^{\prime} 25^{\prime \prime} \mathrm{N}, 136^{\circ}$ 07'00" W; BGN Sixth Report; (map 9).

Local name reported in 1935 by USFS.

Black River: stream, heads in lake at $61^{\circ} 58^{\prime} \mathrm{N}$, $164^{\circ} 06^{\prime} \mathrm{W}$, flows NW $90 \mathrm{mi}$. to Bering Sea, 1.5 mi. N of Black, Yukon-Kuskokwim Delta; $62^{\circ}$ $21^{\prime} \mathrm{N}, 165^{\circ} 20^{\prime} \mathrm{W}$; BGN 1906; (map 76). Var. Kip-nai-ak, Kipniaguk, Kipniuk, Kipunaiak, Kripniyuk, Protoka Kipunayak.

Local name reported by Dall (1870, p. 275), USC\&GS; so called because the waters of this river are clear and black compared to the muddy color of others in this area. Capt. Tebenkov (1852, map 3), IRN, shows the Russian-Eskimo name "Protoka Kipunayak" meaning "Kipunayak Passage" which corresponds to the present-day Eskimo name for this stream often written "Kip-nai-ak." The Eskimo name refers in meaning to the curves or twists of the stream.

Black River: stream, heads at $62^{\circ} 16^{\prime} \mathrm{N}, 148^{\circ} 05^{\prime}$ W, flows NE $31 \mathrm{mi}$. to Oshetna River, $70 \mathrm{mi}$. NW of Gulkana, Copper River Basin; 62 ${ }^{\circ} 30^{\prime}$ $40^{\prime \prime} \mathrm{N}, 147^{\circ} 28^{\prime} 20^{\prime \prime} \mathrm{W}$; (map 82).

Local name reported in 1931 by USGS.

Black River: stream, heads SE of Black Mtn., flows NE $50 \mathrm{mi}$. to Kuskokwim River, $24 \mathrm{mi}$. $\mathrm{S}$ of McGrath, Kilbuck-Kuskokwim Mts.; $62^{\circ}$ $37^{\prime} \mathrm{N}, 155^{\circ} 44^{\prime} \mathrm{W}$; (map 80).

Local name reported in 1908 by Maddren (1910, pl. 1), USGS.

Black River: stream, heads at $65^{\circ} 33^{\prime} \mathrm{N}, 141^{\circ} 58^{\prime}$ W, flows NW $200 \mathrm{mi}$. to Porcupine River, 17 mi. NE of Fort Yukon, Yukon Flats; $66^{\circ} 41^{\prime}$ $30^{\prime \prime} \mathrm{N}, 144^{\circ} 42^{\prime} 00^{\prime \prime} \mathrm{W}$; BGN 1959 (map 119). Var. Big Black River, Orange Creek, Salmon
Fork, Salmon River, Squirrel Creek, Squirrel River.

Named "Big Black" in 1898 by USC\&GS "because of confusion of this stream with Rat and Little Black Rivers on maps."

Black River: stream, flows N $13 \mathrm{mi}$. to Kobuk River, $11 \mathrm{mi}$. W of Shungnak, KotzebueKobuk Low.; $66^{\circ} 55^{\prime} \mathrm{N}, 157^{\circ} 30^{\prime} \mathrm{W}$; (map 115). Var. Am-mok-a-look-tok, Umakalookta, Um-nok-a-luk-ta, Um-ok-a-look-tok.

Name by Lt. G. M. Stoney, USN, in 1885 . Its Eskimo name, according to Lt. Cantwell (1884, p. 61), USRCS, was "Umakalookta," "Am-mok-a-look-tok (or tah)," "Um-nok-aluk-ta," or "Um-ok-a-look-tok."

Black River: stream, see Black Creek.

Black River: stream, see Salmon Fork Black River.

Black River: stream, see Squirrel Creek.

Black River Mountain: mountain range, see Magitchlie Range.

Black River Slough: stream, anabranch of Porcupine River, flows SW $10 \mathrm{mi}$., $11 \mathrm{mi}$. NE of Fort Yukon, Yukon Flats; $63^{\circ} 38^{\prime} 40^{\prime \prime} \mathrm{N}, 144^{\circ}$ 55'00" W; (map 119).

Local name derived from the Black River that flows into Porcupine River just east of Black River Slough. Reported in 1956 by T. E. Taylor, USGS.

Black River Slough: stream, $15 \mathrm{mi}$. long, anabranch of Porcupine River $12 \mathrm{mi}$. NW of Chalkyitsik, Yukon Flats; $66^{\circ} 49^{\prime} \mathrm{N}, 143^{\circ} 56^{\prime}$ W; (map 120).

Local name obtained in 1956 by T. E. Taylor and R. C. Foley, USGS.

Black Rock: island, $0.1 \mathrm{mi}$. long, in Iphigenia Bay, $3 \mathrm{mi}$. E of Warren I., Alex. Arch.; $55^{\circ} 52^{\prime} 25^{\prime \prime} \mathrm{N}, 133^{\circ} 45^{\prime} 45^{\prime \prime} \mathrm{W}$; (map 4).

Descriptive name given in 1904 by $E$. F. Dickins, USC\&GS, "on account of its color."

Black Rock: rock, in Umnak Pass, off NE coast of Umnak I. S of Fort Glenn, Aleutian Is. ; $53^{\circ} 23^{\prime} 30^{\prime \prime} \mathrm{N}, 167^{\circ} 55^{\prime} 55^{\prime \prime} \mathrm{W}$; (map 23).

Published in the 1944 Aleutian Coast Pilot (p. 61).

Black Rock: rock, $1.5 \mathrm{mi}$. S of Middle I., in Barrier Is., Alex. Arch.; $54^{\circ} 45^{\prime} 50^{\prime \prime} \mathrm{N}, 132^{\circ}$ 25'30' W; (map 1).

Local name reported in 1951 by USGS.

Black Rock: rock, $200 \mathrm{ft}$. long, near E shore of Revillagigedo Channel, $4 \mathrm{mi}$. SW of mouth of Boca de Quadra and $32 \mathrm{mi}$. SE of Ketchikan, Coast Mts.; $55^{\circ} 01^{\prime} 30^{\prime \prime} \mathrm{N}, 133^{\circ} 03^{\prime} 45^{\prime \prime}$ W; (map 3).

Descriptive name given in 1883 by Lt. Comdr. H. E. Nichols, USN.

Black Rock: rock, in mouth of Pavlof Bay, off S coast of Alaska Penin., Aleutian Ra.; $55^{\circ} 21^{\prime} 00^{\prime \prime} \mathrm{N}, 161^{\circ} 43^{\prime} 30^{\prime \prime} \mathrm{W}$; (map 28).

Reported in 1943 by USC\&GS.

Black Rock: rock, in Kasaan Bay, on E coast of Prince of Wales I., $1 \mathrm{mi}$. N of Kasaan Point, Alex. Arch.; 55 $27^{\prime} 30^{\prime \prime} \mathrm{N}, 132^{\circ} 17^{\prime} 00^{\prime \prime} \mathrm{W}$; (map 4).

Local navigators' descriptive name reported in 1904 by H. C. Fassett, USBF.

Black Rock: rock, $3.3 \mathrm{mi}$. W of Sitka, in Sitka Sound, Alex. Arch.; $57^{\circ} 03^{\prime} 10^{\prime \prime} \mathrm{N}, 135^{\circ} 25^{\prime} 30^{\prime \prime}$ 
W; (map 9). Var. Golia Kamennya Ostrovki, Golyya Kamennyya Ostrovki, Ostrov Makhnak.

Local name published in 1883 Coast Pilot (p. 140). This may be one of the "Golyya Kamennyya Ostrovki," meaning "bare rocky islets," or the "O[strov] Makhnak" of the Russian navigator Ivan Vasiliev the first, IRN, who named them in 1809; published by Lt. Sarichev (1826, map 19), IRN.

Black Rock: rock, in Khaz Bay, $6.5 \mathrm{mi}$. SSW of Chichagof, on W coast of Chichagof I., Alex. Arch. $57^{\circ} 34^{\prime} 07^{\prime \prime} \mathrm{N}, 136^{\circ} 07^{\prime} 45^{\prime \prime} \mathrm{W}$; BGN 1908; (map 9).

Descriptive name given in 1908 by USC\&GS and published in the 1908 Coast Pilot ( $p$. 171).

Black Rock: rock, rises $128 \mathrm{ft}$., from Bristol Bay, in Walrus Islands, $3.5 \mathrm{mi}$. E of Crooked Island, $22 \mathrm{mi}$. $\mathbf{E}$ of Hagemeister Island, Kilbuck-Kuskokwim Mts. ; $58^{\circ} 42^{\prime} 30^{\prime \prime} \mathrm{N}, 160^{\circ} 11^{\prime}$ 45" W; (map 39). Var. Black Rock Island.

Named and published in 1889 by USBF.

Blackrock Creek: stream, flows SW $4.3 \mathrm{mi}$. to North Fork Bremner River, $4.2 \mathrm{mi}$. SW of Hanagita Peak and $40 \mathrm{mi}$. SW of McCarthy, Chugach Mts. ; $61^{\circ} 00^{\prime} 30^{\prime \prime} \mathrm{N}, 143^{\circ} 44^{\prime} 30^{\prime \prime} \mathrm{W}$ (map 67).

Local name reported by Moffit (1914, pl. 1), USGS

Black Rock Island: rock, see Black Rock.

Black Rock Point: point of land, see Black Head.

Black Sand Creek: stream, flows NW $14 \mathrm{mi}$. to Melozitna River, $44 \mathrm{mi}$. W of Birches, Kokrines-Hodzana High.; $6^{\circ} 07^{\prime} 50^{\prime \prime} \quad$ N, $155^{\circ} 03^{\prime} 30^{\prime \prime} \mathrm{W}$; (map 107).

Local name obtained in 1952 by USGS topographers.

Blacksand Creek: stream, heads at glacier terminus and flows E $14 \mathrm{mi}$. to Kustatan River, 37 mi. NNW of Kenai, Cook Inlet Low.; 60 $57^{\circ}$ N, $151^{\circ} 59^{\prime} \mathrm{W}$; (map 62).

Local descriptive name reported in 1958 by USGS.

Blacksand Island: island, $3.3 \mathrm{mi}$. long, in Gulf of Alaska, between Ahrnklin River and Middle Slough, $0.6 \mathrm{mi}$. SE of Situk and $10 \mathrm{mi}$. SE of Yakutat, Malaspina Coastal Plain; 59 ${ }^{\circ} 5^{\prime} 15^{\prime \prime}$ N, $139^{\circ} 29^{\prime} 30^{\prime \prime}$ W ; (map 46).

A descriptive name published by Lt. Comdr. Moser (1901, pl. 43 and p. 385), USN.

Blacksand Spit: spit, $6.6 \mathrm{mi}$. long, trending NW to cove at mouth of Arhnklin River, $0.6 \mathrm{mi}$. SE of Situk and $10 \mathrm{mi}$. SE of Yakutat, Malaspina Coastal Plain; $59^{\circ} 23^{\prime} \mathrm{N}, 139^{\circ} 26^{\prime} \mathrm{W}$; (map 46).

Descriptive name published by the USGS in 1959.

Black Shale Creek: stream, flows SE $1.5 \mathrm{mi}$. to Boulder Creek, $34 \mathrm{mi}$. NE of Palmer, Talkeetna Mts.; $61^{\circ} 51^{\prime} 25^{\prime \prime} \mathrm{N}, 148^{\circ} 15^{\prime} 05^{\prime \prime} \mathrm{W}$; (map 69). Var. Blackshale Creek.

Local name reported in 1913 by USGS.

Blackshell Creek: stream, flows NW $9 \mathrm{mi}$. to East Fork Chena River, $10 \mathrm{mi}$. SE of Chena Hot Springs and $58 \mathrm{mi}$. N of Big Delta, Yukon-
Tanana High.; $64^{\circ} 58^{\prime} 45^{\prime \prime} \mathrm{N}, 145^{\circ} 44^{\prime} 00^{\prime \prime} \mathrm{W}$; (map 101).

Named by prospectors; reported in 1910 by USGS (Prindle, 1913b, pl. 1).

Blacks Landing: locality, on Koyukuk I., about $2 \mathrm{mi}$. SE of Koyukuk and $17 \mathrm{mi}$. NE of Nulato, Koyukuk Low.; $64^{\circ} 52^{\prime} \mathrm{N}, 157^{\circ} 39^{\prime} \mathrm{W}$ : (map 97).

Riverboat pilots' name shown on a 1940 "Navigation Chart of the Tanana-Yukon Rivers" published by U.S. Dept. of Interior.

Black Slough: stream, $4 \mathrm{mi}$. long, continuation of Little Muklung River, flows W to Nushagak River, $3 \mathrm{mi}$. NE of Dillingham, Bristol Bay Low.; $59^{\circ} 03^{\prime} 45^{\prime \prime} \mathrm{N}, 158^{\circ} 23^{\prime} 00^{\prime \prime} \mathrm{W}$; (map 52).

Local name reported in 1910 on a blueprint by $H$. C. Fassett, USBF,

Blackstone Bay: estuary, on NE coast of Kenai Penin., trends NE 15 mi. to Passage Canal, $10 \mathrm{mi}$. E of Whittier, Chugach Mts.; $60^{\circ} 46^{\prime}$ $30^{\prime \prime} \mathrm{N}, 148^{\circ} 25^{\prime} 00^{\prime \prime} \mathrm{W}$; BGN 1915; (map 63).

Local name reported in 1899 by $W$. C. Mendenhall, USGS. See Blackstone Glacier.

Blackstone Glacier: glacier, trends NE $7 \mathrm{mi}$. to its terminus at the head of Blackstone Bay, 8 mi. S. of Whittier, Chugach Mts.; 60'39'30" $\mathrm{N}, 148^{\circ} 42^{\prime} 30^{\prime \prime} \mathrm{W}$; (map 63).

Local name reported in 1899 by W. C. Mendenhall, USGS. "Named for a miner, who with two companions, lost his life there in the winter of 1896" (Mendenhall, 1900, p. 325).

Blackstone Point: point of land, on NE coast of Kenai Penin., at $\mathbf{E}$ entrance to Blackstone Bay, $10 \mathrm{mi}$. E of Whittier, Chugach Mts.; $60^{\circ} 46^{\prime}$ $55^{\prime \prime} \mathrm{N}, 148^{\circ} 23^{\prime} 30^{\prime \prime} \mathrm{W}$; BGN 1915; (map 63).

Named in 1915 by USC\&GS. Name derived from nearby Blackstone Bay.

Blackthorn Peak: peak, 4,100 ft., in Glacier Bay National Monument, E of Geikie Glacier, 52 mi. NW of Hoonah, St. Elias Mts.; $58^{\circ} 34^{\prime} 25^{\prime \prime}$ $\mathrm{N}, 136^{\circ} 34^{\prime} 15^{\prime \prime} \mathrm{W}$; (map 10). Var. Black Thorn.

Named by Reid (1896, p. 428), USGS.

Black Tit: peak, 6,640 ft., $3.3 \mathrm{mi}$. NW of Crescent Mtn. and $24 \mathrm{mi}$. NE of Yakutat, St. Elias Mts.; $59^{\circ} 37^{\prime} 55^{\prime \prime} \mathrm{N}, 139^{\circ} 03^{\prime} 35^{\prime \prime} \mathrm{W}$; (map 46).

Name appears on a 1906 map of Fourth Glacier, by the Canadian section of IBC, published by Tarr and Martin (1914, fig. 15).

Black Top: mountain, 1,759 ft., between Manila and Hobson Creeks, $18 \mathrm{mi}$. N of Nome, Seward Penin. High.; $64^{\circ} 46^{\prime} \mathrm{N}, 165^{\circ} 18^{\prime} \mathrm{W}$; (map 94).

Reported on the 1902 "Map of the Nome and Snake River Country" by J. M. Davidson.

Blacktop Mountain: mountain, see Tungulara Mountain.

Black Tusk: peak, see Tusk, The.

Black Volcano: mountain, see Black Peak.

Blackwater Creek: stream, heads in lake, flows NE 60 mi. to Middle Fork Kuskokwim River $0.8 \mathrm{mi}$. SW of its junc. with Big River, $23 \mathrm{mi}$. $\mathrm{E}$ of McGrath, Kushkokwim Low.; 62 ${ }^{\circ} 57^{\prime} 30^{\prime \prime}$ $\mathrm{N}, 154^{\circ} 53^{\prime} 45^{\prime \prime} \mathrm{W}$; (map 80).

Local name reported in 1931 by USGS
Blade Island: island, $3 \mathrm{mi}$. long, in Devils Elbow of Yukon River, between Cross and Middle Sloughs, $20 \mathrm{mi}$. SE of Marshall, Yukon-Kuskokwim Delta; 61 ${ }^{\circ} 35^{\prime} \mathrm{N}, 161^{\circ} 58^{\prime} \mathrm{W}$; (map 73).

Riverboat pilots' name recorded on a 1916 fieldsheet by $R$. H. Sargent, USGS.

Bladgett Lake: lake, see Blodgett Lake.

Blaine, Mount: mountain, 6,346 ft., on AlaskaCanada boundary, $31 \mathrm{mi}$. NW of Hyder, Coast Mts.; $56^{\circ} 14^{\prime} 50^{\prime \prime} \mathrm{N}, 130^{\circ} 32^{\prime} 20^{\prime \prime} \mathrm{W}$; $B G N$ 1924; (map 7).

Named in 1924 by USGS for James Gillespie Blaine, 1830-93, U.S. Senator from Maine, Speaker of the House of Representatives (1869-75), and Secretary of State (1881, 1889-92).

Blaine Bay: bight, $2 \mathrm{mi}$. across, on $\mathrm{N}$ coast of Alaska Penin., on SW shore of Moffet Lagoon, $11 \mathrm{mi}$. NNE of village of Cold Bay, Bristol Bay Low.; $55^{\circ} 22^{\prime} \mathrm{N}, 162^{\circ} 38^{\prime} \mathrm{W}$; (map 29).

Named in 1888 by USBF, for James Gillespie Blaine, 1830-93. See Blaine, Mount.

Blaine Creek: stream, see Blane Creek.

Blaine Point: point of land, on $\mathrm{W}$ bank of Pearse Canal, at junc. with Portland Canal, Coast Mts. ; $55^{\circ} 02^{\prime} 20^{\prime \prime} \mathrm{N}, 130^{\circ} 13^{\prime} 40^{\prime \prime} \mathrm{W}$; (map 3).

Named in 1891 by USC\&GS for James Gillespie Blaine, 1830-93. See Blaine, Mount.

Blaine Point: point of land, on $\mathrm{N}$ coast of Alaska Penin. between Izembek and Moffet Lagoons, $13 \mathrm{mi}$. NNE of village of Cold Bay, Bristol Bay Low.; 55 $22^{\prime} \mathrm{N}, 162^{\circ} 39^{\prime} \mathrm{W}$; BGN 1966; (map 29). Var. Strawberry Point.

Named in 1888 by USBF for James Gillespie Blaine. In 1964 USC\&GS published "Strawberry Point", and misapplied the name "Blaine" to a point $4 \mathrm{mi}$. to the southwest, on Chart 8860. See Blaine, Mount.

Blair Lake: lake, $0.8 \mathrm{mi}$. long, between Chulitna and Susitna Rivers, $15 \mathrm{mi}$. N of Talkeetna, Talkeetna Mts.; $62^{\circ} 32^{\prime} 45^{\prime \prime} \mathrm{N}, 150^{\circ} 09^{\prime} 50^{\prime \prime} \mathrm{W}$; (map 81).

Local name reported in 1958 by USGS.

Blair Lakes: lakes, between Clear and Dry Creeks, $35 \mathrm{mi}$. SE of Fairbanks, Tanana Low.; $64^{\circ} 21^{\prime} 45^{\prime \prime} \mathrm{N}, 147^{\circ} 21^{\prime} 30^{\prime \prime} \mathrm{W}$; (map 100).

Local name reported in 1950 by USGS topographers.

Blake Channel: water passage, extends SE $12 \mathrm{mi}$. from The Narrows at $S$ end of Eastern Passage to junc. of Bradfield Canal and Ernest Sound, separates Wrangell I. from mainland, Alex. Arch.; $56^{\circ} 20^{\prime} \mathrm{N}, 132^{\circ} 00^{\prime} \mathrm{W}$; (map 6). Var. Black Channel.

Named in 1879 by W. H. Dall, USC\&GS for William Phipps Blake, who explored this region in 1863.

Blake Island: island, $1.6 \mathrm{mi}$. long, between Blake Channel and Bradfield Canal, $30 \mathrm{mi}$. SE of Wrangell, Alex. Arch.; 56 ${ }^{\circ} 13^{\prime} \mathrm{N}, 131^{\circ} 55^{\prime} \mathrm{W}$; $B G N$ 1899; (map 7). Var. Ham Island.

Name derived from Blake Channel in 1891 by Lt. Comdr. H. E. Nichols, USN. In 1886 this island was called "Ham Island" by Lt. Comdr. A. S. Snow, USN.

Blake Point: point of land, see Swaine Point. Blaker Point: point of land, see Blaquiere Point. Blakeslee Creek: stream, flows W to Pargon 
River, about $15 \mathrm{mi}$. NE of Council, Seward Penin. High.; (map 110).

Prospectors' name reported on the 1900 "Map of Nome Peninsula" by J. M. Davidson and B. D. Blakeslee. Presumably named for B. D. Blakeslee, as the next stream north is Davidson Creek. This stream cannot be precisely located on current maps.

Blanchard: area, in S Anchorage, $1 \mathrm{mi}$. SSW of City Hall, Cook Inlet Low.; $61^{\circ} 12^{\prime} 20^{\prime \prime} \mathrm{N}$, $149^{\circ} 52^{\prime} 45^{\prime \prime} \mathrm{W}$; (map 69).

Residential district in city of Anchorage reported in 1954 by office of city engineer of Anchorage.

Blanchard Lake: lake, $0.9 \mathrm{mi}$. long, empties into Patterson Bay, on SE coast of Baranof I., Alex. Arch.; 56 $37^{\circ} 00^{\prime \prime} \mathrm{N}, 134^{\circ} 41^{\prime} 30^{\prime \prime} \mathrm{W}$; BGN 1933; (map 5).

Named in 1933 by USFS "for William Blanchard, master of the ship Ekaterina, who hunted sea otter for Governor Baranov along the coast from Sitka south to California," about 1811. See Baranof Island.

Blanche Rock: rock, in Ernest Sound, $30 \mathrm{mi}$. SE of Wrangell, between Deer and Etolin Is.; Alex. Arch.; $56^{\circ} 05^{\prime} 10^{\prime \prime} \mathrm{N}, 132^{\circ} 05^{\prime} 10^{\prime \prime} \mathrm{W}$; (map 6).

French word meaning "white" given in 1886 by Lt. Comdr. A. S. Snow, USN.

Blanco, Arroyo: stream, flows NW 2 mi. to Port Dolores on Suemez I., Alex. Arch.; $55^{\circ} 20^{\prime} \mathrm{N}$, $133^{\circ} 23^{\prime} \mathrm{W}$; (map 4).

Spanish name meaning "white gulch" reported in 1779 by Don Ignacio Arteaga.

Blane Creek: stream, flows SE 2 mi. to Fox River, $23 \mathrm{mi}$. NE of Solomon, Seward Penin. High.; $64^{\circ} 46^{\prime} \mathrm{N}, 163^{\circ} 50^{\prime} \mathrm{W}$; (map 95). Var. Baaine Creek.

Prospectors' name reported as "Blaine" on the 1900 "Map of Nome Peninsula" by J. M. Davidson and B. D. Blakeslee.

Blank Creek: stream, heads in Dutch Hills, flows NW, between Prospect and Siwash Creeks, 1.5 mi. to Dutch Creek, $35 \mathrm{mi}$. NW of Talkeetna, Alaska Ra.; $62^{\circ} 35^{\prime} \mathrm{N}, 151^{\circ} 03^{\prime} \mathrm{W}$; (map 81).

Prospectors' name reported in the 1930's by USGS.

Blank Creek: stream, flows NW $1.8 \mathrm{mi}$. to Candle Creek, $8 \mathrm{mi}$. SW of Candle and $35 \mathrm{mi}$. NE of Imuruk Lake, Seward Penin. High.; 65 ${ }^{\circ} 49^{\prime}$ N, $162^{\circ} 03^{\prime} \mathrm{W}$; $(\operatorname{map} 110)$.

Prospectors' name reported in 1903 by $D$. C. Witherspoon (in Moffit, 1905, pl. 2), USGS.

Blanket Island: island, $2.8 \mathrm{mi}$. long, between Hetta Inlet and Sukkwan Strait, on NE coast of Sukkwan I., Alex. Arch.; $55^{\circ} 08^{\prime} \mathrm{N}, 132^{\circ} 43^{\prime}$ W; (map 4).

Local name reported in 1916 by USC\&GS.

Blanket Lake: lake, 2,000 ft. long, one of Beaver Lakes, $26 \mathrm{mi}$. $\mathrm{N}$ of Anchorage, Cook Inlet Low. ; $61^{\circ} 35^{\prime} 30^{\prime \prime} \mathrm{N}, 152^{\circ} 30^{\prime} 00^{\prime \prime} \mathrm{W}$; (map 69 ).

Local name reported in 1950 by USGS.

Blank Inlet: estuary, extends NW $3.3 \mathrm{mi}$., off Nichols Passage, on $\mathrm{E}$ coast of Gravina I., Alex. Arch.; $55^{\circ} 16^{\prime} \mathrm{N}, 131^{\circ} 9^{\prime} \mathrm{W}$; (map 3).
Named in 1883 by Lt. Comdr. H. E. Nichols, USN.

Blankisal, Mys del: point of land, see Blanquizal Point.

Blank Islands: islands, two, extend $1.2 \mathrm{mi}$. between Blank Inlet and Nichols Passage, off E coast of Gravina I., Alex. Arch.; $55^{\circ} 16^{\prime} 20^{\prime \prime}$ $\mathrm{N}, 131^{\circ} 38^{\prime} 30^{\prime \prime} \mathrm{W}$; (map 3 ).

Local name published in 1925 Coast Pilot (p. 106).

Blank Lake: lake, see Udrivik, Lake.

Blank Point: point of land, $\mathrm{S}$ point of entrance to Blank Inlet, on $\mathrm{E}$ coast of Gravina I., Alex. Arch.; $55^{\circ} 15^{\prime} 05^{\prime \prime} \mathrm{N}, 131^{\circ} 40^{\prime} 20^{\prime \prime} \mathrm{W}$; (map 3).

Local navigators' name obtained in 1904 by H. C. Fassett, USBF.

Blanquisal, Point del: point of land, see Blanquizal Point.

Blanquizal Islands: islands, group, extends 0.8 mi, in San Christoval Channel, on $W$ coast of Prince of Wales I., Alex. Arch.; 55 $37^{\prime} \mathrm{N}$, $133^{\circ} 24^{\prime}$ W; BGN 1908; (map 4).

Spanish word meaning "pipe-clay" given in 1908 by USC\&GS; derived from Blanquizal Point.

Blanquizal Point: point of land, on $\mathrm{W}$ coast of Prince of Wales I., SE of Saint Philip I., Alex. Arch.; 55 $37^{\prime} 25^{\prime \prime} N, 133^{\circ} 23^{\prime} 40^{\prime \prime} \mathrm{W}$; (map 4). Var. Mys del Blankisal, Point del Blanquisal, Punta del Blanquizal.

Spanish name given in $1775-79$ by Don Juan de la Bodega y Quadra and Francisco Antonio Maurelle as "Punta del Blanquizal," meaning "point of pipe-clay."

Blaquiere Point: point of land, easternmost tip of Mitkof I., $10 \mathrm{mi}$. NW of Wrangell, Alex. Arch.; 56 $35^{\prime} 00^{\prime \prime} \mathrm{N}, 132^{\circ} 32^{\prime} 30^{\prime \prime} \mathrm{W}$; (map 6). Var. Blaker Point.

Named on August 28, 1793, by Capt. George Vancouver, RN, probably in honor of John, Baron of Blaquiere, Member of Parliament (Wagner, 1937, p. 376).

Blarney Creek: stream, flows S $5.5 \mathrm{mi}$. to Hammond River, 2 mi. E of Apoon Mtn. and 36 mi. $N$ of Wiseman, Brooks Ra.; 67 $54^{\prime} \mathrm{N}$, $150^{\circ} 11^{\prime} \mathrm{W}$; BGN 1932; (map 124).

Local name reported about 1930 by Marshall (1956, p. 159).

Blaschke Island: islands, see Blashke Islands.

Blashke Islands: islands, $4 \mathrm{mi}$. long, at $\mathrm{S}$ end of Kashevarof Is., off NE coast of Prince of Wales I., Alex. Arch.; 56 $07^{\prime} \mathrm{N}, 132^{\circ} 54^{\prime} \mathrm{W}$; (map 6). Var. Blaschke Island, Bloshke Island, Ostrov Bloshke.

Published in 1853 on Russian Hydrog. Dept. Chart 1494 as "Os[trov] Bloshke." Named for Edward Leontief Blashke, surgeon of the ship Nikolai in 1839-41, under the command of Capt. A. K. Etolin.

Blatchford Creek: stream, flows NW $2 \mathrm{mi}$. to Snake River, $11 \mathrm{mi}$. NW of Nome, Seward Penin. High.; $64^{\circ} 40^{\prime} \mathrm{N}, 165^{\circ} 26^{\prime} \mathrm{W}$; (map 94).

Local name published by Schrader (1900c, p. 16), USGS.

Blattman Cove : cove, see Beverley Cove.
Blattman Point: point of land, see Beverley Point.

Bligh Island: island, $4.5 \mathrm{mi}$. across, at $\mathrm{N}$ entrance to Port Fidalgo, $40 \mathrm{mi}$. NW of Cordova, Chugach Mts.; $60^{\circ} 50^{\prime} \mathrm{N}, 146^{\circ} 46^{\prime} \mathrm{W}$; (map 64). Var. Blighs Island.

This island was examined by Joseph Whidbey, RN, of Capt. Vancouver's command, on June 11,1794 . It was perhaps named by him or Vancouver for William Bligh, 1754-1817, $\mathrm{RN}$, the master of the HMS Resolution on Capt. James Cook's third voyage (Vancouver, 1798 , v. 3, p. 163). This is the same Capt. Bligh associated with the famous mutiny of the HMS Bounty in 1789.

Bligh Island Reef: reef, see Bligh Reef.

Bligh Reef: reef, $1.5 \mathrm{mi}$. long, in Prince William Sound at SE entrance to its Valdez Arm, $45 \mathrm{mi}$. NW of Cordova, Chugach Mts.; $60^{\circ}$ $50^{\prime} 30^{\prime \prime} \mathrm{N}, 146^{\circ} 52^{\prime} 30^{\prime \prime} \mathrm{W}, B G N$ 1931; (map 64). Var. Bligh Island Reef.

Originally called "Bligh Island Reef"; in 1930 the name was shortened to "Bligh Reef" by USC\&GS.

Blijni Islands: islands, see Near Islands.

Blijnies Islands: islands, see Near Islands.

Blind Breaker: rock, in Shumagin Is., at mouth of Delarof Harbor, on SE coast of Unga I., Aleutian Ra.; 55 $10^{\prime} 13^{\prime \prime} \mathrm{N}, 160^{\circ} 28^{\prime} 57^{\prime \prime} \mathrm{W}$; (map 28).

Reported in 1943 by USC\&GS.

Blind Creek: stream, flows NE $4 \mathrm{mi}$. to West Fork Chulitna River, $50 \mathrm{mi}$. SW of Healy, Alaska Ra.; $63^{\circ} 14^{\prime} 45^{\prime \prime} \mathrm{N}, 149^{\circ} 38^{\prime} 30^{\prime \prime} \mathrm{W}$; (map 87).

Local name obtained in 1951 by USGS.

Blind Creek: stream, flows SE $1.7 \mathrm{mi}$. to Casadepaga River, $14 \mathrm{mi}$. N of Solomon, Seward Penin. High.; $64^{\circ} 46^{\prime} \mathrm{N}, 164^{\circ} 28^{\prime} \mathrm{W}$; (map 95). Var. Nugget Creek.

Prosepctors' name reported on a 1902 prospectors' manuscript map.

Blind Cove: bight, $0.5 \mathrm{mi}$. across, on NE coast of Attu I., on W shore of Holtz Bay, Aleutian Is.; $52^{\circ} 56^{\prime} 45^{\prime \prime} \mathrm{N}, 173^{\circ} 09^{\prime} 45^{\prime \prime} \mathrm{E}$; (map 13).

Name shown on an AMS map published in 1948.

Blind Cove: cove, $0.4 \mathrm{mi}$. across, on $\mathrm{E}$ coast of Adak I., Aleutian Is. ; $51^{\circ} 55^{\prime} 15^{\prime \prime} \mathrm{N}, 176^{\circ} 27^{\prime}$ $00^{\prime \prime}$ W; BGN 1936; (map 17).

So named in 1934 by members of the U.S. Navy Aleutian Island Survey Expedition, "because it is readily mistaken for the entrance to Kagalaska Strait."

Blind Gulch: ravine, trends NW $0.6 \mathrm{mi}$. to Dry Creek, $1.5 \mathrm{mi}$. NE of Nome, Seward Penin. High.; $64^{\circ} 31^{\prime} 06^{\prime \prime} \mathrm{N}, 165^{\circ} 22^{\prime} 00^{\prime \prime} \mathrm{W}$; (map 94).

Prospectors' name reported in 1904 by T. G. Gerdine, USGS.

Blind Island: island, $0.2 \mathrm{mi}$. long, at mouth of Blind Slough, off W coast of Mitkof I., $12 \mathrm{mi}$. $\mathrm{S}$ of Petersburg, Alex. Arch.; 56 $38^{\prime} 10^{\prime \prime} \mathrm{N}$, $132^{\circ} 55^{\prime} 00^{\prime \prime} \mathrm{W}$; (map 6).

Named in 1881 by Lt. Comdr. H. E. Nichols, USN.

Blind Island: island, $1.7 \mathrm{mi}$. long, in Norton Sound between Blind Slough and Kwikoktuk 
Pass, $14 \mathrm{mi}$. SW of Kwiguk, Yukon-Kuskokwim Delta; $62^{\circ} 39^{\prime} \mathrm{N}, 164^{\circ} 55^{\prime} \mathrm{W}$; (map 77).

Local name obtained in 1948 by USC\&GS.

Blind Pass: water passage, $3 \mathrm{mi}$. long, between Black and Hassler Is., in Behm Canal, Alex. Arch.; 55 53 $40^{\prime \prime}$ N, $131^{\circ} 39^{\prime} 15^{\prime \prime} \mathrm{W}$; (map 3).

Named in 1891 by USC\&GS.

Blind Pass: water passage, see Kwikoktuk Pass. Blind Passage: estuary, see Blind Slough.

Blind Passage: estuary, see Tenakee Inlet.

Blind Passage: stream, see Blind River.

Blind Passage Point: point of land, see Blind Point.

Blind Pass Mountain: mountain, 5,700 ft., in Schwatka Mts., Brooks Ra.; 67 $30^{\prime} \mathrm{N}, 156^{\circ} 21^{\prime}$ W; (map 126).

Translation by Orth in 1958 of the Eskimo name Ulaneak [Creek], a stream that heads on the mountain's northwest slope.

Blind Point: point of land, NW point of entrance to Kagalaska Strait on E coast of Adak I., Aleutian Is.; $51^{\circ} 50^{\prime} 45^{\prime \prime} \mathrm{N}, 176^{\circ} 26^{\prime} 15^{\prime \prime} \mathrm{W}$; BGN 1936; (map 17).

Named in 1934 by members of the U.S. Navy Aleutian Island Survey Expedition, "for its proximity to Blind Cove."

Blind Point: point of land, on W coast of Mitkof I., $11 \mathrm{mi}$. S of Petersburg, Alex. Arch.; 56 ${ }^{\circ}$. $39^{\prime} 00^{\prime \prime}$ N, $132^{\circ} 54^{\prime} 50^{\prime \prime}$ W; (map 6). Var. Blind Passage Point.

Feature was named "Blind Passage Point" in 1881 by Lt. Comdr. H. E. Nichols, USN; published as "Blind Point" in 1891 Coast Pilot (p. 132).

Blind River: stream, flows NW $3 \mathrm{mi}$. to Blind Slough, $16 \mathrm{mi}$. SE of Petersburg, on Mitkof I., Alex. Arch.; $56^{\circ} 36^{\prime} 50^{\prime \prime} \mathrm{N}, 132^{\circ} 49^{\prime} 15^{\prime \prime} \mathrm{W}$; (map 6). Var. Blind Passage, Dry Strait, Sukhoy Proliv Blind Slough.

Name published in the 1891 Coast Pilot (p. 132) by Lt. Comdr. H. E. Nichols, USN; previously known as "Blind Passage" because it was supposed that there was a passage here connecting Wrangell Narrows and Sumner Strait, described as being "dry at low water." Name published in 1850 on Russian Hydrog. Dept. Chart 1441 as "Sukhoy Proliv," meaning "dry strait."

Blind River: stream, NE $21 \mathrm{mi}$. to Yukon River, $3 \mathrm{mi}$. E. of Darvin I., $21 \mathrm{mi}$. W of Tanana, Nowitna Low. ; $65^{\circ} 11^{\prime} 15^{\prime \prime} \mathrm{N}, 153^{\circ} 00^{\prime} 00^{\prime \prime} \mathrm{W}$; (map 106). Var. Klatsuta River, Klatsutachakat, Klatsutachargut, Klatsutakakat.

Local name reported in 1952 by USGS. The Indian name was first reported in 1869 as "Klatsutachakat," or "mouth of the Klatsuta," by Capt. Raymond (1871, app. D), U.S. Army Corps of Engineers.

Blind River: estuary, see Blind Slough.

Blind Slough: estuary, trends SE $4 \mathrm{mi}$. to Sumner Strait at $S$ end of Mitkof I., $24 \mathrm{mi}$. SE of Petersburg, Alex. Arch.; $56^{\circ} 31^{\prime} \mathrm{N}, 132^{\circ} 42^{\prime} \mathrm{W}$; (map 6). Var. Blind Strait.

Named in 1869 by Comdr. R. W. Meade, USN. See Blind River.

Blind Slough: estuary, $4 \mathrm{mi}$. long, lower course of Blind River, trends NW of Wrangell Narrows, $14 \mathrm{mi}$. S of Petersburg on Mitkof I., Alex.
Arch.; 56 38'15" N, $132^{\circ} 55^{\prime} 00^{\prime \prime} \mathrm{W}$; (map 6). Var. Blind Passage, Blind River, Sukhoy Proliv.

Local name published in the 1932 Coast Pilot (p. 272). See Blind River.

Blind Slough: water passage, $\mathrm{E}$ of Blind $\mathrm{I}$., in offshore mud flats, extends NW $3 \mathrm{mi}$. to Nurukomarot Channel, $14 \mathrm{mi}$. W of Kwiguk, Yukon-Kuskokwim Delta; $62^{\circ} 40^{\prime} \mathrm{N}, 164^{\circ} 55^{\prime}$ W; (map 77).

Local name obtained in 1948 by USC\&GS. Blind Strait: estuary, see Blind Slough.

Bliskie Island: island, see Near Island.

Blisnie Island: island, see Near Island.

Blister Creek: stream, on Iniskin Penin., flows NE $1.5 \mathrm{mi}$. to Brown Creek, $3.7 \mathrm{mi}$. NW of Dry Bay, Aleutian Ra.; $59^{\circ} 44^{\prime} \mathrm{N}, 153^{\circ} 11^{\prime} \mathrm{W}$; BGN 1962; (map 51).

Local name published in 1958 by USGS Blizhini Point: point of land, see Blizhni Point. Blizhni: island, see Near Island.

Blizhnie Cape: point of land, see Near Point.

Blizhnie Islands: islands, see Near Islands.

Blizhni Point: point of land, end of spit at mouth of Grand Wash River; 21 mi. N of Yakutat, St. Elias Mts.; $59^{\circ} 50^{\prime} 10^{\prime \prime} \mathrm{N}, 139^{\circ} 46^{\prime} 45^{\prime \prime} \mathrm{W}$; (map 46). Var. Blizhini Point, Mys Blizhniy.

Named "M[ys] Bliznniy," meaning "near cape," by Capt. Tebenkov (1852, map 7), IRN.

Blizhniy, Mys: point of land, see Near Point.

Blizhniy, Ostrov: island, see Near Island.

Blizhniye Islands: islands, see Near Islands.

Blizki Island: island, see Near Island.

Blizkiy Island: island, see Near Island.

Blizzard Creek: stream, flows E or SE to Hannum Creek near its head, in Inmachuk River basin, about $20 \mathrm{mi}$. N of Imuruk Lake, Seward Penin. High.; (map 110).

Local name published on a precinct map of Seward Peninsula by Monroe and Hutchins; corrected to June 1903 by Arthur Gibson. This stream cannot be precisely identified on current maps.

Blizzard Creek: stream, flows NE to Klokerblok River, about $25 \mathrm{mi}$. NE of Solomon, Seward Penin. High.; (map 95).

Prospectors' name reported on the 1900 "Map of Nome Peninsula" by J. M. Davidson and B. D. Blakeslee. This stream cannot be precisely located on current maps.

Blizzard Creek: stream, flows $4 \mathrm{mi}$. NW to Troublesome Creek, $16 \mathrm{mi}$. SE of Rampart, Yukon-Tanana High.; $65^{\circ} 23^{\prime} \mathrm{N}, 149^{\circ} 43^{\prime} \mathrm{W}$; (map 105).

Named by prospectors; reported in 1908 by USGS (Covert and Ellsworth, 1909, pl. 5).

Blizzard Lake: lake, $0.4 \mathrm{mi}$. across, on $\mathrm{N}$ shore of Skilak Lake, on Kenai Penin., $30 \mathrm{mi}$. SE of Kenai, Cook Inlet Low.; $60^{\circ} 27^{\prime} 45^{\prime \prime} \mathrm{N}$, $150^{\circ} 25^{\prime} 00^{\prime \prime} \mathrm{W}$; (map 62).

Named about 1963 by officials of Kenai National Moose Range, for administrative purposes.

Blizzard Peak: peak, 7,400 ft., in Storm Ra., 1.8 mi. SE of Mount Ogilvie and $38 \mathrm{mi}$. $\mathrm{N}$ of Juneau, Coast Mts. ; $58^{\circ} 50^{\prime} 38^{\prime \prime} \mathrm{N}, 134^{\circ} 13^{\prime} 10^{\prime \prime}$ $\mathrm{W} ; B G N 1965 ;(\operatorname{map} 11)$
Named by members of the Juneau Icefield Research Project in 1964.

Blockade Glacier: glacier, in Chigmit Mts., heads at NE end of Blockade Lake, trends NE $11 \mathrm{mi}$. to its terminus near head of McArthur River, $33 \mathrm{mi}$. W of Tyonek, Aleutian Ra.; $61^{\circ} 03^{\prime} \mathrm{N}, 152^{\circ} 08^{\prime} \mathrm{W}$; BGN 1964; (map $70)$.

Local name reported in 1958 by USGS. Name probably derived from nearby Blockade Lake.

Blockade Lake: lake, $5.5 \mathrm{mi}$. long, on Alaska Penin., at head of Blockade Glacier, $50 \mathrm{mi}$. NW of Kenai, Aleutian Ra.; $60^{\circ} 57^{\prime} \mathrm{N}$, 152 $27^{\prime} \mathrm{W}$; BGN 1964; (map 62).

So named by USGS in 1962, because the lake is formed by the impounding of melted glacier water behind Blockade Glacier.

Block Creek: stream, on Kenai Penin., flows NW $1.5 \mathrm{mi}$. to Canyon Creek, $14 \mathrm{mi}$. $\mathrm{S}$ of Sunrise, Chugach Mts.; $60^{\circ} 42^{\prime} 00^{\prime \prime} \mathrm{N}, 149^{\circ} 27^{\prime} 35^{\prime \prime} \mathrm{W}$; (map 63).

Local name reported in 1914 by USGS.

Block Island: island, $750 \mathrm{ft}$. long, in Tlevak Narrows, off $\mathbf{N}$ tip of Dall I., Alex. Arch.; $55^{\circ} 15^{\prime} 50^{\prime \prime} \mathrm{N}, 133^{\circ} 07^{\prime} 00^{\prime \prime} \mathrm{W}$; (map 4).

Named in 1881 by Lt. Comdr. H. E. Nichols, USN.

Block Island: island, $1.2 \mathrm{mi}$. long, in Upper Passage, between Eleanor and Ingot Is., 24 mi. NE of Chenega, Chugach Mts.; 60 $31^{\prime} 30^{\prime \prime}$ N, 147 $36^{\prime} 30^{\prime \prime} \mathrm{W}$; (map 63).

Named by USC\&GS in 1930, "for Block Island off Montauk Point, N.Y."

Block Island: island, $1 \mathrm{mi}$. long, in Cedar Bay, off $\mathrm{S}$ coast of Alaska, $47 \mathrm{mi}$. ENE of Whittier, Chugach Mts.; $60^{\circ} 58^{\prime} 15^{\prime \prime} \mathrm{N}, 147^{\circ} 23^{\prime} 45^{\prime \prime} \mathrm{W}$; (map 63).

Local name reported in 1951 by USGS.

Blodgett Island: island, $800 \mathrm{ft}$. long, in Womens Bay, $5.5 \mathrm{mi}$. SW of Kodiak, Kodiak I.; $57^{\circ} 43^{\prime} 15^{\prime \prime} \mathrm{N}, 152^{\circ} 29^{\prime} 20^{\prime \prime} \mathrm{W}$; BGN 1941; (map 34).

Named in 1940 by USC\&GS for Perl D. Blodgett, 1855-1920 (?), who came to Kodiak from Vermont about 1883. Blodgett was one of the early blue-fox ranchers. He built a cannery on Kodiak Island in 1911 and ran a small steam launch for hunting sea otters between the islands which earned him the title of "Captain" Blodgett.

Blodgett Lake: lake, $1 \mathrm{mi}$. long, $\mathrm{S}$ of The Alaska Railroad, $18 \mathrm{mi}$. W of Palmer, Cook Inlet Low.; $61^{\circ} 34^{\prime} 40^{\prime \prime} \mathrm{N}, 149^{\circ} 40^{\prime} 20^{\prime \prime} \mathrm{W}$; (map 69). Var. Bladgett Lake.

Local name reported in 1942 as Bladgett Lake by AMS. The present spelling was published in 1963 by USGS.

Blondeau Glacier, Le: glacier, heads on N slope of Takhinsha Mts., trends $\mathrm{N} 4 \mathrm{mi}$. to its terminus in the valley of the Tsirku River, $1.2 \mathrm{mi}$ $\mathrm{W}$ of mouth of Cottonwood Creek and $35 \mathrm{mi}$. SW of Skagway, St. Elias Mts.; $59^{\circ} 16^{\prime} 35^{\prime \prime} \mathrm{N}$, 136 $13^{\prime} 30^{\prime \prime} \mathrm{W}$; BGN 1965; (map 45). Var. De Blondeau.

A prospector's name reported by Wright (1904, pl. 2), USGS. 
Blonde Cove: cove, $0.6 \mathrm{mi}$. across, part of Steller Cove on $\mathrm{N}$ coast of Attu I., Aleutian Is.; $52^{\circ} 58^{\prime} 50^{\prime \prime} \mathrm{N}, 172^{\circ} 58^{\prime} 20^{\prime \prime} \mathrm{E}$; (map 13).

Named by the U.S. Army during World War II. This name along with Brunette and Auburn Coves, so-called "pin-up" names, may have been suggested by Red Head, a nearby promontory.

Bloomer Mountain: mountain, see Bloomer Peak.

Bloomer Peak: mountain, 1,230 ft., on SE part of Unga I., in Shumagin Is., Aleutian Ra.; $55^{\circ} 12^{\prime} 40^{\prime \prime} \mathrm{N}, 160^{\circ} 34^{\prime} 30^{\prime \prime} \mathrm{W}$; (map 28). Var. Bloomer Mountain.

Named by W. W. Atwood (1911, pl. 2), USGS; published in 1963 as "Bloomer Mountain" on USC\&GS Chart 8700 .

Bloshke Island: islands, see Blashke Islands.

Blossom, Cape: point of land, on Baldwin Penin., extends into Kotzebue Sound, $11 \mathrm{mi}$. S of Kotzebue, Kotzebue-Kobuk Low.; $66^{\circ} 44^{\prime}$ N, $162^{\circ} 30^{\prime} \mathrm{W}$; (map 113).

Named in 1826 by Capt. Beechey (1831, p. 329), RN, for his vessel, the H.M.S. Blossom, while exploring the Kotzebue Sound region.

Blossom Glacier: glacier, trends S $3.5 \mathrm{mi}$. between Hayden and Malaspina Glaciers, $35 \mathrm{mi}$. NNW of Yakutat, St. Elias Mts.; $60^{\circ} 00^{\prime} 33^{\prime \prime} \mathrm{N}$, $140^{\circ} 06^{\prime} 20^{\prime \prime}$ W; (map 66).

Name derived from Blossom Island, a peak east of the glacier terminus.

Blossom Island: peak, 4,110 ft., between Blossom and Hayden Glaciers, $35 \mathrm{mi}$. NNW of Yakutat, St. Elias Mts. ; $60^{\circ} 00^{\prime} 40^{\prime \prime} \mathrm{N}, 140^{\circ} 03^{\prime}$ 20" W; (map 66).

So named by personnel of the joint National Geographic Society-U.S. Geological Survey Expedition to Mount St. Elias, in 1890, because the nunatak, surrounded by ice, was covered by a dense growth of flowers (Russell, 1891, p. 114).

Blossom River: stream, heads in a lake, flows SW $20 \mathrm{mi}$. to Wilson River $0.5 \mathrm{mi}$. N of its mouth, at Wilson Arm, Coast Mts., $55^{\circ} 23^{\prime} 45^{\prime \prime} \mathrm{N}$, $130^{\circ} 36^{\prime} 25^{\prime \prime} \mathrm{W}$; (map 3).

Local name reported in 1955 by USGS.

Blossom Shoals: shoals, in Chukchi Sea, extend NW $10 \mathrm{mi}$. from Icy Cape, $45 \mathrm{mi}$. SW of Wainwright, Arctic Plain; $70^{\circ} 23^{\prime} \mathrm{N}, 161^{\circ} 57^{\prime} \mathrm{W}$; (map 146).

Named in 1826 by Capt. Beechey (1831, v. 1, p. 276), RN, who wrote, "Upon examination with the boats, several successive banks were found at about three quarters of a mile apart, lying parallel with the coast line $* * *$. These shoals lie immediately off Icy Cape * * *," and were named after Beechey's ship H.M.S. Blossom. In September 1889, Lt. Comdr. C. H. Stockton, USN, of the U.S.S. Thetis, erected a beacon on Icy Cape to mark the beginning of Blossom Shoals.

Blowback Creek: stream, heads on Manley Hot Springs Dome, flows N 4.5 mi., joins Killarney Creek to form Baker Creek, $6 \mathrm{mi}$. SSE of Roughtop Mtn. and $40 \mathrm{mi}$. ESE of Tanana, Yukon-Tanana High.; $65^{\circ} 06^{\prime} 00^{\prime \prime}$ N, $150^{\circ} 43^{\prime}$ $15^{\prime \prime} \mathrm{W}$; (map 106).
Prospectors' name reported in 1931 by $\mathrm{J}$. B. Mertie, Jr., USGS.

Blowdown Island: island, $0.1 \mathrm{mi}$. across, between Beecher Pass and Duncan Canal, $15 \mathrm{mi}$. SW of Petersburg, Alex. Arch.; 56 $36^{\circ}$ N, $133^{\circ} 02^{\prime}$ W; (map 6).

Local fishermen's name reported in 1947 by USC\&GS.

Bluebell Creek: stream, flows E $10 \mathrm{mi}$., $\mathrm{N}$ of Gold Hill, to Tozitna River, $14 \mathrm{mi}$. WNW of Tanana, Kokrines-Hodzana High.; $65^{\circ} 16^{\prime} \mathrm{N}$, $152^{\circ} 30^{\prime} \mathrm{W}$; (map 106).

Named by prospectors about 1911 .

Blueberry Bay: bay, $0.5 \mathrm{mi}$. across, on $\mathrm{S}$ coast of Unalaska I., Aleutian Is.; $53^{\circ} 31^{\prime} \mathrm{N}, 166^{\circ} 39^{\prime}$ W; (map 23).

Published in the 1944 Aleutian Coast Pilot (p. 52).

Blueberry Creek: stream, on Alaska Penin., heads at Outlet Glacier on Mount Veniaminof, flows NNE $32 \mathrm{mi}$. to Bristol Bay, $2 \mathrm{mi}$. E of Seal Is., Bristol Bay Low.; 56 $42^{\prime}$ N, $159^{\circ} 15^{\prime}$ W ; (map $30)$.

Name reported in 1923 by R. H. Sargent, USGS; published in 1927 by USGS.

Blueberry Creek: stream, flows SW $3.8 \mathrm{mi}$. to Norton Sound, $4.7 \mathrm{mi}$. N of Unalakleet, Nulato Hills; $63^{\circ} 57^{\prime} \mathrm{N}, 160^{\circ} 51^{\prime} \mathrm{W}$; (map 91).

Local name reported in 1949 by USC\&GS.

Blueberry Creek: stream, flows SW 3 mi. to Fish Lake, $22 \mathrm{mi}$. ESE of Tanana, Yukon-Tanana High.; $65^{\circ} 05^{\prime} \mathrm{N}, 151^{\circ} 20^{\prime} \mathrm{W}$; (map 106).

Local name reported in 1952 by USGS.

Blueberry Dome: hill, $1,645 \mathrm{ft}$., $5 \mathrm{mi}$. E of Sandy Lake and $7 \mathrm{mi}$. SE of Imuruk Lake, Seward Penin. High.; $65^{\circ} 29^{\prime} \mathrm{N}, 163^{\circ} 00^{\prime} \mathrm{W}$; BGN 1952; (map 110).

Reported in 1950 by D. M. Hopkins, USGS; so named because blueberries "are abundant on the slopes and summit."

Blueberry Hill: mountain, 4,490 ft., on NE side of Turnagain Arm, between Twentymile River and Peterson Creek, $16 \mathrm{mi}$. E of Sunrise, Chugach Mts.; $60^{\circ} 54^{\prime} 00^{\prime \prime} \mathrm{N}, 148^{\circ} 58^{\prime} 30^{\prime \prime} \mathrm{W}$; (map 63).

Local name reported in 1952 by USGS.

Blueberry Lake: lake, $0.3 \mathrm{mi}$. long, $1 \mathrm{mi}$. SE of Thompson Pass and $19 \mathrm{mi}$. E of Valdez, Chugach Mts.; $61^{\circ} 07^{\prime} 20^{\prime \prime} \mathrm{N}, 145^{\circ} 41^{\prime} 45^{\prime \prime} \mathrm{W}$; (map 68).

Local name published in the 1950's by USGS.

Blueberry Point: point of land, on shore of Norton Sound, $7.8 \mathrm{mi}$. $\mathrm{N}$ of Unalakleet, Nulato Hills; $63^{\circ} 59^{\prime} \mathrm{N}, 160^{\circ} 53^{\prime} \mathrm{W}$; (map 91 ).

Local name reported in 1949 by USC\&GS.

Blueberry Ridge: ridge, extends SE $4 \mathrm{mi}$. from Mason Creek to Illinois Creek, $13 \mathrm{mi}$. NE of Birches, Kokrines-Hodzana High.; $65^{\circ} 13^{\prime} \mathrm{N}$ $153^{\circ} 10^{\prime} \mathrm{W}$; (map 107).

Prospectors' name reported by USGS in the 1940 's, but probably was used much earlier.

Bluecloud Creek: stream, flows NW $4 \mathrm{mi}$. from Bluecloud Mtn. to Glacier River, $13 \mathrm{mi}$. W of Wiseman, Brooks Ra.; $67^{\circ} 27^{\prime} \mathrm{N}, 150^{\circ} 34^{\prime} \mathrm{W}$; (map 124).

Named for the mountain.
Bluecloud Mountain: mountain, 5,900 ft., $3 \mathrm{mi}$. NW of Emma Dome and $8 \mathrm{mi} \mathrm{W}$ of Wiseman, Brooks Ra.; $67^{\circ} 24^{\prime} \mathrm{N}, 150^{\circ} 25^{\prime} \mathrm{W}$; BGN 1932; (map 124). Var. Blue Cloud Mountain.

Local name reported about 1930 as "Blue Cloud Mountain" by Robert Marshall.

Blue Creek: stream, heads W of Featherly Pass and flows SW $4 \mathrm{mi}$. to Ugashik Creek, on Alaska Penin., 14 mi. NW of Kanatak, Aleutian Ra.; 57 $39^{\prime} 35^{\prime \prime} \mathrm{N}, 156^{\circ} 20^{\prime} 30^{\prime \prime} \mathrm{W}$; (map 36). Var. Little Ugashik Creek.

Local name reported as "Little Ugashik Creek" in 1902 by J. L. McPherson, Deputy Mineral Surveyor; the name "Blue Creek" was published by Capps (1923, pl. 2), USGS.

Blue Creek: stream, see Little Ugashik Greek.

Blue Fiord: estuary, on E coast of Kenai Penin., trends N $4.5 \mathrm{mi}$. to Port Nellie Juan, $26 \mathrm{mi}$. $\mathrm{SE}$ of Whittier, Chugach Mts.; $60^{\circ} 29^{\prime} 30^{\prime \prime} \mathrm{N}$, 148 $15^{\prime} 10^{\prime \prime} \mathrm{W}$; BGN 1910; (map 63).

Named in 1910 by USGS "for the color of the glacier at the head of the fiord."

Bluefish Island: island, $4 \mathrm{mi}$. long, in Yukon River at Devils Bend, $25 \mathrm{mi}$. SW of Russian Mission, Yukon-Kuskokwim Delta; $61^{\circ} 37^{\prime} \mathrm{N}$, $162^{\circ} 00^{\prime} \mathrm{W}$; (map 73).

Riverboat pilots' name recorded on a 1940 navigation chart of the Yukon River.

Bluefox Bay: bay, $2 \mathrm{mi}$. across, on $\mathbf{N}$ coast of Atka I., $W$ of Island Point, Aleutian Is.; $52^{\circ} 06^{\prime} \mathrm{N}, 174^{\circ} 46^{\prime} \mathrm{W}$; (map 18). Var. Blue Fox Bay, Pestsovaia Baie.

Translation of "Pestovaia baie," probably applied to this feature about 1829 by Ingenstrem (cnna), and published by Capt. Lutke (1836, p. 314), IRN.

Bluefox Bay: bay, on NW coast of Afognak I.; extends S $5 \mathrm{mi}$. off Shuyak Strait, Kodiak I.; $58^{\circ} 26^{\prime} \mathrm{N}, 152^{\circ} 41^{\prime} \mathrm{W}$; (map 43). Var. Black Bay.

Named "in reference to a fox farm on one of the islands in entrance"; published in 1926 by USC\&GS.

Blue Jay Rock: rock, 200 yds. across, in Conquer Bay, $0.5 \mathrm{mi}$. W of Conquer Point, on $W$ coast of Kiska I., Aleutian Is.; $52^{\circ} 00^{\prime} 20^{\prime \prime} \mathrm{N}$, $177^{\circ} 28^{\prime} 30^{\prime \prime} \mathrm{E}$; (map 14).

One of the "bird names" arbitrarily applied to features on Kiska I. by USAF for tactical purposes during World War II.

Blue Lake: lake, $1.5 \mathrm{mi}$. long, on Blue River 6 mi. $\mathbf{N}$ of its junc. with Unuk River, $2 \mathrm{mi}$. $\mathbf{S}$ of Alaska-Canada boundary, Coast Mts.; $56^{\circ} 20^{\prime} 30^{\prime \prime} \mathrm{N}, 130^{\circ} 54^{\prime} 00^{\prime \prime} \mathrm{W}$; (map 7 .

Local descriptive name reported in 1955 by USGS.

Blue Lake: lake, $3 \mathrm{mi}$. long, $6 \mathrm{mi}$. $\mathrm{E}$ of Sitka, on W side of Baranof I., Alex. Arch.; 57 $04^{\prime} 30^{\prime \prime}$ N, $135^{\circ} 10^{\prime} 00^{\prime \prime} \mathrm{W}$; BGN 1935; (map 9).

Local descriptive name reported in 1910 by Knopf (1912, fig 4), USGS.

Blue Lake: lake, $0.7 \mathrm{mi}$. long, on $\mathrm{S}$ edge of Red Glacier, $7 \mathrm{mi}$. NE of Chinitna Bay and 52 mi. NW of Homer, Aleutian Ra.; 59 $58^{\prime} 50^{\prime \prime}$ $\mathrm{N}, 152^{\circ} 53^{\prime} 30^{\prime \prime} \mathrm{W}$; (map 50).

Local name reported and published by USGS since 1950. 
Blue Lake: lake, $0.6 \mathrm{mi}$. long, $7 \mathrm{mi}$. NNW of Old Man Lake and $42 \mathrm{mi}$. WNW of Glennallen, Copper River Basin; 62 $13^{\prime} \mathrm{N}, 146^{\circ} 49^{\prime} \mathrm{W}$; (map 83).

Local name reported in 1949 by USGS.

Blue Lake: lake, $0.9 \mathrm{mi}$. long, in Nutzotin Mts., in course of Cooper Creek, $3 \mathrm{mi}$. NW of Cooper Pass, Alaska Ra.; $62^{\circ} 18^{\prime} \mathrm{N}, 142^{\circ} 31^{\prime}$ W (map 84).

Local name reported in 1960 by USGS.

Blue Mountain: mountain, 1,930 ft., on N shore of Becharof Lake, on Alaska Penin., $40 \mathrm{mi}$. SE of Egegik and $54 \mathrm{mi}$. SE of Naknek; Aleutian Ra.; 58 $02^{\prime} 45^{\prime \prime} \mathrm{N}, 156^{\circ} 20^{\prime} 30^{\prime \prime} \mathrm{W}$; (map 41).

Local name reported in 1952 by USGS.

Blue Mouse Cove: water passage, $1 \mathrm{mi}$. across, in Glacier Bay National Monument, $\mathbf{N}$ of Hugh Miller Inlet, $60 \mathrm{mi}$. NW of Hoonah, St. Elias Mts. ; $58^{\circ} 47^{\prime} 30^{\prime \prime} \mathrm{N}, 136^{\circ} 28^{\prime} 30^{\prime \prime} \mathrm{W}$; (map 10).

Local name published by USGS in the 1950's.

Blue River: stream, flows SE 13 mi. through Blue Lake to Unuk River, $7 \mathrm{mi}$. SW of AlaskaCanada boundary, Coast Mts. ; 56 $16^{\circ} 05^{\prime \prime} \mathrm{N}$, $130^{\circ} 50^{\prime 25}$ " W ; (map 7).

Local descriptive name reported in 1905 by F. Morse, USC\&GS

Blue Rock Creek: stream, flows SE $1.5 \mathrm{mi}$. to Fox River, $0.4 \mathrm{mi}$. NE of Lil Creek and $24 \mathrm{mi}$. NE of Solomon, Seward Penin. High.; 64 $44^{\circ} 40^{\prime \prime}$ $\mathrm{N}, 163^{\circ} 47^{\prime} 45^{\prime \prime} \mathrm{W}$; (map 95).

Prospectors' name reported on the 1900 "Map of the Nome Peninsula" by J. M. Davidson and B. D. Blakeslee.

Blue-Stone Creek: stream, see Left Fork Windy Creek.

Bluestone Greek: stream, flows NE $2 \mathrm{mi}$. to Gold Creek $9 \mathrm{mi}$. W of that stream's junc. with North Fork Salcha River and $48 \mathrm{mi}$. N of Big Delta, Yukon-Tanana High.; 64 $44^{\circ} 30^{\prime \prime}$ N, 145 38'15" W; (map 101).

Named by prospectors; reported in 1905 by D. C. Witherspoon (in Prindle, 1913a, pl. 1), USGS.

Bluestone River: stream, heads at junc. of Gold Run and Right Fork Bluestone River, flows NE $13 \mathrm{mi}$. to Tuksuk Channel, $12 \mathrm{mi}$. SE of Teller, Seward Penin. High.; $65^{\circ} 11^{\prime} \mathrm{N}$, $166^{\circ} 01^{\prime} \mathrm{W}$; (map 111)

Local name reported in 1900 by $E$. C. Barnard (in Brooks, 1901, pl. 17), USGS.

Blue Violet Creek: stream, flows $\mathrm{N} 10 \mathrm{mi}$. to Meshik River, $27 \mathrm{mi}$. N of Chignik, Bristol Bay Low.; $56^{\circ} 41^{\prime} \mathrm{N}, 158^{\circ} 18^{\prime} \mathrm{W}$; (map 30).

Descriptive name recorded on a 1923 fieldsheet by R. H. Sargent, USGS.

Bluff: locality, pop. $14(1940)$, at mouth of Daniels Creek, on $\mathrm{N}$ shore of Norton Sound, $21 \mathrm{mi}$. E of Solomon, Seward Penin. High.; $64^{\circ} 34^{\prime} \mathrm{N}, 163^{\circ} 45^{\prime} \mathrm{W}$; (map 95). Var. Agookauchuk, Bluff City.

Site of a mining camp established in the summer of 1900 at the height of the Nome gold rush-"Bluff owes its existence to the rich beach placers which have been developed at the mouth of Daniels Creek" (Brooks, 1901, p. 67). Bluff Post Office was established in 1901 and was discontinued in 1919 (Ricks, 1965, p. 8). Balcom (1965, p. 7) noted "The Eskimos called the place by the native name for bluff, 'Agookauchuk'."

Bluff: locality, on Richardson Highway, $19 \mathrm{mi}$. $\mathrm{SE}$ of Fairbanks, Tanana Low.; 64 $43^{\prime} \mathrm{N}$, $147^{\circ} 11^{\prime}$ W; BGN 1949; (map 100). Var. Mile 20.

Local name derived from nearby Moose Creek Bluff.

Bluff, The: bluff, elev. $112 \mathrm{ft}$., on E bank of Poltes Slough, $4.5 \mathrm{mi}$. N of Marshall, YukonKuskokwim Delta ; $61^{\circ} 55^{\prime} 30^{\prime \prime} \mathrm{N}, 162^{\circ} 08^{\prime} 45^{\prime \prime}$ W; (map 74).

Local name published in 1962 by USGS. Bluff Cabin Ridge: ridge, elev. 1,200 ft., trends $\mathrm{N} 1 \mathrm{mi}$., on $\mathrm{S}$ bank of Tanana River, $5.5 \mathrm{mi}$. E of Big Delta, Alaska Ra.; $64^{\circ} 09^{\prime} 30^{\prime \prime} \mathrm{N}$, $145^{\circ} 39^{\prime} 30^{\prime \prime} \mathrm{W}$; (map 101).

Local name reported in 1950 by USGS.

Bluff Cape: point of land, see Bluff Point.

Bluff Cape: point of land, see Crag Point.

Bluff Cape: point of land, see Otrubistoi Point. Bluff City: locality, see Bluff.

Bluff Cove: cove, $0.5 \mathrm{mi}$. across, $1.3 \mathrm{mi}$. $\mathrm{S}$ of Conquer Point, on $W$ coast of Kiska I., Aleutian Is.; $51^{\circ} 59^{\prime} 20^{\prime \prime} \mathrm{N}, 177^{\circ} 28^{\prime} 30^{\prime \prime} \mathrm{E}$; (map 14).

One of many arbitrary names applied to features on Kiska Island by USAF for tactical purposes during World War II.

Bluff Cove: cove, see Jeanie Cove.

Bluff Creek: stream, on Alaska Penin., flows NW $6.5 \mathrm{mi}$. to Landlocked Creek near NW edge of Aleutian Ra., $22 \mathrm{mi}$. N of Chignik, Bristol Bay Low.; $56^{\circ} 37^{\prime} \mathrm{N}, 158^{\circ} 27^{\prime} \mathrm{W}$; (map 30)

Descriptive name reported in 1923 by R. H. Sargent, USGS

Bluff Creek: stream, heads in Tokosha Mts., flows SE $5.5 \mathrm{mi}$. to Ruth River near terminus of Ruth Glacier, $27 \mathrm{mi}$. NW of Talkeetna, Alaska Ra.; $62^{\circ} 40^{\prime} \mathrm{N}, 150^{\circ} 29^{\prime} \mathrm{W}$; (map 81).

Local descriptive name reported in 1958 by USGS

Bluff Creek: stream, flows NW $1.6 \mathrm{mi}$. to Arctic Creek, $13 \mathrm{mi}$. NW of Nome, Seward Penin. High.; $64^{\circ} 38^{\prime} \mathrm{N}, 165^{\circ} 46^{\prime} \mathrm{W}$; (map 94). Var. Buff Creek.

Prospectors' name published in 1956 by USGS. Shown as "Buff" on the 1900 "Map of Nome Peninsula" by J. M. Davidson and B. D. Blakeslee.

Bluff Creek: stream, flows NW 5 mi. to American Creek, $3 \mathrm{mi}$. SW of Eagle, Yukon-Tanana High.; 64 $45^{\prime} 30^{\prime \prime} \mathrm{N}, 141^{\circ} 14^{\prime} 45^{\prime \prime} \mathrm{W}$; (map 102).

Descriptive name applied by prospectors; reported in 1898 by E. G. Barnard, USGS.

Bluff Creek: stream, flows SW $3 \mathrm{mi}$. to Turner Creek which flows to Noxapaga River, $33 \mathrm{mi}$. W of Imuruk Lake, Seward Penin. High.; $65^{\circ} 34^{\prime} \mathrm{N}, 164^{\circ} 26^{\prime} \mathrm{W}$; (map 110).

Prospectors' name reported in 1901 by T. G. Gerdine (in Collier, 1902, pl. 12), USGS.

Bluff Creek: stream, flows E $3.8 \mathrm{mi}$. to Arctic River, $9 \mathrm{mi}$. E of Ear Mtn. and $48 \mathrm{mi}$. NE of
Teller, Seward Penin. High.; $65^{\circ} 56^{\prime} \mathrm{N}, 165^{\circ}$ 56' W; (map 111).

Prospectors' name reported in 1901 by T. G. Gerdine (in Collier, 1902, pl. 12), USGS.

Bluff Gulch: ravine, extends N $2 \mathrm{mi}$. to Middle Fork Koyukuk River, 5 mi. NNE of Wiseman, Brooks Ra.; $67^{\circ} 28^{\prime} 30^{\prime \prime} \mathrm{N}, 150^{\circ} 00^{\prime} 00^{\prime \prime} \mathrm{W}$; (map 123).

Local name reported in 1956 by T. $E$. Taylor, USGS.

Bluff Island: island, $0.8 \mathrm{mi}$. long, at mouth of Shipley Bay, on NW coast of Kosciusko I., Alex. Arch.; 56 $06^{\circ} 15^{\prime \prime} \mathrm{N}, 133^{\circ} 40^{\prime} 30^{\prime \prime} \mathrm{W}$; (map 6).

Descriptive name given in 1879 by W. H. Dall, USC\&GS.

Bluff Island: island, $0.8 \mathrm{mi}$. long, in Kashevarof Is., off NE coast of Prince of Wales I., Alex. Arch.; $56^{\circ} 10^{\prime} \mathrm{N}, 132^{\circ} 53^{\prime} \mathrm{W}$; (map 6).

Named in 1886 by Lt. Comdr. A. S. Snow, USN; published in 1887 on USC\&GS Chart 706.

Bluff Island: islands, see Buyan Islands.

Bluff Lake: lake, $800 \mathrm{ft}$. long, on Revillagigedo I., on Traitors Creek, 9 mi. E of Bushy Point, on Behm Canal, Alex. Arch.; $55^{\circ} 43^{\prime} 25^{\prime \prime} \mathrm{N}$, $131^{\circ} 29^{\prime} 00^{\prime \prime} \mathrm{W}$; (map 3 ).

Local name reported in 1948 by USGS.

Bluff Lake: lake, $0.6 \mathrm{mi}$. across, near NW coast of Revillagigedo I., $1.5 \mathrm{mi}$. E of Neets Bay, in course of Neets Creek, Alex. Arch.; 55 $46^{\circ} 45^{\prime \prime}$ N, $131^{\circ} 26^{\prime} 30^{\prime \prime} \mathrm{W}$; BGN 1962; (map 3).

Local name recorded in 1921 by USFS.

Bluff Point: hill, on Kenai Penin. at $\mathrm{N}$ entrance to Kachemak Bay, $5 \mathrm{mi}$. NW of Homer, Cook Inlet Low.; $59^{\circ} 40^{\prime} \mathrm{N}, 151^{\circ} 41^{\prime} \mathrm{W}$; (map 50).

Named in 1880 by W. H. Dall, USC\&GS.

Bluff Point: point of land, on NW coast of Dolgoi I., in Pavlof Is., Aleutian Ra.; $55^{\circ} 09^{\prime} 40^{\prime \prime} \mathrm{N}$, $161^{\circ} 53^{\prime} 40^{\prime \prime} \mathrm{W}$; (map 28). Var. Bluff Cape.

Descriptive name published as "Bluff Cape" on an 1890 USBF map, and as "Bluff Point" by USC\&GS in the 1916 Coast Pilot (p. 184).

Bluff Point: point of land, on S coast of Alaska Penin. at Long Beach, near entrance to Pavlof Bay, Aleutian Ra.; $55^{\circ} 20^{\prime} 20^{\prime \prime} \mathrm{N}, 161^{\circ} 46^{\prime} 30^{\prime \prime}$ W; (map 28).

Local name reported by USGS on a 1929 map of Pavlof District, Alaska Peninsula.

Bluff Point: point of land, on S coast of Alaska Penin., on $\mathrm{N}$ shore of Canoe Bay, $\mathrm{E}$ of Pavlof Bay, Aleutian Ra.; $55^{\circ} 33^{\prime} \mathrm{N}, 161^{\circ} 12^{\prime} \mathrm{W}$; (map 28).

Local name reported in 1929 by USGS.

Bluff Point: point of land, on Alaska Penin., N point of entrance to Mine Harbor in SE arm of Herendeen Bay, Bristol Bay Low ; 55 $46^{\prime} 10^{\prime \prime}$ N, $160^{\circ} 43^{\prime} 00^{\prime \prime}$ W; (map 28)

Descriptive name given in 1890 by Lt. Comdr. Z. L. Tanner, USN; published in 1899 by USBF.

Bluff Point: point of land, on NE coast of Cleveland Penin., between Spacious and Yes Bays, Alex. Arch.; 55 $53^{\prime} 05^{\prime \prime} \mathrm{N}, 131^{\circ} 44^{\prime} 40^{\prime \prime} \mathrm{W}$; (map 3).

Descriptive name given in 1891 by USC\&GS. 
Bluff Point: point of land, on $\mathrm{N}$ shore of Woewodski Harbor, on Admiralty I., $42 \mathrm{mi}$. E of Sitka, Alex. Arch.; $57^{\circ} 11^{\prime} 00^{\prime \prime} \mathrm{N}, 134^{\circ} 14^{\prime} 20^{\prime \prime}$ W; (map 9).

Named in 1889 by Lt. Comdr. H. B. Mansfield, USN, and published by USC\&GS in the 1891 Coast Pilot (p. 143).

Bluff Point: point of land, on SW shore of Karluk Lake, $23 \mathrm{mi}$. SE of Karluk, Kodiak I.; $57^{\circ} 19^{\prime} 00^{\prime \prime} \mathrm{N}, 15^{\circ} 02^{\prime} 30^{\prime \prime} \mathrm{W}$; (map 35).

Local descriptive name reported in 1952 by USGS.

Bluff Point: point of land, extends NE $0.5 \mathrm{mi}$, near mouth of Shearwater Bay, on N shore of Kiliuda Bay, on SE coast of Kodiak I.; $57^{\circ} 19^{\prime} 40^{\prime \prime} \mathrm{N}, 152^{\circ} 54^{\prime} 00^{\prime \prime} \mathrm{W}$; (map 34).

Descriptive name published in 1912 by USC\&GS.

Bluff Point: point of land, at NW entrance to Killisnoo Harbor, on $\mathrm{W}$ coast of Admiralty I., $1.8 \mathrm{mi}$. $\mathrm{S}$ of Angoon, Alex. Arch.; $57^{\circ} 28^{\prime} 20^{\prime \prime} \mathrm{N}, 134^{\circ} 33^{\prime} 45^{\prime \prime} \mathrm{W}$; (map 9).

Named in 1869 by Comdr. R. W. Meade, USN; published in 1881 on U.S. Hydrog. Chart 882.

Bluff Point: point of land, $\mathrm{N}$ point of entrance to Hartney Bay, $5 \mathrm{mi}$. SW of Cordova, Chugach Mts.; $60^{\circ} 30^{\prime} \mathrm{N}, 145^{\circ} 52^{\prime} \mathrm{W}$; (map 64).

Local name published in 1943 by USC\&GS.

Bluff Point: point of land, see Cannery Point. Bluff Point: point of land, see Jeanie Point.

Bluff Point: point of land, see Outer Point.

Bluff Point: promontory, elev. $700 \mathrm{ft}$., on S coast of Alaska Penin., E point of entrance to Stepovak Bay, Aleutian Ra.; 55 $45^{\prime} \mathrm{N}, 159^{\circ} 43^{\prime} \mathrm{W}$; (map 27).

Named in 1880 by W. H. Dall, USC\&GS.

Blume Creek: stream, flows SW $5.5 \mathrm{mi}$. to Feather River, $31 \mathrm{mi}$. NW of Nome, Seward Penin. High.; $64^{\circ} 50^{\prime} \mathrm{N}, 166^{\circ} 04^{\prime} \mathrm{W}$; (map 94).

Prospectors' name reported in 1900 by E. C. Barnard (in Brooks, 1901, pl. 17), USGS.

Blunt Mountain: mountain, 2,095 ft., on E coast of Annette I., $1.5 \mathrm{mi}$. SW of Ham I., Alex. Arch.; $55^{\circ} 08^{\prime} 25^{\prime \prime}$ N, $131^{\circ} 23^{\prime} 48^{\prime \prime}$ W ; (map 3).

Descriptive name given in 1883 by Lt. Comdr. H. E. Nichols, USN.

Blunt Point: point of land, on $\mathrm{W}$ bank of Portland Canal, $2.7 \mathrm{mi}$. NE of Astronomical Point, Coast Mts.; $55^{\circ} 14^{\prime} 55^{\prime \prime} \mathrm{N}, 130^{\circ} 02^{\prime} 20^{\prime \prime} \mathrm{W}$; (map 3 ).

Descriptive name published in 1911 by USC\&GS.

Blunt Point: point of land, on $\mathbf{S}$ coast of Alaska Penin. between Windbound and American Bays, on $\mathrm{W}$ shore of Stepovak Bay, Aleutian Ra.; $55^{\circ} 40^{\prime} \mathrm{N}, 160^{\circ} 08^{\prime} \mathrm{W}$; (map 28).

Named in 1880 by W. H. Dall, USC\&GS.

Blunt Point: point of land, on NW side of Mitkof I., along $\mathrm{E}$ shore of Wrangell Narrows at $\mathrm{N}$ end of Scow Bay, 2.5 mi. SW of Petersburg, Alex. Arch.; 56 $48^{\prime} \mathrm{N}, 132^{\circ} 58^{\prime} \mathrm{W}$; (map 6). Var. Mys Tupoy, Mys Zhila.

Translation about 1882 by USC\&GS of "Mys Tupoy" which was published in 1850 on Russian Hydrog. Dept. Chart 1441. In
1838 the navigator G. Lindenberg called it "Mys Zhila," meaning "vein (or lode) cape." Blygh Gulch: ravine, trends NE $1.9 \mathrm{mi}$. to White Creek S of its confluence with Chititu Creek, $15 \mathrm{mi}$. SE of McCarthy, St. Elias Mts.; $61^{\circ} 17^{\prime} 30^{\prime \prime} \mathrm{N}, 142^{\circ} 34^{\prime} 40^{\prime \prime} \mathrm{W}_{\text {; (map 67). }}$.

Local name reported in 1959 by USGS.

Blyings, Canal: bight, see Blying Sound.

Blying Sound: bight, $28 \mathrm{mi}$. wide, between Clape Fairfield and Aialik Cape, on SE coast of Kenai Penin., $24 \mathrm{mi}$. SE of Seward, Chugach Mts.; $59^{\circ} 50^{\prime} \mathrm{N}, 149^{\circ} 15^{\prime} \mathrm{W}$; (map 49). Var. Canal Blyings, Port Andrews.

According to Capt. Vancouver (1798, v. 3 , p. 147-148), $\mathrm{RN}$, this is a Russian name, although it appears to be English. Vancouver stated that this feature was called "Port Andrews" by Capt. Nathaniel Portlock in 1787. The Spanish charts call it "Canal Blying."

Boat Creek: stream, on Beaufort Sea coast, heads in lake, flows NW 6 mi. to Smith Bay, $1 \mathrm{mi}$. S of Drew Point, Arctic Plain; 70 $51^{\prime} 40^{\prime \prime} \mathrm{N}$, $153^{\circ} 56^{\prime} 20^{\prime \prime} \mathrm{W}$; (map 148).

This name was originally applied, August 6, 1837 , by P. W. Dease and Thomas Simpson, to a stream "behind Point M'Pherson" (Thomas Simpson, 1843, p. 169). See McLeod, Point.

Boat Extreme: locality, on coast of Beaufort Sea, SE extremity of off-shore barrier islands, $E$ of Dease Inlet, Arctic Plain; $71^{\circ} 05^{\prime} 30^{\prime \prime} \mathrm{N}, 154^{\circ}$ $48^{\prime} 10^{\prime \prime}$ W; (map 153). Var. Toolemina, Tulimanak, Tullimanirk.

Named by P. W. Dease and Thomas Simpson $(1843$, p. 143) in 1837 , being the limit of their journey by boat. While Dease stayed behind, Simpson continued the trip westward to Point Barrow overland. The Eskimo name "Toolemina (Tulimanak)," shown on Comdr. Maguire's map (Great Britain, 1854, map facing p. 186), means "whale rib." The same native name with a slightly different spelling is applied today to nearby Tulimanik Island.

Boat Harbor: bay, $0.6 \mathrm{mi}$. across, on $\mathbf{E}$ shore of Revillagigedo Channel, Coast. Mts. ; $54^{\circ} 47^{\prime} 30^{\prime \prime}$ N, $130^{\circ} 54^{\prime} 30^{\prime \prime} \mathrm{W}$; (map 2).

Local name published in 1943 by USC\&GS.

Boat Harbor: bay, $1 \mathrm{mi}$. across, on W shore of Lynn Canal, $4 \mathrm{mi}$. N of Point Whidbey and 35 mi. NW of Juneau, St. Elias Mts.; $58^{\circ} 38^{\prime}$ $15^{\prime \prime} \mathrm{N}, 135^{\circ} 09^{\prime} 15^{\prime \prime} \mathrm{W}$; (map 11).

Named by USC\&GS in 1891 and published in 1893 on Chart 8300.

Boat Harbor: bight, $1 \mathrm{mi}$. wide, on $\mathrm{N}$ shore of Norton Sound at Topkok, $15 \mathrm{mi}$. E of Solomon, Seward Penin. High.; $64^{\circ} 34^{\prime}$ N, $163^{\circ} 56^{\prime}$ W.; (map 95).

Named in 1899 by USC\&GS.

Boat Island: island, in Yakutat Bay.

Name published on a 1794 chart by Henry Roberts (Wagner, 1937, p. 361).

Boat Lake: lake, 4 mi. SW of Fivemile Lake and $19 \mathrm{mi}$. NE of Roundabout Mtn., Koyukuk Low.; $65^{\circ} 42^{\prime} \mathrm{N}, 156^{\circ} 04^{\prime} \mathrm{W}$; (map 108).

This is a partial translation of a Koyukuk Indian name meaning "place where boats are made." Reported and so named in 1956 by Orth.
Boatmakers Creek: stream, flows NW $8.5 \mathrm{mi}$. to Nayuka River, $4 \mathrm{mi}$. S of Sadokhten Lake and $25 \mathrm{mi}$. WNW of Hochandochtla Mtn., Kokrines-Hodzana High.; $65^{\circ} 37^{\prime} 30^{\prime \prime} \mathrm{N}, 155^{\circ} 44^{\prime}$ $00^{\prime \prime} \mathrm{W}$; (map 107).

Name reported as a general translation of a Koyukan Indian name in 1956 by Orth.

Boatman Pass: pass, 2,000 ft., $3 \mathrm{mi}$. S of West Buttons and $33 \mathrm{mi}$. SW of Chandalar, Brooks Ra.; $67^{\circ} 11^{\prime} 30^{\prime \prime} \mathrm{N}, 149^{\circ} 26^{\prime} 00^{\prime \prime} \mathrm{W}$; (map 123).

Local name reported in 1956 by T. E. Taylor, USGS.

Boat Rock: rock, in mouth of Nakat Bay $2 \mathrm{mi}$. NE of Cape Fox, Coast Mts.; 54 $46^{\prime} 50^{\prime \prime} \mathrm{N}$, $130^{\circ} 47^{\prime} 50^{\prime \prime} \mathrm{W}$; (map 2).

Descriptive name given in 1883 by Lt. Comdr. H. E. Nichols, USN; so called "because it looks like a boat from a distance."

Boat Rocks: rocks, NW rocks of Barrier Is., extend $400 \mathrm{ft}$. in Cordova Bay, Alex. Arch.; $54^{\circ} 49^{\prime} 30^{\prime \prime} \mathrm{N}, 132^{\circ} 29^{\prime} 50^{\prime \prime} \mathrm{W}$; (map 1).

Local name published in 1943 by USC\&GS.

Bob Creek: stream, flows NE $4.6 \mathrm{mi}$. to Bear Creek, $23 \mathrm{mi}$. NW of Haycock, Seward Penin. High.; 65⒊' N, $161^{\circ} 33^{\prime} \mathrm{W}$; (map 109).

Local name shown on a 1903 fieldsheet by D. C. Witherspoon, USGS.

Bob Creek: stream, flows $\mathrm{N}$ to Agiapuk River near its junc. with American River, about 20 mi. NE of Teller, Seward Penin. High.; (map 111).

Prospectors' name shown on a map of Cape Nome gold fields by David Fox, Jr., dated 1901. This feature cannot be precisely identified on current maps.

Bober: island, see Otter Island.

Bob Lake: lake, $2.4 \mathrm{mi}$. long, $4 \mathrm{mi}$. S of Brown Grass Lake and $22 \mathrm{mi}$. NW of Christian, Brooks Ra.; $67^{\circ} 32^{\prime}$ N, $145^{\circ} 54^{\prime}$ W; (map 122).

Local name reported in 1956 by T. E. Taylor, USGS.

Bobrof: reef, see Douglas Reef.

Bobroff Island: island, see Bobrof Island.

Bobroff Island: island, see Sea Otter Island.

Bobrof Island: island, $2.5 \mathrm{mi}$. across, in Andreanof Is. between Kanaga and Tanaga Is., Aleutian Is.; $51^{\circ} 54^{\prime} \mathrm{N}, 177^{\circ} 27^{\prime} \mathrm{W}$; (map 17). Var. Beaver Island, Beaver Islet, Bobroff Island, Bobrovie Islet, Bobrovy Islet, Bobrow Islet, Ostrov Bobrovoy Vilga, Sea Otter Islet.

Name reported in 1790 by Commodore Joseph Billings, IRN. Capt. Tebenkov (1852, map 28), IRN, published "O[strov] Bobrovoy Vilga," or "Sea Otter Vilga Island". "Vilga" may have been the Aleut name. Baker (1906, p. 558) published "Sea Otter Islet".

Bobrof Volcano: peak, 2,419 ft., on Bobrof I., Aleutian Is.; $51^{\circ} 54^{\prime} 30^{\prime \prime} \mathrm{N}, 177^{\circ} 26^{\prime} 20^{\prime \prime} \mathrm{W}$; (map 17).

Published by USC\&GS in the 1947 Coast Pilot (p. 469).

Bobrovaia Baie: bay, see Beaver Bay.

Bobrovi: island, see Otter Island.

Bobrovia: island, see Otter Island.

Bobrovia Mountain: mountain, $1,000 \mathrm{ft}$., on Alaska Penin., at E entrance to Pavlof Bay, 
$11 \mathrm{mi}$. E of Cape Tolstoi, Aleutian Ra.; $55^{\circ} 23^{\prime}$

N, $161^{\circ} 13^{\prime} \mathrm{W}$; (map 28$)$.

Local name reported in 1929 by USGS.

Bobrovie: point of land, see Beaver Point.

Bobrovie Island: island, see Sea Otter Island.

Bobrovie Islands: rocks, see Latax Rocks.

Bobrovie Islet: island, see Bobrof Island.

Bobrovoi: island, see Otter Island.

Bobrovoi: reef, see Douglas Reef.

Bobrovoi: sea, see Bering Sea.

Bobrovoi, Zaliv: bay, see Beaver Bay.

Bobrovoi Guba: bay, see Beaver Inlet.

Bobrovoi Point: point of land, $2 \mathrm{mi}$. NW of Cape Ommaney, on $\mathbf{S}$ coast of Baranof I., Alex. Arch.; $56^{\circ} 11^{\prime} 00^{\prime \prime} \mathrm{N}, 134^{\circ} 42^{\prime} 30^{\prime \prime} \mathrm{W}$; (map 5). Var. Point Bobrovoy, Mys Bobrovoy.

Russian name meaning "sea otter" published in 1850 by the Russian American Company as "Mys Bobrovoy."

Bobrovoy, Mys: point of land, see Bobrovoi Point.

Bobrovoy, Ostrov: island, see Sea Otter Island.

Bobrovoy, Point: point of land, see Bobrovoi Point.

Bobrovoy Guba: bay, see Beaver Inlet.

Bobrovoy (valga), Ostrov: island, see Sea Otter Island.

Bobrovoy Vilga, Ostrov: island, see Bobrof Island.

Bobrovskoi: mountain, see Beaver Mountain.

Bobrovy Island: island, see Sea Otter Island.

Bobrovy Islet: island, see Bobrof Island.

Bobrovyy, Mys: point of land, see Beaver Point.

Bobrovyy, Ostrov: island, see Sea Otter Island.

Bobrovyy, Zaliv: bay, see Otter Bay.

Bobrow: reef, see Douglas Reef.

Bobrow Island: island, see Sea Otter Island.

Bobrow Islet: island, see Bobrof Island.

Bobrowskoje: village, see Uyak.

Bobs Bay: bay, on NW coast of Dall I., extends E 3 mi., $N$ of Diver Point, Alex. Arch.; $55^{\circ} 12^{\prime}$ $\mathrm{N}, 133^{\circ} 14^{\prime} \mathrm{W}$; (map 4).

Local name published in 1914 by USC\&GS.

Bobs Creek: stream, flows NW $1.6 \mathrm{mi}$. to West Fork Kuyukutuk River, $10 \mathrm{mi}$. E of Marshall, Nulato Hills; $61^{\circ} 52^{\prime} 15^{\prime \prime} \mathrm{N}, 161^{\circ} 46^{\prime} 50^{\prime \prime} \mathrm{W}$; (map 73).

Prospectors' name reported in 1916 by Harrington (1918, map), USGS.

Bobs Creek: stream, see Babs Creek.

Bobs Lake: lake, $1 \mathrm{mi}$. long, $5 \mathrm{mi}$. $\mathrm{S}$ of Lake Louise and $34 \mathrm{mi}$. WNW of Glennallen, Copper River Basin; $62^{\circ} 12^{\prime} \mathrm{N}, 146^{\circ} 35^{\prime} \mathrm{W}$; (map 83).

Local name reported in 1949 by USGS.

Bobs Place: locality, on SE tip of St. Philip I., in Gulf of Esquibel, Alex. Arch.; 55 $38^{\prime} 10^{\prime \prime}$ $\mathrm{N}, 133^{\circ} 24^{\prime} 10^{\prime \prime} \mathrm{W}$; (map 4).

This is "an old Indian village, known locally as Bobs Place" (U.S. Coast and Geodetic Survey, 1925, p. 146). One building is shown at this site on a 1964 USGS map.

Bobs Point: point of land, $\mathrm{W}$ tip of Blanquizal Is., between Gulf of Esquibel and San Christoval Channel, Alex. Arch.; 55 $37^{\prime} 00^{\prime \prime} \mathrm{N}$, $133^{\circ} 24^{\prime} 15^{\prime \prime} \mathrm{W}$; (map 4).

Local name recorded in 1951 by USGS.
Bocan Mountain: mountain, see Bokan Mountain.

Bocas Point: point of land, in Ulloa Channel, on E coast of Suemez I., Alex. Arch.; 55 $17^{\prime} 40^{\prime \prime}$ N, $133^{\circ} 16^{\prime} 15^{\prime \prime} \mathrm{W}$; (map 4). Var. Boras Point, Mys de las Bokas, Punta Bocas, Punta de las Bocas.

Spanish name given in 1775-79 by Don Juan de la Bodega y Quadra and Francisco Antonio Maurelle as "Punta de las Bocas," meaning "point of the mouths."

Bocharof Lake: lake, see Becharof Lake.

Bochonoff, Lake: lake, see Becharof Lake.

Bock Bight: cove, extends NW $2 \mathrm{mi}$. to Thomas Bay, on $\mathrm{N}$ coast of Point Agassiz Penin., $13 \mathrm{mi}$. NE of Petersburg, Coast Mts.; 56 $59^{\prime} 45^{\prime \prime}$ N, $132^{\circ} 53^{\prime} 00^{\prime \prime} \mathrm{W}$; (map 6).

Local name published by USC\&GS in the 1901 Coast Pilot (p. 131).

Bodenburg Butte: hill, $881 \mathrm{ft}$., $4 \mathrm{mi}$. SE of Palmer, between Glenn Highway and Matanuska River, Cook Inlet Low.; 61 $32^{\circ} 45^{\prime \prime} \mathrm{N}, 149^{\circ}$ $03^{\prime} 00^{\prime \prime} \mathrm{W}$; (map 69).

Local name reported in 1951 by USGS.

Bodfish Island: barrier island, $1 \mathrm{mi}$. long, in Jones Is., on Beaufort Sea coast, $3.2 \mathrm{mi}$. NW of Beechey Point, Arctic Plain; $70^{\circ} 31^{\prime} 45^{\prime \prime} \mathrm{N}$, $149^{\circ} 15^{\prime} 28^{\prime \prime} \mathrm{W}$; (map 150).

Named in 1910 by Leffingwell $(1919$, p. 94) "After Capt. Bodfish, of the whaling fleet."

Boer Creek: stream, flows NE $1 \mathrm{mi}$. to Hudson Creek, $25 \mathrm{mi}$. NE of Nome, Seward Penin. High.; $64^{\circ} 52^{\prime} \mathrm{N}, 165^{\circ} 18^{\prime} \mathrm{W}$; (map 94).

Prospectors' name reported in 1904 by T. G. Gerdine, USGS. Name was probably suggested by the Boer War in Africa.

Boga Slof Hill: hill, see Bogoslof Hill.

Boga Slov: hill, see Bogoslof Hill.

Bog Cape: point of land, see Yanaliuk, Cape.

Bogert Point: point of land, on E shore of Port Snettisham, $1.2 \mathrm{mi}$. NNE of Fannie I. and 29 mi. SE of Juneau, Coast Mts.; 58 $03^{\prime} 55^{\prime \prime} \mathrm{N}$, $133^{\circ} 46^{\prime} 20^{\prime \prime} \mathrm{W}$; (map 12).

Named in 1888 by Lt. Comdr. C. M. Thomas, USN.

Bogie Creek: stream, in De Long Mts., flows NE $8 \mathrm{mi}$. to Jubilee Creek, $61 \mathrm{mi}$. NE of Misheguk Mtn., Brooks Ra. ; $68^{\circ} 41^{\prime}$ N, $159^{\circ} 00^{\prime}$ W.; BGN 1960; (map 131).

Named in 1953 by I. L. Tailleur, USGS, for "parts of a weasel vehicle needing repair[?]." Bogosloff Hill: hill, see Bogoslof Hill.

Bogoslof Hill: hill, $590 \mathrm{ft}$., on central Saint Paul I., in Pribilof Is.; $57^{\circ} 10^{\prime} 45^{\prime \prime} \mathrm{N}, 170^{\circ} 17^{\prime} 25^{\prime \prime}$ W; (map 38). Var. Boga Slof Hill, Boga Slov, Bogosloff Hill.

Local name reported by Elliott (1881, Saint Paul notes) as "Boga Slov," or "word of God." The name has an indefinite application to the place, but is derived perhaps due to the fact that: "the pious Russians, immediately after landing at Zapadnie in 1787 , ascended the hill and erected a huge cross thereon."

Bogoslof Island: island, $1 \mathrm{mi}$. long, in Bering Sea, $27 \mathrm{mi}$. N of Umnak I., Aleutian Is.; 53 $3^{\circ} 56^{\prime} \mathrm{N}$, $168^{\circ} 02^{\prime} \mathrm{W}$; BGN 1890; (map 22). Var. Agaschagoch Island, Agashogok Island, Amnak Island, Amnuk Island, Bogoslov
Island, Castle Island, Jean Bogosloff Island, Johan Bogoslow Island, Ostrov Bogoslova, Ostrov Ioanna Bogoslova.

Russian name meaning "theologian"; given because the island "rose from the sea May 18, 1796, St. John's Day * **" (Baker, 1906, p. 142). The name "O[strov] Ioanna Bogoslova," or "John the Theologian's Island," was published by Lt. Sarichev (1826, map 3), IRN. Capt. Tebenkov (1852, map 25), IRN, published the name "O[strova] Bogoslova," or "theologian's island."

Bogoslova, Ostrov: island, see Bogoslof Island. Bogoslov Island: island, see Bogoslof Island.

Bogus Creek: stream, heads at $61^{\circ} 11^{\prime} \mathrm{N}, 159^{\circ} 56^{\prime}$ $\mathrm{W}$, and flows W $50 \mathrm{mi}$. to Kuskokwim River, $8 \mathrm{mi} \mathrm{NE}$ of Tuluksak and $42 \mathrm{mi}$. NE of Bethel, Yukon-Kuskokwim Delta; $61^{\circ} 11^{\prime} 2^{\prime \prime}$ N, $160^{\circ}$ 47'15" W; (map 73).

Local name reported in 1943 by USGS.

Bohemia Basin: valley, extends $\mathrm{E} 1.5 \mathrm{mi}$., along Bohemia Greek, on E coast of Yakobi I., 26 mi. NW of Chichagof, Alex. Arch.; 57 $59^{\prime} \mathrm{N}$, $136^{\circ} 25^{\prime} \mathrm{W}$; (map 9).

Name published in 1929 by USC\&GS on Chart 8260.

Bohemia Creek: stream, flows E $2 \mathrm{mi}$. through Bohemia Basin to Lisianski Strait, off $W$ coast of Chichag of I., $26 \mathrm{mi}$. NW of Chichagof, Alex. Arch.; 57 $59^{\prime} 15^{\prime \prime} \mathrm{N}, 136^{\circ} 22^{\prime} 35^{\prime \prime} \mathrm{W}$; (map 9)

Name published by USGS (Reed and Dorr, 1942, pl. 20).

Bohemian Range: mountain range, elev. 2,000$2,511 \mathrm{ft}$., extends NW $12 \mathrm{mi}$. from Kupreanof Mtn., 17 mi. NW of Petersburg, on $\mathrm{N}$ coast of Kupreanof I., Alex. Arch.; $56^{\circ} 58^{\prime} \mathrm{N}, 133^{\circ} 27^{\prime}$ W; (map 6).

Named in 1887 by Lt. Comdr. C. M. Thomas, USN, for charting purposes; published in 1888 on USC\&GS Chart 705.

Bohrow Island: island, see Sea Otter Island. Boidarka Island : island, see Boidarkin Island.

Boidarkin Group: islands, see Kutchuma Islands.

Boidarkin Island: island, $0.2 \mathrm{mi}$. across, in Kutchuma Is., $3 \mathrm{mi}$. $\mathrm{S}$ of Sitka, off $\mathrm{W}$ coast of Baranof I., Alex. Arch.; 57 $00^{\prime} 40^{\prime \prime} \mathrm{N}$, $135^{\circ} 18^{\prime} 40^{\prime \prime}$ W; (map 9). Var. Boidarka Island, Hawley Island, Ostrov Boydarkin.

Russian name meaning "skin boat," given in 1809 by navigator Ivan Vasiliev the first; published by Lt. Sarichev (1826, map 19), IRN, as "O[strov] Boydarkin." "This is derived from "baydarka [bidarka]," meaning "chiton," a name used by the Russians for the Aleut skin boats."

Boil, Mys: peninsula, see Mohican, Cape.

Boil Creek: stream, flows NE 2 mi. to Skookum River which flows to Klokerblok River, $16 \mathrm{mi}$. NE of Solomon, Seward Penin. High.; 64 ${ }^{\circ} 41^{\prime}$ N, $163^{\circ} 59^{\prime} \mathrm{W}$; (map 95). Var. Rock Creek.

Prospectors' name reported in 1900 by E. C. Barnard, USGS. This appears to be the stream shown as "Rock Creek" on a map of Cape Nome gold fields by David Fox, Jr., dated 1901.

Boiler Point: point of land, on $W$ shore of Morzhovoi Bay, $22 \mathrm{mi}$. SW of village of Cold 
Bay, on SW end of Alaska Penin., Aleutian Ra.; $55^{\circ} 00^{\prime} 40^{\prime \prime}$ N, $163^{\circ} 09^{\prime} 00^{\prime \prime}$ W; (map 29).

"So named because a large ship's boiler washed up on the beach"; published in 1925 by USC\&GS.

Boiling Pinnacles: rocks, $1.5 \mathrm{mi}$. N of Umnak Island and $6 \mathrm{mi}$. W of Cape Tanak, Aleutian Is.; $53^{\circ} 34^{\prime} \mathrm{N}, 168^{\circ} 10^{\prime} \mathrm{W}$; BGN 1940; (map 22).

Named in 1939 by USC\&GS because "light tide rips and swirls occur over the shoal on changes of tide."

Boise Creek: stream, flows SW $3 \mathrm{mi}$. to Coal Greek, $14 \mathrm{mi}$. NE of Solomon, Seward Penin. High.; $64^{\circ} 44^{\prime} \mathrm{N}, 164^{\circ} 12^{\prime} \mathrm{W}$; (map 95).

Prospectors' name reported in 1900 by E. C. Barnard (in Brooks, 1901, pl. 17), USGS.

Bokan Mountain: mountain, 2,500 ft., on $S$ end of Prince of Wales I. between South Arm Moira Sound and West Arm Kendrick Bay, Alex. Arch.; 54 ${ }^{\circ} 5^{\prime} \mathrm{N}, 132^{\circ} 09^{\prime} \mathrm{W}$; BGN 1922; (map 1). Var. Bocan Mountain.

Recorded on a 1911 manuscript map by USFS as "Bocan Mountain"; published as "Bokan Mountain" by USC\&GS in 1922.

Bokas, Mys de las: point of land, see Bocas Point.

Bokay Inlet: estuary, see Quadra, Boca de.

Bok Island: island, see Ban Island.

Bold Bluff Point: point of land, on Alaska Penin., on $\mathrm{S}$ shore of Herendeen Bay, Aleutian Ra.; $55^{\circ} 45^{\prime} \mathrm{N}, 160^{\circ} 46^{\prime} \mathrm{W}$; (map 28).

Descriptive name, given in 1890 by Lt. Comdr. Z. L. Tanner, USN.

Bold Cape: point of land, on SW end of Alaska Penin., between Cold and Belkofski Bays, 23 $\mathrm{mi}$. SE of village of Cold Bay, Aleutian Ra.; $55^{\circ} 01^{\prime} 30^{\prime \prime}$ N, $162^{\circ} 15^{\prime} 00^{\prime \prime}$ W; (map 29). Var. Mys Stolb, Pillar Cape.

Local name reported by USBF in 1888. Published as "M[ys] Stolb," meaning "Pillar Cape," in 1847 on Russian Hydrog. Dept. Chart 1379.

Bold Cliff: cliff, on E shore of Killisnoo Harbor, on $W$ coast of Admiralty I., $1 \mathrm{mi}$. $E$ of Killisnoo and $2.5 \mathrm{mi}$. SE of Angoon, Alex. Arch.; $57^{\circ} 28^{\prime} 00^{\prime \prime} \mathrm{N}, 134^{\circ} 32^{\prime} 30^{\prime \prime} \mathrm{W}$; (map 9).

Descriptive name probably given in 1869 by Comdr. R. W. Meade, USN; published in 1881 on U.S. Hydrog. Chart 882 . Name not shown on recent maps.

Bold Island: island, $3 \mathrm{mi}$. long, in Revillagigedo Channel, between Annette and Revillagigedo Is., Alex. Arch.; $55^{\circ} 15^{\prime} \mathrm{N}, 131^{\circ} 25^{\prime} \mathrm{W}$; (map 3).

Descriptive name given in 1883 by $\mathbf{L t}$. Comdr. H. E. Nichols, USN.

Bold Island: island, $0.5 \mathrm{mi}$. long, in Ernest Sound, $32 \mathrm{mi}$. SE of Wrangell, on $E$ coast of Etolin I., Alex. Arch.; $56^{\circ} 03^{\prime} 45^{\prime \prime} \mathrm{N}, 132^{\circ} 08^{\prime}$ $30^{\prime \prime} \mathrm{W}$; (map 6).

Named in 1924 by USC\&GS.

Bold Peak: mountain, 7,522 ft., E of S end of Eklutna Lake, $19 \mathrm{mi}$. SE of Palmer, Chugach Mts.; $61^{\circ} 20^{\prime} 40^{\prime \prime} \mathrm{N}, 148^{\circ} 55^{\prime} 25^{\prime \prime} \mathrm{W}$; BGN 1964; (map 69).

So named in 1958 by members of the Mountaineering Club of Alaska, because of its bold appearance when viewed from Eklutna Lake.

Boldrin Creek: stream, flows E $4.5 \mathrm{mi}$. to Eldorado River, $24 \mathrm{mi}$. NW of Solomon, Seward Penin. High.; $64^{\circ} 50^{\prime} \mathrm{N}, 164^{\circ} 58^{\prime} \mathrm{W}$; (map 95).

Prospectors' name reported in 1900 by E. C. Barnard (in Brooks, 1901, pl. 17), USGS.

Boldrin Creek: stream, in Baird Mts., flows S $7.5 \mathrm{mi}$. to Klery Creek $3.4 \mathrm{mi}$. NE of that stream's junc. with Squirrel River, $12 \mathrm{mi}$. N of Kiana, Brooks Ra.; $67^{\circ} 08^{\prime} \mathrm{N}, 160^{\circ} 35^{\prime} \mathrm{W}$; (map 127).

Prospectors' name; reported in 1910 by P. S. Smith (in Brooks and others, 1911, pl. 13), USGS.

Bolgen Creek: stream, flows SW $3 \mathrm{mi}$. to Birch Creek, $11 \mathrm{mi}$. SW of Circle, Yukon-Tanana High.; $65^{\circ} 42^{\prime} 30^{\prime \prime} \mathrm{N}, 144^{\circ} 20^{\prime} 00^{\prime \prime} \mathrm{W}$; (map 104).

Prospectors' name reported in 1954 or 1955 by USGS topographers.

Bolio Lake: lake, $1.5 \mathrm{mi}$. long, between Delta River and Richardson Highway, $10 \mathrm{mi}$. SW of Delta Junction, Alaska Ra.; $63^{\circ} 53^{\prime} 45^{\prime \prime} \mathrm{N}$, $145^{\circ} 51^{\prime} 20^{\prime \prime} \mathrm{W}$; (map 86).

Name published on relatively recent maps.

Bolles Inlet: cove, extends N $1.3 \mathrm{mi}$., off Kargani Strait, on $W$ coast of Dall I., Alex. Arch.; $54^{\circ} 51^{\prime} 00^{\prime \prime} \mathrm{N}, 132^{\circ} 44^{\prime} 45^{\prime \prime} \mathrm{W}$; (map 1).

Local name published in 1924 by USC\&GS. Probably named for Lt. Timothy Dix Bolles, USN.

Bolles Ledge: rock, in Ward Cove, on SW coast of Revillagigedo I., Alex. Arch.; 55 $24^{\prime} 15^{\prime \prime}$ N, $131^{\circ} 43^{\prime} 25^{\prime \prime} \mathrm{W}$; (map 3 ).

This feature was named in 1882 by W. H. Dall, USC\&GS, for Lt. Timothy Dix Bolles, a crew member of Coast Survey steamer Hassler when this rock was discovered.

Bolshoi: peak, see Foraker, Mount.

Bolshoiger: locality, see Bolshoigor.

Bolshoigor: locality, on right bank of Yukon River, about $25 \mathrm{mi}$. upstream from mouth of Koyuk River, Koyukuk Low.; (map 97). Var. Bolshoiger.

Former Eskimo camp or settlement listed by Petroff $(1884$, map) in the 10 th Census, in 1880.

Bolshoi Island: island, $1 \mathrm{mi}$. long, largest of Bolshoi Is., in Nazan Bay on $\mathbf{E}$ coast of Atka I., Aleutian Is.; $52^{\circ} 11^{\prime} 50^{\prime \prime} \mathrm{N}, 174^{\circ} 10^{\prime} 30^{\prime \prime}$ W; BGN 1915; (map 18). Var. Bomchoi Island, Bomshoi Island, Large Island, Ostrov, Bolshoy.

Published as "O[strov] Bolshoy," or "Large Island," by Capt. Tebenkov (1852, map 27), IRN.

Bolshoi Islands: islands, group, extends $2.3 \mathrm{mi}$. in Nazan Bay on E coast of Atka I., Aleutian Is.; $52^{\circ} 11^{\prime} 50^{\prime \prime} \mathrm{N}, 174^{\circ} 10^{\prime} 00^{\prime \prime} \mathrm{W}$; (map 18).

Published by USC\&GS in the 1944 Aleutian Coast Pilot (p. 100).

Bolshoi Koniuzhi: island, see Big Koniuji Island.

Bolshoi Krieposti: island, see Big Fort Island. Bolshoi Malinof: island, see Raspberry Island.
Bolshoi Point: point of land, see Manby Point. Bolshoi Rock: rock, see Big Rock.

Bolshoi Roukav: estuary, see Great Arm Whale Bay.

Bolshoi Rukav: bay, see Big Branch Bay.

Bolshoi Strelka: bay, see Big Branch Bay.

Bolshoy, Ostrov: island, see Big Island.

Bolshoy, Ostrov: island, see Bolshoi Island.

Bolshoy Krypost, Ostrov: island, see Big Fort Island.

Bolshoy Rukav: bay, see Big Branch Bay.

Bolshoy Rukav: estuary, see Great Arm Whale Bay.

Bolshoy Vrangel, Ostrov: island, see Wrangel Island.

Bombardment Creek: stream, flows NW $4 \mathrm{mi}$. from Midnight Mtn. to North Fork Koyukuk River, 2 mi. N of Hanging Glacier Mtn. and $38 \mathrm{mi}$. NW of Wiseman, Brooks Ra.; $67^{\circ} 55^{\prime} 40^{\prime \prime}$ N., $150^{\circ} 42^{\prime} 00^{\prime \prime}$ W; (map 124).

Named in 1939 by Marshall (1956, p. 148) who wrote, "Marvelous waterfalls were plunging down on every side. I was continuously in their spray, so narrow was the chasm ***. In this mile and a half I counted thirteen falls with an estimated drop of 200 feet or more * * *."

Bomb Point: point of land, between Orca and Simpson Bays, $7 \mathrm{mi}$. NW of Cordova, Chugach Mts.; $60^{\circ} 37^{\prime} \mathrm{N}, 145^{\circ} 54^{\prime} \mathrm{W}$; (map 64).

Named by Capt. Abercrombie (1899, map), USA.

Bomchoi Island: island, see Bolshoi Island

Bommer Creek: stream, flows SE $4.5 \mathrm{mi}$. to Big Bar Creek which flows to Koyuk River, $6 \mathrm{mi}$. SW of Kiwalik Mtn. and $26 \mathrm{mi}$. SE of Imuruk Lake, Seward Penin. High.; $65^{\circ} 27^{\prime} \mathrm{N}, 162^{\circ} 21^{\prime}$ W; (map 110).

Prospectors' name reported in 1903 by D. C. Witherspoon (in Moffit, 1905, pl. 2), USGS.

Bomshoi Island: island, see Bolshoi Island.

Bona, Mount: mountain, $16,500 \mathrm{ft}$., at head of Hawkins Glacier, $39 \mathrm{mi}$. E of McCarthy, St. Elias Mts.; $61^{\circ} 23^{\prime} \mathrm{N}, 141^{\circ} 45^{\prime} \mathrm{W}$; (map 67).

Named by His Royal Highness, Prince Luigi Amedeo di Savoia, Duke of the Abruzzi, for the Bona, his racing yacht (Filippi, 1900, p. 160). Its first ascent was made by Allen Carpé Andrew Taylor, and Terris Moore on July 2, 1930 (Farquhar, 1959, p. 214).

Bonanza: locality, at the junc. of Bonanza and Chathenda Creeks in the Nutzotin Mts.; 10 mi. E of Euchre Mtn., Alaska Ra.; 62 ${ }^{\circ} 05^{\prime} \mathrm{N}$, $141^{\circ} 53^{\prime} \mathrm{W}$; (map 84).

Mining camp reported by USGS in 1942.

Bonanza Bar: locality, on $\mathbf{S}$ bank of Fortymile River, at Canyon Creek, $38 \mathrm{mi}$. S of Eagle, Yukon-Tanana High.; $64^{\circ} 15^{\prime} \mathrm{N}, 141^{\circ} 11^{\prime} \mathrm{W}$; (map 102).

Mining camp, now abandoned, reported in 1905 by L. M. Prindle, USGS.

Bonanza Bar: bar, in Fortymile River, $1 \mathrm{mi} . \mathrm{E}$ of Nugget Gulch, $37 \mathrm{mi}$. S of Eagle, YukonTanana High.; $64^{\circ} 15^{\prime} 30^{\prime \prime} \mathrm{N}, 141^{\circ} 12^{\prime} 00^{\prime \prime} \mathrm{W}$; (map 102).

Named by prospectors and reported in 1896 by Spurr (1898, pl. 46), USGS. 
Bonanza California River: stream, see Bonanza River.

Bonanza Creek: stream, heads at Bonanza Hills, flows SW $28 \mathrm{mi}$. to Mulchatna River, $50 \mathrm{mi}$. NW of Nondalton, Alaska Ra.; 6043'30" N, $155^{\circ} 08^{\prime} 00^{\prime \prime} \mathrm{W}$; (map 61).

Local name reported in 1954 by USGS; derived from the Bonanza Hills at the head of the stream.

Bonanza Creek: stream, flows SE $4.9 \mathrm{mi}$. to Bear Creek, $7.8 \mathrm{mi}$. NE of Nyac and $37 \mathrm{mi}$. SW of Aniak, Kilbuck-Kuskokwim Mts.; 61 ${ }^{\circ} 04^{\prime} \mathrm{N}$, $159^{\circ} 45^{\prime} \mathrm{W}$; (map 73 ).

Prospectors' name, reported in 1914 by A. G. Maddren, USGS.

Bonanza Creek: stream, flows SW 3 mi. to Kennicott Glacier, $1 \mathrm{mi}$. NE of McCarthy, Wrangell Mts.; $61^{\circ} 29^{\prime} \mathrm{N}, 142^{\circ} 54^{\prime} \mathrm{W}$; (map 67).

Named for the Bonanza mine by prospectors; reported by Moffit (1914, pl. 1), USGS.

Bonanza Creek: stream, flows WNW $1.5 \mathrm{mi}$. to Crooked Creek, $65 \mathrm{mi}$. NE of Palmer, Talkeetna Mts.; 61 ${ }^{\circ} 57^{\prime} 45^{\prime \prime} \mathrm{N}, 147^{\circ} 17^{\prime} 00^{\prime \prime} \mathrm{W}$; BGN 1960; (map 69).

Local name reported in 1956 by USGS. Placer gold locations occur on the stream.

Bonanza Creek: stream, in Nutzotin Mts., flows SW $5 \mathrm{mi}$. to Chathenda Creek $7 \mathrm{mi}$. E of that stream's junc. with Chisana River, Alaska Ra.; $62^{\circ} 05^{\prime} \mathrm{N}, 141^{\circ} 52^{\prime} \mathrm{W}$; (map 84).

Named by W. E. James and Peter Nelson, prospectors, who made a discovery on this stream May 3, 1913 (Brooks and others, 1914, p. 315).

Bonanza Creek: stream, heads $4 \mathrm{mi}$. S of Camelback Mtn., flows SW $60 \mathrm{mi}$. to Iditarod River, $\mathrm{E}$ of Swinging Dome, $10 \mathrm{mi}$. SW of Flat and $52 \mathrm{mi}$. NE of Holy Cross, Kilbuck-Kuskokwim Mts., $62^{\circ} 20^{\prime} 10^{\prime \prime} \mathrm{N}, 158^{\circ} 11^{\prime} 40^{\prime \prime} \mathrm{W}$; (map 79).

Prospectors' name obtained in 1913 by Eakin (1914, pl. 1), USGS.

Bonanza Creek: stream, heads $W$ of Chelatna Lake, flows SE $4.5 \mathrm{mi}$. to Sunflower Creek, $45 \mathrm{mi}$. NW of Talkeetna, Alaska Ra.; $62^{\circ} 26^{\prime} 30^{\prime \prime} \mathrm{N}, 151^{\circ} 30^{\prime} 30^{\prime \prime} \mathrm{W}$; (map 81).

Prospectors' name reported in 1906 by R. W. Porter, USGS.

Bonanza Creek: stream, flows W $4 \mathrm{mi}$. to California Creek, $40 \mathrm{mi}$. SE of Nenana, Alaska

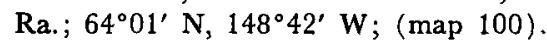

Named by prospectors; reported in 1910 by USGS (Capps, 1912, pl. 1).

Bonanza Creek: stream, flows SW $4 \mathrm{mi}$. to Timber Creek, $3.5 \mathrm{mi}$. S of Poorman and $48 \mathrm{mi}$. SW of Ruby, Kilbuck-Kuskokwim Mts.; $64^{\circ} 03^{\prime} 00^{\prime \prime} \mathrm{N}, 155^{\circ} 34^{\prime} 50^{\prime \prime} \mathrm{W}$; BGN 1936; (map 98).

Prospectors' name reported in 1935 by USGS.

Bonanza Creek: stream, flows NW $21 \mathrm{mi}$. to Sulatna River, $4 \mathrm{mi}$. SW of Monzonite Hills, Nowitna Low.; $64^{\circ} 22^{\prime} 00^{\prime \prime} \mathrm{N}, 154^{\circ} 45^{\prime} 30^{\prime \prime} \mathrm{W}$; (map 98).

Local name reported about 1952 by USGS.

Bonanza Creek: stream, flows NW $28 \mathrm{mi}$. to Khotol River, $3 \mathrm{mi}$. NE of junc. of Khotol River and Canoe Portage Creek, $20 \mathrm{mi}$. SE of Nulato, Koyukuk Low.; $64^{\circ} 27^{\prime}$ N, $157^{\circ} 52^{\prime}$ W; (map 97).

Local name reported in 1935 by Frederica de Laguna, BAE.

Bonanza Creek: stream, flows SW $11 \mathrm{mi}$. to Tanana River, $18 \mathrm{mi}$. NE of Nenana, Tanana Low.; $64^{\circ} 39^{\prime} 25^{\prime \prime} \mathrm{N}, 148^{\circ} 30^{\prime} 40^{\prime \prime} \mathrm{W}$; (map 100).

Prospectors' name reported in 1950 by USGS topographers.

Bonanza Creek: stream, flows E $8 \mathrm{mi}$. to North Fork Salcha River, $10 \mathrm{mi}$. E of The Butte and $45 \mathrm{mi}$. NNE of Big Delta, Yukon-Tanana High.; $64^{\circ} 46^{\prime} \mathrm{N}, 145^{\circ} 19^{\prime} \mathrm{W}$; (map (101).

A prospectors' name, applied by mistake in 1905 by D. C. Witherspoon, USGS, to a stream which flows north to Gold Creek near Flume Creek (Prindle, 1906, pl. 1). In 1913, the USGS published the name "Bonanza Creek" for its present location.

Bonanza Creek: stream, flows NE $2.3 \mathrm{mi}$. to Jasper Creek which flows to Salmon Lake, 29 mi. NE of Nome, Seward Penin. High.; 64 $53^{\prime}$ N, $165^{\circ} 00^{\prime} \mathrm{W}$; (map 94).

Prospectors' name reported in 1900 by $\mathrm{E}$. C. Barnard (in Brooks, 1901, pl. 17), USGS.

Bonanza Creek: stream, flows E $7 \mathrm{mi}$. to Casadepaga River, $28 \mathrm{mi}$. NE of Solomon, Seward Penin. High.; 64 $54^{\circ} \mathrm{N}, 164^{\circ} 08^{\prime} \mathrm{W}$; (map 95).

Prospectors' name reported in 1900 by E. C. Barnard (in Brooks, 1901, pl. 17), USGS.

Bonanza Creek: stream, flows NE $2.5 \mathrm{mi}$. to Seventymile River, $39 \mathrm{mi}$. NW of Eagle, Yukon-Tanana High.; $65^{\circ} 00^{\prime} \mathrm{N}, 142^{\circ} 23^{\prime} \mathrm{W}$; (map 102).

Local name published in 1956 by USGS.

Bonanza Creek: stream, flows SW $2.5 \mathrm{mi}$. to Little Chena River, $10 \mathrm{mi}$. W of Chena Dome and $32 \mathrm{mi}$. NE of Fairbanks, Yukon-Tanana High.; $65^{\circ} 04^{\prime} 45^{\prime \prime} \mathrm{N}, 146^{\circ} 49^{\prime} 00^{\prime \prime} \mathrm{W}$; (map 104).

Prospectors' name reported in 1954 or 1955 by USGS topographers.

Bonanza Creek: stream, formed by Derwent and Fisher Creeks, flows NW $5 \mathrm{mi}$. to Charley River, $6 \mathrm{mi}$. SE of that stream's junc. with Yukon River, Yukon-Tanana High; $65^{\circ} 14^{\prime} 20^{\prime \prime} \mathrm{N}, 142^{\circ} 44^{\prime} 00^{\prime \prime} \mathrm{W}$; (map 103). Var. Big Bonanza Creek, Fish Greek.

Prospectors' name reported in 1902 by Collier (1903, p. 29), USGS. "Big Bonanza Creek" was recorded on an unpublished map by E. J. Chamberlain, dated 1902 . In the same year "Fish Creek" was shown on an unpublished map by Lt. Hjalmar Erickson and William Yanert, USA.

Bonanza Creek: stream, in Rampart Mts., flows SW $4 \mathrm{mi}$. to Morelock Creek $4.3 \mathrm{mi}$. NW of that stream's junc. with Yukon River, $24 \mathrm{mi}$. ENE of Tanana, Kokrines-Hodzana High.; $65^{\circ} 19^{\prime} 30^{\prime \prime} \mathrm{N}, 151^{\circ} 21^{\prime} 00^{\prime \prime} \mathrm{W}$; (map 106).

Prospectors' name reported in 1911 by H. M. Eakin (in Brooks and others, 1912, pl. 13), USGS.

Bonanza Creek: stream, flows NW $9.5 \mathrm{mi}$. to Kuzitrin River, $15 \mathrm{mi}$. N of Mount Benedeleben, $32 \mathrm{mi}$. SW of Imuruk Lake, Seward
Penin. High.; $65^{\circ} 23^{\prime} \mathrm{N}, 164^{\circ} 11^{\prime} \mathrm{W} ; B G N$ 1952; (map 110).

Prospectors' name reported in 1901 by T. G. Gerdine (in Collier, 1902, pl. 12), USGS.

Bonanza Creek: stream, flows NE $6 \mathrm{mi}$. to Porcupine Creek, $42 \mathrm{mi}$. SW of Circle, YukonTanana High.; $65^{\circ} 33^{\prime} 30^{\prime \prime}$ N, $145^{\circ} 19^{\prime} 00^{\prime \prime}$ W; (map 104).

Named by prospectors; reported in 1896 by USGS (Spurr, 1898, pl. 50).

Bonanza Creek: stream, flows NE $13 \mathrm{mi}$. to Kiwalik River, $43 \mathrm{mi}$. NW of Haycock, Seward Penin. High.; 65⒋ $45^{\prime}$, $161^{\circ} 52^{\prime}$ W; (map 109).

Local name shown on a 1903 fieldsheet by D. C. Witherspoon, USGS.

Bonanza Creek: stream, flows $\mathrm{N} 14 \mathrm{mi}$. to Sanaguich River, $21 \mathrm{mi}$. SE of Shishmaref, Kotzebue-Kobuk Low, ; $66^{\circ} 03^{\prime} \mathrm{N}, 165^{\circ} 32^{\prime} \mathrm{W}$; (map 112).

Prospectors' name reported in 1950 by USGS.

Bonanza Creek: stream, flows W $35 \mathrm{mi}$. to Fish Creek $14 \mathrm{mi}$. E of its junc. with South Fork Koyukuk River, $28 \mathrm{mi}$. SE of Bettles, Kanuti Flats; $66^{\circ} 35^{\prime} 30^{\prime \prime} \mathrm{N}, 151^{\circ} 03^{\prime} 30^{\prime \prime} \mathrm{W}$; (map 117).

Name used by prospectors and reported in 1899 by G. H. Wonson, Master of the steamer Dorothy, on his manscript map of the Koyukuk River.

Bonanza Creek: stream, flows SW $6.5 \mathrm{mi}$. to North Fork Koyukuk River, 9 mi. S of Eroded Mtn. and $22 \mathrm{mi}$. NW of Wiseman, Brooks Ra.; $67^{\circ} 29^{\prime} 15^{\prime \prime} \mathrm{N}, 150^{\circ} 56^{\prime} 30^{\prime \prime} \mathrm{W}$; BGN 1932; (map 124).

Local name reported in 1929 by Marshall (1956, p. 9).

Bonanza Creek: stream, flows NW to Dome Creek which flows to American River, about $30 \mathrm{mi}$. NE of Teller, Seward Penin. High.; (map 111).

Prospectors' name shown on a map of Cape Nome gold fields by David Fox, Jr., dated 1901. This feature cannot be precisely identified on current maps.

Bonanza Creek: stream, see Big Bonanza Creek. Bonanza Creek: stream, see Bullion Creek.

Bonanza Creek: stream, see Jasper Creek.

Bonanza Creek: stream, see Larsen Creek.

Bonanza Flats: swamp, between Bonanza Creek and Iditarod River, $8 \mathrm{mi}$. SW of Flat and 52 mi. NE of Holy Cross, Kilbuck-Kuskokwim Mts. ; $62^{\circ} 21^{\prime} \mathrm{N}, 158^{\circ} 09^{\prime} \mathrm{W}$; BGN 1945; (map 79).

Prospectors' name submitted in 1944 by USGS.

Bonanza Gulch: ravine, heads on $\mathrm{W}$ side of Bonanza Hill, trends NW $0.5 \mathrm{mi}$. to Glacier Creek, $6.5 \mathrm{mi}$. $\mathrm{N}$ of Nome, Seward Penin. High.; $64^{\circ} 35^{\prime} 50^{\prime \prime} \mathrm{N}, 165^{\circ} 25^{\prime} 45^{\prime \prime} \mathrm{W}$; (map 94).

Prospectors' name reported on the 1903 Campion Mining and Trading Co. map by George M. Ashford.

Bonanza Hill: hill, $640 \mathrm{ft}$., $5 \mathrm{mi}$. N of Nome, Seward Penin. High.; 64 $35^{\prime}$ N, $165^{\circ} 24^{\prime}$ W; (map 94). Var. Saddle Rock. 
Local name published in 1956 by USGS. Shown as "Saddle Rock" on the 1902 "Map of Nome and Snake River Country" by J. M. Davidson.

Bonanza Hills: mountains, $3,500 \mathrm{ft}$., $15 \mathrm{mi}$. SE of Whitefish Lake and $50 \mathrm{mi}$. NE of Nondalton, Alaska Ra.; $60^{\circ} 43^{\prime} \mathrm{N}, 154^{\circ} 33^{\prime} \mathrm{W}$; (map 61).

Name shown on a 1929 field sheet by Gerald FitzGerald, USGS.

Bonanza Peak: mountain, 6,983 ft., $7 \mathrm{mi}$. NE of McCarthy, Wrangell Mts.; $61^{\circ} 31^{\prime} \mathrm{N}, 142^{\circ} 50^{\prime}$ W; (map 67).

Local name reported by Moffit (1914, pl. 1), USGS.

Bonanza Ridge: ridge, $15 \mathrm{mi}$. long, trends $\mathrm{N}-\mathrm{S}$ between McCarthy Creek and Root and Kennicott Glaciers, NE of McCarthy, Wrangell Mts.; $61^{\circ} 37^{\prime} \mathrm{N}, 142^{\circ} 50^{\prime} \mathrm{W}$ [N end], $61^{\circ} 26^{\prime} \mathrm{N}$, $142^{\circ} 49^{\prime} \mathrm{W}$ [S end]; $B G N$ 1965; (map 67).

So named by E. M. MacKevett, Jr., USGS, in 1965. Name "taken from Bonanza Peak *** and from the nearby Bonanza mine, one of the famous Kennecott mines."

Bonanza River: stream, heads at junc. of Lone and Sigard Creeks, flows SE $25 \mathrm{mi}$. to Norton Sound $2 \mathrm{mi}$. SW of Solomon, Seward Penin.

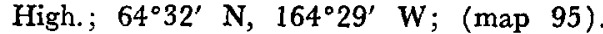
Var. Bonanza Galifornia River.

Prospectors' name reported in 1899 by Schrader and Brooks (1900, map 3), USGS. Bonasila: locality, see Paradise.

Bonasila Dome: mountain, 1,807 ft., SE of Two Spot Mtn., 25 mi. NW of Holy Cross, Nulato Hills; $62^{\circ} 19^{\prime} 25^{\prime \prime} \mathrm{N}, 160^{\circ} 29^{\prime} 55^{\prime \prime} \mathrm{W}$; (map 78). Var. Simel Mountain.

Name reported in 1916 by G. L. Harrington, USGS. It was also known as Simel Mountain after a local resident.

Bonasila Island: island, $3.5 \mathrm{mi}$. long, in Yukon River, 24 mi. NW of Holy Cross, Nulato Hills; $62^{\circ} 30^{\prime} \mathrm{N}, 160^{\circ} 12^{\prime} \mathrm{W}$; (map 78).

Riverboat pilots' name shown on a 1940 "Navigation Chart of the Tanana-Yukon Rivers" published by U.S. Dept. of Interior.

Bonasila River: stream, heads at $62^{\circ} 56^{\prime} \mathrm{N}$, $161^{\circ} 12^{\prime} \mathrm{W}$, flows SE $125 \mathrm{mi}$. to Bonasila Slough, $0.7 \mathrm{mi}$. W of Elkhorn I. in Yukon River and $27 \mathrm{mi}$. NW of Holy Cross, Nulato Hills; $62^{\circ} 32^{\prime} \mathrm{N}, 160^{\circ} 13^{\prime} \mathrm{W}$; (map 78).

Local name shown on a 1916 fieldsheet by R. H. Sargent, USGS. Hrdlička (1943, p. 50) noted, "Bonasila [buena, good, and silla, seat]-an odd Spanish name for these regions * * *." It may be an English form of a native name.

Bonasila Slough: stream, anabranch of Yukon River, heads SE of Elkhorn I., flows SE $7 \mathrm{mi}$., $8 \mathrm{mi}$. S of Anvik and $21 \mathrm{mi}$. NW of Holy Cross, Nulato Hills; $62^{\circ} 29^{\prime} 40^{\prime \prime} \mathrm{N}, 160^{\circ} 09^{\prime} 00^{\prime \prime}$ W; (map 78). Var. Simel Slough.

Name shown on a 1916 fieldsheet by R. H. Sargent, USGS.

Bond Bay: cove, $0.6 \mathrm{mi}$. across, on $\mathrm{SE}$ coast of Cleveland Penin., 2 mi. $\mathrm{N}$ of Caamano Point, Alex. Arch.; 55 $31^{\prime} 30^{\prime \prime}$ N, $131^{\circ} 57^{\prime} 00^{\prime \prime} \mathrm{W}$; (map 3).

Local navigators' name obtained in 1904 by H. C. Fassett, USBF.
Bond Creek: stream, flows NW $10 \mathrm{mi}$. to Nabesna River, $6 \mathrm{mi}$. SE of Nabesna, Wrangell Mts.; 62 $17^{\prime} \mathrm{N}, 142^{\circ} 53^{\prime} \mathrm{W}$; (map 84). Var. Ts-um-bon-da.

Name derived in 1902 by F. C. Schrader, USGS, from the native name "Ts-um-bon-da."

Bone Creek: stream, flows SE and SW $14 \mathrm{mi}$. to Slana River in Mentasta Mts., $5 \mathrm{mi}$. NW of Mentasta Lake, Alaska Ra.; $62^{\circ} 57^{\prime} \mathrm{N}, 143^{\circ} 56^{\prime}$ W; (map 84).

Local name reported in 1960 by USGS.

Bone Creek: stream, flows NE $3 \mathrm{mi}$. to Burnside Greek, $45 \mathrm{mi}$. NW of Haycock, Seward Penin High.; $65^{\circ} 46^{\prime}$ N, $161^{\circ} 57^{\prime}$ W; (map 109). Var. Bono Creek.

Local name published on maps after 1950. Boney Creek: stream, flows NW $45 \mathrm{mi}$. to Yukon River S of Circle I., $11 \mathrm{mi}$. SW of Tanana, Nowitna Low.; $65^{\circ} 06^{\prime} \mathrm{N}, 152^{\circ} 26^{\prime} \mathrm{W}$; (map 106)

Local name reported in 1952 by USGS.

Bonibrook: suburb, SW of Nunaka Valley, $\mathbf{E}$ of Anchorage, Cook Inlet Low.; 61 $11^{\prime} \mathrm{N}$, $149^{\circ} 47^{\prime} \mathrm{W}$; (map 69).

Local name reported in 1952 by USGS.

Bonilla, Isla de: island, see Shuyak Island.

Bonita Creek: stream, flows E $1.5 \mathrm{mi}$., joins New Eldorado Creek to form Osborn Creek, $12 \mathrm{mi}$. NE of Nome, Seward Penin. High.; 64 $38^{\prime}$ N, $165^{\circ} 10^{\prime} \mathrm{W}$; (map 94).

Prospectors' name shown on a 1900 "Map of Nome Peninsula" by J. M. Davidson and B. D. Blakeslee.

Bonita Creek: stream, flows $\mathrm{N} 1 \mathrm{mi}$. to Canyon Creek which flows to Casadepaga River, 21 mi. NE of Solomon, Seward Penin. High.; $64^{\circ} 51^{\prime} \mathrm{N}, 164^{\circ} 24^{\prime} \mathrm{W}$; (map 95).

Prospectors' name reported in 1905 by T. G. Gerdine, USGS.

Bonnerfield: locality, see Bonnifield.

Bonnerville: locality, see Bonnifield.

Bonnes Nouvelles Baie: bay, see Goodnews Bay. Bonnet Creek: stream, see Bennett Greek.

Bonneville: locality, see Bonnifield.

Bonnie Creek: stream, flows NE $25 \mathrm{mi}$. to Takotna River, $33 \mathrm{mi}$. SW of McGrath, Kilbuck-Kuskokwim Mts.; $62^{\circ} 42^{\prime} 15^{\prime \prime} \mathrm{N}, 156^{\circ} 31^{\prime}$ 10" W; (map 79). Var. Banner Creek.

Local name obtained in 1952 by USGS topographers.

Bonnie Lake: lake, $1 \mathrm{mi}$. long, in course of Sawmill Creek, $1 \mathrm{mi}$. $\mathrm{N}$ of Glenn Highway and $30 \mathrm{mi}$. NE of Palmer, Talkeetna Mts. $61^{\circ} 48^{\prime} 50^{\prime \prime} \mathrm{N}, 148^{\circ} 18^{\prime} 15^{\prime \prime} \mathrm{W}$; (map 69).

Local name reported in 1948 by USGS.

Bonnifield: locality, on right bank of Gold King Creek, at $\mathrm{S}$ terminus of Bonnifield Trail, 54 mi. S of Fairbanks, Alaska Ra.; $64^{\circ} 00^{\prime} \mathrm{N}$, $148^{\circ} 02^{\prime} \mathrm{W}$; (map 100). Var. Bonnerfield, Bonnerville, Bonneville.

Named by prospectors for John E. Bonnifield, who, in 1903, was one of the first to locate a mining claim in the region south of the Tanana River. The name is shown on an ARC map dated 1925.

Bonnifield Creek: stream, heads at $64^{\circ} 01^{\prime} \mathrm{N}$, $147^{\circ} 56^{\prime} \mathrm{W}$, flows $\mathrm{N} 30 \mathrm{mi}$. to Wood River, 36 mi. S of Fairbanks, Tanana Low.; $64^{\circ} 20^{\prime} \mathrm{N}$, $148^{\circ} 02^{\prime} \mathrm{W}$; (map 100).

Named by prospectors for John E. Bonnifield. The name was reported in 1906 by $\mathrm{L}$. M. Prindle (in Brooks and others, 1907, pl. 4, and p. 207), USGS.

Bono Creek: stream, see Bone Creek.

Bonton Creek: stream, flows $\mathrm{NE} 2 \mathrm{mi}$. to Champion Creek, $30 \mathrm{mi}$. SW of Eagle, YukonTanana High.; $64^{\circ} 33^{\prime} \mathrm{N}, 142^{\circ} 01^{\prime} \mathrm{W}$; (map 102).

Prospectors' name shown on an 1898 manuscript map by C. A. Woodruff, Fort Cudahy, Canada.

Boob Creek: stream, flows NW $4 \mathrm{mi}$. to Mastodon Creek $1.5 \mathrm{mi}$. E of its junc. with Tolstoi Creek, $22 \mathrm{mi}$. NW of Ophir and $52 \mathrm{mi}$. NW of McGrath, Kilbuck-Kuskokwim Mts.; $63^{\circ}$. $21^{\prime} \mathrm{N}, 157^{\circ} 01^{\prime} \mathrm{W}$; (map 90).

Prospectors' name reported in 1916 by G. L. Harrington, USGS.

Boomerang Creek: stream, heads at glacier terminus near Bow Pass, flows NW $5 \mathrm{mi}$. to Chisana Glacier, Wrangell Mts.; $62^{\circ} 01^{\prime} \mathrm{N}$, $142^{\circ} 17^{\prime} \mathrm{W}$; (map 84). Var. Boomerange Creek.

Local name reported in 1960 by USGS

Boomerange Creek: stream, see Boomerang Creek.

Boomerang Lake: lake, $0.9 \mathrm{mi}$. long, $11 \mathrm{mi}$. SE of junc. of Copper and Slana Rivers and 30 mi. NW of Nabesna, Wrangell Mts.; $62^{\circ} 32^{\prime}$ N, $143^{\circ} 52^{\prime} \mathrm{W}$; (map 84 ).

So named because the lake is shaped like an Australian boomerang; published in 1948 by USGS.

Booshu Camp: locality, near W coast of St. Lawrence I. on Moghoweyik River, $8 \mathrm{mi}$. N of Bunnell Cape and $22 \mathrm{mi}$. S of Gambell; 63⒉ $8^{\prime} \mathrm{N}, 171^{\circ} 48^{\prime} \mathrm{W}$; BGN 1951; (map 93). Var. Imughialuk, Mokhoweyik Camp, Moowookyik Camp.

Named for an Eskimo family at Gambell, which freqently occupies this camp.

Boot Bay: bay, on SE coast of Adak I., extends NNE 3 mi., $W$ of Boot Point, Aleutian Is.; $51^{\circ} 43^{\prime} 30^{\prime \prime} \mathrm{N}, 176^{\circ} 30^{\prime} 00^{\prime \prime} \mathrm{W}$; (map 17).

Name published by USC\&GS in the 1944 Aleutian Coast Pilot (p. 113).

Boothby Creek: stream, flows S $0.8 \mathrm{mi}$. to diversion ditch parallel to Pioneer Greek, $1.6 \mathrm{mi}$. $\mathrm{NE}$ of Eureka and $20 \mathrm{mi}$. S of Rampart Yukon-Tanana High.; $65^{\circ} 11^{\prime} 30^{\prime \prime} \mathrm{N}, 150^{\circ} 10^{\prime}$ 15" W; (map 106).

Prospectors' name reported in 1904 by Prindle and Hess (1906, pl. 3), USGS.

Boot Lake: lake, $2 \mathrm{mi}$. long, $\mathrm{E}$ of Iliamna Lake, at SW end of Chigmit Mts., between Kakhonak and Upper Copper Lakes, Aleutian Ra.; 59 $34^{\prime} 30^{\prime \prime} \mathrm{N}, 154^{\circ} 05^{\prime} 15^{\prime \prime} \mathrm{W}$; (map 51).

Locally named because its shape resembles a boot; published in 1954 by USGS.

Boot Lake: lake, see Miners Lake.

Bootleg Bend: bend, on Porcupine River, $35 \mathrm{mi}$. $\mathrm{NE}$ of Fort Yukon, Yukon Flats; $66^{\circ} 48^{\prime} \mathrm{N}$, $144^{\circ} 07^{\prime} \mathrm{W}$; (map 119).

Local descriptive name obtained in 1956 by USGS. 
Bootlegger Cove: bay, $1.2 \mathrm{mi}$. across, on $\mathrm{S}$ shore of Knik Arm Cook Inlet, at mouth of Fish Creek in Anchorage, Cook Inlet Low. ; $61^{\circ} 12^{\prime}$ 28" N, 149 $55^{\prime} 45^{\prime \prime} \mathrm{W}$; (map 69).

Local name reported in 1962 by USGS.

Bootlegger Slough: channel, in Yukon River, flows SW $4 \mathrm{mi}$. around N side of Straight I., 4 mi NE of Ruby, Nowitna Low.; $64^{\circ} 47^{\prime} \mathrm{N}$, $155^{\circ} 25^{\prime} \mathrm{W}$; (map 98).

Riverboat pilots' name shown on 1940 "Navigation Chart, Tanana-Yukon Rivers," of the River Boat Service, U.S. Dept. of Interior.

Boot Point: point of land, SE coast of Adak I., E point of entrance to Boot Bay, Aleutian Is.; $51^{\circ} 43^{\prime} 45^{\prime \prime} \mathrm{N}, 176^{\circ} 28^{\prime} 00^{\prime \prime} \mathrm{W}$; $B G N$ 1936; (map 17).

Named in 1934 by members of the U.S. Navy Aleutian Island Survey Expedition, "for its shape."

Boot Point: point of land, SW tip of Warren I., Alex. Arch.; 55 $50^{\prime} 50^{\prime \prime} \mathrm{N}, 133^{\circ} 54^{\prime} 30^{\prime \prime} \mathrm{W}$; BGN 1961; (map 4).

Descriptive name given by the commander of the USC\&\&S steamer Hodgson in 1960, who made surveys in this vicinity.

Boot Point: point of land, $2 \mathrm{mi}$. S of Kaguyak, on SE coast of Kodiak I. ; $56^{\circ} 50^{\prime} \mathrm{N}, 153^{\circ} 46^{\prime} \mathrm{W}$; $B G N 1934$; (map 33).

Descriptive name given in 1934 by USC\&GS, "because the point in outline resembles a boot."

Boots Mountain: hill, see Mumtrak Hill.

Bophor Cape: point of land, see Beaufort, Cape. Bopof Island: island, see Popof Island.

Boras Point: point of land, see Bocas Point.

Border Lake: lake, $0.6 \mathrm{mi}$. long, on Kenai Penin. W of Tustumena Lake, $25 \mathrm{mi}$. S of Kenai, Cook Inlet Low.; $60^{\circ} 11^{\prime} 30^{\prime \prime} \mathrm{N}, 151^{\circ} 12^{\prime} 20^{\prime \prime}$ W; (map 62).

Named about 1963 by officials of Kenai National Moose Range, because the lake lies on the border (boundary) of the range.

Border Rocks: rocks, between Little Gavanski and Middle Is., $6 \mathrm{mi}$. NW of Sitka, off NW coast of Baranof I., Alex. Arch.; 57 $12^{\prime} 10^{\prime \prime}$ N, $135^{\circ} 26^{\prime} 00^{\prime \prime}$ W; (map 9). Var. Griada Rocks, Kamena Gryada.

This is an 1882 translation by USC\&GS of the name given in 1809 by the Russian navigator Ivan Vasiliev the first; reported by Lt. Sarichev (1826, map 19), IRN, as "K[amena] Gryada."

Boreal Mountain: mountain, 6,666 ft., one of Gates of the Arctic, on E bank of North Fork Koyukuk River, $35 \mathrm{mi}$. NW of Wiseman, Brooks Ra.; $67^{\circ} 50^{\prime} \mathrm{N}, 150^{\circ} 46^{\prime} \mathrm{W}$; BGN 1932; (map 124).

Named in 1924 by Marshall (1956, p. 12) who wrote, "Close at hand $* * *$ was a precipitous pair of mountains, one on each side of the North Fork. I bestowed the name of 'Gates of the Arctic' on them, christening the east portal 'Boreal Mountain' and the west portal 'Frigid Crags.' "'

Boreas Point: point of land, $\mathrm{N}$ point of entrance to Breezy Bay, on E coast of Dall I, Alex. Arch.; 55 $10^{\prime} 10^{\prime \prime} \mathrm{N}, 133^{\circ} 03^{\prime} 30^{\prime \prime} \mathrm{W}$; (map 4).
Named in 1882 by W. H. Dall, USC\&GS, for the "Greek god of the north wind."

Bore Greek: stream, flows E $3.5 \mathrm{mi}$. from Poss Mtn. to Glacier Creek, $9 \mathrm{mi}$. NNW of that stream's junc. with South Fork Koyukuk River and $28 \mathrm{mi}$. W of Chandalar, Brooks Ra.; $67^{\circ} 27^{\prime} 30^{\prime \prime} \mathrm{N}, 149^{\circ} 32^{\prime} 00^{\prime \prime} \mathrm{W}$; (map 123).

Local name reported in 1956 by T. E. Taylor, USGS.

Borg Creek: stream, flows NW $1.8 \mathrm{mi}$. to Snake River, $12 \mathrm{mi}$. N of Nome, Seward Penin. High.; $64^{\circ} 41^{\prime} \mathrm{N}, 165^{\circ} 25^{\prime} \mathrm{W}$; (map 94). Var. Berg Creek, Burg Creek, Quartz Creek.

Published as "Burg Creek" in January 1900 by Schrader (1900c, p. 16), USGS. Schrader labeled the head of this stream, "Quartz Creek." It is shown as "Berg Creek" on map dated 1900 by S. E. King. Reported as "Borg" on the 1900 "Map of Nome Peninsula" by J. M. Davidson and B. D. Blakeslee.

Borka: village, see Biorka.

Borka: island, see Sedanka Island.

Borka, Ostrov: island, see Sedanka Island.

Borlace, Point: point of land, see Borlase, Point.

Borlase, Point: point of land, on NW coast of Warren I., Alex. Arch.; 55 $55^{\prime} 10^{\prime \prime} \mathrm{N}$, $133^{\circ} 56^{\prime 2} 8^{\prime \prime} \mathrm{W}$; (map 4). Var. Mys Borlyez, Point Borlace.

Named on September 22, 1793, by Capt. George Vancouver, RN, for Sir John Borlase Warren (Wagner, 1937, p. 377) ; published in 1853 as "Mys Borlyez" on Russian Hydrog. Dept. Chart 1494.

Borlase Rock: rock, in Sumner strait, $0.8 \mathrm{mi}$. W of Point Borlase, NW coast of Warren I., Alex. Arch.; 55 $55^{\prime} 00^{\prime \prime} \mathrm{N}, 133^{\circ} 57^{\prime} 40^{\prime \prime} \mathrm{W}$; $B G N$ 1961; (map 4).

Local name reported by the commander of the USC\&GS steamer Hodgson in 1960, who made surveys in this vicinity.

Borlyez, Mys: point of land, see Borlase, Point.

Bornite: settlement, pop. 20, near Shungnak, Kotzebue-Kobuk Low.; (map 126).

Mining camp established since 1960 , named for a sulfide of cópper mineral.

Borodino Lake: lake, $2 \mathrm{mi}$. long, $8.5 \mathrm{mi}$. NW of village of Port Alexander, on $\mathbf{S}$ coast of Baranof I., Alex. Arch.; $56^{\circ} 22^{\prime} \mathrm{N}, 134^{\circ} 44^{\prime}$ W; BGN 1935; (map 5).

Named in 1935 by USFS "for a Russian ship on which forty people died during a voyage from Sitka to Kronstadt in 1821."

Boroshki Bay: bay, see No Thorofare Bay.

Bosnuk Island: island, see Ham Island.

Boss Creek: stream, flows NW 10 mi. to Holukuk River $4 \mathrm{mi}$. SW of its junc. with Girl Creek, $25 \mathrm{mi}$. SE of Little Mountain Village and $51 \mathrm{mi}$. SW of Sleetmute, Kilbuck-Kuskokwim Mts.; $61^{\circ} 13^{\prime} \mathrm{N}, 158^{\circ} 23^{\prime} \mathrm{W}$; $B G N$ 1948; (map 72). Var. Adanarayak.

Translation of Eskimo name "Adanarayak" reported in 1945 by USGS.

Boston: locality, on right bank of Pargon River, $40 \mathrm{mi}$. S of Imuruk Lake, Seward Penin. High.; 65 $01^{\circ} \mathrm{N}, 163^{\circ} 17^{\prime} \mathrm{W}$; (map 110).

Site of a mining camp; reported in 1951 by USGS.
Boston Creek: stream, flows NW $4.5 \mathrm{mi}$. to Graham Creek $5 \mathrm{mi}$. S of its junc. with Colorado Creek, $33 \mathrm{mi}$. NE of Ophir and $45 \mathrm{mi}$. NW of McGrath, Kilbuck-Kuskokwim Mts.; 63॰34'$25^{\prime \prime} \mathrm{N}, 156^{\circ} 09^{\prime} 00^{\prime \prime} \mathrm{W}$; (map 90).

Prospectors' name obtained in 1933 by J. B. Mertie, Jr. (in Smith, P. S., 1936, pl. 4), USGS.

Boston Creek: stream, flows $\mathrm{NE} 0.4 \mathrm{mi}$. to Shovel Creek, $6 \mathrm{mi}$. N of Solomon, Seward Penin. High.; 64 ${ }^{\circ} 38^{\prime}$ N, $164^{\circ} 24^{\prime}$ W; (map 95). Var. Johnson Creek.

Prospectors' name reported on prospectors' manuscript map dated 1902

Boston Creek: stream, heads on Boston Dome, flows W $9.5 \mathrm{mi}$. to Main Creek, $9 \mathrm{mi}$. SW of Ruby, Kilbuck-Kuskokwim Mts. ; 64 $39^{\circ} 10^{\prime \prime}$ N, $155^{\circ} 43^{\prime} 42^{\prime \prime} \mathrm{W}$; (map 98).

Prospectors' name reported in 1908 by A. G. Maddren (in Brooks and others, 1909, p. 230), USGS.

Boston Creek: stream, heads in Bendeleben Mts., flows SE $38 \mathrm{mi}$. to Fish River, $38 \mathrm{mi}$. S of Imuruk Lake, Seward Penin. High.; 65 $02^{\prime} \mathrm{N}$, $163^{\circ} 02^{\prime} \mathrm{W}$; (map 110).

Prospectors' name reported on a map of Cape Nome gold fields by David Fox, Jr. dated 1901.

Boston Creek: streams, flows SW $2.2 \mathrm{mi}$. to Eureka Creek, $2.5 \mathrm{mi}$. S of Eureka Dome and $21 \mathrm{mi}$. S of Rampart, Yukon-Tanana High.; $65^{\circ} 11^{\prime} 30^{\prime \prime} \mathrm{N}, 150^{\circ} 13^{\prime} 25^{\prime \prime} \mathrm{W}$; (map 106).

Named in 1898 by six prospectors from New England nicknamed the "Boston Boys."

Boston Creek: stream, flows SW $5.5 \mathrm{mi}$. to Chatanika River, $30 \mathrm{mi}$. NE of Fairbanks, Yukon-Tanana High.; $65^{\circ} 13^{\prime} 15^{\prime \prime} \mathrm{N}, 147^{\circ} 07^{\prime}$ 30 " W; (map 105).

Named by prospectors; published in 1907 by USGS.

Boston Creek: stream, flows E to Shovel Creek, about $6 \mathrm{mi}$. N of Solomon, Seward Penin. High.; (map 95).

Prospectors' name reported on the 1900 "Map of Nome Peninsula" by J. M. Davidson and B. D. Blakeslee. This stream cannot be precisely located on current maps.

Boston Dome: mountain, $1,473 \mathrm{ft}$., $7 \mathrm{mi}$. SE of

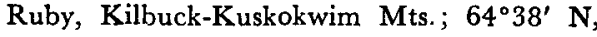
$155^{\circ} 26^{\prime} \mathrm{W}$; (map 98). Var. Cecil Dome.

Prospectors' name reported by Eakin (1916, pl. 1), USGS

Boston Gulch: ravine, trends NW $0.3 \mathrm{mi}$. to Glacier Creek, $7 \mathrm{mi}$. N of Nome, Seward Penin. High.; $64^{\circ} 36^{\prime} 28^{\prime \prime} \mathrm{N}, 165^{\circ} 21^{\prime} 45^{\prime \prime} \mathrm{W}$; (map 94).

Prospectors' name reported on the 1900 "Map of Nome Peninsula" by J. M. Davidson and B. D. Blakeslee.

Boston Gulch: ravine, extends $\mathrm{SW} 1.5 \mathrm{mi}$. to Boston Creek, $7 \mathrm{mi}$. S of Ruby, KilbuckKuskokwim Mts. ; $64^{\circ} 38^{\prime} \mathrm{N}, 155^{\circ} 29^{\prime} \mathrm{W}$; (map 98).

Prospectors' name reported in 1911 by A. G. Maddren, USGS.

Boston Gulch: ravine, trends SW $2.2 \mathrm{mi}$. to Bonanza Creek, $10 \mathrm{mi}$. SE of junc. of Charley 
and Yukon Rivers, Yukon-Tanana High.; $65^{\circ}$ $12^{\prime} \mathrm{N}, 142^{\circ} 34^{\prime} \mathrm{W}$; (map 103 ).

Prospectors' name from an unpublished map by E. J. Ghamberlain, dated 1902.

Bostwick Creek: stream, on Gravina I., heads in lake, flows S $8 \mathrm{mi}$. through Bostwick Lake, to Bostwick Inlet, Alex. Arch.; $55^{\circ} 15^{\prime} 45^{\prime \prime} \mathrm{N}$, $131^{\circ} 46^{\prime} 05^{\prime \prime}$ W ; BGN 1962; (map 3).

Local name reported in 1961 by USFS.

Bostwick Inlet: estuary, $5 \mathrm{mi}$. long, on SE coast of Gravina I., off Nichols Passage, Alex. Arch.; $55^{\circ} 13^{\prime} \mathrm{N}, 131^{\circ} 43^{\prime} \mathrm{W}$; (map 3 ).

Named in 1883 by Lt. Comdr. H. E. Nichols, USN, after Lt. Frank Matteson Bostwick, USN, a member of his party.

Bostwick Lake: lake, $0.6 \mathrm{mi}$. long, on Gravina I., in course of Bostwick Creek, $3 \mathrm{mi}$. SW of Ketchikan, Alex. Arch.; 55 ${ }^{\circ} 19^{\prime} 30^{\prime \prime}$ N, $131^{\circ}$ 44'35" W; BGN 1962; (map 3).

Local name reported in 1961 by USFS.

Bostwick Point: point of land, NE point of entrance to Bostwick Inlet, on E coast of Gravina

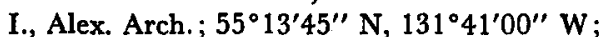
BGN 1917; (map 3).

Named in 1917 by USC\&GS.

Bostwick Reef: reef, in Felice Strait, off SE coast of Annette I., Alex. Arch; 55 02'15" N, $131^{\circ}$ $18^{\prime} 50^{\prime \prime} \mathrm{W}$; (map 3).

Named in 1883 by Lt. Comdr. H. E. Nichols, USN. See Bostwick Inlet.

Boswell Bay: village, pop. 32, near Boswell Bay, $16 \mathrm{mi}$. SW of Cordova, Ghugach Mts.; $60^{\circ} 24^{\prime}$ $\mathrm{N}, 146^{\circ} 08^{\prime} \mathrm{W}$; (map 64$)$.

Local name obtained in 1952 by USGS.

Boswell Bay: estuary, $3 \mathrm{mi}$. long, on NE coast of Hinchinbrook 1., $16 \mathrm{mi}$. SW of Cordova, Chugach Mts.; $60^{\circ} 24^{\prime} \mathrm{N}, 146^{\circ} 08^{\prime} \mathrm{W}$; (map 64).

Local name reported in 1899 by $H$. P. Ritter, USG\&GS.

Boswell Rock: rock, in $\mathbf{N}$ entrance to Boswell Bay, on NE coast of Hinchinbrook I., $15 \mathrm{mi}$. SW of Cordova, Chugach Mts.; 60 $25^{\prime} \mathrm{N}$, $146^{\circ} 06^{\prime} \mathrm{W}$; BGN 1933; (map 64).

Local name reported in 1933 by $H$. E. Smith, USFS.

Botan, Mys: point of land, see Batan, Point.

Botany, Mount: mountain, see Botany Peak.

Botany Peak: mountain, 2,940 ft., $5 \mathrm{mi}$. S of Hasselborg Lake, on central Admiralty I., Alex. Arch.; 57 $35^{\prime} 40^{\prime \prime} \mathrm{N}, 134^{\circ} 12^{\prime} 30^{\prime \prime} \mathrm{W}$; $B G N$ 1928; (map 9). Var. Mount Botany.

So named by A. E. Hasselborg of Mole Harbor, "because the mountain always had a most unusual flora consisting of many species of plants, some of which are rare in other parts of Alaska." The name was reported in 1925 by $H$. J. Coolidge.

Botcharoff, Mount: peak, see Becharof, Mount. Botcharoff Lake: lake, see Becharof Lake.

Botinski Island: island, in vicinity of Unimak Pass, SW of Unimak I., Aleutian Is. ; $54^{\circ} 15^{\prime}$ $\mathrm{N}, 165^{\circ} 00^{\prime} \mathrm{W}$; (map 24$)$.

Georg Heinrich von Langsdorff (1813-14, v. 2, p. 54) mentioned this Russian-named island, but its identification cannot be presently determined.
Bottenintnin Lake: lake, $1 \mathrm{mi}$. long, on Kenai Penin. S of Sterling Highway, $7.5 \mathrm{mi}$. E of Sterling and $25 \mathrm{mi}$. ESE of Kenai, Cook Inlet Low.; 60 $31^{\prime} \mathrm{N}, 150^{\circ} 34^{\prime} \mathrm{W}$; (map 62).

Named about 1963 by officials of Kenai National Moose Range, for administrative purposes.

Bottle Cork Hill: mountain, 1,160 ft., $2 \mathrm{mi}$. NE of Temnac Bay, on Attu I., Aleutian Is.; $52^{\circ} 50^{\prime} 30^{\prime \prime} \mathrm{N}, 173^{\circ} 06^{\prime} 15^{\prime \prime} \mathrm{E}$; (map 13).

Published in 1948 by AMS.

Bottle Creek: stream, heads in Link Lake, flows SE $3 \mathrm{mi}$. to Yentna River, $61 \mathrm{mi}$. N of Tyonek, Cook Inlet Low.; $61^{\circ} 57^{\prime} 50^{\prime \prime} \mathrm{N}, 151^{\circ} 04^{\prime} 30^{\prime \prime}$ W; (map 70).

Local name reported in 1954 by USGS.

Bottleneck Pass: mountain pass, extends SE from Stepanof Cove, on central Umnak I., Aleutian Is.; $53^{\circ} 16^{\prime} 30^{\prime \prime} \mathrm{N}, 168^{\circ} 19^{\prime} 00^{\prime \prime} \mathrm{W}$; (map 22). Name published by Byers (1959, pl. 41), USGS.

Bottley Creek: stream, flows N $19 \mathrm{mi}$. to Nelchina River, $3 \mathrm{mi}$. NE of Twin Lakes and $61 \mathrm{mi}$. NNW of Valdez, Copper River Basin; $61^{\circ} 58^{\prime} 50^{\prime \prime}$ N, $146^{\circ} 44^{\prime} 15^{\prime \prime} \mathrm{W}$; (map 68). Var. Paradise Greek.

Local name published in the 1950's by USGS.

Bottom Dollar Creek: stream, flows SSE $4.5 \mathrm{mi}$. to Harrison Creek, $9 \mathrm{mi}$. SSW of Circle Hot Springs and $38 \mathrm{mi}$. SW of Circle, YukonTanana High.; $65^{\circ} 23^{\prime} \mathrm{N}, 144^{\circ} 49^{\prime} \mathrm{W}$; BGN 1938; (map 104). Var. Squaw Creek, Squaw Gulch, Bottom Gulch.

This stream was called Squaw Creek by Prindle (1906, pl. 1), USGS. However, as another stream bore that name, the local prospectors applied the present name to the above described stream, which was reported in 1908 by USGS as "Bottom Gulch." The name was reported in 1910 by C. E. Ellsworth and G. L. Parker (in Brooks and others, 1911, p. 164), USGS.

Bottom Gulch: stream, see Bottom Dollar Greek.

Bottomless Lake: lake, on Alaska Penin., SE of Herendeen Bay, Aleutian Ra.; (map 28). Var. Ozero Bezdonnoye.

Translation of the name "Ozero Bezdonnoye," published in 1852 by the Russian Hydrog. Dept. on Chart 1455.

Botuk Creek: stream, see Baituk Creek.

Boulder: locality, on left bank of Boulder Creek, in Noxapaga River basin, $33 \mathrm{mi}$. W of Imuruk Lake, Seward Penin. High.; 65 $32^{\prime} \mathrm{N}$, $164^{\circ} 19^{\prime} \mathrm{W}$; (map 110).

Site of a mining camp; name reported in 1951 by USGS.

Boulder: island, see Karpa Island.

Boulder Bay: bight, on W coast of Unalaska I., extends E $0.5 \mathrm{mi}$. off Umnak Pass, Aleutian Is., $53^{\circ} 21^{\prime} 45^{\prime \prime} \mathrm{N}, 167^{\circ} 44^{\prime} 15^{\prime \prime} \mathrm{W}$; (map 23).

Reported in 1942 by the U.S. Army Corps of Engineers; published in the 1944 Aleutian Coast Pilot (p. 50).

Boulder Bay: bay, $1.5 \mathrm{mi}$. across, on $\mathrm{S}$ coast of Alaska Penin., on E shore of Stepovak Bay,
Aleutian Ra.; $55^{\circ} 35^{\prime} 30^{\prime \prime} \mathrm{N}, 159^{\circ} 44^{\prime} 00^{\prime \prime} \mathrm{W}$; (map 27).

Named in 1880 by W. H. Dall, USC\&GS.

Boulder Bay: bay, extends N 4 mi. between Dangerous and Outer Right Capes, $E$ of Kiliuda Bay, on SE coast of Kodiak I.; $57^{\circ} 16^{\prime}$ $\mathrm{N}, 152^{\circ} 45^{\prime} \mathrm{W}$; (map 34 ).

Local name reported in 1949 by USGS.

Boulder Bay: bight, $2.5 \mathrm{mi}$. wide, on $\mathrm{N}$ shore of Port Fidalgo, $38 \mathrm{mi}$. NW of Cordova, Chugach Mts.; $60^{\circ} 54^{\prime} \mathrm{N}, 146^{\circ} 38^{\prime} \mathrm{W}$; (map 64).

Local descriptive name reported in 1900 by H. P. Ritter, USC\&GS. See Fidalgo, Port. Boulder Creek: stream, flows $2 \mathrm{mi}$. SE to Eagle River, $2.4 \mathrm{mi}$. SW of 1962 terminus of Eagle Glacier and $21 \mathrm{mi}$. NW of Juneau, Coast Mts.; $58^{\circ} 32^{\prime} 30^{\prime \prime} \mathrm{N}, 134^{\circ} 47^{\prime} 00^{\prime \prime} \mathrm{W}$; BGN 1929; (map 11).

Descriptive local name first recorded in 1900 on a placer claim by D. J. Stamp (DeArmond, 1957 , p. 8 ). The name was published by USGS in 1912 (Knopf, pls. 1, 2, and 5).

Boulder Creek: stream, in Glacier Bay National Monument, flows SW $1.5 \mathrm{mi}$. to Gulf of Alaska, $3 \mathrm{mi}$. SE of Harbor Point and $34 \mathrm{mi}$. NW of Hoonah, Malaspina Coastal Plain; $58^{\circ} 35^{\prime} 30^{\prime \prime} \mathrm{N}, 137^{\circ} 34^{\prime} 30^{\prime \prime} \mathrm{W}$; (map 10).

Name reported by members of the HarvardDartmouth Expedition of 1933-34.

Boulder Creek: stream, flows SE $1 \mathrm{mi}$. to Salmon River, $27 \mathrm{mi}$. NE of Cape Newenham, Kil'buck-Kuskokwim Mts.; $58^{\circ} 56^{\prime} 35^{\prime \prime}$ N, $161^{\circ} 42^{\prime}$ 20" W; BGN 1938; (map 39).

Local descriptive name published in a 1933 report on mineral investigation and mine inspection in Alaska by the U.S. Department of the Interior.

Boulder Creek: stream, flows NE $4 \mathrm{mi}$. to Arolik River, $32 \mathrm{mi}$. N of Goodnews, Kilbuck-Kuskokwim Mts.; 59॰35' N, 161 $30^{\prime} \mathrm{W}$; (map 53).

Name published in 1919 by G. L. Harrington (in Brooks and others, 1921, pl. 7), USGS.

Boulder Creek: stream, flows SE $2.5 \mathrm{mi}$ to Hickerson Lake, $5 \mathrm{mi}$. $\mathrm{N}$ of Chinitna Bay, 55 mi. NW of Homer, Aleutian Ra.; 59 $57^{\prime} 15^{\prime \prime}$ $\mathrm{N}, 152^{\circ} 56^{\prime} 30^{\prime \prime} \mathrm{W}$; (map 50).

Local name reported and published by USGS in the 1950's.

Boulder Creek: stream, heads in glacier on SW slope of Robinson Mts. and flows SW $7 \mathrm{mi}$. to North Channel Yakataga River, $104 \mathrm{mi}$. NW of Yakutat, Chugach Mts.; $60^{\circ} 07^{\prime} 50^{\prime \prime} \mathrm{N}$, 142 $27^{\prime} 45^{\prime \prime} \mathrm{W}$; BGN 1945; (map 65).

Named in 1945 by USGS.

Boulder Creek: stream, on Kenai Penin., flows SE $7.5 \mathrm{mi}$. to Resurrection River, $14 \mathrm{mi}$. NW of Seward, Chugach Mts. ; $60^{\circ} 16^{\prime} 15^{\prime \prime} \mathrm{N}, 149^{\circ}$. $40^{\prime} 45^{\prime \prime} \mathrm{W}$; (map 63).

Local name reported about 1914 by B. L. Johnson (in Martin, G. C., and others, 1915, pl. 2), USGS.

Boulder Creek: stream, on Hawkins I., flows E $1 \mathrm{mi}$. to Mud Bay, $3 \mathrm{mi}$. W of Cordova, Chugach Mts.; $60^{\circ} 34^{\prime} \mathrm{N}, 145^{\circ} 50^{\prime} \mathrm{W}$; (map 64). 
Local name reported by Capt. Abercrombie (1899, p. 312), USA.

Boulder Creek: stream, heads in series of lakes, flows NE $5 \mathrm{mi}$. to Tiekel River, $2 \mathrm{mi}$. SE of Rice Mtn. and $35 \mathrm{mi}$. NE of Valdez, Chugach Mts. ; $61^{\circ} 20^{\prime} 10^{\prime \prime} \mathrm{N}, 145^{\circ} 18^{\prime} 20^{\prime \prime} \mathrm{W}$; (map 68).

Name reported in 1899 by Oscar Rohn of Capt. W. R. Abercrombie's party.

Boulder Creek: stream, flows $S 1 \mathrm{mi}$. to Dan Creek, 14 mi. SE of McCarthy, St. Elias Mts.; $61^{\circ} 22^{\prime} \mathrm{N}, 142^{\circ} 32^{\prime} \mathrm{W}$; (map 67).

Reported in 1908 by D. C. Witherspoon (in Moffit and Capps, 1911, pl. 2), USGS.

Boulder Creek: stream, heads at glacier terminus, flows SW $25 \mathrm{mi}$. to Chichaloon River, $3 \mathrm{mi}$. NE of Chichaloon and $28 \mathrm{mi} \mathrm{NE}$ of Palmer, Talkeetna Mts.; $61^{\circ} 49^{\prime} 45^{\prime \prime} \mathrm{N}, 148^{\circ} 25^{\prime} 00^{\prime \prime} \mathrm{W}$; $B G N$ 1906; (map 69). Var. Schoonhoven Creek, Schoonoven Creek.

Name used by local prospectors; reported in 1898 by Lt. J. C. Castner, USA, (in Glenn and Abercrombie, 1899, map). In 1898 this stream was also named "Schoonoven Creek," presumably for Pvt. George W. Van Schoonhoven, USA, a member of Capt. Glenn's expedition (Mendenhall, 1900, map 16).

Boulder Creek: stream, heads in Terra Cotta Mts., flows SE $6.3 \mathrm{mi}$. to Hartman River 2.2 mi. SW of that stream's junc. with South Fork Kuskokwim River and $94 \mathrm{mi}$. NW of Tyonek, Alaska Ra.; 61 ${ }^{\circ} 56^{\prime} \mathrm{N}, 153^{\circ} 21^{\prime} \mathrm{W}$; (map 71). Local name reported in 1958 by USGS.

Boulder Creek: stream, flows S $2.4 \mathrm{mi}$. to Otter Creek $9 \mathrm{mi}$. E of its junc. with Iditarod River, $1.6 \mathrm{mi}$. E of Flat and $58 \mathrm{mi}$. NW of Sleetmute, Kilbuck-Kuskokwim Mts. ; $62^{\circ} 27^{\prime} 15^{\prime \prime}$ N, $157^{\circ}$ 57'10" W; (map 79).

Name shown on a 1910 manuscript map of "Iditarod Placer Fields."

Boulder Creek: stream, flows NW $23 \mathrm{mi}$. from glacier terminus to Copper River $1.5 \mathrm{mi}$. NE of its junc. with Chistochina River, Copper River Basin; $62^{\circ} 36^{\prime} \mathrm{N}, 144^{\circ} 35^{\prime} \mathrm{W}$; (map 83). Var. Bowlder Creek.

Name reported in 1898 by Capt. W. R. Abercrombie, USA.

Boulder Creek: stream, heads near $W$ end of Amphitheater Mts., flows SW $10 \mathrm{mi}$. to Maclaren River, 33 mi. NW of Paxson, Alaska

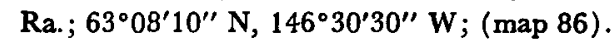

Local descriptive name reported on 1910 fieldsheet by C. E. Giffin, USGS.

Boulder Creek: stream, flows NW $14 \mathrm{mi}$. to East Fork Susitna River, $65 \mathrm{mi}$. SE of Healy,

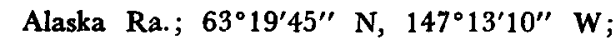
(map 87).

Descriptive name reported in 1910 by D. C. Witherspoon and C. E. Giffin, USGS.

Boulder Creek: stream, flows NW $8 \mathrm{mi}$. to Nixon Fork Takotna River, 19 mi. NE of Medfra,

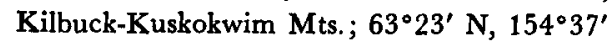
W; (map 89).

Local name reported in 1924 by J. S. Brown (in Smith, P. S., and others, 1926, pl. 5), USGS.

Boulder Creek: stream, flows W $4 \mathrm{mi}$. to Delta River, crossing Richardson Highway $28 \mathrm{mi}$.
SE of Mount Hayes, Alaska Ra. ; $63^{\circ} 28^{\prime} 40^{\prime \prime}$ N, $145^{\circ} 51^{\prime} 30^{\prime \prime} \mathrm{W}$; (map 86).

Descriptive name reported in 1909 by USGS.

Boulder Greek: stream, flows NE $5 \mathrm{mi}$. to Tatlanika River, $44 \mathrm{mi}$. SE of Nenana, Alaska Ra.; $64^{\circ} 04^{\prime} \mathrm{N}, 148^{\circ} 13^{\prime} \mathrm{W}$; (map 100).

Prospectors' name reported in 1950 by USGS topographers.

Boulder Creek: stream, flows NE $11 \mathrm{mi}$. to Eisenmenger Fork, $56 \mathrm{mi}$. ENE of Big Delta, Yukon-Tanana High.; $64^{\circ} 25^{\prime} \mathrm{N}, 144^{\circ} 03^{\prime} \mathrm{W}$; (map 101).

Local descriptive name published in 1943 by USGS.

Boulder Creek: stream, flows SE $4.6 \mathrm{mi}$. to Snake River, $9 \mathrm{mi}$. NW of Nome, Seward Penin. High.; $64^{\circ} 38^{\prime} \mathrm{N}, 165^{\circ} 28^{\prime} \mathrm{W}$; (map 94). Var. Bowlder Creek.

Prospectors' name published as "Bowlder Creek" by Schrader and Brooks (1900, map 3), USGS, and as "Boulder Creek" by USC\& GS on Chart 9380.

Boulder Creek: stream, flows SE $2.8 \mathrm{mi}$. to Sinuk River, $21 \mathrm{mi}$. NW of Nome, Seward Penin. High.; $64^{\circ} 41^{\prime} \mathrm{N}, 165^{\circ} 59^{\prime} \mathrm{W}$; (map 94).

Prospectors' name reported in 1900 by E. C. Barnard (in Brooks, 1901, pl. 17), USGS.

Boulder Creek: stream, flows NW $2.3 \mathrm{mi}$. to Stewart River, $20 \mathrm{mi}$. N of Nome, Seward Penin High.; $64^{\circ} 48^{\prime} 30^{\prime \prime} \mathrm{N}, 165^{\circ} 25^{\prime} 30^{\prime \prime} \mathrm{W}$; (map 94).

Prospectors' name reported in 1900 by E. C. Barnard (in Brooks, 1901, pl. 17), USGS.

Boulder Creek: stream, flows NE $3 \mathrm{mi}$. to Yukon River, $4 \mathrm{mi}$. NE of Eagle, Yukon-Tanana High.; $64^{\circ} 50^{\prime} 45^{\prime \prime} \mathrm{N}, 1^{\circ} 01^{\prime} 40^{\prime \prime} \mathrm{W}$; (map 102).

Prospectors' name obtained in 1898 by E. C. Barnard, USGS.

Boulder Creek: stream, flows SE $2.8 \mathrm{mi}$. to Canyon Creek which flows to Casadepaga River $21 \mathrm{mi}$. N of Solomon, Seward Penin. High.; $64^{\circ} 52^{\prime} \mathrm{N}, 164^{\circ} 23^{\prime} \mathrm{W}$; (map 95).

Prospectors' name reported on a map of Cape Nome gold fields by David Fox, Jr., dated 1901.

Boulder Creek: stream, flows E $9 \mathrm{mi}$. to Salcha River, $S$ of West Point, $68 \mathrm{mi}$. NE of Big Delta, Yukon-Tanana High.; 64 ${ }^{\circ} 55^{\prime} \mathrm{N}, 144^{\circ} 33^{\prime} \mathrm{W}$; (map 101).

Local name reported in 1958 by USGS.

Boulder Creek: stream, flows E $4.5 \mathrm{mi}$. to Vulcan Creek which flows to Tubutulik River, $22 \mathrm{mi}$. NE of Elim, Seward Penin. High.; 64 ${ }^{\circ} 56^{\prime}$ N, $162^{\circ} 10^{\prime} \mathrm{W}$; (map 95).

Prospectors' name reported in 1900 by W. J. Peters (in Mendenhall, 1901, pl. 20), USGS.

Boulder Creek: stream, flows SE 2 mi. to Tubutulik River, $29 \mathrm{mi}$. N of Elim and $47 \mathrm{mi}$. SE of Imuruk Lake, Seward Penin. High.; 65 ${ }^{\circ} 02^{\prime}$ N, $162^{\circ} 13^{\prime} \mathrm{W}$; (map 110).

Prospectors' name published on the 1908 "Map of Seward Peninsula" by Arthur Gibson.

Boulder Creek: stream, flows W $1 \mathrm{mi}$. to Gold Run which flows to Bluestone River, $16 \mathrm{mi}$. SE of Teller, Seward Penin. High.; 65 $03^{\prime} \mathrm{N}$, $166^{\circ} 10^{\prime} \mathrm{W}$; (map 111).

Prospectors' name reported on a map of Cape Nome goldfields by David Fox, Jr., dated 1901.

Boulder Creek: stream, flows WSW $22 \mathrm{mi}$. to Fish Lake, between Boulder and Serpentine Ridges, $21 \mathrm{mi}$. ESE of Tanana, Yukon-Tanana High.; $65^{\circ} 05^{\prime} \mathrm{N}, 151^{\circ} 23^{\prime} \mathrm{W}$; (map 106). Var. Guthna Creek.

Prospectors' name reported in 1911 by H. M. Eakin, USGS. The Indian name "Guthna" was extended up this stream on earlier maps.

Boulder Creek: stream, flows SW 5 mi. to North Fork Chena River, $70 \mathrm{mi}$. SW of Circle, Yukon-Tanana High.; $65^{\circ} 09^{\prime} \mathrm{N}, 146^{\circ} 56^{\prime} \mathrm{W}$; (map 104).

Named by prospectors; reported in 1911 by USGS (Prindle, 1913, pl. 1).

Boulder Creek: stream, flows E $4 \mathrm{mi}$. to Granite Creek $2.5 \mathrm{mi}$. SW of that stream's junc. with Minook Creek, 15 mi. S of Rampart, YukonTanana High.; $65^{\circ} 16^{\prime} 40^{\prime \prime} \mathrm{N}, 150^{\circ} 13^{\prime} 00^{\prime \prime} \mathrm{W}$; (map 106).

Prospectors' name reported by USGS in 1906.

Boulder Greek: stream, flows NW 2 mi. to Coal Creek, $4.4 \mathrm{mi}$. SW of that stream's junc. with Yukon River and $45 \mathrm{mi}$. SE of Circle, YukonTanana High.; $65^{\circ} 17^{\prime} 45^{\prime \prime} \mathrm{N}, 143^{\circ} 10^{\prime} 20^{\prime \prime} \mathrm{W}$; (map 103).

Prospectors' name reported by C. E. Ellsworth and R. W. Davenport (in Brooks and others, 1913, p. 213), USGS.

Boulder Creek: stream, flows SE $4.6 \mathrm{mi}$. to Peace River, $14 \mathrm{mi}$. N of Haycock, Seward Penin. High.; $65^{\circ} 24^{\prime} \mathrm{N}, 161^{\circ} 01^{\prime} \mathrm{W}$; (map 109). Var. Anzac Creek.

Local name reported in 1917 by G. L. Harrington, USGS.

Boulder Creek: stream, flows SE $8 \mathrm{mi}$. to Agiapuk River, $18 \mathrm{mi}$. NE of Teller, Seward Penin. High.; $65^{\circ} 28^{\prime} \mathrm{N}, 165^{\circ} 57^{\prime} \mathrm{W}$; (map 111).

Prospectors' name reported on the 1908 "Map of Seward Peninsula" by Arthur Gibson.

Boulder Creek: stream, flows S $6 \mathrm{mi}$. to Turner Creek which flows to Noxapaga River, $30 \mathrm{mi}$. SW of Imuruk Lake, Seward Penin. High.; $65^{\circ} 31^{\prime} \mathrm{N}, 164^{\circ} 18^{\prime} \mathrm{W}$; (map 110).

Prospectors' name reported in 1901 by T. G. Gerdine (in Collier, 1902, pl. 12), USGS.

Boulder Greek: stream, flows SE $1 \mathrm{mi}$. to Baituk Creek which flows to Bering Sea, $11 \mathrm{mi}$. E of Cape Prince of Wales and $44 \mathrm{mi}$. NW of Teller, Seward Penin. High.; $65^{\circ} 33^{\prime} \mathrm{N}$, $167^{\circ} 43^{\prime} \mathrm{W}$; (map 111).

Prospectors' name reported on the 1908 "Map of Seward Peninsula" by Arthur Gibson.

Boulder Creek: stream, flows NE $13 \mathrm{mi}$. to Crooked Creek, $30 \mathrm{mi}$. SW of Circle, YukonTanana High.; 65 $34^{\prime} 30^{\prime \prime}$ N, $145^{\circ} 53^{\prime} 00^{\prime \prime}$ W; (map 104). Var. Boulder Gulch.

Named by prospectors; reported in 1896 by USGS (Spurr, 1898, pl. 50). 
Boulder Creek: stream, flows NE $4.9 \mathrm{mi}$. to Gold Run, 36 mi. NW of Haycock, Seward Penin. High.; $65^{\circ} 36^{\prime} \mathrm{N}, 161^{\circ} 57^{\prime} \mathrm{W}$; (map 109).

Prospectors' descriptive name reported in 1911 by USGS.

Boulder Greek: stream, on Seward Penin., flows $\mathrm{N} 3 \mathrm{mi}$. to Lopp Lagoon, $4 \mathrm{mi}$. NE of Cape Prince of Wales and $54 \mathrm{mi}$. NW of Teller, Kotzebue-Kobuk Low.; $65^{\circ} 38^{\prime} \mathrm{N}, 167^{\circ} 59^{\prime} \mathrm{W}$; (map 111). Var. Lagoon Creek.

Local name reported in 1944 by USGS. Reported in 1907 as "Lagoon Creek" by Knopf (1908, pl. 1), USGS.

Boulder Creek: stream, flows $S$ and E $11 \mathrm{mi}$. to South Fork Koyukuk River, in South Fork Flats, $32 \mathrm{mi}$. SW of Chandalar, Brooks Ra.; $67^{\circ} 16^{\prime} \mathrm{N}, 149^{\circ} 30^{\prime} \mathrm{W}$; (map 123).

Prospectors' name obtained in 1901 by Schrader (1904, pl. 3), USGS.

Boulder Creek: stream, flows W 3 mi. to North Fork Chandalar River at $\mathrm{N}$ end of Chandalar Lake, $5 \mathrm{mi} \mathrm{N}$ of Chandalar, Brooks Ra.; $67^{\circ} 33^{\prime} 40^{\prime \prime} \mathrm{N}, 148^{\circ} 27^{\prime} 15^{\prime \prime} \mathrm{W}$; (map 123).

Prospectors' name obtained in 1909 by A. G. Maddren (in Brooks and others, 1910, pl. 7), USGS.

Boulder Creek: stream, flows ENE $40 \mathrm{mi}$. to Coleen River, $34 \mathrm{mi}$. N of Coleen Mtn., Brooks Ra.; $67^{\circ} 35^{\prime}$ N, $142^{\circ} 37^{\prime}$ W; (map 121).

Local name reported in 1956 by $T$. E. Taylor, USGS.

Boulder Creek: stream, see Big Boulder Creek. Boulder Creek: stream, see Colorado Creek.

Boulder Creek: stream, see Fish Creek.

Boulder Creek: stream, see Rock Creek.

Boulder Creek: stream, see Stibnite Creek.

Boulder Creek Flats: flats, extend $4 \mathrm{mi}$. along Boulder Creek, at $W$ end of Anthracite Ridge, $35 \mathrm{mi}$. NE of Palmer, Talkeetna Mts.; $61^{\circ} 51^{\prime} 30^{\prime \prime} \mathrm{N}, 148^{\circ} 14^{\prime} 00^{\prime \prime} \mathrm{W}$; (map 69).

Local name reported in 1948 in USGS.

Boulder Flat: tidal flat, see Boulder Flats.

Boulder Flats: tidal fat, in Wrangell Narrows, at mouth of Colorado Creek, on $E$ coast of Lindenberg Penin., $12 \mathrm{mi}$. S of Petersburg, Alex, Arch.; 56 $38^{\prime} 40^{\prime \prime} \mathrm{N}, 132^{\circ} 56^{\prime} 30^{\prime \prime} \mathrm{W}$; (map 6). Var. Boulder Flat.

Named by W. H. Dall, USC\&GS ; published in 1883 Coast Pilot.

Boulder Gulch: ravine, extends NE $0.5 \mathrm{mi}$. to Chititu Creek, 14 mi. SE of McCarthy, St. Elias Mts. ; $61^{\circ} 18^{\prime} \mathrm{N}, 142^{\circ} 36^{\prime \prime} \mathrm{W}$; (map 67).

Local name reported by Moffit and Maddren (1909, fig. 9), USGS.

Boulder Gulch: stream, see Boulder Greek.

Boulder Hill: mountain, 2,858 ft., in Crazy Mts., $18 \mathrm{mi}$. SW of circle, Yukon-Tanana High.; $65^{\circ} 41^{\prime} 45^{\prime \prime} \mathrm{N}, 144^{\circ} 39^{\prime} 00^{\prime \prime} \mathrm{W}$; (map 104).

Named by prospectors; reported in 1903 by USGS (Prindle, 1905, pl. 13).

Boulder Island: island, island $2 \mathrm{mi}$. $\mathrm{N}$ of Strawberry I., in Glaicer Bay National Monument, $37 \mathrm{mi}$. NW of Hoonah, St. Elias Mts.; $58^{\circ} 33^{\prime} 36^{\prime \prime} \mathrm{N}, 136^{\circ} 01^{\prime} 03^{\prime \prime}$ " W ; (map 10$)$.

Descrip tive name given in 1942 by USC\&GS "because of the island's extensive boulder flats exposed at low water."

Boulder Island: island, see Boulder Shoals.
Boulder Lake: lake, $2 \mathrm{mi}$. long, $5 \mathrm{mi}$. SE of Point Warde, at mouth of Bradfield Canal, Alex. Arch.; 56 $06^{\circ} 30^{\prime \prime} \mathrm{N}, 131^{\circ} 52^{\prime} 00^{\prime \prime} \mathrm{W}$; (map 7).

Local name reported in 1955 by USGS.

Boulder Lake: lake, $1.4 \mathrm{mi}$. long, $3 \mathrm{mi}$. NE of Ewan Lake and $27 \mathrm{mi}$. $\mathrm{N}$ of Glennallen, Copper River Basin; $62^{\circ} 30^{\prime} \mathrm{N}, 145^{\circ} 40^{\prime} \mathrm{W}$; (map 83).

Local name reported in 1950 by USGS.

Boulder Point: point of land, on SW coast of Alaska Penin., N point of entrance to Traders Cove in Bechevin Bay, Aleutian Ra.; $54^{\circ} 55^{\prime} 00^{\prime \prime} \mathrm{N}, 163^{\circ} 19^{\prime} 30^{\prime \prime} \mathrm{W}$; (map 25).

Descriptive name reported in 1912 by USC\&GS.

Boulder Point: point of land, on E coast of Kuiu I. in Sumner Strait, $8 \mathrm{mi}$. SW of Point Baker, Alex. Arch.; $56^{\circ} 19^{\prime} 30^{\prime \prime} \mathrm{N}, 133^{\circ} 49^{\prime} 45^{\prime \prime} \mathrm{W}$; (map 6).

Named in 1886 by Lt. J. M. Helm, USN, for charting purposes; name published in 1887 by USC\&GS on Chart 706.

Boulder Point: point of land, on NE coast of Woewodski I., $16 \mathrm{mi}$. S of Petersburg, Alex. Arch.; $56^{\circ} 34^{\prime} 55^{\prime \prime} \mathrm{N}, 132^{\circ} 58^{\prime} 35^{\prime \prime} \mathrm{W}$; (map 6).

Local descriptive name obtained in 1953 by USGS.

Boulder Point: point of land, on $\mathrm{N}$ coast of Kupreanof I., at entrance to Portage Bay, 77 mi. E of Sitka, Alex. Arch.; $57^{\circ} 00^{\prime} 50^{\prime \prime} \mathrm{N}$, $133^{\circ} 18^{\prime} 55^{\prime \prime} \mathrm{W}$; (map 8).

So named in 1882 by Lt. Comdr. H. E. Nichols, USN, because the point "is fringed by large boulders"; published by USC\&GS in the 1883 Coast Pilot (p. 125).

Boulder Point: point of land, on NE shore of Karluk Lake, $20 \mathrm{mi}$. SE of Karluk, Kodiak I.; $57^{\circ} 24^{\prime} 00^{\prime \prime} \mathrm{N}, 154^{\circ} 02^{\prime} 20^{\prime \prime} \mathrm{W}$; (map 35 ).

Local descriptive name reported in 1952 by USGS.

Boulder Point: promontory, $216 \mathrm{ft}$., on NW coast of Kenai Penin., N point of entrance to Nikishka Bay, $16 \mathrm{mi}$. N of Kenai, Cook Inlet Low.; $60^{\circ} 46^{\prime} 25^{\prime \prime} \mathrm{N}, 151^{\circ} 15^{\prime} 50^{\prime \prime} \mathrm{W}$; (map 62).

Local descriptive name published in 1912 by USG\&GS.

Boulder Ridge: ridge, elev. 1,800 ft., extends $\mathrm{E}$ $10 \mathrm{mi}$. from junc. of Little Boulder and Boulder Creeks to Roughtop Mtn., $39 \mathrm{mi}$. E of Tanana, Yukon-Tanana High.; $65^{\circ} 10^{\prime} \mathrm{N}$, 15055' W; BGN 1961; (map 106).

Named in 1960 by D. M. Hopkins and Bond Taber, USGS, because "The proposed new name reflects the position of the ridge between Boulder Creek and Little Boulder Creek."

Boulder Shoals : shoals, in Camden Bay between Collinson and Konganevik Points, Arctic Plain; (map 151). Var. Boulder Island, Tingowaiak Island.

In $1826 \mathrm{Sir}$ John Franklin (1828, p. 148), RN, wrote: "There was another island adjoining which, seemed to be a collection of boulder stones; from whence its designation on the map." John Simpson's native map, dated 1855, gives the Eskimo name "Tingowaiak I." Leffingwell (1919, p. 94) states, "The island * * * has since been washed away, leaving shoals", which he named "Boulder Shoals."

Bouldir Island: island, see Buldir Island.

Bouldyr Island: island, see Karpa Island.

Bouldyr Island: island, see Buldir Island.

Boulevard Creek: stream, on Aleutian Penin., flows NW $5 \mathrm{mi}$. to Alec River, $17 \mathrm{mi}$. NW of Chignik, Aleutian Ra.; $56^{\circ} 26^{\prime} \mathrm{N}, 158^{\circ} 46^{\prime}$ W; (map 30).

So named in 1923 by R. H. Sargent, USGS, "because the valleys of this and Through Creek afford an easy route [boulevard] to Chignik Bay."

Boulevard Creek: stream, heads in Yukon, Canada, flows SW $11 \mathrm{mi}$. to a $\mathrm{N}$ tributary $5 \mathrm{mi}$. $\mathrm{N}$ of that stream's junc. with Mancha Creek, 66 mi. N of Table Mtn., Brooks Ra.; $68^{\circ} 46^{\prime}$ N, $141^{\circ} 19^{\prime} \mathrm{W}$; (map 137).

Local name reported in 1911 by IBC survey crew.

Boundary: settlement, $50 \mathrm{mi}$. S of Eagle on $\mathrm{N}$ bank of Walker Fork, Yukon-Tanana High.; $64^{\circ} 04^{\prime} \mathrm{N}, 141^{\circ} 06^{\prime} \mathrm{W}$; BGN 1954; (map 102). Var. Walkers Fork.

Placer mining camp with a post office established in 1940; discontinued in 1956. So called because of its nearness (three miles) to the Alaska-Canada boundary.

Boundary Butte: bluff, see Eagle Bluff.

Boundary Creek: stream, flows NW $1.7 \mathrm{mi}$. to Salmon River, $2.7 \mathrm{mi}$. NW of Mount Welker and Alaska-Canada boundary, Coast Mts.; $56^{\circ} 02^{\prime} 20^{\prime \prime} \mathrm{N}, 130^{\circ} 02^{\prime} 40^{\prime \prime} \mathrm{W}$; (map 7 ).

Name published in 1920 by L. G. Westgate (in Brooks and others, 1922, fig. 2), USGS. Boundary Creek: stream, flows SE $11 \mathrm{mi}$. to Taku River, $2 \mathrm{mi}$. above Canyon I. and $34 \mathrm{mi}$. NE of Juneau, Coast Mts. 58 $34^{\prime} 50^{\prime \prime} \mathrm{N}, 133^{\circ}$ $40^{\prime} 00^{\prime \prime}$ W; BGN 1932; (map 12).

Local descriptive name published in 1929 by USFS.

Boundary Creek: stream, in Mount McKinley National Park, flows N 8 mi. to Stony Creek, $10 \mathrm{mi}$. $\mathrm{N}$ of Eielson Visitor Center, Alaska Ra.; $63^{\circ} 34^{\prime} 15^{\prime \prime} \mathrm{N}, 150^{\circ} 19^{\prime} 00^{\prime \prime} \mathrm{W}$; (map 88).

Local name shown on a 1916 fieldsheet by C. E. Giffin, USGS.

Boundary Creek: stream, flows NE $12 \mathrm{mi}$. to Yukon River on Alaska-Canada boundary, 10 mi. SE of Eagle, Yukon-Tanana High.; $64^{\circ} 41^{\prime} \mathrm{N}, 141^{\circ} 00^{\prime} \mathrm{W}$; BGN 1912; (map 102).

Named by William Ogilvie, Surveyor to the Dominion of Canada, and reported in 1898 by E. C. Barnard, USGS.

Boundary Glacier: glacier, heads in Alaska, 1 mi. N of Texas Glacier, trends NE 3 mi. into British Columbia, Canada, to Salmon Glacier, $14 \mathrm{mi}$. N of Hyder, Alaska, Coast Mts.; $56^{\circ}$ $06^{\prime} 45^{\prime \prime} \mathrm{N}, 130^{\circ} 04^{\prime} 00^{\prime \prime} \mathrm{W}$; BGN 1966; (map 7). Var. Munro Glacier.

Local descriptive name published in 1928 by USGS.

Boundary Glacier: glacier, heads in Alaska, $3 \mathrm{mi}$. SE of Mount Henry Glay, trends SW $5 \mathrm{mi}$. into British Columbia, Canada, to Tsirku Gla- 
cier, $43 \mathrm{mi}$. W of Skagway, Alaska, St. Elias Mts.; 59 $19^{\prime} \mathrm{N}, 136^{\circ} 29^{\prime} \mathrm{W}$; BGN 1966; (map 45). Var. Munro Glacier.

So named by the IBC in 1922, "because the glacier lies on the Alaska-Canada boundary."

Boundary Lake: lake, $0.5 \mathrm{mi}$. across, on Boundary Creek, $32 \mathrm{mi}$. NE of Juneau, Coast Mts.; $58^{\circ} 35^{\prime} 30^{\prime \prime} \mathrm{N}, 133^{\circ} 42^{\prime} 40^{\prime \prime} \mathrm{W}$; (map 12).

Name derived from Boundary Creek; published in 1960 on a USGS map.

Boundary Lake: lake, $0.4 \mathrm{mi}$. long, on Kenai Penin., $9 \mathrm{mi}$. NE of Kenai, Cook Inlet Low.; $60^{\circ} 40^{\prime} 45^{\prime \prime} \mathrm{N}, 151^{\circ} 10^{\prime} 30^{\prime \prime} \mathrm{W}$; (map 62).

So named about 1963 by officials of Kenai National Moose Range, because the lake lies on the boundary of the range.

Boundary Landing Strip: airfield, $1 \mathrm{mi}$. $\mathrm{N}$ of Boundary, $49 \mathrm{mi}$. S of Eagle, Yukon-Tanana High.; $64^{\circ} 04^{\prime} 30^{\prime \prime} \mathrm{N}, 141^{\circ} 06^{\prime} 30^{\prime \prime} \mathrm{W}$; (map 102).

Local name published in 1956 by USGS.

Boundary Mountain: mountain, see Canalaska Mountain.

Boundary Peak 70: peak, see Kates Needle.

Boundary Peak 71: mountain, see Devils Thumb.

Boundary Peak 72: mountain, see T, Mount.

Boundary Peak 78: peak, see Hill Peak.

Boundary Peak 84: mountain, see Brundage, Mount.

Boundary Peak 85: mountain, see Fremont Morse, Mount.

Boundary Peak 86: mountain, see Ogden, Mount.

Boundary Peak 93 : peak, see Devils Paw.

Boundary Peak 98: mountain, see Nesselrode, Mount.

Boundary Peak 102: peak, see Poletica, Mount.

Boundary Peak 105: peak, see Canning, Mount.

Boundary Peak 106: peak, see Snow Top.

Boundary Peak 144: mountain, see Surgeon Mountain.

Boundary Peak 150: mountain, see McDonnell, Mount.

Boundary Peak 151: peak, see Henry Clay, Mount.

Boundary Peak 156: mountain, see Harris, Mount.

Boundary Peak 163: mountain, see Quincy Adams, Mount.

Boundary Peak 164 : mountain, see Fairweather, Mount.

Boundary Peak 165 : mountain, see Root, Mount. Boundary Peak 166: mountain, see Lodge, Mount.

Boundary Peak 167: mountain, see Hay, Mount.

Boundary Peak 172: peak, see Herbert, Mount.

Boundary Peak 173: mountain, see Wade, Mount.

Boundary Peak 174: mountain, see Duff, Mount.

Boundary Peak 175: mountain, see Armour, Mount.

Boundary Peak 176: mountain, see Aylesworth, Mount.

Boundary Peak 177 : mountain, see Jetté, Mount.

Boundary Peak 178: mountain, see Seattle, Mount.

Boundary Peak 179: mountain, see Hubbard, Mount.
Boundary Peak 180: mountain, see Alverstone, Mount.

Boundary Peak 181: mountain, see Vancouver, Mount.

Boundary Peak 182: mountain, see Cook, Mount.

Boundary Peak 183: mountain, see Augusta, Mount.

Boundary Peak 186: mountain, see Saint Elias, Mount.

Boundary Ranges: mountain range, portion of Coast Mts. along Alaska-Canada boundary between Mount Foster at NW end and Portland Canal at SE end; $60^{\circ} 48^{\prime} \mathrm{N}, 135^{\circ} 28^{\prime} \mathrm{W}$ [NW end], $55^{\circ} 00^{\prime} \mathrm{N}, 130^{\circ} 15^{\prime} \mathrm{W}$ [SE end].

Name published in 1907 by Blackwelder (p. $417,428)$, USGS

Boundary Roadhouse: locality, roadhouse on Alaska-Canada boundary, $9 \mathrm{mi}$. N of Hyder, Coast Mts.; $56^{\circ} 02^{\prime} 50^{\prime \prime} \mathrm{N}, 130^{\circ} 02^{\prime} 05^{\prime \prime} \mathrm{W}$; (map 7).

Name of a site reported in 1955 by USGS shown as a cabin in ruins.

Boundary Strait: water passage, see Dixon Entrance.

Boundary Mountain: mountain, see Canalaska Mountain.

Bourbon Creek: stream, flows SW $3 \mathrm{mi}$. to Snake River at Nome, Seward Penin. High. ; $64^{\circ} 30^{\prime}$ N, $165^{\circ} 25^{\prime} \mathrm{W}$; (map 94).

Prospectors' name reported in 1899 by D. C. Witherspoon (in Schrader and Brooks, 1900, map 2), USGS.

Bourbon Creek: stream, sce Maylay Creek.

Bourdiens Bay: bay, see Kamishak Bay.

Bourdieus Bay: bay, see Kamishak Bay.

Bourne Creek: stream, flows $\mathbf{S}$ to Fish River, between Baker and Miller Creeks, about $43 \mathrm{mi}$. NE of Solomon, Seward Penin. High.; (map 95).

Prospectors' name reported on the 1900 "Map of Nome Peninsula" by J. M. Davidson and B. D. Blakeslee. This stream cannot be precisely located on current maps.

Bouronov, Cape: point of land, see Burunof, Cape.

Boussole, Pointe de: point of land, see Riou, Point.

Boussole Bay: bay, $1 \mathrm{mi}$. across, in Glacier Bay National Monument $\mathrm{N}$ of Boussole Head, $58 \mathrm{mi}$. NW of Hoonah, St. Elias Mts.; $58^{\circ} 23^{\prime} 30^{\prime \prime} \mathrm{N}, 136^{\circ} 55^{\prime} 30^{\prime \prime} \mathrm{W}$; (map 10).

Named in 1929 by USC\&GS for "the Boussole, one of the two French ships which explored this area in 1786, under the command of La Perouse."

Boussole Head: promontory, between Boussole and Astrolabe Bays, in Glacier Bay National Monument, $57 \mathrm{mi}$. NW of Hoonah, St. Elias Mts.; $58^{\circ} 23^{\prime} \mathrm{N}, 136^{\circ} 55^{\prime} \mathrm{W}$; BGN 1930; (map 10). Var. False Island Head

Named in 1929 by USC\&GS, for the Boussole. See Boussole Bay.

Bow Creek: stream, on Iniskin Penin., flows SE $7 \mathrm{mi}$. to Cook Inlet $\mathbf{N}$ of Chinitna Point, Aleutian Ra.; $59^{\circ} 42^{\prime} 30^{\prime \prime} \mathrm{N}, 153^{\circ} 02^{\prime} 30^{\prime \prime} \mathrm{W}$; (map 51).
Descriptive name for the curved course of the creek, published by USGS in 1922 .

Bow Creek: stream, heads at lake in Bow Pass, flows $\mathrm{N} 9 \mathrm{mi}$. to Chisana River, $3.5 \mathrm{mi}$. E of Chisana Glacier terminus and $38 \mathrm{mi}$. SE of Nabesna, Wrangell Mts. ; $62^{\circ} 01^{\prime} \mathrm{N}, 142^{\circ} 07^{\prime}$ W; (map 84).

Named in 1902 by F. C. Schrader, USGS. Bow Creek: stream, flows NE $3.5 \mathrm{mi}$. to Fortymile River, $36 \mathrm{mi}$. $\mathrm{S}$ of Eagle, Yukon-Tanana High.; $64^{\circ} 16^{\prime} 45^{\prime \prime} \mathrm{N}, 141^{\circ} 19^{\prime} 00^{\prime \prime} \mathrm{W}$; (map 102).

Local name published in 1956 by USGS.

Bowen Anchorage: cove, $0.5 \mathrm{mi}$. across, on $\mathbf{E}$ coast of Kenai Penin., SE side of Day Harbor, $16 \mathrm{mi}$. SE of Seward, Chugach Mts.; $60^{\circ} 01^{\prime} 15^{\prime \prime} \mathrm{N}, 149^{\circ} 04^{\prime} 00^{\prime \prime} \mathrm{W}$; BGN 1929; (map 63)

Named in 1927 by USC\&GS for William H. Bowen, of the USC\&GS vessel Surveyor, "who was drowned October 3, 1927, at Seward, Alaska, in heroic effort to rescue two of his shipmates who had been thrown into the water by the swamping of their skiff."

Bower Lake: lake, $1.3 \mathrm{mi}$. long, drains $\mathrm{S}$ to Humpback Lake, Coast Mts.; 55 02' N, $130^{\circ} 35^{\prime} \mathrm{W}$; BGN 1963; (map 3). Var. Bowers Lake.

Named in 1914 by E. Lester Jones, USBF, for Ward T. Bower, Alaska agent for USBF at that time.

Bower Lake: lake, see Humpback Lake.

Bowers Bank: shoal, in Bering Sea, $\mathbf{N}$ of Semisopochnoi I., Aleutian Is.; $54^{\circ} 00^{\prime} \mathrm{N}, 179^{\circ} 59^{\prime}$ E; (map 15). Var. Bowers Ridge, North Rat Island Ridge.

Discovered and named in 1935 by members of the USCG cutter Chelan, under the command of Comdr. L. V. Kielhorn; published in the 1944 Aleutian Coast Pilot (p. 121).

Bowers Lake: lake, see Bower lake.

Bowhead Creek: stream, flows SW 3 mi. to Cripple River, $11 \mathrm{mi}$. WNW of Nome, Seward Penin. High.; $64^{\circ} 33^{\prime} \mathrm{N}, 165^{\circ} 47^{\prime} \mathrm{W}$; (map 94). Var. Bowheads Creek, Bowherd Creek.

Prospectors' name reported in 1899 as "Bowheads Creek" by D. C. Witherspoon (in Schrader and Brooks, 1900, map 2), USGS.

Bowheads Creek : stream, see Bowhead Creek. Bowherd Creek: stream, see Bowhead Creek. Bowie Bay: bay, see Two Moon Bay.

Bowlder Creek: stream, see Boulder Creek.

Bow Pass: pass, 5,700 ft., at head of Bow Creek, $5 \mathrm{mi}$. SE of Chisana Glacier terminus and 44 mi. NE of McCarthy, Alaska Ra.; 61 ${ }^{\circ} 57^{\prime} 30^{\prime \prime}$ $\mathrm{N}, 142^{\circ} 10^{\prime} 00^{\prime \prime} \mathrm{W}$; (map 67).

Local name reported by USGS in 1960.

Bow River: stream, flows N $6 \mathrm{mi}$. to Buckland River, 42 mi. NE of Haycock, Seward Penin. High.; $65^{\circ} 49^{\prime} \mathrm{N}, 160^{\circ} 55^{\prime} \mathrm{W}$; (map 109).

Local name published on maps after 1950.

Bowser Creek: stream, flows SW $7 \mathrm{mi}$. to Oil Bay, $20 \mathrm{mi}$. N of Augustine I., Aleutian Ra.; $59^{\circ} 40^{\prime} \mathrm{N}, 153^{\circ} 19^{\prime} \mathrm{W}$; BGN 1906; (map 51). 
Named for August Bowser, oil operator in the area about 1900, and reported in 1903 by G. C. Martin (1905, pl. 4), USGS.

Box Canyon: stream, see Dry Canyon Creek.

Boxcar Hills: ridge, elev. 2,100 ft., $3 \mathrm{mi}$. long, on Kenai Penin., $1 \mathrm{mi}$. $\mathbf{N}$ of Garibou Lake and $24 \mathrm{mi}$. NE of Homer, Cook Inlet Low.; 59 $56^{\prime} \mathrm{N}, 151^{\circ} 04^{\prime} \mathrm{W}$; ( $\operatorname{map} 50$ ).

Local name reported and published by USGS in the 1950's.

Boxer Bay: bay, extends NW $1.5 \mathrm{mi}$, at mouth of Boxer River W of Iwoonut Point, on SW coast of St. Lawrence I.; $63^{\circ} 20^{\prime} \mathrm{N}, 171^{\circ} 36^{\prime}$ W; BGN 1951; (map 93).

So named in 1926 by Geist (1936, p. 26), Univ. of Alaska, for the U.S.M.S. Boxer, because the ship took shelter here during a storm.

Boxer River: stream, flows S $7 \mathrm{mi}$. to Boxer Bay, on SW coast of St. Lawrence I.; $63^{\circ} 20^{\prime} \mathrm{N}$, $171^{\circ} 36^{\prime}$ W; $B G N 1951$; (map 93).

Named in 1926 by O. W. Geist, Univ. of Alaska, for Boxer Bay.

Box Island: island, $150 \mathrm{ft}$. across, in Andreanof Is. in Great Sitkin Pass, between Kanu and Great Sitkin Is., Aleutian Is.; $51^{\circ} 57^{\prime} 50^{\prime \prime}$ N, $176^{\circ} 02^{\prime} 20^{\prime \prime} \mathrm{W}$; BGN 1934; (map 17).

So named in 1934 by members of the U.S. Navy Aleutian Island Survey Expedition, "because of the signal Box on the island."

Box Point: point of land, on SE coast of Montague I., $1 \mathrm{mi}$. NE of Patton Bay, $75 \mathrm{mi}$. SE of Seward, Chugach Mts.; 59 $57^{\prime} 45^{\prime \prime} \mathrm{N}$, $147^{\circ} 21^{\prime} 00^{\prime \prime}$ W; BGN 1936; (map 49).

So named by a 1934 USC\&GS field party "because of its box-like appearance."

Box River: stream, flows NE $26 \mathrm{mi}$. to Kateel River, $27 \mathrm{mi}$. W of that stream's junc. with Koyukuk River, Nulato Hills. ; $65^{\circ} 23^{\prime} \mathrm{N}, 158^{\circ}$ 33' W; (map 108).

Local name obtained at Huslia in 1954 or 1955 by USGS.

Boyan, Mount: mountain, 3,018 ft., in Bendeleben Mts.; $2 \mathrm{mi}$. S of Kuzitrin Lake and $17 \mathrm{mi}$. $S$ of Imuruk Lake, Seward Penin. High.; $65^{\circ}$ $21^{\prime} \mathrm{N}, 162^{\circ} 14^{\prime} \mathrm{W} ; \mathrm{BGN} 1952$; (map 110).

Reported in 1950 by D. M. Hopkins, USGS. So named because "from the north the contours of the mountain suggest a reclining nude figure. 'Boyan' is a Swedish feminine given name and was selected by members of the Geological Survey Field party in 1948 for its euphoniousness and femininity."

Boy Creek: siream, see Bay Creek.

Boydarkin, Ostrov: island, see Boidarkin Island.

Byodarkin, Ostrov: islands, see Kutchuma Islands.

Boyden Creek: stream, heads in Mentasta Mts., flows SW $4.2 \mathrm{mi}$. to Jack Creek, $7 \mathrm{mi}$. NW of Devils Mtn., Alaska Ra.; $62^{\circ} 29^{\prime}$ N, $143^{\circ} 07^{\prime}$ W; (map 84).

Local name reported by USGS in 1960 .

Boyer Peak: peak, 1,624 ft., $17 \mathrm{mi}$. SE of Kodiak, Kodiak I.; 57 $32^{\prime} 30^{\prime \prime} \mathrm{N}, 152^{\circ} 18^{\prime} 15^{\prime \prime}$ W; (map 34).

Local name reported in 1949 by USGS.
Boy Scout Island: island, $300 \mathrm{ft}$. long, in Eyak Lake, $3.5 \mathrm{mi}$. E of Cordova, Chugach Mts. $60^{\circ} 32^{\prime} 30^{\prime \prime} \mathrm{N}, 145^{\circ} 39^{\prime} 20^{\prime \prime} \mathrm{W}$; (map 64).

Local name published in 1951 by USGS.

Bozman, Mount: mountain, see Seattle, Mount. Brabazon Mountains: mountain range, see Brabazon Range.

Brabazon Range: mountain range, $28 \mathrm{mi}$. long, trends from Alsek River at Gateway Knob NW to Harlequin Lake, $44 \mathrm{mi}$ SE of Yakutat, St. Elias Mts.; $59^{\circ} 20^{\prime} \mathrm{N}, 138^{\circ} 30^{\prime} \mathrm{W}$; (map 46). Var. Brabazon Mountains.

Named in 1906 by Blackwelder (1907, p. 415 ), USGS, for A. J. Brabazon of the Canadian section of the IBC, who made a photographic survey of the Yakutat Bay region in 1895, and, with the help of those pictures, compiled the first topographic map of this area.

Brach Creek: stream, flows SE $3 \mathrm{mi}$. to Galifornia Creek which flows to Bonanza River, $11 \mathrm{mi}$. NW of Solomon, Seward Penin. High.; $64^{\circ} 41^{\prime} 45^{\prime \prime}$ N, 164 $36^{\prime} 10^{\prime \prime}$ W; (map 95). Var. Brush Creek.

Prospectors' name reported on the 1900 "Map of Nome Peninsula" by J. M. Davidson and B. D. Blakeslee. Shown as "Brush" on a map of Cape Nome gold fields by David Fox, Jr., dated 1901.

Brachiopod Gulch: ravine, trends NW $4 \mathrm{mi}$. to Fossil Creek, $34 \mathrm{mi}$. NE of Livengood, YukonTanana High.; $65^{\circ} 35^{\prime} 50^{\prime \prime} \mathrm{N}, 147^{\circ} 24^{\prime} 00^{\prime \prime} \mathrm{W}$; (map 105).

So named "because the ravine has many fossils of the mollusklike shellfish that became nearly extinct toward the end of the Permian geologic period 200 million years ago." The name appears on recent USGS maps.

Bradfield Canal: estuary, heads at mouth of Bradfield River, extends W $19 \mathrm{mi}$. to Ernest Sound at Point Warde, $30 \mathrm{mi}$. SE of Wrangell, Alex. Arch.; 56 $11^{\prime} \mathrm{N}, 131^{\circ} 59^{\prime} \mathrm{W}$; (map 7). Var. Bradfield Channel.

Named "Bradfield Channel" in 1793 by Capt. George Vancouver, RN, after it was explored August 26, by James Johnstone.

Bradfield Channel : estuary, see Bradfield Canal.

Bradfield River: stream, heads at confluence of its North and East Forks, flows W $2.5 \mathrm{mi}$. to form Bradfield Canal, Coast Mts.; 56 $6^{\circ} 13^{\prime} 30^{\prime \prime}$ N, 131 $30^{\prime} 45^{\prime \prime} \mathrm{W}$; BGN 1954; (map 7).

Name published in 1955 on USGS map.

Bradfield River: stream, see North Fork Bradfield River.

Bradford Creek: stream, flows SE $5.2 \mathrm{mi}$. to Gerstle River, $30 \mathrm{mi}$. SE of Delta Junction, Alaska Ra.; $63^{\circ} 39^{\prime} 50^{\prime \prime} \mathrm{N}, 145^{\circ} 13^{\prime} 40^{\prime \prime} \mathrm{W}$; BGN 1937; (map 86).

Name reported in 1937 by USGS.

Bradford Point: point of land, on right bank of Nushagak River at its mouth, W of Grassy I., $4 \mathrm{mi}$. SW of Dillingham, Bristol Bay Low.; $59^{\circ} 00^{\prime} \mathrm{N}, 158^{\circ} 32^{\prime} \mathrm{W}$; (map 52 ).

Local name published in the 1916 Coast Pilot (p. 240).

Bradley, Mount: mountain, 3,337 ft., $2.3 \mathrm{mi}$. S of Douglas and $4 \mathrm{mi}$. S of Juneau, Coast Mts.; $58^{\circ} 14^{\prime} 55^{\prime \prime} \mathrm{N}, 134^{\circ} 24^{\prime} 30^{\prime \prime} \mathrm{W}$; BGN 1939; (map 11). Var. Jumbo Mountain, Mount Jumbo.

The name "Jumbo Mountain" was published by USGS in 1904, perhaps from the Jumbo mine at its base. Renamed "Mount Bradley" in 1939 by the people of Douglas in honor of Frederick W. Bradley 18631933, who was active in mining in California, Idaho, Oregon, and Alaska. He was president of the American Mining Institute and in 1931 was awarded the Saunder Gold Medal for outstanding achievement in mining (DeArmond, 1957).

Bradley Lake: lake, $3 \mathrm{mi}$. long, on Kenai Penin., $26 \mathrm{mi}$. NE of Homer, Chugach Mts.; 59 . $44^{\prime} 30^{\prime \prime} \mathrm{N}, 150^{\circ} 48^{\prime} 00^{\prime \prime} \mathrm{W}$; (map 50).

Published by USGS in 1951; probably named for the river that drains the lake.

Bradley Lake: lake, 2,100 ft. long, in Matanuska Valley, $3 \mathrm{mi}$. SW of Palmer, Cook Inlet Low.;

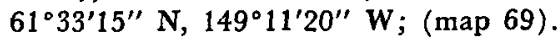

Local name reported in 1951 by USGS.

Bradley River: stream, on Kenai Penin., flows $\mathrm{NW} 7 \mathrm{mi}$. to Kachemak Bay, $25 \mathrm{mi}$. NE of Homer, Chugach Mts.; $59^{\circ} 47^{\prime} 30^{\prime \prime}$ N, $150^{\circ}$ $55^{\prime} 30^{\prime \prime} \mathrm{W}$; $(\operatorname{map} 50)$.

Local name publised by USGS in 1951. The stream was possibly named for John A. Bradley, a local prospector.

Bradley River: stream, see Totatlanika River. Bradley River: stream, see Wood River.

Brad Rock: rock, in Kakul Narrows, at E end of Salisbury Sound, $36 \mathrm{mi}$ NE of Sitka, Alex. Arch.; 57 $22^{\prime} 30^{\prime \prime} \mathrm{N}, 1^{\circ} 45^{\circ} 30^{\prime \prime} \mathrm{W}$; (map 9).

Named in 1896 by Lt. Comdr. E. K. Moore, USN, probably for Ens. G. B. Bradshaw, USN, a member of his party.

Bradshaw Cove: bay, $1 \mathrm{mi}$. across, in Kakul Narrows, on $\mathbf{S}$ coast of Chichagof I., Alex. Arch.; $57^{\circ} 23^{\prime} 00^{\prime \prime} \mathrm{N}, 135^{\circ} 40^{\prime} 30^{\prime \prime} \mathrm{W}$; (map 9).

Named in 1896 by Lt. Comdr. E. K. Moore, USN, for Ens. G. B. Bradshaw, USN, a member of his party.

Brady: locality, on left bank of Kiligwa River, $6 \mathrm{mi}$. NNW of Liberator Lake, Arctic Slope; $68^{\circ} 58^{\prime} \mathrm{N}, 158^{\circ} 28^{\prime} \mathrm{W}$; (map 132). Var. Camp Brady.

The site of a Naval Petroleum Reserve No. 4 camp.

Brady Glacier: glacier, in Glacier Bay National Monument, heads at $58^{\circ} 40^{\prime} \mathrm{N}, 136^{\circ} 47^{\prime} \mathrm{W}$, trends S $24 \mathrm{mi}$. to Taylor Bay, $46 \mathrm{mi}$. NW of Hoonah, St. Elias Mts.; $58^{\circ} 20^{\prime} 45^{\prime \prime} \mathrm{N}$, $136^{\circ} 37^{\prime} 00^{\prime \prime} \mathrm{W}$; (map 10).

Named in 1883 by USC\&GS for Rev. John Green Brady, 1848-1921, Alaskan missionary and later governor from 1897-1909.

Brady Island: island, $0.3 \mathrm{mi}$. long, in Krestof Sound, $12 \mathrm{mi}$. NW of Sitka, Alex. Arch.; $57^{\circ} 11^{\prime} 00^{\prime \prime} \mathrm{N}, 135^{\circ} 33^{\prime} 15^{\prime \prime} \mathrm{W}$; (map 9). Var. Polnoi Island.

Named "Brady Island" in 1897 by Lt. Comdr. W. I. Moore, USN. Named "Polnoi," meaning "gull," in 1833 by Ens. Vasilief.

Braided Creek: stream, on Alaska Penin., flows NW $11 \mathrm{mi}$. to lower Meshik River, $16 \mathrm{mi}$. S of Port Heide Airfield, Bristol Bay Low.; 
$56^{\circ} 44^{\prime} \mathrm{N}, 158^{\circ} 35^{\prime} \mathrm{W}$; (map 30). Var. Jack River.

Descriptive name reported in 1923 by R. H. Sargent, USGS.

Brailand Slough: cove, see Bains Cove.

Brakes Bottom: locality, on left bank of Quartz Creek, $1.3 \mathrm{mi}$. SE of Dahl and $46 \mathrm{mi}$. SW of Imuruk Lake, Seward Penin. High.; $65^{\circ} 21^{\prime} \mathrm{N}$, $164^{\circ} 40^{\prime} \mathrm{W}$; (map 110).

Site of a mining camp; name published in 1956 by USGS.

Branch Bay: bay, $1.5 \mathrm{mi}$. across, on $\mathrm{W}$ coast of Baranof I., $9 \mathrm{mi}$. NW of Port Alexander, Alex. Arch.; 56 $16^{\circ} \mathrm{N}, 134^{\circ} 51^{\prime} \mathrm{W}$; (map 5).

Local name published in 1943 by USC\&GS.

Branch Cowpack River: stream, on Seward Penin., flows NW $5.3 \mathrm{mi}$, to Cowpack River, $65 \mathrm{mi}$. NW of Deering, Kotzebue-Kobuk Low.; $66^{\circ} 19^{\prime} \mathrm{N}, 164^{\circ} 58^{\prime} \mathrm{W}$; (map 113).

Local name reported in 1950 by USGS.

Branch Creek: stream, flows NE $9 \mathrm{mi}$. to Kala Creek, $39 \mathrm{mi}$. SE of Nulato, Kilbuck-Kuskow-

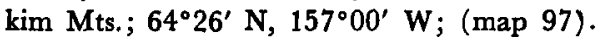

Local descriptive name reported in 1954 by USGS.

Branch Creek: stream, flows NE to West Greek which flows to Shovel Creek, $\mathrm{N}$ of Willow Creek, $8 \mathrm{mi}$. NNW of Solomon, Seward Penin. High.; (map 95).

Prospectors' name reported on a prospector's manuscript map dated 1902. This stream cannot be precisely located on current maps.

Brandon Gulch: ravine, trends W $0.4 \mathrm{mi}$. to Glacier Creek, $8 \mathrm{mi}$. N. of Nome, Seward Penin. High.; $64^{\circ} 37^{\prime} 00^{\prime \prime} \mathrm{N}, 165^{\circ} 20^{\prime} 35^{\prime \prime} \mathrm{W}$; (map 94).

Prospectors' name reported on the 1903 Campion Mining and Trading Co. map by George M. Ashford.

Brandy Creek: stream, flows NE $0.8 \mathrm{mi}$. to Washington Creek which flows to Kougarok River, $10 \mathrm{mi}$. SW of Midnight Mtn. and $51 \mathrm{mi}$. of NW of Imuruk Lake, Seward Penin. High.; $65^{\circ} 44^{\prime} \mathrm{N}, 164^{\circ} 56^{\prime} \mathrm{W}$; (map 110).

Prospectors' name reported on the 1908 "Map of Seward Peninsula" by Arthur Gibson.

Brandy Creek: stream, see Major Creek.

Brannon Ridge: ridge, elev. 2,400 ft., $1.4 \mathrm{mi}$. long, on Attu I., $4 \mathrm{mi}$. W of Holtz Bay, Aleutian Is.; $52^{\circ} 56^{\prime} 35^{\prime \prime} \mathrm{N}, 173^{\circ} 04^{\prime} 00^{\prime \prime} \mathrm{E}$; (map 13).

Named by the U.S. Army during World War II ; published in 1948 by AMS.

Branson Creek: stream, see Mailbox Creek.

Brant Bluff: bluff, on left bank of Yukon River, at NW end of Brant I., $13 \mathrm{mi}$. E. of Birches, Nowitna Low.; $65^{\circ} 10^{\prime} \mathrm{N}, 153^{\circ} 07^{\prime} \mathrm{W}$; (map 107).

Riverboat pilots' name shown on a 1940 "Navigation Chart of the Tanana-Yukon Rivers" published by the Department of the Interior.

Brant Island: island, $3.5 \mathrm{mi}$. across, in Yukon River, opposite the mouth of Illinois Creek at Kallands, $13 \mathrm{mi}$. upstream from Birches,
Nowitna Low.; $65^{\circ} 10^{\prime} \mathrm{N}, 153^{\circ} 04^{\prime} \mathrm{W}$; (map 107).

Riverboat pilots' name shown on a 1940 "Navigation Chart of the Tanana-Yukon Rivers" published by the Department of the Interior.

Brant Point: point of land, extends NE into Elson Lagoon, $6 \mathrm{mi}$. NE of Barrow, Arctic Plain; $71^{\circ} 20^{\prime} 05^{\prime \prime} \mathrm{N}, 156^{\circ} 33^{\prime} 45^{\prime \prime} \mathrm{W}$; (map 153). Var. Argogak.

The Eskimo name for this point is "Argogak" meaning, in a general sense, "ducks heading into wind"; obtained in 1965 by Orth.

Brasil Springs: springs, in Matanuska Valley, 3 mi. NW of Palmer, Cook Inlet Low.; $61^{\circ}$ $37^{\prime} 45^{\prime \prime} \mathrm{N}, 149^{\circ} 11^{\prime} 00^{\prime \prime} \mathrm{W}$; (map 69).

Local name reported in 1951 by USGS.

Brassiere Hills: mountains, one 2,405 ft., the other 2,360 ft., at $\mathrm{N}$ end of Taku Inlet, $4.5 \mathrm{mi}$. $\mathrm{N}$ of Taku Point and $18 \mathrm{mi}$. NE of Juneau, Coast Mts.; $58^{\circ} 27^{\prime} 45^{\prime \prime} \mathrm{N}, 134^{\circ} 01^{\prime} 00^{\prime \prime} \mathrm{W}$; (map 11)

Name published by USGS on a preliminary edition of the 1962 Juneau topographic map; map later published with the name deleted.

Brass Pan Creek: stream, flows NE $10 \mathrm{mi}$. to Shaktoolik River, $27 \mathrm{mi}$. E of Christmas Mtn., Nulato Hills; $64^{\circ} 37^{\prime} \mathrm{N}, 159^{\circ} 41^{\prime} \mathrm{W}$; (map 96).

Local name reported about 1954 by U.S. Army Corps of Engineers.

Braye Lakes: lakes, two, extend $2.3 \mathrm{mi}$., NE of Braye Pass, in Nutzotin Mts., $34 \mathrm{mi}$. E of Euchre Mtn., Alaska Ra.; $62^{\circ} 03^{\prime} \mathrm{N}, 141^{\circ} 06^{\prime}$ W; (map 84).

Local name reported by USGS in 1959.

Braye Pass: pass, 4,000 ft., SW of Braye Lakes, in Nutzotin Mts., Alaska Ra.; 62 $01^{\prime} 30^{\prime \prime} \mathrm{N}$, $141^{\circ} 09^{\prime} 00^{\prime \prime} \mathrm{W}$; (map 84).

Local name reported by USGS in 1959.

Breadline, The: cliffs, $1.2 \mathrm{mi}$. long, on $\mathrm{E}$ shore of Favorite Channel, $1.2 \mathrm{mi}$. S of Pearl Harbor and $17 \mathrm{mi}$. NW of Juneau, Coast Mts.; $58^{\circ} 27^{\prime} 00^{\prime \prime} \mathrm{N}, 134^{\circ} 46^{\prime} 30^{\prime \prime} \mathrm{W}$; (map 11).

Local name published by USGS in 1962.

Breadloaf Island: island, $0.2 \mathrm{mi}$. across, off $\mathrm{SW}$ coast of Umnak I., Aleutian Is.; $52^{\circ} 49^{\prime} 45^{\prime \prime} \mathrm{N}$, $169^{\circ} 03^{\prime} 45^{\prime \prime} \mathrm{W}$; BGN 1942; (map 21 ).

Descriptive name given in 1939 by USC\&GS.

Breaker Number Three: rocks, see Khaz Breakers.

Breaker Number Two: rock, $3.5 \mathrm{mi}$. SW of Khaz Point, on Khaz Penin., Chichagof $\mathrm{I}$., $16 \mathrm{mi}$. S of Chichagof, Alex. Arch.; 57 $29^{\prime} 30^{\prime \prime} \mathrm{N}$, $136^{\circ} 01^{\prime} 30^{\prime \prime} \mathrm{W}$; (map 9). Var. Middle Breaker.

Name published by USC\&GS in the 1901 Coast Pilot (p. 199). The name Middle Breaker was proposed in 1908 by USC\&GS.

Breakfast Rock: rock, $4 \mathrm{mi}$. off Cape Ommaney, on $\mathrm{S}$ coast of Baranof I., Alex. Arch.; $56^{\circ}$ -

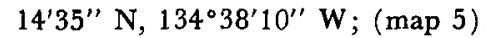

Named in 1917 by USC\&GS.

Breast Island: island, $0.1 \mathrm{mi}$. across, in Galankin Is., $1 \mathrm{mi} \mathrm{S}$ of Sitka, on $\mathbf{W}$ coast of Baranof I.,
Alex. Arch.; $57^{\circ} 02^{\prime} 20^{\prime \prime} \mathrm{N}, 1^{\circ} 5^{\circ} 19^{\prime} 45^{\prime \prime} \mathrm{W}$; (map 9).

Named in 1880 by U.S. Navy and published by USC\&GS in the 1883 Coast Pilot (p. 143). Breast Mountain: mountain, 2,387 ft., $75 \mathrm{mi}$. SE of Bethel, Kilbuck-Kuskokwim Mts.; $60^{\circ}$ $10^{\prime} \mathrm{N}, 160^{\circ} 11^{\prime} \mathrm{W}$; (map 59).

Local descriptive name reported in 1955 by J. M. Hoare, USGS.

Breast Mountain: mountain, 2,912 ft., at $\mathrm{N}$ end of Greenstone Ridge, $58 \mathrm{mi}$. SE of Bethel, Kilbuck-Kuskokwim Mts.; $60^{\circ} 21^{\prime} 30^{\prime \prime} \mathrm{N}$, $160^{\circ} 12^{\prime} 00^{\prime \prime} \mathrm{W}$; (map 59).

Local name reported in 1955 by J. M. Hoare, USGS.

Breed Island: island, see Pustoi Island.

Breed Island: island, see Tanginak Island.

Breen Creek: stream, flows SE $0.6 \mathrm{mi}$. to Left Fork Dome Creek, in Pilgrim River basin, 23 mi. NW of Solomon, Seward Penin. High.; $64^{\circ} 53^{\prime} 20^{\prime \prime} \mathrm{N}, 164^{\circ} 38^{\prime} 50^{\prime \prime} \mathrm{W}$; (map 95).

Prospectors' name reported in 1908 by $\mathbf{P}$. S. Smith (in Brooks and others, 1909, pl. 10), USGS.

Breeze Lake: lake, $0.4 \mathrm{mi}$. long, on Kenai Penin. SW of Dolly Varden Lake, $18 \mathrm{mi}$. NE of Kenai, Cook Inlet Low.; $60^{\circ} 41^{\prime} 50^{\prime \prime}$ N, $150^{\circ}$. $48^{\prime} 00^{\prime \prime} \mathrm{W}$; (map 62).

Named about 1963 by officials of Kenai National Moose Range for administrative purposes.

Breezy Bay: estuary, extends W 2 mi., off Tlevak Strait, on E coast of Dall I., Alex Arch.; $55^{\circ} 09^{\prime} 40^{\prime \prime} \mathrm{N}, 133^{\circ} 03^{\prime} 30^{\prime \prime} \mathrm{W}$; (map 4 ).

Descriptive name given in 1881 by Lt. Comdr. H. E. Nichols, USN, "on account of the strong winds encountered there."

Breezy Point: point of land, on W bank of Portland Canal, $5.4 \mathrm{mi}$. NW of Hattie I., Canada, Coast Mts.; $55^{\circ} 21^{\prime} 25^{\prime \prime} \mathrm{N}, 130^{\circ} 02^{\prime} 25^{\prime \prime} \mathrm{W}$; (map 3).

Named in 1868 by Staff Comdr. David Pender, RN.

Brehnard Creek: stream, flows SW $2.7 \mathrm{mi}$., joins Elephant Creek to form Wilson Creek, $7 \mathrm{mi}$. $E$ of Marshall, Nulato Hills; $61^{\circ} 52^{\prime} 10^{\prime \prime} \mathrm{N}$, 161 '52'15" W; (map 73).

Prospectors' name reported in 1916 by Harrington (1918, map), USGS.

Bremner: locality, on right bank of Copper River, $55 \mathrm{mi}$. NW of Katalla, Chugach Mts.; $60^{\circ} 57^{\prime} 45^{\prime \prime} \mathrm{N}, 144^{\circ} 47^{\prime} 00^{\prime \prime} \mathrm{W}$; (map 64).

Local name derived from the nearby river; listed as a station in the Copper River and Northwestern Railway guide of 1911.

Bremner Glacier: glacier, heads at $60^{\circ} 52^{\prime} \mathrm{N}$, $143^{\circ} 16^{\prime} \mathrm{W}$, trends NW $8 \mathrm{mi}$. to its 1950 terminus at head of North Fork Bremner River, $22 \mathrm{mi}$. ENE of Cordova, Chugach Mts.; $60^{\circ} 50^{\prime} 30^{\prime \prime} \mathrm{N}, 143^{\circ} 57^{\prime} 30^{\prime \prime} \mathrm{W}$; (map 65).

Named for the Bremner River; reported in 1911 by Moffit (1914, fig. 2), USGS.

Bremner River: stream, heads at junc. of its North and Middle Forks, and flows SW 40 $\mathrm{mi}$. to Copper River, $45 \mathrm{mi}$. N of Katalla, Chugach Mts.; 60 $50^{\prime} 45^{\prime \prime} \mathrm{N}, 144^{\circ} 31^{\prime} 00^{\prime \prime}$ W; (map 64). Var. Brenner River, Tetahena River. 
Named in 1885 by Lt. H. T. Allen (1887, p. 44, 45), USA, for John Bremner, prospector who ascended the Copper River, in 1884, as far as Taral and wintered there. See John River. Lt. Allen also gave the Indian name as "Tetahena," which means "flowing river."

Brennan River: stream, see Montana Creek.

Brentwood Lake: lake, $1 \mathrm{mi}$. across, one of the Brentwood Lakes, emptying into Patterson Bay, on SE coast of Baranof I., Alex. Arch.; $56^{\circ} 37^{\prime} 45^{\prime \prime} \mathrm{N}, 134^{\circ} 42^{\prime} 00^{\prime \prime} \mathrm{W}$; (map 5). Var. Lake Brentwood.

Name published in 1943 by USC\&GS.

Brentwood Lakes: lakes, $3 \mathrm{mi}$. across, includes Brentwood Lake and Upper Brentwood Lake, empties into Patterson Bay, on SE coast of Baranof I., Alex. Arch.; $56^{\circ} 37^{\prime} \mathrm{N}, 134^{\circ} 45^{\prime}$ W; BGN 1933; (map 5).

Named in 1933 by USFS.

Bressler, Mount: peak, 7,856 ft., on AlaskaCanada boundary, $2.7 \mathrm{mi}$. S. of Mount Nesselrode and $43 \mathrm{mi}$. $\mathrm{N}$ of Juneau, designated Boundary Peak 97, Coast Mts. ; 58 $55^{\prime} 23^{\prime \prime}$ N, $134^{\circ} 20^{\prime} 10^{\prime \prime} \mathrm{W}$; BGN 1965; (map 11).

Named by the Juneau Icefield Research Project in 1964 for Dr. Calder T. Bressler, 1919-59, geologist, head of the Dept. of Geology, Western Washington College. As geologist with USGS, he spent several years working in the Brooks Range. He was killed on Mount Rainier during Project Crater, a glacio-physical investigation.

Brevier Creek: stream, heads in glacier, flows 1.2 mi. NE to Mineral Creek, $0.1 \mathrm{mi}$. N of Smith Mill and $7.2 \mathrm{mi}$. NW of Valdez, Chugach Mts. ; $61^{\circ} 13^{\prime} 05^{\prime \prime} \mathrm{N}, 146^{\circ} 19^{\prime} 10^{\prime \prime} \mathrm{W}$; (map 68).

Prospectors' name published by USGS (Brooks and others, 1912, pl. 6).

Brevig Lagoon: lagoon, see Breving Lagoon.

Brevig Mission: village, see Teller Mission.

Breving Lagoon: lagoon, extends NW-SE $13 \mathrm{mi}$. along $\mathrm{N}$ coast of Bering Sea and Port Clarence, $13 \mathrm{mi}$. NW of Teller, Seward Penin. High.; $65^{\circ} 21^{\prime}$ N, $166^{\circ} 45^{\prime} \mathrm{W}$; (map 111). Var. Brevig Lagoon.

Local name published in 1956 by USGS. Probably named for Rev. T. L. Brevig, teacher and superintendent of the Teller Reindeer Station at the turn of the century.

Brewer Peak: peak, see Southwest Peak.

Brian Islands: islands, see Inian Islands.

Brickyard Harbor: lagoon, see Cook Bay.

Bride Point: point of land, on $\mathrm{W}$ bank of Speel Arm, $1.2 \mathrm{mi}$. S of Star Point, $29 \mathrm{mi}$. SE of Juneau, Coast Mts. ; $58^{\circ} 06^{\prime} 35^{\prime \prime} \mathrm{N}, 133^{\circ} 43^{\prime} 40^{\prime \prime}$ W; (map 12).

Local name reported in 1951 by USGS

Bridge, Point: point of land, on $\mathrm{N}$ shore of Kootznahoo Inlet, $2.5 \mathrm{mi}$. NE of Angoon, on W central Admiralty I., Alex. Arch.; $57^{\circ} 31^{\prime} 25^{\prime \prime} \mathrm{N}, 134^{\circ} 32^{\prime} 15^{\prime \prime} \mathrm{W}$; (map 9).

Named in 1869 by Comdr. R. W. Meade, USN, and published by USC\&GS in the 1883 Coast Pilot (p. 177).

Bridge Creek: stream, on Kenai Penin., flows 5 mi. NW to Twitter Creek, $5 \mathrm{mi}$, NW of Homer,
Cook Inlet Low.; $59^{\circ} 42^{\prime} 20^{\prime \prime} \mathrm{N}, 1^{\circ} 51^{\circ} 37^{\prime} 15^{\prime \prime}$ W; (map 50).

Local name reported and published by USGS in the 1950's.

Bridge Creek: stream, flows W $7 \mathrm{mi}$. to Meadow Creek, $39 \mathrm{mi}$. SE of Ruby, Kilbuck-Kuskokwim Mts. ; $63^{\circ} 47^{\prime} \mathrm{N}, 154^{\circ} 42^{\prime} \mathrm{W}$; (map 89). Local name reported in 1924 by USGS.

Bridge Creek: stream, flows N $6 \mathrm{mi}$. to Tolovana River, $9 \mathrm{mi}$. SE of Livengood, Yukon-Tanana High.; $65^{\circ} 28^{\prime} \mathrm{N}, 148^{\circ} 16^{\prime} \mathrm{W}$; (map 105). Local name reported in 1916 by J. B. Mertie, Jr. (in Brooks and others, 1918, pl. 13), USGS.

Bridge Creek: stream, flows NW $9 \mathrm{mi}$. to Koyukuk River, S of Stout I. 6 mi. SE of Allakaket, Kanuti Flats; $66^{\circ} 31^{\prime} \mathrm{N}, 152^{\circ} 27^{\prime} \mathrm{W}$; (map 117).

Local name reported in 1956 by T. E. Taylor, USGS.

Bridge Creek: stream, flows E $4.5 \mathrm{mi}$. to Kern Creek, $19 \mathrm{mi}$. NE of Chandalar, Brooks Ra.; $67^{\circ} 40^{\prime} 45^{\prime \prime} \mathrm{N}, 147^{\circ} 56^{\prime} 30^{\prime \prime} \mathrm{W}$; (map 123).

Prospectors' name obtained in 1909 by $\mathrm{A}$. G. Maddren (in Brooks and others, 1910, pl. 7), USGS.

Bridge Lake: lake, $0.7 \mathrm{mi}$. across, $8 \mathrm{mi}$. SE of Minto and $38 \mathrm{mi}$. W of Fairbanks, Tanana Low.; $64^{\circ} 50^{\prime} \mathrm{N}, 148^{\circ} 59^{\prime} \mathrm{W}$; (map 100).

Local name published on a 1952 USGS map.

Bridge Point: point of land, on $\mathbf{N}$ coast of Kanaga I., $1 \mathrm{mi}$. SSW of Ship Rock, Aleutian Is.; $51^{\circ} 46^{\prime} \mathrm{N}, 177^{\circ} 23^{\prime} \mathrm{W}$; (map 17).

Published in 1956 by USC\&GS on Chart 9145.

Bridge Point: point of land, see Lisa Point.

Bridget, Point: point of land, on $\mathrm{E}$ shore of Lynn Canal, at $S$ entrance to Berners Bay, $2 \mathrm{mi}$. W of Echo Cove and $33 \mathrm{mi}$. NW of Juneau, Coast Mts.; 58 $40^{\prime} 45^{\prime \prime} \mathrm{N}, 134^{\circ} 59^{\prime} 20^{\prime \prime} \mathrm{W}$; (map 11).

Named in 1794 by Capt. Vancouver (1798, atlas, pl. 12), RN, probably for his mother whose name was Bridget Berners (Wagner, 1937 , p. 377). Capt. Tebenkov (1852, map 8), IRN, transliterates the English name as "Bridzhyet."

Bridget Cove: cove, $1 \mathrm{mi}$. across, on $\mathrm{E}$ shore of Lynn Channel $\mathrm{E}$ of Mab Island, $3 \mathrm{mi}$. SE of Point Bridget and $30 \mathrm{mi}$. NW of Juneau, Coast Mts.; 58 $38^{\prime} \mathrm{N}, 134^{\circ} 57^{\prime} \mathrm{W}$; (map 11).

Named by Lt. Comdr. H. B. Mansfield, USN, in 1890 and published in 1893 by USC\&GS on Chart 8300 .

Bridget Creek: stream, flows SW $3 \mathrm{mi}$. to Bering Sea, $19 \mathrm{mi}$. SW of Teller, Seward Penin. High.; $65^{\circ} 02^{\prime} \mathrm{N}, 166^{\circ} 41^{\prime} \mathrm{W}$; (map 111).

Local name reported about 1940 by USC\&GS and published on Chart 9380.

Brigham Creek: stream, flows SW $12 \mathrm{mi}$. to Beaver Creek, $30 \mathrm{mi}$. N of Fairbanks, YukonTanana High.; $65^{\circ} 27^{\prime} 40^{\prime \prime} \mathrm{N}$, $147^{\circ} 31^{\prime} 30^{\prime \prime} \mathrm{W}$; (map 105)

Named by prospectors; reported in 1908 by USGS (Covert and Ellsworth, 1909, pl. 2).

Brightman, Point: point of land, at $\mathrm{W}$ point of entrance to Herring Bay, on $\mathrm{S}$ coast of Ad- miralty I., $37 \mathrm{mi}$. E of Sitka, Alex. Arch.; 57 $05^{\prime} 50^{\prime \prime} \mathrm{N}, 134^{\circ} 22^{\prime} 20^{\prime \prime} \mathrm{W}$; (map 9). Var. Point Townshend.

Named in 1899 by USC\&GS. This point may be identical to Point Townshend named by Capt. Vancouver in 1794 "for one of the Townshend brothers, who were statesmen of that time" (Wagner, 1937, p. 520).

Brilliant Glacier: glacier, trends SW $2.3 \mathrm{mi}$. to its terminus at head of a stream which drains into Unakwik Inlet, $40 \mathrm{mi}$. W of Valdez, Chugach Mts.; $61^{\circ} 07^{\prime} 15^{\prime \prime} \mathrm{N}, 147^{\circ} 28^{\prime} 30^{\prime \prime} \mathrm{W}$; $B G N$ 1910; (map 69). Var. Lois Glacier.

So named in 1910 by U. S. Grant, USGS, because of the brilliancy of the ice.

Brinterson, Mount: mountain, see Brynteson, Mount.

Bristol, Riviere: stream, see Kvichak River.

Bristol Bay: gulf, $270 \mathrm{mi}$. wide at mouth, ex. tends E $200 \mathrm{mi}$. from Bering Sea; it is between Cape Newenham on $\mathrm{N}$ and Alaska Penin. and Unimak I. on S; $57^{\circ} \mathrm{N}, 162^{\prime} \mathrm{W} ; B G N$ 1944; Var. Bristolskiy Zaliv, Kwitschak-Sund.

Named in 1778 by Capt. Cook (1785, p. 433), RN, "in honour of the Admiral Earl of Bristol [England]."

Bristol Cape: point of land, see Etolin Point. Bristol River: stream, see Kvichak River. Bristol River: stream, see Nushagak River. Bristolskiy, Mys: point of land, see Etolin Point. Bristolskiy Zaliv: gulf, see Bristol Bay.

British Chain: mountains, see British Mountains. British Mountains: mountains, at $\mathrm{E}$ end of Brooks Ra., extend SE $100 \mathrm{mi}$. into Canada from Kongakut River; bounded on NW by Romanzoff Mts. and on SW by Davidson Mts. $69^{\circ} 00^{\prime} \mathrm{N}, 142^{\circ} 00^{\prime} \mathrm{W}$ [NW end], $68^{\circ} 30^{\prime} \mathrm{N}$, $139^{\circ} 00^{\prime} \mathrm{W}$ [SE end]; $B G N 1954$; (map 138). Var. British Chain.

On July 21, 1826, Sir John Franklin (1828, p. 135), RN, wrote: "This distant range was afterwards distinguished by the name of the British Chain, ** *."

Broad Bay: bight, $1.8 \mathrm{mi}$. long, on NE coast of Unalaska I., $5 \mathrm{mi}$. NW of Unalaska, Aleutian Is.; $53^{\circ} 55^{\prime} 20^{\prime \prime} \mathrm{N}, 166^{\circ} 38^{\prime} 15^{\prime \prime} \mathrm{W}$; (map 23). Var. Shirokaia.

Translation of a descriptive name reported by Father Veniaminov (1840, v. 1, p. 163) as "Shirokaya."

Broad Beach: beach, $0.5 \mathrm{mi}$. long, NW of Witchcraft Point, on NW coast of Kiska I. Aleutian Is.; $52^{\circ} 03^{\prime} 15^{\prime \prime} \mathrm{N}, 177^{\circ} 30^{\prime} 45^{\prime \prime} \mathrm{E}$; (map 14).

One of many arbitrary names applied to features on Kiska Island by USAAF for tactical purposes during World War II.

Broad Bight; bay, $2 \mathrm{mi}$. across, on $\mathrm{S}$ coast of Akutan I., E of Cascade Bight, Aleutian Is.; $54^{\circ} 03^{\prime} 45^{\prime \prime} \mathrm{N}, 165^{\circ} 55^{\prime} 00^{\prime \prime} \mathrm{W}$; BGN 1936; (map 24).

Descriptive name reported in 1901 by J. J. Gilbert, USC\&GS.

Broad Cape: point of land, see Burunof, Cape. Broad Cape: point of land, see Tolstoi, Cape.

Broad Creek: stream, on Alaska Penin., flows SW $6.5 \mathrm{mi}$. to head of Alec River, $15 \mathrm{mi}$. NW of 
Chignik, Aleutian Ra.; $56^{\circ} 26^{\prime}$ N, $158^{\circ} 42^{\prime}$ W; (map 30).

Descriptive name reported in 1923 by $R$. H. Sargent, USGS.

Broad Island: island, $0.3 \mathrm{mi}$. across, in Peril Strait, off $\mathbf{N}$ tip of Baranof I., Alex. Arch.; $57^{\circ} 35^{\prime} 15^{\prime \prime} \mathrm{N}, 135^{\circ} 23^{\prime} 30^{\prime \prime} \mathrm{W}$; (map 9). Var. Ostrov Poperechnyy, Poperechni Island, Poperetch Island.

Local name published about 1880 by USC\&GS. This island was named "Ostrov Poperechnyy," meaning "transverse island," in 1833 by the Russian pilot Ens. Vasiliev.

Broadmoor: village, residential suburb, $5 \mathrm{mi}$. SW of Fairbanks, on $S$ bank of Chena River adjacent to Fairbanks International Airport, Tanana Low.; 64 $49^{\prime} 30^{\prime \prime} \mathrm{N}, 147^{\circ} 52^{\prime} 30^{\prime \prime} \mathrm{W}$; (map 100). Var. South Bjerremark.

Local name, also called "South Bjerremark" because it was part of the Bjerremark Homestead before it was subdivided. The name was published in 1955 by USGS.

Broad Pass: settlement, pop. 10, mile 304.3 on The Alaska RR. in Broad Pass, $12 \mathrm{mi}$. SW of Cantwell and $45 \mathrm{mi}$. SW of Healy, Talkeetna Mts.; $63^{\circ} 14^{\prime} \mathrm{N}, 149^{\circ} 16^{\prime} \mathrm{W}$; (map 87).

Name taken from pass in which it is located; reported by The Alaska RR. on its 1922 timetable.

Broad Pass: pass, 2,300 ft., trends SW $16 \mathrm{mi}$. from Cantwell, $36 \mathrm{mi}$. S of Healy, Talkeetna Mts, ; 6320' N, 14905' W; BGN 1914; (map 87). Var. Caribou Pass.

Descriptive name given in 1898 by G. $\mathrm{H}$. Eldridge and Robert Muldrow, USGS.

Broad Point: point of land, between Middle and Kalsin Bays, 7 mi. S of Kodiak, on E coast of Kodiak I.; $57^{\circ} 41^{\prime} \mathrm{N}, 152^{\circ} 24^{\prime} \mathrm{W}$; (map 34). Var. Mys Tolstoy, Tolstoi Point, Tolstoy Point.

This is a translation by USC\&GS in the late 1890's of the name "M[ys] Tolstoy," published by Lt. Sarichev (1826, map 16), IRN.

Broad Point: point of land, on $\mathbf{N}$ coast of St. Michael I., 5 mi. NW of St. Michael, YukonKuskokwim Delta ; $63^{\circ} 31^{\prime} 40^{\prime \prime} \mathrm{N}, 162^{\circ} 09^{\prime} 30^{\prime \prime}$ W; (map 92).

Descriptive name given in $1898-1900$ by USC\&GS.

Broad Point: point of land, see Chiniak, Cape. Broad Point: point of land, see Tolstoi Point.

Brockman Isand: island, $0.4 \mathrm{mi}$. long, in El Capi$\tan$ Passage, between Orr and Prince of Wales Is., Alex. Arch.; $55^{\circ} 58^{\prime} 15^{\prime \prime} \mathrm{N}, 133^{\circ} 17^{\prime} 55^{\prime \prime} \mathrm{W}$; (map 4).

Name published in 1925 by USC\&GS; derived from Brockman Pass.

Brockman Pass: water passage, $1.5 \mathrm{mi}$. long, between Orr and Spanberg Is., Alex. Arch.; $55^{\circ} 59^{\prime} 30^{\prime \prime} \mathrm{N}, 133^{\circ} 20^{\prime} 15^{\prime \prime} \mathrm{W}$; (map 4).

Local name published in 1924 by USC\& GS.

Brockways Bar: bar, in Kuzitrin River, $\mathrm{S}$ of Bunker Hill, $17 \mathrm{mi}$. W of Mount Bendeleben, Seward Penin. High.; 65 $13^{\prime} \mathrm{N}, 164^{\circ} 38^{\prime} \mathrm{W}$; (map 110). Var. Idaho Bar.

Local name reported in 1950 by USGS.

Broken Mountain: mountain, 3,786 ft., on Alaska
Penin., in Katmai National Monument, $7 \mathrm{mi}$. W of Mount Katmai, Aleutian Ra.; 58 $17^{\prime} 15^{\prime \prime}$ $\mathrm{N}, 155^{\circ} 08^{\prime} 45^{\prime \prime} \mathrm{W}$; $B G N$ 1940; (map 42). Var. Broken Mountains.

Descriptive name given in 1919 by R. F. Griggs of the National Geographic Society "because of the fissured faulted surface."

Broken Mountains: mountain, see Broken Mountain.

Broken Neck Creek: stream, flows S $2.5 \mathrm{mi}$. to Seventymile River, $18 \mathrm{mi}$. NW of Eagle, Yukon-Tanana High.; $64^{\circ} 55^{\prime} 45^{\prime \prime} \mathrm{N}, 141^{\circ} 43^{\prime}$ $20^{\prime \prime} \mathrm{W}$; (map 102).

Prospectors' name shown on a 1902 manuscript map by E. J. Chamberlain, U.S. Deputy Surveyor.

Broken Point: point of land, on $\mathrm{S}$ shore of Inanudak Bay, on $\mathrm{W}$ central coast of $\mathrm{Um}$ nak I., Aleutian Is.; $53^{\circ} 16^{\prime} 15^{\prime \prime} \mathrm{N}, 168^{\circ} 28^{\prime}$ 15" W; BGN 1940; (map 22).

Descriptive name given in 1938 by USC\&GS, "because of its ragged and broken character."

Broken Point: point of land, on $\mathrm{W}$ shore of Uganik Bay, on $\mathbf{N}$ coast of Kodiak I.; $57^{\circ} 52^{\prime} 50^{\prime \prime} \mathrm{N}, 153^{\circ} 37^{\prime} 10^{\prime \prime} \mathrm{W}$; BGN 1910; (map 34). Var. Low Point.

Descriptive name given in 1910 by USC\&GS. This feature was previously called "Low Point" by USC\&GS.

Broken Snowshoe Creek: stream, flows NW 18 mi. to Nixon River, $30 \mathrm{mi}$. W of Medfra, Kilbuck-Kuskokwim Mts. ; $63^{\circ} 08^{\prime} \mathrm{N}, 155^{\circ} 38^{\prime}$ W; (map 89).

Local name reported in 1955 by USGS.

Bronaugh Islands: islands, group, extend $1.5 \mathrm{mi}$. between Clarence Strait and Nichols Passage, $\mathrm{S}$ of Gravina I., Alex. Arch.; 55 ${ }^{\circ} 07^{\prime} \mathrm{N}$, $131^{\circ} 43^{\prime} \mathrm{W}$; (map 3). Var. Bronough Island.

Named in 1883 by Lt. Comdr. H. E. Nichols, USN, for Lt. William Venable Bronaugh, USN, a member of his party.

Bronough Island: islands, see Bronaugh Islands.

Brontosaurus Mountain: mountain, 5,837 ft., trends E-W $3 \mathrm{mi} ., 5 \mathrm{mi}$. SE of Audubon Mtn. and $27 \mathrm{mi}$. NW of Valdez, Chugach Mts.; $61^{\circ} 27^{\prime} 35^{\prime \prime} \mathrm{N}, 146^{\circ} 39^{\prime} 00^{\prime \prime} \mathrm{W}$; $B G N$ 1965; (map 68).

Named about 1959 by L. E. Nielsen "after the dinosaur Brontosaurus which the mountain resembles in shape."

Bronx Creek: stream, heads at $69^{\circ} 22^{\prime} \mathrm{N}$., $155^{\circ} 03^{\prime} \mathrm{W}$, flows $\mathrm{N} 50 \mathrm{mi}$. to Ikpikpuk River $29 \mathrm{mi}$. $\mathrm{N}$ of its head, Arctic Plain; $69^{\circ} 45^{\prime} \mathrm{N}$, $154^{\circ} 48^{\prime} \mathrm{W}$; BGN 1960; (map 142). Var. Big Bend Creek.

Name proposed in 1951 by USGS for use in geologic mapping. The variant name appeared in 1924 on a fieldsheet by Gerald FitzGerald, USGS.

Brood Lake: lake, 0.4 mi. long, on Kenai Penin., 6 mi. SE of junc. of East Fork with Moose River and $28 \mathrm{mi}$. E of Kenai, Cook Inlet Low.; $60^{\circ} 34^{\prime} \mathrm{N}, 150^{\circ} 26^{\prime} \mathrm{W}$; (map 62).

Named about 1963 by officials of Kenai National Moose Range, for administrative purposes.
Brooker Mountain: hill, 3,774 ft., at $\mathbf{S}$ end of Kantishna Hills, $5.5 \mathrm{mi}$. W of Wonder Lake, Alaska Ra.; $63^{\circ} 30^{\prime} 10^{\prime \prime} \mathrm{N}, 151^{\circ} 04^{\prime} 45^{\prime \prime} \mathrm{W}$; (map 88).

Local name reported in 1925 by S. $R$. Capps, USGS.

Brookers Lagoon: cove, $1 \mathrm{mi}$. across, on $\mathrm{E}$ shore of Kalsin Bay, $12 \mathrm{mi}$. S of Kodiak, Kodiak I.; $57^{\circ} 37^{\prime} 30^{\prime \prime} \mathrm{N}, 52^{\circ} 20^{\prime} 30^{\prime \prime} \mathrm{W} ; B G N$ 1964; (map 34). Var. Isthmus Cove.

Local name reported in 1951 by USGS; published in 1949 by USGS as "Isthmus Cove."

Brookfield, Mount: mountain, at head of Klutina Glacier, $17 \mathrm{mi}$. N of Valdez, Chugach Mts.; $61^{\circ} 21^{\prime} 45^{\prime \prime} \mathrm{N}, 146^{\circ} 17^{\prime} 00^{\prime \prime} \mathrm{W}$; BGN 1960; (map 68).

Named by L. E. Nielsen, who made what was reported as the first ascent of the mountain June 22, 1959, for "Lt. R. M. Brookfield, a companion of $F$. C. Schrader [USGS] on his 1898 expedition up the Valdez Glacier. $\mathrm{He}$ [Brookfield] camped a few miles E[ast] of the mountain * * *"'

Brooks: village, see Livengood.

Brooks, Lake: lake, $11 \mathrm{mi}$. long, S of Naknek Lake on Alaska Penin., in Katmai National Monument, $35 \mathrm{mi}$. NW of Mount Katmai, Aleutian Ra.; $58^{\circ} 33^{\prime} \mathrm{N}, 155^{\circ} 50^{\prime} \mathrm{W}$; $B G N$ 1925; (map 42). Var. Ketihuvick, Ketivik Lake, Tom Lake.

Named in 1919 by R. F. Griggs of the National Geographic Society for Alfred Hulse Brooks. The Eskimo name was Ketivik, to which R. H. Sargent, USGS, in 1923, gives the long meaning "beavers broke their houses a long time ago." See Brooks Range.

Brooks, Mount: peak, 11,940 ft., in Mount McKinley National Park, between Brooks and Traleika Glaciers, $14 \mathrm{mi}$. NE of Mount McKinley, Alaska Ra.; $63^{\circ} 11^{\prime} 15^{\prime \prime} \mathrm{N}, 150^{\circ} 38^{\prime} 50^{\prime \prime}$ W; BGN 1947; (map 88). Var. Brooks Mountain, Mount Pamela.

Named by Belmore Browne in 1912 for Alfred Hulse Brooks, USGS. The mountain was first climbed by Thayer Scudder, Winslow Briggs, J. S. Humphreys, and David Bernays on July 5, 1952 (Farquhar, 1959, p. 215). See Brooks Range.

Brooks Camp: locality, between Lake Brooks and Naknek Lake, on Alaska Penin., in Katmai National Mounment, $35 \mathrm{mi}$. NW of Mount Katmai, Aleutian Ra.; $58^{\circ} 33^{\prime} 15^{\prime \prime} \mathrm{N}, 155^{\circ} 46^{\prime}$ 20" W; (map 42).

Camp near Brooks Falls; published in 1952 by USGS.

Brooks Creek: stream, flows W $10 \mathrm{mi}$, to Ospook Greek, $35 \mathrm{mi}$. NE of Nondalton, Aleutian Ra.; $60^{\circ} 06^{\prime} \mathrm{N}, 153^{\circ} 49^{\prime} \mathrm{W}$; (map 61).

Local name reported in 1954 by USGS.

Brooks Greek: stream, flows NE $16 \mathrm{mi}$. to Tolovana River, $13 \mathrm{mi}$. SW of Livengood, Yukon-Tanana High.; $65^{\circ} 21^{\prime} 30^{\prime \prime} \mathrm{N}, 148^{\circ}$ $43^{\prime} 00^{\prime \prime} \mathrm{W}$; (map 105).

Local name published by USGS in the 1950's.

Brooks Falls: waterfalls, between Lake Brooks and Naknek Lake, on Alaska Penin. in Katmai 
National Monument, $36 \mathrm{mi}$. NW of Mount Katmai, Aleutian Ra.; 58 $33^{\prime} 15^{\prime \prime} \mathrm{N}, 155^{\circ}$ 47'15" W; BGN 1925; (map 42). Var. Ketivik Falls, Salmon Falls.

Named in 1919 by R. F. Griggs of the National Geographic Society for Alfred Hulse Brooks, USGS. See Brooks Range.

Brooks Gap: pass, 11,000 ft., in Mount McKinley National Park, at head of Brooks Glacier, $1.5 \mathrm{mi}$. SE of Mount Silverthrone and 13 mi. E of Mount McKinley, Alaska Ra. ; 63 ${ }^{\circ} 06^{\prime}$ 20" N, 150'37'30" W; BGN 1948; (map 88). Var. Brooks Pass.

Named "Brooks Pass" in 1945 by a USAAF climbing party, "for Brooks Glacier."

Brooks Glacier: glacier, in Mount McKinley National Park, trends $N 9 \mathrm{mi}$. from Mount Silverthrone to Muldrow Glacier E of Mount Brooks, $11 \mathrm{mi}$. NE of Mount McKinley, Alaska Ra.; $63^{\circ} 10^{\prime} \mathrm{N}, 150^{\circ} 35^{\prime} \mathrm{W} ; B G N$ 1947; (map 88).

Named about 1900 by T. G. Gerdine, USGS, for Alfred Hulse Brooks, USGS. See Brooks Range.

Brooks Glacier: glacier, see Meares Glacier.

Brooks Harbor: lagoon, see Constantine Harbor.

Brooks Lake: lake, see Kontrashibuna Lake.

Brooks Mountain: mountain, 2,898 ft., in York Mts., $30 \mathrm{mi}$. NW of Teller, Seward Penin. High.; $65^{\circ} 32^{\prime} \mathrm{N}, 167^{\circ} 09^{\prime} \mathrm{W}$; (map 111).

Named in 1901 by T. G. Gerdine (in Collier, 1902, pl. 12), USGS, for Alfred Hulse Brooks, USGS, who made a brief reconnaissance of this area in 1900 (Brooks, 1901, p. 13).

Brooks Mountain: peak, see Brooks, Mount.

Brooks Pass: pass, see Brooks Gap.

Brooks Range: mountain range, 4,000-9,000 ft., extends E-W about $600 \mathrm{mi}$. from Canada on $E$ to Chukchi Sea on $W$ and forms divide between Arctic slope drainage to $\mathrm{N}$ and Kobuk and Yukon Rivers to $\mathrm{S} ; 69^{\circ} \mathrm{N}, 141^{\circ} \mathrm{W}[\mathrm{E}$ end], $68^{\circ} \mathrm{N}, 163^{\circ} \mathrm{W}$ [W end]; BGN 1925. Var. Arctic Mountains, Hooper Mountains, Meade Mountains, Meade River Mountains, Rocky Mountains.

Named in 1925 by USGS for Alfred Hulse Brooks, 1871-1924, chief Alaskan geologist of the Geological Survey from July, 1903, to his death. Sir John Franklin, RN, in 1826 called the range the "Rocky Mountains." In 1916 Brooks (1916b, p. 252-253), USGS, wrote, "A new name, Arctic Mountain system, is proposed for the east and west trending mountain system of northern Alaska formerly regarded as part of the Rocky Mountain system. Recent investigations by Canadian and American geologists have shown that this is a distinct system from the Rocky Mountains, * * *" However, Wahrhaftig (1965, p. 18), USGS, places the Brooks Range in the Rocky Mountain system. This appears to be the range that Lt. P. H. Ray (1885, p. 28), USA, referred to when he wrote, "From the break of the country, I have no doubt Meade River has its source in that range, so I named them
Meade River Mountains." See Hooper Mountains.

Broon Buttes: ridge, extends NW 2 mi. from Reynolds Peak, on Latouche I., $21 \mathrm{mi}$. SE of Chenega, Chugach Mts.; $60^{\circ} 01^{\prime} 10^{\prime \prime} \mathrm{N}, 147^{\circ}$ 54'15" W; (map 63).

Local name reported in 1909 by Grant and Higgins (1910, pl. 12), USGS.

Brophy Creek: stream, flows NW $2 \mathrm{mi}$. to Arkansas Creek, $49 \mathrm{mi}$. S of Eagle, YukonTanana High.; 64 $06^{\circ} \mathrm{N}, 141^{\circ} 04^{\prime} \mathrm{W}$; (map 102). Var. Camp Creek.

Local name published in 1956 by USGS.

Brothers, The: islands, group, $3 \mathrm{mi}$. across, in Stephens Passage $4 \mathrm{mi}$. E of Pybus Point on Admiralty I. and $59 \mathrm{mi}$. NE of Sitka, Alex. Arch.; $57^{\circ} 18^{\prime} \mathrm{N}, 133^{\circ} 50^{\prime} \mathrm{W}$; (map 8).

Named in 1882 by Lt. Comdr. H. E. Nichols, USN; published by USC\&GS in the 1883 Coast Pilot (p. 129).

Brothers, The: islands, see Hazy Islands.

Brothers, The: islands, see Hermagos Islands.

Brothers, The: islands, see Lynn Brothers.

Brower, Point: point of land, $W$ point of entrance to Foggy Island Bay, on Beaufort Sea coast, $35 \mathrm{mi}$. SE of Beechey Point, Arctic Plain; $70^{\circ} 17^{\prime} 40^{\prime \prime} \mathrm{N}, 147^{\circ} 48^{\prime} 00^{\prime \prime} \mathrm{W}$; (map 150).

Named by Leffingwell $(1919$, p. 94$)$, after Charles DeWitt Brower (locally known as "King of the Arctic"), "a trader and guide with whom I [Leffingwell] * * * spent many weeks $* * *$, during visits to that place" ( $p$. 13).

Brower Ridge: ridge, trends E $13 \mathrm{mi}$. from locality of Cape Yakataga to White River Glacier, $97 \mathrm{mi}$. NW of Yakutat, Chugach Mts.; $60^{\circ} 05^{\prime} \mathrm{N}, 142^{\circ} 18^{\prime} \mathrm{W}$; BGN 1946; (map 65).

Locally named in 1945 for Carol Frederick Brower, USGS, "who lost his life in the Yakataga River while assisting in the surveying of the area, July 20, 1944."

Browerville: locality, on Chukchi Sea coast, NE of Barrow, Arctic Plain; $71^{\circ} 17^{\prime} 55^{\prime \prime} \mathrm{N}$, $156^{\circ} 46^{\prime} 15^{\prime \prime} \mathrm{W}$; (map 153). Var. Broweville.

Named for Charles D. Brower, who came to the Barrow area in 1886 as head of a whaling station. He later established a trading post. This locality is near the site of the U.S. Polar Station established by Lt. P. H. Ray in 1881 (Murdoch, 1892, p. 26), USA. See Barrow.

Broweville: locality, see Browerville.

Brown, Point: point of land, in Hayward Strait, on $\mathrm{E}$ coast of Kruzof I., $11 \mathrm{mi}$. NW of Sitka, Alex. Arch.; 57 $09^{\prime} \mathrm{N}, 135^{\circ} 34^{\prime} \mathrm{W}$; (map 9).

Named in 1897 by Lt. Comdr. E. K. Moore, USN. This feature was probably named for Lt. Guy Warner Brown, USN, who in that year was serving aboard the steamer Patterson with Comdr. Moore.

Brown Bear Basin: basin, at head of Basin Creek, $12 \mathrm{mi}$. NW of Mount Russell, Alaska Ra.; $62^{\circ} 52^{\prime} 45^{\prime \prime} \mathrm{N}, 152^{\circ} 16^{\prime} 00^{\prime \prime} \mathrm{W}$; (map 81).

Local name reported in 1954 by USGS.

Brown Bear Rock: rock, $300 \mathrm{ft}$. long, on $\mathrm{S}$ coast of Prince of Wales I., $\mathrm{S}$ of Surf Point, Alex.
Arch.; 54 $44^{\circ} 41^{\prime} 29^{\prime \prime} \mathrm{N}, 132^{\circ} 09^{\prime} 45^{\prime \prime} \mathrm{W}$; (map 1). Local name reported in 1948 by USGS.

Brown Canal: water passage, see Portland Canal.

Brown Cove: cove, extends $\mathrm{N} 1 \mathrm{mi}$. off Frederick Sound, $8 \mathrm{mi}$. NE of Petersburg, Coast Mts.; $56^{\circ} 53^{\prime} 15^{\prime \prime} \mathrm{N}, 132^{\circ} 48^{\prime} 30^{\prime \prime} \mathrm{W}$; (map 6).

Named in 1887 by Lt. Comdr. C. M. Thomas, USN, for charting purposes; name published in 1888 on USC\&GS Chart 705.

Brown Cove Lake: lake, $0.6 \mathrm{mi}$. long., on left bank of Muddy River, $5.5 \mathrm{mi} \mathrm{SE}$ of Point Agassiz Penin., $11 \mathrm{mi}$. NE of Petersburg, Coast Mts.; $56^{\circ} 54^{\prime} 40^{\prime \prime} \mathrm{N}, 132^{\circ} 45^{\prime} 00^{\prime \prime} \mathrm{W}$; (map 6).

Local name recorded in 1961 by USGS.

Brown Creek: stream, in Tilted Hills, on Iniskin Penin., flows SE $7 \mathrm{mi}$. to Dry Bay, Aleutian Ra. ; $59^{\circ} 41^{\prime} \mathrm{N}, 153^{\circ} 08^{\prime} \mathrm{W}$; BGN 1906; (map 51).

Named locally for "Andrew Brown, a pioneer"; reported by G. C. Martin (1905, pl. 4), USGS.

Brown Creek: stream, flows NE $7 \mathrm{mi}$. to Beaver Greek, $34 \mathrm{mi}$. W of McGrath, Kilbuck-Kuskokwim Mts.; $62^{\circ} 57^{\prime} 30^{\prime \prime} \mathrm{N}, 156^{\circ} 42^{\prime} 40^{\prime \prime} \mathrm{W}$; (map 79).

Prospectors' name obtained in 1952 by USGS topographers.

Brown Creek: stream, flows NW $2 \mathrm{mi}$. to Taylor Creek which flows to Kougarok River, $6 \mathrm{mi}$. SW of Midnight Mtn. and $44 \mathrm{mi}$. NW of Imuruk Lake, Seward Penin. High.; $65^{\circ} 41^{\prime} \mathrm{N}$, $164^{\circ} 41^{\prime} \mathrm{W}$; (map 110).

Prospectors' name reported in 1901 by T. G. Gerdine (in Collier, 1902, pl. 12), USGS.

Brown Creek: stream, flows S $5.5 \mathrm{mi}$. to Middle Fork Chandalar River, $0.5 \mathrm{mi}$. NE of junc. of Grave Creek and $19 \mathrm{mi}$. E of Chandalar, Brooks Ra.; $67^{\circ} 32^{\prime} 00^{\prime \prime} \mathrm{N}, 147^{\circ} 46^{\prime} 30^{\prime \prime} \mathrm{W}$; (map 123).

Local name reported in 1956 by T. E. Taylor, USGS.

Browne: $R R$. station, mile 381.2 on The Alaska RR., at $\mathrm{E}$ bank of Nenana River, $29 \mathrm{mi}$. S of Nenana, Alaska Ra.; $64^{\circ} 09^{\prime} \mathrm{N}, 149^{\circ} 14^{\prime} \mathrm{W}$; (map 100).

Named for "F. D. Browne, Locating Engineer of The Alaska Railroad," published on a timetable in 1922.

Browne Tower: promontory, 14,600 ft., in Mount McKinley National Park, E of Parker Pass, $6.5 \mathrm{mi}$. NE of summit of Mount McKinley, Alaska, Ra.; $63^{\circ} 06^{\prime} 10^{\prime \prime} \mathrm{N}, 150^{\circ} 55^{\prime} 40^{\prime \prime} \mathrm{W}$; BGN 1947; (map 88).

Named in 1913 by Archdeacon Stuck (1921, p. 72) for Belmore Browne, 1880-1954, artist, author, and explorer, who, with H. C. Parker and Merl LaVoy, almost reached the south summit of Mount McKinley on July 29, 1912, having been turned back by a storm (Farquhar, 1959, p. 227).

Brown Glacier: glacier, heads at South Sawyer Glacier, trends W $6 \mathrm{mi}$. to its terminus 2 mi. E of Fords Terror and $96 \mathrm{mi}$. NE of Sitka, Coast Mts.; $57^{\circ} 41^{\prime} 30^{\prime \prime} \mathrm{N}, 133^{\circ} 02^{\prime} 15^{\prime \prime}$ W; (map 8).

Named in 1895 by USC\&GS, probably because of the color of the morainal debris. 
Brown Grass Lake: lake, $1.3 \mathrm{mi}$. long, $8 \mathrm{mi}$. SE of Little Rock Mtn. and $24 \mathrm{mi}$. NW of Christian, Brooks Ra.; $67^{\circ} 36^{\prime} \mathrm{N}, 1^{\circ} 5^{\circ} 51^{\prime} \mathrm{W}$; (map 122).

Local name reported in 1956 by T. E. Taylor, USGS.

Brownie Creek: stream, flows SE $2.2 \mathrm{mi}$. to Goldbottom Creek $5 \mathrm{mi}$. NNE of its junc. with Niukluk River, $9 \mathrm{mi}$. NW of Council, Seward Penin. High.; $65^{\circ} 00^{\prime} \mathrm{N}, 163^{\circ} 52^{\prime} \mathrm{W}$; (map 110).

Prospectors' name published on the 1908 "Map of Seward Peninsula" by Arthur Gibson.

Brown Lake: lake, $0.4 \mathrm{mi}$. across, $7 \mathrm{mi}$. SW of Livengood, Yukon-Tanana High.; $65^{\circ} 26^{\prime} 50^{\prime \prime}$ N, 148 $42^{\prime} 30^{\prime \prime}$ W; (map 105).

Named for Edward W. Brown, 1870-1952, "an early pioneer who came to the area in 1912. He farmed and trapped here until his death."

Brownlow, Point: point of land, on Beaufort Sea coast between Camden and Lion Bays, Arctic Plain; $70^{\circ} 10^{\prime} \mathrm{N}, 145^{\circ} 51^{\prime} \mathrm{W}$; (map 151). Var. Brownlow Point.

Named by Sir John Franklin (1828, p. 150) who landed there August 5, 1826.

Brown Mountain: mountain, 2,978 ft., on Southwestern Revillagigedo I., 6 mi. N of Ketchikan, Alex. Arch.; $55^{\circ} 25^{\prime} 25^{\prime \prime} \mathrm{N}, 131^{\circ} 38^{\prime} 00^{\prime \prime}$ W.; (map 3).

Named in 1885 by Lt. Comdr. Richardson C. Clover, USN.

Brown Mountain: mountain, 2,000 ft., in Kenai Mts. on Kenai Penin., on $W$ shore of Nuka Passage, $30 \mathrm{mi}$. SE of Seldovia, Chugach Mts.; $59^{\circ} 20^{\prime} 30^{\prime \prime} \mathrm{N}, 150^{\circ} 52^{\prime} 00^{\prime \prime} \mathrm{W} ; B G N$ 1911; (map 50).

So named in 1911 by U. S. Grant (in Martin and others, 1915, pl. 2), USGS, because of the color of the rock.

Brown Mountain: peak, 3,405 $\mathrm{ft}$., in Chigmit Mts. N of Chinitna Bay, Aleutian Ra.; 59 ${ }^{\circ}$ -

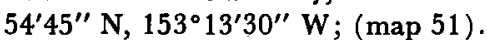

Local name published in 1958 by USGS.

Brown Peak: mountain, 1,267 ft., $20 \mathrm{mi}$. SW of False Pass, on SE coast of Unimak I., Aleutian Is.; $54^{\circ} 38^{\prime} 30^{\prime \prime} \mathrm{N}, 163^{\circ} 44^{\prime} 30^{\prime \prime} \mathrm{W}$; (map 25).

Reported in 1901 by Ferdinand Westdahl, USC\&GS.

Brown Peak: mountain, 2,340 ft., on Alaska Peninsula, $3.3 \mathrm{mi}$. NW of Ursus Head and 13 mi. NW of Augustine I., Aleutian Ra.; $59^{\circ}$ 34'25" N, 153 $43^{\prime} 30^{\prime \prime}$ W; BGN 1916; (map 51).

Named for its color and published on the 1913 USC\&GS Chart 3420.

Brown Rock: rock, $7 \mathrm{mi}$. SW of Chichagof, on W coast of Chichagof I., Alex. Arch.; 57 $35^{\circ}$ $30^{\prime \prime} \mathrm{N}, 136^{\circ} 14^{\prime} 00^{\prime \prime} \mathrm{W}$; (map 9).

Named by USC\&GS and published in 1928 on Chart 8280.

Browns Creek: stream, heads in a glacier, flows $\mathrm{N} 9.5 \mathrm{mi}$. to Lowe River, $2 \mathrm{mi}$. SW of Keystone Canyon and $11 \mathrm{mi}$. ESE of Valdez, Chugach Mts.; $61^{\circ} 02^{\prime} 50^{\prime \prime} \mathrm{N}, 145^{\circ} 48^{\prime} 45^{\prime \prime} \mathrm{W}$; (map 68).
Local name published in the 1950 's by USGS.

Browns Fork Sulukna River: stream, flows NW $14 \mathrm{mi}$. to head of Sulukna River, $40 \mathrm{mi}$. NW of Telida, Kilbuck-Kuskokwim Mts. ; $63^{\circ} 47^{\prime}$ $\mathrm{N}, 154^{\circ} 10^{\prime} \mathrm{W}$; (map 89).

Local name reported in 1954 by USGS.

Browns Hill: hill, $800 \mathrm{ft} ., 7 \mathrm{mi}$. E of Fairbanks Tanana Low.; $64^{\circ} 49^{\prime} 50^{\prime \prime} \mathrm{N}, 147^{\circ} 28^{\prime} 30^{\prime \prime} \mathrm{W}$; (map 100).

Local name published on a 1949 USGS map.

Browns Lagoon: stream, heads in lake, flows NW $4 \mathrm{mi}$. to Uyak Bay $\mathrm{E}$ of Amook I., on NW coast of Kodiak I.; $57^{\circ} 30^{\prime} 50^{\prime \prime} \mathrm{N}, 153^{\circ} 48^{\prime} 00^{\prime \prime}$ W; (map 34)

Local name reported in 1954 by USGS.

Brownson Bay: estuary, extends N $4 \mathrm{mi}$. from Dixon Entrance, on $\mathrm{S}$ coast of Prince of Wales I., Alex. Arch.; $54^{\circ} 43^{\prime} \mathrm{N}, 132^{\circ} 15^{\prime} \mathrm{W}$; (map 1).

Named by USC\&GS for Comdr. Willard Herbert Brownson, USN; published in the 1891 Coast Pilot (p. 85).

Brownson Island: island, $8 \mathrm{mi}$. long, in Ernest Sound, off SE coast of Etolin I., Alex. Arch.; $55^{\circ} 59^{\prime} \mathrm{N}, 132^{\circ} 10^{\prime} \mathrm{W}$; (map 4$)$.

Named in 1891 by USC\&GS for Lt. Cmdr. Willard Herbert Brownson, USN.

Brownson Peak: mountain, 1,942 ft., on Brownson I., Ernest Sound, Alex. Arch.; 55 ${ }^{\circ}$ 57'30' $\mathrm{N}, 132^{\circ} 10^{\prime} 30^{\prime \prime} \mathrm{W}$; (map 4).

Local name recorded in 1949 by USGS.

Browns Point: point of land, on Alaska Penin., $1 \mathrm{mi}$. $\mathrm{S}$ and across from tip of sand spit at entrance of Chignik Lagoon, $5 \mathrm{mi}$. NW of Chignik, Aleutian Ra.; $56^{\circ} 20^{\prime} \mathrm{N}, 158^{\circ} 30^{\prime}$ W ; (map 30).

Local name reported by a 1951 USGS field party.

Brow Point: point of land, between Neets Bay and Gedney Pass, $\mathrm{N}$ of $\mathrm{Chin}$ and Nose Points, on NW coast of Revillagigedo I., Alex. Arch.; $55^{\circ} 50^{\prime} 20^{\prime \prime} \mathrm{N}, 131^{\circ} 42^{\prime} 00^{\prime \prime} \mathrm{W}$; (map 3 ).

Named in 1891 by USC\&GS; Chin and Nose Points are nearby.

Browse Lake: lake, $0.5 \mathrm{mi}$. long, on Kenai Penin., NW of Campsite Lake, $4.2 \mathrm{mi}$. N of Hidden Lake and $33 \mathrm{mi}$. E of Kenai, Cook Inlet Low.; $60^{\circ} 34^{\prime} 00^{\prime \prime} \mathrm{N}, 150^{\circ} 18^{\prime} 30^{\prime \prime} \mathrm{W}$; (map 62).

Named about 1963 by officials of Kenai National Moose Range, for administrative purposes.

Broxson Gulch: ravine, heads at glacier terminus, extends S $4 \mathrm{mi}$. to Eureka Creek, $26 \mathrm{mi}$. NW of Paxson, Alaska Ra. ; $63^{\circ} 16^{\prime} 30^{\prime \prime} \mathrm{N}, 146^{\circ} 08^{\prime}$ $00^{\prime \prime} \mathrm{W}$; (map 86).

Named published on relatively recent maps. Bruce Hills: ridge, elev. 2,000 to 2,200 ft., in Glacier Bay National Monument, extends NW-SE $7 \mathrm{mi}$. between Burroughs and Plateau Glaciers, St. Elias Mts.; $58^{\circ} 59^{\prime} \mathrm{N}, 136^{\circ}$ $19^{\prime} \mathrm{W}$; (map 10).

Named by the American Geographical Society (Field, 1947, map) for Minor Wait Bruce, the author of "Alaska, Its History and Resources," who visited Glacier Bay in 1889.
Bruhn Point: point of land, at head of Womens Bay, $8 \mathrm{mi}$. SW of Kodiak, Kodiak I.; $57^{\circ} 42^{\prime}$ $00^{\prime \prime} \mathrm{N}, 152^{\circ} 32^{\prime} 40^{\prime \prime} \mathrm{W}$; (map 34).

Local name published in 1943 by USC\&GS.

Bruin Bay: estuary, $5 \mathrm{mi}$. long, on $\mathrm{E}$ coast of Alaska Penin., $20 \mathrm{mi}$. W of Augustine I., Aleutian Ra.; $59^{\circ} 22^{\prime} 30^{\prime \prime} \mathrm{N}, 153^{\circ} 57^{\prime} 00^{\prime \prime} \mathrm{W}$; $B G N$ 1906; (map 51). Var. Bear Bay.

The name "Bear Bay" was reported in 1904 by G. C. Martin, USGS, but because of duplication, the name was changed in 1906 by BGN.

Bruin Creek: stream, in Nutzotin Mts., flows N $14 \mathrm{mi}$. to Chisana River, Alaska Ra.; $62^{\circ} 25^{\prime}$ $30^{\prime \prime} \mathrm{N}, 141^{\circ} 40^{\prime} 20^{\prime \prime} \mathrm{W}$; (map 84).

Name published by Capps (1916, pl. 2), USGS.

Bruin Point: point of land, $\mathrm{N}$ point of entrance to Sakie Bay, on W coast of Dall I., Alex. Arch.; $55^{\circ} 05^{\prime} 10^{\prime \prime} \mathrm{N}, 133^{\circ} 14^{\prime} 00^{\prime \prime} \mathrm{W}$; BGN 1929; (map 4).

So named in 1928 by R. S. Patton, USC\& GS, "because of the proximity of Bear Mountain."

Bruin Reef: reef, on $\mathrm{W}$ shore of Deadman Bay, on $S$ coast of Kodiak I.; $57^{\circ} 04^{\prime} 15^{\prime \prime} \mathrm{N}, 153^{\circ}$ 56'50" W; BGN 1934; (map 34).

Named in 1934 by Capt. R. R. Lukens, USC\&GS.

Brumeaux, Cape: promontory, see Foggy Cape. Brumez, Point: point of land, see Foggy Point. Brumez (Tumannie) : point of land, see Foggy Point.

Brundage, Mount: mountain, elev. 6,464 ft., Boundary Peak 84 on Alaska-Canada boundary, $5 \mathrm{mi}$. ESE of terminus of Speel Glacier and $39 \mathrm{mi}$. E of Juneau, Coast Mts.; $58^{\circ} 16^{\prime}$ $40^{\prime \prime} \mathrm{N}, 133^{\circ} 20^{\prime} 45^{\prime \prime} \mathrm{W}$; BGN 1927; (map 12). Var. Boundary Peak 84 .

Named in 1926 by IBC for Frank $H$. Brundage, a member of IBC from 1909 to 1926.

Brundage Head: point of land, on NE coast of Unalaska 1., $13 \mathrm{mi}$. NE of Unalaska, Aleutian Is.; $53^{\circ} 56^{\prime} 00^{\prime} \mathrm{N}, 166^{\circ} 12^{\prime} 30^{\prime \prime} \mathrm{W}$; $B G N$ 1965; (map 23). Var. Brundage Point.

Probably named for Frank $H$. Brundage, USC\&GS, who served under J. J. Gilbert, commander of the USC\&GS steamer Pathfinder during 1900-01.

Brundige Rock: reef, see Hassler Reef.

Brunette Cove: cove, $1.2 \mathrm{mi}$. across, part of Steller Cove, on N coast of Attu I., Aleutian Is.; $52^{\circ} 58^{\prime} 35^{\prime \prime} \mathrm{N}, 172^{\circ} 56^{\prime} 45^{\prime \prime} \mathrm{E}$; (map 13 ).

Named by the U.S. Army during World War II. This name, along with Auburn and Blonde Coves, so-called "pin-up" names, may have been suggested by Red Head, a nearby promontory.

Brunn Point: point of land, on Revillagigedo I., on $\mathbf{E}$ bank of Carroll Inlet, $10 \mathrm{mi}$. NE of Ketchikan, Alex. Arch.; 55 $22^{\prime}$ N, $131^{\circ} 23^{\prime}$ W; (map 3).

Local navigators' name obtained in 1904 by H. C. Fassett, USBF; probably named for Capt. Brunn [cnna], a local seaman and pilot. Bruno Creek: stream, flows NE $4 \mathrm{mi}$. to Beaver 
Creek, 12 mi. SE of Ruby, Kilbuck-Kuskokwim Mts.; $64^{\circ} 35^{\prime} 36^{\prime \prime} \mathrm{N}, 155^{\circ} 17^{\prime} 00^{\prime \prime} \mathrm{W}$; (map 98).

Local name obtained in 1956 by Orth.

Brunteson Peak: mountain, see Brynteson, Mount.

Brush Creek: stream, heads in Teocalli Mts., flows SW $3.4 \mathrm{mi}$. to South Fork Kuskowim River $10 \mathrm{mi}$. S of that stream's junc. with Tatina River, $92 \mathrm{mi}$. SE of McGrath, Alaska Ra.; 62 $09^{\prime} 20^{\prime \prime} \mathrm{N}, 153^{\circ} 20^{\prime} 45^{\prime \prime} \mathrm{W}$; (map 80). Local name reported in 1931 by USGS.

Brush Creek: stream, heads SW of King Mtn., flows SE $1 \mathrm{mi}$. to Nome River, $7 \mathrm{mi}$. NNE of Nome, Seward Penin. High.; 64 $35^{\prime}$ N, $165^{\circ}$ $17^{\prime \prime} \mathrm{W}$; (map 94).

Prospectors' name published on the 1900 "Map of Nome Peninsula" by J. M. Davidson and B. D. Blakeslee.

Brush Creek: stream, flows NW $1 \mathrm{mi}$. to North Fork Kougarok River near its mouth, $5 \mathrm{mi}$. SW of Harris Dome and $45 \mathrm{mi}$. W of Imuruk Lake, Seward Penin. High.; $65^{\circ} 36^{\prime}$ N, $164^{\circ} 46^{\prime}$ W; (map 110).

Prospectors' name reported on the 1908 "Map of Seward Peninsula" by Arthur Gibson.

Brush Creek: stream, flows N $12 \mathrm{mi}$. to Buckland River, $48 \mathrm{mi}$. NE of Haycock, Nulato Hills; $65^{\circ} 48^{\prime} \mathrm{N}, 160^{\circ} 16^{\prime} \mathrm{W}$; (map 109).

Local name published on maps after 1950. Brush Creek: stream, see Brach Creek.

Brush Hill: hill, $700 \mathrm{ft}$., on Revillagigedo I., E of Ward Cove, on N slope of Signal Mtn., Alex. Arch.; 55 $24^{\prime} 00^{\prime \prime} \mathrm{N}, 131^{\circ} 42^{\prime} 45^{\prime \prime} \mathrm{W}$; (map 3). Var. Bush Hill.

Descriptive name given in 1883 by $\mathrm{Lt}$. Comdr. H. E. Nichols, USN.

Brushkana Creek: stream, heads at $63^{\circ} 11^{\prime} \mathrm{N}$, $148^{\circ} 30^{\prime \prime} \mathrm{W}$, flows NE $28 \mathrm{mi}$. to Nenana River, $45 \mathrm{mi}$. SE of Healy, Talkeetna Mts.; $63^{\circ} 19^{\prime}$ $30^{\prime \prime} \mathrm{N}, 148^{\circ} 04^{\prime} 20^{\prime \prime} \mathrm{W}$; (map 87).

Tanana Indian name reported in 1913 by F. H. Moffit, USGS.

Brushman Annex: peak, see Little Brushman.

Brushman Mountain: peak, 5,130 ft., $12 \mathrm{mi}$. NW of Table Mtn. and $44 \mathrm{mi}$. NE of Arctic Village, Brooks Ra.; $68^{\circ} 27^{\prime} \mathrm{N}, 144^{\circ} 03^{\prime} \mathrm{W}$; (map 136).

Local name reported in 1927 by Gerald FitzGerald, USGS.

Brush Peak: mountain, 1,932 ft., $7 \mathrm{mi}$. N of Medfra, Kilbuck-Kuskokwim Mts. ; $63^{\circ} 13^{\prime} \mathrm{N}$, $154^{\circ} 41^{\prime} \mathrm{W}$; (map 89).

Local name reported in 1920 by G. C. Martin (in Brooks and others, 1922, fig. 5), USGS.

Bruskasna Creek: stream, heads in lake at $63^{\circ} 30^{\prime} \mathrm{N}, 148^{\circ} 21^{\prime} \mathrm{W}$, flows SW $12 \mathrm{mi}$. to Nenana River, $32 \mathrm{mi}$. SE of Healy, Alaska Ra.; $63^{\circ} 26^{\prime} 15^{\prime \prime} \mathrm{N}, 148^{\circ} 37^{\prime} 45^{\prime \prime} \mathrm{W}$; (map 87).

Tanana Indian name reported in 1914 by F. H. Moffit, USGS.

Bryan Creek: stream, in Nutzotin Mts., flows W $8 \mathrm{mi}$. to Geohenda Creek $2.5 \mathrm{mi}$. SW of that stream's junc. with Chisana River, Alaska Ra.; $62^{\circ} 02^{\prime} \mathrm{N}, 142^{\circ} 02^{\prime} \mathrm{W}$; (map 84).

Local name published by Capps (1915, p. 222), USGS.
Bryan Creek: stream, flows SW $2.4 \mathrm{mi}$. to Mastodon Creek, $18 \mathrm{mi}$. NW of Ophir and $47 \mathrm{mi}$. NW of McGrath, Kilbuck-Kuskokwim Mts.; $63^{\circ} 20^{\prime} 50^{\prime \prime} \mathrm{N}, 156^{\circ} 52^{\prime} 00^{\prime \prime} \mathrm{W}$; (map 90).

Prospectors' name published in 1921 by USGS.

Bryan Creek: stream, flows S $6 \mathrm{mi}$. to McKinley Creek, $6 \mathrm{mi}$. SE of Golovin and $48 \mathrm{mi}$. $\mathrm{E}$ of Solomon, Seward Penin. High.; 64 $31^{\prime}$ N, $162^{\circ} 51^{\prime} \mathrm{W}$; (map 95).

Prospectors' name published on 1908 "Map of Seward Peninsula" by Arthur Gibson.

Bryan Creek: stream, flows $\mathrm{N} 2 \mathrm{mi}$. to Slate Creek, $47 \mathrm{mi}$. SW of Eagle, Yukon-Tanana High.; 64ㅇ․ $35^{\prime} \mathrm{N}, 142^{\circ} 36^{\prime} \mathrm{W}$; (map 102). Var. Ryan Creek.

Named by prospectors and shown on a 1902 manuscript map by E. J. Chamberlain, U.S. Deputy Surveyor; name shown as "Ryan Creek" in 1898 on a manuscript map by C. A. Woodruff, Fort Cudahy, Canada.

Bryan Creek: stream, flows NE 14 mi., joins Schlitz Creek to form Serpentine River, $13 \mathrm{mi}$. NW of Midnight Mtn. and $54 \mathrm{mi}$. NW of Imuruk Lake, on Seward Penin., KotzebueKobuk Low.; 65 $5^{\circ} 5^{\prime}$ N, $164^{\circ} 55^{\prime}$ W; (map 110).

Prospectors' name reported in 1901 by T. G. Gerdine (in Collier, 1902, pl. 12), USGS.

Bryan Creek : stream, flows $N$ to Cleveland Creek which flows into Cripple River, about $32 \mathrm{mi}$. NW of Nome, Seward Penin. High; (map 94).

Prospectors' name reported on the 1900 "Map of Nome Peninsula" by J. M. Davidson and B. D. Blakeslee; this feature has not been positively identified.

Bryan Creek: stream. see O'Brien Creek.

Bryant, Point: point of land, on NW coast of Montague I., $5.5 \mathrm{mi}$. NE of Cape Cleare and $58 \mathrm{mi}$. SE of Seward, Chugach Mts.; $59^{\circ} 51^{\prime}$ $20^{\prime \prime} \mathrm{N}, 147^{\circ} 53^{\prime} 30^{\prime \prime} \mathrm{W}$; (map 49).

Named by Capt. Nathaniel Portlock about April 29, 1787, probably for the mate of the vessel Nootka. The name is shown only on his chart.

Bryant Creek: stream, flows NE $13 \mathrm{mi}$. to Seventymile River, $13 \mathrm{mi}$. NW of Eagle, Yukon-Tanana High.; $64^{\circ} 54^{\prime} 30^{\prime \prime} \mathrm{N}, 141^{\circ} 33^{\prime}$ $00^{\prime \prime} \mathrm{W}$; (map 102).

Prospectors' name obtained in 1898 by E. C. Barnard, USGS.

Bryant Point: point of land, at junc. of Davis Creek and Lighter Creek, on Admiralty I., $6 \mathrm{mi}$. E of Angoon, Alex. Arch.; 57 $31^{\prime} 20^{\prime \prime} \mathrm{N}$, $134^{\circ} 26^{\prime} 35^{\prime \prime} \mathrm{W}$; (map 9).

Named in 1869 by Comdr. R. W. Meade, USN, for Capt. Charles Bryant, who for several years was an agent of the U.S. Treasury Dept. on the Pribilof Islands. The name was published in 1881 on U.S. Hydrog. Chart 882. The name does not appear on recent maps.

Bryn Mawr Creek: stream, flows NE $3 \mathrm{mi}$. to West Fork Chulitna River, $50 \mathrm{mi}$. SW of Healy, Alaska Ra.; $63^{\circ} 14^{\prime} 30^{\prime \prime} \mathrm{N}, 149^{\circ} 37^{\prime} 30^{\prime \prime}$ W; (map 87).

Local name obtained in 1951 by USGS.
Bryn Mawr Glacier: glasier, trends SE $4.5 \mathrm{mi}$. to Harvard Arm College Fiord, $2 \mathrm{mi}$. NW of College Point and $52 \mathrm{mi}$. NW of Valdez, Chugach Mts.; $61^{\circ} 13^{\prime} 30^{\prime \prime} \mathrm{N}, 147^{\circ} 48^{\prime} 00^{\prime \prime} \mathrm{W}$; (map 69).

Named by members of the Harriman Alaska Expedition in 1899 after Bryn Mawr College, Bryn Mawr, Pa.

Brynteson, Mount: mountain, 1,757 ft., $9 \mathrm{mi}$. N of Nome, Seward Penin. High.; 64 $38^{\prime} \mathrm{N}$, $165^{\circ} 24^{\prime}$ W; (map 94). Var. Brunteson Peak, Mount Brinterson.

Reported as "Brunteson Peak" on the 1900 "Map of Nome Peninsula" by J. M. Davidson and B. D. Blakeslee. Named for John Brynteson, one of the "three Swedes" who discovered gold in the Nome area in the summer of 1898. Brynteson, a native of Sweden, was 40 years old in 1898 and an experienced coal and iron miner who went to Alaska to search for coal. Prior to the gold discovery, he directed work at the coal mine on Norton Sound operated by the Swedish mission at Unalakleet (Rickard, 1909, p. 330). See Lindblom Creek.

Bryson Bar: bar, on $\mathrm{N}$ bank of Chitina River, $9 \mathrm{mi}$. E of Bear I. and $34 \mathrm{mi}$. SE of McCarthy, St. Elias Mts. ; $61^{\circ} 07^{\prime} \mathrm{N}, 142^{\circ} 09^{\prime} \mathrm{W}$; ; (map 67).

Local name, obtained by USGS and published on maps since 1954.

Bryumyez (Foggy): point of land, see Foggy Point.

Bryumyez (Tumannyy), Mys: point of land, see Foggy Point.

Bubb Creek: stream, heads at Limestone Gap in Limestone Hills, flows E $8 \mathrm{mi}$. to Flat Creek, $12 \mathrm{mi}$. NW of Tahenta Pass, Talkeenta Mts.; $62^{\circ} 03^{\prime} 40^{\prime \prime} \mathrm{N}, 147^{\circ} 25^{\prime} 10^{\prime \prime} \mathrm{W}$; (map 82). Var. Sladen Creek, Taiklano Creek.

Named in 1898 by Capt. E. F. Glenn, USA, who reported its native name as "Taiklano." Bubb Creek: stream, see Little Nelchina River.

Bubbling Brook: stream, flows SE $1 \mathrm{mi}$. to Cooper Creek, on central Kiska I., Aleutian Is. ; $51^{\circ} 59^{\prime} 20^{\prime \prime} \mathrm{N}, 177^{\circ} 32^{\prime} 35^{\prime \prime} \mathrm{E}$; (map 14).

One of many arbitrary names applied to features on Kiska Island by USAF for tactical purposes during World War II.

Bubbling Lake: lake, $0.9 \mathrm{mi}$. long, $1 \mathrm{mi}$. $\mathrm{N}$ of Big Grass Lake and $15 \mathrm{mi}$. W of Beaver, Yukon Flats; $66^{\circ} 19^{\prime} 40^{\prime \prime} \mathrm{N}, 147^{\circ} 55^{\prime} 30^{\prime \prime} \mathrm{W}$; (map 118).

Probably named by William Yanert who showed it on a 1916 manuscript map of the Yukon Flats (Stuck, 1917, map facing p. 122).

Bucareli, Puerto y Entrada de: water passage, see Bucareli Bay.

Bucareli Bay: water passage, extends NE $25 \mathrm{mi}$. off Pacific Ocean between Baker and Suemez Is., Alex. Arch.; $55^{\circ} 13^{\prime} \mathrm{N}, 133^{\circ} 32^{\prime} \mathrm{W} ; B G N$ 1899; (map 4). Var. Buccarelli Bay, Buccarelli Gulf, Bukarel Bay, Gavan Bukareli, Port Bukarelli, Puerto del Baylio Bucareli, Puerto y Entrada de Bucareli.

Spanish name given on August 24, 1775, by Don Juan de la Bodega y Quadra as 
"Puerto y Entrada de Bucareli," meaning "port and entrance of Bucareli," in honor of Don Antonio Maria Bucareli y Ursua, Viceroy of Mexico. According to Wagner (1937, p. 377), Capt. Vancouver called it "Puerto del Baylio Bucareli," meaning "port of the Judge Bucareli."

Buccaneer Creek: stream, heads in DeLong Mts. flows SSW $17 \mathrm{mi}$. to Anisak River, $54 \mathrm{mi}$ WNW of Howard Pass, Brooks Ra.; $68^{\circ} 04^{\prime} \mathrm{N}$, $158^{\circ} 59^{\prime} \mathrm{W}$; BGN 1960; (map 132).

So named in 1951 by I. L. Tailleur, USGS, because it was involved in "stream piracy."

Buccarelli Bay: water passage, see Bucareli Bay. Buccarelli Gulf: water passage, see Bucareli Bay. Buccleugh Sound: water passage, NE part of Dixon Entrance, between Clarence Strait and Revillagigedo Channel, $\mathrm{S}$ of Duke I., Alex. Arch.; 54 $45^{\prime} \mathrm{N}, 131^{\circ} 18^{\prime} \mathrm{W}$; (map 2). Var. Buccleughs Sound, Bucclugh Sound, Bucclughs Sound.

Named "Buccleughs Sound" on June 8, 1789 , by Capt. John Meares. See Wagner (1937, p. 435).

Buccleugh Sound: water passage, see Dixon Entrance.

Buccleughs Sound: water passage, see Buccleugh Sound.

Bucclugh Sound: water passage, see Buccleugh Sound.

Bucclugh Sound: water passage, see Dixon Entrance.

Bucclughs Sound: water passage, see Buccleugh Sound.

Buchanan Creek: stream, flows NE $22 \mathrm{mi}$. to West Fork Little Delta River, $1 \mathrm{mi}$. S of that stream's junc. with East Fork, $24 \mathrm{mi}$. NW of Mount Hayes, Alaska Ra.; $63^{\circ} 57^{\prime} \mathrm{N}, 146^{\circ} 56^{\prime}$ W; (map 86). Var. Buckanan Creek.

Local name reported in 1910 by J. W. Bagley (in Capps, 1912, pl. 1), USGS.

Buchanan Head: point of land, see Buchanan Point.

Buchanan Point: point of land, E tip of Attu I., Aleutian Is.; $52^{\circ} 51^{\prime} 08^{\prime \prime} \mathrm{N}, 173^{\circ} 25^{\prime} 55^{\prime \prime} \mathrm{E}$; (map 13). Var. Buchanan Head.

Published in 1948 as "Buchanan Head" by AMS.

Buchanan Ridge: ridge, $1.5 \mathrm{mi}$. long, between Addison Valley and Scout Canyon on NE coast of Attu I., Aleutian Is.; $52^{\circ} 55^{\prime} 50^{\prime \prime} \mathrm{N}$, $173^{\circ} 04^{\prime} 30^{\prime \prime} \mathrm{E}$; (map 13 ).

Named by the U.S. Army during World War II; published in 1948 by AMS.

Bucher Glacier: glacier, $11 \mathrm{mi}$. long, heads in Coast Mts., trends $6 \mathrm{mi}$. to Gilkey Glacier, 8 mi. SW of Mount Ogilvie and $35 \mathrm{mi}$. $\mathrm{N}$ of Juneau; $58^{\circ} 47^{\prime} 50^{\prime \prime} \mathrm{N}, 134^{\circ} 28^{\prime} 00^{\prime \prime} \mathrm{W}$; $B G N$ 1966; (map 11). Var. Matthes Glacier.

Name proposed for BGN decision by members of the Juneau Icefield Project in 1964 although name was used in some scientific literature before then.

Buchia Creek: stream, flows NE $5.6 \mathrm{mi}$. to Tyone Creek, $20 \mathrm{mi}$. N of Tahneta Pass, Talkeetna Mts.; $62^{\circ} 10^{\prime} 10^{\prime \prime} \mathrm{N}, 147^{\circ} 21^{\prime} 00^{\prime \prime} \mathrm{W}$; $B G N$ 1959; (map 82).
Named in 1958 by USGS "because of outcroppings of Buchia-type fossils in the area." Buckanan Creek: stream, see Buchanan Creek. Buck Bight: bight, $1.2 \mathrm{mi}$. across, on SW coast of Unalaska I., Aleutian Is.; $53^{\circ} 28^{\prime} 10^{\prime \prime} \mathrm{N}$, $167^{\circ} 12^{\prime} 30^{\prime \prime} \mathrm{W}$; (map 23).

Published in the 1944 Aleutian Coast Pilot (p. 48)

Buck Creek: stream, in Mentasta Mts., flows NW $12 \mathrm{mi}$. to Little Tok River, $12 \mathrm{mi}$. SE of Mentasta Pass, Alaska Ra.; $62^{\circ} 51^{\prime} \mathrm{N}, 143^{\circ} 19^{\prime} \mathrm{W}$; (map 84).

So named in 1902 by F. C. Schrader, USGS, because of the dense growth of "buck brush" in its valley.

Buck Creek: stream, flows SE $4 \mathrm{mi}$. to Fortymile River, $31 \mathrm{mi}$. SW of Eagle, Yukon-Tanana High.; $64^{\circ} 18^{\prime} 30^{\prime \prime} \mathrm{N}, 141^{\circ} 25^{\prime} 00^{\prime \prime} \mathrm{W}$; (map 102).

Local name published in 1956 by USGS.

Buck Creek: stream, flows NE $6.4 \mathrm{mi}$. to Anakeksik Creek, 12 mi. S of Christmas Mtn., Nulato Hills; 642 $24^{\prime} \mathrm{N}, 160^{\circ} 34^{\prime} \mathrm{W}$; (map 96).

Local name reported about 1954 by U.S. Army Corps of Engineers.

Buck Creek: stream, flows E $2 \mathrm{mi}$. to North Fork Fortymile Creek, $32 \mathrm{mi}$. SW of Eagle, Yukon-Tanana High.; $64^{\circ} 35^{\prime} \mathrm{N}, 142^{\circ} 10^{\prime} \mathrm{W}$; (map 102).

Named by prospectors and shown on a 1905 manuscript map by Maj. W. A. Glassford, USA. This stream is not identified on presentday maps.

Buck Creek: stream, flows SW $8 \mathrm{mi}$. to Quartz Creek, $27 \mathrm{mi}$. NW of Haycock, Seward Penin. High.; $65^{\circ} 35^{\prime} \mathrm{N}, 161^{\circ} 29^{\prime} \mathrm{W}$; (map 109).

Local name reported in 1908 by USGS (Brooks and others, 1909, fig. 21).

Buck Creek: stream, flows SE $3.5 \mathrm{mi}$. to South Fork Grouse Creek, in Mint River basin, 41 mi. NW of Teller, Seward Penin. High.; $65^{\circ}$ $38^{\prime} \mathrm{N}, 167^{\circ} 29^{\prime} \mathrm{W}$; (map 111).

Prospectors' name reported in 1901 by T. G. Gerdine (in Collier, 1902, pl. 12), USGS.

Buck Creek: stream, see Happy New Year Creek.

Bucket Lake: lake, $10 \mathrm{mi}$. SW of Coffee Can Lake and $31 \mathrm{mi}$. SW of Roundabout Mtn., Koyukuk Low.; $65^{\circ} 10^{\prime} \mathrm{N}, 157^{\circ} 08^{\prime} \mathrm{W}$; (map 108).

Local name obtained at Huslia by USGS in 1954 or 1955.

Buckeye Creek: stream, flows SW $4 \mathrm{mi}$. to Banner Creek, $19 \mathrm{mi}$. NW of Big Delta, YukonTanana High.; $64^{\circ} 18^{\prime} \mathrm{N}, 146^{\circ} 20^{\prime} \mathrm{W}$; (map 101).

Named by prospectors; reported in 1910 by USGS (Capps, 1912, pl. 1).

Buckeye Creek: stream, flows N 5 mi. to Yukon River, 3 mi. E of Eagle, Yukon-Tanana High.; $64^{\circ} 47^{\prime} \mathrm{N}, 141^{\circ} 06^{\prime} \mathrm{W}$; (map 102).

Prospectors' name obtained in 1898 by E. C. Barnard, USGS.

Buckeye Creek: stream, flows SE $3.5 \mathrm{mi}$. to Left Fork Goose Creek, $23 \mathrm{mi}$. SE of Rampart, Yukon-Tanana High.; $65^{\circ} 20^{\prime} \mathrm{N}, 149^{\circ} 30^{\prime} \mathrm{W}$; (map 105).
Named by prospectors; reported in 1908 by USGS (Covert and Ellsworth, 1909, pl. 5). Buckholtz Roadhouse: locality, see Kemperville. Buckhorn Lake: lake, $0.9 \mathrm{mi}$. long, on Revillagigedo I., between Carroll and Geogre Inlets, Alex. Arch.; $55^{\circ} 27^{\prime} \mathrm{N}, 131^{\circ} .24^{\prime} \mathrm{W}$; BGN 1923; (map 3).

Named in 1921 by USFS.

Buck Island: island, $0.4 \mathrm{mi}$. across, in mouth of Kashega Bay, off SW coast of Unalaska I., Aleutian Is.; $53^{\circ} 28^{\prime} 40^{\prime \prime} \mathrm{N}, 167^{\circ} 11^{\prime} 50^{\prime \prime} \mathrm{W}$; (map 23).

Published in the 1944 Aleutian Coast Pilot (p. 47).

Buck Island: island, $0.2 \mathrm{mi}$. across, in Seymour Canal, $4.5 \mathrm{mi}$. N of Mole Harbor and 24 mi. NE of Angoon, Alex. Arch. ; $57^{\circ} 44^{\prime} 00^{\prime \prime} \mathrm{N}$, $134^{\circ} 06^{\prime} 20^{\prime \prime} \mathrm{W}$; (map 9).

Local name reported in 1951 by USGS.

Buck Lake: lake, $0.3 \mathrm{mi}$. long, on Admiralty I., $3.5 \mathrm{mi}$. NW of Mole Harbor and $23 \mathrm{mi}$. NE of Angoon, Alex. Arch.; $57^{\circ} 43^{\prime} 35^{\prime \prime} \mathrm{N}, 134^{\circ}$ $08^{\prime} 10^{\prime \prime} \mathrm{W}$; $(\operatorname{map} 9)$.

Local name reported in 1951 by USGS.

Buckland: village, on Buckland River, $54 \mathrm{mi}$. $\mathrm{N}$ of Haycock, Seward Penin. High.; $65^{\circ} 59^{\prime}$ N, 161 ${ }^{\circ} 08^{\prime} \mathrm{W}$; BGN 1944; (map 109). Var. Old Buckland.

Eskimo village and trading post reported by USGS in 1914. Its population was 52 in $1920 ; 104$ in 1930; and 115 in 1940 . The Buckland post office was established here in 1935 and discontinued about 1941. The present Buckland post office is located at Elephant Point.

Buckland: village, see Elephant Point.

Buckland, Mount: mountain, 1,540 ft., in Lisburne Hills, $8 \mathrm{mi}$. E of Cape Dyer, Arctic Slope; $68^{\circ} 39^{\prime} 45^{\prime \prime} \mathrm{N}, 165^{\circ} 5^{\prime} 45^{\prime \prime} \mathrm{W}$; $B G N$ 1965; (map 129).

Named in 1965 by B. P. Exploration Co. for use in geologic mapping. The name commemorates William Buckland, 1784-1856, British geologist who correlated the Lisburne Hills fossils with the Lower Carboniferous. Buckland River: stream, formed by its north and south forks, flows NW $67 \mathrm{mi}$. to Eschscholtz Bay, $40 \mathrm{mi}$. SW of Selawik, Kotzebue-Kobuk Low.; $66^{\circ} 14^{\prime} \mathrm{N}, 161^{\circ} 01^{\prime} \mathrm{W}$; (map 114). Var. Konguk, Kotsokhotana, Kúngiuk River, Reka Kanyk.

Named in 1826 by Capt. Beechey (1831, p. 323$), \mathrm{RN}$, who wrote, "*** upon the river *** I bestowed the name *** of Buckland, in compliment to Dr. Buckland, the Professor of Geology at Oxford * * *." Russian Hydrog. Dept. Chart 1455 of 1852 gives the stream's Eskimo name as "Kanyk" and its Koyukan Indian name as "Kotsokhotana." Dall (1871, p. 284) gives the Eskimo name as "Kúng-uk."

Buckley Bar Creek: stream, flows SW $4.6 \mathrm{mi}$. to Birch Creek, $37 \mathrm{mi}$. SW of Circle, YukonTanana High.; $65^{\circ} 19^{\prime} 45^{\prime \prime} \mathrm{N}, 144^{\circ} 33^{\prime} 45^{\prime \prime} \mathrm{W}$; (map 104).

Named by prospectors; reported in 1911 by USGS (Prindle, 1913, pl. 1). 
Buck Mountain: mountain, 2,016 ft., on Revillagigedo I., $2.5 \mathrm{mi}$. SE of Ketchikan, Alex. Arch.; 55 $19^{\prime} 40^{\prime \prime} \mathrm{N}, 131^{\circ} 34^{\prime} 05^{\prime \prime} \mathrm{W}$; (map 3).

Named in 1883 by H. E. Nichols, USN. See Deer Mountains.

Buckner Creek: stream, flows SE $1 \mathrm{mi}$. to Anikovik River, $14 \mathrm{mi}$. SE of Cape Prince of Wales and $41 \mathrm{mi}$. NW of Teller, Seward Penin. High.; $65^{\circ} 32^{\prime} \mathrm{N}, 167^{\circ} 37^{\prime} \mathrm{W}$; (map 111). Var. Buhner Creek.

Prospectors' name published in 1957 by USGS. Reported in 1899 as "Buhner Creek" by Schrader and Brooks (1900, map 3), USGS.

Buckskin Creek: stream, flows E $20 \mathrm{mi}$. to South Fork Fortymile River, $45 \mathrm{mi}$. SW of Eagle, Yukon-Tanana High.; $64^{\circ} 10^{\prime} 50^{\prime \prime} \mathrm{N}, 141^{\circ}$. $45^{\prime} 00^{\prime \prime} \mathrm{W}$; (map 102).

Named by prospectors and reported in 1896 by Spurr (1898, pl. 44), USGS.

Buckskin Glacier: glacier, heads $\mathrm{E}$ of The Mooses Tooth, trends SE $14 \mathrm{mi}$. to its terminus near head of Hidden River, $44 \mathrm{mi}$. N of Talkeetna, Alaska Ra. ; $62^{\circ} 57^{\prime} \mathrm{N}, 150^{\circ} 13^{\prime} \mathrm{W}$; (map 81).

Local name reported in 1940 by USGS.

Buckstock Creek; stream, see Buckstock River.

Buckstock River: stream, heads in Kuskokwim Mts. and flows NW $33 \mathrm{mi}$. to Aniak River $18 \mathrm{mi}$. SE of Aniak, Yukon-Kuskowim Delta; $61^{\circ} 21^{\prime} \mathrm{N}, 159^{\circ} 14^{\prime} \mathrm{W}$; BGN 1948; (map 73). Var. Buckstock Creek, Buksta Greek.

Local name reported by USGS in 1919 ; derived from the Eskimo word reported to be "buksta[k]" meaning "swampy river." There is a Doestock Creek 15 miles to the north.

Buck Valley: valley, extends SW $4 \mathrm{mi}$. from Herendeen Bay, on SW coast of Alaska Penin. Aleutian Ra.; $55^{\circ} 43^{\prime} 40^{\prime \prime} \mathrm{N}, 160^{\circ} 49^{\prime} 30^{\prime \prime} \mathrm{W}$; (map 28).

Local name reported by Atwood (1911, pl. 2), USGS.

Bud Creek: stream, flows NW $2.2 \mathrm{mi}$. to Wilson Creek Slough, $2.5 \mathrm{mi}$. S of Marshall, YukonKuskokwim Delta; $61^{\circ} 50^{\prime} 45^{\prime \prime}$ N, $162^{\circ} 02^{\prime} 30^{\prime \prime}$ W; (map 74).

Local name reported by Harrington (1918, map), USGS, in 1916.

Budd Creek: stream, flows SW 15 mi. to American River, $31 \mathrm{mi}$. NE of Teller, Seward Penin. High.; $65^{\circ} 36^{\prime} \mathrm{N}, 165^{\circ} 39^{\prime} \mathrm{W}$; (map 111).

Prospectors' name reported in 1900 by Messrs. Kemp and David Fox (in Brooks, 1901, pl. 11).

Buen Abrigo, Puerto del: cove, in Port Etches, Hinchinbrook I. (map 64)

Named in 1779 by Don Ignacio Arteaga.

Buen Ayre, Isla: island, $0.4 \mathrm{mi}$. across, in Port Refugio, Suemez I., Alex. Arch.; $55^{\circ} 17^{\prime} \mathrm{N}$, $133^{\circ} 19^{\prime} \mathrm{W}$; (map 4).

Spanish name meaning "good air island" probably given in 1779 by Don Ignacio Arteaga.

Buentiempo, Mount: mountain, see Fairweather, Mount.

Buffalo Center: village, see Delta Junction.
Buffalo Creek: stream, heads in Wishbone Lake, flows SW $2 \mathrm{mi}$. to Moose Creek, $8 \mathrm{mi}$. N of Palmer, Cook Inlet Low.; $61^{\circ} 43^{\prime} \mathrm{N}, 149^{\circ} 04^{\prime}$ W; (map 69).

Local name reported in 1951 by USGS.

Buffalo Creek: stream, flows $S 5 \mathrm{mi}$. to Nome River, $25 \mathrm{mi}$. NE of Nome, Seward Penin. High.; $64^{\circ} 52^{\prime} \mathrm{N}, 165^{\circ} 16^{\prime} \mathrm{W}$; (map 94). Var. McFadden Greek.

Prospectors' name reported in 1900 by $\mathrm{E}$. C. Barnard (in Brooks, 1901, pl. 17), USGS.

Buffalo Head: hill, $960 \mathrm{ft}$., on Attu I. S of Mirror Lake, $2.1 \mathrm{mi}$. SSW of Attu, Aleutian Is.; $52^{\circ} 54^{\prime} 30^{\prime \prime} \mathrm{N}, 173^{\circ} 13^{\prime} 30^{\prime \prime} \mathrm{E}$; (map 13).

Named by the U.S. Army during World War II; published in 1948 by AMS.

Buffalo Mountain: mountain, 4,550 ft., $17 \mathrm{mi}$. $\mathrm{N}$ of Big Rock Mtn. and $51 \mathrm{mi}$. NW of Christian, Brooks Ra.; $67^{\circ} 55^{\prime} \mathrm{N}, 146^{\circ} 29^{\prime} \mathrm{W}$; (map 122).

Local name reported in 1956 by T. E. Taylor, USGS.

Buff Creek: stream, see Bluff Creek.

Bufflehead Lake: lake, $0.8 \mathrm{mi}$. long, on Kenai Penin. W of Snag Lake, $27 \mathrm{mi}$. NE of Kenai, Cook Inlet Low.; $60^{\circ} 49^{\prime} 30^{\prime \prime} \mathrm{N}, 150^{\circ} 44^{\prime} 00^{\prime \prime}$ W; (map 62).

Named about 1963 by officials of Kenai National Moose Range, for the Bufflehead (Bucephala albeola), a small duck that breeds throughout southern Alaska.

Bugge Lake: lake, $1.3 \mathrm{mi}$. long, at $\mathrm{SW}$ end of Cleveland Penin., near head of Helm Bay, Alex. Arch.; $55^{\circ} 39^{\prime} 45^{\prime \prime} \mathrm{N} 132^{\circ} 03^{\prime} 30^{\prime \prime} \mathrm{W}$; (map 4).

Local name recorded in 1951 by USGS.

Bug Gulch: ravine, in Nutzotin Mts., extends $\mathrm{S} 0.5 \mathrm{mi}$. to Little Eldorado Creek $0.8 \mathrm{mi}$. N of that stream's junc, with Bonanza Creek and $5 \mathrm{mi}$. $\mathrm{N}$ of Beaver Lake, Alaska Ra.; $62^{\circ} 06^{\prime} 50^{\prime \prime} \mathrm{N}, 141^{\circ} 05^{\prime} 10^{\prime \prime} \mathrm{W}$; (map 84).

Local name reported in 1914 by Capps (in Brooks and others, 1915, p. 222), USGS.

Bug Island: island, 1,100 ft. long, in Neets Bay, on NW coast of Revillagigedo I., Alex. Arch.; $55^{\circ} 46^{\prime} 50^{\prime \prime} \mathrm{N}, 131^{\circ} 39^{\prime} 10^{\prime \prime} \mathrm{W}$; (map 3).

One of many arbitrary names applied to features in this area in 1891 by USC\&GS.

Bug Island: island, $2 \mathrm{mi}$. long, in Seymour Canal, $28 \mathrm{mi}$. NE of Angoon, on $E$ coast of Admiralty I., Alex. Arch.; $57^{\circ} 55^{\prime} 00^{\prime \prime} \mathrm{N}, 134^{\circ} 09^{\prime} 30^{\prime \prime} \mathrm{W}$; (map 9).

Named in 1890 by Lt. Comdr. H. B. Mansfield, USN.

Bug Lake: lake, $500 \mathrm{ft}$. long, on Glenn Highway, $3.7 \mathrm{mi}$. NE of Glacier Point and $53 \mathrm{mi}$. NE of Palmer, Talkeetna Mts.; 61 ${ }^{\circ} 48^{\prime} 10^{\prime \prime} \mathrm{N}$, $147^{\circ} 33^{\prime} 30^{\prime \prime} \mathrm{W}$; BGN 1960; (map 69).

Local name reported in 1956 by USGS.

Bugle Creek: stream, on E coast of Great Sitkin I., flows NE $2 \mathrm{mi}$. to Bering Sea, between Bugle and Sulphur Points, Aleutian Is.; $52^{\circ} 02^{\prime} 43^{\prime \prime} \mathrm{N}, 176^{\circ} 00^{\prime} 15^{\prime \prime} \mathrm{W}$; (map 17).

Local name derived from Bugle Point ; published in 1951 by USGS.

Bugle Point: point of land, E tip of Great Sitkin I., Aleutian Is.; $52^{\circ} 02^{\prime} 30^{\prime \prime} \mathrm{N}, 175^{\circ} 58^{\prime} 15^{\prime \prime} \mathrm{W}$; $B G N$ 1936; (map 18).
So named by personnel of the U.S. Navy expedition of 1933, because "a bugler was stationed there during the survey."

Bugomowik Pass: watercourse, in distributary system of Yukon River, trends NW $30 \mathrm{mi}$. from Kwikluak Pass to Norton Sound, YukonKuskokwim Delta ; $62^{\circ} 57^{\prime} 30^{\prime \prime} \mathrm{N}, 164^{\circ} 46^{\prime} 00^{\prime \prime}$ W; (map 77). Var. Pagornawik Pass.

Eskimo name spelled "Pagomawik" in 1899 by G. R. Putnam, USC\&GS.

Buhner Creek: stream, see Buckner Creek.

Bukarel Bay: water passage, see Bucareli Bay. Bukareli, Gavan: water passage, see Bucareli Bay.

Bukarelli, Port: water passage, see Bucareli Bay.

Bukhta Neva: bay, see Neva Bay.

Bukhti Point: point of land, on Kiska I., S tip of Cobra Penin. between Gertrude and Jeff Coves, Aleutian Is.; $51^{\circ} 55^{\prime} \mathrm{N}, 177^{\circ} 28^{\prime} \mathrm{E}$; $B G N$ 1937; (map 14). Var. Zaliva Point.

Russian word meaning "bay"; named in 1933 by U.S. Navy Hydrog. Office.

Bukhty, Mys: point of land, see Bukti Point.

Buksta Creek: stream, see Buckstock River.

Bukti Point: point of land, on SW coast of Raspberry I., $16 \mathrm{mi}$. W of Afognak, Kodiak I.; $58^{\circ} 01^{\prime} 50^{\prime \prime} \mathrm{N}, 153^{\circ} 12^{\prime} 00^{\prime \prime} \mathrm{W}$; (map 43). Var. Cove Point, Mys Bukhty.

Transliteration by USC\&GS of "M[ys] Bukhty," given by Sub-Lt. Mikhail Murashev, IRN, in 1839 or 1840 and published in 1849 on Russian Hydrog. Dept. Chart 1425. Baker (1906, p. 199), USGS, published the translation, "Cove Point."

Bulchitna Lake: lake, $1.2 \mathrm{mi}$. long, $9 \mathrm{mi}$. SE of Skwentna and $59 \mathrm{mi}$. N of Tyonek, Cook Inlet Low. ; 61 ${ }^{\circ} 56^{\prime} 15^{\prime \prime} \mathrm{N}, 150^{\circ} 55^{\prime} 50^{\prime} \mathrm{W}$; (map 70).

Local name published in 1954 by USGS.

Buldir Island: island, elev. 2,152 ft., $4 \mathrm{mi}$ across, one of Rat Is., Aleutian Is.; $52^{\circ} 21^{\prime}$ N, $175^{\circ} 56^{\prime}$ E; BGN 1890; (map 14). Var. Bouldir Island, Bouldyr Island, Saint Stephen Island.

The October 28, 1741 (O.S.), entry in the log book of the St. Peter, commanded by Vitus Bering, reads "By the will of God Stephan Buldirev [later written Stephan Bogdriev], naval cooper, died of scurvey" (Golder, 1922, p. 201). The same day Bering named an island "St. Stephen." Many scholars, including Golder, correlate the island of Bering with that of present-day Buldir Island, and, if so, it may have been named for the sailor that died on its discovery day. The name "Ostrov Buldir" was published on a 1791 map by Lt. Sarichev (1826, map 3), IRN, and thus he may be responsible for the naming.

Baker (1906, p. 151), USGS, gives the meaning of "Buldir" as "hut (or hovel)," implying a descriptive name. Von Langsdorff (1813-14, v. 2, p. 247) appears to translate the name as "round".

Buldir Reef: reef, in Bering Sea, $18 \mathrm{mi}$. SE of Buldir I. and $45 \mathrm{mi}$. NW of Kiska I., Rat Is., Aleutian Is.; $52^{\circ} 12^{\prime} \mathrm{N}, 176^{\circ} 22^{\prime} \mathrm{E}$; (map 14).

Listed in 1944 Aleutian Coast Pilot (p. 129). 
Buldir Volcano: volcano, 2,152 ft. on $S$ end of Buldir I, Aleutian Is; $52^{\circ} 21^{\prime} 00^{\prime \prime} \mathrm{N}, 175^{\circ} 54^{\prime}$ $50^{\prime \prime} \mathrm{E}$; (map 14).

Name reported by Coats $(1953$, p. 8$)$, USGS.

Buldyr: island, see Karpa Island.

Bulger Hill: hill, knob on $\mathbf{N}$ side of Mount Roberts, between Icy Gulch and Quartz Gulch, $2 \mathrm{mi}$. E of Juneau, Coast Mts.; $58^{\circ} 18^{\prime} \mathrm{N}$, $134^{\circ} 21^{\prime} \mathrm{W}$; (map 11).

Named by miners for Peter Bulger, who had mining claims on the hill. In 1881, Bulger came to Juneau from Sitka and claimed two lots in the early settlement. He located mining claims in association with Pat McGlinchy and John Olds in Silver Bow Basin. He died in Wrangell in 1897 (DeArmond, 1957, p. 9).

Bulky, Mount: mountain, 3,359 ft., in Glacier Bay National Monument, $1.7 \mathrm{mi}$. S of Red Bed Peak, and $54 \mathrm{mi}$. NW of Hoonah, St. Elias Mts.; $58^{\circ} 38^{\prime} 40^{\prime \prime} \mathrm{N}, 136^{\circ} 30^{\prime} 55^{\prime \prime} \mathrm{W}$; (map 10).

Local name reported by USGS in 1951.

Bullard Mountain: mountain, 4,225 ft., $2 \mathrm{mi}$. NE of Mendenhall Lake, at 1962 terminus of Mendenhall Glacier and $9.7 \mathrm{mi}$. NW of Juneau, Coast Mts. ; $58^{\circ} 26^{\prime} \mathrm{N}, 134^{\circ} 30^{\prime} \mathrm{W}$; (map 11).

Named for Benjamin Bullard, 1848-1933, a mining engineer who came to the Klondike from California in 1897 and later moved to Juneau. In 1907 he began mining on Nugget Creek where he later built a hydroelectric powerplant (DeArmond, 1957, p. 9-10).

Bullards Landing: locality, on E side of Taku Inlet, Coast Mts.; 58 $26^{\prime} \mathrm{N}, 1^{\circ} 3^{\circ} 56^{\prime} \mathrm{W}$; $B G N$ 1932; (map 12).

Former site of a boat landing owned by Ben Bullard, first permanent white settler in the area.

Bull Creek: stream, flows NE $4 \mathrm{mi}$. to Yukon River at Nation Reef, $28 \mathrm{mi}$. ESE of its junc. with Charley River, Yukon-Tanana High.; $65^{\circ} 12^{\prime} \mathrm{N}, 141^{\circ} 51^{\prime} \mathrm{W}$; BGN 1962; (map 103). Var. Spring Greek.

Prospectors' name from an unpublished map by E. J. Ghamberlain, dated 1902 .

Bull Creek: stream, flows SW $6 \mathrm{mi}$. to Victoria Creek, $38 \mathrm{mi}$. NE of Livengood, Yukon-Tanana High.; $65^{\circ} 48^{\prime} 15^{\prime \prime} \mathrm{N}, 147^{\circ} 26^{\prime} 00^{\prime \prime} \mathrm{W}$; (map 105).

Local name published by USGS in the 1950's.

Bull Creek: stream, heads in Canada, flows NW $60 \mathrm{mi}$. to Grayling Fork Black River, $30 \mathrm{mi}$. SE of Salmon Village, Porcupine Plat.; $66^{\circ}$. $14^{\prime} 15^{\prime \prime} \mathrm{N}, 141^{\circ} 44^{\prime} 45^{\prime \prime} \mathrm{W}$; BGN 1959; (map 120). Var. Siwash Creek.

The former name, "Siwash Creek," was given in 1910 by the IBC survey. "Bull Creek" reflects present-day local usage.

Bull Creek: stream, flows SW $12 \mathrm{mi}$. to Tulebagh Lake $30 \mathrm{mi}$. W of Beaver, Yukon Flats; $66^{\circ} 22^{\prime}$. $45^{\prime \prime} \mathrm{N}, 148^{\circ} 35^{\prime} 30^{\prime \prime} \mathrm{W}$; (map 118).

Local name obtained in 1956 by USGS.

Bull Creek: stream, see Butte Creek.

Bulldog Cove: cove, $1 \mathrm{mi}$. wide, on $\mathrm{E}$ coast of Aialik Penin., $16 \mathrm{mi}$. SW of Seward, Chu- gach Mts.; $59^{\circ} 53^{\prime} 45^{\prime \prime} \mathrm{N}, 149^{\circ} 33^{\prime} 30^{\prime \prime} \mathrm{W}$; (map 49).

Local name reported in the early 1950 's by USC\&GS.

Bulldog Creek: stream, $8 \mathrm{mi}$. long, flows NE to Kipchuk River, 79 mi SE of Bethel, KilbuckKuskokwim Mts. ; 60 $38^{\prime}$ N, $159^{\circ} 27^{\prime}$ W ; (map 59).

Local name reported in 1955 by J. M. Hoare, USGS.

Bulldog Point: point of land, see Kshaliuk Point.

Bullen: locality, on Beaufort Sea coast, $0.5 \mathrm{mi}$. $\mathrm{SE}$ of Bullen Point and $15 \mathrm{mi}$. W of Flaxman I., Arctic Plain ; $70^{\circ} 10^{\prime} 50^{\prime \prime} \mathrm{N}, 146^{\circ} 51^{\prime} 00^{\prime \prime} \mathrm{W}$; (map 151).

Eskimo camp site shown on a 1902 manuscript map by S. J. Marsh.

Bullen Point: point of land, on Beaufort Sea coast, $\mathrm{E}$ point of entrance to Mikkelson Bay, Arctic Plain; $70^{\circ} 11^{\prime} 10^{\prime \prime} \mathrm{N}, 146^{\circ} 52^{\prime} 00^{\prime \prime} \mathrm{W}$; (map 151). Var. Point Bullen, Savakvik Point, Shavugavik Point.

Named "Point Bullen" on August 7, 1826 by Sir John Franklin (1828, p. 152). The Eskimo name "Shavugavik," meaning "working place" was reported in 1913 by Leffingwell (1919, p. 94).

Bullfrog Creek: stream, flows SE $1 \mathrm{mi}$. to Salcha River, $37 \mathrm{mi}$. N of Big Delta, Yukon-Tanana High. ; $64^{\circ} 40^{\prime} \mathrm{N}, 145^{\circ} 38^{\prime} \mathrm{W}$; (map 101).

Local name reported in 1950 by USGS.

Bullfrog Island: island, $5.5 \mathrm{mi}$. across, in Yukon River, $45 \mathrm{mi}$. W of Unalakleet, Innoko Low.; $63^{\circ} 43^{\prime} \mathrm{N}, 159^{\circ} 16^{\prime} \mathrm{W}$; (map 91 ).

Local name reported in 1949 by USC\&GS.

Bull Head: promontory, on SE coast of Glacier I., $12 \mathrm{mi} \mathrm{NE}$ of Storey I., $54 \mathrm{mi}$. NE of Whittier, Chugach Mts. ; $60^{\circ} 51^{\prime} 15^{\prime \prime} \mathrm{N}, 147^{\circ} 09^{\prime} 15^{\prime \prime}$ W; (map 63).

Local name reported in 1951 by USGS.

Bullhead Cove: estuary, extends E $1.8 \mathrm{mi}$. off Revillagigedo Channel, S of Kah Shakes Point, Coast Mts.; 55 $03^{\prime} 20^{\prime \prime} \mathrm{N}, 130^{\circ} 59^{\prime} 30^{\prime \prime} \mathrm{W}$; (map 3). Var. Bull Head Cove.

Local name reported in 1955 by USGS.

Bullion Creek: stream, $1.6 \mathrm{mi}$. long, on Douglas I., flowing NE to Gastineau Channel, $5 \mathrm{mi}$. SE of Juneau, Coast Mts. ; $58^{\circ} 14^{\prime} 45^{\prime \prime}$ N, $134^{\circ} 20^{\prime}$ $10^{\prime \prime} \mathrm{W}$; (map 11). Var. Ready Bullion Creek.

The name "Bullion Creek" was first used as the name of a claim for water for mining use by G. W. Picket and Stillman Lewis in 1881 (DeArmond, 1957, p. 10). Recent maps have transposed the names Bullion Creek and Ready Bullion Creek.

Bullion Creek: stream, flows NE $9 \mathrm{mi}$. to Mosquito Fork, $55 \mathrm{mi}$. SW of Eagle, YukonTanana High.; $64^{\circ} 05^{\prime} 50^{\prime \prime} \mathrm{N}, 142^{\circ} 04^{\prime} 20^{\prime \prime} \mathrm{W}$; (map 102).

Named by prospectors and reported in 1898 by E. F. Ball, prospector.

Bullion Creek: stream, flows NE $12 \mathrm{mi}$. to North Fork Fortymile River, $37 \mathrm{mi}$. SW of Eagle, Yukon-Tanana High.; $64^{\circ} 26^{\prime} 30^{\prime \prime}$ N, $142^{\circ} 08^{\prime}$ $20^{\prime \prime} \mathrm{W}$; (map 102). Var. Granite Creek, Bonanza Creek, Lucky Gulch.
Named by prospectors and shown on an 1898 manuscript map by C. A. Woodruff.

Bullion Creek: stream, flows W $4 \mathrm{mi}$. to Sherrette Creek which flows to Pilgrim River, $17 \mathrm{mi}$. SW of Mount Bendeleben, Seward Penin. High.; $65^{\circ} 01^{\prime} \mathrm{N}, 164^{\circ} 32^{\prime} \mathrm{W}$; (map 110).

Prospectors' name reported on a map of Cape Nome gold fields by David Fox, Jr., dated 1901. The lower course of this stream is now part of Sherrett Greek.

Bullion Creek: stream, flows E $5 \mathrm{mi}$. to Star Creek, $13 \mathrm{mi}$. NE of Council and $38 \mathrm{mi}$. S of Imuruk Lake, Seward Penin. High.; $65^{\circ} 02^{\prime}$ N, $163^{\circ} 23^{\prime} \mathrm{W}$; (map 110). Var. Anaconda Creek, Birch Creek, Lone Creek.

Prospectors' name published in 1956 by USGS. Shown as "Lone" at its head, "Birch" in its middle, and "Anaconda" in its lower course, on a 1901 map of Cape Nome gold fields by David Fox, Jr.

Bullion Mountain: mountain, 4,852 ft., extends NE-SW $4 \mathrm{mi}$. between Craigie and Upper Willow Creeks, $14 \mathrm{mi}$. NW of Palmer, Talkeetna Mts. ; $61^{\circ} 47^{\prime} 15^{\prime \prime} \mathrm{N}, 149^{\circ} 20^{\prime} 00^{\prime \prime} \mathrm{W}$; (map 69).

Local name reported in 1951 by USGS.

Bull Island: island, $1.8 \mathrm{mi}$. long, near head of George Inlet, off Revillagigedo I., Alex.

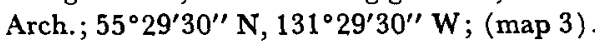

Arbitrary name given in 1891 by USC\&GS.

Bull Island: island, $1.7 \mathrm{mi}$. long, in Yukon River, $0.5 \mathrm{mi}$. NW of Long I. and $2 \mathrm{mi}$. W of Tanana, Nowitna Low.; $65^{\circ} 10^{\prime} 30^{\prime \prime} \mathrm{N}, 152^{\circ} 10^{\prime} 00^{\prime \prime} \mathrm{W}$; (map 106). Var. Long Island.

Local name reported in 1952 by USGS.

Bull Island: island, see Long Island.

Bull Pup: stream, see Bull Pup Creek.

Bull Pup Creek: stream, flows NE $1 \mathrm{mi}$. to Gold Run which flows to Bluestone River, $15 \mathrm{mi}$. SE of Teller, Seward Penin. High.; $65^{\circ} 03^{\prime} 40^{\prime \prime}$ N, $166^{\circ} 11^{\prime} 50^{\prime \prime} \mathrm{W}$; (map 111). Var. Bull Pup.

Prospectors' name reported on the 1908 "Map of Seward Peninsula."

Bull River: stream, flows SE $25 \mathrm{mi}$. to West Fork Chulitna River, $50 \mathrm{mi}$. SW of Healy, Alaska Ra. ; $63^{\circ} 10^{\prime} 45^{\prime \prime} \mathrm{N}, 149^{\circ} 30^{\prime} 10^{\prime \prime} \mathrm{W}$; (map 87).

Local name reported in 1913 by J. W. Bagley, USGS.

Bullrun Creek: stream, flows W $7.5 \mathrm{mi}$. to John River, $12 \mathrm{mi}$. S of Gunsight $\mathrm{Mtn}$. and 51 mi. W of Wiseman, Brooks Ra.; $67^{\circ} 18^{\prime} \mathrm{N}$, $152^{\circ} 01^{\prime} \mathrm{W}$; BGN 1932; (map 124).

Local name in general use since 1905 ; reported by Robert Marshall in 1932.

Bullrush Lake: lake, $1 \mathrm{mi}$. across, between Meadow Creek and Long Lake, $25 \mathrm{mi}$. SW of Beaver, Yukon Flats; $66^{\circ} 16^{\prime} 30^{\prime \prime} \mathrm{N}, 148^{\circ}$ $18^{\prime} 00^{\prime \prime} \mathrm{W}$; ( $\operatorname{map} 118$ ).

Local name obtained in 1956 by USGS.

Bull Seal Point: point of land, $4 \mathrm{mi}$. S of Glory of Russia Cape, on NE coast of St. Matthew I. ; 60³3' $\mathrm{N}, 172^{\circ} 55^{\prime} \mathrm{W}$; (map 56).

Published in 1932 by USC\&GS on Chart 8851.

Bully Boy Creek: stream, heads on Mount Jumbo, near center of Prince of Wales I., flows N $2.3 \mathrm{mi}$. to Gould Passage at Portage Bay, 
Alex. Arch.; $55^{\circ} 16^{\prime} 40^{\prime \prime} \mathrm{N}, 1^{\circ} 32^{\circ} 35^{\prime} 28^{\prime \prime} \mathrm{W}$; (map 4).

Local name reported in 1908 by C. W. Wright (in Brooks and others, 1909, pl. 3) USGS.

Bulova, Mount: mountain, see Kangukhsam Mountain.

Bulshaia Gora: mountain, see McKinley, Mount.

Bulshaya Gora: mountains, see McKinley, Mount.

Bulshi River: stream, see Tlikakila River.

Bulwark Creek: stream, see Eagle Creek.

Bumble Bay: bay, $1.5 \mathrm{mi}$. across, $22 \mathrm{mi}$. SW of Karluk, on W coast of Kodiak I.; 57 $16^{\prime} 30^{\prime \prime}$ $\mathrm{N}, 154^{\circ} 41^{\prime} 30^{\prime \prime} \mathrm{W}$; (map 35 ).

Local name published in 1943 by USC\&GS.

Bumpy Point: point of land, on $\mathrm{N}$ coast of Tanaga I., Aleutian Is.; $51^{\circ} 55^{\prime} 00^{\prime \prime} \mathrm{N}, 177^{\circ}$ $57^{\prime} 45^{\prime \prime} \mathrm{W}$; (map 17).

Descriptive name published in 1951 by USGS.

Bumyok Ridge: ridge, elev. $1,400 \mathrm{ft}$. , trends NE-SW $7 \mathrm{mi}$. between Lakes Nerka and Aleknagik, $30 \mathrm{mi}$. NW of Dillingham, KilbuckKuskokwin Mts.; $59^{\circ} 26^{\prime} \mathrm{N}, 158^{\circ} 50^{\prime} \mathrm{W}$; BGN 1932; (map 52).

Eskimo name reported in 1932 by Gerald FitzGerald, USGS.

Bunco Creek: stream, heads in Peters Hills, flows $\mathrm{SE}$ and NE $15 \mathrm{mi}$. to Tokositna River, $19 \mathrm{mi}$. NW of Talkeetna, Cook Inlet Low.; $62^{\circ} 32^{\prime} 50^{\prime \prime}$ N, $150^{\circ} 30^{\prime} 05^{\prime \prime} \mathrm{W}$; (map 81).

Prospectors' name reported in the 1930's by USGS.

Bunco Lake: lake, $1.2 \mathrm{mi}$. long, near mouth of Bunco Creek, $19 \mathrm{mi}$. NW of Talkeetna, Cook Inlet Low.; $62^{\circ} 32^{\prime} 15^{\prime \prime} \mathrm{N}, 150^{\circ} 00^{\prime} 20^{\prime \prime} \mathrm{W}$; (map 81).

Local name reported in 1958 by USGS.

Bunitlana Lake: lake, $1.6 \mathrm{mi}$. long, on $\mathrm{E}$ bank of Kustatan River, $31 \mathrm{mi}$. NW of Kenai, Cook Inlet Low.; $60^{\circ} 52^{\prime} \mathrm{N}, 151^{\circ} 52^{\prime} \mathrm{W}$; (map 62). Local name reported in 1958 by USGS.

Bunka Lake: lake, $3,000 \mathrm{ft}$. long, $1 \mathrm{mi}$. SW of Tyonek, Cook Inlet Low.; $61^{\circ} 03^{\prime} 50^{\prime \prime} \mathrm{N}, 151^{\circ}$ $10^{\prime} 45^{\prime \prime} \mathrm{W}$; (map 70).

Local name reported in 1958 by USGS.

Bunker Hill: locality, on left bank of Kuzitrin River, across from Bunker Hill, $49 \mathrm{mi}$. SW of Imuruk Lake, Seward Penin. High.; 651 $13^{\prime}$ N, 164'37' W; BGN 1966; (map 110). Var. Bunker Hill Crossing, Bunker Hill Station.

RR. station established in 1935 when the Seward Peninsula RR. was extended from Shelton to here; named for the hill to the west.

Bunker Hill: hill, $825 \mathrm{ft}$., on bank of Kuzitrin River $3 \mathrm{mi}$. SW of its junc. with Kougarok River, $17 \mathrm{mi}$. W of Mount Bendeleben, Seward Penin. High.; $65^{\circ} 14^{\prime} \mathrm{N}, 164^{\circ} 39^{\prime} \mathrm{W}$; (map 110).

Local name reported in 1900 by Brooks (1901, pl. 11), USGS.

Bunker Hill Creek: stream, flows NE $1.5 \mathrm{mi}$. to Kougarok River $1.5 \mathrm{mi}$. NW of its junc, with Kuzitrin River, $48 \mathrm{mi}$. SW of Imuruk Lake, Seward Penin. High.; $65^{\circ} 16^{\prime} \mathrm{N}, 164^{\circ} 36^{\prime} \mathrm{W}$; (map 110).
Prospectors' name reported on the 1908 "Map of Seward Peninsula" by Arthur Gibson. Bunker Hill Crossing: locality, see Bunker Hill Bunker Hill Station: locality, see Bunker Hill.

Bunnell Cape: point of land, $1 \mathrm{mi}$. SW of Ivekan Mtn., $29 \mathrm{mi}$. S of Gambell, on SW coast of Saint Lawrence I.; $63^{\circ} 22^{\prime} \mathrm{N}, 171^{\circ} 44^{\prime} \mathrm{W}$; $B G N$ 1951; (map 93). Var. Cape Bunnell, Asi Cape, West Cape.

Named by Otto William Geist, University of Alaska, for Charles E. Bunnell, 1878-1956, founding president of the University of Alaska, 1921-49.

Bunny Creek: stream, see Barney Creek.

Bun Point: point of land, on Moser Penin., between Moser and Alitak Bays, at $\mathrm{S}$ end of Kodiak I.; $56^{\circ} 58^{\prime} 25^{\prime \prime}$ N, $154^{\circ} 06^{\prime} 00^{\prime \prime} \mathrm{W}$; (map 32).

Name published in 1943 by USC\&GS.

Bun Rock: rock, in Pacific Ocean S of Let I., $4 \mathrm{mi}$. SW of Deer I., Aleutian Ra.; 54 $50^{\prime} 20^{\prime \prime}$ N, $162^{\circ} 26^{\prime} 20^{\prime \prime} \mathrm{W}$; BGN 1942; (map 25).

So named in 1941 by USC\&GS because, "it resembles a bun."

Bunshefoot Creek: stream, heads S of Iknutak Mtn., flows E $2.3 \mathrm{mi}$. to Golovnin Bay, $41 \mathrm{mi}$. SE of Solomon, Seward Penin. High.; $64^{\circ} 27^{\prime}$ $\mathrm{N}, 163^{\circ} 06^{\prime} \mathrm{W}$; (map 95).

Prospectors' name published on the 1908 "Map of Seward Peninsula" by Arthur Gibson.

Bupto, Mount: mountain, 4,000 ft., $26 \mathrm{mi}$. NW of Howard Pass, Brooks Range; 68 $31^{\prime} \mathrm{N}$, $157^{\circ} 30^{\prime} \mathrm{W}$; BGN 1960; (map 132).

Named in 1949 by Carl Benson, USGS, "after a baby one of the geologist's wife had." Bupto Creek: stream, heads SW of Mount Bupto, flows E $18 \mathrm{mi}$. to Ipnavik River, Brooks Ra.; $68^{\circ} 29^{\prime} \mathrm{N}, 157^{\circ} 12^{\prime} \mathrm{W}$; BGN 1960; (map 132 ).

Named in 1951 by I. L. Tailleur, USGS, "for Mount Bupto."

Burg Creek: stream, see Borg Creek.

Burgeman: locality, see Bergman.

Burger Point: point of land, on $\mathrm{N}$ coast of Chichagof I., in Icy Strait, $4 \mathrm{mi}$. NW of mouth of Port Frederick and $43 \mathrm{mi}$. SW of Juneau, Alex. Arch.; 58 $12^{\prime} 30^{\prime \prime} \mathrm{N}, 135^{\circ} 35^{\prime}$. $00^{\prime \prime}$ W; (map 11).

Local name published in 1926 by USC\&GS.

Burgos, Bahia de: bay, between Cape Suckling and Kayak I.; $60^{\circ} 00^{\prime} \mathrm{N}, 144^{\circ} 00^{\prime} \mathrm{W}$.

Named by Capt. Alessandro Malaspina and shown on his 1791 chart.

Burial Lake: lake, $0.5 \mathrm{mi}$. across, in DeLong Mts., 12 mi. NW of Desperation Lake, Brooks Ra.; $68^{\circ} 25^{\prime} 30^{\prime \prime} \mathrm{N}, 159^{\circ} 12^{\prime} 00^{\prime \prime} \mathrm{W}$; BGN 1960; (map 131).

Named in 1951 by I. L. Tailleur, USGS, "for [Eskimo] burial site near lake."

Burka: village, see Biorka.

Burka: island, see Sedanka Island.

Burka Cape: point of land, see Sedanka Cape.

Burk Creek: stream, see Goldrun Creek.

Burke Creek: stream, flows SW $6 \mathrm{mi}$. to American River, $36 \mathrm{mi}$. NE of Teller, Seward Penin. High.; $65^{\circ} 40^{\prime} \mathrm{N}, 165^{\circ} 38^{\prime} \mathrm{W}$; (map 111). Var. Fisher Creek.
Prospectors' name reported in 1901 by $\mathrm{T}$. G. Gerdine (in Collier, 1902, pl. 12), USGS.

Burkett, Mount: mountain, $9,730 \mathrm{ft}$., $1.5 \mathrm{mi}$. W of Alaska-Canada boundary, $6 \mathrm{mi}$. NE of Devils Thumb and $116 \mathrm{mi}$. E of Sitka, Coast Mts.; $57^{\circ} 10^{\prime} 30^{\prime \prime} \mathrm{N}, 132^{\circ} 18^{\prime} 00^{\prime \prime} \mathrm{W}$; BGN 1930; (map 8). Var. Burkett Needle.

Named by Julian D. Sears, USGS, for Lt. Eugene F. Burkett, USN, a member of the Alaskan Aerial Survey Expedition of the Navy Department in 1926 and second in command of the Alaska Aerial Survey Detachment in 1929; Burkett was killed in an airplane crash in 1930 .

Burkett Needle: mountain, see Burkett, Mount. Burley Creek: stream, see Star Creek.

Burlow Cove: bay, see Barlow Cove.

Burls, Mount: peak, 2,710 ft., N of Burls Pass, $45 \mathrm{mi}$. NE of Ugashik, Aleutian Ra.; $57^{\circ} 40^{\prime}$ $45^{\prime \prime} \mathrm{N}, 156^{\circ} 14^{\prime} 35^{\prime \prime} \mathrm{W}$; (map 36).

Named by J. L. McPherson of Iliamna "for H. T. Burls, petroleum expert from London, England, who was on the mountain in 1903."

Burls Creek: stream, heads near Burls Pass, flows NE $7 \mathrm{mi}$. to Becharof Lake, $51 \mathrm{mi}$. NE of Ugashik, Aleutian Ra.; $57^{\circ} 41^{\prime} 50^{\prime \prime} \mathrm{N}, 156^{\circ}$ 05'50' W; (map 36).

Local name reported in 1902 by J. L. McPherson of Iliamna. Named for H. T. Burls. See Burls, Mount.

Burls Creek: stream, flows S $5 \mathrm{mi}$ to Controller Bay, $8 \mathrm{mi}$. E of Katalla, Malaspina Coastal Plain; $60^{\circ} 11^{\prime} \mathrm{N}, 144^{\circ} 17^{\prime} \mathrm{W}$; (map 64). Var. Burrs Creek.

Named by J. L. McPherson, deputy U.S. Mineral Surveyor, for H. T. Burls, the London petroleum expert; reported in 1903 by G. C. Martin, USGS.

Burls Pass: pass, elev. 1,600 ft., S of Mount Burls, near head of Burls Creek, on Alaska Penin., $45 \mathrm{mi}$. NE of Ugashik, Aleutian Ra.; $57^{\circ} 40^{\prime} 00^{\prime \prime} \mathrm{N}, 156^{\circ} 15^{\prime} 30^{\prime \prime} \mathrm{W}$; (map 36).

Named in 1902 by J. L. McPherson of Iliamna; published by G. C. Martin (1921, pl. 10), USGS. See Burls, Mount.

Burman Lake: lake, $4 \mathrm{mi}$. long, $39 \mathrm{mi}$. SW of Fort Yukon, Yukon-Tanana High.; 66 ${ }^{\circ} 04^{\prime} \mathrm{N}$, $145^{\circ} 58^{\prime} \mathrm{W}$; (map 119).

Local name obtained in 1956 by USGS.

Burnett, Mount: mountain, 2,874 ft., near mouth of Ernest Sound, SW Cleveland Penin., Alex. Arch.; 55 $46^{\prime} 45^{\prime \prime} \mathrm{N}, 132^{\circ} 07^{\prime} 30^{\prime \prime} \mathrm{W}$; (map 4).

Named in 1915 by E. Lester Jones, USBF, for William Burnett, who "did considerable work in Alaska."

Burnett Inlet: estuary, extends $\mathrm{S} 8 \mathrm{mi}$. to Clarence Strait, on SW coast of Etolin 1.; Alex. Arch.; $56^{\circ} 04^{\prime} \mathrm{N}, 132^{\circ} 28^{\prime} \mathrm{W}$; (map 6).

Named in 1886 by Lt. Comdr. A. S. Snow, USN; name published in 1887 on USC\&GS Chart 706

Burnett Lake: lake, $1.5 \mathrm{mi}$. long, $\mathrm{E}$ of Burnett Inlet, on Etolin I., Alex. Arch.; 56 $06^{\circ} 30^{\prime \prime} \mathrm{N}$, $132^{\circ} 26^{\prime} 00^{\prime \prime} \mathrm{W}$; (map 6).

Local name reported in 1900 by Lt. Comdr. J. F. Moser, USN.

Burning Mountain: mountain, see Iliamna Volcano. 
Burns Cabins: locality, on $\mathbf{S}$ coast of Alaska Penin., at head of Albatross Anchorage, Aleutian Ra.; $55^{\circ} 36^{\prime} 35^{\prime \prime} \mathrm{N}, 160^{\circ} 36^{\prime} 00^{\prime \prime} \mathrm{W}$; (map 28).

Local name reported by Atwood (1911, pl. 2), USGS.

Burns Glacier: glacier, heads in Kenai Mts., trends NW $3 \mathrm{mi}$. to Portage Glacier, $4 \mathrm{mi}$. SW of Whittier, Chugach Mts.; $60^{\circ} 45^{\prime} 00^{\prime \prime} \mathrm{N}$, $148^{\circ} 46^{\prime} 30^{\prime \prime} \mathrm{W}$; (map 63).

Named in 1915 by USC\&GS, "in honor of Robert Burns, the poet."

Burns Gulch: ravine, trends S $0.7 \mathrm{mi}$. to Glacier Creek, $9 \mathrm{mi}$. N of Nome, Seward Penin. High.; $64^{\circ} 38^{\prime} \mathrm{N}, 165^{\circ} 21^{\prime} \mathrm{W}$; (map 94).

Prospectors' name shown on map, dated September 1901, of Cape Nome gold fields by David Fox, Jr.

Burnside Creek: stream, flows SE $5 \mathrm{mi}$. to Eldorado Creek, $44 \mathrm{mi}$. NW of Haycock, Seward Penin. High.; $65^{\circ} 45^{\prime} \mathrm{N}, 161^{\circ} 55^{\prime} \mathrm{W}$; (map 109).

Local name shown on a 1903 fieldsheet by D. C. Witherspoon, USGS.

Burns Island: island, $1.6 \mathrm{mi}$. long, in Yukon River, $2 \mathrm{mi}$. W of Youngs I. and $10 \mathrm{mi}$. SW of Birches, Nowitna Low.; $65^{\circ} 03^{\prime} 15^{\prime \prime} \mathrm{N}, 153^{\circ}$ $51^{\prime} 00^{\prime \prime} \mathrm{W}$; (map 107).

Riverboat pilots' name shown on a 1940 "Navigation Chart of the Tanana-Yukon Rivers" published by the Department of the Interior.

Burnt Cabin Creek: stream, flows $\mathrm{S} 10 \mathrm{mi}$. to Nushagak River, $4 \mathrm{mi}$. NW of Big Bend and $88 \mathrm{mi}$. S of Sleetmute, Kilbuck-Kuskokwim Mts.; $60^{\circ} 28^{\prime} \mathrm{N}, 156^{\circ} 47^{\prime} \mathrm{W}$; (map 60).

Local name reported in 1952 by USC\&GS.

Burnt Creek: stream, heads W of Sikonsina Pass, flows SW, through Burnt Lake, $4.8 \mathrm{mi}$. to Bone Creek, $34 \mathrm{mi}$. SW of Tok, Alaska Ra.; $63^{\circ} 00^{\prime}$ $\mathrm{N}, 143^{\circ} 50^{\prime} \mathrm{W}$; (map 85).

Local name; reported by USGS in 1964.

Burnt Creek: stream, flows NW $7.7 \mathrm{mi}$. to Arathlatuluk Creek, $20 \mathrm{mi}$. NW of Elim and $53 \mathrm{mi}$. NE of Solomon, Seward Penin. High. $64^{\circ} 49^{\prime} \mathrm{N}, 162^{\circ} 45^{\prime} \mathrm{W}$; (map 95).

Prospectors' name published on the 1908 "Map of Seward Peninsula" by Arthur Gibson.

Burnt Hill: peak, 4,005 ft., $2.3 \mathrm{mi}$. NW of junc. of Divide Creek and White River and $53 \mathrm{mi}$. $\mathrm{NE}$ of McCarthy, Alaska Ra.; 61 ${ }^{\circ} 46^{\prime} \mathrm{N}$, $141^{\circ} 29^{\prime} \mathrm{W}$; (map 67).

Local name obtained by USGS and published on maps since 1954 .

Burnt Island: island, in El Capitan Passage, $1 \mathrm{mi}$. $S$ of Tenass I., on W coast of Prince of Wales I., Alex. Arch.; $55^{\circ} 58^{\prime} 30^{\prime \prime} \mathrm{N}, 133^{\circ} 17^{\prime} 45^{\prime \prime} \mathrm{W}$; (map 4).

Descriptive name published in 1924 by USC\&GS.

Burnt Island: island, $500 \mathrm{ft}$. long, in Wrangell Narrows, 14 mi. S of Petersburg, Alex. Arch.; $56^{\circ} 36^{\prime} 35^{\prime \prime} \mathrm{N}, 132^{\circ} 58^{\prime} 30^{\prime \prime} \mathrm{W}$; (map 6). Var. Burnt Islet, Captain's Island, Obgorielie Island, Ostrov Obgorelyy.

Name published by USC\&GS in 1883 Coast Pilot (p. 144); translated from the Russian name "Ostrov Obgorelyy," given in 1838 by G. Lindenberg. The name "Captain's Island" was given in 1869 by Comdr. R. W. Meade, USN.

Burnt Island: island, $0.3 \mathrm{mi}$. across, in $\mathrm{E}$ end of Chickaloon Bay, near mouth of Turnagain Arm, 9 mi. WNW of Hope, Cook Inlet Low.; $60^{\circ} 57^{\prime} 00^{\prime \prime} \mathrm{N}, 149^{\circ} 53^{\prime} 35^{\prime \prime} \mathrm{W}$; (map 63).

Local name reported in 1914 by USGS.

Burnt Island: island, see Gareloi Island.

Burnt Island Creek: stream, on NW end of Kenai Penin., flows NW 2 mi. to Chickaloon Bay, $10 \mathrm{mi}$. WNW of Hope, Cook Inlet Low. $60^{\circ} 56^{\prime} 10^{\prime \prime} \mathrm{N}, 149^{\circ} 54^{\prime} 55^{\prime \prime} \mathrm{W}$; (map 63).

Local name published in 1952 by USGS Name derived from nearby Burnt Island.

Burnt Island Reef: reef, NE of Burnt I., in Wrangell Narrows, $14 \mathrm{mi}$. S of Petersburg, Alex. Arch.; $56^{\circ} 36^{\prime} 40^{\prime \prime} \mathrm{N}, 132^{\circ} 58^{\prime} 10^{\prime \prime} \mathrm{W}$; (map 6). Var. Burnt Islet.

Descriptive name given for charting purposes by USC\&GS in 1883 Coast Pilot ( $p$ 114)

Burnt Islet: island, see Burnt Island.

Burnt Islet: reef, see Burnt Island Reef.

Burnt Lake: lake, $0.9 \mathrm{mi}$. long, in Sikonsina Pass,

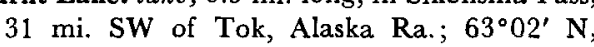
$143^{\circ} 46^{\prime} \mathrm{W}$; (map 85).

Local name reported by USGS in 1964

Burnt Lake: lake, $0.9 \mathrm{mi}$. across, between Highpower Creek and Deep Creek, $35 \mathrm{mi}$. SSW of village of Lake Minchumina, Kuskokwim Low.; $63^{\circ} 23^{\prime} 20^{\prime \prime} \mathrm{N}, 152^{\circ} 29^{\prime} 00^{\prime \prime} \mathrm{W}$; (map 88).

Local name reported about 1954 by Fabian Carey.

Burnt Mountain: mountain, 2,684 ft., $17 \mathrm{mi}$. NE of Christian and $14 \mathrm{mi}$. SW of White Snow Mtn., Brooks Ra.; $67^{\circ} 25^{\prime} \mathrm{N}, 144^{\circ} 36^{\prime} \mathrm{W}$; (map 122)

Local name reported in 1956 by T. E. Taylor, USGS.

Burnt Mountain: volcano, see Redoubt Volcano. Burnt Paw: locality, site of an Indian village on right bank of Porcupine River, $8 \mathrm{mi}$. SE of Coleen Mtn., Porcupine Plat.; $67^{\circ} 02^{\prime} \mathrm{N}, 142^{\circ}$ $35^{\prime} \mathrm{W}$; (map 121).

This was a Kutcha-kutchin Indian village.

Burnt Point: point of land, in Port Frederick, on $\mathrm{N}$ coast of Chichagof $\mathrm{I}$., $6.2 \mathrm{mi}$. SW of Hoonah and $45 \mathrm{mi}$. SW of Juneau, Alex. Arch.; 58 $02^{\prime} 40^{\prime \prime} \mathrm{N}, 135^{\circ} 33^{\prime} 30^{\prime \prime} \mathrm{W}$; (map 11).

Local name published by USC\&GS in the 1925 Coast Pilot (p. 345).

Burnt River: stream, heads NE of Imuruk Lake, flows NE $22 \mathrm{mi}$. to Kugruk River, $27 \mathrm{mi}$. NE of Imuruk Lake, Seward Penin. High.; $65^{\circ} 53^{\prime}$ N, $162^{\circ} 35^{\prime}$ W ; BGN 1952; (map 110). Var Wade Creek.

Prospectors' name published on the 1908 "Map of Seward Peninsula" by Arthur Gibson. Reported as "Wade Creek" in 1901 by D. L. Reaburn (in Mendenhall, 1902, pl. 4a) USGS.

Buron Creek: stream, flows SE $1 \mathrm{mi}$ to No Mans Creek near its head, in Casadepaga
River basin, $25 \mathrm{mi}$. NE of Solomon, Seward Penin. High.; (map 95).

Prospectors' name reported on a prospector's manuscript map, dated 1902. This stream cannot be precisely located on current maps.

Bur Point: point of land, on NE coast of Kenai Penin., at $W$ entrance to Shotgun Cove, 5 mi. NE of Whittier, Chugach Mts.; 60 $48^{\prime}$ $10^{\prime \prime} \mathrm{N}, 148^{\circ} 32^{\prime} 55^{\prime \prime} \mathrm{W}$; BGN 1915; (map 63).

Descriptive name given in 1914 by USC\&GS.

Burr Creek: stream, see Barr Creek.

Burr House Cove: cove, $0.4 \mathrm{mi}$. across, on $\mathrm{N}$ coast of Amchitka I., Rat Is., Aleutian Is.; $51^{\circ} 38^{\prime} 08^{\prime \prime} \mathrm{N}, 178^{\circ} 44^{\prime} 15^{\prime \prime} \mathrm{E}$; (map 15).

Name published on a 1955 AMS map.

Burrong Bay: estuary, see Burroughs Bay.

Burroughs Bay: estuary, extends NE $9 \mathrm{mi}$, off Behm Canal, Coast Mts.; $55^{\circ} 59^{\prime} 30^{\prime \prime} \mathrm{N}, 1^{\circ} 1^{\circ}$ $14^{\prime} 00^{\prime \prime} \mathrm{W}$; (map 3). Var. Burrong Bay, Burrough's Bay.

Named on August 11, 1793, by Capt. George Vancouver, RN (Wagner, 1937, p. 378).

Burroughs Glacier: glacier, in Glacier Bay National Monument, trends SE $9 \mathrm{mi}$. to Plateau Glacier W of Muir Inlet, $64 \mathrm{mi}$. NW of Hoonah, St. Elias Mts.; $58^{\circ} 57^{\prime} \mathrm{N}, 136^{\circ} 12^{\prime} \mathrm{W}$; $B G N$ 1948; (map 10). Var. Cushing Plateau.

Named "Cushing Plateau" by Reid (1896, pl. 86), USGS, for Harry Platt Cushing, who accompanied him on his expedition to Muir Glacier in 1890. Renamed for John Burroughs, 1837-1921, an American naturalist, who visited Muir Inlet with the Harrington Expedition of 1899.

Burr Point: point of land, on $\mathrm{N}$ coast of Augustine I., $55 \mathrm{mi}$. SE of Iliamna, Aleutian Ra.; $59^{\circ} 25^{\prime} \mathrm{N}, 153^{\circ} 26^{\prime} \mathrm{W}$; BGN 1916; (map 51).

So named in 1914 by USC\&GS "because of the burr-like appearance of the mounds forming the end of the island."

Burrs Creek: stream, see Burls Creek.

Burun, Kamen: rock, see Surf Rock.

Burunof, Cape: point of land, $N$ of Three Entrance Bay, $5 \mathrm{mi}$. SW of Sitka, on $W$ coast of Baranof I., Alex. Arch.; 56 $56^{\circ} 9^{\prime}$ N, $135^{\circ} 23^{\prime}$ W; BGN 1897; (map 5). Var. Broad Cape, Cape Bouronov, Cape Burunoff, Cape Tolstoi, Mys Burunov, Mys Tolstoy.

Named in 1809 by the Russian navigator, Ivan Vasiliev the first, IRN; published by Lt. Sarichev (1826, map 19), IRN, as "M[ys] Burunov" or "cape of breakers." The name "Mys Tolstoy," meaning "broad cape," was given to this point in 1849 by Capt. M. D. Tebenkov, IRN.

Burunoff, Cape: point of land, see Burunof, Cape.

Burunov, Mys: point of land, see Burunof, Cape. Burun Rocks: rock, see Surf Rock.

Busby Bay: cove, see West Bay.

Busby Island: island, $1.3 \mathrm{mi}$. across, in $\mathrm{S}$ entrance to Valdez Arm, $45 \mathrm{mi}$. NW of Cordova, Chugach Mts.; $60^{\circ} 53^{\prime} 30^{\prime \prime} \mathrm{N}, 146^{\circ} 42^{\prime} 00^{\prime \prime} \mathrm{W}$; $B G N$ 1908; (map 64). Var. Fox Island. 
Local name reported in 1908 by USGS. The island was first known as Fox Island, because blue foxes were propagated there in the late 19 th century.

Busch Creek: stream, flows NE $5.8 \mathrm{mi}$. to Goose Creek $13 \mathrm{mi}$. SW of its junc. with Susitna River, $20 \mathrm{mi}$. SE of Mount Watana, Talkeetna Mts. ; $62^{\circ} 30^{\prime} 20^{\prime \prime} \mathrm{N}, 147^{\circ} 40^{\prime} 50^{\prime \prime} \mathrm{W}$; (map 82). Local name reported in 1951 by USGS.

Buschman Creek: stream, see Buschmann Creek. Buschmann Creek: stream, flows NW $2.5 \mathrm{mi}$. to Hugh Smith Lake, Coast Mts. ; 55 06'22" N, 130'37'30' W; BGN 1915; (map 3). Var. Buschman Creek, Bushman Creek.

Local name published in 1911 by USC\&GS as "Bushman Creek"; reported in 1915 by $\mathbf{E}$. Lester Jones, USBF, as "Buschman Creek".

Buschmann Pass: water passage, $3 \mathrm{mi}$. long, $\mathrm{S}$ and $E$ of Hessa I., on SW coast of Prince of Wales I., Alex. Arch.; $54^{\circ} 46^{\prime} \mathrm{N}, 132^{\circ} 19^{\prime} \mathrm{W}$; (map 1).

Local name reported in 1948 by USGS.

Busen Altua: bay, see Lituya Bay.

Bush Hill : hill, see Brush Hill.

Bush Islets: islands, $0.1 \mathrm{mi}$. across, $10 \mathrm{mi}$. NE of Cape Decision, in Affleck Canal off $S$ coast of Kuiu I., Alex. Arch.; $56^{\circ} 08^{\prime} 20^{\prime \prime}$ N, $134^{\circ}$ 05'45" W; (map 5).

Named in 1886 by Lt. Comdr. A. S. Snow, USN; published in 1887 on USC\&GS Chart 706.

Bush Islets: rocks, extend $0.5 \mathrm{mi}$. in Meares Passage, N of Dall I., Alex. Arch.; 55 $5^{\circ} 15^{\prime} 45^{\prime \prime}$ $\mathrm{N}, 133^{\circ} 09^{\prime} 00^{\prime \prime} \mathrm{W}$; (map 4).

Local name published in 1925 Coast Pilot (p. 140).

Bushman Creek: stream, see Buschman Greek.

Bush Mountain: mountain, 1,736 ft., on Annette I., $E$ of Bingo Mtn., $7 \mathrm{mi}$. NE of Metlakatla, Alex. Arch.; $55^{\circ} 13^{\prime} 45^{\prime \prime} \mathrm{N}, 131^{\circ} 30^{\prime} 50^{\prime \prime} \mathrm{W}$; (map 3).

Descriptive name given in 1883 by Lt. Comdr. H. E. Nichols, USN.

Bush Point: point of land, $\mathrm{E}$ point of entrance to Midway Bay, on SE coast of Kodiak I.; $57^{\circ}$ $13^{\prime} 10^{\prime \prime} \mathrm{N}, 153^{\circ} 12^{\prime} 55^{\prime \prime} \mathrm{W}$; (map 34).

Local name published in 1943 by USC\&GS.

Bush Point: point of land, southwesternmost point on Perry I., $29 \mathrm{mi}$. NE of Chenega and $24 \mathrm{mi}$. SE of Whittier, Chugach Mts.; $60^{\circ} 41^{\prime} 15^{\prime \prime} \mathrm{N}, 148^{\circ} 00^{\prime} 00^{\prime \prime} \mathrm{W}$; BGN 1958; (map 63).

Named by the U.S. Navy for Capt. Ellsworth Lincoln Bush, USN, who sailed Alaskan waters for 40 years before his death in 1957 . At his request, "on December 1957, Captain Bush's ashes were strewn upon the waters of Prince William Sound near the southwesternmost unnamed point of land on Perry Island."

Bush Rock: rock, in Lake Bay, on NE coast of Prince of Wales I., Alex. Arch.; 56 $03^{\prime} 40^{\prime \prime}$ $\mathrm{N}, 132^{\circ} 54^{\prime} 35^{\prime \prime} \mathrm{W}$; (map 6).

Local navigators' name reported in 1904 by H. C. Fassett, USBF.

Bush Rock: rock, in First Narrows, Redfish Bay, $10 \mathrm{mi}$. NW of village of Port Alexander, on $\mathrm{S}$ coast of Baranof I., Alex. Arch.; $56^{\circ} 19^{\prime}$ $40^{\prime \prime} \mathrm{N}, 134^{\circ} 52^{\prime} 10^{\prime \prime} \mathrm{W}$; (map 5).
Named in 1897 by Lt. Comdr. J. F. Moser, USN, commander of USBF steamer Albatross. Bush Top Island: island, $0.1 \mathrm{mi}$. long, in Wrangell Narrows, $12 \mathrm{mi}$. S of Petersburg, Alex. Arch.; $56^{\circ} 38^{\prime} 05^{\prime \prime} \mathrm{N}, 132^{\circ} 56^{\prime} 55^{\prime \prime} \mathrm{W}$; (map 6). Var. Bushtop Islet, Goloi Island, Ostrov Golyy.

Named in 1881 by Lt. Comdr. H. E. Nichols, USN. The navigator, G. Lindenberg, called it "Ostrov Golyy," meaning "bare island," and the name was published as such in 1850 on Russian Hydrog. Dept. Chart 1441. Bushtop Island: island, $400 \mathrm{ft}$. long, in Bocas de Finas, $0.4 \mathrm{mi}$. NE of Tonina I., at $\mathrm{N}$ end of Maurelle Is., Alex. Arch.; 55 $41^{\prime} 40^{\prime \prime} \mathrm{N}, 133^{\circ}$ 35'25" W.; BGN 1908; (map 4).

Local descriptive name reported in 1907 by E. F. Dickins, USG\&GS.

Bushtop Islet: island, see Bush Top Island. Bushy Creek: stream, flows NW $11 \mathrm{mi}$. to Kuna River, $20 \mathrm{mi}$. SE of Liberator Lake, Brooks Ra.; $68^{\circ} 39^{\prime} \mathrm{N}, 157^{\circ} 50^{\prime} \mathrm{W}$; (map 132).

So named in 1950 by USGS geologists doing Naval Petroleum Reserve No. 4 explorations, "because of heavy brush along the creek; published in 1951 by USGS."

Bushy Island: island, $300 \mathrm{ft}$., long, in Kaigani Strait, on $\mathbf{E}$ coast of Dall I., $\mathbf{E}$ of Rose Inlet, Alex. Arch.; 54 $56^{\prime} 45^{\prime \prime}$ N, $132^{\circ} 54^{\prime} 20^{\prime \prime} \mathrm{W}$; (map 1)

Named in 1881 by Lt. Comdr. H. E. Nichols, USN

Bushy Island: island, $2 \mathrm{mi}$. long, northernmost of Kashevarof Is., between Zarembo and Prince of Wales Is., Alex. Arch.; 56 ${ }^{\circ} 16^{\prime} \mathrm{N}$, $132^{\circ} 59^{\prime} \mathrm{W}$; (map 6). Var. Biugam Island.

Named on September 1, 1793, by Capt. George Vancouver, RN, (Wagner, 1937, p 378 ).

Bushy Islands: islands, in Endicott Arm, $1 \mathrm{mi}$. NE of Sumdum I. and $54 \mathrm{mi}$. SE of Juneau, Coast Mts.; $57^{\circ} 42^{\prime} 15^{\prime \prime} \mathrm{N}, 133^{\circ} 25^{\prime} 50^{\prime \prime} \mathrm{W}$; (map 8). Var. Bushy Islets.

Named in 1868 by Comdr. R. W. Mead, USN; published by USC\&GS in the 1891 Coast Pilot (p. 147).

Bushy Islets: islands, see Bushy Islands.

Bushy Point: point of land, between Behm Canal and Bushy Point Cove, on W coast of Revillagigedo I., Alex. Arch.; $55^{\circ} 44^{\prime} \mathrm{N}, 131^{\circ} 44^{\prime}$ W; $(\operatorname{map} 3)$.

Named in 1891 by USC\&GS.

Bushy Point Cove: cove, $0.5 \mathrm{mi}$. across, $2 \mathrm{mi}$. N of Traitors Cove, on $\mathrm{W}$ coast of Revillagigedo I., Alex. Arch.; 55 $44^{\prime} 10^{\prime \prime} \mathrm{N}, 131^{\circ} 43^{\prime} 45^{\prime \prime} \mathrm{W}$; (map 3).

Local navigators' name obtained in 1904 by H. C. Fassett, USBF; derived from Bushy Point.

Busia Mountain: mountain, $3,246 \mathrm{ft}$., at junc. of Eldorado and Moose Creeks, $2.7 \mathrm{mi}$. WNW of Wonder Lake, Alaska Ra.; $63^{\circ} 30^{\prime} 20^{\prime \prime} \mathrm{N}$, 150 $58^{\prime} 05^{\prime \prime}$ W; BGN 1958; (map 88).

Named by G. H. Pearson for John "Little Johnnie" Busia, prospector and trapper, who arrived in 1918 and spent the remaining 39 years of his life in the Kantishna area.
Buskin: locality, at mouth of Buskin River, $4 \mathrm{mi}$. SW of Kodiak, on NE coast of Kodiak I.; $57^{\circ} 45^{\prime} 13^{\prime \prime} \mathrm{N}, 152^{\circ} 28^{\prime} 40^{\prime \prime} \mathrm{W}$; (map 34). Var. Seleniye Sapozhkovo.

Name published as "Seleniye Sapozhkovo," meaning "Buskin [a type of boot] Settlement," by Lt. Sarichev (1826, map 16), IRN.

Buskin Lake: lake, $1 \mathrm{mi}$. across, at head of Buskin River, on NE coast of Kodiak I. ; $57^{\circ} 46^{\prime} 35^{\prime \prime} \mathrm{N}$, $152^{\circ} 33^{\prime} 00^{\prime \prime} \mathrm{W}$; BGN 1933; (map 34).

Local name derived from the river name; reported in 1933 by Gerald FitzGerald, USGS.

Buskin River: stream, heads at Buskin Lake, flows NE $3.5 \mathrm{mi}$. to Saint Paul Harbor, 3.7 mi. SW of Kodiak, Kodiak I.; 57 $45^{\prime} 13^{\prime \prime} \mathrm{N}$, $152^{\circ} 28^{\prime} 40^{\prime \prime}$ W; (map 34). Var. Reka Sapozhkova, Sapozhkova.

Russian name "Reka Sapozhkova," published by Lt. Sarichev (1826, map 16), IRN. See Buskin.

Bussy Greek: stream, flows SE $3 \mathrm{mi}$. to Le Conte Bay, $16 \mathrm{mi}$, E of Petersburg, Coast Mts. ; 56 $47^{\prime} 25^{\prime \prime} \mathrm{N}, 132^{\circ} 30^{\prime} 30^{\prime \prime} \mathrm{W}$; (map 6).

Local name recorded in 1961 by USGS.

Buster Bay: bight, $1.5 \mathrm{mi}$. across, $7 \mathrm{mi}$. E of Point Baker, on $\mathbf{N}$ coast of Prince of Wales $\mathbf{I}$., Alex. Arch.; 56 $20^{\prime}$ N, $133^{\circ} 26^{\prime}$ W ; (map 6).

Local name recorded in 1949 by USGS.

Buster Creek: stream, flows $\mathrm{N} 7 \mathrm{mi}$. to Buster Bay, on $\mathrm{N}$ coast of Prince of Wales I., Alex. Arch.; $56^{\circ} 19^{\prime} 30^{\prime \prime} \mathrm{N}, 133^{\circ} 26^{\prime} 20^{\prime \prime} \mathrm{W}$; $B G N$ 1962; (map 6). Var. Charcoal Creek.

Local name reported in 1961 by USFS; called "Charcoal Creek" in 1929 by USFS.

Buster Creek: stream, flows SW $3.5 \mathrm{mi}$. to Nome River, $7 \mathrm{mi}$. NE of Nome, Seward Penin. High.; $64^{\circ} 35^{\prime} \mathrm{N}, 165^{\circ} 16^{\prime} \mathrm{W}$; (map 94 ).

Prospectors' name published by Schrader and Brooks (1900, map 3), USGS.

Buster Greek: stream, flows S $1 \mathrm{mi}$. to Big Hurrah Creek, between Huff and Trilby Greeks, $9 \mathrm{mi}$. NE of Solomon, Seward Penin. High.; $64^{\circ} 39^{\prime} \mathrm{N}, 164^{\circ} 15^{\prime} \mathrm{W}$; (map 95 ).

Prospectors' name reported on a 1902 prospectors' manuscript map.

Buster Creek: stream, heads on S side of Switchback Mtn., flows SW 5 mi. to Mason Creek, $7 \mathrm{mi}$. ENE of Birches, Kokrines-Hodzana High.; $65^{\circ} 11^{\prime} 35^{\prime \prime} \mathrm{N}, 153^{\circ} 18^{\prime} 45^{\prime \prime} \mathrm{W}$; (map 107).

Prospectors' name reported by USGS in the 1940 's, but probably was used much earlier.

Buster Creek: stream, flows N $2.5 \mathrm{mi}$. to Chatanika River, $40 \mathrm{mi}$. NE of Fairbanks, YukonTanana High.; $65^{\circ} 13^{\prime} \mathrm{N}, 146^{\circ} 58^{\prime} \mathrm{W}$; (map 104).

Named by prospectors; published by USGS (Prindle, 1908, pl. 4).

Butcher Creek: stream, on Kenai Penin., flows NW $2 \mathrm{mi}$. to Canyon Creek, $18 \mathrm{mi}$. S of Sunrise, Chugach Mts. ; $60^{\circ} 38^{\prime} 35^{\prime \prime} \mathrm{N}, 149^{\circ} 29^{\prime} 30^{\prime \prime}$ W; (map 63).

Local name reported in 1914 by USGS.

Butch Lake: lake, 1,800 ft. across, $1 \mathrm{mi}$. NE of junc. of Jarvis and Ober Creeks, $15 \mathrm{mi}$. SE of Delta Junction, Alaska Ra.; $63^{\circ} 49^{\prime} 55^{\prime \prime} \mathrm{N}$, $145^{\circ} 38^{\prime} 40^{\prime \prime} \mathrm{W}$; (map 86).

Name published on relatively recent maps. 
Butch Mountain: mountain, 1,900 ft., $29 \mathrm{mi}$. N of Sleitat Mtn. and $88 \mathrm{mi}$. S of Sleetmute, Kilbuck-Kuskokwim Mts.; $60^{\circ} 28^{\prime} \mathrm{N}, 157^{\circ} 10^{\prime} \mathrm{W}$; $B G N$ 1932; (map 60).

Local name reported in 1931 by Gerald FitzGerald, USGS; probably named for "Butch" Smith [cnna], "river man."

Buteo Lake: lake, $1 \mathrm{mi}$. long, on Kenai Penin. $2 \mathrm{mi}$. W of Moose Lake and $34 \mathrm{mi}$. NE of Kenai, Cook Inlet Low.; $64^{\circ} 45^{\prime} \mathrm{N}, 150^{\circ} 24^{\prime}$ W; (map 62).

Named about 1963 by officials of Kenai National Moose Range, probably for Swainson's Hawk (Buteo swainsoni), "** * most useful and beneficial of all our Hawks."

Butler Glacier: glacier, heads near summit of Mount Jette, trends S. $9 \mathrm{mi}$. to its 1961 terminus, $1.8 \mathrm{mi}$. $\mathrm{N}$ of Nunatak Fiord and $32 \mathrm{mi}$. $\mathrm{NE}$ of Yakutat, St. Elias Mts.; $59^{\circ} 53^{\prime} \mathrm{N}$, $139^{\circ} 07^{\prime} \mathrm{W}$; (map 46).

Local name published by the USGS in 1959.

Butler Peak: mountain, 1,060 ft., on E shore of Stephens Passage, $18 \mathrm{mi}$. SE of Juneau, Coast Mts.; 58 $07^{\prime} 15^{\prime \prime} \mathrm{N}, 134^{\circ} 04^{\prime} 15^{\prime \prime} \mathrm{W}$; (map 11).

Named by Lt. Comdr. C. M. Thomas, USN, in 1888 and published in 1893 on USC\&GS Chart 8229 .

Butler Rock: rock, $200 \mathrm{ft}$. long, in Pacific Ocean, $0.3 \mathrm{mi}$. W of $\mathrm{N}$ coast of Forrester I., Alex. Arch.; $54^{\circ} 49^{\prime} 55^{\prime \prime} \mathrm{N}, 133^{\circ} 33^{\prime} 02^{\prime \prime} \mathrm{W}$; (map 1).

Local name published in 1943 by USG\&GS.

Butt Creek: stream, see Butte Creek.

Butte: village, pop. 559, near Palmer, NE of Anchorage, Talkeetna Mts.; (map 69).

Relatively recent development on Glenn Highway, probably named for Bodenburg Butte.

Butte, The: peak, 4,561 ft., at head of Butte Creek, $44 \mathrm{mi}$. N of Big Delta, Yukon-Tanana High.; 64 $46^{\prime} 20^{\prime \prime} \mathrm{N}, 145^{\circ} 39^{\prime} 30^{\prime \prime} \mathrm{W}$; (map 101).

Named by prospectors; reported in 1905 by D. C. Witherspoon (in Prindle, 1913a, pl. 1), USGS.

Butte Creek: stream, flows $4 \mathrm{mi}$. W to Trail Creek, $8 \mathrm{mi}$. W of Jacksmith Bay and $27 \mathrm{mi}$. N of Goodnews; Kilbuck-Kuskokwim Mts.; $59^{\circ} 29^{\prime} \mathrm{N}, 161^{\circ} 29^{\prime} \mathrm{W}$; (map 53).

Local name reported by G. L. Harrington (in Brooks, 1900, pl. 7 and p. 221), USGS. Gold was found in this creek about 1900, and some placer mining has been done along it.

Butte Creek: stream, flows S $2.6 \mathrm{mi}$. to Bonanza Creek, $8.6 \mathrm{mi}$. SE of Flat and $50 \mathrm{mi}$. NW of Sleetmute, Kilbuck-Kuskokwim Mts.; $62^{\circ} 19^{\prime}$ $40^{\prime \prime}$ N., $157^{\circ} 56^{\prime} 40^{\prime \prime} \mathrm{W}$; (map 79).

Name shown on a 1910 manuscript map of the "Iditarod Placer Fields."

Butte Creek: stream, heads at Butte Lake, flows SE $24 \mathrm{mi}$. to Susitna River, $72 \mathrm{mi}$. SE of Healy, Talkeetna Mts. ; $63^{\circ} 03^{\prime} 30^{\prime \prime} \mathrm{N}, 147^{\circ} 31^{\prime} 40^{\prime \prime} \mathrm{W}$; (map 87).

Prospectors' name shown on a 1910 fieldsheet by D. C. Witherspoon, USGS ; published by Moffit (1912, pl. 1), USGS.

Butte Creek: stream, flows SE $4 \mathrm{mi}$. to Canyon Creek, $47 \mathrm{mi}$. NW of Medfra, Kilbuck-
Kuskokwim Mts. ; $63^{\circ} 28^{\prime} \mathrm{N}, 155^{\circ} 56^{\prime} \mathrm{W}$; $B G N$ 1937; (map 89).

Local name reported in 1914 by USGS.

Butte Creek: stream, formed by junc. of Quartz and Shorty Creeks, on W. slope of Cripple Creek Mts., flows SW $6 \mathrm{mi}$. to Folger Creek, $25 \mathrm{mi}$. NE of Ophir, Kilbuck-Kuskokwim Mts. ; $63^{\circ} 28^{\prime} 20^{\prime \prime} \mathrm{N}, 156^{\circ} 13^{\prime} 20^{\prime \prime} \mathrm{W}$; (map 90).

Prospectors' name obtained in 1933 by J. B. Mertie, Jr., (in Smith, P. S., 1936, pl. 4), USGS.

Butte Creek: stream, flows $\mathrm{E} 7 \mathrm{mi}$. to South Fork Fortymile River, $44 \mathrm{mi}$. SW of Eagle, YukonTanana High.; $64^{\circ} 13^{\prime} 20^{\prime \prime} \mathrm{N}, 141^{\circ} 47^{\prime} 15^{\prime \prime} \mathrm{W}$; (map 102). Var. Butt Creek.

Prospectors' name obtained in 1898 by E. C. Barnard, USGS.

Butte Creek: stream, flows SW $20 \mathrm{mi}$. to North Fork Fortymile River, $32 \mathrm{mi}$. SW of Eagle, Yukon-Tanana High.; $64^{\circ} 36^{\prime} \mathrm{N}, 142^{\circ} 10^{\prime} \mathrm{W}$; (map 102).

Named by prospectors; reported in 1903 by T. G. Gerdine (in Prindle, 1905, pl. 16), USGS.

Butte Creek: stream, heads on The Butte, flows SW $13 \mathrm{mi}$. to Salcha River, $34 \mathrm{mi}$. N of Big Delta, Yukon-Tanana High.; 64 $34^{\prime} \mathrm{N}$, $145^{\circ} 55^{\prime} \mathrm{W}$; (map 101).

Named by prospectors; reported in 1905 by D. C. Witherspoon (in Prindle, 1913a, pl. 1), USGS.

Butte Creek: stream, flows E $1.7 \mathrm{mi}$. to Solomon River, $11 \mathrm{mi}$. NE of Solomon, Seward Penin. High.; $64^{\circ} 43^{\prime} \mathrm{N}, 164^{\circ} 19^{\prime} \mathrm{W}$; (map 95).

Prospectors' name reported on a map of Cape Nome gold fields by David Fox, Jr., dated 1901.

Butte Creek: stream, flows SE $1.5 \mathrm{mi}$. to Copper Creek which flows to Koyuk River, $40 \mathrm{mi}$. SE of Imuruk Lake, Seward Penin. High.; $65^{\circ} 14^{\prime} \mathrm{N}, 162^{\circ} 08^{\prime} \mathrm{W}$; (map 110).

Prospectors' name reported on the 1908 "Map of Seward Peninsula" by Arthur Gibson.

Butte Creek: stream, flows NE $10 \mathrm{mi}$. to Yukon River, $24 \mathrm{mi}$. ESE of junc. of Charley River, Yukon-Tanana High.; 65 $15^{\prime} 20^{\prime \prime} \mathrm{N}, 141^{\circ} 57^{\prime}$ $20^{\prime \prime}$ W; BGN 1962; (map 103). Var. Bull Creek, Dewey Creek.

Prospectors' name from an unpublished map by E. J. Chamberlain, dated 1902.

Butte Creek: stream, flows NW $5 \mathrm{mi}$. to Birch Creek, $52 \mathrm{mi}$. SW of Eagle, Yukon JTanana High.; $65^{\circ} 24^{\prime} 30^{\prime \prime} \mathrm{N}, 145^{\circ} 34^{\prime} 45^{\prime \prime} \mathrm{W}$; (map 104).

Named by prospectors; reported in 1903 by T. G. Gerdine (in Prindle, 1905, pl. 13), USGS.

Butte Creek: stream, flows N4 mi. to Crater Creek, $19 \mathrm{mi}$. NE of Livengood, YukonTanana High.; $65^{\circ} 42^{\prime} \mathrm{N}, 148^{\circ} 04^{\prime} \mathrm{W}$; (map 105).

Named by prospectors; reported in 1916 by J. B. Mertie, Jr. (in Brooks and others, 1918, pl. 13), USGS.

Butte Creek: stream, flows NE $15 \mathrm{mi}$. to Lost Creek, $27 \mathrm{mi}$. SW of Beaver, Yukon Flats; $66^{\circ} 02^{\prime 2} 5^{\prime \prime} \mathrm{N}, 147^{\circ} 56^{\prime} 30^{\prime \prime} \mathrm{W}$; (map 118).
Local descriptive name obtained in 1956 by USGS.

Butte Creek: stream, see Surprise Creek.

Butte Lake: lake, $2 \mathrm{mi}$. long, $58 \mathrm{mi}$. SE of Healy, Talkeetna Mts.; $63^{\circ} 11^{\prime} \mathrm{N}, 147^{\circ} 51^{\prime} \mathrm{W}$; (map 87). Var. Nadiwen Lake.

Name reported in 1951 by USGS.

Butterball Lake: lake, $0.2 \mathrm{mi}$. across, on Heceta I., $1 \mathrm{mi} . \mathrm{E}$ of head of Port Alice and $3 \mathrm{mi}$. SW of Camp I., Alex. Arch.; 55 $47^{\prime} 45^{\prime \prime} \mathrm{N}$, 13333'30' W; BGN 1966; (map 4).

Named by USFS in 1965; "This lake was observed by USFS personnel *** in 1962. At that time several flocks of butterball ducks (Charitoneita albeala) were on the lake ***. Apparently the lake is a natural nesting grounds."

Butter Creek : stream, see Logan Creek.

Butterfield Canyon: ravine, trends NE $1.5 \mathrm{mi}$. to Bangor Creek, $13 \mathrm{mi}$. NW of Nome, Seward Penin. High.; $64^{\circ} 41^{\prime} \mathrm{N}, 165^{\circ} 29^{\prime} \mathrm{W}$; (map 94). Var. Butterfield Gulch.

Prospectors' name shown on map dated September 1901 of Cape Nome gold fields by David Fox, Jr.

Butterfield Gulch: ravine, see Butterfield Canyon.

Butterfy Creek: stream, flows SE $1 \mathrm{mi}$. to Nome River, about $17 \mathrm{mi}$. NE of Nome, Seward Penin. High.; $64^{\circ} 44^{\prime} \mathrm{N}, 165^{\circ} 14^{\prime} \mathrm{W}$; (map 94).

Prospectors' name shown on the 1904 "Map of Cape Nome Precinct" by Arthur Gibson.

Butterfly Creek: stream, flows $\mathrm{S}$ to Melsing Creek at Council, $32 \mathrm{mi}$. NE of Solomon, Seward Penin. High.; (map 95).

Prospectors' name reported on the 1900 "Map of Nome Peninsula" by J. M. Davidson and B. D. Blakeslee. This stream cannot be precisely located on current maps.

Butterfly Lake: lake, $1.5 \mathrm{mi}$. long, $10 \mathrm{mi}$. $\mathrm{S}$ of Willow and $27 \mathrm{mi}$. $\mathrm{N}$ of Anchorage, Cook Inlet Low.; $61^{\circ} 36^{\prime} \mathrm{N}, 150^{\circ} 05^{\prime} \mathrm{W}$; (map 70).

Local name reported in 1958 by USGS.

Butterworth Island: island, $1 \mathrm{mi}$. long, at mouth of Duncan Canal, $19 \mathrm{mi}$. SW of Petersburg, on $S$ coast of Kupreanof I., Alex. Arch.; 56 $36^{\circ}$ $30^{\prime \prime} \mathrm{N}, 133^{\circ} 04^{\prime} 00^{\prime \prime} \mathrm{W}$; (map 6).

Local name published by F. E. Wright and C. W. Wright (1908, fig. 20), USGS.

Buttes Gap, The: pass, $1 \mathrm{mi}$. W of Three Sleep Point and $23 \mathrm{mi}$. SW of Beaver, Yukon Flats; $66^{\circ} 07^{\prime} \mathrm{N}, 147^{\circ} 56^{\prime} \mathrm{W}$; (map 118).

Local descriptive name obtained in 1956 by USGS.

Button Greek: stream, flows NE to Adams Greek -which flows to Shovel Creek, E of Madison Creek, $10 \mathrm{mi}$. N of Solomon, Seward Penin. High.; (map 95)

Prospectors' name reported on a prospector's manuscript map dated 1902. This stream cannot be precisely located on current maps. Button Island: island, $0.2 \mathrm{mi}$. long, in Zimovia Strait between Wrangell and Etolin Is., $22 \mathrm{mi}$. SE of Wrangell, $0.5 \mathrm{mi}$. N of Whaletail Cove, Alex. Arch.; $56^{\circ} 11^{\prime} 50^{\prime \prime} \mathrm{N}, 132^{\circ} 15^{\prime} 15^{\prime \prime} \mathrm{W}$; (map 6). 
Descriptive name given for charting purposes in 1925 Coast Pilot (p. 121).

Button Mountain: mountain, 2,351 ft., between Death Valley and John River, $\mathrm{S}$ of Threetime Mtn. and $\mathbf{N}$ of Ninemile Hills, $48 \mathrm{mi}$. SW of Wiseman, Brooks Ra.; $67^{\circ} 10^{\prime} 30^{\prime \prime} \mathrm{N}, 151^{\circ} 47^{\prime}$ $00^{\prime \prime} \mathrm{W}$; (map 124).

Local name obtained in 1956 by USGS topographers.

Buttress Mountain: mountain range, see Buttress Range.

Buttress Point: point of land, on SW coast of Unalaska I., Aleutian Is.; $53^{\circ} 22^{\prime} 40^{\prime \prime} \mathrm{N}, 167^{\circ}$ 15'00" W; BGN 1939; (map 23).

Descriptive name given in 1938 by USC\&GS.

Buttress Range: mountain range, 3,500 ft., extends N $10 \mathrm{mi}$., W of Valley of Ten Thousand Smokes, on Alaska Penin., in Katmai National Monument, $10 \mathrm{mi}$. W of Mount Katmai, Aleutian Ra.; 58 $17^{\prime} \mathrm{N}, 155^{\circ} 17^{\prime} \mathrm{W}$; $B G N$ 1924; (map 42). Var. Buttress Mountain.

Descriptive name given in 1919 by R. F. Griggs of the National Geographic Society as Buttress Mountain and mapped as Buttress Range.

Buyan Islands: islands, $2 \mathrm{mi}$. across, in Pacific Ocean $6 \mathrm{mi}$. E of Deer I., Aleutian Ra.; $54^{\circ}$ $52^{\prime} 30^{\prime \prime} \mathrm{N}, 162^{\circ} 06^{\prime} 00^{\prime \prime} \mathrm{W}$; (map 25). Var. Bluff Island.

Russian word meaning "wharf" or "larding place," named in 1888 by USBF.

Buyers Cove: cove, $0.5 \mathrm{mi}$. across, on $\mathrm{S}$ coast of Alaska off Prince Wiliam Sound, $1 \mathrm{mi}$. $\mathrm{N}$ of Glacier I. and $51 \mathrm{mi}$. NE of Whittier, Chugach Mts.; $60^{\circ} 55^{\prime} \mathrm{N}, 147^{\circ} 16^{\prime} \mathrm{W}$; (map 63).

Local name reported in 1951 by USGS.

Buzodoc Slough: lake, $2 \mathrm{mi}$. long on $\mathrm{W}$ bank of Alatna River, $4 \mathrm{mi}$. N of Allakaket, Kanuti Flats; $66^{\circ} 37^{\prime} 30^{\prime \prime} \mathrm{N}, 152^{\circ} 40^{\prime} 30^{\prime \prime} \mathrm{W}$; (map 117).

Koyukan Indian name obtained in 1956 at Allakaket by T. E. Taylor, USGS.

Buzzard Creek: stream, flows NW $7 \mathrm{mi}$. to Totatlanika River, $36 \mathrm{mi}$. SE of Nenana, Alaska Ra.; $64^{\circ} 06^{\prime} \mathrm{N}, 148^{\circ} 30^{\prime} \mathrm{W}$; (map 100).

Named by prospectors; reported in 1906 by L. M. Prindle (in Brooks and others, 1907, pl. 4), USGS.

Buzzard Creek: stream, flows S $0.8 \mathrm{mi}$. to Noxapaga River, $0.5 \mathrm{mi}$. E of Black Creek and 27 mi. SW of Imuruk Lake, Seward Penin. High.; $65^{\circ} 31^{\prime} \mathrm{N}, 164^{\circ} 11^{\prime} \mathrm{W}$; BGN 1952; (map $110)$.

Prospectors' name reported in 1901 by $T$. G. Gerdine (in Collier, 1902, pl. 12), USGS.

Buzzard Rock : island, 1,300 ft. long, W of Witchcraft Point, on NW coast of Kiska I., Aleutian Is. ; $52^{\circ} 02^{\prime} 30^{\prime \prime} \mathrm{N}, 177^{\circ} 29^{\prime} 40^{\prime \prime} \mathrm{E}$; (map 14).

One of the "bird names" arbitrarily applied to features on Kiska Island in 1943 by USAF for tactical purposes during World War II.

Buzzy Island: island, see Pearl Island.

Bychron River: stream, see Amakatatee Creek.

Byers Creek: stream, flows SW through Byers Lake, $19 \mathrm{mi}$. to Chulitna River, $27 \mathrm{mi}$. $\mathrm{N}$ of
Talkeetna, Cook Inlet Low.; $62^{\circ} 43^{\prime} \mathrm{N}, 150^{\circ}$ $13^{\prime} \mathrm{W}$; (map 81).

Local name reported in 1958 by USGS.

Byers Island: island, $0.6 \mathrm{mi}$. long, in Tanana River, opposite mouth of Marconi Slough, 6 mi. SW of Fairbanks, Tanana Low.; $64^{\circ} 47^{\prime} 45^{\prime \prime}$ N, $147^{\circ} 56^{\prime} 00^{\prime \prime} \mathrm{W}$; (map 100).

Local name published on a 1955 USGS map. Byers Lake: lake, $1.5 \mathrm{mi}$. long, in course of Byers Creek, $28 \mathrm{mi}$. $\mathbf{N}$ of Talkeetna, Cook Inlet Low.; $62^{\circ} 44^{\prime} 20^{\prime \prime} \mathrm{N}, 150^{\circ} 06^{\prime} 45^{\prime \prime} \mathrm{W}$; (map 81).

Local name reported in 1958 by USGS.

Bylers Roadhouse: locality, on right bank of Tanana River $18 \mathrm{mi}$. SE of Fairbanks, Tanana Low.; $64^{\circ} 42^{\prime} \mathrm{N}, 147^{\circ} 18^{\prime} \mathrm{W}$; (map 100). Var. Byler's Station.

Former roadhouse on the Fairbanks-Valdez Trail reported by Capps (1912, pl. 1), USGS. Byler's Station: locality, see Bylers Roadhouse. Byloy, Kamen : rock, see White Rock.

Byron Bay: bay, $0.5 \mathrm{mi}$. across, $13 \mathrm{mi}$. NW of village of Port Alexander, on $S$ coast of Baranof I., Alex. Arch.; 56 $23^{\prime} \mathrm{N}, 1^{\circ} 4^{\circ} 55^{\prime} \mathrm{W}$; (map 5).

Local name used by fishermen; published in 1917 by USC\&GS.

Byron Glacier: glacier, on Kenai Penin., trends $\mathrm{N} 2 \mathrm{mi}$. to its terminus, $1 \mathrm{mi}$. SW of Portage Lake, 6 mi. WSW of Whittier, Chugach Mts.; $60^{\circ} 45^{\prime} 55^{\prime \prime} \mathrm{N}, 148^{\circ} 50^{\prime} 35^{\prime \prime} \mathrm{W}$; (map 63).

Local name reported in 1951 by USGS.

Bywoonat, Cape: point of land, see Chibukak Point.

Caamaño, Punta: point of land, see Caamano Point.

Caamano Point: point of land, S tip of Cleveland Penin., between Behm Canal and Clarence Strait, Alex. Arch.; 55 $30^{\prime} \mathrm{N}, 1^{\circ} 1^{\circ} 58^{\prime} \mathrm{W}$; (map 3). Var. Gabo Caamaño, Punta Gaamaño.

The name "Cabo Caamaño" was recorded in 1792 by Jacinto Caamaño and adopted for this feature in 1793 by Capt. George Vancouver, RN (Wagner, 1937, p. 378).

Cabin Bay: bay, on $W$ side of Naked $I$., extends $2.5 \mathrm{mi}$. W to Prince William Sound, $44 \mathrm{mi}$. $\mathrm{SE}$ of Whittier, Chugach Mts.; $60^{\circ} 40^{\prime} \mathrm{N}$, $147^{\circ} 30^{\prime} \mathrm{W}$; (map 63).

Name published in 1943 by USC\&GS.

Cabin Bay: bay, see Yalik Bay.

Cabin Cove: cove, $0.7 \mathrm{mi}$. across, including its Upper and Lower Arms, on $\mathbf{E}$ coast of Kagalaska I., Aleutian Is.; $51^{\circ} 50^{\prime} \mathrm{N}, 176^{\circ} 17^{\prime} \mathrm{W}$; $B G N 1936$; (map 17).

Named by members of the U.S. Navy Aleutian Island Survey Expedition in 1934.

Cabin Creek: stream, on Prince of Wales, I., W of Polk Inlet, flows NE $5.5 \mathrm{mi}$. to Skowl Arm, Alex. Arch.; $55^{\circ} 25^{\prime} 20^{\prime \prime} \mathrm{N}, 132^{\circ} 28^{\prime} 40^{\prime \prime}$ W; (map 4).

Local name published in 1920 by USC\&GS. Cabin Creek: stream, flows NW $0.7 \mathrm{mi}$. to Boundary Creek, upstream from Salmon River, $2.4 \mathrm{mi}$. NW of Mount Welker and Alaska-
Canada boundary, Coast Mts.; $56^{\circ} 02^{\prime} 10^{\prime \prime} \mathrm{N}$, $130^{\circ} 02^{\prime} 20^{\prime \prime} \mathrm{W}$; (map 7).

Local name reported in 1955 by USGS.

Cabin Creek: stream, flows E $2.2 \mathrm{mi}$. to Jacksina Creek $3 \mathrm{mi}$. W of its junc. with Nabesna River, Wrangell Mts.; $62^{\circ} 22^{\prime} \mathrm{N}, 142^{\circ} 58^{\prime} \mathrm{W}$; $B G N$ 1939; (map 84).

Local name reported by Capps (1915, p. 202), USGS.

Cabin Creek: stream, in Wyoming Hills, flows W $2 \mathrm{mi}$. to Toklat River, $5 \mathrm{mi}$. $\mathrm{N}$ of Denali Highway crossing, Alaska Ra.; 63 $35^{\prime} 30^{\prime \prime} \mathrm{N}$, $150^{\circ} 02^{\prime} 00^{\prime \prime} \mathrm{W}$; (map 88).

Local name reported in 1954 by USGS.

Cabin Creek: stream, see Bar Creek.

Cabin Gully: ravine, heads on $\mathrm{E}$ side of North Hill, trends SE $0.5 \mathrm{mi}$. to Eldorado Creek, $1.9 \mathrm{mi}$. NE of The Ears on Ear Mtn., Seward Penin. High.; $65^{\circ} 56^{\prime} 20^{\prime \prime} \mathrm{N}, 166^{\circ} 10^{\prime} 15^{\prime \prime} \mathrm{W}$; (map 111).

So named in 1945 by a USGS field party because there is a cabin site nearby.

Cabin Lake: lake, $0.2 \mathrm{mi}$. long, $3 \mathrm{mi}$. W of terminus of Sheridan Glacier and $10 \mathrm{mi}$. E of Cordova, Chugach Mts.; $60^{\circ} 32^{\prime} \mathrm{N}, 1^{\circ} 5^{\circ} 28^{\prime}$ W; (map 64).

Name published in 1950 by USGS.

Cabin Lake: lake, $0.7 \mathrm{mi}$. across, $13 \mathrm{mi}$. NE of Chalkyitsik, Yukon Flats; $66^{\circ} 49^{\prime} \mathrm{N}, 143^{\circ}$ $33^{\prime} \mathrm{W}$; (map 120).

Local descriptive name reported in 1956 by R. C. Foley, USGS.

Cabin Point: point of land, on $\mathbf{N}$ central Kanaga I., Aleutian Is.; $51^{\circ} 45^{\prime} 20^{\prime \prime} \mathrm{N}, 177^{\circ} 27^{\prime} 30^{\prime \prime}$ W; (map 17).

Name published by USC\&GS in 1956 on Chart 9145.

Cabin Point: point of land, on $\mathrm{N}$ shore of Hood Bay, $9 \mathrm{mi}$. SE of Angoon, on $\mathrm{W}$ coast of Admiralty I., Alex. Arch.; $57^{\circ} 23^{\prime} 10^{\prime \prime} \mathrm{N}$, $134^{\circ} 27^{\prime} 45^{\prime \prime}$ W ; BGN 1929; (map 9). Var. Village Point.

So named in 1929 by USC\&GS, "because of a cabin at the base of the point." It had been called Village Point by local pilots.

Cabin Point: point of land, see Muir Point.

Cabin Slough: lake, oxbow, $0.3 \mathrm{mi}$. W of Natrahazuivum Lake and $22 \mathrm{mi}$. NE of Fort Yukon, Yukon Flats; $66^{\circ} 38^{\prime} \mathrm{N}, 144^{\circ} 29^{\prime} \mathrm{W}$; (map 119).

Local descriptive name obtained in 1956 by USGS.

Cabin Slough: stream, $2.5 \mathrm{mi}$. long, on flood plain of Alsek River, $\mathbf{N}$ of First Rapids, 51 mi. SE of Yakutat, St. Elias Mts.; $59^{\circ} 12^{\prime} 15^{\prime \prime}$ $\mathrm{N}, 138^{\circ} 25^{\prime} 00^{\prime \prime} \mathrm{W}$; (map 46).

Local name published by the USGS in 1951. Cable Bay: bight, $1.5 \mathrm{mi}$. wide, on $\mathrm{N}$ side of Tanaga Bay, Tanaga I., Aleutian Is.; $51^{\circ} 47^{\prime}$ $15^{\prime \prime} \mathrm{N}, 178^{\circ} 01^{\prime} 00^{\prime \prime} \mathrm{W}$; (map 16).

Name published by USC\&GS in the 1944 Aleutian Coast Pilot (p. 118).

Cabras, Isla de: islands, see Cabras Islands.

Cabras Islands: islands, a group, largest of which is $1,600 \mathrm{ft}$. long, extend $1 \mathrm{mi}$. in Bucareli Bay, off $\mathrm{N}$ coast of Suemez I., Alex. Arch.; $55^{\circ} 21^{\prime}$ $15^{\prime \prime} \mathrm{N}, 133^{\circ} 23^{\prime} 30^{\prime \prime} \mathrm{W}$; (map 4). Var. Isla de Cabras, Ysla de Cabras. 
Spanish name given in 1775-79 by Don Juan de la Bodega y Quadra and Francisco Antonio Maurelle as "Isla de Cabras," meaning "island of goats."

Cabrini: stream, heads at NE end of Nushagak Hills, flows N $20 \mathrm{mi}$. to Hoholitna River, 32 mi. E of Taylor Mts., Kilbuck-Kuskokwim Mts. ; $60^{\circ} 56^{\prime} 55^{\prime \prime} \mathrm{N}, 156^{\circ} 26^{\prime} 00^{\prime \prime} \mathrm{W}$; (map 60).

Named for St. Francis Xavier Cabrini, 1850-1917, who, in 1946, was the first American citizen to be canonized.

Cache: $R R$. station, mile 447.7 on The Alaska RR., at junc. of Cache Creek and The Alaska RR., $18 \mathrm{mi}$. W of Fairbanks, YukonTanana High.; $64^{\circ} 50^{\prime} 40^{\prime \prime} \mathrm{N}, 148^{\circ} 18^{\prime} 30^{\prime \prime} \mathrm{W}$; (map 100).

Local name derived from Cache Creek and published on a USGS 1924 map.

Cache Creek: stream, heads in Alaska, flows SE $10 \mathrm{mi}$. across Alaska-Canada boundary to White River, $8 \mathrm{mi}$. SE of Rock Lake, YukonTanana High.; $61^{\circ} 45^{\prime} \mathrm{N}, 140^{\circ} 57^{\prime} \mathrm{W} ; B G N$ 1954; (map 67).

Named in 1912 by IBC.

Cache Creek: stream, heads on Slide Mtn., flows $\mathrm{NE}$ and SE $8.5 \mathrm{mi}$. to Nelchina River, 38 mi. SW of Glennallen, Copper River Basin; $62^{\circ} 00^{\prime} \mathrm{N}, 146^{\circ} 41^{\prime} \mathrm{W}$; (map 83).

Local name published by ARC in 1924.

Cache Creek: stream, heads in Dutch Hills, flows SW $21 \mathrm{mi}$. to Kahiltna River, $33 \mathrm{mi}$. W of Talkeetna, Alaska Ra.; $62^{\circ} 22^{\prime} 45^{\prime \prime} \mathrm{N}, 151^{\circ}$ 07'50" W; (map 81).

Prospectors' name reported by Sidney Paige and Adolph Knopf, USGS, in 1906, the year gold was discovered here.

Cache Creek: stream, heads in lake, flows SE 8.5 mi. to Talkeetna River, $38 \mathrm{mi}$. NE of Talkeetna, Talkeetna Mts.; $62^{\circ} 35^{\prime} 45^{\prime \prime} \mathrm{N}, 149^{\circ}$ $05^{\prime} 30^{\prime \prime} \mathrm{W}$; (map 82).

Local name reported in 1904 by T. G. Gerdine, USGS.

Cache Creek: stream, heads at McGonagall Pass in Mount McKinley National 'Park, flows $\mathbf{N}$ $9 \mathrm{mi}$. to Clearwater Creek, $20 \mathrm{mi}$. NNE of Mount McKinley, Alaska Ra.; $63^{\circ} 21^{\prime} \mathrm{N}, 150^{\circ}$ 49' W; BGN 1948; (map 88). Var. Newcomer Creek.

Probably a local name reported in 1910 by A. H. Brooks, USGS.

Cache Creek: stream, flows NW $3.4 \mathrm{mi}$. to Poorman Creek, $7 \mathrm{mi}$. SW of Poorman and $50 \mathrm{mi}$. SW of Ruby, Kilbuck-Kuskokwim Mts.; $64^{\circ}$ $01^{\prime} 36^{\prime \prime} \mathrm{N}, 155^{\circ} 42^{\prime} 20^{\prime \prime} \mathrm{W}$; (map 98).

Local name reported in 1933 by USGS.

Cache Creek: stream, flows SW $7.5 \mathrm{mi}$. to lagoon on Norton Sound, $6 \mathrm{mi}$. E of Solomon, Seward Penin. High.; $64^{\circ} 34^{\prime} \mathrm{N}, 164^{\circ} 14^{\prime} \mathrm{W}$; (map 95). Var. Spruce Creek.

Prospectors' name reported in 1900 by E. C. Barnard (in Brooks, 1901, pl. 17), USGS.

Cache Creek: stream, heads at junc. of Dawson and Keystone Creeks, flows SE $6 \mathrm{mi}$. to Goldstream Creek, $17 \mathrm{mi}$. W of Fairbanks, YukonTanana High.; $64^{\circ} 50^{\prime} 20^{\prime \prime}$ N, $148^{\circ} 17^{\prime} 45^{\prime \prime} \mathrm{W}$; (map 100). Var. Keystone Creek.

Named by prospectors in 1905 and published on a USGS map in 1906. This stream is shown as Keystone Creek with a west tributary named Cash Creek on C. W. Joint's 1905 manuscript map.

Cache Creek: stream, flows NE then NW $11 \mathrm{mi}$ to Fish River, $18 \mathrm{mi}$. NE of Council and 50 mi. NE of Solomon, Seward Penin. High.; $64^{\circ} 58^{\prime} \mathrm{N}, 163^{\circ} 06^{\prime} \mathrm{W}$; BGN 1910; (map 95).

Prospectors' name published on the 1908 "Map of Seward Peninsula" by Arthur Gibson.

Cache Creek: stream, flows SW 8 mi., joins Sullivan Creek to form Patterson Creek, $33 \mathrm{mi}$. ESE of Tanana, Yukon-Tanana High.; $65^{\circ}$ $02^{\prime} 30^{\prime \prime} \mathrm{N}, 150^{\circ} 55^{\prime} 55^{\prime \prime} \mathrm{W}$; BGN 1965; (map 106). Var. Ferguson Gulch.

Prospectors' name reported in 1906 by USGS (Prindle, 1908, pl. 5).

Cache Creek: stream, flows NNE $7 \mathrm{mi}$. to Rock Creek, $13 \mathrm{mi}$. NNE of Porcupine Dome and $38 \mathrm{mi}$. WSW of Circle, Yukon-Tanana High.; $65^{\circ} 41^{\prime} 15^{\prime \prime} \mathrm{N}, 145^{\circ} 20^{\prime} 40^{\prime \prime} \mathrm{W}$; (map 104).

Prospectors' name reported in 1954 or 1955 by USGS topographers.

Cache Creek: stream, flows W $19 \mathrm{mi}$. through Ikiakpaurak Valley to Canning River, at Shublik I., $45 \mathrm{mi}$. NW of Mount Michelson, Arctic Slope; $69^{\circ} 24^{\prime} \mathrm{N}, 146^{\circ} 06^{\prime} \mathrm{W}$; (map 139). Var. Cash Creek, Ikiokpaurak Creek.

S. J. Marsh, prospector, wrote, "The 7th of April, 1902, I left the coast alone, hauling 1,250 pounds by relays, and reached Gache Creek on June $1, * * *$. After building a cache of rock to protect my supplies I proceeded up the Kooguru [Canning] River ***" (Brooks, 1906, p. 260).

Cache Creek: stream, see Patterson Creek.

Cache Island: island, $0.2 \mathrm{mi}$. long, in Naha Bay, on $\mathrm{W}$ coast of Revillagigedo I., Alex. Arch.; $55^{\circ} 35^{\prime} 30^{\prime \prime} \mathrm{N}, 131^{\circ} 40^{\prime} 55^{\prime \prime} \mathrm{W}$; (map 3).

Named in 1886 by USC\&GS.

Cache Island: island, "in Koyukuk river, a little below the mouth of Batza river. Koyukuk Low; $65^{\circ} \mathrm{N}, 154^{\circ} \mathrm{W}$. So named by Allen, 1885" (Baker, 1906, p. 154)

Cache Lake: lake, $0.5 \mathrm{mi}$. long, $13 \mathrm{mi}$. W of Bearman Lake, $40 \mathrm{mi}$. NW of Fort Yukon, Yukon Flats; $66^{\circ} 46^{\prime} 30^{\prime \prime} \mathrm{N}, 146^{\circ} 35^{\prime} 00^{\prime \prime} \mathrm{W}$; (map 119).

Local descriptive name obtained in 1956 by USGS.

Cache Lake: lake, $0.7 \mathrm{mi}$. long, $2 \mathrm{mi}$. $\mathrm{S}$ of Vorzui Mtn. and $11 \mathrm{mi}$. E of Arctic Village, Brooks Ra.; $68^{\circ} 09^{\prime} 30^{\prime \prime} \mathrm{N}, 145^{\circ} 06^{\prime} 00^{\prime \prime} \mathrm{W}$; (map 136).

Local name reported in 1956 by $R$. C. Foley, USGS.

Cache Lake: lake, $0.6 \mathrm{mi}$. long, $2 \mathrm{mi}$. NW of Napaktualuit Lake, in headwaters of Anaktuvuk River, $4 \mathrm{mi}$. N of Anaktuvuk Pass, Brooks Ra.; 68 $11^{\circ} 00^{\prime \prime} \mathrm{N}, 151^{\circ} 38^{\prime} 00^{\prime \prime} \mathrm{W}$; (map 134).

So named in 1901 by W. J. Peters, USGS, because "the outfit was packed over by the men and horse to a small lake ***" (Schrader, 1904, p. 22).

Cache Mountain: mountain, 4,772 ft., $36 \mathrm{mi}$. $E$ of Livengood and $48 \mathrm{mi}$. NE of Fairbanks, Yukon-Tanana High.; $65^{\circ} 31^{\prime} 15^{\prime \prime}$ N, 147 $17^{\circ}$ '$30^{\prime \prime} \mathrm{W}$; (map 105).
Named by prospectors; published in 1906 by USGS.

Cache One Lake: lake, $1 \mathrm{mi}$. long, $\mathrm{E}$ of Echooka River, $29 \mathrm{mi}$. SE of junc. of Ivishak and Sagavanirktok Rivers, Arctic Slope ; $69^{\circ} 18^{\prime} \mathrm{N}$, $147^{\circ} 26^{\prime} \mathrm{W}$; (map 140).

Named about 1950 by USGS geologists.

Cactus Point: point of land, between Behm Canal and Sargent Bay, on $\mathrm{E}$ coast of Revillagigedo I., Alex. Arch.; 55 $33^{\prime} 18^{\prime \prime} \mathrm{N}, 130^{\circ} 56^{\prime} 30^{\prime \prime} \mathrm{W}$; (map 3).

Arbitrary name given in 1891 by USC\&GS. Cadelac Creek : stream, see Cadillac Creek.

Cadell, Mount: mountain, 4,300 ft., in Glacier Bay National Monument, $4 \mathrm{mi}$. NW of Pyramid Peak and $63 \mathrm{mi}$. NW of Hoonah, St. Elias Mts.; $58^{\circ} 53^{\prime} 50^{\prime \prime} \mathrm{N}, 136^{\circ} 19^{\prime} 25^{\prime \prime} \mathrm{W}$; (map 10).

Named by members of the American Geographical Society's Glacier Bay Expedition of 1941, for Henry Moubray Cadell, 1860-1934, who visited Muir Inlet in 1913.

Cadiack Island. island, see Kodiak Island.

Cadillac Creek: stream, flows SW $1 \mathrm{mi}$. to Shovel Creek, $6 \mathrm{mi}$. N of Solomon, Seward Penin. High.; 64. $39^{\prime} \mathrm{N}, 164^{\circ} 25^{\prime} \mathrm{W}$; (map 95). Var. Cadelac Creek.

Prospectors' name shown on Arthur Gibson's "Map of Cape Nome Precinct" dated 1904. J. M. Davidson and B. D. Blakeslee show a "Cadelac" near the head of the Solomon River on their 1900 "Map of Nome Peninsula."

Cadocernas Creek: stream, flows NE $4 \mathrm{mi}$. to Little Nelchina River $\mathrm{N}$ of Limestone Hills, $18 \mathrm{mi}$. NW of Tahneta Pass, Talkeetna Mts.; $62^{\circ} 06^{\prime} 15^{\prime \prime} \mathrm{N}, 147^{\circ} 39^{\prime} 00^{\prime \prime} \mathrm{W}$; (map 82).

Named about 1952 by USGS geologists "after a fossil."

Caenotaphe, Isle du: island, see Cenotaph Island.

Caetani, Lake: lake, $1.5 \mathrm{mi}$. long on Caetani River, W of terminus (1950) of Malaspina Glacier, $4 \mathrm{mi}$. SE of head of Icy Bay and $58 \mathrm{mi}$. NW of Yakutat, St. Elias Mts.; $60^{\circ}$ $00^{\prime} 45^{\prime \prime} \mathrm{N}, 141^{\circ} 11^{\prime} 00^{\prime \prime} \mathrm{W}$; (map 65). Var. Lake Castani.

Named by Prof. W. L. Libbey of Princeton Univ. in 1886 "in honor of the Duke of Sermoneta, President of the Italian Geographic Society" (Libbey, 1886, p. 149). Misspelled Castani (Russell, 1891, pl. 8).

Caetani River: stream, heads in a small glacier and flows SW $10 \mathrm{mi}$. to Icy Bay, $6 \mathrm{mi}$. NE of Moraine I. and $61 \mathrm{mi}$. NW of Yakutat, St. Elias Mts.; $59^{\circ} 59^{\prime} 30^{\prime \prime} \mathrm{N}, 141^{\circ} 16^{\prime} 00^{\prime \prime} \mathrm{W}$; (map 47).

Named after the lake of the same name, located on the east bank of the river at the 1950 terminus of Malaspina Glacier. Name published by USGS in 1948.

Cahill Creek: stream, flows SE $1.4 \mathrm{mi}$. to Lower Willow Creek, $18 \mathrm{mi}$. N of Solomon, Seward Penin. High.; $64^{\circ} 49^{\prime} \mathrm{N}, 164^{\circ} 27^{\prime} \mathrm{W}$; (map 95).

Prospectors' name reported on a map of Cape Nome gold fields by David Fox, Jr., dated 1901 . 
Cahoon Creek: stream, heads in glacier, $1.7 \mathrm{mi}$. SW of Porcupine Peak, flows N $4 \mathrm{mi}$. to McKinley Creek, $2.4 \mathrm{mi}$. S of Porcupine and $33 \mathrm{mi}$. W of Skagway, St. Elias Mts.; $59^{\circ} 23^{\prime}$ $10^{\prime \prime} \mathrm{N}, 136^{\circ} 14^{\prime} 10^{\prime \prime} \mathrm{W}$; (map 45).

Prospectors' name reported in 1903 by C. W. Wright, USGS.

Gaiganee, Cape: point of land, see Muzon, Gape. Caines Head: promontory, on E coast of Kenai Penin., $10 \mathrm{mi}$. SE of Seward, Chugach Mts. $59^{\circ} 59^{\prime} \mathrm{N}, 149^{\circ} 23^{\prime} \mathrm{W}$; BGN 1906; (map 49).

Local name reported in 1905 by USC\&GS. Cain Island: island, see Gain Island.

Cairn Creek: stream, in DeLong Mts., flows $S$ $5 \mathrm{mi}$. to Kugururok River $15 \mathrm{mi}$. N of Misheguk Mtn., Brooks Ra.; $68^{\circ} 28^{\prime} 30^{\prime \prime} \mathrm{N}, 161^{\circ} 08^{\prime}$ $00^{\prime \prime}$; BGN 1961; (map 131).

Named by USGS geologists in 1950 "for an old cairn found on the pass [Nachralik] between this stream and the Utukok River drainage."

Cairn Hill: peak, see Cairn Peak.

Cairn Island: island, "near entrance to Snag cove, Gambier bay, Admiralty I., Alex. Arch."

Named by USC\&GS in 1889 (Baker, 1906, p. 155).

Gairn Mountain: mountain, 3,783 ft., $12 \mathrm{mi}$. SE of Tundra Lake and $72 \mathrm{mi}$. SE of Sleetmute, Lime Hills; $61^{\circ} 09^{\prime} 45^{\prime \prime} \mathrm{N}, 155^{\circ} 19^{\prime} 45^{\prime \prime} \mathrm{W}$; (map 71).

Named in 1914 by P. S. Smith (1917, p. 31), USGS, "because of a cairn located on its top."

Cairn Mountain: mountain, 4,620 ft., $9 \mathrm{mi}$. NE of Sillyasheen Mtn. and $68 \mathrm{mi}$. NW of Wiseman, Brooks Ra.; $67^{\circ} 50^{\prime} 20^{\prime \prime} \mathrm{N}, 152^{\circ} 26^{\prime} 00^{\prime \prime}$ W; BGN 1932; (map 124).

Named in 1931 by Marshall (1956, p. 107), because "we found indeed a rocky cairn which apparently had been built thirty years before by the Schrader-Peters expedition ***."

Cairn Peak: peak, 4,500 ft., $1.1 \mathrm{mi}$. N of Salmon Creek Reservoir and $4 \mathrm{mi}$. NW of Juneau, Coast Mts.; $58^{\circ} 21^{\prime} 35^{\prime \prime} \mathrm{N}, 134^{\circ} 22^{\prime} 30^{\prime \prime} \mathrm{W}$; (map 11). Var, Cairn Hill.

Named "Cairn Hill" by George R. Putnam, USC\&GS, in 1899. The name Cairn Peak was published in 1902 by USC\&GS (Bauer, 1902 , p. 274) and has been used since.

Cairn Peak: mountain, 4,500 ft., 2 mi. NE of 1961 terminus of South Crillon Glacier, $77 \mathrm{mi}$. NW of Hoonah, St. Elias Mts.; $58^{\circ} 36^{\prime} 40^{\prime \prime} \mathrm{N}$, $137^{\circ} 20^{\prime} 15^{\prime \prime} \mathrm{W}$; (map 10).

Name reported by members of the HarvardDartmouth Expedition, 1933-34.

Cairn Point: point of land, on $\mathbf{E}$ shore of Knik Arm Cook Inlet, $2.8 \mathrm{mi}$. $\mathrm{N}$ of Anchorage, Cook Inlet Low.; $61^{\circ} 15^{\prime} 30^{\prime \prime} \mathrm{N}, 149^{\circ} 52^{\prime} 40^{\prime \prime}$ W; (map 69).

Local name published in 1912 by USC\&GS named for a cairn once located on its summit. Cairn Point: point of land, "in Albatross anchorage, Portage bay, Alaska Penin."

So named by the Fish Commission in 1893. (Baker, 1906, p. 155).

Cairo Creek: stream, flows SW $4 \mathrm{mi}$. to Hutlinana Creek, 22 mi. SE of Rampart, Yukon-
Tanana High.; $65^{\circ} 12^{\prime} 30^{\prime \prime} \mathrm{N}, 149^{\circ} 59^{\prime} 00^{\prime \prime} \mathrm{W}$; (map 105).

Named by prospectors; reported in 1908 by USGS (Covert and Ellsworth, 1909, pl. 5).

Cajoneta, Punta: point of land, see Caponeta, Point.

Calahonda Creek: stream, heads in a glacier and flows NW $6.5 \mathrm{mi}$. to Disenchantment Bay, 3.6 $\mathrm{mi}$. NE of Point Latouche and $28 \mathrm{mi}$. NNE of Yakutat, St. Elias Mts.; 59 $56^{\prime} 00^{\prime \prime} \mathrm{N}$, $139^{\circ} 32^{\prime} 15^{\prime \prime}$ W; (map 46). Var. Cala Honda.

Named "Cala Honda" meaning "deep creek," on July 3, 1791, by Capt. Alessandro Malaspina, "because at its mouth no bottom was found at 120 fathoms."

Calamity Creek: stream, on Revillagigedo I., flows SW $5 \mathrm{mi}$. to Carroll Inlet, $5.2 \mathrm{mi}$. N of Island Point, Alex. Arch.; $55^{\circ} 31^{\prime} 45^{\prime \prime} \mathrm{N}$, $131^{\circ} 19^{\prime} 20^{\prime \prime}$ W; BGN 1923; (map 3).

Named in 1923 by USFS.

Calamity Creek: stream, flows SW $9 \mathrm{mi}$. to Indian River, $57 \mathrm{mi}$. N of Birches, KokrinesHodzana High.; $65^{\circ} 57^{\prime} 40^{\prime \prime}$ N, $153^{\circ} 25^{\prime} 00^{\prime \prime}$ W (map 107).

Local name obtained in 1952 by USGS topographers.

Calamity Gulch: ravine, heads at glacier, trends SW $4 \mathrm{mi}$. to Young Creek $4 \mathrm{mi}$. W of junc. of Sheep Creek, $20 \mathrm{mi}$. SE of McCarthy, St. Elias Mts.; $61^{\circ} 13^{\prime} 30^{\prime \prime} \mathrm{N}, 142^{\circ} 31^{\prime} 45^{\prime \prime} \mathrm{W}$; (map 67).

Name "used by disappointed prospectors" and reported by Mendenhall and Schrader (1903, fig. 5), USGS.

Calder: locality, at mouth of Marble Creek, on E shore of Shakan Bay, on NW coast of Prince of Wales I., Alex. Arch.; $56^{\circ} 10^{\prime} 30^{\prime \prime} \mathrm{N}, 133^{\circ}$. $27^{\prime} 30^{\prime \prime} \mathrm{W}$; (map 6).

This is the site of an abandoned marble quarry, first discovered in 1896 and expanded by the Alaska Marble Co, in 1904 (F. E Wright and C. W. Wright, 1908, p. 192-195). The mining settlement obtained a post office the name being derived from Mount Calder 6 miles to the northwest) in 1906, discontinued in 1918 (Ricks, 1965, p. 8).

Calder, Mount: mountain, 3,370 ft., $3 \mathrm{mi}$. N of Shakan Bay, on $\mathbf{N}$ coast of Prince of Wales I., Alex. Arch.; $56^{\circ} 14^{\prime} 00^{\prime \prime} \mathrm{N}, 133^{\circ} 35^{\prime} 30^{\prime \prime} \mathrm{W}$ (map 6).

Named on September 21, 1793, by Capt. George Vancouver, RN, for Capt. Robert Calder, RN (Wagner, 1937, p. 378).

Caldera, Port: estuary, extends $\mathrm{S} 1 \mathrm{mi}$. off Bucareli Bay, on W coast of Prince of Wales I., $6.5 \mathrm{mi}$. S of Craig, Alex. Arch.; 55 ${ }^{\circ} 23^{\prime} \mathrm{N}$, $133^{\circ} 10^{\prime} \mathrm{W}$; (map 4). Var. Puerto de Caldera.

Named "Puerto de Caldera" on June 1, 1779 , by F. A. Maurelle. Caldera, in Spanish, means "caldron," the reference probably being the shape of the estuary.

Caldera, Puerto de: estuary, see Caldera, Port. Galder Bay: cove, extends S $1.3 \mathrm{mi}$. to Shakan Bay, on NW coast of Prince of Wales I., Alex. Arch.; $56^{\circ} 11^{\prime} 30^{\prime \prime} \mathrm{N}, 133^{\circ} 31^{\prime} 30^{\prime \prime} \mathrm{W}$; (map 6 ).
Named in 1886 by Lt. J. M. Helm, USN; derived from Mount Calder.

Calder Rocks: rocks, in Sumner Strait, $8.5 \mathrm{mi}$. SW of village of Point Baker, off NW coast of Prince of Wales I., Alex. Arch.; 56 $14^{\circ} 30^{\prime \prime} \mathrm{N}$, $133^{\circ} 42^{\prime} 50^{\prime \prime} \mathrm{W}$; (map 6).

Named in 1879 by W. H. Dall, USC\&GS.

Caldwell Glacier: glacier, heads on Gurney Peak, in Cathedral Spires of Kichatna Mts., trends SW $5 \mathrm{mi}$. to its terminus at head of Kichatna River, $84 \mathrm{mi}$. W of Talkeetna, Alaska Ra.; $62^{\circ} 21^{\prime} 30^{\prime \prime} \mathrm{N}, 152^{\circ} 43^{\prime} 00^{\prime \prime} \mathrm{W}$; (map 81).

Named in 1899 by Lt. J. S. Herron, USA.

Cale Creek: stream, flows NW $7 \mathrm{mi}$. to Bear Creek, $2.2 \mathrm{mi}$. E of Nyac and $40 \mathrm{mi}$. SW of Aniak, Kilbuck-Kuskokwim Mts.; $61^{\circ} 00^{\prime} 45^{\prime \prime}$ N, 159 $52^{\prime} 15^{\prime \prime} \mathrm{W} ;(\operatorname{map} 73$ ).

Prospectors' name shown on a 1914 fieldsheet by A. G. Maddren, USGS.

Calf Lake: lake, $0.2 \mathrm{mi}$. long, on Kenai Penin. SW of Cow Lake, $6 \mathrm{mi}$. NW of Sterling and $14 \mathrm{mi}$. E of Kenai, Cook Inlet Low.; $60^{\circ} 36^{\prime}$ $\mathrm{N}, 150^{\circ} 51^{\prime} \mathrm{W}$; (map 62).

Named about 1963 by the officials of Kenai National Moose Range for administrative purposes.

Calghsit, Cape: point of land, see Aghsit Point. Calico Bluff: bluff, extends $1 \mathrm{mi}$. on right bank of Yukon River, $8 \mathrm{mi}$. $\mathbf{N}$ of Eagle, Yukon-Tanana High.; $64^{\circ} 55^{\prime} \mathrm{N}, 141^{\circ} 11^{\prime} \mathrm{W}$; (map 102).

Riverboat pilots' descriptive name shown on a 1901 manuscript chart.

Calico Creek: stream, flows NW $6 \mathrm{mi}$. to Teklanika River, 26 mi. SW of Healy, Alaska Ra.; $63^{\circ} 35^{\prime} \mathrm{N}, 149^{\circ} 32^{\prime} \mathrm{W}$; (map 87).

Local name shown on a 1916 fieldsheet by C. E. Giffin, USGS.

Califernia: area, a name applied to the northern part of North America within the Arctic Circle in the Alaska area shown on a 1593 map of Corneille de Jode.

California: locality, $5 \mathrm{mi}$. W of Standard and $30 \mathrm{mi}$. W of Fairbanks, Yukon-Tanana High.; $64^{\circ} 47^{\prime} \mathrm{N}, 148^{\circ} 41^{\prime} \mathrm{W}$; (map 100).

Local name applied to a station on The Alaska RR. and published in 1924 by USGS.

California Bar: ridge, elev. 2,800 ft., extends SE $3 \mathrm{mi}$. from junc. of Hoosier and Minook Creeks, $4.5 \mathrm{mi}$. SE of Rampart, Yukon-Tanana High.; 65 $26^{\prime} 30^{\prime \prime} \mathrm{N}, 150^{\circ} 04^{\prime} 00^{\prime \prime} \mathrm{W}$; (map 106).

Prospectors' name reported in 1931 by $\mathrm{J}$. B. Mertie, Jr., USGS.

California Bay: bight, $2 \mathrm{mi}$. across, $2 \mathrm{mi}$. E of Red Bay, on $\mathbf{N}$ coast of Prince of Wales $\mathbf{I}$, Alex. Arch.; 56 $20^{\prime} \mathrm{N}, 133^{\circ} 14^{\prime} \mathrm{W}$; (map 6). Var. Carroll Anchorage.

Named in 1883 by W. H. Dall, USC\&GS, for the Coast Survey steamer California.

California Boulder: rocks, see California Boulder Patch.

California Boulder Patch: rocks, in Wrangell Narrows, on W coast of Mitkof I., $12 \mathrm{mi}$. S of Petersburg, Alex. Arch.; 56 $38^{\prime} 40^{\prime \prime} \mathrm{N}, 132^{\circ}$ 44'45" W; (map 6). Var. Galifornia Boulder. 
Named in 1881 by Lt. Comdr. H. E. Nichols, USN, presumably for the steamer California.

California Cove: cove, "on east side California head, Carroll inlet. Revillagigedo I., southeastern Alaska."

Name applied by local navigators, and reported by H. C. Fassett, USBF, 1904 (Baker, 1906, p. 155).

California Creek: estuary, extends $\mathrm{N} 1 \mathrm{mi}$. off Carroll Inlet, on $\mathbf{S}$ coast of Revillagigedo $\mathbf{I}$., Alex. Arch.; $55^{\circ} 20^{\prime} 05^{\prime \prime} \mathrm{N}, 131^{\circ} 27^{\prime} 30^{\prime \prime} \mathrm{W}$; (map 3). Var. California Cove.

Local navigators' name obtained in 1904 by H. C. Fassett, USBF.

California Creek: stream, heads in lake, flows E $4.5 \mathrm{mi}$. to Campbell Lagoon, near mouth of Uganik Bay, on $N$ coast of Kodiak I.; $57^{\circ} 51^{\prime}$ $45^{\prime \prime} \mathrm{N}, 153^{\circ} 40^{\prime} 00^{\prime \prime} \mathrm{W}$; (map 34).

Local name reported in 1952 by USGS.

California Creek: stream, flows SE $8 \mathrm{mi}$. to Glacier Greek, near Girdwood, $10 \mathrm{mi}$. NE of Sunrise, Chugach Mts.; $60^{\circ} 56^{\prime} 30^{\prime \prime} \mathrm{N}, 149^{\circ}$ $09^{\prime} 40^{\prime \prime} \mathrm{W}$; (map 63).

Local prospectors' name reported about 1914 by B. L. Johnson (in Martin and others, 1915 , pl. 2), USGS.

California Creek: stream, flows SW $4.7 \mathrm{mi}$. to Tuluksak River, $3.2 \mathrm{mi}$. N of Nyac and 38 mi. SW of Aniak, Kilbuck-Kuskokwim Mts.; $61^{\circ} 03^{\prime} 10^{\prime \prime} \mathrm{N}, 159^{\circ} 56^{\prime} 20^{\prime \prime} \mathrm{W}$; (map 73).

Prospectors' name reported by A. G. Maddren, USGS, in 1914.

California Creek: stream, heads on Castle Mtn., flows SE $3.8 \mathrm{mi}$. to Chickaloon River at Chickaloon, $25 \mathrm{mi}$. NE of Palmer, Talkeetna Mts. ; $61^{\circ} 47^{\prime} 50^{\prime \prime} \mathrm{N}, 1^{\circ} 8^{\circ} 28^{\prime} 30^{\prime \prime} \mathrm{W}$; (map 69).

Local name reported in 1948 by USGS.

California Creek: stream, flows SW $4.5 \mathrm{mi}$, to Kuskokwim River, $14 \mathrm{mi}$. NW of Red Devil and $20 \mathrm{mi}$. NW of Sleetmute, KilbuckKuskokwim Mts.; 61 ${ }^{\circ} 53^{\prime}$ N, 157 39' W; BGN 1943; (map 72).

Named in 1910 by prospectors; reported in 1943 by USGS.

California Creek: stream, in Nutzotin Mts., flows W $4 \mathrm{mi}$. to Chathenda Creek $7.5 \mathrm{mi} \mathrm{E}$ of its junc. with Chisana River, Alaska Ra.; $62^{\circ} 04^{\prime} 30^{\prime \prime} \mathrm{N}, 141^{\circ} 50^{\prime} 30^{\prime \prime} \mathrm{W}$; BGN 1912; (map 84).

Local name reported by Capps (1915, p. 202), USGS.

California Creek: stream, flows SE $4.8 \mathrm{mi}$. to Sunshine Creek, in Sunflower Basin, $50 \mathrm{mi}$. NW of Talkeetna, Alaska Ra.; $62^{\circ} 29^{\prime} 40^{\prime \prime} \mathrm{N}$, $151^{\circ} 38^{\prime} 10^{\prime \prime} \mathrm{W}$; (map 81). Var. Idaho Creek.

Prospectors' name published by Hyatt and Smith (1905, pl. 15), USGS. R. W. Porter, USGS, reported this feature as "Idaho Creek" in 1906.

California Creek: stream, formed by Billy Goat and Moose Creeks, flows NW $2.6 \mathrm{mi}$. to Windy Creek, $36 \mathrm{mi}$. NE of Flat, Kilbuck-Kuskokwim Mts.; $62^{\circ} 52^{\prime} 30^{\prime \prime} \mathrm{N}, 157^{\circ} 21^{\prime} 10^{\prime \prime} \mathrm{W}$; (map 79).
Prospectors' name obtained in 1952 by USGS.

California Creek: stream, flows NE $3.6 \mathrm{mi}$. to Yankee Creek near its confluence with Innoko River, $8 \mathrm{mi}$. SE of Ophir and $25 \mathrm{mi}$. NW of McGrath, Kilbuck-Kuskokwim Mts.; $63^{\circ}$ $03^{\prime} 40^{\prime \prime} \mathrm{N}, 156^{\circ} 20^{\prime} 20^{\prime \prime} \mathrm{W}$; BGN 1936; (map 90)

Prospectors' name obtained in 1933 by J. B. Mertie, Jr. (in Smith, P. S., 1936, pl. 4), USGS.

California Creek: stream, flows N $12 \mathrm{mi}$. to Totatlanika River, $32 \mathrm{mi}$. SE of Nenana, Alaska Ra.; $64^{\circ} 08^{\prime} \mathrm{N}, 148^{\circ} 41^{\prime} \mathrm{W}$; (map 100).

Named by prospectors; reported in 1906 by L. M. Prindle (in Brooks and others, 1907, pl. 4), USGS.

California Creek: stream, flows NE $4.3 \mathrm{mi}$. to Titna River $3 \mathrm{mi}$. W of its junc. with Telsitna River, 36 mi. SE of Monzonite Hills, KilbuckKuskokwim Mts. ; $64^{\circ} 20^{\prime} \mathrm{N}, 153^{\circ} 28^{\prime} \mathrm{W}$; (map 98).

Local name reported about 1952 by USGS.

California Creek: stream, flows SW to Central Creek $10 \mathrm{mi}$. E of its junc. with Goodpaster River and $40 \mathrm{mi}$. ENE of Big Delta, YukonTanana High.; $64^{\circ} 21^{\prime} \mathrm{N}, 144^{\circ} 36^{\prime} \mathrm{W}$; (map 101). Var. Louis Creek.

Named by prospectors; published in 1950 by USGS

California Greek: stream, flows SW $3.5 \mathrm{mi}$. to Topkok River, $3.2 \mathrm{mi}$. NE of Topkok on Norton Sound and $16 \mathrm{mi}$. E of Solomon, Seward Penin. High.; 64 $36^{\prime} 20^{\prime \prime}$ N, $163^{\circ} 54^{\prime}$ 00" W; (map 95). Var. Allen Creek.

Prospectors' name reported on the 1904 "Map of Cape Nome Precinct" by Arthur Gibson.

California Creek: stream, flows SW $10 \mathrm{mi}$. to Bonanza River, $10 \mathrm{mi}$. NW of Solomon, Seward Penin. High.; $64^{\circ} 39^{\prime} \mathrm{N}, 164^{\circ} 43^{\prime} \mathrm{W}$; (map 95).

Prospectors' name reported in 1900 by $\mathrm{E}$. C. Barnard (in Brooks, 1901, pl. 17), USGS.

California Greek: stream, flows NE $1 \mathrm{mi}$. to Ophir Creek which flows to Niukluk River, $38 \mathrm{mi}$. NE of Solomon, Seward Penin. High.; $64^{\circ} 59^{\prime} \mathrm{N}, 163^{\circ} 39^{\prime} \mathrm{W}$; (map 95 ).

Prospectors' name recorded on a 1902 prospector's manuscript map.

California Creek: stream, flows NE $8 \mathrm{mi}$. to Pargon Creek, $15 \mathrm{mi}$. NE of Council and $39 \mathrm{mi}$. $\mathrm{S}$ of Imuruk Lake, Seward Penin. High.; $65^{\circ} 01^{\prime} \mathrm{N}, 163^{\circ} 14^{\prime} \mathrm{W}$.; (map 110 ).

Prospectors' name reported on a map of Cape Nome gold fields by David Fox, Jr., dated 1901.

California Creek: stream, flows SW $1 \mathrm{mi}$. to Alder Creek, in Bluestone River basin, $14 \mathrm{mi}$. SE of Teller, Seward Penin. High.; $65^{\circ} 05^{\prime} \mathrm{N}$, $166^{\circ} 08^{\prime} \mathrm{W}$; (map 111).

Prospectors' name reported on a map of Cape Nome gold fields by David Fox, Jr., dated 1901.

California Creek: stream, flows E $2.7 \mathrm{mi}$., joins Cash Creek to form Bear Creek, $14 \mathrm{mi}$. E of Far Mtn. and $62 \mathrm{mi}$. SW of Circle, Yukon-
Tanana High.; $65^{\circ} 05^{\prime} 45^{\prime \prime} \mathrm{N}, 145^{\circ} 18^{\prime} 00^{\prime \prime} \mathrm{W}$; (map 104).

Named by prospectors and reported in 1913 by Ellsworth (in Ellsworth and Davenport, 1915b, pl. 11), USGS.

California Creek: stream, headwaters partially diverted by Thanksgiving Ditch, flows SW $6.2 \mathrm{mi}$. to New York Creek, $23 \mathrm{mi}$. SSW of Rampart, Yukon-Tanana High.; $65^{\circ} 11^{\prime} 20^{\prime \prime}$ N, $150^{\circ} 05^{\prime} 50^{\prime \prime} \mathrm{W}$; (map 106).

Prospectors' name reported in 1906 by USGS (Prindle 1908, pl. 5).

California Creek: stream, flows NW $1.4 \mathrm{mi}$. to Minook Greek, $7 \mathrm{mi}$. S of Rampart, YukonTanana High.; $65^{\circ} 24^{\prime} 05^{\prime \prime} \mathrm{N}, 150^{\circ} 07^{\prime} 30^{\prime \prime} \mathrm{W}$; (map 106).

Prospectors' name reported in 1904 by $\mathbf{L}$. M. Prindle, USGS.

California Creek: stream, flows NE $3.8 \mathrm{mi}$. to Kougarok River, $7 \mathrm{mi}$. SW of Midnight Mtn. and $47 \mathrm{mi}$. W of Imuruk Lake, Seward Penin. High.; $65^{\circ} 38^{\prime} \mathrm{N}, 164^{\circ} 48^{\prime} \mathrm{W}$; (map 110).

Prospectors' name reported in 1901 by T. G. Gerdine (in Collier, 1902, pl. 12), USGS.

California Creek: stream, flows NW $2 \mathrm{mi}$. to South Fork Hess Creek, $10 \mathrm{mi}$. NE of Livengood, Yukon-Tanana High.; $65^{\circ} 39^{\prime} \mathrm{N}, 148^{\circ}$ 24' W; (map 105).

Named by prospectors; reported by J. B. Mertie, Jr. (in Brooks and others, 1918, pl. 13), USGS.

California Creek: stream, flows NE $6 \mathrm{mi}$. to Kugruk River, $25 \mathrm{mi}$. NE of Imuruk Lake, Seward Penin. High.; $65^{\circ} 55^{\prime} \mathrm{N}, 162^{\circ} 44^{\prime} \mathrm{W}$; (map 110).

Prospectors' name reported in 1908 by F. F. Henshaw (in Brooks and others, 1909, fig. 21), USGS.

California Creek: stream, on Seward Penin., flows NW $8 \mathrm{mi}$. to Kugrupaga River, $14 \mathrm{mi}$. NW of Ear Mtn. and $50 \mathrm{mi}$. NW of Teller, Kotzebue-Kobuk Low.; $65^{\circ} 58^{\prime}$ N, $166^{\circ} 44^{\prime} \mathrm{W}$; (map 111)

Prospectors' name reported in 1901 by T. G. Gerdine (in Collier, 1902, pl. 12), USGS.

California Creek: stream, flows W $4 \mathrm{mi}$. to Kogoluktuk River, $12 \mathrm{mi}$. NE of Shungnak, Brooks Ra.; $66^{\circ} 58^{\prime}$ N, $156^{\circ} 45^{\prime}$ W; (map 115).

Prospectors' name reported after 1940 by USGS.

California Creek: stream, flows $2 \mathrm{mi}$. NW, then $1.8 \mathrm{mi}$. SW, to Glacier Creek, $4.5 \mathrm{mi}$. S of Glacier Lake and $27 \mathrm{mi}$. WSW of Chandalar, Brooks Ra.; 67 $27^{\prime} 40^{\prime \prime}$ N, $149^{\circ} 32^{\prime} 00^{\prime \prime}$ W; (map 123).

Local name reported in 1956 by T. E. Taylor, USGS.

California Creek: stream, see Surprise Creek.

California Gulch: ravine, heads on Serpentine

Ridge, extends SE $1.3 \mathrm{mi}$. to American Creek, $4 \mathrm{mi}$. E of Fish Lake and $26 \mathrm{mi}$. ESE of Tanana, Yukon-Tanana High.; $65^{\circ} 05^{\prime} 27^{\prime \prime} \mathrm{N}$, $151^{\circ} 12^{\prime} 10^{\prime \prime} \mathrm{W}$; (map 106).

Local name reported in 1952 by USGS.

California Gulch: ravine, see Little Specimen Gulch.

California Head: point of land, between Carroll and George Inlets, on $\mathbf{S}$ coast of Revillagigedo 
I., Alex. Arch.; $55^{\circ} 19^{\prime} 35^{\prime \prime} \mathrm{N}, 131^{\circ} 29^{\prime} 00^{\prime \prime} \mathrm{W}$; (map 3).

Named in 1880 by USC\&GS for the steamer California.

California Range: ridge, see California Ridge.

California Ridge: ridge, extends NW $14 \mathrm{mi}$. from Bostwick Point to Vallenar Point, on Gravina I., Alex. Arch.; 55 $19^{\prime}$ N, $131^{\circ} 46^{\prime} \mathrm{W}$; (map 3). Var. California Range.

Named in 1883 by Lt. Comdr. H. E. Nichols, USN, probably for the steamer California.

California River: stream, heads in Black Mtn., flows SW $16 \mathrm{mi}$ to Breving Lagoon, $10 \mathrm{mi}$. NW of Teller, Seward Penin. High.; $65^{\circ} 21^{\prime}$ N, 166 $39^{\prime}$ W; (map 111).

Prospectors' name reported in 1901 by T. G. Gerdine (in Collier, 1902, pl. 12), USGS.

California Rock: rock, in East Channel of Tongass Narrows, $0.2 \mathrm{mi}$. SW of Saxman on Revillagigedo I., Alex. Arch.; 55 ${ }^{\circ} 18^{\prime} 55^{\prime \prime} \mathrm{N}$, $131^{\circ} 36^{\prime} 05^{\prime \prime} \mathrm{W}$; (map 3). Var. Wayanda Rock, Wyanda Rock.

Named in 1885 by USC\&GS for the steamer California; previously called "Wayanda" after the USRCS cutter Wayanda.

Calligan Island: island, $0.3 \mathrm{mi}$. long, $1.3 \mathrm{mi}$. NW of Goddard, on W coast of Baranof I., Alex. Arch.; 56 $51^{\prime} 10^{\prime \prime} \mathrm{N}, 135^{\circ} 23^{\prime} 15^{\prime \prime} \mathrm{W}$; (map 5).

Local name used by fishermen; published in 1929 by USC\&GS.

Callisto Head: promontory, on $\mathrm{E}$ coast of Kenai Penin., $14 \mathrm{mi}$. S of Seward, Chugach Mts.; $59^{\circ} 55^{\prime} 10^{\prime \prime} \mathrm{N}, 149^{\circ} 27^{\prime} 40^{\prime \prime} \mathrm{W}$; BGN 1930; (map 49).

Named in 1930 by USC\&GS "for the nymph in mythology who was changed into a bear and set in the heavens as Ursa Major."

Calming Island: island, $200 \mathrm{ft}$. across, on $W$ coast of Baranof I., $7 \mathrm{mi}$. SW of Sitka, Alex. Arch.; $56^{\circ} 58^{\prime} 05^{\prime \prime} \mathrm{N}, 135^{\circ} 25^{\prime} 15^{\prime \prime} \mathrm{W}$; (map 5). Var. Calming Islet, Ostrov Utichey, Utichi Island.

Name published by Lt. Comdr. H. E. Nichols, USN, in 1891 Coast Pilot (p. 169) as "Calming Islet." In 1809, Ivan Vasiliev the first, IRN, called this island "Ostrov Utichey," meaning "escape island"; possibly it is derived from "Utikhat," meaning "to grow calm."

Calming Islet: island, see Calming Island. Calm Point: point of land, see Peirce, Cape.

Calton Point: point of land, see Catton.

Camacho, Canal de: watter passage, see Unalga Pass.

Camacho, Isla de : island, see Marmot Island.

Cambon, Cape: point of land, on NW coast of San Juan Bautista I., Alex. Arch.; 55 $25^{\prime} 30^{\prime \prime}$ N, $133^{\circ} 19^{\prime} 15^{\prime \prime}$ W; (map 4). Var. Cabo Cambon, Mys Kambon.

Named "Cabo Cambon," i.e. "Cape Cambon," in 1779 by Francisco Antonio Maurelle, "probably after Father Benito Cambon, a Franciscan in upper California" (Wagner, 1937, p. 437).

Camden, Point: point of land, E point of entrance to Port Camden, on NE coast of Kuiu
I., Alex. Arch.; $56^{\circ} 48^{\prime} 30^{\prime \prime} \mathrm{N}, 133^{\circ} 53^{\prime} 00^{\prime \prime} \mathrm{W}$; (map 6)

Named in 1892 by Lt. W. I. Moore, USN. Camden, Port: bay, extends N $16 \mathrm{mi}$. to Keku Strait, $35 \mathrm{mi}$. W of Petersburg, on E coast of Kuiu I., Alex. Arch.; $56^{\circ} 48^{\prime} \mathrm{N}, 133^{\circ} 55^{\prime} \mathrm{W}$; (map 6).

Named on August 10, 1794, by Capt. George Vancouver, RN, "probably in honor of Charles Pratt, Earl of Camden" (Wagner, 1937, p. 378). See Camden Bay.

Camden Bay: bight, $50 \mathrm{mi}$. across, on Beaufort Sea coast between Barter I. and Point Brownlow, Arctic Plain; $70^{\circ} 09^{\prime} \mathrm{N}, 144^{\circ} 45^{\prime} \mathrm{W}$; (map 151).

Named August 4, 1826, by Sir John Franklin (1826, p. 147) who wrote: "we embarked, *** to cross the bay, which has been named in honour of the Marquess Camden." The son of Lord Chancellor Pratt, the Earl of Camden, "the Marquess became successively a Lord of the Admiralty, a Lord of the Treasury, and Lord Lt. of Ireland in the ministry of William Pitt" (Stuck, 1920, p. 301).

Camelback Mountain: mountain, 2,756 ft., in Kuskokwim Mts., near heads of Bonanza and Moore Creeks, $22 \mathrm{mi}$. NE of Flat and $62 \mathrm{mi}$. SW of McGrath, Kilbuck-Kuskokwim Mts.; $62^{\circ} 32^{\prime} 45^{\prime \prime} \mathrm{N}, 157^{\circ} 21^{\prime} 00^{\prime \prime} \mathrm{W}$; (map 79).

Prospectors' descriptive name reported in 1912 by H. M. Eakin, USGS.

Camel Cove: cove, $1 \mathrm{mi}$. across, on $\mathrm{S}$ coast of Adak I., Aleutian Is.; $51^{\circ} 42^{\prime} 30^{\prime \prime}$ N, $176^{\circ} 36^{\prime}$ $00^{\prime \prime} \mathrm{W}$; (map 17)

Name published by USC\&GS in 1951 on Chart 9193.

Camel Islet: rock, $53 \mathrm{ft}$. high, $0.5 \mathrm{mi}$. off NW coast of Seguam I., Aleutian Is.; 52 $21^{\prime} \mathrm{N}$, $172^{\circ} 35^{\prime} \mathrm{W}$; (map 19).

Descriptive name given by a special U.S. Navy survey party because the top resembles a camel's hump; listed in the Aleutian Coast Pilot (1944, p. 86).

Camel Lake: lake, $0.7 \mathrm{mi}$. across, $5 \mathrm{mi}$. E of junc. of Nizina and Chitina Rivers, $8 \mathrm{mi}$. SW of McCarthy, Wrangell Mts. ; $61^{\circ} 20^{\prime} 45^{\prime \prime} \mathrm{N}, 143^{\circ}$. 05'15" W; BGN 1966; (map 67)

Named in 1965 by L. A. Yehle, USGS, for publication and geologic description purposes. Camel Mountain: mountain, 2,011 ft., on W coast of Baranof I., $13 \mathrm{mi}$. S of Sitka, Alex. Arch.; 56 $52^{\prime} 10^{\prime \prime}$ N, $135^{\circ} 19^{\prime} 40^{\prime \prime}$ W; BGN 1926; (map 5). Var. Kliuchevaya Gora.

So named in 1926 by USC\&GS, "because of its double hump, like a camel." The mountain was called "Gora Klyuchevaya," meaning "[water] spring mountain," on 1848 Russian Hydrog. Dept. Chart 1397. See Kliuchef, Mount.

Camel Rock: rock, on S shore of Nikolski Bay, SW side of Umnak I., Aleutian Is.; 52 ${ }^{\circ} 56^{\prime} 10^{\prime \prime}$ N, $168^{\circ} 56^{\prime} 30^{\prime \prime} \mathrm{W}$; BGN 1940; (map 21).

Named in 1938 by USC\&GS, "because when seen from the east, the rock resembles a kneeling camel."

Camel Rock: rock, at NE entrance to Seldovia Bay, $0.5 \mathrm{mi}$. N of Seldovia, Chugach Mts.; $59^{\circ}$ $27^{\prime} 10^{\prime \prime} \mathrm{N}, 151^{\circ} 43^{\prime} 00^{\prime \prime} \mathrm{W}$; (map 50).
Local name published by USGS in 1951 and so called "because it resembles a camel."

Cameron, Mount: mountain, 5,360 ft., $4.3 \mathrm{mi}$. NW of Mount Shasta and $15 \mathrm{mi}$. WNW of Valdez, Chugach Mts.; $61^{\circ} 12^{\prime} 40^{\prime \prime} \mathrm{N}, 146^{\circ}$ 39'50" W; (map 68).

Prospectors' name reported in 1912 by $\mathrm{J}$. W. Bagley and C. E. Giffin, USGS.

Cameron Creek: stream, flows WNW $1.5 \mathrm{mi}$. to Corbin Creek, $0.9 \mathrm{mi}$. W of terminus of Corbin Glacier and $5 \mathrm{mi}$. E of Valdez, Chugach Mts.; $61^{\circ} 06^{\prime} 35^{\prime \prime} \mathrm{N}, 146^{\circ} 04^{\prime} 50^{\prime \prime} \mathrm{W}$; (map 68).

Local name published in the 1950's by USGS.

Cameron Pass: pass, 4,100 ft., in Horn Mts., 10 mi. N of Tahneta Pass, Talkeetna Mts.; $62^{\circ}$. $02^{\prime} 10^{\prime \prime} \mathrm{N}, 147^{\circ} 21^{\prime} 10^{\prime \prime} \mathrm{W}$; BGN 1960; (map $82)$.

Local name reported in 1939 by USGS, "named for either Jack Cameron, a 40-year local resident, or Cameron placer gold mines on nearby Albert Creek."

Cameron Pass: water passage, in Rakof Is., extends NE $1.5 \mathrm{mi}$. from Scow I. to Middle Channel, W of Baranof I., $9 \mathrm{mi}$. SE of Goddard, Alex. Arch.; $56^{\circ} 43^{\prime} 00^{\prime \prime}$ N, $135^{\circ} 16^{\prime} 30^{\prime \prime}$ W; (map 5).

Local name published in 1926 by USG\&GS.

Cameron Point: point of land, on coast of Beaufort Sea, 12 mi. NW of Cape Halkett, Arctic Plain; $70^{\circ} 53^{\prime} \mathrm{N}, 152^{\circ} 38^{\prime} \mathrm{W}$; (map 149). Var. Point Cameron.

Shown as "Point Cameron" on P. W. Dease's and Thomas Simpson's map (Simpson, Thomas, 1843)

Camicia Creek: stream, heads at terminus of Camicia Glacier, flows SW $2 \mathrm{mi}$. to Valdez Glacier, 5 mi. NE of Valdez, Ghugach Mts.; $61^{\circ} 09^{\prime} 20^{\prime \prime} \mathrm{N}, 146^{\circ} 08^{\prime} 10^{\prime \prime} \mathrm{W}$; BGN 1965; (map 68).

Local name reported in 1952 by USGS. Camicia Glacier: glacier, heads at $61^{\circ} 11^{\prime} \mathrm{N}$, $145^{\circ} 59^{\prime} \mathrm{W}$, trends SW $4 \mathrm{mi}$. to Camicia Greek, $8 \mathrm{mi}$. NE of Valdez, Chugach Mts.; $61^{\circ} 10^{\prime} 15^{\prime \prime} \mathrm{N}, 146^{\circ} 05^{\prime} 15^{\prime \prime} \mathrm{W} ; B G N$ 1965; (map 68)

Local name reported in 1914 by USGS. Named for Dr. L. S. Camicia, optician and watchmaker at Valdez who measured the retreat of Valdez Glacier nearly every year from 1898 to 1911.

Camille Cone: $h i l l, 1,370 \mathrm{ft} ., 4 \mathrm{mi} . \mathrm{SW}$ of Imuruk Lake, Seward Penin. High.; 6532' N, $163^{\circ}-$ 23' W; (map 110).

Local name reported in 1951 by USGS

Cam Island: island, $0.2 \mathrm{mi}$. lang, in Port Camden, $29 \mathrm{mi}$. NW of Point Baker, on $E$ coast of Kuiu I., Alex. Arch.; 56 $43^{\circ} 50^{\prime \prime}$ N, $133^{\circ}$ $55^{\prime} 00^{\prime \prime} \mathrm{W}$; (map 6).

Named in 1892 by Lt. W. I. Moore, USN.

Camp Bay: cove, $0.8 \mathrm{mi}$. across, $\mathrm{S}$ of Fort Glenn, on NE coast of Umnak I., Aleutian Is.; $53^{\circ}$ $21^{\prime} 50^{\prime \prime} \mathrm{N}, 167^{\circ} 53^{\prime} 30^{\prime \prime} \mathrm{W}$; (map 23).

Name reported by U.S. Army Corps of Engineers in 1942.

Campbell: locality, on Prince of Wales I., at head of Twelvemile Arm Kasaan Bay, 10 
mi. SE of Craig, Alex. Arch.; $55^{\circ} 22^{\prime} \mathrm{N}, 132^{\circ}-$ $43^{\prime} \mathrm{W}$; (map 4).

This is the site of a temporary logging camp. According to the postmaster at Ketchikan, "It will be located there for a few more years until it is logged off and then moved to some other area."

Campbell: locality, mile 109.3 on The Alaska RR., $3.5 \mathrm{mi}$. S of Anchorage, Cook Inlet Low.; $61^{\circ} 10^{\prime} 00^{\prime \prime} \mathrm{N}, 149^{\circ} 53^{\prime} 40^{\prime \prime} \mathrm{W}$; (map 69).

Name of a flag stop on The Alaska Railroad listed in the 1918 Official Railroad Guide.

Campbell, Mount: mountain, 1,600 ft., at terminus of Bering Glacier, $2 \mathrm{mi}$. SE of Nichawak Mtn. and $67 \mathrm{mi}$. SE of Cordova, Malaspina Coastal Plain; $60^{\circ} 13^{\prime} 30^{\prime \prime} \mathrm{N}, 143^{\circ} 54^{\prime} 00^{\prime \prime} \mathrm{W}$; (map 65).

Named in 1903 "for a petroleum operator" by J. F. Pratt, USC\&GS.

Campbell, Point: point of land, between Knik and Turnagain Arms, Cook Inlet, $5.2 \mathrm{mi}$. SW of Anchorage, Cook Inlet Low.; $61^{\circ} 09^{\prime}$ $24^{\prime \prime} \mathrm{N}, 150^{\circ} 04^{\prime} 20^{\prime \prime} \mathrm{W}$; (map 70). Var. Mys Kambelya.

Named May 4, 1794, by Joseph Whidbey, probably for Sir Joseph Campbell, governor of Jamaica in 1785 when Capt. George Vancouver, RN, was in the West Indies (Wagner, 1937 , p. 379).

Campbell Bay: bight, $1 \mathrm{mi}$. across, on NW coast of Glacier I., $50 \mathrm{mi}$. NE of Whittier, Chugach Mts.; $60^{\circ} 53^{\prime} 40^{\prime \prime} \mathrm{N}, 147^{\circ} 16^{\prime} 15^{\prime \prime} \mathrm{W}$; (map 63).

Local name reported in 1951 by USGS.

Campbell Cabin: locality, at head of Keystone Creek, $17 \mathrm{mi}$. NW to Big Delta, Yukon-Tanana High.; $64^{\circ} 22^{\prime} \mathrm{N}, 146^{\circ} 08^{\prime} \mathrm{W}$; (map 101).

Local name for a cabin; published in 1956 by USGS.

Campbell Greek: stream, flows SW $1 \mathrm{mi}$. to Gulf of Alaska, $0.4 \mathrm{mi}$. SE of mouth of Steelhead Greek, Malaspina Coastal Plain ; $58^{\circ} 34^{\prime} 30^{\prime \prime} \mathrm{N}$, $137^{\circ} 32^{\prime} 30^{\prime \prime} \mathrm{W}$; (map 10).

Name reported by members of the HarvardDartmouth Expedition, 1933-34.

Campbell Creek: stream, formed by its North and South Forks, flows SW $10 \mathrm{mi}$. through Campbell Lake to Turnagain Arm, $7 \mathrm{mi}$. SW of Anchorage, Cook Inlet Low.; $61^{\circ} 07^{\prime} 28^{\prime \prime} \mathrm{N}$, $149^{\circ} 58^{\prime} 30^{\prime \prime} \mathrm{W}$; (map 69).

Local name reported in 1906 by T. G. Gerdine and R. H. Sargent, USGS; derived from nearby Point Campbell.

Campbell Creek: stream, "tributary to Yukon on left bank $20 \mathrm{mi}$. below Rampart, near longitude $150^{\circ} 40^{\prime} . "$

"Local name, from Edward's Track Chart of the Yukon, 1899" (Baker, 1906, p. 157).

Campbell Lagoon: lagoon, $1.3 \mathrm{mi}$. long, near mouth of Uganik Bay, on $\mathrm{N}$ coast of Kodiak I. ; $57^{\circ} 51^{\prime} 40^{\prime \prime} \mathrm{N}, 153^{\circ} 39^{\prime} 20^{\prime \prime} \mathrm{W}$; (map 34).

Local name reported in 1952 by USGS.

Campbell Lake: lake, $0.7 \mathrm{mi}$. long, between Harding River and Tom Creek, $5 \mathrm{mi} . \mathrm{N}$ of Bradfield Canal, Coast Mts.; 56 $16^{\prime} 30^{\prime \prime} \mathrm{N}$, $131^{\circ} 41^{\prime} 30^{\prime \prime} \mathrm{W}$; (map 7).

Local name reported in 1955 by USGS.
Campbell Lake: lake, $1.3 \mathrm{mi}$. long, in course of Campbell Creek, $5.7 \mathrm{mi}$. SW of Anchorage, Cook Inlet Low.; $61^{\circ} 08^{\prime} 20^{\prime \prime} \mathrm{N}, 149^{\circ} 56^{\prime} 20^{\prime \prime}$ W; (map 69).

Name of a former lake reported in 1962 by USGS. Lake drained during the earthquake of 1964.

Campbell Lake: lake, $0.3 \mathrm{mi}$. long, $1.7 \mathrm{mi}$. $\mathrm{E}$ of Point Campbell and $5.8 \mathrm{mi}$. SW of Anchorage, Cook Inlet Low.; $61^{\circ} 09^{\prime} 42^{\prime \prime} \mathrm{N}, 150^{\circ} 01^{\prime} 15^{\prime \prime}$ W; (map 70).

Local name published in 1951 by USGS; probably derived from nearby Point Campbell. Campbell River: stream, flows W $8 \mathrm{mi}$. to Controller Bay, $12 \mathrm{mi}$. SE of Katalla, Malaspina Coastal Plain; $60^{\circ} 09^{\prime} \mathrm{N}, 144^{\circ} 12^{\prime} \mathrm{W}$; (map 64).

Local name reported in 1903 by G. C. Martin (1905, pl. 3), USGS.

Campbell River: stream, flows NW $18 \mathrm{mi}$. to Porcupine River $7 \mathrm{mi}$. NNE of Smith Lake, $39 \mathrm{mi}$. NE of Coleen Mtn., Porcupine Plat., $67^{\circ} 19^{\prime} \mathrm{N}, 141^{\circ} 29^{\prime} \mathrm{W}$; (map 121).

Name published by Kindle (1908, fig. 1), USGS.

Camp Brady: locality, see Brady.

Camp Cogan Bay: bay, Camp Coogan Bay

Camp Collier: locality, see Kangee Camp.

Camp Coogan Bay: bay, $0.2 \mathrm{mi}$. across, $4.5 \mathrm{mi}$. SE of Sitka, on W coast of Baranof I., Alex. Arch.; $57^{\circ} 00^{\prime} 30^{\prime \prime} \mathrm{N}, 135^{\circ} 14^{\prime} 00^{\prime \prime} \mathrm{W}$; $B G N$ 1901; (map 9). Var. Bukhta Kadyakskaya, Camp Cogan Bay, Camp Kogan Bay, Kadiak Cove, Nachlezhnia.

Named about 1871 for Michael Coogan, a soldier with Battery I, Second U.S. Artillery, who in 1871 was reported to have been detailed to extra duty in charge of a wood party. He established a wood-cutting camp on the bay. The Russians called it "B[ukhta] Kadyakskaya," or "Kadyak Bay" (Tebenkov, 1852, map 38).

Camp Cove: bay, $0.2 \mathrm{mi}$. across, on Miller I., in Alitak Bay, at $\mathrm{S}$ end of Kodiak I.; $56^{\circ} 57^{\prime} 20^{\prime \prime} \mathrm{N}, 154^{\circ} 07^{\prime} 45^{\prime \prime} \mathrm{W}$; (map 32).

Name published in 1943 by USC\&GS.

Camp Cove: cove, $0.6 \mathrm{mi}$. across, on $\mathrm{W}$ coast of Dall I., $\mathrm{N}$ of Welcome Point, Alex. Arch.; $54^{\circ} 59^{\prime} 45^{\prime \prime} \mathrm{N}, 133^{\circ} 10^{\prime} 00^{\prime \prime} \mathrm{W}$; (map 1).

Local name published by USC\&GS in 1943.

Camp Cove: estuary, extends SW $0.2 \mathrm{mi}$. off Revillagigedo Channel on E coast of Ham I., Alex. Arch.; $55^{\circ} 10^{\prime} 25^{\prime \prime} \mathrm{N}, 131^{\circ} 20^{\prime} 00^{\prime \prime} \mathrm{W}$; (map 3).

Name published in 1917 by USC\&GS.

Camp Creek: locality, on left bank of Camp Creek, $30 \mathrm{mi}$. SE of Nulato, KilbuckKuskokwim Mts. ; $64^{\circ} 23^{\prime} \mathrm{N}, 157^{\circ} 32^{\prime} \mathrm{W}$; (map 97). Var. Tlatskokot.

Local name reported in 1954 by USGS.

Camp Creek: stream, flows SE to Camp Bay, S of Fort Glenn, on NE coast of Umnak I., Aleutian Is.; $53^{\circ} 22^{\prime} \mathrm{N}, 167^{\circ} 54^{\prime} \mathrm{W}$; (map 23).

Name reported by U.S. Army Corps of Engineers in 1942

Camp Creek: stream, flows NW $1 \mathrm{mi}$. to Buster Bay, on $\mathrm{N}$ coast of Prince of Wales I., Alex.
Arch.; $56^{\circ} 19^{\prime} 50^{\prime \prime} \mathrm{N}, 133^{\circ} 24^{\prime} 10^{\prime \prime} \mathrm{W}$; (map 6). Local name recorded in 1949 by USGS.

Camp Creek: stream, flows NE $3.3 \mathrm{mi}$. to Becharof Lake, $3.5 \mathrm{mi}$. S. of Severson Penin., on Alaska Penin., $3 \mathrm{mi}$. NW of Kanatak, Aleutian Ra.; $57^{\circ} 44^{\prime} 45^{\prime \prime} \mathrm{N}, 156^{\circ} 08^{\prime} 40^{\prime \prime} \mathrm{W}$; (map 36).

Name reported in 1920 by G. C. Martin (1921, pl. 10), USGS; based on information given in 1902 by J. L. McPherson, Deputy Mineral Surveyor.

Camp Creek: stream, flows $4 \mathrm{mi}$. to Slug River, $23 \mathrm{mi}$. E. of Cape Newenham, Kilbuck-Kuskokwim Mts.; 58 $42^{\prime} \mathrm{N}, 161^{\circ} 32^{\prime} \mathrm{W}$; (map 39).

Local name shown on a 1947 fieldsheet by J. B. Mertic, Jr., USGS.

Camp Creek: stream, flows E $4 \mathrm{mi}$. to Barnum Creek, $15 \mathrm{mi}$. N of Goodnews, Kilbuck-Kuskokwim Mts.; $59^{\circ} 18^{\prime} \mathrm{N}, 161^{\circ} 30^{\prime} \mathrm{W}$; (map 53).

Local name reported in 1920 by G. L. Harrington (in Brooks and others, 1921, pl. 7), USGS.

Camp Creek: stream, heads near Moraine Pass and flows NE $4.2 \mathrm{mi}$. to Raven Creek, $26 \mathrm{mi}$. $\mathrm{SE}$ of Anchorage, Chugach Mts.; $61^{\circ} 08^{\prime} 10^{\prime \prime}$

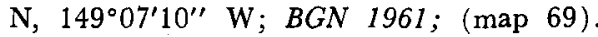
Var. Magpie Creek.

"Magpie Creek" was approved by BGN in 1932. Name changed by local usage; Camp Creek was published by ARC on a map dated 1943.

Camp Creek: stream, flows NE $3.5 \mathrm{mi}$. to Holokuk River, $16 \mathrm{mi}$. SE of Little Mountain Village, Kilbuck-Kuskokwim Mts.; 61 ${ }^{\circ} 22^{\prime} \mathrm{N}$, $158^{\circ} 18^{\prime} \mathrm{W}$; (map 72$)$.

Descriptive name reported in 1954 by $W$. M. Cady, R. E. Wallace, J. M. Hoare, and E. J. Webber, USGS.

Camp Creek: stream, heads on Gunsight Mtn., flows SE $2.7 \mathrm{mi}$. to Trail Creek, $59 \mathrm{mi}$. NE of Palmer, Copper River Basin; 61 $49^{\circ} 10^{\prime \prime} \mathrm{N}$, $147^{\circ} 23^{\prime} 10^{\prime \prime} \mathrm{W}$; (map 69).

Local name reported in 1952 by USGS.

Camp Creek: stream, flows NW $8 \mathrm{mi}$. to Nabesna River, $8 \mathrm{mi}$. SE of Nabesna, Wrangell Mts. ; $62^{\circ} 17^{\prime} \mathrm{N}, 142^{\circ} 52^{\prime} \mathrm{W}$; (map 84).

Local name reported in 1960 by USGS.

Camp Creek: stream, heads on Mount Kliskon, flows SE $21 \mathrm{mi}$. to Lake Creek, $36 \mathrm{mi}$. W of Talkeetna, Alaska Ra.; $62^{\circ} 18^{\prime} 45^{\prime \prime} \mathrm{N}$, $151^{\circ} 14^{\prime} 45^{\prime \prime} \mathrm{W}$; (map 81).

Prospectors' name reported in 1906 by R. W. Porter, USGS.

Camp Creek: stream, flows N $5 \mathrm{mi}$. to Nabesna River, $8 \mathrm{mi}$. NE of Nabesna, Wrangell Mts.; $62^{\circ} 24^{\prime} \mathrm{N}, 142^{\circ} 47^{\prime} \mathrm{W}$; (map 84). Var. Thekonda.

Named in 1902 by F. C. Schrader, USGS, because of "the good camp ground at the creek's mouth." He also reports the Indian name to be "Thekonda."

Camp Creek: stream, heads in Roundabout Mts., flows $\mathrm{N} 3 \mathrm{mi}$. to Cash Creek $0.2 \mathrm{mi}$. S of its junc. with Candle Creek, $4.3 \mathrm{mi}$. SW of McGrath, Kilbuck-Kuskokwim Mts.; 62 ${ }^{\circ} 55^{\prime} 30^{\prime \prime}$ N, $155^{\circ} 43^{\prime} 00^{\prime \prime} \mathrm{W}$; (map 80). 
Local name reported in 1910 by G. G. Anderson (in Eakin, 1914, pl. 2), USGS.

Camp Greek: stream, flows NW $5 \mathrm{mi}$. to Canyon Creek $1.2 \mathrm{mi}$. $\mathrm{S}$ of its junc. with Boulder Creek, $16 \mathrm{mi}$. NW of Mount Russell, Alaska Ra.; 62 $56^{\prime} 12^{\prime \prime}$ N. $152^{\circ} 18^{\prime} 05^{\prime \prime}$ W; (map 81). Local name reported in 1954 by USGS.

Camp Creek: stream, flows SW $3.5 \mathrm{mi}$. to Costello Creek, $45 \mathrm{mi}$. SW of Healy, Alaska Ra.; $63^{\circ} 16^{\prime} 10^{\prime \prime} \mathrm{N}, 149^{\circ} 31^{\prime} 45^{\prime \prime} \mathrm{W}$; (map 87).

Local name obtained in 1951 by USGS.

Camp Creek: stream, in Mount McKinley National Park, flows NW $2.3 \mathrm{mi}$. to Thorofare River, $2.8 \mathrm{mi}$. SW of Eielson Visitor Center, Alaska Ra.; $63^{\circ} 24^{\prime} 45^{\prime \prime}$ N, $150^{\circ} 24^{\prime} 30^{\prime \prime} \mathrm{W}$; (map 88).

Local name reported in 1954 by USGS.

Camp Creek: stream, flows SW $13.5 \mathrm{mi}$. to North Fork Innoko River, $79 \mathrm{mi}$. SE of Nulato, Kilbuck-Kuskokwim Mts.; $64^{\circ} 00^{\prime} \mathrm{N}, 156^{\circ} 05^{\prime}$ W; (map 97).

Local name reported in 1954 by USGS.

Camp Creek: stream, flows NW $3 \mathrm{mi}$. to join Woods Creek to form Canyon Creek, $48 \mathrm{mi}$. $\mathrm{S}$ of Eagle, Yukon-Tanana High.; 64 $4^{\circ} 06^{\prime} 45^{\prime \prime}$ N, $141^{\circ} 06^{\prime} 45^{\prime \prime} \mathrm{W}$; (map 102).

Prospectors' name obtained in 1898 by E. C. Barnard, USGS.

Camp Creek: stream, flows NW $28 \mathrm{mi}$. to Khotol River, $19 \mathrm{mi}$. SE of Nulato, Koyukuk Low.; $64^{\circ} 28^{\prime} \mathrm{N}, 157^{\circ} 50^{\prime} \mathrm{W}$; (map 97). Var. Canoe Portage Creek.

Local name reported in 1954 by USGS.

Camp Creek: stream, flows W $16 \mathrm{mi}$. to South Fork Salcha River $4.4 \mathrm{mi}$. S of that stream's junc. with Salcha River and $34 \mathrm{mi}$. NE of Big Delta, Yukon-Tanana High.; 64 $36^{\prime}$ N, $145^{\circ} 24^{\prime} \mathrm{W}$; (map 101).

Local name reported in 1958 by USGS.

Camp Creek: stream, flows E $1 \mathrm{mi}$. to Nome River, $8 \mathrm{mi}$. NNE of Nome, Seward Penin. High.; $64^{\circ} 37^{\prime} \mathrm{N}, 165^{\circ} 17^{\prime} \mathrm{W}$; (map 94). Var. Upper Camp Creek.

Prospectors' name published on the 1900 "Map of Nome Peninsula" by J. M. Davidson and B. D. Blakeslee.

Camp Creek: stream, flows SW $4 \mathrm{mi}$. to Sinuk River, $25 \mathrm{mi}$. NW of Nome, Seward Penin. High.; $64^{\circ} 39^{\prime} \mathrm{N}, 166^{\circ} 11^{\prime} \mathrm{W}$; (map 94).

Prospectors' name reported in 1900 by E. C. Barnard (in Brooks, 1901, pl. 17), USGS.

Camp Creek: stream, flows SE $2 \mathrm{mi}$. to Fox River, $25 \mathrm{mi}$. NE of Solomon, Seward Penin. High.; $64^{\circ} 48^{\prime} \mathrm{N}, 163^{\circ} 47^{\prime} \mathrm{W}$; (map 95).

Prospectors' name published on the 1908 "Map of Seward Peninsula" by Arthur Gibson. Camp Creek: stream, flows NE $7 \mathrm{mi}$. to Niukluk River, $30 \mathrm{mi}$. NE of Solomon, Seward Penin. High.; 64 $56^{\prime} 10^{\prime \prime} \mathrm{N}, 163^{\circ} 55^{\prime} 45^{\prime \prime} \mathrm{W}$; (map 95). Var. Pine Creek.

This appears to be the stream reported in 1899 as "Pine Creek" by Schrader and Brooks (1900, may 3), USGS.

Camp Creek: stream, flows SE and S $3.3 \mathrm{mi}$. to Hot Springs Slough, $48 \mathrm{mi}$. ESE of Tanana, Yukon-Tanana High.; $65^{\circ} 01^{\prime} 00^{\prime \prime} \mathrm{N}, 150^{\circ}$ 27'25" W; BGN 1965; (map 106).
Local name reported in 1963 by Bond Taber, USGS.

Camp Creek: stream, flows SW $3.5 \mathrm{mi}$. to Woodchopper Creek $3.3 \mathrm{mi}$. N of that stream's junc. with Patterson Creek, $31 \mathrm{mi}$. ESE of Tanana, Yukon-Tanana High.; $65^{\circ} 04^{\prime} \mathrm{N}$, $151^{\circ} 03^{\prime} \mathrm{W}$; (map 106).

Prospectors' name reported in 1906 by USGS (Prindle, 1908, pl. 5).

Camp Creek: stream, flows SW $2 \mathrm{mi}$. to Chatanika River, $15 \mathrm{mi}$. NE of Chatanika, $35 \mathrm{mi}$. NE of Fairbanks, Yukon-Tanana High. ; $65^{\circ} 13^{\prime} \mathrm{N}$, $147^{\circ} 00^{\prime} \mathrm{W}$; (map 105).

Local name published by USGS in the 1950's.

Camp Creek: stream, flows NE $2.6 \mathrm{mi}$. to Coffee Creek, in Kougarok River basin, $50 \mathrm{mi}$. SW of Imuruk Lake, Seward Penin. High. ; $65^{\circ} 18^{\prime}$ $N, 1^{\circ} 46^{\prime} \mathrm{W}$; (map 110).

Prospectors' name reported on the 1908 "Map of Seward Peninsula" by Arthur Gibson.

Camp Creek: stream, in York Mts., flows NW 0.7 $\mathrm{mi}$. to Cassiterite Creek which flows to Lost River, $27 \mathrm{mi}$. NW of Teller, Seward Penin. High.; $65^{\circ} 28^{\prime} \mathrm{N}, 167^{\circ} 10^{\prime} \mathrm{W}$; (map 111).

Prospectors' name reported in 1918 by Steidtman and Cathcart (1922, fig. 5), USGS. Camp Creek: stream, flows NW $4 \mathrm{mi}$. to American River, $25 \mathrm{mi}$. NE of Teller, Seward Penin. High.; $65^{\circ} 31^{\prime} \mathrm{N}, 165^{\circ} 44^{\prime} \mathrm{W}$; (map 111). Var. Sandy Creek.

Prospectors' name reported in 1901 by T. G. Gerdine (in Collier, 1902, pl. 12), USGS. This appears to be the "Sandy Creek" reported in 1900 by Messrs. Kemp and David Fox (in Brooks, 1901, pl. 11).

Camp Creek: stream, flows SW $2 \mathrm{mi}$. to Bear Creek, 27 mi. N of Haycock, Seward Penin. High.; $65^{\circ} 36^{\prime}$ N, $161^{\circ} 08^{\prime}$ W; (map 109).

Local name shown on a 1903 fieldsheet by D. C. Witherspoon, USGS.

Camp Creek: stream, flows SE $1 \mathrm{mi}$. to Eureka Creek which flows to North Fork Kougarok River, $4 \mathrm{mi}$. W of Harris Dome and $44 \mathrm{mi}$. W of Imuruk Lake, Seward Penin. High.; $65^{\circ}$ $36^{\prime} \mathrm{N}, 164^{\circ} 41^{\prime} \mathrm{W}$; (map 110).

Prospectors' name reported on the 1908 "Map of Seward Peninsula" by Arthur Gibson.

Camp Creek: stream, flows S $5 \mathrm{mi}$. to Wesley Creek, 4 mi. NE of Shungnak, Kotzebue-Kobuk Low.; $66^{\circ} 56^{\prime} \mathrm{N}, 157^{\circ} 03^{\prime} \mathrm{W}$; (map 115).

Prospectors' name reported after 1940 by USGS.

Camp Creek: stream, on Seward Penin., flows NE $4.7 \mathrm{mi}$. to Willow Creek, $11 \mathrm{mi}$. SE of Deering, Kotzebue-Kobuk Low.; $66^{\circ} 02^{\prime} \mathrm{N}$, $162^{\circ} 22^{\prime} \mathrm{W}$; (map 113).

Local name reported in 1903 by Moffit (1905, pl. 2), USGS.

Camp Creek: stream, "tributary to Kotzebue sound from south near longitude $162^{\circ} 30^{\prime}$."

"So named by Mendenhall and Reaburn, 1901" (Baker, 1906, p. 157).

Camp Creek: stream, "tributary to Sinuk River, from the north, Seward Penin."

"Name from Barnard, 1900" (Baker, 1906, p. 157).
Camp Creek: stream, see American Creek.

Camp Creek: stream, see Arkansas Creek.

Camp Creek: stream, see Brophy Creek.

Camp Denali: locality, resort, in upper canyon of Moose Creek, $2 \mathrm{mi}$. N of Wonder Lake, Alaska Ra.; $63^{\circ} 31^{\prime} 10^{\prime \prime} \mathrm{N}, 150^{\circ} 53^{\prime} 00^{\prime \prime} \mathrm{W}$; (map 88).

Local name reported in 1954 by USGS.

Camper Creek: stream, flows SW $1.5 \mathrm{mi}$. to $\mathrm{Ni}$ ukluk River, $33 \mathrm{mi}$. NE of Solomon, Seward Penin. High.; $64^{\circ} 52^{\prime} \mathrm{N}, 163^{\circ} 38^{\prime} \mathrm{W}$; (map 95). Var. Cooper Creek.

Prospectors' name published in 1956 by USGS. Published as "Cooper Cr." on the 1908 "Map of Seward Peninsula" by Arthur Gibson.

Campers Cove: cove, $0.4 \mathrm{mi}$. across, on $\mathrm{E}$ coast of Adak I., Aleutian Is.; 51 ${ }^{\circ} 47^{\prime} 05^{\prime \prime} \mathrm{N}, 176^{\circ}$ 26'15" W; BGN 1936; (map 17).

Named by members of the U.S. Navy Aleutian Island Survey Expedition in 1934, "for its good campsite and trappers' hut."

Campers Lake: lake, $0.7 \mathrm{mi}$. long, one of the Swanson Lakes on Kenai Penin. SW of Swanson Lake, $32 \mathrm{mi}$. NE of Kenai, Cook Inlet Low.; $60^{\circ} 49^{\prime} 15^{\prime \prime} \mathrm{N}, 150^{\circ} 32^{\prime} 30^{\prime \prime} \mathrm{W}$; (map 62).

Named about 1963 by officials of Kenai National Moose Range, for administrative purposes.

Campers Point: point of land, on $\mathrm{E}$ coast of Adak I., Aleutian Is.; $51^{\circ} 47^{\prime} 30^{\prime \prime} \mathrm{N}, 176^{\circ} 25^{\prime}$ 15" W; BGN 1936; (map 17).

Name derived from Campers Cove, given by members of the U.S. Navy Aleutian Island Survey Expedition in 1934.

Campfire Lake: lake, $0.6 \mathrm{mi}$. long, on Kenai Penin. S of Goose Lake in course of Swan Creek, $27 \mathrm{mi}$. NE of Kenai, Cook Inlet Low.; $60^{\circ} 44^{\prime} 30^{\prime \prime} \mathrm{N}, 150^{\circ} 36^{\prime} 15^{\prime \prime} \mathrm{W}$; (map 62).

Named in 1963 by officials of Kenai National Moose Range, for administrative purposes.

Camp 15 Peak: peak, 5,905 ft., E of Battle Glacier, $3 \mathrm{mi}$. SW of The Tusk and $28 \mathrm{mi}$. N of Juneau, Coast Mts.; 58 $41^{\prime} 23^{\prime \prime} \mathrm{N}, 134^{\circ}$. 33'50" W; BGN 1965; (map 11).

Local name reported in 1964 by members of the Juneau Icefield Research Project.

Camp 4 Peak: peak, 5,200 ft., between East and West Twin Glaciers, $3.5 \mathrm{mi}$. N of Twin Glacier Lake and $27 \mathrm{mi}$. NE of Juneau, Coast Mts.; $58^{\circ} 36^{\prime} 45^{\prime \prime} \mathrm{N}, 133^{\circ} 57^{\prime} 15^{\prime \prime} \mathrm{W}$; BGN 1965; (map 12). Var. Research Mountain.

Named in 1965 for use in glaciologic studies by Maynard Miller, director of the Juneau Icefield Research Project.

Gamp Haven: locality, on left bank of Haven Creek $39 \mathrm{mi}$. SE of Imuruk Lake, Seward Penin. High.; $65^{\circ} 12^{\prime} \mathrm{N}, 162^{\circ} 17^{\prime} \mathrm{W}$; (map 110). Var. Haven.

Site of a mining camp reported on the 1908 "Map of Seward Peninsula" by Arthur Gibson.

Camp Island: island, $350 \mathrm{ft}$. long, in Hook Arm Sea Otter Harbor, on W coast of Dall I., Alex. Arch.; $55^{\circ} 07^{\prime} 30^{\prime \prime} \mathrm{N}, 133^{\circ} 10^{\prime} 20^{\prime \prime} \mathrm{W}$; (map $4)$. 
Name published in 1924 by USC\&GS.

Camp Island: island, $0.9 \mathrm{mi}$. long, in Sea Otter Sound, off N central coast of Heceta I., Alex. Arch.; $55^{\circ} 48^{\prime} \mathrm{N}, 133^{\circ} 28^{\prime} \mathrm{W}$; (map 4).

Local name recorded in 1951 by USGS.

Camp Island: island, $0.4 \mathrm{mi}$. long, between Le Conte Bay and Frederick Sound, $16 \mathrm{mi}$. SE of Petersburg, Coast Mts. ; 56 $44^{\circ} 10^{\prime \prime} \mathrm{N}, 132^{\circ}$ $33^{\prime} 45^{\prime \prime}$ W; (map 6).

Named in 1887 by Lt. Comdr. C. M. Thomas, USN, for charting purposes; name published in 1888 on USC\&GS Chart 705.

Camp Island: island, $0.5 \mathrm{mi}$. long, in Karluk Lake, $21 \mathrm{mi}$. SE of Karluk, Kodiak I.; 57 $22^{\prime}$ $00^{\prime \prime} \mathrm{N}, 154^{\circ} 01^{\prime} 30^{\prime \prime} \mathrm{W}$; (map 35).

Local name reported in 1952 by USGS.

Camp Island Lake: lake, $1.4 \mathrm{mi}$. long, on Kenai Penin. in course of West Fork Moose River, $19 \mathrm{mi}$. NE of Kenai, Cook Inlet Low.; $60^{\circ}$ $38^{\prime} \mathrm{N}, 150^{\circ} 43^{\prime} \mathrm{W}$; (map 62).

Named about 1963 by officials of Kenai National Moose Range, for administrative purposes.

Camp Iveetok: locality, $20 \mathrm{mi}$. SE of Savoonga, NE coast of St. Lawrence I.; $63^{\circ} 29^{\prime} 45^{\prime \prime} \mathrm{N}$, $170^{\circ} 03^{\prime} 10^{\prime \prime}$ W; (map 93). Var. Camp Iveektok.

Eskimo name published as "Iveektok" by the Univ. of Alaska in 1932. The name probably means "place where there is grass," and may be best spelled Iviktok.

Camp Iveektok: locality, see Camp Iveetok.

Camp Kogan Bay: bay, see Camp Coogan Bay.

Camp Kulowiye: locality, $2 \mathrm{mi}$. W of Northeast Cape, at $\mathrm{E}$ end of S. Lawrence I.; $63^{\circ} 19^{\prime} \mathrm{N}$, $168^{\circ} 37^{\prime}$ W; (map 93). Var. Camp Kulowyl, Seevooka Camp.

Eskimo name reported in 1932 by $\mathrm{O}$. W. Geist, Univ. of Alaska.

Camp Kulowyl: locality, see Camp Kulowiye.

Camp Mountain: mountain, 5,700 ft., $1.3 \mathrm{mi}$. NNE of Sharp Peak and $23 \mathrm{mi}$. NNE of Valdez, Chugach Mts.; $61^{\circ} 26^{\prime} 15^{\prime \prime} \mathrm{N}, 146^{\circ} 01^{\prime}$ $05^{\prime \prime} \mathrm{W}$; (map 68).

Named in 1898 by Capt. W. R. Abercrombie, USA, "because Sagmill Camp was at the foot of this mountain."

Camp Muir: point of land, see Muir Point.

Camp 19: locality, on left bank of Candle Creek, $5 \mathrm{mi}$. SW of Candle and $37 \mathrm{mi}$. NE of Imuruk Lake, Seward Penin. High.; $65^{\circ} 60^{\prime} \mathrm{N}$, $162^{\circ} 02^{\prime} \mathrm{W}$; (map 110).

Site of a mining camp reported in 1951 by USGS.

Camp Number 6: locality, $2.4 \mathrm{mi}$. NE of Thane and $7 \mathrm{mi}$. SE of Juneau, Coast Mts. ; $58^{\circ} 16^{\prime}$ $50^{\prime \prime} \mathrm{N}, 134^{\circ} 16^{\prime} 25^{\prime \prime} \mathrm{W}$; (map 11).

Local name published in 1952 by USGS.

Camp Pleasant: locality, on Taiya River, about $12 \mathrm{mi}$. N of Skagway; (map 45).

A stopping place near timberline on the Dyea Trail to Ghilkoot Pass. Shown on a sketch map in "En Route to the Klondike," a series of photographic views by F. LaRoche, published in 1898 by W. B. Conkey Co., Chicago. Not identified on modern maps.

Camp Point: point of land, on $\mathrm{W}$ bank of Portland Canal, $1.5 \mathrm{mi}$. SW of Hattie I., Canada,
Coast Mts.; $55^{\circ} 16^{\prime} 30^{\prime \prime}$ N, $130^{\circ} 00^{\prime} 00^{\prime \prime}$ W; (map 3).

Named in 1868 by Staff Comdr. David Pender, RN.

Camp Point: point of land, on Iniskin Penin., on S shore of Chinitna Bay W of Sea Otter Point, Aleutian Ra.; $59^{\circ} 50^{\prime} \mathrm{N}, 153^{\circ} 05^{\prime} \mathrm{W}$; (map 51).

Local name published by USGS in 1922.

Camp Robber Peak: peak, 5,855 ft., $2 \mathrm{mi}$. SE of Moraine Pass and $26 \mathrm{mi}$. SE of Anchorage, Chugach Mts.; $61^{\circ} 03^{\prime} 50^{\prime \prime} \mathrm{N}, 149^{\circ} 10^{\prime} 15^{\prime \prime} \mathrm{W}$; $B G N$ 1964; (map 69). Var. Camprobber Peak.

Named in 1963 by members of the Mountaineering Club of Alaska for the Alaska gray jay (perisoreus canadensis arcus).

Camp Sevok: fish camp, see Sevak Camp.

Camp Shaheen: locality, on E shore of Hasselborg Lake, on Admiralty I., $18 \mathrm{mi}$. NE of Angoon, Alex. Arch.; 57 $42^{\prime} 10^{\prime \prime} \mathrm{N}, 134^{\circ}-$ $16^{\prime} 30^{\prime \prime} \mathrm{W}$; (map 9).

The name of this locality, shown with two cabins, was published on a 1957 USGS map. Campsite Lake: lake, $0.5 \mathrm{mi}$. long, on Kenai Penin. between Browse and Picnic Lakes, 4 mi. $\mathbf{N}$ of Hidden Lake and $33 \mathrm{mi}$. E of Kenai, Cook Inlet Low.; $60^{\circ} 33^{\prime} 30^{\prime \prime} \mathrm{N}, 150^{\circ} 17^{\prime} 30^{\prime \prime}$ W; (map 62).

Named about 1963 by officials of Kenai National Moose Range, for administrative purposes.

Camptail Creek: stream, flows SW $1 \mathrm{mi}$. to Hamilton Bay, $7 \mathrm{mi}$. SE of Kake, on NW coast of Kupreanof I., Alex. Arch.; 56 54' $\mathrm{N}, 133^{\circ} 49^{\prime} \mathrm{W}$; (map 6).

Local name recorded in 1951 by USGS.

Camp Taylor: locality, on El Capitan Passage, $3.5 \mathrm{mi}$. SE of Devilfish Bay, on NW coast of Prince of Wales I., Alex. Arch.; 56 $02^{\prime} 55^{\prime \prime} \mathrm{N}$, $133^{\circ} 15^{\prime} 30^{\prime \prime} \mathrm{W}$; (map 6). Var. Taylor.

This is the site of an abandoned fishing station. Named by the owners and reported in 1904 by E. F. Dickins, USC\&GS.

Camp Terry Creek: stream, flows NW $1.6 \mathrm{mi}$. to Delta River, crosses Richardson Highway $36 \mathrm{mi}$. NW of Paxson, Alaska Ra.; 63 $51^{\prime} 20^{\prime \prime}$ $\mathrm{N}, 145^{\circ} 51^{\prime} 20^{\prime \prime} \mathrm{W}$; (map 86).

Name published on relatively recent maps. Camp 263 Creek: stream, heads on Mount Weller, in Sadlerochit Mts., flows SE $7.5 \mathrm{mi}$. to Sadlerochit River $2 \mathrm{mi}$. W of junc. with Kekiktuk River, $21 \mathrm{mi}$. NW of Mount Michelson, Brook, Ra.; $69^{\circ} 33^{\prime} \mathrm{N}, 144^{\circ} 40^{\prime} \mathrm{W}$; $B G N 1961$; (map 139).

Leffingwell (1919, p. 113), USGS, does not list this as a geographic name but wrote of it in his text, "at the east end of the outside belt of mountains, at Camp 263 Creek * * *."

Canadian Creek: stream, flows NW $4.6 \mathrm{mi}$. to Innoko River, $11 \mathrm{mi}$. SE of Ophir and $20 \mathrm{mi}$. NW of McGrath, Kilbuck-Kuskokwim Mts.; $63^{\circ} 03^{\prime} 45^{\prime \prime} \mathrm{N}, 156^{\circ} 12^{\prime} 30^{\prime \prime} \mathrm{W}$; BGN 1936; (map 90).

Prospectors' name reported in 1933 by USGS.

Canal, Punta de la: point of land, see Canal Point.
Canal, The: channel, see Lomavik Slough.

Canalaska Mountain: mountain, 2,260 ft., on international boundary, $\mathbf{S}$ of Porcupine River, $52 \mathrm{mi}$. NE of Coleen Mtn., Porcupine Plat.; $67^{\circ} 22^{\prime} \mathrm{N}, 141^{\circ} 00^{\prime} \mathrm{W}$; (map 121). Var. Boundary Mountain, Boundry Mountain.

Composite name from Canada-Alaska given by J. H. Turner, USC\&GS, in 1889-90.

Canal Point: point of land, on NE coast of Baker I., on Port Mayoral, Alex. Arch.; $55^{\circ} 23^{\prime} 55^{\prime \prime} \mathrm{N}, 133^{\circ} 27^{\prime} 25^{\prime \prime} \mathrm{W}$; (map 4). Var. Mys de la Kanal, Punta de la Canal.

Translation of the name "Punta de la Canal," or "point of the canal," given in 1775-79 by Don Juan de la Bodega y Quadra and Francisco Antonio Maurelle.

Canal Point: point of land, at mouth of Big St. Michael Canal, on Norton Sound, $13 \mathrm{mi}$. SW of St. Michael, Yukon-Kuskokwim Delta; $63^{\circ} 24^{\prime} \mathrm{N}, 162^{\circ} 26^{\prime} \mathrm{W}$; (map 92).

Navigators' descriptive name reported in 1898 by USC\&GS; given for "its nearness to the mouth of St. Michael Canal."

Canary Beach: barrier beach, 100 yds. across, backed by lagoon, $0.8 \mathrm{mi} \mathrm{NW}$ of Bukhti Point, on S coast of Kiska I., Aleutian Is.; $51^{\circ} 55^{\prime} 15^{\prime \prime} \mathrm{N}, 177^{\circ} 27^{\prime} 30^{\prime \prime} \mathrm{E}$; (map 14).

One of the "bird names" arbitrarily applied to features on Kiska I. in 1943 by USAAF for tactical purposes during World War II.

Gañas, Punta de : point of land, see Saint Elias, Cape.

Cañas, Ysla de: island, see Canas Island.

Canas Island: island, $0.4 \mathrm{mi}$. long, in Trocadero Bay, on $W$ coast of Prince of Wales I., Alex. Arch.; 55 $22^{\prime} 50^{\prime \prime} \mathrm{N}, 133^{\circ} 02^{\prime} 00^{\prime \prime} \mathrm{W}$; (map 4). Var. Ysla de Cañas.

Spanish name given in $1775-79$ by Don Juan de la Bodega y Quadra and Francisco Antonio Maurelle as "Ysla de Cañas," i.e. "island of canes (plants)."

Can Creek: stream, flows W and NW $32 \mathrm{mi}$. to Stony River, $21 \mathrm{mi}$. N of Whitefish Lake and $75 \mathrm{mi}$. NW of Lake Clark, Lime Hills; $61^{\circ} 16^{\prime}$ $\mathrm{N}, 155^{\circ} 01^{\prime} \mathrm{W}$; (map 71$)$.

Prospectors' name published in 1951 by USGS.

Candle: village, pop. 103, on left bank of Kiwalik River, $54 \mathrm{mi}$. NW of Haycock, Seward Penin. High.; $65^{\circ} 55^{\prime} \mathrm{N}, 161^{\circ} 56^{\prime} \mathrm{W}$; BGN 1944; (map 109).

Mining camp established about 1901-2 and named for Candle Creek; published by USGS (Moffit, 1905, pl. 3). Its population was 204 in 1910; 91 in $1920 ; 85$ in $1930 ; 119$ in 1939; and 105 in 1950 . The Candle post office was established in 1902.

Candle Creek: stream, heads in Candle Hills, flows NE $11 \mathrm{mi}$, to Tatalina River, $2.3 \mathrm{mi}$. W of McGrath, Kilbuck-Kuskokwim Mts.; $62^{\circ}$ $58^{\prime} \mathrm{N}, 155^{\circ} 40^{\prime} \mathrm{W}$; (map 80).

Local name reported in 1910 by C. G. Anderson (in Eakin, 1914, pl. 2), USGS.

Candle Creek: stream, flows NE $16 \mathrm{mi}$. to the Kiwalik River at Candle, $54 \mathrm{mi}$. NW of Haycock, Seward Penin. High.; $65^{\circ} 55^{\prime}$ N, $161^{\circ} 5^{\prime}$ W; (map 109). 
Prospectors' name reported in 1903 by D. C. Witherspoon (in Moffit, 1905, pl. 3), USGS. The name is derived from a bush or shrub that grew along the banks of the stream, which resembles "candlewood" or "greasewood' in that it will light afire easily (Hick, 1954, p. 14).

Candle Creek: stream, flows SE $12 \mathrm{mi}$. to Hadweenzic River, $43 \mathrm{mi}$. NW of Beaver, KokrinesHodzana High.; $66^{\circ} 53^{\prime} \mathrm{N}, 148^{\circ} 12^{\prime} \mathrm{W}$; (map 118).

Local name obtained in 1956 by USGS.

Candle Ditch: ditch, heads at Glacier Greek at $65^{\circ} 35^{\prime} \mathrm{N}, 162^{\circ} 08^{\prime} \mathrm{W}$, flows $\mathrm{NE} 42 \mathrm{mi}$. to Rain Gulch, $43 \mathrm{mi}$. NW of Haycock, Seward Penin. High.; $65^{\circ} 50^{\prime} \mathrm{N}, 162^{\circ} 00^{\prime} \mathrm{W}$; (map 109).

Local name reported in 1949 by U.S. Army Corps of Engineers.

Candle Hills: hills, 1,842 ft., extend $5 \mathrm{mi}$. at SW end of Roundabout Mts., $8 \mathrm{mi}$. SW of McGrath, Kilbuck-Kuskokwim Mts.; $62^{\circ} 51^{\prime}$ $\mathrm{N}, 155^{\circ} 51^{\prime} \mathrm{W}$; (map 80).

Local name taken from that of the stream which heads in Candle Hills; reported in 1940 by USGS.

Candle Island: island, $0.4 \mathrm{mi}$. long, in Behm Canal, S of Winstanley I., Coast Mts., 55 ${ }^{\circ}$ $23^{\prime} 45^{\prime \prime}$ N, $130^{\circ} 53^{\prime} 45^{\prime \prime}$ W; (map 3).

Named in 1879 by W. H. Dall, USC\&GS, for an engineer associated with the history of the Eddystone Lighthouse; published in the 1883 Coast Pilot (p. 72).

Candle Landing: locality, see Sterling Landing.

Candlestick Point: point of land, NW end of Kagamil I., $40 \mathrm{mi}$. W of Umnak I., Aleutian Is.; $53^{\circ} 01^{\prime} 30^{\prime \prime} \mathrm{N}, 169^{\circ} 44^{\prime} 15^{\prime \prime} \mathrm{W}$; (map 22).

Descriptive name published by USC\&GS in the 1944 Aleutian Coast Pilot. (p. 74); so named because the feature consists "of a long, thin wall of rock with a 75 foot arch to form the point proper, and a group of 10 tall pinnacles close by ***."

Cane Creek: stream, flows SE $22 \mathrm{mi}$. to East Fork Chandalar River, $40 \mathrm{mi}$. NE of Arctic Village, Brooks Ra.; $68^{\circ} 38^{\prime} \mathrm{N}, 144^{\circ} 47^{\prime} \mathrm{W}$; (map 136).

Local name reported in 1956 by $R$. C. Foley, USGS.

Cane Mountain: mountain, see Cone Mountain. Cangrejo, Point: point of land, N tip of Suemez I., Alex. Arch.; $55^{\circ} 20^{\prime} 50^{\prime \prime}$ N, $133^{\circ} 21^{\prime} 20^{\prime \prime} \mathrm{W}$; (map 4). Var. Mys Kangrekho, Point Grego, Punta Cangrejos.

Spanish name given in $1775-79$ by Don Juan de la Bodega y Quadra and Francisco Antonio Maurelle as "Punta Cangrejos," meaning "crab point."

Cangrejos, Punta: point of land, see Cangrejo, Point.

Canine Gulch: ravine, trends $\mathrm{S} 1 \mathrm{mi}$. to its junc. with Berkley Canyon at head of Francisco Creek which flows to Stewart River, $20 \mathrm{mi}$. N of Nome, Seward Penin. High.; 64 $44^{\circ} 20^{\prime \prime} \mathrm{N}$, $165^{\circ} 29^{\prime} 30^{\prime \prime} \mathrm{W}$; (map 94).

Prospectors' name shown on the 1904 "Map of Cape Nome Precinct" by Arthur Gibson.

Canirco, Lake: lake, $0.7 \mathrm{mi}$. long, $\mathrm{S}$ of Chichagof
Harbor, on E coast of Attu I., Aleutian Is.; $52^{\circ} 55^{\prime} 10^{\prime \prime} \mathrm{N}, 173^{\circ} 15^{\prime} 05^{\prime} \mathrm{E}$; (map 13 ).

Named by the U.S. Army during its occupation of the island during World War II; name shown on an AMS map published in 1948.

Cañizares, Cabo: point of land, on south side of the Alaska Penin.

Name shown by Don Juan de la Bodega y Quadra on the maps of 1791 and 1792 . See Wagner (1937, p. 438).

Gañizares, Islas de: islands, "probably a part of Afognak Island."

Name appearing on Josef Camacho's map showing the results of the 1779 expedition; named for José de Cañizares, first pilot on the ship La Favorita on that expedition.

Cann Creek: stream, flows ENE $2.5 \mathrm{mi}$. to Lisianski Inlet, $1.5 \mathrm{mi}$. W of Pelican, on Chichagof I., Alex. Arch.; 57 $57^{\prime} 45^{\prime \prime}$ N, 136 $16^{\circ}$ $00^{\prime \prime} \mathrm{W}$; (map 9).

Name reported in 1923 by Buddington (1925, fig. 5), USGS. This stream was named for John $H$. Cann who operated a mine in the area.

Cannery: locality, on Chichagof I., on Tenakee Inlet, $4 \mathrm{mi}$. E of Tenakee Springs, Alex. Arch.; $57^{\circ} 47^{\prime} 05^{\prime \prime} \mathrm{N}, 135^{\circ} 05^{\prime} 40^{\prime \prime} \mathrm{W}$; (map 9). Var. Tenakee.

Named for a cannery located here with a general store and radio station which operated during the season (U.S. Coast and Geodetic Survey, 1943, p. 343).

Cannery Bay: bay, $0.6 \mathrm{mi}$. across, in Makushin Bay, on W coast of Unalaska I., Aleutian Is. ; $53^{\circ} 42^{\prime} 30^{\prime \prime} \mathrm{N}, 166^{\circ} 47^{\prime} 30^{\prime \prime} \mathrm{W}$; (map 23).

Named for a cannery of the Pacific American Fisheries which was listed as inoperative in the 1944 Aleutian Coast Pilot (p. 45).

Cannery Cove: cove, $0.5 \mathrm{mi}$. across, near head of North Arm Moira Sound, on SE coast of Prince of Wales I., Alex. Arch.; 55 $06^{\prime} 50^{\prime \prime}$ N, $132^{\circ} 08^{\prime} 30^{\prime \prime} \mathrm{W}$; (map 4).

Local name reported in 1905 by E. F. Dickins, USC\&GS.

Cannery Cove: cove, $0.7 \mathrm{mi}$. across, at mouth of Akalura Creek, on N shore of Olga Bay, 30 mi. SE of Karluk, Kodiak I.; $57^{\circ} 09^{\prime} 30^{\prime \prime} \mathrm{N}$, $154^{\circ} 13^{\prime} 30^{\prime \prime} \mathrm{W}$; (map 35).

Local name reported in 1900 by Lt. Comdr. J. F. Moser, USN.

Cannery Cove: cove, $0.8 \mathrm{mi}$. across, on $\mathrm{W}$ shore of Pybus Bay, on SE coast of Admiralty I., 22 mi. SE of Angoon, Alex. Arch.; 57 $18^{\prime} 30^{\prime \prime} \mathrm{N}$, $134^{\circ} 09^{\prime} 00^{\prime \prime} \mathrm{W}$; ( $\operatorname{map} 9$ ).

Name published by USC\&GS in 1943 Coast Pilot (p. 284).

Cannery Creek: stream, distributary of Ustay River, flows SE $6 \mathrm{mi}$. to Dry Bay, $0.6 \mathrm{mi}$. SW of mouth of Muddy Creek and $47 \mathrm{mi}$. SE of Yakutat, Malaspina Coastal Plain; 59 $09^{\prime} 30^{\prime \prime}$ N, 138 $38^{\prime} 45^{\prime \prime}$ W; BGN 1962; (map 46). Var. Gines River, Hines River, Stuhinuk Creek.

So called because of a cannery located at its mouth on Dry Bay. Name was published by USGS in 1959. The Indian name "Stuhinuk" was reported by Lt. Comdr. Moser
(1901, pl. 43 and p. 387), USN, but because of 40 years of local usage the name "Cannery Creek" was approved by BGN in 1962. This stream appears to correspond in application with Gines or Hines River of Capt. Tebenkov (1852, map 7), IRN.

Cannery Creek: stream, flows E $13 \mathrm{mi}$. to Rust Slough, $30 \mathrm{mi}$. W of Kenai, Cook Inlet Low.; $60^{\circ} 35^{\prime} \mathrm{N}, 152^{\circ} 10^{\prime} \mathrm{W}$; (map 62).

Local name reported in 1958 by USGS.

Cannery Creek: stream, see Akalura Creek.

Cannery Passage: water passage, $1.3 \mathrm{mi}$. long, in Kukak Bay, on S coast of Alaska Penin., in Katmai National Monument, between Aguligik I. and Kukak, 28 mi. E of Mount Katmai, Aleutian Ra.; 58 $19^{\prime} \mathrm{N}, 154^{\circ} 11^{\prime} \mathrm{W}$; (map 42).

Local name reported in 1955 by USC\&GS. Cannery Point: point of land, between Cannery and Portage Bays, in Makushin Bay, on W coast of Unalaska I., Aleutian Is.; $53^{\circ} 42^{\prime} 55^{\prime \prime}$ N, $166^{\circ} 47^{\prime} 25^{\prime \prime}$ W; BGN 1939; (map 23). Var. Bluff Point.

Named in 1939 by USC\&GS for an abandoned cannery near the point.

Cannery Point: point of land, on SE coast of Prince of Wales I., near head of North Arm Moira Sound, Alex. Arch.; $55^{\circ} 06^{\prime} 45^{\prime \prime} \mathrm{N}, 132^{\circ}$ 08'15" W; (map 4).

Local name reported in 1905 by E. F. Dickins, USC\&GS.

Cannery Point: point of land, $\mathrm{W}$ entrance to Burnett Inlet, on SW coast of Etolin I., Alex. Arch.; 56 $04^{\prime} \mathrm{N}, 132^{\circ} 29^{\prime} \mathrm{W}$; (map 6).

Local name published by USC\&GS in the 1925 Coast Pilot (p. 89)

Cannery Point: point of land, on NE shore of Tenakee Inlet, $5.5 \mathrm{mi}$. E of Tenakee Springs, on $\mathrm{E}$ coast of Chichagof I., Alex. Arch.; $57^{\circ}$. $46^{\prime} 35^{\prime \prime} \mathrm{N}, 135^{\circ} 04^{\prime} 00^{\prime \prime} \mathrm{W}$; (map 9).

Name published by USC\&GS in the 1925 Coast Pilot (p. 274).

Cannery Rock: rock, between Cannery Cove and North Arm Moira Sound, on SE coast of Prince of Wales I., Alex. Arch.; $55^{\circ} 06^{\prime} 50^{\prime \prime}$ N, $132^{\circ} 08^{\prime} 05^{\prime \prime} W$; (map 4).

Local name reported in 1905 by E. F. Dickins, USC\&GS.

Canning, Mount: mountain peak, 6,967 ft. on Alaska-British Columbia boundary, 9 mi. ESE of Snow Top, $26 \mathrm{mi}$. SE of Skagway, Coast Mts.; $59^{\circ} 14^{\prime} 55^{\prime \prime}$ N, $134^{\circ} 42^{\prime} 00^{\prime \prime}$ W ; $B G N$ 1923; (map 44). Var. Boundary Peak 105. Named in 1923 by Lawrence Martin for the Rt. Hon. George Canning, 1770-1827, British Secretary of State for Foreign Affairs in 1822, who conducted the negotiations with Russia concerning the Alaskan boundary. George Canning was born in London and educated at Oxford. He entered Parliament in 1793, and was appointed Undersecretary of the Foreign Office in 1796. He was a commissioner to India, 1799-1801, and Treasurer of the Navy, 1804-06. In 1807, he was appointed Secretary of State for Foreign Affairs. In 1809 , he resigned and held only minor posts until 1822, when he was again made Secretary of State for Foreign Affairs. In 1827 he was 
appointed Prime Minister, a position he held until his death. Between 1822 and 1827, he was a most powerful influence in England and one of the most powerful diplomats in European politics.

Canning River: stream, heads at glacier in Franklin Mts. at $69^{\circ} 04^{\prime} 30^{\prime \prime} \mathrm{N}, 145^{\circ} 06^{\prime} 00^{\prime \prime} \mathrm{W}$; and flows N $125 \mathrm{mi}$. to Camden Bay, Arctic Plain; $70^{\circ} 04^{\prime} \mathrm{N}, 145^{\circ} 30^{\prime} \mathrm{W}$; (map 151). Var. Kogruak River, Koogaro River, Kooguru River, Kugruak River, Kuguru River, Staines River.

On August 5, 1826, Franklin (1828, p. 149) wrote: "we arrived opposite to the large river, which was named in honour of the late $\mathrm{Mr}$. Canning * * *." See Canning, Mount. The Eskimo name "Kogruak" first appears on Surg. John Simpson's native map of 1855, and is reported by Leffingwell $(1919$, p. 94$)$ to mean "old river".

Canning Valley: valley, extends NW $40 \mathrm{mi}$. along Ganning River, $N$ of junc. of Marsh Fork and $30 \mathrm{mi}$. S of Flaxman I., Arctic Slope ; $69^{\circ} 30^{\prime} \mathrm{N}, 146^{\circ} 15^{\prime} \mathrm{W}$; (map 139).

Leffingwell (1919, p. 139) wrote, "The Canning Valley within the Franklin Mountains is floored for the first 6 or 8 miles with gravels, ***."

Cannonball Creek: stream, on Kenai Penin., flows $\mathrm{E} 4 \mathrm{mi}$. to Resurrection Creek, $10 \mathrm{mi}$. SW of Hope, Chugach Mts.; 60 $46^{\prime} 35^{\prime \prime} \mathrm{N}$, $149^{\circ} 41^{\prime} 00^{\prime \prime} \mathrm{W}$; (map 63).

Local prospectors' name; reported in 1904 by Moffit (1906, pl. 2), USGS.

Cannon Island: island, $0.1 \mathrm{mi}$. across, in Jamestown Bay, $1.5 \mathrm{mi}$. SE of Sitka, on W coast of

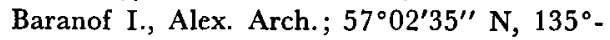
$18^{\prime} 00^{\prime \prime}$ W; (map 9). Var. Ostrov Pushki.

This is an 1882 translation by USC\&GS of the name given in 1809 by the Russian navigator Ivan Vasiliev the first, IRN; reported by Lt. Sarichev (1826, map 19), IRN, as "O[strov] Pushki."

Canoa, Punta de la: point of land, see Canoa Point.

Canoa Point: point of land, on NE shore of Trocadero Bay, $W$ coast of Prince of Wales I., Alex. Arch.; $55^{\circ} 22^{\prime} 55^{\prime \prime} \mathrm{N}, 1^{\circ} 03^{\circ} 25^{\prime \prime} \mathrm{W}$; (map 4). Var. Canoe Point, Mys de la Kanoa, Punta de la Canoa.

Spanish name given in 1775-79 by Don Juan de la Bodega y Quadra and Francisco Antonio Maurelle as "Punta de la Canoa," meaning "point of the canoe." See Canoe Point.

Canoe Bay: bay, extends E $10 \mathrm{mi}$. from head of Pavlof Bay, Alaskan Penin., Aleutian Ra.; $55^{\circ} 34^{\prime} \mathrm{N}, 161^{\circ} 18^{\prime} \mathrm{W}$; (map 28 ).

Named by W. H. Dall, USC\&GS, in 1880 .

Canoe Bay River: stream, flows SW $10 \mathrm{mi}$. to Canoe Bay, 11 mi. E of Pavlof Bay, Alaska Penin., Aleutian Ra.; $55^{\circ} 31^{\prime} 50^{\prime \prime} \mathrm{N}, 161^{\circ} 08^{\prime}$ $40^{\prime \prime} \mathrm{W}$; (map 28).

Named for Canoe Bay; published on 1929 USGS map.

Canoe Cove: cove, $1 \mathrm{mi}$. across, on $\mathrm{SW}$ coast of Annette I., Alex. Arch.; 55 02'45" N, $131^{\circ}$ $38^{\prime} 00^{\prime \prime} \mathrm{W}$; (map 3).
Named in 1883 by Lt. Comdr. H. E. Nichols, USN; so called "because it is a stopping place for the natives when waiting for good weather and provides good shelter for their canoes."

Canoe Cove: cove, $0.1 \mathrm{mi}$. across, between $\mathrm{W}$ end of Canoe Pass and S end of Lisianski Strait, $17 \mathrm{mi}$. NW of Chichagof, on $W$ coast of Chichagof I., Alex. Arch.; $57^{\circ} 50^{\prime} 30^{\prime \prime} \mathrm{N}$, $136^{\circ} 25^{\prime} 15^{\prime \prime} \mathrm{W}$; (map 9).

Name published by USC\&GS in the 1925 Coast Pilot (p. 325).

Canoe Creek: stream, on Hawkins I., flows NE $2 \mathrm{mi}$. to Canoe Passage, $13 \mathrm{mi}$. SW of Cordova, Chugach Mts.; $60^{\circ} 31^{\prime} \mathrm{N}, 146^{\circ} 07^{\prime} \mathrm{W}$; (map 64).

Name published in 1950 by USGS.

Canoe Creek: stream, flows SE, then NE $9.9 \mathrm{mi}$. to Kiwalik River, $31 \mathrm{mi}$. NW of Haycock, Seward Penin. High.; $65^{\circ} 34^{\prime}$ N, $161^{\circ} 49^{\prime}$ W; (map 109).

Local name reported in 1908 by USGS (Brooks and others, 1909, fig. 21).

Canoe Creek: stream, flows NE 7.5 mi. from May Lake to Ayiyak River at Hatbox Mesa, 50 mi. NW of Anaktuvuk Pass, Arctic Slope; $68^{\circ} 43^{\prime} \mathrm{N}, 152^{\circ} 53^{\prime} \mathrm{W}$; (map 134).

Named about 1950 by W. W. Patton, USGS, for the canoe-shaped hills in the vicinity.

Canoe Hills: hills, $6 \mathrm{mi}$. long, between Canoe Creek and Ayiyak River, $46 \mathrm{mi}$. NW of Anaktuvuk Pass, Arctic Slope; $68^{\circ} 38^{\prime} 20^{\prime \prime} \mathrm{N}$, $152^{\circ} 56^{\prime} 30^{\prime \prime} \mathrm{W}$; (map 134)

Named in 1949 by W. W. Patton, USGS, "for the canoe-shape of the anticline."

Canoe Island: island, $0.1 \mathrm{mi}$. long, in Yakutat Roads, 1 mi. NW of Yakutat, Malaspina Coastal Plain; $59^{\circ} 33^{\prime} 45^{\prime \prime} \mathrm{N}, 139^{\circ} 44^{\prime} 55^{\prime \prime} \mathrm{W}$; (map 46).

Local name published in 1964 (de Laguna and others, map 4).

Canoe Island: island, see Povorotni island.

Canoe Lake: lake, $1.2 \mathrm{mi}$. long, on Kenai Penin., northwestern terminus of Canoe Lake Chain, $5.5 \mathrm{mi}$. NW of Swan Lake and $23 \mathrm{mi}$. NE of Kenai, Cook Inlet Low.; $60^{\circ} 43^{\prime} 00^{\prime \prime} \mathrm{N}, 150^{\circ}$. $41^{\prime} 30^{\prime \prime} \mathrm{W}$; (map 62).

Named about 1963 by officials of Kenai National Moose Range, for administrative purposes.

Canoe Lake Chain: lakes, chain of seven, extends $4 \mathrm{mi}$. on Kenai Penin., $3.8 \mathrm{mi}$. NW of Swan Lake and $24 \mathrm{mi}$. NE of Kenai, Cook Inlet Low.; $60^{\circ} 42^{\prime} \mathrm{N}, 150^{\circ} 40^{\prime} \mathrm{W}$; (map 62).

Named about 1963 by officials of Kenai National Moose Range, for administrative purposes.

Canoe Mountain: mountain, 2,047 ft., in Kuskokwim Mts., between Kuskokwim and Oskawalik Rivers, $30 \mathrm{mi}$. W of Sleetmute, Kilbuck-Kuskokwim Mts.; 61 $41^{\circ} 45^{\prime \prime} \quad$ N, $158^{\circ} 05^{\prime} 45^{\prime \prime} \mathrm{W}$; (map 72 ).

Local name published by USGS (Cady and others, 1955, pl. 1).

Canoe Pass: water passage, between Klawak and Prince of Wales Is., $0.5 \mathrm{mi}$. $\mathrm{S}$ of Klawock,
Alex. Arch.; $55^{\circ} 32^{\prime} 35^{\prime \prime} \mathrm{N}, 1^{\circ} 33^{\circ} 06^{\prime} 00^{\prime \prime} \mathrm{W}$; (map 4).

Local name published in 1932 by USC\&GS. Canoe Pass: water passage, in Peril Strait, $1 \mathrm{mi}$. $\mathrm{N}$ of Fish Bay, $27 \mathrm{mi}$. NW of Sitka, Alex. Arch.; 57 $24^{\prime} \mathrm{N}, 135^{\circ} 38^{\prime} \mathrm{W}$; (map 9).

Local name reported in 1917 and published in 1919 by USGS.

Canoe Pass: water passage, between Lumber Cove and $\mathrm{S}$ end of Lisianski Strait, $17 \mathrm{mi}$. NW of Chichagof, on W coast of Chichagof I., Alex. Arch.; $57^{\circ} 50^{\prime} 20^{\prime \prime} \mathrm{N}, 136^{\circ} 25^{\prime} 00^{\prime \prime} \mathrm{W}$; (map 9).

Name published by USC\&GS in 1943 Coast Pilot (p. 394).

Canoe Pass: water passage, $0.2 \mathrm{mi}$. long, between Gonakadetseat Bay and Johnstone Passage, 3 mi. N of Yakutat, Malaspina Coastal Plain; $59^{\circ} 35^{\prime} 20^{\prime \prime} \mathrm{N}, 139^{\circ} 43^{\prime} 55^{\prime \prime} \mathrm{W}$; (map 46).

Local name published by the USGS in 1959.

Canoe Pass: water passage, see Hatchet Pass.

Canoe Passage: bay, $1.2 \mathrm{mi}$. wide, on NW coast of Hawkins I., $14 \mathrm{mi}$. W of Cordova, Chugach Mts.; $60^{\circ} 32^{\prime} \mathrm{N}, 146^{\circ} 08^{\prime} \mathrm{W}$; (map 64).

Named by H. P. Ritter, USC\&GS, while doing survey work in the Prince William Sound area aboard the steamer Taku in 1899.

Canoe Passage: water passage, $9.5 \mathrm{mi}$. long, between Brownson and Etolin Is., Alex. Arch.; $55^{\circ} 59^{\prime} \mathrm{N}, 132^{\circ} 12^{\prime} \mathrm{W}$; (map 4).

Descriptive name given in 1886 by Lt. Comdr. A. S. Snow, USN.

Canoe Point: point of land, on W coast of Prince of Wales I., on $\mathbf{E}$ shore of Trocadero Bay, $8 \mathrm{mi}$. SE of Craig, Alex. Arch.; 55 $22^{\prime} 50^{\prime \prime}$ N, $133^{\circ} 01^{\prime} 15^{\prime \prime} \mathrm{W}$; BGN 1966; (map 4). Var. Punta de la Canoa.

This point of land and Canoa Point received their names from the Spanish name "Punta de la Canoa," or "point of the canoe," given by Don Juan de la Bodega y Quadra and Francisco Antonio Maurelle in 1775-79. Canoe Point: point of land, on $\mathrm{W}$ end of Cape Fanshaw, $3 \mathrm{mi}$. SW of village of Cape Fanshaw and $68 \mathrm{mi}$. E of Sitka, Coast Mts.; $57^{\circ} 11^{\prime} 30^{\prime \prime} \mathrm{N}, 133^{\circ} 34^{\prime} 00^{\prime \prime} \mathrm{W}$; (map 8).

Named in 1889 by Lt. Comdr. H. B. Mansfield, USN; published in 1892 by USC\&GS. Canoe Point: point of land, see Canoa Point.

Canoe Portage Creek: stream, flows NW $20 \mathrm{mi}$. to Kaiyuh Slough, $21 \mathrm{mi}$. SE of Nulato, Koyukuk Low.; $64^{\circ} 25^{\prime} \mathrm{N}, 157^{\circ} 57^{\prime} \mathrm{W}$; (map 97). Var. Midsitena.

Appears to be a translation of an Indian name; reported in 1935 by Frederica de Laguna, BAE.

Canoe Portage Creek: stream, see Camp Creek.

Canoe Slough: water passage, $0.1 \mathrm{mi}$. long, between Canoe Pass and Lumber Cove, $17 \mathrm{mi}$. NW of Chichagof, on $\mathrm{W}$ coast of Chichagof I., Alex. Arch.; $57^{\circ} 50^{\prime} 15^{\prime \prime}$ N, $136^{\circ} 24^{\prime} 50^{\prime \prime} \mathrm{W}$; $(\operatorname{map} 9)$

Name published in 1943 by USC\&GS 
Canoe Village: locality, on $\mathrm{W}$ bank of Kuskokwim River, $5.5 \mathrm{mi}$. S of village of Crooked Creek and $33 \mathrm{mi}$. W of Sleetmute, KilbuckKuskokwim Mts.; 61 ${ }^{\circ} 47^{\prime} 35^{\prime \prime} \mathrm{N}, 158^{\circ} 09^{\prime} 00^{\prime \prime}$ W; (map 72).

Local name taken from mountain on opposite bank of Kuskokwim River; reported in 1921 by USGS.

Ganon Creek: stream, see Canyon Creek.

Canooskie Island: island, see Koniuji Island.

Cantishna River: stream, see Kantishna River.

Cantu Mountain: mountain, 3,008 ft., $0.3 \mathrm{mi}$. $\mathrm{W}$ of Alaska-Canada boundary and $11 \mathrm{mi}$. N of Hyder, Coast Mts. ; 56 $04^{\prime} 45^{\prime \prime}$ N, $130^{\circ} 04^{\prime}$ $30^{\prime \prime} \mathrm{W}$; (map 7).

Local name reported in 1928 by USGS.

Cantwell: village, pop. 85 , mile 319.5 on the Alaska RR., $8 \mathrm{mi}$. SW of Panorama Mtn. and $33 \mathrm{mi}$. S of Healy, Alaska Ra.; $63^{\circ} 23^{\prime} 30^{\prime \prime} \mathrm{N}$, $148^{\circ} 56^{\prime} 30^{\prime \prime} \mathrm{W}$; (map 87). Var. Cantwell River Station.

Cantwell began as a flag stop on The Alaska $R R$. as reported on its 1922 timetable. It was named for the "Cantwell River," the former name of the Nenana River.

Cantwell Greek: stream, heads at Cantwell Glacier, flows E $21 \mathrm{mi}$. to Jack River, $34 \mathrm{mi}$. $\mathrm{S}$ of Healy, Alaska Ra.; $63^{\circ} 23^{\prime} 30^{\prime \prime} \mathrm{N}, 148^{\circ}$ 55'45" W; (map 87). Var. Cantwell River, Halfmoon Creek.

This headwater stream of the Nenana River carries the residual name of that river ("Cantwell River"). The name "Cantwell River" as a separate entity was shown on a 1914 railroad survey map, although a year later USGS gave local usage as "Half Moon Creek." In 1923 S. R. Capps, USGS, cited local usage as "Cantwell Creek."

Cantwell Glacier: glacier, trends SE $3 \mathrm{mi}$. to terminate at head of Cantwell Creek, $32 \mathrm{mi}$. SW of Healy, Alaska Ra ; $63^{\circ} 25^{\prime} 48^{\prime \prime} \mathrm{N}, 149^{\circ}$ $22^{\prime} 00^{\prime \prime} \mathrm{W}$; (map 87).

Name reported on a 1923 manuscript map of The Alaska RR.

Gantwell River: stream, see Cantwell Creek.

Cantwell River: stream, see Nenana River.

Cantwell River Station: village, see Cantwell.

Canvasback Lake: lake, $2 \mathrm{mi}$. long, $0.5 \mathrm{mi}$. NE of Lower Mouth Birch Creek and $33 \mathrm{mi}$. SW of Fort Yukon, Yukon Flats; $66^{\circ} 23^{\prime} 20^{\prime \prime}$ N, $146^{\circ} 22^{\prime} 00^{\prime \prime} \mathrm{W}$; (map 119).

Local name obtained in 1956 by USGS.

Canwell Glacier: glacier, heads near Icefall Peak, trends NE $13 \mathrm{mi}$. to its 1934 terminus at head of Miller Creek, $24 \mathrm{mi}$. NW of Paxson, Alaska Ra.; $63^{\circ} 22^{\prime} 25^{\prime \prime} \mathrm{N}, 145^{\circ} 40^{\prime} 30^{\prime \prime} \mathrm{W}$; (map 86).

Named in 1898 by Gapt. E. F. Glenn, USA, for a member of his party, "Private Canwell of the hospital corps."

Canyon: $R R$. station, mile 268.4 on The Alaska RR. $38 \mathrm{mi}$. NE of Talkeetna, Talkeetna Mts.; $62^{\circ} 49^{\prime} 18^{\prime \prime} \mathrm{N}, 149^{\circ} 38^{\prime} 40^{\prime \prime} \mathrm{W}$; (map 82).

Descriptive name given about 1916. The station has been in use since the opening of the line.

Canyon Cove: cove, $0.4 \mathrm{mi}$. across, in Kuliliak Bay, on S coast of Unalaska I., Aleutian Is.; $53^{\circ} 26^{\prime} 30^{\prime \prime} \mathrm{N}, 167^{\circ} 01^{\prime} 04^{\prime \prime} \mathrm{W} ; B G N$ 1939; (map 23).

Descriptive name given by USC\&GS in 1937 because the cove is deep, narrow, and has steep sides.

Canyon Creek: stream, flows NW and SW $6 \mathrm{mi}$. to O'Malley River, at Karluk Lake, on Kodiak I. ; $57^{\circ} 16^{\prime} 40^{\prime \prime} \mathrm{N}, 153^{\circ} 59^{\prime} 40^{\prime \prime} \mathrm{W}$; (map 34).

Local name reported in 1954 by USGS.

Canyon Creek: stream, flows NW $3 \mathrm{mi}$. to join Lemon Creek, $4 \mathrm{mi}$. NE of Gastineau Channel and $6 \mathrm{mi}$. N of Juneau, Coast Mts. ; $58^{\circ} 28^{\prime}$ $25^{\prime \prime} \mathrm{N}, 134^{\circ} 25^{\prime} 50^{\prime \prime} \mathrm{W}$; (map 11).

Local name published in 1962 by USGS. Canyon Creek: stream, flows NW $3 \mathrm{mi}$. to Cowee Creek, $4.4 \mathrm{mi}$. E of Bridget Cove and $27 \mathrm{mi}$. $\mathrm{NW}$ of Juneau, Coast Mts.; $58^{\circ} 38^{\prime} \mathrm{N}, 134^{\circ}$ $49^{\prime} 30^{\prime \prime} \mathrm{W}$; (map 11).

Name published in 1912 by USGS (Knopf, 1912a, pl. 1).

Canyon Creek: stream, flows SE $14 \mathrm{mi}$. to Goodnews River, $26 \mathrm{mi}$. NE of Goodnews, KilbuckKuskokwim Mts.; $59^{\circ} 20^{\prime} \mathrm{N}, 161^{\circ} 00^{\prime} \mathrm{W}$; (map 53).

Local descriptive name reported in 1920 by G. L. Harrington (in Brooks and others, 1921, pl. 7), USGS.

Canyon Creek: stream, flows NE $8 \mathrm{mi}$. to Faro Creek, $30 \mathrm{mi}$. $\mathbf{N}$ of Goodnews, KilbuckKuskokwim Mts. ; 59॰32' N, $161^{\circ} 30^{\prime}$ W ; (map 53).

Descriptive name reported in 1920 by G. L. Harrington (in Brooks and others, 1921, pl. 7), USGS.

Canyon Creek: stream, flows SW $16 \mathrm{mi}$. to Fox and Knutson Bays, in Iliamna Lake, Aleutian $\mathrm{Ra}$; $59^{\circ} 47^{\prime} 30^{\prime \prime} \mathrm{N}, 154^{\circ} 22^{\prime} 00^{\prime \prime} \mathrm{W}$; (map 51).

Descriptive name published by Martin and Katz (1912, pl. 1), USGS.

Canyon Creek: stream, $2.5 \mathrm{mi}$. lang, flows NW to Furk Creek, $29 \mathrm{mi}$. W of Chikuminuk Lake and $74 \mathrm{mi}$. SE of Bethel, Kilbuck-Kuskokwim Mts. ; $60^{\circ} 11^{\prime} \mathrm{N}, 160^{\circ} 00^{\prime} \mathrm{W}$; BGN 1959; (map 59).

Named by prospectors, "probably 'Jens Kramme' who mined gold on Canyon Creek since 1911." Descriptive name given because it flows in a deep narrow valley; reported in 1956 by USGS.

Canyon Creek: stream, heads at 1950 terminus of Martin River Glacier, flows S $6 \mathrm{mi}$. to Bering River, $3.5 \mathrm{mi}$. SW of Berg Lake and $62 \mathrm{mi}$. SE of Cordova, Chugach Mts.; $60^{\circ} 23^{\prime} 00^{\prime \prime} \mathrm{N}, 143^{\circ} 57^{\prime} 30^{\prime \prime} \mathrm{W}$; (map 65).

Prospectors' name reported in 1903 by G. C. Martin, USGS.

Canyon Creek: stream, flows NW $0.3 \mathrm{mi}$. to Canoe Passage, on Hawkins I., $12 \mathrm{mi}$. SW of Cordova, Chugach Mts.; $60^{\circ} 30^{\prime} 30^{\prime \prime} \mathrm{N}, 146^{\circ}$ $05^{\prime} 00^{\prime \prime} \mathrm{W}$; (map 64).

Local descriptive name published in 1950 by USGS.

Canyon Creek: stream, on Kenai Penin., flows N 17 mi. to junc. with East Fork Sixmile Creek to form Sixmile Creek, $7 \mathrm{mi}$. S of Sunrise, Chugach Mts. ; $60^{\circ} 47^{\prime} 00^{\prime \prime} \mathrm{N}, 149^{\circ} 25^{\prime} 20^{\prime \prime} \mathrm{W}$; (map 63).
Local descriptive name reported about 1914 by B. L. Johnson (in Martin and others, 1915, pl. 2), USGS.

Canyon Creek: stream, flows S $21 \mathrm{mi}$. from glacier to Chitina River $7 \mathrm{mi}$. NE of Bear I., $35 \mathrm{mi}$. SE of McCarthy, St. Elias Mts. ; $61^{\circ} 08^{\prime}$ N, $142^{\circ} 13^{\prime} \mathrm{W}$; (map 67).

Local name reported by USGS (Brooks and others, pl. 5, 1916).

Canyon Creek: stream, heads at glacier, flows NW $15 \mathrm{mi}$. to Copper River at Wood Canyon, $62 \mathrm{mi}$. ENE of Valdez, Chugach Mts. ; $61^{\circ} 24^{\prime}$ $35^{\prime \prime} \mathrm{N}, 144^{\circ} 28^{\prime} 20^{\prime \prime} \mathrm{W}$; (map 68).

Local name published in the 1950 's by USGS.

Canyon Creek: stream, flows SW $6.5 \mathrm{mi}$. to Peters Creek, $23 \mathrm{mi}$. NW of Palmer, Talkeetna Mts. ; $61^{\circ} 48^{\prime} 45^{\prime \prime} \mathrm{N}, 149^{\circ} 39^{\prime} 55^{\prime \prime} \mathrm{W}$; (map 69).

Local name published on the 1961 Alaska General Highway map.

Canyon Creek: stream, flows NE $18 \mathrm{mi}$. to Skwentna River, $57 \mathrm{mi}$. NW of Tyonek, Alaska Ra.; 61 ${ }^{\circ} 53^{\prime} \mathrm{N}, 151^{\circ} 32^{\prime} \mathrm{W}$; (map 70).

Local name reported in 1902 by A. H. Brooks, USGS.

Canyon Creek: stream, heads in a lake, flows SE $13 \mathrm{mi}$. to Happy River, $6.3 \mathrm{mi}$. SE of Rainy Pass Lodge and $82 \mathrm{mi}$. SW of Talkeetna, Alaska Ra.; $62^{\circ} 02^{\prime} \mathrm{N}, 152^{\circ} 35^{\prime} \mathrm{W}$; (map 81).

Local name reported in 1945 by USGS.

Canyon Creek: stream, heads on Gold Hill, in Nutzotin Mts., flows SE $1.4 \mathrm{mi}$. to Bonanza Creek, $3.5 \mathrm{mi}$. N of Beaver Lake, Alaska Ra.; $62^{\circ} 05^{\prime} 30^{\prime \prime} \mathrm{N}, 141^{\circ} 51^{\prime} \mathrm{W}$; (map 84).

Local name reported in 1914 by S. R. Capps (in Brooks and others, 1915, p. 209), USGS. Canyon Creek: stream, flows SE $6 \mathrm{mi}$. to Jacksina Greek $6 \mathrm{mi}$. W of its junc. with Nabesna River, Wrangell Mts.; $62^{\circ} 20^{\prime} \mathrm{N}, 143^{\circ} 03^{\prime} \mathrm{W}$; $B G N 1939$; (map 84).

Local name reported by P. S. Smith, USGS, in 1939.

Canyon Creek: stream, heads in Dutch Hills, flows SE $2 \mathrm{mi}$, joins Divide Creek to form Long Greek, $27 \mathrm{mi}$. NW of Talkeetna, Alaska Ra.; $62^{\circ} 35^{\prime} 25^{\prime \prime} \mathrm{N}, 150^{\circ} 44^{\prime} 45^{\prime \prime} \mathrm{W}$; (map 81 ).

Local descriptive name reported in 1958 by USGS.

Canyon Creek: stream, flows NW $6.5 \mathrm{mi}$. to Boulder Creek, $17 \mathrm{mi}$. NW of Mount Russell, Alaska Ra.; 62 $57^{\prime} 15^{\prime \prime}$ N, $152^{\circ} 18^{\prime} 40^{\prime \prime} \mathrm{W}$; (map 81).

Local descriptive name reported in 1958 by USGS.

Canyon Greek: stream, flows SE $7.3 \mathrm{mi}$. to Mankomen Lake, 29 mi. E of Paxson, Alaska Ra.; $63^{\circ} 01^{\prime} \mathrm{N}, 144^{\circ} 34^{\prime} \mathrm{W}$; (map 86).

Name published on relatively recent maps.

Canyon Creek: stream, flows SW $1.5 \mathrm{mi}$. to Ohio Creek, $58 \mathrm{mi}$. SW of Healy, Alaska Ra.; $63^{\circ}$ $08^{\prime} 40^{\prime \prime} \mathrm{N}, 149^{\circ} 52^{\prime} 10^{\prime \prime} \mathrm{W}$; (map 87).

Local descriptive name obtained in 1951 by USGS.

Canyon Creek: stream, flows W $15 \mathrm{mi}$. to Anvik River, $43 \mathrm{mi}$. S of Unalakleet, Nulato Hills; $63^{\circ} 14^{\prime} 45^{\prime \prime} \mathrm{N}, 160^{\circ} 41^{\prime} 20^{\prime \prime} \mathrm{W}$; (map 91).

Local name reported in 1949 by USC\&GS. 
Canyon Creek: stream, heads $\mathbf{N}$ of Butte Lake, flows NE $6 \mathrm{mi}$. to Monahan Creek, $54 \mathrm{mi}$. SE of Healy, Talkeetna Mts. ; $63^{\circ} 17^{\prime} \mathrm{N}, 147^{\circ} 45$, W; (map 87).

Local name reported in 1951 by USGS.

Canyon Creek: stream, heads on $\mathrm{E}$ slope of Cripple Greek Mts., flows W $20 \mathrm{mi}$., joins South Fork Folger Creek to form Folger Creek, $23 \mathrm{mi}$. NE of Ophir and $36 \mathrm{mi}$. NW of McGrath, Kilbuck-Kuskokwim Mts.; 63 $26^{\prime} 30^{\prime \prime}$ N, 156 $09^{\prime} 30^{\prime \prime} \mathrm{W}$; (map 90).

Prospectors' name reported in 1933 by USGS.

Canyon Creek: stream, flows NW $3.7 \mathrm{mi}$. to Whirlwind Creek, $26 \mathrm{mi}$. NE of Medfra, Kilbuck-Kuskokwim Mts.; $63^{\circ} 27^{\prime} \mathrm{N}, 154^{\circ} 23^{\prime} \mathrm{W}$; (map 89).

Prospectors' name published in 1926 by USGS.

Canyon Creek: stream, in Kantishna Hills, flows W $2.5 \mathrm{mi}$. to Moose Creek, $6.8 \mathrm{mi}$. NW of Wonder Lake, Alaska Ra. ; $63^{\circ} 34^{\prime} 08^{\prime \prime} \mathrm{N}, 151^{\circ}$ $02^{\prime} 00^{\prime \prime} \mathrm{W}$; BGN 1932; (map 88).

Local name obtained in 1931 by F. G. Wells and S. C. Kain, USGS.

Canyon Creek: stream, in Kantishna Hills, flows NE $8.5 \mathrm{mi}$. to Clearwater Fork, $8 \mathrm{mi}$. S of that stream's junc. with Toklat River, Alaska Ra.; $63^{\circ} 41^{\prime} 45^{\prime \prime} \mathrm{N}, 150^{\circ} 22^{\prime} 20^{\prime \prime} \mathrm{W}$; (map 88).

Local name shown on a 1916 fieldsheet by C. E. Giffin, USGS.

Canyon Creek: stream, flows NW $11 \mathrm{mi}$. to Meadow Creek, $40 \mathrm{mi}$. N of Medfra, KilbuckKuskokwim Mts. ; $63^{\circ} 42^{\prime} \mathrm{N}, 154^{\circ} 43^{\prime} \mathrm{W}$; (map 89).

Local name reported in 1953 by USGS

Canyon Creek: stream, flows NE $5 \mathrm{mi}$. to Wood River, 34 mi. E of Healy, Alaska Ra.; 63 $53^{\prime}$ $\mathrm{N}, 147^{\circ} 51^{\prime} \mathrm{W}$; (map 87).

Local name reported in 1951 by USGS

Canyon Creek: stream, flows N $9 \mathrm{mi}$. to Fortymile River, $38 \mathrm{mi}$. S of Eagle, Yukon-Tanana High.; $64^{\circ} 15^{\prime} \mathrm{N}, 141^{\circ} 09^{\prime} \mathrm{W}$; (map 102). Var. Canon Creek.

Local descriptive name; reported in 1896 by Spurr (1898, pl. 46), USGS.

Canyon Creek: stream, flows SE $4 \mathrm{mi}$. to Tanana River, 22 mi. NW of Big Delta, Yukon-Tanana High.; 64 $17^{\prime} 30^{\prime \prime} \mathrm{N}, 146^{\circ} 28^{\prime} 30^{\prime \prime} \mathrm{W}$; (map 101).

Named by prospectors; reported in 1910 by C. E. Ellsworth and G. L. Parker (in Brooks and others, 1911, p. 193), USGS.

Canyon Creek: stream, flows SE $0.6 \mathrm{mi}$. to Slate Creek $0.6 \mathrm{mi}$. $\mathrm{N}$ of its junc. with Banner Greek, $11 \mathrm{mi}$. N of Nome, Seward Penin. High.; $64^{\circ} 39^{\prime} 20^{\prime \prime} \mathrm{N}, 165^{\circ} 20^{\prime} 15^{\prime \prime} \mathrm{W}$; (map 94). Var. Canon Creek.

Prospectors' name reported in 1904 by $T$. G. Gerdine, USGS.

Canyon Creek: stream, flows E $6 \mathrm{mi}$. to Casadepaga River, $21 \mathrm{mi}$. NE of Solomon, Seward Penin. High.; 64. $51^{\prime} \mathrm{N}, 164^{\circ} 19^{\prime} \mathrm{W}$; (map 95).

Prospectors' name reported in 1900 by $\mathrm{E}$. C. Barnard (in Brooks, 1901, pl. 17), USGS.

Canyon Creek: stream, flows NE $7.5 \mathrm{mi}$., joins Dome Creek to form Iron Creek, $24 \mathrm{mi}$. NW of Solomon, Seward Penin. High.; 64 $54^{\prime}$ N, $164^{\circ} 43^{\prime} \mathrm{W}$; (map 95).

Prospectors' name reported in 1900 by $\mathbf{E}$. C. Barnard (in Brooks, 1901, pl. 17), USGS.

Canyon Creek: stream, flows NE $1 \mathrm{mi}$. to Seventymile River, $20 \mathrm{mi}$. NW of Eagle, YukonTanana High.; $64^{\circ} 55^{\prime} 40^{\prime \prime}$ N, $141^{\circ} 50^{\prime} 00^{\prime \prime} \mathrm{W}$; (map 102).

Local name published in 1956 by USGS.

Canyon Creek: stream, flows NE $25 \mathrm{mi}$. to Imuruk Basin, 17 mi. SE of Teller, Seward Penin. High.; $65^{\circ} 07^{\prime} \mathrm{N}, 165^{\circ} 53^{\prime} \mathrm{W}$; (map 111).

Local name reported in 1900 by E. C. Barnard (in Brooks, 1901, pl. 17), USGS.

Canyon Creek: stream, flows S $3 \mathrm{mi}$. to Yukon River, $7 \mathrm{mi}$. NNE of junc. of Charley River, Porcupine Plat.; $65^{\circ} 24^{\prime} \mathrm{N}, 142^{\circ} 38^{\prime} \mathrm{W}$; (map 103).

Descriptive name published by Archdeacon Stuck $(1917$, p. 83$)$.

Canyon Creek: stream, in Rampart Mts., flows NE and SE $17 \mathrm{mi}$. to Yukon River, $2.5 \mathrm{mi}$. W of Garnet I., and $42 \mathrm{mi}$. NE of Tanana, Kokrines-Hodzana High.; $65^{\circ} 26^{\prime} \mathrm{N}, 150^{\circ} 48^{\prime} \mathrm{W}$; (map 106).

Local descriptive name reported by Orth in 1956.

Canyon Creek: stream, flows NW 3 mi. to Budd Creek which flows to American River, $6 \mathrm{mi}$. $\mathrm{SW}$ of Kougarok Mtn. and $38 \mathrm{mi}$. NE of Teller, Seward Penin. High.; $65^{\circ} 39^{\prime}$ N, $165^{\circ}$ 24' W; (map 111).

Prospectors' name reported on a map of Cape Nome goldfields by David Fox, Jr., dated 1901.

Canyon Creek: stream, flows SW 6 mi. to Buckland River, $49 \mathrm{mi}$. NE of Haycock, Nulato Hills ; $65^{\circ} 55^{\prime} \mathrm{N}, 161^{\circ} 01^{\prime} \mathrm{W}$; (map 109).

Local name published on maps after 1950 .

Canyon Creek: stream, flows N $3 \mathrm{mi}$. to Kogoluktuk River, $16 \mathrm{mi}$. NE of Shungnak, Brooks Ra.; $67^{\circ} 02^{\prime} \mathrm{N}, 156^{\circ} 40^{\prime} \mathrm{W}$; (map 126).

Local name given by prospectors and reported by USGS in 1956 .

Canyon Creek: stream, flows NW $13 \mathrm{mi}$. to Squirrel River, $7.5 \mathrm{mi}$. NNW of Kiana, Brooks Ra.; $67^{\circ} 04^{\prime} \mathrm{N}, 160^{\circ} 30^{\prime} \mathrm{W}$; (map 127).

Name used by prospectors; reported in 1910 by P. S. Smith (in Brooks and others, 1911, pl. 13), USGS.

Canyon Creek: stream, flows SE $4.5 \mathrm{mi}$. to Hammond River, $3 \mathrm{mi}$. E of Vermont Dome and $8.5 \mathrm{mi}$. N of Wiseman, Brooks Ra.; 67. $31^{\prime} 50^{\prime \prime}$ $\mathrm{N}, 150^{\circ} 06^{\prime} 00^{\prime \prime} \mathrm{W} ; B G N$ 1932; (map 124)

Local name reported in 1931 by Marshall (1956, p. 165)

Canyon Creek, stream, tributary to Canning River, Arctic Slope; $69^{\circ} 00^{\prime} \mathrm{N}, 145^{\circ} 30^{\prime} \mathrm{W}$; (map 139).

Named in 1903 by S. J. Marsh, a prospector. Canyon Creek Camp: locality, highway-maintenance camp, on $\mathrm{N}$ bank of Tanana River at mouth of Canyon Creek, $22 \mathrm{mi}$. NW of Big Delta, Yukon-Tanana High.; $64^{\circ} 17^{\prime} 30^{\prime \prime} \mathrm{N}$, $146^{\circ} 28^{\prime} 30^{\prime \prime} \mathrm{W}$; (map 101). Var. Sixty-six Mile Camp.

Name published in 1949 by ARC as "Sixtysix Mile Camp," probably because the site is
66 miles SE of Fairbanks; present name published in 1955 by USGS.

Canyon Creek Glacier: glacier, see Shoup Glacier.

Canyon Glacier: glacier, on W slope of Brabazon Ra., trending $3 \mathrm{mi}$. W and $S$ to its 1961 terminus, at head of Split Creek, $3 \mathrm{mi}$. E of Tanis Lake and $49 \mathrm{mi}$. SE of Yakutat, St. Elias Mts.; $59^{\circ} 15^{\prime} 50^{\prime \prime} \mathrm{N}, 138^{\circ} 27^{\prime} 00^{\prime \prime} \mathrm{W}$; (map 46). Var. Steep Glacier.

Name reported by Blackwelder (1907, p. 428), USGS, "It derives its name from the fact that it is sunk deep in a canyon."

Canyon Island: island, $0.8 \mathrm{mi}$. across, in Taku River, $2.5 \mathrm{mi}$. NE of mouth of Wright River, $32 \mathrm{mi}$. NE of Juneau, Coast Mts.; $58^{\circ} 43^{\prime} 00^{\prime \prime}$ $\mathrm{N}, 133^{\circ} 40^{\prime} 30^{\prime \prime} \mathrm{W}$; (map 12).

Local name reported in 1960 by USGS.

Canyon Lake: lake, $2 \mathrm{mi}$. long, at head of Canyon Creek, $28 \mathrm{mi}$. NE of Goodnews, KilbuckKuskokwim Mts. ; $59^{\circ} 26^{\prime} \mathrm{N}, 161^{\circ} 09^{\prime} \mathrm{W}$; (map 53). Var. Kliqtluaq.

Local name derived from Canyon Creek, "Kliqtluaq" is the Eskimo name reportedly meaning "lake below"; published in 1951 by USGS.

Canyon Lake: lake, $0.7 \mathrm{mi}$. long, between Canyon Creek and Skwentna River, $59 \mathrm{mi}$. NW of Tyonek, Alaska Ra.; 61 '53'45" N, 151 $37^{\circ}$ '05" W; (map 70).

Local descriptive name reported in 1954 by USGS.

Canyon Ridge: ridge, $2 \mathrm{mi}$. long, $\mathrm{W}$ of Canyon Creek, extends $\mathbf{N}$ from Blackerby Ridge to Lemon Creek, 5 mi. $\mathrm{N}$ of Juneau, Coast Mts.; $58^{\circ} 22^{\prime} 30^{\prime \prime} \mathrm{N}, 134^{\circ} 25^{\prime} 00^{\prime \prime} \mathrm{W}$; (map 11).

Local name reported in 1965 by D. A. Brew and A. B. Ford, USGS.

Canyon Slough: stream, heads in lake, flows NNW $3.5 \mathrm{mi}$. to Lowe River, $5.5 \mathrm{mi}$. SE of Valdez, Chugach Mts.; 61 ${ }^{\circ} 03^{\prime} 45^{\prime \prime} \mathrm{N}, 146^{\circ}$ $07^{\prime} 15^{\prime \prime} \mathrm{W}$; (map 68).

Local name published in the 1950's by USGS.

Canyon Village: locality, in Fort Yukon region, Yukon Flats.

Village reported in 1966 (Rand McNally, 1966, p. 61).

Cap, Point du: point of land, see Black Point.

Capaloa: locality, site of an Eskimo village on Chukchi Sea coast, at Kapaloak Creek, 0.5 mi. SE of Cape Dyer, Arctic Slope; $68^{\circ} 38^{\prime}$ $45^{\prime \prime} \mathrm{N}, 166^{\circ} 13^{\prime} 15^{\prime \prime} \mathrm{W}$; (map 129). Var. Capaloah, Kapaloa, Kapalowa.

Eskimo name obtained by J. B. Driggs, Point Hope missionary, and reported in 1904 by Collier (1906, p. 44) who wrote "An abandoned native settlement here bears the name Capaloa * * *." See Cape Dyer and Kapaloak Creek.

Capaloa: Point of land, see Dyer, Cape. Capaloa Creek: stream, see Kapaloak Creek. Capaloah: locality, see Capaloa.

Cap Creek: stream, flows SW $6.3 \mathrm{mi}$. to Unimak Pass, on SW coast of Unimak I., Aleutian Is.; $54^{\circ} 24^{\prime} 25^{\prime \prime} \mathrm{N}, 164^{\circ} 48^{\prime} 00^{\prime \prime} \mathrm{W}$; (map 24).

Name published in 1951 by the USGS. 
The stream derives its name from Scotch Cap, a promontory east of its mouth.

Cape Creek: stream, flows SW $2.2 \mathrm{mi}$. to Bering Sea at Tin City, $5 \mathrm{mi}$. SE of Cape Prince of Wales and $50 \mathrm{mi}$. of Teller, Seward Penin. High.; $65^{\circ} 34^{\prime} \mathrm{N}, 167^{\circ} 57^{\prime} \mathrm{W}$; BGN 1947; (map 111).

Local name reported in 1907 by Knopf (1908, pl. 1), USGS.

Cape Current Narrow: water passage, $1.3 \mathrm{mi}$. long between Shuyak and Afognak Is., at Cape Current, $34 \mathrm{mi}$. NNE of Afognak, Kodiak I.; $58^{\circ} 28^{\prime} 05^{\prime \prime} \mathrm{N}, 152^{\circ} 30^{\prime} 00^{\prime \prime} \mathrm{W}$; (map 43).

Descriptive name derived from Cape Current and published in 1943 by USC\&GS.

Cape Edward Pass: water passage, see Kukkan Passage.

Cape Elizabeth Island: island, see Elizabeth Island.

Cape Fanshaw: locality, pop. 5, on $\mathrm{W}$ coast of penin. between Port Houghton and Frederick Sound, at S tip of Whitney I., $71 \mathrm{mi}$. E of Sitka, Coast Mts.; $57^{\circ} 12^{\prime} 50^{\prime \prime} \mathrm{N}, 133^{\circ} 30^{\prime} 15^{\prime \prime}$ W; (map 8). Var. Fanshaw.

Named for Cape Fanshaw 3 miles to the southwest. In 1901, the town was a fishing village and the site of a cannery. The Cape Fanshaw post office was established in 1902; it was renamed "Fanshaw" in 1932 (Ricks, 1965, p. 9).

Cape Fox Village: locality, site of a native village, at Cape Fox, on E shore of Revillagigedo Channel, 4 mi. S of Boca de Quadra, Coast Mts.; $55^{\circ} 00^{\prime} 30^{\prime \prime} \mathrm{N}, 131^{\circ} 00^{\prime} 15^{\prime \prime} \mathrm{W}$; (map 3$)$.

Name recorded in 1880 by Ivan Petroff $(1884$, p. 32$)$, in the 10 th Census, who reported 100 Tlingit Indians living there.

Cape Horne Creek: stream, flows NE $4.5 \mathrm{mi}$, to Kilulikpuk Creek, $35 \mathrm{mi}$. N of Haycock, Seward Penin. High.; $65^{\circ} 42^{\prime}$ N, $161^{\circ} 03^{\prime}$ W ; (map 109).

Local name published on maps after 1950.

Cape Horn Rocks: rocks, extend $0.5 \mathrm{mi}$. in Pacific Ocean, between Forrester and Lowrie Is., Alex. Arch.; $54^{\circ} 50^{\prime} 50^{\prime \prime} \mathrm{N}, 133^{\circ} 33^{\prime} 00^{\prime \prime}$ W; (map 1).

Local name published by USC\&GS in 1943. Cape Island: island, see Barwell Island.

Cape Island: island, see Saint Lazaria Islands.

Cape Lewis Mountain: mountain, 1,222 ft., on Chukchi Sea coast, at Cape Lewis, $16 \mathrm{mi}$. S of Cape Lisburne, Arctic Slope; $68^{\circ} 43^{\prime} \mathrm{N}$, $166^{\circ} 11^{\prime} \mathrm{W}$; (map 129).

Named in 1904 by Chester Washburne, field assistant to A. J. Collier, USGS.

Cape Mountain: mountain, 2,289 ft., at $W$ end of Seward Penin., 3 mi. SE of Cape Prince of Wales and $53 \mathrm{mi}$. NW of Teller, Seward Penin. High.; $65^{\circ} 34^{\prime} \mathrm{N}, 168^{\circ} 00^{\prime} \mathrm{W}$; (map 111).

Local name reported in 1900 by Brooks (1901, pl. 13), USGS.

Cape Nome: locality, 2 mi. NE of Cape Nome and $17 \mathrm{mi}$. SW of Solomon, Seward Penin. High.; $64^{\circ} 28^{\prime} \mathrm{N}, 164^{\circ} 57^{\prime} \mathrm{W}$; (map 95).

Site of a mining camp; reported in 1951 by USGS.
Cape Pole: village, pop. 92, at Cape Pole, on E shore of Fishermans Harbor, on SW coast of Kosciusko I., Alex. Arch.; 55 ${ }^{\circ} 7^{\prime} 55^{\prime}$ N, $133^{\circ} 47^{\prime} 55^{\prime \prime}$ W; (map 4).

The Cape Pole post office was established in 1949 and discontinued in 1953 (Ricks, 1965, p. 9). Cape Pole is a logging community with a population of about 100 (Alaska Sportsman, 1962, no. 12, p. 28).

Cape Sepping: locality, site of an Eskimo village at Cape Sepping, on Chukchi Sea coast; (map 128). Var. Kechemudluk, Kivalinagmiut, Kivalinge.

Eskimo village or camp, now abandoned, mentioned by $P$. Tiknmeniev on his 1861 map as "Kivalinag-miut" (Baker, 1906, p. 160). This may refer to the present village of Kivalina. On U.S. Navy Hydrog. Office Chart 68, it is shown as "Kechemudluk."

Cape Yakataga: village, pop. 48, at Cape Yakataga, on $\mathrm{N}$ coast of Gulf of Alaska, 25 mi. WNW of Icy Cape, Chugach Mts.; $60^{\circ}$ $04^{\prime} 05^{\prime \prime} \mathrm{N}, 142^{\circ} 25^{\prime} 45^{\prime \prime} \mathrm{W}$; (map 65). Var. Yakatag, Yakataga.

Local name reported in 1904 by G. C. Martin, USGS. The Indian name "Yakataga" is said to mean "canoe road" because of two reefs forming a canoe passage to the village. A post office was established here in 1935.

Cap Glacier: glacier, on S coast of Alaska, 0.8 mi. E of Port Wells, trends $W 1 \mathrm{mi}$., $3 \mathrm{mi}$. SE of mouth of Avery River and $29 \mathrm{mi}$. NE of Whittier, Chugach Mts.; $60^{\circ} 57^{\prime} 30^{\prime \prime} \mathrm{N}$, $147^{\circ} 55^{\prime} 05^{\prime \prime} \mathrm{W}$; (map 63).

Descriptive name given in 1910 by Lawrence Martin, USGS.

Cap Island: island, $1.5 \mathrm{mi}$. long, in El Capitan Passage, on NW coast of Tuxekan I., Alex.

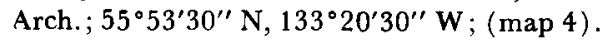

Named in 1904 by E. F. Dickins, USC\&GS, "for signal station called Cap located here." Capitaine, Baie du: bay, see Unalaska Bay.

Capital Mountain: mountain, 7,731 ft., $15 \mathrm{mi}$. $\mathrm{N}$ of Mount Sanford and $20 \mathrm{mi}$. SW of Chistochina, Wrangell Mts.; $62^{\circ} 25^{\prime} 39^{\prime \prime} \mathrm{N}$, $144^{\circ} 07^{\prime} 00^{\prime \prime} \mathrm{W}$; (map 83).

Local name reported in 1902 by T. G. Gerdine (in Mendenhall, 1905, pl. 4), USGS.

Capitan Island, El: island, $3.5 \mathrm{mi}$. long, in El Capitan Passage, between Orr and Prince of Wales Is., Alex. Arch.; 55 $56^{\prime}$ N, $133^{\circ} 19^{\prime} \mathrm{W}$; (map 4).

Named in 1932 by USC\&GS because "This is the largest island in the passage and the name is especially appropriate * * *." El Capitan is Spanish meaning "the captain."

Capitan Lake, El: lake, $0.7 \mathrm{mi}$. long, $\mathrm{N}$ of El Capitan Passage, $4 \mathrm{mi}$. E of Shakan Bay, on NW coast of Prince of Wales I., Alex. Arch.; $56^{\circ} 10^{\prime} 30^{\prime \prime} \mathrm{N}, 133^{\circ} 23^{\prime} 00^{\prime \prime} \mathrm{W}$; (map 6).

Local name recorded in 1949 by USGS.

Capitan Passage, El: water passage, extends 27 mi., from Sea Otter Sound to Shakan Strait, between Kosciusko I. and Prince of Wales I., Alex. Arch.; $55^{\circ} 53^{\prime} \mathrm{N}, 133^{\circ} 22^{\prime} \mathrm{W}$, to $56^{\circ} 09^{\prime}$ N, $133^{\circ} 28^{\prime}$ W; BGN 1908; (map 4). Var. Dry Pass, Klawak Passage.
Named in 1904 by E. F. Dickins, USC\&GS, "after El Capitan Marble Quarry and Mill, on $\mathrm{N}$ shore ***",

Capitan Passage, El: water passage, see Dry Pass.

Capitan Peak, El: mountain, 2,566 ft., $7 \mathrm{mi}$. NW of Neck Lake, on $\mathbf{N}$ part of Prince of Wales I., Alex. Arch.; $56^{\circ} 11^{\prime} 00^{\prime \prime} \mathrm{N}, 133^{\circ} 18^{\prime} 30^{\prime \prime} \mathrm{W}$; (map 6).

Local name used by fishermen and published in 1924 by USC\&GS.

Capones, Point: point of land, SW point of entrance to Port Mayoral, on NE coast of Baker I., Alex. Arch.; 55 $22^{\prime} 50^{\prime \prime} \mathrm{N}, 133^{\circ} 27^{\prime} 30^{\prime \prime} \mathrm{W}$; (map 4). Var. Mys de Kaponyes, Punta de Capones.

Spanish name given in $1775-79$ by Don Juan de la Bodega y Quadra and Francisco Antonio Maurelle as "Punta de Capones," meaning "point of capons [the anchor stopper at the cat-head of a ship]" (Wagner, 1937, p. 379 ).

Caponeta, Point: point of land, on $\mathrm{N}$ coast of St. Ignace Island behind Bibora Island, Alex. Arch.; $55^{\circ} 26^{\prime} \mathrm{N}, 133^{\circ} 25^{\prime} \mathrm{W}$; (map 4). Var. Punta Cajoneta, Punta Caponeta.

Probably named by the Don Ignacio Arteaga expedition of 1779 ; it is an old way to spell "Acaponeta" (Wagner, 1937, p. 439).

Caponeta, Punta: point of land, see Caponeta, Point.

Capps, Mount: peak, 10,790 ft., in Mount McKinley National Park at head of Kahiltna Glacier, $5.7 \mathrm{mi}$. W of Mount McKinley, Alaska Ra.; $63^{\circ} 04^{\prime} 45^{\prime \prime} \mathrm{N}, 151^{\circ} 11^{\prime} 00^{\prime \prime} \mathrm{W}$; (map 88).

Named in 1952 by NPS for Stephen Reid Capps, 1881-1949, USGS geologist who did field work in the area for several seasons.

Capps Creek: stream, heads in lake, flows NE $9 \mathrm{mi}$. to Chichantna River, $3 \mathrm{mi}$. S of Beluga Lake and $24 \mathrm{mi}$. NW of Tyonek, Cook Inlet Low.; $61^{\circ} 20^{\prime} 00^{\prime \prime} \mathrm{N}, 151^{\circ} 36^{\prime} 45^{\prime \prime} \mathrm{W}$; BGN 1964 ; $(\operatorname{map} 70)$.

Named in 1962 by USGS; derived from nearby Capps Glacier.

Capps Glacier: glacier, in Tordrillo Mts., heads on Mt. Torbert, trends SE $24 \mathrm{mi}$. to its terminus at head of Chichantna River, $26 \mathrm{mi}$. NW of Tyonek, Alaska Ra.; $61^{\circ} 21^{\prime} \mathrm{N}, 151^{\circ} 43^{\prime} \mathrm{W}$; (map 70).

Named for Stephen Reid Capps, 1881-1949, USGS, a geologist who did extensive field work in the area. Name published by USGS in 1958.

Captain Creek: stream, flows NW $5 \mathrm{mi}$. to Pilot Creek, $22 \mathrm{mi}$. NE of Fairbanks, Yukon-Tanana High.; $65^{\circ} 08^{\prime} 15^{\prime \prime} \mathrm{N}, 147^{\circ} 24^{\prime} 20^{\prime \prime} \mathrm{W}$; (map 105).

Named by prospectors; reported in 1903 by USGS (Prindle, 1905, pl. 13)

Captain Harbor: cove, $0.5 \mathrm{mi}$. across, in northern part of Belkofski Bay, $25 \mathrm{mi}$. E of village of Gold Bay, at SW end of Alaska Penin., Aleutian Ra.; $55^{\circ} 10^{\prime} \mathrm{N}, 162^{\circ} 05^{\prime} \mathrm{W}$; BGN 1916; (map 29). Var. Bailey Harbor.

Named by USC\&GS in 1916. This feature was originally named "Bailey Harbor" by the Revenue-Marine Service in 1879 for Capt. 
George W. Bailey, USRCS, who survéyed this cove. He was lost overboard on the return voyage to San Francisco in 1879.

Captains Bay: bay, $1.5 \mathrm{mi}$. across, southern arm of Unalaska Bay, on NE coast of Unalaska I., Aleutian Is.; $53^{\circ} 52^{\prime} \mathrm{N}, 166^{\circ} 34^{\prime} \mathrm{W}$; BGN 1931; (map 23). Var. Captains Harbor, Port Levashef, Saint Paul Harbor.

Translation of the name given by Lt. Sarichev (1826, map 14, dated 1792), IRN, as "Kapitanskaya Gavan" meaning "Captain's Harbor" in honor of Capt. Lt. Michael Levashev, IRN, who spent the winter at the head of this bay (Port Lavashev) during 1768-69 (Coxe, 1787, p. 209-210).

Captains Bay: bay, see Unalaska Bay

Captains Harbor: bay, see Captains Bay.

Captains Harbor: bay, see Levashef, Port.

Captains Harbor: bay, see Unalaska Bay.

Captain's Island: island, see Burnt Island.

Caracol, Point: point of land, on E coast of Baker

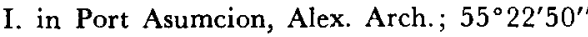
$\mathrm{N}, 133^{\circ} 31^{\prime} 30^{\prime \prime} \mathrm{W}$; (map 4). Var. Punta del Caracol.

Spanish name given in 1775-79 by Don Juan de la Bodega y Quadra and Francisco Antonio Maurelle as "Punta del Caracol," meaning "point of the snail."

Caracol, Punta del: point of land, see Caracol, Point.

Caracol, Punta del : point of land, see Snail Point.

Caracol Island: island, 1,600 ft. long, in Portillo Channel, off $W$ coast of San Fernando I., Alex. Arch.; $55^{\circ} 31^{\prime} 15^{\prime \prime} \mathrm{N}, 133^{\circ} 26^{\prime} 50^{\prime \prime} \mathrm{W}$; (map 4).

Named and published by USC\&GS in 1943 ; derived from Point Caracol.

Caray Creek: stream, flows SE to Cripple River, about $32 \mathrm{mi}$. NW of Nome, Seward Penin. High.; ( $\operatorname{map} 94$ ).

Prospectors' name reported on the 1900 "Map of Nome Peninsula" by J. M. Davidson and B. D. Blakeslee; this feature has not been positively identified.

Carbon Camp: locality, on left bank of Carbon Creek, 17 mi. NE of Katalla, Chugach Mts.; $60^{\circ} 23^{\prime} \mathrm{N}, 144^{\circ} 12^{\prime} \mathrm{W}$; (map 64).

Mining camp on Carbon Creek. Recent USGS maps indicate a site with one building. Carbon Creek: stream, fows $3 \mathrm{mi}$. SW to Shepherd Creek, $16 \mathrm{mi}$. NE of Katalla, Chugach Mts.; $60^{\circ} 23^{\prime} \mathrm{N}, 144^{\circ} 13^{\prime} \mathrm{W}$; (map 64).

Local name used by prospectors; reported in 1903 by G. G. Martin (1905, pl. 3), USGS.

Carbon Creek: stream, flows NW $7.4 \mathrm{mi}$. to Matanuska River, $24 \mathrm{mi}$. NE of Palmer, Chugach Mts.; $61^{\circ} 46^{\prime} 45^{\prime \prime} \mathrm{N}, 148^{\circ} 28^{\prime} 00^{\prime \prime}$ W (map 69).

Local name reported in 1905 by G. C. Martin, USGS.

Carbon Creek: stream, heads in Darby Mts., flows NE $3 \mathrm{mi}$. to Tubutulik River, at $S$ end of Death Valley, $41 \mathrm{mi}$. SE of Imuruk Lake, Seward Penin. High.; $65^{\circ} 07^{\prime}$ N. $162^{\circ} 17^{\prime} \mathrm{W}$; (map 110).

Prospectors' name published on the 1908 "Map of Seward Peninsula" by Arthur Gibson.
Carbon Creek: stream, flows W $45 \mathrm{mi}$. to Utukok River, $\mathrm{N}$ of Lookout Ridge, $90 \mathrm{mi}$. S of Wainwright, Arctic Slope; $69^{\circ} 21^{\prime} \mathrm{N}, 159^{\circ} 50^{\prime} \mathrm{W}$; $B G N$ 1925; (map 144). Var. Tolugakruak.

Named by personnel of the 1924 USGS field party; appeared on a fieldsheet by O. L. Wix.

Carbon Lake: lake, $2 \mathrm{mi}$. long, $4 \mathrm{mi}$. $\mathrm{S}$ of Baranof, on E coast of Baranof I., Alex. Arch.; $57^{\circ} 01^{\prime} 30^{\prime \prime} \mathrm{N}, 134^{\circ} 49^{\prime} 00^{\prime \prime} \mathrm{W}$; BGN 1923; (map 9).

Named by USFS, probably in 1922 .

Carbon Mountain: mountain, 3,800 ft., $2 \mathrm{mi}$. $\mathrm{N}$ of Berg Lake and $66 \mathrm{mi}$. $\mathbf{E}$ of Cordova, Chugach Mts.; $60^{\circ} 27^{\prime} \mathrm{N}, 143^{\circ} 53^{\prime} \mathrm{W}$; (map $65)$.

Local name obtained in 1903 by G. C. Martin, USGS, and published in 1904 by USC\&GS

Carbon Ridge: ridge, elev. 1,700 ft., $1.5 \mathrm{mi}$. long, $1.3 \mathrm{mi}$. SE of Lake Charlotte and $19 \mathrm{mi}$. NE of Katalla, Ghugach Mts.; $60^{\circ} 24^{\prime} \mathrm{N}$, $144^{\circ} 10^{\prime} \mathrm{W}$; (map 64$)$.

Local name used by prospectors; reported by G. C. Martin, USGS, in 1905.

Carden Creek: stream, heads in Nutzotin Mts., flows NE $19 \mathrm{mi}$. to Snag Creek, NE of Carden Hills, Alaska Ra.; $62^{\circ} 22^{\prime} 15^{\prime \prime}$ N, $141^{\circ} 03^{\prime} 50^{\prime \prime}$ W; (map 84).

Local name published by Moffit (1943, p. 164), USGS.

Carden Hills: ridge, elev. 5,000 ft., extends W $9 \mathrm{mi}$. between Carden and Snag Creeks, in Nutzotin Mts., $50 \mathrm{mi}$. SE of Northway, Alaska $\mathrm{Ra} ; 62^{\circ} 19^{\prime} \mathrm{N}, 141^{\circ} 12^{\prime} \mathrm{W}$; (map 84).

Local name reported by USGS in 1960 .

Carden Lake: lake, 2 mi. long, in Nutzotin Mts., $\mathrm{S}$ of Carden Hills, Alaska Ra.; $62^{\circ} 17^{\prime} \mathrm{N}$, $141^{\circ} 11^{\prime} \mathrm{W}$; (map 84).

Local name reported by USGS in 1951.

Cardioceras Creek: stream, heads at glacier, flows NE $6.8 \mathrm{mi}$. to Little Nelchina River, $\mathrm{S}$ of Horsepasture Pass, $19 \mathrm{mi}$. NW of Tahneta Pass, Talkeetna Mts.; $62^{\circ} 06^{\prime} 52^{\prime \prime} \mathrm{N}, 14^{\circ} 38^{\prime}$ $08^{\prime \prime} \mathrm{W} ; B G N$ 1960; (map 82).

Named in 1956 by USGS "for the abundant occurrence of well-preserved ammonities [fossils] belonging to the genus Cardioceras." Cardozo, Mount: mountain, 10,958 $\mathrm{ft}$., at head of Yale Glacier, $35 \mathrm{mi}$. NW of Valdez, Chugach Mts.; $61^{\circ} 21^{\prime} 30^{\prime \prime} \mathrm{N}, 147^{\circ} 12^{\prime} 45^{\prime \prime} \mathrm{W}$; (map 69).

Named for Benjamin Nathan Cardozo, 1870-1938, Supreme Court Justice: name published by Nielson (1963, p. 135).

Careening Harbor: bay, see Chalmers, Port.

Careful Point: point of land, $\mathrm{W}$ point of entrance to Bay of Islands, on W coast of Adak I., Aleutian Is. ; $51^{\circ} 49^{\prime} 30^{\prime \prime} \mathrm{N}, 176^{\circ} 52^{\prime} 00^{\prime \prime} \mathrm{W}$; $B G N 1936$; (map 17).

Named in 1934 by members of the U.S. Navy Aleutian Island Survey Expedition.

Carex Creek: stream, flows W $6 \mathrm{mi}$. to Noxapaga River near its head, $10 \mathrm{mi}$. W of Imuruk Lake, Seward Penin. High.; 65 $38^{\prime}$ N, $163^{\circ} 36^{\prime} \mathrm{W}$; BGN 1952; (map 110). Var. Arcy Creek, Carey Creek.

Reported in 1950 by D. M. Hopkins, USGS; so named because "through much of its course the creek flows through a Carex [sedge] marsh,"

Carey Creek: stream, tributary to Canning River, presumably between Shublik I. and junc. of Marsh Fork, Brooks, Ra.; (map 139).

The location of this stream, mentioned by S. J. Marsh to Leffingwell $(1919$, p. 94), is unknown but the name may represent an error, because it probably was named for H. T. (Ned) Arey who spent about eleven years in the area in the early 20 th century.

Carey Creek: stream, see Carex Creek.

Carey Lake: lake, $1.2 \mathrm{mi}$. long, drains SSW to Deep Creek, $34 \mathrm{mi}$. SSW of village of Lake Minchumina, Kuskokwim Low.; 63' $24^{\prime} 30^{\prime \prime} \mathrm{N}$, $152^{\circ} 36^{\prime} 00^{\prime \prime} \mathrm{W}$; (map 88).

Local name reported in 1954 by USGS; named for Fabian Carey who trapped in this area for several years.

Cariboo Creek: stream, flows SE $1 \mathrm{mi}$. to Walker Fork, $50 \mathrm{mi}$. S of Eagle, YukonTanana High.; 64 $04^{\prime} \mathrm{N}, 141^{\circ} 25^{\prime} \mathrm{W}$; (map 102).

Prospectors' name shown on an 1898 manuscript map by G. A. Woodruff, Fort Cudahy, Canada.

Caribou: locality, on right bank of Salcha River, at mouth of No Grub Creek, $37 \mathrm{mi}$. NE of Big Delta, Yukon-Tanana High.; $64^{\circ} 40^{\prime} \mathrm{N}$, $145^{\circ} 37^{\prime} \mathrm{W}$; (map 101).

Local name for an ARC shelter cabin; published in 1925.

Caribou Bar: locality, on $\mathbf{N}$ bank of Hodzana River, $45 \mathrm{mi}$. N of Stevens Village, KokrinesHodzana High.; $66^{\circ} 39^{\prime} 20^{\prime \prime}$ N, $149^{\circ} 14^{\prime} 30^{\prime \prime}$ W; (map 118). Var. Hodcana, Hodzana.

Mining camp established about 1914 and published in the 1916 Polk's Gazetteer as "Hodcana." USGS reported the name "Caribou Bar" in 1956, presumably for the same place; if not, the two places must be near each other.

Caribou Creek: stream, on Kenai Penin., flows NW $6 \mathrm{mi}$. to Resurrection Creek, $9.5 \mathrm{mi}$. S of Hope, Chugach Mts.; $60^{\circ} 47^{\prime} 00^{\prime \prime}$ N, $149^{\circ}$. $40^{\prime} 30^{\prime \prime} \mathrm{W}$; (map 63).

Local prospectors' name reported in 1904 by Moffit (1906, pl. 2), USGS

Caribou Creek: stream, heads at glacier terminus, flows SE $35 \mathrm{mi}$. to Matanuska River, 50 mi. NE of Palmer, Talkeetna Mts. $61^{\circ} 47^{\prime} 10^{\prime \prime} \mathrm{N}, 147^{\circ} 39^{\prime} 10^{\prime \prime} \mathrm{W}$; (map 69).

Local name reported in 1898 by Schrader (1900a, p. 321), USGS.

Caribou Creek: stream, flows NW $15 \mathrm{mi}$. to Iditarod River, $9 \mathrm{mi}$. NW of Flat and $50 \mathrm{mi}$. SE of Holikachuck, Kilbuck-Kuskokwin Mts.; $62^{\circ} 34^{\prime} 20^{\prime \prime} \mathrm{N}, 158^{\circ} 07^{\prime} 00^{\prime \prime} \mathrm{W}$; (map 79).

Prospectors' name obtained in 1913 by Eakin (1914, pl. 1), USGS

Caribou Creek: stream, heads in Mentasta Mts., flows W $15 \mathrm{mi}$. to Tanada Creek $1 \mathrm{mi}$. S of its junc. with Copper River, Copper River Basin; $62^{\circ} 37^{\prime} \mathrm{N}, 143^{\circ} 46^{\prime} \mathrm{W}$; BGN 1939; (map 84).

Local name reported in 1939 by $P$. S. Smith, USGS. 
Caribou Creek: stream, fows S $1.5 \mathrm{mi}$. to Valdez Creek, $67 \mathrm{mi}$. SE of Healy, Alaska Ra.; $63^{\circ} 12^{\prime} \mathrm{N}, 147^{\circ} 23^{\prime} \mathrm{W}$; (map 87).

Local name obtained in 1951 by USGS.

Caribou Creek: stream, flows NW $6 \mathrm{mi}$. to Innoko River, $35 \mathrm{mi}$. N of Ophir $51 \mathrm{mi}$. NW of McGrath, Kilbuck-Kuskokwin Mts.; 633'. $30^{\prime \prime} \mathrm{N}, 156^{\circ} 20^{\prime} 30^{\prime \prime} \mathrm{W}$; (map 90).

Prospectors' name reported in 1913 by H. M. Eakin, USGS.

Caribou Creek: stream, in Kantishna Hills, flows $\mathrm{W}$ and N $16 \mathrm{mi}$. to Bearpaw River, $15 \mathrm{mi}$. N

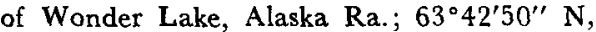
$150^{\circ} 57^{\prime} 20^{\prime \prime} \mathrm{W}$; (map 88).

Name shown on a 1905 manuscript map of "Kantishna Gold Fields" by A. Friedrich, prospector.

Caribou Creek: stream, heads at $64^{\circ} 08^{\prime} \mathrm{N}$, $143^{\circ} 07^{\prime} \mathrm{W}$, flows SE $3 \mathrm{mi}$. to Kechumstuk Creek, $76 \mathrm{mi}$. SW of Eagle, Yukon-Tanana High.; $64^{\circ} 06^{\prime} 20^{\prime \prime} \mathrm{N}, 143^{\circ} 04^{\prime} 00^{\prime \prime} \mathrm{W}$; (map 102).

Local name published in 1956 by USGS.

Caribou Creek: stream, flows S $12 \mathrm{mi}$. to Shaw Creek, $9 \mathrm{mi}$. NNW of Big Delta, Tanana Low.; $64^{\circ} 16^{\prime} \mathrm{N}, 146^{\circ} 01^{\prime} \mathrm{W}$; (map 101).

Named by prospectors reported in 1910 by USGS (Capps, 1910, pl. 1)

Caribou Creek: stream, flows NE $5 \mathrm{mi}$. to Middle Fork Fortymile River, $44 \mathrm{mi}$. SW of Eagle, Yukon-Tanana High.; $64^{\circ} 28^{\prime} \mathrm{N}, 142^{\circ} 28^{\prime} \mathrm{W}$; (map 102)

Prospectors' name shown on an 1898 manuscript map by C. A. Woodruff, Fort Cudahy. Canada.

Caribou Creek: stream, flows SW $7 \mathrm{mi}$. to Salcha River, $36 \mathrm{mi}$. N of Big Delta, Yukon-Tanana High.; $64^{\circ} 40^{\prime} \mathrm{N}, 145^{\circ} 43^{\prime} \mathrm{W}$; (map 101).

Named by prospectors and reported in 1905 by D. C. Witherspoon, USGS

Caribou Creek: stream, flows NW 3 mi. to Flume Creek, $42 \mathrm{mi}$. NW of Eagle, Yukon-Tanana High.; $64^{\circ} 55^{\prime} \mathrm{N}, 142^{\circ} 32^{\prime} \mathrm{W}$; (map 102).

Prospectors' name shown on a 1902 manuscript map by E. J. Chamberlain, U.S. Deputy Surveyor.

Caribou Creek: stream, fows SW $5 \mathrm{mi}$. to Little Chena River, $22 \mathrm{mi}$. ENE of Fairbanks, Yukon-Tanana High.; $64^{\circ} 59^{\prime} \mathrm{N}, 14^{\circ} 01^{\prime} \mathrm{W}$; (map 101).

Local name reported in 1952 by USGS

Caribou Creek: stream, flows SW $4 \mathrm{mi}$. to East Fork Chena River, $63 \mathrm{mi}$. SW of Circle, Yukon-Tanana High.; $65^{\circ} 03^{\prime} \mathrm{N}, 145^{\circ} 11^{\prime} \mathrm{W}$; (map 104).

Named by prospectors; reported in 1911 by USGS (Prindle, 1913, pl. 1).

Caribou Creek: stream, flows NE $16.7 \mathrm{mi}$. to The Kateel River, $64 \mathrm{mi}$. SE of Haycock, Nulato Hills, $65^{\circ} 05^{\prime} \mathrm{N}, 159^{\circ} 01^{\prime} \mathrm{W}$; (map 109).

Local name reported in 1910 by P. S. Smith and H. M. Eakin, USGS.

Caribou Creek: stream, flows NE $5 \mathrm{mi}$. to Poker Creek, 22 mi. NE of Fairbanks, YukonTanana High.; $65^{\circ} 09^{\prime} 15^{\prime \prime}$ N, $147^{\circ} 29^{\prime} 00^{\prime \prime}$ W ; (map 105).

Local name published in 1908 by USGS.
Caribou Creek: stream, heads in Darby Mts., flows NE $11 \mathrm{mi}$. to Tubutulik River in Death Valley, $38 \mathrm{mi}$. SE of Imuruk Lake, Seward Penin. High.; $65^{\circ} 10^{\prime} \mathrm{N}, 162^{\circ} 17^{\prime} \mathrm{W}$; (map 110).

Prospectors' name reported in 1909 by Smith and Eakin (1911, pl. 1), USGS.

Caribou Creek: stream, fiows NW $8 \mathrm{mi}$. to South Fork Birch Creek, $18 \mathrm{mi}$. NNE of West Point and $45 \mathrm{mi}$. SSW of Circle, Yukon-Tanana High.; $65^{\circ} 10^{\prime} 40^{\prime \prime} \mathrm{N}, 144^{\circ} 19^{\prime} 30^{\prime \prime} \mathrm{W}$; (map 104)

Prospectors' name reported in 1954 or 1955 by USGS topographers.

Caribou Creek: stream, flows NE $5 \mathrm{mi}$. to Woodchopper Creek, $8 \mathrm{mi}$. SW of that stream's junc. with Yukon River and $42 \mathrm{mi}$. SSE of Circle, Yukon-Tanana High.; $65^{\circ} 16^{\prime} \mathrm{N}$, $143^{\circ} 30^{\prime} \mathrm{W}$; (map 103).

Local name published in 1956 by USGS.

Caribou Creek: stream, flows S $3.3 \mathrm{mi}$. to Chatanika River, $9 \mathrm{mi}$. WNW of Mount Ryan and $48 \mathrm{mi}$. NE of Fairbanks, Yukon-Tanana High.; $65^{\circ} 17^{\prime} 10^{\prime \prime} \mathrm{N}, 146^{\circ} 32^{\prime} 50^{\prime \prime} \mathrm{W}$; (map 104).

Prospectors' name reported in 1954 or 1955 by USGS topographers.

Caribou Creek: stream, flows S $3 \mathrm{mi}$. to Hutlinana Creek, $18 \mathrm{mi}$. SE of Rampart, YukonTanana High.; $65^{\circ} 17^{\prime} 15^{\prime \prime} \mathrm{N}, 149^{\circ} 53^{\prime} 20^{\prime \prime} \mathrm{W}$; (map 105)

Named by prospectors; published in 1906 by USGS.

Caribou Creek: stream, fows SW $6 \mathrm{mi}$. to Igloo Creek which flows to American River, $12 \mathrm{mi}$. S of Kougarok Mtn. and $39 \mathrm{mi}$. NE of Teller, Seward Penin. High.; $65^{\circ} 30^{\prime}$ N, $165^{\circ} 13^{\prime} \mathrm{W}$ (map 111).

Prospectors' name reported in 1900 by Messrs. Kemp and David Fox (in Brooks, 1901, pl. 11).

Caribou Creek: stream, heads in Zane Hills, flows E $17 \mathrm{mi}$. to Hogatza River, $35 \mathrm{mi}$. WNW of Hughes, Hogatza High.; $66^{\circ} 11^{\prime}$ N, $155^{\circ} 27^{\prime}$ W; (map 116)

Named about 1955 by mining engineers for Caribou Mountain; reported in 1956 by Orth. Caribou Creek; stream, flows SE to Flnmbeau River, about $26 \mathrm{mi}$. NE of Nome, Seward Penin. High.; (map 94).

Prospectors' name reported on the 1900 "Map of Nome Peninsula" by J. M. Davidson and B. D. Blakeslee; this feature has not been positively identified.

Caribou Creek; stream, flows NW to Kuzitrin River, about $17 \mathrm{mi}$. N of Mount Bendeleben, Seward Penin. High.: (map 110)

Prospectors' name shown on a map of Cape Nome gold fields by David Fox, Jr., dated 1901. This stream cannot be precisely iocated on current maps.

Caribou Gulch: ravine, trends N $1.5 \mathrm{mi}$. to join Grognon Gulch at the head of Bonanza Creek, $3.3 \mathrm{mi}$. E of Porcupine Dome and $44 \mathrm{mi}$. SW of Circle, Yukon-Tanana High.; $65^{\circ} 30^{\prime} 45^{\prime \prime}$ N, $145^{\circ} 24^{\prime} 45^{\prime \prime}$ W; (map 104).

Prospectors' name reported in 1954 or 1955 by USGS topographers.
Caribou Hills: hills, on Kenai Penin., highest peak is Ptarmigan Head, 2,850 ft., bounded on $\mathrm{S}$ by Boxcar Hills and on $\mathrm{N}$ by North Fork Deep Creek, $30 \mathrm{mi}$. NE of Homer, Cook Inlet Low.; $59^{\circ} 59^{\prime} \mathrm{N}, 151^{\circ} 04^{\prime} \mathrm{W}$; (map 50 ).

Local name reported and published by USGS in the 1950's.

Caribou Island: island, $3 \mathrm{mi}$. long, on Kenai Penin., in Tustumena Lake, $24 \mathrm{mi}$. SSE of Kenai, Cook Inlet Low.; $60^{\circ} 14^{\prime} \mathrm{N}, 151^{\circ} 01^{\prime}$ W; (map 62).

Local name reported in 1939 by USGS.

Caribou Islands: islands, two, in Shilak Lake, on Kenai Penin., $30 \mathrm{mi}$. ESE of Kenai, Cook Inlet Low. ; $60^{\circ} 25^{\prime} \mathrm{N}, 150^{\circ} 25^{\prime} \mathrm{W}$; (map 62).

Local name reported in 1904 by Moffit and Stone (1906, pl. 2), USGS.

Caribou Lake: lake, $2.3 \mathrm{mi}$. long, on Kenai Penin., $1 \mathrm{mi}$. S of Boxcar Hills and $25 \mathrm{mi}$. NE of Homer, Cook Inlet Low.; $59^{\circ} 59^{\prime} 20^{\prime \prime} \mathrm{N}$, $151^{\circ} 03^{\prime} 00^{\prime \prime} \mathrm{W}$; (map 50).

Local name reported and published by USGS 1950's.

Caribou Lake: lake, $0.3 \mathrm{mi}$. long, between Long and Frenchman Lakes, $21 \mathrm{mi}$. NW of Glennallen, Copper River Basin: $62^{\circ} 11^{\prime} 20^{\prime \prime} \mathrm{N}$ $146^{\circ} 10^{\prime} 00^{\prime \prime} \mathrm{W}$; (map 83)

Local name reported by USGS in 1949.

Caribou Lake: lake, $0.6 \mathrm{mi}$. long, $9 \mathrm{mi}$. E of Paxson, Alaska Ra.; $63^{\circ} 02^{\prime} 00^{\prime \prime} \mathrm{N}, 145^{\circ} 11^{\prime} 30^{\prime \prime}$ W; (map 86)

Local name reported in 1949 by T. L. Péwé, USGS

Caribou Lake: lake, $0.7 \mathrm{mi}$. across, $1.5 \mathrm{mi}$. SW of Spectacle Lake and $23 \mathrm{mi}$. S of village of Lake Minchumina, Tanana Low.; 63 $33^{\prime} 15^{\prime \prime}$ $\mathrm{N}, 152^{\circ} 27^{\prime} 00^{\prime \prime} \mathrm{W}$; (map 88)

Local name reported in 1954 by USGS

Caribou Mountain: mountain, 1,916 ft., on W slope of Kuskokwim Mts., at heads of Dominion and Henry Creeks, $8.7 \mathrm{mi}$. N of Ophir and $37 \mathrm{mi}$. NW of McGrath, KilbuckKuskokwim Mts.; $63^{\circ} 16^{\prime} \mathrm{N}, 156^{\circ} 35^{\prime} \mathrm{W}$; (map 90)

Local name obtained from Joseph Ferris in 1954 by R. E. Isto, USGS.

Caribou Mountain: mountain, 3,600 ft. in Zane Hills, $48 \mathrm{mi}$. WNW of Hughes, Hogatza High.; $66^{\circ} 10^{\prime} 30^{\prime \prime} \mathrm{N}, 155^{\circ} 56^{\prime} 00^{\prime \prime} \mathrm{W}$ : (map 116)

Local name recorded in 1956 by Orth

Caribou Mountain: mountain, 3,183 ft., on $S$ bank of Kanuti River, $46 \mathrm{mi}$. SE of Bettles, Kokrines-Hodzana High.; $66^{\circ} 22^{\prime} 30^{\prime \prime}$ N, $150^{\circ}$. $41^{\prime} 00^{\prime \prime} \mathrm{W}$; (map 117).

Name shown on a 1901 fieldsheet by $\dot{D}$. $\mathrm{L}$. Raeburn, USGS.

Caribou Pass: pass, 4,800 ft., in Nutzontin Mts. at head of Glacier Creek, $12 \mathrm{mi}$. NE of Euchre Mtn, Alaska Ra.: 62 $02^{\circ} 7^{\prime} \mathrm{N}, 141^{\circ} 51^{\prime} \mathrm{W}$; (map 84).

Local name reported by USGS in 1960

Caribou Pass: pass, 3,400 ft., trends NW-SE 5 mi., $11 \mathrm{mi}$. SSE of Cantwell and $42 \mathrm{mi}$. S of Healy, Talkeetna Mts. : $63^{\circ} 15^{\prime} \mathrm{N}, 148^{\circ} 50^{\prime} \mathrm{W}$; (map 87)

Local name reported in 1898 by USGS.

Caribou Pass: pass, see Broad Pass. 
Caribou River: stream, heads near Trader Mtn., flows NE $50 \mathrm{mi}$. to Nelson Lagoon, $32 \mathrm{mi}$. W of settlement of Port Moller, near SW end of Bristol Bay Low., Alaska Penin.; 55 57'00" $\mathrm{N}, 161^{\circ} 22^{\prime} 30^{\prime \prime} \mathrm{W}$; (map 28).

Local name reported by USGS in 1929.

Caribou River: stream, see Cutler River.

Caribou Snare Creek: stream, heads SW of Cairn Mtn., flows NW $13 \mathrm{mi}$. to Tundra Lake, $59 \mathrm{mi}$. $\mathrm{SE}$ of Sleetmute, Lime Hills; $61^{\circ} 13^{\prime} 50^{\prime \prime} \mathrm{N}$, $155^{\circ} 41^{\prime} 00^{\prime \prime} \mathrm{W}$; (map 71 ).

Local name published in 1951 by USGS. Car-ilt-nu Glacier: glacier, see Kahiltna Glacier. Cariltnu River: stream, see Kahiltna River.

Carlanna: area, residential district in city limits of Ketchikan, on Revillagigedo I., Alex. Arch.; $55^{\circ} 21^{\prime} 30^{\prime \prime} \mathrm{N}, 131^{\circ} 41^{\prime} 00^{\prime \prime} \mathrm{W}$; (map 3 ).

Name reported in 1960 by the U.S. Census.

Carlanna Creek: stream, flows SW 2 mi., through Carlanna Lake, to Tongass Narrows at Charcoal Point, on SW coast of Revillagigedo I., Alex. Arch.; $55^{\circ} 21^{\prime} 30^{\prime \prime} \mathrm{N}, 131^{\circ} 41^{\prime} 48^{\prime \prime} \mathrm{W}$; (map 3).

Local name recorded in 1954 by USGS.

Carlanna Lake: lake, on Revillagigedo I., NW of Ketchikan, in course of Carlanna Creek, Alex. Arch.; $55^{\circ} 22^{\prime} 18^{\prime \prime} \mathrm{N}, 131^{\circ} 41^{\prime} 10^{\prime \prime} \mathrm{W}$; (map 3).

Local name recorded in 1954 by USGS.

Carl Creek: stream, heads at Carl Glacier terminus, in Nutzotin Mts., flows $S 9 \mathrm{mi}$. to Beaver Creek, $20 \mathrm{mi}$. SE of Euchre Mtn., Alaska Ra.; $62^{\circ} 00^{\prime} \mathrm{N}, 141^{\circ} 35^{\prime} \mathrm{W}$; (map 84).

Name published by Capps (1916, pl. 1), USGS.

Carl Creek: stream, flows E $17 \mathrm{mi}$. to Kuskokwim River, $14 \mathrm{mi}$. SW of McGrath, KilbuckKuskokwim Mts. ; $62^{\circ} 46^{\prime} \mathrm{N}, 155^{\circ} 47^{\prime} \mathrm{W}$; (map $80)$.

Local name obtained in 1954 by USGS.

Carl Creek: stream, flows SW $2.8 \mathrm{mi}$. to Eldorado River, $17 \mathrm{mi}$. NW of Solomon, Seward Penin. High.; $64^{\circ} 42^{\prime} \mathrm{N}, 164^{\circ} 55^{\prime} \mathrm{W}$; (map 95).

Prospectors' name reported in 1900 by E. C. Barnard (in Brooks, 1901, pl. 17), USGS.

Carl Creek: stream, flows $S$ to Sinuk River, about $38 \mathrm{mi}$. NW of Nome, Seward Penin. High.; (map 94).

Prospectors' name reported on the 1900 "Map of Nome Peninsula" by J. M. Davidson and B. D. Blakeslee; this feature has not been positively identified.

Carl Glacier: glacier, in Nutzotin Mts., trends SW 3 mi. to its 1957 terminus at head of Carl Creek, Alaska Ra.; 62 $07^{\prime}$ N, $141^{\circ} 34^{\prime}$ W; (map 84).

Name published by Capps (1916, pl. 1), USGS.

Carlin Creek: stream, see Carline Creek.

Carline Creek: stream, flows W $1 \mathrm{mi}$. to Cherry Creek, $52 \mathrm{mi}$. S of Eagle, Yukon-Tanana High.; $64^{\circ} 03^{\prime} \mathrm{N}, 141^{\circ} 09^{\prime} \mathrm{W}$; (map 102). Var. Carlin Creek.

Prospectors' name shown on an 1898 manuscript map by C. A. Woodruff, Fort Cudahy, Canada.
Carlisle Island: island, $5 \mathrm{mi}$. across, one of Islands of Four Mts., Aleutian Is.; 52 $53^{\prime} 30^{\prime \prime}$ $N, 170^{\circ} 03^{\prime} 30^{\prime} \mathrm{W}$; (map 20). Var. Kigalgin Island, Ollaga Island, Ostrov Kigalgin, Ostrov Tanakh-Angunakh, Ostrov Tano, Ostrov Ullyaga, Ostrov Ullyagin, Ostrov Ulyaga, Ostrov Ulyagan, Oulliaghin Island, TanachAngunach Island, Tanakh-Angunakh Island, Tana-Unok Island, Tano Island, Ulaga Island, Uliaga Island, Uliagant Island, Ulliaga Island, Ulliagin Island.

Named by the U.S. Navy Hydrog. Office in 1894 for John G. Carlisle, 1835-1910, Secretary of the Treasury. This island was called "O[strov] Tano" or "Tano Island" by Lt. Sarichev (1876, map 3), IRN; "O[strov] Tanakh-Angunakh" or "Tanakh-Angunakh Island" by the Russian Hydrog. Dept. in 1847 on Chart 1379; and "O[strov] Kigalgin" or "Kigalgin Island" by Capt. Tebenkov (1852, map 25 dated 1849) IRN. These variant names differ from those published by Baker (1906, p. 264). See Four Mountains, Islands of.

Carlisle Pass: water passage, between Carlisle and Chuginadak Is., Aleutian Is.; $52^{\circ} 52^{\prime} \mathrm{N}$, $170^{\circ} 00^{\prime} \mathrm{W}$; (map 20).

Name derived from Carlisle Island and published by USC\&GS in the 1944 Aleutian Coast Pilot (p. 72).

Carlo: $R R$ station, mile 334.4 on The Alaska $R R$, on left bank of Nenana River, $0.3 \mathrm{mi}$. $\mathrm{N}$ of mouth of Carlo Creek and $22 \mathrm{mi}$. S of Healy, Alaska Ra.; $63^{\circ} 34^{\prime} \mathrm{N}, 148^{\circ} 50^{\prime} \mathrm{W}$; (map 87)

Local name first reported by The Alaska RR. on a 1923 manuscript map.

Carlo Creek: stream, flows NW $10 \mathrm{mi}$. to Nenana River, $20 \mathrm{mi}$. S of Healy, Alaska Ra.; 63 $34^{\prime} \mathrm{N}, 148^{\circ} 50^{\prime} \mathrm{W}$ : (map 87).

Local name reported by The Alaska Railroad on a 1923 manuscript map.

Carlo Island: island, $5.2 \mathrm{mi}$. long, in Yukon River, $13 \mathrm{mi}$. NW of Holy Cross, Innoko Low.; $62^{\circ} 24^{\prime} \mathrm{N}, 160^{\circ} 00^{\prime} \mathrm{W}$; (map 78).

Riverboat pilots' name shown on a 1916 fieldsheet by R. H. Sargent, USGS.

Carlook: village, see Karluk.

Carls Cache Lake: lake, $1 \mathrm{mi}$. long, $\mathrm{N}$ of Otter Lake and $24 \mathrm{mi}$. SSW of village of Lake Minchumina, Tanana Low.; $63^{\circ} 33^{\prime} 15^{\prime \prime} \mathrm{N}, 152^{\circ}$ $32^{\prime} 40^{\prime \prime} \mathrm{W}$; (map 88).

Local name obtained in 1962 from Fabian Carey by USGS.

Carlsen Point: point of land, between Uyak and Zachar Bays, on NW coast of Kodiak I.; 57 $34^{\prime} 35^{\prime \prime} \mathrm{N}, 153^{\circ} 49^{\prime} 05^{\prime \prime} \mathrm{W}$; (map 34).

Local name published in 1943 by USC\&GS.

Carlsen Reef: reef, between Uyak and Zachar Bays, on NE ocast of Kodiak I.; $57^{\circ} 35^{\prime} 00^{\prime \prime}$ $\mathrm{N}, 153^{\circ} 49^{\prime} 50^{\prime \prime} \mathrm{W}$; (map 34).

Local name published in 1943 by USC\&GS.

Carlson Creek: stream, flows SE $4 \mathrm{mi}$. to Sunny Cove on Taku Inlet, $3 \mathrm{mi}$. SW of Flat Point and $10 \mathrm{mi}$. E of Juneau, Coast Mts.; $58^{\circ} 18^{\prime}$ $20^{\prime \prime} \mathrm{N}, 134^{\circ} 08^{\prime} 30^{\prime \prime} \mathrm{W}$; (map 11$)$.

Local name published in 1906 by USGS (Spencer and Wright, pl. 37).
Carlson Creek: stream, flows $\mathbf{E}$ through Carlson Lake, $5 \mathrm{mi}$. to Slana River, $12 \mathrm{mi}$. SW of Mentasta Pass, Alaska Ra.; $62^{\circ} 45^{\prime} 35^{\prime \prime} \mathrm{N}, 143^{\circ}$ $46^{\prime} 10^{\prime \prime} \mathrm{W}$; (map 84).

Local name reported by USGS in 1963.

Carlson Creek: stream, in Mount McKinley National Park, flows N $9 \mathrm{mi}$. to Clearwater Creek, $20 \mathrm{mi}$. NNE of Mount McKinley, Alaska Ra.; $63^{\circ} 21^{\prime} 15^{\prime \prime} \mathrm{N}, 150^{\circ} 52^{\prime} 30^{\prime \prime} \mathrm{W}$; BGN 1947; (map 88).

Local name reported in 1925 by $S$. $R$. Capps, USGS.

Carlson Lake: lake, 2,500 ft. long, E of Beluga River, $16 \mathrm{mi}$. $\mathrm{N}$ of Tyonek, Cook Inlet Low.; $61^{\circ} 17^{\prime} 50^{\prime \prime} \mathrm{N}, 151^{\circ} 13^{\prime} 15^{\prime \prime} \mathrm{W}$; (map 70).

Local name reported in 1954 by USGS

Carlson Lake: lake, $1.1 \mathrm{mi}$. long, in course of Carlson Creek, $12 \mathrm{mi}$. SW of Mentasta Pass, Alaska Ra.; $62^{\circ} 46^{\prime} \mathrm{N}, 143^{\circ} 52^{\prime} \mathrm{W}$; (map 84). Local name reported in 1960 by USGS.

Carlson Lake: lake, $1.1 \mathrm{mi}$. long, drains NW to Foraker River, $13 \mathrm{mi}$. SSE of village of Lake Minchumina, Tanana Low.; $63^{\circ} 48^{\prime} 30^{\prime \prime} \mathrm{N}$, $151^{\circ} 54^{\prime} 40^{\prime \prime} \mathrm{W}$; $(\operatorname{map} 88)$.

Local name reported in 1954 by USGS.

Carlton Island: island, $1 \mathrm{mi}$. across, in Dewey Anchorage, between Etolin and Onslow Is., Alex Arch.; $55^{\circ} 55^{\prime} \mathrm{N}, 132^{\circ} 22^{\prime} \mathrm{W}$; (map 4). Named in 1886 by Lt. Comdr. A. S. Snow, USN.

Carmack, Mount: mountain, 6,605 ft., in Coast Mts., $3.2 \mathrm{mi}$. S of Mount Cleveland and $7 \mathrm{mi}$. NW of Skagway; $59^{\circ} 33^{\prime} 55^{\prime \prime} \mathrm{N}, 135^{\circ} 15^{\prime} 00^{\prime \prime}$ W; (map 45).

Named in 1898 by John A. Flemer, USC\&GS, probably for George W. Carmack whose discovery of gold on Bonanza Creek in 1896 resulted in the Klondike gold rush. Carmack was born in Illinois and came to Alaska during the Juneau gold rush in 1881 . $\mathrm{He}$ married an Indian girl and for several years he and his wife and her relatives fished for salmon along the Klondike River. In 1896 he met Bob Henderson, an ex-sailor turned prospector, who told him about his gold discovery in the Yukon basin the previous summer. Carmack with his two in-laws, Tagish Jim and Tagish Charlie, visited the site of Henderson's discovery. After prospecting in the area for a few days, they found gold on Rabbit Creek, now called Bonanza Creek. The subsequent finding of large gold nuggets on this creek led to the Klondike gold rush.

Carmel: locality, at head of Nushagak Bay, 2 mi. NE of Nushagak and $6 \mathrm{mi}$. SE of Dillingham, Bristol Bay Low.; 58 $58^{\prime} \mathrm{N}, 158^{\circ} 28^{\prime} \mathrm{W}$; (map 52).

A Moravian mission and school named for a biblical town in Judea. It was established in 1885 and adjoined the Eskimo village of Kanulik. Later, a hospital and industrial schools for boys and girls were added. The population in 1890 was 189 ; in 1900,381 . It was abandoned about 1910 .

Carmen Creek: stream, flows SE $1 \mathrm{mi}$. to Baituk Creek which flows to Bering Sea, $11 \mathrm{mi}$. SE 
of Cape Prince of Wales and $45 \mathrm{mi}$. NW of Teller, Seward Penin. High.; 65 $32^{\prime} \mathrm{N}$, $167^{\circ} 43^{\prime} \mathrm{W}$; (map 111).

Prospectors' name reported on the 1908 "Map of Seward Peninsula" by Arthur Gibson.

Carmen Island: island, see Kayak Island.

Carmen Lake: lake, $2.5 \mathrm{mi}$. long, at head of Glacier River, $9 \mathrm{mi}$. NW of Whittier, Chugach Mts.; 60 $54^{\prime} 30^{\prime \prime} \mathrm{N}, 148^{\circ} 46^{\prime} 00^{\prime \prime} \mathrm{W}$; (map 63). Local name reported in 1951 by USGS.

Carnegie Creek: stream, flows SW $1.9 \mathrm{mi}$. to Wasilla Creek, $3.5 \mathrm{mi}$. NW of Palmer, Cook Inlet Low.; $61^{\circ} 38^{\prime} 00^{\prime \prime} \mathrm{N}, 149^{\circ} 11^{\prime} 50^{\prime \prime} \mathrm{W}$; (map 69).

Local name shown on a town plat, reported in 1913 by USGS.

Carnivore Creek: stream, heads at glacier, in Franklin Mts. flows N $9 \mathrm{mi}$. to Lake Peters, $9 \mathrm{mi}$. W of Mount Michelson, Brooks Ra.; $69^{\circ} 17^{\prime} \mathrm{N}, 145^{\circ} 02^{\prime} \mathrm{W}$; (map 139). Var. Lake Fork Sadlerochit River.

So named by Bee and Hall (1956, p. 295) because the flat floored canyon of this stream is the frequent habitat of the carnivorous grey wolf (Canis lupus tundrarum).

Carnivore Lakes: lakes, three, along course of Carnivore Creek, in Lake Peters area, in Franklin Mts., Brooks Ra.; (map 139).

Name published by Bee and Hall (1965, p. 296).

Caro: locality, on $\mathrm{N}$ bank of Chandalar River, at mouth of Flat Creek, $26 \mathrm{mi}$. SSE of Chandalar, Brooks Ra.; $67^{\circ} 10^{\prime} 15^{\prime \prime} \mathrm{N}, 148^{\circ} 00^{\prime} 00^{\prime \prime}$ W; (map 123).

This place was established as a mining camp about 1906, and it obtained a post office in 1907. The post office was discontinued in 1912 (Ricks, 1965, p. 9). The camp was named for Caro Kingsland Clum, daughter of the postmaster of Fairbanks in 1907

Carol Channel: estuary, see Carroll Inlet.

Carolina Creek: stream, "drains to Flint Creek in Ruby District,' Kilbuck-Kuskokwim Mts.; (map 98).

This stream is mentioned in a 1913 letter by A. H. Brooks in which he says it was "named for a city in Spain in a lead mining area."

Caroline, Lake: lake, $900 \mathrm{ft}$. long, drains SW through Lake Aurel to Russian Creek, $9.9 \mathrm{mi}$. SW of Kodiak, Kodiak I.; 57 $42^{\prime} 05^{\prime \prime} \mathrm{N}$, $152^{\circ} 36^{\prime} 50^{\prime \prime} \mathrm{W}$; (map 34 ).

Local name reported in 1949 by USGS. Caroline Point: point of land, in Glacier Bay $\mathrm{Na}$ tional Monument, $0.4 \mathrm{mi}$. NE of Sebree I., at mouth of Muir Inlet, $53 \mathrm{mi}$. NW of Hoonah, St. Elias Mts.; $58^{\circ} 46^{\prime} 45^{\prime \prime} \mathrm{N}$, $136^{\circ} 08^{\prime} 30^{\prime \prime} \mathrm{W} ; B G N 1948$; (map 10). Var. Caroline Shoal.

Named by USC\&GS in 1940, "because Caroline Shoal extends "eastward from this point."

Caroline Shoal: shoal, in Muir Inlet, $0.7 \mathrm{mi}$. SE of Caroline Point, in Glacier Bay National Monument, and $52 \mathrm{mi}$. NW of Hoonah, St. Elias Mts.; $58^{\circ} 46^{\prime} 35^{\prime \prime} \mathrm{N}, 136^{\circ} 07^{\prime} 30^{\prime \prime} \mathrm{W}$; (map 10).
Origin of name unknown. Name first appears on Br. Adm. Chart 2431, corrected to 1890.

Caroline Shoal: point of land, see Caroline Point.

Carol Point; point of land, see Carroll Point.

Carolus, Point: point of land, at $\mathrm{W}$ entrance to Glacier Bay, in Glacier Bay National Monument, $4.5 \mathrm{mi}$. W of Point Gustavus and $29 \mathrm{mi}$. NW of Hoonah, St. Elias Mts.; $58^{\circ} 23^{\prime} 00^{\prime} \mathrm{N}$ $136^{\circ} 02^{\prime} 15^{\prime \prime}$ W; (map 10). Var. Carolus Point.

Named by USC\&GS in 1879 ; published in the 1883 Coast Pilot (p. 188) as Point Carolus.

Carolyn Island: island, $0.3 \mathrm{mi}$. long, in Golovnin Bay, $47 \mathrm{mi}$. ESE of Solomon, Seward Penin. High. ; $64^{\circ} 27^{\prime} \mathrm{N}, 162^{\circ} 53^{\prime} \mathrm{W}$; (map 95).

Named in 1900 by USC\&GS and published on Chart 9380.

Carpathian Peak: peak, 6,050 ft., in Kenai Mts., at head of Portage Glacier, $8 \mathrm{mi}$. SW of Whittier, Chugach Mts.; $60^{\circ} 41^{\prime} 50^{\prime \prime} \mathrm{N}, 148^{\circ} 49^{\prime}$ $45^{\prime \prime} \mathrm{W}$; (map 63).

Named in 1959, when the "first ascent was made by Keith Hart, Ted Barrett, and Mat Nitsch," for the Carpathian Mts. of MiddleEurope.

Carp Creek: stream, flows N $6 \mathrm{mi}$. to Smeaton Bay, $2 \mathrm{mi}$. E of Point Nelson, on Behm Canal, Coast Mts.; $55^{\circ} 17^{\prime} 30^{\prime \prime} \mathrm{N}, 130^{\circ} 52^{\prime} 40^{\prime \prime} \mathrm{W}$ $B G N 1962$; $(\operatorname{map} 3)$.

Local name recorded in 1955 by USGS.

Carpe, Mount: peak, 12,550 ft., in Mount McKinley National Park, highest peak on Carpe Ridge, $7 \mathrm{mi}$. NE of Mount McKinley, Alaska Ra. ; $63^{\circ} 09^{\prime} 10^{\prime \prime} \mathrm{N}, 150^{\circ} 51^{\prime} 30^{\prime \prime} \mathrm{W}$; $B G N 1947$; (map 88)

Named in March 1943 by the U.S. Army Test Expedition for Allen Carpé. See Carpe Ridge.

Carpenter Creek: stream, heads at a glacier, flows NW $10 \mathrm{mi}$. to Matanuska River, $19 \mathrm{mi}$. $\mathrm{NE}$ of Palmer, Chugach Mts.; $61^{\circ} 45^{\prime} 15^{\prime} \mathrm{N}$, $148^{\circ} 37^{\prime} 00^{\prime \prime} \mathrm{W}$; ( $\left.\operatorname{map} 69\right)$.

Local name reported in 1960 by USGS

Carpe Ridge: ridge, elev. 7,000-12,550 ft., in Mount McKinley National Park, extends SW $8 \mathrm{mi}$. between Traleika and Muldrow Glaciers, Alaska Ra.; $63^{\circ} 10^{\prime} 30^{\prime \prime} \mathrm{N}, 150^{\circ} 49^{\prime} 00^{\prime \prime} \mathrm{W}$ BGN 1933; ( $\operatorname{map} 88$ ).

Named in 1933 by H. M. Albright, NPS, for Allen Carpé, member of the Rockefeller Cosmic Ray Expedition, who, with Theodore Koven, in May 1932, was killed by falling into a crevasse on Muldrow Glacier. See Koven, Mount.

Carpet Peak: peak, 5,500 ft., on edge of Taku Glacier, near $\mathbf{N}$ end of Taku Ridge, $24 \mathrm{mi}$. $\mathbf{N}$ of Juneau, Coast Mts.; $58^{\circ} 39^{\prime} 30^{\prime \prime} \mathrm{N}, 134^{\circ}$ 23'00" W; (map 11 )

Local name published in 1960 by USGS

Carp Island: island, $0.3 \mathrm{mi}$. across, near mouth of Smeaton Bay, Coast Mts.; $55^{\circ} 17^{\prime} 55^{\prime \prime} \mathrm{N}$, $130^{\circ} 53^{\prime} 05^{\prime \prime} \mathrm{W}$; (map 3 )

Arbitrary name given in 1891 by USC\&GS. Carrew, Point: point of land, at mouth of Monti Bay, at $\mathrm{N}$ end of Phipps Penin., $8 \mathrm{mi}$. $\mathrm{W}$ of
Yakutat, Malaspina Coastal Plain ; 59 $33^{\prime} 30^{\prime \prime}$ N, 139 $50^{\prime} 15^{\prime \prime}$ W; (map 46). Var. Phipps Point.

Named in 1787 by Capt. Dixon (1789, p. 170). There has been confusion in the application of the names "Phipps, Carrew and Ocean Points." According to the 1883 Coast Pilot (p. 206) Capt. Kromchenko, IRN, in 1823 applied the name "Phipps" to this point.

Carrie Creek : stream, see Cary Creek.

Carrigan Creek: stream, flows N $5 \mathrm{mi}$. to Kuzitrin River $2 \mathrm{mi}$. downstream from mouth of Kougarok River, $16 \mathrm{mi}$. NW of Mount Bendeleben, Seward Penin. High.; $65^{\circ} 14^{\prime}$ N, $164^{\circ} 37^{\prime}$ W; (map 110).

Prospectors' name shown on a map of Cape Nome gold fields by David Fox, Jr., dated 1901.

Carrillo, Punta de: point of land, see Middle Point.

Carrizales, Punta de: point of land, see San Roque, Point.

Carrol Channel: estuary, see Carroll Inlet.

Carroll Anchorage: bight, see California Bay.

Carroll Channel: estuary, see Carroll Inlet.

Carroll Creek: stream, heads in a lake on $\mathrm{Re}$ villagigedo I., flows SE $11 \mathrm{mi}$. to Carroll Inlet, Alex. Arch.; $55^{\circ} 39^{\prime} \mathrm{N}, 131^{\circ} 21^{\prime} \mathrm{W}$; $B G N$ 1923; (map 3). Var. Carroll River.

Named in 1923 by USFS.

Carroll Glacier: glacier, in Glacier Bay National Monument, heads near the Alaska-Canada boundary, trends SE $15 \mathrm{mi}$. to its 1950 terminus, $1 \mathrm{mi}$. $\mathbf{N}$ of Queens Inlet, $71 \mathrm{mi}$. NW of Hoonah, St. Elias Mts.; $58^{\circ} 58^{\prime} 50^{\prime \prime} \mathrm{N}, 136^{\circ}$ $30^{\prime} 30^{\prime \prime}$ W; BGN Sixth Report; (map 10). Var. Woods Glacier.

Named in 1892 by Reid (1896, p. 422), USGS, for Capt. James Carroll of the SS Queen who, in that year, was the first to take a ship into the upper part of Glacier Bay. It was called Woods Glacier by the IBC in 1898 .

Carroll Inlet: estuary, extends S $29 \mathrm{mi}$. from center of Revillagigedo $I$. to Revillagigedo Channel, $6 \mathrm{mi}$. SE of Ketchikan, Alex. Arch.; $55^{\circ} 17^{\prime} \mathrm{N}, 131^{\circ} 30^{\prime} \mathrm{W}$; (map 3). Var. Carol Channel, Carrol Channel, Carroll Channel.

Named in 1880 by USC\&GS for Capt. James Carroll who commanded ships in this area for many years; the generic "channel" was changed to "inlet" after it was discovered that the feature was not a passage.

Carroll Island: island, $0.3 \mathrm{mi}$. across, in Frederick Sound, off S coast of Admiralty I., Alex. Arch.; $57^{\circ} 01^{\prime} 40^{\prime \prime} \mathrm{N}, 134^{\circ} 28^{\prime} 30^{\prime \prime} \mathrm{W}$; (map 9).

Named for Capt. James Carroll who, for many years, commanded steamships in these waters. Name published by USC\&GS in 1899. Carroll Point: point of land, on S coast of Revillagigedo I., near mouth of Carroll Inlet, $7 \mathrm{mi}$. SE of Ketchikan, Alex. Arch.; $55^{\circ} 18^{\prime} \mathrm{N}$, $131^{\circ} 29^{\prime} \mathrm{W}$; (map 3$)$. Var. Carol Point.

Named in 1880 by USC\&GS for Capt. James Carroll. See Carroll Inlet.

Carroll Strait: water passage, see Gastineau Channel. 
Carrot Lake: lake, $0.7 \mathrm{mi}$. long, $1 \mathrm{mi}$. E of Summit of Slide Mountain, $50 \mathrm{mi}$. SW of Gulkana, Copper River Basin; 62 $01^{\prime} 30^{\prime \prime} \mathrm{N}$, $146^{\circ} 48^{\prime} 00^{\prime \prime} \mathrm{W}$; (map 83). Var. Fossil Lake. Descriptive local name reported in 1956 by USGS.

Carry Gulch: ravine, trends S $2 \mathrm{mi}$. to Cripple River, $16 \mathrm{mi}$. NW of Nome, Seward Penin. High.; $64^{\circ} 40^{\prime} 30^{\prime \prime} \mathrm{N}, 165^{\circ} 45^{\prime} 00^{\prime \prime} \mathrm{W}$; (map 94).

Prospectors' name shown on the 1904 "Map of Cape Nome Precinct" by Arthur Gibson.

Carry Inlet: bay, $0.5 \mathrm{mi}$. across, on $\mathrm{N}$ coast of Shuyak I., $47 \mathrm{mi}$. N of Kodiak I., $58^{\circ} 35^{\prime} \mathrm{N}$, $152^{\circ} 32^{\prime}$ W; (map 43). Var. Perevainoy, Perewamno.

Name published by USC\&GS in 1911 on Chart 8555. Baker (1906, p. 163) applied this name to the largest of the Perevalnie Islands, though it seems that the generic "Inlet" is a typographical error for Islet. See Perevalnie Islands.

Carry Inlet: islands, see Perevalnie Islands.

Carry Island: islands, see Perevalnie Islands.

Garshan Point: point of land, between Carry Inlet and Shagin Bay, on N coast of Shuyak I., $51 \mathrm{mi}$. N of Kodiak I.; $58^{\circ} 37^{\prime} 40^{\prime \prime} \mathrm{N}$, $152^{\circ} 27^{\prime} 30^{\prime \prime} \mathrm{W}$; BGN 1933; (map 43).

Named by USC\&GS in 1931 by combining parts of the names "Carry [Inlet]" and "Shangin [Bay]," features which lie on both sides of this point of land.

Carson Creek: stream, heads in Robinson Mts. and flows $2.5 \mathrm{mi}$. S to Icy Bay, $2.8 \mathrm{mi}$. NE of Claybluff Point and $69 \mathrm{mi}$. NW of Yakutat, Chugach Mts.; $59^{\circ} 59^{\prime} 20^{\prime \prime} \mathrm{N}, 141^{\circ} 31^{\prime} 00^{\prime \prime} \mathrm{W}$; (map 47).

Local name published by USGS in 1948 . Carson Creek: stream, flows SE $3.4 \mathrm{mi}$. to Norton Bay, $19 \mathrm{mi}$. SW of Elim, Seward Penin. High.; $64^{\circ} 29^{\prime} \mathrm{N}, 162^{\circ} 36^{\prime} \mathrm{W}$; BGN 1910; (map 95). Var. East Portage Creek.

Shown as "East Portage" on a precinct map of Seward Peninsula by Monroe and Hutchins, corrected to June 1903 by Arthur Gibson.

Local name reported in 1909 by Smith and Eakin (1911, pl. 1), USGS

Carter: locality, on shore of Carter Bay, $\mathrm{S}$ of mouth of Carter Creek, $18 \mathrm{mi}$. NW of Goodnews, Kilbuck-Kuskokwim Mts.; $59^{\circ} 17^{\prime} \mathrm{N}$, $161^{\circ} 56^{\prime} \mathrm{W}$; (map 53 ).

Name of former settlement now identified by two abandoned cabins. The name was published by USC\&GS in 1916 Coast Pilot (p. 284).

Carter, Mount: mountain, 4,300 ft., $4.4 \mathrm{mi}$. W of The Gorge on Klutina River, $50 \mathrm{mi}$. NNE of Valdez, Chugach Mts. ; $61^{\circ} 47^{\prime} 50^{\prime \prime} \mathrm{N}, 145^{\circ}$ $43^{\prime} 50^{\prime \prime} \mathrm{W}$; (map 68).

Named in 1898 by Capt. W. R. Abercrombie, USA.

Carter Bay: bay, separated from Kuskokwim Bay by Carter Spit, W of Carter, $20 \mathrm{mi}$. NW of Goodnews Kilbuck-Kuskokwim Mts.; 59 $19^{\prime}$ N, $161^{\circ} 59^{\prime} \mathrm{W}$; (map 53). Var. Kigchakok. Local name reported about 1913 by USC\&GS; published in 1916 on Chart 9103. Its Eskimo name is given as "Kigchakok."
Carter Bay Spit: point of land, see Carter Spit. Carter Creek: stream, flows NW $12 \mathrm{mi}$. to Carter Bay at Carter, $18 \mathrm{mi}$. NW of Goodnews, Kilbuck-Kuskokwim Mts.; $59^{\circ} 17^{\prime} \mathrm{N}, 161^{\circ} 56^{\prime} \mathrm{W}$; (map 53).

Name derived from Carter Bay; published in 1938 by USGS.

Carter Creek: stream, on Kenai Penin., heads on Madson Mtn., flows NE $1 \mathrm{mi}$. to Moose Creek, $0.5 \mathrm{mi}$. W of Upper Trail Lake, $26 \mathrm{mi}$. N of Seward, Chugach Mts.; $60^{\circ} 30^{\prime} 10^{\prime \prime} \mathrm{N}, 149^{\circ}$ $26^{\prime} 00^{\prime \prime} \mathrm{W}$; (map 63 ).

Local name reported in 1898 by Mendenhall (1900, map 16), USGS.

Carter Creek: stream, heads in Sadlerochit Mts., flows N 25 mi. to Camden Bay, 5 mi. SE of Collinson Point, $25 \mathrm{mi}$. SW of Barter I., Arctic Plain; $69^{\circ} 58^{\prime} \mathrm{N}, 144^{\circ} 42^{\prime} \mathrm{W}$; (map 139). Var. Ekalukliurak Creek.

Named by Leffingwell $(1919$, p. 94) for the prospector F. G. Carter. USC\&GS reported in 1948 that the Eskimo name for this stream is "Ekalukliurak" which generally refers in meaning to "place where fish are caught early."

Carter Horn: peak, 20,220 ft., in Mount McKinley National Park. E of summit of Mount McKinley, Alaska Ra.; $63^{\circ} 04^{\prime} 15^{\prime \prime} \mathrm{N}, 150^{\circ}$ 59'55" W: (map 88).

Named in 1913 by Archdeacon Stuck (1921, p. 186), for Clara Carter, missionary at Nenana. See Farthing Horn.

Carter Pass: pass, 3,600 ft., in Philip Smith Mts. at head of Spring Creek, $38 \mathrm{mi}$. NW of Artic Village, Brooks Ra:; $68^{\circ} 38^{\prime} \mathrm{N}, 146^{\circ} 07^{\prime} \mathrm{W}$; (map 136).

Named in 1903 by S. J. Marsh for F. G. Carter, a companion prospector, who preceded him through the pass by 2 months.

Carter Spit: spit, extends N 7 mi. into Kuskokwim Bay, forms W shore of Carter Bay, $21 \mathrm{mi}$. NW of Goodnews, Kilbuck-Kuskokwim Mts.; $59^{\circ} 19^{\prime} \mathrm{N}, 162^{\circ} 00^{\prime} \mathrm{W}$; (map 54). Var. Carter Bay Spit, Long Island.

Name published by USC\&GS in 1914; derived from nearby village of Carter.

Cary Creek: stream, flows NE $1.2 \mathrm{mi}$. to Quartz Creek which flows to Kougarok River, $47 \mathrm{mi}$. SW of Imuruk Lake, Seward Penin. High.; $65^{\circ} 21^{\prime} \mathrm{N}, 164^{\circ} 41^{\prime} \mathrm{W}$; (map 110 ). Var. Carrie Creek.

Prospectors' name reported as "Carrie Creek" in 1901 by T. G. Gerdine (in Collier, 1902, pl. 12), USGS.

Casaan Bay: bay, see Kasaan Bay.

Casadepaga: locality, on Casadepaga River, $1 \mathrm{mi}$. $\mathrm{S}$ of Ruby and $17 \mathrm{mi}$. N of Solomon, Seward Penin. High.; $64^{\circ} 48^{\prime} \mathrm{N}, 164^{\circ} 21^{\prime} \mathrm{W}$; (map 95).

Site of a mining camp listed in the 1915-16 Polk's Gazetteer.

Casadepaga River: stream, flows NE $32 \mathrm{mi}$. to Niukluk River, $31 \mathrm{mi}$. NE of Solomon, Seward Penin. High.; $64^{\circ} 58^{\prime} \mathrm{N}, 164^{\circ} 04^{\prime} \mathrm{W}$; BGN 1904; (map 95). Var. Casa-de-Parga Creek, Kassdeparka Creek, Koksukdeparga Creek, Koksuktapaga River, Koshotok Creek, Kosoktok Creek.
Eskimo name published in January 1900 as "Casa-de-Parga (or Kosoktok Creek)" by Schrader (1900 c, p. 16), USGS.

Casa-de-Parga Creek: stream, see Casadepaga River.

Casca, Mount: mountain, 4,874 ft., $1.5 \mathrm{mi} \mathrm{E}$ of Alaska-Canacla boundary and $39 \mathrm{mi}$. $\mathrm{N}$ of Eagle, Porcupine Plat.; 65 $21^{\prime} \mathrm{N}, 141^{\circ} 03^{\prime} \mathrm{W}$; (map 103).

Named by D. D. Cairnes (Canada Geological Survey Mem. 67, map) in 1911-1912 after triangulation station "Casca" established by the International Boundary Survey on this mountain in 1910. The station, in turn, was named for the "British" steamboat Casca which was engaged in Yukon River trade.

Cascade: point of land, see Cascade Point.

Cascade Bay: bay, $0.5 \mathrm{mi}$. across, $5 \mathrm{mi}$. SE of Baranof, on E' coast of Baranof I., Alex. Arch.; $57^{\circ} 01^{\prime} 30^{\prime \prime} \mathrm{N}, 134^{\circ} 45^{\prime} 00^{\prime \prime} \mathrm{W}$; (map 9).

Named in 1895 by Lt. Comdr. E. K. Moore, USN.

Cascade Bay: estuary, extends SE $1.5 \mathrm{mi}$. to Eaglek Bay, $32 \mathrm{mi}$. NE of Whittier, Chugach Mts.; $60^{\circ} 54^{\prime} 30^{\prime \prime} \mathrm{N}, 147^{\circ} 45^{\prime} 45^{\prime \prime} \mathrm{W}$; (map 63).

Local name reported in 1952 by USGS.

Cascade Bight: cove, $1 \mathrm{mi}$. across, on $\mathrm{S}$ coast of Akutan I. W of Broad Bight, Krenitzin Is., Aleutian Is. ; $54^{\circ} 04^{\prime} 00^{\prime \prime} \mathrm{N}, 165^{\circ} 58^{\prime} 20^{\prime \prime} \mathrm{W}$; BCN 1936; (map 24).

Local name reported in 1901 by J. J. Gilbert, USCi\&GS

Cascade Creek: stream, flows $\mathbf{W} 8 \mathrm{mi}$. to Thomas Bay, $2 \mathrm{mi}$. E of Ruth I. and $100 \mathrm{mi}$. E of Sitka, Coast Mts.; $57^{\circ} 00^{\prime} 15^{\prime \prime}$ N, $132^{\circ} 46^{\prime} 50^{\prime \prime}$ $W ;(\operatorname{map} 8)$.

Descriptive name published by USGS (Martin and others, 1919, pl. 1). So named because "from the outlet of a lake [Swan Lake] at an elevation of $1,200 \mathrm{ft}$. above sea level and 3 miles from tidewater the river descends in a continuous series of rapids and falls through a narrow, deep canyon."

Cascade Creek: stream, flows SW $2.5 \mathrm{mi}$. to Western Channel in Sitka Sound, $2 \mathrm{mi}$. NW of Sitka, on W coast of Baranof I., Alex., Arch.; $57^{\circ} 04^{\prime} 25^{\prime \prime} \mathrm{N}, 135^{\circ} 22^{\prime} 10^{\prime \prime} \mathrm{W}$; (map 9). Named in 1880 by USN.

Cascade Creek: stream, flows $\mathrm{N} 3 \mathrm{mi}$. to $\mathrm{S}$ tip of Karluk Lake, $27 \mathrm{mi}$. SE of Karluk, Kodiak I.; $57^{\circ} 16^{\prime} 45^{\prime \prime}$ IN, $154^{\circ} 00^{\prime} 20^{\prime \prime}$ W; (map 35).

Local narne reported in 1952 by USG.S. Cascade Creek: stream, fows SE $5 \mathrm{mi}$. to Slate Creek, 20 rni. NE of Goodnews, KilbuckKuskokwim Mts.; $59^{\circ} 19^{\prime}$ N, 161 $14^{\prime}$ W ; (map 53).

Local descriptive name published by $\mathbf{G}$. $\mathbf{L}$. Harrington (in Brooks and others, 1921, p. 7), USGS.

Cascade Creek: stream, flows $\mathrm{N} 4 \mathrm{mi}$. to Tsina River, 2.4 mi. $\mathrm{E}$ of Ptarmigan and $24 \mathrm{mi}$. ENE of Valdez, Chugach Mts. ; $61^{\circ} 11^{\prime} 55^{\prime \prime} \mathrm{N}$, $145^{\circ} 33^{\prime} 10^{\prime \prime} \mathrm{W}$; (map 68).

Local name published in the 1950's by USGS.

Cascade Creek: stream, heads on Anthracite Ridge, flows SW $5.2 \mathrm{mi}$. to Matanuska River, 
$36 \mathrm{mi}$. NE of Palmer, Talkeetna Mts.; $61^{\circ} 47^{\prime}$ $\mathrm{N}, 148^{\circ} 06^{\prime} \mathrm{W}$; (map 69).

Local name reported in 1913 by $R$. $H$. Sargent, USGS.

Cascade Creek: stream, flows SE $10 \mathrm{mi}$. to East Fork Yentna River, $60 \mathrm{mi}$. W of Talkeetna, Alaska Ra.; 62 $24^{\prime} 35^{\prime \prime} \mathrm{N}, 151^{\circ} 59^{\prime} 00^{\prime \prime} \mathrm{W}$; (map 81).

Local descriptive name reported in 1958 by USGS.

Cascade Creek: stream, flows NW $4.7 \mathrm{mi}$. to Norton Sound, $8.5 \mathrm{mi}$. S of Unalakleet, Nulato Hills ; $63^{\circ} 44^{\prime} 45^{\prime \prime} \mathrm{N}, 160^{\circ} 47^{\prime} 10^{\prime \prime} \mathrm{W}$; (map 91). Var. Glacier Creek.

Local name reported in 1924 by USC\&GS.

Cascade Creek: stream, flows NE $4.5 \mathrm{mi}$. to Peregrine Creek, $20 \mathrm{mi}$. SE of Table Top and $42 \mathrm{mi}$. NE of Anaktuvuk Pass, Arctic Slope $68^{\circ} 27^{\prime} 30^{\prime \prime} \mathrm{N}, 150^{\circ} 24^{\prime} 00^{\prime \prime} \mathrm{W}$; (map 134).

Descriptive name given by USGS geologists during the exploration of Naval Petroleum Reserve No. 4; name given in 1944.

Cascade Glacier: glacier, in Glacier Bay National Monument, heads on SW slope of Fairweather Ra., trends W $3.7 \mathrm{mi}$. to head of Lituya Bay, $84 \mathrm{mi}$. NW of Hoonah, St. Elias Mts.; $58^{\circ}$. $39^{\prime} 55^{\prime \prime} \mathrm{N}, 137^{\circ} 28^{\prime} 15^{\prime \prime} \mathrm{W}$; BGN 1945; (map 10). Var. Centre Glacier, Dead Glacier, Middle Glacier

Descriptive name reported by IBC on a map dated 1894. J. B. Mertie, Jr. (in Smith and others, 1935, p. 123), USGS, noted, "called Middle Glacier by La Perouse." Mertie further noted that it has been locally called "Dead Glacier" because it retreated during recent years, whereas Lituya and Crillon Glaciers at the head of the bay have apparently advanced more than 3 miles during the last 180 years. It was called "Centre Glacier" by members of the Harvard-Dartmouth Expedition, 1933-34 (Washburn and Goldthwait, 1936, map).

Cascade Glacier: glacier, heads on Mount Augusta on Alaska-Canada boundary, trends SSE $6 \mathrm{mi}$. to Seward Glacier, $55 \mathrm{mi}$. NW of Yakutat, St. Elias Mts.; $60^{\circ} 12^{\prime} \mathrm{N}, 140^{\circ} 28^{\prime}$ W; (map 66).

So named in 1890 by Russell (1891, p. 144), USGS, "on account of its splendid icefall."

Cascade Glacier: glacier, trends S $4.5 \mathrm{mi}$. to Barry Arm Port Wells, $W$ of Barry Glacier, $57 \mathrm{mi}$. E of Anchorage, Chugach Mts.; 61 ${ }^{\circ} 07^{\prime}$ N, $148^{\circ} 10^{\prime} \mathrm{W}$; BGN 1910; (map 69).

Descriptive name given in 1899 by members of the Harriman Alaska Expedition.

Cascade Inlet: estuary, extends SE $3.3 \mathrm{mi}$. to Felice Strait, between Annette and Ham Is., $17 \mathrm{mi}$. SE of Ketchikan, Alex. Arch.; 55 $09^{\prime}$ $40^{\prime \prime} \mathrm{N}, 131^{\circ} 21^{\prime} 20^{\prime \prime} \mathrm{W}$; (map 3$)$.

Descriptive name obtained from local pilots; published in 1883 Coast Pilot (p. 77).

Cascade Island: island, $0.1 \mathrm{mi}$. across, in Eaglek Bay, near mouth of Cascade Bay, $34 \mathrm{mi}$. NE of Whittier, Chugach Mts.; $60^{\circ} 54^{\prime} 45^{\prime \prime} \mathrm{N}$, $147^{\circ} 44^{\prime} 55^{\prime \prime} \mathrm{W}$; (map 63).

Local name reported in 1951 by USGS.
Cascade Lake: lake, $0.8 \mathrm{mi}$. long, on $\mathrm{E}$ coast of Annette I., $0.5 \mathrm{mi}$. W of Cascade Inlet, Alex. Arch.; $55^{\circ} 10^{\prime} \mathrm{N}, 131^{\circ} 23^{\prime} \mathrm{W}$; (map 3 ).

Named in 1917 by USC\&GS.

Cascade Lake: lake, $1.5 \mathrm{mi}$. long, $12 \mathrm{mi}$. NW of Lake Chauekuktuli and $81 \mathrm{mi}$. SE of Bethel, Kilbuck-Kuskokwim Mts.; $60^{\circ} 08^{\prime} \mathrm{N}, 159^{\circ} 24^{\prime}$ W; BGN 1959; (map 59).

Descriptive name reported in 1956 by USGS because "of the almost continuous cascades in the short stream which drains the lake."

Cascade Lake: lake, $1.7 \mathrm{mi}$. long, one of the Kurupa Lakes, $E$ of Kurupa Lake, $18 \mathrm{mi}$. NW of junc. of Easter Creek and Killik River, Brooks Ra. ; $68^{\circ} 22^{\prime} \mathrm{N}, 154^{\circ} 35^{\prime} \mathrm{W}$; BGN 1960 ; (map 133).

So named about 1951 by a USGS geologist during exploration of Naval Petroleum Reserve No. 4, "because the short stream that drains this lake cascades [about $500 \mathrm{ft}$.] to Kurupa Lake."

Cascade Point: point of land, on $\mathbf{S}$ coast of $\mathbf{S t}$. George I., in Pribilof Is.; $56^{\circ} 32^{\prime} 00^{\prime \prime} \mathrm{N}, 169^{\circ}$ $34^{\prime} 30^{\prime \prime}$ W; (map 38). Var. Cascade, Egithrotogh, Iuzhnie, Mys Yuzhnyy, Niyan-kiya, Southeast Point, Waterfall Head.

Local name derived from a waterfall on the point. Capt. Tebenkov (1852, map 21), IRN, called it "M[ys] Yuzhnyy" meaning "southern cape," and Elliott (1881, p. 55) called it both "Southeast Point" and "Waterfall Head." The Aleut names listed by Putnam (1903, p. 1015), USC\&GS, are "Egithrot'ogh," meaning "waterfall" and "Niyan-kiya," meaning "ridge."

Cascade Rock: rock, in central Bay of Is., Adak I., Aleutian Is.; $51^{\circ} 49^{\prime} 37^{\prime \prime} \mathrm{N}, 176^{\circ} 49^{\prime} 29^{\prime \prime} \mathrm{W}$; (map 17).

Named by members of the U.S. Navy Aleutian Island Survey Expedition in 1934. Cascading Glacier: glacier, trends NE $2 \mathrm{mi}$. to its 1961 terminus, SE of Mount Draper and $31 \mathrm{mi}$. NE of Yakutat, St. Elias Mts.; $59^{\circ} 49^{\prime} 10^{\prime \prime} \mathrm{N}, 139^{\circ} 03^{\prime} 15^{\prime \prime} \mathrm{W}$; (map 46).

So named in 1899 by the Harriman Alaska Expedition (Gilbert, 1904, p. 61), because the glacier descends steeply over a series of rock terraces, giving it the appearance of an ice cascade.

Cascales, Punta: point of land, in Port Etches on Hinchinbrook $\mathbf{I}$.

Name shown on an anonymous 1779 "plano." Cascales may be an error for "Cascajales," meaning "a place full of pebbles" (Wagner, 1937, p. 440).

Casco Bay: cove, see Casco Cove.

Casco Beach: beach, $0.4 \mathrm{mi}$. long, in Casco Cove, on SE coast of Attu I., Aleutian Is. $52^{\circ} 49^{\prime} 30^{\prime \prime} \mathrm{N}, 173^{\circ} 10^{\prime} 15^{\prime \prime} \mathrm{E}$; (map 13).

Named by the U.S. Army during its occupation of the island during World War II; name shown on an AMS map published in 1948.

Casco Cove: cove, $1.4 \mathrm{mi}$. long, $\mathrm{N}$ of Murder Point, on SE coast of Attu I., Aleutian Is.; $52^{\circ} 49^{\prime} 00^{\prime \prime}$ N, $173^{\circ} 10^{\prime} 15^{\prime \prime}$ E; (map 13). Var. Casco Bay, Hulu Bay.
This cove was shown as "Hulu Bay" on a manuscript map drawn by L. M. Turner in the 1880 's, and was published as "Casco Cove" in the 1944 Aleutian Coast Pilot (p. 133).

Casco Point; point of land, at $\mathrm{N}$ entrance to Casco Cove, between Casco and Pyramid Coves, on SE coast of Attu I., Aleutian Is.; $52^{\circ} 48^{\prime} 50^{\prime \prime} \mathrm{N}, 173^{\circ} 10^{\prime} 45^{\prime \prime} \mathrm{E}$; (map 13).

Named by the U.S. Army during its occupation of the island during World War II; name shown on an AMS map published in 1948.

Case, Mount: mountain, 5,500 ft., in Glacier Bay National Monument, $0.5 \mathrm{mi}$. N of head of White Glacier and $66 \mathrm{mi}$. NW of Juneau, St. Elias Mts.; $58^{\circ} 49^{\prime} 05^{\prime \prime} \mathrm{N}, 1^{\circ} 55^{\circ} 05^{\prime \prime} \mathrm{W}$; (map 11).

Named in 1890 by H. F. Reid (1892, p. 30) for his school, the Case School of Applied Science, Cleveland, Ohio.

Case Creek: stream, flows $1.5 \mathrm{mi}$. S to North Fork Slug Creek, 22 mi. NE of Cape Newenham, Kilbuck-Kuskokwin Mts.; $58^{\circ} 44^{\prime} \mathrm{N}$, $161^{\circ} 34^{\prime} \mathrm{W}$; (map 39).

Local name shown on a 1937 fieldsheet by J. B. Mertie, Jr., USGS.

Case Creek: stream, see Whitman Creek.

Casement Glacier: glacier, in Glacier Bay National Monument, heads in Takhinsha Mts., trends SW $14 \mathrm{mi}$. to its 1962 terminus, $3 \mathrm{mi}$. $\mathrm{N}$ of Adams Inlet and $71 \mathrm{mi}$. NW of Juneau, St. Elias Mts.; $58^{\circ} 15^{\prime} \mathrm{N}, 135^{\circ} 59^{\prime} \mathrm{W}$; (map 11). Var. First North Tributary.

Named in 1890 "First North Tributary (of the Muir Glacier)" by H. F. Reid (1892, p. 21), and later "Casement Glacier" for R. L. Casement, a member of his party in 1890 .

Gasey Glacier: glacier, heads $2 \mathrm{mi}$. NW of Ninemile $\mathrm{Mtn}$., trends $\mathrm{N} 2 \mathrm{mi}$. to its 1955 terminus $10 \mathrm{mi}$. NW of Hyder, Coast Mts.; $56^{\circ} 03^{\prime} \mathrm{N}$, $130^{\circ} 11^{\prime} \mathrm{W}$; (map 7 ).

Local name published by A. F. Buddington (in Brooks and others, 1925, p. 85), USGS.

Casey Road House: locality, on left bank of Tolovana River, $1 \mathrm{mi}$. E of Wilber Creek, 7 mi. SE of Livengood, Yukon-Tanana High., $65^{\circ} 28^{\prime} \mathrm{N}, 148^{\circ} 20^{\prime} \mathrm{W}$; (map 105).

Former roadhouse, probably named for its owner, reported in 1915 by USGS (Brooks and others, 1916, pl. 9).

Caseys Channel: water passage, in Yukon Delta, extends N-S 6 mi. between Kwikluak Pass and Nurukomarot Channel, $12 \mathrm{mi}$. SW of Kwiguk, Yukon-Kuskokwim Delta; $62^{\circ} 39^{\prime}$ N, $164^{\circ} 50^{\prime}$ W; (map 77). Var. Nurukomarot Channel. Local name obtained in 1948 by USC\&GS.

Cash Creek: stream, heads in Roundabout Mts., flows NE $4.6 \mathrm{mi}$. to Candle Creek $3 \mathrm{mi}$. S of its junc. with Tatalina River, $4.2 \mathrm{mi}$. SW of McGrath, Kilbuck-Kuskokwim Mts.; 62 ${ }^{\circ} 55^{\prime}$ $45^{\prime \prime} \mathrm{N}, 155^{\circ} 43^{\prime} 00^{\prime \prime} \mathrm{W}$; (map 80)

Local name reported in 1910 by C. G. Anderson (in Eakin, 1914, pl. 2), USGS.

Cash Creek: stream, flows SW $6 \mathrm{mi}$. and joins California Creek to form Bear Creek, $62 \mathrm{mi}$. SW of Circle, Yukon-Tanana High.; $65^{\circ} 05^{\prime}$ $45^{\prime \prime} \mathrm{N}, 145^{\circ} 18^{\prime} 00^{\prime \prime} \mathrm{W}$; (map 104).

Local name reported in 1955 by USGS. 
Cash Creek: stream, see Cache Creek. Cash Creek: stream, see Hosford Creek. Cash Creek: stream, see Jasper Creek. Cash Creek: stream, see Left Fork Cache Creek. Cash Creek: stream, see Martin Creek.

Cashka Lake: lake, $0.2 \mathrm{mi}$. long, on Kenai Penin., $1.2 \mathrm{mi}$. N of Dolly Varden Lake and $20 \mathrm{mi}$. NE of Kenai, Cook Inlet Low.; $60^{\circ} 43^{\prime} 45^{\prime \prime} \mathrm{N}$, $150^{\circ} 47^{\prime} 00^{\prime \prime} \mathrm{W}$; (map 62).

Named about 1963 by officials of Kenai National Moose Range, for administrative purposes.

Cashman, Mount: mountain, 8,249 ft., $0.7 \mathrm{mi}$. $\mathbf{N}$ of head of Valdez Glacier, $19 \mathrm{mi}$. NW of Valdez, Ghugach Mts.; 61 $21^{\prime} 55^{\prime \prime} \mathrm{N}$, $146^{\circ} 27^{\prime} 30^{\prime \prime} \mathrm{W}$; BGN 1960; (map 68). Var. Jeep Mountain.

Named in 1959 by L. E. Nielsen, for "Edward Cashman who during the winter of 1898-99 made a trip from Valdez to the Copper River, over Valdez Glacier are back * * *." Cashman was a member of Capt. W. R. Abercrombie's party.

Casino Creek: stream, flows NE $3 \mathrm{mi}$. to Crater Creek, $26 \mathrm{mi}$. NE of Goodnews, KilbuckKuskokwim Mts.; $59^{\circ} 26^{\prime} 45^{\prime \prime} \mathrm{N}, 161^{\circ} 20^{\prime} 00^{\prime \prime}$ W; (map 53).

Local name published in 1951 by USGS

Casper Slough: streams, $2.5 \mathrm{mi}$. long, partially filled distributary of Alexander Creek, $S$ of Dinglishna Hill, $28 \mathrm{mi}$. NW of Anchorage, Cook Inlet Low.; $61^{\circ} 25^{\prime} 15^{\prime \prime} \mathrm{N}, 150^{\circ} 37^{\prime} 00^{\prime \prime}$ W; (map 70).

Local name reported in 1958 by USGS.

Cass Creek: stream, see Cuss Creek.

Cassiar Creek: stream, flows SE $5 \mathrm{mi}$. to Butte Creek, $30 \mathrm{mi}$. SW of Eagle, Yukon-Tanana High.; $64^{\circ} 38^{\prime} \mathrm{N}, 142^{\circ} 05^{\prime} \mathrm{W}$; (map 102).

Prospectors' name shown on an 1898 manuscript map by C. A. Woodruff, Fort Cudahy, Canada.

Cassiar Creek: stream, flows NW $5 \mathrm{mi}$. to Chatanika River, $45 \mathrm{mi}$. NE of Fairbanks, YukonTanana High.; $65^{\circ} 16^{\prime} 15^{\prime} \mathrm{N}, 146^{\circ} 42^{\prime} 05^{\prime \prime} \mathrm{W}$; (map 104)

Named by prospectors and published by USGS (Prindle, 1908, pl. 4).

Cassiope Cone: hill, 1,307 ft., 2 mi. S of Hoodoo Hill and $4 \mathrm{mi}$. W of Imuruk Lake, Seward Penin. High.; $65^{\circ} 34^{\prime} \mathrm{N}, 163^{\circ} 27^{\prime} \mathrm{W} ; B G N$ 1952; (map 110).

Reported in 1950 by D. M. Hopkins, USGS; one of "four conspicuous volcanic cones * * named for wild flowers which are common on the slopes of all four cones."

Cassiterite Creek: stream, in York Mts., flows SW 3 mi. to Lost River which fows to Bering Sea, $27 \mathrm{mi}$. NW of Teller, Seward Penin. High.; $65^{\circ} 28^{\prime} \mathrm{N}, 167^{\circ} 11^{\prime} \mathrm{W}$; (map 111).

Prospectors' name reported in 1903 by Collier (1904, pl. 2), USGS. Named for the mineral cassiterite which occurs in its valley.

Cassiterite Peak: mountain, 2,009 ft., in York Mts., $23 \mathrm{mi}$. NW of Teller, Seward Penin High.; $65^{\circ} 28^{\prime} \mathrm{N}, 167^{\circ} 00^{\prime} \mathrm{W}$; (map 111).

Local name reported in 1918 by Steidtmann and Cathcart (1922, fig. 5), USGS; applied by them to a mountain near the mouth of Cassiterite Creek, 4 mi. west.

Castalia Creek: stream, flows $\mathrm{N} 5 \mathrm{mi}$. to Yukon River, at Eagle, Yukon-Tanana High.; $64^{\circ} 47^{\prime} \mathrm{N}, 141^{\circ} 10^{\prime} \mathrm{W}$; (map 102).

Prospectors' name obtained in 1898 by E. C. Barnard, USGS.

Castani, Lake: lake, see Caetani, Lake.

Castigo, Punta de: point of land, see Punishment Point.

Castilla, Ensenada de: This name is shown on Capt. Alessandro Malaspina's manuscript chart in about $58^{\circ} 43^{\prime} \mathrm{N}$. The feature to which the name was intended to be applied cannot be identified. See Wagner (1937, p. 440).

Castle: locality, on Glenn Highway at Thirtymile Lake, $20 \mathrm{mi}$. NE of Palmer, Talkeetna Mts. ; 61 ${ }^{\circ} 45^{\prime} 35^{\prime \prime} \mathrm{N}, 148^{\circ} 35^{\prime} 00^{\prime \prime} \mathrm{W}$; (map 69).

Name reported by USGS in 1948.

Castle Bay: $b a y$, trends NE $10 \mathrm{mi}$. to Chignik Bay, along NW coast of Castle Cape, $9 \mathrm{mi}$. SE of Chignik, on Alaska Penin., Aleutian Ra.; $56^{\circ} 16^{\prime} \mathrm{N}, 158^{\circ} 09^{\prime} \mathrm{W}$; (map 30 ).

Named in 1899 by Lt. Comdr. J. F. Moser, USN, of the USBF steamer Albatross, "after Castle Cape to the southeast."

Castle Cape: peninsula, trends NE $11 \mathrm{mi}$., along SE shore of Castle Bay, $9.5 \mathrm{mi}$. SE of Chignik, on Alaska Penin., Aleutian Ra.; $56^{\circ} 10^{\prime} \mathrm{N}$, $158^{\circ} 20^{\prime}$ W; BGN 1926; (map 30). Var. Castle Point, Mys Tuliumnit, Tulioumnint, Tuliumnit Point, Tutiumnik.

This cape was described in 1898 by Lt. Comdr. J. F. Moser, USN, of the USBF steamer Albatross, as "a high-turreted or castellated point, called Tuliumnit Point or Castle Cape." The native name was shown as "M[ys] Tuliumnit" on Russian Hydrog. Dept. Chart 1379 (1847). Locally called "Castle Cape" according to USGS in 1911 and named thus in 1926.

Castle Cape: promontory, see Tuiliumnit Point.

Castle Creek: stream, flows SW $0.8 \mathrm{mi}$. to E1liott Greek, $1.7 \mathrm{mi}$. SE of Alice Peak and 80 mi. NE of Valdez, Wrangell Mts.; $61^{\circ} 38^{\prime} 20^{\prime \prime}$ N, $144^{\circ} 05^{\prime} 20^{\prime \prime} \mathrm{W}$; (map 68)

Prospectors' name reported in 1902 by W. C. Mendenhall, USGS.

Castle Creek: stream, flows SW $1.6 \mathrm{mi}$. to Big Four Creek which flows to Casadepaga River, $23 \mathrm{mi}$. NE of Solomon, Seward Penin. High.; $64^{\circ} 52^{\prime} \mathrm{N}, 164^{\circ} 08^{\prime} \mathrm{W}$; (map 95).

Prospectors' name reported in 1905 by T. G. Gerdine, USGS.

Castle Creek: stream, flows NW $6.5 \mathrm{mi}$. to Kiruktagiak River, W of Castle Mtn., $38 \mathrm{mi}$. NW of Anaktuvuk Pass, Arctic Slope : 68 ${ }^{\circ} 33^{\prime}$ $20^{\prime \prime} \mathrm{N}, 152^{\circ} 35^{\prime} 00^{\prime \prime} \mathrm{W}$; (map 134).

Named in 1951 by W. W. Patton, USGS, for nearby mountain.

Castle Hill: hill, $54 \mathrm{ft}$., in "Sitka, on W coast of Baranof I., Alex. Arch.; $57^{\circ} 02^{\prime} 57^{\prime \prime}$ N, $135^{\circ}$ $20^{\prime} 10^{\prime \prime}$ W ; (map 9). Var. Katalan's Rock.

On this rocky headland was the "castle" where the Russian governors resided. It is reported that the early Russian settlers called the hill "Katalan's Rock" for the Tlingit Indian chief who once lived on it. Two build- ings occupied the site prior to the "castle." The first, a crude block house, was destroyed by fire; the second building was demolished by an earthquake. The "castle," or "Baranovs Castle" as it is sometimes referred to, was built about 1830 of heavy cedar logs and its richly furnished elegance was the scene of many social events. A light was placed at the top as a guide to mariners, and it thus became the first lighthouse in Alaska. After the purchase of Alaska by the United States in 1867 the "Castle" fell into disrepair, and in 1894 it burned to the ground. The site is now a historical monument.

Castle Hill: hill, $437 \mathrm{ft}$., in Askinuk Mts., $2.8 \mathrm{mi}$ $\mathrm{E}$ of village of Scammon Bay, Yukon-Kuskokwim Delta; $61^{\circ} 50^{\prime} \mathrm{N}, 165^{\circ} 30^{\prime} \mathrm{W}$; (map 75).

Named by G. R. Putnam, USC\&GS, in 1899

Castle Island: island, $0.3 \mathrm{mi}$. long, off West Chunu Point, off SW coast of Kanaga I., Aleutian Is.; $51^{\circ} 39^{\prime} 20^{\prime \prime} \mathrm{N}, 177^{\circ} 40^{\prime} 40^{\prime \prime} \mathrm{W}$; (map 17)

Name published by USC\&GS in 1956 (Chart 9145)

Castle Island: island, $4.5 \mathrm{mi}$. long, at delta of Copper River, $25 \mathrm{mi}$. SE of Cordova, Malaspina Coastal Plain; $60^{\circ} 20^{\prime} \mathrm{N}, 145^{\circ} 12^{\prime} \mathrm{W}$; (map 64)

Named by H. P. Ritter, USG\&GS, in 1898 . "The Knoll is about $30 \mathrm{ft}$. high and covered with Alder bushes. There are five large Cottonwood trees on this knoll, and from a distance they resemble the tower of a castle."

Castle Island: island, see Bogoslof Island.

Castle Islands: islands, extend N-S $2.2 \mathrm{mi}$. in Duncan Canal between Lindenberg Penin. and Kupreanof I., $8 \mathrm{mi}$. SW of Petersburg, Alex. Arch.; $56^{\circ} 40^{\prime} \mathrm{N}, 133^{\circ} 10^{\prime} \mathrm{W}$; (map 6).

Named in 1889 by Lt. Comdr. C. M Thomas, USN, for charting purposes; name published in 1888 by USC\&GS on Chart 705 .

Castle Island Slough: stream, $8 \mathrm{mi}$. long, distributary of Copper River, $20 \mathrm{mi}$. SE of Cordova, Malaspina Coastal Plain; $60^{\circ} 20^{\prime} \mathrm{N}$ $145^{\circ} 18^{\prime} \mathrm{W}$; (map 64)

Local name derived from the island situated at the mouth of the stream, and reported in 1903 by G. C. Martin (1905, pl. 2), USGS. Castle Mountain: mountain, 7,329 ft., on AlaskaCanada boundary, $31 \mathrm{mi}$. E of Petersburg, Coast Mts.; $56^{\circ} 52^{\prime} 50^{\prime \prime}$ N, $132^{\circ} 07^{\prime} 20^{\prime \prime}$ W ; (map 6). Var. Castle Peak, Cathedral Peak.

Local name used by fishermen; name published in 1895 by USC\&GS ; called Cathedral Peak in 1893 by USC\&GS

Castle Mountain: mountain, 8,620 ft., $2 \mathrm{mi}$. N of Skolai Pass and $35 \mathrm{mi}$. NE of McCarthy, Wrangell Mts.; 61 ${ }^{\circ} 39^{\prime} \mathrm{N}, 141^{\circ} 59^{\prime} \mathrm{W}$; (map 67)

Descriptive name reported in 1914 by C. E. Giffin, USGS.

Castle Mountain: mountain, 5,500 ft., extends NE $6 \mathrm{mi}$. from Kings River, $24 \mathrm{mi}$. NE of Palmer, Talkeetna Mts.; $61^{\circ} 50^{\prime} 30^{\prime \prime} \mathrm{N}$, $148^{\circ} 30^{\prime} 00^{\prime} \mathrm{W}$; (map 69$)$.

Name reported in 1898 by W. C. Mendenhall, USGS. 
Castle Mountain: mountain, 3,409 ft., between Chandler and Kiruktagiak Rivers, $21 \mathrm{mi}$. $\mathrm{N}$. of Chandler Lake and $37 \mathrm{mi}$. NW of Anaktuvuk Pass, Arctic Slope ; $68^{\circ} 34^{\prime} \mathrm{N}, 152^{\circ} 35^{\prime} \mathrm{W}$; (map 134).

Descriptive name shown on 1940 USC\&GS Chart 9400.

Castle Peak: mountain, 11,000 ft., $21 \mathrm{mi}$. NW of McCarthy, Wrangell Mts.; 61 ${ }^{\circ} 35^{\prime} \mathrm{N}$, $143^{\circ} 27^{\prime} \mathrm{W}$; ( $\left.\operatorname{map} 67\right)$.

Name given by prospectors; reported in 1901 by T. G. Gerdine (in Moffit and Knopf, pl. 1, 1910), USGS.

Castle Peak: mountain, see Castle Mountain.

Castle Peak: peak, see Castle Rock.

Castle Point: peninsula, see Castle Cape.

Castle Point: promontory, see Tuliumnit Point.

Castle River: stream, flows SE $12 \mathrm{mi}$. to W shore of Duncan Canal, on S coast of Kupreanof I., $16 \mathrm{mi}$. SW of Petersburg, Alex. Arch.; $56^{\circ} 38^{\prime}$ $30^{\prime \prime} \mathrm{N}, 133^{\circ} 15^{\prime} 30^{\prime \prime} \mathrm{W} ; B G N$ 1930; (map 6).

Named in 1930 by USFS; derived from Castle Islands.

Castle Rock: island, $0.6 \mathrm{mi}$. long, $2 \mathrm{mi}$. $\mathrm{N}$ of Big Koniuji I., in Shumagin Is., Aleutian Ra.; $55^{\circ} 17^{\prime} \mathrm{N}, 159^{\circ} 30^{\prime} \mathrm{W}$; (map 27).

Descriptive name given by fishermen because of the island's abrupt rise to 825 feet; reported in 1872 by $\mathrm{W} . \mathrm{H}$. Dall, USC\&GS.

Castle Rock: peak, 5,765 ft., in Mount McKinley National Park, W of Sunset Glacier terminus, $4.5 \mathrm{mi}$. SSE of Eielson Visitor Center, Alaska Ra.; $63^{\circ} 22^{\prime} 00^{\prime \prime} \mathrm{N}, 150^{\circ} 16^{\prime} 20^{\prime \prime} \mathrm{W} ; B G N 1932$; (map 88). Var. Castle Peak.

So named in 1931 by USGS because the "very large irregular rocks on this peak give it the appearance, from a distance, of an old castle."

Castle Rock: point of land, W end of Security Cove, $3 \mathrm{mi}$. N of Gap Mtn. and $8.5 \mathrm{mi}$. NE of Cape Newenham, Kilbuck-Kuskokwim Mts.; 58 $40^{\prime} 30^{\prime \prime} \mathrm{N}, 161^{\circ} 56^{\prime} 15^{\prime \prime} \mathrm{W}$; (map 39).

Descriptive name given in 1914 by USC\&GS ; published in 1916 Coast Pilot ( $p$. 247).

Castle Rocks: hill, see Hen and Chickens Mountain.

Castle Rocks: peak, 1,900 ft., $16 \mathrm{mi}$. S of junc. of Foraker and Herron Rivers, Tanana Low.; $63^{\circ} 25^{\prime} 15^{\prime \prime} \mathrm{N}, 152^{\circ} 04^{\prime} 30^{\prime \prime} \mathrm{W}$; (map 88).

Descriptive name reported in 1931 by USGS.

Castle Rocks Lake: lake, $1.1 \mathrm{mi}$. long, drains SW to Herron River, $20 \mathrm{mi}$. $S$ of that stream's junc. with Foraker River, Tanana Low.; $63^{\circ}$. $21^{\prime} 30^{\prime \prime} \mathrm{N}, 152^{\circ} 08^{\prime} 00^{\prime \prime} \mathrm{W}$; (map 88).

Name obtained in 1962 from Fabian Carey by USGS.

Castner, Mount: mountain, 5,535 ft., at head of Ranney Glacier, $44 \mathrm{mi}$. W of Valdez, Chugach Mts.; 61 $11^{\prime} 40^{\prime \prime} \mathrm{N}, 147^{\circ} 35^{\prime} 00^{\prime \prime} \mathrm{W}$; (map 69)

Name reported in 1960 by USGS. Named by Lawrence Martin in 1910 for Lt. Joseph C. Castner, USA, who was with Capt. E. F. Glenn during the exploration of 1898.
Castner Creek: stream, heads at Castner Glacier terminus, flows W $1.5 \mathrm{mi}$. to Delta River, crosses Richardson Highway $27 \mathrm{mi}$. NW of Paxson, Alaska Ra.; $63^{\circ} 24^{\prime} 20^{\prime \prime} \mathrm{N}, 145^{\circ} 45^{\prime} 45^{\prime \prime}$ W; (map 86).

Locally named for Castner Glacier.

Castner Glacier: glacier, heads on White Princess, trends NW and SW $12 \mathrm{mi}$. to its 1934 terminus at head of Castner Creek, $27 \mathrm{mi}$. NW of Paxson, Alaska Ra.; $63^{\circ} 24^{\prime} 10^{\prime \prime} \mathrm{N}$, $145^{\circ} 43^{\prime} 00^{\prime \prime} \mathrm{W}$; (map 86).

Named in 1898 by Capt. E. F. Glenn, USA, for Lt. J. C. Castner, USA, a member of his party.

Caswell: $R R$. station, mile 202.3 on The Alaska RR. $15 \mathrm{mi}$. N of Willow and $52 \mathrm{mi}$. N. of Anchorage, Cook Inlet Low.; 61 $58^{\prime} 50^{\prime \prime} \mathrm{N}$, $150^{\circ} 02^{\prime} 30^{\prime \prime} \mathrm{W}$; (map 70$)$.

The Caswell post office was established in 1929; discontinued in 1931.

Caswell Creek: stream, flows SW, through Caswell Lake, $12 \mathrm{mi}$. to Susitna River, $14 \mathrm{mi}$. N of Willow and $50 \mathrm{mi}$. NNW of Anchorage, Cook Inlet Low.; $61^{\circ} 56^{\prime} 30^{\prime \prime} \mathrm{N}, 150^{\circ} 04^{\prime} 45^{\prime \prime}$ W; (map 70).

Named for a local prospector and reported on 1917 Alaska RR. manuscript map.

Caswell Lake: lake, $1 \mathrm{mi}$. long, in course of Caswell Creek, $22 \mathrm{mi}$. SE of Talkeetna, Cook Inlet Low.; $62^{\circ} 01^{\prime} \mathrm{N}, 149^{\circ} 58^{\prime} \mathrm{W}$; (map 82).

Local name recorded in 1950 by USGS.

Catalina Island: island, 1,800 ft. long, between San Christoval Channel and San Alberto Bay, off NE coast of San Fernando I., Alex. Arch.; $55^{\circ} 32^{\prime} 55^{\prime \prime} \mathrm{N}, 133^{\circ} 17^{\prime} 20^{\prime \prime} \mathrm{W}$; (map 4). Var. Isla Catalina, Ostrov Katalina, Ysla Catalina.

Spanish name given in 1775-79 by Don Juan de la Bodega y Quadra and Francisco Antonio Maurelle as "Isla Catalina," meaning "Catalina Island."

Catalla: settlement, see Katalla.

Catalla Bay: bay, see Katalla Bay.

Catalla River: stream, see Katalla River.

Cataract Bight: cove, in Bay of Waterfalls, on SW coast of Adak I., Aleutian Is.; $51^{\circ} 41^{\prime} 50^{\prime \prime}$ N, $176^{\circ} 49^{\prime} 20^{\prime \prime} \mathrm{W}$; BGN 1936; (map 17)

Descriptive name published by the U.S. Navy Hydrog. Office in 1895.

Cataract Cove: bight, $3.5 \mathrm{mi}$. across, on $\mathrm{W}$ coast of Unimak I., Aleutian Is. ; $54^{\circ} 38^{\prime} 45^{\prime \prime} \mathrm{N}, 164^{\circ}$ $46^{\prime} 00^{\prime \prime} \mathrm{W}$; BGN 1942; (map 24). Var. Dublin Bay.

Named in 1942 by USC\&GS because of small waterfalls along the shore.

Cataract Cove: cove, $0.8 \mathrm{mi}$. wide, on $\mathrm{W}$ coast of Harris Penin., N of Crater Bay, $30 \mathrm{mi}$. SW of Seward, Chugach Mts.; 59 $42^{\prime} 30^{\prime \prime} \mathrm{N}, 149^{\circ}$ $50^{\prime} 00^{\prime \prime} \mathrm{W}$; BGN 1930; (map 49).

Named by the 1928 USC\&GS field party "for the spectacular cascades (cataracts) falling over $1000 \mathrm{ft}$. cliffs at north end of cove." Cataract Glacier: glacier, E of Surprise Glacier, trends NE $2.7 \mathrm{mi}$. to its terminus at head of stream which drains into Surprise Inlet $\mathbf{5 2}$ mi. SE of Anchorage, Chugach Mts.; $61^{\circ} 02^{\prime}$ $30^{\prime \prime} \mathrm{N}, 148^{\circ} 23^{\prime} 10^{\prime \prime} \mathrm{W}$; (map 69).

Descriptive name given in 1899 by members of the Harriman Alaska Expedition.
Catella: settlement, see Katalla.

Catella Bay: bay, see Katalla Bay

Catella River: stream, see Katalla River.

Cat Head: point of land, on $W$ coast of Knight I., at $\mathrm{S}$ entrance to Drier Bay, $7.5 \mathrm{mi}$. NE of Chenega, Chugach Mts.; $60^{\circ} 18^{\prime} 10^{\prime \prime} \mathrm{N}, 147^{\circ}$. $51^{\prime} 30^{\prime \prime} \mathrm{W}$; (map 63).

Name published in 1908 by USC\&GS.

Cathead Bay: estuary, on W coast of Knight I., extends N $1 \mathrm{mi}$. to Drier Bay, $8 \mathrm{mi}$. NE of Chenega, Chugach Mts.; $60^{\circ} 18^{\prime} 10^{\prime \prime} \mathrm{N}, 147^{\circ}$. $50^{\prime} 30^{\prime \prime} \mathrm{W}$; (map 63).

Name published in 1908 by USC\&GS

Cathedral Bluff: locality, see Cathedral Rapids.

Cathedral Bluffs: bluffs, extend $1.2 \mathrm{mi}$. on $\mathrm{N}$ bank of Tanana River, at Cathedral Rapids, 12 mi. W of Tanacross, Yukon-Tanana High. : $63^{\circ} 23^{\prime} 30^{\prime \prime} \mathrm{N}, 143^{\circ} 44^{\prime} 00^{\prime \prime} \mathrm{W}$; ( $\operatorname{map} 85$ ).

Descriptive name reported in 1885 by Lt. Allen (1887, p. 80), USA

Cathedral Creek: stream, flows SW $9 \mathrm{mi}$. to Alex River, $18 \mathrm{mi}$. NW of Chignik, on Alaska Penin., Aleutian Ra.; $56^{\circ} 26^{\prime} \mathrm{N}, 158^{\circ} 47^{\prime} \mathrm{W}$; (map 30).

Name shown on a 1923 fieldsheet by $R . H$. Sargent, USGS; "so named because of the steep-sided valley bounded by castellated ridges."

Cathedral Creek: stream, heads at glacier, flows W $5 \mathrm{mi}$. to Tonzona River, $16 \mathrm{mi}$. NW of Mount Russell, Alaska Ra.; 62 $50^{\prime} 15^{\prime \prime} \mathrm{N}$, $152^{\circ} 22^{\prime} 45^{\prime \prime} \mathrm{W}$; (map 81).

Prospectors' name reported in 1925 by $\mathrm{S}$. $\mathrm{R}$. Capps, (in Brooks, 1925, pl. 2), USGS.

Cathedral Creek: stream, heads at glacier terminus, flows E $2 \mathrm{mi}$. to Maclaren Glacier $2.5 \mathrm{mi}$. $\mathrm{N}$ of its terminus, $22 \mathrm{mi}$. SE of Mount Hayes, Alaska Ra.; $63^{\circ} 19^{\prime} 05^{\prime \prime} \mathrm{N}, 146^{\circ} 32^{\prime} 50^{\prime \prime} \mathrm{W}$; (map 86).

Name published on relatively recent maps. Cathedral Creek: stream, heads in Canada, flows SW across Alaska-Canada boundary $18 \mathrm{mi}$. to Hard Luck Creek, $23 \mathrm{mi}$. N of Eagle, Porcupine Plat.; $65^{\circ} 08^{\prime} 15^{\prime \prime} \mathrm{N}, 141^{\circ} 11^{\prime} 20^{\prime \prime} \mathrm{W}$; $B G N 1965$; (map 103).

So named in 1909 by IBC survey because of the bare cathedrallike mountains along its course.

Cathedral Creek: stream, see Hard Luck Creek. Cathedral Falls Creek: stream, flows SW $7 \mathrm{mi}$. to Hamilton Bay, $9.5 \mathrm{mi}$. SE of Kake, on NW coast of Kupreanof I, Alex. Arch.; 56 $53^{\prime} 30^{\prime \prime}$ $\mathrm{N}, 133^{\circ} 44^{\prime} 00^{\prime \prime} \mathrm{W}$; (map 6).

Local name recorded in 1951 by USGS

Cathedral Island: island, $0.3 \mathrm{mi}$. across, between Sitkalidak I. and SE coast of Kodiak I.; $57^{\circ} 12^{\prime} \mathrm{N}, 153^{\circ} 08^{\prime} \mathrm{W}$; BGN 1930; (map 34).

Descriptive name given in 1928 by USC\&GS, "because the island resembles a cathedral."

Cathedral Mountain: mountain, 5,730 ft., S of Portage Pass, $86 \mathrm{mi}$. NW of Tyonek, Alaska Ra.; $61^{\circ} 57^{\prime} 15^{\prime \prime} \mathrm{N}, 152^{\circ} 57^{\prime} 30^{\prime \prime} \mathrm{W}$; (map 70).

Descriptive name given in 1898 by J. E. Spurr, USGS.

Cathedral Mountain: mountain, 4,900 ft., $4 \mathrm{mi}$. W of Double Mtn. and $27 \mathrm{mi}$. SW of Healy,

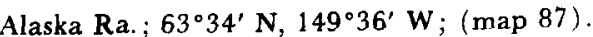


Local name reported in 1954 by USGS; so called because "the face of the mountain resembles the facade of a cathedral."

Cathedral Mountain: mountain, 3,440 ft., between Rosie Creek Pass and Middle Fork Koyukuk River, 17 mi. S of Wiseman, Brooks Ra.; $67^{\circ} 10^{\prime} \mathrm{N}, 150^{\circ} 15^{\prime} \mathrm{W}$; (map 124). Var. Rosie Mountain.

Local descriptive name obtained in 1956 by USGS topographers.

Cathedral Mountain: mountain, see Cathedral Peak.

Cathedral Mountain: mountain, see Deborah, Mount.

Cathedral Mountain: peaks, see Cathedral Spires.

Cathedral Peak: mountain, 2,963 ft., $15 \mathrm{mi}$. $\mathrm{N}$ of Unga I., near SW end of Alaska Penin., Aleutian Ra.; $55^{\circ} 36^{\prime} 30^{\prime \prime} \mathrm{N}, 161^{\circ} 43^{\prime} 00^{\prime \prime} \mathrm{W}$; (map 28). Var. Cathedral Mountain.

Local name reported by Atwood (1911, pl. 2), USGS; shown as "Cathedral Mountain" on 1929 USGS map.

Cathedral Peak: mountain, see Castle Mountain.

Cathedral Peak: mountain, see Emmerich, Mount.

Cathedral Peak: mountain, see Kahshagnak, Mount.

Cathedral Peak: peak, 6,500 ft., in Taku Ra., $0.8 \mathrm{mi}$. S of Little Matterhorn and $22 \mathrm{mi}$. N of Juneau, Coast Mts.; $58^{\circ} 36^{\prime} 45^{\prime \prime} \mathrm{N}, 134^{\circ}$ 21'49" W; BGN 1965; (map 11).

Named in 1964 by members of the Juneau Icefield Research Project.

Cathedral Point: point of land, $\mathrm{S}$ tip of Tagalak I., Aleutian Is.; $51^{\circ} 56^{\prime} 10^{\prime \prime} \mathrm{N}, 175^{\circ} 43^{\prime} 10^{\prime \prime} \mathrm{W}$; $B G N 1936$; ( $\operatorname{map} 18$ ).

Descriptive name published by the USC\&GS in the 1944 Aleutian Coast Pilot (p. 104), and suggested by the U.S. Navy Aleutian Island Survey Expedition of 1934, "because of its church-like appearance."

Cathedral Point: point of land, on NE shore of Makushin Bay, on $W$ coast of Unalaska $I$., Aleutian Is.; $53^{\circ} 44^{\prime} 30^{\prime \prime} \mathrm{N}, 166^{\circ} 51^{\prime} 45^{\prime \prime} \mathrm{W}$; (map 23).

Descriptive local name published in 1951 on a USGS map.

Cathedral Rapids: locality, on Alaska Highway, on $\mathbf{S}$ bank of Tanana River opposite Cathedral Bluffs, $12 \mathrm{mi}$. W of Tanacross, Tanana Low.; $63^{\circ} 23^{\prime} \mathrm{N}, 143^{\circ} 45^{\prime} \mathrm{W}$; (map 85). Var. Cathedral Bluff.

Named for the adjacent rapids in the Tanana River. See Cathedral Rapids.

Cathedral Rapids: rapids, extend $1.5 \mathrm{mi}$., in Tanana River, E of Cathedral Bluffs, $13 \mathrm{mi}$. W of Tanacross, Yukon-Tanana High,; $63^{\circ} 23^{\prime} 20^{\prime \prime} \mathrm{N}, 143^{\circ} 45^{\prime} 00^{\prime \prime} \mathrm{W}$; (map 85).

Name reported in 1885 by Lt. Allen (1887, p. 81), USA; named after the Cathedral Bluffs.

Cathedral Rapids Creek Number 1: stream, flows N 5.5 mi. to Tanana River at $\mathbf{E}$ end of $\mathbf{C a}$ thedral Rapids, $12 \mathrm{mi}$. W of Tanacross,

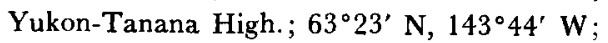
(map 85).

Named for the rapids at the stream's mouth.
Cathedral Rapids Creek Number 2: stream, flows $\mathrm{N} 4.3 \mathrm{mi}$. to Tanana River at $\mathrm{W}$ end of Cathedral Rapids, $13 \mathrm{mi}$. W of Tanacross, Yukon-Tanana High.; $63^{\circ} 23^{\prime} \mathrm{N}, 143^{\circ} 45^{\prime} \mathrm{W}$; (map 85).

Named for the rapids at the stream's mouth.

Cathedral River: stream, flows NW $24 \mathrm{mi}$. to Bering Sea, at Cape Leontovitch, on SW end of Alaska Penin., Bristol Bay Low.; 55 $37^{\prime} \mathrm{N}$, $162^{\circ} 19^{\prime} \mathrm{W}$; (map 29).

Local name published in 1943 on a USGS map.

Cathedral Rocks: rocks, off Cathedral Point, in Makushin Bay, on $W$ coast of Unalaska $I$. Aleutian Is.; $53^{\circ} 44^{\prime} 18^{\prime \prime} \mathrm{N}, 166^{\circ} 53^{\prime} 00^{\prime \prime} \mathrm{W}$; (map 23).

This name was published in the 1944 Aleutian Coast Pilot (p. 44).

Cathedral Spires: peaks, in center of Kichatna Mts., $85 \mathrm{mi}$. W of Talkeetna, Alaska Ra.; $62^{\circ} 25^{\prime} \mathrm{N}, 152^{\circ} 45^{\prime} \mathrm{W}$; (map 81). Var. Cathedral Mountain.

Named in 1898 by J. E. Spurr, USGS.

Cathedral Valley: valley, formed by Cathedral River, extends NW-SE $10 \mathrm{mi}$., $31 \mathrm{mi}$. NE of village of Cold Bay, Bristol Bay Low.; $55^{\circ} 31^{\prime} \mathrm{N}, 162^{\circ} 08^{\prime} \mathrm{W}$; (map 29).

Local name published in 1943 on a USGS map.

Cathenda Creek: stream, see Chathenda Creek.

Catherina Archipelago: islands, see Aleutian Islands.

Catherine, Lake: lake, $0.4 \mathrm{mi}$. long, drains $\mathrm{S}$ through Lake Louise to Buskin River, $3.5 \mathrm{mi}$. SW of Kodiak, Kodiak I.; 57 $46^{\prime} 00^{\prime \prime} \mathrm{N}$, $152^{\circ} 29^{\prime} 45^{\prime \prime} \mathrm{W}$; (map 34). Var. Margaret Lake.

Local name reported in 1949 by USGS. Published in 1957 by AMS as "Margaret Lake."

Catherine Archipelago: islands, see Aleutian Islands.

Catherine Island: island, $10 \mathrm{mi}$. long, off $\mathrm{NE}$ coast of Baranof I., $14 \mathrm{mi}$. N of Baranof, Alex. Arch.; 57 $22^{\prime} \mathrm{N}, 134^{\circ} 53^{\prime} \mathrm{W}$; BGN 1935; (map 9).

Named in 1935 by USFS for Catherine I, 1684-1727, Empress and Tsarina of Russia, 1725-27, "who financed and encouraged Vitus Bering in his early explorations of the Aleutian Islands and Alaska."

Cathul Mountain: mountain, see Kathul Mountain.

Cathut Mountain: mountain, see Kathul Mountain.

Catinakh: locality, see Chatinak.

Cat Island: island, $2.3 \mathrm{mi}$. long, between Felice Strait and Revillagigedo Channel, $0.8 \mathrm{mi}$. N of Grave Point, Duke Island, Alex. Arch.; $55^{\circ} 01^{\prime} 20^{\prime \prime} \mathrm{N}, 131^{\circ} 15^{\prime} 00^{\prime \prime} \mathrm{W}$; (map 3$)$.

Named in 1883 by Lt. Comdr. H. E. Nichols, USN.

Cat Island: island, between Harris River Bay and Hollis Anchorage, on Prince of Wales I., 18 mi. E of Craig, Alex. Arch.; $55^{\circ} 28^{\prime} \mathrm{N}, 132^{\circ} 40^{\prime}$ W; (map 4).

Local name recorded in 1949 by USGS.
Cat Island: island, in Yukon River, $28 \mathrm{mi}$. NE of Nulato, Koyukuk Low.; $64^{\circ} 48^{\prime} \mathrm{N}, 175^{\circ} 10^{\prime}$ W; (map 97)

Riverboat pilots' name shown on a 1940 "Navigation Chart of the Tanana-Yukon Rivers" published by the U.S. Dept. of Interior.

Cat Island: island, see Cub Island.

Cat Lake: lake, $0.6 \mathrm{mi}$. long, $14 \mathrm{mi}$. SW of Lake Louise and $25 \mathrm{mi}$. NE of Tahneta Pass, Copper River Basin; $62^{\circ} 13^{\prime} \mathrm{N}, 147^{\circ} 00^{\prime} \mathrm{W} ; B G N$ 1959; (map 83).

Local name reported by USGS in 1959.

Caton Cove: cove, $0.2 \mathrm{mi}$. across, arm of Sanborn Harbor, on NW coast of Nagai I., in Shumagin Is., Aleutian Ra.; $55^{\circ} 09^{\prime} 15^{\prime \prime} \mathrm{N}, 160^{\circ} 01^{\prime}$ 00" W; (map 28). Var. Catons Cove.

Local name published as "Catons Cove" in USC\&GS 1916 Coast Pilot (v. 2, p. 173), and as "Caton Cove" in 1947 Coast Pilot (v. 2, p. 317).

Caton Harbor: harbor, $1.5 \mathrm{mi}$. across, on SE coast of Sanak I., between Sanak and Caton Is., Aleutian Ra.; $54^{\circ} 24^{\prime} \mathrm{N}, 162^{\circ} 32^{\prime}$ W ; (map 25).

Name derived from Caton Island; reported by Ferdinand Westdahl, USC\&GS, commander of the Coast Survey steamer $\mathrm{Mc}$ Arthur, who made surveys in this area in 1901.

Caton Island: island, $5 \mathrm{mi}$. long, easternmost of Sanak Is., $48 \mathrm{mi}$. SE of False Pass, Aleutian Ra. ; 54 $23^{\prime} 30^{\prime \prime} \mathrm{N}, 162^{\circ} 25^{\prime} 30^{\prime \prime} \mathrm{W}$; ( $\operatorname{map} 25$ ).

Named in 1888 by USBF.

Catons Cove: cove, see Caton Cove.

Caton Shoal: shoal, southern part of Unga Reef, in Popof Strait, in Shumagin Is., Aleutian Ra.; $55^{\circ} 19^{\prime} 52^{\prime \prime} \mathrm{N}, 160^{\circ} 31^{\prime} 40^{\prime \prime} \mathrm{W}$; (map 28).

Named for a "Mr. Caton (cnna) who reported it" in 1880; shown on USC\&GS Chart 8891.

Cat Passage: water passage, connecting Felice Strait and Revillagigedo Channel, between Cat and Duke Is., Alex. Arch.; $55^{\circ} 00^{\prime} 30^{\prime \prime} \mathrm{N}$, $131^{\circ} 16^{\prime} 00^{\prime \prime} \mathrm{W}$; BGN 1917; (map 3).

Named in 1917 by USC\&GS.

Caution, Point: point of land, $\mathrm{S}$ point of entrance to Whitewater Bay, on Admiralty I., $17 \mathrm{mi}$. S of Angoon, Alex. Arch.; $57^{\circ} 14^{\prime} 45^{\prime \prime} \mathrm{N}, 134^{\circ}$ $38^{\prime} 10^{\prime \prime}$ W: (map 9).

Named in 1869 by Comdr. R. W. Meade, USN, (USC\&GS, 1883, p. 174).

Caution Island: island, $500 \mathrm{ft}$. across, on $\mathrm{W}$ coast of Baranof I., $8 \mathrm{mi}$. S of Sitka, Alex. Arch.; $56^{\circ} 56^{\prime} 10^{\prime \prime} \mathrm{N}, 135^{\circ} 21^{\prime} 30^{\prime \prime} \mathrm{W}$; (map 5). Var. Berezhnoi Island, Ostrov Berezhnoy.

This is a translation by USC\&GS of the name given by the navigator Ivan Vasiliev the first, IRN. Lt. Sarichev (1826, map 19), IRN, published it as "O[strov] Berezhnoy."

Caution Pass: water passage, between Skinner and Post Is., $13 \mathrm{mi}$. NW of Chichagof I., Alex. Arch.; $57^{\circ} 47^{\prime} 20^{\prime \prime} \mathrm{N}, 136^{\circ} 20^{\prime} 35^{\prime \prime} \mathrm{W}$; $B G N$ 1929; (map 9). Var. Cautious Pass. Coutous Pass.

Local name reported in 1917 by USC\&GS as "Coutous Pass" and "Cautious Pass." Renamed in 1929 by USC\&GS because the pass 
is narrow, navigation through it is dangerous, and caution is necessary.

Cautious Pass: water passage, see Caution Pass.

Cavanaugh Creek: stream, flows W $1 \mathrm{mi}$. to Allene Creek, in Agiapuk River basin, $10 \mathrm{mi}$. NE of 'Teller, Seward Penin. High.; $65^{\circ} 19^{\prime} \mathrm{N}$, $166^{\circ} 03^{\prime} \mathrm{W}$; (map 111 )

Prospectors' name reported on the 1908 "Map of Seward Peninsula" by Arthur Gibson.

Cave Creek: stream, on Prince of Wales I., flows NE $3 \mathrm{mi}$. to Twelvemile Creek, at head of Twelvernile Arm Kasaan Bay, Alex. Arch.; $55^{\circ} 20^{\prime} 50^{\prime \prime} \mathrm{N}, 132^{\circ} 44^{\prime} 05^{\prime \prime} \mathrm{W} ; B G N$ 1962; (map 4).

Local name reported in 1962 by USFS.

Cave Creek: stream, flows $2.5 \mathrm{mi}$. SE to Canyon Creek $\mathbf{N}$ of junc. of Erickson Creek, $29 \mathrm{mi}$. SE of McCarthy, St. Elias Mts.; 61 ${ }^{\circ} 14^{\prime} 00^{\prime \prime}$ $\mathrm{N}, 142^{\circ} 10^{\prime} 00^{\prime \prime} \mathrm{W}$; (map 67$)$

Local name obtained by USGS and published on maps since 1954.

Cave Off Cliffs: bluff, on right bank of Yukon River, $41 \mathrm{mi}$. E of Nulato, Koyukuk Low.; $64^{\circ} 42^{\prime} \mathrm{N}, 156^{\circ} 45^{\prime} \mathrm{W}$; (map 97).

Local descriptive name reported in 1954 by USGS.

Cave Point: point of land, on $\mathrm{W}$ coast of Unimak I., Aleutian Is.; $54^{\circ} 47^{\prime} 10^{\prime \prime} \mathrm{N}, 164^{\circ} 37^{\prime} 00^{\prime \prime} \mathrm{W}$; (map 24). Var. Cape Lapin, Chichkoff Cap, Mys Pogromnaya, Mys Shishkova, Pogromnoi, Pogromnoi Second.

Local name reported by USBF in 1890 because "cave point takes its name from a cave on its face." Capt. Lutke (1836, p. 293), IRN, wrote it in French as "Chichkoff Cap," and the name was published by the Russians as "M[ys] Shishkova (Pogromnaya)" meaning "knobby cape (desolate)" (Tebenkov, 1852, map 26).

Cave Point: point of land, on $\mathbf{S}$ coast of Alaska, on E end of Katalla Bay, $3 \mathrm{mi}$. SE of Katalla, Malaspina Coastal Plain; $60^{\circ} 10^{\prime} \mathrm{N}, 144^{\circ} 26^{\prime}$ W; (map 64).

Local name reported in 1903 by G. C. Martin, USGS.

Cave Point: point of land, on $\mathbf{S}$ coast of Glacier I., at $\mathrm{E}$ entrance to Chamberlain Bay, $52 \mathrm{mi}$. ENE of Whittier, Chugach Mts.; 60 $51^{\prime} 45^{\prime \prime}$ N, $147^{\circ} 11^{\prime} 30^{\prime \prime} \mathrm{W}$; (map 63).

Local name reported in 1951 by USGS.

Cave Point: point of land, see Peirce, Cape.

Cavern Lake: lake, $0.3 \mathrm{mi}$. long, $3.5 \mathrm{mi}$. N of Neck Lake, on Prince of Wales I., Alex. Arch.; $56^{\circ} 09^{\prime} 25^{\prime \prime} \mathrm{N}, 133^{\circ} 11^{\prime} 00^{\prime \prime} \mathrm{W}$; (map 6).

Local descriptive name reported in 1949 by USGS.

Cave Rock: rock, on SW coast of Amaknak I., in Unalaska Bay, on NE coast of Unalaska I., Aleutian Is.; $53^{\circ} 53^{\prime} 10^{\prime \prime} \mathrm{N}, 166^{\circ} 33^{\prime} 12^{\prime \prime} \mathrm{W}$; (map 23).

Descriptive name reported by $\mathbf{W}$. H. Dall, USC\&GS, in 1872. There is a burial cave under the rock which he investigated and called "Amaknak Cave."

Caves Lake: lake, $0.3 \mathrm{mi}$. long, on $\mathrm{W}$ bank of Knik Arm at head of Soldier Creek, $16 \mathrm{mi}$.
NE of Anchorage, Cook Inlet Low. ; $61^{\circ} \mathbf{2 6}^{\prime}$ $40^{\prime \prime} \mathrm{N}, 149^{\circ} 46^{\prime} 25^{\prime \prime} \mathrm{W}$; (map 69).

Local name reported in 1952 by USGS.

Caviar Creek: stream, heads in lake, flows NE

$7 \mathrm{mi}$. to Koyuk River near its head, $3 \mathrm{mi}$. NE of Sturgeon Ridge and $13 \mathrm{mi}$. SE of Imuruk Lake, Seward Penin. High.; $65^{\circ} 25^{\prime} \mathrm{N}, 163^{\circ}$. $01^{\prime} \mathrm{W}$; BGN 1952; (map 110).

So named in 1950 by D. M. Hopkins, USGS, "because of the proximity of the creek to Sturgeon Ridge." Caviar is the salted roe of the sturgeon used as an appetizer.

Cawtaskákat: locality, see Kautas.

Cayman Point: point of land, $\mathrm{S}$ point of entrance to North Bay, on NE coast of Dall I., Alex. Arch.; $55^{\circ} 13^{\prime} 00^{\prime \prime} \mathrm{N}, 133^{\circ} 05^{\prime} 40^{\prime \prime} \mathrm{W} ; B G N$ 1966 ; (map 4).

Named in 1882 by W. H. Dall, USC\&GS, "from its fancied resemblance to an alligator's head"; derived from the Spanish word "caiman," meaning "American crocodile."

Cay Rocks: rocks, see Alice Rocks.

Cecil, Mount: mountain, 3,261 ft., on SE coast of Baranof I., Alex. Arch.; 56 $38^{\prime} 20^{\prime \prime} \mathrm{N}, 134^{\circ}$. $39^{\prime} 00^{\prime \prime}$ W; BGN 1917; (map 5). Var. The Sisters, Mount Elizabeth.

Local name published in 1910 by USC\&GS; reported to be named for one of the daughters of Superintendent E. Lester Jones, USC\&GS. However, in 1915, Jones stated "not named by me * * * named by native of Alaska of 30 years residence."

Cecil, Mount: mountain, see Elizabeth, Mount.

Cecil Dome: mountain, 1,410 ft., 9 mi SE of

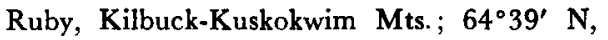
$155^{\circ} 14^{\prime} \mathrm{W}$; (map 98$)$.

Prospectors' name reported by Eakin (1916, pl. 1), USGS.

Cecil Dome: mountain, see Boston Dome.

Cedar Bay: cove, $0.2 \mathrm{mi}$. wide, on NW coast of Hawkins I., $9 \mathrm{mi}$. WW of Cordova, Chugach Mts.; $60^{\circ} 33^{\prime} 30^{\prime \prime}$ N., $146^{\circ} 00^{\prime} 30^{\prime \prime}$ W ; (map 64).

Local name published by USG\&GS in 1900.

Cedar Bay: estuary, extends SW $4.5 \mathrm{mi}$. to Wells Bay, $44 \mathrm{mi}$. NE of Whittier, Chugach Mts.; $60^{\circ} 56^{\prime} \mathrm{N}, 147^{\circ} 27^{\prime} \mathrm{W}$; (map 63).

Local name reported in 1905 by U. S. Grant (in Brooks and others, 1906, fig. 4), USGS.

Cedar Bight: bay, $1.5 \mathrm{mi}$. across, on $\mathbf{E}$ shore of Security Bay, on $\mathbf{N}$ coast of $\mathbf{K u i u} \mathbf{I}$., Alex. Arch.; 56 $51^{\prime} \mathrm{N}, 134^{\circ} 19^{\prime} \mathrm{W}$; (map 5).

Named in 1869 by Comdr. R. W. Meade, USN.

Cedar Cove: cove, $0.2 \mathrm{mi}$. across, on $\mathrm{N}$ shore of Katlian Bay, $9 \mathrm{mi}$. N of Sitka, on NW coast of Baranof I., Alex. Arch.; $57^{\circ} 11^{\prime} \mathrm{N}, 135^{\circ} 21^{\prime} \mathrm{W}$; $B G N 1937$; (map 9).

Local name reported in 1936 by USFS.

Cedar Cove: cove, $0.4 \mathrm{mi}$. across, on $\mathrm{S}$ shore of Freshwater Bay, $8.5 \mathrm{mi}$. NE of Tenakee Springs, on $\mathbf{E}$ coast of Chichagof I., Alex. Arch.; $57^{\circ} 51^{\prime} 40^{\prime \prime} \mathrm{N}, 135^{\circ} 03^{\prime} 00^{\prime \prime} \mathrm{W}$; (map 9).

Name published in 1899 by USC\&GS.

Cedar Creek: stream, on Hawkins I., flows NW $2 \mathrm{mi}$. to Cedar Bay, $9 \mathrm{mi}$. W of Cordova,
Chugach Mts.; $60^{\circ} 33^{\prime} 15^{\prime \prime} \mathrm{N}, 146^{\circ} 00^{\prime} 05^{\prime \prime} \mathrm{W}$ (map 64).

Name published in 1950 by USGS.

Cedar Creek: stream, flows NE $8 \mathrm{mi}$. to Kechumstuk Creek, $70 \mathrm{mi}$. SW of Eagle, YukonTanana High.; $64^{\circ} 05^{\prime} \mathrm{N}, 142^{\circ} 48^{\prime} \mathrm{W}$; (map 102).

Local name published in 1956 by USGS.

Cedar Island: island, $0.6 \mathrm{mi}$. long, between Moser and Naha Bays, on W coast of Revillagigedo I., Alex. Arch.; $55^{\circ} 35^{\prime} \mathrm{N}, 131^{\circ} 41^{\prime} \mathrm{W}$; (map 3).

Local navigators' name obtained in 1904 by H. C. Fassett, USBF.

Cedar Island: island, $0.1 \mathrm{mi}$. across, in Security Bay, on $\mathbf{N}$ coast of Kuiu I., Alex. Arch.; $56^{\circ} 51^{\prime} 50^{\prime \prime} \mathrm{N}, 134^{\circ} 20^{\prime} 20^{\prime \prime} \mathrm{W}$; (map 5).

Named in 1869 by Comdr. R. W. Meade, USN

Cedar Island: island, $0.3 \mathrm{mi}$. across, in Freshwater Bay, $9 \mathrm{mi}$. NE of Tenakee Springs, on E coast of Chichagof I., Alex. Arch.; $57^{\circ} 52^{\prime} 00^{\prime \prime} \mathrm{N}, 1^{\circ} 05^{\circ} 30^{\prime \prime} \mathrm{W} ; B G N$ 1935; (map 9).

Local name reported in 1935 by USFS.

Cedar Lake: lake, $0.7 \mathrm{mi}$. long, NE of Orchard Lake on Revillagigedo I., $18 \mathrm{mi}$. NE of Loring and $36 \mathrm{mi}$. NNE of Ketchikan, Alex. Arch.; $55^{\circ} 49^{\prime} 30^{\prime \prime} \mathrm{N}, 131^{\circ} 22^{\prime} 30^{\prime \prime} \mathrm{W}$; (map 3 ).

Local name reported in 1921 by USFS

Cedar Pass: water passage, $3 \mathrm{mi}$. long, between Crawfish and West Crawfish Inlet, on $W$ coast of Baranof I., Alex. Arch.; 56 $46^{\prime} \mathrm{N}, 135^{\circ} 11^{\prime}$ W; (map 5).

Local name used by fishermen: published in 1929 by USC\&GS.

Cedar Point: point of land, $\mathrm{N}$ point of entrance to Smuggler Cove, on SW coast of Annette I. Alex. Arch.; $55^{\circ} 05^{\prime} 50^{\prime \prime} \mathrm{N}, 1^{\circ} 31^{\prime} 25^{\prime \prime} \mathrm{W}$; (map 3).

Named in 1883 by Lt. Comdr. H. E. Nichols, USN

Cedar Point: point of land, at E end of Kootznahoo Inlet, on Admiralty I., $5 \mathrm{mi}$. NE of Angoon, Alex. Arch.; $57^{\circ} 32^{\prime} 25^{\prime \prime} \mathrm{N}, 134^{\circ} 29^{\prime}$. $40^{\prime \prime} \mathrm{W}$; (map 9).

Named in 1869 by Comdr. R. W. Meade, USN; published in 1881 on U.S. Navy Hydrog. Chart 883. Name not shown on recent maps.

Celenie Lake: lagoon, see Selenie Lagoon.

Cement Creek: stream, flows W $10 \mathrm{mi}$. to Dennison Fork $6 \mathrm{mi}$. S of junc. of its West Fork, Yukon-Tanana High.; $63^{\circ} 49^{\prime} 15^{\prime \prime} \mathrm{N}, 142^{\circ}$. $00^{\prime} 15^{\prime \prime} \mathrm{W}$; (map 85). Var. Clement Creek.

Local name reported by J. B. Mertie, Jr. (1931, pl. 1), USGS.

Cement Hill: hill, $595 \mathrm{ft}$, , on right bank of Yukon River, $21 \mathrm{mi}$. NW of Holy Cross, Nulato Hills; $62^{\circ} 27^{\prime} 30^{\prime \prime} \mathrm{N}, 160^{\circ} 06^{\prime} 00^{\prime \prime} \mathrm{W}$; (map 78 )

Local name reported in 1916 by G. L. Harrington and R. H. Sargent (in Harrington, 1918, pl. 1), USGS.

Cemetary Point: point of land, see Cemetery Point.

Cemetery Cove: cove, $1.3 \mathrm{mi}$, across, in Inanudak Bay, on W central coast of Umnak I., Aleutian 
Is.; $53^{\circ} 15^{\prime} 40^{\prime \prime} \mathrm{N}, \mathbf{1 6 8}^{\circ} 25^{\prime} 35^{\prime \prime} \mathrm{W}$; BGN 1940; (map 22). Var. Southwest Anchorage.

This feature was first called "Southwest Anchorage" in 1938 by USC\&GS "because it affords shelter in westerly and southerly weather"; the descriptive name of "Cemetery Cove" was applied in 1939 by USC\&GS "because of the graveyard of the natives on the shore of this cove."

Cemetery Lake: lake, $0.2 \mathrm{mi}$. long, $\mathrm{E}$ of Skate Lake, 1.2 mi. N of Northway, Alaska Ra.; $62^{\circ} 58^{\prime} 50^{\prime \prime} \mathrm{N}, 141^{\circ} 55^{\prime} 55^{\prime \prime} \mathrm{W}$; (map 84).

Local name reported by USGS in 1954.

Cemetery Point: point of land, on $\mathrm{E}$ coast of Kagalaska I., Aleutian Is.; $51^{\circ} 49^{\prime} 10^{\prime \prime} \mathrm{N}$, $176^{\circ} 16^{\prime} 10^{\prime \prime} \mathrm{W}$; BGN 1936; (map 17). Var. Cemetary Point.

So named by members of the U.S. Navy Aleutian Island Survey Expedition in 1934, because "an Aleut graveyard is located at this point."

Cemetery Point: point of land, at S tip of Peratrovich I., in Klawak Inlet, $\mathbf{N}$ of Klawock, Alex. Arch.; $55^{\circ} 33^{\prime} 50^{\prime \prime} \mathrm{N}, 133^{\circ} 06^{\prime} 10^{\prime \prime} \mathrm{W}$; (map 4).

Local name recorded in 1949 by USGS

Cemetery Point: point of land, $1 \mathrm{mi}$. S of Wrangell, on N coast of Wrangell I., Alex. Arch. $56^{\circ} 27^{\prime} 15^{\prime \prime} \mathrm{N}, 132^{\circ} 22^{\prime} 50^{\prime \prime} \mathrm{W}$; BGN 1939; (map 6). Var. Graveyard Point, Station Point.

Local name reported in 1937 by USC\&GS Point had been called "Station Point" in 1886 by USC\&GS ; "Graveyard Point" in 1902

Cenotaph Island: island, $0.8 \mathrm{mi}$. across, in Lituya Bay, in Glacier Bay National Monument, 3 mi. NE of Harbor Point, $86 \mathrm{mi}$. NW of Hoonah, Malaspina Coastal Plain 58 $38^{\prime} 20^{\prime \prime}$ N, $137^{\circ} 35^{\prime} 00^{\prime \prime}$ W ; (map 10). Var. Egg Island, Isle du Caenotaphe.

Named "Isle du Caenotaphe" in 1786 by Capt. La Pérouse (1797, atlas 19), in memory of 26 members of his crew who, in that year, were drowned at the mouth of Lituya Bay when their two boats were caught in a strong ebb tide. A cenotaph, or memorial, was erected at that time on the southeast end of the island to commemorate the event, but no trace of it has been found. The island was called "O[strov] Yaichnoy," meaning "egg island," by Capt. Tebenkov (1852, map 7), IRN.

Cenotaph Point: point of land, on S end of Cenotaph I. in Lituya Bay, in Glacier Bay National Monument, $3.2 \mathrm{mi}$. NE of Harbor Point, 86 mi. WNW of Hoonah, Malaspina Coastal Plain ; $58^{\circ} 38^{\prime} 00^{\prime \prime} \mathrm{N}, 137^{\circ} 34^{\prime} 40^{\prime \prime} \mathrm{W}$; (map 10).

Named by W. H. Dall, USC\&GS, in 1874 . The name was published in the 1883 Coast Pilot (p. 204). See Cenotaph Island.

Centennial Range: mountain range, $12,000 \mathrm{ft}$. trends E-W $35 \mathrm{mi}$. on Alaska-Canada boundary, $45 \mathrm{mi}$. $\mathrm{N}$ of Mount St. Elias, bounded on $\mathrm{S}$ by Walsh Glacier and on $\mathrm{N}$ by Chitina Glacier, St. Elias Mts. ; $61^{\circ} 00^{\prime} \mathrm{N}, 140^{\circ} 50^{\prime} \mathrm{W}$ (maps 65, 67)
Named in 1966 to commemorate the centennials of the Alaska purchase and the Canadian confederation in 1867 by joint action of the Canadian Permanent Committee on Geographical Names and the U.S. Board on Geographic Names.

Center Beach: beach, $0.7 \mathrm{mi}$. long, at mouth of Kent Creek in Brunette Cove, on $\mathrm{N}$ coast of Attu I., Aleutian Is.; $52^{\circ} 58^{\prime} 23^{\prime \prime} \mathrm{N}, 172^{\circ} 56^{\prime}$ 45" E; (map 13).

Named by the U.S. Army during its occu. pation of the island during World War II ; descriptive name shown on an AMS map published in 1948.

Center Creek: stream, on Kenai Penin., flows W $7 \mathrm{mi}$. to East Fork Sixmile Creek, $20 \mathrm{mi}$. WSW of Whittier, Chugach Mts.; $60^{\circ} 43^{\prime} 15^{\prime \prime} \mathrm{N}$, $149^{\circ} 17^{\prime} 45^{\prime \prime} \mathrm{W}$; BGN 1912; (map 63). Var. Divide Creek

Local name reported in 1911 by USGS

Center Creek: stream, flows SW 2 mi. to Snake River, 2 mi. W of Nome, Seward Penin. High.; $64^{\circ} 31^{\prime} \mathrm{N}, 165^{\circ} 28^{\prime} \mathrm{W}$; (map 94). Var. Wonder Creek.

Prospector's name reported in 1899 by D. C. Witherspoon (in Schrader and Brooks, 1900, map 2), USGS.

Center Creek: stream, flows NW $2 \mathrm{mi}$. to Yukon River, $3.5 \mathrm{mi}$. NE of Ruby, Kilbuck-Kuskokwim Mts.; $64^{\circ} 46^{\prime} 30^{\prime \prime} \mathrm{N}, 155^{\circ} 24^{\prime} 00^{\prime \prime} \mathrm{W}$; (map 98).

Prospectors' name reported in 1908 by A. G. Maddren, USGS.

Center Creek: stream, see Divide Creek.

Center Island: island, $300 \mathrm{ft}$. long, in Eureka Channel, an eastern island off Barrier Is. group, Alex. Arch.; 54 $48^{\prime} 10^{\prime \prime}$ N, $132^{\circ} 22^{\prime} 35^{\prime \prime}$ W; (map 1)

Local descriptive name published by USC\&GS in 1943

Center Island: island, $0.2 \mathrm{mi}$. across, in Dewey Anchorage, between Etolin and Onslow Is., Alex. Arch.; 55 $56^{\prime} \mathrm{N}, 132^{\circ} 24^{\prime} \mathrm{W}$; (map 4).

Descriptive name given in 1886 by Lt Comdr. A. S. Snow, USN

Center Island: island, see Ninemile Island.

Center Islets: islands, three, extend $500 \mathrm{ft}$. in Fitzgibbon Cove along mainland, $1.3 \mathrm{mi}$. SE of Point Fitzgibbon, Coast Mts.; 55 $58^{\prime} 25^{\prime \prime}$ N, $131^{\circ} 11^{\prime} 10^{\prime \prime} \mathrm{W}$; (map 3$)$.

Local name published in the 1925 Coast Pilot (p. 66).

Center Mountain: mountain, 3,400 ft., $22 \mathrm{mi}$ SW of Kodaik. Kodiak I.; 57 $37^{\prime} 30^{\prime \prime}$ N, $152^{\circ} 45^{\prime} 00^{\prime \prime} \mathrm{W}$ : BGN 1933; (map 34).

Named in 1933 by Gerald FitzGerald, USGS, "because [it] is a prominent landmark about half way between Kizhuyak Bay and Ugak Bay."

Center Point: point of land, between West and East Arms Holtz. Bay on northern coast of Attu I., Aleutian Is.; $52^{\circ} 55^{\prime} 40^{\prime \prime} \mathrm{N}, 173^{\circ} 09^{\prime} 45^{\prime \prime}$ E; (map 13). Var. Middle Point.

This name is listed in the 1944 Aleutian Coast Pilot and is shown as "Middle Point" on an AMS map published in 1948. So named because of its position between East and West Arms Holtz Bay.
Center Slough: stream, on $\mathbf{S}$ coast of Alaska, flows SW $1 \mathrm{mi}$. to Gulf of Alaska, $5 \mathrm{mi}$ SE of Cordova, Malaspina Coastal Plain; $60^{\circ} 28^{\prime}$ $\mathrm{N}, 145^{\circ} 42^{\prime} \mathrm{W}$; (map 64 )

Local descriptive name published in 1951 by USGS.

Center Slough: stream, channel of Yukon River, heads $8 \mathrm{mi}$. W of Marshall, flows W $18 \mathrm{mi}$. to Dogtooth Bend, Yukon-Kuskokwim Delta; $61^{\circ} 54^{\prime} 30^{\prime \prime} \mathrm{N}, 162^{\circ} 39^{\prime} 00^{\prime \prime} \mathrm{W}$; (map 74).

Riverboat pilots' name shown on a fieldsheet by R. H. Sargent, USGS, in 1916 . So called because the stream's west mouth is in the center of Dogtooth Bend.

Central: village, pop. $28,28 \mathrm{mi}$. SW of Circle, Yukon-Tanana High.; $65^{\circ} 34^{\prime} 30^{\prime \prime} \mathrm{N}, 144^{\circ}$ $48^{\prime} 15^{\prime \prime} \mathrm{W}$; (map 104). Var. Central House.

The name was reported in 1896 by USGS to be "Central House," a roadhouse on the trail to Circle (Spurr, 1898, pl. 50). In 1925, a post office was established under the present name (Ricks, 1965, p. 9)

Central Creek: stream, flows S $5 \mathrm{mi}$. to Kuskokwim River $7.5 \mathrm{mi}$. SW of its junc. with George River, $28 \mathrm{mi}$. NW of Sleetmute, KilbuckKuskokwim Mts.; 61 ${ }^{\circ} 52^{\prime} \mathrm{N}, 157^{\circ} 56^{\prime} \mathrm{W}$; (map 72).

Local name published by USGS (in Cady and others, 1955, pl. 1).

Central Creek: stream, flows W $18 \mathrm{mi}$. to Goodpaster River, $32 \mathrm{mi}$. NE of Big Delta, YukonTanana High.; 64 ${ }^{\circ} 23^{\prime} \mathrm{N}, 144^{\circ} 57^{\prime} \mathrm{W}$; (map 101)

Named by prospectors for the Central Telegraph Station and reported in 1905 by D. C. Witherspoon (in Prindle, 1913a, pl. 1) USGS.

Central Creek: stream, heads in Kallarichuk Hills of Baird Mts., flows SW $15 \mathrm{mi}$. to Squirrel River, 8.4 mi. NNW of Kiana, Brooks Ra.; $67^{\circ} 05^{\prime} \mathrm{N}, 160^{\circ} 32^{\prime} \mathrm{W}$; (map 127).

Name used by prospectors: reported in 1910 by P. S. Smith (in Brooks and others, 1911, pl. 13), USGS.

Central House: village, see Central.

Central Marsh: swamp, $2.5 \mathrm{mi}$. long, $3 \mathrm{mi}$. E of Barrow, Arctic Plain; $71^{\circ} 19^{\prime} \mathrm{N}, 156^{\circ} 38^{\prime}$ W ; (map 153)

Named for scientific purposes (Carson and Hussey, 1962). This swamp was a lake that has been naturally drained by Central Marsh Slough.

Central Marsh Slough: stream, flows NE $3.4 \mathrm{mi}$, drains Central Marsh into Elson Lagoon, 5 mi. NE of Barrow, Arctic Plain; $71^{\circ} 18^{\prime} 40^{\prime \prime} \mathrm{N}$, $156^{\circ} 33^{\prime} 00^{\prime \prime} \mathrm{W}$; (map 153). Var. Wohlschlag Slough.

Named in 1965 for scientific purposes.

Central Point: point of land, between North and Middle Arms of Three Arm Bay, on W coast of Adak I., Aleutian Is. ; $51^{\circ} 45^{\prime} 30^{\prime \prime} \mathrm{N}, 176^{\circ}$ 51'45" W; BGN 1936; (map 17).

Named by members of the U.S. Navy Aleutian Island Survey Expedition in 1934, "because of its location."

Central Pyramid Peak: peak, 11,310 ft., in Mount McKinley National Park, center of three peaks on Mount Tripyramid, $12 \mathrm{mi}$. 
NE of summit of Mount McKinley, Alaska Ra.; $63^{\circ} 09^{\prime} 30^{\prime \prime} \mathrm{N}, 150^{\circ} 40^{\prime} 30^{\prime \prime} \mathrm{W} ; B G N$ 1948; (map 88).

Named in 1948 by Bradford Washburn.

Central Telegraph Station: locality, on right bank of Goodpaster River at Central Creek, $32 \mathrm{mi}$. NE of Big Delta, Yukon-Tanana High.; $64^{\circ} 23^{\prime} \mathrm{N}, 144^{\circ} 57^{\prime} \mathrm{W}$; (map 101).

This former telegraph station was established by the U.S. Army Signal Corps in 1903. The name was published by Prindle (1913a, pl. 16), USGS.

Centre Glacier: glacier, see Cascade Glacier.

Centurian Peak: peak, 6,400 ft., 2 mi. S of Stronghold Peak and $30 \mathrm{mi}$. N of Juneau, Coast Mts.; $58^{\circ} 44^{\prime} 12^{\prime \prime} \mathrm{N}, 134^{\circ} 16^{\prime} 00^{\prime \prime} \mathrm{W}$; $B G N 1965$; (map 11). Var. Unnamed Peak.

Named in 1964 by members of the Juneau Icefield Research Project.

Cerberus, Mount: peak, $3,687 \mathrm{ft}$. on Alaska Penin., in Katmai National Monument, $8 \mathrm{mi}$. W of Mount Katmai, Aleutian Ra. ; 58 ${ }^{\circ} 14^{\prime} 45^{\prime \prime}$ $\mathrm{N}, 155^{\circ} 11^{\prime} 50^{\prime \prime} \mathrm{W}$; BGN 1924; (map 42).

Named in 1917 by R. F. Griggs of the National Geographic Society "descriptive of this mountain as being the [three-headed] watchdog guarding Hades [Valley of the Ten Thousand Smokes]." From Greek mythology.

Cerberus, Mount: volcano, 2,673 ft., on Semisopochnoi I., Rat Is., Aleutian Is.; 51 ${ }^{\circ} 56^{\prime} 02^{\prime \prime}$ N, 179'35'20" E; BGN 1948; (map 15).

So named by 1935 U.S. Navy Survey Expedition "because the three connected summits comprising the volcano are analogous to the three-headed dog of Greek mythology, the guardian of the entrance to the underworld."

Chacktoole Bay: bay, see Shaktoolik Bay.

Chacon, Cape: point of land, $\mathrm{S}$ tip of Prince of Wales I., Alex. Arch.; 54 $41^{\prime} 30^{\prime \prime}$ N, $132^{\circ}$ $00^{\prime} 50^{\prime \prime}$ W; (map 1). Var. Bald Cape, Cape de Chacon, Cape Murray, Cape Shakon, Intankoon, Murderers Cape, Musatchie Nose, Mys Shakon.

Named "Cabo de Chacon," i.e. "Cape Chacon," by Lt. Don Jacinto Caamaño on July 23, 1792, "probably for Antonio Chacon, a Spanish fleet commander who died in 1803 , or possibly [for] Jose Maria Chacon, a Brigadier in the navy in 1797" (Wagner, 1937, p. 441-442). In 1789, Capt. William Douglas, RN, called this point "Cape Murray," The Indian name "Intankoon" [possibly from "Intungidi"], was given for this point in the log book of the Boston whaler Eliza, commanded by Capt. Rowan in 1799, who also called it "Bald Cape." The name was published in Russian as "M[ys] Shakon," i.e. "Cape Shakon" by Capt. Tebenkov (1852, map 9), IRN. This point was locally known as "Musatchie Nose" in the late 1800's (U.S. Coast and Geodetic Survey, 1891, p. 86).

This may also have been called "Murderers Cape" although the identification of the feature so named is uncertain. Caswell, one of the mates of the Columbia, had been killed by Indians here on a voyage *** under
Gray in August 1792" (Wagner, 1937, p. 475).

Chagafka Cove: bight, see Shahafka Cove.

Chagak, Cape: point of land, on $\mathrm{N}$ coast of Umnak I., Aleutian Is.; $53^{\circ} 31^{\prime} 40^{\prime \prime} \mathrm{N}, 168^{\circ}$ $13^{\prime} 50^{\prime \prime}$ W; (map 22). Var. Chidak, Mys Chagakh, Mys Chigakh.

Aleut name published by Capt. Tebenkov (1852, map 25), IRN, as "M[ys] Chagakh" and "M[ys] Chigakh," or "Cape Chagakh" and "Cape Chigakh." These names are probably from the word "cidaq," meaning "young bird," or "cagaq," meaning "trench," according to R. H. Geohegan. Father Ioann Veniaminov in 1846 translated the Aleut word "chagaq" as "natural hole" or "chasm."

Chagak Bay: bay, see Shagak Bay.

Chagakh, Mys: point of land, see Chagak, Cape. Chagakh Bay: bay, see Shagak Bay.

Chagalook: stream, see Shageluk Slough.

Chagavenapuk River: stream, see Swift River. Chagawakamiut: locality, see Chakwakamiut. Chageliuk: stream, see Innoko River.

Chageluk: village, see Shageluk.

Chageluk: stream, see Shageluk Slough.

Chagelyuk: stream, see Shageluk Slough.

Chä'ginä: ravine, cleft in bluff between Dalnoi and Suskaralogh Points, on W coast of St. George I., Pribilof Is. ; $56^{\circ} 35^{\prime} 50^{\prime \prime}$ N., $169^{\circ} 46^{\prime}$ $00^{\prime \prime} \mathrm{W}$; (map 38).

Aleut name, "Chä'ginä," meaning "crack"; reported by Putnam (1903, p. 1014), USC\&GS

Chagulah Island: island, $2.5 \mathrm{mi}$. across, one of Islands of Four Mts., Aleutian Is.; 52 $34^{\prime} 30^{\prime \prime}$ $\mathrm{N}, 171^{\circ} 08^{\prime} 00^{\prime \prime} \mathrm{W}$; $B G N$ 1931; (map 20). Var. Chegoula Island, Chugul Island, Tchegoula Island, Tchougoulok Island.

Aleut name given by USC\&GS in 1931 "in order to avoid the repetition of the name Chugul ***." The island was called "Os[trov] Chugula," or "Chugul Island," by Lt. Sarichev (1826, map 3), IRN.

Chagulak Pass: water passage, between Chagulak and Amukta Is., Aleutian Is.; $52^{\circ} 32^{\prime} 30^{\prime \prime}$ $\mathrm{N}, 171^{\circ} 10^{\prime} 00^{\prime \prime} \mathrm{W}$; (map 20).

Named after Chagulak Island by USC\&GS in 1931 .

Chagunakhchugvik: locality, site of summer village on $\mathrm{N}$ bank of Kuskokwim River near longitude $158^{\circ} 30^{\prime} \mathrm{W}$; (map 72). Var. Chugunakhchugvik.

Reported in $1842-44$ by Lt. L. A. Zagoskin, IRN. He also reported a group of mountains of the same name in this area.

Chagvagchat: locality", "near the headwaters of the Anvik River" in Nulato Hills. Var. Tchagvagtchatchachat.

Former Eskimo camp or settlement reported as "Tchagvagtchatchachat" by Lt. L. A. Zagoskin, IRN, on an 1850 map.

Chagvagchat: village, see Shageluk.

Chagvanakhtuli: stream, see Swift River.

Chagvan Bay: bay, $5 \mathrm{mi}$. across, at mouth of Kinegnak River, $21 \mathrm{mi}$. NE of Cape Newenham, Kilbuck-Kuskokwim Mts.; $58^{\circ} 46^{\prime} \mathrm{N}$, $161^{\circ} 46^{\prime} \mathrm{W}$; (map 39). Var. Portage Bay, Tchagvan Bay.
Eskimo name published by Lt. Sarichev (1826, map 3), IRN, as "Z[aliv] Chagvan." It was called "Portage Bay" on an 1899 chart by USC\&GS.

Chagvan Mountain: mountain, consists of two peaks, $1,593 \mathrm{ft}$. and $1,707 \mathrm{ft}$., $15 \mathrm{mi}$. NE of Cape Newenham, Kilbuck-Kuskokwim Mts.; $58^{\circ} 42^{\prime} 45^{\prime \prime} \mathrm{N}, 161^{\circ} 48^{\prime} 00^{\prime \prime} \mathrm{W}$; (map 39).

Named in 1914 by USC\&GS; published in 1916 Coast Pilot (p. 247).

Chagyulak: island, see Chugul Island.

Chahalie Lake: lake, $2 \mathrm{mi}$. long, $6 \mathrm{mi}$. NE of Chalkyitsik, Yukon Flats; $66^{\circ} 44^{\prime} \mathrm{N}, 143^{\circ} 34^{\prime}$ W; (map 120).

Tranjik-kutchin Indian name obtained in 1956 by T. E. Taylor, USGS.

Chahovun Lakes: lakes, along course of Kokacho Creek, $37 \mathrm{mi}$. NW of Fort Yukon, Yukon Flats: $66^{\circ} 58^{\prime} \mathrm{N}, 146^{\circ} 09^{\prime} \mathrm{W}$; (map 119).

Kutchin Indian name obtained in 1956 by T. E. Taylor, USGS.

Chaiachie: point of land, see Chiachi Point.

Chaichei Islands: islands, in Sitka Sound, $5 \mathrm{mi}$. NW of Sitka, Alex. Arch.; 57 $04^{\prime} 30^{\prime \prime} \mathrm{N}$, $135^{\circ} 27^{\prime} 30^{\prime \prime}$ W; (map 9). Var. Ostrov Chaichey.

Russian name meaning "gull" given in 1809 by the navigator Ivan Vasiliev the first; published by Lt. Sarichev (1826, map 19), IRN, as "O[strov] Chaichey."

Chaichey, Mys: point of land, see Gull Point. Chaichey, Ostrov: island, see Gull Island.

Chaichey, Ostrov: islands, see Chaichei Islands. Chaichi: island, see Gull Island.

Chaichie Island: island, see Gull Island. Chaichi Islands: islands, see Baby Islands.

Chaichi Rock: island, see Chaika Rock.

Chaichiy, Mys: point of land, see Chiachi Point. Chaicht Islands: islands, see Chiachi Islands. Chaik: locality, "on $\mathrm{N}$ shore Norton Sound near Golovnin Bay," Seward Penin. High.; (map 45). Var. Chai-miut, Chaimut, Chay-myut, Tchaimuth.

Former Eskimo camp or settlement reported as "Chay-myut" by Lt. L. A. Zagoskin, IRN, on an 1850 map.

Chaika Point: island, see Chaika Rock.

Chaika Rock: island, $0.2 \mathrm{mi}$. long, in Little Tanaga Strait, off SE coast of Kagalaska I., Aleutian Is.; $51^{\circ} 46^{\prime} 50^{\prime \prime} \mathrm{N}, 176^{\circ} 15^{\prime} 35^{\prime \prime} \mathrm{W}$; BGN 1936; (map 17). Var. Chaichi Rock, Chaika Point.

Russian name meaning "gull"; given by members of the U.S. Navy Aleutian Island Survey Expedition in 1934 because "it is a nesting place for sea gulls."

Chaik Bay: bay, $1.3 \mathrm{mi}$. across, $12 \mathrm{mi}$. S of Angoon, on W coast of Admiralty I., Alex. Arch.; $57^{\circ} 19^{\prime} \mathrm{N}, 134^{\circ} 35^{\prime} \mathrm{W}$; (map 9). Var. Cha-ik Bay, Chaque Bay, Chaque Cove.

Tlingit Indian name published in 1896 by USC\&GS as "Cha-ik Bay." The bay is probably identical to that called "Chaqua Cove" by Capt. Rowan of the Eliza in 1799, and "Chaque Bay" by Comdr. R. W. Meade, USN, in 1869 .

Chaiki: island, see Gull Islet.

Chaiki Islands: islands, see Baby Islands. 
Chai-miut: locality, see Chaik.

Chaimut: locality, see Chaik.

Chainruk: locality, "at Port Clarence" in the Seward Penin. High.; (map 111).

Eskimo camp or settlement listed with a population of 162 in the 1890 Census.

Chaitna River: stream, see Chuitna River.

Chaix Hill: ridge, see Chaix Hills.

Chaix Hills: ridge, extends NE $8 \mathrm{mi}$., between Tyndall Glacier and Malaspina Glacier, $5 \mathrm{mi}$. $\mathrm{E}$ of head of Icy Bay and $60 \mathrm{mi}$. NW of Yakutat, St. Elias Mts.; $60^{\circ} 03^{\prime \prime} \mathrm{N}, 141^{\circ} 05^{\prime} \mathrm{W}$; (map 65). Var. Chaix Hill.

Named by the New York Times Expedition of 1886 for Paul Chaix, President of the Geneva Geogaphical Society (Libbey, 1886, p. 287 and 290).

Chakachamna Lake: lake, trends E-W $15 \mathrm{mi}$., between Chigmit and Tordrillo Mts., $42 \mathrm{mi}$. NW of Tyonek, Alaska Ra.; 61 ${ }^{\circ} 12^{\prime} 30^{\prime \prime} \mathrm{N}$, $152^{\circ} 35^{\prime} 30^{\prime \prime} \mathrm{W} ;$ BGN 1930; (map 70).

Tanaina Indian name reported in 1927 by R. H. Sargent, USGS; "obtained from Chilligan, an old Tyonek Indian."

Chakachatna River: stream, heads at Chakachamna Lake, flows SE $36 \mathrm{mi}$. to McArthur River $3 \mathrm{mi}$. N of Trading Bay, $32 \mathrm{mi}$. NW of Kenai, Cook Inlet Low.; 60 $56^{\prime} 40^{\prime \prime} \mathrm{N}, 151^{\circ}$ $44^{\prime} 30^{\prime \prime}$ W; BGN 1930 ; (map 62).

Tanaina Indian name "obtained from Chilligan, an old Tyonek man, who was familiar with the region"; reported in 1929 by USGS.

Chakaktolik: village, pop. 32 , on banks of Kashunuk River at mouth of Chakaktolik Creek, $52 \mathrm{mi}$. W of Marshall, Yukon-Kuskokwim Delta; 61 $66^{\circ} 15^{\prime \prime} \mathrm{N}, 163^{\circ} 37^{\prime} 30^{\prime \prime} \mathrm{W}$; (map 74). Var. Chuckaktoligamut, Chukaktolik, Chukfaktoolik.

Eskimo village name supposed to mean "many animal bones."

Chakaktolik Creek: stream, W of Hut Creek, flows NW $50 \mathrm{mi}$., through Partway Lake, to Kashunuk River at Chakaktolik, $1.2 \mathrm{mi}$. S of its junc. with Pitmik River and $52 \mathrm{mi}$. W of Marshall, Yukon-Kuskokwim Delta; 61 ${ }^{\circ} 46^{\prime}$ $15^{\prime \prime}$ N, 1633' $30^{\prime \prime}$ W; (map 74). Var. Churartwlik River.

Eskimo name shown as "Churartwlik" on a manuscript map by "Father Delon" dated 1937, and reported by USC\&GS in 1949.

Chakatonkno Creek: stream, see Chokotonk River.

Chakawunapuk River: stream, see Swift River.

Chakchak: locality, on left bank of Chakchak Creek on Nelson I., $5.5 \mathrm{mi}$. W of Baird Inlet and $88 \mathrm{mi}$. W of Bethel, Yukon-Kuskokwim Delta; $60^{\circ} 44^{\prime} \mathrm{N}, 164^{\circ} 24^{\prime} \mathrm{W}$; (map 58). Var. Chukchagemiut, Chukchak, Chukchuk.

Eskimo name reported in 1949 by USC\&GS. The village is abandoned with "two or three graves the only sign of former habitation. It is sometimes used as a summer camp." Name reported to mean "mouth."

Chakchak Creek: stream, on Nelson I., flows SE $16 \mathrm{mi}$. to Kolovinerak River, $88 \mathrm{mi}$. W of Bethel, Yukon-Kuskokwim Delta; $60^{\circ} 39^{\prime} \mathrm{N}$, $164^{\circ} 19^{\prime}$ W; (map 58). Var. Chuckchak Creek, Chukchak Creek, Chukchak River.

Eskimo name reported in 1949 to mean "mouth" by USC\&GS.

Chakhwakhamiut-Kauirat River: stream, see Chakwakamiut River.

Chakik, Cape: point of land, on W coast of Umak I., Aleutian Is.; $51^{\circ} 53^{\prime} 15^{\prime \prime} \mathrm{N}, 176^{\circ} 06^{\prime} 40^{\prime \prime} \mathrm{W}$; $B G N$ 1936; (map 17). Var. Tchakhikh.

Aleut name reported as "Tchakhikh" by the North Pacific Exploring Expedition in 1855. According to R. H. Geoghegan, the Aleut meaning of this name is "both hands" or "pair of hands." He suggests that it may be derived from the word "chagig," meaning "shelter" or "refuge."

Chakina River: stream, flows NW $27 \mathrm{mi}$. to Chitina River, $13 \mathrm{mi}$. SW of McCarthy, Chugach Mts.; $61^{\circ} 19^{\prime} 30^{\prime \prime} \mathrm{N}, 143^{\circ} 08^{\prime} 00^{\prime \prime} \mathrm{W}$; (map 67).

Indian name obtained in 1900 from a manuscript map drawn by prospectors.

Chakok River: stream, on Kenai Penin., flows SW $9 \mathrm{mi}$. to North Fork Anchor River, 3.5 mi. NE of village of Anchor Point and $13 \mathrm{mi}$. $\mathrm{NW}$ of Homer, Cook Inlet Low.; $59^{\circ} 48^{\prime} \mathrm{N}$, $151^{\circ} 44^{\prime} \mathrm{W}$; (map 50). Var. Tchakoch.

Apparently a Kenai Indian name reported by I. G. Wosnesenski, who explored the area about 1840

Chaktolimont, Baie: bay, see Shaktoolik Bay. Chakumnuk Lake: lake, see Chikuminuk Lake. Chakwakamiut: locality, on left bank of Chakwakamiut River, $23 \mathrm{mi}$. NW of Cape Mendenhall, Nunivak I.; $59^{\circ} 56^{\prime} \mathrm{N}, 166^{\circ} 47^{\prime} \mathrm{W}$; (map 55). Var. Chagawakamiut, Chaxwaxamiut.

Eskimo fish camp reported in 1949 by USC\&GS.

Chakwakamiut River: stream, flows SW $20 \mathrm{mi}$. to Bering Sea, $24 \mathrm{mi}$. NW of Cape Mendenhall, Nunivak I.; $59^{\circ} 56^{\prime} \mathrm{N}, 166^{\circ} 50^{\prime} \mathrm{W}$; (map 55). Var. Chakhwakhamiut-Kauirat River, Chaxwaximiut-Koweerat River.

Eskimo name obtained in 1949 by USC\&GS

Chakwaktolik: village, pop. 23 , on $\mathrm{N}$ shore of Aropuk Lake, $70 \mathrm{mi}$. SW of Marshall, YukonKuskokwim Delta ; 61 $13^{\prime} 45^{\prime \prime} \mathrm{N}, 163^{\circ} 46^{\prime} 15^{\prime \prime}$ W; (map 74). Var. Chokaglaligamute, Chokfaktoligamute, Chokfoktoleghagamint, Chowhoctolik, Chuckwatoli, Chuckwucktolig, Chuckwuktoligamut, Chukwoktulik, Chukwotuliugamute, Chukwuktoligamut, Shokfak, Shokfaktolik, Tschokfachtolígamut.

Eskimo village visited in 1897 by Lt. J. H. Jarvis, USRCS, and reported as "Chukwoktuligamute," meaning "many pike lake [?]."

Chalatna Greek: stream, see Siruk Creek.

Chalchitna River: stream, see Chilchitna River. Chalit: locality, on left bank of Kuguklik River, $6 \mathrm{mi}$. NE of Kipnuk, Yukon-Kusekokwim Delta; $59^{\circ} 58^{\prime} \mathrm{N}, 163^{\circ} 51^{\prime} \mathrm{W}$; (map 54). Var. Chalitmuit.

Former Eskimo village reported as "Chalitmiut" or "Chalit people" in 1878 by E. W. Nelson, U.S. Signal Service. Ivan Petroff recorded a population of 54 in the 1880 Census. It is now an Eskimo summer camp.
Chalitmuit: locality, see Chalit.

Chalitnak: stream, see Holitna River.

Chaliuknak: locality, on $\mathrm{N}$ shore of Beaver Inlet, on NE coast of Unalaska I., Aleutian Is.; $53^{\circ} 51^{\prime} \mathrm{N}, 166^{\circ} 20^{\prime} \mathrm{W}$; (map 23). Var. Selo Chalyuknakh.

Former Aleut village reported as "Sel[o] Chalyuknakh," i.e. "Chalyuknakh Village," by Lt. Sarichev (1826, map 14, dated 1792), IRN. Baker (1906, p. 168), USGS, wrote, "An Aleut village bearing this name existed, in 1790 , on the northern shore of Beaver Bay, * **."

Chalk Creek: stream, in Mentasta Mts., flows SW $10 \mathrm{mi}$. to Jack Creek E of Lost Creek, $33 \mathrm{mi}$. SE of Mentasta Pass, Alaska Ra.; $62^{\circ} 30^{\prime} \mathrm{N}$ $143^{\circ} 10^{\prime}$ W; BGN 1939; (map 84). Var. Suicide Creek.

Locally named because a prospector named Chalk (cnna) committed suicide here in the 1930's; reported in 1939 by P. S. Smith, USGS.

Chalkyitsik: village, pop. 57 , on left bank of Black River, $4 \mathrm{mi}$. N of Ohtig Lake and 45 mi. NE of Fort Yukon, Yukon Flats; $66^{\circ} 39^{\prime}$ N, $143^{\circ} 43^{\prime}$ W; BGN 1945; (map 120). Var. Fishhook, Fishhook Town, Fishhook Village, Julkitsik.

Tranjik-kutchin Indian name reported to mean "to fish with a hook, at the mouth of the creek." The village was known as "Fishhook" primarily among nonnatives.

Chalkyitsik Slough: lake, cutoff oxbow of Black River, $1.5 \mathrm{mi}$. long, $0.2 \mathrm{mi}$. E of Chalkyitsik, Yukon Flats; $66^{\circ} 39^{\prime} \mathrm{N}, 143^{\circ} 43^{\prime} \mathrm{W}$; (map 120).

Tranjik-kutchin Indian name obtained in 1956 by T. E. Taylor, USGS.

Challenge Entrance: water passage, on Beaufort Sea coast between Maguire and Stockton Is., $10 \mathrm{mi}$. NW of Flaxman I., Arctic Plain; $70^{\circ} 14^{\prime}$ $\mathrm{N}, 146^{\circ} 45^{\prime} \mathrm{W}$; (map 151).

Named by Leffingwell (1919, p. 94) about 1913, "after the schooner Challenge of the Canadian Arctic Expedition, which is believed to have been the first vessel to pass through the passage."

Challenge Island: barrier island, $1 \mathrm{mi}$. long, on Beaufort Sea coast, westernmost of Maguire Is., $10 \mathrm{mi}$. NW of Flaxman I., Arctic Plain; $70^{\circ} 14^{\prime} \mathrm{N}, 146^{\circ} 38^{\prime} \mathrm{W}$; (map 151).

See Challenge Entrance.

Challono, Reka: stream, see Selatna River.

Chalmer Harbor: bay, see Chalmcrs, Port.

Chalmers, Port: bay, $2 \mathrm{mi}$. long, on NW coast of Montague I., $4 \mathrm{mi}$. W of Montague Peak, Chugach Mts.; $60^{\circ} 14^{\prime} 30^{\prime \prime} \mathrm{N}, 147^{\circ} 17^{\prime} 00^{\prime \prime} \mathrm{W}$; (map 63). Var. Careening Harbor, Chalmer Harbor, Chalmers Harbor, Chalmer's Harbour, Puerto de Flores.

Name reported in 1787 as "Chalmer's Harbour" by Capt. Portlock (1789, map facing $p$. 215), RN. The bay was probably named by Portlock "because they anchored here from May 2-14, 1787" (Wagner, 1937, p. 380).

It was called "Puerto de Flores" by Estéban José Martínez in honor of the Viceroy, Manuel Antonio Flores, when he took possession June 
1, 1788. Martínez was there from May 28 to June 15 (ibid., p. 454). Capt. George Dixon called it "Careening Harbor" in 1786 because his ships were careened (heeled over for repairs and scraping) here.

Chalmers Harbor: bay, see Chalmers, 'Port.

Chalmer's Harbour: bay, see Chalmers, Port.

Chalono, Reka: stream, see Selatna River.

Chaloo'ga Rocks: rocks, on SE coast of Attu I., Aleutian Is.: $52^{\circ} 46^{\prime} \mathrm{N}, 173^{\circ} 18^{\prime} \mathrm{E}$; (map 13).

Shown on a manuscript map by $L$. $M$. Turner in the 1880's.

Chalugas Bay: bay, $1.5 \mathrm{mi}$. across, on $\mathrm{N}$ coast of Amlia I., Aleutian Is.; $52^{\circ} 09^{\prime} \mathrm{N}, 173^{\circ} 34^{\prime} \mathrm{W}$ (map 19).

Name published by USC\&GS in 1944 Aleutian Coast Pilot (p. 90).

Chaluka: locality, on Umnak I. S of Inanudak Bay, Aleutian Is.; near $53^{\circ} 30^{\prime} \mathrm{N}, 168^{\circ} 30^{\prime} \mathrm{W}$; (map 22).

Archeological site reported by Giddings (1964, p. 262).

Chalzékahin River: stream, see Kicking Horse River.

Chamberlain, Mount: mountain, see Chamberlin, Mount.

Chamberlain Bay: estuary, on S coast of Glacier I., extends SW $1.7 \mathrm{mi}$. to Prince William Sound, $51 \mathrm{mi}$. ENE of Whittier, Chugach Mts.; $60^{\circ} 51^{\prime} 45^{\prime \prime} \mathrm{N}, 147^{\circ} 12^{\prime} 30^{\prime \prime} \mathrm{W}$; (map 63 ).

Locally "named for a miner"; reported in 1908 by U. S. Grant (in Brooks and others, 1909 , pl. 4), USGS

Chamberlain Glacier: glacier, heads on W slope of Brabazon Ra., 6 mi. SE of Mount Reaburn, trends W $8 \mathrm{mi}$. to its 1961 terminus, $0.2 \mathrm{mi}$ $\mathrm{N}$ of Akwe Lake and $37 \mathrm{mi}$. SE of Yakutat, St. Elias Mts.; $59^{\circ} 21^{\prime} 05^{\prime \prime} \mathrm{N}, 138^{\circ} 45^{\prime} 00^{\prime \prime} \mathrm{W}$; (map 46).

Named by Lt. Comdr. J. F. Moser (1902, p. 386), USN, for F. M. Chamberlain, a member of his party.

Chamberlain Lake: lake, $1.4 \mathrm{mi}$. long, on Revillagigedo I., W of head of Carroll Inlet, in course of Naha River, Alex. Arch.; 55 $38^{\prime} \mathrm{N}$ $131^{\circ} 29^{\prime} \mathrm{W} ; B G N$ 1962; (map 3).

Local name reported in 1961 by USFS.

Chamberlin, Mount: mountain, 9,020 ft., in Franklin Mts., $3 \mathrm{mi}$. SE of Lake Peters, $16 \mathrm{mi}$ W of Mount Michelson, Brooks Ra.; 69 ${ }^{\circ} 17^{\prime}$ N, 144 '54" W; BGN 1961; (map 139). Var. Mount Chamberlain.

Named by Leffingwell (1919, p. 94) for Thomas Chrowder Chamberlin, 1843-1928, geologist of the Peary Auxiliary Expedition of 1894.

Chamberlin Creek: stream, $2 \mathrm{mi}$. long, in Franklin Mts., draining Chamberlin Glacier into Lake Peters, $19 \mathrm{mi}$. W of Mount Michelson,

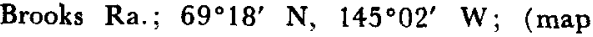
139).

So named in 1959 by members of the Air Force Cambridge Research Center because the stream heads at Chamberlin Glacier.

Chamberlin Glacier: glacier, in Franklin Mts., on $\mathrm{N}$ slope of Mount Chamberlin $2 \mathrm{mi}$. $\mathrm{E}$ of
Lake Peters, $15 \mathrm{mi}$. W of Mount Michelson, Brooks Ra.; 69'17' N, $144^{\circ} 54^{\prime} \mathrm{W}$; (map 139).

Named in 1959, after Mount Chamberlin, by members of the Air Force Cambridge Research Center.

Chambers: stream, see Eureka Creek.

Chamil Island: island, see Kagamil Island.

Chamisso: locality, "on Chamisso Island in Spafarief Bay," Kotzebue-Kobuk Low.; (map 114). Var. E-ow-ick.

Former Eskimo camp or settlement reported in 1827 as "E-ow-ick" by Capt. F. W. Beechey, RN. E. W. Nelson, U.S. Signal Service, used the entry spelling in 1899.

Chamisso Anchorage: water passage, extends EW $5 \mathrm{mi}$. between Choris Penin. and Chamisso I., connecting Eschscholtz Bay with Kotzebue Sound, $57 \mathrm{mi}$. SW of Selawik; KotzebueKobuk Low.; 66 $15^{\prime} \mathrm{N}, 161^{\circ} 51^{\prime} \mathrm{W}$; (map 114).

Name taken from that of the island to the south; shown on a chart of Capt. F. W. Beechey, RN, dated 1826.

Chamisso Island: island, $1 \mathrm{mi}$. long in Spafarief Bay, $57 \mathrm{mi}$. SW of Selawik, $3 \mathrm{mi}$. S of Choris Penin., Kotzebue-Kobuk Low.; 66 ${ }^{\circ} 13^{\prime} \mathrm{N}$, $161^{\circ} 50^{\prime} \mathrm{W}$ : (map 114). Var. E-ow-ick.

Named in 1816 by Lt. Otto von Kotzebue, IRN, for Louis Adelbert von Chamisso, a member of his expedition.

Champion Creek: stream, flows W $23 \mathrm{mi}$. to North Fork Fortymile River, $32 \mathrm{mi}$. SW of Eagle, Yukon-Tanana High.; 64 ${ }^{\circ} 33^{\prime} 15^{\prime \prime} \mathrm{N}$, $142^{\circ} 07^{\prime} 30^{\prime \prime} \mathrm{W}$; (map 102). Var. Arkansas Creek.

Prospectors' name obtained in 1898 by E. C. Barnard, USGS.

Champion Creek: stream, flows SW 15 mi., joins Bear Creek to form Beaver Creek, 3 mi. NNW of Table Top Mtn. and $52 \mathrm{mi}$. NE of Fairbanks, Yukon-Tanana High.; $65^{\circ} 25^{\prime} \mathrm{N}, 146^{\circ}$. $59^{\prime} \mathrm{W}$; (map 104). Var. Big Champion Creek.

Local name of stream shown in 1910 by USGS to flow to Beaver Creek at Nomet Creek (Brooks and others, 1910, pl. 6). In 1913 the stream was shown in its present location.

Champion Creek: stream, flows SW $1.7 \mathrm{mi}$. to Mina Creek which flows to Kugruk River, 24 mi. NE of Imuruk Lake, Seward Penin High.; $65^{\circ} 44^{\prime} \mathrm{N}, 162^{\circ} 23^{\prime} \mathrm{W}$; (map 110).

Prospeciors' name reported in 1903 by D. C. Witherspoon (in Moffit, 1905, pl. 2), USGS Chance Cove: cove, $1.5 \mathrm{mi}$. long, on $\mathrm{S}$ coast of Kenai Penin., $0.5 \mathrm{mi}$. NE of Ragged I. and $50 \mathrm{mi}$. ENE of Seldovia, Chugach Mts. ; $59^{\circ}$ $28^{\prime} 15^{\prime \prime} \mathrm{N}, 150^{\circ} 18^{\prime} 00^{\prime \prime} \mathrm{W}$; BGN 1929; (map 50)

Named by USC\&GS in 1927.

Chance Creek: stream, see Last Chance Creek. Chance Lagoon: cove, $500 \mathrm{ft}$. across, at $\mathrm{N}$ end of Chance Cove, on $S$ coast of Kenai Penin., $50 \mathrm{mi}$. ENE of Seldovia, Chugach Mts.; $59^{\circ}-$ $28^{\prime} 15^{\prime \prime} \mathrm{N}, 150^{\circ} 18^{\prime} 45^{\prime \prime} \mathrm{W}$; BGN 1929; (map $50)$.

Named by USC\&GS in 1927.

Chandalar: settlement, pop. 5 , on $\mathrm{E}$ shore of Chandalar Lake, at Rosalie Creek, Brooks Ra.; $67^{\circ} 30^{\prime} \mathrm{N}, 148^{\circ} 30^{\prime} \mathrm{W}$; (map 123). Var. Chandlar, Little Squaw.

This place developed as a mining camp about 1906 or 1907. A post office was established there in 1908 and was permanantly discontinued in 1944. It appears that the earlier location of Chandalar was farther downstream near Flat Creek. Named for the lake it is located on

Chandalar Creek: stream, heads at $67^{\circ} 24^{\prime} \mathrm{N}$, $143^{\circ} 26^{\prime} \mathrm{W}$, flows $43 \mathrm{mi}$. S to Sixmile Slough on $\mathbf{N}$ side of Porcupine River, $17 \mathrm{mi}$. $\mathrm{N}$ of Chalkyitsik, Yukon Flats; $66^{\circ} 53^{\prime} \mathrm{N},: 43^{\circ} 50^{\prime}$ W; (map 120).

Local name obtained in 1956 by T. E. Taylor and R. C. Foley, USGS.

Chandalar Lake: lake, $9.5 \mathrm{mi}$. long, in course of North Fork Chandalar River, $19 \mathrm{mi}$. S of Bend Mtn., Brooks Ra.; $67^{\circ} 30^{\prime} 00^{\prime \prime} \mathrm{N}, 148^{\circ} 30^{\prime} 30^{\prime \prime}$ W; BGN 1907; (map 123). Var. Achenchik, Chan-d'lar, Chand-lar, Chandlar Lake, Gens de Large, Tadrandike.

Local name shown on an 1899 fieldsheet by T. G. Gerdine, USGS.

Chand-da-large River: stream, see Chandalar River.

Chand da larg River: stream, see Chandalar River.

Chandalar River: stream, heads at its North and West Forks, flows SE $100 \mathrm{mi}$. to Yukon River $20 \mathrm{mi}$. NW of Fort Yukon, Yukon Flats; $66^{\circ}$. $36^{\prime} 35^{\prime \prime} \mathrm{N}, 146^{\circ} 00^{\prime} 20^{\prime \prime} \mathrm{W}$; BGN 1944; (map 119). Var. Achenchik River, Chand-da-large River, Chand da larg River, Chandelar River, Chand'lar River, Chandler River, Gens de Large, Tadrandike River.

Local name derived from the name given to the Kutchin Indians along this stream by the French employees of the Hudson's Bay Company located at Fort Yukon. The French name was "Gens de Large," or "nomadic people," which, when written into English from its local pronunciation evolved into its present form. Early USGS field notes spelled the name "Chand-da-larg." Capt. C. W. Raymond, U.S. Army Corps of Engineers, recorded the stream's Indian name as "Achenchik" in 1869.

Chandelar River: stream, see Chandalar River. Chandlar: settlement, see Chandalar.

Chandlar Lake: lake, see Chandalar Lake.

Chandler Lake: lake, $5 \mathrm{mi}$. long, at head of Chandler River, $26 \mathrm{mi}$. W of Anaktuvuk Pass, Brooks Ra.; 68 ${ }^{\circ} 14^{\prime} \mathrm{N}, 152^{\circ} 42^{\prime} \mathrm{W}$; (map 134). Var. Najwarwak, Narivakvak, Narivakvuk.

Named by Lt. Stoney (1900, p. 44), USN, who discovered this lake March 18,1886 , for William E. Chandler, 1835-1917, Secretary of the Navy during President Arthur's administration. The Eskimo name for this lake is Narivakpak, meaning "big lake."

Chandler River: stream, heads in Chandler Lake, flows NE through Little Chandler Lake $125 \mathrm{mi}$. to Colville River, $17 \mathrm{mi}$. NE of Umiat, Arctic Slope; $69^{\circ} 27^{\prime} \mathrm{N}, 151^{\circ} 30^{\prime} \mathrm{W} ; B G N$ 1945; (map 141). Var. Ninuluk Creek. 
This name was originally applied to Okokmilaga River by the 1924 USGS expedition (Smith and Mertie, 1930, map), because it was thought the stream headed in Stoney's Chandler Lake. The name was reapplied by USGS about 1944.

Chandler River: stream, see Chandalar River.

Chandler River: stream, see Okokmilaga River.

Chandos, Point: point of land, on Beaufort Sea coast, $26 \mathrm{mi}$. SE of Beechey Point, Arctic Plain; (map 150).

This point has not been positively identified Named by Sir John Franklin (1828, p. 158), August 16, 1826, who wrote, "between Point Anxiety and Point Chandos, which is eight miles further to the westward." From this description Point Chandos was located tentatively as the western side of the delta of the Sagavanirktok (in Leffingwell, 1919, p. 94), and as "the eastern point of entrance to Yarboro inlet * * *" according to Baker (1906, p. 168).

Chandris Cove: bight, $0.3 \mathrm{mi}$. wide, on $\mathrm{W}$ coast of Amatignak I., Delarof Is., Aleutian Is.; $51^{\circ} 14^{\prime} 40^{\prime \prime} \mathrm{N}, 179^{\circ} 08^{\prime} 30^{\prime \prime} \mathrm{W}$; (map 16).

Local name published on a 1954 USGS map.

Chaneeliut: village, see Chaniliut.

Chaneeliut Slough: stream, see Chaniliut Slough. Chanega: village, see Chenega.

Chaneliak: village, see Chaniliut.

Change Island: island, $0.1 \mathrm{mi}$. long, in Seward Passage, $0.9 \mathrm{mi}$. E of Point Peters, off W coast of Cleveland Penin., Alex. Arch.; 55 58'25" $\mathrm{N}, 132^{\circ} 00^{\prime} 25^{\prime \prime} \mathrm{W}$; (map 4).

Local name published in 1925 Coast Pilot (p. 119).

Chaniliak: village, see Chaniliut.

Chaniliut: village, pop. 25, in Yukon Delta, on Chaniliut Slough, $2 \mathrm{mi}$. SE of Pastol Bay and $39 \mathrm{mi}$. NE of Kwiguk, Yukon-Kuskokwim Delta; $63^{\circ} 02^{\prime} \mathrm{N}, 163^{\circ} 25^{\prime} \mathrm{W}$; BGN 1942; (map 92). Var. Chaneeliut, Chaneliak, Chaniliak, Chineleat, Nachliwagimiut, Nakhliwak.

Eskimo village reported by the twelfth census enumerator in 1899 who spelled the name "Chineleat." In 1940 it consisted of a church, school, and several cabins on both sides of the slough.

Chankliut Island: island, $2.9 \mathrm{mi}$. long, in Pacific Ocean $6 \mathrm{mi}$. S of Castle Cape on Alaska Penin. Aleutian Ra.; $56^{\circ} 08^{\prime} \mathrm{N}, 158^{\circ} 07^{\prime} \mathrm{W}$; (map 30). Var. Ostrov Chankliut, Chankluit Island.

Native name shown as "O[strov] Chankliut," meaning "Chankliut Island," on Russian Hydrog. Dept. Chart 1379 in 1847 and published as "Chankliut Island" on USC\&GS Chart 797.

Chankluit Island: island, see Chankliut Island. Chaniliut Slough: stream, in Yukon Delta, flows N $13 \mathrm{mi}$. to Apoon Pass at Chaniliut, E of Pastol Bay, $40 \mathrm{mi}$. NE of Kwiguk, Yukon-

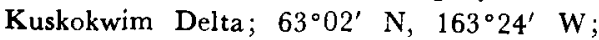
(map 92). Var. Chaneeliut Slough.

Eskimo name obtained in 1952 by USC\&GS.
Channel Bluff: promontory, $473 \mathrm{ft}$., on right bank of Yukon River, in Paimiut Hills, $13 \mathrm{mi}$. SW of Holy Cross, Nulato Hills; 62 $03^{\prime} 05^{\prime \prime}$ $\mathrm{N}, 160^{\circ} 02^{\prime} 00^{\prime \prime} \mathrm{W}$; (map 78).

Riverboat pilots' name shown on a 1940 "Navigation Chart of the Tanana-Yukon Rivers" published by U.S. Dept. of Interior. Channel Island: island, $0.5 \mathrm{mi}$. long, in Hook Arm Sea Otter Harbor, on W coast of Dall I., Alex. Arch.; $55^{\circ} 07^{\prime} 40^{\prime \prime} \mathrm{N}, 133^{\circ} 09^{\prime} 40^{\prime \prime} \mathrm{W}$; (map 4).

Descriptive name published in 1924 by USC\&GS.

Channel Island: island, $300 \mathrm{ft}$. long, in Tongass Narrows near Ward Cove, $4.5 \mathrm{mi}$. NW of Ketchikan, Alex. Arch.; $55^{\circ} 23^{\prime} 45^{\prime \prime} \mathrm{N}, 131^{\circ}$. $45^{\prime} 45^{\prime \prime} \cdot \mathrm{W}$; (map 3$)$.

Named about 1880 by W. E. George, a local pilot.

Channel Island: island, $0.2 \mathrm{mi}$. long, $0.5 \mathrm{mi}$. $\mathrm{N}$ of Coronation 1., Alex. Arch.; 55 55'20" N, $134^{\circ} 11^{\prime} 25^{\prime \prime} \mathrm{W}$; (map 4)

Local name published by USC\&GS in 1943.

Channel Island: island, $0.7 \mathrm{mi}$. long, near S end of Eastern Passage, NE coast of Wrangell I., Alex., Arch.; $56^{\circ} 22^{\prime} \mathrm{N}, 132^{\circ} 10^{\prime} \mathrm{W}$; (map 6 ).

Local navigators' name reported in 1904 by H. C. Fassett, USBF.

Channel Island: island, $0.1 \mathrm{mi}$. across, on $\mathrm{W}$ coast of Chichagof I., in Ford Arm, $8 \mathrm{mi}$. SE of Chichagof, Alex. Arch ; $57^{\circ} 34^{\prime} 35^{\prime \prime} \mathrm{N}, 135^{\circ}$ $57^{\prime} 00^{\prime \prime} \mathrm{W}$; (map 9).

Local descriptive name reported in 1951 by USGS.

Channel Island: island, $0.2 \mathrm{mi}$. long, in Montague Strait, $1.5 \mathrm{mi}$. SE of Green I. and $25 \mathrm{mi}$. ESE of Chenega, Chugach Mts.; $60^{\circ} 14^{\prime} 25^{\prime \prime} \mathrm{N}$, $147^{\circ} 22^{\prime} 45^{\prime \prime} \mathrm{W}$; (map 63).

Local name reported in 1951 by USGS.

Channel Island: island, $0.4 \mathrm{mi}$. long, in St. Michael Bay, $1.3 \mathrm{mi}$. S of St. Michael, YukonKuskokwim Delta ; $63^{\circ} 27^{\prime} 25^{\prime \prime}$ N, $162^{\circ} 02^{\prime} 45^{\prime \prime}$ W; (map 92)

Local name recorded in 1942 by USGS.

Channel Islands: islands, $0.2 \mathrm{mi}$. long, in Bay of Islands, Adak I., Aleutian Is.; $51^{\circ} 49^{\prime} 00^{\prime \prime} \mathrm{N}$, $176^{\circ} 49^{\prime} 17^{\prime \prime} \mathrm{W}$; BGN 1936; (map 17).

Named by members of the U.S. Navy Aleutian Island Survey Expedition in 1933.

Channel Islands: islands, two, extend $0.5 \mathrm{mi}$. in $\mathrm{N}$ entrance to Howkan Narrows, between Dall and Long Is., Alex. Arch.; 54 $52^{\prime} 50^{\prime \prime} \mathrm{N}, 132^{\circ}$ $49^{\prime} 10^{\prime \prime} \mathrm{W}$; ( map 1$)$.

Local descriptive name published by USC\&GS in 1943.

Channel Islands: islands, two, extend $0.5 \mathrm{mi}$. in Behm Canal, 2 mi. S of mouth of Chickamin River, Coast Mts. ; $55^{\circ} 45^{\prime} 00^{\prime \prime} \mathrm{N}, 130^{\circ} 57^{\prime} 20^{\prime \prime}$ W: (map 3).

Descriptive name given in 1891 by USC\&GS

Channel Islands: islands, $0.6 \mathrm{mi} . \mathrm{N}$ of $\mathrm{NE}$ tip of Hawkins I. and $5 \mathrm{mi}$. NW of Cordova, Chugach Mts.; $60^{\circ} 37^{\prime} \mathrm{N}, 145^{\circ} 48^{\prime} \mathrm{W}$; (map 64).

Named by Lt. Comdr. J. F. Moser, USN, commander of the steamer Albatross, while collecting hydrographic notes and making harbor sketches in 1897.

Channel Islets: rocks, see Channel Rocks.

Channel Lake: lake, $0.6 \mathrm{mi}$. long, on Kenai Penin. E of Paddle Lake, $31 \mathrm{mi}$. NE of Kenai, Cook Inlet Low.; $60^{\circ} 46^{\prime} 15^{\prime \prime} \mathrm{N}, 150^{\circ} 29^{\prime} 15^{\prime \prime}$ W; (map 62).

Named about 1963 by officials of Kenai National Moose Range, for administrative purposes.

Channel Point: point of land, SW tip of an unnamed island, at $W$ end of Kootznahoo Inlet, $0.8 \mathrm{mi}$. $E$ of Angoon, on $W$ coast of Admiralty I., Alex. Arch.; $57^{\circ} 30^{\prime} 25^{\prime \prime}$ N, $134^{\circ}$ $33^{\prime} 45^{\prime \prime}$ W; (map 9).

Descriptive name given in 1869 by Comdr. R. W. Meade, USN, and published by USC\&GS in the 1883 Coast Pilot (p. 177).

Channel Rock: rock, $1 \mathrm{mi}$. NW of Sitka, off NW coast of Baranof I., Alex. Arch.; 57 $03^{\prime} 40^{\prime \prime} \mathrm{N}, 135^{\circ} 22^{\prime} 00^{\prime \prime} \mathrm{W}$; ( $\operatorname{map} 9$ ).

Descriptive name given in 1880 by Capt. Beardslee, USN, and published by USC\&GS in the 1883 Coast Pilot (p. 149).

Channel Rock: rock, $300 \mathrm{ft}$. long, in Wide Bay, between East and West Channel Is., on S coast of Alaska Penin., $16 \mathrm{mi}$. SW of Kanatak, Aleutian Ra.; $57^{\circ} 24^{\prime} 05^{\prime \prime} \mathrm{N}, 156^{\circ} 13^{\prime} 25^{\prime \prime} \mathrm{W}$; (map 36).

So named in 1923 by USC\&GS because "it is beside the main entrance channel."

Channel Rock: rock, in $\mathrm{N}$ end of Woody Island Channel, S of Spruce Cape, $2.8 \mathrm{mi}$. NE of Kodiak, Kodiak I.; $57^{\circ} 48^{\prime} 48^{\prime \prime} \mathrm{N}, 152^{\circ} 19^{\prime} 42^{\prime \prime}$ W; (map 34).

Descriptive name given in 1869 by USC\&GS.

Channel Rock: rock, in NE end of Knight Island Passage, $10 \mathrm{mi}$. NE of Chenega, Chugach Mts.; $60^{\circ} 23^{\prime} 15^{\prime \prime} \mathrm{N}, 147^{\circ} 52^{\prime} 55^{\prime \prime} \mathrm{W}$; (map 63).

So named in 1910 by USC\&GS, "because of its location."

Channel Rocks: rocks, in Kakul Narrows, between Baranof and Chichagof Is., $26 \mathrm{mi}$. NW of Sitka, Alex. Arch.; (map 9). Var. Channel Islets.

Descriptive name given in 1884 by Comdr. J. B. Coghlan, USN.

Chanuk Creek: stream, flows ENE $5 \mathrm{mi}$. to junc. with September Creek to form Weasel Creek, $35 \mathrm{mi}$. SW of Whitefish Lake and $52 \mathrm{mi}$. NW of Nondalton, Lime Hills; $60^{\circ} 34^{\prime} 30^{\prime \prime} \mathrm{N}, 155^{\circ}$. $43^{\prime} 30^{\prime \prime} \mathrm{W}$; (map 61).

Local name reported in 1950 by USC\&GS. Chapeau Mountain: mountain, 2,100 ft., on Annette I. E of Tamgas Harbor, Alex. Arch.; $55^{\circ} 03^{\prime} 02^{\prime \prime} \mathrm{N}, 151^{\circ} 28^{\prime} 45^{\prime \prime} \mathrm{W}$; (map 3).

Named in 1883 by Lt. Comdr. H. E. Nichols, USN.

Chapel Cove: cove, $0.2 \mathrm{mi}$. across, on $\mathrm{N}$ coast of Amchitka I., Rat Is., Aleutian Is.; $51^{\circ}$ 37'05" N, 178 51'15" E; (map 15).

Name published on a 1957 AMS map.

Chapel Cove: cove, $0.7 \mathrm{mi}$. across, in Bay of Waterfalls, on SW coast of Adak I., Aleutian Is. ; $51^{\circ} 38^{\prime} 50^{\prime \prime} \mathrm{N}, 176^{\circ} 48^{\prime} 20^{\prime \prime} \mathrm{W}$; BGN 1936; (map 17). 
Named by Lt. William Gibson, USN, commander of the schooner Fenimore Cooper, during the North Pacific Exploring Expedition in 1855 .

Chapel Island: island, $0.3 \mathrm{mi}$. across, at entrance to Gambier Bay, on $\mathrm{E}$ coast of Admiralty I., $61 \mathrm{mi}$. NE of Sitka, Alex. Arch.; 57 $26^{\prime} 45^{\prime \prime}$ N, $133^{\circ} 53^{\prime} 45^{\prime \prime}$ W; (map 8). Var. Chapel Islet.

Named in 1889 by Lt. Comdr. H. B. Mansfield, USN.

Chapel Islet: island, see Chapel Island.

Chapel Roads: anchorage, at mouth of Chapel Cove, on SW coast of Adak I., Aleutian Is.; $51^{\circ} 38^{\prime} 50^{\prime \prime} \mathrm{N}, 176^{\circ} 49^{\prime} 20^{\prime \prime} \mathrm{W} ;$ BGN 1936; (map 17).

Name derived from Chapel Cove, and given by members of the U.S. Navy Aleutian Island Survey Expedition in 1934.

Chapeluk Slough: stream, heads in a lake, flows E $3.4 \mathrm{mi}$. to Etokek Slough, $1.2 \mathrm{mi}$. E of Apoon Pass and 26 mi. NE of Kwiguk, Yukon-Kuskokwim Delta; $62^{\circ} 59^{\prime} 15^{\prime \prime} \mathrm{N}, 163^{\circ} 50^{\prime} 00^{\prime \prime} \mathrm{W}$; (map 77).

Eskimo name obtained in 1899 by R. L. Faris, USC\&GS; published in 1901 on Chart 9372.

Chapin Bay: bay, $1 \mathrm{mi}$. across, on SE coast of Admiralty I., $28 \mathrm{mi}$. SE of Angoon, Alex. Arch.; $57^{\circ} 08^{\prime} \mathrm{N}, 134^{\circ} 19^{\prime} \mathrm{W}$; (map 9).

Named in 1892 by Lt. Comdr. E. K. Moore, USN, for Ens. Frederick Lincoln Chapin, USN, a member of his party.

Chapin Island: island, $0.2 \mathrm{mi}$. long, in Karheen Passage, off E coast of Heceta I., Alex. Arch.; $55^{\circ} 47^{\prime} 45^{\prime \prime} \mathrm{N}, 133^{\circ} 18^{\prime} 40^{\prime \prime} \mathrm{W}$; (map 4).

Local name published in 1923 by USC\&GS.

Chapman Creek: stream, flows $\mathrm{W} 5 \mathrm{mi}$. to $\mathrm{Mi}$ nook Creek, $58 \mathrm{mi}$. NE of Tanana, YukonTanana High.; $65^{\circ} 20^{\prime} \mathrm{N}, 150^{\circ} 09^{\prime} \mathrm{W}$; (map 106).

Prospectors' name published in 1898 by USC\&GS

Chapman Creek: stream, flows W $3 \mathrm{mi}$. from a lake to Middle Fork Koyukuk River at Tramway $B a r, 4.5 \mathrm{mi}$. S of Twelvemile Mtn. and 24 mi. S of Wiseman, Brooks Ra.; $67^{\circ} 05^{\prime} 30^{\prime \prime} \mathrm{N}$, $150^{\circ} 29^{\prime} 30^{\prime \prime} \mathrm{W}$; (map 124).

Reported by G. H. Wonson, master of the steamer Dorothy, on his manuscript map of the Koyukuk River, published in 1899.

Chapman Island: island, in Middle Fork Koyukuk River, $\mathrm{S}$ of mouth of Chapman Creek, 24 mi. S of Wiseman, Brooks Ra.; $67^{\circ} 05^{\prime} 00^{\prime \prime}$ N, $150^{\circ} 29^{\prime} 30^{\prime \prime} \mathrm{W}$; (map 124).

Local name obtained in 1956 by USGS topographers.

Chapolda Creek: stream, see Chavolda Creek.

Chaque Bay: bay, see Chaik Bay.

Chaque Cove: bay, see Chaik Bay.

Charcoal Creek: stream, on Prince of Wales I., flows $\mathrm{N}$ to Sumner Strait, about $6 \mathrm{mi}$. $\mathrm{E}$ of Point Baker, Alex. Arch.; $56^{\circ} 21^{\prime} \mathrm{N}, 133^{\circ} 27^{\prime}$ W; BGN 1923; (map 6).

Named in 1923 by USFS. This feature cannot be precisely identified on present maps. Charcoal Creek: stream, see Buster Creek.
Charcoal Island: island, $0.4 \mathrm{mi}$. across, tied to Japonski I., $0.7 \mathrm{mi}$. SW of Sitka, Alex. Arch.; $57^{\circ} 02^{\prime} 45^{\prime \prime} \mathrm{N}, 135^{\circ} 21^{\prime} 10^{\prime \prime} \mathrm{W}$; (map 9). Var. Ostrov Ugolnoy.

This is an 1882 translation by USC\&GS of the name given in 1809 by the Russian navigator Ivan Vasiliev the first; reported by Lt. Sarichev (1826, map 19), IRN, as "Os[trov] Ugolnoy."

Charcoal Point: suburb, residential district within city limits of Ketchikan, Alex. Arch.; $55^{\circ} 21^{\prime} 30^{\prime \prime} \mathrm{N}, 131^{\circ} 41^{\prime} 30^{\prime \prime} \mathrm{W}$; (map 3 ).

Local name published in 1925 Coast Pilot (p. 61).

Chariot: locality, on Chukchi Sea coast, E of Ogotoruk Creek, $6.5 \mathrm{mi}$. SE of Cape Thompson, Arctic Slope; $68^{\circ} 06^{\prime} \mathrm{N}, 165^{\circ} 45^{\prime} \mathrm{W} ; B G N$ 1963; (map 129).

Named about 1962 for Project Chariot by personnel of the project. The name probably refers to a headquarters building on the site. Charity Creek: stream, flows SW $3.5 \mathrm{mi}$., joins Hope Creek to form Faith Creek, $70 \mathrm{mi}$. SW of Circle, Yukon-Tanana High.; $65^{\circ} 23^{\prime} 45^{\prime \prime} \mathrm{N}$, $146^{\circ} 16^{\prime} 00^{\prime \prime} \mathrm{W}$; (map 104).

Name originated with the prospectors in the area. Early maps show that this name was applied to the stream now known as "Hope Creek" (Prindle, 1905, pl. 3). The present Charity Creek was reported in 1908 by USGS (Covert and Ellsworth, 1909, pl. 2).

Charity Creek: stream, see Hope Creek.

Charleetna River: stream, see Chulitna River.

Charles, Point: point of land, on $\mathbf{S}$ shore of Elson Lagoon, probably in or near Ross Bay, Arctic Plain; (map 153).

Named by Thomas Simpson (1843, p. 151) in 1837 along with Point Rowand "in compliment to * * valued friends, partners in the fur trade."

Charles Creek: stream, flows S $1.3 \mathrm{mi}$. to Sulatna River at Tamarack Bluff, $40 \mathrm{mi}$. S of Ruby, Kilbuck-Kuskokwim Mts.; $64^{\circ} 10^{\prime} \mathrm{N}$, $155^{\circ} 19^{\prime} \mathrm{W}$; (map 98).

Prospectors' name reported in 1913 by Eakin (1914, pl. 3), USGS. The stream's identity is in doubt.

Charles Creek: stream, flows S $1.3 \mathrm{mi}$. to Ophir Creek, $13 \mathrm{mi}$. NW of Council and $38 \mathrm{mi}$. SW of Imuruk Lake, Seward Penin. High.; $65^{\circ} 04^{\prime}$ $\mathrm{N}, 163^{\circ} 44^{\prime} \mathrm{W}$; (map 110$)$.

Prospectors' name published on the 1908 "Map of Seward Peninsula" by Arthur Gibson.

Charleskin Creek: stream, see Charlieskin Creek.

Charley Creek: stream, heads in a small lake. flows S $4.5 \mathrm{mi}$. to Edna Bay on Kosciusco I., Alex. Arch.; 55 $57^{\prime} 40^{\prime \prime}$ N, $133^{\circ} 38^{\prime} 30^{\prime \prime} \mathrm{W}$; $B G N 1963$; (map 4).

Local name recorded in 1951 by USGS.

Charley Creek: stream, see Charlie Creek.

Charley Creek: stream, see Kandik River.

Charley Glacier: glacier, $1 \mathrm{mi}$. long, in Glacier Bay National Monument, terminates $1 \mathrm{mi}$. W of Johns Hopkins Inlet, $80 \mathrm{mi}$. NW of Hoonah, St. Elias Mts.; $58^{\circ} 53^{\prime} 45^{\prime \prime} \mathrm{N}, 136^{\circ}$. 04'30" W; BGN 1937; (map 10).
Named by W. O. Field, Jr., and W. S. Cooper (Cooper, 1937, p. 62, fig. 17) for "Sitka Charley," one of John Muir's Tlingit Indian guides on his 1879 trip to Glacier Bay.

Charley Green Creek: stream, flows NW $17 \mathrm{mi}$. to Pastol Bay, $34 \mathrm{mi}$. SW of St. Michael, Yukon-Kuskokwim Delta ; $63^{\circ} 09^{\prime} \mathrm{N}, 162^{\circ} 52^{\prime}$ W; (map 92).

Local name obtained in 1952 by USC\&GS; named for "a prospector who was overcome by cabin fever ***."

Charley Lake: lake, see Crosswind Lake.

Charley River: stream, heads at $64^{\circ} 40^{\prime} \mathrm{N}$, $144^{\circ} 02^{\prime} \mathrm{W}$, flows NE $88 \mathrm{mi}$. to Yukon River, $55 \mathrm{mi}$. NW of Eagle, Yukon-Tanana High.; $65^{\circ} 19^{\prime} \mathrm{N}, 142^{\circ} 47^{\prime} \mathrm{W}$; (map 103). Var. Charleys River, Charlie River, Traodee Creek.

The Indian name "Traodee" was recorded by Schwatka (1885b, sheet 8 ). E. F. Ball named the stream "Charlie River" on an unpublished map dated 1898, probably for nearby Charlie Village or Chief Charlie. Lt. Cantwell (1902, p. 277), USRCS, appears to have established the "Charley" spelling for the stream.

Charleys River: stream, see Charley River.

Charleys Village: locality, see Charlie Village.

Charley Village: locality, on right bank of Yukon River at mouth of Kandik River, Porcupine Plat.; $65^{\circ} 17^{\prime} \mathrm{N}, 142^{\circ} 30^{\prime} \mathrm{W}$; (map 103). Var. Charleys Village, Charlies Village, Charlie Village, Charlieville, Tadoosh, Tadush.

Former Indian village of which Lt. Schwatka (1885b, p. 41 and 42), USA, wrote, "On the 23d of July [1883] we reached another Indian village, called Charley's Village, which is the exact counterpart of the one called Johnny's, even to the number of houses (6) ***. We met a Canadian voyageur among them who calls them and Johnny's village the Tadoosh Indians, and says they are the most friendly and best natured Indians on this part of the river." Archdeacon Stuck $(1917$, p. 82) stated that the village was named for a "Chief Charley." The village stood until the high water of the 1914 ice breakup when it was washed away, and the natives moved to Circle.

Charlie Creek: stream, fows NW $2.3 \mathrm{mi}$, to Sinuk River, $25 \mathrm{mi}$. N of Nome, Seward Penin. High.; 64 $52^{\circ} \mathrm{N}, 165^{\circ} 30^{\prime} \mathrm{W}$; (map 94). Var. Charley Creek.

Prospectors' name reported as "Charley Creek" in 1900 by E. C. Barnard (in Brooks, 1901, pl. 17), USGS.

Charlie Creek: stream, see Kandik River.

Charlie Glacier: glacier, in Glacier Bay National Monument, $1 \mathrm{mi}$. long, trends $\mathrm{E}$ to its 1961 terminus, $1 \mathrm{mi}$. W of Johns Hopkins Inlet and $80 \mathrm{mi}$. NW of Hoonah, St. Elias Mts. ; $58^{\circ} 51^{\prime} 15^{\prime \prime} \mathrm{N}, 137^{\circ} 09^{\prime} 10^{\prime \prime} \mathrm{W}$; (map $10)$.

Named in 1936 by W. O. Field, Jr., and W. S. Cooper (Cooper, 1937, p. 62) for "Sitka Charley" one of the Tlingit Indians who accompanied John Muir on his 1879 visit (Muir, 1915, p. 115). 
Charlie Lake: lake, $0.5 \mathrm{mi}$. long, $3 \mathrm{mi}$. NW of junc. of South Fork Kuskokwim and Post Rivers and $75 \mathrm{mi}$. SE of McGrath, Alaska Ra.; $62^{\circ} 26^{\prime} 25^{\prime \prime} \mathrm{N}, 153^{\circ} 31^{\prime} 40^{\prime \prime} \mathrm{W}$; (map 80).

Local name obtained in 1958 by USGS.

Charlie River: stream, see Charley River.

Charlieskin Creek: stream, heads in Dog Lake, flows $N 9 \mathrm{mi}$. to Mark Creek, $5 \mathrm{mi}$. S of Northway Junction, Alaska Ra.; $62^{\circ} 59^{\prime} \mathrm{N}, 141^{\circ} 47^{\prime}$ W; (map 84). Var. Charleskin Creek. Local name reported by USGS in 1954.

Charlieskin Village: village, on Charlieskin Creek, $5.5 \mathrm{mi}$. S of Northway Junction, Alaska Ra.; $62^{\circ} 58^{\prime} \mathrm{N}, 141^{\circ} 49^{\prime} \mathrm{W}$; (map 84). Local name reported by USGS in 1954.

Charlies Village: locality, see Charley Village.

Charlieville: locality, see Charley Village.

Charlotte, Lake: lake, $2 \mathrm{mi}$. long, at $\mathrm{S}$ edge of Martin River Glacier, 19 mi. NE of Katalla, Chugach Mts.; $60^{\circ} 26^{\prime} \mathrm{N}, 144^{\circ} 11^{\prime} \mathrm{W}$; (map 64).

Named in 1904 by G. C. Martin (1905, pl. 3 ), USGS, probably after nearby Charlotte Ridge.

Charlotte Ridge: ridge, elev. 2,000 ft., $1.5 \mathrm{mi}$. long, $1 \mathrm{mi}$. $\mathrm{E}$ of Lake Charlotte and $21 \mathrm{mi}$. NE of Katalla, Chugach Mts. ; $60^{\circ} 25^{\prime} \mathrm{N}, 144^{\circ} 09^{\prime}$ W; (map 64).

Local name used by prospectors; reported in 1905 by G. C. Martin, USGS.

Charm, Point: point of land, see Chasina Point.

Charnrokruit: locality, "on Seahorse Is.," Arctic Plain; (map 147).

Former Eskimo camp or settlement listed with a population of 162 in the 1890 Census. Charpentier Glacier: glacier, see Rendu Glacier. Charpentier Inlet: estuary, $7 \mathrm{mi}$. long, trends NW, $2 \mathrm{mi}$. S of Gilbert I., in Glacier Bay National Monument, $57 \mathrm{mi}$. NW of Hoonah, St. Elias Mts.; $58^{\circ} 45^{\prime} 00^{\prime \prime} \mathrm{N}, 136^{\circ} 31^{\prime} 30^{\prime} \mathrm{W}$; BGN 1962; (map 10.) Var. Favorite Fiord.

Named in 1937 for the Charpentier Glacier which, along with Favorite Glacier, once occupied this inlet.

Chase: $R R$. station, mile 236.2, on The Alaska RR., on E bank of Susitna River, $9 \mathrm{mi}$. N of Talkeetna, Cook Inlet Low.; $62^{\circ} 27^{\prime} 30^{\prime \prime} \mathrm{N}$, $150^{\circ} 06^{\prime} 45^{\prime \prime} \mathrm{W}$; (map 81).

This flag stop was named in 1922; published in the official timetable.

Chasen, Point: point of land, see Chasina Point.

Chasina Anchorage: anchorage, 1,700 ft. across, between Chasina and Prince of Wales Is., near entrance to Cholmondeley Sound, Alex. Arch.; $55^{\circ} 16^{\prime} 20^{\prime \prime} \mathrm{N}, 132^{\circ} 02^{\prime} 30^{\prime \prime} \mathrm{W}$; (map 4).

Surveyed and named in 1886 by Lt. Comdr. Richardson Clover, USN. See Chasina Point. Chasina Bay: bay, see Cholmondeley Sound.

Chasina Island: island, $900 \mathrm{ft}$. long, between Cholmondeley Sound and Clarence Strait, on E coast of Prince of Wales I., Alex. Arch.; $55^{\circ} 16^{\prime} 30^{\prime \prime} \mathrm{N}, 132^{\circ} 02^{\prime} 40^{\prime \prime} \mathrm{W}$; (map 4)

Local name reported in 1904 by H. C. Fassett, USBF. See Chasina Point.

Chasina Point: point of land, between Cholmondeley Sound and Clarence Strait, on $\mathrm{E}$ coast of Prince of Wales I., Alex. Arch.; $56^{\circ}$. $16^{\prime} 50^{\prime \prime} \mathrm{N}, 132^{\circ} 01^{\prime} 30^{\prime \prime} \mathrm{W}$; (map 4). Var.
Mys Chasiny, Point Charm, Point Chasen, Point Chasina, Point Tchaseni.

This is probably an Indian name published by Capt. Tebenkov (1852, map 9), IRN, as "M[ys] Chasiny," or "Chasiny Point"; it is shown on Russian Hydrog. Chart 1493, published in 1853, as "M[ys] Chasina," or "Chasina Point." See Chasintsev and Cholmondeley Sound.

Chasintsef: locality, see Chasintsev.

Chasintsev: locality, on E shore of Cholmondeley Sound, opposite Chasino I., on SE coast of Prince of Wales I., Alex. Arch.; $55^{\circ} 16^{\prime} \mathrm{N}$, $132^{\circ} 02^{\prime} \mathrm{W}$; (map 4). Var. Chasintsef, Chasintzeff, Selenie Chasintsev.

This is probably an abandoned Indian village shown as "Sel[enie] Chasintsev," or "Chasintsev settlement," on Russian Hydrog. Dept. Chart 1493. This chart, published in 1853 , shows three large buildings at this site; no evidence of this settlement can be found on current sources.

Chasintzeff: locality, see Chasintsev.

Chasiny, Mys: point of land, see Chasina Point. Chasiny, Zaliv: bay, see Cholmondeley Sound.

Chasovina Cove: cove, $0.2 \mathrm{mi}$. across, in Icon Bay, on E coast of Spruce I., NE of Kodiak I.; $57^{\circ} 54^{\prime} 00^{\prime \prime} \mathrm{N}, 152^{\circ} 20^{\prime} 50^{\prime \prime} \mathrm{W}$; (map 34). Transliteration of the Russian word "chasovnya," meaning "chapel."

Chataneka River: stream, see Chatanika River. Chatanika: settlement, pop. $30,2 \mathrm{mi}$. E of junc. of Cleary Creek and Chatanika River, $20 \mathrm{mi}$. NE of Fairbanks, Yukon-Tanana High.; $65^{\circ}$. $06^{\prime} 45^{\prime \prime} \mathrm{N}, 147^{\circ} 28^{\prime} 20^{\prime \prime} \mathrm{W}$; BGN 1944; (map 105). Var. Chatanika River Village, Old Chatanika.

Mining settlement established about 1904; railroad station established when the Tanana Valley Railroad was completed in 1907. The Chatanika post office was established in 1908. Its population was 63 in 1930 and 106 in 1940. It was named after the stream.

Chatanika River: stream, heads at junc. of McManus and Smith Creeks, flows SW $128 \mathrm{mi}$. to Tolovana River, $48 \mathrm{mi}$. NW of Fairbanks, Tanana Low.; (map 105). Var. Chataneka River, Chatinka River, Tolovana River.

Tanana Indian name obtained in 1903 by T. G. Gerdine, USGS.

Chatanika River Village: settlement, see Chatanika.

Chat-chee-nie: locality, see Old Kasaan.

Chat Cove: cove, $0.8 \mathrm{mi}$. wide, $0.5 \mathrm{mi}$. SE of Cliff Bay, on W coast of Aialik Penin., $29 \mathrm{mi}$. S of Seward, Chugach Mts. : $59^{\circ} 43^{\prime}$ N, $149^{\circ}$. $34^{\prime} \mathrm{W}$; BGN 1930; (map 49).

Named by the 1928 USC\&GS field party "for the island in front of the cove."

Chatelain Lake: lake, $0.6 \mathrm{mi}$. long, on Kenai Penin. N of Hidden Lake, $34 \mathrm{mi}$. E of Kenai, Cook Inlet Low.; $60^{\circ} 30^{\prime} \mathrm{N}, 150^{\circ} 16^{\prime} \mathrm{W}$; (map 62).

Named about 1963 by officials of Kenai National Moose Range, for administrative purposes.

Chatenda Creek: stream, see Chathenda Creek.
Chatham: village, pop. 4, on W shore of Sitkoh Bay, on Chichagof 1., $22 \mathrm{mi}$. SE of Tenakee

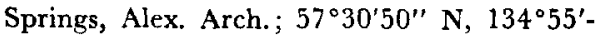
$30^{\prime \prime} \mathrm{W}$; (map 9).

Cannery village named for Chatham Strait, established about 1905. The Chatham post office was established in 1906; discontinued in 1963 (Ricks, 1965, p. 10).

Chatham, Port: bay, $1.5 \mathrm{mi}$. wide, on $\mathrm{S}$ coast of Kenai Penin., 2 mi. $\mathrm{N}$ of Elizabeth $\mathrm{I}$. and 16 mi. S of Seldovia, Chugach Mts.; $59^{\circ} 12^{\prime} 30^{\prime \prime}$ N, $151^{\circ} 47^{\prime} 00^{\prime \prime} \mathrm{W}$; (map 50). Var. Ensenada de Nuestra Señora de Regla.

Named in 1794 by Capt. George Vancouver $(1798$, v. 3 , p. 132$)$, RN, for one of his vessels, the tender H.M.S. Chatham. This is probably the bay named' by Don Ignacio Arteaga on August 2, 1779, "Ensenada de Nuestra Señora de Regla."

Chatham Creek: stream, flows NW 2 mi. to Cleary Creek, $18 \mathrm{mi}$. NE of Fairbanks, Yukon-Tanana High.; $65^{\circ} 04^{\prime} 30^{\prime \prime} \mathrm{N}, 147^{\circ} 25^{\prime}$. 45" W ; (map 105).

Named by prospectors when gold was discovered along the stream in 1902; name reported in 1903 by T. G. Gerdine (Prindle, 1905, pl. 13), USGS.

Chatham Island: island, $500 \mathrm{ft}$. long, at entrance to Port Chatham on Kenai Penin., $16 \mathrm{mi}$. S of Seldovia, Chugach Mts.; $59^{\circ} 12^{\prime} 30^{\prime \prime} \mathrm{N}$, $151^{\circ} 46^{\prime} 30^{\prime \prime} \mathrm{W}$; BGN 1908; (map 50). Var. El Sombrero.

Named by USC\&GS in 1908 for Port Chatham. The island was named "El Sombrero," meaning "the hat," on an unpublished Spanish map by Don Ignacio Arteaga, Don Juan Francisco de la Bodega y Quadra, and Francisco Antonio Maurelle in 1779.

Chatham Strait: water passage, extends N 150 mi. from Coronation I. on Gulf of Alaska to junc. of Icy Strait and Lynn Canal, Alex. Arch.; 57 $03^{\prime}$ N, 134 $32^{\prime}$ W; (map 9). Var. Chirikof Bay, Christian Sound, Enseñada del Principe, Menzies Strait.

Named in August 1794 by Capt. George Vancouver, RN, for the Earl of Chatham, William Pitt Chatham, 1708-78; English statesman (Wagner, 1937, p. 380). It was called "Menzies Strait" by the early fur traders, probably for Archibald Menzies, a naturalist who accompanied Vancouver. The southern part of the strait was called "Christian Sound" in 1789 by J. Colnett and "Tschirikow Bay" in 1786 by La Pérouse. In 1775 this portion of the strait was also called "Enseñada del Principe," meaning "teacher of the prince," by Don Juan de la Bodega y Quadra.

Chathenda Creek: stream, flows SW $17 \mathrm{mi}$. to Chisana River, $3 \mathrm{mi}$. NE of Euchre Mtn. and $40 \mathrm{mi}$. SE of Nabesna, Alaska Ra.; $62^{\circ} 05^{\prime} \mathrm{N}$, $142^{\circ} 06^{\prime}$ W; BGN 1964; (map 84). Var. Cathenda Creek, Chatenda Creek, Johnson Creek.

Indian name obtained in 1902 by $D$. C. Witherspoon, USGS. In 1910, prospectors called the stream "Johnson Creek." 
Chatinak: locality, "near the mouth of Yukon River," Yukon-Kuskokwim Delta. Var. Catinakh, Chatinakh.

Former Eskimo village listed by Ivan Petroff in the 1880 Census with a population of 40 . Chatinakh: locality, see Chatinak.

Chatinakh Hills: mountains, along $S$ side of Norton Sound in what is now Nulato Hills.

So shown by Ivan Petroff in the 1880 Census.

Chatinka River: stream, see Chatanika River. Chat Island: island, $0.7 \mathrm{mi}$. long, $0.8 \mathrm{mi}$. SW of Aialik Penin., in Aialik Bay, $30 \mathrm{mi}$. S of Seward, Chugach Mts. ; $59^{\circ} 42^{\prime} \mathrm{N}, 149^{\circ} 34^{\prime} \mathrm{W}$; BGN 1910; (map 49)

Named in 1909 by U. S. Grant, USGS.

Chatritt Lake: lake, $1.5 \mathrm{mi}$. long, $5 \mathrm{mi}$. SE of Chalkyitsik, Yukon Flats; $66^{\circ} 38^{\prime} \mathrm{N}, 143^{\circ} 56^{\prime}$ W; (map 120).

Tranjik-kutchin Indian name obtained in 1956 by T. E. Taylor, USGS

Chauekuktuli, Lake: lake, $23 \mathrm{mi}$. long, among Tikchik Lakes, $125 \mathrm{mi}$. SW of Sleetmute, Kilbuck-Kuskokwim Mts. ; $60^{\circ} 04^{\prime} \mathrm{N}, 158^{\circ} 33^{\prime} \mathrm{W}$; BGN 1932; (map 60). Var. Chauiskuktuli Lake.

Eskimo name spelled "Chauiskuktuli"; obtained in 1915 by USBF.

Chaufchivak, Mount: hill, $900 \mathrm{ft}$, E of Lake Chauekuktuli, $125 \mathrm{mi}$. SW of Sleetmute, Kilbuck-Kuskokwim Mts.; $60^{\circ} 04^{\prime} \mathrm{N}, 158^{\circ} 32^{\prime} \mathrm{W}$; BGN 1932; (map 60)

Eskimo name reported in 1931 by Gerald FitzGerald, USGS.

Chaugriakpak: locality, on Seward Penin., between Golovin and Port Clarence; (map 110).

Eskimo camp mentioned by Sheldon Jackson $(1898$, p. 74$)$.

Chauik Mountain: mountain, 3,464 ft., in Bendeleben Mts., $10 \mathrm{mi}$. SE of Mount Bendeleben and $37 \mathrm{mi}$. SW of Imuruk Lake, Seward Penin. High.; $65^{\circ} 08^{\prime} \mathrm{N}, 163^{\circ} 46^{\prime} \mathrm{W}$; (map 110). Var. Chaulk Mountain, Chowik Mountain.

Local name reported in 1900 by W. J. Peters (in Brooks, 1901, pl. 17), USGS.

Chauiskuktuli Lake: lake, see Chauekuktuli Lake.

Chaulk Mountain: mountain, see Chauik Mountain.

Chau-off-pad-le-rok: stream, see Nikadavna Creek.

Chaussee, La: point of land, see Chaussee Spit, La.

Chaussee Spit, La: Point of land, $1 \mathrm{mi}$. long, at mouth of Lituya Bay, in Glacier Bay National Monument, $0.4 \mathrm{mi}$. NW of Harbor Point, 88 mi. NW of Hoonah, Malaspina Costal Plain; $58^{\circ} 36^{\prime} 50^{\prime \prime} \mathrm{N}, 137^{\circ} 39^{\prime} 50^{\prime \prime} \mathrm{W}$; (map 10). Var. Chaussee.

Called "la Chaussée," meaning "the road," by La Pérouse (1786, Atlas). On the English edition of his chart (map 19) it is designated as "Road to the Fishery and Morai." "Morai" means "burial place."

Chavolda Creek: stream, flows W $13 \mathrm{mi}$. to Chisana River, $10 \mathrm{mi}$. $\mathrm{N}$ of Euchre Mtn. and 40 mi. SE of Nabesna, Alaska Ra.; $62^{\circ} 11^{\prime} \mathrm{N}$, $142^{\circ} 05^{\prime} \mathrm{W}$; BGN 1964; (map 84). Var. Chapolda Creek, Wilson Creek.

Indian name obtained in 1902 by D. C. Witherspoon, USGS. About 1910, the stream was called "Wilson Creek" by prospectors.

Chawekat Mountain: mountain, 1,679 ft., S of Explorer Mtn., $6 \mathrm{mi}$. $\mathrm{N}$ of Goodnews, Kilbuck-Kuskokwim Mts.; $59^{\circ} 12^{\prime} 30^{\prime \prime} \mathrm{N}, 161^{\circ}$. $33^{\prime} 30^{\prime \prime}$ W ; (map 53).

Native name published in 1951 by USGS. Chaxwaxamiut: locality, see Chakwakamiut.

Chaxwaxmiut-Koweerat River: stream, see Chakwakamiut River.

Chayki, Kamen: island, see Gull Islet.

Chay-myut: locality, see Chaik.

Chealikh Hill: hill, see Jayalik Hill.

Chealikh River: stream, see Jayalik River.

Chebanika Creek: stream, flows SSW $15 \mathrm{mi}$. to Alatna River, $54 \mathrm{mi}$. NE of Hughes, Hogatza High.; $66^{\circ} 46^{\prime} \mathrm{N}, 153^{\circ} 27^{\prime} \mathrm{W}$; (map 116).

Indian name obtained in 1956 at Allakaket by Orth.

Chebukak Island: island, see Saint Lawrence Island.

Chetats Cove: cove, $0.6 \mathrm{mi}$. across, on $\mathrm{E}$ shore of Behm Canal, $1.8 \mathrm{mi}$. NE of Winstanley I, and $32 \mathrm{mi}$. NE of Ketchikan, Coast Mts.; $55^{\circ}$ $29^{\prime} 30^{\prime \prime} \mathrm{N}, 130^{\circ} 53^{\prime} 00^{\prime \prime} \mathrm{W}$; (map 3$)$.

Tlingit Indian name reported in 1897 by Lt. Comdr. J. F. Moser, USN.

Checats Creek: stream, flows W $3.5 \mathrm{mi}$., to Checats Cove, $2 \mathrm{mi}$. NE of Winstanley I. and 32 mi. NE of Ketchikan, Coast Mts.; $55^{\circ} 29^{\prime} 05^{\prime \prime}$ N, 130 $52^{\prime} 15^{\prime \prime} \mathrm{W}$; BGN 1930; (map 3).

Tlingit Indian name reported in 1897 by Lt. Comdr. J. F. Moser, USN.

Checats Lake: lake, see Upper Checats Lake. Checats Point: point of land, $\mathrm{S}$ point of entrance to Checats Cove, on E bank of Behm Canal, $1.8 \mathrm{mi}$. NE of Winstanley I., Coast Mts.; $55^{\circ}$. $29^{\prime} 15^{\prime \prime} \mathrm{N}, 130^{\circ} 53^{\prime} 00^{\prime \prime} \mathrm{W}$; (map 3).

Local navigators' name obtained in 1904 by H. C. Fassett, USBF

Chechinamiut: locality, see Chichinak.

Cheching: locality, $1 \mathrm{mi}$. ESE of Cheching Mtn., $12 \mathrm{mi}$. SE of mouth of Ooksokwak River and $95 \mathrm{mi}$. SW of Bethel, Yukon-Kuskokwim Delta; $60^{\circ} 04^{\prime} \mathrm{N}, 164^{\circ} 13^{\prime} \mathrm{W}$; (map 58). Var. Cheeching, Cheecking, Chickingmute.

Eskimo name reported in 1949 by USC\&GS, applying to a village with a 1950 population of 54 people.

Cheching Mountain: hill, $443 \mathrm{ft}$., S of Ooksokwak River, $90 \mathrm{mi}$. SW of Bethel, YukonKuskokwim Delta; $60^{\circ} 06^{\prime} \mathrm{N}, 164^{\circ} 08^{\prime} \mathrm{W}$; (map 58).

Eskimo name reported in 1949 by USC\&GS. Chechitno: village, see Chitina.

Chechitno: stream, see Chitina River.

Chechitno Peak: mountain, see Wrangell Mount.

Checkerman Creek: stream, flows $\mathbf{S} 7 \mathrm{mi}$. to West Fork Tolovana River, Yukon-Tanana High.; $65^{\circ} 24^{\prime} 20^{\prime \prime} \mathrm{N}, 149^{\circ} 08^{\prime} 10^{\prime \prime} \mathrm{W}$; (map 105$)$.

Local name published by USGS in the 1950's.

Checkers: locality, see Kougarok.
Checkers Creek: stream, flows SE $6.5 \mathrm{mi}$. to Quartz Creek which flows to Kougarok River, $46 \mathrm{mi}$. SW of Imuruk Lake, Seward Penin. High.; $65^{\circ} 21^{\prime} \mathrm{N}, 164^{\circ} 39^{\prime} \mathrm{W}$; (map 110).

Prospectors' name reported in 1901 by T. G. Gerdine (in Collier, 1902, pl. 12), USGS.

Checock Bay: bight, see Chekok Bay.

Checock Creek: stream, see Chekok Creek.

Chedatna Lakes: lakes, extend NE $17 \mathrm{mi}$. from mouth of Beluga River, $27 \mathrm{mi}$. W of Anchorage, Cook Inlet Low.; $61^{\circ} 16^{\prime} \mathrm{N}, 150^{\circ} 45^{\prime} \mathrm{W}$; (map 70).

Tanaina Indian name reported in 1958 by USGS.

Chedotlothna Glacier: glacier, heads at junc. of three forks, $W$ of Mount McKinley National Park, trends N $9.5 \mathrm{mi}$. to Swift Fork Kuskokwim River, $30 \mathrm{mi}$. SW of Denali Pass, Alaska Ra.; 62 $57^{\prime} 20^{\prime \prime} \mathrm{N}, 151^{\circ} 56^{\prime} 30^{\prime \prime} \mathrm{W}$; (map 81). Var. Chedotlothno Glacier.

Indian name reported in 1925 by $S$. $R$. Capps (in Moffit, 1927, pl. 3), USGS.

Chedotlothna River: stream, see Swift Fork.

Chedotlothno Glacier: glacier, see Chedotlothna Glacier.

Cheechako Creek: stream, see Peterson Creek. Cheechako Gulch: ravine, trends W $0.7 \mathrm{mi}$. to Cache Creek, opposite mouth of Short Creek, $31 \mathrm{mi}$. NW of Talkeetna, Alaska Ra.; $62^{\circ} 28^{\prime}$ $15^{\prime \prime} \mathrm{N}, 151^{\circ} 01^{\prime} 20^{\prime \prime} \mathrm{W}$; (map 81).

Local name reported in 1958 by USGS. Cheeching: village, see Cheching.

Cheechocna: glacier, see Chichokna Glacier.

Cheechocna: stream, see Chichokna River.

Cheecking: village, see Cheching.

Cheekok Bay: bight, see Chekok Bay.

Cheekok Creek: stream, see Chekok Creek.

Cheekok Village: locality, see Chekok.

Cheeneetnuk River: stream, heads at $62^{\circ} 12^{\prime} \mathrm{N}$, $154^{\circ} 50^{\prime} \mathrm{W}$, flows SW $70 \mathrm{mi}$. to Swift River $11 \mathrm{mi}$. SE of its junc. with Kuskokwim River. $39 \mathrm{mi}$. NE of Sleetmute, Stony River Low.; $61^{\circ} 48^{\prime} 50^{\prime \prime} \mathrm{N}, 156^{\circ} 00^{\prime} 30^{\prime \prime} \mathrm{W}$; (map 72). Var. Chinitnak River.

Eskimo name obtained in 1948 by USC\&GS. Chernik: village, see Golovin.

Cheenik Greek: stream, flows SW $11 \mathrm{mi}$. to Golovnin Bay, $0.2 \mathrm{mi}$. E of Golovin and $43 \mathrm{mi}$. $\mathrm{E}$ of Solomon, Seward Penin. High.; 64 ${ }^{\circ} 33^{\prime}$ N, $163^{\circ} 01^{\prime} \mathrm{W}$; BGN 1910; (map 95). Var. Tichnak Creek.

The 1900 "Map of Nome Peninsula" by J. M. Davidson and B. D. Blakeslee spelled this Eskimo name as "Tichnak." Prospectors' name published on the 1908 "Map of Seward Peninsula" by Arthur Gibson.

Cheep River: stream, see Chipp River.

Cheerful: locality, old village site at Cape Cheerful, on $\mathbf{N}$ coast of Unalaska I., Aleutian Is.; $54^{\circ} 00^{\prime} 50^{\prime \prime} \mathrm{N}, 166^{\circ} 40^{\prime} 30^{\prime \prime} \mathrm{W}$; (map 23). Var. Veselofski, Vysylovskoe.

Translation of a Russian name published by Lt. Sarichev (1826, map 14, dated 1792), IRN, as "Sel[o] Vysylovskoe," meaning "cheerful village."

Cheerful, Cape: point of land, on $\mathbf{N}$ coast of Unalaska I., Aleutian Is.; $54^{\circ} 00^{\prime} 50^{\prime \prime} \mathrm{N}$, 
$166^{\circ} 40^{\prime} 20^{\prime \prime}$ W; (map 23). Var. Cape Večélovskoi, Cape Veselofski, Mys Veselovskiy.

Translation of a Russian name reported in 1817 by Lt. Otto von Kotzebue, IRN, as "Veselofski," probably from the name of the village located on this point. It was published by Lt. Sarichev (1826, map 15), IRN, as "M[ys] Veselovskiy," meaning "cape cheerful."

Cheerful Mountain: volcano, see Makushin Volcano.

Cheericoff, Cape; point of land, see Bartolome, Cape.

Cheese Creek: stream, flows NW $1.5 \mathrm{mi}$. to Coal Creek, $5.5 \mathrm{mi}$. SW of that stream's junc. with Yukon River and $45 \mathrm{mi}$. SE of Circle, YukonTanana High.; $65^{\circ} 17^{\prime} \mathrm{N}, 143^{\circ} 13^{\prime} \mathrm{W}$; (map 103).

Local name reported in 1936 by Mertie (1938a, pl. 5), USGS.

Cheetdeekahyu, Mount: mountain, 5,320 ft., 2.2 mi. SW of Four Winds Mtn. and $26 \mathrm{mi}$. SW of Skagway, St. Elias Mts.; $59^{\circ} 28^{\prime} 45^{\prime \prime} \mathrm{N}$, $136^{\circ} 12^{\prime} 20^{\prime \prime} \mathrm{W}$; (map 45).

Tlingit Indian name reported by $E$. C. Robertson, geologist, and published in 1952 by USGS

Chefokhlagamiut: locality, see Chifukluk.

Chefokhlagamute: locality, see Chifukluk.

Chefoklak: locality, see Chifukluk.

Chefornak: village, pop. 133 , at the junc. of Keguk and Kinia Rivers, $93 \mathrm{mi}$. SW of Bethel, Yukon-Kuskokwim Delta; $60^{\circ} 13^{\prime} \mathrm{N}, 164^{\circ} 12^{\prime}$ W; (map 58).

Eskimo village listed in the 1950 Census with a population of 106 .

Chegoula Island: island, see Chagulak Island.

Chegula: island, see Chugul Island.

Chegulak, Ostrov: island, see Uliaga Island.

Chegulak Island: island, see Herbert Island.

Chekhechunnjik Creek: stream, flows SE $18 \mathrm{mi}$. to North Fork Chandalar River, $45 \mathrm{mi}$. W of Christian, Brooks Ra.; $67^{\circ} 22^{\prime}$ N, $146^{\circ} 53^{\prime} \mathrm{W}$; (map 122).

Kutcha-kutchin Indian name obtained in 1956 by T. E. Taylor, USGS.

Chekok: locality, on N shore of Iliamna Lake, $3 \mathrm{mi}$. NE of Chekok Point and $21 \mathrm{mi}$. E of Iliamna, Aleutian Ra.; $59^{\circ} 48^{\prime} 25^{\prime \prime} \mathrm{N}, 154^{\circ} 19^{\prime}$ 20" W; BGN 1910; (map 51). Var. Chekok Village, Cheekok Village, Chikak, Chikak Village.

Eskimo village, now abandoned, listed in the 1880 Census as "Chikak," with a population of 51 .

Chekok Bay: bight, $2.4 \mathrm{mi}$. across, in Iliamna Lake, $W$ of Chekok Point, $15 \mathrm{mi}$. E of Iliamna, Aleutian Ra.; $59^{\circ} 47^{\prime} 20^{\prime \prime} \mathrm{N}, 1^{\circ} 4^{\circ} 27^{\prime} 00^{\prime \prime} \mathrm{W}$; $B G N$ 1910; (map 51). Var. Checock Bay, Cheekok Bay, Chikak Bay.

Eskimo name recorded on a 1909 fieldsheet by D. C. Whitherspoon, USGS.

Chekok Creek: stream, flows $S$ through Chekok Lake $14 \mathrm{mi}$. to Iliamna Lake, $15 \mathrm{mi}$. $\mathrm{E}$ of Iliamna, Aleutian Ra.; $59^{\circ} 47^{\prime} 30^{\prime \prime} \mathrm{N}, 154^{\circ} 23^{\prime}$ 00' W; BGN 1910; (map 51). Var. Checock Creek, Cheekok Creek, Chekok River, Chikak Creek.
Eskimo name recorded as "Cheekok" on a 1907 manuscript map by W. E. Smith, engineer for the proposed Alaska Short Line Railway.

Chekok Island: island, see Big Island.

Chekok Lake: lake, $0.8 \mathrm{mi}$. long, $\mathrm{N}$ of Iliamna Lake, in course of Chekok Creek, $20 \mathrm{mi}$. $\mathbf{E}$ of Nondalton, Aleutian Ra.; 59 $58^{\prime} 45^{\prime \prime} \mathrm{N}, 154^{\circ}$. $15^{\prime} 30^{\prime \prime} \mathrm{W}$; (map 51).

Eskimo name reported in 1954 by USGS.

Chekok Point: point of land, on $\mathrm{N}$ shore of Iliamna Lake, $15 \mathrm{mi}$. E of Iliamna, Aleutian Ra. ; $59^{\circ} 47^{\prime} \mathrm{N}, 154^{\circ} 24^{\prime} \mathrm{W}$; (map 51 ).

Eskimo name reported in 1954 by USGS.

Chekok River: stream, see Chekok Creek.

Chekok Village: locality, see Chekok.

Chelan Bank: shoal, $5 \mathrm{mi}$. long, $5 \mathrm{mi}$. NE of Cape Cheerful, off $\mathrm{N}$ coast of Unalaska I., Aleutian Is.; $54^{\circ} 04^{\prime} \mathrm{N}, 166^{\circ} 34^{\prime} \mathrm{W}$; $B G N$ 1937; (map 23).

Named in 1933 by the survey party that discovered the shoal, while aboard the USCG cutter Chelan.

Chelantna Lake: lake, see Chelatna Lake.

Chelatna Lake: lake, $8 \mathrm{mi}$. long, at head of Lake Creek, $42 \mathrm{mi}$. NW of Talkeetna, Alaska Ra.; $62^{\circ} 29^{\prime} \mathrm{N}, 151^{\circ} 28^{\prime} \mathrm{W}$; (map 81). Var. Chelantna Lake.

Indian name reported in 1929 by USGS.

Chelatna Lodge: roadhouse, at $\mathbf{S}$ end of Chelatna Lake, $42 \mathrm{mi}$. NW of Talkeetna, Alaska Ra.; $62^{\circ} 26^{\prime} 05^{\prime \prime} \mathrm{N}, 151^{\circ} 24^{\prime} 05^{\prime \prime} \mathrm{W}$; (map 81).

Local name reported in 1945 by USGS.

Chélékhoff Strait: water passage, see Shelikof Strait.

Chelekoff, Lake: lake, see Iliamna Lake

Chelunginik River: stream, flows NW $20 \mathrm{mi}$. to Kokechik River, $15 \mathrm{mi}$. S of village of Scammon Bay, Yukon-Kuskokwim Delta ; $61^{\circ} 39^{\prime}$ $\mathrm{N}, 165^{\circ} 24^{\prime} \mathrm{W}$; (map 75). Var. Kvicharak River.

Eskimo name reported by USC\&GS in 1951 . Chena: locality, on $\mathrm{N}$ bank of Tanana River, 1 mi. W of mouth of Chena River and $7 \mathrm{mi}$. SW of Fairbanks, Tanana Low.; $64^{\circ} 48^{\prime} \mathrm{N}$, $147^{\circ} 56^{\prime} \mathrm{W}$; (map 100). Var. Chena City, Chena Junction.

Name derived from the Chena River and reported in 1903 by T. G. Gerdine and R. B. Oliver (in Prindle, 1905, pl. 16), USGS. The village was called "Chena Junction" because it was the south terminus of the Tanana Valley Railroad; however, it was incorporated as "Chena" in 1903. A post office was established in 1903 and discontinued in 1918 (Ricks, 1965, p. 10). With the growth of Fairbanks, Chena decreased, having only 18 persons in 1920.

Chena City: locality, see Chena.

Chena Dome: mountain, $4,421 \mathrm{ft}$., $12 \mathrm{mi}$. W of Chena Hot Springs and $45 \mathrm{mi}$. NW of Fairbanks, Yukon-Tanana High.; $65^{\circ} 05^{\prime} \mathrm{N}, 146^{\circ}$. $28^{\prime}$ W ; (map 104).

Name derived from Chena River; reported in 1903 by T. G. Gerdine (in Prindle, 1905, pl. 13), USGS.

Chena Hot Springs: locality, summer pop. 10, $8.5 \mathrm{mi}$. WSW at Far Mtn. and $80 \mathrm{mi}$. SW of
Eagle, Yukon-Tanana High.; $65^{\circ} 03^{\prime} 10^{\prime \prime} \mathrm{N}$, 146 $03^{\prime} 45^{\prime \prime}$ W ; BGN 1944; (map 104.) Var. Hot Spring.

Local name derived from the Chena River near headwaters of which the hot springs are located. The springs were reported in 1907 by C. C. Covert, USGS, and the name was reported in 1912 by Ellsworth and Davenport (1915b, p. 59), USGS.

Chena Junction: locality, see Chena.

Chenango Mountain: mountain, 2,905 ft., on Annette I., $4.3 \mathrm{mi}$. NE of Metlakatla, Alex. Arch.; $55^{\circ} 11^{\prime \prime} \mathrm{N}, 131^{\circ} 31^{\prime} \mathrm{W}$; (map 3).

Named in 1883 by Lt. Comdr. H. E. Nichols, USN.

Chena Ridge: mountain, $1,550 \mathrm{ft}$., trends $\mathrm{SW}$ $7.5 \mathrm{mi}$. between Cripple Creek ard Chena River, $6 \mathrm{mi}$. W of Fairbanks, Yukon-Tanana High.; $64^{\circ} 48^{\prime} \mathrm{N}, 148^{\circ} 00^{\prime} \mathrm{W}$; (map 100).

Local name derived from Chena River; published in 1952 by USGS.

Chena River: stream, heads at junc. of North and West Forks Chena River, flows SW 100 mi. to Tanana River, $6.5 \mathrm{mi}$. SW of Fairbanks, Yukon-Tanana High.; $64^{\circ} 47^{\prime} 45^{\prime \prime} \mathrm{N}$, $147^{\circ} 54^{\prime} 45^{\prime \prime} \mathrm{W} ; B G N$ 1965; (map 100). Var. Big Chena River, Chena Slough, Chenoa River.

Indian name reported in 1898 by F. C. Schrader, USGS, and published on a USC\&GS chart in 1899. See Chena Slough.

Chena River: stream, see East Fork Chena River.

Chena Slough: stream, distributary, flows from Piledriver Slough NW $13 \mathrm{mi}$. to Chena River, 7 mi. E of Fairbanks, Tanana Low.; $64^{\circ} 50^{\prime}$ $30^{\prime \prime} \mathrm{N}, 147^{\circ} 29^{\prime} 00^{\prime \prime} \mathrm{W}$; BGN 1954; (map 100); Var. Thirty Mile Slough, Thirtymile Slough, Fairbanks Slough.

Name derived from Chena River; reported in 1903 by T. G. Gerdine and R. B. Oliver (in Prindle, 1905, pl. 16), USGS. The application of the name originally included Piledriver Slough and the lower course of the Chena River. However, when water from the Tanana was diverted during highway construction, the name "Chena Slough" was applied only to the drier course of the distributary.

Chena Slough: stream, see Chena River.

Chena Slough: stream, see Piledriver Slough. Cheneathda Hill: hill, 3,595 ft., $5 \mathrm{mi}$. long, E of confluence of Chisana and Nabesna Rivers, $43 \mathrm{mi}$. SE of Tok, Yukon-Tanana High.; $63^{\circ}$ $03^{\prime} \mathrm{N}, 141^{\circ} 44^{\prime} \mathrm{W}$; BGN 1961; (map 85).

Indian name said to mean "long hill," reported by USGS in 1960 .

Chenega: locality, on Kenai Penin., on $\mathrm{S}$ tip of Chenega I., at head of Chenega Cove, $42 \mathrm{mi}$. SE of Whittier, Chugach Mts.; $60^{\circ} 16^{\prime} 45^{\prime \prime}$ $\mathrm{N}, 148^{\circ} 04^{\prime} 30^{\prime \prime} \mathrm{W}$; BGN 1942; (map 63). Var. Chanega, Chenega Village, Cheniga, Ingamatsha.

Name of an Indian village reported by Ivan Petroff in the 1880 Census $(1884$, p. 29). A post office was established here in 1946 (Ricks, 1965, p. 10) but was discontinued when the 
village was abandoned after the 1964 earthquake.

Chenega Cove: bight, $0.5 \mathrm{mi}$. across, on Kenai Penin., on S coast of Chenega I., $42 \mathrm{mi}$. SE of Whittier, Chugach Mts.; $60^{\circ} 16^{\prime} 40^{\prime \prime} \mathrm{N}$, $148^{\circ} 05^{\prime} 00^{\prime \prime} \mathrm{W}$; (map 63 ).

Name published on recent USGS maps; derived from Chenega Island.

Chenega Creek: stream, see Eshamy Creek.

Chenega Glacier: glacier, heads in Sargent Icefield, on Kenai Penin., trends NE $12 \mathrm{mi}$. to Nassau Fiord, $11 \mathrm{mi}$. W of Chenega, Chugach Mts.; $60^{\circ} 16^{\prime} 30^{\prime \prime} \mathrm{N}, 148^{\circ} 23^{\prime} 35^{\prime \prime} \mathrm{W}$; (map 63).

Name reported in 1905 by U.S. Grant (in Brooks and others, 1906, fig. 4), USGS. Name derived from village of Chenega on nearby Chenega Island.

Chenega Island: island, on Kenai Penin., extends N-S $10 \mathrm{mi}$., between Knight Island Passage and Dangerous Passage, $36 \mathrm{mi}$. SE of Whittier, Chugach Mts.; $60^{\circ} 19^{\prime} \mathrm{N}, 148^{\circ} 05^{\prime} \mathrm{W}$; $B G N$ 1942; (map 63). Var. Cheniga Island.

Local name published in 1898 by Glenn and Abercrombie (1899, map), USA.

Chenega Lake: lake, see Eshamy Lake.

Chenega Point: point of land, on Kenai Penin., on SE tip of Chenega I., on W side of Knight Island Passage, 2 mi. E of Chenega, Chugach Mts.; $60^{\circ} 16^{\prime} 40^{\prime \prime} \mathrm{N}, 148^{\circ} 01^{\prime} 30^{\prime \prime} \mathrm{W}$; $B G N$ 1934; (map 63).

Named in 1933 by a USC\&GS field party; derived from name of island.

Chenega Village: village, see Chenega.

Cheniga: village, see Chenega.

Cheniga Creek: stream, see Eshamy Creek.

Cheniga Island: island, see Chenega Island.

Cheniga Lake: lake, see Eshamy Lake.

Chenik: locality, site of Eskimo village, on $\mathrm{W}$ shore of Kamishak Bay, $27 \mathrm{mi}$. SE of Kakhonak, Aleutian Ra.; $59^{\circ} 13^{\prime} \mathrm{N}, 154^{\circ} 08^{\prime} \mathrm{W}$; (map 51).

Eskimo name reported by USGS (in Brooks and others, 1925, pl. 3).

Chenik: locality, see Chimekliak.

Chenik Head: point of land, on $\mathrm{W}$ shore of $\mathrm{Ka}$ mishak Bay, 28 mi. SE of Kakhonak, Aleutian Ra.; $59^{\circ} 13^{\prime} \mathrm{N}, 154^{\circ} 07^{\prime} \mathrm{W}$; (map 51).

Eskimo name reported about 1954 by USGS.

Chenik Lake: lake, $1.5 \mathrm{mi}$. long, $2.5 \mathrm{mi}$. $\mathrm{W}$ of Chenik Head on Kamishak Bay and $26 \mathrm{mi}$. SE of Kakhonak, Aleutian Ra.; 59 $12^{\prime} \mathrm{N}$, $154^{\circ} 13^{\prime} \mathrm{W}$; (map 51 ).

Eskimo name reported in 1925 by USGS.

Chenik Mission: village, see Golovin.

Chenik Mountain: mountain, 3,117 ft., on $W$ shore of Kamishak Bay, $24 \mathrm{mi}$. SE of Kakhonak, Aleutian Ra.; $59^{\circ} 14^{\prime} \mathrm{N}, 154^{\circ} 15^{\prime} \mathrm{W}$; (map 51). Var. Three Peaks.

Eskimo name reported in 1954 by USC\&GS.

Chennik: village, see Golovin.

Chenoa River: stream, see Chena River.

Chentansitztan: locality, on right bank of Yukon River $30 \mathrm{mi}$. below mouth of Melozitna River, Kilbuck-Kuskokwim Mts. ; $64^{\circ} 30^{\prime} \mathrm{N}, 156^{\circ} 30^{\prime}$ W; (map 97).
Indian settlement or camp listed by Hodge (1907, p. 243); first published in 1898 by USC\&GS.

Cheokook: locality, see Chiukak.

Chernaboor Island: island, see Cherni Island. Chernabour: island, see Chernabura Island.

Chernaboura Island: island, see Cherni Island.

Chernabour Rocks: island, see Cherni Island.

Chernabur: island, see Chernabura Island.

Chernabura Island: island, $5 \mathrm{mi}$. long, southernmost of Shumagin Is., Aleutian Ra.; $54^{\circ} 47^{\prime}$ N, 159 33' W; BGN 1937; (map 26). Var. Chernabour, Chernabur, Chernobour, Chernoburie, Naimak Islet, Nijunjak, Niunak, Niunyak, Nuniak, Nunik, Ostrov Nanimak, Tounak.

"Chernoburie" is the Russian word for "black-brown" and sometimes refers to a priest clad in this color. The island was shown as "Chernobour Island" by USC\&GS on an 1891 coast chart and was listed by Baker (1906, p. 173), USGS, as "Chernabura Island." The Aleut name is "Nunik," meaning "porcupine," which was published as "Nunak," by Lt. Sarichev (1806, v. 2, p. 15), IRN. Capt. Lutke (1836, p. 267) IRN, showed the island as "Nuniak" and "Tounak," the latter name probably a typographical error, whereas Father Veniaminov $(1840$, v. 1, p. 65) spelled the name "Nyunyak" and "Nunik."

Chernabura Island: island, see Cherni Island. Chernabur Island: island, see Cherni Island. Chernie: point of land, see Black Point.

Chernieshef : bay, see Monashka Bay.

Cherni Island: island, $2 \mathrm{mi}$. long, part of Sandman Reefs, $15 \mathrm{mi}$. S of Deer Island, Aleutian Ra.; 54 $38^{\prime}$ N, $162^{\circ} 22^{\prime}$ W ; BGN 1937; (map 25). Var. Chernaboor Island, Chernabura Island, Chernaboura Island, Chernabour Rocks, Chernabur Island, Chernobour Rocks, Kagak Unimak, Tagamak, Taganak, Tchernobour Island, Tchernoboury Island.

Name given by USC\&GS in 1936 to avoid conflict with the larger Chernabura $I$. of the Shumagin Islands, $90 \mathrm{mi}$. to the northeast. The Russian name "Chernabura," from the words "chyorny," meaning "black," and "burnastyy," meaning "brown," was given to this island by USBF in 1888. The Aleut name was published as "Taganak" by Lt. Sarichev (1826, map 3), IRN, from the word "taganaq" meaning "it alighted."

Chernila: locality, see Chinila.

Chernilof: locality, see Chinila.

Chernobour: island, see Chernabura Island.

Chernobour Rocks: island, see Cherni Island.

Chernoburie: island, see Chernabura Island.

Chernoburii Island: island, see Augustine Island.

Chernoburoy, Ostrov: island, see Augustine Island.

Chernoffski Harbor: harbor, see Chernofski Harbor.

Chernoffsky Harbor: harbor, see Chernofski Harbor.

Chernof Glacier: glacier, heads in Harding Icefield, on Kenai Penin., trends NW $9 \mathrm{mi}$. to a terminus at Fox River and SE $5 \mathrm{mi}$. to Mc- carty Glacier, $42 \mathrm{mi}$. NE of Homer, Chugach Mts.; $59^{\circ} 50^{\prime} \mathrm{N}, 150^{\circ} 21^{\prime} \mathrm{W}$ [center]; $B G N$ 1913; (map 50).

Named by A. H. Brooks, USGS, in 1913, for Ivan Chernov of the Russian American Company who explored part of the west coast of the Kenai Peninsula in 1834.

Chernof Point: point of land, $22 \mathrm{mi}$. NW of Kodiak, in Kupreanof Strait, on N coast of Kodiak I.; 57 $56^{\prime} 55^{\prime \prime}$ N, $152^{\circ} 57^{\prime} 00^{\prime \prime} \mathrm{W}$; (map 34). Var. Mys Chernova.

Named "M[ys] Chernova," "Chernov's Cape," in 1839 or 1840 by Sub-Lt. Mikhail Murashev, IRN, probably for Ivan Chernov, who made explorations and surveys in the Russian American colonies from 1832 to 1838. The name was published in 1849 on Russian Hydrog. Dept. Chart 1425.

Chernofski: locality, pop. 5, near Chernofski Harbor, SW coast of Unalaska I., Aleutian Is.; (map 23). Var. Chernovskoi, Chernovsky, Selo Chernovskoe, Tschernowskoje.

Lt. Sarichev (1826, map 14), IRN, published the name of this former Aleut village as "Sel[o] Chernovskoe," or "Chernovski Village." Baker (1906, p. 173) says, "In 1831 it consisted of 4 huts (yourts) and 44 people." The population was 70 in $1874 ; 101$ in 1880 ; 78 in 1890.

Chernofski Harbor: harbor, $0.7 \mathrm{mi}$. across, on SW coast of Unalaska I., Aleutian Is.; $53^{\circ} 24^{\prime} 30^{\prime \prime} \mathrm{N}, 167^{\circ} 33^{\prime} 00^{\prime \prime} \mathrm{W}$; (map 23). Var. Chernoffski Harbor, Chernoffsky Harbor, Chernovskoy Bay, Tchernofskaia Baie, Zaliv Chernovskoi, Zaliv Chernovskoy.

Russian name published by Lt. Sarichev (1826, may 14, dated 1792), IRN, as "Zal[iv] Chernovskoy," or "Chernovskoy Bay." Baker (1906, p. 173) wrote that the name is "presumably from 'Chernof,' a Russian family name * * *."

Chernofski Point: point of land, at entrance of Chernofski Harbor, on SW coast of Unalaska I., Aleutian Is. ; $53^{\circ} 24^{\prime} 56^{\prime \prime} \mathrm{N}, 167^{\circ} 33^{\prime} 10^{\prime \prime} \mathrm{W}$; $B G N$ 1940; (map 23). Var. Cape Tshernov, East Point.

Named by USC\&GS in 1938 because of its association with the Bay. It was called "East Point" by USBF in 1888 .

Chernoi Cape: point of land, see Black Cape. Chernova, Mys: point of land, see Chernof Point.

Chernovskoe, Selo: village, see Chernofski.

Chernovskoi: village, see Chernofski.

Chernovskoi, Zaliv: harbor, see Chernofski Harbor.

Chernovskoy, Zaliv: harbor, see Chernofski Harbor.

Chernovskoy Bay: harbor, see Chernofski Harbor.

Chernovsky: village, see Chernofski.

Chernoy, Mys: point of land, see Black Cape. Chernyi, Mys: point of land, see Black Point. Chernysheva, Zaliv: bay, see Monashka Bay. Cherokee Flats: shoals, on $\mathrm{N}$ shore of Stephens Passage, at mouth of Grindstone Creek, 12 mi. SE of Juneau, Coast Mts.; $58^{\circ} 12^{\prime} 30^{\prime \prime} \mathrm{N}$, $134^{\circ} 10^{\prime} 30^{\prime \prime} \mathrm{W}$; (map 11 ). 
An early miners' name published in 1951 USGS (DeArmond, 1957, p. 11).

Cherry Creek: stream, flows $\mathrm{N} 8 \mathrm{mi}$. to Walker Fork, $51 \mathrm{mi}$. S of Eagle, Yukon-Tanana High.; $64^{\circ} 03^{\prime} 45^{\prime \prime} \mathrm{N}, 141^{\circ} 09^{\prime} 50^{\prime \prime} \mathrm{W}$; (map 102).

Prospectors' name obtained in 1898 by E. C. Barnard, USGS.

Chertchip Creek: stream, in De Long Mts., flows NW $7 \mathrm{mi}$. to Nuka River, $46 \mathrm{mi}$. NE of Misheguk Mtn., Brooks Ra.; $68^{\circ} 43^{\prime} \mathrm{N}, 159^{\circ}$ 48' W; BGN 1961; (map 131).

Named by USGS geologists in 1951, "because of the abundant chert fragments found in its gravels."

Chert Creek: stream, flows NE $5 \mathrm{mi}$. to Ayiyak River at Horseshoe Mtn., $43 \mathrm{mi}$. NW of Anaktuvuk Pass, Arctic Slope; $68^{\circ} 41^{\prime} 30^{\prime \prime} \mathrm{N}$, $152^{\circ} 48^{\prime} 00^{\prime \prime}$ W; (map 134). Var. Clint Creek.

Named about 1950 by I. L. Tailleur, USGS, because of the abundance of chert along the stream.

Cheshnena: stream, see Cheshnina River.

Cheshnena Glacier: glacier, see Cheshnina Glacier.

Cheshnina Falls: falls, at terminus of Cheshnina Glacier, at head of Cheshnina River, $86 \mathrm{mi}$. NE of Valdez, Wrangell Mts.; $61^{\circ} 51^{\prime} 30^{\prime \prime} \mathrm{N}$, $144^{\circ} 07^{\prime} 00^{\prime \prime} \mathrm{W}$; (map 68).

Local name published in 1950 by USGS.

Cheshnina Glacier: glacier, heads at $61^{\circ} 57^{\prime} \mathrm{N}$, $144^{\circ} 05^{\prime} \mathrm{W}$, trends S $6 \mathrm{mi}$. to its terminus at head of Cheshnina River, $86 \mathrm{mi}$. NE of Valdez, Wrangell Mts.; 61 ${ }^{\circ} 51^{\prime} 30^{\prime \prime} \mathrm{N}, 144^{\circ}$ 07'00" W; (map 68). Var. Cheshnena Glacier, Cheshni River Glacier.

Name published by USGS (Moffit, 1914, pl. 1).

Cheshnina River: stream, heads at Cheshnina Glacier, flows SW $24 \mathrm{mi}$. to Copper River, 3.3 mi. NW of Lower Tonsina and $65 \mathrm{mi}$. NE of Valdez, Copper River Basin; 61 ${ }^{\circ} 42^{\prime} 00^{\prime \prime} \mathrm{N}$, $144^{\circ} 41^{\prime} 55^{\prime \prime} \mathrm{W}$; BGN 1903; (map 68). Var. Cheshnena, Cheshni River.

Indian name obtained in 1898 by Capt. W. R. Abercrombie, USA, who spelled it "Cheshnena," or "Cheshni River."

Cheshni River: stream, see Cheshnina River.

Cheshni River Glacier: glacier, see Cheshnina Glacier.

Cheslina Creek: stream, see Cheslina River.

Cheslina River: stream, heads in Mentasta Mts., flows NE $27 \mathrm{mi}$. to Nabesna River, $30 \mathrm{mi}$. SW of Northway Junction, Alaska Ra.; $62^{\circ} 46^{\prime} \mathrm{N}$, $142^{\circ} 10^{\prime} \mathrm{W}$; BGN 1935; (map 84). Var. Cheslina Creek, Kalutna River.

Indian name reported in 1935 by USGS.

Chesloknu: village, see Seldovia.

Chesloknu Bay: estuary, see Seldovia Bay.

Chestakoff, Ile: barrier island, see Chistiakof Island.

Chestakof Island: barrier island, see Chistiakof Island.

Chestalena: stream, see Chetaslina River.

Chester: area, in S Anchorage $1 \mathrm{mi}$. SSW of City Hall, Cook Inlet Low.; 61 ${ }^{\circ} 12^{\prime} 25^{\prime \prime} \mathrm{N}$, $149^{\circ} 55^{\prime} 15^{\prime \prime}$ W; (map 69).
Residential district in city of Anchorage reported in 1954 by office of city engineer of Anchorage.

Chester, Port: $b a y, 3.5 \mathrm{mi}$. across, on $\mathrm{W}$ coast of Annette I., Alex. Arch.; 55 $09^{\prime} \mathrm{N}, 131^{\circ} 36^{\prime} \mathrm{W}$; (map 3).

Named in 1883 by Lt. Comdr. H. E. Nichols, USN, for Comdr. Colby Mitchell Chester, USN.

Chester Bluff: bluff, extends $1.5 \mathrm{mi}$. along right bank of Yukon River, 3 mi. NE of junc. of Charley and Yukon Rivers, Porcupine Plat.; $65^{\circ} 21^{\prime} \mathrm{N}, 142^{\circ} 42^{\prime} \mathrm{W}$; (map 103).

Name published on a 1956 USGS map.

Chester Creek: stream, formed by its Middle and South Forks, flows W $4.1 \mathrm{mi}$. to Knik Arm Cook Inlet, in Anchorage, Cook Inlet Low.; $61^{\circ} 12^{\prime} 34^{\prime \prime} \mathrm{N}, 149^{\circ} 55^{\prime} 25^{\prime \prime} \mathrm{W}$; (map 69).

Local name reported in 1906 by $T$. G. Gerdine and R. H. Sargent, USGS.

Chester Lake: lake, $0.5 \mathrm{mi}$. across, on Annette I., $1.8 \mathrm{mi}$. SE of Metlakatla, Alex. Arch.; 55 ${ }^{\circ}$ $07^{\prime} 10^{\prime \prime} \mathrm{N}, 131^{\circ} 31^{\prime} 28^{\prime \prime} \mathrm{W}$; (map 3).

Named in 1897 by USC\&GS; name derived from Port Chester.

Ches-tna: stream, see Chisana River.

Chestochena: village, see Chistochina.

Chestochina: stream, see Chistochina River.

Chestochina Village: village, see Chistochina.

Chestoknu Bay: estuary, see Seldovia Bay.

Chetaht: stream, see Ray River.

Chetaslena: stream, see Chetaslina River.

Chetaslina Glacier: glacier, heads at $62^{\circ} 00^{\prime} \mathrm{N}$, $144^{\circ} 14^{\prime} \mathrm{W}$, trends SW $5.5 \mathrm{mi}$. to its terminus at head of Chetaslina River, $84 \mathrm{mi}$. NE of Valdez, Wrangell Mts.; $61^{\circ} 56^{\prime} 50^{\prime \prime} \mathrm{N}, 144^{\circ}$. $21^{\prime} 10^{\prime \prime} \mathrm{W}$; (map 68).

Name reported by USGS (Moffit, 1914, pl. 1).

Chetaslina River: stream, heads in Chetaslina Glacier, flows SW $24 \mathrm{mi}$. to Copper River, $4.3 \mathrm{mi}$. NW of Lower Tonsina and $64 \mathrm{mi}$. NE of Valdez, Copper River Basin; 61 ${ }^{\circ} 42^{\prime} 30^{\prime \prime} \mathrm{N}$, $144^{\circ} 43^{\prime} 50^{\prime \prime} \mathrm{W}$; (map 68). Var. Chestalena, Chetaslena, Liebigstag River.

Ahtena Indian name meaning "marmot river [che-les'chi-tna]" obtained in 1898 by Capt. W. R. Abercrombie, USA, who spelled it "Chestalena." This is the same stream that Lt. H. T. Allen (1887, map), USA, called in 1885 "Liebigstag," for a local Indian chief (p. 58). W. C. Mendenhall (1905, p. 21), USGS, says that this latter name still had limited use as late as 1902.

Chetaut : stream, see Ray River.

Chetchitno: village, see Chitina.

Chetchitno: stream, see Chitina River.

Chethakne Creek: stream, see Beaver Creek.

Chetierek Glavaia, Gora: mountain, see Fourpeaked Mountain.

Chetirekh Ugoloni Piramidoi, Gora: mountain, see Kinkaid, Mount.

Chetkina: island, see Great Sitkin Island.

Chetlechak Island: island, $3 \mathrm{mi}$. long, in Yukon River, $5 \mathrm{mi}$. N of Fort Hamlin, $42 \mathrm{mi}$. NE of Rampart, Yukon Flats; $65^{\circ} 59^{\prime} \mathrm{N}, 149^{\circ} 14^{\prime}$ W; (map 105).
Local name published by USGS in the 1950's.

Chettyna: village, see Chitina.

Chettyna: stream, see Chitina River.

Chetyrekh Ugolnoy Piramidoy, Gora: mountain, see Kinkaid, Mount.

Chetyre Soposhnye, Ostrova: islands, see Four Mountains, Islands of.

Cheukee River: stream, see Chiuki River.

Chevak: village, pop. 315 , on right bank of Ninglikfak River, $17 \mathrm{mi}$. E of village of Hooper Bay, Yukon-Kuskokwim Delta; $61^{\circ} 31^{\prime} 40^{\prime \prime} \mathrm{N}$, $165^{\circ} 35^{\prime} 00^{\prime \prime} \mathrm{W}$; (map 75). Var. New Chevak.

This Eskimo village, reported by USC\&GS in 1948, is fairly new because of the abandonment of "old' Chevak and the relocation of its population to "new" Chevak. The name refers to "a connecting slough" on which old Chevak was located. A post office was established at "new" Chevak in 1951 (Ricks, 1965, p. 10).

Cheval Island: island, $1.5 \mathrm{mi}$. long, off $\mathrm{E}$ coast of Aialik Penin., $24 \mathrm{mi}$. S of Seward, Chugach Mts.; 59 $46^{\prime}$ N, $149^{\circ} 31^{\prime} \mathrm{W}$; BGN 1906; (map 49. Var. Horse Island.

Named on June 6,1906 , by USC\&GS to replace the common name "Horse Island" given by that agency the year before. "Cheval" is the French word for "horse."

Chevron Hill: mountain, 3,000 ft., $7 \mathrm{mi}$. SW of Tingmerkpuk Mtn. and $63 \mathrm{mi}$. NE of Noatak, Brooks Ra.; $68^{\circ} 27^{\prime} 55^{\prime \prime}$ N, $162^{\circ} 37^{\prime} 00^{\prime \prime} \mathrm{W}$; $B G N$ 1965; (map 130).

So named in 1965 by geologists of the B.P. Exploration Co., Inc., "because the hill displays chevron folds."

Cheyenne Creek: stream, flows NE $7 \mathrm{mi}$. to Yukon River, $25 \mathrm{mi}$. ENE of Tanana, YukonTanana High.; $65^{\circ} 15^{\prime} 15^{\prime \prime} \mathrm{N}, 151^{\circ} 14^{\prime} 30^{\prime \prime} \mathrm{W}$; (map 106). Var. Jesse Creek.

Local name reported in 1956 by Orth.

Cheyenne Creek: stream, see Jordan Creek.

Chiachi, Mys: point of land, see Gull Point.

Chiache Islands: islands, see Chiachi Islands.

Chiachi Bay: bay, $0.6 \mathrm{mi}$. across, on $\mathrm{E}$ coast of Chiachi I., in Chiachi Is., $23 \mathrm{mi}$. E of Stepovak Bay, Aleutian Ra.; 55 $51^{\prime} \mathrm{N}, 1^{\circ} 59^{\circ} 06^{\prime} \mathrm{W}$; (map 27).

Named for Chiachi Is.; shown on USC\&GS Chart 8851 (1953).

Chiachi Cape: point of land, see Chiachi Point. Chiachi Island: island, $4 \mathrm{mi}$. across, in Chiachi Is., $22 \mathrm{mi}$. E of Stepovak Bay, Aleutian Ra.; $55^{\circ} 51^{\prime} \mathrm{N}, 159^{\circ} 08^{\prime} \mathrm{W}$; (map 27).

Named in 1891 by USC\&\&S.

Chiachi Islands: islands, five, $5 \mathrm{mi}$. across, 22 mi. E of Stepovak Bay, include Chiachi, Petrel, Pinusuk and Shapka Is., and one unnamed island, Aleutian Ra.; $55^{\circ} 51^{\prime} \mathrm{N}, 159^{\circ}$ 08' W; BGN 1890; (map 27). Var. Chiache Islands, Chaicht Islands.

Named by Capt. Tebenkov (1852, map 24), IRN, "O[strova] Chiachi," from "chaika," meaning "gull." The present name was published in 1888 by USC\&GS.

Chiachi Point: point of land, on NW coast of Whale I., $4 \mathrm{mi}$. SW of Afognak, $\mathrm{N}$ of Kodiak 
I.; $57^{\circ} 58^{\prime} 10^{\prime \prime} \mathrm{N}, 152^{\circ} 50^{\prime} 50^{\prime \prime} \mathrm{W}$; (map 34). Var. Chaiachie, Chiachi Cape, Mys Chaichiy.

The name "M[ys] Chaichiy" was given in 1839 or 1840 by Sub-Lt. Mikhail Murashev, IRN, and published in 1849 on Russian Hydrog. Dept. Chart 1425.

Chiaktuak Creek: stream, on Alaska Penin., flows NW $12 \mathrm{mi}$. to Chignik River, $2 \mathrm{mi}$. S of Black Lake and $22 \mathrm{mi}$. NM of Chignik, Aleutian Ra.; $56^{\circ} 23^{\prime} \mathrm{N}, 158^{\circ} 56^{\prime} \mathrm{W}$; (map 30 ).

Native name obtained in 1923 by G. C. Martin, USGS, and shown on a 1924 USGS map.

Chibukak: village, see Gambell.

Chibukak, Cape: point of land, see Chibukak Point.

Chibukak Cape: point of land, see Chibukak Point.

Chibukak Point: point of land, formed by the $\mathrm{N}$ end of Sevuokuk Mtn. on NW coast of St. Lawrence I.; $63^{\circ} 47^{\prime} \mathrm{N}, 171^{\circ} 39^{\prime} \mathrm{W}$; $B G N$ 1951; (map 93). Var. Cape Bywoonat, Cape Chibukak, Chibukak Cape, Mys NW, Oywoonat, Seevookuk, Sivukuk, Tchibukak, Tchiboukoukak.

In 1849 Capt. M. D. Tebenkov, IRN, published "Mys NW [Northwest]" as the name of this point and showed the Eskimo village of "Chibukak" on the cape. In copying his map, cartographers applied the village name to this point.

Chicago Bay: bay, see Chichagof Bay.

Chicago Boy Creek: stream, flows NW $5 \mathrm{mi}$. to join Little Manila Creek to form Manila Creek, $50 \mathrm{mi}$. SW of Eagle, Yukon-Tanana High.; $64^{\circ} 21^{\prime} 45^{\prime \prime} \mathrm{N}, 142^{\circ} 35^{\prime} 00^{\prime \prime} \mathrm{W}$; (map 102).

Prospectors' name shown on an 1898 manuscript map by C. A. Woodruff, Fort Cudahy, Canada.

Chicago Creek: locality, on right bank of Kugruk River $29 \mathrm{mi}$. NE of Imuruk Lake, Seward Penin. High.; $65^{\circ} 54^{\prime} \mathrm{N}, 162^{\circ} 27^{\prime} \mathrm{W}$; (map 110).

Site of a mining camp named on a 1951 USGS map. A coal mine was opened here in 1903 (Moffit, 1905, p. 67) and for many years supplied coal to the Candle Creek and Fairhaven gold mining districts.

Chicago Creek: stream, flows NW $8.3 \mathrm{mi}$. to Yukon River, $4 \mathrm{mi}$. NNE of Rampart, YukonTanana High.; $65^{\circ} 03^{\prime} 30^{\prime \prime} \mathrm{N}, 150^{\circ} 07^{\prime} 00^{\prime \prime} \mathrm{W}$; (map 106).

Name shown on Edwards Track Chart of the Yukon, dated 1899.

Chicago Creek: stream, flows SW $1.3 \mathrm{mi}$. to Thanksgiving Ditch, $4.1 \mathrm{mi}$. W of Eureka and $22 \mathrm{mi}$. SSW of Rampart, Yukon-Tanana High.; $65^{\circ} 10^{\prime} 50^{\prime \prime} \mathrm{N}, 150^{\circ} 21^{\prime} 30^{\prime \prime} \mathrm{W}$; (map 106).

Prospectors' name reported in 1904 by Prindle and Hess (1906, pl. 3), USGS.

Chicago Creek: stream, flows NW $9 \mathrm{mi}$. to Yukon River, 4 mi. N of Rampart, Yukon-Tanana High.; $65^{\circ} 35^{\prime} \mathrm{N}, 150^{\circ} 08^{\prime} \mathrm{W}$; (map 106).

Local name from "Edwards Track Chart of the Yukon," dated 1899.
Chicago Creek: stream, flows SW $10 \mathrm{mi}$. to Kugruk River, $28 \mathrm{mi}$. NE of Imuruk Lake, Seward Penin. High.; 65 $54^{\prime} \mathrm{N}, 162^{\circ} 28^{\prime}$ W; (map 110 ).

Prospectors' name reported in 1901 by D. L. Reaburn (in Mendenhall, 1902, pl. 4a), USGS.

Chicago Creek: stream, see Flat Creek.

Chicago Gulch: ravine, trends SE $1 \mathrm{mi}$., between Fergy and Orin Gulches to Mills Creek $45 \mathrm{mi}$. W of Talkeetna, Alaska, Ra.; $62^{\circ} 21^{\prime} 30^{\prime \prime} \mathrm{N}$, $151^{\circ} 30^{\prime} 58^{\prime \prime} \mathrm{W}$; (map 81).

Prospectors' name reported in the 1930's by USGS.

Chicago Harbor: cove, $0.4 \mathrm{mi}$. across, $0.8 \mathrm{mi} \mathrm{E}$ of Eleanor I. and $14 \mathrm{mi}$. NE of Yakutat, St. Elias Mts.; $59^{\circ} 42^{\prime} 10^{\prime \prime} \mathrm{N}, 139^{\circ} 28^{\prime} 30^{\prime \prime} \mathrm{W}$; (map 46).

Local name published in 1959 by USGS.

Chicago Lakes: lakes, group, extends $4 \mathrm{mi}$., on $\mathrm{E}$ bank of Yukon River, $10 \mathrm{mi}$. NNE of Rampart and $67 \mathrm{mi}$. NE of Tanana, Yukon-Tanana High.; $65^{\circ} 39^{\prime} \mathrm{N}, 150^{\circ} 05^{\prime} \mathrm{W}$; (map 106). $V$ ar. Twelvemile Lakes.

Local name reported in 1956 by Orth.

Chicago Point: point of land, on $\mathrm{W}$ shore of Sandy Bay, on S central coast of Sanak I.. Aleutian Ra.; $54^{\circ} 23^{\prime} 25^{\prime \prime} \mathrm{N}, 162^{\circ} 41^{\prime} 40^{\prime \prime} \mathrm{W}$; (map 25).

Name published in 1949 on a USGS map. Chicagos Island: island, see Chichagof Island. Chicakaclachno: stream, see Tlikakila River. Chicaloon Creek: stream, see Chickaloon River. Chican: locality, see Shakan.

Chic-cloon Bay: bight, see Chickaloon Bay.

Chic Cloon River: stream, see Chickaloon River.

Chichagof: village, at head of Klag Bay, on $W$ coast of Chichagof I., Alex. Arch.; 57 $39^{\prime} 50^{\prime \prime}$ $\mathrm{N}, 136^{\circ} 05^{\prime} 40^{\prime \prime} \mathrm{W}$; (map 9).

Name probably derived from Chichagof Island. The town was established about 1905 when gold was found on Klag Bay. A post office was established here in 1909 . In 1943 the settlement included a general store, a stamp mill, and a wharf.

Chichagof: village, see Attu.

Chichagof, Cape: bluff, elev. $70 \mathrm{ft}$., on $\mathrm{N}$ coast of Alaska Penin., N point of entrance to Egegik Bay, $34 \mathrm{mi}$. SW of Naknek, Bristol Bay Low.; $58^{\circ} 20^{\prime} \mathrm{N}, 157^{\circ} 32^{\prime} \mathrm{W}$; (map 41). Var. Cape Chichagoff, Cape Chichagov, Cape Chichagow, Gape Tchitchagow, Cap Tchitchagoff, Mys Chichagova.

Named "Cap Tchitchagoff" by Capt. Lutke (1836, p. 258), IRN, for Adm. Vasili Yakov Chichagov, IRN, who explored the Arctic regions in 1765-66.

Chichagof Bay: bay, $2.5 \mathrm{mi}$. across, on $\mathrm{W}$ shore of Stepovak Bay, Alaska Penin., Aleutian Ra.; $55^{\circ} 39^{\prime} \mathrm{N}, 160^{\circ} 14^{\prime} \mathrm{W}$; (map 28). Var. Chicago Bay, Chichagof Cove.

Local name reported by members of the Harriman Alaska Expedition of 1899 (v. 4, p. 69-78). Commonly called Chicago Bay according to USC\&GS 1916 Coast Pilot (v. 2, p. 165). Named for Adm. Vasili Yakov Chichagov, IRN, who, with a fleet of three ships, made explorations in the Arctic regions in 1765-66.

Chichagof Bay: bay, see Chichagof Harbor.

Chichagof Bay: cove, $0.5 \mathrm{mi}$. across, on SE coast of Prince of Wales I., $0.6 \mathrm{mi}$. N of Polk I., Alex. Arch.; $55^{\circ} 01^{\prime} 30^{\prime \prime} \mathrm{N}, 1^{\circ} 31^{\circ} 58^{\prime} 50^{\prime \prime} \mathrm{W}$; (map 3). Var. Chichagof Bay, Chichagof Harbor, Chitchagoff Bay, Gavan Chichagova, Tehitchagoff Bay.

Name published in 1848 on Russian Hydrog. Dept. Chart 1396 as "Gavan Chichagova" or "Chichagof Harbor"; possibly given for Adm. Vasili Yakov Chichagov who made explorations in the Arctic region in 1765-66.

Chichag of Beach: beach, $0.5 \mathrm{mi}$. long, at head of Chichagof Harbor, on NE coast of Attu I., Aleutian Is.; $52^{\circ} 55^{\prime} 30^{\prime \prime} \mathrm{N}, 173^{\circ} 14^{\prime} 45^{\prime \prime} \mathrm{E}$; (map 13).

Named by U.S. Army during World War II; published in 1948 by AMS.

Chichagof Cove: bay, see Chichagof Bay.

Chichagof Creek: stream, on $\mathrm{W}$ coast of Chichagof I., fows S. $1.5 \mathrm{mi}$. to Klag Bay, $0.6 \mathrm{mi}$. $\mathrm{NE}$ of Chichagof, Alex. Arch.; 57 $40^{\circ} 05^{\prime \prime} \mathrm{N}$, $136^{\circ} 04^{\prime} 40^{\prime \prime} \mathrm{W}$; (map 9).

Local name reported in 1951 by USGS. Chichagoff Bay: bay, see Chichagof Bay. Chichagoff Cape: bluff, see Chichagof, Cape. Chichagoff Harbor: bay, see Chichagof Harbor. Chichagoff Island: island, see Chichagof Island. Chichagof Harbor: cove, $0.5 \mathrm{mi}$. across, on $\mathrm{N}$ coast of Attu I., Aleutian Is.; 52 $56^{\prime} \mathrm{N}, 173^{\circ}$ 15' E; BGN 1890; (map 13). Var. Chichagof Bay, Chichagoff Harbor, Gavan Chichigova, Tschitschagoff Harbor, Gavan Chichigova, Chichagov Harbor.

Probably named by A. K. Etolin for the brig Chichagof, which he commanded, in 1830 . The name was first published by Capt. Tebenkov (1852, map 30), IRN, as "Gavan Chichigova," i.e. "Chichagov Harbor."

Chichagof Harbor: bay, see Chichagof Bay.

Chichagof Island: island, $72 \mathrm{mi}$. long, extends SE from Cross Sound and Icy Strait on $\mathrm{N}$ end to Peril Strait on $\mathrm{S}$ end, Alex. Arch.; $57^{\circ} 30^{\circ}$ N, $135^{\circ} 30^{\prime} \mathrm{W} ; B G N$ 1944; (map 9). Var. Chicagos Island, Chichagoff Island, Chichagov Island, Hoonah Island, Jacobi Island, Khunna Island, Ostrov Chichagova, Yakobi Island.

Named in 1805 by Capt. U. F. Lisianski, IRN, for Adm. Vasili Yakov Chichagov. This island was previously known as "Yakobi," a name given to an island off the northwest coast of Chichagof Island. See Chichagof, Cape, Yakobi Island.

Chichagof Pass: water passage, between Etolin and Woronkofski Is., Alex. Arch.; 56 ${ }^{\circ} 21^{\prime} \mathrm{N}$, $132^{\circ} 28^{\prime} \mathrm{W}$; (map 6). Var. Chichagof Passage, Chichagof Strait, Proliv Chichagova, Tchitchakoff Strait.

Published in 1853 on Russian Hydrog. Dept. Chart 1494 as "Proliv Chichagova" or "Chichagov Strait." Lt. Comdr. H. E. Nichols, USN, published the present name in 1891 Coast Pilot (p. 114). Name was probably given to the vessel Chichagof. 
Chichagof Passage: water passage, see Chichagof Pass.

Chichagof Peak: mountain, 2,600 ft., between Chichagof Bay and Port Moller on Alaska Penin., Aleutian Ra.; $55^{\circ} 43^{\prime} \mathrm{N}, 160^{\circ} 18^{\prime} \mathrm{W}$; (map 28).

Named by members of the Harriman Alaska Expedition of 1899.

Chichagof Peak: mountain, 2,600 ft., $6.5 \mathrm{mi}$. S of Wrangell, on NW coast of Wrangell I., Alex. Arch.; $56^{\circ} 22^{\prime} 25^{\prime \prime} \mathrm{N}, 132^{\circ} 20^{\prime} 20^{\prime \prime} \mathrm{W}$; (map 6).

Named in 1886 by Lt. Comdr. A. S. Snow, USN; name published in 1887 on USC\&GS Chart 706.

Chichagof Point: point of land, between Holtz Bay and Chichagof Harbor, on NE coast of Attu I., Aleutian Is.; $52^{\circ} 56^{\prime} 50^{\prime \prime} \mathrm{N}, 173^{\circ}$ 15'15" E; (map 13). Var. Cape Turner.

Name derived from Chichagof Harbor by U.S. Army during World War II ; published in 1948 by AMS. Shown as "Cape Turner" on a manuscript map by L. M. Turner in the 1880 's.

Chichagof Strait: water passage, see Chichagof Pass.

Chichagov, Cape: bluff, see Chichagof, Cape.

Chichagov Harbor: bay, see Chichagof Harbor. Chichagov Island: island, see Chichagof Island. Chichagova, Gavan: bay, see Chichagof Bay. Chichagova, Mys: bluff, see Chichak of, Cape. Chichagova, Ostrov: island, see Chichagof Island.

Chichagova, Proliv: water passage, see Chichagof Pass.

Chichagow, Cape: bluff, see Chichagof, Cape.

Chichaldinskoi: mountain, see Shishaldin Volcano.

Chichantna Creek: stream, flows NE $7.5 \mathrm{mi}$. to Chichantna River, $22 \mathrm{mi}$. NW of Tyonek, Cook Inlet Low.; $61^{\circ} 20^{\prime} 15^{\prime \prime} \mathrm{N}, 151^{\circ} 30^{\prime} 30^{\prime \prime}$ W; BGN 1964; (map 70)

Named in 1962 by USGS; derived from Chichantna River.

Chichigova, Gavan: bay, see Chichagof Harbor.

Chichinagamiut: locality, see Chichinak.

Chichinagamute: locality, see Chichinak.

Chichinak: locality, "on bank of stream near Etolin Strait;" (map 57 or 58). Var. Chechinamiut, Chichinagamuit, Chichinagamute.

Former Eskimo village visited in 1878 by E. W. Nelson who reported the name as "Chichinagamiut," i.e. "Chichinak people." In the 1880 Census, Ivan Petroff lists "Chichinagamute" with a population of 6 ; the 1890 Census lists "Chechinamiut" with a population of 84 .

Chichitnak, Reka: stream, see Chichitnok River. Chi-chit-nok: stream, see Chichitnok River.

Chichitnok River: stream, heads at $60^{\circ} 54^{\prime} \mathrm{N}$, $157^{\circ} 27^{\prime} \mathrm{W}$; flows S 32 mi. to Nushagak River, $90 \mathrm{mi}$. S of Sleetmute, Kilbuck-Kuskokwim Mts.; $60^{\circ} 23^{\prime} \mathrm{N}, 157^{\circ} 17^{\prime} \mathrm{W}$; BGN 1932; (map 60). Var. Chi-chit-nok, Tschitschitnak, Reka Chichitnak.
Eskimo name published by Lt. Sarichev (1826, map 3), IRN, as "R[eka] Chichitnak." Chichkoff Cap: point of land, see Cave Point. Chichmareff, Cape: point of land, see Northeast Cape.

Chichmareff Inlet: bay, see Shishmaref Inlet.

Chichokna Glacier: glacier, heads between Chetaslina and Dadina Glaciers, trends SW $4.5 \mathrm{mi}$. to its terminus at head of Chichokna River, $33 \mathrm{mi}$. SE of Glennallen, Wrangell Mts.; $62^{\circ} 00^{\prime} \mathrm{N}, 144^{\circ} 22^{\prime} \mathrm{W}$; (map 83). Var. Cheechocna, Chiehokna.

Local name recorded in 1902 by USGS (in Mendenhall, 1905, pl. 4); named for the river. Chichokna River: stream, heads $1.5 \mathrm{mi}$. W of terminus of Chichokna Glacier, flows SW 12 mi. to Chetaslina River, $28 \mathrm{mi}$. NE of Valdez, Wrangell Mts.; $61^{\circ} 53^{\prime} 40^{\prime \prime} \mathrm{N}, 144^{\circ} 30^{\prime} 30^{\prime \prime} \mathrm{W}$; (map 68). Var. Cheechocna, Chiekokna River.

Indian name obtained in 1902 by T. G. Gerdine, USGS, and written "Cheechocna." Chickalachno River: stream, see Tlikakila River. Chickadee Lake: lake, $0.7 \mathrm{mi}$. long, on Kenai Penin., $0.5 \mathrm{mi}$. SE of Konovalof Lake and 8 mi. NNE of Kenai, Cook Inlet Low.; 60³9'$00^{\prime \prime} \mathrm{N}, 151^{\circ} 08^{\prime} 30^{\prime \prime} \mathrm{W}$; (map 62$)$.

Named in 1963 by officials of Kenai National Moose Range, probably for the "Yukon Chickadee (Penthestes atricapillus turneri), which is found in Alaska north and west of Cook Inlet." (Pearson, 1944, pt. 3, p. 211). Chickak River: stream, heads in Tordrillo Mts., flows NE $11 \mathrm{mi}$. to Skwentna River, $75 \mathrm{mi}$. NW of Tronek, Alaska Ra.; $60^{\circ} 58^{\prime} 50^{\prime \prime} \mathrm{N}$, $152^{\circ} 23^{\prime} 00^{\prime \prime} \mathrm{W}$ : (map 70$)$.

Tanaina Indian name reported in 1958 by UCGS.

Chickaloon: village, pop. 43, on Chickaloon River, 26 mi. NE of Palmer, Talkeetna Mts. $61^{\circ} 47^{\prime} 45^{\prime \prime} \mathrm{N}, 148^{\circ} 28^{\prime} 00^{\prime \prime} \mathrm{W}$; (map 69).

Village, named for the Chickaloon River, was established about 1916 as the terminus of the Matanuska Branch of The Alaska Railroad in this coal-rich region. The Chickaloon post office operated from 1918 to 1922 and 1931 to 1933 (Ricks, 1965, p. 11). Its population was 28 in 1930 .

Chickaloon Bay: bight, $18 \mathrm{mi}$. across, on $\mathrm{N}$ coast of Kenai Penin., at SW end of Turnagain Arm, $15 \mathrm{mi}$. SSW of Anchorage, Cook Inlet Low.; $61^{\circ} 57^{\prime} \mathrm{N}, 150^{\circ} 06^{\prime} \mathrm{W}$; (map 62).

Indian name reported in 1898 by Eldridge (1900, map 3), USGS.

Chickaloon Creek: stream, see Chickaloon River. Chickaloon Glacier: glacier, trends NE $9 \mathrm{mi}$. to head of Chickaloon River, $37 \mathrm{mi}$. NW of Tahneta Pass, Talkeetna Mts.; 62 ${ }^{\circ} 08^{\prime} \mathrm{N}$, $148^{\circ} 20^{\prime} \mathrm{W}$; ( $\left.\operatorname{map} 82\right)$.

Local name recorded in 1952 by USGS.

Chickaloon River: stream, heads in Swan Lake, on Kenai Penin., flows NW 36 mi. to Chickaloon Bay, $19 \mathrm{mi}$. SSW of Anchorage, Cook Inlet Low.; $60^{\circ} 54^{\prime} 30^{\prime \prime} \mathrm{N}, 150^{\circ} 03^{\prime} 00^{\prime \prime} \mathrm{W}$; (map 62). Var. Chic Cloon River.

Indian name reported in 1895 as "Chic Cloon" by G. F. Becker (in Baker, 1902, p. 124), USGS.
Chickaloon River: stream, heads at Chickaloon Glacier, flows SW 34 mi. to Matanuska River, $25 \mathrm{mi}$. NE of Palmer, Talkeetna Mts.; 61 ${ }^{\circ} 47^{\prime}$ $10^{\prime \prime} \mathrm{N}, 148^{\circ} 27^{\prime} 00^{\prime \prime} \mathrm{W}$; (map 69). Var. Chicaloon Creek, Chickaloon Creek.

Tanaina Indian name reported in 1898 by Mendenhall (1900, p. 332), USGS.

Chickamin Creek: stream, flows N $0.4 \mathrm{mi}$. to Dome Creek which flows to Iron Creek, $23 \mathrm{mi}$. NW of Solomon, Seward Penin. High.; 64 ${ }^{\circ} 53^{\prime}$ N, 164.30' W; (map 95).

Prospectors' name reported in 1908 by P. S. Smith (in Brooks and others, 1909, pl. 10), USGS.

Chickamin Glacier: glacier, heads at AlaskaCanada boundary, trends SW $7.5 \mathrm{mi}$. to its terminus at head of Chickamin River, $17 \mathrm{mi}$. NW of Hyder, Coast Mts.; $56^{\circ} 03^{\prime} 30^{\prime \prime} \mathrm{N}$, $130^{\circ} 23^{\prime} 45^{\prime \prime} \mathrm{W}$; (map 7).

Local name published by A. F. Buddington (in Brooks and others, 1925, p. 85), USGS.

Chickamin River: stream, heads at Chickamin Glacier, flows SW $40 \mathrm{mi}$. to Behm Canal, Coast Mts.; $55^{\circ} 47^{\prime} \mathrm{N}, 130^{\circ} 58^{\prime} \mathrm{W}$; $B G N$ 1962; (map 3).

Indian name reported in 1891 by USC\&GS. Chicken: village, pop. 23 (1958), on right bank of Chicken Creek $1 \mathrm{mi} \mathrm{N}$ of Mosquito Fork, $58 \mathrm{mi}$. SW of Eagle, Yukon-Tanana High.; $64^{\circ} 04^{\prime} 30^{\prime \prime} \mathrm{N}, 141^{\circ} 56^{\prime} 00^{\prime \prime} \mathrm{W} ; B G N$ 1944; (map 102). Var. Chicken Post Office.

Mining camp and post office established in 1903. "Chicken" is a common name for the ptarmigan. Its population was 20 in 1930.

Chicken Cove: cove, $0.3 \mathrm{mi}$. across, $\mathrm{S}$ of Glass Lake, on Vega Bay, S coast of Kiska I., Aleutian Is.; $51^{\circ} 55^{\prime} 40^{\prime \prime} \mathrm{N}, 177^{\circ} 23^{\prime} 55^{\prime \prime} \mathrm{E}$; (map 14).

One of the "bird names" arbitrarily applied to features on Kiska I. in 1943 by USAAF for tactical purposes during World War II.

Chicken Creek: stream, on N end of Chichagof I., flows $10 \mathrm{mi}$. NE to Icy Strait, $2.7 \mathrm{mi}$. W of Eagle Point and $13 \mathrm{mi}$. NW of Hoonah, Alex. Arch.; $58^{\circ} 14^{\prime} \mathrm{N}, 135^{\circ} 43^{\prime} \mathrm{W}$; BGN 1959; (map 11).

Local name reported in 1959 by USGS.

Chicken Creek: stream, flows N 5.4 mi. to Aniak River $36 \mathrm{mi}$. SF of Aniak. Kilbuck-Kuskokwim Mts.; $61^{\circ} 05^{\prime} \mathrm{N}, 159^{\circ} 09^{\prime} \mathrm{W}$; (map 73).

Prospectors' name reported by A. G. Maddren, USGS, in 1914.

Chicken Creek: stream, in Nutzotin Mts., flows SW $1 \mathrm{mi}$. to Glacier Creek at Caribou Pass, Alaska Ra.; $62^{\circ} 07^{\prime} \mathrm{N}, 141^{\circ} 52^{\prime} \mathrm{W}$; (map 84).

Local name reported in 1914 by S. R. Capps (in Brooks and others, 1915, p. 223), USGS. Chicken Creek: stream, heads on Chicken Mtn., flows S $4 \mathrm{mi}$. to Bonanza Creek $7.7 \mathrm{mi}$. E of its junc. with Iditarod River, $8.5 \mathrm{mi}$. $\mathrm{S}$ of Flat and $54 \mathrm{mi}$. NW of Sleetmute, KilbuckKuskokwim Mts.; $62^{\circ} 19^{\prime} 50^{\prime \prime} \mathrm{N}, 157^{\circ} 57^{\prime} 15^{\prime \prime}$ W; (map 79).

Name shown on a 1910 manuscript map of the "Iditarod Placer Fields."

Chicken Creek: stream, flows S $5 \mathrm{mi}$. to Ladue River, $30 \mathrm{mi}$. NE of Northway Junction, Yu- 
kon-Tanana High.; $63^{\circ} 24^{\prime} \mathrm{N}, 141^{\circ} 21^{\prime} \mathrm{W}$; (map 85).

Local name reported by USGS in 1956

Chicken Creek: stream, heads at $64^{\circ} 08^{\prime} \mathrm{N}, 141^{\circ}$. $53^{\prime} \mathrm{W}$; flows SW $7 \mathrm{mi}$. to Mosquito Fork, 55 mi. SW of Eagle, Yukon-Tanana High.; $64^{\circ} 03^{\prime} 30^{\prime \prime} \mathrm{N}, 141^{\circ} 56^{\prime} 45^{\prime \prime} \mathrm{W}$; (map 102). Var. Left Fork Chicken Creek.

Prospectors' name obtained in 1898 by E. C. Barnard, USGS.

Chicken Creek: stream, flows SW $5 \mathrm{mi}$. to Moose Creek, $27 \mathrm{mi}$. S of Nenana, Alaska Ra.; $64^{\circ} 04^{\prime}$ $\mathrm{N}, 149^{\circ} 05^{\prime} \mathrm{W}$; (map 100).

Local name reported in 1916 by G. G. Martin, USGS.

Chicken Creek: stream, flows $\mathrm{N} 6 \mathrm{mi}$. to Wood River, 42 mi. S of Fairbanks, Tanana Low.; $64^{\circ} 14^{\prime} 30^{\prime \prime} \mathrm{N}, 147^{\circ} 43^{\prime} 45^{\prime \prime} \mathrm{W}$; (map 100).

Prospectors' name reported in 1950 by USGS topographers.

Chicken Creek: stream, flows S $2 \mathrm{mi}$. to Cache Creek, $10 \mathrm{mi}$. NE of Solomon, Seward Penin. High.; $64^{\circ} 37^{\prime} \mathrm{N}, 164^{\circ} 07^{\prime} \mathrm{W}$; (map 95).

Prospectors' name reported in 1900 by E. C. Barnard (in Brooks, 1901, pl. 17), USGS.

Chicken Creek: stream, flows $S 4 \mathrm{mi}$. to Yukon River, $\mathrm{N}$ of Liner I. and $2.5 \mathrm{mi}$. $\mathrm{E}$ of Birches, Kokrines-Hodzana High. ; $65^{\circ} 08^{\prime} 45^{\prime \prime} \mathrm{N}, 153^{\circ}$ $29^{\prime} 45^{\prime \prime} \mathrm{W}$; (map 107).

Local name obtained in 1952 by USGS.

Chicken Creek: stream, flows SW $1.3 \mathrm{mi}$. to Tozimoran Creek $1 \mathrm{mi}$. E of its junc. with Ash Creek, $25 \mathrm{mi}$. NW of Tanana, KokrinesHodzana High.; $65^{\circ} 23^{\prime} \mathrm{N}, 152^{\circ} 47^{\prime} \mathrm{W}$; (map 106).

Prospectors' name reported in 1956 by R. M. Chapman, USGS.

Chicken Creek: stream, flows NE $1.4 \mathrm{mi}$. to Minook Creek, $8 \mathrm{mi}$. S of Rampart, YukonTanana High.; $65^{\circ} 23^{\prime} 20^{\prime \prime} \mathrm{N}, 150^{\circ} 07^{\prime} 40^{\prime \prime} \mathrm{W}$; (map 106).

Prospectors' name shown on a manuscript map dated 1906; reported in 1956 by Orth.

Chicken Creek: stream, flows SW 12 mi. to Wild River, in Death Valley, $2 \mathrm{mi}$. $\mathrm{N}$ of mouth of Death Valley Creek and $41.5 \mathrm{mi}$. SW of Wiseman, Brooks Ra.; $67^{\circ} 08^{\prime} 30^{\prime \prime} \mathrm{N}, 151^{\circ} 29^{\prime} 00^{\prime \prime}$ W; (map 124).

Local name shown on an 1899 fieldsheet by T. G. Gerdine, USGS.

Chicken Creek: stream, see Windy Creek.

Chicken Head Point: point of land, see Hazard Point.

Chicken Island: island, $0.3 \mathrm{mi}$. long, in Latouche Passage, off NW coast of Latouche I., $18 \mathrm{mi}$. SE of Chenega, Chugach Mts.; $60^{\circ} 02^{\prime} 20^{\prime \prime} \mathrm{N}$, 147 $55^{\prime} 50^{\prime \prime}$ W; BGN 1908; (map 63). Var. Hen Island.

. Local name reported in 1908 by USC\&GS.

Chicken Mountain: mountain, 2,380 ft., in Kuskokwim Mts., $19 \mathrm{mi}$. SE of Flat, Kilbuck-Kuskokwim Mts., $62^{\circ} 23^{\prime} 20^{\prime \prime} \mathrm{N}, 157^{\circ} 57^{\prime} 40^{\prime \prime} \mathrm{W}$; (map 79).

Local name obtained in 1952 by USGS topographers.

Chicken Post Office: village, see Chicken.

Chicken Ridge: hill, $50 \mathrm{ft}$., trends $\mathrm{W} 0.5 \mathrm{mi}$. in center of Juneau, Coast Mts.; $58^{\circ} 18^{\prime} 15^{\prime \prime} \mathrm{N}$, $134^{\circ} 24^{\prime} 30^{\prime \prime}$ W; (map 11). Var. Gastineau Heights, Knob Hill, Number 6 Hill, Palo Alto Heights, Vassar Heights.

Although this is the oldest local name in the city of Juneau, its origin is obscure. One source ascribes it to the prevalence of ptarmigan, locally called chickens, along the ridge in early mining days (DeArmond, 1957, p. 11). Chickingmute: village, see Cheching.

Chick Lake: lake, $0.8 \mathrm{mi}$. long, on Kenai Penin. NE of Kayak Lake, $30 \mathrm{mi}$. NE of Kenai, Cook Inlet Low.; $60^{\circ} 45^{\prime} 45^{\prime \prime} \mathrm{N}, 150^{\circ} 32^{\prime} 00^{\prime \prime} \mathrm{W}$; (map 62).

Named about 1963 by officials of Kenai National Moose Range, for administrative purposes.

Chick Rocks: rocks, see Phocena Rocks.

Chickwan Bight: bight, $1.2 \mathrm{mi}$. wide, on $\mathrm{S}$ coast of Dall I., Alex. Arch.; $54^{\circ} 40^{\prime} \mathrm{N}, 132^{\circ} 45^{\prime}$ W; (map 1).

Tlingit Indian name published in 1911 by USC\&GS.

Chidaglekne Creek: stream, heads SW. of Fish Lakes, flows NE $2.8 \mathrm{mi}$. to Moose Creek, 13 mi. S of Northway Junction, Alaska Ra.; $62^{\circ} 49^{\prime} 30^{\prime \prime} \mathrm{N}, 141^{\circ} 51^{\prime} 15^{\prime \prime} \mathrm{W}$; (map 84).

Indian name reported in 1955 by USGS.

Chidak: point of land, see Aguliuk Point.

Chidak: point of land, see Chagak, Cape.

Chidakh, Mys: point of land, see Aguliuk Point.

Chidek Lake: lake, $0.7 \mathrm{mi}$. long, $\mathrm{W}$ of Birch Lake, $7.3 \mathrm{mi}$. SE of Northway, Alaska Ra.; $62^{\circ} 52^{\prime} \mathrm{N}$; $141^{\circ} 49^{\prime} \mathrm{W}$; (map 84).

Indian name reported in 1954 by USGS. Chief Cove: cove, $0.3 \mathrm{mi}$. across, on $\mathbf{E}$ shore of Uyak Bay at mouth of Spiridon Bay, on NE coast of Kodiak I.; $57^{\circ} 42^{\prime} 30^{\prime \prime} \mathrm{N}, 153^{\circ} 54^{\prime} 20^{\prime \prime}$ W; (map 34).

Local name published in 1943 by USC\&GS.

Chief Creek: stream, flows $\mathrm{N}$ and E $14 \mathrm{mi}$. to Tanana R. E of Knob Ridge, $27 \mathrm{mi}$. NW of Tanacross, Yukon-Tanana High.; $63^{\circ} 40^{\prime} \mathrm{N}$, $143^{\circ} 57^{\prime} \mathrm{W}$; BGN 1961; (map 85).

Local name reported in 1950 by USGS.

Chief Creek : stream, see Bear Creek.

Chief Gulch: ravine, trends NW $0.7 \mathrm{mi}$. to Buster Creek, $7 \mathrm{mi}$. NE of Nome, Seward Penin.

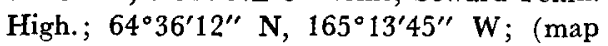
94).

Prospectors' name reported in 1904 by T. G. Gerdine, USGS.

Chief Point: point of land, on $\mathbf{E}$ shore of Uyak Bay, at mouth of Spiridon Bay, on NW coast of Kodiak I.; $57^{\circ} 42^{\prime} 30^{\prime \prime}$ N. $153^{\circ} 55^{\prime} 30^{\prime} \mathrm{W}$; (map 34)

Local name published in 1943 by USC\&GS Ghiehokna: glacier, see Chichokna Glacier. Chiekokna River: stream, see Chichokna River. Chiftak: locality, $7 \mathrm{mi}$. $\mathrm{N}$ of Kaguluk Lake and $58 \mathrm{mi}$. NW of Bethel, Yukon-Kuskokwim Delta; $60^{\circ} 57^{\prime} \mathrm{N}, 163^{\circ} 26^{\prime} \mathrm{W}$; (map 58).

Eskimo settlement or camp reported in 1949 by USC\&GS. Its population was 50 in 1950 . Chifukluk: locality, on the left bank of Yukon River at head of its delta, Yukon-Kuskokwim Delta: $62^{\circ} 15^{\prime} \mathrm{N}, 164^{\circ} 00^{\prime} \mathrm{W}$; (map 77). Var. Chefokhlagamute, Chefokhlagamiut, Chefoklak, Chifukhlugumut.
Eskimo settlement or camp visited by $\mathbf{E}$. W. Nelson, U.S. Signal Service, in December, 1878. He spelled the name "Chefokhlagamiut," or "people of Chefoklak." It then consisted of a village with four huts.

Chigakh, Mys: point of land, see Chagak, Cape. Chigik: bay, see Marmot Bay.

Chiginagak, Mount: peak, 7,000 ft., $10 \mathrm{mi}$. NW of Chiginagak Bay, near $S$ coast of Alaska Penin., $32 \mathrm{mi}$. SE of Ugashik, Aleutian Ra.; $57^{\circ} 08^{\prime} 30^{\prime \prime} \mathrm{N}, 156^{\circ} 28^{\prime} 30^{\prime \prime} \mathrm{W}$; (map 36).

Eskimo name published in 1888 by USBF. Chiginagak Bay: bay, $12 \mathrm{mi}$. wide at entrance, trends SE $8 \mathrm{mi}$. between Cape Providence and Cape Kuyuyukak, $18 \mathrm{mi}$. SE of Mount Chiginagak, on Alaska Penin., Aleutian Ra.; 56 ${ }^{\circ}$ $56^{\prime} \mathrm{N}, 156^{\circ} 41^{\prime} \mathrm{W}$; (map 31). Var. Baie Tehighinagac, Tchighinagak, Tiginagak.

Name shown as " $\mathrm{B}$ [ai]e Tehighinagac" by Adm. von Krusenstern (1827, map 20), IRN; published as "Chiginagak Bay" by USBF in 1888.

Chigmit Khrebet: mountain range, see Alaska Range.

Chigmit Mountains: mountain range, $140 \mathrm{mi}$. long, extend from Iliamna Lake and Kamishak Bay, NE to Chakachatna River, at NE end of Aleutian Ra.; $61^{\circ} 10^{\prime} \mathrm{N}, 152^{\circ} 30^{\prime} \mathrm{W}$ [NE end], $59^{\circ} 25^{\prime} \mathrm{N}, 154^{\circ} 20^{\prime} \mathrm{W}$ [SW end]. Var. Tschigimit Gebirge.

Constantin Grewingk in 1849 applied the Indian-German name "Tschigmit Gebirge" to that part of the Alaska Range northwest of Cook Inlet. In 1870, Dall (p. 286) wrote: "That portion of this range immediately northwest of Cook's Inlet has been termed on some maps the Chigmit Mountains, from what cause I have not been able to discover."

Chigmit Mountains: mountain range, see Alaska Range.

Chignik: village, pop. 99, on S shore of Alaska Penin. at head of Anchorage Bay, Aleutian Ra.; $56^{\circ} 18^{\prime} \mathrm{N}, 158^{\circ} 24^{\prime} \mathrm{W}$; Var. Chignik Bay.

Aleut village, probably established as a fishing village and cannery, named for Chignik Bay. The 11 th Census, in 1890, lists it as "Chignik Bay" with a population of 193 . Its population was 224 in 1939 and 253 in 1950. The Chignik post office was established in 1901.

Chignik Bay: bay, $18 \mathrm{mi}$. across, on SE shore of Alaska Penin., bounded by Cape Kumliun, Nagchamik I. and Castle Cape, $16 \mathrm{mi}$. ENE of Chignik, Aleutian Ra.; $56^{\circ} 22^{\prime} \mathrm{N}, 158^{\circ} 00^{\prime}$ W; (map 30). Var. Ischignik, Tiznik, Zaliv Chignik.

Native name reported in 1847 as "Z[aliv] Chignik" on Russian Hydrog. Dept. Chart 1379.

Chignik Bay: village, see Chignik.

Chignik Head: promontory, on Alaska Penin., $1,050 \mathrm{ft}$., at NE point of entrance to Anchorage Bay, $4 \mathrm{mi}$. NE of Chignik, Aleutian Ra.; $56^{\circ} 20^{\prime} \mathrm{N}, 158^{\circ} 19^{\prime} \mathrm{W}$; (map 30 ).

Name published by USC\&GS in 1954 Coast Pilot (p. 281) but not shown on recent charts. Chignik Island: island, $1.5 \mathrm{mi}$. across, in Chignik Lagoon, $8 \mathrm{mi}$. W of Chignik on Alaska Penin., 
Aleutian Ra.; $56^{\circ} 17^{\prime}$ N, $158^{\circ} 36^{\prime}$ W; (map $30)$.

Name reported in 1923 by R. H. Sargent, USGS; published in 1927 by USGS.

Chignik Lagoon: lagoon, trends NE $8 \mathrm{mi}$. to Chignik Bay, $5 \mathrm{mi}$. NW of Chignik, on Alaska Penin., Aleutian Ra.; $56^{\circ} 20^{\prime} \mathrm{N}, 158^{\circ} 29^{\prime} \mathrm{W}$; (map 30).

Locally named after Chignik Bay in 1899 by Lt. Comdr. J. F. Moser, USN, of the USBF steamer Albatross.

Chignik Lake: village, pop. 99, near Chignik Lake, $15 \mathrm{mi}$. W of Chignik on Alaska Penin., Aleutian Ra.; $56^{\circ} 14^{\prime} \mathrm{N}, 158^{\circ} 47^{\prime} \mathrm{W}$; (map $30)$.

Local name reported in Rand McNally (1966, p. 61).

Chignik Lake: lake, trends SE $8 \mathrm{mi}$, in course of Chignik River, $15 \mathrm{mi} \mathrm{W}$ of Chignik, on Alaska Penin., Aleutian Ra.; $56^{\circ} 14^{\prime} \mathrm{N}, 158^{\circ} 47^{\prime} \mathrm{W}$; (map 30).

Local name "after Chignik Bay"; reported in 1905 by A. G. Maddren, USGS.

Chignik Mountain: mountain, 3,400 ft., on Alaska Penin., $1 \mathrm{mi}$. N of Northwest Arm Castle Bay and $4 \mathrm{mi}$. SE of Chignik, Aleutian Ra.; $56^{\circ} 15^{\prime} \mathrm{N}, 158^{\circ} 21^{\prime} \mathrm{W}$; (map 30).

Local name published in 1927 by USC\&GS.

Chignik River: stream, heads at Black Lake, flows SE $20 \mathrm{mi}$. to Chignik Lagoon, $9 \mathrm{mi}$. W of Chignik, on Alaska Penin., Aleutian Ra.; $56^{\circ} 17^{\prime} \mathrm{N}, 158^{\circ} 38^{\prime} \mathrm{W}$; (map 30).

Local name reported in 1899 by Lt. Comdr. J. F. Moser, USN, of the USBF steamer Albatross, "after Chignik Bay."

Chigohaligamiut: locality, see Chigoorhaligamiut.

Chigoorhaligamiut: locality, $1 \mathrm{mi}$. S of Irwakyaruk Point, on E coast of Cape Mendenhall, Nunivak I.; $59^{\circ} 45^{\prime} 45^{\prime \prime} \mathrm{N}, 166^{\circ} 05^{\prime} 30^{\prime \prime} \mathrm{W}$; (map 55). Var. Chigohaligamiut, Chigoothaligamute.

Eskimo sealing camp reported in 1949 by USC\&GS.

Chigoothaligamute: locality, see Chigoorhaligamiut.

Chigul Island: island, see Chugul Island.

Chikak: locality, see Chekok.

Chikak: locality, see Chiukak.

Chikak Bay: bight, see Chekok May.

Chikak Creek: stream, see Chekok Creek.

Chikak Village: locality, see Chekok.

Chiknik Cape: point of land, see Siknik Cape.

Chikoominuk: lake, see Chikuminuk Lake.

Chikootna Creek: stream, flows SW $0.8 \mathrm{mi}$. to Purinton Creek E of Meadow Creek, $35 \mathrm{mi}$. NE of Palmer, Talkeetna Mts. : $61^{\circ} 49^{\prime} 10^{\prime \prime} \mathrm{N}$, $148^{\circ} 08^{\prime} 30^{\prime \prime} \mathrm{W}$; BGN 1932; (map 69). Var. Chikutna Creek.

Tanaina Indian name reported in 1932 by (G. A. Waring and L. O. Newsome, USGS. Chikululnuk Creek: stream, flows S 12 mi., joins Gemuk River to form Chukowan River, 80 mi. SW of Sleetmute, Kilbuck-Kuskokwim Mts. ; $60^{\circ} 47^{\prime} \mathrm{N}, 158^{\circ} 32^{\prime} \mathrm{W}$; BGN 1945; (map 60). Var. Cycle Creek.

Eskimo name reported in $1842-44$ by Lt. L. A. Zagoskin, IRN.
Chikuminuk Glacier: glacier, $2.5 \mathrm{mi}$. long, 8.5 mi. NW of Lake Chauekuktuli, $3 \mathrm{mi}$. E of Cascade Lake and $95 \mathrm{mi}$. SE of Bethel, Kilbuck-Kuskokwim Mts.; $60^{\circ} 07^{\prime} \mathrm{N}, 159^{\circ} 17^{\prime} \mathrm{W}$; $B G N$ 1959; (map 59). Var. Kilbuck Glacier.

Name reported in 1959 by USGS; so called because it drains into Chikuminuk Lake.

Chikuminuk Lake: lake, $16 \mathrm{mi}$. long, among Tikchik Lakes, $8 \mathrm{mi}$. $\mathrm{N}$ of Lake Chauekuktuli and $120 \mathrm{mi}$. SW of Sleetmute, Kilbuck-Kuskokwim Mts. ; $60^{\circ} 13^{\prime} \mathrm{N}, 158^{\circ} 45^{\prime} \mathrm{W}$; BGN 1932 ; (map 60). Var. Chakumnuk Lake, Chikoominuk.

Eskimo name spelled "Chikoominuk" in 1915 by USBF.

Chikungamiut: locality, on $\mathbf{E}$ shore of a lake, 2 mi. NW of Duchikthluk Bay, Nunivak I.; $59^{\circ} 51^{\prime} 30^{\prime \prime} \mathrm{N}, 166^{\circ} 19^{\prime} 50^{\prime \prime} \mathrm{W}$; (map 55). Var. Difchakimute.

Eskimo summer fish camp reported in 1949 by USC\&GS.

Chikutna Creek: stream, see Chikootna Creek. Chilcat: village, see Klukwan.

Chilcat Inlet: estuary, see Chilkat Inlet.

Chilcat Islands: islands, see Chilkat Islands.

Chilcat Lake: lake, see Chilkat Lake.

Chilcat Mountains: mountain range, see Chilkat Range.

Chilcat River: stream, see Bering River.

Chilcat River: stream, see Chilkat River.

Chilcat River: stream, see Chilkoot River.

Chilchitna River: stream, heads at $60^{\circ} 27^{\prime} \mathrm{N}$, $154^{\circ} 40^{\prime} \mathrm{W}$, flows W $35 \mathrm{mi}$. to Mulchatna River, $45 \mathrm{mi}$. NW of Nondalton, Lime Hills; $60^{\circ} 28^{\prime} \mathrm{N}, 155^{\circ} 37^{\prime} \mathrm{W}$; (map 61). Var. Chalchitna River, South Fork Mulchatna River. Indian name reported in 1914 as "Chalchitna" by R. H. Sargent, USGS, who obtained it from Thomas Hanmore, U.S. Commissioner at Iliamna. The name was published by USGS, however, as "Chilchitna."

Chilchukabena Lake: lake, $2.5 \mathrm{mi}$. long, between Muddy and Kantishna Rivers, $23 \mathrm{mi}$. E of village of Lake Minchumina, Tanana Low.; $63^{\circ} 55^{\prime} \mathrm{N}, 151^{\circ} 30^{\prime} \mathrm{W}$; (map 88 ).

Tanana Indian name shown on an undated manuscript map probably made in the 1920's. See Jim Lake.

Chilcoot: locality, see Chilkoot.

Chilcoot: village, see Haines.

Chilcoot Inlet: estuary, see Chilkoot Inlet.

Chilcoot Lake: lake, see Chilkoot Lake.

Chilcoot Pass: pass, see Chilkoot Pass.

Chilcoot Range: mountain range, see Chilkat Range.

Chilcoot River: stream, see Chilkoot River.

Childs Glacier: glacier, trends SE $8 \mathrm{mi}$. to its terminus at Copper River, $32 \mathrm{mi}$. NW of Katalla, Chugach Mts. ; $60^{\circ} 39^{\prime} \mathrm{N}, 144^{\circ} 46^{\prime} \mathrm{W}$; (map 64).

Named by Capt. W. R. Abercrombie, USA, "after George Washington Childs, of Philadelphia," during Abercrombie's earlier exploration on the Copper River in 1884.

Chileans Cabin: locality, on Fairbanks-Circle Trail (Steese Highway), $4 \mathrm{mi}$. SW of Circle, Yukon-Tanana High.; $65^{\circ} 47^{\prime} \mathrm{N}, 144^{\circ} 05^{\prime} \mathrm{W}$; (map 104).
Name of a shelter cabin reported in 1915 by G. A. Waring, USGS.

Chilikadrotna River: stream, heads at Twin Lakes, flows W $55 \mathrm{mi}$. to Mulchatna River, 46 mi. NW of Nondalton, Lime Hills; $60^{\circ} 36^{\prime} \mathrm{N}$, $155^{\circ} 23^{\prime}$ W; BGN 1931; (map 61). Var. Chilikandresten River.

Indian name reported in 1929 by $\mathbf{S}$. $\mathbf{R}$. Capps and Gerald FitzGerald, USGS. The variant Indian name was published by $P$. S. Smith (1918, p. 42), USGS.

Chilivik: village, see Selawik.

Chilivik: lake, see Selawik Lake.

Chilkaht Inlet: estuary, see Chilkat Inlet.

Chilkaht Islands: islands, see Chilkat Islands. Chilkaht River: stream, see Bering River.

Chilkat: locality, on the Chilkat Penin., on E shore of Chilkat Inlet, $2 \mathrm{mi}$. S of the center of Haines, $18 \mathrm{mi}$. SSW of Skagway, Coast Ra.; $59^{\circ} 12^{\prime} 25^{\prime \prime} \mathrm{N}, 135^{\circ} 26^{\prime} 20^{\prime \prime} \mathrm{W}$; (map 45). Var. Lahach-tak, Klahuchtak.

Former Tlingit Indian village; abandoned about 1910. The name "Chilkat" refers to a tribe of Tlingit, and means "salmon storehouse."

Chilkat: locality, at mouth of Bering River, 11 mi. E of Katalla, Malaspina Coastal Plain; $60^{\circ} 11^{\prime} \mathrm{N}, 144^{\circ} 12^{\prime} \mathrm{W}$; (map 64).

Tlingit Indian subdivision name. It was reported as a "native village" by USC\&GS in the 1890 's.

Chilkat: village, see Klukwan.

Chilkat Creek: stream, flows SW $4.5 \mathrm{mi}$. to Controller Bay, $8 \mathrm{mi}$. E of Katalla, Malaspina Coastal Plain; $60^{\circ} 11^{\prime} \mathrm{N}, 144^{\circ} 17^{\prime} \mathrm{W}$; (map 64).

Tlingit Indian name given to this stream by prospectors in 1903 and reported in 1904 by G. C. Martin (1905, p. 13), USGS.

Chilkat Glacier: glacier, trends NW $12 \mathrm{mi}$. to its terminus at head of Chilkat River in British Columbia, 26 mi. NW of Skagway, Coast Mts.; $59^{\circ} 45^{\prime} 00^{\prime \prime}$ N, $135^{\circ} 48^{\prime} 30^{\prime \prime}$ W; (map 45). Var. Leslie Glacier.

So named by IBC survey party in 1922 , "because it is at the head of the Chilkat River." This may be the "Leslie Glacier" named in 1890 by the Frank Leslie's Illustrated Newspaper expedition.

Chilkat Inlet: estuary, trends $16 \mathrm{mi}$. S from mouth of Chilkat River to Lynn Canal, 31 mi. S of Skagway, Coast Mts. and St. Elias Mts.; 59 $05^{\prime} \mathrm{N}, 135^{\circ} 21^{\prime} \mathrm{W}$; (map 45). Var. Chilcat Inlet, Chilkaht Inlet, Tchillkat Inlet, Tsilkat Inlet.

Named by Comdr. R. W. Meade, USN, in 1880 for the Chilkat River and published by USC\&GS in the 1883 Coast Pilot (p. 196).

Chilkat Islands: islands, group of islands at $\mathbf{N}$ end of Lynn Canal, $2.5 \mathrm{mi}$. NE of Sullivan I. and $30 \mathrm{mi}$. S of Skagway, Coast Mts.; $59^{\circ} 02^{\prime}$ N, $135^{\circ} 16^{\prime} \mathrm{W}$; (map 45). Var. Chilcat Islands, Chilkaht Islands, Tschilkat Islands, Tchillkat Islands, T'silkat Islands.

Named in 1880 by Capt. L. A. Beardslee, USN, and published by USC\&GS in the 1883 Alaska Coast Pilot (p. 196). The islands 
include Kataguni, Shikosi, Anyaka, and Talsani Islands.

Chilkat Lake: lake, $6 \mathrm{mi}$. long, trends NW, $3 \mathrm{mi}$. SW of Klukwan and $23 \mathrm{mi}$. SW of Skagway, St. Elias Mts.; $59^{\circ} 21^{\prime} 40^{\prime \prime} \mathrm{N}, 135^{\circ} 56^{\prime} 00^{\prime \prime} \mathrm{W}$; (map 45). Var. Chilcat Lake, Tschilkat See.

Named for the Chilkat tribe of Tlingit Indians by the U.S. Navy in 1880. The name was published by USC\&GS in the 1883 Coast Pilot (p. 198). It was called "Tschilkat S[ee]," or "Tschilkat Lake," by Aurel and Arthur Krause (1883, map).

Chilkat Peak: peak, 6,100 ft., $1.3 \mathrm{mi}$. NW of Four Winds Mtn. and $2.5 \mathrm{mi}$. SE of Mount Prinsep, on the Alaska-Canada boundary, 30 mi. W of Skagway, St. Elias Mts.; 59 $30^{\prime} 20^{\prime \prime}$ $\mathrm{N}, 136^{\circ} 10^{\prime} 30^{\prime \prime} \mathrm{W}$; (map 45).

Named in 1880 by Gapt. Beardslee, USN; published in the 1883 Coast Pilot (p. 198).

Chilkat Peninsula: peninsula, between Chilkat Inlet and Chilkoot Inlet, extends NNW $11 \mathrm{mi}$. from Seduction Point to Haines, $20 \mathrm{mi}$. S of Skagway, Coast Mts.; $59^{\circ} 10^{\prime} \mathrm{N}, 135^{\circ} 22^{\prime} \mathrm{W}$; $B G N$ 1931; (map 45). Var. Yayik Peninsula.

Named for Chilkat Inlet by C. W. Wright (1904, p. 9), USGS. It was called "Yayik Peninsula" in 1923 by IBC on map 9 (1951 atlas).

Chilkat Range: mountain range, $70 \mathrm{mi}$. long, extends from near Chuck Inlet at the head of the Lynn Canal S to Icy Strait, $26 \mathrm{mi}$. W of Juneau, St. Elias Mts.; $59^{\circ} 10^{\prime} \mathrm{N}, 135^{\circ} 35^{\prime}$ $\mathrm{W}$ [ $\mathrm{N}$ end], $58^{\circ} 15^{\prime} \mathrm{N}, 135^{\circ} 15^{\prime} \mathrm{W}$ [S end]; $B G N$ 1937; (maps 11, 45). Var. Chilcat Mountains, Chilkat Mountains, Chilkoot Mountains, Chilcoot Range, Kotush Mountains, Tschil-kut Mountains.

Named "Chilkat Mountains" in 1879 by USC\&GS for the Chilkat subdivision of the Tlingit Indians. These mountains were called the "Chilkat Range" in 1891 Coast Pilot (p. 202)

Chilkat River: stream, heads at Chilkat Glacier, in Coast Mts. in British Columbia, flows $\mathrm{S}$ and SW $52 \mathrm{mi}$. to head of Chilkat Inlet $1 \mathrm{mi}$. SW of Haines and $18 \mathrm{mi}$. SSW of Skagway, St. Elias Mts.; $59^{\circ} 12^{\prime} 30^{\prime \prime} \mathrm{N}, 135^{\circ} 28^{\prime} 30^{\prime \prime} \mathrm{W}$; $B G N$ 1954; (map 45). Var. Chilcat River, Tchillkat River, Tschilkathin, Tsilkat River, Tsl-kaht River.

Named by the Russians for the Chilkat tribe of Tlingit Indians living in this region. The Indian name "Tschilkathin" was reported by Aurel and Arthur Krause (1883, map).

Chilkat River: stream, see Bering River.

Chilkat River: stream, see Kelsall River.

Chilkogamina Lake: lake, see Jim Lake.

Chilkoot: locality, between Lutak Inlet and Chilkoot Lake, in course of Chilkoot River, $12 \mathrm{mi}$. SW of Skagway, Coast Mts.; $59^{\circ} 20^{\prime} 00^{\prime \prime} \mathrm{N}$, $135^{\circ} 33^{\prime} 10^{\prime} \mathrm{W} ; B G N$ 1892; (map 45). Var. Chilcoot, Tananei, Tenany, Tschilküt.

Former Tlingit village named for the Chilkoot Tribe that lived there. In the 1880 Census, Ivan Petroff listed "Chilcoot." The population in 1890 , including the mission, was
106. In 1881 the U.S. Navy recorded "Chilcoot or Tananei." Aurel and Arthur Krause (1883, map) spelled the name "Tschilkūt." Reported as "Tenany, an Indian fishing village," by C. M. Willard (1884, p. 140).

Chilkoot Barracks: village, see Port Chilkoot.

Chilkoot Inlet: estuary, heads at SE end of Takshanuk Mts., trends S $20 \mathrm{mi}$. to Lynn Canal S of Chilkat Is., $32 \mathrm{mi}$. $\mathbf{S}$ of Skagway, Coast Mts. ; $59^{\circ} 00^{\prime} \mathrm{N}, 135^{\circ} 13^{\prime} \mathrm{W}$; (map 45). Var. Chilcoot Inlet, False Chilkaht, Tschillkat Inlet.

Names for the tribe of Tlingit Indians, who had a village at its head. It was called "False Chilkaht" or "Tschillkat Inlet" by Comdr. R. W. Meade, USN, in the 1883 Coast Pilot (p. 199). The estuary was called "Chilcoot Inlet" by Aurel and Arthur Krause (1883, map).

Chilkoot Lake: lake, $3.6 \mathrm{mi}$. long, in course, near mouth of Chilkoot River, NW of Chilkoot and $12 \mathrm{mi}$. SW of Skagway, Coast Mts. ; $59^{\circ} 20^{\prime} 15^{\prime \prime}$ $\mathrm{N}, 135^{\circ} 33^{\prime} 30^{\prime \prime} \mathrm{W}$; (map 45). Var. Akha Lake, Chilcoot Lake, Tschilkūt See.

Named for the Chilkoot tribe of Tlingit Indians, who lived on its shores. It was called "Chilcoot" or "Akha" in the 1883 Coast Pilot (p. 200). Aurel and Arthur Krause (1883, map) called it "Tschilkūt S[ee]."

Chilkoot Mountains: mountain range, see Chilkat Range.

Chilkoot Pass: pass, 3,739 ft. on Alaska-Canada boundary, $4.1 \mathrm{mi}$. NE of Mount Hoffman and $17 \mathrm{mi}$. N of Skagway, Coast Mts. ; $59^{\circ} 41^{\prime} 50^{\prime \prime}$ N, 135'13'50' W; BGN 1954; (map 45). Var. Chilcoot Pass, Chilkoot Portage, Dejah Pass, Dyea Pass, False Chilkat Pass, Perrier Pass, Shaseki Pass.

Local name published by USC\&GS as "Chilkoot Portage" and "Shasheki Pass" in the 1883 Alaska Coast Pilot (p. 278 and 200). It was called "Perrier Pass" by Lt. Frederick Schwatka, USA, in 1883. The Indian name "Dejah" was published by Arthur and Aurel Krause (1883, map). The first known crossing of this pass by a "white man" was made in 1864 or 1865 by an employee of the Hudson's Bay Co., who started at Fort Selkirk and was delivered by the Chilkoot Indians to Capt. Swandson (cnna), commander of one of the company's steamers. The first expedition to cross the pass was that of George Holt in 1875, who travelled from Lynn Canal to the headwaters of the Yukon River. With the discovery of gold in the Yukon in the 1870's, this pass was used by many prospectors and during the Klondike Gold Rush in 1896, the Dyea-Chilkoot Pass route became one of the important routes to the gold fields.

Chilkoot Portage: pass, see Chilkoot Pass.

Chilkoot River: stream, heads at glacier terminus, flows SE, through Chilkoot Lake, $20 \mathrm{mi}$. to Lutak Inlet, $12 \mathrm{mi}$. SW of Skagway, Coast Mts.; $59^{\circ} 19^{\prime} 30^{\prime \prime} \mathrm{N}, 135^{\circ} 33^{\prime} 00^{\prime \prime} \mathrm{W}$; (map 45). Var. Chilcat River, Chilcoot River, Deyea River, Kachkahin River, Katschkahin River.

Tlingit Indian name published by USC\&GS in the 1883 Coast Pilot as "Chilcoot". The
Tlingit name "Katschkahín" was recorded by Aurel and Arthur Krause (1883, map) for the part of the river above the lake. The part of the river between Lutak Inlet and Chilkoot Lake was called "Deyea" on U.S. Navy Hydrog. Chart 883 in 1881

Chilligan River: stream, heads at glacier $10 \mathrm{mi}$. E of Snowcap Mtn., flows SE 27 mi. to Chakachamna Lake, $54 \mathrm{mi}$. NW of Tyonek, Alaska Ra.; $61^{\circ} 13^{\prime} \mathrm{N}, 152^{\circ} 45^{\prime} \mathrm{W}$; BGN 1930; (map $70)$.

Named for Chief Chilligan of Tyonek, "who built a cabin on this river about 1896"; reported in 1929 by USGS.

Chillimiut: village, see Golovin.

Chilly Creek: stream, see Little Harris Creek. Chiloghumut: locality, $2 \mathrm{mi}$. W of Chilok Lake and $70 \mathrm{mi}$. NW of Bethel, Yukon-Kuskokwim Delta; $60^{\circ} 69^{\prime} \mathrm{N}, 163^{\circ} 50^{\prime} \mathrm{W}$; (map 58).

Eskimo camp or small settlement reported in 1949 by USC\&GS.

Chilok Lake: lake, $3 \mathrm{mi}$. across, $2 \mathrm{mi}$. $\mathrm{N}$ of Kaghasuk Lake and $68 \mathrm{mi}$. NW of Bethel, Yukon-Kuskokwim Delta; $60^{\circ} 59^{\prime} \mathrm{N}, 163^{\circ} 43^{\prime}$ W; (map 58). Var. Groves Lake.

Eskimo name reported in 1949 by USC\&GS. Chimechliachamut: locality, see Chimekliak. Chim-e-kliág-a-mut: locality, see Chimekliak. Chimekliak: locality, $1 \mathrm{mi}$. NE of Beacon Point, on left bank of Kuskokwim River, $50 \mathrm{mi}$. SW of Bethel, Yukon-Kuskokwim Delta; $60^{\circ} 06^{\prime} \mathrm{N}$, $162^{\circ} 13^{\prime} \mathrm{W}$; (map 58). Var. Chenik, Chimechliachamut, Chim-e-kliág-a-mut, Chimiagamute, Chimiak, Chimingyangamute.

Eskimo village reported on an 1898 fieldsheet by W. S. Post, USGS, as "Chim-e-kliága-mut"; name was obtained from J. H. Kilbuck, Moravian missionary. "This may be identical with 'Chenik' of a Russian Admiralty chart of 1802"' (Baker, 1906, p. 178). Ivan Petroff, in the 10th Census, in 1880, calls it "Chimiagamute" with 71 people; the 1890 Census lists it as "Chimingyangamute" with 40 people.

Chimenchun Creek: stream, heads in lake, flows NE $4.5 \mathrm{mi}$. to Naknek River at Horseshoe Bend, on Alaska Penin., $6.8 \mathrm{mi}$. SE of Naknek, Bristol Bay Low; $58^{\circ} 42^{\prime} 36^{\prime \prime} \mathrm{N}, 156^{\circ}$. 49'30" W; (map 41).

Eskimo name reported in 1952 by USGS. Chimenchun Point: bluff, elev. $25 \mathrm{ft}$., on $\mathrm{S}$ bank of Naknek River, on Alaska Penin., $7 \mathrm{mi}$. SE of Naknek, Bristol Bay Low.; 58 $42^{\prime} 45^{\prime \prime} \mathrm{N}$, $156^{\circ} 49^{\prime} 00^{\prime \prime} \mathrm{W}$; (map 41).

Eskimo name reported in 1952 by USGS.

Chimiagamute: locality, see Chimekliak.

Chimiak: locality, see Chimekliak.

Chimingyangamute: locality, see Chimekliak. Chimiudi Islands: islands, see Kudiakof Islands.

Chimney Cove: cove, $0.5 \mathrm{mi}$. across, on $\mathrm{S}$ coast of Avatanak I., Aleutian Is.; 54 $04^{\prime} 20^{\prime \prime} \mathrm{N}$, $165^{\circ} 21^{\prime} 50^{\prime \prime} \mathrm{W}$; BGN 1936; (map 24).

Named in 1935 by USC\&GS because a large rock resembling a chimney is located on the cove.

Chimney Fork: stream, flows S $4 \mathrm{mi}$. from a lake in Chimney Pass, joins Roy Creek to form Glacier River, 27 mi. NW of Wiseman, Brooks 
Ra.; $67^{\circ} 42^{\prime} 45^{\prime \prime} \mathrm{N}, 150^{\circ} 26^{\prime} 00^{\prime \prime} \mathrm{W}$; (map 124).

Named about 1930 by Robert Marshall for the mountain.

Chimney Mountain: mountain, 7,450 ft., between Regal and Rohn Glaciers, $24 \mathrm{mi}$. NE of McCarthy, Wrangell Mts. ; $61^{\circ} 44^{\prime} \mathrm{N}, 142^{\circ}$ $30^{\prime} \mathrm{W}$; (map 67).

Descriptive name reported by Capps (1916, pl. 1), USGS.

Chimney Mountain: mountain, 4,200 ft. S of Chimney Pass, $24 \mathrm{mi}$. NW of Wiseman, Brooks Ra.; $67^{\circ} 44^{\prime} \mathrm{N}, 150^{\circ} 33^{\prime} \mathrm{W}$; BGN 1932; (map 124).

Named in 1931 by Marshall (1956, p. 68) who wrote, "All the way up the valley we kept looking back at this gigantic rock which bore a striking resemblance to Chimney Rock in the Kaniksu National Forest in Idaho. We called it Chimney Mountain."

Chimney Pass: pass, 2,500 ft., N of Chimney Mtn, between valleys of Clear River and Chimney Fork, $26 \mathrm{mi}$. NW of Wiseman, Brooks Ra.; $67^{\circ} 46^{\prime} \mathrm{N}, 150^{\circ} 30^{\prime} \mathrm{W}$; (map 124).

Named about 1930 by Robert Marshall for the mountain.

Chimney Rock: rock, in Port Frederick S of Neka Bay, $8.5 \mathrm{mi}$. SW of Hoonah, Alex. Arch.; $58^{\circ} 01^{\prime} 25^{\prime \prime} \mathrm{N}, 135^{\circ} 36^{\prime} 30^{\prime \prime} \mathrm{W}$; (map 11).

Descriptive name published in 1923 by USC\&GS.

Chimyudy, Ostrova: islands, see Kudiakof Islands.

Chinabora, Mount: mountain, see Augustine Volcano.

China Cove: bay, $1.7 \mathrm{mi}$. wide, S coast of Coronation I., Alex. Arch.; 55 $50^{\prime} 15^{\prime \prime} \mathrm{N}$, $134^{\circ} 15^{\prime} 40^{\prime \prime}$ W; BGN 1961; (map 4).

Named by the commander of the USC\&GS steamer Hodgson in 1960; "based on the wreck in 1908 of the vessel Star of Bengal * * * A total of 110 lives were lost of which all but 15 were Orientals."

China Hills: mountains, see Link Hills.

Chinaldna Creek: stream, see Chunilna Creek. Chinalno Creek: stream, see Chunilna Creek.

Chinaltno Creek: stream, see Chunilna Creek.

Ghinaman Lagoon: lagoon, $1.8 \mathrm{mi}$. long, along W shore of Pavlof Bay, Alaska Penin., Aleutian Ra.; 55 $30^{\prime} 00^{\prime \prime} \mathrm{N}, 161^{\circ} 42^{\prime} 30^{\prime \prime} \mathrm{W}$; (map 28).

Local name reported by USGS in 1929.

Chinaman Slough: stream, a distributary of Abercrombie Creek, flows S $1.7 \mathrm{mi}$. to Miles Lake, $35 \mathrm{mi}$. N of Katalla, Chugach Mts.; $60^{\circ} 41^{\prime} \mathrm{N}, 144^{\circ} 44^{\prime} \mathrm{W}$; (map 64).

Local name reported by Moffit (1914, pl. 1), USGS.

Chin-ana; stream, see Kuskokwim River.

China Poot Bay: lagoon, $2.5 \mathrm{mi}$. wide, on E shore of Kachemak Bay, on Kenai Penin., 9 mi. SE of Homer, Chugach Mts.; $59^{\circ} 34^{\prime} \mathrm{N}, 151^{\circ} 19^{\prime}$ W; (map 50). Var. Chinaput Bay.

Local name reported in 1911 by G. C. Martin (in Grant and Higgins, 1913, pl. 2), USGS.
Chinaput Bay: lagoon, see China Poot Bay. China River: stream, see Tsina River.

China Town: locality, on $\mathbf{N}$ coast of Annette I., near Walden Point, Alex. Arch.; 55 $16^{\prime} 20^{\prime \prime} \mathrm{N}$, $131^{\circ} 35^{\prime} 25^{\prime \prime} \mathrm{W}$; (map 3 ).

Local name recorded in 1948 by USGS.

Chinchan Bay: bay, see Akutan Harbor.

Chinchinbrook Island: island, see Hinchinbrook Island.

Chindagmund Lake: lake, $1.1 \mathrm{mi}$. long, between Kalukna and Tetlin Rivers, $17 \mathrm{mi}$. W of Northway Junction, Alaska Ra.; $63^{\circ} 00^{\prime} \mathrm{N}, 142^{\circ} 20^{\prime}$ W; (map 85)

Tetlin Indian name, said to mean "Moose Lick Lake"; reported by USGS in 1962.

Chineekluk Creek: stream, heads in lake, in Chuilnuk Mts., flows W $18 \mathrm{mi}$. to Holokuk River S of Holokuk Mtn., 16 mi. SE of Little Mountain Village and $43 \mathrm{mi}$. SW of Sleetmute, Kilbuck-Kuskokwim Mts.; $51^{\circ} 22^{\prime} \mathrm{N}$, $158^{\circ} 19^{\prime} \mathrm{W}$; BGN 1948; (map 72).

Name taken from mountain nearby; reported in 1945 by USGS.

Chineekluk Mountain: mountain, 1,500 ft., in Kuskokwim Mts. on S bank of Chineekluk Creek, $37 \mathrm{mi}$. SW of Sleetmute and $50 \mathrm{mi}$. SE of Aniak, Kilbuck-Koskokwim Mts.; $61^{\circ}$. $22^{\prime} \mathrm{N}, 158^{\circ} 05^{\prime} \mathrm{W}$; BGN 1948; (map 72).

Eskimo name meaning "pointed"; reported in 1945 by USGS.

Chineleat: village, see Chaniliut.

Chingeeruk Point: point of land, extends into Bering Sea, at NE end of Nash Harbor, 26 mi. SW of Cape Etolin, on N coast of Nunivak I.; $60^{\circ} 16^{\prime} 15^{\prime \prime} \mathrm{N}, 166^{\circ} 50^{\prime} 00^{\prime \prime} \mathrm{W}$; (map 57). Var. Chingirak Point.

Eskimo name meaning "point of land" reported in 1949 by USC\&GS.

Chingekigtlik Mountain: mountain, 1,200 ft., $26 \mathrm{mi}$. E of Jacksmith Bay, $35 \mathrm{mi}$. NE of Goodnews, Kilbuck-Kuskokwim Mts. ; $59^{\circ} 30^{\prime}$ $\mathrm{N}, 161^{\circ} 00^{\prime} \mathrm{W}$; (map 53$)$.

Eskimo name reportedly meaning "sharp one ;" published in 1951 by USGS.

Chingeleth Point: promontory, see Corwin, Cape.

Chingirak Point: point of land, see Chingeeruk Point.

Ching-myut: village, see Golovin.

Chiniak: locality, "on the E end of Kodiak Island;" (map 32 or 35).

Former Eskimo village reported by Ivan Petroff in the 1880 Census.

Chiniak, Cape: point of land, $\mathrm{S}$ point of entrance to Chiniak Bay, 15 mi. SE of Kodiak, Kodiak I.; $57^{\circ} 37^{\prime} \mathrm{N}, 152^{\circ} 10^{\prime} \mathrm{W}$; BGN 1901; (map (34). Var. Broad Point, Cape Chiniatskoi, Cape Granville, Cape Greville, Cape Hermogenes, Chinik, Elovoi, Mys Chiniatskiy, Tolstoi, Tuniak Point.

Aleut name reported in 1888 by Lt. Comdr. Tanner, USN, of the USBF steamer Albatross. Named "Cape Greville" on June 8, 1778, by Capt. Cook (1785, v. 2, p. 405-406) who wrote, "The land here forms a point, which was named Cape Greville *** and is distant fifteen leagues from Cape St. Hermogenes, in the direction of $\mathrm{S}, 17^{\circ} \mathrm{W} * * *$, Baker
(1906, p. 179) reports "von Langsdorf[f] identifies it [Cape Chiniak] with Cape Hermogenes of Bering, 1741. The Russians usually called it "Tolstoi' (broad) * * *." This is incorrect as the name "Tolstoy" is applied to Cape Greville by the Russians. This feature was identified as "Mys Chiniatskiy," or "Chiniat Cape," by Lt. Sarichev (1826, map 16), IRN, and as "Mys Chiniak," or "Chiniak Cape," by Capt. Tebenkov (1852, map 23), IRN. See Cape Greville.

Chiniak, Cape: point of land, $\mathrm{N}$ point of entrance to Hallo Bay, on NE coast of Alaska Penin., in Katmai National Monument, $43 \mathrm{mi}$. NE of Mount Katmai, Aleutian Ra.; 58 $31^{\prime}$ $00^{\prime \prime} \mathrm{N}, 153^{\circ} 54^{\prime} 30^{\prime \prime} \mathrm{W}$; (map 43). Var. Cape Chiniakskie, Cape Chiniatskiy, Cape Chiniatskoy, Cape Tchineyak, Cape Tuniak.

Native name published by Lt. Sarichev (1826, map 16), IRN, as "M[ys] Chiniatskiy," or "Cape Chiniat," and by the Russian American Company as "M[ys] Chiniakskiy," or "Cape Chiniak," in 1849. The U.S. Navy Hydrog. Office in 1869 called this feature "Tuniak Point (Tchineyak);" it was later changed to "Cape Chiniak" by USC\&GS.

Chiniak, Mys: point of land, see Shakmanof Point.

Chiniak, Seleniye: locality, see Aleksashkina.

Chiniak Bay: bay, $14 \mathrm{mi}$. across, on NE coast of Kodiak I., $57^{\circ} 42^{\prime} \mathrm{N}, 152^{\circ} 20^{\prime} \mathrm{W}$; BGN 1890; (map 34). Var. Chiniat Bay, Tuniak Bay, Zaliv Chiniatskiy.

Aleut name published as "Zaliv Chiniatskiy" or "Chiniat Bay" by Lt. Sarichev (1826, map 16), IRN. Baker (1906, p. 179) wrote, "*** Chiniak is Aleut for a rocky, impassable, wretched sea." Accordingly to R. H. Geoghegan, "the name comes from the Aleut 'Chingaq,' which I do not interpret as a rocky, impassable, wretched sea."

Chiniak Island: island, $0.3 \mathrm{mi}$. across, $\mathrm{N}$ of Cape Chiniak, $15 \mathrm{mi}$. SE of Kodiak, Kodiak I.; $57^{\circ} 37^{\prime} 35^{\prime \prime} \mathrm{N}, 152^{\circ} 09^{\prime} 00^{\prime \prime} \mathrm{W}$; (map 34). Var. Giniak Island, Ostrov Chiniakskoy.

Aleut name, derived from Cape Chiniak. Identified as "Giniak Island" in 1803-06 by von Langsdorff (1813-14, v. 2, p. 56) who said Cape Chiniak "is bounded to the north by two small islands, one of which in the language of the country, is called Giniak * * *." In 1849 the Russian American Company published the name "Os[trov] Chiniakskoy," or "Chiniak Island," for this feature.

Chiniak Lake: lake, $1 \mathrm{mi}$. across, on $\mathrm{S}$ shore of Chiniak Bay, 15 mi. SE of Kodiak, Kodiak I. ; $57^{\circ} 37^{\prime} \mathrm{N}, 152^{\circ} 11^{\prime} \mathrm{W}$; (map 34).

Name published in 1952 by USGS; derived from Cape Chiniak.

Chiniakskie, Cape: point of land, see Chiniak, Cape.

Chiniakskoy, Ostrov: island, see Chiniak Island. Chiniat Bay: bay, see Chiniak Bay.

Chiniatskiy, Cape: point of land, see Chiniak, Cape.

Chiniatskiy, Mys: point of land, see Chiniak, Cape.

Chiniatskiy, Zaliv: bay, see Chiniak Bay. 
Chiniatskoi, Cape: point of land, see Chiniak, Cape.

Chiniatskoy, Cape: point of land, see Chiniak, Cape.

Chinick : village, see Golovin.

Chinig-myut: village, see Golovin.

Chinigyak Cape: point of land, on SW coast of Nelson I., $12 \mathrm{mi}$. SE of Cape Vancouver, Yukon-Kuskokwim Delta; $60^{\circ} 27^{\prime} \mathrm{N}, 165^{\circ} 08^{\prime}$ W; (map 57).

Eskimo name obtained at Tanunak in 1949 by USC\&GS

Chinik: locality, "on S bank of Yukon River, near Yukon-Kuskokwim portage" in YukonKuskokwim Delta; (map 73). Var. Odinochka Chinik, Tchinik.

Former Indian village reported as "Tchinik" by Lt. L. A. Zagoskin, IRN, on an 1850 map.

Chinik: village, see Golovin.

Chinik: point of land, see Chiniak, Cape.

Chiniklik, Mount: mountain, 2,620 ft., at SW end of Ilivit Mts. $12 \mathrm{mi}$. N of Russian Mission, Nulato Hills; $61^{\circ} 57^{\prime} 15^{\prime \prime} \mathrm{N}, 161^{\circ} 11^{\prime} 50^{\prime \prime}$ W; (map 73). Var. Chinik Mountain, Tschiniklik.

Eskimo name reported in Russian by Lt. L. A. Zagoskin, IRN, as "Sopki Chiniklik" or "Mount Chiniklik."

Chinikluk Slough: water course, in Yukon Delta, extends E-W $5.5 \mathrm{mi}$. between Apoon and Kwikpak Passes, Yukon-Kuskokwim Delta; $62^{\circ} 54^{\prime} \mathrm{N}, 163^{\circ} 56^{\prime} \mathrm{W}$; (map 77).

Eskimo name obtained in 1952 by U.S. Army Corps of Engineers.

Chinik Mountain: mountain, see Chiniklik, Mount.

Chinila: locality, "on the E side of Cook Inlet" near the mouth of Kenai River, Cook Inlet Low.; (map 62). Var. Chernila, Chernilof. Former Indian village listed as "Ghernila" with a population of 15 in the 1880 Census by Ivan Petroff.

Chinit Cape: point of land, see Chinit Point.

Chinitna, Mount: mountain, 3,100 ft., at NE end of Tilted Hills on Iniskin Penin., Aleutian Ra.; $59^{\circ} 48^{\prime} \mathrm{N}, 153^{\circ} 01^{\prime} \mathrm{W}$; (map 51).

Local name derived from Chinitna Bay; published in 1912 on USC\&GS Chart 8554.

Chinitna Bay: bay, extends W $14 \mathrm{mi}$. off Cook Inlet, N of Iniskin Penin., Aleutian Ra.; 59 ${ }^{\circ}$ $51^{\prime} \mathrm{N}, 152^{\circ} 54^{\prime} \mathrm{W}$; (map 50). Var. Chinitua Bay.

Indian name published in 1898 as "Chinitua" by USC\&GS.

Chinitnak River: stream, see Cheeneetnuk River.

Chinitna Point: point of land, on $\mathrm{E}$ coast of Iniskin Penin., on SW shore of Cook Inlet, Aleutian Ra.; $59^{\circ} 41^{\prime} 30^{\prime \prime} \mathrm{N}, 153^{\circ} 03^{\prime} 10^{\prime \prime} \mathrm{W}$; (map 51).

Name published in 1912 on USC\&GS Chart 8554.

Chinitna River: stream in Chigmit Mts., flows SE 5 mi. to Chinitna Bay, Aleutian Ra.; $59^{\circ}$ $49^{\prime} 15^{\prime \prime} \mathrm{N}, 153^{\circ} 17^{\prime} 10^{\prime \prime} \mathrm{W}$; BGN 1962; (map 51). Var. Squawgirl Creek.
Local name derived from Chinitna Bay; published in 1958 by USGS.

Chinit Point: point of land, on NW coast of Nelson I., $7 \mathrm{mi}$. NE of Cape Vancouver, YukonKuskokwim Delta; 60 $37^{\prime} \mathrm{N}, 165^{\circ} 15^{\prime} \mathrm{W}$; (map 57). Var. Chinit Cape.

Eskimo name meaning "points of land" refers specifically to Igvak Point, Uiakuiak Point, and Uialigetegevet Point; name obtained at Tanunak in 1949 by USC\&GS.

Chinitua Bay: bay, see Chinitna Bay.

Chinkelyes Creek: stream, heads in Chigmit Mts. and flows SW $13 \mathrm{mi}$. through Summit Lakes to Iliamna River, $32 \mathrm{mi}$. NW of Augustine I., Aleutian Ra.; $59^{\circ} 45^{\prime} \mathrm{N}, 153^{\circ} 52^{\prime} \mathrm{W}$; (map 51).

Name published by Martin and Katz (1912, pl. 1), USGS.

Chin Point: point of land, $\mathrm{N}$ point of entrance to Neets Bay, $S$ of Nose and Brow Points, on NW coast of Revillagigedo I., Alex. Arch.; $55^{\circ} 47^{\prime} 20^{\prime \prime} \mathrm{N}, 131^{\circ} 42^{\prime} 00^{\prime \prime} \mathrm{W}$; (map 3 ).

Named in 1891 by USC\&GS; Brow and Nose Points are nearby.

Chiokuk: locality, see Chiukak.

Chiookak: locality, see Chiukak.

Chiookuk: locality, see Chiukak.

Chip Cove: $b a y, 0.2 \mathrm{mi}$. across, on $\mathrm{W}$ shore of Moser Bay, in SW part of Kodiak I., $40 \mathrm{mi}$. $\mathrm{SE}$ of Karluk; $57^{\circ} 01^{\prime} 30^{\prime \prime} \mathrm{N}, 154^{\circ} 08^{\prime} 20^{\prime \prime} \mathrm{W}$; (map 35).

Named in 1900 by Lt. Comdr. J. F. Moser, USN, commander of the USBF steamer Albatross from 1897 to 1901 , who made investigations and surveys in this area.

Chi Point: point of land, on SE shore of Lake Clark, $13 \mathrm{mi}$. NE of Nondalton, Aleutian Ra.; $60^{\circ} 07^{\prime} \mathrm{N}, 154^{\circ} 33^{\prime} \mathrm{W}$; (map 61).

Local name reported in 1954 by USGS.

Chipp Peak: mountain, 2,550 ft., $15 \mathrm{mi}$. NW of Petersburg, on $\mathrm{N}$ coast of Lindenberg Penin., Kupreanof I., Alex. Arch.; 56 $59^{\circ} 30^{\prime \prime} \mathrm{N}$, $133^{\circ} 11^{\prime} 00^{\prime \prime} \mathrm{W}$; (map 6).

Named in 1887 by Lt. Comdr. C. M. Thomas, USN, for Lt. Charles Winans Chipp, USN, who perished near the Lena River delta in Siberia, November 1881.

Chipp River: stream, western distributary of Ikpikpuk River, heads at $70^{\circ} 19^{\prime} 35^{\prime \prime} \mathrm{N}, 154^{\circ}$. 53'50" W, flows NW $70 \mathrm{mi}$. to Admiralty Bay, $\mathrm{S}$ of Dease Inlet, Arctic Plain; $70^{\prime} 50^{\prime} \mathrm{N}, 155^{\circ}$ $36^{\prime} \mathrm{W}$; BGN 1925; (map 148). Var. Cheep River.

As a footnote to Ens. W. L. Howard's report on his trip from the Kobuk River to Point Barrow, in the spring of 1886 , when mentioning the Eskimo name for the stream as "Ikpikpuk," Lt. G. M. Stoney $(1900$, p. 73) states "I renamed this river the 'Chipp' after $L t$. 'Chipp,' [Charles Winans, USN] who was lost on the Jeannette expedition [De Long expedition in 1881]." The BGN in 1925, however, retained the Eskimo name for the main stream, and reapplied the name "Chipp" to the west distributary of the Ikpikpuk River.

Chipp River: stream, see Ikpikpuk River.
Chips Island: island, in Koyukuk River, $43 \mathrm{mi}$ SW of Roundabout Mtn., Koyukuk Low.; $65^{\circ} 08^{\prime} \mathrm{N}, 157^{\circ} 40^{\prime} \mathrm{W}$; (map 108).

Local name published by USGS in 1959. "Chips Cabin" is located opposite this island.

Chips Slough: stream, anabranch of Koyukuk River, $2 \mathrm{mi}$. long, $43 \mathrm{mi}$. SW of Roundabout Mtn., Koyukuk Low.; $65^{\circ} 06^{\prime}$ N, $157^{\circ} 39^{\prime} \mathrm{W}$; (map 108).

Local name published by USGS in 1959. "Chips Cabin" is located nearby.

Chirikof Bay: water passage, see Chatham Strait.

Chirikof Beach: beach, $0.3 \mathrm{mi}$. long, on $\mathrm{E}$ coast of Attu I., Aleutian Is.; $52^{\circ} 50^{\prime} 40^{\prime \prime} \mathrm{N}, 173^{\circ}$ $25^{\prime} 30^{\prime \prime} \mathrm{E}$; (map 13).

Named by the U.S. Army during its occupation of the island during World War II ; shown on an AMS map published in 1948

Chirikoff: island, see Chirikof Island.

Chirikoff, Cape: point of land, SW tip of Baker I., 1 mi. S of Granite Point, Alex. Arch.; $55^{\circ} 18^{\prime} 10^{\prime \prime} \mathrm{N}, 133^{\circ} 41^{\prime} 10^{\prime \prime} \mathrm{W}$; BGN 1923; (map 4).

Named in 1923 by USC\&GS for Capt. Alexei Ilich Chirikov, commander of the vessel St. Paul, who accompanied Vitus Bering in 1741 .

Chirikoff, Cape: point of land, see Ommaney, Cape.

Chirikoff, Point: point of land, see Bartolome, Cape.

Chirikof Island: island, $11 \mathrm{mi}$. long, in Pacific Ocean, $100 \mathrm{mi}$. SW of Kodiak I.; $55^{\circ} 50^{\prime} \mathrm{N}$, $155^{\circ} 37^{\prime} \mathrm{W}$; $B G N$ 1890; (map 32). Var. Akamok, Chirikoff, Chirikov, Elkamok, Foggy Island, Isla Infante, Ookamok, Oukamok, Tchirikoff, Tscherikow, Tscherikow's Island, Tschirikoff, Tumannoi, Ugamok, Ukamok, Yukamak.

Name published by USC\&GS in 1868 Baker $(1906$, p. 179-80) says "*** The island appears to be the Tumannoi (foggy) Island of [Vitus] Bering, 1741 * * *." Capt. James Cook (1785, v. 2, p. 410), RN, in 1778 says " ** * and it is distinguished in our chart by the name of Foggy Island; having reason to believe, from its situation, that it is the same which had the name given to it by Beering * * * Capt. Vancouver (1798, v. 3 , p. 87), RN, says "*** I have in honor of Beering's companion * * * [Capt. Alexei Cherikov] called this island Tscherikow's Island * * *." The native name "Ukamok" was published by von Langsdorff (1814, v. 2, p. 54). Lt. Sarichev (1826, map 3), IRN, and Capt. Tebenkov (1852, map 22), IRN, published the name "O[strov] Ukamok ili Chirikov" (Ukamok or Chirikov Island). See Keithahn (1962, p. 16). This may be the island called "Isla Infante" by Martínez on July 5, 1788 (Wagner, 1937, p. 463).

Chirikof Point: point of land, E tip of Attu I., Aleutian Is.; $52^{\circ} 50^{\prime} 25^{\prime \prime} \mathrm{N}, 173^{\circ} 25^{\prime} 25^{\prime \prime} \mathrm{E}$; BGN 1945; (map 13). Var. Cape Vostochni, East Cape, East Point, Mys Vostochnoy.

Named for Capt. Lt. Alexei Illich Chirikov who was in command of the Saint Paul on the 
official Russian exploring expedition, under Vitus Bering. This cape was called "Mys Vostochnoy" meaning "east cape" (Tebenkov, 1852, map 30). The translated name "East Cape" was used on American charts until the BGN decision was given.

Chirikov: island, see Chirikof Island.

Chiroskey River: stream, E of South River, flows NE $50 \mathrm{mi}$. to Unalakleet River, $14 \mathrm{mi}$. E of Unalakleet, Nulato Hills; $63^{\circ} 55^{\prime} 20^{\prime \prime} \mathrm{N}, 160^{\circ}$ $19^{\prime} 50^{\prime \prime} \mathrm{W}$; (map 91).

Local name reported in 1949 by USC\&GS. Chisak, Cape: point of land, S tip of Little Tanaga I.; Aleutian Is.; $51^{\circ} 46^{\prime} 30^{\prime \prime} \mathrm{N}, 176^{\circ} 09^{\prime} 20^{\prime \prime}$ W; BGN 1936; (map 17). Var. Cape Kchisakh

Probably an Aleut name reported in 1868 by the U.S. Navy Hydrog. Office; shown on Chart 8 as "Cape Kchisakh" and in 1936 as "Cape Chisak."

Chisak Bay: bay, $1.9 \mathrm{mi}$. across, on $\mathrm{S}$ coast of Little Tanaga I., Aleutian Is.; $51^{\circ} 47^{\prime} 30^{\prime \prime} \mathrm{N}$, $176^{\circ} 08^{\prime} 00^{\prime \prime} \mathrm{W}$; BGN 1936; (map 17). Var. Nazan Bay, Zaliv Nazan.

This feature was called "Z[aliv] Nazan," or "Nazan Bay" by Capt. Tebenkov (1852, map 28), IRN. The name was changed to Chisak Bay (named after Cape Chisak) by the U.S. Navy Hydrog. Office in 1936, because "there are other more important Nazan Bays in the Aleutian Islands."

Chisak Island: island, $0.6 \mathrm{mi}$. long, off S. coast of Little Tanaga I., Aleutian Is.; $51^{\circ} 47^{\prime} 45^{\prime \prime}$ N, $176^{\circ} 08^{\prime} 20^{\prime \prime} \mathrm{W}$; BGN 1936; (map 17).

Name derived from Cape Chisak, and given by members of the U.S. Navy Aleutian Island Survey Expedition in 1934.

Chisana: locality, on E bank of Cross Creek near the Chisana River $30 \mathrm{mi}$. SE of Nabesna, Wrangell Mts.; $62^{\circ} 09^{\prime} 15^{\prime \prime} \mathrm{N}, 142^{\circ} 10^{\prime} 00^{\prime \prime} \mathrm{W}$; (map 84).

Former Indian settlement and mining camp established in 1913 (Swanton, 1952, p. 537). The village population was 148 in $1920 ; 13$ in 1930 ; and 28 in 1939. The Chisana post office operated from 1913 to 1938.

Chisana: village, pop. 5 , in Nutzotin Mts., on $\mathrm{N}$ bank of Chathenda Creek $1.7 \mathrm{mi}$. $\mathrm{E}$ of its junc. with Chisana River and $4.5 \mathrm{mi}$. $\mathbf{E}$ of Euchre Mtn., Alaska Ra.; $62^{\circ} 04^{\prime} \mathrm{N}, 142^{\circ} 03^{\prime}$ W; (map 84). Var. Shushana.

Local name derived from the nearby river, reported by USGS in 1913 (in Brooks and others, 1914, pl. 14).

Chisana Glacier: glacier, heads at Chisana Pass, trends NE $16 \mathrm{mi}$. to its 1957 terminus at head of Chisana River, Wrangell Mts.; $62^{\circ} 01^{\prime} \mathrm{N}$, $142^{\circ} 13^{\prime}$ W; BGN 1908; (map 84). Var. Shusana Glacier, Tanana Glacier.

Named in 1902 by F. C. Schrader, USGS, because "it forms the Chisana River."

Chisana Mountain: mountain, 3,306 ft., $3.5 \mathrm{mi}$. long, between Tetlin Hills and Tanana River, NE of Tetlin Lake, $16 \mathrm{mi}$. SE of Tok, Alaska Ra.; $63^{\circ} 11^{\prime} \mathrm{N}, 142^{\circ} 30^{\prime} \mathrm{W}$; (map 85).

Named in 1898 by W. J. Peters and A. H. Brooks, USGS, "because it is near the Chisana, i.e. Chisa River of [Lt. H. T.] Allen, 1885."
Chisana Pass: pass, 7,300 ft., at head of Chisana Glacier, $39 \mathrm{mi}$. N of McCarthy, Wrangell Mts.; $61^{\circ} 53^{\prime} 15^{\prime \prime} \mathrm{N}, 142^{\circ} 34^{\prime} 00^{\prime \prime} \mathrm{W}$; (map 67).

Local name obtained by USGS and published on maps since 1954.

Chisana River: stream, heads at Chisana Glacier terminus, flows NE and NW $110 \mathrm{mi}$., joins Nabesna River to form Tanana River, $3 \mathrm{mi}$. NW of Northway Junction, Yukon-Tanana High.; $63^{\circ} 02^{\prime} 45^{\prime \prime} \mathrm{N}, 141^{\circ} 51^{\prime} 45^{\prime \prime} \mathrm{W}$; $B G N$ 1960; (map 85). Var. Ches-tna, Chisna River, Chitty Gulch, Chusana River, Shushana River, Tanana River, Tinast.

Indian name sometimes written "Ches-tna" meaning "red river"; reported in 1885 by Lt. Allen (1887, Map of Explorations), USA.

Chishelnoi: island, see Sushilnoi Island.

Chisholm Lake: lake, $0.5 \mathrm{mi}$. long, S of Richardson Highway and Birch Lake, $28 \mathrm{mi}$. NW of Big Delta, Yukon-Tanana High.; 64 ${ }^{\circ} 19^{\prime} 45^{\prime \prime}$ $\mathrm{N}, 146^{\circ} 40^{\prime} 30^{\prime \prime} \mathrm{W}$; (map 101).

Local name published in 1951 by USGS.

Chisik Island: island, $6.5 \mathrm{mi}$. long, at mouth of Tuxedni Bay, Cook Inlet, $55 \mathrm{mi}$. SW of Kenai, Aleutian Ra.; $60^{\circ} 08^{\prime} \mathrm{N}, 152^{\circ} 35^{\prime} \mathrm{W}$; (map 62).

Local name published in 1910 by D. H. Sleem on his map of central Alaska.

Chislechina: stream, see Chistochina River.

Chisna: locality, on $\mathrm{W}$ bank of Chisna River 2 mi. NW of its junc. with Chistochina River, 22 mi. E of Paxson, Alaska Ra.; $63^{\circ} 04^{\prime} 30^{\prime \prime} \mathrm{N}$, $144^{\circ} 48^{\prime} 35^{\prime \prime} \mathrm{W}$; (map 86). Var. Dempsey.

Local name for a mining camp reported in 1900 by T. G. Gerdine (in Mendenhall and Schrader, 1903, pl. 9), USGS. A post office was established here from 1901 to 1925 . The post office name was "Dempsey" from 1908 until it was discontinued. At the present time a supply point called "Dempsey" is shown on maps about two miles to the south on the Chistochina River trail.

Chisna Pass: pass, 4,200 ft., near head of Chisna River, $2.5 \mathrm{mi}$. E of mouth of Slate Creek and 24 mi. NE of Paxson, Alaska Ra.; 63 $3^{\circ} 09^{\prime} 45^{\prime \prime}$ N, 144 $47^{\prime} 15^{\prime \prime} \mathrm{W}$; (map 86).

Name published on relatively recent maps. Chisna River: stream, flows SW $10 \mathrm{mi}$. to Chistochina River, $20 \mathrm{mi}$. E of Paxson, Alaska Ra. $63^{\circ} 03^{\prime} 10^{\prime \prime} \mathrm{N}, 144^{\circ} 51^{\prime} 25^{\prime \prime} \mathrm{W}$; (map 86).

Tanana Indian name meaning "red river" reported in 1900 by T. G. Gerdine (in Mendenhall and Schrader, 1903, pl. 9), USGS.

Chisna River: stream, see Chisana River.

Chissovun Lake: lake, $1.4 \mathrm{mi}$. long, $1.5 \mathrm{mi}$. NE of Upper Mouth Birch Creek and $16 \mathrm{mi}$. SW of Fort Yukon, Yukon Flats; 66 $23^{\prime} 30^{\prime \prime} \mathrm{N}$, $145^{\circ} 39^{\prime} 00^{\prime \prime} \mathrm{W}$; (map 119).

Kutchin Indian name obtained in 1956 by T. E. Taylor, USGS.

Chisswells Islands: islands, see Chiswell Islands. Chistiakof Island: barrier island, $3.5 \mathrm{mi}$. long, forms a SW-NE crescent across NE side of Port Heiden, $2.5 \mathrm{mi}$. SW of Port Heiden Airfield, Bristol Bay Low.; 56 $56^{\prime} \mathrm{N}, 158^{\circ} 41^{\prime} \mathrm{W}$; (map 30). Var. Chestakof Island, Ile Chestakoff.
Name reported as "I[1e] Chestakoff" by Adm. A. J. von Krusenstern (1827, map 20), IRN, possibly for Peter Egorovich Chistiakof, Director of the Russian American Company from 1826 to 1831 .

Chistochina: village, pop. 28, on Glenn Highway, $42 \mathrm{mi}$. NE of Glennallen, Copper River Basin; $62^{\circ} 34^{\prime} \mathrm{N}, 144^{\circ} 40^{\prime} \mathrm{W}$; BGN 1944; (map 83). Var. Chestochena, Chestochina Village.

This place was the name of a U.S. Army Signal Corps telegraph station, established in 1903. During the construction of Glenn Highway, it became the name of a roadhouse. Chistochina Glacier: glacier, heads on Mount Kimball, trends SW $4 \mathrm{mi}$. and forms two arms; one trends SE $2.5 \mathrm{mi}$. to its terminus at head of Middle Fork Chistochina River, and the other trends $W 3 \mathrm{mi}$. to its terminus at head of Chistochina River, $24 \mathrm{mi}$. NE of Paxson, Alaska Ra.; $62^{\circ} 11^{\prime} 30^{\prime \prime} \mathrm{N}, 144^{\circ} 44^{\prime} 00^{\prime \prime} \mathrm{W}$ [center]; (map 86).

Local name reported in 1900 by T. G. Gerdine (in Mendenhall and Schrader, 1903, pl. 9) USGS.

Chistochina River: stream, heading at Chistochina Glacier in Alaska Range and flowing $S$ $48 \mathrm{mi}$. to Copper River, $45 \mathrm{mi}$. NE of Glennallen, Alaska Range; $62^{\circ} 35^{\prime} \mathrm{N}, 144^{\circ} 36^{\prime} \mathrm{W}$; (map 83). Var. Chestochina, Chislechina, Chistotchena, Chitsletchina, Chittlechina, Christachina, Tieschenni.

Indian name recorded by Lt. Allen (1887, p. 65-66), USA, in 1885, as Chitsletchina and (map 1) as Chistotchina. According to R. H. Geoghegan, the name may be derived from, Che-les'-chi-tna, meaninng "marmot creek."

Chistotchena: stream, see Chistochina River.

Chiswell Island: island, $0.5 \mathrm{mi}$. across, one of Chiswell Is., $36 \mathrm{mi}$. SW of Seward, Chugach Mts.; 59³6' N, $149^{\circ} 34^{\prime} \mathrm{W}$; (map 49).

Local name reported in the early 1950's by USC\&GS.

Chiswell Islands: islands, in Gulf of Alaska, 35 mi. SW of Seward, Chugach Mts.; $59^{\circ} 37^{\prime} \mathrm{N}$, $149^{\circ} 36^{\prime} \mathrm{W}$; (map 49). Var. Aialki Islands, Ajaliki Islands, Chisswells Islands, Chiswell Isles, Ostrova Ayaliki.

According to Capt. Vancouver (1798, v. 3, p. 152-153), RN, these were named "Chiswell Isles" in 1786 by Capt. Nathaniel Portlock. They may have been named for "Trench Chiswell, a very rich man" (Wagner, 1937, p. 380). The Russians called them "Ostrova Ayaliki," (Ayaliki Islands) which may be an Eskimo name (Tebenkov, 1852, map 6).

Chiswell Isles: islands, see Chiswell Islands.

Chitanadlela: mountain range, see Chitanatala Mountains.

Chitana Mountain: mountain range, see Chitanatala Mountains.

Chitanana River: stream, heads in Chitanatala Mts., flows NE $65 \mathrm{mi}$. to Tanana River, 27 mi. SW of Manley Hot Springs, Nowitna Low.; 64 ${ }^{\circ} 56^{\prime} \mathrm{N}, 151^{\circ} 32^{\prime} \mathrm{W}$; (map 99). Var. Redlands Creek, Redlands River. 
Tanana Indian name reported in 1899 by Lt. J. S. Herron, USA; the stream was known to riverboat pilots as "Redlands Creek."

Chitanatala Mountains: mountain range, 2,900 $\mathrm{ft}$, trends NE-SW $25 \mathrm{mi}$. NW of Bitzshtini Mts., at NE end of Kuskokwim Mts.; 64 ${ }^{\circ} 35^{\prime}$ $\mathrm{N}, 152^{\circ} 10^{\prime} \mathrm{W}$; (map 99). Var. Chitanadlela, Chitana Mountain, Chit-an-at-ala.

Indian name recorded in 1899 as "Chit-anat-ala," meaning "Chita River Mountain," by Lt. J. S. Herron, USA.

Chitashuak: locality, see Sitnazuak.

Chitchagoff Bay: bay, see Chichagof Bay.

Chitina: village, pop. 31, on W bank of Gopper River, $3 \mathrm{mi}$. N of Taral and $66 \mathrm{mi}$. ENE of Valdez, Chugach Mts.; 61 $31^{\circ} 00^{\prime \prime} N, 144^{\circ}$ 26'15" W; BGN 1944; (map 68). Var. Chechitno, Chetchitno, Chettyna, Chittena, Chitty.

Railroad and mining supply town established about 1908 on the northern terminus of the Copper River and Northwestern RR. located at or near an Indian village or camp. Its population was 171 in $1920 ; 116$ in 1930 ; 176 in 1939; and 92 in 1950. The Chitina post office was established in 1910 .

Chitina, Mount: mountain, 8,000 ft., $4 \mathrm{mi}$. NW of junc. of Walsh Glacier with Logan Glacier and $113 \mathrm{mi}$. NW of Yakutat, St. Elias Mts.; $60^{\circ} 58^{\prime} \mathrm{N}, 141^{\circ} 16^{\prime} \mathrm{W}$; (map 65).

Name published on a Canadian topographic map in 1958 and derived from Chitina Glacier located to the north.

Chitina Glacier: glacier, heads in Canada, $W$ of Mount Steele, about $61^{\circ} 05^{\prime} \mathrm{N}, 140^{\circ} 30^{\prime} \mathrm{W}$, trends W $29 \mathrm{mi}$. to its 1951 terminus in Alaska at head of Chitina River, $121 \mathrm{mi}$. NW of Yakutat, St. Elias Mts.; $61^{\circ} 00^{\prime} \mathrm{N}, 141^{\circ} 39^{\prime}$ W; BGN 1954; (map 65).

Named by the IBC survey crew in 1912-13 and published in 1916 on Sheet 35. The glacier received its name from the Chitina River.

Chitina River: stream, heads at Chitina Glacier, flows WNW $112 \mathrm{mi}$. to Copper River, $1.2 \mathrm{mi}$. $\mathrm{E}$ of Chitina and $66 \mathrm{mi}$. NE of Valdez, Chugach Mts.; 61 ${ }^{\circ} 30^{\prime} 45^{\prime \prime} . \mathrm{N}, 1^{\circ} 4^{\circ} 23^{\prime} 45^{\prime \prime} \mathrm{W}$; (map 68). Var. Chechitno, Chetchitno, Chettyna, Chittena, Chittenah River, Chittyna River.

Indian name meaning "copper river" reported by Dall $(1870$, p. 272$)$ who spelled it "Chechitno" and "Chetchitno." L.t. H. T. Allen, USA, spelled it "Chittyna" in 1885. The name was spelled various ways by later explorers.

Chitiok, Mount: mountain, $6,480 \mathrm{ft}$., in Schwatka Mts., 11 mi. W of Mount Igikpak, Brooks Ra.; $67^{\circ} 26^{\prime} \mathrm{N}, 155^{\circ} 23^{\prime} \mathrm{W}$; (map 125).

Eskimo name reported in 1956 by USGS to mean "long ears."

Chitistone Falls: waterfall, on Chitistone River, at head of Chitistone Gorge, $26 \mathrm{mi}$. NE of McCarthy, Wrangell Mts.; 61 $32^{\prime} 45^{\prime \prime} \mathrm{N}$, $142^{\circ} 10^{\prime} 30^{\prime \prime} \mathrm{W}$; (map 67).

Named for the river.

Chitistone Glacier: glacier, trends NW $12 \mathrm{mi}$. to its terminus at head of Chitistone River, 25 mi. NE of McCarthy, St. Elias Mts.; 61 ${ }^{\circ} 32^{\prime}$ $\mathrm{N}, 142^{\circ} 11^{\prime} \mathrm{W}$; (map 67).

Named for the river; published in 1951 by USGS.

Chitistone Gorge: canyon, extends $0.9 \mathrm{mi}$. along Chitistone River to Chitistone Falls, $3.4 \mathrm{mi}$. $\mathrm{SE}$ of Hole-in-the-Wall Glacier and $26 \mathrm{mi}$. NE of McCarthy, Wrangell Mts., $61^{\circ} 32^{\prime} 15^{\prime \prime}$ $\mathrm{N}, 142^{\circ} 11^{\prime} 00^{\prime \prime} \mathrm{W}$; (map 67).

Name was derived from that of the stream; published in 1951 by USGS.

Chitistone Mountain: mountain, 6,844 ft., trends NE-SW $3.5 \mathrm{mi}$., $16 \mathrm{mi}$. NE of McCarthy, Wrangell Mts.; $61^{\circ} 30^{\prime} \mathrm{N}, 142^{\circ} 28^{\prime} \mathrm{W}$; (map 67).

Named for the river; reported in 1959 by USGS.

Chitistone Pass: pass, 5,900 ft, at head of Chitistone River, $30 \mathrm{mi}$. NE of McCarthy, Wrangell Mts.; $61^{\circ} 36^{\prime} 15^{\prime \prime} \mathrm{N}, 142^{\circ} 03^{\prime} 30^{\prime \prime} \mathrm{W}$; (map 67).

Named for the river; name published by Capps (1916, pl. 1), USGS.

Chitistone River: stream, flows SW $20 \mathrm{mi}$. from Chitistone Pass to Nizina River, $12 \mathrm{mi}$. $\mathbf{E}$ of McCarthy, Wrangell Mts. ; $61^{\circ} 25^{\prime} \mathrm{N}, 142^{\circ} 36^{\prime}$ W; (map 67). Var. Chittystone River, Nizina River.

Named in 1885 by Lt. Allen (1887, p. 52), USA, "on account of the copper ore found by the natives near it * * *;" shown as "Chittystone River" on his map. The word "chiti" is Indian for copper, and with the English word "stone" attached, it is "copperstone." The Allen map shows the name applied in part to the strearn later known as "Nizina River."

Chititu Camp: locality, on left bank of Chititu Creek at its junc. with White Creek, $14 \mathrm{mi}$. SE of McCarthy, St. Elias Mts.; 61 ${ }^{\circ} 17^{\prime} 30^{\prime \prime}$ N, $142^{\circ} 34^{\prime} 40^{\prime \prime} \mathrm{W}$; ( $\operatorname{map} 67$ ).

Local name derived from name of creek on which it is situated; reported in 1959 by USGS.

Chititu Creek: stream, flows NW $7 \mathrm{mi}$. to Nizina River, 9 mi. SE of McCarthy, St. Elias Mts.; $61^{\circ} 22^{\prime} 15^{\prime} \mathrm{N}, 142^{\circ} 41^{\prime} 30^{\prime \prime} \mathrm{W}$; (map 67). Var. Ghittyto River, Ghitty-Too River.

The Indian name was reported in 1885 by Lt. Allen (1887, p. 55), USA, to mean "copper water." His map shows "Chitty-Too" while his report spells the name "Chittyto." So named because of its dark brown (or copper) color.

Chitka Cove: bight, $2.3 \mathrm{mi}$. wide, faces Bering Sea on NE coast of Amchitka I., Rat Is., Aleutian Is.; $51^{\circ} 36^{\prime} \mathrm{N}, 178^{\circ} 56^{\prime} \mathrm{E}$; (map 15).

"Chitka," part of the name "Amchitka," was published on a 1951 USGS map.

Chitka Point: point of land, SE entrance point of Chitka Cove, on NE coast of Amchitka I., Rat Is., Aleutian Is.; $51^{\circ} 35^{\prime} 15^{\prime \prime} \mathrm{N}, 178^{\circ} 59^{\prime}$ $00^{\prime \prime} \mathrm{E}$; (map 15)

The name "Chitka" is part of the name "Amchitka"; reported by 1935 U.S. Navy Survey Expedition.

Chitna Creek: stream, flows NE $8 \mathrm{mi}$. to Caribou Creek, 50 mi. NE of Palmer, Talkeetna Mts.; $61^{\circ} 58^{\prime} \mathrm{N}, 147^{\circ} 47^{\prime} \mathrm{W}$; (map 69). Var. Shitna Creek.

Tanana Indian name reported in 1898 by Capt. Glenn (1899, map), USA, as "Shitna."

Chitnak: locality, on S shore of St. Lawrence I. in Bering Sea; (map 93). Var. Shetnak, Shitnak, Sshitnak, Tchitnak.

Former Eskimo camp or settlement reported about 1849 by Capt. M. D. Tebenkov (1852, map 19), IRN, as "Shitnak."

Chitnak, Cape: point of land, see Siknik Cape.

Chitna Pass: pass, 4,700 ft., $47 \mathrm{mi}$. NE of Palmer, between Boulder and Chitna Creeks, Talkeetna Mts.; $61^{\circ} 53^{\prime} 45^{\prime \prime} \mathrm{N}, 147^{\circ} 55^{\prime} 20^{\prime \prime} \mathrm{W}$; (map 69).

Local name reported in 1952 by USGS.

Chitnashuak: locality, see Sitnazuak.

Chitsia Creek: stream, flows NW $19 \mathrm{mi}$. to Kantishna River, $24 \mathrm{mi}$. S of junc. of Toklat and Kantishna Rivers, Tanana Low.; $64^{\circ} 08^{\prime} \mathrm{N}$, $150^{\circ} 39^{\prime} \mathrm{W}$; (map 99).

Tanana Indian name reported in 1916 by S. R. Capps (in Brooks and others, 1918, pl. 15), USGS.

Chitsia Mountain: peak, 3,862 ft., in Kantishna Hills, $6.3 \mathrm{mi}$. NNW of junc. of Toklat River and its East Fork, Alaska Ra.; $63^{\circ} 58^{\prime} 00^{\prime \prime} \mathrm{N}$, $150^{\circ} 17^{\prime} 30^{\prime \prime} \mathrm{W}$; (map 88).

Tanana Indian name reported in 1902 as "Chitsiah," meaning "heart," by A. H. Brooks, USGS.

Chitsletchina: stream, see Chistochina River.

Chittena: village, see Chitina.

Ghittena: stream, see Chitina River.

Chittenah: village, see Chitina.

Chittenah River: stream, see Chitina River. Chittlechina: stream, see Chistochina River.

Chitty: village, see Chitina.

Chitty Gulch: stream, see Chisana River.

Chittyna River: stream, see Chitina River.

Chittystone River: stream, see Chitistone River. Chitty-Too River: stream, see Chititu Creek.

Ghittyto River: stream, see Chititu Creek.

Chiukak: locality, on $\mathrm{N}$ shore of Norton Sound, $10 \mathrm{mi}$. W of Golovin and $32 \mathrm{mi}$. E of Solomon, Seward Penin. High.; $64^{\circ} 31^{\prime} \mathrm{N}, 163^{\circ} 22^{\prime}$ W; (map 95). Var. Cheokook, Chikak, Chiokak, Chiokuk, Chiookak, Chiookuk, Chiukakmyut, Knecktakimut, Scookuk, Seleniye Chiukakmyut.

Site of an Eskimo village reported in 1861 as "Chiukak-myut" by P. Tikhmeniev. The Western Union Telegraph Expedition, 186567 , reported the village as "Knecktakimut." Ivan Petroff in the 10th Census, in 1880, listed "Chiookak" with a population of 15, and showed "Chiokak" on the map.

Chiukak-myut: locality, see Chiukak.

Chiuki River: stream, flows E $6 \mathrm{mi}$. to Kaliakh River $1 \mathrm{mi}$. above its mouth on NE coast of Gulf of Alaska, $12 \mathrm{mi}$. WNW of Cape Yakataga, Malaspina Coastal Plain; $60^{\circ} 06^{\prime} 40^{\prime \prime} \mathrm{N}$, $142^{\circ} 46^{\prime} 00^{\prime \prime}$ W; (map 65). Var. Cheukee River.

Indian name "Cheukee" reported in 1904 by G. C. Martin, USGS.

Chkazhini River: stream, see Katzehin River. 
Chkituk: locality, see Skittok.

Chktuk: locality, see Skittok.

Chlachótsch Island: island, see Pyramid Island. Chlach River: stream, see Klak Creek.

Chlanak, Cape: point of land, on SE coast of Kanaga Island, Aleutian Is.; $51^{\circ} 42^{\prime} 30^{\prime \prime} \mathrm{N}$,

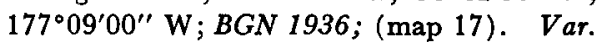
Cape Ulanach.

Aleut name published by Capt. Tebenkov (1852, map 28), IRN, as "M[ys] Chlanakh," or "Cape Chlanakh."

Chla-wak-kon: village, see Klawock.

Chlebnikoff, Cape: point of land, see Khlebnikof Point.

Chleca Lakes: lakes, each $0.7 \mathrm{mi}$. across, $60 \mathrm{mi}$. NE of Medfra, Kuskokwim Low.; 63 $41^{\prime} \mathrm{N}$, $153^{\circ} 18^{\prime} \mathrm{W}$; (map 89).

Indian name obtained in 1958 by T. E. Taylor, USGS.

Chloya Lake: lake, $2.6 \mathrm{mi}$. long, one of Three Lakes, $4 \mathrm{mi}$. SW of the locality of Birch Creek and $30 \mathrm{mi}$. SW of Fort Yukon, Yukon Flats; $66^{\circ} 13^{\prime} \mathrm{N}, 145^{\circ} 55^{\prime} \mathrm{W}$; (map 119).

Kutchin Indian name obtained in 1956 by T. E. Taylor, USGS.

Choak-ha-mut: locality, see I-gl-a-rak.

Choca Creek: stream, fows $\mathrm{N}$, through Gilbert Lake, $7 \mathrm{mi}$. to Chickamin River, $6 \mathrm{mi}$. NE of Trap Point on Behm Canal, Coast Mts.; $55^{\circ}$ $50^{\prime} 00^{\prime \prime} \mathrm{N}, 130^{\circ} 51^{\prime} 10^{\prime \prime} \mathrm{W}$; (map 3 ).

Local name reported in 1955 by USGS.

Chock Island: island, $0.2 \mathrm{mi}$. across, at junc. of Snug Cove and Gambier Bay, on SE coast of Admiralty I., 59 mi. NE of Sitka, Alex. Arch.; $57^{\circ} 27^{\prime} 50^{\prime \prime} \mathrm{N}, 133^{\circ} 57^{\prime} 45^{\prime \prime} \mathrm{W}$; (map 8).

Named in 1889 by Lt. Comdr. H. B. Mansfield, USN; published in 1892 by USC\&GS.

Chocolate Creek: stream, flows SE $3 \mathrm{mi}$, to Goose Creek, $25 \mathrm{mi}$. SE of Rampart, YukonTanana High.; $65^{\circ} 22^{\prime} \mathrm{N}, 149^{\circ} 23^{\prime}$ W ; (map 105).

Named by prospectors; reported in 1908 by USGS (Coveret and Ellsworth, 1909, pl. 5). Chogium: village, see Dillingham.

Chogiung: village, see Dillingham.

Chokaglaligamute: village, see Chakwaktolik.

Chokfaktoligamute: village, see Chakwaktolik.

Chokfoktoleghagamiut: village, see Chakwaktolik.

Chokosna: locality, on Chokosna River $1.5 \mathrm{mi}$. $\mathrm{E}$ of Chokosna Lake, $28 \mathrm{mi}$. NW of McCarthy, Copper River Basin ; $61^{\circ} 27^{\prime} 15^{\prime \prime} \mathrm{N}, 143^{\circ} 45^{\prime} 40^{\prime \prime}$ W; (map 67).

This is the site of a Copper River and Northwestern Railroad station, established in 1911.

Chokosna Lake: lake, $0.4 \mathrm{mi}$. long, $\mathrm{N}$ of Gilahina Butte, $2 \mathrm{mi}$. E of Billy Lake and $30 \mathrm{mi}$. W of McCarthy, Copper River Basin; 61 '27'35' N, $143^{\circ} 48^{\prime} 30^{\prime \prime} \mathrm{W}$; (map 67).

Indian name, first applied to nearby river; published by USGS in 1951.

Chokosna River: stream, flows SW $14 \mathrm{mi}$. to Gilahina River E of Gilahina Butte, $27 \mathrm{mi}$. W of McCarthy, Copper River Basin; 61 '25'30' N, $143^{\circ} 44^{\prime} 00^{\prime \prime}$ W; (map 67). Var. Fitch Creek.
Indian name, first recorded on a manuscript map made by prospectors in 1900 ; reported in 1901 by T. G. Gerdine, USGS. It was named "Fitch Creek" by Oscar Rohn in 1899 , for H. H. Fitch, one of his packers.

Chokotongkna Creek: stream, see Chokotonk River.

Chokotonkna River: stream, see Chokotonk River.

Chokotonk River: stream, flows SW $20 \mathrm{mi}$. to Little Lake Clark, $52 \mathrm{mi}$. NE of Nondalton, Aleutian Ra.; $60^{\circ} 26^{\prime} \mathrm{N}, 153^{\circ} 36^{\prime} \mathrm{W}$; $B G N$ 1910; (map 61). Var. Chakatonko Creek, Chokotongkna Creek, Chokotonkna River, Chokotunkna Creek, Copper River.

Indian name obtained in 1902 by $\mathbf{W}$. $\mathbf{H}$. Osgood, USDA. A. H. Brooks relates that Zachar, chief of the Lake Clark natives, says "chokotunkna" means "beaver creek."

Chokotunkna Creek: stream, see Chokotonk River.

Chokoyik Island: island, $3 \mathrm{mi}$. long, in Yukon River, between Lady and Henry Is., $11 \mathrm{mi}$. WSW of Birches, Kokrines-Hodzana High.; $65^{\circ} 03^{\prime} \mathrm{N}, 153^{\circ} 56^{\prime} \mathrm{W}$; (map 107).

Indian name reported in 1869 by Capt. C. W. Raymond, U.S. Army Corps of Engineers; he shows a fish camp on this island.

Chok-way-chok: stream, see Pah River.

Cho-kwok-stchu-luk: lake, see Beverley, Lake. Cho-kwok-stchu-luk : lake, see Nerka, Lake.

Cholitna: stream, see Holitna River.

Cholitno: stream, see Holitna River.

Cholmondeley Bay: bay, see Cholmondeley Sound.

Cholmondeley Sound: bay, extends W $11 \mathrm{mi}$. from Clarence Strait, on $\mathbf{E}$ coast of Prince of Wales I., Alex. Arch.; 55 ${ }^{\circ} 17^{\prime} \mathrm{N}, 132^{\circ} 04^{\prime} \mathrm{W}$; BGN 1961; (map 4). Var. Bukhta Cholmondelei, Chasina Bay, Cholmondeley Bay, Cholmondeleys Sound, Chomly Sound, Colmondeley Sound, Zaliv Chasiny (Kalmondeley).

Named by Capt. George Vancouver, RN, August 21, 1793, for Hugh, Earl of Cholmondeley (Wagner, 1937, p. 380). Capt. Tebenkov (1852, map 9), IRN, published the name "Zaliv Chasiny (Kalmondeley)," or "Chasiny (Kalmondeley) Bay"; it is shown as "Bukhta i Reid Cholmondelei," meaning "Cholmondeley Bay and Roadstead," on Russian Hydrog. Dept. Chart 1493 published in 1853. See Apodaca, Bocas de.

Cholmondeleys Sound: bay, see Cholmondeley Sound.

Cholmondeli, Bukhta: bay, see Cholmondeley Sound.

Chomby: locality, see Chomly.

Chomly: locality, abandoned settlement, site of a former cannery, on $S$ shore of West Arm Cholmondeley Sound, on Prince of Wales I., Alex. Arch.; $55^{\circ} 14^{\prime} 52^{\prime \prime}$ N, $132^{\circ} 19^{\prime} 25^{\prime \prime} \mathrm{W}$; BGN 1961; (map 4). Var. Chomby.

The Chomly post office was established here in 1900 and discontinued in 1930 (Ricks, 1965, p. 12).

Chomly Sound: bay, see Cholmondeley Sound.
Choonowuck: locality, on $\mathrm{N}$ shore of Grantley Harbor about $5 \mathrm{mi}$. NE of Teller, Seward Penin. High.; (map 111).

Site of an Eskimo village reported in 1827 by Capt. Beechey (1831, p. 542), USGS. Subsequent censuses have not identified this village.

Chopeluk Slough; stream, see Etokek Slough.

Choris Island: island, see Saint Matthew Island.

Choris Peninsula: peninsula, extends S $3.3 \mathrm{mi}$. from Baldwin Penin., $56 \mathrm{mi}$. SW of Selawik, Kotzebue-Kobuk Low.; $66^{\circ} 17^{\prime} \mathrm{N}, 161^{\circ} 53^{\prime} \mathrm{W}$; (map 114).

Named in 1816 by Lt. Otto von Kotzebue, IRN, for Louis Choris, a member of his expedition.

Chornoi: point of land, see Black Cape.

Chornoi Cape: point of land, see Black Cape.

Chornoy, Mys: point of land, see Black Cape.

Chortov, Gora: hill, see Devil Mountain.

Chose Island: island, off $\mathrm{W}$ coast of Knight I., in $E$ end of Drier Bay, $11 \mathrm{mi}$. NE of Chenega, Chugach Mts. ; $60^{\circ} 19^{\prime} 30^{\prime \prime} \mathrm{N}, 147^{\circ} 47^{\prime} 10^{\prime \prime} \mathrm{W}$; (map 63).

Local name published in 1908 by USC\&GS. Chotachkakat; stream, see Kaltag River. Chotschnalitno: stream, see Swift River.

Chottsik Lake: lake, $2.9 \mathrm{mi}$. long, S of Vettekwi Lake and 1.6 mi. E of Arctic Village, Brooks Ra.; 6808' N, $145^{\circ} 28^{\prime} \mathrm{W}$; (map 136).

Kutchin Indian name obtained at Arctic Village in 1956 by T. E. Taylor, USGS.

Chotzatdhah: hill, $3,000 \mathrm{ft}$., $38 \mathrm{mi}$. N of Christian, Brooks Ra.; $67^{\circ} 54^{\prime} \mathrm{N}, 145^{\circ} 09^{\prime} \mathrm{W}$; (map 122).

Kutcha-kutchin Indian name obtained in 1956 by T. E. Taylor, USGS.

Choumaghin Islands: islands, see Shumagin Islands.

Choumagin Islands: islands, see Shumagin Islands.

Chouyak Island: island, see Shuyak Island.

Chowee-et Island : island, see Chowiet Island.

Chowhoctolik: village, see Chakwaktolik.

Chowiet Island: island, $4 \mathrm{mi}$. long, southern large island of Semidi Is., Aleutian Ra.; $56^{\circ}$ $02^{\prime} \mathrm{N}, 156^{\circ} 42^{\prime} \mathrm{W}$; (map 31 ). Var. Choweeet Island, Evdokeeff, Semidin, South Semidi Island.

Native name reported in 1874 by $\mathrm{W}$. $\mathrm{H}$. Dall, USC\&GS.

Chowik Mountain: mountain, see Chauik Mountain.

Chris Island: island, see Axel Lind Island.

Christachina: stream, see Ghistochina River.

Christian: village, pop. 34, $55 \mathrm{mi}$. $\mathrm{N}$ of Fort Yukon, on right bank of Christian River, Yukon Flats; $67^{\circ} 22^{\prime} \mathrm{N}, 145^{\circ} 12^{\prime} \mathrm{W}$; (map 122). Var. Ghristian Village.

Kutcha-kutchin Indian village; named for the stream.

Christiana Sound: Bay, see Christian Sound.

Christian Creek: stream, flows W $1.7 \mathrm{mi}$. to Nome River, $21 \mathrm{mi}$. NE of Nome, Seward Penin. High.; $64^{\circ} 48^{\prime} \mathrm{N}, 165^{\circ} 13^{\prime} \mathrm{W}$; (map 94). 
Prospectors' name shown on a 1900 "Map of Nome Peninsula" by J. M. Davidson and B. D. Blakeslee.

Christian Creek: stream, flows SW $7 \mathrm{mi}$. to Yukon Flats, $6 \mathrm{mi}$. SE of Christian; $67^{\circ} 19^{\prime} \mathrm{N}$, $145^{\circ} 03^{\prime} \mathrm{W}$; (map 122)

Local name reported in 1956 by T. E Taylor, USGS.

Christian River: stream, heads SW of Shark Edge Mtn. at $68^{\circ} 04^{\prime} \mathrm{N}, 147^{\circ} 23^{\prime} \mathrm{W}$, flows S $140 \mathrm{mi}$. to Cutoff Slough of Yukon River, $17 \mathrm{mi}$. NW of Fort Yukon, Yukon Flats; $66^{\circ}$.

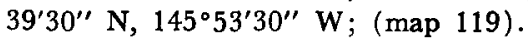

Prospectors' name reported in 1909 by A. G. Maddren (in Brooks and others, 1910, pl. 7), USGS.

Christiansen Lake: lake, $1.4 \mathrm{mi}$. long, largest of Talkeetna Lakes, $1.3 \mathrm{mi}$. SE of Talkeetna, Cook Inlet Low.; $62^{\circ} 19^{\prime} 00^{\prime \prime} \mathrm{N}, 150^{\circ} 03^{\prime} 40^{\prime \prime}$ W; BGN 1959; (map 81).

Named locally for Haakon Christiansen, bush pilot, who used this lake as a landing area; reported in 1958 by W. H. Durch of Talkeetna.

Christianson Lagoon: lagoon, $1.5 \mathrm{mi}$. across, on $\mathrm{N}$ coast of Unimak I., Aleutian Is. ; $54^{\circ} 54^{\prime} 30^{\prime \prime}$ $\mathrm{N}, 164^{\circ} 13^{\prime} 30^{\prime \prime} \mathrm{W}$; (map 24).

Local name published in 1951 by USGS. Christian Sound: bay, $23 \mathrm{mi}$. across, at $\mathrm{S}$ entrance to Chatham Strait, between Baranof and Coronation Is.; Alex. Arch.; 55 $56^{\prime} \mathrm{N}$, $134^{\circ} 40^{\prime}$ W; (map 4). Var. Christiana Sound, Christians Sound.

Named "Christians Sound" in 1789 by the English fur trader, Capt. James Colnett of the Argonaut; "no doubt in honor of Sir Hugh Christians, Rear Admiral and commander in chief of the West Indies in 1795" (Wagner, 1937, p. 380).

Christian Sound: water passage, see Chatham Strait.

Christians Sound: bay, see Christian Sound.

Christian Village: settlement, see Christian.

Christie Point: point of land, $28 \mathrm{mi}$. SE of Barrow, between Dease Inlet and Elson Lagoon, Arctic Plain; $71^{\circ} 11^{\prime} \mathrm{N}, 155^{\circ} 35^{\prime} \mathrm{W}$; (map 153). Var. Christy Point, Cristy Point, Point Christie, Toolavia.

Named by Thomas Simpson (1843, p. 150) August 3, 1837, for Chief Factor Christie of the Hudson's Bay Company, "a warm personal friend, and also a zealous promoter of the interests of the expedition." The Eskimo name Tool-a-via, is shown by Maguire (Great Britain, 1854, map facing p. 186) and may mean (Tulavik) "place for coming ashore."

Christine Bight: bight, $1 \mathrm{mi}$. across, W of Christine Lake, NW coast of Kiska I., Aleutian Is.; $52^{\circ} 05^{\prime} 00^{\prime} \mathrm{N}, 177^{\circ} 32^{\prime} 30^{\prime \prime} \mathrm{E}$; (map 14).

One of many arbitrary names applied to features on Kiska I. by USAAF for tactical purposes during World War II.

Christine Lake: lagoon, $0.8 \mathrm{mi}$. across, separated from Bering Sea by barrier beach on NW coast of Kiska I., Aleutian Is. ; $52^{\circ} 04^{\prime} 50^{\prime \prime} \mathrm{N}, 177^{\circ}$ 33'00' E; (map 14).
One of many arbitrary names applied to features on Kiska I. by USAAF for tactical purposes during World War II.

Christmas Creek: stream, flows SW $14 \mathrm{mi}$. to Ungalik River, $0.8 \mathrm{mi}$. E of Norten Bay, Nulato Hills; $64^{\circ} 36^{\prime} \mathrm{N}, 160^{\circ} 42^{\prime} \mathrm{W}$; (map 96).

Local name reported in 1955 by USGS.

Christmas Creek: stream, fows SE $1 \mathrm{mi}$. to Fish River, NE of Slate Creek, $14 \mathrm{mi}$. E of Council and $44 \mathrm{mi}$. NE of Solomon, Seward Penin. High.; 64ㄷㄴ $55^{\prime} \mathrm{N}, 163^{\circ} 13^{\prime} \mathrm{W}$; (map 95).

Prospectors' name published on the 1908 "Map of Seward Peninsula" by Arthur Gibson. Christmas Creek: stream, see Lost Creek.

Christmas Island: island, $200 \mathrm{ft}$. across, $15 \mathrm{mi}$. SW of Petersburg, between Beecher Pass and Duncan Canal, Alex. Arch.; $56^{\circ} 36^{\prime} 15^{\prime \prime} \mathrm{N}$, 133 $01^{\prime} 45^{\prime \prime} \mathrm{W}$; (map 6).

Local fishermen's name reported in 1947 by USC\&GS.

Christmas Island: island, $0.15 \mathrm{mi}$. across, in Security Bay, on N coast of Kuiu I., Alex. Arch.; $56^{\circ} 51^{\prime} 40^{\prime \prime} \mathrm{N}, 134^{\circ} 22^{\prime} 00^{\prime \prime} \mathrm{W}$; (map 5).

Named in 1881 by Comdr. H. Glass, USN. Christmas Mountain: mountain, 2,276 ft., $12 \mathrm{mi}$. $\mathrm{E}$ of Norton Bay and $21 \mathrm{mi}$. W of Debauch Mtn., Nulato Hills, $64^{\circ} 33^{\prime} \mathrm{N}, 160^{\circ} 36^{\prime} \mathrm{W}$; (map 96).

Local name reported in 1910 by USGS.

Christmas Tree Point: point of land, SW of Twin Bays, on SE coast of Tanaga I., Aleutian Is.; $51^{\circ} 41^{\prime} \mathrm{N}, 177^{\circ} 54^{\prime} \mathrm{W}$; (map 17).

Name published by USC\&GS in 1957 on Chart 9146.

Christy Creek: stream, flows S $3 \mathrm{mi}$. to Ohio Creek, 26 mi. SW of Summit, Alaska Ra.; $63^{\circ}$ $07^{\prime} \mathrm{N}, 149^{\circ} 49^{\prime} \mathrm{W}$; (map 87).

Local name obtained in 1951 by USGS.

Christy Lake: lake, $700 \mathrm{ft}$. long, $0.7 \mathrm{mi}$. SW of junction of Jacksina Creek and Nabesna River, Wrangell Mts.; $62^{\circ} 21^{\prime} \mathrm{N}, 142^{\circ} 54^{\prime} \mathrm{W}$; (map 84).

Local name reported by USGS in 1960 .

Christy Point: point of land, see Christie Point.

Chrome: locality, on Kenai Penin., on W shore of Chrome Bay $17 \mathrm{mi}$. SSW of Seldovia, Chugach Mts. ; 59 $12^{\prime} 30^{\prime \prime} \mathrm{N}, 151^{\circ} 49^{\prime} 30^{\prime \prime} \mathrm{W}$; (map 50). Var. Toqakvik.

Mining camp and townsite reported by Gill (1920, p. 99), Cornell Univ., in 1918. The camp was so named because of its association with the nearby chrome ore mine which began operation in 1917. The camp is now abandoned.

Chrome Bay: cove, $0.5 \mathrm{mi}$. wide, on $\mathrm{S}$ coast of Kenai Penin., $2 \mathrm{mi}$. $\mathrm{N}$ of Elizabeth $\mathrm{I}$. and 17 mi. SSW of Seldovia, Chugach Mts.; $59^{\circ} 12^{\prime}$ $30^{\prime \prime} \mathrm{N}, 151^{\circ} 48^{\prime} 30^{\prime \prime} \mathrm{W}$; BGN 1918; (map 50).

Local name reported by USC\&GS in 1918, and so called because of its association with a chrome ore mine on Claim Point.

Chuarlitiligamut: locality, on right bank of $\mathrm{Ka}-$ nektok River, $9 \mathrm{mi}$. W of Amakatatee Creek and $64 \mathrm{mi}$. NE of Goodnews, Kilbuck-Kuskokwim Mts.; $59^{\circ} 52^{\prime} \mathrm{N}, 160^{\circ} 37^{\prime} \mathrm{W}$; (map 53). Var. Chuarlitilik, Chwarlitiligamut.
Eskimo village, now abandoned, reported in 1898 by J. E. Spurr and W. S. Post, USGS, as "Chwarlitiligamut," meaning "Chwarlitilik people."

Chuarlitilik: locality, see Chuarlitiligamut.

Chuchskin Rocks: rocks, off E tip of Attu I., Aleutian Is.; $52^{\circ} 49^{\prime} 15^{\prime \prime} \mathrm{N}, 173^{\circ} 29^{\prime} 30^{\prime \prime} \mathrm{E}$, (map 13).

This name was shown on a manuscript map by L. M. Turner in the 1880 's.

Chuck-a-won-ugh-toly: stream, see Chukowan River.

Chuck Camp: locality, on Chuck River, $1.5 \mathrm{mi}$. $\mathrm{S}$ of Windham Bay and $64 \mathrm{mi}$. SE of Juneau, Coast Mts.; $57^{\circ} 33^{\prime} 50^{\prime \prime} \mathrm{N}, 133^{\circ} 25^{\prime} 35^{\prime \prime} \mathrm{W}$; (map 8).

Name of a mining camp derived from the Chinook jargon word meaning "water"; name published by USC\&GS in the 1883 Coast Pilot (p. 147).

Chuckchak Creek: stream, see Chakchak Creek.

Chuckchee: sea, see Chukchi Sea.

Chuckchee Sea: sea, see Chukchi Sea.

Chuck Creek: stream, 2 mi. long, flows $S$ through Chuck Lake to Warm Chuck Inlet, SE coast of Heceta I., Alex. Arch.; 55 $45^{\prime} 30^{\prime \prime}$ N, $133^{\circ}$ 28'15" W; (map 4).

Local name reported in 1951 by USGS; "chuck" is Chinook jargon meaning "water." See Salt Chuck, village.

Chuck Lake: lake, $1 \mathrm{mi}$. long, $\mathrm{N}$ central Heceta I., Alex. Arch.; 55 $46^{\prime} 30^{\prime \prime}$ N, $133^{\circ} 27^{\prime} 45^{\prime \prime} \mathrm{W}$; (map 4). Var. Chuck Forward Lake, Forward Lake.

Named in 1935 by USGS. See Salt Chuck, village. In 1952 USFS called it Chuck Forward Lake for Charles Forward, USFS, who worked 25 years in Alaska. The new name, however, did not become popular.

Chuck River: stream, flows $\mathbf{N} 10 \mathrm{mi}$. to Windham Bay, $64 \mathrm{mi}$. SE of Juneau, Coast Mts.; $57^{\circ} 35^{\prime}-$ $00^{\prime \prime} \mathrm{N}, 133^{\circ} 21^{\prime} 15^{\prime \prime} \mathrm{W}$; (map 8). Var. Shuck River.

Probably named for the Chuck Mining Camp near the stream; name published in 1891 by USC\&GS. "Chuck" is a Chinook jargon word meaning "water."

Chuckwatoli: village, see Chakwaktolik.

Chuckwucktolig: village, see Chakwaktolik.

Chuckwuktoligamut: village, see Chakwaktolik. Chudnoi: island, see Queer Island.

Chudnoy, Ostrov: island, see Queer Island.

Chudoekow Islands: islands, see Kudiakof Islands.

Chu-du-lung: lake, see Lynx Lake.

Chugach: locality, site of RR. siding at mile 110.0 on The Alaska RR., S of Spenard, Cook Inlet Low.; $61^{\circ} 10^{\prime} \mathrm{N}, 149^{\circ} 54^{\prime} \mathrm{W}$; BGN 1949; (map 69).

Name suggested in 1949 by the Chugach Electric Company for their newly constructed siding.

Chugach Bay: bay, $2.5 \mathrm{mi}$. wide, on $\mathrm{S}$ coast of Kenai Penin., $18 \mathrm{mi}$. $\mathrm{S}$ of Seldovia, Chugach Mts.; $59^{\circ} 11^{\prime} \mathrm{N}, 151^{\circ} 34^{\prime} \mathrm{W}$; (map 50).

Local name reported by U. S. Grant and D. F. Higgins, in 1909 USGS, (in Brooks and others, 1910, pl. 3). 
Chugach Heights: area, in NE section of Anchorage, between Justamere Ranch and Runstettler, Cook Inlet Low.; $61^{\circ} 13^{\prime} 08^{\prime \prime} \mathrm{N}, 149^{\circ} 47^{\prime}$ $35^{\prime \prime} \mathrm{W}$; (map 69).

Local name reported in 1954 by the city engineer of Anchorage.

Chugachik, Ostrov: island, see Chugachik Island.

Chugachik, Zaliv: bay, see Kachemak Bay.

Chugachik Bay: bay, see Kachemak Bay.

Chugachik Island: island, $0.5 \mathrm{mi}$. long, along NE shore of Kachemak Bay, on Kenai Penin., 19 mi. NE of Homer, Chugach Mts.; 59 $44^{\prime} 45^{\prime \prime}$ $\mathrm{N}, 151^{\circ} 03^{\prime} 00^{\prime \prime} \mathrm{W}$; (map 50). Var. Ostrov Chugachik.

Eskimo name reported in 1848 by Capt. Tebenkov (1852, maps), IRN, as "Ostrov Chugachik," or "Chugachik Island."

Chugach Islands: islands, group of islands, at $\mathbf{S}$ tip of Kenai Penin., $23 \mathrm{mi}$. S of Seldovia, Chugach Mts.; $59^{\circ} 07^{\prime} \mathrm{N}, 151^{\circ} 40^{\prime} \mathrm{W}$; (map 50). Var. Ghugatz Islands, Ostrova Chugatskiya, Ostrova Chugatskiye.

Eskimo name published in 1847 as "Os[trova] Chugatskiye," or "Chugatski Islands" on Russian Hydrog. Dept. Chart 1378.

Chugach Mountains: mountain range, $250 \mathrm{mi}$. long and $60 \mathrm{mi}$. wide, extends from Knik Arm and Turnagain Arm on $W$ to Bering Glacier, Tana Glacier, and Tana River on E; bounded on $\mathrm{N}$ by Matanuska, Copper, and Chitina Rivers; $61^{\circ} 00^{\prime} \mathrm{N}, 142^{\circ} 45^{\prime} \mathrm{W}$ [E end], $61^{\circ} 10^{\prime} \mathrm{N}, 150^{\circ} 00^{\prime} \mathrm{W}$ [W end]. Var. Chugatch Mountains, Chugatz Mountains, Tchougatskoi.

Eskimo tribal name recorded by the Russians and written by them "Chugatz" and "Tchougatskoi"; in 1898 Capt. W. R. Abercrombie, USA, spelled the name "Chugatch" and applied it to the mountains.

Chugach National Forest: on $\mathbf{S}$ central coast between Chugach Mts. and Gulf of Alaska, extends $\mathrm{W}$ from Bering Glacier, $\mathrm{E}$ of Cordova to Kenai Mts. on Kenai Penin.;

The Chugach National Forest was created by Presidential Proclamation on July 23, 1907.

Chugach Passage: water passage, $6 \mathrm{mi}$. long, between Kenai Penin. and Perl and Elizabeth Is., $20 \mathrm{mi}$. $\mathrm{S}$ of Seldovia, $59^{\circ} 09^{\prime} \mathrm{N}, 151^{\circ} 44^{\prime}$ W; BGN 1929; (map 50).

Named in 1929 by "Lighthouse Inspector Dibrell," and reported by USC\&GS the same year.

Chugach Sound: gulf, see Prince William Sound. Chugak Island: island, see Shuyak Island.

Chugal: island, see Chugul İsland.

Chugal Island: island, see Segula Island.

Chugatch Mountains: monutain range, see Chugach Mountains.

Chugatch Sound: gulf, see Prince William Sound.

Chugatskaya, Guba: gulf, see Prince William Sound.

Chugatskay Zaliv: gulf, see Prince William Sound.

Chugatskiya, Ostrova: islands, see Chugach Islands.
Chugatskiye, Ostrova: islands, see Chugach Islands.

Chugatz Islands: islands, see Chugach Islands.

Chugatz Mountains: mountain range, see Chugach Mountains.

Chugiak: village, pop. 51 , on Glenn Highway, $\mathrm{S}$ of Birchwood, $18 \mathrm{mi}$. NE of Anchorage, Cook Inlet Low.; $61^{\circ} 23^{\prime} 50^{\prime \prime} \mathrm{N}, 1^{\circ} 29^{\circ} 20^{\prime} 40^{\prime \prime} \mathrm{W}$; (map 69).

This village is part of the population extension northeast of Anchorage.

Chuginadak Island: island, $14 \mathrm{mi}$. long, largest of Islands of Four Mountains, Aleutian Is.; $52^{\circ} 50^{\prime} \mathrm{N}, 169^{\circ} 45^{\prime} \mathrm{W}$; BGN Sixth Report; (map 21). Var. Amagta, Isla Amogla, Khagamil Island, Kigalmilyakh Island, Kitalga Island, Ostrov Khagamil, Tanaguni Island, Tanak-Agunak Island, Tanakaniunak Island, Tanakh-Angounakh Island, Tano Island, Tchuginadak.

Aleut name published by Capt. Tebenkov (1852, map 25), IRN. According to R. H. Geoghegan, the Aleut stem "chugi" means "to roast or fry." The island was called "O[strov] Khagamil," or "Khagamil Island" by Lt. Sarichev (1826, map 3), IRN, and "O[strov] Kigamilyakh," or "Kigamilyakh Island" by the Russian Hydrog. Dept. (1847, Chart 1379). Some of the variant names come from the Aleut "tanam-anguna," meaning "the great land." According to R. H. Geoghegan, this name applies to "one of the islands of the Four Mountains, whence it is fabled the Aleut race sprang." See Four Mountains, Islands of.

Chuginadak Pass: water passage, between Chuginadak and Herbert Is:, Aleutian Is.; $52^{\circ} 48^{\prime}$ $\mathrm{N}, 170^{\prime} 02^{\prime} \mathrm{W}$; (map 20).

Named after Chuginadak Island and published by USC\&GS in the 1947 Alaska Coast Pilot (pt. 2, p. 424).

Chuginak Island: island, see Herbert Island.

Chuginok Island: island, see Kagamil Island.

Chugowonu Kchugoveet: mountains, see Horn Mountains.

Chugruk Hills: hills, see Uchugrak Hills.

Chugula, Ostrov: island, see Chugul Island.

Chuguliak Island: island, see Herbert Island.

Chugul Island: island, $5 \mathrm{mi}$. long, between Atka and Adak Is., Andreanof Is., Aleutian Is.; $51^{\circ} 56^{\prime} 30^{\prime \prime} \mathrm{N}, 175^{\circ} 48^{\prime} 30^{\prime \prime} \mathrm{W}$; BGN 1901; (map 18). Var. Chagyulak, Chegula, Chigul Island, Chugal, Chugula, Ostrov, Segula, Sigoola, Tchegoulak Island, Tchigul, Tchougoul ile, Tchougoulok, Tchougoulak, Tchougovlak, Tchovgoul, Tschechovla, Tshugulla.

Aleut name reported by early Russian explorers and recorded as "Tshugulla" by Commodore Joseph Billings, IRN, in 1790. Two forms, "Tchougoul" and "Tchougoulak," were published by Capt. Lutke (1836, p. 320), IRN. The island is shown as Chugul Island by the USC\&GS in the 1944 Aleutian Coast Pilot (p. 103).

Chugal Island: island, see Chagulak Island. Ghugul Island: island, see Segula Island.
Chugul Pass: water passage, $4 \mathrm{mi}$. wide, between Chugul and Umak Is., Aleutian Is.; $51^{\circ} 55^{\prime} \mathrm{N}$, 175 $54^{\prime}$ W; BGN 1936; (map 18).

Named for Chugul I. by the U.S. Navy Aleutian Island Survey Expedition of 1934. $\mathrm{It}$ is considered the best passage to Kuluk Bay on Adak I. from the southeast. Name published by the USC\&GS in the 1944 Aleutian Coast Pilot (p. 103).

Chugul Point: promontory, on SW coast of Segula I., Rat Is., Aleutian Is.; $52^{\circ} 00^{\prime} \mathrm{N}, 178^{\circ} 06^{\prime}$ E; BGN 1937: (map 15).

Named by personnel of U.S.S. Oglala of 1935 U.S. Navy Survey Expedition. It is an earlier Aleut name for Segula I.

Chugunakhchugvik: locality, see Chagunakhchugvik.

Chuilanuk River: stream, see Atchuelinguk River.

Chuilnak River: stream, see Atchuelinguk River.

Chuilnuk Mountains: range, 2,500 ft., in Kuskokwim Mts., extends NE-SW $10 \mathrm{mi}$. between Chuilnuk River and Portage Creek, $28 \mathrm{mi}$. SW of Sleetmute, Kilbuck-Kuskokwim Mts.; $61^{\circ}$ $20^{\prime} \mathrm{N}, 157^{\circ} 50^{\prime} \mathrm{W}$; BGN 1948 (map 72).

Local name derived from river which drains its eastern slopes; reported in 1945 by USGS.

Chuilnuk River: stream, heads in lake in Chuilnuk Mts., flows SE $30 \mathrm{mi}$. to Holitna River, $42 \mathrm{mi}$. SW of Sleetmute, Kilbuck-Kuskokwim Mts.; $61^{\circ} 06^{\prime} 30^{\prime \prime} \mathrm{N}, 157^{\circ} 24^{\prime} 00^{\prime \prime} \mathrm{W} ; B G N$ 1948; (map 72).

Eskimo name reported to mean "otter"; reported in 1944 by USGS.

Chuimund Lake: lake, $1 \mathrm{mi}$. long, S of Nuziamund Lake, $24 \mathrm{mi}$. SE of Tok, Alaska Ra.; $63^{\circ} 02^{\prime} \mathrm{N}, 142^{\circ} 31^{\prime} \mathrm{W}$; (map 85$)$.

Indian name reported in 1964 by USGS.

Chuitan River: stream, see Chuitna River.

Chuitbuna Lake: lake, $0.7 \mathrm{mi}$. long, on NW shore of Cook Inlet, $3 \mathrm{mi}$. N of Tyonek, Cook Inlet Low.; $61^{\circ} 07^{\prime} 10^{\prime \prime} \mathrm{N}, 151^{\circ} 09^{\prime} 00^{\prime \prime} \mathrm{W}$; (map 70).

Name reported in 1958 by USGS; derived from nearby Chuitna River.

Chuit Creek: stream, flows SE $12 \mathrm{mi}$. to Chuitna River $13 \mathrm{mi}$. NW of Tyonek, Cook Inlet Low.; $61^{\circ} 09^{\prime} 20^{\prime \prime} \mathrm{N}, 151^{\circ} 30^{\prime} 15^{\prime \prime} \mathrm{W}$; BGN 1964; (map 70). Var. North Fork Chuitna River. Named in 1964 by USGS.

Chuit Flats: tidal flat, at mouth of Chuitna River, $1.5 \mathrm{mi}$. N of Tyonek, Cook Inlet Low.; $61^{\circ} 05^{\prime} 45^{\prime \prime} \mathrm{N}, 151^{\circ} 06^{\prime} 30^{\prime \prime} \mathrm{W}$; (map 70).

Name published in 1958 by USGS.

Chuitkilnachna Creek: stream, distributary of Chakachatna River, flows SE $16 \mathrm{mi}$. to Trading Bay, $32 \mathrm{mi}$. NNW of Kenai, Cook Inlet Low.; $60^{\circ} 58^{\prime} \mathrm{N}, 151^{\circ} 35^{\prime} \mathrm{W}$; (map 70).

Tanaina Indian name reported in 1958 by USGS

Chuitna: locality, see Ladd.

Chuitna River: stream, flows SE $37 \mathrm{mi}$. to Cook Inlet, 2 mi. $\mathrm{N}$ of Tyonek, Cook Inlet Low.; $61^{\circ} 05^{\prime} 45^{\prime \prime}$ N, 151 06'45" W; BGN 1961; (map 70). Var. Chaitna River, Chuitan River, Chuit River, Shuitna River, Shultna River. 
Tanaina Indian name reported in 1898 by Eldridge (1900, map 3), USGS.

Chuitna River: stream, see Chulitna River.

Chuit River: stream, see Chuitna River.

Chuiu River: stream, see Douglas River.

Chukajak Creek: stream, flows SW $10 \mathrm{mi}$. to

Tubutulik River, $22 \mathrm{mi}$. NE of Elim and 72

mi. NE of Solomon, Seward Penin. High.; $64^{\circ} 55^{\prime} \mathrm{N}, 162^{\circ} 09^{\prime} \mathrm{W}$; (map 95).

This is a local Eskimo name reported in 1900 by W. J. Peters (in Mendenhall, 1901, pl. 20), USGS.

Chukaktoligamut: village, see Chakaktolik.

Chukaktolik: village, see Chakaktolik.

Chukawon River: stream, see Chukowan River.

Chukchagemiut: locality, see Chakchak.

Chukchak: locality, see Chakchak.

Chukchak Creek: stream, see Chakchak Creek. Chukchak River: stream, see Chakchak Creek.

Chukchi Sea: sea, on S side of Arctic Ocean, between Siberia on SW and Alaska on SE; it is defined by Point Barrow, Alaska, at NE end, Wrangel I., U.S.S.R., at NW end and is connected by Bering Strait with Bering Sea on S.; $69^{\circ} \mathrm{N}, 174^{\circ} \mathrm{W} ; B G N 1952$. Var. Chuckchee, Chuckchee Sea, Chukotsi Sea, Chukotskoe, Chukotskoe More, Chukotskoye More, Tschuktschen-See.

Chukchuk: locality, see Chakchak.

Chukfaktoolik: village, see Chakaktolik.

Chukotsi Sea: sea, see Chukchi Sea.

Chukotskoe: sea, see Chukchi Sea.

Chukotskoe More: sea, see Chukchi Sea.

Chukotskoye More: sea, see Chukchi Sea.

Chukowan River: stream, heads at junc. of Gemuk River and Chikululnuk Creek, flows NE $30 \mathrm{mi}$. to Holitna River, $64 \mathrm{mi}$. SW of Sleetmute, Kilbuck-Kuskokwim Mts.; $60^{\circ} 50^{\prime}$ N, 157 $50^{\prime} \mathrm{W}$; BGN 1948; (map 60). Var. Big Swift River, Chukawon River, Chuck-awon-ugh-toly.

Eskimo name written "Chuck-a-won-ughtoly" on a manuscript map by W. R. Buckman, who prospected in this area in 1902-03.

Chukwoktulik: village, see Chakaktolik.

Chukwoktulik: village, see Chakwaktolik.

Chukwotuliugamute: village, see Chakwaktolik.

Chukwugwahlik River: flows S $15 \mathrm{mi}$. to an arm of Dall Lake, $60 \mathrm{mi}$. SW of Bethel, Yukon-Kuskokwim Delta; $60^{\circ} 26^{\prime} \mathrm{N}, 163^{\circ} 22^{\prime} \mathrm{W}$; (map 58).

Eskimo name reported in 1949 by USC\&GS.

Chukwuktoligamut: village, see Chakwaktolik.

Chul-chágu: locality, see Klughuggue.

Chuligmiut: locality, see Chulik.

Chulik: locality, "on E coast of Nunivak $\mathrm{I}$." in Bering Sea; (map 57). Var. Chuligmiut, Upper Chuligmiut.

Former Eskimo fishing station comprised of "Chuligmiut" and "Upper Chuligmiut" and listed with a combined population of 62 in the 1890 Census.

Chulitna: $R R$. station, mile 273.8 on The Alaska RR., 43 mi. NE of Talkeetna, Talkeetna Mts.; $62^{\circ} 53^{\prime} 20^{\prime \prime} \mathrm{N}, 149^{\circ} 35^{\prime} 02^{\prime \prime} \mathrm{W}$; (map 82).

This station was named in 1916 for nearby Chulitna River and has been in use since the opening of the line.
Chulitna: stream, see Holitna River.

Chulitna Bay: bay, on W shore of Lake Clark, extends $\mathrm{E} 4 \mathrm{mi}$. from mouth of Chulitna River, $18 \mathrm{mi}$. NE of Nondalton, Alaska Ra.; $60^{\circ} 12^{\prime}$ $\mathrm{N}, 154^{\circ} 27^{\prime} \mathrm{W}$; (map 61).

Name shown on a 1909 fieldsheet by D. C. Witherspoon, USGS.

Chulitna Butte: hill, 2,200 ft., N of Chulitna Pass and $39 \mathrm{mi}$. SW of Cantwell, Talkeetna Mts. ; 62 $55^{\prime} 45^{\prime \prime} \mathrm{N}, 149^{\circ} 37^{\prime} 30^{\prime \prime} \mathrm{W}$; (map 82).

Name shown on a 1918 engineering map of The Alaska Railroad. Named for the river.

Chulitna Glacier: glacier, see Eldridge Glacier. Chulitna Glacier: glacier, see Ruth Glacier.

Chulitna Pass: pass, 1,350 ft., $1.5 \mathrm{mi}$. NW of Chulitna and $39 \mathrm{mi}$. SW of Cantwell, Talkeetna Mts.; $62^{\circ} 54^{\prime} \mathrm{N}, 149^{\circ} 36^{\prime} \mathrm{W}$; (map 82).

Name shown on a 1918 engineering map of The Alaska Railroad. Named for the river. Chulitna River: stream, flows E $90 \mathrm{mi}$. to Turner Bay on NW shore of Lake Clark, $15 \mathrm{mi}$. NE of Nondalton, Alaska Ra.; $60^{\circ} 12^{\prime} \mathrm{N}, 154^{\circ} 34^{\prime}$ W; (map 61). Var. Charleetna River, Chuitna River, Chultina River, Chutina River.

Tanaina Indian name reported in 1890 by Schantz (1893, p. 92), while gathering information for the 1890 Census.

Chulitna River: stream, formed by its Middle and East Forks at $63^{\circ} 06^{\prime} 30^{\prime \prime} \mathrm{N}, 149^{\circ} 31^{\prime} 30^{\prime \prime}$ W, flows SW $70 \mathrm{mi}$. to Susitna River, $1.5 \mathrm{mi}$. NW of Talkeetna, Cook Inlet Low. ; 62 ${ }^{\circ} 20^{\prime} 15^{\prime \prime}$ N, $150^{\circ} 09^{\prime} 15^{\prime \prime} \mathrm{W}$; (map 81). Var. Chulit River, Chulitno River.

Indian name reported in 1898 by G. H. Eldridge, USGS.

Chulitno River: stream, see Chulitna River.

Chulit River: stream, see Chulitna River.

Chultikana Creek: stream, heads $3.9 \mathrm{mi}$. NW of Mount Carter, flows SE $5.5 \mathrm{mi}$. to Klutina Lake, $2 \mathrm{mi}$. SW of Dowling Peak and $46 \mathrm{mi}$. NE of Valdez, Chugach Mts.; $61^{\circ} 44^{\prime} 35^{\prime \prime} \mathrm{N}$, $145^{\circ} 48^{\prime} 20^{\prime \prime}$ W; (map 68). Var. Chultik Creek.

Indian name published on 1932 USGS map. Chultik Creek: stream, see Chultikana Creek.

Chultina River: stream, see Chulitna River.

Chum Creek: stream, flows $\mathrm{N} 4 \mathrm{mi}$. to $\mathrm{S}$ end of Kashevarof Passage, on NE coast of Prince of Wales I., Alex. Arch.; 56 $00^{\circ} 50^{\prime \prime} \mathrm{N}, 132^{\circ} 49^{\prime}$. $10^{\prime \prime} \mathrm{W}$; $(\operatorname{map} 6)$

Local name reported in 1961 by USFS; probably so named "because of heavy chum salmon spawning in it."

Chuna, Cape: point of land, on SW coast of Kanaga I., Aleutian Is.; $51^{\circ} 40^{\prime} \mathrm{N}, 177^{\circ} 39^{\prime}$ W; (map 17), Var. Mys Chuna, Cape Tchuna.

Name published by USC\&GS in the 1944 Aleutian Coast Pilot (p. 119).

Chunak Point: point of land, at $\mathrm{W}$ entrance to Bechevin Bay, on NE coast of Unimak I., Aleutian Is.; $55^{\circ} 02^{\prime} \mathrm{N}, 163^{\circ} 27^{\prime} \mathrm{W}$; (map 29). Var. Chunnak, Chunnok, Mys Chunok, Tchounnok.

Aleut name published by Capt. Lutke (1836, p. 263), IRN, as "Tchounnok" and by
Capt. Tebenkov (1852, map 24), IRN, as "M[ys] Chunok" or "Chunok Cape."

Chunekukleik Mountain: mountain, 5,780 ft., on Takhin Ridge, $2.9 \mathrm{mi}$. SW of mouth of Anman Creek, in Chilkat Lake, $26 \mathrm{mi}$. SW of Skagway, St. Elias Mts. ; $59^{\circ} 17^{\prime} 30^{\prime \prime} \mathrm{N}, 135^{\circ} 57^{\prime} 00^{\prime \prime}$ W; (map 45). Var. Tschuh-nek-kutsch-kleheek.

Tlingit Indian phrase shortened from "Tschuh-nek-kutsch-kleh-eek," me a n ing "notch in the arrow mountain," which refers to the hornlike top of the mountain with a notch resembling that in the back end of an arrow. This name was given by E. C. Robertson, geologist, and published in 1952 by USGS.

Chung-nok-du-li: lake, see Nerka, Lake.

Chuniksak, Mys: point of land, see Chuniksak Point.

Chuniksak Creek: stream, on S coast of Attu I., flows S $4.4 \mathrm{mi}$. to the Pacific Ocean, at Chuniksak Point, Aleutian Is.; $52^{\circ} 47^{\prime} 25^{\prime \prime} \mathrm{N}$, 172 $46^{\prime} 40^{\prime \prime} \mathrm{E}$; (map 13).

Name derived from Chuniksak Point; published in 1948 by AMS.

Chuniksak Point: point of land, on $\mathrm{S}$ coast of Attu I., between Abraham and Nevidiskov Bays, Aleutian Is.; $52^{\circ} 47^{\prime} 45^{\prime \prime} \mathrm{N}, 172^{\circ} 46^{\prime} 30^{\prime \prime}$ E; BGN 1938; (map 13). Var. Mys Chuniksak, Ekdokuch Point.

Aleut name published by Capt. Tebenkov (1852, map 30), IRN, as "M[ys] Chuniksak" or "Cape Chuniksak." The name was shown as "Ekdokuch Point" on manuscript map by L. M. Turner made in the 1880's.

Chunilna Creek: stream, heads at $63^{\circ} 43^{\prime} \mathrm{N}$, $149^{\circ} 15^{\prime} \mathrm{W}$; flows SW $50 \mathrm{mi}$. to Talkeetna River, $4.5 \mathrm{mi}$. NE of Talkeetna, Cook Inlet Low.; $62^{\circ} 22^{\prime} 15^{\prime \prime} \mathrm{N}, 150^{\circ} 00^{\prime} 30^{\prime \prime} \mathrm{W}$; (map 81). Var. Ghinaldna Creek, Chinalno Creek, Chinaltno Creek.

Indian name reported in 1898 by G. $\mathbf{H}$. Eldridge and Robert Muldrisw, USGS. On one manuscript map they spell the name, "Chunilna"; on another, "Chinaldna."

Chunilna Creek: stream, see Talkeetna River.

Chunnak: point of land, see Chunak Point.

Chunnok: point of land, see Chunak Point.

Chunok, Mys: point of land, see Chunak Point. Chunu Bay: bay, $1.6 \mathrm{mi}$. across, on $\mathrm{SW}$ coast of Kanaga I., Aleutian Is.; $51^{\circ} 41^{\prime} 30^{\prime \prime} \mathrm{N}, 177^{\circ}$ $36^{\prime} 45^{\prime \prime}$ W; (map 17).

Name derived from Cape Chunu and published by USC\&GS in 1956 on Chart 9145 .

Chŭnŭng'ŭm-al'gerā: bluff, see Kamina.

Chupador, Cabo: point of land, see Suckling, Cape.

Churartwlik River: stream, see Chakaktolik Creek.

Churchill, Mount: mountain, 15,638 ft., 2 mi. $\mathrm{NE}$ of Mount Bona and $41 \mathrm{mi}$. E of McCarthy, St. Elias Mts.; $61^{\circ} 25^{\prime} 13^{\prime \prime} \mathrm{N}, 141^{\circ} 42^{\prime} 50^{\prime \prime} \mathrm{W}$; $B G N$ 1965; (map 67).

Named in 1965 by Alaska State Legislature in Senate Joint Resolution No. 29, for Winston Churchill, 1874-1965, English statesman. See Churchill Peaks. 
Churchill Peaks: peaks, consisting of two principal peaks of Mount McKinley, North Peak, $19,470 \mathrm{ft}$., and South Peak, 20,320 ft., in Mount McKinley National Park, Alaska, Ra.; $63^{\circ} 05^{\prime} \mathrm{N}, 151^{\circ} 20^{\prime} \mathrm{W}$; BGN 1965; (map 88).

Named in 1965 by NPS for Sir Winston Churchill, 1874-1965, Prime Minister of Great Britain during World War II. See McKinley, Mount.

Church Peak: mountain, $4,719 \mathrm{ft}$., $16 \mathrm{mi}$. NE of Petersburg, Coast Mts.; $56^{\circ} 56^{\prime} 45^{\prime \prime} \mathrm{N}, 132^{\circ}$ $35^{\prime} 00^{\prime \prime} \mathrm{W}$; (map 6).

Named by USC\&GS for charting purposes; name published in 1943.

Church Point: point of land, at entrance to Gambier Bay, on E coast of Admiralty I., $61 \mathrm{mi}$. NE of Sitka, Alex. Arch.; 57 $26^{\prime} 45^{\prime \prime} \mathrm{N}$, $133^{\circ} 54^{\prime} 40^{\prime \prime} \mathrm{W}$; (map 8).

Named in 1889 by Lt. Comdr. H. B. Mansfield, USN; published by USC\&GS in the 1891 Coast Pilot (p. 143)

Church Rock: point of land, protrudes into Spafarief Bay, $54 \mathrm{mi}$. SW of Selawik, KotzebueKobuk Low.; $66^{\circ} 11^{\prime} \mathrm{N}, 161^{\circ} 37^{\prime} \mathrm{W}$; (map 114).

Local name reported in 1925 by USC\&GS.

Church Slough: stream, anabranch of Kuskokwim River, trends SW $5 \mathrm{mi}$., $14 \mathrm{mi}$. SE of Bethel, Yukon-Kuskokwim Delta; 60 $0^{\circ} 7^{\prime}$ N, $161^{\circ} 39^{\prime} \mathrm{W}$; (map 59). Var. Ariarigayarak Slough.

Local name reported in 1955 by J. M. Hoare, USGS.

Chusana River: stream, see Chisana River.

Chusini Cove: bay, $0.8 \mathrm{mi}$. wide, on $\mathrm{W}$ coast of Prince of Wales I., $24 \mathrm{mi}$. N of Craig, Alex. Arch.; 55 $48^{\prime} 45^{\prime \prime} \mathrm{N}, 133^{\circ} 10^{\prime} 15^{\prime \prime} \mathrm{W}$; (map 4). GS

Indian name published in 1964 by USC\&-

Chustylena, Ozero: lake, see Tustumena Lake. Chute Creek: stream, flows NW $6 \mathrm{mi}$. to Wood River, $36 \mathrm{mi}$. NE of Healy, Alaska Ra.; $63^{\circ} 57^{\prime} 30^{\prime \prime} \mathrm{N}, 147^{\circ} 47^{\prime} 15^{\prime \prime} \mathrm{W}$; (map 87).

Prospectors' name shown on a 1910 fieldsheet by J. W. Bagley, USGS; published by Capps (1912, pl. 1), USGS.

Chutina River: stream, see Chulitna River.

Chuttoh Bluffs: bluffs, $4 \mathrm{mi}$. long, along $S$ bank of Chandalar River, opposite mouth of East Fork Chandalar River, $44 \mathrm{mi}$. SE of Chandalar, Brooks Ra.; $67^{\circ} 05^{\prime} \mathrm{N}, 147^{\circ} 14^{\prime} \mathrm{W}$; (map 123).

Local name reported in 1956 by T. E. Taylor, USGS.

Chuyak Island: island, see Shuyak Island.

Chuyak Strait: water passage, see Shuyak Strait.

Chuyu River: stream, see Douglas River.

Chwarlitiligamut: locality, see Chuarlitiligamut.

Chyernysheva, Gory: peaks, see Devils Prongs.

Cicely, Lake: lake, $0.2 \mathrm{mi}$. long, drains $\mathrm{S}$, through

Lake Aurel to Russian Creek, $9.8 \mathrm{mi}$. SW of

Kodiak, Kodiak I. ; $57^{\circ} 42^{\prime} 20^{\prime \prime}$ N, $152^{\circ} 37^{\prime} 00^{\prime \prime}$

W; (map 34).

Local name reported in 1949 by USGS.

Cinder Cove: cove, see Stepanof Cove.
Cinder Creek: stream, see Cinder River.

Cinder Point: point of land, in Inanudak Bay, on W central coast of Umnak I., Aleutian Is.; $53^{\circ} 18^{\prime} \mathrm{N}, 168^{\circ} 22^{\prime} \mathrm{W} ; B G N$ 1940; (map 22).

Descriptive name given in 1938 by USC\&GS "because of the prominent cinder cone on point."

Cinder River: stream, heads at $56^{\circ} 59^{\prime} \mathrm{N}, 157^{\circ} 42^{\prime}$ $\mathrm{W}$, and flows NW $44 \mathrm{mi}$. to Bristol Bay, 136 mi. NE of Port Moller and $175 \mathrm{mi}$. SE of Cape Newenham, Bristol Bay Low.; $57^{\circ} 22^{\prime}$ $30^{\prime \prime} \mathrm{N}, 158^{\circ} 07^{\prime} 30^{\prime \prime} \mathrm{W}$; (map 37). Var. Cinder Creek.

So named by R. H. Sargent, USGS, in 1923 "because its valley had been filled with cinderlike ejecta from Aniakchak Volcano." It was called Cinder Creek by W. R. Smith and A. A. Baker (in Brooks and others, 1924, pl. 8), USGS.

Cinnabar Creek: stream, flows SE $3 \mathrm{mi}$. to Beaver Greek, $85 \mathrm{mi}$. SW of Sleetmute, KilbuckKuskokwim Mts.; $60^{\circ} 46^{\prime} \mathrm{N}, 158^{\circ} 48^{\prime} \mathrm{W}$; $B G N$ 1.945; (map 60).

Local name reported in 1944 by USGS; name derived from the deposits of cinnabar, a mercury ore, that were found here.

Circle: village, pop. 41, on left bank of Yukon River, $130 \mathrm{mi}$. NE of Fairbanks, Yukon Flats; $65^{\circ} 49^{\prime} 30^{\prime \prime} \mathrm{N}, 144^{\circ} 03^{\prime} 30^{\prime \prime} \mathrm{W}$; BGN 1944; (map 104). Var. Circle City.

Mining supply town established in 1887 when L. N. McQuesten located a trading post here (Kitchener, 1915, p. 187). So named because the village was thought to be on the Arctic Circle. The Circle post office was established in 1896. Its population was 144 in $1910 ; 96$ in $1920 ; 50$ in $1930 ; 98$ in 1939 ; and 83 in 1950.

Circle Bay: bight, $1.2 \mathrm{mi}$. across, on SE coast of Woronkofski I., Alex. Arch.; 56 $23^{\prime}$ N, $132^{\circ}-$ $26^{\prime}$ W; BGN 1917; (map 6).

Descriptive name given in 1916 by J. A. Daniels, USC\&GS.

Circle City: village, see Circle.

Circle Creek: stream, flows NE $8 \mathrm{mi}$. to join Spruce Creek, forms Holtz Creek in Kugruk River basin, $19 \mathrm{mi}$. E of Imuruk Lake, Seward Penin. High.; $65^{\circ} 33^{\prime} \mathrm{N}, 162^{\circ} 32^{\prime} \mathrm{W}$; (map 110).

Prospectors' name reported in 1903 by D. C. Witherspoon (in Moffit, 1905, pl. 2), USGS. Circle Hot Springs: village, $29 \mathrm{mi}$. SW of Circle, Yukon-Tanana High.; $65^{\circ} 29^{\prime} \mathrm{N}, 144^{\circ} 38^{\prime} \mathrm{W}$; (map 104). Var. Arctic Circle Hot Springs, Circle Springs, Hot Springs.

The hot springs here were reportedly discovered in 1893 by William Greats. In 1905, Franklin Leach homesteaded 160 acres around the springs and developed the place into a resort. The population of the resort was 17 in $1930 ; 14$ in $1939 ; 36$ in 1958. The "Circle Springs" post office was established in 1924.

Circle Island: island, $1 \mathrm{mi}$. across, in Yukon River 1.2 mi. S of Russian Mission, YukonKuskokwim Delta ; $61^{\circ} 45^{\prime} 30^{\prime \prime}$ N, 161 ${ }^{\circ} 19^{\prime} 00^{\prime \prime}$ W; (map 73).
Riverboat pilots' name shown on a 1916 field sheet by R. H. Sargent, USGS.

Circle Island: island, $1 \mathrm{mi}$. long, $\mathrm{S}$ of Tozitna I., in Yukon River, $11 \mathrm{mi}$. WSW of Tanana, Nowitna Low.; $65^{\circ} 07^{\prime} \mathrm{N}, 152^{\circ} 26^{\prime} \mathrm{W}$; (map 106).

Local name reported in 1952 by USGS.

Circle Lake: lake, $300 \mathrm{ft}$. long, on Kenai Penin., $2 \mathrm{mi}$. SW of Eagle Lake and $18 \mathrm{mi}$. NE of Homer, Cook Inlet Low.; $59^{\circ} 48^{\prime} 10^{\prime \prime} \mathrm{N}, 151^{\circ}$ $09^{\prime} 30^{\prime \prime} \mathrm{W}$; (map 50).

Local name reported and published by USGS in the 1950's.

Circle Point: point of land, on $\mathrm{W}$ shore of Stephens Passage, $0.5 \mathrm{mi}$. NW of Butler Peak and $18 \mathrm{mi}$. SE of Juneau, Coast Mts.; $58^{\circ}$ $07^{\prime} 30^{\prime \prime} \mathrm{N}, 134^{\circ} 04^{\prime} 45^{\prime \prime} \mathrm{W}$; (map 11).

Descriptive name given in 1881 by Lt. Comdr. C. M. Thomas, USN, and published in 1889 by USC\&GS.

Circle Slough: watercourse, $2.2 \mathrm{mi}$. long, channel of Yukon River, W of Circle I., $2 \mathrm{mi}$. S of Russian Mission, Yukon-Kuskokwim Delta; $61^{\circ} 45^{\prime} 30^{\prime \prime} \mathrm{N}, 161^{\circ} 19^{\prime} 50^{\prime \prime} \mathrm{W}$; (map 73).

Riverboat pilots' name shown on a 1922 manuscript chart.

Circle Springs: settlement, see Circle Hot Springs.

Cirque Creek: stream, flows S $2.5 \mathrm{mi}$. to Bow Creek, $30 \mathrm{mi}$. NE of Augustine I., Aleutian Ra.; $59^{\circ} 45^{\prime} \mathrm{N}, 153^{\circ} 06^{\prime} \mathrm{W}$; (map 51 ).

Local name derived from the valley's resemblance to a cirque at the head of the stream. The name was published by USGS in 1958.

Gisca Lake: lake, $0.5 \mathrm{mi}$. long, on Kenai Penin., $0.3 \mathrm{mi}$. W of Tree Lake and $10 \mathrm{mi}$. E of Kenai, Cook Inlet Low.; $60^{\circ} 33^{\prime} 40^{\prime \prime} \mathrm{N}, 150^{\prime} 56^{\prime} 00^{\prime \prime}$ $\mathrm{W}$; $(\operatorname{map} 62)$.

Named about 1963 by officials of Kenai National Moose Range, for administrative purposes.

Citadel, The: peak, 6,830 ft., $1 \mathrm{mi}$. NW of Dipyramid and $35 \mathrm{mi}$. $\mathrm{N}$ of Juneau, Coast Mts.; $58^{\circ} 46^{\prime} 25^{\prime \prime} \mathrm{N}, 1^{\circ} 04^{\circ} 08^{\prime} 20^{\prime \prime} \mathrm{W}$; $B G N$ 1954; (map 11).

Named in 1964 by members of the Juneau Icefield Research Project; published in 1966 by USGS.

Citellus Lake: lake, $2.4 \mathrm{mi}$. long, $\mathrm{W}$ of junc. of Ishuktak Creek and Topagoruk River, $36 \mathrm{mi}$. $\mathrm{SE}$ of village of Meade River, Arctic Plain; $70^{\circ} 10^{\prime} \mathrm{N}, 156^{\circ} 06^{\prime} \mathrm{W}$; (map 147).

Named for the Parry ground squirrel (Citellus parryii barrowensis); published on recent maps.

City of Topeka Rock: rock, in Highfield Anchorage, on $\mathrm{N}$ coast of Wrangell I., Alex. Arch.; $56^{\circ} 29^{\prime} 20^{\prime \prime} \mathrm{N}, 132^{\circ} 22^{\prime} 40^{\prime \prime} \mathrm{W}$; (map 6).

Named in 1901 by USC\&GS for the City of Topeka, a steamer of the Pacific Coast Steamship Co., whose crew discovered this feature.

City View: area, SE of Merrill Field Airport, in Anchorage, Cook Inlet Low.; 61 $12^{\prime} 16^{\prime \prime}$ N, $149^{\circ} 49^{\prime} 50^{\prime \prime} \mathrm{W}$; (map 69).

Local name reported in 1954 by the city engineer of Anchorage. 
Givoutchy Rocher: island, see Goose Island. Givoutchy Rocher: island, see Little Goose Island.

Cladonia Creek: stream, flows SE $9.5 \mathrm{mi}$. from a lake to North Fork Koyukuk River, $5 \mathrm{mi}$. SW of Redstar Mtn. and $31 \mathrm{mi}$. NW of Wiseman, Brooks Ra.; $67^{\circ} 42^{\prime} 45^{\prime \prime} \mathrm{N}, 151^{\circ} 00^{\prime} 25^{\prime \prime}$ W; (map 124).

Name reported about 1930 by Marshall (1956, p. 117). Cladonia is a genus of lichens often referred to as Reindeer Moss.

Clahona River: stream, see Klahini River.

Claikahak: locality, on right bank of Yukon River, near Nunaikak, Innoko Low. Var. Glaikahakamut.

Former Eskimo village shown as "Claikahakamut" on a 1903 post route map.

Claikahakamut: locality, see Claikahak.

Claikehak: locality, "on the north bank of the Yukon River." Var. Claikehakamut.

Former Eskimo village shown as "Claikehakamut" on a 1903 post route map.

Claikehakamut: locality, see Claikehak.

Claim Point: point of land, on S coast of Kenai Penin., $2 \mathrm{mi}$. N of Elizabeth I. and $17 \mathrm{mi}$. SSW of Seldovia, Chugach Mts.; $59^{\circ} 12^{\prime} \mathrm{N}$, 151 ${ }^{\circ} 49^{\prime}$ W; BGN 1908; (map 50).

Local name reported by USC\&GS, in 1908, and probably named for mining claims located in the area.

Clam Cove: cove, $0.4 \mathrm{mi}$. across, on $\mathrm{S}$ shore of Kassa Inlet, on SW coast of Prince of Wales I., Alex. Arch.; $54^{\circ} 56^{\prime} 30^{\prime \prime} \mathrm{N}, 132^{\circ} 28^{\prime} 30^{\prime \prime} \mathrm{W}$; (map 1).

Local name published in 1943 by USC\&GS.

Clam Cove: cove, $0.5 \mathrm{mi}$. across, on NE coast of Gravina I., $1.2 \mathrm{mi}$. S of Ketchikan, Alex. Arch.; $55^{\circ} 19^{\prime} 30^{\prime \prime} \mathrm{N}, 131^{\circ} 39^{\prime} 30^{\prime \prime} \mathrm{W}$; (map 3).

Local name recorded in 1954 by USGS.

Clam Cove: cove, $0.5 \mathrm{mi}$. across, off EI Capitan Passage, on W coast of Prince of Wales I., Alex. Arch.; $55^{\circ} 58^{\prime} 45^{\prime \prime} \mathrm{N}, 133^{\circ} 16^{\prime} 00^{\prime \prime} \mathrm{W}$; (map 4).

Local name published in the 1925 Coast Pilot (p. 156).

Clam Cove: cove, $500 \mathrm{ft}$. wide, on $\mathbf{S}$ coast of Kenai Penin., at NW end of Chrome Bay, 17 mi. SSW of Seldovia, Chugach Mts.; $59^{\circ} 13^{\prime}$ $\mathrm{N}, 151^{\circ} 50^{\prime} \mathrm{W}$; (map 50).

Local name reported in 1939 by USC\&GS on Chart 8531.

Clam Cove: bight, at $\mathrm{N}$ entrance to Chinitna Bay, $52 \mathrm{mi}$. NW of Homer, Aleutian Ra.; $59^{\circ}$ $53^{\prime} \mathrm{N}, 152^{\circ} 58^{\prime} \mathrm{W}$; (map 50$)$.

Local name reported by USGS or USC\&GS in the 1940's.

Clam Creek: stream, on Kenai Penin., flows NW $18 \mathrm{mi}$. to Deep Creek, $2 \mathrm{mi}$. SE of Cape Ninilchik and $39 \mathrm{mi}$. SW of Kenai, Cook Inlet Low.; 6001' N, 151 $39^{\prime}$ W; (map 62). Local name reported in 1964 by USGS.

Clam Gulch: village, pop. 50, on Kenai Penin., on Sterling Highway, $24 \mathrm{mi}$. S of Kenai, Cook Inlet Low.; $60^{\circ} 14^{\prime} 30^{\prime \prime} \mathrm{N}, 151^{\circ} 23^{\prime} 20^{\prime \prime} \mathrm{W}$; (map 62). Var. Clam Gulch Store.

Reported about 1947 by Barnes and Cobb (1959, pl. 17), USGS. Name derived from the ravine Clam Gulch. A post office was established here in 1950 (Ricks, 1965, p. 13).

Clam Gulch: ravine, on Kenai Penin., trends NW $0.5 \mathrm{mi}$. to Cook Inlet, $24 \mathrm{mi}$. S of Kenai, Cook Inlet Low.; $60^{\circ} 14^{\prime} 30^{\prime \prime} \mathrm{N}, 151^{\circ} 24^{\prime} 00^{\prime \prime}$ W; (map 62).

Local name reported about 1911 by USGS. Clam Gulch Store: village, see Clam Gulch.

Clam Island: island, $0.4 \mathrm{mi}$. long, in View Cove, on E coast of Dall I., Alex. Arch.; $55^{\circ} 05^{\prime} 05^{\prime \prime}$ N, 133 $02^{\prime} 10^{\prime \prime} W$; (map 4).

Local name published in 1932 Coast Pilot (p. 192).

Clam Island: island, $0.5 \mathrm{mi}$. long, between Klawak Inlet and San Alberto Bay, $3.2 \mathrm{mi}$. SW of Klawock, Alex. Arch.; 55 $31^{\prime} 10^{\prime \prime} \mathrm{N}$, $133^{\circ} 09^{\prime} 35^{\prime \prime} \mathrm{W}$; (map 4 ).

Named in 1897 by Lt. Comdr. J. F. Moser, USN.

Clam Island: island, $0.2 \mathrm{mi}$. long, in Neets Bay on NW coast of Revillagigedo I., $30 \mathrm{mi}$. N of Ketchikan, Alex. Arch.; $55^{\circ} 46^{\prime} 50^{\prime \prime} \mathrm{N}, 131^{\circ}$ $36^{\prime} 40^{\prime \prime} \mathrm{W}$; (map 3 ).

One of many arbitrary names applied to features in this area in 1891 by USC\&GS.

Clam Island: island, $0.1 \mathrm{mi}$. long, in Clam Cove, $W$ coast of Prince of Wales I., Alex. Arch.; $55^{\circ} 58^{\prime} 48^{\prime \prime} \mathrm{N}, 133^{\circ} 15^{\prime} 40^{\prime \prime} \mathrm{W}$; (map 4).

Local name published in the 1925 Coast Pilot (p. 155).

Clam Island: island, $100 \mathrm{ft}$. across, in Port Walter, $9.3 \mathrm{mi}$. $\mathrm{N}$ of village of Port Alexander, on S coast of Baranof I., Alex. Arch.; 56 $23^{\circ}$ $00^{\prime \prime} \mathrm{N}, 134^{\circ} 40^{\prime} 40^{\prime \prime} \mathrm{W}$; (map 5 ).

Local name used by fisherman; published in 1924 by USC\&GS.

Clam Island: island, see San Clemente Island.

Clam Islands: islands, extend N-S $0.5 \mathrm{mi}$., off $\mathrm{W}$ coast of Knight I., on E side of Knight Island Passage, $7 \mathrm{mi}$. NE of Chenega, Chugach Mts.; $60^{\circ} 19^{\prime} 10^{\prime \prime} \mathrm{N}, 147^{\circ} 53^{\prime} 25^{\prime \prime} \mathrm{W}$; (map 63).

Local name published in 1908 by USC\&GS.

Clam Lagoon: lagoon, $2.3 \mathrm{mi}$. long, on NE coast of Adak I., Aleutian Is.; $51^{\circ} 56^{\prime} 00^{\prime \prime} \mathrm{N}, 176^{\circ}$ 34'30" W; BGN 1936; (map 17).

So named by members of the U.S. Navy Aleutian Island Survey Expedition in 1934, "because they found quantities of clams in the lagoon."

Clam Lake: lake, $1.4 \mathrm{mi}$. long, on Kenai Penin., $2 \mathrm{mi}$. SW of Swan Lake and $22 \mathrm{mi}$. NE of Kenai, Cook Inlet Low.; 60 $38^{\prime}$ N, $150^{\circ} 36^{\prime}$ W; (map 62).

Named about 1963 by officials of Kenai National Moose Range, for administrative purposes.

Clam Lake: lake, 2,000 ft. across, in course of Nolitna Creek, $17 \mathrm{mi}$. SW of Beaver, Yukon Flats; $66^{\circ} 10^{\prime} 30^{\prime \prime} \mathrm{N}, 147^{\circ} 48^{\prime} 50^{\prime \prime} \mathrm{W}$; (map 118).

Local name obtained in 1956 by USGS.

Clam Lake: lake, $1.2 \mathrm{mi}$. long, $1.2 \mathrm{mi}$. S of Beaver Creek and $21 \mathrm{mi}$. SE of Beaver, Yukon Flats; $66^{\circ} 12^{\prime} 00^{\prime \prime} \mathrm{N}, 146^{\circ} 45^{\prime} 30^{\prime \prime} \mathrm{W}$; (map 119).

Local descriptive name obtained in 1956 by USGS.

Clanachargut: stream, see Minook Creek.
Clara Creek: stream, flows SE $1.5 \mathrm{mi}$. to Salmon River, $28 \mathrm{mi}$. NE of Cape Newenham, Kilbuck-Kuskokwim Mts.; $58^{\circ} 57^{\prime} 20^{\prime \prime} \mathrm{N}, 161^{\circ}$ 41'45" W; BGN 1938; (map 39).

A report published in 1933 by USGS stated that Clara Greek is a "well established local name, used in recording mining claims."

Clara Creek: stream, flows S $2 \mathrm{mi}$. to Nome River, $18 \mathrm{mi}$. NE of Nome, Seward Penin. High.; $64^{\circ} 46^{\prime} \mathrm{N}, 165^{\circ} 13^{\prime} \mathrm{W}$; (map 94).

Prospectors' name reported in 1900 by $E$. C. Barnard (in Brooks, 1901, pl. 17), USGS. Clara Creek: stream, flows NW $4 \mathrm{mi}$. to Mint River which flows to Lopp Lagoon, $36 \mathrm{mi}$. NW of Teller, Seward Penin. High.; 65 $37^{\prime}$ N, $167^{\circ} 16^{\prime} \mathrm{W}$; (map 111). Var. Johnston Creek.

Prospectors' name reported in 1901 by T. G. Gerdine (in Collier, 1902, pl. 12), USGS.

Clara Creek: stream, flows NW $1.2 \mathrm{mi}$. to California Creek, $15 \mathrm{mi}$. NE of Shungnak, Brooks Ra.; $66^{\circ} 57^{\prime} 25^{\prime \prime} \mathrm{N}, 156^{\circ} 38^{\prime} 00^{\prime \prime} \mathrm{W}$; (map 115).

Prospectors' name reported after 1940 by USGS.

Clara Creek: stream, flows SW $4.5 \mathrm{mi}$. to Middle Fork Koyukuk River, $1 \mathrm{mi}$. N of mouth of Slate Creek and $9.5 \mathrm{mi}$. S of Wiseman, Brooks Ra.; $67^{\circ} 16^{\prime} 30^{\prime \prime} \mathrm{N}, 150^{\circ} 10^{\prime} 00^{\prime \prime} \mathrm{W}$; (map 124).

Local name reported in 1930 by Marshall (1956, map).

Clara Marie Bay: estuary, see Aiken Cove.

Clara Smith Glacier: glacier, heads in Canada, trends SE $3 \mathrm{mi}$. to its terminus $2 \mathrm{mi}$. $\mathrm{S}$ of Mount Willibert, $26 \mathrm{mi}$. NW of Hyder, Coast Mts.; 56 $13^{\prime} \mathrm{N}, 130^{\circ} 28^{\prime} \mathrm{W}$; $B G N$ 1966; (map 7). Var. Clarasmith Glacier.

Local name reported in 1908 by IBC surveyors; published in 1927 on IBC sheet 3 as "Clarasmith Glacier."

Clare Island: island, $0.8 \mathrm{mi}$. long, between Moira Sound and Niblack Anchorage, on SE coast of Prince of Wales I., Alex. Arch.; 55 $04^{\prime}$ N, $132^{\circ} 06^{\prime} \mathrm{W}$; (map 4).

Named by local fishermen and reported in 1904 by H. C. Fassett, USBF.

Claremont Glacier: glacier, on Kenai Penin., 4 mi. long, terminates $1 \mathrm{mi}$. W of Kings Bay and $18 \mathrm{mi}$. S of Whittier, Chugach Mts.; $60^{\circ} 31^{\prime} \mathrm{N}, 148^{\circ} 40^{\prime} \mathrm{W}$; BGN 1910; (map 63).

Named in 1910 by U. S. Grant, for Robert Fulton's Clarmont (which Grant misspelled), which made the first practical steamboat trip on the Hudson River from New York to Albany in 1807.

Clarence, Port: bay, $18 \mathrm{mi}$. across, on $\mathrm{S}$ coast of Seward Penin., between Grantley Harbor and Bering Sea, $W$ of Teller, Seward Penin. High.; $65^{\circ} 12^{\prime} \mathrm{N}, 166^{\circ} 45^{\prime} \mathrm{W}$; (map 111). Var. Baie Kaviayak, Imagru Bay, Port Klarens, Zaliv Kaviyak, Zaliz Gavyaak, Zaliv Kavyayak.

Named in 1827 by Capt. Beechey (1831, p. 543), RN, who said, "To the outer harbour *** I attached the name of Port Clarence, in honour of his most gracious majesty, then 
Duke of Clarence." This feature was known to the Russians as "Zaliv Kavyayak," i.e. "Kavyayak Bay" (Tebenkov, 1952, map 1). According to Martin Sauer, of the Billings expedition in 1785, the Eskimo name is "Imagru."

Clarence Lake: lake, $2 \mathrm{mi}$. long, $4.5 \mathrm{mi}$. SE of junc. of Gilbert and Kosina Creeks and 14 mi. $W$ of junc. of Oshetna River, Talkeetna Mts. ; 62 ${ }^{\circ} 40^{\prime} 35^{\prime \prime} \mathrm{N}, 147^{\circ} 49^{\prime} 15^{\prime \prime} \mathrm{W}$; (map 82). Local name reported in 1951 by USGS.

Clarence River: stream, heads SW of Mount Paige in Yukon, Canada, and flows NW and NE 35 mi., crosses Alaska-Canada boundary several times, to Clarence Lagoon, $11.5 \mathrm{mi}$. SE of Demarcation Point, Arctic Plain; 69 $37^{\prime} \mathrm{N}$, $140^{\circ} 52^{\prime} \mathrm{W}$; $B G N$ 1963; (map 138).

On July 27, 1826, Sir John Franklin (1828, p. 139) wrote: "This being the most westerly river in the British dominions on this coast, and near the line of demarcation between Great Britian and Russia, I named it the Clarence, in honor of His Royal Highness, the Lord High Admiral."

Clarence Sound: water passage, see Clarence Strait.

Clarence Strait: water passage, $126 \mathrm{mi}$. long, from Dixon Entrance to Sumner Strait, along E coast of Prince of Wales I., Alex. Arch.; $54^{\circ} 45^{\prime} \mathrm{N}, 131^{\circ} 42^{\prime} \mathrm{W}$ [southeast end]; Var. Clarence Sound, Duke of Clarences Strait, Entrada de Nuestra Señora del Carmen.

Named by Capt. George Vancouver, RN, about September 20, 1793, for Prince William Henry, one of the sons of King George III of England (Wagner, 1937, p. 449). Lt. Don Jacinto Caamaño on July 23, 1792, called that part of the water passage between Prince of Wales Island and Cleveland Peninsula, "Entrada de Nuestra Señora del Carmen."

Clark, Lake: lake, $40 \mathrm{mi}$. long, $2 \mathrm{mi}$. NE of Nondalton and $40 \mathrm{mi}$. W of Cook Inlet, Alaska Ra.; $60^{\circ} 13^{\prime} \mathrm{N}, 154^{\circ} 22^{\prime} \mathrm{W}$; (map 61). Var. Ilima, Keeghik, Kichik, Kijik, Kilchik, Kilchikh-vona.

Named for John W. Clark, "chief of the Nushagak trading post in 1891 and discoverer of the lake." Probably named by A. B. Schanz, who was with the Frank Leslie Illustrated Newspaper Expedition and published the name in 1891. According to Schanz, the native name is "Kilchikh-vona," which may represent an Eskimo name with an Indian ending. A Russian map of 1802 shows this lake as "Ilima" (Baker, 1906, p. 186).

Clark Bay: cove, extends W $0.8 \mathrm{mi}$. off Twelvemile Arm Kasaan Bay, near center of Prince of Wales I., Alex. Arch.; 55 $29^{\circ} 20^{\prime \prime}$ N, $132^{\circ}$ $37^{\prime} 00^{\prime \prime} \mathrm{W}$; (map 4).

Local name reported in 1901 by $\mathbf{A}$. $\mathbf{H}$. Brooks, USGS.

Clark Bay: bight, $2.8 \mathrm{mi}$. across, on NW shore of Stepovak Bay, Alaska Penin., Aleutian Ra.; $55^{\circ} 46^{\prime} \mathrm{N}, 160^{\circ} 00^{\prime} \mathrm{W}$; (map 28 ).

Local name published by USC\&GS in 1916 Coast Pilot (p. 164). Its southern part is called "Little Norway."
Clark Creek: stream, flows SE $10 \mathrm{mi}$. to Tsusena River, $75 \mathrm{mi}$. S of Healy, Talkeetna Mts.; $62^{\circ} 55^{\prime} \mathrm{N}, 148^{\circ} 33^{\prime} \mathrm{W}$;

Local name published in 1917 by USGS.

Clark Glacier: glacier, in Glacier Bay National Monument, trends NW $8 \mathrm{mi}$. to its 1961 terminus at head of the Johns Hopkins Inlet, $78 \mathrm{mi}$. NW of Hoonah, St. Elias Mts. ; $58^{\circ} 49^{\prime}$ $55^{\prime \prime}$ N, 137 $06^{\prime} 10^{\prime \prime} \mathrm{W}$; BGN 1937; (map 10).

Named by W. O. Field and W. S. Cooper in 1936 for William Bullock Clark, 18601917. Clark was born in Vermont, taught geology at Johns Hopkins University from 1887 to 1917 , and was a member of USGS from 1888 to 1917 .

Clark Island: island, $0.2 \mathrm{mi}$. across, in Keku Strait, 9 mi. S of Kake, off NE coast of Kuiu I., Alex. Arch.; $56^{\circ} 50^{\prime} 30^{\prime \prime} \mathrm{N}, 133^{\circ} 57^{\prime} 30^{\prime \prime} \mathrm{W}$; (map 6).

Local fishermen's name reported in 1947 by USC\&GS.

Clark Peak: peak, $4,050 \mathrm{ft}$., $2.8 \mathrm{mi}$. NE of Thane on Gastineau Channel and $4.5 \mathrm{mi}$. E of Juneau, Coast Mts.; 58 $18^{\prime} 00^{\prime \prime} \mathrm{N}, 134^{\circ} 17^{\prime} 30^{\prime \prime} \mathrm{W}$; (map 11). Var. Clarks Peak.

Local name reported in 1916 as "Clarks Peak" by D. C. Witherspoon, USGS, and published in 1918.

Clark Point: village, see Clarks Point.

Clark Point: point of land, see Clarks Point.

Clark Slough: stream, flows NW $24 \mathrm{mi}$. to Nushagak Bay, $13 \mathrm{mi}$. S of Dillingham, Bristol Bay Low.; 58 $51^{\prime} 30^{\prime \prime}$ N, 158 $30^{\prime} 30^{\prime \prime}$ W; (map 40).

Local name published in 1911 by USC\&GS; possibly named for Clarks Point.

Clark Spit: spit, $\mathrm{N}$ of Clarks Point, on $\mathrm{E}$ shore of Nushagak Bay, $14 \mathrm{mi}$. S of Dillingham, Bristol Bay Low.; 58 $50^{\prime} 45^{\prime \prime} \mathrm{N}, 158^{\circ} 32^{\prime} 30^{\prime \prime}$ W; (map 40).

Local name reported in 1952 by USGS.

Clarks Peak: peak, see Clark Peak.

Clarks Point: village, pop. 138, at Clarks Point on $E$ shore of Nushagak Bay, $14 \mathrm{mi}$. S of Dillingham, Bristol Bay Low.; $58^{\circ} 50^{\prime} 30^{\prime \prime} \mathrm{N}$, $158^{\circ} 33^{\prime} 00^{\prime \prime}$ W; (map 40). Var. Clark Point, Clarks Point Village, Stagarok, Stugarok.

Established in the 1920's as a cannery. The population was 25 in 1930; 22 in 1939; and 128 in 1950. The Clarks Point post office was established in 1935 . This is the site of the former Eskimo village or camp of "Stugarok," population 7, recorded in the 1890 Census (1893, p. 95).

Clarks Point: point of land, on $\mathrm{E}$ shore of Nushagak Bay, $14 \mathrm{mi}$. S of Dillingham, Bristol Bay Low. ; $58^{\circ} 50^{\prime} 30^{\prime \prime} \mathrm{N}, 158^{\circ} 33^{\prime} 00^{\prime \prime} \mathrm{W}$; (map 40). Var. Clark Point, Ekok Cape.

Named Clark Point in 1890 by USBF possibly for Samuel Fessenden Clark of Williams College.

Clarks Point: point of land, see Ekuk Cape.

Clarks Point Village: village, see Clarks Point.

Clarks Pond: lake, $0.5 \mathrm{mi}$. across, on Baranof I., $6.5 \mathrm{mi}$. NW of Port Alexander, Alex. Arch.; $56^{\circ} 20^{\prime} 00^{\prime \prime} \mathrm{N}, 134^{\circ} 43^{\prime} 40^{\prime \prime} \mathrm{W}$; (map 5 ).

Local name recorded in 1951 by USGS.
Clarno Cove: estuary, $1.5 \mathrm{mi}$. long, at head of North Arm Moira Sound, on SE coast of Prince of Wales I., Alex. Arch.; $55^{\circ} 07^{\prime} 10^{\prime \prime} \mathrm{N}$, $132^{\circ} 09^{\prime} 00^{\prime \prime} \mathrm{W}$; (map 4).

Local name reported in 1905 by E. F. Dickins, USC\&GS.

Claro, Puerto: cove, "just south of Point Whitshed, named by [Don Ignacio] Arteaga in the early part of July, 1779" (Wagner, 1937, p. 442).

Claude Lake: lake, $1 \mathrm{mi}$. long, on $\mathrm{N}$ coast of Revillagigedo I., $1.6 \mathrm{mi}$. S of Claude Point, Alex. Arch.; $55^{\circ} 55^{\prime} 40^{\prime \prime} \mathrm{N}, 132^{\circ} 20^{\prime} 30^{\prime \prime} \mathrm{W}$; $B G N$ 1923; (map 3).

Named in 1923 by USFS.

Claude Point: point of land, on $\mathrm{N}$ coast of Revillagigedo I., E of Bell I., Alex. Arch.; 55 $57^{\prime} \mathrm{N}, 131^{\circ} 22^{\prime} \mathrm{W}$; (map 3 ).

Named in 1891 by USC\&GS.

Clawanmenka Lake: lake, $1 \mathrm{mi}$. long, in course of Kanuti Chalatna Creek, $28 \mathrm{mi}$. SE of Bettles, Kanuti Flats; $66^{\circ} 31^{\prime} \mathrm{N}, 151^{\circ} 22^{\prime} \mathrm{W}$; (map 117).

Koyukan Indian name obtained in 1956 at Allakaket by T. E. Taylor, USGS.

Claw Peak: peak, 2,650 ft., on Kenai Penin., 3 mi. S of Dual Head, $8 \mathrm{mi}$. SW of Chenega, Chugach Mts.; $60^{\circ} 12^{\prime} 30^{\prime \prime} \mathrm{N}, 148^{\circ} 14^{\prime} 15^{\prime \prime} \mathrm{W}$; $B G N 1934$; (map 63 ).

So named in 1907 by a USC\&GS field party, "because of its appearance."

Claybluff Point: point of land, on N shore of Icy Bay, $1 \mathrm{mi}$. E of Icy Cape, Chugach Mts.; $59^{\circ} 58^{\prime} \mathrm{N}, 141^{\circ} 35^{\prime} \mathrm{W}$; (map 47).

Descriptive name published by USC\&GS in 1923 on Chart 8457.

Clayhill Slough: stream, anabranch of Yukon River, flows $\mathrm{N}$ of Caly I., $8 \mathrm{mi}$. ESE of Birches, Nowitna Low.; $65^{\circ} 06^{\prime} 30^{\prime \prime} \mathrm{N}, 153^{\circ} 15^{\prime}$ 00" W; (map 107). Var. Susie Cutoff.

Riverboat pilots' name shown on a 1940 "Navigation Chart of the Tanana-Yukon Rivers," published by the U.S. Department of the Interior.

Clay Island: island, $2 \mathrm{mi}$. $\mathbf{S}$ of Wosnesenski I., $13 \mathrm{mi}$. E of Dolgoi I., Alaska Penin., Aleutian Ra.; $55^{\circ} 08^{\prime} 00^{\prime \prime} \mathrm{N}, 161^{\circ} 19^{\prime} 50^{\prime \prime} \mathrm{W}$; (map 28).

Name shown on 1964 USC\&GS charts.

Clay Island: island, $2.4 \mathrm{mi}$. long, between Clayhill Slough and Yukon River, $8 \mathrm{mi}$. ESE of Birches, Nowitna Low.; $65^{\circ} 06^{\prime} 30^{\prime \prime} \mathrm{N}, 153^{\circ}$ $14^{\prime} 00^{\prime \prime} \mathrm{W}$; (map 107).

Riverboat pilots' name shown on a 1940 "Navigation Chart of the Tanana-Yukon Rivers," published by the U.S. Department of the Interior.

Clay Lake: lake, $0.5 \mathrm{mi}$. long, on course of Marten Creek, 1.5 mi. N of Bradfield Canal, Alex. Arch.; $56^{\circ} 01^{\prime} 00^{\prime \prime} \mathrm{N}, 1^{\circ} 31^{\circ} 37^{\prime} 45^{\prime \prime} \mathrm{W}$; (map 7).

Local name reported in 1955 by USGS

Clay Lake: lake, $2 \mathrm{mi}$. SE of Evan Lake, $19 \mathrm{mi}$. N of Roundabout Mtn., Koyukuk Low.; $65^{\circ}$ $49^{\prime} \mathrm{N}, 156^{\circ} 35^{\prime} \mathrm{W}$; (map 108).

Local name obtained at Huslia by USGS in 1954 or 1955. 
Clay Point: point of land, at W end of Clay I., between Clayhill Slough and Yukon River, $S$ of Cronin I. and $8 \mathrm{mi}$. ESE of Birches, Nowitna Low.; $65^{\circ} 06^{\prime} 30^{\prime \prime} \mathrm{N}, 153^{\circ} 17^{\prime} 00^{\prime \prime} \mathrm{W}$; (map 107).

Riverboat pilots' name shown on a 1940 "Navigation Chart of the Tanana-Yukon Rivers," published by the U.S. Department of the Interior.

Clay Slough: stream, flows S $5 \mathrm{mi}$. to Yukon River opposite Polly I., Innoko Low.; $63^{\circ} 08^{\prime}$ N, 159 $42^{\prime}$ W; (map 91).

Riverboat pilots' name shown on a 1940 "Navigation Chart of the Tanana-Yukon Rivers," published by the U.S. Department of the Interior.

Clear: village, pop. 341 , mile 392.9 on The Alaska RR., $16 \mathrm{mi}$. S of Nenana, Tanana Low.; $64^{\circ} 20^{\prime} \mathrm{N}, 149^{\circ} 10^{\prime} \mathrm{W}$; (map 100). Var. Clear Site.

Established about 1918 as a railroad station; the station name is "Clear Site."

Clear Creek: stream, flows SE $3 \mathrm{mi}$. to Chick. amin River, $3 \mathrm{mi}$. NE of Behm Canal, Coast Mts.; $55^{\circ} 49^{\prime} 30^{\prime \prime} \mathrm{N}, 130^{\circ} 55^{\prime} 35^{\prime \prime} \mathrm{W}$; (map 3 ). Local name reported in 1955 by USGS.

Clear Creek: stream, flows NE $2.5 \mathrm{mi}$. to Crystal Creek $0.5 \mathrm{mi}$. S of its junc. with Muddy River, Coast Mts.; $56^{\circ} 53^{\prime} 10^{\prime \prime} \mathrm{N}, 132^{\circ} 42^{\prime} 05^{\prime \prime} \mathrm{W}$; (map 6).

Local descriptive name reported in 1961 by USGS.

Clear Creek: stream, heads at $\mathbf{N}$ edge of Grand Plateau Glacier, flows $5 \mathrm{mi}$. W to Gulf of Alaska, 2 mi. W of 1961 terminus of Grand Plateau Glacier and $64 \mathrm{mi}$. SW of Yakutat, St. Elias Mts.; $59^{\circ} 01^{\prime} 55^{\prime \prime} \mathrm{N}, 138^{\circ} 13^{\prime} 00^{\prime \prime}$ W; (map 46).

Descriptive name published in 1959 by USGS.

Clear Creek: stream, distributary of Tanis River, flows SE 6 mi. to Dry Bay at mouth of Muddy Creek, $47 \mathrm{mi}$. SE of Yakutat, Malaspina Coastal Plain; $59^{\circ} 09^{\prime} 35^{\prime \prime} \mathrm{N}, 138^{\circ} 37^{\prime} 15^{\prime \prime} \mathrm{W}$; (map 46).

Descriptive name published in 1959 by USGS.

Clear Greek: stream, on Kenai Penin., flows N $2.5 \mathrm{mi}$. to Devils Bay in Tustumena Lake, 41 mi. SE of Kenai, Chugach Mts.; $60^{\circ} 02^{\prime} 30^{\prime \prime}$ N, 150 $38^{\prime} 35^{\prime \prime} \mathrm{W}$; (map 62).

Local descriptive name reported in 1951 by USGS.

Clear Creek: stream, between Yakataga Ridge and Brower Ridge, flows $\mathrm{W} 6 \mathrm{mi}$. to South Channel Yagatago River, $97 \mathrm{mi}$. WNW of Yakutat, Chugach Mts.; $60^{\circ} 06^{\prime} 15^{\prime \prime} \mathrm{N}, 142^{\circ}$ $16^{\prime} 20^{\prime \prime} \mathrm{W}$; BGN 1945; (map 65).

So named in 1945 by USGS because "the water of this stream is markedly clear in contrast to the turbid waters of the neighboring glacial streams."

Clear Creek: stream, flows S $5 \mathrm{mi}$. to the Katalla River, $1.5 \mathrm{mi}$. NE of Katalla, Malaspina Coastal Plain; $60^{\circ} 12^{\prime} \mathrm{N}, 144^{\circ} 29^{\prime} \mathrm{W}$; (map 64). Var. Deep Creek.

G. C. Martin, USGS, reported in 1904 that he incorrectly gave the name "Deep Creek" to the stream instead of "Clear Creek," which is local usage.

Clear Creek: stream, flows SW $3 \mathrm{mi}$. to Stillwater Creek, $22 \mathrm{mi}$. NE of Katalla, Chugach Mts. ; $60^{\circ} 24^{\prime} \mathrm{N}, 144^{\circ} 02^{\prime} \mathrm{W}$; (map 64).

Local name reported by G. C. Martin, USGS, in 1905.

Clear Creek: stream, flows W 14 mi to Kisaralik River, $50 \mathrm{mi}$. SE of Bethel, Kilbuck-Kuskokwim Mts.; $60^{\circ} 41^{\prime} \mathrm{N}, 160^{\circ} 17^{\prime} \mathrm{W}$; (map 59).

Local descriptive name reported in 1955 by J. M. Hoare, USGS.

Clear Creek: stream, heads in lake, flows SE 3.5 mi. to Twin Falls Creek, $0.7 \mathrm{mi}$. NE of head of Sawmill Bay and $17.5 \mathrm{mi}$. SW of Valdez, Chugach Mts.; $61^{\circ} 04^{\prime} 45^{\prime \prime} \mathrm{N}, 146^{\circ} 46^{\prime} 30^{\prime \prime} \mathrm{W}$; (map 68).

Prospectors' name reported in 1911 by USGS and published in 1915.

Clear Creek: stream, flows $4 \mathrm{mi}$. SE to Kuskulana River, $31 \mathrm{mi}$. NW of McCarthy, Wrangell Mts.; $61^{\circ} 34^{\prime} \mathrm{N}, 143^{\circ} 48^{\prime} \mathrm{W}$; (map 67).

Descriptive name reported in 1912 by D. C. Witherspoon, USGS.

Clear Creek: stream, heads $1.8 \mathrm{mi}$. of Scotty Peak, flows SW 9 mi. to Kotsina River, $3 \mathrm{mi}$. $\mathrm{SE}$ of terminus of Long Glacier and $82 \mathrm{mi}$. NE of Valdez, Wrangell Mts.; $61^{\circ} 42^{\prime} 55^{\prime \prime} \mathrm{N}$, $144^{\circ} 06^{\prime} 30^{\prime \prime} \mathrm{W}$; (map 68).

Prospectors' name reported in 1900 by $T$. G. Gerdine, USGS.

Clear Creek: stream, heads on Beluga Mtn., flows SE $17.5 \mathrm{mi}$. to Alexander Lake, $46 \mathrm{mi}$. NE of Tyonek, Cook Inlet Low.; $61^{\circ} 45^{\prime} 05^{\prime \prime} \mathrm{N}$, $150^{\circ} 54^{\prime} 55^{\prime \prime} \mathrm{W}$; (map 70).

Local descriptive name reported in 1954 by USGS.

Clear Creek: stream, flows NW $10 \mathrm{mi}$. to Talkeetna River, $6.5 \mathrm{mi}$. NE of Talkeetna Glacier and $45 \mathrm{mi}$. NW of Tahneta Pass, Talkeetna Mts.; $62^{\circ} 16^{\prime} 15^{\prime \prime} \mathrm{N}, 148^{\circ} 26^{\prime} 00^{\prime \prime} \mathrm{W}$; (map 82).

Local descriptive name reported in 1931 by USGS.

Clear Greek: stream, flows NW $8.4 \mathrm{mi}$. to Nixon Fork, 14 mi. NW of Medfra, Kilbuck-Kuskokwim Mts.; $63^{\circ} 13^{\prime} \mathrm{N}, 155^{\circ} 04^{\prime} \mathrm{W}$; (map 89).

Local name reported in 1958 by USGS.

Clear Creek: stream, flows NW $6.8 \mathrm{mi}$, to Wabash Creek, $19 \mathrm{mi}$. NW of Medfra, Kilbuck-Kuskokwim Mts.; 63ำ $13^{\prime} \mathrm{N}, 155^{\circ} 16 \mathrm{~W}$; (map 89)

Local name reported in 1958 by USGS.

Clear Creek: stream, flows NE $5 \mathrm{mi}$. to Nenana River, $25 \mathrm{mi}$. SE of Healy, Alaska Ra.; $63^{\circ} 30^{\prime}$ $10^{\prime \prime} \mathrm{N}, 148^{\circ} 49^{\prime} 30^{\prime \prime}$ W; (map 87).

Name reported by The Alaska Railroad on a 1923 manuscript map.

Clear Creek: stream, flows NW 11 mi. to Tanana

River, $15 \mathrm{mi}$. WNW of Big Delta, Tanana Low.; $64^{\circ} 14^{\prime} \mathrm{N}, 146^{\circ} 16^{\prime} \mathrm{W}$; (map 101).

Local descriptive name published in 1951 by USGS.

Clear Creek: stream, flows N $3 \mathrm{mi}$, to Glacier Creek, 12 mi. S of Nenana, Tanana Low.; $64^{\circ} 24^{\prime} \mathrm{N}, 149^{\circ} 07^{\prime} \mathrm{W}$; (map 100).

Local name published in 1917 on GLO (BLM) survey map. Originally, the name was applied to the lower part of Glacier Creek flowing to Julius Creek, but local usage has limited it to its present application.

Clear Creek: stream, flows NW $28 \mathrm{mi}$. to Kantishna River, $48 \mathrm{mi}$. SE of Bitzshtini Mts., Tanana Low.; $64^{\circ} 25^{\prime} \mathrm{N}, 150^{\circ} 22^{\prime} \mathrm{W}$; (map 99).

Local descriptive name reported in 1952 by USGS.

Clear Creek: stream, heads at $64^{\circ} 20^{\prime} \mathrm{N}, 147^{\circ} 26^{\prime}$ $\mathrm{W}$, flows N $36 \mathrm{mi}$. to Salchacket Slough, $8 \mathrm{mi}$. SW of Fairbanks, Tanana Low.; $64^{\circ} 44^{\prime} 40^{\prime \prime}$ N, 147 $55^{\prime} 10^{\prime \prime} \mathrm{W}$; (map 100).

Local name shown in 1911 on a fieldsheet by R. H. Sargent, USGS.

Clear Creek: stream, distributary, flows NW 9 mi. from Tanana River to Chena River, $2 \mathrm{mi}$. SE of Fairbanks, Tanana Low.; 64 $50^{\prime} 10^{\prime \prime}$ $\mathrm{N}, 147^{\circ} 38^{\prime} 45^{\prime \prime} \mathrm{W}$; (map 100).

Local name published in 1952 by USGS.

Clear Creek: stream, flows NE $11 \mathrm{mi}$. to Tubutulik River, $19 \mathrm{mi}$. NE of Elim and $72 \mathrm{mi}$. NE of Solomon, Seward Penin. High.; 64 $54^{\prime} \mathrm{N}$, $162^{\circ} 09^{\prime} \mathrm{W}$; (map 95).

Local name reported in 1900 by W. J. Peters (in Mendenhall, 1901, pl. 20), USGS.

Clear Creek: stream, heads in York Mts., flows NW $1.8 \mathrm{mi}$. to Banner Creek, $16 \mathrm{mi}$. E of Cape Prince of Wales and $39 \mathrm{mi}$. NW of Teller, Seward Penin. High.; $65^{\circ} 32^{\prime} \mathrm{N}, 167^{\circ} 33^{\prime} \mathrm{W}$; (map 111).

Prospectors' name reported on the 1908 "Map of Seward Peninsula" by Arthur Gibson.

Clear Creek: stream, heads in Zane Hills, flows E $18 \mathrm{mi}$. to Hogatza River, $36 \mathrm{mi}$. WNW of Hughes, Hogatza High.; $66^{\circ} 14^{\prime} \mathrm{N}, 155^{\circ} 29^{\prime}$ W; (map 116).

Named by mining engineers; recorded in 1956 by Orth.

Clear Creek: stream, see Glacier Creek.

Clear Creek: stream, see Rosaunt Creek.

Clear Creek Butte: hill, $925 \mathrm{ft}$., between Clear and Willow Creeks, $13 \mathrm{mi}$. S of Fairbanks, Tanana Low.; $64^{\circ} 38^{\prime} \mathrm{N}, 147^{\circ} 49^{\prime} \mathrm{W}$; (map 100).

Local name published in 1912 by USGS.

Clear Creek Park: locality, on right bank of Clear Creek, 5 mi. SE of Fairbanks, Tanana Low.; $64^{\circ} 49^{\prime} 15^{\prime \prime} \mathrm{N}, 147^{\circ} 33^{\prime} 45^{\prime \prime} \mathrm{W}$; (map 100).

Local name derived from Clear Creek and published in 1955 by USGS.

Clear Fork: stream, flows NW $40 \mathrm{mi}$. to Little Tonzona River $13 \mathrm{mi}$. E of its junc. with South Fork Kuskokwim River, 60 mi. E of McGrath, Kuskokwim Low.; 62 $57^{\prime}$ N, $153^{\circ} 45^{\prime}$ W; (map 80).

Local name obtained in 1958 by USGS.

Clear Glacier: glacier, $2 \mathrm{mi}$. SE of Moraine Pass, trends NE $1.3 \mathrm{mi}$. to its terminus near head of Raven Creek, $28 \mathrm{mi}$. SE of Anchorage, Chugach Mts.; $61^{\circ} 03^{\prime} 30^{\prime \prime} \mathrm{N}, 149^{\circ} 09^{\prime} 00^{\prime \prime} \mathrm{W} ; B G N$ 1932; (map 69).

So named in 1932 by a USGS field party "because the ice is unusually clear."

Clearing Point: point of land, $\mathrm{S}$ tip of an unnamed island $5 \mathrm{mi}$. SW of Chichagof, $W$ of 
Rough Channel, off W coast of Chichagof I., Alex. Arch.; 57 $35^{\prime} 35^{\prime \prime} \mathrm{N}, 136^{\circ} 08^{\prime} 15^{\prime \prime} \mathrm{W}$; BGN 1908; (map 9). Var. Clear Point.

Named in 1908 by USC\&GS.

Clear Islets: islands, see Battery Islets.

Clear Lake: lake, $0.5 \mathrm{mi}$. long, in Matanuska Valley, $15 \mathrm{mi}$. SW of Palmer, Cook Inlet Low.; $61^{\circ} 34^{\prime} 20^{\prime \prime} \mathrm{N}, 149^{\circ} 34^{\prime} 25^{\prime \prime} \mathrm{W}$; BGN 1957; (map 69). Var. Wallace Lake.

Descriptive name given in 1954 by Leonard L. Stewart of Anchorage.

Clear Lake: lake, $1 \mathrm{mi}$. long, $1.5 \mathrm{mi}$. W of Fish Lake and $19 \mathrm{mi}$. SE of Tanana, Nowitna Low.; $65^{\circ} 04^{\prime} \mathrm{N}, 151^{\circ} 29^{\prime} \mathrm{W}$; (map 106).

Local name reported in 1952 by USGS.

Clear Lakes: lakes, extend $2.4 \mathrm{mi}$. on St. Michael I., $3.7 \mathrm{mi}$. W of St. Michael, Yukon-Kuskokwin Delta; $63^{\circ} 29^{\prime} 30^{\prime \prime} \mathrm{N}, 162^{\circ} 12^{\prime} 00^{\prime \prime} \mathrm{W}$; (map 92)

Local descriptive name obtained in 1952 by USC\&GS; "derived from the clearness of the water in several crater lakes on the north side of St. Michael Island."

Clear Point: point of land, on W coast of Dall I., between Hook and Manhattan Arms Sea Otter Harbor, Alex. Arch.; $55^{\circ} 07^{\prime} 00^{\prime \prime} \mathrm{N}$, $133^{\circ} 10^{\prime} 30^{\prime \prime} \mathrm{W}$; (map 4).

Descriptive name published in 1924 by USC\&GS.

Glear Point: point of land, on W coast of Mansfield Penin., at mouth of Funter Bay, $18 \mathrm{mi}$. SW of Juneau; Alex. Arch.; 58 $04^{\prime} 35^{\prime \prime} \mathrm{N}$, $134^{\circ} 55^{\prime} 00^{\prime \prime} \mathrm{W}$; (map 11).

Named in 1890 by Lt. Comdr. H. B. Mansfield, USN, and published by USC\&GS in the 1891 Coast Pilot.

Clear Point: point of land, see Clearing Point. Clear River: stream, see Andreafsky River.

Clear River: stream, flows NE $6 \mathrm{mi}$. to head of South Arm Kelp Bay, on NE cuast of Baranof I., Alex. Arch.; 57 $15^{\prime} 30^{\prime \prime}$ N, $135^{\circ} 00^{\prime} 35^{\prime \prime}$ W; (map 9).

Name reported in 1942 by USGS.

Clear River: stream, flows SW $33 \mathrm{mi}$. to North Fork Koyukuk River, E of Eroded Mtn., 28 mi. NW of Wiseman, Brooks Ra.; $67^{\circ} 37^{\prime} \mathrm{N}$, $151^{\circ} 01^{\prime} \mathrm{W}$; BGN 1932; (map 124).

Local name reported in 1929 by Marshall (1956, p. 7).

Clear Site: village, see Clear.

Clear Stream: stream, heads at Hawkins Glacier terminus, flows W $6 \mathrm{mi}$. to Chitina River, $33 \mathrm{mi}$. SE of McCarthy, St. Elias Mts.; $61^{\circ}$ $07^{\prime} \mathrm{N}, 142^{\circ} 12^{\prime} \mathrm{W}$; (map 67).

Local name obtained by USGS and pub. lished on maps since 1954.

Clearwater Camp: locality, on Glenn Highway at Clearwater Creek crossing, $13 \mathrm{mi}$. S of Tok, Alaska Ra.; $63^{\circ} 10^{\prime} \mathrm{N}, 143^{\circ} 12^{\prime} \mathrm{W}$; (map 85). Var. Clearwater-Slana Campground.

Named after the creek on which it is situated; reported in 1952 by USGS.

Clearwater Creek: stream, in Chigmit Mts., flows SE $7 \mathrm{mi}$. to mouth of Chinitna River at W end of Chinitna Bay, Aleutian Ra.; 59 $49^{\prime} 15^{\prime \prime}$ N, $153^{\circ} 17^{\prime} 10^{\prime \prime} \mathrm{W}$; BGN 1961; (map 51). Var. Marsh Creek.
Local name reported in 1958 by USGS. So named because it is clear and affords entrance for spawning salmon. At one time the name of nearby "Marsh Creek" was misapplied to this stream.

Clearwater Creek: stream, flows S $20 \mathrm{mi}$. to Yentna River, $49 \mathrm{mi}$. SW of Talkeetna, Alaska Ra.; $62^{\circ} 12^{\prime} 00^{\prime \prime} \mathrm{N}, 151^{\circ} 36^{\prime} 30^{\prime \prime} \mathrm{W}$; BGN 1962; (map 81).

Local name obtained in 1911 by $S . R$. Capps, USGS.

Clearwater Creek: stream, heads in Clearwater Mts., flows SW $40 \mathrm{mi}$. to Susitna River, N of junc. of Maclaren River and $67 \mathrm{mi}$. SE of Cantwell, Alaska Ra.; $62^{\circ} 53^{\prime} 50^{\prime \prime} \mathrm{N}, 147^{\circ} 07^{\prime}$ 40 " W ; (map 82).

Local name reported in 1911 by F. H. Moffit (in Brooks and others, 1911, fig. 14), USGS.

Clearwater Creek: stream, heads on Mount Neuberger, flows SE $12 \mathrm{mi}$. to Tok River, $14 \mathrm{mi}$. S of Tok, Alaska Ra.; $63^{\circ} 09^{\prime} \mathrm{N}, 143^{\circ} 12^{\prime} \mathrm{W}$; $B G N$ 1936; ( $\operatorname{map} 85$ ).

Local name reported in 1936 by USGS.

Clearwater Creek: stream, in Mount McKinley National Park, flows NW $20 \mathrm{mi}$. to McKinley River, $4.6 \mathrm{mi}$. SW of Wonder Lake, Alaska Ra.; $63^{\circ} 24^{\prime} 40^{\prime \prime} \mathrm{N}, 150^{\circ} 58^{\prime} 15^{\prime \prime} \mathrm{W}$; (map 88).

Descriptive name given about 1900 by prospectors.

Clearwater Creek: stream, flows N $19 \mathrm{mi}$. to Nowitna River, $43 \mathrm{mi}$. NW of Medfra, Kilbuck-Kuskokwim Mts.; $63^{\circ} 44^{\prime} \mathrm{N}, 154^{\circ} 53^{\prime} \mathrm{W}$; (map 89).

Local name obtained in 1924 by J. S. Brown (in Smith, P. S., and others, 1926, pl. 5), USGS.

Clearwater Creek: stream, flows NW $23 \mathrm{mi}$. to Tanana River, $9 \mathrm{mi}$. ESE of Big Delta, Alaska Ra.; $64^{\circ} 06^{\prime} \mathrm{N}, 145^{\circ} 34^{\prime} \mathrm{W}$; (map 101).

Local descriptive name published in 1951 by USGS.

Clearwater Creek: stream, see Fourth of July Creek.

Clearwater Fork Toklat River: stream, in Kantishna Hills, flows NE $30 \mathrm{mi}$. to Toklat River, $8 \mathrm{mi}$. SSW of junc. of that stream's East Fork, Alaska Ra.; $63^{\circ} 48^{\prime} 30^{\prime \prime} \mathrm{N}, 150^{\circ}$ $17^{\prime} 10^{\prime \prime} \mathrm{W}$; (map 88).

Descriptive name reported in 1913 by Archdeacon Stuck (1921, p. 15).

Clearwater Lake: lake, $0.6 \mathrm{mi}$. long, $4.2 \mathrm{mi}$. W of Tsolmund Lake and $8.3 \mathrm{mi}$. SE of Northway, Alaska Ra.; $62^{\circ} 50^{\prime} 30^{\prime \prime} \mathrm{N}, 141^{\circ} 53^{\prime} 10^{\prime \prime}$ W; (map 84).

Local name reported in 1954 by USGS.

Clearwater Lake: lake, $1.5 \mathrm{mi}$. long, $1 \mathrm{mi}$. SW of junc. of Tanana River and Clearwater Creek and $9 \mathrm{mi}$. ESE of Big Delta, Alaska Ra.; $64^{\circ} 05^{\prime} \mathrm{N}, 145^{\circ} 35^{\prime} \mathrm{W}$; (map 101).

Local descriptive name published in 1951 by USGS.

Clearwater Mountains: mountains, 6,000 ft., 20 mi. wide, extends SW $25 \mathrm{mi}$. from Maclaren River to Susitna River, $72 \mathrm{mi}$. SE of Healy, Alaska Ra.; $63^{\circ} 12^{\prime} \mathrm{N}, 147^{\circ} 10^{\prime} \mathrm{W}$; BGN 1959; (map 87). Var. Clear Water Mountains.

Named in 1954 by USGS for the stream,
Glearwater Creek, which drains the central part of the mountains.

Clearwater-Slana Campground: locality, see Clearwater Camp.

Clearwater Slough: stream, on Kenai Penin., flows W $9 \mathrm{mi}$. to Fox River, $6 \mathrm{mi}$. E of Caribou Lake and $30 \mathrm{mi}$. NE of Homer, Cook Inlet Low.; 59 $53^{\prime} 30^{\prime \prime} \mathrm{N}, 150^{\circ} 51^{\prime} 00^{\prime \prime} \mathrm{W}$; (map $50)$.

Local name reported and published in the 1950 's by USGS.

Cleary: locality, $2 \mathrm{mi}$. SE of Chatanika, $20 \mathrm{mi}$. NE of Fairbanks, Tanana-Yukon High.; $65^{\circ}$ $05^{\prime} 30^{\prime \prime} \mathrm{N}, 147^{\circ} 25^{\prime} 00^{\prime \prime} \mathrm{W}$; (map 105). Var. Gleary City.

Mining camp established about 1904 . The Cleary post office operated from 1905 to 1942. The camp was possibly named for Frank Cleary.

Cleary City: locality, see Cleary.

Cleary Creek: stream, flows NW $8 \mathrm{mi}$. to Chatanika River, $20 \mathrm{mi}$. NE of Fairbanks, Yukon-Tanana High.; $65^{\circ} 07^{\prime} 15^{\prime \prime} \mathrm{N}, 147^{\circ}$. $32^{\prime} 00^{\prime \prime} \mathrm{W}$; (map 105).

Named by prospectors; reported in 1903 by T. G. Gerdine (Prindle, 1905, pl. 13), USGS Cleary Creek: stream, flows SW $3 \mathrm{mi}$. to Tolovana River, $6 \mathrm{mi}$. SE of Livengood, Yukon-Tanana High.; $65^{\circ} 27^{\prime} 50^{\prime \prime} \mathrm{N}, 148^{\circ} 22^{\prime}$ $30^{\prime \prime} \mathrm{W}$; (map 105).

Named by prospectors; reported in 1915 by USGS (Brooks and others, 1916, pl. 9).

Cleary Summit: pass, $2,233 \mathrm{ft}$., $16 \mathrm{mi}$. NE of Fairbanks, Yukon-Tanana High.; $65^{\circ} 02^{\prime} 45^{\prime \prime}$ N, $147^{\circ} 26^{\prime} 10^{\prime \prime} \mathrm{W}$; (map 105).

Name derived from the locality of Cleary. Cleary Summit Lodge: locality, $0.5 \mathrm{mi}$. W of Cleary Summit, $15 \mathrm{mi}$. NE of Fairbanks, Yukon-Tanana High.; $65^{\circ} 03^{\prime} \mathrm{N}, 147^{\circ} 27^{\prime} \mathrm{W}$; (map 105). Var. Summit Roadhouse.

Former roadhouse originally reported in 1907 by C. C. Covert, USGS, as "Summit Roadhouse"; however, "local usage adopted the present name" about 1908 .

Cleave Creek: stream, heads in a glacier, flows E $6 \mathrm{mi}$. to Copper River, $3 \mathrm{mi}$. S of mouth of Thunder Creek and $70 \mathrm{mi}$. E of Valdez, Chugach Mts.; $61^{\circ} 08^{\prime} 10^{\prime \prime} \mathrm{N}, 144^{\circ} 54^{\prime} 00^{\prime \prime} \mathrm{W}$; (map 68).

Local name reported in 1898 by $F$. C. Schrader, USGS.

Cleave Creek Glacier: glacier, $5 \mathrm{mi}$. across, 9 mi. ENE of Marshall Pass and $34 \mathrm{mi}$. E of Valdez, Chugach Mts. ; $61^{\circ} 10^{\prime} \mathrm{N}, 145^{\circ} 18^{\prime} \mathrm{W}$; (map 68).

Local name published in 1950 by USGS.

Cleft Island: island, $0.6 \mathrm{mi}$. long, in Security Bay, on $N$ coast of Kuiu I., Alex. Arch.; $56^{\circ}$ $50^{\prime} 50^{\prime \prime} \mathrm{N}, 134^{\circ} 20^{\prime} 00^{\prime \prime} \mathrm{W}$; (map 5).

Descriptive name given in 1869 by Comdr. R. W. Meade, USN, "because of its shape." Clement Creek: stream, see Cement Creek.

Clement Island: island, see San Clemente Island.

Glem Island: island, see San Clemente Island. Glem Mountain: mountain, $1,562 \mathrm{ft}$., $54 \mathrm{mi}$. NW of Haycock, Seward Penin. High.; 65 $59^{\prime}$ N, $161^{\circ} 24^{\prime} \mathrm{W}$; (map 109) 
Local name shown on a 1903 fieldsheet by D. C. Witherspoon, USGS.

Cleo Creek: stream, on Alaska Penin., flows NW $5.6 \mathrm{mi}$. to Becharof Lake, $\mathrm{N}$ of Seal Point, $58 \mathrm{mi}$. NW of Karluk, Aleutian Ra.; 57 $44^{\prime} 40^{\prime \prime} \mathrm{N}, 155^{\circ} 59^{\prime} 30^{\prime \prime} \mathrm{W}$; (map 35).

Local name obtained from J. L. McPherson of Iliamna; published by G. C. Martin (1921, pl. 10), USGS.

Cleo Lake: lake, see Psalm Lake.

Clere, Cape: point of land, at S end of Montague I., $60 \mathrm{mi}$. SE of Seward, Chugach Mts.; $59^{\circ} 46^{\prime} 25^{\prime \prime} \mathrm{N}, 147^{\circ} 54^{\prime} 30^{\prime \prime} \mathrm{W}$; (map 49). Var. Cabo Serena.

Named by Capt. Nathaniel Portlock in 1787. It was called "Cabo Serena" on June 23, 1791, by Capt. Alessandro Malaspina "because it was a beautiful day" (Wagner, 1937, p. 515).

Clere Bower: stream, flows $5 \mathrm{mi}$. SSE to Slug River, $22 \mathrm{mi}$. W of Cape Newenham, Kilbuck-Kuskokwim Mts. ; $58^{\circ} 43^{\prime} \mathrm{N}, 161^{\circ} 34^{\prime} \mathrm{W}$ (map 39).

Local name shown on a 1937 fieldsheet by J. B. Mertie, Jr., USGS.

Clerkes Island: island, see Saint Lawrence Island.

Cleva Bay: bay, extends $1 \mathrm{mi}$. SE on $\mathrm{N}$ coast of Long I., W of Dora Bay, Alex. Arch. $54^{\circ} 56^{\prime} \mathrm{N}, 132^{\circ} 46^{\prime} \mathrm{W} ; B G N$ 1929; (map 1 ).

Name published in 1923 by USFS; derived from "Clevak" (Tlevak Strait).

Cleveland, Mount: mountain, 5,675 ft., on W end of Chuginadak I., Aleutian Is.; 52 $49^{\prime} 30^{\prime \prime}$ N, $169^{\circ} 56^{\prime} 40^{\prime \prime} \mathrm{W}$; (map 21 ).

Name published by USC\&GS in the 1944 Aleutian Coast Pilot (p. 75).

Cleveland, Mount: mountain, 6,350 ft., $4 \mathrm{mi}$ SW of White Pass and $10 \mathrm{mi}$. N of Skagway, Coast Mts.; $59^{\circ} 36^{\prime} 30^{\prime \prime} \mathrm{N}, 135^{\circ} 15^{\prime} 00^{\prime \prime} \mathrm{W}$; (map 45).

Named in 1898 by John A. Flemer, USC\&GS. It may have been named for Stephen Grover Cleveland, 1837-1908, the 22d and 24th President of the United States, 1884-88 and 1892-96.

Cleveland Creek: stream, flows NW $2.2 \mathrm{mi}$. to Cripple River, $15 \mathrm{mi}$. NW of Nome, Seward Penin. High.; $64^{\circ} 40^{\prime} \mathrm{N}, 165^{\circ} 46^{\prime} \mathrm{W}$; (map 94).

Prospectors' name published on the 1900 "Map of Nome Peninsula" by J. M. Davidson and B. D. Blakeslee.

Cleveland Lakes: lakes, series of lakes between the Throat River and Inland Lake, $4 \mathrm{mi}$. SE of Selawik, Kotzebue-Kobuk Low.; $66^{\circ} 33^{\prime}$ N, $159^{\circ} 57^{\prime} \mathrm{W}$; (map 114 ).

Local name reported by the U.S. Army Corps of Engineers in 1955; named for an Eskimo family.

Cleveland Passage: water passage, extends N 5 mi. along $\mathrm{E}$ side of Whitney I., $70 \mathrm{mi}$. E of Sitka, Coast Mts. ; $57^{\circ} 14^{\prime} 35^{\prime \prime}$ N, $133^{\circ} 30^{\prime} 30^{\prime \prime}$ W; (map 8)

Named in 1887 by Lt. Comdr. C. M. Thomas, USN, for Grover Cleveland, 18371908, then President of the United States; published by USC\&GS in the 1891 Coast Pilot (p. 145). See Cleveland, Mount.

Cleveland Peninsula: peninsula, extends from mainland SW $30 \mathrm{mi}$. between Prince of Wales and Revillagigedo Is., Alex. Arch.; 55 $45^{\prime} \mathrm{N}$, $132^{\circ} 00^{\prime} \mathrm{W}$; (maps 3 and 4 ).

Named in 1886 by USC\&GS for President Stephen Grover Cleveland. See Cleveland, Mount.

Clevesy Pass: pass, $800 \mathrm{ft}$., on Attu I., at NW end of Gilbert Ridge, Aleutian Is. ; 52 $52^{\prime} 55^{\prime \prime}$ N, $173^{\circ} 10^{\prime} 30^{\prime \prime} \mathrm{E}$; (map 13).

Named by U.S. Army during World War II; published in 1948 by AMS.

Cliff Bay: bay, on $W$ coast of Aialik Penin, 3 mi. NW of Aialik Cape, $28 \mathrm{mi}$. S of Seward, Chugach Mts.; $59^{\circ} 43^{\prime} 30^{\prime \prime} \mathrm{N}, 149^{\circ} 36^{\prime} 00^{\prime \prime} \mathrm{W}$; (map 49).

Descriptive name published in 1915 by USGS.

Cliff Bay: bay, 1 mi. across, on $\mathbf{N}$ shore of Lake Louise, $38 \mathrm{mi}$. NW of Glennallen, Copper River Basin; $62^{\circ} 22^{\prime}$ N, $146^{\circ} 34^{\prime} \mathrm{W}$; (map 83).

Local name reported in 1963 by USGS.

Cliff Creek: stream, on Iniskin Penin., flows W $2 \mathrm{mi}$. to Fitz Creek, $2.3 \mathrm{mi}$. S of Chinitna Bay, Aleutian Ra.; $59^{\circ} 47^{\prime} 10^{\prime \prime} \mathrm{N}, 153^{\circ} 11^{\prime} 15^{\prime \prime} \mathrm{W}$; $B G N$ 1947; (map 51).

Local name published in 1958 by USGS.

Cliff Creek: stream, flows NW $14 \mathrm{mi}$. to Cache Creek, $51 \mathrm{mi}$. NE of Solomon, Seward Penin. High.; $64^{\circ} 57^{\prime} \mathrm{N}, 163^{\circ} 59^{\prime} \mathrm{W}$; (map 95). Var. Etchepuk River.

Prospectors' name published on the 1908 "Map of Seward Peninsula" by Arthur Gibson. "Etchepuk River" was reported in 1909 by Smith and Eakin (1911, pl. 1), USGS.

Cliff Gulch: ravine, on E slope of White Mtn., N of Nabesna, Alaska Ra.; $62^{\circ} 23^{\prime} \mathrm{N}, 143^{\circ} 02^{\prime} \mathrm{W}$; $B G N$ 1939; (map 84).

Local name reported in 1939 by USGS. This feature cannot be precisely identified on present maps.

Cliff Island: island, $0.1 \mathrm{mi}$. long, $\mathrm{N}$ of Cliff Point in mouth of Womens Bay, $4.5 \mathrm{mi}$. S of Kodiak, Kodiak I, ; $57^{\circ} 43^{\prime} 54^{\prime \prime}$ N, $152^{\circ} 26^{\prime} 55^{\prime \prime}$ W; BGN 1941; (map 34). Var. High Island, Ostrov Vysokoy, Viesokoi Island, Vysokoi Island.

Descriptive name given in 1910 by USC\&GS. Called "Os[trov] Vysokoy" by Lt. Sarichev (1826, map 16), IRN. Baker (1906, p. 305) published "High Island," the translation of Sarichev's name. See Zaimka Island.

Cliff Island: island, see Puffin Island.

Cliff Islet: island, see Zaimka Island.

Cliff Lake: lake, $1.2 \mathrm{mi}$. long, at haad of Deep Cove, on SE coast of Baranof I., Alex. Arch.; $56^{\circ} 32^{\prime} \mathrm{N}, 134^{\circ} 46^{\prime} \mathrm{W}$; BGN 1923; (map 5).

Named in 1923 by USFS.

Cliff Mine: locality, $\mathrm{E}$ of Shoup Bay, on $\mathrm{N}$ side of Port Valdez, $10 \mathrm{mi}$. W of Valdez, Chugach Mts.; $61^{\circ} 07^{\prime} 20^{\prime \prime} \mathrm{N}, 146^{\circ} 33^{\prime} 50^{\prime \prime} \mathrm{W} ; B G N$ 1910; (map 68).

Local name reported in 1910 by USGS.
Clifford, Mount: mountain, 5,570 ft., $1 \mathrm{mi}$. $\mathrm{N}$ of $\mathrm{AB}$ Mtn. and $6 \mathrm{mi}$. NW of Skagway, Coast Mts.; $59^{\circ} 32^{\prime} 30^{\prime \prime} \mathrm{N}, 135^{\circ} 16^{\prime} 30^{\prime \prime} \mathrm{W}$; (map 45). Named in 1898 by John A. Flemer, USC\&GS.

Clifford, Mount: mountain, see AB Mountain.

Clifford Creek: stream, flows NE $5 \mathrm{mi}$. to Mission Creek, $12 \mathrm{mi}$. SW of Eagle, YukonTanana High.; $64^{\circ} 48^{\prime} 35^{\prime \prime} \mathrm{N}, 141^{\circ} 34^{\prime} 00^{\prime \prime} \mathrm{W}$; (map 102)

Prospectors' name obtained in 1898 by $\mathbf{E}$. C. Barnard, USGS.

Clifford Creek: stream, on Seward Penin., flows NW $7.9 \mathrm{mi}$. to Goodhope Bay, $23 \mathrm{mi}$. SW of Deering, Kotzebue-Kobuk Low.; $66^{\circ} 05^{\prime} \mathrm{N}$, $163^{\circ} 30^{\prime} \mathrm{W}$; (map 113).

Local name reported in 1903 by Moffit (1905, pl. 2), USGS.

Clifford Island: island, $1.6 \mathrm{mi}$. long, $2.5 \mathrm{mi}$. S of Sanak I., one of Sanak Is., Aleutian Ra.; $54^{\circ} 22^{\prime} 50^{\prime \prime} \mathrm{N}, 162^{\circ} 46^{\prime} 30^{\prime \prime} \mathrm{W}$; (map 25). $V$ ar. Long Island.

Local name published by USC\&GS in the 1947 Alaska Coast Pilot (p. 348). This name was applied to nearby Long Island in 1890 by USBF.

Clifford Island: island, see Long Island.

Clifford Point: point of land, extends into Kotzebue Sound, $22 \mathrm{mi}$. W of Deering, KotzebueKobuk Low.; $66^{\circ} 05^{\prime} \mathrm{N}, 163^{\circ} 30^{\prime} \mathrm{W}$; (map 113).

Local name reported in 1950 by USGS; derived from nearby Clifford Creek.

Cliff Point: point of land, $\mathrm{E}$ point of entrance to Bay of Islands, on $W$ coast of Adak $I$., Aleutian Is.; $51^{\circ} 50^{\prime} 30^{\prime \prime} \mathrm{N}, 176^{\circ} 47^{\prime} 00^{\prime \prime} \mathrm{W}$; $B G N$ 1936; (map 17).

Named in 1934 by members of the U.S. Navy Aleutian Island Survey Expedition. Cliff Point: point of land, on $\mathrm{W}$ bank of Portland Canal, $16 \mathrm{mi}$. S of Hyder, Coast Mts.; $55^{\circ} 40^{\prime} 50^{\prime \prime} \mathrm{N}, 130^{\circ} 07^{\prime} 25^{\prime \prime} \mathrm{W}$; (map 3)

Descriptive name published in 1897 by USC\&GS.

Cliff Point: point of land, on $\mathrm{W}$ shore of Chiniak Bay, between Womens and Middle Bays, $5 \mathrm{mi}$. SW of Kodiak, Kodiak I.; $57^{\circ} 43^{\prime} 30^{\prime \prime} \mathbf{N}$, $152^{\circ} 26^{\prime} 45^{\prime \prime} \mathrm{W}$; (map 34). Var. Mys Utesov, Utesof.

Translation of the descriptive name "Mys Utesov," published by Lt. Sarichev (1826, map 16), IRN.

Cliff Spring: spring, at base of Artigotrat on Chukchi Sea coast, $3.3 \mathrm{mi}$. SW of Cape Thompson, Arctic Slope; $68^{\circ} 06^{\prime} 55^{\prime \prime} \mathrm{N}, 165^{\circ}$. 52'50' W; BGN 1963; (map 129).

Named by USGS and reported in 1963 by Rubin Kachadoorian, USGS; so called because a "spring emerges at base of cliff." Named in connection with Project Chariot studies.

Clifton: locality, along Skagway River, $1.4 \mathrm{mi}$. W of Goat Lake and $5 \mathrm{mi}$. NE of Skagway, Coast Mts.; 59 $31^{\prime} 30^{\prime \prime} \mathrm{N}, 135^{\circ} 13^{\prime} 30^{\prime \prime} \mathrm{W}$; (map 45).

Name of a telegraph and railroad flag station on the White Pass and Yukon RR. 
Climax Lake: lake, see Tahneta Lake.

Clinker Plateau: plateau, on $W$ part of Saint George I., in Pribilof Is. ; 56 $36^{\circ}$ N, $169^{\circ} 40^{\prime}$ W; (map 38).

Descriptive name published in 1875 by USC\&GS ; probably refers to the volcanic surface of the area.

Clint Creek: stream, see Chert Creek.

Clinton Creek: stream, on Kenai Penin., flows SE $1 \mathrm{mi}$. to Canyon Creek, $8.5 \mathrm{mi}$. S of Sunrise, Ghugach Mts. ; $60^{\circ} 45^{\prime} 45^{\prime \prime} \mathrm{N}, 149^{\circ} 26^{\prime} 55^{\prime \prime}$ W; (map 63).

Local prospectors' name reported about 1914 by B. L. Johnson (in Martin and others, 1915, pl. 2), USGS.

Clinton Creek: stream, heads on $\mathbf{E}$ slope of Fortymile Dome, flows E $0.5 \mathrm{mi}$. into Canada, then SE $12 \mathrm{mi}$. to Fortymile River, $42 \mathrm{mi}$. SE of Eagle, Yukon-Tanana High.; 64 ${ }^{\circ} 24^{\prime}$ N, $140^{\circ} 36^{\prime} \mathrm{W}$; (map 102).

Named by prospectors and reported in 1896 by Spurr (1898, pl. 39), USGS.

Clinton Creek: stream, flows SE $2 \mathrm{mi}$. to Yukon River, $18 \mathrm{mi}$. NE of Rampart, Kokrines-Hodzana High.; $65^{\circ} 43^{\prime} \mathrm{N}, 149^{\circ} 48^{\prime} \mathrm{W}$; (map 105).

Local name published by USGS in the 1950's.

Clipper Creek: stream, see Eclipse Creek.

Clochacohua Lake: lake, $1 \mathrm{mi}$. across, in course of East Fork of The Forks, $22 \mathrm{mi}$. NE of Stevens Village, Yukon Flats; $66^{\circ} 17^{\prime} 20^{\prime \prime} \mathrm{N}$, $148^{\circ} 44^{\prime} 00^{\prime \prime} \mathrm{W}$; (map 118).

Kutchin Indian name obtained in 1956 by T. E. Taylor, USGS.

Close Bay: cove, $0.5 \mathrm{mi}$. long, $\mathrm{S}$ of Whale Bay, on SW coast of Baranof I., $24 \mathrm{mi}$. NW of Port Alexander, Alex. Arch.; 56 $31^{\prime} 15^{\prime \prime} \mathrm{N}$, $135^{\circ} 02^{\prime} 00^{\prime \prime}$ W; (map 5). Var. Bukhta Dushnaya, Doushnai Bay, Dushnaia Bay.

Name published by USC\&GS in the 1883 Coast Pilot (p. 133) ; translated from "Bukhta Dushnaya," which was published in 1849 by the Russian American Company.

Closed Bay: bay, see Banks, Port.

Close Island: island, see Near Island.

Close Lake: lake, $0.5 \mathrm{mi}$. across, on $\mathrm{N}$ bank of Tetlin River, $1 \mathrm{mi}$. NE of Tetlin and $20 \mathrm{mi}$. SE of Tok, Alaska Ra. ; $63^{\circ} 09^{\prime} \mathrm{N}, 142^{\circ} 29^{\prime} \mathrm{W}$; (map 85).

Local name reported by USGS in 1964.

Cloud, Mount: mountain, 6,131 ft., $20 \mathrm{mi}$. NW of mouth of Unuk River at Burroughs Bay, Coast Mts.; $56^{\circ} 19^{\prime} 50^{\prime \prime} \mathrm{N}, 131^{\circ} 18^{\prime} 10^{\prime \prime} \mathrm{W}$; (map 7)

Local name reported in 1955 by USGS.

Cloud, Creek: stream, flows SW $2.4 \mathrm{mi}$. to Crystal Creek, $1.3 \mathrm{mi}$. NE of Coffee River, $37 \mathrm{mi}$. $\mathrm{N}$ of Talkeetna, Alaska Ra.; $62^{\circ} 50^{\prime} 50^{\prime \prime} \mathrm{N}$, $150^{\circ} 16^{\prime} 50^{\prime \prime} \mathrm{W}$; (map 81).

Prospectors' name published in 1940 by USGS.

Cloud Lake: lake, $1 \mathrm{mi}$. across, $5 \mathrm{mi}$. $\mathrm{N}$ of Imuruk Lake, Seward Penin. High.; $65^{\circ} 43^{\prime} \mathrm{N}$, $163^{\circ} 14^{\prime} \mathrm{W}$; BGN 1952; (map 110). Var. Lake Howie.

Reported in 1950 by D. M. Hopkins, USGS. So named by a USGS field party in 1947 "be- cause of its high topographic position *** and because the area surrounding the lake is subject to an exceptionally large quantity of cloudy and foggy weather." This appears to be the "Lake Howie" reported in 1900 by Mendenhall (1901, pl. 4a), USGS.

Cloudman Bay: cove, 0.5 mi. wide, on $\mathrm{E}$ coast of Bligh Island, Chugach Mts.; 60 $50^{\circ} 30^{\prime \prime}$ $\mathrm{N}, 146^{\circ} 43^{\prime} 00^{\prime \prime} \mathrm{W}$; (map 64).

Local name reported by F. C. Schrader, USGS, in 1900.

Cloud Peak: mountain, 2,365 ft., on Afognak I., $15 \mathrm{mi}$. NW of Afognak, Kodiak I.; 58 $09^{\prime} 40^{\prime \prime}$ $\mathrm{N}, 153^{\circ} 02^{\prime} 15^{\prime \prime} \mathrm{W}$; (map 43).

Local name reported in 1952 by USGS.

Cloudy Cape: point of land, on SE coast of Kenai Penin. at $\mathrm{S}$ entrance to Two Arm Bay, $50 \mathrm{mi}$. E of Homer, Chugach Mts, ; $59^{\circ} 34^{\prime} 45^{\prime \prime}$ $\mathrm{N}, 150^{\circ} 05^{\prime} 00^{\prime \prime} \mathrm{W}$; $B G N$ 1930; (map 50).

So named by USC\&GS in 1930 "because the peak [Cloudy Mtn.] *** one-half mile west is usually draped in low hanging clouds." Cloudy Mountain: mountain, 1,810 ft., on SE coast of Kenai Penin., at $S$ entrance to Two Arm Bay, $50 \mathrm{mi}$. E of Homer, Chugach Mts.; $59^{\circ} 35^{\prime} \mathrm{N}, 150^{\circ} 06^{\prime} \mathrm{W}$; (map 50).

So named by USC\&GS in 1930 "because the peak, $1,809 \mathrm{ft}$. high, is usually draped in low hanging clouds."

Gloudy Mountain: mountain, 4,234 ft., in Kuskokwim Mts., near head of Innoko River, 14 mi. NE of Ophir and $21 \mathrm{mi}$. NW of McGrath, Kilbuck-Kuskokwim Mts. ; $63^{\circ} 11^{\prime} \mathrm{N}, 156^{\circ} 03^{\prime}$ W; (map 90).

Prospectors' name reported in 1915 by J. B. Mertie, Jr., and G. L. Harrington, USGS.

Cloudy Pass: pass, 1,120 ft., between Magic Mtn and Leak Hill, $1.2 \mathrm{mi}$. N of Mutt Cove, central Kiska I.; Aleutian Is.; $51^{\circ} 57^{\prime} 30^{\prime \prime} \mathrm{N}$, $177^{\circ} 30^{\prime} 00^{\prime \prime} \mathrm{E}$; (map 14).

One of many arbitrary names applied to features of Kiska I. by USAAF for tactical purposes during World War II.

Clover Bay: estuary, extends W 2 mi., off Clarence Strait, on $\mathrm{E}$ coast of Prince of Wales I. $\mathrm{N}$ of Cholmondeley Sound, Alex. Arch.; $55^{\circ} 18^{\prime} 10^{\prime \prime} \mathrm{N}, 132^{\circ} 07^{\prime} 30^{\prime \prime} \mathrm{W}$; (map 4). Var Thomas Bay.

This feature was surveyed and named "Thomas Bay" in 1885 by Lt. Comdr. Richardson C. Clover, USN; later changed to Clover Bay by USC\&GS "to prevent confusion with another Thomas Bay in the Alexander Archipelago." The present name commemorates Clover himself.

Clover Creek: stream, heads in Clover Lake, flows SE $4.3 \mathrm{mi}$. to Clover Bay, on $\mathrm{E}$ coast of Prince of Wales I., Alex. Arch.; 55 ${ }^{\circ} 17^{\prime} 35^{\prime \prime} \mathrm{N}$, $132^{\circ} 10^{\prime} 25^{\prime \prime} \mathrm{W}$; (map 4).

Local name published in 1943 by USC\&GS.

Clover Island: island, $1,800 \mathrm{ft}$. long, in Clover Passage, $0.7 \mathrm{mi}$. NW of Potter Point, on W coast of Revillagigedo I., Alex. Arch.; $55^{\circ} 29^{\prime} \mathrm{N}, 131^{\circ} 48^{\prime} \mathrm{W}$; (map 3).

Local navigators' name obtained in 1904 by H. C. Fassett, USBF

Clover Lake: lake, $1.3 \mathrm{mi}$. long, $\mathrm{E}$ of Clover Mtn., on Prince of Wales I., at head of Clover
Creek, Alex. Arch.; 55 $19^{\prime} 40^{\prime \prime}$ N, $132^{\circ} 14^{\prime} 50^{\prime \prime}$ W; (map 4).

Local name published in 1920 by USC\&GS. Gloverleaf Island: island, $0.6 \mathrm{mi}$. long, one of Castle Is., in Duncan Canal, $13 \mathrm{mi}$. SW of Petersburg, on $\mathrm{S}$ coast of Kupreanof I., Alex. Arch.; 56 $40^{\prime} 00^{\prime \prime} \mathrm{N}, 133^{\circ} 09^{\prime} 45^{\prime \prime} \mathrm{W}$; BGN 1933; (map 6). Var. Clover Leaf Island.

Local name reported in 1933 by R. H. Sargent, USGS; so named because "The outline of this island suggests a clover leaf."

Clover Mountain: mountain, 2,558 ft., on Prince of Wales I., between Chomondeley Sound and Kasaan Bay, W of Clover Lake, Alex. Arch.; $55^{\circ} 19^{\prime} 45^{\prime \prime} \mathrm{N}, 132^{\circ} 16^{\prime} 30^{\prime \prime} \mathrm{W}$; (map 4).

Local name published in 1920 by USC\&GS. Clover Pass: village, pop. 169, on Clover Passage, at Potter Point, $1.5 \mathrm{mi}$. E of Survey Point, Revillagigedo I., Alex. Arch.; 55 ${ }^{\circ} 8^{\prime}$ $20^{\prime \prime} \mathrm{N}, 131^{\circ} 47^{\prime} 30^{\prime \prime} \mathrm{W}$; (map 3). Var. Knudson Cove.

This is an extension of the settlement area northwest of Ketchikan along the highway.

Glover Passage: water passage, extends NE 8.5 mi. from Survey Point, between Betton and Revillagigedo Is., Alex. Arch.; $55^{\circ} 30^{\prime} \mathrm{N}$, $131^{\circ} 45^{\prime} \mathrm{W}$; (map 3 ).

Named in 1886 by USG\&GS for Comdr. Richardson C. Clover, USN.

Clover Point: point of land, $\mathrm{N}$ point entrance to Clover Bay, on E coast of Prince of Wales I., Alex. Arch.; $55^{\circ} 18^{\prime} 35^{\prime \prime} \mathrm{N}, 132^{\circ} 07^{\prime} 30^{\prime \prime} \mathrm{W}$; (map 4).

Local name reported in 1904 by H. C. Fassett, USBF.

Clover Rock: rock, on S shore of Spiridon Bay, on NW coast of Kodiak I.; $57^{\circ} 39^{\prime} 10^{\prime \prime} \mathrm{N}, 153^{\circ}$ $49^{\prime} 30 \mathrm{~W}$; BGN 1930; (map 34).

Descriptive name given in 1929 by USC\&GS "because the shape of the rock resembles a three leaf clover."

Clover Spur: hill, see Minute Hill.

Clubbing Rocks, The: rocks, part of Sandman Reefs, 10 mi. SW of Deer I., Aleutian Ra.; $54^{\circ} 42^{\prime} \mathrm{N}, 162^{\circ} 26^{\prime} \mathrm{W}$; BGN 1942; (map 25).

Name reported in 1941 by USC\&GS to be "locally known *** since the days when this was a place for clubbing [killing] sea otters." Club Point: point of land, on NW coast of Liesnoi I., at mouth of Eliza Harbor, on Admiralty I., $25 \mathrm{mi}$. S of Angoon, Alex. Arch.; 57 $10^{\prime}$ $25^{\prime \prime} \mathrm{N}, 134^{\circ} 17^{\prime} 00^{\prime \prime} \mathrm{W}$; (map 9).

Named in 1889 by Lt. Comdr. H. B. Mansfield, USN, and published by USC\&GS in the 1891 Coast Pilot (p. 143).

Clump Island: island, $0.1 \mathrm{mi}$. across, in Sea Otter Sound, Alex. Arch.; 55 $51^{\prime} 35^{\prime \prime} \mathrm{N}, 133^{\circ} 29^{\prime} 00^{\prime \prime}$ W; (map 4). Var. Clump Islet.

Name published in 1908 by USC\&GS as "Clump Islet."

Clump Island: island, 1,400 ft. long, in Cordova Bay, on. SW coast of Prince of Wales 1., 1.2 mi. SE of Point Webster, Alex. Arch.; 55 ${ }^{\circ} 7^{\prime}$ $25^{\prime \prime} \mathrm{N}, 132^{\circ} 35^{\prime} 30^{\prime \prime} \mathrm{W}$; (map 1)

Local name reported in 1951 by USGS.

Clump Islet: island, see Clump Island.

Clump Point: point of land, on $\mathrm{W}$ coast of Knight I., E entrance to Mallard Bay on S 
shore of Drier Bay, $9.5 \mathrm{mi}$. NE of Chenega, Chugach Mts.; $60^{\circ} 18^{\prime} 15^{\prime \prime} \mathrm{N}, 147^{\circ} 48^{\prime} 30^{\prime \prime} \mathrm{W}$; (map 63).

Name published in 1943 by USC\&GS.

Clums Fork: stream, heads at confluence of Lawson and Munson Creeks, flows NE $13 \mathrm{mi}$. to Birch Creek, $50 \mathrm{mi}$. SW of Circle, YukonTanana High.; $65^{\circ} 16^{\prime} \mathrm{N}, 145^{\circ} 14^{\prime} \mathrm{W}$; (map 104).

Prospectors' name reported in 1905 by D. C. Witherspoon, USGS; derived from "Coulombe," the surname of four brothers-Peter, Charles, Joseph, and Philip-who came to the Klondike in 1897 from Massachusetts.

Clunie, Lake: lake, $1 \mathrm{mi}$. long, at head of Clunie Creek, $5 \mathrm{mi}$. SW of Birchwood and $13 \mathrm{mi}$. NE of Anchorage, Cook Inlet Low.; 61 ${ }^{\circ} 21^{\prime} 15^{\prime \prime}$ N, $149^{\circ} 36^{\prime} 30^{\prime \prime} \mathrm{W}$; (map 69).

Local name reported in 1906 by T. G. Gerdine and R. H. Sargent, USGS.

Clunie Creek: stream, heads in Lake Clunie, flows SW $4.6 \mathrm{mi}$. to Eagle River, $9 \mathrm{mi}$. NE of Anchorage, Cook Inlet Low.; $61^{\circ} 19^{\prime} 12^{\prime \prime} \mathrm{N}$, $149^{\circ} 43^{\prime} 10^{\prime \prime} \mathrm{W}$; (map 69).

Local name reported in 1952 by USGS.

Coach Butte: hill, $488 \mathrm{ft}$., on $\mathrm{N}$ bank of Montana Bill Creek, $31 \mathrm{mi}$. WNW of Kenai, Cook Inlet Low.; $60^{\circ} 40^{\prime} 30^{\prime \prime} \mathrm{N}, 152^{\circ} 10^{\prime} 45^{\prime \prime} \mathrm{W}$; (map 62).

Local name reported in 1958 by USGS.

Coagalga: island, see Tigalda Island.

Coal Bay: bay, $2.5 \mathrm{mi}$. wide, at $\mathbf{N}$ end of Homer Spit, on W shore of Kachemak Bay, on Kenai Penin., $0.6 \mathrm{mi}$. E of Homer, Cook Inlet Low.; $59^{\circ} 33^{\prime} 15^{\prime \prime} \mathrm{N}, 151^{\circ} 28^{\prime} 30^{\prime \prime} \mathrm{W}$; (map 50). Var. Zaliv Ugolnoy.

This is an 1881 translation by USC\&GS of the name "Zaliv Ugolnoy" that was published by Capt. Tebenkov (1852, map 5), IRN.

Coal Bay: bight, 3 mi. across, $\mathbf{E}$ of Pavlof Bay, Alaska Penin., Aleutian Ra.; 55 $22^{\prime} \mathrm{N}, 161^{\circ}$ 22' W; (map 28).

Named by W. H. Dall, USC\&GS, in 1880 ; probably a translation of "Ukolnoi (Ugol)" the name of an island $10 \mathrm{mi}$. to the southwest.

Coal Bay: bight, see Coal Cove.

Coal Bay: estuary, extends $\mathrm{S} 1 \mathrm{mi}$. from Kasaan Bay, on $\mathbf{E}$ coast of Prince of Wales I., Alex. Arch.; $55^{\circ} 30^{\prime} 30^{\prime \prime} \mathrm{N}, 132^{\circ} 29^{\prime} 25^{\prime \prime} \mathrm{W}$; (map 4).

Descriptive name given in 1891 by Lt. Comdr. H. E. Nichols, USN, who reported, "There are outcrops of coal here."

Coal Bluff: point of land, on E shore of Herendeen Bay, SW end of Bristol Bay Low., Alaska Penin., Aleutian Ra.; 55 $48^{\prime} 40^{\prime \prime} \mathrm{N}, 160^{\circ} 45^{\prime}$ $20^{\prime \prime} \mathrm{W}$; (map 28).

Descriptive name given by $Z$. L. Tanner, USN, in 1890.

Coal Cape: promontory, elev. 1,815 ft., on $\mathrm{S}$ coast of Alaska Penin., $28 \mathrm{mi}$. E of Stepovak Bay, Aleutian Ra.; $55^{\circ} 54^{\prime} \mathrm{N}, 159^{\circ} 01^{\prime} \mathrm{W}$; (map 27).

Named by USC\&GS in 1882 and published in its 1947 Coast Pilot (p. 297).

Coal Cove: bight, $0.5 \mathrm{mi}$. wide, an $\mathrm{N}$ shore of Port Graham, at SW end of Kenai Penin.,
Chugach Mts.; 59 $23^{\prime} 45^{\prime \prime}$ N, $151^{\circ} 54^{\prime} 00^{\prime \prime} \mathrm{W}$; (map 50). Var. Coal Bay, Cool Bay.

Named "Coal Bay" by Capt. Nathaniel Portlock who found coal there July 25, 1786 (Wagner, 1937, p. 442).

Coal Creek: locality, on left bank of Coal Creek at mouth of Beaton Pup, $11 \mathrm{mi}$. W of junc. of Charley and Yukon Rivers, Yukon-Tanana High.; $65^{\circ} 18^{\prime} 30^{\prime \prime} \mathrm{N}, 143^{\circ} 09^{\prime} 00^{\prime \prime} \mathrm{W}$; (map 103 ).

Mining camp where a post office was established in 1936 and discontinued in 1961 (Ricks, 1965, p. 13).

Coal Creek: stream, flows NW $10 \mathrm{mi}$. to Herendeen Bay, Alaska Penin., Aleutian Ra.; 55 $50^{\prime} 45^{\prime \prime} \mathrm{N}, 160^{\circ} 45^{\prime} 40^{\prime \prime} \mathrm{W}$; (map 28).

Prospectors' name reported in 1905 by Sidney Paige (in Brooks and others, 1906, pl. 6), USGS.

Coal Creek: stream, in Glacier Bay National Monument, flows NW $1.5 \mathrm{mi}$. to Lituya Bay, $1.3 \mathrm{mi}$. E of Cenotaph Point and $84 \mathrm{mi}$. NW of Hoonah, St. Elias Mts.; $58^{\circ} 38^{\prime} 05^{\prime \prime}$ N, $137^{\circ}$ $32^{\prime} 30^{\prime \prime} \mathrm{W}$; (map 10).

Local name published by USGS in the 1950's.

Coal Creek: stream, on Kenai Penin., flows SW $6 \mathrm{mi}$. to Kasilof River, $14 \mathrm{mi}$. S. of Kenai, Cook Inlet Low.; $60^{\circ} 21^{\prime} 20^{\prime \prime} \mathrm{N}, 151^{\circ} 17^{\prime} 00^{\prime \prime}$ W; (map 62).

Local name reported in 1958 by USGS. So named because "Coal seams occur along the course of the stream."

Coal Creek: stream, heads near Hayes River Pass, flows SE $37 \mathrm{mi}$. to Beluga Lake, $27 \mathrm{mi}$. NW of Tyonek, Cook Inlet Low.; $61^{\circ} 24^{\prime} 30^{\prime \prime} \mathrm{N}$, $151^{\circ} 31^{\prime} 10^{\prime} \mathrm{W}$; (map 70).

Local name reported in 1958 by USGS.

Coal Creek: stream, heads at glacier terminus and flows NW $13 \mathrm{mi}$. to Matanuska River, 26 mi. NE of Palmer, Chugach Mts.; 61 ${ }^{\circ} 47^{\prime} 10^{\prime \prime}$ $\mathrm{N}, 148^{\circ} 25^{\prime} 30^{\prime \prime} \mathrm{W}$; (map 69).

Descriptive name reported in 1898 by Mendenhall (1900, p. 324), USGS. So named "because of coal outcrops in the bed of the stream."

Coal Creek: stream, heads in Peters Hills, flows NW $1.2 \mathrm{mi}$. to Long Creek $1 \mathrm{mi}$. NE of its junc. with Cache Creek, $28 \mathrm{mi}$. NW of Talkeetna, Alaska Ra.; $62^{\circ} 31^{\prime} 20^{\prime \prime} \mathrm{N}, 150^{\circ} 53^{\prime}$ 05" W; (map 81). Var. Long Creek.

Local dsecriptive name reported in 1958 by USGS.

Coal Creek: stream, flows E $26 \mathrm{mi}$. to Susitna River, $\mathbf{N}$ of junc. of Maclaren River and 70 mi. SE of Cantwell, Talkeetna Mts.; 62 ${ }^{\circ} 52^{\prime}$ $15^{\prime \prime} \mathrm{N}, 147^{\circ} 09^{\prime} 50^{\prime \prime} \mathrm{W}$; (map 82).

Local name published in 1917 on a USGS manuscript map.

Coal Creek: stream, flows S $11 \mathrm{mi}$. to Chulitna River, $40 \mathrm{mi}$. NE of Talkeetna, Alaska Ra.; $62^{\circ} 53^{\prime} \mathrm{N}, 149^{\circ} 51^{\prime} \mathrm{W}$; (map 82).

Local name reported in 1917 by S. R. Capps, USGS.

Coal Creek: stream, flows SW $1.2 \mathrm{mi}$. to Chisna River, $1.8 \mathrm{mi}$. SE of Chisna Pass and $25 \mathrm{mi}$. NE of Paxson, Alaska Ra.; $63^{\circ} 08^{\prime} 55^{\prime \prime} \mathrm{N}, 144^{\circ}$ $47^{\prime} 40^{\prime \prime} \mathrm{W}$; (map 86).
"Named by prospectors for the coal found in the stream"; reported in 1900 by T. G. Gerdine, USGS.

Coal Creek: stream, heads in Clearwater Mts., flows W $1.7 \mathrm{mi}$. to Clearwater Creek, $10 \mathrm{mi}$. N of Denali Highway and $32 \mathrm{mi}$. SW of Mount Hayes, Alaska Ra.; $63^{\circ} 10^{\prime} 40^{\prime \prime} \mathrm{N}, 146^{\circ} 58^{\prime} 42^{\prime \prime}$ W; (map 86).

Local name reported on 1910 fieldsheet by D. C. Witherspoon, USGS.

Coal Creek: stream, flows NW $6 \mathrm{mi}$. to Middle Fork Chulitna River, $43 \mathrm{mi}$. SW of Healy, Talkeetna Mts.; $63^{\circ} 15^{\prime} 25^{\prime \prime} \mathrm{N}, 149^{\circ} 14^{\prime} 10^{\prime \prime} \mathrm{W}$; (map 87).

Local name reported in 1922 by USGS. "Coal is a major product of the area."

Coal Creek: stream, in Mount McKinley National Park, flows NNW $8 \mathrm{mi}$. to Clearwater Creek, $8 \mathrm{mi}$. SSE of Wonder Lake and $21 \mathrm{mi}$. NNE of Mount McKinley, Alaska Ra. ; 63 $21^{\prime}$ $30^{\prime \prime} \mathrm{N}, 150^{\circ} 44^{\prime} 00^{\prime \prime} \mathrm{W}$; (map 88).

Local name reported by S. R. Capps (in Moffit and others, 1927, pl. 3), USGS.

Coal Creek: stream, flows NW $8.5 \mathrm{mi}$. to Healy Creek, 9 mi. NE of Healy, Alaska Ra.; 63 $53^{\prime}$ $\mathrm{N}, 148^{\circ} 41^{\prime} \mathrm{W}$; (map 87$)$.

Local name reported in 1918 by G. C. Martin (1919, pl. 2), USGS.

Coal Creek: stream, flows E $4 \mathrm{mi}$. to Wood River, $40 \mathrm{mi}$. NE of Healy, Alaska Ra.; $63^{\circ} 59^{\prime} 40^{\prime \prime}$ $\mathrm{N}, 147^{\circ} 43^{\prime} 10^{\prime \prime} \mathrm{W}$; (map 87).

Prospectors' name shown on a 1910 fieldsheet by J. W. Bagley, USGS; published by Capps (1912, pl. 1), USGS.

Coal Creek: stream, flows SE 2 mi. to Totatlanika River, $40 \mathrm{mi}$. SE of Nenana, Alaska Ra.; $64^{\circ}$ $02^{\prime} \mathrm{N}, 148^{\circ} 33^{\prime} \mathrm{W}$; (map 100).

Local name reported by USGS (Capps, 1912, pl. 1).

Coal Creek: stream, flows NW $8.7 \mathrm{mi}$. to Solomon River, $13 \mathrm{mi}$. NE of Solomon, Seward Penin. High.; $64^{\circ} 45^{\prime} \mathrm{N}, 164^{\circ} 19^{\prime} \mathrm{W}$; (map 95). Var. Kentucky Greek.

The head of this stream was shown as "Kentucky" on a map of Cape Nome gold fields by David Fox, Jr, dated 1901.

Coal Creek: stream, flows NW $1 \mathrm{mi}$. to Canyon Creek, downstream from El Patrone Creek, $23 \mathrm{mi}$. NW of Solomon, Seward Penin. High.; $64^{\circ} 53^{\prime} \mathrm{N}, 164^{\circ} 45^{\prime} \mathrm{W}$; (map 95).

Prospectors' name reported on a map of Cape Nome gold fields by David Fox, Jr., dated 1901.

Coal Creek: stream, heads at $65^{\circ} 09^{\prime} \mathrm{N}, 143^{\circ} 39^{\prime}$ $W$, flows NE $24 \mathrm{mi}$. to Yukon River, $10 \mathrm{mi}$. $\mathrm{W}$ of junc. of Charley and Yukon Rivers, Yukon-Tanana High.; 65 $21^{\prime} \mathrm{N}, 1^{\circ} 3^{\circ} 07^{\prime} \mathrm{W}$; (map 103). Var. Coaler Creek.

Prospectors' name reported by Lt. Cantwell (1902, p. 277), USRCS, in 1900. Probably named for the coal beds that outcrop along the stream's banks.

Coal Creek: stream, flows SW $4.5 \mathrm{mi}$. to Yukon River, $9 \mathrm{mi}$. ENE of Tanana, KokrinesHodzana High.; $65^{\circ} 12^{\prime} 30^{\prime \prime} \mathrm{N}, 151^{\circ} 46^{\prime} 30^{\prime \prime} \mathrm{W}$; (map 106).

Local name reported in 1952 by USGS. 
Coal Creek: stream, flows SW $7.3 \mathrm{mi}$. to Kiwalik River Valley, $33 \mathrm{mi}$. NW of Haycock, Seward Penin. High.; 65 $37^{\prime} \mathrm{N}, 161^{\circ} 46^{\prime} \mathrm{W}$; (map 109)

Local name reported in 1908 by USGS (Brooks and others, 1909, fig. 21).

Coal Creek: stream, flows NE $12 \mathrm{mi}$. to Dall River, $30 \mathrm{mi}$. NW of Stevens Village, Kokrines-Hodzana High.; $66^{\circ} 19^{\prime} 30^{\prime \prime} \mathrm{N}, 149^{\circ} 49^{\prime}$ 00" W; (map 118).

Prospector's name reported in 1901 by $W$. C. Mendenhall, USGS.

Coal Creek: stream, flows NW $21 \mathrm{mi}$. to Killik River $11 \mathrm{mi}$. SE of its junc. with Colville River, Brooks Ra.; $68^{\circ} 57^{\prime} \mathrm{N}, 153^{\circ} 30^{\prime} \mathrm{W}$; $B G N 1960$; (map 133).

So named about 1950 by USGS geologists during exploration of Naval Petroleum Reserve No. 4, because "numerous beds of coal were found by field party along this stream." Coal Creek: stream, see Long Creek.

Coal Creek: stream, see Suntrana Creek.

Coal Creek Lake: lake, $0.8 \mathrm{mi}$. long, on Kenai Penin., $6 \mathrm{mi}$. $\mathrm{N}$ of Tustumena Lake and 14 mi. SSE of Kenai, Cook Inlet Low.; $60^{\circ} 23^{\prime}$ $\mathrm{N}, 151^{\circ} 03^{\prime} \mathrm{W}$; (map 62).

Local name reported in 1958 by USGS.

Coal Creek Lake: lake, $1.9 \mathrm{mi}$. long, $\mathrm{E}$ of junc. of Coal Creek with West Fork, $32 \mathrm{mi}$. NW of Tyonek, Cook Inlet Low.; $61^{\circ} 29^{\prime} 25^{\prime \prime} \mathrm{N}, 151^{\circ}$ $34^{\prime} 00^{\prime \prime} \mathrm{W}$; (map 70).

Local name reported in 1958 by USGS.

Coaler Creek: stream, see Coal Creek.

Coal Glacier: glacier, heads on E slope of Karx Hills and trends SE $2.5 \mathrm{mi}$. to Tyndall Glacier $10 \mathrm{mi}$. NE of Icy Bay, $67 \mathrm{mi}$. NW of Yakutat, St. Elias Mts. ; $60^{\circ} 11^{\prime} 15^{\prime \prime} \mathrm{N}, 141^{\circ} 10^{\prime} 30^{\prime \prime} \mathrm{W}$; (map 65)

Named by H. W. Topham in 1888 (Topham, 1889)

Coal Harbor: locality, W shore of Zachary Bay, Unga I., Shumagin Is., Aleutian Ra.; 55 ${ }^{\circ} 20^{\prime}$ $30^{\prime \prime} \mathrm{N}, 160^{\circ} 39^{\prime} 30^{\prime \prime} \mathrm{W}$; (map 28).

A post office was maintained here, from $\mathrm{Au}$ gust 1902 through October 1912 , probably to serve a coal mine which was abandoned before 1916.

Coal Harbor: anchorage, $0.6 \mathrm{mi}$. across, arm of Zachary Bay, Unga I., in Shumagin Is., Aleutian Ra.; $55^{\circ} 20^{\prime} \mathrm{N}, 160^{\circ} 36^{\prime} \mathrm{W}$; (map 28). Var. North Harbor.

Probably named by members of the Western Union Telegraph Expedition in 1865. The name has also been applied to all of Zachary Bay on some maps.

Coal Harbor: bay, see Zachary Bay.

Coal Harbor: cove, see Mine Harbor.

Coalit Creek: stream, flows NW $10 \mathrm{mi}$. to Kutuk River, $11 \mathrm{mi}$. SE of Survey Pass, Brooks Ra.; $67^{\circ} 48^{\prime} \mathrm{N}, 153^{\circ} 42^{\prime} \mathrm{W} ; B G N$ 1932; (map 125).

Named by Robert Marshall in 1931 because the stream is the 10th tributary above the mouth of the Kutuk River; "Coalit [Kolit]" is the Eskimo word for "ten."

Coal Lake: lake, $0.7 \mathrm{mi}$. long, $21 \mathrm{mi}$. $\mathrm{N}$ of junc. of Oshetna nd Susitna Rivers, Talkeetna Mts; $62^{\circ} 56^{\prime} 30^{\prime \prime} \mathrm{N}, 147^{\circ} 24^{\prime} 45^{\prime \prime} \mathrm{W}$; (map 82).

Local name reported in 1951 by USGS.
Coal Mine Creek: stream, flows NW $5 \mathrm{mi}$. to Norton Sound, $0.9 \mathrm{mi}$. S of Jesse Creek and $7.8 \mathrm{mi}$. $\mathrm{S}$ of Unalakleet, Nulato Hills; $63^{\circ} 45^{\prime}$ $30^{\prime \prime} \mathrm{N}, 160^{\circ} 46^{\prime} 45^{\prime \prime} \mathrm{W}$; (map 91).

Local name reported in 1952 by USC\&GS; so called because "there is a coal mine at the mouth of the stream."

Coal Mountain: mountain, 2,800 ft., $6 \mathrm{mi}$. N of Arctic Village, Brooks Ra.; $68^{\circ} 11^{\prime} \mathrm{N}, 145^{\circ} 35^{\prime}$ W; (map 136).

Local descriptive name obtained in 1956 by USGS.

Coal Oil Creek: stream, flows N $16 \mathrm{mi}$. to Bering Sea, $20 \mathrm{mi}$. NW of False Pass, on NW coast of Unimak I., Aleutian Is.; $55^{\circ} 02^{\prime} 25^{\prime \prime} \mathrm{N}, 163^{\circ} 50^{\prime}$ $00^{\prime \prime} \mathrm{W}$; (map 29).

Local name reported by USC\&GS in 1943. Coal Point: point of land, on $\mathrm{W}$ shore of Herendeen Bay, near SW end of Bristol Bay Low., Alaska Penin., Aleutian Ra.; 55 $47^{\circ} 10^{\prime \prime} \mathrm{N}$, $160^{\circ} 52^{\prime} 30^{\prime \prime} \mathrm{W}$; (map 28)

Name shown on 1963 USC\&GS chart.

Coal Point: point of land, on $\mathrm{S}$ coast of Alaska Penin., $14 \mathrm{mi}$. E of Stepovak Bay, Aleutian Ra.; 55 $52^{\prime} \mathrm{N}, 159^{\circ} 18^{\prime} \mathrm{W}$; (map 27).

Listed by USC\&GS in 1916 Coast Pilot (p. 163).

Coal Point: point of land, on $\mathbf{N}$ shore of Wide Bay, on E coast of Alaska Penin., $45 \mathrm{mi}$. SE of Ugashik, Aleutian Ra.; $57^{\circ} 26^{\prime} 20^{\prime \prime} \mathrm{N}, 156^{\circ} 12^{\prime}$ $40^{\prime \prime} \mathrm{W}$; (map 36).

Descriptive name published in 1924 by USC\&GS

Coal Point: point of land, on SE tip of Homer Spit, in Kachemak Bay, on Kenai Penin., $5 \mathrm{mi}$. SE of Homer, Cook Inlet Low.; 59 $36^{\prime} 15^{\prime \prime} \mathrm{N}$, $151^{\circ} 24^{\prime} 30^{\prime \prime} \mathrm{W}$; (map 50). Var. Mys Ugolnoy.

This is an 1881 translation by USC\&GS of the name "Mys Ugolnoy," or "coal cape," that was published by Capt. Tebenkov (1852, map 5), IRN.

Coal River: stream, flows SE $9 \mathrm{mi}$. to East Fork Chandalar River, $48 \mathrm{mi}$. W of Christian, Brooks Ra.; $67^{\circ} 18^{\prime} \mathrm{N}, 146^{\circ} 58^{\prime} \mathrm{W}$; (map 122).

Local name reported in 1909 by A. G. Maddren, USGS.

Coal River: stream, see Chekhechunnjik Creek.

Coal Valley: valley, $5 \mathrm{mi}$. long, formed by upper reaches of Coal Creek, between Port Moller and Herendeen Bay, Alaska Penin., Aleutian Ra.; $55^{\circ} 48^{\prime} 30^{\prime \prime} \mathrm{N}, 160^{\circ} 38^{\prime} 00^{\prime \prime} \mathrm{W}$; (map 28). Name published by USC\&GS in 1900 .

Coarse Gold Creek: stream, flows SW $1.3 \mathrm{mi}$. to Penny Creek, $6 \mathrm{mi}$. NE of Solomon, Seward Penin. High.; $64^{\circ} 39^{\prime} \mathrm{N}, 164^{\circ} 22^{\prime} \mathrm{W}$; (map 95).

Prospectors' name reported on a map of Cape Nome gold fields by David Fox, Jr., dated 1901.

Coarse Gold Creek: stream, flows NE $11 \mathrm{mi}$. to Kougarok River, $14 \mathrm{mi}$. SW of Midnight Mtn. and $46 \mathrm{mi}$. W of Imuruk Lake, Seward Penin. High.; $65^{\circ} 36^{\prime} \mathrm{N}, 164^{\circ} 46^{\prime} \mathrm{W}$; (map 110).

Prospectors' name reported in 1900 by Brooks (1901, pl. 11), USGS.

Coarse Gold Creek: stream, flows SE $1 \mathrm{mi}$. to Candle Creek, $13 \mathrm{mi}$. SW of Candle and 31 mi. NE of Imuruk Lake, Seward Penin. High.; $65^{\circ} 45^{\prime} \mathrm{N}, 162^{\circ} 10^{\prime} \mathrm{W}$; (map 110).

Prospectors' name reported on the 1908 "Map of Seward Peninsula" by Arthur Gibson.

Coarse Money Creek: stream, in Nutzotin Mts., flows SW $1 \mathrm{mi}$. to Bonanza Creek $3.2 \mathrm{mi}$. NE of its junc. with Chathenda Creek and $4.8 \mathrm{mi}$. $\mathrm{N}$ of Beaver Lake, Alaska Ra.; $62^{\circ} 07^{\prime} \mathrm{N}$, $141^{\circ} 49^{\prime} \mathrm{W}$; (map 84).

Name used by prospectors and reported by Capps (1916, p. 222), USGS.

Coastal Mountains: mountain range, see Coast Mountains.

Coast Artillery Hill: hill, $560 \mathrm{ft}$., on Attu I., N of Navy Town, Aleutian Is.; $52^{\circ} 51^{\prime} 10^{\prime \prime} \mathrm{N}$, $173^{\circ} 11^{\prime} 00^{\prime \prime} \mathrm{E}$; (map 13$)$

Named by U.S. Army during World War II; published in 1948 by AMS.

Coast Mountains: mountain range, extends SE about $1,000 \mathrm{mi}$. from $35 \mathrm{mi}$. SE of Haines Junction, Yukon, to Fraser River E of Vancouver, British Columbia; it forms mainland portion of SE Alaska between Skagway and Portland Canal; $60^{\circ} 23^{\prime} \mathrm{N}, 136^{\circ} 40^{\prime} \mathrm{W}$ iNW end], $49^{\circ} 15^{\prime} \mathrm{N}, 122^{\circ} 00^{\prime} \mathrm{W}$ [SE end]. Var. Coastal Mountains, Coast Range.

In 1870, Dall (p. 286) wrote: "The Coast or St. Elias Range contains the highest peaks and most of the volcanoes. It extends along the whole northwest coast from California to the peninsula of Aliáska." The name "Coast Mountains" was standardized and the mountains were defined as above by the CPCGN in 1902. See Coast Range.

Coast Range: a name frequently misapplied to the Coast Mountains. The term "Coast Ranges belt" has been applied in Alaska (Seltzer, 1952, p. 423). As used this feature is a continuation of the Insular Mountains of British Columbia and the Coast Ranges of California, Oregon, and Washington, and is represented in Alaska by Kodiak Island, Kenai Mountains, Chugach Mountains, St. Elias Mountains, and the islands of the Alexander Archipelago. Var. Coast Ranges Belt.

Coast Range: mountain range, see Coast Mountains.

Cobal: locality, see Cobol.

Cobalt Creek: stream, heads in Russian Mts., flows $\mathrm{N} 15 \mathrm{mi}$. to Owhat River $21 \mathrm{mi}$. NE of Aniak, Kilbuck-Kuskokwim Mts.; $61^{\circ} 49^{\prime} 45^{\prime \prime}$ N, $159^{\circ} 10^{\prime} 50^{\prime \prime} \mathrm{W} ; B G N$ 1948; (map 73).

Prospectors' name reported in 1914 by A. G. Maddren, USGS.

Cobb Creek: stream, flows $5 \mathrm{mi} \mathrm{N}$ through a lake to Hugh Smith Lake, Coast Mts.; $55^{\circ}$ 05'45" N, $130^{\circ} 38^{\prime} 30^{\prime \prime} \mathrm{W}$; (map 3).

Local name published in 1943 by USC\&GS. Cobb Island: island, $0.1 \mathrm{mi}$. across, in Eastern Channel, $3 \mathrm{mi}$. SE of Sitka, off $W$ coast of Baranof I., Alex. Arch.; 57 $00^{\prime} 50^{\prime \prime} \mathrm{N}, 135^{\circ}$ 17'35" W; (map 9).

Named in 1880 by USN and published by USC\&GS in the 1883 Coast Pilot (p. 144).

Cobb Lakes: lakes, chain of three, largest $1 \mathrm{mi}$. long, $\mathrm{S}$ of Glenn Highway, $2.8 \mathrm{mi}$. W of junc. of Copper and Slana Rivers, Copper River 
Basin; $62^{\circ} 42^{\prime} \mathrm{N}, 1^{\circ} 44^{\circ} 06^{\prime} \mathrm{W} ; B G N$ 1936; (map 83).

Local name reported by Moffit (in Smith, P. S., and others, 1932, p. 113), USGS.

Cobble Creek: stream, flows NE $8 \mathrm{mi}$. to Kavik

River, $56 \mathrm{mi}$. W of Mount Michelson, Arctic Slope; $69^{\circ} 23^{\prime} 15^{\prime \prime} \mathrm{N}, 146^{\circ} 32^{\prime} 45^{\prime} \mathrm{W}$; (map 139).

So named by USGS geologists in the 1950's, because the "stream gravels were like cobblestones."

Cobblestone Creek: stream, flows NW $23 \mathrm{mi}$. to Nanushuk River, SW of Arc Mtn., 12 mi. E of Table Top and $45 \mathrm{mi}$. NE of Anaktuvuk Pass, Arctic Slope; $68^{\circ} 37^{\prime} \mathrm{N}, 150^{\circ} 34^{\prime} \mathrm{W}$; (map 134).

So named by W. W. Patton, Jr., USGS, about 1950, "because the creek bottom is filled with cobblestones."

Cobblestone River: stream, heads in Kigluaik Mts., flows NE $20 \mathrm{mi}$. to Imuruk Basin, 28 mi. SE of Teller, Seward Penin. High.; $65^{\circ}$ $08^{\prime} \mathrm{N}, 165^{\circ} 27^{\prime} \mathrm{W}$; (map 111).

Local name reported in 1900 by $E$. C. Barnard (in Brooks, 1901, pl. 17), USGS.

Cob Island: island, $0.3 \mathrm{mi}$. long, in Karheen Passage, between Heceta and Tuxekan Is., Alex. Arch.; $55^{\circ} 47^{\prime} 45^{\prime \prime} \mathrm{N}, 133^{\circ} 18^{\prime} 00^{\prime \prime} \mathrm{W}$; (map 4). Var. Cob Islet.

Name published as "Cob Islet" in the 1925 Coast Pilot (p. 152).

Coblura: point of land, on $\mathrm{N}$ shore of Elson Lagoon, $0.8 \mathrm{mi}$. W of Plover Point, Arctic Plain; $71^{\circ} 22^{\prime} \mathrm{N}, 156^{\circ} 22^{\prime} \mathrm{W}$; (map 153).

Eskimo name shown on an 1853 chart compiled by Thomas Hull, Master, H.M.S. Plover. The Plover wintered near the point of land in 1852 and 1853 . The small point evidently does not exist today.

Cobol: locality, on Slocum Arm, on SW coast of Chichagof I., $14 \mathrm{mi}$. SE of Chichagof, Alex. Arch.; $57^{\circ} 29^{\prime} 25^{\prime \prime} \mathrm{N}, 135^{\circ} 52^{\prime} 10^{\prime \prime} \mathrm{W}$; (map 9). Var. Cobal, Kobal.

This former mining camp was probably established soon after gold was found on Mine Mountain in 1921. A post office was established here in 1946 and discontinued in 1954 (Ricks, 1965, p. 13).

Cobolunuk: locality, see Kobolunuk.

Cobra Peninsula: peninsula, extends $\mathbf{S} 2 \mathrm{mi}$., between Gertrude and Jeff Coves on $\mathrm{S}$ coast of Kiska I., Aleutian Is.; $51^{\circ} 55^{\prime} 30^{\prime \prime}$ N, $177^{\circ} 28^{\prime}$ $00^{\prime \prime} \mathrm{E}$; (map 14).

One of many arbitrary names applied to features on Kiska 1 . by USAAF for tactical purposes during World War II.

Co-chee-shluck Hill: hill, see Kochilagok Hill.

Cochrane, Point: point of land, on NE coast of Kenai Penin., at $S$ entrance to Passage Canal, $11 \mathrm{mi}$. E of Whittier, Chugach Mts.; $60^{\circ} 46^{\prime}$ $00^{\prime \prime} \mathrm{N}, 148^{\circ} 21^{\prime} 40^{\prime \prime} \mathrm{W}$; BGN 1915; (map 63). Var. Cochran Point.

This point was investigated by Joseph Whidbey on June 5, 1794, and named by Capt. George Vancouver, RN, probably for Sir Alexander Forrester Inglis Cochrane, British naval officer and later admiral (Wagner, 1937, p. 381).
Cochrane Bay: estuary, trends NE $12 \mathrm{mi}$. to Port Wells on E coast of Kenai Penin., 12 mi. E of Whittier, Chugach Mts.; $60^{\circ} 46^{\prime} 25^{\prime \prime} \mathrm{N}$, $148^{\circ} 19^{\prime} 00^{\prime \prime} \mathrm{W}$; (map 63)

Name published in 1943 by USC\&GS.

Cochranes Post: village, see Kokrines.

Cochran Point: point of land, see Cochrane, Point.

Cochrein: village, see Kokrines.

Cocinas, Punta de: point of land, see Cosinas, Point.

Cockatoo Bight: bight, $0.5 \mathrm{mi}$. across, $\mathrm{N}$ of Sredni Point, in Sredni Bight, on NE coast of Kiska I., Aleutian Is.; $52^{\circ} 03^{\prime} 10^{\prime \prime} \mathrm{N}, 177^{\circ}$ $38^{\prime} 15^{\prime \prime} \mathrm{E}$; (map 14).

One of the "bird names" arbitrarily applied to features on Kiska 1. in 1943 by USAAF for tactical purposes during World War II.

Cockedhat Mountain: mountain, 7,610 ft., E of Nanushuk River headwaters, $\mathrm{N}$ of Als Mountain, $27 \mathrm{mi}$. E of Anaktuvuk Pass, Brooks Ra.; $68^{\circ} 08^{\prime} \mathrm{N}, 150^{\circ} 41^{\prime} \mathrm{W}$; BGN 1932; (map 134).

So named by Robert Marshall in 1932 "because of its peculiar shape."

Cock Island : island, see Cook Island.

Cockscomb, The: ridge, elev. 2,600 ft., trends E-W 3 mi., 24 mi. N of Feniak Lake, Brooks Ra.; $68^{\circ} 37^{\prime} \mathrm{N}, 158^{\circ} 20^{\prime} \mathrm{W}$; BGN 1960; (map 132).

So named in 1951 by a USGS geologist because of the "hogback's resemblance to a rooster's comb."

Cockscomb Creek: stream, heads on Panoramic Peak of Granite Mtn., flows NE $3.4 \mathrm{mi}$. to Arrow Creek, $16 \mathrm{mi}$. SE of Delta Junction, Alaska Ra.; $63^{\circ} 51^{\prime} 45^{\prime \prime} \mathrm{N}, 145^{\circ} 22^{\prime} 00^{\prime \prime} \mathrm{W}$; (map 86).

Named between 1948 and 1955 by T. L. Péwé, USGS.

Coco: locality, along Coco Creek which is tributary to Kaviruk River, $39 \mathrm{mi}$. NE of Teller, Seward Penin. High.; $65^{\circ} 26^{\prime}$ N, $165^{\circ} 04^{\prime}$ W; (map 111).

Site of a mining camp shown on a map, dated August 1907, by George M. Ashford.

Coco Creek: stream, flows SW $9 \mathrm{mi}$. to join Johnston Creek to form Kaviruk River, $37 \mathrm{mi}$. NE of Teller, Seward Penin. High.; $65^{\circ} 22^{\prime}$ N, $165^{\circ} 06^{\prime} \mathrm{W}$; (map 111).

Prospectors' name reported in 1907 by Henshaw and Covert (1908, pl. 7), USGS.

Coco Harbor: estuary, extends W 3 mi. off Baldy Bay, on E coast of Dall I., Alex. Arch.; $55^{\circ} 02^{\prime}$ $\mathrm{N}, 133^{\circ} 00^{\prime} \mathrm{W}$; (map 4$)$.

Local name published in 1914 by USC\&GS.

Cocos, Point: point of land, $\mathrm{S}$ tip of Saint Ignace I., $13 \mathrm{mi}$. SW of Craig, Alex. Arch.; 55 $22^{\prime} 50^{\prime \prime}$ N, $133^{\circ} 26^{\prime} 00^{\prime \prime} \mathrm{W}$; (map 4). Var. Mys Kokos, Punta de Cocos.

Spanish name given in 1775-79 by Don Juan de la Bodega y Quadra and Francisco Antonio Maurelle as "Punta de Cocos," meaning "palm point."

Codfish Cove: bay, $0.3 \mathrm{mi}$. across, just $\mathrm{S}$ of mouth of Port Herbert, on SE coast of Baranof I., Alex. Arch.; $56^{\circ} 25^{\prime} 20^{\prime \prime} \mathrm{N}, 134^{\circ} 38^{\circ} 40^{\prime \prime} \mathrm{W}$; (map 6).
Local fishermen's name reported in 1947 by USG\&GS.

Codiac: island, see Kodiak Island.

C O D Lake: lake, $1.2 \mathrm{mi}$. across, $33 \mathrm{mi}$. sW of Livengood, Tanana Low.; $65^{\circ} 05^{\prime} 30^{\prime \prime} \mathrm{N}$, $149^{\circ} 01^{\prime} 00^{\prime \prime} \mathrm{W}$; (map 105).

Local name published by USGS in the 1950's.

Cod Point: point of land, between Long Arm and mouth of Moser Bay, on W coast of Revillagigedo I., Alex. Arch.; $55^{\circ} 34^{\prime} 20^{\prime \prime} \mathrm{N}$, $131^{\circ} 39^{\prime} 20^{\prime \prime} \mathrm{W}$; (map 3 ).

Local navigators' name obtained in 1904 by H. C. Fassett, USBF.

Cody Creek: stream, flows E $8 \mathrm{mi}$. to Wood River, $30 \mathrm{mi}$. E of Healy, Alaska Ra.; 63 $48^{\prime}$ $20^{\prime \prime} \mathrm{N}, 148^{\circ} 00^{\prime} 25^{\prime \prime} \mathrm{W}$; (map 87).

Prospectors' name shown on a 1910 fieldsheet by J. W. Bagley, USGS; published by Capps (1912, pl. 1), USGS.

Cody Creek: stream, flows W $5 \mathrm{mi}$. to Moose Creek, 36 mi. S of Nenana, Alaska Ra.; 64 ${ }^{\circ} 03^{\prime}$ $\mathrm{N}, 149^{\circ} 02^{\prime} \mathrm{W}$; (map 100$)$.

Local name published in 1915 on a GLO (BLM) survey plat.

Coeur d'Alene Creek: stream, on Kenai Penin., flows NW 2 mi. to Palmer Creek, $4.5 \mathrm{mi}$. SW of Sunrise, Chugach Mts.; $60^{\circ} 51^{\prime} \mathrm{N}, 149^{\circ} 32^{\prime}$ W; BGN 1933; (map 63). Var. Palmer Creek.

Local name reported in 1933 by $R$. H. Sargent, USGS, "as the name by which the location of certain mining claims have been formally stated for recording purposes."

Coffee Can Lake: lake, 2 mi. N of Birch Lake, and $21 \mathrm{mi}$. SW of Roundabout Mtn., Koyukuk Low.; $65^{\circ} 17^{\prime} \mathrm{N}, 156^{\circ} 55^{\prime} \mathrm{W}$; (map 108).

Local name obtained at Huslia by USGS in 1954 or 1955.

Coffee Cove: cove, $0.1 \mathrm{mi}$. across, on NE shore of Tenakee Inlet in $E$ central Chichagof $I$., $6.5 \mathrm{mi}$. E of Tenakee Springs, Alex. Arch.; $57^{\circ} 46^{\prime} 45^{\prime \prime} \mathrm{N}, 135^{\circ} 02^{\prime} 30^{\prime \prime} \mathrm{W}$; (map 9).

Local name reported in 1951 by USGS.

Coffee Creek: locality, on right bank of Coffee Creek, $20 \mathrm{mi}$. NW of Mount Bendeleben and $45 \mathrm{mi}$. SW of Imuruk Lake, Seward Penin. High.; $65^{\circ} 18^{\prime} \mathrm{N}, 164^{\circ} 43^{\prime} \mathrm{W}$; (map 110).

Site of a mining camp; name published in 1956 by USGS.

Coffee Creek: stream, heads in lake, flows W 30 mi. to Kvichak River, on Alaska Penin., 12 mi. N of Naknek, Bristol Bay Low.; 58 $54^{\prime} 10^{\prime \prime}$ N, $156^{\circ} 50^{\prime} 00^{\prime \prime} \mathbf{W}$; (map 41).

Local name reported in 1952 by USGS.

Coffee Creek: stream, flows $4 \mathrm{mi}$. N to Chitina River E of Discovery Creek, $33 \mathrm{mi}$. SE of McCarthy, St. Elias Mts., $61^{\circ} 05^{\prime} \mathrm{N}, 142^{\circ} 14^{\prime} \mathrm{W}$; (map 67).

Local name obtained by USGS and published on maps since 1954 .

Coffee Creek: stream, fows S $3.5 \mathrm{mi}$. to Beluga River, $11 \mathrm{mi}$. $\mathrm{N}$ of Tyonek, Cook Inlet Low.; $61^{\circ} 13^{\prime} 40^{\prime \prime} \mathrm{N}, 151^{\circ} 08^{\prime} 30^{\prime \prime} \mathrm{W}$; (map 70).

Local name reported in 1958 by USGS.

Coffee Creek: stream, flows SW $6.5 \mathrm{mi}$. to Chelatna Lake, $45 \mathrm{mi}$. NW of Talkeetna, Alaska Ra.; $62^{\circ} 31^{\prime} \mathrm{N}, 151^{\circ} 28^{\prime} \mathrm{W}$; (map 81). 
Prospectors' name reported in 1906 by R. W. Porter, USGS.

Coffee Creek: stream, flows NW $19 \mathrm{mi}$. to Dishna River $3 \mathrm{mi}$. S of its junc. with Innoko River, $38 \mathrm{mi}$. NW of Ophir and $66 \mathrm{mi}$. NW of McGrath, Innoko Low.; $63^{\circ} 33^{\prime} 40^{\prime \prime} \mathrm{N}, 157^{\circ} 16^{\prime}$ $30^{\prime \prime} \mathrm{W}$; (map 90).

Local name obtained from Joseph Ferris in 1954 by R. E. Isto, USGS.

Coffee Creek: stream, flows E $8 \mathrm{mi}$. to Quartz Creek which flows to Kougarok River, $46 \mathrm{mi}$. SW of Imuruk Lake, Seward Penin. High.; $65^{\circ} 19^{\prime} \mathrm{N}, 164^{\circ} 37^{\prime} \mathrm{W}$; (map 110).

Prospectors' name reported in 1901 by T. G. Gerdine (in Collier, 1902, pl. 12), USGS.

Coffee Creek: stream, see Colin Creek.

Coffee Creek: stream, see Lame Creek.

Coffee Creek Channel: channel, on $E$ side of Kvichak River, trends SW $5 \mathrm{mi}$. between Kvichak and Koggiung, $10 \mathrm{mi}$. N of Naknek, Bristol Bay Low.; $58^{\circ} 53^{\prime} 30^{\prime \prime} \mathrm{N}, 157^{\circ} 01^{\prime} 00^{\prime \prime}$ W; (map 41).

Local name reported in 1952 by USGS.

Coffee Dome: hill, 1,085 ft., $5 \mathrm{mi}$. NW of junc. of Kougarok and Kuzitrin Rivers and $20 \mathrm{mi}$. NW of Mount Bendeleben, Seward Penin. High.; $65^{\circ} 17^{\prime} \mathrm{N}, 164^{\circ} 44^{\prime} \mathrm{W}$; (map 110). Var. Coffee Dome Mountain, Whacksback Mountain.

Local name reported in 1901 by T. G. Gerdine (in Collier, 1902, pl. 12), USGS.

Coffee Dome: mountain, 2,300 ft., $9.5 \mathrm{mi}$. SE of Chatanika and $23 \mathrm{mi}$. NE of Fairbanks, Yukon-Tanana High.; $65^{\circ} 05^{\prime} 30^{\prime \prime} \mathrm{N}, 147^{\circ} 08^{\prime}$ 45" W; (map 105).

Named by prospectors; reported in 1903 by USGS (Prindle, 1905, pl. 13).

Coffee Dome Mountain: hill, see Coffee Dome.

Coffee Point: bluff, elev. $91 \mathrm{ft}$., on $\mathbf{N}$ bank of Naknek River, on Alaska Penin., $1 \mathrm{mi}$. $\mathbf{E}$ of Naknek, Bristol Bay Low.; 58 ${ }^{\circ} 44^{\prime}$ N, $156^{\circ} 59^{\prime}$ W; (map 41).

Local name reported in 1952 by USGS.

Coffee Point: point of land, on N shore of Egegik Bay, on $\mathrm{N}$ coast of Alaska Penin., $39 \mathrm{mi}$. SW of Naknek, Bristol Bay Low.; $58^{\circ} 12^{\prime} 20^{\prime \prime} \mathrm{N}$, $157^{\circ} 26^{\prime} 15^{\prime \prime} \mathrm{W}$; (map 41).

Local name reported in 1952 by USGS.

Coffee Point: point of land, on $\mathrm{W}$ shore of Nushagak Bay, $11 \mathrm{mi}$. SW of Dillingham, Bristol Bay Low.; $58^{\circ} 54^{\prime} 45^{\prime \prime}$ N, $158^{\circ} 36^{\prime} 45^{\prime \prime}$ W; (map 40).

Traders' name published in 1891 by USBF.

Coffee Point: point of land, on Pastol Bay, 38 mi. SW of St. Michael, Yukon-Kuskokwim Delta; $63^{\circ} 07^{\prime} \mathrm{N}, 162^{\circ} 58^{\prime \prime} \mathrm{W}$; (map 92).

Local name obtained in 1949 by USC\&GS.

Coffee River: stream, flows SE $18 \mathrm{mi}$. to Chul-

' itna River, $27 \mathrm{mi}$. NW of Talkeetna, Cook Inlet Low.; $62^{\circ} 42^{\prime} 35^{\prime \prime} \mathrm{N}, 150^{\circ} 16^{\prime} 30^{\prime \prime} \mathrm{W}$; (map 81).

Prospectors' name published in 1940 by USGS.

Coffin Creek: stream, on Iniskin Penin., flows W 0.5 mi. to mouth of Fitz Creek, $\mathrm{S}$ of Chinitna Bay, Aleutian Ra.; $59^{\circ} 48^{\prime} 30^{\prime \prime}$ N, $153^{\circ} 09^{\prime} 00^{\prime \prime}$ W; BGN 1962; (map 51$)$.
So named by USGS because a coffin washed up on the beach near the mouth of this stream while a field party was working there in 1951 . Coffman Cove: cove, extends N $1.5 \mathrm{mi}$. to SE end of Kashevarof Passage, on NE coast of Prince of Wales I., Alex. Arch.; 56 $01^{\prime} \mathrm{N}, 132^{\circ} 50^{\prime}$ W; (map 6). Var. Coffmans Cove.

Named in 1886 by Lt. Comdr. A. S. Snow, USN, for Lt. Dewitt Coffman, USN, a member of his party.

Coffman Creek: stream, fows N $5 \mathrm{mi}$. to Coffman Cove, on Prince of Wales I., Alex. Arch.; $55^{\circ} 59^{\prime} 57^{\prime \prime} \mathrm{N}, 132^{\circ} 51^{\prime} 15^{\prime \prime} \mathrm{W}$; BGN 1963; (map 4).

Local name reported in 1961 by USFS.

Coffman Island: island, $1 \mathrm{mi}$. long, at SE end of Kashevarof Passage, on NE coast of Prince of Wales I., Alex. Arch.; $56^{\circ} 01^{\prime} 45^{\prime \prime} \mathrm{N}, 132^{\circ}$ $50^{\prime} 30^{\prime \prime} \mathrm{W}$; ( $\left.\operatorname{map} 6\right)$.

Named in 1886 by Lt. Comdr. A. S. Snow, USN, for Lt. Dewitt Coffman, USN, a member of his party.

Coffmans Cove:cove, see Coffman Cove.

Coghill Lake: lake, $4.7 \mathrm{mi}$. long, $\mathrm{E}$ of College Fiord, in course of Coghill River, $50 \mathrm{mi}$. W of Valdez, Chugach Mts. ; $61^{\circ} 06^{\prime} \mathrm{N}, 147^{\circ} 49^{\prime} \mathrm{W}$; (map 69).

Named in 1908 by Grant and Higgins (1910, pls. 1 and 2), USGS.

Coghill Point: point of land, extends SW into College Fiord, near mouth of Coghill River, $66 \mathrm{mi}$. SE of Anchorage, Chugach Mts.; $61^{\circ} 04^{\prime} 05^{\prime \prime} \mathrm{N}, 147^{\circ} 56^{\prime} 45^{\prime \prime} \mathrm{W}$; (map 69).

Name published by USC\&GS in 1919; derived from the Coghill River.

Coghill River: stream, heads at Dartmouth Glacier, flows SW $11 \mathrm{mi}$., through Coghill Lake to College Fiord, $55 \mathrm{mi}$. W of Valdez, Chugach Mts.; $61^{\circ} 04^{\prime} 30^{\prime \prime} \mathrm{N}, 147^{\circ} 54^{\prime} 15^{\prime \prime} \mathrm{W}$; $B G N$ 1910; (map 69).

Named in 1908 by Grant and Higgins (1910, pls. 1 and 2), USGS.

Coghlan Island: island, $1 \mathrm{mi}$. long, in Stephens Passage, at entrance to Auke Bay, $1.2 \mathrm{mi}$. S of Fairhaven and $11 \mathrm{mi}$. NW of Juneau, Coast Mts. ; $58^{\circ} 20^{\prime} 15^{\prime \prime} \mathrm{N}, 134^{\circ} 42^{\prime} 00^{\prime \prime} \mathrm{W}$; (map 11).

Named in 1885 by USC\&GS for Comdr. Joseph Bullock Coghlan, 1843-1908, who commanded the U.S.S. Adams in a survey of this area in 1883-84 (DeArmond, 1957, p. 12).

Cogrua, River: stream, see Kugrua River.

Cogtua River: stream, see Meade River.

Cohen Island: island, $0.1 \mathrm{mi}$. long, off $\mathrm{E}$ shore of Favorite Channel, $1 \mathrm{mi}$. NW of Point Stephens and $16 \mathrm{mi}$. NW of Juneau, Coast Mts.; 58 ${ }^{\circ} 26^{\prime}$ $00^{\prime \prime} \mathrm{N}, 134^{\circ} 46^{\prime} 50^{\prime \prime} \mathrm{W}$; (map 11).

Named by USC\&GS and published in 1893 on Chart 8300.

Cohen Island: island, $0.3 \mathrm{mi}$. across, at $\mathrm{N}$ entrance to Eldred Passage, on $\mathrm{E}$ shore of Kachemak Bay, Kenai Penin., 8 mi. S of Homer, Chugach Mts.; $59^{\circ} 32^{\prime} 30^{\prime \prime} \mathrm{N}, 151^{\circ} 28^{\prime} 30^{\prime \prime} \mathrm{W}$; $B G N$ 1963; (map 50).

Named by W. H. Dall, USC\&GS, for a trader "who was operating in the area, in 1880."
Cohen Reef: reef, $0.1 \mathrm{mi}$. across, in Favorite Channel, $1.6 \mathrm{mi}$. NW of Point Stephens and 17 mi. NW of Juneau, Coast Mts. ; 58 $25^{\prime} 50^{\prime \prime}$ $\mathrm{N}, 134^{\circ} 48^{\prime} 10^{\prime \prime} \mathrm{W}$; (map 11$)$.

Named in 1884 by Comdr. J. B. Coghlan, USN, and published in 1885 by USC\&GS.

Coho Cove: estuary, extends $0.8 \mathrm{mi}$., off Thorne Arm, on $\mathrm{S}$ coast of Revillagigedo I., Alex. Arch.; 55 $00^{\prime} 55^{\prime \prime} \mathrm{N}, 131^{\circ} 22^{\prime} 15^{\prime \prime} \mathrm{W}$; (map 3). Local navigators' name obtained in 1904 by H. C. Fassett, USBF; "coho" is a species of salmon.

Coho Creek: stream, flows NE $5 \mathrm{mi}$. to Petersburg Creek, $1.5 \mathrm{mi}$. W of Petersburg, on E coast of Lindenberg Penin., Kupreanof I., Alex. Arch.; $56^{\circ} 48^{\prime} 45^{\prime \prime} \mathrm{N}, 133^{\circ} 00^{\prime} 20^{\prime \prime} \mathrm{W}$; (map 6).

Local name recorded in 1951 by USGS.

Cohoe: village, pop. 122, on Kenai Penin., on banks of Kasilof River, 13 mi. S of Kenai, Cook Inlet Low.; $60^{\circ} 22^{\prime} \mathrm{N}, 151^{\circ} 18^{\prime} \mathrm{W}$; (map 62).

Agricultural settlement, where a post office was established in 1950 (Ricks, 1965, p. 13).

Coke, Point: point of land, on $\mathrm{S}$ end of Snettisham Penin., at entrance to Holkham Bay, 43 mi. SE of Juneau, Coast Mts.; 57 $47^{\prime} 35^{\prime \prime} \mathrm{N}$, $133^{\circ} 46^{\prime} 45^{\prime \prime}$ W; (map 8). Var. Mys Kok, Mys Kuk.

The point was discovered about August 12, 1794 , by Lt. J. Whidbey, RN, and named by Capt. George Vancouver, RN, for Thomas W. Coke, the Earl of Leicester in England (Wagner, 1937, p. 381).

Coke Creek: stream, heads at glacier on Mount Chamberlin in Franklin Mts., flows NW 6 mi. to Lake Schrader, $8 \mathrm{mi}$. NW of Mount Michelson, Brooks Ra.; $69^{\circ} 23^{\prime} \mathrm{N}, 144^{\circ} 58^{\prime} \mathrm{W}$; $B G N$ 1960; (map 139). Var. Giraffe Creek.

Named in the 1940's for a USGS geologist from Martinique, whose grandmother called him "Ma petit coq," and thus was nicknamed "Coq," or in an anglicized form, "Coke."

Coldbar Mountain: mountain, 6,367 ft., between the Charley River and Middle Fork Fortymile River drainages, $62 \mathrm{mi}$. W of Eagle, YukonTanana High.; $64^{\circ} 41^{\prime} \mathrm{N}, 143^{\circ} 15^{\prime} \mathrm{W}$; (map 102). Var. Copper Mountain.

Prospectors' punning name reported in 1898 by E. C. Barnard, USGS, who noted on his fieldsheet: "Named for a dead bear found near top." The variant name, Copper Mountain, is derived from Copper Creek on the mountain's north side. Neither name is shown on present-day maps.

Cold Bay: village, pop. 86, on W shore of Cold Bay, SW end of Alaska Penin., Bristol Bay Low; $55^{\circ} 12^{\prime} \mathrm{N}, 162^{\circ} 42^{\prime} \mathrm{W}$; BGN 1966; (map 29). Var. Fort Randall.

Local name derived from Cold Bay. This village is located near the site of Fort Randall. A post office was established there in 1954 (Ricks, 1965, p. 14).

Cold Bay: bay, extends $\mathrm{N} 22 \mathrm{mi}$., on $\mathrm{S}$ coast of Alaska Penin., Aleutian Ra.; 54 $59^{\prime} \mathrm{N}, 162^{\circ}$ 28' W; BGN 1890; (map 29). Var. Frozen Bay, Morozofa Bay, Morozoffski Bay, Moro- 
zova Bay, Morozovskie Bay, Zaliv Morozovskiy.

Translation of "Z[aliv] Morozovskiy" published in 1847 on Russian Hydrog. Dept. Chart 1379.

Cold Bay: bay, see Puale Bay.

Cold Cape: point of land, see Vodapoini Point.

Cold Creek: stream, flows SE $1.5 \mathrm{mi}$. to Bonanza River, 14 mi. NW of Solomon, Seward Penin. High.; $64^{\circ} 43^{\prime} \mathrm{N}, 164^{\circ} 44^{\prime} \mathrm{W}$; (map 95).

Prospectors' name reported on the 1900 "Map of Nome Peninsula" by J. M. Davidson and B. D. Blakeslee.

Cold Creek: stream, flows SW $2.5 \mathrm{mi}$. to Grouse Greek, $17 \mathrm{mi}$. N of Nome, Seward Penin. High.; $64^{\circ} 45^{\prime} \mathrm{N}, 165^{\circ} 22^{\prime} \mathrm{W}$; (map 94).

Prospectors' name shown on a 1900 "Map of Nome Peninsula" by J. M. Davidson and B. D. Blakeslee.

Cold Creek: stream, flows NW $0.7 \mathrm{mi}$. to Iron Creek, $27 \mathrm{mi}$. NW of Solomon, Seward Penin. High.; 64 ${ }^{\circ} 56^{\prime} 05^{\prime \prime} \mathrm{N}, 164^{\circ} 40^{\prime} 50^{\prime \prime} \mathrm{W}$; (map 95). Var. Cold Spring Creek, Little Dry Creek.

Prospectors' name published as Cold Spring on the 1908 "Map of Seward Peninsula" by Arthur Gibson.

Cold Creek: stream, flows SE $2.2 \mathrm{mi}$. to Hot Springs Slough, $53 \mathrm{mi}$. NE of Bitzshtini Mts., Yukon-Tanana High.; $64^{\circ} 59^{\prime} 35^{\prime \prime} \mathrm{N}, 150^{\circ} 39^{\prime}$ $00^{\prime \prime}$ W; (map 99).

Local name reported in 1954 by USGS.

Coldfoot: locality, site of a mining camp, at mouth of Slate Creek, on E bank of Middle Fork Koyukuk River, $11 \mathrm{mi}$. S of Wiseman, Brooks Ra.; 67 $15^{\prime} 30^{\prime \prime} \mathrm{N}, 150^{\circ} 11^{\prime} 00^{\prime \prime} \mathrm{W}$; (map 124). Var. Slate Creek.

Marshall (1933, p. 39) wrote, "As early as 1899 the town of Slate Creek was started at the mouth of the creek which bears that name. In the summer of 1900 one of the waves of green stampeders got as far up the Koyukuk as this point, then got cold feet, turned around, and departed. This incident was enough to change the first, unromantic appellation of the settlement to Coldfoot." A post office was established here in 1902 and discontinued in 1912 (Ricks, 1965, p. 14). According to Marshall (p. 39), in 1902, Coldfoot consisted of "one gambling hole, two roadhouses, two stores, and seven saloons." Activity subsided when the mining activity moved upstream to Nolan and Wiseman Creeks, and a new town, called Wiseman, was established about 1912 .

Cold King Camp: locality, $2.2 \mathrm{mi}$. W of Mount Cameron, $17 \mathrm{mi}$. NW of Valdez, Chugach Mts.; $61^{\circ} 12^{\prime} 15^{\prime \prime} \mathrm{N}, 146^{\circ} 43^{\prime} 50^{\prime \prime} \mathrm{W}$; (map 68).

Local name published in 1950 by USGS.

Cold Mountain: peak, 2,400 ft., on Attu I. on Prendergat Ridge, Aleutian Is.; 52 $53^{\prime} 53^{\prime \prime} \mathrm{N}$, $173^{\circ} 09^{\prime} 00^{\prime \prime} \mathrm{E}$; (map 13$)$.

Named by U.S. Army during World War II; published in 1948 by AMS.

Cold Spring Creek: stream, see Cold Creek.

Cold Storage Lake: lake, $0.7 \mathrm{mi}$. across, $10.5 \mathrm{mi}$.
NE of Sitka, on $W$ coast of Baranof I., Alex. Arch.; 57 $12^{\prime} \mathrm{N}, 135^{\circ} 14^{\prime} \mathrm{W}$; (map 9).

Local name reported in 1954 by $R$. N. DeArmond, who states that "planes frequently land hunting parties there."

Coleen, Mount: mountain, see Coleen Mountain.

Coleen Hills: hills, 3,000 ft., extends N-S $40 \mathrm{mi}$. from Rabbit Mtn. to Lower Ramparts of Porcupine River, Porcupine Plat.; $67^{\circ} 15^{\prime} \mathrm{N}$, $142^{\circ} 30^{\prime} \mathrm{W}$; (map 121).

Name reported by FitzGerald (1944, p. 234), USGS, in 1939. Named for the Coleen River.

Coleen Mountain: mountain, 2,343 ft., in Coleen Hills, 30 mi. SW of Rabbit Mtn., Brooks Ra.; $67^{\circ} 06^{\prime}$ N, $142^{\circ} 48^{\prime}$ W; (map 121). Var. Mount Coleen.

Local name reported in 1939 by FitzGerald (1944, p. 234), USGS.

Coleen River: stream, heads at $68^{\circ} 42^{\prime} \mathrm{N}, 143^{\circ} 28^{\prime}$ W, flows SSE $52 \mathrm{mi}$. to Porcupine River, $9 \mathrm{mi}$. $\mathrm{E}$ of Coleen Mtn., Brooks Ra.; 67 $04^{\prime} \mathrm{N}$, $142^{\circ} 30^{\prime} \mathrm{W}$; (map 121). Var. Tucker River. Name reported in 1895 by USC\&GS.

Cole Island: island, $900 \mathrm{ft}$. across in Klawak In-

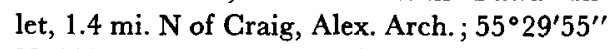
$\mathrm{N}, 133^{\circ} 09^{\prime} 40^{\prime \prime} \mathrm{W}$; (map 4).

Named in 1924 by USC\&GS.

Coleman Bay: bay, on W coast of Aialik Penin., $7 \mathrm{mi}$. N of Three Hole Bay and $20 \mathrm{mi}$. SW of Seward, Chugach Mts.; $59^{\circ} 52^{\prime}$ N, $149^{\circ} 40^{\prime}$ W: (map 49).

Named in 1911 by U.S. Grant, USGS.

Coleman Creek: stream, flows SW $3.5 \mathrm{mi}$. to Albatross Anchorage, $16 \mathrm{mi}$. N of Unga I., Alaska Penin., Aleutian Ra.; $55^{\circ} 36^{\prime} 45^{\prime \prime} \mathrm{N}$, $160^{\circ} 34^{\prime} 00^{\prime \prime} \mathrm{W}$; (map 28).

Named by E. L. Jones, USBF, in 1914.

Coleman Peak: peak, 5,630 ft., in Glacier Bay National Monument, between Casement and McBride Glaciers, $2.4 \mathrm{mi}$. NNE of Red Mountain and $35 \mathrm{mi}$. SW of Skagway, St. Elias Mts.; $59^{\circ} 04^{\prime} 15^{\prime \prime} \mathrm{N}, 135^{\circ} 58^{\prime} 30^{\prime \prime} \mathrm{W}$; (map 45).

Named in 1947 by W. O. Field, American Geographical Society, for A. P. Coleman, 1852-1939, geologist, who visited this area in 1913. Coleman was born and educated in Canada and was professor of geology at Victoria College and Toronto Univ. He was the author of many scientific publications, especially on the glacial and Pleistocene geology of the Great Lakes area.

Coleman Point: point of land, see Thatcher, Point.

Coleman Reef: reef, $1 \mathrm{mi}$. NE of Point Thatcher, $10 \mathrm{mi}$. SW of Angoon, Alex. Arch.; $57^{\circ} 25^{\prime} 40^{\prime \prime}$ $\mathrm{N}, 134^{\circ} 48^{\prime} 50^{\prime \prime} \mathrm{W}$; (map 9).

Named by W. H. Dall, USC\&GS, published in the 1883 Coast Pilot (p. 167).

Colin Creek: stream, flows S then E $1.3 \mathrm{mi}$. to Niukluk River, $2.5 \mathrm{mi}$. NW of Council and $32 \mathrm{mi}$. NE of Solomon, Seward Penin. High.; $64^{\circ} 55^{\prime}$ N, $163^{\circ} 44^{\prime}$ W; (map 95). Var. Coffee Creek, Cosie Creek.

Prospectors' name published in 1956 by USGS. This appears to be the stream shown as "Coffee" on the 1900 "Map of Nome Peninsula" by J. M. Davidson and B. D. Blakeslee.

College: town, pop. 1755 , mile 467.1 on The Alaska RR., 3 mi. NW of Fairbanks, Tanana Low.; $64^{\circ} 51^{\prime} 30^{\prime \prime} \mathrm{N}, 147^{\circ} 48^{\prime} 30^{\prime \prime} \mathrm{W}$; (map $100)$.

So named because it is the location of the Univ. of Alaska, established in 1915.

College Creek: stream, flows SE $12 \mathrm{mi}$. to Lachbuna Lake, $45 \mathrm{mi}$. NE of Nondalton, Alaska Ra.; $60^{\circ} 29^{\prime} \mathrm{N}, 154^{\circ} 02^{\prime} \mathrm{W}$; (map 61).

Local name reported in 1954 by USGS.

College Creek: stream, heads at College Glacier terminus, flows SW $2 \mathrm{mi}$. to Gulkana River, $14 \mathrm{mi}$. N of Paxson, Alaska Ra.; $63^{\circ} 13^{\prime} 45^{\prime \prime} \mathrm{N}$, $145^{\circ} 28^{\prime} 45^{\prime \prime} \mathrm{W}$; (map 86).

Named between 1948 and 1955 by T. L. Péwé, USGS.

College Fiord: estuary, extends NE $18 \mathrm{mi}$., off Port Wells, between Point Pakenham and College Point, $63 \mathrm{mi}$. E of Anchorage, Chugach Mts.; $61^{\circ} 00^{\prime} \mathrm{N}, 148^{\circ} 01^{\prime} \mathrm{W}$; (map 69).

Named in 1898 by members of the Harriman Alaska Expedition after they had named many of the glaciers surrounding the fiord for American colleges.

College Fiord: estuary, see Harvard Arm College Fiord.

College Glacier: glacier, heads on Icefall Peak, trends SW $4 \mathrm{mi}$. to its 1950 terminus at head of College Creek, $15 \mathrm{mi}$. NNE of Paxson, Alaska Ra.; $63^{\circ} 14^{\prime} 20^{\prime \prime}$ N, $145^{\circ} 20^{\prime} 20^{\prime \prime} \mathrm{W}$; (map 86).

Named between 1948 and 1955 by T. L. Péwé, USGS.

College Point: point of land, between Harvard and Yale Arms of College Fiord, $50 \mathrm{mi}$. NW of Valdez, Chugach Mis.; 61 $12^{\prime} 20^{\prime \prime} \mathrm{N}$, $147^{\circ} 45^{\prime} 30^{\prime \prime}$ W; BGN 1910; (map 69).

Named in 1908 by U. S. Grant and D. F. Higgins, USGS.

Collie, Point: point of land, on $\mathrm{N}$ shore of Wainwright Inlet, $2 \mathrm{mi}$. SW of Wainwright, Arctic Plain; $70^{\circ} 36^{\prime} 45^{\prime \prime} \mathrm{N}, 160^{\circ} 06^{\prime} 25^{\prime \prime} \mathrm{W}$; (map 146). Var. Collie Cape, Kalidge Point.

Named "Cape Collie" in September 1826 by Capt. Beechey $(1831$, v. 1 , p. 303$)$, RN, who wrote, "and to the points and inlets to the southward [of Cape Smyth] I with pleasure affixed the names of the officers of the ship, whose merits entitled them to this distinction." This point was named for surgeon Alexander Collie, discoverer of the coal veins near Cape Beaufort, contributor to meteorological observations, natural history, and the Royal Navy's journal of geological research. Russian Hydrog. Dept. Chart 1495, published in 1854 , shows the name "Kalidge," which probably comes from the transliteration of "Collie" into Russian.

Collie Cape: point of land, see Collie, Point.

Collins Creek: stream, flows NE $6.5 \mathrm{mi}$. to Hannum Creek, $21 \mathrm{mi}$. N of Imuruk Lake, Seward Penin. High.; $65^{\circ} 54^{\prime} \mathrm{N}, 163^{\circ} 12^{\prime} \mathrm{W}$; $B G N$ 1952; (map 110).

Prospectors' name reported in 1901 by USGS (Collier, 1902, pl. 12). 
Collins Creek: stream, see Lick Creek.

Collinson Point: point of land, between Simpson Cove and Camden Bay, $30 \mathrm{mi}$. SW of Barter I., Arctic Plain; $69^{\circ} 59^{\prime} 30^{\prime \prime} \mathrm{N}, 1^{\circ} 44^{\circ} 54^{\prime} 00^{\prime \prime}$ W; (map 139). Var. Nuwaak, Nuwuak.

Named by Lt. Comdr. C. H. Stockton, USN, for Capt. Richard Collinson, RN, of the H.M.S. Enterprise who explored along the north coast of Alaska in 1851 and in 1853-54. The Eskimo name for this point of land according to Leffingwell (1919, p. 94) was "Nuwuak," which he indicates may mean "influenza." This may be the word "nuvak," meaning "cough," but may just as likely be "nuvuk," meaning "cape" or "point of land."

Collinsville: settlement, on W bank of Mills Creek, $3 \mathrm{mi}$. SE of Fairview Mtn. and $44 \mathrm{mi}$. W of Talkeetna, Alaska Ra.; $62^{\circ} 20^{\prime} 35^{\prime \prime} \mathrm{N}$, $151^{\circ} 29^{\prime} 30^{\prime \prime} \mathrm{W}$; (map 81).

Mining camp probably established since 1940.

Colly Creek: stream, flows SW $0.5 \mathrm{mi}$. to Venetia Creek, $20 \mathrm{mi}$. NW of Solomon, Seward Penin. High.; $64^{\circ} 49^{\prime} \mathrm{N}, 164^{\circ} 45^{\prime} \mathrm{W}$; (map 95).

Prospectors' name reported on a map of Cape Nome gold fields by David Fox, Jr. dated 1901.

Colmondeley Sound: $b a y$, see Cholmondeley Sound.

Colombo Glacier: glacier, see Columbus Glacier.

Colony Glacier: glacier, trends NNW $8 \mathrm{mi}$. to its terminus at Inner Lake George, $30 \mathrm{mi}$. SE of Palmer, Chugach Mts.; $61^{\circ} 16^{\prime} \mathrm{N}, 148^{\circ}$ $31^{\prime} \mathrm{W}$; (map 69).

Local name reported in 1960 by USGS.

Colony Point: point of land, on S shore of Inner Lake George, $30 \mathrm{mi}$. SE of Palmer, Chugach Mts.; $61^{\circ} 16^{\prime} 15^{\prime \prime} \mathrm{N}, 148^{\circ} 33^{\prime} 15^{\prime \prime} \mathrm{W}$; (map 69).

Name reported in 1951 by $K$. H. Stone (1963, p. 33), Univ. of Wisconsin.

Colorado: locality, mile 297.1 on The Alaska RR., 7 mi. SW of Broad Pass RR. station and $51 \mathrm{mi}$. SW of Healy, Talkeetna Mts.; $63^{\circ} 09^{\prime}$ $30^{\prime \prime} \mathrm{N}, 149^{\circ} 25^{\prime} 45^{\prime \prime} \mathrm{W}$; (map 87).

Name reported as a flag stop by The Alaska RR. on its 1922 timetable.

Colorado Creek: stream, flows NW $4 \mathrm{mi}$, to Bering Sea, $1.5 \mathrm{mi}$. NE of Aguliuk Point, on $\mathrm{N}$ coast of Umnak I., Aleutian Is.; 53 $29^{\prime} 15^{\prime \prime}$ $\mathrm{N}, 168^{\circ} 18^{\prime} 00^{\prime \prime} \mathrm{W}$; (map 22).

Name published by Byers (1959, pl. 41), USGS.

Colorado Creek: stream, flows E $2.5 \mathrm{mi}$. to Wrangell Narrows, on Lindenberg Penin., Kupreanof I., $12 \mathrm{mi}$. S of Petersburg, Alex. Arch.; $56^{\circ} 38^{\prime} 40^{\prime \prime} \mathrm{N}, 132^{\circ} 56^{\prime} 50^{\prime \prime} \mathrm{W}$; (map 6). Var. Colorado River.

Local name recorded in 1953 by USGS.

Colorado Creek: stream, flows E $4 \mathrm{mi}$. to South Fork Arolik River, $24 \mathrm{mi}$. N of Goodnews, Kilbuck-Kuskokwim Mts.; $59^{\circ} 26^{\prime} \mathrm{N}, 161^{\circ} 21^{\prime}$ W; (map 53).

Local name published in 1951 by USGS.

Colorado Creek: stream, on Kenai Penin., flows $\mathrm{N} 2 \mathrm{mi}$, then E $4.5 \mathrm{mi}$. to Canyon Greek, 18 mi. S of Sunrise, Chugach Mts.; $60^{\circ} 38^{\prime} 35^{\prime \prime} \mathrm{N}$, $149^{\circ} 29^{\prime} 30^{\prime \prime} \mathrm{W}$; (map 63)
Local prospectors' name reported in 1904 by Moffit (1906, pl. 2), USGS.

Colorado Creek: stream, flows SW $5.1 \mathrm{mi}$. to join Sunshine Creek to form Sunflower Creek, 50 mi. NW of Talkeetna, Alaska Ra.; $62^{\circ} 29^{\prime} 25^{\prime \prime}$ $\mathrm{N}, 151^{\circ} 37^{\prime} 40^{\prime \prime} \mathrm{W}$; (map 81).

Prospectors' name reported in 1906 by R. W. Porter, USGS.

Colorado Creek: stream, flows SE $10 \mathrm{mi}$. to West Fork Chulitna River, $50 \mathrm{mi}$. SW of Healy, Alaska Ra.; $63^{\circ} 14^{\prime} 10^{\prime \prime} \mathrm{N}, 1^{\circ} 9^{\circ} 33^{\prime} 30^{\prime \prime} \mathrm{W}$; (map 87)

Prospectors' name obtained in 1913 by J. W. Bagley, USGS; published by S. R. Capps (in Martin, 1919, pl. 5 ), USGS.

Colorado Creek: stream, flows NW and SW 35 mi. to Innoko River, $38 \mathrm{mi}$. N of Ophir and 54 mi. NW of McGrath, Innoko Low.; $63^{\circ} 40^{\prime} 20^{\prime \prime}$ $\mathrm{N}, 156^{\circ} 21^{\prime} 30^{\prime \prime} \mathrm{W}$; (map 90).

Prospectors' name reported in 1912 by $\mathrm{H}$. M. Eakin, USGS.

Colorado Creek: stream, heads on Cone Min., flows SW $1 \mathrm{mi}$. to Cripple River, $13 \mathrm{mi}$. NW of Nome, Seward Penin. High.; $64^{\circ} 35^{\prime}$ N, $165^{\circ}$ 48' W; (map 94). Var. Dog Creek, Ryan Greek.

Prospectors' name reported in 1899 by D. C. Witherspoon (in Schrader and Brooks, 1900, map 2), USGS. The 1900 "Map of Nome Peninsula" by J. M. Davidson and B. D. Blakeslee shows two streams, "Dog" and "Ryan," heading on Cone Mountain and flowing SW to Cripple River. Recent topographic maps do not show these streams.

Colorado Creek: stream, flows E $8 \mathrm{mi}$. to Klokerblok River, $30 \mathrm{mi}$. NE of Solomon, Seward Penin. High.; $64^{\circ} 39^{\prime} \mathrm{N}, 163^{\circ} 29^{\prime} \mathrm{W}_{\text {; (map }}$ 95)

Prospectors' name reported in 1900 by E. C. Barnard (in Brooks, 1901, pl. 17), USGS.

Colorado Creek: stream, flows N 3 mi. to Mission Creek, $7 \mathrm{mi}$. NW of Eagle, Yukon-Tanana High.; $64^{\circ} 48^{\prime} \mathrm{N}, 141^{\circ} 26^{\prime} \mathrm{W}$; (map 102). Var. Boulder Greek.

Reported in 1896 as "Boulder Creek" by Spurr (1898, pl. 48), USGS. "Colorado Creek" was published in 1899 by USGS.

Colorado Creek: stream, flows SW $10 \mathrm{mi}$. to Chena River, $13 \mathrm{mi}$. SSW of Chena Dome and $58 \mathrm{mi}$. NW of Big Delta, Yukon-Tanana High.; 64 $54^{\circ} 15^{\prime \prime} \mathrm{N}, 146^{\circ} 37^{\prime} 50^{\prime \prime} \mathrm{W}$; (map 101).

Named by prospectors; reported in 1916 by G. A. Waring, USGS.

Colorado Creek: stream, flows SE $3.6 \mathrm{mi}$. to Utah Creek, $5 \mathrm{mi}$. ESE of Roughtop Mtn. and 28 mi. SW of Rampart, Yukon-Tanana High.; $65^{\circ} 09^{\prime} 12^{\prime \prime} \mathrm{N}, 150^{\circ} 37^{\prime} 50^{\prime \prime} \mathrm{W}$; BGN 1965; (map 106).

Local name reported in 1963 by Bond Taber, USGS.

Colorado Creek: stream, flows NE $6 \mathrm{mi}$. to Coal Creek, $6.5 \mathrm{mi}$. SW of that stream's junc. with Yukon River, Yukon-Tanana High.; $65^{\circ} 16^{\prime}$ $45^{\prime \prime} \mathrm{N}, 143^{\circ} 15^{\prime} 00^{\prime \prime} \mathrm{W}$; (map 103).

Prospectors' name reported by A. H. Brooks (in Brooks and others, 1907, p. 203), USGS.
Colorado Creek: stream, flows NE $7 \mathrm{mi}$. to Beaver Creek, $25 \mathrm{mi}$. E of Livengood, YukonTanana High.; 65 $33^{\prime} \mathrm{N}, 147^{\circ} 41^{\prime} \mathrm{W}$; (map 105).

Local name published by USGS in the 1950's.

Colorado Creek: stream, flows NW $2 \mathrm{mi}$. to Mettenpherg Creek, $20 \mathrm{mi}$. SW of Gunsight Mtn. and $70 \mathrm{mi}$. W of Wiseman, Brooks Ra.; $67^{\circ} 23^{\prime}$ N, $152^{\circ} 44^{\prime}$ W; BGN 1932; (map 124).

Local name reported by Robert Marshall in 1932.

Colorado Gulch: ravine, on Serpentine Ridge, extends SE $1.6 \mathrm{mi}$. to American Creek, $26 \mathrm{mi}$. ESE of Tanana, Yukon-Tanana High.; $65^{\circ}$ $06^{\prime} 00^{\prime \prime} \mathrm{N}, 151^{\circ} 10^{\prime} 45^{\prime \prime} \mathrm{W}$; (map 106).

Prospectors' name reported in 1931 by J. B. Mertie, Jr., USGS.

Colorado Reef: reef, in Wrangell Narrows, $12 \mathrm{mi}$. $\mathrm{S}$ of Petersburg, Alex. Arch.; $56^{\circ} 38^{\prime} 20^{\prime \prime} \mathrm{N}$, $132^{\circ} 56^{\prime} 10^{\prime \prime} \mathrm{W}$; (map 6).

Named by USC\&GS for charting purposes; name published in 1905 .

Colorado River: stream, see Colorado Creek.

Colpas de Isla: island, see Hawkins Island.

Colp Lake: lake, $0.2 \mathrm{mi}$. long, $5 \mathrm{mi}$. NW of Petersburg, on E coast of Lindenberg Penin., Kupreanof I., Alex. Arch.; 56 $52^{\prime} 25^{\prime \prime} \mathrm{N}$, $133^{\circ} 00^{\prime} 50^{\prime \prime} \mathrm{W}$; (map 6 ).

Local name recorded in 1951 by USGS.

Colpoys, Point: point of land, $16 \mathrm{mi}$. E of village of Point Baker, on $\mathrm{N}$ coast of Prince of Wales I., Alex. Arch.; $56^{\circ} 20^{\prime} \mathrm{N}, 133^{\circ} 12^{\prime} \mathrm{W}$; (map 6).

Named by Capt. George Vancouver, RN in September 1793, "probably after Sir John Colpoys, vice admiral in 1795" (Wagner, 1937 , p. 381)

Colsandu Creek: stream, see Glenn Creek.

Colt Island: island, $0.7 \mathrm{mi}$. across, in Stephens Passage, off $\mathbf{E}$ coast of Mansfield Penin., 0.2 $\mathrm{mi}$. N of Horse I. and $11 \mathrm{mi}$. SW of Juneau, Alex. Arch.; 58 $16^{\prime} 10^{\prime \prime} \mathrm{N}, 134^{\circ} 43^{\prime} 40^{\prime \prime} \mathrm{W}$; (map 11).

Name published by USC\&GS in the 1891 Coast Pilot (p. 150).

Columbia Bay: estuary, extends S $5.5 \mathrm{mi}$. from terminus of Columbia Glacier, $56 \mathrm{mi}$. NE of Whittier, Chugach Mts. ; $60^{\circ} 56^{\prime} 30^{\prime \prime} \mathrm{N}, 147^{\circ}$. 05'30" W; (map 63). Var. Glacier Bay.

Named by members of the Harriman Alaska Expedition in 1899, presumably for Columbia Univ., New York, N.Y.

Columbia Creek: stream, heads at $60^{\circ} 35^{\prime} \mathrm{N}$, $160^{\circ} 45^{\prime} \mathrm{W}$, flows NW $18 \mathrm{mi}$. Kasigluk River, $28 \mathrm{mi}$. E of Bethel, Yukon-Kuskokwim Delta; $60^{\circ} 48^{\prime} \mathrm{N}, 160^{\circ} 56^{\prime} \mathrm{W}$; (map 59).

Local name reported in 1955 by J. M. Hoare, USGS.

Columbia Creek: stream, flows SW $3 \mathrm{mi}$. to Cache Creek, between Dutch and Peters Hills, $29 \mathrm{mi}$. NW of Talkeetna, Alaska Ra. ; $62^{\circ} 31^{\prime}$ 15" N, 150 54'30" W; (map 81).

Prospectors' name reported in the 1930's by USGS.

Columbia Creek: stream, flows SE $9 \mathrm{mi}$. to O'Brien Creek, $26 \mathrm{mi}$. S of Eagle, Yukon- 
Tanana High.; $64^{\circ} 26^{\prime} \mathrm{N}, 141^{\circ} 21^{\prime} \mathrm{W}$; (map 102).

Prospectors' name obtained in 1898 by $E$. C. Barnard, USGS.

Columbia Creek: stream, flows $\mathbf{S} 7 \mathrm{mi}$. to Chena River, $4.6 \mathrm{mi}$. SE of Fairbanks, Tanana Low.; $64^{\circ} 49^{\prime} 58^{\prime \prime} \mathrm{N}, 147^{\circ} 34^{\prime} 00^{\prime \prime} \mathrm{W}$; (map 100).

Named by prospectors; reported in 1907 by C. C. Covert (in Henshaw and Covert, 1908, pl. 9), USGS.

Columbia Creek: stream, flows NE $4 \mathrm{mi}$. to Washington Creek which flows to Kougarok River, $50 \mathrm{mi}$. NE of Teller, Seward Penin. High.; $65^{\circ} 44^{\prime} \mathrm{N}, 165^{\circ} 01^{\prime} \mathrm{W}$; (map 111).

Prospectors' name reported in 1906 by A. H. Brooks (in Collier and others, 1908, pl. 9), USGS.

Columbia Glacier: glacier, heads $2 \mathrm{mi}$. SE of Mount Witherspoon, at $61^{\circ} 22^{\prime} \mathrm{N}, 147^{\circ} 09^{\prime} \mathrm{W}$, trends SE $40 \mathrm{mi}$. to Columbia Bay, $28 \mathrm{mi}$. SW of Valdez, Chugach Mts.; $60^{\circ} 59^{\prime} 30^{\prime \prime} \mathrm{N}, 147^{\circ}$. 02'30" W; BGN 1965; (map 68).

Named by the Harriman Alaska Expedition in 1899, for Columbia Univ., New York, N.Y. founded in 1754 .

Columbia Peak: mountain, 9,489 ft., S of Second Branch Columbia Glacier, $32 \mathrm{mi}$. NW of Valdez, Chugach Mts. ; $61^{\circ} 14^{\prime} 40^{\prime \prime} \mathrm{N}, 147^{\circ}$. $11^{\prime} 45^{\prime \prime} \mathrm{W}$; (map 69).

Local name reported in 1906 by USGS.

Columbia Peak: mountain, 5,324 ft., $5 \mathrm{mi} \mathrm{NW}$ of junc. of Happy and Skwentna Rivers, $77 \mathrm{mi}$. SW of Talkeetna, Alaska Ra.; $62^{\circ} 02^{\prime} 45^{\prime \prime} \mathrm{N}$, $152^{\circ} 25^{\prime} 30^{\prime \prime} \mathrm{W}$; (map 81).

Named in 1898 by W. S. Post and J. E. Spurr, USGS.

Columbia Point: point of land, on NE shore of Tenakee Inlet, on E central Chichagof I., 3.8 mi. E of Tenakee Springs, Alex. Arch.; 57 $46^{\prime} 45^{\prime \prime} \mathrm{N}, 135^{\circ} 13^{\prime} 00^{\prime \prime} \mathrm{W}$; (map 9).

Local name reported in 1951 by USGS.

Columbine Rock: rock, on E coast of Partofshikof I., $17 \mathrm{mi}$. NW of Sitka, Alex. Arch.; 57 $15^{\prime} 48^{\prime \prime} \mathrm{N}, 135^{\circ} 35^{\prime} 00^{\prime \prime} \mathrm{W}$; (map 9).

Named in 1901 by USC\&GS for the lighthouse tender Columbine.

Columbus Glacier: glacier, heads in Canada at $60^{\circ} 24^{\prime} \mathrm{N}, 140^{\circ} 54^{\prime} \mathrm{W}$, trends $\mathrm{W} 8 \mathrm{mi}$. to Bagley Icefield, $5 \mathrm{mi}$. SW of Table Mtn. and $80 \mathrm{mi}$. NW of Yakutat, St. Elias Mts.; $60^{\circ}$ $25^{\prime} \mathrm{N}, 141^{\circ} 13^{\prime} \mathrm{W}$; BGN 1954; (map 65). Var. Colombo Glacier.

Named on July 31, 1897, for Christopher Columbus, by His Royal Highness, Prince Luigi Amedeo, Duke of the Abruzzi, who saw the Bagley Icefield from the summit of Mount St. Elias (Filippi, 1900, p. 159); the name "Columbus Glacier" has been relegated to a part of the east end of Bagley Icefield.

Column Point: point of land, on NW coast of Chichagof I., at mouth of Lisianski Inlet, 3.5 mi. SW of Point Lucan, 37 mi. W. of Hoonah, Alex. Arch.; 58 $07^{\prime} 15^{\prime \prime} \mathrm{N}, 136^{\circ} 26^{\prime} 50^{\prime \prime}$. W; (map 10). Var. Point Lucan.

Descriptive name given by W. H. Dall, USC\&GS, in 1880 "because this point, which is low and rocky, has several rock pinnacles or columns near it." Some of the older charts show it mistakenly as Point Lucan.

Colvile River: stream, see Colville River.

Colville, Mount: mountain, $4,570 \mathrm{ft}$., W of Mount Emerson, $61 \mathrm{mi}$. E of Anchorage, Chugach Mts.; $61^{\circ} 07^{\prime} 15^{\prime \prime} \mathrm{N}, 148^{\circ} 04^{\prime} 15^{\prime \prime} \mathrm{W}$; (map 69).

Local name reported in 1939 by USGS.

Colville Bend: bend, on right bank of Three Day Slough, $18 \mathrm{mi}$. NW of Roundabout Mtn., Koyukuk Low.; $65^{\circ} 37^{\prime} \mathrm{N}, 157^{\circ} 10^{\prime} \mathrm{W}$; (map 108).

Named "Colwell Bend" in 1885 by Lt. H. T. Allen, USA, who wrote, "in honor of Mr. Colwell [cnna], of the Adjutant-General's Office, who gave me such conscientious work in working up my observations and making my maps" (Baker, 1906, p. 192).

Colville River: stream, formed by Thunder and Storm Creeks in De Long Mts. at $68^{\circ} 49^{\prime} 20^{\prime \prime}$ $\mathrm{N}, 160^{\circ} 20^{\prime} 00^{\prime \prime} \mathrm{W}$; flows $\mathrm{ENE} 350 \mathrm{mi}$. to Harrison Bay, Arctic Plain; $70^{\circ} 27^{\prime} \mathrm{N}, 150^{\circ} 07^{\prime}$ W; BGN 1961; (map 149). Var. Coleville River, Colvile River, Goose River, Gubik, Kang'-e-a-nok, Kangianik, Kar-n'yer-nok, Kungyanook, Kun-ya-nook, Kupik, Nig'aleh, Nig'-a-lek Kōk, Or-kim-ya-nook.

Named July 24, 1837, by Peter Warren Dease and Thomas Simpson, who wrote, "We called it Colvile River, as a mark of our respect for Andrew Colvile, Esquire, of the Hudson's Bay Company"; however, their map shows the spelling "Colville." Archdeacon Stuck (1920, p. 278) recorded, "Andrew Colville, governor of the Hudson's Bay Company, 1852-1856, and brother-in-law to Thomas, fifth earl of Selkirk." In 1852 Surgeon John Simpson (Great Britain, 1855, v. 3, p. 918), RN, wrote of the Colville, "it bears the native name of Nig'-a-lek Kōk, or Goose River," and also gave "Kang'-e-a-nok" as the Eskimo name meaning "headwaters." Variants of this name were reported in 1885 and 1886 by Lt. J. C. Cantwell, USRCS, and Lt. G. M. Stoney, USN. For the lower river, Leffingwell (1919, p. 95) noted the Eskimo name "Kupik," meaning "big river."

Coma Lake: lake, see Comna Lake.

Combine Flats: tidal flats, extend $\mathrm{N} 7 \mathrm{mi}$. from Clark Spit, on E shore of Nushagak Bay, $7 \mathrm{mi}$. $\mathrm{S}$ of Dillingham, Bristol Bay Low.; $58^{\circ} 54^{\prime} \mathrm{N}$, $158^{\circ} 30^{\prime} \mathrm{W}$; (map 40). Var. Combine Flat.

Local name published by USC\&GS in the 1954 Coast Pilot (p. 508).

Comeback Creek: stream, flows SE $4 \mathrm{mi}$. to Aloha Creek, $42 \mathrm{mi}$. WNW of Hughes, Hogatza High.; $66^{\circ} 15^{\prime} \mathrm{N}, 155^{\circ} 42^{\prime} \mathrm{W}$; (map 116).

Named about 1955 by mining engineers; reported in 1956 by Orth.

Comet: locality, on E shore of Lynn Canal, 1 mi. NE of Point Sherman and $47 \mathrm{mi}$. NW of Juneau, Coast Mts. ; $58^{\circ} 52^{\prime} 05^{\prime \prime} \mathrm{N}, 135^{\circ} 08^{\prime} 25^{\prime \prime}$ W; BGN 1954; (map 11). Var. Seward City.

Prospectors' name of a mining camp and landing reported in 1903 by Spencer and Wright (1906, pl. 38), USGS.
Comet Creek: stream, flows SW $18 \mathrm{mi}$. to North Fork Fortymile River, $32 \mathrm{mi}$. SW of Eagle, Yukon-Tanana High.; $64^{\circ} 34^{\prime} 20^{\prime \prime} \mathrm{N}, 142^{\circ}$ $08^{\prime} 00^{\prime \prime}$ W; (map 102). Var. Count Creek.

Named by prospectors and reported in 1898 by E. C. Barnard (in U.S. Geological Survey, 1899, map 10). This stream was reported in 1899 by Capt. W. R. Abercrombie, USA, as "Count Creek."

Comet Mountain : mountain, see Glacier Mountain.

Comfort: locality, on Richardson Highway, 9 mi. SE of Valdez, Chugach Mts.; $61^{\circ} 04^{\prime} \mathrm{N}$, $146^{\circ} 00^{\prime} \mathrm{W}$; (map 68). Var. Comfort Roadhouse.

Former roadhouse on the Valdez Trail reported in 1908 by USGS (Moffit and Maddren, 1909, pl. 1).

Comfort, Point: point of land, on $\mathrm{W}$ shore of Harrison Bay, $13 \mathrm{mi}$. S of Cape Halkett, Arctic Plain; $70^{\circ} 36^{\prime} \mathrm{N}, 152^{\circ} 18^{\prime} \mathrm{W}$; (map 149).

Named by P. W. Dease and Thomas Simpson, July 24, 1837 (Simpson, Thomas, 1843, p. 131), "In gratitude for these seasonable enjoyments [comforts]."

Comfort Cove: cove, $0.3 \mathrm{mi}$. wide, on $\mathrm{S}$ shore of Port Gravina, $17 \mathrm{mi}$. NW of Cordova, Chugach Mts.; $60^{\circ} 44^{\prime} \mathrm{N}, 146^{\circ} 07^{\prime} \mathrm{W}$; BGN 1910 ; (map 64).

Local name reported in 1909 by Grant and Higgins (1910, pl. 2), USGS.

Comfort Roadhouse: locality, see Comfort.

Coming Portage Lake: lake, $0.8 \mathrm{mi}$. long, $5 \mathrm{mi}$. NE of Arctic Village, Brooks Ra.; $68^{\circ} 08^{\prime} 45^{\prime \prime}$ $\mathrm{N}, 145^{\circ} 19^{\prime} 30^{\prime \prime} \mathrm{W}$; (map 136).

Translation of a Kutchin Indian name reported in 1956 by T. E. Taylor, USGS.

Comma Island: island, $1 \mathrm{mi}$. long, in Sukkwan Strait, $1 \mathrm{mi}$. NW of Hydaburg, on W coast of Prince of Wales I., Alex. Arch.; 55 $13^{\prime} 05^{\prime \prime} \mathrm{N}$, $132^{\circ} 50^{\prime} 45^{\prime \prime} \mathrm{W}$; (map 4 ).

Local name published in 1965 by USC\&GS. Comna Lake: lake, $0.5 \mathrm{mi}$. long, $25 \mathrm{mi}$. SW of Nenana, Tanana Low.; 64 $19^{\prime} 15^{\prime \prime} \mathrm{N}, 149^{\circ}$ $47^{\prime} 30^{\prime \prime}$ W; (map 100). Var. Coma Lake.

Local name shown on recent maps.

Company Creek: stream, flows NW $3 \mathrm{mi}$. to Asikpan Creek, Arctic Slope ; $67^{\circ} 53^{\prime} \mathrm{N}, 164^{\circ}$ $44^{\prime} \mathrm{W}$; (map 128).

Local name reported in 1966 by $E$. S. Burch; name derived from Kivalina Reindeer Company which had its winter range in this area at least one winter.

Company Mountain: hill, $525 \mathrm{ft}$, , between Asikpak and Kivalina Rivers, $10 \mathrm{mi}$. N of Kivalina, Arctic Slope; $67^{\circ} 49^{\prime} \mathrm{N}, 164^{\circ} 38^{\prime} \mathrm{W}$; (map 128).

Local name reported in 1950 by USC\&GS. E. S. Burch places the name on another hill at $67^{\circ} 52^{\prime} \mathrm{N}, 164^{\circ} 43^{\prime} \mathrm{W}$, with an elevation of about 345 feet. See Company Creek.

Composite Island: island, $1.4 \mathrm{mi}$. across, in Glacier Bay, in Glacier Bay National Monument, $3 \mathrm{mi}$. N of Gilbert I. and $67 \mathrm{mi}$. NW of Hoonah, St. Elias Mts.; 58 $53^{\prime} 15^{\prime \prime}$ N, $136^{\circ}-$ $33^{\prime} 45^{\prime \prime}$ W; (map 10). 
Descriptive name reported in 1892 by Reid (1896, p. 425 and pl. 86 ), USGS.

Comptroller's Bay: bay, see Controller Bay.

Comstock Creek: stream, flows SE $7 \mathrm{mi}$. to $\mathrm{Ho}$ gatza River $\mathrm{N}$ of junc. of Clear Creek, $37 \mathrm{mi}$. NW of Hughes, Hogatza High.; $66^{\circ} 13^{\prime} \mathrm{N}$, $155^{\circ} 30^{\prime} \mathrm{W}$; (map 116).

Named by mining engineers; recorded in 1956 by Orth.

Comte Heyden, Baie: bay, see Heiden, Port.

Comtroller Bay: bay, see Controller Bay.

Conbert Creek: stream, see Convert Creek.

Conclusion, Point: point of land, S point of entrance to Port Conclusion, $1.5 \mathrm{mi}$. N of village of Port Alexander, on $S$ coast of Baranof $I$., Alex. Arch.; $56^{\circ} 16^{\prime} 20^{\prime \prime} \mathrm{N}, 134^{\circ} 38^{\prime} 35^{\prime \prime} \mathrm{W}$; (map 5).

Local name used by fishermen; published in 1901 by USC\&GS.

Conclusion, Port: estuary, $3 \mathrm{mi}$. long, $2 \mathrm{mi}$. $\mathrm{N}$ of Port Alexander, on E coast of Baranof I., Alex. Arch.; $56^{\circ} 17^{\prime} \mathrm{N}, 134^{\circ} 38^{\prime} \mathrm{W}$; (map 5).

So named by Capt. George Vancouver, RN, because his work on the northwest coast of North America was ended at this point. "Vancouver's vessels were anchored here from August 1-22, 1794" (Wagner, 1937, p. 382).

Conclusion Island: island, $4 \mathrm{mi}$. long, at $\mathrm{S}$ end of Keku Strait, between Kupreanof and Kuiu Is., Alex. Arch.; $56^{\circ} 29^{\prime} \mathrm{N}, 133^{\circ} 49^{\prime} \mathrm{W}$; (map $6)$.

So named by Capt. George Vancouver, RN, "because he finished here the season of 1793" (Wagner, 1937, p. 382).

Concord Creek: stream, heads in a lake, flows NE 3 mi. to Flambeau River, 12 mi. ENE of Nome, Seward Penin. High, ; 64 $32^{\prime} 05^{\prime \prime}$ N, $164^{\circ} 59^{\prime} 35^{\prime \prime}$ W ; (map 94).

Prospectors' name reported in 1904 by T. G. Gerdine, USGS.

Concordia Glacier: glacier, heads in Kenai Mts., trends SE $1.2 \mathrm{mi}$. to its terminus $1 \mathrm{mi}$. W of $\mathrm{SE}$ end of Blackstone Bay, $6 \mathrm{mi}$. S of Whittier, Chugach Mts.; $60^{\circ} 41^{\prime} 30^{\prime \prime} \mathrm{N}, 148^{\circ} 41^{\prime} 30^{\prime \prime} \mathrm{W}$; (map 63).

Named in 1910 by Lawrence Martin for Concordia College, Milwaukee, Wisconsin (in Tarr and Martin, 1914, p. 355).

Concord Point: point of land, on SE coast of Chuginadak I., Aleutian Is. ; $52^{\circ} 47^{\prime} \mathrm{N}, 1^{\circ} 9^{\circ}$ $43^{\prime} \mathrm{W}$; (map 21).

Named in 1894 by U.S. Navy Hydrog. Office for the U.S.S. Concord which was used during a survey of the area.

Cone, The: mountain, $3,028 \mathrm{ft}$, $3 \mathrm{mi}$. W of Ursus Cove and $19 \mathrm{mi}$. NW of Augustine I., Aleutian Ra.; $59^{\circ} 32^{\prime}$ N, $153^{\circ} 51^{\prime}$ W ; BGN 1916; (map 51).

Named by USC\&GS in 1912 for the mountain's conical shape.

Cone Bay: bay, $1.5 \mathrm{mi}$. across, NW coast of Heceta I., Alex. Arch.; $55^{\circ} 48^{\prime} \mathrm{N}, 133^{\circ} 41^{\prime} \mathrm{W}$; (map 4).

Named in 1904 by E. F. Dickins, USC\&GS, probably because of its proximity to Cone Peak.

Cone Glacier: glacier, on Alaska Penin., on W slope of Mount Veniaminof, trends W $5 \mathrm{mi}$. to its terminus, $42 \mathrm{mi}$. NE of Port Moller, Aleutian Ra.; $56^{\circ} 13^{\prime} \mathrm{N}, 159^{\circ} 33^{\prime} \mathrm{W}$; (map 30).

So named in 1923 by R. H. Sargent, USGS, "because its source is near a small volcanic cone in Veniaminof Crater."

Cone Hill: hill, $551 \mathrm{ft}$., on west-central St. Paul I., in Pribilof Is.; $57^{\circ} 10^{\prime} 30^{\prime \prime} \mathrm{N}, 170^{\circ} 21^{\prime} 30^{\prime \prime}$ W; (map 38).

Descriptive name published by USC\&GS in 1875; probably obtained from Elliott (1881, St. Paul map), who was there in 1873-74. Cone Hill: mountain, see Potato Mountain. Cone-Hill River: stream, see Fortymile River.

Cone Island: island, 100 yds. across, near W shore of Nazan Bay, on $\mathbf{E}$ coast of Atka I., Aleutian Is.; $52^{\circ} 12^{\prime} 28^{\prime \prime} \mathrm{N}, 174^{\circ} 11^{\prime} 02^{\prime \prime} \mathrm{W}$; (map 18). Var. Cone Islands.

Descriptive name published by the USC\&GS in the 1944 Aleutian Coast Pilot (p. 100 ) as "Cone Islands" because the most northeastern island of the three had three remarkable pinnacles.

Cone Island: island, 2,200 ft. long, between Revillagigedo Channel and Thorne Arm, $\mathrm{W}$ of Cone Point, Revillagigedo I., Alex. Arch.; $55^{\circ} 14^{\prime} 40^{\prime \prime} \mathrm{N}, 131^{\circ} 19^{\prime} 15^{\prime \prime} \mathrm{W}$; (map 3 ).

Descriptive name given in 1883 by $L t$. Comdr. H. E. Nichols, USN.

Cone Island: island, $2.5 \mathrm{mi}$. long, between St. Nicholas Channel and Siketi Sound, $18 \mathrm{mi}$ W of Craig, Alex. Arch.; $55^{\circ} 26^{\prime} \mathrm{N}, 133^{\circ} 38^{\prime}$ W; (map 4).

Name published in 1914 by USC\&GS.

Cone Island: island, see Krishka Island.

Cone Island Point: point of land, see Ape Point. Cone Island Point: point of land, see Cone Point. Cone Islands: island, see Cone Island.

Cone Mountain: hill, $492 \mathrm{ft}$., on SW coast of Dall I., S of Port Bazan, Alex. Arch.; 54 ${ }^{\circ} 49^{\prime}$ $10^{\prime \prime} \mathrm{N}, 132^{\circ} 56^{\prime} 45^{\prime \prime} \mathrm{W}$; (map 1).

Local descriptive name published by USC\&GS in 1943.

Cone Mountain: mountain, 3,200 ft., between $\mathrm{N}$ ends of Willard and Fillmore Inlets, Coast Mts.; $54^{\circ} 55^{\prime} 50^{\prime \prime} \mathrm{N}, 130^{\circ} 37^{\prime} 30^{\prime \prime} \mathrm{W}$; (map 2).

Local name published in 1943 by USC\&GS.

Cone Mountain: mountain, 2,075 ft., E of Cape Lookout, on W coast of Dall I., Alex. Arch.; $55^{\circ} 05^{\prime} 45^{\prime \prime} \mathrm{N}, 133^{\circ} 13^{\prime} 15^{\prime \prime} \mathrm{W}$; (map 4).

Descriptive name published in 1924 by USC\&GS.

Cone Mountain: mountain, 2,615 ft., on Annette I., $5.5 \mathrm{mi}$ NE of Metlakatla, Alex. Arch.; $55^{\circ} 11^{\prime} 30^{\prime \prime} \mathrm{N}, 131^{\circ} 29^{\prime} 20^{\prime \prime} \mathrm{W}$; (map 3 ).

Descriptive name given in 1883 by $L t$. Comdr. H. E. Nichols, USN.

Cone Mountain: mountain, 5,855 ft., $5.5 \mathrm{mi}$. S of Alaska-Canada boundary, $26 \mathrm{mi}$. NE of Wrangell, Coast Mts. ; $56^{\circ} 31^{\prime} 30^{\prime \prime} \mathrm{N}, 131^{\circ} 43^{\prime}$ $10^{\prime \prime} \mathrm{W}$; (map 7). Var. Cane Mountain.

Name published in 1899 by USC\&GS, which had erroneously published the name "Cane" in $\mathbf{1 8 9 1}$ for this feature.

Cone Mountain: mountain, 2,061 $\mathrm{ft}$., in Kenai Mts., $2.5 \mathrm{mi}$. W of Windy Bay and $16 \mathrm{mi}$. S of Seldovia, Chugach Mts.; 59 $19^{\prime} 30^{\prime \prime}$ N, $151^{\circ}$ 37'15" W; BGN 1911; (map 50).
Named by U. S. Grant, USGS, in 1909 because of its conelike shape.

Cone Mountain: mountain, $1,400 \mathrm{ft} ., 7 \mathrm{mi}$. $\mathrm{N}$ of Tooth Mtn. and $18 \mathrm{mi}$. N of Goodnews, Kilbuck-Kuskokwim Mts.; $59^{\circ} 21^{\prime} \mathrm{N}, 161^{\circ} 43^{\prime}$ W ; (map 53).

Local descriptive name published in 1915 by USC\&GS on Chart 9103 .

Cone Mountain: mountain, 1,380 ft., between Cripple and Penny Rivers, $3 \mathrm{mi}$. $\mathrm{N}$ of Norton Sound and $12 \mathrm{mi}$. NW of Nome, Seward Penin. High.; $64^{\circ} 36^{\prime} \mathrm{N}, 165^{\circ} 45^{\prime} \mathrm{W}$; (map 94).

Prospectors' name reported in 1899 by D. C. Witherspoon (in Schrader and Brooks, 1900, map 2), USGS.

Cone Mountain: mountain, $4,053 \mathrm{ft}$., $56 \mathrm{mi}$. SE of Shungnak, Hogatza High.; $66^{\circ} 13^{\prime} \mathrm{N}$, $156^{\circ} 04^{\prime} \mathrm{W}$; (map 115$)$.

Descriptive name given by Lt. $H$. T. Allen USA, in 1885 .

Cone Peak: mountain, 1,085 ft., on Agattu I., $3.2 \mathrm{mi}$. SW of Krugloi Point, Aleutian Is.; $52^{\circ} 29^{\prime} 50^{\prime \prime} \mathrm{N}, 173^{\circ} 41^{\prime} 37^{\prime \prime} \mathrm{E}$; (map 13).

Name published in 1953 by USGS.

Cone Peak: mountain, 1,280 ft., between Canoe and Pavlof Bays, Alaska Penin., Aleutian Ra.; $55^{\circ} 33^{\prime} \mathrm{N}, 161^{\circ} 20^{\prime} \mathrm{W}$; (map 28).

Local name reported by USGS in 1929 .

Cone Peak: mountain, $1,079 \mathrm{ft}$., on $\mathrm{W}$ coast of Heceta I., Alex. Arch.; 55 $47^{\prime} 15^{\prime \prime} \mathrm{N}$, $133^{\circ} 38^{\prime} 45^{\prime \prime} \mathrm{W}$; (map 4).

Descriptive name given in 1904 by E. F. Dickins, USC\&GS, "on account of its conical shape."

Cone Point: point of land, on S coast of Revillagigedo I., E of Cone I., between Revillagigedo Channel and Thorne Arm, Alex. Arch.; 55 $5^{\circ} 15^{\prime} \mathrm{N}, 131^{\circ} 19^{\prime} \mathrm{W}$; (map 3). Var. Cone Island Point.

Descriptive name given in 1883 by Lt. Comdr. H. E. Nichols, USN.

Cone Point: point of land, at junc. of Pilot Mtn. Slough and Yukon River, $21 \mathrm{mi}$. NE of Nulato, Koyukuk Low.; $64^{\circ} 48^{\prime} \mathrm{N}, 157^{\circ} 25^{\prime} \mathrm{W}$; (map 97).

Local name reported in 1954 by USGS. Cone Point: point of land, see Grindall Point. Cone Point: point of land, see Turn Point.

Coney Island: island, $0.3 \mathrm{mi}$. long, at $\mathrm{S}$ end of Frederick Sound, $14 \mathrm{mi}$. SE of Peterburg, Alex Arch.; $56^{\circ} 41^{\prime} 30^{\prime \prime} \mathrm{N}, 132^{\circ} 38^{\prime} 30^{\prime \prime} \mathrm{W}$; (map 6).

Named in 1887 by Lt. Comdr. C. $M$. Thomas, USN, for charting purposes; name published in 1888 on USC\&GS Chart 705.

Confederate Creek: stream, flows NE $3 \mathrm{mi}$. to Hutchinson Creek, $49 \mathrm{mi}$. SW of Eagle, Yukon-Tanana High.; $64^{\circ} 17^{\prime} 40^{\prime \prime} \mathrm{N}, 142^{\circ}$ $19^{\prime} 00^{\prime \prime} \mathrm{W}$; (map 102).

Prospectors' name shown on an 1898 manuscript map by C. A. Woodruff, Fort Cudahy, Canada.

Confusion Creek: stream, flows $\mathrm{N} 22 \mathrm{mi}$. from a glacier to Siksikpuk River, $27 \mathrm{mi}$. N of Anaktuvuk Pass, Brooks Ra.; $68^{\circ} 31^{\prime} \mathrm{N}, 152^{\circ} 03^{\prime} \mathrm{W}$; (map 134). 
So named in the 1949-50 field season by W. W. Patton and A. S. Keller, USGS, "because the closely-spaced parallel tributaries in this area caused confusion locating ourselves in the field, and because the preliminary map of this area was in error and was confusing."

Congahbuna Lake: lake, $2.2 \mathrm{mi}$. long, $9 \mathrm{mi}$. W of Tyonek, Cook Inlet Low.; $61^{\circ} 04^{\prime} 15^{\prime \prime} \mathrm{N}, 151^{\circ}$ $25^{\prime} 30^{\prime \prime} \mathrm{W}$; (map 70).

Tanaina Indian name reported in 1958 by USGS.

Conglomerate Creek: stream, on Alaska Penin., flows $\mathrm{W} 4 \mathrm{mi}$. to join Broad Creek to form Alec River, $15 \mathrm{mi}$. NW of Chignik, Aleutian Ra.; $56^{\circ} 26^{\prime} \mathrm{N}, 158^{\circ} 42^{\prime} \mathrm{W}$; (map 30 ).

So named in 1923 by R. H. Sargent, USGS, because "the creek flows through conglomerate beds."

Conglomerate Creek: stream, flows SW $2 \mathrm{mi}$. from Glenn Highway to Matanuska River, 35 mi. NE of Palmer, Talkeetna Mts.; $61^{\circ} 47^{\prime} \mathrm{N}$, $148^{\circ} 07^{\prime} \mathrm{W}$; (map 69).

Named in 1932 by G. A. Waring and L. O. Newsome, USGS, because "a conglomerate formation [exists] along this creek."

Conglomerate Creek: stream, flows NE $7 \mathrm{mi}$. to Little Oshetna River, $23 \mathrm{mi}$. NW of Tahneta Pass, Talkeetna Mts.; $62^{\circ} 11^{\prime} 35^{\prime \prime} \mathrm{N}, 147^{\circ} 35^{\prime}$. $40^{\prime \prime} \mathrm{W}$; BGN 1960; (map 82).

Named in 1956 by USGS "for the thick conglomerate rock beds through which the stream has cut."

Conglomerate Creek: stream, flows SE $14 \mathrm{mi}$. to Glacier River, $2.5 \mathrm{mi}$. E of Delay Pass and 13 mi. W of Wiseman, Brooks Ra.; 67 $26^{\prime} \mathrm{N}$, $150^{\circ} 37^{\prime} \mathrm{W}$; (map 124).

Local name shown on an 1899 fieldsheet by T. G. Gerdine, USGS.

Conglomerate Creek: stream, flows W $2.8 \mathrm{mi}$. to Ogotoruk Creek, $\mathrm{N}$ of Mitik Creek, $6.8 \mathrm{mi}$. $\mathrm{E}$ of Cape Thompson, Arctic Slope; $68^{\circ} 07^{\prime} 38^{\prime \prime}$

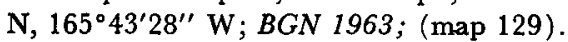

Named about 1962 by geologists associated with Project Chariot studies.

Conglomerate Mountain: ridge, elev. 4,000 5,000 ft., in Davidson Mts., extends $13 \mathrm{mi}$., on $\mathbf{N}$ bank of Coleen River near its head, $25 \mathrm{mi}$. NE of Table Mtn., Brooks Ra.; $68^{\circ} 36^{\prime} \mathrm{N}$, $142^{\circ} 47^{\prime} \mathrm{W}$; (map 137).

Local name reported in 1956 by USGS.

Conical Hill: mountain, see Potato Mountain.

Conical Red Hill: hill, $596 \mathrm{ft}$., on SE coast of Unimak I., $26 \mathrm{mi}$. SW of False Pass, Aleutian Is., $54^{\circ} 47^{\prime} 00^{\prime \prime} \mathrm{N}, 163^{\circ} 59^{\prime} 40^{\prime \prime} \mathrm{W}$; (map 25).

Descriptive name published in 1949 on a USGS map.

Conical Volcano: mountain, on Cape Potainikof, $6.5 \mathrm{mi}$. NE of Cape Korovin, on NW coast of Atka I., Aleutian Is.; $52^{\circ} 22^{\prime} \mathrm{N}, 174^{\circ} 18^{\prime} \mathrm{W}$; (map 18). Var. Konichesk Volcano, Konicheskaia, Konicheskaya Sopka.

Descriptive name from the Russian "Konicheskaya Sopka," or "cone-shaped volcano," so called by Ingenstrem in 1829 and by Ivan Chernov in 1832; published in 1848 on Russian Hydrog. Dept. Chart 1400. Described as "not a volcano" by Coats (1950, p. 39) USGS.
Coni Mound: peak, see Cony Mountain.

Coning Inlet: estuary, extends NW $3.5 \mathrm{mi}$. off Cordova Bay, on E coast of Long I., Alex. Arch.; 54 $50^{\prime} \mathrm{N}, 132^{\circ} 38^{\prime} \mathrm{W}$; (map 1).

Name recorded in 1905 by E. F. Dickins, USC\&GS. See Nina Cove.

Coning Point: point of land, $\mathrm{N}$ point of entrance to Coning Inlet, on $\mathrm{E}$ coast of Long I., Alex. Arch.; $54^{\circ} 50^{\prime} 15^{\prime \prime} \mathrm{N}, 132^{\circ} 38^{\prime} 00^{\prime \prime} \mathrm{W}$; BGN 1929; (map 1).

Named by Capt. R. S. Patton, USC\&GS, in 1928.

Connecticut Creek: stream, flows $4 \mathrm{mi}$. NW to Bering Sea, $1 \mathrm{mi}$. SW of Cape Chagak, on N coast of Umnak I., Aleutian Is. ; $53^{\circ} 30^{\prime} 45^{\prime \prime} \mathrm{N}$, $168^{\circ} 15^{\prime} 00^{\prime \prime} \mathrm{W}$; (map 22).

Name published by Byers (1959, pl. 41), USGS.

Connecticut Creek: stream, flows NE $1.4 \mathrm{mi}$. to Canyon Creek which flows to Casadepaga River, $20 \mathrm{mi}$. NE of Solomon, Seward Penin. High., $64^{\circ} 51^{\prime} \mathrm{N}, 164^{\circ} 26^{\prime} \mathrm{W}$; (map 95).

Prospectors' name reported in 1905 by T. G. Gerdine, USGS.

Connection Pass: water passage, $0.7 \mathrm{mi}$. long, between Polk Inlet and Skowl Arm, near center of Prince of Wales I., Alex. Arch.; 55 $24^{\prime} 15^{\prime \prime}$ N, $132^{\circ} 28^{\prime} 00^{\prime \prime} \mathrm{W} ; B G N 1963$; (map 4).

Local descriptive name reported in 1961 by USFS.

Connell Lake, lake, $1.9 \mathrm{mi}$. long, on Revillagigedo I., $4.5 \mathrm{mi}$. N of Ketchikan, Alex. Arch.; $55^{\circ} 26^{\prime} \mathrm{N}, 131^{\circ} 40^{\prime} \mathrm{W}$; BGN 1938; (map 3).

Named in 1937 by USFS "for Capt. Connell [cnna], who died in 1933, a prominent resident of Ketchikan, who built a sawmill nearby in 1900."

Conner Creek: stream, flows SW $2.5 \mathrm{mi}$. to Kokomo Creek, $27 \mathrm{mi}$. NE of Fairbanks, YukonTanana High.; $65^{\circ} 08^{\prime} 20^{\prime \prime} \mathrm{N}, 147^{\circ} 06^{\prime} 40^{\prime \prime} \mathrm{W}$; (map 105). Var. Connor Creek.

Named by prospectors; reported in 1903 by T. G. Gerdine (in Prindle, 1905, pl. 13), USGS.

Conners Lake: lake, see Connors Lake.

Connolly Creek: stream, flows NW $9.9 \mathrm{mi}$. to Hunter Creek, $38 \mathrm{mi}$. NW of Haycock, Seward Penin. High.; 65 $42^{\prime} \mathrm{N}, 161^{\circ} 46^{\prime} \mathrm{W}$; (map 109).

Local name published on maps after 1950. Connor Creek: stream, see Conner Creek.

Connors Lake: lake, $0.3 \mathrm{mi}$. across, $3.7 \mathrm{mi}$. SW of Anchorage, Cook Inlet Low.; $61^{\circ} 10^{\prime} \mathrm{N}$, $149^{\circ} 56^{\prime} \mathrm{W}$; (map 69). Var. Conners Lake, Conors Lake.

Local name reported in 1941 by AMS.

Conors Lake: lake, see Connors Lake.

Conquer Bay: bay, 2 mi. across, $\mathrm{S}$ of Conquer Point, including Beach and Bluff Coves, $W$ coast of Kiska I., Aleutian Is.; $51^{\circ} 59^{\prime} 45^{\prime \prime} \mathrm{N}$, $177^{\circ} 28^{\prime} 30^{\prime \prime}$ E ; (map 14).

One of many arbitrary names applied to features on Kiska I. by USAAF for tactical purposes during World War II.

Conquer Point: point of land, backed by $933-\mathrm{ft}$. Lady Hill, on W coast of Kiska I., Aleutian Is.; $52^{\circ} 00^{\prime} 25^{\prime \prime} \mathrm{N}, 177^{\circ} 29^{\prime} 15^{\prime \prime} \mathrm{E}$; (map 14).
One of many arbitrary names applied to features on Kiska I. by USAAF for tactical purposes during World War II.

Consa: locality, see Cos Jacket.

Consa: locality, see Cosna.

Constance, Lake: lake, see Constant, Lake.

Constance Creek: stream, flows SE $1 \mathrm{mi}$. to Silverbow Creek which flows to Norton Sound, $19 \mathrm{mi}$. NE of Solomon, Seward Penin. High.; $64^{\circ} 36^{\prime} \mathrm{N}, 163^{\circ} 50^{\prime} \mathrm{W}$; (map 95). Var. Contact Creek.

Prospectors' name published on the 1908 "Map of Seward Peninsula" by Arthur Gibson, but shown as "Contact Cr." on his "Map of Cape Nome Precinct" dated 1902.

Constance Creek: stream, flows SW $5.5 \mathrm{mi}$. to Don River which flows to Breving Lagoon, 17 mi. NW of Teller, Seward Penin. High.; $65^{\circ}$ $26^{\prime} \mathrm{N}, 166^{\circ} 48^{\prime} \mathrm{W}$; (map 111).

Prospectors' name reported on the 1908 "Map of Seward Peninsula" by Arthur Gibson.

Constant, Lake: lake, $0.6 \mathrm{mi}$. long, Adak I., Aleutian Is.; $51^{\circ} 48^{\prime} 02^{\prime \prime} \mathrm{N}, 176^{\circ} 42^{\prime} 40^{\prime \prime} \mathrm{W}$; $B G N$ 1936; (map 17). Var. Lake Constance.

Named by members of the U.S. Navy Aleutian Island Survey Expedition in 1933.

Constantin, Cap: point of land, see Constantine, Cape.

Constantin Bay: bay, see Constantine Harbor. Constantine, Cape: point of land, $\mathrm{S}$ tip of Nushagak Penin., $48 \mathrm{mi}$. SW of Dillingham, Bristol Bay Low.; $58^{\circ} 23^{\prime} 30^{\prime \prime} \mathrm{N}, 158^{\circ} 53^{\prime} 30^{\prime \prime}$ W.; (map 40). Var. Mys Konstantina, Mys Konstantinya, Cap Constantin.

Named by a Mr. Ustiugov (cnna) who surveyed this region in 1818; probably named for the Russian American Company's ship Constantine. The name was published by Capt. Lutke (1836, map 14), IRN, as "M[ys] Konstantina" and as "Cap Constantin" (1836, p. 256).

Constantine Anchorage: cove, see Constantine Cove.

Constantine Bay: bay, $0.7 \mathrm{mi}$. across, in Unalaska Bay, NE coast of Unalaska I., $7 \mathrm{mi}$. NE of Unalaska, Aleutian Is.; $53^{\circ} 57^{\prime} \mathrm{N}, 166^{\circ} 25^{\prime} \mathrm{W}$; (map 23).

Name published by Father Veniaminov (1840, v. 1, p. 163) as "Konstantinovskaya," or "Constantine"; probably named for the Russian American Company's ship Constantine which was wrecked while attempting to enter the bay.

Constantine Cove: cove, $0.1 \mathrm{mi}$. across, in Ilin Bay, at head of Islas Bay, $16 \mathrm{mi}$. NW of Chichagof, on $W$ coast of Chichagof I., Alex. Arch.; 57 $50^{\prime} 30^{\prime \prime} \mathrm{N}, 136^{\circ} 23^{\prime} 15^{\prime \prime} \mathrm{W}$; (map 9). Var. Constantine Anchorage.

Named by the Russian pilot Peter Ivanovich Ilin, who mapped this area about 1800 .

Constantine Harbor: bay, $2 \mathrm{mi}$. long, on NE coast of Amchitka I., Aleutian Is.; $51^{\circ} 24^{\prime} 30^{\prime \prime}$ N, 179 19'00" E; BGN 1937; (map 15). Var. Constantin Bay, Constantin Harbor, Gavan Konstantina. 
Named apparently by the navigator Klinkofstrem before 1849 (Baker, 1906, p. 194); called "G[avan] Konstantina," or "Constantine Harbor," by Capt. Tebenkov (1852, map 29), IRN.

Constantine Harbor: lagoon, $3 \mathrm{mi}$. long, on Hinchinbrook I., $35 \mathrm{mi}$. SW of Cordova, Chugach Mts.; $60^{\circ} 21^{\prime} 30^{\prime \prime} \mathrm{N}, 146^{\circ} 37^{\prime} 30^{\prime \prime} \mathrm{W}$; (map 64). Var. Brooks Harbor, Harbor of Czar Konstantin, Konstantin Harbor, Nuchek Harbor.

A Russian chart dated 1802 shows a fortified post and harbor at this location with the name of "Czar Konstantin and Helena." In 1830, Ivan Chernov of the Russian American Co. referred to it as "Konstantin Harbor." The English form "Constantine" was first reported by USC\&GS in 1904. Capt. Portlock (1789, map facing p. 227), who with Capt. Dixon explored the region in 1787 , called it "Brooks Harbor."

Constantine Point: point of land, $\mathrm{E}$ entrance point of Constantine Harbor, on $\mathrm{N}$ coast of Amchitka I., Rat Is., Aleutian Is.; $51^{\circ} 24^{\prime} 30^{\prime \prime}$ $\mathrm{N}, 179^{\circ} 21^{\prime} 10^{\prime \prime} \mathrm{E}$; (map 15).

Name listed in the 1944 Aleutian Coast Pilot (p. 122).

Constantin Harbor: bay, see Constantine Harbor.

Contact Creek: stream, flows SW $24 \mathrm{mi}$., joins Takayofo Creek to form King Salmon River, on Alaska Penin. in Katmai National Monument, $39 \mathrm{mi}$. SW of Mount Katmai, Aleutian Ra.; 58 $09^{\prime} 45^{\prime \prime} \mathrm{N}, 156^{\circ} 00^{\prime} 25^{\prime \prime} \mathrm{W}$; (map 41).

Descriptive name given by R. H. Sargent, USGS, in 1923 "because it flows along a fault in the rock."

Contact Creek: stream, flows NE $7 \mathrm{mi}$. to Canyon Creek, $7 \mathrm{mi}$. E of Dickason Mtn. and $58 \mathrm{mi}$. NW of Tyonek, Alaska Ra.; 61 ${ }^{\circ} 52^{\prime} 32^{\prime \prime} \mathrm{N}$, $151^{\circ} 41^{\prime} 00^{\prime \prime} \mathrm{W}$; BGN 1964; (map 70).

So named in 1962 by USGS geologists because "the contact between granite and coalbearing rocks is well exposed along its banks."

Contact Creek: stream, in Mount McKinley National Park, flows NE $1 \mathrm{mi}$, to Thorofare River, $3.7 \mathrm{mi}$. SSE of Eielson Visitor Center, Alaska Ra.; $63^{\circ} 23^{\prime} 00^{\prime \prime} \mathrm{N}, 150^{\circ} 15^{\prime} 30^{\prime \prime} \mathrm{W}$; $B G N 1932$; ( $\operatorname{map} 88$ ).

Named in 1931 by J. C. Reed, Sr., USGS, "as an important geologic contact lies along the valley of this creek."

Contact Creek: stream, heads near Hayes Glacier terminus, flows NE 6 mi. to Ptarmigan Creek 2 mi. W of its junc. with Delta Creek, 14 mi. NE of Mount Hayes, Alaska Ra.; $63^{\circ} 48^{\prime} 00^{\prime \prime} \mathrm{N}, 146^{\circ} 32^{\prime} 35^{\prime \prime} \mathrm{W}$; (map 86).

Name published on relatively recent maps.

Contact Creek: stream, flows SE $9 \mathrm{mi}$. to John River at Anaktuvuk Pass, Brooks $\mathrm{Ra}$; $68^{\circ} 09^{\prime} \mathrm{N}, 151^{\circ} 44^{\prime} \mathrm{W}$; (map 134). Var. Nachramkunga Creek.

So named in 1901 by Schrader (1904, p. $63)$, USGS, because the stream follows a faultline, being a contact between two different geological formations. The Eskimo name for this stream is "Nachramkunga," meaning "divide creek" (Rausch, 1951, p. 151); so called because it is on the divide between the John and Anaktuvuk Rivers.

Contact Creek: stream, see Constance Creek.

Contact Glacier: glacier, on $\mathrm{E}$ side of Kenai Penin., heads in Sargent Icefield, trends $\mathrm{N}$ $2 \mathrm{mi}$. to its terminus, $1 \mathrm{mi}$. SW of Head of Deep Water Bay, $22 \mathrm{mi}$. SE of Whittier, Chugach Mts. ; $60^{\circ} 29^{\prime} \mathrm{N}, 148^{\circ} 25^{\prime} \mathrm{W}$; BGN 1910; (map 63).

Named in 1910 by U. S. Grant, USGS, "because it covers contact between granite and sediments."

Contact Glacier: glacier, heads on Mount Hubley in Romanzof Mts., trends $\mathrm{E} 2 \mathrm{mi}$. to its terminus, $13 \mathrm{mi}$. SE of Mount Michelson, Brooks Ra.; $69^{\circ} 16^{\prime}$ N, $143^{\circ} 42^{\prime}$ W; (map 138).

Named about 1957 by personnel participating in the International Geophysical Year glaciological work in the Romanzof Mountains.

Contact Gulch: ravine, extends $2.9 \mathrm{mi}$. SE to Chitistone River $9.5 \mathrm{mi}$. E of its junc. with Nizina River and $20 \mathrm{mi}$. NE of McCarthy, Wrangell Mts.; $61^{\circ} 29^{\prime} \mathrm{N}, 142^{\circ} 19^{\prime} \mathrm{W}$; (map 67).

Local name obtained by USGS and published on maps since 1954.

Contact Nunatak: peak, 3,846 ft., on E side of Reid Glacier $2 \mathrm{mi}$. NE of its head, Glacier Bay National Monument, $64 \mathrm{mi}$. NW of Hoonah, St. Elias Mts.; $58^{\circ} 43^{\prime} 00^{\prime \prime} \mathrm{N}, 136^{\circ}$ $46^{\prime} 30^{\prime \prime} \mathrm{W}$; (map 10).

Local name published by USGS in the 1950 's.

Contact Point: point of land, at entrance to Bruin Bay, $20 \mathrm{mi}$. W of Augustine I., Aleutian Ra.; 59 $21^{\prime} 45^{\prime \prime}$ N, $153^{\circ} 56^{\prime} 40^{\prime \prime}$ W; (map 51).

So named in 1926 by USGS because a fault contact between two geologic formations is exposed here

Con-tay-th-no: stream, see Kantishna River.

Conte, Isla del: island, see Glacier Island.

Contlechebna Lake: lake, see Kontrashibuna Lake.

Control Lake: lake, $0.7 \mathrm{mi}$. long, on Prince of Wales I., $13 \mathrm{mi}$. NE of Klawock, Alex. Arch.; $55^{\circ} 41^{\prime} 30^{\prime \prime} \mathrm{N}, 132^{\circ} 51^{\prime} 55^{\prime \prime} \mathrm{W}$; BGN 1966; (map 4).

Local name reported in 1963 by USFS.

Controller Bay: bay, extends $15 \mathrm{mi}$. SE from mouth of Bering River to Okalee Spit, on $S$ coast of Alaska, $5 \mathrm{mi}$. SE of Katalla, Malaspina Coastal Plain; $60^{\circ} 05^{\prime} \mathrm{N}, 144^{\circ} 15^{\prime} \mathrm{W}$; $B G N$ 1891; (map 64). Var. Bering Haven, Comptroller's Bay, Comtroller Bay, Zaliv Kontrolyer.

Named "Comptrollers Bay" by Capt. Cook (1785, v. 2, p. 353), RN, about May 11, 1778, probably for Maurice Suckling who was comptroller of the Royal Navy when Cook left on this expedition (Wagner, 1937, p. 382). The name was adopted by Capt. George Vancouver, RN. The Russians transliterated the name to "Zal(iv) Kontrolyer" on Hydrog. Dept. Chart 1378, dated 1847.
Convenient Cove: estuary, $0.5 \mathrm{mi}$. long, on SW coast of Hassler I., off NE coast of Revillagigedo I., Alex. Arch.; 55 52' N, $131^{\circ} 41^{\prime}$ W; (map 3).

Named in 1891 by USC\&GS.

Convert Creek: stream, flows NE $8 \mathrm{mi}$. to Preacher Creek, $65 \mathrm{mi}$. SW of Circle, YukonTanana High.; $65^{\circ} 31^{\prime} 30^{\prime \prime} \mathrm{N}, 146^{\circ} 13^{\prime} 00^{\prime \prime} \mathrm{W}$; (map 104). Var. Conbert Creek.

Name originally reported in 1903 by USGS as "Conbert Creek" (Prindle, 1905, pl. 13). However, through local usage, the name has become "Convert Greek."

Conway Creek: stream, flows NW $0.8 \mathrm{mi}$. to Solomon River near its head, $0.6 \mathrm{mi}$. NE of Nugget Creek and $16 \mathrm{mi}$. NE of Solomon, Seward Penin. High.; $64^{\circ} 46^{\prime} 50^{\prime \prime} \mathrm{N}, 164^{\circ} 16^{\prime}$ 20" W; (map 95).

Prospectors' name reported in 1907 by USGS geologists (in Smith, P. S., 1910, pl. 4).

Cony Mountain: peak, 7,300 ft., near head of Gulkana Glacier, $18 \mathrm{mi}$. NNE of Paxson, Alaska Ra.; $63^{\circ} 17^{\prime} 45^{\prime \prime} \mathrm{N}, 145^{\circ} 26^{\prime} 20^{\prime \prime} \mathrm{W}$; (map 86). Var. Coni Mound.

Named between 1948 and 1955 by T. L. Péwé, USGS.

Coogalga: island, see Tigalda Island.

Cook, Baie de: estuary, see Cook Inlet.

Cook, Mount: peak, $13,760 \mathrm{ft}$., on AlaskaCanada boundary, $19 \mathrm{mi}$. ESE of Mount Augusta and $45 \mathrm{mi}$. NNW of Yakutat, St. Elias Mts.; $60^{\circ} 11^{\prime} 00^{\prime \prime} \mathrm{N}, 139^{\circ} 58^{\prime} 30^{\prime \prime} \mathrm{W}$; (map 66). Var. Boundary Peak 182.

Named in 1874 by W. H. Dall, USC\&GS, for Capt. James Cook, 1728-79, English navigator and explorer who was responsible for considerable exploration of the Alaska coast as far north as Icy Cape, near latitude $70^{\circ}$.

Cook Bay: lagoon, $1.4 \mathrm{mi}$. long, on NW coast of Long I., 5 mi. SE of Kodiak, NE of Kodiak I.; $57^{\circ} 46^{\prime} 30^{\prime \prime} \mathrm{N}, 152^{\circ} 16^{\prime} 00^{\prime \prime} \mathrm{W}$; (map 34). Var. Brickyard Harbor.

Name published in 1965 by USGS. Baker (1906, p. 147) calls this feature "Brickyard Harbor" because "Old Russian charts [Sarichev, 1826, map 16] indicate the existence of a brickyard on the shores of this $* * *$ harbor."

Cook Inlet: estuary, $30 \mathrm{mi}$, wide, $\mathrm{W}$ of Kenai Penin, extends SW 220 mi. from Anchorage to its junc. with Shelikof Strait at Barren Is., Aleutian Ra.; $59^{\circ} 05^{\prime} \mathrm{N}, 152^{\circ} 30^{\prime} \mathrm{W}$; $B G N$ 1890; (map 50). Var. Baie de Cook, Baie Kenaiskaia, Cook's Arm, Cooks Inlet, Cook's Inlet, Cooks River, Groosgincloose, Kenai Bay, Kenaiskischer, Kenaiskischev Meerbusen, Kenaiaskoi Golfe, Kenaischev, Ttunaiskysch, Zaliv Kenayskoy.

Named by the Earl of Sandwich for Capt. James Cook, 1728-79, RN, who explored and mapped the region in 1778. Capt. George Vancouver called it "Cooks Inlet" (Wagner, 1937 , p. 382). The inlet was recorded as "Zaliv Kenayskov," or "Kenay [Kenai] Bay," by Lt. Sarichev (1826, map 3), IRN.

Cook Island: island, in Yukon River, $32 \mathrm{mi}$. NE of Nulato, Koyukuk Low.; $64^{\circ} 49^{\prime} \mathrm{N}, 157^{\circ} 04^{\prime}$ W; (map 97). Var. Cock Island. 
Riverboat pilots' name shown on a 1940 "Navigation Chart of the Tanana-Yukon Rivers" published by U.S. Dept. of Interior. Cook Lake: lake, $0.8 \mathrm{mi}$. long, on Kenai Penin., $22 \mathrm{mi}$. SW of Anchorage, Cook Inlet Low.; $61^{\circ} 00^{\prime} 10^{\prime \prime} \mathrm{N}, 150^{\circ} 22^{\prime} 45^{\prime \prime} \mathrm{W}$; (map 70).

Named about 1963 for administrative purposes by officials of the Kenai National Moose Range.

Cook River: stream, see Nushagak River.

Cook's Arm: estuary, see Cook Inlet.

Cooks Bend: bend, on Klutina River, $4.3 \mathrm{mi}$. ESE of Hudson Lake, $57 \mathrm{mi}$. NNE of Valdez, Chugach Mts. ; $61^{\circ} 52^{\prime} 45^{\prime \prime} \mathrm{N}, 145^{\circ} 31^{\prime} 30^{\prime \prime} \mathrm{W}$; (map 68).

Local name published in 1950 by USGS. Cooks Inlet: estuary, see Cook Inlet.

Cooks River: estuary, see Cook Inlet.

Gook's Rock: rocks, see Inner Signal.

Cook's Rock : rocks, see Outer Signal.

Cook Strait: water passage, see Etolin Strait.

Coo Lake: lake, $0.5 \mathrm{mi}$. long, on Admiralty I., W of Hasselborg Lake, $18 \mathrm{mi}$. NE of Angoon, Alex. Arch.; $57^{\circ} 42^{\prime} 15^{\prime \prime} \mathrm{N}, 134^{\circ} 18^{\prime} 00^{\prime \prime} \mathrm{W}$; (map 9).

Local name reported in 1951 by USGS.

Cool Bay: bay, see Graham, Port.

Cool Bay: bight, see Coal Cove.

Coolgardie Creek: stream, flows $\mathbf{S}$ to Arctic Creek which flows to Cripple River, about 30 mi. NW of Nome, Seward Penin. High; (map 94).

Prospectors' name reported on the 1900 "Map of Nome Peninsula" by J. M. Davidson and B. D. Blakeslee; this feature has not been positively identified.

Coolic Lake: lake, see Kulik Lake.

Coolie Hat: hill, $284 \mathrm{ft}$, on Kanaga I., Aleutian Is. ; $51^{\circ} 44^{\prime} 30^{\prime \prime} \mathrm{N}, 177^{\circ} 36^{\prime} 55^{\prime \prime} \mathrm{W}$; (map 17).

Descriptive name published by USC\&GS in 1956 on Chart 9145 . This name was probably given because the 200-ft. contour on the NW side of the hill resembles the shape of a hat commonly worn by oriental laborers.

Cool Lake: lake, $0.8 \mathrm{mi}$. long, on Kuiu I., W of Saginaw Bay, $42 \mathrm{mi}$. SE of Sitka, Alex. Arch.; $56^{\circ} 50^{\prime} 30^{\prime \prime} \mathrm{N}, 134^{\circ} 15^{\prime} 00^{\prime \prime} \mathrm{W}$; (map 5).

Local name recorded in 1948 by USGS.

Coon Cove: estuary, on Revillagigedo I., extends NE $1.3 \mathrm{mi}$. off George Inlet, E of Coon I., Alex. Arch.; $55^{\circ} 27^{\prime} 20^{\prime \prime} \mathrm{N}, 131^{\circ} 29^{\prime} 15^{\prime \prime} \mathrm{W}$; (map 3).

Local navigators' name obtained in 1904 by H. C. Fassett, USBF.

Cooney Cove: cove, NE arm of Rocky Bay, 3 mi. long, on SW coast of Etolin I., Alex. Arch.; $56^{\circ} 04^{\prime} 00^{\prime \prime} \mathrm{N}, 132^{\circ} 34^{\prime} 30^{\prime \prime} \mathrm{W}$; (map 6).

Local navigators' name reported in 1904 by H. C. Fassett, USBF.

Cooney Creek: stream, flows S $4 \mathrm{mi}$. to Killarney Creek $0.8 \mathrm{mi}$. $\mathrm{N}$ of that stream's junc, with Baker Creek, $40 \mathrm{mi}$. ESE of Tanana, YukonTanana High.; $65^{\circ} 06^{\prime} 45^{\prime \prime} \mathrm{N}, 150^{\circ} 43^{\prime} 50^{\prime \prime} \mathrm{W}$; BGN 1961; (map 106).

Prospectors' name reported in 1911 by $\mathrm{H}$. M. Eakin, USGS.

Coongilak, Cape: point of land, see Reef, Point.
Coon Gulch: gulch, extends NW $1.7 \mathrm{mi}$. to Middle Fork Koyukuk River, $0.6 \mathrm{mi}$. E of mouth of Bluff Gulch and $39 \mathrm{mi}$. W of Chandalar, Brooks Ra.; 67 $28^{\prime} 30^{\prime \prime}$ N, $149^{\circ} 58^{\prime} 30^{\prime \prime} \mathrm{W}$; (map 123).

Local name reported in 1956 by T. E. Taylor, USGS.

Coon Island: island, $0.7 \mathrm{mi}$. long, in George Inlet W of Coon Cove, off Revillagigedo I., Alex. Arch.; $55^{\circ} 27^{\prime} 40^{\prime \prime} \mathrm{N}, 131^{\circ} 30^{\prime} 00^{\prime \prime} \mathrm{W}$; (map 3).

Arbitrary name given in 1891 by USG\&GS. Gooper: locality, see Jabbertown.

Cooper Creek: stream, flows SE 2 mi. to Kiska Harbor, central Kiska I., Aleutian Is.; $51^{\circ} 59^{\prime} 10^{\prime \prime} \mathrm{N}, 177^{\circ} 32^{\prime} 55^{\prime \prime} \mathrm{E}$; (map 14).

One of many arbitrary names applied to features on Kiska I. by USAAF for tactical purposes during World War II.

Cooper Creek: stream, on Kenai Penin., heads at Cooper Lake, flows NW 5 mi. to Kenai River, $32 \mathrm{mi}$. SW of Hope, Chugach Mts.; $60^{\circ} 29^{\prime} 30^{\prime \prime} \mathrm{N}, 1^{\circ} 9^{\circ} 52^{\prime} 40^{\prime \prime} \mathrm{W}$; (map 63).

Local name reported in 1898 by Mendenhall (1899, map 6), USGS.

Cooper Creek: stream, flows NW $15 \mathrm{mi}$. to $\mathrm{Na}$ besna River, $7 \mathrm{mi}$. E. of Devils Mtn. and 11 mi. NE of Nabesna, Wrangell Mts.; $62^{\circ} 26^{\prime} \mathrm{N}$, $142^{\circ} 41^{\prime} \mathrm{W}$; (map 84). Var. The-con-da, Thekonda.

Local name reported in 1902 by F. C. Schrader, USGS, who also gave the stream's Indian name as "The-con-da."

Cooper Creek: stream, fows N $15 \mathrm{mi}$. to Nuluk River, which flows to Arctic Lagoon, $42 \mathrm{mi}$. NW of Teller, Seward Penin. High.; 65 $51^{\prime}$ N, $166^{\circ} 42^{\prime} \mathrm{W}$; (map 111).

Prospectors' name reported in 1901 by T. G. Gerdine (in Collier, 1902, pl. 12), USGS.

Cooper Creek: stream, see Camper Creek.

Cooper Gulch: ravine, trends SW $1 \mathrm{mi}$., on S side of Anvil Mountain, $3 \mathrm{mi}$. NE of Nome, Seward Penin. High.; $64^{\circ} 33^{\prime}$ N, $165^{\circ} 23^{\prime} \mathrm{W}$; (map 94). Var. Coopers Gulch.

Prospectors' name shown on the 1902 "Map of the Nome and Snake River Country" by J. M. Davidson.

Cooper Island: barrier island, $3 \mathrm{mi}$. long, on Beaufort Sea coast, in Plover Is., $23 \mathrm{mi}$. E of Barrow, Arctic Plain; $71^{\circ} 14^{\prime} 15^{\prime \prime} \mathrm{N}, 155^{\circ} 41^{\prime}$ $30^{\prime \prime} \mathrm{W}$; (map 153). Var. Cooper's Island, Iglorak, Iglurak.

Named by Comdr. Thomas E. L. Moore, RN, in 1849-50 for one of his officers on the H.M.S. Plover (Leffingwell, 1919, p. 97). The Eskimo name is "Iglurak," meaning, in a general sense, "sod house like," because two mounds on the island appear like sod houses from a distance. Leffingwell (1919, p. 95) gives the meaning as "small iglu."

Cooper Island: islands, see Cooper Islands.

Cooper Islands: islands, on NE coast of Attu I., extend $0.3 \mathrm{mi}$. in Bering Sea, $1 \mathrm{mi}$. NE of Attu, Aleutian Is.; $52^{\circ} 56^{\prime} 25^{\prime \prime} \mathrm{N}, 1^{173^{\circ}} 15^{\prime} 25^{\prime \prime}$ E; (map 13). Var: Cooper Island.

Named in July 1855 for the schooner Fenimore Cooper by Lt. William Gibson, USN.
Cooper Lake: lake, on Kenai Penin., extends SE $6 \mathrm{mi}$. from head of Cooper Creek, on NE side of Cooper Mtn., $22 \mathrm{mi}$. NW of Seward, Chugach Mts.; $60^{\circ} 24^{\prime} \mathrm{N}, 149^{\circ} 46^{\prime} \mathrm{W}$; (map 63). Var. Ben Lake.

Local name reported in 1898 by Mendenhall (1899, map 6), USGS.

Cooper Landing: village, pop. 88, on Kenai Penin., at $W$ end of Kenai Lake, $30 \mathrm{mi}$. NW of Séward, Chugach Mts.; $60^{\circ} 29^{\prime} 25^{\prime \prime} \mathrm{N}$, $149^{\circ} 50^{\prime} 00^{\prime \prime} \mathrm{W}$; (map 63).

Local name published on recent USGS maps; derived from nearby Cooper Lake.

Cooper Mountain: mountain, 5,270 ft., on Kenai Penin., between Cooper Lake and Upper Russian Lake, $24 \mathrm{mi}$. NW of Seward, Chugach Mts.; $60^{\circ} 22^{\prime} 45^{\prime \prime} \mathrm{N}, 149^{\circ} 50^{\prime} 10^{\prime \prime} \mathrm{W}$; (map 63).

Local name published on recent USGS maps; derived from nearby Cooper Lake.

Cooper Pass: pass, 6,000 ft., between heads of Notch and Cooper Creeks, $20 \mathrm{mi}$. SE of Nabesna, Wrangell Mts. ; $62^{\circ} 16^{\prime} \mathrm{N}, 142^{\circ} 28^{\prime} \mathrm{W}$; (map 84).

Local name derived from Cooper River; published by USGS in 1951.

Cooper Point: point of land, on W shore of Taku Inlet, $2.8 \mathrm{mi}$. NE of Bishop Point and $12 \mathrm{mi}$. $\mathrm{SE}$ of Juneau, Coast Mts.; $58^{\circ} 14^{\prime} 10^{\prime \prime} \mathrm{N}$, $134^{\circ} 06^{\prime} 10^{\prime \prime} \mathrm{W}$; (map 11).

Named in 1890 by Lt. Comdr. H. B. Mansfield, USN, and published in 1893 on USC\&GS Chart 8300.

Coopers Gulch : ravine, see Cooper Gulch.

Cooper's Island: barrier island, see Cooper Island.

Coot Cove: cove, $0.4 \mathrm{mi}$. across, in Funter Bay on Mansfield Penin., $0.7 \mathrm{mi}$. N of Clear Point and $18 \mathrm{mi}$. SW of Juneau, Alex. Arch.; $58^{\circ} 15^{\prime} 20^{\prime \prime} \mathrm{N}, 134^{\circ} 54^{\prime} 20^{\prime \prime} \mathrm{W}$; (map 11).

Named in 1890 by Lt. Comdr. H. B. Mansfield, USN, and published in the 1891 Coast Pilot (p. 161).

Copeland Creek: stream, flows SE $12 \mathrm{mi}$. to Ohio Creek, $61 \mathrm{mi}$. SW of Healy, Alaska Ra.; $63^{\circ} 03^{\prime} 15^{\prime \prime} \mathrm{N}, 149^{\circ} 43^{\prime} 00^{\prime \prime} \mathrm{W}$; (map 87).

Prospectors' name obtained in 1913 by $\mathrm{J}$. W. Bagley, USGS; published by S. R. Capps (in Martin, 1919, pl. 5), USGS.

Copeland Creek: stream, flows NW $4 \mathrm{mi}$. to Moody Creek, $3 \mathrm{mi}$. SE of Healy, Alaska Ra.; $63^{\circ} 50^{\prime} 40^{\prime \prime} \mathrm{N}, 148^{\circ} 52^{\prime} 30^{\prime \prime} \mathrm{W}$; (map 87).

Local name reported in 1913 by J. W. Bagley, USGS.

Cope Mountain: mountain, 2,400 ft., $9 \mathrm{mi}$. SW of Kodiak, Kodiak I.; $57^{\circ} 43^{\prime} \mathrm{N}, 152^{\circ} 37^{\prime} \mathrm{W}$; BGN 1941; (map 34).

Named in 1910 by USC\&GS for Harry P. Cope, an Englishman who came to Kodiak from San Francisco in 1868 . He was the first postmaster at Kodiak and was known locally as "Uncle Harry."

Copenhagen Creek: stream, heads in lake, flows SE $13 \mathrm{mi}$. to Kvichak Bay, $10 \mathrm{mi}$. NW of Naknek, Bristol Bay Low.; 58 $50^{\prime} 45^{\prime \prime}$ N., $157^{\circ} 11^{\prime}$ $10^{\prime \prime} \mathrm{W}$; (map 41).

Local name reported in 1952 by USGS. 
Copleston, Mount: mountain, 3,840 ft., at $\mathrm{W}$ end of Shublik Mts., $47 \mathrm{mi}$. NW of Mount Michelson, Brook Ra.; $69^{\circ} 30^{\prime} \mathrm{N}, 146^{\circ} 06^{\prime} \mathrm{W}$; (map 139). Var. Mount Cobblestone, Mount Coplestone.

On August 5, 1826, Sir John Franklin (1828, p. 150) wrote, "Lieutenant Back made a sketch of the most western mountain, *** which I had the pleasure of naming in honour of Dr. Copleston, Provost of Oriel College, now Bishop of Landaff."

Coplestone, Mount: mountain, see Copleston, Mount.

Coply Reef: reef, $0.1 \mathrm{mi}$. long, at $\mathbf{S}$ tip of Keene I., at junc. of Beecher Pass and Wrangell Narrows, $14 \mathrm{mi}$. S of Petersburg, Alex. Arch.; $56^{\circ} 36^{\prime} \mathrm{N}, 132^{\circ} 59^{\prime} \mathrm{W}$; (map 6).

Local name used by fishermen; name published in 1898 by USC\&GS.

Coposo Island: island, $300 \mathrm{ft}$. long, in Port Real Marina, between Baker and Lulu Is., Alex. Arch.; $55^{\circ} 25^{\prime} 50^{\prime \prime}$ N. $133^{\circ} 28^{\prime} 00^{\prime \prime} \mathrm{W}$; (map 4). Var. Isla Coposo, Ostrov Koposo, Ysla Coposo.

Spanish name given in $1775-79$ by Don Juan de la Bodega y Quadra and Francisco Antonio Maurelle as "Isla Coposo," meaning "tufted island."

Copper Bay: cove, see Nehenta Bay.

Copper Bay: estuary, on SW coast of Knight I., extends W 2 mi. to Long Channel, in Knight Island Passage, $6.5 \mathrm{mi}$. ESE of Chenega, Chugach Mts.; $60^{\circ} 16^{\prime} \mathrm{N}, 147^{\circ} 54^{\prime} \mathrm{W}$; $B G N$ 1910; (map 63).

Local name published in 1909 by USC\&GS.

Copper Center: village, pop. 151, on Klutina River $1 \mathrm{mi}$. W of its junction with Copper River and $66 \mathrm{mi}$. NE of Valdez, Copper River Basin; BGN 1944; (map 68).

Trading post located here about 1896 . Village established as a mining camp when about 300 prospectors wintered here in 1898-99. With the establishment of a telegraph station by the U.S. Army Signal Corps about 1901, and being on the Fairbanks-Valdez trail, the village became the principal settlement and supply center in the Nelchina-Susitna Region. Its population was 91 in $1910 ; 71$ in $1920 ; 80$ in $1930 ; 138$ in 1939; and 90 in 1950 . The Copper Center post office was established in 1901 (Ricks, 1965, p. 14).

Copper Center Lake: lake, $0.2 \mathrm{mi}$. long, near head of Kasaan Penin., on $\mathbf{E}$ coast of Prince of Wales I., Alex. Arch.; 55 $37^{\prime} 05^{\prime \prime} \mathrm{N}$, $132^{\circ} 29^{\prime} 45^{\prime \prime} \mathrm{W}$; (map 4).

Local name recorded in 1949 by USGS.

Copper City: locality, site of village, on SW coast of Prince of Wales I., $5.5 \mathrm{mi}$. N of Lime Point, on E shore of Hetta Inlet, Alex. Arch.; $55^{\circ} 08^{\prime} 05^{\prime \prime} \mathrm{N}, 132^{\circ} 36^{\prime} 30^{\prime \prime} \mathrm{W}$; (map 4).

Local name reported in 1905 by E. F. Dickins, USC\&GS. Current sources show this is an abandoned mining camp.

Copper City: locality, see Old Valdez.

Copper City: town, see Valdez.
Copper Creek: stream, flows N 2 mi. to Millard Creek, $38 \mathrm{mi}$. NW of Cordova, Chugach Mts.; $60^{\circ} 53^{\prime} 15^{\prime \prime} \mathrm{N}, 146^{\circ} 32^{\prime} 30^{\prime \prime} \mathrm{W}$; (map 64).

Local name published in 1912 by USGS.

Copper Creek: stream, flows NW $6.2 \mathrm{mi}$. to Dan Creek $3.5 \mathrm{mi}$. E of its junc. with Nizina River, 15 mi. E of McCarthy, Wrangell Mts. ; $61^{\circ} 22^{\prime} 20^{\prime \prime} \mathrm{N}, 142^{\circ} 28^{\prime} 40^{\prime \prime} \mathrm{W}$; (map 67).

Name used by prospectors and reported by Mendenhall (in Mendenhall and Schrader, 1903, fig. 5), USGS.

Copper Creek: stream, flows $4 \mathrm{mi}$. N to Kotsina River, $3 \mathrm{mi}$. NE of Sheep Mtn. and $82 \mathrm{mi}$. ENE of Valdez, Wrangell Mts. ; $61^{\circ} 42^{\prime} 40^{\prime \prime} \mathrm{N}$, $144^{\circ} 03^{\prime} 45^{\prime \prime} \mathrm{W}$; (map 68).

Prospectors' name obtained in 1900 by T. G. Gerdine, USGS.

Copper Creek: stream, flows E $8 \mathrm{mi}$. to Wood River, $34 \mathrm{mi}$. NE of Healy, Alaska Ra.; $63^{\circ} 53^{\prime} 30^{\prime \prime} \mathrm{N}, 147^{\circ} 50^{\prime} 45^{\prime \prime} \mathrm{W}$; (map 87).

Prospectors' name reported in 1910 by $\mathrm{J}$. W. Bagley, USGS.

Copper Creek: stream, flows NE $3 \mathrm{mi}$. to Cedar Creek, $72 \mathrm{mi}$. SW of Eagle, Yukon-Tanana High.; $64^{\circ} 03^{\prime} 45^{\prime \prime} \mathrm{N}, 142^{\circ} 54^{\prime} 00^{\prime \prime} \mathrm{W}$; (map 102).

Local name published in 1956 by USGS. Copper Creek: stream, heads at $64^{\circ} 50^{\prime} \mathrm{N}$, $142^{\circ} 42^{\prime} \mathrm{W}$, flows NW $27 \mathrm{mi}$. to Charley River, $28 \mathrm{mi}$. W of Eagle, Yukon-Tanana High.; 64.52' N, $143^{\circ} 30^{\prime} \mathrm{W}$; (map 102). Var. Godfrey Fork of Charley River.

Named by prospectors and reported in 1904 by D. C. Witherspoon, USGS. The stream is shown as "Godfrey Fork of Charlie River" on 1902 manuscript map by E. J. Chamberlain, U.S. Deputy Surveyor.

Copper Creek: stream, flows N $1.7 \mathrm{mi}$. to Nugget Creek which flows to Grand Central River, 27 mi. N of Nome, Seward Penin. High.; $64^{\circ} 53^{\prime} \mathrm{N}, 165^{\circ} 10^{\prime} \mathrm{W}$; (map 94).

Prospectors' name reported in 1900 by $\mathrm{E}$. C. Barnard (in Brooks, 1901, pl. 17), USGS. Copper Creek: stream, flows E $12 \mathrm{mi}$. to Koyuk River, $22 \mathrm{mi}$. W of Haycock, Seward Penin. High.; $65^{\circ} 13^{\prime} \mathrm{N}, 161^{\circ} 55^{\prime} \mathrm{W}$; (map 109).

Local name published on maps after 1950 . Copper Creek: stream, flows W 2 mi. to head of Dry Creek, 3 mi. NE of Nome, Seward Penin. High.; (map. 94).

Prospectors' name published in 1900 by Schrader (1900c, p. 16), USGS. Subsequent maps show a different drainage pattern at the head of Dry Creek.

Copper Creek: stream, see Cross Creek.

Copper Creek: stream, see Kletsan Creek.

Copper Glacier: glacier, heads on Mount Wrangell, trends N $15 \mathrm{mi}$. to its 1957 terminus at head of Copper River, $28 \mathrm{mi}$. SW of Nabesna, Wrangell Mts. ; $62^{\circ} 12^{\prime} 30^{\prime \prime} \mathrm{N}, 143^{\circ} 47^{\prime} 00^{\prime \prime} \mathrm{W}$; (map 84).

Named in 1902 by F. C. Schrader, USGS, for the Copper River.

Copper Glacier: glacier, see Ellsworth Glacier. Copper Harbor: estuary, extends NE $1 \mathrm{mi}$., off Hetta Inlet, on SW coast of Prince of Wales I., Alex. Arch.; $55^{\circ} 12^{\prime} 30^{\prime \prime} \mathrm{N}, 132^{\circ} 37^{\prime} 45^{\prime \prime} \mathrm{W}$; (map 4).
Local name recorded in 1901 by Brooks (1902, p. 105), USGS.

Copper Lake: lake, $0.8 \mathrm{mi}$. long, $1 \mathrm{mi}$. NE of Copper Mtn. and $35 \mathrm{mi}$. NW of Cordova, Chugach Mts.; $60^{\circ} 54^{\prime} \mathrm{N}, 146^{\circ} 34^{\prime} \mathrm{W}$; (map 64).

Local name published in 1952 by USGS.

Copper Lake: lake, $5.5 \mathrm{mi}$. long, $\mathrm{W}$ of Tanada Lake, Wrangell Mts.; $62^{\circ} 25^{\prime} \mathrm{N}, 143^{\circ} 33^{\prime} \mathrm{W}$; (map 84).

Locally named because it lies in the headwaters of the Copper River; reported by USGS in 1960.

Copper Lake: lake, on Unalaska I., Aleutian Is.; (map 23).

Father Veniaminov (1840, v. 1, p. 171), from information obtained from the natives, wrote "Near Makushin Bay between a long isthmus and Tarasof Bay, in the mountain, is a lake on whose shores occurs native cooper." The name was published by Baker (1906, p. 196), but does not appear on modern maps.

Coppermount: locality, site of village, on SW coast of Prince of Wales I., at head of Copper Harbor, E of Hetta Inlet, Alex. Arch.; 55 ${ }^{\circ} 3^{\prime}$ $00^{\prime \prime} \mathrm{N}, 132^{\circ} 36^{\prime} 30^{\prime \prime} \mathrm{W}$; (map 4).

The Coppermount post office was established here in 1900 and transferred to Sulzer in 1907 (Ricks, 1965, p. 14). This former mining settlement is shown as abandoned on current sources. "Few signs remain of the salmon cannery, formerly located on the northern shore of the bay" (U.S. Coast and Geodetic Survey, 1962, p. 77).

Copper Mountain: mountain, 3,916 ft., between Hetta Inlet and Lake Josephine, on SW coast of Prince of Wales I., Alex. Arch.; 55 $14^{\prime} 15^{\prime \prime}$ N, $132^{\circ} 36^{\prime} 15^{\prime \prime} \mathrm{W}$; (map 4).

Local descriptive name published in 1901 by USC\&GS.

Copper Mountain: mountain, 5,000 ft., N of Kontrashibuna Lake, $33 \mathrm{mi}$. NE of Nondalton, Aleutian Ra.; $60^{\circ} 14^{\prime} \mathrm{N}, 153^{\circ} 58^{\prime} \mathrm{W}$; (map 61).

Local name reported in 1954 by USGS.

Copper Mountain: mountain, 3,858 ft., at $\mathrm{N}$ end of Landlocked Bay, $37 \mathrm{mi}$. NW of Cordova, Chugach Mts.; $60^{\circ} 52^{\prime} \mathrm{N}, 146^{\circ} 35^{\prime} \mathrm{W}$; BGN 1914; (map 64).

Named by Capt. W. R. Abercrombie, USA. in 1898 , and published by USC\&GS in 1901 Copper Mountain: mountain, 1,690 ft., $3.5 \mathrm{mi}$. WSW of Salmon Lake and $27 \mathrm{mi}$. NE of Nome, Seward Penin. High.; $64^{\circ} 53^{\prime} \mathrm{N}, 165^{\circ}$. $12^{\prime} \mathrm{W}$; (map 94).

Local name reported in 1920 by $S$. $H$. Cathcart (in Brooks and others, 1922, fig. 15), USGS.

Copper Mountain: peak, see Eielson, Mount. Copper Mountain Bar: ridge, elev, 3,300 ft., in Mount McKinley National Park, extends W $1.4 \mathrm{mi}$. between Grant Creek and Thorofare River, $1.5 \mathrm{mi}$. SW of Eielson Visitor Center, Alaska Ra.; $63^{\circ} 24^{\prime} 30^{\prime \prime} \mathrm{N}, 150^{\circ} 21^{\prime} 00^{\prime \prime} \mathrm{W}$; $B G N 1932$; (map 88).

Local name reported in 1931 by J. C. Reed, Sr., and S. N. Stoner, USGS. 
Copper Mountain Peninsula: peninsula, extends $3 \mathrm{mi}$. into $\mathbf{N}$ edge of Port Fidalgo, $35 \mathrm{mi}$. NW of Cordova, Chugach Mts.; $60^{\circ} 50^{\prime} \mathrm{N}$, $146^{\circ} 37^{\prime} \mathrm{W}$; BGN 1914; (map 64). Var. Copper Mountain Point.

Local name derived from nearby Copper Mountain, reported in 1909 by Grant and Higgins (1910, pl. 2), USGS.

Copper Mountain Point: point of land, see Bidarka Point.

Copper Mountain Point: peninsula, see Copper Mountain Peninsula.

Copper Point: point of land, on W. coast of Annette I., $2 \mathrm{mi}$. NE of Metlakatla, Alex. Arch.; $55^{\circ} 09^{\prime} 00^{\prime \prime} \mathrm{N}, 131^{\circ} 32^{\prime} 30^{\prime \prime} \mathrm{W}$; (map 3 ).

Named in 1883 by Lt. Comdr. H. E. Nichols, USN.

Copper Point: point of land, $\mathrm{S}$ tip of island $4 \mathrm{mi}$. SSW of Chichagof, Alex. Arch.; 57 $36^{\prime} 27^{\prime \prime}$ N, $136^{\circ} 07^{\prime} 45^{\prime \prime} \mathrm{W}$; (map 9).

Local name reported in 1928 by USC\&GS.

Copper River: stream, heads in Meadow Lake, flows SW, through Upper and Lower Copper Lakes $21 \mathrm{mi}$. to Copper River Bay, $10 \mathrm{mi}$. NE of Kakhonak, Aleutian Ra.; 59 31'40' N, $154^{\circ} 31^{\prime} 10^{\prime \prime} \mathrm{W}$; (map 51).

Local name reported in 1954 by USGS.

Copper River: stream, heads on $\mathrm{N}$ side of Wrangell Mts., flows S $250 \mathrm{mi}$. through Chugach Mts. to Gulf of Alaska, $20 \mathrm{mi}$. NW of Katalla; $60^{\circ} 18^{\prime} \mathrm{N}, 145^{\circ} 03^{\prime} \mathrm{W}$; (map 64). Var. Aetna River, Atna River, At River, Miednaia, Rio de los Perdidos, Ryka Mydnaya.

This is a translation of the Indian name for the stream spelled "Atna" or "Ahtena." The explorer Nagaiev also translated the name into Russian as "Mydnaya," sometimes transliterated as "Miednaia." Don Ignacio Arteaga called it "Rio de los Perdidos," meaning "river of the lost," in 1779.

Copper River: stream, see Chokotonk River.

Copper River Delta: delta, $20 \mathrm{mi}$. wide, at mouth of Copper River, $20 \mathrm{mi}$. NW of Katalla, Malaspina Coastal Plain; $60^{\circ} 25^{\prime} \mathrm{N}, 145^{\circ} 00^{\prime}$ W; (map 64).

Local name reported in 1908 by Grant and Higgins (1909, pl. 4), USGS.

Copper River Rapids: rapids, see Abercrombie Rapids.

Copper Sands: bar, $7.5 \mathrm{mi}$. long, $\mathrm{S}$ coast of Alaska, $15 \mathrm{mi}$. SE of Cordova, Malaspina Coastal Plain; $60^{\circ} 20^{\prime} \mathrm{N}, 145^{\circ} 35^{\prime} \mathrm{W}$; (map 64).

Local descriptive name published in 1951 by USGS.

Copter Peak: peak, 4,250 ft., in De Long Mts., $18 \mathrm{mi}$. NNW of Misheguk Mtn., Brooks Ra.; $68^{\circ} 30^{\prime} \mathrm{N}, 161^{\circ} 18^{\prime} \mathrm{W}$; (map 131).

Named by Orth, USGS, because of a difficult helicopter landing there in 1956.

Coquenhena: locality, see Kokinhenik.

Coquenhena: island, see Kokinhenik Island.

Coquenhena Slough: stream, see Kokinhenik Branch.

Cora Creek: stream, flows SW $2.7 \mathrm{mi}$. to Bering Sea, $42 \mathrm{mi}$. NW of Nome, Seward Penin.
High.; $64^{\circ} 55^{\prime} \mathrm{N}, 166^{\circ} 26^{\prime} \mathrm{W}$; (map 94).

Prospectors' name reported in 1900 by E. C. Barnard (in Brooks, 1901, pl. 17), USGS

Cora Gulch: ravine, trends NE $0.7 \mathrm{mi}$. to Cleary Creek, $20 \mathrm{mi}$. NE of Fairbanks, Yukon-Tanana High.; $65^{\circ} 06^{\prime} 20^{\prime \prime} \mathrm{N}, 147^{\circ} 27^{\prime} 00^{\prime \prime} \mathrm{W}$; (map 105).

Named by prospectors; published in 1908 by USGS.

Cora Gulch: stream, see Lulu Creek.

Cora Island: island, $0.2 \mathrm{mi}$. long, $0.7 \mathrm{mi}$. S of Cora Point, E tip of Coronation I., Alex. Arch.; 55 $54^{\prime} 10^{\prime \prime} \mathrm{N}, 134^{\circ} 47^{\prime} 15^{\prime \prime} \mathrm{W}$; $B G N$ 1961; (map 4).

Named in 1960 by the commander of the USC\&GS steamer Hodgson, who made surveys in this vicinity.

Coral Creek: stream, flows NE $8 \mathrm{mi}$. to Akulikutak River, $38 \mathrm{mi}$. SE of Bethel, KilbuckKuskokwim Mts. ; $60^{\circ} 29^{\prime} \mathrm{N}, 160^{\circ} 49^{\prime} \mathrm{W}$; (map 59).

Local name reported in 1949 by USGS.

Coral Lake: lake, $0.6 \mathrm{mi}$. long, on Norton Sound, $2.8 \mathrm{mi}$. S of Unalakleet, Nulato Hills ; $63^{\circ} 49^{\prime}$ $30^{\prime \prime} \mathrm{N}, 160^{\circ} 45^{\prime} 30^{\prime \prime} \mathrm{W}$; (map 91). Var. Corral Lake.

Local name reported in 1952 by USC\&GS.

Cora Point: point of land, E tip of Coronation I., Alex. Arch.; 55 $54^{\prime} 50^{\prime \prime} \mathrm{N}, 134^{\circ} 06^{\prime} 55^{\prime \prime} \mathrm{W}$; (map 4).

Named in 1886 by Lt. Comdr. Snow, USN. Corbin Creek: stream, heads at terminus of Corbin Glacier, flows $\mathrm{W}$ and S $6 \mathrm{mi}$. to Robe Lake, $3 \mathrm{mi}$. SE of Valdez, Chugach Mts.; $61^{\circ} 05^{\prime} 25^{\prime \prime} \mathrm{N}, 146^{\circ} 10^{\prime} 30^{\prime \prime} \mathrm{W}$; (map 68).

Local name published in 1950 by USGS.

Corbin Glacier: glacier, heads in Keystone Glacier, trends W $3 \mathrm{mi}$. to its terminus at head of Corbin Creek, 7 mi. E of Valdez, Chugach Mts.; $61^{\circ} 06^{\prime} 35^{\prime \prime} \mathrm{N}, 146^{\circ} 03^{\prime} 15^{\prime \prime} \mathrm{W}$; $B G N$ 1965; (map 68).

Named in 1898 by Capt. Abercrombie (1899, p. 300), USA, for Adj. Gen. Henry C. Corbin, 1842-1909, USA.

Corbin Glacier: glacier, see Keystone Glacier.

Corbin Point: point of land, on Prince of Wales I., near head of Hetta Inlet, Alex. Arch. $55^{\circ} 14^{\circ} 05^{\prime \prime} \mathrm{N}, 132^{\circ} 39^{\prime} 15^{\prime \prime} \mathrm{W}$; (map 4).

Local name reported in 1905 by E. F. Dickins, USC\&GS.

Corbusier Slough: channel of Yukon River flows W $7 \mathrm{mi}$, from Tanana $\mathbf{I}$., $2 \mathrm{mi}$. $\mathrm{S}$ of Tanana, Nowitna Low.; $65^{\circ} 09^{\prime} 15^{\prime \prime} \mathrm{N}, 152^{\circ} 14^{\prime} 00^{\prime \prime} \mathrm{W}$; (map 106).

Local name reported in 1952 by USGS.

Corda Creek: stream, flows NW $8 \mathrm{mi}$. to Shaw Creek, $18 \mathrm{mi}$. NE of Big Delta, Yukon-Tanana High.; 64 $21^{\prime} 45^{\prime \prime} \mathrm{N}, 1^{\prime} 45^{\circ} 31^{\prime} 30^{\prime \prime} \mathrm{W}$; (map 101).

Local name reported in 1908 by J. W Bagley, USGS.

Cordova: town, pop. 1,128, on SE shore of Orca Inlet, opposite Hawkins I., Chugach Mts. $60^{\circ} 33^{\prime} \mathrm{N}, 145^{\circ} 45^{\prime} \mathrm{W}$; (map 64).

Named by Michael J. Heney, builder of the Copper River and Northwestern Railroad, about 1906. A post office was established here in October 1906 (Ricks, 1965, p. 14).
The town had its origin as the railroad terminus and ocean shipping port for the copper ore shipped from the Kennicott mine up the Copper River. "On April 8, 1911, Cordova celebrated 'Copper Day,' when the first trainload of copper ore, approximately 1,200 tons of it, arrived from the mines and was poured into the holds of the steamship Northwestern, bound for the smelter at Tacoma [Washington]" (Roguszka, 1964, p. 9). The name of the town was derived from the original name "Puerto Cordova," given to what is now known as Orca Bay, by Senor Don Calvador Fidalgo who visited the region in 1790 .

Cordova Puerto: $b a y$, see Orca Bay.

Cordova Creek: stream, see Rude River.

Cordova Glacier: glacier, trends SE $9 \mathrm{mi}$. to its terminus at Rude Lake, $20 \mathrm{mi}$. NE of Cordova, Chugach Mts.; $60^{\circ} 49^{\prime} \mathrm{N}, 145^{\circ} 33^{\prime} \mathrm{W}$; map 64).

Local name published in 1952 by USGS.

Cordova Peak: peak, 7,730 ft., at head of Schwan Glacier, $27 \mathrm{mi}$. NE of Cordova, Chugach Mts.; $60^{\circ} 50^{\prime} 50^{\prime \prime} \mathrm{N}, 145^{\circ} 17^{\prime} 30^{\prime \prime} \mathrm{W}$; $B G N$ 1933; (map 64).

Local name derived from nearby town of Cordova; reported in 1925 by USFS.

Cordwood Creek: stream, on N end of Mansfield Penin. of Admiralty I., flows W $2.5 \mathrm{mi}$. to Lynn Canal, $1.4 \mathrm{mi}$. S of False Point Retreat and $20 \mathrm{mi}$. NW of Juneau, Alex. Arch;; $58^{\circ} 21^{\prime} 00^{\prime \prime} \mathrm{N}, 1^{\circ} 4^{\circ} 57^{\prime} 15^{\prime \prime} \mathrm{W}$; (map 11).

Local name published in 1962 by USGS.

Corea Creek: stream, on W coast of Kenai Penin., flows SW $1 \mathrm{mi}$. to Cook Inlet, $28 \mathrm{mi}$. S of Kenai, Cook Inlet Low.; $60^{\circ} 10^{\prime} \mathrm{N}, 151^{\circ} 29^{\prime}$ W; (map 62).

Local name reported about 1947 by Barnes and Cobb (1959, pl. 17), USGS. It was reported that the name "Corea" was derived from an old sailing bark that was wrecked in the area in 1880 .

Cories, Lake: lake, $0.7 \mathrm{mi}$. long, on Attu I., 1.5 mi. S of Chichagof Harbor, Aleutian Is.; $52^{\circ} 54^{\prime} 15^{\prime \prime} \mathrm{N}, 173^{\circ} 14^{\prime} 15^{\prime \prime} \mathrm{E}$; (map 13).

Named by U.S. Army during World War II; published in 1948 by AMS.

Corkscrew Creek: stream, heads near $S$ end of Clearwater Mts., flows SE $6.5 \mathrm{mi}$. to Clearwater Creek, $2 \mathrm{mi}$. S of Denali Highway and $43 \mathrm{mi}$. SW of Mount Hayes, Alaska Ra.; $63^{\circ} 01^{\prime} 10^{\prime \prime} \mathrm{N}, 146^{\circ} 58^{\prime} 20^{\prime \prime} \mathrm{W} ; B G N$ 1960; (map 86).

Descriptive name given in 1954 by USGS geologists.

Corlies Islands: islands, extend $1.7 \mathrm{mi}$. in Tlevak Strait off NW coast of Sukkwan I., Alex. Arch.; 55 $08^{\prime} \mathrm{N}, 132^{\circ} 55^{\prime} \mathrm{W}$; (map 4). Var. Rankin and Young Islands.

Named in 1882 by W. H. Dall, USC\&GS, "for Rev. W. H. R. Corlies of Philadelphia, a missionary who began work in Alaska in 1879." The northern island was called "Rankin," and the southern "Young" by Jackson (1880, p. 376).

Corlies Point: point of land, $\mathrm{N}$ of Ham Cove, on E coast of Dall I., Alex. Arch.; 54 $52^{\prime} 50^{\prime \prime}$ $\mathrm{N}, 132^{\circ} 50^{\prime} 58^{\prime \prime} \mathrm{W}$; (map 1 ). 
Named by Sheldon Jackson in 1886 for Rev. W. H. R. Corlies, a missionary.

Cormant Island: island, see Cormorant Island. Cormorans, Roche des: rock, see Cormorant Rock.

Cormorant Island: island, $0.1 \mathrm{mi}$. across, $\mathrm{W}$ of Dora I., in Bay of Is., Adak I., Aleutian Is.; $51^{\circ} 48^{\prime} 42^{\prime \prime} \mathrm{N}, 176^{\circ} 48^{\prime} 27^{\prime \prime} \mathrm{W}$; BGN 1936. (map 17). Var. Cormant Island.

Named by members of the U.S. Navy Aleutian Island Survey Expedition in 1934.

Cormorant Island: island, $0.1 \mathrm{mi}$. across, in Davison Bay, $11.5 \mathrm{mi}$. NW of Chichagof, on W coast of Chichagof I., Alex. Arch.; $57^{\circ} 46^{\prime} 45^{\prime \prime}$ $\mathrm{N}, 136^{\circ} 19^{\prime} 10^{\prime \prime} \mathrm{W}$; (map 9).

Name published by USC\&GS in the 1943 Coast Pilot (p. 392). Named for one of several families of Phalacrocoracidae, a large swimming bird, found in the coastal areas of Alaska.

Cormorant Rock: rock, on W shore of Uyak Bay, S of Harvester I., on NW coast of Kodiak I.; $57^{\circ} 37^{\prime} 45^{\prime \prime} \mathrm{N}, 153^{\circ} 58^{\prime} 45^{\prime \prime} \mathrm{W}$; (map 34).

Named in 1897 by Lt. Comdr. Moser, USN, of the USBF steamer Albatross.

Cormorant Rock: rock, at mouth of Lituya Bay, in Glacier Bay National Monument, $0.1 \mathrm{mi}$. W of Harbor Point, $87 \mathrm{mi}$. NW of Hoonah, Malaspina Coastal Plain; $58^{\circ} 36^{\prime} 35^{\prime \prime} \mathrm{N}$, $137^{\circ} 39^{\prime} 25^{\prime \prime}$ W; ' (map 10). Var. Roche des Cormorans.

Named Cormorants Rock in 1786 by La Pérouse (1798, aitas 19).

Cornelius Lake: lake, 2,000 ft. long, in Matanuska Valley, $4.8 \mathrm{mi}$. NW of Palmer, Cook Inlet Low.; $61^{\circ} 37^{\prime} 45^{\prime \prime} \mathrm{N}, 149^{\circ} 15^{\prime} 10^{\prime \prime} \mathrm{W}$; (map $69)$.

Local name reported in 1950 by USGS.

Corner Bay: bay, $1 \mathrm{mi}$. across, on $\mathrm{S}$ shore of Tenakee Inlet, on E central Chichagof I., Alex. Arch.; $57^{\circ} 44^{\prime} 20^{\prime \prime} \mathrm{N}, 1^{\circ} 35^{\circ} 07^{\prime} 30^{\prime \prime} \mathrm{W}$; $B G N$ 1930; (map 9).

Local descriptive name reported in 1929 by USFS.

Corner Lake: lake, $0.6 \mathrm{mi}$. long, between Slippery and Birch Creeks, $16 \mathrm{mi}$. SE of village of Lake Minchumina, Tanana Low.; 63 $41^{\prime} 20^{\prime \prime}$ $\mathrm{N}, 151^{\circ} 48^{\prime} 00^{\prime \prime} \mathrm{W}$; (map 88).

Local name reported in 1954 by USGS.

Cornfield Ridge: ridge, elev. 1300-1400 ft., 1 mi. long, extends SE from Loren Hill, 2 mi. N. of Mutt Cove, central Kiska I., Aleutian Is.; $51^{\circ} 58^{\prime} \mathrm{N}, 177^{\circ} 28^{\prime} \mathrm{E}$; (map 14).

This is one of the names arbitrarily applied to features on Kiska Island in 1943 by USAAF for tactical purposes during World War II.

Cornforth Peak: mountain, see Mesa Mountain.

Cornoi Island: island, see Gornoi Island.

Cornucopia Creek: stream, flows NW $9 \mathrm{mi}$. to East Fork Chandalar River, $48 \mathrm{mi}$. W of Christian, Brooks Ra.; 67 $7^{\circ} 18^{\prime} \mathrm{N}, 146^{\circ} 56^{\prime} \mathrm{W}$; (map 122).

Local name reported in 1909 by Maddren (1910, pl. 7), USGS.

Cornucopia Creek: stream, see Crater Creek.

Cornwallis, Point: point of land, extends $\mathrm{W}$ into the Pacific Ocean from SW coast of Dall I.,
Alex. Arch.; $54^{\circ} 42^{\prime} 15^{\prime \prime} \mathrm{N}, 132^{\circ} 52^{\prime} 10^{\prime \prime} \mathrm{W}$; (map 1).

Name published in 1882 by the U.S. Navy Hydrog. Office.

Cornwallis Point: point of land, NE point of entrance to Saginaw Bay, on $\mathrm{N}$ coast of Kuiu I., $42 \mathrm{mi}$. SE of Sitka, Alex. Arch.; 56 $56^{\prime} \mathrm{N}$, $134^{\circ} 16^{\prime} \mathrm{W}$; (map 5).

Named by Capt. George Vancouver, RN, on August 9, 1794, "no doubt in honor of Charles, Lord Cornwallis, first marquess and second earl" (Wagner, 1937, p. 382).

Coronados Islands: islands, group, extends 1.5 mi. between Bucareli Bay and Port Saint Nicholas, on W coast of Prince of Wales I., Alex. Arch.; $55^{\circ} 26^{\prime} \mathrm{N}, 133^{\circ} 06^{\prime} \mathrm{W}$; (map 4). Var. Islas Coronados, Islas Gallegas, Los Coronado, Los Koronados.

Spanish name given in $1775-79$ by Don Juan de la Bodega y Quadra and Francisco Antonio Maurelle as "Islas Coronados," meaning "priest islands." Lt. Don Jacinto Caamaño called them "Islas Gallegas" in 1792.

Coronation Island: island, $10 \mathrm{mi}$. long, between Chatham and Sumner Straits, Alex. Arch.; $55^{\circ} 53^{\prime} \mathrm{N}, 134^{\circ} 14^{\prime} \mathrm{W}$; (map 4). Var. Koronotsii Island, Ostrov Koronotsii.

Named by Capt. George Vancouver, RN, on September 22, 1793, in honor of "the anniversary of the coronation of George III" (Wagner, 1937, p. 382). Capt. Vancouver (1798, v. 2, p. 423) wrote, "the day of our passing it having been the anniversary of that happy event." The name was transliterated into Russian as "Ostrov. Koronotsii" by Capt. M. D. Tebenkov (1852, map 9), IRN

Corral Lake: lake, see Coral Lake.

Corser Lake: lake, $0.3 \mathrm{mi}$. long, $2.5 \mathrm{mi}$. W of Sheridan Glacier and $10 \mathrm{mi}$. E of Cordova, Chugach Mts.; $60^{\circ} 32^{\prime} \mathrm{N}, 145^{\circ} 27^{\prime} \mathrm{W}$; (map 64).

\section{Name published in 1950 by USGS.}

Corvie Bay: cove, $600 \mathrm{ft}$. across, $5.5 \mathrm{mi}$. WSW of Bukhti Point, on W shore of Vega Bay, on SE coast of Kiska I., Aleutian Is.; 51 ${ }^{\circ} 53^{\prime} 55^{\prime \prime}$ N, $177^{\circ} 20^{\prime} 50^{\prime \prime}$ E; (map 14). Var. Tom Thumb Cove.

Name shown on a 1957 AMS map; variant shown on a 1943 USAAF map.

Corwin: locality, see Initkilly.

Corwin, Cape: promontory, SW entrance point to Etolin Strait, $22 \mathrm{mi}$. NE of Cape Mendenhall, on Nunivak I.; $59^{\circ} 55^{\prime} \mathrm{N}, 165^{\circ} 35^{\prime} \mathrm{W}$; $B G N$ 1944; (map 55). Var. Atahgo Point, Chingeleth Point, Vasilief Point.

Name reported about 1908 by USC\&GS.

Corwin Bluff: cliff, 547 ft., 2 mi. long, on Chukchi Sea coast, $27 \mathrm{mi}$. E of Cape Lisburne, Arctic Slope; $68^{\circ} 52^{\prime} 40^{\prime \prime} \mathrm{N}, 165^{\circ} 03^{\prime} 15^{\prime \prime} \mathrm{W}$; (map 129)

Named in 1901 by W. J. Peters and F. C. Schrader, USGS, after the Corwin coal mine which is at the base of the bluff.

Corwin Creek: stream, flows NW $2 \mathrm{mi}$. to Chukchi Sea, W of Corwin Bluff, $27 \mathrm{mi}$. E of Cape Lisburne, Arctic Slope; 68 $52^{\prime} 35^{\prime \prime} \mathrm{N}$, $165^{\circ} 05^{\prime} 50^{\prime \prime} \mathrm{W}$; (map 129).
Named in 1901 by USGS for the coal mine there; not published until recently.

Corwin Lagoon: lagoon, see Kivalina Lagoon. Corwin Mine: locality, at coal vein, at base of Corwin Bluff, on Chukchi Sea coast, $27 \mathrm{mi}$. E of Cape Lisburne, Arctic Slope; 68 $8^{\circ} 2^{\prime} 05^{\prime \prime} \mathrm{N}$, $165^{\circ} 08^{\prime} 15^{\prime \prime} \mathrm{W}$; (map 129).

Named by Capt. C. L. Hooper, USRGS, after his ship Corwin which took on 20 tons of coal here in 1881.

Corwin Rock: rock, off NE coast of Chuginadak I., Aleutian Is. ; $52^{\circ} 53^{\prime} 40^{\prime \prime} \mathrm{N}, 169^{\circ} 40^{\prime} 45^{\prime \prime} \mathrm{W}$; (map 21).

Named in 1894 by U.S. Navy Hydrog. Office for the U.S. revenue cutter Corwin, and published in 1895 on Chart 8.

Cosacoots River: stream, see Kosakuts River.

Cos-chaget: locality, see Cos Jacket.

Coshaget: locality, see Cos Jacket.

Cosie Creek: stream, see Colin Creek.

Cosinas, Point: point of land, on $\mathrm{E}$ coast of Baker I., near entrance to Port Asumcion, Alex. Arch.; 55 $21^{\prime} 50^{\prime \prime} \mathrm{N}, 1^{\circ} 33^{\circ} 30^{\prime} 30^{\prime \prime} \mathrm{W}$; (map 4). Var. Mys Kosinas, Punta de Cocinas, Punta de Cosinas.

Spanish name given in $1775-79$ by Don Juan de la Bodega y Quadra and Francisco Antonio Maurelle as "Punta de Cosinas" (from Cocina or Cosina), meaning "kitchen point" (Wagner, 1937, p. 382).

Cos Jacket: locality, on left bank of Tanana River, at mouth of Cosna River, $25 \mathrm{mi}$. SW of Manley Hot Springs, Nowitna Low.; 64 ${ }^{\circ} 52^{\prime}$ N, $151^{\circ} 25^{\prime} \mathrm{W}$; (map 99). Var. Cos-chaget, Coshaget, Coskakat, Consa, Cosna, Cross Jacket, Koskakat.

Small Tanana Indian village reported in 1899 by Lt. J. S. Herron, USA, who wrote the name "Cos-chaget," meaning "the mouth of the Cos [River]." A telegraph station named "Cosna" was established here, or near here, in 1903 by the U.S. Army Signal Corps. Coskakat: locality, see Cos Jacket.

Coskaket: stream, see Cosna River.

Cosmos, Point: point of land, $10 \mathrm{mi}$. S of Tebenkof Bay, on W coast of Kuiu I., Alex. Arch.; $56^{\circ} 20^{\prime} 55^{\prime \prime} \mathrm{N}, 134^{\circ} 17^{\prime} 30^{\prime \prime} \mathrm{W}$; (map 5).

Name published in 1901 by USC\&GS; named for the launch Cosmos.

Cosmos Cove: bay, $0.3 \mathrm{mi}$. across, $10.5 \mathrm{mi}$. N of Baranof, on NE coast of Baranof I., Alex. Arch.; 57 $14^{\prime} 40^{\prime \prime} \mathrm{N}, 134^{\circ} 51^{\prime} 00^{\prime \prime} \mathrm{W}$; (map 9).

Named in 1895 by Lt. Comdr. E. K. Moore, USN, for the steam launch Cosmos of the USC\&GS steamer Patterson, which aided in the exploration of this region.

Cosmos Creek: stream, flows SW $16 \mathrm{mi}$. to Kobuk River, $4 \mathrm{mi}$. W of Shungnak, Kotzebue-Kobuk Low.; $66^{\circ} 52^{\prime} \mathrm{N}, 157^{\circ} 18^{\prime} \mathrm{W}$; (map 115). Var. A-vi-lu-legorack.

Named in 1901 by W. C. Mendenhall, USGS, after Lt. G. M. Stoney's naval expedition camp called Fort Cosmos, which was located at the mouth of this stream in 188586. The stream's Eskimo name according to Stoney (1900, map) was "A-vi-lu-legorack."

Cosmos Pass: water passage, $0.5 \mathrm{mi}$. long, between two islands, off $\mathbf{S}$ tip of Kosciusko I., 
Alex. Arch.; $55^{\circ} 53^{\prime} 40^{\prime \prime} \mathrm{N}, 133^{\circ} 42^{\prime} 10^{\prime \prime} \mathrm{W}$; (map 4).

Named in 1904 by E. F. Dickins, USC\&GS, "after Launch Cosmos in which I first explored the passage."

Cosmos Hills: hills, extend WNW-ESE $30 \mathrm{mi}$. between Ambler Low. and Kobuk River, Brooks Ra.; $67^{\circ} 00^{\prime} \mathrm{N}, 157^{\circ} 00^{\prime} \mathrm{W}$; (map 126).

P. S. Smith and H. M. Eakin, USGS, wrote "This name is given because [Lt. G. M.] Stoney's winter camp on the Kobuk was called Fort Cosmos" (in Brooks and others, 1911, p. 274).

Cosmos Mountain: mountain, $3,117 \mathrm{ft}$, $8 \mathrm{mi}$ $\mathrm{N}$ of Shungnak, Brooks Ra.; $67^{\circ} 00^{\prime} \mathrm{N}, 157^{\circ}$. 03' W; (map 126).

Local name reported by USGS in 1956 . See Cosmos Creek.

Cosmos Peak: peak, 4,740 ft., on $\mathrm{W}$ end of Cosmos Ra., 2 mi. E of Thomas Bay and 107 mi. E of Sitka, Coast Mts.; $57^{\circ} 00^{\prime} 15^{\prime \prime} \mathrm{N}$, $132^{\circ} 43^{\prime} 50^{\prime \prime} \mathrm{W}$; ( $\operatorname{map} 8$ ).

Name published in 1950 by USC\&GS.

Cosmos Point: point of land, on $\mathrm{E}$ coast of Mitkof I., $15 \mathrm{mi}$. NW of Wrangell, Alex. Arch.; $56^{\circ} 40^{\prime} 05^{\prime \prime} \mathrm{N}, 132^{\circ} 37^{\prime} 20^{\prime \prime} \mathrm{W}$; (map 6).

Named in 1887 by Lt. Comdr. C. M Thomas, USN, for the steam launch Cosmos of the Coast Survey steamer Patterson.

Cosmos Range: mountain range, trends E $4 \mathrm{mi}$. from Cosmos Peak on Thomas Bay, $110 \mathrm{mi}$. E of Sitka, Coast Mts. ; $57^{\circ} 00^{\prime} 30^{\prime \prime} \mathrm{N}, 132^{\circ}$. $43^{\prime} 00^{\prime \prime} \mathrm{W}$; (map 8).

Named in 1887 by Lt. Comdr. C. M. Thomas, USN, for the steam launch Cosmos attached to the USC\&GS steamer Patterson, which was under his command.

Cosna: locality, on right bank of Tanana River, $37 \mathrm{mi}$. NE of Bitzshtini Mts., Yukon-Tanana High.; $64^{\circ} 54^{\prime} \mathrm{N}, 151^{\circ} 15^{\prime} \mathrm{W}$; (map 99). Var. Consa.

This was a telegraph station named in 1903 for the Cosna River by the U.S. Army Signal Corps.

Cosna: locality, see Cos Jacket.

Cosna Bluff: bluff, on right bank of Tanana River, $20 \mathrm{mi}$. SW of Manley Hot Springs; Nowitna Low.; $64^{\circ} 52^{\prime} \mathrm{N}, 151^{\circ} 22^{\prime} \mathrm{W}$; (map 99).

Riverboat pilots' name published on a 1940 "Navigation Chart of the Tanana-Yukon Rivers" by the U.S. Dept. of Interior.

Cosna River: stream, flows NE $44 \mathrm{mi}$. to Tanana River, $32 \mathrm{mi}$. NE of Bitzshtini Mts., Nowitna Low.; 64 $51^{\prime} \mathrm{N}, 151^{\circ} 23^{\prime} \mathrm{W}$; (map 99). Var. Coskaket, Goschacket, Koskakat, Kosna.

Tanana Indian name reported in 1899 by Lt. J. S. Herron, USA.

Costa Fork: stream, flows NNE $5.5 \mathrm{mi}$. to Preacher Creek, $12 \mathrm{mi}$. NE of Mount Prindle and $64 \mathrm{mi}$. SW of Circle, Yukon-Tanana High.; $65^{\circ} 31^{\prime} 30^{\prime \prime} \mathrm{N}, 146^{\circ} 04^{\prime} 20^{\prime \prime} \mathrm{W}$; (map 104).

Named by prospectors and reported in 1909 by C. E. Ellsworth (in Brooks and others, 1910, p. 238), USGS.
Costello Creek: stream, flows SE $12 \mathrm{mi}$. to Bull River, $50 \mathrm{mi}$. SW of Healy, Alaska Ra.; $63^{\circ} 12^{\prime} \mathrm{N}, 149^{\circ} 29^{\prime} \mathrm{W}$; (map 87).

Prospectors' name obtained in 1913 by J. W. Bagley, USGS; published by S. R. Capps (in Martin, 1919, pl. 5), USGS.

Cote, Mount: mountain, 4,375 ft., on AlaskaCanada boundary, $4 \mathrm{mi}$. S of Stikine River, Coast Mts. ; $56^{\circ} 36^{\prime} \mathrm{N}, 131^{\circ} 50^{\prime} \mathrm{W}$; (map 7). Name reported in 1912 by USC\&GS.

Cotillakakat River: stream, see Kateel River.

Cot Mountain: mountain, 1,400 ft., $3 \mathrm{mi}$. NE of Tooth Mtn., 15 mi. NW of Goodnews, Kilbuck-Kuskokwim Mts.; $59^{\circ} 18^{\prime} \mathrm{N}, 161^{\circ} 42^{\prime} \mathrm{W}$; (map 53).

Name published in 1915 by USC\&GS on Chart 9103

Cotter Creek: stream, flows N 2 mi. to California Creek which flows to Pargon River, $14 \mathrm{mi}$. $\mathrm{NE}$ of Council and $26 \mathrm{mi}$. SE of Mount Bendeleben, Seward Penin. High.; $65^{\circ} 01^{\prime} \mathrm{N}$, $163^{\circ} 17^{\prime} \mathrm{W}$; (map 110).

Prospectors' name reported on a map of Cape Nome gold fields by David Fox, Jr., dated 1901.

Cotterell Glacier: glacier, heads $2.5 \mathrm{mi}$. SE of head of Blackstone Bay, trends SE $3.5 \mathrm{mi}$. to its terminus $2.5 \mathrm{mi}$. NW of W shore of Kings Bay, $14 \mathrm{mi}$. SE of Whittier, Chugach Mts.; $60^{\circ} 35^{\prime} 50^{\prime \prime} \mathrm{N}, 148^{\circ} 33^{\prime} 30^{\prime \prime} \mathrm{W} ; B G N 1910$; (map 63).

Named in 1910 by U. S. Grant, USGS.

Cottle Island: barrier island, $4 \mathrm{mi}$. Inng, on Beaufort Sea coast, easteinmost island of the Jones Is., $2.8 \mathrm{mi}$. NE of Beechey Point, Artic Plain; $70^{\circ} 30^{\prime} 45^{\prime \prime} \mathrm{N}, 1^{\circ} 49^{\circ} 07^{\prime} 15^{\prime \prime} \mathrm{W}$; (map 150).

Named in 1910 by Leffingwell $(1919$, p. 95) for "Capt. Steven Cottle, of the whaling fleet."

Cotton Cove: cove, $0.7 \mathrm{mi}$. across, $\mathrm{S}$ of Witchcraft Point, on W coast of Kiska I, Aleutian Is. ; $52^{\circ} 02^{\prime} 30^{\prime \prime} \mathrm{N}, 177^{\circ} 30^{\prime} 00^{\prime \prime} \mathrm{E}$; (map 14).

This is one of the plant names arbitrarily applied to features on Kiska Island in 1943 by USAAF for tactical purposes during World War II

Cotton Creek: stream, flows SW $5.5 \mathrm{mi}$. to Duktoth River, 6 mi. NW of Cape Yakataga St. Elias Mts.; $60^{\circ} 07^{\prime} 20^{\prime \prime} \mathrm{N}, 142^{\circ} 32^{\prime} 50^{\prime \prime} \mathrm{W}$; (map 65).

Local name published in 1950 by USGS. Cottonwood: locality, on E bank of Cottonwood Creek, 16 mi. SW of Palmer, Cook Inlet Low.; $61^{\circ} 30^{\prime} 45^{\prime \prime} \mathrm{N}, 149^{\circ} 34^{\prime} 55^{\prime \prime} \mathrm{W}$; (map 49).

Name of a roadhouse and camp reported by USGS in 1911.

Cottonwood Bay: estuary, extending E $3 \mathrm{mi}$. to Iliamna Bay, $21 \mathrm{mi}$. NW of Augustine I. Aleutian Ra.; 59 $38^{\prime} \mathrm{N}, 153^{\circ} 38^{\prime} \mathrm{W}$; (map 51).

Name published by Osgood (1904, p. 11), USDA.

Cottonwood Beach: beach, at Beluga, on NW shore of Cook Inlet, $8 \mathrm{mi}$. NE of Tyonek, Cook Inlet Low.; $61^{\circ} 11^{\prime} \mathrm{N}, 151^{\circ} 01^{\prime} \mathrm{W}$; (map 70).
Local descriptive name reported in 1958 by USGS.

Cottonwood Creek: stream, flows W $2.5 \mathrm{mi}$. to Karluk Lake, $19 \mathrm{mi}$. SE of Karulk, Kodiak I.; $57^{\circ} 24^{\prime} 20^{\prime \prime} \mathrm{N}, 154^{\circ} 02^{\prime} 20^{\prime \prime} \mathrm{W}$; (map 35 ). Local name reported in 1952 by USGS.

Cottonwood Creek: stream, heads $3 \mathrm{mi}$. SW of Porcupine Peak, flows SE $4 \mathrm{mi}$. to Tsirku River, $33 \mathrm{mi}$. SW of Skagway, St. Elias Mts.; $59^{\circ} 16^{\prime} 55^{\prime \prime} \mathrm{N}, 136^{\circ} 11^{\prime} 20^{\prime \prime} \mathrm{W}$; (map 45).

Prospector's name reported in 1903 by C. W. Wright, USGS.

Cottonwood Creek: stream, on Kenai Penin., flows $\mathrm{S} 2 \mathrm{mi}$. to Kachemak Bay $14 \mathrm{mi}$. NE of Homer, Gook Inlet Low.; $59^{\circ} 44^{\prime} \mathrm{N}, 151^{\circ} 12^{\prime}$ W; $(\operatorname{map} 50)$.

Named by W. H. Dall, USG\&GS, in 1898. Cottonwood Creek: stream, on Kenai Penin., flows ENE $3.5 \mathrm{mi}$. to Resurrection River, 11 mi. NW of Seward, Chugach Mts.; $60^{\circ} 14^{\prime} 20^{\prime \prime}$ $\mathrm{N}, 149^{\circ} 39^{\prime} 00^{\prime \prime} \mathrm{W}$; (map 63).

Local name reported in 1912 by Grant and Higgins (1913, pl. 1), USGS.

Cottonwood Creek: stream, on Kenai Penin., in Kenai Mts., flows N 4 mi. to Skilak Lake, 36 mi. ESE of Kenai, Chugach Mts. ; $60^{\circ} 23^{\prime} 00^{\prime \prime}$ N, $150^{\circ} 17^{\prime} 30^{\prime \prime} \mathrm{W}$; (map 62).

Local name reported in 1958 by USGS.

Cottonwood Creek: stream, heads in Wasilla Lake, flows SW $13 \mathrm{mi}$. to Knik Arm, $7 \mathrm{mi}$. NW of Birchwood and 20 mi. NE of Anchorage, Cook Inlet Low.; $61^{\circ} 29^{\prime} 45^{\prime \prime} \mathrm{N}, 149^{\circ} 35^{\prime}$ $30^{\prime \prime} \mathrm{W}$; (map 69).

Local name reported in 1906 by T. G. Gerdine and R. H. Sargent, USGS.

Cottonwood Creek: stream, heads at a glacier flows NE $2.7 \mathrm{mi}$. to Metal Creek, $24 \mathrm{mi}$. E of Palmer, Chugach Mts. ; $61^{\circ} 34^{\prime} 15^{\prime \prime}$ N, $148^{\circ} 23^{\prime}$ 30 " W; (map 69).

Local name reported in 1960 by USGS.

Cottonwood Creek: stream, heads in a lake in Matanuska Valley, flows SW $1.8 \mathrm{mi}$. to Cottonwood Lake, $6 \mathrm{mi}$. W of Palmer, Cook Inlet Low. ; $61^{\circ} 36^{\prime} 15^{\prime \prime} \mathrm{N}, 149^{\circ} 18^{\prime} 10^{\prime \prime} \mathrm{W}$; (map 69).

Local name reported in 1912 by Alaska Railroad Commission.

Cottonwood Creek: stream, flows NW $2.5 \mathrm{mi}$. to Crooked Creek, $11 \mathrm{mi}$. NE of Tehneta Pass and $63 \mathrm{mi}$. SW of Gulkana, Talkeetna Mts. $62^{\circ} 02^{\prime} 15^{\prime \prime} \mathrm{N}, 147^{\circ} 15^{\prime} 10^{\prime \prime} \mathrm{W}$; BGN 1960 (map 82).

Local name published by Theodore Chapin (in Brooks and others, 1915, fig. 3), USGS.

Cottonwood Creek: stream, flows NE $4.3 \mathrm{mi}$. to Camp Creek, $40 \mathrm{mi}$. W of Talkeetna, Alaska Ra.; 62 $23^{\prime} 35^{\prime \prime}$ N, $151^{\circ} 27^{\prime} 40^{\prime \prime}$ W ; (map 81).

Descriptive name reported in 1906 by R. W. Porter, USGS.

Cottonwood Creek: stream, flows NE $22 \mathrm{mi}$. from Nutzotin Mts. to lake on $E$ bank of Snag Creek, $\mathrm{E}$ of Wellesley Mtn., $48 \mathrm{mi}$. SE of Northway Junction, Alaska Ra.; $62^{\circ} 24^{\prime} 10^{\prime \prime} \mathrm{N}$, $141^{\circ} 01^{\prime} 40^{\prime \prime} \mathrm{W}$; (map 84).

Local name reported by Theodore Chapin (in Brooks and others, 1915, p. 129), USGS 
Cottonwood Creek: stream, flows SW $4 \mathrm{mi}$. to Peters Creek, $27 \mathrm{mi}$. NW of Talkeetna, Alaska Ra.; 62 $32^{\prime} 35^{\prime \prime}$ N, $150^{\circ} 49^{\prime} 10^{\prime \prime}$ W; (map 81).

Descriptive name reported by F. A. Cook (1908, map).

Cottonwood Creek: stream, heads at glacier terminus near $\mathbf{N}$ end of Clearwater $\mathrm{Mts.}$, flows SE $6 \mathrm{mi}$. to Maclaren River, $4 \mathrm{mi}$. S of Maclaren Glacier terminus and $28 \mathrm{mi}$. SE of Mount Hayes, Alaska Ra. ; $63^{\circ} 13^{\prime} 25^{\prime \prime} \mathrm{N}, 146^{\circ}$ $32^{\prime} 50^{\prime \prime}$ W; (map 86).

Name published on relatively recent maps.

Cottonwood Creek: stream, flows SW $16 \mathrm{mi}$. to Nixon Fork Takotna River, $20 \mathrm{mi}$. NE of Medfra, Kilbuck-Kuskokwim Mts. ; $63^{\circ} 24^{\prime}$ N, $154^{\circ} 37^{\prime} \mathrm{W}$; (map 89 ).

Local name obtained in 1924 by J. S. Brown (in Smith, P. S., and others, 1926, pl. 5), USGS.

Cottonwood Creek: stream, flows SW $5 \mathrm{mi}$. to Caribou Creek, $9 \mathrm{mi}$. $\mathrm{N}$ of Big Delta, Tanana Low.; $64^{\circ} 17^{\prime} \mathrm{N}, 145^{\circ} 51^{\prime} \mathrm{W}$; (map 101).

Prospectors' name reported in 1910 by USGS (Capps, 1912, pl. 1).

Cottonwood Creek: stream, flows NW $7.1 \mathrm{mi}$, to Sulatna River, $11 \mathrm{mi}$. SW of Monzonite Hills, Nowitna Low.; $64^{\circ} 19^{\prime} 20^{\prime \prime} \mathrm{N}, 154^{\circ} 55^{\prime} 30^{\prime \prime} \mathrm{W}$; (map 98).

Local name reported about 1952 by USGS.

Cottonwood Creek: stream, flows S $5 \mathrm{mi}$. to Lost Creek $14 \mathrm{mi}$. NE of that stream's junc. with Salcha River and $75 \mathrm{mi}$. NE of Big Delta, Yukon-Tanana High.; $64^{\circ} 57^{\prime} \mathrm{N}, 144^{\circ} 10^{\prime} \mathrm{W}$; (map 101).

Local name reported in 1958 by USGS.

Cottonwood Creek: stream, heads $1 \mathrm{mi}$. NW of Cloud Lake, flows NW $14 \mathrm{mi}$. to Goodhope River, $16 \mathrm{mi}$. NW of Imuruk Lake, Seward Penin. High.; $65^{\circ} 48^{\prime} \mathrm{N}, 163^{\circ} 37^{\prime} \mathrm{W}$; $B G N$ 1952; (map 110).

Prospectors' name reported in 1901 by USGS (Collier, 1902, pl. 12).

Cottonwood Creek: stream, see Sleigh Creek.

Cottonwood Hills: hills, 1,500-1,770 ft., extend E-W 2.5 mi. on W bank of Highpower Creek, $43 \mathrm{mi}$. WNW of Mount McKinley, Kuskokwim Low.; $63^{\circ} 14^{\prime} \mathrm{N}, 152^{\circ} 21^{\prime} \mathrm{W}$; (map 88).

Local name reported in 1954 by USGS.

Cottonwood Island: island', $2 \mathrm{mi}$. long, in Stikine River, $5 \mathrm{mi}$. NNW of International Boundary Monument 62 on Mount Cote, Coast Mts.; $56^{\circ} 39^{\prime} \mathrm{N}, 131^{\circ} 51^{\prime} \mathrm{W}$; (map 7). Var. Cottonwood Islands.

Named "Cottonwood Islands" in 1887 by Lt. Comdr. C. M. Thomas, USN.

Cottonwood Islands: islands, $5 \mathrm{mi}$. long, at mouth of Stikine River, $10 \mathrm{mi}$. N. of Wrangell, Coast Mts.; $56^{\circ} 38^{\prime} \mathrm{N}, 132^{\circ} 18^{\prime} \mathrm{W}$; (map 6).

These low wooded islands were named in 1887 by Lt. Comdr. C. M. Thomas, USN.

Cottonwood Islands: Island, see Cottonwood Island.

Cottonwood Lake: lake, $1.3 \mathrm{mi}$. long, in Matanuska Valley, 6.2 mi. W of Palmer, Cook Inlet Low.; $61^{\circ} 36^{\prime} \mathrm{N}, 149^{\circ} 19^{\prime} \mathrm{W}$; (map 69).
Local name reported in 1950 by USGS; name derived from Cottonwood Creek.

Cottonwood Lake: lake, $0.5 \mathrm{mi}$. long, $4.2 \mathrm{mi}$. NNW of Old Man Lake and $39 \mathrm{mi}$. WNW of Glennallen, Copper River Basin; $62^{\circ} 13^{\prime} \mathrm{N}$, $146^{\circ} 44^{\prime} \mathrm{W}$; (map 83).

Local name reported in 1949 by USGS.

Cottonwood Point: point of land, at mouth of Copper River, $16 \mathrm{mi}$. NW of Katalla, Malaspina Coastal Plain; $60^{\circ} 17^{\prime} \mathrm{N}, 144^{\circ} 56^{\prime} \mathrm{W}$; (map 64).

Named in 1898 by Capt. Abercrombie (Glenn and Abercrombie, 1899, map), USA.

Cottonwood Point: point of land, on S bank of Yukon River $15 \mathrm{mi}$. NE of Russian Mission, Yukon-Kuskokwim Delta; 61 $55^{\prime} 25^{\prime \prime} \mathrm{N}$, $161^{\circ} 57^{\prime} 00^{\prime \prime} \mathrm{W}$; (map 73).

Riverboat pilots' name shown on a 1922 manuscript chart.

Cottonwood Slough: stream, distributary of the Chakachatna River, flows SE $6 \mathrm{mi}$. to Trading Bay, $30 \mathrm{mi}$. NNW of Kenai, Cook Inlet Low.; $60^{\circ} 57^{\prime} \mathrm{N}, 151^{\circ} 38^{\prime} \mathrm{W}$; (map. 62).

Local name reported in 1859 by USGS.

Cottonwood Slough: stream, flows $2 \mathrm{mi}$. SW, in a swamp $14 \mathrm{mi}$. SW of Palmer, Cook Inlet Low.; 61 $31^{\prime} 40^{\prime \prime} \mathrm{N}, 149^{\circ} 30^{\prime} 20^{\prime \prime} \mathrm{W}$; (map 69).

Local name reported in 1950 by USGS; name derived from Cotonwood Creek.

Cottonwood Slough: stream, $2.4 \mathrm{mi}$. long, anabranch of Yukon River, $1 \mathrm{mi}$. E of Horse I. and $10 \mathrm{mi}$. S of Holy Cross, Innoko Low.; $62^{\circ} 03^{\prime} 30^{\prime \prime} \mathrm{N}, 159^{\circ} 55^{\prime} 15^{\prime \prime} \mathrm{W}$; (map 78).

Descriptive name reported in 1916 by G. L Harrington and R. H. Sargent (in Harrington, 1918, pl. 1), USGS.

Couloir Peak: mountain peak, 6,320 ft., at junc. of Hades Highway and Devils Paw, $24 \mathrm{mi}$. NE of Juneau, Coast Mts. ; $58^{\circ} 43^{\prime} 15^{\prime \prime}$ N, $133^{\circ} 55^{\prime}$ 15" W; (map 12).

Local name reported in 1960 by USGS.

Council: locality, pop. 41, on left bank of Niukluk River, $33 \mathrm{mi}$. NE of Solomon, Seward Penin. High.; $64^{\circ} 54^{\prime} \mathrm{N}, 163^{\circ} 40^{\prime} \mathrm{W}$; $B G N$ 1944; (map 95). Var. Council City.

Site of village and recording office in the center of the Council gold mining precinct. "Council City * * * was first started by $\mathrm{Mr}$. Libby [Daniel B. Libby, a member of the von Bendeleben expedition of 1866 and who with three others found gold in the area] and party in the fall of 1897 . * * In October, 1898, the city consisted of about fifty $\log$ houses, and probably about 300 persons were then there, the majority of whom had come in during the months of August and September, after the news of the first disooveries had reached St. Michaels." (North American Transportation and Trading Company, 1900, p. 26). The Council Post Office was established in 1900 and discontinued in 1953 (Ricks, 1965, p. 15). The population was 686 in 1910, 109 in 1933 (Colby, 1939, 363), and 9 in the fifties (Balcom, 1965, p. 10).

Council City: locality, see Council.

Council Landing: locality, on right bank of Fish River, $3 \mathrm{mi}$. NW of Golovnin Lagoon and 32 mi. NE of Solomon, Seward Penin. High.; $64^{\circ} 37^{\prime} \mathrm{N}, 163^{\circ} 24^{\prime} \mathrm{W}$; (map 95).

Site of a boat landing; published in 1956 by USGS.

Count, Cape: point of land, see Romanzof, Cape.

Count Creek: stream, see Comet Creek.

Countess, Point: point of land, on SE coast of Kenai Penin., at $\mathrm{N}$ end of Bainbridge Passage, $4.5 \mathrm{mi}$. $\mathrm{S}$ of Chenega, Chugach Mts.; $60^{\circ} 13^{\prime} \mathrm{N}, 148^{\circ} 05 \mathrm{~W}$; (map 63).

Named on June 3, 1794, by Capt. George Vancouver, (1798, v. 3, p. 178), RN, for "Capt. Countess," RN.

Course Point: point of land, on Narrow Strait, $7.5 \mathrm{mi}$. NW of Kodiak, Kodiak I.; 57 $53^{\prime} 35^{\prime \prime}$ N, $152^{\circ} 28^{\prime} 00^{\prime \prime}$ W; (map 34). Var. Mys Kursa, Mys Povorota, Turn Cape.

Translation of the name "M[ys] Kursa" [from the French "cours"] given in 1839 or 1840 by Sub-Lt. Mikhail Murashev, IRN, and published in 1849 on Russian Hydrog. Dept. Chart 1425. The name "M[ys] Povorota," meaning "turn cape," was published for this point by Capt. Tebenkov (1852, map 23), IRN.

Court House Hill: hill, $50 \mathrm{ft}$., on Chicken Ridge in center of Juneau, Coast Mts.; $58^{\circ} 18^{\prime} 15^{\prime \prime}$ N, $134^{\circ} 24^{\prime} 30^{\prime \prime} \mathrm{W}$; (map 11). Var. Government Hill, Horseshoe Hill, Knob Hill, Navy Hill, Telegraph Hill.

The name was derived from the court house built on the hill in 1898 . In 1881 it was known as Knob Hill and Telegraph Hill and also as Navy Hill because of the Navy barracks built there that year. The miners referred to it as "Chicken Ridge." It was also known as "Government Hill" because it was a government reserve. About 1904 it was known locally as "Horsehoe Hill" probably for the Horseshoe Saloon located nearby. The southern part is also known as "Telephone Hill" because of the telephone offices and exchange located here (De Armond, 1957, p. 12).

Coutous Pass: water passage, see Caution Pass.

Couverden, Point: point of land, on SE end of Couverden I., at mouth of Lynn Canal, $7 \mathrm{mi}$. SW of Funter and $24 \mathrm{mi}$. SW of Juneau, St. Elias Mts.; $58^{\circ} 11^{\prime} 25^{\prime \prime} \mathrm{N}, 135^{\circ} 03^{\prime} 10^{\prime \prime} \mathrm{W}$; (map 11).

Observed by Joseph Whidbey, July 13, 1794, and named by Capt. Vancouver (1789, v. 3, p. 245), RN, for Couverden, England, the home of his ancestors. Capt. Tebenkov (1852, map 8), IRN, transliterated the English name as "M[ys] Kouverden."

Couverden Island: island, $3 \mathrm{mi}$. long, off W shore of Lynn Canal at junc. with Icy Strait, $7 \mathrm{mi}$. SW of Funter and $25 \mathrm{mi}$. SW of Juneau, St. Elias Mts.; $58^{\circ} 12^{\prime} \mathrm{N}, 135^{\circ} 05^{\prime} \mathrm{W}$; (map 11).

Probably named in 1868 by Comdr. R. W. Meade, USN, for nearby Point Couverden, and published in 1881 on Hydrog. Chart 882.

Couverden Rock: rock, near mouth of Lynn Canal, 2 mi. NE of Point Couverden and 23 mi. SW of Juneau, St. Elias Mts. ; $58^{\circ} 13^{\prime} 00^{\prime \prime}$ $\mathrm{N}, 135^{\circ} 01^{\prime} 40^{\prime \prime} \mathrm{W}$; (map 11). 
Name published in 1948 by USGS; derived from the nearby point of the same name.

Covearak River: stream, see Kaviruk River.

Cove Creek: stream, on $\mathbf{N}$ end of Douglas 1 ., flows NE $1 \mathrm{mi}$. to Fritz Cove, $0.8 \mathrm{mi}$. SW of Entrance Point and $7.6 \mathrm{mi}$. NW of Juneau, Coast Mts.; $58^{\circ} 19^{\prime} 25^{\prime \prime} \mathrm{N}, 134^{\circ} 36^{\prime} 40^{\prime \prime} \mathrm{W}$; (map 11)

Local name published in 1962 by USGS.

Cove Hill: hill, $690 \mathrm{ft}$., $0.7 \mathrm{mi}$. NE of Tongass

I., Coast Mts.; $54^{\circ} 47^{\prime} 15^{\prime \prime} \mathrm{N}, 130^{\circ} 43^{\prime} 20^{\prime \prime} \mathrm{W}$; (map 2).

Named in 1883 by Lt. Comdr. H. E. Nichols, USN.

Cove Island: island, $0.7 \mathrm{mi}$. across, in Applegate Cove, $8 \mathrm{mi}$. NW of village of Cold Bay, at SW end of Alaska Penin., Bristol Bay Low.; $55^{\circ} 14^{\prime} \mathrm{N}, 162^{\circ} 55^{\prime} \mathrm{W}$; (map 29).

Named by USBF in 1888 .

Cove Mountain: hill, $700 \mathrm{ft}$., on Revillagigedo I., between Connell and Ward Lakes, $5 \mathrm{mi}$. N of Ketchikan, Alex. Arch.; $55^{\circ} 25^{\prime} 45^{\prime \prime} \mathrm{N}$, $131^{\circ} 40^{\prime} 40^{\prime \prime} \mathrm{W}$; (map 3 ).

Named in 1886 by USC\&GS.

Cove Point: point of land, on $\mathbf{N}$ end of Glass Penin., $2 \mathrm{mi}$. S of Arden Point and $15 \mathrm{mi}$. SE of Juneau, Alex. Arch.; $58^{\circ} 07^{\prime} 45^{\prime \prime} \mathrm{N}$, $134^{\circ} 10^{\prime} 00^{\prime \prime} \mathrm{W}$; (map 11).

Descriptive name published in 1893 by USC\&GS.

Cove Point: point of land, on W shore of Berners Bay, $1.5 \mathrm{mi}$. NE of Point St. Mary and 38 mi. NW of Juneau, Coast Mts.; 58 $45^{\prime} 15^{\prime \prime}$ $\mathrm{N}, 135^{\circ} 01^{\prime} 00^{\prime \prime} \mathrm{W}$; (map 11).

Descriptive name published in 1924 by USC\&GS

Cove Point: point of land, see Bukti Point.

Cove Point: point of land, see Mountain Point.

Covey Creek: stream, on Iniskin Penin., flows NW 1.5 mi. to Park Creek, $0.8 \mathrm{mi}$. S of Chinitna Bay, Aleutian Ra.; $59^{\circ} 49^{\prime} 00^{\prime \prime} \mathrm{N}$, $153^{\circ} 05^{\prime} 30^{\prime \prime} \mathrm{W}$; BGN 1962; (map 51).

Local name published by USGS in 1958.

Coville, Lake: lake, $10 \mathrm{mi}$. long, at mouth of American Creek, NW of Lake Grosvenor, on Alaska Penin., in Katmai National Monument, 37 mi. NW of Mount Katmai, Aleutian Ra.; 58 $45^{\prime}$ N, $155^{\circ} 37^{\prime} \mathrm{W}$; BGN 1926; (map 43). Var. Alinak Lake, Colville Lake, Nahulkavik, Savonoski Lakes.

Named by Griggs (1922, p. 307) for Frederick V. Coville, chairman of the Research Committee of the National Geographic Society.

Covina Gulch: ravine, trends SW $0.5 \mathrm{mi}$. to Glacier Creek, $9 \mathrm{mi}$. N of Nome, Seward Penin. High.; $64^{\circ} 37^{\prime} 45^{\prime \prime}$ N, $165^{\circ} 20^{\prime} 35^{\prime \prime}$ W; (map 94).

Prospectors' name reported on the 1903 Campion Mining and Trading Co. map by George M. Ashford.

Covroeruk Lagoon: lagoon, see Kavrorak Lagoon.

Covroeruk Mountain: hill, see Kavrorak Hill. Covroeruk Spring: springs, see Kavrorak Springs.

Cov-vee-arak River: stream, see Kaviruk River.
Cow and Calf Moose Lake: lake, $1 \mathrm{mi}$. long, $6 \mathrm{mi}$. NE of Salmon Village and $38 \mathrm{mi}$. W of Chalkyitsik, Porcupine Plat.; $66^{\circ} 37^{\prime} \mathrm{N}, 142^{\circ}$ $20^{\prime} \mathrm{W}$; (map 120).

Local name reported in 1956 by $T$. $E$. Taylor, USGS. It may be a form of translation of an Indian name.

Cowcow Creek: stream, flows SE to Anikovik River near its head, about $15 \mathrm{mi}$. E of Cape Prince of Wales, Seward Penin. High.; (map 111).

Prospectors' name shown on the 1900 "Map of Nome Peninsula" by J. M. Davidson and B. D. Blakeslee. This feature cannot be precisely identified on current maps.

Cow Creek: stream, flows NW $9 \mathrm{mi}$. to Behm Canal, $W$ of Claude Point, on $\mathbf{N}$ coast of Revillagigedo I., Alex. Arch.; $55^{\circ} 56^{\prime} 10^{\prime \prime} \mathrm{N}$, $131^{\circ} 22^{\prime} 45^{\prime \prime} \mathrm{W}$; BGN 1929; (map 3 ).

Local name reported in 1929 by USFS.

Cow Creek: stream, flows SSW $2.2 \mathrm{mi}$. to Benito Creek, $3.4 \mathrm{mi}$. W of Iron Mtn. and $78 \mathrm{mi}$. NE of Valdez, Wrangell Mts. ; $61^{\circ} 37^{\prime} 00^{\prime \prime} \mathrm{N}, 144^{\circ}$ 08'15" W; (map 68).

Name reported $1912-13$ by USGS; published in 1915 by USGS (Moffit, pl. 5). Cow Creek: stream, flows E $1 \mathrm{mi}$. to Middle Fork Koyukuk River, 2 mi. S of Wiseman, Brooks Ra.; $67^{\circ} 23^{\prime} 30^{\prime \prime} \mathrm{N}, 150^{\circ} 08^{\prime} 00^{\prime \prime} \mathrm{W}$; (map 124).

Local name obtained in 1956 by USGS topographers.

Cow Creek: stream, flows $\mathbf{N}$ to Arctic River, about $10 \mathrm{mi}$. SE of Ear Mtn. and $40 \mathrm{mi}$. NE of Teller, Seward Penin. High.; (map 111).

Prospectors' name reported on a precinct map of Seward Peninsula gold fields by Monroe and Hutchins, corrected up to June 1903 by Arthur Gibson. This feature cannot be precisely identified on current maps.

Cowee Creek: stream, heads in unnamed glacier, flows mostly W $6.5 \mathrm{mi}$. to Davies Creek, 1.6 mi. NE of Bridget Cove on Favorite Channel and $30 \mathrm{mi}$. NW of Juneau, Coast Mts.; $58^{\circ}$ $38^{\prime} 50^{\prime \prime}$ N, $134^{\circ} 54^{\prime} 30^{\prime \prime} \mathrm{W}$; (map 11).

Prospectors name reported by Spencer and Wright (1906, pl. 37 and p. 89), USGS. Named for Chief Kowee of the Auk Tlingit Indians. See Kowee Creek.

Cowee Creek: stream, see Kowee Creek.

Cowen Creek : stream, see Golden Creek.

Cow Island: island, $0.5 \mathrm{mi}$. long, northernmost of Percy Is., Alex. Arch.; 54 $58^{\circ} 00^{\prime \prime}$ N, $131^{\circ}$ 35'00" W; (map 2).

Named in 1886 by USC\&GS.

Cow Lake: lake, $1 \mathrm{mi}$. long on Kenai Penin., $6 \mathrm{mi}$. NW of Sterling and $14 \mathrm{mi}$. E of Kenai, Cook Inlet Low.; $60^{\circ} 36^{\prime} 30^{\prime \prime} \mathrm{N}, 150^{\circ} 51^{\prime} 00^{\prime \prime}$ W; (map 62).

Named about 1963 by officials of Kenai National Moose Range, for administrative purposes.

Cow Lake: lake, $1.1 \mathrm{mi}$. long, $\mathrm{S}$ of Red Shirt Lake, $26 \mathrm{mi}$. NW of Anchorage, Cook Inlet Low.; 61 $35^{\prime} 00^{\prime \prime} \mathrm{N}, 150^{\circ} 11^{\prime} 20^{\prime \prime} \mathrm{W}$; (map $70)$.

Local name reported in 1958 by USGS.
Cow Lake: lake, $0.6 \mathrm{mi}$. long, between Fox and Shack Lakes, $20 \mathrm{mi}$. W of Beaver, Yukon Flats; $66^{\circ} 18^{\prime} 20^{\prime \prime} \mathrm{N}, 148^{\circ} 06^{\prime} 00^{\prime \prime} \mathrm{W}$; (map 118).

Probably named by William Yanert who showed it on a 1916 manuscript map of the Yukon Flats (Stuck, 1917, map facing p. 122). Cowpack Inlet: bay, extends S 3 mi. at mouth of Cowpack River, $30 \mathrm{mi}$. NE of Shishmaref, Kotzebue-Kobuk Low. ; $66^{\circ} 26^{\prime} \mathrm{N}, 165^{\circ} 01^{\prime} \mathrm{W}$; (map 112).

Local name reported in 1901 by T. G Gerdine, USGS.

Cowpack River: stream, heads in lake, flows NE $18 \mathrm{mi}$. to Cowpack Inlet, $30 \mathrm{mi}$. NE of Shishmaref, Kotzebue-Kobuk Low.; $66^{\circ} 23^{\prime} \mathrm{N}$, $165^{\circ} 01^{\prime} \mathrm{W}$; (map 112).

Local name reported in 1901 by T. G. Gerdine, USGS.

Cowvinik Lake: lake, see Imuruk Basin.

Coxcomb, Mount: mountain, 1,808 ft., on SE shore of Unalaska Bay, on NE coast of Unalaska I., Aleutian Is.; $53^{\circ} 53^{\prime} 34^{\prime \prime} \mathrm{N}, 166^{\circ} 28^{\prime}$ $26^{\prime \prime} \mathrm{W}$; BGN 1935; (map 23).

Descriptive name given by a USC\&GS field party in 1934 "because, on one side near its top, is a projecting ledge of rock which gave the appearance of a cock's comb."

Coxcomb Point: point of land, on $\mathrm{N}$ shore of Kiliuda Bay, on SE coast of Kodiak I.; $57^{\circ}$ $20^{\prime} \mathrm{N}, 153^{\circ} 01^{\prime} \mathrm{W}$; $B G N$ 1933; (map 34).

Descriptive name given in 1933 by USC\&GS, "because the fringe of reefs on the side of the point resembles a cock's comb."

Coxe Glacier: glacier, trends SW $6.7 \mathrm{mi}$. to Barry Arm, E of Barry Glacier, $5.9 \mathrm{mi}$. E of Anchorage, Chugach Mts.; $61^{\circ} 07^{\prime} \mathrm{N}, 148^{\circ}$. 08' W; BGN 1910; (map 69). Var. Emerson Glacier.

Named in 1910 by U. S. Grant and D. F. Higgins, USGS, for the Rev. William Coxe, who in 1780 published an account of Russian discoveries.

Coxe River: stream, heads in Cold Storage Lake, flows SW $2.5 \mathrm{mi}$. to Katlian Bay, $8 \mathrm{mi}$. $\mathrm{N}$ of Sitka, Alex. Arch.; $57^{\circ} 10^{\prime} 20^{\prime \prime} \mathrm{N}$,

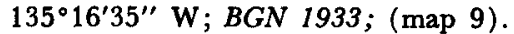

Named by USFS in 1933 "for Captain Coxe commander of the Swedish cruiser Mercury, who went to Alaska in 1790 to destroy the Russian trade and colonizations. But because of the deplorable state of the settlers he abstained from hostilities, and helped them instead."

Coyote Creek: stream, flows W $1.5 \mathrm{mi}$. to Nenana River, $4.7 \mathrm{mi}$. N of village of McKinley Park, Alaska Ra.; $63^{\circ} 48^{\prime} 00^{\prime \prime} \mathrm{N}, 148^{\circ} 55^{\prime} 45^{\prime \prime} \mathrm{W}$; $B G N$ 1965; (map 87).

Named in 1965 by the Alaska Dept. of Highways because "park rangers report that the Nenana Canyon is the only section of the park in which coyotes are found." See Iceworm Gulch.

Coyote Creek: stream, flows NW $5 \mathrm{mi}$. to Grantley Harbor, $2 \mathrm{mi}$. SE of Teller, Seward Penin. High.; $65^{\circ} 15^{\prime} \mathrm{N}, 166^{\circ} 18^{\prime} \mathrm{W}$; (map 111).

Local name reported in 1900 by E. C. Barnard (in Brooks, 1901, pl. 17), USGS. 
Coyote Lake: lake, $1.5 \mathrm{mi}$. long, on Kenai Penin., $4.5 \mathrm{mi}$. NE of Swan Lake and $31 \mathrm{mi}$. NE of Kenai, Gook Inlet Low.; $60^{\circ} 44^{\prime}$ N, $150^{\circ} 27^{\prime}$ W.; (map 62).

Named about 1963 by officials of Kenai National Moose Range, for administrative purposes.

Coyukuk River: stream, see Koyukuk River.

Cozian Reef: reef, in Peril Strait, $\mathrm{N}$ of Duffield Penin., $36 \mathrm{mi}$. N of Sitka, Alex. Arch,; 57 $34^{\prime}$ N, $135^{\circ} 26^{\prime} \mathrm{W}$; BGN 1897; (map 9). Var. Cozian Rock, Cozian Shoal, Kozian Reef, Nikolas Reef.

Named by U.S. Navy in 1880 for Anton George Cozian, a native of Dalmatia, who was for many years a pilot in the employ of the Russian American Company during the latter part of 1800's. The reef has also been called Nikolas Rock, because the Russian steamer Nikolas struck it in 1854.

Cozian Rock: reef, see Cozian Reef.

Cozian Shoal: reef, see Cozian Reef.

Cozy Cove: cove, $0.2 \mathrm{mi}$. across, on $\mathrm{N}$ coast of Sitkalidak I., at mouth of Amee Bay, SE of Kodiak I.; $57^{\circ} 11^{\prime} 50^{\prime \prime} \mathrm{N}, 153^{\circ} 10^{\prime} 30^{\prime \prime} \mathrm{W}$; BGN 1930; (map 34). Var. Snug Cove.

Descriptive name given in 1930 by USC\&GS, because it "is a good anchorage for small boats in southerly winds * * *" A USC\&GS field party called this feature "Snug Cove" in 1928.

Cqagué: village, see Skagway.

Crab Bay: locality, at W entrance to Crab Bay, on $E$ coast of Evans I., 16 mi. SSE of Chenega, Chugach Mts.; $60^{\circ} 03^{\prime} 45^{\prime \prime} \mathrm{N}, 148^{\circ} 00^{\prime} 30^{\prime \prime} \mathrm{W}$; (map 63).

Fishing village reported in 1943 by USC\&GS. Recent USGS maps indicate a site with four or five buildings.

Crab Bay: bay, $0.3 \mathrm{mi}$. across, on $\mathbf{E}$ coast of Kruzof I., 10.5 mi. NW of Sitka, Alex. Arch.; $57^{\circ} 08^{\prime} 30^{\prime \prime} \mathrm{N}, 135^{\circ} 33^{\prime} 40^{\prime \prime} \mathrm{W}$; BGN Sixth Report; (map 9).

Name published in 1943 by USC\&GS.

Crab Bay: bay, trends S $1 \mathrm{mi}$. to Sawmill Bay, on $\mathbf{E}$ coast of Evans I., $16 \mathrm{mi}$. SSE of Chenega, Chugach Mts.; $60^{\circ} 03^{\prime} 45^{\prime \prime} \mathrm{N}, 148^{\circ} 00^{\prime} 00^{\prime \prime} \mathrm{W}$; (map 63).

Local name reported in 1951 by USGS.

Crab Bay: cove, $0.7 \mathrm{mi}$. across, on $\mathrm{W}$ coast of Prince of Wales I., $\mathrm{N}$ of Craig, Alex. Arch.; $55^{\circ} 29^{\prime} \mathrm{N}, 133^{\circ} 08^{\prime} \mathrm{W}$; (map 4).

Local name recorded in 1951 by USGS.

Crab Bay: estuary, $1.2 \mathrm{mi}$. long, on $\mathrm{E}$ coast of Annette I., Alex. Arch.; $55^{\circ} 06^{\prime} 25^{\prime \prime} \mathrm{N}$, 131 221'30' W; BGN 1917; (map 3).

Named in 1917 by USC\&GS.

Crab Bay: estuary, $5 \mathrm{mi}$. long, on $\mathrm{S}$ shore of Tenakee Inlet, on Chichagof I., $5 \mathrm{mi}$. SW of Tenakee Springs, Alex. Arch.; 57 $44^{\prime} 30^{\prime \prime} \mathrm{N}$, $135^{\circ} 19^{\prime} 00^{\prime \prime} \mathrm{W}$; BGN 1929; (map 9).

Local name reported in 1928 by USFS.

Crab Cove: cove, $0.3 \mathrm{mi}$. across, in Funter Bay, on Mansfield Penin., $1.2 \mathrm{mi}$. S of Green Mtn. and $17 \mathrm{mi}$. SW of Juneau, Alex. Arch.; $58^{\circ} 15^{\prime} 10^{\prime \prime} \mathrm{N}, 134^{\circ} 52^{\prime} 45^{\prime \prime} \mathrm{W}$; (map 11 ).
Named in 1890 by Lt. Comdr. H. B. Mansfield, USN, and published in the 1891 Coast Pilot (p. 161).

Crab Creek: stream, $5 \mathrm{mi}$. long, on $\mathrm{W}$ coast of Prince of Wales I., flows N and SW to Crab Bay, E of Craig, Alex. Arch.; 55 $29^{\prime} 05^{\prime \prime} \mathrm{N}$, $133^{\circ} 07^{\prime} 30^{\prime \prime} \mathrm{W}$; BGN 1963; (map 4).

Local name reported in 1961 by USFS.

Crab Creek: stream, flows NW $7 \mathrm{mi}$. to Middle Fork Fortymile River, $51 \mathrm{mi}$. SW of Eagle, Yukon-Tanana High.; $64^{\circ} 27^{\prime} \mathrm{N}, 142^{\circ} 39^{\prime} \mathrm{W}$; (map 102). Var. Cribbs Creek, Crib Greek. Local name originally shown in 1898 as "Cribbs Creek" on a manuscript map by C. A. Woodruff, Fort Cudahy, Canada; present spelling published in 1956 by USGS.

Crab Glacier: glacier, on NE slope of Mount Veniaminof, Alaska Penin., trends NE $3 \mathrm{mi}$. to its terminus at head of Rapid Creek, Aleutian Ra.; 56 $16^{\prime} \mathrm{N}, 159^{\circ} 17^{\prime} \mathrm{W}$; (map 30).

Name reported in 1923 by R. H. Sargent, USGS; published in 1927 by USGS.

Crab Island: island, 0.1 mi. long, $0.3 \mathrm{mi}$. E of end of Gilbert Spit and $5 \mathrm{mi}$. N of Yakutat, Malaspina Coastal Plain; 59 $37^{\prime} 30^{\prime \prime} \mathrm{N}$, $139^{\circ} 43^{\prime} 05^{\prime \prime} \mathrm{W}$; (map 46).

Local name published in 1964 (de Laguna and others, map 4).

Crab Lagoon: lagoon, $0.2 \mathrm{mi}$. long, on $\mathrm{N}$ coast of Woody I., $5 \mathrm{mi}$. NE of Kodiak, NE of Kodiak I.; $57^{\circ} 47^{\prime} 45^{\prime \prime} \mathrm{N}, 152^{\circ} 19^{\prime} 45^{\prime \prime} \mathrm{W}$; (map 34).

Local name published in 1943 by USC\&GS. Crab Point: point of land, on W shore of Tamgas Harbor, on $\mathrm{S}$ coast of Annette I., $20 \mathrm{mi}$. $\mathrm{S}$ of Ketchikan, Alex. Arch.; $55^{\circ} 04^{\prime} 05^{\prime \prime} \mathrm{N}, 131^{\circ}$ $32^{\prime} 55^{\prime \prime} \mathrm{W}$; (map 3).

Named by USC\&GS; published in the 1891 Coast Pilot (p. 92).

Crab Trap Cove: cove, extends W $0.6 \mathrm{mi}$. off South Pass, on E coast of Goat I., Alex. Arch.; $55^{\circ} 12^{\prime} 15^{\prime \prime} \mathrm{N}, 132^{\circ} 52^{\prime} 30^{\prime \prime} \mathrm{W}$; (map 4).

Local name published in 1965 by USC\&GS.

Crafton Island: island, $2 \mathrm{mi}$. long, in Prince William Sound, off E coast of Kenai Penin., at NW end of Knight Island Passage, $16 \mathrm{mi}$. NE of Chenega, Chugach Mts.; $60^{\circ} 30^{\prime} 10^{\prime \prime} \mathrm{N}$, $147^{\circ} 56^{\prime} 25^{\prime \prime} \mathrm{W}$; (map 63).

Local name reported in 1900 by F. C. Schrader, USGS.

Crag Creek: stream, flows S $2 \mathrm{mi}$. from Crag Peak to Wolverine Creek, $14 \mathrm{mi}$. SE of Sillyasheen Mtn. and $61.5 \mathrm{mi}$. NW of Wiseman,

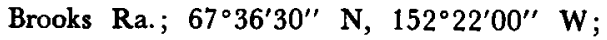
(map 124).

Local name obtained in 1956 by USGS topographers.

Crag Mountain: mountain, 3,326 ft., $3 \mathrm{mi}$. SE of head of Port Althrop, on Chichagof I., $29 \mathrm{mi}$. W of Hoonah, Alex. Arch.; 58 $03^{\prime} 08^{\prime \prime}$ N, 136 $15^{\prime} 15^{\prime \prime}$ W; BGN 1960; (map 10).

Descriptive name given by USGS in 1955 "because of its jagged cliffs and rough broken top."

Crag Peak: peak, 4,094 ft., NW of junc. of Wolverine Creek and John River, $63.5 \mathrm{mi}$.
NW of Wiseman, Brooks Ra.; $67^{\circ} 39^{\prime} \mathrm{N}$, $152^{\circ} 25^{\prime} \mathrm{W}$; (map 124).

Local descriptive name obtained in 1956 by USGS topographers.

Crag Point: point of land, $11.5 \mathrm{mi}$. NW of Kodiak, between Anton Larsen and Sharatin Bays, Kodiak I.; $57^{\circ} 52^{\prime} 45^{\prime \prime} \mathrm{N}, 152^{\circ} 40^{\prime} 25^{\prime \prime} \mathrm{W}$; BGN 1909; (map 34). Var. Bluff Cape, Mys Otrubistoy, Otrubistoi.

Name given in 1909 by USC\&GS to eliminate duplication of names in this area. This point was first named "M[ys] Otrubistoy," meaning "cape with a piece cut off," in 1839 or 1840 by Sub-Lt. Mikhail Murashev, IRN. Baker (1906, p. 139) published "Bluff Cape" as the translation of Murashev's name.

Craig: village, pop. 273, on Craig and Prince of Wales Is. at $S$ end of Klawak Inlet, $60 \mathrm{mi}$. NW of Ketchikan, Alex. Arch.; 55 $28^{\prime} 30^{\prime \prime} \mathrm{N}$, $133^{\circ} 09^{\prime} 00^{\prime \prime} \mathrm{W}$; BGN 1944; (map 4). Var. Craig City, Craig Millar, Fish Egg.

Originally named "Fish Egg" for nearby Fish Egg Island, the name was changed to "Craig Millar" for a cannery owner (Alaska Sportsman, 1962, no. 12, p. 28). The present name was adopted in 1912 when a post office was established (Ricks, 1965, p. 15). On March 1, 1922, Craig was incorporated. In 1939 , with a population of 231 , Craig had a salmon cannery, a sawmill and a Customs Office serving as a port of clearance for vessels traveling from British Columbia to the United States (Colby, 1939, p. 145).

Craig City: village, see Craig.

Craig Creek: stream, flows S $3 \mathrm{mi}$. to Valdez Creek, $70 \mathrm{mi}$. SE of Healy, Alaska Ra.; $63^{\circ} 12^{\prime} 25^{\prime \prime} \mathrm{N}, 147^{\circ} 15^{\prime} 45^{\prime \prime} \mathrm{W}$; (map 87).

Local name obtained in 1951 by USGS.

Craig Creek: stream, flows $15 \mathrm{mi}$. NE into Canada to Clarence River Delta, Yukon, Canada, $11 \mathrm{mi}$. SE of Demarcation Point, Arctic Plain; 69 $37^{\prime} 30^{\prime \prime} \mathrm{N}, 140^{\circ} 54^{\prime} 00^{\prime \prime} \mathrm{W} ; B G N$ 1914; (map 138).

Named in 1912 by the IBC survey party, probably for J. D. Craig, D.L.S., Surveyor in charge for His Majesty.

Craigie Creek: stream, flows SW 6 mi. to Willow Creek, W of Bullion Mtn., $16 \mathrm{mi}$. NW of Palmer, Talkeetna Mts. $61^{\circ} 45^{\prime} 35^{\prime \prime} \mathrm{N}, 149^{\circ}$ $26^{\prime} 20^{\prime \prime} \mathrm{W}$; (map 69).

Local name reported in 1906 by $T$. G. Gerdine and R. H. Sargent, USGS.

Craig Island: island, $0.5 \mathrm{mi}$. wide, at $\mathrm{S}$ entrance to Klawak Inlet, off $\mathrm{W}$ coast of Prince of Wales I., Alex. Arch.; 55 $28^{\prime} 30^{\prime \prime}$ N, $133^{\circ}$ 09'00"' W; (map 4).

Local name published in 1932 by USC\&GS. Craig Lake: lake, 1,800 ft. long, $2.6 \mathrm{mi}$. W of junc. of Johnson and Tanana Rivers and $38 \mathrm{mi}$. SE of Delta Junction, Tanana Low.; $63^{\circ} 43^{\prime} 45^{\prime \prime} \mathrm{N}, 144^{\circ} 42^{\prime} 55^{\prime \prime} \mathrm{W}$; (map 86).

Name published on relatively recent maps. Craig Millar: village, see Craig.

Craig Point: point of land, on NE coast of Zarembo I., Alex. Arch.; $56^{\circ} 27^{\prime} 20^{\prime \prime} \mathrm{N}, 132^{\circ}$ $44^{\prime} 00^{\prime \prime} \mathrm{W}$; (map 6). 
Discovered by James Johnstone, RN, on August 29, 1793, and named by Capt. George Vancouver (Wagner, 1937, p. 382)

Craig Rock: rock, in Nakat Bay, $0.8 \mathrm{mi}$. W of Tongass I., Coast Mts.; 54 $46^{\circ} 35^{\prime \prime} \mathrm{N}$, $130^{\circ} 45^{\prime} 55^{\prime \prime} \mathrm{W}$; (map 2).

Named in 1888 by Lt. Comdr. H. E. Nichols, USN.

Crain Creek: stream, see Crane Creek.

Cramberry Slough: stream, flows W $0.6 \mathrm{mi}$. to mouth of Unalakleet River, $\mathrm{S}$ of Unalakleet, Nulato Hills; $63^{\circ} 52^{\prime} 10^{\prime \prime} \mathrm{N}, 160^{\circ} 46^{\prime} 30^{\prime \prime} \mathrm{W}$; (map 91). Var. Cranberry Slough.

Local name reported in 1952 by USC\&GS.

Cranberry Creek: stream, flows SW $20 \mathrm{mi}$. to Nushagak River, $67 \mathrm{mi}$. NE of Dillingham, Bristol Bay Low.; $59^{\circ} 44^{\prime} \mathrm{N}, 157^{\circ} 11^{\prime} \mathrm{W}$; (map 52).

Local name published in 1951 by USGS.

Cranberry Peak: peak, 4,602 ft., $1.8 \mathrm{mi}$. N of mouth of St. Anne Creek in Klutina Lake, 46 mi. NE of Valdez, Chugach Mts.; 61 ${ }^{\circ} 46^{\prime} 00^{\prime \prime}$ $\mathrm{N}, 145^{\circ} 56^{\prime} 10^{\prime \prime} \mathrm{W}$; (map 68).

Named in 1898 by Capt. W. R. Abercrombie, USA.

Cranberry Slough: stream, see Cramberry Slough.

Crane Cove: estuary, $3 \mathrm{mi}$. long, on $\mathrm{W}$ coast of Baranof I., 13 mi. S of Sitka, Alex. Arch.; $56^{\circ} 50^{\prime} 55^{\prime \prime} \mathrm{N}, 135^{\circ} 22^{\prime} 30^{\prime \prime} \mathrm{W}$; (map 5). Var Guba Zhuravlina, Zhuravlina Cove.

This is a translation by USC\&GS of the name given in 1809 by the navigator Ivan Vasiliev the first, IRN. Lt. Sarichev (1826, map 19), IRN, published it as "G[uba] Zhuravlina [from Zhuravets]."

Crane Creek: stream, flows NE $3 \mathrm{mi}$. to Port Camden, on E coast of Kuiu I., Alex. Arch.; $56^{\circ} 43^{\prime} 30^{\prime \prime} \mathrm{N}, 133^{\circ} 56^{\prime} 20^{\prime \prime} \mathrm{W}$; (map 6).

Named by USC\&GS for charting purposes; name published in 1943.

Crane Creek: stream, flows SE $1.5 \mathrm{mi}$. to Fairbanks Creek, $21 \mathrm{mi}$. NE of Fairbanks, YukonTanana High.; $65^{\circ} 04^{\prime} 45^{\prime \prime} \mathrm{N}, 147^{\circ} 14^{\prime} 00^{\prime \prime} \mathrm{W}$; (map 105). Var. Crain Creek.

Named by prospectors; reported in 1903 by T. G. Gerdine (Prindle, 1905, pl. 13), USGS.

Crane Lake: lake, $0.5 \mathrm{mi}$. long, on Kenai Penin., $3 \mathrm{mi}$. E of Number Three Bay and $20 \mathrm{mi}$. NE of Kenai, Cook Inlet Low.; $60^{\circ} 47^{\prime} 30^{\prime \prime} \mathrm{N}$, $150^{\circ} 57^{\prime} 15^{\prime \prime} \mathrm{W}$; (map 62).

Named about 1963 by officials of Kenai National Moose Range, for the Lesser Sandhill or Little Brown Crane (Grus canadensis canadensis), a marsh-dwelling bird, which breeds throughout Alaska.

Crash Creek: stream, in Ray Mts., flows S $4.5 \mathrm{mi}$ to Tozitna River, $5 \mathrm{mi}$. SW of Mount Tozi and $48 \mathrm{mi}$. NE of Tanana, Kokrines-Hodzana High.; $65^{\circ} 38^{\prime} 00^{\prime \prime} \mathrm{N}, 150^{\circ} 51^{\prime} 30^{\prime \prime} \mathrm{W}$; (map 106).

So named in 1956 by Orth, because there was wreckage of a plane crash on the slope above the stream.

Crassico Creek: stream, flows NE $7 \mathrm{mi}$. to Ipnavik River, $29 \mathrm{mi}$. N of Howard Pass,
Brooks Ra.; $68^{\circ} 37^{\prime} 30^{\prime \prime} \mathrm{N}, 157^{\circ} 07^{\prime} 00^{\prime \prime} \mathrm{W}$; (map 132).

Named in 1950 by I. L. Tailleur, USGS, geologist, with the Naval Petroleum Reserve No. 4 explorations; name published by USGS in 1951. So named because of the abundant fossils of this name along the creek.

Crater Anchorage: bay, $3 \mathrm{mi}$. across, on NW coast of Yunaska I., Aleutian Is.; $52^{\circ} 40^{\prime} \mathrm{N}$, $170^{\circ} 45^{\prime} \mathrm{W}$; (map 20).

Name published by USC\&GS in the 1944 Aleutian Coast Pilot (p. 80)

Crater Bay: bay, $1.8 \mathrm{mi}$. long, on $\mathrm{W}$ coast of Harris Penin., $5 \mathrm{mi}$. NW of Aligo Point, 33 mi. SW of Seward, Chugach Mts.; $59^{\circ} 41^{\prime} 45^{\prime \prime}$ N, 149 $49^{\prime} 00^{\prime \prime}$ W; BGN 1930; (map 49).

So named by the 1928 USC\&GS field party "because of its being encircled by ridges of of igneous rock."

Crater Bay: bight, $1.3 \mathrm{mi}$. wide, faces Bering Sea on W coast of Davidof I., Rat Is., Aleutian Is.; $51^{\circ} 58^{\prime} 15^{\prime \prime} \mathrm{N}, 178^{\circ} 20^{\prime} 10^{\prime \prime} \mathrm{E}$; $B G N$ 1930; (map 15).

Named in 1928 by USC\&GS "because it is partly encircled by ridges of igneous rock."

Crater Cove: cove, $0.7 \mathrm{mi}$. across, between Chaika Rock and Ragged Point, on SE coast of Kagalaska I., Aleutian Is. ; $51^{\circ} 46^{\prime} 10^{\prime \prime} \mathrm{N}$, $176^{\circ} 17^{\prime} 00^{\prime \prime} \mathrm{W}$; (map 17).

Name published by USC\&GS in 1961 on Chart 9141.

Crater Creek: stream, heading on NE slope of Okmok Caldera, flowing NE to $\mathrm{N}$ coast of Umnak I., Aleutian Is.; $53^{\circ} 33^{\prime} \mathrm{N}, 167^{\circ} 59^{\prime}$ W; (map 23).

Name published by USGS (Byers, 1959, pl. 41). So named because it heads on a caldera or crater.

Crater Creek: stream; flows SW $16 \mathrm{mi}$. to Black Lake, $28 \mathrm{mi}$. NW of Chignik, on Alaska Penin., Bristol Bay Low.; $56^{\circ} 29^{\prime} \mathrm{N}, 159^{\circ} 04^{\prime} \mathrm{W}$; (map 30)

Name reported in 1923 by R. H. Sargent, USGS; so called because the creek heads in Purple Crater.

Crater Creek: stream, flows E $4.5 \mathrm{mi}$. to mouth of Speel River, $28 \mathrm{mi}$. SE of Juneau, Coast Mts. ; 58 $08^{\prime} 10^{\prime \prime} \mathrm{N}, 133^{\circ} 44^{\prime} 45^{\prime \prime} \mathrm{W}$; (map 12).

Local name published by Theodore Chapin (in Brooks and others, 1916, p. 107), USGS.

Crater Creek: stream, flows NW 6 mi. to South Fork Arolik River, $26 \mathrm{mi}$. NE of Goodnews, Kilbuck-Kuskokwim Mts.; $59^{\circ} 27^{\prime}$ N, $161^{\circ} 20^{\prime}$ W; (map 53).

Local name published in 1951 by USGS.

Crater Creek: stream, flows SE $9 \mathrm{mi}$. to Pilgrim River, $28 \mathrm{mi}$. NW of Solomon, Seward Penin. High.; 64 ${ }^{\circ} 55^{\prime} \mathrm{N}, 164^{\circ} 52^{\prime} \mathrm{W}$; (map 95).

Prospectors' name reported in 1900 by E. C. Barnard (in Brooks, 1901, pl. 17), USGS.

Crater Creek: stream, flows SW 2 mi. to American Greek which flows to Niukluk River, 27 mi. $\mathbf{N}$ of Soloman, Seward Penin. High.; $64^{\circ}-$ $56^{\prime} \mathrm{N}, 164^{\circ} 30^{\prime} \mathrm{W}$; (map 95)

Prospectors' name reported in 1908 by P. S. Smith (in Brooks and others, 1909, pl. 10), USGS.
Crater Greek: stream, flows NE $3.5 \mathrm{mi}$. to Bear Creek, $20 \mathrm{mi}$. NE to Livengood, Yukon-Tanana High.; $65^{\circ} 43^{\prime} 30^{\prime \prime} \mathrm{N}, 148^{\circ} 01^{\prime} 15^{\prime \prime} \mathrm{W}$; (map 105).

Local name reported in 1903 by USGS (Prindle, 1905, pl. 16).

Crater Creek: stream, flows W $19 \mathrm{mi}$. to East Fork Chandalar River $12 \mathrm{mi}$. NE of mouth of that stream and $41 \mathrm{mi}$. SE of Chandalar, Brooks Ra.; $67^{\circ} 16^{\prime} 15^{\prime \prime}$ N. $147^{\circ} 04^{\prime} 00^{\prime \prime} \mathrm{W}$; (map 123). Var. Cornucopia Creek.

Prospectors' name obtained in 1909 by A. G. Maddren (in Brooks and others, 1910, pl. 7), USGS.

Crater Hill: hill, $525 \mathrm{ft}$., on west-central St. Paul I., in Pribilof Is.; $57^{\circ} 11^{\prime} 05^{\prime \prime} \mathrm{N}, 170^{\circ}$ 20'00" W; (map 38).

Name published in 1875 by USG\&GS; probably obtained from Elliott (1881, St. Paul map) who was there in 1873-74. It is so named because it is reported to be an extinct volcanic crater.

Crater Hill: mountain, $1,869 \mathrm{ft}$., $65 \mathrm{mi}$. SW of Dome Mountain, $7.5 \mathrm{mi}$. SE of Goodnews, Kilbuck-Kuskokwim Mts.; $59^{\circ} 01^{\prime} \mathrm{N}, 161^{\circ}$. $32^{\prime} \mathrm{W}$; (map 53 ).

Local descriptive name published in 1938 by USGS.

Crater Lake: lake, $0.5 \mathrm{mi}$. across, on Annette I., $0.7 \mathrm{mi}$. SE of Tamgas Mtn. and $23 \mathrm{mi}$. SE of Ketchikan, Alex. Arch.; 55 $03^{\circ} 30^{\prime \prime} \mathrm{N}, 131^{\circ}$ 22'30"' W; BGN 1917; (map 3).

Descriptive name given in 1917 by USC\&GS.

Crater Lake: lake, 2 mi. long on Crater Creek, $27 \mathrm{mi}$. SE of Juneau, Coast Mts.; $58^{\circ} 08^{\prime} 10^{\prime \prime}$ $\mathrm{N}, 133^{\circ} 46^{\prime} 15^{\prime \prime} \mathrm{W}$; (map 12).

Local name published by Theodore Chapin (in Brooks and others, 1916, p. 107), USGS.

Crater Lake: lake, $1.6 \mathrm{mi}$. across, 3,700 ft. below the crater rim, in crater of Mount Katmai, on Alaska Penin., in Katmai National Monument, $47 \mathrm{mi}$. NW of Karluk, Aleutian Ra.; $58^{\circ} 16^{\prime} \mathrm{N}, 154^{\circ} 59^{\prime} \mathrm{W}$; (map 42).

Descriptive name given by R. F. Griggs of the National Geographic Society (1922, map). Crater Lake: lake, $2 \mathrm{mi}$. long, at 1950 terminus of Malaspina Glacier, $8 \mathrm{mi}$. $\mathrm{E}$ of head of Glacier Bay and $59 \mathrm{mi}$. NW of Yakutat, St. Elias Mts.; $60^{\circ} 04^{\prime} \mathrm{N}, 141^{\circ} 03^{\prime} \mathrm{W}$; (map 65).

Descriptive name given by Libbey (1886, p. 298) of Princeton Univ.

Crater Lake: lake, $0.3 \mathrm{mi}$. long, $1 \mathrm{mi}$. E of Orca Inlet, $2.5 \mathrm{mi}$. NE of Cordova, Chugach Mts.; $60^{\circ} 34^{\prime} \mathrm{N}, 145^{\circ} 42^{\prime} \mathrm{W}$; (map 64).

Local descriptive name published in 1951 by USGS

Crater Lake: lake, $0.1 \mathrm{mi}$. across, $1.2 \mathrm{mi}$. E of Robe Lake and $6 \mathrm{mi}$. ESE of Valdez, Chugach Mts. ; $61^{\circ} 05^{\prime} 15^{\prime \prime} \mathrm{N}, 146^{\circ} 04^{\prime} 30^{\prime \prime} \mathrm{W}$; (map 68).

Local name published in 1950 by USGS.

Crater Lake: lake, $2 \mathrm{mi}$. long, $\mathrm{S}$ of Black River, $23 \mathrm{mi}$. SW of junc. of Oshetna and Susitna Rivers, Talkeetna Mts.; $62^{\circ} 21^{\prime} 40^{\prime \prime} \mathrm{N}$, $147^{\circ} 47^{\prime} 30^{\prime \prime} \mathrm{W}$; (map 82).

Local descriptive name reported in 1956 by USGS. Name is a misnomer. The lake is 
a glacial lake and is located in a glaciated valley.

Crater Mountain: hill, $640 \mathrm{ft}$., on mainland, 6 mi. S of St. Michael, Yukon-Kuskokwim Delta; $63^{\circ} 22^{\prime} 10^{\prime \prime} \mathrm{N}, 162^{\circ} 05^{\prime} 30^{\prime \prime} \mathrm{W}$; (map 92).

Named in 1898 by USC\&GS; "It is the largest and tallest of three extinct volcanoes just south of St. Michael Canal."

Crater Mountain: mountain, 3,765 ft., at SE end of Beaver Mts., $38 \mathrm{mi}$. SW of McGrath, Kilbuck-Kuskokwim Mts.; 62 $48^{\prime} 30^{\prime \prime} \mathrm{N}, 156^{\circ}$ $48^{\prime} 00^{\prime \prime} \mathrm{W}$; (map 79).

Prospectors' name reported in 1913 by H. M. Eakin (in Brooks and others, 1913, pl. 11), USGS.

Crater Mountain: mountain, 2,262 ft., $4 \mathrm{mi}$. SW of Mount Distin and $17 \mathrm{mi}$. NNW of Nome Seward Penin. High.; $64^{\circ} 45^{\prime} \mathrm{N}, 165^{\circ} 32^{\prime} \mathrm{W}$; (map 94).

Prospectors' name reported on a map of Cape Nome gold fields by David Fox, Jr., dated 1901.

Crater Peak: peak, 7,575 ft., on Mount Spurr, in Tordrillo Mts., $39 \mathrm{mi}$. NW of Tyonek, Alaska Ra.; $61^{\circ} 16^{\prime} 10^{\prime \prime} \mathrm{N}, 152^{\circ} 14^{\prime} 15^{\prime \prime} \mathrm{W}$; $B G N$ 1930; (map 70).

Named by S. R. Capps and R. H. Sargent (in Smith and others, 1930, pl. 3), USGS, "when they discovered and mapped the crater-like peak in 1927."

Crater Point: promontory, on E tip of Otter I., in Pribilof Is.; $57^{\circ} 02^{\prime} 45^{\prime \prime} \mathrm{N}, 170^{\circ} 23^{\prime} 10^{\prime \prime} \mathrm{W}$; (map 38).

Descriptive name given by Elliott (1881, St. Paul notes) in 1874 "because of a funnelshaped cavity facing the sea."

Crater Ridge: ridge, 2 mi. long, on Kruzof I., 2 mi. NE of Mount Edgecumbe, $14 \mathrm{mi}$. W of Sitka, Alex. Arch.; 57 $05^{\prime} \mathrm{N}, 135^{\circ} 43^{\prime} \mathrm{W}$; BGN 1938; (map 9).

Named in 1936 by USFS because this is the north rim of the crater of an extinct volcano.

Craven, Point: point of land, $\mathrm{W}$ entrance to Florence Bay, on SE tip of Chichagof I., Alex. Arch.; $57^{\circ} 28^{\prime} \mathrm{N}, 134^{\circ} 52^{\prime} \mathrm{W}$; (map 9). Var. Mys Tlyakhinikut, Point Graven, Point Tlakinikut, Point Tliankhini, Point Williams

Named in 1869 by Comdr. R. W. Meade, USN, for Adm. Thomas Tingey Craven, USN. The "correct native [Tlingit Indian] name is said to be T'liankhini"' (Baker, 1906, p. 201); published as "Tlyakhinikut" by Capt. Tebenkov $(1852, \operatorname{map} 8)$, IRN.

Crawfish Cove: cove, see Model Cove.

Crawfish Inlet: estuary, $8 \mathrm{mi}$. long, on W coast of Baranof I., $22 \mathrm{mi}$. SE of Sitka, Alex. Arch.; $56^{\circ} 45^{\prime}$ N, $135^{\circ} 12^{\prime}$ W; (map 5). Var. Rakof Bay, Rakovoi Bay, Rokovay Bay, Zaliv Rakov.

Name published by USC\&GS in the 1883 Coast Pilot (p. 135); translated from "Zaliv Rakov," which was published in 1849 by the Russian American Company.

Crawford Creek: stream, flows N 3 mi. to Chena River, $37 \mathrm{mi}$. ENE of Fairbanks, YukonTanana High.; $64^{\circ} 53^{\prime} 45^{\prime \prime} \mathrm{N}, 146^{\circ} 25^{\prime} 00^{\prime \prime} \mathrm{W}$; (map 101).
Local name reported in 1958 by USGS. Crazy Mountains: mountains, 3,700 ft., trend W $30 \mathrm{mi}$. from junc. of Birch and Crooked Creeks, $18 \mathrm{mi}$. SW of Circle, Yukon-Tanana High.; $65^{\circ} 45^{\prime} \mathrm{N}, 144^{\circ} 50^{\prime} \mathrm{W}$; (map 104).

Local name reported in 1896 by USGS (Spurr, 1898, pl. 39).

Crazy Notch: pass, 3,700 ft., on Denali Highway, $W$ of Maclaren River, $35 \mathrm{mi}$. NW of

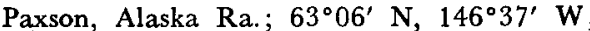
$B G N 1960$; (map 86).

Named in 1954 by USGS geologists because "the geologic history and relations of the notch are so unusual and inexplicable that the term 'Crazy Notch' was coined in the field.'

Crazy Slough: stream, distributary of Chandalar River, flows SW $30 \mathrm{mi}$. to Yukon River at Deadman I., $31 \mathrm{mi}$. W of Fort Yukon, Yukon Flats; $66^{\circ} 32^{\prime} \mathrm{N}, 146^{\circ} 25^{\prime} \mathrm{W}$; (map 119).

Local descriptive name obtained in 1956 by USGS.

Crazy Wolf Creek: stream, heads on the W slope of Mount Eldridge, flows SW $20 \mathrm{mi}$. to the North Fork Fortymile River, $32 \mathrm{mi}$. SW of Eagle, Yukon-Tanana High.; 64. $35^{\prime} 30^{\prime \prime} \mathrm{N}$ $142^{\circ} 09^{\prime} 15^{\prime \prime}$ W ; (map 102). Var. Crazy Dog Creek.

Prospectors' name shown on an 1898 fieldsheet by E. C. Barnard, USGS, with the following note: "Wild wolf kept tied here." The name, however, was never published by USGS.

Cream Brook: stream, see Lazy Creek.

Creede Creek: stream, flows $W$ to head of Bis Four Creek which flows to Casadepaga River, about $18 \mathrm{mi}$. NE of Solomon, Seward Penin High.; (map 95).

Prospectors' name reported on the 1900 "Map of Nome Peninsula" by J. M. Davidson and B. D. Blakeslee. This stream cannot be precisely located on current maps.

Creek Point: point of land, on Annette I., on $\mathrm{F}$ shore of Tamgas Harbor, $21 \mathrm{mi}$. SE of Ketchikan, Alex. Arch.; $55^{\circ} 03^{\prime} 15^{\prime \prime}$ N, $131^{\circ} 30^{\prime} 35^{\prime \prime}$ W; (map 3)

So named in 1891 by USC\&GS because "a stream enters at this point."

Creek Point: point of land, on $\mathbf{E}$ coast of Halleck I., $12.5 \mathrm{mi}$. NW of Sitka, Alex. Arch.; 57 $12^{\prime} 55^{\prime \prime} \mathrm{N}, 135^{\circ} 29^{\prime} 50^{\prime \prime} \mathrm{W}$; (map 9).

Named in 1885 by USC\&GS and published in the 1891 Coast Pilot (p. 177).

Creigh, Cape: cliff, see Greig, Cape

Crescent Bay: bay, $0.3 \mathrm{mi}$. across, on $\mathrm{W}$ coast of Baranof I., E of Sitka, Alex. Arch.; $57^{\circ} 03^{\prime} 00^{\prime \prime}$ $\mathrm{N}, 135^{\circ} 19^{\prime} 30^{\prime \prime} \mathrm{W}$; (map 9)

Local descriptive name reported in 1951 by USGS.

Crescent Bay: bight, $2.2 \mathrm{mi}$. wide, $5.5 \mathrm{mi}$. E of Cape Kigun, on $\mathrm{N}$ coast of Atka I., Aleutian Is.; $52^{\circ} 02^{\prime} 15^{\prime \prime} \mathrm{N}, 175^{\circ} 14^{\prime} 00^{\prime \prime} \mathrm{W}$; (map 18)

Name published by the USC\&GS in the 1944 Aleutian Coast Pilot (p. 99).

Crescent Creek: stream, on Kenai Penin., heads at Crescent Lake, flows WNW $6 \mathrm{mi}$. to Quartz Creek, $28 \mathrm{mi}$. NW of Seward, Chugach Mts.; $60^{\circ} 29^{\prime} 55^{\prime \prime} \mathrm{N}, 149^{\circ} 41^{\prime} 10^{\prime \prime} \mathrm{W}$; BGN 1952; (map 63). Var. Lost Creek.
Local name reported in 1952 by USGS; derived from Grescent Lake.

Crescent Creek: stream, in Nutzotin Mts., flows N 3 mi. to East Fork Snag Creek $5 \mathrm{mi}$. SE of its junc. with Snag Creek, $8 \mathrm{mi}$. SE of Carden Lake, Alaska Ra.; $62^{\circ} 11^{\prime}$ N. $141^{\circ} 22^{\prime}$ W; (map 84)

Local name reported by USGS in 1959.

Crescent Creek: stream, flows W $8 \mathrm{mi}$. to Wapoo Creek 1 mi. E of its junc. with Innoko River, $46 \mathrm{mi}$. NW of Ophir and $74 \mathrm{mi}$. NW of McGrath, Innoko Low.; $63^{\circ} 39^{\prime} 45^{\prime \prime} \mathrm{N}, 157^{\circ} 27^{\prime}$ $00^{\prime \prime} \mathrm{W}$; (map 90).

Local name obtained from Joseph Ferris in 1954 by R. E. Isto, USGS.

Crescent Creek: stream, flows NE $28 \mathrm{mi}$. to Charley River, $70 \mathrm{mi}$. NW of Eagle, YukonTanana High.; 64 $57^{\circ} \mathrm{N}, 143^{\circ} 33^{\prime} \mathrm{W}$; (map 102).

Local name reported in 1943 by USGS.

Crescent Glacier: glacier, trends NW $5.5 \mathrm{mi}$., on $\mathrm{E}$ bank of College Fiord, $55 \mathrm{mi}$. SW of Valdez, Chugach Mts.; 61 $01^{\prime} 15^{\prime \prime} \mathrm{N}, 147^{\circ} 54^{\prime} 30^{\prime \prime} \mathrm{W}$; (map 69)

A descriptive name given in 1898 by members of the Harriman Alaska Expedition.

Crescent Island: island, $2 \mathrm{mi}$. long, in Tanana River, $6 \mathrm{mi}$. W of Minto and $49 \mathrm{mi}$. W of Fairbanks, Tanana Low.; 64 $53^{\prime} 30^{\prime \prime}$ N, $149^{\circ} 20^{\prime} 00^{\prime \prime} \mathrm{W}$; (map 100).

Descriptive name published in 1950 by USGS.

Crescent Island: island, $1.7 \mathrm{mi}$. long, in Yukon River, $4 \mathrm{mi}$. $\mathrm{N}$ of Maypole Hill and $20 \mathrm{mi}$. NE of Rampart, Kokrines-Hodzana High.; $65^{\circ} 45^{\prime} \mathrm{N}, 1^{\circ} 49^{\circ} 50^{\prime} \mathrm{W}$; (map 105).

Local name published by USGS in the 1950's.

Crescent Lake: lake, $3.8 \mathrm{mi}$. long, $3 \mathrm{mi}$. $\mathrm{N}$ of Snow Tower, $40 \mathrm{mi}$. ESE of Juneau, Coast Mts. ; 58 $11^{\prime} 30^{\prime \prime} \mathrm{N}, 133^{\circ} 19^{\prime} 35^{\prime \prime} \mathrm{W}$; (map 12).

Local name reported in 1951 by USGS.

Crescent Lake: lake, $7 \mathrm{mi}$. long, in course of Lake Fork Crescent River, $56 \mathrm{mi}$. WSW of Kenai, Aleutian Ra.; $60^{\circ} 22^{\prime} \mathrm{N}, 152^{\circ} 55^{\prime} \mathrm{W}$; (map 62).

Local name reported in 1958 by USGS.

Crescent Lake: lake, on Kenai Penin., on V' side of Madson Mt., extends E-W 6 mi., $25 \mathrm{mi}$. NW of Seward, Chugach Mts.; $60^{\circ} 27^{\prime} \mathrm{N}$, $149^{\circ} 31^{\prime} \mathrm{W}$; BGN 1952; (map 63). Var. Lost Lake.

So named in 1952 by USGS "because of the shape of the lake."

Crescent Mountain: mountain, 4,770 ft., $1.8 \mathrm{mi}$. $\mathrm{NE}$ of terminus of Moser Glacier; St. Elias Mts. ; $59^{\circ} 35^{\prime} 25^{\prime \prime} \mathrm{N}, 139^{\circ} 00^{\prime} 50^{\prime \prime} \mathrm{W}$; (map 46).

Descriptive name given by Blackwelder (1907, p. 421), USGS, because of "the crescent-shaped syncline of gray rock visible in its summit."

Crescent River: stream, formed by junc. of its North and Lake Forks, flows SE $12 \mathrm{mi}$. to mouth of Tuxedni Bay in Cook Inlet, Aleutian Ra.; $60^{\circ} 13^{\prime} 30^{\prime \prime} \mathrm{N}, 152^{\circ} 33^{\prime} 30^{\prime \prime} \mathrm{W}$; (map 62). Var. Grecian River.

Local name reported in 1958 by USGS. 
Creston Creek: stream, flows NW $3 \mathrm{mi}$. to Colorado Creek, $53 \mathrm{mi}$. NW of Medfra, Kilbuck-Kuskokwim Mts.; $63^{\circ} 37^{\prime} \mathrm{N}, 156^{\circ} 00^{\prime} \mathrm{W}$; (map 89).

Local name reported in 1954 by USGS.

Crete Creek: stream, flows SW $11 \mathrm{mi}$. to Bering Sea, $39 \mathrm{mi}$. NW of Nome, Seward Penin. High.; 64ํ․ $52^{\prime} \mathrm{N}, 166^{\circ} 24^{\prime} \mathrm{W}$; (map 94).

Prospectors' name reported in 1900 by E. C. Barnard (in Brooks, 1901, pl. 17), USGS.

Crevice Creek: stream, flows NE 5 mi. to Paint River, $7.3 \mathrm{mi}$. SE of Spectacle Lake and $46 \mathrm{mi}$. SW of Augustine I., Aleutian Ra.; 59 $08^{\prime} 30^{\prime \prime}$ N, 154 $37^{\prime} 30^{\prime \prime} \mathrm{W}$; (map 51).

Local descriptive name published on the USGS Kamishak-Katmai map of 1926.

Crevice Creek: stream, flows W $4.4 \mathrm{mi}$. to Crooked Creek, $10 \mathrm{mi}$. NW of its junc. with Kuskokwim River and $10 \mathrm{mi}$. NW of village of Crooked Creek, Kilbuck-Kuskokwim Mts.; $61^{\circ} 59^{\prime} 10^{\prime \prime} \mathrm{N}, 158^{\circ} 15^{\prime} 10^{\prime \prime} \mathrm{W}$; (map 72).

Descriptive name reported in 1910 by C. G. Anderson (in Eakin, 1914, pl. 1), USGS.

Crevice Creek: stream, in Kantishna Hills, flows WNW $2.8 \mathrm{mi}$. to Caribou Creek, $9 \mathrm{mi}$.

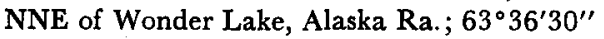
$\mathrm{N}, 150^{\circ} 46^{\prime} 35^{\prime \prime} \mathrm{W}$; (map 88).

Local name shown on a 1916 fieldsheet by C. E. Giffin, USGS.

Crevice Creek: stream, flows W $9 \mathrm{mi}$. to John River, $0.5 \mathrm{mi}$. $\mathrm{S}$ of mouth of Allen River, $8 \mathrm{mi}$. S of Gunsight Mtn. and $51 \mathrm{mi}$. W of Wiseman, Brooks Ra.; $67^{\circ} 22^{\prime} \mathrm{N}, 152^{\circ} 02^{\prime} \mathrm{W}$; (map 124).

Local name shown on an 1899 fieldsheet by T. G. Gerdine, USGS.

Cribbee Creek: stream, flows SE $5 \mathrm{mi}$. to Kuskokwim River, $1.3 \mathrm{mi}$. N of Red Devil and $7 \mathrm{mi}$. NW of Sleetmute, Kilbuck-Kuskokwim Mts.; $61^{\circ} 46^{\prime} 45^{\prime \prime} \mathrm{N}, 157^{\circ} 18^{\prime} 40^{\prime \prime} \mathrm{W}$; (map 72). Var. Cribby Greek.

Locally named for W. J. Cribbee, trapper and prospector; reported in 1943 by USGS.

Cribbs Creek: stream, see Crab Creek.

Cribby Creek: stream, see Cribbee Creek.

Crib Creek: stream, see Crab Creek.

Crib Point: point of land, on $\mathrm{E}$ shore of Speel Arm, $2.5 \mathrm{mi}$. NNE of Bogert Point, $29 \mathrm{mi}$. SE of Juneau, Coast Mts.; $58^{\circ} 05^{\prime} 50^{\prime \prime} \mathrm{N}$, $133^{\circ} 44^{\prime} 25^{\prime \prime} \mathrm{W}$; (map 12).

Local name reported in 1951 by USGS.

Crillon, Mount: mountain, $12,700 \mathrm{ft}$., in Fairweather Ra., in Glacier Bay National Monument at head of Perouse Glacier, St. Elias Mts. ; $58^{\circ} 39^{\prime} 45^{\prime \prime} \mathrm{N}, 137^{\circ} 10^{\prime} 15^{\prime \prime} \mathrm{W}$; (map 10). Var. Gora Krilon.

Named by La Pérouse (1797, v. 2, p. 219) about July 2, 1786, for Gen. Louis des Balbes de Berton, Duke of Crillon, 1543-1615, "who distinguished himself at Lepanto and fought for Henri III and Henri IV" (Farquhar, 1959, p. 215).

Crillon, Mount: mountain, see Lituya Mountain. Crillon Glacier: glacier, see North Crillon Glacier.

Crillon Inlet: cove, $1.4 \mathrm{mi}$. long, in Glacier Bay National Monument, at head of Lituya Bay, at terminus of North Crillon Glacier, $83 \mathrm{mi}$.
NW of Hoonah, St. Elias Mts.; $58^{\circ} 39^{\prime} 45^{\prime \prime} \mathrm{N}$, $137^{\circ} 28^{\prime} 45^{\prime \prime} \mathrm{W}$; (map 10).

Local name published by USGS in the 1950's.

Crillon Lake: lake, $4 \mathrm{mi}$. long, in Glacier Bay National Monument, extends S from terminus of South Grillon Glacier to Grillon River, 77 mi. NW of Hoonah, St. Elias Mts.; 58 $32^{\prime} 10^{\prime \prime}$ N, $137^{\circ} 23^{\prime} 35^{\prime \prime} \mathrm{W}$; (map 10).

Local name published by USGS in the 1950's.

Crillon River: stream, in Glacier Bay National Monument, heads in Crillon Lake, flows 1.5 mi. to Gulf of Alaska, $1 \mathrm{mi}$. NW of mouth of Dagelet River and $77 \mathrm{mi}$. NW of Hoonah, Malaspina Coastal Plain; 58 $31^{\prime} 25^{\prime \prime} \mathrm{N}, 137^{\circ}$ $25^{\prime} 00^{\prime \prime} \mathrm{W}$; (map 10).

Local name published by USGS in the 1950's.

Cripple: locality, on $\mathrm{E}$ bank of Innoko River, $\mathrm{S}$ of junc. of Caribou Creek, $34 \mathrm{mi}$. $\mathrm{N}$ of Ophir, Kilbuck-Kuskokwim Mts. ; $63^{\circ} 37^{\prime} 20^{\prime \prime}$ N, $156^{\circ} 20^{\prime} 30^{\prime \prime} \mathrm{W}$; (map 90).

Mining supply camp and landing, now abandoned, established about 1912.

Cripple Creek: locality, on left bank of Cripple River, near Arctic Creek, $15 \mathrm{mi}$. NW of Nome, Seward Penin. High.; 64 $37^{\prime}$ N, $165^{\circ} 51^{\prime} \mathrm{W}$; (map 94).

Site of a mining camp reported about 1940 by USC\&GS and published on Chart 9302.

Cripple Creek: stream, heads on SE slope of Twin Mtn., flows SW and NW $12 \mathrm{mi}$. to Kuskokwim Bay, $24 \mathrm{mi}$. NW of Goodnews, Kilbuck-Kuskokwim Mts.; $59^{\circ} 25^{\prime} \mathrm{N}, 161^{\circ} 21^{\prime}$ W; BGN 1939; (map 53).

Local name published by Harrington (in Brooks and others, 1921, pl. 7), USGS.

Cripple Greek: stream, flows N 12 mi. to Salmon River, $76 \mathrm{mi}$. E of Bethel, Kilbuck-Kuskokwim Mts.; $60^{\circ} 48^{\prime} \mathrm{N}, 159^{\circ} 32^{\prime} \mathrm{W}$; (map 59).

Prospectors' name reported in 1914 by A. G. Maddren (in Brooks, 1915, pl. 11), USGS.

Cripple Creek: stream, on N end of Kenai Penin., flows NE $4 \mathrm{mi}$. to Resurrection Creek at Hope, Chugach Mts.; $60^{\circ} 54^{\prime} 55^{\prime \prime} \mathrm{N}, 149^{\circ} 38^{\prime} 30^{\prime \prime} \mathrm{W}$; (map 63).

Local prospectors' name reported in 1904 by Moffit (1906, pl. 2), USGS.

Cripple Creek: stream, flows SE $8 \mathrm{mi}$. to Chelatna Lake, $47 \mathrm{mi}$. NW of Talkeetna, Alaska Ra.; $62^{\circ} 31^{\prime} 40^{\prime \prime} \mathrm{N}, 151^{\circ} 31^{\prime} 30^{\prime \prime} \mathrm{W}$; (map 81).

Prospectors' name reported in 1906 by $R$. W. Porter, USGS.

Cripple Creek: stream, flows NW $6.2 \mathrm{mi}$. to Graham Creek $3.7 \mathrm{mi}$. S of its junc. with Colorado Creek, $34 \mathrm{mi}$. NE of Ophir and 46 mi. NW of McGrath, Kilbuck-Kuskokwim Mts.; $63^{\circ} 35^{\prime} 30^{\prime \prime} \mathrm{N}, 156^{\circ} 08^{\prime} 15^{\prime \prime} \mathrm{W}$; (map 90).

Prospectors' name reported in 1915 by J. B. Mertie, Jr., and G. L. Harrington, USGS.

Cripple Creek: stream, flows NW 5 mi. to Healy Creek, $7.4 \mathrm{mi}$. NE of Healy, Alaska Ra.; $63^{\circ}$ $53^{\prime} \mathrm{N}, 148^{\circ} 44^{\prime} \mathrm{W}$; (map 87).

Local name reported in 1916 by G. C. Martin (1919, pl. 2), USGS.
Cripple Creek: stream, flows NW $3 \mathrm{mi}$. to Mission Creek, $10 \mathrm{mi}$. W of Eagle, Yukon-Tanana High.; 64 $45^{\prime} 25^{\prime \prime} \mathrm{N}$; $141^{\circ} 31^{\prime} 40^{\prime \prime} \mathrm{W}$; (map 102).

Prospectors' name obtained in 1898 by E. C. Barnard, USGS.

Cripple Creek: stream, flows NE $1.9 \mathrm{mi}$. to Lower Willow Creek which flows to Casadepaga River, $18 \mathrm{mi}$. N of Solomon, Seward Penin. High.; $64^{\circ} 48^{\prime} 50^{\prime \prime} \mathrm{N}, 164^{\circ} 30^{\prime} 05^{\prime \prime} \mathrm{W}$; (map 95).

Prospectors' name reported on a map of Cape Nome gold fields by David Fox, Jr., dated 1901.

Cripple Creek: stream, flows NE and S $9 \mathrm{mi}$. around Chena Ridge to Chena River, $5 \mathrm{mi}$. SW of Fairbanks, Yukon-Tanana High.; $64^{\circ}$ $49^{\prime} 50^{\prime \prime} \mathrm{N}, 147^{\circ} 53^{\prime} 00^{\prime \prime} \mathrm{W}$; (map 100).

Local name shown on Tanana Mines RR. location map dated 1904.

Cripple Creek: stream, flows N 1 mi. to Pilot Creek, 22 mi. NE of Fairbanks, Yukon-Tanana High.; $65^{\circ} 07^{\prime} 30^{\prime \prime} \mathrm{N}, 147^{\circ} 23^{\prime} 20^{\prime \prime} \mathrm{W}$; (map 105).

Named by prospectors; published in 1908 by USGS.

Cripple Creek: stream, flows SW $5 \mathrm{mi}$. to Chatanika River, $45 \mathrm{mi}$. NE of Fairbanks, YukonTanana High.; $65^{\circ} 16^{\prime} 30^{\prime \prime} \mathrm{N}, 146^{\circ} 39^{\prime} 00^{\prime \prime} \mathrm{W}$; (map 104).

Named by prospectors; reported in 1903 by T. G. Gerdine (in Prindle, 1905, pl. 13), USGS.

Cripple Creek: stream, flows NW $2 \mathrm{mi}$. to Eagle Creek, $5 \mathrm{mi}$. SSE of Porcupine Dome and 47 mi. SW of Circle, Yukon-Tanana High.; $65^{\circ} 26^{\prime} 40^{\prime \prime} \mathrm{N}, 145^{\circ} 27^{\prime} 00^{\prime \prime} \mathrm{W}$; (map 104).

Named by prospectors and reported in 1912 by Ellsworth and Davenport (1915b, p. 180), USGS.

Cripple Creek: stream, see Bear Creek.

Cripple Creek: stream, see Cripple River.

Cripple Creek: stream, See Jacksmith Creek.

Cripple Creek Mountains: mountains, 3,200 ft., in group $4 \mathrm{mi}$. across, in Kuskokwim Mts., 17 mi. NW of Page Mtn. and $50 \mathrm{mi}$. NW of Med-

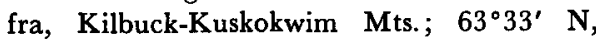
$156^{\circ} 00^{\prime} \mathrm{W}$; (maps 89, 90).

Local name reported in 1913 by USGS.

Cripple Landing: locality, on $\mathrm{E}$ bank of Innoko River, $\mathrm{N}$ of junc. of Hunch Creek and $38 \mathrm{mi}$ $\mathrm{N}$ of Ophir, Innoko Low.; $63^{\circ} 41^{\prime} 15^{\prime \prime} \mathrm{N}$, $156^{\circ} 22^{\prime} 30^{\prime \prime} \mathrm{W}$; (map 90).

Local name reported in 1954 by USGS.

Cripple Mountains: mountains, 4,000 ft., in Kilbuck Mts., $14 \mathrm{mi}$. SE of Fisher Dome and 71 mi. SE of Bethel, Kilbuck-Kuskokwim Mts.; $60^{\circ} 39^{\prime} \mathrm{N}, 159^{\circ} 40^{\prime} \mathrm{W}$; (map 59).

Local name reported in 1955 by J. M. Hoare, USGS.

Cripple River: stream, flows SW $25 \mathrm{mi}$. to Norton Sound, $12 \mathrm{mi}$. W. of Nome, Seward Penin. High.; 64 $32^{\prime} \mathrm{N}, 165^{\circ} 48^{\prime} \mathrm{W}$; (map 94). Var. Cripple Creek.

Prospectors' name reported in 1899 by $\mathbf{D}$. C. Witherspoon (in Schrader and Brooks, 1900, map 2), USGS. 
Cripple River: stream, flows NE $17 \mathrm{mi}$. to Goodhope Bay, $27 \mathrm{mi}$. SW of Deering, KotzebueKobuk Low.; $66^{\circ} 04^{\prime} \mathrm{N}, 163^{\circ} 41^{\prime} \mathrm{W}$; (map 113).

Local name reported in 1903 by Moffit (1905, pl. 2), USGS.

Cristina Island: island, group at high water (once connected), extends $1,000 \mathrm{ft}$., between Bucareli Bay and Port Mayoral, on NE coast of Baker I., Alex. Arch.; 55 $22^{\prime} 45^{\prime \prime}$ N, $133^{\circ} 27^{\prime}$ $05^{\prime \prime}$ W; (map 4). Var. Isla Cristina, Ostrov Krestina, Ysla Cristina.

Spanish name given in $1775-79$ by Don Juan de la Bodega y Quadra and Francisco Antonio Maurelle as "Isla Cristina," meaning "Christina Island."

Crist Point: point of land, on N coast of Chichagof I., at mouth of Port Frederick, $4.5 \mathrm{mi}$. NW of Hoonah, Alex. Arch.; 58 $10^{\prime} 15^{\prime \prime} \mathrm{N}$, $135^{\circ} 29^{\prime} 30^{\prime \prime}$ W ; (map 11). Var. Entrance Point.

Named in 1901 for F. G. Crist, deck officer of the USC\&GS steamer Gedney. It was called "Entrance Point" in 1899 by the USC\&GS.

Cristy Point: point of land, see Christie Point.

Crittenden Creek: stream, heads between Garnet Mountain and Wrangell Peak, flows S $8.5 \mathrm{mi}$. to Eastern Passage, $6 \mathrm{mi}$. E of Wrangell, Coast Mts.; $56^{\circ} 30^{\prime} 00^{\prime \prime} \mathrm{N}, 132^{\circ} 15^{\prime} 15^{\prime \prime} \mathrm{W}$; (map 6).

Local name recorded in 1953 by USGS

Crocker Creek: stream, flows S $3.5 \mathrm{mi}$. to Knik Arm, $7.5 \mathrm{mi}$. NW of Birchwood and $20 \mathrm{mi}$. NE of Anchorage, Cook Inlet Low.; $61^{\circ} 29^{\prime} 40^{\prime \prime} \mathrm{N}, 149^{\circ} 36^{\prime} 15^{\prime \prime} \mathrm{W}$; (map 69).

Local name reported in 1951 by USGS

Grone Island: island, $1.5 \mathrm{mi}$. long, off $\mathrm{S}$ coast of Adak I., Aleutian Is.; $51^{\circ} 40^{\prime} \mathrm{N}, 176^{\circ} 38^{\prime} \mathrm{W}$ (map 17).

Name published by USC\&GS in 1957 on Chart 9193.

Gronin Island: island, $0.3 \mathrm{mi}$. long, one of Herring Is., at NE entrance to Kasitsna Bay, $7 \mathrm{mi}$ $\mathrm{NE}$ of Seldovia, Chugach Mts.; $59^{\circ} 29^{\prime} \mathrm{N}$, $151^{\circ} 31^{\prime} \mathrm{W}$; ( $\operatorname{map} 50$ ).

Local name published by USGS in 1951 .

Cronin Island: island, $5.5 \mathrm{mi}$. across, between Mason Slough and Yukon River, $5 \mathrm{mi}$. E of Birches, Kokrines-Hodzana High.; $65^{\circ} 07^{\prime}$ N, 153 $18^{\prime} \mathrm{W}$; (map 107).

Riverboat pilots' name shown on a 1940 "Navigation Chart of the Tanana-Yukon Rivers" published by the Department of the Interior.

Cronin Slough: stream, extends $\mathrm{S} 2 \mathrm{mi}$, between Cronin and Flora Is., from Mason Slough to Yukon River, $5 \mathrm{mi}$. E of Birches, KokrinesHodzana High.; $65^{\circ} 07^{\prime} 40^{\prime \prime} \mathrm{N}, 153^{\circ} 23^{\prime} 20^{\prime \prime} \mathrm{W}$; (map 107).

Riverboat pilots' name shown on a 1940 "Navigation Chart of the Tanana-Yukon Rivers" published by the Department of the Interior.

Grooked Creek: locality, on W bank of Crooked Creek $18 \mathrm{mi}$. NW of Eagle, Yukon-Tanana High.; $64^{\circ} 56^{\prime} \mathrm{N}, 141^{\circ} 40^{\prime} \mathrm{W}$; (map 102).

Mining camp reported in 1925 by ARC; probably now abandoned.
Crooked Creek: village, pop. 92, on $\mathrm{N}$ bank of Kuskokwim River, E of junc. of Crooked Creek, $33 \mathrm{mi}$. NW of Sleetmute and $50 \mathrm{mi}$. NE of Aniak, Kilbuck-Kuskokwim Mts.; 61 ${ }^{\circ} 52^{\prime}$ $15^{\prime \prime} \mathrm{N}, 158^{\circ} 06^{\prime} 30^{\prime \prime}$ W; (map 72). Var. Parent Roadhouse, Parents, Parents Trading Post, Portage Village.

Village established about 1909 near or at a small Indian village. G. C. Anderson, USGS, in 1910 reported it as "Portage Village" because it was at the south end of a portage route up Crooked Creek to the Iditarod placers. The Parent Trading Post was established here about 1918, and the locality took that name. A post office called "Crooked Creek" was established here in 1927 (Ricks, 1965 , p. 15). Its population was 48 in 1939 and 43 in 1950 . It is now primarily an Indian village.

Crooked Creek: stream, flows NW $26 \mathrm{mi}$. to Upper Ugashik Lake, on Alaska Penin., $30 \mathrm{mi}$. NE of Ugashik, Aleutian Ra.; 57 $38^{\prime} 15^{\prime \prime}$ $\mathrm{N}, 156^{\circ} 37^{\prime} 30^{\prime \prime} \mathrm{W}$; (map 36).

Local descriptive name reported in 1921 by Capps (1923, pl. 2), USGS, "because of its very winding course."

Crooked Creek: stream, flows SW 3 mi. to Gulf of Alaska, $2.8 \mathrm{mi}$. W of Umbrella Reef and 90 mi. W of Yakutat, St. Elias Mts.; $60^{\circ} 01^{\prime} 50^{\prime \prime}$ $\mathrm{N}, 142^{\circ} 07^{\prime} 30^{\prime \prime} \mathrm{W}$; (map 65)

Local descriptive name obtained in 1903 by G. C. Martin, USGS.

Crooked Creek: stream, on Kenai Penin., flows NW $27 \mathrm{mi}$. to Kasilof River, $16 \mathrm{mi}$. S of Kenai, Cook Inlet Low.; $60^{\circ} 19^{\prime} 15^{\prime \prime} \mathrm{N}, 1^{151^{\circ} .16^{\prime} 45^{\prime \prime}}$ W; (map 62).

Local descriptive name reported in 1950 by USGS.

Crooked Creek: stream, heads on Crooked Mts., flows NW $40 \mathrm{mi}$. to Kwethluk River, $65 \mathrm{mi}$. SE of Bethel, Kilbuck-Kuskokwim Mts.; $60^{\circ}$ $16^{\prime} \mathrm{N}, 160^{\circ} 16^{\prime} \mathrm{W}$; BGN 1959; (map 59). Var. Canyon Creek, Swift Creek.

Descriptive name given by prospectors about 1911-14; reported in 1955 by USGS.

Crooked Creek: stream, flows $W 4 \mathrm{mi}$. to Nushagak River, $1 \mathrm{mi}$. $\mathrm{N}$ of Big Bend and 90 mi. S of Sleetmute, Kilbuck-Kuskokwim Mts.; $60^{\circ} 26^{\prime} \mathrm{N}, 156^{\circ} 40^{\prime} \mathrm{W}$; (map 60).

Local name reported in 1952 by USC\&GS.

Crooked Creek: stream, heads in Arhymot Lake, flows SW $15 \mathrm{mi}$. to Johnson River, $26 \mathrm{mi}$. SE of Russian Mission, Yukon-Kuskokwim Delta; $61^{\circ} 33^{\prime} \mathrm{N}, 160^{\circ} 41^{\prime} \mathrm{W}$; (map 73).

Descriptive name shown on a 1919 fieldsheet by R. H. Sargent, USGS.

Crooked Creek: stream, heads at confluence of Flat and Donlin Creeks, flows SE $30 \mathrm{mi}$. to Kuskokwim River SW of village of Crooked Creek, $33 \mathrm{mi}$. WNW of Sleetmute, KilbuckKuskokwim Mts.; $61^{\circ} 52^{\prime} 10^{\prime \prime} \mathrm{N}, 158^{\circ} 08^{\prime} 00^{\prime \prime}$ W; BGN 1948; (map 72). Var. Nowat River.

Local name reported by the Alaska Road Commission on its 1923 map. In 1910 C. G. Anderson, USGS, reported the native name as "Nowat River."
Crooked Creek: stream, heads in lake, flows NE $16 \mathrm{mi}$. to Little Nelchina River, $12 \mathrm{mi}$. NE of Tahneta Pass, Talkeetna Mts.; 62 $06^{\prime} 15^{\prime \prime}$ N, $147^{\circ} 08^{\prime} 40^{\prime \prime} \mathrm{W}$; (map 82).

Local name published by G. C. Martin and J. B. Mertie, Jr. (in Brooks and others, 1914, pl. 11), USGS.

Crooked Creek: stream, flows SW $15 \mathrm{mi}$. to Kuskokwim River, $14 \mathrm{mi}$. SW of Medfra, Kilbuck-Kuskokwim Mts.; $63^{\circ} 00^{\prime} \mathrm{N}, 155^{\circ} 05^{\prime} \mathrm{W}$; BGN 1937; (map 89).

Local name published in 1926 by USGS.

Crooked Creek: stream, flows N $6.5 \mathrm{mi}$. to East Fork Chulitna River, $50 \mathrm{mi}$. S of Healy, Talkeetna Mts.; $63^{\circ} 09^{\prime} 30^{\prime \prime} \mathrm{N}, 149^{\circ} 09^{\prime} 00^{\prime \prime} \mathrm{W}$; (map 87).

Local descriptive name reported in 1922 by USGS.

Crooked Creek: stream, in Kantishna Hills, flows NE $12 \mathrm{mi}$. to Toklat River, $3.5 \mathrm{mi}$. N of junc. of that stream's Clearwater Fork, Alaska Ra.; 63 $51^{\prime} 45^{\prime \prime} \mathrm{N}, 150^{\circ} 15^{\prime} 20^{\prime \prime} \mathrm{W}$; (map 88).

Local name shown on a 1916 fieldsheet by C. E. Giffin, USGS.

Crooked Greek: stream, flows NE $2.4 \mathrm{mi}$. to Birch Creek, $20 \mathrm{mi}$. SE of Ruby, Kilbuck-

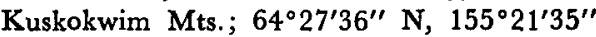
W; BGN 1936; (map 98).

Prospectors' name reported in 1913 by Eakin (1914, pl. 3), USGS

Crooked Creek: stream, heads at $64^{\circ} 25^{\prime} \mathrm{N}$, $147^{\circ} 55^{\prime} \mathrm{W}$, flows NW $24 \mathrm{mi}$. to Tanana River, 25 mi. SW of Fairbanks, Tanana Low.; $64^{\circ}$. $39^{\prime} \mathrm{N}, 148^{\circ} 17^{\prime} \mathrm{W}$; (map 100).

Descriptive name shown on a railroad manuscript map in 1914.

Crooked Creek: stream, flows SE $6 \mathrm{mi}$. to Seventymile River, $18 \mathrm{mi}$. NW of Eagle, Yukon-Tanana High.; $64^{\circ} 55^{\prime} \mathrm{N}, 141^{\circ} 41^{\prime} \mathrm{W}$; (map 102).

Prospectors' name obtained in 1898 by $\mathbf{E}$. C. Barnard, USGS; so named because of the many meanders near its mouth.

Crooked Creek: stream, flows SE $2.4 \mathrm{mi}$. to Ophir Creek, $8 \mathrm{mi}$. N of Council and $44 \mathrm{mi}$. SW of Imuruk Lake, Seward Penin. High.; $65^{\circ} 01^{\prime} \mathrm{N}, 163^{\circ} 39^{\prime} \mathrm{W}$; (map 110).

Prospectors' name reported in 1900 by $\mathrm{E}$ C. Barnard (in Brooks, 1901, pI. 17), USGS

Crooked Creek: stream, flows E $5 \mathrm{mi}$. to Chatanika River, $28 \mathrm{mi}$. NE of Fairbanks, Yukon-Tanana High.; $65^{\circ} 12^{\prime} \mathrm{N}, 147^{\circ} 14^{\prime} \mathrm{W}$; (map 105).

Descriptive name applied by prospectors; reported in 1908 by USGS (Covert and Ellsworth, 1909, pl. 2).

Crooked Creek: stream, flows E $9 \mathrm{mi}$. to Harrington Fork Birch Creek, $63 \mathrm{mi}$. SW of Circle, Yukon-Tanana High.; $65^{\circ} 16^{\prime} 45^{\prime \prime} \mathrm{N}, 145^{\circ} 49^{\prime}$ $10^{\prime \prime} \mathrm{W}$; (map 104).

Named by prospectors and reported in 1911 by USGS (Prindle, 1913, pl. 1).

Crooked Creek: stream, flows NE $3 \mathrm{mi}$. to Windy Creek which flows to Kougarok River, $49 \mathrm{mi}$. SW of Imuruk Lake, Seward Penin. High.; $65^{\circ} 27^{\prime} \mathrm{N}, 164^{\circ} 50^{\prime} \mathrm{W}$; (map 110).

Prospectors' name reported on the 1908 "Map of Seward Peninsula" by Arthur Gibson. 
Crooked Creek: stream, heads in Ray Mts., flows SW $21 \mathrm{mi}$. to Tozitna River, $26 \mathrm{mi}$. $\mathrm{N}$ of Tanana, Kokrines-Hodzana High; $65^{\circ} 33^{\prime} \mathrm{N}$, $152^{\circ} 07^{\prime} \mathrm{W}$; (map 106).

Local descriptive name reported in 1956 by Orth.

Crooked Creek: stream, heads at junc. of Mammoth and Porcupine Creeks, flows NE $26 \mathrm{mi}$. to Birch Creek, $18 \mathrm{mi}$. SW of Circle, YukonTanana High.; $65^{\circ} 37^{\prime} 45^{\prime \prime} \mathrm{N}, 144^{\circ} 26^{\prime} 00^{\prime \prime} \mathrm{W}$; (map 104).

Named by prospectors; reported in 1896 by USGS (Spurr, 1898, pl. 39).

Crooked Creek: stream, in Kallarichuk Hills of Baird Mts., flows W 4.8 mi. to Klery Creek, 20 mi. N of Kiana, Brooks Ra.; $67^{\circ} 15^{\prime} \mathrm{N}, 160^{\circ}$ 25' W; (map 127).

Name used by prospectors; reported in 1910 by P. S. Smith (in Brooks and others, 1911, pl. 13), USGS.

Crooked Creek: stream, flows SE $15 \mathrm{mi}$. to North Fork Chandalar River, $16 \mathrm{mi}$. WSW of Chandalar, Brooks Ra.; $67^{\circ} 17^{\prime} 00^{\prime \prime} \mathrm{N}, 148^{\circ} 48^{\prime} 30^{\prime \prime}$ W; BGN 1912; (map 123). Var. West Fork Chandalar River.

Prospectors' name obtained in 1909 by $\mathrm{A}$. G. Maddren (in Brooks and others, 1910, pl. 7), USGS.

Crooked Creek: stream, see Johnson Creek. Crooked Creek: stream, see Swift Creek.

Crooked Gulch: ravine, somewhere along Sheep Creek, about $5 \mathrm{mi}$. SE of Juneau, Coast Mts.; $58^{\circ} 16^{\prime} \mathrm{N}, 134^{\circ} 19^{\prime} \mathrm{W}$; (map 11 ).

Miners' name reported by DeArmond (1957, p. 39).

Crooked Island: island, $0.7 \mathrm{mi}$. long, $\mathrm{SE}$ of Near I., $1 \mathrm{mi}$. SE of Kodiak, on NE coast of Kodiak I.; $57^{\circ} 46^{\prime} 30^{\prime \prime} \mathrm{N}, 152^{\circ} 23^{\prime} 30^{\prime \prime} \mathrm{W}$; (map 34). Var. Krivoi Island, Ostrov Krivoy.

Translation of the name "Os[trov] Krivoy," published by Lt. Sarichev (1826, map 16), IRN.

Crooked Island: island, $6.5 \mathrm{mi}$. long, in Walrus Is., $20.5 \mathrm{mi}$. $\mathrm{E}$ of Hagemeister I., KilbuckKuskokwim Mts.; $58^{\circ} 40^{\prime} \mathrm{N}, 160^{\circ} 15^{\prime} \mathrm{W}$; (map 39). Var. Ostrov Nizkoy, Ostrov Nunalyugak, Ostrov Ugushtu.

Descriptive name given in 1890 by USBF. It was named "Os[trov]Nizkoy," meaning "low island," by Lt. Sarichev (1826, map 3), IRN. Capt. Tebenkov (1852, map 4), IRN, shows it as two islands with Eskimo names; the southern one "O[strov] Ugushtu" and the northern one "O[strov] Nunalyugak."

Crooked Island: island, see Kriwoi Island.

Crooked Lake: lake, $0.5 \mathrm{mi}$. long, E central Heceta I., Alex. Arch.; 55 $46^{\prime} 20^{\prime \prime}$ N, $133^{\circ}$ $25^{\prime} 30^{\prime \prime} \mathrm{W}$; (map 4).

Local name recorded in 1951 by USGS.

Crooked Lake: lake, $1 \mathrm{mi}$. long, on Kenai Penin., $1.5 \mathrm{mi}$. NW of King Lake and $37 \mathrm{mi}$. NE of Kenai, Cook Island Low.; $69^{\circ} 50^{\prime} 15^{\prime \prime} \mathrm{N}, 150^{\circ}$ $20^{\prime} 45^{\prime \prime} \mathrm{W}$; (map 62).

Named about 1963 by officials of Kenai National Moose Range, for administrative purposes.
Crooked Lake: lake, $9 \mathrm{mi}$. long, S of Holy Cross Hills, $4.5 \mathrm{mi}$. SW of Holy Cross, Nulato Hills; $62^{\circ} 07^{\prime} 30^{\prime \prime} \mathrm{N}, 160^{\circ} 00^{\prime} 00^{\prime \prime} \mathrm{W}$; (map 78).

Local descriptive name obtained in 1952 by USGS.

Crooked Mountain: mountain, 4,700 ft., between Kisaralik River and Canyon Creek, $15 \mathrm{mi}$. W of Chikuminuk Lake and $85 \mathrm{mi}$. SE of Bethel, Kilbuck-Kuskokwim Mts.; $60^{\circ} 14^{\prime} \mathrm{N}, 159^{\circ}$ 35' W; (map 59). Var. Crooked Mountains. Named in 1955 by J. M. Hoare, USGS, because Crooked Creek heads on its western slope.

Crooked Mountains: mountain, see Grooked Mountain.

Crooked River: stream, see Igushik River.

Crooze Island: island, see Kruzof Island.

Cropley Lake: lake, $0.2 \mathrm{mi}$. across, on Douglas I., $2 \mathrm{mi}$. SW of Table Top Mtn. and $5 \mathrm{mi}$. SW of Juneau, Coast Mts.; $58^{\circ} 15^{\prime} 50^{\prime \prime} \mathrm{N}, 134^{\circ}$ $31^{\prime} 15^{\prime \prime} \mathrm{W}$; (map 11).

Locally named for Issac Cropley, who came to Juneau about 1887 and worked for many years for a local mining company. He died in 1913 in Juneau (DeArmond, 1957, p. 13).

Crosby Creek: stream, heads $\mathbf{E}$ of Ear Mtn., flows $S 2 \mathrm{mi}$., then W $9 \mathrm{mi}$. to Kugrupaga River, $42 \mathrm{mi}$. $\mathrm{N}$ of Teller, Seward Penin. High.; $65^{\circ} 52^{\prime} \mathrm{N}, 166^{\circ} 26^{\prime} \mathrm{W}$; (map 111).

Prospectors' name reported in 1901 by $\mathrm{T}$. G. Gerdine (in Gollier, 1902, pl. 12), USGS. Cross, Cape: point of land, $\mathrm{S}$ tip of Takanis Penin., on Yakobi I., $25 \mathrm{mi}$. NW of Chichagof, Alex. Arch.; 57 $55^{\prime} 00^{\prime \prime} \mathrm{N}, 136^{\circ} 33^{\prime} 30^{\prime \prime} \mathrm{W}$; (map 9). Var. Mys Kresta.

Named on May 3, 1778, by Capt. James Cook, RN, because it was "first seen on that day [Holy Cross Day] so marked in our calendar" (1785, v. 2, p. 345-346). The name was published by the Russians (Tebenkov, 1852, map 8) as "Mys Kresta" meaning "Cape Cross."

Cross, Cape: point of land, see Bingham, Cape. Cross, Cape: point of land, see Kresta Point.

Cross, Port: bight, see Krestof, Port.

Cross Bay: cove, $1.4 \mathrm{mi}$. across, on SE coast of Akun I., just $\mathrm{S}$ of Seredka Bay, Aleutian Is.; $54^{\circ} 09^{\prime} 15^{\prime \prime} \mathrm{N}, 165^{\circ} 29^{\prime} 30^{\prime \prime} \mathrm{W}$; (map 24).

Named in 1901 by J. J. Gilbert, USC\&GS.

Cross Bay Creek: stream, flows SW $0.8 \mathrm{mi}$. to Gastineau Channel, $1.7 \mathrm{mi}$. SE of Juneau, Coast Mts.; $58^{\circ} 16^{\prime} 30^{\prime \prime} \mathrm{N}, 134^{\circ} 21^{\prime} 20^{\prime \prime} \mathrm{W}$; (map 11).

Name apparently derived from the Cross Bay lode claim located there in 1894 (DeArmond, 1957).

Cross Cape: point of land, NE point of Unga I., Shumagin Is., Aleutian Ra.; $55^{\circ} 23^{\prime} \mathrm{N}, 160^{\circ}$ 33' W; (map 28).

Translation of the Russian "M[ys] Kresti" shown on 1847 Russian Hydrog. Dept. Ghart 1379.

Cross Creek: stream, heads at Cross Creek Glacier terminus, flows NE $15 \mathrm{mi}$. to Chisana River, Wrangell Mts. ; $62^{\circ} 10^{\prime} 40^{\prime \prime} \mathrm{N}, 142^{\circ} 05^{\prime}$ 20" W; (map 84). Var. Copper Creek.

Local name reported in 1902 by F. C. Schrader, USGS. The Indians, according to
Schrader, considered this stream part of Chisana River (Mendenhall and Schrader, 1903, p. 40 ).

Cross Creek: stream, in Baird Mts., flows S 14 mi. to Klery Creek $2 \mathrm{mi}$. $\mathrm{N}$ of its junc. with Squirrel River, $12 \mathrm{mi}$. N of Kiana, Brooks Ra.; $67^{\circ} 07^{\prime} \mathrm{N}, 160^{\circ} 38^{\prime} \mathrm{W}$; (map 127).

Reported in 1910 by J. Tyapay to P. S. Smith, USGS.

Cross Creek: stream, flows S $16 \mathrm{mi}$. to Ambler River, 20 mi. $N$ of Shungnak, Brooks Ra.; $67^{\circ}$ $10^{\prime} \mathrm{N}, 157^{\circ} 24^{\prime} \mathrm{W}$; (map 126).

Local name reported by the U.S. Army Corps of Engineers in 1955.

Cross Creek Glacier: glacier, E of Nabesna Glacier, trends NE $5 \mathrm{mi}$. to its terminus at head of Cross Creek, Wrangell Mts.; $62^{\circ} 03^{\prime}$ $\mathrm{N}, 142^{\circ} 35^{\prime} \mathrm{W}$; (map 84).

Local name reported in 1959 by USGS.

Crossfox Butte: mountain, 2,000 ft., $5 \mathrm{mi}$. NW of Asses Ears and $13 \mathrm{mi}$. NW of Imuruk Lake, Seward Penin. High.; $65^{\circ} 48^{\prime} \mathrm{N}, 163^{\circ} 17^{\prime} \mathrm{W}$; $B G N 1952$; (map 110).

Reported in 1950 by D. M. Hopkins, USGS; so named because "a variety of red fox commonly known as the cross fox is common in the area and one was seen on this hill."

Cross Hill: hill, $96 \mathrm{ft}$., on NE coast of St. Paul I., in Pribilof Is. ; 57 $14^{\prime} \mathrm{N}, 170^{\circ} 07^{\prime} \mathrm{W}$; (map 38). Var. St. Johns Hill.

Elliott (1881, p. 56) writes “' 'Cross,' or 'St. Johns Hill,' which rises near the lake, to a height of 60 or 70 feet, and is quite a landmark itself, is a perfect cone of sand $* * *$ is growing constantly higher by the fresh deposit brought by wind, and its retention by the annually rising grasses."

Cross Island: barrier island, $2 \mathrm{mi}$. long, $12 \mathrm{mi}$. $\mathbf{N}$ of Anxiety Point, between McClure and Midway Is., on Beaufort Sea coast, 27 mi. E of Beechey Point, Arctic Plain; 70 29'30' N, $147^{\circ} 56^{\prime} 30^{\prime \prime} \mathrm{W}$; (map 150).

Named by Capt. Stockton (1890, p. 185), USN, in 1889, who wrote "the island, though nameless, was marked by a wooden cross, from which fact it was called Cross Island."

Cross Island: island, 300 yds. long, Delarof Harbor, on SE coast of Unga I., in Shumagin Is., Aleutian Ra.; $55^{\circ} 10^{\prime} 45^{\prime \prime} \mathrm{N}, 160^{\circ} 29^{\prime} 00^{\prime \prime} \mathrm{W}$; (map 28).

Local name published in USC\&GS 1916 Coast Pilot (v. 2, p. 179).

Cross Island: island, see Krestof Island.

Cross Island: islands, see Cruz Islands.

Cross Jacket: locality, see Cos Jacket.

Crossman Ridge: ridge, on Kenai Penin., $5 \mathrm{mi}$. long, $3 \mathrm{mi}$. N of Homer, Cook Inlet Low.; $59^{\circ}$ $41^{\prime} 30^{\prime \prime} \mathrm{N}, 151^{\circ} 32^{\prime} 00^{\prime \prime} \mathrm{W}$; (map 50).

Local name reported and published by USGS in the 1950's.

Cross Mountain: peak, 2,597 ft., hump on W side of Mount Verstovia $2 \mathrm{mi}$. $\mathbf{E}$ of Sitka on W coast of Baranof I., Alex. Arch.; 57 03'30" $N, 135^{\circ} 16^{\prime} 00^{\prime \prime} \mathrm{W}$.

Local name reported in 1869 by G. Davidson, USC\&GS. The name was applied in early years because it is said the Russians erected a cross here. 
Cross Mountain: mountain, see Cupola Peak.

Crosson, Mount: peak, $12,800 \mathrm{ft}$., in Mount McKinley National Park, $10 \mathrm{mi}$. SW of Mount McKinley, Alaska Ra.; $63^{\circ} 00^{\prime} 30^{\prime \prime}$ N, $151^{\circ}$ 16'30' W; BGN 1949; (map 88).

Named in 1949 by Bradford Washburn, for Joseph Crosson, "pioneer aviator of Alaska."

Crosson Glacier: glacier, see Straightaway Glacier.

Cross Point: point of land, on SE coast of Akun I., Aleutian Is. ; $54^{\circ} 04^{\prime} 35^{\prime \prime} \mathrm{N}, 165^{\circ} 28^{\prime} 45^{\prime \prime} \mathrm{W}$; (map 24).

Local name published in 1950 by USC\&GS.

Cross Point: point of land, on $\mathrm{S}$ bank of Nushagak River, $16 \mathrm{mi}$. SE of Dillingham, Bristol Bay Low.; $58^{\circ} 56^{\prime} 20^{\prime \prime} \mathrm{N}, 158^{\circ} 03^{\prime} 00^{\prime \prime} \mathrm{W}$; $B G N$ 1937; (map 40).

Local name published in 1934 by USBF.

Cross Point: point of land, on left bank of Yukon River, at mouth of Nowitna River, $38 \mathrm{mi}$. NE of Ruby, Nowitna Low.; $64^{\circ} 56^{\prime} \mathrm{N}, 154^{\circ} 16^{\prime}$ W; (map 98).

Riverboat pilots' name shown on 1940 "Navigation Chart, Tanana-Yukon Rivers" of the River Boat Service, U.S. Dept. of Interior.

Cross Slough: stream, $6 \mathrm{mi}$. long, connects Nungatak River with Manokinak River, $4 \mathrm{mi}$. E of Nuigalak Lake, Yukon-Kuskokwim Delta; $61^{\circ} 31^{\prime} 15^{\prime \prime} \mathrm{N}, 164^{\circ} 23^{\prime} 10^{\prime \prime} \mathrm{W}$; (map 74).

Local name obtained at Bethel by Orth in 1965.

Cross Slough: watercourse, $5 \mathrm{mi}$. long, channel of Yukon River E of Blade I., $20 \mathrm{mi}$. SE of Marshall, Yukon-Kuskokwim Delta; 61 ${ }^{\circ} 35^{\prime}$ $\mathrm{N}, 161^{\circ} 56^{\prime} \mathrm{W}$; (map 73).

Riverboat pilots' name shown on a 1916 field sheet by R. H. Sargent, USGS. So called because it was a "cross cut" around the Devils Elbow.

Cross Sound: water passage, $12 \mathrm{mi}$. long, trends from Icy Strait SW to Gulf of Alaska, N of Soapstone Point, $45 \mathrm{mi}$. W of Hoonah, St. Elias Mts.; $58^{\circ} 08^{\prime} \mathrm{N}, 136^{\circ} 35^{\prime} \mathrm{W}$; (map 10). Var. Entrada de la Gruz, Icy Strait, Kresta Strait, Lohtianoi, Puerto de la Cruz.

So named in 1778 by Capt. Cook (1785, v. 2, p. 345), RN., because it was discovered on May 3, designated on his calendar as Holy Cross Day. It has been called "Pr[oliv] Kresta" meaning "cross sound" and "Pr[oliv] Ledyanoy" meaning "icy strait" by the Russians. The Spanish explorers called the passage "Entrada de la Cruz" meaning "entry of the cross" and "Puerto de la Cruz" meaning "port of the cross." The name originally included what is now Icy Strait.

Cross Sound: sound, see Krestof Sound.

Crosstrail Lake: lake, $0.5 \mathrm{mi}$. across, $1 \mathrm{mi}$. W of Little Preacher Creek and $39 \mathrm{mi}$. SE of Fort Yukon, Yukon Flats; $66^{\circ} 03^{\prime} \mathrm{N}, 144^{\circ} 44^{\prime} \mathrm{W}$; (map 119).

Local descriptive name obtained in 1956 by USGS.

Crossway: moraine, $3 \mathrm{mi}$. long, $28 \mathrm{mi}$. SE of Palmer, between Inner and Upper Lake
George, Chugach Mts.; $61^{\circ} 16^{\prime} 15^{\prime \prime} \mathrm{N}, 148^{\circ}$ $35^{\prime} 30^{\prime \prime} \mathrm{W}$; (map 69).

Local name reported in 1960 by USGS.

Crosswind Lake: lake, $8 \mathrm{mi}$. long, NW of Lake Louise, $23 \mathrm{mi}$. NW of Glennallen, Copper River Basin; $62^{\circ} 20^{\prime} \mathrm{N}, 146^{\circ} 00^{\prime} \mathrm{W}$; (map 83). Var. Charley Lake.

Local name published by USGS in 1951; named because of crosswinds encountered by planes when landing on this lake.

Crosswise Islands: islands, $0.6 \mathrm{mi}$. across, at mouth of Nakwasina Sound, $9 \mathrm{mi}$. $\mathbf{N}$ of Sitka, NW coast of Baranof I., Alex. Arch.; 57 $10^{\prime}$ $50^{\prime \prime}$ N, $135^{\circ} 25^{\prime} 30^{\prime \prime}$ W; (map 9). Var. Ostrov Poperechnoy, Poperechnoi Islet.

This is an 1882 translation by USC\&GS of the name given in 1809 by the Russian navigator Ivan Vasiliev the first, IRN; reported by Lt. Sarichev (1826, map 19), IRN, as "Ostrov Poperechnoy."

Croto River: stream, see Kroto Creek.

Croto Slough: stream, see Kroto Slough.

Crow Arm: bay, $0.3 \mathrm{mi}$. across, NE arm of Raven Bay, on $\mathrm{S}$ coast of Unalaska I., Aleutian Is. ; $53^{\circ} 27^{\prime} 45^{\prime \prime} \mathrm{N}, 166^{\circ} 50^{\prime} 30^{\prime \prime} \mathrm{W}$; BGN 1940; (map 23).

Named by a USC\&GS field party in 1937 "because of its association with Raven Bay." Crowbill Cape: promontory, see Crowbill Point. Crowbill Point: point of land, on Chukchi Sea, $5.5 \mathrm{mi}$. SE of Cape Thompson, Arctic Slope; $68^{\circ} 06^{\prime} 05^{\prime \prime} \mathrm{N}, 165^{\circ} 48^{\prime} 07^{\prime \prime} \mathrm{W}$; BGN 1959; (map 129).

Descriptive name given in 1959 by USGS for the USG\&GS bench mark "Crow bill" on top of the sheer cliffs on the point.

Crow Creek: stream, heads at Crystal Lake, flows SE $6 \mathrm{mi}$. to Glacier Creek, $15 \mathrm{mi}$. NE of Sunrise, Chugach Mts. ; $60^{\circ} 59^{\prime} 40^{\prime \prime} \mathrm{N}, 149^{\circ} 04^{\prime} 30^{\prime \prime}$ W; (map 63).

Local name reported in 1899 by W. C. Mendenhall, USGS.

Crow Creek: stream, flows NE $3 \mathrm{mi}$. to Cherry Creek, $54 \mathrm{mi}$. S of Eagle, Yukon-Tanana High.; $64^{\circ} 00^{\prime} 45^{\prime \prime} \mathrm{N}, 141^{\circ} 09^{\prime} 45^{\prime \prime} \mathrm{W}$; (map 102).

Named by prospectors and shown on an 1898 manuscript map by E. F. Ball, prospector. Grow Creek Pass, pass, see Crow Pass.

Crowell Point: point of land, $\mathrm{W}$ point of entrance to North Arm Moira Sound, on SE coast of Prince of Wales I., Alex. Arch.; $55^{\circ} 04^{\prime} 45^{\prime \prime} \mathrm{N}, 132^{\circ} 05^{\prime} 05^{\prime \prime} \mathrm{W}$; (map 4).

Local name reported in 1905 by E. F. Dickins, USC\&GS.

Crow Glacier: Glacier, $3.3 \mathrm{mi}$. SE of Moraine Pass, trends NE $1 \mathrm{mi}$. to its terminus $29 \mathrm{mi}$. $\mathrm{SE}$ of Anchorage, Chugach Mts.; $61^{\circ} 02^{\prime} 50^{\prime \prime}$ N, 149 08'45" W; BGN 1932; (map 69).

Local name reported in 1932 by W. G. Carson and C. F. Park, USGS.

Crow Island: island, $0.2 \mathrm{mi}$. long, in Ham Cove, on E coast of Dall I., Alex. Arch.; 54 $52^{\prime} 45^{\prime \prime}$ $\mathrm{N}, 132^{\circ} 51^{\prime} 15^{\prime \prime} \mathrm{W}$; (map 1). Var. James Island.

Named in 1881 by Lt. Comdr. H. E. Nichols, USN.
Crow Island: island, $1.3 \mathrm{mi}$. long, in Sitka Sound, $6.5 \mathrm{mi}$. NW of Sitka, Alex. Arch.; $57^{\circ} 06^{\prime} 30^{\prime \prime} \mathrm{N}, 135^{\circ} 28^{\prime} 30^{\prime \prime} \mathrm{W}$; (map 9). Var. Ostrov Voroney.

This is an 1882 translation by USC\&GS of the name given in 1809 by the Russian navigator Ivan Vasiliev the first, IRN; reported by Lt. Sarichev (1826, map 19), IRN, as "O[strov] Voroney."

Crow Island: island, $0.4 \mathrm{mi}$. across at $\mathrm{S}$ entrance to Port Houghton on Stephens Passage, $2 \mathrm{mi}$. NE of Fort Point and $72 \mathrm{mi}$. E of Sitka, Coast Mts. ; $57^{\circ} 18^{\prime} 05^{\prime \prime} \mathrm{N}, 133^{\circ} 29^{\prime} 30^{\prime \prime} \mathrm{W}$; (map 8).

Local name reported in 1955 by USGS.

Crow Island: island, $0.5 \mathrm{mi}$. across, in Kelp Bay, on Baranof I., $15 \mathrm{mi}$. N of Baranof, Alex. Arch.; $57^{\circ} 18^{\prime} \mathrm{N}, 134^{\circ} 55^{\prime} \mathrm{W}$; (map 9).

Named in 1895 by Lt. Comdr. E. K. Moore, USN, and published by USC\&GS in the 1901 Coast Pilot (p. 160).

Grow Island: island, see Korga Island.

Crow Lake: lake, $1 \mathrm{mi}$. S of Moose Lake and $17 \mathrm{mi}$. NW of Roundabout Mtn., Koyukuk Low.; $65^{\circ} 46^{\prime} \mathrm{N}, 156^{\circ} 48^{\prime} \mathrm{W}$; (map 108).

Local name obtained at Huslia by USGS in 1954 or 1955.

Crowley, Point: point of land, on $\mathrm{W}$ coast of Kuiu I., $9 \mathrm{mi}$. NW of Cape Decision and $16 \mathrm{mi}$. SE of Port Alexander, Alex. Arch.; 56 $07^{\prime} 10^{\prime \prime}$ $\mathrm{N}, 134^{\circ} 15^{\prime} 30^{\prime \prime} \mathrm{W}$; (map 5).

Named in 1900 by USC\&GS "for B. F. Crowley, first watch officer of the Coast Survey steamer McArthur."

Crowley Bight: bay, 2 mi. across, on $\mathrm{W}$ coast of Kuiu I., $8 \mathrm{mi}$. NW of Cape Decision, Alex. Arch.; 56 $05^{\prime} 15^{\prime \prime} \mathrm{N}, 134^{\circ} 14^{\prime} 00^{\prime \prime} \mathrm{W}$; (map 5).

Local name derived from Crowley Point and published by USC\&GS in the 1925 Coast Pilot (p. 253).

Crowley Creek: stream, flows NNE $6 \mathrm{mi}$. to Fourth of July Creek, $5.5 \mathrm{mi}$. SW of that stream's junc. with Yukon River and $32 \mathrm{mi}$. NW of Eagle, Yukon-Tanana High.; $65^{\circ}$ $08^{\prime} 20^{\prime \prime} \mathrm{N}, 141^{\circ} 55^{\prime} 30^{\prime \prime} \mathrm{W}$; (map 103).

Prospectors' name from an unpublished map by E. J. Chamberlain, dated 1902.

Crowley Rock: rock, $2.7 \mathrm{mi}$. NE of village of Sanak, in Sanak Is., Aleutian Ra.; $54^{\circ} 30^{\prime} 35^{\prime \prime}$ N, $162^{\circ} 46^{\prime} 00^{\prime \prime} \mathrm{W}$; (map 25).

Named by Ferdinand Westdahl, USC\&GS, commander of the Coast Survey steamer McArthur, who made surveys in this area in 1901. Presumably named for Watch Officer B. F. Crowley of the McArthur.

Crow Nest Rock: peak; 3,800 ft., on E bank of Grow Nest Creek, $14 \mathrm{mi}$. SW of Arctic Village, Brooks Ra.; $68^{\circ} 05^{\prime} \mathrm{N}, 146^{\circ} 05^{\prime} \mathrm{W}$; (map 136).

Local name reported in 1926 by J. B. Mertie, Jr., (in Smith, P. S., 1929, pl. 1), USGS.

Crown Mountain: mountain, 4,000 ft., $22 \mathrm{mi}$. SW of Kodiak, Kodiak I. ; $57^{\circ} 36^{\prime} 00^{\prime \prime}$ N, $152^{\circ}$ 54'30" W; (map 34).

Descriptive local name published in 1943 by USC\&GS.

Crown Peak: peak, 5,350 ft., on E side of Kenai Penin., $28 \mathrm{mi}$. NE of Seward and $32 \mathrm{mi}$. S of 
Whittier, Chugach Mts.; $60^{\circ} 20^{\prime} 30^{\prime \prime} \mathrm{N}, 148^{\circ}$ 47'00" W; BGN 1929; (map 63).

Named in 1929 by Capt. R. S. Patton, USC\&GS, "because of its situation on the crown of the glacier."

Crown Point: locality, mile 24.5 on The Alaska RR., on Kenai Penin., on Seward Highway, $22 \mathrm{mi}$. N of Seward, Chugach Mts.; $60^{\circ} 26^{\prime} 00^{\prime \prime}$ N, $149^{\circ} 22^{\prime} 05^{\prime \prime}$ W; (map 63). Var. Trail, Trail Lake Station, Trail Station.

Name published on recent USGS maps which indicate a site with one or two buildings. Grant and Higgins (1912, pl. 1), USGS, reported a RR. station called "Trail Lake Station" at this site.

Crow Pass: pass, 3,600 ft., at head of Crow Creek, $28 \mathrm{mi}$. SE of Anchorage, Chugach Mts.; $61^{\circ}$ 03'30" N, $149^{\circ} 06^{\prime} 45^{\prime \prime}$ W ; BGN 1932; (map 69). Var. Crow Creek Pass.

Local name reported about 1910 by A. H. Brooks, USGS.

Crow Peak: peak, 5,950 ft., between Clear and Crow Glaciers, $26 \mathrm{mi}$. ESE of Anchorage, Chugach Mts.; $61^{\circ} 03^{\prime} 25^{\prime \prime}$ N, $149^{\circ} 08^{\prime} 40^{\prime \prime}$ W; BGN 1966; (map 69).

Named in 1966 by the Mountaineering Club of Alaska for nearby Crow Creek, Crow Pass, and Crow Glacier.

Crow Point: point of land, on SE shore of Herendeen Bay, Alaska Penin, Aleutian Ra.; $55^{\circ} 45^{\prime} 20^{\prime \prime} \mathrm{N}, 160^{\circ} 41^{\prime} 30^{\prime \prime} \mathrm{W}$; (map 28).

Named by Z. L. Tanner, USN, in 1890 .

Crow Reef: reef, $1 \mathrm{mi}$. W of Crow Bay, in Herendeen Bay, Alaska Penin., Aleutian Ra.; $55^{\circ} 45^{\prime} 30^{\prime \prime} \mathrm{N}, 160^{\circ} 43^{\prime} 20^{\prime \prime} \mathrm{W}$; (map 28).

Named by Z. L. Tanner, USN, in 1890 .

Crowther, Mount: mountain, 2,847 ft., $13 \mathrm{mi}$.

NNW of Chichagof, on $W$ coast of Chichagof

I., Alex. Arch.; $57^{\circ} 50^{\prime} \mathrm{N}, 136^{\circ} 15^{\prime} \mathrm{W}$; (map 9).

Name published in 1928 by USC\&GS on Chart 8258.

Crow Village: locality, on $N$ bank of Kuskokwim

River, $8 \mathrm{mi}$. W of Aniak, Yukon-Kusko-

kwim Delta; 61 $34^{\prime} 15^{\prime \prime} \mathrm{N}, 159^{\circ} 47^{\prime} 00^{\prime \prime} \mathrm{W}$; (map 73).

Name reported by W. S. Post, USGS, on an 1898 field sheet, at which time the village consisted of two cabins. It is now abandoned.

Croyalgu: island, see Tigalda Island.

Croyere, Isles de la: islands, see Hazy Islands.

Crumb Gulch: ravine, W of Williams Peak, extends $4.8 \mathrm{mi}$. NW to Lake Creek, $11 \mathrm{mi}$. SE of McCarthy, St. Elias Mts.; $61^{\circ} 22^{\prime} \mathrm{N}, 142^{\circ} 38^{\prime}$ W; (map 67).

Local name obtained by USGS and published on maps since 1954.

Grush Creek: stream, flows SE $0.5 \mathrm{mi}$. to California Creek about $2.5 \mathrm{mi}$. NE of its junc. with Bonanza River, $9 \mathrm{mi}$. NW of Solomon, Seward Penin. High.; (map 95).

Prospectors' name reported on the 1900 "Map of Nome Peninsula" by J. M. Davidson and B. D. Blakeslee. This stream cannot be precisely located on current maps.

Cruz, Caños de: water passage, see Cruz Pass.
Cruz, Entrada de la: water passage, see Cross Sound.

Cruz, Point: point of land, on $\mathrm{W}$ coast of Suemez I., in Port Santa Cruz, Alex. Arch.; $55^{\circ} 16^{\prime} 15^{\prime \prime} \mathrm{N}, 133^{\circ} 25^{\prime} 30^{\prime \prime} \mathrm{W}$; (map 4).

Named and published by USC\&GS in 1916; derived from Cruz Islands.

Cruz, Puerto de la: water passage, see Cross Sound.

Cruz, Punta de la: point of land, on S shore of Port Etches, Hinchinbrook Island; $60^{\circ} 18^{\prime} \mathrm{N}$ $146^{\circ} 35^{\prime} \mathrm{W}$.

Spanish name meaning "point of the cross," named by the 1779 Don Ignacio Arteaga expedition. "The cross marking the spot where possession was taken is a short distance southeast of the point" (Wagner, 1937, p. 445).

Cruz Islands: islands, group, extends $1.8 \mathrm{mi}$., in San Christoval Channel, off NE coast of San Fernando I., Alex. Arch.; 55 $33^{\prime} 30^{\prime \prime} \mathrm{N}$, $133^{\circ} 18^{\prime} 30^{\prime \prime} \mathrm{W}$; BGN 1908; (map 4). Var. Cross Island, Yslas de la Cruz.

Named "Isla de la Cruz" or "cross island" about May 24, 1779, by Francisco Antonio Maurelle (Wagner, 1937, p. 383).

Cruz Pass: water passage, $1.5 \mathrm{mi}$. long, between San Fernando I. and Cruz Is., Alex. Arch.; $55^{\circ} 33^{\prime} \mathrm{N}, 133^{\circ} 19^{\prime} \mathrm{W}$; BGN 1908; (map 4). Var. Caños de Cruz, Canos de la Cruz.

Named "Caños de Cruz" or "cross pass" about May 24, 1779, by Francisco Antonio Maurelle (Wagner, 1937, p. 383).

Crystal Creek: stream, flows N $4.5 \mathrm{mi}$. to Muddy River, $12 \mathrm{mi}$. NE of Petersburg, Coast Mts.; $56^{\circ} 53^{\prime} 15^{\prime \prime} \mathrm{N}, 132^{\circ} 42^{\prime} 05^{\prime \prime} \mathrm{W}$; (map 6).

Local descriptive name reported in 1961 by USGS.

Crystal Creek: stream, heads in a small glacier and flows $2.8 \mathrm{mi}$. S to Priest River, $1.7 \mathrm{mi}$. $\mathrm{NE}$ of Mud Bay and $74 \mathrm{mi}$. NW of Yakutat, Malaspina Coastal Plain; 59 $58^{\prime} 35^{\prime \prime} \mathrm{N}$, $141^{\circ} 40^{\prime} 00^{\prime \prime} \mathrm{W}$; (map 47).

Local name published by USGS in 1948.

Crystal Creek: stream, on Kenai Penin., flows NW $4.5 \mathrm{mi}$. to Devils Bay in Tustumena Lake, $41 \mathrm{mi}$. SE of Kenai, Chugach Mts.; $60^{\circ} 02^{\prime} 30^{\prime \prime} \mathrm{N}, 150^{\circ} 40^{\prime} 20^{\prime \prime} \mathrm{W}$; (map 62).

Local name reported in 1951 by USGS.

Crystal Creek: stream, flows $11 \mathrm{mi}$. SW to Chitina River $11 \mathrm{mi}$. W of its junc. with Nizina River and $23 \mathrm{mi}$. SW of McCarthy, Copper River Basin; 61 $11^{\circ} 19^{\prime} \mathrm{N}, 143^{\circ} 32^{\prime} \mathrm{W}$; (map 67)

Local name recorded on a 1909 blue print of the Copper River and Northwestern Railway.

Crystal Creek: stream, flows NE $10 \mathrm{mi}$. to Skwentna River, $70 \mathrm{mi}$. NW of Tyonek, Alaska Ra.; $61^{\circ} 38^{\prime} 15^{\prime \prime} \mathrm{N}, 152^{\circ} 53^{\prime} 40^{\prime \prime} \mathrm{W}$; (map 70).

Local name reported in 1926 by S. R. Capps (in Smith and others, 1929, pl. 1), USGS.

Crystal Creek: stream, flows S $5.8 \mathrm{mi}$. to Coffee River $9 \mathrm{mi}$. $\mathbf{N}$ of Chulitna River, $27 \mathrm{mi}$. N of Talkeetna, Alaska Ra.; $62^{\circ} 49^{\prime} 55^{\prime \prime} \mathrm{N}$, $150^{\circ} 18^{\prime} 15^{\prime \prime} \mathrm{W}$; (map 81)

Prospectors' name published in 1940 by USGS.
Crystal Creek: stream, in Mount McKinley National Park, flows NW 3.7 mi. to Glacier Creek $\mathrm{E}$ of Muldrow Glacier, $4.5 \mathrm{mi}$. SSW of Eielson Visitor Center, Alaska Ra.; 63 $22^{\prime} 30^{\prime \prime} \mathrm{N}$, $150^{\circ} 22^{\prime} 30^{\prime \prime} \mathrm{W}$; BGN 1932; (map 88).

So named in 1931 by USGS, because "the water in this creek is unusually clear for this region."

Crystal Creek: stream, flows SW $2 \mathrm{mi}$. to Snake River, $5 \mathrm{mi}$. NW of Nome, Seward Penin. High.; 64 $33^{\prime} 36^{\prime \prime} \mathrm{N}, 165^{\circ} 30^{\prime} 28^{\prime \prime} \mathrm{W}$; (map 94). Var. American Creek.

Prospectors' name reported on the 1903 Campion Mining and Trading Co. map by George M. Ashford.

Crystal Creek: stream, in York Mts., flows SW $2 \mathrm{mi}$. to Lost River, $1.5 \mathrm{mi}$. N of Cassiterite Creek and $28 \mathrm{mi}$. NW of Teller, Seward Penin. High.; $65^{\circ} 29^{\prime} 15^{\prime \prime} \mathrm{N}, 167^{\circ} 09^{\prime} 40^{\prime \prime} \mathrm{W}$; $B G N$ 1948; (map 111).

So named in 1940 by J. B. Mertie, Jr., because of "numerous specimens of well-crystallized minerals which were found along its course."

Crystal Falls: locality, along right bank of Mountain Slough, $4 \mathrm{mi}$. S of Cordova, Malaspina Coastal Plain; $60^{\circ} 29^{\prime} \mathrm{N}, 145^{\circ} 44^{\prime} \mathrm{W}$; $B G N$ 1948; (map 64).

Local name reported in 1905 by G. G. Martin (1906, pl. 12), USGS.

Crystal Gulch: ravine, trends SW $0.5 \mathrm{mi}$. to Ruby Creek, $9 \mathrm{mi}$. NW of Medfra, KilbuckKuskokwim Mts.; $63^{\circ} 14^{\prime}$ N, $154^{\circ} 47^{\prime}$ W; (map 89).

Prospectors' name obtained in 1921 by G. C. Martin (in Brooks, 1922, fig. 5), USGS.

Crystal Lake: lake, $1 \mathrm{mi}$. long, $1 \mathrm{mi}$. S of Blind Slough, in SW part of Mitkof I., Alex. Arch.; $56^{\circ} 35^{\prime} 30^{\prime \prime} \mathrm{N}, 132^{\circ} 50^{\prime} 30^{\prime \prime} \mathrm{W}$; (map 6).

Local descriptive name obtained in 1953 by USGS.

Crystal Lake: lake, $0.2 \mathrm{mi}$. across, $3.5 \mathrm{mi}$. SE of Moraine Pass, at head of Crow Creek, 28 mi. SE of Anchorage, Chugach Mts.; $61^{\circ} 03^{\prime} 10^{\prime \prime} \mathrm{N}, 149^{\circ} 02^{\prime} 25^{\prime \prime} \mathrm{W}$; (map 69).

Local name reported in 1950 by USGS.

Crystal Lake: lake, $0.8 \mathrm{mi}$. across, $2.8 \mathrm{mi}$. SW of Willow and $35 \mathrm{mi}$. $\mathrm{N}$ of Anchorage, Cook Inlet Low.; 61 $42^{\prime} 30^{\prime \prime} \mathrm{N}, 150^{\circ} 06^{\prime} 15^{\prime \prime} \mathrm{W}$; $B G N$ 1960; (map 70).

Named in 1959 by Hubert D. Cox who had a homestead on the shore of this lake. Crystal Peak: peak, 4,200 ft., between McLellan Pass and Squaw Lake, $10 \mathrm{mi}$. NE of Chandalar, Brooks Ra.; 67 $33^{\prime} 15^{\prime \prime}$ N, 148 $08^{\prime} 00^{\prime \prime}$ W; (map 123).

Local name reported in 1956 by T. E. Taylor, USGS.

Cuban Gulch: ravine, trends NE $3.5 \mathrm{mi}$. to Yukon River, $5 \mathrm{mi}$. SE of Eagle, Yukon-Tanana High.; 64 ${ }^{\circ} 44^{\prime} \mathrm{N}, 141^{\circ} 03^{\prime} \mathrm{W}$; (map 102).

Prospectors' name reported in 1898 by E. C. Barnard, USGS; probably suggested by involvement of the United States in the Spanish-American War.

Cub Bear Creek: stream, flows SW $5.8 \mathrm{mi}$. to Yukon River, $31 \mathrm{mi}$. NE of Nulato, Koyukuk Low.; $64^{\circ} 49^{\prime} \mathrm{N}, 157^{\circ} 05^{\prime} \mathrm{W}$; (map 97). 
Local name reported in 1935 by Frederica de Laguna, BAE.

Cub Creek: stream, on Alaska Penin., flows S $4 \mathrm{mi}$. to a tributary of Meshik River, $10 \mathrm{mi}$. $\mathrm{S}$ of Vent Mtn., Aleutian Ra.; $56^{\circ} 45^{\prime} \mathrm{N}$, $158^{\circ} 03^{\prime} \mathrm{W}$; (map 30).

So named in 1923 by R. H. Sargent, USGS, because "several bear cubs were seen in the valley."

Cub Creek: stream, on $\mathbf{N}$ end of Kenai Penin., flows $\mathrm{E} 2.5 \mathrm{mi}$. to Sixmile Creek, $1 \mathrm{mi}$. S of Sunrise, Chugach Mts.; 60 $52^{\prime} 15^{\prime \prime}$ N, $149^{\circ}$ 25'45" W; (map 63).

Local prospectors' name reported about 1914 by B. L. Johnson (in Martin and others, 1915, pl. 2), USGS.

Cub Creek: stream, heads at glacier terminus, flows $12 \mathrm{mi}$. N to White River, $5 \mathrm{mi}$. E of Pingpong Mtn. and $61 \mathrm{mi}$. NE of McCarthy, St. Elias Mts.; $61^{\circ} 44^{\prime} \mathrm{N}, 141^{\circ} 11^{\prime} \mathrm{W}$; (map 67).

Local name obtained by USGS and published on maps since 1954.

Cub Creek: stream, flows NE $7 \mathrm{mi}$. to Bear Creek, $22 \mathrm{mi}$. NE of Haycock, Seward Penin. High.; $65^{\circ} 31^{\prime} \mathrm{N}, 161^{\circ} 00^{\prime} \mathrm{W}$; (map 109).

Local name shown on a 1903 fieldsheet by D. C. Witherspoon, USGS.

Cube Cove: cove, $0.4 \mathrm{mi}$. across, on $\mathrm{W}$ coast of Admiralty I., $26 \mathrm{mi}$. $\mathrm{N}$ of Angoon, Alex. Arch.; 57 $56^{\prime} 30^{\prime \prime} \mathrm{N}, 134^{\circ} 45^{\prime} 00^{\prime \prime} \mathrm{W}$; (map 9).

Local name reported in 1951 by USGS.

Cube Point: point of land, on S shore of Square Cove, $33 \mathrm{mi}$. N of Angoon, on $\mathrm{W}$ coast of Admiralty I., Alex. Arch.; 57 $58^{\prime} 30^{\prime \prime} \mathrm{N}$, $134^{\circ} 46^{\prime} 00^{\prime \prime} \mathrm{W}$; (map 9).

Named in 1880 by W. H. Dall, USC\&GS, and published in the 1883 Coast Pilot (p. 179).

Cub Island: island, $700 \mathrm{ft}$. long, in Sitkalidak Strait, between Sitkalidak I. and SE coast of Kodiak I.; $57^{\circ} 12^{\prime} 48^{\prime \prime}$ N, $153^{\circ} 12^{\prime} 15^{\prime \prime}$ W; $B G N$ 1930; (map 34). Var. Cat Island.

Named in 1930 by USC\&GS.

Cub Mountain: mountain, 3,012 ft., S of Stag Bay, on Chichagof I., $18 \mathrm{mi}$. NW of Chichagof, Alex. Arch.; 57 $54^{\prime} 00^{\prime \prime}$ N, $136^{\circ}$ $18^{\prime} 30^{\prime \prime} \mathrm{W}$; (map 9).

Name published in 1929 by USC\&GS on Chart 8260.

Cub Point: point of land, on S coast of Alaska Penin. on E shore of Stepovak Bay, Aleutian Ra.; 55 $37^{\prime} \mathrm{N}, 159^{\circ} 44^{\prime} \mathrm{W}$; (map 27).

Named by W. H. Dall, USC\&GS, in 1880 . Cucumber Reef: reef, $0.2 \mathrm{mi}$. long, in Keku Strait, W of Horseshoe I., $14 \mathrm{mi}$. SE of Kake, Alex. Arch.; 56 $47^{\prime} 15^{\prime \prime}$ N, 133 ${ }^{\circ} 45^{\prime} 35^{\prime \prime} \mathrm{W}$; BGN 1929; (map 6).

Descriptive name given in 1927 for charting purposes by USC\&GS, as the reef "has the outline of a cucumber."

Cue Creek, stream, flows NE $5 \mathrm{mi}$. to Inmachuk River, $26 \mathrm{mi}$. NE of Imuruk Lake, Seward Penin. High.; $65^{\circ} 58^{\prime} 55^{\prime \prime} \mathrm{N}, 162^{\circ} 57^{\prime} 00^{\prime \prime} \mathrm{W}$; (map 110).

Prospectors' name reported in 1901 by D. L. Reaburn (in Mendenhall, 1902, pl. 4a), USGS.
Cuerbo, Point: point of land, on SE coast of San Fernando I., $6.4 \mathrm{mi}$. W of Craig, Alex. Arch.; $55^{\circ} 28^{\prime} 30^{\prime \prime} \mathrm{N}, 133^{\circ} 18^{\prime} 55^{\prime \prime} \mathrm{W}$; (map 4). Var. Punta del Cuerbo.

Spanish name meaning. "crow [cuervo]" given as "Punta del Cuerbo" by Francisco Antonio Maurelle about May 26, 1779.

Cuerbo, Punta del: point of land, see Cuerbo, Point.

Cula Creek: stream, heads in Brooks Ra. on Rim Butte, flows NE $20 \mathrm{mi}$. to Ipnavik River, 37 $\mathrm{mi}$. N of Howard Pass, Arctic Slope; $68^{\circ} 45^{\prime} \mathrm{N}$, $156^{\circ} 51^{\prime} \mathrm{W}$; (map 132).

Named in 1950 by I. L. Tailleur, geologist, with the Naval Petroleum Reserve No. 4 explorations; name published by USGS in 1951. The name is an "arbitrary assignment of shipping code from weasels."

Culebra Islands: islands, group, extends $1.6 \mathrm{mi}$., in Gulf of Esquibel, NW of Saint Philip I., Alex. Arch.; $55^{\circ} 40^{\prime} \mathrm{N}, 133^{\circ} 26^{\prime} \mathrm{W}$; (map 4). Var. Culebra Island, Isla Culebra, La Culebra, Snake Island.

Spanish name given in 1775-79 by Don Juan de la Bodega y Quadra and Francisco Antonio Maurelle as "Isla Culebra," meaning "snake island." The name originally was applied to one island, but USC\&GS extended the name about 1883 .

Culebrina Island: island, $0.4 \mathrm{mi}$. long, between Doyle and Trocadero Bays, off $\mathrm{W}$ coast of Prince of Wales I., Alex. Arch.; 55 $24^{\prime} 50^{\prime \prime}$ N, $133^{\circ} 04^{\prime} 40^{\prime \prime} \mathrm{W}$; (map 4). Var. Kulebrina.

Spanish name given in 1775-79 by Don Juan de la Bodega y Quadra and Francisco Antonio Maurelle; probably from "culebra," meaning "snake."

Culitna: stream, see Holitna River.

Culkana: stream, see Gulkana River.

Culkena: stream, see Gulkana River.

Cull Ross Point: point of land, see Culross, Point.

Culross, Point: point of land, on $\mathrm{N}$ coast of Culross I. at NW entrance to Culross Bay, $18 \mathrm{mi}$. E of Whittier, Chugach Mts.; $60^{\circ} 45^{\prime}$ $30^{\prime \prime} \mathrm{N}, 148^{\circ} 08^{\prime} 35^{\prime \prime} \mathrm{W}$; (map 63). Var. Cull Ross Point, Gulrass Point.

Named in 1794 by Capt. Vancouver (1798, v. 3, p. 179), RN.

Culross Bay: estuary, on $\mathrm{N}$ coast of Culross $\mathrm{I}$., trends NE $2 \mathrm{mi}$. to Wells Passage, $19 \mathrm{mi}$. E of Whittier, Chugach Mts.; $60^{\circ} 45^{\prime} 15^{\prime \prime} \mathrm{N}$, $148^{\circ} 08^{\prime} 20^{\prime \prime} \mathrm{W}$; BGN 1914; (map 63). Var. Thomas Bay.

Local name reported in 1914 by Andrew Braid, USC\&GS.

Culross Island: island, $10 \mathrm{mi}$. long, in Prince William Sound, between Perry Passage and Culross Passage, $16 \mathrm{mi}$. SE of Whittier, Chugach Mts.; $60^{\circ} 43^{\prime} \mathrm{N}, 148^{\circ} 09^{\prime} \mathrm{W}$; $B G N$ 1906; (map 63). Var. Grant Island.

Local name reported by U. S. Grant, USGS, in 1905.

Culross Passage: water passage, trends N-S 12 mi. between Culross I. and E coast of Kenai Penin., from Wells Passage on the $\mathbf{N}$ to Port Nellie Juan on the S, $18 \mathrm{mi}$. SE of Whittier,
Chugach Mts.; $60^{\circ} 41^{\prime} \mathrm{N}, 148^{\circ} 14^{\prime} \mathrm{W}$; (map 63).

Named in 1908 by U. S. Grant, USGS.

Cultas Creek: stream, flows E $9 \mathrm{mi}$. to Charley River, $9 \mathrm{mi}$. $\mathbf{S}$ of that stream's junc. with Yukon River, Yukon-Tanana High.; $65^{\circ} 11^{\prime}$ $30^{\prime \prime} \mathrm{N}, 142^{\circ} 47^{\prime} 50^{\prime \prime} \mathrm{W}$; (map 103).

Prospectors' name from an unpublished map by E. J. Chamberlain, dated 1902.

Cultheeth Mountain: peak, see Kulthieth Mountain.

Gultheeth River: stream, see Kaliakh River.

Cultheeth River: stream, see Kulthieth River.

Cumberland Creek: stream, flows SE $6 \mathrm{mi}$. to Klokerblock River, $26 \mathrm{mi}$. E of Solomon, Seward Penin. High.; $64^{\circ} 41^{\prime} \mathrm{N}, 163^{\circ} 38^{\prime} \mathrm{W}$; (map 95).

Prospectors' name reported in 1900 by E. C. Barnard (in Brooks, 1901, pl. 17), USGS.

Cummings Creek: stream, flows SW $8 \mathrm{mi}$. to Iniakuk River, Brooks Ra. ; 67 ${ }^{\circ} 13^{\prime} \mathrm{N}, 153^{\circ} 08^{\prime}$ W; (map 125).

Local name reported by Orth, USGS, in 1956.

Cunningham, Lake: lake, intermittent, $0.5 \mathrm{mi}$. long, on Falls Creek, $12 \mathrm{mi}$. NW of Chichagof, on $W$ coast of Chichagof Is., Alex. Arch.; $57^{\circ} 49^{\prime} 30^{\prime \prime} \mathrm{N}, 136^{\circ} 17^{\prime} 10^{\prime \prime} \mathrm{W}$; (map 9).

Name published in 1928 by USC\&GS on Chart 8258.

Cunningham Creek: stream, flows S $1.5 \mathrm{mi}$. to Norton Sound, $7 \mathrm{mi}$. SE of Nome, Seward Penin. High.; $64^{\circ} 27^{\prime} 48^{\prime \prime} \mathrm{N}, 165^{\circ} 10^{\prime} 20^{\prime \prime} \mathrm{W}$; (map 94).

Prospectors' name reported in 1904 by T. G. Gerdine, USGS.

Cunningham Creek: stream, flows SE $3 \mathrm{mi}$. to Hannum Creek which flows to Inmachuk River, 22 mi. N of Imuruk Lake, Seward Penin. High.; $65^{\circ} 55^{\prime} \mathrm{N}, 163^{\circ} 19^{\prime} \mathrm{W}$; (map 110).

Prospectors' name reported in 1903 by $D$. C. Witherspoon (in Moffit, 1905, pl. 2), USGS.

Cunningham Mountain: hill, $250 \mathrm{ft}$, , on right bank of Yukon River, at Devils Elbow, $24 \mathrm{mi}$. SW of Russian Mission, Yukon-Kuskokwim Delta; $61^{\circ} 37^{\prime} \mathrm{N}, 161^{\circ} 56^{\prime} \mathrm{W}$; (map 73).

Riverboat pilots' name shown on a 1940 navigation chart of Yukon River. Reported to be named for Jimmy Cunningham, riverboat captain and storekeeper from Huslia, on the Koyukuk.

Cunningham Ridge: ridge, elev. 2,000 ft., $4 \mathrm{mi}$. long, on E side of Monument Mtn., $25 \mathrm{mi}$. NE of Katalla, Chugach Mts.; $60^{\circ} 26^{\prime} \mathrm{N}, 144^{\circ} 01^{\prime}$ W; (map 64).

Name used by local prospectors; reported in 1905 by G. C. Martin, USGS.

Cunningham Slough: watercourse, see Honeymoon Slough.

Cup Cove: cove, $0.3 \mathrm{mi}$. wide, on SE coast of Kenai Penin., $\mathrm{N}$ of Harris Point, $38 \mathrm{mi}$. SW of Seward, Chugach Mts.; $59^{\circ} 39^{\prime} 45^{\prime \prime}$ N, $149^{\circ}$ $56^{\prime} 40^{\prime \prime} \mathrm{W}$; (map 49).

Local name reported in the early 1950 's by USG\&GS.

Cupel Creek: stream, see Sherrette Creek. 
Cupola Peak: mountain, 3,976 ft., on $\mathrm{W}$ coast of Baranof I., 9 mi. SE of Sitka, Alex. Arch.; $57^{\circ} 00^{\prime} 30^{\prime \prime} \mathrm{N}, 1^{\circ} 05^{\circ} 30^{\prime \prime} \mathrm{W}$; BGN 1940; (map 9). Var. Cross Mountain, Gora Kupolnaia, Gora Kupolnaya, Koupolinaia Hill.

Russian name meaning "cupola" given in 1809 by the navigator Ivan Vasiliev the first, IRN; published by Lt. Sarichev (1826, map 19), IRN, as "Gora Kupolnaya."

Cupps Hill: mountain, 2,760 ft., on Attu I., 3 mi. WSW of Goltsov Point, Aleutian Is.; $52^{\circ} 57^{\prime} 03^{\prime \prime} \mathrm{N}, 173^{\circ} 06^{\prime} 15^{\prime \prime} \mathrm{E}$; (map 13).

Named by U.S. Army during World War II; published in 1948 by AMS.

Curacao Reef: reef, in Gulf of Esquibel, $1 \mathrm{mi}$. SW of Culebra Is., Alex. Arch.; $55^{\circ} 39^{\prime} 20^{\prime \prime} \mathrm{N}$, $133^{\circ} 28^{\prime} 10^{\prime \prime} \mathrm{W}$; (map 4).

Named in 1915 by USC\&GS "for the island of Curacao in the Netherlands-Antilles and the sour, orange-flavored liqueur made there, called Curacao."

Curlew Lake: lake, $0.8 \mathrm{mi}$. long, on Kenai Penin. NW of Snag Lake, $28 \mathrm{mi}$. NE of Kenai, Cook Inlet Low.; $60^{\circ} 50^{\prime} 30^{\prime \prime} \mathrm{N}, 150^{\circ} 43^{\prime} 30^{\prime \prime} \mathrm{W}$; (map 62).

Named about 1963 by officials of Kenai National Moose Range, probably for the BristleThighed Curlew (Numenius tahitiensis), a bird "known as a migrant between Alaska and the South Pacific Islands * * *" (Gabrielson and Lincoln, 1959, p. 347).

Curlew Point: point of land, at junc. of Behm Narrows and Hassler Pass, on NW coast of Revillagigedo I., $40 \mathrm{mi}$. N of Ketchikan, Alex. Arch.; 55 $54^{\prime} 55^{\prime \prime} \mathrm{N}, 131^{\circ} 35^{\prime} 00^{\prime \prime} \mathrm{W}$; (map 3).

One of many arbitrary names applied to features in this area in 1891 by USC\&GS.

Currant Creek: stream, flows W $20 \mathrm{mi}$. to Lake Clark, $36 \mathrm{mi}$. NE of Nondalton, Aleutian Ra.; $60^{\circ} 19^{\prime} \mathrm{N}, 154^{\circ} 00^{\prime} \mathrm{W}$; (map 61). Var. Salmon Creek.

Name published by USGS (Martin and Katz, 1912, pl. 1).

Current, Cape: point of land, on $\mathrm{W}$ shore of Perenosa Bay, $34 \mathrm{mi}$. NE of Afognak, on N coast of Afognak I., $\mathrm{N}$ of Kodiak I. ; 58 $27^{\circ} 40^{\prime \prime}$ N, $152^{\circ} 29^{\prime} 10^{\prime \prime} \mathrm{W}$; (map 43).

Name published by USC\&GS from the descriptive name "M[ys] Silnago techeniya," or "strong current cape," published by the Russian American Company in 1849. The name was first applied by Sub.-Lt. Mikhail Murashev, IRN, in 1839 or 1840 to a point farther west because of the strong currents between Afognak and Shuyak Islands (Baker, 1906, p. 205).

Currin Slough: stream, distributary of Ibeck Greek, flows W $1.7 \mathrm{mi}$. to Eyak River, Ghugach Mts.; $60^{\circ} 32^{\prime} \mathrm{N}, 145^{\circ} 38^{\prime} \mathrm{W}$; (map 64).

Local name published in 1951 by USGS.

Curry: locality, pop. 3 , mile 248.5 on the Alaska RR., on $\mathbf{E}$ bank of Susitna River, $20 \mathrm{mi}$. NE of Talkeetna, Talkeetna Mts.; 62 $37^{\circ} 00^{\prime \prime} \mathrm{N}$, $150^{\circ} 00^{\prime} 40^{\prime \prime} \mathrm{W}$; (map 81). Var. Dead Horse, Deadhorse.

The Alaskan Engineering Commission Annual Report for 1916 lists the name Dead
Horse for this canp along the Alaska RR. route. As a $R R$. station the name was changed in 1922 to Curry. It was named for Charles Forrest Curry, 1858-1935, of Sacramento, Calif., a member of Congress. It had a population of 44 in 1958, but this decreased rapidly after the closing of the railroad agency a year later.

Curtis, Mount: mountain, 4,052 ft., on E bank of Barry Arm, $61 \mathrm{mi}$. SE of Anchorage, Chugach Mts. ; $61^{\circ} 04^{\prime} 35^{\prime \prime} \mathrm{N}, 148^{\circ} 05^{\prime} 40^{\prime \prime} \mathrm{W}$; (map 69).

Named in 1910 by Lawrence Martin, USGS, for E. S. Curtis, photographer on the Harriman Alaska expedition.

Curtis Bar Creek: stream, flows NE $1.5 \mathrm{mi}$. to Seventymile River, $16 \mathrm{mi}$. NW of Eagle, Yukon-Tanana High.; 64.54'40" N, 141 ${ }^{\circ} 39^{\prime}$ $20^{\prime \prime} \mathrm{W}$; (map 102).

Named by prospectors; reported in 1914 by C. E. Ellsworth and R. W. Davenport, USGS.

Curtis Creek: stream, flows N $2.3 \mathrm{mi}$. to Casadepaga River, $15 \mathrm{mi}$. N of Solomon, Seward Penin. High.; $64^{\circ} 47^{\prime}$ N, $164^{\circ} 26^{\prime} \mathrm{W}$; (map 95).

Prospectors' name reported in 1900 by E. C. Barnard (in Brooks, 1901, pl. 17), USGS.

Curtis Gulch: ravine, $1 \mathrm{mi}$. long, $4 \mathrm{mi}$. SE of Dyke Mtn. and $37 \mathrm{mi}$. $\mathrm{N}$ of Valdez, Chugach Mts.; $61^{\circ} 39^{\prime} \mathrm{N}, 146^{\circ} 04^{\prime} \mathrm{W}$; (map 68).

Prospectors' name reported in 1898 by Capt. W. R. Abercrombie, USA.

Curtis Hills: hills, $2 \mathrm{mi}$. across, highest 1,406 $\mathrm{ft}$., $\mathbf{N}$ of Wachusetts Inlet, in Glacier Bay National Monument, $64 \mathrm{mi}$. NW of Hoonah, St. Elias Mts.; $58^{\circ} 57^{\prime} 15^{\prime \prime} \mathrm{N}, 136^{\circ} 11^{\prime} 00^{\prime \prime} \mathrm{W}$; (map 10).

Named by the American Geographical Society Glacier Bay Expedition of 1941 for Edward S. Curtis, photographer with the Harriman Expedition, who visited Muir Inlet in 1899.

Curtis Lake: lake, $0.9 \mathrm{mi}$. long, $13 \mathrm{mi}$. W of Lake Louise and $47 \mathrm{mi}$. WNW of Glennallen; Copper River Basin; 62 $18^{\prime} 30^{\prime \prime} \mathrm{N}, 146^{\circ} 59^{\prime}$ $00^{\prime \prime} \mathrm{W}$; (map 83).

Local name reported in 1952 by USGS.

Curtis Slough: stream, an anabranch of Porcupine River, flows SW $26 \mathrm{mi}$. to a point 31 mi. NE of Fort Yukon, Yukon Flats; $66^{\circ} 46^{\prime}$ $35^{\prime \prime} \mathrm{N}, 144^{\circ} 15^{\prime} 30^{\prime \prime} \mathrm{W}$; (map 119).

Local name obtained in 1956 by USGS.

Curve Creek: stream, in York Mts., flows SE $3.5 \mathrm{mi}$. to Lost River which flows to Bering Sea, $26 \mathrm{mi}$. NW of Teller, Seward Penin. High.; $65^{\circ} 26^{\prime} \mathrm{N}, 167^{\circ} 11^{\prime} \mathrm{W}$; BGN 1948; (map 111)

So named in 1940 by J. B. Mertie, Jr., USGS because the stream "near its mouth makes an abrupt curve."

Curve Mountain: mountain, $1,680 \mathrm{ft}$., on Gravina I., between Blank Inlet and Bostwick Lake, Alex. Arch.; 55 $19^{\prime} 10^{\prime \prime} \mathrm{N}, 131^{\circ} 44^{\prime} 00^{\prime \prime}$ W; (map 3).

Descriptive name given in 1883 by $L t$. Comdr. H. E. Nichols, USN.
Gurve Slough: channel, of Koyukuk River along S side of Dog Is., $30 \mathrm{mi}$. NE of Hughes, Hogatza High.; $66^{\circ} 22^{\prime} \mathrm{N}, 153^{\circ} 30^{\prime} \mathrm{W}$; (map 116).

Local name reported by Orth in 1956.

Cushing Glacier: glacier, in Glacier Bay National Monument, heads on Alaska-Canada boundary, $7 \mathrm{mi}$. SW of Mount Harris, trends SE 14 mi. to Burroughs Glacier, $49 \mathrm{mi}$. SW of Skagway, St. Elias Mts.; $59^{\circ} 01^{\prime} \mathrm{N}, 136^{\circ} 24^{\prime} \mathrm{W}$; (map 45). Var. Cushing Plateau, Northwest Tributary.

Named "Cushing Plateau" by Reid (1896, pl. 90), USGS, for Henry Platt Cushing, 1860 1921 , one of his companions on his expedition to the Muir Glacier in 1890. Cushing was born in Ohio and was educated at Cornell and Columbia Universities and in Germany. He taught geology at Western Reserve University from 1891 until his death. His principal investigations were done on the geology of New York State. In 1890 he accompanied H. F. Ried to Muir Glacier, and was in charge of the meteorologic records, geologic studies, and the collection of plants. This glacier is shown as the Northwest Tributary of Muir Glacier by Reid (1892 pl. 14), USGS. It was published as Cushing Glacier by IBC in 1923 on map 9 (1951 atlas).

Cushing Inlet: estuary, see Wachusett Inlet.

Cushing Plateau: plateau, of ice, in Glacier Bay National Monument, in area of the Burroughs and Plateau Glaciers, $66 \mathrm{mi}$. NW of Hoonah, St. Elias Mts. $58^{\circ} 58^{\prime}$ N., $136^{\circ} 20^{\prime}$ W; (map 10). Var. Cushing Glacier.

Named by Reid (1896, pl. 86), USGS, for Henry Platt Cushing, 1860-1921, a companion of Reid in 1890 on his trip to Glacier Bay. Cushing taught geology at Western Reserve University, 1892-1921. He was also a member of the New York State Geological Survey. He wrote several papers on the geology of the Muir Glacier region. In 1890 the Muir Glacier was much more extensive than now because it terminated below Adams Inlet and produced a plateau-like glacial expanse in the vicinity of the present Wachusett Inlet.

Cushing Plateau: glacier, see Burroughs Glacier. Cushing Plateau: glacier, see Cushing Glacier.

Cushing Point: point of land, see Rowlee Point.

Cushman Creek: stream, flows S 6 mi. to Washington Creek, $20 \mathrm{mi}$. NW of Fairbanks, YukonTanana High.; $65^{\circ} 09^{\prime} \mathrm{N}, 147^{\circ} 53^{\prime} \mathrm{W}$; (map 105 ).

Local name published by USGS in the 1950 's.

Cuss Creek: stream, flows SW $1.6 \mathrm{mi}$. to Osborn Creek, $12 \mathrm{mi}$. NE of Nome, Seward Penin High.; $64^{\circ} 38^{\prime} \mathrm{N}, 165^{\circ} 09^{\prime} \mathrm{W}$; (map 94). Var. Cass Creek, Guss Creek.

Prospectors' name reported in 1904 by T. G. Gerdine, USGS. Shown as "Guss" on a 1901 map of Cape Nome gold fields by David Fox, Jr.

Customhouse Cove: cove, $0.3 \mathrm{mi}$. across, on NW coast of Mary I., off Felice Strait, Alex. Arch.; $55^{\circ} 05^{\prime} 35^{\prime \prime} \mathrm{N}, 131^{\circ} 13^{\prime} 35^{\prime \prime} \mathrm{W}$; (map 3). Var. Custom House Cove. 
Local name published in 1893 by USC\&GS; "a custom-house which existed here for some years moved to Ketchikan in 1900."

Cutaway Creek: stream, heads near Rim Butte, flows NNW $18 \mathrm{mi}$. to the Kuna River, $16 \mathrm{mi}$. E of Liberator Lake, Arctic Slope; $68^{\circ} 51^{\prime} \mathrm{N}$, $157^{\circ} 42^{\prime} \mathrm{W}$; (map 132).

So named in 1950 by geologists connected with the Naval Petroleum Reserve No. 4 explorations, because of the characteristic cut banks along the upper part.

Cutler River: stream, heads at $67^{\circ} 25^{\prime} \mathrm{N}, 157^{\circ} 37^{\prime}$ W, flows NW $45 \mathrm{mi}$. to Noatak River $45 \mathrm{mi}$. SW of Howard Pass, Brooks Ra.; 67 $51^{\prime} \mathrm{N}$, $158^{\circ} 20^{\prime} \mathrm{W}$; (map 126). Var. Garibou River.

P. S. Smith (1913, p. 31), USGS, writes "The Cutler [River] was called by Lt. [G. M.] Stoney [USN] the Caribou, but this name was not published [Stoney, 1900, map] until after the other [Cutler] had been adopted." The name Cutler River was published by USC\&GS on Chart 900 in 1890.

Cutnu Creek: stream, see Kutna Greek.

Cutoff: village, see Huslia.

Cutoff Creek: stream, on Hinchinbrook I., flows NE 6 mi. to Hawkins Island Cutoff, $25 \mathrm{mi}$. SW of Cordova, Chugach Mts. ; $60^{\circ} 26^{\prime} \mathrm{N}, 146^{\circ} 22^{\prime}$ W; (map 64).

Local descriptive name published in 1950 by USGS.

Cutoff Slough: channel, flows W $3.4 \mathrm{mi}$. from Christian River to Chandalar River, $19 \mathrm{mi}$. NW of Fort Yukon, Yukon Flats; $66^{\circ} 40^{\prime} \mathrm{N}$, $145^{\circ} 54^{\prime} \mathrm{W}$; (map 119).

Local descriptive name obtained in 1956 by USGS.

Cutoff Slough: stream, anabranch, on S side of Treat I., flows SW $28 \mathrm{mi}$. to Koyukuk River, $24 \mathrm{mi}$. NE of Roundabout Mtn., Koyukuk Low.; $65^{\circ} 52^{\prime} \mathrm{N}, 156^{\circ} 15^{\prime} \mathrm{W}$; (map 108). Var. Cut Off.

"River pilot's name" reported by Lt. B. $H$. Camden, USRCS; so called because it was thought to be considerably shorter in distance than the main channel (Cantwell, 1904, p. 243).

Cutoff Trading Post. village, see Huslia.

Cutter Point: point of land, in Chernofski Harbor, on SW coast of Unalaska I., Aleutian Is.; $53^{\circ} 23^{\prime} 35^{\prime \prime} \mathrm{N}, 167^{\circ} 30^{\prime} 35^{\prime \prime} \mathrm{W}$; BGN 1940; (map 23). Var. Middle Spit.

Named by a USC\&GS field party of 193738 which reported that, "anchorage and shelter from the wind, particularly for small craft, is found behind this point." The field party first used the name Middle Spit.

Cutter Rock. rocks, see Cutter Rocks.

Cutter Rocks: rocks, extend $500 \mathrm{ft}$. between Carroll Inlet and Revillagigedo Channel, $0.6 \mathrm{mi}$. $\mathrm{E}$ of Mountain Point, on Revillagigedo I., Alex. Arch.; $55^{\circ} 17^{\prime} 25^{\prime \prime} \mathrm{N}, 131^{\circ} 31^{\prime} 20^{\prime \prime} \mathrm{W}$; (map 3). Var. Cutter Rock.

Named in 1883 by Lt. Comdr. H. E. Nichols, USN.

Cuvacan Cove: cove, $0.4 \mathrm{mi}$. across, on $\mathrm{N}$ shore of Shelikof Bay, on Kruzof I., $17 \mathrm{mi}$. NW of Sitka, Alex. Arch.; 57 $10^{\prime} 20^{\prime \prime}$ N, $135^{\circ} 47^{\prime} 00^{\prime \prime}$ W; (map 9).
Name published by USC\&GS in the 1943 Coast Pilot (p. 368).

Cyane Rock: rock, $0.5 \mathrm{mi}$. E of Kodiak, NE of Near I, Kodiak I.; $57^{\circ} 47^{\prime} 28^{\prime \prime} \mathrm{N}, 152^{\circ} 23^{\prime} 05^{\prime \prime}$ W; (map 34).

Name published in 1910 by USC\&GS. Named for the bark Cyane (Cyano), one of the vessels purchased by Hutchinson, Kohl, \& Company from the Russian American Company in 1869.

Cycle Creek: stream, see Chikululnuk Creek.

Cygnet Island: island, $0.1 \mathrm{mi}$. long, at mouth of Mink Bay, off Boca de Quadra, $40 \mathrm{mi}$. SE of Ketchikan, Coast Mts. ; $55^{\circ} 05^{\prime} 22^{\prime \prime}$ N, $130^{\circ}$ $43^{\circ} 40^{\prime \prime} \mathrm{W}$; (map 3).

One of many arbitrary names applied to features in this area in 1891 by USC\&GS.

Cygnet Lake: lake, $0.5 \mathrm{mi}$. long on Kenai Penin. $0.5 \mathrm{mi}$. W of Swan Lake and $25 \mathrm{mi}$. NE of Kenai, Cook Inlet Low.; 60 $40^{\prime} 50^{\prime \prime} \mathrm{N}, 150^{\circ}$ $34^{\prime} 15^{\prime \prime} \mathrm{W}$; (map 62).

Named about 1963 by officials of Kenai National Moose Range. A cygnet is a young swan.

Cynthia, Lake: lagoon, see Killoknak Lagoon.

Cynthia, Lake: lagoon, see Maknik Lagoon.

Cynthia Falls: waterfall, on Iniskin Penin., in course of Hardy Creek, $2.8 \mathrm{mi}$. SW of mouth of Fitz Creek at Chinitna Bay, Aleutian Ra.; $59^{\circ} 47^{\prime} 15^{\prime \prime} \mathrm{N}, 153^{\circ} 12^{\prime} 30^{\prime \prime} \mathrm{W}$; BGN 1947; (map 51).

Local name reported by USGS in 1947; derived from the name of a geological formation in the vicinity given by oil company geologists in 1938 because "the waterfall is formed by a distinctive unit of sedimentary rocks."

Cy Peak: peak, 2,140 ft., on Iniskin Penin., $N$ of Shark Tooth Hill and $1 \mathrm{mi}$. NE of Oil Bay, Aleutian Ra.; $59^{\circ} 40^{\prime} 45^{\prime \prime} \mathrm{N}, 153^{\circ} 15^{\prime} 20^{\prime \prime} \mathrm{W}$; (map 51).

Local name published in 1958 by USGS.

Cyril Cove: cove, $0.6 \mathrm{mi}$. across, on NE coast of Amchitka I., Rat Is., Aleutian Is. ; $51^{\circ} 27^{\prime} 15^{\prime \prime}$ $\mathrm{N}, 179^{\circ} 12^{\prime} 15^{\prime \prime} \mathrm{E}$; (map 15$)$.

Name listed in 1944 Aleutian Coast Pilot (p. 123).

Cyrus Cove: bay, $2 \mathrm{mi}$. long, on $\mathrm{S}$ coast of Orr I., Alex. Arch.; $55^{\circ} 54^{\prime} \mathrm{N}, 133^{\circ} 25^{\prime} \mathrm{W}$; (map 4).

Named in 1904 by E. F. Dickins, USC\&GS "after Captain Cyrus Orr, who informed me of this anchorage."

Cytex Creek: stream, on Kenai Penin., flows W $7 \mathrm{mi}$. to Deep Creek, $6 \mathrm{mi}$. NW of Caribou Lake and $24 \mathrm{mi}$. NE of Homer, Cook Inlet Low.; 59 $57^{\prime} \mathrm{N}, 151^{\circ} 13^{\prime} \mathrm{W}$; (map 50).

Local name reported and published by USGS in the 1950's.

Czar Konstantin, Harbor of : lagoon, see Constantine Harbor.

\section{D}

Dabbler Lake: lake, $0.4 \mathrm{mi}$, long, on Kenai Penin. $\mathrm{SE}$ of Dolly Varden Lake, $19 \mathrm{mi}$. NE of Kenai, Cook Inlet Low.; 60⒋ $41^{\prime} 45^{\prime \prime} \mathrm{N}, 150^{\circ} 46^{\prime} 20^{\prime \prime}$ W; (map 62).
Named about 1963 by officials of Kenai National Moose Range, for administrative purposes.

Dachikirowrak Gove: cove, see Dachirowruk Cove.

Dachikjowaruk Cove: cove, on E shore of Nash Harbor, $1 \mathrm{mi}$. N of Dachirowruk Cove, Nunivak I.; $60^{\circ} 14^{\prime} 25^{\prime \prime} \mathrm{N}, 166^{\circ} 48^{\prime} 00^{\prime \prime} \mathrm{W}$; (map 57).

Eskimo name obtained in 1949 by USC\&GS.

Dachirowruk Cove: cove, on $\mathrm{E}$ shore of Nash Harbor, at mouth of Antingmuit Creek, Nunivak I.; $60^{\circ} 13^{\prime} 30^{\prime \prime} \mathrm{N}, 166^{\circ} 48^{\prime} 45^{\prime \prime} \mathrm{W}$; (map 57). Var. Dachikirowrak Cove.

Eskimo name obtained in 1949 by USC\&GS.

Dachlazug Island: island, see Dalasuga Island. Dacy Gulch: ravine, flows NW $0.8 \mathrm{mi}$. to Candle Creek, $6.6 \mathrm{mi}$. SW of Candle and $36 \mathrm{mi}$. NE of Imuruk Lake, Seward Penin. High.; $65^{\circ} 50^{\prime}$ N, $162^{\circ} 02^{\prime} \mathrm{W}$; (map 110).

Prospectors' name reported on the 1908 "Map of Seward Peninsula" by Arthur Gibson. Dadina: stream, see Dadina River.

Dadina Glacier: glacier, trends SW $9.5 \mathrm{mi}$. from Mount Zanetti to its terminus at head of $\mathrm{Da}$ dina River, $15 \mathrm{mi}$. SW of Mount Sanford, Wrangell Mts. ; $62^{\circ} 02^{\prime} 45^{\prime \prime} \mathrm{N}, 144^{\circ} 25^{\prime} 00^{\prime \prime} \mathrm{W}$; (map 83).

Local name reported by USGS in 1902, (in Mendenhall, 1905, pl. 4); named for the river. Dadina Lake: lake, $2.4 \mathrm{mi}$. long, trends $\mathrm{E}-\mathrm{W}$, $8.6 \mathrm{mi}$. ENE of junc. of Dadina River with Copper River, $69 \mathrm{mi}$. NE of Valdez, Wrangell Mts.; 61 $50^{\prime} 35^{\prime \prime} \mathrm{N}, 144^{\circ} 48^{\prime} 30^{\prime \prime} \mathrm{W}$; (map 68). Local name published in 1950 by USGS.

Dadina River: stream, heads in Dadina Glacier, flows SW $35 \mathrm{mi}$. to Copper River, $3 \mathrm{mi}$. SE of mouth of Nadina River and $62 \mathrm{mi}$. NE of Valdez, Copper River Basin; 61 $49^{\prime} \mathrm{N}, 1^{\circ} 5^{\circ}$ 04' W; (map 58). Var. Dadina, Tatina, Tetna.

Indian name published in 1898 by Capt. W. R. Abercrombie, USA, as "Tatena." The present spelling comes from USGS (Mendenhall, 1905, p. 21).

Dadinowiki Creek: stream, flows N 6 mi. to Nash Harbor, E of Ahkolikotak Head and $30 \mathrm{mi}$. SW of Cape Etolin, Nunivak I.; $60^{\circ} 12^{\prime} 15^{\prime \prime}$ N, $166^{\circ} 51^{\prime} 30^{\prime \prime} \mathrm{W}$; (map 57).

Eskimo name reported in 1937 by USAAF.

Dad Rock: rock, among Inian Is., in S Inian Pass, off $\mathrm{N}$ coast of Chichagof 1 ., $1 \mathrm{mi}$. NE of Point Lavinia, $34 \mathrm{mi}$. NW of Hoonah, St. Elias Mts.; $58^{\circ} 14^{\prime} 05^{\prime \prime} \mathrm{N}, 136^{\circ} 20^{\prime} 15^{\prime \prime} \mathrm{W}$; (map 10).

Named by Pratt (1902, p. 14), USC\&GS, in 1901 .

Dads Creek: stream, flows $\mathrm{N} 2 \mathrm{mi}$. to West Fork Kuyukutuk River, $12.1 \mathrm{mi}$. E of Marshall, Nulato Hills; $61^{\circ} 52^{\prime} 25^{\prime \prime} \mathrm{N}, 161^{\circ} 42^{\prime} 50^{\prime \prime} \mathrm{W}$; (map 73).

Prospectors' name reported by Harrington (1918, map), USGS, in 1916.

Daeyshoo: isthmus, see Deshu Isthmus.

Dagelet, Mount: mountain, 9,800 ft., in Fairweather Ra., $4.6 \mathrm{mi}$. S of Mount Crillon, in 
Glacier Bay National Monument, $72 \mathrm{mi}$. NW of Hoonah, St. Elias Mts.; $58^{\circ} 35^{\prime} 50^{\prime \prime} \mathrm{N}, 137^{\circ}$ $10^{\prime} 25^{\prime \prime}$ W; (map 10). Var. Mount D'Agelet. Named by W. H. Dall, USC\&GS, in 1874 for Lepaute Dagelet, astronomer on La Pérouse's expedition of 1786 . The name was published as Mount D'Agelet in the 1883 Coast Pilot (p. 202). The first ascent was made July 29, 1933 by W. S. Child, C. S. Houston, and H. A. Carter (Farquhar, 1959, p. 217).

Dagelet Glacier: glacier, heads on NW slope of Mount Dagelet, trends $2.5 \mathrm{mi}$. S to La Perouse Glacier, $4 \mathrm{mi}$. E of Ptarmigan Dome and 73 mi. NW of Hoonah, St. Elias Mts.; $58^{\circ} 34^{\prime} \mathrm{N}$, $137^{\circ} 12^{\prime} \mathrm{W}$; (map 10).

Named by members of the Harvard-Dartmouth Expedition, 1933-34.

Dagelet River: stream, in Glacier Bay National Monument, heads in La Perouse Glacier, flows SW $3 \mathrm{mi}$. to Gulf of Alaska, $77 \mathrm{mi}$. NW of Hoonah, Malaspina Coastal Plain; 58 $30^{\prime} 30^{\prime \prime}$ N, $137^{\circ} 24^{\prime} 00^{\prime \prime} \mathrm{W}$; (map 10).

Local name published by USGS in the 1950's.

Dagetkakat River: stream, see Dagitli River.

Dagislakhna Creek: stream, flows NE and SE $33 \mathrm{mi}$. to Tozitna River, $24 \mathrm{mi}$. NNW of Tanana, Kokrines-Hodzana High.; $65^{\circ} 33^{\prime} \mathrm{N}$, $152^{\circ} 14^{\prime}$ W; BGN 1960; (map 106). Var. West Fork Tozitna River.

Indian name obtained in 1956 at Tanana by Orth.

Dagitli River: stream, flows SE $30 \mathrm{mi}$. to Koyukuk River, $11 \mathrm{mi}$. NW of Roundabout

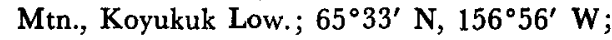
(map 108). Var. Dagetkakat River, Doggetlikat, Doggetlikakat, Doggetlooscat River, Doggetlooskat River, Dogitskakat.

Koyukan Indian name first reported by $L t$. Allen (1887, p. 105), USA, as "Doggetlooskat River" and "Doggetlooscat." F. C. Schrader, USGS, gave the spelling "Doggetlikakat" meaning "mouth of the Dogetli," from which "Dagitli" is derived. This name seems to be related to the Dagislakhna; applied to a stream in the Tozitna drainage.

Dago Creek: stream, heads in lake, $16 \mathrm{mi}$. SE of Egegik, meanders SW $50 \mathrm{mi}$. to Ugashik Bay, 3 mi. $E$ of Smoky Point, on $W$ coast of Alaska Penin., $9 \mathrm{mi}$. NW of Ugashik, Bristol Bay Low.; $57^{\circ} 36^{\prime} 40^{\prime \prime}$ N, $157^{\circ} 36^{\prime} 15^{\prime \prime} \mathrm{W}$; (map 36).

Local name reported in 1900 by $L$ t. Comdr. J. F. Moser, USN, of the USBF steamer Albatross.

Dago Frank Creek: stream, flows E $4.5 \mathrm{mi}$. to Chignik Bay, on Alaska Penin., $7 \mathrm{mi}$. NW of Chignik, Aleutian Ra.; $56^{\circ} 23^{\prime} \mathrm{N}, 158^{\circ} 30^{\prime}$ W; (map 30).

Name derived from the nickname "of a local Italian," reported in 1923 by R. H. Sargent, USGS.

Dagorashapka: locality, see Pogoreshapka.

Dahl: locality, on Kenai Penin., NE shore of Lower Summit Lake, $16 \mathrm{mi}$. S of Sunrise,

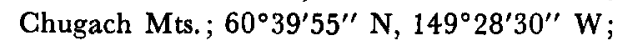
(map 63).
Former mining camp located along Canyon Creek; named for Dahl placer mine. Recent USGS maps indicate a site with three buildings. A post office was established here in 1905 and was discontinued in 1913 (Ricks, 1965, p. 16).

Dahl: locality, on left bank of Quartz Creek which flows to Kougarok River, $47 \mathrm{mi}$. SE of Imuruk Lake, Seward Penin. High.; $65^{\circ} 22^{\prime}$ $\mathrm{N}, 164^{\circ} 43^{\prime} \mathrm{W}$; (map 110). Var. Quartz Creek.

Former mining camp named for an early prospector. It is shown as "Quartz Creek" by T. G. Gerdine (in Collier, 1902, pl. 12), USGS. The camp was established about 1900 at the beginning of mining in this region. The Dahl Post Office was established here in 1905 and was discontinued in 1913, although the community was active through 1914 (Balcom, 1965, p. 10).

Dahlasuk Island: island, see Dalasuga Island.

Dahl Creek: stream, flows NE $3 \mathrm{mi}$. to La Spray Creek, $18 \mathrm{mi}$. NE of Nome, Seward Penin. High.; $64^{\circ} 44^{\prime} \mathrm{N}, 165^{\circ} 08^{\prime} \mathrm{W}$; (map 94).

Prospectors' name shown on the 1902 "Map of the Nome and Snake River Country" by J. M. Davidson.

Dahl Creek: stream, flows NE $5.3 \mathrm{mi}$. to Quartz Creek which flows to Kougarok River, $47 \mathrm{mi}$. SW of Imuruk Lake, Seward Penin. High.; $65^{\circ} 22^{\prime} \mathrm{N}, 164^{\circ} 43^{\prime} \mathrm{W}$; (map 110).

Prospectors' name reported in 1901 by T. G. Gerdine (in Collier, 1902, pl. 12), USGS.

Dahl Creek: stream, flows S $9 \mathrm{mi}$. to Kobuk River $7 \mathrm{mi}$. E of Shungnak, Kotzebue-Kobuk Low.; $66^{\circ} 55^{\prime} \mathrm{N}, 156^{\circ} 54^{\prime} \mathrm{W}$; (map 115).

Local name reported in 1910 by $P$. S. Smith, USGS.

Dahlgren Peak: peak, 3,539 ft., $5 \mathrm{mi}$. NE of village of Cape Fanshaw, $75 \mathrm{mi}$. E of Sitka, Coast Mts.; $57^{\circ} 14^{\prime} \mathrm{N}, 133^{\circ} 22^{\prime} \mathrm{W}$; (map 8).

Named in 1887 by Lt. Comdr. C. M. Thomas, USN, for Rear Adm. J. A. Dahlgren, USN. The name was published in 1888 by USC\&GS on Chart 705.

Dahlgren Ridge: ridge, in Robinson Mts., trends $14 \mathrm{mi}$. SW-NE, $12 \mathrm{mi}$. N of Cape Yakataga and $101 \mathrm{mi}$. NW of Yakutat, Chugach Mts.; $60^{\circ} 13^{\prime} \mathrm{N}, 142^{\circ} 18^{\prime} \mathrm{W} ;$ BGN 1957; (map 65),

Named in 1955 by USGS for Gustave Louis Dahlgren, placer miner and resident of the Yakataga district from 1903 to 1938 .

Dahloongamiut: locality, at mouth of Dahloongamiut Lagoon, $35 \mathrm{mi}$. NW of Cape Mendenhall, Nunivak I.; $59^{\circ} 59^{\prime} 20^{\prime \prime} \mathrm{N}, 167^{\circ} 04^{\prime} 20^{\prime \prime}$ W; (map 55). Var. Daloongmute, Dalungamiut, Tachyhuimiut.

Eskimo name reported about 1949 by USC\&GS.

Dahloongamiut: locality, see Tachyhuimiut.

Dahloongamiut Lagoon: lagoon, $2 \mathrm{mi}$. long, at mouth of Dahloongamiut River, $35 \mathrm{mi}$. NW of Cape Mendenhall, on Nunivak I.; $59^{\circ}$ $59^{\prime} 30^{\prime \prime} \mathrm{N}, 167^{\circ} 04^{\prime} 20^{\prime \prime} \mathrm{W}$; (map 55).

Eskimo name reported in 1937 by USAAF. Dahloongamiut River: stream, heads at $60^{\circ} 09^{\prime}$ $\mathrm{N}, 167^{\circ} 05^{\prime} \mathrm{W}$, flows S $12 \mathrm{mi}$. to Dahloongamiut Lagoon, $36 \mathrm{mi}$. NW of Cape Menden- hall, Nunivak I.; $60^{\circ} 00^{\prime} 45^{\prime \prime} \mathrm{N}, 167^{\circ} 04^{\prime} 30^{\prime \prime}$ W; (map 57). Var. Dalungamiut River.

Eskimo name obtained in 1949 by USC\&GS. Dahl River: stream, see Dall River.

Dahteh: fish camp, along left bank of Black River, $22 \mathrm{mi}$. E of Chalkyitsik, Porcupine Plat.; $66^{\circ} 38^{\prime} \mathrm{N}, 143^{\circ} 03^{\prime} \mathrm{W}$; (map 120).

Tranjik-kutchin Indian name; obtained in 1956 by T. E. Taylor, USGS.

Dahtkit Cove: cove, $17 \mathrm{mi}$. SW of Cape Etolin, at mouth of Gunghoruk Creek, on N coast of Nunivak I.; $60^{\circ} 19^{\prime} 30^{\prime \prime} \mathrm{N}, 166^{\circ} 34^{\prime} 10^{\prime \prime} \mathrm{W}$; (map 57). Var. Datkit Cove.

Eskimo name meaning "small bay" according to USC\&GS in 1949.

Dainty Island: island, on Yukon River, $55 \mathrm{mi}$. E of Nulato, Kilbuck-Kuskokwim Mts.; $64^{\circ} 42^{\prime}$ $N, 156^{\circ} 16^{\prime} \mathrm{W}$; (map 97).

Riverboat pilots' name shown on a 1940 "Navigation Chart of the Tanana-Yukon Rivers" published by U.S. Dept. of Interior.

Daisy Greek: stream, heads in lake, flows NE $6.5 \mathrm{mi}$. to Tyone Creek, $16 \mathrm{mi}$. W of Lake Louise and $27 \mathrm{mi}$. SE of junc. of Oshetna and Susitna Rivers, Talkeetna Mts.; 62 ${ }^{\circ} 17^{\prime} 10^{\prime \prime}$ $\mathrm{N}, 147^{\circ} 05^{\prime} 00^{\prime \prime} \mathrm{W}$; (map 82).

Local name reported in 1951 by USGS.

Daisy Creek: stream, heads in lake, flows SE $4.6 \mathrm{mi}$. to Chistochina River, $21 \mathrm{mi}$. $\mathrm{E}$ of

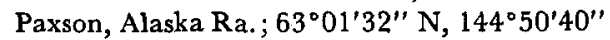
W; (map 86).

Local name reported in 1902 by W. C. Mendenhall (in Moffit, 1912, pl. 3), USGS. Daisy Creek: stream, flows SW $1.3 \mathrm{mi}$. to Tributary Creek which flows to Big Hurrah Creek, $10 \mathrm{mi}$. NE of Solomon, Seward Penin. High.; $64^{\circ} 39^{\prime} \mathrm{N}, 164^{\circ} 10^{\prime} \mathrm{W}$; (map 95). Var. Datsy Creek.

Prospectors' name reported in 1905 by T. G. Gerdine, USGS. Shown as "Datsy" on Arthur Gibson's 1904 "Map of Cape Nome Precinct."

Daisy Glacier: glacier, heads on E slope of Karr Hills and trends SE $2.5 \mathrm{mi}$. to Tyndall Glacier, $9 \mathrm{mi}$. NE of head of Icy Bay, $67 \mathrm{mi}$. NW of Yakutat, St. Elias Mts.; $60^{\circ} 10^{\prime} 30^{\prime \prime} \mathrm{N}, 141^{\circ}$ $10^{\prime} 30^{\prime \prime} \mathrm{W}$; (map 65).

Named in 1888 by H. W. Topham.

Daisy Island: island, $0.7 \mathrm{mi}$. long, in Kasaan Bay, on E coast of Prince of Wales I., $2.3 \mathrm{mi}$. NW of Kassan Point, Alex. Arch.; 55 $28^{\prime} 30^{\prime \prime}$ $\mathrm{N}, 132^{\circ} 19^{\prime} 00^{\prime \prime} \mathrm{W}$; (map 4).

Named by local fishermen and reported in 1904 by H. C. Fassett, USBF.

Daisy Swift Creek: stream, flows NW $0.8 \mathrm{mi}$. to Cripple River, $16 \mathrm{mi}$. NW of Nome, Seward Penin. High.; $64^{\circ} 44^{\prime} \mathrm{N}, 165^{\circ} 40^{\prime} \mathrm{W}$; (map 94).

Prospectors' name reported on Arthur Gibson's "Map of Cape Nome Precinct" dated 1904.

Daiye: locality, see Dyea.

Dakaneek Bay: cove, $0.7 \mathrm{mi}$. across, $8.5 \mathrm{mi}$. SE of Kake, on W coast of Kupreanof I., Alex. Arch.; 56 $51^{\prime} 30^{\prime \prime} \mathrm{N}, 1^{\prime 3} 3^{\circ} 52^{\prime} 00^{\prime \prime} \mathrm{W}$; (map $6)$.

Indian name published in 1943 by USC\&GS 
Dakavak Bay: bay, extends N $3.5 \mathrm{mi}$. off Shelikof Strait, on E coast of Alaska Penin., in Katmai National Monument, $16 \mathrm{mi}$. SE of Mount Katmai, Aleutian Ra.; $58^{\circ} 02^{\prime} \mathrm{N}$, 154 $41^{\prime}$ W; BGN 1924; (map 42). Var. Tagalack Bay, Tagalak Bay, Takkala Bay.

Name published as "Tagalack Bay" by Adm. von Krusenstern (1827, map 17), IRN; reported in 1904 as "Dakavak Bay" by G. C. Martin, USGS, who obtained the name from Nikolai Kalmakof, chief at Katmai. See Dakavak Lake.

Dakavak Lake: lake, $3.5 \mathrm{mi}$. long, $\mathrm{N}$ of Dakavak Bay, on E coast of Alaska Penin. in Katmai National Monument, $10 \mathrm{mi}$. SE of Mount Katmai, Aleutian Ra.; $58^{\circ} 06^{\prime} \mathrm{N}, 154^{\circ} 41^{\prime} \mathrm{W}$; $B G N$ 1924; (map 42). Var. Davak Lake, Tagalack Lake, Takkala Lake.

Native name reported in 1904 by G. C. Martin, USGS. Griggs (1922, map) gave the same native name to the lake, but spelled it "Takkala" for both bay and lake. See Dakavak Bay.

Dakeekalik Creek: stream, flows NE $0.8 \mathrm{mi}$. to Etolin Strait $10 \mathrm{mi}$. SE of Cape Etolin, on NE coast of Nunivak I.; $60^{\circ} 19^{\prime} \mathrm{N}, 166^{\circ} 01^{\prime} \mathrm{W}$; (map 57). Var. Dakikalik Creek.

Eskimo name obtained in 1949 by USC\&GS.

Dakeekathlrimjingia Point: point of land, $10 \mathrm{mi}$. SE of Cape Etolin, on NE coast of Nunivak I.; $60^{\circ} 19^{\prime} 10^{\prime \prime} \mathrm{N}, 166^{\circ} 01^{\prime} \mathrm{C0^{ \prime \prime }} \mathrm{W}$; (map 57). Var. Dakikatlrimjingia Point.

Eskimo name obtained in 1949 by USC\&GS.

Dakikalik Creek: stream, see Dakeekalik Creek.

Dakikatlrimjingia Point: point of land, see Dakeekathlrimjingia Point.

Dakli: river, "tributary to the Koyukuk from the north, near longitude $157^{\circ}$."

"Native name, reported by Allen, 1885 . In his text Allen calls it Dakliakakat and on his map Daklikakat. The latter has been copied by the Coast Survey. See Kakat. According to Stoney the Kobuk Eskimo name for this stream is Togo-tit-nuk." (Baker, 1906, p. 207). See Dagitli River.

Dakoo Islands: islands, see Daykoo Islands.

Dakota Creek: stream, flows SE $3 \mathrm{mi}$. to Walker Fork, $52 \mathrm{mi}$. SW of Eagle, Yukon-Tanana High.; $64^{\circ} 04^{\prime} \mathrm{N}, 141^{\circ} 23^{\prime} \mathrm{W}$; (map 102).

Prospectors' name shown on an 1898 manuscript map by C. A. Woodruff, Fort Cudahy, Canada.

Daktaeluk Creek: stream, see Taktelak Creek.

Dalasuga Island: island, $0.4 \mathrm{mi}$. long, off $\mathrm{S}$ end of Chilkat Penin. in Chilkat Bay, $0.4 \mathrm{mi}$. NW of Seduction Point and $25 \mathrm{mi}$. S of Skagway, Coast Mts.; $B G N$ 1922; $59^{\circ} 05^{\prime} 20^{\prime \prime} \mathrm{N}$, $135^{\circ} 19^{\prime} 05^{\prime \prime}$ W; (map 45). Var. Dahlasuk Island, Dalasuka Island, Dàtàsùk, Datlasuk Island, Dachlazug Island.

Tlingit Indian name meaning "barnacleinfested"; reported by Aurel and Arthur Krause (1883, map) as "Dachlazug."

Dalasuka Island: island, see Dalasuga Island.

Dalbatna: stream, see Dulbi River.

Dale Creek: stream, see Dick Dale Creek.
Dalimaloak Mountain: mountain, 5,000 ft., in Endicott Mts., $15 \mathrm{mi}$. SE of Survey Pass, Brooks Ra.; $67^{\circ} 44^{\prime} \mathrm{N}$, $153^{\circ} 50^{\prime} \mathrm{W}$; $B G N$ 1932; (map 125).

Named in 1932 by USGS; "reported as being an Eskimo word for 'seven' given because the mountain is at the head of the seventh tributary above the Kutuk River."

Dall: locality, see Dall City.

Dall, Cape: point of land, see Dall Point.

Dall, Mount: mountain, 8,756 ft., $9 \mathrm{mi}$. SE of Mystic Pass and $72 \mathrm{mi}$. NW of Talkeetna, Alaska Ra.; 62 $34^{\prime} 45^{\prime \prime} \mathrm{N}, 152^{\circ} 17^{\prime} 30^{\prime \prime} \mathrm{W}$; (map 81).

Named in 1902 by A. H. Brooks, USGS, for William Healy Dall, 1845-1927, "one of the foremost students, explorers, writers, and authorities on Alaskan matters."

Dall Bay: bay, 1.5 mi. wide, at mouth of Nichols Passage, on SE coast of Gravina I., $13 \mathrm{mi}$. SW of Ketchikan, Alex. Arch.; $55^{\circ} 09^{\prime} 30^{\prime \prime}$ $\mathrm{N}, 131^{\circ} 44^{\prime} 30^{\prime \prime} \mathrm{W}$; (map 3).

Name reported in 1901 by Brooks (1902b, pl. 2), USGS; derived from Dall Head.

Dall City: locality, on $\mathbf{S}$ bank of the West Fork Dall River, $32 \mathrm{mi}$. NW of Stevens Village, Kokrines-Hodzana High.; $66^{\circ} 21^{\prime} \mathrm{N}, 149^{\circ} 51^{\prime}$ W; (map 118). Var. Dall.

Prospectors' camp occupied in the winters of 1898-1900; established along the route to the upper Koyukuk River mining areas from the Yukon; shown on a 1901 fieldsheet by D. L. Reaburn, USGS, and published by Mendenhall (1902, pl. 4).

Dall Glacier: glacier, heads at junc. of three branches, trends SW and SE $18 \mathrm{mi}$. to its terminus at glacial lake $W$ of East Fork Yentna River, $60 \mathrm{mi}$. NW of Talkeetna, Alaska Ra.; 62 $33^{\prime} \mathrm{N}, 151^{\circ} 56^{\prime} \mathrm{W}$; (map 81).

Mountain climbers' name published in the late 1940 's.

Dall Head: point of land, S tip of Gravina I., Alex. Arch.; $55^{\circ} 08^{\prime} \mathrm{N}, 131^{\circ} 45^{\prime} \mathrm{W}$; (map 3).

Named by local pilots before 1879 for Capt. C. C. Dall, of the Pacific Mail Steamship Company.

Dall Island: island, $47 \mathrm{mi}$. long, $9 \mathrm{mi}$. wide, $\mathrm{N}$ of Dixon Entrance, Alex. Arch.; 54 $57^{\prime} \mathrm{N}$, $133^{\circ} 00^{\prime} \mathrm{W}$; (map 1). Var. Quadra Island. Named in 1879 by USC\&GS for William Healy Dall, 1845-1927, USC\&GS (187184), USGS (1884-1925), and a member of the Harriman Alaska Expedition in 1899. In 1895 , the USC\&GS called the southern part of this island "Dall" and the northern part "Quadra."

Dall Island: island, see Young Island.

Dall Lake: lake, $23 \mathrm{mi}$. long, $12 \mathrm{mi}$. S of Baird Inlet, $70 \mathrm{mi}$. SW of Bethel, Yukon-Kuskokwim Delta; $60^{\circ} 16^{\prime} \mathrm{N}, 164^{\circ} 04^{\prime} \mathrm{W}$; (map 58 ).

Named in 1878 by E. W. Nelson, U.S. Signal Service, for William Healy Dall, USC\&GS.

Dall Mountain: mountain, 3,494 ft., between Mud Fork and Hodzana River, $38 \mathrm{mi}$. NW of Stevens Village, Kokrines-Hodzana High.; $66^{\circ} 31^{\prime} \mathrm{N}, 149^{\circ} 33^{\prime} \mathrm{W}$; (map 118).

Local name derived from Dall River; published in 1951 by USGS.
Dall Point: point of land, on coast of Bering Sea, $16 \mathrm{mi}$. S of Cape Romanzof and $5 \mathrm{mi}$. NW of village of Hooper Bay, Yukon-Kuskokwim Delta; $61^{\circ} 35^{\prime} \mathrm{N}, 166^{\circ} \mathrm{W}$; BGN 1892; (map 75). Var. Cape Dall, Point Dall.

Named Cape Dall in 1869 (Baker, 1906, p. 207) for William Healy Dall.

Dall Ridge: ridge, 2,700 ft., $14 \mathrm{mi}$. long, on $\mathrm{SW}$ part of Gravina I., $8 \mathrm{mi}$. SW of Ketchikan, Alex. Arch.; 55 ${ }^{\circ} 15^{\prime} \mathrm{N}, 131^{\circ} 40^{\prime} \mathrm{W}$; (map 3).

Named in 1883 by Lt. Comdr. H. E. Nichols, USN, for William Healy Dall, USC\&S. See Dall Island.

Dall River: stream, heads on SW slope of Dall Mountain, flows SE $80 \mathrm{mi}$. to Yukon River, $4.5 \mathrm{mi}$. $W$ of Stevens Village, Yukon Flats; $66^{\circ} 00^{\prime} 30^{\prime \prime} \mathrm{N}, 149^{\circ} 15^{\prime} 30^{\prime \prime} \mathrm{W}$; (map 118). Var. Dahl River, Notochargut River, Notochaugut River, Notokakat River.

Named in 1869 by Capt. Raymond (1871, p. 22), U.S. Army Corps of Engineers, for William Healy Dall, 1845-1927, who a few years earlier explored parts of the Yukon River with the Western Union Telegraph Expedition. Capt. Raymond also reported the Indian name as "Notochargut," meaning "mouth of the Noto [River]."

Dalnie Island: island, see Knight Island.

Dalni Island: island, see Knight Island.

Dalniy, Mys: point of land, see Far Point.

Dalniy Island: island, see Knight Island.

Dalnoi Point: point of land, on $\mathrm{W}$ tip of St. George I., in Pribilof Is.; $56^{\circ} 36^{\prime} 40^{\prime \prime} N, 169^{\circ}$ $46^{\prime} 30^{\prime \prime}$ W; (map 38). Var. Ackanungta, Distant Point, Konetz Point, West Konetz.

The Russian word "dalnoy," meaning "distant," is given by USC\&GS in 1875. The Russians called this feature "West Konets" or "west end" (Tebenkov, 1852, map 21).

Daloongmute: locality, see Dahloongamiut.

Daloongmute: locality, see Tachyhuimiut.

Dalton Glacier: glacier, see Turner Glacier.

Dalton Gulch: ravine, extends S $1.3 \mathrm{mi}$. to Cache Creek, $5 \mathrm{mi}$. NW of Manley Hot Springs Dome, and $37 \mathrm{mi}$. ESE of Tanana, YukonTanana High., $65^{\circ} 05^{\prime} 30^{\prime \prime} \mathrm{N}, 150^{\circ} 50^{\prime} 00^{\prime \prime} \mathrm{W}$; (map 106).

Prospectors' name reported in 1931 by J. B. Mertie, Jr., USGS.

Dalungamiut: locality, see Dahloongamiut.

Dalungamiut River: stream, see Dahloongamiut River.

Daly: locality, on $W$ shore of Nushagak Bay, 5 mi. SW of Dillingham, Bristol Bay Low.; $58^{\circ}$ -

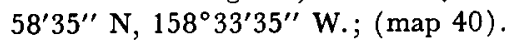

Site of a former camp and "old saltery" reported about 1910.

Daly Creek: stream, flows NW $1.5 \mathrm{mi}$. to Salmon River, $2.5 \mathrm{mi}$. NW of Mount Welker and Alaska-Canada boundary, Coast Mts. ; 56 $02^{\prime}$ $00^{\prime \prime} \mathrm{N}, 130^{\circ} 02^{\prime} 45^{\prime \prime} \mathrm{W}$; (map 7).

Local name reported in 1928 by A. F. Buddington, USGS.

Dalzell: locality, on left bank of Dalzell Creek, $3 \mathrm{mi}$. S of its junc, with Tatina River, $90 \mathrm{mi}$. $\mathrm{SE}$ of McGrath, Alaska Ra.; $62^{\circ} 16^{\prime} \mathrm{N}$, $153^{\circ} 13^{\prime} \mathrm{W}$; (map 80 ).

A cabin reported in 1949 by USGS. 
Dalzell Creek: stream, flows NW $11 \mathrm{mi}$. to Takina River $3.8 \mathrm{mi}$. E of its junc. with South Fork Kuskokwim River, $88 \mathrm{mi}$. SE of McGrath, Alaska Ra.; $62^{\circ} 18^{\prime} \mathrm{N}, 153^{\circ} 16^{\prime} \mathrm{W}$; (map 80).

Named in 1902 by A. H. Brooks, USGS, for a Mr. Dalzell [cnna], a prospector from Pennsylvania who discovered this stream enroute from the Kushokwim River to Tyonek in 1901.

Dam Creek: stream, in Chigmit Mts., heads at glacier terminus, flows $\mathrm{S} 5 \mathrm{mi}$. to Chinitna Bay, $0.4 \mathrm{mi}$. E of West Glacier Creek, Aleutian Ra.; $59^{\circ} 53^{\prime} \mathrm{N}, 153^{\circ} 12^{\prime} \mathrm{W}$; (map 51).

Local name published by USGS in 1958.

Damundtali Lake: lake, $0.4 \mathrm{mi}$. long, SE of Cheneathda Hill, $4 \mathrm{mi}$. NE of Northway Junction, Yukon-Tanana High.; 63 $03^{\prime} \mathrm{N}$, 141 ${ }^{\circ} 39^{\prime}$ W; BGN 1961; (map 85).

Indian name, said to mean "lake on hill," reported by USGS in 1960 .

Dana, Mount: mountain, $4,200 \mathrm{ft}$., $8 \mathrm{mi}$. NE of Pavlof Bay Alaska Penin., Aleutian Ra.; $55^{\circ} 38^{\prime} 30^{\prime \prime} \mathrm{N}, 161^{\circ} 13^{\prime} 00^{\prime \prime} \mathrm{W}$; (map 28).

Local name reported by USGS in 1929.

Dana Peak: peak, 4,365 ft., $2 \mathrm{mi}$. W of 1961 terminus of Baird Glacier and $98 \mathrm{mi}$. E of Sitka, Coast Mts.; $57^{\circ} 07^{\prime} 45^{\prime \prime} \mathrm{N}, 132^{\circ} 52^{\prime} 45^{\prime \prime}$ W; (map 8).

Named in 1887 by Lt. Comdr. C. M. Thomas, USN, for James Dwight Dana, 1813-95, American geologist, mineralogist, and zoologist, who was a professor at Yale Univ., 1850-95.

Dan Bay: bay, on NE coast of Hinchinbrook I., $23 \mathrm{mi}$. SW of Cordova, Chugach Mts. $60^{\circ} 24^{\prime} \mathrm{N}, 146^{\circ} 22^{\prime} \mathrm{W}$; (map 64).

Local name published in 1943 by USC\&GS

Dan Beard, Mount: peak, 10,260 ft., between North and Northwest Forks Ruth Glacier, 9 mi. SE of Mount McKinley, Alaska Ra.; $63^{\circ} 01^{\prime} 15^{\prime \prime} \mathrm{N}, 150^{\circ} 47^{\prime} 20^{\prime \prime} \mathrm{W}$; (map 88).

Named in 1910 by H. C. Parker and BelMore Browne for Daniel Carter Beard, 1850-1941, American painter and illustrator and founder of the Boy Scouts of America in 1910.

Dancka Lake: lake, $0.6 \mathrm{mi}$. long, $1.8 \mathrm{mi}$. SW of Stephen Lake and $43 \mathrm{mi}$ NE of Talkeetna, Talkeetna Mts.; $62^{\circ} 39^{\prime} 20^{\prime \prime} \mathrm{N}, 1^{\circ} 8^{\circ} 57^{\prime} 45^{\prime \prime}$ W; BGN 1963; (map 82).

Indian name meaning "caribou" given in 1962 by L. L. Young of Anchorage, Alaska.

Dan Creek: locality, on Dan Creek 12 mi. ESE of McGarthy, St. Elias Mts.; 61 ${ }^{\circ} 23^{\prime} \mathrm{N}$, $142^{\circ} 35^{\prime} \mathrm{W}$; (map 67).

Mining camp and post office operated from 1911 to 1932 (Ricks, 1965, p. 16).

Dan Creek: stream, on Hinchinbrook I., flows NE $3 \mathrm{mi}$. to Dan Bay, $25 \mathrm{mi}$. SW of Cordova, Chugach Mts.; $60^{\circ} 24^{\prime} \mathrm{N}, 146^{\circ} 22^{\prime} \mathrm{W}$; (map 64).

Name published in 1950 by USGS.

Dan Creek: stream, flows $6 \mathrm{mi}$ E to Nizina River $2.3 \mathrm{mi}$. S of its junc. with Chitistone River and $11 \mathrm{mi}$. E of McCarthy, Wrangell Mts. ; 61 ${ }^{\circ} 23^{\prime}$ $00^{\prime \prime} \mathrm{N}, 142^{\circ} 35^{\prime} 30^{\prime \prime} \mathrm{W}$; (map 67).
In 1901 the stream was staked by C. L. Warner and D. L. Kain for themselves and others.. Kain was known to his companions as "Dan" and they named the creek for him (Moffit and Capps, USGS, 1911, p. 76).

Dan Creek: stream, flows SE $5 \mathrm{mi}$. to Caribou Creek, $48 \mathrm{mi}$. NE of Palmer, Talkeetna Mts.; $61^{\circ} 48^{\prime} 50^{\prime \prime} \mathrm{N}, 147^{\circ} 42^{\prime} 40^{\prime \prime} \mathrm{W}$; (map 69).

Local name reported in 1952 by USGS.

Dan Creek: stream, flows E $16 \mathrm{mi}$. to Salcha River $2.3 \mathrm{mi}$. $\mathbf{N}$ of that stream's junc. with Lost Greek and $63 \mathrm{mi}$. NE of Big Delta, YukonTanana High.; $64^{\circ} 51^{\prime} 40^{\prime \prime} \mathrm{N}, 144^{\circ} 30^{\prime} 40^{\prime \prime} \mathrm{W}$; (map 101).

Local name reported in 1958 by USGS.

Dan Creek: stream, flows NE $1.4 \mathrm{mi}$. to Kougarok River, $17 \mathrm{mi}$. S of Midnight Mtn. and 45 mi. W of Imuruk Lake, Seward Penin. High.; $65^{\circ} 32^{\prime} \mathrm{N}, 164^{\circ} 43^{\prime} \mathrm{W}$; (map 110$)$.

Prospectors' name reported in 1901 by $\mathrm{T}$. G. Gerdine (in Collier, 1902, pl. 12), USGS.

Dandy Gulch: ravine, in Dutch Hills, trends SW $0.5 \mathrm{mi}$. to Poorman Creek, $29 \mathrm{mi}$. NE of Talkeetna, Alaska Ra.; $62^{\circ} 35^{\prime} 15^{\prime \prime} \mathrm{N}, 150^{\circ} 49^{\prime} 00^{\prime \prime}$ $\mathrm{W}$; (map 81).

Prospectors' name reported in 1908 by F. A. Cook.

Dane Creek: stream, flows N $3 \mathrm{mi}$. to Pilgrim River, $1.5 \mathrm{mi}$. E of Salmon Lake and $28 \mathrm{mi}$. NW of Solomon, Seward. Penin. High.; $64^{\circ}-$ $55^{\prime} \mathrm{N}, 164^{\circ} 54^{\prime} \mathrm{W}$; (map 95). Var. Dean Creek.

Local name reported by USGS (Collier and others, 1908, pl. 10).

Danger Bay: bay, see Kazakof Bay.

Danger Creek: stream, flows NW $8 \mathrm{mi}$. to Bessie Creek, $43 \mathrm{mi}$. N of Goodnews, Yukon-Kuskokwim Delta; 59 $38^{\prime} \mathrm{N}, 161^{\circ} 42^{\prime} \mathrm{W}$; (map 53).

Local name published in 1951 by USGS.

Danger Island: island, $1,400 \mathrm{ft}$. long, in Danger Passage, between Felice Strait and Revillagigedo Channel, $26 \mathrm{mi}$. SE of Ketchikan, Alex. Arch.; 55 $02^{\prime} 45^{\prime \prime} \mathrm{N}, 131^{\circ} 12^{\prime} 35^{\prime \prime} \mathrm{W}$; (map 3 ). Var. Dead Island.

Named in 1883 by Lt. Comdr. H. E. Nichols, USN.

Danger Island: island, $400 \mathrm{ft}$. across, in Torgass Narrows, near mouth of Ward Cove, $4.5 \mathrm{mi}$.

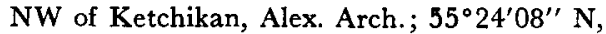
$131^{\circ} 45^{\prime} 45^{\prime \prime} \mathrm{W}$; (map 3$)$.

Named in 1883 by Lt. Comdr. H. E. Nichols, USN.

Danger Island: island, $0.5 \mathrm{mi}$. long, at mouth of Red Bay, on $\mathbf{N}$ coast of Prince of Wales I., Alex. Arch.; 56 $19^{\prime} 15^{\prime \prime}$ N, $133^{\circ} 19^{\prime} 00^{\prime \prime}$ W; (map 6). Var. Dead Island.

Named in 1886 by Lt. J. M. Helm, USN, for charting purposes; name published in 1887 on USC\&GS Chart 706.

Danger Island: island, $0.5 \mathrm{mi}$. across, $1.7 \mathrm{mi}$. $\mathrm{SW}$ of Latouche I., 50 mi. SE of Seward, Chugach Mts.; $59^{\circ} 55^{\prime} 30^{\prime \prime} \mathrm{N}, 148^{\circ} 05^{\prime} 00^{\prime \prime} \mathrm{W}$; (map 49).

Local name reported by U.S. Grant and D. F. Higgins, USGS, in 1908.

Danger Island: island, see Dead Island.

Danger Island Reef : reef, see Danger Reef.

Dangerous Cape: point of land, at mouth of Boulder Bay, between Kiliuda and Ugak Bays, on SE coast of Kodiak I. ; $57^{\circ} 17^{\prime}$ N, $152^{\circ} 42^{\prime}$ W; (map 34). Var. Dangerous Point, Mys Opasnyy, Onatzno Point, Onatzo, Opasnie.

Translation of "Mys Opasnyy," or dangerous point," given in 1805 by Capt. U. T. Lisianski (1814, map facing p. 169), IRN.

Dangerous Cape: point of land, on SW end of Kenai Penin. at $\mathrm{N}$ entrance to Port Graham, 8 $\mathrm{mi}$. SW of Seldovia, Chugach Mts. ; $59^{\circ} 24^{\prime} 00^{\prime \prime}$ N, $151^{\circ} 54^{\prime} 20^{\prime \prime} \mathrm{W}$; (map 50). Var. Onatznoj, Onasnoy, Mys.

This name is a translation from the Russian published by Capt. Tebenkov (1852, map 5) IRN, as "M[ys] Onasnoy," and first published in its present form by USC\&GS in 1883 on Chart 766.

Dangerous Cape: point of land, see Opasni Point. Dangerous Cape Reef: reef, in Cook Inlet, 0.5 mi. W of Kenai Penin. and $8 \mathrm{mi}$. SW of Seldovia, Chugach Mts.; $59^{\circ} 24^{\prime} 15^{\prime \prime} \mathrm{N}, 151^{\circ} 5^{\prime}$ $10^{\prime \prime} \mathrm{W}$; (map 50).

Local name published by USC\&GS in 1909. Named for the nearby cape.

Dangerous Channel: water passage, see Biorka Channel.

Dangerous Passage: water passage, trends SW 8 mi. from Knight Island passage, between Chenega I. and Kenai Penin., $36 \mathrm{mi}$. SE of Whittier, Chugach Mts.; $60^{\circ} 22^{\prime} \mathrm{N}, 148^{\circ} 05^{\prime}$ W; (map 63).

Descriptive name given in 1898 by Capt. W. F. Abercrombie, USA.

Dangerous Point: point of land, see Dangerous Gape.

Dangerous River: stream, heads at Harlequin Lake, flows SW $16 \mathrm{mi}$. to Gulf of Alaska, 25 mi. SE of Yakutat Bay, Malaspina Coastal Plain; $59^{\circ} 20^{\prime} 55^{\prime \prime} \mathrm{N}, 139^{\circ} 18^{\prime} 00^{\prime \prime} \mathrm{W}$; (map 46).

Local name reported by Lt. Comdr. Moser (1901, pl. 43), USN.

Danger Pass: pass, 3,300 ft., in Schwatka Mts., at heads of Ivik Creek to the S, and Kugrak River to the N, Brooks Ra.; $67^{\circ} 25^{\prime} \mathrm{N}, 155^{\circ} 44^{\prime}$ $\mathrm{W}$; (map 125).

Translation of an Eskimo name recorded in Kobuk as "Nanyanaiuktak." Reported by Orth, USGS, in 1956 to be so named because the Ivik Creek side of the pass is extremely precipitous.

Danger Passage: water passage, connects Felice Strait and Revillagigedo Channel, S of Mary I., $26 \mathrm{mi}$. SE of Ketchikan, Alex. Arch.; 55 ${ }^{\circ}$ $02^{\prime} 15^{\prime \prime} \mathrm{N}, 131^{\circ} 13^{\prime} 00^{\prime \prime} \mathrm{W}$; (map 3 ).

Named in 1883 by Lt. Comdr. H. E. Nichols, USN.

Danger Point: point of land, on W coast of Mitkof I., $10 \mathrm{mi}$. S of Petersburg, Alex. Arch.; $56^{\circ} 39^{\prime} 40^{\prime \prime} \mathrm{N}, 132^{\circ} 55^{\prime} 10^{\prime \prime} \mathrm{W}$; (map 6).

Named in 1879 by W. H. Dall, USC\&GS.

Danger Point: point of land, $\mathrm{W}$ entrance to Kootznahoo Inlet, $1 \mathrm{mi}$. NW of Angoon, on W coast of Admiralty I., Alex. Arch.; $57^{\circ} 30^{\prime}$ 45" N, 134 35'10" W; (map 9).

Descriptive name given in 1869 by Comdr. R. W. Meade, USN, and published by USC\&GS in the 1883 Coast Pilot (p. 176). 
Danger Point: point of land, on W shore of Lynn Canal, 2 mi. SE of William Henry Bay and $39 \mathrm{mi}$. NW of Juneau, St. Elias Mts.; $58^{\circ}$ $41^{\prime} 45^{\prime \prime} \mathrm{N}, 135^{\circ} 11^{\prime} 35^{\prime \prime} \mathrm{W}$; (map 11).

Descriptive name published in 1924 by USC\&GS.

Danger Point: point of land, see Pogibshi Point.

Danger Point Reef: reef, in Chatham Strait, off

Danger Point, $1 \mathrm{mi}$. NW of Angoon, on W coast of Admiralty I., Alex. Arch.; $57^{\circ} 30^{\prime} 50^{\prime \prime}$ $\mathrm{N}, 134^{\circ} 36^{\prime} 20^{\prime \prime} \mathrm{W}$; (map 9).

Descriptive name given in 1869 by Comdr. R. W. Meade, USN, and published on Chart 225.

Danger Reef: reef, "in Tongass narrows, near Ward cove, Alex. Arch."

"Named by the Coast Survey in 1883. Name not found on any chart. Also called Danger Island reef" (Baker, 1906, p. 208).

Danger Reef: reef, $1 \mathrm{mi}$. long, $2 \mathrm{mi}$. NE of Afognak, on S coast of Afognak I.; 58 $01^{\prime} 30^{\prime \prime}$ N, $152^{\circ} 44^{\prime} 00^{\prime \prime} \mathrm{W}$; (map 43).

Named in 1900 by Lt. Comdr. J. F. Moser, USN, commander of the USBF steamer Albatross.

Daniel Creek: stream, see Daniels Creek.

Daniel Hills: hills, see Ingrijoak Hills.

Daniels Creek: stream, flows NE $4 \mathrm{mi}$. to Totatlanika River, $36 \mathrm{mi}$. SE of Nenana, Alaska Ra.; $6^{\circ} 06^{\prime} 30^{\prime \prime} \mathrm{N}, 148^{\circ} 31^{\prime} 15^{\prime \prime} \mathrm{W}$; (map 100). Var. Daniel Greek.

Local name reported in 1916 by G. C. Martin (in Brooks and others, 1917, pl. 17), USGS.

Daniels Creek: stream, flows SW $1.2 \mathrm{mi}$. to Norton Sound, $20 \mathrm{mi}$. E of Solomon, Seward Penin. High.; 64 $4^{\circ} 34^{\prime}$ N, $163^{\circ} 45^{\prime}$ W; (map 95).

Prospectors' name reported in 1900 by $\mathrm{E}$. C. Barnard (in Brooks, 1901, pl. 17), USGS.

Daniels Lake: lake, $3 \mathrm{mi}$. long, on Kenai Penin. $2.5 \mathrm{mi}$. SSE of Boulder Point, $12 \mathrm{mi}$. NE of Kenai, Cook Inlet Low.; $60^{\circ} 44^{\prime} \mathrm{N}, 151^{\circ} 11^{\prime}$ W; (map 62).

Local name reported in 1958 by USGS.

Daprakmiut: locality, $8.5 \mathrm{mi}$. SE of Cape Etolin, on NE coast of Nunivak I.; $60^{\circ} 19^{\prime} 30^{\prime \prime} \mathrm{N}$, $166^{\circ} 05^{\prime} 10^{\prime \prime} \mathrm{W}$; (map 57).

Eskimo summer fish camp reported in 1949 by USC\&GS.

Darby, Cape: point of land, $\mathrm{S}$ end of peninsula on $\mathrm{N}$ shore of Norton Sound, $17 \mathrm{mi}$. SE of Golovin and $53 \mathrm{mi}$. SE of Solomon, Seward Peninsula High.; $64^{\circ} 19^{\prime} \mathrm{N}, 162^{\circ} 47^{\prime} \mathrm{W}$; (map 95). Var. Cape Derby, Darby Point, Mys Derbi.

Named in September 1778 by Capt. Cook (1785, v. 2, p. 475), RN.

Darby Mountains: mountain range, extends S 30 mi. from Windy Creek at $\mathrm{E}$ end of Bendeleben Mts. to $10 \mathrm{mi}$. NW of Elim on Norton Bay, Seward Penin. High; $65^{\circ} 00^{\prime} \mathrm{N}, 162^{\circ} 30^{\prime} \mathrm{W}$; (map 96, 110).

Reported in 1900 by Brooks (1901, p. 17), USGS. Presumably named for Cape Darby at the southern extension of the range.

Darby Point: point of land, see Cape Darby.

Dare Creek: stream, see Dora Creek.
Dare Island: island, see Gauge Island.

Dargun Point: point of land, on $\mathrm{W}$ coast of Prince of Wales I., $31 \mathrm{mi}$. NW of Craig, Alex. Arch.; $55^{\circ} 55^{\prime} 00^{\prime \prime} \mathrm{N}, 133^{\circ} 15^{\prime} 45^{\prime \prime} \mathrm{W}$; (map 4).

Indian name published in 1964 by USC\&GS

Dark Cliff : point of land, see Dark Cliffs.

Dark Cliffs: point of land, on NE coast of Popof I., in Shumagin Is., Aleutian Ra.; 55 $20^{\prime} 10^{\prime \prime}$ $\mathrm{N}, 160^{\circ} 19^{\prime} 10^{\prime \prime} \mathrm{W}$; (map 28). Var. Dark Cliff.

Descriptive name published on 1917 USC\& GS Chart 8700.

Dark Cove: cove, $0.6 \mathrm{mi}$. across, SE of Cape St. Stephen on SW coast of Kiska I., Aleutian Is.; $51^{\circ} 52^{\prime} 40^{\prime \prime} \mathrm{N}, 177^{\circ} 13^{\prime} 35^{\prime \prime} \mathrm{E}$; (map 14). Var. Winter Cove.

Name shown on a 1957 AMS map; variant shown on a 1943 USAAF map.

Dark Creek : stream, see Dora Creek.

Dark Hollow: ravine, trends SE $1.2 \mathrm{mi}$. to Nugget Creek, $12 \mathrm{mi}$. NE of Fairbanks, YukonTanana High.; $64^{\circ} 57^{\prime} 00^{\prime \prime} \mathrm{N}, 147^{\circ} 23^{\prime} 45^{\prime \prime} \mathrm{W}$; (map 100).

Local name published in 1908 by USGS.

Dark Island: island, $0.8 \mathrm{mi}$. across, $2 \mathrm{mi}$. $\mathrm{N}$ of Shuyak I., and $52 \mathrm{mi}$. N of Kodiak I.; $58^{\circ} 38^{\prime}$ $30^{\prime \prime} \mathrm{N}, 152^{\circ} 32^{\prime} 30^{\prime \prime} \mathrm{W}$; (map 43). Var. Temnie Island.

Translation of the name "Os[trov] Tyemnyy" published in 1849 by the Russian American Company.

Dark Island Pass: water passage, see Dark Passage.

Dark Islands: island, see Dusk Islands.

Dark Lake: lake, $0.3 \mathrm{mi}$. long, $2 \mathrm{mi}$. NE of Kodiak, Kodiak I.; $57^{\circ} 48^{\prime} 45^{\prime \prime}$ N, $152^{\circ} 22^{\prime} 15^{\prime \prime}$ W; (map 34).

Descriptive local name published in 1943 by USC\&GS

Dark Passage: water passage, between Dark and Shuyak Is., 51 mi. N of Kodiak I.; 58 $37^{\prime} 30^{\prime \prime}$ N, 152 $33^{\prime} 00^{\prime \prime}$ W; BGN 1933; (map 43). Var. Dark Island Pass.

Local name derived from Dark Island, reported by USC\&GS in 1931 .

Dark Point: point of land, southernmost point of mainland between Nakat and Willard Inlets, $\mathrm{N}$ shore of entrance to Stiklan Passage, Coast Mts. ; $54^{\circ} 45^{\prime} 51^{\prime \prime} \mathrm{N}, 130^{\circ} 43^{\prime} 00^{\prime \prime} \mathrm{W}$; (map 2).

Named in 1883 by Lt. Comdr. H. E. Nichols, USN.

Darling Creek: stream, heads at glacier terminus, flows NW 5 mi. to Delta River, crosses Richardson Highway, $33 \mathrm{mi}$. S of Delta Junction, Alaska Ra.; $63^{\circ} 35^{\prime} 00^{\prime \prime} \mathrm{N}, 1^{\circ} 5^{\circ} 52^{\prime} 45^{\prime \prime} \mathrm{W}$; $B G N$ 1938; (map 86).

Local name reported in 1938 by USGS.

Darling Creek: stream, flows W $1.5 \mathrm{mi}$. to Nome River, $17 \mathrm{mi}$. NE of Nome, Seward Penin. High.; $64^{\circ} 44^{\prime} 20^{\prime \prime} \mathrm{N}, 165^{\circ} 14^{\prime} 15^{\prime \prime} \mathrm{W}$; (map 94).

Named for Ned Darling (died 1923) and published on the 1900 "Map of Nome Peninsula" by J. M. Davidson and B. D. Blakeslee.

Darroh Creek: stream, flows NE $3 \mathrm{mi}$. through Lost Lake to Bering Sea, W of Point Hope, on coast of Attu I., Aleutian Is.; 52 $54^{\prime} 53^{\prime \prime} \mathrm{N}$, $173^{\circ} 18^{\prime} 12^{\prime \prime} \mathrm{E}$; (map 13).

Named by the U.S. Army during its occupation of the island during World War II; name shown on an AMS map published in 1948. The name is not used today.

Dartmouth Glacier: glacier, heads SW of Mount Castner, trends SW $3.4 \mathrm{mi}$. to its terminus at head of Coghill River, $47 \mathrm{mi}$. W of Valdez, Chugach Mts.; $61^{\circ} 09^{\prime} 30^{\prime \prime} \mathrm{N}, 147^{\circ} 40^{\prime} 20^{\prime \prime} \mathrm{W}$; $B G N 1910$; (map 69).

Name reported in 1908 by Grant and Higgins (1910, pl. 2), USGS. Presumably named for Dartmouth College, Hanover, N.H., founded in 1769 .

Darvin Island: island, $3 \mathrm{mi}$. long, in Yukon River at junc. of Grant Creek, $25 \mathrm{mi}$. W of Tanana, Nowitna Low.; $65^{\circ} 11^{\prime} 15^{\prime \prime} \mathrm{N}, 153^{\circ} 00^{\prime} 00^{\prime \prime} \mathrm{W}$; (map 106).

Riverboat pilots' name shown on a 1940 "Navigation Chart of the Tanana-Yukon Rivers," published by the U.S. Dept. of the Interior.

Dasani Islands: islands, near $\mathrm{S}$ entrance to Tuxekan Passage, 20 mi. NW of Craig, Alex. Arch.; $55^{\circ} 45^{\prime} 30^{\prime \prime} \mathrm{N}, 133^{\circ} 16^{\prime} 15^{\prime \prime} \mathrm{W}$; (map 4).

Indian name published in 1956 by USC\&GS. Däschū: village, see Haines.

Däschù : isthmus, see Deshu Isthmus.

Dasger Island : island, see Little Eightmile Island.

Dasha Island: island, extends E-W $2.1 \mathrm{mi}$., in Yukon River, $18 \mathrm{mi}$. NE of Ruby, Nowitna

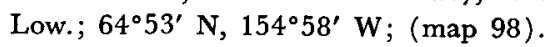

Riverboat pilots' name shown on 1940 "Navigation Chart, Tanana-Yukon Rivers" of the River Boat Service, U.S. Dept. of the Interior.

Dàtàśùk: island, see Dalasuga Island.

Datheekook Point: point of land, extends into Bering Sea, $9 \mathrm{mi}$. SE of Cape Mohican, W coast of Nunivak I; $60^{\circ} 04^{\prime} 20^{\prime \prime} \mathrm{N}, 167^{\circ} 20^{\prime} 00^{\prime \prime} \mathrm{W}$; Var. Datheekoox Point, Dathikuk Point.

Eskimo name obtained in 1949 by USG\&GS.

Datheekoox Point: point of land, see Datheekook Point.

Dathikuk Point: point of land, see Datheekook Point.

Dathlalmund Lake: lake, $3 \mathrm{mi}$. long, $\mathrm{E}$ of Tetlin Lake, $20 \mathrm{mi}$. SE of Tok, Alaska Ra.; $63^{\circ} 05^{\prime}$ N, 142³6' W; BGN 1962; (map 85). Var. Gasoline Lakes, Lake Birch.

Indian name, said to mean "moss lake," reported by USGS in 1960 .

Datkit Cove: cove, see Dahtkit Cove.

Datkokan Creek: stream, flows SW $8 \mathrm{mi}$. to Dall River, $5 \mathrm{mi}$. NW of Stevens Village, Yukon Flats; $66^{\circ} 02^{\prime} \mathrm{N}, 149^{\circ} 15^{\prime} \mathrm{W}$; (map 118).

Kutchin Indian name obtained in 1956 by T. E. Taylor, USGS.

Datkokan Lake: lake, $4 \mathrm{mi}$. long, $6 \mathrm{mi}$. $\mathrm{N}$ of Stevens Village, Yukon Flats; $66^{\circ} 07^{\prime} \mathrm{N}, 149^{\circ}$ 06' W; (map 118).

Kutchin Indian name obtained in 1956 by T. E. Taylor, USGS.

Datlasuk Island : island, see Dalasuga Island. Datsy Creek: stream, see Daisy Creek. 
Datzkoo Harbor: bay, extends $2.5 \mathrm{mi}$. off Kaigani Strait, SE coast of Dall I., Alex. Arch.; $54^{\circ}$ $44^{\prime} 20^{\prime \prime}$ N, $132^{\circ} 42^{\prime} 45^{\prime \prime} \mathrm{W}$; (map 1). Var. Harris Harbor, South Kaigani Harbor, Taddiskey Harbor, Taddys Cove.

Local name published by USC\&GS in the 1925 Coast Pilot (p. 132) as "Kaigani Harbors ***. The southern harbor has been known as Harris Harbor, as Datzkoo Harbor, and in 1799 as Taddiskey Harbor ***"; names derived from the Datzkoo Islands. See Kaigani Harbors.

Datzkoo Islands: islands, group extends $0.5 \mathrm{mi}$. in Kaigani Strait, SE coast of Dall I., Alex. Arch.; $54^{\circ} 43^{\prime} 40^{\prime \prime} \mathrm{N}, 132^{\circ} 41^{\prime} 05^{\prime \prime} \mathrm{W}$; (map 1).

Tlingit Indian name [datzku] published in 1911 by USC\&GS.

Datzkoo Point: point of land, S point of entrance to Datzkoo Harbor on SE coast of Dall I., Alex. Arch.; 54 ${ }^{\circ} 43^{\prime} 50^{\prime \prime} \mathrm{N}, 132^{\circ} 41^{\prime} 45^{\prime \prime} \mathrm{W}$; (map 1).

Name derived from "Datzkoo Is."; published by USC\&GS in 1924.

Davak Lake: lake, see Dakavak Lake.

Dave Gulch: ravine, "Copper River region, at the headwaters of Chititu creek."

"Prospectors name, first appears on map of the Nizina mining district by George M. Esterly, of Valdez" (Baker, 1906, p. 209).

Dave Gulch: ravine, extends N $0.7 \mathrm{mi}$. from south Creek W of Table Mtn., 65 mi. NE of Palmer, Talkeetna Mts.; 61 $59^{\circ} 12^{\prime \prime} \mathrm{N}, 147^{\circ} 19^{\prime} 10^{\prime \prime} \mathrm{W}$; (map 69).

Local name reported in 1951 by USGS.

Dave Lake: lake, $0.5 \mathrm{mi}$. long, $1 \mathrm{mi}$. S of Herman Lake and $28 \mathrm{mi}$. NE of Stevens Village, Yukon Flats; $66^{\circ} 14^{\prime} 30^{\prime \prime} \mathrm{N}, 148^{\circ} 18^{\prime} 00^{\prime \prime} \mathrm{W}$; (map 118).

Local name obtained in 1956 by USGS.

Davenport: locality, on left bank Innoko River $5 \mathrm{mi}$. SE of its North Fork and $46 \mathrm{mi}$. N of Ophir, Innoko Low.; $64^{\circ} 47^{\prime} \mathrm{N}, 156^{\circ} 29^{\prime} \mathrm{W}$; (map 90). Var. Davenports Cabin.

Reported as "Davenports Cabin" on a 1923 ARC map.

Davenports Cabin: locality, see Davenport.

Daves Creek: stream, heads at Mud Lake, on Kenai Penin., flows SW $5 \mathrm{mi}$. to Quartz Creek, $30 \mathrm{mi}$. S of Hope, Chugach Mts.; $60^{\circ} 30^{\prime} 30^{\prime \prime}$ $\mathrm{N}, 149^{\circ} 40^{\prime} 45^{\prime \prime} \mathrm{W}$; (map 63).

Prospectors' name reported in 1908 by USGS.

David Creek: stream, flows W $3.8 \mathrm{mi}$. to Nome River, $24 \mathrm{mi}$. NE of Nome, Seward Penin. High.; $64^{\circ} 50^{\prime} \mathrm{N}, 165^{\circ} 16^{\prime} \mathrm{W}$; (map 94).

Prospectors' name reported in 1900 by E. C. Barnard (in Brooks, 1901, pl. 17), USGS.

David Creek: stream, flows NE $17 \mathrm{mi}$. to Porcupine River $2.3 \mathrm{mi}$. SE of Howling Dog Rock and $26 \mathrm{mi}$. E of Coleen Mtn., Brooks Ra.; $67^{\circ} 09^{\prime} \mathrm{N}, 141^{\circ} 52^{\prime} \mathrm{W}$; (map 121).

Name reported by M. G. White (1952, fig. 1), USGS, in 1948.

David Creek: stream, see Divide Creek.

David Island: island, $1.3 \mathrm{mi}$. across, between Port Wrangell and Pacific Ocean, on $S$ coast of Alaska Penin., $38 \mathrm{mi}$. NE of Sutwik I., Aleutian Ra.; $57^{\circ} 02^{\prime} \mathrm{N}, 156^{\circ} 30^{\prime} \mathrm{W}$; (map
36). Var. Ile David, Ile Davidoff, Ostrov Daviga.

Named by Ens. Vasiliev, IRN, in 1831-32; published on Adm. von Krusenstern's 1827 map (corrected in 1835) as "I[le] David."

Davidoff, Ile: island, see David Island.

Davidoff Island: island, see Davidof Island.

Davidof Island: island, $2.3 \mathrm{mi}$. long, in Rat Is. between Little Sitkin and Khvostof Is., 24 mi. NW of Amchitka I., Aleutian Is.; $51^{\circ} 58^{\prime}$ N, $178^{\circ} 21^{\prime}$ E; BGN 1937; (map 15). Var. Davidoff Island, Isle Dawydoff.

Commemorative name published by Adm. von Krusenstern (1827, sheet 18), IRN, for the Russian naval officer Gavriil Ivanovich Davidov, who, with N. A. Khvostov, explored Alaska during 1802-1804. Adm. von Krusenstern applied the name, "I [sle] Dawydoff," to Segula Island, but in 1855 the U.S. Navy Hydrog. Office clarified the size and position of both Davidof and Segula Islands and reapplied the names.

Davidof Lake: lake, $1.7 \mathrm{mi}$. long, $5 \mathrm{mi}$. $\mathrm{E}$ of Whale Bay, on S central Baranof I., Alex. Arch.; 56 $36^{\prime} 40^{\prime \prime} \mathrm{N}, 134^{\circ} 50^{\prime} 30^{\prime \prime} \mathrm{W}$; BGN 1933; (map 5).

Named in 1933 by USFS "for Lt. Gavriil Ivanovich Davidof of the Russian Imperial Navy, author, and commander of various Russian vessels in Alaskan waters."

David River: stream, flows NE $25 \mathrm{mi}$. to lower Caribou River, near Nelson Lagoon, Bristol Lake Low., Alaska Penin., Aleutian Ra.; 55 ${ }^{\circ}$ $51^{\prime} \mathrm{N}, 161^{\circ} 25^{\prime} \mathrm{W}$; (map 28).

Local name shown on a 1963 USGS map. Davidsen Plateau: mountains, see Davidson Mountains.

Davidson: locality, see Davidsons Landing.

Davidson: locality, see Kougarok.

Davidson, Mount: mountain, on S side of Sanborn Harbor, Nagai I., Shumagin Is., Aleutian Ra.; $55^{\circ} 07^{\prime} \mathrm{N}, 160^{\circ} 03^{\prime} \mathrm{W}$; (map 28).

Named in 1872 by W. H. Dall for George Davidson, 1825-1911. Davidson was born in England and came to the United States in 1832. He joined USC\&GS in 1845 and was in charge of the Pacific Coast area from 1868 to 1895 . He made reconnaissance studies in Alaska in 1867 and 1869 and his notes were the basis of the first Alaska Coast Pilot in 1869. He also made a number of charts which were published by USC\&GS in 1869 under the title "Harbor Charts of Alaska." Davidson was professor of astronomy, geodesy, and geography at the Univ. of California from 1870 to 1911.

Davidson Bank: shoal, extends SW $25 \mathrm{mi}$. from vicinity of Sanak I., Aleutian Ra.; $54^{\circ} \mathrm{N}$, $164^{\circ} \mathrm{W}$; (map 25).

Named in 1888 by USBF for George Davidson, 1825-1911. See Davidson, Mount.

Davidson Creek: stream, heads in glacier at $58^{\circ} 21^{\prime} 30^{\prime \prime} \mathrm{N}, 133^{\circ} 44^{\prime} 55^{\prime \prime} \mathrm{W}$, flows W 10 mi. to Taku Inlet, $16 \mathrm{mi}$. ENE of Juneau, Coast Mts.; $58^{\circ} 21^{\prime} 10^{\prime \prime} \mathrm{N}, 133^{\circ} 59^{\prime} 30^{\prime \prime} \mathrm{W}$; $B G N$ 1932; (map 12). Var. Bear Creek, Twin Creek.
Named in 1932 by B. D. Stewart, USGS, "in honor of the late Charles E. Davidson, who served as United States Surveyor-General and ex-officio Secretary of Alaska from October 18, 1913, to August 8, 1919, on which date he was drowned in Taku Inlet a short distance from the mouth of this stream ***."

Davidson Creek: stream, flows SW to Pargon River about $15 \mathrm{mi}$. NE of Council, Seward Penin. High.; (map 110).

Prospectors' name reported on the 1900 "Map of Nome Peninsula" by J. M. Davidson and B. D. Blakeslee. Presumably named for J. M. Davidson, as the next stream south is Blakeslee Creek. This stream cannot be precisely located on current maps.

Davidson Glacier: glacier, heads on E slope of Chilkat Ra. at $59^{\circ} 01^{\prime} \mathrm{N}, 135^{\circ} 33^{\prime} \mathrm{W}$, trends E $4.6 \mathrm{mi}$ to its terminus (1954), $1.4 \mathrm{mi} \mathrm{SW}$ of Glacier Point on Chilkat Inlet, $26 \mathrm{mi}$. SW of Skagway, St. Elias Mts.; $59^{\circ} 05^{\prime} 30^{\prime \prime} \mathrm{N}$, $135^{\circ} 24^{\prime} 30^{\prime \prime} \mathrm{W}$; (map 45). Var. Ssitkajē.

Named in 1867 by USC\&GS for George Davidson, 1825-1911, and published in the 1869 Coast Pilot (p. 106). The Indian name was reported as "Ssitkajēe" by Aurel and Arthur Krause (1883, map).

Davidson Inlet: bay, $17 \mathrm{mi}$. long, SE part of Kosciusko I., Alex. Arch.; $56^{\circ} 03^{\prime} \mathrm{N}, 133^{\circ} 29^{\prime}$ $\mathrm{W}$ to $55^{\circ} 50^{\prime} \mathrm{N}, 133^{\circ} 41^{\prime} \mathrm{W}$; (map 4).

Named in 1879 by W. H. Dall, USC\&GS, for George Davidson, 1825-1911, who was in charge of Pacific Coast work for USC\&GS from 1868 to 1895; he was professor of geography at University of California from 1898 to 1911.

Davidson Lake: lake, $3.3 \mathrm{mi}$. long, $11 \mathrm{mi}$. NE of Angoon, on central Admiralty I., Alex. Arch.; $57^{\circ} 38^{\prime} \mathrm{N}, 134^{\circ} 20^{\prime} \mathrm{W}$; (map 9).

Named for Charles E. Davidson, who served as U.S. Surveyor General and ex-officio Secretary of Alaska from 1913 to 1919.

Davidson Landing: locality, see Davidsons Landing.

Davidson Mountains: mountains, in group 70 $\mathrm{mi}$. long and $25 \mathrm{mi}$. wide, at $\mathrm{E}$ end of Brooks Ra., bounded by Alaska-Canada boundary on E, Coleen River on SW, Kongagak River on $\mathrm{N}$, and unnamed tributary of Firth River on $\mathrm{NE} ; 68^{\circ} 20^{\prime} \mathrm{N}, 141^{\circ} 30^{\prime} \mathrm{W}$ [SE end], $68^{\circ} 50^{\prime}$ N, $143^{\circ} 20^{\prime} \mathrm{W}$ [NW end]; (map 137). Var. Davidsen Plateau.

Named by J. H. Turner, USC\&GS, in 1890 , for George Davidson, 1825-1911. See Davidson, Mount.

Davidson Point: point of land, on $\mathrm{E}$ side of Klakas Inlet, Prince of Wales I., Alex. Arch.; $54^{\circ} 56^{\prime} \mathrm{N}, 132^{\circ} 24^{\prime} \mathrm{W}$; (map 1).

Local navigators' name reported in 1904 by H. C. Fassett, USBF.

Davidson Point: point of land, on $\mathrm{E}$ shore of Taku Inlet, $4 \mathrm{mi}$. S of Taku Point and $15 \mathrm{mi}$. $\mathrm{NE}$ of Juneau, Coast Mts.; 58 $20^{\prime} 35^{\prime \prime} \mathrm{N}$, $134^{\circ} 00^{\prime} 00^{\prime \prime} \mathrm{W}$; (map 11 ).

Local name published in 1965 by USC\&GS on Chart 8202.

Davidsons Landing: locality, on left bank of Kaviruk River, $1.5 \mathrm{mi}$. N of Marys Lake and 
32 mi. E of Teller, Seward Penin. High.; $65^{\circ} 15^{\prime} \mathrm{N}, 165^{\circ} 16^{\prime} \mathrm{W}$; (map 111). Var. Davidson, Davidson Landing.

A. H. Brooks (in Collier and others, 1908, p. 308), USGS, noted that up to 1906 the Kougarok gold mining district could only be reached by two long or circuitous routes. Brooks added: "J. M. Davidson and Andrew J. Stone, who are among the largest operators in the district, have established a transshipping point on Kaviruk (Marys) River called Davidson Landing and have built a road from that point to the upper Kougarok region, a distance of 40 miles. Small lighters can be towed directly from the ship's side at Port Clarence to Davidson Landing, so that at least one handling of freight is avoided." A post office of "Davidson" was established in 1906 and was discontinued the following year (Ricks, 1965, p. 16); probably at this site.

Davidson Slough: stream, see Davidsons Slough.

Davidsons Slough: stream, anabranch of Kuzitrin River on its $\mathrm{N}$ side, flows $12 \mathrm{mi}$ to head of Imuruk Basin, $30 \mathrm{mi}$. E of Teller, Seward Penin. High.; $65^{\circ} 12^{\prime} \mathrm{N}, 165^{\circ} 24^{\prime} \mathrm{W}$; (map 111). Var. Davidson Slough.

Shown as "Davidson Slough" on the 1908 "Map of Seward Peninsula" by Arthur Gibson. See Davidsons Landing.

Davies Creek: stream, heads in glacier and flows $5 \mathrm{mi}$. SW to join Cowee Creek, $1.6 \mathrm{mi}$. NE of Bridget Cove on Favorite Channel and 30 mi. NW of Juneau, Coast Mts.; $58^{\circ} 38^{\prime} 50^{\prime \prime}$ N, $134^{\circ} 54^{\prime} 30^{\prime \prime} \mathrm{W}$; BGN 1930; (map 11).

Local name reported in 1910 and published by USGS (Knopf, 1912a, pl. 1).

Daviga, Ostrov: island, see David Island.

Davis: railroad station, on Fairbanks-Eielson section of The Alaska Railroad, $12 \mathrm{mi}$. SE of Fairbanks, Tanana Low.; 64 $46^{\prime} \mathrm{N}, 147^{\circ} 24^{\prime}$ W; BGN 1949; (map 100).

Named by personnel of The Alaska Railroad in 1949; so called because "it is in the vicinity of Old Davis Sawmill."

Davis Creek: stream, flows $3.5 \mathrm{mi}$. S and $W$ to Gulf of Alaska at mouth of Johnston Creek, $83 \mathrm{mi}$. NW of Yakutat, St. Elias Mts.; $60^{\circ} 00^{\prime} 20^{\prime \prime} \mathrm{N}, 141^{\circ} 52^{\prime} 45^{\prime \prime} \mathrm{W}$; (map 65).

Local name published in 1950 by USGS.

Davis Creek: stream, flows NW $1.5 \mathrm{mi}$. to Wilson Creek $4.5 \mathrm{mi}$. $\mathrm{E}$ of Marshall, Nulato Hills; $61^{\circ} 52^{\prime} 35^{\prime \prime} \mathrm{N}, 161^{\circ} 56^{\prime} 30^{\prime \prime} \mathrm{W}$; (map 73).

Prospectors' name reported by Harrington (1916, map), USGS, in 1916.

Davis Creek: stream, flows NW 2 mi. to Crooked Creek, $65 \mathrm{mi}$. NE of Palmer, Talkeetna Mts.; $61^{\circ} 58^{\prime} 30^{\prime \prime} \mathrm{N}, 147^{\circ} 17^{\prime} 15^{\prime \prime} \mathrm{W}$; (map 69).

Local name reported in 1951 by USGS.

Davis Creek: stream, flows N $3 \mathrm{mi}$. to Shovel Creek, $17 \mathrm{mi}$. NE of Healy, Alaska Ra.; $63^{\circ} 57^{\prime} 45^{\prime \prime} \mathrm{N}, 148^{\circ} 29^{\prime} 35^{\prime \prime} \mathrm{W}$; (map 87).

Local name reported in 1910 by J. W. Bagley, USGS.

Davis Creek: stream, flows SW $3 \mathrm{mi}$, joins Poker Creek to form Walker Fork, $52 \mathrm{mi}$. S of Eagle, Yukon-Tanana High.; 64 $03^{\circ} 30^{\prime \prime} \mathrm{N}$, $141^{\circ} 02^{\prime} 50^{\prime \prime} \mathrm{W}$; (map 102).
Named by prospectors and reported in 1896 by Spurr (1898, pl. 46), USGS. Gold was discovered along this stream in 1888 (p. 116).

Davis Creek: stream, flows NW $4 \mathrm{mi}$. to South Fork Koyukuk River, E of Eagle Creek, 34 mi. NE of Bettles, Kokrines-Hodzana High.; $66^{\circ} 59^{\prime} 45^{\prime \prime}$ N, $150^{\circ} 28^{\prime} 30^{\prime \prime} \mathrm{W}$; (map 117). Var. Nemod Creek.

Local name originally applied to a nearby stream; reported in 1899 by T. G. Gerdine, (in Schrader, 1900b, pl. 60), USGS.

Davis Creek: stream, see Smith Creek.

Davis Creek: water passage, between Kanalku and Mitchell Bays, $5 \mathrm{mi}$. E of Angoon, on W central Admiralty I., Alex. Arch.; 57 $31^{\prime}$ $00^{\prime \prime} \mathrm{N}, 134^{\circ} 26^{\prime} 30^{\prime \prime} \mathrm{W}$; (map 9).

Named in 1869 by Comdr. R. W. Meade, USN, for Gen. Jefferson C. Davis, USA, in command of the military district of Alaska. The name was published in 1869 on U.S. Navy Hydrog. Chart 225.

Davis Dome: mountain, 4,124 ft., $49 \mathrm{mi}$. S of Eagle, Yukon-Tanana High.; $64^{\circ} 04^{\prime} 30^{\prime \prime} \mathrm{N}$, $141^{\circ} 01^{\prime} 30^{\prime \prime} \mathrm{W}$; (map 102).

Local name published in 1956 by USGS.

Davis Gulch: ravine, in Peters Hills, trends W 2 mi. to Cache Creek, $31 \mathrm{mi}$. NW of Talkeetna, Alaska Ra.; $62^{\circ} 28^{\prime} 25^{\prime \prime} \mathrm{N}, 151^{\circ} 00^{\prime} 45^{\prime \prime} \mathrm{W}$; (map 81).

Prospectors' name reported in the 1930's by USGS.

Davis Gulch: ravine, trends NW $0.5 \mathrm{mi}$. to Buster Creek, NE of Chief Gulch, $8 \mathrm{mi}$. NE of Nome, Seward Penin. High.; 64 $36^{\prime} 15^{\prime \prime} \mathrm{N}$, $165^{\circ} 13^{\prime} 30^{\prime \prime} \mathrm{W}$; (map 94).

Prospectors' name reported on the 1903 Campion Mining and Trading Co. map by George M. Ashford.

Davison, Point: point of land, S coast of Annette I., Alex. Arch.; 54 $55^{\prime} 00^{\prime \prime}$ N, 131 $36^{\prime} 05^{\prime \prime}$ W; (map 2). Var. Devison Cape.

Named in 1793 by Capt. Vancouver (1798, v. 2, p. 369), RN, for "Alexander Davison, Esq., owner of our storeship." This name was published as "M[ys] Devison," or "Devison Cape," by Capt. Tebenkov (1852, map 9), IRN.

Davison Bay: bay, $0.3 \mathrm{mi}$. across, $11.5 \mathrm{mi}$. NW of Chichagof, on W coast of Chichagof I., Alex. Arch.; $57^{\circ} 47^{\prime} \mathrm{N}, 136^{\circ} 19^{\prime} \mathrm{W}$; (map 9).

Name published in 1928 by USC\&GS on Chart 8258.

Davison Creek: stream, see Dawson Creek.

Davison Gulch: ravine, trends SE $0.8 \mathrm{mi}$. to Mystery Creek which flows to Shovel Creek, $6 \mathrm{mi}$. N of Solomon, Seward Penin. High.; $64^{\circ} 39^{\prime} \mathrm{N}, 164^{\circ} 25^{\prime} \mathrm{W}$; (map 95).

Prospectors' name shown as "Davison Gh" on Arthur Gibson's "Map of Cape Nome Precinct" dated 1904.

Davison Mountain: mountain, $2,882 \mathrm{ft}$., on Annette I., E of Tamgas Harbor, Alex. Arch.; $55^{\circ} 02^{\prime} 50^{\prime \prime} \mathrm{N}, 131^{\circ} 28^{\prime} 00^{\prime \prime} \mathrm{W}$; (map 3).

Named in 1883 by Lt. Comdr. H. E. Nichols, USN.

Davison Peak: mountain, see Douglas, Mount.

Davis River: stream, heads at glacier in Seward Mts., flows SE $15 \mathrm{mi}$. to Portland Canal, 12 mi. SW of Hyder, Coast Mts.; $55^{\circ} 45^{\prime} 35^{\prime \prime} \mathrm{N}$, $130^{\circ} 10^{\prime} 30^{\prime \prime} \mathrm{W}$; (map 3 ).

Local name published in 1943 by USC\&GS.

Davis Rock: rock, on W coast of Kuiu I., at mouth of Tebenkof Bay, Alex. Arch.; 56 ${ }^{\circ}$ $29^{\prime} 20^{\prime \prime} \mathrm{N}, 134^{\circ} 14^{\prime} 10^{\prime \prime} \mathrm{W}$; BGN 1929; (map 5).

Named in 1928 by USC\&GS "for a member of Vancouver's expedition in 1794."

Davna Lake: lake, sec Tutna Lake.

Dawes Glacier: glacier, heads at Alaska-Canada boundary, trends NW $15 \mathrm{mi}$. to Endicott Arm, $96 \mathrm{mi}$. NW of Sitka, Coast Mts.; 57 $30^{\prime} 00^{\prime \prime} \mathrm{N}$, $132^{\circ} 53^{\prime} 30^{\prime \prime} \mathrm{W}$; (map 8). Var. Dawes Glaciers, Young Glacier.

Named in 1891 by USC\&GS for Henry Laurens Dawes, 1816-1903, lawyer and statesman from Massachusetts. The glacier was originally called "Young Glacier" in 1880 by John Muir for Rev. S. Hall Young, his companion (Young, 1915, p. 147).

Dawes Glaciers: glacier, see Dawes Glacier.

Dawn Creek: stream, flows $\mathrm{N} 12 \mathrm{mi}$. to Kevuk Greek, $30 \mathrm{mi}$. SE of Survey Pass, Brooks Ra.; $67^{\circ} 45^{\prime} \mathrm{N}, 153^{\circ} 00^{\prime} \mathrm{W}$; $B G N$ 1932; (map 125).

Named by Robert Marshall in 1932 and reported to be a translation of an Eskimo name.

Dawson Creek: stream, flows $\mathrm{S} 3.5 \mathrm{mi}$, joins Keystone Creek to form Cache Creek, $20 \mathrm{mi}$. NW of Fairbanks, Yukon-Tanana High.; $64^{\circ}$ -

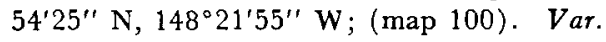
Keystone Creek.

Named by prospectors; published in 1906 by USGS. The stream was shown as "Keystone Creek," extending to Goldstream Creek, on a manuscript map by C. W. Joint in 1905 .

Dawson Creek: stream, flows SE $1 \mathrm{mi}$. to Casa- depaga River, $26 \mathrm{mi}$. NE of Solomon, Seward Penin. High.; $64^{\circ} 55^{\prime} \mathrm{N}, 164^{\circ} 10^{\prime} \mathrm{W}$; (map 95). Var. Davison Creek.

Prospectors' name reported on a 1902 prospectors' manuscript map.

Dawson Creek: stream, flows SE $1 \mathrm{mi}$. to Star Creek, in Pargon River basin, $12 \mathrm{mi}$. N of Council and $22 \mathrm{mi}$. SE of Mount Bendeleben, Seward Penin. High.; $65^{\circ} 02^{\prime} \mathrm{N}, 163^{\circ} 25^{\prime} \mathrm{W}$; (map 110).

Prospectors' name reported on a map of Cape Nome gold fields by David Fox, Jr., dated 1901.

Dawson Creek: stream, flows N $3 \mathrm{mi}$. to Hunter Creek, $6 \mathrm{mi}$. SE of Rampart, Yukon-Tanana High.; $65^{\circ} 29^{\prime} \mathrm{N}, 149^{\circ} 59^{\prime} \mathrm{W}$; (map 105).

Local name published by USGS in the 1950's.

Dawson Creek: stream, flows W $3.5 \mathrm{mi}$. to Don River, $7 \mathrm{mi}$. NE of Brooks Mtn. and $27 \mathrm{mi}$. NW of Teller, Seward Penin. High.; 65 $34^{\prime}$ N, 166 55' W; (map 111).

Prospectors' name shown on the 1900 "Map of Nome Peninsula" by J. M. Davidson and B. D. Blakeslec.

Dawson Creek: stream, see Keystone Creek. Dawydoff, Isle: island, see Davidof Island. Dawydoff Island: island, see Segula Island.

Dayay: locality, see Dyea. 
Daybreak Creek: stream, flows E $0.7 \mathrm{mi}$. to Garfield Creek which flows to Kuzitrin River, 4 mi. S of Baldy Mtn. and $38 \mathrm{mi}$. W of Imuruk Lake, Seward Penin. High.; $65^{\circ} 29^{\prime} 25^{\prime \prime} \mathrm{N}$, $164^{\circ} 33^{\prime} 00^{\prime \prime} \mathrm{W}$; (map 110).

Prospectors' name shown on a map of Cape Nome gold fields by David Fox, Jr., dated 1901.

Day Creek: stream, flows SW $2.5 \mathrm{mi}$. to Big Creek, 9 mi. ESE of Chandalar, Brooks Ra,; $67^{\circ} 27^{\prime} 45^{\prime \prime} \mathrm{N}, 148^{\circ} 09^{\prime} 30^{\prime \prime} \mathrm{W}$; (map 123).

Local name reported in 1956 by T. E. Taylor, USGS.

Daye-Halutu: peninsula, see Halutu Peninsula. Dayehas Creek: stream, heads in glacier, on $\mathrm{N}$ side of Mount Villard, flows NW and SE $5 \mathrm{mi}$. to Taiya Inlet, $1.2 \mathrm{mi}$. E of Taiya Point, and $12 \mathrm{mi}$. S of Skagway, Coast Mts.; 59 $17^{\prime} 30^{\prime \prime}$ $\mathrm{N}, 135^{\circ} 21^{\prime} 50^{\prime \prime} \mathrm{W}$; (map 45).

Indian name published in 1923 on IBC Sheet 9 (1951 atlas).

Day Harbor: bay, $3.6 \mathrm{mi}$. wide, E of Ressurrection Penin., on Kenai Penin., $18 \mathrm{mi}$. SE of Seward, Chugach Mts.; $59^{\circ} 57^{\prime} \mathrm{N}, 149^{\circ} 10^{\prime}$ W; (map 49). Var. Days Harbor.

Named "Days Harbor" in 1787 by Capt. Nathaniel Portlock; shown on his track chart, but not mentioned in his text.

Daykoo Islands: islands, extending $2 \mathrm{mi}$. off $\mathrm{SE}$ coast of Dall I., Alex. Arch.; 54 $42^{\prime} \mathrm{N}$, $132^{\circ} 42^{\prime} \mathrm{W}$; (map 1). Var. Dakoo Islands. Local name published by USC\&GS in 1911.

Daylight Harbor: bay, $0.2 \mathrm{mi}$. across, on $\mathrm{S}$ coast of Shuyak I., $40 \mathrm{mi}$. N of Kodiak I.; $58^{\circ} 29^{\prime}$ $\mathrm{N}, 152^{\circ} 34^{\prime} \mathrm{W}$; (map 43).

Name published by USC\&GS in 1926.

Days Harbor: bay, see Day Harbor.

Dayville: locality, see Fort Liscum.

Deacon Creek: stream, heads in Darby Mts., flows NE $2.3 \mathrm{mi}$. to Caribou Creek which flows to Tubutulik River, $38 \mathrm{mi}$. SE of Imuruk Lake, Seward Penin. High.; $65^{\circ} 08^{\prime}$ N, $162^{\circ} 24^{\prime} \mathrm{W}$; (map 110). Var. Decon Creek.

Prospectors' name published as "Decon Creek" on the 1908 "Map of Seward Peninsula" by Arthur Gibson.

Deacons Rock: rock, in Porcupine River $32 \mathrm{mi}$. NE of Chalkyitsik, Porcupine Plat.; $67^{\circ} 00^{\prime} \mathrm{N}$, $143^{\circ} 02^{\prime} \mathrm{W}$; (map 120).

Local name obtained in 1956 by T. E. Taylor and R. C. Foley, USGS.

Dead Branch Norris Glacier: glacier, trends NE $6 \mathrm{mi}$. to its junc. with Norris Glacier, $3 \mathrm{mi}$. NW of Grizzly Bar on Taku Inlet and $12 \mathrm{mi}$. NE of Juneau, Goast Mts.; 58 $25^{\prime} 30^{\prime \prime} \mathrm{N}$, $134^{\circ} 11^{\prime} 30^{\prime \prime} \mathrm{W}$; (map 11).

Local name published in 1962 by USGS.

Dead Creek: stream, flows SW $8 \mathrm{mi}$. to Gravina River, $22 \mathrm{mi}$. NW of Cordova, Chugach Mts.; $60^{\circ} 50^{\prime} 30^{\prime \prime} \mathrm{N}, 145^{\circ} 59^{\prime} 30^{\prime \prime} \mathrm{W}$; (map 64).

Local name published in 1908 by USGS.

Deadfall Creek: stream, flows NW $22 \mathrm{mi}$. through Amatusuk Hills to Kukpowruk River, $37 \mathrm{mi}$. SE of Point Lay, Arctic Slope; $69^{\circ} 14^{\prime} 15^{\prime \prime} \mathrm{N}$, $162^{\circ} 41^{\prime} 00^{\prime \prime} \mathrm{W}$; (map 145).
Named by Chapman and Sable (1960, p. 53), USGS, in 1949, "because of an Eskimobuilt rock deadfall trap found near the mouth of this stream."

Dead Glacier: glacier, see Cascade Glacier.

Dead Horse: locality, see Curry.

Deadhorse Creek: stream, flows W $4.5 \mathrm{mi}$. to Susitna River, E of Curry, $21 \mathrm{mi}$. N of Talkeetna, Talkeetna Mts.; $62^{\circ} 37^{\prime} 05^{\prime \prime} \mathrm{N}, 150^{\circ} 00^{\prime}$ 15" W; (map 81).

Local name shown on a 1921 manuscript RR. location map. See Curry.

Dead Island: island, $0.1 \mathrm{mi}$. long, at mouth of Red Bay, on $\mathbf{N}$ coast of Prince of Wales $I$., Alex. Arch.; $56^{\circ} 19^{\prime} 30^{\prime \prime} \mathrm{N}, 133^{\circ} 18^{\prime} 00^{\prime \prime} \mathrm{W}$; (map 6). Var. Danger Island.

Named in 1886 by Lt. J. M. Helm, USN, for charting purposes; published in 1887 on USC\&GS Chart 706.

Dead Island: island, see Danger Island.

Deadlock Mountain: mountain, 2,995 ft., $7 \mathrm{mi}$. $\mathrm{N}$ of Sivukat Mtn., $34 \mathrm{mi}$. N of Noatak, Brooks Ra.; $68^{\circ} 03^{\prime} 20^{\prime \prime} \mathrm{N}, 162^{\circ} 45^{\prime} 00^{\prime \prime} \mathrm{W}$; $B G N$ 1965; (map 130).

So named in 1965 by geologists of the B. P. Exploration Co., Inc., because they "became deadlocked in attempt to interpret the local geology."

Deadman Bay: bay, $3 \mathrm{mi}$. across, at head of Alitak Bay, at $\mathrm{S}$ end of Kodiak I.; $57^{\circ} 00^{\prime} \mathrm{N}$, $154^{\circ} 00^{\prime} \mathrm{W}$; (map 32 ).

Name published in 1943 by USC\&GS.

Deadman Creek: stream, flows W $3 \mathrm{mi}$. to Flat Creek, $3.5 \mathrm{mi}$. E of Wild Lake and $35 \mathrm{mi}$. NW of Wiseman, Brooks Ra.; $67^{\circ} 32^{\prime} \mathrm{N}, 151^{\circ} 24^{\prime}$ W; BGN 1932; (map 124).

Local name reported in 1932 by Robert Marshall who wrote "The name has been used since 1909 when Joe McGahy, a prospector, was found dead on the stream."

Deadman Creek: stream, heads in lake, flows SW through Deadmans Lake, $35 \mathrm{mi}$. to Susitna River, $42 \mathrm{mi}$. SE of Cantwell, Talkeetna Mts.; $62^{\circ} 49^{\prime} 50^{\prime \prime} \mathrm{N}, 148^{\circ} 28^{\prime} 20^{\prime \prime} \mathrm{W}$; (map 82).

Local name reported in 1951 by USGS.

Deadman Creek: stream, flows SE $18 \mathrm{mi}$. to East Fork Chandalar River, $3.8 \mathrm{mi}$. N of Arctic Village, Brooks Ra.; $68^{\circ} 11^{\prime} \mathrm{N}, 1^{\circ} 25^{\circ} 29^{\prime} \mathrm{W}$; (map 136).

Local name reported in 1926 by J. B. Mertie, Jr. (in Smith, P. S., 1929, pl. 1), USGS.

Deadman Glacier: glacier, heads between Spencer and Bartlett Glaciers, in Kenai Mts., trends NW $1 \mathrm{mi}$. to its terminus, $3 \mathrm{mi}$. SE of Placer River Valley, $22 \mathrm{mi}$. SE of Sunrise, Chugach Mts.; $60^{\circ} 39^{\prime} 30^{\prime \prime} \mathrm{N}, 149^{\circ} 01^{\prime} 30^{\prime \prime} \mathrm{W}$; (map 63 ).

\section{Local name reported in 1951 by USGS.}

Deadman Island: island, $150 \mathrm{ft}$. long, in South Pass, N of Passage I., Alex. Arch.; 55 $11^{\prime} 05^{\prime \prime}$ N, $132^{\circ} 52^{\prime} 20^{\prime \prime} \mathrm{W}$; (map 4).

Local name published in 1965 by USC\&GS.

Deadman Island: island, $0.2 \mathrm{mi}$. long, on $\mathrm{W}$ shore of Burnett Inlet, on SW coast of Etolin I., Alex. Arch.; $56^{\circ} 04^{\prime} 30^{\prime \prime} \mathrm{N}, 132^{\circ} 28^{\prime} 20^{\prime \prime} \mathrm{W}$; $(\operatorname{map} 6)$.
Local name used by fishermen and published in 1921 by USC\&GS.

Deadman Island: island, $400 \mathrm{ft}$. long, in Fortymile River, $1.5 \mathrm{mi}$. E of Bonanza Bar, $38 \mathrm{mi}$. $\mathrm{S}$ of Eagle, Yukon-Tanana High.; $64^{\circ} 15^{\prime} \mathrm{N}$, $141^{\circ} 08^{\prime} \mathrm{W}$; (map 102).

Local name published in 1956 by USGS.

Deadman Island: island, $3.7 \mathrm{mi}$. long, in Yukon River, $35 \mathrm{mi}$. W of Fort Yukon, Yukon Flats; $66^{\circ} 32^{\prime} \mathrm{N}, 146^{\circ} 30^{\prime} \mathrm{W}$; (map 119).

Local descriptive name obtained in 1956 by USGS.

Deadman Lake: lake, $1.4 \mathrm{mi}$. long, between Alaska Highway and Chisana River, $11 \mathrm{mi}$. $\mathrm{SE}$ of Northway Junction, Alaska Ra.; 62 $53^{\prime}$ $\mathrm{N}, 141^{\circ} 33^{\prime} \mathrm{W}$; (map 84).

Local name reported by USGS in 1954.

Deadman Lake: lake, $1.5 \mathrm{mi}$. long, on Deadman Creek, $16 \mathrm{mi}$. SW of Butte Lake and $64 \mathrm{mi}$. SE of Healy, Talkeetna Mtns.; $63^{\circ} 00^{\prime} 30^{\prime \prime} \mathrm{N}$, $148^{\circ} 15^{\prime} 00^{\prime \prime} \mathrm{W}$; (map 87).

Local name reported in 1910 by J. W. Bagley, USGS.

Deadman Lake: lake, $1.2 \mathrm{mi}$. across, $21 \mathrm{mi}$. SE of Manley Hot Springs and $65 \mathrm{mi}$. W of Fairbanks, Yukon-Tanana High.; $64^{\circ} 51^{\prime} \mathrm{N}, 149^{\circ}$ $58^{\prime} \mathrm{W}$; (map 100).

Local name published in 1952 by USGS.

Deadman Mountain: mountain, 5,525 ft., $3.5 \mathrm{mi}$. $\mathrm{N}$ of Deadman Lake and $60 \mathrm{mi}$. SE of Healy, Talkeetna Mtns.; $63^{\circ} 03^{\prime} 45^{\prime \prime} \mathrm{N}, 148^{\circ} 13^{\prime} 20^{\prime \prime}$ W; (map 87).

Local name reported in 1910 by Moffit (1915, pl. 1), USGS.

Deadman Reach: shoals, $5 \mathrm{mi}$. long, in Peril Strait, off NW coast of Duffield Penin. at N tip of Baranof I., Alex. Arch.; 57 $32^{\prime} \mathrm{N}, 135^{\circ}$ $30^{\prime} \mathrm{W}$; (map 9). Var. Deadman's Bay.

So named "Deadman's Bay" in 1869 by Comdr. R. W. Meade, USN (U.S. Coast and Geodetic Survey, 1883, p. 165), "because 150 Aleuts were killed in the vicinity in 1799 from eating poisonous mussels."

Deadman Riffle: locality, on left bank of Fortymile River, $\mathrm{E}$ of Canyon Creek, $38 \mathrm{mi}$. S of Eagle, Yukon-Tanana High.; $64^{\circ} 15^{\prime} \mathrm{N}, 141^{\circ}$ $09^{\prime} \mathrm{W}$; (map 102).

Mining camp now abandoned. Name derived from the rapids and reported in 1904 by Prindle (1905, pl. 7), USGS.

Deadman Riffle: bar, $0.7 \mathrm{mi}$. long, in Black River, $14 \mathrm{mi}$. E of Chalkyitsik, Porcupine Plat.; $66^{\circ} 39^{\prime} \mathrm{N}, 143^{\circ} 14^{\prime} \mathrm{W}$; (map 120).

Local name reported in 1940 as "Deadmans Riffle" by FitzGerald (1944, p. 230), USGS.

Deadman Riffle: rapids, off Deadman I., in Fortymile River, $38 \mathrm{mi}$. S of Eagle, YukonTanana High.; $64^{\circ} 15^{\prime} \mathrm{N}, 141^{\circ} 07^{\prime} \mathrm{W}$; (map 102). Var. Dead Mans Riffle.

Local name reported in 1896 by Spurr (1898, pl. 46), USGS.

Deadman Sands: shoal, extends $S \& \mathrm{mi}$. from Halfmoon Bay on W side of Kvichak Bay, 11 mi. W of Naknek, Bristol Bay Low.; 58 $42^{\prime}$ N, $157^{\circ} 27^{\prime}$ W; (map 41). Var. Dead Man Sands.

Descriptive name given as "Dead Man Sands" by USC\&GS in the 1954 Coast 
Pilot (p. 500) because "a number of fishermen have been lost when trapped by the tides." Deadman's Bay: shoals, see Deadman Reach.

Deadmans Island: barrier islands, see Tapkaluk Islands.

Deadman Slough: stream, distributary, flows SW $3 \mathrm{mi}$. from Noyes Slough to Chena River, $3 \mathrm{mi}$. $\mathrm{W}$ of Fairbanks, Tanana Low.; $64^{\circ} 50^{\prime} 30^{\prime} \mathrm{N}$, 14750'30" W; BGN 1911; (map 100). Var. Jennie M. Slough, Jennie Slough.

Local name reported in 1910 by W. $N$. Vance, USGS. The stream was shown as "Jennie M. Slough" in 1904 on the Tanana Mines RR. location map and as "Jennie Slough" on a 1907 USGS map by T. G. Gerdine and R. H. Sargent.

Deadmans Riffle: rapids, on Prince of Wales I., between Barnes Lake and Gold and Galligan Lagoon, $37 \mathrm{mi}$. $\mathrm{N}$ of Craig, Alex. Arch.; $56^{\circ}-$ $00^{\prime} \mathrm{N}, 132^{\circ} 58^{\prime} \mathrm{W}$; BGN 1915; (map 6).

Name recorded in 1914 by $\mathrm{E}$. L. Jones, USBF.

Dead Mans Riffle: rapids, see Deadman Riffle.

Deadmans Slough: stream, flows SE $2.8 \mathrm{mi}$. to Yukon River, $4.8 \mathrm{mi}$. S of Anvik and $30 \mathrm{mi}$. NW of Holy Cross, Nulato Hills; $62^{\circ} 35^{\prime} \mathrm{N}$, $160^{\circ} 12^{\prime} \mathrm{W}$; (map 78).

Riverboat pilots' name shown on a 1916 fieldsheet by R. H. Sargent, USGS.

Dead Pine Island: island, $200 \mathrm{ft}$. across, in Kaigani Strait, on NW coast of Long I., Alex. Arch.; 54 $53^{\prime} 30^{\prime \prime} \mathrm{N}, 132^{\circ} 48^{\prime} 30^{\prime \prime} \mathrm{W}$; (map 1)

Local name reported in 1951 by USGS.

Dead Tree Bluff: bluff, on S shore of Mitchell Bay on Admiralty I., $6.5 \mathrm{mi}$. NE of Angoon, Alex. Arch.; 57 $32^{\prime} 00^{\prime \prime} \mathrm{N}, 134^{\circ} 25^{\prime} 30^{\prime \prime} \mathrm{W}$; (map 9).

Descriptive name given by Comdr. R. W. Meade, USN; published in 1869 on Hydrog. Chart 225. Name not shown on recent maps.

Dead Tree Island: island, $0.3 \mathrm{mi}$. across, in Hanus Bay, on N coast of Baranof I., $24 \mathrm{mi}$. N. of Baranof, Alex. Arch.; $57^{\circ} 24^{\prime} 45^{\prime \prime} \mathrm{N}, 135^{\circ}$ $01^{\prime} 00^{\prime \prime} \mathrm{W}$; (map 9).

Descriptive name given in 1895 by Lt. Comdr. E. K. Moore, USN. The name was published by USC\&GS on Chart 8283 .

Dead Tree Point: point of land, on $\mathrm{W}$ coast of Heceta I., Alex. Arch.; 55 44'55' N, $133^{\circ} 39^{\prime}$ 45" W; BGN 1908; (map 4).

Local descriptive name reported in 1907 by E. F. Dickens, USC\&GS.

Deadview Peak: peak, 4,200 ft., $3 \mathrm{mi}$. NW of Olds Mtn. and $6 \mathrm{mi}$. NE of Juneau, Coast Mts.; $58^{\circ} 22^{\prime} 10^{\prime \prime} \mathrm{N}, 134^{\circ} 19^{\prime} 45^{\prime \prime} \mathrm{W}$; (map 11).

Named in 1953 by personnel of the Juneau Icefield Research Project because it was frequently used as a point for the examination of Dead Branch Glacier.

Deadwood: locality, on right bank of Deadwood Creek, $33 \mathrm{mi}$. SW of Circle, Yukon-Tanana High.; $65^{\circ} 30^{\prime} \mathrm{N}, 144^{\circ} 50^{\prime} \mathrm{W}$; (map 104).

Name of a mining camp derived from Deadwood Creek and reported by Ellsworth and Davenport (1915b, pl. 4), USGS. A post office, established here in 1906, was discontinued in 1924 (Ricks, 1965, p. 13, 16).
Deadwood Creek: stream, flows SW $1 \mathrm{mi}$. to join Guggenheim Creek to form Porcupine Creek, $25 \mathrm{mi}$. NE of Flat, Kilbuck-Kuskokwim Mts.; $62^{\circ} 39^{\prime} 45^{\prime \prime} \mathrm{N}, 157^{\circ} 21^{\prime} 30^{\prime \prime} \mathrm{W}$; (map 79).

Prospectors' name reported in 1910 by A. G. Maddren, USGS.

Deadwood Creek: stream, flows SW $8.5 \mathrm{mi}$. to Pedro Creek, $15 \mathrm{mi}$. NE of Fairbanks, YukonTanana High.; $65^{\circ} 01^{\prime} \mathrm{N}, 147^{\prime} 26^{\prime} \mathrm{W}$; (map 105).

Named by prospectors; reported in 1903 by L. M. Prindle (in Emmons and Hayes, 1904, p. 68), USGS.

Deadwood Creek: stream, heads on Elephant Mtn., flows SW $3.5 \mathrm{mi}$. to Pioneer Creek, 20 mi. S of Rampart, Yukon-Tanana High.; $65^{\circ} 12^{\prime} 20^{\prime \prime} \mathrm{N}, 150^{\circ} 06^{\prime} 00^{\prime \prime} \mathrm{W}$; (map 106).

Prospectors' name reported in 1906 by USGS.

Deadwood Creek: stream, flows NE $16 \mathrm{mi}$. to Crooked Creek, $26 \mathrm{mi}$. SW of Circle, YukonTanana High.; $65^{\circ} 32^{\prime} \mathrm{N}, 144^{\circ} 38^{\prime} \mathrm{W}$; (map 104). Var. Deadwood Gulch, Hogem Creek, Hog'em Gulch, Sixteen Gulch.

Local name reported in 1896 by USGS as "Hogem" or "Deadwood Creek" (Spurr, 1898, pl. 50). "Hog'em Gulch received its name from the fact that the discoverer tried to hold a large part of the richest diggings, taking up separate claims for the whole of his numerous family, and, it is said by some, for fictitious personages. When other miners came to the gulch and a meeting was held, among other things the question of naming the diggings came up, and one miner suggested that 'Hog 'em' would be appropriate. This suggestion was not officially adopted, and the name Deadwood was given the gulch as being more dignified, but the original nickname has persisted and among most of the miners is used almost exclusively" (Spurr, 1898, p. 342).

Deadwood Creek: stream, flows SE $4 \mathrm{mi}$. to Victoria Creek, $72 \mathrm{mi}$. NE of Fairbanks, YukonTanana High.; $65^{\circ} 49^{\prime} 31^{\prime \prime} \mathrm{N}, 147^{\circ} 00^{\prime} 40^{\prime \prime} \mathrm{W}$; (map 105).

Local name published by USGS in the 1950's.

Deadwood Gulch: stream, see Deadwood Creek.

Deadwood Lake: lake, $0.3 \mathrm{mi}$. across, $20 \mathrm{mi}$. NE of Katalla, Chugach Mts.; $60^{\circ} 26^{\prime} \mathrm{N}, 144^{\circ} 15^{\prime}$ W; (map 64)

Named by railroad surveyors in 1906 ; reported by G. C. Martin (1908, pl. 2), USGS. Dean Creek: stream, flows NW $5.5 \mathrm{mi}$. to N coast of Kuiu I., between Security and Saginaw Bays, Alex. Arch.; $56^{\circ} 54^{\prime} \mathrm{N}, 134^{\circ} 19^{\prime} \mathrm{W}$; (map 5).

Local name recorded in 1948 by USGS.

Dean Creek: stream, flows SW $12 \mathrm{mi}$, to Yanert Fork, $21 \mathrm{mi}$. SE of Healy, Alaska Ra.; $63^{\circ} 40^{\prime} 30^{\prime \prime} \mathrm{N}, 148^{\circ} 23^{\prime} 30^{\prime \prime} \mathrm{W}$; (map 87).

Local name obtained in 1913 by J. W. Bagley, USGS; published by Moffit (1915, pl. 1).

Dean Creek: stream, see Dane Creek.

Dearborn, Cape: point of land, W tip of Hill I., $10 \mathrm{mi}$. NW of Chichagof, on $W$ coast of
Chichagof I., Alex. Arch.; 57 $45^{\prime} 15^{\prime \prime} \mathrm{N}, 136^{\circ}$ $19^{\prime} 00^{\prime \prime}$ W ; (map 9).

Name published in 1919 by USC\&GS on Chart 8250.

Dearborn Island: island, see Deranof Island.

Dease Bay: bay, see Dease Inlet.

Dease Inlet: bay, $7 \mathrm{mi}$. across, between Christie and Tangent Points, extends S $19 \mathrm{mi}$. to Admiralty Bay, $28 \mathrm{mi}$. SE of Barrow, Arctic Plain; $71^{\circ} 12^{\prime} \mathrm{N}, 155^{\circ} 24^{\prime} \mathrm{W}$; BGN 1944; (map 153). Var. Dease Bay, Dease's Inlet, Kilulea, Pease Inlet.

Named for Peter Warren Dease by Thomas Simpson (1843, p. 149) August 2, 1837, "for my worthy colleague." The Eskimo name "Kilulea," shown by Comdr. Rochfort Maguire (Great Britain, 1854, map facing $\mathrm{p}$. 186), R.N. may be derived from a word meaning "to the back," hence "inland."

Dease's Inlet: $b a y$, see Dease Inlet.

Death Valley: basin, $6 \mathrm{mi}$. across, along Tubutulik River, on E side of Darby Mts., $37 \mathrm{mi}$. SE of Imuruk Lake, Seward Penin. High.; $65^{\circ} 12^{\prime} \mathrm{N}, 162^{\circ} 21^{\prime} \mathrm{W}$; (map 110).

Local name published on a precinct map of Seward Peninsula by Monroe and Hutchins; corrected up to June 1903 by Arthur Gibson.

Death Valley: valley, on Morris Glacier, $2 \mathrm{mi}$. $\mathrm{S}$ of Echo Pass and $11 \mathrm{mi}$. $\mathrm{N}$ of Juneau, Coast Mts. ; $58^{\circ} 28^{\prime} \mathrm{N}, 134^{\circ} 22^{\prime} \mathrm{W}$; (map 11 ).

Local name published in 1962 by USGS.

Death Valley: valley, trends E-W 8 mi., between Button Mtn. and Wild River, $16 \mathrm{mi}$. $\mathrm{N}$ of Bettles, Brooks Ra.; $67^{\circ} 09^{\prime} \mathrm{N}, 151^{\circ} 36^{\prime} \mathrm{W}$; $B G N$ 1932; (map 124)

Local name reported in 1932 by Robert Marshall.

Death Valley Branch Norris Glacier: glacier, heads in Death Valley W of Amherst Peak, trends SE $8 \mathrm{mi}$. to Norris Glacier, $14 \mathrm{mi}$. N of Juneau, Coast Mts.; $58^{\circ} 29^{\prime} \mathrm{N}, 134^{\circ} 15^{\prime} \mathrm{W}$; (map 11).

Local name used by climbers and scientists in the Juneau Icefield area.

Death Valley Creek: stream, flows E $5 \mathrm{mi}$. from a lake to Wild River, $15 \mathrm{mi}$. NE of Bettles,

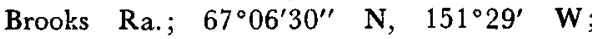
(map 124).

This stream flows into Death Valley; local name reported by USGS in 1932.

De Barr Vista: suburb, E of Anchorage, between Nanuka Valley and Homesite Park, Cook Inlet Low.; $61^{\circ} 12^{\prime} 48^{\prime \prime} \mathrm{N}, 1^{\circ} 49^{\circ} 45^{\prime} 10^{\prime \prime} \mathrm{W}$; (map 69).

Local name reported in 1952 by USGS.

Debauch Mountain: mountain, $3,411 \mathrm{ft}$., $30 \mathrm{mi}$. $E$ of Norton Bay and $55 \mathrm{mi}$. WSW of Nulato; Nulato Hills; $64^{\circ} 31^{\prime} \mathrm{N}, 159^{\circ} 54^{\prime} \mathrm{W}$; (map 96). Var. West Mountain.

Local name reported in 1910 by USGS.

Debetendig: stream, see Shaw Creek.

De Blondeau: glacier, see Le Blondeau Glacier. De Boer Lake: lake, $1.5 \mathrm{mi}$. long, $4.5 \mathrm{mi}$. N of Spurt Point, on Thomas Bay, $96 \mathrm{mi}$. E of Sitka, Coast Mts.; $57^{\circ} 05^{\prime} 10^{\prime \prime} \mathrm{N}, 132^{\circ} 5^{\prime} 00^{\prime \prime} \mathrm{W}$; (map 8).

Local name reported in 1961 by USGS. 
Deborah, Mount: mountain, 12,339 ft., $56 \mathrm{mi}$. $\mathrm{NE}$ of Cantwell and $55 \mathrm{mi}$. SE of Healy, Alaska Ra.; $63^{\circ} 38^{\prime} 15^{\prime \prime} \mathrm{N}, 147^{\circ} 13^{\prime} 30^{\prime \prime} \mathrm{W}$; BGN 1917; (map 87). Var. Cathedral Mountain.

Named in 1907 by James Wickersham, for his wife, Deborah Bell Wickersham.

DeCarey Creek: stream, in Bendeleben Mts., flows SW $2 \mathrm{mi}$. to Paragon River near its head, $12 \mathrm{mi}$. NE of Mount Bendeleben, Seward Penin. High.; $65^{\circ} 13^{\prime} \mathrm{N}, 163^{\circ} 43^{\prime} \mathrm{W}$; (map 110). Var. Jefferson Creek.

This appears to be the stream shown as "Jefferson" on a map of Cape Nome gold fields by David Fox, Jr., dated 1901. Prospectors' name reported in 1909 by Smith and Eakin (1911, pl. 1), USGS.

Deceit, Cape: point of land, on Seward Penin., extends into Kotzebue Sound, $2 \mathrm{mi}$. NW of Deering, Kotzebue-Kobuk Low.; $66^{\circ} 06^{\prime} \mathrm{N}$, $162^{\circ} 44^{\prime} \mathrm{W}$; (map 113). Var. Cape Betrug.

Translation of the German "Betrug," given in 1816 by Lt. Otto von Kotzebue. He was deceived by appearances, which indicated a bay, that did not exist. He found the natives to be expert "cheats."

Deceit Point: point of land, $1.5 \mathrm{mi}$. NW of Cape Tusik, on $\mathbf{S}$ coast of Kanaga I., Aleutian Is.; $51^{\circ} 41^{\prime} 35^{\prime \prime} \mathrm{N}, 177^{\circ} 19^{\prime} 20^{\prime \prime} \mathrm{W}$; (map 17).

Name published in 1957 on an AMS map.

December Creek: stream, flows NE $2 \mathrm{mi}$. to unnamed tributary of Bessie Creek, $36 \mathrm{mi}$. N of Goodnews, Kilbuck-Kuskokwim Mts.; 59 $36^{\prime}$ $\mathrm{N}, 161^{\circ} 18^{\prime} \mathrm{W}$; (map 53$)$.

Local name published in 1951 by USGS.

December Point: point of land, $18 \mathrm{mi}$. S of Petersburg, on SW coast of Mitkof I., Alex. Arch.; 56 $32^{\prime} 55^{\prime \prime} \mathrm{N}, 132^{\circ} 57^{\prime} 30^{\prime \prime} \mathrm{W}$; (map 6). Var. Mys Zelenoy, Mys Zelenyy, Zeloni Point.

Named in 1869 by Comdr. R. W. Meade, USN; named "Mys Zelenoy, meaning "green point," in 1838 by the Russian surveyor, G. Lindenberg.

Deception, Mount: peak, 11,826 ft., in Mount McKinley National Park, $\mathbf{E}$ of Brooks Glacier, $16 \mathrm{mi}$. ENE of Mount McKinley, Alaska Ra.; $63^{\circ} 09^{\prime} 30^{\prime \prime} \mathrm{N}, 150^{\circ} 32^{\prime} 00^{\prime \prime} \mathrm{W}$; BGN 1947; (map 88). Var. Mystery Mountain.

Named and first climbed by four men of a U.S. Army crash investigation party, November 13,1944, after an airplane crash on the mountain two months before.

Deception Greek: stream, heads SW of Alice Peak, flows SW $1 \mathrm{mi}$. to Elliott Creek, $1.9 \mathrm{mi}$. $\mathrm{S}$ of Sheep Mtn. and $80 \mathrm{mi}$. NE of Valdez, Wrangell Mts.; $61^{\circ} 39^{\prime} 15^{\prime \prime} \mathrm{N}, 144^{\circ} 08^{\prime} 15^{\prime \prime} \mathrm{W}$; (map 68)

Named in 1899 by prospectors working on Elliott Creek; reported in 1902 by USGS (Mendenhall, 1905, p. 98).

Deception Creek: stream, flows NW $17 \mathrm{mi}$. to Willow Creek $5 \mathrm{mi}$. E of its junc. with Susitna River, $38 \mathrm{mi}$. N of Anchorage, Cook Inlet Low. ; $61^{\circ} 46^{\prime} \mathrm{N}, 150^{\circ} 02^{\prime} \mathrm{W}$; (map 70).

Name reported on 1916 RR. planning manuscript map.

Deception Hills: mountains, 3,610 ft., extend 6 mi. across, $\mathrm{N}$ of 1961 terminus of Grand
Plateau Glacier, $64 \mathrm{mi}$. SE of Yakutat, St. Elias Mts.; $59^{\circ} 05^{\prime} \mathrm{N}, 138^{\circ} 10^{\prime} \mathrm{W}$; (map 46).

Local name reported by Blackwelder (1907, pp. 416-417), USGS.

Deception Island: island, $0.4 \mathrm{mi}$. long, in NE part of Kootznahoo Inlet, $4.5 \mathrm{mi}$. NE of Angoon, on W central Admiralty I., Alex. Arch.; $57^{\circ} 33^{\prime} 25^{\prime \prime} \mathrm{N}, 134^{\circ} 29^{\prime} 00^{\prime \prime} \mathrm{W}$; (map 9). Var. Deception Islet.

Named in 1869 by Comdr. R. W. Meade, USN, and published on Chart 225.

Deception Islet: island, see Deception Island.

Deception Point: point of land, on $\mathbf{E}$ coast of Woewodski I., $19 \mathrm{mi}$. S of Petersburg, Alex. Arch.; 56 $32^{\prime} 30^{\prime \prime} \mathrm{N}, 132^{\circ} 58^{\prime} 20^{\prime \prime} \mathrm{W}$; (map 6).

Descriptive name given in 1869 by Comdr. R. W. Meade, USN, because the mariner may be deceived as to which is the main channel. Deception Pup: stream, flows NE $3 \mathrm{mi}$. to Albert Creek, $8.5 \mathrm{mi}$. WNW of Central and $33 \mathrm{mi}$. SW of Circle, Yukon-Tanana High.; $65^{\circ}$. $36^{\prime} 30^{\prime \prime} \mathrm{N}, 145^{\circ} 05^{\prime} 15^{\prime \prime} \mathrm{W}$; (map 104).

Prospectors' name reported in 1954 or 1955 by USGS topographers.

Decision, Cape: point of land, S tip of Kuiu I., between Sumner and Chatham Straits, $26 \mathrm{mi}$. SE of Port Alexander, Alex. Arch.; $56^{\circ} 00^{\prime} 10^{\prime \prime}$ N, 134 $08^{\prime} 00^{\prime \prime}$ W; (map 5). Var. Mys Razrishénia, Mys Razrysheniya, Mys Rishénia.

So named by Capt. George Vancouver, RN, "about September 20, 1793, because he said that the emptiness of the stories of Fuca, Fonte, etc., was now decided" (Wagner, 1937, p. 383).

Decision Passage: water passage, connects Chatham and Sumner Straits, off S tip of Kuiu I., Alex. Arch.; 55 $59^{\prime} 40^{\prime \prime} \mathrm{N}, 134^{\circ} 07^{\prime} 00^{\prime \prime} \mathrm{W}$; (map 4).

Named in 1929 by the Bureau of Lighthouses for a nearby point of land.

Decision Point: point of land, on NE Coast of Kenai Penin., at SE end of Passage Canal, $8 \mathrm{mi}$. NE of Whittier, Chugach Mts.; $60^{\circ}$ $48^{\prime} 20^{\prime \prime} \mathrm{N}, 148^{\circ} 27^{\prime} 10^{\prime \prime} \mathrm{W}$; BGN 1910; (map 63). Var. Point Decision.

Named in 1908 by Grant and Higgins (1910, pl. 2), USGS.

Decon Creek: stream, see Deacon Creek.

DeCourcy Mountain: mountain, 1,751 ft., in Kuskokwim Mts., E of Iditarod River, $19 \mathrm{mi}$. NW of village of Crooked Creek and $43 \mathrm{mi}$. SE of Holy Cross, Kilbuck-Kuskokwim Mts.; $62^{\circ} 05^{\prime} 15^{\prime \prime} \mathrm{N}, 158^{\circ} 28^{\prime} 00^{\prime \prime} \mathrm{W}$; BGN 1945; (map 79).

Local name reported in 1944 by USGS; named for a "prospector who discovered quicksilver nearby in $1911 . "$

Decoy Lake: lake, $0.5 \mathrm{mi}$. long, on Kenai Penin., W of Quill Lake, 22 mi. NE of Kenai, Cook Inlet Low.; $60^{\circ} 46^{\prime} 15^{\prime \prime} \mathrm{N}, 150^{\circ} 45^{\prime} 45^{\prime \prime} \mathrm{W}$; (map 62).

Named about 1963 by officials of Kenai National Moose Range, for administrative purposes.

Dèću: isthmus, see Deshu Isthmus.

Deekakat: locality, see Dishkakat.

Deepbank Creek: stream, flows NW $40 \mathrm{mi}$. to Little Tonzona River $8.5 \mathrm{mi}$. $\mathrm{E}$ of its junc. with South Fork Kuskokwim River, $55 \mathrm{mi}$. E of McGrath, Kuskokwim Low.; $62^{\circ} 57^{\prime} 20^{\prime \prime} \mathrm{N}$, $153^{\circ} 53^{\prime} 00^{\prime \prime} \mathrm{W}$; (map 80).

Local descriptive name reported in 1958 by USGS.

Deep Bay: bay, $0.6 \mathrm{mi}$. across, on $\mathrm{N}$ coast of Atka I., Aleutian Is.; 52 $06^{\prime} 50^{\prime \prime} \mathrm{N}, 174^{\circ} 37^{\prime}$ $00^{\prime \prime} \mathrm{W}$; (map 18). Var. Bukhta Gloubokaia.

Russian name published as "Bukhta Gloubokaia" by Capt. Lutke (1836, p. 314), IRN, and as "Deep Bay" by USC\&GS in the 1944 Aleutian Coast Pilot (p. 95).

Deep Bay: bay, $1 \mathrm{mi}$. across, on NE coast of Unalaska I., Aleutian Is. ; $53^{\circ} 53^{\prime} 45^{\prime \prime}$ N, $166^{\circ}$ $14^{\prime} 00^{\prime \prime} \mathrm{W}$; (map 23).

So named in 1901 by J. J. Gilbert, USC\&GS.

Deep Bay: bay, $0.5 \mathrm{mi}$. across, near $W$ end of Peril Strait, on S coast of Chichagof I., Alex. Arch.; $57^{\circ} 26^{\prime} 30^{\prime \prime} \mathrm{N}, 135^{\circ} 37^{\prime} 00^{\prime \prime} \mathrm{W}$; (map 9). Var. Glubokoi Bay, Zaliv Glubokoy.

This is a translation by USC\&GS about 1882 of the name given by the Russian pilot Ens. Vasiliev; published in 1848 on Russian Hydrog. Dept. Chart 1397 as "Zal[iv] Glubokoy."

Deep Bay: $b a y, 1.5 \mathrm{mi}$. long, on NE coast of Hawkins I., $3 \mathrm{mi}$. NW of Cordova, Chugach Mts. ; $60^{\circ} 35^{\prime} 30^{\prime \prime} \mathrm{N}, 145^{\circ} 46^{\prime} 30^{\prime \prime} \mathrm{W}$; (map 64).

Local descriptive name published in 1951 by USGS.

Deep Bay: bay, see Abraham Bay.

Deep Bay: bay, see Banner Bay.

Deep Bay: bay, see Didrickson Bay.

Deep Bay: bay, see Kelp Bay.

Deep Bay: bay, see Pinta Bay.

Deep Bay: cove, $1 \mathrm{mi}$. long, on SE coast of Khantaak I., $0.6 \mathrm{mi}$. E of Point Munoz and 2.6 mi. NW of Yakutat, Malaspina Coastal Plain; $59^{\circ} 35^{\prime} 00^{\prime \prime} \mathrm{N}, 139^{\circ} 45^{\prime} 30^{\prime \prime} \mathrm{W}$; (map 46). Var. Sea Otter Bay.

Descriptive name published by USGS in 1959; shown as Sea Otter Bay on a 1964 map (deLaguna and others, 1964, map 4).

Deep Bay: cove, extends NE $1.2 \mathrm{mi}$. to Stikine Strait, on NE coast of Zarembo I., Alex. Arch.; $56^{\circ} 24^{\prime} 30^{\prime \prime} \mathrm{N}, 132^{\circ} 37^{\prime} 40^{\prime \prime} \mathrm{W}$; (map 6).

Local name used by fishermen and published in 1920 by USC\&GS.

Deep Canyon Creek: stream, flows SE $3.3 \mathrm{mi}$. to Nome River, $25 \mathrm{mi}$. NE of Nome, Seward Penin. High.; $64^{\circ} 52^{\prime} 42^{\prime \prime} \mathrm{N}, 165^{\circ} 15^{\prime} 00^{\prime \prime} \mathrm{W}$; (map 94)

Prospectors' name reported in 1904 by T. G. Gerdine, USGS.

Deep Cove: bay, $0.7 \mathrm{mi}$. across, $20 \mathrm{mi}$. $\mathrm{N}$ of village of Port Alexander, on SE coast of Baranof I., Alex. Arch.; 56 $32^{\prime} 15^{\prime \prime}$ N, $134^{\circ}$ $40^{\prime} 00^{\prime \prime} \mathrm{W}$; BGN 1937; (map 5). Var. Patterson Bay, West Arm.

Named in 1929 by USFS.

Deep Cove: see Mist Cove.

Deep Creek: stream, on Kenai Penin., heads N of Boxcar Hills, flows NW $30 \mathrm{mi}$. to Cook Inlet at Cape Ninilchik, $39 \mathrm{mi}$. SW of Kenai, Cook Inlet Low.; $60^{\circ} 02^{\prime} \mathrm{N}, 151^{\circ} 42^{\prime} \mathrm{W}$; (map 62).

Local descriptive name; reported in 1951 by USGS. 
Deep Creek: stream, on Hawkins I., flows NE $1.5 \mathrm{mi}$. to Deep Bay, $3 \mathrm{mi}$. NW of Cordova, Chugach Mts.; $60^{\circ} 35^{\prime} \mathrm{N}, 145^{\circ} 49^{\prime} \mathrm{W}$; (map 64).

Local descriptive name published in 1951 by USGS.

Deep Creek: stream, heads in lake, flows SE 9 mi. to Talachulitna River, $W$ of Hiline Lake, $47 \mathrm{mi}$. NW of Tyonek, Alaska Ra.; $61^{\circ} 44^{\prime} 10^{\prime \prime}$ $\mathrm{N}, 151^{\circ} 27^{\prime} 30^{\prime \prime} \mathrm{W}$; (map 70).

Local descriptive name reported in 1954 by USGS.

Deep Creek: stream, heads on Beluga Mtn., flows E $17 \mathrm{mi}$. to Alexander Lake, $48 \mathrm{mi}$. N of Tyonek, Cook Inlet Low.; 61 $41^{\circ} 30^{\prime \prime} \mathrm{N}$, $150^{\circ} 54^{\prime} 00^{\prime \prime} \mathrm{W}$; (map 70$)$.

Local descriptive name reported in 1954 by USGS.

Deep Creek: stream, flows NW $5.4 \mathrm{mi}$. to Spruce Creek, $8 \mathrm{mi}$. S5 of Marshall, Yukon-Kuskokwim Delta; $61^{\circ} 47^{\prime} \mathrm{N}, 162^{\circ} 00^{\prime} \mathrm{W}$; (map 73).

Prospectors' name reported by Harrington (1918, map), USGS, in 1916.

Deep Creek: stream, flows SW $5.7 \mathrm{mi}$. to Peters Creek, $21 \mathrm{mi}$. NW of Talkeetna, Alaska Ra.; $62^{\circ} 25^{\prime} 15^{\prime \prime} \mathrm{N}, 150^{\circ} 44^{\prime} 10^{\prime \prime} \mathrm{W}$; (map 81).

Local descriptive name reported in 1958 by USGS.

Deep Creek: stream, flows NW 4.5 mi. to Madison Creek, $5 \mathrm{mi}$. NE of its junc. with Tolstoi Creek, $25 \mathrm{mi}$. NW of Ophir and $54 \mathrm{mi}$. NW of McGrath, Kilbuck-Kuskokwim Mts.; $63^{\circ}$ $26^{\prime} \mathrm{N}, 156^{\circ} 59^{\prime} \mathrm{W}$; (map 90).

Prospectors' name reported in 1917 by G. L. Harrington, USGS.

Deep Creek: stream, flows NW $25 \mathrm{mi}$. to Highpower Creek, $7 \mathrm{mi}$. SSW of Sprucefish Lake and $32 \mathrm{mi}$. SSW of village of Lake Minchumina, Kuskokwim Low.; $63^{\circ} 28^{\prime} 40^{\prime \prime} \mathrm{N}, 152^{\circ}$ $49^{\prime} 30^{\prime \prime} \mathrm{W}$; (map 88).

Local name obtained in 1958 from Fabian Carey and "Val" Blackburn by USGS.

Deep Creek: stream, flows E, across AlaskaCanada boundary $8 \mathrm{mi}$. to North Ladue River in Yukon, Canada, Yukon-Tanana High.; $63^{\circ}$ $29^{\prime} \mathrm{N}, 140^{\circ} 51^{\prime} \mathrm{W}$; (map 85).

Name reported by IBC, 1907-09.

Deep Creek: stream, flows N $21 \mathrm{mi}$. to Lake Minchumina, W of Giles Bay, Tanana Low.; $63^{\circ} 52^{\prime} 15^{\prime \prime}$ N, $152^{\circ} 19^{\prime} 30^{\prime \prime} \mathrm{W}$; (map 88). Var. Dontsólakhnó.

Local name reported in 1954 by USGS. Its Tanana Indian name is said to be "Dontsólakhnó," meaning "suckerfish river."

Deep Creek: stream, flows NW $10 \mathrm{mi}$. to Salcha River, $34 \mathrm{mi}$. N of Big Delta, Yukon-Tanana High.; 64 $38^{\prime} \mathrm{N}, 1^{\circ} 5^{\circ} 55^{\prime} \mathrm{W}$; (map 101).

Local descriptive name; published in 1956 by USGS.

Deep Creek: stream, flows NE 6 mi. to Seventymile River, $37 \mathrm{mi}$. NW of Eagle, YukonTanana High.; 64 $59^{\prime} 30^{\prime \prime} \mathrm{N}, 142^{\circ} 16^{\prime} 30^{\prime \prime} \mathrm{W}$; (map 102). Var. Deer Creek.

Named by prospectors; reported in 1905 by D. C. Witherspoon (in Prindle, 1906, pl. 1), USGS. This stream was erroneously shown as Deer Creek on a 1905 manuscript map drawn by Maj. W. A. Glassford, USA.
Deep Creek: stream, heads in lake, flows W 5 mi. to Pilgrim River, $18 \mathrm{mi}$. SW of Mount Bendeleben, Seward Penin. High.; $65^{\circ} 02^{\prime} \mathrm{N}$, $164^{\circ} 37^{\prime} \mathrm{W}$; (map 110).

Prospectors' name reported on a map of Cape Nome gold fields by David Fox, Jr., dated 1901. The lower course of this stream is now part of Sherrette Creek.

Deep Creek: stream, flows NW $6 \mathrm{mi}$. to Fish Creek, $0.5 \mathrm{mi}$. S of Fish Lake and $23 \mathrm{mi}$. SE of Tanana, Yukon-Tanana High.; 65 $02^{\prime} 30^{\prime \prime}$ N, $151^{\circ} 21^{\prime} 30^{\prime \prime} \mathrm{W}$; (map 106).

Local name reported in 1952 by USGS.

Deep Creek: stream, flows SE $1 \mathrm{mi}$. through Innesvale Gulch, then SW $2 \mathrm{mi}$. to Woodchopper Creek, $32 \mathrm{mi}$. ESE of Tanana, YukonTanana High.; $65^{\circ} 03^{\prime} \mathrm{N}, 151^{\circ} 01^{\prime} \mathrm{W}$; (map 106).

Prospectors' name reported in 1931 by J. B. Mertie, Jr., USGS.

Deep Creek: stream, flows SW 3 mi. to Fairbanks Creek, $22 \mathrm{mi}$. NE of Fairbanks, Yukon-Tanana High.; 65 $03^{\prime} 30^{\prime \prime} \mathrm{N}, 147^{\circ} 09^{\prime} 00^{\prime \prime} \mathrm{W}$; (map $105)$.

Named by prospectors; reported in 1903 by T. G. Gerdine (in Prindle, 1905, pl. 13), USGS.

Deep Creek: stream, flows E 4 mi. to Faith Creek, $9 \mathrm{mi}$. SE of Mount Prindle and $72 \mathrm{mi}$. SW of Circle, Yukon-Tanana High.; $65^{\circ} 22^{\prime} 10^{\prime} \mathrm{N}$, $146^{\circ} 16^{\prime} 30^{\prime \prime} \mathrm{W}$; (map 104).

Named by prospectors and reported in 1907 by C. C. Covert (in Henshaw and Covert, 1908, pl. 9), USGS.

Deep Creek: stream, flows $\mathrm{N} 1.5 \mathrm{mi}$, to Goodhope River, $17 \mathrm{mi}$. NW of Imuruk Lake, Seward Penin. High.; $65^{\circ} 48^{\prime} \mathrm{N}, 163^{\circ} 40^{\prime} \mathrm{W}$; $B G N 1952$; (map 110).

Prospectors' name reported in 1901 by USGS (Collier, 1902, pl. 12).

Deep Creek: stream, flows NW $18 \mathrm{mi}$. to Nuluk River which flows to Arctic Lagoon, $44 \mathrm{mi}$. NW of Teller, Seward Penin. High.; 65 ${ }^{\circ} 52^{\prime}$ N, 166'45' W; (map 111).

Prospectors' name reported on the 1908 "Map of Seward Peninsula" by Arthur Gibson.

Deep Creek: stream, see Clear Creek.

Deep Creek Lakes: lakes, two, each $0.5 \mathrm{mi}$. long, drain $W$ to Deep Creek $S$ of Fish Lake, 24 mi. ESE of Tanana, Yukon-Tanana High.; $65^{\circ} 02^{\prime} 15^{\prime \prime} \mathrm{N}, 151^{\circ} 19^{\prime} 00^{\prime \prime} \mathrm{W}$; (map 106).

Local name reported in 1952 by USGS.

Deep Inlet: estuary, $4.5 \mathrm{mi}$. long, on $W$ coast of Baranof I., 5 mi. S of Sitka, Alex. Arch.; $56^{\circ} 59^{\prime} 00^{\prime \prime} \mathrm{N}, 135^{\circ} 17^{\prime} 30^{\prime \prime} \mathrm{W}$; (map 5). Var. Bukhta Dorokhova, Dorokhova Bay, Glubokaia, Guba Glubokaya.

This is a translation by USC\&GS of the name given in 1809 by the navigator Ivan Vasiliev the first, IRN. Lt. Sarichev (1826, map 19), IRN, published it as "Guba Glubokaya," meaning "deep bay." It was called "Bukhta Dorokhova," meaning "fool's bay," by Capt. Tebenkov (1852, map 38), IRN.

Deep Lake: lake, $0.4 \mathrm{mi}$. long, one of Wakefield Lakes, on $\mathrm{E}$ coast of Baranof I., $16 \mathrm{mi}$. S of Baranof, Alex. Arch.; $56^{\circ} 51^{\prime} 40^{\prime \prime} \mathrm{N}, 134^{\circ}$ $44^{\prime} 00^{\prime \prime} \mathrm{W}$; (map 5).
Local descriptive name obtained in 1951 by USGS.

Deep Lake: lake, $0.2 \mathrm{mi}$. across, $5 \mathrm{mi}$. ESE of Valdez, Chugach Mts.; $61^{\circ} 05^{\prime} 35^{\prime \prime} \mathrm{N}, 146^{\circ}$. $05^{\prime} 50^{\prime \prime} \mathrm{W}$; (map 68).

Local name published in 1950 by USGS.

Deep Lake: lake, $1.8 \mathrm{mi}$. long, at head of Dog Creek, $30 \mathrm{mi}$. NNW of Glennallen, Copper River Basin; 62 $29^{\prime} \mathrm{N}, 146^{\circ} 01^{\prime} \mathrm{W}$; (map 83 ).

Local descriptive name; reported in 1951 by USGS.

Deep Lake: lake, $0.7 \mathrm{mi}$. across, $1.3 \mathrm{mi}$. SW of Tsolmund Lake and $11 \mathrm{mi}$. SE of Northway, Alaska Ra.; $62^{\circ} 49^{\prime} 10^{\prime \prime} \mathrm{N}, 141^{\circ} 46^{\prime} 45^{\prime \prime} \mathrm{W}$; (map 84).

Local name reported by USGS in 1954.

Deep Lake: lake, see Redoubt Lake.

Deep Water Bay: estuary, on E coast of Kenai Penin., extends NE 2 mi. to Port Nellie Juan, $22 \mathrm{mi}$. SE of Whittier, Chugach Mts.; $60^{\circ} 30^{\prime}-$ $30^{\prime \prime} \mathrm{N}, 148^{\circ} 21^{\prime} 30^{\prime \prime} \mathrm{W}$; (map 63).

Local descriptive name published in 1950 by USC\&GS.

Deepwater Point: point of land, E point of entrance to Woewodski Harbor, on SE coast of Admiralty I., Alex. Arch.; $57^{\circ} 10^{\prime} 20^{\prime \prime} \mathrm{N}$, $134^{\circ} 13^{\prime} 40^{\prime \prime} \mathrm{W}$; (map 9). Var. Mys Glubokiy.

An 1882 translation by USC\&GS of name given in 1838 by Capt. Lt. D. F. Zarembo; published in 1848 on Russian Hydrog. Dept. Chart 1396 as "M[ys] Glubokiy," meaning "deep cape."

Deer Bay: cove, $0.2 \mathrm{mi}$. across, $\mathrm{S}$ of Fort Glenn, on NE coast of Umnak I., Aleutian Is. ; $53^{\circ}$ $22^{\prime} 20^{\prime \prime} \mathrm{N}, 167^{\circ} 52^{\prime} 00^{\prime \prime} \mathrm{W}$; (map 23).

Name reported by U.S. Army Corps of Engineers in 1942.

Deer Bay: bay, see Stag Bay.

Deer Bay: estuary, extends NW $1.2 \mathrm{mi}$. off Hetta Inlet, on S coast of Prince of Wales I., Alex. Arch.; $55^{\circ} 14^{\prime} 10^{\prime \prime} \mathrm{N}, 132^{\circ} 40^{\prime} 30^{\prime \prime} \mathrm{W}$; (map 4).

Local name published in 1904 by USC\&GS.

Deer Branch: stream, flows W $1.5 \mathrm{mi}$. to Tozer Creek which flows to Don River, $3.8 \mathrm{mi}$. NW of Black Mtn. and $22 \mathrm{mi}$. N of Teller, Seward Penin. High.; $65^{\circ} 31^{\prime} \mathrm{N}, 166^{\circ} 46^{\prime} \mathrm{W}$; (map 111).

Prospectors' name reported in 1918 by Steidtmann and Cathcart (1922, pl. 12), USGS.

Deer Cove: cove, $0.5 \mathrm{mi}$. across, on $\mathrm{SW}$ coast of Knight I., $7 \mathrm{mi}$. SE of Chenega, Chugach Mts.; $60^{\circ} 14^{\prime} 35^{\prime \prime} \mathrm{N}, 147^{\circ} 54^{\prime} 20^{\prime \prime} \mathrm{W}$; (map 63).

Local name published in 1910 by USC\&GS.

Deer Cove: cove, $0.6 \mathrm{mi}$. wide, on $\mathrm{W}$ coast of Hinchinbrook I., $35 \mathrm{mi}$. SW of Cordova, Chugach Mts.; $60^{\circ} 23^{\prime} \mathrm{N}, 146^{\circ} 43^{\prime} \mathrm{W}$; (map 64).

Name published in 1950 by USGS.

Deer Creek: stream, flows S $4 \mathrm{mi}$. from a lake to Thorne Bay, on $\mathrm{E}$ coast of Prince of Wales I., Alex. Arch.; $55^{\circ} 41^{\prime} \mathrm{N}, 132^{\circ} 31^{\prime} \mathrm{W} ; B G N$ 1960; (map 4). 
Named by C. L. Sainsbury, USGS, in 1956, for "the large deer population of the flats along it."

Deer Creek: stream, heads NE of Deer Mtn., flows NE $19 \mathrm{mi}$. to Upper Ugashik Lake, on Alaska Penin., $29 \mathrm{mi}$. NE of Ugashik, Aleutian Ra.; 57 $38^{\prime} 05^{\prime \prime} \mathrm{N}, 156^{\circ} 38^{\prime} 30^{\prime \prime} \mathrm{W}$; (map 36 ).

Local name reported in 1923 by R. H. Sargent, USGS.

Deer Creek: stream, flows N $4 \mathrm{mi}$, to Arolik River, $30 \mathrm{mi}$. $\mathrm{N}$ of Goodnews, Kilbuck-Kuskokwim Mts.; 59 $32^{\prime} \mathrm{N}, 161^{\circ} 23^{\prime} \mathrm{W}$; (map 53).

Local name reported in 1920 by G. L. Harrington (in Brooks and others, 1921, pl. 7), USGS.

Deer Creek: stream, flows NE $12 \mathrm{mi}$. to Sulatna River, $8 \mathrm{mi}$. NW of Sulatna Crossing and 33 mi. SW of Ruby, Kilbuck-Kuskokwim Mts.; $64^{\circ} 15^{\prime} 40^{\prime \prime} \mathrm{N}, 155^{\circ} 40^{\prime} 00^{\prime \prime} \mathrm{W}$; BGN 1936; (map 98). Var. Wilson Creek.

Prospectors' name reported in 1913 by Eakin $(1914$, pl. 3), USGS.

Deer Creek: stream, flows W $25 \mathrm{mi}$. to Yukon River, 9 mi. NE of Ruby, Nowitna Low.; $64^{\circ}$ $48^{\prime} 48^{\prime \prime} \mathrm{N}, 155^{\circ} 17^{\prime} 00^{\prime \prime} \mathrm{W}$; (map 98). Var. Bandana Creek.

Local name reported about 1952 by USGS.

Deer Creek: stream, flows NW $10 \mathrm{mi}$. to Seventymile River, $26 \mathrm{mi}$. NW of Eagle, Yukon-Tanana High.; $64^{\circ} 58^{\prime} 20^{\prime \prime} \mathrm{N}, 141^{\circ} 58^{\prime} 10^{\prime \prime} \mathrm{W}$; (map 102). Var. Green Creek.

This stream was reported in 1898 by E. C. Barnard, USGS, as "Green Creek"; the present name appeared on a 1905 manuscript map by Maj. W. A. Glassford, USA.

Deer Creek: stream, flows S $2 \mathrm{mi}$. to Anikovik River, $14 \mathrm{mi}$. SE of Cape Prince of Wales and $41 \mathrm{mi}$. NW of Teller, Seward Penin. High.; $65^{\circ} 30^{\prime} \mathrm{N}, 167^{\circ} 39^{\prime} \mathrm{W}$; (map 111).

Local name reported in 1900 by Brooks (1901, pl. 13 and p. 134), USGS.

Deer Creek: siream, flows SW $3.1 \mathrm{mi}$. to Quartz Creek, 25 mi. NW of Haycock, Seward Penin. High.; 65 $33^{\circ} \mathrm{N}, 161^{\circ} 24^{\prime} \mathrm{W}$; (map 109).

Local name reported in 1908 by USGS (Brooks and others, 1909, fig. 21).

Deer Creek: stream, flows S $1.7 \mathrm{mi}$. to Crosby Greek which flows to Kugrupaga River, $4 \mathrm{mi}$. $\mathrm{S}$ of Ear Mtn. and $43 \mathrm{mi}$. NE of Teller, Seward Penin. High.; $65^{\circ} 52^{\prime} \mathrm{N}, 166^{\circ} 13^{\prime} \mathrm{W}$; (map 111).

Prospectors' name reported in 1901 by T. G. Gerdine (in Collier, 1902, pl. 12), USGS.

Deer Creek: stream, see Bear Creek.

Deer Creek: stream, see Deep Creek.

Deer Gulch: ravine, see Grouse Gulch.

Deer Harbor: cove, $0.2 \mathrm{mi}$. across, on Takanis Penin., on Yakobi I., off Chichagof I., $26 \mathrm{mi}$. NW of Chichagof, Alex. Arch.; 57 $56^{\prime} 30^{\prime \prime} \mathrm{N}$, $136^{\circ} 33^{\prime} 00^{\prime \prime} \mathrm{W}$; (map 9).

Name published in 1961 by USC\&GS on Chart 8260.

Deerhorn Creek: stream, flows SE $1 \mathrm{mi}$. to Dese Creek which flows to Grantley Harbor, $6 \mathrm{mi}$. SE of Teller, Seward Penin. High.; $65^{\circ} 13^{\prime} \mathrm{N}$, $166^{\circ} 11^{\prime} \mathrm{W}$; (map 111$)$.
Prospectors' name reported on the 1908 "Map of Seward Peninsula" by Arthur Gibson.

Deer Horn Peak: mountain, 1,704 ft., in York Mts., at head of Tin Creek which flows to Lost River, $27 \mathrm{mi}$. NW of Teller, Seward Penin. High.; $65^{\circ} 28^{\prime} \mathrm{N}, 167^{\circ} 07^{\prime} \mathrm{W}$; (map 111).

Local name reported in 1918 by Steidtmann and Cathcart (1922, fig. 5), USGS.

Deer Hunting Slough: stream, anabranch of Yukon River, heads SW of Carlo I., flows S $12 \mathrm{mi}$. to Kozherevsky River, $9 \mathrm{mi}$. W of Holy Cross, Innoko Low.; $62^{\circ} 13^{\prime} 50^{\prime \prime} \mathrm{N}, 160^{\circ} 01^{\prime}$ $30^{\prime \prime} \mathrm{W}$; (map 78).

Local name obtained in 1952 by USGS.

Deering: village, pop. 95, on Seward Penin., at mouth of Inmachuk River on Kotzebue Sound, 57 mi. SW of Kotzebue, KotzebueKobuk Low.; $66^{\circ} 04^{\prime} \mathrm{N}, 162^{\circ} 42^{\prime} \mathrm{W} ; B G N$ 1944; (map 113).

This village was established in 1901 on Kotzebue Sound as a supply station for the interior mining camps. A post office was located here in 1901 (Ricks, 1965, p. 16). It was probably named for the 90-ton schooner Abbie Deering which was in the nearby waters about 1900 .

Deer Island: island, $11 \mathrm{mi}$. long, $40 \mathrm{mi}$. E of False Pass, at SW end of Aleutian Ra. $54^{\circ} 55^{\prime} \mathrm{N}, 162^{\circ} 18^{\prime} \mathrm{W}$; (map 25). Var. Animak Island, Animok Island, Itkhayak Oleny Island.

This is a translation of the Russian name "O[strov] Olenei," meaning "deer island," published by Lt. Sarichev (1826, map 3), IRN. Father Veniaminov (1846, p. 35) lists the name "Itkhayak" from the Aleut "itxayak," meaning "deer," according to $\mathrm{R}$ H. Geoghegan. In 1888 the USBF called it Deer Island.

Deer Island: island, $5 \mathrm{mi}$. long, between Port Moller and Herendeen Bay, SW end of Alaska Penin., Aleutian Ra.; $55^{\circ} 55^{\prime} \mathrm{N}, 160^{\circ}$ 50' W; (map 28). Var. Kudobin Peninsula.

Named by W. H. Dall, USC\&GS, in 1882 , and apparently can be identified with the "Kudobin [Khoudobine] Peninsula" of Capt. Lutke (1836, p. 263), IRN.

Deer Island: island, $8.5 \mathrm{mi}$. long, in Ernest Sound, $32 \mathrm{mi}$. SE of Wrangell, Alex. Arch.; $56^{\circ} 02^{\prime} \mathrm{N}, 132^{\circ} 01^{\prime} \mathrm{W}$; (map 6).

Named in 1886 by Lt. Comdr. A. S. Snow, USN; name published in 1887 on USC\&GS Chart 706.

Deer Island: island, see Jumbo Island.

Deer Island Passage: water passage, see Deer Passage.

Deer Lake: lake, $3 \mathrm{mi}$. long, $19 \mathrm{mi}$. $\mathrm{N}$ of village of Port Armstrong, on SE coast of Baranof I., Alex. Arch.; $56^{\circ} 31^{\prime} \mathrm{N}, 134^{\circ} 43^{\prime} \mathrm{W}$; BGN 1933; (map 5).

Local name reported in 1923 by USFS

Deer Mountain: peak, 3,300 ft., on Alaska Penin., between Lower Ugashik Lake and Wide Bay, $34 \mathrm{mi}$. SE of Ugashik, Aleutian Ra.; $57^{\circ} 25^{\prime} 45^{\prime \prime} \mathrm{N}, 156^{\circ} 30^{\prime} 45^{\prime \prime} \mathrm{W}$; (map 36).
Local name reported in 1923 by W. R. Smith and A. A. Baker (in Brooks and others, 1924, pl. 11), USGS.

Deer Mountain: mountain, see Deer Mountains.

Deer Mountains: mountain, 3,001 ft., with three peaks, on Revillagigedo 1., $1.3 \mathrm{mi}$. E of Ketchikan, Alex. Arch.; 55 $20^{\prime} 35^{\prime \prime} \mathrm{N}, 1^{\circ} 31^{\circ} 35^{\prime} 50^{\prime \prime}$ W; (map 3). Var. Deer Mountain.

This feature was named "Deer Mountain" in 1883 by Lt. Comdr. H. E. Nichols, USN; it is northwest of Buck, Doe, and Fawn Mountains.

Deer Passage: water passage, between Deer I. and Bold Cape, on SW end of Aleutian Ra.; $55^{\circ} 00^{\prime} \mathrm{N}, 162^{\circ} 20^{\prime} \mathrm{W}$; BGN 1928; (map 25). Var. Deer Island Passage.

Name derived from Deer I. and given by USC\&GS in 1926 as Deer Island Passage. USC\&GS initiated the changing of this name in 1928 to Deer Passage because it "is shorter and eliminates the double descriptive designation which *** is objectionable."

Deer Point: point of land, $\mathrm{S}$ of Fort Glenn, on NE coast of Umnak I., Aleutian Is.; $53^{\circ} 22^{\prime} 10^{\prime \prime} \mathrm{N}, 167^{\circ} 52^{\prime} 10^{\prime \prime} \mathrm{W}$; (map 23).

Name reported by U.S. Army Corps of Engineers in 1942.

Deer Point: point of land, on W shore of Tamgas Harbor, on S coast of Annette I., Alex. Arch.; $55^{\circ} 02^{\prime} 20^{\prime \prime} \mathrm{N}, 131^{\circ} 31^{\prime} 45^{\prime \prime} \mathrm{W}$; (map 3 ).

Named in 1886 by USC\&GS.

Deer Pond: lake, on coast of Beaufort Sea, near Point McLeod, Arctic Plain; $70^{\circ} 54^{\prime} \mathrm{N}$, $153^{\circ} 30^{\prime} \mathrm{W}$; ( $\operatorname{map} 148$ ).

This name is shown as a pond or lake on Simpson's map, but actually is, what he calls, a "reindeer [caribou] pound, simply contrived with double rows of turf [inuksuk] set up to represent men, and enclosing a space of ground lower than the rest. The enclosure was two miles broad at the beach, and narrowed towards a lake of some extent, where the unsuspecting animals are surrounded and speared in the water [tutusiuvaktuat]" (Simpson, Thomas, 1843, p. 135-136).

Deer Rocks: rocks, off $\mathrm{E}$ shore of Stevenson I., Clarence Strait, Alex. Arch.; $56^{\circ} 02^{\prime} \mathrm{N}, 132^{\circ}$ $55^{\prime} \mathrm{W}$; (map 6).

Local navigators' name reported in 1904 by H. C. Fassett, USBF

Deer Valley: valley, extends $\mathrm{N} 5 \mathrm{mi}$, to $\mathrm{SW}$ arm of Herendeen Bay, Alaska Penin., Aleutian Ra.; $55^{\circ} 42^{\prime}$ N., $160^{\circ} 48^{\prime} \mathrm{W}$; (map 28).

Named by Z. L. Tanner, USN, in 1890 .

Deese Creek: stream, see Dese Creek.

Deetna River: stream, see Dishna River.

Defiant, Mount: mountain, 8,348 ft., S of Second Branch Columbia Glacier, $30 \mathrm{mi}$. NW of Valdez, Chugach Mts. ; 61 ${ }^{\circ} 15^{\prime} 15^{\prime \prime} \mathrm{N}, 147^{\circ} 07^{\prime} 30^{\prime \prime}$ W; BGN 1965; (map 69)

So named about 1957 by members of the Chugach Mountains Expedition, sponsored by the Arctic Institute of North America, because "the peak has defied all attempts to find a route up it" (Nielsen, 1963, p. 135).

DeGroff Bay: bay, $0.4 \mathrm{mi}$. across, on $\mathrm{W}$ coast of Krestof I., $11.5 \mathrm{mi}$. NW of Sitka, Alex. 
Arch.; 57 $11^{\prime} 00^{\prime \prime} \quad$ N, $135^{\circ} 31^{\prime} 20^{\prime \prime} \quad$ W ; (map 9).

Named in 1897 by Lt. Comdr. E. K. Moore, USN, "for DeGroff, a prominent merchant of Sitka."

De Groff Island: island, see Klag Island.

Dehjah Inlet: estuary, see Taiya Inlet.

Deichman Island: island, $900 \mathrm{ft}$. long, in North Arm Moira Sound, on SE coast of Prince of Wales I., Alex. Arch.; 55 $06^{\prime} 30^{\prime \prime} \mathrm{N}$, $132^{\circ} 06^{\prime} 10^{\prime \prime} \mathrm{W}$; (map 4).

Local name reported in 1905 by $E$. F. Dickins, USC\&GS.

Deichman Rock: rock, at SE end of Kashevarof Passage, on NE coast of Prince of Wales I., Alex. Arch.; $56^{\circ} 03^{\prime} 30^{\prime \prime} \mathrm{N}, 133^{\circ} 49^{\prime} 30^{\prime \prime} \mathrm{W}$; (map 6).

Local name used by fishermen and published in 1907 by USC\&GS.

Deitrick River: stream, see Dietrich River.

Dejah: locality, see Dyea.

Dejah Inlet: estuary, see Taiya Inlet.

Dejahssánke: bay, see Taiyasanka Harbor.

Dejähssánkessit Glacier: glacier, see Ferebee Glacier.

Dejeh Pass: pass, see Chilkott Pass.

Delancy Lake: lake, $400 \mathrm{ft}$. across, just S of Spenard and $3 \mathrm{mi}$. SW of Anchorage, Cook Inlet Low.; $61^{\circ} 10^{\prime} 30^{\prime \prime} \mathrm{N}, 149^{\circ} 55^{\prime} 00^{\prime \prime} \mathrm{W}$; (map 69).

Local name reported in 1962 by USGS.

De Langle Mountain: mountain, 3,210 ft., in Glacier Bay National Monument, $1 \mathrm{mi}$. E of Palma Bay, on Gulf of Alaska, $58 \mathrm{mi}$. NW of Hoonah, St. Elias Mts.; $58^{\circ} 25^{\prime} 30^{\prime \prime} \mathrm{N}, 136^{\circ}$ $55^{\prime} 05^{\prime \prime} \mathrm{W}$; BGN 1930; (map 10).

Named by USG\&GS in 1929 for Capt. de Langle, commander of the L'Astrolabe of the 1786 La Perouse expedition.

Delarof: village, see Unga.

Delaroff Harbor: cove, see Delarof Harbor.

Delaroff Islands : islands, see Delarof Islands.

Delarof Harbor: cove, $0.8 \mathrm{mi}$. across, on SE coast of Unga I., in Shumagin Is., Aleutian Ra.; $55^{\circ} 10^{\prime} 30^{\prime \prime} \mathrm{N}, 160^{\circ} 30^{\prime} 00^{\prime \prime} \mathrm{W}$; (map 28). Var. Delaroff Harbor, Delarovskoi Harbor, Unga Harbor.

Named by Capt. Tebenkov (1852, map 24), IRN, as "G[avan] Delarova," probably for the Greek-born Eustrate Ivanovich Delarov, director of the Russian American Company about 1784-91; shown as Delarof Harbor on the 1891 USC\&GS Chart 8881.

Delarof Islands: islands, group of nine; Gareloi, Skagul, Oglivga, Kavalga, Unalga, Ilak, Ulak, Tanadak, and Amatignak Is., W of Andreanof Is., between Amchitka and Tanaga Passes, Aleutian Is. ; $51^{\circ} 30^{\prime} \mathrm{N}, 178^{\circ} 45^{\prime} \mathrm{W}$; (map 16). Var. Delaroff Islands.

Commemorative name given by Capt. Lutke (1836, p. 323), IRN, as "Delaroff Iles" for the Greek-born administrator Eustrate Ivanovich Delarov, director of the Russian American Company from 1784-91.

Delarov: village, see Unga.

Delarovskoi : village, see Unga.

Delarovskoi Harbor: cove, see Delarof Harbor.
Delaware Creek: stream, flows NW 4 mi. to Bering Sea, ' $0.5 \mathrm{mi}$. SW of Cape Chagak, on $\mathrm{N}$ coast of Umnak I., Aleutian Is. ; $53^{\circ} 31^{\prime} 00^{\prime \prime} \mathrm{N}$, $168^{\circ} 14^{\prime} 30^{\prime \prime} \mathrm{W}$; (map 22).

Name published by Byers (1959, pl. 41), USGS.

Delay Pass: pass, 1,800 ft., between Glacier and North Fork Koyukuk Rivers, $15 \mathrm{mi}$. W of Wiseman, Brooks Ra.; $67^{\circ} 26^{\prime} \mathrm{N}, 150^{\circ} 41^{\prime} \mathrm{W}$; $B G N$ 1932; (map 124). Var. Jack Delay Pass.

Named for Jack Delay, prospector in the region; reported in 1929 by Marshall (1956, p. 9).

Delenia Island: island, $0.2 \mathrm{mi}$. long, in Dangerous Passage, W of Chenega I., $50 \mathrm{mi}$. NE of Seward, Chugach Mts.; $60^{\circ} 20^{\prime} 22^{\prime \prime}$ N, $148^{\circ}$ $08^{\prime} 18^{\prime \prime} \mathrm{W}$; (map 63). Var. Divide Island.

So named in 1934 by USC\&GS because the island divides the channel into nearly equal parts. The name is reportedly the Russian equivalent of "division."

Delerme Creek: stream, see Delome Creek.

Delgada, Point: point of land, on NE coast of Lulu I., Alex. Arch.; 55 $30^{\prime} 55^{\prime \prime}$ N, 133 28'$40^{\prime \prime} \mathrm{W}$; (map 4). Var. Punta Delgada, Punta del Gada.

Spanish name given in 1775-79 by Don Juan de la Bodega y Quadra and Francisco Antonio Maurelle as "Punta Delgada," meaning "slender point." This name may originally have been applied to Point Arena.

Delia Creek: stream, heads on Arkose Ridge, flows NW $2 \mathrm{mi}$. to Little Susitna River, $13 \mathrm{mi}$. NW of Palmer, Talkeetna Mts.; 61 $46^{\prime} 40^{\prime \prime}$ $\mathrm{N}, 149^{\circ} 11^{\prime} 50^{\prime \prime} \mathrm{W}$; (map 69).

Local name reported in 1913 by USGS (in Brooks and others, 1914, fig. 2).

Delight Lake: lake, 2 mi. long, on Kenai Penin. $2.5 \mathrm{mi}$. NW of Black Mtn. and $45 \mathrm{mi}$. ESE of Homer, Chugach Mts.; 59 $33^{\prime} \mathrm{N}, 150^{\circ} 17^{\prime}$ W; BGN 1911; (map 50).

So named by USGS in 1911 "because of the beauty of the lake."

Dell Island: island, $400 \mathrm{ft}$. across, near head of Hetta Inlet, on W coast of Prince of Wales I., Alex. Arch.; 55 $16^{\prime} 00^{\prime \prime} \mathrm{N}, 132^{\circ} 39^{\prime} 25^{\prime \prime} \mathrm{W}$; (map 4).

Local name reported in 1905 by E. F. Dickins, USC\&GS.

Del Monte Peak: mountain, 2,600 ft., on Lindenberg Penin., Kupreanof I., 5 mi. NW of Petersburg, Alex. Arch.; 56 $52^{\prime} \mathrm{N}, 133^{\circ} 02^{\prime} \mathrm{W}$; (map 6).

Named in 1887 by Lt. Comdr. C. M. Thomas, USN, for charting purposes; name published in 1888 on USC\&GS Chart 705.

Delome Creek: stream, flows SE $12 \mathrm{mi}$. to Kuzitrin River, $13 \mathrm{mi}$. NW of Mount Bendeleben and $40 \mathrm{mi}$. SW of Imuruk Lake, Seward Penin. High.; $65^{\circ} 20^{\prime} \mathrm{N}, 164^{\circ} 23^{\prime} \mathrm{W}$; (map 110). Var. Delerme Greek, Delomes Creek, Delorme Creek.

Prospectors' name reported in 1900 by Brooks (1901, pl. 11), USGS.

Delomes Creek: stream, see Delome Creek.

De Long Islands: islands, $2.5 \mathrm{mi}$. long, in Foggy Bay, E shore Revillagigedo Channel, Coast
Mts.; $54^{\circ} 58^{\prime} \mathrm{N}, 131^{\circ} 00^{\prime} \mathrm{W}$; (map 2). Var. DeLong Islands.

Named in 1885 by USC\&GS for Lt. Comdr. George Washington De Long, USN, commander of the steamer Jeannette, who died in the Lena Delta in November 1881.

De Long Lake: lake, $0.3 \mathrm{mi}$. long, $4.3 \mathrm{mi}$. SW of Anchorage, Cook Inlet Low.; $61^{\circ} 09^{\prime} 47^{\prime \prime} \mathrm{N}$, $149^{\circ} 57^{\prime} 15^{\prime \prime} \mathrm{W}$; (map 69).

Local name reported in 1942 by AMS.

De Long Lake: lake, sec Longmare Lake.

De Long Mountains: mountain range, at $W$ end of Brooks Ra., extend W $150 \mathrm{mi}$. from Uivaksak Creek and head of Kuna River; 68 $27^{\prime}$ $\mathrm{N}, 158^{\circ} 35^{\prime} \mathrm{W}$ [E end], $68^{\circ} 10^{\prime} \mathrm{N}, 163^{\circ} 50^{\prime} \mathrm{W}$ [W end]; (map 131).

Named in 1886 by Lt. G. M. Stoney, USN, for Lt. Comdr. George Washington De Long, USN. See De Long Islands.

De Long Peak: mountain, 3,700 ft., at $\mathbf{E}$ end of Missionary Ra., $13 \mathrm{mi}$. NW of Petersburg, on Lindenberg Penin., Kupreanof I., Alex. Arch.; $56^{\circ} 58^{\prime} 05^{\prime \prime} \mathrm{N}, 133^{\circ} 09^{\prime} 15^{\prime \prime} \mathrm{W}$; (map 6).

Named in 1887 by Lt. Comdr. C. M. Thomas, USN, for Lt. Comdr. George Washington De Long, USN, commander of the steamer Jeannette, who died in 1881 in the Lena Delta.

Delorme Creek: stream, see Delome Creek.

Delphin Bay: bay, $1.5 \mathrm{mi}$. across, part of Perenosa Bay, on $\mathbf{N}$ coast of Afognak I., $\mathbf{N}$ of Kodiak I. ; $58^{\circ} 22^{\prime} \mathrm{N}, 152^{\circ} 28^{\prime} \mathrm{W}$; BGN 1934; (map 43). Var. Dolphin Bay, Middle Arm Perenosa Bay.

Named by USC\&GS in 1934 for the Delphin, one of two vessels, which were launched in 1795. These two vessels were built under the direction of Alexander Baranov of the Shelikov Company, and were the second and third ships to be built in northwestern America (Bancroft, 1886, p. 329-333). See Phoenix Bay.

Delphin Island: island, $0.6 \mathrm{mi}$. long, in Delphin Bay, in Perenosa Bay, on $N$ coast of Afognak I., $\mathrm{N}$ of Kodiak I.; $58^{\circ} 21^{\prime} \mathrm{N}, 152^{\circ} 29^{\prime} \mathrm{W}$; $B G N$ 1934; (map 43).

See Delphin Bay.

Delphin Point: point of land, at mouth of Delphin Bay, in Perenosa Bay, on $\mathbf{N}$ coast of Afognak I., N of Kodiak I.; $58^{\circ} 22^{\prime} 20^{\prime \prime} \mathrm{N}$, $152^{\circ} 26^{\prime} 10^{\prime \prime} \mathrm{W}$; BGN 1934; (map 43). Var. Dolphin Point.

See Delphin Bay.

Delta Creek: stream, heads at Ruth Lake, flows SW $4 \mathrm{mi}$. to Thomas Bay, $13 \mathrm{mi}$. NE of Petersburg, Coast Mts.; 56 $58^{\prime} 30^{\prime \prime}$ N, $132^{\circ}$ $47^{\prime} 00^{\prime \prime} \mathrm{W}$; (map 6).

Named in 1923 by USFS.

Delta Creek: stream, heads at $\mathrm{N}$ terminus of Trident Glacier, flows N $40 \mathrm{mi}$. to Tanana River, 16 mi. NW of Big Delta, Tanana Low.; $64^{\circ} 15^{\prime} 45^{\prime \prime} \mathrm{N}, 146^{\circ} 18^{\prime} 15^{\prime \prime} \mathrm{W}$; (map 101). Var. Little Delta Creek, Mahutzu River, Russel Creek, Silok Creek.

Lt. H. T. Allen, USA, named a stream west of the Delta River, "Delta Creek." Its exact identity has been a problem to map makers. This particular stream, early called "Little 
Delta Creek" by prospectors, was finally given Lt. Allen's name. See Little Delta River. Its Indian name was "Mahutzu" according to A. H. Brooks, USGS, in 1898.

Delta Greek: stream, see Little Delta River.

Delta Dome: mountain, see Donnelly Dome.

Delta Island: hill, see Bear Island.

Delta Island: island, $0.7 \mathrm{mi}$. long, at mouth of Susitna River, $22 \mathrm{mi}$. NW of Anchorage, Cook Inlet Low.; $61^{\circ} 16^{\prime} 50^{\prime \prime} \mathrm{N}, 150^{\circ} 33^{\prime} 10^{\prime \prime}$ W; (map 70).

Local name reported in 1912 by USC\&GS.

Delta Islands: islands, extend $6 \mathrm{mi}$. in course of Susitna River, $4.5 \mathrm{mi}$. W of Willow and 36 mi. NW of Anchorage, Cook Inlet Low.; $61^{\circ} 45^{\prime} \mathrm{N}, 150^{\circ} 14^{\prime} \mathrm{W}$; (map 70).

Local descriptive name reported in 1954 by USGS.

Delta Junction: village, pop. 250, on right bank of Delta River at junc. of Alaska and Richardson Highways, $8.5 \mathrm{mi}$. SE of Big

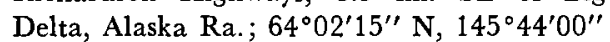
W; BGN 1965; (map 101). Var. Big Delta Junction, Buffalo Center.

Established as a road construction camp about 1919, but has developed into a fairly large village in recent years primarily because of its strategic locality at the junction of two major highways. It was originally called "Buffalo Center" because it is near the site of the winter range for a herd of American bison established in 1927.

Delta Point: point of land, in Cold Bay, $1 \mathrm{mi}$. $\mathrm{E}$ of village of Cold Bay, Bristol Bay Low.; $55^{\circ} 11^{\prime} 45^{\prime \prime} \mathrm{N}, 162^{\circ} 39^{\prime} 00^{\prime \prime} \mathrm{W}$; (map 29).

Descriptive name reported by USC\&GS in 1925.

Delta River: stream, heads at Tangle Lakes, flows N 80 mi. to Tanana River at Big Delta, Tanana Low.; $64^{\circ} 09^{\prime} 30^{\prime \prime} \mathrm{N}, 145^{\circ} 51^{\prime} 30^{\prime \prime} \mathrm{W}$; (map 101). Var. Big Delta River, Delt River, Thöthendig.

Descriptively named in 1885 by Lt. Allen (1887, pl. 3), USA. Its Indian name was "Thöthendig" according to J. T. Geoghegan in 1904.

Delta Telegraph Station: locality, $0.5 \mathrm{mi}$. S of Washburn, on right bank of Tanana River at Little Delta River, $50 \mathrm{mi}$. SE of Fairbanks, Tanana Low.; $64^{\circ} 18^{\prime} \mathrm{N}, 146^{\circ} 44^{\prime} \mathrm{W}$; (map 101). Var. Little Delta.

Site of a telegraph station and reported in 1907 by Prindle (1913a, pl. 4), USGS. Polk's Gazetteer stated in 1916 that the place was a "U.S. military and cable station, 'Little Delta,' one-half mile south" of Washburn.

Delt River: stream see Delta River.

Delusion Creek: stream, flows S 9 mi. to Watan Creek $2.7 \mathrm{mi}$. NE of its junc. with Susitna River and $30 \mathrm{mi}$. NW of junc. of Oshetna and Susitna Rivers, Talkeetna Mts.; 62 $51^{\prime \prime} 30^{\prime \prime}$ $\mathrm{N}, 148^{\circ} 12^{\prime} 00^{\prime \prime} \mathrm{W}$; (map 82).

Local name published in 1917 on a USGS manuscript map.

Delyndia Lake: lake, $1.4 \mathrm{mi}$. long, $\mathrm{W}$ of Butterfly Lake, $26 \mathrm{mi}$. NW of Anchorage, Cook
Inlet Low.; $61^{\circ} 35^{\prime} 30^{\prime \prime} \mathrm{N}, 150^{\circ} 07^{\prime} 40^{\prime \prime} \mathrm{W}$; (map 70).

Local name reported in 1958 by USGS.

Demarcation Bay: bay, $6 \mathrm{mi}$. across, on Beaufort Sea coast, $S$ of Demarcation Point, Arctic Plain; $69^{\circ} 41^{\prime} \mathrm{N}, 141^{\circ} 20^{\prime} \mathrm{W}$; $B G N$ 1913; (map 138). Var. Beauford Bay, Beaufort Bay, Demarkation Bay.

Named by the IBC in 1912.

Demarcation Point: point of land, between Beaufort Sea and Demarcation Bay, $8 \mathrm{mi}$. W of Alaska-Canada boundary and $62 \mathrm{mi}$. SE of Barter I., Arctic Plain; $69^{\circ} 41^{\prime}$ N, $141^{\circ} 19^{\prime} \mathrm{W}$; $B G N$ 1962; (map 138). Var. Demarkation Point, Pataktak, Pataktuk, Point Demarcation.

On July 31,1826 , Sir John Franklin (1828, p. 142), RN, wrote: "Point Demarcation, which has been so named from its being situated in longitude $141^{\circ} \mathrm{W}$, the boundary between the British and Russian dominions on the northern coast of America." The area was a very important winter rendezvous of the Eskimo, who called it "Pataktak," which is reported to mean "place where ducks fly low."

Demar Creek: stream, flows S 5 mi. to East Fork Chena River, $7 \mathrm{mi}$. SSE of Chena Hot Springs and $56 \mathrm{mi}$. N of Big Delta, YukonTanana High.; 64 ${ }^{\circ} 57^{\prime} 30^{\prime \prime} \mathrm{N}, 145^{\circ} 56^{\prime} 45^{\prime \prime} \mathrm{W}$; (map 101). Var. Wolverine Creek.

Prospectors' name reported in 1913 by C. E. Ellsworth, USGS; applied in error to the next stream to the west (Prindle, 1913, pl. 1). The present Demar Creek was called "Wolverine Creek."

Demarkation Bay: bay, see Demarcation Bay.

Demarkation Point: point of land, see Demarcation Point.

Dementi: locality, on right bank of Innoko River, opposite mouth of Iditarod River, 25 mi. ENE of Holikachuk, Innoko Low. ; $63^{\circ} 02^{\prime}$ N, $158^{\circ} 46^{\prime} \mathrm{W}$; (map 90). Var. Deminti, Taliti, Talitui, Talit Village, Tality, Talliti, Tallity, Totascholëden, Totascholjöden, Totaskholeden, Ttality, Ttalitui, Ttallily, Ttallity.

Former Ingalik Indian village, recorded in 1842-44 as "Tallity" on Lt. L. A. Zagoskin's map; referred to in his text as "Ttality 'Byastrago tetseniya [fast stream]," and "Ttallity ili Totaskholëden." Here, later, a boat landing and store, for the Ophir and Iditarod mines, were maintained. The name "Dementi," or "Diminti," was reported in 1908 by Maddren (1910, pl. 1), USGS; possibly derived from "Dementov," name of the Russian garrison commander at Kolmakov Trading Post in 1866.

Demian, Mount: peak, 2,245 ft., S of Mount Lee, on Alaska Penin., $10 \mathrm{mi}$. NW of Kanatak, Aleutian Ra.; $57^{\circ} 38^{\prime} 50^{\prime \prime} \mathrm{N}, 156^{\circ} 15^{\prime} 50^{\prime \prime} \mathrm{W}$; (map 36).

Name reported in 1921 by Capps (1923, pl. 2), USGS.

Deminti: locality, see Dementi.

Democrat Creek: stream, flows SW $5 \mathrm{mi}$. to Junction Creek, $23 \mathrm{mi}$. NW of Big Delta,
Yukon-Tanana High.; $64^{\circ} 20^{\prime} 45^{\prime \prime}$ N, $146^{\circ} 28^{\prime}-$ 30 " W; (map 101).

Named by prospectors and reported in 1910 by C. E. Ellsworth and G. L. Parker (in Brooks and others, 1911, p. 167), USGS.

Demon Creek: stream, flows NW $2.3 \mathrm{mi}$. to Eclipse Creek which flows to Melsing Creek, $38 \mathrm{mi}$. NE of Solomon, Seward Penin. High.; $64^{\circ} 57^{\prime}$ N, $163^{\circ} 33^{\prime} \mathrm{W}$; (map 95).

Prospectors' name published on the 1908 "Map of Seward Peninsula" by Arthur Gibson. De Monti Bay: bay, see Monti Bay.

Demorest Branch: glacier, see Demorest Glacier. Demorest Glacier: glacier, heads at AlaskaCanada boundary and trends S $14 \mathrm{mi}$. to Taku Glacier, $3 \mathrm{mi}$. $\mathrm{N}$ of Hodgkins Peak and $25 \mathrm{mi}$. $\mathrm{NE}$ of Juneau, Coast Mts.; $58^{\circ} 36^{\prime} 40^{\prime \prime} \mathrm{N}$, $134^{\circ} 08^{\prime} 00^{\prime \prime} \mathrm{W}$; BGN 1965; (map 11). Var. Demorest Branch, Northeast Branch Taku Glacier.

Named in 1953 by personnel of the Juneau Icefield Research Project, for Max Harrison Demorest, 1910-42, glaciologist, assistant professor of geology at the Univ. of North Dakota, and Sterling Fellow at Yale Univ., 1939-42. While a lieutenant in the USAAF, he was killed, in 1942, on the Greenland Ice Sheet while attempting a rescue of personnel from a downed military aircraft.

Dempsey: locality, on $W$ bank of Chistochina River $1 \mathrm{mi}$. $\mathrm{S}$ of its junc. with Chisna River, $21 \mathrm{mi}$. E of Paxson, Alaska Ra.; $63^{\circ} 02^{\prime} 20^{\prime \prime} \mathrm{N}$, $144^{\circ} 51^{\prime} 05^{\prime \prime} \mathrm{W}$; (map 86).

See Ghisna.

Dempsey: locality, see Chisna.

Dempsey Creek: stream, flows E $21 \mathrm{mi}$. to Bull Creek, $18 \mathrm{mi}$. NW of Midnight Hill, Porcupine Plat.; $66^{\circ} 08^{\prime} 30^{\prime \prime} \mathrm{N}, 141^{\circ} 42^{\prime} 00^{\prime \prime} \mathrm{W}$; (map 120).

Local name obtained in 1956 by T. E. Taylor and R. C. Foley, USGS.

Denagiemina Lake: lake, at foot of Moose Hill, $24 \mathrm{mi}$. SE of Medfra, Kuskokwim Low.; $63^{\circ} 03^{\prime} \mathrm{N}, 153^{\circ} 57^{\prime} \mathrm{W}$; (map 89).

Indian name obtained in 1958 by T. E. Taylor, USGS.

Denali: locality, pop. 4, E of Susitna River, near mouth of Valdez Creek, $67 \mathrm{mi}$. SE of Healy, Alaska Ra.; $63^{\circ} 10^{\prime} 45^{\prime \prime} \mathrm{N}, 147^{\circ} 27^{\prime} 45^{\prime \prime} \mathrm{W}$; $B G N$ 1944; (map 87). Var. McKinley, Valdez Greek.

Mining camp established about 1907. A post office named "McKinley" existed here in 1908-09, and in 1910 R. H. Sargent reported the camp name as "Valdez Creek." In 1922 a post office was again established, but this time it was called "Denali," the Indian name for Mount McKinley. Its 1940 population was 63 .

Denali: mountain, see McKinley, Mount.

Denali, Mount: mountain, see McKinley, Mount.

Denali Pass: pass, 18,200 ft., in Mount McKinley National Park, at head of Harper Glacier, between Churchill Peaks of Mount McKinley, Alaska Ra.; $63^{\circ} 05^{\prime} 00^{\prime \prime} \mathrm{N}, 151^{\circ}$ 01'40' W; BGN 1948; (map 88).

Named by the U.S. Army Alaskan Test Expedition in March 1943 "so that the old 
Kuskokwim [Tanana] Indian name for McKinley would forever be preserved on a prominent feature near the top of the peak." Denbich, Mys : point of land, see Denbigh, Cape. Denbigh, Cape: point of land, at E end of Norton Sound, southernmost tip of Reindeer Hills, $12 \mathrm{mi}$. WNW of Shaktolik, Nulato Hills; $64^{\circ}$ $23^{\prime} \mathrm{N}, 161^{\circ} 32^{\prime} \mathrm{W}$; (map 96). Var. Cap Denbitch, Cape Noocleet, Cape Nucleet, Cape Nuklit, Mys Denbich, Point Nuclue.

Named on September 11, 1778, by Capt. Cook $(1785$, v. 2, p. 477), RN. The Eskimo name is "Nuklit" (Baker, 1906, p. 214).

Denbitch, Cap: point of land, see Denbigh, Cape.

Deneki Lakes: lakes, extend N-S $0.3 \mathrm{mi}$., $18 \mathrm{mi}$. SE of Healy, Alaska Ra.; $63^{\circ} 36^{\prime} 30^{\prime \prime} \mathrm{N}, 148^{\circ}$ $46^{\prime} 40^{\prime \prime} \mathrm{W}$; (map 87).

Indian name reported by USGS in 1950 .

Deniga Slough: stream, see Hardluck Slough.

Deniktaw Ridge: ridge, see Deniktow Ridge.

Deniktow Ridge: ridge, extends W $10 \mathrm{mi}$. from the Isahultila Mts. to Koyukuk River, $\mathrm{N}$ of Hot Springs Creek and $27 \mathrm{mi}$. N of Hochandochtla Mtn., Kokrines-Hodzana High.; $65^{\circ} 55^{\prime} \mathrm{N}$, $155^{\circ} 00^{\prime} \mathrm{W}$; (map 107). Var. Deniktaw Ridge.

Koyukan Indian name obtained at Huslia in 1956 by Orth.

Denison, Mount: peak, 7,606 ft., on Alaska Penin., in Katmai National Monument, $22 \mathrm{mi}$. $\mathrm{NE}$ of Mount Katmai, Aleutian Ra.; $58^{\circ} 25^{\prime}$ $05^{\prime \prime} \mathrm{N}, 154^{\circ} 26^{\prime} 45^{\prime \prime} \mathrm{W}$; BGN 1925; (map 42).

Name suggested by K. F. Mather, an alumnus of Denison University, Granville, Ohio, and published by USGS (in Brooks and others, 1925, p. 159-181)

Denison Fork: stream, see Dennison Fork.

Denlumungut Lake: lake, $11 \mathrm{mi}$. SW of Roundabout Mtn., Koyukuk Low.; $65^{\circ} 26^{\prime}$ N, $156^{\circ}$ 49' W; (map 108).

Koyukan Indian name meaning "Denlu Lake" reported in 1955 by USGS.

Denmark Cove: cove, $0.1 \mathrm{mi}$. across, on Baranof I., on S shore of Port Walter, $9 \mathrm{mi}$. N of Port Alexander, Alex. Arch.; $56^{\circ} 22^{\prime} 15^{\prime \prime} \mathrm{N}, 134^{\circ} 41^{\prime}$ $20^{\prime \prime} \mathrm{W}$; (map 5).

Local name recorded in 1951 by USGS.

Dennis Creek: stream, flows NW $16 \mathrm{mi}$. to Iliamna Lake, $8 \mathrm{mi}$. E of Big Mtn. and $25 \mathrm{mi}$. $\mathrm{S}$ of Iliamna, Aleutian Ra.; $59^{\circ} 24^{\prime} 30^{\prime \prime} \mathrm{N}$, $155^{\circ} 00^{\prime} 10^{\prime \prime} \mathrm{W}$; (map 51).

Name published in 1951 by USGS.

Dennis Creek: stream, heads in Slow Fork Hills, flows W $35 \mathrm{mi}$. to Tonzona River, $37 \mathrm{mi}$. NE of Medfra and $67 \mathrm{mi}$. NE of McGrath, Kuskokwim Low.; $63^{\circ} 09^{\prime} 30^{\prime \prime} \mathrm{N}, 153^{\circ} 32^{\prime} 10^{\prime \prime} \mathrm{W}$; (map 89).

Local name reported in 1958 by USGS.

Dennis Fork: stream, see Dennison Fork.

Dennis Lake: lake, $0.4 \mathrm{mi}$. long, drains $\mathrm{SW}$ into Dennis Creek, $40 \mathrm{mi}$. E of Medfra and $70 \mathrm{mi}$. NE of McGrath, Kuskokwim Low.; 63 $09^{\prime} 15^{\prime \prime}$ $\mathrm{N}, 153^{\circ} 24^{\prime} 30^{\prime \prime} \mathrm{W}$; (map 89).

Local name reported in 1958 by USGS.

Dennis Manor: suburb, $5.5 \mathrm{mi}$. E of Fairbanks, on $\mathrm{S}$ bank Chena River, Tanana Low.; $64^{\circ} 49^{\prime} 45^{\prime \prime} \mathrm{N}, 147^{\circ} 32^{\prime} 30^{\prime \prime} \mathrm{W}$; (map 100).
Local name reported in 1950 by USGS topographers.

Dennison Creek: stream, see Dennison Fork.

Dennison Fork: stream, heads at $63^{\circ} 25^{\prime} \mathrm{N}$, $142^{\circ} 30^{\prime} \mathrm{W}$, flows NE $60 \mathrm{mi}$. to join Mosquito Fork to form South Fork Fortymile River, 56 mi. SW of Eagle, Yukon-Tanana High.; $64^{\circ} 03^{\prime} 20^{\prime \prime} \mathrm{N}, 141^{\circ} 54^{\prime} 40^{\prime \prime} \mathrm{W}$; (map 102). Var. Denison Fork, Dennis Fork, Dennisons Fork.

Prospectors' name reported in 1896 by Spurr (1898, pl. 45), USGS, as "Dennis Fork." In 1898, the present name was reported by Capt. W. R. Abercrombie, USA.

Dennisons Fork: stream, see Dennison Fork.

Denny Creek: stream, heads in Teocalli Mts. flows NW $7.8 \mathrm{mi}$. to South Fork Kuskokwim River 11 mi. S of its junc. with Tatina River, $93 \mathrm{mi}$. SE of McGrath, Alaska Ra.; $62^{\circ} 08^{\prime} \mathrm{N}$, $153^{\circ} 20^{\prime} \mathrm{W}$; $(\operatorname{map} 80)$.

Local name obtained in 1958 by USGS.

Dennys Gulch: ravine, extends $1.5 \mathrm{mi}$. NE from O'Keefe Hills to headwaters of Crooked Creek, $17 \mathrm{mi}$. WSW of Chandalar, Brooks Ra.; $67^{\circ} 24^{\prime}$ N, $149^{\circ} 05^{\prime} \mathrm{W}$; (map 123).

Local name reported in 1956 by T. E. Taylor, USGS.

Denslow Lake: lake, 1,800 ft. long, between headwaters of Lone and Scarp Creeks, $13 \mathrm{mi}$. NW of Tyonek, Cook Inlet Low.; 61 ${ }^{\circ} 13^{\prime} 55^{\prime \prime}$ $\mathrm{N}, 151^{\circ} 20^{\prime} 40^{\prime \prime} \mathrm{W}$; (map 70$)$.

Local name reported in 1898 by USC\&GS. Densmores Peak: mountain, see McKinley, Mount.

Denson, Mount: mountain, 5,886 ft., $8 \mathrm{mi}$. NE of Copper Mtn. and $32 \mathrm{mi}$. NW of Cordova, Chugach Mts.; $60^{\circ} 54^{\prime} \mathrm{N}, 146^{\circ} 22^{\prime} \mathrm{W}$; (map 64). Var. Rooster Comb.

Named by USC\&GS for Hugh C. Denson, USC\&GS, in 1906. According to S. R. Capps and B. L. Johnson (in Brooks and others, 1913 , p. 86), USGS, this mountain was locally called the Rooster Comb in 1912.

Dent Point: point of land, $\mathrm{S}$ coast of Alaska Penin., on N shore of Stepovak Bay, Aleutian Ra.; 55 $48^{\prime}$ N, $159^{\circ} 53^{\prime} \mathrm{W}$; (map 27).

Name published by USC\&GS in 1947 Coast Pilot (p. 306).

Denver Creek: stream, flows NW $5 \mathrm{mi}$. to Harrington Fork Birch Creek, $60 \mathrm{mi}$. SW of Circle, Yukon-Tanana High.; $65^{\circ} 17^{\prime} \mathrm{N}, 145^{\circ} 43^{\prime} \mathrm{W}$; (map 104)

Named by prospectors and reported in 1911 by USGS (Prindle, 1913, pl. 1).

Denver Glacier: glacier, heads at Alaska-Canada boundary, trends NW $8.5 \mathrm{mi}$. to its terminus, $1.4 \mathrm{mi}$. E of Twin Dewey Peaks and $4 \mathrm{mi}$. E of Skagway, Coast Mts.; $59^{\circ} 28^{\prime} 00^{\prime \prime} \mathrm{N}, 135^{\circ}$. $11^{\prime} 45^{\prime \prime} \mathrm{W}$; (map 45).

Local name published in 1951 by USGS.

Denyeet: village, see Stevens Village.

Denyit: village, see Stevens Village.

Deranof Island: island, $0.5 \mathrm{mi}$. long, between Afognak and Kupreanof Straits, $\mathrm{N}$ of Kodiak I.; $57^{\circ} 58^{\prime} 30^{\prime \prime} \mathrm{N}, 152^{\circ} 53^{\prime} 30^{\prime \prime} \mathrm{W}$; BGN 1909; (map 34). Var. Dearborn Island, Egg Island, Ostrov Yaachnoy, Yachnoi.
Local name reported in 1899 by members of the Harriman Alaska Expedition, for Ivan Deranov, who operated a fox farm on the island. It was called "Os[trov] Yaachnoy" in 1839 or 1840 by Sub-Lt. Mikhail Murashev, IRN, and was so published in 1849 on Russian Hydrog. Dept. Chart 1425. Identified in 1900 as "Dearborn Island" by Lt. Comdr. J. F. Moser, USN, of the USBF steamer Albatross. Baker (1906, p. 237) published " $\mathrm{Egg}$ Island," the translation of Murashev's name. In 1909 USC\&GS reapplied the name "Deranof Island."

Deranof Island: island, see Hunt Island.

Deranof Rock: rock, S of Deranof I., between Afognak and Kupreanof Straits, $\mathrm{N}$ of Kodiak

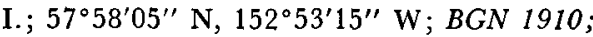
(map 34).

Name given in 1910 by USC\&GS; derived from Deranof Island.

Derbenskoi: water passage, see Derbin Strait.

Derbenskoy: water passage, see Derbin Strait.

Derbi, Mys: point of land, see Cape Darby.

Derbin Bay: bay, $1.7 \mathrm{mi}$. across, on $\mathrm{S}$ coast of Tigalda I., Aleutian Is.; $54^{\circ} 04^{\prime} 30^{\prime \prime} \mathrm{N}, 165^{\circ}$ $07^{\prime} 30^{\prime \prime} \mathrm{W}$; (map 24).

Named for Derbin Strait and shown on recent USG\&GS charts.

Derbin Island: islana', in Krenitzin Is., $0.5 \mathrm{mi}$. across, near SW shore of Tigalda I., Fox Is. Aleutian Is.; $54^{\circ} 07^{\prime} 15^{\prime \prime} \mathrm{N}, 165^{\circ} 07^{\prime} 30^{\prime \prime} \mathrm{W}$; $B G N$ 1936; (map 24).

Named in 1935 by USC\&GS because it is adjacent to Derbin Strait.

Derbinskoi: water passage, see Derbin Strait.

Derbin Strait: water passage, between Avatanak and Tigalda Is., Krenitzin Is., Aleutian Is.; $54^{\circ} 05^{\prime} \mathrm{N}, 165^{\circ} 13^{\prime} \mathrm{W}$; (map 24). Var. Derbenskoi, Derbenskoy, Derbinskoi.

Russian name published by Father Veniaminov (1840, v. 1, p. 200) as "Derbenskoy."

Derby, Cape: point of land, see Cape Darby.

Derby Creek: stream, flows $\mathrm{S} 1.5 \mathrm{mi}$., joins Ptarmigan Creek at Norton Sound, $8.5 \mathrm{mi}$ ESE of Nome, Seward Penin. High.; $64^{\circ} 28^{\prime}$ N, $165^{\circ} 09^{\prime} \mathrm{W}$; (map 94).

Prospectors' name reported in 1904 by $\mathrm{T}$ G. Gerdine, USGS.

Derby Creek: stream, flows NE, then NW, $34 \mathrm{mi}$. to Tagagawik River, $72 \mathrm{mi}$. NW of Roundabout Mtn., Nulato Hills; $65^{\circ} 49^{\prime} \mathrm{N}, 158^{\circ} 59^{\prime}$ W; (map 108).

Named in 1963 by W. W. Patton, USGS, for triangulation station Derby, which in turn is named because the $1,573-\mathrm{ft}$. hill that it is located on "has a distinctive shape like a derby hat." The hill is on the right bank of the stream.

Derby Point: point of land, on SW coast of Umnak I., Aleutian Is.; $53^{\circ} 09^{\prime} 30^{\prime \prime} \mathrm{N}, 168^{\circ}$ $47^{\prime} 30^{\prime \prime}$ W; BGN 1940; (map 22).

l Descriptive name given in 1938 by USC\&GS "because the rounded hill on the point resembles the crown of a derby when viewed from off shore."

Derickson Bay: estuary, on E coast of Kenai Penin., extends NE $3 \mathrm{mi}$. from terminus of Nellie Juan Glacier to Port Nellie Juan, 24 
mi. SE of Whittier, Chugach Mts.; $60^{\circ} 29^{\prime} 45^{\prime \prime}$ N, $148^{\circ} 18^{\prime} 00^{\prime \prime} \mathrm{W}$; (map 63).

Local name published in 1950 by USC\&GS.

Derickson Bay: bay, on NW shore Prince William Sound, extends SE $2 \mathrm{mi}$. to $\mathrm{W}$ side of Eaglek Bay, $32 \mathrm{mi}$. NE of Whittier, Chugach Mts.; 6052' N, $147^{\circ} 47^{\prime} \mathrm{W}$; (map 63).

Local name reported in 1952 by USGS.

Derickson Island: island, $1.5 \mathrm{mi}$. long, off S shore of Alaska Penin., separates the inner and outer parts of Chiginagak Bay, $14 \mathrm{mi}$. SE of Mount Chiginagak, Aleutian Ra.; $56^{\circ} 59^{\prime} \mathrm{N}, 156^{\circ} 43^{\prime}$ W; (map 31).

This local name was published by USC\&GS in the 1947 Alaska Coast Pilot (p. 278)

Derrumba Ridge: cliff, $1,200 \mathrm{ft}$., $\mathrm{SW}$ side of Heceta I., Alex. Arch.; $55^{\circ} 43^{\prime} 30^{\prime \prime}$ N, $133^{\circ}$ $37^{\prime} 00^{\prime \prime}$ W; BGN 1923; (map 4).

Spanish word meaning "landslide," by which the seaward bluff is conspicuously marked. Named in 1923 by USC\&GS.

Dertiefee See: lake, see Redoubt Lake.

Derwent Creek: stream, flows NE $13 \mathrm{mi}$, joins Fisher Creek to form Bonanza Creek, $10 \mathrm{mi}$ SE of junc. of Charley and Yukon Rivers, Yukon-Tanana High.; $65^{\circ} 11^{\prime} 45^{\prime \prime} \mathrm{N}, 142^{\circ}$ $34^{\prime} 00^{\prime \prime} \mathrm{W}$; (map 103).

Prospectors' name from an unpublished map by E. J. Chamberlain, dated 1902.

Desconocida, Point: point of land, $\mathrm{S}$ tip of Heceta

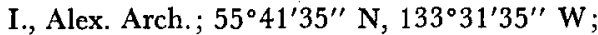
(map 4). Var. Mys de la Deskonosida, Punta de la Desconocida.

Spanish name given in $1775-79$ by Don Juan de la Bodega y Quadra and Francisco Antoinio Maurelle as "Punta de la Desconocida," i.e. "point of the unknown."

Desconocida Reef: reef, between Gulf of Esquibel and Bocas de Finas, $\mathbf{S}$ of Point Desconocida, at $S$ tip of Heceta I., Alex. Arch.; $55^{\circ} 41^{\prime} 30^{\prime \prime}$ N, $133^{\circ} 31^{\prime} 20^{\prime \prime} \mathrm{W}$; (map 4).

Name published in 1943 by USC\&GS; derived from Point Desconocida.

Dese Creek: stream, flows NE $9 \mathrm{mi}$. to Grantley Harbor, $7 \mathrm{mi}$. SE of Teller, Seward Penin. High.; $65^{\circ} 14^{\prime} \mathrm{N}, 166^{\circ} 08^{\prime} \mathrm{W}$; (map 111).

Local name reported in 1900 by E. C. Barnard (in Brooks, 1901, pl. 17), USGS.

Dese Creek: stream, flows NE $2 \mathrm{mi}$. to Agiapuk River, $13 \mathrm{mi}$. NE of Teller, Seward Penin. High.; $65^{\circ} 26^{\prime} \mathrm{N}, 166^{\circ} 15^{\prime} \mathrm{W}$; (map 111). Var. Deese Creek.

Prospectors' name reported as "Deese" on a map of Cape Nome goldfields by David Fox, Jr., dated 1901.

Desengaño, Puerto del: bay, see Disenchantment Bay.

Desert, The: island, $1.3 \mathrm{mi}$. long, sand bar in Stikine River, $15 \mathrm{mi}$. NE of Wrangell, Coast Mts.; $56^{\circ} 40^{\prime} 45^{\prime \prime} \mathrm{N}, 132^{\circ} 15^{\prime} 00^{\prime \prime} \mathrm{W}$; (map 6).

Descriptive name published in 1883 Coast Pilot (p. 109); probably given by prospectors.

Deserted Glacier: glacier, heads $12 \mathrm{mi}$. E of Meteorite Mtn., trends $\mathrm{N} 9 \mathrm{mi}$. to its terminus at head of Lowe River, $24 \mathrm{mi}$. $\mathrm{E}$ of Valdez, Chugach Mts.; $61^{\circ} 05^{\prime} 00^{\prime \prime} \mathrm{N}, 145^{\circ} 33^{\prime} 35^{\prime \prime} \mathrm{W}$; $B G N 1960$; (map 68).
Local name reported in 1960 by H. W. Coulter, USGS.

Desert Island : island, see Limb Island.

Desgraciada, Isla : island, see Unlucky Island.

Desgraciada, La: island, see Unlucky Island.

Deshka River: stream, see Kroto Creek.

Deshka River: stream, see Moose Creek.

Deshu: village, see Haines.

Deshu Isthmus: isthmus, at neck of Chilkat Penin., S of Haines, on Portage Cove, $17 \mathrm{mi}$. SW of Skagway, Coast Mts.; BGN 1922; 59 ${ }^{\circ}$ $13^{\prime} 30^{\prime \prime} \mathrm{N}, 135^{\circ} 26^{\prime} 30^{\prime \prime} \mathrm{W}$; (map 45). Var. Dèćú, Däschú, Däschue, Daeyshoo.

Tlingit Indian name meaning "trail end" reported by Aurel and Arthur Krause (1883, map), who spelled the name "Däschú."

Deskonosida, Mys de la: point of land, see Desconocida, Point.

Des Moines Creek: stream, flows SE $7.2 \mathrm{mi}$. to Wide Bay, W of Coal Point, on S coast of Alaska Penin., 42 mi. SE of Ugashik, Aleutian Ra.; $57^{\circ} 25^{\prime} 40^{\prime \prime} \mathrm{N}, 156^{\circ} 18^{\prime} 35^{\prime \prime} \mathrm{W}$; (map 36). Var. Lee Creek.

Local name reported in 1923 by R. H. Sargent, USGS. S. R. Capps, USGS, reported the name "Lee Creek" in 1921 ; it was named for "a prospector who had a cabin at the stream's mouth."

Desolation Creek: stream, flows NW $14 \mathrm{mi}$. to Siksikpuk River, SW of Gunsight Mtn., $40 \mathrm{mi}$. $\mathrm{N}$ of Anaktuvuk Pass, Arctic Slope ; $68^{\circ} 42^{\prime} 15^{\prime \prime}$ $\mathrm{N}, 151^{\circ} 53^{\prime} 00^{\prime \prime} \mathrm{W}$; (map 134).

So named about 1950 by W. W. Patton, USGS, "because it drains part of a desolate lowland between the Siksikpuk and Anatuvuk Rivers."

Desolation Glacier: glacier, see Lituya Glacier. Desolation Valley: valley, in Glacier Bay National Monument, trends NW $13 \mathrm{mi}$. from Lituya Glacier to 1961 terminus of Grand Plateau Glacier, $95 \mathrm{mi}$. NW of Hoonah, St. Elias Mts.; $58^{\circ} 47^{\prime}$ N, $137^{\circ} 39^{\prime}$ W ; (map 10). Local name published by USGS in the 1950's.

Desperation Lake: lake, $3 \mathrm{mi}$. long, $10 \mathrm{mi}$. NW of Feniak Lake and $48 \mathrm{mi}$. WNW of Howard Pass, Brooks Ra.; $68^{\circ} 20^{\prime} \mathrm{N}, 158^{\circ} 45^{\prime} \mathrm{W}$; $B G N$ 1960; (map 132). Var. Fry Lake, Tupichalik.

Probably named in the 1940's by wolf hunters. The Eskimo name obtained by Orth in 1956 is "Tupichalik," meaning "new tent," a reference to the dry gravel beach along the lake's shore that has been used for camping purposes since man has been in the area.

Desper Creek: stream, flows S and W $20 \mathrm{mi}$. to Scottie Creek, W of Alaska Highway, $31 \mathrm{mi}$. SE of Northway Junction, Alaska Ra.; $62^{\circ}$ $40^{\prime} \mathrm{N}, 141^{\circ} 10^{\prime} \mathrm{W}$; (map 84).

Local name reported by USGS in 1955.

Detached Glacier: glacier, trends S $1 \mathrm{mi}$. to its terminus between Baker and' Surprise Glaciers, $50 \mathrm{mi}$. SE of Anchorage, Chugach Mts.; $61^{\circ} 04^{\prime} \mathrm{N}, 148^{\circ} 24^{\prime} \mathrm{W}$; BGN 1964; (map 69).

Descriptive name given in 1908 by Grant and Higgins (1910, pl. 2), USGS.

Deuce Island: island, $0.2 \mathrm{mi}$. across, in Khaz Bay, $6 \mathrm{mi}$. S of Chichagof, on W coast of Chichagof
I., Alex. Arch.; 57 $34^{\prime} 15^{\prime \prime} \mathrm{N}, 136^{\circ} 05^{\prime} 00^{\prime \prime} \mathrm{W}$; $B G N$ 1908; (map 9). Var. Bald Head.

Named by E. F. Dickins, USC\&GS, and published in the 1908 Coast Pilot (p. 171).

Devastation, Mount: mountain, see Isanotski Peaks.

Devastation Volcano: volcano, see Pogromni Volcano.

Deviation Peak: peak, 2,677 ft., in Kiana Hills, $\mathrm{S}$ of Squirrel River, $19 \mathrm{mi}$. NW of Kiana, Brooks Ra.; $67^{\circ} 04^{\prime} \mathrm{N}, 161^{\circ} 06^{\prime} \mathrm{W}$; BGN 1944; (map 127).

Named in 1827 by Capt. Beechey, (1831, Chart), RN.

Devil Bay: bay, see Devil Inlet.

Devil Bay: $b a y$, see Devils Bay.

Devil Cove: cove, $0.4 \mathrm{mi}$. across, $2.2 \mathrm{mi}$. NE of Cape St. Stephen, W coast of Kiska I., Aleutian Is.; $51^{\circ} 54^{\prime} 35^{\prime \prime} \mathrm{N}, 177^{\circ} 14^{\prime} 30^{\prime \prime} \mathrm{E}$; (map 14).

One of many arbitrary names applied to features on Kiska I. by USAAF for tactical purposes during World War II.

Devil Creek: stream, heads in lake, flows SW 14 mi. to Susitna River, $39 \mathrm{mi}$. S of Cantwell, Talkeetna Mts.; $62^{\circ} 49^{\prime} 30^{\prime \prime} \mathrm{N}, 149^{\circ} 03^{\prime} 00^{\prime \prime}$ W; (map 82).

Local name recorded in 1950 by USGS

Devilfish Bay: cove, extends $\mathrm{E} 3.5 \mathrm{mi}$. to $\mathrm{El}$ Capitan Passage, on $\mathbf{E}$ coast of Kosciusko I., Alex. Arch.; $56^{\circ} 05^{\prime} 20^{\prime \prime} \mathrm{N}, 133^{\circ} 18^{\prime} 30^{\prime \prime} \mathrm{W}$; (map 6).

Local name obtained in 1904 from Capt. Cyrus Orr, of Shakan, by E. F. Dickins, USC\&GS.

Devilfish Point: point of land, between Captains and Nateekin Bays, on $\mathrm{N}$ coast of Unalaska I., Aleutian Is.; $53^{\circ} 53^{\prime} 00^{\prime \prime} \mathrm{N}, 166^{\circ} 35^{\prime} 30^{\prime \prime}$ W; (map 23).

Local name published in 1951 on a USGS map.

Devil Inlet: bay, $1.5 \mathrm{mi}$. long, $27 \mathrm{mi}$. $\mathrm{N}$ of Afognak, on NW coast of Afognak I., $\mathrm{N}$ of Kodiak I.; 58 ${ }^{\circ} 4^{\prime}$ N, $152^{\circ} 46^{\prime}$ W; (map 43). Var. Devil Bay.

Name published by USC\&GS in 1927 on Chart 8555. So called "because of the tidal rapids $1 / 4$ mile inside entrance."

Devil Island: island, 1,700 ft. across, between Camp and Fisherman Coves, off $W$ coast of Dall I., Alex. Arch.; $55^{\circ} 00^{\prime} 25^{\prime \prime} \mathrm{N}, 133^{\circ} 10^{\prime}$ $00^{\prime \prime} \mathrm{W}$; (map 4).

So named in 1914 by USC\&GS

Devil Lake: lake, 2 mi. long, on $\mathrm{W}$ coast of Dall I., E of Devil I., Alex. Arch.; $55^{\circ} 00^{\prime} 30^{\prime \prime} \mathrm{N}$, $133^{\circ} 06^{\prime} 30^{\prime \prime} \mathrm{W}$; (map 4).

So named in 1914 by USC\&GS

Devil Lake: lake, see Devils Lake.

Devil Mountain: hill, $798 \mathrm{ft}$., on Seward Penin., $5 \mathrm{mi}$. S of Devil Mountain Lakes and $53 \mathrm{mi}$. NW of Deering, Kotzebue-Kobuk Low.; $66^{\circ}$ $18^{\prime} \mathrm{N}, 164^{\circ} 31^{\prime} \mathrm{W}$; (map 113). Var. Devils Mountain, Gora Chortov, Teufelsberg.

Named "Teufelsberg," German for "Devils Mountain," by Lt. Otto von Kotzebue in 1816.

Devil Mountain Lakes: lakes, the larger one 3 mi. long, on Seward Penin., $55 \mathrm{mi}$. NW of 
Deering, Kotzebue-Kobuk Low.; $66^{\circ} 24^{\prime}$ N, $164^{\circ} 30^{\prime} \mathrm{W}$; (map 113).

Local name reported in 1950 by USGS; derived from nearby Devil Mountain.

Devilpaw Mountain: mountain, 2,056 ft., $29 \mathrm{mi}$. $\mathrm{N}$ of Afognak, in NW part of Afognak I.; Kodiak I.; $58^{\circ} 25^{\prime} 30^{\prime \prime} \mathrm{N}, 152^{\circ} 43^{\prime} 15^{\prime \prime} \mathrm{W}$; (map 43).

Name published by USC\&GS in 1927 on Chart 8555.

Devils Bay: bay, on Alaska Penin., trends SE 5 mi. to Pacific Ocean, $\mathrm{N}$ of Seal Cape, $17 \mathrm{mi}$. $\mathrm{S}$ of Chignik, Aleutian Ra.; $56^{\circ} 03^{\prime} \mathrm{N}, 158^{\circ}$ 24' W; (map 30). Var. Devil Bay.

Name originally reported as Devil Bay by a 1920 USG\&GS party and published as Devils Bay by W. R. Smith and A. A. Baker (in Brooks and others, 1924, map 8), USGS.

Devils Bay: bay, $3.5 \mathrm{mi}$. across, on Kenai Penin., at $S$ end of Tustumena Lake, $40 \mathrm{mi}$. SE of Kenai, Cook Inlet Low.; $60^{\circ} 04^{\prime} \mathrm{N}, 150^{\circ} 42^{\prime}$ W; (map 62).

Local name reported in 1951 by USGS.

Devils Bay: bay, see Monashka Bay.

Devils Bay: bight, $5 \mathrm{mi}$. across, on NW coast of Afognak I., $34 \mathrm{mi}$. N of Afognak, Kodiak I.; $58^{\circ} 25^{\prime} \mathrm{N}, 152^{\circ} 47^{\prime} \mathrm{W}$; (map 43).

Name published in 1925 by USFS.

Devils Cove: cove, extends W $4 \mathrm{mi}$. from Kukak Point, at mouth of Kukak Bay, on Alaska Penin., in Katmai National Monument, 29 mi. NE of Mount Katmai, Aleutian Ra.; $58^{\circ} 20^{\prime} 30^{\prime \prime} \mathrm{N}, 154^{\circ} 07^{\prime} 30^{\prime \prime} \mathrm{W}$; (map 42).

Local name reported by USC\&GS in 1954 Coast Pilot (p. 265).

Devils Creek: stream, heads W of Old Womens Mtn., flows NE $3.5 \mathrm{mi}$. to Buskin River, 4.5 mi. SW of Kodiak, Kodiak I.; $57^{\circ} 45^{\prime} 25^{\prime \prime} \mathrm{N}$, $152^{\circ} 30^{\prime} 25^{\prime \prime} \mathrm{W}$; (map 34).

Local name reported in 1949 by USGS.

Devils Creek: stream, heads on $\mathrm{N}$ side of Gilpatrick Mtn., flows SE $8.5 \mathrm{mi}$. to Quartz Creek, $28 \mathrm{mi}$. S of Hope, Ghugach Mts.; $60^{\circ} 32^{\prime} 25^{\prime \prime} \mathrm{N}, 149^{\circ} 37^{\prime} 25^{\prime \prime} \mathrm{W}$; (map 63).

Local prospectors' name reported in 1904 by Moffit (1906, pl. 2), USGS.

Devils Desk: peak, 6,411 ft., on ridge at head of Hook Glacier, on Alaska Penin., in Katmai National Monument, $28 \mathrm{mi}$. NE of Mount Katmai, Aleutian Ra.; $58^{\circ} 28^{\prime} 30^{\prime \prime} \mathrm{N}, 154^{\circ}$ $17^{\prime} 55^{\prime \prime}$ W; BGN 1925; (map 42). Var. Devils Desk Peak.

Descriptive name given in 1924 by $\mathrm{R}$. $\mathrm{H}$. Sargent, USGS.

Devils Desk Peak: peak, see Devils Desk.

Devils Elbow: bend, in Yukon River, $W$ of Blade I., $20 \mathrm{mi}$. S of Marshall, Yukon-Kuskokwim Delta; $61^{\circ} 35^{\prime} \mathrm{N}, 162^{\circ} 04^{\prime} \mathrm{W}$; (map 74). Var. The Bend.

Riverboat pilots' name shown on a fieldsheet by R. H. Sargent, USGS, in 1916 . This bend is the southernmost point of the Yukon River in Alaska.

Devils Elbow: bight, $1 \mathrm{mi}$. across, in Rocky Pass of Keku Strait, $20 \mathrm{mi}$. W of Point Baker, on SW coast of Kupreanof I., Alex. Arch.; $56^{\circ}$ $38^{\prime} 10^{\prime \prime} \mathrm{N}, 133^{\circ} 41^{\prime} 00^{\prime} \mathrm{W}$; BGN 1929; (map 6).
Descriptive name reported in 1927 by USC\&GS; "this is a short and dangerous turn in the Keku Strait."

Devils Elbow: point of land, on E bank of Kuskokwim River, $60 \mathrm{mi}$. SW of McGrath, Kilbuck-Kuskokwim Mts. ; $62^{\circ} 08^{\prime} 20^{\prime \prime} \mathrm{N}, 156^{\circ}$ $14^{\prime} 20^{\prime \prime} \mathrm{W}$; (map 79).

Local name obtained in 1945 by USGS topographers.

Devils Gulch: ravine, extends $3.6 \mathrm{mi}$. SW to Chitina River, W of Hells Kitchen Gulch, 22 mi. SE of McCarthy, St. Elias Mts. ; $61^{\circ} 09^{\prime} 00^{\prime \prime}$ $\mathrm{N}, 142^{\circ} 35^{\prime} 30^{\prime \prime} \mathrm{W}$; (map 67).

Local name reported in 1915 by F. H. Moffit, USGS.

Devils Lake: lake, $0.5 \mathrm{mi}$. long, near Gahona Glacier terminus, $14 \mathrm{mi}$. NE of Paxson, Alaska Ra.; $63^{\circ} 09^{\prime} 35^{\prime \prime} \mathrm{N}, 145^{\circ} 09^{\prime} 15^{\prime \prime} \mathrm{W}$; (map 86).

Name published on relatively recent maps.

Devils Lake: lake, $2 \mathrm{mi}$. long, between Long and Big Rat Lakes, 22 mi. SW of Beaver, Yukon Flats; $66^{\circ} 16^{\prime} \mathrm{N}, 148^{\circ} 11^{\prime} \mathrm{W}$; (map 118). Var. Devil Lake.

Probably named by William Yanert who showed it on a 1916 manuscript map of the Yukon Flats (Stuck, 1917, map facing p. 122).

Devils Mountain: peak, 2,450 ft., on Attu I. in Henderson Ridge, Aleutian Is.; $52^{\circ} 51^{\prime} 42^{\prime \prime} \mathrm{N}$, $173^{\circ} 07^{\prime} 47^{\prime \prime} \mathrm{E}$; (map 13).

Named by U.S. Army during World War II; published in 1948 by AMS.

Devils Mountain: mountain, 5,335 ft., at $S$ end of Mentasta Mts., $5 \mathrm{mi}$. NE of Nabesna, Alaska Ra.; $62^{\circ} 25^{\prime} \mathrm{N}, 142^{\circ} 55^{\prime} \mathrm{W}$; BGN 1939; (map 84).

Local name reported in 1939 by P. S. Smith, USGS.

Devils Mountain: hill, see Devil Mountain.

Devils Mountain Lodge: roadhouse, $5 \mathrm{mi}$. SW of Devils Mountain and $4 \mathrm{mi}$. $\mathrm{N}$ of Nabesna, Wrangell Mts., $62^{\circ} 23^{\prime} \mathrm{N}, 142^{\circ} 58^{\prime} \mathrm{W}$; (map 84).

Local name reported in 1960 by USGS.

Devils Mountains: peaks, see Devils Prongs.

Devils Pass: pass, $1.5 \mathrm{mi}$. long, on Kenai Penin., connects headwaters of Devils and Juneau Creeks, $22 \mathrm{mi}$. S of Hope and $35 \mathrm{mi}$. NNW of Seward, Chugach Mts., $60^{\circ} 37^{\prime} \mathrm{N}, 149^{\circ} 43^{\prime}$ W; (map 63).

Local name reported in 1966 by USFS; name derived from Devils Creek.

Devils Pass Lake: lake, $0.5 \mathrm{mi}$. long, on Kenai Penin.; in Devils Pass between Juneau and Devils Creeks, $35 \mathrm{mi}$. NNW of Seward; Chugach Mts.; $60^{\circ} 37^{\prime} \mathrm{N}, 149^{\circ} 43^{\prime} \mathrm{W}$; (map 63). Local name reported in 1966 by USFS.

Devils Paw: mountain peak, elev. 8,584 ft., Boundary Peak 93 on Alaska-Canada boundary, $3.5 \mathrm{mi}$. NE of terminus of Unknown Glacier and $36 \mathrm{mi}$. NE of Juneau, Coast Mts.; $58^{\circ} 43^{\prime} 45^{\prime \prime} \mathrm{N}, 133^{\circ} 50^{\prime} 15^{\prime \prime} \mathrm{W}$; BGN 1922; (map 12). Var. Boundary Peak 93.

Name published in 1908 by USC\&GS on Chart 8000.

Devils Prongs: peaks, elev. 1,974-2,175 ft., extend SW $1.8 \mathrm{mi}$., at head of Monashka Bay, 2 mi. NW of Kodiak, Kodiak I.; 57 $49^{\prime}$ N, $152^{\circ} 27^{\prime}$ W; BGN 1966; (map 34). Var.
Devils Mountains, Gory Chyernysheva, The Three Sisters, Three Sisters.

Named in 1869 by USC\&GS. Russian naval officers in 1808 gave descriptive name "Gory Chyernysheva," meaning "black mountains"; published by Lt. Sarichev (1826, map 16), IRN.

Devils Prongs, The: peaks, see Devils Prongs.

Devils Prongs, The: peaks, see Three Sisters.

Devils Punch Bowl: lake, $0.2 \mathrm{mi}$. across, $1.3 \mathrm{mi}$. SE of Lower Dewey Lake and $2.3 \mathrm{mi}$. SE of Skagway, Coast Mts.; $59^{\circ} 25^{\prime} 45^{\prime \prime}$ N, $135^{\circ}$ $16^{\prime} 40^{\prime \prime} \mathrm{W}$; (map 45).

Local name published in 1951 by USGS.

Devils Thumb: bluff, on right bank of Little Joe Creek, $10 \mathrm{mi}$. S of Ruby, Kilbuck-Kuskokwim Mts.; $64^{\circ} 35^{\prime} \mathrm{N}, 1^{\circ} 25^{\circ} 6^{\prime} \mathrm{W}$; (map 98). Var. The Thumb.

Prospectors' name reported as 'The Thumb" by Eakin (1916, pl. 1), USGS. Orth reported the present form of the name in 1956.

Devils Thumb: mountain, 9,077 ft., Boundary Peak 71 on Alaska-Canada boundary, $6 \mathrm{mi}$. SW of Mount Burkett and $144 \mathrm{mi}$. E of Sitka, Coast Mts.; $57^{\circ} 05^{\prime} 30^{\prime \prime} \mathrm{N}, 132^{\circ} 19^{\prime} 00^{\prime \prime} \mathrm{W}$; (map 8). Var. Boundary Peak 71.

Named by Comdr. R. W. Meade, USN, for a 1,662-foot thumblike projection on the mountain; published in 1869 by U.S. Navy Hydrog. Office.

Devils Wash Basin: lake, see Surprise Lake.

Devine, Cape: promontory, $885 \mathrm{ft}$., SE tip of Korovin I., in Shumagin Is., Aleutian Ra.; $55^{\circ} 22^{\prime} 45^{\prime \prime} \mathrm{N}, 160^{\circ} 09^{\prime} 00^{\prime \prime} \mathrm{W}$; (map 28).

Named by W. H. Dall in 1880 and shown on an 1888 USC\&GS chart.

Devish Lake: lake, $0.2 \mathrm{mi}$. across, $0.3 \mathrm{mi}$. S of mouth of Stellar Creek and $19 \mathrm{mi}$. WSW of Valdez, Chugach Mts.; $61^{\circ} 02^{\prime} 45^{\prime \prime} \mathrm{N}, 146^{\circ}$. $48^{\prime} 30^{\prime \prime} \mathrm{W}$; (map 68).

Local name published in 1950 by USGS.

Devison Cape: point of land, see Davison Point.

Dewey Anchorage: bay, $3 \mathrm{mi}$. wide, between Etolin and Onslow Is., $42 \mathrm{mi}$. NE of Craig, Alex. Arch.; $55^{\circ} 56^{\prime} \mathrm{N}, 132^{\circ} 25^{\prime} \mathrm{W}$; (map 4).

Named in 1886 by Lt. Comdr. A. S. Snow, USN, for Ens. Theodore Gibbs Dewey, USN, a member of his party.

Dewey Creek: stream, flows to Tributary Creek, $\mathrm{S}$ of Green Creek, about $10 \mathrm{mi}$. NE of Solomon, Seward Penin. High.; (map 95).

Prospectors' name reported on a prospector's manuscript dated 1902. This stream cannot be precisely located on current maps.

Dewey Creek: stream, heads in glacier, flows W $5.5 \mathrm{mi}$. to Copper River, $6.2 \mathrm{mi}$. NE of mouth of Gleave Creek, $48 \mathrm{mi}$. $\mathrm{E}$ of Valdez, Chugach Mts.; 61 ${ }^{\circ} 13^{\prime} 15^{\prime \prime} \mathrm{N}, 144^{\circ} 50^{\prime} 05^{\prime \prime} \mathrm{W}$; (map 68).

Named in 1898 by Capt. W. R. Abercrombie, USA, after learning of the American naval victory in Manila Bay on May 1 , led by Commodore George Dewey, 1837-1917, USN.

Dewey Creek: stream, flows NW $11 \mathrm{mi}$. to Liberty Creek, $18 \mathrm{mi}$. W of Alaska-Canada boundary, 
Yukon-Tanana High.; $64^{\circ} 00^{\prime} \mathrm{N}, 141^{\circ} 06^{\prime} \mathrm{W}$; (map 85).

Local name reported by USGS in 1950.

Dewey Creek: stream, flows SW $1 \mathrm{mi}$. to King Solomon Creek, $15 \mathrm{mi}$. S of Eagle, YukonTanana High.; $64^{\circ} 35^{\prime} \mathrm{N}, 141^{\circ} 19^{\prime} \mathrm{W}$; (map 102).

Named by prospectors probably for Commodore George Dewey, 1837-1917, USN. See Dewey Greek. Name shown on a manuscript map by C. A. Woodruff, Fort Cudahy, Canada.

Dewey Creek: stream, flows SW $2 \mathrm{mi}$. to Nome River, $9 \mathrm{mi}$. NE of Nome, Seward Penin. High.; 64 $38^{\prime} \mathrm{N}, 165^{\circ} 18^{\prime} \mathrm{W}$; (map 94). Var. Dorsey Creek.

Local name published in 1900 on USC\&GS Chart 9380. Named in 1899 or 1900 , possibly for Commodore George Dewey, 18371917, USN, who successfully commanded the United States forces in the Battle of Manila Bay on May 1, 1898.

Dewey Creek: stream, flows S $3 \mathrm{mi}$. to Eureka Creek which flows to Skookum River, $19 \mathrm{mi}$. NE of Solomon, Seward Penin. High.; 64 $41^{\prime}$ $\mathrm{N}, 163^{\circ} 51^{\prime} \mathrm{W}$; (map 95).

Prospectors' name reported in 1900 by E. C. Barnard (in Brooks, 1901, pl. 17), USGS.

Dewey Creek: stream, flows NE $0.7 \mathrm{mi}$. to Last Chance Creek which flows to North Fork Snake River, $15 \mathrm{mi}$. N of Nome, Seward Penin. High.; $64^{\circ} 43^{\prime} 10^{\prime \prime} \mathrm{N}, 165^{\circ} 28^{\prime} 30^{\prime \prime} \mathrm{W}$; (map 94).

Prospectors' name reported in 1904 by T. G. Gerdine, USGS.

Dewey Creek: stream, flows SE $7 \mathrm{mi}$. to Charley River, $18 \mathrm{mi}$. SW of that stream's junc. with Yukon River, Yukon-Tanana High.; $65^{\circ} 06^{\prime} \mathrm{N}$, $143^{\circ} 08^{\prime} \mathrm{W}$; (map 103).

Prospectors' name found on an unpublished map by E. J. Chamberlain, dated 1902.

Dewey Creek: stream, flows NE $6 \mathrm{mi}$. to Logan Creek, $0.5 \mathrm{mi}$. SSW of that stream's junc. with Yukon River and $40 \mathrm{mi}$. NW of Eagle, YukonTanana High.; $65^{\circ} 16^{\prime} \mathrm{N}, 142^{\circ} 00^{\prime} \mathrm{W}$; (map 103).

Prospectors' name from an unpublished map by E. F. Ball, dated 1898 .

Dewey Creek: stream, flows SW 2 mi. to Grantley Harbor, $6 \mathrm{mi}$. NE of Teller, Seward Penin. High.; $65^{\circ} 17^{\prime} \mathrm{N}, 166^{\circ} 10^{\prime} \mathrm{W}$; (map 111). Var. Igloo Creek.

Local name reported in 1900 by E. C. Barnard (in Brooks, 1901, pl. 17), USGS. Barnard showed this stream as "Igloo Creek" and applied "Dewey Creek" to the next stream east.

Dewey Creek: stream, see Butte Creek.

Dewey Creek: stream, see McKinley Creek.

Dewey Creek: stream, see Morris Creek.

Dewey Creek: stream, see Squirrel Creek.

Dewey Hill: hill, $400 \mathrm{ft}$., in village of Wrangell, on $\mathrm{N}$ coast of Wrangell I., Alex. Arch.; $56^{\circ}$ $28^{\prime} 30^{\prime \prime} \mathrm{N}, 132^{\circ} 23^{\prime} 00^{\prime \prime} \mathrm{W}$; (map 6).

Local name used by fishermen and published in 1918 by USC\&GS.
Dewey Rocks: rocks, extend 1,200 ft. in Cordova Bay, SW rocks of Barrier Is. group, Alex. Arch.; 54 $45^{\prime} \mathrm{N}, 132^{\circ} 29^{\prime} \mathrm{W}$; (map 1).

Named in 1886 by Lt. Comdr. R. C. Clover, USN, for Ens. T. G. Dewey, USN, a member of his party.

Deweyville: locality, on Sarkar Cove, $\mathrm{W}$ coast of Prince of Wales I., $34 \mathrm{mi}$. $\mathrm{N}$ of Craig, Alex. Arch.; $55^{\circ} 57^{\prime} 30^{\prime \prime} \mathrm{N}, 133^{\circ} 14^{\prime} 35^{\prime \prime} \mathrm{W}$; (map 4).

Local name reported in 1904 by E. F. Dickins, USC\&GS, who "Found name on painted sign board over door of Fishery, probably named by owners." This place was a fishing station, now abandoned.

Dewie Creek: stream, see Hutchinson Creek.

Dew Point: point of land, $\mathrm{S}$ point of entrance to Fitzgibbon Cove, on E side of Behm Canal, Coast Mts.; $55^{\circ} 57^{\prime} 30^{\prime \prime} \mathrm{N}, 131^{\circ} 11^{\prime} 15^{\prime \prime} \mathrm{W}$; (map 3).

One of many arbitrary names applied to features in this area in 1891 by USC\&GS.

Dexter: locality, along Seward Penin. RR., SW of King Mtn., $6 \mathrm{mi}$. NE of Nome, Seward Penin. High.; $64^{\circ} 36^{\prime} \mathrm{N}, 165^{\circ} 20^{\prime} \mathrm{W}$; (map 94).

Site of a mining camp and RR. station reported in 1904 by T. G. Gerdine, USGS.

Dexter: village, see Golovin.

Dexter, Point: point of land, at $\mathrm{N}$ end of Reindeer Hills on $\mathbf{S}$ side of Norton Bay, Nulato Hills: $64^{\circ} 32^{\prime} \mathrm{N}, 161^{\circ} 23^{\prime} \mathrm{W}$; ( $\operatorname{map} 96$ ).

Local name reported on the 1900 "Map of Nome Peninsula" by J. M. Davidson and B. D. Blakeslee.

Dexter Creek: stream, flows NW $5 \mathrm{mi}$. to join All Gold Creek to form the Totatlanika River, $20 \mathrm{mi}$. NE of Healy, Alaska Ra.; 63 $58^{\circ} 30^{\prime \prime}$ N, $148^{\circ} 23^{\prime} 30^{\prime \prime} \mathrm{W}$; (map 87).

Prospectors' name shown on a 1910 fieldsheet by J. W. Bagley, USGS; published by Capps (1912, pl. 1), USGS.

Dexter Creek: stream, heads in Grouse Gulch, flows NE $2.5 \mathrm{mi}$. to Nome River, $6 \mathrm{mi}$. NE of Nome, Seward Penin. High.; $64^{\circ} 35^{\prime} \mathrm{N}, 165^{\circ}$. 17' W; (map 94).

Prospectors' name reported in 1899 by $D$. C. Witherspoon (in Schrader and Brooks, 1900, map 2), USGS

Dexter Greek: stream, flows SE to Canyon Creek, between Phoenix and Premier Creeks, $23 \mathrm{mi}$. NW of Solomon, Seward Penin. High.; $64^{\circ}$. $52^{\prime} \mathrm{N}, 164^{\circ} 46^{\prime} \mathrm{W}$; (map 95).

Prospectors' name reported on a map of Cape Nome gold fields by David Fox, Jr., dated 1901.

Dexter Creek: stream, flows N $2 \mathrm{mi}$. to Flat Creek, $39 \mathrm{mi}$. NE of Fairbanks, Yukon-Tanana High.; $65^{\circ} 12^{\prime} 30^{\prime \prime} \mathrm{N}, 146^{\circ} 50^{\prime} 50^{\prime \prime} \mathrm{W}$; (map 104).

Named by prospectors; published by USGS (in Prindle, 1908, pl. 4).

Dexter Creek: stream, flows NW $11 \mathrm{mi}$. to Clums Fork Birch Creek, $53 \mathrm{mi}$. SW of Circle, Yukon-Tanana High.; $65^{\circ} 14^{\prime} 30^{\prime \prime} \mathrm{N}, 145^{\circ} 16^{\prime} 45^{\prime \prime}$ W; (map 104).

Named by prospectors; reported in 1911 by USGS (in Prindle, 1913, pl. 1).
Dexter Peak: hill, $720 \mathrm{ft} ., 1.2 \mathrm{mi}$. SW of King Mtn. and $5.5 \mathrm{mi}$. N of Nome, Seward Penin. High.; $64^{\circ} 35^{\prime} \mathrm{N}, 165^{\circ} 22^{\prime} \mathrm{W}$; (map 94). Var. Lookout Peak.

Local name published in 1956 by USGS. Shown as "Lookout Peak" on the 1902 "Map of Nome and Snake River Country" by J. M. Davidson.

Dexter Ridge: ridge, trends NE-SW in vicinity of Mount Kachauik about $15 \mathrm{mi}$. NE of Golovin and $20 \mathrm{mi}$. NW of Elim, Seward Penin. High.; (map 95).

Local name published by Schrader (1900c, p. 16), USGS. The ridge was not identified on subsequent maps. Probably named for John Dexter who operated a trading post at Golovin.

Dexter's Store: village, see Golovin.

Deyea River: stream, see Chilkoot River.

Dgak Bay : bay, see Ugak Bay.

Dgak Island: island, see Ugak Island.

Dhahedse Ridge: cliff, elev. $3,000 \mathrm{ft}$., on SE slope of Paddle Mtn., $3 \mathrm{mi}$. E of Arctic Village, Brooks Ra.; $68^{\circ} 08^{\prime} \mathrm{N}, 145^{\circ} 40^{\prime} \mathrm{W}$; (map 136).

Kutchin Indian name obtained at Arctic Village in 1956 by T. E. Taylor, USGS.

Diablo, Mount: mountain, 3,500 ft., on SE coast of Kenai Penin., $1 \mathrm{mi}$. SW of Beauty Bay and $38 \mathrm{mi}$. ENE of Seldovia, Chugach Mts.; $59^{\circ} 31^{\prime} 45^{\prime \prime} \mathrm{N}, 150^{\circ} 40^{\prime} 30^{\prime \prime} \mathrm{W}$; BGN 1911; (map 50). Var. Diablo Peak.

Named by U. S. Grant, USGS, in 1911 (Grant and Higgins, 1913, pl. 2).

Diablo Peak: mountain, see Diablo, Mount.

Diamante, Punta de: point of land, see Diamond Point.

Diamed Islands: islands, see Diomede Islands.

Diamond: locality, site of mining camp, at junc. of Moose Creek and Bearpaw River, $18 \mathrm{mi}$. E of Chilchukabena Lake, Tanana Low.; $63^{\circ} 53^{\prime} 15^{\prime \prime} \mathrm{N}, 150^{\circ} 54^{\prime \prime} 00^{\prime \prime} \mathrm{W}$; (map 88). Var. Diamond City.

This camp was established about 1905 at the head of small-boat navigation on the Bearpaw River. It had a post office in 1906 and again from 1929 to 1951 (Ricks, 1965, p. 16).

Diamond City: locality, see Diamond.

Diamond Creek: stream, flows NW to Pinnell River near its head in Inmachuk River basin, about $11 \mathrm{mi}$. NE of Imuruk Lake, Seward Penin. High.; (map 110).

Local name published on a precinct map of Seward Peninsula by Monroe and Hutchins; corrected to June 1903 by Arthur Gibson. This stream cannot be precisely identified on current maps.

Diamond Creek: stream, on Kenai Penin., flows W $5 \mathrm{mi}$. to Kachemak Bay, $5.7 \mathrm{mi}$. WNW of Homer, Cook Inlet Low.; 59 $40^{\prime} 20^{\prime \prime} \mathrm{N}$, $151^{\circ} 42^{\prime} 00^{\prime \prime} \mathrm{W}$; (map 50$)$.

Local name reported and published by USGS in the 1950's.

Diamond Creek: stream, flows $2.4 \mathrm{mi}$. W to McCarthy Creek, 8 mi. NE of McCarthy, Wrangell Mts.; $61^{\circ} 31^{\prime} 40^{\prime \prime} \mathrm{N}, 142^{\circ} 47^{\prime} 05^{\prime \prime} \mathrm{W}$; $B G N$ 1964; (map 67). 
Local name ibtained by USGS and published on mape since 1954.

Diamond Creek: sjeam, flows E 3 mi. to Beaver Creek, $5.8 \mathrm{mi}$. SW of Poorman and $47 \mathrm{mi}$. SW of Ruby, Kilbuck-Kuskokwim Mts.; $64^{\circ} 03^{\prime} 50^{\prime \prime} \mathrm{N}, 155^{\circ} 43^{\prime} 07^{\prime \prime} \mathrm{W} ; B G N$ 1936; (map 98).

Prospector' rame reported in 1935 by USGS.

Diamond Creek: skeam, flows $S 1 \mathrm{mi}$. to Quartz Creek, $12 \mathrm{mi}$. SE of Long and $31 \mathrm{mi}$. SSE of Ruby, Kilbuck-Kuskokwim Mts.; $64^{\circ} 19^{\prime} \mathrm{N}$, $155^{\circ} 09^{\prime} \mathrm{W}$; (map98).

Prospectors' name reported in 1913 by Eakin (1914, pl 3), USGS. The stream's identity is in doubt.

Diamond Creek: stream, flows NW $9.7 \mathrm{mi}$, to Ungalik River, $6.7 \mathrm{mi}$. SW of Christmas Mtn. Nulato Hills ; $64^{\circ} 32^{\prime} \mathrm{N}, 160^{\circ} 46^{\prime} \mathrm{W}$; (map 96).

Local name reported about 1954 by U.S. Army Corps of Engineers.

Diamond Creek: stream, flows NE $1.8 \mathrm{mi}$. to Minnehaha Creek which flows to Kiwalik Lagoon on Spafarief Bay, $7.5 \mathrm{mi}$. SW of Candle and $35 \mathrm{mi}$. NE of Imuruk Lake, Seward Penin. High.; $65^{\circ} 53^{\prime} \mathrm{N}, 162^{\circ} 11^{\prime} \mathrm{W}$; (map 110)

Prospectors' name reported on the 1908 "Map of Seward Peninsula" by Arthur Gibson.

Diamond Fork: stream, flows $\mathbf{N} 8 \mathrm{mi}$. to Seventymile River, $50 \mathrm{mi}$. NW of Eagle, Yukon-Tanana High.; $64^{\circ} 57^{\prime}$ N, $142^{\circ} 48^{\prime} \mathbf{W}$; (map 102)

Prospectors' name shown on a 1902 manuscript map by E. J. Chamberlain, U.S. Deputy Surveyor.

Diamond Gulch: ravine, $1 \mathrm{mi}$. long, on Kenai Penin., along course of Diamond Creek, $5 \mathrm{mi}$. NW of Homer, Cook Inlet Low.; $59^{\circ} 40^{\prime} 20^{\prime \prime}$ $\mathrm{N}, 151^{\circ} 41^{\prime} 00^{\prime \prime} \mathrm{W}$; (map 50).

Local name reported and published by USGS in the 1950's.

Diamond Island: island, $0.4 \mathrm{mi}$. across, in Mitchell Bay, $6.5 \mathrm{mi}$. NE of Angoon, on W central Admiralty I., Alex. Arch.; $57^{\circ} 32^{\prime} 55^{\prime \prime}$ N, $134^{\circ}$ 25'30' W; (map 9).

Named in 1869 by Lt. Comdr. R. W. Meade, USN, and published on Chart 225.

Diamond Lake: lake, $1.2 \mathrm{mi}$. long, on Kenai Penin., $20 \mathrm{mi}$. SW of Anchorage, Cook Inlet Low.; $61^{\circ} 01^{\prime} 00^{\prime \prime} \mathrm{N}, 150^{\circ} 22^{\prime} 15^{\prime \prime} \mathrm{W}$; (map 70).

Named about 1963 for administrative purposes by officials of the Kenai National Moose Range.

Diamond Lake: lake, $0.9 \mathrm{mi}$. long, $20 \mathrm{mi}$. N of Anchorage, Cook Inlet Low.; $61^{\circ} 30^{\prime} \mathrm{N}, 150^{\circ}$ 01' W; BGN 1959; (map 70).

Named in 1959 by Mrs. Lucille E. Rains of Anchorage, who has a homestead on the lake. So named "because my mother's birthstone is the diamond."

Diamond Mountain: mountain, 5,400 ft., $64 \mathrm{mi}$. SW of Eagle, Yukon-Tanana High.; $64^{\circ} 08^{\prime}$ $\mathrm{N}, 142^{\circ} 39^{\prime} \mathrm{W}$; (map 102 ).

Prospectors' name shown on an 1899 fieldsheet by W. J. Peters, USGS.

Diamond Point: point of land, SW tip of San Juan Bautista I., in Bucareli Bay, Alex. Arch.; $55^{\circ} 24^{\prime} 30^{\prime \prime} \mathrm{N}, 133^{\circ} 19^{\prime} 15^{\prime \prime} \mathrm{W}$; (map 4). Var. Punta de Diamante.

Translation of the name "Punta de Diamante" given in 1775-1779 by Don Juan de la Bodega y Quadra and Francisco Antonio Maurelle.

Diamond Point: point of land, in Chigmit Mts. on SW shore of Cook Inlet, between Iliamna and Cottonwood Bays, Aleutian Ra.; $59^{\circ} 38^{\prime}$ $45^{\prime \prime} \mathrm{N}, 153^{\circ} 37^{\prime} 45^{\prime \prime} \mathrm{W}$; (map 51).

Name published in 1907 on USC\&GS Chart 8665.

Diamond Ridge: ridge, 1,100 ft., $5 \mathrm{mi}$. long, on Kenai Penin., 1.5 mi. N of Homer, Cook Inlet Low.; $59^{\circ} 40^{\prime} \mathrm{N}, 151^{\circ} 35^{\prime} \mathrm{W}$; (map 50).

Local name reported and published by USGS in the 1950's.

Diana, Lake: lake, $1.7 \mathrm{mi}$. long, $18 \mathrm{mi}$. SE of Sitka, on central Baranof I., Alex. Arch.; 56 ${ }^{\circ}$ $53^{\prime} \mathrm{N}, 135^{\circ} 02^{\prime} \mathrm{W}$; BGN 1935; ( $\operatorname{map} 5$ ).

Named in 1935 by USFS "for the first Russian warship to reach Sitka, in 1810."

Diana Mountain: mountain, 3,014 ft., on Revillagigedo I., $4.4 \mathrm{mi}$. N of Ketchikan, Alex. Arch.; $55^{\circ} 24^{\prime} 35^{\prime \prime} \mathrm{N}, 131^{\circ} 38^{\prime} 10^{\prime \prime} \mathrm{W}$; (map 3 ). Named in 1886 by USC\&GS.

Diary: locality, a residential area on the $S$ coast of Revillagigedo I., $3.5 \mathrm{mi}$. SE of Ketchikan, Alex. Arch.; 55 $18^{\prime} 25^{\prime \prime} \mathrm{N}, 131^{\circ} 33^{\prime} 50^{\prime \prime} \mathrm{W}$; (map 3).

This is an extension of the settlement area southeast of Ketchikan along the highway.

Di-bot-i-chit-in-da: stream, see Jacksina Creek. Dichna River: stream, see Dishna River.

Dickason Mountain: mountain, $4,684 \mathrm{ft}$., in Tordrillo Mts., between Canyon Creek and Hayes River, $60 \mathrm{mi}$. NW of Tyonek, Alaska Ra.; $61^{\circ} 51^{\prime} 30^{\prime \prime} \mathrm{N}, 151^{\circ} 54^{\prime} 15^{\prime \prime}$ W; (map 70). Var. Dickerson Mountain.

Named in 1898 by W. S. Post, USGS, "for Col. L. T. Dickason."

Dick Creek: stream, flows $\mathrm{S} 4.5 \mathrm{mi}$. to Bering Lake, 12 mi. NE of Katalla, Chugach Mts.; $60^{\circ} 19^{\prime} \mathrm{N}, 144^{\circ} 19^{\prime} \mathrm{W}$; (map 64).

Local name used by prospectors; reported in 1905 by G. C. Martin, USGS

Dick Creek: stream, flows NE $8 \mathrm{mi}$. to Albert Greek, $8.3 \mathrm{mi}$. N of Tahneta Pass, Talkeetna Mts.; $62^{\circ} 00^{\prime} 25^{\prime \prime} \mathrm{N}, 147^{\circ} 20^{\prime} 00^{\prime \prime} \mathrm{W}$; (map 82).

Prospectors' name published by G. C. Martin and J. B. Mertie, Jr. (in Brooks and others, 1914, pl. 11), USGS

Dick Creek: stream, flows SW $11 \mathrm{mi}$. to Yanert Fork, $28 \mathrm{mi}$. SE of Healy, Alaska Ra.; 63 $38^{\prime}$ $\mathrm{N}, 148^{\circ} 14^{\prime} \mathrm{W}$; $(\operatorname{map} 87)$.

Local name obtained in 1913 by J. W. Bagley, USGS; published by Moffit (1915, pl. 1) USGS.

Dick Creek: stream, fows NW 3.5 mi. to Bryan Creek, in Serpentine River basin, $12 \mathrm{mi}$. NW of Midnight Mtn. and $54 \mathrm{mi}$. NW of Imuruk Lake Seward Penin. High.; $65^{\circ} 50^{\prime}$ N, $165^{\circ} 00^{\prime}$ W; (map 110).

Prospectors' name reported in 1901 by T. G. Gerdine (in Collier, 1902, pl. 12), USGS.

Dick Dale Creek: stream, flows NW $5 \mathrm{mi}$. to Dome Creek, $30 \mathrm{mi}$. S of Eagle, Yukon-Tanana
High.; $64^{\circ} 22^{\prime} 15^{\prime \prime} \mathrm{N}, 141^{\circ} 18^{\prime} 00^{\prime \prime} \mathrm{W}$; (map 102). Var. Dale Creek, Dick Vale Creek.

Prospectors' name reported in 1903 by T. G. Gerdine (in Prindle, 1905, pl. 16), USGS. Shown as "Dale" on a 1898 manuscript map by E. F. Ball.

Dickens Creek: stream, flows W $1.5 \mathrm{mi}$. to Nome River, $25 \mathrm{mi}$. NE of Nome, Seward Penin. High.; $64^{\circ} 52^{\prime} \mathrm{N}, 165^{\circ} 16^{\prime} \mathrm{W}$; (map 94).

Prospectors' name reported in 1900 by E. C. Barnard (in Brooks, 1901, pl. 17), USGS.

Dickens Peak: mountain, see Dickins Peak.

Dickerson Mountain: mountain, see Dickason Mountain.

Dickey, Mount: peak, 9,545 ft., 1 mi E of Pittock Pass and $14 \mathrm{mi}$. SE of Denali Pass, in Mount McKinley National Park, Alaska Ra.; 62 ${ }^{\circ} 56^{\prime}$. $50^{\prime \prime} \mathrm{N}, 150^{\circ} 43^{\prime} 15^{\prime \prime} \mathrm{W}$; BGN 1960; (map 81).

Named in 1914 by Dora Keen [Handy] for William A. Dickey, 1862-1943, who while prospecting in this area in 1896 was responsible for naming Mount McKinley.

Dickey Lake: lake, $2.1 \mathrm{mi}$. long, in course of Middle Fork Gulkana River, $18 \mathrm{mi}$. W of Paxson Lake, Alaska Ra.; $62^{\circ} 56^{\prime} \mathrm{N}, 146^{\circ} 07^{\prime}$ W; (map 83).

Local name reported by USGS in 1951.

Dickie Creek: stream, see Texas Creek.

Dickinson Cove: bay, see Thumb Cove.

Dickins Peak: mountain, 6,172 ft., $3 \mathrm{mi}$. W of Mount Middleton and Alaska-Canada boundary, 36 mi. NW of Hyder, Coast Mts.; 56 ${ }^{\circ} 16^{\prime}$ N. $130^{\circ} 42^{\prime} \mathrm{W}$; BGN 1923; (map 7). Var. Dickens Peak

Named in 1923 by USC\&GS for Edmund Finlay Dickins, 1846-1923, USC\&GS, who was an IBC surveyor in 1893 and 1895 and later commanded the Coast Survey steamer Gedney from 1899 to 1905.

Dickman Bay: estuary, extends NW $5 \mathrm{mi}$. off West Arm Moira Sound, on S coast of Prince of Wales I., Alex. Arch.; $55^{\circ} 00^{\prime} \mathrm{N}, 132^{\circ} 13^{\prime}$ W; (map 4).

Local name reported in 1904 by $H$. C. Fassett, USBF.

Dick Point: point of land, see Gore Point.

Dick, Port: bay, 3 mi. wide, on S coast of Kenai Penin., $26 \mathrm{mi}$. SE of Seldovia, Chugach Mts.; $59^{\circ} 13^{\prime} \mathrm{N}, 151^{\circ} 03^{\prime} \mathrm{W}$; (map 50). Var. Dick's Harbour.

Name published by Capt. George Vancouver, $\mathrm{RN}$, in 1798 . This bay was originally called "Dick's Harbour" by Capt. Portlock (1789, map opposite p. 1), of the English vessel King George, who, in company with Capt. George Dixon, of the English vessel Queen Charlotte, explored the area in 1786 and 1787.

Dicks Arm: estuary, in Glacier Bay National Monument, trends $2.5 \mathrm{mi}$. SW to $\mathrm{N}$ shore of Cross Sound, at Cape Spencer, $45 \mathrm{mi}$. NW of Hoonah, St. Elias Mts.; $58^{\circ} 12^{\prime} 45^{\prime \prime} \mathrm{N}$, $136^{\circ} 39^{\prime} 30^{\prime \prime} \mathrm{W}$; (map 10).

Named in 1901 by J. F. Pratt, USC\&GS, and published in 1904 on Chart 8304.

Dick's Harbour: bay, see Dick, Port.

Dick Slough: stream, flows NE $14 \mathrm{mi}$, to Eschscholtz Bay, 45 mi. SW of Selawik, Kotzebue- 
Kobuk Low.; $66^{\circ} 14^{\prime}$ N, $161^{\circ} 19^{\prime}$ W; (map 114).

Local name reported by the U.S. Army Corps of Engineen in 1955.

Dickson: locality, on $\mathbf{E}$ bank of Solomon River on Norton Sound, $0.8 \mathrm{mi}$. SE of Solomon, Seward Penin. High.; 64 $33^{\prime} \mathrm{N}, 164^{\circ} 25^{\prime} \mathrm{W}$; (map 95).

This place was extablished about 1903 as the southern terminus and port of the Council Gity and Solomon River Railroad.

Dickson Creek: stream, flows S $1.5 \mathrm{mi}$. to Mason Creek, $8 \mathrm{mi}$. NE of Birches, KokrinesHodzana High.; $65^{\circ} 14^{\prime} 00^{\prime \prime} \mathrm{N}, 153^{\circ} 23^{\prime} 40^{\prime \prime}$ W; (map 107).

Local name reported in 1908 by Maddren (1910, pl. 5), USGS.

Dicks Point: point of land, on left bank of Yukon River at $W$ end of Herman Slough, on NW end of Flora I., 3 mi. E of Birches, KokrinesHodzana High.; $65^{\circ} 08^{\prime} 33^{\prime \prime} \mathrm{N}, 153^{\circ} 26^{\prime} 45^{\prime \prime}$ W; (map 107).

Riverbout pilots' name shown on a 1940 "Navigation Chart of the Tanana-Yukon Rivers," published by the U.S. Department of the Interior.

Dick Vale Greek: stream, see Dick Dale Greek.

Dicky Creek: stream, flows SE $4.5 \mathrm{mi}$. to Yukon River S of Blueberry Ridge, $12 \mathrm{mi}$. ENE of Birches, Kokrines-Hodzana High.; $65^{\circ} 10^{\prime} \mathrm{N}$, $153^{\circ} 09^{\prime} \mathrm{W}$; (map 107 ).

Riverboat pilots' name shown on a 1940 "Navigation Chart of the Tanana-Yukon Rivers," published by the U.S. Department of the Interior.

Dictator Creek: stream, flows S $5 \mathrm{mi}$. to Middle Fork Chandalar River, $14 \mathrm{mi}$. SE of Chandalar, Brooks Ra.; $67^{\circ} 20^{\prime} 15^{\prime \prime} \mathrm{N}, 148^{\circ} 09^{\prime} 30^{\prime \prime} \mathrm{W}$; (map 123).

Prospectors' name obtained in 1909 by A. G. Maddren (in Brooks and others, 1910, pl. 7), USGS.

Didrickson Bay: bay, 0.2 mi. across, on $\mathbf{E}$ shore of Portlock Harbor, $6 \mathrm{mi}$. NW of Chichagof, on W coast of Chichagof I., Alex. Arch.; $57^{\circ} 44^{\prime} \mathrm{N}, 136^{\circ} 11^{\prime} \mathrm{W}$; (map 9). Var. Deep Bay.

Name published in 1928 by USC\&GS on Chart 8258.

Diehm Creek: stream, on $\mathbf{N}$ coast of Attu I., flows $\mathrm{N}$ through Winter Lake $5.5 \mathrm{mi}$. to Blonde Cove, in Steller Cove, Aleutian Is.; 52 58'46" $\mathrm{N}, 172^{\circ} 58^{\prime} 22^{\prime \prime} \mathrm{E}$; (map 13).

Named by the U.S. Army during World War II; published in 1948 by AMS.

Dierovatie Point: point of land, see Dirovati Point.

Dietrich River: stream, flows S $35 \mathrm{mi}$. to join Bettles River to form Middle Fork Koyukuk River, $4.5 \mathrm{mi}$. NW of Wiehl Mtn. and $35 \mathrm{mi}$. WNW of Chandalar, Brooks Ra.; 67 $38^{\prime} 30^{\prime \prime}$ N, $149^{\circ} 45^{\prime} 00^{\prime \prime}$ W; (map 123). Var. Dietrick River, Middle Fork Koyukuk River.

Local name shown on an 1899 fieldsheet by $T$. G. Gerdine, USGS.

Difchahak: locality, on E shore of Norton Sound, $1.5 \mathrm{mi}$. S of Shaktoolik, Nulato Hills; $64^{\circ} 18^{\prime}$ $\mathrm{N}, 161^{\circ} 06^{\prime} \mathrm{W}$; (map 96). Var. Tifcha-ak.
Eskimo name for an archeological site reported in 1948 by Giddings $(1964$, p. 3 ).

Difchakimute: locality, see Chikungamiut.

Difchakimute: locality, see Difjakamiut.

Difficult Creek: stream, flows NE $7 \mathrm{mi}$. to Tuxedni Bay, $58 \mathrm{mi}$. SW of Kenai, Aleutian Ra.; $60^{\circ} 10^{\prime} 40^{\prime \prime} \mathrm{N}, 152^{\circ} 44^{\prime} 10^{\prime \prime} \mathrm{W}$; (map 62 ).

Local name reported in 1958 by USGS.

Difjakamiut: locality, on $\mathrm{N}$ shore of Duchikthluk Bay, $3.5 \mathrm{mi}$. NW of Cape Mendenhall, Nunivak I.; 59 $51^{\prime} \mathrm{N}, 166^{\circ} 16^{\prime} \mathrm{W}$; (map 55). Var. Difchakimute, Difjaxamiut, Pachikmiut.

Eskimo village reported in 1932 by USC\&GS. This may be the same place given as "Pachikmiut" by Calvin J. Lensink, USF\&WS, in 1966.

Digges Sound: bay, see Disenchantment Bay.

Dike Creek: stream, on Kenai Penin., in Kenai Mts., flows W $6 \mathrm{mi}$. to Mystery Creek, $39 \mathrm{mi}$. E of Kenai, Chugach Mts. ; $60^{\circ} 33^{\prime} \mathrm{N}, 150^{\circ} 06^{\prime}$ W; (map 62).

Local name reported in 1944 by USGS.

Dikeman: locality, on $\mathrm{E}$ bank of Iditarod River, $35 \mathrm{mi}$. N of Flat and $48 \mathrm{mi}$. E of Holikachuck, Innoko Low.; $62^{\circ} 57^{\prime} 30^{\prime \prime} \mathrm{N}, 157^{\circ} 59^{\prime} 30^{\prime \prime} \mathrm{W}$; (map 79).

Locally named about 1910 for William A. Dikeman, who with John Beaton discovered gold on Otter Creek on Christmas day, 1908. A post office was maintained here from 1911 to 1915 (Ricks, 1965, p. 16).

Dike Mountain: peak, 6,600 ft., $0.8 \mathrm{mi}$. NW of Mustang Peak and $26 \mathrm{mi}$. $\mathrm{N}$ of Juneau, Coast

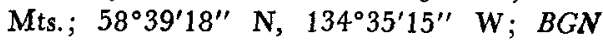
1965; (map 11).

Named in 1964 by personnel of the Juneau Icefield Research Project; published in 1966 by USGS.

Dikna River: stream, see Dishna River.

Dillinger River: stream, heads near Shellabarger Pass in Kichatna Mts., flows W 30 mi. to South Fork Kuskokwim River, $2 \mathrm{mi}$. NE of Farewell Lake and $70 \mathrm{mi}$. SE of McGrath, Kuskokwim Low.; 62 $34^{\prime} 40^{\prime \prime} \mathrm{N}, 153^{\circ} 33^{\prime} 40^{\prime \prime} \mathrm{W}$; (map 80).

Named in 1899 by Lt. J. S. Herron, USA, for Pvt. Gilbert Dillinger, a member of his party.

Dillingham: village, pop. 424, on S side of Snag Point at junc. of Wood and Nushagak Rivers, $360 \mathrm{mi}$. SW of Anchorage, Bristol Bay Low.; $59^{\circ} 02^{\prime} 30^{\prime \prime} \mathrm{N}, 158^{\circ} 27^{\prime} 30^{\prime \prime} \mathrm{W}$; (map 52). Var. Ah-lek-nug-uk, Chogium, Chogiung, Kanakanak, Ke-ek-sel-hak, Nelsonville, Nushagak, Snag Point.

Named in 1904 for William Paul Dilling ham, 1843-1923, Governor of Vermont, 1888-90, and U.S. Senator, 1903-23. In 1903, Dillingham conducted an extensive tour with his Senate subcommittee through Alaska. This was the first comprehensive investigation of Alaska by a congressional committee, and Senators Dillingham and Nelson became for many years the Senate's authorities on Alaska.

This location was originally occupied by an Eskimo village recorded as "Ah-lek-nug-uk," by Ivan Petroff in the 1880 Census and as "Kanakanak" in the 1890 Census; it was also known as "Chogium." The poet office of Dillingham was established a Snag Point in 1904 (Ricks, 1965, p. 16), athough the town of Dillingham was located at what is now known as "Nelsonville," 3 niles to the SW. About 1944 the name "Dillingham" was transferred to this site. Dillinglam is now the principal settlement and source of supply on Nushagak Bay. See Nelmonille.

Dillingham: locality, see Nelsonville.

Dillon Creek: stream, in Bendeleben Mts., flows E $3 \mathrm{mi}$. to Pargon River, $29 \mathrm{ni}$. SW of Imuruk Lake, Seward Penin. High.: $65^{\circ} 13^{\prime}$ N, $163^{\circ}$ 44' W; (map 110).

Prospectors' name published on the 1908 "Map of Seward Peninsula" by Arthur Gibson. Dim Creek: stream, see Jim Creek.

Dime Creek: stream, flows SE $2 \mathrm{mi}$. to O'Brien Creek, $22 \mathrm{mi}$. S of Eagle, Yukon-Tanana High.; $64^{\circ} 28^{\prime} 30^{\prime \prime} \mathrm{N}, 141^{\circ} 13^{\prime} 10^{\prime \prime} \mathrm{W}$; (map 102).

Locai name published in 1956 by USGS

Dime Creek: strsam, flows SE $11 \mathrm{mi}$. to Koyuk River, $6 \mathrm{mi}$. SE of Haycock, Seward Penin. High.; $65^{\circ} 07^{\prime} \mathrm{N}, 16^{\circ} 06^{\prime} \mathrm{W}$; (map 109).

Named about 1913 by prospectors; reported by A. H. Brooks, USGS, in 1915. The prevailing story is that the stream received its name because "about a dimes worth of gold was found in each panning."

Dime Landing: locality, on left bank of the Koyuk River, $6 \mathrm{mi}$. S of Haycock, Seward Penin. High.; $65^{\circ} 07^{\prime} \mathrm{N}, 161^{\circ} 10^{\prime} \mathrm{W}$; (map 109).

River supply landing for Haycock and the mining on Dime Creek, established about 1916.

Dimond, Mount: mountain, 7,202 ft., $4.4 \mathrm{mi} \mathrm{N}$ of Marshall Pass and $26 \mathrm{mi}$. E of Valdez, Chugach Mts.; $61^{\circ} 09^{\prime} 45^{\prime \prime} \mathrm{N}, 145^{\circ} 29^{\prime} 45^{\prime \prime} \mathrm{W}$; $B G N$ 1960; (map 68).

Named in 1960 by Secretary of the Interior F. A. Seaton and U.S. Senator E. L. Bartlett for Anthony Joseph Dimond, 1881-1953, Territorial Senator, Delegate to Congress, and District Judge for the Third Division of Alaska.

Din-al-ee: mountain, see McKinley, Mount.

Din-al-ee: peak, see Foraker, Mount.

Din-az-ee: mountain, see McKinley, Mount.

Din-az-ee: peak, see Foraker, Mount.

Dinglestadt Glacier: glacier, in Kenai Mts., heads on ridge $\mathrm{W}$ of McCarty Glacier, extends SW $3.5 \mathrm{mi}$. to divide; one branch trends NW $9 \mathrm{mi}$. to its terminus at head of Sheep Creek and the other trends SW $5 \mathrm{mi}$. to East Arm Nuka Bay, $50 \mathrm{mi}$. NW of Seldovia, Chugach Mts.; $59^{\circ} 42^{\prime} \mathrm{N}, 150^{\circ} 25^{\prime} \mathrm{W}$ [center]; $B G N 1913$; (map 50).

Named by A. H. Brooks, USGS, in 1913, "for Mate Dinglestadt, who in company with Mate [Ivan] Chernof in 1834, as employees of the Russian American Fur Company, explored a portion of the west coast of Kenai Peninsula."

Dinglishna Hill: hill, $479 \mathrm{ft}$, an W bank of Alexander Creek, $28 \mathrm{mi}$. NW of Anchorage, 
Cook Inlet Low.; $61^{\circ} 26^{\prime} 45^{\prime \prime} \mathrm{N}, 150^{\circ} 36^{\prime} 10^{\prime \prime}$ W; (map 70).

Tanaina Indian name reported in 1958 by USGS.

Dinkum Point: point of land, on SE coast of Ulak I., Aleutian Is. ; $51^{\circ} 20^{\prime} 30^{\prime \prime} \mathrm{N}, 178^{\circ} 54^{\prime}$ $30^{\prime \prime} \mathrm{W}$; (map 16).

Name published on a 1950 AMS map.

Dinkum Rocks: rocks, $1 \mathrm{mi}$. off SW coast of Unalga I., Delarof Is., Aleutian Is.; 51 $34^{\prime}$ N, $179^{\circ} 04^{\prime} \mathrm{W}$; (map 16).

Name published on a 1950 AMS map.

Dinkum Sands: barrier island, $0.2 \mathrm{mi}$. long, between McClure and Midway Is., on Beaufort Sea coast, $31 \mathrm{mi}$. E of Beechey Point, Arctic Plain; $70^{\circ} 25^{\prime} 25^{\prime \prime} \mathrm{N}, 147^{\circ} 45^{\prime} 45^{\prime \prime} \mathrm{W}$; (map 150).

Name published by AMS in 1962.

Dinsmore Creek: stream, flows SW $1.4 \mathrm{mi}$. to Crosby Greek which flows to Kugrupaga River, $4.5 \mathrm{mi}$. SW of Ear Mtn. and $42 \mathrm{mi}$. N of Teller, Seward Penin. High.; $65^{\circ} 52^{\prime} \mathrm{N}, 166^{\circ} 19^{\prime}$ W; (map 111).

Prospectors' name reported in 1901 by T. G. Gerdine (in Collier, 1902, pl. 12) USGS.

Dinty, Lake: lagoon, $0.9 \mathrm{mi}$. long, at $\mathrm{SW}$ end of Lake Louise, $35 \mathrm{mi}$. WNW of Glennallen, Copper River Basin; 62 $19^{\circ} 00^{\prime \prime} \mathrm{N}, 146^{\circ} 35^{\prime}$ $30^{\prime \prime} \mathrm{W}$; (map 83).

Local name reported in 1952 by USGS

Diomede Islands: islands, two, in Bering Strait, $25 \mathrm{mi}$. NW of Cape Prince of Wales, at $W$ end of Seward Penin., Big Diomede I. is in U.S.S.R. and Little Diomede I. is in U.S. $65^{\circ} 47^{\prime} \mathrm{N}, 169^{\circ} 00^{\prime} \mathrm{W} ; B G N 1944$; (map 111). Var. Diamed Islands, Diomedis Islands, Gwosdew Islands, Gwozdeff Islands, Ostrova Gvozdeva, Ostnova Gvozdevy, Ostrova Svataya Diomida, Saint Demetrius Islands, Saint Demoid Islands, Saint Dimitre Islands, Saint Diomede Islands, Saint Diomed Islands.

These islands presumably were first discovered by Capt. Comdr. Vitus Bering, IRN, on August 16, 1728 (OS) and named for Saint Diomede, whose day it was. They were called "O[stro]va Gvozdevy," or "Gvozdev Islands" (Sarichev, 1826, map 4), by the Russians for Michael Gvozdev, a surveyor who explored the Bering Strait in 1730. According to Capt. Beechey (1831, p. 245), RN, Capt. James Cook, RN, "placed three islands in the middle of the strait $* * *$ Kotzebue fancied he saw a fourth ***." The international boundary between the United States and the U.S.S.R. passes between Big Diomede and Little Diomede Islands.

Diomedis Islands: islands, see Diomede Islands.

Dipper Lake: lake, $0.7 \mathrm{mi}$. long, on Kenai Penin. near $\mathrm{W}$ shore of Chickaloon Bay, $44 \mathrm{mi}$. NE of Kenai, Cook Inlet Low.; $60^{\circ} 59^{\prime} 30^{\prime \prime} \mathrm{N}, 150^{\circ}$ $20^{\prime} 30^{\prime \prime} \mathrm{W}$; (map 62).

Named about 1963 by officials of Kenai National Moose Range, for administrative purposes.

Dippy Island: island, $0.1 \mathrm{mi}$. across, in Surveyor Passage, $2.5 \mathrm{mi}$. NW of Chichagof, on $\mathrm{W}$ coast of Chichagof 1., Alex. Arch.; $57^{\circ} 41^{\prime} 30^{\prime \prime} \mathrm{N}$, $136^{\circ} 07^{\prime} 30^{\prime \prime} \mathrm{W}$; BGN 1908; (map 9).

Named by E. F. Dickins, USC\&GS, and published in the 1908 Coast Pilot (p. 174).

Dipyramid: peaks, $6,400 \mathrm{ft}$., two peaks $0.2 \mathrm{mi}$. apart, $1 \mathrm{mi}$. SE of The Citadel and $34 \mathrm{mi}$. N of Juneau, Coast Mts.; $58^{\circ} 45^{\prime} 53^{\prime \prime} \mathrm{N}, 134^{\circ}$. 07'05" W; BGN 1965; (map 11).

Named in 1964 by personnel of the Juneau Icefield Research Project and published in 1966 by USGS

Dirovati Point: point of land, on SE coast of Whale I., $\mathrm{N}$ of Kodiak I.; $57^{\circ} 55^{\prime} 35^{\prime \prime} \mathrm{N}$, $152^{\circ} 45^{\prime} 30^{\prime \prime} \mathrm{W}$; BGN 1939; (map 34). Var. Dierovatie Point, Holes Point, Mys Dyrovatyy.

Transliteration of "M[ys] Dyrovatyy," meaning "full of holes point," name given in 1839 or 1840 by Sub-Lt. Mikhail Murashev, IRN, and published in 1849 on Russian Hydrog. Dept. Chart 1425. Baker (1906, p. 309) published the name "Holes Point." Because of duplication, the name was changed to its present form in 1938 by USC\&GS.

Dirt Glacier: glacier, in Glacier Bay National Monument, heads $1 \mathrm{mi}$. NE of Mount Wright, trends $2 \mathrm{mi}$. NW to its terminus, $0.5 \mathrm{mi}$. S of Adams Inlet and $53 \mathrm{mi}$. NW of Hoonah, St. Elias Mts.; $58^{\circ} 50^{\prime} 00^{\prime \prime} \mathrm{N}, 136^{\circ} 02^{\prime} 30^{\prime \prime} \mathrm{W}$; (map 10).

Descriptive name given in 1892 by Reid, (1892, p. 33), USGS, because "for a mile or more the glacier is so completely covered by debris that no ice can be seen." Since 1892 this glacier has retreated almost three miles and has nearly disappeared.

Dirt Gulch: valley, $2.5 \mathrm{mi}$. long, extends from NW slope of Mount Case NW to Adams Inlet, $2 \mathrm{mi}$. NE of Muir Point and $56 \mathrm{mi}$. NW of Hoonah, St. Elias Mts.; $58^{\circ} 50^{\prime} 20^{\prime \prime} \mathrm{N}$, $136^{\circ} 02^{\prime} 45^{\prime \prime} \mathrm{W}$; (map 10).

Descriptive name given by the American Geographical Society Glacier Bay Expedition of 1941 and published in 1947. This valley was formerly occupied by Dirt Glacier, which has nearly disappeared.

Dirty Glacier: glacier, trends NW $1.5 \mathrm{mi}$. to its treminus $0.7 \mathrm{mi}$. SE of head of Harriman Fiord, 16 mi. NE of Whittier, Chugach Mts.; $60^{\circ} 57^{\prime} 50^{\prime \prime} \mathrm{N}, 148^{\circ} 25^{\prime} 30^{\prime \prime} \mathrm{W}$; BGN 1910; (map 63).

Descriptive name reported in 1908 by Grant and Higgins (1910, pls. 1, 2), USGS.

Disappearing Lake: lake, $0.1 \mathrm{mi}$. across, $0.7 \mathrm{mi}$. W of head of West Fork Texas Creek, $13 \mathrm{mi}$. NW of Hyder, Coast Mts.; 56 $03^{\circ} 05^{\prime \prime} \mathrm{N}$, $130^{\circ} 16^{\prime} 40^{\prime \prime} \mathrm{W}$; (map 7 )

Local descriptive name published in 1928 by USGS.

Disappointment Creek: stream, flows N $2.4 \mathrm{mi}$., between Elephant and Surprise Creek, to Wilson Creek, $6.4 \mathrm{mi}$. E of Marshall, Nulato Hills ; 61 $52^{\prime} 35^{\prime \prime} \mathrm{N}, 161^{\circ} 53^{\prime} 10^{\prime \prime} \mathrm{W}$; (map 73).,

Prospectors' name reported by Harrington (1918, map), USGS, in 1916.

Disappointment Creek: stream, flows SW $18 \mathrm{mi}$. to Talkeetna River, $17 \mathrm{mi}$. NE of Talkeetna,
Talkeetna Mts. ; $62^{\circ} 27^{\prime} 20^{\prime \prime} \mathrm{N}, 149^{\circ} 40^{\prime} 05^{\prime \prime} \mathrm{W}$; (map 82).

Local name recorded in 1906 by T. G. Gerdine and R. H. Sargent, USGS.

Disappointment Creek: stream, flows NW $0.5 \mathrm{mi}$. to California Creek which flows to Bonanza River, between Hanson and Stella Creeks, 9 mi. NW of Solomon, Seward Penin. High.; $64^{\circ} 40^{\prime} \mathrm{N}, 164^{\circ} 37^{\prime} \mathrm{W}$; (map 95).

Prospectors' name reported on a map of Cape Nome gold fields by David Fox, Jr., dated 1901.

Disappointment Creek: stream, flows N $25 \mathrm{mi}$. to Utukok River, W of Lookout Ridge, $95 \mathrm{mi}$. $\mathrm{S}$ of Wainwright, Arctic Slope; $69^{\circ} 15^{\prime} \mathrm{N}$, $159^{\circ} 51^{\prime} \mathrm{W}$; $B G N$ 1925; (map 144).

Named by W. T. Foran, USGS, in 1924, for his disappointment "when it was discovered that the creek did not head in a pass through the De Long Mts." (in Chapman and Sable, 1960, p. 53).

Discher Escarpment: ridge, $1.2 \mathrm{mi}$. long, on Attu I., $0.8 \mathrm{mi}$. $\mathrm{N}$ of Temnac Bay, Aleutian Is.; $52^{\circ} 50^{\prime} 45^{\prime \prime} \mathrm{N}, 173^{\circ} 04^{\prime} 00^{\prime \prime} \mathrm{E}$; (map 13).

Name shown on an AMS map published in 1948.

Dischkatat: locality, see Dishkakat.

Dischna River: stream, see Dishna River.

Discontented Pup: stream, flows W 1 mi. to Little Eldorado Creek, $16 \mathrm{mi}$. NE of Fairbanks, Yukon-Tanana High.; 65 $03^{\prime} 50^{\prime \prime}$ N, 147 $32^{\prime}$ $10^{\prime \prime} \mathrm{W}$; (map 105).

Local name published by USGS in the 1950's.

Discoverer Bay: bay, 1 mi. across, part of Perenosa Bay, on $N$ coast of Afognak $I$., $N$ of Kodiak I.; $58^{\circ} 21^{\prime} \mathrm{N}, 152^{\circ} 24^{\prime} \mathrm{W}$; (map 43).

Named by USC\&GS in 1934 for one of its ships, the Discoverer.

Discoverer Island: island, $1 \mathrm{mi}$. long, in Discoverer Bay, part of Perenosa Bay, on $\mathrm{N}$ coast of Afognak I., N of Kodiak I.; 58 $20^{\prime} 00^{\prime \prime} \mathrm{N}$, $152^{\circ} 23^{\prime} 30^{\prime \prime} \mathrm{W}$; (map 43).

Named by USC\&GS in 1934 for one of its ships, the Discoverer.

Discovery: locality, on $\mathrm{N}$ bank of Otter Creek, $2 \mathrm{mi}$. E of Flat and $62 \mathrm{mi}$. NE of Holy Cross, Kilbuck-Kuskokwim Mts.; $62^{\circ} 27^{\prime} 10^{\prime \prime}$ N, $157^{\circ}$ $56^{\prime} 00^{\prime \prime} \mathrm{W}$; (map 79)

Mining camp, now abandoned, reported in 1912 by H. M. Eakin, USGS ; named after the Discovery claim located by W. A. Dikeman and John Beaton on Christmas day, 1908. Population was about 50 in 1912, excluding miners.

Discovery: locality, along Seward Peninsula RR., about $3 \mathrm{mi}$. N of Nome, Seward Penin. High.; $64^{\circ} 32^{\prime} \mathrm{N}, 165^{\circ} 24^{\prime} \mathrm{W}$; (map 94).

Site of a mining camp and RR. station. The Wild Goose RR. (later Seward Peninsula RR.) was built from Nome to Discovery in the summer of 1900 (Cole, C. O., 1953, p. 14).

Discovery: village, see Ester.

Discovery Bay: bay, see Snug Harbor.

Discovery Creek: stream, flows $4.3 \mathrm{mi}$. $\mathrm{N}$ to Chitina River W of Coffee Creek, $32 \mathrm{mi}$. SE 
of McCarthy, St. Elias Mts.; $61^{\circ} 04^{\prime} 30^{\prime \prime} \mathrm{N}$, $142^{\circ} 14^{\prime} 40^{\prime \prime} \mathrm{W}$; (map 67).

Name obtained from prospectors, reported in 1915 by F. H. Moffit, USGS.

Discovery Creek: stream, heads on $\mathrm{S}$ slope of Mount Hamilton, flows NE and NW $65 \mathrm{mi}$. to Kuskokwim River, $15 \mathrm{mi}$. W of Aniak, Yukon-Kuskokwim Delta; $61^{\circ} 31^{\prime} 05^{\prime \prime} \mathrm{N}, 160^{\circ}$ 02'40" W; (map 73).

Local name reported by USC\&GS in 1948.

Discovery Creek: stream, flows $\mathbf{S} 2 \mathrm{mi}$. to Fortymile River, $37 \mathrm{mi}$. S of Eagle, Yukon-Tanana High.; $64^{\circ} 15^{\prime} 30^{\prime \prime} \mathrm{N}, 141^{\circ} 06^{\prime} 20^{\prime \prime} \mathrm{W}$; (map 102).

Named by prospectors; reported in 1912 by C. E. Ellsworth, USGS.

Discovery Creek: stream, flows $3 \mathrm{mi}$. W to Big Four Creek which flows to Casadepaga River, $21 \mathrm{mi}$. NE of Solomon, Seward Penin. High.; $64^{\circ} 48^{\prime} \mathrm{N}, 164^{\circ} 05^{\prime} \mathrm{W}$; (map 95).

Prospectors' name reported on a map of Cape Nome gold fields by David Fox, Jr., dated 1901.

Discovery Creek: stream, flows N $6 \mathrm{mi}$. to Dome Creek, $24 \mathrm{mi}$. NW of Solomon, Seward Penin. High.; $64^{\circ} 53^{\prime} \mathrm{N}, 164^{\circ} 42^{\prime} \mathrm{W}$; (map 95).

Prospectors' name reported on a map of Cape Nome gold fields by David Fox, Jr., dated 1901.

Discovery Creek: stream, flows NW $47 \mathrm{mi}$. to Lower Mouth Birch Creek, $24 \mathrm{mi}$. SW of Fort Yukon, Yukon Flats; $66^{\circ} 16^{\prime} 30^{\prime \prime} \mathrm{N}, 145^{\circ} 43^{\prime}$ $30^{\prime \prime} \mathrm{W}$; (map 119).

Prospectors' name published by USG\&GS in 1898.

Discovery Creek: stream, heads on Niitltoktalogi Mtn., flows NE and SE $17 \mathrm{mi}$. to Koyukuk River, $37 \mathrm{mi}$. NE of Hughes, Hogatza High.; $66^{\circ} 25^{\prime} \mathrm{N}, 153^{\circ} 18^{\prime} \mathrm{W}$; (map 116).

Local name recorded at Hughes in 1956 by Orth.

Discovery Creek: stream, heads $27 \mathrm{mi}$. NW of Birthday Pass, flows SE $30 \mathrm{mi}$. to Awuna River, $120 \mathrm{mi}$. SE of Wainwright, Arctic Slope; $69^{\circ} 11^{\prime} \mathrm{N}, 157^{\circ} 21^{\prime} \mathrm{W}$; (map 143 ).

Named by geologists in the 1950's, and published by USGS in 1956.

Discovery Creek: stream, see Discovery Fork.

Discovery Creek: stream, see Flambeau River.

Discovery Fork: stream, flows N $3 \mathrm{mi}$. to join Teddys Fork to form American Creek, $10 \mathrm{mi}$. SW of Eagle, Yukon-Tanana High.; 64 $4^{\circ} 41^{\prime} \mathrm{N}$, $141^{\circ} 19^{\prime}$ W; (map 102). Var. Discovery Creek.

Prospectors' name obtained in 1898 by E. C. Barnard, USGS.

Discovery Fork Anvil Creek: stream, flows SW 2 mi., joins South Fork to form Anvil Creek, $4 \mathrm{mi}$. NE of Nome, Seward Penin. High.

Prospectors' name published in 1900 by Schrader (1900c, p. 16), USGS. Subsequent maps show a different drainage pattern at the head of Anvil Creek.

Discovery Gulch: ravine, trends E 2 mi. to Deadwood Creek, $34 \mathrm{mi}$. SW of Gircle, YukonTanana High.; $65^{\circ} 28^{\prime} \mathrm{N}, 144^{\circ} 56^{\prime} \mathrm{W}$; (map 104).
Named by prospectors; reported in 1909 by B. L. Johnson (in Brooks and others, 1910, fig. 5), USGS.

Discovery Point: point of land, on SE coast of Knight I., $14 \mathrm{mi}$. SE of Chenega, Chugach Mts.; $60^{\circ} 14^{\prime} 45^{\prime \prime} \mathrm{N}, 147^{\circ} 42^{\prime} 00^{\prime \prime} \mathrm{W}$; $B G N$ 1910; (map 63).

Local name reported in 1910 by USC\&GS. Discovery Pup: ravine, heads on Gold Hill, in Nutzotin Mts., extends NE $0.3 \mathrm{mi}$. to Gold Run Creek, Alaska Ra.; $62^{\circ} 07^{\prime} 24^{\prime \prime} \mathrm{N}$, $141^{\circ} 54^{\prime} 00^{\prime \prime} \mathrm{W}$; (map 84).

Name used'by prospectors and reported in 1914 by S. R. Capps (in Brooks and others, 1915 , p. 219), USGS. The generic "Pup" is a local term for a small gulch.

Discovery Pup: stream, flows SW $1.4 \mathrm{mi}$. to South Fork Hess Creek, $7 \mathrm{mi}$. NE of Livengood, Yukon-Tanana High.; $65^{\circ} 36^{\prime} 50^{\prime \prime} \mathrm{N}$, $148^{\circ} 22^{\prime} 30^{\prime \prime} \mathrm{W}$; (map 105).

Named by prospectors; reported in 1916 by J. B. Mertie, Jr. (in Brooks and others, 1918, pl. 13), USGS.

Discovery Rock : rocks, see Discovery Rocks.

Discovery Rocks: rocks, in Chiniak Bay, $2 \mathrm{mi}$. S of Kodiak, on E coast of Kodiak I. ; $57^{\circ} 45^{\prime} 25^{\prime \prime}$ N, $152^{\circ} 25^{\prime} 00^{\prime \prime} \mathrm{W}$; (map 34). Var. Atkritoi, Discovery Rock, Otkryt Kamen.

Translation of the name "Otkryt Kamen," published by Lt. Sarichev (1826, map 16), IRN.

Disenchantment Bay: bay, $3 \mathrm{mi}$. across, extends SW $10 \mathrm{mi}$. from mouth of Russell Fiord to Point Latouche, at head of Yakutat Bay, St. Elias Mts.; $59^{\circ} 55^{\prime} \mathrm{N}, 139^{\circ} 40^{\prime} \mathrm{W}$; (map 46). Var. Bahia de las Bancas, Digges Sound, Puerto del Desengaño.

Named "Puerto del Desengaño," meaning "bày of disenchantment," in Spanish, by Capt. Alessandro Malaspina in 1792 (Galiano, 1802, Atlas, map 3). The name refers to the frustration of his hopes of finding a passage to the Atlantic-one of the purposes of his voyage. Sailing $\mathbf{N}$ from Sitka in 1791, he reached the entrance to Yakutat Bay, which he hoped was the passage he sought. He sailed up the bay as far as Haenke I., at which point he found the passage blocked by ice. The bay was called "Digges Sound" by Lt. Peter Puget, RN, and "Bahia de las Bancas" by Capt. Malaspina in reference to the ice (U.S. Coast and Geodetic Survey, 1883, p. 210).

Dishkakat: locality, on S bank of Innoko River, $6 \mathrm{mi}$. W of junc. of Dishna River, $45 \mathrm{mi}$. NW of Ophir and $73 \mathrm{mi}$. NW of McGrath, Innoko Low.; 633 $37^{\prime} 20^{\prime \prime} \mathrm{N}, 157^{\circ} 29^{\prime} 00^{\prime \prime} \mathrm{W}$; (map 90). Var. Deekakat, Dischkatat, Dishkaket, Innoko.

Dishkakat had been an Ingalik Indian settlement for many years prior to the first rush of prospectors to the valley in 1907. Those prospectors who came up the Innoko by boat or across from Kaltag by winter trail naturally made this place a stopping point, as it afforded the questionable comforts of established habitations, dried salmon for dog food in winter, and the services of Indians as guides. The "Innoko" post office was maintained here from 1907 to 1915 . The place is now abandoned.

Dishkakat River: stream, see Dishna River.

Dishkaket: locality, see Dishkakat.

Dishna River: stream, heads in Kuskokwim Mts. at $62^{\circ} 32^{\prime} \mathrm{N}, 157^{\circ} 31^{\prime} \mathrm{W}$, flows $\mathrm{N} 60 \mathrm{mi}$. to Innoko River, $40 \mathrm{mi}$. NW of Ophir and 68

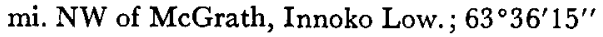
N, $157^{\circ} 17^{\prime} 00^{\prime \prime} \mathrm{W}$; (map 90). Var. Deetna River, Dichna River, Dikna River, Dischna River, Dishkakat River, Ditna River.

Ingalik Indian name recorded as "Deetna," or "Deet River," in 1907 by A. H. Brooks, USGS. In 1908 the name was spelled "Dischna" and "Dishna" by A. G. Maddren, USGS, and "Dichna" on a post-route map, probably a corruption of "Dikna" by the prospectors.

Dishno Pond: lake, $1,300 \mathrm{ft}$. long, $\mathrm{N}$ of Ship Creek, $8.2 \mathrm{mi}$. NE of Anchorage, Cook Inlet Low.; $61^{\circ} 14^{\prime} 08^{\prime \prime} \mathrm{N}, 1^{\circ} 9^{\circ} 38^{\prime} 50^{\prime \prime} \mathrm{W}$; (map 69).

Local name reported in 1962 by USGS.

Disk Island: island, extends N-S 2 mi., between Foul Pass and Lower Passage, in Prince William Sound, $42 \mathrm{mi}$. SE of Whittier, Chugach Mts.; $60^{\circ} 30^{\prime} \mathrm{N}, 147^{\circ} 39^{\prime} \mathrm{W}$; BGN 1908; (map 63).

Descriptive name given in 1908 by USC\&GS. Disston, Mount: peak, see Hunter, Mount. Disston, Mount: peak, see Huntington, Mount.

Distant Island: island, see Otstoia Island.

Distant Point: point of land, $S$ point of entrance to Hood Bay, on W coast of Admiralty I., Alex. Arch.; 57 $24^{\prime} 00^{\prime \prime} \mathrm{N}, 134^{\circ} 34^{\prime} 30^{\prime \prime} \mathrm{W}$; (map 9).

Named by Comdr. R. W. Meade, USN, and published on Chart 225.

Distant Point: point of land, see Dalnoi Point.

Distik, Mount: mountain, 3,801 ft., $5 \mathrm{mi}$. SW of Mole Harbor, on E central Admiralty I., Alex. Arch.; 57 $35^{\prime} 45^{\prime \prime} \mathrm{N}, 134^{\circ} 08^{\prime} 00^{\prime \prime} \mathrm{W}$; $B G N$ 1948; (map 9). Var. Mount Distick, Shadeetic Mountain, Shadistik.

Tlingit Indian name associated with the mountain reported in 1926 by $\mathrm{H}$. J. Coolidge. "Mount Distick is a mountain that the Indians say was the place where a squaw and her son took refuge at the time of the great floods. Only by going to the top of the mountain were they able to survive the water which drowned all other people and flooded the earth."

Distin, Mount: mountain, 2,115 ft., $18 \mathrm{mi}$. NE of Nome, Seward Penin. High.; $64^{\circ} 46^{\prime} \mathrm{N}, 165^{\circ}$ 23' W; (map 94). Var. Mount Testin.

Prospectors' name reported in 1900 by E. C. Barnard (in Brooks, 1901, pl. 17), USGS.

Distin Lake: lake, $2.5 \mathrm{mi}$. long, $11 \mathrm{mi}$. NE of Angoon, on $\mathrm{W}$ central Admiralty I., Alex. Arch.; 57 $38^{\prime} \mathrm{N}, 134^{\circ} 23^{\prime} \mathrm{W}$; (map 9).

Named for William L. Distin who was appointed Suveyor General for Alaska in 1897 and who served until 1913.

Distin Peak: mountain, 6,508 ft., $9.6 \mathrm{mi}$. NW of junc. of Happy and Skwentna Rivers, $80 \mathrm{mi}$. SW of Talkeetna, Alaska Ra.; $62^{\circ} 05^{\prime} 25^{\prime \prime} \mathrm{N}$, $152^{\circ} 32^{\prime} 20^{\prime \prime} \mathrm{W}$; (map 81). 
Named in 1898 by W. S. Post, USGS. This could be named for Henry Disston. See Hunter, Mount.

Diston, Mount: peak, see Huntington Mount.

Distress Cove: bay, see Bazan, Port.

Ditch, The: water passage, between Trunk Point and Eider Reef, E coast of Tanaga I., Aleutian Is. ; $51^{\circ} 46^{\prime} 00^{\prime \prime} \mathrm{N}, 177^{\circ} 46^{\prime} 30^{\prime \prime} \mathrm{W}$; (map 17).

Name published by USC\&GS in 1956 on Chart 9145.

Ditna River: stream, see Dishna River.

Ditto Islands: islands, two, each $500 \mathrm{ft}$. long, in Spiridon Bay, on NW coast of Kodiak I.; $57^{\circ} 39^{\prime} 15^{\prime \prime} \mathrm{N}, 153^{\circ} 40^{\prime} 40^{\prime \prime} \mathrm{W}$; BGN 1931; (map 34).

Descriptive name given in 1931 by USC\&GS, "because these islands are nearby, the same size and shape, and resemble ditto marks."

Diver Bay: estuary, extends SE 2.5 mi. off Pacific Ocean on NE coast of Dall I., Alex. Arch.; $55^{\circ} 11^{\prime} \mathrm{N}, 133^{\circ} 15^{\prime} \mathrm{W}$; BGN 1928; (map 4). Var. Divers Bay.

So named by Capt. Patton, USC\&GS, in 1927, "because of its proximity to Diver Island."

Diver Islands, islands, a group $0.6 \mathrm{mi}$. long, between Diver Bay and Pacific Ocean, off NW coast of Dall I., Alex. Arch.; $55^{\circ} 10^{\prime} 40^{\prime \prime} \mathrm{N}$, $133^{\circ} 15^{\prime} 30^{\prime \prime} \mathrm{W}$; (map 4). Var. Divers Islands.

Named "Divers Islands" in 1914 by USC\&GS.

Diver Point: point of land, between Bobs and Diver Bays, on NW coast of Dall I., Alex. Arch.; 55 $11^{\prime} \mathrm{N}, 133^{\circ} 14^{\prime} \mathrm{W}$; (map 4).

Named in 1927 by Capt. R. S. Patton, USC\&GS, "because of its proximity to Diver Islands and Diver Bay."

Divers Bay: estuary, see Diver Bay.

Divers Islands: islands, see Diver Islands.

Divide: locality, on Kenai Penin., mile 12.0 on The Alaska RR., $10 \mathrm{mi}$. NE of Seward, Chugach Mts.; $60^{\circ} 15^{\prime} 12^{\prime \prime} \mathrm{N}, 149^{\circ} 21^{\prime} 00^{\prime \prime} \mathrm{W}$; (map 63). Var. Summit Station.

Former station on The Alaska RR., now shown as a site of two or three buildings. The name was listed in the 1922 Railway Index.

Divide, Mount: mountain, 4,290 ft., $2.7 \mathrm{mi}$. NW of Threesome Mtn., in Glacier Bay National Monument, $56 \mathrm{mi}$. NW of Hoonah, St. Elias Mts.; $58^{\circ} 36^{\prime} \mathrm{N}, 136^{\circ} 40^{\prime} \mathrm{W}$; (map 10 ).

Local name reported in 1951 by USGS.

Divide, Point: point of land, between Port Moller and Herendeen Bay, near the SW end of Alaska Penin., Aleutian Ra.; 55 $53^{\prime} \mathrm{N}, 160^{\circ}$ $47^{\prime} \mathrm{W}$; (map 28).

Named by USBF; shown on an 1890 USC\&GS chart.

Divide Creek: stream, heads $3 \mathrm{mi}$. SW of Placer River Valley, flows NW 3 mi. to Center Creek, $16 \mathrm{mi}$. SE of Sunrise, Chugach Mts.; $60^{\circ} 41^{\prime}$ $55^{\prime \prime} \mathrm{N}, 1^{\circ} 9^{\circ} 11^{\prime} 20^{\prime \prime} \mathrm{W}$; (map 63). Var. Center Creek.

Local name published in 1899 by USGS. The name at that time was applied to the complete stream reaching to Sixmile Creek, but now only applies to a short tributary of Center Creek.

Divide Creek: stream, heads in a glacier, flows W $5 \mathrm{mi}$. to Canyon Creek, $0.1 \mathrm{mi}$. S of mouth of Pass Creek and $65 \mathrm{mi}$. ENE of Valdez, Chugach Mts.; 61 $22^{\prime} 25^{\prime \prime} \mathrm{N}, 144^{\circ} 22^{\prime} 15^{\prime \prime} \mathrm{W}$; (map 68).

Local name reported in 1912 by USGS.

Divide Creek: stream, flows $9 \mathrm{mi}$. SE to White River, $2.5 \mathrm{mi}$. W of Pingpong Mtn. and 55 mi. NE of McCarthy, Alaska Ra.; 61 ${ }^{\circ} 44^{\prime} 30^{\prime \prime}$ N, $141^{\circ} 26^{\prime} 30^{\prime \prime} \mathrm{W}$; (map 67).

Local name obtained by USGS and published on maps since 1954.

Divide Creek: stream, heads in Dutch Hills, flows E 2.4 mi. to join Canyon Creek to form Long Creek, $27 \mathrm{mi}$. NW of Talkeetna, Alaska Ra.; 62 $35^{\prime} 25^{\prime \prime} \mathrm{N}, 150^{\circ} 44^{\prime} 55^{\prime \prime} \mathrm{W}$; (map 81).

Prospectors' name reported in the 1930's by USGS.

Divide Creek: stream, flows S $6 \mathrm{mi}$ to South Fork Goodpaster River, $50 \mathrm{mi}$. NE of Big Delta, Yukon-Tanana High.; $64^{\circ} 13^{\prime} 30^{\prime \prime} \mathrm{N}$, $144^{\circ} 11^{\prime} 55^{\prime \prime} \mathrm{W}$; (map 101).

Local name published in 1956 by USGS and applied to a stream now known as "Serpentine Creek"; reapplied by USGS in 1959 to above location.

Divide Creek: stream, flows NE $1 \mathrm{mi}$. to Nome River, $23 \mathrm{mi}$. NE of Nome, Seward Penin. High.; $64^{\circ} 50^{\prime} 20^{\prime \prime} \mathrm{N}, 165^{\circ} 15^{\prime} 45^{\prime \prime} \mathrm{W}$; (map 94).

Prospectors' name shown on the 1902 "Map of the Nome and Snake River Country" by J. M. Davidson.

Divide Creek: stream, flows SW $5.6 \mathrm{mi}$. to Cottonwood Creek which flows to Goodhope River, $16 \mathrm{mi}$. NW of Imuruk Lake, Seward Penin. High.; $65^{\circ} 48^{\prime} \mathrm{N}, 163^{\circ} 32^{\prime} \mathrm{W} ; B G N$ 1952; (map 110). Var. David Creek.

Prospectors' name reported in 1901 by USGS (in Collier, 1902, pl. 12).

Divide Creek: stream, see Center Creek.

Divide Head: point of land, between Dora Bay and South Arm Gholmondeley Sound, on SE coast of Prince of Wales I., Alex. Arch.; $55^{\circ} 14^{\prime} \mathrm{N}, 132^{\circ} 16^{\prime} \mathrm{W}$; (map 4).

Named by local fishermen and reported in 1904 by H. C. Fassett, USBF.

Divide Island: island, $1 \mathrm{mi}$. long, in Shakan Bay between Prince of Wales and Kosciusko Is., Alex. Arch.; $56^{\circ} 09^{\prime} 30^{\prime \prime} \mathrm{N}, 133^{\circ} 31^{\prime} 00^{\prime \prime} \mathrm{W}$; (map 6)

Descriptive name given in 1886 by Lt. J. M. Helm, USN, because it divides the bay into two parts.

Divide Island: island, see Delenia Island.

Divide Lake: lake, $0.5 \mathrm{mi}$. across, $8 \mathrm{mi}$. $\mathrm{N}$ of Pavlof Volcano, near the SW end of Alaska Penin., Aleutian Ra.; $55^{\circ} 32^{\prime} 00^{\prime \prime}$ N, $161^{\circ} 54^{\prime}$ 30 " W ; (map 28).

Reported in 1929 by USGS.

Divide Lake: lake, $0.5 \mathrm{mi}$. long, on $\mathrm{N}$ end of Kenai Penin., between Portage Lake and Passage Canal, $2.5 \mathrm{mi}$. SE of Whittier, Chugach Mts.; $60^{\circ} 46^{\prime} 00^{\prime \prime} \mathrm{N}, 148^{\circ} 45^{\prime} 30^{\prime \prime} \mathrm{W}$; (map 63).

Local name reported in 1951 by USGS.
Divide Mountain: mountain, 5,195 ft., in Mount McKinley National Park W of Toklat River, $12 \mathrm{mi}$. SW of Sable Mtn., Alaska Ra.; $63^{\circ} 29^{\prime} 40^{\prime \prime} \mathrm{N}, 150^{\circ} 00^{\prime} 00^{\prime \prime} \mathrm{W}$; (map 88).

Local name shown on a 1916 fieldsheet by C. E. Giffin, USGS.

Divide Mountain: mountain, 5,125 ft., $4 \mathrm{mi}$. W of Alaska-Canada boundary, $59 \mathrm{mi}$. of Northway Junction, Yukon-Tanana High.; 63 $49^{\prime}$ N, $141^{\circ} 09^{\prime} \mathrm{W}$; (map 85$)$.

Name reported in 1956 by USGS; so named because it separates two important drainage systems.

Dividend Creek: stream, flows NW $0.5 \mathrm{mi}$. to join Oversight Creek to form Telegram Creek, in Pilgrim River basin, $21 \mathrm{mi}$. N of Solomon, Seward Penin. High.; 64 $51^{\prime} 45^{\prime \prime} \mathrm{N}$, $164^{\circ} 34^{\prime} 00^{\prime \prime} \mathrm{W}$; (map 95).

Prospectors' name reported in 1908 by $\mathbf{P}$. S. Smith (in Brooks and others, 1909, pl. 10), USGS.

Divide Peak: mountain, see Traverse Peak.

Divider Mountain: mountain ridge, trends SW 6 mi. forming a divide between Columbia Glacier and its East Branch, $22 \mathrm{mi}$. NW of Valdez, Chugach Mts.; $61^{\circ} 14^{\prime} 00^{\prime \prime} \mathrm{N}$, $146^{\circ} 52^{\prime} 30^{\prime \prime} \mathrm{W}$; BGN 1965; (map 68).

This feature was probably named in 1959 by L. E. Nielsen (1963, p. 135).

Dividing Point: point of land, on island at junc. of Kozherevsky and Yukon Rivers, $7.2 \mathrm{mi}$. NW of Holy Cross, Innoko Low.; 62 ${ }^{\circ} 14^{\prime} 40^{\prime \prime}$ $\mathrm{N}, 159^{\circ} 58^{\prime} 40^{\prime \prime} \mathrm{W}$; (map 78).

Local name reported in 1916 by G. L. Harrington and R. H. Sargent (in Harrington, 1918 , pl. 1), USGS.

Divining Creek: stream, flows W $2 \mathrm{mi}$. to Snake River, $13 \mathrm{mi}$. $\mathrm{N}$ of Nome, Seward Penin. High.; $64^{\circ} 40^{\prime} \mathrm{N}, 165^{\circ} 27^{\prime} \mathrm{W}$; (map 94).

Prospectors' name published on the 1900 "Map of Nome Peninsula" by J. M. Davidson and B. D. Blakeslee.

Divining Creek: stream, flows $\mathrm{S}$ to Bering Sea, about $35 \mathrm{mi}$. NW of Nome, Seward Penin. High.; (map 94).

Prospectors' name reported on the 1900 "Map of Nome Peninsula" by J. M. Davidson and B. D. Blakeslee; this feature has not been positively identified.

Division Island: island, $0.3 \mathrm{mi}$. long, in Nuka Passage, between Nuka I. and Kenai Penin., $36 \mathrm{mi}$. $\mathbf{E}$ of Seldovia, Chugach Mts.; $59^{\circ} 25^{\prime} 20^{\prime \prime} \mathrm{N}, 150^{\circ} 41^{\prime} 30^{\prime \prime} \mathrm{W}$; (map 50).

Named by USC\&GS in 1931, "because it stands nearly in the middle of Nuka Passage."

Division Point: point of land, $\mathbf{N}$ tip of Lydonia I., $4.5 \mathrm{mi}$. NW of Chichagof, on $\mathrm{W}$ coast of Chichagof I., Alex. Arch.; 57 $43^{\prime} 02^{\prime \prime} \mathrm{N}$, $136^{\circ} 10^{\prime} 30^{\prime \prime} \mathrm{W}$; (map 9).

Name published in 1928 by USC\&GS on Chart 8258.

Division Point: point of land, on E coast of Kenai Penin., between Derickson Bay and Blue Fiord, $25 \mathrm{mi}$. SE of Whittier, Chugach Mts.; $60^{\circ}$ $29^{\prime} 25^{\prime \prime} \mathrm{N}, 148^{\circ} 16^{\prime} 00^{\prime \prime} \mathrm{W}$; (map 63).

Local name published in 1950 by USC\&GS. Dix Bow Basin: valley, see Lurvey Basin. Dix Creek: stream, see Lurvey Creek. 
Dix Gulch: ravine, tributary to Gold Creek at Silverbow Basin, 2 mi. W of Juneau, Coast Mts.; $58^{\circ} 18^{\prime} \mathrm{N}, 134^{\circ} 20^{\prime} \mathrm{W}$; (map 11).

Name first found in mining records in 1881 when John Dix located mining claims in the area. Dix was at Sitka in 1880 and moved to Juneau in 1881.

Dix Gulch: stream, see Lurvey Creek.

Dixie Creek: stream, flows NE $1.4 \mathrm{mi}$. to Independence Creek in Kugruk River basin, $24 \mathrm{mi}$. E of Imuruk Lake, Seward Penin. High.; $65^{\circ} 32^{\prime} \mathrm{N}, 162^{\circ} 22^{\prime} \mathrm{W}$; (map 110).

Prospectors' name reported in 1903 by $\mathrm{D}$. C. Witherspoon (in Moffit, 1905, pl. 2), USGS.

Dixie Pass: pass, at head of Rock Creek, $7 \mathrm{mi}$. W of Kuskulana Glacier terminus, $35 \mathrm{mi}$. NW of McCarthy, Wrangell Mts.; $61^{\circ} 37^{\prime} 45^{\prime \prime} \mathrm{N}$, $143^{\circ} 54^{\prime} 00^{\prime \prime} \mathrm{W}$; (map 67).

Local name reported in 1912 by $D$. C. Witherspoon, USGS.

Dixon, Mount: mountain, 1,505 ft., $6 \mathrm{mi}$. W of Bermudez Bluff and $26 \mathrm{mi}$. NE of Solomon, Seward Penin. High.; $64^{\circ} 56^{\prime} \mathrm{N}, 164^{\circ} 15^{\prime} \mathrm{W}$; (map 95). Var. Nipple Mountain.

Local name reported in 1905 by T. G. Gerdine, USGS; a 1900 map by S. E. King showed the variant.

Dixon Creek: stream, flows SE $2.3 \mathrm{mi}$. to Casadepaga River, $23 \mathrm{mi}$. NE of Solomon, Seward Penin. High.; $64^{\circ} 53^{\prime} \mathrm{N}, 164^{\circ} 13^{\prime} \mathrm{W}$; (map 95).

Prospectors' name reported in 1900 by E. C. Barnard (in Brooks, 1901, pl. 17), USGS.

Dixon Creek: stream, see Dixon River.

Dixon Entrance: water passage, between Queen Charlotte Is., British Columbia, Canada, and Alex. Arch.; $54^{\circ} 30^{\prime} \mathrm{N}, 133^{\circ} 00^{\prime} \mathrm{W}$; (map 1). Var. Boundary Strait, Buccleugh. Sound, Bucclugh Sound, Dixon's Straits, Douglass Entrance, Entrada de Perez, Graenzstrasse, Granitsa Channel, Granitsy Strait, Hancocks Straits, Kaigani Strait, Kaygany Strait.

Named in 1787 by Sir Joseph Banks for Capt. George Dixon, who visited it and called it "Dixons Straits" (Wagner, 1937, p. 385). Baker (1906, p. 220) wrote "Dixon's Entrance was discovered by the Spaniards [probably Juan Perez], in 1774, and called Entrada de Perez [Perez Entrance]. ** Capt. Meares at about the same time named it Douglass Entrance, after Capt. William Douglass (or Douglas) *** To its northeastern part he applied the name Buccleugh Sound, which he also spelled Bucclugh ***." The Tlingit Indian name was published in Russian as Prol[iv] Kaygany, or "Kaygany Strait," by Capt. Tebenkov (1852, map 9), IRN. The name "Proliv Granitsy," meaning "boundary strait," was published for this feature in 1853 on Russian Hydrog. Dept. Chart 1493. See Wagner (1937, p. 461-Hancocks Straits).

Dixon Glacier: glacier, on Kenai Penin., trends NW $5 \mathrm{mi}$. to tributary of Martin River, $21 \mathrm{mi}$. E of Homer, Chugach Mts.; 59 $41^{\prime} 30^{\prime \prime} \mathrm{N}$, 150'56'30" W; BGN 1913; (map 50).

Named by A. H. Brooks, USGS, in 1913, for Capt. George Dixon, commander of the
English vessel Queen Charlotte, who with Capt. Nathaniel Portlock, commander of the English vessel King George, did extensive exploration along the south coast of Alaska in 1786 and 1787

Dixon Harbor: bay, $2 \mathrm{mi}$. across, $\mathrm{E}$ of Astrolabe Penin., in Glacier Bay National Monument, 55 mi. NW of Hoonah, St. Elias Mts.; 58 20 $0^{\prime} 15^{\prime \prime}$ $\mathrm{N}, 136^{\circ} 52^{\prime} 00^{\prime \prime} \mathrm{W}$; (map 10).

Name published by USC\&GS in 1889 probably for Capt. George Dixon, who had accompanied Capt. Cook, RN, on his last voyage in 1778 and who, with Capt. Nathaniel Portlock, explored this area in 1787.

Dixon River: stream, in Glacier Bay National Monument, heads in branch of Brady Glacier, flows $9 \mathrm{mi}$. $\mathrm{S}$ to Dixon Harbor, on Gulf of Alaska, St. Elias Mts.; 58 $22^{\prime} 05^{\prime \prime}$ N, $136^{\circ}$ $50^{\prime} 35^{\prime \prime}$ W; BGN 1962; (map 10). Var. Dixon Creek.

Local name reported by NPS in 1961 . Name was derived from Dixon Harbor.

Dixon's Straits: water passage, see Dixon Entrance.

Dix Point: point of land, $\mathrm{N}$ point of entrance to American Bay, on $\mathrm{E}$ coast of Dall I., Alex. Arch.; 54 $51^{\prime} 20^{\prime \prime} \mathrm{N}, 132^{\circ} 48^{\prime} 45^{\prime \prime} \mathrm{W}$; (map 1). Var. Graham Point.

Named in 1882 by W. H. Dall, USC\&GS, for Lt. F. Dix Bolles, USN. This point was called "Graham" in 1880 by Sheldon Jackson.

Dlugatauzaratlna: stream, see Fish Choked Greek.

Doame River: stream, heads in Upper Doame Lake, flows $17 \mathrm{mi}$. N and SW to Gulf of Alaska, at $\mathbf{E}$ end of Dry Bay, $59 \mathrm{mi}$. SE of Yakutat, St. Elias Mts.; $59^{\circ} 04^{\prime} 10^{\prime \prime}$ N, $138^{\circ}$ $20^{\prime} 55^{\prime \prime} \mathrm{W}$; (map 46).

Local name published in 1959 by USGS.

Dobriek Vestei, Port: bay, see Goodnews Bay. Dobrykh Vestey, Port: bay, see Goodnews Bay.

Doby Creek: stream, flows $0.3 \mathrm{mi}$. $\mathrm{N}$ to Kiagna River $4.5 \mathrm{mi}$. SE of its junc. with Chitina River and $30 \mathrm{mi}$. SE of McCarthy, St. Elias Mts.; $61^{\circ} 03^{\prime} \mathrm{N}, 142^{\circ} 26^{\prime} \mathrm{W}$; (map 67).

Name reported in 1915 by F. H. Moffit, USGS.

Doc Creek: stream, flows S $2.6 \mathrm{mi}$. to Sweepstakes Creek, $8 \mathrm{mi}$. NW of Haycock, Seward Penin. High.; $65^{\circ} 19^{\prime}$ N, $161^{\circ} 12^{\prime}$ W ; (map 109).

Local name reported in 1917 by G. L. Harrington, USGS.

Doctor Beaver Creek: stream, flows NW $13 \mathrm{mi}$. to Innoko River, $38 \mathrm{mi}$. NW of Ophir, Innoko Low.; $63^{\circ} 38^{\prime} \mathrm{N}, 156^{\circ} 58^{\prime} \mathrm{W}$; (map 90).

Local name obtained in 1945 by USGS.

Doctor Cook Lake: lake, $1 \mathrm{mi}$. long, $1 \mathrm{mi}$. E of Roaring Bear Lake and $17 \mathrm{mi}$. W of Beaver, Yukon Flats; $66^{\circ} 22^{\prime} \mathrm{N}, 148^{\circ} 01^{\prime} \mathrm{W}$; (map 118). Var. Second Lake.

Local name reported in 1956 by T. E. Taylor, USGS. Shown in 1916 as "Second Lake" on a manuscript map by William Yanert (in Stuck, 1917, map facing p. 122).

Doctor Island: island, see Kolosh Island.

Doctor Point: point of land, on $\mathrm{E}$ coast of Prince of Wales I., $\mathrm{N}$ of Cholmondeley Sound, $1 \mathrm{mi}$.
NW of Clover Point, Alex. Arch.; 55 $19^{\prime} 15^{\prime \prime}$ $\mathrm{N}, 132^{\circ} 08^{\prime} 35^{\prime \prime} \mathrm{W}$; (map 4).

Name published in 1923 by USC\&GS.

Dodds Bay: $b a y, 1 \mathrm{mi}$. across, on $\mathrm{S}$ central coast of Sanak I., Aleutian Ra.; $54^{\circ} 23^{\prime} 50^{\prime \prime} \mathrm{N}, 162^{\circ}$. $44^{\prime} 00^{\prime \prime} \mathrm{W}$; (map 25).

Name published in 1949 on a USGS map. Dodge Creek: stream, flows NE $5 \mathrm{mi}$. to Innoko River, $1.5 \mathrm{mi}$. NW of Ophir and $33 \mathrm{mi}$. NW of McGrath, Kilbuck-Kuskokwim Mts.; $63^{\circ}$ $09^{\prime} \mathrm{N}, 156^{\circ} 34^{\prime} \mathrm{W}$; BGN 1936; (map 90).

Prospectors' name obtained in 1933 by J. B. Mertie, Jr. (in Smith, P. S. 1936, pl. 4), USGS.

Dodo Creek: stream, heads in Sadlerochit Mts. 3 mi. SW of Mount Weller, flows SE $6.5 \mathrm{mi}$. to Sadlerochit River $5 \mathrm{mi}$. W of its junc. with Kekiktuk River, 21 mi. NW of Mount Michelson, Brooks Ra.; $69^{\circ} 32^{\prime} \mathrm{N}, 144^{\circ} 54^{\prime} \mathrm{W}$; $B G N$ 1961; (map 139).

Named in 1948 by USGS.

Doe Lake: lake, $0.1 \mathrm{mi}$. across, on $\mathrm{E}$ coast of Admiralty I., $5 \mathrm{mi}$. NW of Mole Harbor and $23 \mathrm{mi}$. NE of Angoon, Alex. Arch.; 57 $43^{\prime} 20^{\prime \prime}$ $\mathrm{N}, 134^{\circ} 08^{\prime} 45^{\prime \prime} \mathrm{W}$; (map 9).

Local name reported in 1951 by USGS.

Doe Mountain: mountain, 2,200 ft., on Revillagigedo I. 2 mi. E of Ketchikan, Alex. Arch.; $55^{\circ} 00^{\prime} 25^{\prime \prime} \mathrm{N}, 131^{\circ} 34^{\prime} 45^{\prime \prime} \mathrm{W}$; (map 3).

Named in 1883 by H. E. Nichols, USN. See Deer Mountains.

Doe Point: point of land, SE tip of Deer I., at mouth of Herendeen Bay, near SW end of Alaska Penin., Aleutian Ra.; 55 $54^{\prime} 20^{\prime \prime} \mathrm{N}$, $160^{\circ} 48^{\prime} 10^{\prime \prime} \mathrm{W}$; (map 28).

Named by Z. L. Tanner, USN, in 1890 .

Doestock Creek: stream, heads on $\mathrm{N}$ slope of Kuskokwim Mts, and flows $40 \mathrm{mi}$. NW to Aniak River, $5 \mathrm{mi}$. SE of Aniak, Yukon-Kuskokwim Delta; $61^{\circ} 32^{\prime} \mathrm{N}, 159^{\circ} 24^{\prime} \mathrm{W}$; (map 73). Var. Kay Creek.

Local name reported by USC\&GS in 1948. See Buckstock River.

Dog Bay: bay, $1 \mathrm{mi}$. across, off Felice Strait, between $W$ coast of Dog I. and $N$ coast of

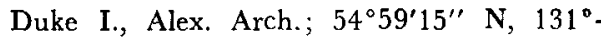
$20^{\prime} 15^{\prime \prime} \mathrm{W}$; BGN 1917; (map 2).

Name given in 1917 by USC\&GS; derived from Dog Island.

Dogbone Lake: lake, 2 mi. long, between Henry Creek and Kogosukruk River, $16 \mathrm{mi}$. $\mathrm{N}$ of Umiat, Arctic Plain; $69^{\circ} 36^{\prime} \mathrm{N}, 152^{\circ} 03^{\prime} \mathrm{W}$; $B G N 1959$; (map 141).

So named by geologists of Naval Petroleum Reserve No. 4 in 1945 "because the lake is shaped like a dog bone."

Dog Cape: point of land, see Sabak, Cape.

Dog Creek: stream, heads in Deep Lake, flows SE and $N$ through Dog and Fish Lakes, 19 mi. to West Fork Gulkana River, 28 mi. NW of Glennallen, Copper River Basin; $62^{\circ}$ $31^{\prime} \mathrm{N}, 145^{\circ} 50^{\prime} \mathrm{W}$; (map 83).

Local name reported by USGS in 1950.

Dog Creek: stream, flows NE $2.3 \mathrm{mi}$. to Concord Creek, $11 \mathrm{mi}$. E of Nome, Seward, Penin. High.; $64^{\circ} 31^{\prime} 40^{\prime \prime} \mathrm{N}, 165^{\circ} 01^{\prime} 00^{\prime \prime} \mathrm{W}$; (map 94). 
Prospectors' name reported in 1904 by T. G. Gerdine, USGS.

Dog Creek: stream, flows N $0.8 \mathrm{mi}$. to Ruby Greek which flows to Casadepaga River, 17 mi. NE of Solomon, Seward Penin. High.; $64^{\circ} 48^{\prime} \mathrm{N}, 164^{\circ} 19^{\prime} \mathrm{W}$; (map 95).

Prospectors' name reported on a map of Cape Nome gold fields by David Fox, Jr., dated 1901.

Dog Creek: stream, flows SW $2.1 \mathrm{mi}$. to Sweepstakes Creek, $9 \mathrm{mi}$. NW of Haycock, Seward Penin. High.; $65^{\circ} 19^{\prime} \mathrm{N}, 161^{\circ} 14^{\prime} \mathrm{W}$; (map 109).

Local name reported in 1917 by G. L. Harrington, USGS.

Dog Creek: stream, flows SW to Cripple River, about $25 \mathrm{mi}$. NW of Nome, Seward Penin. High.; (map 94).

Prospectors' name reported on the 1900 "Map of Nome Peninsula" by J. M. Davidson and B. D. Blakeslee; this feature has not been positively identified.

Dog Creek : stream, see Colorado Creek.

Dog Creek: stream, see Long Creek.

Dog Ear Mountain: mountain, 3,360 ft., between East and Northeast Arms Uganik Bay, on $\mathbf{N}$ coast of Kodiak I., $57^{\circ} 44^{\prime} 40^{\prime \prime} \mathrm{N}, 153^{\circ} 25^{\prime} 00^{\prime \prime}$ W; (map 34).

Descriptive named published in 1911 by USC\&GS.

Dogfish: $b a y$, see Koyuktolik Bay.

Dogfish Island: island, $0.3 \mathrm{mi}$. long, at $\mathrm{E}$ end of Naha Bay, on W coast of Revillagigedo I., 18 mi. N of Ketchikan, Alex. Arch.; $55^{\circ} 35^{\prime} 45^{\prime \prime}$ N, $131^{\circ} 37^{\prime} 45^{\prime} \mathrm{W}$; (map 3).

Local navigators' name obtained in 1904 by H. C. Fassett, USBF.

Dogfish Mountain: mountain, 1,783 ft., in Ilivit Mts. $\mathrm{E}$ of Baldhead Mtn., on $\mathrm{N}$ bank of Yukon River $13 \mathrm{mi}$. NE of Russian Mission, Nulato Hills; $61^{\circ} 56^{\prime} \mathrm{N}, 161^{\circ} 62^{\prime} \mathrm{W}$; (map 73).

Named for Dogfish Village, located at its foot. Shown on a 1922 manuscript river chart.

Dogfish Village: settlement, on $\mathrm{N}$ bank of Yukon River $11.5 \mathrm{mi}$. NE of Russian Mission, Yukon-Kuskokwim Delta ; 61 ${ }^{\circ} 54^{\prime} 15^{\prime \prime} \mathrm{N}$, $161^{\circ} 04^{\prime} 30^{\prime \prime}$ W; (map 73). Var. Dog Village, Ikaligwigmjut, Ikaligvigmiut, Ikalinigmjut, Ikaligvigmyut.

This name is a form of a translation of the Eskimo name reported in Russian by Lt. L. A. Zagoskin, IRN, in 1842-44, as "Ikaligvigmyut," meaning "fish village people." R. H. Sargent, USGS, shows Dogfish Village on a 1916 field sheet. This place is probably a fishing camp, now consisting of about 3 cabins. Most of the inhabitants died of influenza in 1900 (Hrdlička, 1943, p. 63).

Doggetlikakat: stream, see Dagitili River.

Doggetlikat: stream, see Dagitili River.

Doggetlooscat River: stream, see Dagitli River. Doggetlooskat River: stream, see Dagitli River. Doghouse Cabin: locality, on right bank of Black River $10 \mathrm{mi}$. NE of Chalkyitsik, Yukon Flats ; $66^{\circ} 41^{\prime} \mathrm{N}, 143^{\circ} 21^{\prime} \mathrm{W}$; (map 120).
Local name obtained in 1956 by T. E. Taylor and R. C. Foley, USGS.

Doghouse Lake: lake, $0.3 \mathrm{mi}$. long, on Kenai Penin. W of Fish Lake, $22 \mathrm{mi}$. NE of Kenai, Cook Inlet Low.; $60^{\circ} 43^{\prime} 30^{\prime \prime} \mathrm{N}, 150^{\circ} 44^{\prime} 15^{\prime \prime}$ W; (map 62).

Named about 1963 by officials of Kenai National Moose Range, for administrative purposes.

Doghouse Lake: lake, $1.1 \mathrm{mi}$. long, $2.7 \mathrm{mi}$. SSE of Lake Snohomish and $13 \mathrm{mi}$. SSW of village of Lake Minchumina, Tanana Low.; 63 ${ }^{\circ} 42^{\prime}$ $25^{\prime \prime} \mathrm{N}, 152^{\circ} 27^{\prime} 10^{\prime \prime} \mathrm{W}$; (map 88).

Local name reported in 1954 by USGS.

Dog Island: island, $2 \mathrm{mi}$. long, in Pond Bay, on $\mathrm{N}$ coast of Duke I., Alex. Arch.; 54 $59^{\prime} \mathrm{N}$, $131^{\circ} 19^{\prime} \mathrm{W}$; (map 2).

Named in 1883 by Lt. Comdr. H. E. Nichols, USN.

Dog Island: island, $0.1 \mathrm{mi}$. long, in Iliamna Lake, at mouth of Roadhouse Bay, $0.8 \mathrm{mi}$. E of Iliamna, Bristol Bay Low.; 59 $44^{\prime} 50^{\prime \prime} \mathrm{N}$, $154^{\circ} 49^{\prime} 15^{\prime \prime} \mathrm{W}$; (map 51).

Local name published in 1954 by USGS.

Dog Island: island, $1.5 \mathrm{mi}$. long, in Koyukuk River, $30 \mathrm{mi}$. NE of Hughes, Hogatza High.; $66^{\circ} 22^{\prime} \mathrm{N}, 153^{\circ} 30^{\prime} \mathrm{W}$; (map 116).

Local name reported by Orth in 1956.

Dogitskakat: stream, see Dagitli River.

Dog Lake: lake, 1,200 ft. across, $W$ of Talachulitna River, $52 \mathrm{mi}$. NW of Tyonek, Alaska Ra.; $61^{\circ} 49^{\prime} 15^{\prime \prime} \mathrm{N}, 151^{\circ} 22^{\prime} 40^{\prime \prime} \mathrm{W}$; (map 70). Local name reported in 1954 by USGS.

Dog Lake: lake, $3 \mathrm{mi}$. long, $1 \mathrm{mi}$. $\mathrm{N}$ of Lake Louise and $36 \mathrm{mi}$. NW of Glennallen, Copper River Basin; $62^{\circ} 23^{\prime} \mathrm{N}, 146^{\circ} 30^{\prime} \mathrm{W}$; (map 83).

Local name reported in 1951 by USGS.

Dog Lake: lake, $3.4 \mathrm{mi}$. long, in course of Dog Creek, $3 \mathrm{mi}$. W of Ewan Lake and $26 \mathrm{mi}$. NNW of Glennallen, Copper River Basin; $62^{\circ} 28^{\prime} \mathrm{N}, 145^{\circ} 56^{\prime} \mathrm{W}$; (map 83).

Local name reported in 1951 by USGS.

Dog Lake: lake, $2.6 \mathrm{mi}$. long, at head of Charlieskin Creek, 5.4 mi. SE of Northway, Alaska Ra.; 62 $53^{\prime} \mathrm{N}, 141^{\circ} 46^{\prime} \mathrm{W}$; (map 84).

Local name reported by USGS in 1954.

Dogpatch: locality, $3 \mathrm{mi}$. $\mathrm{N}$ of College and $5 \mathrm{mi}$. NW of Fairbanks, Yukon-Tanana High.; $64^{\circ}$. $54^{\prime} \mathrm{N}, 147^{\circ} 50^{\prime} \mathrm{W}$; (map 100).

Name reported in 1954 by USGS.

Dog Point: point of land, on W tip of Lisianski Penin., $9 \mathrm{mi}$. $\mathrm{N}$ of Sitka, on $\mathrm{W}$ coast of Baranof I., Alex. Arch.; $57^{\circ} 10^{\prime} 10^{\prime \prime}$ N, $135^{\circ}$. $25^{\prime} 20^{\prime \prime}$ W; (map 9). Var. Mys Sabachey.

This is an 1882 translation by USC\&GS of the name given in 1809 by the Russian navigator Ivan Vasiliev the first, IRN; reported by Lt. Sarichev (1826, map 19), IRN, as "M[ys] Sabachey."

Dog Salman: bay, see Koyuktolik Bay.

Dog Salmon Creek: stream, flows NE $4.7 \mathrm{mi}$. to Polk Inlet, near center of Prince of Wales I., Alex. Arch.; $55^{\circ} 20^{\prime} 55^{\prime \prime} \mathrm{N}, 132^{\circ} 30^{\prime} 05^{\prime \prime} \mathrm{W}$; (map 4).

Local name published in 1943 by USC\&GS.

Dog SaImon Creek: stream, heads at Fraser Lake, flows S $6 \mathrm{mi}$. to Olga Bay, $33 \mathrm{mi}$. SE of
Karluk, in SW part of Kodiak I.; $57^{\circ} 07^{\prime} 40^{\prime \prime}$ $\mathrm{N}, 154^{\circ} 01^{\prime} 40^{\prime \prime} \mathrm{W}$; (map 35).

Descriptive local name published in 1943 by USC\&GS.

Dog Salmon Flats: delta, $1 \mathrm{mi}$. across, at mouth of Dog Salmon Creek, $33 \mathrm{mi}$. SE of Karluk, Kodiak I.; $57^{\circ} 08^{\prime} 00^{\prime \prime}$ N, $154^{\circ} 01^{\prime} 30^{\prime \prime}$ W; (map 35).

Local name reported in 1952 by USGS.

Dog Salmon River: stream, flows NW $70 \mathrm{mi}$. to Ugashik River $4 \mathrm{mi}$. SE of Ugashik Bay, on $\mathrm{N}$ coast of Alaska Penin., $4 \mathrm{mi}$. SW of Ugashik, Bristol Bay Low.; $57^{\circ} 29^{\prime} 40^{\prime \prime}$ N, $157^{\circ}$ $30^{\prime} 00^{\prime \prime} \mathrm{W}$; (map 36).

Local name reported in 1900 by Lt. Comdr. J. F. Moser, USN, of the USBF steamer Albatross.

Dogshead Glacier: glacier, in Tordrillo Mts. N of Capps Glacier, trends SE $3.3 \mathrm{mi}$. to its terminus, $35 \mathrm{mi}$. NW of Tyonek, Alaska Ra.; $61^{\circ} 21^{\prime} 30^{\prime \prime} \mathrm{N}, 151^{\circ} 58^{\prime} 30^{\prime \prime} \mathrm{W}$; (map 70).

Local name reported in 1958 by USGS.

Dogteam Lake: lake, $0.2 \mathrm{mi}$. long, on Kenai Penin. W of Upper Jean Lake, $36 \mathrm{mi}$. E of Kenai, Chugach Mts.; $60^{\circ} 31^{\prime} 50^{\prime \prime} \mathrm{N}, 150^{\circ}$ $13^{\prime} 40^{\prime \prime} \mathrm{W}$; (map 62).

Named about 1963 by officials of Kenai National Moose Range, for Administrative purposes.

Dogtooth Bend: bend, in Yukon River, at mouth of Reindeer River, $19 \mathrm{mi}$. W of Marshall, Yukon-Kuskokwim Delta; $61^{\circ} 54^{\prime} \mathrm{N}, 162^{\circ} 40^{\prime}$ W; (map 74).

Riverboat pilots' name shown on a fieldsheet by R. H. Sargent, USGS, in 1916.

Dog Village: settlement, see Dogfish Village.

Doherty Creek: stream, flows SE $12 \mathrm{mi}$. to Michigan Greek $5 \mathrm{mi}$. NW of its junc. with George River, $22 \mathrm{mi}$. SE of Flat, KilbuckǨuskokwim Mts.; $62^{\circ} 16^{\prime} \mathrm{N}, 157^{\circ} 26^{\prime} \mathrm{W}$; (map 79).

Local name obtained in 1945 by USGS topographers.

Dok Point: point of land, on $\mathrm{N}$ bank of Chilkat River, $3 \mathrm{mi}$. NW of McClellan Flats and $17 \mathrm{mi}$. SW of Skagway, Coast Mts.; BGN 1922; $59^{\circ}$ $15^{\prime} 55^{\prime \prime} \mathrm{N}, 135^{\circ} 36^{\prime} 15^{\prime \prime} \mathrm{W}$; (map 45).

This is a contracted form of the Tlingit Indian name "dokhaku," formed by the words "dok," meaning "cottonwood," and "haku," meaning "point of land." The Indian name is also sometimes given as "doq xaku." The shortened form of the name was given by USC\&GS in 1922.

Doleika: mountain, see McKinley, Mount.

Doleika, Mount: mountain, see McKinley, Mount.

Doleyka: mountain, see McKinley, Mount.

Dolgay Island: island, see Long Island.

Dolgoi Cape: point of land, on $\mathrm{S}$ coast of Dolgoi I., in Pavlov Is., Aleutian Ra.; $55^{\circ} 03^{\prime} 30^{\prime \prime} \mathrm{N}$, $161^{\circ} 04^{\prime} 30^{\prime \prime} \mathrm{W}$; (map 28).

Russian word meaning "long" given by W. H. Dall, USC\&GS, in 1880.

Dolgoi Harbor: bay, $5 \mathrm{mi}$. long, nearly separates $\mathrm{E}$ and $\mathrm{W}$ parts of Dolgoi I., in Pavlof Is., Aleutian Ra.; $55^{\circ} 07^{\prime} \mathrm{N}, 161^{\circ} 47^{\prime} \mathrm{W}$; (map 28). 
Probably a local name; shown on 1882 USC\&GS chart. It is Russian for "Iong."

Dolgoi Island: island, $1.6 \mathrm{mi}$. long, at mouth of Port Bazan on SW coast of Dall I., Alex. Arch.; $54^{\circ} 49^{\prime} 15^{\prime \prime} \mathrm{N}, 132^{\circ} 58^{\prime} 30^{\prime \prime} \mathrm{W}$; (map 1). Var. Long I sland, Ostrov Dolgoy.

Descriptive name transliterated in 1869 by the U.S. Navy, Hydrog. Office from "O[strov] Dolgoy," meaning "long island," given by Capt. Lt. Zarembo, IRN, in 1834.

Dolgoi Island: island, $10 \mathrm{mi}$. long, one of Pavlof Is., Aleutian Ra.; $55^{\circ} 07^{\prime} \mathrm{N}, 161^{\circ} 44^{\prime} \mathrm{W}$; (map 28). Var. Ananakeik, Long Island.

Shown by Capt. Tebenkov (1852, map 24), IRN, as "O[strov] Dolgoi," meaning "long island" and reported by Capt. F. P. Lutke, IRN, 1836, as "Lile Dolgoi." The Aleut name was "Ananakeik," according to Father Veniaminov (1840, v. 1, p. 252).

Dolgoi Island: island, $2.2 \mathrm{mi}$. long, $2.4 \mathrm{mi}$. W of Redfield Cove and $4.5 \mathrm{mi}$. NE of Yakutat, Malaspina Coastal Plain; $59^{\circ} 36^{\prime} 15^{\prime \prime} \mathrm{N}, 1^{\circ} 9^{\circ}$ $41^{\prime} 00^{\prime \prime} \mathrm{W}$; (map 46).

Descriptive name given by Capt. Tebenkov (1852, map 7), IRN, as "O[strov] Dolgoy," meaning "long island."

Dolgoi Island: island, see Long Island.

Dolgoi Lake: lake, $0.8 \mathrm{mi}$. long, on Long Island, $4.8 \mathrm{mi}$. SE of Kodiak, NE of Kodiak I., $57^{\circ}$ $45^{\prime} 50^{\prime \prime} \mathrm{N}, 152^{\circ} 16^{\prime} 40^{\prime \prime} \mathrm{W}$; (map 34). Var. Lower Lake, Nizhni Lake, Ozero Dolgoye, Ozero Nizhniye.

Transliteration of the descriptive name "Oz[ero] Dolgoye," meaning "long lake," published by Lt. Sarichev (1826, map 16) IRN. This lake was called "Oz[ero] Nizhniye" by Capt. Tebenkov, IRN (1852, map 23). Baker (1906, p. 415) published "Lower Lake," the translation of Capt. Tebenkov's name, for this feature. Because of duplication, the name was changed to its present form about 1909.

Dolgoy, Ostrov: island, see Dolgoi Island.

Dolgoy, Ostrov: island, see Long Island.

Dolgoye, Ozero: lake, see Dolgoi Lake.

Dolina Point: point of land, on NW coast of Sitkinak I., in Trinity Is., Kodiak I. ; 56 $36^{\prime}$ $45^{\prime \prime} \mathrm{N}, 154^{\circ} 13^{\prime} 10^{\prime \prime} \mathrm{W}$; BGN 1934; (map 32).

Russian name meaning "valley," given to the point by USC\&GS in 1934 "because of its peculiar conformation."

Dollar Creek: stream, heads in Dutch Hills, flows S $7 \mathrm{mi}$. to Cache Creek, $31 \mathrm{mi}$. NW of Talkeetna, Alaska Ra.; $62^{\circ} 27^{\prime} 05^{\prime \prime} \mathrm{N}, 151^{\circ} 02^{\prime} 10^{\prime \prime}$ W; (map 81).

Prospectors' name reported in 1906 by Sidney Paige and Adolph Knopf, USGS.

Dollar Creek: strecom, flows NW $2.3 \mathrm{mi}$. to Beaver Creek, $8 \mathrm{mi}$. SW of Ophir and $33 \mathrm{mi}$. NW of McGrath, Kilbuck-Kuskokwim Mts. ; $63^{\circ} 02^{\prime}$ $30^{\prime \prime} \mathrm{N}, 156^{\circ} 39^{\prime} 45^{\prime \prime} \mathrm{W}$; BGN 1936; (map 90).

Prospectors' name obtained in 1933 by J. B. Mertie, Jr. (in Smith, P. S., 1936, pl. 4), USGS.

Dollar Creek: stream, flows SW $5.3 \mathrm{mi}$. to Dime Creek, $5 \mathrm{mi}$. SE of Haycock, Seward Penin. High.; $65^{\circ} 09^{\prime} \mathrm{N}, 161^{\circ} 08^{\prime} \mathrm{W}$; (map 109).
Local name reported in 1917 by G. L. Harrington, USGS.

Doll Creek: stream, flows NW to Pinnell River which flows to Inmachuk River between Snow and Hurd Creeks, about $14 \mathrm{mi}$. N of Imuruk Lake, Seward Penin. High.; (map 110).

Local name published on a precinct map of Seward Peninsula by Monroe and Hutchins; corrected to June 1903 by Arthur Gibson. This stream cannot be precisely identified on current maps.

Dolls Island: island, see Young Island.

Dolly, Mount: mountain, 4,300 ft., in Reverdy Mts. on Alaska-Canada boundary, $3.5 \mathrm{mi}$. N of Hyder, Coast Mts.; $55^{\circ} 58^{\prime} 15^{\prime \prime}$ N, $130^{\circ} 00^{\prime}$ $30^{\prime \prime} \mathrm{W}$; (map 3$)$.

Local name recorded in 1915 by Theodore Chapin (in Brooks and others, 1916, fig. 5), USGS.

Dolly Varden Lake: lake, $1.5 \mathrm{mi}$. long, on Kenai Penin. W of Drake Lake, $18 \mathrm{mi}$. NE of Kenai, Cook Inlet Low.; $60^{\circ} 42^{\prime} 30^{\prime \prime} \mathrm{N}, 150^{\circ} 47^{\prime} 30^{\prime \prime}$ W; (map 62).

Named about 1963 by officials of Kenai National Moose Range, for the Dolly Varden (Salvelinus parkeii), sometimes called "salmon trout."

Dolomi: locality, site of mining village, at head of Dolomi Bay, $0.8 \mathrm{mi}$. $\mathrm{N}$ of Port Johnson, on SE coast of Prince of Wales I., Alex. Arch.; $55^{\circ} 08^{\prime} 00^{\prime \prime} \mathrm{N}, 132^{\circ} 03^{\prime} 05^{\prime \prime} \mathrm{W}$; (map 4).

Former mining camp established in the late 1890 's and named "Dolomite" because of the predominance of dolomite rock in the area. The name was later shortened to "Dolomi." In 1906 it had a population of 50. The Dolomi post office was established in 1900 and was discontinued in 1926 (Ricks, 1965, p. 17).

Dolomi Bay: estuary, on SE coast of Prince of Wales I., extends S $0.8 \mathrm{mi}$. to Port Johnson, Alex. Arch.; $55^{\circ} 07^{\prime} 20^{\prime \prime} \mathrm{N}, 132^{\circ} 03^{\prime} 00^{\prime \prime} \mathrm{W}$; (map 4).

Local name derived from the town of Dolomi, reported in 1923 and published in the 1925 Coast Pilot (p. 77).

Dolores, Port: bay, $1.4 \mathrm{mi}$. long, on NW coast of Suemez I., Alex. Arch.; $55^{\circ} 20^{\prime}$ N, $133^{\circ} 25^{\prime}$ W; (map 4). Var. Proliv Dolores, Puerto de los Dolores, Zaliv de los Dolores.

Name given by Francisco Antonio Maurelle as "Puerto de los Dolores," i.e. "port of the sorrows," on "June 4 or 5,1779 , as he was there both days" (Wagner, 1937, p. 384).

Dolores, Proliv: bay, see Dolores, Port.

Dolores, Puerto de: water passage, "perhaps the entrance to Kaigani Strait * * * named by [Don Jacinto] Caamaño in 1792" (Wagner, 1937, p. 448).

Dolores, Puerto de los: bay, see Dolores, Port.

Dolores, Zaliv de los: $b a y$, see Dolores, Port.

Dolphin Bay: bay, see Delphin Bay.

Dolphin Point: point of land, NE tip of Whale I., N of Kodiak I.; $57^{\circ} 59^{\prime} 10^{\prime \prime} \mathrm{N}, 152^{\circ} 43^{\prime} 25^{\prime \prime}$ W; (map 34). Var. Mys Melkowadia, Mys Melkouodiya.

Called "M[ys] Melkouodiya," meaning "shallow water cape," in 1839 or 1840 by Sub-
Lt. Mikhail Murashev, IRN. The name "Dolphin Point" was given in 1900 by Lt. Comdr. J. F. Moser, USN, of the USBF steamer Albatross.

Dolphin Point: point of land, $15.5 \mathrm{mi}$. NW of Afognak, on SW coast of Afognak I.; 58 $06^{\circ}$ $30^{\prime \prime} \mathrm{N}, 153^{\circ} 09^{\prime} 00^{\prime \prime} \mathrm{W}$; (map 43).

Local name reported in 1900 by Lt. Comdr. J. F. Moser, USN, commander of the USBF steamer Albatross.

Dolphin Point: point of land, see Delphin Point.

Dolph Rock: rock, in Peril Strait, $1 \mathrm{mi}$. E of mouth of Ushk Bay, on Chichagof I., $22 \mathrm{mi}$. SE of Chichagof, Alex. Arch.; 57 $33^{\prime} 25^{\prime \prime} \mathrm{N}$, $135^{\circ} 32^{\prime} 45^{\prime \prime} \mathrm{W}$; (map 9).

Named in 1895 by Lt. Comdr. E. K. Moore, USN, for quartermaster George Dolph, USN, of the SS Patterson. The name was published in 1900 by USC\&GS on Chart 8282 .

Dome: hill, $767 \mathrm{ft}$., $8 \mathrm{mi}$. NNE of Slug Mtn. and $21 \mathrm{mi}$. ENE of Cape Newenham KilbuckKuskokwim Mts.; 58 $44^{\prime} \mathrm{N}, 161^{\circ} 36^{\prime} \mathrm{W}$; (map 39)

Local descriptive name shown on 1937 fieldsheet by J. B. Mertie, Jr., USGS.

Dome: locality, see Dome Camp.

Dome: locality, see Olnes.

Dome: mountain, see Fortymile Dome.

Dome: mountain, see Roundtop Mountain.

Dome, The: hill, SW of junc. of Ahtell Creek and its West Fork, $8 \mathrm{mi}$. NNW of junc. of Copper and Slana Rivers, Alaska Ra.; 62 $48^{\prime} 30^{\prime \prime} \mathrm{N}, 144^{\circ} 05^{\prime} 30^{\prime \prime} \mathrm{W}$; BGN 1936; (map 83).

Local name reported in 1936 by USGS.

Dome, The: mountain, see Fortymile Dome.

Dome Camp: locality, on left bank of Dome Creek, $14 \mathrm{mi}$. N of Fairbanks, Yukon-Tanana High.; $65^{\circ} 02^{\prime} \mathrm{N}, 147^{\circ} 37^{\prime} \mathrm{W}$; (map 105). Var. Dome City, Dome.

Name of a former mining camp. Settled about 1905 (Kitchener, 1954, p. 297); a post office, established here in 1906, was transferred to Olnes in 1922 (Ricks, 1965, p. 17). Name published in 1907 by USGS.

Dome City: locality, see Dome Camp.

Dome Greek: stream, heads on Dome, flows 0.8 mi. E to North Fork Stag River, $22 \mathrm{mi}$. ENE of Cape Newenham, Kilbuck-Kuskokwim Mts.; $58^{\circ} 44^{\prime} \mathrm{N}, 1^{6} 1^{\circ} 34^{\prime} \mathrm{W}$; (map 39).

Local name shown on a 1937 fieldsheet by J. B. Mertie, Jr., USGS.

Dome Creek: stream, flows NE $7 \mathrm{mi}$. to Cripple Creek, $75 \mathrm{mi}$. SE of Bethel, Kilbuck-Kuskokwim Mts.; $60^{\circ} 44^{\prime} 30^{\prime \prime} \mathrm{N}, 159^{\circ} 34^{\prime} 30^{\prime \prime} \mathrm{W}$; (map 59).

Prospectors' name reported in 1914 by A. G. Maddren (in Brooks, 1915, pl. 11), USGS.

Dome Creek: stream, flows NW $5.3 \mathrm{mi}$. to Donlin Creek 1.9 mi. NE of its junc. with Flat Creek, $15 \mathrm{mi}$. N of village of Crooked Creek and $42 \mathrm{mi}$. NW of Sleetmute, Kilbuck-Kuskokwim Mts.; $62^{\prime} 05^{\prime} 15^{\prime \prime} \mathrm{N}, 158^{\circ} 09^{\prime} 50^{\prime \prime} \mathrm{W}$; $B G N$ 1936; (map 79).

Prospectors' name obtained in 1913 by Eakin (1914, pl. 1), USGS. 
Dome Creek: stream, flows SE $0.5 \mathrm{mi}$. to Big Skookum Creek $0.5 \mathrm{mi}$. $\mathrm{N}$ of its junc. with Mills Creek, $45 \mathrm{mi}$. W of Talkeetna, Alaska Ra.; 62 $21^{\prime} 30^{\prime \prime}$ N, $151^{\circ} 30^{\prime} 40^{\prime \prime}$ W ; (map 81). Prospectors' name reported in 1911 by Capps (1913, fig. 7), USGS.

Dome Creek: stream, flows SW $9 \mathrm{mi}$. to Innoko River, $1.4 \mathrm{mi}$. SE of Ophir and $30 \mathrm{mi}$. NW of McGrath, Kilbuck-Kuskokwim Mts.; $63^{\circ} 08^{\prime} \mathrm{N}, 156^{\circ} 28^{\prime} \mathrm{W}$; (map 90).

Prospectors' name reported in 1912 by A. G. Maddren and H. M. Eakin, USGS.

Dome Creek: stream, flows W $3.3 \mathrm{mi}$. to Tolstoi Creek, $19 \mathrm{mi}$. NW of Ophir and $50 \mathrm{mi}$. NW of McGrath, Kilbuck-Kuskokwim Mts.; $63^{\circ} 13^{\prime} \mathrm{N}, 157^{\circ} 06^{\prime} \mathrm{W}$; (map 90).

Prospectors' name published in 1921 by USGS.

Dome Creek: stream, flows SW $15 \mathrm{mi}$. to O'Brien Creek, $32 \mathrm{mi}$. S. of Eagle, Yukon-Tanana High.; 64 $21^{\prime} \mathrm{N}, 141^{\circ} 23^{\prime} \mathrm{W}$; (map 102).

Prospectors' name obtained in 1898 by E. C. Barnard, USGS.

Dome Creek: locality, on $\mathrm{N}$ bank of Dome Greek, at mouth of Georgie Creek, $29 \mathrm{mi}$. S of Eagle, Yukon-Tanana High.; 64 ${ }^{\circ} 23^{\prime} 30^{\prime \prime}$ $\mathrm{N}, 141^{\circ} 15^{\prime} 10^{\prime \prime} \mathrm{W}$; (map 102).

Mining camp, now abandoned, reported in 1903 by Prindle $(1905$, p. 10), USGS.

Dome Creek: stream, flows N $4.6 \mathrm{mi}$. to Beaver Creek, $10 \mathrm{mi}$. SE of Ruby, Kilbuck-Kusko-

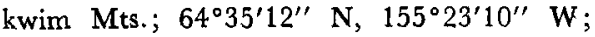
BGN 1936; (map 98).

Prospectors' name reported in 1908 by A. G. Maddren (in Brooks and others, 1909, p. 230), USGS.

Dome Creek: stream, flows NW $3 \mathrm{mi}$. to Teddys Forks, $12 \mathrm{mi}$. SW of Eagle, Yukon-Tanana High.; 64 $39^{\circ} \mathrm{N}, 141^{\circ} 26^{\prime} \mathrm{W}$; (map 102).

Prospectors' name obtained in 1898 by E. C. Barnard, USGS

Dome Creek: stream, heads at junc. of Telegram and Eldorado Creeks, flows NW $2.3 \mathrm{mi}$. to join Canyon Creek to form Iron Creek, $25 \mathrm{mi}$. NW of Solomon, Seward Penin. High.; $64^{\circ} 54^{\prime} \mathrm{N}, 164^{\circ} 43^{\prime} \mathrm{W}$; (map 95).

Prospectors' name reported on a map of Cape Nome gold fields by David Fox, Jr., dated 1901.

Dome Creek: stream, flows S $4.4 \mathrm{mi}$. to Tisuk River, $39 \mathrm{mi}$. NW of Nome, Seward Penin. High.; $64^{\circ} 55^{\prime} \mathrm{N}, 166^{\circ} 18^{\prime} \mathrm{W}$; (map 94).

Prospectors' name reported in 1900 by E. C. Barnard (in Brooks, 1901, pl. 17), USGS.

Dome Creek: stream, flows NW $7 \mathrm{mi}$. to Chatanika River, $16 \mathrm{mi}$. N of Fairbanks, Yukon-Tanana High.; $65^{\circ} 04^{\prime} 30^{\prime \prime}$ N, $147^{\circ} 45^{\prime}$ $00^{\prime \prime} \mathrm{W}$; (map 105).

Local name derived from Pedro Dome located at head of stream. The name was reported in 1903 by T. G. Gerdine (Prindle, 1905, pl. 13), USGS.

Dome Creek: stream, flows NE $8 \mathrm{mi}$. to Washington Creek, $14 \mathrm{mi}$. S. of that stream's junc. with Yukon River and $40 \mathrm{mi}$. NW of Eagle, Yukon-Tanana High.; $65^{\circ} 07^{\prime} 30^{\prime \prime} \mathrm{N}, 142^{\circ}$ $17^{\prime} 30^{\prime \prime} \mathrm{W}$; (map 103)
Prospectors' name from an unpublished map by E. J. Chamberlain, dated 1902.

Dome Creek: stream, heads on Serpentine Ridge and flows S $1.5 \mathrm{mi}$. to Quartz Creek, $4.5 \mathrm{mi}$. $\mathrm{S}$ of Roughtop Mtn. and $36 \mathrm{mi}$. E. of Tanana, Yukon-Tanana High.; $65^{\circ} 07^{\prime} 35^{\prime \prime} \mathrm{N}, 150^{\circ}$ $52^{\prime} 00^{\prime \prime} \mathrm{W}$; (map 106).

Local name reported in 1952 by USGS.

Dome Creek: stream, flows $\mathrm{N} 2 \mathrm{mi}$. to Hudson Creek, $\mathrm{N}$ of Gold Mtn., about $8 \mathrm{mi}$. NNW of Birches, Kokrines-Hodzana High.; $65^{\circ} 15^{\prime} \mathrm{N}$, $153^{\circ} 40^{\prime} \mathrm{W}$; (map 107)

Local name reported by Maddren (1910, pl. 5), USGS.

Dome Creek: stream, flows NE $1.4 \mathrm{mi}$. to Coffee Creek, in Kougarok River basin, $49 \mathrm{mi}$. SW of Imuruk Lake, Seward Penin. High.; $6^{\circ}{ }^{\circ} 19^{\prime}$ $\mathrm{N}, 164^{\circ} 44^{\prime} \mathrm{W}$; (map 110$)$.

Prospectors' name reported on the 1908 "Map of Seward Peninsula" by Arthur Gibson.

Dome Creek: stream, flows WNW $4 \mathrm{mi}$. to Woodchopper Creek, $2 \mathrm{mi}$. $\mathrm{S}$ of that stream's junc. with Yukon River and $40 \mathrm{mi}$. SE of Circle, Yukon-Tanana High.; $65^{\circ} 19^{\prime} 30^{\prime \prime} \mathrm{N}, 143^{\circ} 20^{\prime}$ $00^{\prime \prime} \mathrm{W}$; (map 103).

Local name reported in 1938 by Mertie (1942, p. 248), USGS.

Dome Creek: stream, in Kokrines Hills, flows NW $7 \mathrm{mi}$. to Melozitna River, $30 \mathrm{mi}$. NNW of Birches, Kokrines-Hodzana High.; 65 $30^{\prime} 50^{\prime \prime}$ N, $154^{\circ} 03^{\prime} 35^{\prime \prime} \mathrm{W}$; (map 107).

Local name obtained in 1954 by USGS topographers.

Dome Creek: stream, flows N $1.3 \mathrm{mi}$. to Porcupine Creek, $2 \mathrm{mi}$. NW of Porcupine Dome and $48 \mathrm{mi}$. SW of Circle, Yukon-Tanana High.; $65^{\circ} 32^{\prime} 25^{\prime \prime} \mathrm{N}, 145^{\circ} 34^{\prime} 00^{\prime \prime} \mathrm{W}$; (map 104).

Named by prospectors and reported in 1936 by Mertie (1938a, p. 225), USGS.

Dome Creek: stream, flows NW $9 \mathrm{mi}$. to American River, 29 mi. NE of Teller, Seward Penin. High.; $65^{\circ} 34^{\prime} \mathrm{N}, 165^{\circ} 42^{\prime} \mathrm{W}$; (map 111).

Prospectors' name reported in 1901 by T. G. Gerdine (in Collier, 1902, pl. 12), USGS.

Dome Creek: stream, flows NE $13 \mathrm{mi}$. to Kiwalik River, 39 mi. NW of Haycock, Seward Penin. High.; 65 ${ }^{\circ} 41^{\prime} N, 161^{\circ} 52^{\prime} \mathrm{W}$; (map 109).

Local name shown on a 1903 fieldsheet by D.C. Witherspoon, USGS.

Dome Creek: stream, flows NE $1.2 \mathrm{mi}$. to Jim Creek, in Kougarok River basin, $7 \mathrm{mi}$. SE of Midnight Min. and $40 \mathrm{mi}$. NW of Imuruk Lake, Seward Penin. High.; $65^{\circ} 41^{\prime}$ N, 164 ${ }^{\circ} 33^{\prime}$ W; (map 110).

Prospectors' name reported in 1901 by T. G. Gerdine (in Collier, 1902, pl. 12), USGS.

Dome Creek: stream, flows SE to Agiapuk River, about $15 \mathrm{mi}$. NW of Teller, Seward Penin. High.; (map 111).

Prospectors' name shown on a map of Cape Nome gold fields by David Fox, Jr., dated 1901. This feature cannot be precisely identified on current maps.

Dome Islets: islands, extend $0.3 \mathrm{mi}$. across, $\mathrm{N}$ Maurelle Is., Alex. Arch.; 55 $41^{\prime} 30^{\prime \prime}$ N, $1^{\circ} 3^{\circ}-$ $37^{\prime} 45^{\prime \prime} \mathrm{W}$; (map 4).
Descriptive name given in 1924 by USG\&GS

Dome Mountain: mountain, 3,109 ft., in Peabody Mts., $2.7 \mathrm{mi}$. NE of Hidden Inlet, Coast Mts. ; $55^{\circ} 03^{\prime} 45^{\prime \prime} \mathrm{N}, 130^{\circ} 17^{\prime} 00^{\prime \prime} \mathrm{W}$; (map 3).

Descriptive name given in 1868 by Staff Comdr. David Pender, RN.

Dome Mountain: mountain, $1,424 \mathrm{ft}$., $4.5 \mathrm{mi}$. NE of Pyramid Mtn. and $8 \mathrm{mi}$. SE of Goodnews, Kilbuck-Kuskokwim Mts.; 59 $04^{\prime} 15^{\prime \prime}$ $\mathrm{N}, 161^{\circ} 23^{\prime} 30^{\prime \prime} \mathrm{W}$; (map 53 ).

Local descriptive name published in 1915 by USC\&GS on Chart 9103.

Dome Mountain: mountain, see Fortymile Dome.

Dome Pass: pass, 3,800 ft., on Cascade Glacier, $6.5 \mathrm{mi}$. SSW of Mount Augusta and $54 \mathrm{mi}$. NNW of Yakutat, St. Elias Mts.; $60^{\circ} 13^{\prime} \mathrm{N}$, $140^{\circ} 30^{\prime} \mathrm{W}$; (map 66).

Named in 1890 by Russell (1891, p. 146), USGS.

Dome Peak: mountain, 5,271 ft., in Rousseau Ra., $4.8 \mathrm{mi}$. NW of Breezy Point on Portland Canal and $62 \mathrm{mi}$. E of Ketchikan, Coast Mts.; $55^{\circ} 23^{\prime} 15^{\prime \prime} \mathrm{N}, 130^{\circ} 10^{\prime} 40^{\prime \prime} \mathrm{W}$; (map 3 ).

Descriptive name given in 1868 by staff Comdr. David Pender, RN, because of its shape.

Dome Peak: peak, 5,570 ft., $18 \mathrm{mi}$. NW of Devils Thumb and $100 \mathrm{mi}$. E of Sitka, Coast Mts.; $57^{\circ} 11^{\prime} 15^{\prime \prime} \mathrm{N}, 132^{\circ} 49^{\prime} 35^{\prime \prime} \mathrm{W}$; (map 8).

Descriptive name given in 1887 by Lt. C. M. Thomas, USN; published in 1888 by USG\&GS.

Dome Peak: mountain, 1,853 ft., on Afognak I, $5 \mathrm{mi}$. SE of Black Cape and $26 \mathrm{mi}$. N of Afognak, Kodiak I.; $58^{\circ} 22^{\prime} 30^{\prime \prime} \mathrm{N}, 152^{\circ} 45^{\prime}$ $30^{\prime \prime} \mathrm{W}$; (map 43).

Local descriptive name reported in 1952 by USGS.

Dome Peak: mountain, see Nun Mountain.

Dome Point: point of land, on $\mathrm{S}$ coast of Alaska Penin., E shore of Stepovak Bay, Aleutian Ra.; $55^{\circ} 40^{\prime} \mathrm{N}, 159^{\circ} 42^{\prime} \mathrm{W}$; (map 27).

Named by W. H. Dall, USC\&GS in 1880 ; published in 1888 by USBF.

Dome Rock: rock, off $\mathrm{N}$ coast of Amatignak I., Aleutian Is. ; $51^{\circ} 18^{\prime} 00^{\prime \prime} \mathrm{N}, 179^{\circ} 07^{\prime} 10^{\prime \prime} \mathrm{W}$; (map 16).

Local name published in 1954 on a USGS map.

Dome Rock: rock, off Repetition Point, in Kuliliak Bay, on S coast of Unalaska I., Aleutian Is.; $53^{\circ} 26^{\prime} 55^{\prime \prime} \mathrm{N}, 167^{\circ} 02^{\prime} 28^{\prime \prime} \mathrm{W}$; $B G N$ 1939; (map 23).

Descriptive name given by a USC\&GS field party in 1937.

Dome Spur: RR. station, on The Alaska RR., 13 mi. NW of Fairbranks, Yukon-Tanana High.; $64^{\circ} 55^{\prime} 25^{\prime \prime} \mathrm{N}, 148^{\circ} 06^{\prime} 00^{\prime \prime} \mathrm{W}$; (map 100). Var. Drouin Ranch.

Local name published in 1949 by USGS.

Domingo Creek: stream, flows NE $1.5 \mathrm{mi}$. to Faro Creek, $24 \mathrm{mi}$. N of Goodnews, Killbuck-Kuskokwim Mts.; $59^{\circ} 27^{\prime} \mathrm{N}, 161^{\circ} 31^{\prime} \mathrm{W}$; (map 53).

Name reported in 1920 by G. L. Harrington (in Brooks and others, 1921, pl. 7), USGS. 
Dominion Creek: stream, flows SE $10 \mathrm{mi}$, to Salmon River, $80 \mathrm{mi}$. NE of Bethel, KilbuckKuskokwim Mts. ; $60^{\circ} 58^{\prime} \mathrm{N}, 159^{\circ} 24^{\prime} \mathrm{W}$; (map 59).

Prospectors name reported in 1914 by $A$ G. Maddren (in Brooks, 1915, pl. 11), USGS

Dominion Creek: stream, heads on Caribou Mtn., flows NE $25 \mathrm{mi}$. to Folger Creek, $25 \mathrm{mi}$. NE of Ophir and $40 \mathrm{mi}$. NW of McGrath, Kil-

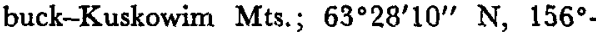
14'30" W; BGN 1936; (map 90).

Prospectors' name reported in 1933 by USGS.

Dominion Creek: stream, flows SE $5.7 \mathrm{mi}$. to Flint Creek, $10 \mathrm{mi}$. NE of Long and $20 \mathrm{mi}$. SE of Ruby, Nowitna Low.; $64^{\circ} 29^{\prime} 00^{\prime \prime} \mathbf{N}$, $155^{\circ} 11^{\prime} 20^{\prime \prime} \mathrm{W}$; (map 98).

Prospectors' name reported in 1912 by $\mathrm{H}$ M. Eakin (in Brooks and others, 1913, pl. 10), USGS.

Dominion Greek: stream, flows NE $2 \mathrm{mi}$. to Mission Creek, $11 \mathrm{mi}$. SW of Eagle, Yukon-Tanana High.; $64^{\circ} 42^{\prime} \mathrm{N}, 141^{\circ} 31^{\prime} \mathrm{W}$; (map 102).

Prospectors' name obtained in 1898 by $\mathrm{E}$. G. Barnard, USGS.

Dominion Creek: stream, flows NW $5 \mathrm{mi}$. to Tolovana River, $10 \mathrm{mi}$. SE of Livengood, $\mathrm{Yu}$ kon-Tanana High.; $65^{\circ} 28^{\prime} 30^{\prime \prime} \mathrm{N}, 148^{\circ} 12^{\prime} 45^{\prime \prime}$ W; (map 105).

Local name published by USGS in the 1950's.

Dominion Creek: stream, flows SW $6.2 \mathrm{mi}$. to Independence Creek, in Kugruk River basin, $20 \mathrm{mi}$. NE of Imuruk Lake, Seward Penin. High.; 65 $36^{\prime} \mathrm{N}, 162^{\circ} 27^{\prime} \mathrm{W}$; (map 110).

Prospectors' name reported in 1901 by $D$. L. Reaburn (in Mendenhall, 1902, pl. 4a), USGS.

Donahoe Lake: lake, $0.5 \mathrm{mi}$, long, drains $W$ to Hay Slough, $8 \mathrm{mi}$. ESE of Tanana, Yukon-Tanana High.; $65^{\circ} 09^{\prime} \mathrm{N}, 151^{\circ} 51^{\prime} \mathrm{W}$; (map 106).

Local name reported in 1952 by USGS.

Donahue Mountain: hill, $575 \mathrm{ft}$., on shore of Norton Sound, $0.8 \mathrm{mi}$. E of village of Bluff and $22 \mathrm{mi}$. E of Solomon, Seward Penin. High.; $64^{\circ} 34^{\prime} \mathrm{N}, 163^{\circ} 44^{\prime} \mathrm{W}$; (map 95).

Local name reported on Arthur Gibson's "Map of Cape Nome Precinct" dated 1904.

Don Albert River: stream, see Don River.

Donald Ridge: ridge, elev. 2,500 ft., $3 \mathrm{mi}$. long, in Robertson Mts. between Bering Glacier and Kosakuts River, $90 \mathrm{mi}$. SE of Cordova, St. Elias Mtns. ; $60^{\circ} 15^{\prime} \mathrm{N}, 143^{\circ} 07^{\prime} \mathrm{W}$; BGN 1960; (map 65).

Named by Don Miller, USGS, for Corporal Donald, RGAF, who was killed in a plane crash on this ridge about 1943.

Donaldson Creek: stream, on Kenai Penin., flows NE $3.5 \mathrm{mi}$. to Canyon Creek, $9 \mathrm{mi}$. SE of Sunrise, Ghugach Mts. ; $60^{\circ} 45^{\prime} 40^{\prime \prime} \mathrm{N}, 149^{\circ}$. $27^{\prime} 00^{\prime \prime} \mathrm{W}$; (map 63).

Local name reported in 1912 by Grant and Higgins (1913, pl. 1), USGS.

Don-che-loch-no: stream, see Donchelok Creek.

Donchelok Creek: stream, flows NE $9 \mathrm{mi}$. from North Snohomish Lake, through Slim Lake, to
Lake Minchumina, Tanana Low.; 6352' N, $152^{\circ} 21^{\prime} W_{\text {; }}$ (map 88). Var. Don-che-lochno.

Tanana Indian name obtained in 1899 by Lt. J. S. Herron, USA, who spelled it "Donche-loch-no."

Dondadulik : locality, see Tuntutuli.

Doneleys: locality, see Donnelly.

Donkey Bay: bay, $0.7 \mathrm{mi}$. across, on NW shore of Pybus Bay, on Admiralty I., $20 \mathrm{mi}$. SE of Angoon, Alex. Arch.; 57 $20^{\prime} 15^{\prime \prime} \mathrm{N}, 134^{\circ} 09^{\prime}$ $30^{\prime \prime} \mathrm{W}$; (map 9).

Name published in 1924 by USC\&GS on Chart 8200.

Donkey Creek: stream, heads in lake, flows SE $26 \mathrm{mi}$. to Donkey Creek Slough, $43 \mathrm{mi}$. SW of Talkeetna, Alaska Ra.; $62^{\circ} 05^{\prime} 10^{\prime \prime} \mathrm{N}, 151^{\circ}$ $19^{\prime} 45^{\prime \prime} \mathrm{W}$; (map 81).

Prospectors' name reported in 1911 by S. R. Capps (in Brooks, 1912, pl. 9), USGS.

Donkey Creek Lake: lake, $0.9 \mathrm{mi}$. long, $5 \mathrm{mi}$. W of Mount Yenlo and $44 \mathrm{mi}$. SW of Talkeetna Alaska Ra.; $62^{\circ} 09^{\prime} 00^{\prime \prime} \mathrm{N}, 151^{\circ} 26^{\prime} 30^{\prime \prime} \mathrm{W}$; (map 81).

Local name reported in 1958 by USGS.

Donkey Creek Slough: stream, anabranch of Yentna River, flows SE $15 \mathrm{mi}$., $43 \mathrm{mi}$. SW of Talkeetna, Alaska Ra.; $62^{\circ} 02^{\prime} \mathrm{N}, 151^{\circ} 18^{\prime}$ W; (map 81)

Local name reported in 1958 by USGS.

Donkey Lake: lake, $1.6 \mathrm{mi}$. long, on Kenai Penin., $1.5 \mathrm{mi}$. E of Elephant Lake and $12 \mathrm{mi}$. $\mathrm{NE}$ of Kenai, Cook Inlet Low.; $60^{\circ} 35^{\prime} 45^{\prime \prime}$ $N, 150^{\circ} 55^{\prime} 30^{\prime \prime} \mathrm{W}$; (map 62).

Named about 1963 by officials of Kenai National Moose Range, for administrative purposes.

Donlin Creek: stream, flows SW $14 \mathrm{mi}$., joins Flat Creek to form Crooked Creek, $15 \mathrm{mi}$. NW of village of Crooked Creek and $43 \mathrm{mi}$. NW of Sleetmute, Kilbuck-Kuskokwim Mts.; 62 ${ }^{\circ}$ $04^{\prime} 45^{\prime \prime} N, 158^{\circ} 13^{\prime} 00^{\prime \prime} W$; (map 79).

Prospectors' name reported in 1910 by by A. G. Maddren, USGS.

Don Miller Hills: mountains, 2,000 ft., extend $9 \mathrm{mi}$. S from Bering Lake to Controller Bay, $6 \mathrm{mi}$. NE of Katalla, Chugach Mts.; $60^{\circ} 14^{\prime}$ $\mathrm{N}, 144^{\circ} 20^{\prime} \mathrm{W}$; (map 64).

Named in 1963 by USGS for Don Miller, 1919-61, geologist with USGS.

Donnelly: locality, on Richardson Highway, 26 mi. S of Delta Junction, Alaska Ra.; $63^{\circ} 40^{\prime}$ $30^{\prime \prime} \mathrm{N}, 145^{\circ} 52^{\prime} 55^{\prime \prime} \mathrm{W}$; (map 86). Var. Doneleys, Donnellys Roadhouse.

Established as a telegraph station about 1904 by the U.S. Army Signal Corps, and a stage station on the Fairbanks-Chitina trail.

Donnelly Dome: mountain, $3,910 \mathrm{ft}$., $\mathrm{W}$ of Richardson Highway, $18 \mathrm{mi}$. S of Delta Junction, Alaska Ra.; $63^{\circ} 47^{\prime} 00^{\prime \prime} \mathrm{N}, 145^{\circ} 47^{\prime} 15^{\prime \prime}$ W; BGN 1937; (map 86). Var. Delta Dome, Donnellys Dome.

Local name established in the 1920's and derived from name of nearby telegraph station. Prior to that time it was called "Delta Dome"; named after Delta River.

Donnelly Point: point of land, on SE shore of Naha Bay, on W coast of Revillagigedo I.,
$17 \mathrm{mi} . \mathrm{N}$ of Ketchikan, Alex. Arch.; $55^{\circ} 35^{\prime} 35^{\prime \prime} \mathrm{N}, 131^{\circ} 39^{\prime} 00^{\prime \prime} \mathrm{W}$; (map 3 ).

Local navigators' name obtained in 1904 by H. C. Fassett, USBF.

Donnellys Dome: mountain, see Donnelly Dome. Donnellys Roadhouse: locality, see Donnelly.

Donoho Peak: peak, 6,696 ft., between Root and Kennicott Glaciers, $8 \mathrm{mi}$. N of McCarthy, Wrangell Mts.; $61^{\circ} 33^{\prime} 30^{\prime \prime} \mathrm{N}, 142^{\circ} 58^{\prime} 00^{\prime \prime} \mathrm{W}$; (map 67).

Name reported by USGS in 1931 (Moffit, 1938, pl. 1).

Donovan Creek: stream, heads on Mount Hurst, flows SW $5.7 \mathrm{mi}$. to Tolstoi Creek, $19 \mathrm{mi}$. NW of Ophir and $50 \mathrm{mi}$. NW of McGrath, Kilbuck-Kuskokwim Mts.; $63^{\circ} 11^{\prime} 15^{\prime \prime}$ N, $157^{\circ} 06^{\prime} 20^{\prime \prime} \mathrm{W}$; ( $\operatorname{map} 90$ ).

Prospectors' name published in 1921 by USGS.

Don River: stream, flows SW $19 \mathrm{mi}$. to Breving Lagoon, $17 \mathrm{mi}$. NW of Teller, Seward Penin. High.; $65^{\circ} 23^{\prime} \mathrm{N}, 166^{\circ} 53^{\prime} \mathrm{W}$; (map 111). Var. Don Albert River, Linden River, Rapid River.

Prospectors' name reported in 1901 by $\mathrm{T}$. G. Gerdine (in Collier, 1902, pl. 12), USGS Shown as "Don Albert River" on the 1900 "Map of Nome Peninsula" by J. M. Davidson and B. D. Blakeslee and as "Linden River" on a map of Cape Nome goldfields by David Fox, Jr., dated 1901.

Dontsólakhmena: lake, see Slim Lake.

Dontsólakhnó: stream, see Deep Creek.

Dooksook Lagoon: lagoon, $1.4 \mathrm{mi}$. long, at mouth of Dooksook River, $43 \mathrm{mi}$. NW of Cape Mendenhall, on SW coast of Nunivak $I$.; $60^{\circ} 03^{\prime} 50^{\prime \prime}$ N, $167^{\circ} 15^{\prime} 45^{\prime \prime} \mathrm{W}$; (map 57). Var. Duksuk Lagoon.

Eskimo name obtained in 1949 by USC\&GS.

Dooksook River: stream, flows SW $7 \mathrm{mi}$. to Dooksook Lagoon, $2 \mathrm{mi}$. W of Ingriruk Hill and $44 \mathrm{mi}$. NW of Cape Mendenhall, Nunivak I.; $60^{\circ} 05^{\prime} \mathrm{N}, 167^{\circ} 16^{\prime} \mathrm{W}$; (map 57). Var. Duksuk River, Tuxsuk River.

Eskimo name obtained in 1949 by USC\&GS

Doolth Mountain: mountain, 2,159 ft., NW of Chichagof, on W coast of Chichagof I., Alex. Arch.; 57 $40^{\prime} 30^{\prime \prime} \mathrm{N}, 136^{\circ} 06^{\prime} 30^{\prime \prime} \mathrm{W} ; B G N$ 1908; (map 9). Var. Dulth Mountain.

Tlingit Indian name given by USC\&GS in 1907 and published in 1909 on Chart 8280. The word "doolth" [dulth], according to Andrew Braid, "means everything good and plentiful, referring to the abundance of game, fish, berries, and other resources in this whole region."

Doone Creek: stream, flows E $3.7 \mathrm{mi}$. to Chicka loon River, W of Puddingstone Hill, $30 \mathrm{mi}$. NE of Palmer, Talkeetna Mts.; 61 $51^{\circ} 30^{\prime \prime} \mathrm{N}$ $148^{\circ} 53^{\prime} 15^{\prime \prime} \mathrm{W}$; (map 69).

Local name reported in 1913 by USGS.

Doonerak, Mount: mountain, 7,610 ft., one of highest in Brooks Ra., $32 \mathrm{mi}$. SE of Anaktuvuk Pass and $38 \mathrm{mi}$. N of Wiseman, Brooks Ra.; $67^{\circ} 54^{\prime}$ N, $150^{\circ} 37^{\prime}$ W; BGN 1932; (map 124). 
Named in 1929 by Marshall (1956, p. 22). He wrote, "I called it "Matterhorn of the Koyukuk' * * Later I renamed it 'Doonerak' * * * the name 'Doonerak' I took from an Eskimo word which means 'a spirit,' or, as they would translate it, 'a devil.'" It was first climbed June 30,1952 by G. W. Beadle, Gunnar Bergman, and Alfred Tissieres (Farquhar, 1959, p. 218).

Doo-Nuk-Chav-Uk: water course, see Dunukchavuk Slough.

Dootny Lake: lake, see Tutna Lake.

Dora Bay: estuary, extends S $4 \mathrm{mi}$. of Cholmondeley Sound, on SE coast of Prince of Wales I., $40 \mathrm{mi}$. SE of Craig, Alex. Arch.; $55^{\circ} 14^{\prime} \mathrm{N}, 132^{\circ} 13^{\prime} \mathrm{W}$; (map 4).

Named in 1886 by Lt. Comdr. R. Clover, USN, for the steamer Dora, one of Alaska's most famous vessels with a record of over 40 years of service in northern waters. See Brooks (1953, p. 402).

Dora Creek: stream, flows $\mathrm{S}$ through Muskrat Lake $6.5 \mathrm{mi}$. to Chitina River, $2.2 \mathrm{mi}$. W of junc. of Gilahina River and $31 \mathrm{mi}$. W of McCarthy, Copper River Basin; $61^{\circ} 23^{\prime} \mathrm{N}, 143^{\circ}$ 57' W; (map 67). Var. Dark Creek, Dare Creek.

Named in 1885 by Lt. Allen (1887, p. 57), USA, for Miss Dora Johnston of Chicago, later his wife. Probably he applied it to the stream subsequently known as the Gilahina River. The name "Dora Creek" applied as above was reported by the USGS in 1951.

Dora Creek: stream, flows NW $4 \mathrm{mi}$. to Healy Creek, $5 \mathrm{mi}$. E of Healy, Alaska Ra.; $63^{\circ} 51^{\prime}$ $30^{\prime \prime} \mathrm{N}, 148^{\circ} 48^{\prime} 10^{\prime \prime} \mathrm{W}$; BGN 1946; (map 87).

Local name reported in 1944 by USGS.

Dora Creek: stream, flows NE $0.6 \mathrm{mi}$. to Cleary Creek, $1.2 \mathrm{mi}$. SE of Chatanika and $20 \mathrm{mi}$. NE of Fairbanks, Yukon-Tanana High.; $65^{\circ}$ $06^{\prime} \mathrm{N}, 147^{\circ} 27^{\prime} \mathrm{W}$; (map 105).

Local name published by USGS in the 1950's.

Dora Harbor: harbor, $1 \mathrm{mi}$. across, on Ikatan Penin., Unimak I., Aleutian Is.; $54^{\circ} 42^{\prime} \mathrm{N}$, $163^{\circ} 16^{\prime} \mathrm{W}$; (map 25). Var. Loras Harbor, Lords Harbor.

Local name published by USBF as "Loras Harbor" in 1888, and as "Lords Harbor" by USC\&GS in 1900.

Dorai Bay: bay, see Kuiukta Bay.

Dora Island: island, $1 \mathrm{mi}$. long, on $\mathrm{W}$ coast of Adak I. in Bay of Islands, Aleutian Is.; $51^{\circ}$ $48^{\prime} 45^{\prime \prime} \mathrm{N}, 176^{\circ} 47^{\prime} 10^{\prime \prime} \mathrm{W}$; BGN 1936; (map 17). Var. Dorothy Island.

Named in 1934 by members of the U.S. Navy Aleutian Island Survey Expedition, for the steamer Dora, "long engaged in trade in southwestern Alaska."

Dora Island: island, $0.1 \mathrm{mi}$. long, $3 \mathrm{mi}$. $\mathrm{S}$ of Sanak Is., one of Sanak Is., Aleutian Ra.; $54^{\circ} 19^{\prime} 40^{\prime \prime} \mathrm{N}, 162^{\circ} 37^{\prime} 40^{\prime \prime} \mathrm{W}$; (map 25).

Name published in 1949 on a USGS map.

Dora Island: island, southernmost of Twin Islands, $34 \mathrm{mi}$. SW of Seward, Chugach Mts.; $59^{\circ} 39^{\prime} 45^{\prime \prime} \mathrm{N}, 149^{\circ} 42^{\prime} 45^{\prime \prime}$ W; BGN 1930; (map 49).
Named in 1928 by USG\&GS "after the steamship Dora which plied these waters in 1912 and earlier."

Dora Keen Range: ridge, elev, 8,500 ft., extends NE $30 \mathrm{mi}$. from College Point, between Harvard and Yale Glaciers, $40 \mathrm{mi}$. NW of Valdez, Chugach Mts.; $61^{\circ} 20^{\prime} \mathrm{N}, 147^{\circ} 25^{\prime} \mathrm{W}$; $B G N 1965$; (map 69).

Named in 1965 by Lawrence Nielsen for Dora Keen Handy, 1871-1963, who led the first expedition into this area in 1914, and in 1912 had made the first ascent of Mount Blackburn.

Dora Lake: lake, $1.3 \mathrm{mi}$. long, at head of Dora Bay, on SE coast of Prince of Wales I., $41 \mathrm{mi}$. $\mathrm{SE}$ of Craig, Alex. Arch.; $55^{\circ} 10^{\prime} 00^{\prime \prime} \mathrm{N}$, $132^{\circ} 14^{\prime} 30^{\prime \prime} \mathrm{W}$; (map 4).

Name published by Wright and Wright (1908, fig. 16), USGS; derived from Dora Bay.

Doran, Mount: mountain, $4,000 \mathrm{ft}$., $4 \mathrm{mi}$. SW of Point Doran and $57 \mathrm{mi}$. SW of Anchorage, Chugach Mts.; $61^{\circ} 01^{\prime} 20^{\prime \prime} \mathrm{N}, 148^{\circ} 14^{\prime} 00^{\prime \prime} \mathrm{W}$; $B G N$ 1911; (map 69). Var. Doran Point. Named in 1911 by U. S. Grant, USGS, for Peter Doran, captain of the SS George $W$. Elder, the ship used by the Harriman Alaska Expedition.

Doran, Point: point of land, between Harriman Fiord and Barry Arm Port Wells, $59 \mathrm{mi}$. SE of Anchorage, Chugach Mts.; $61^{\circ} 04^{\prime} 20^{\prime \prime} \mathrm{N}$, $148^{\circ} 10^{\prime} 00^{\prime \prime} \mathrm{W}$; BGN 1910; (map 69).

Named in 1910 by U. S. Grant, USGS. See Doran, Mount.

Doran Point: mountain, see Doran, Mount.

Doran Strait: water passage, $1.2 \mathrm{mi}$. across, at mouth of Harriman Fiord, $57 \mathrm{mi}$. SE of Anchorage, Chugach Mts.; $61^{\circ} 04^{\prime} 45^{\prime \prime} \mathrm{N}, 148^{\circ}$ $09^{\prime} 30^{\prime \prime} \mathrm{W}$; (map 69).

Named in 1899 by members of the Harriman Alaska Expedition for Capt. Peter Doran of their steamer SS George W. Elder.

Dora Passage: water passage, extends $\mathrm{S} 4 \mathrm{mi}$. from Aialik Bay to the Gulf of Alaska, between Harbor I. and Twin Is., $32 \mathrm{mi}$. SW of Seward, Ghugach Mts.; $59^{\circ} 40^{\prime} \mathrm{N}, 149^{\circ} 41^{\prime} \mathrm{W} ; B G N$ 1930; (map 49).

Named in 1912 by USC\&GS "after the ship Dora". See Dora Island.

Dora Peak: mountain, 1,798 ft., $13 \mathrm{mi}$. SE of False Pass, Ikatan Penin., on Unimak I., Aleutian Is.; $54^{\circ} 42^{\prime} 45^{\prime \prime} \mathrm{N}, 163^{\circ} 11^{\prime} 30^{\prime \prime} \mathrm{W}$; (map 25).

Local name derived from Dora Harbor and reported in 1926 by USC\&GS.

Dora Peak: mountain, 5,572 ft., $10 \mathrm{mi}$. S of Jumb Dome and $8 \mathrm{mi}$. SE of Healy, Alaska Ra.; $63^{\circ} 49^{\prime} 30^{\prime \prime} \mathrm{N}, 148^{\circ} 42^{\prime} 30^{\prime \prime} \mathrm{W}$; (map 87). Name reported in 1950 by USGS.

Dora Reef: reef, in Gulf of Alaska, $3.3 \mathrm{mi}$. WSW of Perl I. and $25 \mathrm{mi}$. SW of Seldovia, Chugach Mts.; $59^{\circ} 00^{\prime} 20^{\prime \prime} \mathrm{N}, 151^{\circ} 48^{\prime} 00^{\prime \prime} \mathrm{W}$; $B G N$ 1908; (map 50).

Local name reported by USC\&GS in 1908.

Dorenoi Bay: bay, 2 mi. across, on $W$ shore of Stepovak Bay, Alaska Penin., Aleutian Ra.; $55^{\circ} 38^{\prime} \mathrm{N}, 160^{\circ} 22^{\prime} \mathrm{W}$; (map 28 ).
Local Russian name reported by Atwood (1911, pl. 2), USGS.

Doric Creek: stream, flows S $1.3 \mathrm{mi}$. to diversion ditch parallel to Pioneer Creek, $1 \mathrm{mi}$. NE of Eureka and $22 \mathrm{mi}$. S of Rampart, Yukon-Tanana High.; $65^{\circ} 11^{\prime} 10^{\prime \prime} \mathrm{N}, 150^{\circ} 11^{\prime} 30^{\prime \prime} \mathrm{W}$; (map 106).

Prospectors' name reported in 1904 by Prindle and Hess (1906, pl. 3), USGS.

Doris Bay: estuary, see Mud Bay.

Dornin Rock: rock, sunk in Stephens Passage at entrance to Fritz Cove, $0.3 \mathrm{mi}$. NW of Outer Point and $10 \mathrm{mi}$. W of Juneau, Coast Mts.; $58^{\circ} 19^{\prime} 40^{\prime \prime} \mathrm{N}, 134^{\circ} 41^{\prime} 05^{\prime \prime} \mathrm{W}$; (map 11).

Named in 1890 by Lt. Comdr. H. B. Mansfield, USN, for J. B. Dornin, a member of his party; published by USC\&GS in the 1891 Coast Pilot (p. 150).

Dorn Island: island, $1 \mathrm{mi}$. long, in Seymour Canal, $27 \mathrm{mi}$. NE of Angoon, on E coast of Admiralty I., Alex. Arch; $57^{\circ} 47^{\prime} \mathrm{N}, 134^{\circ} 03^{\prime}$ W; (map 9).

Named in 1890 by Lt .Comdr. R. W. Meade, USN, for Lt. Edward J. Dorn, USN, a member of his party. The name was published in 1890 by USC\&GS.

Dorokhova, Bukhta : estuary, see Deep Inlet.

Dorokhova Bay: estuary, see Deep Inlet.

Doroshin Bay: cove, $0.4 \mathrm{mi}$. across, on $\mathrm{E}$ shore of Skilak Lake, on Kenai Penin., $40 \mathrm{mi}$. ESE of

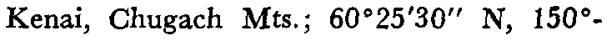
$08^{\prime} 00^{\prime \prime} \mathrm{W}$; (map 62).

Local name reported in 1959 by USGS. Possibly named for Peter P. Doroshin, a Russian mining engineer who made investigations in Cook Inlet in 1848.

Doroshin Glacier: glacier, heads at $59^{\circ} 28^{\prime} \mathrm{N}$, $151^{\circ} 00^{\prime} \mathrm{W}$, trends NW $6 \mathrm{mi}$. to its terminus at unnamed stream, $20 \mathrm{mi}$. ENE of Seldovia, Chugach Mts.; $59^{\circ} 29^{\prime} \mathrm{N}, 151^{\circ} 08^{\prime} \mathrm{W}$; (map 50).

So named by W. H. Dall in 1880 , "after Peter P. Doroshin, a Russian mining engineer, who made investigations in Cook Inlet in 1848."

Doroshin Lake: lake, $0.7 \mathrm{mi}$. long, on Kenai Penin., $1.3 \mathrm{mi}$. S of the Finger Lakes and 9 mi. NE of Kenai, Cook Inlet Low. ; 60 $36^{\prime} 30^{\prime \prime}$ $\mathrm{N}, 150^{\circ} 53^{\prime} 45^{\prime \prime} \mathrm{W}$; (map 62).

Named about 1963 by officials of Kenai National Moose Range, for administrative purposes.

Dorothy, Lake: lake, $3.3 \mathrm{mi}$. long, $5 \mathrm{mi}$. $\mathrm{S}$ of Taku Inlet and $17 \mathrm{mi}$. SE of Juneau, Coast Mts. ; $58^{\circ} 15^{\prime} \mathrm{N}, 133^{\circ} 58^{\prime} \mathrm{W}$; (map 12).

Name published in 1943 by USC\&GS.

Dorothy Cove: bay, $1 \mathrm{mi}$. across, near head of Necker Bay, on SW coast of Baranof I., Alex. Arch.; $56^{\circ} 43^{\prime} 40^{\prime \prime} \mathrm{N}, 135^{\circ} 04^{\prime} 30^{\prime \prime} \mathrm{W}$; (map 5).

Local name used by fishermen; published in 1925 by USC\&GS.

Dorothy Creek: stream, flows WSW $5 \mathrm{mi}$., through Lake Dorothy and Lieuy and Bart Lakes, to Taku Inlet, $16 \mathrm{mi}$. ESE of Juneau, Coast Mts. ; $58^{\circ} 14^{\prime} 15^{\prime \prime} \mathrm{N}, 37^{\circ} 03^{\prime} 20^{\prime \prime} \mathrm{W}$; (map 11). 
Name reported by USGS about 1950; probably derived from Lake Dorothy.

Dorothy Creek: stream, flows NE $2.3 \mathrm{mi}$. to Nome River, $23 \mathrm{mi}$. NE of Nome, Seward Penin. High.; $64^{\circ} 49^{\prime} \mathrm{N}, 165^{\circ} 14^{\prime} \mathrm{W}$; (map 94).

Prospectors' name reported in 1900 by E. C. Barnard (in Brooks, 1901, pl. 17), USGS.

Dorothy Creek: stream, flows SW $19 \mathrm{mi}$. to Lake Creek, $11 \mathrm{mi}$. NNW of Rabbit Mtn. and $38 \mathrm{mi}$. NW of Coleen Mtn., Brooks Ra.; 67 ${ }^{\circ} 37^{\prime}$ $\mathrm{N}, 142^{\circ} 24^{\prime} \mathrm{W}$; (map 121).

Local name reported in 1956 by T. E. Taylor, USGS.

Dorothy Island: island, see Dora Island.

Dorothy Narrows: water passage, $1.2 \mathrm{mi}$. S of Goddard, between Elovoi I. and W coast of Baranof I., Alex. Arch.; $56^{\circ} 49^{\prime} 00^{\prime \prime}$ N, $135^{\circ} 22^{\prime}$ $30^{\prime \prime} \mathrm{W}$; (map 5).

Local name used by fishermen; published in 1925 by USC\&GS.

Dorothy Narrows: water passage, see Windy Passage.

Dorothy Slough: stream, 1 mi. long, on left bank of Koyukuk River, $6 \mathrm{mi}$. SW of Allakaket, Kokrines-Hodzana High.; $66^{\circ} 30^{\prime}$ N, $152^{\circ} 47^{\prime}$ $\mathrm{W}$; (map 117).

Named in 1899 for the riverboat Dorothy which wintered there in 1898-99.

Dorozhnoy, Ostrov: island, see Road Island.

Dorozhoi Island: island, see Road Island.

Dorsey Creek: stream, see Dewey Creek.

Dosennaughten Lake: lake, $0.8 \mathrm{mi}$. long, on $\mathrm{E}$ bank of Alatna River, $3.5 \mathrm{mi}$. N of Allakaket, Kanuti Flats; $66^{\circ} 37^{\prime} \mathrm{N}, 152^{\circ} 36^{\prime} \mathrm{W}$; (map 117).

Koyukan Indian name obtained in 1956 at Allakaket by T. E. Taylor, USGS.

Dot Hill: hill, see Ridge Hill.

Dot Island: island, $0.2 \mathrm{mi}$. long, between El Capitan and Cap Is., Alex. Arch.; 55 $54^{\prime} 20^{\prime \prime}$ N, $133^{\circ} 19^{\prime} 50^{\prime \prime} \mathrm{W}$; (map 4).

Named in 1904 by E. F. Dickins, USC\&GS, for the "Name of signal Dot."

Dot Island: island, $300 \mathrm{ft}$. across, in Afognak Bay, $3.3 \mathrm{mi}$. $\mathrm{N}$ of Afognak, on $\mathrm{S}$ coast of Afognak I.; $58^{\circ} 03^{\prime} 20^{\prime \prime} \mathrm{N}, 152^{\circ} 45^{\prime} 25^{\prime \prime} \mathrm{W}$; (map 43).

Named in 1900 by Lt. Comdr. J. F. Moser, USN, commander of the USBF steamer Albatross.

Dot Lake: village, pop. 56, on Alaska Highway at Dot Lake, $40 \mathrm{mi}$. NW of Tok, Tanana Low.; $63^{\circ} 39^{\prime} 45^{\prime \prime} \mathrm{N}, 144^{\circ} 04^{\prime} 00^{\prime \prime} \mathrm{W}$; (map 86).

Commercial and Indian settlement established about 1954 on the highway at an emergency landing field.

Dot Lake: lake, 1,500 ft. long, E of Alaska Highway, at Dot Lake village, $40 \mathrm{mi}$. NW of Tok, Tanana Low.; 63⒊ $39^{\prime} 45^{\prime \prime} \mathrm{N}, 144^{\circ} 04^{\prime} 00^{\prime \prime} \mathrm{W}$; (map 86).

Name published on relatively recent maps.

Dotle: locality, on the Koyukuk River; (map 108). Var. Dotlèkakát.

Koyukan Indian camp or small settlement listed by Hodge (1907, p. 399), who lists a population of 12 in 1885 .

Dotlèkakát: locality, see Dotle.
Dotsons Landing: locality, on $\mathrm{W}$ shore of Favorite Channel, on Amalga Harbor, $0.7 \mathrm{mi}$. N of Pearl Harbor and $19 \mathrm{mi}$. NW of Juneau, Coast Mts.; $58^{\circ} 29^{\prime} 30^{\prime \prime} \mathrm{N}, 1^{\circ} 34^{\circ} 47^{\prime} 05^{\prime \prime} \mathrm{W}$; (map 11). Var. Eagle River Landing.

Named for John Dotson, 1862-1937, and his wife, 1866-1933. They came to Juneau in 1912 and lived near this landing for many years (DeArmond, 1957, p. 14). Called Eagle River Landing prior to about 1940.

Doty Cove: cove, $1 \mathrm{mi}$. across, on NE coast of Glass Peninsula, $3 \mathrm{mi}$. S of False Arden and $16 \mathrm{mi}$. SE of Juneau, Alex. Arch.; $58^{\circ} 07^{\prime} \mathrm{N}$, $134^{\circ} 10^{\prime} \mathrm{W}$; $B G N$ 1930; (map 11). Var. Dotys Cove.

Locally named for Charles Doty, who was born in Massachusetts and served in the U.S. Navy during the Civil War. He came to Alaska in 1886 and about 1900 claimed a homestead at Doty Cove. He died at Douglas in 1914 (DeArmond, 1966). The name was reported by USFS in 1929.

Dotys Cove : cove, see Doty Cove.

Double Bay: estuary, on $\mathrm{N}$ coast of Hinchinbrook I., at mouths of Bear and Double Creeks, 25 mi. SW of Cordova, Chugach Mts.; 60 $28^{\prime} \mathrm{N}$, $146^{\circ} 28^{\prime} \mathrm{W}$; (map 64$)$.

So named locally "because a short peninsula extends into a large bay, partially dividing it into two smaller bays." Name published in 1950 by USGS.

Double Cove: cove, $0.2 \mathrm{mi}$. across, $5 \mathrm{mi}$. S. of Chichagof, on Takeena Penin., W coast of Chichagof I., Alex. Arch.; 57 $35^{\prime} 30^{\prime \prime} \mathrm{N}$, 136 $03^{\prime} 30^{\prime \prime}$ W; BGN 1908; (map 9). Var. Portage Cove.

Descriptive name given in 1908 by USC\&GS "because the cove is divided into two parts by islands."

Double Creek: stream, on Hinchinbrook I., flows NE $3.5 \mathrm{mi}$. to Double Bay, $25 \mathrm{mi}$. SW of Cordova, Chugach Mts.; $60^{\circ} 28^{\prime} \mathrm{N}, 146^{\circ} 27^{\prime}$ W; (map 64).

Name published in 1950 by USGS; derived from Double Bay to which the stream flows.

Double Glacier: glacier, trends N $2 \mathrm{mi}$. to its 1958 terminus $\mathrm{S}$ of Johnson Glacier terminus, $12 \mathrm{mi}$. W of Slope Mtn., $68 \mathrm{mi}$. SW of Kenai, Aleutian Ra.; $60^{\circ} 06^{\prime} \mathrm{N}, 152^{\circ} 58^{\prime} \mathrm{W}$; (map 62).

Local descriptive name reported in 1958 by USGS.

Double Glacier: glacier, trends E $11 \mathrm{mi}$. to head of its Big River Lobe, $47 \mathrm{mi}$. WNW of Kenai, Aleutian Ra.; $60^{\circ} 42^{\prime} \mathrm{N}, 152^{\prime} 38^{\prime} \mathrm{W}$; (map 62).

Local name reported in 1958 by USGS. So named because the glacier is divided into two lobes.

Double Headed Point: island, see Twoheaded Island.

Double Island: island, $0.1 \mathrm{mi}$. across, in Krestof Sound, $13 \mathrm{mi}$. NW of Sitka, Alex. Arch; $57^{\circ} 11^{\prime} 25^{\prime \prime} \mathrm{N}, 135^{\circ} 34^{\prime} 30^{\prime \prime} \mathrm{W}$; (map 9).

Descriptive name given in 1908 by USC\&GS and published in 1909 on Chart 8280 . It was "so named because it is shaped like a figure ' 8 '."
Double Island: islands, extend 1,600 ft., in Cordova Bay, on SW coast of Prince of Wales I., at entrance to Klakas Inlet, Alex. Arch.; $54^{\circ} 52^{\prime} 45^{\prime \prime} \mathrm{N}, 132^{\circ} 24^{\prime} 00^{\prime \prime} \mathrm{W}$; (map 1).

Descriptive name given in 1897 by Lt. Comdr. J. F. Moser, USN

Double Island: islands, extend $0.5 \mathrm{mi}$. in Clarence Strait, on SW coast of Etolin I., Alex. Arch.; $55^{\circ} 56^{\prime} 45^{\prime \prime} \mathrm{N}, 132^{\circ} 27^{\prime} 00^{\prime \prime} \mathrm{W}$; (map 4).

Descriptive name given in 1886 by Lt. Comdr. A. S. Snow, USN. "The island is double at high water."

Double Islands: islands, extend $0.5 \mathrm{mi}$. in Cat Passage, $27 \mathrm{mi}$. SE of Duke I., Alex Arch.; $55^{\circ} 00^{\prime} 10^{\prime \prime} \mathrm{N}, 131^{\circ} 18^{\prime} 15^{\prime \prime} \mathrm{W}$; (map 3).

Named in 1883 by Lt. Comdr. H. E. Nichols, USN; so called because they consist of two islands.

Double Lake: lake, see Lodge Lake.

Double Mountain: mountain, 5,899 ft., $9 \mathrm{mi}$. NW of Fang Mtn., 24 mi. SW of Healy, Alaska Ra.; $63^{\circ} 36^{\prime} 15^{\prime \prime} \mathrm{N}, 149^{\circ} 28^{\prime} 10^{\prime \prime} \mathrm{W}$; (map 87).

Local name shown on a 1916 fieldsheet by C. E. Griffin, USGS.

Double Mountain: mountain, 6,750 ft., on W bank of Sheenjek River, $28 \mathrm{mi}$. NW of Table Mtn., Brooks Ra.; $68^{\circ} 45^{\prime} \mathrm{N}, 143^{\circ} 48^{\prime} \mathrm{W}$; (map 137).

Local name reported in 1956 by USGS.

Double Peak: peak, 6,818 ft., N of Double Glacier, $47 \mathrm{mi}$. WNW of Kenai, Aleutian Ra.; $60^{\circ} 43^{\prime} 45^{\prime \prime} \mathrm{N}, 152^{\circ} 35^{\prime} 30^{\prime \prime} \mathrm{W}$; (map 62).

Local name published in 1912 by USC\&GS; derived from the glacier.

Double Point: point of land, on SW coast of Little Sitkin I., Rat Is., Aleutian Is.; $51^{\circ} 55^{\prime}$ $45^{\prime \prime} \mathrm{N}, 178^{\circ} 27,45^{\prime \prime} \mathrm{E}$; (map 15).

Name reported by Snyder (1959, p. 177179), USGS.

Double Point Mountain: mountain, 1,700 ft., N of Koyukuk River, extends W $10 \mathrm{mi}$. from Henshaw Creek, $7.5 \mathrm{mi}$. NE of Allakaket, Hogatza High.; $66^{\circ} 40^{\prime} \mathrm{N}, 152^{\circ} 25^{\prime} \mathrm{W}$; (map 117).

Descriptive name given in 1885 by Lt. Allen (1887, map 4), USA.

Doubtful Creek: stream, flows $5.4 \mathrm{mi}$. NW to Nizina River, $4 \mathrm{mi}$. E of Nizina Mtn. and 19 mi. NE of McCarthy, Wrangell Mts.; $61^{\circ}$ $35^{\prime} 45^{\prime \prime} \mathrm{N}, 142^{\circ} 27^{\prime} 45^{\prime \prime} \mathrm{W}$; (map 67).

Local name obtained by USGS and published on maps since 1954.

Doubtful Slough: stream, about $6 \mathrm{mi}$. long, on left bank of Yukon River, encloses southeastern half of Ninemile I., $4 \mathrm{mi}$. SW of Nualto, Koyukuk Low.; $64^{\circ} 37^{\prime} 00^{\prime \prime} \mathrm{N}, 158^{\circ} 16^{\prime} 30^{\prime \prime}$. W ; (map 97).

Riverboat pilots' name shown on a 1940 "Navigation Chart of Tanana-Yukon Rivers" published by U.S. Dept. of Interior.

Dougherty, Point: point of land, on $\mathrm{N}$ shore of Bertha Bay, $13 \mathrm{mi}$. NW of Chichagof, on W coast of Chichagof I., Alex. Arch.; 57 $48^{\prime} 30^{\prime \prime}$ $\mathrm{N}, 136^{\circ} 21^{\prime} 20^{\prime \prime} \mathrm{W}$; (map 9).

Name published in 1928 by USC\&GS on Chart 8258.

Dougherty Creek: stream, flows NE $13 \mathrm{mi}$. to Gerstle River, $29 \mathrm{mi}$. SE of Delta Junction, 
Alaska Ra.; $63^{\circ} 47^{\prime} 20^{\prime \prime} \mathrm{N}, 144^{\circ} 58^{\prime} 30^{\prime \prime} \mathrm{N}$; $B G N$ 1937; (map 86).

Local name shown on a 1927 manuscript map of the "Endicott and Haley Hunting Expedition."

Doughton Peak: peak, 2,600 ft., on Carbon Mtn., $1 \mathrm{mi}$. NW of Berg Lake and $64 \mathrm{mi}$. $\mathbf{E}$ of Cordova, Chugach Mts.; $60^{\circ} 26^{\prime} \mathrm{N}, 143^{\circ} 53^{\prime} \mathrm{W}$; (map 65).

Prospectors' name reported in 1905 by G. C. Martin, USGS.

Douglas: town, pop. 1,042, on NE coast of Douglas I., on Gastineau Channel, $1.8 \mathrm{mi}$. SW of Juneau, Coast Mts.; $58^{\circ} 16^{\prime} 40^{\prime \prime} \mathrm{N}$, $134^{\circ} 23^{\prime} 35^{\prime \prime}$ W; (map 11). Var. Douglas City, Douglas Village, Edwardsville.

Named about 1886 for the island on which it is located. The early name was "Edwardsville," perhaps for $\mathrm{H}$. H. Edwards, an early miner and resident. The town was established in 1881 as the result of mining activity in the area. It became an incorporated city in 1902. Since then it has suffered several serious fires which have destroyed much of the original town (DeArmond, 1957, pp. 14-15).

Douglas, Cape: point of land, $\mathrm{S}$ entrance to Sukoi Bay, on NE coast of Alaska Penin., in Katmai National Monument, $33 \mathrm{mi}$. SE of Augustine I., Aleutian Ra.; $58^{\circ} 51^{\prime} \mathrm{N}, 153^{\circ}$ 15' W; (map 43). Var. Kamieshatskoi, Koukhat, Kuchat, Kukuak.

Name given by Capt. Cook (1785, p. 385), $\mathrm{RN}$, on May 25, 1778, who wrote "This promontory I named Cape Douglas in honor of my very good friend, Dr. [John] Douglas, canon of Windsor ***”. Wagner $(1937$, p. 384) says "in reality he [Cook] considered the twoheaded mountain to be the cape as he was at some distance from it * * *." Baker (1906, p. 224) reported "The native name is given as Kukuak, Koukhat, and Kuchat * * *."

Douglas, Cape: point of land, on Bering Sea, 51 mi. NW of Nome, Seward Penin. High.; $65^{\circ}-$ $00^{\prime \prime} \mathrm{N}, 166^{\circ} 42^{\prime} \mathrm{W}$; (map 94). Var. Mys Duglas, Ongneak.

Named in 1826 by Capt. Beechey (1831, map facing p. 328), RN.

Douglas, Mount: mountain, 2,074 ft., $11 \mathrm{mi}$. NW of Chichagof, on $W$ coast of Chichagof I., Alex. Arch.; $57^{\circ} 47^{\prime} 45^{\prime \prime} \mathrm{N}, 136^{\circ} 16^{\prime} 00^{\prime \prime} \mathrm{W}$; (map 9). Var. Davison Peak.

Name published in 1928 by USC\&GS on Chart 82.58. It was published as Davison Peak by Overbeck (1919, pl. 2), USGS.

Douglas, Mount: peak, 7,000 ft, on NE coast of Alaska Penin., in Katmai National Monument, $32 \mathrm{mi}$. S of Augustine I., Aleutian Ra.; $58^{\circ}$ $51^{\prime} 35^{\prime \prime} \mathrm{N}, 153^{\circ} 32^{\prime} 00^{\prime \prime} \mathrm{W}$.; (map 43).

Name derived from Cape Douglas and reported by G. C. Martin, USGS, in 1904.

Douglas Bay: bight, $5 \mathrm{mi}$. across, on $\mathrm{S}$ coast of Kupreanof I., Alex. Arch.; $56^{\circ} 28^{\prime}$ N, $133^{\circ} 17^{\prime}$ W; (map 6). Var. Douglass Bay.

Named in 1886 by Lt. J. M. Helm, USN, for charting purposes; name published in 1887 on USC\&GS Chart 706.

Douglas Gity:town, see Douglas.
Douglas Creek: stream, flows W $7.5 \mathrm{mi}$. to Jim River, $31 \mathrm{mi}$. E of Bettles, Kokrines-Hodzana High.; $66^{\circ} 51^{\prime} 20^{\prime \prime} \mathrm{N}, 150^{\circ} 34^{\prime} 30^{\prime \prime} \mathrm{W}$; (map 117).

Local name reported in 1956 by T. E. Taylor, USGS.

Douglas Creek: stream, flows SW 9 mi. to Noatak River, $26 \mathrm{mi}$. SE of Howard Pass, Brooks Ra.; $67^{\circ} 52^{\prime} \mathrm{N}, 156^{\circ} 32^{\prime} \mathrm{W}$; (map 126).

Local personal name obtained at Noatak by Orth in 1956.

Douglas Island: island, $0.4 \mathrm{mi}$. long, in Cordova Bay, on SW coast of Prince of Wales I., $3 \mathrm{mi}$. NW of Point Marsh, Alex. Arch.; 54 ${ }^{\circ} 45^{\prime} 30^{\prime \prime}$ $\mathrm{N}, 132^{\circ} 20^{\prime} 40^{\prime \prime} \mathrm{W}$; (map 1 ).

Local name reported in 1951 by USGS.

Douglas Island: island, $17 \mathrm{mi}$. long, extends NW-SE between Gastineau Channel and Stephens Passage, $0.5 \mathrm{mi}$. S of Juneau, Coast Mts.; $58^{\circ} 15^{\prime} 30^{\prime \prime} \mathrm{N}, 134^{\circ} 16^{\prime} 30^{\prime \prime} \mathrm{W}$; (map 11). Var. Douglass Island.

Named by Capt. Vancouver (1798, v. 3, p. 277), RN, for John Douglas, who in 1791 became Bishop of Salisbury. He was the editor of Capt. James Cook's journal (Wagner, 1937, p. 384).

Douglas Island: island, see Forrester Island.

Douglas Reef: reef, extends $2 \mathrm{mi}$., in Shelikof Strait, on NE coast of Alaska Penin., in Katmai National Monument, $5 \mathrm{mi}$. S of Cape Douglas and $39 \mathrm{mi} \mathrm{S}$ of Augustine I; Aleutian Ra.; $58^{\circ} 45^{\prime} 45^{\prime \prime} \mathrm{N}, 153^{\circ} 16^{\prime} 00^{\prime \prime} \mathrm{W}$; $B G N$ 1910; (map 43). Var. Beaver Reef, Bobrof, Bobrovoi, Bobrow, Sea Otter Reef, Sea Otter Rocks.

Name derived from Cape Douglas and given by USC\&GS in 1910 in an effort to eliminate duplication of the names "Bobrovyy," (meaning "sea otter"), and "Sea Otter" in this area. Baker (1906, p. 558) published the name "Sea Otter" for this feature.

Douglas River: stream, heads at $58^{\circ} 48^{\prime} \mathrm{N}$, $153^{\circ} 48^{\prime} \mathrm{W}$, flows N $28 \mathrm{mi}$. to Kamishak Bay, $25 \mathrm{mi}$. SW of Augustine I., Aleutian Ra.; $59^{\circ} 04^{\prime} 30^{\prime \prime} \mathrm{N}, 153^{\circ} 48^{\prime} 30^{\prime \prime} \mathrm{W}$; (map 51). Var. Andrews River, Chuiu River, Chuyu River, Tschuiou River, Tschuiow River.

Local name reported in 1904 by G. C. Martin, USGS. It was also locally called Andrews River (Brooks and others, 1905, p. 138). This is probably the same stream shown by Capt. Tebenkov (1852, map 5), IRN, as "R[eka] Chuyu," i.e. "Chuyu River." Douglass: locality, see Kaguyak.

Douglass Bay: bay, $0.6 \mathrm{mi}$. across, between Patterson Bay and South Arm Hoonah Sound, $13 \mathrm{mi}$. $\mathrm{E}$ of Chichagof, on $\mathrm{S}$ central Chichagof I., Alex. Arch.; 57 $41^{\prime}$ N, $135^{\circ} 44^{\prime}$ W; (map 9).

Named in 1895 by Lt. Comdr. Moore, USN.

Douglass Bay: bight, see Douglas Bay.

Douglass Entrance: water passage, see Dixon Entrance.

Douglass Island: island, see Douglas Island.

Douglas Village: town, see Douglas.

Doushnai Bay: cove, see Close Bay.

Dova Bay: bay, extends SW $2 \mathrm{mi}$. off Tlevak Strait, on N coast of Long I., Alex. Arch.; $54^{\circ} 55^{\prime} 30^{\prime \prime} \mathrm{N}, 132^{\circ} 42^{\prime} 15^{\prime \prime} \mathrm{W} ; B G N$ 1929; (map 1).

Named in 1928 by Capt. R. S. Patton, USC\&GS, who derived it "from the last part of the name 'Cordova,' the adjoining bay."

Dove Island: island, $0.1 \mathrm{mi}$. long, in Davidson Inlet, $0.4 \mathrm{mi}$. E of White Cliff I., Alex. Arch.; $55^{\circ} 54^{\prime} 50^{\prime \prime} \mathrm{N}, 133^{\circ} 27^{\prime} 55^{\prime \prime} \mathrm{W}$; (map 4).

Descriptive name given in 1917 by USC\&GS because "fancied resemblance of charted outline *** to a dove."

Dove Island: island, $0.1 \mathrm{mi}$. across, in Jamestown Bay, 2 mi. SE of Sitka, on $W$ coast of Baranof I., Alex. Arch.; $57^{\circ} 02^{\prime} 25^{\prime \prime} \mathrm{N}, 135^{\circ} 17^{\prime} 30^{\prime \prime} \mathrm{W}$; (map 9.) Var. Dove Islet.

Named by USN in 1880 for "Mr. Dove," who was employed on the U.S.S. Jamestown that year. The name was published by USC\&GS in the 1883 Coast Pilot (p. 144).

Dove Islet: island, see Dove Island.

Dovelawik Bay: bight, $4 \mathrm{mi}$. SE of Gambell, between Meruwtu Point and Agtapuk Point, on $\mathrm{N}$ coast of Saint Lawrence $\mathrm{I} ; 63^{\circ} 44^{\prime} \mathrm{N}$, $171^{\circ} 39^{\prime}$ W; BGN 1951; (map 93). Var. Tiflighak Bay, Tivlarak Bay.

Eskimo name reported in 1944 by Lawrence Kulukhan of Gambell. Orth recorded the name "Tivlarak," meaning "portage," in 1965 at Gambell; named because it is the east end of a trail which extends over the hills from Gambell and south end of Troutman Lake.

Doverspike Creek: stream, flows $\mathrm{SE} 1 \mathrm{mi}$. to Adam Creek, $10 \mathrm{mi}$. N of Solomon, Seward Penin. High.; $64^{\circ} 42^{\prime}$ N, $164^{\circ} 27^{\prime}$ W; (map 95).

Prospectors' name reported on a map of Cape Nome gold fields by David Fox, Jr., dated 1901.

Dovolno Point: point of land, at head of Kizhuyak Bay, 16 mi. SW of Kodiak, on N coast of Kodiak I.; $57^{\circ} 44^{\prime} 30^{\prime \prime} \mathrm{N}, 152^{\circ} 50^{\prime} 40^{\prime \prime}$ W; (map 34). Var. Mys Nizmennyy.

Russian name meaning "sufficiently," published in 1943 by USC\&GS. The descriptive name "M[ys] Nizmennyy," meaning "low cape," was given to this point in 1839 or 1840 by Sub-Lt. Mikhail Murashev, IRN, and published in 1849 on Russian Hydrog. Dept. Chart 1425.

Dowling Peak: peak, 4,104 ft., $2.5 \mathrm{mi}$. SW of Mount Carter and $48 \mathrm{mi}$. NE of Valdez, Chugach Mts.; $61^{\circ} 46^{\prime} 15^{\prime \prime} \mathrm{N}, 145^{\circ} 47^{\prime} 00^{\prime \prime} \mathrm{W}$; (map 68).

Named in 1898 by Capt. W. R. Abercrombie, USA.

Downbeat Mountain: mountain, 2,140 ft., 2.5 mi. E of Red Mtn. and $16 \mathrm{mi}$. NW of Hagemeister I., Kilbuck-Kuskokwim Mts.; 58 $58^{\prime}$ N, $161^{\circ} 03^{\prime} \mathrm{W}$; (map 39$)$.

Local name published in 1951 by USGS. Downer Glacier: glacier, trends W $2.6 \mathrm{mi}$., in in Dora Keen Ra., $46 \mathrm{mi}$. NW of Valdez, Chugach Mts.; $61^{\circ} 16^{\prime} 50^{\prime \prime} \mathrm{N}, 147^{\circ} 38^{\prime} 30^{\prime \prime} \mathrm{W}$; $B G N$ 1930; (map 69).

Named in 1910 by Lawrence Martin for the Milwaukee-Downer College for Women, Milwaukee, Wis. 
Downey Creek: stream, flows NE $16 \mathrm{mi}$. to Kuskokwim River, $14 \mathrm{mi}$. NW of Red Devil and $20 \mathrm{mi}$. NW of Sleetmute, Kilbuck-Kuskokwim Mts.; 61 $52^{\circ} 45^{\prime \prime} \mathrm{N}, 157^{\circ} 39^{\prime} 10^{\prime \prime} \mathrm{W}$; $B G N$ 1943; (map 72).

Named in 1943 by USGS "for a trapper who lived near the mouth."

Downwind Lake: lake, $0.5 \mathrm{mi}$. long, $\mathrm{N}$ of Denali Highway, $22 \mathrm{mi}$. W of Paxson, Alaska Ra.; $63^{\circ} 04^{\prime} 40^{\prime \prime} \mathrm{N}, 146^{\circ} 11^{\prime} 20^{\prime \prime} \mathrm{W}$; (map 86).

Named betwen 1948 and 1955 by T. L. Péwé, USGS.

Dowry Creek: stream, flows SE $1 \mathrm{mi}$. to Salmon River, $1.5 \mathrm{mi}$. E of Red Mtn. and $27 \mathrm{mi}$. NE of Cape Newenham, Kilbuck-Kuskokwim Mts.; $58^{\circ} 57^{\prime} \mathrm{N}, 161^{\circ} 42^{\prime} \mathrm{W}$; $B G N$ 1938; (map 39).

Local name established before 1933.

Doyhof: settlement, on $\mathrm{N}$ coast of Mitkof I., 1 mi. SW of Petersburg, Alex. Arch.; $56^{\circ} 47^{\prime} 00^{\prime \prime}$ N, 132 $58^{\prime} 30^{\prime \prime}$ W; (map 6). Var. Doyhoff.

Former cannery, the name of which was derived from part of the last names of Myer Hofstad and his partner "Doyan." The Doyhof post office was established in 1918; discontinued in 1936 (Ricks, 1965, p. 17). See Scow Bay.

Doyhof: area, see Scow Bay.

Doyhoff: settlement, see Doyhof.

Doyle Bay: cove, $1.3 \mathrm{mi}$. across, on $\mathrm{W}$ coast of Prince of Wales I., $5 \mathrm{mi}$. SE of Craig, Alex. Arch.; $55^{\circ} 24^{\prime} 50^{\prime \prime} \mathrm{N}, 133^{\circ} 02^{\prime} 40^{\prime \prime} \mathrm{W}$; $B G N$ 1966; (map 4).

Local name reported in 1963 by USFS. "Pioneer residents in Craig and general area believe the bay was named after an old prospector by the name of Doyle, who lived in the area in the early settlement of Craig."

Doyle Island: island, extends $\mathrm{E}-\mathrm{W} 4 \mathrm{mi}$., in Yukon River, $0.4 \mathrm{mi}$. $\mathrm{N}$ of Edith I. and 38 mi. NE of Ruby, Nowitna Low.; 64 ${ }^{\circ} 56^{\prime} \mathrm{N}$, $154^{\circ} 17^{\prime} \mathrm{W}$; (map 98).

Riverboat pilots' name shown on 1940 "Navigation Chart, Tanana-Yukon Rivers" of the River Boat Service, U.S. Dept of Interior.

Drag Island: island, $0.2 \mathrm{mi}$. long, in Chichagof Pass between Etolin and Woronofski Is., Alex. Arch.; $56^{\circ} 21^{\prime} 05^{\prime \prime} \mathrm{N}, 132^{\circ} 32^{\prime} 50^{\prime \prime} \mathrm{W}$; $B G N$ 1917; (map 6).

Named in 1913 by USC\&GS.

Dragonfly Creek: stream, flows W $1.5 \mathrm{mi}$. to Nenana River, $4.5 \mathrm{mi}$. $\mathrm{N}$ of village of $\mathrm{Mc}$ Kinley Park, Alaska Ra.; $63^{\circ} 47^{\prime} 45^{\prime \prime} \mathrm{N}$, 148 55'27" W; BGN 1965; (map 87).

Named in 1965 by Alaska Dept. of Highways for the "dragonflies that are abundant in the area." See Iceworm Gulch.

Dragon Point: point of land, on $\mathrm{S}$ coast of Carlisle I., Aleutian Is.; $52^{\circ} 51^{\prime} 35^{\prime \prime} \mathrm{N}$, $170^{\circ} 02^{\prime} 50^{\prime \prime} \mathrm{W}$; (map 20).

Name published by USC\&GS in the 1944 Aleutian Coast Pilot (p. 77).

Drake, Mount: mountain, 1,925 ft., $12.5 \mathrm{mi}$. NW of Chichagof, on $\mathrm{W}$ coast of Chichagof $\mathrm{I}$., Alex. Arch.; $57^{\circ} 49^{\prime} 10^{\prime \prime} \mathrm{N}, 136^{\circ} 16^{\prime} 10^{\prime \prime} \mathrm{W}$; (map 9).

Name published in 1928 by USC\&GS on Chart 8258.
Drake Head: point of land, between Kempff and Lazy Bays, on Alitak Bay at $\mathrm{S}$ end of Kodiak I. ; $56^{\circ} 56^{\prime} 20^{\prime \prime} \mathrm{N}, 154^{\circ} 12^{\prime} 50^{\prime \prime} \mathrm{W}$; (map 32 ).

Name reported in 1900 by Lt. Comdr. J. F. Moser, USN.

Drake Island: island, $3.2 \mathrm{mi}$. long, in Glacier Bay, at $\mathrm{N}$ end of Whidbey Passage, in Glacier Bay National Monument, $3 \mathrm{mi}$. W of Marble Mtn. and $48 \mathrm{mi}$. NW of Hoonah, St. Elias Mts. ; 58 $39^{\prime} 15^{\prime \prime} \mathrm{N}, 136^{\circ} 13^{\prime} 30^{\prime \prime} \mathrm{W}$; (map 10).

Origin of name unknown. It first appears on Brit. Adm. Chart 2431, corrected in 1890.

Drake Lake: lake, $1 \mathrm{mi}$. long, on Kenai Penin., E of Dolly Varden Lake, $20 \mathrm{~m}$. NE of Kenai, Cook Inlet Low.; $60^{\circ} 42^{\prime} 15^{\prime \prime} \mathrm{N}, 150^{\circ} 45^{\prime} 00^{\prime \prime}$ W; (map 62).

Named about 1963 by officials of Kenai National Moose Range for administrative purposes.

Dranish, Mount: mountain, see Dranishnikof, Mount.

Dranishikoff Settlement: locality, see The Redoubt.

Dranishnikof, Mount: mountain, 3,220 ft., $10 \mathrm{mi}$. S of Sitka, on $W$ coast of Baranof I., Alex. Arch.; 56 54' N, $135^{\circ} 17^{\prime} \mathrm{W}$; (map 5). Var. Dranishnikoff Peak, Gora Dranishnikova Mount Dranish, Redoubt Mountain.

Named in 1809 by the Russian navigator, Ivan Vasiliev the first, IRN; published by Lt. Sarichev (1826, map 19), IRN, as "G[ora] Dranishnikova" or "Dranishnikov Mountain."

Dranishnikoff Peak : mountain, see Dranishnikof, Mount.

Dranishnikova, Gora: mountain, see Dranishnikof, Mount.

Dranishnikova, Ryka: stream, see Dranishnikov River.

Dranishnikov River: stream, on $\mathrm{W}$ side of Baranof I., heads on S side of Mount Dranishnikov, flows S $1 \mathrm{mi}$. to head of Redoubt Bay, Alex. Arch.; 56 53'15" N, $135^{\circ} 17^{\prime} 15^{\prime \prime}$ W; (map 5). Var. Ryka Dranishnikova.

Name published by Lt. Sarichev (1826, map 19), IRN, as "Ryka Dranishnikova," or "Dranishnikov River." This feature is not shown on current maps.

Draper, Mount: mountain, 5,670 ft., $2.3 \mathrm{mi}$. SW of Nunatack and $29 \mathrm{mi}$. NE of Yakutat, St. Elias Mts.; $59^{\circ} 48^{\prime} 25^{\prime \prime} \mathrm{N}, 139^{\circ} 04^{\prime} 40^{\prime \prime} \mathrm{W}$; (map 46).

Named by Russell (1892, p. 86) for John W. Draper, his "highly esteemed teacher."

Dravnoi': cove, $0.3 \mathrm{mi}$. across, $\mathrm{SW}$ of Garden Cove, on SE coast of St. George I., Pribilof Is. ; $56^{\circ} 33^{\prime} 30^{\prime \prime} \mathrm{N}, 169^{\circ} 32^{\prime} 00^{\prime \prime} \mathrm{W}$; (map 38). Var. Kologho.

Russian name listed by Putnam (1903, p. 1014), USC\&GS, meaning "wooded"; "so called because of the amount of drift-wood found on the beach." The Russian word "drova" means "fire-wood." Putnam (p. 1015) lists the Aleut name as "Kologho" meaning "choked" or "full," again referring to beach drift-wood.

Drayham Creek: stream, flows NW $6 \mathrm{mi}$. to Charley River, $16 \mathrm{mi}$. SW of that stream's junc. with Yukon River, Yukon-Tanana High.; $65^{\circ} 07^{\prime} \mathrm{N}, 143^{\circ} 02^{\prime} \mathrm{W}$; (map 103).

Prospectors' name from an unpublished map by E. J. Chamberlain, dated 1902.

Dream Creek: stream, flows W 6 mi. to Gibraltar Lake, $30 \mathrm{mi}$. SE of Iliamna, Aleutian Ra.; $59^{\circ} 20^{\prime} \mathrm{N}, 154^{\circ} 36^{\prime} \mathrm{W}$; (map 51).

Name published by K. F. Mather (in Brooks and others, 1925, pl. 3), USGS, because in 1923 a field party led by R. H. Sargent "experienced some dreams there."

Dream Gulch: ravine, on W slope of Fourth of July Hill, trends W to Deep Creek, $23 \mathrm{mi}$. NE of Fairbanks, Yukon-Tanana High.; $65^{\circ} 04^{\prime}$ N, $147^{\circ} 08^{\prime} \mathrm{W}$; BGN 1939; (map 105).

Local name published in 1939 by USGS.

Dreamland Creek: stream, in Ray Mts., flows $\mathbf{N}$ $10 \mathrm{mi}$. to Big Salt River, $27 \mathrm{mi}$. NNW of Rampart and $67 \mathrm{mi}$. NE of Tanana, KokrinesHodzana High. ; $65^{\circ} 52^{\prime} 12^{\prime \prime} \mathrm{N}, 150^{\circ} 30^{\prime} 00^{\prime \prime} \mathrm{W}$; (map 106).

Prospectors' name reported in 1956 by Orth. The name expresses a ribald connotation.

Dreamy Gulch: ravine, trends NW to Kougarok River, between Arctic and Eldorado Creeks, $11 \mathrm{mi}$. SW of Midnight Mtn. and $47 \mathrm{mi}$. W of Imuruk Lake, Seward Penin. High.; (map 110).

Prospectors' name reported on the 1908 "Map of Seward Peninsula" by Monroe and Hutchins; corrected to 1903 by Arthur Gibson. This ravine cannot be precisely located on current maps.

Dredge Lake: lake, $0.1 \mathrm{mi}$. across, near head of Duck Creek, $1.2 \mathrm{mi}$. S of Mendenhall Lake and $8.7 \mathrm{mi}$. NW of Juneau, Coast Mts. ; $58^{\circ} 24^{\prime} 00^{\prime \prime}$

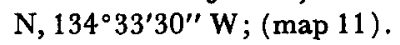

Local name published by USGS in 1962.

Dreist Point: point of land, see Driest Point.

Drenchwater Creek: stream, heads in DeLong Mts., flows NE $10 \mathrm{mi}$. to Kiligwa River, $22 \mathrm{mi}$. $\mathrm{N}$ of Feniak Lake, Brooks Ra.; $68^{\circ} 07^{\prime} \mathrm{N}$, $158^{\circ} 30^{\prime} \mathrm{W}$; BGN 1960; (map 132).

So named in 1951 by I. L. Tailleur, USGS, "because of excessive rain experienced there."

Dress Point: point of land, between Gedney and Hassler Passes, on NW coast of Revillagigedo I., Alex. Arch.; 55 $51^{\prime} 10^{\prime \prime} \mathrm{N}, 131^{\circ} 33^{\prime} 40^{\prime \prime} \mathrm{W}$; (map 3).

One of many arbitrary names applied to features in this area in 1891 by USC\&GS.

Drew Creek: stream, flows SE to Snowshoe Creek which flows to Cripple River, about $33 \mathrm{mi}$. NW of Nome, Seward Penin. High.; (map 94).

Prospectors' name reported on the 1900 "Map of Nome Peninsula" by J. M. Davidson and B. D. Blakeslee; this feature has not been positively identified.

Drew Point: point of land, on coast of Beaufort Sea, E point of entrance to Smith Bay, Arctic Plain; 70 $52^{\prime} 30^{\prime \prime} \mathrm{N}, 153^{\circ} 56^{\prime} 00^{\prime \prime} \mathrm{W}$; (map 148). Var. Amil-rhoen, Point Drew.

On July 28, 1837, Thomas Simpson (1843, p. 138) wrote, "we reached a point, named after Richard Drew, Esquire, of the Hudson's Bay Company * * *." The Eskimo name "Amil-rhoen" appears on Maguire's map (Great Britain, 1854, facing p. 186). 
Drier Bay: estuary, on W coast of Knight I., extends SW $5 \mathrm{mi}$. to Knight Island Passage, $7.5 \mathrm{mi}$. NE of Chenega, Chugach Mts.; $60^{\circ} 18^{\prime} 30^{\prime \prime} \mathrm{N}, 147^{\circ} 52^{\prime} 30^{\prime \prime} \mathrm{W}$; (map 63).

Local name reported in 1900 by F. C. Schrader, USGS.

Driest Point: point of land, between Port Chester and Sylburn Harbor, on W coast of Annette I., $11 \mathrm{mi}$. S of Ketchikan, Alex. Arch.; 55 $10^{\prime} 40^{\prime \prime}$ N, 131 36'15" W; (map 3). Var. Dreist Point.

Named in 1883 by Lt. Comdr. H. E. Nichols, USN.

Drifting Snow Creek: stream, heads in Canada at $66^{\circ} 06^{\prime} \mathrm{N}, 140^{\circ} 15^{\prime} \mathrm{W}$, flows NW $35 \mathrm{mi}$. to Salmon Fork Black River, $30 \mathrm{mi}$. NW of Midnight Hill, Porcupine Plat.; 66 $27^{\prime} 32^{\prime \prime}$ N, $141^{\circ} 27^{\prime} 40^{\prime \prime} \mathrm{W}$; BGN 1959; (map 120). Var. Bern Creek.

Local name reported in 1956 by R. E. Isto, USGS. The name is a translation of the Indian name "khattsiltatlenjik."

Drift River: stream, heads at glacier terminus, flows E $35 \mathrm{mi}$. to Redoubt Bay, Cook Inlet, $30 \mathrm{mi}$. W of Kenai, Cook Inlet Low.; $60^{\circ} 35^{\prime}$ $\mathrm{N}, 152^{\circ} 07^{\prime} \mathrm{W}$; (map 62).

Local name reported in 1912 by USC\&GS.

Drift River Lobe Double Glacier: glacier, extends S $4 \mathrm{mi}$. from Double Glacier to its 1958 terminus, at head of tributary of Drift River, $42 \mathrm{mi}$. W of Kenai, Aleutian Ra.; $60^{\circ} 38^{\prime} \mathrm{N}$, $152^{\circ} 28^{\prime} \mathrm{W}$; (map 62 ).

Local name reported in 1958 by USGS.

Driftwood Bay: bay, 2 mi. across, on $\mathbf{S}$ coast of Umnak I., Aleutian Is.; $52^{\circ} 56^{\prime} \mathrm{N}, 168^{\circ} 45^{\prime} \mathrm{W}$; (map 21). Var. Bay of Firewood, Bukhta Drovenaya, Drovenaia, Drovianaia, Dvoinoi, Dvoynoy, Staraia gavan, Twin Bay.

Name taken from descriptive Russian name published by Capt. Tebenkov (1852, map 25), IRN, as "B[ukhta] Drovenaya," meaning "bay of firewood." This feature was also called "Dvoynoy," meaning "double," because of its shape.

Driftwood Bay: bay, $1.7 \mathrm{mi}$. across, on $\mathrm{N}$ coast of Unalaska I., Aleutian Is.; $53^{\circ} 59^{\prime} \mathrm{N}, 166^{\circ}$ $51^{\prime} \mathrm{W}$; (map 23).

This name was published in the 1944 Aleutian Coast Pilot (p. 42).

Driftwood Bay: bay, 2 mi. wide, on $\mathrm{W}$ coast of Resurrection Penin., 16 mi. SE of Seward, Chugach Mts.; $59^{\circ} 56^{\prime} \mathrm{N}, 149^{\circ} 13^{\prime} \mathrm{W}$; (map 49).

Local name reported in 1908 by U. S. Grant, USGS.

Driftwood Cove: bay, $0.3 \mathrm{mi}$. across, $7 \mathrm{mi}$. W of Port Alexander, on E coast of Baranof I., Alex. Arch. ; 56 $16^{\prime} 15^{\prime \prime} \mathrm{N}, 134^{\circ} 49^{\prime} 15^{\prime \prime} \mathrm{W}$; (map 5).

Descriptive name given for charting purposes by USC\&GS in the 1925 Coast Pilot (p. 279).

Driftwood Creek: stream, heads at Thunder Mtn., in DeLong Mts., and flows NW $35 \mathrm{mi}$. to Utukok River, $42 \mathrm{mi}$. N of Misheguk Mtn., Brooks' Ra.; 68 ${ }^{\circ} 51^{\prime} \mathrm{N}, 161^{\circ} 07^{\prime} \mathrm{W}$; BGN 1961; (map 131). Var. Karvak Creek.

Named by the 1925 USGS exploring expedition, "because of the utilization of driftwood found along its banks for fuel." The Eskimo name for this stream is "Karvak" (Chapman and Sable, 1960, p. 53).

Driftwood Slough: water course, in distributary system of Yukon River, extends NW $22 \mathrm{mi}$. between Kashunuk Slough and Yukon River, $43 \mathrm{mi}$. NW of Marshall, Yukon-Kuskokwim Delta; 62 $02^{\prime} 30^{\prime \prime} \mathrm{N}, 163^{\circ} 22^{\prime} 30^{\prime \prime} \mathrm{W}$; (map 77).

Local name reported by Harrington (1918, p. 1), USGS.

Drill Creek: stream, flows SW $16 \mathrm{mi}$. to Beluga River, $1 \mathrm{mi}$. E of Beluga Lake and $24 \mathrm{mi}$. NW of Tyonek, Cook Inlet Low.; 61 ${ }^{\circ} 23^{\prime} 30^{\prime \prime} \mathrm{N}$, $151^{\circ} 26^{\prime} 45^{\prime \prime} \mathrm{W}$; BGN 1964; (map 70).

So named in 1962 by USGS because "there was extensive drilling along the stream by the U.S. Bureau of Mines in 1959-1961."

Drill Lake: lake, 2,100 ft. long, $W$ of Ghickaloon $24 \mathrm{mi}$. NE of Palmer, Talkeetna Mts.; $61^{\circ}$ $47^{\prime} 35^{\prime \prime}$ N, $148^{\circ} 00^{\prime} 45^{\prime \prime} \mathrm{W}$; (map 69).

Local name reported in 1942 by AMS; so named for the oil wells that were drilled in the area.

Drip Point: point of land, $\mathrm{W}$ point of an unnamed island, in Ogden Passage, $2.5 \mathrm{mi}$. W of Chichagof, on W coast of Chichagof I., Alex. Arch.; 57 $39^{\prime} 22^{\prime \prime} \mathrm{N}, 139^{\circ} 09^{\prime} 50^{\prime \prime} \mathrm{W}$; (map 9).

Name published in 1928 by USC\&GS on Chart 8280.

Driver Bay: bight, $1 \mathrm{mi}$. across, on NW coast of Raspberry I., $22 \mathrm{mi}$. WNW of Afognak, Kodiak I., $58^{\circ} 06^{\prime} 30^{\prime \prime}$ N., $153^{\circ} 20^{\prime} 30^{\prime \prime}$ W; (map 43).

Local name published in 1943 by USC\&GS. Drolette's: locality, see Kings Slough Village. Drop Creek: stream, heads at Drop Glacier terminus, flows $\mathrm{N} 25 \mathrm{mi}$. to Copper River, $57 \mathrm{mi}$. SW of Tok, Copper River Basin; $62^{\circ} 40^{\prime} \mathrm{N}, 144^{\circ} 06^{\prime} \mathrm{W}$; (map 83).

Descriptive name derived in 1902 by F. C. Schrader, USGS "from its steep slope and torrential flow."

Drop Glacier: glacier, heads on Mount Sanford, trends NE $12 \mathrm{mi}$. to its 1960 terminus at head of Drop Creek, $11 \mathrm{mi}$. WSW of Copper Lake, Wrangell Mts.; $62^{\circ} 23^{\prime} \mathrm{N}, 143^{\circ} 58^{\prime} \mathrm{W}$; (map 83)

Named in 1902 by F. C. Schrader, USGS, for Drop Creek.

Drouin Ranch: RR station, see Dome Spur. Drovenaia: bay, see Driftwood Bay.

Drovenaya, Bukhta: bay, see Driftwood Bay.

Drovianaia: bay, see Driftwood Bay.

Drozdof Island: island, see Blackbird Island.

Drozdov, Ostrov: island, see Blackbird Island.

Drug Island: island, $200 \mathrm{ft}$. across, in Ryus Bay, $\mathrm{N}$ of Duke I., Alex. Arch.; 54 ${ }^{\circ} 57^{\prime} 55^{\prime \prime} \mathrm{N}$, $131^{\circ} 24^{\prime} 45^{\prime \prime} \mathrm{W}$; (map 2).

Local name published in 1920 by USC\&GS. Drum, Mount: mountain, $12,010 \mathrm{ft}$., $18 \mathrm{mi}$. SW of Mount Sanford and $21 \mathrm{mi}$. SE of Gulkana, Wrangell Mts.; $62^{\circ} 07^{\prime} \mathrm{N}, 144^{\circ} 38^{\prime} \mathrm{W}$; (map 83).

Named in 1885 by Lt. Allen (1887, p. 59), USA, for Adj. Gen. Richard Coulter Drum, 1825-1909, who entered the army in 1846, served in the Mexican War, participated in an expedition against the Sioux Indians in 1856, and became a Brig. Gen. during the Civil War. It was first climbed June 4, 1954 by Heinrich Harrer, Keith Hart, and George Schaller (Farquhar, 1959, p. 219).

Drunkard Bay: bay, on SE coast of Kodiak I., (map 34). Var. Drunkard's Bay.

Name recorded in 1805 as "Drunkard's Bay" by Lisianski (1814, p. 178). Location unknown.

Drunkard's Bay: bay, see Drunkard Bay.

Dryas Cone: hill, $762 \mathrm{ft}$., $6.5 \mathrm{mi}$. E of Lava Lake and $12 \mathrm{mi}$. W of Imuruk Lake, Seward Penin. High.; $65^{\circ} 35^{\prime} N, 163^{\circ} 39^{\prime} \mathrm{W}$; (map 110).

Reported in 1950 by D. M. Hopkins, USGS; one of "four conspicuous volcanic cones * * named for wildflowers which are common on the slopes of all four cones."

Dryas Creek: stream, flows SW 2 mi. to Glacier River, $4 \mathrm{mi}$. E of Foggytop Mtn. and $19 \mathrm{mi}$. N of Wiseman, Brooks Ra.; $67^{\circ} 40^{\prime} \mathrm{N}, 150^{\circ} 24^{\prime}$ W; BGN 1932; (map 124).

Named about 1930 by Robert Marshall, because of "the abundance of the white flower of the genus dryus, growing near the mouth of the stream."

Dry Bay: bay, $1 \mathrm{mi}$. across, $3 \mathrm{mi}$. $\mathrm{N}$ of Point Vandeput, $88 \mathrm{mi}$. E of Sitka, Coast Mts.; $57^{\circ} 03^{\prime} 30^{\prime \prime} \mathrm{N}, 1^{\circ} 03^{\circ} 08^{\prime \prime} \mathrm{W}$; (map 8).

Local name reported in 1951 by USGS.

Dry Bay: bay, $2.7 \mathrm{mi}$. long, on $\mathrm{E}$ coast of Alaska Penin., $47 \mathrm{mi}$. W of Karluk, Aleutian Ra.; $57^{\circ} 37^{\prime} 40^{\prime \prime}$ N, $155^{\circ} 43^{\prime} 00^{\prime \prime}$ W; (map 35).

Descriptive local name obtained from J. $L$. McPherson of Iliamna, reported in 1903, and published by G. C. Martin (1905, pl. 6), USGS.

Dry Bay: bay, see Sukhoi Bay.

Dry Bay: bay, see Sukoi Bay.

Dry Bay: bight, on $\mathbf{S}$ coast of Iniskin Penin., SW of Chinitra Point, Aleutian Ra.; $59^{\circ}$. $40^{\prime} \mathrm{N}, 153^{\circ} 08^{\prime} \mathrm{W}$; (map 51).

Named by prospectors; published by G. C. Martin (1905, p. 48), USGS.

Dry Bay: delta, $16 \mathrm{mi}$. across, on NE shore of Gulf of Alaska, at mouth of Alsek River, 48 mi. SE of Yakutat, Malaspina Coastal Plain; $59^{\circ} 08^{\prime} \mathrm{N}, 138^{\circ} 25^{\prime} \mathrm{W}$; BGN 1966; (map 46). Var. Beerings Bay, Behrings River, Five Rivers, Shallow Bay.

Named in 1869 by G. Davidson, USC\&GS, because it appeared to be a shallow lagoon fed by silt laden glacial streams, In 1778 Capt. James Cook (1785, v. 2, 347), RN, named it "Beering's Bay" as he thought that Bering anchored here in 1741.

Dry Bay: tidal flat, $0.5 \mathrm{mi}$. across and $2 \mathrm{mi}$. long, on E shore of Stephens Passage, $1 \mathrm{mi}$. S of Point Lookout and $53 \mathrm{mi}$. SE of Juneau, Coast Mts.; $57^{\circ} 38^{\prime} 15^{\prime \prime} \mathrm{N}, 133^{\circ} 40^{\prime} 15^{\prime \prime} \mathrm{W}$; (map 8).

Prospectors' name reported in 1903 by Spencer and Wright (1906, fig. 4), USGS.

Dry Birch Creek: stream, see Birch Greek.

Dry Canyon Creek: stream, flows NW $11 \mathrm{mi}$. to Arathlatuluk Creek, $26 \mathrm{mi}$. NW of Elim and $55 \mathrm{mi}$. NE of Solomon, Seward Penin. High.; $64^{\circ} 55^{\prime} \mathrm{N}, 162^{\circ} 48^{\prime} \mathrm{W}$; (map 95). Var. Box Canyon. 
Prospectors' name published as "Dry or Box Canyon" on the 1908 "Map of Seward Peninsula" by Arthur Gibson.

Dry Cove: cove, extends SE $1 \mathrm{mi}$. to Portage Bay, on $\mathbf{N}$ coast of Kupreanof I., Alex. Arch.; $56^{\circ} 59^{\prime} \mathrm{N}, 133^{\circ} 20^{\prime} \mathrm{W}$; (map 6 ).

Descriptive name given in 1882 by $L t$. Comdr. H. E. Nichols, USN.

Dry Creek: stream, trends S $4 \mathrm{mi}$. to Chignik Bay, on Alaska Penin., 13 mi. N of Chignik, Aleutian Ra.; $56^{\circ} 29^{\prime} \mathrm{N}, 158^{\circ} 20^{\prime}$ W; (map $30)$.

Local name published in 1927 by USC\&GS.

Dry Creek: stream, on E coast of Alaska Penin., flows NE $6.3 \mathrm{mi}$. to Teresa Creek, $5 \mathrm{mi}$. NNE of Cape Aklek and $45 \mathrm{mi}$. NW of Karluk, Aleutian Ra.; $57^{\circ} 44^{\prime} 50^{\prime \prime} \mathrm{N}, 155^{\circ} 37^{\prime} 20^{\prime \prime} \mathrm{W}$; (map $35)$.

Local name obtained from J. L. McPherson of Iliamna; published by G. C. Martin (1905, p. 54), USGS.

Dry Creek: stream, flows NW $3 \mathrm{mi}$. to Faro Creek, $25 \mathrm{mi}$. N of Goodnews, Kilbuck-Kuskokwim Mts.; $59^{\circ} 27^{\prime} 30^{\prime \prime} \mathrm{N}, 161^{\circ} 31^{\prime} 00^{\prime \prime} \mathrm{W}$; (map 53).

Name reported in 1920 by G. L. Harrington (in Brooks and others, 1921, p. 17), USGS.

Dry Creek: stream, heads at a small lake $1.5 \mathrm{mi}$. W of Crescent Lake, flows NW $4.5 \mathrm{mi}$. to Quartz Creek, $1 \mathrm{mi}$. NW of Kenai Lake, 28 mi. NW of Seward, Chugach Mts.; $60^{\circ} 29^{\prime} 15^{\prime \prime}$ $\mathrm{N}, 149^{\circ} 42^{\prime} 25^{\prime \prime} \mathrm{W}$; (map 63$)$.

Local name reported in 1952 by USGS.

Dry Creek: stream, flows NW $4 \mathrm{mi}$. to Tuluksak River, $58 \mathrm{mi}$. NE of Bethel, Kilbuck-Kuskokwim Mts.; $60^{\circ} 58^{\prime} 30^{\prime \prime} \mathrm{N}, 160^{\circ} 06^{\prime} 00^{\prime \prime} \mathrm{W}$; (map 59).

Local descriptive name reported in 1955 by J. M. Hoare, USGS.

Dry Creek: stream, flows SW $3 \mathrm{mi}$. to Kuskulana River, $35 \mathrm{mi}$. NW of McCarthy, Wrangell Mts.; $61^{\circ} 33^{\prime} \mathrm{N}, 143^{\circ} 56^{\prime} \mathrm{W}$; (map 67).

Local descriptive name reported in 1912 by D. C. Witherspoon, USGS.

Dry Creek: stream, flows SE $6 \mathrm{mi}$. to Copper River, $4 \mathrm{mi}$. E of Glennallen, Copper River Basin; 62 $07^{\prime} 45^{\prime \prime} \mathrm{N}, 1^{\circ} 5^{\circ} 25^{\prime} 00^{\prime \prime} \mathrm{W}$; (map 83).

Named in 1898 by Capt. W. R. Abercrombie (in Glenn and Abercrombie, 1899, map 7), USA.

Dry Greek: stream, heads in Dutch Hills, flows SE $2 \mathrm{mi}$. to Cottonwood Creek, $27 \mathrm{mi}$. NW of Talkeetna, Alaska Ra.; $62^{\circ} 32^{\prime} 45^{\prime \prime} \mathrm{N}, 150^{\circ}$ 49'15" W ; (map 81).

Local descriptive name reported in 1958 by USGS.

Dry Creek: stream, flows NW $1 \mathrm{mi}$. to Timberline Creek, $67 \mathrm{mi}$. SE of Healy, Alaska Ra.; $63^{\circ} 11^{\prime} \mathrm{N}, 147^{\circ} 26^{\prime} \mathrm{W}$; (map 87).

Local descriptive name obtained in 1951 by USGS.

Dry Creek: stream, in Kantishna Hills, flows SW $2 \mathrm{mi}$. to Moose Creek, $3.2 \mathrm{mi}$. ENE of Wonder Lake, Alaska Ra.; $63^{\circ} 31^{\prime} \mathrm{N}, 150^{\circ} 47^{\prime} \mathrm{W} ; B G N$ 1932; (map 88)

Local name reported in 1916 by Capps (1919, p. 74), USGS.
Dry Creek: stream, heads in lake, on Macomb Plateau, and flows NE $15 \mathrm{mi}$. to Johnson Slough, $2 \mathrm{mi}$. SE of junc. of Johnson and Tanana Rivers and $43 \mathrm{mi}$. SE of Delta Junction, Tanana Low.; $63^{\circ} 42^{\prime} 00^{\prime \prime} \mathrm{N}, 144^{\circ} 34^{\prime} 05^{\prime \prime}$ W; (map 86).

Name published on relatively recent maps. Dry Creek: stream, flows NE $12 \mathrm{mi}$. to Nenana River, 2 mi. N of Healy, Alaska Ra.; $63^{\circ} 53^{\prime}$ $20^{\prime \prime} \mathrm{N}, 148^{\circ} 58^{\prime} 30^{\prime \prime} \mathrm{W}$; (map 87).

Local name shown on a 1916 fieldsheet by C. E. Griffin, USGS

Dry Creek: stream, flows SW $5 \mathrm{mi}$. to Snake River at Nome, Seward Penin. High.; $64^{\circ} 30^{\prime}$ N, $165^{\circ} 25^{\prime} \mathrm{W}$; (map 94).

Prospectors' name reported in 1899 by $\mathrm{D}$. C. Witherspoon (in Schrader and Brooks, 1900, map 2), USGS.

Dry Creek: stream, heads at $63^{\circ} 50^{\prime} \mathrm{N}, 147^{\circ} 36^{\prime}$ W, flows N $66 \mathrm{mi}$. to Clear Creek, $24 \mathrm{mi}$. S of

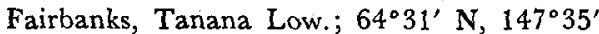
W; (map 100). Var. Silok Creek.

So called locally because "It is said to join Wood River in times of flood, but during low water it sinks into the gravels and disappears" (Capps, 1912, p. 13).

Dry Creek: stream, flows S $4.8 \mathrm{mi}$. to Camp Creek, which flows to Sinuk River, $24 \mathrm{mi}$. NW of Nome, Seward Penin. High.; $64^{\circ} 40^{\prime} \mathrm{N}$, $166^{\circ} 10^{\prime} \mathrm{W}$; (map 94).

Prospectors' name reported in 1900 by E. C. Barnard (in Brooks, 1901, pl. 17), USGS.

Dry Creek: stream, flows SE $1.8 \mathrm{mi}$. to Casadepaga River, $23 \mathrm{mi}$. NE of Solomon, Seward Penin. High.; $64^{\circ} 53^{\prime} \mathrm{N}, 164^{\circ} 13^{\prime} \mathrm{W}$; (map 95).

Prospectors' name reported on a map of Cape Nome gold fields by David Fox, Jr., dated 1901.

Dry Creek: stream, on Seward Penin., flows NW $3 \mathrm{mi}$. to Lopp Lagoon, $15 \mathrm{mi}$. NE of Cape Prince of Wales and $48 \mathrm{mi}$. NW of Teller, Kotzebue-Kobuk Low, ; $65^{\circ} 43^{\prime} \mathrm{N}, 167^{\circ} 38^{\prime} \mathrm{W}$; (map 111).

Prospectors' name reported on the 1908 "Map of Seward Peninsula" by Arthur Gibson. Dry Creek: stream, heads on Caribou Mtn., in Zane Hills, flows E $6 \mathrm{mi}$. to Moraine Creek, $40 \mathrm{mi}$. WNW of Hughes, Hogatza High.; $66^{\circ}-$ $10^{\prime} 15^{\prime} \mathrm{N}, 155^{\circ} 38^{\prime} 00^{\prime \prime} \mathrm{W}$; (map 116).

Descriptive name applied about 1955 by mining engineers; reported in 1956 by Orth.

Dry Creek: stream, heads in Darby Mts., flows W. to Arathlatuluk Creek or Omilak Creek, about $30 \mathrm{mi}$. NW of Elim, Seward Penin. High.; (map 95).

Local name reported in 1909 by Smith and Eakin (1911, pl. 1), USGS. The exact application of the name cannot be determined from maps.

Dry Creek: locality, see Lignite.

Dry Creek: village, see Healy.

Dry Creek: stream, see Lanagan Creek.

Dry Creek Mountain: mountain, see Newton Peak.

Dry Gulch: ravine, trends SE $0.5 \mathrm{mi}$. to Platinum Greek, $25 \mathrm{mi}$. NE of Cape Newenham, Kil-
buck-Kuskokwim Mts.; $58^{\circ} 55^{\prime} 15^{\prime \prime} \mathrm{N}, 161^{\circ}$ $44^{\prime} 15^{\prime \prime}$ W; BGN 1938; (map 39).

Local name established before 1933.

Dry Gulch: ravine, extends $0.7 \mathrm{mi}$. S to White Creek, 2 mi. SW of head of Chititu Creek and $17 \mathrm{mi}$. SE of McCarthy, St. Elias Mts.; $61^{\circ}$ $17^{\prime} \mathrm{N}, 142^{\circ} 32^{\prime} \mathrm{W}$; (map 67).

Local name obtained by USGS and published on maps since 1954.

Dry Gulch: ravine, in Nutzotin Mts., extends SE $2.5 \mathrm{mi}$. from Chavolda Creek $4.2 \mathrm{mi}$. SE of its junc. with Chisana River, Alaska Ra.; $62^{\circ}$ $08 \mathrm{~N}, 142^{\circ} 01^{\prime} \mathrm{W}$; (map 84).

Name used by prospectors because of insufficient water for sluicing operations; reported in 1914 by S. R. Capps (in Brooks and others, 1915, p. 222), USGS.

Dry Gulch: ravine, trends NW $0.8 \mathrm{mi}$. to Hidden Creek, $7 \mathrm{mi}$. N of Medfra, Kilbuck-Kuskokwim Mts.; $63^{\circ} 13^{\prime} \mathrm{N}, 154^{\circ} 45^{\prime} \mathrm{W}$; (map 89). Prospectors' name obtained in 1924 by J. S. Brown (in Smith, P. S., 1926, pl. 5), USGS. Dry Gulch: ravine, extends W $2.4 \mathrm{mi}$. to Middle Fork Koyukuk River, $1 \mathrm{mi}$. downstream from Moose Creek and $3.2 \mathrm{mi}$. from Wiseman, Brooks Ra.; $67^{\circ} 21^{\prime} 30^{\prime \prime}$ N, $150^{\circ} 08^{\prime} 00^{\prime \prime} \mathrm{W}$; (map 124).

Local descriptive name obtained in 1956 by USGS topographers.

Drying Point: point of land, on $\mathrm{E}$ shore of Dry Spruce Bay, $24 \mathrm{mi}$. NW of Kodiak, Kodiak I.; $57^{\circ} 57^{\prime} 15^{\prime \prime} \mathrm{N}, 152^{\circ} 59^{\prime} 40^{\prime \prime} \mathrm{W}$; BGN 1939; (map 34). Var. Cape Obsiekaiushie, Cape Obsikhaiuschchi, Mys Obsykhayushchiy, Portage Point.

Translation in 1910 by USC\&GS of the name "M[ys] Obsykhayushchiy," given in 1839 or 1840 by Sub-Lt. Mikhail Murashev, IRN; and published in 1849 on Russian Hydrog. Dept. Chart 1425. Baker (1906, p. 507) applied "Drying Point" to "Perenosa Point" and calls this feature "Portage Point." See Perenosa Point.

Drying Point: point of land, see Perenosa Point. Dry Island: island, $6 \mathrm{mi}$. long, at $\mathrm{S}$ end of Frederick Sound, $20 \mathrm{mi}$. SE of Petersburg and $12 \mathrm{mi}$. NW of Wrangell, Coast Mts.; $56^{\circ} 39^{\prime}$ $\mathrm{N}, 132^{\circ} 30^{\prime} \mathrm{W}$; (map 6$)$.

Named in 1887 by Lt. Comdr. C. M. Thomas, USN.

Dry Lagoon: lagoon, trends NW $1 \mathrm{mi}$., inner Pavlof Bay, Bristol Bay Low., Alaska Penin. Aleutian Ra.; 55 $35^{\prime} 30^{\prime \prime} \mathrm{N}, 161^{\circ} 36^{\prime} 50^{\prime \prime} \mathrm{W}$; (map 28).

Local name reported in 1929 by USGS.

Dry Lake: lake, $1,200 \mathrm{ft}$. long, in Matanuska Valley $6.9 \mathrm{mi}$. NW of Palmer, Cook Inlet Low.; $61^{\circ} 37^{\prime} 35^{\prime \prime} \mathrm{N}, 149^{\circ} 18^{\prime} 50^{\prime \prime} \mathrm{W}$; (map 69).

Local name reported in 1942 by AMS.

Dry Lake: lake, intermittent, $1.8 \mathrm{mi}$. long, $4 \mathrm{mi}$. SE of Barrow, Arctic Plain; $71^{\circ} 20^{\prime} \mathrm{N}, 156^{\circ}$ $36^{\prime} \mathrm{W}$; (map 153).

Descriptive name of a drained lake used in 1957 for scientific purposes.

Dry Mystery Creek: stream, flows SW $4.5 \mathrm{mi}$. to Niukluk River, $3.5 \mathrm{mi}$. SE of Council and 
$33 \mathrm{mi}$. NE of Solomon, Seward Penin. High.; $64^{\circ} 51^{\prime} \mathrm{N}, 163^{\circ} 35^{\prime} \mathrm{W}$; (map 95).

Prospectors' name published on the 1908 "Map of Seward Peninsula" by Arthur Gibson.

Dry Pass: water passage, in W end of El Capitan Passage, $2.5 \mathrm{mi}$. E of Shakan Bay, between Prince of Wales and Kosciusko Is., Alex. Arch.; $56^{\circ} 09^{\prime} 45^{\prime \prime} \mathrm{N}, 133^{\circ} 24^{\prime} 30^{\prime \prime} \mathrm{W} ; B G N$ 1925; (map 6). Var. El Capitan Passage, Klawak Passage.

Local descriptive name obtained from Capt. Cyrus Orr, of Shakan, reported in 1904 by E. F. Dickins, USC\&GS; so called because "in the narrows it runs dry at ebb of every large tide." This feature was called " "Klawak Passage' by the local fishermen because it is the beginning of the inside passage taken $* * *$ from Shakan to Klawak."

Dry Pass: water passage, $10 \mathrm{mi}$. NW of Chichagof, between Hill $\mathrm{I}$. and $\mathrm{W}$ coast of Chichagof I., Alex. Arch.; 57 $46^{\prime} \mathrm{N}, 136^{\circ} 18^{\prime}$ W; BGN 1925; (map 9). Var. El Capitan Passage, Klawak Passage.

Local name reported about 1903 by USC \&GS. 'It is called 'dry' because during the ebb of large tides the narrows are dry." It was called Klawak Passage by USC\&GS on Chart 8050 in 1902, which is the name of a passage 50 miles to the south. The name El Capitan Passage was suggested in 1904 by E. F. Davidson, USC\&GS, because of the nearby El Capitan marble quarries.

Dry Pass: water passage, see El Capitan Passage.

Dry Rock: rock, $0.8 \mathrm{mi}$. S of Tugidak Passage, in Trinity Is., Kodiak I.; $56^{\circ} 29^{\prime} 15^{\prime \prime}$ N, $154^{\circ} 25^{\prime} 25^{\prime \prime} \mathrm{W}$; (map 32).

Descriptive name published in 1943 by USC\&GS.

Dry Spruce Bay: bay, $1 \mathrm{mi}$. across, in Kupreanof Strait, on N coast of Kodiak I.; $57^{\circ} 56^{\prime} \mathrm{N}$, $153^{\circ} 02^{\prime} \mathrm{W}$; (map 34). Var. EInik, Eminik Bay, Sucho, Sukhoi, Zaliv Sukhoy Yelnik.

Translation of the name "Z[aliv] Sukhoy Yelnik," published by Capt. Tebenkov (1852, map 23); derived from the name given to "Dry Spruce Island" in. 1839 or 1840 by Sub-Lt. Mikhail Murashev, IRN. See Dry Spruce Island.

Dry Spruce Island: island, $1.5 \mathrm{mi}$. long, between Dry Spruce Bay and Kupreanof Strait, off $\mathbf{N}$ coast of Kodiak I.; $57^{\circ} 57^{\prime} 20^{\prime \prime} \mathrm{N}, 153^{\circ} 02^{\prime} 30^{\prime \prime}$ W; (map 34). Var. Poluostrov Sukhago Yelnika.

Named "Poluostrov Sukhago Yelnika," meaning "dry spruce peninsula," in 1839 or 1840 by Sub-Lt. Mikhail Murashev, IRN; published in 1849 on Russian Hydrog. Dept. Chart 1425 which shows a sand bar connecting this island to the north coast of Kodiak Island.

Dry Strait: water passage, extends SE $5 \mathrm{mi}$. from Frederick Sound to Koknuk Flats, at mouth of Stikine River, $10 \mathrm{mi}$. NW of Wrangell, Alex. Arch.; 56 $36^{\prime} \mathrm{N}, 132^{\circ} 31^{\prime} \mathrm{W}$; (map 6). Var. Proliv Sukhoy, Soukhoi Strait, Suchoi Channel, Sukhoi Strait.
Translation about 1880 by USC\&GS of the name "Proliv Sukhoy" published in 1853 on Russian Hydrog. Dept. Chart 1493.

Dry Strait: stream, see Blind River.

Dry Strait: water passage, see Sukoi Inlet.

Dry Tok Creek: stream, flows E $18 \mathrm{mi}$. to Tok River, $25 \mathrm{mi}$. SW of Tok, Alaska Ra. ; $63^{\circ} 09^{\prime}$ N, $143^{\circ} 42^{\prime} \mathrm{W}$; BGN 1936; (map 85). Var. Big Tokio River, Dry Tok River.

Local name reported by USGS in 1936 . So named because "it is so often dry during midsummer."

Dry Tok River: stream, see Dry Tok Creek.

Dry Wash: stream, flows SE $2 \mathrm{mi}$. from Mount Basargin to Stikine River, $17 \mathrm{mi}$. NE of Wrangell, Coast Mts.; $56^{\circ} 42^{\prime} 15^{\prime \prime} \mathrm{N}$, $132^{\circ} 10^{\prime} 30^{\prime \prime} \mathrm{W}$; (map 6).

Local descriptive name recorded in 1960 by USGS.

Dtehshuh: village, see Haines.

Dual Head: promontory, 1,732 ft., on E coast of Kenai Penin., between Icy Bay and Whole Bay, $4.5 \mathrm{mi}$. SW of Chenega, Chugach Mts. $60^{\circ} 15^{\prime} \mathrm{N}, 148^{\circ} 12^{\prime} \mathrm{W}$; BGN 1934; (map 63). So named in 1933 by a USC\&GS field party "because the two peaks close together at the summit are the dominant feature."

Dubin Point: point of land, on right bank of Koyukuk River, $8 \mathrm{mi}$. S of Roundabout Mtn., Koyukuk Low.; $65^{\circ} 27^{\prime} \mathrm{N}, 156^{\circ} 27^{\prime} \mathrm{W}$; (map 108).

Local name obtained at Huslia by USGS in 1954 or 1955.

Dublin Bay: bight, see Cataract Cove.

Dubli River: stream, see Dulbi River.

Dubuque Mountain: mountain, 2,405 ft., on Annette I., $5.8 \mathrm{mi}$. E of Metlakatla, Alex. Arch.; $55^{\circ} 07^{\prime} 05^{\prime \prime} \mathrm{N}, 131^{\circ} 25^{\prime} 30^{\prime \prime} \mathrm{W}$; (map 3).

Named in 1883 by Lt. Comdr. H. E. Nichols, USN; "named after the city in Iowa." Duchess Island: barrier island, $2 \mathrm{mi}$. long, on Beaufort Sea coast, in Maguire Is., $4 \mathrm{mi}$. NW of Flaxman I., Arctic Plain; $70^{\circ} 14^{\prime} \mathrm{N}$, $146^{\circ} 24^{\prime} \mathrm{W}$; (map 151).

Named by Leffingwell $(1919$, p. 95) in 1913 after the schooner Duchess of Bedford of the Anglo-American Polar Expedition, 1906-07.

Duchikmiut: locality, on right bank of Duchikmiut River, $2.5 \mathrm{mi}$. $\mathrm{N}$ of Cape Mendenhall, Nunivak I.; $59^{\circ} 51^{\prime} 20^{\prime \prime} \mathrm{N}, 166^{\circ} 08^{\prime} 30^{\prime \prime} \mathrm{W}$; (map 55). Var. Duchixthluk, Tachikhthlamiut.

Eskimo fish camp reported in 1932 by USC\&GS.

Duchikmiut River: stream, heads at Karon Lake flows SE $12 \mathrm{mi}$. to Duchithluk Bay, $2.5 \mathrm{mi}$. N of Cape Mendenhall, Nunivak I.; 59 $51^{\prime}$ N, $166^{\circ} 09^{\prime}$ W; (map 55). Var. Duchixthluk River, Dutchikamiut.

Eskimo name obtained in 1949 by USC\&GS.

Duchikthluk Bay: bay, $5 \mathrm{mi}$. across, $\mathbf{N}$ of Cape Mendenhall, Nunivak I.; $59^{\circ} 49^{\prime} \mathrm{N}, 166^{\circ} 08^{\prime}$ W; (map 55). Var. Tachikthluk Bay.

Eskimo name reported in 1937 by USAAF. Duchixthluk River: stream, see Duchikmiut River.
Duck Bay: bay, $6 \mathrm{mi}$. across, $13 \mathrm{mi}$. NE of Afognak, on SE coast of Afognak I., $\mathrm{N}$ of Kodiak I.; $58^{\circ} 06^{\prime} \mathrm{N}, 152^{\circ} 28^{\prime} \mathrm{W}$; (map 43). Var. Kalagin, Selezneva.

Translation by Baker (1906, p. 227) of "Z[aliv] Selezneva" as "drake [wild duck] bay," published by Capt. Tebenkov (1852, map 23) IRN.

Duck Bay: cove, "an indentation of the coast line of Udagak Strait on Unalaska Island" (Wagner, 1937, p. 449). Name published in 1791 by Alexander Dalrymple (p. 356).

Duckbill Lake: lake, $0.3 \mathrm{mi}$. long, on Kenai Penin. between Otter and Weasel Lakes, 21 mi. NE of Kenai, Cook Inlet Low.; $60^{\circ} 39^{\prime} 45^{\prime \prime}$ $\mathrm{N}, 150^{\circ} 41^{\prime} 10^{\prime \prime} \mathrm{W}$; (map 62).

Named about 1963 by officials of Kenai National Moose Range, for administrative purposes.

Duck Cape: point of land, in Seal Bay, $33 \mathrm{mi}$. NE of Afognak, on NE coast of Afognak $I$., $\mathrm{N}$ of Kodiak I.; $58^{\circ} 23^{\prime} \mathrm{N}, 152^{\circ} 13^{\prime} \mathrm{W}$; (map 43). Var. Selezneva.

Translation of the name "M[ys] Selezneva" published in 1849 by the Russian American Company.

Duck Creek: stream, flows NE $2.5 \mathrm{mi}$. to W shore of Red Bay, on N coast of Prince of Wales I.; Alex. Arch.; $56^{\circ} 18^{\prime} \mathrm{N}, 133^{\circ} 21^{\prime} \mathrm{W}$; (map 6).

Named in 1886 by Lt. J. M. Helm, USN, for charting purposes; name published in 1887 on USC\&GS Chart 706.

Duck Creek: stream, flows $3.5 \mathrm{mi}$. SW to Gastineau Channel at Juneau Airport, 7.8 mi. NW of Juneau, Coast Mts.; $58^{\circ} 24^{\prime} \mathrm{N}$, $134^{\circ} 27^{\prime} \mathrm{W}$; (map 11). Var. Knudson Creek, Sand Bar Creek.

Originally named by Daniel Foster in 1885 . In 1886 the name was changed by Frederick Barney to "Sand Bar Creek." For many years the creek was also known locally as "Knudson Creek," for Thomas Knudson, who it is said was the first (1905) Alaskan homesteader to secure title to his ground. The name "Duck Creek" reappeared on a map by USGS in 1912 and it has been in use since then (DeArmond, 1957, p. 16).

Duck Creek: stream, heads in lake, flows SE $4.7 \mathrm{mi}$. to Kvichak River, $3 \mathrm{mi}$. N of Telephone Point and $15 \mathrm{mi} . \mathrm{N}$ of Naknek, Bristol Bay Low.; $58^{\circ} 57^{\prime} 30^{\prime \prime} \mathrm{N}, 157^{\circ} 01^{\prime} 30^{\prime \prime} \mathrm{W}$; (map 41).

Local name reported in 1952 by USGS.

Duck Creek: stream, flows SE $13 \mathrm{mi}$. to Imuruk Basin, $25 \mathrm{mi}$. SE of Teller, Seward Penin. High.; $65^{\circ} 10^{\prime} \mathrm{N}, 165^{\circ} 32^{\prime} \mathrm{W}$; (map 111).

Prospectors' name published in 1956 by USGS.

Duck Creek: stream, flows NE $33.5 \mathrm{mi}$. to Buckland River, $49 \mathrm{mi}$. SW of Selawik, KotzebueKobuk Low.; $66^{\circ} 06^{\prime} \mathrm{N}, 161^{\circ} 12^{\prime} \mathrm{W}$; (map 114).

Local name reported in 1908 by USGS (Brooks and others, 1909, fig. 21).

Duck Flats: flats, extend $6 \mathrm{mi}$. W of mouth of Matanuska River, between Knik Arm Cook Inlet and Palmer Slough, $7.5 \mathrm{mi}$. SW of 
Palmer, Cook Inlet Low.; 61 $31^{\prime} 30^{\prime \prime} \mathrm{N}$, $149^{\circ} 20^{\prime} 30^{\prime \prime} \mathrm{W}$; (map 69).

Local name reported in 1942 by AMS.

Duck Island: island, $150 \mathrm{ft}$. across, $2.5 \mathrm{mi}$. WNW of Chichagof, on $\mathrm{W}$ coast of Chichagof I., Alex. Arch.; 57 $40^{\prime} 30^{\prime \prime} \mathrm{N}, 136^{\circ} 09^{\prime} 33^{\prime \prime} \mathrm{W}$; (map 9).

Name published in 1928 by USC\&GS on Cart 8258.

Duck Island: island, $0.2 \mathrm{mi}$. long, in mouth of Tuxedni Bay, E of Chisik I., in Cook Inlet, $55 \mathrm{mi}$. SW of Kenai, Aleutian Ra.; $60^{\circ} 09^{\prime} \mathrm{N}$, $152^{\circ} 34^{\prime} \mathrm{W}$; (map 62).

Local name published in 1912 by USC\&GS.

Duck Island: island, $0.3 \mathrm{mi}$. long, in Sagavanirktok River Delta, on Beaufort Sea coast, $33 \mathrm{mi}$. SE of Beechey Point, Arctic Plain; 70 $18^{\prime} 29^{\prime \prime}$ N, 147 $54^{\prime} 30^{\prime \prime} \mathrm{W}$; (map 150).

Named by Leffingwell (1919, p. 95) in 1911.

Duck Island: islands, see Duck Islands.

Duck Island: peninsula (at high water an island), $1 \mathrm{mi}$. across, on $\mathrm{S}$ shore of Bradfield Canal $4 \mathrm{mi}$. SW of its head, Coast Mts.; $56^{\circ}$ $11^{\prime} 30^{\prime \prime} \mathrm{N}, 131^{\prime} 36^{\prime} 00^{\prime \prime} \mathrm{W}$; (map 7).

Named in 1886 by Lt. Comdr. A. S. Snow, USN.

Duck Islands: islands, extend $1 \mathrm{mi}$. along NE coast of Duke I., Alex. Arch.; $54^{\circ} 59^{\prime} 00^{\prime \prime} \mathrm{N}$, $131^{\circ} 14^{\prime} 30^{\prime \prime} \mathrm{W}$; (map 2). Var. Duck Island.

Name reported by USFS as "Duck Island"; published in 1943 by USC\&GS as Duck Islands.

Duck Lake: lake, $250 \mathrm{ft}$. across, $12 \mathrm{mi}$. NW of Chichagof, on W coast of Chichagof I., Alex. Arch.; $57^{\circ} 47^{\prime} 40^{\prime \prime} \mathrm{N}, 136^{\circ} 18^{\prime} 45^{\prime \prime} \mathrm{W}$; (map 9).

Name published in 1928 by USC\&GS on Chart 8258.

Duck Lake: lake, $0.6 \mathrm{mi}$. long, on Kenai Penin., $2.5 \mathrm{mi}$. NW of Swan Lake and $24 \mathrm{mi}$. NE of Kenai, Cook Inlet Low.; $60^{\circ} 41^{\prime} 45^{\prime \prime} \mathrm{N}, 150^{\circ}$ 37'15" W; (map 62).

Named about 1963 by officials of Kenai National Moose Range, for administrative purposes.

Duck Lake: lake, $1 \mathrm{mi}$. across, $4 \mathrm{mi}$. SW of Solsmunket Lake and $65 \mathrm{mi}$. SE of Shungnak, Koyukuk Low.; $65^{\circ} 02^{\prime} \mathrm{N}, 156^{\circ} 15^{\prime} \mathrm{W}$; (map 115).

Local name reported by USGS in 1952.

Duck Lake: lake, $3.5 \mathrm{mi}$. SW of Roundabout Mtn., Koyukuk Low.; $65^{\circ} 30^{\prime} \mathrm{N}, 156^{\circ} 38^{\prime} \mathrm{W}$; (map 108).

Local name obtained at Huslia by USGS in 1954 or 1955.

Duckling Lake: lake, $0.6 \mathrm{mi}$. long, on Kenai Penin. SE of Kayak Lake, $4 \mathrm{mi}$. N of Swan Lake and $28 \mathrm{mi}$. NE of Kenai, Cook Inlet Low.; $60^{\circ} 44^{\prime} 30^{\prime \prime} \mathrm{N}, 150^{\circ} 33^{\prime} 00^{\prime \prime} \mathrm{W}$; (map 62).

Named about 1963 by officials of Kenai Nationla Moose Range, for administrative purposes.

Duck Mountain: mountain, 2,048 ft., $16 \mathrm{mi}$. NE of Afognak, on SE coast of Afognak I., $\mathbf{N}$ of Kodiak I. ; $58^{\circ} 10^{\prime} 10^{\prime \prime} \mathrm{N}, 152^{\circ} 29^{\prime} 00^{\prime \prime} \mathrm{W}$; (map 43).
Name derived from Duck Bay and published by USC\&GS in 1843.

Duck Point: point of land, on NW tip of Duck I., on S shore of Bradfield Canal $4.5 \mathrm{mi}$. SW of its head, Coast Mts.; $56^{\circ} 11^{\prime} 40^{\prime \prime} \mathrm{N}, 131^{\circ}$ $36^{\prime} 40^{\prime \prime} \mathrm{W}$; (map 7$)$.

Local name derived from Duck Island and published in 1955 by USGS.

Duck Point: point of land, on $\mathbf{S}$ end of Whitney I., in Fanshaw Bay, 71 mi. E of Sitka, Coast Mts.; $57^{\circ} 12^{\prime} 45^{\prime \prime} \mathrm{N}, 133^{\circ} 31^{\prime} 00^{\prime \prime} \mathrm{W}$; (map 8). Name published in 1891 by USC\&GS.

Duck River: stream, flows SW $1.5 \mathrm{mi}$. from Silver Lake to the Lagoon at head of Galena Bay, $40 \mathrm{mi}$. NW of Cordova, Chugach Mts.; $60^{\circ}$ $57^{\prime} \mathrm{N}, 146^{\circ} 33^{\prime} \mathrm{W}$; (map 64).

Prospectors' name reported in 1912 by USGS (in Brooks and others, 1912, pl. 4).

Duck Village: locality, E shore of Kazakof Bay, $S$ coast of Afognak I., $12 \mathrm{mi}$. NE of Afognak, Kodiak I. ; 58 $06^{\prime} 30^{\prime \prime} \mathrm{N}, 152^{\circ} 33^{\prime} 00^{\prime \prime} \mathrm{W}$; (map 43). Var. Kalagin, Selezneva.

Translation by Baker (1906, p. 227) of "Seleniye Selezneva," meaning "drake village," published by Capt. Tebenkov (1852, map 23), IRN. The Russian Hydrog. Dept. published the name "M[ys] Seleznevskago Seleniya," meaning "drake village cape," in 1849 on Chart 1425. According to Father Veniaminov (1846) the Aleut name for this village is "Kalagak," which according to $\mathbf{R}$. H. Geoghegan, comes from the word "kalagaq" meaning "drake."

Duck Village: locality, see Little Afognak.

Ductoth River: stream, see Duktoth River.

Dude Creek: stream, flows N $9 \mathrm{mi}$. to Liberty Creek, $19 \mathrm{mi}$. SE of Chicken and $61 \mathrm{mi}$. NE of Tok, Yukon-Tanana High.; $63^{\circ} 53^{\prime} \mathrm{N}, 141^{\circ}$ $28^{\prime} \mathrm{W}$; (map 85).

Local name reported by USGS in 1950.

Dude Mountain: mountain, 2,848 ft., on Revillagigedo I., 5 mi. N of Ketchikan, Alex. Arch.; $55^{\circ} 24^{\prime} 55^{\prime \prime} \mathrm{N}, 131^{\circ} 36^{\prime} 50^{\prime \prime} \mathrm{W}$; (map 3).

Named in 1886 by USC\&GS.

Dudosa, Isla: island, see Wingham Island.

Duff, Mount: mountain, 7,170 ft., on AlaskaCanada boundary, $4.5 \mathrm{mi}$. SE of Mount Armour and $42 \mathrm{mi}$. NE of Yakutat, St. Elias Mts.; $59^{\circ} 50^{\prime} 30^{\prime \prime} \mathrm{N}, 138^{\circ} 40^{\prime} 30^{\prime \prime} \mathrm{W}$; $B G N$ 1954; (map 46). Var. Boundary Peak 174.

Named by IBC in 1923 for Sir Lyman Poore Duff, 1865-1948, a junior counsel before IBC in 1903, and Judge of the Supreme Court of Canada. Born in Canada, he was educated at the Univ. of Toronto and later served as Judge of the Supreme Court of British Columbia and the Supreme Court of Canada. He became Chief Justice in 1933, which position he held until his retirement in 1944.

Duffield Glacier: glacier, see Turner Glacier.

Duffield Peninsula: peninsula, $8 \mathrm{mi}$. long, on $\mathrm{N}$ coast of Baranof I., $30 \mathrm{mi}$. $\mathbf{N}$ of Sitka, Alex. Arch.; 57 $30^{\prime} \mathrm{N}, 1^{\circ} 25^{\circ} \mathrm{W}$; (map 9).

Named in 1895 by Lt. Comdr. E. K. Moore, USN, for Gen. William Ward Duffield, 18231907 , a general in the Civil War, an engineer, and superintendent of USC\&GS, 1894-97.
Dugan Creek: stream, flows NE $10 \mathrm{mi}$. to Yukon River S. of Eagle I., $47 \mathrm{mi}$. SE of Unalakleet, Nulato Hills; $63^{\circ} 29^{\prime} 30^{\prime \prime} \mathrm{N}, 159^{\circ} 00^{\prime} 50^{\prime \prime} \mathrm{W}$; (map 91).

Local name reported in 1949 by USC\&GS.

Dugan Creek: stream, flows SW $12 \mathrm{mi}$. to Tanana River, $58 \mathrm{mi}$. NE of Bitzshtini Mts., Tanana

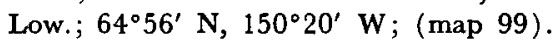

Local name reported in 1937 by USGS.

Dugan Hills: hills, trends W $33 \mathrm{mi}$. from Tolovana River, along $\mathrm{N}$ side of Tanana River, $60 \mathrm{mi}$. WNW of Fairbanks, YukonTanana High.; $65^{\circ} 00^{\prime} \mathrm{N}, 150^{\circ} 00^{\prime} \mathrm{W}$; $B G N$ 1965; (map 105).

Local name reported in 1963 by USGS; derived from nearby Dugan River.

Dugan River: stream, see Kantishna River.

Duga Point: point of land, see Nemo Point.

Duglas, Mys: point of land, see Douglas, Cape.

Duitatuk Lake: lake, $1.8 \mathrm{mi}$. long, $3 \mathrm{mi}$. NW of Tikyitsal Mtn. and $5 \mathrm{mi}$. NE of Arctic Village, Brooks Ra.; $68^{\circ} 11^{\prime}$ N, $145^{\circ} 23^{\prime}$ W ; (map 136). Kutchin Indian name obtained at Arctic Village in 1956 by T. E. Taylor, USGS.

Duke Hill: hill, $540 \mathrm{ft}$., on $\mathrm{E}$ coast of Duke I., Alex. Arch.; $54^{\circ} 55^{\prime} \mathrm{N}, 131^{\circ} 12^{\prime} \mathrm{W}$; (map 2). Name derived from Duke Island; given in 1879 by W. H. Dall, USC\&GS.

Duke Island: island, $12 \mathrm{mi}$. across, between Clarence Strait and Revillagigedo Channel, Alex. Arch.; $54^{\circ} 55^{\prime} \mathrm{N}, 131^{\circ} 20^{\prime} \mathrm{W}$; (map 2).

Named in 1879 by W. H. Dall, USG\&GS. He probably took the name from the Duke of Northumberland, after whom the southern tip of this island had been named in 1793 by Capt. Vancouver, RN. See Cape Northumberland.

Duke of Clarences Strait: water passage, see Clarence Strait.

Duke of York Island: island, see Zarembo Island. Duke Point: point of land, on $\mathrm{E}$ coast of Duke I., extends into Revillagigedo Channel, Alex.

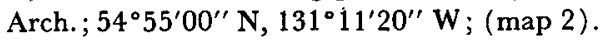

Name derived from Duke Island; given in 1879 by W. H. Dall, USC\&GS.

Dukes, The: peaks, 6,300 ft., two peaks $0.2 \mathrm{mi}$. apart, in Taku Range $0.7 \mathrm{mi}$. SE of Emperor Peak and $19 \mathrm{mi}$. N of Juneau, Coast Mts.; $58^{\circ} 34^{\prime} 40^{\prime \prime} \mathrm{N}, 134^{\circ} 22^{\prime} 15^{\prime \prime} \mathrm{W}$; BGN 1965; (map 11).

Descriptive name submitted by personnel of the Juneau Icefield Research Project in 1964. Duksuk Lagoon: lagoon, see Dooksook Lagoon. Duksuk River: stream, see Dooksook River.

Duktoth Mountain: mountain, 4,000 ft., $6.5 \mathrm{mi}$. $\mathrm{N}$ of mouth of Duktoth River and $106 \mathrm{mi}$. NW of Yakutat, Chugach Mts. ; $60^{\circ} 10^{\prime} 50^{\prime \prime} \mathrm{N}$, $142^{\circ} 29^{\prime} 30^{\prime \prime} \mathrm{W}$; (map 65).

Local name derived from the Duktoth River and published in 1951 by USGS.

Duktoth River: stream, heads at glacier terminus, flows SW and SE $28 \mathrm{mi}$. to Gulf of Alaska, $4 \mathrm{mi}$. WNW of Cape Yakataga, St. Elias Mts.; $60^{\circ} 05^{\prime} 15^{\prime \prime} \mathrm{N}, 142^{\circ} 32^{\prime} 30^{\prime \prime} \mathrm{W}$; (map 65). Var. Ductoth River, Quetoth River.

Indian name reported as "Ductoth" in 1903 by G. C. Martin, USGS, and published by error as "Quetoth" by him (1905). 
Dulbatna Mountain, mountain, 2,811 ft., N of Dulbi River and $W$ of Radio Creek, $53 \mathrm{mi}$. WNW of Birches, Kokrines-Hodzana High.; $65^{\circ} 22^{\prime} 00^{\prime \prime} \mathrm{N}, 155^{\circ} 16^{\prime} 30^{\prime \prime} \mathrm{W}$; (map 107).

Local name reported in 1956 as "Dalbatna Mountain" by Orth

Dulbi Flats: flat, extends NE $30 \mathrm{mi}$. from Dulbi Slough to Koyukuk River, $35 \mathrm{mi}$. NW of Hochandochtla Mtn., Kokrines-H od z a n a High.; $65^{\circ} 45^{\prime} \mathrm{N}, 155^{\circ} 45^{\prime} \mathrm{W}$; (map 107).

Local name shown on a 1932 sketch map of the area; author unknown.

Dulbikakat : stream, see Dulbi River.

Dulbi River: stream, flows NW $121 \mathrm{mi}$, to Koyukuk River, 6 mi. SE of Roundabout Mtn., Koyukuk Low.; $65^{\circ} 27^{\prime} \mathrm{N}, 156^{\circ} 31^{\prime} \mathrm{W}$; BGN 1961; (map 108). Var. Dalbatna, Dulbikakat, Dulebekakat, Dubli River.

Koyukuk Indian name published by $\mathrm{Lt}$. Allen (1887, map), USA, as "Dulbikakat," meaning "mouth of the Dulbi." This name is shown as "Dulebekakat" by Lt. B. H. Camden, USRCS, in 1900 (Cantwell, 1904, p. 244).

In 1956 Orth recorded the stream name as "Dalbatna," meaning "river of young geese."

Dulbi Slough: stream, heads at $65^{\circ} 39^{\prime} \mathrm{N}, 156^{\circ} 02^{\prime}$ W, flows SW $63 \mathrm{mi}$. to Koyukuk River, $9 \mathrm{mi}$. SE of Roundabout Mtn., Koyukuk Low.; $65^{\circ}$ $27^{\prime} \mathrm{N}, 156^{\circ} 19^{\prime} \mathrm{W}$; (map 108).

Name published in 1959 by USGS. See Dulbi River.

Dulebekakat: stream, see Dulbi River.

Dull Ax Lake: lake, $0.7 \mathrm{mi}$. long, drains. NW to Dry Greek, $5 \mathrm{mi}$ SW of Carey Lake and 39 mi. SSW of village of Lake Minchumina, Kuskokwim Low.; $63^{\circ} 20^{\prime} 45^{\prime \prime} \mathrm{N}, 152^{\circ} 42^{\prime} 30^{\prime \prime} \mathrm{W}$; (map 88).

Local name obtained in 1962 from "Val" Blackburn and Fabian Carey by USGS.

Dulth Mountain: mountain, see Doolth Mountain.

Dumbbell Lake: lake, $0.8 \mathrm{mi}$. long, on $\mathrm{N}$ shore of Iliamna Lake, between Pedro and Pile Bays, Aleutian Ra.; $59^{\circ} 47^{\prime} \mathrm{N}, 154^{\circ} 03^{\prime} \mathrm{W}$; (map 51).

Locally so named, because the lake is shaped like a dumbbell; published by USGS in 1954. Dumbell Lake: lake, see Dumbbell Lake.

Dummy Creek: stream, flows W $20 \mathrm{mi}$. to Mulchatna River, $40 \mathrm{mi}$. W of Nondalton, Lime Hills; $60^{\circ} 30^{\prime} \mathrm{N}, 1^{\circ} 5^{\circ} 36^{\prime} \mathrm{W}$; (map 61).

Local name reported in 1914 by $R$. H. Sargent (in Smith and others, 1917, pl. 1), USGS.

Dumpling Mountain: mountain, 2,520 ft., between Lake Brooks and Naknek Lake, on Alaska Penin., in Katmai National Monument, $39 \mathrm{mi}$. NW of Mount Katmai, Aleutian Ra.; $58^{\circ} 35^{\prime} \mathrm{N}, 155^{\circ} 51^{\prime} \mathrm{W}$; BGN 1924; (map 42).

Descriptive name given in 1919 by R. F. Griggs, National Geographic Society.

Dumplings, The: hills, see Klotz Hills.

Dunbar: $R R$. station, mile 431.6 on The Alaska RR., $33 \mathrm{mi}$. SW of Fairbanks, Yukon-Tanana High.; 64. $45^{\prime} 30^{\prime \prime} \mathrm{N}, 148^{\circ} 47^{\prime} 30^{\prime \prime} \mathrm{W}$; (map 100). Var. Goldstream.

Local name published on a timetable in 1922. The station was first called Goldstream because it was near the crossing over Goldstrearn Creek.

Dunbar Inlet: estuary, extends NE $2.7 \mathrm{mi}$., off Tlerak Strait on W coast of Sukkwan I., 30 mi. SE of Craig, Alex. Arch.; $55^{\circ} 04^{\prime} 30^{\prime \prime} \mathrm{N}$, $132^{\circ} 52^{\prime} 00^{\prime \prime} \mathrm{W}$; (map 4).

Named in 1882 by W. H. Dall, USC\&GS, "for Miss Margaret J. Dunbar, of Steubenville, Ohio, who began missionary work in Alaska in 1879" (Jackson, 1880 , p. 375).

Duncan Canal: estuary, extends SE $22 \mathrm{mi}$. to Sumner Strait, on Kupreanof I., Alex. Arch.; $56^{\circ} 30^{\prime} \mathrm{N}, 133^{\circ} 03^{\prime} \mathrm{W}$; (map 6). Var. Duncan Channel, Canal de Dunkan.

Named on August 30, 1793, by Capt. George Vancouver, RN, "for Admiral Adam Duncan" (Wagner, 1937, p. 315).

Duncan Channel: estuary, see Duncan Canal.

Duncan Creek: stream, flows W $7.3 \mathrm{mi}$. to head of Duncan Canal, $11 \mathrm{mi}$. W of Petersburg, on $W$ coast of Lindenberg Penin., Kupreanof I., Alex. Arch.; $56^{\circ} 46^{\prime} 30^{\prime \prime} \mathrm{N}, 133^{\circ} 14^{\prime} 00^{\prime \prime} \mathrm{W}$; BGN 1960; (map 6).

Local name reported in 1937 by USFS.

Duncan Creek: stream, flows SW $1.5 \mathrm{mi}$. to Poorman Creek, 1.2 mi. SE of Poorman and $46 \mathrm{mi}$. S of Ruby, Kilbuck-Kuskokwim Mts.; $64^{\circ} 05^{\prime} 25^{\prime \prime} \mathrm{N}, 155^{\circ} 30^{\prime} 45^{\prime \prime} \mathrm{W}$; BGN 1936; (map 98).

Prospectors' name reported in 1914 by $\mathrm{H}$. M. Eakin, USGS.

Duncan Creek: stream, flows NE $3.4 \mathrm{mi}$. to Bullion Creek, in Pargon River basin, 12 mi. NE of Council and $38 \mathrm{mi}$. S of Imuruk Lake, Seward Penin. High.; $65^{\circ} 01^{\prime} \mathrm{N}, 163^{\circ} 25^{\prime} \mathrm{W}$ (map 110). Var. Anaconda Creek.

Prospectors' name reported in 1906 by USGS geologists (in Collier and others, 1908, pl. 8).

Duncan Creek: stream, flows W $6.7 \mathrm{mi}$. to Tolovana River, $12 \mathrm{mi}$. E of Livengood, Yukon-Tanana High.; $65^{\circ} 30^{\prime} 40^{\prime \prime} \mathrm{N}, 148^{\circ} 08^{\prime}$ $40^{\prime \prime}$ W; (map 105).

Named by prospectors; reported in 1916 by J. B. Mertie, Jr. (in Brooks and others, 1918, pl. 13), USGS.

Duncan Passage: water passage, see Beecher Pass.

Duncan Peaks: peaks, 3,600 ft., on Portage Mtn., W coast of Lindenberg Penin., Kupreanof I., $12 \mathrm{mi}$. W of Petersburg, Alex. Arch.; 56 $51^{\circ}$ $15^{\prime \prime} \mathrm{N}, 133^{\circ} 13^{\prime} 10^{\prime \prime} \mathrm{W}$; (map 6).

Named in 1887 by Lt. Comdr. C. $M$. Thomas, USN.

Dunce Cap Point: point of land, on right bank of Yukon River, $2 \mathrm{mi}$. NE of Old Kaltag and $51 \mathrm{mi}$. SW of Nulato, Nulato Hills; $64^{\circ} 02^{\prime} \mathrm{N}$, $158^{\circ} 46^{\prime} \mathrm{W}$; ( $\operatorname{map} 97$ ).

Riverboat pilots' name shown on a 1940 "Navigation Chart of the Tanana-Yukon Rivers" published by the U.S. Dept. of Interior.

Dundas, Point: point of land, in Glacier Bay National Monument, on $\mathrm{N}$ coast of Icy Strait, at North Inian Pass, $3 \mathrm{mi}$. $\mathrm{N}$ of Inian Is., $34 \mathrm{mi}$. WNW of Hoonah, St. Elias Mts.; $58^{\circ} 19^{\prime} 00^{\prime \prime}$ $\mathrm{N}, 136^{\circ} 16^{\prime} 45^{\prime \prime} \mathrm{W}$; (map 10$)$.
Named in 1794 by Capt. George Vancouver, RN, for Henry Dundas, Treasurer of the British Navy at the time (Wagner, 1937, p. 385). Henry Dundas was born in Edinburgh and became Solicitor General of Scotland in 1766 . He was elected to Parliament in 1774 and became Treasurer of the Navy in 1782. He was appointed Home Secretary in 1791 and First Lord of the Admiralty in 1804.

Dundas Bay: bay, $6 \mathrm{mi}$. long, in Glacier Bay National Monument, in Icy Strait, $\mathbf{N}$ of North Inian Pars, $35 \mathrm{mi}$. WNW of Hoonah, St. Elias Mts.; $58^{\circ} 19^{\prime} \mathrm{N}, 136^{\circ} 14^{\prime} \mathrm{W}$; (map 10).

Named by W. H. Dall, USC\&GS, in 1879 , probably for Dundas Point. Name was published in the 1883 Coast Pilot (p. 188).

Dundas River: river, in Glacier Bay National Monument, heads in Abyss Lake, flows SE 16 mi. to Dundas Bay on Icy Strait, $4 \mathrm{mi}$. N of Point Dundas and $37 \mathrm{mi}$. NW of Hoonah, St. Elias Mts.; $58^{\circ} 22^{\prime} 30^{\prime \prime}$ N, $136^{\circ} 19^{\prime} 00^{\prime \prime} \mathrm{W}$; (map 10).

Local name published by USGS in the 1950's.

Dune Lake: lake, $1.3 \mathrm{mi}$. long, $9 \mathrm{mi}$. $\mathrm{N}$ of Totek Hills, Tanana Low. ; 64 ${ }^{\circ} 25^{\prime} 30^{\prime \prime} \mathrm{N}, 149^{\circ} 53^{\prime} 50^{\prime \prime}$ W; (map 100).

Local name reported in 1950 by USGS topographers.

Dunkan, Canal de: estuary, see Duncan Canal.

Dunlin Lake: lake, $0.4 \mathrm{mi}$. across, on NW coast of Kenai Penin. SW of Gull Lake, $20 \mathrm{mi}$. NE of Kenai, Cook Inlet Low.; $60^{\circ} 48^{\prime} 30^{\prime \prime} \mathrm{N}$, $150^{\circ} 57^{\prime} 30^{\prime \prime} \mathrm{W}$; (map 62 ).

Named about 1963 by officials of Kenai National Moose Range, for administrative purposes.

Dunukchavuk Slough: water course, in Yukon Delta, narrow portion of Kwikpak Pass, extends NW $10 \mathrm{mi}$. between Apoon and Kawanak Passes, 19 mi. N of Kwiguk, Yukon-Kuskokwim Delta; $63^{\circ} 01^{\prime} \mathrm{N}, 164^{\circ} 19^{\prime} \mathrm{W}$; (map 92). Var. Dook-Nuk-Chav́-Uk.

Eskimo name obtained in 1952 by USC\&GS.

Dunuletak Creek: stream, flows S $14 \mathrm{mi}$. to Paint River, $1.6 \mathrm{mi}$. W of Akjemguiga Cove and 34 mi. SW of Augustine I., Aleutian Ra.; 59 09'$30^{\prime \prime} \mathrm{N}, 154^{\circ} 17^{\prime} 00^{\prime \prime} \mathrm{W}$; (map 51).

Native name reported in 1923 by K. F. Mather (in Brooks and others, 1925, pl. 3), USGS.

Dunulimjingia Point: point of land, $14 \mathrm{mi}$. SE of Cape Etolin, on NE coast of Nunivak I.; $60^{\circ} 20^{\prime} 00^{\prime \prime} \mathrm{N}, 165^{\circ} 48^{\prime} 40^{\prime \prime} \mathrm{W}$; (map 57).

Eskimo name obtained in 1949 by USC\&GS.

Dununak: village, see Tanunak.

Dununuk: village, see Tanunak.

Dupone Creek: stream, see Dupont Creek.

Dupont: locality, on NE shore of Gastineau Channel, $4.2 \mathrm{mi}$. NW of Point Salisbury and $7.5 \mathrm{mi}$. SE of Juneau, Coast Mts.; $58^{\circ} 13^{\prime} 45^{\prime \prime}$ $\mathrm{N}, 134^{\circ} 15^{\prime} 00^{\prime \prime} \mathrm{W}$; (map 11$)$.

Named for the Dupont Powder Co. powder magazine built here in 1914 and used until the local mines closed (DeArmond, 1957, p. 16).

Dupont Creek: stream, $1.2 \mathrm{mi}$. long, flowing SW to Gastineau Ghannel at Dupont, $7.5 \mathrm{mi}$. SE 
of Juneau, Coast Mts.; 58 $13^{\prime} 45^{\prime \prime} \mathrm{N}, 134^{\circ} 15^{\prime}$ $00^{\prime \prime} \mathrm{W}$; (map 11). Var. Dupone Creek, Mission Creek.

Named for the Dupont Powder Co., which stored powder for miners in a magazine built in 1914 near the mouth of the creek. Also called Mission Creek by miners for many years. There is some evidence that a Friends Mission was located here. Land along the beach, including the creek, was claimed for such a mission in 1889 (DeArmond, 1957, p. 16). The name Dupont Greek was published by USGS in 1918.

Dupont Peak: mountain, 3,765 ft., $17 \mathrm{mi}$. ENE of Petersburg, Coast Mts.; 56 $53^{\prime} 45^{\prime \prime}$ N, $132^{\circ}$ $32^{\prime} 40^{\prime \prime} \mathrm{W}$; (map 6).

Named by USC\&GS for charting purposes; name published in 1943.

Durants Cove: cove, $0.3 \mathrm{mi}$. across, at $\mathrm{E}$ end of Iliamna Lake, on $\mathrm{S}$ shore of Pile Bay, $8 \mathrm{mi}$. NE of Squirrel Point, Aleutian Ra.; 59 $42^{\prime} 35^{\prime \prime}$ $\mathrm{N}, 154^{\circ} 02^{\prime} 30^{\prime \prime} \mathrm{W}$; (map 51).

Local name published in 1954 by USGS.

DuRelle, Mount: mountain, 4,074 ft., $10 \mathrm{mi}$. NW of Tonsina and $51 \mathrm{mi}$. NE of Valdez, Chugach Mts.; 61 $44^{\prime} 25^{\prime \prime} \mathrm{N}, 145^{\circ} 25^{\prime} 00^{\prime \prime} \mathrm{W}$; (map 68). Var. Durelle Mountain.

Named in 1898 by Capt. W. R. Abercrombie, USA.

Durham Creek: stream, heads in lake, flows NE $10 \mathrm{mi}$. to Tazlina River, $13 \mathrm{mi}$. SW of Glennallen, Copper River Basin, $62^{\circ} 04^{\prime} \mathrm{N}, 145^{\circ}$ 56' W; (map 83).

Local name reported by USGS (in Chapin, 1918, pl. 1).

Durrant Creek: stream, flows NE $3.7 \mathrm{mi}$. to Stewart River, $20 \mathrm{mi}$. NW of Nome, Seward Penin. High.; $64^{\circ} 47^{\prime} \mathrm{N}, 165^{\circ} 38^{\prime} \mathrm{W}$; map 94).

Prospectors' name reported in 1900 by $\mathrm{E}$. C. Barnard (in Brooks, 1901, pl. 17), USGS. Dushistoi Island: island, see Fragrant Island.

Dushistoy, Ostrov: island, see Fragrant Island.

Dushkin Lagoon: lagoon, $3 \mathrm{mi}$. long, arm of Volcano Bay, $5 \mathrm{mi}$. NW of Dolgoi I., Aleutian Ra.; $55^{\circ} 13^{\prime} 30^{\prime \prime} \mathrm{N}, 161^{\circ} 55^{\prime} 00^{\prime \prime} \mathrm{W}$; (map 28).

Local Russian name reported by USGS in 1929.

Dushkot Island: island, $0.4 \mathrm{mi}$. long, in Beaver Inlet, on E coast of Unalaska I., Aleutian Is. ; $53^{\circ} 45^{\prime} 35^{\prime \prime} \mathrm{N}, 166^{\circ} 30^{\prime} 05^{\prime \prime} \mathrm{W}$; (map 23).

Name published by Lt. Sarichev (1826, map 14), IRN, as "O[strov] Dushkhot" or "Dushkot Island." The name may have been derived from the Aleut word "daxtuk" meaning "kidney."

Dushnaia Bay: cove, see Close Bay.

Dushnaya, Bukhta: cove, see Close Bay.

Dusk Islands: islands, two, each less than 2,000 ft. long, in Kiliuda Bay, $0.7 \mathrm{mi}$. W of Ermine Point, on SE coast of Kodiak I.; 57 $17^{\prime} 15^{\prime \prime}$ $N$, $152^{\circ} 53^{\prime} 15^{\prime} W$; $B G N$ 1930; (map 34). Var. Dark Islands.

Called "Dark Islands" in 1928 by USC\&GS, "because of the characteristic dark appearance * * *, The name was changed to "Dusk Islands" in 1930 by USC\&GS, "by reason of numerous duplications."

Dust Creek: stream, flows NW $19 \mathrm{mi}$. to Tonsina River, $4.7 \mathrm{mi}$. NE of Tonsina and $56 \mathrm{mi}$. NE of Valdez, Chugach Mts. ; $61^{\circ} 42^{\prime} 15^{\prime \prime} \mathrm{N}, 145^{\circ}$ $03^{\prime} 00^{\prime \prime} \mathrm{W}$; (map 68).

Local name published in 1950 by USGS.

Dusty Mountain: mountain, $4,400 \mathrm{ft} ., 4 \mathrm{mi}$. N of Vermont Dome and $13 \mathrm{mi}$. $\mathrm{N}$ of Wiseman, Brooks Ra.; $67^{\circ} 35^{\prime} 30^{\prime \prime} \mathrm{N}, 150^{\circ} 15^{\prime} 00^{\prime} \mathrm{W}$; $B G N$ 1932; (map 124).

Named by Robert Marshall about 1930.

Dutch Camp: fat, see Dutch Flat.

Dutch Creek: stream, heads $W$ of Dutch Hills, flows SW $10 \mathrm{mi}$. to Granite Greek, $37 \mathrm{mi}$. NW of Talkeetna, Alaska Ra.; $62^{\circ} 32^{\prime} 10^{\prime \prime} \mathrm{N}, 151^{\circ}$ $10^{\prime} 10^{\prime \prime} \mathrm{W}$; (map 81).

Prospectors' name reported in 1906 by $R$. W. Porter, USGS.

Dutch Creek: stream, flows W $2.5 \mathrm{mi}$. to Snowball Creek, $7 \mathrm{mi}$. NNE of Council and 39 mi. NE of Solomon, Seward Penin. High.; $65^{\circ} 00^{\prime} \mathrm{N}, 163^{\circ} 36^{\prime} \mathrm{W}$; (map 95).

Prospectors' name reported in 1899 by Schrader and Brooks (1900, map 3), USGS.

Dutch Flat: flat, 2 mi. long, along Lowe River, $\mathrm{N}$ of Keystone Canyon, $14 \mathrm{mi}$. E of Valdez, Chugach Mts.; $61^{\circ} 06^{\prime} \mathrm{N}, 145^{\circ} 52^{\prime} \mathrm{W}$; (map 68). Var. Dutch Camp.

Named in 1898 by Capt. W. R. Abercrombie (in Glenn and Abercrombie, 1899, map 7), USA.

Dutch Group: islands, $1.5 \mathrm{mi}$. long, in NW part of Prince William Sound, at $\mathbf{E}$ end of Wells Passage, 30 mi. E of Whittier, Chugach Mts.;

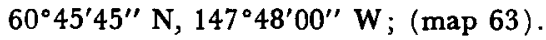

Name reported in 1908 by U.S. Grant (in Brooks and others, 1909, pl. 4), USGS.

Dutch Harbor: village, pop. 52, on Amaknak I., on shore of Dutch Harbor, on Unalaska Bay, Unalaska I., Aleutian Is.; $53^{\circ} 53^{\prime} 27^{\prime \prime} \mathrm{N}, 166^{\circ}$. 32'05" W; BGN 1931; (map 23).

Name published by USC\&GS in 1931.

Dutch Harbor: anchorage, on $\mathrm{E}$ coast of Amaknak $I$., in Unalaska Bay, on $N$ coast of Unalaska I., Aleutian Is.; $53^{\circ} 54^{\prime} \mathrm{N}, 166^{\circ} 31^{\prime}$ W; (map 23). Var. Dutch Harbor Bay, Holland Harbor, Ougadakh Harbor, Udakhta Harbor, Ulakhta Harbor.

It was so named by the Russians because it is believed that a Dutch vessel was the first to enter the harbor; Father Veniaminov (1840, v. 1, p. 188) reported that earlier navigators called it "Holland Harbor." Its Aleut name was published by Lt. Sarichev (1826, map 14, dated 1792), IRN, as "Udakhta," which may be from the words "uddaq" and "daxtakuqing." According to R. H. Geoghegan; these words mean "bay" and "to rest." Sarichev may have used this name because he spent the winter of 1791-92 in this bay (Lutke, 1836, p. 282).

Dutch Harbor: bay, $0.7 \mathrm{mi}$. across, near $\mathrm{N}$ entrance to Port Johnson, on SE coast of Prince of Wales I., Alex. Arch.; 55 $09^{\prime} 20^{\prime \prime}$ N, $132^{\circ} 00^{\prime} 15^{\prime \prime} \mathrm{W}$; BGN 1966; (map 4).

Local name recorded in 1948 by USGS.
Dutch Harbor Bay: anchorage, see Dutch Harbor.

Dutch Hills: ridge, elev. 4,400 ft., extends NE $15 \mathrm{mi}$. from 1958 terminus of Kahiltna Glacier, $30 \mathrm{mi}$. NW of Talkeetna, Alaska Ra.; $62^{\circ} 35^{\prime} 30^{\prime \prime} \mathrm{N}, 150^{\circ} 58^{\prime} 00^{\prime \prime} \mathrm{W}$; (map 81).

Prospectors' name reported in 1911 by $S$. R. Capps (in Brooks, 1912, pl. 9), USGS.

Dutchikamiut: stream, see Duchikmiut River.

Dutton: locality, in Chigmit Mts., at head of Cottonwood Bay, $6 \mathrm{mi}$. WNW of South Head, Aleutian Ra.; $59^{\circ} 38^{\prime} \mathrm{N}, 153^{\circ} 52^{\prime} \mathrm{W}$; (map 51).

This mining camp was named for George W. Dutton who was its first postmaster in 1905. The post office was discontinued in 1909.

Dutton, Mount: mountain, $4,834 \mathrm{ft} ., 18 \mathrm{mi}$. E of village of Cold Bay, NW of head of Belkofski Bay, at SW end of Alaska Penin., Aleutian Ra.; $55^{\circ} 11^{\prime} \mathrm{N}, 162^{\circ} 16^{\prime} \mathrm{W}$; (map 29).

Named by T. A. Jaggar, USGS, in 1927 for Clarence Edward Dutton, a volcano geologist of the 19th century.

Duvna Lake: lake, see Tutna Lake.

Dvoini Bratev: islands, see Twins, The.

Dvoinoi : bay, see Driftwood Bay.

Dvoinoi: rocks, see Twin Islet.

Dvoynoy: bay, see Driftwood Bay.

Dvoynoy, Ostrova : rocks, see Twin Islet.

Dyckman Mountain: mountain, 1,910 ft., $69 \mathrm{mi}$. NE of Medfra, Kilbuck-Kuskokwim Mts.; $63^{\circ} 50^{\prime} \mathrm{N}, 153^{\circ} 11^{\prime} \mathrm{W}$; (map 89).

Local name reported in 1958 by USGS.

Dyea Inlet: estuary, see Taiya Inlet.

Dyea: locality, at mouth of Taiya River, $3 \mathrm{mi}$. NW of Skagway, Coast Mts.; $59^{\circ} 29^{\prime} 35^{\prime \prime} \mathrm{N}$, $135^{\circ} 21^{\prime} 45^{\prime \prime} \mathrm{W}$; BGN 1898; (map 45). Var. Daiye, Dayay, Dejah, Taiya, Tyya.

Former Chilkat Tlingit Indian village which became noted during the Yukon gold excitement in the late 1800's. The name seems to have been derived from the Indian name "Dyaytahk." Dyea was the port of entry to the Dyea Trial through Chilkoot Pass, one of the most popular routes to the Klondike. After the construction of the White Pass and Yukon RR. in 1902 the town began to decline. The Dyea post office was established in 1896; discontinued in 1902 (Ricks, 1965, p. 17).

Dyea Pass: pass, see Chilkoot Pass.

Dyea Point: point of land, on Taiya Inlet, $1 \mathrm{mi}$. $\mathrm{S}$ of mouth of Taiya River and $1.2 \mathrm{mi}$. W of Skagway, Coast Mts.; $59^{\circ} 27^{\prime} 45^{\prime \prime}$ N, $135^{\circ}$ $20^{\prime} 45^{\prime \prime}$ W ; (map 45).

Indian name published in 1951 by USGS. Name probably derived from the former village of Dyea, a short distance north of the point.

Dyea River: stream, see Taiya River.

Dyer, Cape: point of land, on Chukchi Sea coast, $16 \mathrm{mi}$. S of Cape Lisburne, Arctic Slope; $68^{\circ} 39^{\prime} 08^{\prime \prime} \mathrm{N}, 166^{\circ} 13^{\prime} 50^{\prime \prime} \mathrm{W}$; (map 129). Var. Capaloa, Kapaloa, Kapaloak, Kapalowa.

Named about 1827 by Capt. Beechey (1831, map p. 328), RN. The Eskimo name for Cape 
Dyer, as well as the old village, is Capaloa [Kapaloak], according to J. B. Driggs, a Point Hope missionary (Collier, 1906, p. 44).

Dyer, Point: point of land, on S shore of Scammon Bay, $E$ point of entrance to Kongishluk Bay and $12 \mathrm{mi}$. E of Cape Romanzof, YukonKuskokwim Delta: $61^{\circ} 50^{\prime} 30^{\prime \prime} \mathrm{N}, 165^{\circ} 44^{\prime} 30^{\prime \prime}$ W; (map 75).

Named by Dall (1870, p. 277), in 1869, for Lt. Joseph T. Dyer of Washington D.C. who, with Capt. E. E. Smith, explored the delta of the Yukon River in 1867 for the Western Union Telegraph Co.

Dyevison, Mys: point of land, see Davison, Point.

Dyevison Cape: point of land, see Davison, Point.

Dying Glacier: glacier, former glacier, in Glacier Bay National Monument, trended E-W, $1 \mathrm{mi}$. SE of Pyramid Peak and $57 \mathrm{mi}$. NW of Hoonah, St. Elias Mts.; $58^{\circ} 49^{\prime} 50^{\prime \prime} \mathrm{N}, 136^{\circ}$ $15^{\prime} 10^{\prime \prime} \mathrm{W}$; (map 10 ).

Descriptive name given in 1890 by Reid (1892, p. 36), USGS, "because the glacier was rapidly melting away. Between 1886 and 1890 it had receded more than 1,000 yards." It has now entirely disappeared.

Dyke Mountain: mountain, 5,660 ft., $3.2 \mathrm{mi}$. SW of Powell Peak and $41 \mathrm{mi}$. N of Valdez, Chugach Mts.; $61^{\circ} 42^{\prime} 00^{\prime \prime} \mathrm{N}, 146^{\circ} 07^{\prime} 45^{\prime \prime} \mathrm{W}$; (map 68).

Named in 1898 by Capt. W. R. Abercrombie, USA.

Dyrovatyy, Mys: point of land, see Dirovati Point.

E

Eagan's River: stream, see Egans Creek.

Eagle: village, pop. 92, on left bank of Yukon River at mouth of Mission Creek, $6 \mathrm{mi}$. W of Alaska-Canada boundary, Yukon-Tanana High.; $64^{\circ} 47^{\prime} \mathrm{N}, 141^{\circ} 12^{\prime} \mathrm{W}$; BGN 1944. Var. Belle Isle, Eagle City, Eagle City Camp, Fort Egbert.

Established as a log house trading station called "Belle Isle" by Moses Mercier about 1874 and operated intermittently until its development as a mining camp in 1898 (Kitchener, 1954, p. 255). The village, then with a population of about 800, was platted and named "Eagle City" for the American eagles nesting on nearby Eagle Bluff (Henning, 1965, p. 204). The Eagle post office was established in 1898 and the Valdez-Eagle telegraph line was completed in 1903.

The U.S. Army established the "Eagle City Camp" in 1899 at Eagle and a year later Fort Egbert was built; abandoned in 1911.

The population of Eagle was 383 in 1900 ; 178 in 1910; 98 in 1920; 54 in 1930; 73 in 1939 ; 55 in 1950.

Eagle Bay: bay, $1.2 \mathrm{mi}$. across, on $\mathrm{S}$ coast of Unalaska I., Aleutian Is.; $53^{\circ} 26^{\prime} 30^{\prime \prime} \mathrm{N}, 166^{\circ}$ 56'30" W; (map 23).

Name given by the USBF in 1888 .

Eagle Bay: bay, $1 \mathrm{mi}$. across, on $\mathbf{N}$ shore of Iliamna Lake, $9 \mathrm{mi}$. E of Iliamna, Aleutian Ra.; $59^{\circ} 45^{\prime} 35^{\prime \prime} \mathrm{N}, 154^{\circ} 40^{\prime} 00^{\prime \prime} \mathrm{W}$; (map 51 ).
Name published by Martin and Katz (1912, pl. 1), USGS.

Eagle Bay: bay, 3.6 mi. across, in Knik Arm, at mouth of Eagle River, $8.5 \mathrm{mi}$. NE of Anchorage, Cook Inlet Low.; $61^{\circ} 21^{\prime} \mathrm{N}, 149^{\circ} 45^{\prime}$ W; (map 69).

Name reported in 1922 by USGS; derived from Eagle River.

Eagle Bay: estuary, of Eagle River, $0.2 \mathrm{mi}$. across, enters Bradfield Canal, $5 \mathrm{mi}$. SW of its head, Coast Mts.; $56^{\circ} 10^{\prime} 45^{\prime \prime} \mathrm{N}, 131^{\circ} 36^{\prime} 30^{\prime \prime} \mathrm{W}$; (map 7).

Local name reported in 1955 by USGS.

Eagle Bay: estuary, on $\mathrm{N}$ coast of Glacier I., extends NE $1.5 \mathrm{mi}$. to Prince William Sound, $54 \mathrm{mi}$. NE of Whittier, Chugach Mts.; $60^{\circ}$. $54^{\prime} 10^{\prime \prime} \mathrm{N}, 147^{\circ} 10^{\prime} 00^{\prime \prime} \mathrm{W}$; (map 63).

Local name reported in 1916 by J. W. Bagley, USGS.

Eagle Bay Creek: stream, on $\mathrm{N}$ shore of Iliamna Lake, flows SW $6 \mathrm{mi}$. to Eagle Bay, $9 \mathrm{mi}$. E of Iliamna, Aleutian Ra.; 59 $46^{\prime} 15^{\prime \prime} \mathrm{N}$, $154^{\circ} 38^{\prime} 30^{\prime \prime} \mathrm{W}$; ( $\operatorname{map} 51$ ).

Local name published by USGS in 1954 .

Eagle Bay Island: island, $0.7 \mathrm{mi}$. long, in Iliamna Lake, $\mathrm{S}$ of Eagle Bay, $8 \mathrm{mi}$. E of Iliamna, Aleutian Ra.; $59^{\circ} 45^{\prime} \mathrm{N}, 154^{\circ} 40^{\prime} \mathrm{W}$; (map 51 ).

Local name published in 1954 by USGS.

Eagle Bluff: bluff, 2,000 ft., at junc. of Mission Creek and Yukon River, $0.5 \mathrm{mi}$. N of Eagle, Yukon-Tanana High.; $64^{\circ} 48^{\prime} \mathrm{N}, 1^{\circ} 1^{\circ} 11^{\prime} \mathrm{W}$; (map 102). Var. Boundary Butte, Ta-tot-lee.

Local name given in the late 1890 's; so named because of American eagles nesting there (Henning, 1965, p. 204). It was called "Boundary Butte" in 1883 by Lt. Schwatka (1885, p. 260), USA, because of its relationship to the Canada-Alaska boundary. Schawatka gives the Indian name as "Ta-tot-lee."

Eagle Bluff: promontory, on S shore of Iliamna Lake, $3 \mathrm{mi}$. NE of Big Mtn. and $25 \mathrm{mi}$. SW Iliamna, Aleutian Ra.; $59^{\circ} 25^{\prime} 30^{\prime \prime} \mathrm{N}, 155^{\circ}$ $10^{\prime} 00^{\prime \prime} \mathrm{W}$; (map 51).

Name published in 1951 by USGS.

Eagle Bluff : promontory, see Eagle Slide.

Eagle Cape: point of land, on $\mathrm{W}$ coast of Shuyak I., $44 \mathrm{mi}$. N of Kodiak I.; $58^{\circ} 32^{\prime} 20^{\prime \prime}$ $\mathrm{N}, 152^{\circ} 39^{\prime} 30^{\prime \prime} \mathrm{W}$; (map 43). Var. Amakaktuli, Orlinie Cape.

Translation of the name "M[ys] Orlinyy" (Amakhkaktuli) published by the Russian American Company in 1849, who "seem to have taken it from the native name Amakaktuli, supposed to mean eagle" (Baker, 1906, p. 229).

Eagle Cape: point of land, see Eagle Point.

Eagle City: village, see Eagle.

Eagle City Camp: village, see Eagle.

Eagle Cliff: hill, opposite mouth of Hidden Creek, on South Fork Koyukuk River, 24.5 mi. S of Wiseman, Brooks Ra.; $67^{\circ} 03^{\prime} 15^{\prime \prime} \mathrm{N}$, $150^{\circ} 00^{\prime} 00^{\prime \prime} \mathrm{W}$; (map 124).

Local name obtained in 1956 by USGS topographers.

Eagle Creek: locality, see Berry Camp.
Eagle Creek: stream, flows NE $1.5 \mathrm{mi}$. to Karluk Lake, $22 \mathrm{mi}$. SE of Karluk, Kodiak I.; $57^{\circ} 19^{\prime} 30^{\prime \prime} \mathrm{N}, 154^{\circ} 02^{\prime} 30^{\prime \prime} \mathrm{W}$; (map 35).

Local name reported in 1952 by USGS.

Eagle Creek: stream, on N part of Douglas I. flows $3 \mathrm{mi}$. NE to Gastineau Channel $2 \mathrm{mi}$. NW of Juneau, Coast Mts.; 58 $18^{\prime} 50^{\prime \prime} \mathrm{N}$, $134^{\circ} 27^{\prime 2} 25^{\prime \prime} \mathrm{W}$; (map 11). Var. Auk Creek, Fall Creek.

Local name first appears in mining records in 1884 and was published by USGS in 1904. Auk Creek and Fall Creek were local names used by early miners (DeArmond, 1957, p. 16).

Eagle Creek: stream, in Glacier Bay National Monument, flows S $7 \mathrm{mi}$. to Gulf of Alaska, $1.5 \mathrm{mi} . \mathrm{N}$ of $\mathrm{La}$ Chaussee Spit and $89 \mathrm{mi}$. NW of Hoonah Malaspina Coastal Plain; $58^{\circ} 38^{\prime} 50^{\prime \prime} \mathrm{N}, 137^{\circ} 40^{\prime} 20^{\prime \prime} \mathrm{W}$; (map 10).

Local name published by USGS in the 1950's.

Eagle Creek: stream, on Hinchinbrook I., flows NE $2.5 \mathrm{mi}$. to Anderson Bay, $28 \mathrm{mi}$. SW of Cordova, Chugach Mts.; $60^{\circ} 28^{\prime} \mathrm{N}, 146^{\circ} 34^{\prime}$ W; (map 64).

Name published in 1950 by USGS.

Eagle Creek: stream, flows SE $12 \mathrm{mi}$. to Salmon River, $75 \mathrm{mi}$. E of Bethel, Kilbuck-Kuskokwim Mts.; $60^{\circ} 38^{\prime} \mathrm{N}, 150^{\circ} 32^{\prime} \mathrm{W}$; (map 59).

Prospectors' name reported in 1914 by A. G. Maddren (in Brooks, 1915, pl. 11), USGS.

Eagle Creek: stream, heads in glacier, flows NE $2.5 \mathrm{mi}$. to Bremner River, $1.6 \mathrm{mi}$. SW of mouth of Salmon Creek and $64 \mathrm{mi}$. $\mathrm{E}$ of Valdez, Chugach Mts.; 61 $00^{\prime} 30^{\prime \prime} \mathrm{N}$, $144^{\circ} 19^{\prime} 50^{\prime \prime} \mathrm{W}$; (map 68).

Local name published by USGS (Moffit, 1914, pl. 1).

Eagle Creek: stream, flows $4 \mathrm{mi}$. W from glacier terminus to Copper Creek $3 \mathrm{mi}$. SE of its junc. with Dan Creek and $18 \mathrm{mi}$. SE of McCarthy, Wrangell Mts.; 61 $20^{\circ} 30^{\prime \prime} \mathrm{N}$, $142^{\circ} 24^{\prime} 30^{\prime \prime} \mathrm{W}$; (map 67).

Local name obtained by USGS and published on maps since 1954.

Eagle Creek: stream, flows SE $4.8 \mathrm{mi}$. to Crooked Creek $9 \mathrm{mi}$. NW of its junc. with Kuskokwim River, $9 \mathrm{mi}$. NW of village of Crooked Creek, Kilbuck-Kuskokwim Mts.; 61 ${ }^{\circ} 58^{\prime} 45^{\prime \prime}$, N, 158 15'45' W; BGN 1948; (map 72).

Local name reported in 1944 by USGS.

Eagle Creek: stream, flows S $7.5 \mathrm{mi}$. to East Fork Chistochina River, $28 \mathrm{mi}$. NE of Chistochina, Alaska Ra.; 62 $57^{\prime} 45^{\prime \prime} \mathrm{N}$, $144^{\circ} 27^{\prime} 30^{\prime \prime} \mathrm{W}$; (map 83).

Local name reported by USGS (in Mendenhall, 1905, p. 41).

Eagle Creek: stream, flows SW $5 \mathrm{mi}$ to Crooked Creek, $6 \mathrm{mi}$. W. of Medfra, KilbuckKuskokwim Mts.; $63^{\circ} 06^{\prime} \mathrm{N}, 154^{\circ} 54^{\prime} \mathrm{W}$; (map 89).

Local name reported in 1958 by USGS.

Eagle Creek: stream, flows SE $7 \mathrm{mi}$. to Yukon River, $4 \mathrm{mi}$. $\mathrm{N}$ of Bullfrog I., Nulato Hills; $63^{\circ} 48^{\prime} \mathrm{N}, 159^{\circ} 12^{\prime} \mathrm{W}$; (map 91 ).

Riverboat pilots' name shown on a 1940 "Navigation Chart of the Tanana-Yukon 
Rivers" published by the U.S. Dept of Interior.

Eagle Creek: stream, flows SW $3 \mathrm{mi}$. to McAdam Creek, $40 \mathrm{mi}$. SE of Nenana, Alaska Ra.; $64^{\circ} 02^{\prime} \mathrm{N}, 148^{\circ} 40^{\prime} \mathrm{W}$; (map 100).

Prospectors' name reported in 1950 by USGS topographers.

Eagle Creek: stream, flows S $2 \mathrm{mi}$. to Mosquito Fork, $56 \mathrm{mi}$. SW of Eagle, Yukon-Tanana High.; $64^{\circ} 04^{\prime} \mathrm{N}, 141^{\circ} 57^{\prime} \mathrm{W}$; (map 102).

Prospectors' name shown on an 1898 manscript map by C. A. Woodruff, Fort Cudahy, Canada.

Eagle Creek: stream, flows NW $19 \mathrm{mi}$. to Shaw Greek, $17 \mathrm{mi}$. NE of Big Delta, Yukon-Tanana High.; 64 $21^{\prime} \mathrm{N}, 145^{\circ} 33^{\prime} \mathrm{W}$; (map 101).

Local name reported in 1908 by J. W. Bagley, USGS.

Eagle Creek: stream, flows SW $14 \mathrm{mi}$. to Kachauik Creek, $22 \mathrm{mi}$. NW of Elim and $45 \mathrm{mi}$. NE of Solomon, Seward Penin. High.: $64^{\circ} 42^{\prime} \mathrm{N}, 162^{\circ} 59^{\prime} \mathrm{W}$; (map 95).

Prospectors' name published on the 1908 "Map of Seward Peninsula" by Arthur Gibson.

Eagle Creek: stream, flows SW $1.2 \mathrm{mi}$. to Bonanza River, $18 \mathrm{mi}$. NW of Solomon, Seward Penin. High.; 64 ${ }^{\circ} 46^{\prime} 05^{\prime \prime} \mathrm{N}, 164^{\circ} 47^{\prime}$ $10^{\prime \prime} \mathrm{W}$; (map 95).

Prospectors' name reported on the 1900 "Map of Nome Peninsula" by J. M. Davidson and B. D. Blakeslee.

Eagle Creek: stream, heads in Canada at $64^{\circ} 42^{\prime \prime} \mathrm{N}, 140^{\circ} 10^{\prime} \mathrm{W}$, flows NW $30 \mathrm{mi}$. to Yukon River, $5 \mathrm{mi}$. SE of Eagle, Porcupine Plat.; $64^{\circ} 46^{\prime} 20^{\prime \prime} \mathrm{N}, 141^{\circ} 02^{\prime} 45^{\prime \prime} \mathrm{W}$; (map 102).

Named by prospectors and reported in 1898 by E. C. Barnard, USGS. So named because eagles nested on the bluffs near the stream's mouth.

Eagle Creek: stream, flows NW $1 \mathrm{mi}$. to Iron Creek, $26 \mathrm{mi}$. NW of Solomon, Seward Penin. High.; $64^{\circ} 55^{\prime} 20^{\prime \prime} \mathrm{N}, 164^{\circ} 41^{\prime} 15^{\prime \prime} \mathrm{W}$; (map 95). Var. Easy Creek.

Prospectors' name published in 1956 by USGS. Reported as "Easy" on a map of Cape Nome gold fields by David Fox, Jr., dated 1901.

Eagle Creek: stream, flows $\mathrm{N} 0.8 \mathrm{mi}$. to Treasure Creek, $11 \mathrm{mi}$. N of Fairbanks, Yukon-Tanana High.; $65^{\circ} 01^{\prime} \mathrm{N}, 147^{\circ} 46^{\prime} \mathrm{W}$; (map 105).

Local name published in 1933 by USGS.

Eagle Creek: stream, flows NE $5 \mathrm{mi}$. to Right Fork Bluestone River, $11 \mathrm{mi}$. S. of Teller, Seward Penin. High.; $65^{\circ} 06^{\prime}$ N, $166^{\circ} 22^{\prime}$ W; (map 111). Var. Igloo Creek.

Local name reported in 1900 by $E$. C. Barnard (in Brooks, 1901, pl. 17), USGS.

Eagle Creek: stream, flows NW $7 \mathrm{mi}$. to Washington Creek, $13 \mathrm{mi}$. S of that stream's junc. with Yukon River and $40 \mathrm{mi}$. NW of Eagle, Yukon-Tanana High,; $65^{\circ} 08^{\prime} \mathrm{N}, 142^{\circ} 17^{\prime} \mathrm{W}$; (map 103).

Prospectors' name reported by Brooks (in Brooks and others, 1907, p. 201), USGS.
Eagle Creek: stream, flows W $3.7 \mathrm{mi}$. to Tolovana River, $10 \mathrm{mi}$. S of Livengood, YukonTanana High.; $65^{\circ} 23^{\prime} 30^{\prime \prime} \mathrm{N}, 148^{\circ} 39^{\prime} 00^{\prime \prime} \mathrm{W}$; (map 105).

Local name reported by USGS in 1950 .

Eagle Creek: stream, flows SW $3 \mathrm{mi}$., joins Ptarmigan Crcek to form Birch Creek, 50 mi. SW of Circle, Yukon-Tanana High.; $65^{\circ} 26^{\prime} 20^{\prime \prime} \mathrm{N}, 145^{\circ} 31^{\prime} 45^{\prime \prime} \mathrm{W}$; (map 104).

Named by prospectors; reported in 1896 by USGS (Spurr, 1898, p. 354).

Eagle Creek: stream, flows SE $3.8 \mathrm{mi}$. to Bear Creek, $27 \mathrm{mi}$. N of Haycock, Seward Penin. High.; $65^{\circ} 36^{\prime} \mathrm{N}, 161^{\circ} 08^{\prime} \mathrm{W}$; (map 109).

Local name shown on a 1903 fieldsheet by D. C. Witherspoon, USGS.

Eagle Creek: stream, on Seward Penin., flows NE $14 \mathrm{mi}$. to Goodhope River, $33 \mathrm{mi}$. SSW of Deering, Kotzebue-Kobuk Low.; $66^{\circ} 01^{\prime} \mathrm{N}$, $163^{\circ} 53^{\prime} \mathrm{W}$; (map 113).

Prospectors' name reported in 1908 by F. F. Henshaw (in Brooks and others, 1909, fig. 21), USGS.

Eagle Creek: stream, heads in lake, flows N 3 mi. to South Fork Koyukuk River, W of Davis Creek, $33 \mathrm{mi}$. NE of Betties, Kokrines-Hodzana High.; $66^{\circ} 59^{\prime} 45^{\prime \prime} \mathrm{N}, 150^{\circ} 30^{\prime} 00^{\prime \prime} \mathrm{W}$; (map 117). Var. Bear Creek.

Name originally applied to a nearby stream; reported in 1901 by W. J. Peters (in Schrader, 1904, pl. 2), USGS.

Eagle Creek: stream, flows N $3.5 \mathrm{mi}$, then E 4 $\mathrm{mi}$. to John River, $5 \mathrm{mi}$. S of mouth of Wolverine Creek and $56 \mathrm{mi}$. W of Wiseman, Brooks Ra.; $67^{\circ} 32^{\prime} 30^{\prime \prime} \mathrm{N}, 152^{\circ} 12^{\prime} 00^{\prime \prime} \mathrm{W}$ (map 124).

Local name obtained in 1956 by USGS topographers.

Eagle Creek: stream, in DeLong Mts., flows NW $36 \mathrm{mi}$. to Kukpowruk River, $6 \mathrm{mi}$. W of Igloo Mtn. and $39 \mathrm{mi}$. SE of Cape Sabine, Arctic Slope; $68^{\circ} 46^{\prime} 35^{\prime \prime} \mathrm{N}, 163^{\circ} 08^{\prime} 00^{\prime \prime} \mathrm{W}$; BGN 1965; (map 130). Var. Bulwark Creek.

Name proposed in 1965 by geologists of the B. P. Exploration Co., Inc.

Eagle Creek: stream, heads in Franklin Mts., flows W $23 \mathrm{mi}$. through Ikiakpuk Valley to Canning River $1 \mathrm{mi}$. $\mathrm{S}$ of junc. of Cache Creek, $44 \mathrm{mi}$. NW of Mount Michelson, Arctic Slope; $69^{\circ} 23^{\prime} \mathrm{N}, 146^{\circ} 04^{\prime} \mathrm{W}$; BGN 1960 ; (map 139). Var. Ikiakpuk Creek.

Named by S. J. Marsh, prospector, about 1902 (Leffingwell, 1919, p. 95).

Eagle Creek: stream, see Ingle Creek.

Eagle Glacier: glacier, heads at $58^{\circ} 36^{\prime} \mathrm{N}$, $134^{\circ} 38^{\prime} \mathrm{W}$, trends generally SW $9 \mathrm{mi}$. to unnamed lake at head of Eagle River, $22 \mathrm{mi}$. NW of Juneau, Coast Mts.; 58 $32^{\prime} \mathrm{N}$, $134^{\circ} 42^{\prime} \mathrm{W}$; BGN 1965; (map 11). Var. Auk Glacier.

So named by Comdr. Richard W. Meade, USN, in 1869, because of the feature's resemblance to an eagle with outstretched wings.

Eagle Glacier: glacier, trends NW $8 \mathrm{mi}$. to its terminus at head of Eagle River, $29 \mathrm{mi}$. SE of Anchorage, Chugach Mts. ; $61^{\circ} 07^{\prime} 45^{\prime \prime} \mathrm{N}$, $149^{\circ} 08^{\prime} 50^{\prime \prime} \mathrm{W}$; (map 69).
Local name reported about 1911 by B. L. Johnson (in Martin and others, 1915, pl. 2), USGS.

Eagle Gorge: canyon, of McKinley River, extends NW-SE $4 \mathrm{mi}$., at $\mathrm{N}$ boundary of Mount McKinley National Park, SSW of Kantishna Hills and $8.5 \mathrm{mi}$. SSW of Wonder Lake, Alaska Ra.; $63^{\circ} 27^{\prime} \mathrm{N}, 151^{\circ} 11^{\prime} \mathrm{W}$; (map 88).

Local name reported in 1925 by $S$. R. Capps, USGS.

Eage Harbor: locality, on Eagle Harbor, on S shore of Ugak Bay, E coast of Kodiak I.; $57^{\circ} 25^{\prime} 45^{\prime \prime}$ N, $152^{\circ} 43^{\prime} 30^{\prime \prime}$ W; (map 34). Var. Orlova, Orlovsk, Saint Orloff, Saint Orlovsk, Seleniye Orlovsk.

Former Eskimo village reported in 1890 in the 11 th Census (1893, p. 76), which stated "The native village on Eagle Harbor was named Orlova by the Russians, and erroneously renamed St. Orloff on our coast survey maps. It [Eagle Harbor] is now popularly known only by the name of the bay. The Kodiak Eskimo inhabiting this village number between 60 and 70." Petroff (1881, p. 32) wrote, "The next inhabited point $* * *$ is Orlovsk village, situated on *** Eagle Harbor. Here is a large settlement of 278 natives and creoles." This village was called "S[eleniye] Orlovsk," or "Orlovsk Settlement," by Capt. Tebenkov (1852, map 23), IRN, which was misinterpreted as "St. Orlovsk" in 1868 by USC\&GS.

Eagle Harbor: bay, $1.5 \mathrm{mi}$. across, on $\mathrm{W}$ coast of Nagai I., in Shumagin Is., Aleutian Ra.; $55^{\circ} 07^{\prime} 30^{\prime \prime} \mathrm{N}, 160^{\circ} 08^{\prime} 00^{\prime \prime} \mathrm{W}$; (map 28).

Named by W. H. Dall, USC\&GS, in 1872 .

Eagle Harbor: bight, $0.5 \mathrm{mi}$. across, on NE coast of Forrester I., Alex. Arch.; 54 $49^{\circ} 45^{\prime \prime} \mathrm{N}$, $133^{\circ} 31^{\prime} 15^{\prime \prime} \mathrm{W}$; (map 1).

Local name published by USC\&GS in 1943.

Eagle Harbor: bight, $2 \mathrm{mi}$. across, on $\mathrm{S}$ shore of Ugak Bay, on E coast of Kodiak I.; $57^{\circ}$ $25^{\prime} 30^{\prime \prime} \mathrm{N}, 152^{\circ} 41^{\prime} 00^{\prime \prime} \mathrm{W}$; (map 34 ).

Local name recorded by Petroff (1881, p. 32 ) in the 10th Census in 1880. See Eagle Harbor, locality.

Eagle Harbor: cove, $0.5 \mathrm{mi}$. across, on $\mathrm{E}$ shore of Favorite Channel, $1 \mathrm{mi}$. N of Pearl Harbor and $19 \mathrm{mi}$. NW of Juneau, Coast Mts.; $58^{\circ}$ $29^{\prime} 45^{\prime \prime} \mathrm{N}, 134^{\circ} 47^{\prime} 30^{\prime \prime} \mathrm{W}$; (map 11).

Local name, part of the "Eagle" name complex derived from Eagle Glacier. It was published by USC\&GS in 1919 on Chart 8300 .

Eagle Island: island, $2 \mathrm{mi}$. long, $\mathrm{N}$ of Onslow Point, at mouth of Ernest Sound, Alex. Arch.; $55^{\circ} 52^{\prime} \mathrm{N}, 132^{\circ} 19^{\prime} \mathrm{W}$; (map 4).

Named in 1886 by Lt. Comdr. A. S. Snow, USN.

Eagle Island: island, $2 \mathrm{mi}$. across, in Sea Otter Sound, Alex. Arch.; 55 $53^{\prime} \mathrm{N}, 133^{\circ} 30^{\prime} \mathrm{W}$; (map 4).

Named in 1903 or 1904 by E. F. Dickins, USC\&GS, who wrote "named by our party, has no local name."

Eagle Island: island, $1 \mathrm{mi}$. long, in Rocky Pass of Keku Strait between Kuiu and Kupreanof 
Is., 19 mi. $\mathrm{N}$ of Point Baker, Alex. Arch.; $56^{\circ} 37^{\prime} 15^{\prime \prime} \mathrm{N}, 133^{\circ} 41^{\prime} 30^{\prime \prime} \mathrm{W}$; (map 6).

Local name published in 1943 by USC\&GS.

Eagle Island: island, $0.25 \mathrm{mi}$. across, off $\mathrm{S}$ shore of Alaska Penin., round, flat topped, in SW entrance to Amber Bay, $5.5 \mathrm{mi}$. W of Cape Kunmik, Aleutian Ra.; $56^{\circ} 46^{\prime} \mathrm{N}, 157^{\circ} 20^{\prime} \mathrm{W}$; (map 31).

Local name published by USG\&GS in the 1947 Coast Pilot, (p. 281).

Eagle Island: island, $6 \mathrm{mi}$. long, in Yukon River, $16 \mathrm{mi}$. N of Anvik and $48 \mathrm{mi}$. N of Holy Cross, Innoko Low.; $62^{\circ} 56^{\prime} \mathrm{N}, 160^{\circ} 00^{\prime} \mathrm{W}$; (map 78). Var. Grayling Island.

Local name obtained in 1952 by USGS.

Eagle Island: island, $9.5 \mathrm{mi}$. long, in Yukon River, $44 \mathrm{mi}$. SE of Unalakleet, Innoko Low.; $63^{\circ} 34^{\prime} \mathrm{N}, 159^{\circ} 28^{\prime} \mathrm{W}$; (map 91). Var. Blackburn Island.

Local name reported in 1949 by USC\&GS.

Eagle Island: island, $2 \mathrm{mi}$. long, in Yukon River $\mathrm{N}$ of Bullfrog I., Innoko Low.; $63^{\circ} 46^{\prime} \mathrm{N}$, $159^{\circ} 18^{\prime} \mathrm{W}$; (map 91).

Riverboat pilots' name shown on a 1940 "Navigation Chart of the Tanana-Yukon Rivers" published by the U.S. Dept. of Interior.

Eaglek Bay: estuary, extends S $8 \mathrm{mi}$. to Prince William Sound, $34 \mathrm{mi}$. NE of Whittier, Chugach Mts.; $60^{\circ} 50^{\prime} \mathrm{N}, 147^{\circ} 42^{\prime} \mathrm{W}$; (map 63).

Name published by Capts. Glenn and Abercrombie (1899, map ), USA.

Eaglek Glacier: glacier, $1.5 \mathrm{mi}$. across, on $\mathrm{S}$ coast of Alaska, $1 \mathrm{mi}$. N of head of Cascade Bay, 32 mi. NE of Whittier, Chugach Mts.; $60^{\circ} 56^{\prime} 15^{\prime \prime} \mathrm{N}, 147^{\circ} 48^{\prime} 30^{\prime \prime} \mathrm{W}$; (map 63).

Local name reported in 1952 by USGS.

Eaglek Island: island, $0.5 \mathrm{mi}$. long, in Prince William Sound at W entrance to Eaglek Bay, $33 \mathrm{mi}$. NE of Whittier, Chugach Mts.; $60^{\circ}-$ $49^{\prime} \mathrm{N}, 147^{\circ} 43^{\prime} \mathrm{W}$; (map 63).

Name published in 1943 by USC\&GS.

Eagle Lake: lake, $4 \mathrm{mi}$. long, at head of Eagle River, $12 \mathrm{mi}$. S of head of Bradfield Canal, Coast Mts.; $56^{\circ} 03^{\prime} \mathrm{N}, 131^{\circ} 28^{\prime} \mathrm{W}$; (map 7). Local name reported in 1955 by USGS.

Eagle Lake: lake, $0.3 \mathrm{mi}$. long, on Kenai Penin., $5.5 \mathrm{mi}$. SW of Caribou Lake and $19 \mathrm{mi}$. NE of Homer, Cook Inlet Low.; 59 $49^{\prime} 40^{\prime \prime} \mathrm{N}, 151^{\circ}$ $08^{\prime} 00^{\prime \prime} \mathrm{W}$; (map 50 ).

Local name reported and published by USGS in the 1950's.

Eagle Lake: lake, $0.8 \mathrm{mi}$. long, on Kenai Penin. between Elephant and Woodpecker Lakes, 8 mi. NE of Kenai, Cook Inlet Low.; 60 $36^{\prime} 30^{\prime \prime}$ $N, 151^{\circ} 00^{\prime} 00^{\prime \prime} \mathrm{W}$; (map 62).

Named about 1963 by officials of Kenai National Moose Range, probably for the Northern Bald Eagle (Haliaeetus leucocephalus alascanus), which occurs from northwestern Alaska south to British Columbia (Pearson, 1944, pt. 2, p. 81).

Eagle Lake: lake, $1.3 \mathrm{mi}$. long, in course of South Fork Eagle River, $19 \mathrm{mi}$. E of Anchorage, Chugach Mts.; $61^{\circ} 10^{\prime} 40^{\prime \prime} \mathrm{N}, 149^{\circ} 21^{\prime} 40^{\prime \prime}$ W; (map 69).

Local name reported in 1942 by AMS.
Eagle Lake: lake, see Little Eagle Lake.

Eagle Mountain: mountain, 1,700 ft., near head of Eagle Harbor, on Nagai I., Shumagin Is., Aleutian Ra.; $55^{\circ} 05^{\prime} \mathrm{N}, 160^{\circ} 03^{\prime} \mathrm{W}$; (map 28).

Named by W. H. Dall, USC\&GS, in 1872 .

Eagle Mountain: mountain, 3,369 ft., between Lake Kulik and Nuyakuk Lake, $60 \mathrm{mi}$. NW of Dillingham, Kilbuck-Kuskokwim Mts.; $59^{\circ} 51^{\prime} \mathrm{N}, 158^{\circ} 57^{\prime} \mathrm{W}$; BGN 1932; (map 52).

So named in 1932 by Gerald FitzGerald, USGS, because of the "numerous bald eagles which were observed on the mountain during the summer of 1931."

Eagle Mountain Creek: stream, flows SW $10 \mathrm{mi}$. to Stony River, $5.3 \mathrm{mi}$. NW of its junc. with Telaquana River, $65 \mathrm{mi}$. N of Lake Clark, Alaska Ra.; $61^{\circ} 08^{\prime} \mathrm{N}, 154^{\circ} 29^{\prime} \mathrm{W}$; (map 71).

Prospectors' name published in 1951 by USGS.

Eagle Peak: mountain, see Newton Peak.

Eagle Peak: peak, 4,650 ft., $2.5 \mathrm{mi}$. SW of Young Lake on Admiralty I. and $14 \mathrm{mi}$. SW of Juneau, Alex. Arch.; $58^{\circ} 06^{\prime} 50^{\prime \prime} \mathrm{N}, 134^{\circ}$ $32^{\prime} 45^{\prime \prime} \mathrm{W}$; (map 11).

Local name published by USGS in 1951.

Eagle Peak: peak, 6,955 ft., in Chugach Mts., about $3 \mathrm{mi}$. ESE of Eagle Lake and $20 \mathrm{mi}$. ESE of Anchorage, Chugach Mts.; $61^{\circ} 10^{\prime} 00^{\prime \prime}$ N, 149 16'15" W; BGN 1966; (map 69). Var. Polar Bear Peak.

Local name reported in 1966 by the Mountaineering Club of Alaska.

Eagle Point: point of land, $\mathrm{S}$ coast of Unalaska, Aleutian Is.; $53^{\circ} 23^{\prime} 40^{\prime \prime} \mathrm{N}, 166^{\circ} 59^{\prime} 00^{\prime \prime} \mathrm{W}$; (map 23). Var. Amtchik Peninsula, Amchik Point, Eagle Cape, East Point.

Name published by USBF in 1888 . Lt. Sarichev (1826, map 14), IRN, called it "Amchik" or "Amtchik." It was also published, in 1869, by USC\&GS as "East Point." Eagle Point: point of land, on NW tip of Dall I., Alex. Arch.; $55^{\circ} 14^{\prime} 30^{\prime \prime} \mathrm{N}, 133^{\circ} 13^{\prime} 10^{\prime \prime} \mathrm{W}$; (map 4).

Name published in 1914 by USC\&GS.

Eagle Point: point of land, formed by junc. of Salmon River and Portland Canal, on AlaskaCanada boundary, Coast Mts.; 55 $54^{\prime} 30^{\prime \prime} \mathrm{N}$, $130^{\circ} 01^{\prime} 00^{\prime \prime} \mathrm{W}$; (map 3).

Name published in 1891 by USC\&GS; possibly named in 1868 by Staff Comdr. David Pender, RN.

Eagle Point: point of land; on $\mathrm{N}$ coast of Chichagof I., in Icy Strait $2.2 \mathrm{mi}$. NW of Burger Point and $11 \mathrm{mi}$. NW of Hoonah, Alex. Arch.; $58^{\circ} 13^{\prime} 50^{\prime \prime} \mathrm{N}, 135^{\circ} 38^{\prime} 30^{\prime \prime} \mathrm{W}$; (map 11).

Named by John F. Pratt, USC\&GS, in 1901 and published in 1904 on Chart 8304.

Eagle Point: point of land, on $N$ coast of Hinchinbrook I., $28 \mathrm{mi}$. SW of Cordova, Chugach Mts. ; $60^{\circ} 29^{\prime} \mathrm{N}, 146^{\circ} 32^{\prime} \mathrm{W}$; ( $\operatorname{map} 64$ ).

Name published in 1950 by USGS.

Eagle Point: promontory, see Eagle Slide.

Eagle Reef: reef, $0.4 \mathrm{mi}$. long, in Favorite Channel, $1.8 \mathrm{mi}$. SW of Pearl Harbor and $18 \mathrm{mi}$. $\mathrm{NW}$ of Juneau, Coast Mts.; $58^{\circ} 27^{\prime} 40^{\prime \prime} \mathrm{N}$, $134^{\circ} 49^{\prime} 15^{\prime \prime} \mathrm{W}$; (map 11$)$.
Named by Comdr. Joseph B. Coghlan, USN, in 1884 and published by USG\&GS in 1885 on Chart 728.

Eagle River: locality, mile 126.6 on The Alaska RR., $3.5 \mathrm{mi}$. SE of mouth of Eagle River and $11 \mathrm{mi}$. NE of Anchorage, Cook Inlet Low.; $61^{\circ} 19^{\prime} 40^{\prime \prime} \mathrm{N}, 149^{\circ} 38^{\prime} 30^{\prime \prime} \mathrm{W}$; (map 69).

Name of a flagstop on The Alaska Railroad, published in timetables in 1922. Name derived from nearby Eagle River.

Eagle River: village, pop. 130 , on N.bank of Eagle River on Glenn Highway, $13 \mathrm{mi}$. NE of Anchorage, Cook Inlet Low.; $61^{\circ} 19^{\prime} 20^{\prime \prime} \mathrm{N}$, $149^{\circ} 34^{\prime} 00^{\prime \prime} \mathrm{W}$; (map 69).

Local name reported in 1939 by USGS. The Eagle River post office was established in 1961.

Eagle River: stream, heads in Eagle Lake, flows NW $8 \mathrm{mi}$. to Eagle Bay, $5 \mathrm{mi}$. SW of the head of Bradfield Canal, Coast Mts.; $56^{\circ} 10^{\prime} \mathrm{N}$, $131^{\circ} 36^{\prime} \mathrm{W}$; (map 7).

Local name published in 1943 by USC\&GS.

Eagle River: stream, heads in unnamed lake $S$ of 1962 terminus of Eagle Glacier and flows $5 \mathrm{mi}$. SW to unnamed bay on Favorite Channel, $2 \mathrm{mi}$. $\mathrm{N}$ of Dotsons Landing and $20 \mathrm{mi}$. NW of Juneau, Coast Mts.; 58 $31^{\prime} 20^{\prime \prime} \mathrm{N}$, $134^{\circ} 48^{\prime} 00^{\prime \prime}$ W; (map 11). Var. Glacier River, Sitk Creek.

Name derived from Eagle Glacier, which it drains, and published in 1906 by USGS (Spencer and Wright, p. 129). Early miners called this stream Glacier River and Sitk Creek (DeArmond, 1957, p. 17).

Eagle River: stream, heads at Eagle Glacier, flows NW $40 \mathrm{mi}$. to Eagle Bay, $9 \mathrm{mi}$. NE of Anchorage, Cook Inlet Low.; $61^{\circ} 19^{\prime} 40^{\prime \prime}$ $\mathrm{N}, 149^{\circ} 44^{\prime} 25^{\prime \prime} \mathrm{W}$; $B G N$ 1916; (map 69). Var. Yukla Creek, Yuklahina River, Yuklahitna River.

Local name reported in 1916 by the Alaska Engineering Commission. Its Indian name was "Yukla-hina" according to USGS in 1898.

Eagle River Flats: swamp, extends $2.5 \mathrm{mi}$. S from mouth of Eagle River, $8 \mathrm{mi}$. NE of Anchorage, Cook Inlet Low.; $61^{\circ} 19^{\circ} \mathrm{N}, 149^{\circ} 44^{\prime}$ W; (map 69).

Local name reported in 1952 by USGS.

Eagle River Landing : locality, see Dotsons Landing.

Eagle Rock: rock, at mouth of Agamgik Bay, on NE coast of Unalaska I., Aleutian Is.; $53^{\circ}$. $52^{\prime} 06^{\prime \prime} \mathrm{N}, 166^{\circ} 19^{\prime} 10^{\prime \prime} \mathrm{W}$; (map 23).

This name was published in the 1944 Aleutian Coast Pilot (p. 32).

Eagle Rock: rock, in Northeast Harbor, Sanak I., Aleutian Ra.; $54^{\circ} 26^{\prime} 37^{\prime \prime} \mathrm{N}, 162^{\circ} 35^{\prime} 35^{\prime \prime} \mathrm{W}$; (map 25).

Name reported by Ferdinand Westdahl, USC\&GS, commander of the Coast Survey steamer McArthur, who made surveys in this area in 1901.

Eagle Rock: rock, near $\mathrm{E}$ shore of Herendeen Bay, off North coast of Bristol Bay Low.; $55^{\circ} 49^{\prime} 30^{\prime \prime} \mathrm{N}, 160^{\circ} 45^{\prime} 40^{\prime \prime} \mathrm{W}$; (map 28).

Named by Z. L. Tanner, USN, in 1890. 
Eagle Rock: rock, $0.5 \mathrm{mi}$. across, in Chignik Bay, 250 yds. off NW entrance point to Anchorage Bay, 3 mi. N of Chignik, Aleutian Ra.; $56^{\circ}$ $20^{\prime} \mathrm{N}, 158^{\circ} 24^{\prime} \mathrm{W}$; (map 30$)$.

Name reported in 1923 by R. H. Sargent, USGS; published in 1927 by USGS.

Eagle Rock: rock, off Kruzof I., 2 mi. S of mouth of Salisbury Sound. $27 \mathrm{mi}$. NW of Sitka, Alex. Arch.; $57^{\circ} 18^{\prime} 25^{\prime \prime} \mathrm{N}, 135^{\circ} 52^{\prime} 45^{\prime \prime}$ W; (map 9).

Named in 1897 by Lt. Comdr. E. K. Moore, USN, and published in 1900 by USC\&GS on Chart 8282.

Eagle Rocks: rocks, on $\mathrm{W}$ shore of Ommaney Bay, at $\mathrm{S}$ tip of Baranof I., Alex. Arch.; $56^{\circ}$ $10^{\prime} 30^{\prime \prime} \mathrm{N}, 134^{\circ} 42^{\prime} 20^{\prime \prime} \mathrm{W}$; (map 5).

Local name published in 1926 by USG\&GS.

Eagle Slide: promontory, $847 \mathrm{ft}$., on right bank of Yukon River, $1.6 \mathrm{mi}$. N of Bullfrog I. and $47 \mathrm{mi}$. E of Unalakleet, Nulato Hills; $63^{\circ} 47^{\prime}$ $\mathrm{N}, 159^{\circ} 15^{\prime} \mathrm{W}$; (map 91). Var. Eagle Bluff, Eagle Point.

Name reported about 1950 by R. M. Chapman, USGS; so called because of a prominent landslide at the point.

Eagle Summit: pass, 3,624 ft., between Mastodon and Porcupine Domes $45 \mathrm{mi}$. SW of Circle, Yukon-Tanana High.; $65^{\circ} 29^{\prime} \mathrm{N}, 145^{\circ} 25^{\prime} \mathrm{W}$; (map 104).

Named after Eagle Creek by prospectors about 1902.

Eaglet Rocks: rocks, 100 yds. across, E of Ringgold I., in S part of Bay of Islands, Adak I., Aleutian Is.; $51^{\circ} 47^{\prime} 55^{\prime \prime} \mathrm{N}, 176^{\circ} 48^{\prime} 10^{\prime \prime} \mathrm{W}$; $B G N 1936$; (map 17).

Named by members of the U.S. Navy Aleutian Island Survey Expedition in 1933.

Eagle Village: village, on left bank of Yukon River, $3 \mathrm{mi}$. E of Eagle, Yukon-Tanana High.; $64^{\circ} 47^{\prime} \mathrm{N}, 141^{\circ} 07^{\prime} \mathrm{W}$; (map 102). Var. Johnnys Indians, Johns Village.

Han Kutchin Indian village associated with nearby Eagle which was the original site of this Indian village before the mining camp was established there. The early village was called "Johnnys" by "the whites" because its chief was known as "John." See Eagle.

Eanceec Hill : hill, see Ingri Butte.

Earl Cove: cove, $0.6 \mathrm{mi}$. across, on $\mathrm{N}$ part of Inian Is., on South Inian Pass, $0.4 \mathrm{mi}$. E of Inian Cove and $23 \mathrm{mi}$. NW of Hoonah, St. Elias Mts.; $58^{\circ} 15^{\prime} 20^{\prime \prime} \mathrm{N}, 136^{\circ} 17^{\prime} 40^{\prime \prime} \mathrm{W}$; (map 10).

Named by E. F. Dickins, USC\&GS, in 1902; published on Chart 8304 in 1904.

Earle Cove: bight, $1 \mathrm{mi}$. across, on NW coast of Attu I. at mouth of Earle River, Aleutian Is. ; $53^{\circ} 00^{\prime} 05^{\prime \prime} \mathrm{N}, 172^{\circ} 43^{\prime} 15^{\prime \prime} \mathrm{E}$; (map 13). Var. Eftugem Bay.

Name published in 1948 by AMS; shown as "Eftugem Bay" on a manuscript map by $L$. M. Turner in the 1880's.

Earle Lake: lake, $0.4 \mathrm{mi}$. long, on NW coast of Attu I. SE of Earle Cove, Aleutian Is.; $52^{\circ}$ $59^{\prime} 25^{\prime \prime} \mathrm{N}, 172^{\circ} 44^{\prime} 30^{\prime \prime} \mathrm{E}$; (map 13).

Name derived from Earle Cove; published in 1948 by AMS.
Earle River: stream, on NW Attu I., flows N through Etienne Pass, $6.5 \mathrm{mi}$. to Earle Cove, Aleutian Is.; $53^{\circ} 00^{\prime} 00^{\prime \prime} \mathrm{N}, 172^{\circ} 43^{\prime} 53^{\prime \prime} \mathrm{E}$; (map 13).

Name derived from Earle Cove; published in 1948 by AMS.

Earl River: stream, heads at Simpson Pass, flows NW $7 \mathrm{mi}$. to Tatina River $12 \mathrm{mi}$. NE of its junc. with South Fork Kuskokwim River, 93 mi. SE of McGrath, Alaska Ra.; $62^{\circ} 22^{\prime} \mathrm{N}$, $153^{\circ} 02^{\prime} \mathrm{W}$; (map 80).

Named in 1899 by Lt. J. S. Herron, USA.

Ear Mountain: mountain, 2,329 ft., $3 \mathrm{mi}$. across, consisting of Ears Peak, East Peak, and West Peak, $13 \mathrm{mi}$. SW of Shishmaref Inlet and 46 mi. N of Teller, Seward Penin. High.; 65 ${ }^{\circ} 55^{\prime}$ N, 166 15' W; BGN 1944; (map 111). Var. Air Mountain.

Named for "The Ears," the two granite pinnacles at the summit of Ears Peak. Shown as "Ears" by Capt. Beechey (1831, map facing p. $328), \mathrm{RN}$, and as "Ear Mountain" by Collier (1902, pl. 12), USGS. See The Ears.

Ear Peak: peak, 5,620 ft., $4.5 \mathrm{mi}$. E of Shainin Lake between Erratic Creek and Kanayut River, $26 \mathrm{mi}$. NE of Anaktuvuk Pass, Brooks Ra.; $68^{\circ} 19^{\prime} 20^{\prime} \mathrm{N}, 150^{\circ} 52^{\prime} 30^{\prime \prime} \mathrm{W}$; (map 134).

Descriptive name given by USGS geologists during the exploration of Naval Petroleum Reserve No. 4; name given in 1944.

Ear River: stream, heads in lake, flows S $25 \mathrm{mi}$. to Kum River $3.5 \mathrm{mi}$. E of village of Scammon Bay, Yukon-Kuskokwim Delta; $61^{\circ} 51^{\prime} \mathrm{N}$, $165^{\circ} 28^{\prime} \mathrm{W}$; (map 75$)$.

This is an abbreviated translation of an Eskimo name "Tsut-muilk," reported by USC\&GS in 1949.

Ears, The: mountains, 1,300 ft., between Chukchi Sea and Akalolik Creek, $5 \mathrm{mi}$. S of Cape Dyer, Arctic Slope; $68^{\circ} 35^{\prime} \mathrm{N}, 166^{\circ} 09^{\prime} \mathrm{W}$; (map 129).

Descriptive name given about 1827 by Capt. Beechey (1831, map p. 328), RN; presumably applied to a small feature or features on the eroded cliffs. Because it lacks a positive object for application, the name subsequently was transferred to the mountains behind the cliff.

Ears, The: pinnacles, two, on Ears Peak on Ear Mtn., $13 \mathrm{mi}$. SW of Shishmaref Inlet and 46 mi. N of Teller, Seward Penin. High.; $65^{\circ} 55^{\prime}-$ $35^{\prime \prime} \mathrm{N}, 166^{\circ} 13^{\prime} 45^{\prime \prime} \mathrm{W}$; (map 111). Var. Enigarok.

Shown as "Ears" by Capt. Beechey (1831, map facing p. 328), RN. The Ears were distinguished from Ear Mountain by Collier (1902, pl. 7), USGS. Collier (1902, p. 9) also noted: "The Eskimo know it by the name 'Enigarok,' which translated into English is said to mean ears, so that it is probable that this name could also have been applied to the two hills now referred to as Iviangik Mountain."

Ears Peak: peak, 2,292 ft., on Ear Mtn., 0.5 mi. NE of West Peak and $46 \mathrm{mi}$. N of Teller, Seward Penin. High.; $65^{\circ} 55^{\prime} 35^{\prime \prime}$ N, $166^{\circ} 13^{\prime} 45^{\prime \prime}$ W; (map 111). Var. North Summit Ear Mountain.
Descriptive name given in 1945 by a USGS field party.

Easley Creek: stream, flows NE $7 \mathrm{mi}$. to Ketchem Creek, $5.5 \mathrm{mi}$. SE of Central and $26 \mathrm{mi}$. SW of Circle, Yukon-Tanana High.; $65^{\circ} 31^{\prime} 30^{\prime \prime} \mathrm{N}$, $144^{\circ} 39^{\prime} 00^{\prime \prime} \mathrm{W}$; (map 104).

Prospectors' name reported in 1954 or 1955 by USGS topographers.

East Albert Creek: stream, flows SE $12 \mathrm{mi}$. to Albert Creek, $3 \mathrm{mi}$. NE of Central and $24 \mathrm{mi}$. SW of Circle, Yukon-Tanana High.; $65^{\circ} 36^{\prime}$ N, 144․ $43^{\prime}$ W; (map 104).

Prospectors' name reported in 1954 or 1955 by USGS topographers.

East Alsek River: stream, distributary of Alsek River, heads $0.6 \mathrm{mi}$. W of upper rapids, flows $10 \mathrm{mi}$. SW through marshes to a lagoon, 7 mi. SE of Dry Bay and $56 \mathrm{mi}$. SE of Yakutat, Malaspina Coastal Plain; 59 $05^{\prime} 20^{\prime \prime}$ N, $138^{\circ}$ $26^{\prime} 30^{\prime \prime} \mathrm{W}$; ( $\left.\operatorname{map} 46\right)$.

Local name published in 1959 by USGS.

East Amatuli Island: island, $2.5 \mathrm{mi}$. long, in Gulf of Alaska, easternmost of Barren Is., 70 mi. NE of Afognak, Chugach Mts.; 58 ${ }^{\circ} 55^{\prime} \mathrm{N}$, $152^{\circ} 00^{\prime} \mathrm{W}$; (map 43). Var. Amatuli Island, Islas de Langara.

Named by USGS in 1908 . This island is part of the group named "O[strova] Amatuli" by Capt. Tebenkov (1852, map 22), IRN. The island is also one of the "Islas de Langara" named in 1779 by Don Juan de la Bodega y Quadra and Francisco Antonio Maurelle for Juan de Langara.

East Anchor Cove: cove, 2 mi. across, on Ikatan Penin., Unimak I., Aleutian Is.; 54 $41^{\prime} 30^{\prime \prime}$ N, $163^{\circ} 04^{\prime} 00^{\prime \prime} \mathrm{W}$; (map 25).

Descriptive name given in 1888 by USBF.

East Arcuate Ridge: ridge, on $\mathrm{E}$ side of Okmok Caldera, on NE part of Umnak I., Aleutian Is.; $54^{\circ} 27^{\prime} \mathrm{N}, 168^{\circ} 03^{\prime} \mathrm{W}$; (map 22).

Name published by Byers (1959, pl. 41), USGS.

East Arm Holtz Bay: bay, $0.9 \mathrm{mi}$. across, SE part of Holtz Bay on NE coast of Attu I., Aleutian Is.; $52^{\circ} 55^{\prime} 15^{\prime \prime} \mathrm{N}, 173^{\circ} 10^{\prime} 15^{\prime \prime} \mathrm{E}$; (map 13).

Descriptive name published in 1947 Coast Pilot (pt. 2, p. 492).

East Arm Naknek Lake: bay, see Iliuk Arm Naknek Lake.

East Arm Nevidiskov Bay: bay, $1.6 \mathrm{mi}$. across, NE part of Nevidiskov Bay on S coast of Attu I., Aleutian Is.; $52^{\circ} 47^{\prime} 20^{\prime \prime} \mathrm{N}, 172^{\circ} 52^{\prime} 00^{\prime \prime} \mathrm{E}$; (map 13).

Descriptive name referred to as the "East Arm" in the 1946 supplement to the 1944 Aleutian Coast Pilot.

East Arm Nuka Bay: estuary, $2.5 \mathrm{mi}$. wide, on SE coast of Kenai Penin., $45 \mathrm{mi}$. E of Seldovia, Chugach Mts.; $59^{\circ} 28^{\prime} \mathrm{N}, 150^{\circ} 27^{\prime} \mathrm{W} ; B G N$ 1929; (map 50).

Descriptive local name reported by USC\& GS in 1927.

East Arm Uganik Bay: bay, extends SE $4 \mathrm{mi}$. inland to mouth of Uganik River, on $\mathbf{N}$ coast of Kodiak I. ; $57^{\circ} 43^{\prime} \mathrm{N}, 153^{\circ} 29^{\prime} \mathrm{W}$; (map 34 ).

Descriptive name given in 1897 by Lt. Comdr. J. F. Moser, USN, of the USBF steamer Albatross. 
East Arm Yale Fiord: estuary, see Yale Arm College Fiord.

East Bay: bay, see Nazan Bay.

East Bay: lagoon, see Long John Lagoon.

East Bay Lagoon: lagoon, see Long John Lagoon.

East Bee Rock: rock, one of Bee Rocks in Clarence Strait, $3 \mathrm{mi}$. SW of Duke I., Alex. Arch.; 54 $53^{\prime} 15^{\prime \prime} \mathrm{N}, 131^{\circ} 32^{\prime} 00^{\prime \prime} \mathrm{W}$; (map 2).

Local name published in 1943 by USC\&GS.

East Bight: bay, $3 \mathrm{mi}$. across, on $\mathrm{E}$ coast of Nagai I., in Shumagin Is., Aleutian Ra.; $55^{\circ} 06^{\prime} \mathrm{N}, 159^{\circ} 55^{\prime} \mathrm{W}$; (map 27).

Named by W. H. Dall, USC\&GS, in 1872 .

East Boulder Creek: stream, flows SW $8.4 \mathrm{mi}$. to Boulder Creek, $36 \mathrm{mi}$. NE of Palmer, Talkeetna Mts. ; $61^{\circ} 53^{\prime} 00^{\prime \prime} \mathrm{N}, 148^{\circ} 10^{\prime} 20^{\prime \prime} \mathrm{W}$; (map 69).

Local name reported in 1948 by USGS.

East Bradfield River: stream, see East Fork Bradfield River.

East Brother Island: island, $2 \mathrm{mi}$. across, one of The Brothers Islands in Stephens Passage, $5 \mathrm{mi}$. E of Point Pybus and $61 \mathrm{mi}$. E of Sitka, Alex. Arch.; $57^{\circ} 18^{\prime} \mathrm{N}, 133^{\circ} 43^{\prime} \mathrm{W}$; (map 8).

Descriptive name published in 1940 by USGS.

East Buttons: mountain, elev, $3,420 \mathrm{ft}$, $6 \mathrm{mi} \mathrm{E}$ of West Buttons and $22 \mathrm{mi}$. SSW of Chandalar, Brooks Ra. ; $67^{\circ} 15^{\prime} \mathrm{N}, 149^{\circ} 04^{\prime} \mathrm{W}$; (map 123). Local name reported in 1956 by T. E. Taylor, USGS.

East Buttress: ridge, elev. $14,000 \mathrm{ft}$., in Mount McKinley National Park, extends W 3 mi. from head of Traleika Glacier to Thayer Basin, Alaska Ra.; $63^{\circ} 03^{\prime} 30^{\prime \prime} \mathrm{N}, 150^{\circ} 53^{\prime} 00^{\prime \prime}$ W; (map 88).

Mountain climbers' name published on recent maps.

East Cape: point of land, E tip of Amchitka I., Rat Is., Aleutian Is. ; $51^{\circ} 22^{\prime} 45^{\prime \prime} \mathrm{N}, 179^{\circ} 27^{\prime} 00^{\prime \prime}$ E; BGN 1937; (map 15).

Named by the U.S. Navy 1855 North Pacific Exploring Expedition.

East Cape: point of land, E tip of Buldir I., Aleutian Is.; $52^{\circ} 21^{\prime} 45^{\prime \prime} \mathrm{N}, 1^{\circ} 5^{\circ} 58^{\prime} 30^{\prime \prime} \mathrm{E}$; (map 14).

Descriptive name shown on a 1950 AMS map.

East Cape: point of land, E tip Spruce I., NE of Kodiak I.; $57^{\circ} 55^{\prime} 00^{\prime \prime} \mathrm{N}, 152^{\circ} 19^{\prime} 30^{\prime \prime} \mathrm{W}$; (map 34). Var. Mys Vostochnyy, Ostrovskoi Point, Vostochnie.

Translation of the descriptive name "M[ys] Vostochnyy" given in 1839 or 1840 by SubLt. Mikhail Murashev, IRN, and published in 1849 on Russian Hydrog. Dept. Chart 1425.

East Cape: point of land, see Apavawook Cape.

East Cape: point of land, see Chirikof Point.

East Cape Volcano: volcano, 1,667 ft., eastern Buldir I., Aleutian Is. ; $52^{\circ} 21^{\prime} 30^{\prime \prime} \mathrm{N}, 175^{\circ} 56^{\prime}$ 25" E ; (map 14).

Name reported by Coats (1953, p. 8), USGS.

East Channel: water passage, between Iliuliuk Harbor and Iliuliuk Bay, in Unalaska Bay, on NE coast of Unalaska I., Aleutian Is.; $53^{\circ}$. $52^{\prime} 42^{\prime \prime} \mathrm{N}, 166^{\circ} 32^{\prime} 00^{\prime \prime} \mathrm{W}$; (map 23).
This name was published in the 1944 Aleutian Coast Pilot (p. 37).

East Channel Hayward Strait: water passage, between Krestof I., and Magoun Is., $11 \mathrm{mi}$. NW of Sitka, Alex. Arch.; $57^{\circ} 10^{\prime} \mathrm{N}, 135^{\circ} 33^{\prime}$ W; (map 9).

Descriptive name published in 1900 by USC\&GS on Chart 8281.

East Channel Island: island, $0.5 \mathrm{mi}$. long, in Wide Bay, $S$ of Coal Point, on $S$ coast of Alaska Penin., $13 \mathrm{mi}$. SW of Kanatak, Aleutian Ra.; $57^{\circ} 24^{\prime} 35^{\prime \prime} \mathrm{N}, 156^{\circ} 11^{\prime} 50^{\prime \prime} \mathrm{W}$; (map 36).

Descriptive name given in 1923 by USC\&GS "because of its location east of the main channel to Wide Bay."

East Channel Massacre Bay: water passage, eastern entrance to Massacre Bay, on SE coast of Attu I., Aleutian Is. ; $52^{\circ} 48^{\prime} 30^{\prime \prime} \mathrm{N}, 173^{\circ}$ $16^{\prime} 30^{\prime \prime} \mathrm{E}$; (map 13).

Descriptive name listed in 1944 Aleutian Coast Pilot.

East Chester: area, in S part of Anchorage, Cook Inlet Low.; $61^{\circ} 12^{\prime} 18^{\prime \prime} \mathrm{N}, 149^{\circ} 51^{\prime} 50^{\prime \prime} \mathrm{W}$; (map 69). Var. Eastchester.

Local name reported in 1954 by the city engineer of Anchorage.

East Chugach Island: island, $4 \mathrm{mi}$. long, off $\mathrm{S}$ tip of Kenai Penin., $22 \mathrm{mi}$. S of Seldovia, Chugach Mts.; $59^{\circ} 08^{\prime} \mathrm{N}, 151^{\circ} 28^{\prime} \mathrm{W}$; $B G N$ 1908; (map 50). Var. Isla de San Angel.

Local name reported by USC\&GS in 1908. This island was called "Isla (or Ysla) de San Angel" by Don Ignacio Arteaga about August 1, 1779, "after El Santo Angel celebrated in Tortosa August 2" (Wagner, 1937, p. 496).

East Clem Creek: stream, flows NE $4 \mathrm{mi}$. to Kanik Creek, $53 \mathrm{mi}$. NW of Haycock, Seward Penin. High.; $65^{\circ} 58^{\prime} \mathrm{N}, 161^{\circ} 15^{\prime} \mathrm{W}$; (map 109).

Local name published on maps after 1950.

East Clump: island, $400 \mathrm{ft}$. long, in Tongass Narrows, along NE coast of Gravina I., $1 \mathrm{mi}$. W of Ketchikan, Alex. Arch.; $55^{\circ} 20^{\prime} 42^{\prime \prime} \mathrm{N}$, $131^{\circ} 41^{\prime} 15^{\prime \prime} \mathrm{W}$; (map 3). Var. Seat Island.

Named by local pilots about 1880 ; it was called "Seat Island" in 1883 by W. H. Dall, USC\&GS, because of a seat-shaped rock at its outer end.

East Cove: cove, $1 \mathrm{mi}$. across, on $\mathrm{E}$ coast of Yunaska I., Aleutian Is. ; $52^{\circ} 39^{\prime} 40^{\prime \prime}$ N, $170^{\circ}$ $33^{\prime} 30^{\prime \prime}$ W; (map 20).

Descriptive name published by USC\&GS in the 1944 Aleutian Coast Pilot (p. 78).

East Cove: cove, see Mutton Cove.

East Creek: stream, on Kenai Penin., flows NW $6.5 \mathrm{mi}$. to Resurrection Creek, $16 \mathrm{mi}$. SW of Hope, Chugach Mts.; $60^{\circ} 42^{\prime} 15^{\prime \prime}$ N, $149^{\circ}$ $45^{\prime} 05^{\prime \prime} \mathrm{W}$; (map 63).

Local prospectors' name reported in 1904 by Moffit (1906, pl. 2), USGS.

East Creek: stream, flows W $4.5 \mathrm{mi}$. to Michigan Creek, $5.5 \mathrm{mi}$. NW of Ipnek Mtn. and $29 \mathrm{mi}$. W of Wiseman, Brooks Ra.; 67 $23^{\prime} \mathrm{N}, 151^{\circ}$ 11' W; BGN 1932; (map 124).

Local name reported by Robert Marshall in 1932.

East Douglass River: stream, see East Fork Kuskokwim River.
East End Creek: stream, see Glacial Fan Creek.

Easter Creek: stream, flows NE $1.5 \mathrm{mi}$. to Chelatna Lake, $47 \mathrm{mi}$. NW of Talkeetna, Alaska Ra.; 62 $31^{\prime} 35^{\prime \prime} \mathrm{N}, 151^{\circ} 30^{\prime} 30^{\prime \prime} \mathrm{W}$; (map 81).

Prospectors' name reported in 1911 by $R$. W. Porter, USGS.

Easter Creek: stream, flows NE $1.6 \mathrm{mi}$. to Seventymile River, $38 \mathrm{mi}$. NW of Eagle, Yukon-Tanana High.; $64^{\circ} 59^{\prime} 30^{\prime \prime} \mathrm{N}, 142^{\circ} 20^{\prime} 30^{\prime \prime}$ W; (map 102).

Local name published in 1956 by USGS.

Easter Creek: stream, flows NW $36 \mathrm{mi}$. to Killik River, $19 \mathrm{mi}$. SE of Kurupa Lake, Brooks Ra.; 6809' N, $154^{\circ} 10^{\prime} \mathrm{W}$; (map 133).

Probably named by J. B. Mertie, Jr., of the 1924 USGS expedition, who explored this stream on Easter Sunday. Shown on a fieldsheet by Gerald FitzGerald.

Easter Creek: stream, see Foster Creek.

Easterly Island: island, $0.3 \mathrm{mi}$. long, $3.2 \mathrm{mi}$. N of Vixen Point, in SE Ernest Sound, Alex. Arch.; 55 $53^{\prime} 40^{\prime \prime} \mathrm{N}, 132^{\circ} 05^{\prime} 15^{\prime \prime} \mathrm{W}$; (map 4). Var. Oval Island.

Descriptive name given in 1923 by USC\&GS "to distinguish this from Westerly I., on opposite side of fairway."

Eastern Anchorage: anchorage, near mouth of Jamestown Bay, $1 \mathrm{mi}$. SE of Sitka, on W coast of Baranof I., Alex. Arch.; 57 $02^{\prime} 20^{\prime \prime} \mathrm{N}$, $135^{\circ} 18^{\prime} 00^{\prime \prime} \mathrm{W}$; (map 9).

"Old local descriptive name" published by USC\&GS in the 1891 Coast Pilot (p. 174).

Eastern Arm Nakwasina Passage: sound, see Nakwasina Sound.

Eastern Bay: bay, $1 \mathrm{mi}$. across, between Siginaka Is. and $\mathrm{E}$ coast of Krestof $1 ., 9 \mathrm{mi}$. NW of Sitka, Alex. Arch.; $57^{\circ} 10^{\prime} \mathrm{N}, 135^{\circ} 28^{\prime} \mathrm{W}$; (map 9).

Name published in 1962 by USC\&GS on Chart 8281.

Eastern Channel: water passage, extends E 6 mi. from Sitka Sound to Silver Bay, $2.5 \mathrm{mi}$. $S$ of Sitka, on W coast of Baranof I., Alex. Arch.; $57^{\circ} 01^{\prime} \mathrm{N}, 135^{\circ} 20^{\prime} \mathrm{W}$; (map 9). Var. Farvater Vostochnyy.

An 1882 translation by USC\&GS of the name "Farv[ater] Vostochnyy" published by Tebenkov (1852, map 38).

Eastern Glacier: glacier, see South Crillon Glacier.

Eastern Ocean : sea, see Bering Sea.

Eastern Passage: water passage, extends SE 18 mi. from mouth of Stikine River to The Narrows, between Wrangell $I$. and mainland, Alex. Arch.; $56^{\circ} 28^{\prime} \mathrm{N}, 132^{\circ} 15^{\prime} \mathrm{W}$; (map 6). Named in 1877 by W. H. Dall, USC\&GS.

Eastern Passage: water passage, in Marmot Bay, between Skipwith Reefs and Hog I., $3 \mathrm{mi}$. E of Afognak, between Afognak and Kodiak Is.; $58^{\circ} 00^{\prime} 30^{\prime \prime} \mathrm{N}, 152^{\circ} 41^{\prime} 00^{\prime \prime} \mathrm{W}$; (map 43 ).

Named in 1900 by Lt. Comdr. J. F. Moser, USN, commander of the USBF steamer Albatross.

Eastern Point: point of land, on $\mathrm{E}$ coast of Krestof I., $9.5 \mathrm{mi}$. NW of Sitka, Alex. Arch.; $57^{\circ} 10^{\prime} 40^{\prime \prime} \mathrm{N}, 135^{\circ} 27^{\prime} 10^{\prime \prime} \mathrm{W}$; (map 9). 
Probably named by W. H. Dall, USC\&GS, and published in the 1883 Coast Pilot (p. 152).

Eastern Sitkin Island: island, see Great Sitkin Island.

East Finger Lake: lake, $0.7 \mathrm{mi}$. long, easternmost of the Finger Lakes, on Kenai Penin., 13 mi. NE of Kenai, Cook Inlet Low.; 60 $39^{\prime} \mathrm{N}$, $150^{\circ} 53^{\prime} \mathrm{W}$; (map 62).

Named about 1963 by officials of Kenai National Moose Range, for administrative purposes.

East Flank Island: island, $0.5 \mathrm{mi}$. long, at SE end of Esther Passage, $28 \mathrm{mi}$. NE of Whittier, Chugach Mts. ; $60^{\circ} 49^{\prime} 15^{\prime \prime} \mathrm{N}, 147^{\circ} 52^{\prime} 25^{\prime \prime} \mathrm{W}$; (map 63).

Local name reported in 1952 by USGS.

East Foreland: point of land, on E shore of Cook Inlet, $13 \mathrm{mi}$. NE of Kenai, Cook Inlet Low.; $60^{\circ} 43^{\prime} \mathrm{N}, 151^{\circ} 24^{\prime} \mathrm{W}$; (map 62). Var. Cap Mikischkin, Mys Kamyushkin, Mys Vostochnyy, Mys Vostoi Forland, Punta de Martinez, South Foreland, Tuchan Tan.

Named by Capt. George Vancouver, RN, about April 18, 1794. The Tanaina Indian name, reported by the Russian scientist I. G. Wosnesenski in 1840, was "Mikischkin" or "Tuchan Tan," "tan," meaning "cape." This point of land appears to be the same called "Punta de Martinez" by Don Juan de la Bodega y Quadra in 1791. "Perhaps Bodega named it from some account by Mondofía who was in charge of the launch [that went ashore near there], or Mondofía himself, who had been with Estéban Martínez in 1788, named it" (Wagner, 1937, p. 471).

East Forest Lake: lake, $0.6 \mathrm{mi}$. long, on Kenai Penin. E of West Forest Lake, $15 \mathrm{mi}$. NE of Kenai, Cook Inlet Low.; $60^{\circ} 40^{\prime} \mathrm{N}, 150^{\circ} 09^{\prime}$ W; (map 62). Var. Forest Lake.

Named about 1963 by officials of Kenai National Moose Range, for administrative purposes.

East Fork: locality, at junc. of East Fork Solomon River and Solomon River, $10 \mathrm{mi}$. NE of Solomon, Seward Penin. High.; 64 $44^{\prime} \mathrm{N}$, $164^{\circ} 17^{\prime} \mathrm{W}$; (map 95).

Site of a mining camp and railroad station along the Council City and Solomon River Railroad. Reported in 1904 by T. G. Gerdine, USGS.

East Fork: ravine, see East Gulch.

East Fork: stream, see Atsaksovluk Creek.

East Fork: stream, see East Fork Matanuska River.

East Fork Anan Creek: stream, flows NW $8 \mathrm{mi}$. to Anan Creek, $4 \mathrm{mi}$. E of mouth of Bradfield Canal, Coast Mts.; 56 $10^{\prime} 00^{\prime \prime} \mathrm{N}, 131^{\circ} 52^{\prime} 20^{\prime \prime}$ W; (map 7).

Local name reported in 1955 by USGS.

East Fork Andreafsky River: stream, heads on Iprugalet Mtn. at $63^{\circ} 09^{\prime} \mathrm{N}, 161^{\circ} 35^{\prime} \mathrm{W}$, flows SW $125 \mathrm{mi}$. to Andreafsky River, $5 \mathrm{mi}$. NE of its junc. with Yukon River, Nulato Hills; $62^{\circ}$ $03^{\prime} 30^{\prime \prime} \mathrm{N}, 163^{\circ} 06^{\prime} 30^{\prime \prime} \mathrm{W}$; (map 77).

Local name reported in 1942 by USC\&GS.

East Fork Aniak River: stream, see Atsaksovluk Creek.
East Fork Arolic River: stream, see East Fork Arolik River.

East Fork Arolik River: stream, heads at Arolik Lake, flows NW $8 \mathrm{mi}$. to join South Fork Arolik River where it forms the Arolik River, $30 \mathrm{mi}$. NE of Goodnews, Kilbuck-Kuskokwim Mts.; $59^{\circ} 31^{\prime} \mathrm{N}, 161^{\circ} 21^{\prime} \mathrm{W}$; (map 53). Var. East Fork Arolic River, East Fork Arolic Creek.

Name published by G. L. Harrington (in Brooks and others, 1921, pl. 7), USGS, as "East Fork Arolic Creek."

East Fork Bear Creek: stream, flows NW $5.5 \mathrm{mi}$. to Bear Creek, $4.8 \mathrm{mi}$. NE of Nyac and $39 \mathrm{mi}$. SW of Aniak, Kilbuck-Kuskokwim Mountains; $61^{\circ} 02^{\prime} 15^{\prime \prime} \mathrm{N}, 159^{\circ} 48^{\prime} 50^{\prime \prime} \mathrm{W}$; (map 73 ).

Prospectors' name shown on a 1914 field sheet by A. G. Maddren, USGS.

East Fork Bradfield River: stream, flows SW 20 mi. to join North Fork to form Bradfield River, 2 mi. E of head of Bradfield Canal, Coast Mts.; $56^{\circ} 14^{\prime} \mathrm{N}, 131^{\circ} 27^{\prime} \mathrm{W}$; BGN 1959; (map 7). Var. East Bradfield River.

Named by IBC surveyors; published in 1927 on sheet 5 .

East Fork Chandalar River: stream, heads at $69^{\circ} 00^{\prime} \mathrm{N}, 144^{\circ} 06^{\prime} \mathrm{W}$, flows SW $175 \mathrm{mi}$. to Chandalar River, $44 \mathrm{mi}$. SW of Chandalar, Brooks Ra.; 67 $06^{\prime} \mathrm{N}, 147^{\circ} 15^{\prime} \mathrm{W}$; (map 123).

Prospectors' name reported in 1899 by Schrader (1900b, pl. 60), USGS.

East Fork Chena River: stream, heads at $65^{\circ}-$ $05^{\prime} 32^{\prime \prime} \mathrm{N}, 144^{\circ} 43^{\prime} 25^{\prime \prime} \mathrm{W}$ and flows SW $53 \mathrm{mi}$. to Chena River, $43 \mathrm{mi}$. ENE of Fairbanks, Yukon-Tanana High.; 64.56'28' N, $146^{\circ}$. 15'05' W; BGN 1965; (map 101). Var. Chena River.

Local name published in 1966 by USGS.

East Fork Chetaslina River: stream, heads in a glacier, flows SW $19 \mathrm{mi}$ to Chetaslina River $3.8 \mathrm{mi}$. NE of its junc. with Copper River, 68 mi. NW of Valdez, Wrangell Mts.; $61^{\circ} 45^{\prime} 15^{\prime \prime}$ $\mathrm{N}, 144^{\circ} 40^{\prime} 40^{\prime \prime} \mathrm{W}$; (map 68).

Local name published in the 1950's by USGS.

East Fork Chistochina River: stream, flows SW $18 \mathrm{mi}$. from Mankomen Lake to Chistochina River, $15 \mathrm{mi}$. N of Chistochina, Alaska Ra.; $62^{\circ} 46^{\prime} 50^{\prime \prime} \mathrm{N}, 144^{\circ} 39^{\prime} 48^{\prime \prime} \mathrm{W}$; (map 83).

Local name reported by USGS.

East Fork Chulitna River: stream, flows W 30 mi. to join Middle Fork Chulitna River to form Chulitna River, $55 \mathrm{mi}$. SW of Healy, Talkeetna Mts. ; $63^{\circ} 06^{\prime} 30^{\prime \prime} \mathrm{N}, 149^{\circ} 31^{\prime} 30^{\prime \prime} \mathrm{W}$ (map 87)

Name reported in 1913 by J. W. Bagley, USGS.

East Fork Clearwater Creek: stream, heads at glacier in Mount McKinley National Park, flows NW $14 \mathrm{mi}$. to Clearwater Creek, $8 \mathrm{mi}$. SSE of Wonder Lake, Alaska Ra.; 63 $21^{\prime} 30^{\prime \prime}$ $\mathrm{N}, 150^{\circ} 43^{\prime} 30^{\prime \prime} \mathrm{W}$; (map 88).

Local name reported in 1925 by S. R. Capps, USGS.

East Fork Copper Creek: stream, flows NW 3.5 mi. to Copper Creek, 1 mi. S of Kotsina River,
$83 \mathrm{mi}$. ENE of Valdez, Wrangell Mts.; $61^{\circ}$ $41^{\prime} 45^{\prime \prime} \mathrm{N}, 144^{\circ} 03^{\prime} 15^{\prime \prime} \mathrm{W}$; (map 68).

Local name obtained in 1912 by D. C. Witherspoon, USGS.

East Fork Dennison Fork: stream, flows SW 28 mi. to Dennison Fork, $40 \mathrm{mi}$. NE of Tok, Yukon-Tanana High.; $63^{\circ} 37^{\prime} 30^{\prime \prime} \mathrm{N}, 141^{\circ}$ $54^{\prime} 00^{\prime \prime} \mathrm{W}$; $(\operatorname{map} 85)$.

Local name reported by J. B. Mertie, Jr. (1937 b, p. 29), USGS.

East Fork Etivluk River: stream, heads in Brooks Ra., flows NW $55 \mathrm{mi}$. to Etivluk River, $49 \mathrm{mi}$. NNE of Howard Pass, Arctic Slope ; 68 $51^{\circ}$ " N, $156^{\circ} 07^{\prime} \mathrm{W}$; (map 132).

This name appears on a 1925 fieldsheet by Gerald FitzGerald, USGS.

East Fork Fishhook Creek: stream, flows S 1.2 to Fishhook Creek, $13 \mathrm{mi}$. NW of Palmer, Talkeetna Mts.; $61^{\circ} 46^{\prime} 45^{\prime \prime} \mathrm{N}, 149^{\circ} 16^{\prime} 40^{\prime \prime}$ W; (map 69).

Local name reported in 1942 by AMS.

East Fork Flat Creek: stream, flows NE $12 \mathrm{mi}$., joins West Fork Flat Creek to form Flat Creek, $25 \mathrm{mi}$. SE of Beaver, Yukon-Tanana High.; $66^{\circ} 04^{\prime} \mathrm{N}, 146^{\circ} 52^{\prime} \mathrm{W}$; (map 119).

Local name obtained in 1956 by USGS.

East Fork George River: stream, heads at junc. of Munther Creek and Little East Fork, flows SW $60 \mathrm{mi}$. to George River, $7.4 \mathrm{mi}$. NE of its junc. with Kuskokwim River, $25 \mathrm{mi}$. NW of Sleetmute, Kilbuck-Kuskokwim Mts.; $61^{\circ} 59^{\prime} 40^{\prime \prime} \mathrm{N}, 157^{\circ} 36^{\prime} 20^{\prime \prime} \mathrm{W}$; (map 72).

Local name reported in 1914 by R. H. Sargent, USGS.

East Fork Glen Creek: stream, in Kantishna Hills, flows S $1.5 \mathrm{mi}$., joins West Fork to form Glen Creek $6 \mathrm{mi}$. NE of Wonder Lake,

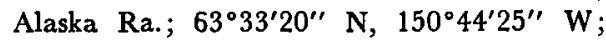
(map 88).

Prospectors' name reported in 1905 by $\mathrm{L}$. M. Prindle, USGS.

East Fork Grouse Creek: stream, heads in York Mts, flows NW $7.5 \mathrm{mi}$. to join South Fork Grouse Creek to form Grouse Creek, $41 \mathrm{mi}$. NW of Teller, Seward Penin. High.; $65^{\circ} 38^{\prime}$ N, $167^{\circ} 27^{\prime} \mathrm{W}$; (map 111).

Prospectors' name reported on the 1908 "Map of Seward Peninsula" by Arthur Gibson.

East Fork Henshaw Creek: stream, heads on Heart Mtn. in Alatna Hills, flows S $30 \mathrm{mi}$, joins West Fork to form Henshaw Creek, $14 \mathrm{mi}$. NE of Allakaket, Hogatza High.; $66^{\circ} 43^{\prime} \mathrm{N}, 152^{\circ} 20^{\prime} \mathrm{W}$; (map 117).

Koyukan Indian name obtained in 1956 at Allakaket by T. E. Taylor, USGS.

East Fork Hess Creek; stream, see Bear Creek.

East Fork Hills: hills, 1,900 ft., trend NE-SW $15 \mathrm{mi}$. between North Fork and East Fork Kuskokwim River, 24 mi. NE of Medfra, Kuskokwim Low.; $63^{\circ} 12^{\prime} \mathrm{N}, 154^{\circ} 00^{\prime} \mathrm{W}$; (map 89).

Local name reported in 1954 by USGS.

East Fork Indian Creek: stream, flows NE $5 \mathrm{mi}$. to Indian Creek, $88 \mathrm{mi}$. SW of Talkeetna, Alaska Ra.; $62^{\circ} 08^{\prime} 50^{\prime \prime} \mathrm{N}, 152^{\circ} 49^{\prime} 10^{\prime \prime} \mathrm{W}$; (map 81).

Local name reported in 1958 by USGS. 
East Fork Indian Creek: stream, heads in lake, flows SW $14 \mathrm{mi}$. to Indian Creek, $14 \mathrm{mi}$. $\mathrm{NE}$ of Chistochina, Alaska Ra.; $62^{\circ} 44^{\prime} \mathrm{N}$, $144^{\circ} 26^{\prime} \mathrm{W}$; (map 83). Var. Indian Creek.

Name used by prospectors; reported in 1903 by F. C. Schrader, USGS.

East Fork Iron Creek: stream, flows NW $18 \mathrm{mi}$. to Iron Creek, $12 \mathrm{mi}$. SE of its junc. with Talkeetna River and $30 \mathrm{mi}$. E of Talkeetna, Talkeetna Mts.; $62^{\circ} 20^{\prime} 45^{\prime \prime} \mathrm{N}, 149^{\circ} 09^{\prime} 50^{\prime \prime}$ W; (map 82).

Local name recorded by S. R. Capps (in Martin, 1919, pl. 4), USGS.

East Fork Jack River: stream, flows NW to Jack River, $40 \mathrm{mi}$. SE of Healy, Talkeetna Mts.; $6^{\circ} 17^{\prime} 30^{\prime \prime} \mathrm{N}, 148^{\circ} 40^{\prime} 40^{\prime \prime} \mathrm{W}$; (map 87).

Local name reported in 1910 by $D$. C. Witherspoon and J. W. Bagley (in Moffit, 1915, pl. 1), USGS.

East Fork Jackson Creek: stream, see Jackson Creek.

East Fork Kahiltna Glacier: glacier, in Mount McKinley National Park, trends SW $7 \mathrm{mi}$. to Kahiltna Glacier, $6 \mathrm{mi}$. SW of Mount McKinley, Alaska Ra.; $63^{\circ} 00^{\prime} \mathrm{N}, 151^{\circ} 10^{\prime}$ W; (map 88).

Local name reported in 1954 by USGS.

East Fork Kejulik River: stream, flows $7.4 \mathrm{mi}$. NW to Kejulik River, on Alaska Penin., 13 mi. $\mathrm{E}$ of Becharof Lake and $34 \mathrm{mi}$. SW of Mount Katmai, Aleutian Ra.; 57 54'25" N, $155^{\circ} 36^{\prime} 25^{\prime \prime} \mathrm{W}$; (map 35$)$.

Descriptive name published by W. R. Smith and A. A. Baker (in Brooks and others, 1924, p. 9), USGS.

East Fork Kiagna River: stream, flows $7 \mathrm{mi}$. NW to Kiagna River, 6 mi. S of Bear I. and $34 \mathrm{mi}$. SE of McCarthy, St. Elias Mts.; $61^{\circ} 01^{\prime} 10^{\prime \prime} \mathrm{N}, 142^{\circ} 22^{\prime} 40^{\prime \prime} \mathrm{W}$; (map 67).

Local name obtained by USGS and published on maps since 1954.

East Fork Koyuk River: stream, flows SW $33 \mathrm{mi}$. to Koyuk River, $8 \mathrm{mi}$. SE of Haycock, Seward Penin. High.; $65^{\circ} 07^{\prime} \mathrm{N}, 161^{\circ} 00^{\prime} \mathrm{W}$; (map 109).

Local name reported in 1909 by $\mathrm{P}$.S. Smith, USGS.

East Fork Kuskokwim River: stream, $40 \mathrm{mi}$. long, heads at confluence of Slow Fork and Tonzona River, flows WSW to join North Fork Kuskokwim River to form Kuskokwim River, $5 \mathrm{mi}$. E of Medfra, Kuskokwim Low.; $63^{\circ} 07^{\prime} \mathrm{N}, 154^{\circ} 35^{\prime} \mathrm{W}$; BGN 1964; (map 89). Var. Chedotlotna River, Chedtlothno River, East Douglass River.

The stream's Indian name was shown in 1899 as "Chedotlothno River" on a map by Lt. J. S. Herron, USA. The name "East Fork Kuskokwim River" was published in 1898 by Spurr (1900, map 14), USGS.

East Fork Kuskokwim River: stream, see Tonzona River.

East Fork Kuyukutuk River: stream, flows W $9 \mathrm{mi}$. to Kuyukutuk River, $16.5 \mathrm{mi}$. NW of Russian Mission, Nulato Hills; $61^{\circ} 58^{\prime} \mathrm{N}$, $161^{\circ} 39^{\prime}$ W ; (map 73).
Prospectors' name reported by Harrington (1918, map), USGS.

East Fork Little Bremner River: stream, heads in glacier, flows W $12 \mathrm{mi}$. to Little Bremner River, $1.6 \mathrm{mi}$. SE of mouth of Porcupine Creek and $63 \mathrm{mi}$. E of Valdez, Chugach Mts.; $61^{\circ} 05^{\prime} 20^{\prime \prime} \mathrm{N}, 144^{\circ} 20^{\prime} 35^{\prime \prime} \mathrm{W}$; (map 68).

Name published by USGS (Moffit, 1914, fig. 2).

East Fork Little Delta River: stream, heads at Gillam Glacier terminus, flows NE $23 \mathrm{mi}$., joins West Fork to form Little Delta River, 25 mi. NW of Mount Hayes, Alaska Ra.; 63 $57^{\circ}$ $40^{\prime \prime} \mathrm{N}, 146^{\circ} 55^{\prime} 20^{\prime \prime} \mathrm{W}$; (map 86).

Name reported in 1910 by J. W. Bagley, USGS.

East Fork Little Tonzona River: stream, heads at glacier, flows NW $11 \mathrm{mi}$. to Little Tonzona River, $15 \mathrm{mi}$. NW of Shellabarger Pass, Alaska Ra.; 62 $44^{\prime} 10^{\prime \prime} \mathrm{N}, 152^{\circ} 56^{\prime} 50^{\prime \prime} \mathrm{W}$; (map 81).

Local name reported in 1958 by USGS.

East Fork McCarthy Creek: stream, flows SW 6 mi. to McCarthy Creek, E of Porphyry Mtn., 5 mi. NE of McCarthy, Wrangell Mts.; $61^{\circ} 28^{\prime} \mathrm{N}, 142^{\circ} 47^{\prime} \mathrm{W}$; (map 67).

Local name reported in 1908 by D. C. Witherspoon, USGS.

East Fork Maclaren River: stream, heads at glacier terminus, flows SW $6.5 \mathrm{mi}$. to Maclaren River, $1.2 \mathrm{mi}$. S of Maclaren Glacier terminus and $26 \mathrm{mi}$. SE of Mount Hayes, Alaska Ra.; $63^{\circ} 15^{\prime} 50^{\prime \prime} \mathrm{N}, 146^{\circ} 30^{\prime} 45^{\prime \prime} \mathrm{W}$; (map 86).

Local name reported in 1910 by C. E. Giffin, USGS

East Fork Matanuska River: stream, flows N and SW $17 \mathrm{mi}$. to where it joins South Fork, to form Matanuska River, $55 \mathrm{mi}$. NE of Palmer, Copper River Basin ; 61 ${ }^{\circ} 47^{\prime} 30^{\prime \prime} \mathrm{N}, 147^{\circ} 30^{\prime} 15^{\prime \prime}$ W; BGN 1960; (map 69). Var. East Fork.

Local name reported in 1951 by USGS.

East Fork Middle River: stream, see East Middle River.

East Fork Mineral Creek: stream, flows NW 2 mi. to Mineral Creek, $6.2 \mathrm{mi}$. NW of Valdez Chugach Mts.; $61^{\circ} 12^{\prime} 05^{\prime \prime} \mathrm{N}, 146^{\circ} 19^{\prime} 05^{\prime \prime} \mathrm{W}$; (map 68).

Prospectors' name obtained in 1911 by C. E. Giffin, USGS.

East Fork Moose River: stream, heads in Peterson Lake of the Seven Lakes, on Kenai Penin., flows NW $10 \mathrm{mi}$. to Moose River, $24 \mathrm{mi}$. ENE of Kenai, Cook Inlet Low.; $60^{\circ} 36^{\prime} 15^{\prime \prime} \mathrm{N}$, $150^{\circ} 36^{\prime} 00^{\prime \prime} \mathrm{W}$; (map 62).

Local name reported in 1958 by USGS.

East Fork Neukluk River: stream, see Niukluk River.

East Fork Ninuluk Creek: stream, flows N 12 mi. to Ninuluk Creek, $27 \mathrm{mi}$. SW of Umiat, Arctic Slope; $69^{\circ} 02^{\prime} 30^{\prime \prime} \mathrm{N}, 152^{\circ} 47^{\prime} 30^{\prime \prime} \mathrm{W}$; (map 141)

Name published in 1956 by USGS.

East Fork Noxapaga River: stream, flows SW 4 mi. to Noxapaga River, $25 \mathrm{mi}$. SW of Imuruk Lake, Seward Penin. High.; $65^{\circ} 32^{\prime}$ N, $164^{\circ} 07^{\prime}$ W; (map 110).

Prospectors' name reported in 1901 by T. G. Gerdine (in Collier, 1902, pl. 12), USGS.
East Fork of Birch Creek: stream, see Yukon Fork.

East Fork Oolamnagavik River: stream, flows NE $21 \mathrm{mi}$. to Oolamnagavik River $11 \mathrm{mi}$. SW of its junc. with Colville River, Brooks Ra.; $68^{\circ} 52^{\prime} \mathrm{N}, 154^{\circ} 09^{\prime} \mathrm{W}$; BGN 1960; (map 133).

Named about 1950 by USGS geologists during exploration of Naval Petroleum Reserve No. 4.

East Fork Salcha River: stream, see Salcha River.

East Fork Sheenjek River: stream, flows S 30 mi. to Sheenjek River, $18 \mathrm{mi}$. SE of Table Mtn., Brooks Ra.; $68^{\circ} 10^{\prime} \mathrm{N}, 143^{\circ} 11^{\prime} \mathrm{W}$; (map 137)

Local name reported in 1926 by J. B. Mertie, USGS.

East Fork Short Creek: stream, flows S $3.5 \mathrm{mi}$. to Short Creek, $12 \mathrm{mi}$. S of Bradfield Canal, Alex. Arch.; $56^{\circ} 00^{\prime} 30^{\prime \prime} \mathrm{N}, 131^{\circ} 32^{\prime} 00^{\prime \prime} \mathrm{W}$; (map 7).

Local name reported in 1955 by USGS.

East Fork Sixmile Creek: stream, on Kenai Penin., heads at junc. of Granite Creek and Center Creek, flows NW $6.5 \mathrm{mi}$. to Sixmile Creek, $7 \mathrm{mi}$. S of Sunrise, Chugach Mts.; $60^{\circ} 47^{\prime} 00^{\prime \prime} \mathrm{N}, 149^{\circ} 25^{\prime} 20^{\prime \prime} \mathrm{W}$; (map 63).

Local descriptive name reported in 1898 by W. C. Mendenhall, USGS.

East Fork Skagway River: stream, heads in South Glacier, flows $5.5 \mathrm{mi}$. NW to Skagway River, $4.5 \mathrm{mi}$. NE of Yakutania Point on Taiya Inlet and $3.5 \mathrm{mi}$. NE of Skagway, Coast Mts.; $59^{\circ} 30^{\prime} 00^{\prime \prime} \mathrm{N}, 135^{\circ} 15^{\prime} 00^{\prime \prime} \mathrm{W}$; (map 45).

Name published in 1951 by USGS.

East Fork Snag Creek: stream, in Nutzotin Mts., flows NW $9 \mathrm{mi}$. to Snag Creek, $8 \mathrm{mi}$. SW of Carden Hills, Alaska Ra.; $62^{\circ} 14^{\prime} \mathrm{N}, 141^{\circ} 28^{\prime}$ W; (map 84).

Name reported by Capps (1916, pl. 1), USGS.

East Fork Snake River: stream, see Goldbottom Creek.

East Fork Solomon River: stream, flows SW 7.5 mi. to Solomon River, $10 \mathrm{mi}$. NE of Solomon, Seward Penin. High.; $64^{\circ} 42^{\prime} \mathrm{N}, 164^{\circ} 17^{\prime} \mathrm{W}$; (map 95). Var. Right Branch Solomon River, Right Fork Solomon River, Trilby Creek.

Prospectors' name shown on Arthur Gibson's "Map of Cape Nome Precinct" dated 1904. "Trilby Creek" was misapplied to this stream by Schrader and Brooks (1900, map 3), USGS. The name "Right Branch" was reported in 1900 by E. C. Barnard (in Brooks, 1901, pl. 17), USGS.

East Fork Steller River: stream, on Attu I., flows $\mathrm{N}$, through East Steller Valley, $4.5 \mathrm{mi}$. to Steller River, Aleutian Is; 52 $58^{\prime} 35^{\prime \prime} \mathrm{N}$, $172^{\circ} 54^{\prime 25}$ " E ; (map 13).

Name derived from Steller Cove; published in 1948 by AMS.

East Fork Susitna River: stream, heads at a glacier, flows SW $15 \mathrm{mi}$. to Susitna River, 65 mi. SE of Healy, Alaska Ra.; $63^{\circ} 19^{\prime} 30^{\prime \prime} \mathrm{N}$, $147^{\circ} 17^{\prime} 00^{\prime \prime} \mathrm{W}$; (map 87).

Local name reported in 1910 by $D$. C. Witherspoon (in Moffit, 1912, pl. 1), USGS. 
East Fork The Forks: stream, heads at $66^{\circ} 32^{\prime} 30^{\prime \prime}$ $\mathrm{N}, 148^{\circ} 26^{\prime} 30^{\prime \prime} \mathrm{W}$; flows SW $50 \mathrm{mi}$. to join the West Fork to form The Forks, $15 \mathrm{mi}$. $\mathrm{N}$ of Stevens Village, Yukon Flats; $66^{\circ} 13^{\prime} \mathrm{N}$, $149^{\circ} 05^{\prime} \mathrm{W}$; (map 118).

Local name obtained in 1956 by USGS.

East Fork Thumb River: stream, flows NW 7.5 mi. to Thumb Lake E of Karluk Lake, Kodiak I.; $57^{\circ} 21^{\prime} 10^{\prime \prime} \mathrm{N}, 153^{\circ} 58^{\prime} 20^{\prime \prime} \mathrm{W}$; (map 34). Local name reported in 1954 by USGS.

East Fork Toklat River: stream, heads at glacier terminus, in Mount McKinley National Park, flows NNW $40 \mathrm{mi}$. to Toklat River, $36 \mathrm{mi}$. W. of Healy, Alaska Ra.; 635 $54^{\prime} 20^{\prime \prime}$ N., $150^{\circ} 08^{\prime} 40^{\prime \prime} \mathrm{W}$; (map 88).

Local name shown on a 1916 fieldsheet by C. E. Giffin, USGS

East Fork Tolovana River: stream, see Tatalina River.

East Fork Tonowek Creek: stream, heads in a small lake, flows S $0.4 \mathrm{mi}$. to Tonowek Creek, on E coast of Heceta I., Alex. Arch.; $55^{\circ} 46^{\prime} 15^{\prime \prime} \mathrm{N}, 133^{\circ} 22^{\prime} 50^{\prime \prime} \mathrm{W}$; (map 4).

Local name recorded in 1951 by USGS. See Tonowek Bay.

East Fork Tuluga River: stream, flows NW 13 mi. to join the West Fork to form Tuluga River, $6 \mathrm{mi}$. W of Heart Lake and $53 \mathrm{mi}$. N of Anaktuvuk Pass, Brooks Ra.; 68 $54^{\prime}$ N, $151^{\circ} 34^{\prime} \mathrm{W}$; (map 134).

Named by USGS geologists during the exploration of Naval Petroleum Reserve No. 4; name given in 1944.

East Fork Twelvemile Creek: stream, see North Fork Twelvemile Creek.

East Fork Twin Creek: stream, heads at 57 $34^{\prime}$ N, $152^{\circ} 19^{\prime} \mathrm{W}$, flows NNE to join West Fork Twin Creek at Chiniak Bay, $14 \mathrm{mi}$. SE of Kodiak, Kodiak I. ; $57^{\circ} 37^{\prime} 10^{\prime \prime}$ N, $152^{\circ} 15^{\prime} 30^{\prime \prime}$ W; BGN 1966; (map 34).

Local name reported in 1966 by the Alaska State Geographic Board.

East Fork Willow Creek: stream, flows SW 1.1 mi. to Willow Creek 7.4 mi. SE of Marshall, Nula to Hills; $61^{\circ} 48^{\prime} 50^{\prime \prime} \mathrm{N}, 161^{\circ} 54^{\prime} 00^{\prime \prime} \mathrm{W}$; (map 73).

Prospectors' name reported by G. L. Harrington, USGS, in 1914.

East Fork Yentna River: stream, heads at branch of Dall Glacier, $5 \mathrm{mi}$. $\mathrm{N}$ of terminus of Yentna Glacier, flows SE $20 \mathrm{mi}$., joins West Fork to form Yentna River, $53 \mathrm{mi}$. W of Talkeetna, Alaska Ra.; $62^{\circ} 16^{\prime} 50^{\prime \prime}$ N., $151^{\circ} 46^{\prime} 30^{\prime \prime} \mathrm{W}$; (map 81).

Name reported in 1906 by R. W. Porter, USGS.

East Fork Yuki River: stream, flows NE $45 \mathrm{mi}$. to the Yuki River, $57 \mathrm{mi}$. SW of Nulato, Kilbuck-Kuskokwim Mts. ; $64^{\circ} 22^{\prime} \mathrm{N}, 156^{\circ} 23^{\prime}$ W; (map 97).

Local name reported in 1911 by A. G. Maddren (in Brooks, 1912, pl. 14), USGS.

East Francis Rock: rock, in Canoe Pass, at W end of Peril Strait, off NW coast of Baranof $I$., Alex. Arch.; $57^{\circ} 24^{\prime} 05^{\prime \prime} \mathrm{N}, 135^{\circ} 38^{\prime} 10^{\prime \prime} \mathrm{W}$; (map 9).

Discovered and named in 1884 by Comdr. J. B. Coghlan, USN, "for pilot E. H. Francis, who was the first person to make soundings on it" (USC\&GS, 1891, p. 187).

East Glacier Greek: stream, flows SE $10 \mathrm{mi}$. to Chinitna Bay, $52 \mathrm{mi}$. NW of Homer, Aleutian Ra.; 59॰53' N, $152^{\circ} 56^{\prime} \mathrm{W}$; (map 50).

Local name reported and published by USGS in the 1950's.

East Gulch: ravine, trends SW $0.5 \mathrm{mi}$. to Bear Creek, $4 \mathrm{mi}$. NE of Nome, Seward Penin. High.; $64^{\circ} 34^{\prime} \mathrm{N}, 165^{\circ} 20^{\prime} \mathrm{W}$; (map 94). Var. East Fork.

Published as "East Fork [Dry Creek]" on the 1902 "Map of the Nome and Snake River Country" by J. M. Davidson.

East Head: point of land, on NW coast of Popof I., in Shumagin Is., Aleutian Ra.; 55 $21^{\prime} 30^{\prime \prime}$ $\mathrm{N}, 160^{\circ} 29^{\prime} 25^{\prime \prime} \mathrm{W}$; (map 28 ).

Named by W. H. Dall, USC\&GS, in 1872

East Head: promontory, NE entrance point to Sanborn Harbor, on NW coast of Nagai I., in Shumagin Is., Aleutian Ra.; $55^{\circ} 12^{\prime} \mathrm{N}$, $160^{\circ} 03^{\prime} \mathrm{W}$; ( $\operatorname{map} 28$ ).

Named by W. H. Dall, USC\&GS, in 1872.

East Island: island, $0.5 \mathrm{mi}$. long, in Revillagigedo Channel, $1.2 \mathrm{mi}$. SE of Duke I., Alex. Arch.; $54^{\circ} 52^{\prime} 30^{\prime \prime} \mathrm{N}, 131^{\circ} 12^{\prime} 00^{\prime \prime} \mathrm{W}$; (map 2).

Descriptive name given in 1883 by Lt. Comdr. H. E. Nichols, USN.

East Island: island, $100 \mathrm{ft}$. long, in Tongass Narrows, near mouth of Ward Cove, $4 \mathrm{mi}$. NW of Ketchikan, Alex. Arch.; $55^{\circ} 23^{\prime} 47^{\prime \prime} \mathrm{N}$, $131^{\circ} 44^{\prime} 42^{\prime \prime}$ W ; (map 3 ).

Named by W. E. George, a local pilot; published in 1883 by USC\&GS.

East Island: island, $1.8 \mathrm{mi}$. long, in Kashevarof Is., off NE coast of Prince of Wales I., Alex. Arch.; $56^{\circ} 10^{\prime} \mathrm{N}, 132^{\circ} 55^{\prime} \mathrm{W}$; (map 6).

Descriptive name given in 1886 by Lt. Comdr. A. S. Snow, USN, because it is the easternmost of the central group of the Kashevarof Islands.

East Island: island, see Keski Island.

East Kennel Lake: lake, $750 \mathrm{ft}$. across, center of Kiska I., Aleutian Is.; $51^{\circ} 57^{\prime} 50^{\prime \prime} \mathrm{N}, 177^{\circ}$. $22^{\prime} 00^{\prime \prime} \mathrm{E}$; (map 14).

An arbitrary name beginning with " $E$ " to correspond to "E" grid used by the U.S. Army for tactical purposes during World War II ; published in 1953 by AMS.

East Killem Lake: lake, $300 \mathrm{ft}$. across, center of Kiska I., Aleutian Is.; $51^{\circ} 57^{\prime} 45^{\prime \prime} \mathrm{N}, 177^{\circ} 21^{\prime}$. $20^{\prime \prime} \mathrm{E}$; (map 14).

An arbitrary name beginning with " $E$ " to correspond to " $E$ " grid used by the U.S. Army for tactical purposes during World War II; published in 1953 by AMS.

East Kiska Lake: lake, $1.6 \mathrm{mi}$. long, connected with Middle and West Kiska Lakes, northcentral Kiska I., Aleutian Is.; $52^{\circ} 04^{\prime} \mathrm{N}, 177^{\circ}$ 35'E; (map 14).

One of many arbitrary names applied to features on Kiska I. by USAAF for tactical purposes during World War II.

Eastland Creek: stream, on Kenai Penin., flows $S 3 \mathrm{mi}$. to Kachemak Bay, $16 \mathrm{mi}$. NE of Homer, Cook Inlet Low.; $59^{\circ} 45^{\prime} 30^{\prime \prime} \mathrm{N}, 151^{\circ} 09^{\prime} 30^{\prime \prime}$ W; (map 50).
Local name reported and published by USGS in the 1950's.

East Landing: beach, just SE of Saint Paul, on S coast of Saint Paul I., in Pribilof Is. ; 57 07'$10^{\prime \prime} \mathrm{N}, 170^{\circ} 16^{\prime} 00^{\prime \prime} \mathrm{W}$; (map 38).

Local descriptive name reported in 1897 by W. W. Duffield, USC\&GS. So called because it is on the east side of the peninsula.

Eastman Creek: stream, flows W to Nome River, about $20 \mathrm{mi}$. NE of Nome, Seward Penin. High.; (map 94)

Prospectors' name reported on the 1900 "Map of Nome Peninsula" by J. M. Davidson and B. D. Blakeslee; this feature has not been positively identified.

East Massacre Valley: valley, on Attu I., extends $2.2 \mathrm{mi}$. from Clevesy Pass to Massacre Bay, SW of Gilbert Ridge, Aleutian Is.; 52 $51^{\prime} 35^{\prime \prime}$ $\mathrm{N}, 173^{\circ} 12^{\prime} 30^{\prime \prime} \mathrm{E}$; (map 13).

Descriptive name derived from Massacre Bay by U.S. Army during World War II ; published in 1948 by AMS.

East Middle River: stream, distributary, flows N $10 \mathrm{mi}$. from Nenana River to Tanana River, $1.6 \mathrm{mi}$. W of Nenana, Tanana Low.; $64^{\circ} 34^{\prime}$ $35^{\prime \prime} \mathrm{N}, 149^{\circ} 08^{\prime} 20^{\prime \prime} \mathrm{W}$; BGN 1952; (map 100). Var. East Fork Middle River.

Local name originally published in 1916 on a GLO (BLM) survey plat as East Fork Middle River.

East Mountain: mountain, 2,120 ft., on E coast of Woronkofski I., Alex. Arch.; $56^{\circ} 24^{\prime} 10^{\prime \prime} \mathrm{N}$, 132 $26^{\prime} 00^{\prime \prime}$ W; BGN 1917; (map 6). Var. East Peak.

Named in 1916 by USC\&GS.

East Nagai Strait: water passage, between Nagai and Spectacle Is., in Shumagin Is., Aleutian Ra.; $55^{\circ} 08^{\prime} \mathrm{N}, 159^{\circ} 47^{\prime} \mathrm{W}$; (map 27).

Named by W. H. Dall, USC\&GS, in 1872 and published in 1888.

East-northeast Indent: bight, $2.5 \mathrm{mi}$. wide, on NE coast of Semisopochnoi I., Rat Is., Aleutian Is. ; $51^{\circ} 59^{\prime} 40^{\prime \prime} \mathrm{N}, 179^{\circ} 42^{\prime} 40^{\prime \prime} \mathrm{E}$; (map 15).

Name published on a 1943 AMS map.

East-northeast Point: point of land, on NE coast of Little Sitkin I., Rat Is., Aleutian Is.; $51^{\circ}$ $58^{\prime} 05^{\prime \prime} \mathrm{N}, 178^{\circ} 34^{\prime} 15^{\prime \prime} \mathrm{E}$; (map 15).

Name published on a 1943 AMS map.

East Nunatak Glacier: glacier, heads at $59^{\circ} 37^{\prime}$ $\mathrm{N}, 138^{\circ} 39^{\prime} \mathrm{W}$, trends NW $17 \mathrm{mi}$. to Nunatak Fiord, $35 \mathrm{mi}$. NE of Yakutat, St. Elias Mts.; $59^{\circ} 48^{\prime} 30^{\prime \prime} \mathrm{N}, 138^{\circ} 53^{\prime} 00^{\prime \prime} \mathrm{W}$; BGN 1965; (map 46). Var. Nunatak Glacier.

Named by USGS in 1961. Originally this glacier was part of Nunatak Glacier, named in 1891 by Russell $(1892$, p. 86 ), because it then appeared to be a single glacier with a nunatak or rock island projecting through the ice near its terminus. Since then the glacier has retreated seven miles, completely uncovering the nunatak. The glacier now consists of two arms. The arms to the northeast is East Nunatak Glacier, the other arm is West Nunatak Glacier.

East Patuk Creek: stream, in Romanzof Mts., flows NW $8.2 \mathrm{mi}$. to Hulahula River, $12 \mathrm{mi}$. 
SW of Mount Michelson, Brooks Ra.; $69^{\circ} 11^{\prime}$ N, $144^{\circ} 35^{\prime} \mathrm{W}$; (map 139).

Eskimo name reported in 1956 by USGS.

East Peak: peak, $1,319 \mathrm{ft}$., on NE coast of Attu I., $\mathrm{E}$ of Chichagof Harbor, Aleutian Is.; $52^{\circ} 55^{\prime} 30^{\prime \prime} \mathrm{N}, 173^{\circ} 15^{\prime} 50^{\prime \prime} \mathrm{E}$; (map 13).

Descriptive name given in July 1855 by Lt. William Gibson, USN.

East Peak: peak, 6,600 ft., $2 \mathrm{mi}$. SE of terminus of Camicia Glacier and $7 \mathrm{mi}$. NE of Valdez, Chugach Mts.; $61^{\circ} 08^{\prime} 50^{\prime \prime} \mathrm{N}, 146^{\circ} 02^{\prime} 35^{\prime \prime} \mathrm{W}$; (map 68).

Descriptive name given in 1898 by Capt. W. R. Abercrombie, USA.

East Peak: peak, 2,010 ft., on Ear Mtn., 1 mi. E of Ears Peak and $46 \mathrm{mi}$. N of Teller, Seward Penin. High.; $65^{\circ} 55^{\prime} 40^{\prime \prime} \mathrm{N}, 166^{\circ} 11^{\prime} 30^{\prime \prime} \mathrm{W}$; (map 111).

Named in 1941 by $R$. R. Coats, USGS.

East Peak: mountain, see East Mountain.

East Point: point of land, $\mathrm{E}$ entrance point to Chichagof Bay, on NW shore of Stepovak Bay, Aleutian Ra.; $55^{\circ} 39^{\prime} 30^{\prime \prime} \mathrm{N}, 160^{\circ} 13^{\prime} 00^{\prime \prime}$ W; (map 28).

Named by C. Palache of the Harriman Alaska Expedition of 1899 (1910, v. 4, p. 75).

East Point: point of land, on $\mathrm{E}$ coast of Woronkofski I., Alex. Arch.; $56^{\circ} 23^{\prime} 00^{\prime \prime}$ N, $132^{\circ} 24^{\prime}$ $20^{\prime \prime} \mathrm{W}$; $(\operatorname{map} 6)$.

Named in 1886 by Lt. Comdr. A. S. Snow, USN; name published in 1887 on USC\&GS Chart 706.

East Point: point of land, at E side of mouth of Portage Bay, on $\mathrm{N}$ coast of Kupreanof I., 77 mi. E of Sitka, Alex. Arch.: $57^{\circ} 00^{\prime} 15^{\prime \prime} \mathrm{N}$, $133^{\circ} 19^{\prime} 25^{\prime \prime} \mathrm{W}$; (map 8).

Descriptive name given in 1882 by Lt. Comdr H. E. Nichols, USN; published in 1885 by USC\&GS.

East Point: point of land, on E shore of Whitewater Bay, on SW coast of Admiralty $I$., $20 \mathrm{mi}$. S of Angoon, Alex. Arch.; 57 $13^{\prime} 40^{\prime \prime}$ N, $134^{\circ} 33^{\prime} 20^{\prime \prime} \mathrm{W}$; (map 9)

Named in 1881 by Comdr. Henry Glass, USN, and published by USC\&GS on Chart 726.

East Point: point of land, on E coast of Chichagof I., at mouth of Pavlof Harbor, on SW shore of Freshwater Bay, $8 \mathrm{mi}$. NE of Tenakee Springs, Alex. Arch.; $57^{\circ} 50^{\prime} 30^{\prime \prime} \mathrm{N}, 1^{\circ} 35^{\circ} 01^{\prime}$ 15" W; (map 9).

Descriptive name given by Comdr. R. W. Meade, USN; published in 1869 on Hydrog. Chart 225. Name not shown on recent maps.

East Point: point of land, between Uganik Bay and Uganik Passage, on $\mathrm{N}$ coast of Kodiak I.; $57^{\circ} 50^{\prime} 30^{\prime \prime} \mathrm{N}, 153^{\circ} 28^{\prime} 30^{\prime \prime} \mathrm{W}$; (map 34).

Descriptive name given in 1897 by Lt. Comdr. J. F. Moser, USN, of the USBF steamer Albatross.

East Point: point of land, easternmost point of Naked I., in Prince William Sound, $38 \mathrm{mi}$. NE of Chenega, Chugach Mts. ; $60^{\circ} 39^{\prime} 40^{\prime \prime} \mathrm{N}$, $147^{\circ} 18^{\prime} 05^{\prime \prime} \mathrm{W}$; (map 63).

Local name reported in 1951 by USGS.

East Point: point of land, on $\mathrm{N}$ bank of Yukon River, W of Hills I. and $33 \mathrm{mi}$. W of Marshall,
Yukon-Kuskokwim Delta ; $61^{\circ} 55^{\prime} \mathrm{N}, 163^{\circ} 05^{\prime}$ W; (map 74).

Riverboat pilots' name shown on a fieldsheet by R. H. Sargent, USGS, in 1916.

East Point: point of land, see Chernofski Point. East Point: point of land, see Chirikof Point.

East Point: point of land, see Eagle Point.

East Point: point of land, see Orient Point.

East Point: point of land, see Uganik, Cape.

East Portage Creek: stream, flows NW $5 \mathrm{mi}$. to Portage Creek which flows to American River, $12 \mathrm{mi}$. NE of Kougarok Mtn. and $22 \mathrm{mi}$. SE of Ear Mtn., Seward Penin. High.; $65^{\circ} 47^{\prime}$ N, 165'32' W; (map 111).

Prospectors' name reported on the 1908 "Map of Seward Peninsula" by Arthur Gibson. East Portage Creek: stream, see Carson Creek.

East Pyramid Peak: peak, 11,250 ft., in Mount McKinley National Park, on Mt. Tripyramid, $13 \mathrm{mi}$. NE of Mount McKinley, Alaska Ra.; $63^{\circ} 10^{\prime} \mathrm{N}, 150^{\circ} 40^{\prime} \mathrm{W}$; BGN 1948; (map 88).

Named in 1948 by Bradford Washburn.

East Rock: rock, in Pacific Ocean, $10 \mathrm{mi}$. SE of Dolgio I., Aleutian Ra.; 55 $01^{\circ} 00^{\prime \prime} \mathrm{N}, 161^{\circ}$ $25^{\prime} 10^{\prime \prime} \mathrm{W}$; (map 28).

Name shown on a 1953 USGS map.

East Rock: rock, in Sumner Strait, $0.8 \mathrm{mi}$. NE of village of Point Baker, on $\mathrm{N}$ coast of Prince of Wales I., Alex. Arch.; 56 $21^{\prime} 30^{\prime \prime} \mathrm{N}, 133^{\circ}$ $36^{\prime} 00^{\prime \prime} \mathrm{W}$; (map 6).

Local descriptive name reported in 1949 by USGS.

East Rookery: rookery, see Great East Rookery.

East San Lorenzo Island: island, $1 \mathrm{mi}$. long, one of San Lorenzo Is., in Gulf of Esquibel, $1.5 \mathrm{mi}$. SSW of Esquibel I., Alex. Arch.; $55^{\circ} 35^{\prime} \mathrm{N}$, 133 $36^{\prime}$ W ; BGN 1917; (map 4). Var. Barbarossa Island.

Named in 1916 by USC\&GS. See Lorenzo Islands.

East Sentinel Island: island, $500 \mathrm{ft}$. long, in McKenzie Inlet, on $\mathrm{E}$ coast of Prince of Wales I., S of Skowl Arm Kasaan Bay, Alex. Arch.; $55^{\circ} 23^{\prime} 35^{\prime \prime} \mathrm{N}, 132^{\circ} 22^{\prime} 15^{\prime \prime} \mathrm{W}$; (map 4).

Local descriptive name obtained in 1905 by E. F. Dickins, USC\&GS.

East-southeast Bight: bight, $1.2 \mathrm{mi}$. wide, on $\mathrm{SE}$ coast of Semisopochnoi I., Rat Is., Aleutian Is. ; $51^{\circ} 56^{\prime} 40^{\prime \prime} \mathrm{N}, 179^{\circ} 43^{\prime} 20^{\prime \prime} \mathrm{E}$; (map 15).

Name published on a 1943 AMS map.

East-southeast Head: point of land, includes Southeast Point and East-southeast Point, on SE coast of Semisopochnoi Is., Rat Is., Aleutian Is.; $51^{\circ} 55^{\prime} 50^{\prime \prime} \mathrm{N}, 179^{\circ} 44^{\prime} 00^{\prime \prime} \mathrm{E}$; (map 15).

Name published on a 1943 AMS map.

East-southeast Point: point of land, part of Eastsoutheast Head, on SE coast of Semisopochnio I., Rat Is., Aleutian Is.; $51^{\circ} 56^{\prime} \mathrm{N}, 179^{\circ} 44^{\prime}$ E; (map 15)

Name published on a 1943 AMS map.

East Spit: point of land, $0.5 \mathrm{mi}$. $\mathrm{N}$ of village of Cape Fanshaw, extends into South Passage, 72 mi. E of Sitka, Coast Mts.; $57^{\circ} 13^{\prime} 15^{\prime \prime} \mathrm{N}$, $133^{\circ} 30^{\prime} 15^{\prime \prime} \mathrm{W}$; (map 8).

Descriptive name given in 1891 by Lt. Comdr. H. E. Nichols, USN; published by USC\&GS in the 1891 Coast Pilot (p. 145).
East Steller Valley: valley, $2.5 \mathrm{mi}$. long, formed by East Fork Steller River, on $\mathbf{N}$ coast of Attu I., Aleutian Is. ; $52^{\circ} 58^{\prime} 35^{\prime \prime} \mathrm{N}, 172^{\circ} 54^{\prime} 25^{\prime \prime} \mathrm{E}$; (map 13).

Descriptive name derived from Steller Cove by U.S. Army during World War II; published in 1948 by AMS

East Sunshine Lake: lake, $0.4 \mathrm{mi}$. long, one of Sunshine Lakes, $10 \mathrm{mi}$. S. of Talkeetna, Cook Inlet Low. ; $62^{\circ} 10^{\prime} 50^{\prime \prime} \mathrm{N}, 150^{\circ} 02^{\prime} 05 \mathrm{~W}$; (map 81). Local name reported in 1958 by USGS.

East Twin Bay: estuary, on $\mathrm{N}$ side of Perry I., extends $\mathrm{N} 3 \mathrm{mi}$. to $\mathrm{E}$ end of Wells Passage, $24 \mathrm{mi}$. ESE of Whittier, Chugach Mts.; $60^{\circ}$ $44^{\prime} 30^{\prime \prime} \mathrm{N}, 147^{\circ} 56^{\prime} 30^{\prime \prime} \mathrm{W}$; BGN 1914; (map 63).

So named in 1914 by USC\&GS because it is "the eastern one of two bays * * *."

East Twin Glacier: glacier, heads in Hades Highway, trends S $5 \mathrm{mi}$. to Twin Glacier Lake, 6 mi. W of Kluchman Mtn., Coast Mts.; 58 $33^{\prime 2} 5^{\prime \prime} \mathrm{N}, 133^{\circ} 53^{\prime} 25^{\prime \prime} \mathrm{W}$; BGN 1966; (map 12). Var. Twin Glacier, Twin Glaciers.

Named relative to West Twin Glacier, published by Lawrence (1950, p. 195). East and West Twin Glaciers were at one time joined and the resultant feature was reported as "Twin Glacier" by USC\&GS in 1895 . Subsequent recession of the glacial front has resulted in two separate glaciers.

East Twin Lake: lake, $4 \mathrm{mi}$. $\mathrm{E}$ of West Twin Lake and $40 \mathrm{mi}$. E of Bitzshtini Mts., Tanana Low.; $64^{\circ} 26^{\prime} \mathrm{N}, 150^{\circ} 40^{\prime} \mathrm{W}$; (map 99).

Local descriptive name reported in 1952 by USGS.

East Twin Lake: lake, $1.3 \mathrm{mi}$. long, $6.8 \mathrm{mi}$. SE of Barrow, Arctic Plain; $71^{\circ} 16^{\prime} 30^{\prime \prime} \mathrm{N}, 156^{\circ}$ 27'30' W; (map 153).

Descriptive name used for scientific purposes (Carson and Hussey, 1912)

East Twin Peak: peak, 5,873 ft., $2.5 \mathrm{mi}$. N of Eklutna Lake and $11 \mathrm{mi}$. S of Palmer, Chugach Mts. ; 61 $26^{\prime} 45^{\prime \prime} \mathrm{N}, 149^{\circ} 08^{\prime} 30^{\prime \prime} \mathrm{W}$; (map 69)

Descriptive name reported in 1960 by USGS.

East Yahtse River: stream, see Yahtse River.

Easy Cove: cove, $0.6 \mathrm{mi}$. across, on $\mathrm{S}$ tip of Akun I., E of Jackass Point, Krenitzin Is.; $54^{\circ} 06^{\prime} 45^{\prime \prime} \mathrm{N}, 165^{\circ} 33^{\prime} 25^{\prime \prime} \mathrm{W}$; (map 24).

Named in 1901 by J. J. Gilbert, USC\&GS.

Easy Creek: stream, flows SW $0.7 \mathrm{mi}$. to Cache Creek, E of Hansen Bar, $31 \mathrm{mi}$. NW of Talkeetna, Alaska Ra.; $62^{\circ} 26^{\prime} 20^{\prime \prime} \mathrm{N}, 151^{\circ} 02^{\prime} 40^{\prime \prime}$ W; (map 81)

Prospectors' name reported in the 1930's by USGS.

Easy Creek: stream, see Eagle Creek.

Easy Money Creek: stream, flows NE $4.3 \mathrm{mi}$. to Tip Creek, $11 \mathrm{mi}$. NE of Long and $23 \mathrm{mi}$. $\mathrm{SE}$ of Ruby, Nowitna Low.; 64 $27^{\prime} 15^{\prime \prime} \mathrm{N}$, $155^{\circ} 11^{\prime} 10^{\prime \prime} \mathrm{W}$; (map 98).

Prospectors' name reported in 1912 by $\mathrm{H}$. M. Eakin (in Brooks and others, 1913, pl. 10), USGS.

Easy Moose Creek: stream, flows SW $9 \mathrm{mi}$. to Kandik River $12 \mathrm{mi}$. NE of that stream's junc. 
with Yukon River, Porcupine Plat.; $65^{\circ} 28^{\prime} \mathrm{N}$, $142^{\circ} 09^{\prime} \mathrm{W}$; (map 103).

Local name published in 1956 by USGS.

Easy Pass: pass, 3,700 ft., trends E-W $1 \mathrm{mi}$., 3.7 mi. S of Sable Mtn. and $42 \mathrm{mi}$. SW of Healy, Alaska Ra.; $63^{\circ} 22^{\prime} \mathrm{N}, 149^{\circ} 42^{\prime} \mathrm{W}$; (map 87).

Name shown on a 1923 manuscript map of The Alaska RR.

Eaton Creek: stream, flows NW to Inmachuk River, about 16 mi. N of Imuruk Lake, Seward Penin. High.; (map 110).

Prospectors' name reported in 1901 by USGS (Collier, 1902, pl. 12). This stream cannot be identified on current maps.

Eaton Point: point of land, on W coast of Cleveland Penin., $2.5 \mathrm{mi}$. E of Brownson I., Alex. Arch.; 55 56' $20^{\prime \prime} \mathrm{N}, 132^{\circ} 04^{\prime} 10^{\prime \prime} \mathrm{W}$; (map 4).

Named by local fishermen and reported in 1904 by H. C. Fassett, USBF.

Eaton River: stream, flows NW to Imuruk Basin, about $25 \mathrm{mi}$. SE of Teller, Seward Penin. High.; (map 111). Var. Fish River.

Local name reported in 1899 by Schrader and Brooks (1900, map 3), USGS. This name may have been an early name for the Kuzitrin River or Pilgrim River. Baker (1906, p. 234), USGS, said this stream was "Formerly called Fish River * * *."

Eaton River: stream, see Niukluk River.

Eauwan Lake: lake, see Ewan Lake.

Eavok Channel: stream, distributary of Kobuk River, heads at Melvin Channel and flows SW $19 \mathrm{mi}$. to Riley Channel, Kobuk River, $44 \mathrm{mi}$. NW of Selawik, Kotzebue-Kobuk Low.; $66^{\circ} 45^{\prime} \mathrm{N}, 161^{\circ} 33^{\prime} \mathrm{W}$; (map 114).

Eskimo name obtained by U.S. Army Corps of Engineers in 1955.

Eavok Lake: lake, $1 \mathrm{mi}$. across, in Kobuk River Delta, $42 \mathrm{mi}$. NW of Selawik, Kotzebue-Kobuk Low.; $66^{\circ} 49^{\prime} \mathrm{N}, 161^{\circ} 25^{\prime} \mathrm{W}$; (map 114).

Eskimo name obtained by U.S. Corps of Engineers in 1955.

Eayagit, Cape: point of, land, see Eayagit Point.

Eayagit Point: point of land, on $\mathrm{E}$ coast of Saint Lawrence I., $1.3 \mathrm{mi}$. S of Northeast Cape; $63^{\circ} 17^{\prime} \mathrm{N}, 168^{\circ} 42^{\prime} \mathrm{W}$; (map 93). Var. Cape Eayagit.

Eskimo name reported in 1932 by Otto $W$. Geist, Univ. of Alaska.

Ebcyeet: lava bed, see Ibkikwit Lava Bed.

Eberly, Mount: mountain, 7,030 ft., in Robinson Mts., $4.4 \mathrm{mi}$. $\mathrm{N}$ of Munday Peak and $88 \mathrm{mi}$. NW of Yakutat, Chugach Mts. ; $60^{\circ} 08^{\prime} 15^{\prime \prime} \mathrm{N}$, 141 $57^{\prime} 20^{\prime \prime} \mathrm{W}$; BGN 1945; (map 65).

Name reported in 1913 by A. G. Maddren, USGS, and published by G. C. Martin (1921, pl. 6), USGS.

Eberly Glacier: glacier, heads $1.6 \mathrm{mi}$. W of Mount Eberly, trends W $4 \mathrm{mi}$. to Yakataga Glacier, $95 \mathrm{mi}$. NW of Yakutat, Chugach Mts.; $60^{\circ} 08^{\prime} 15^{\prime \prime} \mathrm{N}, 142^{\circ} 06^{\prime} 15^{\prime \prime} \mathrm{W}$; BGN 1945; (map 65).

Named reported by USGS in 1945.

Ebner Falls: falls, just above Last Chance Basin, $1 \mathrm{mi}$. W of Juneau, Coast Mts.; $58^{\circ} 17^{\prime} 30^{\prime \prime} \mathrm{N}$, $134^{\circ} 22^{\prime} 36^{\prime \prime} \mathrm{W}$; (map 11). Var. Big Falls.

Named for William Ebner, 1853-1938, a mining operator from Wisconsin who orga- nized the Ebner Gold Mining Co. with a stamping mill near the falls about 1896 . In 1908 he sold the property and left Juneau. Big Falls was the early miners' name for these falls. The present name was not used until about 1900 (DeArmond, 1957, p. 17).

Eccles, Mount: mountain, 2,357 ft., in Heney Ra., $1.5 \mathrm{mi}$. SE of Cordova, Ghugach Mts.; $60^{\circ} 31^{\prime} 30^{\prime \prime} \mathrm{N}, 145^{\circ} 43^{\prime} 30^{\prime \prime} \mathrm{W}$; BGN 1959; (map 64).

Local name reported by USGS in 1933. Named for S. W. Eccles, first president of the Copper River and Northwestern Railroad.

Eccles Creek: stream, flows W $1 \mathrm{mi}$. to Orca Inlet, $1.5 \mathrm{mi}$. SW of Cordova, Chugach Mts.; $60^{\circ} 32^{\prime} \mathrm{N}, 145^{\circ} 47^{\prime} \mathrm{W}$; BGN 1937; (map 64).

Local name reported by USFS in 1936. Name derived from Mount Eccles.

Eccles Lagoon: estuary, on SE shore of Orca Inlet, $1.5 \mathrm{mi}$. SW of Cordova, Chugach Mts.; $60^{\circ} 32^{\prime} \mathrm{N}, 145^{\circ} 47^{\prime} \mathrm{W}$; BGN 1937; (map 64).

So named by USFS in 1936 "because Eccles Creek flows into it."

Echeatnu River: stream, sec South Fork Kuskokwim River.

Echo Cove: bay, $1.8 \mathrm{mi}$. long, on $\mathrm{S}$ shore of Berners Bay $1.4 \mathrm{mi}$. E of Point Bridget and $33 \mathrm{mi}$. NW of Juneau, Coast Mts. ; 58 $40^{\prime} 15^{\prime \prime}$ N, $134^{\circ} 56^{\prime} 00^{\prime \prime} \mathrm{W}$; (map 11).

Local name reported in 1903 and published by USGS in 1912 (Spencer and Wright, pl. 37).

Echo Cove: cove, $0.2 \mathrm{mi}$. across, on $\mathrm{S}$ tip of Catherine I., off NE coast of Baranof I., Alex. Arch.; 57 $18^{\prime} \mathrm{N}, 134^{\circ} 49^{\prime} \mathrm{W}$; BGN 1935; (map 9).

Local name reported in 1935 by P. S. Smith, USGS. The name was suggested "by perfect echoes audible on boats anchored there."

Echo Creek: stream, in Glacier Bay National Monument, flows $2 \mathrm{mi}$. SW to a marsh $2 \mathrm{mi}$. $\mathrm{SW}$ of mouth of Justice Creek, $92 \mathrm{mi}$. NW of Hoonah, Malaspina Coastal Plain; 58 ${ }^{\circ} 42^{\prime}$ $\mathrm{N}, 137^{\circ} 44^{\prime} \mathrm{W}$; (map 10).

Local name reported by the IBC in 1894 and published by J. B. Mertie, Jr. (in Smith, P. S., and others, 1933, fig. 4, p. 118), USGS.

Echo Glacier: glacier, heads $\mathrm{N}$ of Echo Mtn., trends $\mathrm{N} 4 \mathrm{mi}$. to Avalanche Canyon, $32 \mathrm{mi}$. $\mathrm{N}$ of Juneau, Coast Mts. ; $58^{\circ} 46^{\prime} 15^{\prime \prime} \mathrm{N}, 134^{\circ}$ 25'15" W [1948]; BGN 1965; (map 11).

Named in 1964 by members of the Juneau Research Project.

Echoing Lake: lake, $2 \mathrm{mi}$. long, $19 \mathrm{mi}$. NW of Stevens Village, Yukon Flats; $66^{\circ} 16^{\prime} 30^{\prime \prime} \mathrm{N}$, $149^{\circ} 20^{\prime} 00^{\prime \prime} \mathrm{W}$; (map 118).

Local descriptive name obtained in 1956 by USGS.

Echo Island: island, $0.3 \mathrm{mi}$. long, one of Kashevarof Is., in Kashevarof Passage, off $\mathrm{N}$ coast of Prince of Wales I., Alex. Arch.; 56 $6^{\circ} 14^{\prime} 10^{\prime \prime}$ $\mathrm{N}$; $133^{\circ} 01^{\prime} 20^{\prime \prime} \mathrm{W}$; (map 6 ).

Local navigators' name reported in 1904 by $H$. C. Fassett, USBF.

Echo Lake: lake, $0.5 \mathrm{mi}$. long, in Matanuska Valley, $4.3 \mathrm{mi}$. SW of Palmer, Cook Inlet
Low.; 61 $31^{\circ} 15^{\prime \prime} \mathrm{N}, 149^{\circ} 12^{\prime} 45^{\prime \prime} \mathrm{W}$; (map 69).

Local name reported in 1942 by AMS.

Echo Mountain: peak, 5,300 ft., $4.5 \mathrm{mi}$. E of The Tusk and $29 \mathrm{mi}$. N of Juneau, Coast Mts.; $58^{\circ} 42^{\prime} 45^{\prime \prime} \mathrm{N}, 134^{\circ} 22^{\prime} 17^{\prime \prime} \mathrm{W}$; $B G N$ 1965; (map 11).

Descriptive name given by members of the Juneau Icefield Research Project in 1964.

Echo Mountain: mountain, 3,400 ft., in DeLong Mts., $20 \mathrm{mi}$. NNE of Misheguk Mtn., Brooks Ra.; $68^{\circ} 32^{\prime} \mathrm{N}, 160^{\circ} 53^{\prime} \mathrm{W} ; B G N$ 1966; (map 131).

So called by the B. P. Exploration Co., in 1965 , because of "the acoustical properties of a col on the south side of the mountain."

Echooka River: stream, heads at glacier in Brooks Ra. $68^{\circ} 53^{\prime} 30^{\prime \prime} \mathrm{N}, 146^{\circ} 29^{\prime} 30^{\prime \prime} \mathrm{W}$, flows NW $65 \mathrm{mi}$. to Ivishak River $8 \mathrm{mi}$. SE of junc. with Sagavanirktok River, Arctic Slope; $69^{\circ} 25^{\prime} \mathrm{N}$, $148^{\circ} 16^{\prime} \mathrm{W}$; BGN 1960; (map 140).

Eskimo name reported to mean "wing"; given in 1951 by A. S. Keller and R. L. Ditterman, USGS.

Echo Pass: pass, $\mathbf{S}$ of Amherst Peak on Morris Glacier, $13.5 \mathrm{mi}$. N of Juneau, Coast Mts.; $58^{\circ} 30^{\prime} 00^{\prime \prime} \mathrm{N}, 134^{\circ} 21^{\prime} 30^{\prime \prime} \mathrm{W}$; (map 11).

Local name published by USGS in 1962.

Eckholmes Islands: islands, see Eckholms, The.

Eckholms, The: islands, $0.2 \mathrm{mi}$. across, $\mathrm{S}$ of Eastern Channel, Sitka Sound, $3 \mathrm{mi}$. S of Sitka, Alex. Arch.; $57^{\circ} 00^{\prime} 40^{\prime \prime} \mathrm{N}, 135^{\circ} 21^{\prime} 30^{\prime \prime}$ W; (map 9). Var. Beacon Group, Eckholmes Island, Ek-galit-tch-an, Ostrova Yekgolm Ekgalit-tch.

Named in 1809 by the Russian navigator Ivan Vasiliev the first; published by Lt. Sarichev (1826, map 19), IRN as "O[strova] Yekgolm" or "Yekgolm Islands." Eckholm is a Swedish family name.

Eckman Beach: beach, $0.5 \mathrm{mi}$. long, on Hodikof Bay, Attu I., Aleutian Is.; $52^{\circ} 53^{\prime} 23^{\prime \prime} \mathrm{N}$, $173^{\circ} 17^{\prime} 20^{\prime \prime}$ E; (map 13).

Name shown on an AMS map published in 1948 and given by the U.S. Army during World War II. The name is not used today. Eckman Creek: stream, on E coast of Attu I., flows E $1.7 \mathrm{mi}$. to Hodikof Bay, Aleutian Is.; $52^{\circ} 53^{\prime} 12^{\prime \prime} \mathrm{N}, 173^{\circ} 16^{\prime} 52^{\prime \prime} \mathrm{E}$; (map 13).

Named by U.S. Army during World War II ; published in 1948 by AMS.

Eclipse Creek: stream, flows W $3.8 \mathrm{mi}$. to Melsing Creek $5 \mathrm{mi}$. NE of Council and $37 \mathrm{mi}$. NE of Solomon, Seward Penin. High.; $64^{\circ} 57^{\prime} \mathrm{N}, 163^{\circ} 35^{\prime} \mathrm{W}$; (map 95). Var. Glipper Creek.

Prospectors' name reported in 1899 by Schrader and Brooks (1900, map 3), USGS. Eclipse Slough: stream, anabranch of South Fork Koyukuk River near its mouth, $20 \mathrm{mi}$. $E$ of Allakaket, Kanuti Flats; $66^{\circ} 35^{\prime} \mathrm{N}, 151^{\circ} 55^{\prime}$ W; (map 117). Var. Steamer Eclipse Slough.

Named in 1899 for the riverboat Eclipse which wintered there in 1898-99.

Ecol-ena: stream, see Ekolina Creek. Ecolik Point: point of land, see Ikolik Cape. 
Edaburge Creek: stream, flows SW $7 \mathrm{mi}$. to Medicineman Creek, $56 \mathrm{mi}$. NE of Medfra, Kuskokwim Low.; $63^{\circ} 35^{\prime} \mathrm{N}, 153^{\circ} 17^{\prime} \mathrm{W}$; (map 89).

Local name reported in 1958 by USGS.

Edakh, Cape: point of land, see Idak, Cape.

Ed Berg Slough: stream, flows NW $9 \mathrm{mi}$. to Yukon River, $8 \mathrm{mi}$. NE of Beaver, Yukon Flats; $66^{\circ} 22^{\prime} 02^{\prime \prime} \mathrm{N}, 147^{\circ} 06^{\prime} 45^{\prime \prime} \mathrm{W}$; (map 118). Var. Ed Burkes Slough.

Local name obtained in 1956 by USGS.

Ed Burkes Slough: stream, see Ed Berg Slough.

Eddington, Mys: point of land, see Addington, Cape.

Eddy Creek: stream, flows N $13.5 \mathrm{mi}$. to Khotol River, $22 \mathrm{mi}$. SE of Nulato, Koyukuk Low.; $64^{\circ} 19^{\prime} \mathrm{N}, 157^{\circ} 58^{\prime} \mathrm{W}$; (map 97).

- Local name reported in 1935 by Frederica de Laguna, BAE.

Eddy Island: island, $0.5 \mathrm{mi}$. across, on $\mathrm{W}$ coast of Adak I., Aleutian Is.; $51^{\circ} 49^{\prime} 45^{\prime \prime} \mathrm{N}$ $176^{\circ} 54^{\prime} 00^{\prime \prime} \mathrm{W}$; BGN 1936; (map 17). Var. Oglala Island.

So named by members of the U.S. Navy Aleutian Island Survey Expedition in 1934, "because of the eddies in the water."

Eddy Point: point of land, W tip of Amlia I., Aleutian Is.; $52^{\circ} 07^{\prime} 50^{\prime \prime} \mathrm{N}, 174^{\circ} 03^{\prime} 00^{\prime \prime} \mathrm{W}$; (map 18).

Name published by the USC\&GS on a 1943 coast chart and "so called because of the strong current off the point."

Eddy Rock: rock, $1.7 \mathrm{mi}$. W of Kanaga I., Aleutian Is.; $51^{\circ} 41^{\prime} 20^{\prime \prime} \mathrm{N}, 177^{\circ} 44^{\prime} 00^{\prime \prime} \mathrm{W}$ (map 17).

Name published by USC\&GS in the 1944 Aleutian Coast Pilot (p. 116).

Eddys Range: ridge, elev. 2,200 ft., $4 \mathrm{mi}$. long, at head of Womens Bay, SW of Kodiak, on E coast of Kodiak I.; $57^{\circ} 40^{\prime} \mathrm{N}, 152^{\circ} 37^{\prime} \mathrm{W}$; (map 34).

Local name reported in 1949 by USGS.

Edelman Creek: stream, in Tilted Hills, on Iniskin Penin., flows NW $1.5 \mathrm{mi}$. to Bowzer Greek, $3.3 \mathrm{mi}$. N of Oil Bay, Aleutian Ra. $59^{\circ} 43^{\prime} 10^{\prime \prime} \mathrm{N}, 153^{\circ} 15^{\prime} 50^{\prime \prime} \mathrm{W}$; BGN 1962; (map 51).

Named locally for a prospector who staked mining claims in the area in 1892; published in 1958 by USGS.

Eden Creek: stream, flows SE $22 \mathrm{mi}$. to North Fork Kuskokwim River, $48 \mathrm{mi}$. NE of Medfra, Kilbuck-Kuskokwim Mts.; $63^{\circ} 32^{\prime} \mathrm{N}, 153^{\circ} 34^{\prime}$ W; (map 89).

Local name reported in 1958 by USGS

Edes: railroad station, see Turnagain.

Edes Lake: lake, $1.3 \mathrm{mi}$. long, $1 \mathrm{mi}$. $\mathrm{SE}$ of Mirror Lake, in Broad Pass, $37 \mathrm{mi}$. S of Healy, Talkeetna Mts. ; $63^{\circ} 19^{\prime} 45^{\prime \prime} \mathrm{N}, 149^{\circ} 05^{\prime} 30^{\prime \prime} \mathrm{W}$ $B G N$ 1927; (map 87). Var. Summit Lake. Named in 1927 by BGN for William C. Edes, 1856-1922, Chief Engineer and Chairman of the Alaska Engineering Commission, 1914-1920. It was originally called "Summit Lake" but because of duplication the name was changed.

Edgar Creek: stream, flows SE $4.5 \mathrm{mi}$. to Kuyukutuk River 12.5 mi. NW of Russian
Mission, Nulato Hills; $61^{\circ} 52^{\prime} 20^{\prime \prime} \mathrm{N}, 161^{\circ} 40$ $30^{\prime \prime} \mathrm{W}$; (map 73).

Prospectors' name reported by Harrington (1918, map), USGS; probably named for Andrew Edgar who staked claims in the area in 1913.

Edgar Creek: stream, flows SW $6 \mathrm{mi}$. to Yanert Fork, $35 \mathrm{mi}$. SE of Healy, Alaska Ra.; 63 ${ }^{\circ} 35^{\prime}$ $30^{\prime \prime} \mathrm{N}, 148^{\circ} 01^{\prime} 00^{\prime} \mathrm{W}$; (map 87).

Local name obtained in 1913 by J. W. Bagley, USGS; published by Moffit (1915, pl. 1).

Edgcombe, Cape: point of land, see Edgecumbe, Cape.

Edgcumbe, Cape: point of land, see Edgecumbe, Cape.

Edgecombe, Cape: point of land, see Edgecumbe, Cape.

Edgecombe Lake: lake, $0.5 \mathrm{mi}$. long, on Annette I., 2.5 mi. ESE of Metlakatla, Alex. Arch.; $55^{\circ} 07^{\prime} 10^{\prime \prime} \mathrm{N}, 131^{\circ} 29^{\prime} 30^{\prime \prime} \mathrm{W}$; (map 3). Var. Edgecomb Lake, Edgecumbe Lake.

Named in 1897 by USC\&GS. See Edgecumbe, Cape.

Edgecomb Lake: lake, see Edgecombe Lake.

Edge Creek: stream, heads in Nutzotin Mts., flows NE 14 mi. to Chisana River, Alaska Ra.; $62^{\circ} 24^{\prime} \mathrm{N}, 141^{\circ} 42^{\prime} \mathrm{W}$; (map 84).

Named in 1902 by F. C. Schrader, USGS, because of its position at edge of Nutzotin Mts.; published by USGS (Mendenhall and Schrader, 1903, pl. 3).

Edgecumb, Mount: volcano, see Edgecumbe, Mount.

Edgecumbe, Cape: point of land, on $\mathrm{S}$ coast of Kruzof I., $20 \mathrm{mi}$. W of Sitka, Alex. Arch.; $56^{\circ} 59^{\prime} 45^{\prime \prime} \mathrm{N}, 135^{\circ} 51^{\prime} 00^{\prime \prime} \mathrm{W}$; (map 5). Var. Cabo del Engano, Cape Edgcombe, Cape Edgcumbe, Cape Edgecombe, Cape Edgkomb, Cape Edjecumbe, Cape Saint Lazaria, Cape Saint Lazarius, Cape Trubitsina, Mys Svataya Lazarya, Mys Trubitsina, Sitka Point, Trubitsin Point.

Named on May 2, 1778 by Capt. Cook 1785 , v. 2, p. 344 ), RN, for Mount Edgecumbe. In 1775, F. A. Maurelle and Don Juan de la Bodega y Quadra named this point "Cabo del Engano," meaning "cape of deceit." Lt. Sarichev (1826, map 19), IRN, published three names for this feature: "Cabo del Engano"; "Mys Sv [ataya] Lazarya," or "Saint Lazarus' Cape," derived from the name applied in 1741 to Mount Edgecumbe by Capt. A. I. Chirikov, IRN; and "Mys Trubitsina," or "Trubitsin Cape," given in the 1790's by A. A. Baranov of the Russian American Company, first governor of the Russian American Colonies, for Grigori Trubitsin, a boatswain under Capt. Chirikov's command.

Edgecumbe, Cape: point of land, see Sitka Point.

Edgecumbe, Mount: volcano, 3,201 ft., on S central Kruzof I., $16 \mathrm{mi}$. W of Sitka, Alex. Arch.; 57 $03^{\prime} \mathrm{N}, 135^{\circ} 45^{\prime} \mathrm{W}$; (map 9). Var. Gora Edgkom, Gora Edzhkomb, Mount Saint Hyacinthe, Mount Saint Lazaria, Mount San Jacinto, Mount Edgecumb, Svataya Lazarya.
Named in 1778 by Capt. James Cook, RN, "probably after $\mathrm{Mt}$. Edgecumbe at the entrance of Plymouth Harbor, England, but possibly after George, the first Earl of Edgecumbe. The name was adopted by Vancouver" (Wagner, 1937, p. 385). This feature was also called "Montana de San Jacinto," or "Saint Jacinto Mountain," on August 16, 1775, by Don Juan de la Bodega y Quadra, "in honor of the saint whose day it was" (Wagner, p. 501); "Gora Svataya Lazarya," or "Saint Lazarus Mountain," by Lt. Sarichev (1826, map 19), IRN. This mountain was climbed in July 1805 by Capt. U. T. Lisianski, IRN.

Edgecumbe Lake: lake, see Edgecombe Lake.

Edgecumb Island: island, see Kruzof Island.

Edge Mountain: mountain, 1,928 ft., on SE coast of Afognak I., $24 \mathrm{mi}$. NE of Afognak; $58^{\circ} 11^{\prime} 30^{\prime \prime} \mathrm{N}, 152^{\circ} 06^{\prime} 30^{\prime \prime} \mathrm{W}$; (map 43).

Name published by USC\&GS in 1911 on Chart 8555.

Edge Point: point of land, S tip of Mary I., Alex. Arch.; 55 $02^{\prime} 40^{\prime \prime} \mathrm{N}, 131^{\circ} 11^{\prime} 35^{\prime \prime} \mathrm{W}$; (map 3).

Descriptive name published in 1917 by USC\&GS.

Edgkom, Gora: volcano, see Edgecumbe, Mount.

Edgkomb, Cape: point of land, see Edgecumbe, Cape.

Edison, Mount: mountain, 11,400 ft., in Dora Keen Ra., near head of Columbia Glacier, $36 \mathrm{mi}$. NW of Valdez, Chugach Mts.; $61^{\circ} 24^{\prime} 20^{\prime \prime} \mathrm{N}, 147^{\circ} 11^{\prime} 15^{\prime \prime} \mathrm{W}$; (map 69).

Named by members of the Chugach Mountains Expedition in 1955 for Thomas Alva Edison, 1847-1931, American inventor; reported by Nielsen (1963, p. 135).

Edith Island: island, extends E-W $3.6 \mathrm{mi}$., between East and Main Channels Yukon River, $0.4 \mathrm{mi}$. S of Florence $\mathrm{I}$. and $36 \mathrm{mi}$. NE of Ruby, Nowitna Low.; $64^{\circ} 56^{\prime} \mathrm{N}, 154^{\circ} 22^{\prime} \mathrm{W}$; (map 98).

Riverboat pilots' name shown on 1940 "Navigation Chart, Tanana-Yukon Rivers" of the River Boat Service, U.S. Dept. of Interior.

Edith Point: point of land, $\mathrm{N}$ point of entrance to Checats Cove, on E bank of Behm Canal, $2.3 \mathrm{mi}$. NE of Winstanley I., Coast Mts.; $55^{\circ} 29^{\prime} 45^{\prime \prime} \mathrm{N}, 130^{\circ} 52^{\prime} 48^{\prime \prime} \mathrm{W}$; (map 3).

Local navigators' name obtained in 1904 by H. C. Fassett, USBF.

Edjecumbe, Cape: point of land, see Edgecumbe, Cape.

Edmonds Cove: cove, see Kongishluk Bay.

Edmonds Lake: lake, $3.2 \mathrm{mi}$. NE of Birchwood and $22 \mathrm{mi}$. NE of Anchorage, Cook Inlet Low.; $61^{\circ} 26^{\prime} 00^{\prime \prime} \mathrm{N}, 149^{\circ} 23^{\prime} 20^{\prime \prime} \mathrm{W}$; (map 69).

Local name reported in 1942 by AMS.

Edna Bay: village, pop. 135, on SE coast of Kosciusko I. at W edge of Edna Bay, Alex. Arch.; $55^{\circ} 57^{\prime} \mathrm{N}, 133^{\circ} 40^{\prime} \mathrm{W}$; (map 4).

This is a logging village. A post office was established here in 1943 but was transferred to Ketchikan in 1960 (Ricks, 1965, p. 18). 
Edna Bay: bay, 2 mi. across, SE Kosciusco I., Alex. Arch.; 5556' N, $133^{\circ} 37^{\prime}$ W; (map 4). Named in 1903 or 1904 by E. F. Dickins, USC\&GS, who wrote "named by our party, has no local name."

Edna Creek: stream, flows SE $0.8 \mathrm{mi}$. to Saunders Creek, $8 \mathrm{mi}$. E of Nome, Seward Penin. High.; $64^{\circ} 29^{\prime} 42^{\prime \prime}$ N, $165^{\circ} 06^{\prime} 00^{\prime \prime} \mathrm{W}$; (map 94).

Prospectors' name shown on the 1902 "Map of the Nome and Snake River Country" by J. M. Davidson.

Eduard, Mys: point of land, see Edward, Cape. Eduards Creek: stream, see Edward Creek.

Edvard, Mys: point of land, see Edward, Cape.

Edward, Cape: point of land, W tip of Elkugu I., $6.1 \mathrm{mi}$. WNW of Chichagof, on $\mathrm{W}$ coast of Chichagof I., Alex. Arch.; $57^{\circ} 40^{\prime} 45^{\prime \prime} \mathrm{N}, 136^{\circ}$ $15^{\prime} 20^{\prime \prime}$ W; (map 9). Var. Mys Eduard, Mys Edvard, Mys Elkugu.

Named on July 29, 1794, by Capt. George Vancouver, RN (Wagner, 1937, p. 385). The Tlingit Indian name was published by Capt. Tebenkov (1852, map 8), IRN, as "M[ys] Elkugu," i.e. "Elkugu Cape."

Edward, Point: point of land, NE tip of Cape Rozhnof, $9 \mathrm{mi}$. W of settlement of Port Moller, Bristol Bay Low.; 55 $56^{\prime} 00^{\prime \prime} \mathrm{N}, 160^{\circ} 52^{\prime} 30^{\prime \prime}$ W; $(\operatorname{map} 28)$.

Named by W. H. Dall, USC\&GS, in 1882 , but first applied to the northern tip of Deer I., which is now called Fawn Point. Point Edward is named for Capt. Edward Perry Herendeen, who commanded the USC\&GS schooner Yukon, 1873-74 and 1880.

Edward, Point: point of land, see Fawn Point.

Edward Creek: stream, flows SW $1 \mathrm{mi}$. to Cripple River $1 \mathrm{mi}$. above its mouth on Norton Sound and $12 \mathrm{mi}$. W of Nome, Seward Penin. High.; $64^{\circ} 33^{\prime} \mathrm{N}, 165^{\circ} 46^{\prime} \mathrm{W}$; (map 94). Var. Eduards Creek.

Local name reported as "Eduards Creek" in 1899 by D. C. Witherspoon (in Schrader and Brooks, 1900, map 2), USGS. Subsequent maps show "Edward."

Edwardes River: stream, flows $15 \mathrm{mi}$. SW to Controller Bay, $14 \mathrm{mi}$. SE of Katalla, Malaspina Coastal Plain; $60^{\circ} 07^{\prime} \mathrm{N}, 144^{\circ} 08^{\prime} \mathrm{W}$; (map 64). Var. Puffy River.

Local name reported in 1903 by G. C. Martin, USGS. Named for Cecil Edwardes, brother of Lord Kensington, who was associated with the Alaska Development Co. in 1899.

Edward Islands: islands, $0.7 \mathrm{mi}$. across, $6 \mathrm{mi} . \mathrm{W}$ of Chichagof, on $W$ coast of Chichagof $I$., Alex. Arch.; $57^{\circ} 40^{\prime} \mathrm{N}, 136^{\circ} 15^{\prime} \mathrm{W}$; (map 9).

Name published in 1928 by USC\&GS on Chart 8250.

Edward Passage: water passage, extends $2.5 \mathrm{mi}$. NW from Pearse Canal to Fillmore Inlet, NE of Fillmore I., Coast Mts. ; $54^{\circ} 50^{\prime} \mathrm{N}, 130^{\circ} 30^{\prime}$ W; (map 2).

Local name published in 1943 by USG\&GS.

Edwards Creek: stream, flows S $11 \mathrm{mi}$. to Yukon River, $13 \mathrm{mi}$. W of junc. of Charley River,
Porcupine Plat.; $65^{\circ} 23^{\prime} \mathrm{N}, 143^{\circ} 07^{\prime} \mathrm{W}$; (map 103).

Local name published in 1956 by USGS.

Edwards Island: island, $1.7 \mathrm{mi}$. long, in Port Beauclerc, on E coast of Kuiu I., Alex. Arch.; $56^{\circ} 18^{\prime} \mathrm{N}, 133^{\circ} 57^{\prime} \mathrm{W}$; (map 6).

Named in 1886 by Lt. J. M. Helm, USN, for charting purposes; name published in 1887 on USC\&GS Chart 706

Edwardsville: town, see Douglas.

Edzhkomb, Gora: volcano, see Edgecumbe, Mount.

Eebruligorruk: promontory, see Thompson, Cape.

Eebrulikgorruk: stream, see Ibrulikorak Creek. Eebrulioruk Creek: stream, see Ibrulikorak Creek.

Eedalook: point of land, see Prominence, Cape.

Eeegikrattusuq Creek: stream, see Ibrulikorak Creek.

Ee-gah-rook: hills, see Igrarok Hills.

Eegik-kah-Lik Creek: stream, see Thetis Creek.

Eegikruttoosook Creek: stream, see Ibrulikorak Creek.

Eegikruttoosook Creek: stream, see Ikijaktusak Creek.

Eegillerak Mountain: hill, see Igilerak Hill.

Eegyak : stream, see Throat River.

Eeikrook Mountain: mountain, see Iyikrok Mountain.

Eek: village, pop. 200, on left bank of Eek River, $12 \mathrm{mi}$. E of Kuskokwim River and $41 \mathrm{mi}$. SW of Bethel, Yukon-Kuskokwim Delta; 60 $13^{\prime}$ $30^{\prime \prime} \mathrm{N}, 162^{\circ} 01^{\prime} 30^{\prime \prime} \mathrm{W}$; (map 58). Var. Ik.

Eskimo village named for the stream. It had a reported population of 170 in 1939 and 141 in 1950. The Eek Post Office was established in 1949.

Eekahgyak: ford, see Ikagiak Shallows.

Eekayruk Creek: stream, flows $2 \mathrm{mi}$. W from Eekayruk Mtn. to Hammond River, $32.5 \mathrm{mi}$. $\mathrm{N}$ of Wiseman, Brooks Ra.; 67 $52^{\prime} 15^{\prime \prime} \mathrm{N}$, $150^{\circ} 10^{\prime} 00^{\prime \prime} \mathrm{W}$; (map 124).

Named for the mountain from which it heads; reported in 1930 by Marshall (1956, map).

Eekayruk Mountain: mountain, 6,635 ft., E of Hammond River and $\mathrm{E}$ of Apoon Mtn., 34 mi., $\mathrm{N}$ of Wiseman, Brooks Ra.; $67^{\circ} 54^{\prime} \mathrm{N}$, $150^{\circ} 04^{\prime} \mathrm{W}$; (map 124).

Eskimo name reported in 1930 by Marshall (1956, map).

Eek Channel: channel, extends S $11 \mathrm{mi}$. from Eek Point to Kuskokwim Bay, $55 \mathrm{mi}$. SW of Bethel, Yukon-Kuskokwim Delta; $60^{\circ} 03^{\prime} \mathrm{N}$, $162^{\circ} 20^{\prime} \mathrm{W}$; (map 58).

Named in 1913 by USC\&GS; derived from name "Eek River."

Eek Channel Kuskokwin Bay: water channel, extends S $20 \mathrm{mi}$. from Kuskokwak Channel to point $19 \mathrm{mi}$. SW of Kwinhagak and $25 \mathrm{mi}$. NW of Carter Biy, Yukon-Kuskokim Delta; $59^{\circ} 38^{\prime} \mathrm{N}, 162^{\circ} 18^{\prime} \mathrm{W}$; (map 54).

Local name published in 1943 by USC\&GS; derived from nearby Eek River.

Eeke Inlet: estuary, see Eek Inlet.

Eeke Lake: lake, see Eek Lake.

Eek Fish Camp: locality, see Aklut.
Eekheezhaktusuk Creek: stream, see Ikijaktusak Creek.

Eek Inlet: estuary, extends NW $1 \mathrm{mi}$. off Hetta Inlet, just $\mathrm{N}$ of Eek Point, on SW coast of Prince of Wales I., Alex. Arch.; 55 $08^{\prime} 30^{\prime \prime} \mathrm{N}$, $132^{\circ} 39^{\prime} 30^{\prime \prime} \mathrm{W}$; (map 4). Var. Eeke Inlet. Nome published in 1899 by USC\&GS.

Eek Island: island, $0.8 \mathrm{mi}$. long, in Kuskokwim River, $4 \mathrm{mi}$. N of mouth of Eek Channel, 49 mi. SW of Bethel, Yukon-Kuskokwim Delta; $60^{\circ} 10^{\prime} \mathrm{N}, 162^{\circ} 20^{\prime} \mathrm{W}$; (map 58).

Named in 1913 by USC\&GS.

Eek Lake: lake, $0.8 \mathrm{mi}$. long, on $\mathrm{SW}$ coast of Prince of Wales I., $2.2 \mathrm{mi}$. N of Eek Point, Alex., Arch.; $55^{\circ} 10^{\prime} 35^{\prime \prime}$ N, $132^{\circ} 40^{\prime} 30^{\prime \prime} \mathrm{W}$; (map 4). Var. Eeke Lake.

Indian name recorded in 1897 as "Eeke" by Lt. Comdr. J. F. Moser, USN.

Eek Lake: lake, $1.4 \mathrm{mi}$. long, between Eek and Kwethluk Rivers, $15 \mathrm{mi}$. SE of Eluwaktak Mtn. and $53 \mathrm{mi}$. SE of Bethel, KilbuckKuskokwim Mts. ; $60^{\circ} 14^{\prime} \mathrm{N}, 160^{\circ} 19^{\prime} \mathrm{W}$; (map 59).

Local name reported in 1935 by USGS.

Eek Lake: lake, $4 \mathrm{mi}$. across, $20 \mathrm{mi}$. S of Bethel, Yukon-Kuskokwim Delta ; $60^{\circ} 30^{\prime} \mathrm{N}, 161^{\circ} 45^{\prime}$ W; (map 59).

Local name reported in 1949 by USGS.

Eek Mountains: mountains, 4,000 ft., trend NE $28 \mathrm{mi}$. from junc. of Nakailingak Creek and Kanektok River to Eek River, $75 \mathrm{mi}$. NE of Goodnews, Kilbuck-Kuskokwim Mts.; $60^{\circ} 00^{\prime}$ $\mathrm{N}, 160^{\circ} 30^{\prime} \mathrm{W}$; (map 53$)$.

Name derived from Eek River; published in 1951 by USGS.

Eek Point: point of land, between Hetta Inlet and Sukkwan Strait, on SW coast of Prince of

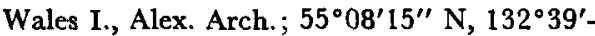
$55^{\prime \prime}$ W ; (map 4).

Local name reported in 1905 by $E$. F. Dickins, USC\&GS; derived from Eek Inlet.

Eek Point: point of land, at junc. of Eek and Eenayarak Rivers, $45 \mathrm{mi}$. SW of Bethel, Yukon-Kuskokwim Delta; $60^{\circ} 12^{\prime} \mathrm{N}, 162^{\circ} 15^{\prime}$ W; (map 58)

Named in 1898 by USC\&GS after the Eek River.

Eek River: stream, heads at $59^{\circ} 59^{\prime}$ N., $160^{\circ} 05^{\prime}$ W, flows NW $108 \mathrm{mi}$., joins Eenayarak River to form Eek Channel Kuskokwim River, $45 \mathrm{mi}$. SW of Bethel, Yukon-Kuskokwim Delta; $60^{\circ}$. $12^{\prime} \mathrm{N}, 162^{\circ} 15^{\prime} \mathrm{W}$; (map 58). Var. Reka Ik.

Eskimo name published as "Ik" by Lt. Sarichev (1826, map 3). It has been spelled "Eek" since 1880.

Eekuknuk Pond: lake, see Ikaknak Pond.

Eelikrak Creek: stream, see Ilikrak Creek.

Eel Island: island, see Esquibel Island.

Eelooweechook: hill, see Iluituk Hill.

Eeluichuk Mountain: hill, see Iluituk Hill.

Eelyeerak Creek : stream, see Ilyirak Creek.

Eenanukhto Bluffs: bluffs, see Einahnuhto Bluffs.

Eenanukhto Hills: hills, see Einahnuhto Hills.

Eenayarak River: stream, heads at $60^{\circ} 19^{\prime} \mathrm{N}$, $161^{\circ} 25^{\prime} \mathrm{W}$, flows SW $48 \mathrm{mi}$ to join Eek River to form Eek Channel, Kuskokwim River, 45 mi. SW of Bethel, Yukon-Kuskokwim Delta; 
$60^{\circ} 12^{\prime} \mathrm{N}, \quad 162^{\circ} 15^{\prime} \mathrm{W} ;(\operatorname{map} 58)$. Var. Inayarak River.

Eskimo name reported in 1910 by A. G. Maddren, USGS.

Eenyitkaleeoom Tehsaya: lagoon, see Krusenstern Lagoon.

Eenyookpasook: hill, see Inukpasuk Hill.

Eepkagnaktowgruk : mountain, see Ipkagnaktaugrak Mountain.

Ee-ree-nick Cape: promontory, see Lewis, Cape.

Eerie Point: point of land, in Glacier Bay National Monument, on $\mathrm{E}$ side of Brady Glacier, $5.8 \mathrm{mi}$. S of July Fourth Mountain, and $57 \mathrm{mi}$. NW of Hoonah, St. Elias Mts. ; $58^{\circ} 33^{\prime} 30^{\prime \prime} \mathrm{N}$, $136^{\circ} 43^{\prime} 00^{\prime \prime} \mathrm{W}$; (map 10$)$.

Local name published by USGS in the 1950's.

Eesook Creek: stream, see Isuk Creek.

Eetiblaeruk: locality, see Itublarak.

Eetiptigveerak: neck of land, see Itiptigvirak Neck.

Eetiptigvik: portage, see Itiptigvik.

Eetiviahk: portage, see Itiviak Portage.

Eetublaruk: locality, see Itublarak.

Eeveagech Mountain: hills, see Iviangik Mountain.

Eevook Lake: lake, $0.3 \mathrm{mi}$. long, on Kenai Penin, $1.3 \mathrm{mi}$. E of Sunken Island Lake, and $14 \mathrm{mi}$. E of Kenai, Cook Inlet Low.; $60^{\circ}$ $35^{\prime} 45^{\prime \prime} \mathrm{N}, 150^{\circ} 49^{\prime} 40^{\prime \prime} \mathrm{W}$; (map 62).

Named about 1963 by officials of Kenai National Moose Range, for administrative purposes.

Eevruktoosuk: locality, see Ivruktusuk.

Eevwak Point: point of land, $5 \mathrm{mi}$. SW of Savoonga, N coast of St. Lawrence I.; $63^{\circ} 40^{\prime}$ N, $170^{\circ} 39^{\prime}$ W, BGN 1951; (map 93). Var. Cape Evwak, Cape Evwhak, Eevwak Cape, Evwhak Cape, Evwhak Point, Ivwak Cape.

Eskimo name recorded by Orth as "Ivwak," meaning "to go around." The name appears to have been first reported in 1932 as "Cape Evwhak" by O. W. Geist, Uni. of Alaska. This name is synonymous with "Wevok" near Cape Lisburne.

Eeyikrook Mountain: mountain, see Iyikrok Mountain.

Eftugem Bay: bight, see Earle Cove.

Egaksrak Entrance: water passage, in barrier bar connecting Beaufort Sea and Beaufort Lagoon, near mouth of Aichilik River, $21 \mathrm{mi}$. NW of Demarcation Point, Arctic Plain; $69^{\circ} 49^{\prime} \mathrm{N}$, $141^{\circ} 55^{\prime} \mathrm{W}$; (map 138).

Named by USC\&GS for the nearby Egaksrak River.

Egaksrak Lagoon: lagoon, 2 mi. across, on Beaufort Sea coast, $E$ of Siku Point and $17 \mathrm{mi}$. NW of Demarcation Point, Arctic Plain; 69 $49^{\prime} \mathrm{N}$, $141^{\circ} 58^{\prime} \mathrm{W}$; (map 138).

See Egaksrak River.

Egaksrak River: strean, heads in Romanzof Mts. at $69^{\circ} 13^{\prime} \mathrm{N}, 142^{\circ} 15^{\prime} \mathrm{W}$, flows $\mathrm{NW}$ and $\mathrm{NE}$ $56 \mathrm{mi}$. to Beaufort Lagoon, $20 \mathrm{mi}$. NW of Demarcation Point, Arctic Plain; $69^{\circ} 50^{\prime} \mathrm{N}$, $142^{\circ} 03^{\prime} \mathrm{W}$; $B G N$ 1959; (map 138). Var. Aichilik River, Aichillik River.

Eskimo name of undetermined meaning reported by USC\&GS in 1948.
Egan, Mount: mountain, see Logan, Mount.

Egans Creek: stream, flows N $2 \mathrm{mi}$. to Bering Sea, $2 \mathrm{mi}$. E of Tomname Lagoon, St. Lawrence I.; $63^{\circ} 21^{\prime} \mathrm{N}, 169^{\circ} 21^{\prime} \mathrm{W}$; BGN 1951; (map 93). Var. Eagan's River.

Local name recommended in 1949, for map use, by the Savoonga village council.

Ėgănŭt'a: bluffs, see High Bluffs.

Ēgănŭt'a-kōverūshkä: hill, see Maynard Hill.

Egashak River: stream, see Igushik River.

Egashik River: stream, see Igushik River.

Egaupak Lake: lake, $0.8 \mathrm{mi}$. across, $2 \mathrm{mi}$. SE of junc. of Kerchurak Creek and Kugarak River, $27 \mathrm{mi}$. SW of Shungnak, KotzebueKobuk Low.; $66^{\circ} 48^{\prime} \mathrm{N}, 158^{\circ} 06^{\prime} \mathrm{W}$; (map 115).

Eskimo name shown on a 1927 manuscript map by the "trader at Selawik."

Egavik: village, pop. 23, on Norton Sound, 0.2 mi. S of mouth of Egavik Creek and $39 \mathrm{mi}$. SW of Christmas Mtn., Nulato Hills; $64^{\circ} 02^{\prime}$ $\mathrm{N}, 160^{\circ} 55^{\prime} \mathrm{W}$; (map 96). Var. Egawik, Egowik, Igavik, Ighauvik, Igouik, Igowik, Iguik.

Eskimo village reported in 1867 by members of the Western Union Telegraph Expedition.

Egavik Creek: stream, flows SW $29 \mathrm{mi}$. to Norton Sound, $38 \mathrm{mi}$. SW of Christmas Mtn., Nulato Hills; $64^{\circ} 03^{\prime} \mathrm{N}, 160^{\circ} 55^{\prime} \mathrm{W}$; (map 96). Var. Egawik Creek, Egowik Creek, Igavik Creek, Igouik Creek, Igowik Creek.

Eskimo name reported in 1867 by members of the Western Union Telegraph Expedition as "Igouik Creek."

Egawik: village, see Egavik.

Egawik Creek: stream, see Egavik Creek.

Egegak: village, see Egegik.

Egegik: village, pop. 150 , on $\mathrm{S}$ bank and near mouth of Egegik River on $\mathrm{N}$ coast of Alaska Penin., $38 \mathrm{mi}$. SW of Naknek, Bristol Bay Low.; 58 $13^{\prime} \mathrm{N}, 157^{\circ} 22^{\prime} \mathrm{W}$; $B G N$ 1917; (map 41). Var. Agouyak, Egegak, Igagik, Igiagik, Ougagik, Ougagouk, Ugagik, Ugaguk, Ugiagik.

Eskimo name published in 1888 as "Igagik" by USBF; the spelling "Egegik" was given in field notes of a 1903 mineral survey.

Egegik Bay: bay, extends E $5 \mathrm{mi}$. off Kvichak Bay at mouth of Egegik River, on $\mathrm{N}$ coast of Alaska Penin., $38 \mathrm{mi}$. SW of Naknek, Bristol Bay Low.; $58^{\circ} 13^{\prime} \mathrm{N}, 157^{\circ} 31^{\prime} \mathrm{W}$; (map 41).

Name published in 1955 by USGS. See Egegik.

Egegik River: stream, heads in Becharof Lake, flows NW $28 \mathrm{mi}$. to Egegik Bay, on $\mathbf{N}$ coast of Alaska Penin., $38 \mathrm{mi}$. SW of Naknek, Bristol Bay Low.; $58^{\circ} 12^{\prime} \mathrm{N}, 157^{\circ} 24^{\prime} \mathrm{W}$; BGN 1917; (map 41). Var. Agouyak River, Igagik River, Fleuve Ougagouck, Ugagik River, Ugaguk River.

Eskimo name published in 1835 by Adm. A. J. von Krusenstern, IRN, as "F[leuve] Ougagouck." It was shown in 1888 as "Ugaguk River" by USBF and reported in 1915 as "Egegik River" by mineral surveyor G. A. Parks. See Egegik.

Egegik River: stream, see Ugashik River.
Egg Bay: bay, $1.3 \mathrm{mi}$. across, on $\mathrm{N}$ coast of Atka I., Aleutian Is.; $52^{\circ} 12^{\prime} \mathrm{N}, 174^{\circ} 28^{\prime} \mathrm{W}$; (map 18). Var. Iaitchnoi.

Translation of "Iaitchnaia baie" published by Capt. Lutke (1836, p. 314), IRN.

Egg Cape: point of land, see Egg Point.

Egg Harbor: estuary, $1.5 \mathrm{mi}$. long, $W$ of Alikula Bay, NW coast of Coronation I., Alex. Arch.; $55^{\circ} 55^{\prime} 30^{\prime \prime} \mathrm{N}, 134^{\circ} 19^{\prime} 15^{\prime \prime} \mathrm{W}$; (map 4).

Descriptive name given in 1886 by Lt. Comdr. A. S. Snow, USN. "It is a rendezvous for the Indians, who here await favorable weather to go out to the Hazy Islands to gather eggs."

Egg Island: barrier island, $1.5 \mathrm{mi}$. long, one of Return Is., on Beaufort Sea coast, $10 \mathrm{mi}$. SE of Beechey Point, Arctic Plain; $70^{\circ} 26^{\prime} \mathrm{N}$, $148^{\circ} 43^{\prime} \mathrm{W}$; (map 150). Var. Return Reef.

Named by Leffingwell (1919, p. 95) in 1911. This island is probably Sir John Franklin's Return Reef.

Egg Island: island, $0.7 \mathrm{mi}$. long, in Egg Bay, $\mathrm{N}$ coast of Atka I., Aleutian Is.; $52^{\circ} 10^{\prime} 30^{\prime \prime} \mathrm{N}$, $174^{\circ} 26^{\prime} 15^{\prime \prime} \mathrm{W}$; (map 18).

Name published by the USC\&GS in the 1944 Aleutian Coast Pilot (p. 93). The island could have been so named because of its steep-sided, round-topped shape.

Egg Island: island, $0.7 \mathrm{mi}$. across, $2 \mathrm{mi}$. NE of NE tip of Sedanka I., Aleutian Is.; $53^{\circ} 51^{\prime} 50^{\prime \prime}$ N, $166^{\circ} 03^{\prime} 00^{\prime \prime} \mathrm{W}$; (map 23). Var. Gagalgin Island, Iachnie Island, Iachnoi Island, Jaitschoi Island, Kigalgin Island, Orieshik Island, Ugalgal Island, Ugalgan Island, Ugalohan Island.

Translation from the descriptive Russian name given by Lt. Sarichev (1826, map 14, dated 1792), IRN, as "O[strov] Yaichnoy," meaning "island of egg." Sarichev also called the island "O[strov] Ugalgan" or "Ugalgan Island," probably from Capt. Lt. Krenitzin, IRN, 1768 (Coxe, 1787, Chart 2, dated 1780 , p. 205). It was published by USBF as "Egg Island" in 1888.

Egg Island: island, $0.5 \mathrm{mi}$. across, at mouth of Morzhovoi Bay, Aleutian Ra.; 54 $56^{\prime} 00^{\prime \prime} \mathrm{N}$, $162^{\circ} 54^{\prime} 20^{\prime \prime} \mathrm{W}$; (map 25).

Name reported by Ferdinand Westdahl, USC\&GS, commander of the Coast Survey steamer McArthur, who made surveys in this area in 1901.

Egg Island: island. $0.4 \mathrm{mi}$. across, in middle of Popof Strait, in Shumagin Is., Aleutian Ra.; $55^{\circ} 06^{\prime} 50^{\prime \prime} \mathrm{N}, 160^{\circ} 31^{\prime} 00^{\prime \prime} \mathrm{W}$; (map 28). Var. Egg Islands.

Egg Island and Little Egg Island were listed in the 1916 USC\&GS Coast Pilot (p. 177); they were named Egg Is. by W. H. Dall, USC\&GS, in 1872.

Egg Island: island, $\mathrm{N}$ of Wosnesenski I., $14 \mathrm{mi}$. NE of Dolgoi I., Aleutian Ra.; $55^{\circ} 13^{\prime} 50^{\prime \prime} \mathrm{N}$, $161^{\circ} 21^{\prime} 10^{\prime \prime} \mathrm{W}$; (map 28).

Name shown on a 1964 USC\&GS chart.

Egg Island, island, $1.5 \mathrm{mi}$. long, off $\mathrm{S}$ coast of Alaska Penin., $12 \mathrm{mi}$. E of Stepovak Bay, Aleutian Ra.; 55 $50^{\prime} \mathrm{N}, 159^{\circ} 22^{\prime} \mathrm{W}$; (map 27).

Reported by USC\&GS in 1943; published in its 1947 Coast Pilot (v. 2, p. 299). 
Egg Island: island, off NE shore of Port Moller, Bristol Bay Low.; 55 $53^{\prime} 10^{\prime \prime} \mathrm{N}, 160^{\circ} 23^{\prime} 00^{\prime \prime}$ W; (map 28).

Name shown on a 1963 USC\&GS chart.

Egg Island: island, $0.1 \mathrm{mi}$. across, on $\mathrm{W}$ shore of Alitak Bay, Kodiak I.; $56^{\circ} 53^{\prime} 35^{\prime \prime} \mathrm{N}, 154^{\circ}$ $13^{\prime} 00^{\prime \prime} \mathrm{W}$; (map 32).

Name reported in 1900 by Comdr. J. F. Moser, USN.

Egg Island: island, $1.3 \mathrm{mi}$. long, in Egegik River $2.5 \mathrm{mi}$. E of Egegik and $37 \mathrm{mi}$. SW of Naknek, Bristol Bay Low.; $58^{\circ} 12^{\prime}$ N, $157^{\circ} 17^{\prime} \mathrm{W}$; (map 41).

Local name reported in 1952 by USGS.

Egg Island: island, $0.4 \mathrm{mi}$. long, in Norton Sound $12 \mathrm{mi}$. NE of Saint Michael; 63 $63^{\circ} 36^{\prime} 30^{\prime \prime} \mathrm{N}$, $161^{\circ} 44^{\prime} 15^{\prime \prime} \mathrm{W}$; (map 91). Var. L'ile des Oeufs, Ostrov Iachnoi, Ostrov Yaichnyy, Ostrov Yaignoy, Ostrov Zharof, Ostrov Zharov.

This is a translation of the Russian name "Yaichnoi" which was translated into French in 1827 by Capt. F. P. Lutke, IRN, who gave it as "L'ile des Oeufs" meaning "the island of eggs." It is so named because of the thousands of bird eggs found there certain times of the year. Capt. Archimandritov shows the name "Zharov" on a chart dated about 1850.

Egg Island: island, see Cenotaph Island.

Egg Island: island, see Deranof Island.

Egg Island: island, see Fish Egg Island.

Egg Island: island, see Haenke Island.

Egg Island: island, see Hunt Island.

Egg Island Channel: channel, $3.5 \mathrm{mi}$. long, $\mathrm{E}$ of Egg I., $10 \mathrm{mi}$. S of Cordova, Malaspina Coastal Plain; $60^{\circ} 22^{\prime} \mathrm{N}, 145^{\circ} 43^{\prime} \mathrm{W}$; (map 64).

Local name published in 1951 by USGS.

Egg Island Passage: water passage, see Sedanka Pass.

Egg Islands: island, see Egg Island.

Egg Islands: island, see Guibert Islets.

Egg Islands: island, see Little Egg Island.

Egg Islands: islands, group, extend $1 \mathrm{mi}$. near entrance to Moira Sound, on SE coast of Prince of Wales I., Alex. Arch.; $55^{\circ} 03^{\prime} 15^{\prime \prime} \mathrm{N}$, $132^{\circ} 04^{\prime} 00^{\prime \prime} \mathrm{W}$; (map 4$)$.

Descriptive name recorded in 1885 by Lt. Comdr. R. C. Clover, USN.

Egg Islands: islands, $2.5 \mathrm{mi}$. long, off $\mathrm{S}$ coast of Alaska, $6 \mathrm{mi}$. SE of Point Whitshed and 12 mi. S of Cordova, Malaspina Coastal Plain; $60^{\circ} 23^{\prime} \mathrm{N}, 145^{\circ} 46^{\prime} \mathrm{W}$; (map 64).

Local name reported in 1905 by G. C. Martin (1906, pl. 12), USGS.

Egg Islets: islands, see Guibert Islets.

Egg Passage: water passage, $2 \mathrm{mi}$. long, in Barrier Is., E of Round Is., Alex. Arch.; 54 $47^{\prime} \mathrm{N}$, $132^{\circ} 29^{\prime} \mathrm{W}$; (map 1$)$.

Local name reported in 1951 by USGS.

Egg Point: point of land, on N coast of Atka I., Aleutian Is.; $52^{\circ} 13^{\prime} 00^{\prime \prime} \mathrm{N}, 174^{\circ} 27^{\prime} 20^{\prime \prime} \mathrm{W}$; (map 18). Var. Egg Cape, Iachnoi, Iaitchnoi Cap, Cape Jaichnoi, Mys Yaichnoy, Mys Yaichnyy, Mys Yaitchni.

Russian name published as "Iaitchnoi Cap," or "egg cape," by Capt. Lutke (1836, p. 313), IRN.
Egg Rock: rock, in Cordova Bay, a western rock of Barrier Is. group, Alex. Arch.; 54 $47^{\prime} 45^{\prime \prime}$ $\mathrm{N}, 132^{\circ} 30^{\prime} 05^{\prime \prime} \mathrm{W}$; (map 1$)$.

Local name published by USC\&GS in 1943.

Egg Rock: rock, see Oval Rock.

Egg Rocks: rocks, off SE coast of Esther I., in Wells Passage, $24 \mathrm{mi}$. E of Whittier, Chugach Mts. ; $60^{\circ} 46^{\prime} 30^{\prime \prime} \mathrm{N}, 147^{\circ} 57^{\prime} 45^{\prime \prime} \mathrm{W}$; (map 63). GS

Descriptive name given in 1913 by USC\&

Egil Island: peninsula, $0.6 \mathrm{mi}$. across, surrounded by an oxbow lake of Birch Creek, $23 \mathrm{mi}$. SW of Fort Yukon, Yukon Flats; $66^{\circ} 15^{\prime} 00^{\prime \prime} \mathrm{N}$, $145^{\circ} 24^{\prime} 30^{\prime \prime} \mathrm{W}$; (map 119).

Local name reported in 1956 by T. E. Taylor, USGS.

Egilka Island: island, see Igitkin Island.

Ëgìthrōtōgh: point of land, see Cascade Point.

Egoashik River: stream, see Igushik River.

Egoochshac: $b a y$, on NE coast of Unalaska I., Aleutian Is. ; (map 23).

Capt. Cook (1785, v. 2, p. 492), RN, entered this bay in 1778 and wrote "I hauled into a bay, that lies 10 miles to the westward of Samganoodha [English Bay], known by the name of 'Egoochshac'; but we found very deep water; so that we were glad to get out again." This name was published by Baker (1906, p. 237), but is not found on modern maps. It is possible that Capt. Cook may have been referring to Unalaska Bay.

Egoosik Creek: stream, see Egusik Creek.

Egorkovskoi : village, formerly located near Cape Tanak, on $\mathrm{N}$ coast of Umnak I., Aleutian Is.; $53^{\circ} 33^{\prime} 50^{\prime \prime} \mathrm{N}, 168^{\circ} 00^{\prime} 00^{\prime \prime} \mathrm{W}$; (map 22).

Baker (1906, p. 615) says that this Aleut village was destroyed in 1817 by the explosion of Tulik volcano. He further states the "village was rebuilt in Inanudak bay and is, presumably the Nikolski village of to-day:"

Egorkovskoi: point of land, see Tanak, Cape.

Egoushik River: stream, see Igushik River.

Egowik: village, see Egavik.

Egowik Creek: Stream, see Egavik Creek.

Egozuk Creek: stream, flows NW $10 \mathrm{mi}$. to Holokuk River, $22 \mathrm{mi}$. SE of Little Mountain Village and $47 \mathrm{mi}$. SW of Sleetmute, KilbuckKuskokwim Mts.; $61^{\circ} 17^{\prime} \mathrm{N}, 158^{\circ} 17^{\prime} \mathrm{W}$; $B G N$ 1948; (map 72).

Eskimo name said to mean "elbow"; reported in 1945 by USGS.

Eguia, Punta de: point of land, see Martin, Point.

Egumen Lake: lake, $0.6 \mathrm{mi}$. long, on Kenai Penin., one of Seven Lakes in course of East Fork Moose River, $4 \mathrm{mi}$. NW of Hidden Lake and $29 \mathrm{mi}$. SE of Kenai, Cook Inlet Low.; $60^{\circ} 31^{\prime} 30^{\prime \prime} \mathrm{N}, 150^{\circ} 25^{\prime} 30^{\prime \prime} \mathrm{W}$; (map 62).

Named about 1963 by officials of Kenai National Moose Range for administrative purposes.

Egusik Creek: stream, flows SW $8 \mathrm{mi}$. to Shaktoolik River, $28 \mathrm{mi}$. NE of Christmas Mtn., Nulato Hills; $64^{\circ} 42^{\prime} \mathrm{N}, 159^{\circ} 42^{\prime} \mathrm{W}$; (map 96). Var. Egoosik Creek.

Eskimo name reported about 1954 by U.S. Army Corps of Engineers.
Egypt Mountain: mountain, 3,190 ft., on W bank of South Fork Kuskokwim River 6 mi. $\mathbf{N}$ of its junc. with Post River, $74 \mathrm{mi}$. SE of McGrath, Alaska Ra.; $62^{\circ} 29^{\prime} \mathrm{N}, 153^{\circ} 33^{\prime} \mathrm{W}$; (map 80).

So named in 1898 by W. S. Post and J. E. Spurr, USGS, "because of the fancied resemblance to the Egyptian pyramids."

Eickelberg Bay: estuary, extends SE $1.5 \mathrm{mi}$. to Prince William Sound, $1.5 \mathrm{mi}$. NW of Glacier I., $50 \mathrm{mi}$. NE of Whittier, Chugach Mts.; $60^{\circ} 55^{\prime} 00^{\prime \prime}$ N. $147^{\circ} 17^{\prime} 30^{\prime \prime}$ W ; (map 63).

Local name reported in 1951 by USGS.

Eickelberg Peak: mountain, $3,590 \mathrm{ft}$., on $W$ Unimak I., Aleutian Is.; $54^{\circ} 40^{\prime} 40^{\prime \prime}$ N, $164^{\circ}$ $28^{\prime} 30^{\prime \prime} \mathrm{W}$; (map 24).

Local name published in 1951 on USGS map.

Eidannoo: village, see Wales.

Eider: village, at Eider Point, $\mathrm{N}$ coast of $\mathrm{Un}$ alaska I., Aleuteian Is.; (map 23). Var. Selo Pestrekovo.

This village was called "Sel[o] Pestrekovo," meaning "eider duck village," by Lt. Sarichev (1826, map 14), IRN. Father Veniaminov (1840, v. 1 , p. 177-178) says it was composed of 5 huts (yourts) and 37 people in 1830 . The name "Eider" was published by Baker (1906, p. 238) but does not appear on modern maps.

Eider Creek: stream, flows SE $1.5 \mathrm{mi}$. to Glacier Creek, $2 \mathrm{mi}$. S of Glacier Lake and $28 \mathrm{mi}$. W of Chandalar, Brooks Ra.; $67^{\circ} 29^{\prime} 30^{\prime \prime} \mathrm{N}, 149^{\circ}$ $32^{\prime} 30^{\prime \prime} \mathrm{W}$; (map 123).

Local name reported in 1956 by T. E. Taylor, USGS.

Eider Duck Island: island, $0.3 \mathrm{mi}$. long, in Norton Sound, W of Klikitarik and $16 \mathrm{mi}$. E of Saint Michael, Yukon-Kuskokwim Delta; $63^{\circ}$ $28^{\prime} 15^{\prime \prime} \mathrm{N}, 161^{\circ} 29^{\prime} 50^{\prime \prime} \mathrm{W}$; (map 91).

Local name reported in 1952 by USC\&GS.

Eider Island: island, $0.3 \mathrm{mi}$. long, in Narrow Strait between Spruce and Kodiak Is.; $57^{\circ}$ $53^{\prime} 10^{\prime \prime} \mathrm{N}, 152^{\circ} 23^{\prime} 50^{\prime \prime} \mathrm{W}$; (map 34).

Local name published in 1943 by USC\&GS.

Eider Lake: lake, $0.7 \mathrm{mi}$. long, on Kenai Penin. $\mathrm{S}$ of Pepper Lake, $34 \mathrm{mi}$. NE of Kenai, Cook Inlet Low.; $60^{\circ} 49^{\prime} 30^{\prime \prime} \mathrm{N}, 150^{\circ} 26^{\prime} 30^{\prime \prime} \mathrm{W}$; (map 62).

Named about 1963 by officials of Kenai National Moose Range, probably for Steller's Eider (Polystica stelleri), "considered the swiftest of all Alaskan ducks" (Gabrielson and Lincoln, 1959, p. 214).

Eider Point: point of land, W shore of Unalaska Bay, NE coast of Unalaska I., Aleutian Is.; $53^{\circ} 57^{\prime} 40^{\prime \prime}$ N, $166^{\circ} 35^{\prime} 30^{\prime \prime}$ W; (map 23). Var. Igognak, Pestriakovo.

Named derived from a village located on this point. The name was published by Lt. G. A. Sarichev, IRN, in $\mathbf{1 8 2 6}$ as "Sel[o] Pestrekovo" (map 14) and as "Sel[o] Igognak ili Pestryakovo" (map 15) meaning "Igognak or Eiderduck village" (Baker, 1906, p. 238).

Eider Point: point of land, see Tekegakrok Point. 
Eider Reef: reef, $0.5 \mathrm{mi}$. E of Trunk Point, off E coast of Tanaga I., Aleutian Is.; $51^{\circ} 45^{\prime} 45^{\prime \prime}$ $\mathrm{N}, 177^{\circ} 46^{\prime} 00^{\prime \prime} \mathrm{W}$; (map 17).

Name published by USC\&GS in 1956 on Chart 9145

Eider Rock: rock, in Nikolski Bay, off SW coast of Umnak I., Aleutian Is.; $52^{\circ} 52^{\prime} 13^{\prime \prime} \mathrm{N}, 168^{\circ}$ $52^{\prime} 30^{\prime \prime} \mathrm{W}$; BGN 1940; (map 21 ).

Named in 1938 by USC\&GS, "because of the number of eider ducks that nest there."

Eielson, Mount: peak, 5,802 ft., in Mount McKinley National Park, $3.5 \mathrm{mi}$. S of Eielson Visitor Center, Alaska Ra.; $63^{\circ} 23^{\prime} \mathrm{N}, 150^{\circ} 10^{\prime}$ W; BGN 1932; (map 88). Var. Copper Mountain.

Named by U.S. Congress on June 14, 1930, for Carl Ben Eielson "in honor of the pioneer work in aviation performed in Alaska and the North * * *." Eielson had recently been killed in a plane crash in Siberia. The local name "Copper Mountain" was reported in 1925 by S. R. Capps, USGS.

Eigalorak Mountain: hill, see Eigaloruk Mountain.

Eigaloruk Mountain: hill, $757 \mathrm{ft}$., in Igichuk Hills, $10 \mathrm{mi}$. NE of Cape Krusenstern, Arctic Slope; $67^{\circ} 15^{\prime} \mathrm{N}, 163^{\circ} 30^{\prime} \mathrm{W}$; (map 128). Var. Eigalorak Mountain.

Eskimo name meaning "little window" according to USC\&GS in 1950.

Eiganuta Bluffs: bluffs, see Einahnuhto Bluffs.

Eiganuta Hills: hills, see Einahnuhto Hills.

Eighteen Gulch: ravine, in Kantishna Hills, extends $\mathrm{N} 0.6 \mathrm{mi}$. to Glacier Creek, $6 \mathrm{mi}$. N of Wonder Lake, Alaska Ra.; $63^{\circ} 35^{\prime} 00^{\prime \prime} \mathrm{N}$, 150 54'38" W; BGN 1932; (map 88).

Prospectors' name reported in 1931 by $F$. G. Wells and S. C. Kain, USGS.

Eighteen Hundred Forty-eight Hill: mountain, see 1848 Hill.

Eighteen-mile Arm: estuary, see Twelvemile Arm Kasaan Bay.

Eight Fathom Bight: bight, $0.5 \mathrm{mi}$. across, in Salt Lake Bay on Port Frederick on Chichagof I., $2 \mathrm{mi}$. SW of South Bight and $13 \mathrm{mi}$. SW of Hoonah, Alex. Arch.; $58^{\circ} 00^{\prime} \mathrm{N}, 135^{\circ} 44^{\prime}$ W; (map 11).

Name published by USGS in 1962.

Eight Gulch: ravine, extends SE $1.2 \mathrm{mi}$. to Fourth of July Creek, $33 \mathrm{mi}$. NW of Eagle, Yukon-Tanana High; $65^{\circ} 08^{\prime} 30^{\prime \prime} \mathrm{N}, 141^{\circ} 57^{\prime}$ 20" W; (map 103).

Local name published in 1956 by USGS.

Eightmile Bend: bend, in the Koyukuk River, 5 mi. E of Allakaket, Kanuti Flats; $66^{\circ} 33^{\prime 2} 25^{\prime \prime}$ N, $152^{\circ} 30^{\prime} 00^{\prime \prime} \mathrm{W}$; (map 117).

Named in 1885 by Lt. Allen (1887, map 4), USA; so called because it is 8 miles upstream from the mouth of the Alatna River.

Eightmile Cove: bay, $1 \mathrm{mi}$. wide, off Norton Sound, $7 \mathrm{mi}$. SE of Saint Michael, YukonKuskokwin Delta; $63^{\circ} 27^{\prime} \mathrm{N}, 161^{\circ} 49^{\prime} \mathrm{W}$; (map 91).

"Sled runners' name" reported in 1952 by USC\&GS

Eightmile Greek: stream, flows NE $11 \mathrm{mi}$. to Kuskokwin River, $8.8 \mathrm{mi}$. NW of Red Devil and $15 \mathrm{mi}$. NE of Sleetmute, Kilbuck-Kuskok- wim Mts.; $61^{\circ} 49^{\prime} \mathrm{N}, 157^{\circ} 33^{\prime} \mathrm{W} ; B G N$ 1943; (map 72).

Named in 1910 at the time of the Georgetown gold strike by prospectors who thought it to be 8 miles upstream from Georgetown on the Kuskokwim; name reported in 1943 by USGS.

Eightmile Creek: stream, heads in lake, flows $\mathrm{SE}$ and NW $28 \mathrm{mi}$. to Skwentna River at Skwentna, $62 \mathrm{mi}$. $\mathrm{N}$ of Tyonek, Cook Inlet Low.; $61^{\circ} 57^{\prime} 35^{\prime \prime} \mathrm{N}, 151^{\circ} 01^{\prime} 55^{\prime \prime} \mathrm{W}$; (map 70).

Local name reported in 1954 by USGS.

Eightmile Creek: stream, flows NW $3.6 \mathrm{mi}$. to Bettles River, opposite mouth of Limestone Creek, $24 \mathrm{mi}$. WNW of Chandalar, Brooks

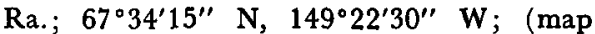
123).

Prospectors' name obtained in 1901 by Schrader (1904, pl. 3), USGS.

Eightmile Creek: stream, see Kiklukh River.

Eightmile Island: island, $2 \mathrm{mi}$. long, in Tanana River, $6.5 \mathrm{mi}$. ESE of Tanana, Nowitna Low.; $65^{\circ} 08^{\prime} \mathrm{N}, 151^{\circ} 57^{\prime} \mathrm{W}$; (map 106).

Riverboat pilots' name shown on Navigation Chart of the Tanana-Yukon Rivers, dated 1940

Eightmile Lake: lake, ò.8 mi. long, drains into Eightmile Creek, $53 \mathrm{mi}$. N of Tyonek, Cook Inlet Low.; $61^{\circ} 50^{\prime} 45^{\prime \prime} \mathrm{N}, 151^{\circ} 08^{\prime} 40^{\prime \prime} \mathrm{W}$; (map 70).

Local name reported in 1954 by USGS.

Eightmile Lake: lake, $0.6 \mathrm{mi}$. long, on Fish Creek, $9 \mathrm{mi}$. NW of Healy, Alaska Ra.; $63^{\circ}$ $53^{\prime} 30^{\prime \prime} \mathrm{N}, 149^{\circ} 15^{\prime} 15^{\prime \prime} \mathrm{W}$; (map 87).

Local name reported in 1951 by USGS.

Eightmile Slough: stream, flows N $1.3 \mathrm{mi}$. from Tanana River to Hay Slough, $6 \mathrm{mi}$. E of Tanana, Nowitna Low.; $65^{\circ} 10^{\prime} \mathrm{N}, 151^{\circ} 53^{\prime}$ W; (map 106).

Local name reported in 1952 by USGS.

Eightmile Slough: stream, heads at Seventeenmile Slough, flows NW $12 \mathrm{mi}$. to Porcupine River, $6 \mathrm{mi}$. NE of Fort Yukon, Yukon Flats; $66^{\circ} 40^{\prime} 00^{\prime \prime} \mathrm{N}, 145^{\circ} 06^{\prime} 30^{\prime \prime} \mathrm{W}$; (map 119).

Local name reported in 1956 by T. $E$. Taylor, USGS; so called because the stream is 8 miles from Fort Yukon along the Yukon and Porcupine Rivers.

Eight Thousand Nine Hundred, Peak: mountain, see Aylesworth, Mount.

Eighty-nine Hundred, Peak: mountain, see Aylesworth, Mount.

Einahnuhto Bluffs: bluffs, on W coast of Saint Paul I., in Pribilof Is.; $57^{\circ} 11^{\prime} 05^{\prime \prime} \mathrm{N}, 170^{\circ}$ $24^{\prime} 40^{\prime \prime} \mathrm{W}$; (map 38). Var. Eenanukhto Bluffs, Eiganuta Bluffs, Ein-ahnuh-to Cliffs, High Bluffs.

Aleut name reported by Elliott (1881, Saint Paul notes) as "Ein-ahnuh-to Cliffs" meaning "three mammae [breasts]." See Einahnuhto Hills.

Ein-ahnuh-to Cliffs: bluffs, see Einahnuhto Bluffs.

Einahnuhto Hills: hills, $655 \mathrm{ft}$., includes Rush Hill, on W coast of Saint Paul I., in Pribilof Is.; $57^{\circ} 11^{\prime} 15^{\prime \prime} \mathrm{N}, 170^{\circ} 24^{\prime} 00^{\prime \prime} \mathrm{W}$; (map 38).
Var. Eenanukhto Hills, Eiganuta Hills, Rush Hills.

This is an Aleut name, according to Elliott (1881, St. Paul notes), meaning "three mammae [breasts]"; so called because the hills appear to consist of three tops.

Einstein, Mount: mountain, 11,552 ft., at head of Yale Glacier, $32 \mathrm{mi}$. NW of Valdez, Chugach Mts., $61^{\circ} 21^{\prime} 25^{\prime \prime} \mathrm{N}, 147^{\circ} 05^{\prime} 45^{\prime \prime} \mathrm{W}$; (map 69).

Named in 1955 by members of the Chugach Mountains Expedition (Nielsen, 1963, p. 135), for Albert Einstein, 1879-1955, physicist.

Eisenmenger Fork: stream, flows NW $24 \mathrm{mi}$. to Goodpaster River, 52 mi. NE of Big Delta, Yukon-Tanana High.; 64. $28^{\prime} 15^{\prime \prime} \mathrm{N}, 144^{\circ}$ 15'10" W; BGN 1965; (map 101). Var. Goodpaster River, South Fork Goodpaster River.

Originally reported in 1903 as South Fork Goodpaster River (Prindle, 1913a, pl. 16). However, another stream, nearer to the mouth of the Goodpaster River, was later called by that name. Therefore, to avoid confusion, this stream was named for William Eisenmenger who "was a miner in this area at the headwaters of the Goodpaster River. $\mathrm{He}$ is now deceased."

Eivoogiena Island: island, see Saint Lawrence Island.

Eivugen Island: island, see Saint Lawrence Island.

Ekakevik Mountain: mountain, 3,040 ft., in Brooks Ra., $25 \mathrm{mi}$. N of Howard Pass; 68 ${ }^{\circ} 35^{\prime}$ N, 157 $00^{\prime} \mathrm{W} ; B G N$ 1949; (map 132).

Named by geologists connected with the Naval Petroleum Reserve No. 4 explorations; Eskimo name meaning "basin" published by USGS in 1951.

Ekalgruak Lake: lake, $5 \mathrm{mi}$. long, $7 \mathrm{mi}$. W of Admiralty Bay and $22 \mathrm{mi}$. SE of Barrow, Arctic Plain; $70^{\circ} 58^{\prime} \mathrm{N}, 156^{\circ} 23^{\prime} \mathrm{W}$; (map 147)

Eskimo name obtained in 1956 at Wainwright by T. E. Taylor, USGS.

Ekalooksik River: stream, see Ikalooksik River. Ekaluakat River: stream, flows $28 \mathrm{mi}$. NE to Egaksrak River, $20 \mathrm{mi}$. NW of Demarcation Point, Arctic Plain; $69^{\circ} 45^{\prime} \mathrm{N}, 142^{\circ} 05^{\prime} \mathrm{W}$; $B G N$ 1959; (map 138). Var. Aichilik River, Aichillik River.

Eskimo name reported by USC\&GS in 1948, to mean "small fish place."

Ekalukliurak Creek: stream, see Carter Creek.

Ekaluktagumiut: locality, see Ekaluktaluk.

Ekaluktaluk: locality, "in the Kuskokwim district." Var. Ekaluktagumiut.

Former Eskimo camp or settlement listed as "Ekaluktagumiut" with a population of 24 in the 1890 Census (Hodge, 1907, p. 420).

Ekashluak Creek: stream, heads in Towak Mtn., flows N $3.7 \mathrm{mi}$. to Scammon Bay, $6.6 \mathrm{mi}$. E of Cape Romanzof, Yukon-Kuskokwim Delta; $61^{\circ} 49^{\prime} 35^{\prime \prime} \mathrm{N}, 165^{\circ} 54^{\prime} 10^{\prime \prime} \mathrm{W}$; (map 75). Var. Ekashluktuli River, Ikashlocktuli River.

Eskimo name reported by USC\&GS in 1949. It appears to be somewhat similar to the 
name "Ekasluktuli River, the name of a stream" on the other side of Towak Mtn.

Ekashluktuli River: stream, see Ekashluak Creek.

Ekashluktuli River: stream, see Ekasluktuli River.

Ekasluktuli River: stream, in Askinuk Mts., flows SW $4.5 \mathrm{mi}$. to Igiak Bay, $8 \mathrm{mi}$. SE of Cape Romanzof, Yukon-Kuskokwim Delta; $61^{\circ} 43^{\prime}$ N, $165^{\circ} 58^{\prime}$ W; (map 75). Var. Ekashluktuli River.

Eskimo name which means "trout"; obtained at Hooper Bay by USC\&GS in 1951.

Ekaterina, Lake: lake, $2.5 \mathrm{mi}$. long, $11 \mathrm{mi} \mathrm{E}$ of Goddard, on central Baranof I., Alex. Arch.; $56^{\circ} 51^{\prime} 00^{\prime \prime} \mathrm{N}, 1^{\circ} 05^{\circ} 30^{\prime \prime} \mathrm{W}$; BGN 1935; (map 5).

Named in 1935 by USFS "for one of the ships of the Shelikov Company, sent to Alexander Baranof, in 1794." See Baranof Island.

Ekathlic: stream, see Fish River.

Ekdokuch Point: point of land, see Chuniksak Point.

Ek-galit-tch-an: islands, see Eckholms, The.

Ekichuk Lake: bay, $4 \mathrm{mi}$. across, on Hotham Inlet, $48 \mathrm{mi}$. NW of Selawik, KotzebueKobuk Low.; $66^{\circ} 58^{\prime}$ N, $161^{\circ} 33^{\prime}$ W ; (map 114).

Eskimo name obtained by U.S. Army Corps of Engineers in 1955.

Ekiek Creek: stream, flows $\mathrm{N} 17 \mathrm{mi}$. to Selawik River, $55 \mathrm{mi}$. SW of Shungnak, KotzebueKobuk Low.; $66^{\circ} 26^{\prime} \mathrm{N}, 158^{\circ} 45^{\prime} \mathrm{W}$; (map 115).

Eskimo name shown on a 1927 manuscript map by the "trader at Selawik."

Ekiligamut: locality, $2 \mathrm{mi}$. N of Togiak Village, on right bank of Togiak River, $44 \mathrm{mi}$. $\mathrm{E}$ of Goodnews, Kilbuck-Kuskokwim Mts.; 59 $05^{\prime}$ N, $160^{\circ} 22^{\prime}$ W; (map 53). Var. Ekilik, Ikalinkamiut, Ikaliukha.

This Eskimo village was first mentioned by Ivan Petroff in the 10th Census in 1880 as "Ekilik;" later it was called "Ikalinkamiut," or "Ikalink people." This may have been the same village as Ekilik because the names are similar or possibly the same group of people reported at two places.

Ekiligamut: locality, see Ekilik.

Ekilik: locality, on right bank of Togiak River, $45 \mathrm{mi}$. E of Goodnews, Kilbuck-Kuskokwim Mts., $59^{\circ} 11^{\prime}$ N, $160^{\circ} 19^{\prime}$ W; (map 53). Var. Ekiligamut, Ikalinkamuit, Ikaliukha.

Eskimo village or camp first mentioned by Ivan Petroff in the 10 th census in 1880 as "Ikaliukha." Its name was reported in 1898 as "Ekiligamut," meaning "Ekilik people," by J. E. Spurr and W. S. Post, USGS. Its population was 192 in $1880 ; 60$ in 1890; it is now abandoned. See Ekiligamut.

Ekilik: locality, see Ekiligamut.

Ekiluk Pass: water passage, see Eluitkak Pass.

Ekilukruak Entrance: water passage, on Beaufort Sea coast, between Cooper I. and the Tapkaluk Is., $20 \mathrm{mi}$. W of Barrow, Arctic Plain; $71^{\circ} 15^{\prime} \mathrm{N}, 155^{\circ} 50^{\prime} \mathrm{W}$; (map 153).
Eskimo name recorded at Barrow in 1951 by USC\&GS, and is reported to mean "wide, rough inlet."

Eklootna Creek: stream, see Eklutna River.

Eklootna Lake: lake, see Eklutna Lake.

Eklutna: village, pop. 50, mile 141.2 on The Alaska RR. at the head of Knik Arm at the mouth of Eklutna River $25 \mathrm{mi}$. NE of Anchorage, Cook Inlet Low.; $61^{\circ} 28^{\prime} \mathrm{N}, 149^{\circ} 22^{\prime}$ W; (map 69). Var. Old Knik.

Tanaina Indian village and railroad station, the latter established in 1918. This place may have originally been one of the Knik Villages. See Knik. The Eklutna Power House, a hydro-electric project supplying electricity to Anchorage is located near here. The Eklutna post office was established in 1926; discontinued in 1945 (Ricks, 1965 , p. 18).

Eklutna, Mount: mountain, $4,110 \mathrm{ft}$., $4 \mathrm{mi}$. E of Birchwood, between Thunder Bird and Peters Creeks, $22 \mathrm{mi}$. NE of Anchorage, Chugach Mts.; $61^{\circ} 24^{\prime} 15^{\prime \prime} \mathrm{N}, 149^{\circ} 21^{\prime} 00^{\prime \prime} \mathrm{W}$; (map 69).

Local name reported in 1942 by AMS; derived from nearby Eklutna River.

Eklutna Creek: stream, see Eklutna River.

Eklutna Glacier: glacier, trends N $7.7 \mathrm{mi}$. to its terminus at head of Eklutna River, $23 \mathrm{mi}$. SE of Palmer, Chugach Mts.; $61^{\circ} 17^{\prime} \mathrm{N}, 148^{\circ} 58^{\prime}$ W; BGN 1964; (map 69).

Local name reported in 1964 by USGS; derived from the river. See Eklutna Lake and Eklutna River.

Eklutna Lake: lake, $6.9 \mathrm{mi}$. long, near head of Eklutna River, $13 \mathrm{mi}$. S of Palmer, Chugach Mts.; $61^{\circ} 23^{\prime}$ N, $149^{\circ} 03^{\prime}$ W ; (map 69). Var. Eklootna Lake.

Tanaina Indian name reported in 1906 as "Eklootna" by T. G. Gerdine, USGS. Present spelling was published in 1915 by S. R. Capps (in Brooks and others, 1916, pl. 1), USGS.

Eklutna River: stream, heads at Eklutna Glacier terminus, flows NW through Eklutna Lake $22 \mathrm{mi}$. to Knik Arm, $4 \mathrm{mi}$. NE of Birchwood and $23 \mathrm{mi}$. NE of Anchorage, Cook Inlet Low.; 61 $27^{\circ} 25^{\prime \prime} \mathrm{N}, 1^{\circ} 9^{\circ} 25^{\prime} 00^{\prime \prime} \mathrm{W}$; (map 69). Var. Eklootna Creek, Eklutna Creek.

Tanaina Indian name reported in 1906 as "Eklootna" (Eklut River) by T. G. Gerdine, USGS. Reported in 1915 as "Eklutna Creek" by S. R. Capps (in Brooks and others, 1916, pl. 1), USGS.

Ekogmute: village, see Russian Mission

E-ko-go-mute: village, see Ohogamiut.

Ekok Cape: point of land, see Clarks Point.

Ekokpuk Creek: stream, flows E $22 \mathrm{mi}$. to John River, $12 \mathrm{mi}$. SW of Anaktuvuk Pass, Brooks Ra.; $68^{\circ} 01^{\prime} 20^{\prime \prime} \mathrm{N}, 152^{\circ} 05^{\prime} 45^{\prime \prime} \mathrm{W}$; BGN 1932; (map 134). Var. Ikiakpuk Creek.

Name reported by Robert Marshall in 1932; said to be of Eskimo origin and means "split in two."

Ekolina Creek: stream, flows SW $9 \mathrm{mi}$. to East Fork Kuskokwim River, $30 \mathrm{mi}$. NE of Medfra, Kuskokwim Low.; $63^{\circ} 10^{\prime} \mathrm{N}, 153^{\circ} 47^{\prime} \mathrm{W}$; (map 89). Var. Ecol-ena.
Indian name obtained in 1899 by Lt. J. S. Herron, USA, who wrote it "Ecol-ena."

Ekouk: village, see Ekuk.

Ekouk: village, see Ekwok.

Ekron, Mount: mountain, 2,830 ft., in the Lockwood Hills $50 \mathrm{mi}$. NW of Hughes, KokrinesHodzana High.; $66^{\circ} 39^{\prime} \mathrm{N}, 155^{\circ} 15^{\prime} \mathrm{W}$; (map 116).

Name shown on an 1886 manuscript map by Lt. G. M. Stoney, USN, with the note: "Bible Name." Probably named for Ekron, a city on the Philistine Plain mentioned in the Book of Joshua 13:3 and 15:11.

Ekrugavik Lake: lake, see Ikroavik Lake.

Ekseavuk: locality, near Kobuk River, about 50 mi. NE of Selawik, Brooks Ra.; near $67^{\circ} 00^{\prime}$ $\mathrm{N}, 159^{\circ} 00^{\prime} \mathrm{W}$; (map 126$)$.

Archeological site reported by Giddings (1964, p. 28)

Ekuk: village, pop. 40, Ekuk Spit, on $E$ shore of Nushagak Bay, $16 \mathrm{mi}$. S of Dillingham, Bristol Bay Low. ; $58^{\circ} 49^{\prime} 00^{\prime \prime} \mathrm{N}, \mathbf{1 5 8}^{\circ} 33^{\prime} 30^{\prime \prime} \mathrm{W}$; (map 40). Var. Ekouk, Ekuk Village, Ikuk, Village Ekouk, Yekuk.

Eskimo settlement reported in 1828 as "V[illage] Ekouk" and "S[eleniye] Ikuk" by F. P. Lutke. It had a population of 37 in 1930. It is the location of a cannery. It appears that this village has sometimes been confused with Ekwok.

Ekuk: village, see Ekwok.

Ekuk Bluff: bluff, $170 \mathrm{ft}$., extends $5 \mathrm{mi}$., on $\mathrm{E}$ shore of Nushagak Bay, SE of Ekuk and 18 mi. S of Dillingham, Bristol Bay Low.; $58^{\circ} 47^{\prime}$ $\mathrm{N}, 158^{\circ} 30^{\prime} \mathrm{W}$; (map 40)

Name published by USC\&GS in 1916 Coast Pilot (p. 239).

Ekuk Cape: point of land, on E shore of Nushagak Bay, $3 \mathrm{mi}$. S of village of Clarks Point and $16 \mathrm{mi}$. S of Dillingham, Bristol Bay Low.; $58^{\circ} 48^{\prime} \mathrm{N}, 158^{\circ} 33^{\prime} \mathrm{W}$; (map 40). Var. Clarks Point.

Eskimo name spelled "Erouk" by F. P. Lutke in 1828. Called "Clarks Point" by USBF in 1898

Ekuk Spit: spit, on E shore of Nushagak Bay, N of Ekuk, $15 \mathrm{mi}$. S of Dillingham, Bristol Bay Low.; $58^{\circ} 49^{\prime} 05^{\prime \prime} \mathrm{N}, 158^{\circ} 33^{\prime} 25^{\prime \prime} \mathrm{W}$ (map 40). Var. Haller Spit.

Name published by USC\&GS in 1947 Coast Pilot (p. 524). The Eskimo village of Ekuk is located on this spit. It was also called "Haller Spit" after the Hallers Cannery located there.

Ekuk Village: village, see Ekuk.

Ekwak: village, see Ekwok.

Ekwok: village, pop. 106, on W bank of Nushagak River at junc. with Klutuk Creek, $42 \mathrm{mi}$. NE of Dillingham, Kilbuck-Kuskokwim Mts.; $59^{\circ} 22^{\prime} \mathrm{N}, 157^{\circ} 30^{\prime} \mathrm{W}$; BGN 1966; (map 52). Var. Billy Hurleys, Ekouk, Ekuk, Ekwak, Ikwok, Ikwokhamut, Yekuk.

Eskimo village reported in 1828 as "Ekouk" by "Ekwak" by Capt. F. P. Lutke, IRN. H. C. Fassett, USBF, established the present spelling on his 1910 map. The village has also been known as "Billy Hurleys," the name of a "white" trader who had a store here. 
The village population was 40 in 1930 [Ekwak]; 68 in 1939 [Ekwok]; and 1,311 in 1950. A post office called "Ekwak" was established here in 1935

Elaine Creek: stream, flows N $1 \mathrm{mi}$. to No Mans Creek near its head, in Casadepaga River basin, $25 \mathrm{mi}$. NE of Solomon, Seward Penin. High.; (map 95).

Prospectors' name reported on a prospector's manuscript map dated 1902. This stream cannot be precisely located on current maps.

Elaktoveach Channel: stream, distributary of Kupigruak Channel, in Colville River Delta, flows NW $8 \mathrm{mi}$. to Harrison Bay, Arctic Plain; $70^{\circ} 28^{\prime} \mathrm{N}, 150^{\circ} 47^{\prime} \mathrm{W}$; (map 149).

Eskimo name reported by USC\&GS in 1951 , meaning "the wide stream in the middle."

Elapuk Hill: hill, see Alapak Hill.

Elaroniluk Creek: stream, heads in Waring Mts., flows $\mathrm{N}$ and $\mathrm{W} 9.5 \mathrm{mi}$. to Kobuk River $5 \mathrm{mi}$. $\mathrm{S}$ of its junc. with Kallarichuk River, $17 \mathrm{mi}$. NE of Kiana, Brooks Ra.; $67^{\circ} 03^{\prime} \mathrm{N}, 159^{\circ} 50^{\prime}$ W; (map 127).

Eskimo name obtained in 1955 by U.S. Army Corps of Engineers.

Elbo Mountain: hill, see Elbow Mountain.

Elbow Bay: bay, extends S and E $1.5 \mathrm{mi}$. off Cordova Bay, on E coast of Long I., Alex. Arch.; 54 $54^{\prime} 30^{\prime \prime} \mathrm{N}, 132^{\circ} 39^{\prime} 30^{\prime \prime} \mathrm{W}$; BGN 1929; (map 1). 1928.

Descriptive name given by USC\&GS in

Elbow Creek: stream, flows NE and NW $8.5 \mathrm{mi}$. to Sharatin Bay, $12 \mathrm{mi}$. W of Kodiak, Kodiak I. ; $57^{\circ} 49^{\prime} 00^{\prime \prime} \mathrm{N}, 153^{\circ} 44^{\prime} 15^{\prime \prime} \mathrm{W}$; BGN 1933; (map 34).

Descriptive name given in 1933 by Gerald FitzGerald, USGS, "because of the very abrupt clange in the course of the creek."

Elbow Creek: stream, heads in De Long Mts., flows NW and NE to Driftwood Creek, $36 \mathrm{mi}$. NNE of Misheguk Mtn., Brooks Ra.; $68^{\circ} 44^{\prime} 15^{\prime \prime} \mathrm{N}, 160^{\circ} 42^{\prime} 00^{\prime \prime} \mathrm{W}, ;$ BGN 1961; (map 131).

Named by USGS geologists in 1951 "because of the elbowlike bends in its course."

Elbow Hill: hill, $420 \mathrm{ft}$., at SW end of Umnak I., Aleutian Is.; $52^{\circ} 52^{\prime} 10^{\prime \prime} \mathrm{N}, 169^{\circ} 00^{\prime} 13^{\prime \prime} \mathrm{W}$; (map 21).

Name published by USC\&GS in 1944 Aleutian Coast Pilot (p. 68).

Elbow Lake: lake, 2 mi. long, $\mathrm{N}$ of Hodzana Slough, $12 \mathrm{mi}$. W of Beaver, Yukon Flats; $66^{\circ} 19^{\prime} \mathrm{N}, 147^{\circ} 52^{\prime} \mathrm{W}$; (map 118).

Probably named by William Yanert who showed it on a 1916 manuscript map of the Yukon Flats (Stuck, 1917, map facing p. 122).

Elbow Mountain: hill, $904 \mathrm{ft}$., $23 \mathrm{mi}$. NW of Eek Lake and $44 \mathrm{mi}$. SE of Bethel, KilbuckKuskokwim Mts. ; $60^{\circ} 19^{\prime} \mathrm{N}, 160^{\circ} 57^{\prime} \mathrm{W}$; (map 59). Var. Elbo Mountain.

Local name reported in 1955 by J. M. Hoare, USGS; named for the bend in Kwethluk River.

Elbow Mountain: mountain, 4,246 ft., on AlaskaCanada boundary, $3 \mathrm{mi}$. N of Stikine River,
Coast Mts.; $56^{\circ} 42^{\prime} 10^{\prime \prime} \mathrm{N}, 131^{\circ} 51^{\prime} 30^{\prime \prime} \mathrm{W}$; (map 7).

Descriptive name given by USC\&GS, probably in the 1890 's.

Elbow Mountain: mountain, 2,950 ft., $12 \mathrm{mi}$. SE of Kodiak, Kodiak I.; 57 $45^{\prime} 30^{\prime \prime} \mathrm{N}$, $152^{\circ} 45^{\prime} 05^{\prime \prime} \mathrm{W}$; BGN 1933; (map 34).

Name derived from Elbow Creek, given in 1933 by Gerald FitzGerald, USGS

Elbow Passage: water passage, $2 \mathrm{mi}$. long, 3.5 mi. S of Chichagof, on $\mathrm{W}$ coast of Chichagof I., Alex. Arch.; $57^{\circ} 37^{\prime} \mathrm{N}, 136^{\circ} 05^{\prime} \mathrm{W}$; BGN 1908; (map 9)

Descriptive name given in 1907 by Andrew Braid and published by USC\&GS in the 1908 Coast Pilot (p. 172).

Elbow Point: point of land, on $\mathrm{E}$ coast of Little Tanaga I., Aleutian Is.; $51^{\circ} 50^{\prime} 40^{\prime \prime} \mathrm{N}, 176^{\circ}$ 01'40" W; BGN 1936; (map 17).

Descriptive name given by members of the U.S. Navy Aleutian Island Survey Expedition in 1934.

Elbow Point: point of land, between the two arms of Lake Nerka, at W end of Frog Mts., $40 \mathrm{mi}$. NW of Dillingham, Kilbuck-Kuskokwim Mts.; $59^{\circ} 33^{\prime} \mathrm{N}, 159^{\circ} 00^{\prime} \mathrm{W}$; BGN 1931; (map 52).

Name reported in 1929 by USBF ; so called because of the "point's location at the bend or elbow of Lake Nerka."

Elder, Mount: mountain, 4,600 ft., in Glacier Bay National Monument, $4.7 \mathrm{mi}$. NW of Berg Mtn. and $70 \mathrm{mi}$. NW of Juneau, St. Elias Mts.; $58^{\circ} 58^{\prime} 50^{\prime \prime} \mathrm{N}, 135^{\circ} 50^{\prime} 50^{\prime \prime} \mathrm{W}$; (map 11). Var. Snow Dome.

Local name published in 1962 by USGS.

Elder Point: point of land, northernmost point on Glacier I., 2 mi. S of Flent Point, on S coast of Alaska, $56 \mathrm{mi}$. NE of Whittier, Chugach Mts. ; $60^{\circ} 54^{\prime} 50^{\prime \prime} \mathrm{N}, 147^{\circ} 08^{\prime} 00^{\prime \prime} \mathrm{W}$; (map 63).

Local name reported in 1951 by USGS.

Eldorado: locality, see Eldorado Camp.

Eldorado Camp: locality, $\mathrm{E}$ of headwaters of Little Eldorado Greek, $12 \mathrm{mi}$. N of Fairbanks, Yukon-Tanana High.; $65^{\circ} 03^{\prime} 45^{\prime \prime} \mathrm{N}, 147^{\circ} 31^{\prime}$ $10^{\prime \prime} \mathrm{W}$; (map 105). Var, Eldorado.

Mining camp reported in 1908 by USGS. A post office was established here in 1907 and discontinued in 1910.

Eldorado Creek: stream, flows SW $8.5 \mathrm{mi}$. to George River, $26 \mathrm{mi}$. E of Flat, KilbuckKuskokwim Mts.; $62^{\circ} 24^{\prime} 20^{\prime \prime} \mathrm{N}, 157^{\circ} 11^{\prime} 30^{\prime \prime}$ W; (map 79).

Prospectors' name obtained in 1952 by USGS topographers.

Eldorado Creek: stream, flows N $3.5 \mathrm{mi}$. to Roosevelt Creek, $72 \mathrm{mi}$. SE of Healy, Alaska Ra.; $63^{\circ} 11^{\prime} 35^{\prime \prime} \mathrm{N}, 147^{\circ} 13^{\prime} 30^{\prime \prime} \mathrm{W}$; (map 87).

Local name obtained in 1951 by USGS.

Eldorado Creek: stream, flows NW $5.4 \mathrm{mi}$. to Madison Creek $6.7 \mathrm{mi}$. NE of its junc. with Tolstoi Creek and $53 \mathrm{mi}$. NW of McGrath, Kilbuck-Kuskokwim Mts.; $63^{\circ} 27^{\prime} \mathrm{N}, 156^{\circ} 56^{\prime}$ W; (map 90)

Prospectors' name reported in 1917 by G. L. Harrington, USGS.

Eldorado Creek: stream, in Kantishna Hills, flows NE $5.5 \mathrm{mi}$. to Moose Creek, $3.5 \mathrm{mi}$. NNW of Wonder Lake, Alaska Ra.; $63^{\circ} 31^{\prime} 50^{\prime \prime} \mathrm{N}$, $150^{\circ} 58^{\prime} 15^{\prime \prime} \mathrm{W}$; (map 88).

Name shown on a 1905 manuscript map of "Kantishna Gold Fields" by A. Friedrich, prospector.

Eldorado Creek: stream, flows SE $4.9 \mathrm{mi}$. to Poorman Creek, $4.4 \mathrm{mi}$. SW of Poorman and $47 \mathrm{mi}$. SW of Ruby, Kilbuck-Kuskokwim Mts.; $64^{\circ} 04^{\prime} 20^{\prime \prime} \mathrm{N}, 155^{\circ} 40^{\prime} 25^{\prime \prime} \mathrm{W}$; BGN 1936; (map 98).

Prospectors' name reported in 1935 by USGS.

Eldorado Creek: stream, flows SE $2 \mathrm{mi}$. to Flint Creek, $4.5 \mathrm{mi}$. SE of Long and $26 \mathrm{mi}$. S of Ruby, Kilbuck-Kuskokwim Mts.; $64^{\circ} 22^{\prime} 10^{\prime \prime}$ $\mathrm{N}, 155^{\circ} 25^{\prime} 00^{\prime \prime} \mathrm{W}$; (map 98).

Prospetcors' name reported in 1911 by A. G. Maddren, USCG. The identity of this stream is in doubt.

Eldorado Creek: stream, flows SW $3.4 \mathrm{mi}$. to Norton Sound, $19 \mathrm{mi}$. E of Solomon, Seward Penin. High.; 64 $34^{\prime} \mathrm{N}, 163^{\circ} 47^{\prime} \mathrm{W}$; (map 95). Var. Ryan Creek.

Prospectors' name shown on Arthur Gibson's "Map of Cape Nome Precinct" dated 1904.

Eldorado Creek: stream, flows SE $10 \mathrm{mi}$. to Fish River, $32 \mathrm{mi}$. NE of Solomon, Seward Penin. High.; $64^{\circ} 37^{\prime} \mathrm{N}, 163^{\circ} 25^{\prime} \mathrm{W}$; (map 95).

Prospectors' name published in 1956 by USGS.

Eldorado Creek: stream, flows N $1.5 \mathrm{mi}$. to Gold Creek, $48 \mathrm{mi}$. N of Big Delta, Yukon-Tanana High.; $64^{\circ} 49^{\prime} 30^{\prime \prime} \mathrm{N}, 145^{\circ} 35^{\prime} 50^{\prime \prime} \mathrm{W}$; (map 101).

Named by prospectors and reported in 1905 by Witherspoon (Prindle, 1913a, pl. 1), USGS.

Eldorado Creek: stream, flows N $3 \mathrm{mi}$., joins Telegram Creek to form Dome Creek $23 \mathrm{mi}$. NW of Solomon, Seward Penin. High.; 64 ${ }^{\circ} 53^{\prime}$ N, 164'38' W; (map 95).

Prospectors' name reported on a 1901 map of Cape Nome gold fields by David Fox, Jr. Eldorado Creek: stream, flows NW $4.5 \mathrm{mi}$. to Crooked Creek, $18 \mathrm{mi}$. NW of Eagle, YukonTanana High.; $64^{\circ} 56^{\prime} 30^{\prime \prime} \mathrm{N}, 141^{\circ} 39^{\prime} 40^{\prime \prime} \mathrm{W}$; (map 102).

Local name published in 1956 by USGS. Eldorado Creek: stream, flows NW $4.5 \mathrm{mi}$. to Tisuk River, $40 \mathrm{mi}$. NW of Nome, Seward Penin. High.; $64^{\circ} 58^{\prime} \mathrm{N}, 166^{\circ} 13^{\prime} \mathrm{W}$; (map 94).

Prospectors' name reported in 1900 by $\mathrm{E}$. C. Barnard (in Brooks, 1901, pl. 17), USGS. Eldorado Creek: stream, flows $\mathrm{S}$ and W $8.5 \mathrm{mi}$. to Fish Lake, $23 \mathrm{mi}$. ESE of Tanana, Nowitna Low.; $65^{\circ} 03^{\prime} \mathrm{N}, 151^{\circ} 20^{\prime} \mathrm{W}$; (map 106).

Prospectors' name reported in 1903 by $\mathrm{T}$. G. Gerdine, USGS.

Eldorado Creek: stream, flows SE $4 \mathrm{mi}$. to Dime Creek at Haycock, Seward Penin. High.; $65^{\circ} 11^{\prime} \mathrm{N}, 161^{\circ} 08^{\prime} \mathrm{W}$; (map 109).

Local name reported in 1917 by G. L. Harrington, USGS.

Eldorado Creek: stream, flows SE $11 \mathrm{mi}$. to Noxapaga River, 23 mi. NW of Imuruk Lake, 
Seward Penin. High.; 65 $39^{\prime} \mathrm{N}, 164^{\circ} 04^{\prime} \mathrm{W}$; $B G N$ 1952; (map 110). Var. North Fork Kugrukruk River, North Fork Noxapaga River. Prospectors' name reported in 1901 by $T$. G. Gerdine (in Collier, 1902, pl. 12), USGS. This appears to be the North Fork of Noxapaga River in Brooks (1901, pl. 11), USGS.

Eldorado Creek: stream, flows W $7 \mathrm{mi}$. to Budd Creek which flows to American River, $40 \mathrm{mi}$. NE of Teller, Seward Penin. High.; 65 ${ }^{\circ} 39^{\prime}$ $\mathrm{N}, 165^{\circ} 22^{\prime} \mathrm{W}$; (map 111).

Prospectors' name reported in 1900 by Messrs. Kemp and David Fox (in Brooks, 1901, pl. 11).

Eldorado Creek: stream, flows NW $1.2 \mathrm{mi}$. to Kougarok River, 9 mi. SW of Midnight Mtn. and $47 \mathrm{mi}$. W of Imuruk Lake, Seward Penin. High.; $65^{\circ} 40^{\prime} \mathrm{N}, 164^{\circ} 48^{\prime} \mathrm{W}$; (map 110).

Prospectors' name reported on the 1908 "Map of Seward Peninsula" by Arthur Gibson.

Eldorado Creek: stream, flows NE $15 \mathrm{mi}$. to Kiwalik River, $43 \mathrm{mi}$. NW of Haycock, Seward Penin. High.; $65^{\circ} 46^{\prime} \mathrm{N}, 161^{\circ} 51^{\prime} \mathrm{W}$; (map 109).

Local name shown on a 1903 fieldsheet by D. C. Witherspoon, USGS.

Eldorado Creek: stream, NE of Ear Mtn., flows E $3 \mathrm{mi}$. to Kreuger Creek which flows to Arctic River, Seward Penin. High.; 65 ${ }^{\circ} 56^{\prime}$ N, $166^{\circ} 06^{\prime} \mathrm{W}$; (map 111).

Frospectors' name reported in 1907 by Knopf (1908, p. 27), USGS.

Eldorado Creek: stream, flows $\mathrm{N} 20 \mathrm{mi}$. to Serpentine River, $21 \mathrm{mi}$. SE of Shishmaref, Kotzebue-Kobuk Low.; $66^{\circ} 07^{\prime} \mathrm{N}, 165^{\circ} 23^{\prime}$ W; (map 112).

Prospectors' name reported in 1950 by USGS.

Eldorado Creek: stream, heads in Jack White Ra., flows SE 2.2 mi. to South Fork Koyukuk River, $22 \mathrm{mi}$. E of Bettles, Kokrines-Hodzana High.; $66^{\circ} 56^{\prime} \mathrm{N}, 150^{\circ} 54^{\prime} \mathrm{W}$; (map 117).

Local name reported in 1956 by $T$. E. Taylor, USGS.

Eldorado Creek: stream, see Eldorado River.

Eldorado Creek: stream, see Little Eldorado Greek.

Eldorado Narrows: water passage, extends S 4 mi. from Sandspit Point, between Renard I. and Resurrection Peninsula, $14 \mathrm{mi}$. SE of Seward, Chugach Mts. ; $59^{\circ} 55^{\prime} \mathrm{N}, 149^{\circ} 19^{\prime} \mathrm{W}$; (map 49).

Local name reported in the early 1950's by USC\&GS.

Eldorado River: stream, flows SE $30 \mathrm{mi}$ to Flambeau River, $4 \mathrm{mi}$. N of Safety Sound and 14 mi. W of Solomon, Seward Penin. High.; $64^{\circ} 32^{\prime} \mathrm{N}, 164^{\circ} 55^{\prime} \mathrm{W}$; (map 95). Var. Eldorado Creek.

Local name reported in 1899 by Schrader and Brooks (1900, map 3), USGS.

Eldred Passage: water passage, $0.7 \mathrm{mi}$. wide, SE of Yukon I., along SE shore of Kachemak Bay, $8 \mathrm{mi}$. SSE of Homer, Chugach Mts.; $59^{\circ} 31^{\prime} \mathrm{N}, 151^{\circ} 28^{\prime} \mathrm{W}$; (map 50).

Named by W. H. Dall, USC\&GS, in 1880 for Sarah Eldred, wife of Marcus Baker.
Eldred Rock: rock, in Lynn Canal, $2.7 \mathrm{mi}$. SE of Kataguni I., and $55 \mathrm{mi}$. NW of Juneau, Coast Mts.; $58^{\circ} 58^{\prime} 15^{\prime \prime}$ N, $135^{\circ} 13^{\prime} 10^{\prime \prime}$ W; (map 11). Var. Nechraje.

Visited, located, and named in 1880 by Marcus Baker for his wife, Sarah Eldred. Name published by USC\&GS in 1883 Coast Pilot (p. 196). According to Dr. Arthur Krause the Tlingit Indian name is "Nechraje." Eldridge, Mount: mountain, 6,250 ft., $12 \mathrm{mi}$. SE of North Peak and $18 \mathrm{mi}$. W of Eagle, YukonTanana High.; $64^{\circ} 45^{\prime} \mathrm{N}, 141^{\circ} 47^{\prime} \mathrm{W}$; (map 102).

Named by prospectors and reported in 1899 by W. J. Peters, USGS.

Eldridge, Mount: peak, 10,456 ft., $21 \mathrm{mi}$. ENE of Mount McKinley, Alaska Ra.; $63^{\circ} 08^{\prime} 03^{\prime \prime}$ $\mathrm{N}, 150^{\circ} 20^{\prime} 48^{\prime \prime} \mathrm{W}$; (map 88).

Named in 1953 by Bradford Washburn for George Homans Eldridge, 1854-1905, USGS geologist, who made a reconnaissance of the Susitna River basin and crossed Broad Pass in 1898.

Eldridge Glacier: glacier, heads on Explorers Peak and trends SE $30 \mathrm{mi}$. to its terminus (1951) at head of Fountain River, $40 \mathrm{mi}$. $\mathrm{N}$ of Talkeetna, Alaska Ra.; 62 $54^{\prime} 30^{\prime \prime} \mathrm{N}$, $149^{\circ} 59^{\prime} 00^{\prime \prime} \mathrm{W}$; (map 82). Var. Chulitna Glacier, Fidele Glacier.

Named in 1913 by A. H. Brooks, USGS, for George Homans Eldridge, 1854-1905, USGS geologist who, with Robert Muldrow, made a reconnaissance in the Susitna River basin in 1898.

Eleanor, Mount: peak, 3,988 ft., in Chigmit Mts. at head of Iniskin Bay, Aleutian Ra.; 59 $47^{\prime}$ N, $153^{\circ} 22^{\prime} W$; (map 51$)$.

Name published by G. C. Martin (1905, pl. 4), USGS.

Eleanor, Point: point of land, northernmost point of Eleanor I., $28 \mathrm{mi}$. NE of Chenega, Chugach Mts. ; $60^{\circ} 34^{\prime} 55^{\prime \prime} \mathrm{N}, 147^{\circ} 33^{\prime} 45 \mathrm{~W}$; (map 63).

Named in 1794 by Capt. George Vancouver, RN. The name appears on Vancouver's chart, but is not mentioned in his text (Wagner, 1937, p. 385).

Eleanor Cove: cove, $1.2 \mathrm{mi}$. across, $1 \mathrm{mi}$. $\mathrm{E}$ of Knight I., $14 \mathrm{mi}$. NE of Yakutat, Malaspina Coastal Plain; $59^{\circ} 42^{\prime} 15^{\prime \prime} \mathrm{N}, 139^{\circ} 29^{\prime} 30^{\prime \prime} \mathrm{W}$; (map 46). Var. Eleanors Cove.

Named in 1794 by Lt. Peter Puget (in Vancouver, 1798, v. 3, p. 226-227).

Eleanor Island: island, $0.4 \mathrm{mi}$. across, $0.8 \mathrm{mi}$ $\mathrm{SE}$ of Knight $\mathrm{I}$. and $13 \mathrm{mi}$. NE of Yakutat, Malaspina Coastal Plain; $59^{\circ} 42^{\prime} 05^{\prime \prime} \mathrm{N}, 139^{\circ}$ 30'15" W; (map 46).

Named by H. E. Smith, USFS, in 1928, probably for nearby Eleanor Cove.

Eleanor Island: island, $4 \mathrm{mi}$. long, in Prince William Sound, $4 \mathrm{mi}$. SW of Naked I. and 24 mi. NE of Chenega, Chugach Mts. ; $60^{\circ} 33^{\prime} \mathrm{N}$, 147³5' W; BGN 1908; (map 63).

Local name reported in 1908 by Andrew Braid, USC\&GS. Capt. George Vancouver, $\mathrm{RN}$, gave the name "Eleanor" to the prominent northern point of the island in 1794 . This name was later adopted for the entire island.
Eleanor Lake: lake, $600 \mathrm{ft}$. long, $1.7 \mathrm{mi}$. W of terminus of Sheridan Glacier and $10 \mathrm{mi}$. E of Cordova, Chugach Mts.; $60^{\circ} 32^{\prime} \mathrm{N}, 145^{\circ} 25^{\prime}$ W; (map 64).

Name published in 1950 by USGS.

Eleanor Lake: lake, $0.5 \mathrm{mi}$. long, in Anaktuvuk Pass, drains into headwaters of Anaktuvuk River, Brooks Ra.; $68^{\circ} 09^{\prime} \mathrm{N}, 151^{\circ} 42^{\prime} \mathrm{W}$; (map 134).

Named in 1901 by F. C. Schrader or W. S. Peters, USGS, on their reconnaissance expedition into northern Alaska.

Eleanor Passage: water passage, see Upper Passage.

Eleanors Cove: cove, see Eleanor Cove.

Elena Bay: estuary, $5 \mathrm{mi}$. long, on Kuiu I., on E shore of Tebenkof Bay, Alex. Arch.; 56 ${ }^{\circ} 30^{\prime}$ $\mathrm{N}, 134^{\circ} 06^{\prime} \mathrm{W}$; BGN 1929; (map 5).

Named in 1928 by USC\&GS for "the vessel Elena in which [Capt. M. D.] Tebenkiv [sic] [IRN] sailed for Sitka in 1835 to carry on explorations in Alaska."

Elephant Creek: stream, flows NW $2.1 \mathrm{mi}$. to join Brehnard Creek to form Wilson Creek 7 mi. E of Marshall, Nulato Hills; $61^{\circ} 52^{\prime} 10^{\prime \prime}$ $\mathrm{N}, 161^{\circ} 52^{\prime} 15^{\prime \prime} \mathrm{W}$; (map 73).

Prospectors' name reported by Harrington (1918, p. 59), USGS, in 1916.

Elephant Creek: stream, flows $\mathrm{N} 2 \mathrm{mi}$. to Trail Creek, $6.5 \mathrm{mi}$. E of Long and $25 \mathrm{mi}$. SSE of Ruby, Kilbuck-Kuskokwim Mts. ; 64 ${ }^{\circ} 23^{\prime} 30^{\prime \prime}$ N, $155^{\circ} 16^{\prime} 20^{\prime \prime} \mathrm{W}$; (map 98).

Prospectors' name reported in 1913 by Eakin (1914), pl. 3), USGS. The stream's identity is in doubt.

Elephant Gulch: ravine, trends SE $2 \mathrm{mi}$ to Hutlinana Creek, $20 \mathrm{mi}$. SE of Rampart, YukonTanana High.; $65^{\circ} 13^{\prime} 30^{\prime \prime} \mathrm{N}, 149^{\circ} 59^{\prime} 00^{\prime \prime} \mathrm{W}$; (map 105)

Named by prospectors; reported in 1908 by USGS (Covert and Ellsworth, 1909, pl. 5).

Elephant Head Point: point of land, on S shore of Alaska Penin., NE shore of Cape Kumlik, extends $0.6 \mathrm{mi}$. into Aniakchak Bay, $12 \mathrm{mi}$. SW of Cape Kunmik, Aleutian Ra.; $56^{\circ} 40^{\prime} \mathrm{N}$, $157^{\circ} 29^{\prime} \mathrm{W}$; (map 31).

Local name published by USC\&GS in the 1947 Alaska Coast Pilot (p. 281).

Elephant Hill: hill, see Middle Hill.

Elephant Lake: lake, $0.3 \mathrm{mi}$. long, on Woody I., $3 \mathrm{mi}$. SE of Kodiak, NE of Kodiak I.; $57^{\circ} 46^{\prime}$ $20^{\prime \prime} \mathrm{N}, 152^{\circ} 19^{\prime} 30^{\prime \prime} \mathrm{W}$; (map 34).

Local name published in 1943 by USC\&GS. Elephant Lake: lake, $1.6 \mathrm{mi}$. long, on Kenai Penin. $8 \mathrm{mi}$. ENE of Kenai, Cook Inlet Low.; $60^{\circ} 35^{\prime} 45^{\prime \prime} \mathrm{N}, 150^{\circ} 59^{\prime} 15^{\prime \prime} \mathrm{W}$; (map 62).

Named about 1963 by officials of Kenai National Moose Range, for administrative purposes.

Elephant Mountain: mountain, 2,200 ft., on Alaska Penin., 25 mi. NW of Cape Kunmik, Aleutian Ra.; $56^{\circ} 57^{\prime} \mathrm{N}, 157^{\circ} 46^{\prime} \mathrm{W}$; (map 31 ).

Descriptive name shown on a 1915 USGS map.

Elephant Mountain: mountain, 2,275 ft., on N part of Chichagof I., $4.4 \mathrm{mi}$. S of Neck Point in Icy Strait and $37 \mathrm{mi}$. SW of Juneau, 
Alex. Arch.; $58^{\circ} 03^{\prime} 10^{\prime \prime} \mathrm{N}, 135^{\circ} 19^{\prime} 30^{\prime \prime} \mathrm{W}$; $B G N 1959$; (map 11).

Local name published by USGS in 1962.

Elephant Mountain: mountain, 3,300 to 3,800 ft., extends NE $6.8 \mathrm{mi}$. between Eureka Dome and Wolverine Mtn., $16 \mathrm{mi}$. SSE of Rampart, Yukon-Tanana High.; $65^{\circ} 15^{\prime} \mathrm{N}, 150^{\circ} 00^{\prime} \mathrm{W}$; (map 106).

Prospectors' name reported in 1906 by USGS.

Elephant Nose: mountain, see Elephants Nose.

Elephant Point: point of land, between American and Orzinski Bays, on W shore of Stepovak Bay, Alaska Penin., Aleutian Ra.; 55 $42^{\prime} 20^{\prime \prime}$ $\mathrm{N}, 160^{\circ} 04^{\prime} 00^{\prime \prime} \mathrm{W}$; (map 28 ).

Local name published in 1916 by USC\&GS Coast Pilot.

Elephant Point: village, pop. 87, on a spit on S coast of Eschscholtz Bay, $44 \mathrm{mi}$. SW of Selawik, Kotzebue-Kobuk Low.; $66^{\circ} 16^{\prime}$ N, $161^{\circ}$ 20' W; (map 114). Var. Baldwin, Buckland, Reindeer Point.

Eskimo village and reindeer station; its population in 1950 was 108 . This place appears to be the site of the Baldwin post office from 1930 to 1936 and the Buckland post office established in 1962. See Buckland.

Elephant Point: point of land, extends NE into Eschscholtz Bay, $44 \mathrm{mi}$. SW of Selawik, Kotzebue-Kobuk Low.; $66^{\circ} 16^{\prime} \mathrm{N}, 161^{\circ} 20^{\prime} \mathrm{W}$; (map 114).

Named in 1826 by Capt. Beechey (1831, p. 232), RN, who wrote, "I bestowed the name of Elephant upon the point, to mark its vicinity to the place where the fossils [bones of elephants] were found ***." Name published on British Admiralty Chart 593.

Elephant Promontory: peak, 7,320 ft., on AlaskaCanada boundary, $5.5 \mathrm{mi}$. SE of Mount Ogilvie and $38 \mathrm{mi}$. N of Juneau, Coast Mts.; $58^{\circ} 49^{\prime} 00^{\prime \prime} \mathrm{N}, 134^{\circ} 07^{\prime} 20^{\prime \prime} \mathrm{W}$; BGN 1965; (map 11).

Named by members of the Juneau Icefield Research Project in 1964.

Elephant Rock: point of land, at mouth of Delarof Harbor, on SE coast of Unga I., in Shumagin Is., Aleutian Ra.; 55 $10^{\prime} 02^{\prime \prime} \mathrm{N}$, $160^{\circ} 29^{\prime} 35^{\prime \prime} \mathrm{W}$; (map 28).

Local name published in 1916 USC\&GS Coast Pilot.

Elephant Rock: rock, in Bering Sea, at $\mathbf{N}$ tip of Hall I., $8 \mathrm{mi}$. NW of Glory of Russia Cape, St. Matthew I.; $60^{\circ} 42^{\prime} \mathrm{N}, 173^{\circ} 03^{\prime} \mathrm{W}$; (map 56).

Name published by USC\&GS in 1932 on Chart 8851; "so called because of its resemblance to an elephant's head."

Elephants Head: promontory, NW ridge of Stewart Peak, at head of Thomas Bay, 103 mi. E of Sitka, Coast Mts.; $57^{\circ} 05^{\prime} 15^{\prime \prime} \mathrm{N}$, $132^{\circ} 45^{\prime} 15^{\prime \prime} \mathrm{W}$; BGN 1923; (map 8). Var. Elephant Head.

Descriptive name given in 1887 by $\mathrm{C} . \mathrm{M}$. Thomas, USN; published in 1888 by USC\&GS.

Elephants Nose: mountain, $1,150 \mathrm{ft}$. on $\mathrm{N}$ coast of Woronkofski I., Alex. Arch.; 56 $25^{\prime} 45^{\prime \prime}$ N,
132³0'10" W; BGN 1917; (map 6). Var. Elephant Nose.

Descriptive name given in 1917 for charting purposes by USC\&GS "because of its shape."

Eleutak: locality, on left bank of Kwemeluk Pass, $3.3 \mathrm{mi}$. S of Sheldon Point and $22 \mathrm{mi}$. SW of Kwiguk, Yukon-Kuskokwim Delta; $62^{\circ} 29^{\prime} 10^{\prime \prime} \mathrm{N}, 164^{\circ} 52^{\prime} 00^{\prime \prime} \mathrm{W}$; (map 77). Var. Eleutakamiut.

Eskimo camp or village, now abandoned, reported in 1899 by G. R. Putnam, USC\&GS, and spelled by him "Eleutakamiuk" meaning "Eleutak people."

Eleutakamiut: locality, see Eleutak.

Elevenmile Creek: stream, on N part of Douglas I., flows $1 \mathrm{mi}$. $\mathrm{N}$ to Fritz Cove, $1.6 \mathrm{mi}$. SW of Entrance Point and $8.6 \mathrm{mi}$. W of Juneau, Coast Mts.; $58^{\circ} 19^{\prime} 10^{\prime \prime} \mathrm{N}, 134^{\circ} 38^{\prime} 30^{\prime \prime} \mathrm{W}$; (map 11).

Local name published by USGS in 1962.

Elf Cove: cove, $0.1 \mathrm{mi}$. across, on $\mathrm{N}$ shore of Ford Arm, $7 \mathrm{mi}$. SE of Chichagof, on $\mathrm{W}$ coast of Chichagof I., Alex. Arch.; 57 $35^{\prime} 30^{\prime \prime}$ N, $135^{\circ} 57^{\prime} 10^{\prime \prime} \mathrm{W}$; (map 9).

Name published in 1928 by USC\&GS on Chart 8280.

Elfendahl, Lake: lake, $2.5 \mathrm{mi}$. long, $14.5 \mathrm{mi}$. NW of Chichagof, on W coast of Chichagof I., Alex. Arch.; 57 $51^{\prime} \mathrm{N}, 136^{\circ} 18^{\prime} \mathrm{W}$; (map 9).

Local name reported in 1917 by $R$. M. Overbeck (in Martin and others, 1919, pl. 2), USGS.

Elfin Cove: settlement, pop. 20 , on $\mathbf{E}$ shore of Elfin Cove, $\mathbf{N}$ part of Chichagof I., $2 \mathrm{mi}$. S of Point Lavinia and $33 \mathrm{mi}$. NW of Hoonah, Alex. Arch.; $58^{\circ} 11^{\prime} 40^{\prime \prime} \mathrm{N}, 136^{\circ} 20^{\prime} 35^{\prime \prime} \mathrm{W}$; (map 10).

Village shown on maps since 1930 . The Elfin Cove post office was established in 1935 (Ricks, 1965, p. 19). Its 1958 population was 48.

Elfin Cove: cove, $1 \mathrm{mi}$. across, on $\mathrm{W}$ coast of Inian Penin., on $\mathbf{N}$ coast of Chichagof I., $1 \mathrm{mi}$. S of Point Lavinia, $34 \mathrm{mi}$. NW of Hoonah, Alex Arch.; 58 $12^{\prime} 15^{\prime \prime} \mathrm{N}$, 136 $21^{\prime} 30^{\prime \prime} \mathrm{W}$; BGN 1933; (map 10).

Local name reported by the USFS in 1935 .

Elf Island: island, $2 \mathrm{mi}$. long, off $\mathrm{SE}$ coast of Adak I., Aleutian Is.; $51^{\circ} 43^{\prime} \mathrm{N}, 176^{\circ} 32^{\prime} \mathrm{W}$; (map 17).

Name published by USC\&GS in 1957.

Elf Point: point of land, on Revillagigedo I., on $E$ shore of Thorne Arm, Alex. Arch.; $55^{\circ} 19^{\prime} 15^{\prime \prime} \mathrm{N}, 131^{\circ} 13^{\prime} 20^{\prime \prime} \mathrm{W}$; (map 3).

Local name reported in 1917 by USC\&GS on Chart 8075.

Elf Point: point of land, at $E$ entrance to Columbia Bay, $58 \mathrm{mi}$. NE of Whittier, Chugach Mts.; $60^{\circ} 56^{\prime} 45^{\prime \prime} \mathrm{N}, 147^{\circ} 03^{\prime} 25^{\prime \prime} \mathrm{W}$; BGN 1911; (map 63).

So named about 1910 by U. S. Grant, USGS, "because of the smallness of the point's tip."

Elghi Island: island, $0.4 \mathrm{mi}$. long, between Prince of Wales and Tuxekan Is., $30 \mathrm{mi}$. NW of Craig, Alex. Arch.; 55 $54^{\prime} \mathrm{N}, 133^{\circ} 16^{\prime} \mathrm{W}$; (map 4).

Indian name published in 1964 by USC\&GS.
Elgolm Island: island, see Error Island. Eliazak: island, see Inner Iliasik Island.

Eliazik: island, see Outer Iliasik Island.

Elice, Point: point of land, see Ellice, Point.

Elilakok: locality, on left bank of Nushagak River, $5 \mathrm{mi}$. S of Nunachuak and $62 \mathrm{mi}$. NE of Dillingham, Bristol Bay Low.; $59^{\circ} 33^{\prime} \mathrm{N}, 157^{\circ}$ 07' W; BGN 1931; (map 52). Var. Ah-lailuk-ah.

Eskimo camp or small village reported in 1910 by H. C. Fassett, USBF, as Ah-lai-luk-ah. The present spelling was first used in 1925 by USBF. The site is now abandoned.

Elim: village, pop. 160 , on NW shore of Norton Bay, $65 \mathrm{mi}$. E of Solomon, Seward Penin. High.; 64 $37^{\prime} \mathrm{N}, 162^{\circ} 15^{\prime} \mathrm{W}$; BGN 1937; (map 95). Var. Elim Mission Roadhouse.

Eskimo village established about 1915. A post office was established in 1943 and is continuous today. The population was 162 in $1920 ; 97$ in 1930; and 154 in 1950.

Elim Mission Roadhouse: village, see Elim.

Elingit Lake: bay, see Islands, Bay of.

Eliot Glacier: glacier, heads on Mount Marcus Baker, trends SE $7 \mathrm{mi}$. to Harvard Glacier, 47 mi. NE of Valdez, Chugach Mts.; $61^{\circ} 21^{\prime} \mathrm{N}$, $147^{\circ} 37^{\prime} \mathrm{W}$; BGN 1930; (map 69).

Named in 1910 by Lawrence Martin (in Tarr and Martin, 1914, p. 298), for Charles William Eliot, 1834-1926, former president of Harvard College.

Eli River: stream, heads in Baird Mts., at $67^{\circ} 40^{\prime}$ $\mathrm{N}, 161^{\circ} 16^{\prime} \mathrm{W}$, flows SW $90 \mathrm{mi}$. to Noatak River, $10 \mathrm{mi}$. S of Noatak, Arctic Slope; $67^{\circ}$ $2^{\prime}$ N, $163^{\circ} 00^{\prime}$ W; (map 128). Var. Ely River.

Eskimo name reported in 1926 by USGS.

Elitnik: locality, see Litnik.

Eliza, Point: point of land, between Port Conclusion and Port Armstrong, on $\mathrm{E}$ coast of Baranof I., $2 \mathrm{mi}$. N of Port Alexander, Alex. Arch.; 56 $17^{\prime} 40^{\prime \prime} \mathrm{N}, 134^{\circ} 39^{\prime} 00^{\prime \prime} \mathrm{W}$; (map 5).

Named by Capt. George Vancouver, RN, "during his stay in Port Conclusion between August 1 and 22, 1794" (Wagner, 1937, p. 385 ).

Elizabeth, Cape: point of land, at W tip of Elizabeth I., $21 \mathrm{mi}$. SW of Seldovia, Chugach Mts.; $59^{\circ} 09^{\prime} 30^{\prime \prime} \mathrm{N}, 1^{\circ} 51^{\circ} 53^{\prime} 00^{\prime \prime} \mathrm{W}$; (map 50). Var. Cape St. Elizabeth, Mys Elisaveta.

Named by Capt. Cook, RN, in 1778 (v. 2, p. 382), "as the discovery of it was connected with the Princess Elizabeth's birthday, I named it Cape Elizabeth." It was published by Lt. Sarichev (1826, map 5), IRN, as "M[ys] Elisaveta," or "Cape Elizabeth."

Elizabeth, Mount: mountain, $3,547 \mathrm{ft}$., on SE coast of Baranof I., Alex., Arch.; 56 $39^{\prime} 45^{\prime \prime}$ N, 134.39'30" W; BGN 1917; (map 5). Var. Mount Cecil, The Sisters.

Local name published by USC\&GS in 1910 ; reported to be named for one of the daughters of Superintendent E. Lester Jones, USC\&GS. However, in 1915, Jones stated "not named by me *** named by native of Alaska of 30 years residence."

Elizabeth, Point: point of land, $1 \mathrm{mi}$. $\mathrm{N}$ of Rodman Bay, on Duffield Penin., $N$ coast of 
Baranof I., Alex. Arch.; $57^{\circ} 30^{\prime} 40^{\prime \prime} \mathrm{N}$, $135^{\circ} 17^{\prime} 30^{\prime \prime} \mathrm{W}$; (map 9).

Named in 1895 by Lt. Comdr. E. K. Moore, USN, and published by USC\&GS on Chart 8283.

Elizabeth Creek: stream, flows SE $1.5 \mathrm{mi}$. to Cripple River, $16 \mathrm{mi}$. NW of Nome, Seward

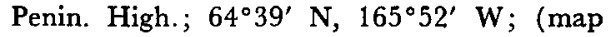
94).

Prospectors' name reported on Arthur Gibson's "Map of Cape Nome Precinct" dated 1904.

Elizabeth Creek: stream, flows E $1 \mathrm{mi}$. to Ruby Creek which flows to Bluestone River, $10 \mathrm{mi}$. SE of Teller, Seward Penin. High.; $65^{\circ} 08^{\prime}$ $\mathrm{N}, 166^{\circ} 13^{\prime} \mathrm{W}$; (map 111).

Prospectors' name reported on the 1908 "Map of Seward Peninsula" by Arthur Gibson.

Elizabeth Creek: stream, flows NW to Nucksack Creek which flows to Kuzitrin River near its head, about $20 \mathrm{mi}$. SW of Imuruk Lake, Seward Penin. High.; (map 110).

Prospectors' name shown on a map of Cape Nome gold fields by David Fox, Jr., dated 1901. This stream cannot be precisely located on current maps.

Elizabeth Island: island, $3 \mathrm{mi}$. across, in Chugach Is., $20 \mathrm{mi}$. SW of Seldovia, Chugach Mts.; 59॰10' N, $151^{\circ} 50^{\prime} \mathrm{W}$; BGN 1908; (map 50). Var. Cape Elizabeth Island, Isla San Aniceto.

Named for the west point of the island which Capt. James Cook, RN, called "Cape Elizabeth," because he did not realize the point was on an island. It was originally called "Cape Elizabeth Island," but changed to "Elizabeth Island" by USC\&GS. It was called "Isla San Aniceto" by Arteaga on August 2, 1779.

Elizabeth Lake: lake, $1 \mathrm{mi}$. long, drains NE into Lower Ugashik Lake, on Alaska Penin, $21 \mathrm{mi}$. SE of Ugashik, Aleutian Ra.; $57^{\circ} 24^{\prime} 15^{\prime \prime} \mathrm{N}$, $156^{\circ} 53^{\prime} 00^{\prime \prime} \mathrm{W}$; (map 36).

Named in 1923 by R. H. Sargent, USGS.

Elizabeth Mountain: mountain, 1,335 ft., at head of Green Gulch, $14 \mathrm{mi}$. NW of Nome, Seward Penin. High.; $64^{\circ} 41^{\prime} \mathrm{N}, 165^{\circ} 55$; W; (map 94).

Local name reported on Arthur Gibson's "Map of Cape Nome Precinct" dated 1904.

Eliza Harbor: estuary, $7 \mathrm{mi}$. long on SE coast of Admiralty I., $26 \mathrm{mi}$. SE of Angoon, Alex. Arch.; 57 $09^{\prime} \mathrm{N}, 134^{\circ} 17^{\prime} \mathrm{W}$; (map 9).

Discovered in 1799 by "Mr. Bumstead" of the fur trading ship Eliza, out of Boston, commanded by "Capt. Rowan." Mr. Bumstead, with members of the crew in a whale boat, "finally * * got in and opened a fine harbor, completely land-locked, which, as our Indian navigator informed us had no name, we called Eliza Harbour, in compliment to our ship." (U.S. Coast and Geodetic Survey, 1883, p. 130).

Eliza Lake: lake, $2 \mathrm{mi}$. long, on Admiralty I., drains into Eliza Harbor, $23 \mathrm{mi}$. SE of Angoon, Alex. Arch.; $57^{\circ} 12^{\prime} \mathrm{N}, 134^{\circ} 20^{\prime} \mathrm{W}$; $B G N$ 1923; (map 9).
Named in 1923 by USFS, probably for Eliza Harbor.

Eliza Lake: lake, $1.5 \mathrm{mi}$. long, between Chisana River and Alaska Highway, $7 \mathrm{mi}$. SE of Northway Junction, Alaska Ra.; $62^{\circ} 59^{\prime} \mathrm{N}, 141^{\circ} 40^{\prime}$ W; (map 84).

Local name reported by USGS in 1954 .

Elkamok: island, see Chirikof Island.

Elk Creek: stream, flows SE $1.4 \mathrm{mi}$. to Nome River, $7 \mathrm{mi}$. NE of Nome, Seward Penin. High.; $64^{\circ} 34^{\prime} 18^{\prime \prime} \mathrm{N}, 1^{\circ} 5^{\circ} 14^{\prime} 30^{\prime \prime} \mathrm{W}$; (map 94).

Prospectors' name shown on the 1902 "Map of the Nome and Snake River Country" by J. M. Davidson.

Elk Creek: stream, see Elkington Creek.

Elk Creek: stream, see Fuurmile Creek.

Elk Creek: stream, see Slow Creek.

Elk Head Point: point of land, on NE tip of Peak I., at SE end of Liljegren Passage, $40 \mathrm{mi}$. $\mathrm{NE}$ of Chenega, Chugach Mts.; 60 $42^{\prime} 55^{\prime \prime} \mathrm{N}$, $147^{\circ} 21^{\prime} 40^{\prime \prime} \mathrm{W}$; (map 63)

Local name reported in 1910 by USC\&GS.

Elkhorn Creek: stream, flows NE $3 \mathrm{mi}$. to Niukluk River, $8.5 \mathrm{mi}$. NW of Council and $30 \mathrm{mi}$. NE of Solomon, Seward Penin. High.; $64^{\circ}$ -

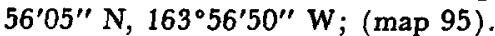

Prospectors' name reported in 1899 by Schrader and Brooks (1900, map 3), USGS

Elkhorn Island: island, $2.8 \mathrm{mi}$. long, in Yukon River, $26 \mathrm{mi}$. N of Holy Cross, Nulato Hills; $62^{\circ} 33^{\prime} \mathrm{N}, 160^{\circ} 11^{\prime} \mathrm{W}$; (map 78 ).

Riverboat pilots' name shown on a 1916 fieldsheet by R. H. Sargent, USGS.

Elkington Creek: stream, flows SW $7 \mathrm{mi}$. to Don River which flows to Breving Lagoon, $25 \mathrm{mi}$. NW of Teller, Seward Penin. High.; $65^{\circ} 32^{\prime}$ N, 167 $53^{\prime} \mathrm{W}$; (map 111). Var. Elk Creek.

Prospectors' name shown on the 1900 "Map of Nome Peninsula" by J. M. Davidson and B. D. Blakeslee.

Elkugu, Mys: point of land, see Edward, Cape. Elkugu Bay: bay, $0.5 \mathrm{mi}$. across, on $W$ coast of Herbert Graves I., $6 \mathrm{mi}$. W of Chichagof, Alex. Arch. ; $57^{\circ} 40^{\prime} 30^{\prime \prime} \mathrm{N}, 136^{\circ} 15^{\prime} 00^{\prime \prime} \mathrm{W}$; (map 9).

Tlingit Indian name for Cape Edward; name given to the bay by USC\&GS and published in 1928 on Chart 8258.

Elkugu Island: island, $0.4 \mathrm{mi}$. long, $\mathrm{W}$ of Herbert Graves I., $6 \mathrm{mi}$. W of Chichagof, on W coast of Chichagof I., Alex. Arch.; 57 $47^{\prime} 50^{\prime \prime}$ N, 136 $15^{\prime} 00^{\prime \prime}$ W; BGN 1926; (map 9).

Named in 1926 by USC\&GS. This is the Tlingit Indian name applied to Cape Edward, the western point of land on this island, by Tebenkov (1852, map 8).

Ella, Mount: hill, $864 \mathrm{ft}$., on right bank of Yukon River, about $4 \mathrm{mi}$. $\mathrm{N}$ of Koyukuk and $20 \mathrm{mi}$. $\mathrm{NE}$ of Nulato, Koyukuk Low.; 64. $56^{\prime} \mathrm{N}$, $157^{\circ} 38^{\prime} \mathrm{W}$; (map 97).

Riverboat pilots' name shown on a 1940 "Navigation Chart of the Tanana-Yukon Rivers" published by the U.S. Dept. of Interior.

Ella Bay: estuary, extends SW $0.7 \mathrm{mi}$, off Behm Canal, on $\mathbf{E}$ coast of Revillagigedo I., Alex.

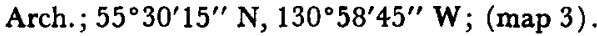
Local name recorded in 1955 by USGS.
Ella Creek: stream, drains Ella and Lower Ella Lakes, flows $\mathrm{E} 5 \mathrm{mi}$. to Ella Bay, on E coast of Revillagigedo I., Alex. Arch.; 55 $29^{\prime} 50^{\prime \prime}$ N, $130^{\circ} 59^{\prime} 30^{\prime \prime} \mathrm{W}$; (map 3$)$.

Local name recorded in 1955 by USGS. See Ella Point.

Ella Creek: stream, heads in Bendeleben Mts., flows NW $10 \mathrm{mi}$, to Kuzitrin River, $28 \mathrm{mi}$. SW of Imuruk Lake, Seward Penin. High.; 65 $24^{\prime}$ $\mathrm{N}, 163^{\circ} 55^{\prime} \mathrm{W}$; BGN 1952; (map 110).

Prospectors' name reported in 1901 by T. G. Gerdine (in Collier, 1902, pl. 12), USGS.

Ella Lake: lake, $5 \mathrm{mi}$. long, on Revillagigedo I., at head of Ella Creek, Alex. Arch.; $55^{\circ} 28^{\prime} \mathrm{N}$, $131^{\circ} 06^{\prime}$ W ; BGN 1966; (map 3). Var. Manzanita Lake.

Local name reported in 1926 by $R$. $H$. Sargent and F. H. Moffitt (in Brooks and others, 1929, pl. 5), USGS.

Ella Lake: lake, see Manzanita Lake.

Ellamar: village, pop. 46, on E shore of Virgin Bay, $40 \mathrm{mi}$. NW of Cordova, Chugach Mts.; $60^{\circ} 53^{\prime} 45^{\prime \prime} \mathrm{N}, 146^{\circ} 42^{\prime} 30^{\prime \prime} \mathrm{W}$; (map 64).

The Ellamar Mining Co. was formed in 1898 , a year after the first claims were located. A post office was established at this copper mining camp in 1900; it was discontinued in 1929 (Ricks, 1965, p. 19).

Ellamar Mountain: mountain, 3,051 ft., on E shore of Valdez Arm, $42 \mathrm{mi}$. NW of Cordova, Chugach Mts.; $60^{\circ} 55^{\prime} 00^{\prime \prime} \mathrm{N}, 146^{\circ} 40^{\prime} 30^{\prime \prime} \mathrm{W}$; (map 64).

Locally named for the village reported by R. H. Sargent and C. E. Giffin (in Brooks and others, 1913, pl. 4), USGS.

Ella Point: point of land, between Ella Bay and Behm Canal, on E coast of Revillagigedo I., Alex. Arch.; 55 $30^{\prime} \mathrm{N}, 130^{\circ} 59^{\prime} \mathrm{W}$; (map 3).

Local navigators' name abtained in 1904 by H. C. Fassett, USBF.

Ell Cove: cove, $0.1 \mathrm{mi}$. across, on $\mathrm{NE}$ coast of Baranof $I$,, between Waterfall Cove and Kasnyku Bay, Alex. Arch.; 57 $12^{\prime} 00^{\prime \prime} \mathrm{N}, 134^{\circ}$ 50'30" W; (map 9).

Local name reported in 1951 by USGS.

Ellen, Lake: lake, $0.4 \mathrm{mi}$. across, on Prince of Wales I., near head of Kasaan Bay, $W$ of village of Salt Chuck, Alex. Arch.; 55 $37^{\prime} 35^{\prime \prime} \mathrm{N}$, $132^{\circ} 34^{\prime} 15^{\prime \prime} \mathrm{W}$; (map 4). Var. Lake Number 2 .

Local name published in 1907 by USC\&GS. Ellice, Point: point of land, on coast of Beaufort Sea, E of Smith River, Arctic Plain; (map 148). Var. Elice Point, Point Elice.

On July 26, 1837, Thomas Simpson (1843, p. 134) wrote, "rounding a point, distinguished by the name of the Right Honorable Edward Ellice ***; a member of Parliament (presumably a privy councillor from his 'right honorable')" (Stuck, 1920, p. 272). This feature is probably present-day Pogik Point.

Ellice Point: point of land, see Pogik Point.

Elliot Beach: beach, $0.2 \mathrm{mi}$. long, $2.4 \mathrm{mi}$. NE of Theodore Point, on SW shore of Temnac Bay, Attu I., Aleutian Is. ; $52^{\circ} 46^{\prime} 00^{\prime \prime} \mathrm{N}, 172^{\circ} 57^{\prime} 20^{\prime \prime}$ E; (map 13). 
Name shown on an AMS map published in 1948 , and given by the U.S. Army during World War II. The name is not used today. Elliot Creek: stream, see Elliott Creek.

Elliott Creek: stream, heads $1.6 \mathrm{mi}$. NE of Iron Mtn., flows WNW 10 mi. to Kotsina River, 3.2 mi. S of Hubbard Peak and $76 \mathrm{mi}$. NE of Valdez, Wrangell Mts.; $61^{\circ} 43^{\prime} \mathrm{N}, 144^{\circ} 17^{\prime} \mathrm{W}$; (map 68). Var. Elliot Creek.

Prospected and named in 1899 by "Messrs. Elliott and Hubbard from Copper Creek ***" (Mendenhall, 1905, p. 98).

Elliott Creek: stream, flows SE $6 \mathrm{mi}$. to Sorrels Creek, 32 mi. NE of Fairbanks, Yukon-Tanana High.; $65^{\circ} 06^{\prime} 45^{\prime \prime} \mathrm{N}, 146^{\circ} 53^{\prime} 30^{\prime \prime} \mathrm{W}$; (map 104).

Local name reported in 1903 by T. G. Gerdine (in Prindle, 1905, pl. 13), USGS.

Elliott Island: island, $0.8 \mathrm{mi}$. across, in Southwest Is., in Pybus Bay, on SE coast of Admiralty I., Alex. Arch.; $57^{\circ} 15^{\prime} 30^{\prime \prime} \mathrm{N}, 134^{\circ}$ $03^{\prime} 30^{\prime \prime} \mathrm{W}$; (map 9).

Name reported in 1924 by USC\&GS and published in 1928 on Chart 8200.

Ellis, Point: point of land, between Tebenkof Bay and Bay of Pillars, on W coast of Kuiu I., $25 \mathrm{mi}$. NE of Port Alexander, Alex. Arch.; $56^{\circ} 33^{\prime} 40^{\prime \prime} \mathrm{N}, 134^{\circ} 19^{\prime} 00^{\prime \prime} \mathrm{W}$; (map 5).

Named by Capt. George Vancouver, RN, on August 6, 1794, "probably in honor of George Ellis, who accompanied Sir James Harris * * on a diplomatic mission" (Wagner, 1937, p. 386).

Ellis Creek: stream, flows SE $1 \mathrm{mi}$. to Glacier Creek, $7 \mathrm{mi}$. N of Nome, Seward Penin. High.; $64^{\circ} 36^{\prime} \mathrm{N}, 165^{\circ} 22^{\prime} \mathrm{W}$; (map 94).

Prospectors' name shown on a 1900 "Map of Nome Peninsula" by J. M. Davidson and B. D. Blakeslee.

Ellsworth Cut: water passage, $2.5 \mathrm{mi}$. SE of Sitka, between Harris $I$. and $W$ coast of

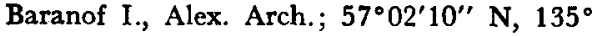
$16^{\prime} 40^{\prime \prime} \mathrm{W}$; (map 9). Var. Ellsworths Cut.

Named in 1880 by the U.S. Navy and published by USG\&GS in 1883 Coast Pilot ( $p$. 144).

Ellsworth Glacier: glacier, on Kenai Penin., trends $18 \mathrm{mi}$. SW to its terminus, $2 \mathrm{mi}$. NE of Day Harbor, $14 \mathrm{mi}$. SE of Seward, Chugach Mts.; $60^{\circ} 05^{\prime} \mathrm{N}, 149^{\circ} 01^{\prime} \mathrm{W}$; BGN 1910; (map 63). Var. Copper Glacier.

Name published in 1907 by USC\&GS.

Ellsworths Cut: water passage, see Ellsworth Cut.

Elma Island: island, $2.7 \mathrm{mi}$. long, between Sanak and Caton Is., one of Sanak Is., Aleutian Ra.; $54^{\circ} 22^{\prime} 15^{\prime \prime} \mathrm{N}, 162^{\circ} 29^{\prime} 30^{\prime \prime} \mathrm{W}$; (map 25).

Named in 1890 by USBF.

Elmendorf Air Force Base: military installation, $\mathrm{N}$ of Anchorage, Cook Inlet Low.; $61^{\circ} 14^{\prime}$ $\mathrm{N}, 149^{\circ} 50^{\prime} \mathrm{W}$; (map 69).

Named in 1940 by U.S. Army Air Force for Capt. Hugh M. Elmendorf, USA, who was killed in an air accident on January 15, 1934.

Elmendorf Moraine: moraine, avg. elev. 400 $\mathrm{ft}$., $30 \mathrm{mi}$. long, extends $\mathrm{S}$ from Big Lake to Knik Arm Cook Inlet, $3.5 \mathrm{mi}$. NW of
Anchorage, extends NE from Cairn Point to Birchwood, Cook Inlet Low.; $61^{\circ} 16^{\prime} \mathrm{N}, 149^{\circ}$ 55' W; BGN 1962; (map 69).

So named in 1955 by Robert D. Miller, USGS, because part of the moraine extends into Elmendorf Air Force Base.

Elmer Creek: stream, flows NE $1.4 \mathrm{mi}$. to Discovery Creek, $12 \mathrm{mi}$. NE of Nome, Seward

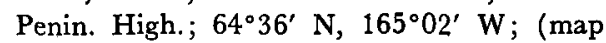
94).

Prospectors' name shown on map dated September 1901 of Cape Nome gold fields by David Fox, Jr.

El Nido: locality, on $W$ shore of Lisiansky Inlet, on Chichagof I., $2 \mathrm{mi}$. W of Pelican, Alex. Arch.; 57 $58^{\prime} \mathrm{N}, 136^{\circ} 16^{\prime} \mathrm{W}$; (map 9).

Spanish name meaning "the nest" reported by A. F. Buddington (in Brooks and others, 1925, fig. 5) USGS. This gold mining camp was established about 1920 . There were two camps here, one on the Inlet called the Beach Camp and the other 1.5 miles south near the mine workings called El Nido Camp.

Elnik : bay, see Dry Spruce Bay.

Elongozheek Slough: watercourse, see Elongozhik Slough.

Elongozhewik Slough: watercourse, see Elongozhik Slough.

Elongozhik Slough: stream, in Yukon Delta, flows NW $2.6 \mathrm{mi}$. to Kawokhawik Pass, 11.5 mi. W of Kwiguk, Yukon-Kuskokwim Delta; $62^{\circ} 47^{\prime} 30^{\prime \prime} \mathrm{N}, 164^{\circ} 51^{\prime} 30^{\prime \prime} \mathrm{W}$; (map 77).

Eskimo name obtained in 1952 by U.S. Army Corps of Engineers.

Elongozhik Slough: watercourse, in Yukon Delta, heads at Mahtkwingak Slough, flows N $20 \mathrm{mi}$. to Norton Sound, $34 \mathrm{mi}$. N of Kwiguk, Yukon-Kuskokwim Delta; $63^{\circ} 14^{\prime} \mathrm{N}$, $164^{\circ} 17^{\prime} \mathrm{W}$; (map 92). Var. Elongozheek Slough, Elongozhewik Slough.

Eskimo name reported in 1899 by G. R. Putnam, USC\&GS; published in 1901 on Chart 9372

Elooweechook: hill, see Iliutuk Hill.

Elovoi: point of land, see Chinaik, Cape.

Elovoi: point of land, see Uzinki Point.

Elovoi Cape: point of land, see Spruce Cape.

Elovoi Island: island, $1.5 \mathrm{mi}$. across, $1 \mathrm{mi}$. SW of Goddard, on W coast of Baranof I., Alex. Arch.; 56 $46^{\prime} \mathrm{N}, 135^{\circ} 24^{\prime} \mathrm{W}$; BGN 1897; (map 5). Var. Fir-tree Island, Ostrov Yelovoy, Spruce Island, Yelowoi Island.

Named in 1809 by the Russian navigator, Ivan Vasiliev the first; published by Lt. Sarichev (1826, map 19) IRN as "O[strov] Yelovoy," meaning "spruce island."

Elovoi Island: island, $0.1 \mathrm{mi}$. long, in Peril Strait, $1 \mathrm{mi}$. NW of Duffield Penin., on Baranof I., $13 \mathrm{mi}$. SE of Chichagof, Alex. Arch.; 57 $34^{\prime}$ $\mathrm{N}, 135^{\circ} 28^{\prime} \mathrm{W}$; (map 9). Var. Elovoi Islet, Firtree Island, Ostrov Yelovoy, Peril Straits Spruce Island, Yelowoi Island.

Russian name meaning "spruce," given in 1833 by the navigator Ens. Vasiliev, IRN; published in 1848 on Russian Hydrog. Dept. Chart 1397 as "Os[trov] Yelovoy."

Elovoi Island: island, see Spruce Island.

Elovoi Islet: island, see Elovoi Island.
Elovoi Strait: water passage, see Narrow Strait. Elovoi Vneshnie Cape : point of land, see Spruce Cape.

Elovyy, Ostrov: island, see Spruce Island.

Elow Island: island, see Spruce Island.

El Patrone Creek: stream, flows NW $1 \mathrm{mi}$. to Canyon Creek, between Coal Creek and Kate and Anna Creek, $23 \mathrm{mi}$. NW of Solomon, Seward Penin. High.; $64^{\circ} 52^{\prime} \mathrm{N}, 164^{\circ} 46^{\prime} \mathrm{W}$; (map 95).

Prospectors' name reported on a 1901 map of Cape Nome gold fields by David Fox, Jr.

Elrington, Point: point of land, at SW tip of Elrington I., $45 \mathrm{mi}$. SE of Seward, Chugach, Mts.; 59 $56^{\prime} 20^{\prime \prime} \mathrm{N}, 148^{\circ} 15^{\prime} 00^{\prime \prime} \mathrm{W}$; (map 49).

Named by Joseph Whidbey, RN, about May 27, 1794, (Vancouver, 1798, v. 3, p. 176).

Elrington Island: island, extends NE-SW $12 \mathrm{mi}$. at SW end of Prince William Sound, between Latouche and Evans Is., $20 \mathrm{mi}$. S of Chenega, Chugach Mts.; $60^{\circ} 00^{\prime} \mathrm{N}, 148^{\circ} 03^{\prime} \mathrm{W}$; BGN 1910; (maps 49 and 63).

Local name reported in 1905 by U. S. Grant, USGS; name derived from Point Elrington at the southern tip of the island.

Elrington Passage: water passage, $5 \mathrm{mi}$. long between Elrington I. and Evans I., on SW edge of Prince William Sound, $20 \mathrm{mi}$. S of Chenega, Chugach Mts.; $60^{\circ} 00^{\prime} \mathrm{N}, 148^{\circ} 04^{\prime}$ W; BGN 1908; (map 63). Var. Prince of Wales Passage.

Local name published in 1908 by USC\&GS; name dervied from nearby Point Elrington.

Elsie Creek: stream, flows NE $13 \mathrm{mi}$. to California Creek, $38 \mathrm{mi}$. SE of Nenana, Alaska Ra.; $64^{\circ} 03^{\prime} 20^{\prime \prime}$ N, $148^{\circ} 43^{\prime} 45^{\prime \prime}$ W; (map 100).

Local name published in 1915 on a GLO [BLM] survey plat.

Elsie Island: island, $1 \mathrm{mi}$. long, on right shore of Yukon River, $18 \mathrm{mi}$. SW of Russian Mission, Yukon-Kuskokwim Delta; $61^{\circ} 37^{\prime} \mathrm{N}$, $161^{\circ} 46^{\prime} \mathrm{W}$; (map 73).

Riverboat pilots' name shown on a 1940 navigation chart of Yukon River.

Elsie Point: point of land, E point of Bell I., between Anchor Pass and Behm Canal, Alex. Arch.; 55 $57^{\prime} 40^{\prime \prime} \mathrm{N}, 131^{\circ} 24^{\prime} 18^{\prime \prime} \mathrm{W}$; (map 3).

Named in 1891 by USC\&GS.

Elsner, Lake: lake, $1 \mathrm{mi}$. long, $3 \mathrm{mi} \mathrm{W}$ of terminus of Sheridan Glacier and $10 \mathrm{mi}$. $E$ of Cordova, Chugach Mts.; $60^{\circ} 33^{\prime} \mathrm{N}, 145^{\circ} 28^{\prime}$ W; (map 64).

Name published in 1950 by USGS.

El Sombrero: island, see Chatham Island.

Elson Bay: lagoon, see Elson Lagoon.

Elson Lagoon: lagoon, extends SE 25 mi. from Point Barrow, between Plover Is. and mainland, Arctic Plain; $71^{\circ} 15^{\prime} \mathrm{N}, 155^{\circ} 51^{\prime} \mathrm{W}$; $B G N$ 1916; (map 153). Var. Elson Bay, Elson's Bay, Tashuk, Tasuk, Tas'yuk.

Named Elson's Bay by Capt. Beechey (1831, p. 302), RN, in September 1826 for Master Thomas Elson, RN, of H.M.S. Blossom. Elson was placed in charge of a party sent in an open boat to explore the coast from NE of Icy Cape to Point Barrow (Beechey, p. 304-321). 
Comdr. Maguire (Great Britain, 1854, map facing p. 186), RN, shows the name Tasuk, which is the common Eskimo generic (tasik) for an enclosed body of water.

Elson's Bay: lagoon, see Elson Lagoon.

Elting Creek: stream, flows NW $10 \mathrm{mi}$. to Johnson River, $40 \mathrm{mi}$. NE of Paxson, Alaska Ra.; $63^{\circ} 31^{\prime} 15^{\prime \prime} \mathrm{N}, 144^{\circ} 49^{\prime} 10^{\prime \prime} \mathrm{W}$; (map 86).

Name published on relatively recent maps.

Eluitkak Pass: water passage, on coast of Beaufort Sea, between Plover Point and Doctor I., $3.5 \mathrm{mi}$. SE of Point Barrow, Arctic Plain; $71^{\circ} 21^{\prime} 40^{\prime \prime} \mathrm{N}, 156^{\circ} 21^{\prime} 15^{\prime \prime} \mathrm{W}$; (map 153). Var. Ekiluk Pass, Ikiraaluk, Ikkeraluk, Moore Channel, Moores Channel.

Eskimo name recorded by USC\&GS in 1951 and means "it's bad [difficult]" referring to the strong current. It was originally named Moore Channel, after Comdr. E. L. Moore, $\mathrm{RN}$, and shown on Comdr. Rockfort Maguire's map (Great Britain, 1854, facing p. 186) with the Eskimo name "Ikkeraluk," which is reported to mean, "a worthless provision rack" (Leffingwell, 1919, p. 97).

Elukozuk Slough: watercourse, in distributary system of Yukon River, trends SW $5.4 \mathrm{mi}$. from Kawokhawik Slough to Norton Sound, 11 mi. W of Kwiguk, Yukon-Kuskokwim Delta; $62^{\circ} 44^{\prime} \mathrm{N}, 164^{\circ} 52^{\prime} \mathrm{W}$; (map 77).

Eskimo name reported to mean "having many branches" (USC\&GS, 1952).

Eluksingiak Point: point of land, $\mathrm{E}$ point of entrance between Kugrua and Peard Bays, $8.5 \mathrm{mi}$. SW of Point Franklin and $24 \mathrm{mi}$. NE of Wainwright, Arctic Plain; $70^{\circ} 49^{\prime} \mathrm{N}, 159^{\circ}$. 04' W; (map 146).

Eskimo name recorded in 1956 by T. E. Taylor, USGS. In 1965 Orth was told by the people at Wainwright that the name means "Eluk's entrance."

Eluktuk: locality, see Lamont.

Elupak: locality, on coast of Beaufort Sea, on NW coast of Barter I., Arctic Plain; $70^{\circ} 08^{\prime}$ $\mathrm{N}, 143^{\circ} 42^{\prime} \mathrm{W}$; (map 152).

Eskimo name of an "old village" site reported by USC\&GS in 1952.

Elurachea Point: point of land, see Humphrey Point.

Elurauchea Point: point of land, see Humphrey Point.

Elusive, Mount: mountain, 11,465 ft., in Dora Keen Ra., $35 \mathrm{mi}$. NW of Valdez, Chugach Mts.; $61^{\circ} 25^{\prime} 40^{\prime \prime} \mathrm{N}, 147^{\circ} 07^{\prime} 30^{\prime \prime} \mathrm{W}$; $B G N$ 1965; (map 69).

So named because "of its elusive character in trying to locate its position on the map from aerial photos." Named about 1957 by members of the Chugach Mountain Expedition sponsored by the Arctic Institute of North America (Neilsen, 1963, p. 135).

Elusive Creek: stream, flows NE $25 \mathrm{mi}$. to Utukok River, $\mathrm{N}$ of Omicron Hill, $83 \mathrm{mi}$. $\mathrm{S}$ of Wainwright, Arctic Slope ; $69^{\circ} 26^{\prime} 30^{\prime \prime} \mathrm{N}, 160^{\circ}$ 04'30' W; BGN 1966; (map 144).

Name proposed in 1924 by W. T. Foran, USGS, because of the "deceptive appearance of the valley and the difficulty of determining its junction with the Utukok River." The name first appears on a 1924 fieldsheet by O. L. Wix.

Elusive Lake: lake, $2 \mathrm{mi}$. long, in Philip Smith Mts., drains E to Ribdon River $15 \mathrm{mi}$. of SE of its junc. with Sagavanirktok River, Brooks Ra.; $68^{\circ} 39^{\prime} 30^{\prime \prime} \mathrm{N}, 148^{\circ} 30^{\prime} 00^{\prime \prime} \mathrm{W}$; $B G N$ 1960; (map 135). Var. Sagavanirktok Lake.

So named by USGS geologists in 1951 because it "is elusive to ground traveller because [the lake is] hidden behind low hills on its NE side."

Elutuc: locality, see New Hamilton.

Elutuli Creek: stream, flows W $40 \mathrm{mi}$. to Hoholitna River $2 \mathrm{mi}$. E of its junc. with Holitna River and $15 \mathrm{mi}$. SE of Sleetmute, Stony River Low.; $61^{\circ} 30^{\prime} 45^{\prime \prime} \mathrm{N}, 156^{\circ} 55^{\prime} 50^{\prime \prime} \mathrm{W}$; (map 72).

Eskimo name obtained in 1948 by USG\&GS. Eluwaktak Mountain: mountain, 1,490 ft., $5 \mathrm{mi}$. SW of junc. of Kwethluk River and Johnson Creek and $50 \mathrm{mi}$. SE of Bethel, KilbuckKuskokwim Mts.; $60^{\circ} 17^{\prime} \mathrm{N}, 160^{\circ} 47^{\prime} \mathrm{W}$; (map 59). Var. Eluwuktuk Mountain.

Eskimo name reported in 1955 by J. M. Hoare, USGS.

Eluwuktuk Mountain: mountain, see Eluwaktak Mountain.

Elva Lake: lake, $1.5 \mathrm{mi}$. long, between Amakuk Arm and Little Togiak Lake, $3.5 \mathrm{mi}$. NW of Lake Nerka, $45 \mathrm{mi}$. NW of Dillingham, Kilbuck-Kuskokwim Mts.; $59^{\circ} 38, \mathrm{~N}, 159^{\circ} 09^{\prime} \mathrm{W}$; $B G N$ 1932; (map 53).

Locally named for Mrs. Elva Polley, who first reported the lake about 1930 .

Elvoi Mission: locality, on E coast of Spruce I., $\mathrm{NE}$ of Kodiak I.; $57^{\circ} 54^{\prime} 20^{\prime \prime} \mathrm{N}, 152^{\circ} 21^{\prime} 20^{\prime \prime}$ W; (map 34).

Russian name meaning "spruce," published in 1934 by USC\&GS.

Elwood, Lake: lake, $0.2 \mathrm{mi}$. across, in West Massacre Valley, on eastern Attu I., Aleutian Is.; $52^{\circ} 51^{\prime} 37^{\prime \prime} \mathrm{N}, 173^{\circ} 10^{\prime} 35^{\prime \prime} \mathrm{E}$; (map 13).

Name shown on an AMS map published in 1948 , and given by the U.S. Army during World War II. The name is not used today. El-yog-o-lok-tok: stream, see Kogoluk River.

El-yog-o-lok-tok: stream, see Kogoluktuk River. Ely River: stream, see Eli River.

Emagayten Island: island, see Emgeten Island.

Emaiksoun Lake: lake, $1.5 \mathrm{mi}$. long, on Chukchi Sea coast, 3 mi. S of Barrow, Arctic Plain; $71^{\circ} 14^{\prime} 30^{\prime \prime} \mathrm{N}, 156^{\circ} 46^{\prime} 15^{\prime \prime} \mathrm{W}$; (map 153). Var. Emarksoun Lake, Imexsaan.

Eskimo name reported by USC\&GS about 1950. The first part of the name probably means "fresh water."

Emangak: locality, on point of land between Kawanak and Kwikpak Passes, $16 \mathrm{mi}$. NE of Kwiguk, Yukon-Kuskokwim Delta ; $62^{\circ} 54^{\prime} \mathrm{N}$, $164^{\circ} 06^{\prime} \mathrm{W}$; (map 77).

Eskimo name obtained in 1952 by U.S. Army Corps of Engineers.

Emanguk: locality, on right bank of Kwiguk Pass, 1.4 mi. N of Kwiguk, Yukon-Kuskokwim Delta; $62^{\circ} 46^{\prime} 40^{\prime \prime} \mathrm{N}, 164^{\circ} 31^{\prime} 45^{\prime \prime} \mathrm{W}$; (map 77). Var. Emonguk.

Eskimo name obtained in 1948 by USC\&GS.
Emanvicrok Channel: stream, distributary of Kobuk River, heads at Nazuruk Channel, Kobuk River, and flows SW $8 \mathrm{mi}$. to Hotham Inlet, $43 \mathrm{mi}$. NW of Selawik, Kotzebue-Kobuk Low.; 66 $33^{\prime} \mathrm{N}, 161^{\circ} 33^{\prime} \mathrm{W}$; (map 114).

Eskimo name obtained by U.S. Army Corps of Engineers in 1955.

Emarksoun Lake: lake, see Eamiksoun Lake.

Embryo Lake: lake, $0.8 \mathrm{mi}$. long, on Kenai Penin., $0.7 \mathrm{mi}$. W of Falcon Lake and $34 \mathrm{mi}$. $\mathrm{NE}$ of Kenai Cook Inlet Low.; $60^{\circ} 47^{\prime} 15^{\prime \prime} \mathrm{N}$, $150^{\circ} 26^{\prime} 00^{\prime \prime} \mathrm{W}$; (map 62 ).

Named about 1963 by officials of Kenai National Moose Range, for administrative purposes.

Emegek Cape: point of land, see Emeghee Point. Emeghee Cape: point of land, see Emeghee Point.

Emeghee Point: point of land, on S coast of Saint Lawrence I., $4 \mathrm{mi}$. NW of Southeast Cape; $62^{\circ} 58^{\prime} \mathrm{N}, 169^{\circ} 46^{\prime} \mathrm{W}$; BGN 1951; (map 93). Var. Emegek Cape, Emeghee Cape, Southeast Cape.

Eskimo name recommended by the Savoonga village council; reported in 1949 by Maj. H. B. Allen, USAF.

Emekyalok Cape: point of land, see Emekyalok Point.

Emekyalok Point: point of land, $5 \mathrm{mi}$. E of Siknik Cape and $65 \mathrm{mi}$. SE of Gambell, S coast of St. Lawrence I.; $63^{\circ} 10^{\prime} \mathrm{N}, 170^{\circ} 09^{\prime}$ W; BGN 1951; (map 93). Var. Emekyalok Cape, Umeyalak Point.

Eskimo name often written "Umeyalak," and of undetermined meaning. This name was recommended in 1949, for map usage, by the Gambell village council.

Emerald Bay: cove, $0.2 \mathrm{mi}$. across, on NE coast of Kenai Penin., on S side of Passage Canal, $4 \mathrm{mi}$. NE of Whittier, Chugach Mts.; $60^{\circ} 48^{\prime}$ $25^{\prime \prime} \mathrm{N}, 148^{\circ} 34^{\prime} 20^{\prime \prime} \mathrm{W}$; BGN 1966; (map 63). Var. King Cove.

Local descriptive name published in 1954 by USC\&GS.

Emerald Bay: estuary, $0.5 \mathrm{mi}$. long, $\mathrm{W}$ coast of Cleveland Penin., $3 \mathrm{mi}$. S of Eaton Point, Alex. Arch.; 55 $53^{\prime} 30^{\prime \prime} \mathrm{N}, 132^{\circ} 02^{\prime} 45^{\prime \prime} \mathrm{W}$; (map 4).

Descriptive name given in 1923 by USC\&GS.

Emerald Cove: cove, $0.5 \mathrm{mi}$. across, on SE side of Columbia Bay, $58 \mathrm{mi}$. NE of Whittier, Chugach Mts.; $60^{\circ} 57^{\prime} 15^{\prime \prime} \mathrm{N}, 147^{\circ} 02^{\prime} 00^{\prime \prime} \mathrm{W}$; BGN 1911; (map 63).

So named in 1910 by U. S. Grant, USGS, "because of the greenness of shores and water."

Emerald Creek: stream, heads at glacier, flows NE $9.5 \mathrm{mi}$. to Skwentna River, $6 \mathrm{mi}$. SE of Mount Estelle and $73 \mathrm{mi}$. NW of Tyonek, Alaska Ra.; $61^{\circ} 49^{\prime} 05^{\prime \prime} \mathrm{N}, 152^{\circ} 43^{\prime} 45^{\prime \prime} \mathrm{W}$; (map 70).

Local name reported by S. R. Capps (in Smith and others, 1926, pl. 1), USGS.

Emerald Creek: stream, flows NW $0.7 \mathrm{mi}$. to Kasson Greek near its head, E of Nobhill Creek and about $9 \mathrm{mi}$. N of Solomon, Seward Penin. High.; 64 $41^{\prime} 40^{\prime \prime} \mathrm{N}, 164^{\circ} 23^{\prime} 00^{\prime \prime} \mathrm{W}$; (map 95). Var. Ruby Creek. 
Prospectors' name reported on Arthur Gibson's 1904 "Map of Cape Nome Precinct." Gibson applied the name "Ruby Creek" to this stream and showed "Emerald Creek" as a SW flowing tributary of Kasson Creek. The above location was reported in 1907 by USGS geologists (Smith, P. S., 1910, p. 13).

Emerald Island: island, $0.3 \mathrm{mi}$. across, off SW tip of Unalaska I., Aleutian Is.; $53^{\circ} 17^{\prime} 20^{\prime \prime} \mathrm{N}$, 167'51'20' W; BGN 1939; (map 23).

Descriptive name given by USC\&GS in 1936 , because, "during the summer months, this island, which is about $200 \mathrm{ft}$. high, and entirely grass covered, is a brilliant green color."

Emerald Island: island, $0.1 \mathrm{mi}$. long, in Iphigenia Bay, $1.3 \mathrm{mi}$. W of Heceta I., Alex. Arch.; $55^{\circ} 43^{\prime} 58^{\prime \prime} \mathrm{N}, 133^{\circ} 40^{\prime} 45^{\prime \prime} \mathrm{W}$; (map 4). Var. Green Island.

Descriptive name given in 1908 by USC\&GS. In 1907 E. F. Dickins, USC\&GS, reported the local name "Green Island." The name was changed to reduce duplication of the name "Green."

Emerald Island: island, at mouth of King Cove, on $\mathrm{S}$ side of Passage Canal, $4 \mathrm{mi}$. NE of Whittier, Chugach Mts.; 60 $48^{\prime} 25^{\prime \prime} \mathrm{N}$, 148³4'10" W; BGN 1915; (map 63). Var. Emerald Isle, Shamrock Isle.

Named in 1915 by USC\&GS.

Emerald Island: island, extends NW-SE $0.9 \mathrm{mi}$. in Yukon River, $0.5 \mathrm{mi}$. SW of Mickey I. and $30 \mathrm{mi}$. NE of Ruby, Nowitna Low.; $64^{\circ} 55^{\prime} \mathrm{N}$, $154^{\circ} 34^{\prime} \mathrm{W}$; (map 98).

Riverboat pilots' name shown on 1940 "Navigation Chart, Tanana-Yukon Rivers" of the River Boat Service, U.S. Dept. of Interior. Emerald Isle: island, see Emerald Island.

Emerald Lake: lake, $1 \mathrm{mi}$. long, $3 \mathrm{mi}$. S of Gibraltar Lake and $32 \mathrm{mi}$. SE of Iliamna, Aleutian Ra.; $59^{\circ} 18^{\prime} 30^{\prime \prime} \mathrm{N}, 154^{\circ} 43^{\prime} 00^{\prime \prime} \mathrm{W}$; (map 51).

So named in 1923 by R. H. Sargent, USGS, because of its emeraldlike appearance and published by K. F. Mather (in Brooks and others, 1925, pl. 3), USGS.

Emerson, Mount: mountain, $5.077 \mathrm{ft}$., on W bank of College Fiord, $8 \mathrm{mi}$. $\mathrm{N}$ of Point Pakenham and $63 \mathrm{mi}$. E of Anchorage, Chugach Mts.; $61^{\circ} 07^{\prime} \mathrm{N}, 148^{\circ} 01^{\prime} \mathrm{W}$; BGN 1910; (map 69).

Named in 1908 by U. S. Grant and D. F. Higgins, USGS, for Benjamin Kendall Emerson, 1843-1920, professor of geology at Amherst College, Amherst, Massachusetts. He was a member of the Harriman Alaska Expedition in 1899.

Emerson Glacier: glacier, see Coxe Glacier.

Emery Creek: stream, flows N $3 \mathrm{mi}$. to Bettles River, S of Wiehl Mtn., $30 \mathrm{mi}$. WNW of Chandalar, Brooks Ra.; $67^{\circ} 34^{\prime} 15^{\prime \prime} \mathrm{N}, 149^{\circ}$ $36^{\prime} 30^{\prime \prime}$ W; (map 123). Var. Emory Creek.

Named about 1900 for his son by August L. Tobin, who prospected in this area from 1898 to 1919.

Emgeten Island: island, $0.3 \mathrm{mi}$. across, $3.5 \mathrm{mi}$. $\mathrm{S}$ of Sitka, W of Baranof I., Alex. Arch.; $57^{\circ} 00^{\prime} 00^{\prime \prime} \mathrm{N}, 135^{\circ} 19^{\prime} 30^{\prime \prime} \mathrm{W}$; BGN 1897; (map 5). Var. Emagayten Island, Emheleni Island, Engaylen Island, Luce Island, Ostrov Emgeten.

Named in 1809 by Ivan Vasiliev IRN; published by Lt. Sarichev (1826, map 19), IRN, as "O[strov] Emgeten," or "Emgeten Island."

Emghem Mountain: hill, $777 \mathrm{ft}$., $3.5 \mathrm{mi}$. NW of Southeast Cape, $85 \mathrm{mi}$. SE of Gambell, on Saint Lawrence I.; $62^{\circ} 58^{\prime} \mathrm{N}, 169^{\circ} 44^{\prime} \mathrm{W}$; BGN 1951; (map 93).

Eskimo name reported in 1949 by Maj. H. B. Allen, USAF.

Emheleni Island: island, see Emgeten Island.

Emikpuk Lake: lake, see Imikpuk Lake.

Emile Creek: stream, heads in a glacial lake in in Brabazon Ra., flows S 6 mi. to Alsek River, $4.6 \mathrm{mi}$. NE of Dry Bay and $50 \mathrm{mi}$. SE of Yakutat, St. Elias Mts.; $59^{\circ} 12^{\prime} 00^{\prime \prime} \mathrm{N}, 138^{\circ}$ $28^{\prime} 20^{\prime \prime} \mathrm{W}$; (map 46).

Local name published in 1959 by USGS.

Emile Lake: lake, $1 \mathrm{mi}$. long, $3.5 \mathrm{mi}$. SE of Fort Yukon, Yukon Flats; $66^{\circ} 32^{\prime} 30^{\prime \prime} \mathrm{N}, 145^{\circ}$ 07'00" W; (map 119).

Local name obtained in 1956 by USGS.

Emily Island: island, $0.1 \mathrm{mi}$. long, in Little Duncan Bay, $16 \mathrm{mi}$. SW of Petersburg, on S coast of Kupreanof I., Alex. Arch.; 56 35'50" $\mathrm{N}, 133^{\circ} 07^{\prime} 50^{\prime \prime} \mathrm{W}$; (map 6 ).

Named in 1887 by Lt. Comdr. C. M. Thomas, USN, for charting purposes; name published in 1888 on USC\&GS Chart 705. Eminik Bay : bay, see Dry Spruce Bay.

Emma, Lake: lake, 0.5 mi. long, on Kenai Penin., drains $\mathbf{S}$ to Indian Creek, $3 \mathrm{mi}$. $\mathbf{E}$ of Tustumena Lake and $40 \mathrm{mi}$. SE of Kenai, Chugach Mts.; $60^{\circ} 08^{\prime} \mathrm{N}, 150^{\circ} 33^{\prime} \mathrm{W}$; (map 62).

Local name reported in 1904 by Moffit (1906, pl. 2), USGS.

Emma, Mount: mountain, 3,235 ft., on Baranof I., $3 \mathrm{mi}$. E of Whale Bay, Alex. Arch.; 56 ${ }^{\circ}$ $37^{\prime} 50^{\prime \prime} \mathrm{N}, 134^{\circ} 54^{\prime} 20^{\prime \prime} \mathrm{W}$; (map 5).

Local name published in 1943 by USC\&GS.

Emma Creek: stream, on Revillagigedo $\mathbf{I}$., $\mathbf{E}$ of Naha Bay, flows SW through Emma Lake 2 mi. to Jordan Lake, Alex. Arch.; 55 $36^{\prime} \mathrm{N}$, $131^{\circ} 34^{\prime} \mathrm{W} ; B G N 1962$; (map 3 ).

Local name reported in 1961 by USFS.

Emma Creek: stream, flows NE $5 \mathrm{mi}$., joins Marguerite Creek to form California Creek, $40 \mathrm{mi}$. SE of Nenana, Alaska Ra.; $64^{\circ} 00^{\prime} 45^{\prime \prime}$ $\mathrm{N}, 148^{\circ} 43^{\prime} 30^{\prime \prime} \mathrm{W}$; (map 100).

Local name reported in 1910 by USGS (Capps, 1912, pl. 1).

Emma Creek: stream, flows SE $2.3 \mathrm{mi}$. to Alder Creek, $11 \mathrm{mi}$. W of Fairbanks, Yukon-Tanana High.; $64^{\circ} 49^{\prime} 15^{\prime \prime} \mathrm{N}, 148^{\circ} 04^{\prime} 55^{\prime \prime} \mathrm{W}$; (map 100).

Name reported in 1907 and published in 1908 by USGS.

Emma Creek: stream, flows E $5 \mathrm{mi}$ to Middle Fork Koyukuk River, 5 mi. SE of Emma Dome and $6.5 \mathrm{mi}$. S of Wiseman, Brooks Ra.; $67^{\circ}$ $19^{\prime} 20^{\prime \prime} \mathrm{N}, 150^{\circ} 10^{\prime} 00^{\prime \prime} \mathrm{W}$; (map 124).

Named by August L. Tobin, who prospected and mined in the area from 1897 to 1918 , for his wife, Emma L. Tobin; name reported by Robert Marshall in 1930.
Emma Dome: mountain, 5,680 ft., $3.5 \mathrm{mi}$. SE of Bluecloud Mtn. and $7 \mathrm{mi}$. SW of Wiseman, Brooks Ra.; $67^{\circ} 22^{\prime} \mathrm{N}, 150^{\circ} 25^{\prime} \mathrm{W}$; BGN 1932; (map 124).

Named by August L. Tobin. See Emma Creek.

Emma Lake: lake, $0.6 \mathrm{mi}$. long, on Revillagigedo I., E of Naha Bay, in course of Emma Creek, Alex. Arch.; $55^{\circ} 37^{\prime} \mathrm{N}, 131^{\circ} 33^{\prime} \mathrm{W}$; $B G N$ 1962; (map 3).

Local name reported in 1961 by USFS.

Emmerich, Mount: mountain, 6,405 ft. in Chilkat Ra., 2 mi. W of terminus of Garrison Glacier, $23 \mathrm{mi}$. SW of Skagway, St. Elias Mts.; $59^{\circ} 11^{\prime} 40^{\prime \prime} \mathrm{N}, 135^{\circ} 42^{\prime} 10^{\prime \prime} \mathrm{W}$; (map 45). Var. Cathedral Peak, Mount Emmerick.

So named by the USC\&GS in 1897. According to E. G. Robertson, USGS, the local name is Cathedral Peak, "because of the mountain's prominence and cathedrallike appearance."

Emmerick, Mount: mountain, see Emmerich, Mount.

Emmerson Peaks: ridge, in Glacier Bay National Monument, $2 \mathrm{mi}$. long, trends NW with a maximum elev. of $4,830 \mathrm{ft}$., $4 \mathrm{mi}$. SE of Triangle I. and $67 \mathrm{mi}$. NW of Hoonah, St. Elias Mts.; $58^{\circ} 55^{\prime} 15^{\prime \prime} \mathrm{N}, 136^{\circ} 26^{\prime} 15^{\prime \prime} \mathrm{W}$; (map 10).

Named by the American Geographical Society's Glacier Bay Expedition of 1941 for Benjamin Kendall Emerson, 1843-1932, professor of geology, who visited the Muir Glacier with the Harriman Alaska Expedition in 1899. Emerson taught geology at Amherst College from 1878-1912. He worked for USGS from 1890 until his death and he is noted for his investigations of the geology of Massachusetts.

Emmet Island: island, $0.1 \mathrm{mi}$. long, in Felice Strait, off $N$ coast of Duke I., Alex. Arch.; $54^{\circ} 58^{\prime} 30^{\prime \prime} \mathrm{N}, 131^{\circ} 24^{\prime} 45^{\prime \prime} \mathrm{W}$; (map 2).

Local name published in 1943 by USC\&GS.

Emmikroak Creek: stream, see Ikijaktusak Creek.

Emmikroak Creek: stream, see Imikrak Creek.

Emmons, Mount: mountain, 4,350 ft., $27 \mathrm{mi}$. NE of village of Cold Bay near SW end of Alaska Penin., Aleutian Ra.; $55^{\circ} 20^{\prime} \mathrm{N}, 162^{\circ} 05^{\prime} \mathrm{W}$; (map 29).

Local name published in 1943 on a USGS map.

Emmons Island: island, $2 \mathrm{mi}$. across, in Hoonah Sound, off S coast of Chichagof I., $11 \mathrm{mi}$. SE of Chichagof, Alex. Arch.; $57^{\circ} 36^{\prime} \mathrm{N}, 135^{\circ} 32^{\prime}$ W; (map 9).

Named by USC\&GS for Lt. George Thornton Emmons, USN, and published in 1899 on Chart 8050.

Emmons Lake: lake, $5 \mathrm{mi}$. long, $1 \mathrm{mi}$. S of Mount Emmons, $25 \mathrm{mi}$. NE of village of Cold Bay, near SW end of Alaska Penin., Aleutian Ra.; $55^{\circ} 19^{\prime} \mathrm{N}, 162^{\circ} 06^{\prime} \mathrm{W}$; (map 29).

Name derived from Mount Emmons and published by USGS (Kennedy and Waldron, 1955, p. 10).

Emmons Point: point of land, SE tip of Emmons I., in Hoonah Sound, off $S$ coast of Chicha- 
gof I., $11 \mathrm{mi}$. SE of Chichagof, Alex. Arch.; $57^{\circ} 35^{\prime} 45^{\prime \prime} \mathrm{N}, 135^{\circ} 30^{\prime} 40^{\prime \prime} \mathrm{W}$; (map 9).

Named in 1895 by Lt. Comdr. E. K. Moore, probably for Lt. George Thornton Emmons, USN, and published in 1900 by USC\&GS on Chart 8282.

Emnavak Ridge: ridge, elev. 1,600 ft., along E side of Lost Temper Creek, $25 \mathrm{mi}$. E of Liberator Lake, Arctic Slope; $68^{\circ} 50^{\prime} \mathrm{N}, 157^{\circ} 20^{\prime}$ W; (map 132).

Eskimo name reported in 1956 by T. E. Taylor, USGS.

Emogarikchoit: lake, see Inland Lake.

Emonguk: locality, see Emanguk.

Emory Creek: stream, flows NW $3 \mathrm{mi}$, to Beaver Creek $2 \mathrm{mi}$. E of that stream's junc. with South Fork Chena River and $46 \mathrm{mi}$. NW of Big Delta, Yukon-Tanana High.; $64^{\circ} 45^{\prime} 50^{\prime \prime}$ N, $146^{\circ} 24^{\prime}$ 15" W; (map 101).

Local name reported in 1958 by USGS.

Emory Creek: stream, see Emery Greek.

Empalizada, Punta: point of land, see Palisade Point.

Emperor Island: island, $1.5 \mathrm{mi}$. long, in Kolavinarak River at mouth of Talaghun River, $93 \mathrm{mi}$. W of Bethel, Yukon-Kuskokwim Delta; $60^{\circ} 33^{\prime} \mathrm{N}, 164^{\circ} 30^{\prime} \mathrm{W}$; (map 58 ).

Named about 1964 by personnel of Clarence Rhode National Wildlife Range for the Emperor Goose.

Emperor Peak: peak, 6,805 ft., in Taku Range, $\mathrm{S}$ of Taku Towers and $20 \mathrm{mi}$. $\mathrm{N}$ of Juneau,

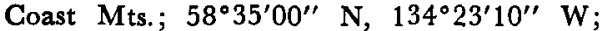
$B G N$ 1965; (map 11). Var. Project Peak.

Named in 1964 by members of the Juneau Icefield Research Project.

Empinado, Cape: point of land, on Prince of Wales I. extending into Bucareli Bay between Tranquil Point and Point Providence, Alex. Arch.; $55^{\circ} 22^{\prime} \mathrm{N}, 133^{\circ} 15^{\prime} \mathrm{W}$; (map 4). Var. Etpinado Cape.

Spanish name meaning "pointed cape" given by the Don Jacinto Arteaga 1779 expedition. The descriptive name does not seem to fit this point and may instead apply to one farther northeast.

Empire Gulch: ravine, trends NW $1 \mathrm{mi}$. to Casadepaga River 2 mi. SW of its junc. with Niukluk River, $28 \mathrm{mi}$. NE of Solomon, Seward Penin. High.; $64^{\circ} 57^{\prime} \mathrm{N}, 164^{\circ} 07^{\prime} \mathrm{W}$; (map 95).

Prospectors' name reported in 1907 by USGS geologists (Smith, P. S., 1910, pl. 4).

Empress Mountain: peaks, see Snow Towers, The.

Empress Peak: peak, see Princess Peak.

Emukpun: lake, see Imikpuk Lake.

Emuruk Lake: lake, see Imuruk Lake.

Enatalik Creek: stream, flows NE $20 \mathrm{mi}$. to Chukowan River, $80 \mathrm{mi}$. SW of Sleetmute, Kilbuck-Kuskokwim Mts.; $60^{\circ} 45^{\prime} \mathrm{N}, 158^{\circ}$ 31' W; BGN 1948; (map 60). Var. Little Swift River, Pyrim Creek, West Fork Chukowan River.

Eskimo name reported in 1945 by USGS. This stream is known locally by white prospectors and trappers as the "Little Swift River."
Encampment Creek: stream, flows N $15 \mathrm{mi}$. to Confusion Creek, $9 \mathrm{mi}$. NW of Natvakruak Lake and $22 \mathrm{mi}$. NW of Anaktuvuk Pass, Brooks Ra.; $68^{\circ} 25^{\prime} 40^{\prime \prime} \mathrm{N}, 152^{\circ} 01^{\prime} 00^{\prime \prime} \mathrm{W}$; (map 134)

So named in 1950 by W. W. Patton and A. S. Keller, USGS, "because our field party camped on the creek."

Enchantment, Cape: promontory, on W shore of Russell Fiord, opposite mouth of Nunatak Fiord, $26 \mathrm{mi}$. NE of Yakutat, St. Elias Mts.; $59^{\circ} 51^{\prime} 15^{\prime \prime} \mathrm{N}, 139^{\circ} 18^{\prime} 35^{\prime \prime} \mathrm{W}$; (map 46).

So named by Russell (1891, p. 86), USGS, because of the "magnificent views from this point."

Encio Gulch: ravine, trends SE $0.5 \mathrm{mi}$. to Hidden Creek, $8 \mathrm{mi}$. N of Medfra, Kilbuck-Kuskokwim Mts.; $63^{\circ} 13^{\prime} \mathrm{N}, 154^{\circ} 44^{\prime} \mathrm{W}$; (map 89).

Local name reported in 1958 by USGS.

Endicott Arm: estuary, fiord, $30 \mathrm{mi}$. long, extends NW from terminus of Dawes Glacier to Holkham Bay, $44 \mathrm{mi}$. SE of Juneau, Coast Mts.; $57^{\circ} 45^{\prime} \mathrm{N}, 1^{\circ} 3^{\circ} 35^{\prime} \mathrm{W}$; BGN 1964; (map 8).

Named in 1889 by Lt. Comdr. H. B. Mansfield, USN, for William Crowninshield Endicott, 1826-1900, Secretary of War under President Grover Cleveland, 1885-89. The name was published by USC\&GS in 1891 Coast Pilot (p. 147).

Endicott Gap: pass, in Glacier Bay National Monument, $0.5 \mathrm{mi}$. W of Endicott Lake and $59 \mathrm{mi}$. NW of Juneau, St. Elias Mts.; $58^{\circ} 49^{\prime}$ $30^{\prime \prime}$ N., $135^{\circ} 42^{\prime} 30^{\prime \prime} \mathrm{W}$; (map 11).

Name published in 1962 by USGS.

Endicott Lake: lake, $0.6 \mathrm{mi}$. long, on Endicott River, in Glacier Bay National Monument, 0.5 mi. E of Endicott Gap and $58 \mathrm{mi}$. NW of Juneau, St. Elias Mts.; 58 $49^{\circ} 30^{\prime \prime}$ N, $135^{\circ}$ 40'30" W; (map 11). Var. Main Lake.

Named in 1890 by Harry F. Reid. The valley in which it is located was named "Main" by John Muir, and the lake was called "Main Lake." The name of the valley and the lake was changed to "Endicott" by Reid when their relation to the Endicott River was established.

Endicott Lake: lake, see Main Lake.

Endicott Mountains: mountains, extend $150 \mathrm{mi}$. from Noatak River, Kaluluktok Creek, and Walker Lake at $W$ end to Atingun River, Dietrich River, and Middle Fork Koyukuk River at $\mathrm{E}$ end, Brooks $\mathrm{Ra}$.; $68^{\circ} 10^{\prime} \mathrm{N}, 149^{\circ} 30^{\prime}$ $W$ [E end], $67^{\circ} 30^{\prime} \mathrm{N}, 154^{\circ} 45^{\prime} \mathrm{W}$ [W end]; (map 124).

Named in 1885 by Lt. H. T. Allen, USA, for William Crowninshield Endicott, 18261900 , Secretary of War under President Grover Cleveland, 1885-89.

Endicott River: stream, heads in unnamed glacier $2 \mathrm{mi}$. S of Mount Young, flows $\mathrm{W}$ and then mainly E $25 \mathrm{mi}$. to Lynn Canal, $25 \mathrm{mi}$. NW of Juneau, St. Elias Mts.; $58^{\circ} 46^{\prime} 45^{\prime \prime} \mathrm{N}$, $135^{\circ} 14^{\prime} 30^{\prime \prime} \mathrm{W}$; (map 11$)$.

Named in 1880 by U.S. Navy officers for William Crowninshield Endicott, 1826-1900, Secretary of War under President Grover Cleveland, 1885-89.
Endicott Valley: valley, of Endicott River, E of Endicott Gap and $56 \mathrm{mi}$. NW of Juneau, St. Elias Mts.; $58^{\circ} 48^{\prime} \mathrm{N}, 135^{\circ} 40^{\prime} \mathrm{W}$; (map 11). Var. Main Valley.

Named by H. F. Reid (1896, pl. 86).

Endicott Valley: valley, see Main Valley.

Endora Mountain: mountain, see Eudora Mountain.

Enekalikruak Creek: stream, flows E $8 \mathrm{mi}$. to Killik River $4 \mathrm{mi}$. N of its junc. with Easter Creek, Brooks Ra.; $68^{\circ} 12^{\prime} \mathrm{N}, 154^{\circ} 07^{\prime} \mathrm{W}$; (map 133).

Eskimo name reported in 1956 by T. E. Taylor, USGS.

Engano Point: point of land, on SW coast of Kruzof I., $10 \mathrm{mi}$. W of Sitka, Alex. Arch.; $57^{\circ} 00^{\prime} 45^{\prime \prime} \mathrm{N}, 135^{\circ} 51^{\prime} 00^{\prime \prime} \mathrm{W}$; BGN 1926; (map 9).

The name "Cabo del Engaño" meaning "cape of deception (or deceit)" was given to Cape Edgecumbe in 1775 by F. A. Maurelle (in La Perouse, 1798, pl. 26). The USC\&GS applied the name to this point of land in 1926.

Engaño, Cabo del: point of land, see Edgecumbe, Cape.

Engaylen Island: island, see Emgeten Island.

Engineer: locality, on Engineer Creek, $9 \mathrm{mi} \mathrm{NE}$ of Fairbanks, Yukon-Tanana High.; 64 ${ }^{\circ} 56^{\prime} \mathrm{N}$, $147^{\circ} 40^{\prime} \mathrm{W}$; (map 100).

Name of a mining camp whose name was derived from Engineer Creek. A post office was established here in 1909 and discontinued in 1911. (Ricks, 1965, p. 19). The camp is now only an abandoned site.

Engineer Creek: stream, flows SW $15 \mathrm{mi}$., through Engineer Lake, to Yukon River, 12 mi. SE of Marshall, Nulato Hills; $61^{\circ} 43^{\prime} \mathrm{N}$, $161^{\circ} 56^{\prime} \mathrm{W}$; (map 73).

Prospectors' name reported by Harrington (1918, map), USGS, in 1916.

Engineer Creek: stream, flows W $5 \mathrm{mi}$. to Goldstream Creek, $9 \mathrm{mi}$. NE of Fairbanks, YukonTanana High.; $64^{\circ} 56^{\prime} 45^{\prime \prime} \mathrm{N}, 147^{\circ} 40^{\prime} 55^{\prime \prime} \mathrm{W}$; (map 100).

Local name reported in 1903 by T. G. Gerdine (in Prindle, 1905, pl. 16), USGS.

Engineer Creek: stream, see Little Blanche Creek.

Engineer Hill: hill, $625 \mathrm{ft}$., at NW end of Gilbert Ridge, on eastern Attu I., Aleutian Is.; $52^{\circ} 53^{\prime} 05^{\prime \prime} \mathrm{N}, 173^{\circ} 11^{\prime} 45^{\prime \prime} \mathrm{E}$; (map 13).

Named by the U.S. Army when it occupied the island during World War II.

Engineer Hill: hill, $633 \mathrm{ft}$., $2 \mathrm{mi}$. NW of Engineer Lake and $11 \mathrm{mi}$. SE of Marshall, Nulato Hills; $61^{\circ} 45^{\prime} 20^{\prime \prime} \mathrm{N}, 161^{\circ} 51^{\prime} 10^{\prime \prime} \mathrm{W}$; (map 73).

Local name reported by the U.S. Army Corps of Engineers in 1952; named for Engineer Lake and Creek.

Engineer Lake: lake, $0.8 \mathrm{mi}$, across, on Kenai Penin., W of Hidden Lake, $33 \mathrm{mi}$. ESE of Kenai, Cook Inlet Low.; $60^{\circ} 29^{\prime} \mathrm{N}, 150^{\circ} 20^{\prime}$ W; (map 62)

Local name reported in 1958 by USGS.

Engineer Lake: lake, $4.5 \mathrm{mi}$. long, E of Yukon River, $13 \mathrm{mi}$. SE of Marshall, Yukon-Kusko- 
kwim Delta; 61 ${ }^{\circ} 44^{\prime} \mathrm{N}, 161^{\circ} 48^{\prime} \mathrm{W}$; (map 73).

Local name reported by the U.S. Army Corps of Engineers in 1952 ; named for Engineer Creek.

Engle Creek: stream, flows NW to Nucksack Creek which flows to Kuzitrin River near its head, about $22 \mathrm{mi}$. SW of Imuruk Lake, Seward Penin. High.; (map 110).

Prospectors' name shown on a map of Cape Nome gold fields by David Fox, Jr., dated 1901. This stream cannot be precisely located on current maps.

English Bay: village, pop. 78, on Kenai Penin. at $S$ entrance to Port Graham, $10 \mathrm{mi}$. SW of Seldovia, Chugach Mts.; $59^{\circ} 21^{\prime} 30^{\prime \prime} \mathrm{N}, 151^{\circ}$ 55'20" W; BGN 1954; (map 50). Var. Alexander, Alexandro, Alexandrovek, Alexandrovsk, Odinochka.

Local name derived from nearby English Bay and reported by the census of 1940 . This village appears to have been originally a Russian Post called Alexandrovsk, meaning "Alexander" (Sarichev, 1826, map 5). It was later called "Odinochka," meaning "a person living in solitude" (Tebenkov, 1852, map 5).

English Bay: bay, $0.6 \mathrm{mi}$. across, NE coast of Unalaska I., Aleutian Is.; $53^{\circ} 56^{\prime} 15^{\prime \prime} \mathrm{N}, 166^{\circ}$ $14^{\prime} 30^{\prime \prime}$ W; BGN 1904; (map 23). Var. Samganoodha Bay, Samganuda Bay, Samganooda Bay.

Aleut name reported by Capt. James Cook (1785, v. 2, p. 424), RN, as "Samganoodha." Lt. Sarichev (1826, map 14), IRN, published the name as "Zaliv Samganuda," or "Samganuda Bay." Because Cook surveyed the area, Father Veniaminov (1840, v. 1, p. 165) called it "Angliiskii," or "English."

English Bay: bay, 1. $5 \mathrm{mi}$. across, on $\mathrm{SW}$ coast of Saint Paul I., in Pribilof Is.; $57^{\circ} 08^{\prime} 30^{\prime \prime} \mathrm{N}$, $170^{\circ} 18^{\prime} 30^{\prime \prime} \mathrm{W}$; (map 38 ).

According to Elliott (1881, Saint Paul notes), this bay was so named because a "large British vessel" was wrecked here, on a reef, in 1847 , as it was coming in to anchor off Zapadni Point.

English Bay: cove, $1.2 \mathrm{mi}$. across, at mouth of English Bay River, on SW end of Kenai Penin., $10 \mathrm{mi}$. SW of Seldovia, Chugach Mts.; $59^{\circ}$ $21^{\prime} 15^{\prime \prime} \mathrm{N}, 151^{\circ} 56^{\prime} 00^{\prime \prime} \mathrm{W}$; (map 50).

The Russians originally applied the name "Bukh[ta] Anglitskaya" (English Bay), to what is now called Port Graham (Tebenkov, 1852, map 5 ) probably because the area was mapped by the English (Portlock, 1789, map facing p. 102). Capt. Nathaniel Portlock, however, called the bay "Grahams Harbour" [Port Graham] and the translated Russian name, "English Bay," was reapplied to the above described small cove by USC\&GS in 1909.

English Bay: cove, $0.5 \mathrm{mi}$. wide, on Hinchinbrook I., on S shore of Port Etches, 35 mi. SW of Cordova, Chugach Mts.; $68^{\circ} 10^{\prime} \mathrm{N}, 146^{\circ} 40^{\prime}$ W; (map 64).

Local name reported in 1908 by Grant and Higgins (1909, pl. 4), USGS.

English Bay: bay, see Graham, Port.

English Bay: bay, see Womens Bay.
English Bay Reef: reef, in Cook Inlet, at SW entrance to Port Graham, off SW end of Kenai Penin., 11 mi. SW of Seldovia, Chugach Mts.; $59^{\circ} 21^{\prime} 45^{\prime \prime} \mathrm{N}, 151^{\circ} 56^{\prime} 45^{\prime \prime} \mathrm{W}$; (map 50).

Name derived from English Bay and published by USC\&GS in 1940.

English Bay River: stream, flows NW $11 \mathrm{mi}$. to English Bay, on S end of Kenai Penin., $10 \mathrm{mi}$. SW of Seldovia, Chugach Mts. ; $59^{\circ} 18^{\prime} 30^{\prime \prime} \mathrm{N}$, $151^{\circ} 51^{\prime} 30^{\prime \prime} \mathrm{W}$; (map 50).

Name derived from English Bay and published by USGS in 1951.

Englishshoe Bar: bar, on Black River, $1 \mathrm{mi}$. S of Graveyard Lakes and $30 \mathrm{mi}$. NE of Fort Yukon, Yukon Flats; $66^{\circ} 42^{\prime} 30^{\prime \prime} \mathrm{N}, 144^{\circ} 16^{\prime}$ $00^{\prime \prime} \mathrm{W}$; (map 119).

Local descriptive name obtained in 1956 by USGS.

Enigarok: pinnacles, see Ears, The.

Ennis, Point: promontory, see Bald Head.

Enochkin Bay: estuary, see Iniskin Bay.

Enright Creek: stream, flows NE to Niukluk River, between Bear River and Holyoke Creek near Council, about $32 \mathrm{mi}$. NE of Solomon, Seward Penin. High.; (map 95).

Prospectors' name reported on the 1900 "Map of Nome Peninsula" by J. M. Davidson and B. D. Blakeslee. This stream cannot be precisely located on current maps.

Enterprise Creek: stream, flows E $6 \mathrm{mi}$. to join Silver Bow Creek to form McKinley Creek, $64 \mathrm{mi}$. SW of Eagle, Yukon-Tanana High.; $64^{\circ} 17^{\prime} \mathrm{N}, 142^{\circ} 58^{\prime} \mathrm{W}$; (map 102). Var. Left Fork McKinley Creek.

Prospectors' name shown on an 1898 manuscript map by C. A. Woodruff, Fort Cudahy, Canada.

Enton Point: point of land, on SE end of Sanak I., Aluetian Ra.; $54^{\circ} 23^{\prime} 00^{\prime \prime} \mathrm{N}, 162^{\circ} 32^{\prime} 20^{\prime \prime} \mathrm{W}$; (map 25).

Name published in 1949 on a USGS map.

Entrance Cape: point of land, see Ustia Point.

Entrance Island: locality, pop. 3 , on S coast of Entrance I. in Hobart Bay, $2.5 \mathrm{mi}$. NE of Point Hobart, $77 \mathrm{mi}$. NE of Sitka, Coast Mts. ; 57 $24^{\prime} 40^{\prime \prime} \mathrm{N}, 133^{\circ} 26^{\prime} 30^{\prime \prime} \mathrm{W}$; (map 8).

Named for Entrance Island. Recent maps show two houses or cabins here. A post office was maintained here from 1946 to 1956 (Ricks, 1965, p. 19).

Entrance Island: island, $0.6 \mathrm{mi}$. long, between Baldy Bay and Coco Harbor, on E coast of Dall I., Alex. Arch.; 55 $02^{\prime} 20^{\prime \prime}$ N, $133^{\circ} 00^{\prime} 00^{\prime \prime}$ W; (map 4).

Local name recorded in 1948 by USGS.

Entrance Island: island, $0.15 \mathrm{mi}$. long, at mouth of Dolgoi Harbor, Dolgoi I., in Pavlof Is., Aleutian Ra.; 55 $05^{\prime} 30^{\prime \prime} \mathrm{N}, 161^{\circ} 19^{\prime} 00^{\prime \prime} \mathrm{W}$; (map 28).

Name shown on a 1907 USC\&GS chart.

Entrance Island: island, $300 \mathrm{ft}$. long, at entrance to Sea Otter Harbor, off $W$ coast of Dall I., Alex. Arch.; 55 $06^{\prime} 35^{\prime \prime} \mathrm{N}, 133^{\circ} 14^{\prime} 30^{\prime \prime} \mathrm{W}$; (map 4).

Descriptive name given in 1924 by USC\&GS.

Entrance Island: island, $0.2 \mathrm{mi}$. long, in Behm Canal, NW of Winstanley I., Coast Mts. ; $55^{\circ}$ - $28^{\prime} \mathrm{N}, 130^{\circ} 55^{\prime} \mathrm{W}$; (map 3$)$.

Descriptive name given in 1891 by USC\&GS.

Entrance Island: island, $0.2 \mathrm{mi}$. long, at mouth of Edna Bay, Kosciusco I., Alex. Arch.; 55 56 $\mathrm{N}, 133^{\circ} 37^{\prime} \mathrm{W}$; (map 4).

Local name recorded in 1951 by USGS.

Entrance Island: island, $0.3 \mathrm{mi}$. long, in Clarence Strait, SW coast of Etolin I., Alex. Arch.; $55^{\circ} 59^{\prime} 40^{\prime \prime} \mathrm{N}, 132^{\circ} 27^{\prime} 40^{\prime \prime} \mathrm{W}$; (map 4).

Descriptive name given in 1900 by Lt. Comdr. J. F. Moser, USN. "It is the guide to the channel at the entrance to McHenry Inlet."

Entrance Island: island, $0.8 \mathrm{mi}$. long, in Keku Strait, $12 \mathrm{mi}$. SE of Kake and $2 \mathrm{mi}$. W of Big John Bay, on W coast of Kupreanof I., Alex. Arch.; 56 $48^{\prime} 45^{\prime \prime} \mathrm{N}, 133^{\circ} 47^{\prime} 30^{\prime \prime} \mathrm{W}$; (map 6).

Local name published in 1943 by USC\&GS.

Entrance Island: island, $0.1 \mathrm{mi}$. across, in Neva Strait, at mouth of Saint John Baptist Bay, 9 mi. N of Sitka, Alex. Arch.; $57^{\circ} 17^{\prime} 30^{\prime \prime} \mathrm{N}$, $135^{\circ} 36^{\prime} 10^{\prime \prime} \mathrm{W}$; (map 9).

Descriptive name given in 1884 by Comdr. J. B. Coghlan, USN, and published in 1885 by USC\&GS on Chart 727.

Entrance Island: island, $0.6 \mathrm{mi}$. across, at entrance to Hobart Bay on E shore of Stephens Passage, $77 \mathrm{mi}$. NE of Sitka, Coast Mts.; $57^{\circ}$ $24^{\prime} 45^{\prime \prime}$ N, $133^{\circ} 26^{\prime} 30^{\prime \prime}$ W; (map 8). Var. Entrance Islet.

Descriptive name given by USC\&GS and published in 1891 Coast Pilot (p. 146).

Entrance Island: island, $0.5 \mathrm{mi}$. long, in Icy Strait, at entrance to Swanson Harbor, $1.6 \mathrm{mi}$. NW of Point Couverden and $26 \mathrm{mi}$. SW of Juneau, St. Elias Mts. ; $58^{\circ} 11^{\prime} 50^{\prime \prime}$ N, $135^{\circ} 05^{\prime}$ 55" W; (map 11).

Descriptive name given in 1880 by U.S. Navy officers; published by USC\&GS in 1883 Coast Pilot (p. 193).

Entrance Island: island, $0.5 \mathrm{mi}$. across, at SE end of Upper Passage, $0.5 \mathrm{mi}$. S of Eleanor I., $24 \mathrm{mi}$. NE of Chenega, Chugach Mts.; $60^{\circ} 31^{\prime}$ N, $147^{\circ} 35^{\prime} \mathrm{W}$; (map 63 ).

Local name reported in 1910 by USC\&GS. So named "because the island is at the south entrance to Upper Passage between Eleanor and Ingot Is."

Entrance Island: island, $0.2 \mathrm{mi}$. long, on S shore of Port Valdez, SW of Valdez, Chugach Mts.; $61^{\circ} 05^{\prime} 05^{\prime \prime} \mathrm{N}, 146^{\circ} 36^{\prime} 30^{\prime \prime} \mathrm{W}$; (map 68).

Name reported in 1901 by $H$. P. Ritter, USGS; so called because it lies near the entrance to Port Valdez.

Entrance Island: island, see Table Island.

Entrance Island: islands, see Twins, The.

Entrance Islet: island, $0.1 \mathrm{mi}$. across, on $\mathrm{N}$ coast of Biorka I., off W coast of Baranof I., Alex. Arch.; 56 $51^{\prime} 55^{\prime \prime} \mathrm{N}, 135^{\circ} 31^{\prime} 20^{\prime \prime} \mathrm{W}$; (map 5).

Named in 1879 by Lt. F. M. Symonds, USN. Entrance Islet: island, see Entrance Island.

Entrance Point: point of land, $\mathrm{N}$ entrance point of Sandy Cove, on Little Koniuji I., in Shumagin Is., Aleutian Ra.; $55^{\circ} 02^{\prime} 10^{\prime \prime} \mathrm{N}, 159^{\circ}$ $20^{\prime} 50^{\prime \prime} \mathrm{W}$; (map 27). 
Reported by USG\&GS in 1943 ; published in 1954 Coast Pilot (p. 301).

Entrance Point: point of land, $\mathrm{S}$ tip of an island between Klawak Inlet and San Alberto Bay, $\mathrm{S}$ of Wadleigh I., Alex. Arch.; $55^{\circ} 31^{\prime} 10^{\prime \prime} \mathrm{N}$, $133^{\circ} 08^{\prime} 55^{\prime \prime} \mathrm{W}$; (map 4).

Descriptive name given in 1897 by Comdr. J. F. Moser, USN. It is at the entrance to Klawak Inlet.

Entrance Point: point of land, $9.5 \mathrm{mi}$. NW of Kodiak, Kodiak I.; $57^{\circ} 54^{\prime} 35^{\prime \prime} \mathrm{N}, 152^{\circ} 31^{\prime} 45^{\prime \prime}$ W; (map 34). Var. Mys Nachalny Nachalnie.

Translation of the descriptive name " $\mathrm{M}[\mathrm{ys}]$ Nachalnyy" given in 1839 or 1840 by Sub-Lt Mikhail Murashev and published in 1849 on Russian Hydrog. Dept. Chart 1425.

Entrance Point: point of land, on $\mathbf{N}$ coast of Douglas I., in Fritz Cove, $1 \mathrm{mi}$. SE of tip of Meridenhall Peninsula and $7.4 \mathrm{mi}$. NW of Juneau, Coast Mts. ; $58^{\circ} 20^{\prime} 00^{\prime \prime} \mathrm{N}, 134^{\circ} 36^{\prime} 20^{\prime \prime}$ W; (map 11).

Descriptive name given in 1880 by Lt. F. M. Symonds, USN, who made surveys of the area. Published by USC\&GS in the 1883 Coast Pilot (p. 173).

Entrance Point: point of land, on $\mathrm{E}$ shore of Valdez Narrows, $1.2 \mathrm{mi}$. NE of Potato Point and $14 \mathrm{mi}$. SW of Valdez, Chugach Mts.; $61^{\circ} 03^{\prime} 45^{\prime \prime} \mathrm{N}, 146^{\circ} 39^{\prime} 35^{\prime \prime} \mathrm{W}$; (map 68).

Name reported in 1898 by Capt. W. R. Abercrombie, USA.

Entrance Point: spit, at settlement of Port Moller, at SW end of Alaska Penin., Bristol Bay Low., Alaska Penin., Aleutian Ra. ; 55 ${ }^{\circ} 59^{\prime} 30^{\prime \prime}$ $\mathrm{N}, 160^{\circ} 34^{\prime} 00^{\prime \prime} \mathrm{W}$; (map 28).

Named by W. H. Dall, USC\&GS, in 1880 . Entrance Point: point of land, see Crist Point. Entrance Point : point of land, see Hoonah Point. Entrance Point: point of land, see Nachalni Point.

Entrance Rock: rock, near SW shore of Cook Inlet, in mouth of Iniskin Bay, E of Knoll Head, Aleutian Ra. ; $59^{\circ} 38^{\prime} 30^{\prime \prime} \mathrm{N}, 153^{\circ} 28^{\prime} 50^{\prime \prime}$ W; (map 51).

Name published in 1917 on USC\&GS Chart 8665.

Entry Cove: cove, trends $\mathrm{SW}$ to $\mathrm{N}$ entrance of Passage Canal, 12 mi. NE of Whittier, Chugach Mts.; $60^{\circ} 48^{\prime} 15^{\prime \prime} \mathrm{N}, 148^{\circ} 21^{\prime} 45^{\prime \prime} \mathrm{W}$; $B G N$ 1915; (map 63).

Named in 1914 by USC\&GS, "because it is at the entrance to Passage Canal."

Eolus Point: point of land, $2 \mathrm{mi}$. SE of Breezy Bay, on $\mathrm{E}$ coast of Dall I., Alex. Arch.; $55^{\circ} 08^{\prime} 20^{\prime \prime} \mathrm{N}, 1^{\circ} 33^{\circ} 01^{\prime} 30^{\prime \prime} \mathrm{W}$; (map 4).

Named in 1882 by W. H. Dall, USC\&GS, for "the Greek god of the wind [Aeolus]."

E-oo-vogen Island: island, see Saint Lawrence Island.

E-ow-ick: locality, see Chamisso.

E-ow-ick : island, see Chamisso Island.

Epiavik Lagoon: lagoon, see Ipiavik Lagoon. Epizetka River: stream, heads in Amatusuk Hills at $69^{\circ} 14^{\prime} \mathrm{N}, 162^{\circ} 05^{\prime} \mathrm{W}$, flows NW $75 \mathrm{mi}$. to Kasegaluk Lagoon, $8 \mathrm{mi}$. S of Point Lay, Arctic Plain; $69^{\circ} 30^{\prime} 30^{\prime \prime} \mathrm{N}, 163^{\circ} 03^{\prime} 00^{\prime \prime} \mathrm{W}$; (map 145). Var. Epizetko River, Epizotka River, Kipisatkak River, Kipisatkuk River.

Eskimo name reported by A. J. Collier (in Brooks and others, 1905, p. 177), USGS, and probably represents the word sometimes written "qipigsatqaq," meaning "it twists" or "crooked." Collier probably obtained the name from a manuscript map (so-called Cullinghow's map of Cape Lisburne) drawn by an Eskimo about 1890. This map shows "Epizetko=crooked."

Epizetko River: stream, see Epizetka River.

Epizotka River: stream, see Epizetka River.

Epperson Knob: hill, 1,369 ft., on Kenai Penin., $9.5 \mathrm{mi}$. E of Anchor Point and $9 \mathrm{mi}$. NW of Homer, Cook Inlet Low.; 59 $46^{\prime} 15^{\prime \prime} \mathrm{N}, 151^{\circ}$ $36^{\prime} 00^{\prime \prime} \mathrm{W}$; (map 50$)$.

Local name reported and published by USGS in the 1950's.

Epsilon Rock: rock, $0.1 \mathrm{mi}$. long, in Woods Is., Maurelle Is., Alex. Arch.; $55^{\circ} 40^{\prime} 28^{\prime \prime} \mathrm{N}, 133^{\circ}$ $43^{\prime} 28^{\prime \prime} \mathrm{W}$; (map 4).

Local name recorded in 1951 by USGS; the 5th letter of the Greek alphabet.

Equibel Boca Fina, Gulf of: bay, see Esquibel, Gulf of.

Erathlic: stream, see Fish River.

Erchakrtuk Mountain: mountain, 1,500 ft. on Nelson I., $2.5 \mathrm{mi}$. S of Ukak, $105 \mathrm{mi}$. W of Bethel, Yukon-Kuskokwim Delta; $60^{\circ} 42^{\prime} \mathrm{N}$, $164^{\circ} 55^{\prime} \mathrm{W}$; (map 58 )

Eskimo name reported by USC\&GS in 1949.

Erecheck Mountain: hills, see Mulik Hills.

Erechek River: stream, see Hugo Creek.

Eric Cove: cove, see Quisling Cove.

Erickson Creek: stream, heads at glacier terminus, flows W $5 \mathrm{mi}$. to Canyon Creek, $6 \mathrm{mi}$. $\mathrm{N}$ of its junc, with Chitina River and $29 \mathrm{mi}$. SE of McCarthy, St. Elias Mts.; 61 ${ }^{\circ} 12^{\prime} 55^{\prime \prime}$ $\mathrm{N}, 142^{\circ} 10^{\prime} 45^{\prime \prime} \mathrm{W}$; (map 67).

Local name obtained by USGS and published on maps since 1954.

Erickson Creek: stream, heads at $65^{\circ} 11^{\prime} \mathrm{N}$, $143^{\circ} 05^{\prime} \mathrm{W}$, flows S $5 \mathrm{mi}$. to Charley River $17 \mathrm{mi}$. SW of junc. of Charley and Yukon Rivers, Yukon-Tanana High.; $65^{\circ} 06^{\prime} \mathrm{N}, 143^{\circ}$ 08' W; (map 103).

Prospectors' name taken from an unpublished map by E. J. Chamberlain dated 1902. It may have been named for Lt. Hjalmar Erickson, USA, who prepared a map of the area dated 1902.

Erickson Creek: stream, flows NW $15 \mathrm{mi}$. to Hess Creek, $36 \mathrm{mi}$. NE of Rampart, Yukon-Tanana High.; $65^{\circ} 40^{\prime} \mathrm{N}, 149^{\circ} 00^{\prime} \mathrm{W}$; (map 105).

Name reported in 1902 by Lt. Hjalmar Erickson, USA; published by USGS (Prindle, 1905, pl. 11). This creek may have been named for Lt. Erickson by W. Yanert.

Erickson Gulch: ravine, in Nutzotin Mts., extends W $1.5 \mathrm{mi}$. to Chathenda Creek $5.3 \mathrm{mi}$. $\mathbf{E}$ of its junc. with Chisana River, Alaska Ra.; $62^{\circ} 04^{\prime} \mathrm{N}, 141^{\circ} 56^{\prime} \mathrm{W}$; (map 84).

Local name reported by USGS in 1960 .

Erickson Gulch: ravine, trends SE $0.6 \mathrm{mi}$. to Glacier Creek, $8 \mathrm{mi}$. NE of Nome, Seward
Penin. High.; 64 $36^{\circ} 58^{\prime \prime} \mathrm{N}, 165^{\circ} 20^{\prime} 40^{\prime \prime} \mathrm{W}$; (map 94). Var. Ericson Gulch.

Prospectors' name shown on the 1902 "Map of the Nome and Snake River Country" by J. M. Davidson.

Ericson Gulch: ravine, see Erickson Gulch.

Ermine Island: island, $0.4 \mathrm{mi}$ long, $9 \mathrm{mi}$. NE of Port William, on E coast of Shuyak I., $45 \mathrm{mi}$. $\mathrm{N}$ of Kodiak I.; $58^{\circ} 31^{\prime} 30^{\prime \prime} \mathrm{N}, 152^{\circ} 21^{\prime} 00^{\prime \prime} \mathrm{W}$; (map 43). Var. Gornostai.

Translation of the name "Os[trov] Gornastay," published in 1849 by the Russian American Company.

Ermine Lake: lake, $0.6 \mathrm{mi}$. long, on Kenai Penin., $1.6 \mathrm{mi}$. NE of Konovalof Lake, $9 \mathrm{mi}$. NE of Kenai, Cook Inlet Low.; $60^{\circ} 40^{\prime} 45^{\prime \prime} \mathrm{N}, 151^{\circ}$ $05^{\prime} 45^{\prime \prime} \mathrm{W}$; (map 62).

Named about 1963 by officials of Kenai National Moose Range, for administrative purposes.

Ermine Point: point of land, on NE shore of Kiliuda Bay, on SE coast of Kodiak I. ; $57^{\circ} 17^{\prime}$ $30^{\prime \prime} \mathrm{N}, 152^{\circ} 52^{\prime} 40^{\prime \prime} \mathrm{W}$; BGN 1930; (map 34).

Descriptive name given in 1928 by USC\&GS, "because of numerous ermine seen around the base of the cliffs at this point."

Ermoshkinskie: point of land, see Kovrizhka, Cape.

Ernestine: locality, on Richardson Highway, 0.8 mi. $\mathbf{N}$ of junc. of Mosquito Creek and Ernestine Creek, $44 \mathrm{mi}$. NE of Valdez, Chugach Mts. ; $61^{\circ} 26^{\prime} 45^{\prime \prime} \mathrm{N}, 145^{\circ} 06^{\prime} 30^{\prime \prime} \mathrm{W}$; (map 68).

Mining camp reported in 1909 by Moffit and Maddren (1909, pl. 1), USGS.

Ernestine Creek: stream, heads in a glacier and flows $\mathrm{N}$ and NW $8 \mathrm{mi}$. to join Mosquito Creek to form Tiekel River, $44 \mathrm{mi}$. NE of Valdez, Chugach Mts. ; $61^{\circ} 26^{\prime} 05^{\prime \prime} \mathrm{N}, 145^{\circ} 07^{\prime} 00^{\prime \prime} \mathrm{W}$; (map 68).

Prospectors' name reported in 1913 by Moffit $(1914$, pl. 1), USGS.

Ernest Point: point of land, S tip of Onslow I., on $\mathrm{N}$ entrance to Ernest Sound, Alex. Arch.; $55^{\circ} 51^{\prime} \mathrm{N}, 132^{\circ} 22^{\prime} \mathrm{W}$; (map 4).

Local navigators' name reported in 1904 by H. C. Fassett, USBF; derived from Emest Sound.

Ernest Sound: water passage, extends $30 \mathrm{mi}$. SW, from mouth of Bradfield Canal at $56^{\circ} 11^{\prime} \mathrm{N}$, $132^{\circ} 18^{\prime} \mathrm{W}$, to Clarence Strait, Alex. Arch.; $55^{\circ} 48^{\prime} \mathrm{N}, 132^{\circ} 18^{\prime} \mathrm{W}$; (map 4). Var. Prince Ernest Sound.

This feature was explored on August 25, 1793, by James Johnstone, RN, on Capt. George Vancouver's second expedition, and named "Prince Ernest Sound" by Vancouver after one of the sons of King George III (Wagner, 1937, p. 486).

Ernie Creek: stream, flows C $14 \mathrm{mi}$. from Ernie Pass to North Fork Koyukuk River, $28 \mathrm{mi}$. SE of Anaktuvuk Pass and $39 \mathrm{mi}$. NW of Wiseman, Brooks Ra.; $67^{\circ} 55^{\prime} \mathrm{N}, 150^{\circ} 51^{\prime} \mathrm{W}$; $B G N$ 1932; (map 124).

Named about 1930 by Marshall (1956, p. 7, 8) for "Ernie Johnson of Bettles, the most famous trapper of the North Fork * * *."

Ernie Lake: lake, $1.5 \mathrm{mi}$. long, between Mattenpherg Creek and Iniakuk River, $27 \mathrm{mi}$. S 
of Sillyasheen Mtn. and $76.5 \mathrm{mi}$. W of Wiseman, Brooks Ra.; $67^{\circ} 23^{\prime} 45^{\prime \prime} \mathrm{N}, 153^{\circ} 00^{\prime} 00^{\prime \prime}$ W; (map 124).

Locally named for "Ernie" Johnson who reportedly had a cabin here; name obtained in 1956 by USGS.

Ernie Pass: pass, 3,200 ft., across Arctic divide, diverts headwaters of Anaktuvuk River to $\mathrm{N}$ and Ernie Creek to S, W of Limestack Mtn., $21 \mathrm{mi}$. E of Anaktuvuk Pass, Brooks Ra.; $68^{\circ} 05^{\prime} \mathrm{N}, 150^{\circ} 55^{\prime} \mathrm{W}$; BGN 1932; (map 134).

Named in 1932 by Marshall (1956, p. 16) who wrote, "I could look into the head of Anaktuvuk River, though the pass to it (later named Ernie Pass) [for his companion, Ernie Johnson, a locally well-known prospector] was hidden ***"

Ernivwing: locally, see Ireniviq.

Eroded Mountain: mountain, 3,236 ft., $\mathrm{N}$ of junc. of Tinayguk and North Fork Koyukuk Rivers and $29 \mathrm{mi}$. NW of Wiseman, Brooks Ra.; 67 $37^{\prime} 30^{\prime \prime} \mathrm{N}, 151^{\circ} 04^{\prime} 00^{\prime \prime} \mathrm{W}$; (map 124).

Name reported in 1939 by Marshall (1956, map).

Erok: locality, see Solomon.

Erratic Creek: stream, flows NW $13 \mathrm{mi}$. from Marshmallow Mtn. to Welcome Creek, $7 \mathrm{mi}$. NNE of Shainin Lake and $30 \mathrm{mi}$. NE of Anaktuvuk Pass, Brooks Ra.; $68^{\circ} 26^{\prime} 40^{\prime \prime} \mathrm{N}, 150^{\circ}$ $55^{\prime} 00^{\prime \prime} \mathrm{W}$; (map 134).

So named in 1950 by A. S. Keller, USGS, "because the valley of the creek is dotted with numerous large glacial erratics."

Error Island: island, $0.2 \mathrm{mi}$. across, in Kutchuma Is., $3 \mathrm{mi}$. $\mathrm{S}$ of Sitka, off $\mathrm{W}$ coast of Baranof I., Alex. Arch.; $57^{\circ} 00^{\prime} 35^{\prime \prime} \mathrm{N}, 135^{\circ} 19^{\prime} 10^{\prime \prime} \mathrm{W}$; (map 9). Var. Elgolm Island, Oshibki Islet, Oshinpi Island, Oshipki Island, Ostrov Oshibki, Ship Island, White Island.

This is an 1882 translation by USC\&GS of the name given in 1809 by the Russian navigator Ivan Vasiliev the first; reported by Lt. Sarichev (1826, map 19), IRN, as "Os[trov] Oshibki."

Erskine Bay: bay, $0.7 \mathrm{mi}$. across, part of Beaver Inlet on $\mathbf{E}$ coast of Unalaska I., Aleutian Is.; $53^{\circ} 44^{\prime} 30^{\prime \prime}$ N, $166^{\circ} 34^{\prime} 30^{\prime \prime}$ W; (map 23). Var. Kikukalen Bay, Kikukali Bay, Kikukalia Bay, Kikukalya Bay.

Named for Capt. Melville C. Erskine of the Alaska Commercial Company by USBF in 1888. Lt. Sarichev (1826, map 14), IRN, referred to it as "Zal[iv] Kikukalen," or "Kikukalen Bay." Father Veniaminov (1840, v. 1, p. 162) called it "Kikukalya."

Erskine Mountain: mountain, 2,563 ft., $7.5 \mathrm{mi}$. SW of Kodiak, Kodiak I. ; $57^{\circ} 44^{\prime} 35^{\prime \prime}$ N, $152^{\circ}$ 35'30' W; BGN 1941; (map 36).

Named in 1940 by USC\&GS for Capt. Melville Cox Erskine, 1835-1909, master of the first American vessel, the Fideleter, owned by the Alaska Commercial Company, to be registered in the new Territory of Alaska in 1867. Capt. Erskine superintended the building of the steamer St. Paul at Philadelphia in 1875. The St. Paul was the first iron ship to sail in the Bering Sea, and it was commanded by Capt. Erskine until 1893 when he was appointed as a San Francisco bar pilot.

Erskine Point: point of land, on NE coast of Unalaska I., Aleutian Is. ; $53^{\circ} 58^{\prime} 55^{\prime \prime} \mathrm{N}, 166^{\circ}$ $16^{\prime} 30^{\prime \prime} \mathrm{W}$; (map 23).

Named by USBF in 1888 for Capt. M. C. Erskine of the Alaska Commerical Company. Esatkuat Lagoon: estuary, $1.5 \mathrm{mi}$. long, on Chukchi Sea coast, E of Barrow, Arctic Plain; $72^{\circ} 17^{\prime} 45^{\prime \prime} \mathrm{N}, 156^{\circ} 45^{\prime} 00^{\prime \prime} \mathrm{W}$; (map 153). Var. Esutkwa, Isetkoak, Isutkwa, Village Slough.

Eskimo name recorded by Murdoch (1892, p. 27) in 1881 as "Isutkwa." He also stated that an ancient village with the same name was located at the estuary's northwest end. Escape Cape: point of land, on E shore of Port Krestof, on E coast of Kruzof I., Alex. Arch.; $57^{\circ} 09^{\prime} 10^{\prime \prime} \mathrm{N}, 135^{\circ} 34^{\prime} 40^{\prime \prime} \mathrm{W}$; (map 9). Var. Mys Koloshskoy Strechi.

USC\&GS derived this name about 1882 from translation of part of "Mys Koloshskoy Strechi," meaning "cape Koloshian-escape"; published by Lt. Sarichev (1826, map 19), IRN; given in 1809 by the navigator Ivan Vasiliev the first. Kolosh is the Russian name for the Tlingit Indians.

Escape Point: point of land, on W coast of Revillagigedo $\mathrm{I}$., at $\mathrm{S}$ point of entrance to $\mathrm{Francis}$ Cove and $2.7 \mathrm{mi}$. $\mathrm{N}$ of Indian Point, Alex. Arch.; 55 $39^{\prime} \mathrm{N}, 131^{\circ} 43^{\prime} \mathrm{W}$; (map 3). Var. Mys Iskep, Mys Izbavleniya, Point Escape.

Named by Capt. Vancouver, RN, "August 12, 1793, because of his escape here from the Indians" (Wagner, 1937, p. 386); Capt. Tebenkov (1852, map 9) published the name "Mys Izbavleniya," meaning "rescue cape."

Esch Creek: stream, in York Mts., flows SE 3 $\mathrm{mi}$. to Lost River which flows to Bering Sea, $28 \mathrm{mi}$. NW of Teller, Seward Penin. High.; $65^{\circ} 28^{\prime} \mathrm{N}, 167^{\circ} 11^{\prime} \mathrm{W}$; BGN 1948; (map 111). Var. West Creek.

Named in 1940 by J. B. Mertie, Jr. "after Peter Esch, deceased, a former prospector and assayer of this area." Shown as "West Creek" on the 1908 "Map of Seward Peninsula" by Arthur Gibson.

Eschholtz Bay: bay, see Eschscholtz Bay.

Escholtz Bay: bay, see Eschscholtz Bay.

Eschscholtz Bay: bay, $11 \mathrm{mi}$. across, arm of Kotzebue Sound, $45 \mathrm{mi}$. SW of Selawik, Kotzebue-Kobuk Low.; $66^{\circ} 20^{\prime}$ N, $161^{\circ} 30^{\prime} \mathrm{W}$; BGN Sixth Report; (map 114). Var. Escholtz Bay, Eschholtz Bay.

Named in 1816 by Lt. Otto von Kotzebue, IRN, for his ship's physician, Dr. Frederick Eschscholtz.

Escures, Mount: mountain, 4,377 ft., in Glacier Bay National Monument, $9 \mathrm{mi}$. E of Cape Fairweather and $95 \mathrm{mi}$. NW of Hoonah, St. Elias Mts.; $58^{\circ} 46^{\prime} 55^{\prime \prime} \mathrm{N}, 137^{\circ} 42^{\prime} 00^{\prime \prime} \mathrm{W}$; (map 10).

Name reported by USFS in 1946.

Escurial Island: island, $0.3 \mathrm{mi}$. long, one of the Maurelle Is., 15 mi. NW of Craig, Alex. Arch.; $55^{\circ} 36^{\prime} 30^{\prime \prime} \mathrm{N}, 133^{\circ} 35^{\prime} 20^{\prime \prime} \mathrm{W}$; (map 4).
Escurial [Escorial] is a palace near Madrid, Spain, built in 1563-84. Name was published in 1925 Coast Pilot (p. 187).

Esetuk Creek: stream, in Romanzof Mts., heads at Esetuk Glacier $3 \mathrm{mi}$. NW of Mount Michelson, flows $\mathrm{N} 8 \mathrm{mi}$. to the Hulahula River, Brooks Ra.; $69^{\circ} 26^{\prime}$ N, $144^{\circ} 27^{\prime}$ W ; BGN 1961; (map 139).

Named for an Eskimo man who died on this stream. It was obtained at Barter I. by USGS and reported in 1960 by C. L. Whittington.

Esetuk Glacier: glacier, in Romanzof Mts., at head of Esetuk Creek, between Tugak Peak and Mount Michelson, Brooks Ra.; $69^{\circ} 18^{\prime} \mathrm{N}$, $144^{\circ} 20^{\prime} \mathrm{W}$; (map 139).

Probably named in 1948 or 1958 by USGS for the stream that heads at its foot.

Eshamey Bay: bay, see Eshamy Bay.

Eshamy Bay: bay, on E coast of Kenai Penin., extends NE $2.5 \mathrm{mi}$. to Knight Island Passage, $14 \mathrm{mi}$. NE of Chenega, Chugach Mts.; $60^{\circ} 28^{\prime} 30^{\prime \prime} \mathrm{N}, 147^{\circ} 58^{\prime} 30^{\prime \prime} \mathrm{W}$; BGN 1942; (map 63). Var. Eshamey Bay.

Local name published in 1906 by USGS. The name signifies "good fishing grounds among the natives."

Eshamy Creek: stream, on Kenai Penin., heads at Eshamy Lake, flows E $0.3 \mathrm{mi}$. to Eshamy Lagoon, $12 \mathrm{mi}$. N of Chenega, Chugach Mts.; $60^{\circ} 27^{\prime} 15^{\prime \prime} \mathrm{N}, 148^{\circ} 05^{\prime} 45^{\prime \prime} \mathrm{W}$; BGN 1942; (map 63). Var. Chenega Creek, Cheniga Greek.

Local name adopted in 1942 by USGS; derived from nearby Eshamy Bay.

Eshamy Lagoon: estuary, on $\mathbf{E}$ coast of Kenai Penin., extends E 3 mi. from mouth of Eshamy Creek to head of Eshamy Bay, $13 \mathrm{mi}$. NE of Chenega, Chugach Mts.; $60^{\circ} 27^{\prime} 40^{\prime \prime} \mathrm{N}$, $148^{\circ} 00^{\prime} 30^{\prime \prime} \mathrm{W}$; BGN 1942; (map 63).

Local name published in 1919 by USC\&GS ; derived from Eshamy Bay.

Eshamy Lake: lake, on $\mathrm{E}$ side of Kenai Penin., $5 \mathrm{mi}$. long, $9 \mathrm{mi}$. N of Chenega, Chugach Mts.; $60^{\circ} 26^{\prime} 30^{\prime \prime} \mathrm{N}, 148^{\circ} 06^{\prime} 30^{\prime \prime} \mathrm{W}$; BGN 1942; (map 63). Var. Chenega Lake, Cheniga Lake.

Local name published in 1935 by USC\&GS ; derived from nearby Eshamy Bay.

Eshamy Peak: peak, 2,978 ft., on E side of Kenai Penin., $1.5 \mathrm{mi}$. N of Eshamy Lagoon, $14 \mathrm{mi}$. $\mathrm{N}$ of Chenega, Chugach Mts.; $60^{\circ} 28^{\prime} 55^{\prime \prime} \mathrm{N}$, 148 $04^{\prime} 30^{\prime \prime} \mathrm{W}$; BGN 1929; (map 63). Var. Nowel Peak.

Named in 1929 by USC\&GS.

Eska: village, pop. 53, on Eska Creek, $12 \mathrm{mi}$. NE of Palmer, Cook Inlet Low.; 61 ${ }^{\circ} 44^{\prime} 15^{\prime \prime}$ N, 148 $54^{\prime} 20^{\prime \prime} \mathrm{W}$; (map 69).

Name of a mining community and railroad station on a branch of The Alaska Railroad. A post office was established here in 1917, discontinued in 1922, but reinstated in 1943 (Ricks, 1965, p. 19).

Eska Creek: stream, heads at a glacier on Eska Mtn., flows S $8.7 \mathrm{mi}$. to Matanuska River, 9.5 mi. NE of Palmer, Cook Inlet Low.; 61 ${ }^{\circ} 42^{\prime} 15^{\prime \prime}$ N, $148^{\circ} 55^{\prime} 00^{\prime \prime} \mathrm{W}$; (map 69). 
Local name reported in 1905 by G. C. Martin (in Brooks and others, 1906, fig. 5), USGS.

Eska Mountain: mountain, 5,680 ft., SW of Granite Peak, 14 mi. NE of Palmer, Talkeetna Mts. ; $61^{\circ} 47^{\prime} \mathrm{N}, 148^{\circ} 57^{\prime} \mathrm{W}$; BGN 1946; (map $69)$.

Local name reported in 1945 by USGS; derived from Eska Creek.

Eska Peak: mountain, see Granite Peak.

Esker Stream: stream, heads in Atrevida Glacier $0.5 \mathrm{mi}$. W of Amphitheater Knob, flows $\mathrm{S}$ and SE $4.5 \mathrm{mi}$. to Yakutat Bay, $4.6 \mathrm{mi}$. SW of Bancas Point and $25 \mathrm{mi}$. N of Yakutat, St. Elias Mts.; $59^{\circ} 54^{\prime} 35^{\prime \prime} \mathrm{N}, 139^{\circ} 43^{\prime} 55^{\prime \prime} \mathrm{W}$; (map 46).

Named by Russell (1892, pl. 4), USGS. An esker is a serpentine ridge of sand and gravel deposited by a stream in association with glacier ice.

Eskimo Creek: stream, heads in lake, flows SW through King Salmon, $7 \mathrm{mi}$. to Naknek River on Alaska Penin., $13 \mathrm{mi}$. SE of Naknek, Bristol Bay Low.; $58^{\circ} 41^{\prime} 00^{\prime \prime} \mathrm{N}, 156^{\circ} 40^{\prime} 30^{\prime \prime} \mathrm{W}$; (map 41).

Local name reported in 1952 by USGS.

Eskimo Creek: stream, flows SW $26 \mathrm{mi}$. to Sheenjek River, $22 \mathrm{mi}$. SE of Table Mtn., Brooks Ra.; 68 ${ }^{\circ} 05^{\prime} \mathrm{N}, 143^{\circ} 09^{\prime} \mathrm{W}$; (map 137).

Local name reported in 1956 by USGS.

Eskimo Creek: stream, flows NW to Anikovik River, about $15 \mathrm{mi}$. E of Cape Prince of Wales, Seward Penin. High.; (map 111).

Prospectors' name shown on the 1900 "Map of Nome Peninsula" by J. M. Davidson and B. D. Blakeslee. This feature cannot be precisely identified on current maps.

Eskimo Creek: stream, flows NW to Granite Creek which flows to Kuzitrin River, about $20 \mathrm{mi}$. NE of Mount Bendeleben, Seward Penin. High.; (map 110).

Prospectors' name shown on a map of Cape Nome gold fields by David Fox, Jr., dated 1901. This stream cannot be precisely located on current maps.

Eskimo Hill: mountain, $1,110 \mathrm{ft}$., at junc. of Carbon Creek and Utukok River, $87 \mathrm{mi}$. S of Wainwright, Arctic Slope; $69^{\circ} 22^{\prime}$ N, $159^{\circ} 46^{\prime}$ W; (map 144).

Named in 1924 by W. T. Foran (in Chapman and Sable, 1960, p. 53), USGS.

Eskimo Island: islands, see Eskimo Islands.

Eskimo Islands: islands, each $2 \mathrm{mi}$. long, in Harrison Bay, at mouth of Kogru River, Arctic Plain; $70^{\circ} 34^{\prime} 30^{\prime \prime} \mathrm{N}, 151^{\circ} 55^{\prime} 00^{\prime \prime} \mathrm{W}$; BGN 1961; (map 149). .Var. Eskimo Island, Esquimaux Island, Saktuina Islands.

On August 7, 1837, P. W. Dease and Simpson (Simpson, Thomas, 1843 , p. 170) named one of the islands "Esquimaux Island" because, "On landing upon it, we found numerous vestiges of Esquimaux, * * *." Comdr. Rochfort Maguire's map (Great Britain, 1854, facing p. 186) shows "Saktuina Island," a name that is now applied to the mainland point west of the islands. Leffingwell (1919, p. 95) is responsible for the present plural form and application to a place "near the place where Dease and Simpson put the name."

Eskims Creek: stream, flows $\mathrm{W}$ to Sinuk River, about $31 \mathrm{mi}$. NW of Nome, Seward Penin. High.; (map 94).

Prospectors' name reported on the 1900 "Map of Nome Peninsula" by J. M. Davidson and B. D. Blakeslee; this feature has not been positively identified.

Esmeralda Mountain: mountain, 1,970 ft., on W coast of Baker I., Alex. Arch.; 52 $20^{\prime} 28^{\prime \prime} \mathrm{N}$, $133^{\circ} 37^{\prime} 45^{\prime \prime}$ W; BGN 1923; (map 4).

Spanish word meaning "emerald," given in 1923 by USC\&GS because this feature is "conspicuous, and vividly green in summer."

E. Smith's Bay: bay, see Smith Bay.

Esogemunga: ravine, $0.5 \mathrm{mi}$. long, $\mathrm{SE}$ of Fox Castle, talus slide on W coast of Saint George I., in Pribilof Is. ; $56^{\circ} 36^{\prime} \mathrm{N}, 169^{\circ} 45^{\prime} \mathrm{W}$; (map 38 ).

This is an Aleut name meaning "hair seal trail"; reported by Putnam (1903, p. 1014), USC\&GS. He said "Hair seals are found on the rocks west of the base of this slide, and the natives can pass up and down here when hunting them."

Esook: locality, see Ikpek.

Esook Trading Post: locality, on coast of Beaufort Sea, $11 \mathrm{mi}$. NW of Cape Halkett, Arctic Plain; $70^{\circ} 53^{\prime} 10^{\prime \prime} \mathrm{N}, 152^{\circ} 36^{\prime} 15^{\prime \prime} \mathrm{W}$; (map 149).

This place has been abandoned for many years.

Espada, Point: point of land, W tip of San Clemente I., in Portillo Channel, between Lulu and San Fernando Is., Alex. Arch.; 55 ${ }^{\circ}$. $28^{\prime} 25^{\prime \prime} \mathrm{N}, 133^{\circ} 24^{\prime} 45^{\prime \prime} \mathrm{W}$; (map 4). Var. Punta del Espada, Sword Point.

Spanish name given in 1779 by Don Juan de la Bodega y Quadra and Francisco Antonio Maurelle as "Punta del Espada," meaning "sword point."

Espada, Punta de: point of land, see Horn, Point. Espada, Punta del: point of land, see Espada, Point.

Espagnols, Iles des: islands, see Spanish Islands. Español, Cabo: point of land, "The name must have been given to the present Cape Hinchinbrook by Salvador Fidalgo when he entered Prince William Sound May 24, 1790. He says he located it in $60^{\circ} 15^{1} / 2^{\prime}$, nearly the latitude of Cape Hinchinbrook. Nevertheless on [Capt. Alessandro] Malaspina's map we find the name attached to the point now called St. Elias in $59^{\circ} 50^{\prime}$ at the south end of Kayak Island and he refers to it as in $59^{\circ} 59^{\prime \prime \prime}$ ' (Wagner, 1937, p. 451 )

Español, Cabo: point of land, see Saint Elias.

Español, Punta: point of land, see Saint Elias, Cape.

Español, Punta de: point of land, see Hinchinbrook, Cape.

Espenberg: locality, on Seward Penin., at mouth of Espenberg River, on Chukchi Sea, $50 \mathrm{mi}$. NW of Deering, Kotzebue-Kobuk Low.; $66^{\circ}$ $36^{\prime} \mathrm{N}, 163^{\circ} 58^{\prime} \mathrm{W}$; (map 113). Var. Toatut.

Former Eskimo settlement named for a nearby cape; reported in 1950 by USGS. Lt.
Jarvis (1899, p. 60), USRCS, mentioned a village of "Toatut" consisting of 2 huts and 20 people.

Espenberg Cape: point of land, on Seward Penin., extends into Kotzebue Sound, $42 \mathrm{mi}$. NW of Deering, Kotzebue-Kobuk Low.; $66^{\circ}$ $33^{\prime} \mathrm{N}, 163^{\circ} 36^{\prime} \mathrm{W} ; B G N$ 1944; (map 113). Var. Cape Espenburg, Cape Spanberg.

Named in 1816 by Lt. Otto von Kotzebue for Dr. Karl Espenberg, a surgeon who accompanied Adm. A. J. von Krusenstern on his voyage around the world in 1803-06.

Espenberg River: stream, on Seward Penin., flows NE $21 \mathrm{mi}$. to Chukchi Sea, $50 \mathrm{mi}$. NW of Deering, Kotzebue-Kobuk Low.; $66^{\circ} 36^{\prime} \mathrm{N}$, $163^{\circ} 58^{\prime} \mathrm{W}$; (map 113).

Local name reported in 1901 by A. J. Collier and T. G. Gerdine, USGS. Name derived from the nearby point of land.

Espenburg, Cape: point of land, see Espenberg, Cape.

Esperanto Creek: stream, flows NW $4.7 \mathrm{mi}$. to Madison Creek, $5 \mathrm{mi}$. N of Madison Mtn. and $23 \mathrm{mi}$. NW of Ophir, Kilbuck-Kuskokwim Mts.; $63^{\circ} 27^{\prime} \mathrm{N}, 156^{\circ} 50^{\prime} \mathrm{W}$; (map 90).

Local name reported in 1917 by G. L. Harrington, USGS.

Esperanza, Punta de la: point of land, see Latouche Point.

Esperanza Creek: stream, flows NW $8.5 \mathrm{mi}$. to Goodhope River, $22 \mathrm{mi}$. NW of Imuruk Lake, Seward Penin. High.; $65^{\circ} 48^{\prime} \mathrm{N}, 163^{\circ} 51^{\prime} \mathrm{W}$; BGN 1952; (map 110).

Prospectors' name reported in 1901 by USGS (Collier, 1902, pl. 12).

Esquibel, Bahia de: $b a y$, see Esquibel, Gulf of. Esquibel, Gulf of: bay, $15 \mathrm{mi}$. long, between Prince of Wales I. and Maurelle Is., Alex. Arch.; 55 $38^{\prime} \mathrm{N}, 133^{\circ} 30^{\prime} \mathrm{W}$; (map 4). Var. Bahia de Esquibel, Esquibel Bay, Gulf of Esquibel Boca Fina, Gulf of Esquible.

Named "Bahia de Esquibel," or "Esquibel Bay" by Francisco Antonio Maurelle "about May 22, 1779, in honor of Mariano Nuñez de Esquivel, the surgeon of the ship La Favorita" (Wagner, 1937, p. 386).

Esquibel Bay: bay, see Esquibel, Gulf of.

Esquibel Island: island, $2.5 \mathrm{mi}$. long, in Maurelle Is., Alex. Arch.; $55^{\circ} 38^{\prime} \mathrm{N}, 133^{\circ} 35^{\prime} \mathrm{W}$; $B G N$ 1917; (map 4). Var. Eel Island.

Named in 1916 by USC\&GS; derived from Gulf of Esquibel. See Wagner (1937, p. 386).

Esquible, Gulf of : $b a y$, see Esquibel, Gulf of.

Esquimaux Island: islands, see Eskimo Islands. Essawa Harbor: lagoon, see Essowah Harbor.

Essawa Lakes: lakes, see Essowah Lakes.

Essie Creek: stream, flows NW $10 \mathrm{mi}$. to Charley River $30 \mathrm{mi}$. SW of that stream's junc. with Yukon River, Yukon-Tanana High.; $65^{\circ}$ $01^{\prime} 45^{\prime \prime} \mathrm{N}, 143^{\circ} 20^{\prime} 30^{\prime \prime} \mathrm{W}$; (map 103).

Prospectors' name; from an unpublished map by E. J. Chamberlain, dated 1902 .

Ess Lake: lake, $0.6 \mathrm{mi}$. long, $4 \mathrm{mi}$. SE of Point Agassiz Penin. and $13 \mathrm{mi}$. NE of Petersburg, Coast Mts.; $56^{\circ} 57^{\prime} 30^{\prime \prime} \mathrm{N}, 132^{\circ} 44^{\prime} 55^{\prime \prime} \mathrm{W}$; (map 6). 
Local descriptive name reported in 1961 by USGS.

Essowah Harbor: estuary, $1 \mathrm{mi}$. long, between Essowah Lakes and Pacific Ocean, on SW coast of Dall I., $12 \mathrm{mi}$. NW of Cape Muzon, Alex. Arch.; 54 $46^{\prime} 45^{\prime \prime} \mathrm{N}, 132^{\circ} 53^{\prime} 15^{\prime \prime} \mathrm{W}$; (map 1). Var. Essawa Harbor.

Indian name reported in 1897 by Lt. Comdr. J. F. Moser, USN, who spelled it "Essawa."

Essowah Lakes: lakes, on SW side of Dall I., 12 mi. NW of Cape Muzon, Alex. Arch.; $54^{\circ} 47^{\prime}$ $\mathrm{N}, 132^{\circ} 52^{\prime} \mathrm{W}$; (map 1), Var. Essawa Lakes.

Indian name reported in 1897 as "Essawa" by Lt. Comdr. J. F. Moser, USN.

Essowah Point: point of land, $\mathrm{S}$ point of entrance to Essowah Harbor, on SW coast of Dall I., Alex. Arch.; 54 $46^{\prime} 20^{\prime \prime} \mathrm{N}, 132^{\circ} 54^{\prime} 15^{\prime \prime} \mathrm{W}$ : BGN Sixth Report; (map 1).

Name derived from Essowah Harbor; given by Capt. R. S. Patton, USC\&GS, in 1928.

Estelle, Mount: mountain, 6,575 ft., between Skwentna and Styx Rivers, $4 \mathrm{mi}$. S of Mount Stoney and $80 \mathrm{mi}$. NW of Tyonek, Alaska Ra.; $61^{\circ} 51^{\prime} 10^{\prime \prime} \mathrm{N}, 152^{\circ} 55^{\prime} 15^{\prime \prime} \mathrm{W}$; (map 70).

Named in 1898 by W. S. Post (in Spurr, 1900, map 6), USGS.

Ester: village, pop. 81, $2.5 \mathrm{mi} \mathrm{SE}$ of Ester Dome and $8.5 \mathrm{mi}$. W of Fairbanks, Yukon-Tanana High.; $64^{\circ} 50^{\prime} 50^{\prime \prime} \mathrm{N}, 148^{\circ} 01^{\prime} 00^{\prime \prime} \mathrm{W}$; $B G N$ 1965; (map 100). Var. Berry, Ester City, Esther, Discovery.

Mining camp name derived from Ester Creek and reported in 1908 by USGS. According to Kitchener (1954, p. 297), the mining camp existed before 1905 . The Berry post office was located here for a while; name changed to Ester post office in 1965. See Berry.

Ester City: village, see Ester.

Ester Creek: stream, flows SW $2 \mathrm{mi}$. to Dollar Creek $1.5 \mathrm{mi}$. SE of its junc. with Beaver Creek, $8 \mathrm{mi}$. SW of Ophir and $31 \mathrm{mi}$. NW of McGrath, Kilbuck-Kuskokwim Mts.; $63^{\circ} 01^{\prime} 50^{\prime \prime} \mathrm{N}, 156^{\circ} 37^{\prime} 15^{\prime \prime} \mathrm{W}$; (map 90).

Prospectors' name reported in 1912 by $\mathbf{H}$. M. Eakin, USGS.

Ester Creek: stream, flows E $5.3 \mathrm{mi}$. to Cripple Creek, $6.5 \mathrm{mi}$. W of Fairbanks, Yukon-Tanana High.; $64^{\circ} 50^{\prime} 25^{\prime \prime} \mathrm{N}, 147^{\circ} 57^{\prime} 20^{\prime \prime} \mathrm{W}$; (map 100). Var. Esther Creek.

Named by prospectors and shown on a manuscript map of the Fairbanks Mining District by C. W. Joint in 1905 as "Esther Creek." By 1907 the present form had become established and was published in 1908 by USGS.

Ester Creek: stream, flows SW $2.5 \mathrm{mi}$. to Tolovana River, $3 \mathrm{mi}$. SE of Livengood, Yukon-Tanana High.; $65^{\circ} 28^{\prime} 30^{\prime \prime} \mathrm{N}, 148^{\circ} 30^{\prime} 00^{\prime \prime}$ W; (map 105).

Named by prospectors; reported in 1915 by USGS (Brooks and others, 1916, pl. 9). The name is probably derived from Ester Creek near Fairbanks.

Ester Dome: mountain, 2,350 ft., $9.5 \mathrm{mi}$. NW of Fairbanks, Yukon-Tanana High.; 64'52'50' $\mathrm{N}, 148^{\circ} 03^{\prime} 05^{\prime \prime} \mathrm{W}$; (map 100).

Local name derived from Ester Creek. The mountain is on the northern limit of the creek drainage basin. The name was reported in 1912 by P. S. Smith (in Prindle, 1913a, fig. 20), USGS.

Esteriles, Islas: islands, see Barren Islands. Ester Siding: RR. station, see Ester Station.

Ester Station: RR. station, mile 465.6 on The Alaska RR., $4.6 \mathrm{mi}$. NW of Fairbanks, YukonTanana High.; 64 $51^{\prime} 45^{\prime \prime} \mathrm{N}, 147^{\circ} 52^{\prime} 20^{\prime \prime} \mathrm{W}$; (map 100). Var. Ester Siding, Esther.

Name derived from the Ester mining camp, which the station served. The name was published in a timetable in 1922. Ester Siding was published in 1908 by USGS.

Esther: village, see Ester.

Esther: RR. station, see Ester Station.

Esther, Point: point of land, on SW coast of Esther I., at junc. of Port Wells and Wells Passage, $19 \mathrm{mi}$. E of Whittier, Chugach Mts.; $60^{\circ} 47^{\prime} 45^{\prime \prime} \mathrm{N}, 148^{\circ} 08^{\prime} 30^{\prime \prime} \mathrm{W}$; BGN 1914; (map 63).

Local name reported in 1914 by USC\&GS; derived from the name of the island.

Esther Bay: estuary, on SE coast of Esther I., extends S $2.5 \mathrm{mi}$. to Wells Passage, $24 \mathrm{mi}$. E of Whittier, Chugach Mts.; $60^{\circ} 48^{\prime} 00^{\prime \prime} \mathrm{N}$, $147^{\circ} 58^{\prime} 30^{\prime \prime} \mathrm{W}$; ( $\operatorname{map} 63$ ).

Local name reported in 1952 by USGS.

Esther Creek: stream, see Ester Creek.

Esther Island: island, $0.1 \mathrm{mi}$. across, at $\mathrm{S}$ end of Lisianski Strait, $18 \mathrm{mi}$. NW of Chichagof, on $\mathrm{W}$ coast of Chichagof I., Alex. Arch.; $57^{\circ} 50^{\prime} 45^{\prime \prime} \mathrm{N}, 136^{\circ} 26^{\prime} 00^{\prime \prime} \mathrm{W}$; (map 9).

Name published by USC\&GS in the 1925 Coast Pilot (p. 324).

Esther Island: island, $12 \mathrm{mi}$. long, off NE coast of Kenai Penin., $20 \mathrm{mi}$. NE of Whittier, Chugach Mts., $60^{\circ} 52^{\prime} \mathrm{N}, 148^{\circ} 01^{\prime} \mathrm{W}$; (map 63).

Named in 1794 by Capt. George Vancouver, RN. The name is shown on Vancouver's chart but is not mentioned in the text (Wagner, 1937, p. 387).

Esther Island: island, $1 \mathrm{mi}$. long, between Flora I. and the main channel of Yukon River $5 \mathrm{mi}$. $\mathrm{S}$ of Russian Mission, Yukon-Kuskokwim Delta ; $61^{\circ} 43^{\prime} \mathrm{N}, 161^{\circ} 19^{\prime} \mathrm{W}$; (map 73).

Riverboat pilots' name shown on a 1940 navigation chart of the Yukon River.

Esther Island Passage: water passage, see Esther Passage.

Esther Lagoon: lagoon, $0.2 \mathrm{mi}$. across, in Bluefox Bay, on N coast of Afognak I., Kodiak I.; $58^{\circ}$ $25^{\prime} 40^{\prime \prime} \mathrm{N}, 152^{\circ} 40^{\prime} 00^{\prime \prime} \mathrm{W}$; (map 43).

Name published by USC\&GS in 1928 on Chart 8573.

Esther Lake: lake, on S side of Esther I., trends N-S 4 mi., 22 mi. NE of Whittier, Chugach Mts.; $60^{\circ} 50^{\prime} \mathrm{N}, 148^{\circ} 05^{\prime} \mathrm{W}$; (map 63).

Name published in 1952 on USGS map; derived from name of island.

Esther Passage: water passage, extends SE 11 mi. from Port Wells to NE end of Wells Passage, between Esther I. and S coast of Alaska, 27 mi. NE of Whittier, Chugach Mts.; 60 $53^{\prime}$ N, $147^{\circ} 56^{\prime} \mathrm{W}$; (map 63). Var. Esther Island Passage.

Local name reported by U.S. Grant (1908, pl. 4), USGS ; derived from Esther Island.

Esther Rock: rock, off SW coast of Esther I., in
SE end of Port Wells, $18 \mathrm{mi}$. E of Whittier, Chugach Mts.; $60^{\circ} 48^{\prime} 05^{\prime \prime} \mathrm{N}, 148^{\circ} 10^{\prime} 40^{\prime \prime} \mathrm{W}$; $B G N$ 1914; (map 64).

Local name reported in 1914 by USC\&GS; derived from nearby Esther Island.

Estrella, Port: estuary, extends E $2 \mathrm{mi}$., off Bucareli Bay, at $\mathrm{N}$ entrance to Ulloa Channel, on $W$ coast of Prince of Wales I., Alex. Arch.; 55 $21^{\prime} 30^{\prime \prime} \mathrm{N}, 133^{\circ} 16^{\prime} 30^{\prime \prime} \mathrm{W}$; (map 4). Var. Puerto de Estrella, Puerto de la Estrella, Zaliv de la Yestrelya.

Named "Puerto de Estrella," or "port of the star," on June 3, 1779, by Francisco Antonio Maurelle (Wagner, 1937, p. 387). The "star" referred to is probably the North Star.

Estrella, Puerto de: estuary, see Estrella Port. Estremadura, Ensenada de: bay, in the vicinity of Icy Cape.

Shown on a 1791 map by Capt. Alessandro Malaspina.

Estuanto, Isla: island, on Don Juan de la Bodega y Quadra's map of 1791 either for Shuyak Island or a small one to the north of it. On his 1792 map it appears as a "cabo." See Wagner (1937, p. 452). Var. Isla Estuardo.

Estuardo, Isla: island, see Estuanto, Isla.

Estus Point: point of land, in Hagemeister Strait, $5 \mathrm{mi}$. SE of Virgo Mtn. and $8 \mathrm{mi}$. NW of Hagemeister I., Kilbuck-Kuskokwim Mts.; 58 47' N, $161^{\circ} 12^{\prime} \mathrm{W}$; (map 39).

Local name reported in 1948 by USAAF. Estu-y-a-rok: stream, see Kakhtul River.

Estu-y-a-rok: stream, see Stuyarok River.

Estu-y-a-rok: stream, see Swan River.

Esuktak River: stream, see Usuktuk River.

Esukteo River: stream, see Usuktuk River.

Esuktuk River: stream, see Usuktuk River.

Esuktu River: stream, see Usuktuk River.

Esutkwa: estuary, see Esatkuat Lagoon.

Etchepuk River: stream, heads on NW side of Mount Kachauik, flows NW $20 \mathrm{mi}$. to Fish River, $32 \mathrm{mi}$. N of Golovin, Seward Penin. High.; $64^{\circ} 58^{\prime} 30^{\prime \prime} \mathrm{N}, 163^{\circ} 06^{\prime} 00^{\prime \prime} \mathrm{W} ; B G N$ 1910; (map 95).

Eskimo name reported in 1910 by USGS. Etchepuk River: stream, see Cliff Creek.

Etches, Port: bay, $10 \mathrm{mi}$. long, on SW coast of Hinchinbrook I., $30 \mathrm{mi}$. SW of Cordova, Chugach Mts.; $60^{\circ} 20^{\prime} \mathrm{N}, 146^{\circ} 37^{\prime} \mathrm{W}$; (map 64). Var. Noocheck, Nooscha, Nuchek, Nutschek, Port Rose, Puerto de Santiago.

Named by Capt. Portlock (1789, p. 244) in July 1787, presumedly for John Cadman Etches, who with "other traders entered into a commercial partnership, under the title of The King George's Sound Company, for carrying a fur trade from the western coast of America to China (1789, p. 4)." Baker (1906, p. 246), USGS, stated that the port was named for "John and Camden Etches and Co., of London, early fur traders of the Northwest coast." Capt. George Dixon, RN, who accompanied Portlock on the voyage, called it "Port Rose." The Russians adopted the Indian name "Nuchek" for this feature, referring to it as "Zaliv Nuchek" on their Hydrog. Dept. Chart 1378, dated 1847. The bay was named "Puerto de Santiago," July 23, 
1779 , by Don Ignacio Arteaga as a novena was prepared to celebrate the saint's day on July 25.

Etches Creek: stream, on Hinchinbrook I., flows $\mathrm{N} 2 \mathrm{mi}$. to Port Etches, $33 \mathrm{mi}$. SW of Cordova, Chugach Mts.; $60^{\circ} 19^{\prime} \mathrm{N}, 146^{\circ} 34^{\prime} \mathrm{W}$; (map 64).

Name published in 1950 by USGS; derived from Port Etches to which the stream flows.

Ethel Cove: cove, $0.5 \mathrm{mi}$. across, on $\mathrm{NW}$ shore of Gertrude Cove, S coast of Kiska I., Aleutian Is. ; $51^{\circ} 56^{\prime} 10^{\prime \prime} \mathrm{N}, 177^{\circ} 26^{\prime} 00^{\prime \prime} \mathrm{E}$; (map 14).

One of many arbitrary names applied to features on Kiska I. by USAAF for tactical purposes during World War II.

Etholin, Point: point of land, see Etolin Point. Etholine Harbor: harbor, see Wrangell Harbor.

Etienne Bay: bay, on SW coast of Attu I., extends E $5.5 \mathrm{mi}$. from Etienne Head, Aleutian Is.; $52^{\circ} 54^{\prime} \mathrm{N}, 172^{\circ} 35^{\prime} \mathrm{E}$; BGN 1938; (map 13). Var. Portage Bay.

Name was proposed in 1938 by U.S. Navy Hydrog. Office; shown as Portage Bay on a manuscript map by L. M. Turner in the 1880's. "Saint Etienne" was possibly a former name for Attu Island (Baker, 1906, p. 108).

Etienne Head: point of land, on SW coast of Attu I., W point of entrance to Etienne Bay, Aleutian Is.; $52^{\circ} 54^{\prime} 25^{\prime \prime} \mathrm{N}, 172^{\circ} 32^{\prime} 00^{\prime \prime} \mathrm{E}$, $B G N$ 1938; (map 13). Var. Muchoo Point.

Name derived from Etienne Bay; proposed in 1938 by U.S. Navy Hydrog. Office. Shown as "Muchoo Point" on a manuscript map by L. M. Turner in the 1880's.

Etienne Lake: lake, $0.8 \mathrm{mi}$. long, on $W$ coast of Attu I., ENE of Etienne Bay, Aleutian Is. ; 52 ${ }^{\circ}$ $55^{\prime} 45^{\prime \prime} \mathrm{N}, 172^{\circ} 40^{\prime} 00^{\prime \prime} \mathrm{E}$; (map 13).

Name derived from Etienne Bay; published in 1948 by AMS.

Etienne Pass: pass, $800 \mathrm{ft}$., on Attu I., $3 \mathrm{mi}$. ENE of Etienne Bay, Aleutian Is.; $52^{\circ} 56^{\prime} 30^{\prime \prime} \mathrm{N}$, $172^{\circ} 42^{\prime} 30^{\prime \prime} \mathrm{E}$; (map 13).

Name derived from Etienne Bay; published in 1948 by AMS.

Etigonik Mountain: hill, 1,909 ft., extends E-W $9 \mathrm{mi}$. along right bank of Colville River, NE of Liberator Lake, Arctic Slope; $68^{\circ} 55^{\prime} \mathrm{N}$, $158^{\circ} 00^{\prime} \mathrm{W}$; (map 132).

Eskimo name obtained at Anaktuvuk Pass by T. E. Taylor, USGS, in 1956 and reported to mean "to smell of [fox] urine."

Etikamiut: locality, on E coast of Cape Mendenhall, $2.5 \mathrm{mi}$. NW of Irwakyaruk Point, Nunivak I.; $59^{\circ} 48^{\prime} 30^{\prime \prime} \mathrm{N}, 166^{\circ} 07^{\prime} 00^{\prime \prime} \mathrm{W}$; (map 55).

Eskimo summer and winter camp reported in 1932 by USC\&GS.

Etivlik Lake: lake, 2 mi. across, in Brooks Ra., $21 \mathrm{mi}$. ESE of Howard Pass; 68 ${ }^{\circ} 07^{\prime} 30^{\prime \prime} \mathrm{N}$, $156^{\circ} 04^{\prime} 00^{\prime} \mathrm{W}$; BGN 1960; (map 132). Var. Etivluk Lake, Itivlik Lake, Nigu Lake, Titarlilik Lake.

Eskimo name published as "Itivlik" by Irving (1954, p. 204). It probably has the same word derivation as the nearby Etivluk River.

Etivluk Lake; lake, see Etivilik Lake.
Etivluk River: stream, heads in Nigtun Lake at Howard Pass in Howard Hills, flows NE 56 mi. to Colville River $13 \mathrm{mi}$. E of its junc, with Ipnavik River, Brooks Ra.; 68 $57^{\circ}$ N, $155^{\circ} 57^{\prime}$ W; (map 133).

Eskimo name obtained by Ens. W. L. Howard, USN, on April 21, 1886, on his expedition from Fort Cosmos on the Kobuk River to Point Barrow (Stoney, 1900, p. 68). Lt. Stoney (p. 39) also appears to have been on this stream in December, 1885 , but he did not give it a name. The name is spelled "E-tiv-lik" on a manuscript map done by an Eskimo about 1890.

Etivolipar Greek : stream, see Kutchaurak Creek. Etohlugamiut: locality, see Etoluk.

Etokek Slough: stream, flows NE $5.4 \mathrm{mi}$. to Apoon Pass, 27 mi. NE of Kwiguk, YukonKuskokwim Delta; $62^{\circ} 59^{\prime} 40^{\prime \prime}$ N, $163^{\circ} 48^{\prime} 00^{\prime \prime}$ W; (map 77). Var. Chopeluk Slough, Etokok Slough.

Eskimo name obtained in 1952 by U.S. Army Corps of Engineers.

Etokok Slough: stream, see Etokek Slough.

Etolin, Cape: point of land, $25 \mathrm{mi}$. SW of Cape Vancouver, extends into Bering Sea, off $\mathbf{N}$ coast of Nunivak I.; $60^{\circ} 26^{\prime} \mathrm{N}, 166^{\circ} 09^{\prime} \mathrm{W}$; (map 57). Var. Khromchenko, Cape.

Named "M[ys] Etolina" by the Russians for Capt. Adolph Karlovich Etolin, governor of the Russian American colonies, 1841-45, who, with Khromchenko, explored this area in 1821.

Etolin, Mount: mountain, 3,705 ft., on Etolin I., $2.5 \mathrm{mi}$. $\mathrm{W}$ of Canoe Passage and $32 \mathrm{mi}$. S of Wrangell, Alex. Arch.; $56^{\circ} 02^{\prime} 15^{\prime \prime} \mathrm{N}, 132^{\circ}$ 16'45" W; (map 6).

Named in 1886 by Lt. Comdr. A. S. Snow, USN, for Capt. Adolph Karlovich Etolin, governor of the Russian American colonies in 1841-45.

Etolin, Mys: point of land, see Etolin Point.

Etolina, Gavan: harbor, see Wrangell Harbor. Etolina, Mys: point of land, see Etolin Point. Etoline, Cap: point of land, see Etolin Point. Etolin Bay: bay, $25 \mathrm{mi}$. SW of Cape Vancouver, off $\mathbf{E}$ coast of Cape Etolin, on Nunivak I.; $60^{\circ} 26^{\prime} \mathrm{N}, 166^{\circ} 08^{\prime} \mathrm{W}$; (map 57).

Name reported about 1908 by USC\&GS. Etolina, Gavan: harbor, see Wrangell Harbor.

Etolin Island: island, extends NW-SE $32 \mathrm{mi}$., separated from Prince of Wales I. on $\mathrm{W}$ by Clarence Straight, $9 \mathrm{mi}$. $\mathrm{S}$ of Wrangell, Alex. Arch.; $56^{\circ} 06^{\prime} \mathrm{N}, 132^{\circ} 21^{\prime} \mathrm{W}$; (map 6).

Named by USC\&GS for charting purposes; name published in 1925 Coast Pilot (p. 120).

Etolin Point: locality, on $\mathrm{E}$ shore of Nushagak Bay, $27 \mathrm{mi}$. SE of Dillingham, Bristol Bay Low.; $58^{\circ} 40^{\prime} 05^{\prime \prime} \mathrm{N}, 158^{\circ} 19^{\prime} 45^{\prime \prime} \mathrm{W}$; (map 40).

Eskimo settlement or camp reported in 1936 by USGS.

Etolin Point: point of land, between Kvickak and Nushagak Bays, $30 \mathrm{mi}$. SE of Dillingham, Bristol Bay Low.; $58^{\circ} 37^{\prime} \mathrm{N}, 158^{\circ} 15^{\prime} \mathrm{W}$; (map 40). Var. Cap Etoline, Mys Etolin, Mys Etolina, Mys Bristolskiy, Point Etholin, Bristol Cape.
Name reported in 1828 by Capt. Lutke (1836, map 14), IRN, as "M[ys] Etolin" and "C[ap] Etoline"; named for Capt. Adolph Karlovich Etolin, governor of the RussianAmerican colonies from 1841 to 1845 , who explored this region in 1821 .

Etolin Strait: water passage, $50 \mathrm{mi}$. long, near E shore of Bering Sea, between Nunivak I. and Yukon-Kuskokwim Delta; $60^{\circ} 00^{\prime} \mathrm{N}, 165^{\circ} 00^{\prime}$ W; (map 57). Var. Cook Strait.

Discovered in 1821 by Capt. A. K. Etolin, later governor of the Russian American colonies, who named it "Cook Strait" for Capt. James Cook, RN. Adm. A. J. von Krusenstern, $\mathrm{RN}$, later proposed that it be named for its discoverer.

Etoluk: locality, "in the Kuskokwim district." Var. Etohlugamiut.

Former Eskimo camp or settlement listed as "Etohlugamiut" with a population of 25 in the 1890 Census.

Etpinado Cape: point of land, see Empinado, Cape.

Etta Creek: stream, flows SW $1.2 \mathrm{mi}$. to East Fork Solomon River, $13 \mathrm{mi}$. NE of Solomon, Seward Penin. High.; $64^{\circ} 42^{\prime} \mathrm{N}, 164^{\circ} 10^{\prime} \mathrm{W}$; (map 95).

Prospectors' name reported on a 1902 prospector's manuscript map.

Ettrain Creek: stream, heads in Canada at $65^{\circ} 17^{\prime} \mathrm{N}, 140^{\circ} 42^{\prime} \mathrm{W}$, flows NW $26 \mathrm{mi}$. to Nation River, $48 \mathrm{mi}$. N of Eagle, Porcupine Plat.; $65^{\circ} 27^{\prime} 50^{\prime \prime} \mathrm{N}, 141^{\circ} 16^{\prime} 10^{\prime \prime} \mathrm{W}$; $B G N$ 1912; (map 103).

Named in 1910 by the IBC survey and reported by Thomas Riggs, of the survey, to be an Indian word meaning "mosquito."

E-tu-le-lig-a-mute: locality, see Itulilik.

Euchalon Point: point of land, see Hooligan Point.

Euchre Mountain: mountain, 6,862 ft., near terminus of Chisana Glacier, $68 \mathrm{mi}$. SW of Northway Junction, Wrangell Mts.; 62 ${ }^{\circ} 03^{\prime} \mathrm{N}$, $142^{\circ} 11^{\prime} \mathrm{W}$; (map 84).

Named in 1899 by A. H. Brooks, USGS, for a favorite horse used on his field trip.

Eudocia Islands: islands, see Semidi Islands.

Eudokievskie Islands: islands, see Semidi Islands. Eudora Mountain: mountain, 3,515 ft., on Prince of Wales I. between Cholmondeley and Moira Sounds, Alex. Arch. ; $55^{\circ} 07^{\prime} 40^{\prime \prime} \mathrm{N}, 132^{\circ} 14^{\prime} 50^{\prime \prime}$ W; (map 4). Var. Endora Mountain.

Named in 1886 by Lt. Comdr. R. Clover, USN. This name was erroneously published as "Endora" in the 1891 Coast Pilot (p. 87)

Eudoxia Islands: islands, see Semidi Islands.

Eugenia, Point: point of land, on NW coast of San Juan Bautista I., Alex. Arch.; 55 $26^{\prime} 45^{\prime \prime}$ N, $133^{\circ} 17^{\prime} 25^{\prime \prime} \mathrm{W}$; (map 4). Var. Punta de Eugenia, Punta San Eugenio.

Spanish name given in 1779 by Don Juan de la Bodega y Quadra and Francisco Antonio Maurelle as "Punta San Eugenio," meaning "Point Saint Eugene."

Eugenia, Punta de: point of land, see Eugenia, Point.

Eulachon Slough: channel, see Hooligan Slough. 
Eureka: locality, site of mining camp, at junc. of Pioneer and Eureka Creeks, $3 \mathrm{mi}$. S of Eureka Dome and $23 \mathrm{mi}$. S of Rampart, Yukon-Tanana High.; $65^{\circ} 11^{\prime} \mathrm{N}, 150^{\circ} 13^{\prime} \mathrm{W}$; (map 106). Var. Glen, Glenn.

This camp was established in 1899. A telegraph station called "Glen" was established here about 1904 and, in 1909 , a post office called "Eureka" which was discontinued in 1918 (Ricks, 1965, p. 20).

Eureka: locality, see Kantishna.

Eureka Bight: cove, $2.2 \mathrm{mi}$. across, on $\mathrm{E}$ coast of Tanaga I., Aleutian Is.; $51^{\circ} 43^{\prime} 45^{\prime \prime} \mathrm{N}, 177^{\circ}$. $49^{\prime} 30^{\prime \prime} \mathrm{W}$; (map 17).

Name published by USC\&GS in 1956 on Chart 9145.

Eureka Channel: water passage, $4 \mathrm{mi}$. long, between Barrier Is. and SW coast of Prince of Wales I., Alex. Arch.; 54 $47^{\prime} \mathrm{N}, 132^{\circ} 23^{\prime} \mathrm{W}$; $B G N$ 1908; (map 1). Var. Eureka Pass.

Local name reported in 1908 as "Eureka Pass" by USC\&GS; BGN changed the generic to "Channel."

Eureka Creek: ravine, see Eureka Gulch.

Eureka Creek: stream, flows NE $4 \mathrm{mi}$. to Dominion Creek, $77 \mathrm{mi}$. NE of Bethel, Kilbuck-Kuskokwim Mts.; $60^{\circ} 59^{\prime}$ N, $159^{\circ} 32^{\prime}$ W; (map 59) .

Prospectors' name reported in 1914 by A. G. Maddren (in Brooks, 1915, pl. 11), USGS.

Eureka Creek: stream, heads in lake, flows $17 \mathrm{mi}$. SW through Lake Leila and NE through Tahneta Lake to Nelchina River, $49 \mathrm{mi}$. SE of Glennallen, Copper River Basin; 61 ${ }^{\circ} 54^{\prime}$ $35^{\prime \prime} \mathrm{N}, 147^{\circ} 00^{\prime} 20^{\prime \prime} \mathrm{W}$; BGN 1960; (map 69).

Local name published in 1951 by USGS

Eureka Creek: stream, heads at glacier terminus, flows $\mathrm{E} 18 \mathrm{mi}$. to Delta River, $18 \mathrm{mi}$. NW of Paxson, Alaska Ra.; $63^{\circ} 15^{\prime} 20^{\prime \prime} \mathrm{N}, 145^{\circ} 48^{\prime}$. 00" W; (map 86). Var. Canyon Creek.

Prospector's name reported on 1910 fieldsheet by C. E. Giffin, USGS.

Eureka Creek: stream, in Kantishna Hills, flows SW 4 mi. to Moose Creek, S of Quigley Ridge, $3 \mathrm{mi}$. NNW of Wonder Lake, Alaska Ra.; $63^{\circ} 31^{\prime} 40^{\prime \prime} \mathrm{N}, 150^{\circ} 57^{\prime} 40^{\prime \prime} \mathrm{W}$; (map 88).

Name shown on a 1905 manuscript map of "Kantishna Gold Fields" by A. Friedrich, prospector.

Eureka Creek: stream, flows W $0.5 \mathrm{mi}$. to Solomon River, $0.3 \mathrm{mi}$. S of Rock Creek and 3.3 mi. NE of Solomon, Seward Penin. High.; $64^{\circ} 36^{\prime} 15^{\prime \prime} \mathrm{N}, 164^{\circ} 22^{\prime} 45^{\prime \prime} \mathrm{W}$; (map 95). Var. Chambers.

Prospectors' name reported in 1905 by T. G. Gerdine, USGS. This appears to be the stream indicated as "Chambers" on a prospector's manuscript map dated 1902.

Eureka Creek: stream, flows SE $1.2 \mathrm{mi}$. to Bonanza River, $10 \mathrm{mi}$. NW of Solomon, Seward Penin. High.; $64^{\circ} 39^{\prime} \mathrm{N}, 164^{\circ} 43^{\prime} \mathrm{W}$; (map 95).

Prospectors' name reported on the 1900 "Map of Nome Peninsula" by J. M. Davidson and B. D. Blakeslee.
Eureka Creek: stream, flows SW $3 \mathrm{mi}$. to Skookum River which flows to Klokerblok River, $19 \mathrm{mi}$. NE of Solomon, Seward Penin. High.; $64^{\circ} 41^{\prime} \mathrm{N}, 163^{\circ} 52^{\prime} \mathrm{W}$; (map 95).

Prospectors' name reported in 1900 by E. C. Barnard (in Brooks, 1901, pl. 17), USGS. Eureka Creek: stream, flows NE $1 \mathrm{mi}$. to Canyon Creek which flows to Casadepaga River, 21 mi. NE of Solomon, Seward Penin. High.; $64^{\circ} 51^{\prime} \mathrm{N}, 164^{\circ} 21^{\prime} \mathrm{W}$; (map 95).

Prospectors' name reported in 1905 by $\mathrm{T}$. G. Gerdine, USGS.

Eureka Creek: stream, flows NE $1.2 \mathrm{mi}$. to Elkhorn Creek which flows to Niukluk River, $28 \mathrm{mi}$. NE of Solomon, Seward Penin. High.; $64^{\circ} 55^{\prime} \mathrm{N}, 164^{\circ} 00^{\prime} \mathrm{W}$; (map 95).

Prospectors' name published in 1956 by USGS.

Eureka Creek: stream, flows E $1 \mathrm{mi}$. to O'Connor Creek, $9 \mathrm{mi}$. NW of Fairbanks, Yukon-Tanana High.; $64^{\circ} 57^{\prime} 25^{\prime \prime} \mathrm{N}, 147^{\circ} 52^{\prime} 55^{\prime \prime} \mathrm{W}$; (map 100).

Name applied by prospectors; published in 1908 by USGS.

Eureka Creek: stream, flows SW $12 \mathrm{mi}$. to Baker Creek at Overland Bluff, $53 \mathrm{mi}$. ESE of Tanana, Yukon-Tanana High.; $65^{\circ} 05^{\prime} 30^{\prime \prime} \mathrm{N}$, $150^{\circ} 17^{\circ} 00^{\prime \prime} \mathrm{W}$; (map 106).

Prospectors' name shown on a manuscript map by Gibbs and Patterson (cnna), dated 1902. Gold was discovered here in February 1899.

Eureka Creek: stream, flows NE $7 \mathrm{mi}$. to Agiapuk River, $17 \mathrm{mi}$. E of Teller, Seward Penin. High.; $65^{\circ} 15^{\prime} \mathrm{N}, 165^{\circ} 46^{\prime} \mathrm{W}$; (map 111).

Prospectors' name reported on the 1908 "Map of Seward Peninsula" by Arthur Gibson.

Eureka Creek: stream, flows NW $13 \mathrm{mi}$. to Little Melozitna River, 19 mi. N of Birches, Kokrines-Hodzana High.; $65^{\circ} 24^{\prime} 30^{\prime \prime} \mathrm{N}, 1^{\circ} 3^{\circ} 28^{\prime}$ $20^{\prime \prime} \mathrm{W}$; (map 107).

Prospectors' name reported in 1908 by Maddren (1910, pl. 5), USGS.

Eureka Creek: stream, flows W 12 mi. to Yukon River $28 \mathrm{mi}$. NW of its junc. with Charley River, Porcupine Plat.; $65^{\circ} 26^{\prime} 15^{\prime \prime} \mathrm{N}, 143^{\circ}$. $34^{\prime} 00^{\prime \prime}$ W; (map 103). Var. Thirtymile River.

Name used by prospectors and reported in 1915 by USGS.

Eureka Creek: stream, flows NW $1 \mathrm{mi}$. to Baituk Creek which flows to Bering Sea, $11 \mathrm{mi}$. E of Cape Prince of Wales and $44 \mathrm{mi}$. NW of Teller, Seward Penin. High.; 65 $33^{\prime} \mathrm{N}$, $167^{\circ} 43^{\prime} \mathrm{W}$; (map 111).

Prospectors' name reported on the 1908 "Map of Seward Peninsula" by Arthur Gibson.

Eureka Creek: stream, flows SW $3 \mathrm{mi}$. to North Fork Kougarok River, $4 \mathrm{mi}$. SW of Harris Dome and $43 \mathrm{mi}$. W of Imuruk Lake, Seward Penin. High.; $65^{\circ} 36^{\prime} \mathrm{N}, 164^{\circ} 42^{\prime} \mathrm{W}$; (map 110).

Prospectors' name reported in 1901 by T. G. Gerdine (in Collier, 1902, pl. 12), USGS.

Eureka Creek: stream, flows NW $1 \mathrm{mi}$. to Candle Creek, $11 \mathrm{mi}$. SW of Candle and $34 \mathrm{mi}$. NE of Imuruk Lake, Seward Penin. High.; $65^{\circ} 46^{\prime} 00^{\prime \prime} \mathrm{N}, 162^{\circ} 06^{\prime} 30^{\prime \prime} \mathrm{W}$; (map 110).

Prospectors' name reported on the 1908 "Map of Seward Peninsula" by Arthur Gibson.

Eureka Creek: stream, flows NW $0.8 \mathrm{mi}$. through Eureka Gulch to Inmachuk River $1.1 \mathrm{mi}$. SW of its junc. with Hannum Creek, $17 \mathrm{mi}$. N of Imuruk Lake, Seward Penin. High.; $65^{\circ} 52^{\prime} \mathrm{N}, 163^{\circ} 11^{\prime} \mathrm{W}$; (map 110 ).

Prospectors' name reported in 1903 by $D$. C. Witherspoon (in Moffit, 1905, pl. 2), USGS.

Eureka Creek: stream, flows $\mathrm{N}$ to Humboldt Creek which flows to Goodhope River, about 37 mi. NW of Imuruk Lake, Seward Penin. High.; (map 110).

Prospectors' name reported in 1901 by USGS (Collier, 1902, pl. 12). This stream cannot be identified on current maps.

Eureka Creek: stream, see Yuonglik River.

Eureka Dome: mountain, 2,393 ft., $3 \mathrm{mi}$. N of Eureka and $20 \mathrm{mi}$. S of Rampart, YukonTanana High.; $65^{\circ} 13^{\prime} 20^{\prime \prime} \mathrm{N}, 150^{\circ} 14^{\prime} 00^{\prime \prime} \mathrm{W}$; (map 106).

Prospectors' name reported in 1906 by USGS (Prindle, 1908, pl. 5); so named because tributaries of Eureka Creek head on its slopes.

Eureka Gulch: ravine, in Nutzotin Mts., extends $\mathrm{NW}$ of $1.8 \mathrm{mi}$. to Lamb Creek, $5 \mathrm{mi}$. NE of Braye Pass, Alaska Ra.; $62^{\circ} 04^{\prime} \mathrm{N}, 141^{\circ} 02^{\prime} \mathrm{W}$; (map 84). Var: Eureka Creek.

Local name obtained from prospectors; reported as Eureka Creek by USGS (Capps, 1916, p. 90).

Eureka Gulch: ravine, trends NE $0.7 \mathrm{mi}$. to Snake River, N of Pioneer Gulch, $13 \mathrm{mi}$. N of Nome, Seward Penin. High.; 64 $42^{\prime}$ N, $165^{\circ} 25^{\prime} \mathrm{W}$; (map 94).

Prospectors' name reported in 1904 by T. G. Gerdine, USGS.

Eureka Gulch: ravine, trends NW $0.8 \mathrm{mi}$. to Inmachuk River $1.1 \mathrm{mi}$. SW of its junc. with Hannum Creek, $17 \mathrm{mi}$. N of Imuruk Lake, Seward Penin. High.; $65^{\circ} 52^{\prime} \mathrm{N}, 163^{\circ} 11^{\prime} \mathrm{W}$; BGN 1952; (map 110).

Reported in 1903 as "Eureka Creek" by D. C. Witherspoon (in Moffit, 1905, pl. 2), USGS

Eureka Lake: lake, see Tahneta Lake.

Eureka Lake: lakes, see Startup Lakes.

Eureka Ledge: reef, see Wayanda Ledge.

Eureka Mountain: mountain, 3,000 ft., on central Baranof I., 8 mi. SE of Sitka, Alex. Arch.; $56^{\circ} 58^{\prime} 10^{\prime \prime} \mathrm{N}, 135^{\circ} 10^{\prime} 30^{\prime \prime} \mathrm{W}$; (map 5).

Local name recorded in 1951 by USGS.

Eureka Pass: water passage, see Eureka Channel.

Eureka Road House: locality, former roadhouse on Valdez Trail which is now Richardson Highway, along Ptarmigan Creek, $1.5 \mathrm{mi}$. W of Ptarmigan and $21 \mathrm{mi}$. NE of Valdez, Chugach Mts. ; $61^{\circ} 11^{\prime} 37^{\prime \prime} \mathrm{N}, 145^{\circ} 39^{\prime} 00^{\prime \prime} \mathrm{W}$; (map 68).

Name published in 1909 by USGS.

Eva, Lake: lake, $1.7 \mathrm{mi}$. long, drains into Hanus Bay, on $\mathrm{N}$ coast of Baranof $\mathrm{I}$., $12 \mathrm{mi}$. NW of 
Baranof, Alex. Arch.; 57 $24^{\prime} 00^{\prime \prime}$ N, $135^{\circ} 06^{\prime}$ $30^{\prime \prime} \mathrm{W}$; $(\operatorname{map} 9)$.

Named in 1895 by Lt. Comdr. E. K. Moore, USN, and published by USG\&GS on Chart 8283.

Eva, Point: point of land, on mainland, $\mathrm{N}$ point of entrance to Rudyerd Bay, on Behm Canal, Coa.t Mts.; $55^{\circ} 33^{\prime} 40^{\prime \prime} \mathrm{N}, 130^{\circ} 52^{\prime} 30^{\prime \prime} \mathrm{W}$; $B G N$ 1906; (map 3). Var. Slide Point.

Named in 1891 by USC\&GS ; USC\&GS published the name "Slide Point" in 1894 for this feature.

Eva Creek: stream, flows E $4 \mathrm{mi}$. to Elsie Creek, $38 \mathrm{mi}$. SE of Nenana, Alaska Ra.; $64^{\circ} 03^{\prime} \mathrm{N}$, $148^{\circ} 45^{\prime}$ W; (map 100). Var. North Fork Elsie Greek.

Local name reported in 1916 by G. C. Martin (in Brooks and others, 1917, pl. 17), USGS. In 1915, the stream had been named North Fork (Elsie Creek), on the GLO [BLM] survey plat of the township, but local usage preferred Eva Creek.

Eva Creek: stream, flows NW $3 \mathrm{mi}$, to My Greek, $80 \mathrm{mi}$. SW of Eagle, Yukon-Tanana High.; $64^{\circ} 07^{\prime} \mathrm{N}, 143^{\circ} 16^{\prime} \mathrm{W}$; (map 102).

Local name published in 1956 by USGS.

Eva Creek: stream, flows SE $2.5 \mathrm{mi}$. to Ester Creek, $7.5 \mathrm{mi}$. W of Fairbanks, Yukon-Tanana High.; $64^{\circ} 51^{\prime} \mathrm{N}, 147^{\circ} 59^{\prime} \mathrm{W}$; (map 100).

Named by prospectors; shown in 1905 on a manuscript map by C. W. Joint.

Eva Island: island, $0.4 \mathrm{mi}$. long, at mouth of Hamilton Bay, $4.5 \mathrm{mi}$. S of Kake, on NW coast of Kupreanof I., Alex. Arch.; 56 $54^{\prime} 50^{\prime \prime}$ $\mathrm{N}, 133^{\circ} 55^{\prime} 00^{\prime \prime} \mathrm{W}$; (map 6).

Named in 1892 by Lt. W. I. Moore, USN.

Eva Islands: islands, $0.5 \mathrm{mi}$. across, $N$ of Catherine I., off Baranof I., 7 mi. SW of Angoon, Alex. Arch.; $57^{\circ} 25^{\prime} 45^{\prime \prime} \mathrm{N}, 134^{\circ} 55^{\prime} 45^{\prime \prime}$ W; (map 9)

Named in 1895 by Lt. Comdr. E. K. Moore, USN, and published on Chart 8283 .

Eva Mountain: mountain, 1,240 ft., $1 \mathrm{mi}$. E of Mukacharni Mtn. and $10 \mathrm{mi}$. NE of Teller, Seward Penin. High.; 65 $22^{\prime}$ N, $166^{\circ} 09^{\prime}$ W; (map 111).

Local name published in 1956 by USGS.

Evan Lake: lake, $2 \mathrm{mi}$. NW of Clay Lake and 22 mi. N of Roundabout Mtn., Koyukuk Low; $65^{\circ} 51^{\prime} \mathrm{N}, 156^{\circ} 38^{\prime} \mathrm{W}$; (map 108).

Local name obtained at Huslia by USGS in 1954 or 1955.

Evans, Mount: mountain, 6,379 ft., $1.4 \mathrm{mi}$. NW of terminus of Klutina Glacier, $20 \mathrm{mi}$. $\mathrm{N}$ of Valdez, Chugach Mts., 61 ${ }^{\circ} 24^{\prime} 45^{\prime \prime} \mathrm{N}, 146^{\circ}$ $09^{\prime} 15^{\prime \prime} \mathrm{W}$; (map 68).

Named in 1898 by Capt. W. R. Abercrombie, USA.

Evans Bay: bay, see Sawmill Bay.

Evans Island: island, extends NE-SW $12 \mathrm{mi}$, at SW end of Prince William Sound, between Prince of Wales Passage on $\mathrm{W}$ and Elrington and Latouche Passages on E, $10 \mathrm{mi}$. SE of Chenega, Chugach Mts.; $60^{\circ} 03^{\prime} \mathrm{N}, 148^{\circ} 04^{\prime}$ W; BGN 1918; (map 63). Var. Bache Island, Flemming Island, Hoodoo Island.

Named in 1918 by USC\&GS for Adm. Robley Evans, USN, 1846-1912, "who many years before, as Captain, had policed the Alaska Sealing grounds." U. S. Grant, USGS, reported the local name of this island as "Hoodoo," a name shown on Federal maps for many years. However, it was found that many mariners feared to approach the island because of its name, which prompted the proposal to commemorate Adm. Evans.

Evans Point: point of land, on SW side of Knight Island Pass, on NE tip of Evans I., $12 \mathrm{mi}$. SE of Chenega, Chugach Mts.; 60 $08^{\prime}$ 00" N, 147 54'45" W; BGN 1929; (map 63).

Named in 1929 by USC\&GS; derived from name of the island.

Evansville: village, pop 77, on S bank of Koyukuk River, $5 \mathrm{mi}$. E of Bettles; $66^{\circ} 55^{\prime} 30^{\prime \prime} \mathrm{N}, 151^{\circ}$. $30^{\prime} 00^{\prime \prime} \mathrm{W}$; (map 117). Var. Bettles Field.

This Indian village developed in 1945 when Bettles Field was built as an attendant facility for exploration of Naval Petroleum Reserve No. 4. Work at the airfield, located about five miles upstream from Bettles, attracted the natives and settlement began near the north end of the landing strip. A post office was established at Bettles Field in 1950 (Ricks, 1965, p. 7).

Eva Peak: mountain, 6,005 ft., $4.5 \mathrm{mi}$. NE of Rainy Pass Lodge and $83 \mathrm{mi}$. WSW of Talkeetna, Alaska Ra.; $62^{\circ} 09^{\prime} 00^{\prime \prime} \mathrm{N}, 152^{\circ} 39^{\prime} 30^{\prime \prime}$ W; (map 81).

Named in 1898 by W. S. Post, USGS.

Evarashichiche: water passage, see Marmot Strait.

Evasha River: stream, see Ivishak River.

Evdokeeff: island, see Chowiet Island.

Evdokeevskie Islands: islands, see Semidi Islands.

Evelookpalik River: stream, see Evelukpalik Creek.

E-vel-she-ark: stream, see Redstone River.

Evelukpalik Creek: stream, heads on Milokrawlok Mtn., flows W $9 \mathrm{mi}$. to Krusenstern Lagoon, 5 mi. NE of Cape Krusenstern, Kotzebue-Kobuk Low. ; $67^{\circ} 11^{\prime} \mathrm{N}, 163^{\circ} 40^{\prime} \mathrm{W}$; (map 128). Var. Evelookpalik River, Evilukpalik River.

Eskimo name meaning "place of big clams," according to USC\&GS in 1950.

Evelyn Lake: lake, $4 \mathrm{mi}$. long, trends $\mathrm{N}-\mathrm{S}$ at mouth of Lacy River, $3 \mathrm{mi}$. $\mathrm{N}$ of Berners Bay and $40 \mathrm{mi}$. NW of Juneau, Coast Mts.; 58 $52^{\prime}$ $\mathrm{N}, 134^{\circ} 55^{\prime} \mathrm{W}$; (map 11$)$.

Name reported in 1923 by J. P. Walker, USFS.

Evening Star Creek: stream, flows W $1 \mathrm{mi}$. to Rose Creek, $11 \mathrm{mi}$. NE of Fairbanks, YukonTanana High.; $64^{\circ} 58^{\prime} 10^{\prime \prime} \mathrm{N}, 147^{\circ} 29^{\prime} 45^{\prime \prime} \mathrm{W}$; (map 100).

Named by prospectors; published in 1908 by USGS.

Eve Point: point of land, on Revillagigedo I., on W shore of Thorne Arm, $15 \mathrm{mi}$. E of Ketchikan, Alex. Arch.; $55^{\circ} 19^{\prime} 55^{\prime \prime} \mathrm{N}, 131^{\circ} 15^{\prime} 48^{\prime \prime}$ W; (map 3).

Local name published in 1917 by USC\&GS on Chart 8075.

Everett Creek: stream, flows N $6 \mathrm{mi}$. to Charley River $12 \mathrm{mi}$. S of that stream's junc. with
Yukon River, Yukon-Tanana High.; $65^{\circ} 09^{\prime}$ N, 142 $51^{\prime}$ W; (map 103).

Prospectors' name from an unpublished map by E. J. Chamberlain, dated 1902.

Everett Peak: mountain peak, elev. 3,797 ft., 2 mi. N of Point Styleman on Stephens Passage and $28 \mathrm{mi}$. SE of Juneau, Coast Mts. ; $58^{\circ} 00^{\prime}-$ $25^{\prime \prime} \mathrm{N}, 133^{\circ} 54^{\prime} 15^{\prime \prime} \mathrm{W}$; (map 12).

Named in 1888 by Lt. Comdr. C. M. Thomas, USN, for Edward Everett, 17941865, American clergyman, orator, and statesman.

Evershichie Bay: bay, see Marmot Bay.

Evesheark: stream, see Redstone River.

Evghinak Cape: point of land, see Evghinak Point.

Evghinak Point: point of land, $9 \mathrm{mi}$. NW of Southwest Cape, SW coast of St. Lawrence I.; $63^{\circ} 21^{\prime} \mathrm{N}, 171^{\circ} 42^{\prime} \mathrm{W}$; (map 93). Var. Evghinak Cape.

Eskimo name recorded in 1949 by Maj. H. B. Allen, USAF, from a survivor of the Eskimo village once located at Southwest Cape. Its meaning is unknown.

Evia, Punta: point of land, "on the east side of Prince of Wales Island."

Named by Lt. Don Jacinto Caamaño on July 23, 1792, "probably in honor of José de Evía who was at that time exploring in the Gulf of Mexico" (Wagner, 1937, p. 452).

Evilukpalik River: stream, see Evelukpalik Creek.

Evrashichie Island : island, see Marmot Island.

Evrulivik Lake: lake, $4.5 \mathrm{mi}$. long, $17 \mathrm{mi}$. S of Barrow, Arctic Plain; $71^{\circ} 01^{\prime} 28^{\prime \prime} \mathrm{N}, 156^{\circ}$ $40^{\prime} 00^{\prime \prime} \mathrm{W}$; (map 153). Var. Iiveruuleviq Lake.

Eskimo name recorded by USC\&GS about 1950. The name was originally applied to the large lake just NE of this one, and would be best rendered as "Ivirulivik" meaning "place where there is moss [for house building]."

Evwak, Cape: point of land, see Eevwak Point.

Evwhak Point: point of land, 'see Eevwak Point.

Ewakewigamiut: locality, see Iwarawiramiut.

Ewaklalik, Mount: mountain, 1,860 ft., in Ilivit Mts., $E$ of Mount Chiniklik and $15 \mathrm{mi}$. NE of Russian Mission, Nulato Hills; 61 ${ }^{\circ} 50^{\circ} \mathrm{N}$, $161^{\circ} 01^{\prime} \mathrm{W}$; (map 73).

Eskimo name reported by Harrington (1918, map), USGS, in 1916.

Ewan Bay: estuary, on E coast of Kenai Penin., extends SE $3.5 \mathrm{mi}$. to Dangerous Passage, 6.5 mi. NW of Chenega, Chugach Mts.; $60^{\circ} 22^{\prime} \mathrm{N}$, $148^{\circ} 07^{\prime} \mathrm{W}$; (map 63).

Local name reported in 1908 by Grant and Higgins (1910, pl. 2), USGS.

Ewan Lake: lake, on $\mathrm{E}$ side of Kenai Penin., extends N-S $1 \mathrm{mi}$., $10 \mathrm{mi}$. NW of Chenega, Chugach Mts.; $60^{\circ} 24^{\prime} 30^{\prime \prime} \mathrm{N}, 148^{\circ} 10^{\prime} 30^{\prime \prime} \mathrm{W}$; (map 63).

Name published on recent USGS maps; derived from nearby Ewan Bay.

Ewan Lake: lake, $4.5 \mathrm{mi}$. long, $4 \mathrm{mi}$. ENE of Crosswind Lake and $22 \mathrm{mi}$. NNW of Glennallen, Copper River Basin; 62 $2^{\circ} 6^{\prime} \mathrm{N}, 1^{145^{\circ}} 47^{\prime}$ W; (map 83). Var. Eauwan Lake. 
Local name recorded in 1910 by D. C. Witherspoon (in Moffit, 1912, pl, 1), USGS. It may be a corruption of the name "Ivan," an Indian chief on the Tanana River.

Ewan Point: point of land, on E coast of Kenai Penin., at $\mathbf{N}$ entrance to Ewan Bay, on $\mathbf{W}$ side of Dangerous Passage, $6 \mathrm{mi}$. $\mathrm{N}$ of Chenega, Chugach Mts.; $60^{\circ} 22^{\prime} 15^{\prime \prime} \mathrm{N}, 148^{\circ} 05^{\prime} 45^{\prime \prime} \mathrm{W}$; $B G N$ 1934; ( $\operatorname{map} 63$ ).

Named in 1933 by a USC\&GS field party. Ewdokijefftian Islands: islands, see Semidi Islands.

Fwe Creek: stream, flows NW $3 \mathrm{mi}$. to Savage River, $12 \mathrm{mi}$. SW of Healy, Alaska Ra.; $63^{\circ} 47^{\prime} \mathrm{N}, 149^{\circ} 18^{\prime} \mathrm{W}$; (map 87).

Local name shown on a 1916 fieldsheet by C. E. Giffin, USGS.

Ewe Ledge: cliff, on $\mathrm{N}$ coast of Yakobi I., on W shore of Lisianski Inlet, $2 \mathrm{mi}$. SE of Sandstone Point and $37 \mathrm{mi}$. W of Hoonah, Alex. Arch.; $58^{\circ} 05^{\prime} 15^{\prime \prime} \mathrm{N}, 136^{\circ} 27^{\prime} 25^{\prime \prime} \mathrm{W}$; (map 10).

Name published by USC\&GS in 1929.

Ewratschitze Bay: bay, see Marmot Bay.

Ex: locality, along Seward Penin. RR., $1 \mathrm{mi}$. $\mathrm{N}$ of King Mtn. and $8 \mathrm{mi} \mathrm{NE}$ of Nome, Seward Penin. High.; $64^{\circ} 37^{\prime} \mathrm{N}, 165^{\circ} 20^{\prime} \mathrm{W}$; (map 94).

Site of a RR. station established in 1905. "The name came from the fact that two large water supply ditches crossed each other's paths near the station, forming a huge X" (Cole, 1953, p. 14).

Excelsior Creek: stream, flows S $17 \mathrm{mi}$. to Gakona River, 21 mi. ESE of Paxson Lake, Alaska Ra.; $62^{\circ} 48^{\prime} 30^{\prime \prime} \mathrm{N}, 145^{\circ} 03^{\prime} 45^{\prime \prime} \mathrm{W}$; (map 83).

Name used by prospectors and reported by Mendenhall and Schrader (1903, pl. 3), USGS.

Excelsior Creek: stream, flows E $10 \mathrm{mi}$. to Mission Creek, $7 \mathrm{mi}$. NW of Eagle, Yukon-Tanana High.; 64 $49^{\prime} 50^{\prime \prime} \mathrm{N}, 141^{\circ} 26^{\prime} 45^{\prime \prime} \mathrm{W}$; (map 102). Var. Twelve Mile Creek.

Named by prospectors and reported in 1898 by E. C. Barnard, USGS; called "Twelve Mile Creek" in 1896 by Spurr (1898, pl. 48), USGS.

Excelsior Creek: stream, flows SW to Cripple River, about $30 \mathrm{mi}$. NW of Imuruk Lake, Seward Penin. High.; (map 110).

Prospectors' name reported in 1901 by USGS (Collier, 1902, pl. 12). This stream cannot be identified on current maps.

Excelsior Glacier: glacier, trends S $6.5 \mathrm{mi}$. to its terminus, $1.5 \mathrm{mi}$. N of Johnstone Bay, on Kenai Penin., 25 mi. SE of Seward, Chugach Mts.; $59^{\circ} 59^{\prime} \mathrm{N}, 148^{\circ} 47^{\prime} \mathrm{W}$; BGN 1910; (map 49).

Local name obtained in 1908 by Grant and Higgins (1910, pl. 1), USGS.

Excelsior Lake: lake, on Kenai Penin., $2.5 \mathrm{mi}$. long, on $\mathrm{E}$ lobe of Excelsior Glacier, $26 \mathrm{mi}$. SE of Seward, Chugach Mts.; $60^{\circ} 02^{\prime} 30^{\prime \prime} \mathrm{N}$, $148^{\circ} 41^{\prime} 30^{\prime \prime} \mathrm{W}$; (map 63).

Name of a water-filled depression in a glacier; published in 1951 by USGS; name derived from nearby Excelsior Glacier.
Exchange Cove: cove, extends N $3.5 \mathrm{mi}$ : to Kashevarof Passage, on $\mathbf{N}$ coast of Prince of Wales I., Alex. Arch.; $56^{\circ} 12^{\prime} \mathrm{N}, 133^{\circ} 04^{\prime} \mathrm{W}$; (map 6).

Named in 1886 by Lt. Comdr. A. S. Snow, USN; published in 1887 on USC\&GS Chart 706.

Exchange Creek: stream, heads in Exchange Lake, fows E $1 \mathrm{mi}$. to Exchange Cove, on Prince of Wales I., $34 \mathrm{mi}$. SW of Wrangell, Alex. Arch.; $56^{\circ} 10^{\prime} 12^{\prime \prime} \mathrm{N}, 133^{\circ} 05^{\prime} 40^{\prime \prime} \mathrm{W}$; (map 6).

Local name reported in 1961 by USFS.

Exchange Island: island, $1.2 \mathrm{mi}$. long, at mouth of Exchange Cove, on $\mathrm{N}$ coast of Prince of Wales I., Alex. Arch.; 56 $12^{\prime} 30^{\prime \prime} \mathrm{N}$, $133^{\circ} 03^{\prime} 30^{\prime \prime} \mathrm{W}$; (map 6).

Named in 1886 by Lt. Comdr. A. S. Snow, USN; name published in 1887 on USC\&GS Chart 706.

Excursion Bay Inlet: estuary, see Excursion Inlet.

Excursion Inlet: village, pop. 23, cannery at mouth of Excursion Inlet, $5 \mathrm{mi}$. $\mathrm{N}$ of the Porpoise Is. and $38 \mathrm{mi}$. NW of Juneau, St. Elias Mts.; $58^{\circ} 25^{\prime} 00^{\prime \prime} \mathrm{N}, 135^{\circ} 26^{\prime} 30^{\prime \prime} \mathrm{W}$; (map 11).

Name published by USC\&GS in the 1943 Coast Pilot (p. 409).

Excursion Inlet: estuary, trends $8 \mathrm{mi}$. S from mouth of Excursion River to Icy Strait, 38 mi. W of Juneau, St. Elias Mts.; $58^{\circ} 25^{\prime} \mathrm{N}$, $135^{\circ} 26^{\prime}$ W; (map 11). Var. Excursion Bay Inlet, Hudson Bay Inlet.

Named by pilot Capt. E. G. George, who entered the estuary in 1883 on the excursion steamer Idaho. Published by USC\&GS in the 1883 Coast Pilot (p. 190).

Excursion River: stream, in Glacier Bay National Monument, heads in unnamed glacier and flows SE $24 \mathrm{mi}$. to Excursion Inlet, $43 \mathrm{mi}$. $\mathrm{NW}$ of Juneau, St. Elias Mts.; $58^{\circ} 30^{\prime} 55^{\prime \prime} \mathrm{N}$, $135^{\circ} 31^{\prime} 10^{\prime \prime} \mathrm{W}$; BGN 1962; (map 11).

Local name published in 1962 by USGS. Name derived from Execursion Inlet.

Expedition Harbor: bay, $4 \mathrm{mi}$. long, on $\mathrm{W}$ coast of Adak I., at head of Bay of Islands, Aleutian Is.; $51^{\circ} 47^{\prime} 30^{\prime \prime} \mathrm{N}, 176^{\circ} 45^{\prime} 30^{\prime \prime} \mathrm{W}$; BGN 1936; (map 17).

Named in 1934 by members of the U.S. Navy Aleutian Island Survey Expedition, "to commemorate the expedition."

Expedition Island: island, $0.2 \mathrm{mi}$. long, off $\mathrm{S}$ coast of Amaknak I., in Unalaska Bay, on NE coast of Unalaska I., Aleutian Is. ; 53 $52^{\prime} 42^{\prime \prime}$ N, $166^{\circ} 32^{\prime} 55^{\prime \prime} \mathrm{W}$; (map 23). Var. Expedition Islet.

Named by W. H. Dall, USC\&GS, in 1871. Expedition Islet: island, see Expedition Island. Expedition Point: point of land, on unnamed island, in":Security Bay, on Kuiu I., $41 \mathrm{mi}$. SE of Sitka, Alex. Arch.; $56^{\circ} 50^{\prime} 45^{\prime \prime}$ N, $134^{\circ} 19^{\prime}$ 05" W; (map 5).

Named in 1869 by Comdr. R. W. Meade, USN.

Exploration Peak: mountain, 5,805 ft., just E of junc. of Matthes and Taku Glaciers, $3.8 \mathrm{mi}$. $\mathrm{SE}$ of Centurian Peak and $28 \mathrm{mi}$. NE of Ju- neau, Coast Mts.; $58^{\circ} 41^{\prime} 15^{\prime \prime} \mathrm{N}, 134^{\circ} 12^{\prime} 45^{\prime \prime}$ W; (map 11).

Name proposed in 1949 by members of the Juneau Icefield Research Project and published in 1960 by USGS.

Explorer Basin: bay, 2 mi. across, on $\mathrm{W}$ coast of Kuiu I., at $\mathrm{S}$ entrance to Tebenkof Bay, Alex. Arch.; $56^{\circ} 26^{\prime} \mathrm{N}, 134^{\circ} 13^{\prime} \mathrm{W}$; BGN 1929; (map 5).

Named in 1928 by USC\&GS for its vessel Explorer.

Explorer Bay: bay, $1 \mathrm{mi}$. across, on $\mathbf{S}$ coast of Atka I., W of Kobakof Bay, NW of Sagchudak I., Aleutian Is.; $52^{\circ} 03^{\prime} 15^{\prime \prime} \mathrm{N}, 174^{\circ} 32^{\prime} 00^{\prime \prime} \mathrm{W}$; $B G N 1961$; (map 18).

Named for the USC\&GS ship Explorer, which surveyed the bay for the first time during the summer of 1959

Explorer Glacier: glacier, on Kenai Pènin., trends NW $1.5 \mathrm{mi}$. to its terminus, $4 \mathrm{mi}$. SE of head of Turnagain Arm and $8 \mathrm{mi}$. W of Whittier, Chugach Mts.; $60^{\circ} 47^{\prime} 10^{\prime \prime} \mathrm{N}, 148^{\circ} 55^{\prime} 30^{\prime \prime} \mathrm{W}$; BGN 1964; (map 63).

Local name reported by the Mountaineering Club of Alaska. So named because Explorer Scouts were trained in glacier techniques on this and neighboring glaciers.

Explorer Island: island, $0.2 \mathrm{mi}$. long, in Hidden Lake on Kenai Penin., $33 \mathrm{mi}$. ESE of Kenai; $60^{\circ} 29^{\prime} 20^{\prime \prime} \mathrm{N}, 150^{\circ} 15^{\prime} 50^{\prime \prime} \mathrm{W}$; BGN 1962; (map 62).

Named in 1962 by Grant B. Walther for Explorer Post No. 25 of the Boy Scouts of America.

Explorer Mountain: mountain, 2,660 ft., contains several peaks, $10 \mathrm{mi}$. $\mathrm{N}$ of Goodnews, Kilbuck-Kuskokwim Mts.; $59^{\circ} 15^{\prime} \mathrm{N}, 161^{\circ} 33^{\prime}$ W; (map 53).

Named in 1914 by USC\&GS for its surveying vessel, the S.S. Explorer; published in 1915 on Chart 9103.

Explorer Passage: water passage, between Annoy Rock and Hazard Point, off E coast of Tanaga I., Aleutian Is.; $51^{\circ} 42^{\prime} \mathrm{N}, 177^{\circ} 48^{\prime} \mathrm{W}$; (map 17).

Name published by USC\&GS in 1956 on Chart 9145.

Explorers Peak: peak, 8,540 ft., at head of Eldridge Glacier, $12 \mathrm{mi}$. ESE of Mount McKinley, Alaska Ra.; $63^{\circ} 02^{\prime} 30^{\prime \prime} \mathrm{N}, 150^{\circ} 38^{\prime} 00^{\prime \prime}$ W; (map 88).

Climbed in 1910 and named for the Explorers Club of New York by H. C. Parker and Belmore Browne.

Extra Dry Creek: stream, flows NE $1.6 \mathrm{mi}$. to Nome Creek, $6 \mathrm{mi}$. NE of Nome, Seward Penin. High.; $64^{\circ} 34^{\prime} \mathrm{N}, 165^{\circ} 15^{\prime} \mathrm{W}$; (map 94).

Prospectors' name reported in 1899 by D. C. Witherspoon (in Schrader and Brooks, 1900, map 2), USGS. Named relative to Dry Creek which is in the same area.

Extra Dry Creek: stream, see Tripple Creek.

Eyack Lake: lake, see Eyak Lake.

Eyak: locality, along Copper River Highway, $5.5 \mathrm{mi}$. SE of Cordova, Malaspina Coastal Plain; $60^{\circ} 31^{\prime} 30^{\prime \prime} \mathrm{N}, 145^{\circ} 36^{\prime} 00^{\prime \prime} \mathrm{W}$; (map 
64). Var. Eyak Village, Hyacks, Ighiak, Ikhiak, Odiak.

Former Eskimo village reported in 1869 as "Hyacks" by Maj. Gen. W. E. Halleck, USA. It was listed by Ivan Petroff in the 1880 Census as "Ihiak." The population was 94 in $1890 ; 222$ in 1900 . In 1899 Lt. Comdr. J. F. Moser, USN, reported it as a cannery called "Odiak" with a population of 273 (Hodge, 1907, p. 448).

Eyak, Mount: mountain, 2,506 ft., between Orca Inlet and Eyak Lake, $2 \mathrm{mi}$. $\mathrm{N}$ of Cordova, Chugach Mts.; $60^{\circ} 34^{\prime} \mathrm{N}, 145^{\circ} 43^{\prime} \mathrm{W}$; BGN 1933; (map 64). Var. Ugalak Mountain.

Originally named "Ugalak" for the Eskimo village of Ugalakmiut ("far people") onice located at the entrance to Port William Sound. Present name reported by H. E. Smith, USFS, in 1933.

Eyak Cannery: locality, on right bank of Eyak River, $4 \mathrm{mi}$. SE of Cordova, Chugach Mts.; $60^{\circ} 30^{\prime} \mathrm{N}, 145^{\circ} 40^{\prime} \mathrm{W}$; (map 64).

Name of a cannery; published on a 1951 USGS map.

Eyak Lake: lake, Y-shaped, each arm 3 mi. long, $0.3 \mathrm{mi}$. E of Cordova, Chugach Mts.; $60^{\circ} 33^{\prime}$ N, $145^{\circ} 40^{\prime} \mathrm{W}$; BGN 1901; (map 64). Var. Eyack Lake, Eyuk Lake, Ighiak Lake, Ikhiak Lake, Odiak Lake.

Named for the nearby Indian village and reported in 1888 by Capt. W. R. Abercrombie, USA, who called it "Eyack Lake."

Eyak River: stream, flows S from Eyak Lake $6 \mathrm{mi}$. to Gulf of Alaska, Malaspina Coastal Plain; $60^{\circ} 28^{\prime} \mathrm{N}, 145^{\circ} 41^{\prime} \mathrm{W}$; (map 64).

Local name reported in 1905 by G. C. Martin (1906, pl. 12), USGS.

Eyak Village: locality, see Eyak.

Eyeautuk Lagoon: lagoon, see Aiautak Lagoon.

Eyeautuk Lagoon: lagoon, see Ayutatak Lagoon.

Eye Opener, The: rock, in Sumner Strait, $13 \mathrm{mi}$. $\mathbf{E}$ of village of Point Baker, between Kupreanof and Prince of Wales Is., Alex. Arch.; $56^{\circ} 23^{\prime} 10^{\prime \prime} \mathrm{N}, 132^{\circ} 16^{\prime} 30^{\prime \prime} W$; (map 6). Var. Atkroiglaza, Otkroy Glaza, Shoo Fly Rock.

Translation about 1882 by USC\&GS of "Otkroy Glaza"; published in 1853 on Russian Hydrog. Dept. Chart 1494. Lt. Comdr. H. E. Nichols, USN reported the name "Shoo Fly Rock" as being used by local navigators for this feature, in 1891 Coast Pilot (p. 128).

Eye Opener Islet: rocks, see Abrejo Rocks.

Eyuk Lake: lake, see Eyak Lake.

Ezrok River: stream, see Kolipsun Creek.

\section{F}

Face Mountain: mountain, 1,275 $\mathrm{ft}$, on SW Kiska I., Aleutian Is. ; 51 ${ }^{\circ} 53^{\prime} 53^{\prime \prime} \mathrm{N}, 177^{\circ} 16^{\prime}$ $00^{\prime \prime} \mathrm{E}$; (map 14).

An arbitrary name beginning with " $F$ " to correspond to "F" grid used by the U.S. Army for tactical purposes during World War II; published on a 1953 AMS map.

Fafnir, Mount: mountain, 10,620 ft., in Dora Keen Ra., $33 \mathrm{mi}$. NW of Valdez, Chugach Mts.; $61^{\circ} 26^{\prime} 30^{\prime \prime} \mathrm{N}, 147^{\circ} 02^{\prime} 15^{\prime \prime} \mathrm{W} ; B G N$ 1965 ; (map 69 ).
Named for a dragon in Norse mythology; published by Nielsen (1963, p. 135).

Faint Mountain: mountain, 1,335 ft., SW part of Kiska I., Aleutian Is.; $51^{\circ} 54^{\prime} 23^{\prime \prime} \mathrm{N}, 177^{\circ}$ 17'15' E; (map 14). Var. Bison Hill.

An arbitrary name beginning with " $F$ " to correspond to "F" grid used by the U.S. Army for tactical purposes during World War II. The name "Bison Hill" was published for this feature on a 1943 USAAF map.

Fairangel Creek: stream, heads in a lake, flows E $1 \mathrm{mi}$. to Archangel Creek, $16 \mathrm{mi}$. NW of Palmer, Talkeetna Mts.; $61^{\circ} 49^{\prime} 10^{\prime \prime} \mathrm{N}, 149^{\circ}$ $14^{\prime} 25^{\prime \prime}$ W; (map 69). Var. Fair Angel Creek.

Local name reported in 1910 by F. J. Katz (in Brooks and others, 1911, p. 140), USGS.

Fairbanks: city, pop. 13,311 , on Chena River, Tanana Low.; $64^{\circ} 50^{\prime} 45^{\prime \prime} \mathrm{N}, 147^{\circ} 43^{\prime} 15^{\prime \prime} \mathrm{W}$; $B G N$ 1944; (map 100). Var. Barnettes Cache.

Founded in 1901 when a trading post was established here by E. T. Barnette. First called "Barnettes Cache," the name was changed in 1902 to honor Charles Warren Fairbanks, 1852-1918, Senator from Indiana and later Vice President of the United States under Theodore Roosevelt. The town began as the supply center for the mining region to its north after gold was discovered by Felix Pedro in 1902, and has since become the commercial and transportation hub of north and central Alaska. Its population was 3,541 in $1910 ; 1,155$ in $1920 ; 2,101$ in $1930 ; 3,455$ in 1939 ; and 5,771 in 1950 . The Fairbanks post office was established in 1903.

Fairbanks Creek: stream, heads $6 \mathrm{mi}$. SW of Swinging Dome, flows NE $19 \mathrm{mi}$. to Iditarod River, $6.5 \mathrm{mi}$. SW of Flat and $53 \mathrm{mi}$. NE of Holy Cross, Kilbuck-Kuskokwim Mts.; 62 ${ }^{\circ}$ $25^{\prime} 10^{\prime \prime} \mathrm{N}, 158^{\circ} 12^{\prime} 00^{\prime \prime} \mathrm{W}$; (map 79).

Prospectors' name published in 1921 by USGS.

Fairbanks Creek: stream, flows SE $8 \mathrm{mi}$. to Fish Creek, 20 mi. NE of Fairbanks, Yukon-Tanana High.; $65^{\circ} 03^{\prime} \mathrm{N}, 147^{\circ} 07^{\prime} \mathrm{W}$; (map 105).

Named by prospectors for Charles W. Fairbanks, 1852-1918, U.S. Senator from Indiana; reported in 1903 by USGS (Prindle, 1905, pl. 13).

Fairbanks Creek Camp: locality, W of Fairbanks Creek, $11 \mathrm{mi}$. SE of Chatanika and $20 \mathrm{mi}$. NE of Fairbanks, Yukon-Tanana High.; $65^{\circ} 03^{\prime}$ $\mathrm{N}, 147^{\circ} 09^{\prime} \mathrm{W}$; (map 105).

Local name of a former gold mining camp; derived from Fairbanks Creek in whose valley gold was found in 1902.

Fairbanks Slough: stream, see Chena Slough.

Fairbanks Slough: stream, see Piledriver Slough.

Fairfield, Cape: promontory, on SE coast of Kenai Penin., at E end of Whidbey Bay, 25 mi. SE of Seward, Chugach Mts.; $59^{\circ} 56^{\prime} \mathrm{N}$, $148^{\circ} 53^{\prime} \mathrm{W}$; (map 49).

Local name reported in 1908 by U. S. Grant, USGS.

Fairfield, Mount: mountain, 3,609 ft., $3 \mathrm{mi}$. NE of Cape Fairfield, on Kenai Penin., 24 mi. SE of Seward, Chugach Mts.; $59^{\circ} 58^{\prime} \mathrm{N}, 148^{\circ} 51^{\prime}$ W; BGN 1929; (map 49).

Named in 1929 by USC\&GS; "name taken from adjoining cape."

Fairhaven: locality, at $\mathbf{N}$ end of Stephens Passage, $0.7 \mathrm{mi}$. E of Point Louisa and $12 \mathrm{mi}$. NW of Juneau, Coast Mts.; $58^{\circ} 22^{\prime} 35^{\prime \prime} \mathrm{N}$, $134^{\circ} 42^{\prime} 25^{\prime \prime} \mathrm{W}$; (map 11).

Name published in 1962 by USGS.

Fairhaven Creek: stream, flows NW $22 \mathrm{mi}$. to Buckland River, $52 \mathrm{mi}$. N of Haycock, Seward Penin. High.; $65^{\circ} 57^{\prime} \mathrm{N}, 161^{\circ} 08^{\prime} \mathrm{W}$; (map 109).

Local name reported in 1908 by USGS (Brooks and others, 1909, fig. 21).

Fair Island: island, 1 mi. long, between Beecher Pass and Duncan Canal, 16 mi. SW of Petersburg, on $\mathbf{N}$ coast of Woewodski I.; Alex. Arch.; $56^{\circ} 35^{\prime} 30^{\prime \prime} \mathrm{N}, 133^{\circ} 03^{\prime} 00^{\prime \prime} \mathrm{W}$; (map 6).

Named in 1887 by Lt. Comdr. C. M. Thomas, USN, for charting purposes; name published in 1888 on USG\&GS Chart 705. Fairman Lake: lake, see Jerome Lake.

Fairmount Bay: estuary, extends SW $1.5 \mathrm{mi}$. to Prince William Sound, $46 \mathrm{mi}$. NE of Whittier, Chugach Mts.; $60^{\circ} 53^{\prime} 30^{\prime \prime} \mathrm{N}, 147^{\circ} 23^{\prime} 45^{\prime \prime} \mathrm{W}$; (map 63).

Local name published on recent USGS maps; derived from nearby Fairmount Island. Fairmount Island: island, $2 \mathrm{mi}$. long, in Prince William Sound, $4 \mathrm{mi}$. W of Glacier I. and 43 mi. NE of Whittier, Chugach Mts. ; $60^{\circ} 52^{\prime} 30^{\prime \prime}$ $\mathrm{N}, 147^{\circ} 26^{\prime} 30^{\prime \prime} \mathrm{W}$; (map 63$)$.

Local name reported in 1900 by F. C. Schrader, USGS.

Fairmount Point: point of land, at $\mathrm{E}$ side of entrance to Wells Bay, $44 \mathrm{mi}$. NE of Whittier,

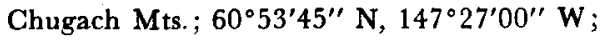
(map 63).

Local name published on recent USGS maps; derived from nearby Fairmount Island.

Fairplay, Mount: mountain, 5,541 ft., at head of Logging Cabin Creek, $34 \mathrm{mi}$. NE of Tok, Yukon-Tanana High.; $63^{\circ} 40^{\prime} \mathrm{N}, 142^{\circ} 13^{\prime} \mathrm{W}$; (map 85)

Name taken from sketch map compiled by Maj. W. M. Glassford, U.S. Army Signal Corps, in 1905.

Fairs Island: island, in Stockdale Harbor on the W side of Mortague I., Prince William Sound; $60^{\circ} 21^{\prime} \mathrm{N}, 147^{\circ} 12^{\prime} \mathrm{W}$.

Named by Capt. Nathaniel Portlock in 1787. See Wagner (1937, p. 352).

Fairview: area, SE part of Mountain View, in Anchorage, Cook Inlet Low.; 61 ${ }^{\circ} 13^{\prime} 36^{\prime \prime} \mathrm{N}$, $149^{\circ} 47^{\prime} 55^{\prime \prime} \mathrm{W}$; (map 69).

Local name reported in 1954 by the city engineer of Anchorage.

Fairview Creek: stream, flows NW $10 \mathrm{mi}$. to Bering Sea, $37 \mathrm{mi}$. NW of Nome, Seward Penin. High.; $64^{\circ} 50^{\prime} \mathrm{N}, 166^{\circ} 23^{\prime} \mathrm{W}$; (map 94).

Prospectors' name reported in 1900 by E. C. Barnard (in Brooks, 1901, pl. 17), USGS.

Fairview Creek: stream, flows SE to Fairview River which flows to Cripple River, about 31 mi. NW of Nome, Seward Penin. High; (map 94). 
Prospectors' name reported on the 1900 "Map of Nome Peninsula" by J. M. Davidson and B. D. Blakeslee; this feature has not been positively identified.

Fairview Mountain: mountain, 3,266 ft., $7 \mathrm{mi}$. SW of Chelatna Lake and $47 \mathrm{mi}$. W of Talkeetna, Alaska Ra.; $62^{\circ} 21^{\prime} 40^{\prime \prime} \mathrm{N}, 151^{\circ} 34^{\prime} 30^{\prime \prime}$ W; (map 81).

Local name reported in 1911 by S. R. Capps (in Brooks, 1912, pl. 9), USGS.

Fairway Island: island, $0.2 \mathrm{mi}$. across, on $\mathrm{S}$ coast of Kuiu I., at $S$ end of Affeck Canal, Alex. Arch.; $56^{\circ} 02^{\prime} 25^{\prime \prime} \mathrm{N}, 134^{\circ} 03^{\prime} 10^{\prime \prime} \mathrm{W}$; (map 5).

Named in 1886 by Lt. Comdr. A. S. Snow; published in 1887 on USC\&GS Chart 706.

Fairway Island: island, $0.2 \mathrm{mi}$. across, at $\mathrm{E}$ end of Peril Strait, $1.5 \mathrm{mi}$. S of Point Craven, $6 \mathrm{mi}$. SW of Angoon, Alex. Arch.; 57 $28^{\prime} \mathrm{N}, 134^{\circ}$ $52^{\prime} \mathrm{W}$; (map 9).

Named by Comdr. R. W. Meade, USN, and published in 1869 on Hydrog. Chart 225.

Fairway Reef: reef, N of Elma I., Sanak Is., Aleutian Ra. ; $54^{\circ} 22^{\prime} 50^{\prime \prime} \mathrm{N}, 162^{\circ} 29^{\prime} 30^{\prime \prime} \mathrm{W}$; (map 25).

Name published in 1949 on a USGS map.

Fairway Rock: rock, 0.1 mi. S of Kinky I., 12 mi. NW of Chichagof, on $W$ coast of Chichagof I., Alex. Arch.; $57^{\circ} 47^{\prime} 12^{\prime \prime} \mathrm{N}, 136^{\circ} 19^{\prime} 45^{\prime \prime}$ W; (map 9).

Name published by USC\&GS in 1925 Coast Pilot (p. 322).

Fairway Rock: rock, in Bering Strait, $10 \mathrm{mi}$. SE of Litle Diomede I. and $18 \mathrm{mi}$. W of Cape Prince of Wales, at $W$ end of Seward Penin., Seward Penin. High.; $65^{\circ} 38^{\prime} \mathrm{N}, 168^{\circ} 45^{\prime} \mathrm{W}$; (map 111). Var. Okivaki, Oo-ghee-ak, Ookeeok, Ugiyak.

So named in 1826 by Capt. Beechey (1831, p. 246), RN, because "it is an excellent guide to the eastern channel, which is the widest and best." Beechey records its Eskimo name as "Oo-ghee-ak" (p. 290).

Fairway Rocks: rocks, see Green Rocks.

Fairweather, Cape: point of land, in Glacier Bay National Monument, on $\mathrm{E}$ shore of Cape of Alaska, $5 \mathrm{mi}$. S of mouth of Sea Otter Creek and $103 \mathrm{mi}$. NW of Hoonah, Malaspina Coastal Plain; $58^{\circ} 48^{\prime} 30^{\prime \prime} \mathrm{N}, 137^{\circ} 56^{\prime} 45^{\prime \prime} \mathrm{W}$; (map 10). Var. Cape Beautems, Cape Buen-tiempo, Cape de Beautemps, Cape Gutwetter, Mys Horoshiy Pogody, Mys Ltua.

Named "Cape Fair Weather" in 1778 by Capt. Cook (1785, v. 2, p. 346), RN, presumably because of the good weather encountered at the time. The name has been translated variously. It was called "Cape Beautemps" by La Pérouse in 1786, "Cape Buen-tiempo" by Galiano in 1802, and "M[ys] Hor[oshiy] Pogody" by the Russians in 1847. Capt. Tebenkov (1852, map 8), IRN, called it "M[ys] Ltua" meaning "Cape Ltua."

Fairweather, Mount: mountain, 15,300 ft., in Glacier Bay National Monument, on AlaskaCanada boundary, $2.6 \mathrm{mi}$. W of Mount Quincy Adams, St. Elias Mts.; $58^{\circ} 54^{\prime} 30^{\prime \prime} \mathrm{N}$, 137'31'30" W; BGN 1922; (map 10). Var. Boundary Peak 164, Koroshiy Pogodi, Mount
Beautemps, Mount Buentiempo, Schönwetterberg, Tánaku.

Named in 1778 by Capt. Cook (1785, v. 2, p. 345 ), RN, presumably because of the good weather encountered at the time of his visit. The name has been variously translated. It was called "Mt. Beautemps" by La Pérouse (1786, atlas), "Mte. Buen-tiempo" by Galiano (1802, map 3), "Gor[a]-Khoroshy-pogody" on Russian Hydrog. Dept. Chart 1378 in 1847, and "G[ora] Fayerveder" by Capt. Tebenkov (1852, map 7), IRN. It was called "Schönwetterberg" by Constantin Grewingk in 1850 and "Schönwetter Berg" by Justus Perthes in 1882. The Tlingit Indians' name for the mountain is reportedly "Tánaku." The mountain was first climbed June 8, 1932, by Allen Carpé and Terris Moore (Farquhar, 1959 , p. 220).

Fairweather Glacier: glacier, in Glacier Bay National Monument, heads on W slope of Mount Salisbury and trends W $19 \mathrm{mi}$. to its 1961 terminus, $0.2 \mathrm{mi}$. E of Cape Fairweather and $100 \mathrm{mi}$. NW of Hoonah, Malaspina Coastal Plain ; 58 $47^{\prime} \mathrm{N}, 138^{\circ} 52^{\prime} \mathrm{W}$; (map 10 ).

Local name published by USGS in the 1950 's.

Fairweather Range: mountain range, extends SE $70 \mathrm{mi}$. from Grand Pacific and Grand Plateau Glaciers to Cross Sound and Icy Strait, in Glacier Bay National Monument, $80 \mathrm{mi}$. NW of Hoonah, St. Elias Mts.; $58^{\circ} 43^{\prime} \mathrm{N}, 137^{\circ} 10^{\prime}$ W; (map 10). Var. Mount Fairweather Range.

The name was used by USC\&GS in 1891 Coast Pilot (p. 207), and presumably derived from Mount Fairweather, the highest peak in the range.

Fairy Hill: hill, 1,335 ft., SW of Fatal Hill, on SW part of Kiska I., Aleutian Is. ; $51^{\circ} 54^{\prime} 28^{\prime \prime}$ $\mathrm{N}, 177^{\circ} 17^{\prime} 40^{\prime \prime} \mathrm{E}$; (map 14$)$.

An arbitrary name beginning with " $F$ " to correspond to "F" grid used by the U.S. Army for tactical purposes during World War II; published on a 1953 AMS map.

Faith Greek: locality, on left bank of Chatanika River, opposite mouth of Faith Creek, $76 \mathrm{mi}$. SW of Circle, Yukon-Tanana High.; $65^{\circ}$ $17^{\prime} 20^{\prime \prime} \mathrm{N}, 146^{\circ} 22^{\prime} 45^{\prime \prime} \mathrm{W}$; (map 104).

Name of a former roadhouse and small settlement; published in 1916 Polk's Gazetteer

Faith Creek: stream, flows SW $5 \mathrm{mi}$. to Spruce Greek, 11 mi. SE of Marshall, Nulato Hills; $61^{\circ} 47^{\prime} 20^{\prime \prime} \mathrm{N}, 161^{\circ} 48^{\prime} 30^{\prime \prime} \mathrm{W}$; (map 73).

Prospectors' name reported in 1916 by Harrington (1918, map), USGS.

Faith Creek: stream, heads at junc. of Charity and Hope Creeks, flows S $10 \mathrm{mi}$. to Chatanika River, $76 \mathrm{mi}$. SW of Circle, Yukon-Tanana High.; 651 $7^{\prime} 20^{\prime \prime} \mathrm{N}, 146^{\circ} 22^{\prime} 45^{\prime \prime} \mathrm{W}$; (map 104).

Named by prospectors; reported in 1903 by T. G. Gerdine (in Prindle, 1905, pl. 13), USGS.

Faith Hill: hill, $800 \mathrm{ft} ., 2 \mathrm{mi}$. SW of Lief Cove, on SW part of Kiska I., Aleutian Is.; 51 ${ }^{\circ} 54^{\prime}$ $45^{\prime \prime} \mathrm{N}, 177^{\circ} 17^{\prime} 45^{\prime \prime} \mathrm{E}$; (map 14).
An arbitrary name beginning with " $F$ " to correspond to " $F$ " grid used by the U.S. Army for tactical purposes during World War II; published on a 1953 AMS map.

Fake Creek: stream, heads in a glacier, $W$ of Alapah Mtn., flows NW 2 mi., then SW 5 mi., joins Graylime Creek to form Anaktuvut River; $68^{\circ} 07^{\prime} 00^{\prime \prime} \mathrm{N}, 151^{\circ} 05^{\prime} 30^{\prime \prime} \mathrm{W}$; $B G N$ 1939; (map 134).

Named by Marshall (1956, p. 123) in 1938. About it he wrote, "we pushed on across a high ridge to the place where all of us except Jesse Allen thought the main Anaktuvuk lay ***. He was right-the creek proved to be nothing but a false alarm-so we called it Fake Creek, and climbed over another ridge."

Fake Pass: water passage, $0.7 \mathrm{mi}$. long, $0.5 \mathrm{mi}$. $\mathrm{N}$ of Whale Head I., near mouth of Davidson Inlet, Alex. Arch.; 55 52' $40^{\prime \prime}$ N, $133^{\circ} 41^{\prime} 15^{\prime \prime}$ W; (map 4).

Descriptive name given in 1904 by E. F. Dickins, USC\&GS, because "we thought we had discovered a good passage but it turned out to be a fake."

Falcon Arm: bay, $0.3 \mathrm{mi}$. across, $2 \mathrm{mi}$. long, 10 mi. SE of Chichagof, on W coast of Chichagof I., Alex. Arch.; $57^{\circ} 32^{\prime} \mathrm{N}, 135^{\circ} 58^{\prime} \mathrm{W}$; BGN 1908; (map 9). Var. Hawkes Arm.

Named in 1908 by USC\&GS and published in the 1908 Coast Pilot (p. 172). It was named Hawkes Arm by E. F. Dickins in 1906 for "Dr. Hawkes" a member of his party.

Falcon Cliffs: bluff, on right bank of Yukon River, $12 \mathrm{mi}$. SW of Nulato, Nulato Hills; $64^{\circ} 32^{\prime} \mathrm{N}, 158^{\circ} 25^{\prime} \mathrm{W}$; (map 97).

Riverboat pilots' name shown on a 1940 "Navigation Chart of the Tanana-Yukon Rivers" published by U.S. Dept. of the Interior.

Falcon Lake: lake, $1.5 \mathrm{mi}$. long, on Kenai Penin., $\mathrm{N}$ of Snowshoe Lake, $35 \mathrm{mi}$. NE of Kenai, Cook Inlet Low.; $60^{\circ} 47^{\prime} 15^{\prime \prime} \mathrm{N}, 150^{\circ} 23^{\prime} 30^{\prime \prime}$ $\mathrm{W}$; (map 62).

Named about 1963 by officials of Kenai National Moose Range, probably for the Gray Gyralcon (Falco rusticolus rusticolus), which breeds from Alaska east to southern Greenland (Pearson, 1944, pt. 2, p. 85).

Falfan Point: point of land, on E coast of Baker I., in Port Asumcion, $17 \mathrm{mi}$. WSW of Craig, Alex. Arch.; $55^{\circ} 22^{\prime} 30^{\prime \prime} \mathrm{N}, 133^{\circ} 32^{\prime} 00^{\prime \prime} \mathrm{W}$; (map 4). Var. Mys de Falfan, Punta de Falfan, Punta de Farfan.

Spanish name given in $1775-79$ by Bodega y Quadra and Francisco Antonio Maurelle as "Punta de Falfan," i.e. "Falfan Point." Wagner (1937, p. 453) spelled the name "Farfan" and said it was a well-known family name.

Fall Camps Lake: lake, $5 \mathrm{mi}$. $\mathrm{S}$ of junc. of Khotol River and Tsurotlurna Slough, $28 \mathrm{mi}$. SE of Nulato, Koyukuk Low.: $64^{\circ} 20^{\prime} \mathrm{N}, 158^{\circ}$ $20^{\prime}$ W; (map 97). Var. Khatsulstit Lake.

Appears to be a translation of an Indian name; reported in 1935 by Frederica de Laguna, BAE.

Fall Creek: stream, flows SW 2 mi. to Pacific 
Ocean, on SW coast of Kiska I., Aleutian Is.; $51^{\circ} 51^{\prime} 40^{\prime \prime} \mathrm{N}, 177^{\circ} 16^{\prime} 20^{\prime \prime} \mathrm{E}$; (map 14).

An arbitrary name beginning with " $F$ " to correspond to "F" grid used by the U.S. Army for tactical purposes during World War II; published on a 1953 AMS map.

Fall Creek: stream, flows $2 \mathrm{mi}$. $\mathrm{N}$ to Nugget Creek, $1.5 \mathrm{mi}$. E of Mendenhall Glacier and $8.5 \mathrm{mi}$. NNW of Juneau, Coast Mts.; $58^{\circ} 25^{\prime}$ $30^{\prime \prime} \mathrm{N}, 134^{\circ} 32^{\prime} 00^{\prime \prime} \mathrm{W}$; (map 11). pl. 1).

Fall Creek: stream, in Glacier Bay National Monument, flows $2.5 \mathrm{mi}$. NW to Lituya Bay, $1.7 \mathrm{mi}$. SW of Crillon Inlet and $84 \mathrm{mi}$. NW of Hoonah, St. Elias Mts. ; $58^{\circ} 38^{\prime} 30^{\prime \prime}$ N, $137^{\circ} 31^{\prime}$ 00" W; BGN 1959; (map 10). Var. Mudslide Creek.

Local name reported by USGS in 1930. The name "Mudslide Creek" was published by members of the Harvard-Dartmouth Expedition, 1933-34 (Washburn and Goldthwaite, 1936, map).

Fall Creek: stream, flows N 8 mi. to Tiekel River, $2.4 \mathrm{mi}$. SW of Ernestine and $43 \mathrm{mi}$. NE of Valdez, Chugach Mts.; $61^{\circ} 25^{\prime} 10^{\prime \prime} \mathrm{N}, 145^{\circ} 09^{\prime}$ $10^{\prime \prime} \mathrm{W}$; (map 68).

Local name reported in 1899 by Oscar Rohn.

Fall Creek: stream, flows SW $2 \mathrm{mi}$. to Knik River, $20 \mathrm{mi}$. SE of Palmer, Chugach Mts.; $61^{\circ} 27^{\prime}$ $15^{\prime \prime} \mathrm{N}, 148^{\circ} 35^{\prime} 30^{\prime \prime} \mathrm{W}$; (map 69).

Local name reported in 1960 by USGS.

Fall Creek: stream, flows S $4.6 \mathrm{mi}$. to Kluvesna River, $18 \mathrm{mi}$. W of Mount Blackburn, Wrangell Mts.; $61^{\circ} 46^{\prime} \mathrm{N}, 1^{2} 3^{\circ} 55^{\prime} \mathrm{W}$; (map 67).

Prospectors name reported in 1900 by T. G. Gerdine, USGS.

Fall Creek: stream, flows NE $11 \mathrm{mi}$. to Imuruk Basin, $20 \mathrm{mi}$. SE of Teller, Seward Penin. High.; $65^{\circ} 05^{\prime} \mathrm{N}, 165^{\circ} 49^{\prime} \mathrm{W}$; (map 111).

Local name reported in 1900 by $E$. C. Barnard (in Brooks, 1901, pl. 17), USGS.

Fall Creek: stream, flows W $6 \mathrm{mi}$. to Michigan Creek, $6 \mathrm{mi}$. SW of Ipnek Mtn. and $31 \mathrm{mi}$. W of Wiseman, Brooks Ra.; $67^{\circ} 18^{\prime} 15^{\prime \prime} \mathrm{N}$, $151^{\circ} 14^{\prime} 00^{\prime \prime} \mathrm{W}$; BGN 1932; (map 124).

Local name reported by Robert Marshall in 1932.

Fall Creek: stream, see Eagle Creek.

Fall Creek: stream, see Falls Creek.

Fall Creek Station: locality, see Falls.

Falling Glacier: glacier, heads at NW end of Sargent Ice Field, trends NW 3 mi. to E side of Kings Bay, $20 \mathrm{mi}$. S of Whittier, Chugach Mts. ; $60^{\circ} 29^{\prime} 30^{\prime \prime} \cdot \mathrm{N}, 148^{\circ} 34^{\prime} 45^{\prime \prime} \mathrm{W}$; $B G N$ 1910; (map 63).

So named in 1910 by U. S. Grant, because of its "falling" appearance.

Falling Mountain: peak, 3,805 ft., on Alaska Penin. in Katmai National Monument, $8 \mathrm{mi}$. W of Mount Katmai, Aleutian Ra.; 58 ${ }^{\circ} 15^{\prime} 20^{\prime \prime}$ N, $155^{\circ} 10^{\prime} 25^{\prime \prime} \mathrm{W}$; BGN 1924; (map 42).

So named in 1917 by R. F. Griggs, National Geographic Society, "on account of the frequent rock avalanches."
Fall Lake: lake, $1 \mathrm{mi}$. long, on Harding River, $5 \mathrm{mi}$. N of Bradfield Canal, Coast Mts.; $56^{\circ} 16^{\prime} 20^{\prime \prime} \mathrm{N}, 131^{\circ} 40^{\prime} 00^{\prime \prime} \mathrm{W}$; (map 7).

Name published in 1943 on a USGS map.

Falls: locality, on Seward Highway, $22 \mathrm{mi}$. $\mathrm{N}$ of Seward, Chugach Mts.; $60^{\circ} 25^{\prime} 10^{\prime \prime} \mathrm{N}, 149^{\circ}$ $22^{\prime} 00^{\prime \prime}$ W; (map 63). Var. Fall Greek Station.

Name of a former station on The Alaska RR. Reported as Fall Creek Station by B. L. Johnson (in Martin and others, 1915, pl. 2), USGS. Recent USGS maps show it with five buildings.

Falls, The: rapids, on W central Admiralty I., between Salt Lake and Mitchell Bay, $9.3 \mathrm{mi}$. NE of Angoon, Alex. Arch.; 57 $33^{\prime} 30^{\prime \prime} \mathrm{N}$ $134^{\circ} 21^{\prime} 20^{\prime \prime} \mathrm{W}$; (map 9).

Local descriptive name reported in 1951 by USGS.

Falls, The: falls, on Seventymile River, $21 \mathrm{mi}$. NW of Eagle, Yukon-Tanana High.; $64^{\circ} 55^{\prime}$. $50^{\prime \prime} \mathrm{N}, 141^{\circ} 50^{\prime} 00^{\prime \prime} \mathrm{W}$; (map 102). Var. Seventymile River at the falls.

Named by prospectors and reported in 1911 by E. A. Porter (in Brooks and others, 1912, p. 232), USGS, as "Seventymile River at the falls."

Falls Bay: bay, $1.3 \mathrm{mi}$. across, on $\mathbf{E}$ coast of Kenai Penin., on $W$ side of Prince William Sound, $18 \mathrm{mi}$. NE of Chenega, Chugach Mts.; $60^{\circ} 31^{\prime} 40^{\prime \prime} \mathrm{N}, 147^{\circ} 59^{\prime} 15^{\prime \prime} \mathrm{W}$; $B G N$ 1914; (map 63).

Local name published in 1913 by USC\&GS

Falls Creek: stream, on $\mathrm{E}$ coast of Cleveland Penin., flows SE $1.3 \mathrm{mi}$. to Smugglers Cove, $\mathrm{E}$ of Helm Bay, Alex. Arch.; $55^{\circ} 36^{\prime} \mathrm{N}, 131^{\circ}$. 59' W; (map 3).

Local name reported in 1949 by USGS.

Falls Creek: stream, on Revillagigedo I., flows W $1.3 \mathrm{mi}$,, drains Swan Lake into Carroll Inlet, Alex. Arch.; 55 $36^{\prime} 50^{\prime \prime} \mathrm{N}, 131^{\circ} 21^{\prime} 15^{\prime \prime}$ W; (map 3).

Local name reported in 1948 by USGS.

Falls Creek: stream, flows $5 \mathrm{mi}$. to Thorne River, on E coast of Prince of Wales I., Alex. Arch.; 55 $42^{\prime} 32^{\prime \prime} \mathrm{N}, 132^{\circ} 36^{\prime} 47^{\prime \prime} \mathrm{W}$; $B G N$ 1960; (map 4).

Descriptive name given by C. L. Sainsbury, USGS, in 1956, because of "the large number of waterfalls in its center portion."

Falls Creek: stream, flows SW $6 \mathrm{mi}$. through McHenry Lake to McHenry Inlet, on SW coast of Etolin I., Alex. Arch.; $56^{\circ} 02^{\prime} 00^{\prime} \mathrm{N}$, $132^{\circ} 22^{\prime} 40^{\prime \prime} \mathrm{W}$; (map 6).

Local descriptive name reported in 1900 by Lt. Comdr. J. F. Moser, USN.

Falls Creek: stream, $8 \mathrm{mi}$. long, flows $E$ and $W$ to Wrangell Narrows, $10 \mathrm{mi}$. $\mathrm{S}$ of Petersburg, Alex. Arch.; $56^{\circ} 41^{\prime} 00^{\prime \prime} \mathrm{N}, 132^{\circ} 55^{\prime} 30^{\prime \prime} \mathrm{W}$; (map 6). Var. Fall Creek, Taain Creek.

Local name published as "Fall Creek" in 1929 by USFS.

Falls Greek: stream, flows NW $4.5 \mathrm{mi}$. to O'Malley River, $0.5 \mathrm{mi}$. SE of Karluk Lake, Kodiak I.; $57^{\circ} 16^{\prime} 25^{\prime \prime}$ N, $153^{\circ} 59^{\prime} 05^{\prime \prime}$ W; (map 34).

Local name reported in 1954 by USGS.
Falls Creek: stream, heads in Lake Morris, flows $\mathrm{S} 2.5 \mathrm{mi}$. to Sea Level Slough, $12 \mathrm{mi}$. NW of Chichagof, on W coast of Chichagof I., Alex. Arch.; $57^{\circ} 48^{\prime} \mathrm{N}, 136^{\circ} 18^{\prime} \mathrm{W}$; (map 9).

Local descriptive name reported in 1920 by G. H. Canfield (in Brooks and others, 1922, p. 96), USGS.

Falls Creek: stream, on Admiralty I., $1.2 \mathrm{mi}$. long, flows NW to Stephens Passage, $1.5 \mathrm{mi}$. $\mathrm{W}$ of Oliver Inlet and $11 \mathrm{mi}$. S of Juneau, Alex. Arch.; $58^{\circ} 08^{\prime} 55^{\prime \prime} \mathrm{N}, 134^{\circ} 22^{\prime} 10^{\prime \prime} \mathrm{W}$; (map 11).

Name published in 1951 by USGS.

Falls Greek: stream, on $\mathbf{N}$ end of Douglas I., flows NE $2 \mathrm{mi}$. to Gastineau Channel, $2.9 \mathrm{mi}$. NW of Juneau, Coast Mts.; $58^{\circ} 19^{\prime} 25^{\prime \prime} \mathrm{N}$, $134^{\circ} 28^{\prime} 45^{\prime \prime} \mathrm{W}$; (map 11).

Local name published in 1962 by USGS.

Falls Creek: stream, on Kenai Penin., flows S $4.5 \mathrm{mi}$. to Kachemak Bay, $17 \mathrm{mi}$. NE of Homer, Cook Inlet Low.; 59 $46^{\prime} 10^{\prime \prime} \mathrm{N}$, $151^{\circ} 08^{\prime} 00^{\prime \prime} \mathrm{W}$; (map 50).

Local name reported by Stone (1906, pl. 3), USGS. Probably so named because of the drop in elevation along the course of the stream.

Falls Creek: stream, on Kenai Penin., flows N 3 mi. in a swamp E of Sterling Highway, $13 \mathrm{mi}$. NE of Ninilchik and $26 \mathrm{mi}$. S of Kenai, Cook Inlet Low.; $60^{\circ} 11^{\prime} 30^{\prime \prime} \mathrm{N}, 151^{\circ} 25^{\prime} 30^{\prime \prime} \mathrm{W}$; (map 62).

Local name reported about 1947 by Barnes and Cobb (1959, pl. 17), USGS.

Falls Creek: stream, flows W $1 \mathrm{mi}$. to Dick Creek, $12 \mathrm{mi}$. NE of Katalla, Chugach Mts.; $60^{\circ} 19^{\prime}$ $\mathrm{N}, 144^{\circ} 19^{\prime} \mathrm{W}$; (map 64).

Local name used by prospectors, reported in 1905 by G. C. Martin, USGS.

Falls Creek: stream, flows WNW $9 \mathrm{mi}$. to Trail River, $23 \mathrm{mi}$. N of Seward, Chugach Mts.; $60^{\circ} 25^{\prime} 50^{\prime \prime} \mathrm{N}, 149^{\circ} 27^{\prime} 25^{\prime \prime} \mathrm{W} ; B G N$ 1912; (map 63). Var. False Creek.

Local name published by $D$. $H$. Sleem on his map of Central Alaska dated 1910. It was called False Creek in 1906 by F. H. Moffit, USGS.

Falls Creek: stream, on Kenai Penin., flows W 6.5 mi. to Juneau Greek, $1 \mathrm{mi}$. S of Juneau Lake and $27 \mathrm{mi}$. SW of Hope, Chugach Mts. ; 60 $33^{\circ}$ $\mathrm{N}, 149^{\circ} 53^{\prime} \mathrm{W}$; (map 63).

Local name published in 1940 by USGS, "because of the falls on the stream."

Falls Creek: stream, on $\mathrm{N}$ end of Kenai Penin., flows NW $4.5 \mathrm{mi}$. to Sixmile Creek, $0.5 \mathrm{mi}$. S of Sunrise, Chugach Mts. ; $60^{\circ} 52^{\prime} 35^{\prime \prime} \mathrm{N}, 149^{\circ}$ 25'20' W; (map 63).

Local name reported by Martin and others (1915, pl. 2), USGS. Presumably named because of the falls that occur on the stream.

Falls Creek: stream, flows S $2.5 \mathrm{mi}$. to Turnagain Arm, $7.5 \mathrm{mi}$. NW of Sunrise, Chugach Mts.; $60^{\circ} 59^{\prime} 05^{\prime \prime} \mathrm{N}, 149^{\circ} 34^{\prime} 30^{\prime \prime} \mathrm{W}$; (map 63).

Local name published in 1922 by USGS, "because of the falls on the stream."

Falls Creek: stream, heads in glacier, flows SSE $9 \mathrm{mi}$. to Little Bremner River, $3.5 \mathrm{mi}$. SW of Tebay Lakes and $61 \mathrm{mi}$. E of Valdez, Chugach Mts. ; $61^{\circ} 09^{\prime} 05^{\prime \prime} \mathrm{N}, 144^{\circ} 25^{\prime} 20^{\prime \prime} \mathrm{W}$; (map 68). 
Local name reported in 1913 by F. H. Moffit, USGS.

Falls Creek: stream, heads in a glacier, flows W and $S 3 \mathrm{mi}$. to Canyon Creek, $2.3 \mathrm{mi}$. NW of Summit Lake and $67 \mathrm{mi}$. NE of Valdez, Chugach Mts.; $61^{\circ} 20^{\prime} 25^{\prime \prime} \mathrm{N}, 144^{\circ} 16^{\prime} 45^{\prime \prime} \mathrm{W}$; (map 68).

Local name published in the 1950's by USGS.

Falls Creek: stream, heads in Dutch Hills, flows S $5.5 \mathrm{mi}$. to Cache Creek, $31 \mathrm{mi}$. NW of Talkeetna, Alaska Ra.; $62^{\circ} 28^{\prime} 30^{\prime \prime} \mathrm{N}, 151^{\circ}$. $00^{\prime} 45^{\prime \prime} \mathrm{W}$; (map 81).

Descriptive name reported in 1906 by $R$. W. Porter, USGS. Gold was first mined here in 1905.

Falls Creek: stream, heads at glacier terminus, flows NW $3.8 \mathrm{mi}$. to Delta River, crosses Richardson Highway, $35 \mathrm{mi}$. NW of Paxson, Alaska Ra.; $63^{\circ} 31^{\prime} 05^{\prime \prime} \mathrm{N}, 1^{\circ} 55^{\circ} 31^{\prime} 30^{\prime \prime} \mathrm{W}$; (map 86).

Name published on relatively recent maps.

Falls Creek: stream, flows E $3 \mathrm{mi}$. to Birch Creek, $6 \mathrm{mi}$. NE of Long and $19 \mathrm{mi}$. SSE of Ruby, Kilbuck-Kuskokwim Mts.; 64 ${ }^{\circ} 28^{\prime} 20^{\prime \prime}$ $\mathrm{N}, 155^{\circ} 23^{\prime} 00^{\prime \prime} \mathrm{W}$; (map 98$)$.

Prospectors' name reported in 1913 by Eakin (1914, pl. 3), USGS. The stream's exact application is in doubt.

Falls Creek: stream, flows NE $2.4 \mathrm{mi}$. to Canyon Creek which flows to Imuruk Basin, $33 \mathrm{mi}$. NW of Nome, Seward Penin. High.; 64 ${ }^{\circ} 55^{\prime}$ $\mathrm{N}, 165^{\circ} 54^{\prime} \mathrm{W}$; (map 94). Var. Fall Creek.

Prospectors' name published on the 1908 "Map of Seward Peninsula" by Arthur Gibson.

Falls Creek: stream, see Reindeer Creek.

Falls Creek: stream, see Whipple Creek.

Falls Lake: lake, $0.8 \mathrm{mi}$. across, on $\mathrm{E}$ coast of Baranof I., $18 \mathrm{mi}$. S of Baranof, Alex. Arch.; $56^{\circ} 49^{\prime} 30^{\prime \prime} \mathrm{N}, 134^{\circ} 42^{\prime} 00^{\prime \prime} \mathrm{W}$; (map 5).

Local descriptive name obtained in 1951 by USGS.

Falls Lake: lake, $0.5 \mathrm{mi}$. long, on Cascade Creek, $2 \mathrm{mi}$. E of Thomas Bay, $103 \mathrm{mi}$. E of Sitka, Coast Mts.; $57^{\circ} 01^{\prime} 15^{\prime \prime} \mathrm{N}, 132^{\circ} 45^{\prime} 15^{\prime \prime} \mathrm{W}$; BGN 1923; (map 8).

Local descriptive name; reported in 1922 by USFS.

Falls Lake: lake, trends $\mathrm{E}-\mathrm{W} 2 \mathrm{mi}$., on Kenai Penin., $0.7 \mathrm{mi}$. SW of head of Falls Bay, 15 mi. N of Chenega, Chugach Mts.; 60 $30^{\prime} 10^{\prime \prime}$ $\mathrm{N}, 148^{\circ} 02^{\prime} 30^{\prime \prime} \mathrm{W}$; (map 63).

Local name reported in 1952 by USGS.

Falls Point: point of land, on $\mathrm{N}$ coast of Tanaga I., Aleutian Is.; $51^{\circ} 55^{\prime} 05^{\prime \prime} \mathrm{N}, 178^{\circ} 02^{\prime} 35^{\prime \prime}$ W; (map 16).

Local name published on a 1954 USGS map.

Falmouth Harbor: bay, $1.5 \mathrm{mi}$. across, on $\mathrm{W}$ coast of Nagai I., in Shumagin Is., Aleutian Ra.; $55^{\circ} 05^{\prime} \mathrm{N}, 160^{\circ} 09^{\prime} \mathrm{W}$; (map 28).

Named by W. H. Dall, USC\&GS, in 1872 , for a vessel of that name which was driven in to the harbor by a gale.

Falsa, Bahia : bay, in about $59^{\circ} 10^{\prime} \mathrm{N}$. So called because Capt. Alessandro Malaspina found no such feature here in 1791, as indicated on a chart. See Wagner (1937, p. 452).

False Arden: point of land, $\mathrm{N}$ end of Glass Peninsula, on Stephens Passage, $1.2 \mathrm{mi}$. NW of Arden Point and $12 \mathrm{mi}$. SE of Juneau, Alex. Arch.; $58^{\circ} 10^{\prime} 00^{\prime \prime} \mathrm{N}, 134^{\circ} 12^{\prime} 15^{\prime \prime} \mathrm{W}$; (map 11).

Named in 1925 by the USC\&GS and published in 1925 on Chart 8300.

False Bay: bay, $2.5 \mathrm{mi}$. across, on $\mathrm{S}$ coast of Adak I., Aleutian Is.; $51^{\circ} 37^{\prime} 30^{\prime \prime} \mathrm{N}, 176^{\circ} 45^{\prime}$ $30^{\prime \prime} \mathrm{W}$; (map 17).

Name published by USC\&GS in the 1944 Aleutian Coast Pilot (p. 115).

False Bay: bay, $1.5 \mathrm{mi}$. across, $17 \mathrm{mi}$. NE of Tenakee Springs, on NE coast of Chichagof I., Alex. Arch.: $57^{\circ} 58^{\prime} \mathrm{N}, 134^{\circ} 55^{\prime} \mathrm{W}$; (map 9).

Descriptive name given by fur traders prior to 1869 and published in 1869 by U.S. Navy on Hydrog. Chart 225. It is "*** said to be fair anchorage in the summer but bad in in blowy weather" (USC\&GS, 1883, p. 181).

False Cape: point of land, between Peard Bay and Chukchi Sea, E of Point Franklin, Arctic Plain; (map 147).

This unidentified point of land appears to have been named by British naval officers as the name is shown on Brit. Adm. Chart 593, 1827-55. Capt. Hooper (1881, p. 40), USRCS, mentions anchoring near False Cape in Peard Bay in 1880.

False Channel Bay: cove, $0.5 \mathrm{mi}$. across, at NE end of Stillwater Anchorage, in Kootznahoo Inlet, on Admiralty I., $1.5 \mathrm{mi}$. NE of Angoon, Alex. Arch.; $57^{\circ} 31^{\prime} 00^{\prime \prime} \mathrm{N}, 1^{\circ} 34^{\circ} 32^{\prime} 45^{\prime \prime} \mathrm{W}$; (map 9).

Named in 1869 by Comdr. R. W. Meade, USN; published in 1881 on Hydrog. Chart 882. The name does not appear on recent charts.

False Chilkaht: estuary, see Chilkoot Inlet.

False Chilkat Pass: pass, see Chilkoot Pass.

False Cove: $b a y, 0.7 \mathrm{mi}$. wide, $E$ coast of Warren

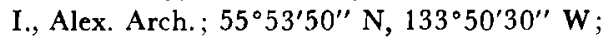
BGN 1924; (map 4).

Named in 1924 by USC\&GS, "because it is often entered by mistake for Warren Cove."

False Creek: stream, see Falls Creek.

False Ears: mountain, on Seward Penin. S. of Goodhope Bay, Kotzebue Sound, Seward Penin. High.; $65^{\circ} \mathrm{N}, 163^{\circ} \mathrm{W}$; $(\operatorname{map} 110)$.

Name shown on Brit. Adm. Chart 573 (1882), also on USC\&GS Chart 3093 (1900); perhaps reported by some English naval officers in the Franklin search expeditions 184954. Not shown on recent maps.

False Island: island, $210 \mathrm{ft}$. long, $0.5 \mathrm{mi}$. $\mathrm{N}$ of village of Point Baker, on NW tip of Prince of

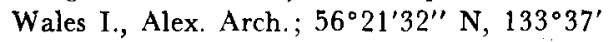
$30^{\prime \prime} \mathrm{W}$; (map 6).

Local name recorded in 1955 by USC\&GS.

False Island: island, $0.4 \mathrm{mi}$. long, in Peril Strait, off $S$ coast of Chichagof I., $9 \mathrm{mi}$. S of Tenakee Springs, Alex. Arch.; $57^{\circ} 31^{\prime} 50^{\prime \prime} \mathrm{N}, 135^{\circ}$ $13^{\prime} 00^{\prime \prime} \mathrm{W}$; ( $\left.\operatorname{map} 9\right)$.

Named in 1895 by Lt. Comdr. E. K. Moore, USN, and published by USC\&GS on Chart
8283. Probably so named because it is connected at low tide to the mainland by a sand bar.

False Island Head: promontory, see Boussole Head.

False Island Point: point of land, on $\mathrm{E}$ coast of Lindenberg Penin., Kupreanof I., $11 \mathrm{mi}$. S of Petersburg, Alex. Arch.; $56^{\circ} 39^{\prime} 40^{\prime \prime} \mathrm{N}, 132^{\circ}$ $56^{\prime} 00^{\prime \prime} \mathrm{W}$; (map 6).

Named in 1887 by Lt. Comdr. C. M. Thomas, USN.

False Lindenberg Head: point of land, $2 \mathrm{mi}$. W of Todd, on $S$ coast of Chichagof I., Alex. Arch.; $57^{\circ} 28^{\prime} \mathrm{N}, 135^{\circ} 05^{\prime} \mathrm{W}$; (map 9).

Local name probably from Alaskan coastal pilots; published by USC\&GS in the 1891 Coast Pilot (p. 187). Probably so named because of its similarity to Lindenberg Head 2 miles to the west.

False Mount Calder: mountain, see Red Bay Mountain.

False Pass: village, pop. 41, on Isanotski Strait, on $\mathrm{E}$ coast of Unimak I., Aleutian Is.; $54^{\circ} 51^{\prime}$ $15^{\prime \prime} \mathrm{N}, 163^{\circ} 24^{\prime} 30^{\prime \prime} \mathrm{W}$; (map 25).

An early English name for Isanotski Strait. The strait was called "False Pass" because it was thought to be impassable at the northern end. A cannery was built which provided the nucleus of the settlement. A post office was established in 1921 (Ricks, 1965, p. 20).

False Pass: water passage, see Isanotski Strait. False Point: point of land, on $\mathrm{N}$ coast of Chichagof I., in Port Frederick, $0.4 \mathrm{mi}$. S of Hoonah and $40 \mathrm{mi}$. SW of Juneau, Alex. Arch.; 58 $06^{\prime} 00^{\prime \prime} \mathrm{N}, 136^{\circ} 26^{\prime} 30^{\prime \prime} \mathrm{W}$; (map 11).

So named by U.S. Navy officers and pub. lished in 1880 on Hydrog. Chart 225.

False Point Pybus: point of land, on E coast of Admiralty I., $5.5 \mathrm{mi}$. NE of Pybus and $61 \mathrm{mi}$. $E$ of Sitka, Alex. Arch.; $57^{\circ} 22^{\prime} 15^{\prime \prime} \mathrm{N}, 133^{\circ}$ $51^{\prime} 40^{\prime \prime}$ W; (map 8). Var. Point Pybus.

Named by W. H. Dall, USC\&GS ; published in 1883 Coast Pilot (p. 130). "This point was mistakenly called Point Pybus on the Russian Hydrographic Department, U.S. Hydrographic, and British Admiralty Charts, but it is not the Point Pybus originally named by Vancouver in 1794 , which is six miles to the southwest; therefore the name False Point Pybus."

False Point Retreat: point of land, on W coast of $\mathrm{N}$ end of Mansfield Peninsula, $2.8 \mathrm{mi}$. S of Point Retreat and $20 \mathrm{mi}$. NW of Juneau, Alex. Arch.; 58 $22^{\prime} 10^{\prime \prime} \mathrm{N}, 134^{\circ} 58^{\prime} 15^{\prime \prime} \mathrm{W}$; (map 11).

So named in 1891 by USC\&GS because, from the south, the feature resembles Point Retreat. Published in the 1891 Coast Pilot (p. 198).

False Rock : rocks, see Liar Rocks.

Falsoola Mountain: mountain, 6,470 ft., E of Blarney Creek and $37 \mathrm{mi}$. N of Wiseman, Brooks Ra.; 67 $57^{\circ} \mathrm{N}, 150^{\circ} 04^{\prime} \mathrm{W}$; (map 124).

Name reported in 1939 by Marshall (1956, map); so named because it could be easily mistaken for Oolah Mountain, farther to the north. 
Fan Creek: stream, flows NW $12 \mathrm{mi}$. to Black Lake, $2 \mathrm{mi}$. $\mathrm{N}$ of head of Chignik River and $23 \mathrm{mi}$. NW of Chignik, Aleutian Ra.; $56^{\circ} 27^{\prime}$ $\mathrm{N}, 158^{\circ} 56^{\prime} \mathrm{W}$; (map 30$)$.

Name reported in 1923 by R. H. Sargent, USGS ; published in 1927 by USGS.

Faneto Hill: peak, 2,610 ft., on Attu I., $0.9 \mathrm{mi}$. $\mathrm{E}$ of Winter Lake, Aleutian Is.; 52 $2^{\circ} 56^{\prime} 15^{\prime \prime} \mathrm{N}$, $173^{\circ} 01^{\prime} 33^{\prime \prime} \mathrm{E}$; (map 13).

Named by U.S. Army during World War II ; published in 1948 by AMS.

Fang Mountain: mountain, 6,736 ft., $14 \mathrm{mi}$. NW of Cantwell, $22 \mathrm{mi}$. SW of Healy, Alaska Ra.; $63^{\circ} 33^{\prime} 30^{\prime \prime} \mathrm{N}, 149^{\circ} 11^{\prime} 00^{\prime \prime} \mathrm{W}$; (map 87).

Local descriptive name published in 1952 by USGS.

Fang Point: point of land, $\mathrm{W}$ point of entrance to Port Hobron, on $\mathrm{N}$ coast of Sitkalidak $\mathbf{I}$., SE of Kodiak I.; $57^{\circ} 11^{\prime} 10^{\prime \prime} \mathrm{N}, 153^{\circ} 09^{\prime} 50^{\prime \prime}$ W; BGN 1930; (map 34).

Descriptive name given in 1930 by USC\&GS, "because of a lone [fang-like] rock off the point."

Fankuda, Ostrov: island, see Fankuda Islet.

Fankuda Islet: island, 0.2 mi. across, in Redoubt Bay, $5.2 \mathrm{mi}$. $\mathrm{N}$ of Goddard, on $\mathrm{W}$ coast of Baranof I., Alex. Arch.; 56 $54^{\prime} 35^{\prime \prime}$ N, $135^{\circ}$ 21'30" W; (map 5). Var. Ostrov Fankuda.

Named in 1809 by the Russian navigator, Ivan Vasiliev the first; published by Lt. Sarichev" (1826, map 19), IRN, as "O[strov] Fankuda" or "Fankuda Island."

Fan Lake: lake, $0.2 \mathrm{mi}$. long, on SW part of Kiska I., Aleutian Is. ; $51^{\circ} 53^{\prime} 20^{\prime \prime} \mathrm{N}, 177^{\circ} 19^{\prime}$ 22" E; (map 14).

An arbitrary name beginning with " $F$ " to correspond to " $F$ " grid used by the U.S. Army for tactical purposes during World War II published on a 1953 AMS map.

Fan Mountain: hill, $1,020 \mathrm{ft}$, , on SW part of Kiska I., Aleutian Is. ; $51^{\circ} 54^{\prime} 55^{\prime \prime} \mathrm{N}, 177^{\circ} 16^{\prime}$ $20^{\prime \prime} \mathrm{E}$; (map 14).

An arbitrary name beginning with " $F$ " to correspond to "F" grid used by the U.S. Army for tactical purposes during World War II; published on a 1953 AMS map.

Fan Mountain: mountain, 7,090 ft., between Anaktuvuk River and Alapah Creek, $18 \mathrm{mi}$. E of Anaktuvuk Pass, Brook Ra.; 68 ${ }^{\circ} 10^{\prime} 30^{\prime \prime}$ N, $151^{\circ} 04^{\prime} 00^{\prime \prime} \mathrm{W}$; BGN 1932; (may 134).

So named by Robert Marshall in 1930 "because of the [fanlike] appearance of the rock strata."

Fannie Island: island, $0.4 \mathrm{mi}$. across, in Port Snettisham, $2.4 \mathrm{mi}$. $\mathrm{N}$ of Sharp Point and $30 \mathrm{mi}$. SE of Juneau, Coast Mts. ; $58^{\circ} 02^{\prime} 45^{\prime \prime}$ $\mathrm{N}, 133^{\circ} 47^{\prime} 10^{\prime \prime} \mathrm{W}$; (map 6).

Named in 1888 by Lt. Comdr. C. M. Thomas, USN.

Fanny Mountain: mountain, 2,044 ft., $5 \mathrm{mi}$. SE of Bear Mtn. and $38 \mathrm{mi}$. W of Midnight Hill, Porcupine Plat.; $66^{\circ} 00^{\prime} 20^{\prime \prime} \mathrm{N}, 142^{\circ} 27^{\prime} 00^{\prime \prime}$ W; (map 120).

Local name obtained in 1956 by T. E. Taylor and R. C. Foley, USGS.

Fan Point: point of land, on NW coast of Tanaga I., Aleutian Is.; $51^{\circ} 50^{\prime} 30^{\prime \prime} \mathrm{N}, 178^{\circ} 10^{\prime} 15^{\prime \prime} \mathrm{W}$ (map 16).
Local name published on a 1954 USGS map.

Fanshaw: locality, see Cape Fanshaw.

Fanshaw, Cape: point of land, at $S$ end of Stephens Passage, between Fanshaw Bay and Frederick Sound, $68 \mathrm{mi}$. E of Sitka, Coast Mts.; $57^{\circ} 11^{\prime} \mathrm{N}, 133^{\circ} 33^{\prime} \mathrm{W}$; (map 8).

Named by Capt. George Vancouver, RN, when it was discovered on August 14, 1794, by Lt. J. Whidbey, RN (Wagner, 1937, p. 387).

Fanshaw, Mount: mountain, 2,720 ft., in Fanshaw Ra., $3 \mathrm{mi}$. E of Whitney I. and $73 \mathrm{mi}$. E of Sitka, Coast Mts.; $57^{\circ} 12^{\prime} 35^{\prime \prime} \mathrm{N}, 133^{\circ}$ $27^{\prime} 00^{\prime \prime} \mathrm{W}$; (map 8).

Named in 1887 by Lt. Comdr. C. M. Thomas, USN; published in 1888 by USC\&GS.

Fanshaw Bay: bight, extends SW $3 \mathrm{mi}$., from Whitney I. to Cape Fanshaw, $66 \mathrm{mi}$. E of Sitka, Coast Mts.; $57^{\circ} 12^{\prime} \mathrm{N}, 133^{\circ} 33^{\prime} \mathrm{W}$; (map 8).

Named in 1887 for Cape Fanshaw by Lt. Comdr. C. M. Thomas, USN; published in 1888 by USC\&GS.

Fanshaw Range: mountain range, trends S 10 mi. from Steamboat Bay along $E$ shore of Cleveland Passage, $72 \mathrm{mi}$. E of Sitka, Coast Mts.; $57^{\circ} 14^{\prime} \mathrm{N}, 133^{\circ} 28^{\prime} \mathrm{W}$; (map 8).

Named in 1887 for Cape Fanshaw by Lt. Comdr. C. M. Thomas, USN; published in 1888 by USC\&GS.

Fantasy Knob: hill, $700 \mathrm{ft}$., on SW end of Kiska I., Aleutian Is. ; $51^{\circ} 54^{\prime} 47^{\prime \prime} \mathrm{N}, 177^{\circ} 16^{\prime} 02^{\prime \prime} \mathrm{E}$; (map 14).

An arbitrary name beginning with " $F$ " to correspond to "F" grid used by the U.S. Army for tactical purposes during World War II ; published on a 1953 AMS map.

Faraday Gulch: ravine, trends NE $0.7 \mathrm{mi}$. to St. Michaels Creek, 9 mi. NE of Nome, Seward Penin. High.; $64^{\circ} 32^{\prime} 45^{\prime \prime} \mathrm{N}, 165^{\circ} 08^{\prime} 20^{\prime \prime} \mathrm{W}$; (map 94).

Prospectors' name reported in 1904 by T. G. Gerdine, USGS

Faraker, Mount: peak, see Foraker, Mount.

Farallon Bay: $b a y$, extends $W 1.2 \mathrm{mi}$. off Tlevak Strait, on E coast of Dall I., Alex. Arch.; $55^{\circ} 11^{\prime} 40^{\prime \prime} \mathrm{N}, 133^{\circ} 04^{\prime} 45^{\prime \prime} \mathrm{W}$; BGN 1908; (map 4). Var. South Bay.

Spanish word meaning "rock (or cliff) in the sea"; given in 1907 by E. F. Dickins, USC\&GS. This feature was called "South Bay" in 1881 by H. E. Nichols, USN. See Kekur Island.

Farewell, Point: point of land, on SW coast of Chernabura I., in Shumagin Is,, Aleutian Ra.; $54^{\circ} 45^{\prime} 45^{\prime \prime} \mathrm{N}, 159^{\circ} 35^{\prime} 30^{\prime \prime} \mathrm{W}$; (map 26).

Name recorded by USC\&GS on an 1882 coast chart.

Farewell Island: island, see Pyramid Island.

Farewell Lake: lake, $2 \mathrm{mi}$. long, $2.2 \mathrm{mi}$. W of junc. of South Fork Kuskokwim and Jones Rivers, $69 \mathrm{mi}$. SE of McGrath, Kuskokwim Low.; 62 $33^{\prime} 30^{\prime \prime} \mathrm{N}, 153^{\circ} 38^{\prime} 00^{\prime \prime} \mathrm{W}$; (map $80)$.
Local name, derived from that of the mountain, reported in 1958 by USGS.

Farewell Landing: locality, on SE bank of Kuskokwim River $3.7 \mathrm{mi}$. E of its junc. with its Middle Fork, $24 \mathrm{mi}$. E of McGrath, Kuskokwim Low.; 62 $59^{\prime} 25^{\prime \prime} \mathrm{N}, 154^{\circ} 56^{\prime} 00^{\prime \prime} \mathrm{W}$; (map 80).

River landing reported in 1949 by USGS. Farewell Mountain: mountain, 2,600 ft., on W bank of Tin Creek, $1.5 \mathrm{mi}$. S of Farewell Lake and $71 \mathrm{mi}$. SE of McGrath, Alaska Ra.; $62^{\circ} 31^{\prime} \mathrm{N}, 153^{\circ} 37^{\prime} \mathrm{W}$; (map 80).

So named in 1898 by W. S. Post and J. E. Spurr, USGS, because "it was the last of the high mountains."

Farfan, Punta de: point of land, see Flafan Point. Far Hill: mountain, 1,350 ft., on southern Kiska I., Aleutian Is.; $51^{\circ} 54^{\prime} 10^{\prime \prime} \mathrm{N}, 177^{\circ} 16^{\prime} 20^{\prime \prime} \mathrm{E}$; (map 14).

An arbitrary name beginning with "F" to correspond to "F" grid used by the U.S. Army for tactical purposes during World War II ; published on a 1953 AMS map.

Faris Peak: mountain, 5,426 ft., on $\mathrm{W}$ end of Unimak I., Aleutian Is.; $54^{\circ} 31^{\prime} 50^{\prime \prime} \mathrm{N}$., $164^{\circ} 40^{\prime} 00^{\prime \prime} \mathrm{W} ; B G N$ 1954; (map 24)

Named by $\mathrm{O}$. H. Tittmann, USC\&GS, for Robert Lee Faris, Assistant Director of USG\&GS until his death in 1932. A member of Ferdinand Westdahl's party, Faris determined the geographic position of this peak in 1901 . Farmer, Cape: point of land, in Dixon Entrance.

Named by Capt. William Douglas, June 8, 1789. See Wagner $(1937$, p. 453$)$ for a discussion on its identification.

Farmer Hill: hill, $700 \mathrm{ft}$., on SW part of Kiska I., Aleutian Is.; $51^{\circ} 53^{\prime} 40^{\prime \prime} \mathrm{N}, 177^{\circ} 18^{\prime} 30^{\prime \prime} \mathrm{E}$; (map 14).

An arbitrary name beginning with " $F$ " to correspond to "F" grid used by the U.S. Army for tactical purposes during World War II; published on a 1953 AMS map.

Farmington: town, see Palmer.

Farm Island: island, $8 \mathrm{mi}$. long, at mouth of Stikine River, $10 \mathrm{mi}$. N of Wrangell, Coast Mts.; $56^{\circ} 38^{\prime} \mathrm{N}, 132^{\circ} 25^{\prime} \mathrm{W}$; (map 6).

Name given in 1887 by Lt. Comdr. C. M. Thomas, USN "because island is low and flat."

Far Mountain: mountain, 4,694 ft., $8 \mathrm{mi}$. ENE of Chena Hot Springs and $70 \mathrm{mi}$. SW of Circle, Yukon-Tanana High.; $65^{\circ} 04^{\prime} 50^{\prime \prime} \mathrm{N}$, $145^{\circ} 46^{\prime} 04^{\prime \prime}$ W; (map 104).

Named by prospectors and reported in 1904 by D. C. Witherspoon, USGS.

Faro Creek: stream, flows N $14 \mathrm{mi}$. to Arolik River, $32 \mathrm{mi}$. $\mathrm{N}$ of Goodnews, Kilbuck-Kuskokwim Mts.; 59 $33^{\prime} \mathrm{N}, 161^{\circ} 28^{\prime} \mathrm{W}$; (map 53). Var. West Fork Arolic Creek.

Local name reported in 1914 by P. S. Smith and A. G. Maddren (in Brooks and others, 1915 , p. 358 ), USGS.

Far Point: point of land, on one of Barrier Is., at $W$ entrance to Eureka Channel, Alex. Arch.; $54^{\circ} 46^{\prime} 35^{\prime \prime} \mathrm{N}, 132^{\circ} 23^{\prime} 35^{\prime \prime} \mathrm{W}$; (map 1).

Descriptive name published in 1899 by USC\&GS 
Far Point: point of land, on N coast of Whale I., $\mathrm{N}$ of Kodiak I. ; $57^{\circ} 58^{\prime} 40^{\prime \prime} \mathrm{N}, 152^{\circ} 47^{\prime} 30^{\prime \prime} \mathrm{W}$; (map 34). Var. Mys Dalniy.

Translation of the descriptive name "M[ys] Dalniy," given in 1839 or 1840 by Sub-Lt. Mikhail Murashev, IRN, and published in 1849 on Russian Hydrog. Dept. Chart 1425.

Farragut Bay: bay, $5 \mathrm{mi}$. across, at NE shore of Frederick Sound, $14 \mathrm{mi}$. SE of Cape Fanshaw and $80 \mathrm{mi}$. E of Sitka, Coast Mts.; $57^{\circ} 06^{\prime} \mathrm{N}$, $133^{\circ} 14^{\prime} \mathrm{W}$; (map 8$)$.

Named in 1887 by Lt. Comdr. C. M. Thomas, USN, for Admiral David Glascoe Farragut, 1801-70, American admiral, hero of the battles of New Orleans and Mobile Bay in the Civil War. The name was published by USC\&GS in 1891 Coast Pilot (p. 136).

Farragut Lake: lake, $4 \mathrm{mi}$. long, in course of Farragut River, $11 \mathrm{mi}$. NW of Farragut Bay and $95 \mathrm{mi}$. E of Sitka, Coast Mts.; $57^{\circ} 14^{\prime} 25^{\prime \prime}$ $\mathrm{N}, 132^{\circ} 57^{\prime} 30^{\prime \prime} \mathrm{W}$; (map 8).

Local name reported in 1961 by USGS.

Farragut River: stream, heads at Glory Lake and flows SW $15 \mathrm{mi}$. to Francis Anchorage of Farragut Bay, 84 mi. E of Sitka, Coast Mts.; $57^{\circ} 09^{\prime} 30^{\prime \prime} \mathrm{N}, 133^{\circ} 08^{\prime} 45^{\prime \prime} \mathrm{W}$; (map 8).

Name published by USGS (Brooks and others, 1916, pl. 4); derived from Farragut Bay.

Farrar Cape: point of land, see Krugloi Point.

Fartalesa, Mys de la: point of land, see Fortaleza, Point.

Farthing Horn: peak, 20,125 ft., in Mount McKinley National Park, NE of summit of Mount McKinley, Alaska Ra.; 63 ${ }^{\circ} 04^{\prime} 25^{\prime \prime} \mathrm{N}$, $151^{\circ} 00^{\prime} 15^{\prime \prime} \mathrm{W}$; BGN 1947; (map 88).

Named in 1913 by Archdeacon Stuck (1921, p. 185) for Annie Farthing, a missionary who died at the Nenana mission "three years ago [1910]." See Garter Horn.

Fasseet Island: island, see Fassett Island.

Fasset Islet: island, see Fassett Island.

Fassett Glacier: glacier, on S slope of Brabazon Ra., trends $3 \mathrm{mi}$. S to its 1961 terminus at Tanis Lake, $46 \mathrm{mi}$. SE of Yakutat, St. Elias Mts.; $59^{\circ} 16^{\prime} 50^{\prime \prime} \mathrm{N}, 138^{\circ} 31^{\prime} 30^{\prime \prime} \mathrm{W}$; (map 46).

Named by Lt. Comdr. J. F. Moser, USN, in 1901, for H. C. Fassett, USBF, who was involved in Alaskan affairs for several years and contributed to our knowledge of native geographic names.

Fassett Island: island, $300 \mathrm{ft}$. across, in Kutchuma Is., $3 \mathrm{mi}$. $S$ of Sitka, off $W$ coast of Baranof $I$., Alex. Arch.; 51 ${ }^{\circ} 00^{\prime} 40^{\prime \prime} \mathrm{N}, 135^{\circ} 18^{\prime} 15^{\prime \prime} \mathrm{W}$; (map 9.) Var. Fasseet Island, Fasset Islet. Named by U.S. Navy in 1880 for Thomas O. Fassett, sailmaker, USN. The name was published by USC\&GS in the 1883 Coast Pilot (p. 144).

Fassett Island: island, see Bassett Island.

Fassett Point: point of land, on E shore of Moser Bay, at $\mathbf{S}$ end of Kodiak I., $2 \mathrm{mi}$. $\mathbf{N}$ of Miller I. ; $56^{\circ} 59^{\prime} 50^{\prime \prime} \mathrm{N}, 154^{\circ} 08^{\prime} 00^{\prime \prime} \mathrm{W}$; (map 32 ).

Named in 1900 by Lt. Comdr. J. F. Moser, USN, commander of the Albatross, for Harry C. Fassett, a member of his party.
Fatal Hill: mountain, 1,270 ft., on southern Kiska I., Aleutian Is.; $51^{\circ} 54^{\prime} 40^{\prime \prime}$ N, $177^{\circ} 18^{\prime}$ 22" E ; (map 14).

An arbitrary name beginning with "F" to correspond to " $F$ " grid used by the U.S. Army for tactical purposes during World War II; published by AMS in 1953.

Fathometer Reef: reef, $8 \mathrm{mi}$. E of Billings Head, Akun I., Aleutian Is.; $54^{\circ} 16^{\prime} 30^{\prime \prime} \mathrm{N}, 165^{\circ} 17^{\prime}$ $10^{\prime \prime} \mathrm{W}$; BGN 1939; (map 24). Var. Swirl Reef.

Named in 1937 by USC\&GS, because it was discovered by the use of the fathometer, an instrument used for measuring water depth.

Fatigue Bay: lagoon, $8 \mathrm{mi}$. long, trends SE from Tangent Point at mouth of Dease Inlet, $40 \mathrm{mi}$. $\mathrm{SE}$ of Barrow, Arctic Plain; $71^{\circ} 07^{\prime} 30^{\prime \prime} \mathrm{N}$, $154^{\circ} 58^{\prime} 00^{\prime \prime}$ W; BGN 1966; (map 153). Var. Mackay Inlet, McKay Inlet, M'Kay Inlet.

So named in 1837 by Thomas Simpson after he completed an arduous walk around the bay.

Fatigue Bay: bay, see McKay Inlet.

Fat John Slough: stream, in drainage system of the Yukon River, flows SW $6.5 \mathrm{mi}$. between Walker and Big Bend Sloughs, $7.2 \mathrm{mi}$. SW of Holy Cross, Innoko Low.; 62 $66^{\circ} 40^{\prime \prime} \mathrm{N}$, $159^{\circ} 53^{\prime} 45^{\prime \prime} \mathrm{W}$; (map 78).

Local name obtained in 1952 by USGS.

Fat Mountain: mountain, 1,100 ft., on SW Kiska I., Aleutian Is.; $51^{\circ} 54^{\prime} 10^{\prime \prime} \mathrm{N}, 177^{\circ} 15^{\prime} 16^{\prime \prime} \mathrm{E}$; (map 14).

An arbitrary name beginning with " $F$ " to correspond to "F" grid used by the U.S. Army for tactical purposes during World War II; published on a 1953 AMS map.

Fault Creek: stream, on N part of Chichagof I., flows SE $2.5 \mathrm{mi}$. to Lisianski Inlet, $1.8 \mathrm{mi}$. N of Miner I. and $33 \mathrm{mi}$. SW of Hoonah, Alex. Arch.; $58^{\circ} 02^{\prime} 15^{\prime \prime} \mathrm{N}, 136^{\circ} 20^{\prime} 00^{\prime \prime} \mathrm{W}$; (map 10).

Local name published by USGS in the 1950's.

Fault Creek: stream, heads in lake, flows S $3 \mathrm{mi}$. to Stellar Creek, $0.4 \mathrm{mi}$. NW of Devish Lake and $19 \mathrm{mi} \mathrm{SW}$ of Valdez, Chugach Mts.: $61^{\circ}$ $03^{\prime} 10^{\prime \prime} \mathrm{N}, 146^{\circ} 48^{\prime} 50^{\prime \prime} \mathrm{W}$; (map 68).

Prospectors' name reported in 1911 by $\mathrm{J}$. W. Bagley and C. E. Giffin, USGS.

Fault Creek: stream, in Mount McKinley National Park, flows W $1 \mathrm{mi}$. to Thorofare River, $4.3 \mathrm{mi}$ SSE of Eielson Visitor Center, Alaska Ra.; $63^{\circ} 22^{\prime} 35^{\prime \prime} \mathrm{N}, 150^{\circ} 14^{\prime} 45^{\prime \prime} \mathrm{W}$; $B G N$ 1932; (map 88).

So named by J. C. Reed, Sr., USGS, because "an important geologic fault occurs along this creek."

Fault Point: point of land, on $\mathrm{E}$ shore of Day Harbor, $16 \mathrm{mi}$. SE of Seward, Chugach Mts.; $59^{\circ} 58^{\prime} \mathrm{N}, 149^{\circ} 07^{\prime} \mathrm{W}$; BGN 1929; (map 49).

So named by the 1928 USC\&GS field party "because of two prominent faults in the cliffline of the point which gives the crest a sawtooth appearance."

Fauna Creek: stream, flows E $20 \mathrm{mi}$. to Aniuk River, S of Howard Pass, Brooks Ra.; 68 ${ }^{\circ}$ $10^{\prime} \mathrm{N}, 157^{\circ} 03^{\prime} \mathrm{W}$; BGN 1926; (map 132).
Named by Gerald FitzGerald, USGS, in 1925.

Faust Island: island, $0.4 \mathrm{mi}$. across, in Seymour Canal, $28 \mathrm{mi}$. NE of Angoon, on E coast of Admiralty I., Alex. Arch.; 57 $48^{\prime} 30^{\prime \prime} \mathrm{N}, 134^{\circ}$. $03^{\prime} 30^{\prime \prime} \mathrm{W}$; (map 9).

Named in 1890 by Lt. Comdr. H. B. Mansfield, USN, for Ens. W. H. Faust, USN, a member of his party. The name was published in 1892 by USC\&GS on Chart 8300 .

Faust Rock: rock, off N end of Mansfield Peninsula, $1 \mathrm{mi}$. NE of Point Retreat and $20 \mathrm{mi}$. NW of Juneau, Alex. Arch.; $58^{\circ} 25^{\prime} 05^{\prime \prime} \mathrm{N}$, $134^{\circ} 55^{\prime} 40^{\prime \prime} \mathrm{W}$; (map 11 ).

Discovered and named in 1890 by Lt. Comdr. H. B. Mansfield, USN for Ensign W. H. Faust, a member of his party. Published by USC\&GS in the 1891 Coast Pilot (p. 198).

Favorita Island: island, $0.6 \mathrm{mi}$. long, $\mathrm{W}$ island of Twin Is., Maurelle Is., Alex. Arch.; $55^{\circ}$ $39^{\prime} 30^{\prime \prime} \mathrm{N}, 133^{\circ} 40^{\prime} 45^{\prime \prime} \mathrm{W}$; (map 4).

Spanish name meaning "favorite"; published in the 1925 Alaska Coast Pilot (p. 185).

Favorite, Mount: mountain, 2,230 ft., in Glacier Bay National Monument, $2.2 \mathrm{mi}$. W of Hugh Miller Mtn., $56 \mathrm{mi}$. NW of Hoonah, St. Elias Mts.; $58^{\circ} 43^{\prime} 05^{\prime \prime} \mathrm{N}, 136^{\circ} 29^{\prime} 30^{\prime \prime} \mathrm{W}$; (map 10)

Local name reported by USGS in 1951.

Favorite Anchorage: water passage, in Deadman Reach, on NW coast of Duffield Penin., N coast of Baranof I., 6 mi. SE of Todd, Alex. Arch.; $57^{\circ} 32^{\prime} 30^{\prime \prime} \mathrm{N}, 1^{\circ} 35^{\circ} 28^{\prime} 20^{\prime \prime} \mathrm{W}$; (map 9 ).

Named by U.S. Navy in 1880 for the SS Favorite, the trading steamer owned by North Western Trading Co., and used in exploring southeastern Alaska.

Favorite Bay: bay, $4 \mathrm{mi}$. long, SE of Angoon, on W coast of Admiralty I., Alex. Arch.; 57 $28^{\prime}$ $30^{\prime \prime} \mathrm{N}, 134^{\circ} 31^{\prime} 00^{\prime \prime} \mathrm{W}$; (map 9).

Named in 1895 by Lt. Comdr. E. K. Moore, USN, and published by USC\&GS in the 1901 Coast Pilot (p. 165). It was probably named for the SS Favorite, the trading steamer owned by North Western Trading Co., which navigated these waters.

Favorite Channel: water passage, $16 \mathrm{mi}$. long, extends NW from Stephens Passage to Lynn Canal, N of Lincoln I. and $28 \mathrm{mi}$. NW of Juneau, Coast Mts.; $58^{\circ} 35^{\prime} \mathrm{N}, 135^{\circ} 00^{\prime} \mathrm{W}$; (map 11).

Named in 1880 by U.S. Navy officers for the 80-ft. steamboat Favorite, built in 1874 . The vessel was chartered by the Navy for Alaskan surveying work and was later used to conduct trading and fishing for the herringreduction plant at Killisnoo. It was in operation until about 1900 (DeArmond, 1957, p. 19).

Favorite Fiord: estuary, see Charpentier Inlet.

Favorite Inlet: estuary, see Tidal Inlet.

Favorite Reef: reef, $0.4 \mathrm{mi}$. long, off $\mathrm{SW}$ coast of Shelter I., $1.2 \mathrm{mi}$. E of Barlow Point, Alex. Arch.; 58 $22^{\prime} 50^{\prime \prime}$ N, $134^{\circ} 51^{\prime} 45^{\prime \prime} \mathrm{W}$; (map 11).

Name recorded in 1885 by the USC\&GS on Chart 728 for the $80-\mathrm{ft}$. steamboat Favorite, 
which was built in 1874 and chartered by the U.S. Navy for Alaskan surveying. The vessel was later used to conduct trading and fishing for the herring-reduction plant at Killisnoo. The vessel was in operation until about 1900 (DeArmond, 1957, p. 19).

Favor Peak: mountain, 1,888 $\mathrm{ft}$., on $\mathbf{E}$ coast of Mitkof I., $10 \mathrm{mi}$. NW of Wrangell, Alex. Arch. ; 56 $35^{\prime} 30^{\prime \prime} \mathrm{N}, 132^{\circ} 34^{\prime} 00^{\prime \prime} \mathrm{W}$; (map 6).

Named in 1887 by Lt. Comdr. C. M. Thomas, USN, for charting purposes; name published in 1888 on USC\&GS Chart 705.

Fawcett, Mount: mountain, 6,213 ft., on AlaskaCanada boundary, $15 \mathrm{mi}$. SE of Stikine River, Coast Mts.; $56^{\circ} 33^{\prime} 15^{\prime \prime} \mathrm{N}, 131^{\circ} 28^{\prime} 15^{\prime \prime} \mathrm{W}$; $B G N$ 1927; (map 7).

Named in 1927 by IBC "for Thomas Fawcett, [IBC] surveyor, Gold Commissioner in the Yukon Territory from 1897-99."

Fawn Creek: stream, heads in lake, flows NW $3.5 \mathrm{mi}$. to Gwydyr Bay, $11 \mathrm{mi}$. SE of Beechey Point, Arctic Plain; $70^{\circ} 25^{\prime} \mathrm{N}, 147^{\circ} 37^{\prime} \mathrm{W}$; $B G N$ 1916; (map 150). Var. Fawn River.

Named Fawn River by P. W. Dease and Thomas Simpson, who recorded on August 8, 1837, "In the evening a little fawn came to the tents ***; an incident that furnished a name for the streamlet" (in T. Simpson, 1843 , p. 174).

Fawn Hill: hill, $630 \mathrm{ft}$., at SW end of Kiska I., Aleutian Is.; $51^{\circ} 52^{\prime} 30^{\prime \prime} \mathrm{N}, 177^{\circ} 16^{\prime} 15^{\prime \prime} \mathrm{E}$; (map 14).

An arbitrary name beginning with " $F$ " to correspond to "F" grid used by the U.S. Army for tactical purposes during World War II; published on a 1953 AMS map.

Fawn Island: island, $0.2 \mathrm{mi}$. long, $1 \mathrm{mi}$. $\mathrm{S}$ of Deer I., Aleutian Ra.; $54^{\circ} 49^{\prime} 30^{\prime \prime} \mathrm{N}, 162^{\circ} 21^{\prime}$ 05" W; BGN 1942; (map 25). Var. Little Sandy Island.

So named by USC\&GS in 1939 "partly because of proximity to Fawn Point and because triangulation station Fawn $* * *$ is on it."

Fawn Island: island, $0.3 \mathrm{mi}$. long, between Mosman and Burnett Inlets, on SW coast of Etolin I., Alex. Arch.; 56 $03^{\prime} 05^{\prime \prime} \mathrm{N}, 132^{\circ} 29^{\prime} 45^{\prime \prime} \mathrm{W}$; BGN 1914; (map 6).

Named in 1914 by USC\&GS

Fawn Lake: lake, $600 \mathrm{ft}$. long, on Revillagigedo I., $0.6 \mathrm{mi}$. NE of Ketchikan, Alex. Arch.; $55^{\circ} 21^{\prime} 07^{\prime \prime} \mathrm{N}, 131^{\circ} 37^{\prime} 05^{\prime \prime} \mathrm{W}$; (map 3).

Name recorded in 1954 by USGS; derived from Fawn Mountain.

Fawn Lake: lake, $0.5 \mathrm{mi}$. across, $23 \mathrm{mi}$. $\mathrm{N}$ of village of Port Alexander, on SE coast of Baranof I., Alex. Arch.; 56 $30^{\prime} 30^{\prime \prime} \mathrm{N}, 134^{\circ} 41^{\prime} 00^{\prime \prime} \mathrm{W}$; BGN 1933; (map 5).

Named in 1933 by USFS "for its proximity to larger Deer Lake to the Northwest."

Fawn Mountain: mountain, 1,853 ft., on Revillagigedo I., $3.4 \mathrm{mi}$. SE of Ketchikan, Alex. Arch.; 55 $19^{\prime} 05^{\prime \prime} \mathrm{N}, 133^{\circ} 33^{\prime} 18^{\prime \prime} \mathrm{W}$; (map 3). Named in 1883 by H. E. Nichols, USN. See Deer Mountains.

Fawn Point: point of land, on S coast of Deer I., at SW end of Aleutian Ra.; $54^{\circ} 49^{\prime} 40^{\prime \prime} \mathrm{N}$, $162^{\circ} 19^{\prime} 00^{\prime \prime} \mathrm{W}$; (map 25). Var. South Cape.
Named by W. H. Dall and published in 1882 by USC\&GS on Chart 806 . This point was called South Cape by USBF in 1888 .

Fawn Point: point of land, $\mathbf{N}$ tip of Deer $\mathrm{I}_{\text {, }}$ at entrance to Herendeen Bay, Bristol Bay Low., Aleutian Ra.; $55^{\circ} 57^{\prime} \mathrm{N}, 160^{\circ} 49^{\prime} \mathrm{W}$; (map 28). Var. Point Edward.

Originally called Point Edward or Edward Point but named Fawn Point by Z. L. Tanner, USN, in 1890 .

Fawn River. stream, see Fawn Creek.

Fay Creek: stream, heads on Kavaksurak Mtn., flows NE 9 mi. to the Etivluk River, $12 \mathrm{mi}$. NE of Howard Pass, Brooks Ra.; $68^{\circ} 22^{\prime} \mathrm{N}, 156^{\circ}$ 42' W; BGN 1932; (map 132).

This name appears on a fieldsheet by Gerald FitzGerald, USGS, in 1925. This feature is "probably named for Fay Delezene, of $\mathrm{Ne}$ nana, who was a camp hand with the expedition."

Featherly Creek: stream, heads on Mount Burls, flows NE $13 \mathrm{mi}$. to Becharof Lake, on Alaska Penin., $14 \mathrm{mi}$. NW of Kanatak, Aleutian Ra.; $57^{\circ} 46^{\prime} 20^{\prime \prime}$ N, $156^{\circ} 07^{\prime} 00^{\prime \prime} \mathrm{W}$; (map 36 ). Var. West Branch Simeon Creek.

Name reported in 1920 by G. C. Martin USGS, as a tributary to Simeon Creek. Featherly Creek is shown as the main stream, with Simeon Creek as a tributary, on a map published in 1924 by S. R. Capps, USGS.

Featherly Pass: pass, $870 \mathrm{ft}$, , between Blue Creek and $W$ tributary of Featherly Creek, on Alaska Penin., 13 mi. NW of Kanatak, Aleutian Ra.; $57^{\circ} 41^{\prime} 40^{\prime \prime} \mathrm{N}, 156^{\circ} 18^{\prime} 45^{\prime \prime} \mathrm{W}$; (map 36).

Name reported in 1920 by G. C. Martin (1921, pl. 10), USGS; based on J. L. McPherson's surveys of 1902.

Feather River: stream, flows W 17 mi. to Bering Sea, 38 mi. NW of Nome, Seward Penin. High.; $64^{\circ} 51^{\prime} \mathrm{N}, 166^{\circ} 24^{\prime} \mathrm{W}$; (map 94).

Local name reported in 1900 by E. C. Barnard (in Brooks, 1901, pl. 17), USGS.

Feather Rock: island, $0.1 \mathrm{mi}$. long, in Maurelle Is., $1.5 \mathrm{mi}$. $\mathrm{N}$ of Wood Is., Alex. Arch.; $55^{\circ}$ $41^{\prime} 35^{\prime \prime} \mathrm{N}, 133^{\circ} 41^{\prime} 05^{\prime \prime} \mathrm{W}$; (map 4).

Named in 1924 by USC\&GS for triangulation station Feather located here.

Felice Strait: water passage, $20 \mathrm{mi}$. long, extends NE from Sealed Passage to Revillagigedo Channel, $\mathrm{N}$ of Duke I., Alex. Arch., $5^{\circ} 00^{\prime}$ $\mathrm{N}, 131^{\circ} 20^{\prime} \mathrm{W}$; (map 2$)$.

Named in 1883 by USC\&GS "for the Felice, one of [Capt. John] Meares ships which visited this coast in 1788."

Feliks, Mys : point of land, see Felix, Cape.

Felix, Cape: point of land, SW tip of Suemez I., Alex. Arch.; 55 $12^{\prime} 35^{\prime \prime} \mathrm{N}, 133^{\circ} 26^{\prime} 00^{\prime \prime} \mathrm{W}$; (map 4). Var. Cabo de San Antonio Maurelle, Cabo de San Feliz, Mys Feliks, Point Saint Felix, Saint Felix Point.

Named by F. A. Maurelle on May 18, 1779, "when Mourelle [sic] began his exploration of Bucareli Bay opposite this point; after San Felix whose day it was" (Wagner, 1937, p. 499).

Fellows, Mount: mountain, 4,476 ft., $5 \mathrm{mi}$. E of McKinley Park, 12 mi. SE of Healy, Alaska
Ra.; $63^{\circ} 42^{\prime} 30^{\prime \prime} \mathrm{N}, 148^{\circ} 45^{\prime} 00^{\prime \prime} \mathrm{W}$; (map 87).

Name reported in 1950 by USGS.

Fels Glacier: glacier, heads on Snow White and M'Ladies Mtn., trends NW 9 mi. to its 1954 terminus, $25 \mathrm{mi}$. NW of Paxson, Alaska Ra. $63^{\circ} 23^{\prime} 10^{\prime \prime} \mathrm{N}, 145^{\circ} 40^{\prime} 00^{\prime \prime} \mathrm{W}$; (map 86).

Name published on relatively recent maps.

Felt Lake: lake, $0.9 \mathrm{mi}$. long, between Scarp Creek and Beluga River, $14 \mathrm{mi}$. NW of Tyonek, Cook Inlet Low. ; 61 ${ }^{\circ} 15^{\prime} 25^{\prime \prime} \mathrm{N}, 151^{\circ}$ $17^{\prime} 45^{\prime \prime} \mathrm{W}$; (map 70).

Local name reported in 1954 by USGS.

Felton Creek: stream, flows $1.5 \mathrm{mi}$. SW to Gulf of Alaska, $4.5 \mathrm{mi}$. NW of Umbrella Reef and $92 \mathrm{mi}$. NW of Yakutat, St. Elias Mts.; $60^{\circ}$ $02^{\prime} 30^{\prime \prime} \mathrm{N}, 142^{\circ} 10^{\prime} 50^{\prime \prime} \mathrm{W}$; (map 65).

Local name published in 1950 by USGS.

Fender Hills: hills, $520 \mathrm{ft}$., on southern Kiska I., Aleutian Is.; $51^{\circ} 51^{\prime} 50^{\prime \prime} \mathrm{N}, 177^{\circ} 17^{\prime} 40^{\prime \prime} \mathrm{E}$; (map 14).

An arbitrary name beginning with " $F$ " to correspond to "F" grid used by the U.S. Army for tactical purposes during World War II; published on a 1953 AMS map.

Feniak Lake: lake, 4 mi. long, on Makpik Creek in the Noatak River valley, $36 \mathrm{mi}$. W of Howard Pass, Brooks Ra.; $68^{\circ} 15^{\prime} \mathrm{N}, 158^{\circ}$ $20^{\prime}$ W; BCN 1960; (map 132). Var. Navarak.

Named by USGS geologists in 1950 for Michael Feniak, a geologist of the Canadian Geological Survey, who drowned in Northwest Canada while on a fieldtrip in the summer of 1949.

Fenimore Pass: water passage, between Fenimore Rock and Tagalak I., Andreanof Is., Aleutian Is.; $51^{\circ} 58^{\prime} \mathrm{N}, 175^{\circ} 34^{\prime} \mathrm{W}$; BGN 1936; (map $18)$.

Named in 1936 by U.S. Navy Hydrog. Office for the U.S.S. Fenimore Cooper, one of the ships of the North Pacific Exploring Expedition of 1855. Name published by the USC\&GS in the 1954 Coast Pilot (p. 435)

Fenimore Rock: island, elev. $214 \mathrm{ft} ., 300 \mathrm{yd}$. across, between Atka and Tagalak Is., Aleutian Is. ; $51^{\circ} 58^{\prime} 45^{\prime \prime} \mathrm{N}, 175^{\circ} 32^{\prime} 55^{\prime \prime} \mathrm{W}$; BGN 1936; (map 18).

Named in 1936 by the U.S. Navy Hydrog. Office for the U.S.S. Fenimore Cooper, one of the ships of the North Pacific Exploring Expcdition of 1855. Name published by the USC\&GS in the 1944 Aleutian Coast Pilot (p. 104).

Fenner Creek: stream, heads at Fenner Lake, flows S 4 mi. to South-southeast Bay, on SE coast of Semisopochnoi I., Rat Is., Aleutian Is. ; $51^{\circ} 54^{\prime} 10^{\prime \prime} \mathrm{N}, 179^{\circ} 39^{\prime} 50^{\prime \prime} \mathrm{E}$; BGN 1950; (map 15).

Named in 1950 by R. R. Coats, USGS, for Clarence Norman Fenner, 1870-1949, authority on Alaskan geology.

Fenner Lake: lake, $1.7 \mathrm{mi}$. long, Semisopochnoi 1., Rat Is., Aleutian Is. ; $51^{\circ} 57^{\prime} 45^{\prime \prime} \mathrm{N}, 179^{\circ} 38^{\prime} 00^{\prime \prime}$ E; BGN 1950; (map 15).

Named in 1950 by R. R. Coats, USGS, for Clarence Norman Fenner, 1870-1949, authority on Alaskan geology. 
Fenno Creek: stream, flows NW $5 \mathrm{mi}$. to River Bay, $30 \mathrm{mi}$. NW of Dillingham, KilbuckKuskokwim Mts.; $59^{\circ} 25^{\prime} \mathrm{N}, 158^{\circ} 48^{\prime} \mathrm{W}$; $B G N$ 1931; (map 52).

Local name published by USBF in 1929 .

Ferabee Rock: rock, see Ferebee Rock.

Ferebee Glacier: glacier, heads at $59^{\circ} 45^{\prime} \mathrm{N}$, $135^{\circ} 40^{\prime} \mathrm{W}$, trends $\mathrm{SE} 9 \mathrm{mi}$. to its terminus, $4.4 \mathrm{mi}$. W of Parsons Peak and $9 \mathrm{mi}$. NW of Skagway, Coast Mts.; $59^{\circ} 28^{\prime} 45^{\prime \prime} \mathrm{N}, 135^{\circ}$ $33^{\prime} 10^{\prime \prime} \mathrm{W}$; (map 45). Var. Dejähssánkessit Glacier.

Named by the U.S. Navy in 1880 for surgeon Nelson MacPherson Ferebee, USN, who visited the region in 1880 . The name was published by USC\&GS in the 1883 Coast Pilot (p. 200). According to Krause (1883, map), the Tlingit Indian name is "Dejähssánkessit."

Ferebee River: stream, heads in Ferebee Glacier, flows SE $13 \mathrm{mi}$. to Taiyasanka Harbor, at head of Chilkoot Inlet, $10 \mathrm{mi}$. SW of Skagway, Coast Mts.; $59^{\circ} 19^{\prime} 45^{\prime \prime} \mathrm{N}, 135^{\circ} 26^{\prime} 00^{\prime \prime} \mathrm{W}$; (map 45).

Named in 1880 by the U.S. Navy for surgeon Nelson MacPherson Ferebee, USN, who visited the region in 1880 . The name was published by USC\&GS in the 1883 Coast Pilot (p. 194).

Ferebee Rock: rock, in Galankin Is., $1 \mathrm{mi}$. S of Sitka, Alex. Arch.; 57 $02^{\prime} 01^{\prime \prime}$ N, $135^{\circ} 20^{\prime} 16^{\prime \prime}$ W; (map 9). Var. Ferabee Rock.

Named by U.S. Navy in 1880 for Nelson Macpherson Ferebee, surgeon, USN, who at that time was on duty at Sitka. The name was published by USC\&GS in the 1883 Coast Pilot (p. 143).

Ferebee Valley: valley, extends SE $22 \mathrm{mi}$. from head of Ferebee Glacier to Chilkoot Inlet, 11 mi. E of Klukwah Mtn. and 12 mi. S of Skag. way, Coast Mts.; $59^{\circ} 19^{\prime} 45^{\prime \prime} \mathrm{N}, 135^{\circ} 26^{\prime} 00^{\prime \prime}$ W; $(\operatorname{map} 45)$.

Named in 1880 by the U.S. Navy for surgeon Nelson MacPherson Ferebee, USN, whe visited the region in 1880 . The name was published by USC\&GS in the 1891 Coast Pilot (p. 203).

Ferguson Draw: ravine, extends $\mathrm{SW} 1 \mathrm{mi}$. to Cache Creek, $6 \mathrm{mi}$. S of Roughtop Mtn. and $37 \mathrm{mi}$. ESE of Tanana, Yukon-Tanana High.;

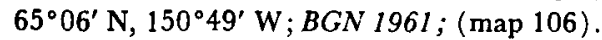
Var. Ferguson Gulch.

Prospectors' name reported in 1931 by J. B. Mertie, USGS.

Ferguson Glacier: glacier, heads $3 \mathrm{mi}$. W of Ninemile Mtn., trends N $3 \mathrm{mi}$. to its 1955 terminus $12 \mathrm{mi}$. NW of Hyder, Coast Mts.; $56^{\circ} 02^{\prime} 50^{\prime \prime} \mathrm{N}, 130^{\circ} 14^{\prime} 00^{\prime \prime} \mathrm{W}$; (map 7).

Local name published by A. F. Buddington (in Brooks and others, 1925, p. 85), USGS. Ferguson Gulch: ravine, see Ferguson Draw.

Ferguson Gulch: stream, see Cache Creek.

Ferguson Peak: mountain, 2,760 ft., $9 \mathrm{mi}$. SE of Ineruvuk Mtn. and $14 \mathrm{mi}$. NE of Shungnak, Brooks Ra.; $66^{\circ} 56^{\prime}$ N, $156^{\circ} 38^{\prime}$ W ; (map 115).

Prospectors' name reported by USGS after 1940.

Fergusson, Point: point of land, see Rocky Point.
Fergy Gulch: ravine, extends NW $0.8 \mathrm{mi}$. , between Chicago and Wagner Gulches, near head of Mills Creek, $46 \mathrm{mi}$. W of Talkeetna, Alaska Ra.; $62^{\circ} 21^{\prime} 30^{\prime \prime} \mathrm{N}, 151^{\circ} 31^{\prime} 20^{\prime \prime} \mathrm{W}$; (map 81).

Prospectors' name reported in 1911 by Capps (1913, fig. 7), USGS.

Fernandez, Volcan de: mountain, see Shishaldin Volcano.

Fernando Daoiz, Isla : island, "one of the group of islands W of Umnak Island," Aleutian Is.

Probably named for Fernando Daoiz, a teniente general in the Spanish navy who died in 1808. Name published on a 1791 chart by Don Juan de la Bodega y Quadra.

Fern Creek: stream, flows E $1.8 \mathrm{mi}$. to Vega Bay, on southern Kiska I., Aleutian Is.; $51^{\circ}$. $54^{\prime} 42^{\prime \prime}$ N, $177^{\circ} 21^{\prime} 13^{\prime \prime} \mathrm{E}$; (map 14).

An arbitrary name beginning with " $F$ " to correspond to " $F$ " grid used by the U.S. Army for tactical purposes during World War II; published on a 1953 AMS map.

Fern Harbor: water passage, $1.6 \mathrm{mi}$. long, in Glacier Bay National Monument, $W$ of Taylor I., $4 \mathrm{mi}$. W of Point Wimbledon and $40 \mathrm{mi}$. NW of Hoonah, St. Elias Mts.; $58^{\circ} 17^{\prime} 30^{\prime \prime} \mathrm{N}$, $136^{\circ} 28^{\prime} 30^{\prime \prime} \mathrm{W}$; (map 10).

Name published by USC\&GS in the 1925 Coast Pilot (p. 330).

Fern Lake: lake, $1 \mathrm{mi}$. long, $6 \mathrm{mi}$. SW of junc. of Cheslina and Nabesna Rivers and $21 \mathrm{mi}$. SW of Northway, Alaska Ra.; $62^{\circ} 42^{\prime} 15^{\prime \prime} \mathrm{N}$, $142^{\circ} 17^{\prime} 30^{\prime \prime} \mathrm{W}$; (map 84).

Local name reported by USGS in 1960 .

Fern Point: point of land, on $\mathrm{E}$ coast of San Fernando I., Alex. Arch.; 55 $30^{\prime} 15^{\prime \prime}$ N, $133^{\circ}$. $16^{\prime} 45^{\prime \prime}$ W; (map 4). Var. Punta Almejas, Mussel Point.

Named in 1897 by Lt. Comdr. J. F. Moser, USN. This feature was called "Punta Almejas" meaning "point of the clams" on Francisco Antonio Maurelle and Don Juan de la Bodega y Quadra's chart (in La Pérouse, 1798, pl. 26).

Fern Reef: reef, extends $0.3 \mathrm{mi}$. in San Alberto Bay, $0.8 \mathrm{mi}$. SE of Fern Point, on E coast of San Fernando I., Alex. Arch.; 55 29'30' N, $133^{\circ} 15^{\prime} 50^{\prime \prime} \mathrm{W}$; (map 4$)$.

Named in 1897 by Lt. Comdr. J. F. Moser, USN.

Ferrell Creek: stream, flows E $14 \mathrm{mi}$. to Oshetna River $10 \mathrm{mi}$. SW of its junc. with Susitna River, Talkeetna Mts.; $62^{\circ} 29^{\prime} 40^{\prime \prime} \mathrm{N}, 147^{\circ}$. $30^{\prime} 30^{\prime \prime} \mathrm{W}$; (map 82).

Name reported in 1943 by ARC.

Ferrer Maldonado, Abra de: water passage, at the head of Disenchantment Bay, Yakutat Bay.

Spanish name meaning "entrance of Ferrer Maldonado" given by Capt. Alessandro Malaspina July 4, 1791 because it was where the entrance to the Strait of Maldonado should have been, but was not (Wagner, 1937, p. 453).

Ferrum Creek: stream, on Kenai Penin., flows E $3 \mathrm{mi}$. to Beauty Bay, at NW end of West Arm Nuka Bay, $32 \mathrm{mi}$. ESE of Homer, Chugach Mts.; $59^{\circ} 33^{\prime} \mathrm{N}, 150^{\circ} 40^{\prime} \mathrm{W}$; BGN 1929; (map 50). Var. Iron Creek.
The local name for this stream was Iron Creek. However, because of numerous "Iron Creeks" in Alaska, a 1927 USC\&GS field party recommended substituting the Latin word "Ferrum."

Ferry: village, pop. 31 , mile 371.2 on The Alaska RR., at Nenana River, $39 \mathrm{mi}$. S of Nenana, Alaska Ra. ; $64^{\circ} 01^{\prime} \mathrm{N}, 149^{\circ} 07^{\prime} \mathrm{W}$; (map 100). Var. Nenana River.

Name published as railroad station on a timetable in 1922. Earlier, the place was listed as Nenana River on a Seattle Chamber of Commerce promotion folder.

Ferry Road House: locality, at junc. of Birch Creek and Fairbanks-Circle Trail (Steese Highway), $11 \mathrm{mi}$. SW of Circle, YukonTanana High.; $65^{\circ} 42^{\prime} \mathrm{N}, 144^{\circ} 22^{\prime} \mathrm{W}$; (map 104).

Name of a former roadhouse derived from the ferry used to cross Birch Creek; reported in 1915 by G. A. Waring, USGS.

Fetutlin: locality, "on upper Yukon River;" Var. Fetoulin.

Former Indian camp or settlement listed by Ivan Petroff as "Fetoulin," population 106, in the 1880 Census.

Fick Cove: cove, $0.6 \mathrm{mi}$. across, part of South Arm Hoonah Sound, $15.5 \mathrm{mi}$. SE of Cinichagof, on S central Chichagof I., Alex. Arch.; $57^{\circ} 38^{\prime} \mathrm{N}, 135^{\circ} 40^{\prime} \mathrm{W}$; (map 9).

Named in 1895 by Lt. Comdr. E. K. Moore, USN, and published in 1900 by USC\&GS on Chart 8282

Fickett Creek: stream, flows E and S $12 \mathrm{mi}$. to Howzerah Creek $3.5 \mathrm{mi}$. NW of its junc, with Koyukuk River, $13 \mathrm{mi}$. SW of Bettles, Kanuti Flats; $66^{\circ} 43^{\prime} 30^{\prime \prime} \mathrm{N}, 151^{\circ} 48^{\prime} 30^{\prime \prime} \mathrm{W}$; (map $117)$.

In 1885 , Lt. Allen $(1887$, p. 101), USA, applied the name "Fickett River" to what is now called the John River in honor of Pvt. Frederick W. Fickett, U.S. Army Signal Corps, who was a member of Lt. Allen's small party. Local usage, however, did not follow Lt. Allen's naming in this case, and in order to save the historical name T. G. Gerdine, USGS, transferred the name "Fickett" to this stream in 1899.

Fickett Glacier: glacier, trends NE $2 \mathrm{mi}$. to its terminus, $3 \mathrm{mi}$. W of Copper River, $30 \mathrm{mi}$. NW of Katalla, Chugach Mts.; $60^{\circ} 34^{\prime} \mathrm{N}, 144^{\circ} 59^{\prime}$ W; BGN 1930; (map 64).

Named about 1912 by Lawrence Martin for Pvt. Fred W. Fickett, USA, "who saw this glacier when he accompanied Lt. H. T. Allen" on his Alaskan expedition of 1885.

Fickett River: stream, see John River.

Fidalgo, Port: estuary, $3 \mathrm{mi}$. wide and $25 \mathrm{mi}$. long, on E shore of Prince William Sound, $40 \mathrm{mi}$. NW of Cordova, Chugach Mts.; $60^{\circ}$ $47^{\prime} \mathrm{N}, 146^{\circ} 45^{\prime} \mathrm{W}$; (map 64). Var. Puerto Fidalgo, Puerto Mazarredo.

This estuary was discovered by Senor Don Salvador Fidalgo's launch party on June 14, 1790 , but there is no record that he named it. The name is not shown on Capt. Alessandro Malaspina's or Don Bodega y Quadra's maps of 1791. As Capt. George Vancouver, RN, 
who had Fidalgo's maps, referred to the feature as "Puerto Fidalgo," it can be assumed that the name appeared either on Fidalgo's own map or Vancouver named it for Fidalgo (Wagner, 1937, p. 387). It appears more likely that Fidalgo intended to call this estuary "Puerto de Mazarredo" in honor of José de Mazarredo.

Fidalgo, Puerto: estuary, see Fidalgo, Port.

Fidele Glacier: glacier, see Eldridge Glacier.

Fielding Lake: lake, $4 \mathrm{mi}$. long, drains $\mathrm{N}$ to Phelan Creek, $10 \mathrm{mi}$. NW of Paxson, Alaska Ra.; $63^{\circ} 10^{\prime} \mathrm{N}, 145^{\circ} 41^{\prime} \mathrm{W}$ (map 86).

Name published on relatively recent maps.

Fifteen Gulch: ravine, in Kantishna Hills, extends $\mathrm{N} 0.9 \mathrm{mi}$. to Glacier Creek, $6.7 \mathrm{mi}$. NNW of Wonder Lake, Alaska Ra.; $63^{\circ} 37^{\prime} 40^{\prime \prime} \mathrm{N}$, 150 55'30" W; BGN 1932; (map 88).

Prospectors' name reported in 1931 by F. G. Wells and $\mathbf{S}$. C. Kain, USGS.

Fifteen Gulch: ravine, trends SE $1.5 \mathrm{mi}$. to Wade Creek, at Jack Wade, $46 \mathrm{mi}$. SW of Eagle, Yukon-Tanana High.; $64^{\circ} 09^{\prime} 15^{\prime \prime} \mathrm{N}, 1^{\circ} 1^{\circ} 27^{\prime}$ 40" W; (map 102).

Prospectors' name shown on an 1898 manuscript map by C. A. Woodruff, Fort Cudahy, Canada.

Fifteen Mile Creek: stream, flows S $13 \mathrm{mi}$. to Nushagak River, $88 \mathrm{mi}$. S of Sleetmute, Kilbuck-Kuskokwim Mts. ; $60^{\circ} 28^{\prime} \mathrm{N}, 157^{\circ} 02^{\prime} \mathrm{W}$; (map 60).

Local name reported in 1952 by USC\&GS.

Fifteenmile Island: island, $0.8 \mathrm{mi}$. long, in Stikine River, $15 \mathrm{mi}$. NE of Wrangell, Coast Mts.; $56^{\circ} 41^{\prime} 45^{\prime \prime} \mathrm{N}, 132^{\circ} 12^{\prime} 00^{\prime \prime} \mathrm{W}$; (map 6).

Local descriptive name obtained in 1953 by USGS.

Fifteen Pup: stream, flows E $1.2 \mathrm{mi}$. to Deadwood Creek, $9.5 \mathrm{mi}$. SSW of Central and $36 \mathrm{mi}$. SW of Circle, Yukon-Tanana High. ; $65^{\circ} 26^{\prime} 50^{\prime \prime} \mathrm{N}$, $144^{\circ} 56^{\prime} 50^{\prime \prime} \mathrm{W}$; (map 104).

Prospectors' name reported in 1954 or 1955 by USGS topographers.

Fifth Berg Lake: lake, see Fifth Lake.

Fifth Lake: lake, $3 \mathrm{mi}$. across, at 1961 terminus of Steller Glacier, E of Berg Lake and $70 \mathrm{mi}$. E of Cordova, Chugach Mts.; $60^{\circ} 23^{\prime} 30^{\prime \prime} \mathrm{N}$, $143^{\circ} 44^{\prime} 00^{\prime \prime} \mathrm{W}$; (map 65). Var. Fifth Berg Lake, Fourth Berg Lake, Fourth Lake.

The local name Fifth Berg Lake was reported in 1905 by G. C. Martin (1908, pl. 2), USGS, and was originally applied to the easternmost of five Berg Lakes. With the retreat of the Steller and Bering Glaciers in recent times, Fourth Berg Lake and Fifth Berg Lakes were united to form Fifth Lake.

Fifth of July Creek: stream, flows NW $2.8 \mathrm{mi}$. to Long Creek, $2.5 \mathrm{mi}$. SW of Long and $25 \mathrm{mi}$. S of Ruby, Kilbuck-Kuskokwim Mts.; 64 ${ }^{\circ} 23^{\prime}$ N, $155^{\circ} 33^{\prime}$ W ; (map 98). Var. 5th of July Creek.

Prospectors' name reported in 1913 by Eakin (1914, pl. 3), USGS.

Fiftynine Mile Creek: stream, flows NE and SE $3.5 \mathrm{mi}$. to Tiekel River, $2 \mathrm{mi}$. NE of Tiekel Cache and $41 \mathrm{mi}$. NE of Valdez, Chugach Mts.; $61^{\circ} 24^{\prime} 05^{\prime \prime} \mathrm{N}, 145^{\circ} 11^{\prime} 00^{\prime \prime} \mathrm{W}$; (map 68).
Local name published in the 1950's by USGS.

Figarok: point of land and village, see Hope, Point and Point Hope.

Figgins Point: point of land, on $\mathbf{E}$ coast of Prince of Wales I., W point of entrance to Lyman Anchorage, on Kasaan Penin., Alex. Arch.; $55^{\circ} 33^{\prime} \mathrm{N}, 132^{\circ} 18^{\prime} \mathrm{W}$; (map 4).

Local name reported in 1905 by $E$. F. Dickins, USC\&GS.

Fighting John Peak: mountain peak, 5,080 ft., $4 \mathrm{mi}$. E of Thomas Bay on Frederick Sound and $103 \mathrm{mi}$. E of Sitka, Coast Mts.; 57 $7^{\circ} 03^{\prime}$ $25^{\prime \prime} \mathrm{N}, 132^{\circ} 44^{\prime} 30^{\prime \prime} \mathrm{W}$; (map 8).

Named by Lt. Comdr. C. M. Thomas, USN; published in 1889 by USC\&GS on Chart 733 .

Figure Creek: stream, flows SE $5 \mathrm{mi}$. to Stone Creek, $48 \mathrm{mi}$. NE of Medfra, Kilbuck-Kuskokwim Mts.; $63^{\circ} 40^{\prime} \mathrm{N}, 153^{\circ} 51^{\prime} \mathrm{W}$; (map 89).

Local name reported in 1958 by USGS.

Figure Eight Creek: stream, heads $W$ on Lone Hill, flows NW through a lake $22 \mathrm{mi}$. to Dog Salmon River, on Alaska Penin., $22 \mathrm{mi}$. SE of Ugashik, Aleutian Ra.; 57 $19^{\prime} \mathrm{N}, 157^{\circ} 01^{\prime}$ W; (map 36).

Descriptive name given in 1923 by $R$. H. Sargent, USGS, because of "its sinuosities".

Figure Eight Lake: lake, $1 \mathrm{mi}$. long, on $\mathrm{SW}$ part of Tanaga I., Aleutian Is. ; $57^{\circ} 41^{\prime} 30^{\prime \prime} \mathrm{N}, \mathbf{1 7 8}^{\circ}$ 03'30' W; (map 16).

Descriptive name applied because the lake's outline is like a figure eight; published on a 1954 USGS map.

Figure Eight Lake: lake, $0.8 \mathrm{mi}$. long, on right bank of Stikine River, $16 \mathrm{mi}$. NE of Wrangell, Coast Mts.; $56^{\circ} 42^{\prime} \mathrm{N}, 132^{\circ} 16^{\prime} \mathrm{W}$; (map 6).

Local descriptive name obtained in 1953 by USGS.

Figure Eight Lake: lake, $3 \mathrm{mi}$. long in Susitna River delta, $19 \mathrm{mi}$. NW of Anchorage, Cook Inlet Low.; $61^{\circ} 18^{\prime} 45^{\prime \prime} \mathrm{N}, 150^{\circ} 27^{\prime} 00^{\prime \prime} \mathrm{W}$; (map 70).

Local descriptive name reported in 1958 by USGS.

Figure Four Mountain: mountain, 2,421 ft., 4 mi. NW of Mitlak Mtn. and $25 \mathrm{mi}$. N of Goodnews, Kilbuck-Kuskokwim Mts.; $59^{\circ} 28^{\prime}$ 15" N, 161 $36^{\prime} 30^{\prime \prime}$ W; (map 53). Var. Figure IV Mountain.

Local name obtained as "Figure IV Mountain" in 1898 from Rev. J. H. Romig, missionary, by J. E. Spurr and W. S. Post, USGS. So called because the deep valleys on the mountain side, wher filled with snow, form the numeral IV when seen from the west.

File Point: point of land, on $\mathrm{E}$ coast of Liesnoi I., at entrance to Woewodski Harbor, on Admiralty I., $26 \mathrm{mi}$. SE of Angoon, Alex. Arch.; $57^{\circ} 09^{\prime} 35^{\prime \prime} \mathrm{N}, 134^{\circ} 15^{\prime} 20^{\prime \prime} \mathrm{W}$; (map 9).

Named in 1889 by Lt. Comdr. H. B. Mansfield, USN, and published by USC\&GS in the 1891 Coast Pilot (p. 142).

Fillmore: locality, on east shore of Nakat Harbor, $25 \mathrm{mi}$. NE of head of Nakat Bay, Alex. Arch.; $54^{\circ} 50^{\prime} \mathrm{N}, 130^{\circ} 42^{\prime} \mathrm{W}$; (map 2$)$.
This place was shown as an abandoned cannery in 1938 on USC\&GS Chart 8141; name derived from nearby Fillmore Island.

Fillmore Inlet: estuary, extends NE $14 \mathrm{mi}$. from mouth of Pearse Canal, between Fillmore I. and mainland, Coast Mts.; $54^{\circ} 47^{\prime} 15^{\prime \prime} \mathrm{N}$, $130^{\circ} 37^{\prime} 15^{\prime \prime}$ W ; (map 2). Var. Nakat Inlet.

Named in 1891 by USC\&GS. Name derived from the island.

Fillmore Island: island, $6 \mathrm{mi}$. long, between Fillmore Inlet and Pearse Canal, Coast Mts.; $54^{\circ} 49^{\prime} 30^{\prime \prime} \mathrm{N}, 130^{\circ} 33^{\prime} 15^{\prime \prime} \mathrm{W}$; (map 2).

Named in 1885 by USC\&GS for Ens. John Hudson Fillmore, USN.

Fillmore Peak: peak, 3,700 ft., $0.2 \mathrm{mi}$. E of Everett Peak and $29 \mathrm{mi}$. SE of Juneau, Coast Mts.; $58^{\circ} 00^{\prime} 30^{\prime \prime} \mathrm{N}, 133^{\circ} 53^{\prime} 00^{\prime \prime} \mathrm{W}$; (map 12).

Named in 1888 by Lt. Comdr. C. M. Thomas, USN, for Millard Fillmore, 1800-74, 13th President of the United States.

Fillmore Rock: rock, in Port Chester, $1.7 \mathrm{mi}$. N of Metlakatla, Alex. Arch.; $55^{\circ} 09^{\prime} 20^{\prime \prime} \mathrm{N}$, $131^{\circ} 35^{\prime} 10^{\prime \prime}$ W; (map 3). Var. Fillmore Rocks.

Named in 1883 by Lt. Comdr. H. E. Nichols, USN.

Fillmore Rocks : rock, see Fillmore Rock.

Filthy Hill: hill, $447 \mathrm{ft}$., on S coast of Kiska I., Aleutian Is.; 51 $51^{\prime} 23^{\prime \prime} \mathrm{N}, 177^{\circ} 19^{\prime} 25^{\prime \prime} \mathrm{E}$; (map 14).

An arbitrary name beginning with " $F$ " to correspond to "F" grid used by the U.S. Army for tactical purposes during World War II ; published on a 1953 AMS map.

Fina, Boka: water passage, see Finas, Bocas de. Final Bay: bay, $0.6 \mathrm{mi}$. across, part of Beaver Inlet, on E coast of Unalaska I., Aleutian Is. ; $53^{\circ} 42^{\prime} 30^{\prime \prime}$ N., $166^{\circ} 31^{\prime} 45^{\prime \prime}$ W.; (map 23 ).

Named by J. J. Gilbert, commander of the USC\&GS steamer Pathfinder during 1900-01.

Finas, Bocas de: water passage, extends $4 \mathrm{mi}$. NW from Gulf of Esquibel, between Heceta $I$. and Maurelle Is., Alex. Arch ; $55^{\circ} 41^{\prime} 30^{\prime \prime} \mathrm{N}$, $133^{\circ} 35^{\prime} 00^{\prime \prime}$ W; (map 4). Var. Boka Fina, Bokas de Finas.

Spanish name given in 1779 by Don Juan de la Bodega y Quadra and Francisco Antonio Maurelle as "Bocas de Finas," i.e. "final [?] passage." According to Wagner (1937, p. 389), "It is perhaps an error for fines-probably the limit of Bucareli Bay at the north end of Mourelle's [sic] reconnaissance in 1779."

Finas, Bokas de: water passage, see Finas, Bocas de.

Finch Cove: bight, $2 \mathrm{mi}$. across, on NE coast of Seguam I., Aleutian Is.; $52^{\circ} 22^{\prime} 30^{\prime \prime} \mathrm{N}$, $172^{\circ} 23^{\prime} 00^{\prime \prime} \mathrm{W}$; (map 19).

Name published by USC\&GS in 1944 Aleutian Coast Pilot (p. 87).

Finch Point: point of land, $\mathrm{N}$ tip of Seguam I., Aleutian Is.; $52^{\circ} 23^{\prime} 20^{\prime \prime} \mathrm{N}, 172^{\circ} 24^{\prime} 30^{\prime \prime} \mathrm{W}$; (map 19).

Named by a special U.S. Navy survey party, and published by USC\&GS in 1944 Aleutian Coast Pilot (p. 87).

Fin Creek: stream, flowing $\mathrm{SW} 1.1 \mathrm{mi}$. to Pacific Ocean, $1.5 \mathrm{mi}$. SE of Cape St. Stephen, 
on S coast of Kiska I., Aleutian Is. ; 51 '52'33" $\mathrm{N}, 177^{\circ} 14^{\prime} 10^{\prime \prime} \mathrm{E}$; (map 14).

An arbitrary name beginning with " $F$ " to correspond to " $F$ " grid used by the U.S. Army for tactical purposes during World War II; published on a 1953 AMS map.

Fin Creek: stream, heads in Brooks Ra., flows NW $30 \mathrm{mi}$. to Juniper Creek, $13 \mathrm{mi}$. SE of head of Shaviovik River, Arctic Plain; 69 $33^{\prime}$ N, $147^{\circ} 28^{\prime} \mathrm{W}$; BGN 1960; (map 140).

So named in 1951 by A. S. Keller, USGS, "to delineate a suggestion of a 'fin' [tributary] to Juniper Greek."

Fine Cape: point of land, see Tonki Cape.

Finegan Point: locality, see Finnegans Point.

Finger Bay: bay, $1 \mathrm{mi}$. across, on $\mathrm{S}$ shore of $\mathrm{Ku}$ luk Bay, on NE coast of Adak I., Aleutian Is.; $51^{\circ} 50^{\prime} 45^{\prime \prime} \mathrm{N}, 176^{\circ} 35^{\prime} 00^{\prime \prime} \mathrm{W}$; BGN 1936; (map 17).

So named by members of the U.S. Navy Aleutian Island Survey Expedition in 1934, "because of its shape."

Finger Bay: bay, $3.6 \mathrm{mi}$. long, on $\mathrm{W}$ shore of Whidbey Passage, in Glacier Bay National Monument, $2 \mathrm{mi}$. W of Willoughby I. and 41 mi. NW of Hoonah, St. Elias Mts. ; $58^{\circ} 35^{\prime} 00^{\prime \prime}$ N, $136^{\circ} 11^{\prime} 30^{\prime \prime} \mathrm{W} ; B G N$ 1942; (map 10).

Named by USC\&GS in 1939 because "it consists of five small inlets on the west, which suggest the name."

Finger Cove: cove, $0.2 \mathrm{mi}$. across, on $W$ shore of Finger Bay, on NE coast of Adak 1., Aleutian Is.; $51^{\circ} 50^{\prime} 00^{\prime \prime} \mathrm{N}, 176^{\circ} 37^{\prime} 20^{\prime \prime} \mathrm{W}$; (map 17).

Descriptive name derived from Finger Bay and published by USC\&GS in 1963 on Chart 9119.

Finger Glacier: glacier, on Alaska Penin., on E slope of Mount Veniaminof, trends E $4 \mathrm{mi}$. to its terminus $5.5 \mathrm{mi}$. SW of Knife Peak, Aleutian Ra.; $56^{\circ} 12^{\prime} \mathrm{N}, 159^{\circ} 09^{\prime} \mathrm{W}$; (map 30).

Descriptive name reported in 1923 by $R . H$. Sargent, USGS.

Finger Glacier: glacier, in Glacier Bay National Monument, heads on E slope of Mount Perouse, trends SW $9 \mathrm{mi}$. to its 1961 terminus 1 mi. N of Gulf of Alaska, $67 \mathrm{mi}$. WNW of Hoonah, St. Elias Mts.; $58^{\circ} 26^{\prime} 15^{\prime \prime} \mathrm{N}, 137^{\circ}$. $10^{\prime} 00^{\prime \prime} \mathrm{W}$; (map 10). 1950's.

Local name published by USGS in the

Finger Islands: islands, $0.3 \mathrm{mi}$. long, $\mathrm{S}$ of entrance to Shipley Bay, on NW coast of Kosciusko I., Alex. Arch., 56 $04^{\prime} 30^{\prime \prime}$ N, 133 ${ }^{\circ} 42^{\prime}$ $20^{\prime \prime} \mathrm{W}$; (map 6). Var. Finger Islets.

Descriptive name given for charting purposes by USC\&GS in 1883 Coast Pilot (p. $101)$ as "Finger Islets."

Finger Islets: islands, see Finger Islands.

Finger Lake: lake, $1 \mathrm{mi}$. long, empties into Patterson Bay, on SE coast of Baranof I., Alex. Arch.; 56 $36^{\prime} 15^{\prime \prime} \mathrm{N}, 134^{\circ} 41^{\prime} 30^{\prime \prime} \mathrm{W}$; BGN 1933; (map 5 ).

Named in 1933 by USFS "because of its shape."

Finger Lake: lake, $2 \mathrm{mi}$. long, between Diamond Lake and Papoose Twins, $21 \mathrm{mi}$. N of Anchor-

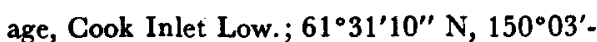
$00^{\prime \prime} \mathrm{W}$; (map 70).

Local name reported by USGS in 1929.

Finger Lake: lake, $1.8 \mathrm{mi}$. long, in Matanuska Valley, $5 \mathrm{mi}$. W of Palmer, Cook Inlet Low.; $61^{\circ} 36^{\prime} 25^{\prime \prime} \mathrm{N}, 149^{\circ} 16^{\prime} 30^{\prime \prime} \mathrm{W}$; (map 69).

Descriptive name given in 1898 by Capt. E. F. Glenn, USA. So named "because when viewing the lake on a map, a point of land in the lake gives the impression of a finger."

Finger Lake: lake, $1.3 \mathrm{mi}$. long, $\mathrm{N}$ of Skwentna River, $70 \mathrm{mi}$. NW of Tyonek, Alaska, Ra.; $61^{\circ}$ $59^{\prime} 00^{\prime \prime} N, 152^{\circ} 04^{\prime} 30^{\prime \prime} \mathrm{W}$; (map 70).

Local name reported in 1958 by USGS.

Finger Lakes: lakes, four, largest of which is 1.5 mi. long, $9 \mathrm{mi}$. NW of Sterling and $13 \mathrm{mi}$. NW of Kenai, Cook Inlet Low.; $60^{\circ} 39^{\prime}$ N, $150^{\circ} 54^{\prime}$ W; (map 62)

Named about 1963 by officials of the Kenai National Moose Range, for administrative purposes.

Finger Lakes: lakes, on $\mathbf{N}$ bank of Knik River, $11 \mathrm{mi} \mathrm{SE}$ of Palmer, Cook Inlet Low. ; $61^{\circ} 30^{\prime}$ $15^{\prime \prime} \mathrm{N}, 148^{\circ} 49^{\prime} 30^{\prime \prime} \mathrm{W}$; (map 69).

Local name published as Finger Lake on D. H. Sleem's 1910 map of central Alaska.

Finger Mountain: mountain, 2,700 ft., $3 \mathrm{mi}$. NE of Hoonah Sound, on Chichagof $1 ., 22 \mathrm{mi}$. W of Chichagof, Alex. Arch.; $57^{\circ} 40^{\prime} 20^{\prime \prime} \mathrm{N}, 135^{\circ}$ $28^{\prime} 45^{\prime \prime} \mathrm{W}$; (map 9).

Descriptive name given in 1895 by Lt. Comdr. E. K. Moore, USN

Finger Point: point of land, on NW coast of Little Sitkin I., Rat Is., Aleutian Is.; $51^{\circ} 58^{\prime}$ $40^{\prime \prime} \mathrm{N}, 178^{\circ} 27^{\prime} 00^{\prime \prime} \mathrm{E}$; (map 15).

Descriptive name reported by Snyder (1959, p. 173), USGS.

Finger Point: point of land, between Kritoi Basin and Port Banks, in Whale Bay, on SW coast of Baranof I., Alex. Arch.; 56 $36^{\prime} 00^{\prime \prime} \mathrm{N}, 135^{\circ}$ 00'15" W ; BGN 1926; (map 5).

Descriptive name given in 1925 by USC\&GS because of its shape.

Finger Point: point of land, $0.1 \mathrm{mi}$. long, on $\mathrm{E}$ coast of Lindenberg Penin., Kupreanof I., 9 mi. S of Petersburg, Alex. Arch.; 56 ${ }^{\circ} 40^{\prime} 45^{\prime \prime} \mathrm{N}$ $132^{\circ} 56^{\prime} 35^{\prime \prime} \mathrm{W}$; (map 6)

Descriptive name given in 1881 by Lt. Comdr. H. E. Nichols, USN.

Finger Shoal: shoal, $0.6 \mathrm{mi}$. NE of Lucky Point, in Kuluk Bay, off NE end of Adak I., Aleutian Is.; $51^{\circ} 51^{\prime} 42^{\prime \prime} \mathrm{N}, 176^{\circ} 34^{\prime} 09^{\prime \prime} \mathrm{W}$; BGN 1936; (map 17).

Name derived from Finger Bay, and given by members of the U.S. Navy Aleutian Island Survey Expedition in 1934.

Finigan's Point: locality, see Finnegans Point.

Fink Creek: settlement, on left bank Inmachuk River, $1 \mathrm{mi}$. SW of Utica and $20 \mathrm{mi}$. NNE of Imuruk Lake, Seward Penin. High. ; $65^{\circ} 54^{\prime} \mathrm{N}$, $163^{\circ} 01^{\prime} \mathrm{W}(\operatorname{map} 110)$.

Reported in 1923 on an ARC map.

Fink Creek: stream, flows NW $1.8 \mathrm{mi}$. to Inmachuk River, 20 mi. NE of Imuruk Lake, Seward Penin. High.; $65^{\circ} 50^{\prime} \mathrm{N}, 162^{\circ} 59^{\prime} \mathrm{W}$; (map 110).

Prospectors' name reported in 1901 by USGS (Collier, 1902, pl. 12).
Finland Creek: stream, flows NW $16 \mathrm{mi}$. to Innoko River, $1.9 \mathrm{mi}$. E of Rennies Landing and $37 \mathrm{mi}$. NW of Ophir, Innoko Low.; 63 $36^{\prime} 50^{\prime \prime} \mathrm{N}, 157^{\circ} 01^{\prime} 00^{\prime \prime} \mathrm{W}$; (map 90).

Local name obtained from Joseph Ferris in 1954 by R. E. Isto, USGS.

Finn, The: point of land, extends $1.4 \mathrm{mi}$. $W$ from Hole-in-the-Wall Glacier, $23 \mathrm{mi}$. NE of McCarthy, Wrangell Mts. ; $61^{\circ} 36^{\prime} \mathrm{N}, 142^{\circ} 19^{\prime} \mathrm{W}$; (map 67).

Local name obtained by USGS in 1954.

Finnegan: railroad station, see Turnagain.

Finnegans Point: locality, on Dyea (Taiya) River $5 \mathrm{mi}$. above its mouth and about $7 \mathrm{mi}$. $N$ of Skagway; (map 45). Var. Finegan Point, Finigan's Point.

Prospectors' name reported as Finegan in 1898 by J. A. Flemer, USC\&GS. This point marked the end of the wagon road from Dyea, on the trail to Chilkoot Pass. It is described in "En Route to the Klondike," a series of photographic views by $F$. LaRoche, published in 1898 by W. B. Conkey Co.; Chicago. Not identified on modern maps.

Finney Beach: beach, see Finny Beach

Finneys Bay: bay, $1 \mathrm{mi}$. across, on NE shore of Sanak I., near Finneys I., Sanak Is., Aleutian Ra.; $54^{\circ} 25^{\prime} 15^{\prime \prime} \mathrm{N}, 162^{\circ} 33^{\prime} 00^{\prime \prime} \mathrm{W}$; (map 25).

Name reported by Ferdinand Westdahl, USC\&GS, commander of the Coast Survey steamer McArthur, who made surveys in this area in 1901.

Finneys Island: island, $0.5 \mathrm{mi}$. long, between Sanak and Wanda Is., Sanak Is., Aleutian Ra.; $54^{\circ} 25^{\prime} \mathrm{N}, 162^{\circ} 32^{\prime} \mathrm{W}$; (map 25).

Name reported by Ferdinand Westdahl, USC\&GS, commander of the Coast Survey steamer McArthur, who made surveys in this area in 1901 .

Finn Lake: lake, see Otto Lake.

Finn Mountain: mountain, 2,480 ft., $36 \mathrm{mi}$. N of Sleitat Mtn. and $75 \mathrm{mi}$. S of Sleetmute, Kilbuck-Kuskokwim Mts.; $60^{\circ} 35^{\prime} \mathrm{N}, 157^{\circ} 10^{\prime} \mathrm{W}$; $B G N$ 1932; (map 60).

Local name obtained in 1931 by Gerald FitzGerald, USGS; name "used by trappers on the Upper Nushagak."

Finny Beach: beach, $0.3 \mathrm{mi}$. long, at head of Nyman Penin., on N shore of Womens Bay, $5 \mathrm{mi}$. SW of Kodiak, Kodiak I. ; $57^{\circ} 44^{\prime} 10^{\prime \prime} \mathrm{N}$, $152^{\circ} 29^{\prime} 35^{\prime \prime}$ W; (map 34). Var. Finney Beach.

Name published as "Finney Beach" in the 1930 's by USC\&GS.

Fin Point: point of land, SE tip of Hassler I., N of Gedney Pass, Alex. Arch.; 55 51'15" N, $131^{\circ} 35^{\prime} 20^{\prime \prime} \mathrm{W}$; (map 3 ).

Local name published in 1943 by USC\&. GS.

Finski Bay: cove, on NE coast of Glacier I., 0.7 mi. across, $3 \mathrm{mi}$. $\mathrm{S}$ of entrance to Columbia Bay, $55 \mathrm{mi}$. NE of Whittier, Chugach Mts.; $60^{\circ} 54^{\prime} 00^{\prime \prime} \mathrm{N}, 147^{\circ} 05^{\prime} 15^{\prime \prime} \mathrm{W}$; BGN 1911; (map 63).

Named in 1905 by U. S. Grant, USGS, "for a prospector who had a cabin there." Finski Point: point of land, on NE coast of Glacier I., E point of entrance to Finski Bay, 
$56 \mathrm{mi}$. NE of Whittier, Chugach Mts. ; $60^{\circ} 54^{\prime}$ $00^{\prime \prime} \mathrm{N}, 147^{\circ} 04^{\prime} 30^{\prime \prime} \mathrm{W}$; BGN 1911; (map 63).

Named in 1911 by U. S. Grant, USGS, "for a prospector who had a claim there."

Fire Cove: cove, extends SW $0.8 \mathrm{mi}$. off Neets Bay, on NW coast of Revillagigedo I., Alex. Arch.; 55 46 $40^{\prime \prime} \mathrm{N}, 131^{\circ} 32^{\prime} 15^{\prime \prime} \mathrm{W}$; BGN 1931; (map 3).

Named in 1931 by USFS.

Fire Cove: cove, $1 \mathrm{mi}$. long, on SW coast of Harris Penin., $34 \mathrm{mi}$. SW of Seward and $1.8 \mathrm{mi}$. NW of Aligo Point, Chugach Mts. ; 59 $39^{\prime} 30^{\prime \prime}$ N, 149 46'45" W; BGN 1911; (map 49).

Named in 1908 by U. S. Grant, USGS.

Fire Creek: stream, heads in Lower Fire Lake, flows N $6.7 \mathrm{mi}$. to Knik Arm, W of Birchwood, $18 \mathrm{mi}$. NE of Anchorage, Cook Inlet Low.; $61^{\circ} 24^{\prime} 30^{\prime \prime} \mathrm{N}, 149^{\circ} 32^{\prime} 50^{\prime \prime} \mathrm{W}$; (map 69).

Local name reported in 1906 by T. G. Gerdine and R. H. Sargent, USGS.

Fire Creek: stream, flows NE $12 \mathrm{mi}$. to Meadow Creek, $40 \mathrm{mi}$. N of Medfra, Kilbuck-Kuskokwim Mts.; $63^{\circ} 42^{\prime} \mathrm{N}, 154^{\circ} 44^{\prime} \mathrm{W}$; (map 89).

Local name reported in 1924 by J. S. Brown (in Smith, P. S., and others, 1926, pl. 5), USGS.

Fire Creek: stream, heads at glacier terminus, flows NE $9 \mathrm{mi}$. to Okokmilaga River $26 \mathrm{mi}$. SE of its junc. with Killik River, Brooks Ra. $68^{\circ} 27^{\prime} \mathrm{N}, 153^{\circ} 10^{\prime} \mathrm{W}$; (map 133).

Named in 1951 by W. W. Patton, W. R Brosgé, and M. D. Mangus, USGS, during exploration of Naval Petroleum Reserve No. 4.

Fire Creek: stream, heads in Shublik Mts., flows NE $13 \mathrm{mi}$. to Sadlerochit River $6 \mathrm{mi}$. W of its junc. with Kekiktuk River, $22 \mathrm{mi}$. NW of Mount Michelson, Brooks Ra.; $69^{\circ} 31^{\prime} 25^{\prime} \mathrm{N}$, 14457'00' W; BGN 1961; (map 139).

So named by USGS geologists in 1948 because it flows partly through Ignek Valley; "ignek" means "fire" in Eskimo.

Fire Island: island, $0.2 \mathrm{mi}$. across, in Bering Sea, $0.5 \mathrm{mi}$. N of Bogoslof $\mathrm{I}$. and $27 \mathrm{mi}$. N of Umnak I., Aleutian Is.; $53^{\circ} 56^{\prime} 40^{\prime \prime} \mathrm{N}, 168^{\circ}$ 02"55" W; (map 22). Var. New Bogoslof Island, Old Bogoslof Island.

Name published in 1943 by USC\&GS. The island first emerged in 1883 and was called "Old Bogoslof"; it was connected to Bogoslof Island by a spit from 1884 to 1890 .

Fire Island: island, $0.1 \mathrm{mi}$. long, $1.5 \mathrm{mi}$. $\mathrm{N}$ of Exchange I., in Kashevarof Passage, on $\mathbf{N}$ coast of Prince of Wales I., Alex. Arch.; $56^{\circ} 14^{\prime} 05^{\prime \prime} \mathrm{N}, 133^{\circ} 03^{\prime} 15^{\prime \prime} \mathrm{W}$; (map 6).

Named in 1886 by Lt. Comdr. A. S. Snow, USN; name published in 1887 on USC\&GS Chart 706.

Fire Island: island, $5.5 \mathrm{mi}$. long, in head of Cook Inlet, $9 \mathrm{mi}$. SW of Anchorage, Cook Inlet Low.; $61^{\circ} 09^{\prime} \mathrm{N}, 150^{\circ} 12^{\prime} \mathrm{W}$; (map 70). Var. Mushukli Island, Ostrov Mushukhli, Turnagain Island.

Name published in 1895 by USC\&GS. Named "Turnagain Island" on April 20, 1794, by Capt. George Vancouver (Wagner, 1937, p. 521). The Tanaina Indian name was published in 1847 as "Os[trov] Mushukhli," or
"Mushukhli Island," on Russian Hydrog. Dept. Chart 1378.

Fire Lake: lake, $0.5 \mathrm{mi}$. long, on Kenai Penin W of Skilak Lake, 25 mi. SE of Kenai, Cook Inlet Low.; $60^{\circ} 26^{\prime} 30^{\prime \prime} \mathrm{N}, 150^{\circ} 33^{\prime} 00^{\prime \prime} \mathrm{W}$; (map 62).

Named about 1963 by officials of Kenai National Moose Range, for administrative purposes.

Fire Lake: lake, see Lower Fire Lake.

Fire Point: point of land, $\mathrm{N}$ point of entrance to Saks Cove, on E side of Behm Canal, Coast Mts.; $55^{\circ} 56^{\prime} \mathrm{N}, 131^{\circ} 09^{\prime} \mathrm{W}$; (map 3).

One of many arbitrary names applied to features in this area in 1891 by USC\&GS.

Fire River: estuary, see Knik Arm.

Fireweed Creek: stream, on Alaska Penin., heads at Island Glacier, flows $\mathrm{N} 22 \mathrm{mi}$. to Blueberry Creek, $28 \mathrm{mi}$. $\mathbf{N}$ of Mount Veniaminof, Bristol Bay Low.; $56^{\circ} 35^{\prime} \mathrm{N}, 159^{\circ} 14^{\prime} \mathrm{W}$; (map 30).

Name reported in 1923 by R. H. Sargent, USGS; published in 1927 by USGS

Fireweed Mountain: mountain, 6,660 ft., $5 \mathrm{mi}$. $\mathrm{W}$ of McCarthy, Wrangell Mts.; $61^{\circ} 27^{\prime} \mathrm{N}$ $143^{\circ} 06^{\prime} \mathrm{W} ; B G N$ 1966; (map 67).

The Mountaineering Club of Alaska reports that this is a local name given by Molly Gilmore, lifelong resident of the McCarthy area who, at age 17 , named this mountain for the abundance of fireweed that followed forest fires on its slopes in the 1920's. Though the most common and wellknown flower in Alaska, it is commemorated on no other Alaskan mountain.

Firewood, Bay of: bay, see Driftwood Bay.

Fir Island: island, see Sosnovoi Island.

Fir Rock: rock, in SW El Capitan Passage, SW of Teal I., Alex. Arch.; $55^{\circ} 55^{\prime} \mathrm{N}, 133^{\circ} 22^{\prime} \mathrm{W}$; (map 4).

Local name published in 1925 Coast Pilot (p. 154).

First Berg Lake: lake, see Berg Lake.

First Bluff: cliff, $\mathbf{5 7 0} \mathrm{ft}$., E of High Bluffs, along $\mathrm{N}$ coast of St. George I., Pribilof Is. ; $56^{\circ} 36^{\prime} 10^{\prime \prime}$ N, 169 37'30" W; (map 38).

Descriptive name published by USC\&GS; so called because it is the first bluff going west from Saint George.

First Canyon: canyon, on left bank of Unuk River, $15 \mathrm{mi}$. NE of its mouth at Burroughs Bay, Coast Mts.; $56^{\circ} 15^{\prime} \mathrm{N}, 130^{\circ} 50^{\prime} \mathrm{W}$; (map 7).

Descriptive name given in 1906 by $F$. Morse, USC\&GS, as it was "the first canyon [in this area] to be caused by a lava flow"; published in 1927 on IBC Sheet 3

First Chance Cabin: locality, see Last Chance.

First Chance Creek: stream, flows W $3.2 \mathrm{mi}$. to Wilson Creek Slough, $2 \mathrm{mi}$. S of Marshall, Yukon-Kuskokwim Delta ; $61^{\circ} 51^{\prime} 20^{\prime \prime}$ N, $162^{\circ}$ 02'40" W; (map 74)

Local miners' name reported in 1916 by Harrington (1918, map), USGS.

First Chance Creek: stream, flows SE $3.3 \mathrm{mi}$. to Bonanza Creek, $9 \mathrm{mi}$. SE of Flat and $50 \mathrm{mi}$. NW of Sleetmute, Kilbuck-Kuskokwim Mts. $62^{\circ} 20^{\prime} 25^{\prime \prime} \mathrm{N}, 157^{\circ} 52^{\prime} 30^{\prime \prime} \mathrm{W}$; (map 79).
Prospectors' name published in 1921 by USGS.

First Chance Creek: stream, flows NW $20 \mathrm{mi}$. to Iditarod River, $25 \mathrm{mi}$. N of Flat and $50 \mathrm{mi}$. SE of Holikachuck, Kilbuck-Kuskokwim Mts.; $62^{\circ} 49^{\prime} \mathrm{N}, 157^{\circ} 56^{\prime} \mathrm{W}$; (map 79).

Prospectors' name reported in 1912 by H. M. Eakin, USGS.

First Chance Creek: stream, flows NW $2.3 \mathrm{mi}$. to Goldstream Creek, $9 \mathrm{mi}$. NE of Fairbanks, Yukon-Tanana High.; 64 ${ }^{\circ} 58^{\prime}$ N, $147^{\circ} 36^{\prime}$ W; (map 100).

Named by prospectors; published in 1908 by USGS.

First Chance Creek: stream, flows SW $16 \mathrm{mi}$. to Koyuk River, $26 \mathrm{mi}$. NW of Haycock, Seward Penin. High.; $65^{\circ} 20^{\prime} \mathrm{N}, 162^{\circ} 00^{\prime} \mathrm{W}$; (map 109).

Local name shown on a 1903 fieldsheet by D. C. Witherspoon, USGS

First Chance Creek: stream, flows NE $1.4 \mathrm{mi}$. to Kiwalik River, $50 \mathrm{mi}$. NW of Haycock, Seward Penin. High.; 65 $51^{\prime} \mathrm{N}, 161^{\circ} 54^{\prime} \mathrm{W}$; (map 109).

Local name published on maps after 1950 .

First Creek: stream, heads in Dutch Hills, flows W $1.4 \mathrm{mi}$. to Dutch Creek, $35 \mathrm{mi}$. NW of Talkeetna, Alaska Ra.; $62^{\circ} 35^{\prime} 45^{\prime \prime} \mathrm{N}, 151^{\circ}$ 02'00" W; (map 81).

Prospectors' name reported in the 1930's by USGS.

First Creek: stream, heads in Tokosha Mts., flows SE $13 \mathrm{mi}$. to Tokositna River, $22 \mathrm{mi}$. NW of Talkeetna, Alaska Ra.; $62^{\circ} 37^{\prime} 30^{\prime \prime} \mathrm{N}, 150^{\circ}$ $37^{\prime} 40^{\prime \prime} \mathrm{W}$; (map 81).

Local descriptive name reported in 1958 by USGS.

First Creek: stream, flows NW $13 \mathrm{mi}$. to Reindeer Cove, $12 \mathrm{mi}$. SW of Christmas Mtn., Nulato Hills; $64^{\circ} 32^{\prime} \mathrm{N}, 161^{\circ} 00^{\prime} \mathrm{W}$; (map 96$)$.

Local name reported about 1954 by U.S. Army Corps of Engineers.

First Creek: stream, heads in Zane Hills, flows $\mathrm{NE}$ and E $12 \mathrm{mi}$. to Hogatza River, $33 \mathrm{mi}$ WNW of Hughes, Hogatza High.; 66 $6^{\circ} 07^{\prime} 30^{\prime \prime}$ $\mathrm{N}, 155^{\circ} 25^{\prime} 00^{\prime \prime} \mathrm{W}$; (map 116$)$.

So named about 1955 because it is the first stream which crosses the road between Hog Landing and Hogatza; reported in 1956 by Orth

First Fork Koksuktapaga: stream, see Lower Willow Creek.

First Fork Selatna River: stream, flows N $30 \mathrm{mi}$ to Selatna River $3.5 \mathrm{mi}$. E of its junc. with Kuskokwim River, $32 \mathrm{mi}$. S of McGrath, Kilbuck-Kuskokwim Mts. ; $62^{\circ} 30^{\prime} 15^{\prime \prime} \mathrm{N}, 155^{\circ}$ 41'30' W; (map 80)

Local name obtained in 1954 by USGS.

First Glacier: glacier, see Popof Glacier.

First Hill Lake: lake, $1.5 \mathrm{mi}$. long, between Crosswind and Second Hill Lakes, $27 \mathrm{mi}$. NW of Glennallen, Copper River Basin; 62 ${ }^{\circ} 2^{\prime}$ $\mathrm{N}, 146^{\circ} 08^{\prime} \mathrm{W}$; (map 83 ).

Local name reported in 1951 by USGS

First Hills Slough: stream, flows NE $10 \mathrm{mi}$. to Huslia River, $15 \mathrm{mi}$. NW of Roundabout Mtn., Koyukuk Low.; $65^{\circ} 31^{\prime} \mathrm{N}, 156^{\circ} 39^{\prime} \mathrm{W}$; (map 108). 
Local name obtained at Huslia by USGS in 1954 or 1955.

First Kekour: rock, see First Kekur.

First Kekur: rock, $0.1 \mathrm{mi}$. across, $\mathrm{S}$ of Kekur Penin., $14 \mathrm{mi}$. NW of village of Port Alexander, on S coast of Baranof I., Alex. Arch.; $56^{\circ} 22^{\prime} 25^{\prime \prime} \mathrm{N}, 134^{\circ} 56^{\prime} 30^{\prime \prime} \mathrm{W}$; (map 5). Var. First Kekour.

Descriptive name meaning "pinnacle rock" given in 1849 by the Russian American Company. See Kekur Island.

First Lake: lake, $700 \mathrm{ft}$. long, in course of Indian Creek, on $\mathrm{W}$ shore of Cook Inlet, Cook Inlet Low.; $61^{\circ} 04^{\prime} 10^{\prime \prime} \mathrm{N}, 151^{\circ} 08^{\prime} 50^{\prime \prime} \mathrm{W}$; (map 70).

Local name reported in 1958 by USGS; named because it is the first lake encountered when traveling from Tyonek to the Chuitna River.

First Lake: lake, $0.5 \mathrm{mi}$. long, $1.3 \mathrm{mi}$. $\mathrm{N}$ of Chitina and $66 \mathrm{mi}$. NE of Valdez, Copper River Basin; 61 $32^{\circ} 20^{\prime \prime} \mathrm{N}, 144^{\circ} 26^{\prime} 55^{\prime \prime} \mathrm{W}$; (map 68).

Local name published in the 1950's by USGS.

First Lake: lake, 4 mi. $\mathrm{E}$ of Whitefish Lake and $21 \mathrm{mi}$. NE of Roundabout Mtn., Koyukuk Low.; $65^{\circ} 47^{\prime} \mathrm{N}, 156^{\circ} 05^{\prime} \mathrm{W}$; (map 108).

Local name obtained at Huslia by USGS in 1954 or 1955

First Lake: lake, see Roaring Bear Lake.

First Narrows: water passage, between Midway I. and $\mathrm{W}$ shore of Redfish Bay, $10.2 \mathrm{mi}$. NW of Port Alexander, on $\mathbf{S}$ coast of Baranof $\mathrm{I}$., Alex. Arch.; $56^{\circ} 19^{\prime} 25^{\prime \prime} \mathrm{N}, 134^{\circ} 52^{\prime} 10^{\prime \prime} \mathrm{W}$; (map 5).

Named in 1897 by Lt. Comdr. J. F. Moser, USN, commander of USBF steamer Albatross.

First Narrows: water passage, between Lodge I. and $\mathrm{N}$ shore of Rakof Is., $6.5 \mathrm{mi}$. SE of Goddard, on W coast of Baranof I., Alex. Arch.; $56^{\circ} 45^{\prime} 20^{\prime \prime} \mathrm{N}, 135^{\circ} 16^{\prime} 45^{\prime \prime} \mathrm{W}$; (map 6).

Local fishermen's name reported in 1947 by USC\&GS.

First North Tributary: glacier, see Casement Glacier.

First Point: point of land, see Shoals Point.

First Pup: stream, flows NW $1.5 \mathrm{mi}$. to Flat Creek, $39 \mathrm{mi}$. NE of Fairbanks, Yukon-Tanana High.; $65^{\circ} 12^{\prime} 30^{\prime \prime} \mathrm{N}, 146^{\circ} 50^{\prime} 00^{\prime \prime} \mathrm{W}$; (map 104).

Named "First Pup" by prospectors; published by USGS (Prindle, 1908, pl. 4). See Second Pup and Third Pup.

First Rapid: rapids, see North Rapid.

First Rapids: rapids, on Alsek River, $6 \mathrm{mi}$. NE of Dry Bay and $52 \mathrm{mi} \mathrm{SE}$ of Yakutat, Mala. spina Coastal Plain; $59^{\circ} 11^{\prime} 20^{\prime \prime} \mathrm{N}, 138^{\circ} 25^{\prime}$ $10^{\prime \prime} \mathrm{W}$; (map 46).

Local name published by USGS in 1959.

First Timber Creek: stream, flows SE $4 \mathrm{mi}$. to Nushagak River, $80 \mathrm{mi}$. SE of Sleetmute, Kilbuck-Kuskokwim Mts.; $60^{\circ} 36^{\prime} \mathrm{N}, 156^{\circ} 35^{\prime} \mathrm{W}$; (map 60).

Local name reported in 1952 by USC\&GS.

First Waterfall Creek: stream, flows NW $4.5 \mathrm{mi}$. to Clover Passage, 1.2 mi. NE of Potter Point, on W coast of Revillagigedo I., Alex. Arch.; $55^{\circ} 29^{\prime} 18^{\prime \prime} \mathrm{N}, 131^{\circ} 45^{\prime} 52^{\prime \prime} \mathrm{W}$; (map 3).

Local name recorded in 1954 by USGS.

Firth River: stream, heads at $\mathrm{E}$ end of Davidson Mts., flows NE $125 \mathrm{mi}$. across Alaska-Canada boundary to Beaufort Sea, SW of Herschel I.,

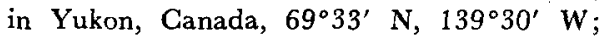
BGN 1954; (map 137).

Named by J. H. Turner, USC\&GS, in 1890 , for John Firth, Hudson's Bay Company agent at Rampart House, who accompanied Turner to the Arctic coast that year.

Firth River: stream, see Malcolm River.

Firtree Island: island, see Elovoi Island.

Fisch Bay: bay, see Fish Bay.

Fish Bay: bay, extends W $6 \mathrm{mi}$. to Peril Straits, on NW coast of Baranof I., $12 \mathrm{mi}$. NE of Sitka, Alex. Arch.; $57^{\circ} 23^{\prime} \mathrm{N}, 135^{\circ} 37^{\prime} \mathrm{W}$; (map 9). Var. Fisch Bay, Fishing Bay, Guba Rybya, Ribnaia Bay, Rieba Bay, Rubia Bay.

An 1882 translation by USC\&GS of name published in 1848 on Russian Hydrog. Dept. chart 1397 as "Guba Rybya."

Fish Bay: bay, on Hinchinbrook I., at mouth of Honker Creek, $22 \mathrm{mi}$. SW of Cordova, Chugach Mts.; $60^{\circ} 27^{\prime} \mathrm{N}, 146^{\circ} 22^{\prime} \mathrm{W}$; (map 64).

\section{Name published in 1950 by USGS}

Fish Bay: bay, 1.2 mi. wide, on $\mathbf{N}$ coast of Port Fidalgo, $30 \mathrm{mi}$. NW of Cordova, Chugach Mts.; $60^{\circ} 49^{\prime} \mathrm{N}, 146^{\circ} 26^{\prime} \mathrm{W}$; (map 64).

Name reported in 1903 by H. P. Ritter, USC\&GS, while doing topographic and hydrographic surveys in the Copper River Delta region.

Fish Bay Creek: stream, flows NW $8 \mathrm{mi}$. to Fish Bay, on NW coast of Baranof I., Alex Arch.; $57^{\circ} 21^{\prime} 30^{\prime \prime} \mathrm{N}, 135^{\circ} 29^{\prime} 00^{\prime \prime} \mathrm{W}$; (map 9).

Local name reported in 1916 by G. A. Waring (1917, fig. 3), USGS.

Fish Camp Lake: lake, $1 \mathrm{mi}$. across, $1.8 \mathrm{mi}$. SW of junc. of Kalutna and Tanana Rivers and $25 \mathrm{mi}$. SW of Tok, Yukon-Tanana High.; $63^{\circ} 09^{\prime} \mathrm{N}, 142^{\circ} 17^{\prime} \mathrm{W}$; (map 85).

Local name reported in 1963 by USGS.

Fish Choked Creek: stream, flows NE $2.7 \mathrm{mi}$. to Khotol River, $1 \mathrm{mi}$. SW of junc. of Khotol River and Kalyuh Slough, $21 \mathrm{mi}$. SE of Nulato, Koyukuk Low.; $64^{\circ} 25^{\prime} \mathrm{N}, 157^{\circ} 59^{\prime} \mathrm{W}$; (map 97). Var. Dlugatauzaratlna.

Appears to be a translation of an Indian name; reported in 1935 by Frederica de Laguna, BAE.

Fish Creek: locality, site of a settlement at $N$ end of Douglas I. at mouth of Fish Creek, $6 \mathrm{mi}$. NW of Juneau, Coast Mts.; 58 $19^{\prime} 50^{\prime \prime} \mathrm{N}$, $134^{\circ} 35^{\prime} 30^{\prime \prime} \mathrm{W}$; (map 11).

Local name from the creek of the same name. Homestead claims were filed here in 1880 , and later a settlement was formed which was called Fish Creek. A school located here in 1936 was in use for several years (DeArmond, 1957, p. 19).

Fish Creek: stream, flows NW $1.1 \mathrm{mi}$. to Bering Sea, on SW Kiska I., Aleutian Is.; $51^{\circ} 54^{\prime} 40^{\prime \prime}$ N, $177^{\circ} 15^{\prime} 15^{\prime \prime} \mathrm{E}$; (map 14).

An arbitrary name beginning with " $F$ " to correspond to " $F$ " grid by the U.S. Army for tactical purposes during World War II; published on a 1953 AMS map.

Fish Creek: stream, on Revillagigedo I., flows S $16 \mathrm{mi}$. through several lakes to Thorne Arm, Alex. Arch.; $55^{\circ} 23^{\prime} 30^{\prime \prime} \mathrm{N}, 131^{\circ} 11^{\prime} 45^{\prime \prime} \mathrm{W}$; (map 3).

Local name reported by F. E. Wright and C. W. Wright (1908, fig. 12), USGS.

Fish Creek: stream, flows $\mathrm{S} 4.5 \mathrm{mi}$. to Salmon River, $3 \mathrm{mi}$. $\mathrm{N}$ of Hyder, Coast Mts.; $55^{\circ} 57^{\prime} 25^{\prime \prime} \mathrm{N}, 130^{\circ} 03^{\prime} 40^{\prime \prime} \mathrm{W}$; BGN 1930; (map 3).

Local name reported in 1915 by Theodore Chapin (in Brooks and others, 1916, fig. 5), USGS.

Fish Creek: stream, on $\mathrm{N}$ end of Douglas I., heads in Cropley Lake and flows $6 \mathrm{mi}$. NW to Fritz Cove, $0.4 \mathrm{mi}$. SE of Hut Point and $7 \mathrm{mi}$. NW of Juneau; $58^{\circ} 19^{\prime} 50^{\prime \prime} \mathrm{N}, 134^{\circ} 35^{\prime}-$ $30^{\prime \prime} \mathrm{W}$; (map 11).

This name first appeared in mining records in 1885 when the water was claimed for the Treadwell mines. The stream subsequently became the northern end of the Treadwell Ditch (DeArmond, 1957, p. 19). The name was reported in 1902 by W. J. Peters, USGS.

Fish Creek: stream, $2.7 \mathrm{mi}$. long, flows $\mathrm{W}$ to join Taku River at $S$ end of Canyon I., $32 \mathrm{mi}$. NE of Juneau, Coast Mts. ; $58^{\circ} 32^{\prime} 40^{\prime \prime}$ N, $133^{\circ} 40^{\prime}$ $50^{\prime \prime} \mathrm{W}$; (map 12).

Local name reported in 1951 by USGS.

Fish Creek: stream, in Glacier Bay National Monument, flows S $0.5 \mathrm{mi}$. from Fish Lake to Lituya Bay, $88 \mathrm{mi}$. NW of Hoonah, Malaspina Coastal Plain; $58^{\circ} 38^{\prime} 40^{\prime \prime} \mathrm{N}, 137^{\circ} 38^{\prime} 00^{\prime \prime}$ W ; (map 10).

Name published by members of the Harvard-Dartmouth Expedition, 1933-34 (Washburn and Goldthwaite, 1936, map).

Fish Creek: stream, flows $\mathrm{W}$ then $\mathrm{N} 6.4 \mathrm{mi}$. to Bootlegger Cove in Anchorage, Cook Inlet Low.; $61^{\circ} 12^{\prime} 27^{\prime \prime} \mathrm{N}, 1^{\circ} 9^{\circ} 55^{\prime} 45^{\prime \prime} \mathrm{W}$; (map 69).

Local name reported in 1942 by AMS.

Fish Creek: stream, heads in Red Shirt Lake, flows SW $26 \mathrm{mi}$. through Flat Horn Lake to Susitna River, $23 \mathrm{mi}$. NW of Anchorage, Cook Inlet Low.; $61^{\circ} 22^{\prime} \mathrm{N}, 150^{\circ} 30^{\prime} \mathrm{W}$; (map 70).

Local name reported in 1958 by USGS.

Fish Creek: stream, heads in Big Lake, flows SE $12 \mathrm{Mi}$. to Knik Arm, $2 \mathrm{mi}$. SW of Knik and 16 mi. NE of Anchorage, Cook Inlet Low.; $61^{\circ}$ $26^{\prime} 15^{\prime \prime} \mathrm{N}, 149^{\circ} 46^{\prime} 05^{\prime \prime} \mathrm{W}$; (map 69).

Local name obtained from GLO[BLM] survey plats of 1911 .

Fish Creek: stream, flows SE $35 \mathrm{mi}$. to Kroto Slough, $4.6 \mathrm{mi}$. NE of Susitna and $33 \mathrm{mi}$. NW of Anchorage, Cook Inlet Low.; 61 $36^{\prime} 30^{\prime \prime}$ N, $150^{\circ} 28^{\prime} 25^{\prime \prime} \mathrm{W}$; (map 70$)$.

Local name reported in 1958 by USGS.

Fish Creek: stream, heads at glacier, flows NE $8.5 \mathrm{mi}$. to Hartman River $10 \mathrm{mi}$. SW of its junc. with South Fork Kuskokwim River, 95 mi. NW of Tyonek, Alaska Ra.; 61 ${ }^{\circ} 50^{\prime} 15^{\prime \prime} \mathrm{N}$, $153^{\circ} 29^{\prime} 00^{\prime \prime} \mathrm{W}$; (map 71).

Local name reported in 1958 by USGS.

Fish Creek: stream, flows NE 9.5 mi. to Jacksina Creek $2 \mathrm{mi}$. SW of its junc. with Nabesna 
River, Wrangell Mts.; $62^{\circ} 20^{\prime} \mathrm{N}, 142^{\circ} 55^{\prime} \mathrm{W}$; $B G N$ 1939; (map 84).

Local name reported in 1939 by P. S. Smith, USGS.

Fish Creek: stream, flows S $5.4 \mathrm{mi}$. to Mentasta Lake, $5 \mathrm{mi}$. W of Mentasta Pass, Alaska Ra.; $62^{\circ} 55^{\prime} \mathrm{N}, 143^{\circ} 49^{\prime} \mathrm{W}$; (map 84).

Local name reported in 1951 by USGS.

Fish Creek: stream, heads in Upper Fish Lake, flows NW through Lower Fish Lake $3.5 \mathrm{mi}$. to Gulkana River, $4.5 \mathrm{mi}$. N of Paxson, Alaska

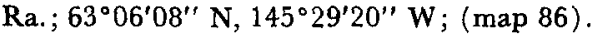

Name published on relatively recent maps.

Fish Creek: stream, heads at Lake Mansfield, flows S $4.7 \mathrm{mi}$. to Little Tanana Slough, 2.3 mi. NW of Tanacross, Yukon-Tanana High.; $63^{\circ} 25^{\prime} \mathrm{N}, 143^{\circ} 24^{\prime} \mathrm{W}$; (map 85).

Local name reported in 1950 by USGS.

Fish Creek: stream, flows W $10 \mathrm{mi}$. to Savage River, $15 \mathrm{mi}$. NW of Healy, Alaska Ra.; $63^{\circ} 54^{\prime} 30^{\prime \prime} \mathrm{N}, 149^{\circ} 26^{\prime} 20^{\prime \prime} \mathrm{W}$; (map 87). Var. Sunday Creek.

Local name reported in 1951 by USGS.

Fish Creek: stream, heads in lake, flows N 40 mi. to North Fork Kuskokwim River, 11 mi. $\mathrm{W}$ of village of Lake Minchumina, Tanana Low.; $63^{\circ} 55^{\prime} 10^{\prime \prime} \mathrm{N}, 152^{\circ} 40^{\prime} 20^{\prime \prime} \mathrm{W}$; (map 88).

Local name reported in 1925 by USGS.

Fish Creek: stream, flows NW $18 \mathrm{mi}$. to Middle Fork Fortymile River, $55 \mathrm{mi}$. SW of Eagle, Yukon-Tanana High.; $64^{\circ} 24^{\prime} \mathrm{N}, 142^{\circ} 49^{\prime} \mathrm{W}$; (map 102).

Prospectors' name obtained in 1898 by E. C. Barnard, USGS.

Fish Creek: stream, flows N $17 \mathrm{mi}$. to Wood River, 34 mi. SW of Fairbanks, Tanana Low.; $64^{\circ} 24^{\prime} \mathrm{N}, 148^{\circ} 11^{\prime} \mathrm{W}$; (map 100).

Local name reported by R. H. Sargent, USGS.

Fish Creek: stream, flows NW $20 \mathrm{mi}$. to Seventeen Mile Slough, $4 \mathrm{mi}$. S of Nenana, Tanana Low.; $64^{\circ} 30^{\prime} 20^{\prime \prime} \mathrm{N}, 1^{\circ} 49^{\circ} 06^{\prime} 45^{\prime \prime} \mathrm{W}$; (map 100).

Local name published in 1917 on a GLO [BLM] survey plat.

Fish Creek: stream, flows SW $0.8 \mathrm{mi}$. to Solomon River, $11 \mathrm{mi}$. NE of Solomon, Seward Penin. High.; $64^{\circ} 43^{\prime} \mathrm{N}, 164^{\circ} 18^{\prime} \mathrm{W}$; (map 95).

Prospectors' name reported on the 1900 "Map of Nome Peninsula" by J. M. Davidson and B. D. Blakeslee.

Fish Creek: stream, heads at junc. of Barnes and Pearl Creeks, flows NE $11 \mathrm{mi}$. to Little Chena River, $28 \mathrm{mi}$. NE of Fairbanks, YukonTanana High.; $65^{\circ} 03^{\prime} 25^{\prime \prime} \mathrm{N}, 146^{\circ} 57^{\prime} 55^{\prime \prime} \mathrm{W}$; (map 104).

Local name reported in 1903 by $T$. G. Gerdine (in Prindle, 1905, pl. 13), USGS.

Fish Creek: stream, heads at Fish Lake, flows NW 11 mi. to Tanana River at Fish Creek I., $15 \mathrm{mi}$. SE of Tanana, Nowitna Low.; $65^{\circ}$ $05^{\prime} \mathrm{N}, 151^{\circ} 38^{\prime} \mathrm{W}$; (map 106). Var. Boulder Creek, Guthna Creek.

This name was probably given or obtained in 1902 by Lt. Gibbs, U.S. Army Signal Corps. The Indian name was "Guthna," meaning "Guth River," according to Lt. J. S. Herron,
USA, in 1899. About 1908 local usage applied the name "Boulder Creek" to the stream's head. Cartographers compromised and used "Fish Creek" for the lower part below Fish Lake and applied the name "Boulder Creek" above the lake.

Fish Creek: stream, flows SW $5.6 \mathrm{mi}$. to Breving Lagoon, $9 \mathrm{mi}$. NW of Teller, Seward Penin. High.; $65^{\circ} 21^{\prime} \mathrm{N}, 166^{\circ} 36^{\prime} \mathrm{W}$; (map 111). Prospectors' name reported on the 1908 "Map of Seward Peninsula" by Arthur Gibson.

Fish Creek: stream, flows NW $18 \mathrm{mi}$. to Garnet Creek $2 \mathrm{mi}$. S of that streams junc. with Yukon River, $19 \mathrm{mi}$. SSW of Rampart, Yukon-Tanana High.; $65^{\circ} 24^{\prime} \mathrm{N}, 150^{\circ} 46^{\prime} \mathrm{W}$; (map 106).

Riverboat pilots' name shown on Edwards Track Chart of the Yukon, dated 1899.

Fish Creek: stream, flows SE to Birch Creek, 50 mi. SW of Eagle, Yukon-Tanana High.; $65^{\circ}$ $25^{\prime} 20^{\prime \prime} \mathrm{N}, 145^{\circ} 33^{\prime} 50^{\prime \prime} \mathrm{W}$; (map 104).

Named by prospectors; reported in 1909 by C. E. Ellsworth (in Brooks and others, 1910, p. 267), USGS.

Fish Greek: stream, flows SW $21 \mathrm{mi}$. to Hess Creek, $35 \mathrm{mi}$. NE of Rampart, Yukon-Tanana High.; $65^{\circ} 41^{\prime} \mathrm{N}, 149^{\circ} 05^{\prime} \mathrm{W}$; (map 105).

Local name reported in 1903 by T. G. Gerdine (in Prindle, 1905, pl. 16), USGS.

Fish Creek: stream, heads in Indian Mts., flows N $9 \mathrm{mi}$. to Koyukuk River, $19 \mathrm{mi}$. NNE of Hughes, Kokrines-Hodzana High.; $66^{\circ} 17^{\prime} \mathrm{N}$, $153^{\circ} 53^{\prime} \mathrm{W}$; (map 116).

Local name recorded at Hughes in 1956 by Orth.

Fish Creek: stream, distributary of Beaver Creek, flows NW $30 \mathrm{mi}$. to Fish Slough, Yukon River, $5.5 \mathrm{mi}$. SE of Beaver, Yukon Flats; $66^{\circ} 17^{\prime} 15^{\prime \prime}$ N, $147^{\circ} 18^{\prime} 00^{\prime \prime} \mathrm{W}$; (map 118).

Local name obtained in 1956 by USGS.

Fish Creek: stream, flows W $60 \mathrm{mi}$. to South Fork Koyukuk River, $20 \mathrm{mi}$. $\mathrm{S}$ of Bettles, Kanuti Flats; $66^{\circ} 37^{\prime} 15^{\prime \prime} \mathrm{N}, 151^{\circ} 35^{\prime} 30^{\prime \prime} \mathrm{W}$ (map 117).

Name reported in 1899 by G. H. Wonson, Master of the steamer Dorothy, on his manuscript map of the Koyukuk River.

Fish Creek: stream, flows S $20 \mathrm{mi}$. to Porcupine River, 11 mi. E of Coleen Mtn., Brooks Ra.; $67^{\circ} 06^{\prime} \mathrm{N}, 142^{\circ} 23^{\prime} \mathrm{W}$; (map 121).

Name reported by M. G. White (1952, fig. 1), USGS, in 1948.

Fish Creek: stream, flows SE $6.5 \mathrm{mi}$. from Gray Mtn. to Kachwona Creek, $2 \mathrm{mi}$. NW of Frigid Crags, $28 \mathrm{mi}$. SE of Anaktuvuk Pass and $38 \mathrm{mi}$. NW of Wiseman, Brooks Ra.; $67^{\circ} 51^{\prime} \mathrm{N}, 151^{\circ} 00^{\prime} \mathrm{W}$; BGN 1932; (map 124).

So named in 1932 by Robert Marshall "because of the quantity of fish caught in the stream."

Fish Creek: stream, heads in lake at $69^{\circ} 52^{\prime} \mathrm{N}$, $153^{\circ} 04^{\prime} \mathrm{W}$, flows NE 110 mi. to Harrison Bay, W of Colville River Delta, Arctic Plain; $70^{\circ}$ $22^{\prime} 45^{\prime \prime} \mathrm{N}, 151^{\circ} 13^{\prime} 30^{\prime \prime} \mathrm{W}$; (map 149).

Local name reported in 1951 by USC\&GS. Fish Creek: stream, flows SW to Solomon River near its head, about $15 \mathrm{mi}$. N of Solomon, Seward Penin. High.; (map 95).
Prospectors' name reported on the 1900 "Map of Nome Peninsula" by J. M. Davidson and B. D. Blakeslee. This stream cannot be precisely located on current maps.

Fish Creek: stream, see Barabara Creek.

Fish Creek: stream, see Bonanza Creek.

Fish Creek: stream, see Ketchikan Creek.

Fish Creek: stream, see Monte Cristo Creek.

Fish Creek: stream, see Sunday Creek.

Fish Creek Island: island, $2.5 \mathrm{mi}$. long, in Tanana River, at mouth of Fish Greek, $14 \mathrm{mi}$. SE of Tanana, Nowitna Low.; $65^{\circ} 05^{\prime} \mathrm{N}, 151^{\circ} 39^{\prime}$ W; (map 106).

Riverboat pilots' name shown on a 1940 Navigation Chart, Tanana-Yukon Rivers.

Fish Creek Lake: lake, $0.4 \mathrm{mi}$. long, $1 \mathrm{mi}$. NW of junc. of Jacksina Creek and Nabesna River, Wrangell Mts.; $62^{\circ} 21^{\prime} 45^{\prime \prime} \mathrm{N}, 142^{\circ} 54^{\prime} 00^{\prime \prime} \mathrm{W}$; (map 84).

Local name reported in 1960 by USGS.

Fish Creek Lake: lake, $0.9 \mathrm{mi}$. long, $7 \mathrm{mi}$. WSW of Lake Snohomish and $17 \mathrm{mi}$. SW of village of Lake Minchumina, Tanana Low.; $63^{\circ} 42^{\prime}$ N, $152^{\circ} 43^{\prime}$ W; (map 88). Var. Lake Telida, Lhakatruntamená.

Name reported in 1954 by USGS. The Tanana Indian name is given as "Lhakatruntamená," meaning "lake where one catches fish."

Fish Creek Lake: lake, $2.4 \mathrm{mi}$. long, drains $\mathrm{N}$ to Fish Creek $3 \mathrm{mi}$. E of its junc. with South Fork Koyukuk River, $22 \mathrm{mi}$. SE of Bettles, Kanuti Flats; $66^{\circ} 35^{\prime} \mathrm{N}, 151^{\circ} 28^{\prime} \mathrm{W}$; (map 117).

Local name reported in 1956 by T. E. Taylor, USGS.

Fish Egg: village, see Craig.

Fish Egg Island: island, $1.8 \mathrm{mi}$. long, $1 \mathrm{mi} . \mathrm{N}$ of Ballena Is., between Klawak Inlet and San Alberto Bay, on $W$ coast of Prince of Wales I., NW of Craig, Alex. Arch.; $55^{\circ} 29^{\prime} 20^{\prime \prime} \mathrm{N}$, $133^{\circ} 10^{\prime} 15^{\prime \prime} \mathrm{W}$; (map 4). Var. Egg Island, Fish Egg Islets, Isla de Paba, La Ballena.

Named in 1897 by Comdr. J. F. Moser, USN. This island was given the Spanish name "La Ballena" meaning "the whale" by Don Juan de la y Quadra and Francisco Antonio Maurelle. H. E. Nichols, USN, published the name "Egg" for this island and "Fish Egg Islets" for Balandra and the Ballena Islands (U.S. Coast and Geodetic Survey, 1891, p. 121). Baker (1906, p. 257) says "Moser, 1897, uses the name Fish Egg for a much larger island about a mile north of these [Balandra I., Ballena Is.] * * Moser's name is here adopted for the island and the islets near it."

Fish Egg Islets: island, see Fish Egg Island.

Fish Egg Reef: reef, extends E 1,000 ft. from Fish Egg I., in Klawak Inlet, $0.4 \mathrm{mi}$. $\mathrm{N}$ of Craig, Alex. Arch.; $55^{\circ} 29^{\prime} 00^{\prime \prime} \mathrm{N}, 133^{\circ} 09^{\prime} 20^{\prime \prime}$ W; (map 4).

Name published in 1932 Coast Pilot (p. 211).

Fisher Caldera: caldera, $7 \mathrm{mi}$. long, on Unimak I., Aleutian Is.; $54^{\circ} 35^{\prime} \mathrm{N}, 164^{\circ} 26^{\prime} \mathrm{W}$; $B G N$ 1948; (map 24). 
Named in 1948 for Bernard Fisher, USGS, who lost his life in Umnak Pass while investigating the volcanic geology of the Aleutian Islands.

Fisher Creek: stream, heads at Fisher Dome, flows SE $11 \mathrm{mi}$. to Salmon River, $75 \mathrm{mi}$. E of Bethel, Kilbuck-Kuskokwim Mts.; $60^{\circ} 50^{\prime} \mathrm{N}$, $159^{\circ} 34^{\prime} \mathrm{W}$; (map 59).

Prospectors' name reported in 1914 by A. G. Maddren (in Brooks, 1915, pl. 11), USGS.

Fisher Creek: stream, flows NE and NW $22 \mathrm{mi}$., joins Derwent Creek to form Bonanza Creek, $10 \mathrm{mi}$. SE of junc. of Charley and Yukon Rivers, Yukon-Tanana High.; 65 $5^{\circ} 1^{\prime} 45^{\prime \prime} \mathrm{N}$, $142^{\circ} 34^{\prime} 00^{\prime \prime} \mathrm{W}$; (map 103).

Prospectors' name; from an unpublished map by E. J. Chamberlain, dated 1902.

Fisher Creek: stream, flows SW $3 \mathrm{mi}$. to Burke Creek which flows to American River, $11 \mathrm{mi}$. W of Kougarok Mtn. and $37 \mathrm{mi}$. NE of Teller, Seward Penin. High.; $65^{\circ} 41^{\prime} \mathrm{N}, 165^{\circ} 36^{\prime} \mathrm{W}$; (map 111). Var. Fletcher Creek.

Prospectors' name reported in 1901 by T. G. Gerdine (in Collier, 1902, pl. 12), USGS.

Fisher Greek: stream, flows NE $8 \mathrm{mi}$. to Fairhaven Creek, $46 \mathrm{mi}$. NE of Haycock, Seward Penin. High.; 65⒌ $\mathrm{N}, 161^{\circ} 06^{\prime} \mathrm{W}$; (map 109).

Local name published on maps after 1950. Fisher Creek: stream, see Burke Creek.

Fisher Dome: mountain, 2,973 ft., in Kilbuck Mts., $68 \mathrm{mi}$. E of Bethel, Kilbuck-Kuskokwim Mts. ; $60^{\circ} 50^{\prime} \mathrm{N}, 159^{\circ} 46^{\prime} \mathrm{W}$; (map 59 ).

Local name reported in 1914 by A. G. Maddren (in Brooks, 1915, pl. 11), USGS.

Fisherman Chuck: water passage, extends $\mathrm{S} 1 \mathrm{mi}$. from Menefee Inlet, $0.5 \mathrm{mi}$. W of Menefee Point, on SE coast of Etolin I., Alex. Arch.; $56^{\circ} 03^{\prime} \mathrm{N}, 132^{\circ} 10^{\prime} \mathrm{W}$; (map 6).

Named by USC\&GS for charting purposes name published in 1924. See Salt Chuck, village.

Fisherman Cove: cove, $0.4 \mathrm{mi}$. across, on SW shore of Bay of Is., Adak I., Aleutian Is.; $51^{\circ} 47^{\prime} 50^{\prime \prime} \mathrm{N}, 176^{\circ} 50^{\prime} 00^{\prime \prime} \mathrm{W}$; BGN 1936; (map 17).

Named by members"of the U.S. Navy Aleutian Island Survey Expedition in 1933.

Fisherman Cove: cove, extends NE $0.8 \mathrm{mi}$. off Pacific Ocean, on $W$ coast of Dall I., Alex. Arch.; 55 $01^{\circ} 15^{\prime \prime} \mathrm{N}, 133^{\circ} 10^{\prime} 10^{\prime \prime} \mathrm{W}$; (map 4).

Local name published in 1923 by USC\&GS.

Fisherman Point: point of land, see Fisherman's Point.

Fishermans Harbor: estuary, $0.9 \mathrm{mi}$. long, $\mathrm{E}$ of Pole Anchorage, SW coast of Kosciusko I., Alex. Arch.; $55^{\circ} 58^{\prime} \mathrm{N}, 133^{\circ} 48^{\prime} \mathrm{W}$; (map 4). Var. Little Pole Anchorage.

Local name recorded in 1937 by USC\&GS.

Fishermans Point: point of land, on Brundage Head, on NE coast of Unalaska I., Aleutian Is. ; $53^{\circ} 56^{\prime} 15^{\prime \prime} \mathrm{N}, 166^{\circ} 13^{\prime} 30^{\prime \prime} \mathrm{W}$; BGN 1965 ; Var. Fisherman Point.

Name given by J. J. Gilbert, commander of the USC\&GS steamer Pathfinder during 1900-01.

Fishery Creek: stream, flows E $13 \mathrm{mi}$ to Chatham Strait, $8 \mathrm{mi}$. E of mouth of Tenakee Inlet, on
W coast of Admiralty I., $20 \mathrm{mi}$. $\mathrm{N}$ of Angoon,

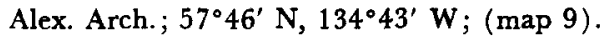

Local name reported in 1929 by USFS. "So named because a salmon fishing station was established at the mouth of the Creek by the Indians during the season of run" (U.S. Coast and Geodetic Survey, 1883, p. 179).

Fishery Point: bluff, elev. $75 \mathrm{ft}$., on $S$ bank of Naknek River, on Alaska Penin., $4.5 \mathrm{mi}$. E of Naknek, Bristol Bay Low.; 58 $43^{\circ} 45^{\prime \prime} \mathrm{N}$, $156^{\circ} 53^{\prime} 10^{\prime \prime} \mathrm{W}$; (map 41).

Local name reported in 1952 by USGS.

Fishery Point: point of land, on Chatham Strait, $8 \mathrm{mi}$. $\mathrm{E}$ of mouth of Tenakee Inlet, on Admiralty I., $10 \mathrm{mi}$. E of Tenakee Springs, Alex.

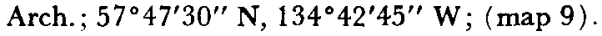

Local name published by USC\&GS in the 1883 Coast Pilot (p. 179). "So named because there was an Indian fishing station just to south on Fishery Creek."

Fish Hill: hill, $400 \mathrm{ft}$., on S coast of Kiska I., Aleutian Is.; $51^{\circ} 52^{\prime} 00^{\prime \prime} \mathrm{N}, 177^{\circ} 19^{\prime} 20^{\prime \prime} \mathrm{E}$; (map 14).

An arbitrary name beginning with " $F$ " to correspond to "F" grid used by the U.S. Army for tactical purposes during World War II ; published on a 1953 AMS map.

Fishhook: village, see Chalkyitsik.

Fishhook Bay: lagoon, trends $1.5 \mathrm{mi}$. $\mathrm{NE}$ to Kuiukta Bay, $14 \mathrm{mi}$. SW of Ship Mtn., on S shore of Alaska Penin., Aleutian Ra.; $56^{\circ} 01^{\prime}$ $\mathrm{N}, 158^{\circ} 39^{\prime} \mathrm{W}$; (map 30 ).

So named "because of the hook-shaped spit extending from the southeast entrance to lagoon"; name reported in 1951 by USGS.

Fishhook Bend: bend, at head of Sixtymile River, on Divide Mountain, $56 \mathrm{mi}$. N of Northway Junction, Yukon-Tanana High.; $63^{\circ} 47^{\prime} \mathrm{N}$, $141^{\circ} 14^{\prime} \mathrm{W}$; (map 85).

Descriptive name reported in 1956 by USGS.

Fishhook Bend: bend, of Porcupine River, 19 mi. NE of Coleen Mtn., Brooks Ra.; 67 $7^{\circ} 13^{\prime}$ $\mathrm{N}, 142^{\circ} 10^{\prime} \mathrm{W}$; (map 121$)$.

Name published by Kindle (1908, fig. 1), USGS.

Fishhook Creek: stream, heads in lake, flows SE $4.5 \mathrm{mi}$. to Little Susitna River, $11 \mathrm{mi}$. NW of Palmer, Talkeetna Mts.; $61^{\circ} 45^{\prime} 15^{\prime \prime} \mathrm{N}, 149^{\circ}$ $13^{\prime} 45^{\prime \prime} \mathrm{W}$; (map 69).

Local name reported in 1910 by F. J. Katz (in Brooks and others, 1911, fig. 18), USGS. Fishhook Creek: stream, flows SW $25 \mathrm{mi}$. to Black River, $0.5 \mathrm{mi}$. NE of Chalkyitsik, Yukon Flats; $66^{\circ} 38^{\prime} \mathrm{N}, 143^{\circ} 43^{\prime} \mathrm{W}$; (map 120).

Name derived from the former name for Chalkyitsik; reported in 1940 by FitzGerald (1944, pl. 18), USGS.

Fishhook Island: island, 1,500 ft. long, in South Pass, N of Passage I., Alex. Arch.; 55 $11^{\prime} 15^{\prime \prime}$ $\mathrm{N}, 132^{\circ} 52^{\prime} 35^{\prime \prime} \mathrm{W}$; (map 4).

Local name published in 1965 by USC\&GS.

Fishhook Junction: locality, at road junc. on Glenn Highway, $1.5 \mathrm{mi}$. N of Palmer, Cook Inlet Low.; $61^{\circ} 37^{\prime} 45^{\prime \prime} \mathrm{N}, 149^{\circ} 07^{\prime} 15^{\prime \prime} \mathrm{W}$; (map 69).

Local name reported in 1951 by USGS.

Fishhook Lake: lake, see Kings Lake.
Fishhook Ridge: ridge, on NE coast of Attu I., extends SW and E $4 \mathrm{mi}$. from West Peak to Mirror Lake, on E shore of Holtz Bay, Aleutian Is.; 52 $55^{\prime} 15^{\prime \prime} \mathrm{N}, 173^{\circ} 12^{\prime} 00^{\prime \prime} \mathrm{E}$; (map 13). Var. Fish Hook Ridge.

Descriptive name by U.S. Army during World War II; shown as "Fish Hook Ridge" on an AMS map published in 1948.

Fishhook Town: village, see Chalkyitsik.

Fishhook Village: village, see Chalkyitsik.

Fishing Bay: bay, see Fish Bay.

Fish Island: island. in Yukon River, $46 \mathrm{mi}$. E of Nulato, Koyukuk Low. ; $64^{\circ} 39^{\prime} \mathrm{N}, 156^{\circ} 30^{\prime} \mathrm{W}$; (map 97).

Riverboat pilots' name shown on a 1940 "Navigation Chart of the Tanana-Yukon Rivers" published by U.S. Dept. of Interior.

Fish Islands: islands, two, each $200 \mathrm{ft}$. long, in Felice Strait, near $W$ entrance to Cat Passage, Alex. Arch.; $55^{\circ} 00^{\prime} 30^{\prime \prime} \mathrm{N}, 131^{\circ} 19^{\prime} 00^{\prime \prime}$ W; (map 3$)$. Var. Fish Islet.

This feature was named "Fish Islet" by Lt. Comdr. H. E. Nichols, USN, in 1883.

Fish Islet: islands, see Fish Islands.

Fish Lake: lake, $1 \mathrm{mi}$. long, in Glacier Bay National Monument, $0.3 \mathrm{mi}$. N of Lituya Bay and $88 \mathrm{mi}$. NW of Hoonah, Malaspina Coastal Plain; $58^{\circ} 38^{\prime} 45^{\prime \prime} \mathrm{N}, 137^{\circ} 38^{\prime} 00^{\prime \prime} \mathrm{W}$; (map $10)$.

Local name published by USGS in the 1950's.

Fish Lake: lake, $0.1 \mathrm{mi}$. long, on Latouche I., $18 \mathrm{mi}$. SE of Chenega, Chugach Mts.; $60^{\circ} 02^{\prime}$ $29^{\prime \prime} \mathrm{N}, 147^{\circ} 53^{\prime} 45^{\prime \prime} \mathrm{W}$; (map 63).

Local name reported in 1909 by Grant and Higgins (1910, pl. 12), USGS.

Fish Lake: lake, $0.5 \mathrm{mi}$. long, on Kenai Penin. NW of Waterfowl Lake, 22 mi. NE of Kenai, Cook Inlet Low.; $60^{\circ} 43^{\prime} 30^{\prime \prime} \mathrm{N}, 150^{\circ} 43^{\prime} 30^{\prime \prime}$ $\mathrm{W}$; (map 62).

Named about 1963 by officials of Kenai National Moose Range, for administrative purposes.

Fish Lake: lake, $0.2 \mathrm{mi}$. long, $1.1 \mathrm{mi}$. S of Sixmile Lake and $4.7 \mathrm{mi}$. NE of Anchorage, Cook Inlet Low.; $61^{\circ} 16^{\prime} 24^{\prime \prime} \mathrm{N}, 149^{\circ} 48^{\prime} 20^{\prime \prime} \mathrm{W}$; (map 69).

Local name reported in 1952 by USGS.

Fish Lake: lake, $0.5 \mathrm{mi}$. long, $22 \mathrm{mi}$. NE of Palmer, between Castle Mtn. and Glenn Highway, Talkeetna Mts.; $61^{\circ} 47^{\prime} 05^{\prime \prime} \mathrm{N}, 148^{\circ} 33^{\prime}$ 40 " $\mathrm{W}$; (map 69).

Local name reported in 1942 by AMS

Fish Lake: lake, $0.6 \mathrm{mi}$. long, $\mathrm{N}$ of Glenn Highway, $34 \mathrm{mi}$. W of Glennallen, Copper River Basin; $62^{\circ} 03^{\prime} \mathrm{N}, 146^{\circ} 32^{\prime} \mathrm{W}$; (map 83).

Local name reported in 1949 by USGS.

Fish Lake: lake, $1 \mathrm{mi}$. long, in course of Birch Creek, $4.7 \mathrm{mi}$. S of Talkeetna, Cook Inlet Low.; $62^{\circ} 15^{\prime} 05^{\prime \prime} \mathrm{N}, 150^{\circ} 03^{\prime} 45^{\prime \prime} \mathrm{W}$; (map 81).

Local name reported by Alaska RR. surveyors in 1917.

Fish Lake: lake, $4.5 \mathrm{mi}$. long, in course of Dog Creek $1 \mathrm{mi}$. $\mathrm{S}$ of its junc. with West Fork Gulkana River, $30 \mathrm{mi}$. NNW of Glennallen, Copper River Basin; $62^{\circ} 33^{\prime} \mathrm{N}, 145^{\circ} 51^{\prime} \mathrm{W}$ : (map 83) 
Name reported by D. C. Witherspoon (in Moffit, 1912, pl. 1), USGS.

Fish Lake: lake, $2.5 \mathrm{mi}$. long, $2.5 \mathrm{mi}$. E of Northway, Alaska Ra.; 62 $57^{\prime} \mathrm{N}, 141^{\circ} 50^{\prime} \mathrm{W}$; (map 84).

Local name reported in 1954 by USGS.

Fish Lake: lake, $4 \mathrm{mi}$. long, $\mathrm{E}$ of Tetlin Lake, $21 \mathrm{mi}$. SE of Tok, Alaska Ra.; $63^{\circ} 02^{\prime} 30^{\prime \prime} \mathrm{N}$, $142^{\circ} 36^{\prime} 00^{\prime \prime} \mathrm{W}$; ( $\operatorname{map} 85$ ).

Local name reported in 1964 by USGS.

Fish Lake: lake, 2 mi. long, drains $\mathrm{N}$ to Eureka Creek, $20 \mathrm{mi}$. NW of Paxson, Alaska Ra.; $63^{\circ} 13^{\prime} 45^{\prime \prime} \mathrm{N}, 145^{\circ} 59^{\prime} 45^{\prime \prime} \mathrm{W}$; (map 86).

Name published on relatively recent maps.

Fish Lake: lake, $2.7 \mathrm{mi}$. long, in course of Little Fish Creek, $6 \mathrm{mi}$. N of Tanacross, YukonTanana High.; $63^{\circ} 28^{\prime} \mathrm{N}, 143^{\circ} 16^{\prime} \mathrm{W}$; (map 85).

Local name reported in 1950 by USGS.

Fish Lake: lake, $1 \mathrm{mi}$. long, $0.5 \mathrm{mi}$. NNE of Big Lake and $24 \mathrm{mi}$. SSW of village of Lake Minchumina, Tanana Low.; $63^{\circ} 32^{\prime} 45^{\prime \prime} \mathrm{N}, 152^{\circ}$ $30^{\prime} 00^{\prime \prime}$ W ; (map 88). Var. White Fish Lake.

Local name reported in 1954 by USGS.

Fish Lake: lake, $0.8 \mathrm{mi}$. long, $\mathrm{SW}$ of Knob Ridge, $43 \mathrm{mi}$. NW of Tok, Alaska, Ra.; $63^{\circ} 33^{\prime} 30^{\prime \prime} \mathrm{N}$, $144^{\circ} 17^{\prime} 20^{\prime \prime} \mathrm{W}$; BGN 1961; (map 86).

Local name reported in 1958 by USGS.

Fish Lake: lake, $3.5 \mathrm{mi}$. across, at head of Fish Greek, $21 \mathrm{mi}$. ESE of Tanana, Yukon-Tanana High.; $65^{\circ} 04^{\prime} \mathrm{N}, 151^{\circ} 21^{\prime} \mathrm{W}$; (map 106).

Prospectors' name reported in 1906 by USGS (Prindle, 1908, p. 5).

Fish Lake: lake, $3 \mathrm{mi}$. NW of Long Lake and $7 \mathrm{mi}$. E of Roundabout Mtn., Koyukuk Low.; $65^{\circ} 35^{\prime} \mathrm{N}, 156^{\circ} 20^{\prime} \mathrm{W}$; (map 108).

Local name obtained at Huslia by USGS in 1954 or 1955.

Fish Lake: lake, see Big Lake.

Fish Lake Creek: stream, heads in northernmost Fish Lakes, flows S $4.6 \mathrm{mi}$. to Yentna River, $59 \mathrm{mi}$. N of Tyonek, Cook Inlet Low.; 61 ${ }^{\circ} 55^{\prime}$ $30^{\prime \prime} \mathrm{N}, 150^{\circ} 57^{\prime} 30^{\prime \prime} \mathrm{W}$; (map 70).

Local name reported in 1954 by USGS.

Fish Lakes: lakes, extend $3.5 \mathrm{mi}$. in course of Fish Lake Creek, $59 \mathrm{mi}$. N of Tyonek, Cook Inlet Low.; $61^{\circ} 57^{\prime} 10^{\prime \prime} \mathrm{N}, 150^{\circ} 57^{\prime} 30^{\prime \prime} \mathrm{W}$; (map 70).

Local name reported in 1954 by USGS

Fish Lakes: lakes, in course of Moose Creek, 10 mi. SE of Northway, Alaska Ra.; $62^{\circ} 48^{\prime} 30^{\prime \prime} \mathrm{N}$, $141^{\circ} 52^{\prime} 00^{\prime \prime} \mathrm{W}$; (map 84).

Local name reported in 1954 by USGS.

Fishless Creek: stream, flows NW $4 \mathrm{mi}$. to North Fork Koyukuk River, $5 \mathrm{mi}$. SW of Boreal Mtn. and $34 \mathrm{mi}$. NW of Wiseman, Brooks Ra.; $67^{\circ}$ $46^{\prime} 30^{\prime \prime} \mathrm{N}, 150^{\circ} 56^{\prime} 00^{\prime \prime} \mathrm{W}$; BGN 1932; (map 124).

Named in 1932 by Robert Marshall "because no fish were caught in the stream."

Fish Mountain: mountain, 2,624 ft., on Revillagigedo I., $2.5 \mathrm{mi}$. NE of Ketchikan, Alex. Arch.; 55 $22^{\prime} 40^{\prime \prime} \mathrm{N}, 1^{\circ} 31^{\circ} 36^{\prime} 15^{\prime \prime} \mathrm{W}$; (map 3).

Named in 1883 by Lt. Comdr. H. E. Nichols, USN.

Fishnet Lake: lake, $3.5 \mathrm{mi}$. long, between Clochacohua and Gushiate Lakes, $18 \mathrm{mi}$. NE of Stevens Village, Y'ukon Flats; $66^{\circ} 15^{\prime} \mathrm{N}$, $148^{\circ} 50^{\prime} \mathrm{W}$; (map 118).

Local name reported in 1956 by $T$. E. Taylor.

Fish Point: point of land, on N bank of Chickamin River at Behm Canal, Coast Mts.; $55^{\circ}$ $48^{\prime} \mathrm{N}, 130^{\circ} 59^{\prime} \mathrm{W}$; (map 3$)$.

One of many arbitrary names applied to features in this area in 1891 by USC\&GS.

Fish Point: point of land, $\mathrm{N}$ entrance to Fish Bay, at W end of Peril Strait, on Baranof I., $26 \mathrm{mi}$. NW of Sitka, Alex. Arch.; 57 $23^{\prime} 25^{\prime \prime}$ $\mathrm{N}, 135^{\circ} 37^{\prime} 30^{\prime \prime} \mathrm{W}$; (map 9). Var. Mys Rybnyy, Point Ribni.

Named "Mys Rybnyy", meaning "fish cape," in 1848 by the Russian Hydrog. Dept.; published on its Chart 1397.

Fishrack Bay: bay, $2.5 \mathrm{mi}$. wide, the northeast arm of Mitrofania Bay, $23 \mathrm{mi}$. SW of Chignik, on $\mathrm{S}$ shore of Alaska Penin., Aleutian Ra.; $55^{\circ} 59^{\prime} \mathrm{N}, 158^{\circ} 45^{\prime} \mathrm{W}$; (map 27).

Name published in 1963 by USGF.

Fish River: stream, flows NW $28 \mathrm{mi}$. to Highpower Creek, $33 \mathrm{mi}$. SW of village of Lake Minchumina, Kuskokwim Low. ; $63^{\circ} 28^{\prime} 30^{\prime \prime} \mathrm{N}$, $152^{\circ} 53^{\prime} 10^{\prime \prime} \mathrm{W}$; (map 88).

Name obtained locally in 1962 from Fabian Carey and "Val" Blackburn by USGS.

Fish River: stream, heads in Bendeleben Mts., flows S $47 \mathrm{mi}$. to Golovnin Lagoon, $35 \mathrm{mi}$. E of Solomon, Seward Penin. High.; 64'35' N, $163^{\circ} 21^{\prime}$ W; BGN 1911; (map 95). Var. Ekathlic, Erathlic, Icathluik, Ikakhtulik, Ikalikhvik, Ikathluik, Ikeutpak, Iksutpak, Irathluik, Kusluik, Nusluik.

Eskimo name reported in 1838 as "Ikalikhvik" meaning "fish or fish place" by Kashevarov. Various spellings were reported by Western Union Telegraph Expedition 1865-67. Dall (1870, p. 284) appears to be the first to have applied the name "Fish River" when he wrote: "Golofnina Bay is connected with a large lagoon which opens in Grantley Harbor by the extremely winding channel of the Fish River, which has one principal tributary, the Kávi-áva-zak." Dall's application heads the Fish River on what is now the Niukluk River.

Fish River: stream, flows SW $30 \mathrm{mi}$. to the Buckland River, $49 \mathrm{mi}$. NE of Haycock, Nulato Hills; 65'51' $N, 160^{\circ} 26^{\prime} W$; (map 109). Var. Reka Ikeut.

Local name obtained in 1900 by USGS.

Fish River: stream, flows SW $24 \mathrm{mi}$. to a lake, 5 mi. NE of Selawik, Kotzebue-Kobuk Low.; $66^{\circ} 40^{\prime} \mathrm{N}, 159^{\circ} 58^{\prime} \mathrm{W}$; (map 114).

Local name reported by the U.S. Army Corps of Engineers in 1955.

Fish River: stream, see Eaton River.

Fish Rock: rock, at $\mathrm{W}$ point of entrance to Margaret Bay, in Iliuliuk Harbor, on $S$ coast of Amaknak I., off $\mathrm{N}$ coast of Unalaska I., Aleutian Is.; $53^{\circ} 52^{\prime} 59^{\prime \prime} \mathrm{N}, 166^{\circ} 32^{\prime} 48^{\prime \prime} \mathrm{W}$; (map 23).

Named by W. H. Dall, USC\&GS, in 1871, but not shown on recent maps.

Fish Slough: stream, an anabranch of Yukon River, flows W $10 \mathrm{mi}$., $3 \mathrm{mi}$. $S$ of Beaver,
Yukon Flats; $66^{\circ} 18^{\prime} 40^{\prime \prime} \mathrm{N}, 147^{\circ} 03^{\prime} 00^{\prime \prime} \mathrm{W}$; (map 118).

Local name obtained in 1956 by USGS.

Fishtrap Lake: lake, 2 mi. long, on Little Mulchatna River, $38 \mathrm{mi}$. NE of Nondalton, Alaska Ra.; $60^{\circ} 29^{\prime} 30^{\prime \prime} \mathrm{N}, 154^{\circ} 20^{\prime} 00^{\prime \prime} \mathrm{W}$; (map 61). Local name reported in 1954 by USGS.

Fish Village: locality, on $\mathrm{W}$ bank of Newhalen River, at $S$ end of Sixmile Lake, $1.5 \mathrm{mi}$. $\mathrm{S}$ of Nondalton, Aleutian Ra. ; $59^{\circ} 56^{\prime} 45^{\prime \prime} \mathrm{N}, 154^{\circ}$. 51'30"' W; (map 51$)$.

Local name reported by P. S. Smith (1917, pl. 1), USGS.

Fish Village: village, on right bank of Kwikpak Pass, $26 \mathrm{mi}$. SE of Kwiguk, Yukon-Kuskokwim Delta; $62^{\circ} 31^{\prime} 15^{\prime \prime} \mathrm{N}, 163^{\circ} 50^{\prime} 50^{\prime \prime} \mathrm{W}$; (map 77).

Eskimo settlement that had a population of 27 in 1940 .

Fitch Creek: stream, see Chokosna River.

Fitz Creek: stream, on Iniskin Penin., flows NE $8 \mathrm{mi}$. to Ghinitna Bay, Aleutian Ra.; $59^{\circ}$ $48^{\prime} 30^{\prime \prime} \mathrm{N}, 153^{\circ} 09^{\prime} 00^{\prime \prime} \mathrm{W}$; (map 51$)$.

Named in 1922 by USGS for Gerald FitzGerald, USGS, topographer, who spent several seasons doing field work in Alaska.

Fitzgerald Island: island, $0.3 \mathrm{mi}$. across, off SE shore of Yakutat Bay, $0.6 \mathrm{mi}$. E of $\mathrm{S}$ tip of Dolgoi I. and $4.2 \mathrm{mi}$. NE of Yakutat, Malaspina Coastal Plain; $59^{\circ} 35^{\prime} 50^{\prime \prime} \mathrm{N}, 1^{\circ} 9^{\circ} 39^{\prime} 30^{\prime \prime}$ W; (map 46).

Named in 1892 by Lt. G. B. Harber, USN, for C. W. Fitzgerald, one of his party.

Fitzgibbon, Point: point of land, on mainland, $E$ point of entrance to Burroughs Bay from Behm Canal, Coast Ra.; $55^{\circ} 59^{\prime} \mathrm{N}, 131^{\circ} 13^{\prime}$ W; (map 3).

Named by Capt. George Vancouver, RN, "August 10,1793, no doubt in honor of John Fitzgibbon, Earl of Clare, Lord Chancellor of India in 1789" (Wagner, 1937, p. 388).

Fitzgibbon Cove: estuary, extends $\mathrm{N} 1.8 \mathrm{mi}$. off Behm Canal, $1.4 \mathrm{mi}$. SE of Point Fitzgibbon, Coast Mts.; 55 $57^{\prime} 45^{\prime \prime} \mathrm{N}, 131^{\circ} 11^{\prime} 15^{\prime \prime} \mathrm{W}$; (map 3).

Named in 1891 by USC\&GS.

Fitz Island: island, $0.2 \mathrm{mi}$. long, in Kimshan Cove, $2 \mathrm{mi}$. NW of Chichagof, on $\mathrm{W}$ coast of Chichagof I., Alex. Arch.; 57 $41^{\prime} 20^{\prime \prime} \mathrm{N}$, $136^{\circ} 07^{\prime} 20^{\prime \prime} \mathrm{W} ; B G N$ 1908; (map 9)

Named in 1908 by USC\&GS and published in the 1908 Coast Pilot (p. 174).

Five, Lake: lake, 1,700 ft. long, between Lake Four and Question Lake, $7 \mathrm{mi}$. S of Talkeetna, Cook Inlet Low.; $62^{\circ} 13^{\prime} 05^{\prime \prime} \mathrm{N}, 150^{\circ} 04^{\prime} 00^{\prime \prime}$ W; (map 81).

Local descriptive name reported in 1958 by USGS.

Five Day Slough: stream, see Atchuelinguk River.

Fivefathom Patch: shoal, $200 \mathrm{ft}$. across, in central Redfish Bay, $9.5 \mathrm{mi}$. NW of village of Port Alexander, on $S$ coast of Baranof I., Alex. Arch.; 56 $18^{\prime} 45^{\prime \prime} \mathrm{N}, 134^{\circ} 51^{\prime} 50^{\prime \prime} \mathrm{W}$; (map 5).

Named in 1897 by Lt. Comdr. J. F. Moser, USN, commander of USBF steamer Albatross.

Five Fingers, The: group of islands, in $\mathrm{S}$ entrance to Stephens Passage, 5 mi. NW of Whitney I. 
and $67 \mathrm{mi}$. E of Sitka, Alex. Arch.; 57 $17^{\prime} 30^{\prime \prime}$ N, $133^{\circ} 40^{\prime} 15^{\prime \prime}$ W; (map 8).

Descriptive name given in 1869 by Comdr. R. W. Meade, USN, “*** perhaps on account of its appearance from certain points of view" (U.S. Coast and Geodetic Survey, 1883, p. 129).

Fivemile Creek: stream, flows SE $4 \mathrm{mi}$ to Frederick Sound, on E coast of Lindenberg Penin., Kupreanof I., $5 \mathrm{mi}$. N of Petersburg, Alex. Arch.; 56 $53^{\prime} 00^{\prime \prime} \mathrm{N}, 132^{\circ} 57^{\prime} 45^{\prime \prime} \mathrm{W}$; (map 6).

Local name recorded in 1951 by USGS.

Fivemile Creek: stream, flows NE $7 \mathrm{mi}$. to Copper River, $5 \mathrm{mi}$. N of Chitina and $68 \mathrm{mi}$. NE of Valdez, Chugach Mts.; 61 $35^{\prime} 15^{\prime \prime} \mathrm{N}$, $144^{\circ} 25^{\prime} 50^{\prime \prime} \mathrm{W}$; (map 68).

Local name published in the 1950's by USGS.

Fivemile Hill: hill, see Fourmile Hill.

Fivemile Island: island, $0.2 \mathrm{mi}$. long, $5 \mathrm{mi}$. W of Wrangell, Alex. Arch.; $56^{\circ} 28^{\prime} 10^{\prime \prime} \mathrm{N}, 132^{\circ}-$ $30^{\prime} 40^{\prime \prime}$ W; (map 6). Var. Five Mile Island, Ostrov Pyati Milnyy, Piatimilni Island, Scraggy Island.

Translation of Russian name "Ostrov Pyati-Milnyy" given in 1863 by the surveyors from the corvette Rynda. "Scraggy Island" was applied to this feature in 1868 by Comdr. R. W. Meade, USN. See Rynda Island.

Fivemile Lake: lake, $4 \mathrm{mi}$. NW of Boat Lake and $17 \mathrm{mi}$. NE of Roundabout Mtn., Koyukuk Low.; $65^{\circ} 45^{\prime} \mathrm{N}, 156^{\circ} 13^{\prime} \mathrm{W}$; (map 108).

Local name reported by Orth in 1957; so called because the lake was thought to be 5 miles from Huslia.

Fivemile Point: point of land, on Norton Sound, $5 \mathrm{mi}$. SE of St. Michael, Yukon-Kuskokwim Delta; $63^{\circ} 27^{\prime} \mathrm{N}, 161^{\circ} 54^{\prime} \mathrm{W}$; (map 91).

So called "because it is the place where the winter trail leaves the shore and crosses the bay five miles from Saint Michael;" reported in 1952 by USC\&GS.

Five Rivers: delta, see Dry Bay.

Five Sheep Creek: stream, flows SW $2 \mathrm{mi}$. to Elliott Creek, $1.9 \mathrm{mi}$. SW of Sheep Mtn. and $78 \mathrm{mi}$. NE of Valdez, Wrangell Mts.; $61^{\circ}$ $39^{\prime} 55^{\prime \prime} \mathrm{N}, 144^{\circ} 10^{\prime} 30^{\prime \prime} \mathrm{W}$; (map 68).

Local name reported in 1907 by A. G. Maddren, USGS.

Fixem Lake: lake, $300 \mathrm{ft}$. across, on southern Kiska I., Aleutian Is.; $51^{\circ} 52^{\prime} 30^{\prime \prime} \mathrm{N}, 177^{\circ} 18^{\prime}$ 18" E; (map 14).

An arbitrary name beginning with " $F$ " to correspond to " $F$ " grid used by the U.S. Army for tactical purposes during World War II; published on a 1953 AMS map.

Flag Creek: stream, heads on Mount Kilskon, flows SW $5.1 \mathrm{mi}$. to East Fork Yentna River, $54 \mathrm{mi}$. W of Talkeetna, Alaska Ra.; $62^{\circ} 19^{\prime} 50^{\prime \prime}$ N, $151^{\circ} 48^{\prime} 00^{\prime \prime} \mathrm{W}$; $(\operatorname{map} 81)$.

Prospectors' name reported in 1911 by $\mathbf{S}$. R. Capps (in Brooks, 1912, pl. 9), USGS.

Flag Crossing: crossing, on Tanana River, $8 \mathrm{mi}$. downstream from mouth of Kantishna River, Tanana Low., $64^{\circ} 49^{\prime} 45^{\prime \prime} \mathrm{N}, 150^{\circ} 09^{\prime} 30^{\prime \prime} \mathrm{W}$; (map 99).

Riverboat crossing (a shift from one side of the stream to the other) published on a
1940 "Navigation Chart of the Tanana-Yukon Rivers" by U.S. Dept. of Interior.

Flag Hill: hill, $600 \mathrm{ft}$., $0.4 \mathrm{mi}$. SE of Farmer Hill, on SW part of Kiska I., Aleutian Is.; $51^{\circ} 53^{\prime} 40^{\prime \prime} \mathrm{N}, 177^{\circ} 18^{\prime} 45^{\prime \prime} \mathrm{E}$; (map 14).

An arbitrary name beginning with " $F$ " to correspond to " $F$ " grid used by the U.S. Army for tactical purposes during World War II; published on a 1953 AMS map.

Flag Hill: hill, $1,445 \mathrm{ft}$., on $\mathrm{E}$ bank of Tanana River, $W$ of Harding Lake, $37 \mathrm{mi}$. NW of Big Delta, Tanana Low.; $64^{\circ} 25^{\prime} \mathrm{N}, 146^{\circ} 57^{\prime} \mathrm{W}$; (map 101).

Descriptive name given in 1898 by Brooks (1900, map 23), USGS. The name is not shown on recent USGS maps.

Flag Hill: hill, $250 \mathrm{ft}$., on W bank of Ogotoruk Creek, $6.5 \mathrm{mi}$. E of Cape Thompson, Arctic Slope; $68^{\circ} 07^{\prime} 50^{\prime \prime} \mathrm{N}, 165^{\circ} 43^{\prime} 50^{\prime \prime}$ iN; $B G N$ 1963; (map 129).

Named about 1962 by personnel of Project Chariot.

Flag Point: point of land, E coast of Duke I., Alex. Arch.; 54 $58^{\prime} 00^{\prime \prime} \mathrm{N}, 131^{\circ} 14^{\prime} 15^{\prime \prime} \mathrm{W}$; (map 2).

Local name published in 1917 by USC\&GS.

Flag Point: point of land, on SW shore of Whitewater Bay, on Admiralty I., $18 \mathrm{mi}$. S of Angoon, Alex. Arch.; $57^{\circ} 14^{\prime} 00^{\prime \prime} \mathrm{N}, 134^{\circ} 36^{\prime}$ $10^{\prime \prime} \mathrm{W}$; (map 9).

Named in 1881 by Comdr. Henry Glass, USN, and published by USC\&GS in the 1883 Coast Pilot (p. 174).

Flag Point: point of land, on right bank of Copper River, $26 \mathrm{mi}$. NW of Katalla, Malaspina Coastal Plain; $60^{\circ} 27^{\prime} \mathrm{N}, 1^{\circ} 5^{\circ} 05^{\prime} \mathrm{W}$; (map 64).

Local name published in 1952 by USGS. Flag Point Station of the Copper River and Northwestern Railway was established on this point in 1911.

Flag Point Channel: stream, anabranch of Copper River, between Flag Point and Round I., $26 \mathrm{mi}$. NW of Katalla, Malaspina Coastal Plain; $60^{\circ} 26^{\prime} \mathrm{N}, 145^{\circ} 05^{\prime} \mathrm{W}$; (map 64).

Local name published in 1952 by USGS.

Flagstaff Creek: stream, heads on Granite Mtn., on $\mathrm{E}$ coast of Prince of Wales I., flows N 3.6 to Karta Lake, Alex. Arch.; 55 $33^{\prime} 30^{\prime \prime} \mathrm{N}$, $132^{\circ} 37^{\prime} 15^{\prime \prime} \mathrm{W}$; BGN 1960; (map 4).

Named by C. L. Sainsbury, USGS, in 1956, who stated "The name as such is not in local usage, but is always referred to as the 'creek that flows past the Flagstaff Mines.' The name is suggested by the Flagstaff Mine."

Flagstaff Hill: hill, $81 \mathrm{ft}$., at Unga, on Delarof Bay, on SE coast of Unga I., in Shumagin Is., Aleutian Ra.; 55 $10^{\prime} 54^{\prime \prime} \mathrm{N}, 160^{\circ} 30^{\prime} 13^{\prime \prime} \mathrm{W}$; (map 28).

Local name published by USC\&GS in 1916. So called because a flagpole was located on the hill.

Flahart Lake: lake, $0.5 \mathrm{mi}$. long, in Teocalli Mts., 4 mi. NE of junc. of South Fork Kuskokwim and Hartman Rivers and $94 \mathrm{mi}$. NW of Tyonek, Alaska Ra.; $61^{\circ} 59^{\prime} 30^{\prime \prime} \mathrm{N}, 153^{\circ} 12^{\prime}$ $30^{\prime \prime} \mathrm{W}$; (map 71).

Local name reported in 1958 by USGS.
Flambeau Creek: stream, see Flambeau River.

Flambeau River: stream, flows SE $23 \mathrm{mi}$. to Safety Sound, $15 \mathrm{mi}$. SW of Solomon, Seward Penin. High.; $64^{\circ} 28^{\prime} \mathrm{N}, 164^{\circ} 53^{\prime} \mathrm{W}$; (map 95). Var. Discovery Creek, Flambeau Creek. Shown as "Discovery Creek" by Schrader and Brooks (1900, map 3), USGS.

Flanner Glacier: glacier, see Battle Glacier.

Flapjack Island: island, $0.5 \mathrm{mi}$. long, $\mathrm{N}$ end of Beardslee Is. in Glacier Bay, Glacier Bay National Monument, $5 \mathrm{mi}$. NW of Strawberry I. and $59 \mathrm{mi}$. NW of Juneau, St. Elias Mts.; $58^{\circ}$ $35^{\prime} 15^{\prime \prime} \mathrm{N}, 135^{\circ} 56^{\prime} 30^{\prime \prime} \mathrm{W}$; BGN 1948; (map 11).

Descriptive name given by USC\&GS in 1942. So named because the island is in shallow water and at low tide "spreads out" like thin batter on a griddle.

Flat: settlement, pop. 27, on Otter Creek, $7 \mathrm{mi}$. $\mathrm{E}$ of junc. with Iditarod River, $59 \mathrm{mi}$. NE of Holy Cross, Kilbuck-Kuskokwim Mts.; $62^{\circ} 27^{\prime} 30^{\prime \prime} \mathrm{N}, 158^{\circ} 00^{\prime} 30^{\prime \prime} \mathrm{W}$; (map 79). Var. Flat City, Flat Creek.

Mining camp reported in 1910 by A. G. Maddren, USGS, at which time Flat was the leading settlement on Otter Creek with a population of about 400 . The post office has been in operation since 1912 . Its population was 158 in 1920 and 124 in 1930.

Flat Bay: cove, $1 \mathrm{mi}$. long, on $\mathrm{E}$ coast of Chilkat Penin., $4 \mathrm{mi}$. S of Battery Point and $22 \mathrm{mi}$. S of Skagway, Coast Mts.; $59^{\circ} 09^{\prime} 00^{\prime \prime}$ $\mathrm{N}, 135^{\circ} 20^{\prime} 30^{\prime \prime} \mathrm{W}$; BGN 1966; (map 45). Var. Mud Bay.

Local name reported by USGS in 1952 . It was published in 1923 as "Flat Bay" on IBC Sheet 9 (1951 atlas). According to E. C. Robertson the name "Mud Bay" is now commonly used.

Flat Bight: cove, $2 \mathrm{mi}$. across, on $\mathrm{SW}$ coast of Akutan I., Aleutian Is.; $54^{\circ} 04^{\prime} 45^{\prime \prime} \mathrm{N}$, $166^{\circ} 03^{\prime} 30^{\prime \prime} \mathrm{W}$; (map 23).

Descriptive name, given by J. J. Gilbert, Comdr. of the USC\&GS steamer Pathfinder during 1900-01.

Flat Cape: promontory, extends $\mathrm{N}$ to $\mathrm{S} 3 \mathrm{mi}$. along shore of Kuskokwim Bay, $1.5 \mathrm{mi}$. W of Thorsen Mtn. and $23 \mathrm{mi}$. NE of Cape Newenham, Kilbuck-Kuskokwim Mts.; $58^{\circ} 53^{\prime} \mathrm{N}$, $161^{\circ} 47^{\prime} \mathrm{W}$; (map 39).

Descriptive name published in 1951 by USGS.

Flat City: settlement, see Flat.

Flat Cove: cove, $0.5 \mathrm{mi}$. across, in Slocum Arm, $1.5 \mathrm{mi}$. SE of Cobol, on Chichagof I., $16 \mathrm{mi}$. SE of Chichagof, Alex. Arch.; $57^{\circ} 28^{\prime} \mathrm{N}$, $135^{\circ} 50^{\prime}$ W; BGN 1908; (map 9). Var. Shoal Cove.

Named in 1908 by USC\&GS and published in 1910 on Chart 8250. It was named Shoal Cove by USC\&GS also because of the low flats at its head.

Flat Creek: stream, flows W $5 \mathrm{mi}$. to Keno Creek, $30 \mathrm{mi}$. N of Goodnews, Kilbuck-Kuskokwim Mts.; $59^{\circ} 33^{\prime} \mathrm{N}, 161^{\circ} 17^{\prime} \mathrm{W}$; (map 53).

Name reported in 1919 by G. L. Harrington (in Brooks and others, 1921, pl. 8), USGS. 
Flat Creek: stream, heads in lake, in Flat Creek Flats, flows NE $4.5 \mathrm{mi}$. to Beaver Creek in Nutzotin Mts., $5.5 \mathrm{mi}$. SE of Beaver Lake, Alaska Ra.; $62^{\circ} 00^{\prime} 25^{\prime \prime} \mathrm{N}, 141^{\circ} 38^{\prime} 10^{\prime \prime} \mathrm{W}$; (map 84)

Local descriptive name reported by Capps (1915, pl. 1), USGS.

Flat Creek: stream, flows S $4.7 \mathrm{mi}$. to its junc. with Dunlin Creek to form Crooked Creek, 15 mi. NW of village of Crooked Creek and 43 mi. NW of Sleetmute, Kilbuck-Kuskokwim Mts.; $62^{\circ} 04^{\prime} 45^{\prime \prime} \mathrm{N}, 158^{\circ} 13^{\prime} 00^{\prime \prime} \mathrm{W}$; $B G N$ 1944; (map 79).

Prospectors' name obtained in 1913 by Eakin (1914, pl. 1), USGS.

Flat Creek: stream, heads in Limestone Hills, flows NE $9.5 \mathrm{mi}$. to Little Nelchina River, 15 mi. $\mathrm{N}$ of Tahneta Pass and $65 \mathrm{mi}$. SW of Gulkana, Talkeetna Mts.; $62^{\circ} 06^{\prime} \mathrm{N}, 147^{\circ} 19^{\prime}$ W; (map 82)

Local name published by Theodore Chapin (in Brooks and others, 1915, fig. 3), USGS.

Flat Creek: stream, flows $\mathbf{N} 5 \mathrm{mi}$. to Otter Creek, $0.6 \mathrm{mi}$. W of Flat and $59 \mathrm{mi}$. NE of Holy Cross, Kilbuck-Kuskokwim Mts., 62 27' $15^{\prime \prime} \mathrm{N}$, $158^{\circ} 01^{\prime} 30^{\prime \prime} \mathrm{W}$; (map 79).

Name shown on a 1910 manuscript map of "Iditarod Placer Fields."

Flat Creek: stream, flows E $5 \mathrm{mi}$. to Ahtell Creek, $4.8 \mathrm{mi}$. NW of junc. of Copper and Slana Rivers, Alaska Ra.; $62^{\circ} 45^{\prime} 15^{\prime \prime} \mathbf{N}$, 1440.'20' W; BGN 1936; (map 83).

Local name reported in 1936 by USGS.

Flat Creek: stream, flows $\mathrm{S} 7.8 \mathrm{mi}$. to Von Frank Creek, 26 mi. NE of Medfra, Kilbuckkuskokwim Mts. ; $63^{\circ} 27^{\prime} \mathrm{N}, 154^{\circ} 26^{\prime} \mathrm{W}$; (map 89). Var. Wanita Creek.

Local name reported in 1955 by USGS.

Flat Creek: stream, in Kantishna Hills, flows N $7.5 \mathrm{mi}$. to Glacier Greek $3.5 \mathrm{mi}$. S of that stream's junc. with Bearpaw River and $13 \mathrm{mi}$. NNW of Wonder Lake, Alaska Ra.; 63 ${ }^{\circ} 41^{\prime} 25^{\prime \prime}$ $\mathrm{N}, 150^{\circ} 59^{\prime} 30^{\prime \prime} \mathrm{W}$; (map 88).

Name shown on a 1905 manuscript map of "Kantishna Gold Fields" by A. Friedrich, prospector.

Flat Creek: stream, flows SW $2 \mathrm{mi}$. to Timber Creek, $3.5 \mathrm{mi}$. SW of Poorman, KilbuckKuskokwim Mts. : $64^{\circ} 03^{\prime} \mathrm{N}, 155^{\circ} 36^{\prime} \mathrm{W}$; (map 98).

Local name reported in 1915 by $\mathrm{H}$. M. Eakin (in Brooks and others, 1916, pl. 10), USGS.

Flat Creek: stream, flows NW $3 \mathrm{mi}$. to Shaw Creek, $10 \mathrm{mi}$. NE of Big Delta, Tanana Low.; $64^{\circ} 15^{\prime} 45^{\prime \prime} \mathrm{N}, 145^{\circ} 45^{\prime} 00^{\prime \prime} \mathrm{W}$; (map 101).

Name derived from the Shaw Creek Flats through which the stream flows for almost its entire length. The name was reported in 1908 by J. W. Bagley, USGS.

Flat Creek: stream, flows S $3 \mathrm{mi}$. to Fortymile River, $35 \mathrm{mi}$. $\mathrm{S}$ of Eagle, Yukon-Tanana High.; $64^{\circ} 17^{\prime} 30^{\prime \prime} \mathrm{N}, 141^{\circ} 19^{\prime} 30^{\prime \prime} \mathrm{W}$; (map 102)

Named by prospectors; reported in 1911 by E. A. Porter (in Brooks and others, 1912, p. 217), USGS
Flat Creek: stream, flows SW $3.5 \mathrm{mi}$. to Long Creek, $7 \mathrm{mi}$. SW of Long and $29 \mathrm{mi}$. S of Ruby, Kilbuck-Kuskokwim Mts. ; $64^{\circ} 19^{\prime} 15^{\prime \prime}$

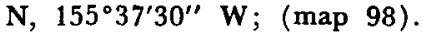

Prospectors' name reported in 1908 by A. G. Maddren, USGS. So called because the lower course of the stream is in a low wetland.

Flat Creek: stream, heads in Gooper Gulch, flows SW 2 mi. to lake at head of Center Creek, $2.5 \mathrm{mi}$. $\mathrm{N}$ of Nome, $64^{\circ} 32^{\prime} 15^{\prime \prime} \mathrm{N}, 165^{\circ} 23^{\prime} 40^{\prime \prime}$ W; (map 94).

Prospectors' name reported in 1904 by T. G. Gerdine, USGS.

Flat Creek: stream, flows NW $16 \mathrm{mi}$. to Salcha River, $32 \mathrm{mi}$. NW of Big Delta, Yukon-Tanana

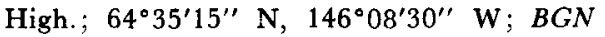
1964; (map 101). Var. McCoy Creek.

Local name originally applied by mistake by USGS to the stream now known as McCoy Creek (Capps, 1912, pl. 1).

Flat Creek: stream, flows SE $9 \mathrm{mi}$. to Chena River, $27 \mathrm{mi}$. E of Fairbanks, Yukon-Tanana High.; $64^{\circ} 52^{\prime} 15^{\prime \prime} \mathrm{N}, 146^{\circ} 46^{\prime} 00^{\prime \prime} \mathrm{W}$; (map 101).

Local name published in 1956 by USGS.

Flat Creek: stream, flows S $5 \mathrm{mi}$. to Ophir Creek, $12 \mathrm{mi}$. NW of Council and $39 \mathrm{mi}$. SW of Imuruk Lake, Seward Penin. High.; 65 ${ }^{\circ} 03^{\prime}$ $\mathrm{N}, 163^{\circ} 42^{\prime} \mathrm{W} ;(\operatorname{map} 110)$.

Prospectors' name published on the 1908 "Map of Seward Peninsula" by Arthur Gibson.

Flat Creek: stream, flows NE $6.1 \mathrm{mi}$. to Salman Creek, 22 mi. SW of Haycock, Seward Penin. High.; $65^{\circ} 08^{\prime} \mathrm{N}, 161^{\circ} 52^{\prime} \mathrm{W}$; (map 109).

Local name reported in 1917 by G. L. Harrington, USGS.

Flat Creek: stream, heads at junc. of Marks and Orthmer Creeks, flows NE $12 \mathrm{mi}$. to Charley River $9 \mathrm{mi}$. S of its junc. with Yukon River, Yukon-Tanana High.; $65^{\circ} 11^{\prime} 15^{\prime \prime} \mathrm{N}$, $142^{\circ} 47^{\prime} 40^{\prime \prime} \mathrm{W}$; (map 103).

Name used by prospectors; taken from an unpublished map by E. J. Chamberlain dated 1902.

Flat Creek: stream, flows NW $9 \mathrm{mi}$. to Chatanika River, $5 \mathrm{mi}$. NNE of Twin Buttes and $40 \mathrm{mi}$. NE of Fairbanks, Yukon-Tanana High.; $65^{\circ}$ $13^{\prime} 45^{\prime \prime} \mathrm{N}, 146^{\circ} 52^{\prime} 55^{\prime \prime} \mathrm{W}$; (map 104).

Named by prospectors and reported in 1907 by C. C. Covert (in Henshaw and Covert, 1908, pl. 9), USGS.

Flat Creek: stream, flows NW $2.5 \mathrm{mi}$. to Peace River, 5 mi. N of Haycock, Seward Penin. High.; $65^{\circ} 16^{\prime} \mathrm{N}, 161^{\circ} 07^{\prime} \mathrm{W}$; (map 109).

Local name reported in 1917 by G. L. Harrington, USGS.

Flat Creek: stream, flows SE 6 mi. to Agiapuk River, $7 \mathrm{mi}$. N of Imuruk Basin and $17 \mathrm{mi}$. $E$ of Teller, Seward Penin. High.; $65^{\circ} 17^{\prime} \mathrm{N}$, $165^{\circ} 49^{\prime} \mathrm{W}$; ( $\operatorname{map} 111$ ).

Prospectors' name reported on the 1908 "Map of Seward Peninsula" by Arthur Gibson.

Flat Creek: stream, flows SE $2 \mathrm{mi}$. to Hutlinana Creek, $18 \mathrm{mi}$. SE of Rampart, Yukon-Tanana High.; $65^{\circ} 18^{\prime} \mathrm{N}, 149^{\circ} 51^{\prime} \mathrm{W}$; (map 105).
Named by prospectors; published in 1906 by USGS.

Flat Creek: stream, flows SW $9 \mathrm{mi}$. to Agiapuk River, $13 \mathrm{mi}$. N of Imuruk Basin and $21 \mathrm{mi}$. NE of Teller, Seward Penin. High.; $65^{\circ} 21^{\prime}$ N, $165^{\circ} 39^{\prime} \mathrm{W}$; (map 111). Var. Chicago Greek.

Prospectors' name reported in 1901 by T. G. Gerdine (in Collier, 1902, pl. 12), USGS.

Flat Creek: stream, flows NW $1.5 \mathrm{mi}$, to Anikovik River, $15 \mathrm{mi}$. SE of Cape Prince of Wales and $40 \mathrm{mi}$. NW of Teller, Seward Penin. High.; $65^{\circ} 30^{\prime} \mathrm{N}, 167^{\circ} 38^{\prime} \mathrm{W}$; (map 111).

Prospectors' name reported in 1901 by T. G. Gerdine (in Collier, 1902, pl. 12), USGS.

Flat Creek: stream, flows NW $5.5 \mathrm{mi}$. to Moose Creek, $13 \mathrm{mi}$. NE of Livengood, YukonTanana High.; $65^{\circ} 39^{\prime} \mathrm{N}, 148^{\circ} 13^{\prime} \mathrm{W}$; (map 105).

Local name reported by J. B. Mertie (in Brooks and others, 1918, pl. 13), USGS.

Flat Creek: stream, flows NE $2.4 \mathrm{mi}$. to Indian River, $1.3 \mathrm{mi}$. E of Utopia and $48 \mathrm{mi}$. NE of Hochandochtla Mtn., Kokrines-Hodzana

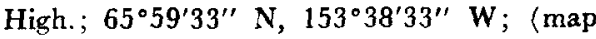
107).

Local name obtained in 1954 by USGS topographers.

Flat Creek: stream, flows NE $12 \mathrm{mi}$. to Big Creek, $28 \mathrm{mi}$. SE of Beaver, Yukon-Tanana High.; $66^{\circ} 05^{\prime} 25^{\prime \prime} \mathrm{N}, 146^{\circ} 38^{\prime} 15^{\prime \prime} \mathrm{W}$; (map 119).

Local name published in 1951 by USGS.

Flat Creek: stream, flows SW $28 \mathrm{mi}$. from S of Ackerman Lake to Chandalar River at Caro, $27 \mathrm{mi}$. SE of Chandalar, Brooks Ra.; $67^{\circ} 10^{\prime}$ $\mathrm{N}, 148^{\circ} 00^{\prime} \mathrm{W}$; (map 123 ).

Prospectors' name shown on an 1899 fieldsheet by T. G. Gerdine, USGS.

Flat Creek: stream, flows S $15 \mathrm{mi}$. to Wild River $\mathrm{E}$ of Mathews Dome, $7 \mathrm{mi}$. S of Wild Lake and $36 \mathrm{mi}$. W of Wiseman, Brooks Ra.; $67^{\circ} 23^{\prime} 30^{\prime \prime}$ N, $151^{\circ} 28^{\prime} 00^{\prime \prime} \mathrm{W}$; BGN 1932; (map 124).

Local name reported by Robert Marshall in 1932.

Flat Creek: settlement, see Flat.

Flat Creek: stream, see McCoy Creek.

Flat Creek Flats: valley, extends $5.6 \mathrm{mi}$. NE, along Flat Creek, $55 \mathrm{mi}$. NE of McCarthy, Alaska Ra.; $61^{\circ} 58^{\prime} \mathrm{N}, 141^{\circ} 41^{\prime} \mathrm{W}$; (map 67)

Local name published by USGS in 1954.

Flat Creek Lake: lake, $0.5 \mathrm{mi}$. long, at head of West Fork Flat Creek, $26 \mathrm{mi}$. S of Beaver, Yukon Flats; $66^{\circ} 00^{\prime} 15^{\prime \prime} \mathrm{N}, 147^{\circ} 01^{\prime} 30^{\prime \prime} \mathrm{W}$; (map 118).

Local name obtained in 1956 by USGS.

Flat Horn Lake: lake, $3 \mathrm{mi}$. long, $\mathrm{E}$ of Susitna River, $23 \mathrm{mi}$. NW of Anchorage, Cook Inlet Low.; $61^{\circ} 27^{\prime} 45^{\prime \prime} \mathrm{N}, 150^{\circ} 25^{\prime} 30^{\prime \prime} \mathrm{W}$; BGN 1962; (map 70). Var. Mud Lake.

Local name published in 1943 by AMS

Flatiron: ridge, elev. 11,600 ft., in Mount McKinley National Park, extends E from Pioneer Ridge to Muldrow Glacier, $5 \mathrm{mi}$. NNE of summit of Mount McKinley, Alaska Ra.; $63^{\circ} 08^{\prime}$ $15^{\prime \prime} \mathrm{N}, 150^{\circ} 57^{\prime} 00^{\prime \prime} \mathrm{W}$; (map 88).

Local name reported in 1954 by USGS 
Flat Island: island, $0.1 \mathrm{mi}$. across, in Pavlof Bay, Alaska Penin., Aleutian Ra.; $55^{\circ} 23^{\prime} 30^{\prime \prime} \mathrm{N}$, $161^{\circ} 37^{\prime} 00^{\prime \prime} \mathrm{W}$; (map 28).

Descriptive name published by USC\&GS in 1924.

Flat Island: island, $0.1 \mathrm{mi}$. long, in El Capi$\tan$ Passage, between El Capitan and Teal Is., Alex. Arch.; $55^{\circ} 55^{\prime} 30^{\prime \prime} \mathrm{N}, 133^{\circ} 20^{\prime} 45^{\prime \prime} \mathrm{W}$; (map 4).

Local name published in 1925 Coast Pilot (p. 154).

Flat Island: island, $0.5 \mathrm{mi}$. long, in Red Bay, on N coast of Prince of Wales I., Alex. Arch.; $56^{\circ} 18^{\prime} 45^{\prime \prime} \mathrm{N}, 133^{\circ} 19^{\prime} 30^{\prime \prime} \mathrm{W}$; (map 6).

Named in 1886 by Lt. J. M. Helm, USN, for charting purposes; name published in 1887 on USC\&GS Chart 706.

Flat Island: island, $0.5 \mathrm{mi}$. long, $2.6 \mathrm{mi}$. SE of Kaguyak on SE coast of Kodiak I.; $56^{\circ} 49^{\prime}$ $50^{\prime \prime} \mathrm{N}, 153^{\circ} 44^{\prime} 15^{\prime \prime} \mathrm{W}$; (map 33).

Descriptive name reported in the 1930's by USC\&GS

Flat Island: island, $0.1 \mathrm{mi}$. across, in Security Bay, on N coast of Kuiu I., Alex. Arch.; $56^{\circ}$ $52^{\prime} 05^{\prime \prime} \mathrm{N}, 134^{\circ} 21^{\prime} 30^{\prime \prime} \mathrm{W}$; (map 5).

Descriptive name given in 1869 by Comdr. R. W. Meade, USN, because of its shape.

Flat Island: island, $0.1 \mathrm{mi}$. long, in Port Wrangell, on S coast of Alaska Penin., $37 \mathrm{mi}$. NE of Sutwik I., Aleutian Ra.; $57^{\circ} 02^{\prime} 40^{\prime \prime} \mathrm{N}, 156^{\circ}$ $34^{\prime} 10^{\prime \prime} \mathrm{W}$; (map 36).

Local descriptive name published in 1956 by USGS.

Flat Island: island, $3.7 \mathrm{mi}$. across, in Iliamna Lake, W of Porcupine I., $23 \mathrm{mi}$. E of Iliamna, Aleutian Ra.; $59^{\circ} 44^{\prime} \mathrm{N}, 154^{\circ} 17^{\prime} \mathrm{W}$; (map 51).

Local descriptive name published in 1954 by USGS.

Flat Island: island, $0.4 \mathrm{mi}$. long, in Lake Clark, $0.7 \mathrm{mi}$. SW of Chi Point and $11 \mathrm{mi}$. NE of Nondalton, Aleutian Ra.; $60^{\circ} 06^{\prime} 20^{\prime \prime} \mathrm{N}, 154^{\circ}$ 33'30" W ; (map 61).

Local name reported in 1954 by USGS.

Flat Island: island, $0.9 \mathrm{mi}$. long, among offshore islands of Yukon Delta, between Acharon and Kwikluak Channels, $19 \mathrm{mi}$. SW of Kwiguk, Yukon-Kuskokwim Delta; $62^{\circ} 35^{\prime} 20^{\prime \prime} \mathrm{N}, 164^{\circ}$ $59^{\prime} 30^{\prime \prime} \mathrm{W}$; (map 77).

Local descriptive name reported in 1936 by U.S. Army Corps of Engineers.

Flat Island: island, $2 \mathrm{mi}$. long, in Yukon River along $S$ coast of Fox Point I., Innoko Low.; $63^{\circ} 01^{\prime} \mathrm{N}, 159^{\circ} 53^{\prime} \mathrm{W}$; (map 93).

Riverboat pilots' name shown on a 1940 "Navigation Chart of the Tanana-Yukon Rivers" published by the U.S. Dept. of Interior.

Flat Island: island, see Wolf Rock.

Flat Islands: islands, group of islands in Cook Inlet, $1 \mathrm{mi}$. W of SW end of Kenai Penin. and $13 \mathrm{mi}$. SW of Seldovia, Chugach Mts.; $59^{\circ}$ $19^{\prime} 45^{\prime \prime} \mathrm{N}, 151^{\circ} 59^{\prime} 45^{\prime \prime} \mathrm{W}$; (map 50). Var. Flat Islet.

Descriptive name given presumably by W. H. Dall, USC\&GS, in 1880.

Flat Islet: islands, see Flat Islands.
Flat Lake: lake, $0.6 \mathrm{mi}$. long, on Kenai Penin., $2.6 \mathrm{mi}$. NW of Lake Outka and $12 \mathrm{mi}$. NNE of Kenai, Cook Inlet Low.; 60 $42^{\prime} 45^{\prime \prime} \mathrm{N}$, $151^{\circ} 05^{\prime} 00^{\prime \prime} \mathrm{W}$; (map 62 ).

Named about 1963 by officials of Kenai National Moose Range, for administrative purposes.

Flat Lake: lake, $1.3 \mathrm{mi}$. lons, $\mathrm{W}$ of Big Lake, 22 mi. N of Anchorage, Cook Inlet Low.; $61^{\circ}$ $31^{\prime} 50^{\prime \prime} \mathrm{N}, 150^{\circ} 00^{\prime} 30^{\prime \prime} \mathrm{W}$; (map 70).

Local name reported in 1958 by USGS.

Flat Lake: lake, $1 \mathrm{mi}$. across, $2 \mathrm{mi}$. NW of Tanjoga Lake and $23 \mathrm{mi}$. NE of Stevens Village, Yukon Flats; $66^{\circ} 18^{\prime} \mathrm{N}, 148^{\circ} 40^{\prime} \mathrm{W}$; (map 118).

Local name obtained in 1956 by USGS.

Flat Mountain: mountain, 1,585 ft., E of Bostwick Inlet, on SE coast of Gravina I., Alex. Arch.; $55^{\circ} 14^{\prime} 50^{\prime \prime} \mathrm{N}, 131^{\circ} 42^{\prime} 40^{\prime \prime} \mathrm{W}$; (map 3 ).

Descriptive name published in 1885 by USC\&GS; "given because of its shape."

Flat Mountain: hill, $908 \mathrm{ft}$., $3.5 \mathrm{mi}$. NW of Dome Mtn., 4 mi. SE of Goodnews, KilbuckKuskokwim Mts.; $59^{\circ} 05^{\prime} 30^{\prime \prime} \mathrm{N}, 161^{\circ} 28^{\prime} 45^{\prime \prime}$ W; (map 53).

Descriptive name given in 1914 by USC\&GS; published in 1915 on Chart 9103.

Flat Point: point of land, on $\mathrm{N}$ shore of Nazan Bay, on $\mathbf{E}$ coast of Atka I., Aleutian Is.; $52^{\circ}$ $13^{\prime} 35^{\prime \prime} \mathrm{N}, 174^{\circ} 07^{\prime} 10^{\prime \prime} \mathrm{W}$; (map 18).

Name published by the USC\&GS on a 1943 coast chart.

Flat Point: point of land, in Portage Bay, $19 \mathrm{mi}$. NW of Petersburg, on N coast of Kupreanof I., Alex. Arch.; $56^{\circ} 59^{\prime} 45^{\prime \prime} \mathrm{N}, 133^{\circ} 20^{\prime} 00^{\prime \prime} \mathrm{W}$; (map 6).

Descriptive name given in 1882 by Lt. Comdr. H. E. Nichols, USN.

Flat Point: point of land, on $\mathrm{W}$ shore of Taku Inlet, $1.6 \mathrm{mi}$. $\mathrm{S}$ of Scow Cove and $13 \mathrm{mi}$. $\mathrm{E}$ of Juneau, Coast Mts. ; 58 $19^{\prime} 50^{\prime \prime} \mathrm{N}, 134^{\circ} 03^{\prime} 30^{\prime \prime}$ W; (map 11).

Descriptive name published in 1925 by USC\&GS on Chart 8300.

Flat Point: point of land, on left bank of Yukon River, across river from Kaltag, $32 \mathrm{mi}$. SW of Nulato, Koyukuk Low.; $64^{\circ} 20^{\prime} \mathrm{N}, 158^{\circ} 12^{\prime} \mathrm{W}$; (map 97).

Riverboat pilots' name shown on a 1940 "Navigation Chart of the Tanana-Yukon Rivers" published by the U.S. Dept. of Interior.

Flatrock Creek: stream, flows SE $15 \mathrm{mi}$. to East Fork Chandalar River, $33 \mathrm{mi}$. NE of Arctic Village, Brooks Ra.; $68^{\circ} 33^{\prime} \mathrm{N}, 145^{\circ} 02^{\prime} \mathrm{W}$; (map 136).

Local descriptive name obtained in 1956 by USGS.

Flat Top: point of land, see Lava Point.

Flat Top Mountain: mountain, 1,736 ft., $4.5 \mathrm{mi}$. $\mathrm{SE}$ of Chichagof, on W coast of Chichagof I., Alex. Arch.; $57^{\circ} 37^{\prime} \mathrm{N}, 136^{\circ} 00^{\prime} \mathrm{W}$; BGN 1939; (map 9). Var. Flattop Mountain.

Descriptive local name published in 1930 by USC\&GS as Flattop Mountain, on Chart 8280.

Flat Top Mountain: mountain, 2,000 ft., between Waterboot and Atsaksovluk Creeks, 82 mi. SW of Sleetmute, Kilbuck-Kuskokwim Mts.; $60^{\circ} 53^{\prime} \mathrm{N}, 158^{\circ} 52^{\prime} \mathrm{W}$; (map 60).

Local descriptive name reported in 1950 by USGS.

Flat Top Mountain: mountain, 4,679 ft., 6.3 mi. long, $W$ of Paxson Lake, Alaska Ra.; $62^{\circ}$. $55^{\prime} \mathrm{N}, 145^{\circ} 42^{\prime} \mathrm{W}$; (map 83).

Local descriptive name reported by USGS in 1950 .

Flattop Mountain: mountain, 3,55C ft., between South Fork Campbell and Rabbit Creeks, 11 mi. SE of Anchorage, Chugach Mts. ; $61^{\circ} 05^{\prime}-$ $25^{\prime \prime} \mathrm{N}, 149^{\circ} 40^{\prime} 05^{\prime \prime} \mathrm{W}$; BGN 1964; (map 69). Var. Flat Top Mountain.

Local descriptive name reported in 1963 by the Mountaineering Club of Alaska.

Flat Top Peak: mountain, 3,445 ft., on $\mathrm{W}$ part of Akutan I., Aleutian Is.; $54^{\circ} 06^{\prime} 45^{\prime \prime} \mathrm{N}$, $166^{\circ} 01^{\prime} 07^{\prime \prime}$. W ; (map 23). Var. Flattop Peak.

Descriptive name, given by J. J. Gilbert, USC\&GS, commander of the USC\&GS steamer Pathfinder during 1900-01.

Flat Top Peak: mountain peak, 9,000 ft., $1 \mathrm{mi}$. E of Mount Haley and $31 \mathrm{mi}$. NW of Valdez, Chugach Mts.; $61^{\circ} 26^{\prime} 00^{\prime \prime} \mathrm{N}, 146^{\circ} 55^{\prime} 35^{\prime \prime} \mathrm{W}$; $B G N 1965$; (map 68).

Descriptive name probably given in 1959 by L. E. Nielsen (1963, p. 135)

Flattop Peak: mountain, see Flat Top Peak.

Flaw Point: point of land, at entrance to Mole Harbor, on E coast of Admiralty I., $24 \mathrm{mi}$. NE of Angoon, Alex. Arch.; $57^{\circ} 40^{\prime} 30^{\prime \prime} \mathrm{N}, 134^{\circ}$. $02^{\prime} 40^{\prime \prime} \mathrm{W}$; ( $\left.\operatorname{map} 9\right)$.

Named in 1889 by Lt. Comdr. H. B. Mansfield, USN, and published by USC\&GS in the 1891 Coast Pilot (p. 144).

Flaxman Island: barrier island, $7 \mathrm{mi}$. long, between Beaufort Sea and Lion Bay, Arctic Plain; $70^{\circ} 11^{\prime} \mathrm{N}, 146^{\circ} 03^{\prime} \mathrm{W}$; (map 151). Var. Sidrak Island.

Named August 6, 1826, by Franklin (1828, p. 151), "in honour of the late eminent sculptor. It is about four miles long, and two broad, and rises, at its highest elevation, about fifty feet ***." John Flaxman, 17551826, was an English sculptor and draftsman, who will probably be remembered "best as the designer of the exquisite little cameos that stand out so charmingly in dead white on the dead blue background of Wedgwood pottery; ***" (Stuck, 1920, p. 289). The Eskimo name, "Sidrak," was reported in 1912 to mean "foxhole," by Leffingwell (1919, p. 95).

Flêches, Iles des: island, see Pinnacle Island.

Fleece Rock: island, $0.1 \mathrm{mi}$. long, at $\mathrm{S}$ end of Lord Is., in mouth of Nakat Bay, Coast Mts.; $54^{\circ} 43^{\prime} 30^{\prime \prime} \mathrm{N}, 130^{\circ} 47^{\prime} 15^{\prime \prime} \mathrm{W}$; (map 2).

Named in 1883 by Lt. Comdr. H. E. Nichols, USN.

Fleischmann Glacier: glacier, $1 \mathrm{mi}$. long, in Kichatna Mts., $0.8 \mathrm{mi}$. NE of Simpson Pass and $87 \mathrm{mi}$. W of Talkeetna 4laska Ra.; $62^{\circ}$ $20^{\prime} 40^{\prime \prime} \mathrm{N}, 152^{\circ} 50^{\prime} 10^{\prime \prime} \mathrm{W}$; (map 81).

Named in 1899 by Lt. J. S. Herron, USA.

Fleishman Ridge: ridge, $3.5 \mathrm{mi}$. long, between O'Donnell Creek and Addison Creek, Attu I., 
Aleutian Is.; $52^{\circ} 54^{\prime} 10^{\prime \prime} \mathrm{N}, 173^{\circ} 04^{\prime} 00^{\prime \prime} \mathrm{E}$; (map 13).

Named by the U.S. Army during its occupation of the island during World War II; name shown on an AMS map published in 1948.

Flemer, Mount: mountain, 4,654 ft., $4 \mathrm{mi}$. W of Alaska-Canada boundary, $3 \mathrm{mi}$. S of Stikine River, Coast Mts. ; $56^{\circ} 37^{\prime} 30^{\prime \prime} \mathrm{N}, 131^{\circ} 57^{\prime} 15^{\prime \prime}$ W; BGN 1922; (map 7).

Named in 1893 by Capt. A. C. Talbot of a Canadian survey party for John Adolph Flemer, USC\&GS. The name was published in 1927 on IBC Sheet 5 (1951 atlas).

Flemer River: stream, heads in British Columbia, flows SE $12 \mathrm{mi}$. to Tahini River, $2 \mathrm{mi}$. $W$ of Mount Raymond and $28 \mathrm{mi}$. WNW of Skagway, St. Elias Mts.; $59^{\circ} 39^{\prime} 15^{\prime \prime} \mathrm{N}, 136^{\circ} 00^{\prime} 30^{\prime \prime}$ W; $(\operatorname{map} 45)$.

Named by Ganada in 1951 for John Adolph Flemer, USC\&GS, who had general charge of two surveying parties in 1898 making topographic surveys of the area near the head of Lynn Canal. He was one of the original surveyors (1904-05) with the IBC while making Sheet 9 (1951 atlas).

Fleming Channel: water passage, between Kinky and Fleming Is., $12 \mathrm{mi}$. NW of Chichagof, on W coast of Chichagof I., Alex. Arch.; 57 $47^{\prime} 15^{\prime \prime} \mathrm{N}, 136^{\circ} 19^{\prime} 40^{\prime \prime} \mathrm{W}$; (map 9).

Named by USC\&GS and published in 1928 on Chart 8258. Name probably derived from Fleming Island.

Fleming Creek: stream, flows SW $1 \mathrm{mi}$. to Orca Inlet, $1 \mathrm{mi}$. $\mathrm{N}$ of Cordova, Chugach Mts.; $60^{\circ} 34^{\prime}$ N, $145^{\circ} 45^{\prime} \mathrm{W}$; (map 64$)$.

Local name published in 1951 by USGS.

Fleming Island: island, $0.5 \mathrm{mi}$. across, $12 \mathrm{mi}$. NW of Chichagof, on $W$ coast of Chichagof $I$., Alex. Arch.; $57^{\circ} 47^{\prime} 30^{\prime \prime} \mathrm{N}, 136^{\circ} 19^{\prime} 00^{\prime \prime} \mathrm{W}$; (map 9).

Local name reported in 1917 by $R$. M. Overbeck (in Martin and others, 1919, p. 125 ), USGS.

Fleming Island: island, see Evans Island.

Fleming Spit: spit, on SE shore of Orca Inlet, $1 \mathrm{mi}$. N of Cordova, Chugach Mts. ; $60^{\circ} 33^{\prime} 50^{\prime \prime}$ $\mathrm{N}, 145^{\circ} 44^{\prime} 30^{\prime \prime} \mathrm{W}$; (map 64)

Local name reported in 1900 by F. C. Schrader, USGS.

Flemming Island: island, $2.5 \mathrm{mi}$. long, in $\mathrm{N}$ end of Prince of Wales Passage, $8 \mathrm{mi}$. SE of Chenega, Chugach Mts.; $60^{\circ} 10^{\prime} \mathrm{N}, 148^{\circ} 01^{\prime}$ W; BGN 1910; (map 63). Var. Gage Island.

Local name reported in 1900 by F. C. Schrader, USGS, who misapplied the name to Evans Islands. This error was corrected in 1904 when USC\&GS applied the name "Flemming" to the proper island. The island was probably named for George Flemming, of Ellamar, who had a fox farm there since 1896.

Flemming Island: island, see Bainbridge Island.

Flemming Island: island, see Evans Island.

Flemming Passage: water passage, see Prince of Wales Passage.

Flent Point: point of land, W entrance to Columbia Bay, $56 \mathrm{mi}$. NE of Whittier, Chugach
Mts.; $60^{\circ} 56^{\prime} 30^{\prime \prime} \mathrm{N}, 147^{\circ} 08^{\prime} 00^{\prime \prime} \mathrm{W} ; B G N$ 1911; (map 63). Var. Flint Point.

Local name reported about 1910 by U. S. Grant, USGS.

Fleshlanana Creek: stream, heads in Ray Mts., flows S $13 \mathrm{mi}$. to Tozitna River, $37 \mathrm{mi}$. NNE of Tanana, Kokrines-Hodzana High.; $65^{\circ} 32^{\prime}$ $30^{\prime \prime} \mathrm{N}, 151^{\circ} 28^{\prime} 00^{\prime \prime} \mathrm{W}$; (map 106).

Indian name obtained in 1956 at Tanana by Orth.

Fletcher Creek: stream, see Fisher Creek.

Flicker Creek: stream, flows $\mathrm{N} 5 \mathrm{mi}$. to Sumner Strait, $4 \mathrm{mi}$. $\mathrm{E}$ of Point Baker, on $\mathrm{N}$ coast of Prince of Wales I., Alex. Arch.; 56 $20^{\prime} 20^{\prime \prime}$ $133^{\circ} 32^{\prime} 00^{\prime \prime} \mathrm{W}$; BGN 1923; (map 6).

Named in 1923 by USFS.

Flickinger Greek: stream, flows N $1.5 \mathrm{mi}$. to Venetia Creek $2 \mathrm{mi}$. E of its junc. with Eldorado River, $22 \mathrm{mi}$. NW of Solomon, Seward Penin. High.; $64^{\circ} 47^{\prime} \mathrm{N}, 164^{\circ} 54^{\prime} \mathrm{W}$; (map 95).

Prospectors' name reported on a map of Cape Nome gold fields by David Fox, Jr., dated 1901.

Flint Creek: stream, flows E $27 \mathrm{mi}$. to Sulatna River, 6 mi. NW of Monzonite Hills, Nowitna Low.; $64^{\circ} 28^{\prime} 36^{\prime \prime} \mathrm{N}, 154^{\circ} 47^{\prime} 30^{\prime \prime} \mathrm{W}$; (map 98).

Prospectors' name reported in 1911 by A. G. Maddren (in Brooks and others, 1921, p. 294296), USGS.

Flint Point: point of land, see Flent Point.

Flock Rock: rock, in Farragut Bay, $0.5 \mathrm{mi}$. N of Read I. and $82 \mathrm{mi}$. E of Sitka; Coast Mts.; $57^{\circ} 07^{\prime} 59^{\prime \prime} \mathrm{N}, 133^{\circ} 12^{\prime} 30^{\prime \prime} \mathrm{W}$; (map 8).

Named by USC\&GS ; published in the 1891 Coast Pilot (p. 137).

Flood Creek: stream, flows $7.8 \mathrm{mi}$. SE to White River at terminus of Russell Glacier, $39 \mathrm{mi}$ NE of McCarthy, Wrangell Mts.; $61^{\circ} 41^{\prime} \mathrm{N}$, $141^{\circ} 50^{\circ} \mathrm{W}$; (map 67)

Local name published by USGS in 1954.

Flood Creek: stream, flows SW $3 \mathrm{mi}$. to Delta River, crosses Richardson Highway, $30 \mathrm{mi}$ NW of Paxson, Alaska Ra.; $63^{\circ} 26^{\prime} 40^{\prime \prime} \mathrm{N}$, $145^{\circ} 48^{\prime} 20^{\prime \prime} \mathrm{N}$; (map 86).

Name published on relatively recent maps.

Flood Creek: stream, heads in Brooks Ra. at $68^{\circ} 50^{\prime} \mathrm{N}, 147^{\circ} 36^{\prime} \mathrm{W}$, flows $\mathrm{NW} 20 \mathrm{mi}$. to Ivishak River $3 \mathrm{mi}$. E of junc. of Saviukviayak River, Arctic Slope ; $69^{\circ} 04^{\prime} 30^{\prime \prime} \mathrm{N}, 147^{\circ} 54^{\prime} 00^{\prime \prime}$ W; BGN 1960; (map 140).

Named in 1951 by A. S. Keller and R. L. Detterman, USGS.

Flooded Lake: lake, $1 \mathrm{mi}$. across, $10 \mathrm{mi}$. SW of Christian, Brooks Ra.; 67 $7^{\circ} 16^{\prime} \mathrm{N}, 145^{\circ} 30^{\prime} \mathrm{W}$; (map 122).

Local name reported in 1956 by T. E. Taylor, USGS.

Floprock Peak: peak, 5,500 ft., $2.2 \mathrm{mi}$. SE of Exploration Peak and $27 \mathrm{mi}$. NE of Juneau, Coast Mts.; $58^{\circ} 40^{\prime} 20^{\prime \prime} \mathrm{N}, 134^{\circ} 09^{\prime} 25^{\prime \prime} \mathrm{W}$; (map 11).

Local name published in 1960 by USGS.

Flora Creek: stream, heads in Inyorurak Lakes, flows W $19 \mathrm{mi}$. to Aniuk River, S of Howard Pass, Brooks Ra.; $68^{\circ} 12^{\prime} \mathrm{N}, 156^{\circ} 57^{\prime} \mathrm{W}$; $B G N$ 1926; (map 132).
Named by Gerald FitzGerald, USGS, in 1925.

Flora Island: island, $4 \mathrm{mi}$. long, near left bank of Yukon River, 5 mi. S of Russian Mission, Yukon-Kuskokwim Delta; $61^{\circ} 43^{\prime} \mathrm{N}, 161^{\circ} 17^{\prime}$ W ; (map 73).

Riverboat pilots' name shown on a 1922 manuscript chart of Yukon River. This island was reportedly named for the riverboat Flora which was built at Lake Bennett, British Columbia, in 1898.

Flora Island: island, $2 \mathrm{mi}$. long, between Mason Slough and Yukon River, W of Cronin I. and Cronin Slough, $3.5 \mathrm{mi}$. E of Birches, KokrinesHodzana High.; $65^{\circ} 18^{\prime} 30^{\prime \prime} \mathrm{N}, 153^{\circ} 25^{\prime} 00^{\prime \prime} \mathrm{W}$; (map 107).

Riverboat pilots' name shown on a 1940 "Navigation Chart of the Tanana-Yukon Rivers" published by the Department of the Interior.

Floral Hills: mountain, 4,000 ft., between Hayden Glacier and Lucia Glacier, $12 \mathrm{mi}$. W of Bancas Point and $30 \mathrm{mi}$. NW of Yakutat, St. Elias Mts.; $59^{\circ} 58^{\prime} 39^{\prime \prime} \mathrm{N}$, $139^{\circ} 57^{\prime} 30^{\prime \prime} \mathrm{W}$; (map 46).

Named in 1890 by Russell (1891, p. 105), because "of the luxuriance of the vegetation covering them."

Floral Pass: pass, $2 \mathrm{mi}$. long, in Floral Hills, extends $\mathrm{E}$ from Hayden Glacier to Lucia Glacier, $11 \mathrm{mi}$. NW of Blizhni Point and 31 mi. NW of Yakutat, St. Elias Mts.; $59^{\circ} 58^{\prime} 30^{\prime \prime}$ N, $140^{\circ} 00^{\prime} 00^{\prime \prime}$ W; (map 46).

Named in 1890 by Russell (1891, p. 105), USGS. The name was derived from "Floral Hills."

Florence, Lake: lake, $4 \mathrm{mi}$. long, $21 \mathrm{mi}$. $\mathrm{N}$ of Angoon, on $W$ coast of Admiralty I., Alex. Arch.; $57^{\circ} 48^{\prime} 10^{\prime \prime} \mathrm{N}, 134^{\circ} 38^{\prime} 00^{\prime \prime} \mathrm{W}$; (map 9).

Named in 1920 by W. T. Tolch, a mining engineer of Juneau.

Florence Bay: bay, $0.7 \mathrm{mi}$. across, an arm of Sitkoh Bay, on SE tip of Chichagof I., $25 \mathrm{mi}$. SE of Tenakee Springs, Alex. Arch.; $57^{\circ} 29^{\prime}$ $30^{\prime \prime} \mathrm{N}, 134^{\circ} 52^{\prime} 30^{\prime \prime} \mathrm{W}$; (map 9).

Name reported by Lt. Comdr. Moser (1899a, p. 124), USN.

Florence Creek: stream, flows E $2 \mathrm{mi}$. to Eldorado River, $16 \mathrm{mi}$. NW of Solomon, Seward Penin. High.; $64^{\circ} 41^{\prime} \mathrm{N}, 164^{\circ} 54^{\prime} \mathrm{W}$; (map 95).

Prospectors' name reported in 1900 by E. C. Barnard (in Brooks, 1901, pl. 17), USGS.

Florence Creek: stream, flows S $10 \mathrm{mi}$. and E 5 mi. to North Fork Koyukuk River, $7 \mathrm{mi}$. NE of mouth of Middle Fork Koyukuk River and $28.5 \mathrm{mi}$. SW of Wiseman, Brooks Ra.; $67^{\circ} 07^{\prime}$. $30^{\prime \prime} \mathrm{N}, 150^{\circ} 54^{\prime} 00^{\prime \prime} \mathrm{W}$; (map 124$)$.

Named for his daughter, Florence, by August L. Tobin, who prospected in the Wiseman region from 1897 to 1918 ; name reported in 1899 by T. G. Gerdine, USGS.

Florence Creek Lake: lake, $1 \mathrm{mi}$. across, $1 \mathrm{mi}$. NE of junc. of Florence Creek and North Fork Koyukuk River and $27.5 \mathrm{mi}$. SW of Wiseman, Brooks Ra.; $67^{\circ} 09^{\prime}$ N, $150^{\circ} 52^{\prime}$ W ; (map 124).

Local name obtained in 1956 by USGS topographers. 
Florence Gulch: ravine, trends SW 2 mi. to Otter Creek, $3 \mathrm{mi}$. E of Nome, Seward Penin. High.; $64^{\circ} 29^{\prime} 45^{\prime \prime} \mathrm{N}, 165^{\circ} 17^{\prime} 35^{\prime \prime} \mathrm{W}$; (map 94).

Prospectors' name reported in 1904 by T. G. Gerdine, USGS.

Florence Island: island, between Western and Main Channels, Yukon River, $36 \mathrm{mi}$. NE of Ruby, Nowitna Low.; $64^{\circ} 57^{\prime} \mathrm{N}, 154^{\circ} 23^{\prime} \mathrm{W}$; (map 98).

Riverboat pilots' name reported in 1900 by Lt. J. C. Cantwell, USRCS. The name was originally applied to several islands; now is applied to only one.

Florence Islands: islands, $2.7 \mathrm{mi}$. long, between Fortymile Slough and Koyukuk River, E of Fry Island, $18 \mathrm{mi}$. N of Hochandochtla Mtn., Kokrines-Hodzana High.; $65^{\circ} 48^{\prime} \mathrm{N}, 154^{\circ} 53^{\prime}$ W; (map 107)

Prospectors' name reported in 1899 by F. C. Schrader, USGS, applied to the feature then described as a "bar on the river."

Florence Lake: lake, $1 \mathrm{mi}$. long, $2.7 \mathrm{mi}$. SW of Willow and $35 \mathrm{mi}$. N of Anchorage, Cook Inlet Low.; 61 ${ }^{\circ} 43^{\prime} 15^{\prime \prime} \mathrm{N}, 150^{\circ} 06^{\prime} 45^{\prime \prime} \mathrm{W}$; BGN 1959; (map 70).

Named in 1959 by Jack E. Cole of Anchorage for his wife, Florence Cole.

Flores, Canal de: water passage, see Shelikof Strait.

Flores, Cape: point of land, $\mathrm{N}$ tip of Joe I., between Port Estrella and Ulloa Channel, on W coast of Prince of Wales I., Alex. Arch.; $55^{\circ} 21^{\prime} 15^{\prime \prime} \mathrm{N}, 133^{\circ} 17^{\prime} 30^{\prime \prime} \mathrm{W}$; (map 4). Var. Cabo de Flores, Mys Flores, Point Flores.

Spanish name found on the maps of the 1779 Don Ignacio Arteaga expedition. Shown as "Cabo de Flores" meaning "cape of flowers"; more likely the place was named after some individual whose name was Flores (Wagner, 1937, p. 388)

Flores, Don Jose de: island, see Unimak Island. Flores, Puerto de: bay, see Chalmers, Port.

Florida Blanca: island, see Kodiak Island.

Florida Creek: stream, flows NW $1.7 \mathrm{mi}$. to Minook Creek SW of McDonald Bar, $6 \mathrm{mi}$. S of Rampart, Yukon-Tanana High.; 65 $25^{\prime} 12^{\prime \prime}$ N, $150^{\circ} 07^{\prime} 20^{\prime \prime} \mathrm{W}$; (map 106).

Prospectors' name reported in 1904 by Prindle and Hess (1906, pl. 3), USGS.

Flotilla Island: island, $0.3 \mathrm{mi}$. long, in Maurelle Is., Alex. Arch.; $55^{\circ} 36^{\prime} 35^{\prime \prime} \mathrm{N}, 133^{\circ} 37^{\prime} 30^{\prime \prime} \mathrm{W}$; BGN 1923; (map 4).

Spanish name meaning "a small fleet," given in 1923 by USC\&GS. "A flotilla of as many as 30 or 40 gasboats at once can be observed, during the salmon season, fishing in the straits adjacent to the $\mathrm{E}$ shore of this island."

Flotsam Island: island, $0.1 \mathrm{mi}$. across, $1.4 \mathrm{mi}$. NE of Port Alexander, on E coast of Baranof I., Alex. Arch.; $56^{\circ} 15^{\prime} 05^{\prime \prime} \mathrm{N}, 134^{\circ} 37^{\prime} 55^{\prime \prime} \mathrm{W}$; (map 5).

Descriptive name given in 1927 for charting purposes by USC\&GS.

Flounder Creek: stream, see Suntaheen Creek. Flounder Flat: tidal fat, extends SE $11 \mathrm{mi}$. from Ekuk Bluff, on $\mathbf{E}$ shore of Nugashak Bay, 18 mi. S of Dillingham, Bristol Bay Low.; 58 $44^{\prime}$ $\mathrm{N}, 158^{\circ} 22^{\prime} \mathrm{W}$; (map 40).

Local name reported in 1952 by USGS.

Flower Hill: hill, $500 \mathrm{ft}$., on southern Kiska I., $0.7 \mathrm{mi}$. NW of Vega Bay, Aleutian Is.; 51 $1^{\circ} 54^{\prime}$ $20^{\prime \prime} \mathrm{N}, 177^{\circ} 19^{\prime} 15^{\prime \prime} \mathrm{E}$; (map 14).

An arbitrary name beginning with " $F$ " to correspond to the "F" grid used by the U.S. Army for tactical purposes during World War II ; published on a 1943 AMS map.

Flower Lakes: lakes, in group extending $1.4 \mathrm{mi}$. SE near junc. of Hunter Creek and Chitina River, $25 \mathrm{mi}$. SE of McCarthy, St. Elias Mts.; $61^{\circ} 05^{\prime} 30^{\prime \prime} \mathrm{N}, 142^{\circ} 35^{\prime} 00^{\prime \prime} \mathrm{W}$; (map 67).

Local name reported in 1915 by F. H. Moffit, USGS.

Flower Mountain: mountain, 6,300 ft., $1.8 \mathrm{mi}$. S of terminus of Saksaia Glacier and $38 \mathrm{mi}$. SW of Skagway, St. Elias Mts. ; $59^{\circ} 21^{\prime} 30^{\prime \prime} \mathrm{N}$, $136^{\circ} 22^{\prime} 25^{\prime \prime} \mathrm{W}$; (map 45).

Name reported in 1952 by E. C. Robertson, USGS, to have been given by "an unknown botanist between 1932-42, who found a luxuriant growth of a great variety of flowers on the mountain."

Flower Tower: peak, 5,830 ft., on Taku Range at edge of Taku Glacier, $2 \mathrm{mi}$. $\mathrm{N}$ of Little Matterhorn and $24 \mathrm{mi}$. $\mathrm{N}$ of Juneau, Coast Mts. ; $58^{\circ} 39^{\prime} 05^{\prime \prime} \mathrm{N}, 134^{\circ} 22^{\prime} 25^{\prime} \mathrm{W}$; (map 11).

Descriptive name proposed in 1949 by members of the Juneau Icefield Research Project and published in 1960 by USGS.

Flume Creek: locality, on S bank of Seventymile River at mouth of Flume Creek, $40 \mathrm{mi}$. NW of Eagle, Yukon-Tanana High.; $64^{\circ} 59^{\prime} \mathrm{N}$, $142^{\circ} 27^{\prime} \mathrm{W}$; (map 102).

Mining camp reported in 1925 by ARC.

Flume Creek: stream, heads S of Limestone Hills, flows $S 8 \mathrm{mi}$. to Alfred Creek, $57 \mathrm{mi}$. NE of Palmer, Talkeetna Mts.; 61 ${ }^{\circ} 7^{\prime} 05^{\prime \prime} \mathrm{N}, 147^{\circ}$ 33'05" W; BGN 1960; (map 69).

Named by USGS in 1956 "for a 400 foot flume constructed on the east side of the stream in 1922."

Flume Creek: stream, heads in Kantishna Hills, flows NW $20 \mathrm{mi}$. to Bearpaw River, Tanana Low.; $64^{\circ} 00^{\prime} 05^{\prime \prime} \mathrm{N}, 150^{\circ} 47^{\prime} 05^{\prime \prime} \mathrm{W}$; (map 99).

Name shown on a 1905 manuscript map of the "Kantishna Gold Fields," by A. Friedrich, prospector.

Flume Creek: stream, flows S $1.5 \mathrm{mi}$. to Gold Creek, $48 \mathrm{mi}$. N of Big Delta, Yukon-Tanana High.; $64^{\circ} 49^{\prime} 30^{\prime \prime} \mathrm{N}, 145^{\circ} 32^{\prime} 50^{\prime \prime} \mathrm{W}$; (map 101).

Named by prospectors and reported in 1905 by D. C. Witherspoon (Prindle, 1913a, pl. 1), USGS.

Flume Creek: stream, flows NE $13 \mathrm{mi}$. to Seventymile River, $40 \mathrm{mi}$. NW of Eagle, Yukon-Tanana High.; $64^{\circ} 59^{\prime} \mathrm{N}, 142^{\circ} 27^{\prime} \mathrm{W}$; (map 102). Var. Plume Creek.

Local name shown on a 1902 manuscript map by E. J. Chamberlain, U.S. Deputy Surveyor.

Flume Creek: stream, flows SE $1.8 \mathrm{mi}$. to Pedro Creek, $12 \mathrm{mi}$. NE of Fairbanks, Yukon-Tanana
High.; $64^{\circ} 59^{\prime} 45^{\prime \prime} \mathrm{N}, 147^{\circ} 31^{\prime} 45^{\prime \prime} \mathrm{W}$; (map 100).

Local name reported in 1903 by T. G. Gerdine (in Prindle, 1905, pl. 16), USGS.

Flume Gulch: ravine, trends NW $1 \mathrm{mi}$. to Crooked Creek, $18 \mathrm{mi}$. NW of Eagle, YukonTanana High.; $64^{\circ} 56^{\prime} \mathrm{N}, 141^{\circ} 40^{\prime} \mathrm{W}$; (map 102).

Local name published in 1956 by USGS.

Fluss Cheuweren: stream, see Kaviruk River.

Flying Eagle Harbor: cove, $0.5 \mathrm{mi}$. across, on $\mathrm{E}$ coast of Big Koniuji I., in Shumagin Is., Aleutian Ra.; $55^{\circ} 09^{\prime} \mathrm{N}, 159^{\circ} 30^{\prime} \mathrm{W}$; (map 27).

Published by USC\&GS in 1938 Coast Pilot.

Flynn Cove: cove, $0.4 \mathrm{mi}$. across, on $\mathrm{N}$ coast of Chicagof I., $2.2 \mathrm{mi}$. SE of Eagle Point and 9 mi. NW of Hoonah, Alex. Arch.; 58 $12^{\prime} 45^{\prime \prime}$ $\mathrm{N}, 135^{\circ} 35^{\prime} 45^{\prime \prime} \mathrm{W}$; (map 11 ).

Named for H. F. Flynn, USC\&GS, assistant with the Edmund F. Dickins survey party in 1901.

Flynn Creek: stream, flows NE $2.5 \mathrm{mi}$. to Mickey Creek $1.5 \mathrm{mi}$. S of that stream's mouth, $4 \mathrm{mi}$. SW of Caro and $26 \mathrm{mi}$. SSE of Chandalar, Brooks Ra.; $67^{\circ} 08^{\prime} 30^{\prime \prime} \mathrm{N}, 148^{\circ} 09^{\prime} 00^{\prime \prime} \mathrm{W}$; (map 123).

Prospectors' narue obtained in 1909 by $\mathrm{A}$. G. Maddren (in Brooks and others, 1910, pl. 7), USGS.

Fog Creek: stream, on Alaska Penin., heads at Fog Glacier, flows NW $26 \mathrm{mi}$. to Ilnik River, $44 \mathrm{mi}$. SW of Port Heiden Airfield, Bristol Bay Low.; 56 $35^{\prime} \mathrm{N}, 159^{\circ} 37^{\prime} \mathrm{W}$; (map 30).

Name reported in 1923 by $R$. H. Sargent, USGS; published in 1927 by USGS.

Fog Creek: stream, heads on Susie Mtn., flows SE $4 \mathrm{mi}$. to Kinegnak River, $7 \mathrm{mi}$. E of Red Mtn. and 30 mi. NE of Cape Newenham, Kilbuck-Kuskokwim Mts.; $58^{\circ} 55^{\prime} \mathrm{N}, 161^{\circ} 33^{\prime}$ W ; BGN 1938; (map 39).

Local name reported in 1938 by USGS.

Fog Creek: stream, flows NW $24 \mathrm{mi}$. to Susitna River, $43 \mathrm{mi}$. SE of Cantwell, Talkeetna Mts.; $62^{\circ} 46^{\prime} 35^{\prime \prime} \mathrm{N}, 148^{\circ} 42^{\prime} 55^{\prime \prime} \mathrm{W}$; (map 82).

Local name reported in 1951 by USGS.

Fogenbera Pass: pass, 6,300 ft., between tributaries of North Fork White River and Ophir Creek, $10 \mathrm{mi}$. NW of Rock Lake and $55 \mathrm{mi}$. NE of McCarthy, Alaska Ra.; 61 ${ }^{\circ} 53^{\prime} 45^{\prime \prime} \mathrm{N}$, $141^{\circ} 33^{\prime} 00^{\prime \prime} \mathrm{W}$; (map 67).

Local name published in 1954 by USGS. Foggi Cape: point of land, see Foggy Point.

Fog Glacier: glacier, on Alaska Penin., on NW slope of Mount Veniaminof, trends NW 4.5 mi. to head of Fog Creek, Aleutian Ra.; $56^{\circ}$. $16^{\prime} \mathrm{N}, 159^{\circ} 29^{\prime} \mathrm{W}$; (map 30 ).

Name reported in 1923 by R. H. Sargent, USGS; published in 1927 by USGS.

Fogg River: stream, see Fog River.

Foggy Bay: bay, $5 \mathrm{mi}$. wide, $\mathrm{E}$ shore Revillagigedo Channel, Coast Mts.; 54 $58^{\prime} \mathrm{N}$, $130^{\circ} 58^{\prime} \mathrm{W}$; ( $\operatorname{map} 2$ ).

Named in 1880 by USC\&GS; name derived from Foggy Point.

Foggy Beach: beach, $0.4 \mathrm{mi}$. long, $0.7 \mathrm{mi}$. W of Vega Point, SW coast of Kiska I., Aleutian Is. ; $51^{\circ} 49^{\prime} 52^{\prime \prime} \mathrm{N}, 177^{\circ} 19^{\prime} 15^{\prime \prime} \mathrm{E}$; (map 14). 
One of many arbitrary names applied to features on Kiska I. by USAAF for tactical purposes during World War II.

Foggy Cape: promontory, elev. $418 \mathrm{ft}$., near S shore of Alaska Penin., at $\mathrm{E}$ end of Sutwik I., $18 \mathrm{mi}$. SE of Cape Kunmik, Aleutian Ra.; $56^{\circ} 32^{\prime} \mathrm{N}, 156^{\circ} 58^{\prime} \mathrm{W}$; (map 31). Var. Cape Brumeaux, Cap Brumeux, Cape Kunliun.

On June 16, 1778, Capt. James Cook located a cape to which he gave this name, concluding that this was Vitus Bering's "Foggy Island." The exact identity of Cook's "Foggy Cape" is also uncertain, as might be guessed from the weather conditions prevailing when it was named. Capt. Lutke (1836, p. 277) identified it as Cape Kumliun. He called this point of land "Cape Brumeaux."

Foggy Cape: peninsula, see Kumliun, Cape.

Foggy Harbor: cove, see Mulgrave, Port.

Foggy Hill: hill, $950 \mathrm{ft} ., \mathrm{E}$ of Fatal Hill on southern Kiska I., Aleutian Is.; $51^{\circ} 54^{\prime} 40^{\prime \prime}$ $\mathrm{N}, 177^{\circ} 18^{\prime} 45^{\prime \prime} \mathrm{E}$; (map 14).

An arbitrary name beginning with " $F$ " to correspond to " $F$ " grid used by the U.S. Army for tactical purposes during World War II; published on a 1953 AMS map.

Foggy Island: island, $3.5 \mathrm{mi}$. long, in Foggy $\mathrm{I}$. Bay, Sagavanirktok River Delta, on Beaufort Sea coast, $35 \mathrm{mi}$. SE of Beechey Point, Arctic Plain; $70^{\circ} 16^{\prime} \mathrm{N}, 147^{\circ} 48^{\prime} \mathrm{W}$; (map 150).

Named by Franklin (1828, p. 155) August 11, 1826, who, having been detained eight days by fogs, described "this dreary place by the name of Foggy Island."

Foggy Island : island, see Andronica Island.

Foggy Island: island, see Chirikof Island.

Foggy Island: island, see Poa Island.

Foggy Island Bay: bay, $14 \mathrm{mi}$. across, between Foggy and Tigvariak Is., on Beaufort Sea coast, $35 \mathrm{mi}$. SE of Beechey Point, Arctic Plain; $70^{\circ} 15^{\prime} \mathrm{N}, 147^{\circ} 30^{\prime} \mathrm{W}$; (map 150).

So named July 20,1837 by P. W. Dease and Thomas Simpson (in Thomas Simpson, 1843, p. 124).

Foggy Islands: islands, see Hazy Islands.

Foggy Islands: islands, see Semidi Islands.

Foggy Pass: pass, 3,100 ft., trends NE-SW 1.5 mi., $8 \mathrm{mi}$. W of Cantwell and $32 \mathrm{mi}$. $\mathrm{S}$ of Healy, Alaska Ra.; $63^{\circ} 24^{\prime} 45^{\prime \prime} \mathrm{N}, 149^{\circ} 14^{\prime} 10^{\prime \prime}$ W; (map 87).

Descriptive name published by The Alaska Railroad on a 1923 manuscript map.

Foggy Point: point of land, S end Foggy Bay, E shore Revillagigedo Channel, Coast Mts.; $54^{\circ} 55^{\prime} 30^{\prime \prime} \mathrm{N}, 130^{\circ} 58^{\prime} 30^{\prime \prime} \mathrm{W}$; (map 2). Var. Brumez (Tumannie), Mys Foggi, Foggi Cape, Point Brumez, Bryumez (Foggy).

Descriptive name given August 4, 1793 by Capt. Vancouver (1798, v. 2, p. 347), RN. In 1853 the Russian Hydrog. Dept. published the name as "M[ys] Foggi ili Bryumez (Tumannyy)," or "Foggi Cape or Bryumez (Foggy)."

Foggytop Mountain: mountain, 4,400 ft., S of Chimney Mtn., between Clear and Glacier Rivers, $22 \mathrm{mi}$. NW of Wiseman, Brooks Ra.; $67^{\circ} 41^{\prime} \mathrm{N}, 150^{\circ} 34^{\prime} \mathrm{W}$; (map 124).

Descriptive name reported in 1939 by Marshall (1956, map).
Fog Lakes: lakes, group extends E-W $9 \mathrm{mi}$. between Fog Creek and Susitna River, $43 \mathrm{mi}$. SE of Cantwell; Talkeetna Mts.; 62 ${ }^{\circ} 47^{\prime} 30^{\prime \prime}$ N, $148^{\circ} 23^{\prime} 30^{\prime \prime} \mathrm{W}$; (map 82).

Local name reported in 1951 by USGS.

Fogniak: island, see Afognak Island.

Fogoi Islas: islands, see Semidi Islands.

Fog River: stream, heads in Kilbuck Mts. at $61^{\circ} 55^{\prime} \mathrm{N}, 159^{\circ} 45^{\prime} \mathrm{W}$, and flows NW $75 \mathrm{mi}$. to Tuluksak River $7 \mathrm{mi}$. E of Tuluksak and $52 \mathrm{mi}$. SE of Russian Mission, 61 $1^{\circ} 05^{\prime} \mathrm{N}$, $160^{\circ} 45^{\prime} \mathrm{W}$; (map 73). Var. Fogg River.

Local name shown in a 1912 manuscript map by H. W. Reeth as Fogg River. A. G. Maddren, USGS, spelled it "Fog" on his 1914 fieldsheet.

Fohlin Creek: stream, flows S $5 \mathrm{mi}$. to Lakina River, $12 \mathrm{mi}$. NW of McCarthy, Wrangell Mts.; 61 ${ }^{\circ} 27^{\prime} 30^{\prime \prime} \mathrm{N}, 143^{\circ} 15^{\prime} 15^{\prime \prime}$ W.; (map 67).

Named in 1899 by Oscar Rohn, for a member of his survey party, John Fohlin, cook and dog handler.

Foley Creek: stream, flows SW $6.2 \mathrm{mi}$. to Sulatna River E of Tamarack Bluff, 7 mi. NE of Poorman, Kilbuck-Kuskokwim Mts. ; $64^{\circ} 10^{\prime} 00^{\prime} \mathrm{N}$, $155^{\circ} 22^{\prime} 30^{\prime \prime} \mathrm{W}$; (map 98).

Prospectors' name reported in 1913 by Eakin (1914, pl. 3), USGS.

Folger: locality, on E bank of Innoko River, 3 mi. SW of junc. of Folger Greek and $26 \mathrm{mi}$. N of Ophir, Kilbuck-Kuskokwim Mts.; 63 $30^{\circ}$ $45^{\prime \prime} \mathrm{N}, 156^{\circ} 27^{\prime} 00^{\prime \prime} \mathrm{W}$; (map 90).

This was a supply landing for the mining camps on Folger Creek. See Folger on Cripple Creek.

Folger: locality, on E bank of Cripple Creek 2.6 mi. SE of its junc. with Graham Creek and $32 \mathrm{mi}$. NE of Ophir, Kilbuck-Kuskokwim Mts.; $63^{\circ} 33^{\prime} 45^{\prime \prime} \mathrm{N}, 156^{\circ} 05^{\prime} 00^{\prime \prime} \mathrm{W}$; (map 90).

Mining camp named for nearby Folger Creek. The Folger post office was maintained in the area from 1935 to 1954.

Folger Creek: stream, formed by junc. of South Fork Folger and Canyon Creeks, flows NW 18 $\mathrm{mi}$. to Innoko River, $29 \mathrm{mi}$. N of Ophir and $47 \mathrm{mi}$. NW of McGrath, Kilbuck-Kuskokwim Mts. ; $63^{\circ} 33^{\prime} \mathrm{N}, 156^{\circ} 23^{\prime} \mathrm{W}$; (map 90).

Prospectors' name obtained in 1908 by Maddren (1910, pl. 1), USGS.

Folger Slough: stream, anabranch, flows NE 1.7 mi. along right bank of Kantishna River, 45 mi. SE of Bitzshtini Mts., Tanana Low.; $64^{\circ}$ $14^{\prime} \mathrm{N}, 150^{\circ} 35^{\prime} \mathrm{W}$; (map 99).

Local name reported in 1952 by USGS.

Font, Streights du; water passage, name used by Joseph Ingraham apparently intended to apply to the entrance of Portland Canal or Revillagagedo Channel, or possibly both (Wagner, 1937, p. 455).

Fontaine Island: island, $0.3 \mathrm{mi}$. long, at head of Shakan Bay, between Prince of Wales and Kosciusko Is., Alex. Arch.; $56^{\circ} 09^{\prime} 00^{\prime \prime} \mathrm{N}, 133^{\circ}$ $28^{\prime} 15^{\prime \prime} \mathrm{W}$; (map 6). Var. Fountain Island.

Named in 1886 by Lt. J. M. Helm, USN, for charting purposes; name published in 1887 on USC\&GS Chart 706.
Fontain Island: island, see Fontaine Island.

Fontan, Podvodnyy Kamen: rock, see Fontain Rock.

Fool Creek: stream, flows E $0.5 \mathrm{mi}$. to Casadepaga River between Bonanza and Dawson Creeks, about $27 \mathrm{mi}$. NE of Solomon, Seward Penin. High.; $64^{\circ} 56^{\prime} \mathrm{N}, 164^{\circ} 08^{\prime} \mathrm{W}$; (map 95).

Prospectors' name reported on a prospector's manuscript map dated 1902.

Fool Creek: stream, see Sixtymile Creek.

Fool Hill: hill, $500 \mathrm{ft}$., $3.4 \mathrm{mi}$. NW of Vega Point, on southern Kiska I., Aleutian Is.; $51^{\circ}$. $52^{\prime} 20^{\prime \prime} \mathrm{N}, 177^{\circ} 17^{\prime} 00^{\prime \prime} \mathrm{E}$; (map 14).

An arbitrary name beginning with " $F$ " to correspond to " $F$ " grid used by the U.S. Army for tactical purposes during World War II; published on a 1953 AMS map.

Fool Inlet: estuary, $5 \mathrm{mi}$. long, on $\mathrm{W}$ coast of Glass Penin., trends NW to Seymour Canal, 19 mi. SE of Juneau, Alex. Archipelago; $58^{\circ} 02^{\prime}$ $\mathrm{N}, 134^{\circ} 14^{\prime} \mathrm{W}$; (map 11).

Local name published in 1951 by USGS.

Fool Island: island, $0.5 \mathrm{mi}$. long, in Prince William Sound, $3 \mathrm{mi}$. SE of Esther I. and $26 \mathrm{mi}$. E of Whittier, Chugach Mts.; 60 $45^{\prime} 55^{\prime \prime} \mathrm{N}$, $147^{\circ} 54^{\prime} 45^{\prime \prime} \mathrm{W}$; (map 63 ).

Name published in 1913 by USC\&GS.

Fools Inlet: estuary, extends SE 4 mi. to Ernest Sound, on S coast of Wrangell I., $23 \mathrm{mi}$. SE of Wrangell, Alex. Arch.; $56^{\circ} 11^{\prime} 00^{\prime \prime} \mathrm{N}, 132^{\circ} 00^{\prime}-$ $30^{\prime \prime} \mathrm{W}$; (map 6).

Named in 1886 by Lt. Comdr. A. S. Snow, USN; name published in 1887 on USC\&GS Chart 706.

Fools Point: point of land, on Portland Canal, $0.9 \mathrm{mi}$. NE of Sandfly Bay, Coast Mts.; $55^{\circ}$ $10^{\prime} 15^{\prime \prime} \mathrm{N}, 130^{\circ} 08^{\prime} 00^{\prime \prime} \mathrm{W}$; (map 3).

Named in 1891 by USC\&GS.

Foot Bay: bay, $1.5 \mathrm{mi}$. across, on $\mathrm{W}$ coast of Kuiukta Bay, $20 \mathrm{mi}$. SW of Chignik, on S shore of Alaska Penin., Aleutian Ra.; 56 $03^{\circ}$ $\mathrm{N}, 158^{\circ} 39^{\prime} \mathrm{W}$; (map 30).

Local name published by USC\&GS in the 1916 Coast Pilot (p. 161).

Foote Peak: peak, 5,175 ft., $5 \mathrm{mi}$. E of Thomas Bay, $2.5 \mathrm{mi}$. N of Swan Lake and $105 \mathrm{mi}$. E of Sitka, Coast Mts. ; $57^{\circ} 03^{\prime} 25^{\prime \prime} \mathrm{N}, 132^{\circ} 44^{\prime} 00^{\prime \prime}$ W; (map 8).

Named in 1887 by Lt. Comdr. C. M. Thomas, USN, for Rear Adm. A. H. Foote, USN. The name was published in 1888 by USC\&GS on Chart 705.

Foot Island: island, $0.6 \mathrm{mi}$. across, in Steamboat Bay, $2 \mathrm{mi}$. $\mathrm{N}$ of Whitney I. and $71 \mathrm{mi} \mathrm{E}$ of Sitka, Coast Mts; $57^{\circ} 16^{\prime} 15^{\prime \prime} \mathrm{N}, 133^{\circ} 31^{\prime} 30^{\prime \prime}$ W; (map 8).

Named in 1889 by Lt. Comdr. H. B. Mansfield, USN; published by USC\&GS in 1891 Coast Pilot (p. 146).

Foot Island: island, see Latouche Island.

Foot Lake: lake, 1,500 ft. long, on Prince of Wales I., near head of Kasaan Bay, $2.3 \mathrm{mi}$. NW of village of Salt Chuck, Alex. Arch.; $55^{\circ} 38^{\prime}$ N, $132^{\circ} 37^{\prime} \mathrm{W}$; BGN 1960; (map 4).

Local descriptive name reported by $C$. $L$. Sainsbury, USGS, in 1956, who stated that 
the name "is suggested by the shape of the Lake."

Foot Mountain: mountain, 1,220 ft., S. of Fox Hill, on southern Kiska I., Aleutian Is.; $51^{\circ} 55^{\prime} 15^{\prime \prime} \mathrm{N}, 177^{\circ} 18^{\prime} 50^{\prime \prime} \mathrm{E}$; (map 14).

An arbitrary name beginning with "F" to correspond to "F" grid used by the U.S. Army for tactical purposes during World War II ; published in 1953 by AMS.

Footprint Lake: lake, intermittent, $1.8 \mathrm{mi}$. long, $2.5 \mathrm{mi}$. SE of Barrow, Arctic Plain ; $71^{\circ} 16^{\prime} 20^{\prime \prime}$ $\mathrm{N}, 156^{\circ} 39^{\prime} 00^{\prime \prime} \mathrm{W}$; (map 153).

So named because it looks like a large human footprint from the air (Carson and Hussey, 1962).

Foraker, Mount: peak, 17,400 ft., at head of Foraker Glacier, in Mount McKinley National Park, 15 mi. SW of Denali Pass, Alaska Ra.; 62 $57^{\prime} 40^{\prime \prime} \mathrm{N}, 151^{\circ} 23^{\prime} 45^{\prime \prime} \mathrm{W}$; (map 81). Var. Bolshoi, Din-al-ee, Din-az-ee, Mount Faraker.

Named in 1899 by Lt. J. S. Herron, USA, for Joseph Benson Foraker, 1846-1917, U.S. Senator from Ohio. Its North Peak was first climbed August 6, 1934, and its South Peak was climbed August 10, 1934, by C. S. Houston, T. G. Brown, and Chychele Waterston (Farquhar, 1959, p. 221). This peak along with Mount McKinley was called "Bolshaya Gora," or "big mountain," by the Russians. The Tanaina Indians of the Susitna River valley and Tanana Indians to the north are reported to have had the same name [Denali] for Mount Foraker as they had for Mount McKinley, and it appears as if the names were not applied to individual peaks but instead to the Mount McKinley massif. The Tanana Indians in the Lake Minchumena area, however, had a broadside view of the mountains and thus gave distinctive names to each. According to Rev. Hudson Stuck, these Indians had two names for Mount Foraker: "Sultana" meaning "the woman" and "Menlale" meaning "Denali's wife," Denali being Mount McKinley.

Foraker Glacier: glacier, in Mount McKinley National Park, trends N 15 mi. from Mount Foraker to head of Foraker River, $19 \mathrm{mi}$. W of Mount McKinley, Alaska Ra.; $63^{\circ} 08^{\prime} \mathrm{N}$, $151^{\circ} 35^{\prime} \mathrm{W}$; (map 88).

Name reported in 1925 by S. R. Capps, USGS.

Foraker Pond: lake, $0.5 \mathrm{mi}$. across, $4.6 \mathrm{mi}$. N of junc. of Herron and Foraker Rivers and 12 mi. SSE of village of Lake Minchumina, Tanana Low.; $63^{\circ} 42^{\prime} 45^{\prime \prime} \mathrm{N}, 152^{\circ} 11^{\prime} 45^{\prime \prime} \mathrm{W}$; (map 88).

Local name reported in 1954 by USGS.

Foraker River: stream, heads in Mount McKinley National Park at Foraker Glacier, flows NW $60 \mathrm{mi}$. to Lake Minchumina, Tanana Low.; $63^{\circ} 52^{\prime} 45^{\prime \prime} \mathrm{N}, 152^{\circ} 06^{\prime} 00^{\prime \prime} \mathrm{W}$; (map 88). Var. Kotalhnó River, Kwalana, Gotothna River.

Name derived from Mount Foraker; reported in 1925 by S. R. Capps, USGS. In 1907, according to Gordon (1917, p. 62), its Tanana Indian name was "Kwalana"; another Indian name reported in 1952 by USGS is "Kotalhnó."

Ford Arm: bay, $0.3 \mathrm{mi}$. across, $4 \mathrm{mi}$. long, 8.5 mi. SE of Chichagof, on W coast of Chichagof I., Alex. Arch.; $57^{\circ} 33^{\prime} \mathrm{N}, 136^{\circ} 00^{\prime} \mathrm{W} ; B G N$ 1908; (map 9).

Named in 1897 by Lt. Comdr. E. K. Moore, USN, for yeoman Harry L. Ford, a member of his party. The name was published by USC\&GS in the 1901 Coast Pilot (p. 199). Ford Creek: stream, flows SE $1.7 \mathrm{mi}$. to Fern Creek, near NW shore of Vega Bay, Kiska I., Aleutian Is.; $51^{\circ} 54^{\prime} 48^{\prime \prime} \mathrm{N}, 177^{\circ} 21^{\prime} 00^{\prime \prime} \mathrm{E}$; (map 14).

An arbitrary name beginning with "F" to correspond to "F" grid used by the U.S. Army for tactical purposes during World War II; published on a 1953 AMS map.

Forde, Mount: mountain, 6,880 ft., in Glacier Bay National Monument, on Alaska-British Columbia boundary, $4 \mathrm{mi}$. W of terminus of Margerie Glacier and $72 \mathrm{mi}$. WSW of Skagway, St. Elias Mts.; BGN 1954; 59 $01^{\prime} 50^{\prime \prime}$ $\mathrm{N}, 137^{\circ} 10^{\prime} 30^{\prime \prime} \mathrm{W}$; (map 45).

Named by Canada in 1929 for John Preston Forde, an engineer of the Public Works Dept. of the Dominion of Canada, who visited Tarr Inlet in 1925 and 1928 and measured the recession of the glacier at the head of the inlet.

Ford Hill: hill, $700 \mathrm{ft}$., $0.6 \mathrm{mi}$. S of Lief Cove, on southern Kiska I., Aleutian Is.; 51 ${ }^{\circ} 55^{\prime}$ $35^{\prime \prime} \mathrm{N}, 177^{\circ} 20^{\prime} 00^{\prime \prime} \mathrm{E}$; (map 14).

An arbitrary name beginning with " $F$ " to correspond to " $F$ " grid used by the U.S. Army for tactical purposes during World War II; published on a 1953 AMS map.

Ford Lake: lake, oxbow, $1.5 \mathrm{mi}$. long, $0.5 \mathrm{mi}$. W of Yukon River and $7.5 \mathrm{mi}$. N of Eagle, Yukon-Tanana High.; $64^{\circ} 53^{\prime} 30^{\prime \prime}$ N, 141 ${ }^{\circ} 13^{\prime}$ $00^{\prime \prime} \mathrm{W}$; (map 102)

Local name published in 1956 by USGS.

Ford Rock: rock, in N part of Peril Strait, between Ushk Bay and N tip of Duffield Penin., $23 \mathrm{mi}$. SE of Chichagof, Alex. Arch.; 57 $34^{\prime}$ N, $135^{\circ} 31^{\prime} \mathrm{W}$; (map 9).

Named in 1895 by Lt. Comdr. E. K. Moore, USN, for yeoman Harry L. Ford, USN, a member of his party from 1895 to 1897 .

Fords Terror: estuary, heads $2 \mathrm{mi}$. W of terminus of Brown Glacier, trends S $7.5 \mathrm{mi}$. to Endicott Arm, $66 \mathrm{mi}$. SE of Juneau, Coast Mts.; $57^{\circ} 36^{\prime} 45^{\prime \prime} \mathrm{N}, 133^{\circ} 11^{\prime} 00^{\prime \prime} \mathrm{W}$; (map 8).

Named in 1889 by Lt. Comdr. H. B. Mansfield, USN, for H. L. Ford, USN, Master-ofArms and a member of his surveying party. "It is very narrow at one point. Floating ice from glaciers, with falling tide, jamming in this contracted throat make it a dangerous place" giving it the name "Fords Terror."

Foresta, Mount: mountain, 11,960 ft., $11 \mathrm{mi}$. NW of Mount Seattle and $47 \mathrm{mi}$. N of Yakutat, St. Elias Mts.; $60^{\circ} 12^{\prime} 05^{\prime \prime}$ N, $139^{\circ} 24^{\prime} 00^{\prime \prime}$ W; BGN 1960; (map 66).

Named for Foresta Hodgson Wood, 190451, who was responsible for logistic planning of Project Snow Cornice of the Arctic Institute of North America. She was killed in an airplane crash about July 27, 1951 with her daughter (see Valerie Glacier) somewhere in the vicinity of this mountain. The name was proposed in 1957 by the Arctic Institute of North America.

Forest Creek: stream, in Glacier Bay National Monument, heads in Casement Glacier, flows W $2 \mathrm{mi}$. to Muir Inlet, $0.8 \mathrm{mi}$. SE of Goose Cove and $62 \mathrm{mi}$. NW of Hoonah, St. Elias Mts.; $58^{\circ} 56^{\prime} 15^{\prime \prime} \mathrm{N}, 136^{\circ} 04^{\prime} 30^{\prime \prime} \mathrm{W}$; (map $10)$.

So named in 1947 by members of the American Geographical Society "because the stream flows through the remains of an interglacial forest."

Forest Creek: stream, flows SW $4 \mathrm{mi}$. to Walker Fork, $55 \mathrm{mi}$. SW of Eagle, Yukon-Tanana High.; $64^{\circ} 03^{\prime} \mathrm{N}, 141^{\circ} 35^{\prime} \mathrm{W}$; (map 102).

Prospectors' name shown on an 1898 manuscript map by C. A. Woodruff, Fort Cudahy, Canada.

Forest Lake: lake, see East Forest Lake.

Forest Lake: lake, see West Forest Lake.

Fork Creek: stream, flows NW $12 \mathrm{mi}$. to Crooked Creek, 67 mi. SE of Bethel, Kilbuck-Kuskokwim Mts.; $60^{\circ} 18^{\prime} \mathrm{N}, 160^{\circ} 09^{\prime} \mathrm{W}$; BGN 1959; (map 59).

Local name reported in 1955 by J. M. Hoare, USGS.

Fork Creek: stream, flows NW $4 \mathrm{mi}$. to Taylor Creek, $6 \mathrm{mi}$. SE of center of Taylor Mts. and $60 \mathrm{mi}$. S of Sleetmute, Kilbuck-Kuskokwim Mts.; $60^{\circ} 53^{\prime} \mathrm{N}, 157^{\circ} 17^{\prime} \mathrm{W}$; BGN 1948; (map 60).

Local name reported in 1945 by USGS. "This name given by prospectors on Taylor Creek, refers to the 'fork' where the stream joins Taylor Greek."

Fork Hill: stream, flows SE $2.8 \mathrm{mi}$. to Pacific Ocean, $3 \mathrm{mi}$. N of Vega Point, on southern Kiska I., Aleutian Is. ; $51^{\circ} 52^{\prime} 30^{\prime \prime}$ N, $177^{\circ} 19^{\prime}$ $28^{\prime \prime} \mathrm{E}$; (map 14). Var. Ginger Creek.

An arbitrary name beginning with " $F$ " to correspond to "F" grid used by U.S. Army for tactical purposes during World War II; published on a 1953 AMS map. Variant published on a 1943 USAAF map.

Fork Peak: peak, 6,063 ft., on E side of John River, 4 mi. S of mouth of Kollutuk Creek and $11 \mathrm{mi}$. SW of Anaktuvuk Pass, Brooks Ra.; $68^{\circ} 00^{\prime} 30^{\prime \prime} \mathrm{N}, 151^{\circ} 57^{\prime} 00^{\prime \prime} \mathrm{W}$; (map 134).

So named in 1901 by F. C. Schrader and W. J. Peters, USGS, because the peak lies near the confluence of several forks of the John River.

Forks, The: stream, formed by its East and West Forks, flows SW $16 \mathrm{mi}$. to Dall River, $10 \mathrm{mi}$. $\mathrm{N}$ of Stevens Village, Yukon Flats; $66^{\circ} 09^{\prime} \mathrm{N}$, $149^{\circ} 13^{\prime} \mathrm{W}$; (map 118).

Local descriptive name obtained in 1956 by USGS.

Forks Creek: stream, in Rampart Mts., flows S $4.5 \mathrm{mi}$. to Bear Creek, $30 \mathrm{mi}$. NE of Tanana, Kokrines-Hodzana High.; 65 $5^{\circ} 25^{\prime} 15^{\prime \prime} \quad \mathrm{N}$, $151^{\circ} 15^{\prime} 00^{\prime \prime} \mathrm{W}$; (map 106).

Local name reported in 1956 by Orth. 
Forky Creek: stream, on Iniskin Penin., flows SE $1.3 \mathrm{mi}$. to Fitz Greek, $3.5 \mathrm{mi}$. S of Chinitna. Bay, Aleutian Ra.; $59^{\circ} 46^{\prime} 20^{\prime \prime} \mathrm{N}, 153^{\circ} 12^{\prime} 30^{\prime \prime}$ $\mathrm{W} ; B G N 1947$; (map 51$)$.

Local descriptive name reported by USGS in 1947.

Form Lake: lake, $450 \mathrm{ft}$. long, on southern Kiska I., Aleutian Is.; $51^{\circ} 51^{\prime} 50^{\prime \prime} \mathrm{N}, 177^{\circ} 18^{\prime} 15^{\prime \prime} \mathrm{E}$; (map 14).

An arbitrary name beginning with " $F$ " to correspond to "F" grid used by the U.S. Army for tactical purposes during World War II; published on a 1953 AMS map.

Form Point: point of land, $0.5 \mathrm{mi}$. long., on W shore of Ryus Bay and N coast of Duke I., Alex. Arch.; $54^{\circ} 58^{\prime} 00^{\prime \prime} \mathrm{N}, 131^{\circ} 25^{\prime} 30^{\prime \prime} \mathrm{W}$; (map 2).

Local name published in 1920 by USC\&GS.

Forney River: stream, see Osar Stream.

Forney Stream: stream, headed in Malaspina Glacier, flowed $5 \mathrm{mi}$. S to Yakutat Bay, $5 \mathrm{mi}$. NE of Point Manby and $20 \mathrm{mi}$. NW of Yakutat, Malaspina Coastal Plain; $59^{\circ} 44^{\prime} 45^{\prime \prime} \mathrm{N}$, $140^{\circ} 09^{\prime} 30^{\prime \prime}$ W; (map 46). Var. Fotney River, Fotney Stream.

Named by J. E. McGrath, USC\&GS, probably for Stehman Forney, USC\&GS. This name may have been originally applied to what is now Oscar Stream. More likely the original Forney Stream, except for a small lagoon, has been destroyed by the advance of the Malaspina Glacier.

Forrest, Cape: point of land, see Icy Point.

Forrester Island: island, 5.2 mi. long, in Pacific Ocean, $20 \mathrm{mi}$. W of Dall I., Alex. Arch.; $54^{\circ} 48^{\prime} \mathrm{N}, 133^{\circ} 31^{\prime} \mathrm{W}$; (map 1). Var. Douglas Island, San Blas Island, San Carlos Island, Santa Catalina Island, Santa Christina Island, Santa Cristina Island.

Named by Capt. George Dixon "about July 1, 1787 and named no doubt after his steward, Henry Forrester" (Wagner, 1937, p. 388). Capt. George Vancouver, RN, adopted Dixon's name in 1793, giving it permanency. Juan Pérez called it "Santa Christina" in 1774; F. A. Maurelle called it "San Carlos" in 1775; and Capt. William Douglas named it "Douglas Island" in 1788 (Meares, 1790, p. 327). Forrester Island is a National Wildlife Refuge under the jurisdiction of USF\&WS.

Forrester's Island: rock, see Wolf Rock.

Forss Cove: cove, $0.7 \mathrm{mi}$. long, on $\mathrm{E}$ coast of Prince of Wales I, $2.2 \mathrm{mi}$. N of Thorne Head, Alex. Arch.; $55^{\circ} 43^{\prime} 10^{\prime \prime} \mathrm{N}, 132^{\circ} 27^{\prime} 15^{\prime \prime} \mathrm{W}$; (map 4).

Name published in 1925 Coast Pilot (p. 85).

Forss Island: island, $0.4 \mathrm{mi}$. long, in Helm Bay, $3.7 \mathrm{mi}$. NW of Helm Point, on $\mathrm{E}$ coast of Cleveland Penin., Alex. Arch.; 55 $37^{\prime} 45^{\prime \prime} \mathrm{N}$, $131^{\circ} 58^{\prime} 15^{\prime \prime} \mathrm{W}$; (map 3 ).

Local navigators' name obtained in 1904 by H. C. Fassett, USBF.

Fort Adams (American Station): locality, see Tanana.

Fort Alexander: locality, see Nushagak.

Fort Alexandra: locality, see Nushagak.
Fort Alexandrofskaia: locality, see Nushagak. Fortaleza, Lake: lake, $0.6 \mathrm{mi}$. long, $\mathrm{W}$ of Fortaleza Bay, on SE coast of Baker I., Alex. Arch.; $55^{\circ} 17^{\prime} 45^{\prime \prime} \mathrm{N}, 1^{\circ} 33^{\circ} 36^{\prime} 30^{\prime \prime} \mathrm{W}$; (map 4).

Named in 1923 by USC\&GS; derived from Fortaleza Point.

Fortaleza, Point: point of land, S point of entrance to Fortaleza Bay, on SE coast of Baker I., Alex. Arch.; $55^{\circ} 17^{\prime} 40^{\prime \prime} \mathrm{N}, 133^{\circ} 35^{\prime} 30^{\prime \prime} \mathrm{W}$; (map 4). Var. Mys de la Fartalesa, Punta de la Forteleza.

The name "Punta de la Forteleza" or "stronghold point" was given by Francisco Antonio Maurelle who discovered it on May 18, 1779. This was "no doubt a settlement of Indians on top of the high rock near Punta San Bartolome [Cape Bartolome], described by Mourelle [sic] in his journal" (Wagner, 1937, p. 388-389)

Fortaleza Bay: bight, $1 \mathrm{mi}$. across, on SE coast of Baker I., Alex. Arch.; 55 $18^{\prime}$ N, $133^{\circ} 35^{\prime}$ W; (map 4).

Named in 1923 by USC\&GS; derived from Fortaleza, Point.

Fortaleza Ridge: ridge, 1,500 ft., extends $\mathrm{E}-\mathrm{W}$ $3 \mathrm{mi}$. across $S$ end of Baker I., $W$ of Point Fortaleza, $55^{\circ} 17^{\prime} 15^{\prime \prime} \mathrm{N}, 133^{\circ} 37^{\prime} 40^{\prime \prime} \mathrm{W}$; (map 4).

Named in 1923 by USC\&GS; derived from Fortaleza, Point.

Fort Archangel Gabriel: locality, see Old Sitka. Fort Cosmos: locality, on right bank of Kobuk River at mouth of Cosmos Creek; 66 $52^{\circ} \mathrm{N}$, $157^{\circ} 18^{\prime} \mathrm{W}$; (map 115).

Winter camp, 1885-86, established and named in August 1885 by Lt. Stoney (1900, p. 19), USN, after the Cosmos Club in San Francisco, Calif., "of which the officers were members."

Fort Creek: stream, heads at $66^{\circ} 52^{\prime} \mathrm{N}, 141^{\circ} 03^{\prime}$ $W$, flows SE $25 \mathrm{mi}$. to the Black River in Canada, $8 \mathrm{mi}$. E of the Alaska-Canada boundary, $50 \mathrm{mi}$. NE of Midnight Hill, Porcupine Plat.; $66^{\circ} 41^{\prime} \mathrm{N}, 140^{\circ} 42^{\prime} \mathrm{W}$; (map 120). Var. Rat Creek.

Named in 1908 by IBC surveyors; published in 1914 on IBC Sheet 12 (1918 Atlas).

Fort Davis: locality, at mouth of Nome River at Norton Sound, $4 \mathrm{mi}$. SE of Nome, Seward Penin. High.; $64^{\circ} 29^{\prime} \mathrm{N}, 165^{\circ} 19^{\prime} \mathrm{W}$; (map 94).

U.S. Army post established in 1900 and named for Gen. Jefferson Columbus Davis, commander of the military district of Alaska in 1867. Much unrest resulted from claim jumping, filing errors, and lack of authority at the outset of the Nome gold rush in 1899 and 1900. The Army was stationed here to maintain order.

Fort Egbert: locality, see Eagle.

Forteleza, Punta de la: point of land, see Fortaleza, Point.

Fort Gibbon: locality, see Tanana.

Fort Glenn. military reservation, on NE end of Umnak I., Aleutian Is.; $53^{\circ} 24^{\prime} \mathrm{N}, 167^{\circ} 53^{\prime}$ W; (map 23).
Named by the U.S. Army for Brig. Gen. E. F. Glenn, USA, in 1942 and published in 1947 on a USGS map.

Fort Hamilton: village, see Hamilton.

Fort Hamlin: locality, on left bank of Yukon River, $\mathrm{N}$ of Hamlin Creek, $40 \mathrm{mi}$. NE of Rampart, Yukon-Tanana High.; 65 $53^{\prime} 45^{\prime \prime}$ N, 149 $13^{\prime} 15^{\prime \prime}$ W; BGN 1954; (map 105).

Name of a trading post of the Alaska Commercial Company named for Charles Sumner Hamlin, 1861-1938, Assistant Secretary of the Treasury from 1893-1897; commissioner at convention between Great Britain and United States to determine the fur seal-fishery controversy in 1897. Name published by USC\&GS in 1897.

Fort Hamlin Hills: mountains, 2,000 ft., extend NW $30 \mathrm{mi}$. from Yukon River at Fort Hamlin, $32 \mathrm{mi}$. NW of Livengood, Kokrines-Hodzana High.; $66^{\circ} 00^{\prime} \mathrm{N}, 149^{\circ} 45^{\prime} \mathrm{W}$; (map 105). Name reported in 1956 by USGS.

Fortification Bluff: cliff, 1,200 ft., $3 \mathrm{mi}$. long, on E coast of Alaska Penin. S of Step Mountain, $16 \mathrm{mi}$. NW of Augustine I., Aleutian Ra.; $59^{\circ} 25^{\prime} 30^{\prime \prime} \mathrm{N}, 153^{\circ} 47^{\prime} 30^{\prime \prime} \mathrm{W}$; BGN 1916; (map 51).

So named in 1914 by USC\&GS because of its fortlike appearance as it rises $1,200 \mathrm{ft}$. from the shore.

Fort Islet: island, NE island of Nichols Is., in Tlevak Strait between Dall and Goat Is., Alex. Arch.; 55 $10^{\prime} 40^{\prime \prime} \mathrm{N}, 132^{\circ} 57^{\prime} 50^{\prime \prime} \mathrm{W}$; (map 4).

Local descriptive name recorded in 1907 by H. C. Graves, USC\&GS. This island "is the site of an old Indian stockade."

Fort Kenai : village, see Kenai.

Fort Liscum: locality, on S shore of Port Valdez $4 \mathrm{mi}$. SW of Valdez, Chugach Mts. ; $60^{\circ} 05^{\prime} \mathrm{N}$, $146^{\circ} 21^{\prime} \mathrm{W}$; Var. Dayville.

Former military post established in 1900, reported to have been named for "Colonel Liscom," USA, commander of the 9th Infantry during the Boxer Rebellion, who died of wounds in China just prior to the founding of this post. The Fort Liscum post office was established in 1900; discontinued in 1922 (Ricks, 1965, p. 21).

Fortman Lake: lake, see Patching Lake.

Fort Mikhailovsky: locality, see Fort Saint Michael.

Fort New Archangel: town, see Sitka.

Fort Nicholas: village, see Kenai.

Fort Point: point of land, on NE end of Tongass I., at NW entrance to Port Tongass, Coast Mts.; $54^{\circ} 46^{\prime} 15^{\prime \prime} \mathrm{N}, 130^{\circ} 44^{\prime} 15^{\prime \prime} \mathrm{W}$; (map 2).

Descriptive name given in 1891 by Lt. Comdr. H. E. Nichols, USN.

Fort Point: point of land, at entrance to Steamboat Bay, $7 \mathrm{mi}$. N of Cape Fanshaw and $61 \mathrm{mi}$. E of Sitka, Coast Mts.; $57^{\circ} 16^{\prime} 45^{\prime \prime} \mathrm{N}, 133^{\circ} 31^{\prime}$ $30^{\prime \prime} \mathrm{W}$; (map 8$)$.

Named in 1889 by Lt. Comdr. H. B. Mansfield, USN; name published in 1892 by USC\&GS.

Fort Randall: village, see Cold Bay.

Fortress Creek: stream, flows SE $6.1 \mathrm{mi}$. to Caribou Creek, $51 \mathrm{mi}$. NE of Palmer, Talkeetna 
Mts.; $61^{\circ} 50^{\prime} 15^{\prime \prime} \mathrm{N}, 147^{\circ} 39^{\prime} 25^{\prime \prime} \mathrm{W}$; $B G N$ 1960; (map 69).

Named by USGS in 1956; derived from Fortress Ridge through which the stream flows.

Fortress Creek: stream, flows NE $15 \mathrm{mi}$. to Ayiyak River, $7 \mathrm{mi}$. NW of Castle Mtn. and $44 \mathrm{mi}$. NW of Anaktuvuk Pass, Arctic Slope; $68^{\circ} 38^{\prime} \mathrm{N}, 152^{\circ} 48^{\prime} \mathrm{W}$; (map 134).

Descriptive name given in 1944 by $W$. W. Patton, USGS, during the exploration of Naval Petroleum Reserve No. 4, for nearby Fortress Mountain.

Fortress Mountain: mountain, 2,870 ft., $10 \mathrm{mi}$. W of Castle Mtn. and $44 \mathrm{mi}$. NW of Anaktuvuk Pass, Arctic Slope; $68^{\circ} 35^{\prime} \mathrm{N}, 152^{\circ} 58^{\prime} \mathrm{W}$; (map 134).

Descriptive name given in 1944 by W. W. Patton, USGS, during the exploration of Naval Petroleum Reserve No. 4, because of its fortress appearance.

Fortress Point: point of land, between Gusty and Rough Bays, on NE coast of Tanaga I., Aleutian Is.; $51^{\circ} 50^{\prime} 40^{\prime \prime} \mathrm{N}, 177^{\circ} 52^{\prime} 00^{\prime \prime} \mathrm{W}$; (map 17).

Name published by USC\&GS in 1956 on Chart 9145.

Fortress Ridge: ridge, elev. 5,000 ft., extends $6.5 \mathrm{mi}$. along W bank of Caribou Creek, 47 mi. NE of Palmer, Talkeetna Mts.; $61^{\circ} 51^{\prime} 45^{\prime \prime}$ N, 147 40'00" W; BGN 1960; (map 69).

Descriptive name given in 1956 by USGS. So named "because bold cliff is suggestive of fortress walls when viewed from the southeast."

Fort Saint Michael: locality, on Baranof I, at Old Sitka, 6 mi. N of Sitka, Alex. Arch.; 57 $17^{\prime} 50^{\prime \prime} \mathrm{N}, 135^{\circ} 22^{\prime} 10^{\prime \prime} \mathrm{W}$; (map 9). Var. Archangel Michael, Fort Archangel Gabriel, Fort Mikhailovsky, Fort Svyatty Mikhail, Mikhailovsk, New Archangel, Novo Arkhangelsk, Redoubt Saint Gabriel.

This is the first Russian settlement built in 1799 at Sitka by Alexander Baranov, first governor of Russian American colonies, who named it "Fort Archangel Gabriel." The site was purchased from the Tlingit Indians. In 1802 natives attacked and destroyed the fort and killed or captured most of its inhabitants. The captives were released after an ultimatum was issued by the officer aboard a British ship in the harbor (Bancroft, 1886, p. 405-406). The Russians recaptured the area in 1804 and erected a new fort called "Fort Archangel Michael" at a new location 5 miles to the south which developed into the present city of Sitka. See Sitka.

Fort Saint Michael: village, see Saint Michael.

Fort Shoemaker: locality, on Dall River just above its junc. with the Yukon River KokrinesHodzana High.; $66^{\circ} 02^{\prime} \mathrm{N}, 149^{\circ} 15^{\prime} \mathrm{W}$; (map 118)

Winter camp established in 1899-1900 for the crew of the revenue cutter Nunivak; named by Lt. Cantwell (1902, p. 46), USRCS, for Capt. Charles F. Shoemaker, USRCS, "who, as chief of the Revenue-Cutter Service, had been indefatigable in his effort to extend the operations of the Service to this region ***."

Fort Souworoff : village, see Naknek.

Fort Stikine: town, see Wrangell.

Fort Suvaroff: village, see Naknek.

Fort Suworof : village, see Naknek.

Fort Svyatty Mikhail: locality, see Fort Saint Michael.

Fort Torngas: locality, see Tongass.

Fort Tongas: locality, see Tongass.

Fortuna Channel: water passage, see Fortuna Strait.

Fortuna Island: island, see Klokachef Island.

Fortuna Ledge: village, see Marshall.

Fortuna Passage: water passage, see Fortuna Strait.

Fortuna Point: point of land, on Klokachef I., off SW coast of Chichagof I., $18 \mathrm{mi}$. SE of Chichagof, Alex. Arch.; 57 $25^{\prime} 00^{\prime \prime} \mathrm{N}$ $135^{\circ} 53^{\prime} 45^{\prime \prime} \mathrm{W}$; BGN 1930; (map 9).

Named in 1930 by USC\&GS for Fortuna Strait. Fortuna was the former name of Klokachef Island.

Fortuna Reefs: reefs, off NW coast of Klokachef, I., SW of Chichagof I., Alex. Ach.; 57 $25^{\prime} 20^{\prime \prime}$ $\mathrm{N}, 135^{\circ} 55^{\prime} 00^{\prime \prime} \mathrm{W}$; BGN 193'); (map 9).

Named in 1930 by USC\&GS for Fortuna Strait.

Fortuna Strait: water passage, between Klokachef I. and Khaz Penin,, Chichagof I., Alex Arch.; $57^{\circ} 25^{\prime} \mathrm{N}, 135^{\circ} 53^{\prime} \mathrm{W}$; (map 9). Var. Fortuna Channel, Fortuna Passage, Proliv Fortuny.

Named by the Russians; published in 1848 on Russian Hydrog. Chart 1397 as "Proliv Fortuny" meaning "Fortuny Strait." "The Spanish schooner Fortuna, *** was found ashore here and taken by the Russian American Company's vessels as a prize in 1819. The name has doubtless come from this circum. stance" (Baker, 1906, p. 262)

Fortune Creek: stream, flows E $7 \mathrm{mi}$. to Cache Creek, $20 \mathrm{mi}$. W of Fairbanks, Yukon-Tanana High.; $64^{\circ} 52^{\prime} 55^{\prime \prime} \mathrm{N}, 148^{\circ} 22^{\prime} 20^{\prime \prime} \mathrm{W}$; (map 100).

Name given by prospectors; published in 1906 by USGS.

Fortune Creek: steam, flows NW to Mystery Creek which flows to Cripple River, about $23 \mathrm{mi}$. NW of Imuruk Lake, Seward Penin. High.; (map 110).

Prospectors' name reported on a precinct map of Seward Peninsula by Monroe and Hutchins; corrected to June 1903 by Arthur Gibson. This stream cannot be precisely located on current maps.

Fortune Hunter Creek: stream, flows SW to Fish River, on $N$ side of White Mtn. about 32 mi. ENE of Solomon, Seward Penin. High.; (map 95).

Prospectors' name reported on the 1900 "Map of Nome Peninsula" by J. M. Davidson and B. W. Blakeslee. The stream cannot be precisely located on current maps.

Fortuny, Proliv: water passage, see Fortuna Strait.

Fort William H. Seward: village, see Port Chilkoot.
Fort Wrangell: town, see Wrangell.

Forty and One-half Mile Creek: stream, flows NE $18 \mathrm{mi}$. to Fortymile Creek, $0.8 \mathrm{mi}$. W of its junc. with Hadweenzic River and $31 \mathrm{mi}$. $\mathrm{N}$ of Beaver, Yukon Flats; $66^{\circ} 48^{\prime} \mathrm{N}, 147^{\circ} 25^{\prime}$ W; (map 118).

Local name obtained in 1956 by USGS; name derived from the distance to Beaver via a year-round trail.

Fortyfive Pup: stream, flows SE $7 \mathrm{mi}$. to Buckskin Creek, $50 \mathrm{mi}$. SW of Eagle, YukonTanana High.; $64^{\circ} 11^{\prime} 30^{\prime \prime} \mathrm{N}, 142^{\circ} 01^{\prime} 00^{\prime \prime} \mathrm{W}$; (map 102).

Prospectors' name shown on a 1902 manuscript map by E. J. Chamberlain, U.S. Deputy Surveyor.

Fortymile: locality, at junction of Bullion Creek and North Fork Fortymile River $37 \mathrm{mi}$. SW of Eagle, Yukon-Tanana High.; $64^{\circ} 26^{\prime} 30^{\prime \prime} \mathrm{N}$, $142^{\circ} 08^{\prime} 20^{\prime \prime}$ W; (map 102). Var. North Fork.

Former telegraph station established in 1903 by the U.S. Army Signal Corps and originally called "North Fork" after the stream. The prospectors called it "Fortymile."

Forty Mile: village, see Tetlin Junction.

Fortymile Greek: stream, heads in lake, flows NE $16 \mathrm{mi}$. to Hadweenzic River, $31 \mathrm{mi}$. N of Beaver, Yukon Flats; $66^{\circ} 48^{\prime} \mathrm{N}, 147^{\circ} 23^{\prime} \mathrm{W}$; (map 118).

Local name obtained in 1956 by USGS; name derived from the distance to Beaver via a year-round trail.

Forty Mile Creek: stream, see Fortymile River.

Fortymile Dome: mountain, 4,187 ft., $1 \mathrm{mi}$. W of Alaska-Canada boundary, $25 \mathrm{mi}$. SE of Eagle, Yukon-Tanana High.; $64^{\circ} 26^{\prime} 20^{\prime \prime} \mathrm{N}$, $141^{\circ} 01^{\prime} 00^{\prime \prime} \mathrm{W}$; (map 102). Var. Dome, Dome Mountain, The Dome.

Named by prospectors and published in 1898 by the USGS. In 1896, the mountain was called "The Dome" by Spurr (1898, pl. 38), USGS

Fortymile Lake: lake, $0.6 \mathrm{mi}$. across, $1.2 \mathrm{mi}$. SSW of Thirtyeight Mile Lake and $15 \mathrm{mi}$. W of junc. of Herron and Foraker Rivers, Tanana Low.; $63^{\circ} 40^{\prime} \mathrm{N}, 152^{\circ} 40^{\prime} \mathrm{W}$; (map 88).

Local name reported in 1954 by USGS.

Fortymile Lake: lake, $0.3 \mathrm{mi}$. across, in course of Fortymile Creek, $29 \mathrm{mi}$. N of Beaver, Yukon Flats; $66^{\circ} 46^{\prime} 40^{\prime \prime} \mathrm{N}, 147^{\circ} 32^{\prime} 30^{\prime \prime} \mathrm{W}$; (map 118).

Local name derived from Fortymile Creek; obtained in 1956 by USGS.

Fortymile River: stream, formed by its North and South Forks, flows NE $60 \mathrm{mi}$. into Canada to Yukon River, $32 \mathrm{mi}$. SE of Eagle, YukonTanana High.; $64^{\circ} 26^{\prime} \mathrm{N}, 140^{\circ} 32^{\prime} \mathrm{W}$; (map 102). Var. Cone-Hill River, Forty Mile Creek, Forty-Mile River, Shitando River.

Prospectors' name given about 1886 ; so called because the mouth of the stream is about 40 miles below the former Hudson's Bay post called "Fort Reliance." It was called "Cone-Hill River" by Lt. Schwatka (1885, p. 248), USA, "from the fact that there is a prominent conical hill in the center of its 
broad valley, near its mouth." Gold was discovered here late in 1886 (Spurr, 1898, p. $115)$.

Fortymile River: stream, see Dennison Fork.

Fortymile Slough: stream, anabranch of Koyukuk River, flows $W 3 \mathrm{mi}$. along the $\mathrm{N}$ side of Florence Is., $18 \mathrm{mi}$. $\mathrm{N}$ of Hackandochtla Mtn., Kokrines-Hodzana High.; $65^{\circ} 48^{\prime} 00^{\prime \prime} \mathrm{N}, 154^{\circ}$. $55^{\prime} 20^{\prime \prime} \mathrm{W}$; (map 107).

Local name shown on a 1932 sketch map of the area; author unknown.

Forty-seven Gulch: ravine, trends W $3 \mathrm{mi}$. to Ninety-two Hunter Creek, $8 \mathrm{mi}$. E of Rampart, Yukon-Tanana High.; $65^{\circ} 28^{\prime} 30^{\prime \prime}$ N, $149^{\circ}$ $54^{\prime} 30^{\prime \prime} \mathrm{W}$; (map 105). Var. Fortyseven Pup, 47 Pup.

Named by prospectors; reported in 1904 by L. M. Prindle and F. L. Hess (in Brooks and others, 1905, fig. 6), USGS, as "47 Pup".

Fortyseven Pup: stream, flows NW $1.6 \mathrm{mi}$. to Hoosier Creek $2.7 \mathrm{mi}$. SE of that stream's junc. with Minook Creek, $7 \mathrm{mi}$. SSE of Rampart, Yukon-Tanana High.; $65^{\circ} 25^{\prime} 10^{\prime \prime} \mathrm{N}$, $150^{\circ} 03^{\prime} 00^{\prime \prime} \mathrm{W}$; (map 106).

'Prospectors' name reported in 1904 by L. M. Prindle, USGS

Fortyseven Pup: ravine, see Forty-seven Gulch. Fortythree Pup: stream, flows N 1.3 mi. to Deadwood Creek, $12 \mathrm{mi}$. SW of Central and $38 \mathrm{mi}$. SW of Circle, Yukon-Tanana High.: $65^{\circ} 25^{\prime}$ $30^{\prime \prime} \mathrm{N}, 145^{\circ} 01^{\prime} 00^{\prime \prime} \mathrm{W}$; (map 104).

Prospectors' name reported in 1954 or 1955 by USGS topographers.

Fortytwo Gulch: ravine, trends NW $1 \mathrm{mi}$. to Mastodon Creek, $1.5 \mathrm{mi}$. NE of Mastodon Dome and $44 \mathrm{mi}$. SW of Circle, Yukon-Tanana High.; $65^{\circ} 27^{\prime} \mathrm{N}, 145^{\circ} 18^{\prime} \mathrm{W}$; (map 104).

Named by prospectors and reported in 1936 by Mertie (1938a, p. 206), USGS.

Fortytwo Mile Creek: stream, flows E $17 \mathrm{mi}$. to Hadweenzic River, $33 \mathrm{mi}$. N of Beaver, Yukon Flats; $66^{\circ} 49^{\prime} 50^{\prime \prime} \mathrm{N}, 147^{\circ} 23^{\prime} 30^{\prime \prime} \mathrm{W}$; (map 118 ).

Local name obtained in 1956 by USGS; name derived from the distance to Beaver via a year-round trail.

Fort Yukon: village, pop. 701, on right bank of Yukon River at its junction with Porcupine River, Yukon Flats; $66^{\circ} 34^{\prime} \mathrm{N}, 145^{\circ} 16^{\prime} \mathrm{W}$; BGN 1944; (map 119). Var. Fort Yukon Village.

Founded as a Hudson's Bay Company trading post by Alexander $H$. Murray in 1847; originally the post and Indian village was located about a mile or two upstream but moved to its present location about 1864 . After the purchase of Alaska it was determined by Capt. C. W. Raymond, U.S. Engineers, that the British trading post was on United States territory and the site was soon taken over by Moses Mercier, trader of the new Alaska Commercial Company. The village population was 107 in $1880 ; 189$ in $1890 ; 321$ in $1910 ; 319$ in $1920 ; 304$ in $1930 ; 274$ in 1939 ; and 446 in 1950. The Fort Yukon post office was established in 1898 (Ricks, 1965, p. 21).

Fort Yukon Village: village, see Fort Yukon.

Forward Lake: lake, see Chuck Lake.
Fossil Bluffs: bluffs, on Kuiu I., on NE shore of Halleck Harbor, in Saginaw Bay, Alex. Arch.; $56^{\circ} 55^{\prime} 00^{\prime \prime} \mathrm{N}, 134^{\circ} 12^{\prime} 30^{\prime \prime} \mathrm{W}$; (map 5).

Local name recorded in 1948 by USGS.

Fossil Greek: stream, flows W $2.7 \mathrm{mi}$. to Lake Kiowa, $9.2 \mathrm{mi}$. NE of Anchorage, Cook Inlet Low.; $61^{\circ} 17^{\prime} 54^{\prime \prime} \mathrm{N}, 149^{\circ} 40^{\prime} 10^{\prime \prime} \mathrm{W}$; (map $69)$.

Local name reported in 1942 by AMS.

Fossil Creek: stream, flows SW $23 \mathrm{mi}$. to Beaver Creek, $25 \mathrm{mi}$. SE of Livengood, Yukon-Tanana High.; 65 $28^{\prime} 30^{\prime \prime} \mathrm{N}, 147^{\circ} 39^{\prime} 30^{\prime \prime} \mathrm{W}$; (map 105).

Named in 1905 by L. M. Prindle, USGS, for "the fossiliferous limestone pebbles in its valley" (Prindle and Hess, 1906, p. 13).

Fossil Creek: stream, flows NE $25 \mathrm{mi}$. to Colville River, $7 \mathrm{mi}$. SW of Umiat, Arctic Slope; $69^{\circ}$ $18^{\prime} \mathrm{N}, 152^{\circ} 22^{\prime} \mathrm{W}$; BGN 1964; (map 141). Var. Ikaksigilak Creek.

So named by USGS geologists during exploration of Naval Petroleum Reserve No. 4 in 1947 "because of the excelient fossil collection made here." The Ekimo name, according to T. E. Taylor, USGS, in 1956, is Ikaksigilak, meaning "hard to cross in summer."

Fossil Lake: lake, see Carrot Lake.

Fossil Mountain: hill, $875 \mathrm{ft}$., $0.5 \mathrm{mi}$. SE of Lief Cove on W coast of Kiska I., Aleutian Is. ; $51^{\circ} 55^{\prime} 45^{\prime \prime} \mathrm{N}, 177^{\circ} 20^{\prime} 00^{\prime \prime} \mathrm{E}$; (map 14).

An arbitrary name beginning with " $F$ " to correspond to "F" grid used by the U.S. Army for tactical purposes during World War II; published on a 1953 AMS map.

Fossil Mountain: mountain, 2,673 ft., $43 \mathrm{mi}$. NW of Medfra, Kilbuck-Kuskokwim Mts.; $63^{\circ} 23^{\prime} \mathrm{N}, 155^{\circ} 54^{\prime} \mathrm{W}$; (map 89). Var. Fossil Ridge.

Local name shown as "Fossil Ridge" on a map published in 1921 by USGS; shown as "Fossil Mountain" on a 1954 USGS map.

Fossil Peak: peak, 4,115 ft., $0.5 \mathrm{mi}$. S of head of Charpentier Glacier, in Glacier Bay National Monument, $58 \mathrm{mi}$. NW of Hoonah, St. Elias Mts. ; $58^{\circ} 39^{\prime} 50^{\prime \prime} \mathrm{N}, 136^{\circ} 36^{\prime} 50^{\prime \prime} \mathrm{W}$.; (map 10)

Local name reported in 1951 by USGS.

Fossil Point: point of land, on S shore of Tuxedni Bay, $\mathbf{N}$ point of entrance to Tuxedni Channel, $56 \mathrm{mi}$. SW of Kenai, Aleutian Ra.; $60^{\circ} 10^{\prime}$ $\mathrm{N}, 152^{\circ} 41^{\prime} \mathrm{W}$; (map 62).

Name published in 1912 by USC\&GS.

Fossil Ridge: mountain, see Fossil Mountain.

Fossil River: stream, flows N $16 \mathrm{mi}$. to Bering Sea at Camp Iveetok, on NE coast of St. Lawrence I.; $63^{\circ} 29^{\prime} 30^{\prime \prime} \mathrm{N}, 170^{\circ} 03^{\prime} 00^{\prime \prime} \mathrm{W}$; $B G N$ 1951; (map 93). Var. Ivektuk River.

Named by USC\&GS in 1932.

Foster, Mount: mountain, 7,127 ft., on AlaskaCanada boundary, $6 \mathrm{mi}$. NW of Mount Van Wagenen and $24 \mathrm{mi}$. NNW of Skagway, Coast Mts.; $B G N$ 1954; $59^{\circ} 47^{\prime} 50^{\prime \prime} \mathrm{N}, 135^{\circ} 28^{\prime} 30^{\prime \prime}$ W.; (map 45).

Named by United States and Canada for John Watson Foster, 1836-1917, former U.S. Secretary of State, who as agent of the United States participated in the Alaska Boundary Tribunal in London in 1903. Foster was born in Indiana and graduated from the Harvard Law School. After serving in the army during the Civil War, he was employed as an editor and as a postmaster. He served as Minister to Mexico, Russia, and Spain from 1873-85. $\mathrm{He}$ was Secretary of State under President Harrison, 1892-93, and in 1893 he represented the United States in arbitration for the Bering Fur-Seal Controversy.

Foster Creek: stream, flows SW $3.5 \mathrm{mi}$. to Lefthand Bay, $12 \mathrm{mi}$. N of Unga I., near SW end of Alaska Penin., Aleutian Ra.; $55^{\circ} 33^{\prime} 30^{\prime \prime} \mathrm{N}$, $160^{\circ} 44^{\prime} 00^{\prime \prime} \mathrm{W}$; (map 28).

Named in 1929 by USGS.

Foster Creek: stream, flows NE $3.5 \mathrm{mi}$. to Camp Creek which flows to Niukluk River, $29 \mathrm{mi}$. NE of Solomon, Seward Penin. High.; 64 ${ }^{\circ} 55^{\prime}$ N, $163^{\circ} 56^{\prime} \mathrm{W}$; (map 95). Var. Easter Creek, Pine Creek.

Prospectors' name reported in 1900 by E. C. Barnard (in Brooks, 1901, pl. 17), USGS. This appears to be the "Pine Creek" shown in 1900 by F. C. Schrader and A. H. Brooks, USGS.

Foster Glacier: glacier, see Taku Glacier.

Fosters Camp: locality, on W shore of Albatross Anchorage, $15 \mathrm{mi}$. $\mathrm{N}$ of Unga I., near SW end of Alaska Penin., Aleutian Ra.; $55^{\circ} 36^{\prime} 00^{\prime \prime}$ N, $160^{\circ} 36^{\prime} 25^{\prime \prime} \mathrm{W}$; (map 28).

Named by Atwood (1911, pl. 2), USGS.

Fotney Stream: stream, see Forney Stream.

Fotshou's Village: locality, "near Taku Inlet, Coast Mts," (map 11).

Former Tlingit Indian summer camp listed by Ivan Petroff in the 1880 Census with a population of 24 .

Foul Bay: bay, $1.5 \mathrm{mi}$. across, $\mathrm{N}$ of Sea Otter Harbor, on W coast of Dall I., Alex. Arch.; $55^{\circ} 08^{\prime} 20^{\prime \prime} \mathrm{N}, 133^{\circ} 13^{\prime} 20^{\prime \prime} \mathrm{W}$; (map 4).

Descriptive name published in 1920 by USG\&GS.

Foul Bay: bay, extends SE 7 mi., off Shelikof Strait, on $\mathrm{W}$ coast of Afognak I., $25 \mathrm{mi}$. N of Afognak, $\mathrm{N}$ of Kodiak I.; $58^{\circ} 22^{\prime} \mathrm{N}, 152^{\circ} 54^{\prime}$ W; (map 43).

Local descriptive name reported in 1952 by USGS.

Foul Bay: bay, $1.5 \mathrm{mi}$. across, on $\mathrm{E}$ coast of Kenai Penin., on W side of Prince William Sound, $22 \mathrm{mi}$. N of Chenega, Chugach Mts.; $60^{\circ} 35^{\prime}$ $\mathrm{N}, 148^{\circ} 04^{\prime} \mathrm{W} ; \mathrm{BGN} 1914$; (map 63 ).

Name published in 1913 by USC\&GS.

Foul Pass: water passage, trends NW-SE 2 mi., between Disk and Ingot Is., in Prince William Sound, $42 \mathrm{mi}$. SE of Whittier, Chugach Mts.; $60^{\circ} 30^{\prime} 00^{\prime \prime} \mathrm{N}, 147^{\circ} 38^{\prime} 15^{\prime \prime} \mathrm{W}$; (map 63).

Local name published in 1910 by USC\&GS.

Found Fish Lake: lake, $1.8 \mathrm{mi}$. long, $\mathrm{N}$ of Khaali Lake, $1.4 \mathrm{mi}$. SW of Arctic Village Brooks Ra.; $68^{\circ} 06^{\prime} 30^{\prime \prime} \mathrm{N}, 145^{\circ} 36^{\prime} 30^{\prime \prime} \mathrm{W}$; (map 136).

Translation of a Kutchin Indian name reported in 1956 by T. E. Taylor, USGS.

Found Island: island, $0.5 \mathrm{mi}$. long, in Ernest Sound S of Wrangell I., $28 \mathrm{mi}$. SE of Wrangell, Alex. Arch.; 56 $06^{\prime} 15^{\prime \prime} \mathrm{N}, 132^{\circ} 04^{\prime} 30^{\prime \prime}$ W; (map 6). 
Named in 1886 by Lt. Comdr. A. S. Snow, USN; name published in 1887 on USC\&GS Chart 706.

Fountain River: stream, heads at Eldridge Glacier, flows SW 9 mi. to Chulitna River, 33 mi. N of Talkeetna, Alaska Ra.; $62^{\circ} 47^{\prime} 50^{\prime \prime}$ $\mathrm{N}, 150^{\circ} 05^{\prime} 10^{\prime \prime} \mathrm{W}$; (map 81).

Local name reported in 1951 by USGS.

Fountain Rock: rock, in Gulf of Alaska, $5 \mathrm{mi}$. NW of Middleton I., Malaspina Goastal Plain; $59^{\circ} 35^{\prime} \mathrm{N}, 146^{\circ} 21^{\prime} \mathrm{W}$; (map 48) Var. Podvodnyy Kamen Fontan.

This is an 1868 translation by USC\&GS of part of the Russian name "Podvodnyy Kamen Fontan," meaning "sunken fountain rock"; published by Capt. Tebenkov (1852, map 6).

Four, Lake: lake, 1,200 ft. across, between Lakes One and Five, $7.5 \mathrm{mi}$. S of Talkeetna, Cook Inlet Low.; $62^{\circ} 12^{\prime} 45^{\prime \prime} \mathrm{N}, 150^{\circ} 03^{\prime} 15^{\prime \prime} \mathrm{W}$; (map 81).

Local descriptive name reported in 1958 by USGS.

Four Bear Creek: stream, flows SW $6 \mathrm{mi}$. to Canoe Bay River at Canoe Bay, $11 \mathrm{mi}$. E of Pavlof Bay, at SW end of Alaska Penin., Aleutian Ra.; $55^{\circ} 31^{\prime} 50^{\prime \prime} \mathrm{N}, 161^{\circ} 08^{\prime} 40^{\prime \prime} \mathrm{W}$; (map 28).

Named in 1929 by USGS

Four Craters, Islands of the: islands, see Four Mountains, Islands of.

Four F Creek: stream, flows SW $2.3 \mathrm{mi}$. to Pacific Ocean, on southern Kiska I., Aleutian Is.; $51^{\circ} 52^{\prime} 20^{\prime \prime} \mathrm{N}, 177^{\circ} 14^{\prime} 50^{\prime \prime} \mathrm{E}$; (map 14).

An arbitrary name beginning with " $F$ " to correspond to "F" grid used by the U.S. Army for tactical purposes during World War II; published on a 1953 AMS map.

Four Gulch: ravine, in Kantishna Hills, trends SE $1 \mathrm{mi}$. to Glen Creek, $6 \mathrm{mi}$. ENE of Wonder Lake, Alaska Ra.; $63^{\circ} 31^{\prime} 50^{\prime \prime} \mathrm{N}, 150^{\circ} 42^{\prime}$ $20^{\prime \prime} \mathrm{W} ; B G N 1932$; (map 88).

Prospectors' name reported in 1931 by $F$. G. Wells and S. G. Kain, USGS.

Fourmile Camp: locality, on right bank of Yukon River, $30 \mathrm{mi}$. SW of Nulato, Nulato Hills.; $64^{\circ} 22^{\prime} \mathrm{N}, 158^{\circ} 41^{\prime} \mathrm{W}$; (map 97 ).

Local descriptive name reported in 1954 by USGS.

Fourmile Creek: stream, in Glacier Bay National Monument, flows SW $6 \mathrm{mi}$. to Gulf of Alaska, $2 \mathrm{mi}$. NW of mouth of Eagle Creek and $91 \mathrm{mi}$. NW of Hoonah, Malaspina Coastal Plain; $58^{\circ} 40^{\prime} 20^{\prime \prime} \mathrm{N}, 137^{\circ} 41^{\prime} 50^{\prime \prime} \mathrm{W}$; (map 10).

Local name published by USGS in the 1950's.

Fourmile Creek: stream, in Nutzotin Mts., flows $\mathrm{SE}$ and NE $10 \mathrm{mi}$. across Alaska-Canada boundary to Beaver Greek, Alaska Ra.; $62^{\circ} 10^{\prime} \mathrm{N}, 141^{\circ} 00^{\prime} \mathrm{W}$; BGN 1912; (map 84). Var. Four Mile Creek.

Local name reported in 1908 by F. $\mathrm{H}$. Moffit (in Brooks and others, 1909, pl. 7), USGS

Fourmile Creek: stream, heads on S slope of Madison Mtn., flows E $8 \mathrm{mi}$. to Innoko River, $17 \mathrm{mi}$. N of Ophir and $42 \mathrm{mi}$. NW of Mc-
Grath, Kilbuck-Kuskokwim Mts.; $63^{\circ} 23^{\prime} \mathrm{N}$, $156^{\circ} 35^{\prime} \mathrm{W}$; (map 90).

Local name obtained in 1954 by $R$. E. Isto, USGS. So called because stream's mouth is about 4 miles from the Carlson cabin.

Fourmile Creek: stream, flows N $17 \mathrm{mi}$. to Innoko River, $4 \mathrm{mi}$. NW of Cripple Landing, $43 \mathrm{mi}$. N of Ophir and $60 \mathrm{mi}$. NW of McGrath, Innoko Low.; $63^{\circ} 44^{\prime} 20^{\prime \prime} \mathrm{N}$, $156^{\circ} 26^{\prime} 10^{\prime \prime} \mathrm{W}$; (map 90).

Local name obtained in 1954 by $R$. E. Isto, USGS. So called because it is about four miles from Cripple Landing.

Fourmile Creek: stream, flows NW and W 30 mi. to North Fork Innoko River, $52 \mathrm{mi}$. N of Ophir and $69 \mathrm{mi}$. NW of McGrath, Kilbuck-Kuskokwim Mts.; 63 $54^{\prime} 30^{\prime \prime} \mathrm{N}, 156^{\circ} 25^{\prime}$ 30" W; BGN 1964; (map 90). Var. Elk Creek, Silver Creek.

Local name obtained in 1954 by R. E. Isto, USGS. So called because the stream was about four miles from Hogan's cabin.

Fourmile Creek: stream, flows S $4 \mathrm{mi}$. to Chena River, $34 \mathrm{mi}$. ENE of Fairbanks, YukonTanana High.; $64^{\circ} 54^{\prime} 15^{\prime \prime} \mathrm{N}, 146^{\circ} 31^{\prime} 10^{\prime \prime} \mathrm{W}$; (map 101).

Descriptive name reported in 1950 by USGS.

Fourmile Hill: hill, 1,239 ft., $3.5 \mathrm{mi}$. E of Big Delta, Alaska Ra.; $64^{\circ} 09^{\prime} \mathrm{N}, 145^{\circ} 43^{\prime} \mathrm{W}$; (map 101). Var. Fivemile Hill.

Local name published in 1956 by USGS. So named because it is 4 miles east-southeast of the junc. of the Delta and Tanana Rivers. In 1951 the USGS reported that the hill was called "Fivemile Hill."

Four Mountains, Islands of: islands, between Fox Is. and Andreanof Is., Aleutian Is.; $52^{\circ} 55^{\prime}$ $\mathrm{N}, 169^{\circ} 40^{\prime} \mathrm{W},\left(\mathrm{E}\right.$ end ) $52^{\circ} 30^{\prime} \mathrm{N}, 171^{\circ} 19^{\prime}$ W, (W end); BGN 1963; (map 21). Var. Islands of the Four Craters, Islands of the Four Mountains, Oone-agun, Ostrova Chetyre Soposhnye, Unigun.

Translation of the Russian "O[strova] Chetyre Soposhnye," meaning "Islands of Four Volcanoes" (Sarichev, 1826, map 3). This name was given because of four prominent volcanoes on four of the five islands. The Aleut name "Unigun" was reported in 1840 by Father Veniaminov. There appears to be much confusion regarding the application of the variant names of these islands, possibly because only four of the five islands are shown on most of the early maps and charts. The present names were gathered in 1894 by a field party on the U.S.S. Concord and published in 1895 by the U.S. Navy Hydrog. Office (Chart 8). See Carlisle, Chuginadak, Herbert, Kagamil, and Uliaga Islands.

Fourpeaked Mountain: mountain, 6,903 ft., on NE coast of Alaska Penin., in Katmai National Monument, $38 \mathrm{mi}$. S of Augustine I., Aleutian Ra.; $58^{\circ} 46^{\prime} 15^{\prime \prime} \mathrm{N}, 153^{\circ} 40^{\prime} 25^{\prime \prime} \mathrm{W}$; $B G N$ 1957; (map 43). Var. Four Peaked Mountain, Gora Chetierek Glavaia, Island of the Four Peaks, Mount Tapirag, Saint Dolmat.

Descriptive name translated by George Davidson, USC\&GS, in 1869 from "G[ora] Chetyrekhglavaya," meaning literally fourheaded mountain," published by Tebenkov (1852, map 5). The Russian Hydro. Dept. had published the name "G[ora] Chetyrekh glavaya," meaning "mountain of four heads," in 1847 on Chart 1378. This may be the mountain called "Saint Dolmat" on a 1748 Russian manuscript map (Wagner, 1937, p. 493).

Fourteen Creek: stream, flows W $2.4 \mathrm{mi}$. to Lower Lake George, $29 \mathrm{mi}$. SE of Palmer, Chugach Mts. ; $61^{\circ} 19^{\prime} 05^{\prime \prime} \mathrm{N}, 148^{\circ} 28^{\prime} 15^{\prime \prime} \mathrm{W}$; (map 69).

Local name reported in 1960 by USGS.

Fourteenmile House : locality, on Birch Creek, 2 $\mathrm{mi}$. S of Twelvemile House and $14 \mathrm{mi}$. SW of Circle, Yukon-Tanana High.; $65^{\circ} 40^{\prime} \mathrm{N}$, $144^{\circ} 25^{\prime} \mathrm{W}$; (map 104).

Name of a roadhouse reported in 1908 by Covert and Ellsworth (1909, pl. 4), USGS. The roadhouse is no longer there.

Fourth Berg Lake: lake, $5 \mathrm{mi}$. long, at 1905 terminus of Bering Glacier, $4 \mathrm{mi}$. NE of Doughton Peak and $69 \mathrm{mi}$. E of Cordova, Chugach Mts. ; $60^{\circ} 27^{\prime} 30^{\prime \prime} \mathrm{N}, 143^{\circ} 46^{\prime} 00^{\prime \prime} \mathrm{W}$; (map 65). Var. Fourth Lake.

Local name reported in 1905 by G. C. Martin (1908, pl. 2), USGS. This lake was originally one of five Berg Lakes. As a result of the retreat of Steller and Bering Glaciers in recent times, Fourth Berg Lake has joined with Fifth Berg Lake to form Fifth Lake.

Fourth Berg Lake: lake, see Fifth Lake.

Fourth Glacier: glacier, heads $1.4 \mathrm{mi}$. W of Black Tit, trends SW $2.8 \mathrm{mi}$. to its 1961 terminus $2.6 \mathrm{mi}$. SE of Mount Pinta, $20 \mathrm{mi}$. NE of Yakutat, St. Elias Mts.; 59 $35^{\prime} 30^{\prime \prime} \mathrm{N}$, $139^{\circ} 09^{\prime} 00^{\prime \prime} \mathrm{W}$; BGN 1910; (map 46). Var. Beasley Glacier.

Local name reported in 1909 by Lawrence Martin as having been used since 1897 or 1898 . This was the fourth glacier within Yakutat Bay, which the prospectors attempted to traverse in the late 1890's to reach the Alsek valley gold fields. The first was the Turner Glacier, the Hubbard Glacier was the second, and Nunatak Glacier was the third. The name "Beasley Glacier" was proposed by Blackwelder (1907, p. 417-418), instead of "Fourth Glacier," for R. W. Beasley of Yakutat, but this name was not accepted by BGN.

Fourth Lake: lake, $0.4 \mathrm{mi}$. across, $1 \mathrm{mi}$. E of Luke Lake and $17 \mathrm{mi}$. W of Beaver, Yukon Flats; $66^{\circ} 22^{\prime} 30^{\prime \prime} \mathrm{N}, 147^{\circ} 57^{\prime} 00^{\prime \prime} \mathrm{W}$; (map 118).

Local name shown on a 1916 manuscript map by William Yanert (in Stuck, 1917, map facing p. 122); so named because it is fourth in a series of lakes which include Roaring Bear, Doctor Cook, and Luke Lakes.

Fourth Lake: lake, see Fifth Lake.

Fourth Lake: lake, see Fourth Berg Lake.

Fourth Lake: lake, see Mikchalk Lake. 
Fourth of July Creek: stream, heads on Resurrection Penin., flows W 5 mi. to Resurrection Bay, $2.5 \mathrm{mi}$. SE of Seward, Chugach Mts.; $60^{\circ} 05^{\prime} 45^{\prime \prime} \mathrm{N}, 1^{\circ} 29^{\circ} 00^{\prime \prime} \mathrm{W}$; BGN 1912; (map 63). Var. Godwin River, Goodwin River.

Local name published by D. H. Sleem on his map of Central Alaska dated 1910.

Fourth of July Creek: stream, flows NNE $4 \mathrm{mi}$. to Slate Creek, $4.6 \mathrm{mi}$. NW of Ernestine and $44 \mathrm{mi}$. NE of Valdez, Chugach Mts.; $61^{\circ} 29^{\prime} 30^{\prime \prime} \mathrm{N}, 145^{\circ} 13^{\prime} 00^{\prime \prime} \mathrm{W}$; ( $\operatorname{map} 68$ ).

Local name published in the 1950's by USGS.

Fourth of July Creek: stream, flows SE $4.9 \mathrm{mi}$. to Kennicott Glacier, $7 \mathrm{mi}$. NW of McCarthy, Wrangell Mts.; $61^{\circ} 30^{\prime} \mathrm{N}, 143^{\circ} 01^{\prime} \mathrm{W}$; (map 67). Var. Kennicott Pass.

Name used by prospectors; reported in 1907 by D. C. Witherspoon, USGS.

Fourth of July Creek: stream, heads at glacier, $7 \mathrm{mi}$. SE of Augustin Peak, flows SE $22 \mathrm{mi}$. to West Fork Yentna River, $58 \mathrm{mi}$. W of Talkeetna, Alaska $\mathrm{Ra}$; $62^{\circ} 18^{\prime} 00^{\prime \prime} \mathrm{N}$, $151^{\circ} 54^{\prime} 30^{\prime \prime} \mathrm{W}$; BGN 1962; (map 81). Var. Clearwater Creek, Fourth-of-July Creek.

Prospectors' name reported in 1954 by USGS.

Fourth of July Creek: stream, flows N $5.5 \mathrm{mi}$. to Sanona Creek, $22 \mathrm{mi}$. S of junc. of Oshetna and Susitna Rivers, Talkeetna Mts.; 62 ${ }^{\circ} 19^{\prime}$ $20^{\prime \prime} \mathrm{N}, 147^{\circ} 17^{\prime} 30^{\prime \prime} \mathrm{W}$; (map 82).

Local name reported by F. H. Moffit (in Brooks and others, 1915, fig. 3), USGS.

Fourth of July Creek: stream, heads $6.5 \mathrm{mi}$. N of village of Moore Creek, flows NE $35 \mathrm{mi}$. to Takotna River, $3 \mathrm{mi}$. SW of Mount Joaquin, $23 \mathrm{mi}$. SW of McGrath, Kilbuck-Kuskokwim Mts. ; $62^{\circ} 49^{\prime} 45^{\prime \prime} \mathrm{N}, 156^{\circ} 19^{\prime} 30^{\prime \prime} \mathrm{W}$; (map 79). Var. July Creek.

Prospectors" name reported as "July Creek" in 1910 by A. G. Maddren, USGS, and called "Fourth of July Creek" in 1913 by H. M. Eakin, USGS.

Fourth of July Creek: stream, flows NW $2 \mathrm{mi}$. to Susitna River, $67 \mathrm{mi}$. SE of Healy, Alaska

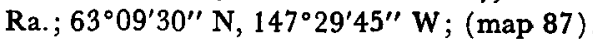

Local name obtained in 1951 by USGS.

Fourth of July Creek: stream, flows SW $4.5 \mathrm{mi}$. to Middle Fork Chulitna River, $47 \mathrm{mi}$. SW of Healy, Talkeetna Mts.; $63^{\circ} 12^{\prime} 30^{\prime \prime} \mathrm{N}$, $149^{\circ} 21^{\prime} 10^{\prime \prime} \mathrm{W}$; (map 87)

Local name reported by The Alaska Railroad on a 1918 manuscript map.

Fourth of July Creek: stream, flows $\mathrm{S} 2 \mathrm{mi}$. to Totatlanika River, $33 \mathrm{mi}$. SE of Nenana, Alaska Ra.; $64^{\circ} 02^{\prime}$ N, $148^{\circ} 32^{\prime}$ W; (map 100).

Prospectors' name reported in 1910 by USGS (Capps, 1912, pl. 1).

Fourth of July Creek: stream, flows NE $3.2 \mathrm{mi}$. to Sulatna River, $1.7 \mathrm{mi}$. SE of Sulatna Crossing and $39 \mathrm{mi}$. S of Ruby, Kilbuck-Kuskokwim Mts.; $64^{\circ} 10^{\prime} \mathrm{N}, 155^{\circ} 26^{\prime} \mathrm{W}$; (map 98).

Prospectors' name reported by Mertie and Harrington (1924, p. 95), USGS.

Fourth of July Creek: stream, flows NW $2 \mathrm{mi}$. to Long Creek, S of Long, $24 \mathrm{mi}$. S of Ruby,
Kilbuck-Kuskokwim Mts.; $64^{\circ} 23^{\prime} 20^{\prime \prime} \quad \mathrm{N}$, $155^{\circ} 30^{\prime} 45^{\prime \prime} \mathrm{W}$; (map 98). Var. 4th of July Creek.

Prospectors' name reported in 1913 by Eakin (1914, pl. 3), USGS.

Fourth of July Creek: stream, flows NE $12 \mathrm{mi}$. to Yukon River, $34 \mathrm{mi}$. NW of Eagle, YukonTanana High. ; $65^{\circ} 11^{\prime} 50^{\prime \prime} \mathrm{N}, 141^{\circ} 49^{\prime} 45^{\prime \prime} \mathrm{W}$; (map 103).

Prospectors' name from an 1898 unpublished map by E. F. Ball, prospector.

Fourth of July Creek: stream, see July Creek. Fourth of July Hill: mountain, 1,870 ft., $25 \mathrm{mi}$. NE of Fairbanks, Yukon-Tanana High.; $65^{\circ} 04^{\prime} \mathrm{N}, 147^{\circ} 04^{\prime} \mathrm{W}$; (map 105).

Named by prospectors; published in 1908 by USGS.

Four Winds Mountain: mountain, 6,512 ft., 6 $\mathrm{mi}$. NE of Porcupine and $29 \mathrm{mi}$. W of Skagway, St. Elias Mts.; $59^{\circ} 29^{\prime} 55^{\prime \prime}$ N., $136^{\circ} 08^{\prime} 45^{\prime \prime}$ W; (map 45). Var. Kukwahyekukwo Mountain.

Local name published in 1952 by USGS. The name, according to E. C. Robertson, USGS, refers to the exposed position of the mountain. He reports that the Indian name is "Kukwahyekukwo," which refers to the abundance of cranberries in the large glacial amphitheater near the top,

Fou-sang: a country east of China, identified by Joseph de Guignes about 1750 to be northwest America. See Wagner (1937, p. 455).

Fowler Creek: stream, $2 \mathrm{mi}$. long, fowing mostly NE to Young Bay on Stephens Passage, $14 \mathrm{mi}$. SW of Juneau, Alex. Arch.; $58^{\circ} 09^{\prime} 45^{\prime \prime} \mathrm{N}$, $134^{\circ} 41^{\prime} 55^{\prime \prime} \mathrm{W}$; BGN 1929; (map 11).

Named in 1928 by H. E. Smith, USFS, for Guy Fowler who homesteaded at the mouth of the stream.

Fowler Island: island, $0.8 \mathrm{mi}$. long, in Kuskokwim River, $27 \mathrm{mi}$. NW of Eek and $20 \mathrm{mi}$. SW of Bethel, Yukon-Kuskokwim Delta; $60^{\circ} 36^{\prime} \mathrm{N}, 162^{\circ} 12^{\prime \prime} \mathrm{W}$; (map 58).

Local name obtained in 1914 by USC\&GS.

Fowl Hill: hill, $700 \mathrm{ft}$., on southern Kiska I., 0.5 mi. SE of Fox Hills, Aleutian Is.; $51^{\circ} 55^{\prime} 20^{\prime \prime}$ $\mathrm{N}, 177^{\circ} 19^{\prime} 40^{\prime \prime} \mathrm{E}$; (map 14).

An arbitrary name beginning with " $F$ " to correspond to "F" grid used by the U.S. Army for tactical purposes during World War II; published by AMS in 1953.

Fox: settlement, on right bank of Fox Creek as it enters Goldstream Creek valley, $10 \mathrm{mi}$. NE of Fairbanks, Yukon-Tanana High. ; $64^{\circ} 57^{\prime} 35^{\prime \prime}$ N, $147^{\circ} 37^{\prime} 30^{\prime \prime} \mathrm{W}$; (map 100).

Former mining camp established before 1905. The Fox post office was established in 1908; discontinued in 1947 (Ricks, 1965, p. 21). Its population was 25 in 1950 .

Fox, Cape: point of land, between Nakat Bay and Revillagigedo Channel, on NE shore of Dixon Entrance, Coast Mts.; $54^{\circ} 46^{\prime} 10^{\prime \prime} \mathrm{N}$, $130^{\circ} 50^{\prime} 45^{\prime \prime} \mathrm{W}$; (map 2).

Named in 1793 by Capt. George Vancouver for Charles James Fox (Wagner, 1937, p. 389).

Fox, Cape: point of land, on $\mathrm{E}$ shore of Revillagigedo Channel, $4 \mathrm{mi}$. $\mathrm{S}$ of Boca de Quadra,
Coast Mts.; $55^{\circ} 00^{\prime} 25^{\prime \prime} \mathrm{N}, 1^{\circ} 1^{\circ} 00^{\prime} 30^{\prime \prime} \mathrm{W}$; (map 3).

Name published by Ivan Petroff in the 10th Census, in 1880.

Fox Bay: bay, $2.5 \mathrm{mi}$. across, on $\mathrm{S}$ coast of Alaska Penin., on E shore of Stepovak Bay, Aleutian Ra.; $55^{\circ} 38^{\prime} \mathrm{N}, 159^{\circ} 40^{\prime} \mathrm{W}$; (map 27).

Named by W. H. Dall, USC\&GS, in 1880 and published in 1888.

Fox Bay: bay, $0.6 \mathrm{mi}$. across, on $\mathrm{N}$ coast of Whale I., $2.3 \mathrm{mi}$. SE of Afognak, $\mathrm{N}$ of Kodak I.; $57^{\circ} 58^{\prime} 45^{\prime \prime} \mathrm{N}, 152^{\circ} 45^{\prime} 00^{\prime \prime} \mathrm{W}$; (map 34).

Local name reported in 1900 by Lt. Comdr. J. F. Moser, USN, commander of the USBF steamer Albatross.

Fox Bay: cove, $1.5 \mathrm{mi}$. acruss, on $\mathrm{N}$ shore of Iliamna Lake between Chekok and Knutson Bays, $19 \mathrm{mi}$. E of Iliamna, Aleutian Ra.; $59^{\circ} 47^{\prime} 15^{\prime \prime} \mathrm{N}, 154^{\circ} 21^{\prime} 00^{\prime \prime} \mathrm{W}$; (map 51).

Local name published in 1954 by USGS.

Fox Beach: beach, $0.1 \mathrm{mi}$. long, on SE coast of Shemya $I$. in the Semichi Is., Aleutian Is.; $52^{\circ} 42^{\prime} 30^{\prime \prime} \mathrm{N}, 174^{\circ} 08^{\prime} 55^{\prime \prime} \mathrm{E}$; (map 13).

Listed in 1946 supplement to 1944 Aleutian Coast Pilot; shown as a "military designation" in 1947 Coast Pilot.

Fox Cairn: hill, see Fox Castle.

Fox Cape: point of land, on E side of Kupreanof Penin., $5 \mathrm{mi}$. E of Stepovak Bay, on S. coast of Alaska Penin., Aleutian Ra.; 55 $39^{\prime} \mathrm{N}$, $159^{\circ} 33^{\prime} \mathrm{W}$; (map 27). Var. Mys Leesy.

Named "M[ys] Leesy," or "fox cape" by Capt. Tebenkov (1852, map 24) ; published on Russian Hydrog. Dept. Chart 1379 (1847). "Fox Cape" was shown in 1888 on USC\&GS Chart 806.

Fox Cape: point of land, see Lises, Cape.

Fox Castle: hill, $671 \mathrm{ft}$, on $W$ coast of St. George I., Pribilof Is.; $56^{\circ} 36^{\prime} 15^{\prime \prime} \mathrm{N}, 169^{\circ} 45^{\prime} 30^{\prime \prime} \mathrm{W}$; (map 38). Var. Fox Cairn, Krad'igy.

Local name reported in 1891 by Joseph Stanley-Brown, USGS, and given as "Fox Cairn" in 1897 by W. W. Duffield, USC\&GS. Putnam (1903, p. 1015) reported the Aleut name as "Krad'igy."

Fox Creek: stream, flows S $3 \mathrm{mi}$. to Sand Bay, Great Sitkin I., Aleutian Is.; 51 $59^{\prime} 53^{\prime \prime} \mathrm{N}$, $176^{\circ} 05^{\prime} 48^{\prime \prime} \mathrm{W}$; (map 17). Var. Big Fox Greek.

Name published in 1951 on a USGS map. Fox Creek: stream, flows N $3 \mathrm{mi}$. to Arolik River, $31 \mathrm{mi}$. N of Goodnews, Kilbuck-Kuskokwim Mts.; $59^{\circ} 33^{\prime} \mathrm{N}, 161^{\circ} 25^{\prime} \mathrm{W}$; (map 53).

Name reported in 1919 by G. L. Harrington (in Brooks and others, 1921, pl. 7), USGS.

Fox Greek: stream, on Kenai Penin., flows S $7.5 \mathrm{mi}$. to Kachemak Bay, $21 \mathrm{mi}$. NE of Homer, Cook Inlet Low.; $59^{\circ} 47^{\prime} 45^{\prime \prime} \mathrm{N}$, $151^{\circ} 03^{\prime} 30^{\prime \prime} \mathrm{W}$; (map 50).

Local name reported by Grant and Higgins (1913, pl. 2). Possibly so named because of its proximity to the Fox River.

Fox Creek: stream, on Kenai Penin., flows NW $3 \mathrm{mi}$. to Tustumena Lake, $31 \mathrm{mi}$. SE of Kenai, Cook Inlet Low.; $60^{\circ} 09^{\prime} \mathrm{N}, 150^{\circ} 54^{\prime}$ W; (map 62).

Local name reported in 1904 by F. H. Moffit, USGS. 
Fox Creek: stream, on Kenai Penin., flows NW $6.5 \mathrm{mi}$. to Resurrection Creek, $14 \mathrm{mi}$. S. of Hope, Chugach Mts.; 60 $44^{\prime} 15^{\prime \prime}$ N, $149^{\circ}$ $43^{\prime} 00^{\prime \prime}$ W; (map 63).

Local name reported in 1904 by F. H. Moffit (in Brooks and others, 1905, p. 91), USGS.

Fox Creek: stream, flows NW $3.5 \mathrm{mi}$. to Bear Creek, $7.8 \mathrm{mi}$. NE of Nyac and $37 \mathrm{mi}$. SW of Aniak, Kilbuck-Kuskokwim Mts.; 61 ${ }^{\circ} 04^{\prime}$ $30^{\prime \prime} \mathrm{N}, 159^{\circ} 44^{\prime} 30^{\prime \prime} \mathrm{W}$; (map 73).

Prospectors' name shown on a 1914 field sheet by A. G. Maddren, USGS.

Fox Creek: stream, flows SE $6 \mathrm{mi}$. to O'Brien Creek, $1.2 \mathrm{mi}$. NW of Taral and $63 \mathrm{mi}$. ENE of Valdez, Chugach Mts.; $61^{\circ} 28^{\prime} 55^{\prime \prime} \mathrm{N}$, $144^{\circ} 38^{\prime} 50^{\prime \prime} \mathrm{W}$; (map 68).

Local name published in the 1950's by USGS.

Fox Creek: stream, flows E 7.1 mi. to Alexander Lake, $48 \mathrm{mi}$. NE of Tyonek, Cook Inlet Low.; $61^{\circ} 45^{\prime} 10^{\prime \prime} \mathrm{N}, 150^{\circ} 54^{\prime} 40^{\prime \prime} \mathrm{W}$; (map 70).

Local name reported in 1954 by USGS.

Fox Creek: stream, east bank tributary of Flat Creek, S of Otter Creek, S of Flat, KilbuckKuskokwim Mts. ; $62^{\circ} 05^{\prime} \mathrm{N}, 158^{\circ} 00^{\prime} \mathrm{W}$; (map 79).

Prospectors' name published in 1921 by USGS; not identified on current sources.

Fox Creek: stream, flows S $1.5 \mathrm{mi}$. to Valdez Creek, $68 \mathrm{mi}$. SE of Healy, Alaska Ra., 63$12^{\prime} \mathrm{N}, 147^{\circ} 21^{\prime} \mathrm{W}$; (map 87).

Local name obtained in 1951 by USGS.

Fox Creek: stream, flows SW $1 \mathrm{mi}$. to Nenana River, $3.4 \mathrm{mi}$. N of village of McKinley Park, Alaska Ra.; $63^{\circ} 46^{\prime} 50^{\prime \prime} \mathrm{N}, 148^{\circ} 54^{\prime} 30^{\prime \prime} \mathrm{W}$; $B G N 1965$; (map 87).

Named in 1965 by Alaska Dept. of Highways "because foxes are said to live in the area.' See Iceworm Gulch.

Fox Creek: stream, flows NE $1 \mathrm{mi}$. to Joint Platte Creek to form Homestake Creek, $16 \mathrm{mi}$. NE of Healy, Alaska Ra. ; $63^{\circ} 59^{\prime} 00^{\prime \prime}$ N, $148^{\circ} 33^{\prime}$ 25" W; (map 87).

Local name reported in 1910 by $S$. $R$. Capps, USGS.

Fox Creek: stream, flows SE 0.7 mi. to Jackson Creek which flows to Bonanza River, $7 \mathrm{mi}$. NW of Solomon, Seward Penin. High.; 64 $34^{\circ}$ N, $164^{\circ} 31^{\prime} \mathrm{W}$; (map 95).

Prospectors' name shown on Arthur Gibson's "Map of Cape Nome Precinct" dated 1904.

Fox Creek: stream, flows E $2.8 \mathrm{mi}$. to Cripple River, $17 \mathrm{mi}$. NW of Nome, Seward Penin. High.; 64 $39^{\prime}$ N, $165^{\circ} 54^{\prime} \mathrm{W}$; (map 94).

Name was used by C. C. Nelson when filing his claim in June 1899.

Fox Creek: stream, flows NW $1 \mathrm{mi}$. to Coal Creek which flows to Solomon River, $14 \mathrm{mi}$. NE of Solomon, Seward Penin. High.; 64 $45^{\prime} \mathrm{N}$, $164^{\circ} 18^{\prime} \mathrm{W}$; (map 95).

Prospectors' name reported on a map of Cape Nome gold fields by David Fox, Jr., dated 1901.

Fox Creek: stream, flows E $5 \mathrm{mi}$. to Eldorado River, $21 \mathrm{mi}$. NW of Solomon, Seward Penin. High.; $64^{\circ} 46^{\prime} \mathrm{N}, 164^{\circ} 59^{\prime} \mathrm{W}$; (map 95).

Prospectors' name reported in 1900 by E. C.
Barnard (in Brooks, 1901, pl. 17), USGS.

Fox Creek: stream, flows SE $7 \mathrm{mi}$. to Seventymile River, $13 \mathrm{mi}$. NW of Eagle, YukonTanana High.; $64^{\circ} 54^{\prime} \mathrm{N}, 141^{\circ} 31^{\prime} \mathrm{W}$; (map 102).

Named by prospectors and shown on a 1902 manuscript map by E. J. Chamberlain, U.S. Deputy Surveyor.

Fox Creek: stream, flows SE $5 \mathrm{mi}$. to Salmon Lake, $30 \mathrm{mi}$. NE of Nome, Seward Penin. High.; 64. $54^{\prime} \mathrm{N}, 165^{\circ} 01^{\prime} \mathrm{W}$; (map 94).

Prospectors' name reported in 1900 by E. C. Barnard (in Brooks, 1901, pl. 17), USGS.

Fox Creek: stream, flows $S 4.6 \mathrm{mi}$. to Goldstream Creek, $7 \mathrm{mi}$. N of Fairbanks, Yukon-Tanana High.; 64 $56^{\prime} 45^{\prime \prime} \mathrm{N}, 147^{\circ} 41^{\prime} 00^{\prime \prime} \mathrm{W}$; (map 100).

Local name reported in 1903 by T. G. Gerdine (in Prindle, 1905, pl. 16), USGS.

Fox Creek: stream, flows E $0.6 \mathrm{mi}$. to Ready Bullion Creek, in Pargon River basin, $9 \mathrm{mi}$. NE of Council and $21 \mathrm{mi}$. SE of Mount Bendeleben, Seward Penin. High.; $65^{\circ} 01^{\prime} \mathrm{N}, 163^{\circ}$ $29^{\prime} \mathrm{W}$; (map 110).

Prospectors' name reported on a map of Cape Nome gold fields by David Fox, Jr., dated 1901.

Fox Creek: stream, flows NE $12 \mathrm{mi}$, to Melozitna River, 2 mi. S of mouth of Turnaround Creek, $48 \mathrm{mi}$. WSW of Birches, Kokrines-Hodzana High.; $65^{\circ} 03^{\prime} 15^{\prime \prime} \mathrm{N}, 155^{\circ} 11^{\prime} 00^{\prime \prime} \mathrm{W}$; (map 107).

Local name reported in 1913 by Eakin (1916, pl. 2), USGS.

Fox Creek: stream, flows NW $2 \mathrm{mi}$. to Port Clarence, $7 \mathrm{mi}$. SW of Teller, Seward Penin. High, $65^{\circ} 10^{\prime} \mathrm{N}, 166^{\circ} 29^{\prime} \mathrm{W}$; (map 111).

Prospectors' name reported on the 1908 "Map of Seward Peninsula" by Arthur Gibson.

Fox Creek: stream, flows W $3.2 \mathrm{mi}$. to Grant Creek W of Gold Hill, $22 \mathrm{mi}$. WNW of Tanana, Kokrines-Hodzana High.; $65^{\circ} 14^{\prime} 40^{\prime \prime} \mathrm{N}$, $152^{\circ} 49^{\prime} 30^{\prime \prime} \mathrm{W}$; (map 106). Orth.

Prospectors' name reported in 1956 by

Fox Creek: stream, flows NE $3.5 \mathrm{mi}$. to South Fork Serpentine River, $12 \mathrm{mi}$. N of Kougarok Mtn. and $28 \mathrm{mi}$. SE of Ear Mtn., Seward Penin. High.; $65^{\circ} 51^{\prime}$ N, $165^{\circ} 17^{\prime}$ W ; (map 111).

Prospectors' name reported on the 1908 "Map of Seward Peninsula" by Arthur Gibson.

Fox Creek: stream, flows NW $9 \mathrm{mi}$. to Arctic River, $7 \mathrm{mi}$. SE of Ear Mtn. and $45 \mathrm{mi}$. NE of Teller, Seward Penin. High.; 65 $53^{\circ} \mathrm{N}$, $166^{\circ} 00^{\prime} \mathrm{W}$; (map 111 ).

Prospectors' name reported in 1901 by T. G. Gerdine (in Collier, 1902, pl. 12), USGS.

Fox Creek: stream, flows N $8 \mathrm{mi}$. to Rogers Creek, $57 \mathrm{mi}$. NE of Rampart, Yukon-Tanana High.; $65^{\circ} 57^{\prime} 25^{\prime \prime} \mathrm{N}, 148^{\circ} 32^{\prime} 45^{\prime \prime} \mathrm{W}$; (map 105).

Named by prospectors; reported by Lt. Hjalmar Erickson, USA; published by USGS (Prindle, 1904, pl. 16).
Fox Creek: stream, on Seward Penin., flows N $0.7 \mathrm{mi}$. to Goodhope Bay, $22 \mathrm{mi}$. W of Deering, Kotzebue-Kobuk Low.; $66^{\circ} 04^{\prime} 15^{\prime \prime} \mathrm{N}$, $163^{\circ} 31^{\prime} 30^{\prime \prime} \mathrm{W}$; (map 113).

Prospectors' name obtained in 1903 by D. C. Witherspoon, USGS (Moffit, 1905, pl. 2).

Fox Creek: stream, flows W to Quartz Creek which flows to Solomon River, about $7 \mathrm{mi}$. NE of Solomon, Seward Penin. High.; (map 95).

Prospectors' name reported on prospector's manuscript map dated 1902 . This stream cannot be precisely located on current maps. Fox Creek: ravine, see Fox Gulch.

Fox Farm Lodge: locality, on Richardson Highway, $5 \mathrm{mi}$. S of Harding Lake and $25 \mathrm{mi}$. NW of Big Delta, Yukon-Tanana High.; $64^{\circ} 20^{\prime}$ $45^{\prime \prime} \mathrm{N}, 146^{\circ} 52^{\prime} 00^{\prime \prime} \mathrm{W}$; (map 101). Var. Overland Roadhouse, Silver Farm Lodge, Silver Fox Lodge, Silver Fox Roadhouse.

This is the site of a roadhouse whose name was originally published in 1913 by USGS as "Overland Roadhouse." During the ensuing years it was reported under a variety of names until it was published in 1955 as Fox Farm Lodge.

Fox Flats: flats, extend $5 \mathrm{mi}$. W of Big River, $31 \mathrm{mi}$. WNW of Kenai, Cook Inlet Low.; $60^{\circ}$ $41^{\prime} \mathrm{N}, 152^{\circ} 08^{\prime} \mathrm{W}$; (map 62$)$.

Local name reported in 1958 by USGS.

Fox Gulch: ravine, trends SE $0.7 \mathrm{mi}$. to Platinum Creek, $25 \mathrm{mi}$. NE of Cape Newenham, Kil-

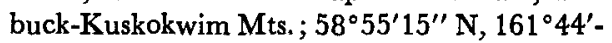
$45^{\prime \prime} \mathrm{W}$; BGN 1938; (map 39). Var. Fox Greek.

Local name reported in 1938 by USGS.

Fox Gulch: ravine, in Peters Hills, trends SW $3.5 \mathrm{mi}$. to Cache Creek, N of Spruce Creek, $30 \mathrm{mi}$. NW of Talkeetna, Alaska Ra.; $62^{\circ} \mathbf{2 5}^{\prime}$ $30^{\prime \prime} \mathrm{N}, 151^{\circ} 01^{\prime} 50^{\prime \prime} \mathrm{W}$; (map 81).

Prospectors' name reported in the 1930's by USGS.

Fox Gulch: ravine, trends E $1 \mathrm{mi}$. to Otter Creek, $3 \mathrm{mi}$. NE of Nome, Seward Penin. High.; $64^{\circ}$ $30^{\prime} 55^{\prime \prime} \mathrm{N}, 165^{\circ} 17^{\prime} 58^{\prime \prime} \mathrm{W}$; (map 94).

Prospectors' name reported in 1904 by T. G. Gerdine, USGS.

Fox Gulch: ravine, trends NE $2.8 \mathrm{mi}$. to Dome Creek, $13 \mathrm{mi}$. S of Ruby, Kilbuck-Kuskokwim

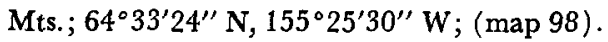

Prospectors' name reported in 1933 by Mertie (1936, pl. 2) USGS.

Fox Hill: mountain, 1,400 ft., $S$ of Lief Cove, on S end of Kiska I., Aleutian Is.; $51^{\circ} 55^{\prime} 35^{\prime \prime}$ N, $177^{\circ} 18^{\prime} 55^{\prime \prime} \mathrm{E}$; (map 14).

An arbitrary name beginning with " $F$ " to correspond to "F" grid used by the U.S. Army for tactical purposes during World War II; published in 1953 by AMS.

Fox Hill: hill, $671 \mathrm{ft}$, on mainland near W entrance to Nakat Bay, Coast Mts. ; 54 $46^{\prime} 45^{\prime \prime}$ $\mathrm{N}, 130^{\circ} 49^{\prime} 50^{\prime \prime} \mathrm{W}$; (map 2).

Named in 1883 by Lt. Comdr. H. E. Nichols, USN.

Fox Hill: hill, $463 \mathrm{ft}$., S of Ridge Hill, on westcentral St. Paul I., Pribilof Is.; $57^{\circ} 10^{\prime} 40^{\prime \prime} \mathrm{N}$, $170^{\circ} 23^{\prime} 00^{\prime \prime} \mathrm{W}$; (map 38$)$. 
Local name published in 1875 by USC\&GS; probably obtained from Elliott (1881, Saint Paul map) who was there in 1873-74.

Fox Hills: hills, 1,866 ft., extend $6 \mathrm{mi}$. NE Reindeer River, $19 \mathrm{mi}$. E of Holy Cross, Kilbuck-Kuskokwim Mts. ; 62 ${ }^{\circ} 13^{\prime} \mathrm{N}, 159^{\circ} 06^{\prime} \mathrm{W}$; (map 78).

Local name obtained in 1952 by USGS.

Fox Hole: anchorage, $0.4 \mathrm{mi}$. across, on NE coast of Popof I., in Shumagin Is., Aleutian Ra.; $55^{\circ} 20^{\prime} 45^{\prime \prime} \mathrm{N}, 160^{\circ} 19^{\prime} 40^{\prime \prime} \mathrm{W}$; BGN 1966; (map 28). Var. Little Harbor.

Local name reported in 1963 by USGS. The 1916 Coast Pilot (p. 175) recorded the name for this feature as "Fox Hole, also called Little Harbor."

Fox Island: island, $0.5 \mathrm{mi}$. long, off Cape Fox in NE Dixon Entrance, Coast Mts. ; $54^{\circ} 45^{\prime} 50^{\prime \prime}$ $\mathrm{N}, 130^{\circ} 51^{\prime} 00^{\prime \prime} \mathrm{W}$; (map 2).

Local name published in 1943 by USC\&GS.

Fox Island: island, $1 \mathrm{mi}$. long, $1 \mathrm{mi}$. NW of Deer I., at SW end of Aleutian Ra.; 54 $57^{\prime} 00^{\prime \prime}$ $\mathrm{N}, 162^{\circ} 25^{\prime} 30^{\prime \prime} \mathrm{W}$; (map 25). Var. Leesy Island.

Translation of the Russian name "O[strov] Lisiy" meaning "fox's island" published by Capt. Tebenkov (1852, map 24).

Fox Island: island, $0.7 \mathrm{mi}$. long, in Deadman Bay, S of Kodiak I.; $56^{\circ} 59^{\prime} 30^{\prime \prime} \mathrm{N}, 154^{\circ} 01^{\prime} 45^{\prime \prime}$ W; (map 32).

Name published in 1943 by USC\&GS.

Fox Island: island, $0.3 \mathrm{mi}$. long, off $\mathrm{S}$ coast of Alaska, $1 \mathrm{mi}$. S of Cape Martin, $3.5 \mathrm{mi}$. SW of Katalla, Malaspina Coastal Plain; $60^{\circ} 10^{\prime} \mathrm{N}$, $144^{\circ} 37^{\prime}$ W; BGN 1966; (map 64. Var. Kiktak Island, Ostrov Kikhtak.

Local name reported in 1905 by G. C. Martin, USGS. The Eskimo name published by Capt. Tebenkov (1852, map 6) was "O[strov] Kikhtak" or "Kiktak Island."

Fox Island: island, extends NE-SW $1.8 \mathrm{mi}$., in Yukon River, $0.7 \mathrm{mi}$. N of Ham I. and $22 \mathrm{mi}$. $\mathrm{NE}$ of Ruby, Nowitna Low. ; $64^{\circ} 54^{\prime} \mathrm{N}, 154^{\circ} 52^{\prime}$ $\mathrm{W}$; (map 98).

Riverboat pilots' name shown on a 1940 "Navigation Chart, Tanana-Yukon Rivers" of the River Boat Service, U.S. Dept. of Interior.

Fox Island: island, see Busby Island.

Fox Island: island, see Marble Island.

Fox Island: island, see Renard Island.

Fox Island: island, see Sumdum Island.

Fox Island Anchorage: anchorage, $2.5 \mathrm{mi}$. across, on NW shore of Deer I., SW end of Alaska Penin., Aleutian Ra.; $54^{\circ} 57^{\prime} \mathrm{N}, 162^{\circ} 23^{\prime} \mathrm{W}$; (map 25).

Name published in 1949 on a USGS map,

Fox Islands: islands, chain composes $\mathrm{E}$ end of Aleutian Is., between Alaska Penin. to the E, and Is. of Four Mts. to the W, extend from Isanotski Strait SW about $290 \mathrm{mi}$. to Samalga Pass; include Samalga, Umnak, Unalaska, Unimak and the Krenitzin Is., along with other smaller islands; $52^{\circ} 46^{\prime} \mathrm{N}, 169^{\circ} 15^{\prime} \mathrm{W}$ [W end], $54^{\circ} 51^{\prime} \mathrm{N}, 163^{\circ} 24^{\prime} \mathrm{W}$ [E end]; $B G N$ 1963. Var. Andreanof Islands, Anglice Islands, Iles aux Renards, Leesy, Ostrova Lisyy.
Name first recorded in May, 1778 by Capt. Cook $(1785$, v. 2, p. 380$)$, RN. Sarichev (1826, map 1) published the name in Russian as "Ostrova Lisyy," or "fox islands" and Capt. Lutke (1836, p. 279) published the name in French as "Iles aux Renards." Baker (1906, p. 265) says "The whole Aleutian chain is known to mariners and whalemen as the Fox Islands * * *." See Aleutian Islands. Fox Islands: islands, see Aleutian Islands. Fox Islands: islands, see Andreanof Islands. Fox Islands: islands, see Martin Islands.

Fox Lake: lake, 1 mi. long, on Kenai Penin. near $\mathrm{N}$ shore of Tustumena Lake, $22 \mathrm{mi}$. SE of Kenai, Cook Inlet Low.; $60^{\circ} 17^{\prime} 15^{\prime \prime} \mathrm{N}$, $150^{\circ} 56^{\prime} 30^{\prime \prime} \mathrm{W}$; (map 62).

Named about 1963 by officials of Kenai National Moose Range, for administrative purposes.

Fox Lake: lake, trends NW-SE $1.5 \mathrm{mi}$., $13 \mathrm{mi}$. $E$ of Nome and $16 \mathrm{mi}$. W of Solomon, Seward

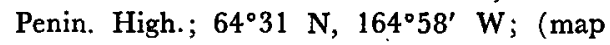
95).

Local name reported in 1900 by E. C. Barnard (in Brooks, 1901, pl. 17), USGS.

Fox Lake: lake, $1.5 \mathrm{mi}$. long, between Black and Cow Lakes, $18 \mathrm{mi}$. W of Beaver, Yukon Flats; $66^{\circ} 19^{\prime} \mathrm{N}, 148^{\circ} 04^{\prime} \mathrm{W}$; (map 118).

Probably named by William Yanert who showed it on a 1916 manuscript map of the Yukon Flats (Stuck, 1917, map facing p. 122).

Fox Point: mountain, 7,610 ft., in Romanzof Mts. at head of Okpirourak Creek, $9 \mathrm{mi}$. $\mathbf{E}$ of Mt. Michelson, Brooks Ra.; $69^{\circ} 19^{\prime} \mathrm{N}, 143^{\circ}$ $58^{\prime} \mathrm{W}$; (map 138).

Named about 1957 by personnel participating in the International Geophysical Year glaciological work in the Romanzof Mountains.

Fox Point: point of land, on $\mathrm{W}$ coast of Staten I., in Bay of Is., Adak I., Aleutian Is. ; $51^{\circ} 47^{\prime}$ $55^{\prime \prime} \mathrm{N}, 176^{\circ} 47^{\prime} 40^{\prime \prime} \mathrm{W} ; B G N 1936$; (map 17).

Named by members of the U.S. Navy Aleutian Island Survey Expedition in 1933.

Fox Point: point of land, on $\mathrm{N}$ coast of Umnak I., Aleutian. Is.; $53^{\circ} 33^{\prime} 10^{\prime \prime} \mathrm{N}, 168^{\circ} 07^{\prime} 20^{\prime \prime} \mathrm{W}$; $B G N$ 1940; (map 22).

Descriptive name given in 1938 by USG\&GS "because of the large number of red foxes noted along the beach in the vicinity."

Fox Point: point of land, on SE coast of Revillagigedo I., $2.2 \mathrm{mi}$. SW of Rudyerd I., Alex. Arch.; 55 $15^{\prime} 40^{\prime \prime} \mathrm{N}, 1^{\circ} 1^{\circ} 03^{\prime} 50^{\prime \prime} \mathrm{W}$; (map 3 ).

Arbitrary name given in 1891 by USC\&GS.

Fox Point: point of land, on NE coast of Herbert Graves I., $2.5 \mathrm{mi}$. NW of Chichagof, off W coast of Chichagof I., Alex. Arch.; 57 $41^{\prime} 30^{\prime \prime}$ N, 136 $08^{\prime} 00^{\prime \prime} \mathrm{W}$; (map 9).

Local name published in 1928 by USC\&GS on Chart 8258.

Fox Point: point of land, on NW coast of Hawkins I., 7 mi. NW of Cordova, Chugach Mts.; $60^{\circ} 35^{\prime} \mathrm{N}, 145^{\circ} 57^{\prime} \mathrm{W}$; (map 64).

Name published in 1950 by USGS.

Fox Point Island: island, $5 \mathrm{mi}$. long, in Yukon River, $55 \mathrm{mi}$. N of Holy Cross, Innoko Low.; $63^{\circ} 01^{\prime} \mathrm{N}, 159^{\circ} 52^{\prime} \mathrm{W}$; (map 91). Var. Helen Island.
Local name reported in 1949 by USC\&GS.

Fox River: stream, on Kenai Penin., heads at terminus of Chernof Glacier, flows SW $27 \mathrm{mi}$. to NE end of Kachemak Bay, $24 \mathrm{mi}$. NE of Homer, Cook Inlet Low.; $59^{\circ} 48^{\prime} \mathrm{N}, 150^{\circ} 59^{\prime}$ W; (map 50).

Name reported by Dall (1895, pl. 51), USGS, and may have been named for Theodore Fox, Vice President of the North Pacific Mining and Transportation Co., which was operating on Kachemak Bay in 1894.

Fox River: stream, flows E $18 \mathrm{mi}$. to Fish River, $32 \mathrm{mi}$. NE of Solomon, Seward Penin. High.; $64^{\circ} 47^{\prime} \mathrm{N}, 163^{\circ} 29^{\prime} \mathrm{W}$; (map 95).

Prospectors' name reported in 1900 by E. C. Barnard (in Brooks, 1901, pl. 17), USGS.

Fox River: stream, heads at Inland Lake and flows NW $3 \mathrm{mi}$. to Tuklomarak Lake, $11 \mathrm{mi}$. SW of Selawik, Kotzebue-Kobuk Low.; $66^{\circ} 27^{\prime}$ $\mathrm{N}, 160^{\circ} 01^{\prime} \mathrm{W}$; (map 114$)$.

Local name reported by the U.S. Army Corps of Engineers in 1955.

Fox Rock: island, $0.1 \mathrm{mi}$. long, in SE Davidson Inlet, Alex. Arch.; 55 $53^{\prime} 10^{\prime \prime} \mathrm{N}, 133^{\circ} 32^{\prime} 00^{\prime \prime}$ W; (map 4).

Named in 1903 or 1904 by E. F. Dickins, USC\&GS, who wrote "named by our party, has no local name."

Fracture Creek: stream, on Alaska Penin., flows NW $15 \mathrm{mi}$. to Ocean River, $24 \mathrm{mi}$. NW of Mount Veniaminof, Bristol Bay Low.; 56 ${ }^{\circ} 8^{\prime}$ N, $159^{\circ} 45^{\prime} \mathrm{W}$; (map 30$)$.

Name reported in 1923 by R. H. Sargent, USGS; published in 1927 by USGS.

Fragrant Island: island, $0.7 \mathrm{mi}$. long, in Necker Is., W of Baranof I., $15 \mathrm{mi}$. S of Sitka, Alex. Arch.; $56^{\circ} 50^{\prime} 30^{\prime \prime} \mathrm{N}, 135^{\circ} 25^{\prime} 00^{\prime \prime} \mathrm{W}$; (map 5). Var. Dushistoi Island, Goddard Island, Ostrov Dushistoy.

Translation in 1929 by USC\&GS of the name given in 1809 by the navigator Ivan Vasiliev the first, IRN. Lt. Sarichev (1826, map 19), IRN, published it as "O[strov] Dushistoy." "Goddard Island" was published in the 1925 Coast Pilot (p. 286).

Frailes, Los: rocks, see Nagahut Rocks.

Français, Port des: bay, see Lituya Bay.

Frances Creek: stream, flows S $3.5 \mathrm{mi}$. to Lignite Creek, $4.5 \mathrm{mi}$. NE of Healy, Alaska Ra.; $63^{\circ}$ $54^{\prime} 30^{\prime \prime} \mathrm{N}, 149^{\circ} 53^{\prime} 30^{\prime \prime} \mathrm{W}$; (map 87).

Local name reported in 1950 by USGS.

Francie Creek: stream, flows SW 2 mi. to Willow Creek $1 \mathrm{mi}$. W of Shorty Creek and $18 \mathrm{mi} \mathrm{NW}$ of Palmer, Talkeetna Mts.; $61^{\circ} 45^{\prime} 55^{\prime \prime} \mathrm{N}$, $149^{\circ} 31^{\prime} 00^{\prime \prime} \mathrm{W}$; (map 69).

Local name reported in 1951 by USGS.

Francis, Mount: mountain, 2,690 ft., S of Shipley Bay, on NW coast of Kosciusko I., Alex. Arch.; $56^{\circ} 03^{\prime} 40^{\prime \prime} \mathrm{N}, 133^{\circ} 36^{\prime} 10^{\prime \prime} \mathrm{W}$; (map 6).

Named in 1886 by Lt. Comdr. A. S. Snow, USN, for "E. H. Francis, a local pilot."

Francis, Mount: mountain, 5,435 ft., $2.5 \mathrm{mi}$. SW of Washbowl Basin, $5 \mathrm{mi}$. SE of Valdez, Chugach Mts.; $61^{\circ} 02^{\prime} 30^{\prime \prime} \mathrm{N}, 146^{\circ} 12^{\prime} 20^{\prime \prime} \mathrm{W}$; (map 68).

Named in 1898 by Capt. W. R. Abercrombie, USA. 
Francis, Point: point of land, S point of entrance to Port Stewart, on $\mathrm{E}$ coast of Cleveland Penin., Alex. Arch.; 55 40 $15^{\prime \prime}$ N, $131^{\circ}$ $50^{\prime} 00^{\prime \prime} \mathrm{W}$; (map 3).

Named in 1886 by USC\&GS for local pilot, E. H. Francis.

Francis Anchorage: bay, $3 \mathrm{mi}$. across, in South Arm Farragut Bay, $1.5 \mathrm{mi}$. N of Read I. and $83 \mathrm{mi}$. E of Sitka, Coast Mts. ; $57^{\circ} 09^{\prime} \mathrm{N}, 133^{\circ}$ $10^{\prime} \mathrm{W}$; (map 8).

Named in 1887 by Lt. Comdr. C. M. Thomas, USN, for Alaskan ship pilot E. H. Francis. Published in 1888 by USC\&GS.

Francisco Creek: stream, heads at junc. of Berkley Canyon and Canine Gulch, flows SE $1.7 \mathrm{mi}$. to Stewart River, $20 \mathrm{mi}$. NE of Nome, Seward Penin. High.; $64^{\circ} 48^{\prime}$ N, $165^{\circ} 29^{\prime}$ W; (map 94).

Prospectors' name reported in 1904 by T. G. Gerdine, USGS.

Francis Cove: cove, $0.7 \mathrm{mi}$. across, between Naha Bay and Traitors Cove, on W coast of Revillagigedo I., Alex. Arch.; 55 $39^{\prime} 30^{\prime \prime}$ N, $131^{\circ}$ $43^{\prime} 00^{\prime \prime} \mathrm{W}$; (map 3).

Local name recorded in 1949 by USGS.

Francis Creek: stream, flows $11 \mathrm{mi}$. E to Ptarmigan Creek, $0.7 \mathrm{mi}$. N of Ptarmigan Lake and $66 \mathrm{mi}$. NE of McCarthy, Alaska Ra.; $61^{\circ} 52^{\prime} 28^{\prime \prime} \mathrm{N}, 141^{\circ} 08^{\prime} 30^{\prime \prime} \mathrm{W}$; (map 67).

Local name published by USGS in 1954.

Francis Creek: stream, on Seward Penin., flows NW $3.3 \mathrm{mi}$. to Goodhope Bay, $25 \mathrm{mi}$. SW of Deering, Kotzbue-Kobuk Low.; $66^{\circ} 04^{\prime} \mathrm{N}$, $163^{\circ} 37^{\prime} \mathrm{W}$; (map 113).

Name used by local prospectors; reported in 1903 by $\mathrm{D}$. 'C. Witherspoon, USGS.

Francis Island: island, $0.6 \mathrm{mi}$. long, in Glacier Bay National Monument, $0.7 \mathrm{mi}$. SE of Drake I. and $45 \mathrm{mi}$. NW of Hoonah, St. Elias Mts.; $58^{\circ} 37^{\prime} 45^{\prime \prime} \mathrm{N}, 136^{\circ} 10^{\prime} 45^{\prime \prime} \mathrm{W}$; (map 10).

Apparently named by the British Admiralty and published on its Chart No. 2431 in 1890.

Francis Point: point of land, on SW tip of Nellay I., at head of Sea Otter Harbor, on W coast of Dall I., Alex. Arch.; $55^{\circ} 06^{\prime} 45^{\prime \prime} \mathrm{N}$, $133^{\circ} 11^{\prime} 10^{\prime \prime} \mathrm{W}$; (map 4).

Local name recorded in 1920 by USC\&GS.

Francis River: stream, see Stikine River.

Frank Creek: stream, flows $7 \mathrm{mi} \mathrm{NE}$ to Nelson Lagoon, $25 \mathrm{mi}$. W of village of Port Moller, Bristol Bay Low.; 55 $57^{\prime} 20^{\prime \prime}$ N, $161^{\circ} 13^{\prime} 40^{\prime \prime}$ W; (map 28).

Named in 1929 by USGS.

Frank Creek: stream, heads at $57^{\circ} 33^{\prime} 30^{\prime \prime} \mathrm{N}$, $152^{\circ} 25^{\prime} 15^{\prime \prime} \mathrm{W}$; flows N $3 \mathrm{mi}$. to SE side of Kalsin Bay, 14 mi. S of Kodiak, Kodiak I.; $57^{\circ} 35^{\prime} 30^{\prime \prime} \mathrm{N}, 152^{\circ} 25^{\prime} 45^{\prime \prime} \mathrm{W}$; BGN 1966; (map 34).

Local name reported in 1966 by the Alaska State Geographic Board.

Frank Creek: stream, flows NE to Agiapuk River near its junc. with American River, about 20 mi. NE of Teller, Seward Penin. High.; (map 111).

Prospectors' name shown on a map of Cape Nome gold fields by David Fox, Jr., dated
1901. This feature cannot be precisely identified on current maps.

Frank Hill: hill, $850 \mathrm{ft}$., on southern Kiska I., Aleutian Is.; $51^{\circ} 54^{\prime} 20^{\prime \prime} \mathrm{N}, 177^{\circ} 16^{\prime} 00^{\prime \prime} \mathrm{E}$; (map 14).

An arbitrary name beginning with " $F$ " to correspond to "F" grid used by the U.S. Army for tactical purposes during World War II; published on a 1953 AMS map.

Franklin: locality, at junc. of Franklin Creek and South Fork Fortymile River, $48 \mathrm{mi}$. SW of Eagle, Yukon-Tanana High.; 64 $09^{\prime} 50^{\prime \prime} \mathrm{N}$, $141^{\circ} 46^{\prime} 30^{\prime \prime} \mathrm{W}$; (map 102). Var. Franklin Gulch.

This mining camp was originally reported as "Franklin Gulch" by Brooks (1900, pl. 47), USGS. A post office named "Franklin" was established here in 1902 and maintained until 1945 (Ricks, 1965, p. 22). The place had a population of 5 in 1940.

Franklin, Point: point of land, between Peard Bay and Chukchi Sea, $33 \mathrm{mi}$. NE of Wainwright, Arctic Plain; $70^{\circ} 54^{\prime} 28^{\prime \prime} \mathrm{N}, 158^{\circ} 47^{\prime} 50^{\prime \prime}$ W; (map 147). Var. Franklin Point.

Capt. Beechey (1831, p. 273), RN, wrote on August 15, 1826, "a cape, which proved the most distant land seen from the ship, I named after Captain [Sir John] Franklin, RN, under whose command I had the pleasure to serve on the first Polar expedition." His map shows "Point Franklin." It is interesting to note that it was just two days later when Sir John Franklin named his "farthest point" after Capt. Beechey.

Franklin Bluffs: bluffs, $830 \mathrm{ft}$., on $E$ bank of Sagavanirktok River, $30 \mathrm{mi}$. S of Prudhoe Bay, Arctic Plain; $69^{\circ} 48^{\prime} \mathrm{N}, 148^{\circ} 40^{\prime} \mathrm{W}$; (map 140).

\section{Named in 1951 by USGS.}

Franklin Creek: stream, flows SE $5 \mathrm{mi}$. to Iditarod River, $11 \mathrm{mi}$. N of Flat, KilbuckKuskokwim Mts.; $62^{\circ} 36^{\prime} 30^{\prime \prime}$ N, $158^{\circ} 06^{\prime} 00^{\prime \prime}$ W; (map 79).

Prospectors' name obtained in 1952 by USGS topographers.

Franklin Creek: stream, flows E $6 \mathrm{mi}$. to South Fork Fortymile River $48 \mathrm{mi}$. SW of Eagle,

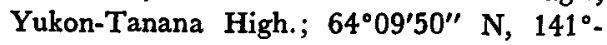
$46^{\prime} 30^{\prime \prime}$ W; (map 102). Var. Franklin Gulch, Franklins Creek.

Named by prospectors for Howard Franklin, prospector, who in 1886 "went up the Fortymile, where on September 7 he found gold in the river bars 25 miles from the mouth and a little later on Franklin Creek, a tributary of the main river" (Brooks, 1953, p. 328). The name was first reported in 1890 by E. H. Wells of the Leslie Expedition.

Franklin Creek: stream, flows SE $1.5 \mathrm{mi}$. to Livengood Creek, $1.5 \mathrm{mi}$. NE of Livengood, Yukon-Tanana High.; $65^{\circ} 32^{\prime} \mathrm{N}, 148^{\circ} 30^{\prime} \mathrm{W}$; (map 105). Var. Franklin Gulch.

Named by prospectors for Calvin Franklin, a local prospector; reported in 1915 by Brooks (Brooks and others, 1916, pl. 9), USGS.

Franklin Extreme: locality, on Elson Lagoon, E of Point Barrow, Arctic Plain; (map 153).
Beechey (1831, p. 302) wrote in 1826 "I named * * the extreme point of our discoveries after Captain Franklin [Sir John] *** of the land expedition. I could have wished that this point had been marked by some conspicuous headland worthy of the name bestowed upon it; but my hope is that the officer who may be so fortunate as to extend our discoveries will do him the justice to transfer his name to the first object beyond it more deserving of honour."

Franklin Gulch: locality, see Franklin.

Franklin Gulch: stream, see Franklin Creek.

Franklin Hill : hill, $800 \mathrm{ft}$., between Hoelsher and Kaufman Creeks, on southern Attu I., Aleutian Is.; $52^{\circ} 49^{\prime} 22^{\prime \prime} \mathrm{N}, 172^{\circ} 58^{\prime} 15^{\prime \prime} \mathrm{E}$; (map 13).

Name shown on an AMS map published in 1948, and given by the U.S. Army during World War II. The name is not used today. Franklin Mountains: mountains, in block 30 mi. wide, bounded on $\mathrm{S}$ and $\mathrm{W}$ by Canning River, on $\mathbf{N}$ by Ikiakpuk Valley and Lake Schrader, on E by Hulahula River, in Brooks Ra., NE of Philip Smith Mts.; 69 $10^{\prime} \mathrm{N}$, $145^{\circ} 10^{\prime} \mathrm{W}$; (map 139).

On July 20, 1837, Thomas Simpson (1843, p. 125) wrote: "The portion at the Rocky Mountains [Brooks Range] visible from the coast does not terminate, as conjectured by Sir John Franklin, with the Romanzof chain. After a brief interval, another chain commences, less lofty perhaps, but equally picturesque; which in honor of the distinguished officer whose discoveries we were following up, we named the Franklin Range."

Franklin Peaks: peaks, elev. 4,005 ft., on ridge $1.5 \mathrm{mi}$. long, $1 \mathrm{mi}$. NW of Hamilton Peak and $88 \mathrm{mi}$. E of Sitka, Coast Mts.; $57^{\circ} 08^{\prime} 15^{\prime \prime} \mathrm{N}$, $133^{\circ} 02^{\prime} 10^{\prime \prime} \mathrm{W}$; (map 8).

Named in 1887 by Lt. Comdr. C. M. Thomas, USN; name published in 1888 by USC\&GS.

Franklins Creek: stream, see Franklin Creek.

Franks Camp: locality, see Unguriak Camp.

Franks Lagoon: lagoon, on Alaska Penin., trends SW $1.5 \mathrm{mi}$. to Bristol Bay, $5.5 \mathrm{mi}$. NE of Port Moller, Bristol Bay Low.; $56^{\circ} 03^{\prime} \mathrm{N}, 160^{\circ} 30^{\prime}$ W; (map 30).

Local name reported by a 1951 USGS field party.

Fran Reef: reef, in Portlock Harbor, $6.5 \mathrm{mi}$. NW of Chichagof, on W coast of Chichagof $I$., Alex. Arch.; $57^{\circ} 44^{\prime} 00^{\prime \prime} \mathrm{N}, 136^{\circ} 13^{\prime} 25^{\prime \prime} \mathrm{W}$; (map 9).

Local name published in 1928 by USC\&GS on Chart 8258.

Franz Point: point of land, on $\mathbf{S}$ shore of Nelson Lagoon, $21 \mathrm{mi}$. W of village of Port Moller, Bristol Bay Low.; 55 $57^{\prime} 30^{\prime \prime} \mathrm{N}, 161^{\circ} 06^{\prime} 30^{\prime \prime}$ W; (map 28).

Name shown on 1963 USC\&GS chart.

Fraser Glacier: glacier, heads at $60^{\circ} 43^{\prime} \mathrm{N}, 141^{\circ}$ $11^{\prime} \mathrm{W}$, trends NW 6 mi. to Baldwin Glacier, $65 \mathrm{mi}$. NE of Cape Yakataga, St. Elias Mts.; $60^{\circ} 47^{\prime} 30^{\prime \prime} \mathrm{N}, 141^{\circ} 17^{\prime} 00^{\prime \prime} \mathrm{W}$; (map 65).

Local name published in 1942 by USGS. 
Fraser Lake: lake, $9 \mathrm{mi}$. long, $23 \mathrm{mi}$. SE of Karluk, Kodiak I.; $57^{\circ} 15^{\prime} \mathrm{N}, 154^{\circ} 08^{\prime} \mathrm{W}$; (map 35). Var. Frazer Lake.

Local name reported in 1952 by USGS.

Frazer Lake: lake, see Fraser Lake.

Frazier Creek: stream, flows SE $1 \mathrm{mi}$. to Moonlight Greek which flows to Grantley Harbor, $6 \mathrm{mi}$. NE of Teller, Seward Penin. High.; $65^{\circ} 18^{\prime} \mathrm{N}, 166^{\circ} 12^{\prime} \mathrm{W} ;$; map 111).

Prospectors' name reported on the 1908 "Map of Seward Peninsula" by Arthur Gibson

Freak Lake: lake, $300 \mathrm{ft}$. across, on west-central Kiska I., Aleutian Is. ; 51 $55^{\prime} 42^{\prime \prime} \mathrm{N}, 177^{\circ} 21^{\prime}$ 58' E; (map 14).

An arbitrary name beginning with " $F$ " to correspond to "F" grid used by the U.S. Army for tactical purposes during World War II; published on a 1953 AMS map.

Fred Creek: stream, flows NW $2.5 \mathrm{mi}$. to Stewart River, $20 \mathrm{mi}$. N of Nome, Seward Penin. High.; $64^{\circ} 48^{\prime} \mathrm{N}, 165^{\circ} 27^{\prime} \mathrm{W}$; (map 94). Var. Mackey Creek.

Prospectors' name reported on a 1901 map of Cape Nome gold fields by David Fox, Jr.

Fred Creek: stream, flows SW $1.2 \mathrm{mi}$. to Canyon Creek which flows to Imuruk Basin, $29 \mathrm{mi}$. NW of Nome, Seward Penin. High.; 64 ${ }^{\circ} 54^{\prime}$ $\mathrm{N}, 165^{\circ} 47^{\prime} \mathrm{W}$; (map 94).

Prospectors' name published on the 1908 "Map of Seward Peninsula" by Arthur Gibson.

Fred Creek: stream, flows NW $6 \mathrm{mi}$. to Porcupine River $3 \mathrm{mi}$. W of Canalaska Mtn. and 49 mi. NE of Coleen Mtn., Porcupine Plat.; $67^{\circ} 23^{\prime} \mathrm{N}, 141^{\circ} 07^{\prime} \mathrm{W}$; (map 121$)$.

Name reported by M. G. White (1952, fig. 1), USGS, in 1948.

Frederick, Port: estuary, on $N$ end of Chichagof I., $19 \mathrm{mi}$. long, from Salt Bay extends NE to Icy Strait, $4 \mathrm{mi}$. $\mathrm{N}$ of Hoonah, Alex. Arch.; $58^{\circ} 13^{\prime} \mathrm{N}, 135^{\circ} 30^{\prime} \mathrm{W}$; (map 9). Var. Komtok Hon, Port Fridrikh.

Named in July, 1794, by Capt. George Vancouver, RN, "no doubt after Adolphus Frederick, Son of [King] George III [of England]" (Wagner, 1937, p. 389). The Tlingit Indian name for this feature was reported in 1869 by Comdr. R. W. Meade, USN, as "Komtok Hon."

Frederick Cove: estuary, extends W $1.8 \mathrm{mi}$., off West Arm Moira Sound, at $S$ end of Prince of Wales I., Alex. Arch.; 54 $59^{\prime} \mathrm{N}, 132^{\circ} 16^{\prime}$ W; (map 1).

Local name recorded in 1904 by $H$. C. Fassett, USBF.

Frederick Creek: stream, flows $\mathrm{S}$ to Hungry Creek which flows to Gripple River, about 33 mi. NW of Nome, Seward Penin. High.; (map 94).

Prospectors' name reported on the 1900 "Map of Nome Peninsula" by J. M. Davidson and B. D. Blakeslee; this feature has not been positively identified.

Frederick Harbor, Port: harbor, see Hoonah Harbor.

Frederick Point: point of land, on NE coast of Mitkof I., W shore of Frederick Sound, $5.5 \mathrm{mi}$. SE of Petersburg, Alex. Arch.; $56^{\circ} 47^{\prime} 40^{\prime \prime} \mathrm{N}$, $132^{\circ} 49^{\prime} 20^{\prime \prime} \mathrm{W}$; (map 6).
Named in 1887 by Lt. Comdr. C. M. Thomas, USN, for charting purposes; name published in 1888 on USC\&GS Chart 705.

Frederick Sound: water passage, $70 \mathrm{mi}$. long, extends $E$ from Ghatham Strait to Dry Strait, Alex. Arch.; $56^{\circ} 50^{\prime} \mathrm{N}, 134^{\circ} 25^{\prime} \mathrm{W}$; (map 8). Var. Frederick Strait, Fridrikhe Zund, Prince Frederick Sound, Prince Fredericks Sound.

Named in 1794 by Capt. George Vancouver, RN, for His Royal Highness Frederick, Duke of York, son of King George III of England, "because of the possession taken at Point Vandeput, August 16, 1794" (Wagner, 1937, p. 486). The Russian transliteration of this name, "Fridrikhe Zund," was published in 1848 on Russian Hydrog. Dept. Chart 1396.

Frederick Strait: water passage, see Frederick Sound.

Frederika Creek: stream, flows S $1.8 \mathrm{mi}$. from Frederika Glacier terminus to Skolai Creek, $30 \mathrm{mi}$. NE of McCarthy, Wrangell Mts.; $61^{\circ} 40^{\prime \prime} \mathrm{N}, 142^{\circ} 12^{\prime} \mathrm{W}$; (map 67).

Local name reported in 1959 by USGS.

Frederika Glacier: glacier, trends SE $10 \mathrm{mi}$. along W slope of Frederika Mtn. to its terminus at head of Frederika Creek, $30 \mathrm{mi}$. NE of McCarthy, Wrangell Mts.; $61^{\circ} 41^{\prime} 30^{\prime \prime} \mathrm{N}$, $142^{\circ} 12^{\prime} 00^{\prime \prime} \mathrm{W}$; (map 67).

Named in 1891 by Hayes (1892, pl. 20), USGS, presumably for Lt. Frederick Schwatka, USA, leader of the party with which Hayes explored the Yukon that year.

Frederika Mountain: mountain, 10,329 ft., E of Frederika Glacier, $33 \mathrm{mi}$. NE of McCarthy, Wrangell Mts.; $61^{\circ} 46^{\prime} 20^{\prime \prime} \mathrm{N}, 142^{\circ} 13^{\prime} 40^{\prime \prime} \mathrm{W}$; (map 67). Var. Mount Abercrombie.

Local name taken from the glacier; reported in 1914 by Capps (1916, pl. 1), USGS. It seems to be the same feature that Oscar Rohn called "Mount Abercrombie," for William R. Abercrombie, USA.

Freds Creek: stream, flows SE $6 \mathrm{mi}$. to Sitka Sound, on SE coast of Kruzof I., $10 \mathrm{mi}$. W of Sitka, Alex. Arch.; $57^{\circ} 04^{\prime} 00^{\prime \prime} \mathrm{N}, 135^{\circ} 36^{\prime} 10^{\prime \prime}$ W; BGN 1933; (map 9).

Local name reported in 1933 by USFS.

Freeburn Mountain: mountain, 3,241 ft., $3.5 \mathrm{mi}$. $\mathrm{E}$ of Chichagof, on $\mathrm{W}$ coast of Chichagof I., Alex. Arch.; $57^{\circ} 40^{\prime} 30^{\prime \prime} \mathrm{N}, 136^{\circ} 00^{\prime} 00^{\prime \prime} \mathrm{W}$; BGN 1939; (map 9).

Named in 1939 by local inhabitants for William C. Freeburn (died in 1937), "who was responsible for much of the mining and prospecting activity in the Chichagof region."

Freemantle, Mount: mountain, 2,572 ft., on $\mathrm{S}$ coast of Alaska, at NW entrance to Valdez Arm, $50 \mathrm{mi}$. NW of Cordova, Chugach Mts.; $60^{\circ} 57^{\prime} \mathrm{N}, 146^{\circ} 58^{\prime} \mathrm{W}, B G N$ 1910; (map 64).

Local name reported by Grant and Higgins (1910, pls. 1, 2). Name derived from nearby Point Freemantle.

Freemantle, Point: point of land, NW entrance to Valdez Arm, $50 \mathrm{mi}$. NW of Cordova, Chugach Mts.; $60^{\circ} 57^{\prime} \mathrm{N}, 146^{\circ} 58^{\prime} \mathrm{W}$; (map 64) ; Var. Point Fremantle.

Named in 1794 by Capt. Vancouver (1798, v. 3, p. 186), RN, who on his chart has "Freemantle" and in his text "Fremantle." In the 8th edition of his voyage, in 1801, it is spelled uniformly "Freemantle."

Fremantle, Point: point of land, see Freemantle, Point.

Fremont Creek: stream, flows SE 2 mi. to Baituk Creek which flows to Bering Sea, $11 \mathrm{mi}$. E of Cape Prince of Wales and $45 \mathrm{mi}$. NW of Teller, Seward Penin. High.; $65^{\circ} 34^{\prime}$ N, $167^{\circ} 43^{\prime}$ W; (map 111).

Prospectors' name reported on the 1908 "Map of Seward Peninsula" by Arthur Gibson.

Fremont Morse, Mount: mountain, elev. 6,734 ft., Boundary Peak 85 on Alaska-Canada boundary, $6 \mathrm{mi}$. N of terminus of Speel Glacier and $36 \mathrm{mi}$. E of Juneau, Coast Mts.; 58 $23^{\prime} 15^{\prime \prime}$ N, 138 $27^{\prime} 30^{\prime \prime}$ W; BGN 1927; (map 12). Var. Boundary Peak 85.

Named in 1926 by IBC for Fremont Morse, USC\&GS, who was "detailed * * * to Alaska Boundary Commission, 1893-1913 ***."

French Creek: stream, flows S $1 \mathrm{mi}$. to East Fork Solomon River, $14 \mathrm{mi}$. NE of Solomon, Seward Penin. High.; $64^{\circ} 42^{\prime} \mathrm{N}, 164^{\circ} 06^{\prime} \mathrm{W}$; (map 95).

Prospectors' name reported on a 1902 prospectors' manuscript map.

French Creek: stream, flows NW $18 \mathrm{mi}$. to Moose Creek, 20 mi. SE of Fairbanks, Tanana Low.; $64^{\circ} 42^{\prime} 40^{\prime \prime} \mathrm{N}, 147^{\circ} 06^{\prime} 40^{\prime \prime} \mathrm{W}$; (map 100).

Local name shown on a 1908 manuscript map by J. W. Bagley, USGS.

French Creek: stream, flows NE $9 \mathrm{mi}$. to Holtz Creek which flows to Kugruk River, $19 \mathrm{mi}$. E of Imuruk Lake, Seward Penin. High.; $65^{\circ} 34^{\prime} \mathrm{N}, 162^{\circ} 32^{\prime} \mathrm{W}$; (map 110$)$.

Prospectors' name reported in 1903 by D. C. Witherspoon (in Moffit, 1905, pl. 2), USGS.

French Creek: stream, flows W $3 \mathrm{mi}$, to join Iron Creek to form North Fork Kougarok River, 3 mi. SE of Harris Dome and $37 \mathrm{mi}$. W of Imuruk Lake, Seward Penin. High.; $65^{\circ} 37^{\prime} \mathrm{N}$, $164^{\circ} 27^{\prime} \mathrm{W}$; (map 110).

Prospectors' name reported in 1901 by $T$. G. Gerdine (in Collier, 1902, pl. 12), USGS.

French Gulch: ravine, trends SE $1.7 \mathrm{mi}$. to Healy Creek, 6 mi. E of Healy, Alaska Ra. ; $63^{\circ} 52^{\prime} \mathrm{N}$, $148^{\circ} 46^{\prime} \mathrm{W}$; (map 87).

Local name reported in 1910 by S. R. Capps (in Brooks and others, 1918, pl. 17), USGS.

French Gulch: ravine, trends SE $1.5 \mathrm{mi}$. to Confederate Greek, $50 \mathrm{mi}$. SW of Eagle, YukonTanana High.; $64^{\circ} 17^{\prime} \mathrm{N}, 142^{\circ} 21^{\prime} \mathrm{W}$; (map 102).

Prospectors' name shown on an 1898 manuscript map by C. A. Woodruff, Fort Cudahy, Canada.

French Harbor: bay, $0.7 \mathrm{mi}$. across, on SE coast of Prince of Wales I., in Port Johnson, Alex. Arch.; $55^{\circ} 09^{\prime} 00^{\prime \prime} \mathrm{N}, 132^{\circ} 01^{\prime} 15^{\prime \prime} \mathrm{W}$; $B G N$ 1966; (map 4).

Local name recorded in 1948 by USGS.

Frenchman Greek: stream, flows SE $1.5 \mathrm{mi}$. to O'Connor Creek, $8 \mathrm{mi}$. NW of Fairbanks, Yukon-Tanana High.; 64. $55^{\prime} 30^{\prime \prime} \mathrm{N}, 1^{\circ} 7^{\circ} 53^{\prime}$ 50 " W; (map 100).

Local name published in 1908 by USGS. 
Frenchman Lake: lake, $0.5 \mathrm{mi}$. long, between Rat and Caribou Lakes, $21 \mathrm{mi}$. NW of Glennallen, Copper River Basin; $62^{\circ} 11^{\prime} 00^{\prime \prime} \mathrm{N}$, $146^{\circ} 09^{\prime} 30^{\prime \prime} \mathrm{W}$; ( $\operatorname{map} 83$ )

Local name reported in 1949 by USGS.

Frenchman's Bay : bay, see Lituya Bay.

French Pete's Creek: stream, see Paris Creek.

Frenchy Creek: stream, on Kenai Penin., flows NE $2.5 \mathrm{mi}$. to Canyon Creek, $9.5 \mathrm{mi}$. S of Sunrise, Chugach Mts.; $60^{\circ} 45^{\prime} 10^{\prime \prime} \mathrm{N}, 149^{\circ} 27^{\prime} 30^{\prime \prime}$ W; (map 63)

Local name reported in 1912 by Grant and Higgins (1913, pl. 1), USGS

Fresara Lake: lake, see High Ridge Lake.

Fresh Creek: stream, flows NW $1 \mathrm{mi}$. to Bering Sea, on SW part of Kiska I., Aleutian Is. ; $51^{\circ}$ $55^{\prime} 21^{\prime \prime} \mathrm{N}, 177^{\circ} 16^{\prime} 35^{\prime \prime} \mathrm{E}$; (map 14).

An arbitrary name beginning with " $F$ " to correspond to " $F$ " grid used by the U.S. Army for tactical purposes during World War II; published on a 1953 AMS map.

Freshwater Bay: estuary, $2.5 \mathrm{mi}$. across, $13 \mathrm{mi}$. long, on $\mathrm{E}$ coast of Chicagof I., Alex. Arch.; $57^{\circ} 51^{\prime} \mathrm{N}, 134^{\circ} 59^{\prime} \mathrm{W}$; (map 9). Var. New Harbor, Novaia Harbor, Novaya Gaban.

Named in 1869 by Comdr. R. W. Meade, USN. He gave the name at the time only to Pavlof Harbor, but now it applies to the whole inlet (U.S. Coast and Geodetic Survey, 1891, p. 163). It was called "Novaya Gavan," meaning "new harbor" by Capt. Lt. M. N. Vasiliev; published as such in 1848 on Russian Hydrog. Dept. Chart 1396.

Freshwater Bay: anchorage, see Pavlof Harbor.

Freshwater Creek: stream, flows W $2 \mathrm{mi}$. to Mitchell Bay, at head of Davis Creek, on Admiralty I., $6 \mathrm{mi}$. NE of Angoon, Alex. Arch.; $57^{\circ} 31^{\prime} 50^{\prime \prime} \mathrm{N}, 134^{\circ} 25^{\prime} 45^{\prime \prime} \mathrm{W}$; (map 9).

Named in 1869 by Comdr. R. W. Meade, USN; published in 1881 on Hydrog. Chart 882. The name does not appear on recent maps.

Freshwater Creek: stream, flows NE $7.5 \mathrm{mi}$. to head of Freshwater Bay, $11 \mathrm{mi}$. $\mathrm{N}$ of Tenakee Springs, on $\mathrm{E}$ coast of Chicagof I., Alex. Arch.; $57^{\circ} 56^{\prime} 30^{\prime \prime} \mathrm{N}, 135^{\circ} 13^{\prime} 30^{\prime \prime} \mathrm{W}$; BGN 1960; (map 9).

Named in 1956 by E. H. Lathram, USGS. The name was derived from Freshwater Bay.

Fresh Water Lake: lake, $1.5 \mathrm{mi}$. long, $7 \mathrm{mi}$. NE of Angoon, on W central Admiralty I., Alex. Arch.; $57^{\circ} 34^{\prime} \mathrm{N}, 134^{\circ} 25^{\prime} \mathrm{W}$; (map 9).

Named by Comdr. R. W. Meade, USN, and published in 1869 on Hydrog. Chart 225

Fresno Creek: stream, on Kenai Penin., flows E $5 \mathrm{mi}$. to Canyon Creek, $0.5 \mathrm{mi}$. $\mathrm{N}$ of Lower Summit Lake and $16 \mathrm{mi}$. S of Sunrise, Chugach Mts.; $60^{\circ} 40^{\prime} 25^{\prime \prime} \mathrm{N}, 1^{\circ} 29^{\prime} 15^{\prime \prime} \mathrm{W}$; (map 63).

Name used by local prospectors; reported by G. F. Becker (1898, p. 80), USGS.

Frezas, Laguna de la: lake, near Point Carrew, $\mathrm{S}$ shore of Yakutat Bay, Malaspina Coastal Plain; $59^{\circ} 33^{\prime} \mathrm{N}, 139^{\circ} 50^{\prime} \mathrm{W}$.

This name is applied to a lake on Capt. Alesandro Malaspina's 1791 chart; so called because wild strawberries were found in the area (Wagner, 1937, p. 456).

Friable, Mount: mountain, 4,725 ft., on $\mathrm{E}$ side of Aurora Glacier, Glacier Bay National Monument, $2.4 \mathrm{mi}$. NE of July Fourth Mountain, $60 \mathrm{mi}$. NW of Hoonah, St. Elias Mts.; $58^{\circ} 40^{\prime} 20^{\prime \prime} \mathrm{N}, 136^{\circ} 40^{\prime} 55^{\prime \prime} \mathrm{W}$; (map 10).

Local name reported in 1951 by USGS.

Friday Creek: stream, flows SW $13 \mathrm{mi}$. to Knik River, $14 \mathrm{mi}$. SW of Palmer, Chugach Mts.; $61^{\circ} 29^{\prime} 20^{\prime \prime} \mathrm{N}, 148^{\circ} 47^{\prime} 50^{\prime \prime} \mathrm{W}$; (map 69).

Local name reported in 1942 by AMS.

Friday Creek: stream, heads NE of Hayes River Pass, flows SE $17 \mathrm{mi}$. to Talachulitna River, SW of Hiline Lake, $46 \mathrm{mi}$. NW of Tyonek, Alaska Ra.; $61^{\circ} 42^{\prime} 45^{\prime \prime} \mathrm{N}, 1^{\circ} 1^{\circ} 27^{\prime} 25^{\prime \prime} \mathrm{W}$; (map 70).

Local name reported in 1954 by USGS.

Friday Creek: stream, in Kantishna Hills, flows SW $1.8 \mathrm{mi}$. from Wickersham Dome to Moose Creek, $4.4 \mathrm{mi}$. NNW of Wonder Lake, Alaska Ra.; $63^{\circ} 32^{\prime} 15^{\prime \prime} \mathrm{N}, 150^{\circ} 59^{\prime} 20^{\prime \prime} \mathrm{W}$; (map 88).

Name shown on a 1905 manuscript map of "Kantishna Gold Fields" by A. Friedrich, prospector.

Fridrikh, Port : estuary, see Frederick, Port.

Fridrikhe Zund: water passage, see Frederick Sound.

Frieda Lake: lake, $0.2 \mathrm{mi}$. long, on southern Kiska I., Aleutian Is.; $51^{\circ} 53^{\prime} 50^{\prime \prime} \mathrm{N}, 177^{\circ} 19^{\prime}$ $15^{\prime \prime} \mathrm{E}$; (map 14).

An arbitrary name beginning with " $F$ " to correspond to "F" grid used by the U.S. Army for tactical purposes during World War II; published on a 1953 AMS map.

Friendly Creek: stream, flows NW $5 \mathrm{mi}$. to Ipnavik River, $16 \mathrm{mi}$. NW of Howard Pass, Brooks Ra.; $68^{\circ} 24^{\prime} \mathrm{N}, 157^{\circ} 16^{\prime} \mathrm{W}$; BGN 1960; (map 132).

Named in 1951 by I. L. Tailleur, USGS, "for its accessibility during spring break up."

Frigid Crags: mountain, 5,550 ft., on W bank of North Fork Koyukuk River, one of Gates of the Arctic, $37 \mathrm{mi}$. NW of Wiseman, Brooks Ra.; $67^{\circ} 50^{\prime} \mathrm{N}, 150^{\circ} 58^{\prime} \mathrm{W}$; BGN 1932; (map 124).

So named in 1929 by Marshall (1956, p. 12). See Boreal Mountain.

Frio, Cabo: point of land, see Johnstone Point. Fripo Island: island, $0.2 \mathrm{mi}$. long, between Felice Strait and Revillagigedo Channel, $1,300 \mathrm{ft}$. $\mathrm{E}$ of $\mathrm{N}$ end of Cat I., Alex. Arch.; 55 $5^{\circ} 02^{\prime} \mathrm{N}$, $131^{\circ} 14^{\prime} \mathrm{W}$; (map 3$)$.

Named in 1883 by Lt. Comdr. H. E. Nichols, USN.

Frisbee Lake: lake, $0.3 \mathrm{mi}$. long, on Kenai Penin SW of Skilak Lake, $27 \mathrm{mi}$. SE of Kenai, Cook Inlet Low.; $60^{\circ} 25^{\prime} 50^{\prime \prime} \mathrm{N}, 150^{\circ} 31^{\prime} 00^{\prime \prime} \mathrm{W}$; (map 62).

Named about 1963 by officials of Kenai National Moose Range, for administrative purposes.

Frisco Creek: stream, flows NW $5.7 \mathrm{mi}$. to Hurst Creek, $17 \mathrm{mi}$. NW of Ophir and $47 \mathrm{mi}$. NW of McGrath, Kilbuck-Kuskokwim Mts.; $63^{\circ}$. $18^{\prime} 15^{\prime \prime} \mathrm{N}, 156^{\circ} 56^{\prime} 00^{\prime \prime} \mathrm{W}$; (map 90).
Prospectors' name reported in 1917 by USGS.

Frisky Creek: stream, flows NW $2.5 \mathrm{mi}$. to Mosquito Fork, $2 \mathrm{mi}$. E of Eagle Cliff and $49 \mathrm{mi}$. SW of Chandalar, Brooks Ra.; $67^{\circ} 03^{\prime} \mathrm{N}$, $149^{\circ} 55^{\prime} \mathrm{W}$; (map 123).

Local name reported in 1956 by T. E. Taylor, USGS.

Fritter Cove: bight, $0.8 \mathrm{mi}$. across, on $\mathrm{E}$ coast of Zarembo I., Alex. Arch.; 56 22'30' N, 132³8'30" W; BGN 1917; (map 6).

Named in 1916 by J. A. Daniels, USC\&GS. Fritz, Mount: mountain, 2,605 ft., $13 \mathrm{mi}$. NNW of Chichagof, on $W$ coast of Chichagof I., Alex. Arch.; $57^{\circ} 50^{\prime} 20^{\prime \prime} \mathrm{N}, 136^{\circ} 16^{\prime} 00^{\prime \prime} \mathrm{W}$; (map 9).

Name published in 1928 by USC\&GS on Chart 8158.

Fritz Cove: $b a y$, in Stephens Channel off NW coast of Douglas I., $8 \mathrm{mi} \mathrm{NW}$ of Juneau, Coast Mts.; $58^{\circ} 19^{\prime} \mathrm{N}, 134^{\circ} 40^{\prime} \mathrm{W}$; (map 11).

Named by Lt. F. M. Symonds, USN, in 1880 for his son, Fritz, and published by USC\&GS in 1881 on Chart 734.

Fritz Creek: stream, on Kenai Penin., flows S 7 mi. to Kachemak Bay, $7 \mathrm{mi}$. NE of Homer, Cook Inlet Low.; $59^{\circ} 41^{\prime} \mathrm{N}, 151^{\circ} 22^{\prime} \mathrm{W}$; (map 50).

Local name reported in 1904 by $R$. W. Stone (in Brooks and others, 1905, p. 3), USGS.

Fritz Island: island, $300 \mathrm{ft}$. across, in Middle Channel, Sitka Sound, $0.7 \mathrm{mi}$. S of Sitka, Alex. Arch.; $57^{\circ} 02^{\prime} 30^{\prime \prime} \mathrm{N}, 135^{\circ} 20^{\prime} 55^{\prime \prime} \mathrm{W}$; (map 9). Var. Fritz Islet.

Named in 1880 by USN for "little" Fritz, son of Lt. F. M. Symonds, USN; name published by USC\&GS in 1883 Coast Pilot (p. 142).

Frocadero Bay: bay, see Trocadero Bay.

Frog Mountains: mountains, 2,400 ft., trend E $10 \mathrm{mi}$. from Elbow Point, between the two arms of Lake Nerka, $35 \mathrm{mi}$. NW of Dillingham, Kilbuck-Kuskokwim Mts.; $59^{\circ} 33^{\prime} \mathrm{N}$, $158^{\circ} 57^{\prime}$ W; BGN 1932; (map 52).

Local name reported in 1932 by USGS

Frog Rock: rock, in Ogden Passage, $3 \mathrm{mi}$. SW of Chichagof, on $W$ coast of Chichagof $I$., Alex. Arch.; 57 $38^{\prime} 35^{\prime \prime} \mathrm{N}, 136^{\circ} 09^{\prime} 30^{\prime \prime} \mathrm{W}$; BGN 1908; (map 9).

Named in 1908 by USC\&GS; published in 1908 Coast Pilot (p. 174).

Frog Rocks: reef, see Hog Rocks.

Front Hill: hill, $700 \mathrm{ft}$., on southern Kiska I., between Ford Hill and Fur Mtn., Aleutian Is.; $51^{\circ} 55^{\prime} 25^{\prime \prime} \mathrm{N}, 177^{\circ} 20^{\prime} 25^{\prime \prime} \mathrm{E}$; (map 14).

An arbitrary name beginning with " $F$ " to correspond to " $F$ " grid by the U.S. Army for tactical purposes during World War II; published on a 1953 AMS map.

Front Mountain: peak, 2,560 ft., in Tilted Hills, on Iniskin Penin., $2.5 \mathrm{mi}$. NE of Oil Bay, Aleutian Ra.; $59^{\circ} 41^{\prime} 40^{\prime \prime} \mathrm{N}, 153^{\circ} 13^{\prime} 30^{\prime \prime} \mathrm{W}$; (map 51).

Name published by Moffit (1927, pl. 1), USGS.

Front Point: point of land, on $\mathrm{E}$ coast of Kenai Penin., at SW entrance to Nuka Passage, 32 
mi. SE of Seldovia, Chugach Mts.; $59^{\circ} 16^{\prime} 30^{\prime \prime}$ N, 150 $53^{\prime} 00^{\prime \prime} \mathrm{W}$; BGN 1931; (map 50).

Named by the USC\&GS in 1931, "because this point forms the front approach range with Point Gore for vessels coming out of Nuka Passage."

Frostbite Peak: mountain peak, 5,660 ft., $2 \mathrm{mi}$. W of Devils Paw, 36 mi. NE of Juneau, Coast Mts.; $58^{\circ} 43^{\prime} 30^{\prime \prime} \mathrm{N}, 133^{\circ} 53^{\prime} 50^{\prime \prime} \mathrm{W}$; (map 12).

Local name reported in 1960 by USGS.

Frost Creek: stream, flows NE $2 \mathrm{mi}$. to Bonanza River, $18 \mathrm{mi}$. NW of Solomon, Seward Penin. High.; $64^{\circ} 46^{\prime} 15^{\prime \prime} \mathrm{N}, 164^{\circ} 47^{\prime} 45^{\prime \prime} \mathrm{W}$; (map 95).

Prospectors' name reported on the 1900 "Map of Nome Peninsula" by J. M. Davidson and B. D. Blakeslee.

Frost Creek: stream, flows SE $1.2 \mathrm{mi}$. to Noxapaga River, $24 \mathrm{mi}$. W of Imuruk Lake, Seward Penin. High.; 65 $35^{\prime} 30^{\prime \prime}$ N, $164^{\circ} 06^{\prime} 30^{\prime \prime}$ W; BGN 1952; (map 110).

Prospectors' name reported in 1901 by $T$. G. Gerdine (in Collier, 1902, pl. 12), USGS.

Frosty Bay: estuary, of Frosty Creek, at $\mathrm{N}$ end of Seward Passage, $8 \mathrm{mi}$. $\mathrm{S}$ of mouth of Bradfield Canal, Alex. Arch.; 56 $04^{\prime}$ N, $131^{\circ} 58^{\prime}$ $B G N 1923$; (map 7).

Local name reported in 1923 by USFS.

Frosty Creek: stream, flows W 5 mi. to Frosty Bay, at $\mathrm{N}$ end of Seward Passage, $8 \mathrm{mi}$. $\mathrm{S}$ of mouth of Bradfield Canal, Alex. Arch.; $56^{\circ} 03^{\prime}$ $30^{\prime \prime} \mathrm{N}, 131^{\circ} 57^{\prime} 30^{\prime \prime} \mathrm{W}$; BGN 1923; (map 7).

Named in 1923 by USFS.

Frosty Peak: peak, 5,784 ft., $8 \mathrm{mi}$. S of village of Cold Bay, on SW end of Alaska Penin., Aleutian Ra.; 55 $04^{\prime} \mathrm{N}, 162^{\circ} 49^{\prime} \mathrm{W}$; (map 29)

Descriptive name given by W. H. Dall, USC\&GS in 1882

Frosty Reef: reef, $1 \mathrm{mi}$. long, $3.5 \mathrm{mi}$. $\mathrm{N}$ of Goddard, on $W$ coast Baranof I., Alex. Arch.; 56 ${ }^{\circ}$ $53^{\prime} 15^{\prime \prime} \mathrm{N}, 135^{\circ} 23^{\prime} 30^{\prime \prime} \mathrm{W}$; (map 6).

Local fishermen's name reported in 1947 by USC\&GS.

Frozen Bay: bay, see Cold Bay.

Frozen Calf Mountain: mountain, 2,268 ft., 22 mi. NE of Chalkyitsik, Porcupine Plat.; $66^{\circ} 47^{\prime} \mathrm{N}, 143^{\circ} 01^{\prime} \mathrm{W}$; (map 120).

Local name reported in 1956 by T. E. Taylor, USGS. It may be a form of translation of an Indian name.

Frozenfoot Creek: stream, flows SE $13 \mathrm{mi}$. to West Fork Chena River, $8.5 \mathrm{mi}$. NW of Chena Hot Springs and $80 \mathrm{mi}$. SW of Circle, YukonTanana High.; $65^{\circ} 08^{\prime} 40^{\prime \prime} \mathrm{N}, 146^{\circ} 14^{\prime} 00^{\prime \prime} \mathrm{W}$; (map 104). Var. West Fork Chena River.

This stream was considered to be the head of the West Fork Chena River by Prindle (1905, pl. 13), USGS. The present name was reported in local usage in 1913 by C. E. Ellsworth, USGS.

Frozen Rock: rock, in $\mathrm{N}$ end of Aialik Bay, 15 mi. SW of Seward, Chugach Mts. ; 59 $56^{\circ} 30^{\prime \prime}$ N, $149^{\circ} 42^{\prime} 28^{\prime \prime}$ W; (map 49).

Local name reported in the early 1950's by USC\&GS.
Fruit Hill: hill, $350 \mathrm{ft}$, on NW shore of Vega Bay, Kiska I., Aleutian Is.; $51^{\circ} 55^{\prime} 08^{\prime \prime} \mathrm{N}$, $177^{\circ} 21^{\prime} 33^{\prime \prime} \mathrm{E}$; (map 14).

An arbitrary name beginning with " $F$ " to correspond to "F" grid used by the U.S. Army for tactical purposes during World War II; published on a 1953 AMS map.

Fruit Island: island, $0.1 \mathrm{mi}$. across, tied to Japonski I., S of Charcoal I., in Sitka Sound, 0.7 mi. SW of Sitka, Alex. Arch.; $57^{\circ} 02^{\prime} 37^{\prime \prime} \mathrm{N}$, $135^{\circ} 21^{\prime} 10^{\prime \prime} \mathrm{W}$; (map 9).

Named for the Fruit Islands in which it is located. Name was published by USG\&GS in 1943 Coast Pilot (p. 360).

Fruit Islands: islands, in Japonski Is. in Sitka Sound $W$ of Sitka, Alexander Arch.; 57 $02^{\prime}$ $37^{\prime \prime} \mathrm{N}, 135^{\circ} 21^{\prime} 10^{\prime \prime} \mathrm{W}$; (map 9).

Named in 1880 by U.S. Naval officers of the U.S.S. Jamestown; published in the 1883 Coast Pilot (p. 142). The name is now restricted to one island of the group.

Fry Creek: stream, heads at $69^{\circ} 22^{\prime} \mathrm{N}, 154^{\circ} 14^{\prime}$ W, flows N $60 \mathrm{mi}$. to Ikpikpuk River $29 \mathrm{mi}$. $\mathrm{N}$ of its head, Arctic Plain; $69^{\circ} 45^{\prime} \mathrm{N}, 154^{\circ}$. $39^{\prime}$ W; BGN 1960; (map 142).

Name proposed in 1951 by I. L. Tailleur, USGS, for two brothers killed in military service during World War II.

Fry Creek: stream, see Uivaksak Creek.

Frye Point: point of land, extends SE from W shore of Womens Bay, $7 \mathrm{mi}$. SE of Kodiak, Kodiak I. ; $57^{\circ} 42^{\prime} 50^{\prime \prime}$ N, $152^{\circ} 33^{\prime} 10^{\prime \prime}$ W; (map 34).

Local name published in 1943 by USC\&GS. Fryingpan Creek: stream, flows SE 6 mi. to Birch Creek, $57 \mathrm{mi}$. SW of Circle, Yukon-Tanana High.; $65^{\circ} 16^{\prime} 50^{\prime \prime} \mathrm{N}, 145^{\circ} 33^{\prime} 45^{\prime \prime} \mathrm{W}$; (map 104).

Named by prospectors; reported in 1903 by T. G. Gerdine, USGS.

Frying Pan Island: island, $0.6 \mathrm{mi}$. long, North island of the Caribou Is., in Skilak Lake on Kenai Penin., $30 \mathrm{mi}$. SE of Kenai, Cook Inlet Low.; $60^{\circ} 25^{\prime} 45^{\prime \prime} \mathrm{N}, 150^{\circ} 26^{\prime} 00^{\prime \prime} \mathrm{W}$; (map 62).

Named about 1963 by officials of Kenai National Moose Range, for administrative purposes.

Fry Island: island, $1.2 \mathrm{mi}$. across, in Koyukuk River at the $W$ end of Fortymile Slough, 18 mi. N of Hochandochtla Mtn., Kokrines-Hodzana High.; $65^{\circ} 47^{\prime} 30^{\prime \prime} \mathrm{N}, 1^{\circ} 4^{\circ} 56^{\prime} 30^{\prime \prime} \mathrm{W}$; (map 107).

Riverboat pilot's name reported by Lt. B. H. Camden, USRCS, in 1900.

Fry Lake: lake, see Desperation Lake.

Fugitive: locality, see Port Hobron.

Fugitive Creek: stream, flows N $1.8 \mathrm{mi}$. to Port Hobron, on $\mathrm{N}$ coast of Sitkalidak I., SE of Kodiak I.; $57^{\circ} 09^{\prime} 40^{\prime \prime} \mathrm{N}, 153^{\circ} 09^{\prime} 30^{\prime \prime} \mathrm{W}$; BGN 1934; (map 34).

Named in 1934 by USC\&GS, for "a thriving village at the locality, reported in Lisianski's voyage ***(1805) [1814, p. 78]." See Port Hobron.

Fugitive Lake: lake, $0.8 \mathrm{mi}$. long, at head of Fugitive Creek, on Sitkalidak I., SE of Kodiak
I.; $57^{\circ} 08^{\prime} \mathrm{N}, 153^{\circ} 09^{\prime} \mathrm{W}$; $B G N$ 1934; (map 34).

Named in 1934 by USC\&GS. See Fugitive Creek.

Fula, Point: point of land, on NW coast of Suemez I., between Points Arboleda and Remedios, Alex. Arch.; $55^{\circ} 19^{\prime} 25^{\prime \prime} \mathrm{N}, 133^{\circ}$ 26'45" W; (map 4). Var. Mys de Fula, Punta de Fula, Punta de Tula.

Spanish name given in 1779 by Don Juan de la Bodega y Quadra and Francisco Antonio Maurelle as "Punta de Tula."

Fuller Creek: stream, flows NE $15 \mathrm{mi}$. to Kuskokwim River, $3.6 \mathrm{mi}$. NW of Red Devil and $9.6 \mathrm{mi}$. NW of Sleetmute, Kilbuck-Kuskokwim Mts.; $61^{\circ} 47^{\prime} 40^{\prime \prime} \mathrm{N}, 157^{\circ} 23^{\prime} 40^{\prime \prime} \mathrm{W}$; BGN 1943; (map 72).

Locally named for a prospector and trapper; reported in 1943 by USGS.

Fuller Lake: lake, 0.4 mi. long, on Kenai Penin., in Kenai Mts. W of Round Mtn., $42 \mathrm{mi}$. E of Kenai, Chugach Mts.; $60^{\circ} 31^{\prime} 30^{\prime \prime} \mathrm{N}$, $150^{\circ} 03^{\prime} 30^{\prime \prime} \mathrm{W}$; (map 62).

Named about 1963 by officials of Kenai National Moose Range, for administrative purposes.

Fulton Creek: stream, flows SW and SE $20 \mathrm{mi}$. to Gulf of Alaska, $3 \mathrm{mi}$. WNW of Umbrella Reef and $91 \mathrm{mi}$. WNW of Yakutat, St. Elias Mts.; $60^{\circ} 02^{\prime} 10^{\prime \prime} \mathrm{N}, 142^{\circ} 14^{\prime} 40^{\prime \prime} \mathrm{W}$; $B G N$ 1966; (map 65).

Named for Walter S. Fulton, who located oil lands at Cape Yaktaga in 1898; reported in 1903 by G. C. Martin (1905, p. 26), USGS. Fulton Falls: waterfalls, see Fultons Falls.

Fulton Peak: peak, 3,271 ft., N of Frederick Sound, $3 \mathrm{mi}$. W of Spurt Point Lake and $94 \mathrm{mi}$. E of Sitka, Coast Mts.; $57^{\circ} 04^{\prime} 20^{\prime \prime} \mathrm{N}$, $132^{\circ} 59^{\prime} 50^{\prime \prime} \mathrm{W}$; (map 8).

Named in 1887 by Lt. Comdr. C. M. 'Thomas, USN, for Robert Fulton, 1765-1815, American inventor, engineer, and painter, who built the Clermont, the first commercially successful American steamboat, launched in 1807. The name was published in 1889 by USG\&GS.

Fultons Fall: waterfalls, see Fultons Falls.

Fultons Falls: waterfalls, in Barrier Range, an Alaska Penin., in Katmai National Monument, $8 \mathrm{mi}$. $\mathrm{S}$ of Mount Katmai, Aleutian Ra.; $58^{\circ} 08^{\prime} 30^{\prime \prime}$ N, $154^{\circ} 59^{\prime} 25^{\prime \prime}$ W; $B G N$ 1925; (map 42). Var. Fulton Falls, Fultons Fall.

Named in 1916 by R. F. Griggs, National Geographic Society "for B. B. Fulton, entomologist of the 1915 National Geographic Society Katmai expedition."

Funchion Creek: stream, flows SW $24 \mathrm{mi}$. to Chandalar River, $10 \mathrm{mi}$. SE of Caro and 35 mi. SE of Chandalar, Brooks Ra.; 67 ${ }^{\circ} 6^{\prime} 30^{\prime \prime}$ N, $147^{\circ} 38^{\prime} 45^{\prime \prime} \mathrm{W}$; (map 123).

Prospectors' name obtained in 1909 by A. G. Maddren (in Brooks and others, 1910, pl. 7), USGS.

Funeral Ridge: ridge, $0.6 \mathrm{mi}$. long, on southern Kiska I., SE of Fox Hill, Aleutian Is.; 51 ${ }^{\circ} 5^{\prime}$ $10^{\prime \prime} \mathrm{N}, 177^{\circ} 19^{\prime} 20^{\prime \prime} \mathrm{E}$; (map 14 ). 
An arbitrary name beginning with " $F$ " to correspond to "F" grid used by the U.S. Army for tactical purposes during World War II; published in 1953 by AMS.

Funnel Creek: stream, heads in a lake at $59^{\circ} 13^{\prime}$ N, $154^{\circ} 40^{\prime}$ W, flows W $13 \mathrm{mi}$. through Mirror Lake to Moraine Creek, $8.5 \mathrm{mi}$. E of $\mathrm{Ku}$ kaklek Lake, $40 \mathrm{mi}$. S of Iliamna, Aleutian Ra.; $59^{\circ} 12^{\prime} 40^{\prime \prime} \mathrm{N}, 154^{\circ} 57^{\prime} 30^{\prime \prime} \mathrm{W}$; (map 51).

So named by $R$. H. Sargent, USGS, in 1923 because of strong winds encountered in the stream valley. Published by USGS (in Brooks and others, 1925, pl. 3).

Funnel Creek: stream, flows S $4 \mathrm{mi}$. to Tatonduk River $15 \mathrm{mi}$. N of Eagle, Porcupine Plat.; $65^{\circ} 00^{\prime} \mathrm{N}, 141^{\circ} 02^{\prime} \mathrm{W}$; BGN 1931; (map 103).

So named in 1930 by J. B. Mertie, Jr., USGS, because "like a funnel, its open upper valley leads into a narrow canyon-like lower valley."

Funny River: stream, on Kenai Penin., flows NW $30 \mathrm{mi}$. to Kenai River, $18 \mathrm{mi}$. ESE of Kenai, Cook Inlet Low.; $60^{\circ} 29^{\prime} 30^{\prime \prime} \mathrm{N}$, $150^{\circ} 51^{\prime} 50^{\prime \prime} \mathrm{W}$; (map 62).

Local name reported in 1904 by Moffit (1906, pl. 2), USGS.

Funshoot Mountain: mountain, 6,115 ft., in Nutzotin Mts., $4 \mathrm{mi}$. SE of Beaver Lake and $15 \mathrm{mi}$. E. of Euchre Mtn., Alaska Ra. ; $62^{\circ} 00^{\prime}$ N, $141^{\circ} 42^{\prime} \mathrm{W}$; (map 84).

Local name reported in 1960 by USGS.

Funter: locality on $\mathrm{N}$ shore of Funter Bay, $1 \mathrm{mi}$. NE of Clear Point and $18 \mathrm{mi}$. W of Juneau, Alex. Arch.; $58^{\circ} 15^{\prime} 25^{\prime \prime} \mathrm{N}, 134^{\circ} 50^{\prime} 45^{\prime \prime} \mathrm{W}$; (map 11).

Forruer cannery named, after 1891, for the bay on which it is located. A post office was established there in 1902.

Funter Bay: bay, $2 \mathrm{mi}$. long, on $\mathrm{W}$ coast of Mansfield Peninsula, $19 \mathrm{mi}$. SW of Juneau, Alex. Arch.; $58^{\circ} 14^{\prime} 15^{\prime \prime} \mathrm{N}, 134^{\circ} 55^{\prime} 00^{\prime \prime} \mathrm{W}$; (map 11).

Named in 1883 by W. H. Dall, USC\&GS, for Capt. Robert Funter, English explorer, who mapped parts of the NW coast of North America in 1788. Name published in the 1883 Coast Pilot (p. 183).

Furlough Hill: hill, $550 \mathrm{ft}$,, on southern Kiska I., $0.5 \mathrm{mi}$. NW of Vega Bay, Aleutian Is. ; $51^{\circ}$ $54^{\prime} 35^{\prime \prime} \mathrm{N}, 177^{\circ} 20^{\prime} 10^{\prime \prime} \mathrm{E}$; (map 14).

An arbitrary name beginning with " $F$ " to correspond to "F" grid used by the U.S. Army for tactical purposes during World War II ; published on a 1953 AMS map.

Fur Mountain: hill, $585 \mathrm{ft}$., on southern Kiska I., between Fron Hill and Fruit Hill, Aleutian Is.; $51^{\circ} 55^{\prime} 20^{\prime \prime} \mathrm{N}, 177^{\circ} 20^{\prime} 52^{\prime \prime} \mathrm{E}$; (map 14).

An arbitrary name beginning with " $F$ " to correspond to "F" grid used by the U.S. Army for tactical purposes during World War II; published on a 1953 AMS map.

Furrow Creek: stream, flows $W 5.3 \mathrm{mi}$. to Turnagain Arm Cook Inlet, $8.5 \mathrm{mi}$. S of Anchorage, Cook Inlet Low.; $61^{\circ} 05^{\prime} 58^{\prime \prime} \mathrm{N}$, $149^{\circ} 54^{\prime} 25^{\prime \prime} \mathrm{W}$; (map 69).

Local name reported in 1942 by AMS

Fur Seal Islands: islands, see Pribilof Islands.
Furuhelm, Mount: mountain, 3,610 ft., $4.5 \mathrm{mi}$. SW of Baranof, on E coast of Baranof I., Alex. Arch.; $57^{\circ} 03^{\prime} \mathrm{N}, 134^{\circ} 56^{\prime} \mathrm{W}$; BGN 1935; (map 9).

Named in 1935 by USFS "for Ivan Vasilievich Furuhelm, mining engineer and Governor of Russian America, 1859-1863."

Fuse Hill: hill, $400 \mathrm{ft}$., on southern Kiska I., near shore of Vega Bay, Aleutian Is.; 51 ${ }^{\circ} 54^{\prime}$ $38^{\prime \prime} \mathrm{N}, 177^{\circ} 20^{\prime} 42^{\prime \prime} \mathrm{E}$; (map 14).

An arbitrary name beginning with " $F$ " to correspond to "F" grid used by the U.S. Army for tactical purposes during World War II; published on a 1953 AMS map.

\section{G}

G: mountain, see Knob G.

Gabolio: locality, on right bank of Selawik River $24 \mathrm{mi}$. E of Selawik; $66^{\circ} 33^{\prime} \mathrm{N}, 159^{\circ} 08^{\prime} \mathrm{W}$; (map 114).

Eskimo camp reported by USGS in 1927.

Gabriel Icefall: icefall, $700 \mathrm{ft}$., extends W $1 \mathrm{mi}$. from Gulkana Glacier, S of Skull Peak, $17 \mathrm{mi}$.

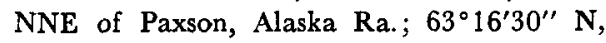
$145^{\circ} 26^{\prime} 00^{\prime \prime} \mathrm{W}$; (map 86).

Named between 1948 and 1955 by T. L. Péwé, USGS

Gada, Punta del: point of land, see Delgada, Point.

Gaff Rock: rock, in Cross Sound, at mouth of Port Althrop, on N coast of Chichagof I., 36 mi. NW of Hoonah, Alex. Arch.; 58 $11^{\prime} 35^{\prime \prime}$ N, $136^{\circ} 24^{\prime} 00^{\prime \prime} \mathrm{W}$; (map 10).

Named by J. F. Pratt, USC\&GS, in 1901 and published in the 1901 Alaska Coast Pilot (p. 212).

Gagalgin Island: island, see Egg Island.

Gagara Lake: lake, $0.9 \mathrm{mi}$. long, on Kenai Penin., $\mathrm{E}$ of Tree Lake, $5 \mathrm{mi}$. NW of Sterling and 12 mi. E of Kenai, Cook Inlet Low.; $60^{\circ} 34^{\prime} \mathrm{N}$, $150^{\circ} 52^{\prime} \mathrm{W}$; (map 62).

Named about 1963 by officials of Kenai National Moose Range, for administrative purposes.

Gagara-Shapka: locality, see Pogoreshapka.

Gagari Island: island, see Gagarin Island

Gagarin Island: island, $0.6 \mathrm{mi}$. long, in Sitka Sound, $6.5 \mathrm{mi}$. NW of Sitka, Alex. Arch.; $57^{\circ} 05^{\prime} 45^{\prime \prime} \mathrm{N}, 135^{\circ} 29^{\prime} 15^{\prime \prime} \mathrm{W}$; BGN 1940; (map 9). Var. Gagari Island, Jet Island, Loon Island, Ostrov Gagarin.

Named in 1809 by the Russian navigator Ivan Vasiliev the first; published by Lt. Sarichev (1826, map 19), IRN, as "O[strov] Gagarin," or "Gagarin Island." Gagarin is a well-known Russian family name. The name "Ostrov Gagary," meaning "loon island," was published for this feature in 1848 on Russian Hydrog. Dept. Chart 1397.

Gagaryah River: stream, heads in lake, flows SW $60 \mathrm{mi}$. to Swift River, $50 \mathrm{mi}$. E of Sleetmute, Lime Hills; $61^{\circ} 37^{\prime} 15^{\prime \prime} \mathrm{N}, 1^{\circ} 5^{\circ} 38^{\prime} 40^{\prime \prime} \mathrm{W}$; (map 71).

Indian name published in 1951 by USGS.

Gage, Mount: mountain, 7,000 ft., at E end of Granite Ra., 58 mi. NE of Cape Yakataga,
Ghugach Mts.; $60^{\circ} 51^{\prime} 30^{\prime \prime} \mathrm{N}, 141^{\circ} 48^{\prime} 00^{\prime \prime} \mathrm{W}$; (map 65).

Name shown on a 1915 fieldsheet by F. H. Moffit, USGS.

Gage Island: island, $0.5 \mathrm{mi}$. long, in Knight Island Passage, $0.5 \mathrm{mi}$. $\mathrm{N}$ of Flemming I., 8 mi. SE of Chenega, Chugach Mts. ; $60^{\circ} 11^{\prime} 20^{\prime \prime}$ $N, 148^{\circ} 00^{\prime} 30^{\prime \prime} \mathrm{W}$; BGN 1929; (map 63).

Named in 1929 by USC\&GS. The name "Gage" was once applied to nearby Flemming Island.

Gage Island: island, see Flemming Island.

Gagemeister, Ostrov: island, see Hagemeister Island.

Gagemeystera, Proliv: water passage, see Hagemeister Strait.

Gage Point: point of land, $\mathrm{N}$ of Gusty Bay, on NE coast of Tanaga I., Aleutian Is. ; $51^{\circ} 52^{\prime} 40^{\prime \prime}$ $\mathrm{N}, 177^{\circ} 54^{\prime} 20^{\prime \prime} \mathrm{W}$; (map 17).

Name published by USC\&GS in 1957 on Chart 9146.

Gagnan Creek: stream, flows SE $14 \mathrm{mi}$. to Kichatna River near its junc. with Yentna River, $48 \mathrm{mi}$. SW of Talkeetna, Alaska Ra.; $62^{\circ} 06^{\prime} 00^{\prime \prime} \mathrm{N}, 151^{\circ} 30^{\prime} 10^{\prime \prime} \mathrm{W}$; (map 81).

Local name reported in 1958 by USGS.

Gagnon Creek: stream, flows SE $2 \mathrm{mi}$. to Healy Creek, $7.5 \mathrm{mi}$. NE of Healy, Alaska Ra.; 63 $53^{\prime} \mathrm{N}, 148^{\circ} 43^{\prime} \mathrm{W}$; (map 87).

Local name reported in 1939 by USGS (Capps, 1940, pl. 3).

Gaikema Creek: stream, on Iniskin Penin., flows E $2.6 \mathrm{mi}$. to Chinitna Bay, Aleutian Ra.; $59^{\circ} 48^{\prime} 50^{\prime \prime} \mathrm{N}, 153^{\circ} 09^{\prime} 00^{\prime \prime} \mathrm{W}$; BGN 1947; (map 51).

Named in 1947 by USGS for "Nick Gaikema, a watchman for the Iniskin Drilling Company, who died in the cabin at the mouth of the creek."

Gailey Lake: lake, $0.9 \mathrm{mi}$. long, between Porcupine and Sheenjek Rivers, $30 \mathrm{mi}$. NE of Fort Yukon, Yukon Flats; $66^{\circ} 49^{\prime} \mathrm{N}, 144^{\circ} 21^{\prime} \mathrm{W}$; (map 119).

Local name obtained in 1956 by USGS.

Gaines Creek: stream, see Ganes Creek.

Gain Island: island, $1 \mathrm{mi}$. long, at entrance to Gambier Bay, $60 \mathrm{mi}$. NE of Sitka, Alex. Arch.; $57^{\circ} 27^{\prime} 20^{\prime \prime} \mathrm{N}, 133^{\circ} 54^{\prime} 15^{\prime \prime} \mathrm{W}$; BGN 1891; (map 8). Var. Gain Island.

Named in 1889 by Lt. Comdr. H. B. Mansfield, USN; name published by USC\&GS in the 1891 Coast Pilot (p. 144).

Gainor Beach: beach, 0.4 mi. long, eastern Attu I., Aleutian Is. ; $52^{\circ} 50^{\prime} 00^{\prime \prime} \mathrm{N}, 173^{\circ} 23^{\prime} 40^{\prime \prime} \mathrm{E}$; (map 13).

Name shown on an AMS map published in 1948 , and given by the U.S. Army during World War II. The name is not used today. Gains Creek: stream, see Ganes Creek.

Ga-ka-tna: stream, see Gakona River.

Gakona: village, pop. 33, on Glenn Highway, at junc. of Copper and Gakona Rivers, $15 \mathrm{mi}$. NE of Glennallen, Copper River Basin; $62^{\circ} 18^{\prime}$ $\mathrm{N}, 145^{\circ} 18^{\prime \prime} \mathrm{W}$; (map 83).

A trading post and post office were established in 1905. The name was derived from the Gakona River. 
Gakona, Mount: peak, 9,700 $\mathrm{ft}$, at head of Gakona Glacier, 22 mi. NE of Paxson, Alaska Ra.; $63^{\circ} 19^{\prime} 20^{\prime \prime}$ N, $145^{\circ} 10^{\prime} 50^{\prime \prime}$ W; (map 86).

Name published on relatively recent maps. Gakona Glacier: glacier, heads on Mount Gakona, trends S $13 \mathrm{mi}$. to its terminus near head of Gakona River, $11 \mathrm{mi}$. NE of Paxson, Alaska Ra.; $63^{\circ} 08^{\prime} \mathrm{N}, 145^{\circ} 13^{\prime} \mathrm{W}$; (map 86).

Name reported in 1900 by T. G. Gerdine (in Mendenhall and Schrader, 1903, pl. 3), USGS.

Gakona Junction: locality, see Big Timber.

Gakona River: stream, flows S $64 \mathrm{mi}$. from Gakona Glacier to Copper River at Gakona, 16 mi. NE of Glennallen, Copper River Basin; $62^{\circ} 18^{\prime} \mathrm{N}, 145^{\circ} 19^{\prime} \mathrm{W}$; BGN 1963; (map 83). Var. Ga-ka-tna, Gako River.

Indian name reported in 1885 by Lt. H. T. Allen (1887, p. 63), USA. R.H. Geoghegan recorded the name as "Ga-ka-tna" in 1903 and gave its meaning as "rabbit river."

Gako River: stream, see Gakona River.

Gala Creek: stream, see Harrison Creek.

Galanikin Island: island, see Galankin Island. Galankin Group: islands, see Galankin Islands. Galankin Island: island, $0.8 \mathrm{mi}$. long, $1.2 \mathrm{mi}$. $S$ of Sitka, off W coast of Baranof I., Alex. Arch.; 57 $02^{\prime} 00^{\prime \prime} \mathrm{N}, 135^{\circ} 19^{\prime} 40^{\prime \prime} \mathrm{W}$; BGN 1897; (map 9). Var. Galanikin Island, Ostrov Galankin, Ostrov. Peschanyy, Sandy Island, Thompson Island.

Named in 1850 by Capt. M. D. Tebenkov (1852, map 38), who published it as "O[strov] Galankin"; name derived from "galanka," meaning "brick stove." In 1809 the Russian navigator Ivan Vasiliev the first named it "Ostrov Peschanyy," meaning "sandy island"; it was published as such by Sarichev (1826, map 19). In 1880 Capt. L. A. Beardslee, USN, named it "Thompson Island" for Richard Wigginton Thompson, 1809-1900, Secretary of the Navy under President Hayes in $1877-80$.

Galankin Islands: islands, $2 \mathrm{mi}$. across, include Bandoroshni, Galankin and Whale Is., with surrounding smaller islands, $1.5 \mathrm{mi}$. S of Sitka, Alex. Arch.; $57^{\circ} 02^{\prime} \mathrm{N}$; $135^{\circ} 20^{\prime} \mathrm{W}$; BGN 1897; (map 9). Var. Galankin Group.

Name apparently first applied by W. H. Dall, USC\&GS, in 1883 Coast Pilot (p. 142). The name was derived from Galankin Island, the largest of the group.

Galas Point: point of land, on W coast of Kagalaska I., Aleutian Is.; $51^{\circ} 47^{\prime} 45^{\prime \prime} \mathrm{N}, 176^{\circ} 24^{\prime}$. 30 " W; BGN 1936; (map 17).

A clipped name derived from Kagalaska Island and given by members of the U.S. Navy Aleutian Island Survey Expedition in 1934.

Galatea Creek: stream, N of Wapoo Hills, flows W $50 \mathrm{mi}$. to Mud River $4.7 \mathrm{mi}$. NE of its junc. with Little Mud River, $61 \mathrm{mi}$. S of Nulato and $62 \mathrm{mi}$. NW of Ophir, Innoko Low.; 63'51'45" $N, 157^{\circ} 41^{\prime} 45^{\prime \prime} \mathrm{W}$; (map 90).

Local name obtained from Joseph Ferris in 1954 by $\mathrm{R}$. E. Isto, USGS.

Galbraith Lake: lake, $3.6 \mathrm{mi}$. long, near NE end of Endicott Mts., on west side of Atigun River,
12 mi. NE of Itkillik Lake, Brooks Ra.; $68^{\circ} 28^{\prime}$ N, 149²5' W; BGN 1960; (map 135). Var. Natravak Lake, Sagavanirktok Lake.

Named by USGS geologists in 1951 for "Bart Galbraith, a bush pilot who was lost while flying * * *" in the area. "Natravak" is the Eskimo name which means "big lake," a common name in nurthern Alaska.

Galea, Lake: lake, $3 \mathrm{mi}$. long, on course of Hatchery Creek, central Prince of Wales I., Alex. Arch.; $55^{\circ} 49^{\prime} 15^{\prime \prime} \mathrm{N}, 132^{\circ} 53^{\prime} 00^{\prime \prime} \mathrm{W}$; (map 4).

Spanish name meaning "an ancient helmet", recorded in 1949 by USGS.

Galen, Mount: peak, 5,022 ft., in Mount McKinley National Park, 3 mi. NNW of Eielson Visitor Center, Alaska Ra.; $63^{\circ} 28^{\prime} 05^{\prime \prime} \mathrm{N}$, 150²1'50" W; BGN 1941; (map 88).

Named by USGS for James L. Galen, Superintendent of Glacier National Park from 1912 to 1914, and later, president and manager of the Mount McKinley Tourist and Transportation Co.

Galena: village, pop. 261, on right bank of Yukon River, $35 \mathrm{mi}$. E of Nulato, Koyukuk Low.; $64^{\circ} 44^{\prime} \mathrm{N}, 156^{\circ} 56^{\prime} \mathrm{W}$; BGN 1937; (map 97). Var. Galera, Natulaten, Nohtalohton, Notaglita, Notaloten.

Established about 1919 as a supply point for the galena (lead ore) prospects south of the Yukon River. Its population was 67 in 1930 ; 44 in 1940 ; and 76 in 1950 . The village is now predominately Indian. With the construction of a major airfield, and the consequent employment, the population has increased. Galena post office was established in 1932 (Ricks, 1965, p. 22). Site of a former Indian village recorded on the 1880 Census map as "Natulaten," by Ivan Petroff, who also recorded Lt. L. A. Zagoskin's 1844 name for the village as "Notaglita," population 37.

Galena Bay: locality, on $\mathrm{S}$ shore of Galena Bay, $40 \mathrm{mi}$. NW of Cordova, Ghugach Mts.; $60^{\circ}$. $55^{\prime} 20^{\prime \prime} \mathrm{N}, 146^{\circ} 37^{\prime} 00^{\prime \prime} \mathrm{W}$; BGN 1910; (map 64).

Name of a former village reported in 1910 by USGS, derived from Galena Bay. Recent USGS maps indicate a site with one building. Galena Bay: estuary, $1.5 \mathrm{mi}$. long, on SE shore of Valdez Arm, $45 \mathrm{mi}$. NW of Cordova, Chugach Mts.; $60^{\circ} 58^{\prime} \mathrm{N}, 146^{\circ} 44^{\prime} \mathrm{W}$; $B G N$ 1910; (map 64).

So named by Capt. W. R. Abercrombie, USA, in 1898 because of the occurrence of galena (lead ore) on its shores.

Galena Creek: stream, flows $17 \mathrm{mi}$. to Kala Slough, $34 \mathrm{mi}$. E of Nulato, Koyukuk Low.; $64^{\circ} 42^{\prime} \mathrm{N}, 156^{\circ} 58^{\prime} \mathrm{W}$; (map 97).

Local name reported in 1954 by USGS.

Galena Creek: stream, in Davidson Mts., flows S $8 \mathrm{mi}$. from Bear Mtn. to Lois Creek $6.5 \mathrm{mi}$. $\mathrm{N}$ of its junc. with Coleen River, $46 \mathrm{mi}$. $\mathrm{E}$ of Table Mtn., Brooks Ra.; $68^{\circ} 17^{\prime} \mathrm{N}, 141^{\circ} 54^{\prime}$ W; (map 137).

Local name reported in 1956 by USGS.

Gale Peak: peak, 7,425 ft., in Storm Range, $1 \mathrm{mi}$. $\mathrm{SE}$ of Mount Ogilvie and $39 \mathrm{mi}$. $\mathrm{N}$ of Juneau,
Coast Mts.; $58^{\circ} 51^{\prime} \mathrm{N}, 134^{\circ} 14^{\prime} \mathrm{W}$; $B G N$ 1965; (map 11).

Named in 1964 by members of the Juneau Icefield Research Project.

Galera: village, see Galena.

Galera, La: island, see Klawak Island.

Galiano Glacier: glacier, heads $1.6 \mathrm{mi}$. W of head of Black Glacier, trends S $3.2 \mathrm{mi}$. to its 1961 terminus, $1.6 \mathrm{mi}$. NE of mouth of Esker Stream and $26 \mathrm{mi}$. N of Yakutat, St. Elias Mts. ; $59^{\circ} 55^{\prime} 40^{\prime \prime} \mathrm{N}, 139^{\circ} 43^{\prime} 00^{\prime \prime} \mathrm{W}$; (map 46).

Named by Russell (1891, p. 89), USGS, for Don Dionisio Alcala Galiano, "the reported writer of the account of Capt. A. Malaspina's voyage to Alaskan shores in 1791."

Galiano Island: island, see Middleton Island.

Galickson Creek: stream, flows SE $9 \mathrm{mi}$. to Takotna River, $39 \mathrm{mi}$. WSW of Medfra, Kuskokwin Low.; $63^{\circ} 00^{\prime} \mathrm{N}, 155^{\circ} 55^{\prime} \mathrm{W}$; (map 89).

Local name reported in 1915 by Mertie and Harrington (1924, pl. 4), USGS.

Galkin Island: island, $0.2 \mathrm{mi}$. long, $2 \mathrm{mi}$. W of Goddard, in the Necker Is., on $W$ coast of Baranof I., Alex. Arch.; 56 $49^{\prime} 50^{\prime \prime}$ N, $135^{\circ}$ $25^{\prime} 25^{\prime \prime} \mathrm{W}$; (map 5$)$.

Local name used by fishermen; published in 1929 by USC\&GS.

Galla, Mys: point of land, see Hall, Cape.

Gallagher Creek: stream, on N part of Chichagof I., flows NE $9 \mathrm{mi}$. to Icy Strait, $6 \mathrm{mi}$. NW of Hoonah, Alex. Arch.; 58 $11^{\prime} \mathrm{N}, 135^{\circ} 33^{\prime} \mathrm{W}$; $B G N$ 1959; (map 11).

Local name reported in 1959 by USGS.

Gallatin, Mount: mountain, $5,098 \mathrm{ft}$., on AlaskaCanada boundary, $7 \mathrm{mi}$. N of Stikine River, Coast Mts.; $56^{\circ} 45^{\prime} 15^{\prime \prime} \mathrm{N}, 131^{\circ} 54^{\prime} 00^{\prime \prime} \mathrm{W}$; $B G N 1954$; (map 7$)$.

Named in 1924 by USGS for Albert Gallatin, 1761-1849, statesman, diplomat, public financier, ethnologist, and one of the U.S. Commissioners who negotiated the Treaty of Ghent.

Gallegas, Islas: islands, see Coronados Islands. Galligan Creek: stream, flows E $4.5 \mathrm{mi}$. to Gold and Galligan Lagoons, $N$ central Prince of Wales I., Alex. Arch.; 55 58 $45^{\prime \prime} \mathrm{N}, 1^{\circ} 2^{\circ}$. $58^{\prime} 10^{\prime \prime} \mathrm{V}^{\prime} ;$; BGN 1963; (map 4).

Local name reported in 1961 by USFS: "a good salmon spawning stream."

Galloping Glaicer: glacier, see Black Rapids Glacier.

Galsovia: locality, see Golsovia.

Galtzora: locality, see Golsovia.

Galvin Creek: stream, flows SW $1.4 \mathrm{mi}$. to Kougarok River, $17 \mathrm{mi}$. S of Midnight Mtn. and $45 \mathrm{mi}$. W of Imuruk Lake, Seward Penin. High.; $65^{\circ} 33^{\prime} \mathrm{N}, 164^{\circ} 44^{\prime} \mathrm{W}$; (map 110).

Prospectors' name reported in 1901 by T. G. Gerdine (in Collier, 1902, pl. 12), USGS.

Gambel: village, see Gambell.

Gambell: village, pop. 358, on Northwest Cape, NW tip of St. Lawrence I.; $63^{\circ} 47^{\prime} \mathrm{N}, 171^{\circ} 45^{\prime}$ W; (map 93). Var. Chibukak, Gambel, Seevookuk, Sevuokok, Sivukuk, Tchiboukoukak.

This village was named for Mr. and Mrs. Vene C. Gambell, Presbyterian missionaries 
and teachers here from 1894-98, who were lost in the schooner Jane Grey on their return from a leave of absence in 1898. The name was introduced the same year by William $F$. Doty, the new teacher. "A signboard with the name 'Gambell' painted on it was placed on the front face of the station building, to the end that the village might thereafter be designated in honor of the noble missionaries * *" (Jackson, 1900, p. 224).

Gambier, Point: point of land, on $\mathrm{S}$ end of Gambier I., in Stephens Passage, $4.4 \mathrm{mi}$. N of False Point Pybus, on Admiralty I., $65 \mathrm{mi}$. NE of Sitka, Alex. Arch.; $57^{\circ} 26^{\prime} 00^{\prime \prime} \mathrm{N}, 133^{\circ} 50^{\prime}-$ $15^{\prime \prime} \mathrm{W}$; (map 8).

This point, discovered August 4, 1794, by Lt. Joseph Whidbey, RN, was named that same year by Capt. George Vancouver, RN, in honor of Baron James Gambier, 1756-1833, English vice admiral. He participated in the capture of Charleston, S.C., in 1780, during the Revolutionary War. He directed the bombardment of Copenhagen and seized the Danish Navy in 1807. As one of the British commissioners, he helped negotiate the Treaty of Ghent with the United States in 1814.

Gambier Bay: estuary, on $\mathrm{E}$ coast of Admiralty I., trends SE $8 \mathrm{mi}$. to Stephens Passage, $57 \mathrm{mi}$. E of Sitka, Alex. Arch.; $57^{\circ} 28^{\prime} \mathrm{N}, 133^{\circ} 55^{\prime} \mathrm{W}$; (map 8).

Named in 1889 by Lt. Comdr. H. B. Mansfield, USN; name published by USC\&GS in 1891 Coast Pilot (p. 143). The name was derived from Point Gambier.

Gambier Island: island, $1.4 \mathrm{mi}$. long, in Stephens Passage off E coast of Admiralty I., $5 \mathrm{mi}$. $\mathrm{N}$ of False Point Pybus and $63 \mathrm{mi}$. NW of Sitka, Alex. Arch.; $57^{\circ} 26^{\prime} 30^{\prime \prime} \mathrm{N}, 133^{\circ} 51^{\prime} 00^{\prime \prime} \mathrm{W}$; (map 8).

Named in 1889 by Lt. Comdr. H. B. Mansfield, USN; name published by USC\&GS in 1891 Coast Pilot (p. 144). The name was derived-from nearby Point Gambier.

Gamble Slough: stream, flows W $7.5 \mathrm{mi}$. to Mail Slough, $10 \mathrm{mi}$. NE of Stevens Village, Yukon Flats; $66^{\circ} 07^{\prime} 15^{\prime \prime} \mathrm{N}, 148^{\circ} 52^{\prime} 30^{\prime \prime} \mathrm{W}$; (map 118).

Local name obtained in 1956 by USGS.

Game Cove: cove, $0.6 \mathrm{mi}$. wide, on $\mathrm{W}$ coast of Admiralty I., $22 \mathrm{mi}$. SW of Juneau, Alex. Arch.; $58^{\circ} 03^{\prime} 45^{\prime \prime} \mathrm{N}, 134^{\circ} 48^{\prime} 00^{\prime \prime} \mathrm{W}$; (map 11).

So named in 1880 by Marcus Baker, USC\&GS, because of the abundance of wildfowl, deer, and other game found here. Published in the 1883 Coast Pilot (p. 182).

Game Creek: stream, on Chichagof I., flows 15 mi. $\mathrm{N}$ to Port Frederick, $2.6 \mathrm{mi}$. SW of Hoonah, Alex. Arch.; $58^{\circ} 04^{\prime} 45^{\prime \prime} \mathrm{N}, 135^{\circ} 28^{\prime}$ $40^{\prime \prime} \mathrm{W}$; (map 11).

Named in 1901 by E. F. Dickins, USC\&GS, and published in 1902 on Chart 8300 .

Game Creek: stream, flows NW $2 \mathrm{mi}$. to American Creek which flows to Niukluk River, 26 mi. N of Solomon Seward Penin. High.; $64^{\circ}$. $56^{\prime} \mathrm{N}, 164^{\circ} 27^{\prime} \mathrm{W}$; (map 95). Var. Auburn Creek.
Prospectors' name reported in 1905 by T. G. Gerdine, USGS. Reported in the above location in 1907 by USGS geologists (P. S. Smith, 1910, pl. 4).

Game Creek: stream, see Gander Creek.

Game Creek: stream, see Lost Creek.

Game Point: point of land, in Port Frederick on $\mathrm{N}$ coast of Chichagof $\mathrm{I}$., $2.2 \mathrm{mi}$. SW of Hoonah, Alex. Arch.; 58 $05^{\prime} 30^{\prime \prime}$ N, $135^{\circ} 29^{\prime}$ $15^{\prime \prime} \mathrm{W}$; (map 11).

Named in 1901 by E. F. Dickins, USC\&GS, and published in 1902 on Chart 8300.

Game Trail Lake: lake, $2 \mathrm{mi}$. across, SE of Salmon Berry Lake, $21 \mathrm{mi}$. NW of Glennallen, Copper River Basin; $62^{\circ} 15^{\prime} \mathrm{N}, 146^{\circ} 05^{\prime}$ W; (map 83).

Local name reported in 1951 by USGS.

Gamon, Mys: point of land, see Saint Elias, Cape.

Gander Creek: stream, flows N 4 mi. to American Creek which flows to Niukluk River, $29 \mathrm{mi}$. $\mathrm{N}$ of Solomon, Seward Penin. High.; 64 ${ }^{\circ} 59^{\prime}$ $\mathrm{N}, 164^{\circ} 22^{\prime} \mathrm{W}$; (map 95). Var. Game Creek.

Reported in 1905 as "Game Creek" by T. G. Gerdine, USGS. Prospectors' name reported in 1907 by USGS geologists (Smith, P. S., 1910, pl. 4).

Gander Hill: hill, $300 \mathrm{ft}$., on E shore of Vega Bay, Kiska I., Aleutian I.; $51^{\circ} 55^{\prime} 27^{\prime \prime} \mathrm{N}$, $177^{\circ} 27^{\prime} 00^{\prime \prime} \mathrm{E}$; (map 14).

An arbitrary name beginning with " $G$ " to correspond to "G" grid used by the U.S. Army for tactical purposes during World War II; published on a 1953 AMS map.

Gandil, Mount: hill, see Gandil Mountain.

Gandil Mountain: hill, $930 \mathrm{ft}$., $18 \mathrm{mi}$. NE of of Katalla, Chugach Mts. ; $60^{\circ} 16^{\prime} \mathrm{N}, 144^{\circ} 01^{\prime}$ W; (map 64). Var. Mount Gandil.

Name used by local miners and reported in 1903 as "Mount Gandil" by G. C. Martin, USGS.

Gandil River: stream, flows SW $9 \mathrm{mi}$. to Berring River, $13 \mathrm{mi}$. NE of Katalla, Chugach Mts.; $60^{\circ} 16^{\prime} \mathrm{N}, 144^{\circ} 10^{\prime} \mathrm{W}$; (map 64).

Local name published by the Norris Peters Company on their 1911 map of southeastern part of Prince William Sound and the Bering River coal field.

Ganes Creek: locality, on W bank of Ganes Creek $0.7 \mathrm{mi}$. S of its junc. with Innoko River and $4.5 \mathrm{mi}$. SE of Ophir, Kilbuck-Kuskokwim Mts. ; $63^{\circ} 05^{\prime} 20^{\prime \prime} \mathrm{N}, 156^{\circ} 26^{\prime} 00^{\prime \prime} \mathrm{W}$; (map 90).

Mining camp established about 1908 for the lower Ganes Creek area; a post office was located here intermittently from 1940 to 1951.

Ganes Creek: stream, heads in Beaver Mts., flows NE $35 \mathrm{mi}$. to Innoko River, $4 \mathrm{mi}$. SE of Ophir and $28 \mathrm{mi}$. NW of McGrath, Kilbuck-Kuskokwim Mts; $63^{\circ} 06^{\prime} 00^{\prime \prime} \mathrm{N}, 156^{\circ}$ 25'30' W; BGN 1936; (map 90). Var. Gaines Creek, Gains Creek.

Prospectors' name reported in 1908 by Maddren (1910, p. 21), USGS, for "Thomas Gane, who with three others discovered gold here in 1906."
Ganiskiya, Kekurya : rocks, see Hanin Rocks.

Gannet Cove: cove, $0.5 \mathrm{mi}$. across, on $\mathrm{W}$ coast of Adak I., on E shore of Expedition Harbor in Bay of Islands, Aleutian Is.; 51 $47^{\prime} 20^{\prime \prime} \mathrm{N}$, $176^{\circ} 43^{\prime} 00^{\prime \prime} \mathrm{W}$; BGN 1936; (map 17).

Named in 1934 by members of the U.S. Navy Aleutian Island Survey Expedition, for the U.S.S. Gannet, one of the ships of the expedition.

Gannet Island: island, 2,500 ft. long, $\mathrm{S}$ side of Boca de Quadra in mouth of Vixen Bay, Coast Mts.; $55^{\circ} 04^{\prime} 30^{\prime \prime} \mathrm{N}, 130^{\circ} 47^{\prime} 45^{\prime \prime} \mathrm{W}$; (map 3).

Named in 1891 by USC\&GS.

Gannett, Mount: mountain, 10,000 ft., at head of Gannett Glacier, $57 \mathrm{mi}$. E of Anchorage, Chugach Mts. ; $61^{\circ} 14^{\prime} 30^{\prime \prime} \mathrm{N}, 148^{\circ} 11^{\prime} 40^{\prime \prime} \mathrm{W}$; $B G N$ 1930; (map 69).

Named by Lawrence Martin in 1911 for Henry Gannett, 1846-1914. Mr. Gannett was a president of the National Geographic Society, Chief Geographer of USGS and Chairman of the Board on Geographic Names. Gannett Bay: estuary, see Pigot Bay.

Gannett Glacier: glacier, heads on Mount Gannett, trends NW $9.5 \mathrm{mi}$. to Knik Glacier, 30 mi. SE of Palmer, Chugach Mts.; $61^{\circ} 20^{\prime} 30^{\prime \prime}$ N, 148 $23^{\prime} 15^{\prime \prime} \mathrm{W}$; (map 69).

Name reported by USGS in 1960; derived from Mount Gannett at the head of the glacier.

Gannett Nunatak: peak, in Nunatak Glacier E of Russell Fiord, St. Elias Mts.; (map 46).

Reported by Tarr and Martin (1906, map), USGS. This feature cannot be precisely identified on present maps.

Gannett Rocks: rocks, in W part of Kuluk Bay, on NE coast of Adak I., Aleutian Is. ; 51 52'$10^{\prime \prime} \mathrm{N}, 176^{\circ} 36^{\prime} 25^{\prime \prime} \mathrm{W}$; BGN 1936; (map 17).

Named by members of the U.S. Navy Aleutian Island Survey Expedition in 1934, for the U.S.S. Gannet, one of the ships of the expedition.

Gannon Bay: bay, see Otkriti Bay.

Gantegaski: locality, see Gantegastaki.

Gan-te-gas-tak-heh: locality, see Gantegastaki.

Gantegastaki: locality, at Haines Airport at mouth of Chilkat River, $17 \mathrm{mi}$. SW of Skagway, Coast Mts.; $59^{\circ} 15^{\prime} 00^{\prime \prime} \mathrm{N}, 135^{\circ} 31^{\prime} 15^{\prime \prime}$ W; (map 45). Var. Gantegaski, Gan-te-gastak-heh, Gantegastaki Hindasetukee, Jendestáka, Jendestake, Tindestak, Tondust, Tondustek, Yendēśtaq!e, Yendestaka, Y'hindastachy, Yindastuki, Yindastuki Indian Reservation, Yondestuk.

Former Tlingit Indian village name obtained in 1880 from an Indian interpreter, as "Gante-gas-tak-heh," meaning "village on right bank of river," by Marcus Baker, USC\&GS. In the 1880 Census Petroff (1884, p. 31) listed "Yondestuk," population 171; and in the same year, Capt. L. A. Beardslee, USN, recorded the name "Tondust." The present inhabitants call it "Yindastuki." In 1867 this Indian village consisted of 12 houses; 13 years later it had grown to 16 houses and 171 people. In 1952 only a few houses remained. 
Gaohi Islands: islands, near S entrance to Tuxekan Passage, $21 \mathrm{mi}$. NW of Craig, Alex. Arch.; $55^{\circ} 46^{\prime} \mathrm{N}, 133^{\circ} 14^{\prime} \mathrm{W}$; (map 4). GS.

Indian names published in 1956 by USC\&

Gaole Mountain: mountain, 4,780 ft., in Glacier Bay National Monument, on NE margin of Carroll Glacier, $51 \mathrm{mi}$. SW of Skagway, St. Elias Mts.; $59^{\circ} 04^{\prime} 30^{\prime \prime} \mathrm{N}, 136^{\circ} 32^{\prime} 15^{\prime \prime} \mathrm{W}$; (map 45).

Local name published in 1961 by USGS.

Gaolsovia: locality, see Golsovia.

Gaot-á-kan: village, see Hoonah.

Gap, The: valley, at W end of Japan Hills, 46 mi. S of Fairbanks, Alaska Ra.; 64'12' N, $147^{\circ} 52^{\prime} \mathrm{W}$; (map 100).

Prospectors' name reported in 1950 by USGS topographers.

Gap Mountain: mountain, 3,495 ft., $3.3 \mathrm{mi}$. N of Hidden Point, between Hidden Inlet and Pearse Canal, Coast Mts.; 54⒌'30' N, $130^{\circ} 18^{\prime} 40^{\prime \prime} \mathrm{W}$; (map 2 ).

Local name published in 1943 by USC\&GS.

Gap Mountain: mountain, 1,045 ft., $8 \mathrm{mi}$. E of Cape Newenham and $32 \mathrm{mi}$. W of Hagemeister I., Kilbuck-Kuskokwim Mts.; $58^{\circ} 38^{\prime} \mathrm{N}, 161^{\circ}$ 57' W ; (map 39).

Descriptive name published in 1951 by USGS. It marks a break in a mountain ridge along the northern shore of Bristol Bay.

Gap Point: point of land, on NE shore of Tebenkof Bay, at $\mathrm{E}$ point of entrance to Elena Bay, on $W$ coast of Kuiu I., Alex. Arch.; $56^{\circ} 38^{\prime}$. $45^{\prime \prime} \mathrm{N}, 134^{\circ} 08^{\prime} 15^{\prime \prime} \mathrm{W} ; B G N$ 1929; (map 5).

Descriptive name given in 1928 by USC\&GS "because of a gap near the end" of the point.

Garcia, Point: point of land, on NW coast of San Fernando I., Alex. Arch.; $55^{\circ} 33^{\prime} 45^{\prime \prime}$ N, $133^{\circ} 26^{\prime} 30^{\prime \prime}$ W; (map 4). Var. Mys de Garcia, Punta de Garcia.

Spanish name given in 1779 by Don Juan de la Bodega y Quadra and Francisco Antonio Maurelle as "Punta de Garcia" or "Point Garcia"; "no doubt in honor of Juan Garcia the surgeon of the vessel La Favorita of the Arteaga expedition * * *" (Wagner, 1937, p. 389)

Garcia Cove: cove, $0.8 \mathrm{mi}$. long, on $\mathrm{NW}$ coast of San Fernando I., Alex. Arch.; 55 $33^{\prime} 30^{\prime \prime}$ $N, 133^{\circ} 25^{\prime} 45^{\prime \prime} \mathrm{W}$; (map 4).

Named by USC\&GS and published in 1925 Coast Pilot (p. 146); derived from Garcia Island and Point.

Garcia Island: island, $0.1 \mathrm{mi}$. across, in Gulf of Esquibel, NW coast of San Fernando I., Alex. Arch.; $55^{\circ} 33^{\prime} 35^{\prime \prime} \mathrm{N}, 133^{\circ} 26^{\prime} 45^{\prime \prime} \mathrm{W}$; (map 4). Var. Isla de Garcia, Ostrov de Garcia, Ysla de Garcia.

Spanish name given in 1779 by Don Juan de la Bodega y Quadra and Francisco Antonio Maurelle as "Isla de Garcia" or "Garcia Island." See Garcia, Point.

Garden Gity : residential area, see Garden Island.

Garden Cove: cove, $0.3 \mathrm{mi}$. across, on $\mathrm{SE}$ coast of Saint George I., in Pribilof Is. ; 56 $34^{\prime} 00^{\prime \prime}$ N, $169^{\circ} 30^{\prime} 45^{\prime \prime}$ W; (map 38). Var. Kra'kankring'a.
This cove is a good anchorage, reported by Elliott (1903, Saint George map and notes) in 1873-74. The Aleut name is "Kra'kankring'a" meaning "facing the east," according to Putnam (1903, p. 1015), USC\&GS. Elliott (p. 19) writes that the early Russians "planted at Garden Cove," which probably is the origin of the name.

Garden Cove: cove, on Hinchinbrook I., at mouth of Garden Creek, $30 \mathrm{mi}$. SW of Cordova, Chugach Mts.; $60^{\circ} 20^{\prime} \mathrm{N}, 146^{\circ} 32^{\prime} \mathrm{W}$; (map 64).

Local name reported by George Davidson, USC\&GS, in the 1869 Alaska Coast Pilot (p. 156). Name derived from the island at entrance to cove.

Garden Creek: stream, on Hinchinbrook I., flows SW $1 \mathrm{mi}$. to Garden Cove, $30 \mathrm{mi}$. SW of Cordova, Chugach Mts.; $60^{\circ} 21^{\prime} \mathrm{N}, 146^{\circ} 31^{\prime} \mathrm{W}$; (map 64).

Name published in 1950 by USGS; derived from nearby Garden Island.

Garden Island: residential area, in Fairbanks at E end of Garden Island, Tanana Low.; 64 ${ }^{\circ} 51^{\prime}$ N, $147^{\circ} 43^{\prime}$ W; (map 100). Var, Garden City.

Garden Island: island, $1 \mathrm{mi}$. long, crescent shaped, between the entrances to Amber and Aniakchak Bays, 6.5 mi. WSW of Cape Kunmik, near S shore of Alaska Penin., Aleutian Ra.; $56^{\circ} 45^{\prime} \mathrm{N}, 157^{\circ} 21^{\prime} \mathrm{W}$; (map 31 ).

Local name published by USC\&GS in the 1947 Alaska Coast Pilot (p. 281).

Garden Island: island, $300 \mathrm{ft}$. long, at mouth of Garden Cove, off Hinchinbrook I., $30 \mathrm{mi}$. SW of Cordova, Chugach Mts.; $60^{\circ} 00^{\prime} 30^{\prime \prime} \mathrm{N}$, $146^{\circ} 02^{\prime} 00^{\prime \prime} \mathrm{W}$; (map 64).

Named by Capt. Portlock (1789, p. 232), on June 6, 1787, while he and Capt. George Dixon visited the region on the English trading vessels Queen Charlotte and King George. Portlock had a garden planted on the island, probably to test the growing ability of numerous vegetables under the Alaskan climate and soil conditions.

Garden Island: island, $5.2 \mathrm{mi}$. long, in Yukon River, E of Anvik and $32 \mathrm{mi}$. NW of Holy Cross, Innoko Low.; $62^{\circ} 40^{\prime} \mathrm{N}, 160^{\circ} 09^{\prime} \mathrm{W}$; (map 78).

Riverboat pilots' name shown on a 1940 "Navigation Chart of the Tanana-Yukon Rivers" published by U.S. Dept. of Interior. Garden Island: island, $3 \mathrm{mi}$. long, formed by Noyes Slough and Chena River $\mathbf{N}$ and $W$ of center of Fairbanks, Tanana Low.; 64 $51^{\prime} \mathrm{N}$, $147^{\circ} 46^{\prime} \mathrm{W}$; (map 100).

Local name published in 1939 by USGS. Garden Islet: island, see Kutkan Island.

Garden Wall, The: ridge, on Alaska Penin., elev. 2,000 ft., extends $S 4.5 \mathrm{mi}$. between $\mathrm{Cub}$ and Wind Creeks on SE slope of Aniakchak Crater, $37 \mathrm{mi}$. NE of Chignik, Aleutian Ra.; 56 $48^{\prime}$ $\mathrm{N}, 158^{\circ} 03^{\prime} \mathrm{W}$; (map 30 ).

So named in 1923 by $\mathbf{R}$. H. Sargent, USGS, because "it resembles a wall from below."

Gardiner Creek: stream, flows S $38 \mathrm{mi}$. to Chisana River, $17 \mathrm{mi}$. SE of Northway Junction,
Alaska Ra.; $62^{\circ} 49^{\prime} 10^{\prime \prime} \mathrm{N}, 1^{\circ} 31^{\circ} 31^{\prime} 20^{\prime \prime} \mathrm{W}$; (map 84). Var. Gardner Creek.

Named in 1898 by A. H. Brooks and W. J. Peters, USGS, for L. D. Gardiner, a member of their field party.

Gardiner Creek Camp: locality, on Alaska Highway, at Gardiner Creek, $15 \mathrm{mi}$. SE of Northway Junction, Alaska Ra.; $62^{\circ} 51^{\prime} 30^{\prime \prime} \mathrm{N}$, $141^{\circ} 28^{\prime} 00^{\prime \prime}$ W; (map 84). Var. Gardner Creek Camp.

Local name reported by USGS in 1952.

Gardiner Islands : islands, see Wood Islands.

Gardner, Point: point of land, on S tip of Admiralty I., $10 \mathrm{mi}$. SE of Baranof, Alex. Arch.; $57^{\circ} 01^{\prime} \mathrm{N}, 134^{\circ} 37^{\prime} \mathrm{W}$; (map 9).

Named in 1794 by Capt. George Vancouver, RN, probably for Sir Alan Gardner (Wagner, 1937, p. 389).

Gardner, Port; estuary, see Gardner Bay.

Gardnera, Gavan: estuary, see Gardner Bay.

Gardner Bay: estuary, extends NW $1.7 \mathrm{mi}$. from Clarence Strait, SE coast of Prince of Wales

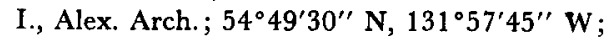
(map 2). Var. Gavan Gardnyera, Port Gardner.

This a transliteration of the name "Gavan Gardnera" given by I. A. Kupreanof in 1848 and published on Russian Hydrog. Dept. Chart 1396 in the same year.

Gardner Creek: stream, flows SE to Pargon River, $15 \mathrm{mi}$. NE of Council, Seward Penin. High.; (map 110).

Prospectors' name reported on the 1900 "Map of Nome Peninsula" by J. M. Davidson and B. D. Blakeslee. This stream cannot be precisely located on current maps.

Gardner Creek : stream, see Gardiner Creek.

Gardner Creek Camp: locality, see Gardiner Creek Camp.

Gareloi, Mount: volcano, 5,160 ft., Gareloi I., Aleutian Is.; $51^{\circ} 47^{\prime} 30^{\prime \prime} \mathrm{N}, 178^{\circ} 47^{\prime} 40^{\prime \prime} \mathrm{W}$; (map 16). Var. Gareloi Volcano.

Named after Gareloi Island; called Gareloi Volcano on a 1954 AMS map and Mount Gareloi on a 1954 USGS map.

Gareloi Island: island, $6 \mathrm{mi}$. across, Delarof Is., Aleutian Is.; $51^{\circ} 48^{\prime} \mathrm{N}, 178^{\circ} 48^{\prime} \mathrm{W}$; $B G N$ 1890; (map 16). Var. Anangusik Island, Burnt Island, Gorelloi Island, Goreloi Island, Gorely Island.

Name published as "O[strov] Goreloi," or "Goreloi Island," by Lt. Sarichev (1826, map 3), IRN, from the Russian word for "burnt" or "burning." Its Aleut name, according to Capt. Tebenkov (1852, map 28), IRN, was "Anangusik." The adopted form "Gareloi," appeared on USC\&GS, U.S. Navy Hydrog., and Brit. Adm. charts, prior to 1902.

Gareloi Volcano: volcano, see Gareloi, Mount. Garfield Creek: stream, heads on Baldy Mtn., flows SE $16 \mathrm{mi}$. to Kuzitrin River, $14 \mathrm{mi}$. NW of Mount Bendeleben, $37 \mathrm{mi}$. SW of Imuruk Lake, Seward Penin. High. ; $65^{\circ} 21^{\prime} \mathrm{N}, 164^{\circ} 18^{\prime}$ W; (map 110).

Prospectors' name reported in 1900 by Brooks (1901, pl. 11), USGS.

Garfield Point: point of land, see Lieskof, Cape. 
Garforth Island: island, $0.6 \mathrm{mi}$. long, in Muir Inlet, in Glacier Bay National Monument, 2.3 mi. S of Muir Point, $52 \mathrm{mi}$. NW of Hoonah, St. Elias Mts.; $58^{\circ} 47^{\prime} 15^{\prime \prime} \mathrm{N}, 136^{\circ} 04^{\prime} 10^{\prime \prime} \mathrm{W}$; (map 10).

Apparently named by the British Admiralty about 1890; published on its Chart 2431.

Gargoyle Islands: islands, $0.2 \mathrm{mi}$. across, in Surveyor Bay, SW coast of Unalaska I., Aleutian Is. ; $53^{\circ} 16^{\prime} 30^{\prime \prime} \mathrm{N}, 167^{\circ} 33^{\prime} 30^{\prime \prime} \mathrm{W}$; BGN 1937; (map 23).

Named by USC\&GS in 1937.

Gariota Islets: rocks, extend $0.4 \mathrm{mi}$. in S entrance to Siketi Sound, on NW Coast of Baker I. ; Alex. Arch., $55^{\circ} 23^{\prime} 35^{\prime \prime}$ N, $133^{\circ} 39^{\prime} 45^{\prime \prime} \mathrm{W}$; (map 4). Var. Gaviota Island, Gaviota Rock. Spanish word meaning "sea gull," given in 1923 by USC\&GS.

Garita Rock: rock, $0.1 \mathrm{mi}$. across, in Bocas de Finas, N of Anguilla I., Maurelle Is., Alex. Arch.; 55 $41^{\prime} 10^{\prime \prime} \mathrm{N}, 133^{\circ} 34^{\prime} 25^{\prime \prime} \mathrm{W}$; (map 4).

Spanish name meaning "sentry-box;" recorded in 1951 by USGS.

Garland Creek: stream, flows SW $11 \mathrm{mi}$. to Kobuk River, $12 \mathrm{mi}$. NW of Shungnak, Kotzebue-Kobuk Low.; $66^{\circ} 57^{\prime} \mathrm{N}, 157^{\circ} 33^{\prime} \mathrm{W}$; (map 115).

Local name reported in 1954 by the U.S. Army Corps of Engineers.

Garner: locality, mile 355.7 on The Alaska RR., W of Nenana River, $2 \mathrm{mi}$. S of Healy, Alaska Ra.; 63⒋ $49^{\prime} 30^{\prime \prime} \mathrm{N}, 148^{\circ} 58^{\prime} 30^{\prime \prime} \mathrm{W}$; (map 87).

Name of a flag stop reported by The Alaska RR. on its 1922 timetable.

Garnet, Point: point of land, on southern part of Choris Penin., $57 \mathrm{mi}$. SW of Selawik, Kotzebue-Kobuk Low.; $66^{\circ} 16^{\prime} \mathrm{N}, 161^{\circ} 52^{\prime} \mathrm{W}$; (map 114).

Named in September 1827 by Capt. F. W. Beechey, RN.

Garnet Creek: stream, flows NW 3 mi. to South Fork Arolik River, $28 \mathrm{mi}$. NE of Goodnews, Kilbuck-Kuskokwim Mts. ; 59 $28^{\circ} 30^{\prime \prime} \mathrm{N}, 161^{\circ}$. 19'00 W; (map 53).

Local name reported in 1954 by USGS

Garnet Creek: stream, flows SE $2.8 \mathrm{mi}$. to Flambeau River, $15 \mathrm{mi}$. NE of Nome, Seward Penin. High.; $64^{\circ} 41^{\prime} \mathrm{N}, 165^{\circ} 05^{\prime} \mathrm{W}$; (map 94).

Prospectors' name reported on Arthur Gibson's "Map of Cape Nome Precinct" dated 1904.

Garnet Creek: stream, flows NW $17 \mathrm{mi}$. to Yukon River at Garnet I., $18 \mathrm{mi}$. WSW of Rampart, Yukon-Tanana High.; $65^{\circ} 25^{\prime} 30^{\prime \prime} \mathrm{N}, 150^{\circ}$. $45^{\prime} 00^{\prime \prime} \mathrm{W}$; (map 106).

Prospectors' name reported in 1904 by L. M. Prindle, USGS.

Garnet Creek: stream, flows NW $3 \mathrm{mi}$. to Bettles River, $2 \mathrm{mi}$. SW of mouth of Eightmile Creek, $25 \mathrm{mi}$. WNW of Chandalar, Brooks Ra.; $67^{\circ} 34^{\prime} 00^{\prime \prime} \mathrm{N}, 149^{\circ} 24^{\prime} 30^{\prime \prime} \mathrm{W}$; (map 123).

Prospectors' name obtained in 1901 by Schrader (1904, pl. 3), USGS.

Garnet Gulch : ravine, on E slope of White Mtn., $\mathrm{N}$ of Nabesna, Alaska Ra.; $62^{\circ} 24^{\prime} \mathrm{N}, 143^{\circ} 02^{\prime}$ W; BGN 1939; (map 84).
Local name reported in 1939 by USGS. This feature cannot be precisely identified on present maps.

Garnet Island: island, $2 \mathrm{mi}$. long, in Yukon River, $16 \mathrm{mi}$. WSW of Rampart, KokrinesHodzana High.; $65^{\circ} 26^{\prime} \mathrm{N}, 150^{\circ} 41^{\prime} \mathrm{W}$; (map 106).

Local name reported in 1956 by Orth.

Garnet Ledge: point of land, at mouth of Stikine River, $6 \mathrm{mi}$. N of Wrangell, Coast Mts.; $56^{\circ}-$ $34^{\prime} 20^{\prime \prime} \mathrm{N}, 132^{\circ} 21^{\prime} 45^{\prime \prime} \mathrm{W}$; (map 6).

Local name recorded in 1948 by USGS.

Garnet Mountain: mountain, 3,150 ft., $6 \mathrm{mi}$. N of Wrangell, Coast Mts.; $56^{\circ} 34^{\prime} \mathrm{N}, 132^{\circ} 20^{\prime}$ W; (map 6).

Local name recorded in 1953 by USGS.

Garnet Point: point of land, at $\mathrm{S}$ end of Kangunut I., Coast Mts.; 54 $43^{\prime} 10^{\prime \prime}$ N, $130^{\circ}$ $41^{\prime} 00^{\prime \prime}$ W; (map 2). Var. Garnot Point.

Name given in 1883 by Lt. Comdr. H. E. Nichols, USN; published erroneously in 1885 as Garnot Point by USC\&GS.

Garnet Point: point of land, see Venisa Point.

Garnot Point: point of land, see Garnet Point. Garns, Point: point of land, see Harris, Point. Garrett Peak: mountain, 5,600 ft., $3.4 \mathrm{mi}$. NE of Camp Mtn., $26 \mathrm{mi}$. NE of Valdez, Chugach Mts. ; $61^{\circ} 29^{\prime} 15^{\prime \prime} \mathrm{N}, 146^{\circ} 05^{\prime} 45^{\prime \prime} \mathrm{W}$; (map 68).

Named in 1898 by Capt. W. R. Abercrom bie, USA, for "Private Garrett" of his party. Garrison Glacier: glacier, heads on NE slope of Takhinsha Mts., trends $7 \mathrm{mi}$. to its terminus at head of Kicking Horse River, $5.6 \mathrm{mi}$. W of Pyramid Harbor and $22 \mathrm{mi}$. SSW of Skagway, St. Elias Mts.; $59^{\circ} 11^{\prime} 30^{\prime \prime} \mathrm{N}, 135^{\circ} 38^{\prime} 45^{\prime \prime}$ W; (map 45). Var. Garrison Glaciers.

Named by W. H. Dall, USC\&GS, and published in the 1883 Coast Pilot (p. 194) as the Garrison Glaciers. IBC Sheet 9 (1951 atlas) applied the name in 1923 as described above.

Garrison Glaciers : glacier, see Garrison Glacier. Garrison Slough: stream, flows NW $10 \mathrm{mi}$. to Moose Creek, $15 \mathrm{mi}$. SE of Fairbanks, Tanana Low.; $64^{\circ} 43^{\prime} 00^{\prime \prime} \mathrm{N}, 147^{\circ} 08^{\prime} 50^{\prime \prime} \mathrm{W}$; (map 100 ).

Local name reported by in 1950 by USGS topographers.

Garry Creek: stream, heads in a lake, flows E $12 \mathrm{mi}$. to Harrison Bay, $13 \mathrm{mi}$. $\mathrm{S}$ of Cape Halkett, Arctic Plain; $70^{\circ} 38^{\prime} 25^{\prime \prime} \mathrm{N}, 152^{\circ}$. 27'05" W; BGN 1916; (map 149). Var. Garry River, River Garry.

First recorded July 25, 1837, as "River Garry" on P. W. Dease and Thomas Simpson's (Thomas Simpson, 1843, p. 132) map and named "after Nicholas Garry, Esquire, whose name has long been associated with Arctic research."

Garryowen Creek: stream, flows SW $9 \mathrm{mi}$. to Little Bear Creek, $28 \mathrm{mi}$. SE of Haycock, Nulato Hills; $65^{\circ} 00^{\prime} \mathrm{N}, 160^{\circ} 20^{\prime} \mathrm{W} ; B G N$ 1966; (map 109).

Prospectors' name reported in 1909 by $P$. S. Smith, USGS.

Garry River: stream, see Garry Greek.
Gartina Creek: stream, on N part of Chichagof I., flows $7 \mathrm{mi}$. S to Port Frederick, $1.4 \mathrm{mi}$. SE of Hoonah, Alex. Arch.; $58^{\circ} 05^{\prime} 10^{\prime \prime} \mathrm{N}, 135^{\circ}$ 25'15" W; (map 11).

Local name published in 1951 by USGS. Gasan: locality, see Old Kasaan.

Gas Creek: stream, heads in Katmai National Monument, flows $9 \mathrm{mi}$ SE on Alaska Penin. to Kejulik River, $23 \mathrm{mi}$. SW of Mount Katmai, Aleutian Ra.; $57^{\circ} 59^{\prime} 35^{\prime \prime} \mathrm{N}, 1^{\circ} 25^{\prime} 45^{\prime \prime} \mathrm{W}$; (map 35).

Descriptive name given by $R$. H. Sargent, USGS, in 1923 "on account of the gas seepages there."

Gash: locality, near Cape Fox, on $\mathrm{N}$ side of Dixon Entrance at W side of Nakat Bay, Coast Mts.; (map 2).

Site of a former Tlingit Indian winter camp. According to J. R. Swanton (in Hodge, 1907, p. 488), BAE, "Most of the people have now moved to Ketchikan."

Gas Hill: hill, $500 \mathrm{ft}$., on N shore of Vega Bay, Kiska I., Aleutian I.; $51^{\circ} 55^{\prime} 40^{\prime \prime} \mathrm{N}, 177^{\circ} 22^{\prime}$ $50^{\prime \prime} \mathrm{E}$; (map 14).

An arbitrary name beginning with " $G$ " to correspond to "G" grid used by the U.S. Army for tactical purposes during World War II ; published on a 1953 AMS map.

Gasilnik Island: island, see Krishka Island.

Gasilo Island: island, see Krishka Island.

Gaskal Creek: stream, see Steelhead Creek.

Gas Lake: lake, $0.7 \mathrm{mi}$. long, $1 \mathrm{mi}$. $\mathrm{N}$ of Lower Halfway Lake and $22 \mathrm{mi}$. SE of Beaver, Yukon-Tanana High.; $66^{\circ} 06^{\prime} \mathrm{N}, 146^{\circ} 56^{\prime} \mathrm{W}$; (map 119).

Local name obtained in 1956 by USGS.

Gasoline Lake: lake, $1.7 \mathrm{mi}$. long, $2.8 \mathrm{mi}$. E of Tetlin Lake, 20 mi. S of Tok, Alaska Ra.; $63^{\circ} 06^{\prime} \mathrm{N}, 142^{\circ} 33^{\prime} \mathrm{W}$; BGN 1962; (map 85). Var. Gasoline Lakes, Lake Gomair, Lake Gumaer.

Local name reported in 1950 by USGS.

Gasoline Lakes: lake, see Dathlalmund Lake.

Gasoline Lakes: lake, see Gasoline Lake.

Gas Rock: island, $0.1 \mathrm{mi}$. long, in Sea Otter Sound, $0.7 \mathrm{mi}$. N of Heceta I., Alex. Arch.; $55^{\circ} 50^{\prime} 50^{\prime \prime} \mathrm{N}, 133^{\circ} 33^{\prime} 45^{\prime \prime} \mathrm{W}$; (map 4).

Named in 1904 by field party under the direction of E. F. Dickins, USC\&GS; so called "because supply of gas was cached here."

Gas Rocks, The: hill, $520 \mathrm{ft}$, , on S shore of Becharof Lake, on Alaska Penin., $27 \mathrm{mi}$. NW of Kanatak, Aleutian Ra.; $57^{\circ} 51^{\prime} 40^{\prime \prime} \mathrm{N}$, $156^{\circ} 30^{\prime} 00^{\prime \prime} \mathrm{W}$; (map 36).

Local name reported in 1923 by W. R. Smith and A. A. Baker (in Brooks and others, 1924, pl. 8), USGS.

Gassman Creek: stream, flows SW $3.5 \mathrm{mi}$. to Eldorado River, $23 \mathrm{mi}$. NW of Solomon, Seward Penin. High.; $64^{\circ} 48^{\prime}$ N, $164^{\circ} 58^{\prime} \mathrm{W}$; (map 95).

Prospectors' name reported in 1900 by E. C. Barnard (in Brooks, 1901, pl. 17), USGS.

Gastineau Channel: water passage, $19 \mathrm{mi}$. long, trends NW from Stephens Passage to Auke Bay, between Douglas I. and the mainland, Coast Mts.; $58^{\circ} 16^{\prime} \mathrm{N}, 134^{\circ} 20^{\prime} \mathrm{W}$; (map 
11). Var. Carroll Straight, Icy Channel. Origin of the name somewhat obscure. Name appears on a manuscript map prepared for the Western Union Telegraph Go. in 1867. It was probably named for John Gastineau, 1820-85, an English civil engineer, who came to Canada in 1858 and did surveying and mapping for the British Columbia government. Baker (1906) says that the name was derived from one of the Hudson Bay Company's steamers. However, this has been questioned since the company had no vessel of this name on this coast. Capt. George Vancouver, who explored this coast in 1794, overlooked this channel, probably because it was choked with ice at the time. The name "Carroll Straight" was probably for Capt. James Carroll, a steamship captain and an early Juneau property owner (DeArmond, 1957, p. 20-21).

Gastineau City: locality, site of realty development at the mouth of Nevada Creek on Gastineau Channel, $6.5 \mathrm{mi}$. SE of Juneau, Coast Mts. ; $58^{\circ} 13^{\prime} 50^{\prime \prime} \mathrm{N}, 134^{\circ} 18^{\prime} 15^{\prime \prime} \mathrm{W}$; (map 11).

Named in 1905 by "Mike" Hudson who had mining property on the creek. He staked and subdivided a homestead at the mouth of the creek, but apparently the business venture was unsuccessful (DeArmond, 1957, p. 21).

Gastineau Heights: ridge, see Chicken Ridge.

Gastineau Peak: peak, 3,666 ft., $1.6 \mathrm{mi}$. W of Sheep Mtn. and $2.4 \mathrm{mi}$. SE of Juneau, Coast Mts.; $58^{\circ} 17^{\prime} 25^{\prime \prime} \mathrm{N}, 134^{\circ} 20^{\prime} 45^{\prime \prime} \mathrm{W}$; (map 11).

Local name reported in 1916 by D. C. Witherspoon, USGS, and published in 1918. Gaston, Cabo: point of land, see Adam, Point.

Gatan Cape: point of land, see Kovrizhka, Cape. Gate, The: water passage, $0.5 \mathrm{mi}$. long, $3.5 \mathrm{mi}$. $S$ of Chichagof, on $W$ coast of Chichagof $I$., Alex. Arch.; $57^{\circ} 36^{\prime} 30^{\prime \prime} \mathrm{N}, 136^{\circ} 06^{\prime} 00^{\prime \prime} \mathrm{W}$; $B G N 1908$; (map 9).

Descriptive name given by $A$. Braid, USC\&GS; published in 1908 Coast Pilot (p. 172). "The Gate is a water passage or gateway from Khaz Bay into Elbow Passage and Klag Bay."

Gate Creek: stream, flows SE $10 \mathrm{mi}$. to Moose Creek, $12 \mathrm{mi}$. SW of Talkeetna, Cook Inlet Low.; $62^{\circ} 14^{\prime} 00^{\prime \prime} \mathrm{N}, 150^{\circ} 26^{\prime} 50^{\prime \prime} \mathrm{W}$; (map 81 ).

Local name reported in 1958 by USGS.

Gate Island: island, $300 \mathrm{ft}$. long, at W entrance to Hook Arm Sea Otter Harbor, off $W$ coast of Dall I., Alex. Arch.; $55^{\circ} 07^{\prime} 00^{\prime \prime} \mathrm{N}, 133^{\circ}$. $11^{\prime} 50^{\prime \prime} \mathrm{W}$; (map 4).

Name published in 1924 by USC\&GS.

Gates, The: water gap, 1,000 ft. deep, cut by Aniakchak River through $\mathrm{E}$ side of Aniakchak Crater, 4 mi. NE of Vent Mtn., Aleutian Ra.; $56^{\circ} 54^{\prime} \mathrm{N}, 158^{\circ} 04^{\prime} \mathrm{W}$; (map 30 ).

Descriptive name given in 1922 by USGS and published by W. R. Smith and A. A. Baker (in Brooks and others, 1924, p. 157), USGS. Gates Glacier: glacier, trends $9 \mathrm{mi}$. $\mathrm{S}$ from Mount Regal to Kennicott Glacier, $12 \mathrm{mi}$. N of McCarthy, Wrangell Mts.; 61 ${ }^{\circ} 35^{\prime} \mathrm{N}$, $143^{\circ} 00^{\prime} \mathrm{W}$; (map 67).

Named by F. C. Schrader, USGS, in 1899 for Edward Gates, a local prospector.

Gates of the Arctic: pass, on North Fork Koyukuk River, between Frigid Crags and Boreal Mtn., $37 \mathrm{mi}$. NW of Wiseman, Brooks Ra.; 67 $50^{\prime}$ $30^{\prime \prime} \mathrm{N}, 150^{\circ} 53^{\prime} 30^{\prime \prime} \mathrm{W}$; (map 124).

Named in 1929 by Marshall (1956, p. 7), who reported, "I bestowed the name of Gates of the Arctic on them * * *."

Gateway, The: pass, 5,200 ft., entrance to The Great Gorge of Ruth Glacier, $12 \mathrm{mi}$. SE of Denali Pass in Mt. McKinley National Park, Alaska Ra.; $62^{\circ} 59^{\prime} \mathrm{N}, 150^{\circ} 42^{\prime} \mathrm{W}$; (map 81).

Mountain climbers' name published in the late 1940's.

Gateway Knob: hill, $600 \mathrm{ft}$., in Alsek River at river bend, $1 \mathrm{mi}$. W of 1961 terminus of Alsek Glacier and $60 \mathrm{mi}$. SE of Yakutat, St. Elias Mts.; $59^{\circ} 11^{\prime} 15^{\prime \prime} \mathrm{N}, 138^{\circ} 10^{\prime} 45^{\prime \prime} \mathrm{W}$; (map 46) .

So named in 1906 by Blackwelder (1907, p. 428,430 ), USGS, because the hill represented the "jumping-off" place when crossing the glacier. The glacier was once at this hill but has since retreated.

Gatherer Rock: rock, in Orca Bay, $2 \mathrm{mi}$. N of Hawkins I., 9 mi. NW of Cordova, Chugach Mts. ; $60^{\circ} 36^{\prime} 30^{\prime \prime} \mathrm{N}, 145^{\circ} 57^{\prime} 40^{\prime \prime} \mathrm{W}$; (map 64).

Named about 1900 by H. P. Ritter, USC\&GS, for the ship Gatherer which was wrecked here.

Gatlena Gap: pass, 1,100 ft., $25 \mathrm{mi} \mathrm{N}$ of Livengood, Yukon-Tanana High.; $65^{\circ} 50^{\prime} 45^{\prime \prime} \mathbf{N}$, $148^{\circ} 33^{\prime} 00^{\prime \prime} \mathrm{W}$; (map 105).

Local name published by USGS in 1950's.

Gattan Cape: point of land, see Kovrizhka, Cape.

Gaudekan: village, see Hoonah.

Gaudy Lake: lake, $0.1 \mathrm{mi}$. across, $\mathrm{E}$ of Vega Bay, Kiska I., Aleutian Is.; $51^{\circ} 55^{\prime} 42^{\prime \prime} \mathrm{N}$, $177^{\circ} 27^{\prime} 07^{\prime \prime} \mathrm{E}$; (map 14).

An arbitrary name beginning with " $G$ " to correspond to "G" grid used by U.S. Army for tactical purposes during World War II; published on a 1943 Army map.

Gauge Island: island, $0.5 \mathrm{mi}$. across, in Funter Bay on W coast of Mansfield Penin., $0.8 \mathrm{mi}$. NE of Clear Point, $17 \mathrm{mi}$. SE of Juneau; Alex. Arch.; $58^{\circ} 15^{\prime} 00^{\prime \prime} \mathrm{N}, 134^{\circ} 53^{\prime} 45^{\prime \prime} \mathrm{W}$; (map 11). Var. Dare Island.

Named by Lt. Comdr. H. B. Mansfield, USN, in 1890 .

Gauntlet Island: island, $0.2 \mathrm{mi}$. long, in Takanis Bay, on SW coast of Yakobi I., off W coast of Chichagof I., Alex. Arch.; 57 $54^{\prime} 35^{\prime \prime} \mathrm{N}$, $136^{\circ} 32^{\prime} 50^{\prime \prime} \mathrm{W} ; B G N$ 1928; (map 9).

Descriptive name given in 1928 by USC\&GS, "because of its [glove-like] shape." The name was published in 1929 on Chart 8260.

Gavan Hill: ridge, elev. 2,600 ft., $1.5 \mathrm{mi}$. long, 2 mi. NE of Sitka, on $W$ coast of Baranof $I$., Alex. Arch., $57^{\circ} 05^{\prime} \mathrm{N}, 135^{\circ} 19^{\prime} \mathrm{W}$; (map 9). Var. Gora Gavanskaya, Harbor Peak.

Russian name meaning "harbor" given in 1809 by the navigator Ivan Vasiliev the first; published by Lt. Sarichev (1826, map 19), IRN, as Gora Gavanskaya (harbor mountain).

Gavan Saint Pavla: town, see Kodiak.

Gavanskaia Bay: harbor, see Iliuliuk Harbor.

Gavanskaya: harbor, see Iliuliuk Harbor.

Gavanskaya, Gora: peak, see Harbor Peak.

Gavanskaya, Gora: ridge, see Gavan Hill.

Gavanski Island: island, see Big Gavanski Island.

Gavanski Islands: islands, $1.4 \mathrm{mi}$. long, includes Big and Little Gavanski Is., $6.5 \mathrm{mi}$. NW of Sitka, Alex. Arch.; $57^{\circ} 08^{\prime} 00^{\prime \prime} \mathrm{N}, 135^{\circ} 25^{\prime} 30^{\prime \prime}$ W; BGN 1897; (map 9). Var. Gavanski Islets, Ostrova Gavanskiy, Ostrova Gavanskiye.

Named by the early Russians in Alaska; published in 1850 as "O[stro]va Gavanskiy," meaning "harbor islands," by the Russian American Company. See Big and Little Gavanski Islands.

Gavanski Islet: island, see Little Gavanski Island.

Gavanski Islets: islands, see Gavanski Islands. Gavanski Point: point of land, see Harbor Point. Gavanskiy, Ostrova: islands, see Gavanski Islands.

Gavanskiye, Ostrova: islands, see Gavanski Islands.

Gavanskoe: village, see Unalaska.

Gavanskoi : village, see Unalaska.

Gavanskoy, Mys: point of land, see Harbor Point.

Gavanskoy, Ostrov: island, see Harbor Island.

Gavanskoy Bolshoy, Ostrov: island, see Big Gavanski Island.

Gavanskoy Menshoy, Ostrov: island, see Little Gavanski Island.

Găvärūsh'ka Lake: lake, see Govorushka Lake.

Gavia Lake: lake, $1 \mathrm{mi}$. long, on Kenai Penin. W of Konchanee Lake, $25 \mathrm{mi}$. NE of Kenai, Cook Inlet Low.; $60^{\circ} 41^{\prime} 30^{\prime \prime} \mathrm{N}, 150^{\circ} 36^{\prime} 00^{\prime \prime}$ W; (map 62).

Named about 1963 by officials of Kenai National Moose Range, for birds of the loon family (Gavia).

Gavimamut: locality, see Uknavik.

Gaviota Island : rocks, see Gariota Islets.

Gaviota Rock: rocks, see Gariota Islets.

Gawanka Brook: stream, flows $\mathbf{N}$ to Chichagof Harbor, on NE coast of Attu I., Aleutian Is.; $52^{\circ} 55^{\prime} 30^{\prime \prime} \mathrm{N}, 173^{\circ} 15^{\prime} 00^{\prime \prime} \mathrm{E}$; (map 13).

Reported by Constantin Grewingk (1850, p. 235). The exact location is not known.

Gay Creek: stream, flows W $4.5 \mathrm{mi}$. to Tuttle Creek which flows to Kugrupaga River, $5 \mathrm{mi}$. SW of Ear Mtn. and $43 \mathrm{mi}$. N of Teller, Seward Penin. High.; $65^{\circ} 53^{\prime} \mathrm{N}, 166^{\circ} 25^{\prime} \mathrm{W}$; (map 111).

Prospectors' name reported in 1901 by T. G. Gerdine (in Collier, 1902, pl. 12), USGS.

Gay Gulch: ravine, trends SW $3 \mathrm{mi}$. to Smallwood Creek, $3 \mathrm{mi}$. S of Gilmore Dome and 12 mi. NE of Fairbanks, Yukon-Tanana High.; $64^{\circ} 56^{\prime} 15^{\prime \prime} \mathrm{N}, 147^{\circ} 21^{\prime} 00^{\prime \prime} \mathrm{W}$; (map 100).

Local name published in 1908 by USGS.

Gazzam Creek: stream, flows W $4 \mathrm{mi}$. to Troublesome Creek, $18 \mathrm{mi}$. SE of Rampart, Yukon- 
Tanana High.; $65^{\circ} 20^{\prime} \mathrm{N}, 149^{\circ} 42^{\prime} \mathrm{W}$; (map 105).

Named by prospectors; reported in 1907 by USGS (Prindle and Hess, 1908, pl. 2).

Geary Gulch: ravine, tributary to Gold Creek, about $2 \mathrm{mi}$. W of Juneau, Coast Mts.; $58^{\circ} 18^{\prime}$ $\mathrm{N}, 134^{\circ} 20^{\prime} \mathrm{W}$; (map 11 ).

Miners' name for a gulch subsequently destroyed by mining operations (DeArmond, 1957, p. 22).

Gechiagamut: locality, see Gechiak.

Gechiak: locality, on left bank of Togiak River, just $S$ of mouth of Gechiak Creek, $48 \mathrm{mi}$. E of Goodnews, Kilbuck-Kuskokwim Mts.; $59^{\circ} 12^{\prime} \mathrm{N}, 160^{\circ} 15^{\prime} \mathrm{W}$; (map 53). Var. Gechiagamut, Gechiang, Kashaiyamut.

Eskimo village or camp, now abandoned, reported as "Gechiagamut," or "Gechiak people," in 1898 by J. E. Spurr and W. S. Post, USGS.

Gechiak Creek: stream, heads at Gechiak Lake, flows SE $12 \mathrm{mi}$. to Togiak River, $48 \mathrm{mi}$. E of Goodnews, Kilbuck-Kuskokwim Mts.; 59 ${ }^{\circ} 13^{\prime}$ N, $160^{\circ} 15^{\prime}$ W; (map 53). Var. Kashaiyak River.

Eskimo name reported in 1898 by J. E. Spurr and W. S. Post, USGS.

Gechiak Lake: lake, $3 \mathrm{mi}$. long, $5 \mathrm{mi}$. NE of Kukaktlim Lake, $48 \mathrm{mi}$. NE of Goodnews, Kilbuck-Kuskokwim Mts. ; $59^{\circ} 23^{\prime} \mathrm{N}, 160^{\circ} 23^{\prime}$ W; (map 53).

Eskimo name published in 1951 by USGS.

Gechiak Mountains: mountains, 2,000 ft., in Ahklun Mts., $3 \mathrm{mi}$. SW of Gechiak Lake and $45 \mathrm{mi}$. NE of Goodnews, Kilbuck-Kuskokwim Mts.; $59^{\circ} 20^{\prime} \mathrm{N}, 160^{\circ} 25^{\prime} \mathrm{W}$; (map 53).

Eskimo name published in 1951 by USGS.

Gechiang : locality, see Gechiak.

Gedney Channel: water passage, $0.7 \mathrm{mi}$. across, just $\mathrm{N}$ of mouth of Port Frederick and $5 \mathrm{mi}$. NW of Hoonah, Alex. Arch.; 58 $11^{\prime} \mathrm{N}$, $135^{\circ} 30^{\prime} \mathrm{W}$; (map 11).

Named in 1901 by E. F. Dickins, USC\&GS, who sounded the passage for his vessel, the USC\&GS steamer, Gedney. Name was published in 1904 on Chart 8304.

Gedney Harbor: bay, $1.5 \mathrm{mi}$. long, on $\mathrm{W}$ coast of Kuiu I., $8 \mathrm{mi}$. $\mathbf{S}$ of Tebenkof Bay, Alex. Arch.; $56^{\circ} 22^{\prime} 20^{\prime \prime} \mathrm{N}, 134^{\circ} 15^{\prime} 00^{\prime \prime} \mathrm{W}$; (map 5).

Named in 1901 by USC\&GS "for the USC\&GS steamer Gedney from which a reconnaissance of the harbor was made in 18991900."

Gedney Island: island, $2.2 \mathrm{mi}$. long, between Behm Canal and Gedney Pass, off NW coast of Revillagigedo I., Alex. Arch.; 55 $51^{\prime} 30^{\prime \prime}$ $\mathrm{N}, 131^{\circ} 41^{\prime} 00^{\prime \prime} \mathrm{W}$; (map 3).

Named in 1891 by USC\&GS for its steamer Gedney.

Gedney Pass: water passage, extends $\mathrm{E} 9 \mathrm{mi}$. off Behm Canal, between Hassler and Revillagigedo Is., Alex. Arch.; 55 $51^{\prime} \mathrm{N}, 131^{\circ} 42^{\prime}$ W; (map 3).

Named in 1891 by USC\&GS for its steamer Gedney.

Geese Channel: water passage, between Geese Is. and $S$ tip of Kodiak I.; $56^{\circ} 45^{\prime} \mathrm{N}, 153^{\circ} 53^{\prime} \mathrm{W}$; BGN 1934; (map 33).
Named by USC\&GS in 1934 for the Geese Islands.

Geese Islands: islands, $6 \mathrm{mi}$. long, at $\mathrm{S}$ tip of Kodiak I.; 56 $44^{\prime}$ N, $153^{\circ} 53^{\prime}$ W; (map 33). Var. Archimandritof Islands, Ostrova Gusinyya.

Translation by USC\&GS in 1868 of the Russian name "O[stro]va Gusinyya," published by Capt. Tebenkov (1852, map 22).

Geese Islands: island, see Aiaktalik Island.

Geese Lake: lake, $1 \mathrm{mi}$. long, in course of West Fork of The Forks, $15 \mathrm{mi}$. N of Stevens Village, Yukon Flats; $66^{\circ} 14^{\prime} \mathrm{N}, 149^{\circ} 07^{\prime} \mathrm{W}$; (may 118).

Local name reported in 1956 by T. E. Taylor, USGS.

Geese Lakes: lakes, S of Crosstrail Lake, $41 \mathrm{mi}$. SE of Fort Yukon, Yukon Flats; $66^{\circ} 01^{\prime} \mathrm{N}$, $144^{\circ} 44^{\prime} \mathrm{W}$; (map 119).

Local name reported in 1956 by USGS.

Gehoenda Creek: stream, see Geohenda Creek. Geicke Glacier; glacier, see Geikie Glacier.

Geike Glacier: glacier, see Geikie Glacier.

Geikie Glacier: glacier, heads $1 \mathrm{mi}$. SW of Blackthorn Peak, trends N 6 mi. to its 1950 terminus, $0.3 \mathrm{mi}$. W of Geikie Inlet, Glacier Bay National Monument, $52 \mathrm{mi}$. NW of Hoonah, St. Elias Mts.; $58^{\circ} 37^{\prime} \mathrm{N}, 136^{\circ} 34^{\prime} \mathrm{W}$; (map 10). Var. Geicke Glacier, Geike Glacier, Greike Glacier.

Named in 1879 by John Muir (1915, p. 144) for James Geikie, 1839-1915, British geologist Geikie was born in Scotland and in 1861 joined the Geological Survey of Great Britain In 1882 he became professor of geology and mineralogy at Edinburgh Univ. $\mathrm{He}$ was the author of "The Great Ice Age" and other geological publications. When H. F. Reid visited Glacier Bay in 1892 he found that the Geikie Glacier of John Muir had retreated so far that it had become two smaller glaciers. He retained the name "Geikie" for the more northerly of the two, and called the other "Wood Glacier" (Reid, 1896, p. 428). Wood Glacier has now disappeared.

Geikie Inlet: estuary, $8 \mathrm{mi}$. long, in Glacier Bay National Monument, trends NE to Glacier Bay, $3 \mathrm{mi}$. W of Drake I. and $51 \mathrm{mi}$. NW of Hoonah, St. Elias Mts. ; 58 $40^{\prime} 00^{\prime \prime} \mathrm{N}$, $136^{\circ} 20^{\prime} 30^{\prime \prime} \mathrm{W}$; (map 10).

Name derived from the Geikie Glacicr, published in 1923 on IBC Sheet 10 (1951 atlas).

Geikie Rock: rock, in Glacier Bay, in Glacier Bay National Monument, $1.5 \mathrm{mi}$. NE of mouth of Geikie Inlet and $51 \mathrm{mi}$. NW of Hoonah, St. Elias Mts.; $58^{\circ} 41^{\prime} 40^{\prime \prime} \mathrm{N}, 136^{\circ} 18^{\prime} 35^{\prime \prime} \mathrm{W}$; (map 10).

Local name derived from Geikie Inlet; published by USC\&GS in 1943.

Geist, Mount: peak, 10,720 ft., $5 \mathrm{mi}$. NW of Mount Hayes and $45 \mathrm{mi}$. SW of Delta Junction, Alaska Ra.; 63⒊ $38^{\prime} 30^{\prime \prime} \mathrm{N}, 146^{\circ} 52^{\prime} 15^{\prime \prime}$ W; BGN 1965; (map 86).

Named by T. L. 'Péwé for Otto William Geist, 1888-1963, Univ. of Alaska, researcher in Alaskan paleontology, archeology, and glaciology.

Gem Cove: estuary, on Revillagigedo I., extends E $0.5 \mathrm{mi}$. off George Inlet, $4 \mathrm{mi}$. NE of California Head, Alex. Arch.; $55^{\circ} 22^{\prime} 45^{\prime \prime} \mathrm{N}$, $131^{\circ} 26^{\prime} 00^{\prime \prime} \mathrm{W}$; BGN 1962; (map 3).

Local name reported in 1961 by USFS.

Gem Creek: stream, flows E to Solomon River, between Butte and Mint Creeks, about $10 \mathrm{mi}$. NE of Solomon, Seward Penin. High.; (map 95).

Prospectors' name reported on a prospector's manuscript map dated 1902. This stream cannot be precisely located on current maps.

Gemodedon Island: island, in Yukon River, 7 mi. NE of Nulato, Koyukuk Low.; 64 $49^{\circ} \mathrm{N}$, $157^{\circ} 57^{\prime} \mathrm{W}$; (map 97).

Koyukan Indian name reported by USGS in 1954.

Gem Point: point of land, on $\mathrm{E}$ shore of Snug Cove, on $\mathrm{E}$ coast of Admiralty $1 ., 2 \mathrm{mi}$. SW of Church Point and $59 \mathrm{mi}$. NE of Sitka, Alex. Arch.; $57^{\circ} 25^{\prime} 45^{\prime \prime} \mathrm{N}, 133^{\circ} 57^{\prime} 30^{\prime \prime} \mathrm{W}$; (map 8).

Named in 1889 by Lt. Comdr. H. B. Mansfield, USN; name published by USC\&GS in 1891 Coast Pilot (p. 144).

Gemuk Creek: stream, flows NW $5 \mathrm{mi}$. to Aukamunuk Creek, $78 \mathrm{mi}$. NE of Goodnews, Kilbuck-Kuskokwim Mts.; $59^{\circ} 48^{\prime} \mathrm{N}, 159^{\circ} 55^{\prime} \mathrm{W}$; (map 53).

Eskimo name reported in 1898 by W. S. Post, USGS. See Gemuk Mountain.

Gemuk Mountain: mountain, 3,996 ft., $11 \mathrm{mi}$. N of Nishlik Lake and $96 \mathrm{mi}$. SW of Sleetmute, Kilbuck-Kuskokwim Mts.; $60^{\circ} 37^{\prime}$ N., $159^{\circ} 02^{\prime}$ W; BGN 1948; (map 60).

Eskimo name reported in 1945 by USGS to mean "lone."

Gemuk River: stream, heads at lake E of Gemuk Mtn., flows NE 24 mi., joins Chikululnuk Creek to form Chukowan River, $80 \mathrm{mi}$. SW of Sleetmute, Kilbuck-Kuskokwim Mts. $60^{\circ} 47^{\prime} \mathrm{N}, 158^{\circ} 32^{\prime} \mathrm{W} ; B G N$ 1945; (map 60). Var. Keenuk River.

Name reported in 1932 by BIA. See Gemuk Mountain.

Genaenda Creek : stream, see Geohenda Creek.

Gene Lake: lake, $1.8 \mathrm{mi}$. long, on Kenai Penin., one of the Swanson Lakes, at head of Swanson River, $15 \mathrm{mi}$. $\mathrm{S}$ of Point Possession and 34 mi. NE of Kenai, Cook Inlet Low.; $60^{\circ} 50^{\prime}$ $\mathrm{N}, 150^{\circ} 28^{\prime} \mathrm{W}$; (map 62 ).

Local name reported in 1958 by USGS.

Genetian Creek: stream, flows NW $4.5 \mathrm{mi}$. to Poorman Creek, $5.5 \mathrm{mi}$. SW of Poorman, Kilbuck-Kuskokwim Mts.; $64^{\circ} 02^{\prime} 45^{\prime \prime} \mathrm{N}, \cdot 155^{\circ}$ $40^{\prime} 30^{\prime \prime} \mathrm{W}$; ( $\operatorname{map} 98$ ).

Local name reported in 1933 by USGS.

Genius Lake: lake, $300 \mathrm{ft}$. across, $\mathrm{N}$ of Bukhti Point, south-central Kiska I., Aleutian Is.; $51^{\circ} 55^{\prime} 02^{\prime \prime} \mathrm{N}, 177^{\circ} 28^{\prime} 22^{\prime \prime} \mathrm{E}$; (map 14).

An arbitrary name beginning with " $G$ " to correspond to "G" grid used by the U.S. Army for tactical purposes during World War II; published on a 1953 AMS map. 
Genivieve Lake: lake, $0.2 \mathrm{mi}$. long, $\mathrm{E}$ of Lake Catherine, $3.3 \mathrm{mi}$. SW of Kodiak, Kodiak I.; $57^{\circ} 46^{\prime} \mathrm{N}, 152^{\circ} 29^{\prime} \mathrm{W}$; (map 34).

Name published in 1957 by AMS.

Gens de Large: lake, see Chandalar Lake.

Gens de Large: stream, see Chandalar River.

Gentle Hill: hill, $260 \mathrm{ft}$., $\mathrm{N}$ of Bukhti Point, south-central Kiska I., Aleutian Is. ; $51^{\circ} 55^{\prime} 00^{\prime \prime}$ $\mathrm{N}, 177^{\circ} 28^{\prime} 35^{\prime \prime} \mathrm{E}$; (map 14).

An arbitrary name beginning with " $G$ " to correspond to "G" grid used by the U.S. Army for tactical purposes during World War II; published on a 1953 AMS map.

Gentle Lake: lake, $300 \mathrm{ft}$. across, $\mathbf{N}$ of Bukhti Point, south-central Kiska I., Aleutian Is.; $51^{\circ} 54^{\prime} 55^{\prime \prime} \mathrm{N}, 177^{\circ} 28^{\prime} 40^{\prime \prime} \mathrm{E}$; (map 14).

An arbitrary name beginning with " $G$ " to correspond to " $G$ " grid used by the U.S. Army for tactical purposes during World War II ; published on a 1953 AMS map.

Genunam Island: island, see Seguam Island.

Geographic Harbor: estuary, extends $3 \mathrm{mi}$. off Amalik Bay, on S coast of Alaska Penin., in Katmai National Monument, 16 mi. SE of Mount Katmai, Aleutian Ra.; $58^{\circ} 06^{\prime} \mathrm{N}$, $154^{\circ} 34^{\prime} \mathrm{W}$; $B G N$ 1924; (map 42).

Named in 1919 by R. F. Griggs for the National Geographic Society.

Geohenda Creek: stream, flows N $15 \mathrm{mi}$. to Chisana River, $3 \mathrm{mi}$. E of Euchre Mtn. and $40 \mathrm{mi}$. SE of Nabesna, Alaska Ra.; $62^{\circ} 03^{\prime} 30^{\prime \prime}$ N, $142^{\circ} 06^{\prime} 00^{\prime \prime}$ W; (map 84). Var. Gehoenda Creek, Genaenda Creek, Trail Creek.

Indian name reported in 1902 as "Gehoenda" by D. C. Witherspoon, USGS. The name was shown as "Genaenda". by $S$. $R$. Capps (1916, pl. 1), USGS, and the current spelling was recommended in 1963 by USGS.

George, Lake: lake, $6.2 \mathrm{mi}$. long, in course of George Creek, $38 \mathrm{mi}$. SE of Delta Junction, Yukon-Tanana High.; $63^{\circ} 47^{\prime} \mathrm{N}, 144^{\circ} 31^{\prime} \mathrm{W}$; BGN 1938; (map 86)

Local name reported in 1938 by USGS.

George, Mount: mountain, 10,335 ft., E of junc. of Chitina and Anderson Glaciers, $63 \mathrm{mi}$. SE of McCarthy, St. Elias Mts.; 61 ${ }^{\circ} 03^{\prime} \mathrm{N}$, 141 ${ }^{\circ} 01^{\prime}$ W; BGN 1917; (map 67).

Named for His Majesty, George $V$, of Great Britain, in 1916 by the IBC.

George, Mount: mountain, 2,025 ft., at NE end of Indian Mts., $28 \mathrm{mi}$. NE of Hughes, Kokrines-Hodzana High.; $66^{\circ} 20^{\prime} \mathrm{N}, 153^{\circ} 37^{\prime}$ W; (map 116).

Local name published in 1956 by USGS.

George, Point: point of land, on Muir Inlet, at mouth of Adams Inlet, Glacier Bay National Monument, $0.5 \mathrm{mi}$. S of Maquinna Cove, $56 \mathrm{mi}$. NW of Hoonah, St. Elias Mts.; $58^{\circ} 51^{\prime} 15^{\prime \prime} \mathrm{N}, 136^{\circ} 03^{\prime} 30^{\prime \prime} \mathrm{W}$; (map 10).

Local name published in the 1950's by USGS.

George Arm: estuary, see George Inlet.

George Creek: stream, heads on S side of Henderson Ridge and flows $S$ to Temnac Bay, Attu I., Aleutian Is.; $52^{\circ} 49^{\prime} 55^{\prime \prime} \mathrm{N}$, $173^{\circ} 04^{\prime} 37^{\prime \prime} \mathrm{E}$; (map 13).

Named by the U.S. Army during its occupation of the island during World War II; name shown on an AMS map published in 1948.

George Creek: stream, flows NW $10 \mathrm{mi}$. to Kosina Creek, $24 \mathrm{mi}$. SW of junc. of Oshetna and Susitna Rivers, Talkeetna Mts.; $62^{\circ} 31^{\prime} 50^{\prime \prime} \mathrm{N}, 148^{\circ} 05^{\prime} 30^{\prime \prime} \mathrm{W}$; (map 82).

Local name recorded in 1917 on a USGS manuscript map.

George Creek: stream, flows SW through Lake George $27 \mathrm{mi}$. to Tanana River, $35 \mathrm{mi}$. SE of Delta Junction, Tanana Low.; 63⒋ $47^{\prime} 30^{\prime \prime}$

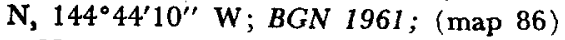

Name reported on 1907 fieldsheet by D. C. Witherspoon, USGS.

George Creek: stream, flows NW $2 \mathrm{mi}$. to Wade Creek, $47 \mathrm{mi}$. SW of Eagle, Yukon-Tanana High.; $64^{\circ} 08^{\prime} \mathrm{N}, 141^{\circ} 31^{\prime} \mathrm{W}$; (map 102).

Prospectors' name shown on an 1898 manuscript map by C. A. Woodruff, Fort Cudahy, Canada.

George Creek: stream, flows SE to Solomon River, $9 \mathrm{mi}$. NE of Solomon, Seward Penin. High.; $64^{\circ} 40^{\prime} \mathrm{N}, 164^{\circ} 18^{\prime} \mathrm{W}$; (map 95).

Prospectors' name reported on the 1900 "Map of Nome Peninsula" by J. M. Davidson and B. D. Blakeslee.

George Creek: stream, flows N $1 \mathrm{mi}$. to Schley Creek, about $17 \mathrm{mi}$. NNE of Nome, Seward Penin. High.; (map 94).

Prospectors' name shown on the 1902 "Map of the Nome and Snake River Country" by J. M. Davidson. This stream cannot be identified on recent maps.

George Creek: stream, see Billy Creek.

George Inlet: estuary, extends S $14 \mathrm{mi}$. to Carroll Inlet, on Revillagigedo I., Alex. Arch.; $55^{\circ} 20^{\prime} \mathrm{N}, 1^{\circ} 31^{\circ} 30^{\prime} \mathrm{W}$; BGN 1917; (map 3). Var. George Arm.

Named in 1880 by USC\&GS for Capt. W. E. George, local pilot, who made the first sketch of Revillagigedo Channel and Tongass Narrows.

George Island: island, $1 \mathrm{mi}$. long, in George Is. in Gross Sound, at mouth of Port Althorp, $36 \mathrm{mi}$. NW of Hoonah, Alex. Arch.; $58^{\circ} 12^{\prime} 00^{\prime \prime}$ $N$, 136 $23^{\prime} 45^{\prime \prime}$ W; (map 10).

Named by W. H. Dall, USC\&GS, in 1880 and published in the 1883 Alaska Coast Pilot (p. 187).

George Island: island, see Saint George Island. George Islands: islands, $1.2 \mathrm{mi}$. across, off W coast of Inian Penin., on $\mathbf{N}$ coast of Chichagof I., $0.4 \mathrm{mi}$. W of Elfin Cove and $36 \mathrm{mi}$. NW of Hoonah, Alex. Arch.; $58^{\circ} 12^{\prime} \mathrm{N}, 136^{\circ} 23^{\prime}$ $\mathrm{W} ;(\operatorname{map} 10)$.

Named by W. H. Dall, USC\&GS, in 1880. George Lake: lake, $0.8 \mathrm{mi}$. long, $5 \mathrm{mi}$. NE of Beaver, Yukon Flats; $66^{\circ} 25^{\prime} 20^{\prime \prime} \mathrm{N}, 147^{\circ} 16^{\prime}$ '30 " W ; (map 118).

Local name obtained in 1956 by USGS.

George Meadow: meadow, $4 \mathrm{mi}$. NW of Beaver, Yukon Flats; $66^{\circ} 26^{\prime} \mathrm{N}, 147^{\circ} 29^{\prime} \mathrm{W}$; (map 118).

Local name obtained in 1956 by USGS.

George Point: point of land, on SW coast of Strawberry I., in Glacier Bay, in Glacier Bay National Monument, $\mathbf{N}$ of Beardslee Entrance, $35 \mathrm{mi}$. NW of Hoonah, St. Elias Mts.; $58^{\circ} 30^{\prime} 30^{\prime \prime} \mathrm{N}, 136^{\circ} 00^{\prime} 45^{\prime \prime} \mathrm{W}$; BGN 1948; (map 10). Var. Strawberry Point.

Local name reported by USC\&GS in 1927. George River: stream, heads at $62^{\circ} 34^{\prime} \mathrm{N}, 157^{\circ}$. $10^{\prime} \mathrm{W}$ and flows SW $80 \mathrm{mi}$. to Kuskokwim River, $23 \mathrm{mi}$. NW of Sleetmute, KilbuckKuskokwim Mts. ; $61^{\circ} 54^{\prime} \mathrm{N}, 157^{\circ} 42^{\prime} \mathrm{W}$; (map 72). Var. Keledzhichagat, Yukwonilnuk River.

Locally named for George Fredericks, proprietor of a trading post at its mouth; reported in 1910 by A. G. Maddren (in Brooks and others, 1911, pl. 11), USGS. In 1842 Lt. L. A. Zagoskin, IRN, called this river by the Indian name "Keledzhichagat." In 1913 A. H. Brooks, USGS, reported the name "Yukwonilnuk" and in 1915 USGS reported local usage to be "George River."

George River: steam, see Aichilik River.

George Rock: rock, in Stephens Passage, $1 \mathrm{mi}$. NW of Outer Point on $W$ end of Douglas I. and $10 \mathrm{mi}$. W of Juneau, Coast Mts.; $58^{\circ} 18^{\prime} 55^{\prime \prime} \mathrm{N}, 134^{\circ} 41^{\prime} 55^{\prime \prime} \mathrm{W}$; (map 11).

Named in 1880 by Comdr. L. A. Beardslee, USN, presumably for Capt. William E. George, an English pilot who came to Alaska in 1868 and was master of some of the early passenger steamers and a frequent visitor to Juneau after the town was founded (DeArmond, 1957, p. 21). Name was published by the USC\&GS in the 1883 Coast Pilot (p. 174).

George Simpson, Cape: point of land, see Cape Simpson.

Georgetown: locality, on right bank of Kuskokwim River, $16 \mathrm{mi}$. NW of village of Red Devil and $22 \mathrm{mi}$. NW of Sleetmute, KilbuckKuskokwim Mts.; $61^{\circ} 53^{\prime} 40^{\prime \prime} \mathrm{N}, 157^{\circ} 43^{\prime} 00^{\prime \prime}$ W; BGN 1948; (map 72).

Name of a trading post reported in 1910 by Maddren (in Brooks and others, 1911, pl. 11), USGS. Presumably named for the post owner, George Fredericks. A post office was located here from 1912 to 1913 . See George River.

Georgiana, Cape: point of land, on NW tip of Kruzof I., $26 \mathrm{mi}$. NW or Sitka, Alex. Arch.; $57^{\circ} 19^{\prime} 45^{\prime \prime}$ N, $135^{\circ} 51^{\prime} 30^{\prime \prime}$ W; (map 9). Var. Mys Olgi, Mys Siuchiy, Point Olga, Sea Lion Point, Siouchi Point.

Named in 1787 by Capt. Nathaniel Portlock (Wagner, 1937, p. 389). This point was also called "Mys Siuchiy," meaning "sealion cape," in 1833 by the Russian navigator Ens. Vasiliev (cnna); "Mys Olgi," or "Olgi Cape," by Capt. Tebenkov (1852, map 8), IRN.

Georgiana, Mount: mountain, $1,383 \mathrm{ft}$., on NW tip of Kruzof I., $26 \mathrm{mi}$. NW of Sitka, Alex. Arch.; $57^{\circ} 19^{\prime} 45^{\prime \prime} \mathrm{N}, 135^{\circ} 50^{\prime} 30^{\prime \prime} \mathrm{W}$; BGN 1930; (map 9).

Named in 1930 by USC\&GS for Cape Georgiana.

Georgie Creek: stream, flows S $1.5 \mathrm{mi}$. to Dome Creek, $29 \mathrm{mi}$. S of Eagle, Yukon-Tanana High.; $64^{\circ} 23^{\prime} 30^{\prime \prime} \mathrm{N}, 141^{\circ} 15^{\prime} 10^{\prime \prime} \mathrm{W}$; (map 102).

Local name published in 1956 by USGS. 
Georgie Creek: stream, flows W 5 mi. to Livengood Creek, $4 \mathrm{mi}$. NE of Livengood, YukonTanana High.; $65^{\circ} 06^{\prime} 30^{\prime \prime} \mathrm{N}, 147^{\circ} 44^{\prime} 10^{\prime \prime} \mathrm{W}$; (map 105).

Local name published by USGS in the 1950's.

Georgiya, Ostrov: island, see Saint George Island.

Gerard Point: point of land, on $\mathbf{E}$ shore of Eastern 'Passage, $3 \mathrm{mi}$. NE of Wrangell, Coast Mts.; $56^{\circ} 30^{\prime} 45^{\prime \prime} \mathrm{N}, 132^{\circ} 20^{\prime} 00^{\prime \prime} \mathrm{W}$; (map 6). Local name reported in 1900 by J. F. Moser, USN.

Gerdine, Mount: mountain, 11,258 ft., in Tordrillo Mts., $55 \mathrm{mi}$. NW of Tyonek, Alaska Ra.; $61^{\circ} 34^{\prime} 45^{\prime \prime} \mathrm{N}, 152^{\circ} 26^{\prime} 30^{\prime \prime} \mathrm{W}$; $B G N$ 1931; (map 70).

Named for Thomas Golding Gerdine, 1872 1930, USGS topographic engineer who made several reconnaissance trips in Alaska at the end of the 19th century.

Germ Hill: hill, $440 \mathrm{ft}$., on $\mathrm{N}$ shore of Vega Bay, Kiska I., Aleutian Is.; $51^{\circ} 55^{\prime} 43^{\prime \prime} \mathrm{N}$, $177^{\circ} 23^{\prime} 15^{\prime \prime} \mathrm{E}$; (map 14).

An arbitrary name beginning with " $G$ " to correspond to "G" grid used by the U.S. Army for tactical purposes during World War II ; published on a 1953 AMS map.

Germogena, Cape: point of land, see Saint Hermogenes, Cape.

Geroe Creek: stream, flows NE $12 \mathrm{mi}$. to North Fork Chandalar River, at Bend Mtn., $22 \mathrm{mi}$. $\mathrm{N}$ of Chandalar, Brooks Ra.; $67^{\circ} 48^{\prime} \mathrm{N}$, $148^{\circ} 26^{\prime} \mathrm{W}$; (map 123)

Prospectors' name reported in 1899 by Schrader (1900b, pl. 60), USGS.

Gerstle Bay: bay, on $\mathbf{N}$ side of Alaska Penin., at mouth of Cathedral River, $W$ of Port Moller, $33 \mathrm{mi}$. NE of Cold Bay, Bristol Bay Low.; $55^{\circ} 37^{\prime} \mathrm{N}, 162^{\circ} 19^{\prime} \mathrm{W}$; (map 29).

Named in 1888 by USBF for Lewis Gerstle, who in 1868 was one of the founders of the Alaska Commercial Company. He held the office of president for a term before his death in 1902. This feature cannot be identified on current maps.

Gerstle Glacier: glacier, heads at Johnson Glacier $\mathrm{E}$ of Sight Peak, trends N $14 \mathrm{mi}$. to its 1955 terminus at head of Gerstle River, $34 \mathrm{mi}$. SE of Delta Junction, Alaska Ra.; $63^{\circ} 35^{\prime} 10^{\prime \prime} \mathrm{N}$, $145^{\circ} 20^{\prime} 05^{\prime \prime} \mathrm{W}$; (map 86).

Name published on relatively recent maps.

Gerstle Point: point of land, on $\mathbf{N}$ shore of Gerstle Bay, at mouth of Cathedral River, 33 mi. NE of the village of Cold Bay, Bristol Bay Low.; $55^{\circ} 37^{\prime} \mathrm{N}, 162^{\circ} 19^{\prime} \mathrm{W}$; (map 29).

Named in 1888 by USBF for Lewis Gerstle. This feature cannot be identified on current maps. See Gerstle Bay.

Gerstle River: stream, heads at Gerstle Glacier and flows $\mathrm{N} 40 \mathrm{mi}$. to Tanana River, $25 \mathrm{mi}$. $\mathrm{SE}$ of Big Delta, Alaska Ra.; $64^{\circ} 03^{\prime} 30^{\prime \prime} \mathrm{N}$, $145^{\circ} 08^{\prime} 00^{\prime \prime}$ W; BGN 1937; (map 101).

Named in 1885 by Lt. H. T. Allen (1887, p. 13), USA, for "Lewis Gerstle, president of the Alaska Commercial Company."

Gertrude, Lake: lake, $0.5 \mathrm{mi}$. across, near center of Prince of Wales I., NE of Lake
Josephine, Alex. Arch.; 55 $15^{\prime} 05^{\prime \prime} \mathrm{N}, 132^{\circ}$ $32^{\prime} 40^{\prime \prime} \mathrm{W}$; (map 4).

Local name reported in 1908 by C. W. Wright (in Brooks and others, 1909, pl. 3), USGS.

Gertrude Cove: cove, $0.5 \mathrm{mi}$. across, in Vega Bay, on $S$ coast of Kiska I., Aleutian Is.; $51^{\circ} 56^{\prime} 00^{\prime \prime} \mathrm{N}, 177^{\circ} 26^{\prime} 45^{\prime \prime} \mathrm{E}$; (map 14).

Shown on a 1943 USAAF map of Kiska Island.

Gertrude Creek: stream, heads in lake, flows NW $15 \mathrm{mi}$. to King Salmon River, on Alaska Penin., $43 \mathrm{mi}$. E of Egegik and $49 \mathrm{mi}$. SE of Naknek, Aleutian Ra.; 58 $10^{\circ} 15^{\prime \prime}$ N, $156^{\circ}$ $12^{\prime} 30^{\prime \prime} \mathrm{W}$; (map 41).

Local name reported in 1952 by USGS.

Gertrude Creek: stream, flows NW $1.5 \mathrm{mi}$. to Livengood Creek, $1.5 \mathrm{mi}$. NE of Livengood, Yukon-Tanana High.; $65^{\circ} 32^{\prime} \mathrm{N}, 148^{\circ} 30^{\prime} \mathrm{W}$; (map 105)

Named by Jay Livengood who prospected this stream; reported in 1915 by A. H. Brooks, USGS.

Getmuna Creek: stream, heads in lake in Horn Mts., flows NE $25 \mathrm{mi}$. to Crooked Creek 4.3 mi. NW of its junc. with Kuskokwim River, $37 \mathrm{mi}$. NW of Sleetmute, Kilbuck-Kuskokwim Mts.; $61^{\circ} 55^{\prime} 10^{\prime \prime} \mathrm{N}, 158^{\circ} 11^{\prime} 30^{\prime \prime} \mathrm{W}$; $B G N$ 1948; (map 72). Var. Salmon River.

In 1945 this name was reported by USGS as a simplification of the native name "Getmun-na-yam-al'ia," which is said to mean "stream which flows in the opposite direction [to the Kuskokwim River]."

Getukti Cliff: cliff, W shore Pearse Canal, 5 mi. NE of Edward Passage, Coast Mts.; 54 ${ }^{\circ}$ $53^{\prime} 15^{\prime \prime} \mathrm{N}, 130^{\circ} 24^{\prime} 30^{\prime \prime}$ W ; BGN 1937; (map 2).

Local name reported in 1955 by USGS.

Geyser Bight: bay, $3 \mathrm{mi}$. across, on $\mathrm{W}$ central coast of Umnak I., Aleutian Is.; $53^{\circ} 15^{\prime} 30^{\prime \prime}$ $\mathrm{N}, 168^{\circ} 32^{\prime} 30^{\prime \prime} \mathrm{W} ; B G N$ 1940; (map 22).

Descriptive name given in 1938 by USC\&GS "because of the geyser which was sighted at the head of the valley extending southeast from this bight."

Geyser Creek: stream, flows NW $5 \mathrm{mi}$. to Geyser Bight, on W central Umnak I., Aleutian Is. $53^{\circ} 15^{\prime} \mathrm{N}, 168^{\circ} 30^{\prime} \mathrm{W}$; (map 22 ).

Name derived from Geyser Bight; published by Byers (1959, pl. 40), USGS

Ghapawit, Mount: mountain, see Myghapowit Mountain.

Ghedotlothna: stream, see Tonzona River.

Gheena Point: point of land, $2 \mathrm{mi}$. SW of Invut Mountain, $69 \mathrm{mi}$. SE of Gambell, on $\mathrm{S}$ coast of Saint Lawrence I.; $63^{\circ} 10^{\prime} \mathrm{N}, 170^{\circ} 02^{\prime} \mathrm{W}$; BCN 1951; (map 93). Var. Ghina Point, Gina Point.

Eskimo name recommended by the Savoonga village council; reported in 1949 by Maj. Allen, USAF

Ghina Point: point of land, see Gheena Point. Ghost Creek: locality, see Gost Creek.

Ghost Rocks: rocks, in Sitkalidak Strait, $5 \mathrm{mi}$. SW of Left Cape, on coast of Kodiak I.; $57^{\circ} 13^{\prime} 00^{\prime \prime} \mathrm{N}, 153^{\circ} 03^{\prime} 40^{\prime \prime} \mathrm{W} ; B G N 1930$; (map 34)
Descriptive name given in 1928 by USC\&GS, "because of the [ghost-like] appearance of the pinnacles."

Ghrael: area, see Graehl.

Ghun River: stream, see Jewn River.

Giant Island: island, see Grant Island.

Giant Point: point of land, $\mathrm{N}$ tip of Mary I., Alex. Arch.; $55^{\circ} 06^{\prime} 50^{\prime \prime} \mathrm{N}, 131^{\circ} 12^{\prime} 25^{\prime \prime} \mathrm{W}$; (map 3). Var. Winslow Point.

Descriptive name given in 1883 by Lt. Comdr. H. E. Nichols, USN.

Gibbon Anchorage: anchorage, on NW coast of Green I., in Prince William Sound, $24 \mathrm{mi}$. E of Chenega, Chugach Mts.; $60^{\circ} 17^{\prime} \mathrm{N}, 147^{\circ} 25^{\prime}$ W; (map 63).

Name published in 1943 by USC\&GS.

Gibbon Peak: peak, 1,750 ft., on $\mathrm{N}$ end of Latouche I., $19 \mathrm{mi}$. SE of Chenega, Chugach Mts.; $60^{\circ} 03^{\prime} 00^{\prime \prime} \mathrm{N}, 147^{\circ} 52^{\prime} 20^{\prime \prime} \mathrm{W}$; (map 63).

Name reported in 1909 by Grant and Higgins (1910, pl. 12), USGS.

Gibbs Rock: rock, in Fitzgibbon Cove along mainland, $1.4 \mathrm{mi}$. E of Point Fitzgibbon, Coast Mts.; $55^{\circ} 58^{\prime} 40^{\prime \prime} \mathrm{N}, 131^{\circ} 10^{\prime} 50^{\prime \prime} \mathrm{W}$; (map 3 ).

Local name published in the 1925 Coast Pilot (p. 66).

Gibby Rock: rock, in Fritz Cove, $1.8 \mathrm{mi}$. N of Outer Point, on W end of Douglas I., $10 \mathrm{mi}$. NW of Juneau, Coast Mts.; $58^{\circ} 19^{\prime} 40^{\prime \prime} \mathrm{N}$, $134^{\circ} 41^{\prime} 15^{\prime \prime} \mathrm{W}$; (map 11).

Name published in 1962 by USGS.

Gibraltar Hill: hill, $2,087 \mathrm{ft}$., on $\mathbf{N}$ bank of Chitina River, $10 \mathrm{mi}$. E of Bear I., $35 \mathrm{mi}$. $\mathrm{SE}$ of McCarthy, St. Elias Mts. ; $61^{\circ} 06^{\prime} 25^{\prime \prime}$ $\mathrm{N}, 142^{\circ} 06^{\prime} 30^{\prime \prime} \mathrm{W}$; (map 67).

Local name reported by Moffit (1918, pl. 2), USGS.

Gibraltar Lake: lake, $7 \mathrm{mi}$. long, $5 \mathrm{mi}$. S of Kakhonak Bay and $28 \mathrm{mi}$. SE of Iliamna, Aleutian Ra.; $59^{\circ} 21^{\prime} \mathrm{N}, 154^{\circ} 41 \mathrm{~W}$; (map 51 ). So named in 1923 by R. H. Sargent, USGS, because a rock on the south shore of this lake was shaped like the Rock of Gibraltar.

Gibralter Point: promontory, on right bank of Kuskokwim River, $30 \mathrm{mi}$. E. of Aniak, Kilbuck-Kuskokwim Mts.; $61^{\circ} 32^{\prime} 15^{\prime \prime} \mathrm{N}, 158^{\circ}$ $36^{\prime} 30^{\prime \prime} \mathrm{W}$; (map 72).

Descriptive name given by W. S. Post and J. E. Spurr, USGS; shown on Post's 1898 fieldsheet.

Gibson Cove: cove, $0.3 \mathrm{mi}$. long, $1.5 \mathrm{mi}$. SW of Kodiak, Kodiak I. ; $57^{\circ} 46^{\prime} 45^{\prime \prime}$ N, $152^{\circ} 26^{\prime} 40^{\prime \prime}$ W; (map 34). Var. Winter Anchorage, Winter Harbor, Zaliv Krestovskin.

Name published in 1949 by USGS. This feature was called "Za[liv] Krestovskin," meaning "cross bay," by Sarichev (1826, map 16) and "Winter Harbor" by Lisianski (1814, p. 144).

Gibson Island: islands, see Gibson Islands.

Gibson Islands: islands, on NE coast of Attu I., extend $0.3 \mathrm{mi}$. in mouth of Chichagof Harbor, $1.2 \mathrm{mi}$. NE of Attu, Aleutian Is. ; $52^{\circ} 56^{\prime} 45^{\prime \prime}$ N, $173^{\circ} 16^{\prime} 15^{\prime \prime} \mathbf{E}$; (map 13). Var. Gibson Island.

Named in July 1855 by North Pacific Surveying Expedition for Lt. William Gibson, USN, commander of the schooner, Fenimore 
Cooper. Name shown as "Gibson Island" on an AMS map published in 1943 and in USC\&GS 1944 Aleutian Coast Pilot.

Giddings, Mount: peak, 10,180 ft., $7 \mathrm{mi}$. NW of Mount Hayes, $45 \mathrm{mi}$. SW of Delta Junction, Alaska Ra.; $63^{\circ} 40^{\prime} \mathrm{N}, 146^{\circ} 55^{\prime} \mathrm{W}$; $B G N$ 1965; (map 86).

Named by T. L. Péwé for James Lewis Giddings, 1909-64, dendrochronologist and Alaskan archeologist.

Gidra, Ostrov: island, see Hydra Island.

Giffin Glacier: glacier, trends N $10 \mathrm{mi}$. to Holmes Creek, $8 \mathrm{mi}$. S of Pingpong Mtn., $54 \mathrm{mi}$. NE of McCarthy, St. Elias Mts.; $61^{\circ} 36^{\prime} 45^{\prime \prime} \mathrm{N}$, $141^{\circ} 19^{\prime} 15^{\prime \prime}$ W; (map 67). Var. Holmes Glacier.

Named by USGS in 1942 for C. E. Giffin, USGS topographer who did considerable work in Alaska; in 1914 he worked in the White River area.

Gig Pass: water passage, $1 \mathrm{mi}$. long, enters Ogden Passage, $4.5 \mathrm{mi}$. SW of Chichagof, off $W$ coast Chichagof I., Alex. Arch.; 57 $37^{\prime} \mathrm{N}, 136^{\circ} 11^{\prime}$ W; BGN 1926; (map 9).

Named in 1925 by a USC\&GS field party, "for a small light boat [gig] that was used for landing."

Gilahina Butte: mountain, 2,783 ft., $7 \mathrm{mi}$. NE of junc. of Chitina and Tebay Rivers, $30 \mathrm{mi}$. $\mathbf{E}$ of McCarthy, Copper River Basin; $61^{\circ} 26^{\prime} 30^{\prime \prime} \mathrm{N}, 143^{\circ} 49^{\prime} 00^{\prime \prime} \mathrm{W}$; (map 67).

Local name reported in 1908 by D. C. Witherspoon (in Moffit, 1914, pl. 1), USGS.

Gilahina River: stream, flows SW $21 \mathrm{mi}$. to Chitina River, $4.5 \mathrm{mi}$. S of Gilahina Butte, $29 \mathrm{mi}$. W of McCarthy, Cooper River Basin; $61^{\circ} 22^{\prime} 20^{\prime \prime} \mathrm{N}, 1^{\circ} 43^{\circ} 46^{\prime} 50^{\prime \prime} \mathrm{W}$; (map 67). Var. Dare Creek, Dark Creek, Dora Creek, Gilhina River.

Indian name taken from a prospector's map drawn in 1900 ; reported the same year by T. G. Gerdine (in Brooks and others, 1908, pl. 3), USGS. It was probably this stream which Lt. H. T. Allen named "Dora Creek". in 1885, a name now applied to the next stream to the west.

Gilak: locality, "near Cape Romanzof on the Yukon-Kuskokwim Delta;" (map 75). Var. Gilakhamiut.

Former Eskimo camp or settlement listed in the 1890 Census as "Gilakhamiut," with a population of 22 .

Gilakhamiut: locality, see Gilak.

Gilanta Rocks: rocks, extend $0.5 \mathrm{mi}$. along E shore Revillagigedo Channel, Coast Mts.; $54^{\circ} 51^{\prime} 00^{\prime \prime} \mathrm{N}, 130^{\circ} 56^{\prime} 30^{\prime \prime} \mathrm{W}$; BGN 1937; (map 2).

Local name published in 1943 by USC\&GS.

Gilbert, Lake: lake, $2 \mathrm{mi}$. Jong, at head of Lansberg Creek, $5 \mathrm{mi} \mathrm{N}$ of Morzhovoi Bay, at SW end of Alaska Penin., Bristol Bay Low.; 55 $08^{\prime} \mathrm{N}, 163^{\circ} 14^{\prime} \mathrm{W}$; (map 29).

Name reported in 1926 by USC\&GS.

Gilbert, Mount: mountain, 2,685 ft., on $\mathrm{N}$ end of Akun I., Aleutian Is.; $54^{\circ} 15^{\prime} 10^{\prime \prime}$ N, $165^{\circ}$ $39^{\prime} 30^{\prime \prime} \mathrm{W}$; (map 24).
Name published in 1947 Coast Pilot (p. 367). It is possible that this feature was named for John J. Gilbert, USC\&GS, commander of Coast Survey steamer Pathfinder during 1900-01.

Gilbert, Mount: mountain, 9,630 ft., near head of Serpentine Glacier, $54 \mathrm{mi}$ E of Anchorage, Chugach Mts.; $61^{\circ} 10^{\prime} 30^{\prime \prime} \mathrm{N}, 148^{\circ} 16^{\prime} 30^{\prime \prime} \mathrm{W}$. $B G N 1910$; (map 69).

Named in 1908 by U. S. Grant and O. F. Higgins for Grove Karl Gilbert, 1843-1918, USGS geologist.

Gilbert Bay: bay, trends N $5 \mathrm{mi}$. to Port Snettisham from mouth of Gilbert Creek, $33 \mathrm{mi}$. SE of Juneau, Coast Mts.; $58^{\circ} 00^{\prime} \mathrm{N}, 133^{\circ} 44^{\prime}$ W; BGN 1930; (map 8).

Named in 1930 by USC\&GS for Charles Henry Gilbert, 1859-1928, ichthyologist. As head of the Department of Zoology of Stanford University he rendered service to agencies in California and British Columbia. It has been stated that "no one has contributed more to our scientific knowledge of the salmon fisheries of Alaska than Dr. Gilbert."

Gilbert Creek: stream, heads about $0.5 \mathrm{mi}$. N of head of Williams Cove in Holkham Bay, flows N $2.5 \mathrm{mi}$. to Gilbert Bay, $38 \mathrm{mi}$. SE of Juneau, Coast Mts. ; $57^{\circ} 55^{\prime} 50^{\prime \prime}$ N, $133^{\circ} 40^{\prime} 45^{\prime \prime}$ W; (map 8).

Local name reported in 1951 by USGS.

Gilbert Creek: stream, heads in lake, flows $\mathbf{N}$ $23 \mathrm{mi}$. to Kosina Creek, $5.5 \mathrm{mi}$. S of its junc. with Susitna River and $20 \mathrm{mi}$. W of junc. of Osheta River, Talkeetna Mts. ; $62^{\circ} 42^{\prime} 20^{\prime \prime} \mathrm{N}$, $147^{\circ} 58^{\prime} 20^{\prime \prime} \mathrm{W}$; (map 82).

Local name reported in 1951 by USGS.

Gilbert Inlet: cove, at head of Lituya Bay, Glacier Bay National Monument, at terminus of Lituya Glacier, $83 \mathrm{mi}$. N.W. of Hoonah, St. Elias Mts. ; $58^{\circ} 40^{\prime} \mathrm{N}, 137^{\circ} 30^{\prime} \mathrm{W}$; (map 10).

Name reported by Mertie (in P. S. Smith and others, 1933, map p. 118), USGS.

Gilbert Island: island, $6.4 \mathrm{mi}$. long, in Glacier Bay, Glacier Bay National Monument, $\mathrm{N}$ of Hugh Miller Inlet, $63 \mathrm{mi}$. NW of Hoonah, St. Elias Mts.; $58^{\circ} 48^{\prime} 30^{\prime \prime} \mathrm{N}, 136^{\circ} 34^{\prime} 00^{\prime \prime} \mathrm{W}$; BGN 1937; (map 10).

Named by Field and Cooper (1937, p. 62) for Grove Karl Gilbert, 1843-1918, geologist with USGS, who visited Glacier Bay in 1899. Grover Gilbert was born in New York and joined the Geological Survey of Ohio in 1869 , and the USGS in 1879 . His numerous publications dealt with a large variety of geological subjects. The first monograph published by USGS in 1890 was his paper on Lake Bonneville.

Gilbert Lake: lake, $1.3 \mathrm{mi}$. long, in Coast Mts., $\mathrm{N}$ of Walker Cove, in course of Choca Creek; $55^{\circ} 47^{\prime} \mathrm{N}, 130^{\circ} 50^{\prime} \mathrm{W} ; B G N 1930$; (map 3).

Named in 1930 by USC\&GS for Charles H. Gilbert, ichthyologist, who made valuable contributions to the scientific knowledge of the salmor fisheries of Alaska.

Gilbert Lake: lake, $1.4 \mathrm{mi}$. long, $2 \mathrm{mi}$. $\mathrm{N}$ of Tivehvun Lake and $21 \mathrm{mi}$. NW of Fort
Yukon, Yukon Flats; $66^{\circ} 52^{\prime} \mathrm{N}, 145^{\circ} 23^{\prime} \mathrm{W}$; (map 119).

Local name obtained in 1956 by USGS. Gilbert Lake: lake, see Lower Sweetheart Lake. Gilbert Lewis, Mount: mountain, 12,200 ft., at $\mathrm{NE}$ end of Dora Keen Ra., $37 \mathrm{mi}$. NW of Valdez, Chugach Mts.; $61^{\circ} 27^{\prime} \mathrm{N}, 147^{\circ} 09^{\prime} \mathrm{W}$; (map 69).

Named about 1957 by members of the Chugach Mountains Expedition sponsored by the Arctic Institute of North America (Nielsen, 1963 , p. 135). Named for Gilbert Newton Lewis, 1875-1946, American chemist and educator.

Gilbert Point: peak, 3,304 ft., $3.2 \mathrm{mi}$. NW of Mount Alexander and $29 \mathrm{mi}$. NE of Yakutat, St. Elias Mts. ; $59^{\circ} 57^{\prime} 15^{\prime \prime} \mathrm{N}, 139^{\circ} 28^{\prime} 55^{\prime \prime} \mathrm{W}$; (map 46).

Named in 1905 by Tarr (1906, p. 155), USGS, for Grove Karl Gilbert, 1843-1918, Chief Geologist of the USGS from 1889-92. Gilbert Reef: rock, see Westdahl Rock.

Gilbert Ridge: ridge, elev, 1,500-1,700 ft., on E coast of Attu I., extends NW $5.5 \mathrm{mi}$. from Alexai Pass to Clevesy Pass. Aleutian Is., $52^{\circ} 51^{\prime} 30^{\prime \prime} \mathrm{N}, 173^{\circ} 15^{\prime} 00^{\prime \prime} \mathrm{E}$; (map 13).

Named by U.S. Army during World War II ; published in 1948 by AMS.

Gilbert Spit: $s p i t, 0.8 \mathrm{mi}$. long, NE end of Khantaak I., $\mathrm{S}$ of Northeast Point and $5.2 \mathrm{mi}$. $\mathrm{N}$ of Yakutat, Malaspina Coastal Plain; 59 $37^{\prime} 30^{\prime \prime}$ $\mathrm{N}, 139^{\circ} 43^{\prime} 30^{\prime \prime} \mathrm{W}$; (map 46).

Local name published in 1959 by USGS. Gilead Creek: stream, heads in Brooks Ra., flows W $25 \mathrm{mi}$. to Ivishak River $16 \mathrm{mi}$. SE of its junc. with Sagavanirktok River, Arctic Slope; $69^{\circ} 18^{\prime} \mathrm{N}, 148^{\circ} 09^{\prime} \mathrm{W}$; (map 140).

Named in 1951 by USGS geologists.

Giles Bay: bay, $1.5 \mathrm{mi}$. across, on SW shore of Lake Minchumina, Tanana Low.; $63^{\circ} 51^{\prime} 45^{\prime \prime}$ $\mathrm{N}, 152^{\circ} 18^{\prime} 00^{\prime \prime} \mathrm{W}$; (map 88 ).

Local name obtained in 1958 from Fabian Carey and "Val" Blackburn by USGS.

Giles Lake: lake, $0.5 \mathrm{mi}$. long, drains WNW to Slow Fork Kuskokwim River, $50 \mathrm{mi}$. W of Mount McKinley, Kuskokwim Low.; 6307'. $20^{\prime \prime} \mathrm{N}, 152^{\circ} 35^{\prime} 10^{\prime \prime} \mathrm{W}$; (map 88).

Name obtained locally in 1962 from Fabian Carey and "Val" Blackburn by USGS.

Gilkey Glacier: glacier, heads at $58^{\circ} 53^{\prime} 30^{\prime \prime} \mathrm{N}$, $134^{\circ} 20^{\prime} 15^{\prime \prime} \mathrm{W}$, trends $\mathrm{S}$ then W $20 \mathrm{mi}$. to its 1948 terminus, $5 \mathrm{mi}$. E of Lance River and $32 \mathrm{mi}$. NW of Juneau, Coast Mts.; $58^{\circ} 56^{\prime}$ $\mathrm{N}, 134^{\circ} 47^{\prime} \mathrm{W} ; B G N 1957$; (map 11).

Named by the American Alpine Club in 1954 for Dr. Arthur Karr Gilkey, 1926-53, geologist, who as leader of a party of three in 1950 , led the first climb to the upper part of this glacier. In 1952 he was in charge of the Juneau Icefield Research Project. He was killed in 1953 by an ice avalanche at the 25,000-foot level of K-2 Mountain in Pakistan, while climbing that mountain with the American Alpine Club. His body was never found.

Gillam Glacier: glacier, heads at $63^{\circ} 40^{\prime} \mathbf{N}$, $147^{\circ} 17^{\prime} \mathrm{W}$, trends NE $10 \mathrm{mi}$. to head of East Fork Little Delta River, $60 \mathrm{mi}$. E of Healy, 
Alaska Ra.; $63^{\circ} 44^{\prime} \mathrm{N}, 147^{\circ} 03^{\prime} \mathrm{W}$; BGN 1959 ; (map 87).

Named in 1958 by R. E. Isto, USGS, for Harold Gillam, "local bush pilot."

Gillam Lake: lake, $0.7 \mathrm{mi}$. long, in Mentasta Mts., 3 mi. NE of Devils Mtn., Alaska Ra.; $62^{\circ} 26^{\prime} 30^{\prime \prime} \mathrm{N}, 142^{\circ} 49^{\prime} 00^{\prime \prime} \mathrm{W}$; (map 84).

Local name reported in 1960 by USGS.

Gillemot Island: island, see Guillemot Island.

Gilles Creek: stream, flows SE $13 \mathrm{mi}$. to Shaw Creek, $17 \mathrm{mi}$. NE of Big Delta, Yukon-Tanana High.; $64^{\circ} 21^{\prime} 15^{\prime \prime} \mathrm{N}, 145^{\circ} 32^{\prime} 30^{\prime \prime} \mathrm{W}$; (map 101).

Local name reported in 1908 by J. W. Bagley, USGS.

Gillespie Cireek: stream, heads at lake, flows SE $6.5 \mathrm{mi}$. to Spring Creek, $17 \mathrm{mi}$. S of Paxson, Copper River Basin; 62 $47^{\circ} 20^{\prime \prime}$ N, $145^{\circ} 26^{\prime}$ $00^{\prime \prime} \mathrm{W}$; (map 83).

Local name reported in 1949 by USGS.

Gillette Creek: stream, flows SE $2.3 \mathrm{mi}$. to Little Garfield Creek which flows to Noxapaga River, $32 \mathrm{mi}$. SW of Imuruk Lake, Seward Penin. High.; $6^{\circ} 29^{\prime} \mathrm{N}, 164^{\circ} 21^{\prime} \mathrm{W}$; (map 110).

Prospectors' name reported in 1901 by T. G. Gerdine (in Collier, 1902, pl. 12), USGS.

Gillett Pass: pass, 3,800 ft., at head of Dry Tok Creek, $5 \mathrm{mi}$. SW of Tok Glacier terminus and $40 \mathrm{mi}$. E of Paxson, Alaska Ra.; $63^{\circ} 04^{\prime}$ $30^{\prime \prime} \mathrm{N}, 144^{\circ} 14^{\prime} 30^{\prime \prime} \mathrm{W}$; (map 86).

Named in 1899 for Edward Gillett, civil engineer with Capt. W. R. Abercrombie, USA. Gilliland Creek: stream, flows SE $3 \mathrm{mi}$. to Wade Creek, $45 \mathrm{mi}$. SW of Eagle, Yukon-Tanana High.; $64^{\circ} 10^{\prime} \mathrm{N}, 141^{\circ} 25^{\prime} \mathrm{W}$; (map 102).

Prospectors' name shown on an 1898 manuscript map by C. A. Woodruff, Fort Cudahy, Canada.

Gillman Creek: stream, flows NE $2.5 \mathrm{mi}$. to Trout Creek, $26 \mathrm{mi}$. NW of Eagle, YukonTanana High.; $65^{\circ} 02^{\prime} 30^{\prime \prime} \mathrm{N}, 141^{\circ} 41^{\prime} 00^{\prime \prime} \mathrm{W}$; (map 103).

Prospectors' name from an unpublished map by E. J. Chamberlain, dated 1902.

Gillmore Islands: islands, $0.2 \mathrm{mi}$. across, in Galankin Is., $1.5 \mathrm{mi}$. S of Sitka, on W coast of Baranof I., Alex. Arch.; $57^{\circ} 02^{\prime} 00^{\prime \prime}$ N, $135^{\circ}-$ $19^{\prime} 20^{\prime \prime} \mathrm{W}$; (map 9). Var. Gilmore Islands.

Named in 1880 by Capt. L. A. Beardslee, USN, for a "Mr. Gilmore," USN; published by USC\&GS in the 1883 Coast Pilot (p. 143).

Gillon Point: point of land, $\mathrm{W}$ tip of Agattu I., Aleutian Is.; $52^{\circ} 24^{\prime} 15^{\prime \prime} \mathrm{N}, 173^{\circ} 21^{\prime} 50^{\prime \prime} \mathrm{E}$; $B G N$ 1938; (map 13). Var. Cape Harrell, West Cape.

Named for Lt. Comdr. John F. Gillon, USN, a naval aviator on duty during the time aerial surveys were being conducted in the Aleutian Islands. Lt. Comdr. Gillon was killed in an airplane cash at sea during naval maneuvers in 1937. He was attached to the Division of Air Navigation, U.S. Navy Hydrog. Office, which proposed his name to BGN in 1938. Shown as "West Cape" on a map by L. M. Turner in the 1880's; published in 1944 Aleutian Coast Pilot (p. 135) as "Gillon Point (Cape Harrell)."
Gilman Glacier: glacier, in Glacier Bay National Monument, trends NW $3 \mathrm{mi}$. to 1961 terminus on Johns Hopkins Inlet, $3 \mathrm{mi}$. NE of terminus of Johns Hopkins Glacier, $78 \mathrm{mi}$. $\mathrm{NW}$ of Hoonah, St. Elias Mts.; $58^{\circ} 51^{\prime} 25^{\prime \prime} \mathrm{N}$, $137^{\circ} 04^{\prime} 15^{\prime \prime} \mathrm{W}$; BGN 1937; (map 10).

Named by Field and Cooper (1937, p. 62) for Daniel Coit Gilman, 1831-1908, educator. He was president of the Univ. of California, 1872-75, first president of Johns Hopkins University, 1876-1901, and president of the Carnegie Institution of Washington, 1902-04.

Gilmer Bay: bay, $1 \mathrm{mi}$. across, $3 \mathrm{mi}$. long, on $\mathrm{W}$ coast of Kruzof I., 22 mi. NW of Sitka, Alex. Arch.; 57 $13^{\prime} \mathrm{N}, 135^{\circ} 50^{\prime} \mathrm{W}$; (map 9).

Named in 1899 by USC\&GS; published on Chart 8050.

Gilmer Cove: cove, $0.1 \mathrm{mi}$. across, on NE coast of Partofshikof I., off NW coast of Baranof I., $20 \mathrm{mi} \mathrm{NW}$ of Sitka, Alex. Arch.; 57 $18^{\prime} 05^{\prime \prime}$ N, $135^{\circ} 38^{\prime} 10^{\prime \prime} \mathrm{W}$; (map 9 ).

Named in 1896 by Lt. Comdr. E. K. Moore, USN, for Ens. W. W. Gilmer, USN, a member of his party.

Gilmore: locality, on right bank of Pedro Creek, $11 \mathrm{mi}$. NE of Fairbanks, Yukon-Tanana High.; $64^{\circ} 59^{\prime} 28^{\prime \prime} \mathrm{N}, 147^{\circ} 32^{\prime} 15^{\prime \prime} \mathrm{W}$; (map 100). Var. Gilmore City.

This mining camp was named for Tom Gilmore, Felix Pedro's partner, and was first shown on a manuscript map by C. W. Joint in 1905. The camp is now abandoned.

Gilmore Creek: stream, flows SW $4 \mathrm{mi}$. to join Pedro Creek to form Goldstream Creek, $10 \mathrm{mi}$. NE of Fairbanks, Yukon-Tanana High.; $64^{\circ}$ $59^{\prime} \mathrm{N}, 147^{\circ} 33^{\prime} \mathrm{W}$; (map'100).

Named for Tom Gilmore, Felix Pedro's partner, who arrived in the region in 1901 . The name was reported in 1903 by T. G. Gerdine (in Prindle, 1905, pl. 16), USGS.

Gilmore Dome: mountain, 2,350 ft., $14 \mathrm{mi}$. NE of Fairbanks, Yukon-Tanana High.; 64 $4^{\circ} 58^{\prime}$ $50^{\prime \prime} \mathrm{N}, 147^{\circ} 21^{\prime} 50^{\prime \prime} \mathrm{W}$; (map 100).

Name derived from Gilmore Creek, which heads on the western slope of the mountain; published on recent maps.

Gilmore Islands: islands, see Gillmore Islands.

Gilmour Point: point of land, on NW coast of Montague I., at NE end of Montague Strait, $30 \mathrm{mi}$. E of Chenega, Chugach Mts.; 60 $15^{\circ}$ $20^{\prime \prime} \mathrm{N}, 147^{\circ} 13^{\prime} 30^{\prime \prime} \mathrm{W}$; (map 63).

Name shown on a 1787 sketch map by Capt. Portlock (1789, sketch facing p. 215). See Wagner (1937, p. 458).

Gilpatrick Mountain: mountain, $4,824 \mathrm{ft}$., on Kenai Penin., between Devils and Summit Creeks, $22 \mathrm{mi}$. $\mathrm{S}$ of Hope, Chugach Mts.; $60^{\circ} 36^{\prime} 00^{\prime \prime} \mathrm{N}, 149^{\circ} 37^{\prime} 30^{\prime \prime} \mathrm{W}$; (map 63).

Local name published in 1909 by USGS (Brosks and others, 1910, pl. 4).

Gilpatricks: locality, on Kenai Penin., on Seward Highway, $22 \mathrm{mi}$. S of Sunrise, Chugach Mts.; $60^{\circ} 36^{\prime} 00^{\prime \prime} \mathrm{N}, 149^{\circ} 32^{\prime} 25^{\prime \prime} \mathrm{W}$; (map 63).

Local name reported by B. L. Johnson (in Martin and others, 1915, pl. 2), USGS. Gilpatricks was originally a small mining camp in the Moose Pass district named for John
C. Gilpatrick who discovered gold on Summit Greek in 1896.

Gilroy Creek: stream, flows SE $3 \mathrm{mi}$. to Wild River, $3 \mathrm{mi}$. SE of Gilroy Mtn. and $39 \mathrm{mi}$. SW of Wiseman, Brooks Ra.; $67^{\circ} 12^{\prime} \mathrm{N}$, $151^{\circ} 27^{\prime} \mathrm{W}$; BGN 1932; (map 124).

Local name said to have been in use since 1914; reported by Robert Marshall in 1932. Gilroy Mountain: mountain, 4,468 ft., on W bank of Wild River, $\mathrm{N}$ of Death Valley and $39 \mathrm{mi}$. W of Wiseman, Brooks Ra.; 67 $14^{\prime} 30^{\prime \prime}$ $\mathrm{N}, 151^{\circ} 30^{\prime} 00^{\prime \prime} \mathrm{W}$; (map 124).

Local named derived from Gilroy Creek obtained in 1956 by USGS topographers.

Gilson Bar: bar, in Cache Creek opposite mouth of Dollar Creek, $31 \mathrm{mi}$. NW of Talkeetna, Alaska Ra.; $62^{\circ} 27^{\prime} 10^{\prime \prime} \mathrm{N}, 151^{\circ} 02^{\prime} 00^{\prime \prime} \mathrm{W}$; (map 81).

Prospectors' name reported in the 1930's by USGS.

Gimlet Creek: stream, flows S $3 \mathrm{mi}$. to Wade Creek, $50 \mathrm{mi}$. SW of Eagle, Yukon-Tanana High.; $64^{\circ} 07^{\prime} \mathrm{N}, 141^{\circ} 32^{\prime} \mathrm{W}$; (map 102). Var. Bailey Creek.

Prospectors' name shown on an 1898 manuscript map by C. A. Woodruff, Fort Cudahy, Canada.

Gina Point: point of land, see Gheena Point.

Gin Brook: stream, see Lick Creek.

Gines Creek: stream, heads at terminus of Martin Glacier, flows S $7 \mathrm{mi}$. to Alsek River, 3.6 mi. NE of Dry Bay and $49 \mathrm{mi}$. SE of Yakutat, St. Elias Mts.; $59^{\circ} 11^{\prime} 40^{\prime \prime} \mathrm{N}, 1^{\circ} 8^{\circ} 30^{\prime} 55^{\prime \prime} \mathrm{W}$; $B G N 1962$; (map 46). Var. Hines River.

Apparently a native name reported by Capt. Tebenkov (1852, map 7), IRN, as "R[eka] Gines" or "Gines River." It was called "Hines Creek" by Baker (1906, p. 307).

Gines Creek: stream, see Williams Creek.

Gines River: stream, see Cannery Creek.

Ginger Creek: stream, flows NW $5.5 \mathrm{mi}$. to Bering Sea, $1.5 \mathrm{mi}$. SW of Aguliuk Point, on $\mathrm{N}$ coast of Umnak I., Aleutian Is.; $53^{\circ} 27^{\prime} 15^{\prime \prime}$ N, $168^{\circ} 21^{\prime} 00^{\prime \prime} \mathrm{W}$; (map 22).

Name published by Byers (1959, pl. 41), USGS.

Ginger Creek: stream, flows S $1.6 \mathrm{mi}$. to Alder Creek, 21 mi. NE of Fairbanks, YukonTanana High.; $65^{\circ} 04^{\prime} 45^{\prime \prime} \mathrm{N}, 147^{\circ} 12^{\prime} 15^{\prime \prime} \mathrm{W}$; (map 105).

Named by prospectors; published in 1908 by USGS.

Ginger Creek : stream, see Fork Creek.

Giniak Island: island, see Chiniak Island.

Ginny Creek: stream, flows NE $2 \mathrm{mi}$. to Copper River, $55 \mathrm{mi}$. NW of Katalla, Chugach Mts.; $60^{\circ} 58^{\prime} \mathrm{N}, 144^{\circ} 47^{\prime} \mathrm{W}$; (map 64).

Name published in 1950 by USGS.

Giraffe Creek: stream, see Coke Crék.

Girdled Glacier: glacier, in Glacier Bay National Monument, heads $0.2 \mathrm{mi}$. SE of Berg Mtn. and trends $W 2.8 \mathrm{mi}$. to head of unnamed stream, $2.6 \mathrm{mi}$. $\mathrm{N}$ of Adams Inlet and $66 \mathrm{mi}$. NW of Juneau, St. Elias Mts.; 58 $56^{\prime} 36^{\prime \prime} \mathrm{N}$, $134^{\circ} 46^{\prime} 15^{\prime \prime} \mathrm{W}$; (map 11).

Descriptive name given in 1890 by H. F. Reid (1892, p. 28) because the glacier was surrounded by moraines. 
Girdwood: village, pop. 63, on Seward Highway and The Alaska Railroad, on NE shore of Turnagain Arm, $11 \mathrm{mi}$. NE of Sunrise and $35 \mathrm{mi}$. SE of Anchorage, Chugach Mts.; $60^{\circ} 56^{\prime} 30^{\prime \prime} \mathrm{N}, 149^{\circ} 10^{\prime} 00^{\prime \prime} \mathrm{W}$; (map 63). Var. Girwood.

Named for James E. Girdwood, a miner, who came to the area in 1896 (DeArmond, 1962, p. 40-41). The Girdwood post office was established in 1907 (Ricks, 1965, p. 23).

Girdwcod Cabins: locality, on Crow Creek, 5.5 mi. NE of village of Girdwood and $30 \mathrm{mi}$. SE of Anchorage, Chugach Mts.; $B G N$ 1932; (map 69). Var. Girdwood Mine Cabins.

Former mining camp established about 1898. See Girdwood.

Girdwood Mine Cabins: locality, see Girdwood Cabins.

Girl Creek: stream, flows NE $10 \mathrm{mi}$. to Holokuk River, $22 \mathrm{mi}$. SE of Little Mountain Village and $48 \mathrm{mi}$. SW of Sleetmute, Kilbuck-Kuskokwim Mts.; $61^{\circ} 16^{\prime} \mathrm{N}, 158^{\circ} 18^{\prime} \mathrm{W}$; $B G N$ 1948; (map 72). Var. Nazowlakdalak.

Local name, translation of Eskimo word "Nazowlakdalak," reported in 1945 by USGS.

Girls Mountain: mountain, 6,134 ft., $2.4 \mathrm{mi}$. NW of terminus of Worthington Glacier, 17 mi. NE of Valdez, Chugach Mts.; $61^{\circ} 00^{\prime} 50^{\prime \prime}$ N, 145 $46^{\prime} 25^{\prime \prime} \mathrm{W}$; (map 68).

Named about 1962 by Austin S. Post, USGS; suggested by the International Geophysical Year Bench Mark "Station Girls, 1957 " located at the mountain's summit.

Giroux Bluff: bluff, on right bank of Tanana River, $0.5 \mathrm{mi}$. SE of Baker and $57 \mathrm{mi}$. NE of Bitzshtini Mts., Nowitna Low.; 64 $57^{\circ} \mathrm{N}$, $150^{\circ} 26$. W; (map 99).

Riverboat pilots' name published on a 1940 "Navigation Chart of the Tanana-Yukon Rivers" by the U.S. Dept. of Interior.

Girwood: locality, on NW coast of Latouche I., $18 \mathrm{mi}$. SE of Chenega, Chugach Mts.; $60^{\circ}$. $03^{\prime} 28^{\prime \prime} \mathrm{N}, 147^{\circ} 53^{\prime} 35^{\prime \prime} \mathrm{W}$; (map 63).

Mining camp reported in 1943 by USC\&GS, now abandoned.

Girwood: village, see Girdwood.

Gisamaluk Mountain: hill, see Kisimilok Mountain.

Gisasa River: stream, flows NE $70 \mathrm{mi}$. to Koyukuk River, $38 \mathrm{mi}$. SW of Roundabout Mtn., Koyukuk Low.; $65^{\circ} 16^{\prime} \mathrm{N}, 157^{\circ} 40^{\prime} \mathrm{W}$; (map 108). Var. Gissakakat, Gissassakakat, Kalyalyakhtna.

Koyukan Indian name published by Lt. Allen (1887, p. 106), USA, as "Gissassakakat" and "Fissakakat" (map), meaning "mouth of the Gisasa." Lt. L. A. Zagoskin, IRN, reported the Indian name as " $R[$ eka] Kalyalyakhtna" in 1842-44.

Gish Bay: bay, 0.7 mi. wide, E of Aats Bay, N coast of Coronation I., Alex. Arch.; $55^{\circ} 54^{\prime}$ $40^{\prime \prime} \mathrm{N}, 134^{\circ} 11^{\prime} 45^{\prime \prime} \mathrm{W}$; BGN 1924; (map 4).

Tlingit Indian word meaning "kelp" given in 1924 by USC\&GS "because this bay is foul with kelp."

Gishna Greek: stream, heads in Ray Mts., flows SW $15 \mathrm{mi}$. to Tozitna River, $33 \mathrm{mi}$. NE of
Tanana, Kokrines-Hodzana High.; 65 $33^{\prime} 15^{\prime \prime}$ N, $\cdot 151^{\circ} 23^{\prime} 00^{\prime \prime}$ W; (map 106). Var. Gish River.

Indian name, "Gish River," abtained in 1956 at Tanana by Orth.

Gish River: stream, see Gishna Creek.

Gissakakat: stream, see Gisasa River.

Gissassakakat: stream, see Gisasa River.

Githgidunka Greek: stream, heads in Sushgitit Hills and flows NNE 11 mi. to Hoyadazzithethno Creek W of that stream's junc. with Mentanontli River, $35 \mathrm{mi}$. ENE of Hughes, Kokrines-Hodzana High.; $66^{\circ} 09^{\prime} \mathrm{N}, 153^{\circ} 06^{\prime}$ W; (map 116).

A broad rendering of an Indian name generally meaning "fished with a hook"; reported in 1956 by Orth.

Flacial Fan Creek: stream, heads on Gunsight Mtn., flows SE $3 \mathrm{mi}$. to East Fork Matanuska River, $56 \mathrm{mi}$. NE of Palmer, Copper River Basin; 61 $48^{\circ} 10^{\prime \prime} \mathrm{N}, 147^{\circ} 27^{\prime} 05^{\prime \prime} \mathrm{W}$; BGN 1962; (map 69). Var. East End Creek, Ivy Wash.

Local descriptive name obtained in 1960 by USGS.

Glacial Lake: lake, $3.7 \mathrm{mi}$. long, trends N-S, 25 mi. NW of Nome, Seward Penin. High.; $64^{\circ} 52^{\prime} \mathrm{N}, 165^{\circ} 42^{\prime} \mathrm{W}$; (map 94).

Local name reported on a map of Cape Nome gold fields by David Fox, Jr., dated 1901.

Glacial River: stream, heads at terminus of a glacier, flows $\mathrm{N} 9 \mathrm{mi}$. to South Arm Kelp Bay, on NE coast of Baranof I., Alex., Arch.; $57^{\circ} 15^{\prime} 40^{\prime \prime} \mathrm{N}, 134^{\circ} 59^{\prime} 40^{\prime \prime} \mathrm{W}$; (map 9).

Descriptive name published in 1910 by USC\&GS on Chart 8250.

Glacier: locality, on Skagway River at $\mathrm{E}$ end of Warm Pass Valley, $1.4 \mathrm{mi}$. NW of terminus of Laughton Glacier and $9 \mathrm{mi}$. NE of Skagway, Coast Mts.; $59^{\circ} 33^{\prime} 05^{\prime \prime} \mathrm{N}, 135^{\circ} 07^{\prime} 20^{\prime \prime}$ W; (map 45).

Name of a former telegraph station on the White Pass and Yukon RR. published in Polk's Gazetteer in 1916.

Glacier: locality, in Kantishna Hills at junc. of Glacier Creek and Bearpaw River, $20 \mathrm{mi}$. SE of Chilchukabena Lake, Alaska Ra.; 63⒋ $40^{\prime \prime} \mathrm{N}, 150^{\circ} 58^{\prime} 20^{\prime \prime} \mathrm{W}$; (map 88). Var. Glacier City.

Mining camp established and named in 1904 or 1905 . It is now abandoned.

Glacier Basin: basin, $1 \mathrm{mi}$. long, along upper course of Glacier Creek, $13.5 \mathrm{mi}$. E of Wrangell, Coast Mts.; $56^{\circ} 28^{\prime} 30^{\prime \prime} \mathrm{N}, 132^{\circ} 01^{\prime} 00^{\prime \prime}$ W; $(\operatorname{map} 6)$.

Local name published by F. E. Wright and C. W. Wright (1908, fig. 22), USGS.

Glacier Basin: valley, somewhere along Sheep Creek about $5 \mathrm{mi}$. SE of Juneau, Coast Mts.; $58^{\circ} 16^{\prime} \mathrm{N}, 134^{\circ} 19^{\prime} \mathrm{W}$; (map 11).

Miners' name reported by R. N. DeArmond (1957, p. 37).

Glacier Bay: estuary, in Glacier Bay National Monument, trends N-S $40 \mathrm{mi}$. to Icy Strait,
$18 \mathrm{mi}$. W of Juneau, St. Elias Mts.; $58^{\circ} 22^{\prime}$ N, $136^{\circ} 00^{\prime} \mathrm{W}$; BGN 1937; (map 11).

Descriptive name given in 1880 by Capt. L. A. Beardslee, USN, and published by USC\&GS in the 1883 Coast Pilot (p. 188). This estuary was first entered by Lt. C. E. S. Wood in 1877 and was explored by John Muir in 1879.

Glacier Bay: estuary, see Columbia Bay.

Glacier Bay National Monument: 3,600 sq. mi. in the area around Glacier Bay, $40 \mathrm{mi}$. NW of Juneau, St. Elias Mts.; $58^{\circ} 45^{\prime} \mathrm{N}, 136^{\circ} 30^{\prime}$ W; (map 11).

Named for Glacier Bay. The monument was established by an act of Congress in 1925. Glacier Canyon: stream, see Glacier Canyon Creek.

Glacier Canyon Creek: stream, heads in Kigluaik Mts. and flows NW $4 \mathrm{mi}$. to Imuruk Basin, $25 \mathrm{mi}$. SE of Teller, Seward Penin. High.; $65^{\circ} 04^{\prime} \mathrm{N}, 165^{\circ} 39^{\prime} \mathrm{W}$; (map 111). Var. Glacier Canyon.

Prospectors' name reported on the 1908 "Map of Seward Peninsula" by Arthur Gibson. Glacier City: locality, see Glacier.

Glacier Creek: stream, flows SW $2 \mathrm{mi}$. to Bering Sea, on W coast of Great Sitkin I., Aleutian Is.; $52^{\circ} 01^{\prime} 18^{\prime \prime} \mathrm{N}, 176^{\circ} 10^{\prime} 48^{\prime \prime} \mathrm{W}$; (map 17).

Local name published in 1951 on a USGS map.

Glacier Creek: stream, heads on Marsha Peak, flows W $7.8 \mathrm{mi}$. to Virginia Lake, $9 \mathrm{mi}$. E of Wrangell, Coast Mts.; $56^{\circ} 28^{\prime} 30^{\prime \prime} \mathrm{N}, 132^{\circ} 09^{\prime}$ 15" W; (map 6).

Local name recorded in 1955 by USGS.

Glacier Creek: stream, $1.6 \mathrm{mi}$. long, flows E and $\mathrm{S}$ to Speel River $0.4 \mathrm{mi}$. N of Star Point, $58^{\circ}$ $08^{\prime} 25^{\prime \prime} \mathrm{N}, 133^{\circ} 43^{\prime} 30^{\prime \prime} \mathrm{W}$; (map 12).

Local descriptive name reported in 1951 by USGS.

Glacier Creek: stream, heads in Saksaia Glacier, flows NE $5 \mathrm{mi}$. to Klehini River, $2.4 \mathrm{mi}$. W of Porcupine and $35 \mathrm{mi}$. W of Skagway, St. Elias Mts.; $59^{\circ} 25^{\prime} 45^{\prime \prime} \mathrm{N}, 136^{\circ} 18^{\prime} 00^{\prime \prime} \mathrm{W}$; (map 45).

Local name published in 1900 by USC\&GS.

Glacier Creek: stream, on Kenai Penin., heads at Tustumena Glacier terminus, flows NE 4.5 mi. to Tustumena Lake, 39 SE of Kenai, Chugach Mts. ; $60^{\circ} 06^{\prime} \mathrm{N}, 150^{\circ} 37^{\prime} \mathrm{W}$; (map 62).

Local name reported in 1904 by Moffit (1906, pl. 2), USGS.

Glacier Creek: stream, flows SW $10 \mathrm{mi}$. to Turnagain Arm near Girwood, $10 \mathrm{mi}$. NE of Sunrise, Chugach Mts.; $60^{\circ} 56^{\prime} 15^{\prime \prime} \mathrm{N}, 149^{\circ}$. $10^{\prime} 15^{\prime \prime} \mathrm{W}$; (map 63).

Local name reported in 1898 by Mendenhall (1900, p. 318 ), USGS.

Glacier Creek: stream, heads in a glacier, flows E $1 \mathrm{mi}$. to Mineral Creek at Smith Mill, 7.2 mi. NNW of Valdez, Chugach Mts.; 61 ${ }^{\circ} 13^{\prime}$ $00^{\prime \prime} \mathrm{N}, 146^{\circ} 19^{\prime} 10^{\prime \prime} \mathrm{W}$; (map 68).

Local name published in the 1950's by USGS.

Glacier Creek: stream, heads in a lake, flows W $3.5 \mathrm{mi}$. to Tonsina River, $4 \mathrm{mi}$. E of terminus 
of Tonsina Glacier and $28 \mathrm{mi}$. NE of Va'dez, Chugach Mts.; $61^{\circ} 20^{\prime} 05^{\prime \prime} \mathrm{N}, 145^{\circ} 32^{\prime} 45^{\prime \prime} \mathrm{W}$; (map 68).

Local name published in the 1950's by USGS.

Glacier Creek: stream, flows NW $5.9 \mathrm{mi}$. from glacier terminus to Chitistone River, $5 \mathrm{mi}$. E of junc. of Chitistone and Nizina Rivers, 17 mi. E of McCarthy, Wrangell Mts.; $61^{\circ} 27^{\prime} \mathrm{N}$, $142^{\circ} 25^{\prime} \mathrm{W}$; (map 67)

Local name reported in 1907 by D. C. Witherspoon, USGS.

Glacier Creek: stream, heads at a glacier, flows $\mathrm{N} 8.5 \mathrm{mi}$. to Matanuska River, $44 \mathrm{mi}$. NE of Palmer, Chugach Mts.; $61^{\circ} 47^{\prime} 30^{\prime \prime} \mathrm{N}, 147^{\circ}$ $50^{\prime} 00^{\prime \prime} \mathrm{W}$; (map 69).

Local name reported in 1952 by USGS.

Glacier Creek: stream, flows SE $1.5 \mathrm{mi}$. to Reed Creek, 16 mi. NW of Palmer, Talkeetna Mts.; $61^{\circ} 49^{\prime} 25^{\prime \prime} \mathrm{N}, 149^{\circ} 11^{\prime} 05^{\prime \prime} \mathrm{W}$; (map 69).

Local name reported in 1950 by USGS.

Glacier Creek: stream, flows $\mathbf{S} 7 \mathrm{mi}$. to Happy River, $3 \mathrm{mi}$. SE of Rainy Pass Lodge and 84 mi. SW of Talkeetna, Alaska Ra.; $62^{\circ} 04^{\prime} 00^{\prime \prime}$ $\mathrm{N}, 152^{\circ} 39^{\prime} 20^{\prime \prime} \mathrm{W}$; (map 81$)$.

Local name reported in 1945 by USGS.

Glacier Greek: stream, in Nutzotin Mts., heads at lake in Caribou Pass, flows NW $2.7 \mathrm{mi}$. to Chavolda Creek 6.2 mi. SE of its junc. with Chisana River, Alaska Ra.; $62^{\circ} 08^{\prime} 05^{\prime \prime} \mathrm{N}$, $141^{\circ} 55^{\prime} 15^{\prime \prime} \mathrm{W}$; (map 84).

Name published by S. R. Capps (in Brooks and others, 1915, pl. 9), USGS.

Glacier Creek: stream, heads on Haystack Butte, flows $\mathrm{N} 12 \mathrm{mi}$. to Iditarod River, $3.5 \mathrm{mi}$. S of Swinging Dome and $14 \mathrm{mi}$. SW of Flat, Kilbuck-Kuskokwim Mts. ; $62^{\circ} 17^{\prime} 10^{\prime \prime} \mathrm{N}, 158^{\circ} 14^{\prime}$ 30" W ; BGN 1948; (map 79).

Local name obtained in 1945 by USGS.

Glacier Creek: stream, flows NW $12 \mathrm{mi}$. to Horsefly Creek $3 \mathrm{mi}$. NE of its junc. with Iditarod River, $33 \mathrm{mi}$. $\mathrm{N}$ of Flat, Innoko Low.; $62^{\circ} 55^{\prime} 20^{\prime \prime} \mathrm{N}, 157^{\circ} 52^{\prime} 50^{\prime \prime} \mathrm{W}$; (map 79).

Local name obtained in 1945 by USGS topographers.

Glacier Creek: stream, in Mount McKinley National Park, flows N $9.5 \mathrm{mi}$. along $\mathrm{E}$ side of Muldrow Glacier to Thorofare River, $30 \mathrm{mi}$. NE of Mount McKinley, Alaska Ra.; 63 ${ }^{\circ} 24^{\prime}$ $45^{\prime \prime} \mathrm{N}, 150^{\circ} 24^{\prime} 45^{\prime \prime} \mathrm{W}$; (map 88).

Local name reported in 1925 by S. R. Capps, USGS.

Glacier Creek: stream, flows NW $4.2 \mathrm{mi}$. to Norton Sound, $2.2 \mathrm{mi}$. SW of Cascade Creek and $10 \mathrm{mi}$. S of Unalakleet, Nulato Hills; $63^{\circ}$ $43^{\prime} 10^{\prime \prime} \mathrm{N}, 160^{\circ} 49^{\prime} 20^{\prime \prime} \mathrm{W}$; ( $\left.\operatorname{map} 91\right)$.

Local name reported in 1952 by USC\&GS; so called "because in winter the ravine fills with snow and looks like a glacier from offshore."

Glacier Creek: stream, in Kantishna Hills, flows N $14 \mathrm{mi}$. to Bearpaw River, Alaska Ra.; 63․$43^{\prime} 20^{\prime \prime} \mathrm{N}, 150^{\circ} 58^{\prime} 25^{\prime \prime} \mathrm{W}$; (map 88).

Name shown on a 1905 manuscript map of "Kantishna Gold Fields" by A. Friedrich, prospector.
Glacier Creek: stream, flows N $5 \mathrm{mi}$. to Wood River, 57 mi. S of Fairbanks, Alaska Ra.; $64^{\circ}$ $03^{\prime} \mathrm{N}, 147^{\circ} 36^{\prime} \mathrm{W}$; (map 100).

Local name shown on recent maps.

Glacier Creek: stream, flows N $12 \mathrm{mi}$. to Sulatna River, $18 \mathrm{mi}$. SE of Long, Kilbuck-Kuskokwim Mts.; $64^{\circ} 09^{\prime} 10^{\prime \prime} \mathrm{N}, 155^{\circ} 20^{\prime} 30^{\prime \prime} \mathrm{W}$; BGN 1936; (map 98).

Prospectors' name reported in 1921 by USGST.

Glacier Creek: stream, flows N $6 \mathrm{mi}$. to Julius Creek, $8 \mathrm{mi}$. S of Nenana, Tanana Low.; $64^{\circ}$ $26^{\prime} 40^{\prime \prime}$ N, $149^{\circ} 06^{\prime} 30^{\prime \prime}$ W; (map 100). Var. Clear Creek.

Local name shown on railroad manuscript map dated 1917.

Glacier Creek: stream, flows S $9 \mathrm{mi}$. to Goodpaster River, $3.5 \mathrm{mi}$. $\mathrm{N}$ of Shawnee Peak and $42 \mathrm{mi}$. NE of Big Delta, Yukon-Tanana High.; $64^{\circ} 29^{\prime} \mathrm{N}, 144^{\circ} 42^{\prime} \mathrm{W}$; (map 101).

Local name reported in 1958 by USGS.

Glacier Creek: stream, heads on $\mathbf{E}$ side of Mount Brynteson, flows SW $6 \mathrm{mi}$. to Snake River, $6 \mathrm{mi}$. NW of Nome, Seward Penin. High.; $64^{\circ}$ $36^{\prime} \mathrm{N}, 165^{\circ} 28^{\prime} \mathrm{W}$; (map 94).

Prospectors' name reported in 1899 by D. C. Witherspoon (in Schrader and Brooks, 1900, map 2), USGS.

Glacier Creek: stream, flows NE $8 \mathrm{mi}$. to South Fork Chena River 42 mi. NW of Big Delta, Yukon-Tanana High.; $64^{\circ} 42^{\prime} \mathrm{N}, 146^{\circ} 24^{\prime} \mathrm{W}$; (map 101).

Named by prospectors and reported in 1903 by T. G. Gerdine (in Prindle, 1913a, pl. 16), USGS.

Glacier Creek: stream, flows NW $3 \mathrm{mi}$. to Big Creek, 2 mi. SE of Ruby, Kilbuck-Kuskokwim Mts.; $64^{\circ} 42^{\prime} 45^{\prime \prime} \mathrm{N}, 155^{\circ} 29^{\prime} 20^{\prime \prime} \mathrm{W} ; B G N$ 1936; (map 98).

Prospectors' name reported in 1933 by Mertie (1936, pl. 2), USGS.

Glacier Creek: stream, flows SE $5.7 \mathrm{mi}$. to Fish River, $11 \mathrm{mi}$. E of Council and $40 \mathrm{mi}$. NE

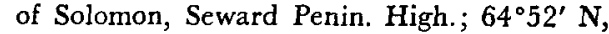
$163^{\circ} 18^{\prime} \mathrm{W}$; (map 95).

Prospectors' name published on the 1908 "Map of Seward Peninsula" by Arthur Gibson. Glacier Creek: stream, flows NE $6 \mathrm{mi}$. to Windy Cove in Imuruk Basin, $23 \mathrm{mi}$. SE of Teller, Seward Penin. High.; $65^{\circ} 03^{\prime} \mathrm{N}, 165^{\circ} 44^{\prime} \mathrm{W}$; (map 111).

Local name reported in 1900 by E. C. Barnard (in Brooks, 1901, pl. 17), USGS.

Glacier Creek: stream, flows SE $1.5 \mathrm{mi}$. to Chatanika River, $18 \mathrm{mi}$. NE of Fairbanks, Yukon-Tanana High.; $65^{\circ} 06^{\prime} 20^{\prime \prime}$ N, $147^{\circ}$ $35^{\prime} 30^{\prime \prime} \mathrm{W}$; (map 105).

Named by prospectors; published in 1908 by USGS.

Glacier Creek: stream, flows S $2.3 \mathrm{mi}$. to Willow Greek, $18 \mathrm{mi}$. N of Fairbanks, Yukon-Tanana High.; $65^{\circ} 06^{\prime} 30^{\prime \prime} \mathrm{N}, 147^{\circ} 44^{\prime} 10^{\prime \prime} \mathrm{W}$; (map 105).

Local name published by USGS in the 1950's.

Glacier Creek: stream, flows NNW $4.5 \mathrm{mi}$. to Hot Springs Creek, $33 \mathrm{mi}$. W of Birches, Kokrines-
Hodzana High.; $65^{\circ} 07^{\prime} 45^{\prime \prime} \mathrm{N}, 154^{\circ} 42^{\prime} 20^{\prime \prime} \mathrm{W}$; (map 107).

Local name obtained in 1952 by USGS topographers.

Glacier Creek: stream, flows SW $2.2 \mathrm{mi}$. to Windy Creek which flows to Kougarok River, $50 \mathrm{mi}$. SW of Imuruk Lake, Seward Penin. High.; $65^{\circ} 28^{\prime} \mathrm{N}, 1^{\circ} 54^{\circ} 50^{\prime} \mathrm{W}$; (map 110).

Prospectors' name reported on the 1908 "Map of Seward Peninsula" by Arthur Gibson. Glacier Creek: stream, flows NE $13.4 \mathrm{mi}$. to Kiwalik River, $38 \mathrm{mi}$. NW of Haycock, Seward Penin. High.; $65^{\circ} 40^{\prime} \mathrm{N}, 161^{\circ} 52^{\prime} \mathrm{W}$; (map 109).

Local name shown on a 1903 fieldsheet by D. C. Witherspoon, USGS.

Glacier Creek: stream, heads in Takhakdona Hills, flows N $11 \mathrm{mi}$. to Koyukuk River, S of Florence Is. and $17 \mathrm{mi}$. $\mathrm{N}$ of Hochandochtla Mtn., Kokrines-Hodzana High.; $65^{\circ} 46^{\prime} 45^{\prime \prime} \mathrm{N}$, $154^{\circ} 54^{\prime} 00^{\prime \prime} \mathrm{W}$; (map 107).

Name reported in 1956 by Orth as a general translation of a Koyukan Indian name.

Glacier Creek: stream, flows SE $6.5 \mathrm{mi}$. to Victoria Creek, $75 \mathrm{mi}$. W of Circle, YukonTanana High.; $65^{\circ} 48^{\prime} 45^{\prime \prime} \mathrm{N}, 146^{\circ} 39^{\prime} 10^{\prime \prime} \mathrm{W}$; (map 104).

Named by prospectors; published in 1907 by USGS.

Glacier Creek: stream, flows SE $2 \mathrm{mi}$. to Kogoluktak River, $12 \mathrm{mi}$. NE of Shungnak, Brooks Ra.; $66^{\circ} 58^{\prime} \mathrm{N}, 156^{\circ} 45^{\prime} \mathrm{W}$; (map 115).

Prospectors' name reported by USGS after 1940.

Glacier Creek: stream, flows SE $14 \mathrm{mi}$. from Glacier Lake to South Fork Koyukuk River, in South Fork Flats, $26 \mathrm{mi}$. SW of Chandalar, Brooks Ra.; $67^{\circ} 20^{\prime}$ N, $149^{\circ} 24^{\prime} \mathrm{W}$; (map 123).

Prospectors' name obtained in 1901 by Schrader (1904, pl. 3), USGS.

Glacier Creek: stream, flows W $3.3 \mathrm{mi}$. to lake $2.5 \mathrm{mi}$. $\mathbf{E}$ of Middle Fork Chandalar River and $27 \mathrm{mi}$. ENE of Chandalar, Brooks Ra.; $67^{\circ} 36^{\prime} \mathrm{N}, 147^{\circ} 32^{\prime} \mathrm{W}$; (map 123).

Local name reported in 1956 by T. E. Taylor, USGS.

Glacier Creek: stream, see Cascade Creek.

Glacier Creek: stream, see Glacier River.

Glacier Fork Glacier Creek: stream, flows SW $2 \mathrm{mi}$. to join the Middle Fork to form Glacier Creek, $8 \mathrm{mi}$. N of Nome, Seward Penin. High.;

Prospectors' name published in 1900 by Schrader (1900c, p. 16), USGS. Subsequent maps show a different drainage pattern at the head of Glacier Creek.

Glacier Fork Knik River: stream, heads at Marcus Baker Glacier, flows W $15.4 \mathrm{mi}$. to join Lake Fork to form Knik River $20 \mathrm{mi}$. SE of Palmer, Chugach Mts.; $61^{\circ} 25^{\prime} 30^{\prime \prime} \mathrm{N}, 148^{\circ}$. $37^{\prime} 30^{\prime \prime} \mathrm{W}$; (map 69).

Local name reported in 1960 by USGS.

Glacier Fork Tlikakila River: stream, heads at glacier terminus, flows SE $7 \mathrm{mi}$. to Tlikakila River, $3 \mathrm{mi}$. SW of Summit Lake and $58 \mathrm{mi}$. 
NW of Kenai, Aleutian Ra.; 60 $45^{\prime} 15^{\prime \prime} \mathrm{N}$, $152^{\circ} 51^{\prime} 30^{\prime \prime} \mathrm{W}$; (map 62).

Local name reported in 1958 by USGS.

Glacier Gap: pass, 3,950 ft., in Amphitheater Mts.; S of Sevenmile Lake and $25 \mathrm{mi}$. NW of Paxson, Alaska Ra.; $63^{\circ} 10^{\prime} \mathrm{N}, 146^{\circ} 15^{\prime} \mathrm{W}$; (map 86).

So named in 1955 by T. L. Péwé, USGS, because a massive glacier once moved through this feature giving "its present topographic expression."

Glacier Gap Lake: lake, $1.5 \mathrm{mi}$. long, near W end of Amphitheater Mts., $24 \mathrm{mi}$. W. of Paxson, Alaska Ra.; $63^{\circ} 07^{\prime} 15^{\prime \prime} \mathrm{N}, 146^{\circ} 15^{\prime} 20^{\prime \prime}$ W; (map 86).

So named in 1955 by Reuben Kachadoorian, USGS, because the lake lies in Glacier Gap.

Glacier Grub Tower: peak, 4,784 ft., $3.2 \mathrm{mi}$. E of Mount Stroller White and $14 \mathrm{mi}$. NW of Juneau, Coast Mts. ; $58^{\circ} 28^{\prime} 48^{\prime \prime} \mathrm{N}, 134^{\circ} 29^{\prime} 30^{\prime \prime}$ W; (map 11).

Local descriptive name reported in 1965 by D. A. Brew and A. B. Ford, USGS.

Glacier Gulch: ravine, extends SW $1.1 \mathrm{mi}$. from a glacier to Crow Creek, $30 \mathrm{mi}$. SE of Anchorage, Chugach Mts. ; $61^{\circ} 01^{\prime} 15^{\prime \prime} \mathrm{N}, 149^{\circ} 05^{\prime} 25^{\prime \prime}$ W; (map 69).

Local name reported in 1942 by AMS.

Glacier Hill: hill, W of Alaska Highway, $2 \mathrm{mi}$. NW of Island Lake and $28 \mathrm{mi}$. SE of Northway Junction, Alaska Ra.; 62 $43^{\prime} \mathrm{N}$, $141^{\circ} 11^{\prime} \mathrm{W}$; (map 84).

Local name reported in 1955 by USGS.

Glacier Island: island, $8.5 \mathrm{mi}$. across, in Prince William Sound, $48 \mathrm{mi}$. NE of Whittier, Chugach Mts.; $60^{\circ} 53^{\prime} \mathrm{N}, 147^{\circ} 11^{\prime} \mathrm{W}$; (map 63). Var. Isla del Conte.

Reported in 1898 by Capt. Abercrombie (Glenn and Abercrombie, 1899, map), USA. "According to Salvador Fidalgo's account of his expedition this island [named Isla del Conte] was at the mouth of the bay which his launch party named "Revilla Gigedo" and was no doubt so named because Revilla Gigedo was a conte" (Wagner, 1937, p. 443).

Glacier King: peak, 6,500 ft., $3 \mathrm{mi}$. W of Echo Mtn. and $28 \mathrm{mi}$. N of Juneau, Coast Mts.; $58^{\circ} 42^{\prime} 35^{\prime \prime} \mathrm{N}, 134^{\circ} 28^{\prime} 10^{\prime \prime} \mathrm{W}$; BGN 1965; (map 11).

Named in 1964 by members of the Juneau Icefield Research Project.

Glacier Lake: lake, $0.4 \mathrm{mi}$, across, on central Baranof I., $10 \mathrm{mi}$. NE of Sitka, Alex. Arch.; $57^{\circ} 05^{\prime} 40^{\prime \prime} \mathrm{N}, 135^{\circ} 04^{\prime} 30^{\prime \prime} \mathrm{W}$; (map 9).

Local descriptive name reported in 1951 by USGS.

Glacier Lake: lake, 0.6 mi. wide, on Kenai Penu., at terminus of Dinglestadt Glacier, $36 \mathrm{mi}$. NE of Homer, Chugach Mts. ; $59^{\circ} 48^{\prime} \mathrm{N}, 150^{\circ} 35^{\prime}$ $\mathrm{W}$; (map 50).

Local name reported and published by USGS in 1950.

Glacier Lake: lake, $1 \mathrm{mi}$. long, at head of Glacier Creek, $2.5 \mathrm{mi}$. S of Bettles River and $28 \mathrm{mi}$. W of Chandalar, Brooks Ra. ; $67^{\circ} 31^{\prime} 30^{\prime \prime} \mathrm{N}, 1^{\circ} 9^{\circ}$ 33'30' W; (map 123).

Local name reported in 1956 by T. E. Taylor, USGS.
Glacier Mountain: mountain, 5,915 ft., $10 \mathrm{mi}$. SE of North Peak, $21 \mathrm{mi}$. W of Eagle, YukonTanana High.; 64 $43^{\prime} 45^{\prime \prime}$ N, $141^{\circ} 50^{\prime} 45^{\prime \prime}$ W ; (map 102). Var. Comet Mountain.

Prospectors' name obtained in 1898 by E. C. Barnard, USGS

Glacier Pass: pass, $1 \mathrm{mi}$. long, NW of Minnesota Ridge, between Muir and Burroughs Glaciers, $47 \mathrm{mi}$. SW of Skagway, St. Elias Mts.; $59^{\circ}$ $01^{\prime} 10^{\prime \prime} \mathrm{N}, 136^{\circ} 17^{\prime} 00^{\prime \prime} \mathrm{W}$; (map 45).

Local name published in 1961 by USGS

Glacier Pass: pass, 1,800 ft., between valleys of Wiseman Creek and Glacier River, SW of Pasco Pass and $\mathrm{N}$ of Bluecloud Mtn., $8 \mathrm{mi}$. NW of Wiseman, Brooks Ra.; 67 $27^{\prime} 30^{\prime \prime} \mathrm{N}$, $150^{\circ} 22^{\prime} 30^{\prime \prime} \mathrm{W}$; (map 124).

Local name obtained in 1956 by USGS topographers.

Glacier Pass : pass, see McGonagall Pass.

Glacier Peak: peak, 4,310 ft., in Mount McKinley National Park, at head of Glacier Creek, $6 \mathrm{mi}$. NE of Wonder Lake, Alaska Ra.; $63^{\circ} 34^{\prime} \mathrm{N}, 150^{\circ} 47^{\prime} \mathrm{W} ; B G N$ 1932; (map 88).

Local name shown on a 1916 fieldsheet by C. E. Giffin, USGS.

Glacier Point: point of land, on W bank of Portland Canal, $7.5 \mathrm{mi}$. SW of Hyder, Coast Mts.; $55^{\circ} 49^{\prime} 10^{\prime \prime} \mathrm{N}, 130^{\circ} 07^{\prime} 00^{\prime \prime} \mathrm{W}$; (map 3).

So named in 1907 by USC\&GS "because of its proximity to Soulé Glacier."

Glacier Point: point of land, on $\mathrm{W}$ shore of Chilkat Inlet, $1.4 \mathrm{mi}$. NE of terminus of Davidson Glacier and $25 \mathrm{mi}$. SW of Skagway, St. Elias Mts.; $59^{\circ} 06^{\prime} 10^{\prime \prime} \mathrm{N}, 1^{\circ} 5^{\circ} 22^{\prime} 45^{\prime \prime} \mathrm{W}$; (map 45). Var. Lohtianoi Point, Icy Point.

Named in 1869 by Comdr. R. W. Meade, USN, and published by USC\&GS in the 1883 Coast Pilot (p. 196). Lindenberg called it Lehtianoi or icy point in 1838 on Russian Hydrog. Dept. Chart 1396.

Glacier Point: point of land, at junc. of Caribou Creek and Matanuska River, $50 \mathrm{mi}$. NE of Palmer, Talkeetna Mts.; $61^{\circ} 42^{\prime} 00^{\prime \prime} \mathrm{N}, 147^{\circ}$. $39^{\prime} 10 \mathrm{~W} ;(\operatorname{map} 69)$

Descriptive name given by W. C. Mendenhall in 1898 and reported in 1900 by him (map 16), USGS.

Glacier Point: point of land, extends $\mathrm{S}$ into Ruth Glacier, at mouth of The Great Gorge, $18 \mathrm{mi}$. SE of Mount McKinley, Alaska Ra.; 62 ${ }^{\circ} 53^{\prime}$ $15^{\prime \prime} \mathrm{N}, 150^{\circ} 35^{\prime} 30^{\prime \prime} \mathrm{W}$; BGN 1963; (map 81).

This grass-covered spur and well-known campsite was named by the Parker-Browne Expedition of 1910.

Glacier Pup: stream, flows S $0.7 \mathrm{mi}$. to Chatanika River, $0.8 \mathrm{mi}$. upstream from the mouth of Sourdough Creek and $48 \mathrm{mi}$. NE of Fairbanks, Yukon-Tanana High.; $65^{\circ} 17^{\prime} 30^{\prime \prime} \mathrm{N}, 146^{\circ} 27^{\prime}$ $30^{\prime \prime} \mathrm{W}$; (map 104).

Prospectors' name reported in 1954 or 1955 by USGS topographers.

Glacier River: stream, heads at terminus of Davidson Glacier, flows W $2 \mathrm{mi}$. to Chilkat Inlet, $1.9 \mathrm{mi}$. S of Glacier Point and $26 \mathrm{mi}$. SW of Skagway, St. Elias Mts.; $59^{\circ} 04^{\prime} 30^{\prime \prime} \mathrm{N}$, $135^{\circ} 22^{\prime} 55^{\prime \prime} \mathrm{W}$; (map 45).

Local name published in 1954 by USGS.
Glacier River: stream, heads at terminus of Sheridan Glacier, flows SW $10 \mathrm{mi}$. to Gulf of Alaska, $10 \mathrm{mi}$. SE of Cordova, Malaspina Coastal Plain; $60^{\circ} 27^{\prime} \mathrm{N}, 145^{\circ} 32^{\prime} \mathrm{W}$; (map 64).

So named in 1900 by USC\&GS "because it heads at a glacier."

Glacier River: stream, heads at terminus of Twentymile Glacier, flows SW $6.5 \mathrm{mi}$. to Twentymile River, $18 \mathrm{mi}$. NE of Sunrise, Chugach Mts.; $60^{\circ} 53^{\prime} 45^{\prime \prime}$ N, $148^{\circ} 55^{\prime} 25^{\prime \prime} \mathrm{W}$; (map 63). Var. Placer River.

Local name reported in 1898 by Capt. E. F. Glenn, USA.

Glacier River: stream, formed by junc. of Chimney Fork and Roy Creek, flows SW $30 \mathrm{mi}$. to North Fork Koyukuk River, $17 \mathrm{mi}$. SW of Wiseman, Brooks Ra.; $67^{\circ} 19^{\prime} 30^{\prime \prime} \mathrm{N}, 150^{\circ} 42^{\prime}$ 15" W; BGN 1932; (map 124).Var. Glacier Creek, Seattle River.

Named "Glacier Creek" by local prospectors; reported in 1929 by Robert Marshall.

Glacier River: stream, see Eagle River.

Glacier River: stream, see Mendenhall River.

Glacier River: stream, see Placer River.

Glacier Spit: spit, on E shore of Kachemak Bay, on Kenai Penin., $12 \mathrm{mi}$. $\mathrm{E}$ of Homer, Chugach Mts. ; $59^{\circ} 39^{\prime} \mathrm{N}, 151^{\circ} 07^{\prime} \mathrm{W}$; (map 50$)$.

Named by W. H. Dall, USC\&GS, in 1880 . Glacier Spit: spit, extends SW $1.3 \mathrm{mi}$. from N shore of Chinitna Bay, Aleutian Ra.; $59^{\circ}$.

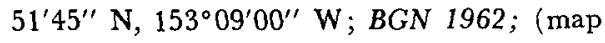
51).

Local name derived from Middle Glacier Creek; published in 1958 by USGS.

Glacier Spring: spring, $3 \mathrm{mi}$. NE of junc. of Your Creek and Middle Fork Chandalar River, $31 \mathrm{mi}$. NE of Chandalar, Brooks Ra.; $67^{\circ} 48^{\prime}$ $\mathrm{N}, 147^{\circ} 39^{\prime} \mathrm{W}$; (map 123).

Local name reported in 1956 by T. E. Taylor, USGS.

Glacier Valley: valley, see Makushin Valley.

Gladhaugh Bay: cove, see Virgin Bay.

Gladhaugh Creek: stream, flows $1.5 \mathrm{mi}$. W to Virgin Bay, $40 \mathrm{mi}$. NW of Cordova, Chugach Mts.; $60^{\circ} 54^{\prime} \mathrm{N}, 146^{\circ} 42^{\prime} \mathrm{W}$; (map 64).

Local name reported in 1912 by S. R. Capps and B. L. Johnson (in Brooks and others, 1913, p1. 4), USGS. Named for M. O. Gladhaugh who, with C. Peterson, staked mining claims here in 1897.

Gladiator Basin: canyon, $5 \mathrm{mi}$. long, $1.5 \mathrm{mi}$. E of Kontrashibuna Lake and $35 \mathrm{mi}$. NE of Nondalton, Aleutian Ra.; $60^{\circ} 09^{\prime} \mathrm{N}, 153^{\circ} 46^{\prime}$ $\mathrm{W}$; (map 61).

Local name reported in 1954 by USGS.

Glagolm, Ostrova : island, see Glagolm Island.

Glagolm Island: island, $0.1 \mathrm{mi}$. across, at mouth of Redoubt Bay, 9 mi. SW of Sitka, on W coast of Baranof. I., Alex. Arch.; 56 $56^{\prime} 15^{\prime \prime} \mathrm{N}$, $135^{\circ} 25^{\prime} 25^{\prime \prime} \mathrm{W}$; (map 5). Var. Glagolm Islets, Ostrova Glagolm.

Named in 1809 by the Russian navigator, Ivan Vasiliev the first; published by Lt. Sarichev (1826, map 19), IRN as "O[strov]a Glagolm," or "Glagolm Islands."

Glagolm Islets: island, see Glagolm Island.

Gla-huts: island, see Kochu Island. 
G Lake: lake, $1.3 \mathrm{mi}$. long, $1 \mathrm{mi}$. S of Grass Lake and $9 \mathrm{mi}$. NE of Arctic Village, Brooks Ra.; $68^{\circ} 29^{\prime} 30^{\prime \prime} \mathrm{N}, 145^{\circ} 20^{\prime} 00^{\prime \prime} \mathrm{W}$; (map 136).

Local name reported in 1956 by $R$. C. Foley, USGS.

Glaman Lake: lake, $1.7 \mathrm{mi}$. wide, between village of Mansfield and Tanana River, $5.5 \mathrm{mi}$. NW of Tanacross, Yukon-Tanana High.; $63^{\circ} 26^{\prime} \mathrm{N}, 143^{\circ} 29^{\prime} \mathrm{W}$; (map 85).

Local name reported in 1950 by USGS.

Gland Hill: hill, $220 \mathrm{ft}$., E of Vega Bay, Kiska I., Aleutian Is.; $51^{\circ} 55^{\prime} 45^{\prime \prime} \mathrm{N}, 177^{\circ} 28^{\prime} 00^{\prime \prime} \mathrm{E}$; (map 14).

An arbitrary name beginning with " $G$ " to correspond to "G" grid used by U.S. Army for tactical purposes during World War II ; published on a 1943 Army map.

Glasenap, Cape: point of land, see Glazenap, Cape.

Glasenapp, Pointe: point of land, see Glazenap, Cape.

Glaser Lake: lake, $0.7 \mathrm{mi}$. long, $4.6 \mathrm{mi}$. W of junc. of Maclaren River and its West Fork, and $31 \mathrm{mi}$. S of Mt. Hayes, Alaska Ra.; $63^{\circ} 10^{\prime} 30^{\prime \prime} \mathrm{N}, 146^{\circ} 42^{\prime} 20^{\prime \prime} \mathrm{W}$; (map 86).

Name published on relatively recent maps.

Glasier Creek: stream, flows E $2.5 \mathrm{mi}$. to Sam Patch Creek, $35 \mathrm{mi}$. S of Eagle, Yukon-Tanana High.; $64^{\circ} 20^{\prime} \mathrm{N}, 141^{\circ} 02^{\prime} \mathrm{W}$; (map 102).

Prospectors' name shown on an 1898 manuscript map by C. A. Woodruff, Fort Cudahy, Canada.

Glass, Point: point of land, on E coast of Glass Penin., on Admiralty I., 3 mi. SE of Washburn Peak and $38 \mathrm{mi}$. SE of Juneau, Alex. Arch.; $57^{\circ} 48^{\prime} 25^{\prime \prime} \mathrm{N}, 133^{\circ} 53^{\prime} 55^{\prime \prime} \mathrm{W}$; (map 8).

Name derived from Glass Peninsula; published in 1892 by USG\&GS.

Glass Creek: stream, flows E $6 \mathrm{mi}$. to Caribou Creek, $21 \mathrm{mi}$. NW of Tahneta Pass, Takleetna Mts.; $62^{\circ} 01^{\prime} 27^{\prime \prime} \mathrm{N}, 147^{\circ} 53^{\prime} 30^{\prime \prime} \mathrm{W}$; $B G N$ 1960; (map 82).

Named in 1956 by USGS "for the beds of volcanic glass found along its valley."

Glass Lake: lake, $0.2 \mathrm{mi}$. across, $0.2 \mathrm{mi}$. from $\mathrm{N}$ shore of Vega Bay, Kiska I., Aleutian I.; $51^{\circ} 56^{\prime} 00^{\prime \prime} \mathrm{N}, 177^{\circ} 23^{\prime} 35^{\prime \prime} \mathrm{E}$; (map 14).

An arbitrary name beginning with " $G$ " to correspond to " $G$ " grid used by the U.S. Army for tactical purposes during World War II; published on a 1953 AMS map.

Glass Peninsula: peninsula, on Admiralty I., extends SE $50 \mathrm{mi}$. along $W$ shore of Stephens Passage, $12 \mathrm{mi}$. SSE of Juneau, Alex. Arch.; $57^{\circ} 35^{\prime} \mathrm{N}, 133^{\circ} 50^{\prime} \mathrm{W}$; (map 8).

Named by USC\&GS for Comdr. Henry Glass, 1844-1908, USN, Commander of the SS Wachusett, which made surveys in this area in 1881. Comdr. Glass rose to Rear Admiral and was Commandant of the Pacific Naval District at the time of his death.

Glass Point: point of land, at junc. of Klehini and Chilkat Rivers, $0.4 \mathrm{mi}$. S of Wells and 22 mi. W of Skagway, St. Elias Mts.; $59^{\circ} 24^{\prime} 30^{\prime \prime}$ $\mathrm{N}, 135^{\circ} 55^{\prime} 35^{\prime \prime} \mathrm{W}$; (map 45).

Named in 1880 by U.S. Navy for Comdr. Henry Glass, USN. See Glass Peninsula. Glave Creek: stream, see Kelsall River.
Glazenap, Cape: point of land, at $\mathrm{W}$ entrance to Applegate Cove, on SW end of Alaska Penin., Bristol Bay Low. ; $55^{\circ} 15^{\prime} \mathrm{N}, 163^{\circ} 00^{\prime} \mathrm{W}$; (map 29). Var. Mys Glazenapa, Pointe Glasenapp, Cape Glasenap, Round Point.

Named by Capt. Lutke (1836, p. 262), IRN, for Vladimir and Gotlieb Glazenap, two members of his party. This feature was described as "Round Point" by USBF in 1888 .

Glazenapa, Mys: point of land, see Glazenap, Cape.

Gleason Creek: stream, in Kenai Mts., flows W $1.5 \mathrm{mi}$. to Bench Creek, $18 \mathrm{mi}$. SE of Sunrise, Chugach Mts. ; $60^{\circ} 40^{\prime} 00^{\prime \prime} \mathrm{N}, 149^{\circ} 13^{\prime} 30^{\prime \prime}$ W; (map 63).

Local name reported in 1951 by USGS.

Glen: locality, site, $0.2 \mathrm{mi}$. $\mathrm{S}$ of settlement of Eureka, $22 \mathrm{mi}$. S of Rampart, Yukon-Tanana High.; $65^{\circ} 10^{\prime} 30^{\prime \prime} \mathrm{N}, 150^{\circ} 13^{\prime} 00^{\prime \prime} \mathrm{W}$; (map 106).

Mining camp and telegraph station established about 1903.

Glen: locality, see Eureka.

Glen Allen: village, see Glennallen.

Glen Alps: area, pop. 10, in Anchorage metropolitan area, Cook Inlet Low.; $61^{\circ} 13^{\prime} 00^{\prime \prime} \mathrm{N}$ 14953'30' W; (map 69).

Local name reported in 1966 (Rand McNally, 1966, p. 62).

Glen Creek : ravine, see Glen Gulch.

Glen Creek: stream, in Kantishna Hills, formed by its East and West Forks, flows $\mathrm{S} 12 \mathrm{mi}$. to North Fork Moose Creek, $6 \mathrm{mi}$. ENE of

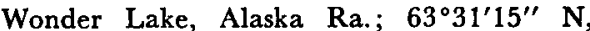
$150^{\circ} 42^{\prime} 15^{\prime \prime} \mathrm{W}$; (map 88)

Name shown on a 1905 manuscript map of "Kantishna Gold Fields" by A. Friedrich, prospector.

Glen Creek: stream, see Glenn Creek.

Glen Gulch: ravine, trends $\mathrm{E} 2 \mathrm{mi}$. to Flint Creek, $4.5 \mathrm{mi}$. E of Long and $21 \mathrm{mi}$. W of Monzonite Hills, Kilbuck-Kuskokwim Mts.; $64^{\circ} 25^{\prime} 00^{\prime \prime} \mathrm{N}, 155^{\circ} 20^{\prime} 30^{\prime \prime} \mathrm{W}$; BGN 1936, (map 98). Var. Glen Greek, Glenn Gulch.

Prospectors' name reported in 1911 by A. G. Maddren (in Brooks and others, 1912, p. 204296), USGS

Glen Gulch: ravine, trends NW $0.7 \mathrm{mi}$. to Gertrude Creek, 2 mi. E of Livengood, YukonTanana High.; $65^{\circ} 32^{\prime} 40^{\prime \prime} \mathrm{N}, 148^{\circ} 29^{\prime} 30^{\prime \prime} \mathrm{W}$; (map 105).

Local name published by USGS in the 1950 's.

Glen Island: island, $3 \mathrm{mi}$. long, southernmost of Kudiakof Is., $11 \mathrm{mi}$. NW of village of Cold Bay, off SW end of Alaska Penin., Bristol Bay Low.; $55^{\circ} 18^{\prime} \mathrm{N}, 162^{\circ} 55^{\prime} \mathrm{W}$; BGN 1966; (map 29). Var. Operl Island.

Named by USBF in 1888.

Glenn: locality, see Eureka.

Glenn, Mount: mountain, 9,806 ft., in Dora Keen Ra., 40 mi. NW of Valdez, Chugach Mts., $61^{\circ} 21^{\prime} 30^{\prime \prime} \mathrm{N}, 147^{\circ} 22^{\prime} 40^{\prime \prime} \mathrm{W}$; BGN 1930; (map 69)

Named about 1911 by Lawrence Martin for Capt. Edwin Forbes Glenn, 1857-1926, USA, "who carried on explorations in College Fiord, 1898."
Glennallen: village, pop. 169, on Glenn Highway, $2 \mathrm{mi}$. W of junc. of Glenn and Richardson Highways, Copper River Basin; $62^{\circ} 07^{\prime} \mathrm{N}$, $145^{\circ} 33^{\prime}$ W; BGN 1961; (map 83). Var. Glen Allen, Glenallen, Glenn-Allen, Port Chilkoot.

This name is derived from the combined last names of Capt. Edwin F. Glenn and Lt. Henry Tureman Allen, USA, both leaders in the early explorations of the Copper River region.

Glenn Creek: locality, on banks of Glenn Greek, $8 \mathrm{mi}$. NE of Fairbanks, Yukon-Tanana High.; $64^{\circ} 57^{\prime} \mathrm{N}, 147^{\circ} 37^{\prime} \mathrm{W}$; (map 100).

This locality was a mining settlement on Glenn Creek in the early 1900's (Kitchener, 1954, p. 297).

Glenn Creek: stream, flows NW $1.5 \mathrm{mi}$. to Goldstream Creek, $8 \mathrm{mi}$. NE of Fairbanks, YukonTanana High.; $64^{\circ} 57^{\prime} 15^{\prime \prime} \mathrm{N}, 147^{\circ} 37^{\prime} 30^{\prime \prime} \mathrm{W}$; (map 100).

Local name published in 1908 by USGS.

Glenn Creek: stream, flows $\mathbf{S} 3.2 \mathrm{mi}$. to Eureka Creek, $2.4 \mathrm{mi}$. S of Eureka and $25 \mathrm{mi}$. S of Rampart, Yukon-Tanana High.; $65^{\circ} 08^{\prime} 45^{\prime \prime}$ N, $150^{\circ} 14^{\prime} 00^{\prime \prime} \mathrm{W}$; BGN 1964; (map 106). Var. Glen Greek.

This stream originally flowed into Rhode Island Creek, but was diverted by mining operations. Name reported in 1904 by USGS (Prindle and Hess, 1906, pl. 3). Gold was discovered here in July 1901.

Glenn Creek: stream, flows NE $7 \mathrm{mi}$. to Yukon River $20 \mathrm{mi}$. E of its junc. with Charley River, Yukon-Tanana High.; $65^{\circ} 18^{\prime} \mathrm{N}, 142^{\circ} 05^{\prime} \mathrm{W}$; (map 103). Var. Colsandu Creek.

Name used by prospectors; taken from an unpublished map by E. J. Chamberlain dated 1902. Lt. Schwatka (1885b, sheet 8), USA, used the Indian name "Golsandu."

Glenn Gulch: ravine, extends $2.1 \mathrm{mi}$. N off Spruce Creek, E of Joe Wise Creek and 9.8 mi. SE of Marshall, Nulato Hills; $61^{\circ} 47^{\prime} \mathrm{N}$, $161^{\circ} 54^{\prime} \mathrm{W}$; (map 73).

Prospectors' name reported in 1916 by Harrington (1918, map), USGS.

Glenn Gulch : ravine, see Glen Gulch.

Glenn Lake: lake, $0.3 \mathrm{mi}$. long, $\mathrm{W}$ of Lake George Glacier, $8.5 \mathrm{mi}$. S of Upper Lake George and $39 \mathrm{mi}$. SE of Anchorage, Chugach Mts.; $61^{\circ} 03^{\prime} 05^{\prime \prime} \mathrm{N}, 148^{\circ} 46^{\prime} 05^{\prime \prime} \mathrm{W}$; (map 69).

Named in 1898 by John S. Bagg (in Glenn and Abercrombie, 1899, p. 290), USA, for Capt. Edwin Forbes Glenn, 1857-1926, USA. Glisen, Mount: peak, 6,200 ft. NE of Glacier Point, E of Ruth Glacier, Alaska Ra.; $62^{\circ} 53^{\prime}$ $55^{\prime \prime} \mathrm{N}, 150^{\circ} 30^{\prime} 15^{\prime \prime} \mathrm{W}$; (map 81).

Mountain climbers' name probably given by members of the 1945 Mazama expedition to the area (Metcalf, 1945, map facing p. 11).

Globe Creek: stream, flows E $7.5 \mathrm{mi}$. to Stuart Creek $0.3 \mathrm{mi}$. SE of that stream's junc. with South Fork Chena River and $47 \mathrm{mi}$. NNW of Big Delta, Yukon-Tanana High.; 64 $4^{\circ} 45^{\prime} \mathrm{N}$, $146^{\circ} 29^{\prime} \mathrm{W}$; (map 101).

Local name reported in 1958 by USGS. 
Globe Creek: stream, flows SW $15 \mathrm{mi}$. to Tatalina River, $20 \mathrm{mi}$. S of Livengood, Yukon-Tanana High.; $65^{\circ} 15^{\prime} \mathrm{N}, 148^{\circ} 24^{\prime} \mathrm{W}$; (map 105).

Local name shown on a manuscript map of The Alaska Railroad dated 1923.

Globe Roadhouse: locality, at junc. of Globe Creek and Livengood-Fairbanks Trail (now Elliott Highway), $20 \mathrm{mi}$. SE of Livengood, Yukon-Tanana High. ;. $65^{\circ} 17^{\prime} \mathrm{N}, 148^{\circ} 09^{\prime} \mathrm{W}$; (map 105).

This former roadhouse was named for Globe Creek. The name was reported in 1915 by USGS (Brooks and others, 1916, pl. 9).

Glorious, Point: nunatak, 5,000 ft., E of Seward Glacier, at $\mathrm{W}$ end of Pinnacle Pass Hills, 49 mi. NW of Yakutat, St. Elias Mts.; $60^{\circ} 10^{\prime} 20^{\prime \prime}$ $\mathrm{N}, 140^{\circ} 23^{\prime} 00^{\prime \prime} \mathrm{W}$; (map 66).

Named in 1890 by Russell (1891, p. 137), USGS, because of the splendid view obtained from the point.

Glory Hole: locality, see Treadwell Glory Hole.

Glory Hole, The: locality, depression caused by former mining operations, $1 \mathrm{mi}$. $\mathrm{N}$ of Gastineau Peak and $2 \mathrm{mi}$. E of Juneau, Coast Mts.; $58^{\circ} 18^{\prime} 30^{\prime \prime} \mathrm{N}, 134^{\circ} 20^{\prime} 00^{\prime \prime} \mathrm{W}$; (map 11).

Named published in 1962 by USGS.

Gloryhole Creek: stream, heads on Eska Mtn., flows $\mathrm{S} 2.7 \mathrm{mi}$. to Eska Creek, $11.5 \mathrm{mi}$. NE of Palmer, Cook Inlet Low.; 61 ${ }^{\circ} 44^{\prime} 45^{\prime \prime}$. N, 148 ${ }^{\circ} 55^{\prime} 15^{\prime \prime} \mathrm{W}$; BGN 1946; (map 69).

Local name reported about 1946 by USGS.

Glory Lake: lake, $4 \mathrm{mi}$. long, at head of Farragut River, $1 \mathrm{mi}$. $\mathrm{N}$ of Farragut Lake and $4.5 \mathrm{mi}$. N of Maury Peak, $90 \mathrm{mi}$. NE of Sitka, Coast Mts.; $57^{\circ} 18^{\prime} 30^{\prime \prime} \mathrm{N}, 132^{\circ} 58^{\prime} 00^{\prime \prime} \mathrm{W}$; (map 8).

Local name reported in 1961 by USGS.

Glory Lake: lake, $2.4 \mathrm{mi}$. long, $1.4 \mathrm{mi}$. W of 1952 terminus of the Norris Glacier, $4 \mathrm{mi}$. W of Taku Point and $11 \mathrm{mi}$. NE of Juneau, Coast Mts.; $58^{\circ} 23^{\prime} 50^{\prime \prime} \mathrm{N}, 134^{\circ} 07^{\prime} 15^{\prime \prime} \mathrm{W}$; (map 11).

Name published in 1952 by USGS.

Glory of Russia: locality, site of Russian penal colony near The Ankau, on SE shore of Yukutat Bay, about $3 \mathrm{mi}$. W of Yakutat, Malaspina Coastal Plain; $59^{\circ} 33^{\prime} \mathrm{N}, 1^{\circ} 9^{\circ} 48^{\prime}$ W; (map 46). Var. New Russia, Novarassi, Slavarassi, Slawa Rossii, Yakutat Colony, Yukutat Settlement.

Site of stockaded Russian penal colony established in 1795 . It has been referred to as "Yakutat colony or settlement," "New Russia," "Novarassi," "Slavarassi" and "Slawa Rossii." It presumably was named after Commodore Joseph Billing's ship, the Slava Rossia or "Glory of Russia." The history of the place is obscure, but it appears as if it was destroyed by Tlingit Indians about 1803. Remains of the settlement were seen by I. C. Russell in 1891.

Glory of Russia Bay: bay, see Tanaga Bay.

Glory of Russia Cape: promontory, extends NE into Bering Sea, at Sarichef Strait, on NW end of St. Matthew I.; $60^{\circ} 36^{\prime} \mathrm{N}, 172^{\circ} 57^{\prime} \mathrm{W}$; (map 56). Var. Mys Slava Rossie, Mys Slavy Rossii.

This promontory appears to have been named "M[ys] Slavy [Slava] Rossii," "Cape Glory of Russia," by the Russian Hydrog. Dept. (Chart 1427) in 1849, for Lt. Sarichev's ship which was anchored off the coast here July 14, 1791 (O.S.).

Glottof, Mount: mountain, 4,505 ft., highest point on Kodiak I., $6 \mathrm{mi}$. NW of head of Ugak Bay; $57^{\circ} 33^{\prime} 00^{\prime \prime} \mathrm{N}, 1^{\circ} 3^{\circ} 06^{\prime} 45^{\prime \prime} \mathrm{W}$; BGN 1964; (map 34).

Named in 1963 by the Kodiak and Aleutian Islands Historical Society, Inc., for Stephan Glotov, commander of the ship Andrean and Natalia, who in 1763 was the first white man to land on Kodiak Island.

Gloubokaia, Bukhta : $b a y$, see Banner Bay.

Gloubokaia, Bukhta: bay, see Deep Bay.

Gloubokoi Lake: lake, see Redoubt Lake.

Glubokaia : estuary, see Deep Inlet.

Glubokaia Bay: cove, see Partov Cove.

Glubokaya, Guba: estuary, see Deep Inlet.

Glubokiy, Mys: point of land, see Deepwater Point.

Glubokoe Lake: lake, see Redoubt Lake.

Glubokoi: cove, see Partov Cove.

Glubokoi: lake, see Redoubt Lake.

Glubokoi Bay: bay, see Banner Bay.

Glubokoi Bay: bay, see Deep Bay.

Glubokoy, Zaliv: bay, see Deep Bay.

Glubokoye, Ozero: lake, see Redoubt Lake.

Gnat Cove: bay, $0.8 \mathrm{mi}$. across, on $\mathrm{E}$ shore of Carroll Inlet, on Revillagigedo I., Alex. Arch.; $55^{\circ} 23^{\prime} 00^{\prime \prime} \mathrm{N}, 131^{\circ} 19^{\prime} 40^{\prime \prime} \mathrm{W}$; (map 3).

Arbitrary name given in 1891 by USC\&GS

Gnat Creek: stream, flows NW $20 \mathrm{mi}$. to Hoholitna River, $20 \mathrm{mi}$. W of Whitefish Lake and $70 \mathrm{mi}$. NW of Nondalton, Lime Hills; $60^{\circ} 56^{\prime} 15^{\prime \prime} \mathrm{N}, 155^{\circ} 36^{\prime} 00^{\prime \prime} \mathrm{W}$; (map 61).

Local name reported by Capps (1935, pl. 2), USGS.

Goat Creek: stream, flows N $8 \mathrm{mi}$. to left bank of Stikine River, $5.5 \mathrm{mi}$. downstream from the U.S.-Canada boundary, Coast Ra. ; 56 $40^{\circ} 15^{\prime \prime}$ N, $131^{\circ} 58^{\prime} 10^{\prime \prime} \mathrm{W}$; (map 7).

Local name published by USGS in 1955.

Goat Creek: stream, flows mostly NW $2 \mathrm{mi}$. to Nugget Creek, $1 \mathrm{mi}$. SE of Bullard Mtn. and $9 \mathrm{mi}$. NW of Juneau, Coast Mts. ; $58^{\circ} 25^{\prime} 45^{\prime \prime}$ $\mathrm{N}, 134^{\circ} 28^{\prime} 30^{\prime \prime} \mathrm{W}$; (map 11).

Name published in 1912 by USGS (Knopf, pl. 1).

Goat Creek: stream, flows NW $15 \mathrm{mi}$. fron glacier terminus to Chitina River S of Gibraltar Hill, $37 \mathrm{mi}$. SE of McCarthy, St. Elias Mts. ; $61^{\circ} 04^{\prime} 30^{\prime \prime} \mathrm{N}, 142^{\circ} 07^{\prime} 30^{\prime \prime} \mathrm{W}$; (map 67).

Local name reported in 1915 by $F$. $H$. Moffit, USGS.

Goat Creek: stream, heads in Rubin Glacier, flows SW $1 \mathrm{mi}$. to Corbin Creek, $0.1 \mathrm{mi}$. W of mouth of Cameron Creek and $6 \mathrm{mi}$. $\mathrm{E}$ of Valdez, Chugach Mts.; $61^{\circ} 06^{\prime} 30^{\prime \prime}$ N, $146^{\circ}$ $05^{\prime} 00^{\prime \prime} \mathrm{W}$; (map 68).

Local name published in the 1950's by USGS.
Goat Creek: stream, flows NW $7.6 \mathrm{mi}$. to Knik River, $8 \mathrm{mi}$. S of Palmer, Cook Inlet Low.; $61^{\circ} 29^{\prime} 20^{\prime \prime} \mathrm{N}, 1^{\circ} 9^{\circ} 05^{\prime} 40^{\prime \prime} \mathrm{W}$; (map 69).

Local name reported in 1942 by AMS.

Goat Creek: stream, heads at Sheep Lake, flows $\mathrm{N} 9 \mathrm{mi}$. to Tanada Lake, $12 \mathrm{mi}$. W of Nabesna, Wrangell Mts.; $62^{\circ} 23^{\prime} \mathrm{N}, 143^{\circ} 22^{\prime} \mathrm{W}$; $B G N$ 1939; (map 84).

Local name reported in 1939 by P. S. Smith, USGS

Goat Gully: ravine, extends N $0.6 \mathrm{mi}$. to Cameron Creek, $1 \mathrm{mi}$. W of terminus of Corbin Glacier and $5 \mathrm{mi}$. E of Valdez, Chugach Mts. ; $61^{\circ} 05^{\prime} 20^{\prime \prime} \mathrm{N}, 146^{\circ} 04^{\prime} 30^{\prime \prime} \mathrm{W}$; (map $68)$.

Local name published in the 1950's by USGS.

Goat Harbor: bay, 1 mi. across, enters Puget Bay on SE coast of Kenai Penin., 34 mi. SE of Seward, Chugach Mts.; $60^{\circ} 00^{\prime} \mathrm{N}, 148^{\circ} 29^{\prime}$ W; BGN 1929; (map 49).

So named by the 1928 USC\&GS field party "because of the numerous wild goats found in this vicinity."

Goat Hill: hill, $200 \mathrm{ft}$., $0.6 \mathrm{mi}$. NW of Bukhti Point, south-central Kiska I., Aleutian Is.; $51^{\circ} 55^{\prime} 10^{\prime \prime} \mathrm{N}, 177^{\circ} 27^{\prime} 52^{\prime \prime} \mathrm{E}$; (map 14).

An arbitrary name beginning with " $G$ " to correspond to "G" grid used by the U.S. Army for tactical purposes during World War II; published on a 1953 AMS map.

Goat Hollow: valley, $1 \mathrm{mi}$. long, on tributary of Chilkat River, $4.2 \mathrm{mi}$. N of Wells and $22 \mathrm{mi}$. W of Skagway, Coast Mts.; $59^{\circ} 27^{\prime} 50^{\prime \prime} \mathrm{N}$, $135^{\circ} 59^{\prime} 00^{\prime \prime} \mathrm{W}$; (map 45).

Local name published in 1954 by USGS. Goat Island: island, $4 \mathrm{mi}$. long, between North and South Passes, NW of Sukkwan I., Alex. Arch.; $55^{\circ} 12^{\prime} \mathrm{N}, 132^{\circ} 55^{\prime} \mathrm{W}$; BGN 1916; (map 4). Var. Goats Island, Goat's Island. Named in 1916 by USC\&GS.

Goat Lake: lake, $0.3 \mathrm{mi}$. across, on $\mathrm{N}$ central Baranof I., $15.5 \mathrm{mi}$. NE of Sitka, Alex. Arch.; $57^{\circ} 13^{\prime} 45^{\prime \prime} \mathrm{N}, 135^{\circ} 04^{\prime} 20^{\prime \prime} \mathrm{W}$; (map 9).

Local name reported in 1951 by USGS.

Goat Lake: lake, $1.2 \mathrm{mi}$. long, $1.6 \mathrm{mi}$. SW of Glacier and $7 \mathrm{mi}$. NE of Skagway, Coast Mts.; $59^{\circ} 31^{\prime} 30^{\prime \prime} \mathrm{N}, 135^{\circ} 11^{\prime} 00^{\prime \prime} \mathrm{W}$; (map 45).

Local name published in 1951 by USGS.

Goat Lake: lake, see Big Goat Lake.

Goat Mountain: mountain, 4,370 ft., $3 \mathrm{mi}$. S of Miles Lake, $30 \mathrm{mi}$. $\mathrm{N}$ of Katalla, Chugach Mts.; 60 $37^{\prime} \mathrm{N}, 144^{\circ} 39^{\prime} \mathrm{W}$; (map 64).

Named in 1910 by a survey crew working on the Copper River and Northwestern RR.

Goat Mountain: mountain, 6,400 ft., at head of Eagle Glacier, $30 \mathrm{mi}$. SE of Anchorage, Chugach Mts.; $61^{\circ} 03^{\prime} \mathrm{N}, 149^{\circ} 03^{\prime} \mathrm{W}$; BGN 1932; (map 69).

Local name reported in 1932 by W. G. Carson and C. F. Park, USGS.

Goat Mouth Inlet: $b a y$, extends $\mathrm{N} 1.8 \mathrm{mi}$. off Tlevak Strait, on S coast of Goat I., Alex. Arch.; $55^{\circ} 10^{\prime} 15^{\prime \prime} \mathrm{N}, 132^{\circ} 54^{\prime} 30^{\prime \prime} \mathrm{W}$; (map 4).

Local name published in 1965 by USC\&GS.

Goat Ridge: ridge, extends from Hole-in-theWall Glacier $7 \mathrm{mi}$. NW to Taku Glacier, 3 
mi. SW of Hodgkins Mtn. and $22 \mathrm{mi}$. NE of Juneau, Coast Mts.; $58^{\circ} 30^{\prime} \mathrm{N}, 134^{\circ} 03^{\prime} \mathrm{W}$; (map 11).

Local name published in 1960 by USGS.

Goat Ridge: ridge, $1.5 \mathrm{mi}$. long, $\mathrm{N}$ of head of Charpentier Glacier, in Glacier Bay National Monument, $58 \mathrm{mi}$. NW of Hoonah, St. Elias Mts.; $58^{\circ} 41^{\prime} \mathrm{N}, 136^{\circ} 37^{\prime} \mathrm{W}$; (map 10).

Local name reported in 1951 by USGS.

Goats Island: island, see Goat Island.

Gobbler Creek: stream, see Gobler Creek.

Gobler Creek: stream, flows $\mathrm{N} 1 \mathrm{mi}$. to Livingston Creek, $25 \mathrm{mi}$. NW of Nome, Seward Penin. High.; $64^{\circ} 47^{\prime} \mathrm{N}, 166^{\circ} 01^{\prime} \mathrm{W}$; (map 94). Var. Gobbler Creek.

Prospectors' name reported in 1900 by E. C. Barnard (in Brooks, 1901, pl. 17), USGS.

Goblet Creek: stream, flows NW $14 \mathrm{mi}$, to Figure Eight Creek $3.5 \mathrm{mi}$. E of its junc. with Dog Salmon River, on Alaska Penin. $24 \mathrm{mi}$. SE of Ugashik, Aleutian Ra.; 57 $18^{\prime} 50^{\prime \prime} \mathrm{N}, 156^{\circ}$ 55'15" W; (map 36).

Descriptive name given in 1923 by R. H Sargent, USGS, as "suggested by the gobletlike shape of Goblet and Figure Eight Creeks on a map."

Goblet Creek: stream, heads at $62^{\circ} 43^{\prime} \mathrm{N}$, $160^{\circ} 29^{\prime} \mathrm{W}$, flows $\mathrm{N}, \mathrm{W}$ and $\mathrm{S} 20 \mathrm{mi}$. to Anvik River, $12 \mathrm{mi}$. W of Anvik and $44 \mathrm{mi}$. NW of Holy Cross, Nulato Hills; $62^{\circ} 43^{\prime} \mathrm{N}, 160^{\circ}$ $34^{\prime} \mathrm{W}$; (map 78). Var. Long Portage Creek.

Prospectors' name reported in 1916 by G. L. Harrington (in Brooks, 1918, pl. 16), USGS.

Goddard: locality, on NE side of Hot Springs Bay, on W coast of Baranof I., $15 \mathrm{mi}$. S of Sitka, Alex. Arch.; 56 $50^{\prime} 05^{\prime \prime} \mathrm{N}, 135^{\circ} 22^{\prime} 20^{\prime \prime}$ W; (map 5). Var. Hot Springs, Klyuchi, Tseplitel Teplyye Klyuchi, Teplyya Tseplitel Yuchya Klyuchi, Sanitarium, Sitka Hot Springs.

This is the site of a health resort locally named about 1924 for Dr. F. L. Goddard, a local businessman. It was probably established about 1800 by the Russians who called it "Teplyya Tseplitel Yuchya Klyuchi," meaning "sheltered curative hot springs" (Sarichev, 1826, map 19). They had a hospital here in 1841. In 1908 a post office named "Sanitarium" was established here, but the name was changed to Goddard in 1924; discontinued in 1944 (Ricks, 1965, p. 23, 56).

Goddard Island: island, see Fragrant Island.

Godfrey Fork of Charley River: stream, see Copper Creek.

Godwin Glacier: glacier, on Kenai Penin., trends SW 6 mi. to its terminus, $5.5 \mathrm{mi}$. E of Seward, Chugach Mts.; $60^{\circ} 06^{\prime} 30^{\prime \prime} \mathrm{N}, 149^{\circ} 17^{\prime} 00^{\prime \prime} \mathrm{W}$; $B G N$ 1910; ( $\operatorname{map} 63$ ).

Named in 1910 by U. S. Grant, USGS. The glacier derived its name from the stream that drains it, which was formerly named "Godwin River."

Godwin River: stream, see Fourth of July Creek. Goff Creek: stream, flows SW $7 \mathrm{mi}$. to Hutlinana Creek, $62 \mathrm{mi}$. E of Tanana, Yukon-Tanana High.; $65^{\circ} 12^{\prime} \mathrm{N}, 150^{\circ} 00^{\prime} \mathrm{W}$; (map 106).
Prospectors' name reported in 1909 by USGS.

Gohn Creek: stream, flows NW $13.8 \mathrm{mi}$. to Yukon River, $51 \mathrm{mi}$. E of Nulato, KilbuckKuskokwim Mts.; $64^{\circ} 39^{\prime}$ N, $156^{\circ} 26^{\prime} \mathrm{W}$; (map 97).

Local name reported in 1954 by USGS.

Gokacheen River: stream, see Gokachin Creek.

Gokachin Creek: stream, on Revillagigedo I., flows SW, through Gokachin Lakes, $8.5 \mathrm{mi}$. to Thorne Arm, Alex. Arch.; $55^{\circ} 22^{\prime} 05^{\prime \prime} \mathrm{N}$, $131^{\circ} 11^{\prime} 20^{\prime \prime} \mathrm{W}$; (map 3). Var. Gokacheen River, Gokatchin Creek.

Tlingit Indian name published as "Gokacheen River" by Brooks (1902b, p. 64), USGS.

Gokachin Lakes: lakes, on Revillagigedo I., extend $4 \mathrm{mi}$. in course of Gokachin Creek, $3 \mathrm{mi}$. NE of Thorne Arm, Alex. Arch.; 55 $24^{\prime} 45^{\prime \prime}$ N, $131^{\circ} 07^{\prime} 40^{\prime \prime} \mathrm{W}$; (map 3). Var. Gokatchin Lakes.

Local name published by F. E. Wright and C. W. Wright (1908, fig. 12), USGS.

Gokatchin Creek: stream, see Gokachin Creek. Gokatchin Lakes: lakes, see Gokachin Lakes.

Golconda Creek: stream, flows SW $7 \mathrm{mi}$. to North Fork Bremner River, $4.5 \mathrm{mi}$. NW of 1950 terminus of Bremner Glacier and $78 \mathrm{mi}$. NE of Cordova, Chugach Mts.; $60^{\circ} 58^{\prime} \mathrm{N}$, $143^{\circ} 04^{\prime} \mathrm{W}$; (map 65).

Local name published by F. H. Moffit (1920, pl. 5), USGS.

Golconde Creek: stream, flows $\mathrm{S}$ to Boulder Greek which flows to Snake River, about 24 mi. NW of Nome, Seward Penin. High.; (map 94).

Prospectors' name reported on the 1900 "Map of Nome Peninsula" by J. M. Davidson and B. D. Blakeslee; this feature has not been positively identified.

Gold and Galligan Lagoon: water passage, $2 \mathrm{mi}$. long, between Barnes and Sweetwater Lakes, NE coast of Prince of Wales I., Alex. Arch. $55^{\circ} 59^{\prime} 20^{\prime \prime} \mathrm{N}, 132^{\circ} 58^{\prime} 15^{\prime \prime} \mathrm{W}$; BGN 1915; $(\operatorname{map} 4)$.

Name recorded in 1914 by E. L. Jones, USBF.

Gold Bar Creek: stream, flows N $3.7 \mathrm{mi}$. to Liberty Creek, $18 \mathrm{mi}$. SE of Chicken and 60 mi. NE of Tok, Yukon-Tanana High. ; 6353'$33^{\prime \prime} \mathrm{N}, 141^{\circ} 31^{\prime} 10^{\prime \prime} \mathrm{W}$; (map 85).

Local name reported in 1956 by USGS.

Gold Basin Creek: stream, flows SE $2.6 \mathrm{mi}$. to Killarney Creek $0.4 \mathrm{mi}$. N of that stream's junc. with Baker Creek, 39 mi. ESE of Tanana, Yukon-Tanana High.; $65^{\circ} 06^{\prime} 25^{\prime \prime} \mathrm{N}, 150^{\circ} 43^{\prime}$ 45" W; (map 106).

Prospectors' name reported in 1931 by J. B. Mertie, USGS.

Gold Bottom Creek: stream, flows NE $7 \mathrm{mi}$. to Silver Bow Creek, $56 \mathrm{mi}$. SW of Eagle, YukonTanana High.; $64^{\circ} 17^{\prime} 10^{\prime \prime} \mathrm{N}, 143^{\circ} 58^{\prime} 00^{\prime \prime} \mathrm{W}$; (map 102).

Prospectors' name shown on an 1898 manuscript map by C. A. Woodruff, Fort Cudahy, Canada.

Gold Bottom Creek: stream, see Grouse Greek.
Goldbottom Creek: stream, flows $\mathrm{E}$ to Agiapuk River, about $22 \mathrm{mi}$. ENE, of Teller, Seward Penin. High.; (map 111)

Prospectors' name shown on a map of Cape Nome gold fields by David Fox, Jr., dated 1901. This feature cannot be precisely identified on current maps.

Goldbottom Creek: stream, flows NE $1.7 \mathrm{mi}$, to Little Creek, $4.4 \mathrm{mi}$. SE of Ophir and $28 \mathrm{mi}$. NW of McGrath, Kilbuck-Kuskokwim Mts.; $63^{\circ} 05^{\prime} \mathrm{N}, 156^{\circ} 27^{\prime} \mathrm{W}$; (map 90).

Prospectors' name reported in 1912 by A. G. Maddren and H. M. Eakin, USGS.

Goldbottom Creek: stream, flows SE $3 \mathrm{mi}$. to Skookum River which flows to Klokerblok River, $17 \mathrm{mi}$. NE of Solomon, Seward Penin. High.; $64^{\circ} 41^{\prime} \mathrm{N}, 163^{\circ} 56^{\prime} \mathrm{W}$; (map 95).

Prospectors' name reported in 1900 by E. C. Barnard (in Brooks, 1901, pl. 17), USGS.

Goldbottom Creek: stream, flows SE $5.5 \mathrm{mi}$, joins North Fork Snake River to form Snake River, $13 \mathrm{mi}$. N of Nome, Seward Penin. High. ; $64^{\circ} 42^{\prime} \mathrm{N}, 165^{\circ} 24^{\prime} \mathrm{W}$; (map 94). Var. East Fork Snake River, North Fork Snake River.

Prospectors' name reported in 1900 by E. C. Barnard (in Brooks, 1901, pl. 17), USGS. Barnard showed North Fork Snake River for this stream and applied Gold Bottom Creek to what is now Grouse Creek. Arthur Gibson's 1908 "Map of Seward Peninsula" applied the names as defined above. This appears to be the stream labled "East Fork [Snake River]" by Schrader (1900c, p. 16), USGS.

Goldbottom Creek: stream, flows NW $1.4 \mathrm{mi}$. to Coal Creek which flows to Solomon River, 14 mi. NE of Solomon, Seward Penin. High.; $64^{\circ} 44^{\prime} \mathrm{N}, 164^{\circ} 12^{\prime} \mathrm{W}$; (map 95)

Prospectors' name reported in a 1902 prospectors' manuscript map.

Goldbottom Creek: stream, flows SW $7 \mathrm{mi}$. to Niukluk River, $8 \mathrm{mi}$. NW of Council and 30 mi. NE of Solomon, Seward Penin. High.; $64^{\circ} 56^{\prime} \mathrm{N}, 163^{\circ} 56^{\prime} \mathrm{W}$; (map 95).

Prospectors' name reported in 1899 by Schrader and Brooks (1900, map 3), USGS. Goldbug Creek: stream, flows NE $7.6 \mathrm{mi}$. to Kugruk River, $26 \mathrm{mi}$. NE of Imuruk Lake, Seward Penin. High.; $65^{\circ} 50^{\prime} \mathrm{N}, 162^{\circ} 27^{\prime} \mathrm{W}$; BGN 1966; (map 110).

Prospectors' name reported in 1908 by F. F. Henshaw (in Brooks and others, 1909, fig. 21), USGS.

Goldbug Creek: stream, flows SW $10 \mathrm{mi}$. to North Fork Chandalar River, 0.7 mi. upstream from mouth of Horse Greek and $13 \mathrm{mi}$. SE of Chandalar, Brooks Ra.; $67^{\circ} 21^{\prime} 15^{\prime \prime}$ N, $148^{\circ}$ 49'00" W; (map 123).

Prospectors' name obtained in 1909 by A. G. Maddren (in Brooks and others, 1910, pl. 7), USGS.

Gold Creek: locality, mile 263.2 on The Alaska RR., 34 mi. NE of Talkeetna, Talkeetna Mts., $62^{\circ} 45^{\prime} 45^{\prime \prime} \mathrm{N}, 149^{\circ} 41^{\prime} 10^{\prime \prime} \mathrm{W}$; (map 82). Var. Susitna River Station.

This is the site of a flag stop on The Alaska Railroad which derives its name from 
nearby Gold Creek. This name was published in 1922 on the official timetable of The Alaska Railroad. It was called "Susitna River Station" in 1921 by the Chamber of Commerce of Seattle, Wash.

Gold Creek: ravine, see Gold Gulch.

Gold Creek: stream, heads in unnamed glacicr $\mathrm{W}$ of Clark Peak and flows $5.5 \mathrm{mi}$. W to Gastineau Channel at Juneau, Coast Mts.; $58^{\circ} 18^{\prime} \mathrm{N}, 134^{\circ} 25^{\prime} \mathrm{W}$; (map 11 ).

Name first appears in mining records in 1880 and was probably named by Richard Harris and Joe Juneau in 1880 when they found gold in the creek (DeArmond, 1951, p. 22). Name was published in the 1883 Coast Pilot (p. 172).

Gold Creek: stream, $13 \mathrm{mi}$. long, flows through Gold Lake to Kisaralik River, $83 \mathrm{mi}$. SE of Bethel, Kilbuck-Kuskokwim Mts.; $60^{\circ} 20^{\prime} \mathrm{N}$, $159^{\circ} 31^{\prime} \mathrm{W}$; (map 59).

Local name reported in 1955 by J. M. Hoare, USGS.

Gold Creek: stream, heads in a glacier, flows $\mathrm{S} 4 \mathrm{mi}$. to Port Valdez, $0.7 \mathrm{mi}$. NE of Camp Bowie, 7 mi. W of Valdez, Chugach Mts.; $61^{\circ} 08^{\prime} 00^{\prime \prime} \mathrm{N}, 146^{\circ} 28^{\prime} 15^{\prime \prime} \mathrm{W}$; (map 68).

Local name published in 1950 by USGS.

Gold Creek: stream, flows N. 5 mi. to Klu River $5.6 \mathrm{mi}$. SW of junc. with Chakina River, 23 mi. SW of McCarthy, Chugach Mits.; $61^{\circ}$ $10^{\prime} 30^{\prime \prime} \mathrm{N}, 143^{\circ} 19^{\prime} 00^{\prime \prime} \mathrm{W}$; (map 67).

Local name reported in 1908 by $D$. C. Witherspoon, USGS.

Gold Creek: stream, flows N $8 \mathrm{mi}$. to Oshetna River, $24 \mathrm{mi}$. SW of its junc. with Susitna River, Talkeetna Mts.; $62^{\circ} 19^{\prime} 45^{\prime \prime} \mathrm{N}, 147^{\circ}$ $41^{\prime 2} 25^{\prime \prime} \mathrm{W}$; (map 82).

Local name reported by F. H. Moffit (in Brooks and others, 1915, fig. 3), USGS.

Gold Creek: stream, heads in Dutch Hills, flows S $2.3 \mathrm{mi}$. to Gache Creek, $29 \mathrm{mi}$. NW of Talkeetna, Alaska Ra.; $62^{\circ} 31^{\prime} 35^{\prime \prime}$ N, $150^{\circ}$ 54'30" W; (map 81).

Prospectors' name reported in 1906 by R. W. Porter, USGS.

Gold Creek: stream, heads in lake, flows W 6.5 mi. to Susitna River, $34 \mathrm{mi}$. NE of Talkeetna, Talkeetna Mts. ; $62^{\circ} 46^{\prime} 05^{\prime \prime} \mathrm{N}, 149^{\circ} 41^{\prime} 20^{\prime \prime} \mathrm{W}$; (map 82).

Local name recorded in 1915 on a blueprint of The Alaska RR.

Gold Creek: stream, flows SW $9 \mathrm{mi}$. to Butte Creek, $62 \mathrm{mi}$. SE of Healy, Talkeetna Mts.; $63^{\circ} 06^{\prime} \mathrm{N}, 147^{\circ} 55^{\prime} \mathrm{W}$; (map 87).

Local name obtained in 1913 by J. W. Bagley, USGS; published by Moffit (1915, pl. 1).

Gold Creek: stream, flows E $2 \mathrm{mi}$. to Chisna River $4 \mathrm{mi}$. $\mathbf{N}$ of its junc. with Chistochina River, $23 \mathrm{mi}$. NE of Paxson, Alaska Ra.; $63^{\circ} 06^{\prime} 20^{\prime \prime} \mathrm{N}, 144^{\circ} 48^{\prime} 00^{\prime \prime} \mathrm{W}$; (map 86).

Prospectors' name reported in 1900 by T. G. Gerdine (in Mendenhall and Schrader, 1903, pl. 9), USGS.

Gold Creek: stream, flows SE $17 \mathrm{mi}$. to Mosquito Fork, $60 \mathrm{mi}$. SW of Eagle, Yukon-Tanana High.; $64^{\circ} 06^{\prime} 15^{\prime \prime} \mathrm{N}, 142^{\circ} 20^{\prime} 10^{\prime \prime} \mathrm{W}$; (map 102).
Named by prospectors and shown on an 1898 manuscript map by E. F. Ball.

Gold Creek: stream, flows NE $4.7 \mathrm{mi}$. to Quartz Creek, $11 \mathrm{mi}$. SE of Long and $18 \mathrm{mi}$. SW of Monzonite Hills, Kilbuck-Kuskokwim Mts.; $64^{\circ} 18^{\prime} 45^{\prime \prime} \mathrm{N}, 155^{\circ} 11^{\prime} 40^{\prime \prime} \mathrm{W}$; (map 98).

Prospectors' name reported in 1913 by Eakin (1914, pl. 3), USGS.

Gold Creek: stream, flows SW $1.1 \mathrm{mi}$. to Snake River, $6 \mathrm{mi}$. NW of Nome, Seward Penin. High.; $64^{\circ} 35^{\prime} 10^{\prime \prime} \mathrm{N}, 1^{\circ} 5^{\circ} 28^{\prime} 00^{\prime \prime} \mathrm{W}$; (map 94).

Prospectors' name reported on the 1903 Campion Mining and Trading Co. map by George M. Ashford.

Gold Creek: stream, flows SW $8 \mathrm{mi}$. to Butte Greek, $30 \mathrm{mi}$. SW of Eagle, Yukon-Tanana High.; $64^{\circ} 40^{\prime} \mathrm{N}, 142^{\circ} 06^{\prime} \mathrm{W}$; (map 102).

Named by prospectors and shown on an 1898 manuscript map by G. A. Woodruff. Gold Creek: stream, flows E $0.4 \mathrm{mi}$. to Nome -River, $13 \mathrm{mi}$. N of Nome, Seward Penin. High.; $64^{\circ} 41^{\prime} 30^{\prime \prime} \mathrm{N}, 165^{\circ} 19^{\prime} 10^{\prime \prime} \mathrm{W}$; (map 94).

Prospectors' name published on the 1900 "Map of Nome Peninsula" by J. M. Davidson and B. D. Blakeslee.

Gold Creek: stream, flows NW $1.5 \mathrm{mi}$. to California Creek which flows to Bonanza River, $11 \mathrm{mi}$. NW of Solomon, Seward Penin. High.; $64^{\circ} 42^{\prime} \mathrm{N}, 164^{\circ} 36^{\prime} \mathrm{W}$; (map 95).

Prospectors' name shown on Arthur Gibson's "Map of Cape Nome Precinct" dated 1904.

Gold Creek: stream, flows SE $13 \mathrm{mi}$. to North Fork Salcha River, $48 \mathrm{mi}$. NE of Big Delta, Yukon-Tanana High.; $64^{\circ} 47^{\prime} 45^{\prime \prime} \mathrm{N}, 145^{\circ}$ 20'05" W; (map 101). Var. Gold Run.

Named by prospectors and reported in 1905 by D. C. Witherspoon (in Prindle, 1913a, pl. 1), USGS.

Gold Creek: stream, flows N 2 mi. to Seventymile River, $20 \mathrm{mi}$. NW of Eagle, YukonTanana High.; $64^{\circ} 55^{\prime} 45^{\prime \prime} \mathrm{N}, 141^{\circ} 48^{\prime} 50^{\prime \prime} \mathrm{W}$; (map 102)

Local name published in 1956 by USGS.

Gold Creek: stream, flows SE $2 \mathrm{mi}$. to Ophir Creek, $38 \mathrm{mi}$. NE of Solomon, Seward Penin. High.; $65^{\circ} 00^{\prime} \mathrm{N}, 163^{\circ} 40^{\prime} \mathrm{W}$; (map 95). Var. Guy Creek.

Prospectors' name published in 1956 by USGS. Reported as "Guy" on a map of Cape Nome gold fields by David Fox, Jr., dated 1901.

Gold Creek: stream, flows NW $1.4 \mathrm{mi}$. to Bluestone River, $12 \mathrm{mi}$. SE of Teller, Seward Penin. High.; $65^{\circ} 08^{\prime} \mathrm{N}, 166^{\circ} 06^{\prime} \mathrm{W}$; (map 111).

Local name reported in 1900 by $E$. C. Barnard (in Brooks, 1901, pl. 17), USGS.

Gold Creek: stream, flows E $3 \mathrm{mi}$. to South Fork Grouse Creek, in Mint River basin, $41 \mathrm{mi}$. NW of Teller, Seward Penin. High.; $65^{\circ} 36^{\prime}$ $\mathrm{N}, 167^{\circ} 30^{\prime} \mathrm{W}$; (map 111 ).

Prospectors' name reported in 1903 by Collier (1904, pl. 2), USGS.

Gold Creek: stream, flows N $3 \mathrm{mi}$. then W $5 \mathrm{mi}$. to Middle Fork Koyukuk River, $6 \mathrm{mi}$. NW of Poss Mtn. and $37 \mathrm{mi}$. W of Chandalar, Brooks Ra.; 67 $30^{\prime} 45^{\prime \prime}$ N, $149^{\circ} 51^{\prime} 30^{\prime \prime} \mathrm{W}$; (map 123).

Prospectors' name reported in 1899 by Schrader (1900b, pl. 60), USGS.

Gold Creek: stream, flows SW 2 mi. to head of Dry Creek, $4 \mathrm{mi}$. NE of Nome, Seward Penin. High.

Prospectors' name published in 1900 by Schrader (1900c, p. 16), USGS. Subsequent maps show a different drainage pattern at the head of Dry Creek.

Gold Creek: stream, see Jorosa Creek.

Gold Creek Valley: valley, of Gold Creek, just W of Juneau, Coast Mts. ; $58^{\circ} 18^{\prime} 30^{\prime \prime} \mathrm{N}, 134^{\circ}$ $24^{\prime} 45^{\prime \prime} \mathrm{W}$; (map 11$)$.

Local name mentioned by DeArmond (1957, p. 10).

Gold Dust Creek: stream, flows NW $6 \mathrm{mi}$. to Birch Creek, $50 \mathrm{mi}$. SW of Circle, YukonTanana High.; $65^{\circ} 26^{\prime} \mathrm{N}, 145^{\circ} 32^{\prime} \mathrm{W}$; (map 104). Var. Golddust Creek.

Named by prospectors; reported in 1896 by USGS (Spurr, 1898, p. 347).

Golden: locality, on E side of Port Wells, $28 \mathrm{mi}$. NE of Whittier, Chugach Mts.; $60^{\circ} 58^{\prime} 10^{\prime \prime}$ N, 147 $59^{\prime} 10^{\prime \prime} \mathrm{W}$; (map 63).

Local name established here as a post office in 1904 and discontinued in 1916 (Ricks, 1965, p. 23). The village is now abandoned. Golden City: locality, at junc. of Twin and Pedro Creeks, $14 \mathrm{mi}$. NE of Fairbanks, Yukon-Tanana High.; $65^{\circ} 00^{\prime} 50^{\prime \prime} \mathrm{N}, 147^{\circ}$. 28'45" W; (map 105).

Name applied by prospectors to a former mining camp; reported in 1903 by T. G. Gerdine (Prindle, 1905, pl. 13), USGS.

Golden Creek: stream, $1.3 \mathrm{mi}$. long, flows $\mathrm{SE}$ to Vega Bay, Kiska I., Aleutian Is.; $51^{\circ} 55^{\prime} 20^{\prime \prime}$ N, $177^{\circ} 22^{\prime} 22^{\prime \prime} \mathrm{E}$; (map 14).

An arbitrary name beginning with " $G$ " to correspond to "G" grid used by the U.S. Army for tactical purposes during World War II; published on a 1953 AMS map.

Golden Creek: stream, flows SW $11 \mathrm{mi}$., joins Wilson Creek to form Illinois Creek, $17 \mathrm{mi}$. NE of Birches, Kokrines-Hodzana High.; $65^{\circ} 17^{\prime} 10^{\prime \prime} \mathrm{N}, 153^{\circ} 07^{\prime} 00^{\prime \prime} \mathrm{W}$; (map 107). Var. Cowen Creek.

Prospectors' name reported in 1908 by Maddren (1910, pl. 5), USGS.

Golden Creek: stream, see Victoria Creek.

Goldeneye Lake: lake, $650 \mathrm{ft}$. long, on Kenai Penin., $4.7 \mathrm{mi}$. E of mouth of Glacier Creek in Tustumena Lake and $41 \mathrm{mi}$. SE of Kenai, Chugach Mts. ; $60^{\circ} 06^{\prime} 55^{\prime \prime} \mathrm{N}, 150^{\circ} 29^{\prime} 00^{\prime \prime} \mathrm{W}$; (map 62).

Named about 1963 by officials of Kenai National Moose Range, probably for Barrow's Golden-eye (Clangula islandica), a duck which breeds and winters in southeastern Alaska (Pearson, 1944, pt. 1, p. 139).

Goldeneye Lake: lake, $4 \mathrm{mi}$. across, $\mathrm{N}$ of Kagalurpak Lake and $80 \mathrm{mi}$. NW of Bethel, YukonKuskokwim Delta; $60^{\circ} 59^{\prime} \mathrm{N}, 164^{\circ} 02^{\prime} \mathrm{W}$; (map 58). 
Named about 1964 for a species of duck by personnel of Clarence Rhode National Wildlife Range.

Golden Gate Creek: stream, heads in Kigluaik Mts., flows NE $5.4 \mathrm{mi}$. to Pilgrim River, 18 mi. SW of Mount Bendeleben and $57 \mathrm{mi}$. SW of Imuruk Lake, Seward Penin. High.; $65^{\circ} 04^{\prime} \mathrm{N}, 164^{\circ} 09^{\prime} \mathrm{W}$; (map 110).

Prospectors' name reported in 1900 by E. C. Barnard (in Brooks, 1901, pl. 17), USGS.

Goldengate Creek: stream, flows SW $2 \mathrm{mi}$. to Norton Sound, $11 \mathrm{mi}$. SE of Nome, Seward Penin. High.; $64^{\circ} 27^{\prime} \mathrm{N}, 165^{\circ} 04^{\prime} \mathrm{W}$; (map 94). Var. Golden Gulch.

Shown as "Golden Gulch" on a map of Cape Nome gold fields by David Fox, Jr., dated 1901.

Goldengate Creek: stream, flows NE $1.5 \mathrm{mi}$. to Eldorado River, $18 \mathrm{mi}$. NW of Solomon, Seward Penin. High.; $64^{\circ} 42^{\prime} \mathrm{N}, 164^{\circ} 57^{\prime} \mathrm{W}$; (map 95).

Prospectors' name reported on a map of Cape Nome gold fields by David Fox, Jr., dated 1901.

Golden Gate Falls: waterfall, $12 \mathrm{mi}$. SE of Spein Mtn., on Kisaralik River, $58 \mathrm{mi}$. SE of Bethel, Kilbuck-Kuskokwim Mts.; $60^{\circ} 30^{\prime} \mathrm{N}, 160^{\circ} 10^{\prime}$ W; (map 59).

Local name reported in 1955 by J. M. Hoare, USGS.

Golden Gulch: stream, see Goldengate Creek. Golden Horn: bay, extends NW $6 \mathrm{mi}$. from W end of Lake Beverly, $48 \mathrm{mi}$. NW of Dillingham, Kilbuck-Kuskokwim Mts.; $59^{\circ} 43^{\prime} \mathrm{N}$, $158^{\circ} 54^{\prime}$ W; BGN 1931; (map 52). Var. Golden Horn Bay, Kang-ek-tu-nok.

Local name reported in 1929 as "Golden Horn Bay" by U.S. Commissioner of Fisheries and as "Golden Horn" in 1931 by Gerald FitzGerald, USGS. The Eskimo name "Kangektunok" was recorded on a 1910 manuscript map by H. C. Fassett, USBF.

Golden Horn: peak, 7,285 ft., W of terminus of Frederika Glacier, $28 \mathrm{mi}$. NE of McCarthy, Wrangell Mts.; $61^{\circ} 41^{\prime} 40^{\prime \prime} \mathrm{N}, 142^{\circ} 15^{\prime} 20^{\prime \prime} \mathrm{W}$; (map 167).

Local name published by USGS in 1954.

Golden Horn Bay: bay, see Golden Horn.

Golden Landing: site, on E shore of Port Wells, $28 \mathrm{mi}$. NE of Whittier, Chugach Mts.; $60^{\circ} 58^{\prime} 10^{\prime \prime} \mathrm{N}, 147^{\circ} 59^{\prime} 10^{\prime \prime} \mathrm{W}$; (map 63).

Local name for a landing at Golden reported in Polk's Gazetteer of 1916.

Golden Peak: mountain, in Bendeleben Mts., E of Mount Bendeleben, Seward Penin. High.; (map 110).

Local name published in 1900 by USC\&GS on Chart 9380. This feature has not been identified on subsequent maps.

Gold Fork: stream, flows $2 \mathrm{mi}$. NE to join Salmon Fork to form Carlson Creek, $4.2 \mathrm{mi}$. NW of Sunny Cove on Taku Inlet and $7 \mathrm{mi}$. $\mathrm{NE}$ of Juneau, Coast Mts.; $58^{\circ} 20^{\prime} 15^{\prime \prime} \mathrm{N}$, $134^{\circ} 14^{\prime} 00^{\prime \prime} \mathrm{W}$; (map 11).

Local name published in 1951 by USGS.

Gold Gulch: ravine, on Kenai Penin., trends ENE $4.5 \mathrm{mi}$. to Resurrection Creek, $5 \mathrm{mi}$. S of Hope, Chugach Mts.; 60'51'30' N, $149^{\circ} 38^{\prime} 00^{\prime \prime} \mathrm{W}$; (map 63).

Local prospectors' name; reported in 1904 by Moffit (1906, pl. 2), USGS.

Gold Gulch: ravine, trends W $0.7 \mathrm{mi}$. to Osborn Creek, $11 \mathrm{mi}$. NE of Nome, Seward Penin. High.; 64 $34^{\prime} 45^{\prime \prime} \mathrm{N}, 165^{\circ} 06^{\prime} 00^{\prime \prime} \mathrm{W}$; (map 94). Var. Gold Creek.

Reported as "Gold Creek" on the 1902 "Map of Nome and Snake River Country" by J. M. Davidson.

Gold Harbor: estuary, extends E $3.5 \mathrm{mi}$., on W coast of Dall I., $\mathrm{S}$ of Waterfall Bay, Alex. Arch.; $54^{\circ} 55^{\prime} \mathrm{N}, 133^{\circ} 05^{\prime} \mathrm{W}$; (map 1).

Local name published by USC\&GS in 1914

Gold Hill: hill, $200 \mathrm{ft}$., on E bank of Kichatna River, $50 \mathrm{mi}$. SW of Talkeetna, Alaska Ra.; $62^{\circ} 07^{\prime} 30^{\prime \prime} \mathrm{N}, 151^{\circ} 36^{\prime} 45^{\prime \prime} \mathrm{W}$; (map 81).

Local name reported in 1958 by USGS.

Gold Hill: hill, $750 \mathrm{ft}$., $6 \mathrm{mi}$. W of Fairbanks, Yukon-Tanana High.; $64^{\circ} 51^{\prime} \mathrm{N}, 147^{\circ} 57^{\prime} \mathrm{W}$ BGN 1939; (map 100).

Local name reported in 1939 by USGS.

Gold Hill: hill, 1,115 ft., $2 \mathrm{mi}$. SW of junc. of Gold Run and Right Fork Bluestone River, at head of Bluestone River, $19 \mathrm{mi}$. SE of Teller, Seward Penin. High.; $65^{\circ} 03^{\prime} \mathrm{N}, 166^{\circ} 16^{\prime} \mathrm{W}$; (map 111).

Prospectors' name reported on a map of Cape Nome goldfields by David Fox, Jr., dated 1901.

Gold Hill: hill, 1,959 ft., on $\mathrm{N}$ bank of Yukon River, extends E $9 \mathrm{mi}$. from Grant Creek to Tozitna River, $15 \mathrm{mi}$. WNW of Tanana, Kokrines-Hodzana High.; $65^{\circ} 15^{\prime} \mathrm{N}, 152^{\circ} 40^{\prime}$ W; (map 106)

Prospectors' name reported in 1899 by Lt. G. C. Cantwell, USRCS.

Gold Hill: mountain, 5,815 ft., in Nutzotin Mts., between Chathenda and Chavolda Creeks, $10 \mathrm{mi}$. NE of Euchre Mtn., Alaska Ra.; $62^{\circ} 06^{\prime} 30^{\prime \prime} \mathrm{N}, 141^{\circ} 54^{\prime} 00^{\prime \prime} \mathrm{W}$; (map 84).

Name used by prospectors and reported by S. R. Capps (in Brooks and others, 1916, p. 202), USGS.

Gold Hill: mountain, $5,150 \mathrm{ft}, 4 \mathrm{mi}$. $S$ of Nabesna, Wrangell Mts. ; $62^{\circ} 19^{\prime} \mathrm{N}, 143^{\circ} 00^{\prime \prime}$ W; BGN 1939; (map 84).

Name used by prospectors and reported in 1939 by P. S. Smith, USGS.

Gold Hill: mountain, $4,974 \mathrm{ft}$., $70 \mathrm{mi}$. SE of Healy, Alaska Ra.; $63^{\circ} 11^{\prime} 30^{\prime \prime} \mathrm{N}, 147^{\circ} 16^{\prime} 20^{\prime \prime}$ W; (map 87).

Local name obtained in 1951 by USGS.

Gold Hill Creek: stream, heads on Gold Hill, flows $\mathrm{S}$ and NW $8 \mathrm{mi}$. to Yukon River, 18 mi. W of Tanana, Kokrines-Hodzana High.; $65^{\circ} 13^{\prime} 30^{\prime \prime} \mathrm{N}, 152^{\circ} 43^{\prime} 00^{\prime \prime} \mathrm{W}$; (map 106).

Prospectors' name reported in 1906 by USGS

Gold Hill Gulch: ravine, trends $\mathrm{S} 1 \mathrm{mi}$. to Norton Sound about $1 \mathrm{mi}$. SE of mouth of Nome River and $4 \mathrm{mi}$. SE of Nome, Seward Penin. High.; $64^{\circ} 29^{\prime} \mathrm{N}, 165^{\circ} 17^{\prime} \mathrm{W}$; (map 94).

Prospectors' name shown on the 1904 "Map of Cape Nome Precinct" by Arthur Gibson. This feature cannot be precisely identified on current maps.
Goldie, Mount: mountain, 6,315 ft., between Kanikula and Tokositna Glaciers, $40 \mathrm{mi}$. NW of Talkeetna, Alaska Ra.; $62^{\circ} 44^{\prime} 50^{\prime \prime} \mathrm{N}, 150^{\circ}$ $57^{\prime} 00^{\prime \prime} \mathrm{W}$; (map 81).

Local name reported in 1958 by USGS.

Gold Island: island, $0.1 \mathrm{mi}$. across, tied to Japonski I., in Sitka Sound, $1.5 \mathrm{mi}$. SW of Sitka, Alex. Arch.; 57 $02^{\prime} 50^{\prime \prime}$ N, $135^{\circ} 22^{\prime} 40^{\prime \prime}$ W; (map 9).

Named in 1880 by U.S. naval officers; published by USC\&GS in 1883 Coast Pilot (p. 142).

Gold King Creek: stream, flows N $29 \mathrm{mi}$. to Bonnifield Creek, $37 \mathrm{mi}$. SW of Fairbanks, Tanana Low.; $64^{\circ} 20^{\prime} 25^{\prime \prime} \mathrm{N}, 148^{\circ} 01^{\prime} 45^{\prime \prime} \mathrm{W}$; (map 100).

Named by prospectors; reported in 1906 by L. M. Prindle (in Brooks and others, 1907, pl. 4), USGS.

Gold Lake: lake, $2 \mathrm{mi}$. long, in Crooked Mts., $10.5 \mathrm{mi}$. W of Chikuminuk Lake and $87 \mathrm{mi}$. SE of Bethel, Kilbuck-Kuskokwim Mts.; $60^{\circ}$. $13^{\prime} \mathrm{N}, 159^{\circ} 28^{\prime} \mathrm{W}$; (map 59).

Local name reported in 1955 by J. M. Hoare, USGS.

Goldmoon Creek: stream, flows SW $1 \mathrm{mi}$. to Quartz Creek, which flows to Goose Creek, in Casadepaga River basin, $23 \mathrm{mi}$. N of Solomon, Seward Penin. High.; 64 $54^{\prime} \mathrm{N}, 164^{\circ} 18^{\prime} \mathrm{W}$; (map 95).

Prospectors' name reported in 1907 by USGS geologists (Smith, P. S., 1910, pl. 4). Gold Mountain: mountain, 2,032 ft., on $\mathbf{E}$ coast of Cleveland Penin., W of Helm Bay, Alex. Arch.; 55 $37^{\prime} \mathrm{N}, 131^{\circ} 59^{\prime} \mathrm{W}$; (map 3).

Local name reported in 1949 by USGS.

Gold Mountain: mountain, 2,845 ft., at head of Hudson and Sunset Creeks, $7 \mathrm{mi}$. NW of Birches, Kokrines-Hodzana High.; $65^{\circ} 12^{\prime} \mathrm{N}$, $153^{\circ} 44^{\prime} \mathrm{W}$; (map 107). Var. Nuhkahllanny.

Local name reported in 1885 by Lt. Allen (1887, map), USA. According to USC\&GS in 1898 the Indian name was "Nuhkahllanny" [Nakalani] meaning "gold."

Gold Mountain: mountain, see Juneau, Mount. Gold Mountain : peak, see Roberts, Mount.

Goldpan Creek: stream, flows SW $3 \mathrm{mi}$. to Minook Creek, 11 mi. S of Rampart, YukonTanana High.; $65^{\circ} 21^{\prime} \mathrm{N}, 150^{\circ} 08^{\prime} \mathrm{W}$; (map 106).

Prospectors' name reported in 1931 by $\mathrm{J}$. B. Mertie, USGS.

Goldpan Gulch: ravine, trends NW $1.5 \mathrm{mi}$. to Snake River, $4 \mathrm{mi}$. NW of Nome, Seward Penin. High.; $64^{\circ} 33^{\prime} 15^{\prime \prime} \mathrm{N}, 165^{\circ} 30^{\prime} 40^{\prime \prime} \mathrm{W}$; (map 94).

Prospectors' name reported on the 1903 Campion Mining and Trading Co. map by George M. Ashford.

Goldpan Peak: mountain, 6,500 ft., $2.5 \mathrm{mi}$. NE of Merrill Pass and $75 \mathrm{mi}$. NW of Tyonek, Alaska Ra.; $61^{\circ} 12^{\prime} 30^{\prime \prime} \mathrm{N}, 153^{\circ} 23^{\prime} 20^{\prime \prime} \mathrm{W}$; (map 71).

Name applied in 1956 by Orth; the name was originally applied to an unidentifiable peak in the area on a 1917 manuscript map done by a prospector. 
Gold Ridge: ridge, extends from West Summit $1 \mathrm{mi}$. S to Gold Pass, $7 \mathrm{mi}$. E of Juneau, Coast Mts.; $58^{\circ} 19^{\prime} \mathrm{N}, 134^{\circ} 18^{\prime} \mathrm{W}$; (map 11).

Local name reported in 1965 by D. A. Brew and A. B. Ford, USGS

Gold Run : locality, along Gold Run which flows to Bluestone River, about $12 \mathrm{mi}$. SE of Teller, Seward Penin. High.; (map 111).

Site of a mining camp listed in the 1915-16 Polk's Gazetteer. It cannot be identified on current maps.

Gold Run: stream, flows N $2.2 \mathrm{mi}$. to Holokuk River 9.2 mi. SE of its junc. with Kuskokwim River, $37 \mathrm{mi}$. SE of Aniak and $10 \mathrm{mi}$. SE of Little Mountain Village, Kilbuck-Kuskokwim Mts.; $61^{\circ} 25^{\prime} 30^{\prime \prime} \mathrm{N}, 158^{\circ} 27^{\prime} 00^{\prime \prime} \mathrm{W}_{\text {; (map }}$ 72).

Local name published by USGS (Cady and others, 1955, pl. 1).

Gold Run: stream, flows NE $4 \mathrm{mi}$. to Innoko River, $0.9 \mathrm{mi}$. NW of Ophir and $33 \mathrm{mi}$. NW $09^{\prime} \mathrm{N}, 156^{\circ} 33^{\prime} \mathrm{W}$; (map 90 ).

Prospectors' name reported in 1912 by $\mathrm{H}$. M. Eakin, USGS.

Gold Run: stream, flows SW $1.5 \mathrm{mi}$. to Healy Croek, $8 \mathrm{mi}$. NE of Healy, Alaska Ra.; $63^{\circ}$ $53^{\prime} \mathrm{N}, 148^{\circ} 42^{\prime} \mathrm{W}$; BGN 1945; (map 87).

Name used by prospectors; reported in 1944 by USGS.

Gold Run: stream, flows NE $8.7 \mathrm{mi}$. to Deer Creek, $7.8 \mathrm{mi}$. NW of Sulatna Crossing and $35 \mathrm{mi}$. SW of Ruby, Kilbuck-Kuskokwim Mts.; $64^{\circ} 14^{\prime} 30^{\prime \prime} \mathrm{N}, 155^{\circ} 41^{\prime} 58^{\prime \prime} \mathrm{W}$; (map 98).

Prospectors' name reported in 1911 by Maddren (in Brooks and others, 1912, p. 294296), USGS.

Gold Run: stream, flows E $2.5 \mathrm{mi}$. to Flint Creek, $4.5 \mathrm{mi}$. E of Long and $24 \mathrm{mi}$. S of Ruby, Kilbuck-Kuskokwim Mts.; 64 ${ }^{\circ} 24^{\prime}$ N, $155^{\circ} 21^{\prime}$ ' W ; (map 98).

Prospectors' name reported in 1911 by A. G. Maddren, USGS. The exact application of this stream is in doubt.

Gold Run: stream, flows N $6 \mathrm{mi}$. to McCoy Creek, $26 \mathrm{mi}$. NW of Big Delta, YukonTanana High.; $64^{\circ} 27^{\prime} 20^{\prime \prime} \mathrm{N}, 146^{\circ} 19^{\prime} 15^{\prime \prime} \mathrm{W}$; (map 101).

Prospectors' name reported in 1910 by USGS (Capps, 1912, pl. 1).

Gold Run: stream, flows NE $1.5 \mathrm{mi}$. to Slate Creek, $52 \mathrm{mi}$. SW of Eagle, Yukon-Tanana High.; $64^{\circ} 36^{\prime} \mathrm{N}, 142^{\circ} 45^{\prime} \mathrm{W}$; (map 102). Var. Gold Run Creek.

Prospectors' name shown on an 1898 manuscript map by C. A. Woodruff, Fort Cudahy, Canada.

Gold Run: stream, flows S $1.9 \mathrm{mi}$., joins Oniga Creek to form Bonita Creek, 11 mi NE of Nome, Seward Penin. High.; 64 $38^{\circ} \mathrm{N}, 165^{\circ}$. $13^{\prime} \mathrm{W}$; (map 94).

Prospectors' name reported in 1904 by $\mathrm{T}$. G. Gerdine, USGS.

Gold Run: stream, flows SW $2.7 \mathrm{mi}$. to Cripple River, $17 \mathrm{mi}$. NW of Nome, Seward Penin. High.; $64^{\circ} 43^{\prime} \mathrm{N}, 165^{\circ} 43^{\prime} \mathrm{W}$; (map 94).

Prospectors' name reported on Arthur Gib- son's "Map of Cape Nome Precinct" dated 1904.

Gold Run: stream, flows SW $3 \mathrm{mi}$. to Grand Central River, $32 \mathrm{mi}$. NE of Nome, Seward Penin. High.; $64^{\circ} 57^{\prime} \mathrm{N}, 165^{\circ} 10^{\prime} \mathrm{W}$; (map 94).

Prospectors' name reported in 1906 by USGS.

Gold Run: stream, flows SE 2 mi. to Goldstream Creek, $10 \mathrm{mi}$. NE of Fairbanks, YukonTanana High.; $64^{\circ} 58^{\prime} \mathrm{N}, 147^{\circ} 34^{\prime} \mathrm{W}$; (map 100). Var. Gold Run Creek.

Local name reported by T. G. Gerdine (in Prindle, 1905, pl. 16), USGS.

Gold Run: stream, flows NW $12 \mathrm{mi}$. to join Right Fork Bluestone River, forms Bluestone River, $13 \mathrm{mi} \mathrm{S}$ of Teller, Seward Penin. High.; $65^{\circ}$ $05^{\prime} \mathrm{N}, 166^{\circ} 13^{\prime} \mathrm{W}$; (map 111).

Local name reported in 1900 by E. C. Barnard (in Brooks, 1901, pl. 17), USGS.

Gold Run: stream, flows SW $0.8 \mathrm{mi}$. to Rhode Island Creek, $1.5 \mathrm{mi}$. W of Eureka, $22 \mathrm{mi}$. S of Rampart, Yukon-Tanana High.; $65^{\circ} 10^{\prime} 50^{\prime \prime}$ N, $150^{\circ} 16^{\prime} 10^{\prime \prime} \mathrm{W}$; (map 106).

Prospectors' name reported in 1904 by Prindle and Hess (1906, pl. 3), USGS.

Gold Run: stream, flows NE 12.2 mi. to Kiwalik River, $37 \mathrm{mi}$. NW of Haycock, Seward Penin. High.; $65^{\circ} 39^{\prime} \mathrm{N}, 161^{\circ} 51^{\prime} \mathrm{W}$; (map 109). *Var. Gold Run Creek.

Local name reported on a 1903 fieldsheet by D. C. Witherspoon, USGS.

Gold Run: stream, see Gold Creek.

Gold Run: stream, see Gold Run Creek.

Gold Run Creek: stream, in Nutzotin Mts., flows NW $1.6 \mathrm{mi}$. from Gold Hill to Glacier Creek $0.6 \mathrm{mi}$. SE of its junc. with Chavolda Creek, $6.5 \mathrm{mi}$. NW of Beaver Lake, Alaska Ra. $62^{\circ} 07^{\prime} 45^{\prime \prime} \mathrm{N}, 141^{\circ} 54^{\prime} 30^{\prime \prime} \mathrm{W}$; (map 84).

Named by prospectors and reported in 1914 by S. R. Capps (in Brooks and others, 1915, p. 218), USGS.

Gold Run Creek: stream, flows SW $2.8 \mathrm{mi}$. to Bonanza River, 7 mi. NW of Solomon, Seward Penin. High.; $64^{\circ} 36^{\prime} \mathrm{N}, 164^{\circ} 41^{\prime} \mathrm{W}$; (map 95). Var. Gold Run.

Prospectors' name reported as "Gold Run" in 1900 by E. C. Barnard (in Brooks, 1901, pl. 17), USGS.

Gold Run Creek, stream, flows SW $2.5 \mathrm{mi}$. to Big Four Creek which flows to Casadepaga River, $22 \mathrm{mi}$. NE of Solomon, Seward Penin. High.; $64^{\circ} 51^{\prime} \mathrm{N}, 164^{\circ} 06^{\prime} \mathrm{W}$; (map 95). Var. Gold Run.

Prospectors' name reported on a map of Cape Nome gold fields by David Fox, Jr., dated 1901.

Gold Run Creek: stream, in Kallarichuk Hills of Baird Mts., flows W $3 \mathrm{mi}$. to Klery Creek, $23 \mathrm{mi}$. N of Kiana, Brooks Ra.; $67^{\circ} 18^{\prime} \mathrm{N}$, $160^{\circ} 22^{\prime} \mathrm{W}$; (map 127).

Name used by prospectors; reported in 1910 by P. S. Smith (in Brooks and others, 1911, pl. 13), US GS.

Gold Run Creek: stream, see Gold Run.
Goldrun Creek: stream, flows SW $5.5 \mathrm{mi}$, to American River, $34 \mathrm{mi}$. NE of Teller, Seward Penin. High.; $65^{\circ} 39^{\prime} \mathrm{N}, 165^{\circ} 37^{\prime} \mathrm{W}$; (map 111). Var. Burk Creek.

Prospectors' name reported in 1900 by Messrs. Kemp and David Fox (in Brooks, 1901, pl. 11).

Goldrun Creek: stream, flows E $10 \mathrm{mi}$. to Pitka Fork just $\mathrm{N}$ of Twin Sisters and $45 \mathrm{mi}$. NW of Beaver, Kokrines-Hodzana High.; $66^{\circ} 49^{\prime}$ N, $148^{\circ} 34^{\prime} \mathrm{W}$; (map 118).

Local name obtained in 1956 by USGS.

Goldrun Creek: stream, see Arctic Creek.

Gold Standard Creek: stream, flows SE $2 \mathrm{mi}$. to Bluestone River, $12 \mathrm{mi}$. SE of Teller, Seward Penin. High.; $65^{\circ} 07^{\prime} \mathrm{N}, 166^{\circ} 12^{\prime} \mathrm{W}$; (map 111).

Prospectors' name reported on a máp of Cape Nome goldfields by David Fox, Jr., dated 1901.

Gold Standard Creek: stream, flows NW $4 \mathrm{mi}$. to Port Clarence, $12 \mathrm{mi}$. SW of Teller, Seward Penin. High.; $65^{\circ} 07^{\prime} \mathrm{N}, 166^{\circ} 33^{\prime} \mathrm{W}$; (map 111).

Prospectors' name reported on the 1908 "Map of Seward Peninsula" by Arthur Gibson. Goldstein Gulch: ravine, $0.7 \mathrm{mi}$. long, on tributary of Grindstone Creek, $0.4 \mathrm{mi}$. E of West Peak and $8 \mathrm{mi}$. SE of Juneau, Coast Mts.; $58^{\circ} 14^{\prime} 52^{\prime \prime} \mathrm{N}, 134^{\circ} 13^{\prime} 48^{\prime \prime} \mathrm{W}$; BGN 1962; (map 11).

Probably named for Robert Goldstein, 18311900 , who came to Juneau in 1885 and opened a store on the waterfront (DeArmond, 1957, p. 22).

Goldstream: $R R$. station, see Dunbar.

Goldstream Creek: stream, heads at junc. of Gilmore and Pedro Creeks, flows W $70 \mathrm{mi}$. to Chatanika River, $37 \mathrm{mi}$. NW of Fairbanks, Yukon-Tanana High.; $64^{\circ} 59^{\prime} \mathrm{N}, 148^{\circ} 54^{\prime} \mathrm{W}$; (map 100). Var. Gold Stream.

Local name reported in 1903 by T. G. Gerdine (in Prindle, 1905, pl. 16), USGS. The valley of this stream, one of the earliest gold mining areas in the Fairbanks region, was settled by 1905 (Kitchener, 1954, p. 297).

Goldstream Creek: stream, flows N $6.5 \mathrm{mi}$, joins Alabam Greek to form South Fork Hess Creek, $6 \mathrm{mi}$. NE of Livengood, Yukon-Tanana High.; $65^{\circ} 58^{\prime} \mathrm{N}, 148^{\circ} 26^{\prime} \mathrm{W}$; (map 105).

Named by prospectors; reported in 1915 by Brooks (Brooks and others, 1916, pl. 9), USGS.

Goldstream Creek : stream, see South Fork Hess Creek.

Goleta Cove: cove, $0.1 \mathrm{mi}$. across, on $\mathrm{N}$ shore of Shelikof Bay, on W coast of Kruzof I., $19 \mathrm{mi}$. NW of Sitka, Alex. Arch.; $57^{\circ} 10^{\prime} 15^{\prime \prime} \mathrm{N}$, $135^{\circ} 48^{\prime} 00^{\prime \prime} \mathrm{W}$; (map 9)

Name published in 1950 by USC\&GS.

Golf Island: island, $2 \mathrm{mi}$. long, $2.5 \mathrm{mi}$. S of Goddard, on W coast of Baranof I., Alex. Arch.; $56^{\circ} 47^{\prime} 30^{\prime \prime} \mathrm{N}, 135^{\circ} 23^{\prime} 00^{\prime \prime} \mathrm{W}$; (map 5).

Local name used by fishermen; published in 1927 by USC\&GS.

Golia Kamennya Ostrovki: rock, see Black Rock. Golofine Bay: bay, see Golovnin Bay. 
Golofnin : locality, see Golovin Mission.

Golofnin: village, see Golovin.

Golofnin, Mys: point of land, see Hope, Point Golofnin Bay: bay, see Golovnin Bay.

Golofnin Bay Station: locality, see Golovin Mission.

Golofnin Sound: lagoon, see Golovnin Lagoon. Gologamiut: locality, see Golok.

Goloi: island, see Bare Island.

Goloi: island, see Rootok Island.

Goloi Island: island, $2.5 \mathrm{mi}$. long, W of Dolgoi $\mathrm{I}$., in Pavlof Is., Aleutian Ra.; $55^{\circ} 06^{\prime} \mathrm{N}$, $161^{\circ} 53^{\prime} \mathrm{W}$; (map 28 ).

Russian word meaning "bare" published as "O[strov] Goloi" or "Goloi Island," by Father Veniaminov in 1840 (v. 1, p. 252). The native name, "Agajanaksikh" or "Agajanaksish," was applied by Lt. Sarichev (1806, v. 2, p. 15), IRN.

Goloi Island: island, $1 \mathrm{mi}$. across, off $\mathrm{S}$ coast of Kruzof I., $13 \mathrm{mi}$. W of Sitka, Alex. Arch.; $57^{\circ} 00^{\prime} 45^{\prime \prime} \mathrm{N}, 135^{\circ} 41^{\prime} 00^{\prime \prime} \mathrm{W}$; (map 9). Var. Ostrov Goloy.

Russian name meaning "bare" given in 1809 by the navigator Ivan Vasiliev the first; published by Lt. Sarichev (1826, map 19), IRN as "O[strov] Goloy."

Goloi Island: island, see Bush Top Island.

Goloi Island: island, see Long Island.

Goloi Islands: islands, $0.1 \mathrm{mi}$. across, in Salisbury Sound, off S coast of Chichagof I., $24 \mathrm{mi}$. $\mathrm{SE}$ of Chichagof, Alex. Arch.; 57 $21^{\prime} 50^{\prime \prime} \mathrm{N}$, $135^{\circ} 44^{\prime} 20^{\prime \prime} \mathrm{W}$; (map 9). Var. Ostrov Goloy.

Russian name meaning "bare" given in 1809 by the navigator Ivan Vasiliev the first; published by Lt. Sarichev (1826, map 19), IRN, as "Os[trova] Goloy."

Goloi Isles: islands, see Passage Islands.

Golok: locality, "in the Nushagak district," Bristol Bay Low. Var. Gologamiut.

Former Eskimo camp or settlement listed in the 1890 Census as "Gologamiut" with a population of 29 .

Golomiannoi Island: island, see Golovni Island. Golomi Island: island, see Golovni Island. Golomyannoy, Ostrov: island, see Golovni Island. Golova, Mys: point of land, see Head Point.

Golovain Bay: bay, see Golovnin Bay.

Golovin: village, pop. 160 , on point between Golovnin Bay and Golovnin Lagoon, $42 \mathrm{mi}$. E of Solomon, Seward Penin. High.; 64 ${ }^{\circ} 33^{\prime}$ N, $163^{\circ} 02^{\prime}$ W; (map 95). Var. Cheenik, Chenik Mission, Chennik, Chillimiut, Chingmyut, Chinick, Chinig-myut, Chinik, Dexter, Dexter's Store, Golofnin, Golovnin, Ikaligvigmiut, Ikaligwigmiut, Ikalikhvig-myut, Seleniye Ikalikhvig-myut, Tchinimuth.

Eskimo village reported in $1842-44$ as "Ikalikhvig-myut" by Lt. L. A. Zagoskin, IRN. About 1890, one of the employees of the neary Omalik mines married an Eskimo woman and established a trading post here. This man, John Dexter, became the center for prospecting information on the Seward Penin. With the discovery of gold in 1898, Golovin became a supply-relay point of the Council goldfields north of here. In 1899 the Chennik Post Office was established here; it was discontinued in 1903. In 1899 the Golovin Post Office was established south of here, probably at Golovin Mission; it was discontinued in 1904. John Dexter was listed as postmaster of both of these offices. A new Golovin Post Office was established at this site in 1906 and was discontinued in 1958 (Ricks, 1965, p. 10, $23,24)$. The name "Golovin," derived from Golovnin Bay and Lagoon, has become well established with only one "n." The population of this village was 38 in $1890 ; 140$ in 1900 ; and 135 in 1930.

Golovin, Mys: point of land, see Hope, Point.

Golovina, Zaliva : bay, see Golovnin Bay.

Golovin Bay: bay, see Golovnin Bay.

Golovine Bay: bay, see Golovnin Bay.

Golovine Sound: lagoon, see Golovnin Lagoon.

Golovin Mission: locality, on E shore of Golovnin Bay, $7 \mathrm{mi}$. N of Cape Darby and $50 \mathrm{mi}$. SE of Solomon, Seward Penin. High.; $64^{\circ} 26^{\prime} \mathrm{N}$, $162^{\circ} 50^{\prime} \mathrm{W}$; (map 95). Var. Golofnin, Golofnin Bay Station.

Site of a Swedish Evangelical Union mission and reindeer station established in 1896 by a loan of 50 deer to the mission by U.S. Government (Jackson, 1906, p. 15). This appears to be the site where the Golovin Post Office was established in 1899; the post office was discontinued in 1906 and reestablished in 1908 at Golovin.

Golovin Sound: lagoon, see Golovnin Lagoon.” Golovnia, Mys: point of land, see Hope, Point. Golovni Island: island, $600 \mathrm{ft}$. across, in Necker Is., W of Baranof I., $20 \mathrm{mi}$. SW of Sitka, Alex. Arch.; $56^{\circ} 48^{\prime} 10^{\prime \prime} \mathrm{N}, 135^{\circ} 29^{\prime} 30^{\prime \prime} \mathrm{W}$; (map 5 ). Var. Golomi Island, Golomiannoi Island, Ostrov Golomyannoy.

Originally named "Ostrov Golomyannoy," meaning "sea breeze island," by Ivan Vasiliev the first, IRN. The name "Golomi" was applied to this island in 1880 and published on Brit. Adm. Chart 2337. The name later became "Golovni," a derivation of "golovnya," meaning "firebrand."

Golovnin: village, see Golovin.

Golovnina, Zund: lagoon, see Golovnin Lagoon.

Golovnin Bay: bay, heads at Golovnin Lagoon and extends S $12 \mathrm{mi}$. to Norton Sound, $45 \mathrm{mi}$. E of Solomon, Seward Penin. High.; 64 ${ }^{\circ} 24^{\prime}$ N, 16300' W; BGN 1937; (map 95). Var. Golofin Bay, Gologine Bay, Golovain Bay, Golovin Bay, Golovine Bay, Tachik, Tatchik, Techik, Zaliva Golovina.

Named "Baie Golovnine" or "Golovnin Bay" in 1821 by Kromchenko (cnna), IRN, for his vessel, the brig Golovnin, which in turn had been named after Capt. Vasili Mikhailovich Golovnin of the Russian Navy (Baker, 1906, p. 280). Capt. F. P. Lutke, IRN, reported the Eskimo name "Tatchik" meaning "bay" in 1836. See Golovnin Sound.

Golovnin Lagoon: lagoon, $9 \mathrm{mi}$. long at head of Golovnin Bay, $39 \mathrm{mi}$. E of Solomon, Seward Penin. High.; $64^{\circ} 35^{\prime} \mathrm{N}, 163^{\circ} 10^{\prime} \mathrm{W}$; BGN 1937; (map 95). Var. Golofnin Sound, Golovine Sound, Golovin Sound, Zund Golovina.
Reported as "Zund Golovina" or "Golovnina Sound" in $1842-44$ by Lt. L. A. Zagoskin, IRN. The generic "Sound" was used until 1937. See Golovnin Bay.

Goloy, Ostrov: island, see Bare Island.

Goloy, Ostrov: island, see Goloi Island.

Goloy, Ostrov: island, see Long Island.

Goloy, Ostrov: islands, see Goloi Islands.

Goloy, Ostrov: islands, see Passage Islands.

Goloy, Ostrovi: island, see Aiktak Island.

Golsova: locality, see Golsovia.

Golsova River: stream, see Golsovia River.

Golsovia: locality, on Norton Sound at mouth of Golsovia River, $4.5 \mathrm{mi}$. SW of Tolstoi Point and $23 \mathrm{mi}$. SW of Unalakleet, Nulato Hills; $63^{\circ} 33^{\prime} 45^{\prime \prime} \mathrm{N}, 161^{\circ} 03^{\prime} 30^{\prime \prime} \mathrm{W}$; (map 91). Var. Galsovia, Galtzora, Gaolsovia, Golsova, Goltzovaia, Nu-wayn-yuk.

Former telegraph station, reindeer camp and corral reported in 1903 by C. O. Lind, Unalakleet. Named after the river which was then spelled "Golsova." The place is now used as a summer fish camp. A. V. Zane, of Lt. G. M. Stoney's expedition, gave the Eskimo name for the place as "Nu-wayn-yuk." See Golsovia River.

Golsovia River: stream, flows NE $50 \mathrm{mi}$. to Norton Sound, $4.5 \mathrm{mi}$. S of Tolstoi Point and 23 mi. SW of Unalakleet, Nulato Hills; $63^{\circ} 34^{\prime}$ N, $161^{\circ} 04^{\prime}$ W; (map 91). Var. Golsova River, Goltzovaia River, Neenivik River, Negvelnuk, Reka Nygvilnuk, Reka Nygvylnuk. Name reported in 1866 by W. H. Dall as "Golsova" and E. W. Nelson, U.S. Signal Service spelled the name "Goltzovaia" which Baker (1906, p. 280) suggests may come from the German "holtz," meaning "wood." Capt. Tebenkov (1852, map 2), IRN, records the Eskimo name "Nygvilnuk [Nigvilnuk]." See Golsova.

Goltsovaia Bay: bay, see Holtz Bay.

Goltsovaya, Bukhta : bay, see Holtz Bay:

Goltsov Point: point of land, on $N$ coast of Attu I., $W$ point of entrance to Holtz Bay, Aleu$\operatorname{tian}$ Is.; 52 $57^{\prime} 30^{\prime \prime} \mathrm{N}, 173^{\circ} 10^{\prime} 30^{\prime \prime} \mathrm{E}$; BGN 1938; (map 13). Var. Goltzeb Point.

Derived from an early name for Holtz Bay; proposed as "Goltzeb Point" by U.S. Navy Hydrog. Office in 1938.

Goltzeb Bay: bay, see Holtz Bay.

Goltzeb Point: point of land, see Goltsov Point. Goltzef Bay: bay, see Holtz Bay.

Goltzovaia: locality, see Golsovia.

Goltzovaia River: stream, see Golsovia River. Goly, Ostrov: island, see Rootok Island.

Golyy, Ostrov: island, see Bush Top Island.

Golyya Kamennyya Ostrovki: rock, see Black Rock.

Gomair, Lake: lake, see Gasoline Lake.

Gomez, Punta de: point of land, see Gomez Point.

Gomez Point: point of land, on the south coast of Kenai Penin. separating Windy and Chugach Bays, Kenai Mts.; $59^{\circ} 13^{\prime} \mathrm{N}, 151^{\circ}$ $27^{\prime} \mathrm{W}$; (map 50). Var. Punta de Gomez.

Named on an unpublished map by F. A. Maurelle and Don Juan de la Bodega y Quadra, dated 1779. 
Gompertz Channel: water passage, $15 \mathrm{mi}$. long, in Cook Inlet, between Middle Ground Shoal and NW coast of Kenai Penin., $24 \mathrm{mi}$. N of Kenai, Cook Inlet Low.; $60^{\circ} 53^{\prime} \mathrm{N}, 151^{\circ} 18^{\prime}$ W; (map 62).

Named "for Capt. Gompertz (cnna), who discovered it"; reported in 1905 by USC\&GS.

Gonaho: locality, at mouth of Alsek River, at Dry Bay, about $50 \mathrm{mi}$. SE of Yakutat, St. Elias Mts.; (map 46). Var. Gonā'xo Gunah-ho.

Former Tlingit Indian town reported in 1904 by J. R. Swanton (in Hodge, 1907, p. 496), BAE.

Gonakadetseat Bay: bay, $1.6 \mathrm{mi}$. long, on SE coast of Khantaak I., 2.2 mi. E of Point Minor and $2.6 \mathrm{mi}$. $\mathrm{N}$ of Yakutat, Malaspina Coastal Plain; $59^{\circ} 35^{\prime} \mathrm{N}, 139^{\circ} 44^{\prime} \mathrm{W}$; (map 46).

Tlingit Indian name published by the USGS in 1959.

Gonā'xo: locality, see Gonaho.

Goober Lake: lake, $0.7 \mathrm{mi}$. long, $12 \mathrm{mi}$. NE of confluence of East and South Forks Matanuska River, $57 \mathrm{mi}$. NW of Valdez, Copper River Basin, 61 $51^{\prime} 15^{\prime \prime} \mathrm{N}, 147^{\circ} 07^{\prime}$ 30" W; BGN 1960; (map 69).

Named in 1956 by USGS "because of its resemblance to a peanut."

Goodall Creek: stream, flows SE $1 \mathrm{mi}$. to Boulder Creek, in Noxapaga River basin, $31 \mathrm{mi}$. W of Imuruk Lake, Seward Penin. High.; 65 $34^{\prime}$ N, $164^{\circ} 20^{\prime} \mathrm{W}$; (map 110).

Prospectors' name reported in 1901 by T. G. Gerdine (in Collier, 1902, pl. 12), USGS.

Good Creek: stream, flows SSW $1.7 \mathrm{mi}$. to Golden Creek near $\mathrm{N}$ shore of Vega Bay, Kiska I. Aleutian Is.; $51^{\circ} 55^{\prime} 23^{\prime \prime} \mathrm{N}, 177^{\circ} 22^{\prime} 15^{\prime \prime} \mathrm{E}$; (map 14).

An arbitrary name beginning with " $G$ " to correspond to "G" grid used by the U.S. Army for tactical purposes during World War II; published on a 1953 AMS map.

Goode, Mount: mountain, 10,610 ft., near head of Knik Glacier, 42 mi. SE of Palmer, Chugach Mts. ; $61^{\circ} 19^{\prime} 40^{\prime \prime} \mathrm{N}, 147^{\circ} 59^{\prime} 00^{\prime \prime} \mathrm{W} ; B G N$ 1924; (map 69).

Named in 1924 by USGS for Richard Urquhart Goode, 1858-1903, "Geographer, USGS, in charge of the Pacific Division, Topographic Branch, at the time the first work in Alaska was executed." See Farquhar (1959, p. 221).

Goodenough Creek: stream, flows NW $1.2 \mathrm{mi}$. to East Fork Solomon River, $12 \mathrm{mi}$. NE of Solomon, Seward Penin. High.; $64^{\circ} 42^{\prime} \mathrm{N}, 164^{\circ}$ 11' W; (map 95).

Prospectors' name reported on a 1902 prospectors' manuscript map.

Goodhope Bay: bay, on $\mathbf{N}$ coast of Seward Penin., $16 \mathrm{mi}$. across, $30 \mathrm{mi}$. W of Deering, Kotzebue-Kobuk Low.; $66^{\circ} 07^{\prime}$ N, $163^{\circ} 39^{\prime}$ W; (map 113).

So named by Lt. Otto von Kotzebue while exploring the region in August 1816 because here he had "good hope" of making important geographic discoveries.

Good Hope Creek: stream, see Goodhope Creek.
Goodhope Creek: stream, flows NW $2 \mathrm{mi}$. to Reed Creek, $15 \mathrm{mi}$. NW of Palmer, Talkeetna Mts. ; 61 ${ }^{\circ} 49^{\prime} 10^{\prime \prime} \mathrm{N}, 149^{\circ} 11^{\prime} 15^{\prime \prime} \mathrm{W}$; (map 69). Var. Good Hope Creek.

Local name reported in 1919 by A. H. Brooks and G. C. Martin (in Brooks and others, 1921, pl. 7), USGS.

Goodhope River: stream, on Seward Penin., flows NE $46 \mathrm{mi}$. to Goodhope Bay, $28 \mathrm{mi}$. W of Deering, Kotzebue-Kobuk Low.; $66^{\circ} 05^{\prime} \mathrm{N}$, $163^{\circ} 44^{\prime}$ W; BGN 1952; (map 113). Var. Right Fork Goodhope River.

Name reported in 1901 by Mendenhall (1902, p. 27), USGS; derived from Goodhope Bay.

Gooding Lake: lake, $0.6 \mathrm{mi}$. long, in Matanuska Valley, $4.4 \mathrm{mi}$. NW of Palmer, Cook Inlet Low.; 61 $37^{\prime} 45^{\prime \prime} \mathrm{N}, 149^{\circ} 14^{\prime} 15^{\prime \prime} \mathrm{W}$; (map 69).

Local name reported in 1942 by AMS.

Good Island: island, $0.6 \mathrm{mi}$. across, off $\mathrm{E}$ coast of Admiralty I., $4 \mathrm{mi}$. NW of Gambier I. and $63 \mathrm{mi}$. NE of Sitka, Alex. Arch.; 57 $28^{\prime} 00^{\prime \prime}$ N, $133^{\circ} 53^{\prime} 45^{\prime \prime} \mathrm{W}$; (map 8).

Named in 1889 by Lt. Comdr. H. B. Mansfield, USN; name published in 1892 by USC\&GS.

Goodlata Peak: mountain, 8,140 ft., $8.4 \mathrm{mi}$. S of junc. of Monahan Creek and Chakina River, $27 \mathrm{mi}$. SW of McCarthy, Chugach Mts.; $61^{\circ} 03^{\prime} 15^{\prime \prime} \mathrm{N}, 143^{\circ} 08^{\prime} 00^{\prime \prime} \mathrm{W}$; (map 67).

Local name reported in 1908 by D. C. Witherspoon, USGS.

Goodluck Creek: stream, see Lucky Creek.

Goodluck Gulch: ravine, trends W $1 \mathrm{mi}$. to Snake River, $1.8 \mathrm{mi}$. NW of Mount Brynteson and $10 \mathrm{mi}$. N of Nome, Seward Penin. High.; $64^{\circ}$ $38^{\prime} 45^{\prime \prime} \mathrm{N}, 165^{\circ} 27^{\prime} 30^{\prime \prime} \mathrm{W}$; (map 94). Var. Good Luck Gulch.

Prospectors' name reported on a map of Cape Nome gold fields by David Fox, Jr., dated 1901.

Goodluck Gulch: ravine, see Woodchuck Gulch. Goodman Glacier: glacier, see Goodwin Glacier.

Goodman Pass: pass, 3,400 ft., in Teocalli Mts., between Denny and Sheep Creeks, $4.5 \mathrm{mi}$. NW of Houston Pass and $98 \mathrm{mi}$. SE of McGrath, Alaska Ra.; 62 $06^{\prime} 45^{\prime \prime} \mathrm{N}, 153^{\circ} 30^{\prime} 00^{\prime \prime} \mathrm{W}$; (map 80).

Local name reported in 1931 by USGS.

Goodnews: village, pop. 154 , on $\mathrm{N}$ shore of Goodnews Bay, at mouth of Goodnews River, $35 \mathrm{mi}$. NW of Hagemeister Island, KilbuckKuskokwim Mts.; $59^{\circ} 07^{\prime} \mathrm{N}, 161^{\circ} 35^{\prime} \mathrm{W}$; BGN 1939; (map 53). Var. Goodnews Bay, Mumtrak.

A post office called "Goodnews Bay" was established here in 1930 (Ricks, 1965, p. 24). Eskimos from the former village of Mumtrak moved here and a government school was founded. The name "Goodnews" was published in 1937 by BIA. The population in 1960 was 154.

Goodnews Bay: village, see Goodnews.

Goodnews Bay: bay, extends from mouth of Goodnews River SW $10 \mathrm{mi}$. to Kuskokwim Bay at North and South Spits, $30 \mathrm{mi}$. NE of
Cape Newenham, Kilbuck-Kuskokwim Mts.; $59^{\circ} 03^{\prime} \mathrm{N}, 161^{\circ} 49^{\prime} \mathrm{W}$; (map 53). Var. Bonnes Nouvelles Baie, Good News Bay, Imakhpiquak Bay, Imakpiguak, Port Dobriek Vestei, Port Dobrykh Vestey, Zaliv Imakhpiguak.

In 1868 USC\&GS derived "Goodnews Bay" from translation of the Russian name "Port Dobrykh Vestey [ili Zaliv Imakhpiguak]" meaning "Port Goodnews [or Imakhpiguak Bay]," (Sarichev, 1826, map 3). The second name is Eskimo. Capt. Lutke (1836, p. 255), IRN, called it in French "Bonnes Nouvelles baie," or "good news bay," and said that "it might better be called the "Bay of false reports.' "' According to Baker (1906, p. 281), "It was visited and probably named 'Good News' by the land expedition of Vstiugof and Korsakof of 1818-19."

Goodnews Lake: lake, $5 \mathrm{mi}$. long, on Goodnews River, $45 \mathrm{mi}$. NE of Goodnews, KilbuckKuskokwim Mts.; 59॰30' N, $160^{\circ} 31^{\prime}$ W ; (map 53).

Local name published in 1938 by USGS.

Goodnews Mining Camp: locality, $\mathrm{N}$ of junc. of Platinum and Squirrel Creeks, $2 \mathrm{mi}$. $\mathrm{S}$ of Red Mtn. and $25 \mathrm{mi}$. NE of Cape Newenham, Kilbuck-Kuskokwim Mts. ; $58^{\circ} 55^{\prime} 30^{\prime \prime} \mathrm{N}, 161^{\circ}$ $43^{\prime} 50^{\prime \prime} \mathrm{W}$; (map 39).

Named for the Goodnews Mining Co.; name published in 1950 by USGS. This semipermanent settlement was the largest mining camp in the district in 1940. The camp was established about 1934 when large-scale operations in mining of platinum-bearing deposits in this area began (Mertie, 1940, p. 57).

Goodnews River: stream, heads in lake at $59^{\circ} 38^{\prime} \mathrm{N}, 160^{\circ} 23^{\prime} \mathrm{W}$, flows SW $60 \mathrm{mi}$. to Goodnews Bay at Goodnews, Kilbuck-Kuskokwim Mts.; (map 53). Var. Kwihcherak.

Name published by P. S. Smith and A. G. Maddren (in Brooks and others, 1915, pl. 10), USGS. G. L. Harrington, USGS, in 1919 reported that the Eskimo name of the river was "Kwihcherak," meaning "little river."

Goodpaster Flats: flats, extend E $13 \mathrm{mi}$. from junc. of Tanana and Goodpaster Rivers, $6 \mathrm{mi}$. $\mathrm{E}$ of Big Delta, Yukon-Tanana High.; 64 ${ }^{\circ} 08^{\prime}$ $\mathrm{N}, 145^{\circ} 30^{\prime} \mathrm{W}$; (map 101).

Local name published in 1951 by USGS.

Goodpaster River: stream, heads at $64^{\circ} 30^{\prime} \mathrm{N}$., $143^{\circ} 40^{\prime} \mathrm{W}$ and flows SW $91 \mathrm{mi}$. to Tanana River $7 \mathrm{mi}$. E of Big Delta, Yukon-Tanana High.; $64^{\circ} 10^{\prime} 15^{\prime \prime} \mathrm{N}, 145^{\circ} 37^{\prime} 30^{\prime \prime} \mathrm{W}$; $B G N$ 1965; (map 101). Var. North Fork Goodpaster River, Volkmar River.

Named "Volkmar" in 1885 by Lt. H. T. Allen, USA. The stream now known as "Volkmar," was called "Goodpaster River" by Lt: Allen "in honor of the Goodpaster family of Kentucky." The two stream names were transposed by later map makers.

Goodpaster River: stream, see Eisenmenger Fork.

Goodpaster River: stream, see Volkmar River. Goodpaster Telegraph Station: locality, on right bank of Tanana River N of Goodpaster River, 
$6 \mathrm{mi}$. E of Big Delta, Yukon-Tanana High.; $64^{\circ} 10^{\prime} \mathrm{N}, 145^{\circ} 38^{\prime} \mathrm{W}$; (map 101).

Former telegraph station established by the U.S. Army Signal Corps in 1903; name published by USGS (Prindle, 1913a, pl. 1).

Goodwin Creek: stream, on Seward Penin., flows NW $5 \mathrm{mi}$. to Lopp Lagoon, $5 \mathrm{mi}$. NE of Cape Prince of Wales and $53 \mathrm{mi}$. NW of Teller, Kotzebue-Kobuk Low. ; $65^{\circ} 39^{\prime} \mathrm{N}, 167^{\circ} 57^{\prime} \mathrm{W}$; (map 111).

Prospectors' name published in 1956 by USGS.

Goodwin Glacier: glacier, trends E $6.5 \mathrm{mi}$. to its terminus $0.7 \mathrm{mi}$. W of Copper River and 30 mi. NW of Katalla, Chugach Mts.; $60^{\circ} 36^{\prime} \mathrm{N}$, $144^{\circ} 53^{\prime}$ W; (map 64). Var. Goodman Glacier.

Named in 1884 by Capt. W. R. Abercrombie, USA, for "Maj. W. E. Goodwin, U.S.V." (USA Volunteers).

Goodwin River: stream, see Fourth of July Creek.

Goolkana Lake: lake, see Paxson Lake.

Goon Dip Mountain: mountain, 1,900 ft., 6.5 mi. $\mathrm{N}$ of Chichagof, on $\mathrm{W}$ coast of Chichagof I., Alex. Arch.; $57^{\circ} 45^{\prime} 10^{\prime \prime} \mathrm{N}, 136^{\circ} 09^{\prime} 00^{\prime \prime} \mathrm{W}$; BGN 1939; ( $\operatorname{map} 9$ ).

Named locally in 1939 "for Goon Dip who died about 1936. He was Chinese consul at Seattle, Wash., for more than 25 years."

Goon Dip River: stream, flows W $7.5 \mathrm{mi}$. to Didrickson Bay, $7 \mathrm{mi}$. NW of Chichagof, on W coast of Chichagof I., Alex. Arch.; 57 $44^{\prime}$ 55" N, 136 11'20" W; BGN 1939; (map 9).

Named locally in 1939 "for Goon Dip." See Goon Dip Mountain.

Goose Bay: bay, $0.5 \mathrm{mi}$. wide, extends SE 1.5 mi., off Polk Inlet, near center of Prince of

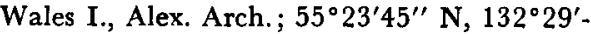
00" W; BGN 1963; (map 4).

"This Bay is called Goose Bay by local people because of a large population of Canada Geese"; reported in 1961 by USFS.

Goose Bay: bay, $3.7 \mathrm{mi}$. across, in $\mathrm{W}$ side of Knik Arm, at mouth of Goose Creek, $11 \mathrm{mi}$. N of Anchorage, Cook Inlet Low.; 61 ${ }^{\circ} 22^{\prime} 30^{\prime \prime}$ $\mathrm{N}, 149^{\circ} 31^{\prime} 30^{\prime \prime} \mathrm{W}$; (map 69).

Local name reported in 1906 by T. G. Gerdine and R. H. Sargent, USGS.

Goose Bay: estuary, on W coast of Culross I., extends SW $1.5 \mathrm{mi}$. to Culross Passage, $16 \mathrm{mi}$. $\mathrm{SE}$ of Whittier, Chugach Mts.; $60^{\circ} 42^{\prime} 15^{\prime \prime} \mathrm{N}$ $148^{\circ} 14^{\prime} 15^{\prime \prime} \mathrm{W}$; (map 63).

Local name reported in 1916 by J. W. Bagley, USGS.

Goose Cove: cove, $0.7 \mathrm{mi}$. across, in Portage Bay, on Kupreanof I., Alex. Arch.; 56 $56^{\prime}$ N, $133^{\circ} 17^{\prime} \mathrm{W}$; (map 6$)$.

Named in 1882 by Lt. Comdr. H. E. Nichols, USN.

Goose Cove: cove, $0.5 \mathrm{mi}$. across, at $\mathrm{S}$ end of Deadman Reach, in Duffield Penin., $\mathrm{N}$ tip of Baranof I., $32 \mathrm{mi}$. N of Sitka, Alex. Arch.; $57^{\circ} 30^{\prime} 30^{\prime \prime} \mathrm{N}, 135^{\circ} 32^{\prime} 30^{\prime \prime} \mathrm{W}$; (map 9).

Local name reported in 1951 by USGS.

Goose Cove: cove, $0.2 \mathrm{mi}$. long, on $\mathrm{E}$ shore of Muir Inlet, in Glacier Bay National Monument, $0.4 \mathrm{mi}$. E of Sealers I. and 63. mi. NW of Hoonah, St. Elias Mts. ; $58^{\circ} 57^{\prime} 30^{\prime \prime} \mathrm{N}, 136^{\circ}$ $06^{\prime} 00^{\prime \prime} \mathrm{W}$; (map 10).

Name published by the American Geographical Society (Field, 1947, map). The name was suggested by W. S. Cooper of the Univ. of Minnesota, who visited this cove in 1929 and "saw a number of young wild geese, who still unable to fly, were flapping over the water."

Goose Greek : ravine, see Goose Gulch.

Goose Creek: stream, near head of Kasaan Bay, on Prince of Wales I., flows $\mathrm{N}$ through Angel Lake, $8 \mathrm{mi}$. to Thorne River, Alex. Arch.; $55^{\circ} 41^{\prime} 15^{\prime \prime} \mathrm{N}, 132^{\circ} 38^{\prime} 10^{\prime \prime} \mathrm{W}$; BGN 1962; (map 4).

"This name has been used locally for a number of years by sportsmen and loggers"; reported by USFS in 1961.

Goose Creek: stream, flows E $0.8 \mathrm{mi}$. to W shore of Red Bay, on $N$ coast of Prince of Wales I.; Alex. Arch.; 56 $18^{\prime} 20^{\prime \prime} \mathrm{N}, 133^{\circ} 20^{\prime} 45^{\prime \prime} \mathrm{W}$; (map 6).

Named in 1886 by Lt. J. M. Helm, USN, for charting purposes; name published in 1887 on USC\&GS Chart 706

Goose Creek: stream, tributary of Peterson Creek, about $15 \mathrm{mi}$. NW of Juneau, Coast Mts.; $58^{\circ} 26^{\prime} \mathrm{N}, 134^{\circ} 43^{\prime} \mathrm{W}$; (map 11).

Named in 1899 by John G. Peterson (DeArmond, 1957, p. 35).

Goose Creek: stream, heads in Stephan Lake. flows S $14 \mathrm{mi}$. to Goose Bay, $11 \mathrm{mi}$. N of Anchorage, Cook Inlet Low.; $61^{\circ} 22^{\prime} 30^{\prime \prime} \mathrm{N}$, $149^{\circ} 53^{\prime} 05^{\prime \prime} \mathrm{W}$; (map 69).

Local name published in 1912 by USC\&GS. Goose Creek: stream, flows SW $7 \mathrm{mi}$. to Susitna River, $18 \mathrm{mi}$. S of Talkeetna, Cook Inlet Low.; $62^{\circ} 03^{\prime} 25^{\prime \prime} \mathrm{N}, 150^{\circ} 05^{\prime} 20^{\prime \prime} \mathrm{W}$; (map 81 ).

Prospectors' name shown on a RR. location blueprint map compiled in 1915.

Goose Creek: stream, heads in lake, flows NE $20 \mathrm{mi}$. to Susitna River, $1.7 \mathrm{mi}$. W of junc. of Oshetna River, Talkeetna Mts.; $62^{\circ} 38^{\prime} 40^{\prime \prime}$ $\mathrm{N}, 147^{\circ} 26^{\prime} 00^{\prime \prime} \mathrm{W}$; (map 82).

Local name reported in 1951 by USGS.

Goose Creek: stream, flows SE $1 \mathrm{mi}$. to Nome River, $\mathrm{N}$ of Hunter Creek, $9 \mathrm{mi}$. NNE of Nome, Seward Penin. High.; $64^{\circ} 38^{\prime}$ N, $165^{\circ}-$ $18^{\prime} \mathrm{W}$; (map 94).

Prospectors' name shown on the 1904 "Map of Cape Nome Precinct" by Arthur Gibson.

Goose Creek: stream, flows S $4 \mathrm{mi}$. to Salcha River $1.5 \mathrm{mi}$. W of junc. of that stream with its South Fork and $36 \mathrm{mi}$. NNE of Big Delta, Yukon-Tanana High.; 64 $39^{\prime} \mathrm{N}, 145^{\circ} 27^{\prime} \mathrm{W}$; (map 101).

Local name reported in 1958 by USGS.

Goose Creek: stream, flows SE $4.5 \mathrm{mi}$. to Casadepaga River, $23 \mathrm{mi}$. NE of Solomon, Seward Penin. High.; $64^{\circ} 53^{\prime} \mathrm{N}, 164^{\circ} 16^{\prime} \mathrm{W}$; (map 95).

Prospectors' name reported in 1900 by E. C. Barnard (in Brooks, 1901, pl. 17), USGS.

Goose Creek: stream, flows W $1 \mathrm{mi}$. to Wolf Creek, 19 mi. NE of Fairbanks, Yukon-Tanana High.; $65^{\circ} 04^{\prime} 55^{\prime \prime} \mathrm{N}, 147^{\circ} 22^{\prime} 05^{\prime \prime} \mathrm{W}$; (map 105).
Named by prospectors; published in 1908 by USGS.

Goose Creek: stream, flows NE $16 \mathrm{mi}$, joins Starvation Creek to form West Fork Tolovana River, $30 \mathrm{mi}$. SE of Rampart, Yukon-Tanana High.; $65^{\circ} 21^{\prime} 20^{\prime \prime} \mathrm{N}, 149^{\circ} 15^{\prime} 00^{\prime \prime} \mathrm{W}$; (map 105).

Named by prospectors; reported in 1904 by Prindle (Prindle and Hess, 1906, pl. 1) USGS.

Goose Creek: stream, flows NW $4.7 \mathrm{mi}$. to French Creek, in Kugruk River basin, $20 \mathrm{mi}$. SE of Imuruk Lake, Seward Penin. High.; $65^{\circ} 31^{\prime} \mathrm{N}, 162^{\circ} 31^{\prime} \mathrm{W}$; (map 110).

Prospectors' name reported in 1903 by D. C. Witherspoon (in Moffit, 1905, pl. 2), USGS. Goose Creek: stream, flows SE $1.3 \mathrm{mi}$. to Noxapaga River, $4 \mathrm{mi}$. SW of its junc. with Andesite Creek, $25 \mathrm{mi}$. W of Imuruk Lake, Seward Penin. High.; $65^{\circ} 31^{\prime} 30^{\prime \prime} \mathrm{N}, 164^{\circ} 08^{\prime} 45^{\prime \prime}$ W; (map 110).

Prospectors' name reported in 1901 by T. G. Gerdine (in Collier, 1902, pl. 12), USGS.

Goose Creek: stream, flows SW $2.7 \mathrm{mi}$. to Kougarok River, $9 \mathrm{mi}$. SW of Midnight Mtn. and $47 \mathrm{mi}$. NW of Imuruk Lake, Seward Penin. High.; $65^{\circ} 41^{\prime} \mathrm{N}, 164^{\circ} 48^{\prime} \mathrm{W}$; (map 110). Var. Wild Goose Creek.

Prospectors' name reported in 1901 by T. G. Gerdine (in Collier, 1902, pl. 12), USGS.

Goose Creek: stream, flows SE $8 \mathrm{mi}$. to West Fork Buckland River, 37 mi. NE of Haycock, Seward Penin. High.; $65^{\circ} 42^{\prime} \mathrm{N}, 160^{\circ} 38^{\prime} \mathrm{W}$; (map 109).

Local name reported in 1917 by G. L. Harrington, USGS.

Goose Creek: stream, flows N $12 \mathrm{mi}$. to Shishmaref Inlet, $10 \mathrm{mi}$. S of Shishmaref, Kotzebue-Kobuk Low. ; $66^{\circ} 06^{\prime} \mathrm{N}, 166^{\circ} 02^{\prime} \mathrm{W}$; (map 112).

Local name published in 1952 by AMS.

Goose Creek: stream, flows to Kuzitrin River, $\mathbf{W}$ of Noxapaga River, about $15 \mathrm{mi}$. NW of Mount Bendeleben, Seward Penin. High.; (map 110).

Prospectors' name shown on a map of Cape Nome gold fields by David Fox, Jr., dated 1901. This stream cannot be precisely located on current maps.

Goose Gulch: ravine, trends S $1.5 \mathrm{mi}$. to Taylor Creek which flows to Kougarok River, 7 mi. $\mathrm{S}$ of Midnight Mtn. and $44 \mathrm{mi}$. NW of Imuruk Lake, Seward Penin. High.; $65^{\circ} 41^{\prime} \mathrm{N}$. 164.41' W; (map 110). Var. Goose Creek.

Prospectors' name shown on a map of Cape Nome gold fields by David Fox, Jr., dated 1901.

Goose Hill: hill, $338 \mathrm{ft}$., E of Vega Bay, Kiska I., Aleutian Is.; $51^{\circ} 55^{\prime} 33^{\prime \prime} \mathrm{N}, 177^{\circ} 27^{\prime} 20^{\prime \prime} \mathrm{E}$; (map 14).

An arbitrary name beginning with " $G$ " to corespond to "G" grid used by U.S. Army for tactical purposes during World War II; published on a 1943 Army map.

Goose Island: locality, see Aiaktalik.

Goose Island: island, $0.7 \mathrm{mi}$. long, part of Sandman Reefs, $10 \mathrm{mi}$. S of Deer I., Aleutian Ra.; $54^{\circ} 41^{\prime} 00^{\prime \prime} \mathrm{N}, 162^{\circ} 13^{\prime} 30^{\prime \prime} \mathrm{W}$; (map 25). 
Var. Civoutchy Rocher, Big Goose Island, Goose Islands, Gusinnoi.

Translation by USBF in 1888 of the Russian name "O[strov] Gusinyy" meaning "island of geese" published in 1847 by the Russian Hydrog. Dept. on Chart 1379. The island was called in Russian-French "Sivoutchy (du lion marin) rocher" meaning "sea lion rock" by Lutke $(1836$, p. 271). It was reported as Big Goose Island by W. H. Dall, USC\&GS, and published on Chart 806 of USC\&GS in 1882

Goose Island: island, $1.6 \mathrm{mi}$. long off $\mathrm{N}$ coast of Chichagof I., $0.5 \mathrm{mi}$. NW of Mud Bay, Alex. Arch.; $58^{\circ} 12^{\prime} 45^{\prime \prime} \mathrm{N}, 136^{\circ} 02^{\prime} 40^{\prime \prime} \mathrm{W}$; (map 10).

Named by master G. C. Hanus, USN, in 1880. The name was published by USG\&GS in the 1883 Alaska Coast Pilot (p. 190).

Goose Island: island, $1.7 \mathrm{mi}$. long, at NW edge of Prince William Sound, $36 \mathrm{mi}$. NW of Cordova, Chugach Mts.; $60^{\circ} 43^{\prime} \mathrm{N}, 146^{\circ} 43^{\prime}$ W; (map 64).

Named in 1898 by Capt. Abercrombie (1900, map), USA, during his exploration of the Copper River region.

Goose Island: island, $2.5 \mathrm{mi}$. long, in Yukon River, $36 \mathrm{mi}$. W of Marshall, Yukon-Kuskokwim Delta; $61^{\circ} 57^{\prime} \mathrm{N}, 163^{\circ} 10^{\prime} \mathrm{W}$; (map 74).

Riverboat pilots' name shown on a 1916 fieldsheet by $R$. H. Sargent, USGS.

Goose Island: island, $1 \mathrm{mi}$. long, in Tanana River, $3 \mathrm{mi}$. $\mathrm{S}$ of Fairbanks, Tanana Low.; $64^{\circ} 47^{\prime} 30^{\prime \prime} \mathrm{N}, 147^{\circ} 43^{\prime} 30^{\prime \prime} \mathrm{W}$; (map 100).

Local name published in 1952 by USGS.

Goose Island: island, see Aiaktalik Island.

Goose Island: island, see Little Goose Island.

Goose Island: island, see Nellag Island.

Goose Islands: island, see Goose Island.

Goose Lake: lake, $1 \mathrm{mi}$. long, on Kenai Penin., $0.6 \mathrm{mi}$. NW of Kayak Lake and $28 \mathrm{mi}$. NE of Kenai, Cook Inlet Low.; $60^{\circ} 46^{\prime} \mathrm{N}, 150^{\circ} 36^{\prime}$ W; (map 62).

Named about 1963 by officials of Kenai National Moose Range, probably for the Goose family (Anitidae), many species of which nest well within the Arctic Circle (Pearson, 1944, pt. 1, p. 154).

Goose Lake: lake, $0.3 \mathrm{mi}$. long, $1.2 \mathrm{mi}$. SE of confluence of North and South Forks Chester Creek and $2.8 \mathrm{mi}$. SE of Anchorage, Cook Inlet Low.; $61^{\circ} 11^{\prime} 45^{\prime \prime}$ N. $149^{\circ} 49^{\prime} 05^{\prime \prime} \mathrm{W}$; (map 69).

Local name reported in 1942 by AMS.

Goose Marsh: marsh, $1.5 \mathrm{mi}$. long $7.5 \mathrm{mi}$. SE of Kake, on NW coast of Kupreanof I., Alex. Arch.; $56^{\circ} 55^{\prime} 30^{\prime \prime} \mathrm{N}, 133^{\circ} 45^{\prime} 30^{\prime \prime} \mathrm{W}$; (map 6).

Local name recorded in 1951 by USGS.

Gooseneck Harbor: estuary, extends NE $2.5 \mathrm{mi}$,, on $W$ coast of Dall I., $\mathbf{N}$ of Port Bazan, Alex. Arch.; 54 $53^{\circ}$ N, $133^{\circ} 03^{\prime} \mathrm{W}$; (map 1).

Descriptive name published by USC\&GS in 1914.

Gooseneck Lake: lake, $0.8 \mathrm{mi}$. long, on Kenai Penin., $0.8 \mathrm{mi}$. S of Stormy Lake, $16 \mathrm{mi}$. NE of Kenai, Cook Inlet Low.; $60^{\circ} 45^{\prime} 10^{\prime \prime} \mathrm{N}$, $151^{\circ} 03^{\prime} 00^{\prime \prime} \mathrm{W}$; (map 62).

Named about 1963 by officials of Kenai National Moose Range, for administrative purposes.

Gooseneck Point: point of land, S point of entrance to Gooseneck Harbor, on W coast of Dall I., Alex. Arch.; 54 $52^{\prime} 45^{\prime \prime}$ N, $133^{\circ} 03^{\prime}$ $00^{\prime \prime} \mathrm{W}$; BGN 1928; (map 1).

Descriptive name given in 1927 by USG\&GS "because of its [the point's] proximity to Gooseneck Harbor and *** [because] the shape of the point resembles a gooseneck."

Goose Point: point of land, at head of Duncan Canal, on $W$ shore of Towers Arm, $14 \mathrm{mi}$. W of Petersburg, on Kupreanof I., Alex. Arch.; $56^{\circ} 47^{\prime} 15^{\prime \prime} \mathrm{N}, 133^{\circ} 19^{\prime} 30^{\prime \prime} \mathrm{W}$; (map 6).

Local name recorded in 1951 by USGS.

Goose Point: point of land, $\mathrm{S}$ point of entrance to Egegik Bay, on $\mathrm{N}$ coast of Alaska Penin., $5.5 \mathrm{mi}$. W of Egegik and $41 \mathrm{mi}$. SW of Naknek, Bristol Bay Low.; 58 $12^{\prime} 15^{\prime \prime}$ N, 157 $31^{\prime}$ $10^{\prime \prime} \mathrm{W}$; (map 41$)$.

Local name reported in 1952 by USGS.

Goose Point: point of land, on Chukchi Sea coast at mouth of Singaruak Creek, $17 \mathrm{mi}$. SW of Barrow, Arctic Plain; $71^{\circ} 04^{\prime} 45^{\prime \prime} \mathrm{N}$, $157^{\circ} 11^{\prime} 45^{\prime \prime} \mathrm{W}$; (map 153).

Name first appears on Brit. Adm. Chart 593 and may have been named by British naval officers connected with the Franklin search expeditions between 1849 and 1853 .

Goose Rocks: rocks, $1 \mathrm{mi}$. of W of Kanaga I., Aleutian Is.; $51^{\circ} 42^{\prime} 10^{\prime \prime} \mathrm{N}, 177^{\circ} 43^{\prime} 35^{\prime \prime} \mathrm{W}$; (map 17).

Name published by USC\&GS in the 1944 Aleutian Coast Pilot (p. 116).

Goose Slough: lake, $0.5 \mathrm{mi}$. long, $17 \mathrm{mi}$. NW of Chalkyitsik, Yukon Flats; $66^{\circ} 52^{\prime} \mathrm{N}, 144^{\circ} 00^{\prime}$ W; (map 120).

Local name obtained in 1956 by T. E. Taylor and R. C. Foley, USGS.

Goose Tongue Island: island, $200 \mathrm{ft}$. long, at entrance to Ryus Bay, $\mathbf{N}$ of Duke I., Alex. Arch.; 54 $58^{\prime} 10^{\prime \prime} \mathrm{N}, 131^{\circ} 25^{\prime} 00^{\prime \prime} \mathrm{W}$; (map 2).

Local name published in 1920 by USC\&GS.

Goosetown: locality, see Nigalik.

Gopher Bay: bay, see Squirrel Bay.

Gopher Gulch: ravine, in Dutch Hills, trends NE $0.5 \mathrm{mi}$. to Willow Creek, $29 \mathrm{mi}$. NW of Talkeetna, Alaska Ra.; $62^{\circ} 34^{\prime} 45^{\prime \prime} \mathrm{N}, 150^{\circ} 50^{\prime} 45^{\prime \prime}$ W; (map 81) .

Prospectors' name reported in the 1930's by USGS.

Gorbotch Rookery: rookery, on N side of Reef Point, Saint Paul I., in Pribilof Is.; 57 $07^{\prime} \mathrm{N}$, $170^{\circ} 17^{\prime} \mathrm{W}$; (map 38$)$.

According to Elliott (1881, p. 51 and 173), who reported this name, it is Russian and means "humpback," from the word "gorbun."

Gorbun Morskoy, Kamen; rock, see Humpback Rock.

Gorbun Rock: rock, see Humpback Rock.

Gorda, Point: point of land, NW tip of Saint Ignace I., $12 \mathrm{mi}$. SW of Craig, Alex. Arch.; $55^{\circ} 25^{\prime} 30^{\prime \prime} \mathrm{N}, 133^{\circ} 26^{\prime} 05^{\prime \prime} \mathrm{W}$; (map 4). Var. Mys Gorda, Punta Gorda.

Spanish name given in 1779 by Don Juan de la Bodega y Quadra and Francisco Antonio Maurelle as "Punta Gorda" i.e. "broad point." Gorda, Punta: point of land, extending into Port Refugio, on Suemez Island, Alex. Arch.; $55^{\circ} 17^{\prime} \mathrm{N}, 133^{\circ} 15^{\prime} \mathrm{W}$; (map 4).

Spanish name meaning "massive point" given by the Don Ignacio Arteaga expedition of 1779 .

Gorda, Punta: point of land, see Ankau Head. Gorda, Punta: point of land, see Gorda Point. Gorda Point: point of land, on the SE shore of Port Etches between Garden Cove and the head of the bay on Hinchinbrook Island. Var. Punta Gorda.

Spanish name meaning "massive" given by the Don Ignacio Arteaga expedition of 1779.

Gordon: locality, site of trading post on NE shore of Demarcation Bay, $2.5 \mathrm{mi}$. E of Demarcation Point, Arctic Plain; $69^{\circ} 40^{\prime} \mathrm{N}, 141^{\circ}$ $12^{\prime} \mathrm{W}$; (map 138).

Named for Thomas Gordon, who came to the $\mathrm{N}$ coast of Alaska from Scotland in 1888 and became a trader (Brower, 1944, p. 134). Gordon, Mount: mountain, 9,040 ft., $8 \mathrm{mi}$. SW Nebesna Glacier terminus, Wrangell Mts.; $62^{\circ} 08, \mathrm{~N}, 143^{\circ} 05^{\prime} \mathrm{W}$; (map 84 ).

Named for a prospector who was in the area in 1899; reported in 1903 by F. C. Schrader, USGS.

Gordon, Point: point of land, on Beaufort Sea coast, $6 \mathrm{mi}$. E of Bullen Point and $10 \mathrm{mi}$. W of Flaxman I., Arctic Plain; $70^{\circ} 11^{\prime} 10^{\prime \prime} \mathrm{N}$, $146^{\circ} 37^{\prime} 30^{\prime \prime} \mathrm{W}$; (map 151).

Named by Leffingwell (1919, p. 95) in 1913, "After Tom Gordon, long a resident at Barrow." See Gordon.

Gordon Gulch: ravine, trends NW $0.6 \mathrm{mi}$. to Anvil Creek, $0.4 \mathrm{mi}$. $\mathrm{N}$ of Banner and $5.3 \mathrm{mi}$. $\mathrm{N}$ of Nome, Seward Penin. High.; 64 $34^{\prime} 40^{\prime \prime}$ N, $165^{\circ} 23^{\prime} 45^{\prime \prime} W$; (map 94).

Prospectors' name reported in 1904 by T. G. Gerdine, USGS.

Gordon Lyon, Mount: peak, 4,100 ft., $2.7 \mathrm{mi}$. SW of junc. of Eagle River and its South Fork, $13 \mathrm{mi}$. NE of Anchorage, Chugach Mts.; $61^{\circ} 15^{\prime} 45^{\prime \prime} \mathrm{N}, 149^{\circ} 30^{\prime} 20^{\prime \prime} \mathrm{W}$; BGN 1964; (map 69).

Named in 1964 by Mrs. Gordon Lyon for her husband, Gordon Miller Lyon, 1906-1964, engineer, who spent much of his professional career working on military construction projects in Alaska.

Goreli Island: island, see Seguam Island. Gorelloi Island: island, see Gareloi Island. Goreloi: volcano, see Redoubt Volcano. Goreloi Island: island, see Gareloi Island. Gorely Island: island, see Gareloi Island. Gorely Island: island, see Seguam Island. Gore Mountain: peak, see Gore Peak.

Gore Peak: peak, 1,411 ft., in Kenai Mts., on E shore of Port Dick, Chugach Mts.; 59 $13^{\prime}$ 
N, $151^{\circ} 00^{\prime}$ W; (map 50). Var. Gore Mountain.

Name reported by U. S. Grant and D. F. Higgins, USGS, in 1912. Named after nearby Gore Point.

Gore Point: point of land, on $\mathrm{S}$ coast of Kenai Penin., $32 \mathrm{mi}$. SE of Seldovia, Chugach Mts.; $59^{\circ} 12^{\prime} 00^{\prime \prime} \mathrm{N}, 150^{\circ} 57^{\prime} 30^{\prime \prime} \mathrm{W}$; (map 50). Var. Point Dick.

Named Point Gore in 1786 by Capt. Nathaniel Portlock, King George's Sound Co., commander of the trading vessel King George during a voyage made from 1785 to 1787 .

Gore Rock: rock, in Gulf of Alaska, $8 \mathrm{mi}$. SW of Gore Point and $28 \mathrm{mi}$. SE of Seldovia, Chugach Mts.; $59^{\circ} 08^{\prime} 30^{\prime \prime} \mathrm{N}, 151^{\circ} 11^{\prime} 15^{\prime \prime} \mathrm{W}$; (map 50).

Name derived from nearby Gore Point and published by USGS in 1951.

Gores Island: island, see Saint Matthew Island.

Gorge, The: canyon, $5 \mathrm{mi}$. long, along course of Lake Fork Knik River, $20 \mathrm{mi}$. SE of Palmer, Chugach Mts.; $61^{\circ} 22^{\prime} \mathrm{N}, 148^{\circ} 35^{\prime} \mathrm{W}$; (map 69)

Descriptive name reported in 1951 by $\mathrm{K}$. $\mathrm{H}$. Stone $(1963$, p. 33$)$.

Gorge, The: canyon, $1 \mathrm{mi}$. long, on Klutina River, $4 \mathrm{mi}$. E of Mount Carter and $50 \mathrm{mi}$. NE of Valdez, Chugach Mts.; 61 $47^{\circ} 30^{\prime \prime} \mathrm{N}$, $145^{\circ} 36^{\prime} 00^{\prime \prime} \mathrm{W}$; (map 68).

Descriptive name reported in 1898 by Capt. W. R. Abercrombie, USA.

Gorge, The: canyon, $2 \mathrm{mi}$. E of Gilbert Bay, on SE shore of Whiting River, $34 \mathrm{mi}$. SE of Juneau, Coast Mts.; $58^{\circ} 00^{\prime} \mathrm{N}, 133^{\circ} 40^{\prime} \mathrm{W}$; (map 8).

Local name reported in 1955 by USGS.

Gorge Creek: stream, flows SE $8 \mathrm{mi}$. to Hardscrabble Creek, on Alaska Penin., forms part of boundary of Katmai National Monument, $25 \mathrm{mi}$. NE of Mount Katmai, Aleutian Ra.; $58^{\circ} 37^{\prime} 20^{\prime \prime} \mathrm{N}, 154^{\circ} 48^{\prime} 00^{\prime \prime} \mathrm{W}$; (map 42).

Local name; reported in 1951 by USGS.

Gorge Creek: stream, flows NE $2 \mathrm{mi}$. to stream in Sunshine Valley, $41 \mathrm{mi}$. NW of Dillingham, Kilbuck-Kuskokwim Mts.; $59^{\circ} 30^{\prime} \mathrm{N}, 159^{\circ} 07^{\prime}$ W; (map 53).

Local descriptive name published in 1951 by USGS.

Gorge Creek: stream, in Mount McKinley National Park, flows W $5.4 \mathrm{mi}$. to Thorofare River, $3.3 \mathrm{mi}$. WSW of Eielson Visitor Center, Alaska Ra.; $63^{\circ} 25^{\prime} 20^{\prime \prime} \mathrm{N}, 150^{\circ} 22^{\prime} 40^{\prime \prime} \mathrm{W}$; $B G N$ 1932; (map 88).

So named by USGS in 1931 because the stream flows through "a very deep gorge."

Gorie: point of land, see Gori Point.

Gori Point: point of land, on S coast of Raspberry I., N of Kodiak 1., 57 $59^{\prime} 30^{\prime \prime}$ N, $153^{\circ} 03^{\prime} 30^{\prime \prime}$ W; BGN 1909 (map 34). Var. Gorie, Mountain Cape, Mys Gory.

Transliteration of "M[ys] Gory," the name given in 1839 or 1840 by Sub-Lt. Mikhail Murashev, IRN, and published in 1849 on Russian Hydrog. Dept. Chart 1425. Baker (1906, p. 447) published "Mountain Cape," the translation of Murashevs' name for this feature. Because of duplication, the name was changed to its present form in 1909 by USC\&GS.

Gorley Lake: lake, $0.3 \mathrm{mi}$. long, $1.7 \mathrm{mi}$. SE of junc. of Puntilla Creek and Happy River, $94 \mathrm{mi}$. SW of Talkeetna, Alaska Ra.; $62^{\circ} 07^{\prime}$ $10^{\prime \prime} \mathrm{N}, 152^{\circ} 59^{\prime} 40^{\prime \prime} \mathrm{W}$; (map 81).

Local name reported in 1958 by USGS.

Gormans Strait: water passage, see Gorman Strait.

Gorman Strait: water passage, between Andronica and Korovin Is., in Shumagin Is. Aleutian Ra.; $55^{\circ} 21^{\prime} \mathrm{N}, 160^{\circ} 07^{\prime} \mathrm{W}$; (map 28). Var. Gorman's Straits, Gormans Strait. Named by fishermen before 1872 ; published as Gormans Straits by USC\&GS in an 1872 report.

Gornoi Island: island, $2.5 \mathrm{mi}$. long, $2.5 \mathrm{mi}$. S of Goddard, on W coast of Baranof I., Alex. Arch ; $56^{\circ} 47^{\prime}$ N, $135^{\circ} 21^{\prime} \mathrm{W}$; (map 5). Var. Cornoi Island, Ostrov Gornoy.

Named in 1809 by the Russian navigator, Ivan Vasiliev the first; published by Lt. Sarichev (1826, map 19), IRN, as "O[strov] Gornoy," meaning "mountainous island."

Gornostai : island, see Ermine Island.

Gornoy, Ostrov: island, see Gornoi Island.

Gorod Vinisali: locality, see Vinasale.

Gorton Creek: stream, flows S $14 \mathrm{mi}$, to Khotol River, 19 mi. SE of Nulato, Koyukuk Low.; $64^{\circ} 28^{\prime} \mathrm{N}, 157^{\circ} 50^{\prime \prime} \mathrm{W}$; (map 97).

Local name reported in 1935 by Frederica de Laguna, BAE.

Gory, Mys : point of land, see Gori Point.

Goryalaya: volcano, see Redoubt Volcano.

Gory Hill: hill, $285 \mathrm{ft}$., $0.6 \mathrm{mi}$. N of Bukhti Point, south-central Kiska I., Aleutian I.; $51^{\circ} 55^{\prime} 20^{\prime \prime} \mathrm{N}, 177^{\circ} 28^{\prime} 35^{\prime \prime} \mathrm{E}$; (map 14).

An arbitrary name beginning with " $G$ " to correspond to the "G" grid used by the U.S. Army for tactical purposes during World War II; published on a 1953 AMS map.

Goschacket: stream, see Cosna River.

Goshelpme Creek: stream, heads at Akabluak Pass, flows NE $14 \mathrm{mi}$. to Alatna River, $19 \mathrm{mi}$ SW of Survey Pass, Brooks Ra.; 67 $36^{\prime} \mathrm{N}$, $154^{\circ} 23^{\prime} \mathrm{W}$; (map 125).

Name found on a prospectors' map drawn in the 1920's and is evidently the combining of the words "gosh-help-me."

Gosling Cone: hill, 1,570 ft., $1 \mathrm{mi}$. NW of Sandy Lake and $6 \mathrm{mi}$. S of Imuruk Lake, Seward Penin. High.; $65^{\circ} 28^{\prime} \mathrm{N}, 163^{\circ} 15^{\prime} \mathrm{W}$; $B G N$ 1952; (map 110).

Reported in 1950 by D. M. Hopkins, USGS so named because the "Geological Survey field party caught four half-grown goslings near the base of the cone in 1947."

Gosling Island: island, $800 \mathrm{ft}$. long, $\mathbf{S}$ of Boca de Quadra, near head of Vixen Bay, Coast Mts. ; $55^{\circ} 02^{\prime} 15^{\prime \prime} \mathrm{N}, 130^{\circ} 46^{\prime} 55^{\prime \prime} \mathrm{W}$; (map 3).

Local name published in 1917 by USC\&GS.

Gost Creek: locality, on $\mathrm{W}$ bank of Walker Slough, $0.7 \mathrm{mi}$. NW of Holy Cross, Innoko Low.; $62^{\circ} 12^{\prime} 40^{\prime \prime} \mathrm{N}, 159^{\circ} 46^{\prime} 50^{\prime \prime} \mathrm{W}$; (map 78). Var. Ghost Creek.

An old native village mentioned by Hrdlickka (1943, p. 219) as "Ghost Creek" and so named "because of many burials here about the creek".

Gotothna River: stream, see Foraker River.

Gotzeb Bay: bay, see Holtz Bay.

Goulding Harbor: bay, $2 \mathrm{mi}$. long, $\mathrm{N}$ part of Portlock Harbor, $10 \mathrm{mi}$. NW of Chichagof, on W coast of Chichagof I., Alex. Arch.; $57^{\circ} 47^{\prime}$ N, 136¹4' W; BGN 1926; (map 9). Var. Pinta Bay.

Named in 1787 by Capt. N. Portlock for the publisher of his book, "A voyage around the World," published in 1789 (Wagner, 1937, p. 390). The name "Pinta Bay" was reported in 1917 by H. R. Bartlett, USC\&GS. A description of Goulding Harbor is given in the 1883 Coast Pilot (p. 183-184).

Goulding Lake: lake, $4 \mathrm{mi}$. long, on Chichagof I., most $\mathrm{E}$ of Goulding Lakes, $11 \mathrm{mi}$. $\mathrm{N}$ of Chichagof, Alex. Arch.; $57^{\circ} 48^{\prime} \mathrm{N}, 136^{\circ} 05^{\prime} \mathrm{W}$; (map 9).

Named in 1955 by USGS and published by Rossman (1959b, map), USGS; so named because it is the longest of the four Goulding Lakes.

Goulding Lakes: lakes, $10 \mathrm{mi}$. N of Chichagof, on W coast of Chichagof I., Alex. Arch.; 57 $49^{\prime}$ N, $136^{\circ} 09^{\prime} \mathrm{W}$; (map 9).

Named in 1955 by USGS and published by Rossman (1959b, map), USGS; derived from Goulding Harbor into which the lakes drain. Gould Island: island, $1.5 \mathrm{mi}$. long, between Hetta Inlet and Portage Bay, near center of Prince of Wales I., Alex. Arch.; $55^{\circ} 17^{\prime}$ N, $132^{\circ} 36^{\prime}$ W; (map 4).

Local name reported in 1905 by E. F. Dickins, USC\&GS.

Gould Passage: water passage, $1.3 \mathrm{mi}$. long, between Hetta Inlet and Portage Bay, $S$ of Gould 1., near center of Prince of Wales I., Alex. Arch.; 55 $16^{\prime} 35^{\prime \prime} \mathrm{N}, 132^{\circ} 36^{\prime} 10^{\prime \prime} \mathrm{W}$; (map 4).

Named in 1908 by USC\&GS.

Gourd Island: island, $1,700 \mathrm{ft}$. long, at mouth of Waterfall Bay, on $W$ coast of Dall I., Alex. Arch.; $54^{\circ} 56^{\prime} 25^{\prime \prime} \mathrm{N}, 133^{\circ} 08^{\prime} 25^{\prime \prime} \mathrm{W}$; $B G N$ 1928; (map 1).

Descriptive name given in 1927 by USC\&GS "because of the shape of the island resembling a gourd."

Government Cabin: locality, a shelter cabin on left bank of West Fork Texas Creek, $12.5 \mathrm{mi}$. NW of Hyder, Coast Mts.; $56^{\circ} 03^{\prime} 30^{\prime \prime} \mathrm{N}$. $130^{\circ} 14^{\prime} 00^{\prime \prime} \mathrm{W}$; ( $\left.\operatorname{map} 7\right)$.

Local name reported in 1928 by USGS.

Government Creek: stream, flows N $2.3 \mathrm{mi}$. to Tongass Narrows, on NE coast of Gravina I., Alex. Arch.; $55^{\circ} 20^{\prime} 55^{\prime \prime} \mathrm{N}, 131^{\circ} 41^{\prime} 40^{\prime \prime} \mathrm{W}$; (map 3).

Local name reported in 1954 by USGS.

Government Creek: stream, flows NW $6 \mathrm{mi}$. to Stikine River $12 \mathrm{mi}$. NE of Wrangell, Coast Mts.; $56^{\circ} 38^{\prime} 45^{\prime \prime} \mathrm{N}, 132^{\circ} 17^{\prime} 00^{\prime \prime} \mathrm{W}$; (map 6).

Local name recorded in 1953 by USGS.

Government Creek: stream, heads on Bald Mtn. Ridge, flows S $5.6 \mathrm{mi}$. to Little Susitna River, $8.5 \mathrm{mi}$. NW of Palmer, Cook Inlet Low.; $61^{\circ} 40^{\prime} 05^{\prime \prime} \mathrm{N}, 149^{\circ} 19^{\prime} 50^{\prime \prime} \mathrm{W}$; (map 69).

Local name reported in 1913 by USGS (Brooks and others, 1914, fig. 2). 
Government Hill: hill, see Court House Hill.

Government Peak: peak, 4,781 ft., on Bald Mountain Ridge, $11 \mathrm{mi}$. NW of Palmer, Talkeetna Mts.; $61^{\circ} 44^{\prime} \mathrm{N}, 149^{\circ} 18^{\prime} \mathrm{W}$; (map 69).

Local name reported in 1939 by USGS.

Government Rock: rock, $500 \mathrm{ft}$. off coast of Point Whitshed, $8 \mathrm{mi}$. SE of Cordova, Chugach Mts.; $60^{\circ} 27^{\prime} \mathrm{N}, 145^{\circ} 53^{\prime} \mathrm{W}$; (map 64).

Local name published in 1943 by USC\&GS.

Government Slough: stream, heads at terminus of Scott Glacier, flows SW $15 \mathrm{mi}$. to Gulf of Alaska, $6 \mathrm{mi}$. SE of Cordova, Malaspina Coastal Plain; $60^{\circ} 28^{\prime} \mathrm{N}, 145^{\circ} 40^{\prime} \mathrm{W}$; (map 64).

Local name published in 1951 by USGS.

Government Station: town, see Barrow.

Governor Simpson, Cape: point of land, see Simpson, Cape.

Governors Ridge: ridge, trends NE $0.8 \mathrm{mi}$. from Mount Moore, $6 \mathrm{mi}$. SE of Mount Ogilvie and $37 \mathrm{mi}$. $\mathrm{N}$ of Juneau, Coast Mts.; $58^{\circ} 48^{\prime}$ $20^{\prime \prime} \mathrm{N}, 134^{\circ} 07^{\prime} 40^{\prime \prime} \mathrm{W}$; BGN 1965; (map 11).

Named in 1964 by members of the Juneau Icefield Research Project because the Governor of Alaska visited this area in 1951.

Goverooskie Lake: lake, see Govorushka Lake.

Govorushechie Island: island, see Whale Island.

Govorushechiy, Mys: point of land, see Gull, Cape.

Govorushechiy, Ostrov: island, see Whale Island. Govorushek, Mys: point of land, see Gull, Cape. Govorushiche, Mys : point of land, see Gull Point. Govorushichiy, Mys: point of land, see Gull Point.

Govorushka Lake: lake, $0.2 \mathrm{mi}$. long, on central St. George I., Pribilof Is.; $56^{\circ} 35^{\prime} 15^{\prime \prime}$ N, $169^{\circ}$ 37'15" W; (map 38). Var Găvärüsh'ka Lake, Goverooskie Lake, Koriumanyi.

According to H. W. Elliott (1881, p. 173), "Goverooskie" is Russian for "Larus brevirostris and L. tridactylus Gulls." Putnam, (1903, p. 1014), USC\&GS lists "Gavarush'ka" as Russian for the "red-legged gull * * [the lake is] so called from the large number of gulls frequenting it." Putnam (p. 1015) lists the Aleut name as "Kōriŭm-an'yi," also referring to the gulls.

Goynk, Cape: point of land, see Ooynik Point.

Grace, Lake: lake, $4.5 \mathrm{mi}$. long, on course of Grace Creek, on E coast of Revillagigedo I., Alex. Arch.; $55^{\circ} 38^{\prime} \mathrm{N}, 131^{\circ} 03^{\prime} \mathrm{W}$.

Local name reported in 1926 by R. H. Sargent and F. H. Moffit (in Smith and others, 1929, pl. 5), USGS.

Grace, Point: point of land, on $\mathrm{N}$ tip of Latouche I., $18 \mathrm{mi}$. SE of Chenega, Chugach Mts.; $60^{\circ}$ $04^{\prime} 45^{\prime \prime} \mathrm{N}, 147^{\circ} 00^{\prime} 59^{\prime \prime} \mathrm{W}$; (map 63).

Probably named by Capt. George Vancouver, $R N$, in 1798 . The name is shown on his chart, but is not mentioned in his text.

Grace Cove: bight, $1.5 \mathrm{mi}$. wide, on NE coast of Revillagigedo I., at mouth of Grace Creek on Behm Canal, Alex. Arch.; 55 $40^{\prime} 30^{\prime \prime} \mathrm{N}, 130^{\circ}$ 57'30" W; (map 3).

Local name reported in 1955 by USGS.
Grace Creek: stream, flows $12 \mathrm{mi}$. E, through Lake Grace to Behm Canal, on $E$ coast of Revillagigedo I., Alex. Arch.; 55 $40^{\prime} 15^{\prime \prime} \mathrm{N}$, $130^{\circ} 57^{\prime} 30^{\prime \prime} \mathrm{W}$; (map 3).

Local name published in 1943 by USC\&GS.

Grace Creek: stream, flows SW $2 \mathrm{mi}$. to join Warner Creek to form Wade Creek, $45 \mathrm{mi}$. SW of Eagle, Yukon-Tanana High.; 64 ${ }^{\circ} 10^{\prime}$ $00^{\prime \prime} \mathrm{N}, 141^{\circ} 24^{\prime} 30^{\prime \prime} \mathrm{W}$; (map 102).

Prospectors' name shown on an 1898 manuscript map by C. A. Woodruff, Fort Cudahy, Canada.

Grace Gulch: ravine, trends NW $0.4 \mathrm{mi}$. to Buster Creek, $9 \mathrm{mi}$. NE of Nome, Seward Penin. High.; $64^{\circ} 36^{\prime} 40^{\prime \prime} \mathrm{N}, 165^{\circ} 12^{\prime} 12^{\prime \prime} \mathrm{W}$; (map 94).

Prospectors' name reported on the 1903 Campion Mining and Trading Co. map by George M. Ashford.

Grace Harbor: estuary, extends ENE $1 \mathrm{mi}$. to Kaigani Strait, on E coast of Dall I., Alex. Arch.; 54 $55^{\prime} \mathrm{N}, 132^{\circ} 55^{\prime} \mathrm{W}$; BGN 1908; (map 1).

Local name reported in 1907 by E. F. Dickins, USC\&GS.

Grace Island: island, $0.2 \mathrm{mi}$. long, in Davison Bay, $11 \mathrm{mi}$. NW of Chichagof, on W coast of

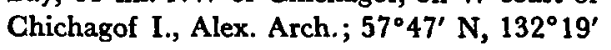
W; (map 9).

Name published by USC\&GS in 1925 Coast Pilot (p. 322).

Grace Mountain: mountain, 2,443 ft., near the center of Dall I., W of Grace Harbor, Alex. Arch.; 54 $55^{\prime} 55^{\prime \prime} \mathrm{N}, 132^{\circ} 57^{\prime} 05^{\prime \prime} \mathrm{W}$; BGN 1929; (map 1).

Name derived from Grace Harbor; given by USC\&GS in 1928.

Grace Point: point of land, see Luke Point.

Gracey Creek: stream, heads at terminus of Gracey Creek Glacier, flows NE into Canada to $56^{\circ} 15^{\prime} 30^{\prime \prime} \mathrm{N}, 130^{\circ} 34^{\prime} 30^{\prime \prime} \mathrm{W}$; Coast Mts. ; $(\operatorname{map} 7)$.

Named in 1920 by IBC surveyors; published in 1927 on IBC Sheet 3 (1951 atlas).

Gracey Greek Glacier: glacier, trends N 5.5 mi. to its terminus at Gracery Creek, $0.1 \mathrm{mi}$. $\mathrm{S}$ of Alaska-Canada boundary, $32 \mathrm{mi}$. NW of Hyder, Coast Mts.; $56^{\circ} 15^{\prime} 15^{\prime \prime}$ N, $130^{\circ} 34^{\prime}$ 30" W; (map 7).

Name derived from Gracey Greek and published in 1955 on USGS map.

Gradual Point: point of land, on N side of Passage Canal, $1 \mathrm{mi}$. SW of Poe Bay and $6 \mathrm{mi}$. NE of Whittier, Chugach Mts.; $60^{\circ} 49^{\prime} 15^{\prime \prime}$ N, 148 32'20" W; BGN 1915; (map 63).

Local descriptive name reported in 1914 by USC\&GS.

Graehl: area, of Fairbanks, on $\mathrm{N}$ bank of Chena River, E of Garden I., Tanana Low.; 64 $51^{\prime}$ N, $147^{\circ} 42^{\prime}$ W; (map 100). Var. Ghrael, Graehl Village.

Originally a townsite listed in 1916 Polk's Gazetteer; the village has been annexed by the city of Fairbanks.

Graehl Village : area, see Graehl.

Graenzstrasse: water passage, see Dixon Entrance.

Graf Heidena, Zaliv: bay, see Heiden, Port.
Graham, Point: point of land, on left bank of Yukon River, $6 \mathrm{mi}$. W of Koyukuk and $11 \mathrm{mi}$. NE of Nulato, Koyukuk Low.; $64^{\circ} 51^{\prime} \mathrm{N}, 157^{\circ}$. 53' W; (map 97).

Riverboat pilots' name shown on a 1940 "Navigation Chart of Tanana-Yukon Rivers" published by U.S. Dept. of Interior.

Graham, Port: bay, $2.5 \mathrm{mi}$. wide, on SW coast of Kenai Penin. $8 \mathrm{mi}$. SW of Seldovia, Chugach Mts.; $59^{\circ} 22^{\prime} \mathrm{N}, 151^{\circ} 55^{\prime} \mathrm{W}$; (map 50). BGN 1954; Var. Bukhta Anglitskaya, Cool Bay, English Bay, Grahams Harbour.

Named "Grahams Harbour" by Capt. Nathaniel Portlock (1787, map facing p. 102), in 1786. The Russians called this bay "Bukh[ta] Anglitskaya," or "English Bay," because of the English mapping and visitation there in the late 18th century. Capt. John Meares called it Cool Bay in 1788.

Graham Creek: stream, flows $\mathrm{N} 10 \mathrm{mi}$. to Colorado Creek, $38 \mathrm{mi}$. NE of Ophir and $50 \mathrm{mi}$. NW of McGrath, Kilbuck-Kuskokwim Mts.; $63^{\circ} 38^{\prime} 45^{\prime \prime} \mathrm{N}, 156^{\circ} 08^{\prime} 00^{\prime \prime} \mathrm{W}$; (map 90).

Prospectors' name reported in 1933 by USGS.

Graham Point: point of land, see Dix Point.

Gramp Rock: island, one of group extending $2.5 \mathrm{mi}$. W of Ilak I., Delarof Is. Aleutian Is.; $51^{\circ} 29^{\prime} 00^{\prime \prime} \mathrm{N}, 178^{\circ} 20^{\prime} 50^{\prime \prime} \mathrm{W}$; (map 16).

Local name published on a 1954 USGS map.

Grand Cañons of the Noatak: canyon, see Grand Canyon.

Grand Canyon: canyon, in Baird Mts., extends $17 \mathrm{mi}$. along course of Noatak River, $60 \mathrm{mi}$. NE of Noatak, Brooks Ra.; $67^{\circ} 55^{\prime} \mathrm{N}, 160^{\circ}$ 45' W; (map 127). Var. Grand Cañons of the Noatak.

The name "Grand Cañons of the Noatak" was first used in 1885 by S. B. McLenegan, USRCS, when he explored the Noatak River. The U.S. Army Corps of Engineers used the present application of the name in 1955 . See Noatak Canyon.

Grand Canyon: canyon, see Noatak Canyon.

Grand Central River: stream, flows SE $12 \mathrm{mi}$. to Salmon Lake, $28 \mathrm{mi}$. NE of Nome, Seward Penin. High.; $64^{\circ} 54^{\prime} \mathrm{N}, 165^{\circ} 05^{\prime} \mathrm{W}$; (map 94 ).

Prospectors' name reported in 1900 by B. C. Barnard (in Brooks, 1901, pl. 17), USGS.

Grand Creek: stream, flows SW $32 \mathrm{mi}$. to Big Mud River $2 \mathrm{mi}$. NE of its junc. with Nowitna River, $31 \mathrm{mi}$. NE of Monzonite Hills, KilbuckKuskokwim Mts.; $64^{\circ} 29^{\prime} \mathrm{N}, 153^{\circ} 38^{\prime} \mathrm{W}$; (map 98).

Local name reported in 1933 by USGS.

Grand Creek: stream, flows N $0.5 \mathrm{mi}$. to Bullion Creek, $0.4 \mathrm{mi}$. W of its junc. with Pargon River, $14 \mathrm{mi}$. NE of Council and $25 \mathrm{mi}$. SE of Mount Bendeleben, Seward Penin. High.; $65^{\circ} 02^{\prime} \mathrm{N}, 163^{\circ} 20^{\prime} \mathrm{W}$; (map 110).

Prospectors' name reported on a map of Cape Nome gold fields by David Fox, Jr., dated 1901.

Grand Greek : stream, see Grand Union Creek. 
Grand Island: island, $0.8 \mathrm{mi}$. long, between Kaigani and Tlevak Straints, E of Dall I., Alex. Arch.; 54 $58^{\prime} 15^{\prime \prime} \mathrm{N}, 132^{\circ} 51^{\prime} 45^{\prime \prime} \mathrm{W}$; (map 1). Var. McNair Island.

Named by Lt. Comdr. H. E. Nichols, USN, in 1881. This island was called "McNair" by Jackson (1880, map facing p. 376).

Grand Island: island, $2 \mathrm{mi}$. across, in Stephens Passage, $2.5 \mathrm{mi}$. NW of Grave Point and 18 mi. SE of Juneau, Alex. Arch.; $58^{\circ} 05^{\prime} 45^{\prime \prime} \mathrm{N}$, $134^{\circ} 07^{\prime} 30^{\prime \prime} \mathrm{W}$; (map 11).

Descriptive name given by Comdr. R. W. Meade, USN, and published in 1869 on Navy Hydrog. Chart 225.

Grand Island: island, $6.7 \mathrm{mi}$. long, in Yukon River $6 \mathrm{mi}$. S of Russian Mission, YukonKuskokwim Delta; $61^{\circ} 40^{\prime} \mathrm{N}, 161^{\circ} 25^{\prime} \mathrm{W}$; (map 73)

Riverboat pilots' name shown on a $191 \mathrm{~b}$ fieldsheet by R. H. Sargent, USGS.

Grand Junction Point: point of land, on $\mathrm{E}$ bank of Yukon River, $6 \mathrm{mi}$. S of Russian Mission, Yukon-Kuskokwim Delta; $61^{\circ} 41^{\prime} \mathrm{N}, 161^{\circ} 20^{\prime}$ W; (map 73).

Riverboat pilots' name shown on a 1916 fieldsheet by R. H. Sargent, USGS.

Grand Kiska Island: island, see Kiska Island.

Grand Pacific Glacier: glacier, heads in St. Elias Mts., $7 \mathrm{mi}$. SW of Mount Hay, trends $\mathrm{E}$ into British Columbia then SE to head of Tarr Inlet at Alaska-Canada boundary, $68 \mathrm{mi}$. SW of Skagway; $59^{\circ} 04^{\prime} 15^{\prime \prime} \mathrm{N}, 137^{\circ} 03^{\prime} 30^{\prime \prime} \mathrm{W}$; $B G N$ 1954; (map 45). Var. Pacific Glacier.

Named by John Muir in 1879. In 1892 Reid (1896, pl. 86 and p. 432), found that the front of the glacier had receded so far as to convert it into three distinct glaciers. He retained the name "Grand Pacific" for the most northerly and largest, and named the middle one "Johns Hopkins Glacier." The smallest and most southerly glacier was named "Reid Glacier" in 1899 by the Harrington Expedition.

Grand Plateau Glacier: glacier, heads about $59^{\circ} 02^{\prime} \mathrm{N}, 137^{\circ} 50^{\prime} \mathrm{W}$, trends W $11 \mathrm{mi}$. to 1961 terminus $2 \mathrm{mi}$. SE of mouth of Glear Creek in Gulf of Alaska and $68 \mathrm{mi}$. SE of Yakutat, St. Elias Mts.; $59^{\circ} 01^{\prime} \mathrm{N}, 138^{\circ} 09^{\prime} \mathrm{W}$; (map 46).

La Pérouse called this glacier Le Grand Plateau in 1786 and Dall (1875, pl. 21), USC\&GS, called it the Grand Plateau Glacier. This latter name was published in the 1883 Coast Pilot (p. 205).

Grand Point: point of land, E point of entrance to Farragut Bay, $5 \mathrm{mi}$. S of Read I., and $82 \mathrm{mi}$. E of Sitka, Coast Mts.; $57^{\circ} 05^{\prime} 00^{\prime \prime} \mathrm{N}, 133^{\circ} 11^{\prime}$ $00^{\prime \prime} \mathrm{W}$; (map 8).

Named in 1887 by Lt. Comdr. C. M. Thomas, USN; name published in 1888 by USC\&GS.

Grand Singatook: mountain, $3,870 \mathrm{ft}$., at $\mathrm{W}$ end of Kigluaik Mts., $1 \mathrm{mi}$. S of Little Singatook and $34 \mathrm{mi}$. NW of Nome, Seward Penin. High.; $64^{\circ} 54^{\prime} \mathrm{N}, 166^{\circ} 05^{\prime} \mathrm{W}$; (map 94).

Named in 1966 by L. G. Madland; he reported 'the name 'Singatook' is the name the Eskimos living in the area used for both peaks."
Grandstand Ridge: ridge, 1,380 ft., $8.5 \mathrm{mi}$. long, between Ayiyak and Chandler Rivers, $59 \mathrm{mi}$. NW of Anaktuvuk Pass, Arctic Slope ; 68 ${ }^{\circ} 58^{\prime}$ N, $152^{\circ} 08^{\prime} \mathrm{W}$; (map 134).

Named by USGS geologists during the exploration of Naval Petroleum Reserve No. 4; name given in 1944 .

Grand Union Creek: stream, heads in Kigluaik Mts., flows NE $11 \mathrm{mi}$. to Pilgrim River $1.3 \mathrm{mi}$. $\mathrm{S}$ of its junc. with Kuzitrin River, $35 \mathrm{mi}$. SE of Teller, Seward Penin. High.; $65^{\circ} 08^{\prime} \mathrm{N}, 165^{\circ}$ 13' W; (map 111). Var. Grand Greek.

Shown as "Grand" on a map of Cape Nome gold fields by David Fox, Jr., dated 1901. Prospectors' name reported on the 1908 "Map of Seward Peninsula" by Arthur Gibson.

Grandview: $R R$. station, $\mathrm{mi} .44 .9$ on The Alaskan RR., near head of Placer River, in Kenai Mts., $24 \mathrm{mi}$. SE of Sunrise, Chugach Mts.; $60^{\circ} 36^{\prime} 30^{\prime \prime} \mathrm{N}, 149^{\circ} 03^{\prime} 40^{\prime \prime} \mathrm{W}$; (map 63)

RR. station established about 1908 ; so named because it is at an elevation of 1,063 feet, "affording a scenic view."

Grandview Gardens: area, in Anchorage, E of Airport Heights, Cook Inlet Low.; 61 $12^{\prime} 30^{\prime \prime}$ N, $149^{\circ} 48^{\prime} 50^{\prime \prime} \mathrm{W}$; (map 69).

Local name reported in 1954 by the city engineer of Anchorage.

Grand Wash: stream, see Kwik Stream

Grand Wash River: stream, braided stream, flows S $7 \mathrm{mi}$. between Malaspina and Lucia Glaciers to Yakutat Bay, $4.5 \mathrm{mi}$. SW of mouth of Esker Stream and $21 \mathrm{mi}$. N of Yakutat, St Elias Mts.; $59^{\circ} 50^{\prime} 45^{\prime \prime} \mathrm{N}, 1^{\circ} 39^{\circ} 47^{\prime} 20^{\prime \prime} \mathrm{W}$; (map 46). Var. Kwik River, Kwik Stream.

Local descriptive name reported by Baker (1906, p. 284), USGS, as a variant of Kwik River. Name is now applied to the lower and braided part of the Kwik River.

Granit Creek: stream, see Granite Creek.

Granite Basin: lake, $0.4 \mathrm{mi}$. long, on Revillagigedo I., $2.2 \mathrm{mi}$. NE of Ketchikan, Alex. Arch.; $55^{\circ} 22^{\prime} \mathrm{N}, 131^{\circ} 35^{\prime} \mathrm{W}$; BGN 1916; (map 3). Var. Granite Basin Lake.

Local name reported in 1911 by USFS.

Granite Basin Lake: lake, see Granite Basin.

Granite Bay: bay, on W coast of Esther I., trends W $2 \mathrm{mi}$. to Port Wells, $22 \mathrm{mi}$. NE of Whittier, Chugach Mts.; $60^{\circ} 53^{\prime} \mathrm{N}, 148^{\circ} 06^{\prime}$ W; (map 63).

Local name reported in 1916 by $J$. W. Bagley, USGS.

Granite Bay: bight, $1.2 \mathrm{mi}$. wide, on $\mathbf{E}$ shore of Imuruk Lake, $3 \mathrm{mi}$. NE of Kettle Dome, Seward Penin. High.; $65^{\circ} 37^{\prime} \mathrm{N}, 163^{\circ} 07^{\prime} \mathrm{W}$; $B G N$ 1954; (map 110).

Reported in 1953 by D. M. Hopkins, USGS; so named because the "shores of the bay are composed of disintegrated granite."

Granite Bay: estuary, on E coast of Kenai Penin., extends SE 2 mi. to Knight Island Passage, 10 mi. NE of Chenega, Chugach Mts. ; $60^{\circ} 25^{\prime} \mathrm{N}$, 147 $59^{\prime} \mathrm{W}$; (map 63).

Descriptive local name reported in 1908 by U. S. Grant and D. F. Higgins (in Brooks and others, 1909, pl. 4), USGS.
Granite Bay: estuary, extends SW $3 \mathrm{mi}$. to Wells Bay, $44 \mathrm{mi}$. NE of Whittier, Chugach Mts.; $60^{\circ} 54^{\prime} 50^{\prime \prime} \mathrm{N}, 147^{\circ} 26^{\prime} 45^{\prime \prime} \mathrm{W}$; (map 63).

Local name reported in 1916 by J. W. Bagley, USGS.

Granite Canyon: canyon, $6 \mathrm{mi}$ long, $2 \mathrm{mi}$. NW of Berg Mtn., in Glacier Bay National Monument and $68 \mathrm{mi}$. NW of Juneau, St. Elias Mts.; $58^{\circ} 56^{\prime} \mathrm{N}, 134^{\circ} 49^{\prime} \mathrm{W}$; (map 11).

Name published in 1960 by USGS.

Granite Cape: point of land, on S tip of Granite I., $35 \mathrm{mi}$. SW of Seward, Chugach Mts.; $59^{\circ} 36^{\prime} 45^{\prime \prime} \mathrm{N}, 149^{\circ} 46^{\prime} 00^{\prime \prime} \mathrm{W} ; B G N$ 1911; (map 49).

Named in 1909 by U. S. Grant, USGS, "for the rocks of which it is composed."

Granite Cove: cove, $0.5 \mathrm{mi}$. across, in George Is., off $\mathrm{N}$ coast of Chichagof $\mathrm{I} ., 1.5 \mathrm{mi}$. W of village of Elfin Cove and $35 \mathrm{mi}$. NW of Hoonah, Alex. Arch.; 58 $11^{\prime} 30^{\prime \prime} \mathrm{N}, 136^{\circ} 23^{\prime}$ 30 " W; (map 10).

Descriptive name given by W. H. Dall, USC\&GS, in 1880 and published in the 1883 Alaska Coast Pilot (p. 187). Capt. George Vancouver, $R N$, anchored in this cove in 1784, but did not give it a name.

Granite Cove: cove, extends SE 2 mi. to Columbia Bay, $56 \mathrm{mi}$. NE of Whittier, Chugach Mts.; $60^{\circ} 58^{\prime} 15^{\prime \prime} \mathrm{N}, 147^{\circ} 08^{\prime} 30^{\prime \prime} \mathrm{W}$; $B G N$ 1911; (map 63).

Named in 1909 by U. S. Grant, USGS. Named for the "granite boss" on north shore of cove.

Granite Creek: stream, on E coast of Cleveland Penin., flows SE $6 \mathrm{mi}$. to Raymond Cove 2 mi. NE of Helm Bay, Alex. Arch.; 55 38'45" N, $131^{\circ} 51^{\prime} 50^{\prime \prime} \mathrm{W}$; (map 3).

Local name recorded in 1949 by USGS.

Granite Creek: stream, on mainland, heads in Lake Manzoni, flows $4 \mathrm{mi}$. W to Behm Canal, 2.5 mi. S of Walker Cove, Coast Mts.; 55 $40^{\prime}$ $\mathrm{N}, 130^{\circ} 54^{\prime} \mathrm{W}$; (map 3).

Local name recorded in 1955 by USGS.

Granite Creek: stream, flows E $6 \mathrm{mi}$. to head of North Arm Hoonah Sound, on Chichagof I., $20 \mathrm{mi}$. SE of Pelican, Alex. Arch.; 57 $45^{\prime}$ $30^{\prime \prime} \mathrm{N}, 135^{\circ} 50^{\prime} 00^{\prime \prime} \mathrm{W} ; B G N$ 1935; (map 9).

Local descriptive name reported in 1935 by USFS.

Granite Creek: stream, flows SW $7 \mathrm{mi}$. to King Salmon River, on Alaska Penin., $40 \mathrm{mi}$. E of Egegik and $46 \mathrm{mi}$. SE of Naknek, Bristol Bay Low.; $58^{\circ} 11^{\prime} 15^{\prime \prime} \mathrm{N}, 156^{\circ} 16^{\prime} 00^{\prime \prime} \mathrm{W}$; (map 41.)

Local name reported in 1952 by USGS.

Granite Creek: stream, flows $2 \mathrm{mi}$. W to Gold Creek, 2 mi. NE of Juneau, Coast Mts.; $58^{\circ}$ $18^{\prime} 55^{\prime \prime} \mathrm{N}, 134^{\circ} 21^{\prime} 00^{\prime \prime} \mathrm{W}$; (map 11).

Name first appeared in mining records in 1884 when Michael Powers claimed water rights there (DeArmond, 1957, p. 22-23). The name was published in 1904 by USGS.

Granite Creek: stream, flows SE $4 \mathrm{mi}$. to Goodnews River, $15 \mathrm{mi}$. NE of Goodnews, Kilbuck-Kuskokwim Mts. ; $59^{\circ} 17^{\prime} \mathrm{N}, 161^{\circ} 18^{\prime} \mathrm{W}$; (map 53).

Descriptive name reported in 1919 by G. L. Harrington (in Brooks and others, 1921, pl. 
7), USGS; "so named because the stream flows over granitic rocks."

Granite Creek: stream, on Kenai Penin., flows SW $8 \mathrm{mi}$. to East Fork Sixmile Creek, $14 \mathrm{mi}$. $\mathrm{SE}$ of Sunrise, Chugach Mts.; $60^{\circ} 43^{\prime} 10^{\prime \prime} \mathrm{N}$, $149^{\circ} 17^{\prime} 45^{\prime \prime} \mathrm{W}$; (map 63).

Local name reported in 1898 by Mendenhall (1900, map 16), USGS.

Granite Creek: stream, heads in glacier, flows W 24 mi. to Tana Glacier, $8 \mathrm{mi}$. SE of head of Tana River and $103 \mathrm{mi}$. NE of Cordova, Chugach Mts. ; $60^{\circ} 45^{\prime} 30^{\prime \prime} \mathrm{N}, 142^{\circ} 42^{\prime} 00^{\prime \prime} \mathrm{W}$; (map 65).

Name published by F. H. Moffit (1918, pl. 6), USGS.

Granite Creek: stream, flows S $8 \mathrm{mi}$. to Tuluksak River, $58 \mathrm{mi}$. NE of Bethel, Kilbuck-Kuskokwim Mts.; $60^{\circ} 58^{\prime} 30^{\prime \prime} \mathrm{N}, 160^{\circ} 05^{\prime} 50^{\prime \prime} \mathrm{W}$; (map 59)

Prospectors' name reported in 1914 by A. G. Maddren (in Brooks, 1915, pl. 11), USGS.

Granite Creek: stream, heads on Mount Susitna, flows SE $6.3 \mathrm{mi}$. to Alexander Creek, $7 \mathrm{mi}$. SW of Susitna and $28 \mathrm{mi}$. NW of Anchorage, Cook Inlet Low.; $61^{\circ} 27^{\prime} \mathrm{N}, 150^{\circ} 36^{\prime} \mathrm{W}$; (map 70)

Name used by local prospectors; reported in 1899 by F. C. Schrader, USGS.

Granite Creek: stream, heads at a glacier, flows S $17 \mathrm{mi}$. to Matanuska River, $11 \mathrm{mi}$. NE of Palmer, Chugach Mts.; $61^{\circ} 42^{\prime} 35^{\prime \prime} \mathrm{N}, 148^{\circ}$ $51^{\prime} 00^{\prime \prime} \mathrm{W}$; (map 69).

Name used by prospectors; reported in 1899 by Mendenhall (1900, pl. facing p. 310), USGS.

Granite Creek: stream, flows $1.4 \mathrm{mi}$. S from Granite Peak to Kotsina River, $37 \mathrm{mi}$. NW of McCarthy, Wrangell Mts.; $61^{\circ} 43^{\prime} \mathrm{N}, 143^{\circ} 52^{\prime}$ W; (map 67).

Local name reported by USGS, in 1923.

Granite Creek: stream, flows SE $6 \mathrm{mi}$. to Oshetna River, $28 \mathrm{mi}$. SW of its junc. with Susitna River and $80 \mathrm{mi}$. W of Gulkana, Talkeetna Mts.; $62^{\circ} 17^{\prime} \mathrm{N}, 147^{\circ} 49^{\prime} \mathrm{W}$.; (map 82).

Local name reported in 1931 by USGS.

Granite Creek: stream, flows SW $4.8 \mathrm{mi}$. to its junc. with Homestake Creek to form Willow Creek, $32 \mathrm{mi}$. SE of Flat and $45 \mathrm{mi}$. N of Sleetmute, Kilbuck-Kuskokwim Mts.; 62 ${ }^{\circ} 21^{\prime}$ N, $157^{\circ} 02^{\prime} \mathrm{W}$; (map 79).

Prospectors' name obtained in 1913 by Eakin (1914, pl. 1), USGS.

Granite Creek: stream, flows S $1.6 \mathrm{mi}$. to Otter Creek $10.5 \mathrm{mi}$. E of its junc, with Iditarod River, $3 \mathrm{mi}$. E of Flat and $58 \mathrm{mi}$. NW of Sleetmute, Kilbuck-Kuskokwim Mts., $62^{\circ} 27^{\prime} 30^{\prime \prime}$ N, 157 $54^{\prime} 30^{\prime \prime} \mathrm{W}$; (map 79).

Name shown on a 1910 manuscript map of "Iditarod Placer Fields."

Granite Creek: stream, heads at glacier, between Kahiltna and Kanikula Glaciers, flows S 22 mi. to Kahiltna River, $35 \mathrm{mi}$. NW of Talkeetna, Alaska Ra.; $62^{\circ} 27^{\prime} 45^{\prime \prime} \mathrm{N}, 151^{\circ}$ $10^{\prime} 10^{\prime \prime} \mathrm{W}$; (map 81 ).

Prospectors' name reported in 1906 by $R$. W. Porter, USGS.

Granite Creek: stream, flows SW $7 \mathrm{mi}$. to Chulitna River, $40 \mathrm{mi}$. SW of Cantwell,
Talkeetna Mts.; $62^{\circ} 56^{\prime} 00^{\prime \prime} \mathrm{N}, 149^{\circ} 42^{\prime} 30^{\prime \prime}$ W; (map 82).

Local name reported in 1917 by $S . R$. Capps (in Martin and others, 1919, pl. 5), USGS.

Granite Creek: stream, flows NW and NE $13 \mathrm{mi}$. to Slana River, $36 \mathrm{mi}$. NE of Chistochina Alaska Ra. ; 62 $59^{\prime} \mathrm{N}, 144^{\circ} 01^{\prime} \mathrm{W}$; (map 83).

Local name reported in 1954 by USGS.

Granite Creek: stream, in Mount McKinley National Park, flows N $1.4 \mathrm{mi}$. from Mount Eielson to Thorofare River, $1.8 \mathrm{mi}$. S of Eielson Visitor Center, Alaska Ra.; $63^{\circ} 24^{\prime} 15^{\prime \prime} \mathrm{N}$, $150^{\circ} 18^{\prime} 10^{\prime \prime} \mathrm{W} ; B G N 1932$; (map 88).

Local name obtained in 1931 by J. C. Reed, Sr., and S. N. Stoner, USGS.

Granite Creek: stream, flows NE $9.5 \mathrm{mi}$. to Sulukna River, $50 \mathrm{mi}$. NE of Medfra, Kilbuck-Kuskokwim Mts. ; $63^{\circ} 47^{\prime} \mathrm{N}, 154^{\circ} 10^{\prime} \mathrm{W}$; (map 89).

Local name reported in 1954 by USGS.

Granite Creek: stream, heads on Granite Mtn., flows NE $30 \mathrm{mi}$. to Sawmill Creek, $18 \mathrm{mi}$. SE of Big Delta, Tanana Low.; $64^{\circ} 01^{\prime} 30^{\prime \prime} \mathrm{N}$, $145^{\circ} 18^{\prime} 00^{\prime \prime} \mathrm{W}$; (map 101).

Named by prospectors; reported in 1910 by S. R. Capps, USGS.

Granite Creek: stream, N of Monument Rocks, flows NE $1.5 \mathrm{mi}$. to Flint Creek, $4.5 \mathrm{mi}$. SE of Long and $27 \mathrm{mi}$. S of Ruby, Kilbuck-Kuskokwim Mts.; $64^{\circ} 21^{\prime} \mathrm{N}, 155^{\circ} 23^{\prime} \mathrm{W}$; (map 98).

Prospectors' name reported in 1913 by Eakin (1914, pl. 3), USGS.

Granite Creek: stream, flows SW $2 \mathrm{mi}$. to Tibb Creek $5.7 \mathrm{mi}$. S of that stream's junc. with Goodpaster River and $50 \mathrm{mi}$. NE of Big Delta, Yukon-Tanana High.; $64^{\circ} 24^{\prime} \mathrm{N}, 144^{\circ} 16^{\prime} \mathrm{W}$; (map 101).

Local name published in 1956 by USGS.

Granite Creek: stream, flows NW $2.5 \mathrm{mi}$. to Sinuk River, $21 \mathrm{mi}$. NW of Nome, Seward Penin. High.; $64^{\circ} 40^{\prime} \mathrm{N}, 166^{\circ} 00^{\prime} \mathrm{W}$; (map 94). Var. Granit Creek.

Prospectors' name published as "Granit" on the 1900 "Map of Nome Peninsula" by J. M. Davidson and B. D. Blakeslee.

Granite Creek: stream, flows NE $22 \mathrm{mi}$. to Seventymile River, $32 \mathrm{mi}$. NW of Eagle, Yukon-Tanana High.; $64^{\circ} 58^{\prime} 45^{\prime \prime} \mathrm{N}, 142^{\circ} 10^{\prime} 10^{\prime \prime}$ W; (map 102).

Named by prospectors apparently for rock prevalent in the area; shown on 1902 field sheet by T. G. Gerdine, USGS.

Granite Creek: stream, flows NW $5 \mathrm{mi}$. to Tisuk River, $40 \mathrm{mi}$. NW of Nome, Seward Penin. High.; 64 $4^{\circ} 59^{\prime} \mathrm{N}, 166^{\circ} 11^{\prime} \mathrm{W}$; (map 94).

Prospectors' name reported in 1900 by E. C. Barnard (in Brooks, 1901, pl. 17), USGS

Granite Creek: stream, flows SE $1.3 \mathrm{mi}$. to Pedro Creek, $13 \mathrm{mi}$. NE of Fairbanks, YukonTanana High.; $65^{\circ} 00^{\prime} 45^{\prime \prime} \mathrm{N}, 147^{\circ} 29^{\prime} 00^{\prime \prime} \mathrm{W}$ (map 105).

Named by prospectors; published in 1908 by USGS.

Granite Creek: stream, heads at $\mathrm{N}$ end of Darby Mts., flows SE $9 \mathrm{mi}$. to Tubutulik River in Death Valley, $35 \mathrm{mi}$. SE of Imuruk Lake,
Seward Penin. High.; $65^{\circ} 11^{\prime} \mathrm{N}, 162^{\circ} 22^{\prime} \mathrm{W}$; (map 110).

Prospectors' name reported in 1909 by Smith and Eakin (1911, pl. 1), USGS.

Granite Creek: stream, flows NE $8.5 \mathrm{mi}$. to Minook Creek, $14 \mathrm{mi}$. S of Rampart, YukonTanana High.; $65^{\circ} 18^{\prime} \mathrm{N}, 150^{\circ} 08^{\prime} \mathrm{W}$; (map 106).

Prospectors' descriptive name reported in 1904 by L. M. Prindle, USGS

Granite Creek: stream, flows SW $3.3 \mathrm{mi}$. to Sweepstakes Creek, $12 \mathrm{mi}$. NW of Haycock, Seward Penin. High.; $65^{\circ} 21^{\prime} \mathrm{N}, 161^{\circ} 18^{\prime} \mathrm{W}$; (map 109).

Local name reported in 1917 by G. L. Harrington, USGS.

Granite Creek: stream, on Seward Penin., flows $\mathrm{N} 3.5 \mathrm{mi}$. to Lopp Lagoon, $4.5 \mathrm{mi}$. NE of Cape Prince of Wales and $53 \mathrm{mi}$. NW of Teller, Kotzebue-Kobuk Low.; $65^{\circ} 38^{\prime} \mathrm{N}$, $167^{\circ} 58^{\prime} \mathrm{W}$; (map 111).

Prospectors' name published in 1956 by USGS

Granite Creek: stream, flows NW $10 \mathrm{mi}$. to Butte Creek, $28 \mathrm{mi}$. SW of Beaver, Yukon Flats; $66^{\circ} 01^{\prime} 30^{\prime \prime} \mathrm{N}, 147^{\circ} 56^{\prime} 30^{\prime \prime} \mathrm{W}$; (map 118).

Local descriptive name obtained in 1956 by USGS

Granite Creek: stream, flows NW $5 \mathrm{mi}$. to Mosquito Fork at Eagle Cliff, 52 mi. SW of Chandalar, Brooks Ra.; $67^{\circ} 02^{\prime} 03^{\prime \prime}$ N, 149 $59^{\circ}$ $00^{\prime \prime}$ W ; (map 123). Var. West Fork Chandalar River.

Prospectors' name obtained in 1909 by A. G. Maddren (1913, pl. 1), USGS.

Granite Creek: stream, flows NW to Kuzitrin River, about $17 \mathrm{mi}$. N of Mount Bendeleben, Seward Penin. High.; (map 110).

Prospectors' name shown on a map of Cape Nome gold fields by David Fox, Jr., dated 1901. This stream cannot be precisely located on current maps.

Granite Greek: stream, see Bullion Creek.

Granite Creek: stream, see West Fork Chandalar River.

Granite Falls: waterfall, see Grindstone Falls.

Granite Fork: stream, flows SE $26 \mathrm{mi}$. to Hodzana River, 47 mi. NW of Beaver, Kokrines-Hodzana High. ; $66^{\circ} 43^{\prime} \mathrm{N}, 148^{\circ} 50^{\prime} \mathrm{W}$; (map 118).

Local name obtained in 1956 by USGS

Granite Fork: stream, see Middle Fork Fortymile River.

Granite Gulch: ravine, trends NW 2 mi. to Mammoth Creek, $13 \mathrm{mi}$. WSW of Central and 40 mi. SW of Circle, Yukon-Tanana High.; $65^{\circ} 31^{\prime} \mathrm{N}, 145^{\circ} 13^{\prime} \mathrm{W}$; (map 104).

Prospectors' name reported in 1954 or 1955 by USGS topographers.

Granite Island: island, $0.6 \mathrm{mi}$. long, at head of George Inlet, on Revillagigedo I., Alex. Arch.; $50^{\circ} 30^{\prime} \mathrm{N}, 131^{\circ} 28^{\prime} \mathrm{W}$; (map 3$)$.

Local name published in the 1925 Coast Pilot (p. 59)

Granite Island: island, $5.5 \mathrm{mi}$. long, $0.5 \mathrm{mi}$. SW of Harris Penin., 35 mi. SW of Seward, Chugach Mts.; $59^{\circ} 39^{\prime} \mathrm{N}, 149^{\circ} 48^{\prime} \mathrm{W}$; BGN 1911 ; (map 49). 
So named in 1909 by U. S. Grant, USGS, because it was "a long high island of granite."

Granite Islands: islands, $1 \mathrm{mi}$. long, $6 \mathrm{mi}$. SW of Chichagof, on W coast of Chichagof I., Alex.

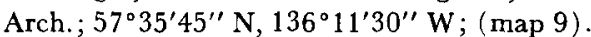

Descriptive name given in 1925 by a USC\&GS field party because of "granite-like rock of which the islands are composed." The name was published in 1928 on Chart 8280 .

Granite Lake: lake, $0.2 \mathrm{mi}$. across, on Revillagigedo I., near head of Thorne Arm, $1.3 \mathrm{mi}$. E of Pop Point, Alex. Arch.; 55 $23^{\prime} 22^{\prime \prime} \mathrm{N}$, $131^{\circ} 10^{\prime} 45^{\prime \prime} \mathrm{W}$; (map 3 ).

Local name reported in 1901 by Brooks (1902b, p. 64), USGS.

Granite Mountain: mountain, 3,445 ft., near center of Prince of Wales I., S of Salmon Lake; $55^{\circ} 31^{\prime} 45^{\prime \prime} \mathrm{N}, 132^{\circ} 40^{\prime} 30^{\prime \prime} \mathrm{W}$; (map 4).

Descriptive name given in 1935 by USGS.

Granite Mountain: mountain, 5,815 ft., extends NW $15 \mathrm{mi}$. from Gerstle River, $20 \mathrm{mi}$. SE of Delta Junction, Alaska Ra.; $63^{\circ} 45^{\prime} \mathrm{N}, 145^{\circ} 22^{\prime}$ W; (map 86).

Local descriptive name reported in 1949 by USGS.

Granite Mountain: mountain, 2,835 ft., $16 \mathrm{mi}$. NW of Haycock, Seward Penin. High.; $65^{\circ} 26^{\prime}$ $\mathrm{N}, 161^{\circ} 14^{\prime} \mathrm{W}$; (map 109).

Local name published on maps after 1950.

Granite Mountain: ridge, 2,923 ft., in Kus. kokwim Mts., extends NE-SW 5 mi. between Moose Creek and Little East Fork George River, $42 \mathrm{mi}$. SE of Flat, Kilbuck-Kuskokwim Mts. ; $62^{\circ} 19^{\prime} \mathrm{N}, 156^{\circ} 43^{\prime} \mathrm{W}$; (map 79).

Local name obtained in 1952 by USGS topographers.

Granite Passage: water passage, trends SE $5 \mathrm{mi}$. between Harris Penin. and Granite I., $34 \mathrm{mi}$. SW of Seward, Chugach Mts.; $59^{\circ} 39^{\prime} \mathrm{N}$, $149^{\circ} 47^{\prime} \mathrm{W}$; (map 49).

Named by the 1912 USC\&GS field party "after Granite Island."

Granite Peak: mountain, 6,870 ft., $5 \mathrm{mi}$. E of junc. of Kluvesna and Kotsina Rivers, $16 \mathrm{mi}$. W of Mount Blackburn, Wrangell Mts.; $61^{\circ}$ $44^{\prime} 45^{\prime \prime} \mathrm{N}, 143^{\circ} 51^{\prime} 50^{\prime \prime} \mathrm{W}$; (map 67).

Local name reported in $1912-13$ as "Granite Mtn." by D. C. Witherspoon, USGS, but published in 1922 as "Granite Peak."

Granite Peak: mountain, 6,729 ft., on W bank of Granite Creek, $16 \mathrm{mi}$. NE of Palmer, Talkeetna Mts.; $61^{\circ} 47^{\prime} 45^{\prime \prime} \mathrm{N}, 1^{\circ} 8^{\circ} 53^{\prime} 05^{\prime \prime} \mathrm{W}$; $B G N$ 1946; (map 69). Var. Eska Peak.

Descriptive name reported about 1946 by USGS.

Granite Point: point of land, at S end of Sanborn Harbor, W coast of Nagai I., in Shumagin Is., Aleutian Ra.; 55 $06^{\prime} 50^{\prime \prime} \mathrm{N}, 160^{\circ} 01^{\prime} 45^{\prime \prime} \mathrm{W}$; (map 28).

Named in 1875 by W. H. Dall, USC\&GS.

Granite Point: point of land, W tip of Baker I., $1 \mathrm{mi}$. N of Cape Chirikof, Alex. Arch.; 55 $19^{\prime}$ $00^{\prime \prime} \mathrm{N}, 133^{\circ} 41^{\prime} 25^{\prime \prime} \mathrm{W}$; (map 4).

Local name published in 1925 Coast Pilot (p. 179).

Granite Point: point of land, near the head of Redfish Bay, $10.4 \mathrm{mi}$. NW of village of Port
Alexander, Alex, Arch.; $56^{\circ} 20^{\prime} 25^{\prime \prime} \mathrm{N}, 134^{\circ}$ $51^{\prime} 40^{\prime \prime} \mathrm{W}$; (map 5).

Named in 1897 by Lt. Comdr. J. F. Moser, USN, commander of USBF steamer Albatross.

Granite Point: point of land, $1.5 \mathrm{mi}$. E of Fairmount I., and $46 \mathrm{mi}$. NE of Whittier, Chugach Mts. ; $60^{\circ} 52^{\prime} 25^{\prime \prime} \mathrm{N}, 147^{\circ} 23^{\prime} 00^{\prime \prime} \mathrm{W}$; (map 63 ).

Local name reported in 1916 by J. W. Bagley, USGS.

Granite Point: point of land, on NW shore of Cook Inlet, $8 \mathrm{mi}$. SW of Tyonek, Cook Inlet Low.; $61^{\circ} 00^{\prime} 40^{\prime \prime} \mathrm{N}, 151^{\circ} 21^{\prime} 00^{\prime \prime} \mathrm{W}$; BGN 1916; (map 70).

Local descriptive name reported in 1916 by USGS.

Granite Range: mountain range, extends $\mathrm{E}$ from head of Tana River $27 \mathrm{mi}$. to Logan Glacier, $120 \mathrm{mi}$. NE of Cordova, Chugach Mts.; $60^{\circ}$ $49^{\prime} \mathrm{N}, 142^{\circ} 18^{\prime} \mathrm{W}$; (map 65$)$.

Name published by F. H. Moffit (1918, pl. 6), USGS.

Granitsa Channel: water passage, see Dixon Entrance.

Granitsy Strait: water passage, see Dixon Entrance.

Grant, Cape: point of land, on $\mathrm{N}$ shore of Halibut Bay, on W coast of Kodiak I., $14 \mathrm{mi}$. SW of Karluk ; $57^{\circ} 25^{\prime} 25^{\prime \prime} \mathrm{N}, 154^{\circ} 42^{\prime} 50^{\prime \prime} \mathrm{W}$; BGN 1931; (map 35).

Named by USC\&GS in 1919 for the U.S. Revenue Cutter Grant.

Grant, Point: point of land, see Whidbey, Point. Grant Cove: cove, $0.3 \mathrm{mi}$. across, on $\mathrm{W}$ coast of Gravina I., $1.7 \mathrm{mi}$. S of South Vallenar Point, Alex. Arch.; 55 $21^{\prime} 15^{\prime \prime} \mathrm{N}, 131^{\circ} 51^{\prime} 30^{\prime \prime} \mathrm{W}$; (map 3).

Local name published in the 1925 Coast Pilot (p. 82).

Grant Creek: locality, on N bank of Yukon River, at mouth of Grant Creek, $24 \mathrm{mi}$. W of Tanana, Kokrines-Hodzana High.; $65^{\circ} 13^{\prime} \mathrm{N}, 152^{\circ} 56^{\prime}$ W; (map 106). Var. Tuklukyet.

Mining camp reported in 1911 by $\mathrm{H}$. M. Eakin, USGS. Baker (1906, p. 639) lists an Indian village, "Tuklukyet *** about $15 \mathrm{mi}$. below Nuklukayet," which would be at or near this point.

Grant Creek: stream, flows SE $14 \mathrm{mi}$. to Burroughs Bay, $6 \mathrm{mi}$. SW of its head at mouth of Unuk River, Coast Mts.; $56^{\circ} 01^{\prime} 30^{\prime \prime} \mathrm{N}, 131^{\circ}$ 11'30" W; BGN 1923; (map 7).

Local name reported in 1923 by USFS.

Grant Creek: stream, on Douglas I., flows 0.7 mi. NE to Gastineau Channel, $1 \mathrm{mi}$. W of Juneau, Coast Mts. ; $58^{\circ} 18^{\prime} 20^{\prime \prime} \mathrm{N}, 134^{\circ} 27^{\prime} 00^{\prime \prime}$ W; (map 11).

Name first used in a mining claim by John McLaughlin and Matt McMahon in 1884. The source of the name is unknown (DeArmond, 1957, p. 23).

Grant Creek: stream, on Kenai Penin., heads at Grant Lake, flows SW 1 mi. to Upper Trail Lake, $24 \mathrm{mi}$. N of Seward, Chugach Mts.; $60^{\circ} 28^{\prime} \mathrm{N}, 148^{\circ} 21^{\prime} \mathrm{W}$; (map 63).

Name published on recent USGS maps; derived from Grant Lake, which it drains.
Grant Creek: stream, flows S $4.5 \mathrm{mi}$. E to Hanagita River, 1 mi. NE of Hanagita Lake and $33 \mathrm{mi}$. SW of McCarthy, Chugach Mts.; $61^{\circ} 15^{\prime} 05^{\prime \prime} \mathrm{N}, 143^{\circ} 49^{\prime} 45^{\prime \prime} \mathrm{W}$; (map 67).

Local name published by USGS in 1954 .

Grant Cireek: stream, heads in Peters Hills, and flows NW $1.5 \mathrm{mi}$. to Cache Creek $0.9 \mathrm{mi}$. NE of its junc. with Trout Creek, $29 \mathrm{mi}$. NW of Talkeetna, Alaska Ra.; $62^{\circ} 30^{\prime} 05^{\prime \prime} \mathrm{N}, 150^{\circ}$. $56^{\prime} 30^{\prime \prime} \mathrm{W}$; (map 81$)$.

Local name reported in 1948 by USGS.

Grant Creek: stream, in Mount McKinley National Park, flows NW $2.5 \mathrm{mi}$. from Mount Eielson to Camp Creek, $\mathbf{E}$ of Muldrow Glacier, $2.8 \mathrm{mi}$. SE of Eielson Visitor Center, Alaska Ra.; $63^{\circ} 24^{\prime} 30^{\prime \prime} \mathrm{N}, 150^{\circ} 22^{\prime} 50^{\prime \prime} \mathrm{W}$; $B G N$ 1932; (map 88).

Locally named in 1931 for O. M. Grant "the best known prospector in the region" according to J. C. Reed, Sr., and S. N. Stoner, USGS.

Grant Creek: stream, flows SE $2.5 \mathrm{mi}$. to Quartz Creek, $11 \mathrm{mi}$. SE of Long and $31 \mathrm{mi}$. SSE of Ruby, Kilbuck-Kuskokwim Mts.; 64 $19^{\prime} \mathrm{N}$, $155^{\circ} 11^{\prime} \mathrm{W}$; (map 98).

Prospectors' name reported in 1913 by Eakin (1914, pl. 3), USGS. The stream's exact application is in doubt.

Grant Greek: stream, heads on Grant Dome, flows SW $11 \mathrm{mi}$. to Yukon River at locality of Grant Creek, 25 mi. W of Tanana, Kokrines-Hodzana High.; $65^{\circ} 13^{\prime} \mathrm{N}, 152^{\circ} 56^{\prime} \mathrm{W}$; (map 106). Var. Newchukli Kaket, Newchuklichargut.

Prospectors' name reported by USGS in 1906. This appears to be the stream spelled "Newchuklichargut," i.e., "mouth of the Newchukli [River]," by Lt. Frederick Schwatka, USA, in 1883 .

Grant Creek: stream, flows NE $5 \mathrm{mi}$. to Lincoln Creek which flows to Kougarok River, $46 \mathrm{mi}$. $\mathrm{NE}$ of Teller, Seward Penin. High.; $65^{\circ} 36^{\prime} \mathrm{N}$, $165^{\circ} 00^{\prime} \mathrm{W}$; (map 111).

Prospectors' name reported on the 1908 "Map of Seward Peninsula" by Arthur Gibson. Grant Creek: stream, flows NW to Kugruk River near its mouth on Kotzebue Sound, about 30 mi. NE of Imuruk Lake, Seward Penin. High.; (map 110).

Local name published on a precinct map of Seward Peninsula by Monroe and Hutchins; corrected to June 1903 by Arthur Gibson. This stream cannot be precisely identified on current maps.

Grant Creek: stream, flows NE to Lone Mountain Creek which flows to American River, about $35 \mathrm{mi}$. NE of Teller, Seward Penin. High.; (map 111).

Prospectors' name shown on a map of Cape Nome gold fields by David Fox, Jr., dated 1901. This feature cannot be precisely identified on current maps.

Grant Creek: stream, see Tom Creek.

Grant Dome: mountain, 2,750 ft., at head of Grant Creek, $24 \mathrm{mi}$. WNW of Tanana, Kokrines-Hodzana High.; $65^{\circ} 18^{\prime} \mathrm{N}, 152^{\circ} 52^{\prime} \mathrm{W}$; (map 106). 
Named about 1908 by prospectors for Grant Creek.

Grant Island: island, $2 \mathrm{mi}$. long, at $\mathrm{N}$ entrance to Clover Passage on $W$ coast of Revillagigedo I., Alex. Arch.; 55 $33^{\prime}$ N, $131^{\circ} 43^{\prime}$ W ; (map 3). Var. Giant Island.

Named in 1885 by Lt. Gomdr. Richardson Clover, USN.

Grant Island: island, see Culross Island.

Grant Lagoon: lagoon, $1 \mathrm{mi}$. long, on $\mathrm{W}$ coast of Kodiak I., $10 \mathrm{mi}$. SW of Karluk; $57^{\circ} 28^{\prime}$ N, 154³9' W; BGN 1931; (map 35).

Named by USC\&GS in 1929 for Cape Grant.

Grant Lake: lake, $3 \mathrm{mi}$. long, $4 \mathrm{mi}$. S of Agenuk Mtn. and $54 \mathrm{mi}$. $\mathrm{N}$ of Dillingham, KilbuckKuskokwim Mts.; $59^{\circ} 48^{\prime} \mathrm{N}, 158^{\circ} 33^{\prime} \mathrm{W} ; B G N$ 1932; (map 52). Var. Nan-y-vuk-cho-ak.

Named by local people for a prospector who lived on the lake many years ago; reported in 1932 by Gerald FitzGerald, USGS; published by Mertie (1938b, p1. 1), USGS.

Grant Lake: lake, 7 mi. long, on Kenai Penin., $27 \mathrm{mi}$. NE of Seward, Chugach Mts.; $60^{\circ} 29^{\prime}$ $30^{\prime \prime} \mathrm{N}, 149^{\circ} 18^{\prime} 00^{\prime \prime} \mathrm{W}$; BGN 1910; (map 63).

"Named for a local miner"; reported in 1909 by U. S. Grant and D. F. Higgins (in Brooks and others, 1910, pl. 4), USGS.

Grantley Harbor: bay, extends SE $10 \mathrm{mi}$. from Port Clarence at Teller to Tuksuk Channel, Seward Penin. High.; $65^{\circ} 17^{\prime} N, 166^{\circ} 15^{\prime} \mathrm{W}$; (map 111). Var. Port Griantle, H. Griantle. Named in 1827 by Capt. Beechey (1831, p. 543), RN, "in compliment to Lord Grantley."

Grant Peak: peak, 4,575 ft., $8 \mathrm{mi}$. NE of Farragut Bay and 87 mi. E of Sitka, Coast Mts.; $57^{\circ} 12^{\prime} 50^{\prime \prime} \mathrm{N}, 133^{\circ} 04^{\prime} 40^{\prime \prime} \mathrm{W}$; (map 8).

Named in 1887 by Lt. Comdr. C. $M$. Thomas, USN, for Ulysses Simpson Grant, 1822-1885, 18th President of the United States.

Grant Point: point of land, between Izembek Lagoon and Applegate Cove, $8 \mathrm{mi}$. NW of village of Cold Bay, at SW end of Alaska Penin., Bristol Bay Low.; 55 $16^{\prime}$ N, $162^{\circ} 53^{\prime} \mathrm{W}$; (map 29).

Named by USBF in 1888 for Ulysses Simpson Grant, 1822-85, President of the United States from 1868-76.

Grants Cabin: locality, on $\mathrm{W}$ bank of Theodore River, 16 mi. NE of Tyonek, Cook Inlet Low.; $61^{\circ} 15^{\prime} 45^{\prime \prime} \mathrm{N}, 150^{\circ} 52^{\prime} 30^{\prime \prime} \mathrm{W}$; (map 70).

Local name reported on a 1958 USGS map which indicates a site having two buildings and a winter airplane landing strip.

Granville, Cape: point of land, see Chiniak, Cape.

Granville Portage: pass, $4.5 \mathrm{mi}$. long, trends NE across base of Kupreanof Penin., between Stepovak and Ivanof Bays, Aleutian Ra.; 55 ${ }^{\circ} 51^{\prime}$ N, $159^{\circ} 36^{\prime} \mathrm{W}$; (map 27).

Local name published by USG\&GS in 1916 Coast Pilot.

Grape Creek: stream, see Bertha Creek.

Graphite Bay: bight, see Windy Cove.

Graphite Lake: lake, extends NW-SE $4.4 \mathrm{mi} ., 17$ mi. W of Coleen Mtn., Yukon Flats; $67^{\circ} 04^{\prime} \mathrm{N}$, $143^{\circ} 26^{\prime} \mathrm{W}$; (map 121).
Local name reported in 1956 by T. E. Taylor, USGS.

Graphite Point: bluff, elev. $60 \mathrm{ft}$., on right bank of Porcupine River, $28 \mathrm{mi}$. NE of Chalkyitsik, Yukon Flats; $66^{\circ} 59^{\prime} \mathrm{N}, 143^{\circ} 17^{\prime} \mathrm{W}$; (map 120).

Local name reported in 1940 by FitzGerald (1944, p. 224), USGS; it "marks the northeastern limit of Yukon Flats" (p. 233).

Grass Creek: stream, flows SE $1.8 \mathrm{mi}$, to Saunders Greek, 9 mi. E of Nome, Seward Penin. High.; $64^{\circ} 29^{\prime} \mathrm{N}, 165^{\circ} 06^{\prime} \mathrm{W}$; (map 94).

Prospectors' name shown on a 1900 "Map of Nome Peninsula" by J. M. Davidson and B. D. Blakeslee.

Grass Gulch: ravine, heads at locality of Summit, trends E $0.5 \mathrm{mi}$. to Dexter Creek, $6 \mathrm{mi}$. NE of Nome, Seward Penin. High. ; $64^{\circ} 35^{\prime} 45^{\prime \prime}$ N, $165^{\circ} 20^{\prime} 30^{\prime \prime} \mathrm{W}$; (map 94).

Prospectors' name shown on the 1902 "Map of the Nome and Snake River Country" by J. M. Davidson.

Grasshopper Creek: stream, flows SE to Norton Sound, about $6 \mathrm{mi}$. E of village of Bluff and $27 \mathrm{mi}$. E of Solomon, Seward Penin. High. (map 95).

Prospectors' name shown on Arthur Gibson's "Map of Nome Precinct" dated 1904. This stream cannot be precisely located on current maps.

Grasshopper Valley: valley, extends $3.5 \mathrm{mi}$. along Glacier Fork Knik River, between Knik and Marcus Baker Glaciers, $29 \mathrm{mi}$. SE of Palmer, Chugach Mts.; $61^{\circ} 25^{\prime} 30^{\prime \prime} \mathrm{N}, 148^{\circ} 18^{\prime} 45^{\prime \prime} \mathrm{W}$; (map 69).

Local name reported in 1960 by USGS.

Grass Island: island, $0.1 \mathrm{mi}$. long, at $S$ end of Eldred Passage, on $\mathrm{S}$ shore of Kachemak Bay, $10 \mathrm{mi}$. S of Homer, Chugach Mts.; $59^{\circ} 30^{\prime}$ $\mathrm{N}, 151^{\circ} 29^{\prime} \mathrm{W}$; (map 50).

Local name reported and published by USGS in 1950.

Grass Island: island, $500 \mathrm{ft}$. long, $0.7 \mathrm{mi}$. S of Copper River Delta, $25 \mathrm{mi}$. NW of Katalla, Malaspina Coastal Plain; $60^{\circ} 17^{\prime} 30^{\prime \prime}$ N, $145^{\circ}$. $11^{\prime} 30^{\prime \prime} \mathrm{W}$; (map 64).

Descriptive name given by H. P. Ritter, USC\&GS, during his survey work in the area in 1898.

Grass Island: island, $300 \mathrm{ft}$. across, $E$ of Hawkins I., in Orca Inlet, $2 \mathrm{mi}$. NW of Cordova, Chugach Mts.; $60^{\circ} 34^{\prime} 20^{\prime \prime} \mathrm{N}, 145^{\circ} 46^{\prime} 50^{\prime \prime} \mathrm{W}$; (map 64).

Named by Lt. Comdr. J. F. Moser, USN, during his cruise aboand the Fish Commission steamer Albatross along the south coast of Alaska in 1897.

Grass Island Bar: bar, $5 \mathrm{mi}$. long, at Copper River Delta, $4 \mathrm{mi}$. off S coast of Alaska, 25 mi. SE of Cordova, Malaspina Coastal Plain; $60^{\circ} 15^{\prime} \mathrm{N}, 145^{\circ} 17^{\prime} \mathrm{W}$; (map 64).

Local descriptive name published in 1951 by USGS.

Grass Lake: lake, $0.4 \mathrm{mi}$. long, $\mathbf{E}$ of Rock Lake, $20 \mathrm{mi}$. NNW of Glennallen, Copper River Basin; 62 $21^{\prime} \mathrm{N}, 145^{\circ} 53^{\prime} \mathrm{W}$; (map 83).
Local name reported in 1951 by USGS. "So named because it is filled with swamp grasses."

Grass Lake: lake, $0.8 \mathrm{mi}$. long, $\mathrm{SW}$ of Midway Lake, $21 \mathrm{mi}$. SE of Tok, Yukon-Tanana High.; $63^{\circ} 13^{\prime} \mathrm{N}, 142^{\circ} 21^{\prime} \mathrm{W}$; (map 85).

Local name reported in 1964 by USGS.

Grass Lake: lake, $8 \mathrm{mi}$. NE of Roundabout Mtn., Koyukuk Low.; $65^{\circ} 38^{\prime} \mathrm{N}, 156^{\circ} 25^{\prime} \mathrm{W}$; (map 108).

Local name obtained at Huslia by USGS in 1954 or 1955.

Grass Lake: lake, $2 \mathrm{mi}$. long, $5 \mathrm{mi}$. NW of Swan Mtn. and $11 \mathrm{mi}$. NE of Arctic Village, Brooks Ra.; $68^{\circ} 16^{\prime} \mathrm{N}, 145^{\circ} 18^{\prime} \mathrm{W}$; (map 136).

Local descriptive name obtained in 1956 by USGS.

Grass Lake: lake, see Big Grass Lake.

Grass Lake: swamp, $3.5 \mathrm{mi}$. long, $\mathrm{W}$ of Windmill Lake, $27 \mathrm{mi}$. E of Ruby, Nowitna Low.; $64^{\circ}$ $47^{\prime} \mathrm{N}, 154^{\circ} 35^{\prime} \mathrm{W}$; (map 98).

Local name obtained in 1956 by Orth.

Grass River: stream, N distributary of Little Black River, flows NW $41 \mathrm{mi}$. to Seventeenmile Slough, $12 \mathrm{mi}$. NE of Fort Yukon, Yukon Flats; 66 $36^{\prime} 35^{\prime \prime} \mathrm{N}, 144^{\circ} 50^{\prime} 35^{\prime \prime} \mathrm{W}$; $B G N$ 1959; (map 119). Var. Little Black River.

Local name reported in 1952 by USGS.

Grass Rock: rock, $400 \mathrm{ft}$. long, at mouth of Klakas Inlet, on SW coast of Prince of Wales I., Alex. Arch.; 54 $52^{\prime} 55^{\prime \prime}$ N, $132^{\circ} 23^{\prime} 20^{\prime \prime}$ W; (map 1).

Named in 1897 by Lt. Comdr. J. F. Moser, USN.

Grass Rock: rock, at mouth of Tamgas Harbor, on $S$ coast of Annette I., Alex. Arch.; $55^{\circ} 01^{\prime} 28^{\prime \prime} \mathrm{N}, 131^{\circ} 31^{\prime} 55^{\prime \prime} \mathrm{W}$; (map 3 ).

Descriptive name given in 1883 by Lt. Comdr. H. E. Nichols, USN.

Grasstop Rock: rock, $0.1 \mathrm{mi}$. across, at mouth of Deep Bay, in Peril Strait, $25 \mathrm{mi}$. SE of Chichagof, Alex. Arch.; $57^{\circ} 26^{\prime} 05^{\prime \prime} \mathrm{N}$, $135^{\circ} 36^{\prime} 10^{\prime \prime} \mathrm{W}$; (map 9).

Descriptive name given in 1884 by Comdr. J. B. Coghlan, USN; published by USC\&GS in 1891 Coast Pilot (p. 183).

Grass Valley: valley, $5 \mathrm{mi}$. long, extended NW to Herendeen Bay, near SW end of Alaska Penin., $19 \mathrm{mi}$. S of Village of Port Moller, Aleutian Ra.; $55^{\circ} 43^{\prime} \mathrm{N}, 160^{\circ} 38^{\prime} \mathrm{W}$; (map 28).

Named in 1890 by Lt. Comdr. Z. L. Tanner, USN.

Grass Valley: valley, along Kingsley Creek, extends NW 2 mi. to mouth of Nesbit River, 7 mi. SE of Mount Bendeleben and $41 \mathrm{mi}$. SW of Imuruk Lake, Seward Penin. High.; $65^{\circ} 06^{\prime} \mathrm{N}, 163^{\circ} 55^{\prime} \mathrm{W}$; (map 110).

Prospectors' name published on the 1908 "Map of Seward Peninsula" by Arthur Gibson.

Grassy Island: island, $0.2 \mathrm{mi}$. across, $31 \mathrm{mi} . \mathrm{N}$ of Afognak, $1 \mathrm{mi}$. off $\mathrm{N}$ coast of Afognak $\mathrm{I}$; $58^{\circ} 27^{\prime} \mathrm{N}, 152^{\circ} 47^{\prime} \mathrm{W}$; (map 43).

Name published by USC\&GS in 1928 on Chart 8573

Grassy Island: island, $2.5 \mathrm{mi}$. long, awash at highest tides, near head of Nushagak Bay, 
$2 \mathrm{mi}$. S of Dillingham, Bristol Bay Low.; $59^{\circ}$ $00^{\prime} \mathrm{N}, 158^{\circ} 28^{\prime} \mathrm{W}$; (map 40). Var. Williams Island, William's Island.

Descriptive name given in 1952 by USGS; called "William's Island" in 1890 by USBF.

Grassy Island: island, $500 \mathrm{ft}$. long, in Iliamna Lake, $4.3 \mathrm{mi}$. SE of Chekok Point and $23 \mathrm{mi}$. $\mathrm{E}$ of Iliamna, Aleutian Ra.; $59^{\circ} 46^{\prime} \mathrm{N}$ $154^{\circ} 17^{\prime} \mathrm{W}$; (map 51).

Local name published in 1954 by USGS.

Grassy Island: island, see Sozavarika Island.

Grassy Lake: lagoon, extends $\mathrm{N} 1 \mathrm{mi}$. to Lake Bay, on NE coast of Prince of Wales I., Alex. Arch.; 56 $01^{\prime} 00^{\prime \prime} \mathrm{N}, 1^{\circ} 2^{\circ} 53^{\prime} 30^{\prime \prime} \mathrm{W}$; (map 6 ).

Local descriptive name reported in 1949 by USGS.

Grass Lake: lake, $0.3 \mathrm{mi}$. across, $6 \mathrm{mi}$. NE of Minto and $38 \mathrm{mi}$. W of Fairbanks, Tanana Low.; $64^{\circ} 55^{\prime} \mathrm{N}, 149^{\circ} 01^{\prime} \mathrm{W}$; (map 100).

Local descriptive name published in 1950 by USGS

Grassy Lake: lake, $1.3 \mathrm{mi}$. across, $12 \mathrm{mi}$. NW of Minto and $55 \mathrm{mi}$. NW of Fairbanks, Tanana

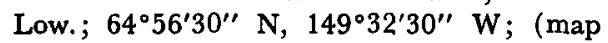
100).

Local descriptive name published in 1952 by USGS.

Grassy Mountain: mountain, 3,207 ft., $1.8 \mathrm{mi}$. SE of Bald Mtn., $80 \mathrm{mi}$. NW of Hoonah, St. Elias Mts.; $58^{\circ} 36^{\prime} 00^{\prime \prime} \mathrm{N}, 137^{\circ} 26^{\prime} 55^{\prime \prime} \mathrm{W}$; (map 10).

Descriptive name published by members of the Harvard-Dartmouth Expedition, 1933-34 (Washburn and Goldthwait, 1936, map).

Grassy Point: bluff, elev. $50 \mathrm{ft}$., on $\mathbf{N}$ bank of Naknek River $\mathbf{S}$ of King Salmon, on Alaska Penin. $13 \mathrm{mi}$. SW of Naknek, Bristol Bay Low.; $58^{\circ} 40^{\prime} 00^{\prime \prime} \mathrm{N}, 156^{\circ} 39^{\prime} 30^{\prime \prime} \mathrm{W}$; (map 41).

Local name reported in 1952 by USǴS.

Grassy Point: point of land, on W shore of Karluk Lake, $19 \mathrm{mi}$. SE of Karluk, Kodiak I.; $57^{\circ} 23^{\prime} 15^{\prime \prime} \mathrm{N}, 154^{\circ} 04^{\prime} 15^{\prime \prime} \mathrm{W}$; (map 35$)$.

Local descriptive name reported in 1952 by USGS.

Grassy Pond: lake, $0.4 \mathrm{mi}$. across, in Glacier Bay National Monument, $1.3 \mathrm{mi}$. SW of head of Crillon Lake and $80 \mathrm{mi}$. NW of Hoonah, St. Elias Mts.; $58^{\circ} 34^{\prime} 40^{\prime \prime} \mathrm{N}, 137^{\circ} 24^{\prime} 10^{\prime \prime} \mathrm{W}$; (map 10).

Name published by members of the Harvard-Dartmouth Expedition, 1933-34 (Washburn and Goldthwait, 1936, map).

Grassy Ridge: ridge, $2 \mathrm{mi}$. long, extends $2 \mathrm{mi}$. SE of Grassy Mtn., $80 \mathrm{mi}$. WNW of Hoonah, St. Elias Mts. ; $58^{\circ} 35^{\prime} 30^{\prime \prime} \mathrm{N}, 137^{\circ} 26^{\prime} 00^{\prime \prime} \mathrm{W}$; (map 10).

Descriptive name published by members of the Harvard-Dartmouth Expedition, 1933-34 (Washburn and Goldthwait, 1936, map).

Grassy Rock: island, $0.1 \mathrm{mi}$. across, off the W shore of Port Frederick on Chichagof I., 6.2 $\mathrm{mi}$. SW of Hoonah, Alex. Arch.; 58 $02^{\prime} 50^{\prime \prime} \mathrm{N}$, $135^{\circ} 33^{\prime} 45^{\prime \prime} \mathrm{W}$; (map 11).

Descriptive name published by USC\&GS in the 1925 Coast Pilot (p. 345).

Grave Creek: stream, heads at junc. of Slate and McLellan Creeks, flows SE $6 \mathrm{mi}$. to Middle
Fork Chandalar River, $18 \mathrm{mi}$. E of Chandalar, Brooks Ra.; 67 $7^{\circ} 32^{\prime} \mathrm{N}, 147^{\circ} 48^{\prime} \mathrm{W}$; (map 123).

Prospectors' name reported in 1899 by Schrader (1900b, pl. 60), USGS.

Grave Island: island, $0.2 \mathrm{mi}$. long, $1 \mathrm{mi}$. S of of Kake, in Keku Strait on NW coast of Kupreanof I., Alex. Arch.; 56 $57^{\prime} 35^{\prime \prime}$ N, $133^{\circ} 57^{\prime} 00^{\prime \prime} \mathrm{W}$; (map 6).

Local name published by USC\&GS in 1925 Coast Pilot (p. 215).

Grave Island: island, $0.1 \mathrm{mi}$. across, in Southwest Is., in Pybus Bay, on Admiralty I., $25 \mathrm{mi}$. $\mathrm{SE}$ of Angoon, Alex. Arch.; $57^{\circ} 16^{\prime} \mathrm{N}$, $134^{\circ} 05^{\prime} \mathrm{W}$; (map 9).

Name published in 1928 by USC\&GS on Chart 8218. Grave Island Light is located here.

Grave Island: island, $0.1 \mathrm{mi}$. across, in Tenakee Inlet in $\mathrm{E}$ central Chichagof I., $1 \mathrm{mi}$. SE of Tenakee Springs, Alex. Arch.; $57^{\circ} 46^{\prime} 30^{\prime \prime} \mathrm{N}$, $135^{\circ} 11^{\prime} 50^{\prime \prime} \mathrm{W}$; (map 9)

Local name reported in 1951 by USGS.

Gravel Creek: stream, heads at glacier, flows N $11 \mathrm{mi}$. to Matanuska River, $38 \mathrm{mi}$. NE of Palmer, Chugach Mts.; $61^{\circ} 46^{\prime} 50^{\prime \prime} \mathrm{N}, 148^{\circ}$. $00^{\prime} 05^{\prime \prime} \mathrm{W}$; (map 69).

Local name reported in 1913 by $\mathbf{R}$. H. Sargent, USGS.

Gravel Creek: stream, in Nutzotin Mts., flows SE $9 \mathrm{mi}$. to easternmost of Braye Lakes, $36 \mathrm{mi}$. E of Euchre Mtn., Alaska Ra.; 62 $03^{\prime} 10^{\prime \prime} \mathrm{N}$, $141^{\circ} 04^{\prime} 45^{\prime \prime} \mathrm{W}$; (map 84).

Descriptive name used by prospectors; reported by Capps (1916, pl. 1), USGS.

Gravel Creek: streom, heads in Shublik Mts. flows E $6 \mathrm{mi}$. to Sadlerochit River, $7.5 \mathrm{mi}$. $\mathrm{N}$ of Lake Schrader and $24 \mathrm{mi}$. NW of Mount Michelson, Brooks Ra.; $69^{\circ} 29^{\prime} 30^{\prime \prime} \mathrm{N}, 145^{\circ} 06^{\prime}$ 00" W; BGN 1961; (map 139).

So named in 1948 by USGS geologists "because of a prominent gravel terrace exposed along the stream." It was reported in 1960 by C. L. Whittington, USGS.

Gravel Creek: stream, flows $\mathbf{S} 2 \mathrm{mi}$. to North Fork Snake River, $15 \mathrm{mi}$. NW of Nome, Seward Penin. High.

Published in 1900 by Schrader (1900c, p. 16), USGS. Subsequent maps show no stream at this location.

Gravel Island: island, see Martin Island.

Gravel Mountain: peak, 5,936 ft., in Mount McKinley Naticnal Park, $3.7 \mathrm{mi}$. E of Eielson Visitor Center, Alaska Ra.; 63 $25^{\prime} 40^{\prime \prime} \mathrm{N}$, $150^{\circ} 11^{\prime} 25^{\prime \prime} \mathrm{W}$; BGN 1932; (map 88).

So named by USGS in 1931 because "a curious gravel bank was discovered on top of this mountain ***."

Gravel Point: point of land, on S shore of Herendeen Bay, near SW end of Alaska Penin., 19 mi. SW of village of Port Moller, Aleutian Ra.; $55^{\circ} 44^{\prime}$ N, $160^{\circ} 42^{\prime}$ W ; (map 28).

Descriptive name given in 1890 by Lt. Comdr. Z. L. Tanner, USN.

Gravel Point: point of land, on SE shore of Orca Inlet, $8 \mathrm{mi}$. SW of Cordova, Chugach Mts. ; $60^{\circ} 28^{\prime} \mathrm{N}, 145^{\circ} 58^{\prime} \mathrm{W}$; (map 64).

Local name published in 1943 by USC\&GS.
Gravel Spit Anchorage: anchorage, in Kvichak Bay between Albert Channel and Half Moon Bay, 9 mi. NW of Naknek, Bristol Bay Low.; $58^{\circ} 50^{\prime} \mathrm{N}, 157^{\circ} 13^{\prime} \mathrm{W}$; (map 41).

Local name reported in 1952 by USGS. Graven, Point: point of land, see Craven, Point. Grave Point: point of land, E point of entrance to Klakas Inlet, on SW coast of Prince of Wales I., Alex. Arch.; $54^{\circ} 53^{\prime} 40^{\prime \prime} \mathrm{N}, 132^{\circ} 22^{\prime} 30^{\prime \prime} \mathrm{W}$; (map 1).

Named in 1897 by Lt. Comdr. J. F. Moser, USN.

Grave Point: point of land, NE tip of Duke I., Alex. Arch.; $55^{\circ} 00^{\prime} 15^{\prime \prime} \mathrm{N}, 131^{\circ} 14^{\prime} 35^{\prime \prime} \mathrm{W}$; (map 3)

Descriptive name published by USC\&GS in 1883 Coast Pilot (p. 72) ; obtained from local pilots.

Grave Point: point of land, on $\mathrm{W}$ shore of Stephens Passage, $1.6 \mathrm{mi}$. W of Taku Harbor and $21 \mathrm{mi}$. SE of Juneau, Coast Mts.; 58 $03^{\prime} 45^{\prime \prime} \mathrm{N}, 134^{\circ} 03^{\prime} 00^{\prime \prime} \mathrm{W}$; (map 11).

So named in 1869 by Comdr. R. W. Meade, USN, because of some Indian graves on the point. The name was published in 1869 on Navy Hydrog. Chart 225.

Grave Point: point of land, N end of Pitt I. at $\mathrm{N}$ end of Port Frederick on Chichagof I., 0.2 mi. W of Hoonah, Alex. Arch.; 58 $06^{\prime} 35^{\prime \prime} \mathrm{N}$, $135^{\circ} 27^{\prime} 15^{\prime \prime} \mathrm{W}$; (map 11).

Named by U.S. Navy in 1880 and published by the USC\&GS in the 1891 Coast Pilot (p. 196). The point of land was probably the location of an Indian cemetery.

Graves Harbor: bay, $4 \mathrm{mi}$. long, in Glacier Bay National Monument, on Gulf of Alaska, $49 \mathrm{mi}$. NW of Hoonah, St. Elias Mts. ; 58 ${ }^{\circ} 16^{\prime}$ N, $136^{\circ} 45^{\prime} \mathrm{W}$; (map 10).

Named by USC\&GS in 1901 for Herbert Cornelius Graves, 1869-1919, civil engineer. $\mathrm{He}$ was born in Virginia and was a railroad and land surveyor, 1889-95. In 1895 he became a nautical expert with the U.S. Navy Hydrog. Office, and later with USC\&GS. In 1915 he was appointed Chief of Hydrography and Topography, USC\&GS, and supervised the compilation of the Coast Pilots of the United States and Alaska.

Graves Rocks: rocks, in Glacier Bay National Monument, $1.2 \mathrm{mi}$. long, $\mathrm{S}$ of Graves Harbor, $49 \mathrm{mi}$. NW of Hoonah, St. Elias Mts.; $58^{\circ}$ $14^{\prime} 45^{\prime \prime} \mathrm{N}, 136^{\circ} 45^{\prime} 15^{\prime \prime} \mathrm{W}$; (map 10).

Named by USC\&GS in 1901 and published in the 1901 Alaska Coast Pilot (p. 212).

Graveyard Cape: point of land, see Graveyard Point.

Graveyard City: locality, on right bank of Yukon River, $2.5 \mathrm{mi}$. S of Russian Mission, YukonKuskokwim Delta ; $61^{\circ} 45^{\prime} \mathrm{N}, 161^{\circ} 18^{\prime} \mathrm{W}$; (map 73).

Riverboat pilots' name shown on a 1940 navigation chart of the Yukon River, with the annotation " 3 cabins and large grave yard."

Graveyard Cove: cove, $0.6 \mathrm{mi}$. across, on $\mathrm{E}$ coast of Baranof I., $1.3 \mathrm{mi}$. NE of Port Alexander, Alex. Arch.; $56^{\circ} 16^{\prime} \mathrm{N}, 134^{\circ} 38^{\prime} \mathrm{W}$; (map 5).

Local name published in 1927 by USC\&GS 
Graveyard Gove: cove, $0.1 \mathrm{mi}$. across, $\mathrm{S}$ end of Khantaak I., $0.2 \mathrm{mi}$. $\mathbf{N}$ of Point Turner and 2 mi. NNW of Yakutat, Malaspina Coastal Plain; $59^{\circ} 33^{\prime} 40^{\prime \prime} \mathrm{N}, 139^{\circ} 46^{\prime} 50^{\prime \prime} \mathrm{W}$; (map 46).

Local name published in 1959 by USGS. Name derived from a nearby graveyard.

Graveyard Creek: stream, flows W $16 \mathrm{mi}$. to Kvichak Bay, S of Koggiung, on Alaska Penin., $9 \mathrm{mi}$. N of Naknek, Bristol Bay Low.; 58 $51^{\prime}$ $30^{\prime \prime} \mathrm{N}, 157^{\circ} 00^{\prime} 45^{\prime \prime} \mathrm{W}$; (map 41).

Local name reported in 1952 by USGS.

Graveyard Creek: stream, flows NE $9 \mathrm{mi}$. io Crooked Creek, $4.5 \mathrm{mi}$. ESE of Central and $26 \mathrm{mi}$. SW of Circle, Yukon-Tanana High.; $65^{\circ} 33^{\prime} \mathrm{N}, 144^{\circ} 40^{\prime} \mathrm{W}$; BGN 1938; (map 104).

Name used by prospectors in recording mining claims; reported in 1937 by USGS.

Graveyard Island: island, $0.1 \mathrm{mi}$. long in EI Capitan Passage, $0.5 \mathrm{mi}$. N of Sarkar Point, W of Prince of Wales I., Alex. Arch.; 55 57'$50^{\prime \prime} \mathrm{N}, 133^{\circ} 16^{\prime} 50^{\prime \prime} \mathrm{W}$; (map 4).

Descriptive name given in 1924 by USC\&GS, because "There are a few Indian graves on the Island."

Graveyard Island: island, see Peratrovich Island.

Graveyard Lakes: lakes, between Black and Porcupine Rivers, $31 \mathrm{mi}$. NE of Fort Yukon, Yukon Flats; $66^{\circ} 44^{\prime} \mathrm{N}^{\prime} 144^{\circ} 16^{\prime} \mathrm{W}$; (map 119).

Local descriptive name obtained in 1956 by USGS.

Graveyard Point: point of land, at Afognak, on $\mathrm{S}$ coast of Afognak I., $\mathrm{N}$ of Kodiak I.; $58^{\circ} 00^{\prime}$ $45^{\prime \prime} \mathrm{N}, 152^{\circ} 45^{\prime} 30^{\prime \prime}$ W; (map 43). Var. Graveyard Cape, Kladbitsha.

Translation of the name "M[ys] Kladbishcha," given by Sub-Lt. Mikhail Murashev in 1839 or 1840 , and published by the Russian Hydrog. Dept. in 1849 on Chart 1425.

Graveyard Point: point of land, between Kvichak River and Kvichak Bay, on Alaska Penin., 10 mi. N of Nankek, Bristol Bay Low.; $58^{\circ} 52^{\prime} \mathrm{N}$, $157^{\circ} 01^{\prime} \mathrm{W}$; (map 41).

Local name reported in 1910 by Lt. Comdr. J. F. Moser, USN, of the USBF steamer Albatross.

Graveyard Point: point of land, on NW end of Montague I., at $S$ end of Prince William Sound, $32 \mathrm{mi}$. NE of Chenega, Chugach Mts.; $60^{\circ} 20^{\prime} \mathrm{N}, 147^{\circ} 13^{\prime} \mathrm{W}$; (map 63).

Local name reported in 1908 by U. S. Grant and D. F. Higgins (in Brooks and others, 1909, pl. 4), USGS.

Graveyard Point: point of land, extends into Kuskokwim River, 4 mi. S of Bethel, YukonKuskokwim Delta; 60 $44^{\prime} 15^{\prime \prime}$ N, $161^{\circ} 44^{\prime} 00^{\prime \prime}$ W; (map 59).

Name reported in 1951 by USC\&GS; so called "because of an Eskimo graveyard there."

Graveyard Point: point of land, on N shore of Port Fidalgo, $35 \mathrm{mi}$. NW of Cordova, Chugach Mts.; $60^{\circ} 48^{\prime} 30^{\prime \prime} \mathrm{N}, 146^{\circ} 33^{\prime} 30^{\prime \prime} \mathrm{W}$; $B G N$ 1910; (map 64).

Local name reported in 1905 by U. S. Grant, USGS.

Graveyard Point: point of land, see Cemetery Point.
Graveyard Slough: stream, anabranch, flows 4 mi. to Porcupine River, $32 \mathrm{mi}$. NE of Fort Yukon, Yukon Flats; $66^{\circ} 45^{\prime} 30^{\prime \prime} \mathrm{N}, 144^{\circ} 12^{\prime}$ $00^{\prime \prime} \mathrm{W}$; (map 119).

Local descriptive name obtained in 1956 by USGS

Gravine, Isla de: islands, see Gravina Islands.

Gravina, Port: bay, $9 \mathrm{mi}$. wide, on $\mathbf{N}$ edge of Orca Bay, $22 \mathrm{mi}$. NW of Cordova, Chugach Mts. ; $60^{\circ} 38^{\prime} \mathrm{N}, 146^{\circ} 23^{\prime} \mathrm{W}$; (map 64).

Named by Salvador Fidalgo when he took possession June 10, 1790. Probably named for Frederico Gravina, a prominent Spanish naval officer of the day (Wagner, 1937, p. 390).

Gravina Island: island, $21 \mathrm{mi}$. long and $9.5 \mathrm{mi}$. wide, in Clarence Strait, between Revillagigedo and Prince of Wales Is., Alex. Arch.; $55^{\circ} 17^{\prime} \mathrm{N}, 131^{\circ} 46^{\prime} \mathrm{W}$; (map 3). Var. Gravina Islands.

This island is the northernmost of the group named in 1792 by Don Jacinto Caamaño; this name was formally applied to this island in 1793 by Capt. George Vancouver, RN. "It was without doubt named for Federico Gravina, the prominent Spanish naval officer of the day" (Wagner, 1937, p. 390).

Gravina Island: island, $0.2 \mathrm{mi}$. long, at $\mathrm{S}$ entrance of Port Gravina, $20 \mathrm{mi}$. NW of Cordova, Chugach Mts. ; $60^{\circ} 38^{\prime} 30^{\prime \prime} \mathrm{N}, 146^{\circ} 17^{\prime}$ $30^{\prime \prime} \mathrm{W}$; (map 64).

Named in 1898 by Capt. Abercrombie (1900, map), USA. The name is derived from Port Gravina.

Gravina Islands: islands, between Clarence Strait and Revillagigedo Channel, include Annette, Duke, Gravina, and Mary Is., Alex. Arch.; $55^{\circ} 10^{\prime} \mathrm{N}, 131^{\circ} 35^{\prime} \mathrm{W}$; (map 3). Var. Isla de Gravina.

Named "Isle de Gravina," referring to present-day Gravina and Annette Islands, by Don Jacinto Caamaño in 1792. See Gravina Island.

Gravina Islands: island, see Gravina Island.

Gravina Point: point of land, on Gravina I., between Nichols Passage and Tongass Narrows, $3 \mathrm{mi}$. S of Ketchikan, Alex. Arch.; $55^{\circ} 17^{\prime} 15^{\prime \prime} \mathrm{N}, 131^{\circ} 36^{\prime} 45^{\prime \prime} \mathrm{W}$; (map 3).

Named in 1879 by W. H. Dall, USC\&GS; published in the 1883 Goast Pilot (p. 79).

Gravina Point: point of land, at $\mathrm{N}$ edge of Orca Bay, $18 \mathrm{mi}$. NW of Cordova, Chugach Mts.; $60^{\circ} 37^{\prime} 30^{\prime \prime} \mathrm{N}, 146^{\circ} 15^{\prime} 00^{\prime \prime} \mathrm{W}$; (map 64).

Named in 1898 by Capt. Abercrombie (1900, map), USA, during his exploration of the Ciopper River region. Name derived from nearby Port Gravina.

Gravina River: stream, flows W $17 \mathrm{mi}$. to Port Gravina, $21 \mathrm{mi}$. NW of Cordova, Chugach Mts. ; $60^{\circ} 47^{\prime} 45^{\prime \prime} \mathrm{N}, 146^{\circ} 02^{\prime} 45^{\prime \prime} \mathrm{W}$; (map 64).

Local name reported in 1908 by U. S. Grant and D. F. Higgins (in Brooks and others, 1909, pl. 4), USGS

Gravina Rocks: group of rocks, on S shore of Port Gravina, $20 \mathrm{mi}$. NW of Cordova, Chugach Mts.; $60^{\circ} 40^{\prime} 00^{\prime \prime} \mathrm{N}, 146^{\circ} 15^{\prime} 30^{\prime \prime} \mathrm{W}$; BGN 1910; (map 64).
Named in 1908 by Grant and Higgins, (1910, pl. 1 and 2), USGS. Name derived from Port Gravina.

Grayback Mountain: mountain, 3,100 ft., $4 \mathrm{mi}$. $W$ of head of Deadman Bay, on $S$ coast of Kodiak I.; $57^{\circ} 08^{\prime} 35^{\prime \prime} \mathrm{N}, 153^{\circ} 54^{\prime} 10^{\prime \prime} \mathrm{W}$; $B G N 1934$; (map 34).

Named in 1934 by USC\&GS.

Gray Cliff: promontory, on NE shore on Seldovia Bay, $0.5 \mathrm{mi}$. $\mathrm{N}$ of Seldovia, Kenai Penin., Chugach Mts.; $59^{\circ} 27^{\prime} 15^{\prime \prime} \mathrm{N}, 151^{\circ} 43^{\prime} 00^{\prime \prime} \mathrm{W}$; $B G N 1908$; (map 50).

Descriptive name reported in 1908 by by USC\&GS

Gray Cliff: cliff, $100 \mathrm{ft}$., extends $1.5 \mathrm{mi}$., on NW coast of Kenai Penin., 22 mi. NE of Kenai, Cook Inlet Low.; $60^{\circ} 50^{\prime} \mathrm{N}, 150^{\circ} 57^{\prime} \mathrm{W}$; (map 62).

Local name reported in 1943 by USC\&GS. Gray Cliff : cliff, see Graystone Cliff.

Gray Glacier: glacier, heads on NW slope of Ninemile Mtn., trends S $2 \mathrm{mi}$. to its 1955 terminus $8 \mathrm{mi}$. NW of Hyder, Coast Mts.; $56^{\circ} 00^{\prime} \mathrm{N}, 133^{\circ} 10^{\prime} \mathrm{W}$; BGN 1927; (map 7).

Descriptive name given in 1926 by A. F. Buddington, USGS, because the "moraine of this glacier is composed almost wholly of gray granodiorite boulders * * *."

Graylime Creek: stream, heads at Limestack Mountain, flows W $9 \mathrm{mi}$. to Anaktuvuk River, $7.5 \mathrm{mi}$. N of Rumbling Mtn. and $17 \mathrm{mi}$. E of Anaktuvuk Pass, Brooks Ra.; $68^{\circ} 07^{\prime} \mathrm{N}$, $151^{\circ} 05^{\prime} \mathrm{W}$; (map 134)

About this stream Marshall (1956, p. 123) wrote, "It was a large side creek, emerging from a canyon world exclusively made of gray limestone, * * * so we called it 'Graylime Creek'."

Grayline Lake: lake, $0.7 \mathrm{mi}$. long, $1.8 \mathrm{mi}$. NW of Arctic Village, Brooks Ra.; $8^{\circ} 09^{\prime} 30^{\prime \prime} \mathrm{N}$, $145^{\circ} 34^{\prime} 30^{\prime \prime} \mathrm{W}$; (map 136).

Local name reported in 1956 by R. C. Foley, USGS.

Grayling: locality, on right bank of Yukon River, $\mathrm{W}$ of Eagle Island, about $21 \mathrm{mi}$. $\mathrm{N}$ of Anvik, Nulato Hills; $62^{\circ} 57^{\prime} \mathrm{N}, 160^{\circ} 03^{\prime} \mathrm{W}$; (map 78). Var. Greyling.

Lt. Cantwell (1902, p. 144), USRCS, described this place in 1900 as having a store, a large woodyard to supply steamers and an Indian village of about 75 people. Recent USGS maps indicate a site with three cabins.

Grayling Creek: stream, heads in swamp and flows SE $40 \mathrm{mi}$. to Colville River, Arctic Slope; $B G N$ 1926; $59^{\circ} 59^{\prime} \mathrm{N}, 158^{\circ} 10^{\prime} \mathrm{W}$; (map 132).

Named in 1925 by Gerald FitzGerald, USGS, because it was in this creek his "party caught the first grayling of the season."

Grayling Creek: stream, flows S $16 \mathrm{mi}$. to Yukon River, W of Eagle Island, $49 \mathrm{mi}$. $\mathrm{N}$ of Holy Cross, Nulato Hills; $62^{\circ} 54^{\prime} \mathrm{N}, 160^{\circ} 04^{\prime} \mathrm{W}$; (map 78).

Local name reported in 1903 by A. J. Collier, USGS.

Grayling Creek: stream, flows S $13 \mathrm{mi}$. to Kuskokwim River, $1.5 \mathrm{mi}$. E of Stewart Bend, 11.5 
mi. E of McGrath, Kilbuck-Kuskokwim Mts.; $62^{\circ} 59^{\prime} \mathrm{N}, 155^{\circ} 15^{\prime} \mathrm{W}$; (map 80).

Local name reported in 1931 by USGS.

Grayling Creek: stream, flows SW $15 \mathrm{mi}$. through Grayling Lake to Dennis Creek, $44 \mathrm{mi}$. E of Medfra, Kuskokwim Low.; $63^{\circ} 10^{\prime} \mathrm{N}, 153^{\circ}$ $19^{\prime} \mathrm{W}$; (map 89).

Local name reported in 1958 by USGS.

Grayling Creek: stream, flows SE $9.4 \mathrm{mi}$. to Melozitna River, $7 \mathrm{mi}$. NW of Ruby, Kokrines-Hodzana High.; 64 $49^{\prime} 30^{\prime \prime} \mathrm{N}$, $155^{\circ} 35^{\prime} 40^{\prime \prime} \mathrm{W}$; (map 98).

Local name obtained in 1956 by Orth.

Grayling Creek: stream, flows N $19 \mathrm{mi}$. to Serpentine River, $30 \mathrm{mi}$. SE of Shishmaref, Kotzebue-Kobuk Low., $66^{\circ} 03^{\prime} \mathrm{N}, 165^{\circ} 08^{\prime} \mathrm{W}$; (map 112).

Local name published in 1952 by AMS.

Grayling Creek: stream, heads in lake, flows $\mathrm{S}$ $3.8 \mathrm{mi}$. through Grayling Lake to Jim River, $34.5 \mathrm{mi} . \mathrm{E}$ of Bettles, Kokrines-Hodzana High.; $66^{\circ} 55^{\prime} \mathrm{N}, 150^{\circ} 25^{\prime} \mathrm{W}$; (map 117).

Local name reported in 1956 by T. E. Taylor, USGS.

Grayling Creek: stream, flows SE $16 \mathrm{mi}$. to Coleen River, $13 \mathrm{mi}$. NNW of Coleen Mtn., Brooks Ra.; $67^{\circ} 17^{\prime} \mathrm{N}, 142^{\circ} 58^{\prime} \mathrm{W}$; (map 121).

Local name reported in 1956 by $T$. E. Taylor, USGS.

Grayling Creek: stream, sec Greyling Creek.

Grayling Creek: stream, see Manker Creek.

Grayling Fork Black River: stream, heads in Canada at $65^{\circ} 50^{\circ} \mathrm{N}, 140^{\circ} 20^{\prime} \mathrm{W}$, flows NW $80 \mathrm{mi}$. to Black River, $36 \mathrm{mi}$. NW of Midnight Hill, Porcupine Plat.; $66^{\circ} 09^{\prime} 30^{\prime \prime} \mathrm{N}, 142^{\circ} 19^{\prime}$ $30^{\prime \prime} \mathrm{W}$; BGN 1959; (map 120). Var. Little Black River, Orange Creek, Orange Fork, Orange River.

Local name reported in 1956 by $R$. G. Foley and T. E. Taylor, USGS. The former name, "Orange Creek," was applied in 1910 by the IBC survey.

Grayling Hill: mountain, 1,414 ft., $48 \mathrm{mi}$. NE of Medfra, Kuskokwim Low.; $63^{\circ} 15^{\prime} \mathrm{N}$, $153^{\circ} 13^{\prime} \mathrm{W}$; (map 89).

Local name reported in 1958 by USGS.

Grayling Island: island, see Eagle Island.

Grayling Lake: lake, $0.3 \mathrm{mi}$. long, on Kenai Penin., $4.5 \mathrm{mi}$. $\mathrm{S}$ of Kenai Lake and $10 \mathrm{mi}$. $\mathrm{N}$ of Seward, Chugach Mts.; $60^{\circ} 16^{\prime} 20^{\prime \prime} \mathrm{N}$, $149^{\circ} 22^{\prime} 15^{\prime \prime} \mathrm{W}$; (map 63).

So named in 1964 by Alaska Department of Fish and Game "because the grayling (genus Thymallus) was the fish used to stock the lake."

Grayling Lake: lake, $0.9 \mathrm{mi}$. long, $9 \mathrm{mi}$. W of Lake Louise and $46 \mathrm{mi}$. WNW of Glennallen, Copper River Basin; $62^{\circ} 18^{\prime} \mathrm{N}, 146^{\circ} 52^{\prime} \mathrm{W}$; (map 83).

Local name reported in 1952 by USGS. Named for the fish, Arctic Grayling (Thymallus signifer).

Grayling Lake: lake, $0.8 \mathrm{mi}$. long, in course of Grayling Creek, $36 \mathrm{mi}$. E of Bettles, KokrinesHodzana High. ; $66^{\prime} 57^{\prime} 30^{\prime \prime} \mathrm{N}, 150^{\circ} 23^{\prime} 30^{\prime \prime} \mathrm{W}$; (map 117).
Local na.me reported in 1956 by T. E. Taylor, USGS.

Grayling Lake: lake, $1.5 \mathrm{mi}$. long, $\mathrm{N}$ of Seven Dikes Mtn. and $60 \mathrm{mi}$. NNW of Coleen Mtn., Brooks Ra.; $67^{\circ} 58^{\prime} \mathrm{N}, 143^{\circ} 07^{\prime} \mathrm{W}$; (map 121).

Local name reported in 1956 by $\mathbf{T}$. E. Taylor, USGS.

Grayling Lake: lake, $5 \mathrm{mi}$. across, in course of Grayling Creek, $48 \mathrm{mi}$. NE of Medfra, Kuskokwim Low.; $68^{\circ} 13^{\prime} \mathrm{N}, 153^{\circ} 11^{\prime} \mathrm{W}$; (map 89).

Local name reported in 1958 by USGS.

Grayling Peak: peak, $1,055 \mathrm{ft}$., $1.5 \mathrm{mi}$. S of Grayling River, near the right bank of Yukon River, $16 \mathrm{mi}$. N of Anvik, Nulato Hills; $62^{\circ}$ $53^{\prime} \mathrm{N}, 160^{\circ} 06^{\prime} \mathrm{W}$; (map 78).

Riverboat pilots' name shown on a 1940 "Navigation Chart of the Tanana-Yukon Rivers" published by U.S. Dept. of Interior. Grayling Slough: stream, $8.5 \mathrm{mi}$. long, on left bank of Yukon River, $E$ of Eagle I., $16 \mathrm{mi}$. $\mathrm{N}$ of Anvik, Innoko Low.; 62 $52^{\circ} \mathrm{N}, 1^{\circ} 59^{\circ} 53^{\prime}$ W; (map 78).

Riverboat pilots' name shown on a 1940 "Navigation Chart of the Tanana-Yukon Rivers" published by U.S. Dept. of Interior. Gray Mountain: mountain, 6,300 ft., $10 \mathrm{mi}$. long, $17 \mathrm{mi}$. SE of Anaktuvuk Pass and 45 mi. NW of Wiseman, Brooks Ra.; $67^{\circ} 55^{\prime} \mathrm{N}$, $151^{\circ} 16^{\prime}$ W; BGN 1932; (map 124).

Named about 1930 by Marshall (1956, p. 107) who wrote, "One mountain to the east was of such striking gray contrast we could not resist giving it the trite name "Gray Mountain." "

Gray Peak: mountain peak, 4,770 ft., $5 \mathrm{mi}$. N of Thomas Bay and $97 \mathrm{mi}$. E of Sitka, Coast Mts.; $57^{\circ} 10^{\prime} 20^{\prime \prime} \mathrm{N}, 132^{\circ} 53^{\prime} 20^{\prime \prime} \mathrm{W}$; (map 8).

Named in 1887 by Lt. Comdr. C. M. Thomas, USN, presumably for Asa Gray, 1810-88, botanist at Harvard College; published in 1888 by USG\&GS.

Gray Rock: rock, in Khaz Bay, $5.5 \mathrm{mi}$. S of Chichagof, on $W$ coast of Chichagof I., Alex. Arch.; $57^{\circ} 35^{\prime}$ N, $136^{\circ} 07^{\prime}$ W; BGN 1908; (map 9).

Descriptive name given in 1908 by E. F. Dickins, USC\&GS ; published in 1908 Coast Pilot (p. 171)

Graystone Cliff: cliff, on $\mathbf{E}$ coast of Baranof $\mathrm{I}$. facing Chatham Strait, $\mathrm{S}$ of Cosmos Cove, $10 \mathrm{mi}$. N of Baranof, Alex. Arch.; 57 $14^{\prime} 20^{\prime \prime}$ N, 134 $50^{\prime} 40^{\prime \prime} \mathrm{W}$; BGN 1966; (map 9). Var. Gray Cliff.

Recorded about 1948 by USGS.

Graystone Creek: stream, flows NE $3 \mathrm{mi}$. to Gold Creek, $48 \mathrm{mi}$. N of Big Delta, Yukon-Tanana High.; 64 $44^{\circ} 35^{\prime \prime} \mathrm{N}, 145^{\circ} 36^{\prime} 15^{\prime \prime} \mathrm{W}$; (map 101).

Named by prospectors and reported in 1905 by D. C. Witherspoon (in Prindle, 1913a, pl. 1), USGS.

Great Arm Whale Bay: estuary, extends SW 11 mi. to Whale Bay, on W coast of Baranof I., $28 \mathrm{mi}$. NW of Port Alexander, Alex. Arch.; $56^{\circ} 36^{\prime} 30^{\prime \prime} \mathrm{N}, 134^{\circ} 57^{\prime} 30^{\prime \prime} \mathrm{W}$; (map 5). Var. Bolshoi Roukav, Bolshoy Rukav.

Name published by USC\&GS in 1883 Coast Pilot (p. 165) ; derived from "Bolshoy Ruka," meaning "great sleeve"; published in 1849 by the Russian American Company.

Great Bay: bay, see Starrigavan Bay.

Great Bend: point of iand, on S bank of Kuskokwim River, 32 mi. INW of Sleetmute, KilbuckKuskokwim Mts. ; $61^{\circ} 52^{\prime} \mathrm{N}, 158^{\circ} 06^{\prime} \mathrm{W}$; (map 72).

Name obtained in 1898 from J. H. Kilbuck, missionary, by J. E. Spurr and W. S. Post, USGS.

Great Eastern Rookery: rookery, see Great East Rookery.

Great East Rookery: rookery, $0.5 \mathrm{mi}$. NW of Tolstoi Point, on NE coast of St. George I., Pribilof Is.; $56^{\circ} 36^{\prime} \mathrm{N}, 169^{\circ} 29^{\prime} \mathrm{W}$; (map 38). Var. An'agchuckn'um-algara'logray, East Rookery, Great Eastern Rookery.

H. W. Elliott (1872-1874) called this sea rookery, with $900 \mathrm{ft}$. of sea-margin, "Great Eastern Rookery." Present usage appears to be "Great East Rookery." The Aleut name, according to Putnam (1903, p. 1014), USC\&GS, was "An'agchucknun'um-algara'logray" meaning "the rookery at Anagchucknunum." "Anagchucknunum" is the Aleut name for a bluff along the east part of this rookery.

Great Glacier: glacier, heads on Alaska-Ganada boundary, $36 \mathrm{mi}$. NE of Petersburg, trends SE to Stikine River in British Columbia; Coast Mts.; 56 $50^{\prime} \mathrm{N}, 131^{\circ} 47^{\prime} \mathrm{W}$; (map 6).

Name reported in 1877 by Joseph Hunter, Canadian engineer and surveyor, who wrote "Great Glacier is said to extend northwestwardly to the coast about 70 miles, from 350 to 400 feet high."

Great Gorge, The: canyon, in upper course of Ruth Glacier, extends SE $8 \mathrm{mi}$. from Ruth Amphitheater to Glacier Point, $12 \mathrm{mi}$. SE of Denali Pass in Mt. McKinley National Park, Alaska Ra.; 62 ${ }^{\circ} 53^{\prime}$ N, $150^{\circ} 37^{\prime}$ W; (map 81).

Mountain climbers' name published in the late 1940's.

Great Icefall: icefall, of $800 \mathrm{ft}$., in Mount McKinley National Park, extends $\mathrm{N} 0.8 \mathrm{mi}$. in Muldrow Glacier, $W$ of Mount Carpé and 6.5 mi. NNE of Mount McKinley, Alaska Ra.; $63^{\circ} 09^{\prime} \mathrm{N}, 150^{\circ} 55^{\prime} \mathrm{W}$; (map 88).

Climbers' descriptive name published on recent maps.

Great Island: island, see Kodiak Island.

Great Kobuk Sand Dunes: sand dunes, $11 \mathrm{mi}$. long and $3 \mathrm{mi}$, wide, in Kobuk River Valley, $45 \mathrm{mi}$. NW of Shungnak; $67^{\circ} 04^{\prime} \mathrm{N}, 158^{\circ} 54^{\prime}$ W; (map 126).

Descriptive name given by Orth in 1956 . See Little Kobuk Sand Dunes.

Great Kysa Island: island, see Kiska Island.

Great Lake: lake, see Big Lake.

Great Lake: lake, see Nanvakfak Lake.

Great Muddy, The: stream, see Muddy River.

Great Net Island: island, see Great Sitkin Island.

Great Paimiut Island: island, see Paimiut Island.

Great Ridge: ridge, 2,900 ft., trends SW $20 \mathrm{mi}$. from Eek River to Middle Fork Eek River, 64 
mi. SE of Bethel, Kilbuck-Kuskokwim Mts.; $60^{\circ} 04^{\prime} \mathrm{N}, 160^{\circ} 50^{\prime} \mathrm{W}$; (map 59).

Local descriptive name; reported in 1955 by J. M. Hoare, USGS.

Great Sitchin Island: island, see Great Sitkin Island.

Great Sitchine Island: island, see Great Sitkin Island.

Great Sitkin Island: island, $7.5 \mathrm{mi}$. across, one of Andreanof Is., Aleutian Is.; $52^{\circ} 03^{\prime} \mathrm{N}, 176^{\circ}$ 06' W; BGN 1890; (map 17). Var. Chetkina, Eastern Sitkin Island, Great Net Island, Great Sitchin Island, Grean Sitchine Island, Nitalikh Island, Seetien Island, Sigdak Island, Sitchin Island, Sitchini Island, Sitkhin Ostrov, Sitkin Island, Tschechina Island, Tsetchina Island.

Aleut name published by the Russians as "Os[trov] Sitkhin," or "Sitkhin Island" (in Sarichev, 1826, map 3). The island was called "Great Net Island" by W. H. Dall, USC\&GS (1880, p. 247).

Great Sitkin Pass: water passage, S of Great Sitkin I., Aleutian Is.; $51^{\circ} 58^{\prime} \mathrm{N}, 176^{\circ} 04^{\prime} \mathrm{W}$; BGN 1936; (map 17).

Name derived from Great Sitkin Island, and given by members of the U.S. Navy Aleutian Island Survey Expedition in 1934.

Great Sitkin Volcano: volcano, 5,740 ft., on central Great Sitkin I., Aleutian Is.; $52^{\circ} 05^{\prime}$ N, $176^{\circ} 08^{\prime} \mathrm{W}$; (map 17).

Named for Great Sitkin Island and published by USGS (Coats, 1950, pl. 1).

Great Strelki Bay: bay, see Big Branch Bay.

Great Unknown Creek: stream, flows S $8 \mathrm{mi}$, to Birch Creek, $11 \mathrm{mi}$. S of Mastodon Dome and $55 \mathrm{mi}$. SW of Circle, Yukon-Tanana High.; $65^{\circ} 16^{\prime} 20^{\prime \prime} \mathrm{N}, 145^{\circ} 24^{\prime} 50^{\prime \prime} \mathrm{W}$; (map 104).

Named by prospectors and reported in 1905 by D. C. Witherspoon, USGS.

Great Valley: valley, $3 \mathrm{mi}$. long extends NE, 3 mi. NE of Ptarmigan Dome, $75 \mathrm{mi}$. NW of Hoonah, St. Elias Mts.; $58^{\circ} 36^{\prime} 30^{\prime \prime} \mathrm{N}, 137^{\circ}$. $14^{\prime} 00^{\prime \prime} \mathrm{W}$; ( $\left.\operatorname{map} 10\right)$.

Descriptive name published by members of the Harvard-Dartmouth Expedition, 1933-34 (Washburn and Goldthwait, 1936, map).

Grebe Lake: lake, $1 \mathrm{mi}$. across, on Kenai Penin. SE of Camp Island Lake, $20 \mathrm{mi}$. NE of Kenai, Cook Inlet Low. ; $60^{\circ} 37^{\prime} \mathrm{N}, 150^{\circ} 42^{\prime} \mathrm{W}$; (map 62).

Named about 1963 by officials of Kenai National Moose Range, for Holboell's RedNecked Grebe (Podiceps grisegena holboellii). Grecian River; stream, see Crescent River.

Greeley, Point: point of land, see Greely Point.

Greely Point: point of land, on E shore on Taku Inlet near its mouth in Stephens Passage, 14 mi. SE of Juneau, Coast Mts.; $58^{\circ} 12^{\prime} 50^{\prime \prime} \mathrm{N}$, $134^{\circ} 05^{\prime} 00^{\prime \prime} \mathrm{W}$; BGN 1900; (map 11). Var. Point Greeley.

Named in 1890 by Lt. Comdr. H. B. Mansfield, USN, for Gen. Adolphus Washington Greely, 1844-1935, USA, who was a major during the Civil war and commanded the ill-fated International Polar Expedition to Lady Franklin Bay in 1881-84. He was awarded several medals from American and European geographical societies for his achievements. He was also an author of several books on Alaska and the polar regions. Name was published by USC\&GS in the 1891 Coast Pilot (p. 153).

Green Acres: suburb, adjacent to S edge of Anchorage $2.7 \mathrm{mi}$. SE of City Hall, Cook Inlet Low.; $61^{\circ} 11^{\prime} 10^{\prime \prime} \mathrm{N}, 149^{\circ} 50^{\prime} 30^{\prime \prime} \mathrm{W}$; (map 69).

Residential district in city of Anchorage reported in 1954 by office of city engineer of Anchorage.

Green Bight: bight, $1.3 \mathrm{mi}$. across on $\mathbf{E}$ end of Akutan I., Krenitzin Is., Aleutian Is.; 54 $06^{\prime}$ $30^{\prime \prime} \mathrm{N}, 165^{\circ} 40^{\prime} 00^{\prime \prime} \mathrm{W}$; (map 24).

Named in 1901 by J. J. Gilbert, USC\&GS.

Green Butte: peak, 6,145 ft., on E bank of McCarthy Creek, $7.5 \mathrm{mi}$. NE of McCarthy, Wrangell Mts.; $61^{\circ} 30^{\prime} 30^{\prime \prime} \mathrm{N}, 142^{\circ} 45^{\prime} 30^{\prime \prime} \mathrm{W}$; (map 67).

Local name published by USGS in 1954.

Green Cove: cove, $1 \mathrm{mi}$. across, on $\mathrm{N}$ end of Glass Peninsula, $2.6 \mathrm{mi}$. SW of False Arden and $11 \mathrm{mi}$. SE of Juneau, Alex. Arch.; $58^{\circ} 09^{\prime}$. $15^{\prime \prime} \mathrm{N}, 134^{\circ} 16^{\prime} 35^{\prime \prime} \mathrm{W}$; (map 11).

Local name published in 1940 by USGS.

Green Cove: cove, $0.2 \mathrm{mi}$. across, on W coast of Iniskin Penin., on N shore of Right Arm Iniskin Bay, Aleutian Ra.; $59^{\circ} 44^{\prime} 10^{\prime \prime} \mathrm{N}, 153^{\circ}$. $21^{\prime} 30^{\prime \prime} \mathrm{W}$; (map 51 ).

Local name published in 1958 by USGS.

Green Creek: stream, flows NE $3 \mathrm{mi}$. to Ruby Creek, $52 \mathrm{mi}$. SW of Eagle, Yukon-Tanana High.; $64^{\circ} 38^{\prime} \mathrm{N}, 142^{\circ} 50^{\prime} \mathrm{W}$; (map 102).

Prospectors' name shown on a 1902 manuscript map by E. J. Chamberlain, U.S. Deputy Surveyor.

Green Creek: stream, flows $\mathrm{N} 1 \mathrm{mi}$. to Lower Willow Creek, which flows to Casadepaga River, $18 \mathrm{mi}$. N of Solomon, Seward Penin. High.; 64 $48^{\prime} 50^{\prime \prime} \mathrm{N}, 164^{\circ} 29^{\prime} 50^{\prime \prime} \mathrm{W}$; (map 95)

Prospectors' name reported on a map of Cape Nome gold fields by David Fox, Jr., dated 1901.

Green Creek: stream, flows N $7.5 \mathrm{mi}$. to Moran Creek, $17 \mathrm{mi}$. NNE of Birches, Kokrines-Hodzana High.; $65^{\circ} 22^{\prime} 15^{\prime \prime} \mathrm{N}, 153^{\circ} 21^{\prime} 45^{\prime \prime} \mathrm{W}$; (map 107).

Prospectors' name reported by USGS in the 1940's, but probably was used much earlier Green Creek: stream, flows to Tributary Creek near its head, about $10 \mathrm{mi}$. NE of Solomon, Seward Penin. High.; (map 95).

Prospectors' name reported on a prospector's manuscript map dated 1902. This stream cannot be precisely located on current maps.

Green Creek: stream, see Deer Creek.

Green Dome: peak, 6,400 ft., in Mount McKinley National Park, $4.5 \mathrm{mi}$. ESE of Eielson Visitor Center, Alaska Ra.; $63^{\circ} 24^{\prime} 25^{\prime \prime} \mathrm{N}, 150^{\circ} 10^{\prime} 40^{\prime \prime}$ W; (map 88).

Local name reported in 1954 by USGS. Greene Creek: stream, flows SW through Greene Lake $5.4 \mathrm{mi}$. to North Fork White River, 52 mi. NE of McCarthy, Alaska Ra.; $61^{\circ} 47^{\prime} 25^{\prime \prime}$ N, $141^{\circ} 33^{\prime} 35^{\prime \prime} \mathrm{W}$; (map 67).

Local name published by USGS in 1954.

Greene Lake: lake, $0.6 \mathrm{mi}$. long, in course of Greene Creek $0.8 \mathrm{mi}$. E of its junc. with North Fork White River and $52 \mathrm{mi}$. NE of McCarthy, Alaska Ra.; $61^{\circ} 47^{\prime} 30^{\prime \prime} \mathrm{N}, 141^{\circ} 34^{\prime} 00^{\prime \prime} \mathrm{W}$; (map 67).

Local name published in 1954 by USGS.

Green Gulch: ravine, trends NW $1.9 \mathrm{mi}$. to Sinuk River, $21 \mathrm{mi}$. NW of Nome, Seward Penin. High.; $64^{\circ} 43^{\prime} \mathrm{N}, 165^{\circ} 56^{\prime} \mathrm{W}$; (map 94).

Prospectors' name published on the 1900 "Map of Nome Peninsula" by J. M. Davidson and B. D. Blakeslee.

Green Gulch: ravine, trends SE $1.3 \mathrm{mi}$. to Woodchopper Creek, $5.5 \mathrm{mi}$. SW of that stream's junc. with Yukon River and $41 \mathrm{mi}$. SE of Gircle, Yukon-Tanana High.; $65^{\circ} 17^{\prime} 30^{\prime \prime} \mathrm{N}$, $143^{\circ} 26^{\prime} 20^{\prime \prime} \mathrm{W}$; (map 103).

Local name published in 1956 by USGS.

Green Gulch : ravine, see Greer Gulch.

Greenhorn Creek: stream, flows W $1.3 \mathrm{mi}$. to Bottom Dollar Creek, $36 \mathrm{mi}$. SW of Circle, Yukon-Tanana High.; $65^{\circ} 24^{\prime} 20^{\prime \prime} \mathrm{N}, 144^{\circ} 48^{\prime}$ 40" W; (map 104).

Named by prospectors; reported in 1911 by E. A. Porter (in Brooks and others, 1912, p. 245), USGS

Greenhorn Gulch: ravine, trends N $2.5 \mathrm{mi}$. to Boulder Creek, $39 \mathrm{mi}$. SW of Circle, YukonTanana High.; $65^{\circ} 28^{\prime} \mathrm{N}, 145^{\circ} 04^{\prime} \mathrm{W}$; (map 104).

Named by prospectors; reported in 1896 by USGS (in Spurr, 1898, pl. 50).

Greenhorn Lake: lake, $2 \mathrm{mi}$. long, $6.5 \mathrm{mi}$. S of Beaver, Yukon Flats; $66^{\circ} 15^{\prime} 40^{\prime \prime} \mathrm{N}, 147^{\circ} 21^{\prime}$ $00^{\prime \prime} \mathrm{W}$; (map 118).

Local name obtained in 1956 by USGS.

Green Horn Mountain Range: mountain range, see Bendeleben Mountains.

Greenhorn Mountains: mountain range, see Bendeleben Mountains.

Green Inlet: estuary, extends SW $0.8 \mathrm{mi}$. off Yiew Gove, on $\mathbf{E}$ coast of Dall I., Alex. Arch.; $55^{\circ} 04^{\prime} \mathrm{N}, 133^{\circ} 02^{\prime} \mathrm{W}$; (map 4$)$.

Local name published in 1932 Coast Pilot (p. 192)

Green Island: island, $0.5 \mathrm{mi}$. long, in SW Davidson Inlet, Alex. Arch.; $50^{\circ} 55^{\prime} \mathrm{N}, 133^{\circ} 37^{\prime} \mathrm{W}$; $(\operatorname{map} 4)$.

Named in 1903 or 1904 by E. F. Dickins, USC\&GS, who wrote "named by our party, has no local name."

Green Island: island, $0.5 \mathrm{mi}$. long, in $\mathrm{W}$ part of Bay of Is., Adak I., Aleutian Is. ; 51 $48^{\prime} 50^{\prime \prime}$ N, $176^{\circ} 50^{\prime} 00^{\prime \prime} \mathrm{W}$; BGN 1936; (map 17).

Named by members of the U.S. Navy Aleutian Island Survey Expedition in 1934.

Green Island: island, $0.5 \mathrm{mi}$. long, in the Village Is. of Uganik Bay, on $\mathrm{N}$ coast of Kodiak $\mathrm{I}$; $57^{\circ} 46^{\prime} 20^{\prime \prime} \mathrm{N}, 153^{\circ} 31^{\prime} 45^{\prime \prime} \mathrm{W}$; (map 34).

Descriptive name given in 1897 by Lt. Comdr. J. F. Moser, USN, of the USBF steamer Albatross. 
Green Island: island, $1 \mathrm{mi}$. across, in Shelikof Strait on W coast of Shuyak I.; Kodiak I.; $58^{\circ} 31^{\prime} 35^{\prime \prime} \mathrm{N}, 152^{\circ} 40^{\prime} 00^{\prime \prime} \mathrm{W}$; (map 43 ).

Name published by USC\&GS in 1928 on Chart 8573.

Green Island: island, $8 \mathrm{mi}$. long, in Montague Strait, $22 \mathrm{mi}$. E of Chenega, Chugach Mts.; $60^{\circ} 15^{\prime} 00^{\prime \prime} \mathrm{N}, 147^{\circ} 28^{\prime} 30^{\prime \prime} \mathrm{W}$; (map 63). Var. Nicholas Island, Ostrov Nikolay.

Descriptive name given by Capt. James Cook (1785, v. 2, p. 364 ), RN, on May 18, 1778 , who said "being entirely free from snow, and covered with wood and verdure, on this account they were called Green Islands." This feature was called "Os[trov] Nikolay," meaning "Nicholas Island," by Sarichev (1826, map 5).

Green Island: island, see Emerald Island.

Green Lake: lake, $0.18 \mathrm{mi}$. across, $\mathbf{E}$ of Vega Bay, Kiska I., Aleutian Is.; $52^{\circ} 55^{\prime} 46^{\prime \prime}$ N. $177^{\circ} 27^{\prime} 36^{\prime \prime} \mathrm{E}$; (map 14).

An arbitrary name beginning with " $G$ " to correspond to "G" grid used by U.S. Army for tactical purposes during World War II; published on a 1943 Army map.

Green Lake: lake, $1 \mathrm{mi}$. long, near head of Silver Bay, $10 \mathrm{mi}$. SE of Sitka, on central Baranof I., Alex. Arch.; $56^{\circ} 59^{\prime} 45^{\prime \prime} \mathrm{N}, 135^{\circ} 05^{\prime} 30^{\prime \prime} \mathrm{W}$; (map 5).

Local descriptive name reported in 1910 by Adolph Knopf (1912, fig. 4), USGS.

Green Lake: lake, $1 \mathrm{mi}$. long, on Kenai Penin. in Kenai Mts., $5 \mathrm{mi}$. E of Tustumena Lake and $44 \mathrm{mi}$. SE of Kenai, Chugach Mts.; $60^{\circ}$ $03^{\prime} 30^{\prime \prime} \mathrm{N}, 150^{\circ} 29^{\prime} 30^{\prime \prime} \mathrm{W}$; (map 62).

Named about 1963 by officials of Kenai National Moose Range, for administrative purposes.

Green Lake: lake, 1,400 ft. long, on $\mathrm{E}$ shore of Knik Arm Cook Inlet, $4.5 \mathrm{mi}$. NE of Anchorage, Cook Inlet Low.; $61^{\circ} 16^{\prime} 46^{\prime \prime} \mathrm{N}, 149^{\circ}$ $50^{\prime} 05^{\prime \prime} \mathrm{W}$; (map 69).

Local descriptive name reported in 1942 by AMS.

Green Monster Mountain: mountain, on Prince of Wales I., near head of Hetta Inlet, $\mathrm{E}$ of Lake Josephine, Alex. Arch.; 55 $14^{\prime} 45^{\prime \prime} \mathrm{N}$, $132^{\circ} 32^{\prime} 00^{\prime \prime} \mathrm{W}$; (map 4).

Local name recorded in 1908 by C. W. Wright (in Brooks and others, 1909, pl. 3), USGS. According to Wright (1915, p. 62), USGS, the Green Monster Mines were located here in 1900.

Green Mountain: mountain, 2,385 ft., $10 \mathrm{mi}$. S of Tebenkof Bay, on W coast of Kuiu 1., Alex. Arch.; $56^{\circ} 20^{\prime} 15^{\prime \prime} \mathrm{N}, 134^{\circ} 15^{\prime} 30^{\prime \prime} \mathrm{W}$; BGN 1929; (map 5).

Descriptive name given in 1928 by USC\& GS because this mountain has a prominent green top.

Green Mountain: mountain, 1,100 ft., on Mansfield Peninsula, $1 \mathrm{mi}$. N of Funter Bay and 16 mi. W of Juneau, Alex. Arch.; $58^{\circ} 16^{\prime} 45^{\prime \prime} \mathrm{N}$, $134^{\circ} 52^{\prime} 10^{\prime \prime} \mathrm{W}$; (map 11$)$.

Local name published in 1962 by USGS.

Greenough, Mount: mountain, 7,240 ft., in British Mts., E of Kongakut River, $38 \mathrm{mi}$. SW of Demarcation Point, Brooks Ra.; 69 $09^{\prime} 30^{\prime \prime}$ N, $141^{\circ} 39^{\prime} 30^{\prime \prime} \mathrm{W}$; (map 138).

In 1826 Sir John Franklin named a prominent mountain in this area probably for George Bellas Greenough, 1778-1855, founder of the Geological Society of London and first president in 1811. The exact location of this mountain is unknown. E. de K. Leffingwell is responsible for the present application of the name.

Green Point: peak, 4,235 ft. in Mount McKinley National Park, E of Muldrow Glacier, 5.4 mi. SSW of Eielson Visitor Center, Alaska Ra.; $63^{\circ} 21^{\prime} 30^{\prime \prime} \mathrm{N}, 150^{\circ} 22^{\prime} 00^{\prime \prime} \mathrm{W}$; BGN 1932; (map 88).

Local name obtained in 1925 by S. R. Capps, USGS.

Green Point: point of land, NE tip of Hemlock I. in Port Chester, off $\mathrm{W}$ coast of Annette I., Alex. Arch.; $55^{\circ} 09^{\prime} 55^{\prime \prime} \mathrm{N}, 131^{\circ} 33^{\prime} 40^{\prime \prime} \mathrm{W}$; (map 3).

Name published in 1876 by USC\&\&S.

Green Point: point of land, on SE side of Chignik Lagoon and NE side of Mallard Duck Bay, $6.5 \mathrm{mi}$. W of Chignik, Aleutian Ra.; $56^{\circ}$ $16^{\prime} 30^{\prime \prime} \mathrm{N}, 158^{\circ} 34^{\prime} 00^{\prime \prime} \mathrm{W}$; (map 30$)$.

Local descriptive name reported by 1951 USGS field party.

Green Point: point of land, on NE shore of Eastern Passage, $5 \mathrm{mi}$. N of Wrangell, Coast Mts.; $56^{\circ} 32^{\prime} 30^{\prime \prime} \mathrm{N}, 132^{\circ} 21^{\prime} 45^{\prime \prime} \mathrm{W}$; $B G N$ 1900; (map 6). Var. Mys Zelenyy, Zelenoi Point, Zelonoi Point, Zelony Point.

Translation about 1882 by USC\&GS of descriptive Russian name "Mys Zelenyy" given in 1863 by the surveyors from the corvette Rynda. See Rynda Island.

Green Point: point of land, $7 \mathrm{mi}$. S of Petersburg, on $E$ coast of Lindenberg Penin., Kupreanof I., Alex. Arch.; $56^{\circ} 42^{\prime} 00^{\prime \prime}$ N, $132^{\circ} 57^{\prime} 25^{\prime \prime} \mathrm{W}$; (map 6). Var. Mys Mely, Point Meli.

Named in 1883 by W. H. Dall, USC\&GS; name published in 1883 Coast Pilot (p. 115). In 1838 the point was called "Mys Mely" meaning "shoal cape" by the Russian, Lindenberg (cnna).

Green Point: point of land, at $N$ entrance to Pyramid Harbor, in Chilkat Inlet, $1 \mathrm{mi}$. SW of Pyramid I. and $20 \mathrm{mi}$. SW of Skagway, St. Elias Mts.; $B G N$ 1900; $59^{\circ} 11^{\prime} 10^{\prime \prime} \mathrm{N}$, $135^{\circ} 28^{\prime} 00^{\prime \prime} \mathrm{W}$; (map 45). Var. Indian Point, M[ys] Zelenoi ; Pyramid Point.

Named "M[ys] Zelenoi" meaning "green cape" by Lindenberg (cnna) in 1838; published in 1848 on Russian Hydrog. Dept. Chart 1396. It was called Indian Point in 1869 by Comdr. R. W. Meade, USN. It is the "Pyramid Point" of Capt. L. A. Beardslee, USN, given in 1880 ; published by USG\&GS in the 1883 Coast Pilot (p. 197).

Greenpoint Glacier: glacier, trends NW $3 \mathrm{mi}$. to Through Glacier, $13.5 \mathrm{mi}$. NW of Hyder, Coast Mts.; $56^{\circ} 01^{\prime} 30^{\prime \prime} \mathrm{N}, 130^{\circ} 19^{\prime} 00^{\prime \prime} \mathrm{W}$; $B G N 1927$; (map 7).

Descriptive name given in 1926 by A. F. Buddington, USGS, because the "two shoulders on either side where it joins the large glacier are both conspicuously covered with trees up to considerable height."

Green Ridge: mountain, 1,200 ft., on W shore of Nakat Bay, on mainland $2 \mathrm{mi}$. NE of Cape Fox, Coast Mts.; 54 $47^{\prime} 45^{\prime \prime}$ N, $130^{\circ} 48^{\prime} 30^{\prime \prime} \mathrm{W}$; (map 2).

Descriptive name given in 1888 by Lt. Comdr. H. E. Nichols, USN.

Green Rock: rock, see Lone Spruce Rock.

Green Rocks: rocks, in Wrangell Narrows between Lindenberg Penin. and Mitkoff I., 10 mi. S of Petersburg, Alex. Arch.; 56 ${ }^{\circ} 40^{\prime} 05^{\prime \prime}$ N, $132^{\circ} 55^{\prime} 55^{\prime \prime} \mathrm{W}$; (map 6). Var. Fairway Rocks, Zelenoi Rocks.

Published by USC\&GS in 1883 Coast Pilot (p. 115); translated from the Russian name "Zelenyy" given in 1838 by Lindenberg (cnna). Comdr. R. W. Meade, USN, called this feature "Fairway Rocks" in 1869.

Green Rocks Lake: lake, $0.2 \mathrm{mi}$. long, $10 \mathrm{mi}$. S of Petersburg, on E coast of Lindenberg Penin., Kupreanof I., Alex. Arch.; 56 $39^{\prime} 50^{\prime \prime}$ N, $132^{\circ} 58^{\prime} 00^{\prime \prime} \mathrm{W}$; (map 6).

Local descriptive name obtained in 1953 by USGS.

Greens Creek: stream, on Admiralty I., heads S of Eagle Peak and flows $5 \mathrm{mi}$. W to mouth of Hawk Inlet, $19 \mathrm{mi}$, SW of Juneau, Alex. Arch.; 58 $05^{\prime} 55^{\prime \prime} \mathrm{N}, 134^{\circ} 45^{\prime} 40^{\prime \prime} \mathrm{W}$; (map 11).

Local name published in 1942 by USGS.

Greens Head: mountain, $1,820 \mathrm{ft}$., $6 \mathrm{mi}$. NW of Medfra, Kilbuck-Kuskokwim Mts.; $63^{\circ} 12^{\prime} \mathrm{N}$, $154^{\circ} 44^{\prime} \mathrm{W}$; (map 89).

Local name reported in 1920 by G. C. Martin (in Brooks and others, 1922, fig. 5), USGS.

Greens Slough: stream, heads in lake, flows NW $9 \mathrm{mi}$. to Tanana River, $9 \mathrm{mi}$. SE of Tanana, Nowitna Low. ; $65^{\circ} 05^{\prime} 30^{\prime \prime} \mathrm{N}, 151^{\circ} 49^{\prime} 00^{\prime \prime} \mathrm{W}$; (map 106).

Riverboat pilots' name shown on a 1940 Navigation Chart of Tanana-Yukon Rivers. Greenstone Creek: stream, flows SW $5 \mathrm{mi}$. to Long Creek, $7.5 \mathrm{mi}$. NW of Sulatna Crossing and $32 \mathrm{mi}$. SW of Ruby, Kilbuck-Kuskokwim Mts.; $64^{\circ} 16^{\prime} 45^{\prime \prime} \mathrm{N}, 155^{\circ} 35^{\prime} 55^{\prime \prime} \mathrm{W}$; (map 98).

Prospectors' name reported in 1913 by Eakin (1914, pl. 3), USGS.

Greenstone Creek: stream, flows SW $3.5 \mathrm{mi}$. to Dime Creek, 2 mi. SE of Haycock, Seward Penin. High.; $65^{\circ} 11^{\prime} \mathrm{N}, 161^{\circ} 08^{\prime} \mathrm{W}$; (map 109).

Local name reported in 1917 by G. L. Harrington, USGS.

Green Stone Mountain: mountains, see Jade Mountains.

Greenstone Ridge: ridge, trends SW $13 \mathrm{mi}$. from junc. of Kisaralik River and Swift Creek, 57 mi. SE of Bethel, Kilbuck-Kuskokwim Mts., $60^{\circ} 25^{\prime} \mathrm{N}, 160^{\circ} 13^{\prime} \mathrm{W}$; BGN 1959; (map 59).

So named in 1955 by J. M. Hoare, USGS, because "the ridge consists chiefly of greenish colored rocks * * *"

Greentop Harbor: $b a y, 0.7 \mathrm{mi}$. across, at $\mathrm{S}$ tip of Yakobi I., off W coast of Chichagof I., 
Alex. Arch.; 57 $51^{\prime} 30^{\prime \prime} \mathrm{N}, 136^{\circ} 28^{\prime} 00^{\prime \prime} \mathrm{W}$; (map 9).

Local name reported in 1951 by USGS.

Greentop Island: island, $0.1 \mathrm{mi}$. across, $1.2 \mathrm{mi}$. NW of Point Theodore, off $S$ coast of Yakobi I., $20 \mathrm{mi}$. NW of Chicagof, Alex. Arch.; $57^{\circ} 51^{\prime} 20^{\prime \prime} \mathrm{N}, 136^{\circ} 29^{\prime} 00^{\prime \prime} \mathrm{W}$; (map 9).

Descriptive name'published in 1928 by USGS. "The top is grass covered."

Green Water Creek: stream, flows SSW $18 \mathrm{mi}$. to Kaiyuh Slough, $13 \mathrm{mi}$. S of Nulato, Koyukuk Low.; $64^{\circ} 32^{\prime} \mathrm{N}, 158^{\circ} 10^{\prime} \mathrm{W}$; (map 97). Var. Tulatdlukhna.

Appears to be a translation of an Indian name; reported in 1935 by Frederica de Laguna, BAE.

Greenwood Pass: pass, NE of McNew Hill, eastern Attu I., Aleutian Is.; $52^{\circ} 50^{\prime} 50^{\prime \prime} \mathrm{N}$, $173^{\circ} 23^{\prime} 45^{\prime \prime} \mathrm{E}$; (map 13).

Name given by the U.S. Army during World War II and shown on a AMS map published in 1948. The name is not used today.

Greer Gulch: ravine, trends NW $0.6 \mathrm{mi}$. to Puzzle Creek, $11 \mathrm{mi}$. N of Medfra, KilbuckKuskokwim Mts.; $63^{\circ} 15^{\prime} \mathrm{N}, 154^{\circ} 45^{\prime} \mathrm{W}$; (map 89). Var. Green Gulch.

Local name reported in 1953 by USGS.

Grego, Point: point of land, see Cangrejo, Point.

Gregson Island: island, $0.2 \mathrm{mi}$. across, off $\mathrm{E}$ shore of Yakutat Bay, $0.5 \mathrm{mi}$. E of Dolgoi I. and $3.9 \mathrm{mi}$. NE of Yakutat, Malaspina Coastal Plain; $59^{\circ} 35^{\prime} 30^{\prime \prime} \mathrm{N}, 139^{\circ} 39^{\prime} 30^{\prime \prime} \mathrm{W}$; (map 46).

Named in 1892 by Lt. G. B. Harber, USN, for G. S. Gregson, one of his party. The name was published by USC\&GS on Chart 8455.

Greig, Cape: cliff, elev. $292 \mathrm{ft}$, on $\mathrm{N}$ coast of Alaska Penin., $7 \mathrm{mi}$. N of Ugashik Bay and $17 \mathrm{mi}$. NW of Ugashik, Bristol Bay Low.; $57^{\circ} 43^{\prime} 30^{\prime \prime} \mathrm{N}, 157^{\circ} 41^{\prime} 30^{\prime \prime} \mathrm{W}$; BGN 1897; (map 36). Var. Cape Creigh, Cape Greigh, Gape Grey, Cap Greigh.

Named "C[ap] Greigh" by von Krusenstern (1827, map 17) for Adm. Alexis Greig, 17751844, IRN.

Greig, Mount: mountain, 6,240 ft., $5.6 \mathrm{mi}$. NE of junc. of South Fork Kuskokwim and Styx Rivers, $90 \mathrm{mi}$. NW of Tyonek, Alaska Ra.; $61^{\circ} 56^{\prime} 15^{\prime \prime} \mathrm{N}, 153^{\circ} 01^{\prime} 30^{\prime \prime} \mathrm{W}$; (map 71). Var. Mount Grieg.

Named in 1898 by W. S. Post and J. E. Spurr, USGS.

Greigh, Cape : cliff, see Greig, Cape.

Greike Glacier: glacier, see Geikie Glacier.

Grenwich Cavo: point of land, see Greville, Cape.

Grenwile Cape : point of land, see Greville, Cape.

Greta Creek: stream, flows E $3.5 \mathrm{mi}$. to Flat Creek, $12 \mathrm{mi}$. NW of Tahneta Pass and $70 \mathrm{mi}$. SW of Gulkana, Talkeetna Mts.; $62^{\circ} 02^{\prime} 40^{\prime \prime}$ $\mathrm{N}, 147^{\circ} 30^{\prime} 20^{\prime \prime} \mathrm{W}$; (map 82)

Local name reported in 1917 by USGS.

Gretchen Lake: lake, $0.6 \mathrm{mi}$. long, on Afognak I. $\mathrm{N}$. of Izhut Bay, $28 \mathrm{mi}$. NE of Afognak,
Kodiak I.; $58^{\circ} 18^{\prime} 00^{\prime \prime} \mathrm{N}, 152^{\circ} 14^{\prime} 30^{\prime \prime} \mathrm{W}$; (map 43).

Local name reported in 1952 by USGS.

Greville, Cape: point of land, $17 \mathrm{mi}$. SE of Kodiak, Kodiak I.; $57^{\circ} 35^{\prime} 30^{\prime \prime} \mathrm{N}, 152^{\circ} 09^{\prime} 30^{\prime \prime}$ W; (map 34). Var. Grenwich Cavo, Grenwile Cape.

Named on June 8, 1778, by Capt. Cook $(1785$, v. 2 , p. $405-406)$, who applied the name to a point $2 \mathrm{mi}$. north, which is now "Cape Chiniak." He wrote, "The land here forms a point, which was named Cape Greville. It lies in the latitude of $57^{\circ} 33^{\prime}$ and is distant fifteen leagues from Cape St. Hermogenes, in the direction of South, $17^{\circ}$ West." Greville, Cape: point of land, see Chiniak, Cape.

Grewingk Creek: stream, on Kenai Penin., flows NW $3.5 \mathrm{mi}$. to Kachemak Bay, $12 \mathrm{mi}$. E of Homer, Chugach Mts.; 59 $39^{\prime} \mathrm{N}, 151^{\circ} 10^{\prime} \mathrm{W}$; $(\operatorname{map} 50)$.

Named for Grewingk Glacier and published by USGS in 1961. See Grewingk Glacier.

Grewingk Glacier: glacier, on Kenai Penin., trends NW $12 \mathrm{mi}$. to its terminus at Grewingk Creek 3 mi. SW of Kachemak Bay, 15 mi. ESE of Homer, Chugach Mts. ; $59^{\circ} 36^{\prime} 30^{\prime \prime} \mathrm{N}, 151^{\circ}$ 07'00' W; (map 50).

Named by W. H. Dall, USC\&GS, in 1880 , for Constantin Grewingk, who in 1850, published a work in German on the geology and volcanism of Alaska.

Grey, Cape : cliff, see Greig, Cape.

Grey Lake: lake, $0.1 \mathrm{mi}$ across, E of Vega Bay, Kiska I., Aleutian Is.; $51^{\circ} 55^{\prime} 53^{\prime \prime} \mathrm{N}, 177^{\circ} 27^{\prime}$ $50^{\prime \prime} \mathrm{E}$; (map 14).

An arbitrary name beginning with "G" to correspond to " $G$ " grid used by U.S. Army for tactical purposes during World War II; published on a 1943 Army map.

Greyling: locality, see Grayling.

Greyling Creek: stream, heads in Greyling Lake, flows NE $14 \mathrm{mi}$. to Tonsina Lake, $2.2 \mathrm{mi}$. E of mouth of Tonsina Creek and $35 \mathrm{mi}$. NE of Valdez, Chugach Mts.; 61 $31^{\prime} 15^{\prime \prime} \mathrm{N}$, $145^{\circ} 32^{\prime} 00^{\prime \prime}$ W; BGN 1932; (map 68). Var. Grayling Greek.

Named in 1898 by prospectors for the Alaska grayling, Thymallus signifer, a fresh water fish; reported by Oscar Rohn, of Capt. W. R. Abercrombie's expedition in 1899. USGS published the present spelling in 1932.

Greyling Lake: lake, $1.3 \mathrm{mi}$. long, at head of Greyling Creek, $26 \mathrm{mi}$. NE of Valdez, Chugach Mts. ; $61^{\circ} 23^{\prime} 45^{\prime \prime} \mathrm{N}, 145^{\circ} 44^{\prime} 30^{\prime \prime} \mathrm{W}$; (map 68).

Local name published in the 1950's by USGS.

Grey Point: point of land, on W shore of Tamgas Harbor, on S coast of Annette I., Alex. Arch.; $55^{\circ} 01^{\prime} 38^{\prime \prime} \mathrm{N}, 131^{\circ} 32^{\prime} 38^{\prime \prime} \mathrm{W}$; (map 3).

Named in 1891 by USC\&GS.

Greys Island: island, $1 \mathrm{mi}$. long, in Sumner Strait, $6.5 \mathrm{mi}$. NW of Wrangell, Alex. Arch.; $56^{\circ} 31^{\prime} \mathrm{N}, 132^{\circ} 33^{\prime} \mathrm{W}$; (map 6).

Named in 1869 by Comdr. R. W. Meade, USN.

Griada Rocks: rocks, see Border Rocks.

Griantle, H.: bay, see Grantley Harbor.

Griantle, Port: bay, see Grantley Harbor.
Grief Island: island, $0.2 \mathrm{mi}$. long, in Duncan Canal, $14 \mathrm{mi}$. SW of Petersburg, on SW coast of Lindenberg Penin., Kupreanof I., Alex. Arch.; $56^{\circ} 37^{\prime} 10^{\prime \prime} \mathrm{N}, 133^{\circ} 04^{\prime} 00^{\prime \prime} \mathrm{W}$; (map 6).

Named in 1887 by Lt. Comdr. C. M. Thomas, USN, for charting purposes; name published in 1888 on USC\&GS Chart 705.

Griffin Creek: stream, in Tilted Hills, on Iniskin Penin., flows SW 3 mi. to Brown Creek, 4.5 mi. NW of Dry Bay, Aleutian Ra.; 59 $44^{\prime} 15^{\prime \prime}$ N, $153^{\circ} 11^{\prime} 00^{\prime \prime} \mathrm{W}$; BGN 1962; (map 51).

Locally named for a prospector who staked claims and drilled for oil in the area prior to 1903; published in 1958 by USGS.

Griffin Point: point of land, between Beaufort Sea and Oruktalik Lagoon, Arctic Plain; $70^{\circ}$ $04^{\prime} \mathrm{N}, 142^{\circ} 54^{\prime} \mathrm{W}$; (map 152). Var. Point Griffin, Oruktalik Nuvugak.

On August 3, 1825, Sir John Franklin (1828, p. 145) wrote, "We halted to sup on a gravel reef that extends from the main shore to Point Griffin, * * *" The Eskimo name for this point of land is "Oruktalik Nuvugak," reported by USC\&GS in 1952.

Griffith Island: island, 60 yd. across, in Sitka Harbor, off W coast of Baranof I., Alex. Arch.; $57^{\circ} 03^{\prime} 30^{\prime \prime} \mathrm{N}, 135^{\circ} 20^{\prime} 57^{\prime \prime} \mathrm{W}$; (map 9).

Name published in 1885 by USG\&GS on Chart 727.

Griggs, Mount: volcano, 7,600 ft., on Alaska Penin., in Katmai National Monument, 7 mi. NW of Mount Katmai, Aleutian Ra.; 58 $21^{\prime}$ $15^{\prime \prime} \mathrm{N}, 155^{\circ} 05^{\prime} 30^{\prime \prime} \mathrm{W}$; BGN 1962; (map 42). Var. Knife Peak, Knife Peak Volcano, Mount Griggs Volcano.

Named in 1956 by Gilbert Grosvenor, National Geographic Society, for Robert Fiske Griggs (1881-1962), botanist and leader of six National Geographic Society expeditions to the Katmai District from 1915 to 1930 ; these expeditions led to the creation in 1918 of the Katmai National Monument. "Knife Peak" was published by USC\&GS on a 1911 Coast Chart.

Griggs Volcano, Mount: volcano, see Griggs, Mount.

Grikhdalitna Creek: stream, heads E of Hochandochtla Mtn., flows N $18 \mathrm{mi}$. to Koyukuk River, $8 \mathrm{mi}$. SW of Huggins I., Kokrines-Hodzana High.; $65^{\circ} 46^{\prime} 30^{\prime \prime} \mathrm{N}, 154^{\circ} 45^{\prime} 00^{\prime \prime} \mathrm{W}$; (map 107).

Koyukan Indian name obtained at Huslia in 1956 by Orth.

Grimm Creek: stream, flows NE $6 \mathrm{mi}$. to Melozimoran Creek, $3.5 \mathrm{mi}$. N of Moran Dome and $30 \mathrm{mi}$. NW of Tanana, Kokrines-Hodzana High.; $65^{\circ} 25^{\prime} 50^{\prime \prime} \mathrm{N}, 152^{\circ} 56^{\prime} 00^{\prime \prime} \mathrm{W}$; $B G N$ 1960; (map 106)

Prospectors' name reported in 1955 by R. M. Chapman, USGS.

Grindall: locality, site of village, on $\mathrm{E}$ coast of Prince of Wales I., on Kasaan Penin., at Grindall Point, Alex. Arch.; $55^{\circ} 27^{\prime} \mathrm{N}, 132^{\circ} 09^{\prime} \mathrm{W}$; (map 4)

The Grindall post office was established at Grindall Point in 1900 and discontinued in 1904 (Ricks, 1965, p. 24). 
Grindall Island: island, $1.5 \mathrm{mi}$. long, between Clarence Strait and Kasaan Bay, on E coast of Prince of Wales I., Alex. Arch.; 55 26 $35^{\prime \prime}$ $\mathrm{N}, 132^{\circ} 07^{\prime} 30^{\prime \prime} \mathrm{W}$; (map 4).

Named in 1880 by W. H. Dall, USG\&GS; derived from Grindall Point.

Grindall Passage: water passage, $1 \mathrm{mi}$. long, between Grindall I. and Kasaan Penin., on E coast of Prince of Wales I., Alex. Arch.; 55 $27^{\prime} \mathrm{N}, 132^{\circ} 09^{\prime} \mathrm{W}$; (map 4).

Local name recorded by Lt. Comdr. H. E. Nichols (U.S. Coast and Geodetic Survey, 1891, p. 90), USN.

Grindall Point: point of land, SE tip of Kasaan Penin., on E coast of Prince of Wales I., Alex.

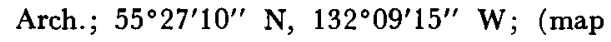
4). Var. Cape Grindall, Cone Point.

Named by Capt. George Vancouver, RN, for Capt. Grindall, RN, "having been discovered by James Johnstone, August 25, 1793" (Wagner, 1937, p. 390). This feature is "Sometimes called by the traders Cone Point" (U.S. Coast and Geodetic Survey, 1883, p. 85).

Grindle Hills: hills, 2,700 ft., extend NW-SE $7 \mathrm{mi}$. between Bering Glacier and Hanna Lake, $18 \mathrm{mi}$. SW of Mount Steller, Chugach Mts.; $60^{\circ} 16^{\prime} \mathrm{N}, 143^{\circ} 13^{\prime} \mathrm{W}$; BGN 1960; (map 65).

Named in 1938 by oil company geologists for Melvin Grindle who trapped and guided in this area for many years.

Grindstone Creek: stream, heads just $\mathrm{E}$ of Middle Peak and flows S $4.5 \mathrm{mi}$. to Stephens Passage at Cherokee Flats, $12 \mathrm{mi}$. SE of Juneau, Coast Mts.; $58^{\circ} 12^{\prime} 30^{\prime \prime} \mathrm{N}, 134^{\circ} 10^{\prime} 30^{\prime \prime} \mathrm{W}$; BGN 1962; (map 11).

Name first used in a mining location notice by J. G. Peterson and Chris Fuhr in 1890 . The source of the name is not known (DeArmond, 1957, p. 23). Name was published in 1906 by USGS (Spencer and Wright, pl. 37 ).

Grindstone Falls: waterfall, on Grindstone Creek, $11 \mathrm{mi}$. SE of Juneau, Coast Mts.; $58^{\circ} 13^{\prime} \mathrm{N}$, $134^{\circ} 15^{\prime} \mathrm{W}$; (map 11). Var. Granite Falls. Local name mentioned by DeArmond (1957, p. 23).

Grinnell Glacier: glacier, trends E $4 \mathrm{mi}$. to its terminus $1 \mathrm{mi}$. NW of Miles Lake, $35 \mathrm{mi}$. N of Katalla, Chugach Mts.; $60^{\circ} 43^{\prime} \mathrm{N}, 144^{\circ} 43^{\prime}$ $\mathrm{W}$; (map 64).

Named by Lawrence Martin in 1910 presumably for Grinnell College, Grinnell, Iowa, founded 1846.

Grisley Creek: stream, see Grizzly Creek.

Grizzly Bar: moraine, moraine of Norris Glacier, $3 \mathrm{mi}$. across, on $W$ shore of Taku Inlet just $\mathrm{S}$ of Taku Glacier, $15 \mathrm{mi}$. NE of Juneau, Coast Mts. ; $58^{\circ} 24^{\prime} \mathrm{N}, 134^{\circ} 04^{\prime} \mathrm{W}$; (map 11). Var. Norris Outwash.

Local name published in 1962 by USGS.

Grizzly Creek: stream, flows NE $1.4 \mathrm{mi}$. to Daisy Creek, $1 \mathrm{mi}$. W of its junc. with Tyone Creek and $26 \mathrm{mi}$. SE of junc. of Oshetna and Susitna Rivers, Talkeetna Mts.; $62^{\circ} 16^{\prime} 45^{\prime \prime} \mathrm{N}$, $147^{\circ} 06^{\prime} 40^{\prime \prime} \mathrm{W}$; BGN 1960; (map 82).
Local name reported in 1956 to USGS. The name was "recorded in placer locations on the stream by Pennington and Tyler."

Grizzly Creek: stream, flows NE $6 \mathrm{mi}$. to Wood River, $30 \mathrm{mi}$. SE of Healy, Alaska Ra.; $63^{\circ} 46^{\prime}$ N, $147^{\circ} 59^{\prime} \mathrm{W}$; (map 87).

Prospectors' name shown on a 1910 fieldsheet by J. W. Bagley, USGS; published by Capps (1912, pl. 1), USGS.

Grizzly Creek: stream, flows SW $1.5 \mathrm{mi}$. to Nenana River, $3 \mathrm{mi}$. N of village of McKinley Park, Alaska Ra.; $63^{\circ} 46^{\prime} 35^{\prime \prime} \mathrm{N}, 148^{\circ} 54^{\prime} 48^{\prime \prime}$ W; BGN 1965; (map 87).

Named in 1965 by Alaska Dept. of Highways because "Toklat Grizzlies are regular visitors to this creek." See Iceworm Gulch.

Grizzly Greek: stream, flows S $1 \mathrm{mi}$. to Norton Sound, $24 \mathrm{mi}$. E of Solomon, Seward Penin. High.; $64^{\circ} 34^{\prime} \mathrm{N}, 163^{\circ} 39^{\prime} \mathrm{W}$; (map 95). Var. Trilby Creek.

Prospectors' name published in 1956 by USGS. Shown as "Trilby" on Arthur Gibson's "Map of Cape Nome Precinct," dated 1904.

Grizzly Creek: stream, flows NW $6 \mathrm{mi}$. to Wolf Creek, $47 \mathrm{mi}$. SW of Circle, Yukon-Tanana High.; $65^{\circ} 14^{\prime} 45^{\prime \prime} \mathrm{N}, 144^{\circ} 57^{\prime} 50^{\prime \prime} \mathrm{W}$; (map 104). Var. Grisley Creek.

Named by prospectors and reported as "Grisley Creek" by D. C. Witherspoon (in Prindle, 1906, pl. 1), USGS, in 1905.

Grizzly Creek: stream, flows NE $6.5 \mathrm{mi}$. to John River, $11 \mathrm{mi}$. S of Gunsight Mtn. and 51 mi. W of Wiseman, Brooks Ra.; $67^{\circ} 19^{\prime} 30^{\prime \prime} \mathrm{N}$, $152^{\circ} 02^{\prime} 00^{\prime \prime} \mathrm{W}$; (map 124).

Local name obtained in 1956 by USGS topographers.

Grizzly Creek: stream, flows SE then SW $7 \mathrm{mi}$. from a glacier on Limestack Mtn. to Ernie Creek, $23 \mathrm{mi}$. E of Anaktuvuk Pass, Brooks $\mathrm{Ra}$; $68^{\circ} 03^{\prime} 30^{\prime \prime} \mathrm{N}, 150^{\circ} 51^{\prime} 00^{\prime \prime} \mathrm{W}$; $B G N$ 1932; (map 134).

In reporting his naming of this stream, Marshall (1956, p. 19) first recounted the events of the previous day when two grizzlies had sent the horses running. Finally he wrote, "I set out up the northeast fork, which we named Grizzly Greek because of our recent adventure."

Grizzly Lake: lake, $1.4 \mathrm{mi}$. long, $11 \mathrm{mi}$. S of Tanada Lake, Wrangell Mts.; $62^{\circ} 13^{\prime} \mathrm{N}$, $143^{\circ} 22^{\prime} \mathrm{W}$; (map 84).

Local name reported in 1959 by USGS.

Grizzly Lake: lake, $0.4 \mathrm{mi}$. long, S of Glenn Highway, $18 \mathrm{mi}$. NE of Chistochina, Copper River Basin; $62^{\circ} 42^{\prime} 45^{\prime \prime} \mathrm{N}, 144^{\circ} 12^{\prime} 00^{\prime \prime} \mathrm{W}$; (map 83).

Local name reported in 1963 by USGS.

Grizzly Lake: lake, $0.3 \mathrm{mi}$. long, drains $\mathrm{N}$ to Swift Fork Kuskokwim River, $47 \mathrm{mi}$. W of Mount McKinley, Kuskokwim Low.; $63^{\circ} 02^{\prime}$ $20^{\prime \prime} \mathrm{N}, 152^{\circ} 30^{\prime} 00^{\prime \prime} \mathrm{W}$; (map 88).

Local name obtained in 1958 from Fabian Carey and "Val" Blackburn by USGS.

Grogg Creek: stream, flows NW $2.5 \mathrm{mi}$. to Valdez Greek, $72 \mathrm{mi}$. SE of Healy, Alaska Ra.; $63^{\circ}$ $13^{\prime} \mathrm{N}, 147^{\circ} 10^{\prime} \mathrm{W}$; (map 87).

Local name obtained in 1951 by USGS.
Grognon Gulch: ravine, trends NE $1 \mathrm{mi}$. to join Caribou Gulch at the head of Bonanza Creek, $3.3 \mathrm{mi}$. E of Porcupine Dome and $44 \mathrm{mi}$. SW of Circle, Yukon-Tanana High,; 65 $30^{\prime} 45^{\prime \prime}$ N, $145^{\circ} 24^{\prime} 45^{\prime \prime} \mathrm{W}$; (map 104).

Prospectors' name reported in 1954 or 1955 by USGS topographers.

Gromkopa: locality, off right bank of Yukon River, $27 \mathrm{mi}$. NE of Nulato, Koyukuk Low.; $64^{\circ} 48^{\prime} \mathrm{N}, 157^{\circ} 13^{\prime} \mathrm{W}$; (map 97).

Indian name shown on a 1905 manuscript navigation chart of Yukon River.

Groosgincloose : estuary, see Cook Inlet.

Grooze: island, see Kruzof Island.

Grose Creek: stream, heads on King Mtn., flows E $0.5 \mathrm{mi}$. to Nome River, $0.3 \mathrm{mi}$. S of Becher Creek and $7 \mathrm{mi}$. NNE of Nome, Seward Penin. High.; $64^{\circ} 36^{\prime} \mathrm{N}, 165^{\circ} 17^{\prime} \mathrm{W}$; (map 94).

Prospectors' name published on the 1900 "Map of Nome Peninsula" by J. M. Davidson and B. D. Blakeslee.

Grosvenor, Lake: lake, $18 \mathrm{mi}$. long, on Alaska Penin., in N part of Katmai National Monument, $22 \mathrm{mi}$. NW of Mount Katmai, Aleutian Ra.; 58 $41^{\prime} \mathrm{N}, 155^{\circ} 15^{\prime} \mathrm{W}$; BGN 1925; (map 42). Var. Alinak Lake, Kalhvit Lake, Savonoski Lakes.

Named in 1921 by R. F. Griggs, National Geographic Society. Both Lakes Coville and Grosvenor were called "Savonoski Lakes" by the National Geographic Society in 1919; in 1923 both lakes were called "Alinak Lake" by the American Geographical Society, after a former native village near Lake Grosvenor's outlet. The Indian name, "Kalhvit," was reported in 1923 by R. H. Sargent, USGS.

Grosvenor, Mount: mountain, 5,540 ft., E of Meares Glacier, $39 \mathrm{mi}$. W of Valdez, Chugach Mts.; $61^{\circ} 11^{\prime} 05^{\prime \prime} \mathrm{N}, 147^{\circ} 25^{\prime} 40^{\prime \prime} \mathrm{W}$; (map 69).

Named in 1910 by Lawrence Martin for Gilbert Hovey Grosvenor, 1875-1966, National Geographic Society.

Grosvenor Camp: locality, between Lakes Coville and Grosvenor, on Alaska Penin., in Katmai National Monument, $36 \mathrm{mi}$. NW of Mount Katmai, Aleutian Ra.; $58^{\circ} 43^{\prime} 45^{\prime \prime} \mathrm{N}, 155^{\circ}$. 29'30" W; (map 42).

Name reported in 1957 by AMS; probably named for Gilbert Hovey Grosvenor, 18751966, National Geographic Society.

Grosvold Bay: bay, $1 \mathrm{mi}$. across, on $\mathrm{N}$ coast of Korovin I., in Shumagin Is., Aleutian Ra.; $55^{\circ} 27^{\prime} \mathrm{N}, 160^{\circ} 12^{\prime} \mathrm{W}$; (map 28).

Published by USC\&GS in 1916 Coast Pilot (p. 175).

Grotto Creek: stream, flows $4.3 \mathrm{mi}$. S to Chitistone River E of Chitistone Mtn., $16 \mathrm{mi}$. NE of McCarthy, Wrangell Mts.; $61^{\circ} 27^{\prime} 45^{\prime \prime} \mathrm{N}$, $142^{\circ} 26^{\prime} 15^{\prime \prime} \mathrm{W}$; (map 67).

Local name published by USGS in 1954.

Grotto Creek: stream, flows SE $5 \mathrm{mi}$. to Hammond River, $4 \mathrm{mi}$. E of Grotto Mtn. and 12 mi. N of Wiseman, Brooks Ra.; $67^{\circ} 34^{\prime} 30^{\prime \prime} \mathbf{N}$, $150^{\circ} 02^{\prime} 00^{\prime \prime} \mathrm{W}$; BGN 1932; (map 124).

Named about 1930 by Robert Marshall for the mountain. 
Grotto Mountain: mountain, 5,140 ft., $12 \mathrm{mi}$. N of Wiseman, Brooks Ra.; $67^{\circ} 35^{\prime} \mathrm{N}, 150^{\circ} 08^{\prime}$ W; $B G N 1932$; (map 124).

Named in 1932 by Robert Marshall "because of the appearance of its limestone summits."

Grouch Creek: stream, heads NW of Old Grouchtop, flows SW and NW $50 \mathrm{mi}$. to Innoko River, $52 \mathrm{mi}$. NE of Holikachuck and $53 \mathrm{mi}$. $\mathrm{NW}$ of Ophir, Innoko Low.; $63^{\circ} 21^{\prime} 45^{\prime \prime} \mathrm{N}$, $158^{\circ} 09^{\prime} 10^{\prime \prime} \mathrm{W}$; (map 90).

Name published in 1965 by USGS.

Groudy Creek: stream, flows W $1 \mathrm{mi}$. to Allene Creek in Agiapuk River basin, $10 \mathrm{mi}$. NE of Teller, Seward Penin. High.; $65^{\circ} 20^{\prime}$ N, $166^{\circ}$. 03' W; (map 111).

Prospectors' name reported on the 1908 "Map of Seward Peninsula" by Arthur Gibson. Groundhog Basin: valley, extends NW $1.5 \mathrm{mi}$. to Porterfield Greek, $12 \mathrm{mi}$. E of Wrangell, Coast Mts.; $56^{\circ} 31^{\prime} 25^{\prime \prime} \mathrm{N}, 132^{\circ} 04^{\prime} 30^{\prime \prime} \mathrm{W}$; (map 6).

Local name published by F. E. Wright and C. W. Wright (1908, fig. 22), USGS.

Groundhog Greek : stream, on N slope of Gastineau Peak, flows $0.5 \mathrm{mi}$. NW to Icy Gulch, 2.4 mi. E of Juneau, Coast Mts.; $58^{\circ} 18^{\prime} 10^{\prime \prime} \mathrm{N}$, $134^{\circ} 20^{\prime} 25^{\prime \prime} \mathrm{W}$; (map 11).

Local name published by Spencer and Wright (1906, pl. 15), USGS. Apparently this creek has been destroyed by mining operations.

Groundhog Creek: stream, flows N $9 \mathrm{mi}$. to Rock Creek, $10 \mathrm{mi}$. NW of Nondalton, Alaska Ra.; $60^{\circ} 06^{\prime} \mathrm{N}, 155^{\circ} 04^{\prime} \mathrm{W}$; (map 61).

Local name reported in 1914 by $R$. $H$. Sargent, USGS.

Groundhog Greek: stream, on Kenai Penin. flows NE $4 \mathrm{mi}$. to Bench Creek, $18 \mathrm{mi}$. SE of Sunrise, Chugach Mts.; $60^{\circ} 40^{\prime} 05^{\prime \prime} \mathrm{N}, 149^{\circ}$. $13^{\prime} 30^{\prime \prime}$ W; (map 63)

Local name reported in 1912 by Grant and Higgins (1913, pl. 1), USGS

Groundhog Hill: hill, probably on $\mathbf{N}$ slope of Mount Roberts, about $3 \mathrm{mi}$. SE of Juneau, Coast Mts. ; $58^{\circ} 18^{\prime} \mathrm{N}, 134^{\circ} 19^{\prime} \mathrm{W}$; (map 11).

Named by miners about 1885 (DeArmond, 1957, p. 37).

Groundhog Islands: islands, see Porcupine Islands.

Groundhog Mountain: mountain, 2,700 ft., 12 mi. W of Nondalton and $20 \mathrm{mi}$. NW of Iliamna, Alaska Ra.; $60^{\circ} 00^{\prime} \mathrm{N}, 155^{\circ} 10^{\prime} \mathrm{W}$; (map 51 ).

Local name published in 1933 by USGS.

Ground Surface Slough: stream, flows S $3.7 \mathrm{mi}$. to Khotol River, $1.5 \mathrm{mi}$. $\mathrm{N}$ of junc. of Khotol River and Tsurotlurna Slough, $23 \mathrm{mi}$. SE of Nulato, Koyukuk Low, ; $64^{\circ} 25^{\prime} \mathrm{N}, 158^{\circ} 17^{\prime} \mathrm{W}$; (map 97). Var. Tlatsqeqatna.

Appears to be a translation of an Indian name; reported in 1935 by Frederica de Laguna, BAE.

Grouse Creek: stream, flows NE and SE $5.5 \mathrm{mi}$. to Crooked Creek $13 \mathrm{mi}$. NW of its junc. with Kuskokwim River, $43 \mathrm{mi}$. NW of Sleetmute, Kilbuck-Kuskokwim Mts.; $62^{\circ} 02^{\prime} 30^{\prime \prime} \mathrm{N}$, $158^{\circ} 15^{\prime} 30^{\prime \prime} \mathrm{W}$; (map 79 ).
Local name reported in 1916 by $G$. A Waring, USGS.

Grouse Creek: stream, flows SW $4.3 \mathrm{mi}$. to Goldbottom Creek, $15 \mathrm{mi}$. N of Nome, Seward Penin. High.; $64^{\circ} 43^{\prime} \mathrm{N}, 165^{\circ} 23^{\prime} \mathrm{W}$; (map 94). Var. Gold Bottom Creek.

Prospectors' name shown on a 1900 "Map of Nome Peninsula" by J. M. Davidson and B. D. Blakeslee. See Goldbottom Creek.

Grouse Creek: stream, flows NW $1 \mathrm{mi}$. to Casadepaga River, $14 \mathrm{mi}$. N of Solomon, Seward Penin. High.; 64 $46^{\prime} \mathrm{N}, 164^{\circ} 29^{\prime} \mathrm{W}$; (map 95).

Prospectors' name reported in 1905 by T. G. Gerdine, USGS.

Grouse Creek: stream, flows NW $1 \mathrm{mi}$. to Ophir Creek, which flows to Niukluk River, $3 \mathrm{mi}$. NW of Council and $34 \mathrm{mi}$. NE of Solomon, Seward Penin High.; 64 ${ }^{\circ} 56^{\prime} \mathrm{N}, 163^{\circ} 43^{\prime} \mathrm{W}$; (map 95).

Prospectors' name reported on a 1902 prospectors' manuscript map.

Grouse Creek: stream, flows SE $6.2 \mathrm{mi}$. to Pilgrim River, $28 \mathrm{mi}$. NW of Solomon, Seward Penin. High.; $64^{\circ} 57^{\prime} \mathrm{N}, 164^{\circ} 44^{\prime} \mathrm{W}$; (map 95).

'Prospectors' name reported in 1900 by E. C. Barnard (in Brooks, 1901, pl. 17), USGS.

Grouse Creek: stream, flows SW 2 mi. to Boulder Creek which flows to Tubutulik River, $29 \mathrm{mi}$. $\mathrm{N}$ of Elim and $46 \mathrm{mi}$. SE of Imuruk Lake, Seward Penin. High.; $65^{\circ} 02^{\prime}$ N, $162^{\circ} 13^{\prime} \mathrm{W}$; (map 110)

Prospectors' name reported in 1900 by W. J. Peters (in Mendenhall, 1901, pl. 20), USGS.

Grouse Creek: stream, flows S $2.5 \mathrm{mi}$. to Chatanika River, $5 \mathrm{mi}$. NNE of Twin Buttes and 40 mi. NE of Fairbanks, Yukon-Tanana High. $65^{\circ} 13^{\prime} 45^{\prime \prime} \mathrm{N}, 146^{\circ} 53^{\prime} 00^{\prime \prime} \mathrm{W}$; (map 104).

Prospectors' name reported in 1902 by $\mathrm{Lt}$. Hjalmar Erickson, USA.

Grouse Creek : stream, tributary of Woodchopper Creek, about $10 \mathrm{mi}$. SW of that stream's junc. with Yukon River, Porcupine Plat.; $65^{\circ} 15^{\prime} \mathrm{N}, 143^{\circ} 30^{\prime} \mathrm{W}$; (map 103)

Mentioned by Brooks (in Brooks and others, 1907, p. 203), USGS; this feature has not been positively identified.

Grouse Creek: stream, flows S $1.5 \mathrm{mi}$. to Hunter Creek, $8 \mathrm{mi}$. SE of Rampart, Yukon-Tanana High. $-65^{\circ} 29^{\prime} \mathrm{N}, 149^{\circ} 56^{\prime} \mathrm{W}$; (map 105).

Local name published by USGS in the 1950's.

Grouse Creek: stream, flows SE $1 \mathrm{mi}$. to Noxapaga River, $0.6 \mathrm{mi}$. SW of Black Creek and $30 \mathrm{mi}$. SW of Imuruk Lake, Seward Penin.

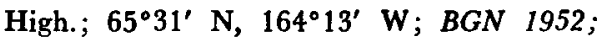
(map 110).

Prospectors' name reported in 1901 by T. G. Gerdine (in Collier, 1902, pl. 12), USGS.

Grouse Creek: stream, flows NW $1.2 \mathrm{mi}$. to Aurora Creek which flows to Noxapaga River $27 \mathrm{mi}$. W of Imuruk Lake, Seward Penin. High.; $65^{\circ} 38^{\prime} \mathrm{N}, 164^{\circ} 12^{\prime} \mathrm{W}$; (map 110).

Prospectors' name reported in 1901 by T. G. Gerdine (in Collier, 1902, pl. 12), USGS.
Grouse Creek: stream, formed by junc. of its East and South Forks, flows NE $6 \mathrm{mi}$. to Mint River, $41 \mathrm{mi}$. NW of Teller, Seward Penin. High.; $65^{\circ} 41^{\prime} \mathrm{N}, 167^{\circ} 21^{\prime} \mathrm{W}$; (map 111).

Prospectors' name reported in 1900 by Brooks (1901, pl. 13), USGS.

Grouse Creek: stream, flows SW $14 \mathrm{mi}$. to Bear Creek, $20 \mathrm{mi}$. NE of Livengood, Yukon-Tanana High.; $65^{\circ} 43^{\prime} 30^{\prime \prime} \mathrm{N}, 148^{\circ} 01^{\prime} 45^{\prime \prime} \mathrm{W}$; (map 105).

Local name reported in 1903 by USGS (in Prindle, 1905, pl. 16).

Grouse Creek: stream, flows NE $1.2 \mathrm{mi}$. to $\mathrm{Ki}-$ walik River, $50 \mathrm{mi}$. NW of Haycock, Seward Penin. High.; $65^{\circ} 51^{\prime} \mathrm{N}, 161^{\circ} 55^{\prime} \mathrm{W}$; (map 109)

Name "taken from prospectors' stakes"; reported in 1900 by W. J. Peters, USGS.

Grouse Creek: stream, see Hot Springs Creek. Grouse Gulch: ravine, tributary to Gold Creek, about $2 \mathrm{mi}$. W of Juneau, Coast Mts. ; 58 $18^{\prime}$ N, $134^{\circ} 20^{\prime} \mathrm{W}$; (map 11$)$.

Miners' name for a gulch subsequently destroyed by mining operations (DeArmond, 1957, p. 22).

Grouse Gulch: ravine, at head of Dexter Creek, trends SE $0.5 \mathrm{mi}$. to valley of Dexter Creek, $6 \mathrm{mi}$. NE of Nome, Seward Penin. High.; $64^{\circ} 34^{\prime} 45^{\prime \prime} \mathrm{N}, 165^{\circ} 20^{\prime} 20^{\prime \prime} \mathrm{W}$; (map 94). Var. Deer Gulch.

Prospectors' name shown on the 1903 Campion Mining and Trading Co. map by George M. Ashford. Shown as "Deer" on a 1901 map of Cape Nome gold fields by David Fox, Jr.

Grouse Lake: lake, on Kenai Penin., $0.5 \mathrm{mi}$. long, $6.5 \mathrm{mi}$. NE of Seward, Chugach Mts.; $60^{\circ} 12^{\prime} 00^{\prime \prime} \mathrm{N}, 149^{\circ} 22^{\prime} 15^{\prime \prime} \mathrm{W}$; (map 63).

Local name reported in 1904 by Moffit (1906, pl. 2), USGS.

Grouse Lake: lake, $1.5 \mathrm{mi}$. long, on Kenai Penin., $2.3 \mathrm{mi}$. SE of King Lake and $36 \mathrm{mi}$. $\mathrm{NE}$ of Kenai, Cook Inlet Low.; $60^{\circ} 46^{\prime} 30^{\prime \prime} \mathrm{N}$, $150^{\circ} 17^{\prime} 15^{\prime \prime} \mathrm{W}$; (map 62).

Named about 1963 by officials of Kenai National Moose Range, probably for the Willow Ptarmigan or Snow Grouse (Lagopus lagopus lagopus), which breeds in northern Alaska and winters only as far south as Sitka and the Aleutian Is. (Pearson, 1944, pt. 2, p. 20).

Grouse Peak: mountain, 3,185 ft., on $\mathrm{E}$ coast of Baranof I., $8.5 \mathrm{mi}$. NW of Port Alexander, Alex. Arch.; $56^{\circ} 21^{\prime} 05^{\prime \prime} \mathrm{N}, 134^{\circ} 46^{\prime} 30^{\prime \prime} \mathrm{W}$; (map 5).

Local name recorded in 1951 by USGS

Grouse Rock: rock, along mainland, near mouth of Mink Bay, $2 \mathrm{mi}$. ESE of Porpoise Point, Coast Mts., $55^{\circ} 05^{\prime} 05^{\prime \prime} \mathrm{N}, 130^{\circ} 43^{\prime} 30^{\prime \prime} \mathrm{W}$; (map 3).

Local name published in the 1932 Coast Pilot (p. 96)

Grouse Rock: rock, at junc. of Clarence Strait and Nichols Passage, $3.5 \mathrm{mi}$. SE of Gravina I., Alex. Arch.; $55^{\circ} 05^{\prime} 08^{\prime \prime} \mathrm{N}, 131^{\circ} 42^{\prime} 05^{\prime \prime} \mathrm{W}$; (map 3).

Local name reported in 1952 by USGS. 
Groves Lake: lake, see Chilok Lake.

Growler Bay: estuary, on E side of Glacier I., extends NE $3 \mathrm{mi}$. to Prince William Sound, $54 \mathrm{mi}$. NE of Whittier, Chugach Mts.; $60^{\circ}$ $54^{\prime} 00^{\prime \prime} \mathrm{N}, 147^{\circ} 06^{\prime} 30^{\prime \prime} \mathrm{W}$; (map 63).

Local name reported in 1916 by J. W. Bagley, USGS, "because of some ice seen in the water." A growler is a small piece of floating ice.

Grub Gulch: bay, 1.5 mi. across, on $\mathrm{S}$ coast of Alaska Penin. on NW shore of Stepovak Bay, Aleutian Ra.; $55^{\circ} 48^{\prime} \mathrm{N}, 159^{\circ} 57^{\prime} \mathrm{W}$; (map 27).

Published by USC\&GS in 1916 Coast Pilot.

Grub Gulch: ravine, trends $\mathrm{W} 1 \mathrm{mi}$. to Goldbottom Creek, $15 \mathrm{mi}$. N of Nome, Seward Penin. High.; $64^{\circ} 43^{\prime} 10^{\prime \prime} \mathrm{N}, 165^{\circ} 23^{\prime} 45^{\prime \prime} \mathrm{W}$; (map 94).

Prospectors' name reported in 1904 by T. G. Gerdine, USGS.

Grubstake Creek: stream, heads in a lake, flows NW 3 mi., through Grubstake Gulch to Willow Creek, 15 mi. NW of Palmer, Talkeetna Mts.; $61^{\circ} 45^{\prime} 30^{\prime \prime} \mathrm{N}, 149^{\circ} 25^{\prime} 50^{\prime \prime} \mathrm{W}$; (map 69).

Local name reported in 1942 by AMS.

Grubstake Creek: stream, flows W $1.7 \mathrm{mi}$. to Ahtell Creek, $6.3 \mathrm{mi}$. NW of junc. of Copper and Slana Rivers, Alaska Ra.; $62^{\circ} 47^{\prime} \mathrm{N}, 144^{\circ}$ 05' W; BGN 1936; (map 83).

Name used by prospectors and reported in 1935 by USGS.

Grubstake Creek: stream, flows NW $5 \mathrm{mi}$. to Tatlanika Creek, $45 \mathrm{mi}$. SE of Nenana, Alaska Ra.; $64^{\circ} 02^{\prime} \mathrm{N}, 148^{\circ} 13^{\prime} \mathrm{W}$; (map 100).

Named by prospectors, reported in 1906 by L. M. Prindle (in Brooks and others, 1907, pl. 4), USGS.

Grubstake Gulch: ravine, trends SW $1 \mathrm{mi}$. from glacier to White Creek, $17 \mathrm{mi}$. SE of McCarthy, St. Elias Mts.; $61^{\circ} 16^{\prime} 45^{\prime \prime} \mathrm{N}, 142^{\circ}$ $31^{\prime} 45^{\prime \prime} \mathrm{W}$; (map 67).

Prospectors' name taken from a map of Nizina Mining District by George Esterly of Valdez; published by Mendenhall and Schrader (1903, fig. 5), USGS.

Grubstake Gulch: ravine, heads on Bald Mtn. Ridge, extends NW $3 \mathrm{mi}$. to Willow Creek, $15 \mathrm{mi}$. NW of Palmer, Talkeetna Mts.; $61^{\circ}$ $45^{\prime} 30^{\prime \prime} \mathrm{N}, 149^{\circ} 25^{\prime} 50^{\prime \prime} \mathrm{W}$; (map 69).

Prospectors' name reported in 1906 by T.G. Gerdine and R. H. Sargent, USGS.

Grundler: village, see Big Delta.

Grunt Point: point of land, on E coast of Admiralty I., $2 \mathrm{mi}$. NW of Gambier I., and 63 mi. NE of Sitka, Alex. Arch.; $57^{\circ} 25^{\prime} 00^{\prime \prime} \mathrm{N}$, $133^{\circ} 50^{\prime} 15^{\prime \prime} \mathrm{W}$; (map 8).

Named in 1889 by Lt. Comdr. H. B. Mansfield, USN; name published in 1892 by USC\&GS.

Gruskka Lake: lake, $0.5 \mathrm{mi}$. long, on Kenai Penin., $0.9 \mathrm{mi}$. W of Quill Lake and $21 \mathrm{mi}$. NE of Kenai, Cook Inlet Low.; $60^{\circ} 45^{\prime} 20^{\prime \prime} \mathrm{N}$, $150^{\circ} 47^{\prime} 30^{\prime \prime} \mathrm{W}$; (map 62).

Named about 1963 by officials of Kenai National Moose Range, for administrative purposes.

Grus Lake: lake, 1 mi. long, on Kenai Penin., $12 \mathrm{mi}$. S of Moose Point and $27 \mathrm{mi}$. NE of Kenai, Cook Inlet Low.; $60^{\circ} 46^{\prime} 30^{\prime \prime} \mathrm{N}, 150^{\circ}$ $40^{\prime} 20^{\prime \prime} \mathrm{W}$; (map 62).
Named about 1963 by officials of Kenai National Moose Range, probably for the Whooping crane (Grus americana).

Gryada, Kamena: rocks, see Border Rocks.

Guadalupe, Ensenada de: bay, see Shelikof Bay. Guard Hill: hill, $455 \mathrm{ft}$., between Ogotoruk and Ugalak Creeks, $9.3 \mathrm{mi}$. E of Cape Thompson, Arctic Slope; $68^{\circ} 08^{\prime} 42^{\prime \prime} \mathrm{N}, 165^{\circ} 37^{\prime} 05^{\prime \prime} \mathrm{W}$; BGN 1963; (map 129).

Named about 1962 by personnel of Project Chariot.

Guardian Mountain: mountain, 5,060 ft., $2.4 \mathrm{mi}$. SW of Slanting Peak and $15 \mathrm{mi}$. NE of Juneau, Coast Mts. ; $58^{\circ} 30^{\prime} 20^{\prime \prime} \mathrm{N}, 134^{\circ} 14^{\prime} 40^{\prime \prime}$ W; (map 11).

Local name published in 1960 by USGS.

Guard Island: island, see Hive Island.

Guard Islands: islands, two, larger of which is $600 \mathrm{ft}$. long, NW of Gravina I., between Glarence Strait and Tongass Narrows, Alex. Arch.; $55^{\circ} 26^{\prime} 48^{\prime \prime} \mathrm{N}, 131^{\circ} 52^{\prime} 45^{\prime \prime} \mathrm{W}$; (map 3).

Named about 1880 by local navigators; reported by USC\&GS.

Gubik: stream, see Colville River.

Gudrum Mountain: hill, $482 \mathrm{ft}$., $20 \mathrm{mi}$. W of Northeast Cape, $3 \mathrm{mi}$. NE of Soomaghat Mtn., on Saint Lawrence I.; $63^{\circ} 16^{\prime} 30^{\prime \prime} \mathrm{N}, 169^{\circ}$ 18'30" W; BGN 1951; (map 93).

Eskimo name reported in 1949 by Maj. H. B. Allen, USAF.

Guemes: island, see Suemez Island.

Güemes, Isla de: island, see Suemez Island.

Guerin, Lake: lake, $2 \mathrm{mi}$. long, $14 \mathrm{mi}$. NE of Angoon, on central Admiralty I., Alex. Arch.; $57^{\circ} 39^{\prime} 00^{\prime \prime} \mathrm{N}, 134^{\circ} 19^{\prime} 30^{\prime \prime} \mathrm{W}$; (map 9).

Name published in 1940 by USGS. Probably named for Eckley C. Guerin, USGS, cadastral engineer, who for many years was actively engaged in Alaskan surveys.

Guerin Glacier: glacier, trends N $6 \mathrm{mi}$. from Mount Natazhat to its terminus at head of Traver Creek, $61 \mathrm{mi}$. NE of McCarthy, St. Elias Mts.; $61^{\circ} 38^{\prime} 30^{\prime \prime} \mathrm{N}, 141^{\circ} 07^{\prime} 30^{\prime \prime} \mathrm{W}$; (map 67).

Local name published by USGS in 1954.

Guerin Slough: stream, flows W $3.5 \mathrm{mi}$. from Canada near boundary monument 65 to right bank Stikine River, Coast Mts.; $56^{\circ} 40^{\prime} \mathrm{N}$, $131^{\circ} 51^{\prime} \mathrm{W}$; (map 7 ).

Local name reported in 1955 by USGS.

Guertin Island: island, $0.2 \mathrm{mi}$. across, $2 \mathrm{mi}$. SE of Sitka, on W coast of Baranof I., Alex. Arch.; $57^{\circ} 02^{\prime} 20^{\prime \prime} \mathrm{N}, 135^{\circ} 17^{\prime} 00^{\prime \prime} \mathrm{W}$; (map 9).

Named in 1880 for Guertin[cnna], USN, and published by USC\&GS in the 1883 Coast Pilot (p. 144).

Guerto de Guadalupe, Puerto de : bay, see Mary, Port.

Gufmut: locality, on left bank of Jewn River, $3 \mathrm{mi}$. E of Tagayarak and $48 \mathrm{mi}$. SW of Bethel, Yukon-Kuskokwim Delta; $60^{\circ} 17^{\prime} \mathrm{N}, 162^{\circ} 41^{\prime}$ W; (map 58).

Eskimo camp or small settlement reported in 1949 by USC\&GS.

Gugenheim Creek: stream, see Guggenheim Creek.

Guggenheim Creek: stream, heads $1 \mathrm{mi}$. $\mathrm{N}$ of Camelback Mtn., flows N 8.5 mi., to join Dead- wood Creek to form Porcupine Greek, $25 \mathrm{mi}$. NE of Flat, Kilbuck-Kuskokwim Mts.; $62^{\circ} 39^{\prime} 45^{\prime \prime}$ N, $157^{\circ} 21^{\prime} 30^{\prime \prime}$ W; (map 79). Var. Gugenheim Creek.

Prospectors' name obtained in 1952 by USGS topographers.

Guguak Bay: cove, $0.5 \mathrm{mi}$. across, on NW coast of Evans I., on NE side of Prince of Wales Passage, $14 \mathrm{mi}$. S of Chenega, Chugach Mts.; $60^{\circ} 06^{\prime} 15^{\prime \prime} \mathrm{N}, 148^{\circ} 02^{\prime} 30^{\prime \prime} \mathrm{W}$; (map 63).

Local name reported in 1951 by USGS.

Guhao Inlet: estuary, $1 \mathrm{mi}$. long, on $\mathrm{E}$ coast of Tuxekan I., $28 \mathrm{mi}$. NW of Craig, Alex. Arch.; $55^{\circ} 52^{\prime} 20^{\prime \prime} \mathrm{N}, 133^{\circ} 16^{\prime} 05^{\prime \prime} \mathrm{W}$; (map 4).

Indian name published in 1964 by USC\&GS.

Guibert, Port: $b a y$, see Whale Bay.

Guibert Islets: islands, $1.5 \mathrm{mi}$. across, between Necker and Whale Bays, on SW coast of Barnanof I., Alex. Arch.; 56 $38^{\prime} 30^{\prime \prime} \mathrm{N}$, $135^{\circ} 10^{\prime} 00^{\prime \prime} \mathrm{W}$; (map 5). Var. Egg Islands, Egg Islets, Necker Isles, Ostrova Yaichnyya, Yaichnia Islets, Yaitchny Islets.

Named in 1883 by W. H. Dall, USC\&GS; originally named "Necker Isles" by La Pérouse on September 5, 1786 (Wagner, 1937, p. $475)$; in 1850 it was called "O[stro]va Yaichnyya," meaning "egg islands," by the Russian American Company.

Guide Island: island, $600 \mathrm{ft}$. long, in Tlevak Strait, between Dall and Prince of Wales I., Alex. Arch.; $55^{\circ} 13^{\prime} \mathrm{N}, 133^{\circ} 05^{\prime} \mathrm{W}$; $B G N$ 1908; (map 4).

Local name reported in 1907 by E. F. Dickins, USC\&GS.

Guide Island: island, $0.1 \mathrm{mi}$. long, at $\mathrm{S}$ entrance to Hayward Strait, Sitka Sound, $9 \mathrm{mi}$. NW of Sitka, Alex. Arch.; 57 $08^{\prime} 00^{\prime \prime} \mathrm{N}$, $135^{\circ} 31^{\prime} 10^{\prime \prime} \mathrm{W}$; (map 9). Var. Guide Islet, Index Islet, Krestofski Islet, Ostrov Krestovskoy, Ostrov Ukazatel, Unastal Island.

An 1882 translation by USC\&GS of the name published in 1848 on Russian Hydrog. Dept. Chart 1397 as "Os[trov] Ukazatel." This island was originally named "Krestovskoy," meaning "cross," in 1809 by the Russian navigator Ivan Vasilliev the first; published as such by Sarichev (1826, map 19). It was published in 1882 on Brit. Adm. Chart 2431 as "Index Islet."

Guide Islet: island, see Guide Island.

Guide Point: point of land, on NW coast of Eagle I. in Yukon River, Innoko Low. ; $63^{\circ} 36^{\prime}$ $\mathrm{N}, 159^{\circ} 28^{\prime} \mathrm{W}$; (map 91).

Riverboat pilots' name shown on a 1940 "Navigation Chart of the Tanana-Yukon Rivers" published by the U.S. Dept. of Interior.

Guide Rock: rock, in Khaz Bay, 5 mi. S of Chichagof, on W coast of Chichagof I., Alex.

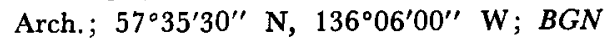
1908; (map 9).

Descriptive name given by USC\&GS in 1908 and published in 1908 Coast Pilot (p. 171). So named "because it stands at the west point of entrance to Smooth Channel like a guide." 
Guide Rocks: rocks, extend $700 \mathrm{ft}$. off SW coast of Prince of Wales I., $\mathrm{E}$ of Barrier Is., Alex. Arch.; $54^{\circ} 49^{\prime} 30^{\prime \prime} \mathrm{N}, 132^{\circ} 21^{\prime} 00^{\prime \prime} \mathrm{W}$; $B G N$ 1922; (map 1).

Name reported in 1897 by Lt. Comdr. J. F. Moser, USN.

Gui-guok-lok: stream, see Peace River.

Gui-guok-lok: stream, see Wind River.

Guiguoklokpuk: locality, on right bank and at mouth of Peace River, $49 \mathrm{mi}$. NW of Dillingham, Kilbuck-Kuskokwim Mts.; $59^{\circ} 43^{\prime} \mathrm{N}$, $158^{\circ} 51^{\prime} \mathrm{W}$; (map 52$)$.

Eskimo village or camp shown as "Guiguok-lok-puk" on a 1910 manuscript map by H. C. Fassett, USBF. It is now abandoned.

Gui Kangulas: island, $300 \mathrm{ft}$. long, in Tlevak Strait, between Corlies and McFarland Is., on W coast of Sukkwan I., Alex. Arch.; $55^{\circ} 06^{\prime} 40^{\prime \prime} \mathrm{N}, 132^{\circ} 55^{\prime} 30^{\prime \prime} \mathrm{W}$; BGN 1959; (map 4). Var. Profit Island.

This is a Haida Indian name meaning "an island that is easily recognizable from afar;" reported to be in local use by USC\&GS in 1958. The name "Profit Island" was published by USC\&GS in 1927 for the triangulation station Profit located here.

Guillemont Island: island, see Guillemot Island.

Guillemot Island: island, $1.7 \mathrm{mi}$. long, near mouth of Stepovak Bay, Aleutian Ra.; 55 . $32^{\prime} 45^{\prime \prime} \mathrm{N}, 160^{\circ} 22^{\prime} 00^{\prime \prime} \mathrm{W}$; BGN 1939; (map 28). Var. Gillemot Island, Guillemont Island, Iachnoi Island, San Diego Island, Yaichni Island.

Named "O[strov] Iachnoi," meaning "egg island," by Capt. Tebenkov (1852, map 24), IRN; renamed "Guillemot Island" in 1880 by W. H. Dall, USC\&GS.

Guingmetolik Creek: stream, see Kingmetolik Creek.

Guishiemana Lake: lake, $1 \mathrm{mi}$. long, $8 \mathrm{mi}$. SW of Echoing Lake and $21 \mathrm{mi}$. NW of Stevens Village, Yukon Flats; $66^{\circ} 14^{\prime} 00^{\prime \prime} \mathrm{N}, 149^{\circ}$ $36^{\prime} 30^{\prime \prime} \mathrm{W}$; (map 118).

Indian name reported in 1956 by T. E. Taylor, USGS.

Guktu Point: point of land, on W coast of Prince of Wales I., $20 \mathrm{mi}$. N of Graig, Alex. Arch.; $55^{\circ} 45^{\prime} 05^{\prime \prime} \mathrm{N}, 133^{\circ} 17^{\prime} 15^{\prime \prime} \mathrm{W}$; (map 4).

Indian name published in 1956 by USC\&GS.

Gukyuk Slough: channel, $4.5 \mathrm{mi}$. long, anabranch of Kawanak Pass, in distributary system of Yukon River, $17 \mathrm{mi}$. NE of Kwiguk, Yukon-Kuskokwim Delta ; $62^{\circ} 58^{\prime} 30^{\prime \prime} \mathrm{N}, 164^{\circ}$ $13^{\prime} 00^{\prime \prime} \mathrm{W}$; (map 77).

Eskimo name obtained in $1899^{\circ}$ by $R$. L. Faris, USC\&GS; published in 1901 on Chart 9372.

Gula Point: point of land, N tip of Segula I., Rat Is., Aleutian Is.; $52^{\circ} 03^{\prime} 30^{\prime \prime} \mathrm{N}, 178^{\circ}$ $08^{\prime} 40^{\prime \prime}$ E; BGN 1937; (map 15).

This point of land was named by 1935 U.S. Navy Survey Expedition. "Gula" comes from "Segula," the island's name.

Gulch Creek: stream, on Kenai Penin., flows SW $5.5 \mathrm{mi}$. to East Fork Sixmile Creek, $7.5 \mathrm{mi}$. $\mathrm{SE}$ of Sunrise, Chugach Mts.; $60^{\circ} 46^{\prime} 30^{\prime \prime} \mathrm{N}$, $149^{\circ} 24^{\prime} 00^{\prime \prime} \mathrm{W}$; (map 63).
Local name reported in 1895 by G. F. Becker (1898, p. 82), USGS.

Gulch Creek: stream, flows NE $6 \mathrm{mi}$. to Salcha River, $22 \mathrm{mi}$. W of Twin Mtn. and $52 \mathrm{mi}$. S of Circle, Yukon-Tanana High.; $65^{\circ} 04^{\prime} 45^{\prime \prime}$ $\mathrm{N}, 144^{\circ} 03^{\prime} 30^{\prime \prime} \mathrm{W}$; (map 104).

Prospectors' name reported in 1954 or 1955 by USGS topographers.

Gulkana: village, pop. 59, on Richardson Highway at Gulkana River crossing, $1.6 \mathrm{mi}$. SW of junc. of Glenn and Richardson Highways, Copper River Basin; 62 $2^{\circ} 16^{\prime} \mathrm{N}, 145^{\circ} 23^{\prime} \mathrm{W}$; (map 83). Var. Kulkana.

This village was established about 1903 as a telegraph station and named "Kulkana" by the U.S. Army Signal Corps after the nearby river. The Gulkana post office operated between 1909 and 1954 (Ricks, 1965, p. 24).

Gulkana Glacier: glacier, heads on Icefall Peak, trends SW 6 mi. to its 150 terminus at head of Gulkana River, $14 \mathrm{mi}$. N of Paxson, Alaska Ra.; $63^{\circ} 14^{\prime} 30^{\prime \prime} \mathrm{N}, 145^{\circ} 28^{\prime} 00^{\prime \prime} \mathrm{W}$; (map 86). Var. West Gulkana Glacier.

Local name shown on 1910 fieldsheet by C. E. Giffin, USGS.

Gulkana Lake: lake, see Paxson Lake.

Gulkana River: stream, flows S $60 \mathrm{mi}$. from Gulkana Glacier to Copper River, $9 \mathrm{mi}$. NE of Glennallen, Alaska Ra.; $62^{\circ} 13^{\prime} \mathrm{N}, 145^{\circ} 24^{\prime}$ W; (map 83). Var. Culkana, Culkena, Gulkena, Kulkana, Tonkiná.

Indian name reported by Oscar Rohn in 1899 as "Kulkana." Capt. W. R. Abercrombie, USA, changed Rohn's spelling to its present form. Lt. H. T. Allen, USA, reported "Tonkiná" as the stream's Indian name in 1885.

Gulkena: stream, see Gulkana River.

Gull, Cape: point of land, on S coast of Alaska Penin., in Katmai National Monument, between Kaflia and Kuliak Bays, $30 \mathrm{mi}$. E of Mount Katmai, Aleutian Ra.; 58 $13^{\prime} 00^{\prime \prime} \mathrm{N}$, $154^{\circ} 08^{\prime} 30^{\prime \prime}$ W; (map 42). Var. Cape Govorushek, Mys Govorushechiy, Mys Govorushek, Mys Zowoputchek.

H. W. Elliott's translation (1882, p. 173) of "M[ys] Govorushechiy" published in 1847 on Russian Hydrog. Dept. Ghart 1378. "Cape Gull" was published by USC\&GS in the 1916 Coast Pilot (p. 155).

Gull Bay: bay, see Udamat Bay.

Gull City: area, on flats near mouth of Gold Creek, in Juneau, Coast Mts.; $58^{\circ} 18^{\prime} 00^{\prime \prime} \mathrm{N}$, $134^{\circ} 25^{\prime} 10^{\prime \prime} \mathrm{W}$; (map 11).

Name is said to have been derived from the seagulls which frequented this area. The name was in common usage in the 1800's, but is now seldom used (DeArmond, 1957, p. 23).

Gull Cove: cove, $0.6 \mathrm{mi}$. across, on $\mathrm{N}$ end of Chichagof I., $5 \mathrm{mi}$. W of Mud Bay, $27 \mathrm{mi}$. NW of Hoonah, Alex. Arch.; $58^{\circ} 12^{\prime} 50^{\prime \prime} \mathrm{N}$, $136^{\circ} 09^{\prime} 45^{\prime \prime} \mathrm{W}$; (map 10).

Named by E. F. Dickins, USC\&GS, in 1902 and published on Chart 8304 in 1904.

Gull Creek: stream, flows NE $6 \mathrm{mi}$ from Gull Pass to Alatna River, Brooks Ra.; 67 $41^{\prime} \mathrm{N}$, $154^{\circ} 38^{\prime} \mathrm{W}$; (map 125).
P. S. Smith (1913, p. 35-36), USGS, reports that according to prospectors the stream and pass were named for the first white man to use this route between the Alatna and Noatak Rivers, probably about 1898.

Gullhead Point: point of land, see Toawlevic Point.

Gull Hill: hill, $509 \mathrm{ft}$., E of Tolstoi Point, on $\mathrm{E}$ coast of St. George I., Pribilof Is.; $56^{\circ} 35^{\prime}$ $40^{\prime \prime} \mathrm{N}, 169^{\circ} 30^{\prime} 15^{\prime \prime} \mathrm{W}$; (map 38). Var. Älchō'-kôverūshkä'.

Local name reported by Elliott (1881, Saint George map). Putnam (1903, p. 1014), USC\&GS, lists the Aleut-Russian name as Älchō'-kõverūshkä'," meaning "lower hill"; so called because it is about $136 \mathrm{ft}$. lower than adjacent North Sealion Hill.

Gull Hill: hill, between village of St. Paul and Reef Point, on S coast of St. Paul I., Pribilof Is.; $57^{\circ} 06^{\prime} 50^{\prime \prime} \mathrm{N}, 170^{\circ} 16^{\prime} 13^{\prime \prime} \mathrm{W}$; (map 38).

Name reported in 1897 by W. W. Duffield, USC\&GS.

Gullied Peak: peak, 3,350 ft., $1.2 \mathrm{mi}$. SE of Hugh Miller Glacier, in Glacier Bay National Monument, $61 \mathrm{mi}$. NW of Hoonah, St. Elias Mts.; $58^{\circ} 44^{\prime} 20 \mathrm{~N}, 136^{\circ} 36^{\prime} 45^{\prime \prime} \mathrm{W}$; (map 10).

Descriptive name reported in 1951 by USGS.

Gull Island: island, $0.5 \mathrm{mi}$. across, in Anderson Bay, part of Makushin Bay, on $W$ coast of Unalaska I., Aleutian Is. ; $53^{\circ} 40^{\prime} 10^{\prime \prime} \mathrm{N}, 166^{\circ}$ $49^{\prime} 00^{\prime \prime} \mathrm{W}$; (map 23).

Local name published in 1951 on a USGS map.

Gull Island: island, $600 \mathrm{ft}$. long, between Nichols Passage and Port Chester, $1 \mathrm{mi}$. NW of Metlakatla, Alex. Arch.; $55^{\circ} 08^{\prime} 30^{\prime \prime} \mathrm{N}, 131^{\circ} 35^{\prime} 30^{\prime \prime}$ W; (map 3$)$.

Named in 1883 by Lt. Comdr. H. E. Nichols, USN.

Gull Island: island, $0.1 \mathrm{mi}$. across, near $\mathrm{W}$ entrance to Zachary Bay, Unga I., in Shumagin Is., Aleutian Ra.; $55^{\circ} 24^{\prime} 30^{\prime \prime} \mathrm{N}, 160^{\circ} 38^{\prime} 30^{\prime \prime}$ W; (map 28).

Probably named by Western Union Telegraph Expedition in 1865; published by USC\&GS in 1872 report.

Gull Island: island, $0.1 \mathrm{mi}$. across, in Pavlof Bay near SW end of Alaska Penin., Aleutian Ra.; 55 29'30' N, 161 $37^{\prime} 15^{\prime \prime} \mathrm{W}$; (map 28). Named in 1929 by USGS.

Gull Island: island, $0.2 \mathrm{mi}$. wide, in Iphigenia Bay, $2.7 \mathrm{mi}$. SW of Cape Lynch, Heceta I., Alex. Arch.; $55^{\circ} 45^{\prime} 00^{\prime \prime} \mathrm{N}, 133^{\circ} 44^{\prime} 20^{\prime \prime} \mathrm{W}$; (map 4).

Name published in 1906 by USC\&GS

Gull Island: island, in Mine Harbor, on SE shore of Herendeen Bay, Aleutian Ra.; 55 $45^{\prime} 40^{\prime \prime}$ N, $160^{\circ} 41^{\prime} 30^{\prime \prime} \mathrm{W}$; (map 28).

Named in 1890 by Lt. Comdr. Z. L. Tanner, USN.

Gull Island: island, $0.3 \mathrm{mi}$. long, in Saint Paul Harbor 1 mi. SW of Kodiak, Kodiak I.; $57^{\circ}$ $46^{\prime} 40^{\prime \prime} \mathrm{N}, 152^{\circ} 25^{\prime} 20^{\prime \prime} \mathrm{W}$; (map 34). Var. Chaichi, Ostrov Chaichey.

This is a translation of the Russian name "O[strov] Chaichey" published by Sarichev (1826, map 16). 
Gull Island: island, $0.4 \mathrm{mi}$. across, in Favorite Channel, $3.5 \mathrm{mi}$. NW of Pearl Harbor and 22 mi. NW of Juneau, Coast Mts.; $58^{\circ} 30^{\prime} 10^{\prime \prime} \mathrm{N}$, $134^{\circ} 52^{\prime} 00^{\prime \prime} \mathrm{W}$; (map 11).

Named in 1880 by Capt. L. A. Beardslee, USN, and published by USC\&GS in the 1883 Coast Pilot (p. 195). The island was so named because "it was covered by sea gulls."

Gull Island: island, $0.2 \mathrm{mi}$. long, off NW coast of Shuyak I., $48 \mathrm{mi}$. $\mathrm{N}$ of Kodiak I.; $58^{\circ} 36^{\prime} 00^{\prime \prime}$ N, 152 $38^{\prime} 30^{\prime \prime} \mathrm{W}$; (map 48). Var. Chaichie Island.

Translation of the name "Os[trov] Chaichyey," published by Lt. Sarichev (1826, map 16), IRN.

Gull Island: island, $0.1 \mathrm{mi}$. long, at entrance to Peterson Bay, on E shore of Kachemak Bay, Kenai Penin., $8 \mathrm{mi}$. SE of Homer, Chugach Mts.; $59^{\circ} 35^{\prime} 10^{\prime \prime} \mathrm{N}, 151^{\circ} 19^{\prime} 45^{\prime \prime} \mathrm{W}$; (map 50 ).

Local name reported in 1895 by W. H. Dall, USGS.

Gull Island: island, $0.3 \mathrm{mi}$. long, at entrance to Chinitna Bay, 54 mi. NW of Homer, Alaska Penin., Aleutian Ra.; 59 $50^{\prime} 30^{\prime \prime}$ N, 152 59'$10^{\prime \prime} \mathrm{W}$; (map 50).

Local name published in 1923 by the ARC. So named "for the number of gulls that inhabit the island."

Gull Island: island, $600 \mathrm{ft}$. long, at NW end of Prince William Sound, $0.5 \mathrm{mi}$. E of Goose I., $35 \mathrm{mi}$. NW of Cordova, Chugach Mts.; $60^{\circ}$ $43^{\prime} 30^{\prime \prime} \mathrm{N}, 146^{\circ} 42^{\prime} 10^{\prime \prime} \mathrm{W}$; (map 64).

Local name reported by $H$. P. Ritter, USC\&GS, while doing hydrographic surveys in the Prince William Sound region in 1903.

Gull Island: island, $0.5 \mathrm{mi}$. long, in Yukon River, $19 \mathrm{mi}$. NE of Stevens Village, Yukon Flats; $66^{\circ} 09^{\prime} \mathrm{N}, 148^{\circ} 31^{\prime} \mathrm{W}$; (map 118).

Local name obtained in 1956 by USGS

Gull Island: island, $0.3 \mathrm{mi}$. long, at mouth of Prudhoe Bay, on Beaufort Sea coast, $20 \mathrm{mi}$. SE of Beechey Point, Arctic Plain; $70^{\circ} 22^{\prime} \mathrm{N}$, $148^{\circ} 22^{\prime} \mathrm{W}$; (map 150).

Named by Leffingwell (1919, p. 96) while he was mapping the coast with Samuel McIntyre in September, 1910.

Gull Island: island, see Kutkan Island.

Gull Island: rock, in Chignik Bay, $1 \mathrm{mi}$. S of Cape Kumliun and $21 \mathrm{mi}$. NE of Chignik, Aleutian Ra.; $56^{\circ} 28^{\prime} \mathrm{N}, 157^{\circ} 57^{\prime} \mathrm{W}$; (map 31).

A USC\&GS party established a triangulation station here calied Gull in 1920; the island was named in 1923 by R. H. Sargent, USGS.

Gull Island : rock, see Gull Rock.

Gull Islands: islands, two, largest $0.3 \mathrm{mi}$ long, in Imuruk Lake, $4.7 \mathrm{mi}$. W of Kettle Dome, Seward Penin. High.; $65^{\circ} 36^{\prime}$ N, $163^{\circ} 11^{\prime}$ W $B G N$ 1954; (map 110).

Reported in 1953 by D. M. Hopkins, USGS ; islands so named "because they are the nesting place of a large colony of herring gulls."

Gull Islands: islands, see Baby Islands.

Gull Islet: island, $0.2 \mathrm{mi}$. across, W of Baranof I., $4 \mathrm{mi}$. S of Sitka, Alex. Arch.; $56^{\circ} 59^{\prime} 45^{\prime \prime}$ $\mathrm{N}, 135^{\circ} 20^{\prime} 30^{\prime \prime} \mathrm{W}$; (map 5). Var. Chaiki, Gull Rocks, Kamen Chayki.
This is a translation by USGS of the name given in 1809 by the navigator Ivan Vasiliev the first, IRN. Lt. Sarichev (1826, map 19), IRN, published it as "K[amen] Chayki." Lt. Comdr. H. E. Nichols, USN, later translated the name literally as "Gull Rocks" which was published in the 1891 Coast Pilot (p. 173).

Gulliver Cove: cove, in two parts, $0.4 \mathrm{mi}$. across, $0.5 \mathrm{mi}$. $\mathrm{N}$ of Vega Point, SE coast of Kiska I., Aleutian Is.; $51^{\circ} 50^{\prime} 15^{\prime \prime} \mathrm{N}, 177^{\circ} 19^{\prime} 30^{\prime \prime} \mathrm{E}$; (map 14)

One of many arbitrary names applied to features on Kiska I. by USAAF for tactical purposes during World War II.

Gull Lake: lake, $0.6 \mathrm{mi}$. long, on NW coast of Kenai Penin., S of Gray Cliff, $21 \mathrm{mi}$. NE of Kenai, Cook Inlet Low.; $60^{\circ} 44^{\prime} \mathrm{N}, 150^{\circ} 57^{\prime}$ W; (map 62).

Named about 1963 by officials of Kenai National Moose Range for administrative purposes.

Gull Lake: lake, $1 \mathrm{mi}$. long, $2 \mathrm{mi}$. SE of Gailey Lake and $31 \mathrm{mi}$. NE of Fort Yukon, Yukon Flats; $66^{\circ} 47^{\prime} 40^{\prime \prime} \mathrm{N}, 144^{\circ} 17^{\prime} 00^{\prime \prime} \mathrm{W}$; (map 119).

Local descriptive name obtained in 1956 by USGS.

Gull Lake: lake, see Norutak Lake.

Gull Pass: pass, 3,500 ft., between Lucky Six Creek to the S and Gull Creek to the N, 25 mi. SW of Survey Pass, Brooks Ra.; 67 $37^{\prime} \mathrm{N}$, $154^{\circ} 47^{\prime} \mathrm{W}$; (map 125)

P. S. Smith (1913, p. 35-36), USGS, reports that according to prospectors the pass and stream were named for the first white man that used this route between the Alatna and Noatak Rivers, probably about 1898.

Gull Point: point of land, on S shore of Herendeen Bay, at SW end of Alaska Penin., Aleutian Ra.; $55^{\circ} 43^{\prime} 30^{\prime \prime} \mathrm{N}, 160^{\circ} 40^{\prime} 30^{\prime \prime} \mathrm{W}$; (map 28).

Named in 1890 by Lt. Comdr. Z. L. Tanner, USN.

Gull Point: point of land, NW tip of Onslow I., Alex. Arch.; $55^{\circ} 54^{\prime} 20^{\prime \prime} \mathrm{N}, 132^{\circ} 23^{\prime} 45^{\prime \prime} \mathrm{W}$; (map 4).

Named in 1886 by Lt. Comdr. Snow, USN. Gull Point: point of land, on S shore of Ugak Bay, on E coast of Kodiak I.; $57^{\circ} 23^{\prime} \mathrm{N}, 152^{\circ}$ 06' W; (map 34). Var. Gulls Point, Mys Chaichey, Mys Chiachi, Mys Govorushiche, Mys Govorushichiy.

Name recorded in 1805 as "Gulls Point" by Lisianski (1814, map facing p. 169). In 1848 the Russian American Gompany published the name "M[ys] Chaichey," meaning "seagull cape," for this feature; Capt. Tebenkov (1852, map 23) called it "M[ys] Govorushichiy" meaning "Kittiwake (gull) Cape." H. W. Elliot says "Chikie" is the Russian for the Burgomaster gull (Larus glaucus).

Gull Rock: point of land, on N coast of Kenai Penin., near mouth of Turnagain Arm, 5.5 mi. NW of Hope, Chugach Mts.; $60^{\circ} 58^{\prime} 05^{\prime \prime}$ $\mathrm{N}, 149^{\circ} 46^{\prime} 00^{\prime \prime} \mathrm{W}$; (map 63)

Name published in 1943 by USC\&GS.
Gull Rock: rock, in Lake Bay, on NE coast of Prince of Wales I., Alex. Arch.; $56^{\circ} 02^{\prime} 20^{\prime \prime} \mathrm{N}$, $132^{\circ} 52^{\prime} 00^{\prime \prime} \mathrm{W}$; (map 6).

Local name used by fishermen and published in 1907 by USC\&GS.

Gull Rock: rock, in Davison Bay, $12 \mathrm{mi}$. NW of Chichagof, on W coast of Chichagof I., Alex. Arch.; 57 $47^{\prime} 10^{\prime \prime} \mathrm{N}, 136^{\circ} 19^{\prime} 05^{\prime \prime} \mathrm{W}$; (map 9).

Name published by USC\&GS in 1925 Coast Pilot (p. 322).

Gull Rock: rock, in Bering Sea, $1 \mathrm{mi}$. W of Pinnacle I., $12 \mathrm{mi}$. S of St. Matthew I.; $60^{\circ}$ $12^{\prime} \mathrm{N}, 172^{\circ} 48^{\prime} \mathrm{W}$; (map 56).

Named by H. W. Elliott in 1874 . Lt. Sarichev (1826, map 3), IRN, notes that it is a "rock with gravel."

Gull Rock: rocks, two, off S coast of Alaska Penin., at head of Stepovak Bay, Aleutian Ra.; $55^{\circ} 50^{\prime} 30^{\prime \prime} \mathrm{N}, 159^{\circ} 45^{\prime} 00^{\prime \prime} \mathrm{W}$; (map 27). Var. Gull Island, Gull Rocks.

Published by USC\&GS in 1916 Coast Pilot. Gull Rocks : islands, see Baby Islands

Gull Rocks: island, see Gull Islet.

Gull Rocks: rocks, see Gull Rock.

Gulls Point: point of land, see Gull Point.

Gulo Creek: stream, flows NW $1.2 \mathrm{mi}$. to Niyiklik Creek $2.1 \mathrm{mi}$. N of its junc. with Ogotoruk Creek and $10 \mathrm{mi}$. NE of Cape Thompson, Arctic Slope; $68^{\circ} 10^{\prime} 55^{\prime \prime} \mathrm{N}, 16^{\circ} 37^{\prime} 30^{\prime \prime} \mathrm{W}$; $B G N$ 1963; (map 129).

Named about 1962 by personnel of Project Chariot.

Gulrass Point: point of land, see Culross, Point. Gumaer, Lake: lake, see Gasoline Lake.

Gum Bay: bay, see Lagoma Bay.

Gumbo Creek: stream, flows SW to Delome Creek which flows to Kuzitrin River, about $15 \mathrm{mi}$. NW of Mount Bendeleben, Seward Penin. High.; (map 110).

Prospectors' name shown on a map of Cape Nome gold fields by David Fox, Jr., dated 1901. This stream cannot be precisely located on current maps.

Gumboot Basin: basin, $2 \mathrm{mi}$. long, on Millard Creek, $38 \mathrm{mi}$. NW of Cordova, Chugach Mts.; $60^{\circ} 54^{\prime} 30^{\prime \prime} \mathrm{N}, 146^{\circ} 33^{\prime} 00^{\prime \prime} \mathrm{W}$; (map 64).

Local name reported in 1912 by S. R. Capps and B. L. Johnson (in Brooks and others, 1913, pl. 1), USGS.

Gumboot Gulch: ravine, trends SW $1 \mathrm{mi}$. to Cleveland Creek which flows to Cripple River, $14 \mathrm{mi}$. NW of Nome, Seward Penin. High.; $64^{\circ} 39^{\prime} 20^{\prime \prime} \mathrm{N}, 165^{\circ} 44^{\prime} 00^{\prime \prime} \mathrm{W}$; (map 94)

Prospectors' name shown on the 1904 'Map of Cape Nome Precinct" by Arthur Gibson.

Gu-nah-ho: locality, see Gonaho.

Gunboat Island: island, $0.1 \mathrm{mi}$. across, between Sanak and Caton Is., one of Sanak Is. Aleutian Ra.; $54^{\circ} 21^{\prime} 25^{\prime \prime} \mathrm{N}, 162^{\circ} 28^{\prime} 40^{\prime \prime} \mathrm{W}$; (map 25)

Name published in 1949 on a USGS map.

Gunboat Lakes: lakes, on $\mathrm{E}$ coast of Kenai Penin., trends NW-SE $1.7 \mathrm{mi}$., $15 \mathrm{mi}$. NE of Chenega, Chugach Mts.; $60^{\circ} 29^{\prime} \mathrm{N}, 148^{\circ} 00^{\prime}$ W; (map 63).

Name published on 1950 USGS map. 
Gunboat Rock: rock, W of Baranof I., in Biorka Channel, among Necker Is., Alex. Arch.; $56^{\circ}$ $49^{\prime} 50^{\prime \prime}$ N, $135^{\circ} 30^{\prime} 50^{\prime \prime}$ W; BGN 1926; (map 5).

Named in 1925 by USC\&GS because "from a distance it looks like a gunboat."

Gun Creek: stream, see Gunn Creek.

Gungnoruk Creek: stream, flows W $3 \mathrm{mi}$. to Dahtkit Cove, 17 mi. SW of Cape Etolin, on N coast of Nunivak I.; $60^{\circ} 19^{\prime} 30^{\prime \prime} \mathrm{N}, 166^{\circ}$ $34^{\prime} 00^{\prime \prime} \mathrm{W}$; (map 57).

Eskimo name reported in 1937 by USAAF. Gungnuk: locality, on E shore of Golovnin Bay, $\mathrm{N}$ side of Norton Sound near Mission, $10 \mathrm{mi}$. $\mathrm{N}$ of Cape Darby, Seward Penin. High.; $64^{\circ}$. $15^{\prime} 24^{\prime \prime} \mathrm{N}, 162^{\circ} 48^{\prime} 00^{\prime \prime} \mathrm{W}$; (map 95).

Eskimo name for an archeological site reported by Giddings (1964, p. 179) who discovered a "culture earlier than those of the neo-Eskimos of the region ***" here.

Gunguk: locality, on right bank of Nushagak River, $5 \mathrm{mi}$. S of mouth of Kokwok River, 32 mi. NE of Dillingham, Bristol Bay Low.; $59^{\circ} 15^{\prime} \mathrm{N}, 157^{\circ} 40^{\prime} \mathrm{W}$; (map 52). Var. Gunguk-ha-mut.

Eskimo village or camp shown as "Gunguk-ha-mut" on a 1910 manuscript map by H. C. Fassett, USBF. The place is now abandoned.

Gun-guk-ha-mut: locality, see Gunguk.

Gunn Creek: stream, flows S and NW $13 \mathrm{mi}$. to Gulkana River, $0.8 \mathrm{mi}$. N of Summit Lake and $10 \mathrm{mi}$. N of Paxson, Alaska Ra.; $63^{\circ} 10^{\prime} 12^{\prime \prime}$ N, $145^{\circ} 31^{\prime} 55^{\prime \prime} \mathrm{W}$; (map 86). Var. Gun Creek.

Name published on relatively recent maps. Gunners Cove: cove, $0.4 \mathrm{mi}$. across, on NE coast of Rat I., Aleutian Is.; $51^{\circ} 48^{\prime} 45^{\prime \prime} \mathrm{N} ; 178^{\circ}$ 19'10" E; BGN 1937; (map 15).

Named by 1935 U.S. Navy Survey Expedition.

Gunnison Creek: stream, flows NW $2 \mathrm{mi}$. to Washington Creek, $20 \mathrm{mi}$. N of Fairbanks, Yukon-Tanana High.; $65^{\circ} 09^{\prime} \mathrm{N}, 147^{\circ} 53^{\prime} \mathrm{W}$; (map 105).

Local name published by USGS in the 1950 's.

Gunnison Creek: stream, flows NW $6.5 \mathrm{mi}$. to Troublesome Creek, $15 \mathrm{mi}$. SE of Rampart, Yukon-Tanana High.; $65^{\circ} 27^{\prime} \mathrm{N}, 149^{\circ} 41^{\prime} \mathrm{W}$; (map 105).

Named by prospectors; reported in 1908 by USGS (Covert and Ellsworth, 1909, pl. 5).

Gunn Lakes: lakes, two, larger is $1.7 \mathrm{mi}$. long, W of Gakona Glacier terminus, $8 \mathrm{mi}$. NE of Paxson, Alaska Ra.; $63^{\circ} 07^{\prime} 40^{\prime \prime} \mathrm{N}, 145^{\circ} 18^{\prime} 30^{\prime \prime}$ W; (map 86).

Name published on relatively recent maps. Gunnuk Creek: stream, flows SW $5 \mathrm{mi}$. to Keku Strait at Kake, on NW coast of Kupreanof I., Alex. Arch.; 56 $58^{\prime} 10^{\prime \prime} \mathrm{N}, 133^{\circ} 55^{\prime} 55^{\prime \prime} \mathrm{W}$; (map 6).

Local name recorded in 1951 by USGS.

Gunnysack Creek: stream, heads at glacier terminus, flows NW $4 \mathrm{mi}$. to Delta River, crosses Richardson Highway, $36 \mathrm{mi}$. S of Delta Junction, Alaska Ra.; $63^{\circ} 31^{\prime} 30^{\prime \prime}$ N, $145^{\circ} 51^{\prime} 20^{\prime \prime}$ W; (map 86)
So called, about 1903, because two men, nicknamed "Gunny Sack Kid" and "Gunny Sack Jack," carried supplies in a gunny sack to their cabin at a prospect on this stream (Davies, 1965, p. 23).

Gunnysack Creek: stream, flows SE $3 \mathrm{mi}$. to Birch Lake, $28 \mathrm{mi}$. NW of Big Delta, YukonTanana High.; $64^{\circ} 19^{\prime} 30^{\prime \prime}$ N, $146^{\circ} 40^{\prime} 00^{\prime \prime}$ W (map 101).

Local name published in 1956 by USGS.

Gunsight Creek: stream, on Revillagigedo I., flows NE $3.3 \mathrm{mi}$. to Carroll Inlet, Alex. Arch.; $55^{\circ} 30^{\prime} 45^{\prime \prime} \mathrm{N}, 131^{\circ} 20^{\prime} 07^{\prime \prime} \mathrm{W}$; BGN 1923; (map 3).

Named in 1923 by USFS.

Gunsight Creek: stream, heads on Gunsight Mtn. and flows NE $2.5 \mathrm{mi}$. to Squaw Creek, 59 mi. NE of Palmer, Talkeetna Mts.; $61^{\circ} 53^{\prime} 20^{\prime \prime}$ N, $147^{\circ} 25^{\prime} 25^{\prime \prime} \mathrm{W}$; BGN 1960; (map 69).

Named in 1956 by USGS for Gunsight Mountain.

Gunsight Creek: stream, flows W $2 \mathrm{mi}$. from $\mathrm{N}$ flank of Gunsight Mtn. to John River, $8.5 \mathrm{mi}$. $\mathrm{N}$ of mouth of Allen River and $53 \mathrm{mi}$. W of Wiseman, Brooks Ra.; $67^{\circ} 29^{\prime} 30^{\prime \prime} \mathrm{N}, 152^{\circ}$ $06^{\prime} 00^{\prime \prime} \mathrm{W}$; (map 124)

Local name obtained in 1956 by USGS topographers.

Gunsight Mountain: peak, 6,441 ft., at E end of Sheep Mtn., $56 \mathrm{mi}$. NE of Palmer, Talkeetna Mts.; $61^{\circ} 50^{\prime} 45^{\prime \prime} \mathrm{N}, 147^{\circ} 27^{\prime} 50^{\prime \prime} \mathrm{W}$; (map $69)$.

Local name reported in 1952 by USGS.

Gunsight Mountain: peak, 7,460 ft., in Mount McKinley National Park, W of Muldrow Glacier and $12 \mathrm{mi}$. NE of Mount McKinley, Alaska Ra.; $63^{\circ} 13^{\prime} \mathrm{N}, 150^{\circ} 50^{\prime} \mathrm{W}$; (map 88).

Glimbers' name shown on recent maps.

Gunsight Mountain: mountain, 4,225 ft., $\mathbf{N}$ of junc. of Allen and John Rivers and $50 \mathrm{mi}$. W of Wiseman, Brooks Ra.; $67^{\circ} 28^{\prime} 40^{\prime \prime} \mathrm{N}, 152^{\circ}$ $00^{\prime} 45^{\prime \prime} \mathrm{W}$; (map 124).

Local descriptive name obtained in 1956 by USGS topographers.

Gunsight Mountain: mountain, 2,976 ft., E of Siksikpuk River, $10 \mathrm{mi}$. S of junc. Siksikpuk and Chandler Rivers and $41 \mathrm{mi}$. $\mathrm{N}$ of Anaktuvuk Pass, Arctic Slope; 68 $43^{\prime} \mathrm{N}$, $151^{\circ} 50^{\prime} \mathrm{W}$; BGN 1960; (map 134).

So named by USGS geologists about 1950 because it forms a "prominent landmark used by pilots flying between Fairbanks and Umiat."

Gunsight Pass: pass, 6,400 ft., in Mount McKinley National Park, $W$ of Muldrow Glacier, $11 \mathrm{mi}$. NE of Mount McKinley, Alaska Ra. $63^{\circ} 12^{\prime} 15^{\prime \prime} \mathrm{N}, 150^{\circ} 57^{\prime} 00^{\prime \prime} \mathrm{W} ; B G N$ 1947; (map 88).

So named in 1942 by the U.S. Army Alaska Test Expedition, because it is a "V-shaped declevity separating the Muldrow and Peters Glacier valleys."

Gunsight Pass: pass, on Siksikpuk River, W of Gunsight Mtn., $42 \mathrm{mi}$. N of Anaktuvuk Pass, Arctic Slope; $68^{\circ} 44^{\prime} 15^{\prime \prime} \mathrm{N}, 151^{\circ} 54^{\prime} 30^{\prime \prime} \mathrm{W}$; BGN 1960; (map 134).

Named by USGS geologists about 1950 "after the mountain."
Gurkin Greek: stream, flows SE 2.5 mi. to Nizina Glacier, $20 \mathrm{mi}$. NE of McCarthy, Wrangell Mts.; $61^{\circ} 36^{\prime} 50^{\prime \prime} \mathrm{N}, 142^{\circ} 29^{\prime} 30^{\prime \prime} \mathrm{W}$; $B G N$ 1964; (map 67)

Named in 1962 by E. M. MacKevett, Jr., and D. L. Jones, USGS, for Ernie Gurkin who died in 1960. Gurkin was a packer for F. H. Moffit, USGS, in 1907-08.

Gurney Bay: bay, $1 \mathrm{mi}$. across, $17 \mathrm{mi}$. SW of Karluk, on W coast of Kodiak I. ; 57 $48^{\prime} 00^{\prime \prime}$ $\mathrm{N}, 154^{\circ} 45^{\prime} 30^{\prime \prime} \mathrm{W}$; (map 35$)$.

Local descriptive name reported in 1952 by USGS.

Gurney Peak: peak, 8,400 ft., in Cathedral Spires of Kichatna Mts., $83 \mathrm{mi}$. W of Talkeetna, Alaska Ra. ; $62^{\circ} 24^{\prime} 50^{\prime \prime} \mathrm{N}, 152^{\circ} 41^{\prime} 10^{\prime \prime}$ W; (map 81).

Named in 1899 by Lt. J. S. Herron, USA.

Gusdagane Point: point of land, $N$ point of entrance to Klinkwan Cove, on SW coast of Prince of Wales I., Alex. Arch.; $54^{\circ} 30^{\prime} 00^{\prime \prime} \mathrm{N}$, $132^{\circ} 21^{\prime} 30^{\prime \prime} \mathrm{W}$; BGN 1922; (map 1).

Haida Indian name recorded in 1901 by J. R. Swanton, BAE.

Gushdoiman Lake: lake, $2 \mathrm{mi}$. long, $4 \mathrm{mi}$. SW of Abraham Lake and $9.5 \mathrm{mi}$. N of Stevens Village, Yukon Flats; $66^{\circ} 09^{\prime} \mathrm{N}, 149^{\circ} 04^{\prime} \mathrm{W}$; (map 118).

Indian name reported in 1956 by T. E. Taylor, USGS

Gushiate Lake: lake, $3.7 \mathrm{mi}$. long, $2 \mathrm{mi}$. N of Abraham Lake and $14 \mathrm{mi}$. NE of Stevens Village, Yukon Flats; $66^{\circ} 12^{\prime} \mathrm{N}, 148^{\circ} 55^{\prime} \mathrm{W}$; (map 118).

Kutchin Indian name obtained in 1956 by T. E. Taylor, USGS.

Gusinnoi: island, see Goose Island.

Gusinnoi: island, see Little Goose Island.

Gusinyya, Ostrova: islands, see Geese Islands.

Guss Creek: stream, see Cuss Creek.

Gus Steven Slough: stream, $7 \mathrm{mi}$. long, distributary of Copper River, $20 \mathrm{mi}$. SE of Cordova, Malaspina Coastal Plain; $60^{\circ} 21^{\prime} \mathrm{N}$, $145^{\circ} 20^{\prime} \mathrm{W}$; (map 64).

Local name published in 1951 by USGS.

Gustavus: village, pop. 107, on $\mathrm{N}$ shore of $\mathrm{Icy}_{\mathrm{c}}$ Passage at mouth of Salmon River, $7 \mathrm{mi}$. NE of Point Gustavus and $48 \mathrm{mi}$. NW of Juneau, St. Elias Mts.; $58^{\circ} 24^{\prime} 45^{\prime \prime} \mathrm{N}, 135^{\circ} 44^{\prime} 15^{\prime \prime} \mathrm{W}$; $B G N$ 1948; (map 11). Var. Strawberry Point.

Local name reported in 1940 by USFS; derived from nearby Point Gustavus.

Gustavus, Point: point of land, on Icy Strait at entrance to Glacier Bay, $7 \mathrm{mi}$. SW of Gustavus and $55 \mathrm{mi}$. NW of Juneau; St. Elias Mts.; $58^{\circ} 23^{\prime} \mathrm{N}, 135^{\circ} 55^{\prime} \mathrm{W}$; (map 11).

Named in 1879 by W. H. Dall, USC\&GS and published in the 1883 Coast Pilot (p. 188).

Gusty Bay: bay, $1 \mathrm{mi}$. across, on NE coast of Tanaga I., Aleutian Is.; $51^{\circ} 51^{\prime} 30^{\prime \prime} \mathrm{N}, 177^{\circ}$ $54^{\prime} 30^{\prime \prime}$ W; (map 17).

Name published by USC\&GS in the 1944 Aleutian Coast Pilot (p. 118).

Gut Bay: bay, $5 \mathrm{mi}$. long, $0.1 \mathrm{mi}$. across at its mouth, on SE coast of Baranof I., Alex. Arch.; $56^{\circ} 44^{\prime} 00^{\prime \prime} \mathrm{N}, 134^{\circ} 38^{\prime} 30^{\prime \prime} \mathrm{W}$; (map 5). 
Local narne used by fishermen; published in 1889 by USC\&GS.

Gutchi Cove: estuary, $0.7 \mathrm{mi}$. long, on W coast of Prince of Wales I., at mouth of Gutchi Creek, $28 \mathrm{mi}$. N of Craig, Alex. Arch.; 55 53' N, $133^{\circ} 09^{\prime} \mathrm{W}$; (map 4).

Indian name published in 1964 by USC\&GS.

Gutchi Creek: stream, on W coast of Prince of Wales I., flows NW 3 mi. to Gutchi Gove in Naukati Bay, $29 \mathrm{mi}$. N of Graig, Alex. Arch.; $55^{\circ} 52^{\prime} 50^{\prime \prime} \mathrm{N}, 133^{\circ} 07^{\prime} 45^{\prime \prime} \mathrm{W}$; (map 4).

Indian name recorded in 1949 by USGS.

Guthna Creek: stream, see Boulder Creek.

Guthna Creek: stream, see Fish Creek.

Gutqklaqatna: stream, see Pike Trap Creek.

Gutwetter, Cape: point of land, see Fairweather, Cape.

Guyat Glacier: glacier, see Guyot Glacier.

Guy Greek : stream, see Gold Creek.

Guyot Bay: lagoon, $2 \mathrm{mi}$. long, $\mathrm{N}$ of Icy Cape, at mouth of Icy Bay, Malaspina Coastal Plain; $59^{\circ} 57^{\prime} 04^{\prime \prime} \mathrm{N}, 141^{\circ} 41^{\prime} 30^{\prime \prime} \mathrm{W}$; BGN 1966; (map 47). Var. Mud Bay.

Name published by USC\&GS in 1923 on Chart 8457. Called Guyot or Mud Bay in 1926 Coast Pilot. Until 1966 these names were used interchangeably.

Guyot Glacier: glacier, heads in Robinson Mts., $2.5 \mathrm{mi}$. N of Yaka Peak, trends SE $19 \mathrm{mi}$. to 1963 terminus at head of Icy Bay, $68 \mathrm{mi}$. NW of Yakutat, Chugach Mts.; $60^{\circ} 03^{\prime} 50^{\prime \prime} \mathrm{N}$, $141^{\circ} 22^{\prime} 00^{\prime \prime} \mathrm{W}$; BGN 1964; (map 65). Var. Guyat Glacier.

Named by the New York Times Expedition of 1886 for Arnold Henry Guyot, 1807-84, of Princeton Univ., and applied to what was then the west lobe of the Malaspina Glacier (Libbey, 1886, p. 296).

Guyot Hills: mountains, maximum elev. 6,168 ft., $7 \mathrm{mi}$. long, trend NW-SE, $6 \mathrm{mi}$. NW of Icy Bay and $75 \mathrm{mi}$. NW of Yakutat, Chugach Mts. ; $60^{\circ} 11^{\prime} \mathrm{N}, 141^{\circ} 28^{\prime} \mathrm{W}$; (map 65). Var. Karr Hills.

Local name derived from Guyot Glacier; published in 1951 by USGS.

Guy Rowe Greek: stream, flows SE $2 \mathrm{mi}$. to Fox River opposite Hugh Rowe Creek, $20 \mathrm{mi}$. NE of Solomon, Seward Penin. High.; 64 $45^{\prime} \mathrm{N}$, $163^{\circ} 54^{\prime} \mathrm{W}$; (map 95).

Prospectors' name reported on a map of Cape Nome gold fields by David Fox, Jr., dated 1901.

Grozdeva, Mys: point of land, see Prince of Wales, Cape.

Grozdeva, Ostrova: islands, see Diomede Islands.

Gvozdevy, Ostrova : islanids, see Diomede Islands.

Gweek River: stream, anabranch of the Kuskokwim River, heads at $61^{\circ} 12^{\prime} \mathrm{N}, 160^{\circ} 49^{\prime} \mathrm{W}$, flows SW $70 \mathrm{mi}$., $7 \mathrm{mi}$. NE of Bethel, YukonKuskokwim Delta ; $60^{\circ} 51^{\prime} 30^{\prime \prime}$ N, 161 $34^{\prime} 30^{\prime \prime}$ W; (map 59). Var. Kwek River.

Eskimo name shown as "Kwek River" on an 1898 fieldsheet by W. S. Post; USC\&GS.

Gwenn Lake: lake, 1,250 ft. long, $W$ of Lake Kiowa, $9 \mathrm{mi}$. NE of Anchorage, Cook Inlet Low.; $61^{\circ} 17^{\prime} 54^{\prime \prime} \mathrm{N}, 149^{\circ} 40^{\prime} 30^{\prime \prime} \mathrm{W}$; (map 69 ).

Local name reported in 1964 by USGS.
Gwent Cove: cove, $0.3 \mathrm{mi}$. across, on $\mathrm{W}$ shore of Pearse Canal, $\mathrm{S}$ of Hidden Inlet, Coast Mts.; $54^{\circ} 56^{\prime} 35^{\prime \prime} \mathrm{N}, 130^{\circ} 20^{\prime} 00^{\prime \prime} \mathrm{W}$; BGN 1937; (map 2).

Local name published in 1936 by USC\&GS. Gwosdew Islands: islands, see Diomede Islands. Gwozdeff Islands: islands, see Diomede Islands. Gwyder Bay: bay, see Gwydyr Bay.

Gwydir Bay : bay, see Gwydyr Bay.

Gwydyr Bay: bay, $8 \mathrm{mi}$. across, between Back Point and Point Storkersen, on Beaufort Sea coast, $3 \mathrm{mi}$. SE of Beechey Point, Arctic Plain; $70^{\circ} 27^{\prime} \mathrm{N}, 148^{\circ} 51^{\prime} \mathrm{W}$; (map 1950). Var. Gwyder Bay, Gwydir Bay.

Named on August 17, 1826, by Franklin (1828, p. 166), who wrote, "we had *** the gratification of being able to trace the land round Gwydyr Bay to its outer point [Point Back] * * *."

Gypsum: locality, on Iyoukeen Cove, $12 \mathrm{mi}$. NE of Tenakee Springs, on E coast of Chichagof I., Alex. Arch.; 57 $54^{\prime} \mathrm{N}, 134^{\circ} 59^{\prime} \mathrm{W}$; (map 9).

An abandoned gypsum mining camp settled in 1904. A post office was established here in 1906, discontinued in 1925, reestablished in 1939, and was finally discontinued in 1941 (Ricks, 1965). In 1923 the mine located here was the only source of commercial gypsum in Alaska.

Gypsum Creek: stream, flows SE $5.5 \mathrm{mi}$. to Iyoukeen Cove, $12 \mathrm{mi}$. NE of Tenakee Springs, on $\mathrm{E}$ coast of Chichagof I., Alex. Arch.; $57^{\circ} 54^{\prime}$ N, $134^{\circ} 59^{\prime} \mathrm{W}$; (map 9).

Name reported by C. W. Wright (in Brooks and others, 1908, p. 124), USGS. "So named because a large deposit of commercial gypsum occurs along the creek." This deposit was extensively developed between 1905 and 1925 .

Gypsum Creek: stream, heads on Sheep Mtn. and flows S $2.7 \mathrm{mi}$. to Matanuska River, 54 mi. NE of Palmer, Talkeetna Mts.; 61 $41^{\circ} 40^{\prime \prime}$ N, $147^{\circ} 32^{\prime} 20^{\prime \prime} \mathrm{W} ; B G N$ 1952; (map 69). Var. Jackass Canyon.

Named in 1949 by USGS.

\section{$\mathbf{H}$}

Hacha Island: island, $0.2 \mathrm{mi}$, across, in Maurelle Is., Alex. Arch.; $55^{\circ} 37^{\prime} 30^{\prime \prime} \mathrm{N}, 133^{\circ} 39^{\prime} 00^{\prime \prime}$ W; (map 4).

Spanish name meaning "axe"; recorded in 1951 by USGS.

Hachimuk: locality, on Agattu I. in the Near Is., Aleutian Is. ; (map 13).

Former Aleut village reported as "uninhabited" by Hodge (1907, p. 519), BAE.

Hackett Creek: stream, flows NW $8 \mathrm{mi}$. to Koyukuk River, $6 \mathrm{mi}$. SE of Ninemile Hills and $43 \mathrm{mi}$. SW of Wiseman, Brooks Ra.; $67^{\circ} 00^{\prime} 30^{\prime \prime} \mathrm{N}, 151^{\circ} 18^{\prime} 30^{\prime \prime} \mathrm{W}$; BGN 1932; (map 124).

Local name reported in 1932 by USGS.

Hades Creek: stream, flows SE 1 mi. to Eldorado Creek which flows to Candle Creek, 30 mi. NE of Imuruk Lake, Seward Penin. High.; $65^{\circ} 45^{\prime} \mathrm{N}, 162^{\circ} 09^{\prime} \mathrm{W}$; (map 110).

Local name reported in 1950 by USGS.
Hades Highway: glacier, heads at $58^{\circ} 43^{\prime} \mathrm{N}$, $134^{\circ} 53^{\prime} \mathrm{W}$, trends SW $8 \mathrm{mi}$. to Demorest Glacier, $3 \mathrm{mi}$. N of Hodgkins Peak and 26 mi. NE of Juneau, Coast Mts.; $58^{\circ} 38^{\prime} \mathrm{N}$, $134^{\circ} 03^{\prime} \mathrm{W}$; BGN 1965; (map 11).

So named in 1964 by members of the Juneau Icefield Research Project because the roughness of the glacier made travel difficult.

Hadley: locality, on $E$ coast of Prince of Wales I., at Lyman Anchorage on Kasaan Penin., Alex. Arch.; $55^{\circ} 32^{\prime}$ N, $132^{\circ} 17^{\prime} \mathrm{W}$; (map 4).

Name of village site reported in 1904 by H. C. Fassett, USBF. The Hadley post office was established here in 1912 and transferred to Ketchikan in 1918 (Ricks, 1965, p. 24). "Hadley is an abandoned settlement * * * It was the shipping point for mines in the vicinity, which are not now in operation. The wharf is in ruins" (U.S. Coast and Geodetic Survey, 1962, p. 57).

Hadley, Port: anchorage, see Lyman Anchorage.

Hadley Creek: stream, flows SW $1.5 \mathrm{mi}$. to Tongass Narrows, $1.5 \mathrm{mi}$. NW of Ketchikan Harbor, on SW coast of Revillagigedo I., Alex. Arch.; $55^{\circ} 21^{\prime} 15^{\prime \prime} \mathrm{N}, 131^{\circ} 41^{\prime} 15^{\prime \prime} \mathrm{W}$; (map 3).

Local name reported in 1954 by USGS.

Hadley Island: island, $2 \mathrm{mi}$. long, in Tanana River, $18 \mathrm{mi}$. SW of Fairbanks, Tanana Low. ; $64^{\circ} 42^{\prime} \mathrm{N}, 148^{\circ} 13^{\prime} \mathrm{W}$; (map 100).

Local name reported in 1950 by USGS topographers.

Hadokhten Lake: lake, $1.8 \mathrm{mi}$. across, $\mathrm{N}$ of Nayuka River, $1 \mathrm{mi}$. $W$ of Hadotohedan and Hahanudan Lakes and $25 \mathrm{mi}$. WNW of Hochandochtla Mtn., Kokrines-Hodzana High.; $65^{\circ} 41^{\prime} \mathrm{N}, 155^{\circ} 40^{\prime} \mathrm{W}$; (map 107).

Koyukan Indian name obtained at Huslia in 1956 by Orth.

Hadons Peak: peak, see Haydon Peak.

Hadotohedan Lake: lake, $0.4 \mathrm{mi}$, across, $\mathrm{N}$ of Nayuka River between Hahanudan and Hadokhten Lakes and $24 \mathrm{mi}$. NW of Hochandochtla Mtn., Kokrines-Hodzana High. ; $65^{\circ} 41^{\prime}$ $45^{\prime \prime} \mathrm{N}, 155^{\circ} 36^{\prime} 30^{\prime \prime} \mathrm{W}$; (map 107).

Koyukan Indian name obtained at Huslia in 1956 by Orth.

Hadweenzic River: stream, heads at $66^{\circ} 55^{\top} \mathrm{N}$, $148^{\circ} 30^{\prime} \mathrm{W}$ and flows SE $93 \mathrm{mi}$. to Yukon River, $43 \mathrm{mi}$. SW of Fort Yukon, Yukon Flats; $66^{\circ} 27^{\prime} \mathrm{N}, 146^{\circ} 51^{\prime} \mathrm{W}$; BGN 1948; (map 119). Var. Orensie, Orensik, Orenzik.

Indian name reported in 1907 by Archdeacon Hudson Stuck. The name "Orenzik" was reported by Mertie (1930, pl. 2), USGS, in 1926.

Haenke Glacier: glacier, trends SE $7 \mathrm{mi}$. to its terminus at Disenchantment Bay, $35 \mathrm{mi}$. NNE of Yakutat, St. Elias Mts.; $60^{\circ} 02^{\prime} 30^{\prime \prime} \mathrm{N}$, $139^{\circ} 36^{\prime} 00^{\prime \prime} \mathrm{W}$; (map 66).

Named in 1906 by Tarr (1909, pl. 11), USGS.

Haenke Island: island, $1 \mathrm{mi}$. across, in Disenchantment Bay near head of Yakutat Bay and $30 \mathrm{mi}$. NE of Yakutat, St. Elias Mts, ; $59^{\circ}$ $58^{\prime} \mathrm{N}, 139^{\circ} 32^{\prime} \mathrm{W}$; (map 46). Var. Egg Island. 
Named in 1791 by Capt. Alessandro Malaspina (Galiano, 1802, map 9) for Thaddeus Haenke, botanist and naturalist with Malaspina's expedition.

Hagelbarger Pass: pass, see Hagelbargers Pass.

Hagelbargers Pass: pass, 1,700 ft., on Alaska Penin., in Katmai National Monument, $12 \mathrm{mi}$. $\mathrm{SE}$ of Mount Katmai, Aleutian Ra.; $58^{\circ} 12^{\prime}$ $00^{\prime \prime} \mathrm{N}, 154^{\circ} 00^{\prime} 30^{\prime \prime} \mathrm{W}$; BGN 1925; (map 42). Var. Hagelbarger Pass.

Named in 1919 by R. F. Griggs, National Geographic Society, for Paul R. Hagelbarger, ass't. botanist (in 1917, and topographer in 1919) of the National Geographic Society's Katmai Expeditions.

Hagemeister, Mount: mountain, 3,225 ft., 20 mi. NW of village of Port Alexander, on $S$ central Baranof I., Alex. Arch.; $56^{\circ} 30^{\prime} 40^{\prime \prime} \mathrm{N}$, $134^{\circ} 53^{\prime} 10^{\prime \prime} \mathrm{W}$; BGN 1935; (map 5).

Named in 1935 by USFS "for Leonti Andreanovich Hagemeister, governor of Russian America from January 11, 1818, to Octơber 24, 1818." See Hagemeister Island.

Hagemeister Island: island, $24 \mathrm{mi}$. long, in Bristol Bay, $19 \mathrm{mi}$. SW of Togiak, Kilbuck-Kuskokwim Mts.; $58^{\circ} 39^{\prime} \mathrm{N}, 160^{\circ} 54^{\prime} \mathrm{W}$; (map 39). Var. Hagmeister Island, Hagenmeister Island, Ostrov Gagemeister.

Named for Capt. Leonti Andreanovich Hagemeister, who was in command of three voyages to the Russian American colony and around the world; 1806-07 on the Neva, $1816-19$ on the Kutuzov, and in 1828-30 on the Krothoy. The name was erroneously published as "Os[trov] Gagemeister" by Lt. Sarichev (1826, map 3).

Hagemeister Strait: water passage, trends SW 25 mi. from Rocky Point to Calm Point, between Hagemeister I. and the mainland, KilbuckKuskokwim Mts. ; $58^{\circ} 45^{\prime} \mathrm{N}, 161^{\circ} 00^{\prime} \mathrm{W}$; (map 39). Var. Hagmeister Channel, Proliv Gagemeystera.

Named for Hagemeister Island by the Russians; published as "Prol[iv] Gagemeystera" by Lt. Sarichev (1826, map 3), IRN. It was called "Hagmeister Channel" in 1890 by USBF.

Hagen Lake: lake, $0.3 \mathrm{mi}$. long, between Happy River and Puntilla Creek, 2 mi. NE of Houston Pass and $93 \mathrm{mi}$. NW of Tyonek, Alaska Ra.; $62^{\circ} 04^{\prime} 15^{\prime \prime} \mathrm{N}, 153^{\circ} 03^{\prime} 00^{\prime \prime} \mathrm{W}$; (map 80).

Local name obtained in 1958 by USGS.

Haggard Creek: stream, flows S $7 \mathrm{mi}$. to Sourdough Creek, $\mathrm{E}$ of Hogan Hill, $24 \mathrm{mi}$. N of Gulkana, Copper River Basin; 62 $37^{\prime} \mathrm{N}$, $145^{\circ} 26^{\prime} \mathrm{W}$; (map 83).

Local name reported by USGS in 1950 . Named for the roadhouse once located on Richardson Highway near the stream's mouth.

Hagmeister Channel: water passage, see Hagemeister Strait.

Hagmeister Island: island, see Hagemeister Island.

Hag Peak: mountain, 1,274 ft., on S coast of Alaska Penin., on E side of Kupreanof Penin., 6 mi. E of Stepovak Bay, Aleutian Ra.; $55^{\circ}$ $41^{\prime} 40^{\prime \prime} \mathrm{N}, 159^{\circ} 32^{\prime} 20^{\prime \prime} \mathrm{W}$; (map 27)
Published by USC\&GS in 1947 Coast Pilot p. 303).

Hague, Cape: point of land, see Sedanka Point. Hague, Mount: mountain, 3,900 ft., $12 \mathrm{mi}$. W of mouth of Pavlof Bay, near SW end of Alaska Penin., Aleutian Ra.; 55 $22^{\prime} 30^{\prime \prime}$ N, $161^{\circ} 58^{\prime}$ 25" W; (map 28).

Named in 1929 by USGS.

Hague Channel: channel, at $N$ end of bay of Port Moller, leads to Herendeen Bay, $5 \mathrm{mi}$. SW of village of Port Moller, Bristol Bay Low. ; $5^{\circ} 55^{\prime} \mathrm{N}, 160^{\circ} 45^{\prime} \mathrm{W}$; (map 28).

Named in 1890 by Z. L. Tanner, USN.

Hague Rock: rock, $10 \mathrm{mi}$. N of Caton I., in Sanak Is., part of Sandman Reefs, Aleutian Ra.; $54^{\circ} 33^{\prime} 30^{\prime \prime} \mathrm{N}, 162^{\circ} 24^{\prime} 00^{\prime \prime} \mathrm{W}$; (map 25). Var. Midway Island.

Named by USBF in 1890; published as Midway Island by USC\&GS in 1900.

Hahalitha River: stream, see Hoholitna River.

Hahanudna Lake: lake, $1.9 \mathrm{mi}$. across, $\mathrm{N}$ of Nayuka River, $1.8 \mathrm{mi}$. E of Hadokhten Lake and $23 \mathrm{mi}$. NW of Hochandochtla Mtn., Kokrines-Hodzana High.; $65^{\circ} 42^{\prime} \mathrm{N}, 155^{\circ} 34^{\prime} \mathrm{W}$; (map 107).

Koyukan Indian name obtained at Huslia in 1956 by Orth.

Hahkt-luk: lake, $0.8 \mathrm{mi}$. long, $6 \mathrm{mi} . \mathrm{N}$ of Okstukuk Lake and $42 \mathrm{mi}$. $\mathrm{N}$ of Dillingham, Bristol Bay Low. ; $59^{\circ} 37^{\prime} 30^{\prime \prime} \mathrm{N}, 158^{\circ} 19^{\prime} 00^{\prime \prime} \mathrm{W}_{\text {; (map }}$ 52).

Eskimo name reported in 1910 by H. C. Fassett, USBF.

Haiden, Port: bay, see Heiden, Port.

Haidilatna River: stream, see Iditarod River. Haiditarod River: stream, see Iditarod River.

Haines: village, pop. 392, on Portage Cove in Chilkoot Inlet, $0.5 \mathrm{mi}$. SW of Nukdik Point and $16 \mathrm{mi}$. SW of Skagway, Coast Mts.; BGN 1944; $59^{\circ} 14^{\prime} 10^{\prime \prime} \mathrm{N}, 135^{\circ} 26^{\prime} 15^{\prime \prime} \mathrm{W}$; (map 45). Var. Chilcoot, Deshu, Däschū, Dtehshuh.

Originally an Indian village called "Dtehshuh," meaning "end of the trail." According to Aurel and Arthur Krause (1883, map), it was called "Deshu" or "Däschū." It was a trading post for both the Chilkat and Interior Indians. The first white man to settle here was George Dickinson, an agent for the Northwest Trading Co., who came to the post in 1878. In 1881 a Presbyterian missionary, $\mathrm{S}$. Hall Young, founded the Willard Mission, the name of which was later changed to Haines Mission. In 1884 a post office called Haines P.O. was established here, although the place was locally known as Chilcoot. The town became an important outlet for the Porcupine mining district and marked the beginning of the Dalton Trail. During the Klondike Gold Rush a large number of reindeer imported from Norway was landed at Haines to be used in traversing the passes into the upper Yukon Basin.

Haines Islands: island, $0.8 \mathrm{mi}$. across, in Tanana River, $3 \mathrm{mi}$. $S$ of Fairbanks, Tanana Low.; $64^{\circ} 47^{\prime} 30^{\prime \prime} N, 147^{\circ} 45^{\prime} 30^{\prime \prime} \mathrm{W}$; (map 100).

Local name reported in 1950 by USGS topographers.
Haines Lake: lake, $1 \mathrm{mi}$. long, at $\mathrm{E}$ end of Slow Fork Hills, drains $\mathrm{N}$ to Slow Fork Kuskokwim River, $56 \mathrm{mi}$. W of Mount McKinley, Kuskokwim Low.; $63^{\circ} 01^{\prime} 25^{\prime \prime} \mathrm{N}, 152^{\circ} 47^{\prime} 20^{\prime \prime} \mathrm{W}$; (map 88). Var. Jacks Lake.

Local name obtained in 1958 from Fabian Carey and "Val" Blackburn by USGS.

Haines Mission: village, see Haines.

Hains Landing: locality, on $E$ bank of Dishna River $6 \mathrm{mi}$. $\mathrm{S}$ of its junc. with Innoko River and $35 \mathrm{mi}$. NW of Ophir, Innoko Low.; $63^{\circ}$ $31^{\prime} \mathrm{N}, 157^{\circ} 17^{\prime} \mathrm{W}$; (map 90).

Former riverboat landing reported by USGS in 1925.

Hair Seal Cape: point of land, see Seal Cape.

Hajdukovich, Mount: peak, 9,600 ft., E of Gerstle Glacier, 36 mi. NE of Paxson, Alaska Ra.; 6332'25" N, $145^{\circ} 12^{\prime} 40^{\prime \prime} \mathrm{W}$; BGN 1966; (map 86).

Named for John Hajdukovich, 1878-1965, prospector, hunter and trapper, who served with the Alaska Game Commission.

Hajdukovich Creek: stream, heads on Granite Mtn., flows NE, through Portalus Valley, 10 mi. to Sawmill Creek, $2.7 \mathrm{mi}$. S of Alaska Highway and $20 \mathrm{mi}$. SE of Delta Junction, Alaska Ra.; $63^{\circ} 51^{\prime} 40^{\prime \prime} \mathrm{N}, 145^{\circ} 12^{\prime} 10^{\prime \prime} \mathrm{W}$; (map 86).

Named for John Hajdukovich. See Hajdukovich, Mount.

Haley, Mount: mountain, 9,145 ft., $1 \mathrm{mi}$. W of Flat Top Peak and $32 \mathrm{mi}$. NW of Valdez, Chugach Mts.; $61^{\circ} 25^{\prime} 52^{\prime \prime} \mathrm{N}, 146^{\circ} 57^{\prime} 15^{\prime \prime} \mathrm{W}$; $B G N$ 1965; (map 68).

Probably named about 1959 by L. E. Nielsen (1963, p. 135) for Herbert Haley, "Alaska bush pilot" who was reported to be first to land a plane on the upper Columbia Glacier, and who was killed in a plane crash in 1955.

Haley Anchorage: bight, $0.8 \mathrm{mi}$. across, on $\mathrm{S}$ shore of Fish Bay, on NW coast of Baranof I., $24 \mathrm{mi}$. NW of Sitka, Alex. Arch.; $57^{\circ} 22^{\prime} 20^{\prime \prime}$ $\mathrm{N}, 135^{\circ} 37^{\prime} 00^{\prime \prime} \mathrm{W}$; (map 9).

Named in 1884 by Comdr. J. B. Coghlan, USN, for "a miner Nicholas Haley." The name was published by USC\&GS in 1891 Coast Pilot (p. 181).

Haley Creek: stream, flows E $17 \mathrm{mi}$. to Copper River at Wood Canyon, $62 \mathrm{mi}$. NE of Valdez, Chugach Mts.; $61^{\circ} 25^{\prime} 00^{\prime \prime} \mathrm{N}, 144^{\circ} 28^{\prime} 30^{\prime \prime} \mathrm{W}$; (map 68).

Local name published in the 1950's by USGS.

Haley Point: point of land, on an island connected by a sandbar to $S$ shore of Fish Bay, on Baranof I., 24 mi. NE of Sitka, Alex. Arch.; $57^{\circ} 22^{\prime} 15^{\prime \prime} \mathrm{N}, 135^{\circ} 36^{\prime} 10^{\prime \prime} \mathrm{W}$; (map 9).

Named in 1896 by Lt. Comdr. E. K. Moore, USN; published by USC\&GS in 1901 Coast Pilot (p. 185). Name derived from Haley Anchorage of which the point marks the eastern boundary.

Haley Rock: rock, at mouth of Fish Bay, $3 \mathrm{mi}$. E of Salisbury Sound, off coast of Baranof I., $25 \mathrm{mi}$. NW of Sitka, Alex, Arch.; $57^{\circ} 22^{\prime} 40^{\prime \prime}$ $\mathrm{N}, 135^{\circ} 38^{\prime} 00^{\prime \prime} \mathrm{W}$; (map 9 ). 
Named in 1896 by Lt. Comdr. E. K. Moore, USN. Name derived from Haley Anchorage of which the rock marks the western boundary.

Half Cabin Lake: lake, $1.5 \mathrm{mi}$. long, $8 \mathrm{mi}$. S of Whitefish Lake and $57 \mathrm{mi}$. N of Nondalton, Lime Hills; $60^{\circ} 49^{\prime} \mathrm{N}, 154^{\circ} 53^{\prime} \mathrm{W}$; (map 61).

Local name reported in 1954 by USGS.

Half Cone: mountain, 3,000 ft., projects from $\mathrm{NE}$ rim of Aniakchak Crater, $5 \mathrm{mi}$. NE of Vent Mtn., Aleutian Ra.; $56^{\circ} 57^{\prime} \mathrm{N}, 158^{\circ} 07^{\prime} \mathrm{W}$; (map 30).

Descriptive name given in 1923 by $\mathbf{R}$. $H$. Sargent, USGS.

Half Dollar Creek: stream, flows SW $2 \mathrm{mi}$. to Bottom Dollar Creek, $35 \mathrm{mi}$. SW of Circle, Yukon-Tanana High.; $65^{\circ} 25^{\prime} 05^{\prime \prime} \mathrm{N}, 144^{\circ}$ 47'50" W; (map 104).

Named by prospectors; reported in 1911 by E. A. Porter (in Brooks and others, 1912, p. 245), USGS.

Halfmile Creek: stream, flows S $1.8 \mathrm{mi}$. to Hollis Anchorage, $\mathrm{N}$ of Cat I., near center of Prince of Wales I., Alex. Arch.; $55^{\circ} 29^{\prime} 15^{\prime \prime} \mathrm{N}, 132^{\circ}$ 39'35" W; BGN 1963; (map 4). Var. Halfmile Creek.

Local descriptive name reported as "Halfmile Creek" in 1897 by Lt. Comdr. J. F. Moser, USN.

Halfmile Creek: stream, heads in lake, near W coast of Prince of Wales I., flows SW 3.5 mi. to Klawak Lake, $2.5 \mathrm{mi}$. E of Klawock, Alex. Arch.; 55 $32^{\prime} 50^{\prime \prime}$ N., $133^{\circ} 01^{\prime} 35^{\prime \prime}$ W; (map 4). Var. Half-mile Creek.

Local name reported in 1897 by Lt. Comdr. J. F. Moser, USN.

Halfmoon Anchorage: anchorage, $1.2 \mathrm{mi}$. wide, in Wrangell Narrows, on W coast of Mitkof I., $12 \mathrm{mi}$. S of Petersburg, Alex. Arch.; 56 $38^{\prime} 10^{\prime \prime}$ N, $132^{\circ} 56^{\prime} 00^{\prime \prime}$ W; (map 6). Var. Half Moon Anchorage.

Feature was named by local traders; reported in 1868 by Comdr. R. W. Meade, USN.

Halfmoon Bay: bight, $5.5 \mathrm{mi}$. wide, on $\mathrm{N}$ shore of Kvichak Bay, $13 \mathrm{mi}$. NW of Naknek, Bristol Bay Low. ; $58^{\circ} 49^{\prime} \mathrm{N}, 157^{\circ} 21^{\prime} \mathrm{W}$; (map 41).

Local name published in 1962 by USGS.

Halfmoon Creek: stream, flows NW $4 \mathrm{mi}$. to Hess Creek, $14 \mathrm{mi}$. N of Livengood, YukonTanana High.; $65^{\circ} 43^{\prime} \mathrm{N}, 148^{\circ} 34^{\prime} \mathrm{W}$; (map 105).

Named by prospectors; reported in 1916 by J. B. Mertie (in Brooks and others, 1918, pl. 13), USGS.

Halfmoon Creek: stream, see Cantwell Creek.

Halfmoon Lake: lake, $1.5 \mathrm{mi}$. long, in Tongass National Forest, $7.5 \mathrm{mi}$. ESE of Frosty Bay, on Seward Passage, $38 \mathrm{mi}$. SE of Wrangell, Coast Mts.; $56^{\circ} 02^{\prime} 00^{\prime \prime} \mathrm{N}, 131^{\circ} 45^{\prime} 35^{\prime \prime} \mathrm{W}$; $B G N$ 1963; (map 7). Var. Half Moon Lake, Half-Moon Lake.

Local descriptive name reported in 1961 by USFS.

Half Moon Three Ranch: locality, see Alaktak.

Halftide Rock: rock, on $\mathrm{E}$ shore of Herendeen Bay, $13 \mathrm{mi}$. SW of village of Port Moller, Bristol Bay Low.; $55^{\circ} 50^{\prime} 00^{\prime \prime} \mathrm{N}, 160^{\circ} 46^{\prime} 30^{\prime \prime}$ W; (map 28). Var. Half Tide Rock.
Descriptive name given as "Half Tide" in 1890 by Lt. Comdr. Z. L. Tanner, USN.

Half way Creek: stream, flows NE $2 \mathrm{mi}$. to Karluk Lake, $21 \mathrm{mi}$. SE of Karluk, Kodiak I.; $57^{\circ}$. $21^{\prime} 30^{\prime \prime} \mathrm{N}, 154^{\circ} 03^{\prime} 30^{\prime \prime} \mathrm{W}$; (map 35).

Local descriptive name reported in 1952 by USGS.

Halfway Island: island, off $\mathrm{N}$ coast of Kenai Penin., in SW end of Turnagain Arm, $2.5 \mathrm{mi}$. NW of Hope, Chugach Mts.; 60 $0^{\circ} 57^{\prime} 00^{\prime \prime} \mathrm{N}$, $149^{\circ} 40^{\prime} 45^{\prime \prime} \mathrm{W}$; (map 63 ).

Local name reported in 1952 by USGS.

Halfway Island: island, $5.5 \mathrm{mi}$. long, in Yukon River, $18 \mathrm{mi}$. SW of Nulato, Koyukuk Low.; $64^{\circ} 30^{\prime} \mathrm{N}, 158^{\circ} 24^{\prime} \mathrm{W}$; (map 97).

Local descriptive name reported in 1954 by USGS.

Halfway Lake: lake, $0.5 \mathrm{mi}$. long, $2 \mathrm{mi}$. SE of junc. of Happy River and Pass Creek, $89 \mathrm{mi}$. SW of Talkeetna, Alaska Ra.; $62^{\circ} 09^{\prime} 40^{\prime \prime} \mathrm{N}$, $152^{\circ} 51^{\prime} 45^{\prime \prime} \mathrm{W}$; (map 81).

Local descriptive name reported in 1958 by USGS.

Halfway Lake: lake, 1,200 ft. long, SW of Spruce Lake, $8 \mathrm{mi}$. SE of Talkeetna, Cook Inlet Low.; $62^{\circ} 12^{\prime} 28^{\prime \prime} \mathrm{N}, 150^{\circ} 02^{\prime} 00^{\prime \prime} \mathrm{W}$; (map 81).

Local descriptive name reported in 1958 by USGS.

Halfway Lake: lake, $1,000 \mathrm{ft}$. long, $1 \mathrm{mi}$. $\mathrm{N}$ of Beaver Creek and $20 \mathrm{mi}$. SE of Beaver, Yukon Flats; $66^{\circ} 14^{\prime} 40^{\prime \prime} \mathrm{N}, 146^{\circ} 44^{\prime} 20^{\prime \prime} \mathrm{W}$; (map 119).

Local descriptive name obtained in 1956 by USGS.

Halfway Mountain: mountain, 3,213 ft., between Hoholitna and Mulchatna Rivers, $58 \mathrm{mi}$. NW of Nondalton, Lime Hills; $60^{\circ} 47^{\prime} 30^{\prime \prime} \mathrm{N}$ $155^{\circ} 23^{\prime} 30^{\prime \prime} \mathrm{W}$; (map 61).

Named in 1914 by R. H. Sargent, USGS, "because the mountain is on the divide between the Mulchatna and Kuskokwim Rivers."

Halfway Mountain: mountain, 1,856 ft., $13 \mathrm{mi}$ W of Medfra, Kilbuck-Kuskokwim Mts.; $63^{\circ}$. $04^{\prime} \mathrm{N}, 155^{\circ} 07^{\prime} \mathrm{W}$; (map 89).

Local name reported in 1958 by USGS.

Half-way Pillar: hill, 1,200 ft., on right bank of Porcupine River, $6 \mathrm{mi}$. $\mathrm{N}$ of Old Rampart and $32 \mathrm{mi}$. ENE of Coleen Mtn., Yukon Flats; $67^{\circ} 16^{\prime} \mathrm{N}, 141^{\circ} 38^{\prime} \mathrm{W}$; (map 121).

Name reported by R. G. McConnell, Canadian Geological Survey, in 1888, for "a projecting column of rock, which was supposed by the traders to be equidistant from Lapierre House and Fort Yukon" (FitzGerald, 1944, p. 227). The name is now applied to a nearby hill.

Halfway Point: point of land, on $\mathrm{E}$ coast of St. Paul I., in Pribilof Is.; $57^{\circ} 09^{\prime} 45^{\prime \prime} \mathrm{N}, 170^{\circ}$ $10^{\prime} 15^{\prime \prime}$ W; (map 38). Var. Mys Polovinnoy, Polavina Point, Polovina Point, Polovinnoi Point

This is a translation of a Russian name reported by Elliott (1881, Saint Paul notes) as "Polavina," which "literally signifies 'halfway,' so used by the natives because it is practically halfway between the salt-houses at
Northeast Point and the village [Saint Paul]." Published as "M[ys] Polovinnoy" (Halfway Cape) by Capt. Tebenkov (1852, map 21), IRN.

Halfway Rock: rock, near $\mathrm{N}$ entrance point to Delarof Harbor, off SE coast of Unga I., in Shumagin Is., Aleutian Ra.; 55 $10^{\prime} 50^{\prime \prime} \mathrm{N}$, $160^{\circ} 27^{\prime} 35^{\prime \prime} \mathrm{W}$; (map 28).

Name published by USC\&GS in 1916 Coast Pilot (p. 179)

Halfway Whirlpool: whirlpool, in Yukon River, $4 \mathrm{mi}$. SE of Saloon I. and $32 \mathrm{mi}$. SE of Fort Yukon, Yukon Flats; 66 $16^{\prime} \mathrm{N}, 144^{\circ} 37^{\prime} \mathrm{W}$; (map 119).

Local descriptive name obtained in 1956 by USGS.

Halibut Bay: bay, $4.5 \mathrm{mi}$. across, $15 \mathrm{mi}$. SW of Karluk, on W coast of Kodiak I., 57 $23^{\prime}$ N, $154^{\circ} 43^{\prime} \mathrm{W}$; (map 35).

Descriptive local name published in 1943 by USC\&GS.

Halibut Bay: estuary, extends N $2.8 \mathrm{mi}$. from Portland Canal at Astronomical Point, Coast Mts.; $55^{\circ} 13^{\prime} \mathrm{N}, 130^{\circ} 05^{\prime} \mathrm{W}$; (map 3).

Named in 1868 by Staff Comdr. David Pender, RN.

Halibut Cove: bay, $3 \mathrm{mi}$. wide, on $\mathrm{E}$ shore of Kachemak Bay, Kenai Penin., $12 \mathrm{mi}$. ESE of Homer, Chugach Mts. ; $59^{\circ} 37^{\prime} \mathrm{N}, 151^{\circ} 14^{\prime} \mathrm{W}$; (map 50).

Named by W. H. Dall, USC\&GS, in 1880.

Halibut Cove: cove, $0.2 \mathrm{mi}$. across, off $\mathrm{N}$ end of Shelter I. in Favorite Channel, $20 \mathrm{mi}$. NW of Juneau, Alex. Arch.; $58^{\circ} 27^{\prime} 50^{\prime \prime} \mathrm{N}, 134^{\circ} 53^{\prime} 15^{\prime \prime}$ W; (map 11).

Local name published in 1962 by the USGS. "Named for a marine food fish, a large flatfish, Hippoglossus stenolepis."

Halibut Cove Lagoon: lagoon, $0.7 \mathrm{mi}$. wide, at $S$ end of Halibut Cove, on $E$ shore of Kachemak Bay, Kenai Penin., 13 mi. ESE of Homer, Chugach Mts.; $59^{\circ} 35^{\prime} 15^{\prime \prime} \mathrm{N}, 151^{\circ} 11^{\prime} 00^{\prime \prime} \mathrm{W}$; (map 50).

Named for Halibut Cove and published by USGS in 1961.

Halibut Creek: stream, on N part of Chichagof I., flows $4 \mathrm{mi}$. NE to Port Frederick, $2.3 \mathrm{mi}$. SW of Christ Point and 6.4 mi. NW of Hoonah, Alex. Arch.; 58 $11^{\prime} 05^{\prime \prime} \mathrm{N}, 135^{\circ} 33^{\prime}$ $00^{\prime \prime} \mathrm{W}$; BGN 1960; (map 11).

Local name published in 1951 by USGS.

Halibut Creek: stream, on Kenai Penin., flows NW $7.5 \mathrm{mi}$. to Halibut Cove, on $\mathrm{E}$ shore of Kachemak Bay, 14 mi. ESE of Homer, Chugach Mts. ; $59^{\circ} 35^{\prime} 20^{\prime \prime} \mathrm{N}, 151^{\circ} 10^{\prime} 00^{\prime \prime} \mathrm{W}$; (map 50).

Named for Halibut Cove and published by USGS in 1961

Halibut Harbor: bay, $1.3 \mathrm{mi}$. wide, SW coast of Kosciusko I., Alex. Arch.; 55 ${ }^{\circ} 55^{\prime} \mathrm{N}, 133^{\circ} 46^{\prime}$ W; (map 4).

Local name reported in 1904 by $E$. F. Dickins, USC\&GS, "from information obtained from Captain [Cyrus] Orr."

Halibut Head: mountain, see Sanak Peak.

Halibut Island: island, $0.2 \mathrm{mi}$. across, off $\mathrm{N}$ coast of Chichagof I. at mouth of Port Frederick, 
$4.5 \mathrm{mi}$. NW of Hoonah, Alex. Arch.; $58^{\circ} 09^{\prime}$ $00 \mathrm{~N}, 135^{\circ} 29^{\prime} 30^{\prime \prime} \mathrm{W}$; (map 11).

Local name derived from Halibut Rock and published by the USC\&GS in the 1901 Coast Pilot.

Halibut Island: island, see Sanak Island.

Halibut Nose: point of land, on $\mathrm{W}$ coast of Prince of Wales I., S of Soda Bay, Alex. Arch.; $55^{\circ} 12^{\prime} 35^{\prime \prime} \mathrm{N}, 133^{\circ} 02^{\prime} 25^{\prime \prime} \mathrm{W}$; (map 4).

Local name published in 1905 by USC\&GS.

Halibut Point: point of land, on $\mathrm{W}$ bank of Portland Canal, W point of entrance to Halibut Bay, Coast Mts.; $55^{\circ} 12^{\prime} 35^{\prime \prime} \mathrm{N}$, $130^{\circ} 06^{\prime} 50^{\prime \prime} \mathrm{W}$; (map 3).

Name published in 1897 by USC\&GS.

Halibut Point: point of land, $4 \mathrm{mi}$. NW of Sitka, on NW coast of Baranof I., Alex. Arch.; $57^{\circ} 06^{\prime} \mathrm{N}, 135^{\circ} 24^{\prime} \mathrm{W}$; (map 9). Var. Mys Paltusey, Mys Peschanyy, Peschani Point.

This is an 1882 translation by USC\&GS of the name given in 1809 by the Russian navigator Ivan Vasiliev the first, IRN; reported by Lt. Sarichev (1826, map 19), IRN, as "M[ys] Paltusey." The name "Mys Peschanyy," meaning 'sandy cape," was published for this point in 1848 by the Russian Hydrog. Dept. on Chart 1397.

Halibut Rock: rock, at $\mathrm{N}$ end of Port Frederick, $1.1 \mathrm{mi}$. NW of Inner Point Sophia and 1.6 mi. NW of Hoonah, Alex. Arch.; 58 $08^{\prime \prime} 20^{\prime \prime}$ N, $135^{\circ} 29^{\prime} 25^{\prime \prime} \mathrm{W}$; (map 11).

Name published by the USC\&GS in the 1883 Coast Pilot (p. 191).

Haliknuk River: stream, see Hoholitna River.

Halket, Cape: point of land, see Halkett, Cape.

Halkett, Cape: point of land, on coast of Beaufort Sea, $W$ point of entrance to Harrison Bay, Arctic Plain; $70^{\circ} 48^{\prime} 10^{\prime \prime} \mathrm{N}, 152^{\circ} 11^{\prime} 05^{\prime \prime}$ W; BGN 6th Report; (map 149). Var. Atliggaru, Cape Halket, Halket Cape, Halkett Cape, Ishuk, Isuk.

P. W. Dease and Thomas Simpson (Simpson, Thomas, 1843 , p. 133) on July 26, 1837 , reported that "this remarkable point was named Cape Halkett, in compliment to one of the Company's [Hudson's Bay] Directors." Leffingwell (1919, p. 96) gives the Eskimo name as Ishuk, which he says Vilhjalmur Stefansson spells 'Isuk," meaning "end."

Hall, Cape: point of land, on NW coast of Hall I., $8 \mathrm{mi}$. NW of Glory of Russia Cape, Saint Matthew I.; $60^{\circ} 40^{\prime} \mathrm{N}, 173^{\circ} 05^{\prime} \mathrm{W}$; (map 56). Var. Mys Galla, North Cape.

Named "M[ys] Galla," or "Cape Hall," by Capt. Tebenkov (1852, map 20), IRN, in 1849, for Lt. Robert Hall who accompanied Commodore Joseph Billings to this locality in 1791.

Hall Cove: estuary, $3.6 \mathrm{mi}$. long, on $\mathrm{SW}$ coast of Duke I., Alex. Arch.; $54^{\circ} 53^{\prime} 30^{\prime \prime} \mathrm{N}$, $131^{\circ} 23^{\prime} 15^{\prime \prime} \mathrm{W}$; (map 2).

Local navigators' name recorded in 1904 by H. C. Fassett, USBF.

Hall Greek: stream, heads in Canada, flows NW $7 \mathrm{mi}$. to Canyon Creek, $45 \mathrm{mi}$. S of Eagle, Yukon-Tanana High.; $64^{\circ} 09^{\prime} 15^{\prime \prime} \mathrm{N}, 141^{\circ}$ $07^{\prime} 30^{\prime \prime} \mathrm{W}$; (map 102).
Prospectors' name obtained in 1898 by E. C. Barnard, USGS.

Halleck Harbor: bay, 2 mi. across, in Saginaw Bay, on $\mathrm{N}$ coast of Kuiu I., Alex. Arch.; $56^{\circ} 55^{\prime} \mathrm{N}, 134^{\circ} 13^{\prime} \mathrm{W}$; (map 5).

Named in 1869 by Comdr. R. W. Meade, USN, for charting purposes; named for Maj. Gen. Henry Wager Halleck, USA, then in command at Sitka.

Halleck Island: island, $4.5 \mathrm{mi}$. across, $11 \mathrm{mi}$. NW of Sitka, Alex. Arch.; 57 $13^{\prime}$ N, $135^{\circ} 27^{\prime}$ W; (map 9).

Named in 1869 by Comdr. R. W. Meade, USN, for Maj. Gen. Henry Wager Halleck, 1815-72, USA, then in command at Sitka. Gen. Halleck upon graduating from West Point was appointed to the Corps of Engineers. During the Givil War he was commander in chief of the Union armies from 1862 to 1864, when he was replaced by Gen. U.S. Grant. He was in command of the military division of the Pacific, 1865-69.

Halleck Point: point of land, on W tip of Halleck I., $14 \mathrm{mi}$. NW of Sitka, Alex. Arch.; $57^{\circ} 13^{\prime} 45^{\prime \prime} \mathrm{N}, 135^{\circ} 30^{\prime} 45^{\prime \prime} \mathrm{W}$; (map 9).

Named in 1896 by Lt. Comdr. E. K. Moore, USN; published in 1900 by USC\&GS on Ghart 8281. Name was derived from Halleck Island.

Halleck Range: mountain range, 4,900 ft., extends N-S 11 mi. along W bank of Portland Canal, NW of River Point, Coast Mts.; $55^{\circ} 38^{\prime} \mathrm{N}, 130^{\circ} 12^{\prime} \mathrm{W}$; (map 3 ).

Named in 1868 by Staff Comdr. David Pender, RN.

Haller Spit: spit, see Ekuk Spit.

Hallersville: locality, on' left bank of Kvichak River, $60 \mathrm{mi}$. E of Dillingham, Bristol Bay Low.; $59^{\circ} 02^{\prime} 40^{\prime \prime} \mathrm{N}, 156^{\circ} 50^{\prime} 20^{\prime \prime} \mathrm{W}$; (map 52).

Name of a village published on the 1941 Cannery Map of Alaska. Several cabins are here, but there is no recorded permanent population.

Hallersville Creek: stream, flows SW $5 \mathrm{mi}$. to Kvichak River, $4 \mathrm{mi}$. S of Levelock and 60 mi. E of Dillingham, Bristol Bay Low.; $59^{\circ} 03^{\prime} \mathrm{N}, 156^{\circ} 51^{\prime} \mathrm{W}$; (map 52 ).

Local name published by USGS in 1952; named for the nearby locality.

Hallet River: stream, heads in glacier, flows NE $19 \mathrm{mi}$. to head of Klutina Lake, $34 \mathrm{mi}$. N of Valdez, Chugach Mts.; 61 $36^{\prime} 20^{\prime \prime} \mathrm{N}$, $146^{\circ} 00^{\prime} 00^{\prime \prime} \mathrm{W}$; (map 68). Var. Hallett River.

Named in 1898 by Capt. W. R. Abercrombie, USA, for "Private Hallett," a member of his party.

Hallett River: stream, see Hallet River.

Halliday, Point: point of land, NE point of entrance to North Arm Moira Sound, on SE coast of Prince of Wales I., Alex. Arch.; $55^{\circ} 04^{\prime} 50^{\prime \prime} \mathrm{N}, 132^{\circ} 04^{\prime} 30^{\prime \prime} \mathrm{W}$; (map 4).

Local name reported in 1905 by E. F. Dickins, USC\&GS.

Hall Island: island, $1 \mathrm{mi}$. long, between Big and Little Koniuji Is., in Shumagin Is., Aleutian Ra.; $55^{\circ} 05^{\prime} \mathrm{N}, 159^{\circ} 29^{\prime} \mathrm{W}$; (map 27).
Named by W. H. Dall, USC\&GS, in 1874 for Capt. Hall of the USC\&GS schooner Humbolt which was in these waters in 1871 and 1872 .

Hall Island: island, $5 \mathrm{mi}$. long, $3.5 \mathrm{mi}$. NW of St. Matthew I.; $60^{\circ} 40^{\prime} \mathrm{N}, 173^{\circ} 06^{\prime} \mathrm{W}$; (map 56). Var. Mojovy Island, Morjovi Island, Morzhovoi Island, Ostrov Morzhovoy, Ostrov Sindsha, Sindsha Island.

The early Russian hunters called this island "O[strov] Morzhovoy" (Tebenkov, 1852, map 20) meaning "walrus island." The Russian Hydrog. Dept. Chart 1427 called it "O[strov] Sindsha" probably for Lt. Sind, its alleged discoverer, in 1764. See Saint Matthew Island. Commodore Joseph Billings and Lt. G. A. Sarichev anchored between this island and St. Matthews on July 14, 1791 (O.S). On American maps, since 1875 , this island has been called "Hall," presumably for Lt. Robert Hall, who was with Capt. Billings, or for Cape Hall.

Hall Lake: lake, see Siksik Lake.

Hallo Bay: bight, $7.5 \mathrm{mi}$, across, on $\mathrm{S}$ coast of Alaska Penin., in Katmai National Monument, $35 \mathrm{mi}$. NE of Mount Katmai, Aleutian Ra.; $58^{\circ} 27^{\prime}$ N, $153^{\circ} 57^{\prime} \mathrm{W}$; (map 42). Var. Ago Bay, Aho Bay, Aiu Bay, Aja Bay, Hioo Bay, Porte Aiou, Zaliv Ayo.

Published in 1868 by USC\&GS ; transliteration of a native word, published in French as P[ort]e Aiou by Adm. von Krusenstern (1827, map 17), IRN; in Russian as Z[aliv] Ayu by Capt. Tebenkov (1852, map 22 ), IRN. Local pronunciation of the name was like "Hello," according to W. H. Dall, USC\&GS, in 1868; whereas G. C. Martin, USGS, in 1905 reported the native pronunciation as "Ayou" or "Aiv."

Hallo Creek: stream, heads in glacier lake at terminus of Halio Glacier, flows E $5.8 \mathrm{mi}$. to Hallo Bay, on Alaska Penin., Katmai National Monument, $35 \mathrm{mi}$. NE of Mount Katmai, Aleutian Ra.; 58 $24^{\prime} 35^{\prime \prime} \mathrm{N}$, 154'02'45" W; (map 42).

Named for Hallo Bay; reported in 1951 by USGS.

Hallo Glacier: glacier, heads on ridge between Mount Denison and Devils Desk, trends E $11 \mathrm{mi}$. to its 1951 terminus at glacier lake, on $\mathrm{S}$ coast of Alaska Penin., in Katmai National Monument, $30 \mathrm{mi}$. NE of Mount Katmai, Aleutian Ra.; $58^{\circ} 25^{\prime} \mathrm{N}, 154^{\circ} 10^{\prime} \mathrm{W}$; $B G N$ 1957; (map 42)

Named for Hallo Bay; reported in 1956 by USGS.

Hall Peak: mountain, 3,700 ft., in Missionary Ra., 13.5 mi NW of Petersburg, on N central Lindenberg Penin., Kupreanof I., Alex. Arch.; $56^{\circ} 58^{\prime} 45^{\prime \prime} \mathrm{N}, 133^{\circ} 09^{\prime} 45^{\prime \prime} \mathrm{W}$; (map 6).

Named in 1887 by Lt. Comdr. C. M. Thomas, USN, for Capt. Charles Francis Hall, Arctic explorer, who died in 1871.

Halthalda Hill: hill, 2,124 ft., $3.7 \mathrm{mi}$. long, N of Halthmund Lake, $12 \mathrm{mi}$. W of Northway, Alaska Ra.; $62^{\circ} 58^{\prime} \mathrm{N}, 142^{\circ} 22^{\prime} \mathrm{W}$; (map 84). 
Tetlin Indian name, said to mean "hill-bya-fish-lake" or "fish lake hill"; reported in 1962 by USGS.

Halthmund Lake: lake, $2.5 \mathrm{mi}$. long, $11 \mathrm{mi}$. W of Northway, Alaska Ra.; $62^{\circ} 57^{\prime} \mathrm{N}, 142^{\circ} 20^{\prime}$ W; (map 84).

Tetlin Indian name reported to mean "fish lake" by USGS in 1962

Halu Creek: stream, in Ray Mts., flows NE 13 mi. to Big Salt River, $12 \mathrm{mi}$. NE of Mount Tozi and $61 \mathrm{mi}$. NE of Tanana, KokrinesHodzana High.; $65^{\circ} 50^{\prime} 15^{\prime \prime} \mathrm{N}, 150^{\circ} 42^{\prime} 30^{\prime \prime} \mathrm{W}$; (map 106).

Prospectors' name reported in 1956 by Orth.

Halutu Peninsula: peninsula, $14 \mathrm{mi}$. long, extends from Parsons Peak to Taiya Point on Chilkoot Inlet, $3 \mathrm{mi}$. W of Skagway, Coast Mts.; $59^{\circ} 25^{\prime} \mathrm{N}, 135^{\circ} 25^{\prime} \mathrm{W}$; BGN 1923; (map 45). Var. Daye-Halutu.

Tlingit Indian name, "Haluta," meaning "promontory," reported by James W. McGuire, USC\&GS, in 1923. The entire projection was called "Daye-Halutu" by the Tlingit Indians.

Halutu Ridge: ridge, $5 \mathrm{mi}$. long, trends $\mathrm{N}$ from Taiya Point, at head of Chilkoot Inlet, $8 \mathrm{mi}$. SW of Skagway, Coast Mts.; $B G N$ 1923; $59^{\circ} 21^{\prime} 00^{\prime \prime} \mathrm{N}, 135^{\circ} 25^{\prime} 00^{\prime \prime} \mathrm{W}$; (map 45).

Indian name probably meaning "promontory"; reported in 1923 by James W. McGuire, USC\&GS.

Hamburger Point: point of land, SW tip of Cobra Penin., S coast of Kiska I., Aleutian Is.; $51^{\circ} 55^{\prime} 20^{\prime \prime} \mathrm{N}, 177^{\circ} 26^{\prime} 50^{\prime \prime} \mathrm{E}$; (map 14).

One of many arbitrary names applied to features on Kiska I. by USAAF for tactical purposes during World War II.

Ham Cove: estuary, extends SW $0.8 \mathrm{mi}$. off Kaigani Strait, on $\mathrm{E}$ coast of Dall I., Alex. Arch.; 54 ${ }^{\circ} 53^{\prime} 00^{\prime \prime} \mathrm{N}, 132^{\circ} 50^{\prime} 45^{\prime \prime} \mathrm{W}$; $B G N$ 1929; (map 1). Var. Sawmill Gove.

Named in 1880 by Rev. Sheldon Jackson for Mrs. J. M. Ham of New York who financed the Jackson Presbyterian Mission at Howkan and contributed funds for the erection of a sawmill here in 1882 . This feature was named "Sawmill Cove" in 1891 by Lt. Comdr. H. E. Nichols, USN.

Ham Cove: cove, see Sawmill Cove

Ham Island: island, $3 \mathrm{mi}$. long, off $\mathrm{E}$ coast of Annette I., at north entrance to Felice Strait, Alex. Arch.; $55^{\circ} 10^{\prime} 30^{\prime \prime} \mathrm{N}, 131^{\circ} 21^{\prime} 00^{\prime \prime} \mathrm{W}$; (map 3).

Named in 1883 by Lt. Comdr. H. E. Nichols, USN.

Ham Island: island, extends $\mathrm{E}-\mathrm{W} 3 \mathrm{mi}$., in Yukon River, $0.7 \mathrm{mi}$. S of Fox I. and $20 \mathrm{mi}$. $\mathrm{NE}$ of Ruby, Nowitna Low.; $64^{\circ} 53^{\prime} \mathrm{N}, 154^{\circ}$ 53' W; (map 98). Var. Bosnuk Island, Sea Gull Island.

Riverboat pilots' name shown on 1940 "Navigation Chart, Tanana-Yukon Rivers" of the River Boat Service, U.S. Dept. of Interior.

Ham Island: island, see Blake Island.

Ham Island: islands, see Ham Islands.

Ham Island Reef : islands, see Ham Islands.
Ham Islands: islands, in S part of Karheen Passsage, $0.5 \mathrm{mi}$. E of Heceta I., $22 \mathrm{mi}$. NW of Craig, Alex. Arch.; $55^{\circ} 47^{\prime} 05^{\prime \prime} \mathrm{N}, 133^{\circ} 18^{\prime} 20^{\prime \prime}$ W; BGN 1965; (map 4). Var. Ham Island, Ham Island Reef, Ham Islets.

Name originally published in 1917 by USC\&GS as "Ham Islets."

Ham Islets : islands, see Ham Islands.

Hamilton: village, pop. 3.5, on right bank of Apoon Pass, $21 \mathrm{mi}$. NE of Kwiguk, YukonKuskokwim Delta; $62^{\circ} 53^{\prime} 45^{\prime \prime} \mathrm{N}, 163^{\circ} 53^{\prime} 10^{\prime \prime}$ W; (map 77). Var. Aungua-mut, Fort Hamilton, Old Fort Hamilton, Old Hamilton.

The North American Transportation and Trading Company established a supply post and riverboat landing here about 1897; named for Charles $\mathrm{H}$. Hamilton, assistant manager of the company. L.t. L. A. Zagoskin, IRN, recorded in 1844 an Eskimo settlement or camp at or near this place spelled "Aunguamut" on an 1850 map.

Hamilton, Mount: mountain, 2,039 ft., $13 \mathrm{mi}$ NE of Katalla, Chugach Mts.; $60^{\circ} 20^{\prime} \mathrm{N}$, $144^{\circ} 17^{\prime} \mathrm{W}$; (map 64).

Local name reported in 1904 by G. C. Martin, USGS.

Hamilton, Mount: mountain, 3,645 ft., in Kilbuck Mts., 27 mi. SW of Aniak, KilbuckKuskokwim Mts.; $61^{\circ} 10^{\prime} 15^{\prime \prime} \mathrm{N}, 159^{\circ} 46^{\prime} 00^{\prime \prime}$ W; (map 73)

Named by W. S. Post, USGS, in 1898.

Hamilton, Point: point of land, S point of entrance to Hamilton Bay, on NW coast of Kupreanof I., $5.5 \mathrm{mi}$. S of Kake, Alex. Arch. $56^{\circ} 54^{\prime} 10^{\prime \prime} \mathrm{N}, 133^{\circ} 53^{\prime} 45^{\prime \prime} \mathrm{W}$; (map 6).

Named in 1892 by Lt. W. I. Moore, USN.

Hamilton Bay: bay, extends W $6 \mathrm{mi}$. to Keku Strait, $6 \mathrm{mi}$. SE of Kake, on NW coast of Kupreanof I., Alex. Arch.; $56^{\circ} 54^{\prime}$ N, $133^{\circ} 52^{\prime}$ W; (map 6). Var. Hamilton Harbor.

Named by U.S. Navy; published in the 1883 Coast Pilot (p. 118).

Hamilton Creek: stream, flows W $14 \mathrm{mi}$. to Hamilton Bay, $9.5 \mathrm{mi}$. SE of Kake, on NW coast of Kupreanof I., Alex. Arch.; 56 $53^{\circ} 30^{\prime \prime}$ $\mathrm{N}, 133^{\circ} 44^{\prime} 00^{\prime \prime} \mathrm{W}$; (map 6).

Local name published in 1943 by USC\&GS

Hamilton Creek: stream, on S slope of Brower Ridge, flows S 2 mi. to Gulf of Alaska, $95 \mathrm{mi}$. NW of Yakutat, St. Elias Mts. ; $60^{\circ} 03^{\prime} 15^{\prime \prime} \mathrm{N}$, $142^{\circ} 16^{\prime} 20^{\prime \prime} \mathrm{W}$; (map 65)

Named for Thomas J. Hamilton, U.S. Marshal, Territory of Washington; reported in 1903 by G. C. Martin, USGS.

Hamilton Island: island, $5 \mathrm{mi}$. long, in Shakan Bay, between Prince of Wales and Kosciusko Is., Alex. Arch.; $56^{\circ} 08^{\prime} 30^{\prime \prime} \mathrm{N}, 133^{\circ} 31^{\prime} 00^{\prime \prime} \mathrm{W}$; (map 6)

Named by W. H. Dall, USC\&GS ; published in 1883 Coast Pilot.

Hamilton Island: island, $3.5 \mathrm{mi}$. long, $2.5 \mathrm{mi}$. SE of Kake, on NW coast of Kupreanof I., Alex. Arch.; 56 $56^{\prime} \mathrm{N}, 133^{\circ} 54^{\prime} \mathrm{W}$; (map 6).

Local fishermen's name reported in 1947 by USC\&GS.

Hamilton Peak: peak, 4,020 ft., $4 \mathrm{mi}$. N of Dry Bay in Frederick Sound, $89 \mathrm{mi}$. E of Sitka,
Coast Mts.; $57^{\circ} 07^{\prime} 07^{\prime \prime} \mathrm{N}, 133^{\circ} 00^{\prime} 37^{\prime \prime} \mathrm{W}$; (map 8).

Local name reported in 1951 by USGS.

Hamiltons Mill: locality, see Shakan.

Hamlet, Mount: mountain, 2,034 ft., in Lisburne Hills, $10 \mathrm{mi}$. SE of Cape Lisburne, Arctic Slope; $68^{\circ} 46^{\prime} \mathrm{N}, 165^{\circ} 57^{\prime} \mathrm{W}$; (map 129). Var. Igiksukrak, Ikgisukruk, Ikgisuqraq.

Named in 1904 by A. J. Collier, USGS, for Capt. D. C. Hamlet, commander of the U.S. Revenue Marine steamer Thetis. The Eskimo name "Igiksukrak" means "highest mountain."

Hamlin Creek: stream, flows NW 3 mi. to Yukon River, $40 \mathrm{mi}$. NE of Rampart, Yukon-Tanana High.; $65^{\circ} 53^{\prime} 40^{\prime \prime} \mathrm{N}, 149^{\circ} 13^{\prime} 15^{\prime \prime} \mathrm{W}$; (map $105)$.

Local name derived from Fort Hamlin; published in 1906 by USGS.

Hammer Creck: stream, heads on $\mathrm{N}$ slope of Old Grouchtop, flows $\mathrm{N}$ and $\mathrm{W} 50 \mathrm{mi}$. to $\mathrm{In}$ noko River, $55 \mathrm{mi}$. NW of Ophir and $58 \mathrm{mi}$. NE of Holikachuck, Innoko Low.; $63^{\circ} 27^{\prime} 35^{\prime \prime}$ $\mathrm{N}, 158^{\circ} 07^{\prime} 20^{\prime \prime} \mathrm{W}$; (map 90). Var. Swing Creek.

Local name reported in 1964 by Arthur Gervais, USGS.

Hammerhead: point of land, on $\mathrm{SW}$ shore of Sweeper Cove, Kuluk Bay, on NE coast of Adak I., Aleutian Is.; $51^{\circ} 51^{\prime} 04^{\prime \prime}$ N, $176^{\circ} 38^{\prime}$ $33^{\prime \prime} \mathrm{W}$; (map 17).

Name published by USC\&GS in 1963 (Chart 9119).

Hammerhead Cove: cove, $0.05 \mathrm{mi}$. across, on $\mathrm{S}$ shore of Sweeper Cove, Kuluk Bay, on NE coast of Adak I., Aleutian Is.; 51 $51^{\prime} 04^{\prime \prime} \mathbf{N}$, $176^{\circ} 38^{\prime} 20^{\prime \prime} \mathrm{W}$; (map 17).

Name published by USC\&GS in the 1947 Coast Pilot p. 463).

Hammerhead Island: island, $800 \mathrm{ft}$. long, one of Semichi Is., in Shemya Pass between Nizki and Shemya Is., Aleutian Is.; $52^{\circ} 43^{\prime} 20^{\prime \prime} \mathrm{N}, 174^{\circ}$. 02'35" E; (map 13)

Listed in 1946 supplement to 1944 Aleutian Coast Pilot, as "the most prominent island in the passes between Nizki and Shemya Islands."

Hammer Point: point of land, between Amos Cove and Sargeant Cove, on SE coast of Kiska I., Aleutian Is. ; $51^{\circ} 55^{\prime} 20^{\prime \prime}$ N, $177^{\circ} 34^{\prime}$ 25" E; (map 14). Var. Highball Point.

An arbitrary name beginning with " $\mathrm{H}$ " to correspond to "H" grid used by U.S. Army for tactical purposes during World War II; published on a 1953 AMS map. Variant published on a 1943 USAAF map.

Hammersly Camp: locality, at junc. of Nonvianuk Lake and Nonvianuk River, $57 \mathrm{mi}$. SW of Iliamna, Aleutian Ra.; $59^{\circ} 01^{\prime} \mathrm{N}, 155^{\circ} 36^{\prime}$ W; $(\operatorname{map} 51)$.

Local name published on a 1952 USGS map.

Hammersly Lake: lake, $5 \mathrm{mi}$. long, in course of American Creek, on Alaska Penin., $37 \mathrm{mi}$. NW of Mount Katmai, Aleutian Ra.; 58 $51^{\prime} \mathrm{N}$, $155^{\circ} 08^{\prime} \mathrm{W}$; (map 42).

Reported in 1951 by USGS.

Hammond Creek: stream, see Hammond River. Hammond Point: point of land, see Saint Elias, Cape. 
Hammond River: stream, heads on Alhamblar Mtn., flows S $38 \mathrm{mi}$. to Middle Fork Koyukuk River, $\mathrm{E}$ of Midnight Dome, $4 \mathrm{mi}$. NE of Wiseman, Brooks Ra.; $67^{\circ} 27^{\prime} 35^{\prime \prime} \mathrm{N}, 150^{\circ} 02^{\prime}-$ $00^{\prime \prime} \mathrm{W}$; (map 124). BGN 1932; Var. Hammond Creek.

Local name shown on an 1899 fieldsheet by T. G. Gerdine, USGS.

Hamnulik: locality, on Agattu I. in the Near Is., Aleutian Is.; (map 13).

Former Aleut village reported as "uninhabited" by Hodge (1907, p. 529), BAE.

Hamond, Cape: point of land, see Saint Elias, Cape.

Hanagita Lake: lake, $1 \mathrm{mi}$. long, in course of Hanagita River, $32 \mathrm{mi}$. SW of McGarthy, Chugach Mts.; $61^{\circ} 14^{\prime} \mathrm{N}, 143^{\circ} 48^{\prime} \mathrm{W}$; (map 67).

This is the name of a chief of the Athena Indians at Taral; reported in 1911 by D. C. Witherspoon (Moffit, 1914, pl. 1), USGS.

Hanagita Peak: peak, $8,520 \mathrm{ft}$, near head of Klu River, $36 \mathrm{mi}$. SW of McCarthy, Chugach Mts.; $61^{\circ} 04^{\prime} \mathrm{N}, 143^{\circ} 42^{\prime} \mathrm{W}$; (map 67).

Name reported in 1911 by D. C. Witherspoon (Moffit, 1914, pl. 1), USGS. See Hanagita Lake.

Hanagita River: stream, heads in group of lakes 12 mi. ESE of Hanagita Lake, flows WNW 17 mi. to Tebay River, $4 \mathrm{mi}$. SE of Summit Lake and $73 \mathrm{mi}$. ENE of Valdez, Chugach Mts.; $61^{\circ} 17^{\prime} 00^{\prime \prime} \mathrm{N}, 144^{\circ} 03^{\prime} 25^{\prime \prime} \mathrm{W}$; (map 68).

Named in 1900 by T. G. Gerdine, USGS, for Hanagita, "Ahtena Indian Chief."

Hancock Pass: pass, 4,000 ft., at head of Dan Creek, $18 \mathrm{mi}$. SE of McCarthy, St. Elias Mts.; $61^{\circ} 21^{\prime} 15^{\prime \prime} \mathrm{N}, 142^{\circ} 25^{\prime} 00^{\prime \prime} \mathrm{W}$; (map 67).

Local name published by USGS in 1954.

Hancock Peak: peak, 3,763 ft., N of Frederick Sound, $7 \mathrm{mi}$. E of Grand Point and $90 \mathrm{mi}$. $\mathrm{E}$ of Sitka, Coast Mts.; $57^{\circ} 05^{\prime} 10^{\prime \prime} \mathrm{N}, 132^{\circ}$ $59^{\prime} 40^{\prime \prime} \mathrm{W}$; (map 8).

Named in 1887 by Lt. Comdr. C. M. Thomas, USN, for the SS Hancock, "the first steamship to cross the Atlantic."

Hancocks Straits: water passage, see Dixon Entrance.

Hangar Lake: lake, $0.5 \mathrm{mi}$. across, $1.5 \mathrm{mi}$. NE of Bethel, Yukon-Kuskokwim Delta ; 60 $0^{\circ} 48^{\prime} 15^{\prime \prime}$ N, $161^{\circ} 43^{\prime} 15^{\prime \prime} \mathrm{W}$; $(\operatorname{map} 59)$.

Local name reported in 1949 by USGS.

Hanging Glacier: glacier, heads at $59^{\circ} 50^{\prime} 45^{\prime \prime} \mathrm{N}$, $138^{\circ} 53^{\prime} 30^{\prime \prime} \mathrm{W}$, trends $4 \mathrm{mi}$. W to 1961 terminus $1 \mathrm{mi}$. NE of Nunatak Fiord and $33 \mathrm{mi}$. NE of Yakutat, St. Elias Mts.; $59^{\circ} 51^{\prime} 35^{\prime \prime} \mathrm{N}$, $139^{\circ} 00^{\prime} 20^{\prime \prime} \mathrm{W}$; (map 46).

Descriptive name given in 1906 by Tarr (1909, fig. 4). This is one of many glaciers of this type in the Yakutat Bay area, such as Cataract Glacier, Cascading Glacier, and Toboggan Glacier. Because of glacial erosion by the main valley glacier, the tributary glaciers often "hang" above the main valley.

Hanging Glacier Mountain: mountain, 6,600 ft., $3 \mathrm{mi}$. W of Mount Doonerak and $39 \mathrm{mi}$. NW of Wiseman, Brooks Ra.; 6754' N, $150^{\circ} 45^{\prime}$ W; BGN 1932; (map 124).
Named about 1930 by Marshall (1956, p. 22) who wrote, "They [the mountains] were topped by hanging glaciers. The most westerly of these two mountain masses I called 'Hanging Glacier.'"

Hanging Lake: lake, $0.2 \mathrm{mi}$. long, on $\mathrm{N}$ side of North Fork Chandalar River, $8 \mathrm{mi}$. NW of Bend Mtn. and $25 \mathrm{mi}$. N of Chandalar, Brooks Ra.; $67^{\circ} 51^{\prime} \mathrm{N}, 148^{\circ} 35^{\prime} \mathrm{W}$; (map 123).

Local name reported in 1956 by T. E. Taylor, USGS.

Hangmans Ridge: ridge, elev. 1,200-1,300 ft., trending NE from Fat Mtn. $3.5 \mathrm{mi}$. to Foot Mtn., west-central Kiska I., Aleutian Is., $51^{\circ}$ $55^{\prime} 15^{\prime \prime} \mathrm{N}, 177^{\circ} 18^{\prime} 50^{\prime \prime} \mathrm{E}$; (map 14).

One of many arbitrary names applied to features on Kiska I. by USAAF for tactical purposes during World War II.

Hanilik: locality, on Agattu I. in Near Is., Aleutian Is.; (map 13).

Former Aleut village reported as "uninhabited" by Hodge (1907, p. 531), BAE.

Hanin Rocks: rocks, $5 \mathrm{mi}$. NE of Kodiak, 0.8 mi. NE of Spruce Cape, Kodiak I.; 57 $50^{\prime} 05^{\prime \prime}$ $\mathrm{N}, 152^{\circ} 18^{\prime} 45^{\prime \prime} \mathrm{W}$; (map 34). Var. Haninskia, Kekurya Ganinskiya, Twins.

Name published by Baker (1906, p. 296); derived from the name "Kekurya Ganinskiya," meaning "Ganin pinnacles [rocks]," given in 1839 or 1840 by Sub-Lt. Mikhail Murashev, IRN. The name "Twins" was published in 1881 on USC\&GS Chart 776.

Haninskia: rocks, see Hanin Rocks.

Hanks Island: island, $300 \mathrm{ft}$. long, in Orca Bay, $2.5 \mathrm{mi}$. N of Hawkins $\mathrm{I}$. and $10 \mathrm{mi}$. NW of Cordova, Chugach Mts. ; $60^{\circ} 36^{\prime} 50^{\prime \prime}$ N, $145^{\circ}$ $58^{\prime} 30^{\prime \prime}$ W; (map 64).

Local name reported by Lt. Comdr. J. F. Moser, USN, while doing hydrographic studies along the coast of Alaska in 1897.

Hanna Creek: stream, flows E $17 \mathrm{mi}$. to Charley River $22 \mathrm{mi}$. SW of that stream's junc. with Yukon River, Yukon-Tanana High.; $65^{\circ} 04^{\prime}$ N, $143^{\circ} 03^{\prime} \mathrm{W}$; (map 103).

Prospectors' name from an unpublished map by E. J. Chamberlain, dated 1902.

Hanna Glacier: glacier, see Peters Glacier.

Hannah Creek: stream, flows NE $5 \mathrm{mi}$. to Yukon River, $5 \mathrm{mi}$. N of Rampart and $63 \mathrm{mi}$. ENE of Tanana, Kokrines-Hodzana High.; $65^{\circ} 34^{\prime}$ $30^{\prime \prime} \mathrm{N}, 150^{\circ} 09^{\prime} 30^{\prime \prime} \mathrm{W}$; (map 106).

Named in 1956 by Orth for the Hannah, one of the three largest and handsomest steamboats on the Yukon during the gold rush days. The Hannah was named for Mrs. Hannah Gerstle, wife of Lewis Gerstle, of the Alaska Commercial Company. The Hannah, along with her sister ships, Sarah and Susie, were built at Unalaska in the spring of 1898 for the Alaska Commercial Company. See Susie Creek and Sarah Creek.

Hanna Lake: lake, $2.3 \mathrm{mi}$. long, at 1950 terminus of Bering Glacier, $10 \mathrm{mi}$. NW of Sunshine Point and $90 \mathrm{mi}$. SE of Cordova, Malaspina Coastal Plain; $60^{\circ} 14^{\prime} 00^{\prime \prime}$ N. $143^{\circ} 09^{\prime} 30^{\prime \prime}$ $\mathrm{W}$; (map 65).

Local name published in 1951 by USGS.
Hanning Bay: bay, $2.3 \mathrm{mi}$. across, on NW coast of Montague I., $16 \mathrm{mi}$. NE of Cape Cleare, $63 \mathrm{mi}$. SE of Seward, Chugach Mts.; 59 $58^{\prime}$ N; $147^{\circ} 43^{\prime}$ W; (map 49). Var. Hunnings Bay, Port Bazil.

Named "'Hannings Bay' by [Capt.] Nathaniel Portlock when examined by him April 29,1787 , after a family interested in the company which sent him out. [The name was later erroneously] adopted by [Capt.] Vancouver as 'Hunning's Harbor'" (Wagner, 1937, p. 391). Russian Hydrog. Dept. Chart 1378 , dated 1847, gave the name "Port Bazil" for this feature.

Hannum Creek: stream, flows NE, then SE, $10 \mathrm{mi}$. to Inmachuk River, $20 \mathrm{mi}$. N of Imuruk Lake, Seward Penin. High.; 65 ${ }^{\circ} 53^{\prime} \mathrm{N}$; $163^{\circ} 10^{\prime}$ W; $B G N$ 1952; (map 110).

Prospectors' name reported in 1901 by D. L. Reaburn (in Mendenhall, 1902, pl. 4a), USGS.

Hansen Bar: bar, in Cache Creek, $31 \mathrm{mi}$. NW of Talkeetna, Alaska Ra.; $62^{\circ} 26^{\prime} 30^{\prime \prime} \mathrm{N}, 151^{\circ}$ 03'00' W; (map 81).

Prospectors' name reported in the 1930's by USGS.

Hanson Creek: stream, flows NW $0.5 \mathrm{mi}$. to California Creek which flows to Bonanza River, between Disappointment and Harrison Creeks, 9 mi. NW of Solomon, Seward Penin. High.; (map 95).

Prospectors' name reported on the 1900 "Map of Nome Peninsula" by J. M. Davidson and B. D. Blakeslee. This stream cannot be precisely located on current maps.

Hantak Island: island, see Khantaak Island.

Hanus, Point: point of land, on NW coast of Catherine I., $24 \mathrm{mi}$. $\mathrm{N}$ of Baranof, Alex. Arch.; $57^{\circ} 25^{\prime} 30^{\prime \prime} \mathrm{N}, 134^{\circ} 59^{\prime} 00^{\prime \prime} \mathrm{W}$; (map 9).

Named in 1895 by Lt. Comdr. E. K. Moore, USN, "for Lt. G. C. Hanus, USN."

Hanus Bay: bay, $2.3 \mathrm{mi}$. across, between Catherine I. and N coast of Baranof I., $27 \mathrm{mi}$. NE of Sitka, Alex. Arch.; $57^{\circ} 25^{\prime} \mathrm{N}, 135^{\circ} 02^{\prime} \mathrm{W}$; (map 9). Var. Hanus Inlet.

Named in 1880 by U.S. naval officers for "Lt. G. C. Hanus"; published by USC\&GS as "Hanus Inlet" in 1883 Coast Pilot (p. 166).

Hanus Inlet: $b a y$, see Hanus Bay.

Hanus Islet: island, $0.1 \mathrm{mi}$. across, at NE point of Biorka I., off the $W$ coast of Baranof I., Alex. Arch.; $56^{\circ} 51^{\prime} 55^{\prime \prime} \mathrm{N}, 135^{\circ} 30^{\prime} 15^{\prime \prime} \mathrm{W}$; (map 5).

Named in 1879 by Lt. F. M. Symonds, USN, for Lt. Gustavus Charles Hanus, USN.

Hanus Point: point of land, N tip of Hanus Islet, just off NE point of Biorka I., on W coast of Baranof I., Alex. Arch., 56 $51^{\prime} 58^{\prime \prime}$ N, $135^{\circ}$ $30^{\prime} 20^{\prime \prime} \mathrm{W}$; (map 5$)$.

Named in 1895 by Lt. Comdr. E. K. Moore, USN, for Lt. Gustavus Charles Hanus, USN.

Hanus Reef: reef, in Chatham Strait, $6.5 \mathrm{mi}$. NW of Point Augusta on Chichagof $I$. and $24 \mathrm{mi}$. SW of Juneau, Alex. Arch.; 58 ${ }^{\circ} 12^{\prime} 45^{\prime \prime}$ N, 134 $59^{\prime} 55^{\prime \prime}$ W; (map 11). Var. Hanus Rocks. 
Named in 1880 by Capt. L. A. Beardslee, USN, for Lt. Gustavus Charles Hanus, USN, who discovered and surveyed the reef. Name was published by the USC\&GS in the 1883 Coast Pilot (p. 181) as Hanus Rocks.

Hanus Rocks: reef, see Hanus Reef.

Hapkug: locality, on Agattu I. in Near Is., Aleutian Is. ; (map 13).

Former Aleut village reported as "uninhabited" by Hodge (1907, p. 532), BAE.

Happy: $R R$. station, mile 463.0 on The Alaska RR., in Happy Creek valley, $8 \mathrm{mi}$. NW of Fairbanks, Yukon-Tanana High.; 64 $4^{\circ} 53^{\prime} 15^{\prime \prime}$ N, $147^{\circ} 55^{\prime} 30^{\prime \prime}$ W ; (map 100). Var. Happy Station.

Local name derived from Happy Creek and published on timetable in 1922.

Happy Beach: beach, $0.6 \mathrm{mi}$. long, SW of Cliff Point, at mouth of Middle Bay, $7.5 \mathrm{mi}$. SW of Kodiak, Kodiak I. ; $57^{\circ} 41^{\prime} 10^{\prime \prime}$ N, $152^{\circ} 28^{\prime}$ $20^{\prime \prime} \mathrm{W}$; (map 34).

Local name reported in 1949 by USGS.

Happy Cove: cove, $0.2 \mathrm{mi}$. across, on Kuiu I., on $\mathrm{N}$ shore of Tebenkof Bay, Alex. Arch.; $56^{\circ}$ $30^{\prime} \mathrm{N}, 134^{\circ} 09^{\prime} \mathrm{W}$; BGN 1929; (map 5).

Named in 1928 by USC\&GS.

Happy Creek: stream, flows SW 2 mi. to Salmon River, $27 \mathrm{mi}$. NE of Cape Newenham, Kilbuck-Kuskokwim Mts.; $58^{\circ} 52^{\prime} \mathrm{N}, 161^{\circ} 42^{\prime} \mathrm{W}$; $B G N$ 1938; (map 39).

Local name reported in 1938 by USGS.

Happy Creek: stream, on Kenai Penin., flows SW $5 \mathrm{mi}$. to Cook Inlet, $4 \mathrm{mi}$. NE of Cape Starichkof, $21 \mathrm{mi}$. NW of Homer, Cook Inlet Low.; $59^{\circ} 57^{\prime} 10^{\prime \prime} \mathrm{N}, 151^{\prime} 44^{\prime} 15^{\prime \prime} \mathrm{W}$; (map 50).

Local name reported and published in 1950 by USGS.

Happy Creek: stream, flows S $1.3 \mathrm{mi}$. to King Creek, $7.4 \mathrm{mi}$. E of Marshall, Nulato Hills; $61^{\circ} 53^{\prime} \mathrm{N}, 161^{\circ} 51^{\prime} \mathrm{W}$; (map 73 ).

Prospectors' name reported in 1916 by Harrington (1918, map), USGS.

Happy Creek: stream, flows W $2.2 \mathrm{mi}$. to Willow Creek, $4.6 \mathrm{mi}$. SW of Flat and $57 \mathrm{mi}$. NE of Holy Cross, Kilbuck-Kuskokwim Mts.; 62 ${ }^{\circ}$ $23^{\prime} 10^{\prime \prime} \mathrm{N}, 158^{\circ} 03^{\prime} 20^{\prime \prime} \mathrm{W}$; (map 79).

Prospectors' name reported in 1915 by $\mathrm{J}$. B. Mertie and G. L. Harrington, USGS.

Happy Creek: stream, flows SE $6 \mathrm{mi}$. to Cripple Creek, $5 \mathrm{mi}$. W of Fairbanks, Yukon-Tanana High.; $64^{\circ} 50^{\prime} \mathrm{N}, 147^{\circ} 53^{\prime} \mathrm{W}$; (map 100).

Name applied by prospectors about 1905 ; published in 1908 by USGS.

Happy Creek: stream, flows SW to Hash Creek which flows to Niukluk River, about $9 \mathrm{mi}$. SE of Mount Bendeleben, Seward Penin. High.; (map 110).

Prospectors' name published on 1908 "Map of Seward Peninsula" by Arthur Gibson. This stream cannot be precisely located on current maps.

Happy Gulch: ravine, $0.8 \mathrm{mi}$. long, on $\mathrm{N}$ bank of Bear Creek $4.4 \mathrm{mi}$. NE of Nyac and $39 \mathrm{mi}$. SW of Aniak, Kilbuck-Kuskokwim Mts.; $61^{\circ}$ $02^{\prime} 10^{\prime \prime} \mathrm{N}, 159^{\circ} 49^{\prime} 30^{\prime \prime} \mathrm{W}$; (map 73).

Prospectors' name shown on a 1914 fieldsheet by A. G. Maddren, USGS.
Happy New Year Creek: stream, flows $\mathrm{N} 5 \mathrm{mi}$. to Slate Creek, $40 \mathrm{mi}$. SW of Eagle, YukonTanana High.; $64^{\circ} 37^{\prime} 10^{\prime \prime} \mathrm{N}, 142^{\circ} 28^{\prime} 45^{\prime \prime} \mathrm{W}$; (map 102). Var. Buck Creek.

Prospectors' name shown on a 1902 manuscript map by E. J. Chamberlain, U.S. Deputy Surveyor.

Happy River: stream, heads in Teocalli Mts., $4.4 \mathrm{mi}$. SW of Houston Pass, flows NE and $\mathrm{SE} 45 \mathrm{mi}$. to Skwentna River, $75 \mathrm{mi}$. NW of Tyonek, Alaska Ra.; 61 $59^{\prime} \mathrm{N}, 152^{\circ} 21^{\prime} \mathrm{W}$; BGN 1965; (map 70). Var. Moose Creek, Pass Creek.

This appears to be a whimsical name given by Spurr $(1900$, p. 50), USGS, who wrote on June 27, 1898, "this stream, which we named Happy River, we worked *** in constant risk of losing our boats and provisions, and succeeded in advancing only about a half mile * * *."

Happy River: stream, see Pass Creek.

Happy Slough: stream, flows NW $4 \mathrm{mi}$. to Patsy Slough, $7 \mathrm{mi}$. NE of Nulato, Koyukuk Low.; $64^{\circ} 46^{\prime} \mathrm{N}, 157^{\circ} 54^{\prime} \mathrm{W}$; (map 97).

Local name reported in 1954 by USGS

Happy Slough: stream, anabranch of Koyukuk River, $16 \mathrm{mi}$. long, $17 \mathrm{mi}$. NE of Roundabout Mtn., Koyukuk Low. ; $65^{\circ} 47^{\prime} \mathrm{N}, 156^{\circ} 23^{\prime} \mathrm{W}$; (map 108).

Local name obtained at Huslia by USGS in 1954 or 1955.

Happy Station: RR. station, see Happy.

Happy Valley: locality, on $\mathrm{W}$ coast of Kenai Penin., $4.5 \mathrm{mi}$. NE of Cape Starichkof and $22 \mathrm{mi}$. NW of Homer, Cook Inlet Low.; 59 ${ }^{\circ}$ $56^{\prime} \mathrm{N}, 151^{\circ} 44^{\prime} \mathrm{W}$; (map 50).

Local name reported and published by USGS in 1950.

Happy Valley: valley, $0.4 \mathrm{mi}$. long, between Mitt Lake and Sweeper Cove, on NE coast of Adak I., Aleutian Is.; $51^{\circ} 51^{\prime} 00^{\prime \prime} \mathrm{N}, 176^{\circ} 39^{\prime} 10^{\prime \prime} \mathrm{W}$; (map 17).

Name published by USC\&GS in 1963 on Chart 9119.

Happy Valley Creek: stream, flows SW $1 \mathrm{mi}$. to East Fork Solomon River, between Mitchell and Vinegar Creeks, $11 \mathrm{mi}$. NE of Solomon Seward Penin. High.; $64^{\circ} 42^{\prime} \mathrm{N}, 164^{\circ} 15^{\prime} \mathrm{W}$; (map 95)

Prospectors' name reported on a 1902 prospectors' manuscript map.

Harbor, Lake : bay, see Pearl Harbor.

Harbor Hat Point: point of land, on $\mathrm{E}$ shore of Port Hobron, on N coast of Sitkalidak I., SE of Kodiak I.; $57^{\circ} 10^{\prime} 30^{\prime \prime} \mathrm{N}, 153^{\circ} 06^{\prime} 30^{\prime \prime} \mathrm{W}$ (map 34).

Local name published in 1943 by USC\&GS

Harbor Island: island, $500 \mathrm{ft}$. across, in Security Bay, on N coast of Kuiu I., $40 \mathrm{mi}$. SE of Sitka Alex. Arch.; $56^{\circ} 51^{\prime} 45^{\prime \prime} \mathrm{N}, 134^{\circ} 21^{\prime} 05^{\prime \prime} \mathrm{W}$; (map 5).

Named in 1869 by Comdr. R. W. Meade, USN.

Harbor Island: island, $1.5 \mathrm{mi}$, across, in Holkham Bay at entrance to Endicott Arm, 3 mi. NW of Wood Spit and $48 \mathrm{mi}$. SE of Juneau, Coast Mts. ; $57^{\circ} 00^{\prime} 45^{\prime \prime} \mathrm{N}, 133^{\circ} 36^{\prime} 45^{\prime \prime} \mathrm{W}$; (map 8).
Named in 1869 by Comdr. R. W. Meade, USN; name published by USC\&GS in 1883 Coast Pilot (p. 168).

Harbor Island: island, $300 \mathrm{ft}$. across, tied to Japonski I., $0.4 \mathrm{mi}$. SW of Sitka, Alex. Arch.; $57^{\circ} 02^{\prime} 52^{\prime \prime}$ N, $135^{\circ} 20^{\prime} 35^{\prime \prime} \mathrm{W}$; (map 9). Var. Ostrov Gavanskoy.

This is an 1882 translation by USC\&GS of the name given in 1809 by the Russian navigator Ivan Vasiliev the first, IRN; reported by Lt. Sarichev (1826, map 19), IRN, as "O[strov] Gavanskoy."

Harbor Island: island, $4 \mathrm{mi}$. long, at entrance to Aialik Bay, $32 \mathrm{mi}$. SW of Seward, Chugach Mts. ; $59^{\circ} 40^{\prime} \mathrm{N}, 149^{\circ} 39^{\prime} \mathrm{W}$; BGN 1911; (map 49).

Descriptive name given in 1909 by U. S. Grant, USGS.

Harbor Island: island, see Pitt Island.

Harbor Peak: peak, 2,193 ft., $1.5 \mathrm{mi}$. NNW of Sitka, on Baronof I., Alex. Arch.; 57 $04^{\prime} 25^{\prime \prime}$ $\mathrm{N}, 135^{\circ} 19^{\prime} 45^{\prime \prime} \mathrm{W}$; (map 9). Var. Gora Gavanskaya.

This is an 1882 translation by USC\&GS of the name given in 1809 by the Russian navigator Ivan Vasiliev the first, IRN; reported by Lt. Sarichev (1826, map 19), IRN, as "Gora Gavanskaya," meaning "harbor mountain."

Harbor Peak: ridge, see Gavan Hill.

Harbor Point: point of land, northeast point of entrance to Hassler Harbor, in Revillagigedo Channel, on NE coast of Annette I., Alex. Arch.; $55^{\circ} 13^{\prime} \mathrm{N}, 131^{\circ} 25^{\prime} \mathrm{W}$; (map 3).

Descriptive name given in 1883 by Lt: Comdr. H. E. Nichols, USN.

Harbor Point: point of land, on $\mathrm{N}$ shore of Port Moller, Bristol Bay Low. ; 55 $55^{\prime} 00^{\prime \prime} \mathrm{N}, 160^{\circ}$ $34^{\prime} 30^{\prime \prime} \mathrm{W}$; (map 28).

Named in 1882 by W. H. Dall, USC\&GS.

Harbor Point: point of land, $5.5 \mathrm{mi}$. NW of Sitka, on NW coast of Baranof I., Alex. Arch.; $57^{\circ} 07^{\prime} 30^{\prime \prime} \mathrm{N}, 135^{\circ} 23^{\prime} 20^{\prime \prime} \mathrm{W}$; (map 9). Var. Gavanski Point, Mys Gavanskoy.

This is an 1882 translation by USC\&GS of the name given in 1809 by the Russian navigator Ivan Vasiliev the first, IRN; reported by Lt. Sarichev (1826, map 19), IRN, as "Mys Gavanskoy" (Harbor Cape).

Harbor Point: point of land, E end of Long I. in Port Frederick on Chichogof I., $1 \mathrm{mi}$. SW of Hoonah, Alex. Arch.; 58 $05^{\prime} 45^{\prime \prime} \mathrm{N}, 135^{\circ}$. $27^{\prime} 30^{\prime \prime} \mathrm{W}$; (map 11)

Named in 1880 by U.S. Navy and published in 1881 on Hydrog. Chart 883.

Harbor Point: point of land, at mouth of Lituya Bay, in Glacier Bay National Monument, 0.3 $\mathrm{mi}$. SE of the La Chaussee Spit, $87 \mathrm{mi}$. NW of Hoonah, Malaspina Coastal Plain; 58 $36^{\prime}$ 45" N, $137^{\circ} 39^{\prime} 20^{\prime \prime}$ W; (map 10). Var. South Point.

Named by W. H. Dall, USG\&GS, in 1874 and published in the 1883 Alaska Coast Pilot (p. 202). It was called "M[ys] Yuzhnoy" meaning "cape southern" by Capt. Tebenkov (1852, map 8), IRN.

Harbor Ridge: ridge, elev. 1,700 ft., $5.5 \mathrm{mi}$. long, on mainland, W of Willard Inlet, Coast Mts.; $54^{\circ} 49^{\prime} \mathrm{N}, 130^{\circ} 41^{\prime} \mathrm{W}$; (map 2). 
Named in 1883 by Lt. Comdr. H. E. Nichols, USN.

Harbor Rock: rock, in Sitka Harbor, off W coast of Baronof I., Alex. Arch.; 57 $03^{\prime} 14^{\prime \prime}$ N, $135^{\circ} 20^{\prime} 48^{\prime \prime} \mathrm{W}$; (map 9).

Name reported by W. H. Dall, USC\&GS; published in 1883 Coast Pilot (p. 149). So named because of its location in Sitka Harbor.

Hardenburg Bay: cove, $0.8 \mathrm{mi}$. long, on SE shore of Lake Clark, $23 \mathrm{mi}$. NE of Nondalton, Aleutian Ra.; $60^{\circ} 12^{\prime \prime} 15^{\prime \prime} \mathrm{N}, 154^{\circ} 18^{\prime} 15^{\prime \prime} \mathrm{W}$; (map 61).

Local name reported in 1954 by USGS.

Harding, Mount: mountain, 3,000 ft., $17.5 \mathrm{mi}$. $S$ of Baranof, on $E$ coast of Baranof I., Alex. Arch.; 56 $50^{\prime} 10^{\prime \prime} \mathrm{N}, 134^{\circ} 45^{\prime} 30^{\prime \prime} \mathrm{W}$; (map 5).

Named for charting purposes; name published in 1943 by USC\&GS.

Harding Gateway: water passage, extends SE 4 mi. from Resurrection Bay to Blying Sound, between Cheval and Rugged Is., $21 \mathrm{mi}$. S of Seward, Chugach Mts.; $59^{\circ} 49^{\prime} \mathrm{N}, 149^{\circ} 27^{\prime} \mathrm{W}$; $B G N 1923$; (map 49).

This feature was "Ceremoniously christened by Governor Scott Bone of Alaska and officers of the transport Henderson and destroyers Cory and Bull as these vessels passed through the channel July 3, 1923 with President Warren G. Harding on board the transport."

Harding Icefield: icefield, extends SW $30 \mathrm{mi}$. from Lowell and Bear Glaciers to Chernof Glacier, in Kenai Mts., $18 \mathrm{mi}$. W of Seaward, Chugach Mts.; $60^{\circ} 00^{\prime} \mathrm{N}, 150^{\circ} 00^{\prime} \mathrm{W}$; (map 49).

Name published in 1950 by USGS; presumably named for Warren Gamaliel Harding, 1865-1923, 28th President of the United States.

Harding Lake: lake, $2.3 \mathrm{mi}$. across, $4 \mathrm{mi}$. SE of junc. of Salcha and Tanana Rivers and $38 \mathrm{mi}$. NW of Big Delta, Tanana Low.; 64 ${ }^{\circ} 25^{\prime} \mathrm{N}$, 14650' W; BGN 1964; (map 101). Var. Lake Harding, Salchaket Lake.

Named for Warren Gamaliel Harding, 1865-1923, the 29th President of the United States, who visited Alaska just before his death. The lake was originally reported by USGS in 1909 as "Salchaket Lake."

Harding Point: point of land, $\mathrm{N}$ tip of Smeaton I. in Behm Canal, Coast .Mts. ; 55 $18^{\prime} 00^{\prime \prime} \mathrm{N}$, $130^{\circ} 56^{\prime} 50^{\prime \prime} \mathrm{W}$; (map 3$)$.

Local navigators' name obtained in 1904 by H. C. Fassett, USBF

Harding River: stream, flows S $20 \mathrm{mi}$. through Fall Lake to Bradfield Canal, Coast Mts. ; $56^{\circ}$ $12^{\prime} 15^{\prime \prime} \mathrm{N}, 131^{\circ} 37^{\prime} 00^{\prime \prime} \mathrm{W}$; (map 7).

Local name reported in 1923 by USFS.

Hardluck Bay: $b a y$, N shore of Lake Beverley, $46 \mathrm{mi}$. N of Dillingham, Kilbuck-Kuskokwim Mts.; $59^{\circ} 42^{\prime} \mathrm{N}, 158^{\circ} 45^{\prime}$ W; BGN 1931; (map 52).

Named in 1910 by Beverley N. Polley, prospector; reported by USBF in 1929.

Hard Luck Creek: stream, flows SW $1 \mathrm{mi}$. to junc. of Eldorado and Telegram Creeks, at head of Dome Creek, $22 \mathrm{mi}$. NW of Solomon, Seward Penin. High.; $64^{\circ} 53^{\prime} \mathrm{N}, 164^{\circ} 38^{\prime} \mathrm{W}$; (map 95).
Prospectors' name reported on a map of Cape Nome gold fields by David Fox, Jr. dated 1901.

Hard Luck Creek: stream, flows NW $6.5 \mathrm{mi}$. to Chatanika River, $28 \mathrm{mi}$. NW of Fairbanks, Y'ukon-Tanana High, ; $64^{\circ} 58^{\prime} 45^{\prime \prime} \mathrm{N}, 148^{\circ}$ $36^{\prime} 35^{\prime \prime}$ W; (map 100). Var. Hardluck Creek.

Name applied by prospectors; published in 1906 by USGS.

Hard Luck Creek: stream, formed by Harrington and Pleasant Creeks, flows NW $24 \mathrm{mi}$. to Nation River, $37 \mathrm{mi}$ NNW of Eagle, Porcupine

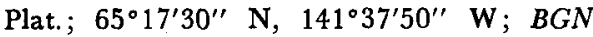
1965; (map 103). Var. Cathedral Creek.

Named in 1910 by IBC survey; application of the name was originally extended to apply to Harrington Creek.

Hard Luck Creek: stream, see Harrington Creek.

Hardluck Island: island, extends E-W $3.5 \mathrm{mi}$. in Yukon River, $0.4 \mathrm{mi}$. $\mathrm{N}$ of Mickey I. and Ruby, Nowitna Low.; $64^{\circ} 56^{\prime} \mathrm{N}, 154^{\circ} 34^{\prime} \mathrm{W}$; (map 98).

Riverboat pilots' name shown on 1940 "Navigation Chart, Tanana-Yukon Rivers" of the River Boat Service, U.S. Dept. of Interior.

Hardluck Slough: stream, heads at Victor Slough, flows W $4 \mathrm{mi}$. around $\mathrm{N}$ side of Hardluck I. to Yukon River, $29 \mathrm{mi}$. NE of Ruby, Nowitna Low.; 64 $57^{\prime} \mathrm{N}, 154^{\circ} 38^{\prime} \mathrm{W}$; (map 98). Var. Deniga Slough, Moose Slough.

Riverboat pilots' name shown on a 1940 "Navigation Chart, Tanana-Yukon Rivers" of the River Boat Service, U.S. Dept. of Interior.

Hardover Point: point of land, at NW tip of Nuka I., 36 mi. E of Seldovia, Chugach Mts.; $59^{\circ} 25^{\prime} \mathrm{N}, 150^{\circ} 42^{\prime} \mathrm{W}$; BGN 1931; (map 50).

So named by USC\&GS in 1931 "because it is necessary to put the helm hard over in making the turn in the passage."

Hardpac Creek: stream, flows E $12 \mathrm{mi}$. to Pitka Fork, $4 \mathrm{mi}$. $\mathrm{N}$ of Twin Sisters, and $48 \mathrm{mi}$. NW of Beaver, Kokrines-Hodzana High.; $66^{\circ}$ $52^{\prime} 30^{\prime \prime} \mathrm{N}, 148^{\circ} 35^{\prime} 30^{\prime \prime} \mathrm{W}$; (map 118).

Local name obtained in 1956 by USGS.

Hardscrabble, Point: point of land, on SW

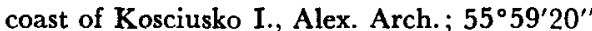
$\mathrm{N}, 133^{\circ} 47^{\prime} 00^{\prime \prime} \mathrm{W}$; (map 4).

Named by local fishermen and reported in 1904 by H. C. Fassett, USBF.

Hardscrabble Creek: stream, heads in lake, flows SW $30 \mathrm{mi}$. to Lake Grosvenor, on Alaska Penin., in Katmai National Monument, $23 \mathrm{mi}$. $\mathrm{N}$ of Mount Katmai, Aleutian Ra.; $58^{\circ} 36^{\prime} \mathrm{N}$, $155^{\circ} 03^{\prime} \mathrm{W}$; (map 42).

So named in 1923 by $R$. H. Sargent's USGS party, "on account of difficult travelling."

Hardscrabble Creek: stream, flows SE $19 \mathrm{mi}$. to North Fork Kuskokwim River, $42 \mathrm{mi}$. NE of Medfra, Kilbuck-Kuskokwim Mts. ; $63^{\circ} 28^{\prime}$ N, $153^{\circ} 39^{\prime} \mathrm{W}$; (map 89)

Local name reported in 1958 by USGS.

Hardscrabble Gulch: ravine, tributary to Gold Creek, about $2 \mathrm{mi}$. W of Juneau, Coast Mts.; $58^{\circ} 18^{\prime} \mathrm{N}, 134^{\circ} 20^{\prime} \mathrm{W}$; (map 11$)$
Miners' name for a gulch subsequently destroyed by mining operations (DeArmond, 1957, p. 22).

Hardscratch Point: point of land, on $\mathrm{E}$ coast of Unga I., in Shumagin Is., Aleutian Ra.; $55^{\circ} 15^{\prime} 45^{\prime \prime} \mathrm{N}, 160^{\circ} 32^{\prime} 00^{\prime \prime} \mathrm{W}$; (map 28).

Named in 1943 by USC\&GS.

Hardway Creek: stream, flows $\mathrm{N} 11 \mathrm{mi}$. to Ipnavik River, $35 \mathrm{mi}$. $\mathbf{N}$ of Howard Pass, Arctic Slope; $68^{\circ} 43^{\prime} 30^{\prime \prime} \mathrm{N} ; 156^{\circ} 52^{\prime} 00^{\prime \prime} \mathrm{W}$; (map 132).

So named in 1950 by B. H. Kent, USGS, geologist connected with the Naval Petroleum Reserve No. 4 explorations as a result of a "camping incident". Name published by USGS in 1951.

Hardy Creek: stream, on Attu I., flows SW 1.5 $\mathrm{mi}$. to Peaceful River, $3.5 \mathrm{mi}$. W of Navy Town, Aleutian Is. ; $52^{\circ} 50^{\prime} 50^{\prime \prime} \mathrm{N}, 173^{\circ} 06^{\prime} 00^{\prime \prime}$ E; (map 13).

Named by U.S. Army during World War II; published in 1948 by AMS.

Hardy Creek: stream, on Iniskin Penin., flows E $1 \mathrm{mi}$. to Fitz Creek, $2.4 \mathrm{mi}$. S of Chinitna Bay, Aleutian Ra.; $59^{\circ} 47^{\prime} \mathrm{N}, 153^{\circ} 12^{\prime} \mathrm{W}$; BGN 1947; (map 51).

Local name reported by USGS in 1947 ; named for Charles W. Hardy, "a well-known engineer of Salt Lake City, Utah."

Hare Island: island, $0.2 \mathrm{mi}$. across, in Keku Strait, $8 \mathrm{mi}$. S of Kake, off NE coast of Kuiu I., Alex. Arch.; $56^{\circ} 51^{\prime} 30^{\prime \prime} \mathrm{N}, 133^{\circ} 58^{\prime} 00^{\prime \prime} \mathrm{W}$; (map 6).

Local fishermen's name reported in 1947 by USC\&GS.

Harem Rock: rock, $0.7 \mathrm{mi}$. off SW coast of Tanaga I., Aleutian Is.; $51^{\circ} 39^{\prime} 20^{\prime \prime} \mathrm{N}, 178^{\circ}$ 05'50" W; (map 16).

Local name published on a 1954 USGS map.

Harlampy's Hill: mountain, see Bear Mountain. Harlampy's Mountain: mountain, see Bear Mountain.

Harlem Creek: stream, flows SW $1 \mathrm{mi}$. to Shovel Greek near its head, $12 \mathrm{mi}$. $\mathrm{N}$ of Solomon,

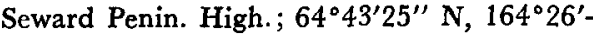
$00^{\prime \prime} \mathrm{W}$; (map 95).

Prospectors' name reported on a 1902 prospectors' manuscript map.

Harlequin Lake: lake, $6.5 \mathrm{mi}$. long, at 1961 terminus of Yakutat Glacier, $30 \mathrm{mi}$. SE of Yakutat Bay, St. Elias Mts. ; $59^{\circ} 26^{\prime}$ N, $138^{\circ} 56^{\prime}$ W; (map 46). Var. Terminal Lake.

Named by Blackwelder (1907, p. 424) USGS, "*** from the fact that a pair of harlequin ducks (Histrionicus histrionicus) were the only living things seen upon it." Also called Terminal Lake on a USGS manuscript map dated 1907.

Harman Point: point of land, see Pyke, Point.

Harmony Island: islands, extend $1.2 \mathrm{mi}$., at mouth of Tonowek Bay, off $W$ coast of Prince of Wales I., Alex. Arch.; 55 $43^{\prime}$ N, $133^{\circ} 24^{\prime}$ W; BGN 1928; (map 4).

Named in 1928 by USFS.

Haro, Riviere: strait, "forming part of Delisle's fantastic geography connecting Lac Velasco and a large gulf to the south in about $56^{\circ}$. 
Named after a personage mentioned in the Fonte narrative." (Wagner, 1937, p. 461).

Harper, Mount: mountain, 6,515 ft., $70 \mathrm{mi}$. NW of Tok Junction, $90 \mathrm{mi}$. SW of Eagle, YukonTanana High.; $64^{\circ} 14^{\prime} \mathrm{N}, 143^{\circ} 21^{\prime} \mathrm{W}$; (map 102).

Prospectors' name thought to be for Arthur Harper, 1835-1897, Yukon River valley pioneer. Name shown on a 1911 USGS fieldsheet.

Harper Bend: bend, in Tanana River $5 \mathrm{mi}$. N of junc. of Chitanana River, $18 \mathrm{mi}$. SE of Tanana, Nowitna Low.; $65^{\circ} 00^{\prime} \mathrm{N}, 152^{\circ} 37^{\prime}$ W; (map 106).

Named as early as 1890 for Arthur Harper, born 1835, prospector, trader, and explorer of the Yukon River. Harper reached the Yukon in 1873 and his name, along with Napoleon Leroy McQuesten and Alfred Mayo, stands out prominently in the history of the Yukon "country" the last third of the nineteenth century (see Brooks, 1953, p. 311-320). In 1875, Harper ascended the Tanana and built a cabin near this bend. Later, in 1878, this cabin was the home and scene of the murder, by Indians, of Mrs. Edmond Bean, wife of the first trader to establish himself on the Tanana (Allen, 1887, p. 86). See McQuesten Creek and Mayo Bend.

Harper Glacier: glacier, in Mount McKinley National Park, trends NE $4 \mathrm{mi}$., from Denali Pass on Mount McKinley to Harper Icefall, Alaska Ra.; $62^{\circ} 06^{\prime} 45^{\prime \prime} \mathrm{N}, 150^{\circ} 48^{\prime} 00^{\prime \prime} \mathrm{W}$; $B G N$ 1946; ( $\operatorname{map} 88$ ).

Named in 1913 by Archdeacon Stuck (1921, p. 121-122) for Walter Harper, a son of Arthur Harper who was an early pioneer and who was "the first man to make written reference to this mountain [McKinley], since Vancouver *** in 1794." Walter Harper, Archdeacon Hudson Stuck, Henry Karstens, and Robert Tatum made the "first official ascent" of Mount McKinley on June 7, 1913. See McKinley, Mount.

Harper Ice Fall: icefall, of 2,500 ft., in Mount McKinley National Park, at terminus of Harper Glacier, $3 \mathrm{mi}$. NE of summit of Mount McKinley, Alaska Ra.; 6306 $30^{\prime \prime} \mathrm{N}$, $150^{\circ} 06^{\prime} 00^{\prime \prime} \mathrm{W}$; BGN 1947; (map 88).

Probably named by Bradford Washburn about 1945.

Harpers Station: locality, see Tanana.

Harpoon Glacier: glacier, on E slope of Mount Veniaminof, trends NE $4 \mathrm{mi}$. to its terminus 3 mi. SW of Knife Peak, Aleutian Ra.; $56^{\circ}$ $15^{\prime} \mathrm{N}, 159^{\circ} 10^{\prime} \mathrm{W}$; (map 30 ).

Descriptive name reported in 1923 by R. H. Sargent, USGS.

Harpoon Glacier: glacier, in Tordrillo Mts., heads on Mount Torbert, trends SW $9 \mathrm{mi}$. to its terminus at Nagishlamina River, $52 \mathrm{mi}$. NW of Tyonek, Alaska Ra.; $61^{\circ} 20^{\prime} \mathrm{N}, 152^{\circ}$ $38^{\prime} \mathrm{W}$; BGN 6th Report; (map 70).

Named in 1927 by S. R. Capps and R. H. Sargent (in Smith and others, 1930, pl. 1, 2), USGS; "suggested by the outline of the glacier on our map."
Harpoon Point: point of land, on SE coast of Kiska I., Aleutian Is.; $51^{\circ} 55^{\prime} 25^{\prime \prime} \mathrm{N}, 177^{\circ}$ $36^{\prime} 00^{\prime \prime}$ E; ( $\operatorname{map} 14$ ). Var. Sea Lion Point.

An arbitrary name beginning with " $H$ " to correspond to " $\mathrm{H}$ " grid used by U.S. Army for tactical purposes during World War II; published on a 1953 AMS map. Variant published on a 1943 USAAF map.

Harpson Creek: stream, see Harrison Creek.

Harpsons Creek: stream, see Harrison Creek.

Harrell Island: island, $1.9 \mathrm{mi}$. long, in Wilson Lake, on $\mathrm{E}$ bank of Kuskokwim River, $12 \mathrm{mi}$. SW of McGrath, Kuskokwim Low.; $62^{\circ} 46^{\prime}$ $45^{\prime \prime} \mathrm{N}, 155^{\circ} 42^{\prime} 00^{\prime \prime} \mathrm{W}$; (map 80).

Named in 1898 by J. E. Spurr, USGS, for A. E. Harrell, a member of his party.

Harriet Creek: stream, flows SE $16 \mathrm{mi}$. to Redoubt Bay, Cook Inlet, $36 \mathrm{mi}$. WSW of Kenai, Aleutian Ra.; $60^{\circ} 25^{\prime} \mathrm{N}$, $152^{\circ} 17^{\prime} \mathrm{W}$; (map 62).

Name derived from nearby Harriet Point and used by local prospectors; reported in 1899 by F. C. Schrader, USGS,

Harriet Creek: stream, flows NW $7 \mathrm{mi}$. from Pope Creek Dome to Koyukuk River, $2 \mathrm{mi}$. SW of junc. of North and Middle Forks of Koyukuk River and $38.5 \mathrm{mi}$. SW of Wiseman, Brooks Ra.; $67^{\circ} 01^{\prime} 30^{\prime \prime} \mathrm{N}, 151^{\circ} 08^{\prime} 00^{\prime \prime} \mathrm{W}$; (map 124).

Local name shown on an 1899 fieldsheet by T. G. Gerdine, USGS.

Harriet Hunt, Lake: lake, $0.9 \mathrm{mi}$. across, on Revillagigedo I., W of George Inlet, Alex. Arch.; 55 $29^{\prime} 15^{\prime \prime} \mathrm{N}, 131^{\circ} 35^{\prime} 00^{\prime \prime} \mathrm{W}$; (map 3). Var. Lake Hunt.

Local name reported in 1954 by USGS.

Harriet Point: point of land, W shore of Cook Inlet, $S$ point of entrance to Redoubt Bay, 36 mi. WSW of Kenai, Aleutian Ra.; $60^{\circ} 24^{\prime} \mathrm{N}$, $152^{\circ} 15^{\prime} \mathrm{W}$; (map 62).

Name reported by Capt. George Vancouver, RN; published in 1798 in his atlas (Wagner, 1937, p. 391).

Harriman Fiord: estuary, extends NE $12 \mathrm{mi}$. from terminus of Harriman Glacier to Barry Arm, $28 \mathrm{mi}$. NE of Whittier, Chugach Mts.; $61^{\circ} 05^{\prime} \mathrm{N}, 148^{\circ} 11^{\prime} \mathrm{W}$; (map 63).

Named by the members of the Harriman Alaska Expedition for Edward Henry Harriman, 1848-1909, the organizer and sponsor of the expedition in 1899.

Harriman Glacier: glacier, trends NE $8 \mathrm{mi}$. to its terminus at head of Harriman Fiord, 16 mi. NE of Whittier, Chugach Mts. ; $60^{\circ} 58^{\prime} 30^{\prime \prime}$ $\mathrm{N}, 148^{\circ} 26^{\prime} 30^{\prime \prime} \mathrm{W}$; (map 63).

Named by the members of the Harriman Alaska Expedition in 1899. See Harriman Fiord.

Harrington, Point: point of land, northernmost tip of Observation I., $S$ point of entrance to Steamer Bay, off $W$ coast of Etolin I., Alex. Arch.; $56^{\circ} 10^{\prime} 10^{\prime \prime} \mathrm{N}, 132^{\circ} 43^{\prime} 30^{\prime \prime} \mathrm{W}$; (map 6).

Named in September 1793, by Capt. George Vancouver, RN, (Wagner, 1937, p. 391).

Harrington Greek: stream, heads in Canada, flows SW 9 mi. to join Pleasant Creek to form Hard Luck Creek, 23 mi. NE of Eagle, Porcu- pine Plat.; $65^{\circ} 06^{\prime} 40^{\prime \prime} \mathrm{N}, 141^{\circ} 04^{\prime} 00^{\prime \prime} \mathrm{W}$; $B G N$ 1965; (map 103). Var. Hard Luck Creek.

Name first published in 1914 by D. D. Cairnes. The stream was considered part of Hard Luck Creek by the IBC survey.

Harrington Fork: stream, flows SE $12 \mathrm{mi}$. to Birch Creek, $60 \mathrm{mi}$. SW of Circle, YukonTanana High.; $65^{\circ} 17^{\prime} \mathrm{N}, 1^{\circ} 45^{\circ} 43^{\prime} \mathrm{W}$; (map 104).

Named by prospectors and reported in 1911 by USGS (Prindle, 1913, pl. 1).

Harrington Point: point of land, on $\mathrm{N}$ shore of Nuka Bay, $43 \mathrm{mi}$. E of Seldovia, Chugach Mts.; $59^{\circ} 27^{\prime} 30^{\prime \prime} \mathrm{N}, 150^{\circ} 30^{\prime} 00^{\prime \prime} \mathrm{W} ; B G N$ 1929; (map 50).

Local name reported by USC\&GS in 1928.

Harrington Rock: rock, in Portage Bay, off $\mathbf{N}$ coast of Kupreanof I., $16 \mathrm{mi}$. NW of Petersburg, Alex. Arch.; $56^{\circ} 57^{\prime} 30^{\prime \prime} \mathrm{N}, 133^{\circ} 17^{\prime} 40^{\prime \prime}$ W; (map 6).

Named in 1882 by Lt. Comdr. H. E. Nichols, USN.

Haxris, Mount: mountain, 6,392 ft., in Takhinsha Mts., $3.2 \mathrm{mi}$. SW of terminus of Tsirku Glacier, on Alaska-Canada boundary, $44 \mathrm{mi}$. SW of Skagway, St. Elias Mts.; BGN 1923; 59¹5'$35^{\prime \prime}$ N, $136^{\circ} 29^{\prime} 20^{\prime \prime}$ W; (map 45). Var. Boundary Peak 156.

Named by the IBG in 1923 for D. R. Harris, a surveyor in the Canadian section of the Boundary Survey in 1904.

Harris, Point: point of land, $N$ point of entrance to Port Malmsbury, on W coast of Kuiu I., $15 \mathrm{mi}$. NE of Port Alexander, Alex. Arch.; $56^{\circ} 17^{\prime} 30^{\prime \prime} \mathrm{N}, 134^{\circ} 17^{\prime} 45^{\prime \prime} \mathrm{W}$; (map 5). Var. Point Garns.

Named by Capt. Gecrge Vancouver, RN, on August 4, 1794, "no doubt for James Harris, first Earl of Malmsbury" (Wagner, 1937, p. 391).

Harris Bay: bay, just W of Harris Penin., extends $\mathbf{S} 18 \mathrm{mi}$. from Northwestern Lagoon, 35 mi. SW of Seward, Chugach Mts.; $59^{\circ} 40^{\prime} \mathrm{N}$, $149^{\circ} 54^{\prime} \mathrm{W}$; BGN 1910; (map 49).

Name reported in 1909 by U. S. Grant and D. F. Higgins, USGS.

Harris Bay: lagoon, see Northwestern Lagoon. Harrisburg: city, see Juneau.

Harris Cove: bay, $1.5 \mathrm{mi}$. across, on $\mathrm{W}$ coast of Kuiu I., $1 \mathrm{mi}$. $\mathrm{N}$ of Port Malmsbury, Alex. Arch.; $56^{\circ} 19^{\prime} 30^{\prime \prime} \mathrm{N}, 134^{\circ} 17^{\prime} 00^{\prime \prime} \mathrm{W}$; $B G N$ 1929; (map 5).

Named in 1928 by USC\&GS; name derived from Point Harris.

Harris Creek: stream, flows SW $28 \mathrm{mi}$. to Nushagak River, $75 \mathrm{mi}$. NE of Dillingham, Kilbuck-Kuskokwim Mts.; 59 $58^{\prime}$ N, $157^{\circ} 25^{\prime}$ W; BGN 1932; (map 52).

Local name reported in 1932 by Gerald FitzGerald, USGS; published by Mertie (1938, pl. 1), USGS.

Harris Creek: stream, flows NE $1 \mathrm{mi}$, to Bluestone River, $13 \mathrm{mi}$. SE of Teller, Seward Penin. High.; $65^{\circ} 06^{\prime} \mathrm{N}, 166^{\circ} 14^{\prime} \mathrm{W}$; (map 111).

Prospectors' name reported on a map of Cape Nome goldfields by David Fox, Jr., dated 1901. 
Harris Creek: stream, formed by junc. of Lucky and Shasta Creeks, flows SW $8.5 \mathrm{mi}$. to North Fork Kougarok River, $W$ of Harris Dome, $41 \mathrm{mi}$. W of Imuruk Lake, Seward Penin. High.; $65^{\circ} 37^{\prime} \mathrm{N}, 164^{\circ} 35^{\prime} \mathrm{W}$; (map 110).

Prospectors' name reported in 1900 by Brooks (1901, pl. 11), USGS.

Harris Creek: stream, see Harrison Creek.

Harris Creek: stream, see Harris River.

Harris Dome: mountain, 1,855 ft., on $\mathrm{N}$ side of North Fork Kougarok River, $11 \mathrm{mi}$. S of Midnight Mtn. and $38 \mathrm{mi}$. W of Imuruk Lake, Seward Penin. High.; 65 $37^{\prime} \mathrm{N}, 164^{\circ} 33^{\prime} \mathrm{W}$; (map 110).

Local name reported in 1901 by T. G. Gerdine (in Collier, 1902, pl. 12), USGS.

Harris Harbor: bay, see Datzkoo Harbor.

Harris Island: island, 1,500 ft. across, off $\mathrm{S}$ coast of Annette I., between Felice Strait and Tamgas Harbor, Alex. Arch.; $55^{\circ} 00^{\prime} 08^{\prime \prime} \mathrm{N}$, $131^{\circ} 32^{\prime} 00^{\prime \prime} W$; (map 3).

Named in 1885 by Lt. Comdr. Richardson Clover, USN.

Harris Island: island, $0.3 \mathrm{mi}$. across, $2.5 \mathrm{mi}$. SE of Sitka, on W coast of Baranof I., Alex. Arch.; 57 $02^{\circ} 00^{\prime \prime} \mathrm{N}, 1^{\circ} 5^{\circ} 16^{\prime} 30^{\prime \prime} \mathrm{W}$; (map 9). Var. Harris Islet.

Named in 1880 by Capt. L. A. Beardslee, USN; published by USC\&GS in 1883 Coast Pilot (p. 144).

Harrison Bay: bay, $57 \mathrm{mi}$. across, on coast of Beaufort Sea, between Cape Halkett and Oliktok Point, Arctic Plain; $70^{\circ} 40^{\prime} \mathrm{N}, 151^{\circ} 30^{\prime} \mathrm{W}$; $B G N$ 1944; (map (149). Var. Harrison's Bay.

On July 26, 1837, Dease and Simpson (Simpson, Thomas, 1843, p. 133), "conferred the name of Harrison Bay, in honour of the Deputy Governor [Hudson's Bay Company; Benjamin Harrison, Deputy Governor, 183539] * * * whose attention had been so long sedulously directed to the moral and religious improvement of the natives of the Indian country * * *."

Harrison Creek: stream, flows SE 3.8 mi. to Portland Canal, $1.1 \mathrm{mi}$. N of Reef I., Coast Mts.; $55^{\circ} 06^{\prime} 25^{\prime \prime} \mathrm{N}, 130^{\circ} 11^{\prime} 30^{\prime \prime} \mathrm{W}$; (map 3).

Local name recorded in 1955 by USGS. See Harrison Point.

Harrison Creek: stream, flows NW $0.7 \mathrm{mi}$. to California Creek which flows to Bonanza River, $9 \mathrm{mi}$. NW of Solomon, Seward Penin. High.; $64^{\circ} 39^{\prime} \mathrm{N}, 164^{\circ} 40^{\prime} \mathrm{W}$; (map 95). Var. Harris Creek.

Prospectors' name shown on Arthur Gibson's "Map of Cape Nome Precinct" dated 1904. Reported as "Harris" on map of Cape Nome gold fields by David Fox, Jr., dated 1901

Harrison Creek: stream, flows SE $0.7 \mathrm{mi}$, to Ophir Creek which flows to Niukluk River, $37 \mathrm{mi}$. NE of Solomon, Seward Penin. High.; $64^{\circ} 57^{\prime} \mathrm{N}, 163^{\circ} 40^{\prime} \mathrm{W}$; (map 95). Var. Gala Creek, Harpson Creek, Harpsons Creek.

Prospectors' name published in 1956 by USGS. This appears to be the stream reported as "Gala" on a map of Cape Nome gold fields by David Fox, Jr., dated 1901.
Shown as "Harpson" on the 1908 "Map of Seward Peninsula" by Arthur Gibson.

Harrison Creek: stream, heads at junc. of North and South Forks of Harrison Creek, flows SE $13 \mathrm{mi}$. to Birch Creek, $39 \mathrm{mi}$. SW of Circle, Yukon-Tanana High.; $65^{\circ} 20^{\prime} 30^{\prime \prime} \mathrm{N}, 144^{\circ} 45^{\prime}$ 00" W; (map 104).

Named by prospectors; reported in 1896 by USGS. "At the junction of these two streams [Harrison and Birch Creeks] is Pitkas Bar, where, in 1893, gold in the Birch Creek district was first discovered" (Spurr, 1898, p. 351).

Harrison Creek: stream, see South Fork Harrison Creek.

Harrison Fork: stream, flows N $2 \mathrm{mi}$. to Independence Creek, $4.5 \mathrm{mi}$. NE of Mastodon Dome and $41 \mathrm{mi}$. SW of Eagle, Yukon-Tanana High.; $65^{\circ} 28^{\prime} 25^{\prime \prime} \mathrm{N}, 145^{\circ} 13^{\prime} 00^{\prime \prime} \mathrm{W}$; (map 104).

Named by prospectors and reported in 1936 by Mertie (1938a, p. 220), USGS.

Harrison Lagoon: lagoon, $0.5 \mathrm{mi}$. across, on $\mathrm{W}$ side of Port Wells, $22 \mathrm{mi}$. NE of Whittier, Chugach Mts.; $60^{\circ} 59^{\prime} 15^{\prime \prime} \mathrm{N}, 148^{\circ} 12^{\prime} 00^{\prime \prime} \mathrm{W}$; (map 63).

Local name reported in 1916 by J. W. Bagley, USGS.

Harrison Lake: lake, $600 \mathrm{ft}$. long, $0.5 \mathrm{mi}$. W of Chickaloon and $24 \mathrm{mi}$. NE of Palmer, Talkeetna Mts.; $61^{\circ} 47^{\prime} 40^{\prime \prime} \mathrm{N}, 148^{\circ} 29^{\prime} 45^{\prime \prime} \mathrm{W}$; (map 69).

Local name reported in 1948 by USGS.

Harrison Lakes: lakes, largest of which is 0.7 mi. long extends $W 1.6 \mathrm{mi}$. at head of Harrison Creek, near $\mathrm{W}$ bank of Portland Canal, Coast Mts.; $55^{\circ} 08^{\prime} 30^{\prime \prime} \mathrm{N}, 130^{\circ} 14^{\prime} 30^{\prime \prime} \mathrm{W}$; (map 3)

Local name recorded in 1955 by USGS See Harrison Point.

Harrison Point: point of land, on $\mathrm{W}$ bank of Portland Canal NE of Harrison Creek, $3 \mathrm{mi}$ $\mathrm{N}$ of Blaine Point, Coast Mts.; 55 $07^{\prime} 15^{\prime \prime} \mathrm{N}$, $130^{\circ} 10^{\prime} 10^{\prime \prime}$ W; (map 3). Var. Leading Point.

Name published in 1897 by USC\&GS; this feature is called "Leading Point" on Brit. Adm. Chart 2431, 1865-88.

Harrison River: stream, see Alsek River.

Harrison's Bay : bay, see Harrison Bay.

Harris Peak: mountain, near center of Prince of Wales I., on $\mathrm{N}$ bank of Harris River, $14 \mathrm{mi}$. E of Craig, Alex. Arch.; $55^{\circ} 28^{\prime} 40^{\prime \prime}$ N, $132^{\circ}$. 46'30" W; (map 4).

Local name recorded in 1949 by USGS.

Harris Peninsula: peninsula, extends SE $16 \mathrm{mi}$. between Harris and Aialik Bays, $30 \mathrm{mi}$. SW of Seward, Chugach Mts. ; $59^{\circ} 40^{\prime} \mathrm{N}, 149^{\circ} 45^{\prime}$ W; $B G N 1930$; (map 49).

Named in 1928 by USC\&GS "after the adjoining bay."

Harris Point: point of land, $\mathrm{S}$ tip of Smeaton $\mathrm{I}$. in Behm Canal, Coast Mts. ; $55^{\circ} 19^{\prime} \mathrm{N}, 130^{\circ} 58^{\prime}$ W; (map 3 )

Local navigators' name obtained in 1904 by H. C. Fassett, USBF

Harris Point: point of land, on SE coast of Kenai Penin., $4 \mathrm{mi}$. W of Granite I., $38 \mathrm{mi}$.
SW of Seward, Chugach Mts.; $59^{\circ} 39^{\prime} 30^{\prime \prime} \mathrm{N}$, $149^{\circ} 56^{\prime} 45^{\prime \prime} \mathrm{W}$; (map 49).

Local name reported in the early 1950's by USC\&GS

Harris River: stream, flows S and E $14 \mathrm{mi}$. to Harris River Bay, near center of Prince of Wales I., $17 \mathrm{mi}$. E of Craig, Alex. Arch.; $55^{\circ} 27^{\prime} 40^{\prime \prime} \mathrm{N}, 132^{\circ} 41^{\prime} 30^{\prime \prime} \mathrm{W}$; (map 4). Var. Harris Creek.

Local name reported in 1906 as "Harris Creek" by Wright and Wright (1908, fig. 15), USGS. The generic "river" was applied to this stream by USC\&GS in 1920.

Harris River Bay: estuary, extends W $1.5 \mathrm{mi}$., off Twelvemile Arm Kasaan Bay, S of Cat I., near center of Prince of Wales I., Alex. Arch.; $55^{\circ} 27^{\prime} 20^{\prime \prime} \mathrm{N}, 132^{\circ} 39^{\prime} 30^{\prime \prime} \mathrm{W}$; (map 4).

Local name published in 1925 Coast Pilot (p. 113).

Harry Bay: estuary, extends NW $3 \mathrm{mi}$. from Nakat Bay SW of Peninsula Ridge, Coast Mts.; $54^{\circ} 48^{\prime} 00^{\prime \prime} \mathrm{N}, 130^{\circ} 46^{\prime} 30^{\prime \prime} \mathrm{W}$; (map 2).

Local navigator's name reported in 1904 by $H$. C. Fassett, USBF.

Harry Creek: stream, flows W $4 \mathrm{mi}$. to Dahl Creek, $9 \mathrm{mi}$. NE of Shungnak, Brooks Ra.; $66^{\circ} 59^{\prime} \mathrm{N}, 156^{\circ} 51^{\prime} \mathrm{W}$; (map 115)

Local name reported in 1943 by $R$. $R$. Coats, USGS.

Harry Island: island, off $\mathrm{N}$ coast of Chichagof I. in Icy Strait, $0.4 \mathrm{mi}$. NW of Burger Point and $9 \mathrm{mi}$. NW of Hoonah; Alex. Arch.; $58^{\circ}$ $13^{\prime} 00^{\prime \prime} \mathrm{N}, 135^{\circ} 35^{\prime} 50^{\prime \prime} \mathrm{W}$; (map 11).

Named in 1901 by E. F. Dickins, USC\&GS and published in 1904 on Chart 8304.

Harry Saddle: mountain, 2,060 ft., on mainland near mouth of Revillagigedo Channel, $2 \mathrm{mi}$. $\mathrm{N}$ of Cape Fox, Coast Mts.; $54^{\circ} 48^{\prime} \mathrm{N}, 130^{\circ}$ $50^{\prime} \mathrm{W}$; (map 2).

Named by Comdr. R. W. Meade, USN, in 1869.

Harrys Gulch: ravine, extends $7 \mathrm{mi}$. SE to North Fork Bremner River, $6 \mathrm{mi}$. SW of Hanagita Peak and $42 \mathrm{mi}$. SW of McCarthy, Chugach Mts. ; $61^{\circ} 01^{\prime} 15^{\prime \prime} \mathrm{N}, 143^{\circ} 50^{\prime} 40^{\prime \prime} \mathrm{W}$; (map 67).

Local name reported in 1911 by $D$. C. Witherspoon, USGS.

Harrys Lake: lake, $0.4 \mathrm{mi}$. long, on SW coast of Woewodski I., $19 \mathrm{mi}$. SW of Peterburg, Alex. Arch.; 56 $32^{\prime} 30^{\prime \prime} \mathrm{N}, 133^{\circ} 02^{\prime} 00^{\prime \prime} \mathrm{W}$; (map 6).

Local name recorded in 1951 by USGS.

Hart Greek: stream, flows NW $0.7 \mathrm{mi}$, to Glacier Creek, $7 \mathrm{mi}$. N of Nome, Seward Penin. High.; $64^{\circ} 36^{\prime} \mathrm{N}, 165^{\circ} 21^{\prime} \mathrm{W}$; (map 94).

Prospectors' name shown on a 1900 'Map of Nome Peninsula" by J. M. Davidson and B. D. Blakeslee.

Harter Gulch: ravine, extends S $1.9 \mathrm{mi}$. to Cache Creek, $1.2 \mathrm{mi}$. SE of Tofty and $36 \mathrm{mi}$. ESE of Tanana, Yukon-Tanana High.; $65^{\circ} 05^{\prime} 08^{\prime \prime}$ N, $150^{\circ} 50^{\prime} 50^{\prime \prime} \mathrm{W}$; (map 106).

Prospectors' name reported in 1931 by J. B. Mertie, USGS.

Hart Lake: lake, 1,250 ft. across, in Matanuska Valley, $7 \mathrm{mi}$. NW of Palmer, Cook Inlet Low.; $61^{\circ} 38^{\prime} 35^{\prime \prime} \mathrm{N}, 149^{\circ} 18^{\prime} 25^{\prime \prime} \mathrm{W}$; (map 69).

Local name reported in 1942 by AMS. 
Hartman Island: island, $1.3 \mathrm{mi}$. long, one of a chain, in entrance to Wide Bay, SW of Terrace I., on S coast of Alaska Penin., $22 \mathrm{mi}$. SW of Kanatak, Aleutian Ra.; 57 $22^{\prime} \mathrm{N}$, $156^{\circ} 17^{\prime} \mathrm{W}$ : (map 36).

Local name published in 1924 by USC\&GS; based on a 1923 survey.

Hartman Lake: lake, $0.4 \mathrm{mi}$. across, W of Harding Lake and $38 \mathrm{mi}$. NW of Big Delta, YukonTanana High.; $64^{\circ} 25^{\prime} 50^{\prime \prime} \mathrm{N}, 146^{\circ} 54^{\prime} 00^{\prime \prime} \mathrm{W}$; (map 101).

Local name published in 1951 by USGS.

Hartman River: stream, heads at glacier, flows NE $27 \mathrm{mi}$. to South Fork Kuskokowim River $5.3 \mathrm{mi}$. NW of its junc. with Styx River, 95 mi. NW of Tyonek, Alaska Ra.; $61^{\circ} 57^{\prime} 40^{\prime \prime} \mathrm{N}$, $153^{\circ} 19^{\prime} 00^{\prime \prime} \mathrm{W}$; (map 71).

Named in 1898 by J. E. Spurr, USGS, for George Hartman, a member of his party.

Hartnet Island: island, on Yukon River, $0.8 \mathrm{mi}$. $\mathrm{NW}$ of Fish I. and $45 \mathrm{mi}$. E of Nulato, Koyukuk Low.; 64 ${ }^{\circ} 38^{\prime} \mathrm{N}, 156^{\circ} 36^{\prime} \mathrm{W}$; (map 97).

Riverboat pilots' name shown on a 1940 "Navigation Chart of the Tanana-Yukon Rivers" published by the U.S. Dept. of Interior.

Hartney Bay: bight, $3 \mathrm{mi}$. wide, on SE shore of Orca Inlet, $5 \mathrm{mi}$. SW of Cordova, Chugach Mts.; $60^{\circ} 29^{\prime} \mathrm{N}, 145^{\circ} 53^{\prime} \mathrm{W} ; B G N$ 1933; (map 64).

Local name reported in 1933 by H. E. Smith, USFS.

Hartney Bay Creek: stream, see Hartney Creek.

Hartney Creek: stream, flows W $3 \mathrm{mi}$. to Hartney Bay, on $\mathrm{S}$ shore of Orca Inlet, $4 \mathrm{mi}$. SW of Cordova, Chugach Mts.; $60^{\circ} 30^{\prime} \mathrm{N}$, $145^{\circ} 50^{\prime} \mathrm{W} ; B G N$ 1961; (map 64). Var. Hartney Bay Creek, Heney Creek.

Local name reported in 1960 by USFS; derived from Hartney Bay.

Harvard Arm College Fiord: estuary, extends NE $5.5 \mathrm{mi}$. between College Fiord and Harvard Glacier, $51 \mathrm{mi}$. NW of Valdez, Chugach Mts.; $61^{\circ} 13^{\prime} \mathrm{N}, 147^{\circ} 47^{\prime} \mathrm{W}$; (map 69). Var. College Fiord.

Named in 1910 by Lawrence Martin (in Tarr and Martin, 1914, map 7).

Harvard Glacier: glacier, heads at NE end of Dora Keen Range, trends SW $24 \mathrm{mi}$. to Harvard Arm College Fiord, $48 \mathrm{mi}$. NW of Valdez, Chugach Mts.; 61 $41^{\prime} 40^{\prime \prime} \mathrm{N}$, $147^{\circ} 42^{\prime} 00^{\prime \prime}$ W; (map 69). Var. Twin Glaciers.

So named by members of the Harriman Alaska Expedition in 1899 for Harvard Univ., Cambridge, Mass. Harvard and Yale Glaciers were called "twin glaciers" by Capt. E. F. Glenn in 1898

Harvester Island: island, $1.4 \mathrm{mi}$. long, in Uyak Bay, on NW coast of Kodiak I.; $57^{\circ} 39^{\prime} \mathrm{N}$, $154^{\circ} 00^{\prime} \mathrm{W}$; (map 34 ).

Named in 1899 for the USBF bark Harvester by Lt. Comdr. J. F. Moser, USN, of the USBF steamer Albatross.

Harvey Creek: stream, flows SE $11 \mathrm{mi}$. to Buckland River, $49 \mathrm{mi}$. NE of Haycock, Nultato Hills ; $65^{\circ} 52^{\prime} \mathrm{N}, 160^{\circ} 34^{\prime} \mathrm{W}$; (map 109).

Local name published on maps after 1950.
Harvey Lake: lake, $1 \mathrm{mi}$. long, on Woewodski I., $17 \mathrm{mi}$. S of Petersburg, Alex. Arch; 56 $33^{\circ}$ $15^{\prime \prime} \mathrm{N}, 133^{\circ} 03^{\prime} 00^{\prime \prime} \mathrm{W}$; BGN 1933; Var. Woewodski Lake.

Local name reported in 1933 by $R$. H. Sargent, named for a "Mr. Harvey" (cnna) who "has lived near it for the last 20 years and owns mining claims in the locality."

Harvey Lake: lake, $0.8 \mathrm{mi}$. long, on Kenai Penin., drains NE to Killey River, $39 \mathrm{mi}$. SE of Kenai, Cook Inlet Low.; $60^{\circ} 18^{\prime} 30^{\prime \prime} \mathrm{N}, 150^{\circ} 32^{\prime} 00^{\prime \prime}$ W; (map 62).

Local name reported in 1951 by USGS.

Harvey Mountain: mountain, 5,200 ft., $3 \mathrm{mi}$. S of Apoon Mtn. and $32 \mathrm{mi}$. N of Wiseman, Brooks Ra.; $67^{\circ} 51^{\prime} 45^{\prime \prime} \mathrm{N}, 150^{\circ} 16^{\prime} 00^{\prime \prime} \mathrm{W}$; $B G N 1932$; (map 124).

Named about 1930 by Marshall (1956, pp. 141-166) for Kenneth Harvey, a local prospector and hunter who joined Marshall in his attempt to scale Mount Doonerak.

Hasen Creek: stream, flows $5 \mathrm{mi}$. SE to Chitistone River $3.5 \mathrm{mi}$. W of Chitistone Glacier terminus and $24 \mathrm{mi}$. NE of McCarthy, Wrangell Mts. ; $61^{\circ} 31^{\prime} 10^{\prime \prime} \mathrm{N}, 142^{\circ} 14^{\prime} 30^{\prime \prime} \mathrm{W}$; (map 67).

Local name published by USGS in 1954.

Hasgox Point: point of land, S tip of Ulak I., Delarof Is., Aleutian Is. ; $51^{\circ} 19^{\prime} 00^{\prime \prime} \mathrm{N}, 178^{\circ}$ $59^{\prime} 20^{\prime \prime} \mathrm{W}$; (map 16).

Name published on a 1950 AMS map.

Hash Creek: stream, flows SW $2.4 \mathrm{mi}$. to Niukluk River, $10 \mathrm{mi}$. SW of Mount Bendeleben and $18 \mathrm{mi}$. NW of Council, Seward Penin. High.; $65^{\circ} 02^{\prime} \mathrm{N}, 164^{\circ} 12^{\prime} \mathrm{W}$; (map 110).

Prospectors' name reported on a map of Cape Nome gold fields by David Fox, Jr., dated 1901.

Haska Creek: stream, flows NE $2 \mathrm{mi}$. to McClellan Flats, at mouth of Chilkat River, 2.7 mi. NW of Green Point, on Chilkat Inlet, 19 mi. SW of Skagway, St. Elias Mts.; $B G N$ $1922 ; 59^{\circ} 13^{\prime} \mathrm{N}, 135^{\circ} 32^{\prime} \mathrm{W}$; (map 45). Var. Hask Falls, Xask Creek, Khask Creek.

Tlingit Indian name Haska or Khask, meaning "little falls," because of its torrential character reported in 1912 by Louis Shotridge, USC\&GS. It was called Hask Falls by the IBC (1923, map 9).

Hask Falls: stream, see Haska Creek.

Hasselborg Creek: stream, heads in Hasselborg Lake, flows SW $6 \mathrm{mi}$. to Salt Lake, $11 \mathrm{mi}$. NE of Angoon, central Admiralty I., Alex. Arch.; $57^{\circ} 35^{\prime} 30^{\prime \prime} \mathrm{N}, 134^{\circ} 19^{\prime} 45^{\prime \prime} \mathrm{W}$; BGN 1928; (map 9).

Named by members of the Alexander Alaska Expedition of 1907 (1909, fig. 1, p. 217-220) "for Allen E. Hasselborg, a Juneau prospector, who lived at Mole Harbor as a hermit for over 24 years."

Hasselborg Homestead: locality, at head of Mole Harbor, $5 \mathrm{mi}$. E of Hasselborg Lake, on Admiralty I., $21 \mathrm{mi}$. NE of Angoon, Alex. Arch.; $57^{\circ} 38^{\prime} 45^{\prime \prime} \mathrm{N}, 134^{\circ} 06^{\prime} 10^{\prime \prime} \mathrm{W}$; (map 9).

Named by members of the Alexander Alaska Expedition of 1907 (1909, fig. 1) "for the homestead of Allen E. Hasselborg, a Juneau prospector.
Hasselborg Lake: lake, $8.5 \mathrm{mi}$. long, $17 \mathrm{mi}$. NE of Angoon, on central Admiralty I., Alex. Arch.; $57^{\circ} 41^{\prime} \mathrm{N}, 134^{\circ} 16^{\prime} \mathrm{W}$; BGN 1928; (map 9).

Named by members of the Alexander Alaska Expedition fo 1907 "for Allen E. Hasselborg, a prospector of Juneau, who acted as a guide for the expedition and who lived as a hermit in a homestead on Mole Harbor for over 24 years."

Hassiah Inlet: estuary, extends NE $2.7 \mathrm{mi}$, off Cordova Bay, on $W$ coast of Prince of Wales I., Alex. Arch.; 55 $00^{\circ} 30^{\prime \prime} \mathrm{N}, 132^{\circ} 35^{\prime} 30^{\prime \prime} \mathrm{W}$; (map 4).

Indian name used by navigators and reported in 1905 by E. F. Dickins, USC\&GS.

Hassler Harbor: bay, $1 \mathrm{mi}$. across, on NE coast of Annette I., Alex. Arch.; $55^{\circ} 13^{\prime} 00^{\prime \prime} \mathrm{N}$, $131^{\circ} 25^{\prime} 45^{\prime \prime} \mathrm{W}$; (map 3).

Named in 1883 by Lt. Comdr. H. E. Nichols, USN, for the Coast Survey steamer Hassler, which he commanded from 1881 to 1883.

Hassler Island: island, between Behm Canal and Carroll Inlet, $\mathrm{S}$ of Revillagigedo I., Alex. Arch.; $55^{\circ} 30^{\prime} \mathrm{N}, 131^{\circ} 10^{\prime} \mathrm{W}$; (map 3).

In 1882 it was thought that Carroll Inlet divided Revillagigedo Island, the southern half being named "Hassler." However, the name is inapplicable as this assumption was not true.

Hassler Island: island, $4.2 \mathrm{mi}$. across, off NW coast of Revillagigedo I., between Gedney and Hassler Passes, Alex. Arch.; 55 53' N, 131 ${ }^{\circ} 38^{\prime}$ W; (map 3).

Named in 1891 by USC\&GS for its steamer Hassler.

Hassler Lake: lake, 2 mi. long, on Annette I., S of Hassler Harbor, $5.5 \mathrm{mi}$. NE of Metlakatla, Alex. Arch.; $55^{\circ} 11^{\prime} 15^{\prime \prime} \mathrm{N}, 131^{\circ} 27^{\prime} 00^{\prime \prime} \mathrm{W}$; (map 3).

Local name recorded in 1955 by USGS.

Hassler Pass: water passage, extends $4.5 \mathrm{mi}$. between Hassler and Revillagigedo Is., Alex. Arch.; $55^{\circ} 53^{\prime} \mathrm{N}, 131^{\circ} 35^{\prime} \mathrm{W}$; (map 3).

Arbitrary name given in 1891 by USC\&GS.

Hassler Point: point of land, point of entrance to North Bay, on NE coast of Dall I., Alex. Arch.; $55^{\circ} 13^{\prime} 20^{\prime \prime} \mathrm{N}, 133^{\circ} 06^{\prime} 00^{\prime \prime} \mathrm{W}$; (map 4).

Named in 1882 by W. H. Dall, USC\&GS, for the Coast Survey steamer Hassler, which was on a surveying cruise in this vicinity in 1881. The Hassler was in turn named for Ferdinand Rudolph Hassler, 1770-1843, first Director of the U.S. Coast and Geodetic Survey, 1807-18, 1832-43.

Hassler Reef: reef, extends $3 \mathrm{mi}$. between Clarence Strait and Dixon Entrance, $5 \mathrm{mi}$. SW of Duke I., Alex Arch.; 54 $51^{\prime}$ N, $131^{\circ}$ $34^{\prime}$ W; (map 2). Var. Brundige Rock.

Named in 1883 by Lt. Comdr. H. E. Nichols, USN, (probably for the USC\&GS ship Hassler), who said the reef is "Probably identical with Brundige Rock" (USC\&GS, 1891, p. 74). "Capt. Brundige discovered this reef." 
Hastings Creek: locality, on $\mathrm{N}$ coast of Norton Sound, at mouth of Hastings Creek, $10 \mathrm{mi}$. SE of Nome, Seward Penin. High.; 64 $32^{\prime} \mathrm{N}$, $165^{\circ} 06^{\prime} \mathrm{W}$; (map 94).

Site of a mining camp reported in the 191516 Polk's Gazetteer.

Hastings Creek: stream, flows NW then SW 6 mi. to Norton Sound, $10 \mathrm{mi}$. SE of Nome, Seward Penin. High.; $64^{\circ} 27^{\prime} \mathrm{N}, 165^{\circ} 06^{\prime} \mathrm{W}$; (map 94).

Prospectors' name published by Schrader and Brooks (1900, map 3), USGS.

Hastings Creek: stream, flows N $5 \mathrm{mi}$. to Chatanika River, $15 \mathrm{mi}$. NW of Fairbanks, Yukon-Tanana High.; $65^{\circ} 03^{\prime} \mathrm{N}, 147^{\circ} 57^{\prime} \mathrm{W}$; (map 105).

Named by prospectors; published in 1908 by USGS.

Hasvampa Creek: stream, flows $\mathrm{NE}$ to Placer Creek which flows to Goodhope River, about $25 \mathrm{mi}$. NW of Imuruk Lake, Seward Penin. High.; (map 110).

Prospectors' name shown on a map of Cape Nome gold fields by David Fox, Jr., dated 1901. This stream cannot be precisely located on current maps.

Hatan, Cape: point of land, see Kovrizhka, Cape. Hatay Mountain: mountain, see Spurr, Mount. Hatbox Mesa: mountain, 2,470 ft., extends E 20 mi. between Ayiyak and Chandler Rivers, $47.5 \mathrm{mi}$. NW of Anaktuvuk Pass, Arctic Slope; $68^{\circ} 45^{\prime} \mathrm{N}, 152^{\circ} 30^{\prime} \mathrm{W}$; (map 134).

So named by a USGS geology party in 1945 "because of the mesa's peculiar manner of weathering into boxlike blocks that from a distance resemble hatboxes."

Hatch Creek: stream, flows $\mathrm{S} 1 \mathrm{mi}$. to Pacific Ocean, 1 mi. NW of Hatchet Point, Kiska I., Aleutian Is.; $51^{\circ} 55^{\prime} 40^{\prime \prime} \mathrm{N}, 177^{\circ} 31^{\prime} 57^{\prime \prime} \mathrm{E}$; (map 14)

An arbitrary name beginning with " $\mathrm{H}$ " to correspond to "H" grid used by the U.S. Army for tactical purposes during World War II; published on a 1943 Army map.

Hatch Creek: stream, flows NE $1 \mathrm{mi}$. to Nome River, $0.6 \mathrm{mi}$. downstream from Basin Creek and $12 \mathrm{mi}$. NE of Nome, Seward Penin. High.; $64^{\circ} 40^{\prime} \mathrm{N}, 165^{\circ} 18^{\prime} \mathrm{W}$; (map 94).

Prospectors' name reported on a map by S. E. King dated 1900 .

Hatcher Creek: stream, heads $\mathbf{E}$ of Hatcher Pass, flows $\mathrm{E} 1 \mathrm{mi}$. to Fishhook Creek, $13 \mathrm{mi}$. NW of Palmer, Talkeetna Mts. ; $61^{\circ} 46^{\prime} 25^{\prime \prime}$ N, $149^{\circ}$ $16^{\prime} 25^{\prime \prime} \mathrm{W}$; (map 69).

Local name reported in 1913 by USGS (Brooks and others, 1914, fig. 2).

Hatcher Pass: pass, 3,886 ft., at $\mathbf{S}$ end of Skyscraper Mtn., NE of Summit Lake, $13 \mathrm{mi}$. NW of Palmer, Talkeetna Mts.; $61^{\circ} 46^{\prime} 10^{\prime \prime} \mathrm{N}$, $149^{\circ} 18^{\prime} 30^{\prime \prime} \mathrm{W}$; (map 69).

Local name reported in 1951 by USGS.

Hatchery Creek: stream, flows N $18 \mathrm{mi}$. through Lake Galea and two unnamed lakes to Sweetwater Lake, $\mathrm{N}$ central Prince of Wales I., Alex. Arch.; $55^{\circ} 56^{\prime} 28^{\prime} \mathrm{N}, 132^{\circ} 58^{\prime} 15^{\prime \prime} \mathrm{W}$; $B G N$ 1963; (map 4).

Local name recorded in 1949 by USGS.
Hatchery Creek: stream, flows SW $2 \mathrm{mi}$ to Afognak Lake, $7.5 \mathrm{mi}$. NW of Afognak, in SW part of Afognak I., $N$ of Kodiak I.; $58^{\circ}$ $06^{\prime} 05^{\prime \prime} \mathrm{N}, 152^{\circ} 52^{\prime} 45^{\prime \prime} \mathrm{W}$; (map 43).

Name derived from Hatchery Peak; published in 1952 on a USGS map.

Hatchery Lake: lake, $0.7 \mathrm{mi}$. long, $\mathrm{N}$ of $\mathrm{Mc}$ Henry Inlet, on Etolin I., Alex. Arch.; 56 ${ }^{\circ}-$ $02^{\prime} 30^{\prime \prime} \mathrm{N}, 132^{\circ} 24^{\prime} 00^{\prime \prime} \mathrm{W}$; (map 6).

Local name recorded in 1953 by USGS.

Hatchery Peak: mountain, 2,089 ft., $8 \mathrm{mi}$. N of Afognak, in $\mathbf{S}$ central Afognak $\mathbf{I}$., $\mathbf{N}$ of Kodiak I.; $58^{\circ} 07^{\prime} 10^{\prime \prime} \mathrm{N}, 152^{\circ} 47^{\prime} 30^{\prime \prime} \mathrm{W}$; (map 43).

Name reported in 1922 on a USFS map.

Hatchet Lake: lake, $2.7 \mathrm{mi}$. long, on W Adak I., Aleutian Is.; $51^{\circ} 44^{\prime} \mathrm{N}, 176^{\circ} 46^{\prime} \mathrm{W}$; (map 17).

Local descriptive name published in 1951 on a USGS map.

Hatchet Lake: lake, $0.7 \mathrm{mi}$. long, $31 \mathrm{mi}$. E of Deadman Lake and $80 \mathrm{mi}$. SE of Healy, Alaska Ra.; $63^{\circ} 01^{\prime} \mathrm{N}, 147^{\circ} 15^{\prime} \mathrm{W}$; BGN 1959; (map 87).

Named in 1954 by USGS because "a member of a survey party was hospitalized as.a result of cutting his knee with a hatchet while setting up a camp beside the lake."

Hatchet Pass: water passage, $0.8 \mathrm{mi}$. long, S of Dolgoi I., $3.3 \mathrm{mi}$. NE of Yakutat, Malaspina Coastal Plain; $59^{\circ} 35^{\prime} 15^{\prime \prime} \mathrm{N}, 139^{\circ} 40^{\prime} 15^{\prime \prime}$ W; (map 46). Var. Canoe Pass.

Named in 1892 by Lt. G. B. Harber, USN, probably for nearby Hatchet Point.

Hatchet Point: point of land, 2 mi. S. of Kiska Harbor on E coast of Kiska I., Aleutian Is. $51^{\circ} 55^{\prime} \mathrm{N}, 177^{\circ} 33^{\prime} \mathrm{E}$; (map 14). Var. Zaliva Point.

An arbitrary name beginning with " $\mathrm{H}$ " to correspond to "H" grid used by U.S. Army for tactical purposes during World War II ; published on a 1953 AMS map. Variant published on a 1943 USAAF map.

Hatchet Point: point of land, on $\mathbf{E}$ shore of Johnstone Passage, $1.7 \mathrm{mi}$. N of Puget Cove and $2.9 \mathrm{mi}$. NE of Yakutat, Malaspina Coastal Plain ; 59 $35^{\prime} 00^{\prime \prime} \mathrm{N}, 1^{\circ} 9^{\circ} 42^{\prime} 05^{\prime \prime} \mathrm{W}$; (map 46). Var. Mys Topor, Tapor Point.

Called "M[ys] Toper," meaning "hatchet cape," by Capt. Tebenkov (1852, map 7), IRN.

Hatdolitna: stream, see Hughes Creek.

Hatdolitna Canyon: canyon, $3 \mathrm{mi}$. long, on Hughes Creek, $5 \mathrm{mi}$. NW of Hughes, Hogatza High.; $66^{\circ} 08^{\prime} \mathrm{N}, 154^{\circ} 22^{\prime} \mathrm{W}$; (map 116).

"Hatdolitna" is the Indian name for Hughes Creek; reported in 1956 by Orth.

Hatdolitna Hills: mountains, $1,989 \mathrm{ft}$., extend NE $19 \mathrm{mi}$. from Hatdolitna Canyon, between Hughes Creek and Koyukuk River, $10 \mathrm{mi}$. N of Hughes, Hogatza High.; $66^{\circ} 15^{\prime}$ N, $154^{\circ} 09^{\prime}$ W; (map 116).

Name derived from the Indian name for Hughes Creek; recorded in 1956 by Orth.

Hather Creek: stream, heads in Kaiyuh Mts. flows NE $60 \mathrm{mi}$, to Magitchlie Creek $4.1 \mathrm{mi}$. NW of its junc, with Innoko River, $60 \mathrm{mi}$. NE of Holikachuck and $63 \mathrm{mi}$. NW of Ophir, Innoko Low.; $63^{\circ} 35^{\prime} \mathrm{N}, 158^{\circ} 18^{\prime} \mathrm{W}$; (map 90).
Name published in 1965 by USGS.

Hati Rock: rock, see Hattie Rock.

Hat Island: island, $0.1 \mathrm{mi}$. long, at mouth of Circle Bay, on SE coast of Woronkofski I., Alex. Arch.; $56^{\circ} 22^{\prime} 30^{\prime \prime} \mathrm{N}, 132^{\circ} 25^{\prime} 30^{\prime \prime} \mathrm{W}$; $B G N 1917$; (map 6).

Named in 1916 by USC\&GS.

Hat Island: island, $0.7 \mathrm{mi}$. long, in Iliamna Lake, $2.5 \mathrm{mi}$. SE of Chekok Point and $21 \mathrm{mi}$. E of Iliamna, Aleutian Ra.; $59^{\circ} 46^{\prime} 45^{\prime \prime}$ N, $154^{\circ}$. $19^{\prime} 30^{\prime \prime} \mathrm{W}$; (map 51).

So named locally because it resembles the shape of a prospector's hat. Name published by USGS in 1954.

Hat Island: island, $0.2 \mathrm{mi}$. across, in Resurrection Bay, $1 \mathrm{mi}$. $\mathrm{S}$ of Humpy Cove and $11 \mathrm{mi}$. SE of Seward, Chugach Mts.; $59^{\circ} 57^{\prime} 29^{\prime \prime} \mathrm{N}$, $149^{\circ} 18^{\prime} 30^{\prime \prime} \mathrm{W}$; (map 49).

Local name reported in the 1940 's by USC\&GS.

Hat Island: island, $1 \mathrm{mi}$. long, at $\mathrm{S}$ end of Eagle 1. in Yukon River, Innoko Low.; $63^{\circ}$ $30^{\prime} \mathrm{N}, 159^{\circ} 30^{\prime} \mathrm{W}$; (map 91).

Riverboat pilots' name shown on a 1940 "Navigation Chart of the Tanana-Yukon Rivers" published by the U.S. Dept. of Interior.

Hat Lie Lakes: lakes, $2 \mathrm{mi}$. NE of Upper Mouth Birch Creek and $17 \mathrm{mi}$. SW of Fort Yukon, Yukon Flats; $66^{\circ} 22^{\prime} \mathrm{N}, 145^{\circ} 32^{\prime} \mathrm{W}$; (map 119).

Local name obtained in 1956 by USGS.

Hatseegatloth Lake: lake, $12 \mathrm{mi}$. SW of Roundabout Mtn., Koyukuk Low.; $65^{\circ} 23^{\prime} \mathrm{N}, 156^{\circ}$ $46^{\prime} \mathrm{W}$; (map 108).

Koyukan Indian name reported in 1955 by USGS.

Hattan, Cape: point of land, see Kovrizhka, Cape.

Hattie Creek: stream, flows SE $1.5 \mathrm{mi}$. to O'Connor Creek, $10 \mathrm{mi}$. NW of Fairbanks, YukonTanana High.; $64^{\circ} 58^{\prime} \mathrm{N}, 147^{\circ} 52^{\prime} \mathrm{W}$; (map 100).

Local name published in 1908 by USGS.

Hattie Rock: rock, off W coast of Dall I., in Augustine Bay, $1 \mathrm{mi}$. N of Cape Augustine, Alex. Arch.; 54 $57^{\prime} 50^{\prime \prime}$ N, $133^{\circ} 09^{\prime} 50^{\prime \prime} \mathrm{W}$; $B G N$ 1923; (map 1). Var. Hati Rock, Hattuh Rock, Utta Rock, White Rock.

Named in 1923 by USC\&GS from the Tlingit word meaning "white."

Hattuh Rock : rock, see Hattie Rock.

Hauke Creek: stream, in Mount McKinley National Park, flows N $15 \mathrm{mi}$. to Birch Creek, $22 \mathrm{mi}$. WSW of Wonder Lake and $28 \mathrm{mi}$. NW of Mount McKinley, Tanana Low.; $63^{\circ} 22^{\prime} 45^{\prime \prime}$ N, $151^{\circ} 34^{\prime} 20^{\prime \prime} \mathrm{W}$; (map 88)

Local name reported in 1954 by USGS.

Hauti Island: island, $0.1 \mathrm{mi}$. long, in Naukati Bay, $28 \mathrm{mi}$. N of Craig, Alex. Arch.; 55 $52^{\circ}$ $15^{\prime \prime} \mathrm{N}, 133^{\circ} 09^{\prime} 25^{\prime \prime} \mathrm{W}$; (map 4).

Indian name published in 1964 by USC\&GS.

Haven: locality, see Camp Haven.

Haven Creek: stream, flows W $2.2 \mathrm{mi}$. to Tubutulik River in Death Valley, $36 \mathrm{mi}$. SE of Imuruk Lake, Seward Penin. High.; $65^{\circ} 11^{\prime} \mathrm{N}$, $162^{\circ} 19^{\prime} \mathrm{W}$; (map 110$)$. 
Prospectors' name published on the 1908 "Map of Seward Peninsula" by Arthur Gibson.

Havenstrite Ridge: ridge, elev. $1,210 \mathrm{ft}$., on Iniskin Penin., extends $1.6 \mathrm{mi}$. on $\mathrm{E}$ bank of Fitz Creek, Aleutian Ra.; $59^{\circ} 45^{\prime} \mathrm{N}, 153^{\circ} 13^{\prime}$ W; BGN 1947; (map 51).

Local name reported by USGS in 1947; "originally named by geologists of the Iniskin Drilling Company for the Havenstrite brothers who were connected with the development of this area for some time prior to 1947. In December , 1946, one of the brothers, Homer Havenstrite, was killed in an automobile accident."

Hawk Bluff: bluff, $386 \mathrm{ft}$, , on right bank of Yukon River, SE of Anvik, and $33 \mathrm{mi}$. N of Holy Cross, Nulato Hills; $62^{\circ} 38^{\prime} 30^{\prime \prime} \mathrm{N}, 160^{\circ}$ $11^{\prime} 00^{\prime \prime} \mathrm{W}$; (map 78).

Local name reported in 1916 by G. L. Harrington and R. H. Sargent (in Harrington, 1918, pl. 1), USGS.

Hawk Creek: stream, see Billy Hawk Creek.

Hawkes Arm: bay, see Falcon Arm.

Hawk Inlet: locality, cannery, with summer pop. of 500, on E shore of Hawk Inlet on Admiralty I., 2 mi. $\mathbf{N}$ of mouth of Greens Greek and 17 mi. SW of Juneau, Alex. Arch.; 58 $07^{\circ} 40^{\prime \prime}$ $\mathrm{N}, 134^{\circ} 45^{\prime} 15^{\prime \prime} \mathrm{W}$; (map 11).

Name published by USC\&GS in the 1943 Coast Pilot (p. 341).

Hawk Inlet: inlet, $7 \mathrm{mi}$. long, trending N-S on NW coast of Admiralty I., $20 \mathrm{mi}$. SW of Juneau, Alex. Arch.; $58^{\circ} 05^{\prime} 30^{\prime \prime} \mathrm{N}, 134^{\circ} 46^{\prime} 30^{\prime \prime}$ W; (map 11).

Name published in the 1883 Coast Pilot (p. 182).

Hawkins, Mount: peak, 10,000 ft., in Chugach Mts., $7 \mathrm{mi}$. NE of Mount Tom White and 17 mi. NW of Mount Steller, Chugach Mts.; $60^{\circ} 41^{\prime} \mathrm{N}, 143^{\circ} 29^{\prime} \mathrm{W}$; BGN 1930; (map 65).

Named in 1930 by Lawrence Martin, USGS, for E. C. Hawkins, the chief engineer, who built the Copper River and Northwestern Railroad.

Hawkins Creek: stream, on Hawkins I., flows NW 2 mi. to Orca Bay, $10 \mathrm{mi}$. W of Cordova, Chugach Mts.; $60^{\circ} 31^{\prime} \mathrm{N}, 146^{\circ} 13^{\prime} \mathrm{W}$; (map 64).

Name published in 1950 by USGS.

Hawkins Glacier: glacier, trends SW $22 \mathrm{mi}$. from Mount Bona to its terminus at Chitina River W of Barnard Glacier, $37 \mathrm{mi}$. SE of McCarthy, St. Elias Mts.; $61^{\circ} 06^{\prime} \mathrm{N}, 142^{\circ} 00^{\prime} \mathrm{W}$; (map 67)

Local name shown on undated fieldsheet by F. H. Moffit, USGS, presumably drafted about 1910.

Hawkins Island: island, $22 \mathrm{mi}$. long, $\mathrm{S}$ of Orca Bay, $\mathrm{N}$ of Hinchinbrook I., $2 \mathrm{mi}$. W of Cordova, Chugach Mts.; $60^{\circ} 31^{\prime} \mathrm{N}, 146^{\circ} 05^{\prime} \mathrm{W}$; (map 64). Var. Isla de Colpas.

Examined by James Johnstone of Vancouver's party on June 5,1794 , and named by Capt. George Vancouver, RN (in Wagner, 1937, p. 391). It was called "Isla de Colpas" by Don Ignacio Arteaga on July 20, 1779.

Hawkins Island Cutoff: channel, $14 \mathrm{mi}$. long, between Hawkins I. and Hinchinbrook I., 18 mi. SW of Cordova, Chugach Mts.; $60^{\circ} 27^{\prime} \mathrm{N}$, $146^{\circ} 12^{\prime} \mathrm{W}$; (map 64).

Local name reported in 1908 by Grant and Higgins (1909, pl. 4), USGS.

Hawkins Point: point of land, see Salmo Point. Hawk Point: point of land, in Alitak Bay, on $\mathrm{W}$ coast of Aliulik Penin., at S end of Kodiak I., Kodiak I.; $56^{\circ} 48^{\prime} 25^{\prime \prime} \mathrm{N}, 154^{\circ} 06^{\prime} 00^{\prime \prime} \mathrm{W}$; BGN 1934; (map 32).

Descriptive name given in 1929 by Capt. R. R. Lukens, USC\&GS, "who observed a species of fishhawk nesting on adjacent bluffs."

Hawk Point: point of land, S tip of Mansfield Peninsula at mouth of Hawk Inlet, 17 mi. SW of Juneau, Alex. Arch.; $58^{\circ} 05^{\prime} 45^{\prime \prime} \mathrm{N}$, $134^{\circ} 47^{\prime} 00^{\prime \prime} \mathrm{W}$; BGN 1934; (map 11).

Name published in 1943 by USC\&GS.

Hawk River: stream, flows NW and E $50 \mathrm{mi}$. to Bonasila River, $41 \mathrm{mi}$. NW of Holy Cross, Nulato Hills, $62^{\circ} 30^{\prime} \mathrm{N}, 160^{\circ} 53^{\prime} \mathrm{W}$; (map 78).

So named by R. H. Sargent, USGS, in 1916, because he "found a hawk's nest near its [the stream's] mounth." It is said by some, however, that the last syllable of the nearby Stuyahok (River) was arbitrarily picked and converted in spelling to "Hawk."

Hawk River: stream, heads on Purcell Mtn., flows SE $25 \mathrm{mi}$. to Huslia River, $56 \mathrm{mi}$. S of Shungnak, Koyukuk Low.; 66 $09^{\prime}$ N, $157^{\circ}$ $10^{\prime} \mathrm{W}$; (map 115).

Local name reported in 1952 by USGS.

Hawley Island: island, see Boidarkin Island.

Hawthorne Peak, peak, 4,210 ft., $3.2 \mathrm{mi}$. W of Thane on Gastineau Channel and $7 \mathrm{mi}$. SE of Juneau, Coast Mts.; $58^{\circ} 15^{\prime} 45^{\prime \prime} \mathrm{N}, 134^{\circ} 14^{\prime}$ $30^{\prime \prime} \mathrm{W}$; (map 11).

Named in 1890 by Lt. Comdr. H. B. Mansfield, USN. Published in 1893 by USC\&GS on Chart 8235.

Hawthorne Ridge: ridge, $4 \mathrm{mi}$. long, extending NE from Hawthorne Peak to Carlson Creek, $7 \mathrm{mi}$. E of Juneau, Coast Mts. ; 58 $17^{\prime} \mathrm{N}, 134^{\circ}$ $13^{\prime} \mathrm{N}$; (map 11).

Local name derived from nearby Hawthorne Peak and reported in 1965 by D. A. Brew and A. B. Ford, USGS.

Hawzerah Creek: stream, heads in lake, flows SE $6 \mathrm{mi}$. to Koyukuk River, $15 \mathrm{mi}$. S of Bettles, Kanuti Flats; $66^{\circ} 42^{\prime} \mathrm{N}, 151^{\circ} 42^{\prime} \mathrm{W}$; $B G N$ 1932; (map 117). Var. Howzerah Creek.

Koyukan Indian name reported in 1931 as "Howzerah Creek" by Robert Marshall.

Hawzerah Lake: lake, $1.2 \mathrm{mi}$. long, drains $\mathrm{S}$ to Peavey Creek, $15 \mathrm{mi}$. SW of Bettles, Hogatza High.; $66^{\circ} 42^{\prime} \mathrm{N}, 151^{\circ} 52^{\prime} \mathrm{W}$; (map 117).

Koyukan Indian name obtained in 1956 at Allakaket by T. E. Taylor, USGS.

Hay, Mount: mountain, $8,870 \mathrm{ft}$., in Saint Elias Mts., on Alaska-Canada boundary, $10 \mathrm{mi}$. NW of Mount Lodge and $82 \mathrm{mi}$. SW of Skagway, St. Elias Mts. ; $59^{\circ} 14^{\prime} 40^{\prime \prime} \mathrm{N}, 137^{\circ} 36^{\prime} 2^{\prime \prime} \mathrm{W}$; BGN 1954; (map 45). Var. Boundary Peak 167.

Named in 1923 by United States and Canada for John Milton Hay, 1838-1905, author and diplomat. John Hay was born in Indiana and was private secretary to Abraham Lincoln.
He served in foreign legations and worked as a journalist until 1879 when he became Assistant Secretary of State. In 1897 he became Ambassador to Great Britain. From 1897 to 1905 he served as Secretary of State under Presidents McKinley and Theodore Roosevelt. In 1903 he helped negotiate the treaty providing for the Alaskan Boundary Tribunal.

Haycock: village, pop. 6, on Eldorado Creek, $16 \mathrm{mi}$. S of Granite Mtn., Seward Penin. High.; $65^{\circ} 13^{\prime} \mathrm{N}, 161^{\circ} 10^{\prime} \mathrm{W}$; (map 109).

Mining camp established about 1914; so named because a mound near here looks like a haycock. Its population was 162 in 1920; 74 in 1930; 81 in 1939; and 21 in 1950. The Haycock post office was established in 1916 and operated until 1957 (Ricks, 1965, p. 25).

Haycock Rock: rock, $750 \mathrm{ft}$. across, $1.1 \mathrm{mi}$. S of Northeast Rocks, off NE coast of Kiska I., Aleutian Is.; $52^{\circ} 04^{\prime} 50^{\prime \prime} \mathrm{N}, 177^{\circ} 40^{\prime} 45^{\prime \prime} \mathrm{E}$; BGN 1937; (map 14).

Local descriptive name reported in 1906 by U.S. Navy Hydrog. Office.

Hayden, Lake: lake, $0.2 \mathrm{mi}$. across, on NW end of Latouche I., $20 \mathrm{mi}$. SE of Chenega, Chugach Mts. ; 60002'01" N, $147^{\circ} 54^{\prime} 10^{\prime \prime} \mathrm{W}$; (map 63)

Local name reported in 1909 by Grant and Higgins (1910, pl. 12), USGS.

Hayden Glacier: glacier, heads at $60^{\circ} 04^{\prime} \mathrm{N}$, $140^{\circ} 00^{\prime} \mathrm{W}$, trends $\mathrm{S} 5 \mathrm{mi}$. to Malaspina Glacier, 32 mi. NW of Yakutat, St. Elias Mts.; $59^{\circ} 59^{\prime} 00^{\prime \prime} \mathrm{N}, 140^{\circ} 02^{\prime} 30^{\prime \prime} \mathrm{W}$; (map 46). Var. Haydon Glacier.

Named in 1890 by Russell (1891, p. 108), USGS, for Ferdinand Vandiveer Hayden, 1829-87, American geologist and founder of the U.S. Geological Survey of the Territories. Born in Massachusetts, he, received his M.D. at Albany Medical College where he became interested in geology. After serving as a surgeon in the Civil War, he taught geology at University of Pennsylvania. He headed the Survey of the Territories from 1872 to 1879 . In 1879 he was appointed to the newly created U.S. Geological Survey and was in charge of the Montana Division until 1886.

Haydon Glacier: glacier, see Hayden Glacier.

Haydon Peak: peak, 11,920 ft., on AlaskaCanada boundary, $3.5 \mathrm{mi}$. SW of Mount St. Elias and $66 \mathrm{mi}$. NW of Yakutat, St. Elias Mts.; $60^{\circ} 15^{\prime} 20^{\prime \prime} \mathrm{N}, 140^{\circ} 55^{\prime} 30^{\prime \prime} \mathrm{W}$; $B G N$ 1917; (map 66). Var. Hadonas Peak, Mount Hayden, Mount Hayd, Mount Huxley.

Named "Hadon Peak" in 1888 by W. H. Topham for Henry E. Haydon, Secretary of Alaska at the time of his expedition to St. Elias Mountain, and for his wife. The spelling "Hadon" was corrected in subsequent publications.

Hayes, Mount: peak, 13,832 ft., at head of Hayes Glacier, $43 \mathrm{mi}$. SW of Delta Junction, Alaska Ra.; 633' $15^{\prime \prime} \mathrm{N}, 146^{\circ} 43^{\prime} 00^{\prime \prime} \mathrm{W}$; (map 86).

Named in 1898 by W. J. Peters and A. H. Brooks, USGS, for Charles Willard Hayes, 1858-1916, geologist with USGS from 1887 to 1911. The first ascent of this mountain 
was made August 1, 1941 (Farquhar, 1959, p. 222).

Hayes, Point: point of land, E point of entrance to Florence and Sitkoh Bays, on Chichagof I., $10 \mathrm{mi}$. W of Angoon, Alex. Arch.; 5 $7^{\circ} 29^{\prime} 00^{\prime \prime}$ N, $134^{\circ} 50^{\prime} 30^{\prime \prime}$ W; (map 9). Var. Hayes Point.

Named in 1880 by U.S. Navy, presumably for Rutherford Birchard Hayes, 1822-93, 19th President of the United States.

Hayes Creek: stream, heads at terminus of $\mathrm{N}$ arm of Hayes Glacier, flows NW $\mathbf{5}$ mi. to East Fork Little Delta River, $12 \mathrm{mi}$. NW of Mount Hayes, Alaska Ra.; $63^{\circ} 47^{\prime} 15^{\prime \prime} \mathrm{N}, 146^{\circ} 48^{\prime} 00^{\prime \prime}$ W; (map 86).

Name reported in 1942 by USGS.

Hayes Creek: stream, heads at Hayes Glacier terminus, flows NE $7 \mathrm{mi}$. to Delta Creek, $15 \mathrm{mi}$. NE of Mount Hayes, Alaska Ra.; $63^{\circ} 48^{\prime} 10^{\prime \prime}$ N, $146^{\circ} 28^{\prime} 00^{\prime \prime} \mathrm{W}$; (map 86).

Name published on relatively recent maps.

Hayes Creek: stream, flows SW $5 \mathrm{mi}$. to Chatanika River, $17 \mathrm{mi}$. NW of Fairbanks, YukonTanana High.; $65^{\circ} 02^{\prime} 45^{\prime \prime} \mathrm{N}, 148^{\circ} 04^{\prime} 00^{\prime \prime} \mathrm{W}$; (map 105).

Named by prospectors; published in 1907 by USGS.

Hayes Creek: stream, see Paris Creek.

Hayes Glacier: glacier, in Tordrillo Mts., heads on Mount Gerdine, trends N and NE $27 \mathrm{mi}$. to its terminus at head of Hayes River, Alaska Ra.; $61^{\circ} 50^{\prime} \mathrm{N}, 152^{\circ} 09^{\prime} \mathrm{W}$; BGN 1963; (map 70). Var. Hayes Glaciers.

Named in 1898 by Spurr $(1900$, p. 172), USGS, for Charles Willard Hayes, 1859-1916, USGS geologist.

Hayes Glacier: glacier, heads on Mount Hayes, trends NE $12 \mathrm{mi}$. to head of Hayes Creek, 34 mi. SW of Delta Junction, Alaska Ra.; $63^{\circ}$ $43^{\prime} 30^{\prime \prime} \mathrm{N}, 146^{\circ} 33^{\prime} 00^{\prime \prime} \mathrm{W}$; BGN 1949; (map 86)

Name published in the American Alpine Journal (Ferris, 1942, map facing p. 337).

Hayes Glacier: glacier, see North Branch Trimble Glacier.

Hayes Glacier: glacier, see South Branch Trimble Glacier.

Hayes Glacier: glacier, see Trimble Glacier.

Hayes Glaciers: glacier, see Hayes Glacier.

Hayes River: stream, heads at terminus of Hayes Glacier in Tordrillo Mts., flows NE $23 \mathrm{mi}$. to Skwentna River, 65 mi. NW of Tyonek, Alaska Ra.; $61^{\circ} 57^{\prime} \mathrm{N}, 151^{\circ} 47^{\prime} \mathrm{W}$; BGN 1963; (map 70).

Named in 1898 by Spurr (1900, p. 172), USGS, for Charles Willard Hayes, 1859-1916 USGS geologist.

Hayes River Pass: pass, 2,000 ft., in Tordrillo Mts., E of Trimble Glacier, $52 \mathrm{mi}$. NW of Tyonek, Alaska Ra. ; $61^{\circ} 43^{\prime} 45^{\prime \prime} \mathrm{N}, 151^{\circ} 55^{\prime} 00^{\prime \prime}$ W; (map 70)

Local name reported by USGS in 1958 ; so named because the pass forms a route from Coal Creek to the Hayes River drainage.

Hayford, Mount: mountain, 6,300 ft., W of Verdure Point, $15 \mathrm{mi}$. SW of Hyder, Coast Mts. ; 55 ${ }^{\circ} 45^{\prime} \mathrm{N}, 130^{\circ} 17^{\prime} \mathrm{W}$; BGN 1925; (map 3). Var. Hayford Mountain, Hayfork Peak.
Named in 1925 by USC\&GS after John Filmore Hayford, 1868-1925, Director of the College of Engineering, Northwestern Univ., from 1909 to 1925; he achieved international recognition for his work in isostasy.

Hayford Mountain: mountain, see Hayford, Mount.

Hayfork Peak: mountain, see Hayford, Mount. Hay Island: island, $0.2 \mathrm{mi}$. long, part of Sandman Reefs, 14 mi. SE of Deer I., Aleutian Ra.; $54^{\circ} 39^{\prime} 15^{\prime \prime} \mathrm{N}, 162^{\circ} 07^{\prime} 00^{\prime \prime} \mathrm{W}$; (map 25).

Named in 1888 by USBF.

Hay Lake: lake, $0.4 \mathrm{mi}$. across, $1.6 \mathrm{mi}$. W of Jim Lake and $4.8 \mathrm{mi}$. NW of village of Lake Minchumina, Tanana Low.; $63^{\circ} 55^{\prime} 10^{\prime \prime} \mathrm{N}$, $152^{\circ} 27^{\prime} 30^{\prime \prime} \mathrm{W}$; (map 88).

Local name reported in 1954 by USGS.

Haynie Cove: cove, see Karab Cove.

Hay Slough: stream, flows NW $18 \mathrm{mi}$. to junc. of Tanana and Yukon Rivers, $3.5 \mathrm{mi}$. E of Tanana, Nowitna Low.; $65^{\circ} 10^{\prime} \mathrm{N}, 151^{\circ} 57^{\prime}$ W; (map 106)

Riverboat pilots' name shown on a 1940 navigation chart, Tanana-Yukon Rivers.

Haystack: rock, E of village of Saint Paul, on $S$ coast of Saint Paul I., in Pribilof Is.; 57 $07^{\circ}$ $10^{\prime \prime} \mathrm{N}, 170^{\circ} 16^{\prime} 00^{\prime \prime} \mathrm{W}$; (map 38$)$.

Name reported in 1897 by W.W. Duffield, USC\&GS

Haystack: mountain, see Kwiniuk, Mount.

Haystack, The: point of land, on S shore of Port Houghton, $3.4 \mathrm{mi}$. E of Robert Is. and $78 \mathrm{mi}$. $\mathrm{E}$ of Sitka, Coast Mts.; $57^{\circ} 17^{\prime} 15^{\prime \prime} \mathrm{N}, 133^{\circ}$. $21^{\prime} 30^{\prime \prime} \mathrm{W}$; (map 8).

Local name reported in 1955 by USGS.

Haystack, The: rock, at mouth of Brownson Bay, on SW coast of Prince of Wales I., Alex. Arch.; $54^{\circ} 43^{\prime} 05^{\prime \prime} \mathrm{N}, 132^{\circ} 14^{\prime} 00^{\prime \prime} \mathrm{W}$; (map 1).

Local descriptive name reported in 1948 by USGS.

Haystack Butte: mountain, 1,140 ft. in Kuskokwim Mts., E of Iditarod River, $20 \mathrm{mi}$. NW of village of Crooked Creek, Kilbuck-Kuskokwim Mts.; $62^{\circ} 08^{\prime} 45^{\prime \prime} \mathrm{W}$; $158^{\circ} 16^{\prime} 00^{\prime \prime} \mathrm{W}$; (map 79).

Local name obtained in 1945 by USGS topographers.

Haystack Mountain: mountain, 3,003 ft., $23 \mathrm{mi}$. SW of Bitzshtini Mts.; Kilbuck-Kuskokwim Mts.; $64^{\circ} 10^{\prime} \mathrm{N}, 152^{\circ} 20^{\prime} \mathrm{W}$; (map 99). Var. Unsuzi Mountain, Un-suz-ee.

Local descriptive name reported in 1945 by USC\&GS. The Indian name "Un-suz-ee" was reported in 1899 by Lt. J. S. Herron, USA.

Haystack Mountain: mountain, 2,525 ft., $5 \mathrm{mi}$. $\mathbf{W}$ of Chatanika, $20 \mathrm{mi}$. $\mathbf{N}$ of Fairbanks, Yukon-Tanana High.; $65^{\circ} 07^{\prime} 50^{\prime \prime} \mathrm{N}, 147^{\circ} 37^{\prime}$ $00^{\prime \prime} \mathrm{W}$; (map 105).

Local name published by USGS in the 1950's.

Haystack Rock: rock, 400 yds. off SW coast of Amlia I., Aleutian Is.; $52^{\circ} 03^{\prime} 30^{\prime \prime} \mathrm{N}, 173^{\circ}$ $56^{\prime} 00^{\prime \prime} \mathrm{W}$; (map 19).

Descriptive name published on a 1951 USGS map.

Haystack Rock: rock, 8 mi. S of Sanak I., part of Sanak Reefs, Aleutian Ra.; 54 $17^{\prime} 50^{\prime \prime}$ N, $162^{\circ} 40^{\prime} 40^{\prime \prime} \mathrm{W}$; (map 25).
Name published in 1949 on a USGS map. Haystacks, The: islands, four, and broken chain of rocks, $1.5 \mathrm{mi}$. across, between Nagai and Andronica Is., in Shumagin Is., Aleutian Ra.; $55^{\circ} 16^{\prime} 30^{\prime \prime} \mathrm{N}, 160^{\circ} 03^{\prime} 00^{\prime \prime} \mathrm{W}$; (map 28).

Named in 1875 by W. H. Dall, USC\&GS. Hayward Point: point of land, on $\mathrm{N}$ tip of Partofshikof I., off NW coast of Baranof I., $23 \mathrm{mi}$. NW of Sitka, Alex. Arch.; 57 $19^{\prime} 15^{\prime \prime}$ $\mathrm{N}, 135^{\circ} 41^{\prime} 00^{\prime \prime} \mathrm{W}$; (map 9).

Named by W. H. Dall, USC\&GS; published in 1883 Coast Pilot (p. 155)

Hayward's Straits: water passage, see Hayward Strait.

Hayward Strait: water passage, between Sitka Sound and Krestof Sound, $10 \mathrm{mi}$. NW of Sitka, Alex. Arch.; $57^{\circ} 09^{\prime} \mathrm{N}, 135^{\circ} 33^{\prime} \mathrm{W}$; BGN 1931; (map 9). Var. Hayward's Straits, Proliv Sukhoy, Soukhoi Strait, Soukoi Inlet.

Named in 1787 by Capt. Nathaniel Portlock, for Samuel Hayward, his third mate, who was the first white man to pass through this Strait (Wagner, 1937, p. 391). In 1931 USC\&GS divided this feature into two parts calling the northern part "Sukoi Inlet" and the southern part "Hayward." The Russian American Company in 1850 called it "Proliv Sukhoy," meaning "dry strait."

Hayward Strait: water passage, see Sukoi Inlet.

Hazard Point: point of land, $2 \mathrm{mi}$. W of Annoy Rock, on $E$ coast of Tanaga I., Aleutian Is.; $51^{\circ} 42^{\prime} 30^{\prime \prime} \mathrm{N}, 177^{\circ} 49^{\prime} 20^{\prime \prime} \mathrm{W}$; (map 17). Var. Chicken Head Point.

Name published by USC\&GS in 1956 on Chart 9145. It was listed as Chicken Head Point in the 1944 Aleutian Coast Pilot (p. 116).

Hazel Creek: stream, flows SW $2.2 \mathrm{mi}$. to Nome River, $6 \mathrm{mi}$. NE of Nome, Seward Penin. High.; $64^{\circ} 33^{\prime} \mathrm{N}, 165^{\circ} 13^{\prime} \mathrm{W}$; (map 94).

Prospectors' name reported in 1900 by E. C. Barnard (in Brooks, 1901, pl. 17), USGS.

Hazel Creek: stream, flows $\mathrm{E} 2 \mathrm{mi}$. to Flambeau River, $17 \mathrm{mi}$. NE of Nome, Seward Penin. High.; $64^{\circ} 42^{\prime} \mathrm{N}, 165^{\circ} 05^{\prime} \mathrm{W}$; (map 94).

Prospectors' name reported on a map by S. E. King dated 1900.

Hazel Creek: stream, flows SE to Flambeau River, about $27 \mathrm{mi}$. NE of Nome, Sew,ard Penin. High.; (map 94).

Prospectors' name reported on the 1900 "Map of Nome Peninsula" by J. M. Davidson and B. D. Blakeslee; this feature has not been positively identified.

Hazelet, Mount: mountain, 1,500 ft., $2.5 \mathrm{mi}$. E of Katalla, Chugach Mts.; $60^{\circ} 12^{\prime} \mathrm{N}, 144^{\circ} 26^{\prime}$ W; BGN 1928; (map 64).

Named by C. R. Rachford, USFS, in 1927 for G. C. Hazelet, "an early outstanding pioneer of Alaska, who was largely responsible for development of the Katalla oil fields, which contain the only producing well in Alaska."

Hazel Gulch: ravine, trends NW $0.8 \mathrm{mi}$. to Last Chance Creek, $14 \mathrm{mi}$. NW of Nome, Seward Penin. High.; $64^{\circ} 43^{\prime} \mathrm{N}, 165^{\circ} 28^{\prime} \mathrm{W}$; (map 94). 
Prospector's name reported in 1904 by T. G. Gerdine, USGS.

Hazen Bay: bay, $10 \mathrm{mi}$. across, on coast of Bering Sea, $37 \mathrm{mi}$. SE of Hooper Bay, YukonKuskokwim Delta; $61^{\circ} 01^{\prime} \mathrm{N}, 165^{\circ} 20^{\prime} \mathrm{W}$; (map 75).

Named by E. W. Nelson, U. S. Signal Service, in 1878, for Gen. William Babcock Hazen, Chief Signal Officer, USA.

Hazy Islands: islands, extend $2.7 \mathrm{mi}$., in Christian Sound, $9 \mathrm{mi}$. W of Coronation I., Alex. Arch.; $55^{\circ} 52^{\prime} \mathrm{N}, 134^{\circ} 35^{\prime} \mathrm{W}$; (map 4). Var. Foggy Islands, Isles de la Croyere, Las Hermanas, Los Hermanos, Ostrova Tumannoi, The Brothers, The Sisters.

According to Wagner (1937, p. 391), "It is uncertain who named them, but no doubt it was George Dixon, who passed them June 28, 1787. The name was adopted by Vancouver * * *" Called "Las Hermanas," meaning "the sisters," by Don Juan de la Bodega y Quadra and Francisco Antonio Maurelle in 1799; "Isles de la Croyere", i.e. "The Croyere Islands," by Pérouse in 1786; "Los Hermanos," meaning "the brothers," by Galiano (1802, map 3); "O[strova] Tumannoi," meaning "foggy islands," by Capt. Tebenkov (1852, map 9), IRN.

Head Cape: point of land, see Head Point.

Headland Island: island, see Sebree Island.

Head of Passes: locality, head of Kwikluak and Kwikpak Passes, $\mathbf{N}$ of Fish Village and $24 \mathrm{mi}$. SE of Kwiguk, Yukon-Kuskokwim Delta; $62^{\circ} 31^{\prime} \mathrm{N}, 163^{\circ} 52^{\prime} \mathrm{W}$; (map 77).

Riverboat pilots' name, used as early as 1900 , for the junction of the two major distributary channels of the Yukon River.

Head Point: point of land, $1 \mathrm{mi}$. S of Afognak, on $\mathrm{S}$ coast of Afognak I., $\mathrm{N}$ of Kodiak I.; $57^{\circ}$ $59^{\prime} 40^{\prime \prime} \mathrm{N}, 152^{\circ} 46^{\prime} 10^{\prime \prime} \mathrm{W}$; (map 34). Var. Golova, Head Cape, Mys Golova, Mys Zhila, Zhila Point.

Translation of the name "M[ys] Golova" given in 1849 by the Russian American Company. "M[ys] Zhila," meaning "inhabited cape," was applied to this point in 1839 or 1840 by Sub-Lt. Mikhail Murashev and published in 1849 on Russian Hydrog. Dept. Chart 1425.

Headquarters Lake: lake, $0.9 \mathrm{mi}$. long, on Kenai Penin., $2 \mathrm{mi}$. N of Slikok Lake and $9 \mathrm{mi}$. SE of Kenai, Cook Inlet Low.; $60^{\circ} 27^{\prime} 40^{\prime \prime} \mathrm{N}$, $151^{\circ} 03^{\prime} 43^{\prime \prime} \mathrm{W}$; (map 62).

Named about 1963 by officials of Kenai National Moose Range, for administrative purposes.

Head Rock: rock, $1.8 \mathrm{mi}$. NE of Zeto Point, on NE coast of Adak I., Aleutian Is. ; 51 '55'37' N, $176^{\circ} 31^{\prime} 25^{\prime \prime} \mathrm{W}$; BGN 1936; (map 17).

Named by members of the U.S. Navy Aleutian Island Survey Expedition in 1933 for the survey signal $\mathrm{Hed}$, located on this feature.

Heald Point: point of land, $\mathrm{E}$ point of entrance to Prudhoe Bay, on Beaufort Sea coast, 24 mi. SE of Beechey Point, Arctic Plain; $70^{\circ} 21^{\prime} \mathrm{N}$, $148^{\circ} 12^{\prime} \mathrm{W}$; (map 150). Var. Hearld Point, Mead Point, Mys Zdorovya, Point Heald, Point Herald.
Named Point Heald by Franklin (1828, p. 159) August 16, 1826; the name was erroneously printed "Herald" in the Philadelphia edition of Franklin's book. The name was misunderstood and translated by Lt. L. A. Zagoskin, IRN, appearing on his 1848 map in Cyrillic, which when transliterated back into English becomes $\mathbf{M}$ [ys] Zdorovya, meaning "cape of health."

Healey Fork: village, see Healy.

Healy: locality, on $E$ shore of Liebes Cove, 3 mi. SE of Saint Michael, Yukon-Kuskokwim Delta; $63^{\circ} 26^{\prime} 45^{\prime \prime} \mathrm{N}, 161^{\circ} 57^{\prime} 45^{\prime \prime} \mathrm{W}$; (map 91).

Settlement, now abandoned; published in the 1916 Polk's Gazetteer. According to USC\&GS this was a settlement of miners not in agreement with certain U.S. Army regulations at Saint Michael.

Healy: village, pop. 77, mile 358.1 on The Alaska RR., on Nenana River, W of mouth of Healy Creek, $9 \mathrm{mi}$. N of community of McKinley Park, Alaska Ra.; $63^{\circ} 51^{\prime} 30^{\prime \prime}$ N, $148^{\circ} 58^{\prime} 00^{\prime \prime}$ W; (map 87). Var. Dry Creek, Healy Fork, Healey Fork.

Village established as a mining camp about 1905; named after the Healy Creek. Because of its nearness to The Alaska RR. right-ofway it became a RR. station and supply point. The Healy Fork post office was established in 1921 (Ricks, 1965, p. 25). Its population was 36 in 1930 . It is a major coal mining supply center.

Healy, Mount: mountain, 5,716 ft., $W$ of Nenana River, 6 mi. S of Healy, Alaska Ra.; $63^{\circ} 46^{\prime} 30^{\prime \prime}$ $\mathrm{N}, 149^{\circ} 00^{\prime} 30^{\prime \prime} \mathrm{W}$; (map 87).

Name reported in 1921 by Mabry Abbey on his survey map of the boundaries of Mount McKinley National Park.

Healy Creek: stream, flows W $25 \mathrm{mi}$. to Nenana River $0.5 \mathrm{mi}$. SE of Healy, Alaska Ra.; $63^{\circ}$. $51^{\prime} \mathrm{N}, 148^{\circ} 57^{\prime} \mathrm{W}$; (map 87). Var. Healy River.

Name reported in 1953 by AMS.

Healy Fork : village, see Healy.

Healy Lake: lake, $6 \mathrm{mi}$. long, in course of Healy River, $29 \mathrm{mi}$. E of Delta Junction, YukonTanana High.; $63^{\circ} 49^{\prime} \mathrm{N}, 144^{\circ} 44^{\prime} \mathrm{W}$; (map 86).

Local name reported in 1914 by J. W. Bagley, USGS.

Healy Lake: lake, $5 \mathrm{mi}$. long, in course of Healy River $1.5 \mathrm{mi}$. E of its junc. with Tanana River, $33 \mathrm{mi}$. SE of Big Delta, Yukon-Tanana High.; $64^{\circ} 00^{\prime} \mathrm{N}, 144^{\circ} 45^{\prime} \mathrm{W}$; (map 101).

Local name published in 1951 by USGS.

Healy River: stream, heads on SW slope of Mount Harper and flows SW $43 \mathrm{mi}$. to Tanana River, $32 \mathrm{mi}$. SE of Big Delta, Yukon-Tanana High. ; $64^{\circ} 01^{\prime} \mathrm{N}, 144^{\circ} 48^{\prime} \mathrm{W}$; (map 101).

Named by prospectors about $1902-04$; reported in 1905 by L. M. Prindle, USGS.

Healy River: stream, see Healy Creek.

Healy Rock: rock, in Whitewater Bay, on SW coast of Admiralty I., Alex. Arch.; 57 $14^{\prime} 15^{\prime}$ $\mathrm{N}, 134^{\circ} 36^{\prime} 00^{\prime \prime} \mathrm{W}$; (map 9).
Named in 1881 by Comdr. H. Glass, USN; published by USC\&GS in 1883 Coast Pilot (p. 175).

Hearld Point: point of land, see Heald Point.

Hearst Creek: stream flows W $5 \mathrm{mi}$. to Tatlanika Creek, $42 \mathrm{mi}$. SE of Nenana, Alaska Ra.; $64^{\circ} 05^{\prime} 30^{\prime \prime} \mathrm{N}, 148^{\circ} 13^{\prime} 00^{\prime \prime} \mathrm{W}$; (map 100).

Named by prospectors for William Randolph Hearst, 1863-1951, American newspaper publisher. Reported in 1906 by L. M. Prindle (in Brooks and others, 1907, pl. 4), USGS.

Heart Island: island, $2.7 \mathrm{mi}$. long, in Copper River, $21 \mathrm{mi}$. NW of Katalla, Malaspina Coastal Plain; $60^{\circ} 27^{\prime} \mathrm{N}, 144^{\circ} 54^{\prime} \mathrm{W}$; (map 64).

Name reported in 1912 by the Alaska Railroad Commission (1913, pl. 5).

Heart Lake: lake, 2,500 ft. across, on mainland $2 \mathrm{mi}$. N of Chickamin River, $4.5 \mathrm{mi}$. NE of Fish Point on Behm Canal, Coast Mts.; $55^{\circ} 51^{\prime} 15^{\prime \prime} \mathrm{N}, 130^{\circ} 54^{\prime} 45^{\prime \prime} \mathrm{W}$; (map 3 ).

Descriptive name recorded in 1955 . by USGS.

Heart Lake: lake, $0.1 \mathrm{mi}$. across on $\mathrm{W}$ coast of Baranof I., $3.5 \mathrm{mi}$. E of Sitka, Alex. Arch.; 5 $7^{\circ} 03^{\prime} 00^{\prime \prime} \mathrm{N}, 135^{\circ} 14^{\prime} 20^{\prime \prime} \mathrm{W}$; (map 9).

Local name reported in 1951 by USGS.

Heart Lake: lake, $3 \mathrm{mi}$. long, $\mathrm{S}$ of Crooked Mts., $86 \mathrm{mi}$. SE of Bethel, Kilbuck-Kuskokwim Mts.; $60^{\circ} 06^{\prime} \mathrm{N}, 159^{\circ} 40^{\prime} \mathrm{W}$; BGN 1959; ( $\operatorname{map} 59$ ).

Named in 1954 by J. M. Hoare and W. L. Coonrad, USGS.

Heart Lake: lake, $0.3 \mathrm{mi}$. across between Mallard and Marten Lakes, $16 \mathrm{mi}$. W of Beaver, Yukon Flats; $66^{\circ} 20^{\prime} 40^{\prime \prime} \mathrm{N}, 147^{\circ} 58^{\prime} 00^{\prime \prime} \mathrm{W}$; (map 118).

Local name obtained in 1956 by USGS.

Heart Mountain: mountain, 3,055 ft., $\mathrm{S}$ of Bedrock Canyon, $\mathrm{E}$ of Deadman Mtn., and $67 \mathrm{mi}$. SW of Wiseman, Brooks Ra.; $67^{\circ} 05^{\prime} \mathrm{N}, 152^{\circ}$. 28' W; (map 124).

Descriptive local name (the outline of the base traces the outline of a heart) reported in 1956 by USGS.

Heart Mountain: peak, 6,500 ft., near head of Boulder Creek, $10 \mathrm{mi}$. NW of Mount Russell, Alaska Ra.; 62 $53^{\prime} 30^{\prime \prime} \mathrm{N}, 152^{\circ} 07^{\prime} 30^{\prime \prime} \mathrm{W}$; (map 81).

Local name reported in 1954 by USGS.

Heather Creek: stream, flows NW $50 \mathrm{mi}$. to Kurupa River $12 \mathrm{mi}$. S of its junc. with Colville River, Brooks Ra.; $68^{\circ} 53^{\prime} \mathrm{N}, 155^{\circ} 07^{\prime} \mathrm{W}$; BGN 1960; (map 133).

Named about 1950 by USGS geologists during exploration of Naval Petroleum Reserve No. 4, "for the abundant heather that grows in the area."

Heather Island: island, $3 \mathrm{mi}$. long, in Columbia Bay, just $\mathbf{S}$ of terminus of Columbia Glacier, $57 \mathrm{mi}$. NE of Whittier, Chugach Mts.; $60^{\circ}$. $58^{\prime} 30^{\prime \prime} \mathrm{N}, 147^{\circ} 02^{\prime} 30^{\prime \prime} \mathrm{W}$; (map 63).

Named by members of the Harriman Alaska Expedition in 1899; "so named because heather, a species of health (Calluna vulgaris), grows on the island."

Heather Nunatak: peak, 4,435 ft., in Glacier Bay National Monument, $3 \mathrm{mi}$. NE of end of 
Aurora Glacier and $62 \mathrm{mi}$. NW of Hoonah, St. Elias Mts. ; $58^{\circ} 42^{\prime} 20^{\prime \prime} \mathrm{N}, 136^{\circ} 42^{\prime} 10^{\prime \prime} \mathrm{W}$; (map 10).

Local name reported by USGS in 1951. Probably so called for the heathers or false heather, Phyllodoce glanduliflora, that grows profusely on exposed mountain slopes in SE Alaska (Sharples, 1938, p. 101)

Heavenly Ridge: ridge, $4 \mathrm{mi}$. long, $1.8 \mathrm{mi}$. S of Twin Lakes and $58 \mathrm{mi}$. NW of Valdez, Copper River Basin ; 61 $53^{\prime} 30^{\prime \prime} \mathrm{N}, 146^{\circ} 51^{\prime} 30^{\prime \prime}$ W; (map 68).

Local name published on a 1952 USGS map. Its name may have some relation to nearby Paradise Creek.

He Beaver Slough: stream, see Hodzana Slough.

Heceta Island: island, $15 \mathrm{mi}$. wide, between Iphigenia Bay and Prince of Wales I., Alex. Arch.; $55^{\circ} 45^{\prime} \mathrm{N}, 133^{\circ} 30^{\prime} \mathrm{W}$; (map 4).

Named in 1879 by W. H. Dall, USC\&GS, for Don Bruno Heceta, a Spaniard, who explored and surveyed in this vicinity in 1775 (Bancroft, 1886, p. 197).

Heckman Lake: lake, 2 mi. long, on Revillagigedo I., in course of Naha River, $3 \mathrm{mi}$. $\mathrm{E}$ of Naha Bay, Alex. Arch.; $55^{\circ} 35^{\prime} \mathrm{N}, 131^{\circ} 32^{\prime} \mathrm{W}$; $B G N$ 1962; (map 3). Var. Hickman Lake.

Local name probably reported by H. C. Fassett, USBF, in 1904; published as "Hickman Lake" on the 1960 Tongass National Forest map. See Heckman Point.

Heckman Point: point of land, on $\mathrm{W}$ bank Behm Canal, $6 \mathrm{mi}$. $\mathrm{S}$ of Spacious Bay, on NE coast of Cleveland Penin., Alex. Arch.; 55 $45^{\prime} 20^{\prime \prime} \mathrm{N}, 1^{\circ} 1^{\circ} 47^{\prime} 40^{\prime \prime} \mathrm{W}$; (map 3).

Local name reported in 1904 by H. C. Fassett, USBF; probably given for J. R. Heckman, superintendent of the cannery at Loring. Hedlunds: locality, $\mathrm{N}$ of Iliamna Lake, on $\mathrm{W}$ bank of Chekok Creek $1.5 \mathrm{mi}$. N of Chekok Point, 16 mi. E of Iliamna, Aleutian Ra.; 59 $9^{\circ}$ $48^{\prime} N, 154^{\circ} 23^{\prime} \mathrm{W}$; (map 51 ).

Name of a former village or camp reported in 1952 by USGS.

Hefty, Mount: mountain, $7,047 \mathrm{ft}$., on AlaskaCanada boundary, $2.2 \mathrm{mi}$. SW of Boundary Peak 3 and $8 \mathrm{mi}$. E of Skagway, Coast Mts.; $59^{\circ} 27^{\prime} 05^{\prime \prime} \mathrm{N}, 135^{\circ} 04^{\prime} 30^{\prime \prime} \mathrm{W}$; BGN 1954; (map 45). Var. Hefty Mountain, Hefty Peak.

Named in 1927 by the IBC for J. G. Hefty, United States section of the IBC.

Hefty Mountain: mountain, see Hefty, Mount. Hefty Peak: mountain, see Hefty, Mount.

Hegenmeister Island: island, see Hagemeister Island.

Heiden, Port: bay, $12 \mathrm{mi}$. wide, extends NW 12 mi. from the Meshik River to Bristol Bay, entrance $3 \mathrm{mi}$. wide, between Strogonof Point and Chistiakof I. $9 \mathrm{mi}$. SW of Port Heiden Airfield, Bristol Bay Low.; $56^{\circ} 54^{\prime} \mathrm{N}, 158^{\circ} 48^{\prime}$ W; (map 30). Var. Baie Comte Heyden, Baie Houdobin, Port Haiden, Zaliv Graf Heidena, Port Hayden.

Named "Baie Comte Heyden" in 1828 by Capt. F. P. Lutke, IRN, for "Count Heiden." Adm. von Krusenstern (1827, map 20), IRN, named it "Baie Houdobin" for the officer on
Lutke's corvette Moller. In 1888, USBF called it "Port Haiden".

Heiden Canyon: canyon, $6 \mathrm{mi}$. long on Lowe River, $2 \mathrm{mi}$. E of Wortmanns and $19 \mathrm{mi} . \mathrm{E}$ of Valdez, Chugach Mts.; $61^{\circ} 06^{\prime} 45^{\prime \prime} \mathrm{N}, 145^{\circ}$. $39^{\prime} 00^{\prime \prime}$ W; (map 68). Var. Hyden Canyon.

Named in 1898 by Capt. W. R. Abercrombie, USA, for "Corp. Robert Heiden" a member of his party.

Heiden Creek: stream, heads at terminus of Heiden Glacier, flows N $2.7 \mathrm{mi}$. to Lowe River in Heiden Canyon, $19 \mathrm{mi}$. E of Valdez, Chugach Mts. ; $61^{\circ} 05^{\prime} 35^{\prime \prime} \mathrm{N}, 145^{\circ} 40^{\prime} 05^{\prime \prime} \mathrm{W}$; $B G N$ 1964: (map 68)

Named about 1962 by Austin S. Post, USGS; derived from Heiden Canyon.

Heiden Glacier: glacier, trends N $3.5 \mathrm{mi}$. to head of Heiden Creek, $5.7 \mathrm{mi}$. SE of Wortmanns and $20 \mathrm{mi}$. $\mathrm{E}$ of Valdez, Chugach Mts.; $61^{\circ}$ 04'30" N, 145 $39^{\prime} 55^{\prime \prime}$ W; BGN 1964; (map 68).

Named about 1962 by Austin S. Post, USGS; derived from Heiden Canyon.

Heim Creek: stream, flows SE $2.5 \mathrm{mi}$. to Mille Creek, $25 \mathrm{mi}$. NE of Fairbanks, Yukon-Tanana High.; $65^{\circ} 05^{\prime} \mathrm{N}, 147^{\circ} 01^{\prime} \mathrm{W}$; (map 105).

Named by prospectors; reported in 1903 by USGS (Prindle, 1905, pl. 13).

Heine Creek: locality, on Heine Creek, $5 \mathrm{mi}$. $\mathrm{NE}$ of Livengood, Yukon-Tanana High.; $65^{\circ}$ $34^{\prime} 15^{\prime \prime} \mathrm{N}, 148^{\circ} 23^{\prime} 50^{\prime \prime} \mathrm{W}$; (map 105).

Local name of an ephemeral mining settlement established during the early mining period of the Livengood region, 1914-20.

Heine Creek: stream, flows SE $2.5 \mathrm{mi}$. to Livengood Creek, $5 \mathrm{mi}$. NE of Livengood, YukonTanana High.; $65^{\circ} 33^{\prime} 20^{\prime \prime} \mathrm{N}, 148^{\circ} 25^{\prime} 10^{\prime \prime} \mathrm{W}$ (map 105).

Named by prospectors; reported in 1916 by J. B. Mertie (in Brooks and others, 1918, pl. 13).

Heintzleman Ridge: ridge, $4,170 \mathrm{ft}$., trends SW $7 \mathrm{mi}$. from Gastineau Channel to Nugget Mtn., $8 \mathrm{mi}$. N of Juneau, Coast Mts.; $58^{\circ} 21^{\prime} 45^{\prime \prime} \mathrm{N}$, $134^{\circ} 34^{\prime} 00^{\prime \prime} \mathrm{W}$ [SW end], $58^{\circ} 25^{\prime} 25^{\prime \prime} \mathrm{N}$, $134^{\circ} 25^{\prime} 00^{\prime \prime} \mathrm{W}$ [NE end]; $B G N$ 1966; (map 11).

Named in 1966 by the State of Alaska for B. Frank Heintzleman, 1888-1965, Governor of Alaska, 1953 57. Heintzleman, in a way, chose his own memorial by casually remarking that, if anything were ever named for him, he hoped it would be "that ridge."

Heitman Mountain: mountain, 2,305 ft., $10 \mathrm{mi}$ SW of Kodiak, Kodiak I.; $57^{\circ} 39^{\prime} 55^{\prime \prime} \mathrm{N}$ $152^{\circ} 32^{\prime} 05^{\prime \prime} \mathrm{W}$; BGN 1941; (map 34).

Named in 1940 by USC\&GS for August Heitman who came to Kodiak about 1890 and resided there until his death, about 1930.

Helen, Lake: lake, $0.8 \mathrm{mi}$. long, on $\mathrm{W}$ coast of Cleveland Penin., SE of Santa Anna Inlet,

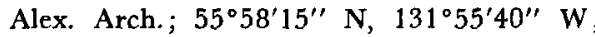
$B G N 1915$; (map 3).

Local name reported in 1914 by $E$. Lester Jones, USBF.

Helen, Lake: lake, $0.1 \mathrm{mi}$. across, on Porcupine River, on Chichagof I., $15 \mathrm{mi}$. NW of Chi- chagof, Alex. Arch.; 57 $49^{\prime} 55^{\prime \prime} \mathrm{N}, 136^{\circ} 20^{\prime} 40^{\prime \prime}$ W; BGN 1966; (map 9).

Local name published in 1928 by USC\&GS.

Helen, Point: point of land, on $S$ tip of Knight I., $16 \mathrm{mi}$. SE of Chenega, Chugach Mts.; $60^{\circ} 09^{\prime} 15^{\prime \prime} \mathrm{N}, 147^{\circ} 00^{\prime} 45^{\prime \prime} \mathrm{W}$; (map 63).

Local name published in 1907 by USC\&GS. Helena: locality, see Nuchek.

Helena Creek: stream, flows S $0.5 \mathrm{mi}$. to Victoria Greek which flows to Coal Creek, $16 \mathrm{mi}$. NE of Solomon, Seward Penin. High.; 64 $46^{\circ}$ N, $164^{\circ} 12^{\prime} \mathrm{W}$; (map 95).

Prospectors' name shown on Arthur Gibson's "Map of Cape Nome Precinct" dated 1904.

Helena Creek: stream, in Bendeleben Mts., flows SE $4 \mathrm{mi}$. to Pargon River, $33 \mathrm{mi}$. SW of Imuruk Lake, Seward Penin. High.; $65^{\circ} 08^{\prime} \mathrm{N}$, $163^{\circ} 37^{\prime}$ W; (map 110). Var. Helen Creek. Prospectors' name reported in 1906 as "Helen Creek" by P. S. Smith (in Brooks and others, 1907, p. 150), USGS.

Helen Bay: cove, $0.3 \mathrm{mi}$. across, on NE coast of Long I. ; $6 \mathrm{mi}$. $\mathrm{E}$ of Kodiak, NE of Kodiak I.; $57^{\circ} 46^{\prime} 35^{\prime \prime} \mathrm{N}, 152^{\circ} 14^{\prime} 30^{\prime \prime} \mathrm{W}$; (map 34).

Local name reported in 1949 by USGS.

Helen Creek: stream, on E coast of Alaska Penin., flows W $4.2 \mathrm{mi}$. to Puale Bay, $40 \mathrm{mi}$. NW of Karluk, Aleutian Ra.; $57^{\circ} 45^{\prime} 20^{\prime \prime} \mathrm{N}$, $155^{\circ} 29^{\prime} 10^{\prime \prime} \mathrm{W}$; (map 35).

Local name obtained from J. L. McPherson of Iliamna; published by G. C. Martin (1921, pl. 10), USGS.

Helen Creek: stream, flows NE $1.5 \mathrm{mi}$. to Silverbow Greek, near Norton Sound, $18 \mathrm{mi}$. E. of Solomon, Seward Penin. High.; 64 $34^{\prime} 45^{\prime \prime}$ N, 16351'20' W; (map 95).

Prospectors' name shown on Arthur Gibson's "Map of Cape Nome Precinct" dated 1904.

Helen Creek: stream, flows E $0.5 \mathrm{mi}$. to Nome River, $0.6 \mathrm{mi}$. S of Dexter Creek and $6 \mathrm{mi}$. NE of Nome, Seward Penin. High.; $64^{\circ} 35^{\prime}$ N, $165^{\circ} 16^{\prime} \mathrm{W}$; (map 94).

Prospectors' name reported on the 1903 Campion Mining and Trading Co. map by George M. Ashford.

Helen Creek: stream, at $\mathrm{E}$ end of Brooks Ra., flows E $8.5 \mathrm{mi}$. to Mancha Creek $3 \mathrm{mi}$. W of point where it crosses Alaska-Canada boundary, $68 \mathrm{mi}$. NE of Table Mtn.; $68^{\circ} 40^{\prime} \mathrm{N}$, $141^{\circ} 09^{\prime} \mathrm{W}$; ( $\operatorname{map} 137$ ).

Local name reported in 1956 by USGS.

Helen Creek: stream, see Helena Creek.

Helen Gulch: ravine, trends SW $1.2 \mathrm{mi}$. to South

Fork Hess Creek, $7 \mathrm{mi}$. NE of Livengood, Yukon-Tanana High.; $65^{\circ} 36^{\prime} \mathrm{N}, 148^{\circ} 24^{\prime} \mathrm{W}$; (map 105).

Named by prospectors; reported in 1916 by J. B. Mertie, (in Brooks and others, 1918, pl. 13) USGS.

Helen Island: island, 1,400 ft. long, in Mabel Bay, on SW coast of Prince of Wales I., Alex. Arch.; $54^{\circ} 49^{\prime} 20^{\prime \prime} \mathrm{N}, 132^{\circ} 34^{\prime} 45^{\prime \prime} \mathrm{W}$; (map 1).

Local name reported in 1905 by E. F. Dickins, USC\&GS 
Helen Island: island, $0.1 \mathrm{mi}$. long, in Ryus Bay, N coast of Duke I., Alex. Arch.; 54 $58^{\prime} 10^{\prime \prime}$ $\mathrm{N}, 131^{\circ} 24^{\prime} 55^{\prime \prime} \mathrm{W}$; (map 2).

Local name published in 1920 by USC\&GS. Helen Island: island, see Fox Point Island.

Helen Peak: mountain, 3,856 ft., on Etolin I., Alex. Arch.; $56^{\circ} 15^{\prime} 10^{\prime \prime} \mathrm{N}, 132^{\circ} 29^{\prime} 15^{\prime \prime} \mathrm{W}$; (map 6).

Named in 1886 by Lt. Comdr. A. S. Snow, USN; published in 1887 on USC\&GS Chart 706.

Helen Todd Lake: lake, $0.8 \mathrm{mi}$. long, on Annette I. $5.5 \mathrm{mi}$. NNE of Metlakatla, Alcx. Arch.; $59^{\circ} 12^{\prime} 20^{\prime \prime} \mathrm{N}, 1^{\circ} 31^{\circ} 30^{\prime} 30^{\prime \prime} \mathrm{W}$; BGN 1966; (map 3).

Named in 1965 by Methakatla Indian Community through the Council Annette Islands Reserve in commemoration of Helen Constance Todd, who in 1965, crashed her plane on the lake and died subsequently.

Helianthus Cove: cove, $1.7 \mathrm{mi}$. across, part of Akun Bay, on NE coast of Akun I., Krenitzin Is., Aleutian Is.; $54^{\circ} 14^{\prime} 20^{\prime \prime}$ N, $165^{\circ} 32^{\prime}$ 45" W; BGN 1939; (map 24).

Named by USC\&GS for its motor launch Helianthus, which in 1934 was frequently used in the cove.

Helianthus Passage: water passage, on $W$ coast of Kuiu I., S of Troller Is., between Explorer Basin and Tebenkof Bay, Alex. Arch.; 56 ${ }^{\circ}$ $26^{\prime} 45^{\prime \prime} \mathrm{N}, 134^{\circ} 11^{\prime} 30^{\prime \prime} \mathrm{W}$; BGN 1929; (map $5)$.

Named in 1928 by USC\&GS for the USC\& GS launch Helianthus.

Helikoff Strait: water passage, see Shelikof Strait.

Hellbent Creek: stream, in Rampart Mts., flows WNW $12 \mathrm{mi}$. to Tozitna River, $18 \mathrm{mi}$. NNW of Tanana, Kokrines-Hodzana High.; 65 ${ }^{\circ} 23^{\prime}$ $30^{\prime \prime} \mathrm{N}, 152^{\circ} 34^{\prime} 00^{\prime \prime} \mathrm{W}$; (map 106).

Local name reported in 1956 by Orth.

Hell Gate: water passage, S of Ringgold I. in Bay of Is., off Adak I., Aleutian Is.; 51 ${ }^{\circ} 47^{\prime} 50^{\prime \prime} \mathrm{N}$, $176^{\circ} 48^{\prime} 50^{\prime \prime} \mathrm{W}$; BGN 1936; (map 17).

Named by members of the U.S. Navy Aleutian Island Survey Expedition in 1934, "for Hell Gate, N.Y."

Hell Roaring Creek: stream, flows SE $3.5 \mathrm{mi}$, to Unuk River $15 \mathrm{mi}$. NE of its mouth at Burroughs Bay, Coast Mts., $56^{\circ} 20^{\prime} 20^{\prime \prime} \mathrm{N}, 131^{\circ}$. $45^{\prime} 10^{\prime \prime} \mathrm{W}$; (map 7)

Name published in 1927 on IBC Sheet 3

Hell's Acre: water passage, at W end of Kootznahoo Inlet along $\mathrm{W}$ coast of Admiralty I., 0.3 mi. N of Angoon, Alex. Arch.; 57 $30^{\prime 25}$ " N, $134^{\circ} 34^{\prime} 40^{\prime \prime} \mathrm{W}$; (map 9).

Descriptive name given in 1869 by Comdr. R. W. Meade, USN. "From Turn Point there extend certain rocks directly transverse to the channel *** About the rocks the strong tidal currents produce a race and ripples which have secured from Meade for this place the expressive name of 'Hell's Acre' " (U.S. Coast and Geodetic Survey, 1883, p. 177).

Hellsgate: canyon, of South Fork Kuskokwim River, $W$ of its junc. with Styx River, $90 \mathrm{mi}$. NW of Tyonek, Alaska Ra.; 61 $55^{\prime} 15^{\prime \prime} \mathrm{N}$, $153^{\circ} 15^{\prime} 00^{\prime \prime} \mathrm{W}$; (map 71 ).
Local name reported in 1958 by USGS.

Hells Hole: lagoon, $1.5 \mathrm{mi}$. wide, on $\mathrm{N}$ shore of Port Gravina, $25 \mathrm{mi}$. NW of Cordova, Chugach Mts.; $60^{\circ} 44^{\prime} 30^{\prime \prime} \mathrm{N}, 146^{\circ} 23^{\prime} 10^{\prime \prime} \mathrm{W}$; $B G N$ 1933; (map 64).

Local name reported in 1908 by U. S. Grant and D. F. Higgins (in Broqks and others, 1909, pl. 4), USGS.

Hells Kitchen: locality, site of mining camp, on $\mathrm{N}$ bank of Chitina River, $2.5 \mathrm{mi}$. NW of Bear I., and $26 \mathrm{mi}$. SE of McCarthy, St. Elias Mts.; $61^{\circ} 07^{\prime} \mathrm{N}, 142^{\circ} 30^{\prime} \mathrm{W}$; (map 67).

Local name reported in 1915 by F. H. Moffit, USGS.

Hells Kitchen Gulch: ravine, extends $S 5 \mathrm{mi}$. to Chitina River, $3 \mathrm{mi}$. NW of Bear I. and 24 mi. SE of McCarthy, St. Elias Mts. ; $61^{\circ} 08^{\prime} 00^{\prime \prime}$ $\mathrm{N}, 142^{\circ} 30^{\prime} 30^{\prime \prime} \mathrm{W}$; (map 67).

Local name reported in 1915 by F. H. Moffit, USGS; derived from a nearby locality once named Hells Kitchen.

Helm Bay: locality, on E coast of Cleveland Penin., at Helm Bay, $3.3 \mathrm{mi}$. W of Helm Point Alex. Arch.; $55^{\circ} 37^{\prime} 15^{\prime \prime} \mathrm{N}, 131^{\circ} 58^{\prime} 00^{\prime \prime} \mathrm{W}$; (map 3).

Local name recorded in 1949 by USC\&GS.

Helm Bay: estuary, extends NW $8 \mathrm{mi}$. off Behm Canal, on E coast of Cleveland Penin., Alex. Arch.; $55^{\circ} 36^{\prime} \mathrm{N}, 131^{\circ} 55^{\prime} \mathrm{W}$; (map 3).

Named in 1886 by Lt. Comdr. A. S. Snow, USN, for Lt. James Meredith Helm, USN, a member of his party.

Helmet Mountain: mountain, 3,801 ft., between East and Northeast Arms Uganik Bay, on N coast of Kodiak I.; $57^{\circ} 44^{\prime} \mathrm{N}, 153^{\circ} 25^{\prime} \mathrm{W}$; (map 34).

Descriptive name published in 1911 by USC\&GS

Helmet Mountain: mountain, 3,343 ft., $14 \mathrm{mi}$. $\mathrm{N}$ of White Snow Mtn. and $38 \mathrm{mi}$. NE of Christian, Brooks Ra.; $67^{\circ} 44^{\prime} \mathrm{N}, 144^{\circ} 12^{\prime} \mathrm{W}$; (map 122).

Local name reported in 1927 by Mertie (1929, pl. 3), USGS.

Helmick Mountain: mountain, see Thumb Mountain.

Helmick Point: point of land, on left bank of Kuskokwim River, $43 \mathrm{mi}$. SW of Bethel, Yukon-Kuskokwim Delta ; $60^{\circ} 18^{\prime} \mathrm{N}, 162^{\circ} 27^{\prime}$ W; (map 58).

Named about 1925 by USC\&GS for Helmick Mountain, or directly for Rev. Benjamin Helmick, Moravian missionary.

Helm Lake: lake, $1.3 \mathrm{mi}$. long, $0.5 \mathrm{mi}$. E of Helm Bay, on $E$ coast of Cleveland Penin., Alex. Arch.; 55 38 $05^{\prime \prime} \mathrm{N}, 131^{\circ} 56^{\prime} 15^{\prime \prime} \mathrm{W}$; (map 3).

Local name recorded in 1949 by USGS.

Helm Point: point of land, between Helm Bay and Wadding Cove, on $\mathbf{E}$ coast of Cleveland Penin., Alex. Arch.; $55^{\circ} 36^{\prime} \mathrm{N}, 131^{\circ} 53^{\prime} \mathrm{W}$; (map 3).

Local name reported in 1904 by H. C. Fassett, USBF

Helm Point: point of land, $\mathrm{S}$ tip of Coronation I., Alex. Arch.; $55^{\circ} 49^{\prime} 30^{\prime \prime}$ N, $134^{\circ} 17^{\prime} 00^{\prime \prime} \mathrm{W}$; (map 4).
Named in 1886 by Lt. Comdr. A. S. Snow for Lt. James M. Helm, USN, a member of his party.

Helm Rock: rock, in Sumner Strait, $1.3 \mathrm{mi}$. NW of village of Point Baker, off $\mathrm{N}$ coast of Prince of Wales I., Alex. Arch.; 56 $21^{\prime} 10^{\prime \prime} \mathrm{N}$, $133^{\circ} 35^{\prime} 10^{\prime \prime} \mathrm{W}$; (map 6).

Named in the late 1880's by USC\&GS for Lt. James M. Helm, USN, commander of the Coast Survey steamer McArthur, who made surveys in this vicinity in 1886 .

Helpmejack Creek: stream, heads at Alatna Portage, flows E and SSE $15 \mathrm{mi}$. to Alatna River, $66 \mathrm{mi}$. NNE of Hughes, Brooks Ra.; $66^{\circ} 57^{\prime} \mathrm{N}, 153^{\circ} 26^{\prime} \mathrm{W}$; (map 116). Var. Kotaglikark.

Name obtained from prospectors by Mendenhall (1902, p. 46), USGS. Eskimo name "Ko-tag-lik-ark" was recorded by Stoney (1900, map), USN.

Helpmejack Hills: hills, in a group $28 \mathrm{mi}$. long and $13 \mathrm{mi}$. wide, $3 \mathrm{mi}$. SE of Walker Lake; they are bounded on the $\mathrm{N}$ by Helpmejack and Kichaiakaka Creeks, on E by Alatna River and on $W$ by the Kobuk River, Brooks Ra.; $66^{\circ} 59^{\prime} \mathrm{N}, 153^{\circ} 50^{\prime} \mathrm{W}$; BGN 1966; (map 116).

Named in 1966 for Helpmejack Creek by W. W. Patton, Jr., USGS.

Helpmejack Lakes: lakes, group, largest of which is $3.3 \mathrm{mi}$. long, $\mathrm{W}$ of junc. of Helpmejack Creek and Alatna River, $66 \mathrm{mi}$. NNE of Hughes, Brooks Ra.; $66^{\circ} 56^{\prime} \mathrm{N}, 153^{\circ} 33^{\prime} \mathrm{W}$; (map 116).

Named by Orth in 1956

Helughi Bay: bay, see Nevidiskov Bay.

Hemlock Creek: stream, on Hawkins I., flows NW $1 \mathrm{mi}$. to Cedar Bay, $9 \mathrm{mi}$. W of Cordova, Chugach Mts.; $60^{\circ} 33^{\prime} 30^{\prime \prime} \mathrm{N}, 146^{\circ} 00^{\prime} 00^{\prime \prime} \mathrm{W}$; (map 64).

Name published in 1950 by USGS.

Hemlock Island: island, $0.8 \mathrm{mi}$. long, in Port Chester, on W coast of Annette I., Alex. Arch.; $55^{\circ} 09^{\prime} 40^{\prime \prime} \mathrm{N}, 131^{\circ} 33^{\prime} 45^{\prime \prime} \mathrm{W}$; (map 3 ).

Named in 1883 by Lt. Comdr. H. E. Nichols, USN.

Hemlock Point: point of land, on NE shore of Kootznahoo Inlet, $5 \mathrm{mi}$. NE of Angoon, on W central Admiralty I., Alex. Arch.; 57 $32^{\prime}$ $35^{\prime \prime} \mathrm{N}, 134^{\circ} 28^{\prime} 45^{\prime \prime} \mathrm{W}$; (map 9).

Named by Comdr. R. W. Meade, USN; published in 1869 on Hydrog. Chart 225.

Hen and Chickens Mountain: hill, $748 \mathrm{ft}$., between Kuzitrin and Pilgrim Rivers, $22 \mathrm{mi}$. W of Mount Benedeleben, Seward Penin. High.; $65^{\circ} 08^{\prime} \mathrm{N}, 164^{\circ} 52^{\prime} \mathrm{W}$; (map 110). Var. Castle Rocks.

Prospectors' name reported on the 1908 "Map of Seward Peninsula" by Arthur Gibson.

Henderson Creek: stream, flows SW $2.7 \mathrm{mi}$. to Mason Creek $6.5 \mathrm{mi}$. NW of that stream's mouth, $9 \mathrm{mi}$. WNW of Kallands, KokrinesHodzana High.; $65^{\circ} 13^{\prime} 40^{\prime \prime} \mathrm{N}, 153^{\circ} 22^{\prime} 30^{\prime \prime} \mathrm{W}$; (map 107)

Local name reported in 1908 by Maddren (1910, pl. 5), USGS.

Henderson Island: island, $0.3 \mathrm{mi}$. long, $\mathrm{W}$ of Korovin Is., in Shumagin Is., Aleutian Ra.; $55^{\circ} 25^{\prime} 05^{\prime \prime} \mathrm{N}, 160^{\circ} 21^{\prime} 15^{\prime \prime} \mathrm{W}$; (map 28).

Named in 1872 by W. H. Dall, USC\&GS. 
Henderson Mountain: mountain, 2,267 ft., in Kuskokwim Mts., on W bank of Oskawalik River, $21 \mathrm{mi}$. SW of Sleetmute, KilbuckKuskokwim Mts.; $61^{\circ} 31^{\prime} 15^{\prime \prime} \mathrm{N}, 157^{\circ} 43^{\prime} 00^{\prime \prime}$ W; BGN 1948; (map 72).

Named for "Big Jim" Henderson, who prospected near the mountain from 1914 to 1916 ; reported in 1945 by USGS.

Henderson Ridge: ridge, $\max$ elev. $3,000 \mathrm{ft}$., on Attu I., extends W $6 \mathrm{mi}$. from Terrible Mtn. NW of Navy Town, Aleutian Is.; $52^{\circ} 58^{\prime} 00^{\prime \prime} \mathrm{N}$, $172^{\circ} 52^{\prime} 30^{\prime \prime} \mathrm{E}$; (map 13).

Named by U.S. Army during World War II ; published in 1948 by AMS.

Henderson Slough: stream, $9 \mathrm{mi}$. long, anabranch of Porcupine River 16 mi. NE of Chalkyitsik, Yukon Flats; $66^{\circ} 53^{\prime} \mathrm{N}, 143^{\circ} 36^{\prime} \mathrm{W}$; (map 120).

Local name published in 1951 by USGS.

Hendida Island: island, $0.2 \mathrm{mi}$. across, one of Maurelle Is., $\mathrm{N}$ of Twin Is., Alex. Arch.; 55 ${ }^{\circ}$ $40^{\prime} 45^{\prime \prime} \mathrm{N}, 133^{\circ} 40^{\prime} 15^{\prime \prime} \mathrm{W}$; (map 4).

Named and published in 1943 by USC\&GS. Hendricksen, Mount: mountain, see Hendrickson, Mount.

Hendrickson, Mount: mountain, 4,590 ft., 0.6 mi. SW of Cape Enchantment and $21 \mathrm{mi}$. NE of Yakutat, St. Elias Mts.; $59^{\circ} 49^{\prime} 15^{\prime \prime}$ N, $139^{\circ}$ 28'15' W; (map 46). Var. Hendrickson Mountain, Mount Hendricksen, Mount Hendriksen.

Named in 1890 by Russell (1892, p. 88), for Rev. Carl J. Hendrickson, a Swedish missionary at Yakutat at the time.

Hendrickson Creek: stream, on $\mathrm{N}$ end of Douglas Is., flows $\mathrm{N} 1 \mathrm{mi}$. to Gastineau Channel, 5 mi. NW of Juneau, Coast Mts.; $58^{\circ} 20^{\prime} 30^{\prime \prime}$ $\mathrm{N}, 134^{\circ} 31^{\prime} 20^{\prime \prime} \mathrm{W}$; (map 11).

Named for Henry H. Hendrickson, 1862 1945 , miner and fisherman, who was born in Finland. He came to Juneau in 1894 and homesteaded on the creek (DeArmond, 1957, p. 24). Name published in 1962 by USGS.

Hendrickson Glacier: glacier, heads on $\mathrm{N}$ slope of Mount Hendrickson, trends E $1.4 \mathrm{mi}$. to 1961 terminus $3.4 \mathrm{mi}$. SW of Cape Enchantment and $23 \mathrm{mi}$. NE of Yakutat, St. Elias Mts.; $59^{\circ} 49^{\prime} 20^{\prime \prime} \mathrm{N}, 139^{\circ} 23^{\prime} 20^{\prime \prime} \mathrm{W}$; (map 46).

Named in 1905 by Tarr (1906, p. 145), USGS, for Mount Hendrickson.

Hendrickson Mountain: mountain, see Hendrickson, Mount.

Hendriksen, Mount: mountain, see Hendrickson, Mount.

Heney Creek: stream, flows W $2.5 \mathrm{mi}$. to Orca Inlet, $2 \mathrm{mi}$. SW of Cordova, Chugach Mts.; $60^{\circ} 31^{\prime} 30^{\prime \prime} \mathrm{N}, 145^{\circ} 47^{\prime} 30^{\prime \prime} \mathrm{W}$; BGN 1961; (map 64).

Named by USFS in 1927 for Michael J. Heney, builder of the Copper River and Northwestern Railroad.

Heney Creek: stream, see Hartney Creek.

Heney Glacier: glacier, trends NE $12 \mathrm{mi}$, to its terminus $0.5 \mathrm{mi}$. W of Copper River, $55 \mathrm{mi}$. NW of Katalla, Chugach Mts.; $60^{\circ} 56^{\prime} \mathrm{N}$, $144^{\circ} 44^{\prime} \mathrm{W}$; (map 64).
Named by Lawrence Martin, in 1910, for Michael J. Heney, builder of the Copper River and Northwestern Railroad.

Heney Peak: peak, 3,151 ft., in Heney Ra., 2.5 mi. S of Cordova, Chugach Mts.; $60^{\circ} 30^{\prime} 30^{\prime \prime}$ N, $145^{\circ} 49^{\prime} 00^{\prime \prime}$ W; BGN 1928; (map 64).

Named in 1927 by USFS for Michael J. Heney, builder of the Copper River and Northwestern Railroad.

Heney Range: mountain range, $3,000 \mathrm{ft}$., extends SW $8 \mathrm{mi}$. from Eyak Lake, $3 \mathrm{mi}$. S of Cordova, Chugach Mts., $60^{\circ} 30^{\prime} \mathrm{N}, 145^{\circ} 45^{\prime} \mathrm{W}$; $B G N 1933$; (map 64).

Locally named in honor of Michael $\mathrm{J}$. Heney, builder of the Copper River and Northwestern Railroad; reported by USGS in 1933.

Hen Island: island, in Yukon River, $30 \mathrm{mi}$. NE of Nulato, Koyukuk Low. $64^{\circ} 48^{\prime} \mathrm{N}, 157^{\circ} 07^{\prime}$ W; (map 97).

Riverboat pilots' name shown on a 1940 "Navigation Chart of the Tanana-Yukon Rivers" published by U.S. Dept. of Interior. Hen Island: island, see Chicken Island.

Hennig Rock: rock, submerged, $8 \mathrm{mi}$. W of Sanak I., Aleutian Ra.; 54 $25^{\prime} 15^{\prime \prime} \mathrm{N}, 162^{\circ}$ $57^{\prime} 00^{\prime \prime}$ W; (map 25). Var. Hennig Rock.

Named by Capt. E. Hennig, and published in 1882 by USC\&GS on Chart 806 .

Hennig Rock: rock, see Hennig Rock.

Henry Clay, Mount: mountain peak, 7,434 ft., on Alaska-Canada boundary, $6.2 \mathrm{mi}$. S of Mount McDonell and $41 \mathrm{mi}$. W of Skagway, St. Elias Mts. ; $59^{\circ} 22^{\prime} 30^{\prime \prime}$ N, $136^{\circ} 28^{\prime} 30^{\prime \prime}$ W; $B G N$ 1954; (map 45). Var. Boundary Peak 151, Mount Leland.

Named in 1924 by the IBC for Henry Clay, 1777-1852, United States statesman.

Henry Creek: stream, heads in Kenai Mts. $8 \mathrm{mi}$. SW of Grandview, flows SE $2.5 \mathrm{mi}$. to a lake 25 mi. SE of Sunrise, Chugach Mts.; $60^{\circ} 34^{\prime} 40^{\prime \prime}$ N, $149^{\circ} 06^{\prime} 30^{\prime \prime} \mathrm{W}$; (map 63).

Local name reported in 1951 by. USGS.

Henry Creek: stream, on Kenai Penin., flows W $1.5 \mathrm{mi}$. to Devils Creek, $24 \mathrm{mi}$. S of Hope, Chugach Mts.; $60^{\circ} 34^{\prime} 59^{\prime \prime} \mathrm{N}, 149^{\circ} 41^{\prime} 30^{\prime \prime} \mathrm{W}$; (map 63).

Local name reported by G. C. Martin (in Martin and others, 1915, pl. 6), USGS.

Henry Creek: stream, heads on Caribou Mt., flows $\mathbf{N} 10 \mathrm{mi}$. to Innoko River, $18 \mathrm{mi}$. N of Ophir and $42 \mathrm{mi}$. NW of McGrath, KilbuckKuskokwim Mts.; $63^{\circ} 23^{\prime} 45^{\prime \prime} \mathrm{N}, 156^{\circ} 33^{\prime} 30^{\prime \prime}$ W; (map 90).

Prospectors' name reported in 1933 by USGS.

Henry Creek: stream, flows E $1 \mathrm{mi}$. to Garfield Creek which flows to Kuzitrin River, $40 \mathrm{mi}$. SW of Imuruk Lake, Seward Penin. High.; $65^{\circ} 28^{\prime} \mathrm{N}, 164^{\circ} 32^{\prime} \mathrm{W}$; (map 110).

Prospectors' name reported in 1901 by T. G. Gerdine (in Collier, 1902, pl. 12), USGS.

Henry Creek: stream, flows NE $12 \mathrm{mi}$. to Koukarok River, $9 \mathrm{mi}$. SW of Midnight Mtn. and $47 \mathrm{mi}$. W. of Imuruk Lake, Seward Penin. High.; $65^{\circ} 39^{\prime} \mathrm{N}, 164^{\circ} 49^{\prime} \mathrm{W}$; (map 110). Var. Kugrupaga Creek.
Prospectors' name reported in 1901 by T. G. Gerdine (in Collier, 1902, pl. 12), USGS.

Henry Creek: stream, flows S $15 \mathrm{mi}$. to Koyukuk River, 39 mi. NE of Hughes, Hogatza High.; $66^{\circ} 26^{\prime} \mathrm{N}, 153^{\circ} 15^{\prime} \mathrm{W}$; (map 116).

Local name recorded at Allakaket in 1956 by Orth.

Henry Creek: stream, heads $6 \mathrm{mi}$. NE of Umiat, flows $\mathrm{N} 20 \mathrm{mi}$. to Kogosukruk River, Arctic Plain; 69 $38^{\prime} \mathrm{N}, 151^{\circ} 55^{\prime} \mathrm{W}$; BGN 1959; Var. Kogohokruk River, Kogosukruk River.

Named about 1945 by USGS geologists of the Naval Petroleum Reserve No. 4.

Henry Glacier: glacier, heads at $59^{\circ} 51^{\prime} \mathrm{N}$, $139^{\circ} 29^{\prime} \mathrm{W}$, trends NE $1 \mathrm{mi}$. to 1961 terminus, $2.7 \mathrm{mi}$. SW of Mount McCarty and $25 \mathrm{mi}$. NE of Yakutat, St. Elias Mts.; $59^{\circ} 52^{\prime} 10^{\prime \prime} \mathrm{N}$, $139^{\circ} 28^{\prime} 25^{\prime \prime} \mathrm{W}$; (map 46).

Named in 1905 by Tarr (1906, p. 145), USGS, for T. J. Henry, one of his Indian guides.

Henry Island: island, $2.7 \mathrm{mi}$. long, in Yukon River, $14 \mathrm{mi}$. SW of Birches, Nowitna Low.; $65^{\circ} 01^{\prime} 45^{\prime \prime} \mathrm{N}, 154^{\circ} 00^{\prime} 00^{\prime \prime} \mathrm{W}$; (map 107).

Riverboat pilots' name shown on a 1940 "Navigation Chart of the Tanana-Yukon Rivers" published by the Department of the Interior.

Henry Martin Island: island, $1.5 \mathrm{mi}$. long, in Fishhook Bend of Porcupine River, $20 \mathrm{mi}$ ENE of Coleen Mtn., Porcupine Plat.; 67'12' N, $142^{\circ} 07^{\prime} \mathrm{W}$; (map 121). Var. Martins Bar.

Local name reported in 1956 by J. E. Taylor, USGS. Fitzgerald (1944, p. 228), USGS, recorded a Martins Bar on the Porcupine River, in 1939, about three miles upstream from this island.

Henry Peak: peak, 3,480 ft., $4 \mathrm{mi}$. NW of head of Thomas Bay and $96 \mathrm{mi}$. E of Sitka, Coast Mts. ; $57^{\circ} 08^{\prime} 10^{\prime \prime} \mathrm{N}, 132^{\circ} 54^{\prime} 55^{\prime \prime} \mathrm{W}$; (map 8).

Named in 1887 by Lt. Comdr. C. M. Thomas, USN, for Joseph Henry, 1799-1878, inventor. He invented the first electromagnet and the first telegraph. He was also the discoverer of many other important electric principles. In 1846, while professor of natural philosophy at Princeton Univ., he became the first secretary of the Smithsonian Institution in Washington, D.C., which position he held until his death. Under his direction were organized the activities of the Institution, which included all branches of science.

Henshaw Creek: stream, formed by junc. of its East and West Forks, flows S $15 \mathrm{mi}$. to Koyukuk River, $12 \mathrm{mi}$. E of Allakaket, Kanuti Flats; $66^{\circ} 33^{\prime} \mathrm{N}, 152^{\circ} 14^{\prime} \mathrm{W}$; (map 117). Var. Soyhekla Creek, Sozhekla River.

Henshaw Creek was first reported about 1950 by USGS; recorded as "Sozhekla River" in 1901 by W. J. Peters (in Schrader, 1904, pl. 2), USGS.

Hepburn, Cape: point of land, between Portage and Deadman Bay, at head of Alitak Bay, at $S$ end of Kodiak I.; $56^{\circ} 07^{\prime} 30^{\prime \prime} \mathrm{N}, 153^{\circ} 58^{\prime} 00^{\prime \prime}$ W; $(\operatorname{map} 33)$.

Named in 1900 by Comdr. J. F. Moser, USN, for Ens. A. J. Hepburn, USN, a member of his party on the USBF steamer Albatross. 
Hepburn, Point: point of land, on $\mathrm{S}$ shore of Cube Cove, $31 \mathrm{mi}$. N of Angoon, on $W$ coast of Admiralty I., Alex. Arch.; $57^{\circ} 56^{\prime} 25^{\prime \prime} \mathrm{N}$, $134^{\circ} 45^{\prime} 20^{\prime \prime}$ W; (map 9).

Named in 1867 by "Homfray, cartographer, for James Hepburn, Esq., of Victoria, British Columbia, who worked in this area for many years as a naturalist and explorer."

Hepburn Peninsula: peninsula, between Deadman and Portage Bays, at head of Alitak Bay, on S coast of Kodiak I.; $57^{\circ} 00^{\prime} \mathrm{N}, 153^{\circ} 55^{\prime}$ W; BGN 1934; (map 33). Var. Uhaiak Peninsula.

Name derived from Cape Hepburn in 1934 by USC\&GS. "Uhaiak" was suggested in 1934 by USC\&GS as an alternative name "after a native village that has now disappeared." See Uhaiak.

Herb Creek: stream, flows S $8.6 \mathrm{mi}$. to Khotol River, $3 \mathrm{mi}$. N5 of junc. of Manslaughter Greek and Khotol River, $21 \mathrm{mi}$. SE of Nulato, Koyukuk Low.; $64^{\circ} 25^{\prime} \mathrm{N}, 158^{\circ} 07^{\prime} \mathrm{W}$; (map 97). Var. Tlitlna.

Appears to be a translation of an Indian name; reported in 1935 by Frederica de Laguana, BAE.

Herbert, Mount: peak, 6,090 ft., on AlaskaGanada boundary, $3.2 \mathrm{mi}$. SE of Mount Wade and $42 \mathrm{mi}$. NE of Yakutat, St. Elias Mts.; $59^{\circ} 46^{\prime} 00^{\prime \prime} \mathrm{N}, 138^{\circ} 37^{\prime} 30^{\prime \prime}$ W; BGN 1954; (map 46). Var. Boundary Peak 172.

Named by BGN in 1923 for the Rt. Hon. Sir Michael Henry Herbert, 1857-1903, British Ambassador to the United States during the early history of the Alaskan Boundary Tribunal, who assisted in framing the treaty by which the tribunal was created. He served in British foreign service at The Hague, Constantinople, Rome, and Paris, and was British Ambassador at Washington, D.C., from 1902 to 1903.

Herbert, Port: bay, $0.5 \mathrm{mi}$. across, $12.5 \mathrm{mi}$. N of village of Port Alexander, on $\mathrm{S}$ coast of Baranof I., Alex. Arch. ; $56^{\circ} 26^{\prime}$ N, $134^{\circ} 39^{\prime} \mathrm{W}$; (map 5).

Local name used by fishermen; published in 1901 by USC\&GS; named "for Herbert C. Graves, nautical expert."

Herbert Glacier: glacier, heads at $58^{\circ} 37^{\prime} \mathrm{N}$, $134^{\circ} 34^{\prime} \mathrm{W}$ and trends SW $8 \mathrm{mi}$. to unnamed lake at head of Herbert River, $2 \mathrm{mi}$. $\mathrm{N}$ of Windfall Lake and $20 \mathrm{mi}$. NW of Juneau, Coast Mts.; $58^{\circ} 32^{\prime} \mathrm{N}, 134^{\circ} 42^{\prime} \mathrm{W}$; (map 11). Named in 1890 by Lt. Comdr. H. B. Mansfield, USN, for Hon. Hilary Abner Herbert, 1834-1919, lawyer, Colonel in the Army of the Confederate States of America during the Givil War, member of Congress, 1877-93, and Secretary of the Navy in the Cabinet of President Cleveland, 1893-97. Name published by USC\&GS in 1897 on Chart 8302 .

Herbert Graves Island: island, $5 \mathrm{mi}$. across, 3 mi. W of Chichagof, on W coast of Chichagof I., Alex. Arch.; $57^{\circ} 41^{\prime} \mathrm{N}, 136^{\circ} 12^{\prime} \mathrm{W}$; $B G N$ 1920; (map 9). Var. Peel Island.

Named by USC\&GS for Capt. Herbert Cornelius Graves, 1869-1919, hydrographic and geodetic engineer of USC\&GS, who died in 1919 while in England on an important official mission to that country. Capt. Graves, as Chief of the Division of Hydrography and Topography, was, for 5 years preceding his death, in direct charge of USC\&GS work in Alaska. Peel Island, the local name of the island, was reported by Overbeck (1919, pl. 2), USGS.

Herbert Island: island, $5.5 \mathrm{mi}$. across, one of the Islands of Four Mts., Aleutian Is.; 52 ${ }^{\circ} 49^{\prime} 30^{\prime \prime}$ $\mathrm{N}, 1^{\circ} 59^{\circ} 30^{\prime \prime} \mathrm{W}$; (map 20). Var. Chegulak I., Ghuginak I., Chuguliak I., Tchagulak I., Tchegoulak I., Ishugid I., Ullyagin I., Ulyaga I.

Named by the U.S. Navy Hydrog. Office in 1894 for Hilary Abner Herbert, 1834-1919, Secretary of the Navy. This island was called "O[strov] Ulyaga," or "Ulyaga Island," by Lt. Sarichev (1826, map 3), IRN, and "O[strov] Ullyagin," or "Ullyagin Island," by the Russian Hydrog. Dept. in 1847 on Chart 1379. These variant names differ from those published by Baker (1906, p. 264). See Four Mountains, Islands of.

Herbert River: stream, heads in lake at 1962 terminus of Herbert Glacier and flows $4 \mathrm{mi}$. generally $\mathrm{W}$ to Favorite Channel, $2 \mathrm{mi}$. $\mathrm{N}$ of Dotsons Landing and $20 \mathrm{mi}$. NW of Juneau, Coast Mts.; $58^{\circ} 31^{\prime} 20^{\prime \prime} \mathrm{N}, 134^{\circ} 48^{\prime} 00^{\prime} \mathrm{W}$; $B G N$ 1929; (map 11).

Local name derived from the Herbert Glacier; reported by A. C. Spencer (1906, p. 126), USGS.

Herbs Lagoon: bight, between Red River Delta and Spring Point, on W shore of Cook Inlet, Aleutian Ra.; 59 $53^{\prime} 30^{\prime \prime} \mathrm{N}, 152^{\circ} 48^{\prime} 00^{\prime \prime} \mathrm{W}$; (map 50).

Local name reported by USGS or USC\&GS in the 1940's.

Herd Rock: rock, off Cape Sasmik. off S coast of Tanaga I., Aleutian Is.; $51^{\circ} 35^{\prime} 52^{\prime \prime} \mathrm{N}$, $177^{\circ} 56^{\prime} 00^{\prime \prime} \mathrm{W}$; (map 17).

Name published by USC\&GS in 1957 on Chart 9146.

Herendeen Bay: bay, $20 \mathrm{mi}$. long and $5 \mathrm{mi}$. wide, $12 \mathrm{mi}$. SW of village of Port Moller, Bristol Bay Low.; $55^{\circ} 50^{\prime} \mathrm{N}, 160^{\circ} 50^{\prime} \mathrm{W}$; (map 28).

Named about 1890 by USC\&GS for Capt. Edward Perry Herendeen of Survey schooner Yukon, who first explored and sketched the bay in 1881 .

Herendeen Island: island, $1 \mathrm{mi}$. long, $\mathrm{N}$ of Little Koniuji I., in Shumagin Is., Aleutian Ra.; $55^{\circ} 04^{\prime} \mathrm{N}, 159^{\circ} 25^{\prime} \mathrm{W}$; (map 27).

Named by W. H. Dall, USC\&GS, in 1874 for Capt. Edward Perry Herendeen of the USC\&GS schooner Yukon, 1873-74.

Hermagos, Los: islands, see Hermagos Islands. Hermagos Islands: islands, extend $0.4 \mathrm{mi}$., off NW coast of San Fernando I., Alex. Arch.; $55^{\circ} 34^{\prime} 20^{\prime \prime} \mathrm{N}, 133^{\circ} 25^{\prime} 25^{\prime \prime} \mathrm{W}$; BGN 1908; (map 4). Var. Las Hormigas, Los Hermagos, Los Hermanos, Los Hermigos, The Brothers.

Spanish name given in $1775-79$ by Don Juan de la Bodega y Quadra and Francisco Antonio Maurelle as "Las Hormigas," meaning "the ants" (Wagner, 1937, p. 462). Baker (1906, p. 148) assumed that the name should have been "Los Hermanos," meaning "the brothers."

Herman, Mount: mountain, 1,623 ft., on Spruce I., NE of Kodiak I.; $57^{\circ} 55$, N, $152^{\circ} 23^{\prime} \mathrm{W}$; $B G N$ 1933; (map 34).

Named in 1933 by Gerald FitzGerald, USGS, "in honor of Monk Herman of the Greek Russian Church Mission, who established a hermitage at the base of this mountain, where he remained until his death in 1837 . Monk Herman was buried on the site of the hermitage and the Russian Church still maintains a shrine in his honor."

Hermanas, Las: islands, see Hazy Islands.

Herman Creek: stream, flows NE $4 \mathrm{mi}$. to Klehini River, $6 \mathrm{mi}$. W of Wells and $28 \mathrm{mi}$. W of Skagway, St. Elias Mts.; $59^{\circ} 25^{\prime} \mathrm{N}, 136^{\circ} 06^{\prime \prime}$ W; (map 45).

Local name published in 1954 by USGS.

Herman Lake: lake, $0.3 \mathrm{mi}$. long, on Herman Creek, $3.4 \mathrm{mi}$. E of Porcupine and $29 \mathrm{mi}$. SW of Skagway, St. Elias Mts.; $59^{\circ} 24^{\prime} 40^{\prime \prime} \mathrm{N}$, $136^{\circ} 08^{\prime} 30^{\prime \prime} \mathrm{W}$; (map 45).

Local name published in 1952 by USGS.

Herman Lake: lake, $0.8 \mathrm{mi}$. long, $1 \mathrm{mi}$. SW of Albert Lake and $26 \mathrm{mi}$. SW of Beaver, Yukon Flats; $66^{\circ} 15^{\prime} \mathrm{N}, 148^{\circ} 17^{\prime} \mathrm{W}$; (map 118). Var. Herman's Lake.

Probably named by William Yanert who showed it on a 1916 manuscript map of the Yukon Flats (Stuck, 1917, map facing p. 122). Hermanos, Los: islands, see Hazy Islands.

Hermanos, Los: islands, see Hermagos Islands. Hermanos Islands: islands, between San Alberto Bay and San Christoval Channel, SE of Rosary I., Alex. Arch.; $55^{\circ} 34^{\prime} 10^{\prime \prime} \mathrm{N}, 133^{\circ} 17^{\prime} 45^{\prime \prime}$ W; $B G N$ 1908; (map 4). Var. Los Hermanos, The Brothers.

Spanish name "Los Hermanos," meaning "The Brothers," given in 1775 by Don Juan de la Bodega y Quadra and Francisco Antonio Maurelle. Baker (1906, p. 148) published the translation, "Brothers (the)"; changed back to "Hermanos" in 1908 by USC\&GS to avoid duplication.

Herman's Lake: lake, see Herman Lake.

Herman Slough: stream, see Mason Slough.

Hermit Gulch: ravine, extends SW $5 \mathrm{mi}$. from Hermit Ridge $20 \mathrm{mi}$. W of Beaver, Yukon Flats; $66^{\circ} 21^{\prime} 55^{\prime} \mathrm{N}, 148^{\circ} 09^{\prime} 40^{\prime \prime} \mathrm{W}$; (map. 118)

Local name obtained in 1956 by USGS.

Hermit Ridge: ridge, extends W $20 \mathrm{mi}$. from Hodzana River, $\mathrm{S}$ of Owl Creek, $18 \mathrm{mi}$. NW of Beaver, Kokrines-Hodzana High. ; $66^{\circ} 26^{\prime} \mathrm{N}$, $148^{\circ} 10^{\prime} \mathrm{W}$; (map 118)

Local name obtained in 1956 by USGS.

Hermogenes, Cape: point of land, see Chiniak, Cape.

Herring Bay: bay, $0.2 \mathrm{mi}$. across, on $\mathbf{S}$ coast of Elovoi I., $2 \mathrm{mi}$. SW of Goddard, on W coast of Baranof I., Alex. Arch.; $56^{\circ} 48^{\prime} 30^{\prime \prime} \mathrm{N}$, $135^{\circ} 24^{\prime} 10^{\prime \prime} \mathrm{W}$; (map 5).

Local name used by fishermen; published in 1929 by USC\&GS.

Herring Bay: bay, $2 \mathrm{mi}$. across, on $\mathrm{S}$ coast of Admiralty I., $18 \mathrm{mi}$. E of Baranof, Alex. Arch.; 
$57^{\circ} 07^{\prime} N, 134^{\circ} 22^{\prime} W_{\text {; }}$ (map 9). Var. Seldovaia Bay.

This is a translation about 1882 by USG\&GS of "Seldovaya;" named about 1850 by the Russians.

Herring Bay: bay, at $\mathrm{N}$ end of Knight I., extends N $6 \mathrm{mi}$. to Prince William Sound, $40 \mathrm{mi}$. SE of Whittier, Chugach Mts.; $60^{\circ} 29^{\prime} \mathrm{N}, 147^{\circ}$ $45^{\prime} \mathrm{W}$; (map 63 ).

Local name reported in 1900 by F. C. Schrader, USGS.

Herring Bay: estuary, extends NW $0.8 \mathrm{mi}$., near mouth of George Inlet, on $S$ coast of Revillagigedo I., Alex. Arch.; 5519'25" N, $131^{\circ}$ $31^{\prime} 00^{\prime \prime} \mathrm{W}$; (map 3 ).

Local navigators' name obtained in 1904 by H. C. Fassett, USBF; derived from village of Herring Cove.

Herring Bay: estuary, see Seldovia Bay.

Herring Cove: suburb, pop. 126, on Herring Bay, $2 \mathrm{mi}$. N of Mountain Point, on $\mathrm{S}$ coast of Revillagigedo I., Alex. Arch.; 55 $19^{\prime} 30^{\prime \prime}$ N, $131^{\circ} 31^{\prime} 20^{\prime \prime} \mathrm{W}$; (map 3).

This residential suburb of Ketchikan was reported in 1960 by the U.S. Census Bureau.

Herring Cove: bay, $0.4 \mathrm{mi}$. across, $5 \mathrm{mi}$. $\mathrm{E}$ of Sitka, on W coast of Baranof I., Alex. Arch.; $57^{\circ} 02^{\prime} 30^{\prime \prime} \mathrm{N}, 135^{\circ} 12^{\prime} 00^{\prime \prime} \mathrm{W}$; BGN 1940; (map 9). Var. Salmon Bay, Salmon Cove, Seldovaya Bay.

Local name reported in 1924 by the Federal Power Commission.

Herring Islands: islands, at entrance to Tutka Bay, Kenai Pennin. $8 \mathrm{mi}$. NE of Seldovia, Chugach Mts.; $59^{\circ} 29^{\prime} \mathrm{N}, 151^{\circ} 30^{\prime} \mathrm{W}$; (map .50). Var. Herring Islets.

Named by W. H. Dall, USC\&GS, in 1880. Herring Islets: islands, see Herring Islands.

Herring Point: point of land, on NW coast of Knight I., at W entrance to Herring Bay, 38 mi. SE of Whittier, Chugach Mts.; $60^{\circ} 29^{\prime} 00^{\prime \prime}$ N, 147 $46^{\prime} 30^{\prime \prime} \mathrm{W}$; BGN 1908; (map 63).

Local name published in 1909 by USC\&GS.

Herron Glacier: glacier, in Mount McKinley National Park, trends N $14 \mathrm{mi}$. from Mount Foraker to head of Herron River, Alaska Ra.; $63^{\circ} 06^{\prime} \mathrm{N}, 151^{\circ} 41^{\prime} \mathrm{W}$; (map 88).

Named in 1902 by A. H. Brooks, USGS, for Lt. Joseph S. Herron, USA, who conducted an exploring expedition in 1899 from Cook Inlet north along the west slope on the Alaska Range to the Tanana River.

Herron River: stream, in Mount McKinley $\mathrm{Na}$ tional Park, flows NW $48 \mathrm{mi}$. from Herron Glacier to Foraker River, $17 \mathrm{mi}$. S of village to Lake Minchumina, Tanana Low; $63^{\circ} 38^{\prime}$ $50^{\prime \prime} \mathrm{N}, 152^{\circ} 09^{\prime} 15^{\prime \prime} \mathrm{W}$; (map 88). Var. Tsatasronick, Tsatasronik, Sishulathna River.

Name derived from Herron Glacier; reported in 1925 by S. R. Capps, USGS. The Tanana Indian name for this stream is said to be "Tsatasronik," meaning "black rock."

Hery Point: point of land, see Hey Point.

Hesketh Island: island, $1.2 \mathrm{mi}$. long, on S shore of Kachemak Bay, Kenai Penin. 0.5 mi. SW of Yukon I. and $8 \mathrm{mi}$. SW of Seldovia, Chugach Mts.; 59 $30^{\prime} 30^{\prime \prime} \mathrm{N}, 151^{\circ} 31^{\prime} 00^{\prime \prime} \mathrm{W}$; (map 50).
Named by W. H. Dall, USC\&GS, in 1880 , for Sir Thomas Hesketh "who in his yacht, the Lancashire Witch, visited Cook Inlet in 1880." Hessa Inlet: estuary, extends NE $4.3 \mathrm{mi}$. on SW coast of Prince of Wales I., NE of Hessa I., Alex. Arch.; $54^{\circ} 48^{\prime} 15^{\prime \prime} \mathrm{N}, 132^{\circ} 17^{\prime} 00^{\prime \prime} \mathrm{W}$; (map 1).

Name reported by Lt. Comdr. J. F. Moser, USN, in 1897.

Hessa Island: island, $1.5 \mathrm{mi}$. long, in Winter Bay, on SW coast of Prince of Wales I., Alex. Arch.; $54^{\circ} 46^{\prime} 30^{\prime \prime} \mathrm{N}, 132^{\circ} 19^{\prime} 15^{\prime \prime} \mathrm{W}$; (map 1).

Name derived from Hessa Inlet; published in 1948 by USGS.

Hessa Lake: lake, $1.2 \mathrm{mi}$. long, $3 \mathrm{mi}$. W of Kendrick Bay on $S$ end of Prince of Wales 1 ., Alex. Arch.; $54^{\circ} 53^{\prime} \mathrm{N}, 132^{\circ} 09^{\prime} \mathrm{W}$; (map 1).

Name reported in 1887 by Lt. Comdr. J. F. Moser, USN.

Hessa Narrows: water passage, $0.7 \mathrm{mi}$. long, from Hessa Inlet to Winter Bay, on SW coast of Prince of Wales I., Alex. Arch.; 54 ${ }^{\circ} 46^{\prime} 45^{\prime \prime}$ N, $132^{\circ} 18^{\prime} 30^{\prime \prime} \mathrm{W}$; (map 1).

Name derived from Hessa Inlet; published by USGS in 1948.

Hess Creek: stream, heads at junc. of its North and South Forks, flows W $50 \mathrm{mi}$. to Yukon River, $18 \mathrm{mi}$. NE of Rampart, Yukon-Tanana High.; $65^{\circ} 40^{\prime} \mathrm{N}, 149^{\circ} 48^{\prime} \mathrm{W}$; (map 105). Var. Hess River, Mike Hess Creek, Whymper Creek, Whymper River, Yokuchargut Creek, Yukochakat Creek, Yukutzcharkat Creek.

Named by prospectors for "Mike" Hess, who dicovered gold on this stream in 1892. The Indian name, according to Capt. C. W. Ray* mond, USA, in 1869, was "Yokuchargut" (spelled by W. H. Dall, "Yukutzcharkat" [Yukokakat]), meaning "mouth of the Yuko." Dall says that in 1866 Capt. F. E. Ketchum called the stream "Whymper River" after his friend and companion "Frederick Whymper, artist of the [Western Union Telegraph] Expedition" (Dall, 1870, p. 25, 281).

Hess Mountain: peak, 11,940 ft., $3 \mathrm{mi}$. E of Mount Deborah and $53 \mathrm{mi}$. E of McKinley Park, Alaska Ra. ; 68 $38^{\prime}$ N, $147^{\circ} 09^{\prime}$ W, (map 87).

Reported by D. C. Witherspoon (in Moffit, 1912, pl. 1), USGS.

Hess River: stream, see Hess Creek.

Hetta: locality, site of village, on SW coast of Prince of Wales I., E of Hetta Inlet, on S shore

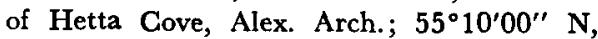
$132^{\circ} 34^{\prime} 35^{\prime \prime} \mathrm{W}$; (map 4). Var. Hettah.

Local name reported in 1905 as "Hettah" by E. F. Dickins, USC\&GS. Current sources show this village to be abandoned.

Hetta Cove: cove, extends E $0.8 \mathrm{mi}$. off Hetta Inlet, on SW coast of Prince of Wales I., Alex. Arch.; $55^{\circ} 10^{\prime} 15^{\prime \prime} \mathrm{N}, 132^{\circ} 35^{\prime} 00^{\prime \prime} \mathrm{W}$; (map 4).

Named by local fishermen and reported in 1904 by H. C. Fassett, USBF.

Hetta Creek: stream, flows S through Hetta Lake $5 \mathrm{mi}$. to Hetta Cove, on SW coast of Prince of Wales I., Alex. Arch.; 55 $10^{\prime} 20^{\prime \prime} \mathrm{N}, 132^{\circ}$ $34^{\prime} 30^{\prime \prime}$ W; (map 4).
Local name reported in 1901 by Comdr. J. F. Moser, USN; derived from Hetta Inlet. Hettah: locality, see Hetta.

Hetta Inlet: estuary, extends $\mathrm{N} 20 \mathrm{mi}$. off Cordova Bay, on SW coast of Prince of Wales I., Alex Arch.; $55^{\circ} 03^{\prime} \mathrm{N}, 132^{\circ} 40^{\prime} \mathrm{W}$; (map 4).

Name reported in 1897 by J. F. Moser, USN; published by USC\&GS in 1899 .

Hetta Lake: lake, $2 \mathrm{mi}$. long, on $\mathrm{SW}$ coast of Prince of Wales I., E of Hetta Inlet, in course of Hetta Creek, Alex. Arch.; 55 $11^{\prime}$ N, $132^{\circ}$ $33^{\prime} \mathrm{W}$; (map 4).

Name reported in 1897 by J. F. Moser, USN; published by USC\&GS in 1899.

Hetta Mountain: mountain, 2,931 ft., on SW coast of Prince of Wales I., E of Hetta Inlet; Alex. Arch.; $55^{\circ} 12^{\prime} \mathrm{N}, 132^{\circ} 34^{\prime} \mathrm{W}$; (map 4)

Local name reported in 1905 by F. E. and C. W. Wright (in Brooks and others, 1906, fig. 1), USGS.

Hetta Point: point of land, between Hetta Cove and Hetta Inlet on SW coast of Prince of Wales I., Alex. Arch.; $55^{\circ} 10^{\prime} 15^{\prime \prime} \mathrm{N}, 132^{\circ}$ $35^{\prime} 20^{\prime \prime} \mathrm{W}$; (map 4).

Local name reported in 1905 by E. F. Dickins, USC\&GS.

Hewitt Creek: stream, heads in lake, flows E $10 \mathrm{mi}$. through Whiskey Lake to Yentna River. $4.3 \mathrm{mi}$. NW of Skwentna and $64 \mathrm{mi}$. N of Tyonek, Alaska Ra.;61 $59^{\prime} 30^{\prime \prime} \mathrm{N}, 151^{\circ} 17^{\prime} 45^{\prime \prime}$ W; (map 70).

Local name reported in 1954 by USGS. Hewitt Lake: lake, $2.9 \mathrm{mi}$. long, $10 \mathrm{mi}$. SW of Mount Yenlo, $46 \mathrm{mi}$. SW of Talkeetna, Alaska Ra.; $62^{\circ} 00^{\prime} 10^{\prime \prime} \mathrm{N}, 151^{\circ} 23^{\prime} 00^{\prime \prime} \mathrm{W}$; (map 81).

Local name reported in 1958 by USGS.

Hey, Point: point of land, on S coast of Alaska, at NW end of Controller Bay, $6 \mathrm{mi}$. SE of Katalla, Malaspina Coastal Plain; $60^{\circ} 10^{\prime} \mathrm{N}$, $144^{\circ} 22^{\prime}$ W ; (map 64). Var. Hery Point.

Named by Capt. George Vancouver, RN, while exploring the Controller Bay region in 1794.

Hibahibgik: rock, see Pinnacle Rock.

Hibahibgik, Cape: promontory, see Scotch Cap.

Hickerson Lake: lake, $3 \mathrm{mi}$. long, $3 \mathrm{mi}$. $\mathrm{N}$ of $\mathrm{N}$ entrance to Chinitna Bay, $52 \mathrm{mi}$. NW of Homer, Aleutian Ra.; $59^{\circ} 56^{\prime} \mathrm{N}, 152^{\circ} 55^{\prime} \mathrm{W}$; (map 50).

Local name reported and published by USGS in 1950.

Hickey Creek: stream, flows W $8.5 \mathrm{mi}$. to Moose Creek, $5 \mathrm{mi}$. SE of its junc. with Iditarod River, $17 \mathrm{mi}$. N of Flat and $54 \mathrm{mi}$. SE of Holikachuk, Kilbuck-Kuskokwim Mts.; $62^{\circ}$. $41^{\prime} 35^{\prime \prime} \mathrm{N}, 157^{\circ} 53^{\prime} 00^{\prime \prime} W$; (map 79).

Prospectors' name reported in 1912 by H. M. Eakin, USGS.

Hickman Lake: lake, see Heckman Lake.

Hicks Creek: stream, flows SW through Hicks Lake, $12.4 \mathrm{mi}$. to Matanuska River, $41 \mathrm{mi}$. NE of Palmer, Talkeetna Mts.; $61^{\circ} 47^{\prime} 40^{\prime \prime} \mathrm{N}$, $147^{\circ} 56^{\prime} 05^{\prime \prime} \mathrm{W}$; (map 69).

Named in 1898 by Capt. E. F. Glenn, USA, for $\mathrm{H}$. H. Hicks, guide of his expedition.

Hicks Lake: lake, $3,400 \mathrm{ft}$. long, in course of Hicks Creek, 49 mi. NE of Palmer, Talkeetna Mts.; $61^{\circ} 54^{\prime} \mathrm{N}, 147^{\circ} 46^{\prime} \mathrm{W}$; (map 69).

Local name reported in 1954 by USGS. 
Hicks Point: point of land, on SW coast of Mitkof I., $16 \mathrm{mi}$. S of Petersburg, Alex. Arch.; $56^{\circ} 34^{\prime} 35^{\prime \prime} \mathrm{N}, 132^{\circ} 58^{\prime} 00^{\prime \prime} \mathrm{W}$; (map 6).

Named in 1869 by Comdr. R. W. Meade, USN, for charting purposes for a "Mr. Hicks" (cnna), a local pilot and trader of the Hudson Bay Company, who piloted the U.S.S. Saginaw on her first trip in Alaskan waters in 1868.

Hidalgo Beach: beach, $0.3 \mathrm{mi}$. long, just NE of Bedard Cove, on SE coast of Attu I., Aleutian Is.; 52 $49^{\prime} 55^{\prime \prime} \mathrm{N}, 173^{\circ} 19^{\prime} 50^{\prime \prime} \mathrm{E}$; $B G N 1945$; (map 13).

Tactical name used by the U.S. Army and Navy during and subsequent to the Battle of Attu in 1942.

Hidden Basin: lagoon, $2 \mathrm{mi}$. across, at head of Ugak Bay, on E coast of Kodiak I.; $57^{\circ} 30^{\prime}$ $30^{\prime \prime} \mathrm{N}, 152^{\circ} 56^{\prime} 00^{\prime \prime} \mathrm{W}$; (map 34).

Descriptive local name; published in 1943 by USC\&GS.

Hidden Bay: bay, 0.2 mi. across, on $\mathrm{S}$ coast of Adak I., Aleutian Is.; $51^{\circ} 41^{\prime} 30^{\prime \prime} \mathrm{N}, 176^{\circ} 39^{\prime}$ 20" W; BGN 1936; (map 17).

Named by members of the U.S. Navy Aleutian Island Survey Expedition in 1934.

Hidden Bay: estuary, $2.6 \mathrm{mi}$. long, SE coast of Prince of Wales I., Alex. Arch.; 54 $56^{\prime} 30^{\prime \prime}$ $\mathrm{N}, 131^{\circ} 58^{\prime} 30^{\prime \prime} \mathrm{W}$; (map 2).

Local name published in 1911 by USC\&GS.

Hidden Bay: estuary, on E coast of Culross I., extends E $4 \mathrm{mi}$. to Perry Passage, $20 \mathrm{mi}$. SE of Whittier, Chugach Mts.; $60^{\circ} 42^{\prime} 30^{\prime \prime} \mathrm{N}$, $148^{\circ} 06^{\prime} 00^{\prime \prime} \mathrm{W}$; BGN 1914; (map 63).

Descriptive name reported in 1914 by USC\&GS.

Hidden Cove: cove, $0.1 \mathrm{mi}$. across, near head of Slocum Arm, $3 \mathrm{mi}$. SE of Cobol, on SW coast of Chichagof I., Alex. Arch.; 57 $27^{\prime} 40^{\prime \prime}$ N, 135 $49^{\prime} 05^{\prime \prime}$ W; BGN 1908; (map 9).

Descriptive name given in 1908 by USC\&GS; published in 1909 on Chart 8280.

Hidden Cove: cove, $600 \mathrm{ft}$. across, on SE coast of Hawkins I., $9 \mathrm{mi}$. SW of Cordova, Chugach Mts.; $60^{\circ} 30^{\prime} 30^{\prime \prime} \mathrm{N}, 146^{\circ} 00^{\prime} 00^{\prime \prime} \mathrm{W}$; (map 64)

Local descriptive name published in 1950 by USGS.

Hidden Creek: stream, flows NE $1.8 \mathrm{mi}$. to join Bradfield River, at head of Bradfield Canal, Coast Mts.; $56^{\circ} 13^{\prime} 00^{\prime \prime} \mathrm{N}, 1^{\circ} 31^{\circ} 30^{\prime} 15^{\prime \prime} \mathrm{W}$; $(\operatorname{map} 7)$.

Local descriptive name published in 1955 by USGS,

Hidden Creek: stream, on Alaska Penin., flows SE $8 \mathrm{mi}$. to Aniakchak River, $9 \mathrm{mi}$. E of Vent Mtn., Aleutian Ra.; $56^{\circ} 51^{\prime} \mathrm{N}, 157^{\circ} 54^{\prime} \mathrm{W}$; (map 31).

So named in 1923 by R. H. Sargent, USGS, "because of its underground course of four or five miles beneath ash and cinders from Aniakchak Volcano."

Hidden Creek: stream, heads at unnamed glacier flows NW $8 \mathrm{mi}$. to head of Wright River and $31 \mathrm{mi}$. NE of Juneau, Coast Mts. ; 58 $29^{\prime} 30^{\prime \prime}$ N, $133^{\circ} 39^{\prime} 00^{\prime \prime} \mathrm{W}$; BGN 1932; (map 12).

Descriptive name given in 1932 by $B$. D. Stewart, USGS, "on acconut of the fact that the canyon and valley occupied by this stream are hidden from view by surrounding mountains * * *."

Hidden Creek: stream, heads at Hidden Lake, on Kenai Penin., S $2 \mathrm{mi}$. of Skilak Lake, $38 \mathrm{mi}$. ESE of Kenai, Chugach Mts.; 60 $26^{\prime} 20^{\prime \prime} \mathrm{N}$, $150^{\circ} 12^{\prime} 15^{\prime \prime} \mathrm{W}$; (map 62).

Local descriptive name; reported by USGS (Brooks and others, 1912, pl. 9).

Hidden Creek: stream, flows SE $1.2 \mathrm{mi}$. to Orca Inlet, $9 \mathrm{mi}$. SW of Cordova, Chugach Mts.; $60^{\circ} 31^{\prime} 15^{\prime \prime} \mathrm{N}, 146^{\circ} 01^{\prime} 15^{\prime \prime} \mathrm{W}$; (map 64).

Local descriptive name published in 1950 by USGS.

Hidden Creek: stream, flows E $3.5 \mathrm{mi}$. to Hidden Creek Lake, $W$ of Kennicott Glacier, $11 \mathrm{mi}$. NW of McCarthy, Wrangell Mts.; 61 ${ }^{\circ} 33^{\prime} 30^{\prime \prime}$ $\mathrm{N}, 143^{\circ} 08^{\prime} 00^{\prime \prime} \mathrm{W}$; (map 67).

Local name reported in 1900 by T. G. Gerdine, USGS.

Hidden Creek: stream, heads at glacier $W$ of Granite Creek and flows SW 6 mi. to Kahiltna Glacier, $39 \mathrm{mi}$. NW of Talkeetna, Alaska Ra.; $62^{\circ} 34^{\prime} 30^{\prime \prime} \mathrm{N}, 151^{\circ} 12^{\prime} 10^{\prime \prime} \mathrm{W}$; (map 81).

Local name reported in 1949 by USGS.

Hidden Creek: stream, flows S $3.5 \mathrm{mi}$. to Flat Creek $3.5 \mathrm{mi}$. W of its junc. with Ahtell Creek, $7.5 \mathrm{mi}$. NW of Slana, Alaska Ra.; $62^{\circ} 45^{\prime} \mathrm{N}$, $144^{\circ} 10^{\prime} \mathrm{W}$; (map 83).

Local name reported in 1954 by USGS.

Hidden Creek: stream, flows W $12 \mathrm{mi}$. to Nixon Fork Takotna River, $13 \mathrm{mi}$. NW of Medfra, Kilbuck-Kuskokwim Mts. ; $63^{\circ} 14^{\prime} \mathrm{N}, 155^{\circ} 03^{\prime}$ W; (map 89).

Local name reported in 1920 by G. C. Martin (in Brooks and others, 1922, fig. 5), USGS.

Hidden Creek: stream, flows $\mathrm{N} 3 \mathrm{mi}$. to South Fork Koyukuk River at Eagle Cliff, $3 \mathrm{mi}$. E of mouth of Wilson Creek and $25 \mathrm{mi}$. S of Wiseman, Brooks, Ra.; $67^{\circ} 02^{\prime} 45^{\prime \prime} \mathrm{N}$, $150^{\circ} 04^{\prime} 00^{\prime \prime} \mathrm{W}$; (map 124).

Local descriptive name obtained in 1956 by USGS topographers.

Hidden Creek Lake: lake, $1.8 \mathrm{mi}$. long, at mouth of Hidden Creek, W of Kennicott Glacier, 11 mi. NW of McCarthy, Wrangell Mts.; $61^{\circ} 33^{\prime} 40^{\prime \prime}$ N., $143^{\circ} 06^{\prime} 30^{\prime \prime} \mathrm{W}$; (map 67).

Local name reported in 1951 by USGS.

Hidden Falls: waterfall, between Hidden Falls Lake and Kasnyku Bay, on NE coast of Baranof I., Alex. Arch.; 57 $13^{\prime} 00^{\prime \prime} \mathrm{N}, 134^{\circ} 52^{\prime} 30^{\prime \prime}$ W; BGN 1923; (map 9).

Descriptive name given in 1923 by USFS; "so called because they are not seen until the upper end of the small lagoon at the head of Kasnyku Bay is reached."

Hidden Falls Lake: lake, $1 \mathrm{mi}$. long, at head of Kasnyku Bay, 9 mi. $\mathrm{N}$ of Baranof, on NE coast of Baranof I., Alex. Arch.; 57 $13^{\prime} \mathrm{N}$, $134^{\circ} 53^{\prime} \mathrm{W}$; BGN 1923; (may 9).

Named in 1923 by USFS for Hidden Falls at its head.

Hidden Glacier: glacier, heads on $\mathrm{N}$ slope of Ninemile Mtn., trends NE $1.5 \mathrm{mi}$. to its 1955 terminus $9 \mathrm{mi}$. NW of Hyder, Coast Mts.; $56^{\circ} 02^{\prime} 10^{\prime \prime} \mathrm{N}, 130^{\circ} 07^{\prime} 00^{\prime \prime} \mathrm{W}$; (map 7).
Local descriptive name published in 1924 by USGS.

Hidden Glacier: glacier, heads at $59^{\circ} 41^{\prime} \mathrm{N}$, $138^{\circ} 59^{\prime} \mathrm{W}$, trends NW $9 \mathrm{mi}$. to its 1961 terminus, $3.5 \mathrm{mi}$. SE of Seal Bay and $25 \mathrm{mi}$. NE of Yakutat, St. Elias Mts.; $59^{\circ} 46^{\prime} 10^{\prime \prime} \mathrm{N}$, $139^{\circ} 10^{\prime} 20^{\prime \prime} \mathrm{W}$; (map 46).

Descriptive name given in 1891 by Russell (1892, p. 87), USGS, who glimpsed it as he passed by.

Hidden Harbor: estuary, extends $\mathrm{N} 1 \mathrm{mi}$. at head of Kinak Bay, on S coast of Alaska Penin., in Katmai National Monument, 18 mi. ESE of Mount Ktamai, Aleutian Ra.; $58^{\circ} 11^{\prime} 30^{\prime \prime} \mathrm{N}, 154^{\circ} 29^{\prime} 00^{\prime \prime} \mathrm{W}$; BGN 1924; map 42).

So named in 1919 by R. F. Griggs, National Geographic Society, "on account of its constricted entrance."

Hidden Inlet: estuary, trends S 6 mi. to Pearse Canal, Coast Mts.; $54^{\circ} 57^{\prime} \mathrm{N}, 130^{\circ} 21^{\prime} \mathrm{W}$; (map 2).

Local name published in 1891 by USC\&GS.

Hidden Inlet Lake: lake, $3.3 \mathrm{mi}$. long, $2.6 \mathrm{mi}$. NW of Hidden Point, on Pearse Canal, Coast Mts.; $54^{\circ} 59^{\prime} \mathrm{N}, 130^{\circ} 28^{\prime} \mathrm{W}$; (map 2).

Local descriptive name published in 1943 by USC\&GS.

Hidden Island: island, $1 \mathrm{mi}$. long, at $\mathrm{S}$ end of Frederick Sound, $18 \mathrm{mi}$. SE of Petersburg, Coast Mts.; $56^{\circ} 40^{\prime} 00^{\prime \prime}$ N, $132^{\circ} 33^{\prime} 30^{\prime \prime}$ W; (map 6).

Named in 1887 by Lt. Comdr. C. M. Thomas, USN, for charting purposes; name published in 1888 on USC\&GS Ghart 70.

Hidden Lake: lake, $2.5 \mathrm{mi}$. long, on Afognak I., $6 \mathrm{mi}$. SE of Black Cape and $26 \mathrm{mi}$. $\mathrm{N}$ of Afognak, Kodiak I.; $58^{\circ} 22^{\prime} \mathrm{N}, 152^{\circ} 42^{\prime} \mathrm{W}$; (map 43).

Local descriptive name reported in 1952 by USGS.

Hidden Lake: lake, $4.5 \mathrm{mi}$. long, on Kenai Penin., $3 \mathrm{mi}$. $\mathrm{N}$ of Skilak Lake and $33 \mathrm{mi}$. E of Kenai, Cook Inlet Low.; $60^{\circ} 30^{\prime} \mathrm{N}, 150^{\circ} 19^{\prime} \mathrm{W}$; (map 62).

Local name reported about 1911 by USGS (Martin, G. C., and others, 1915, pl. 2).

Hidden Lake: lake, $0.6 \mathrm{mi}$. long, in course of Maclaren River, $2.5 \mathrm{mi}$. $\mathrm{S}$ of Maclaren Glacier terminus and $26 \mathrm{mi}$. SE of Mount Hayes, Alaska Ra. ; $63^{\circ} 14^{\prime} 30^{\prime \prime} \mathrm{N}, 146^{\circ} 32^{\prime} 30^{\prime \prime}$ $\mathrm{W}$; (map 86).

Name published on relatively recent maps. Hidden Point: point of land, between Pearse Canal and Hidden Inlet, Coast Mts.; 55 ${ }^{\circ} 6^{\prime}$ $45^{\prime \prime} \mathrm{N}, 130^{\circ} 19^{\prime} 30^{\prime \prime} \mathrm{W}$; BGN 1929; (map 2).

Descriptive name given in 1929 by USFS.

Hidden River: stream, heads at Buckskin Glacier, flows SE $11 \mathrm{mi}$. to Fountain River $1.5 \mathrm{mi}$. N of its junc. with Chulitna River, $35 \mathrm{mi}$. $\mathrm{N}$ of Talkeetna, Alaska Ra.; $62^{\circ} 49^{\prime} 10^{\prime \prime} \mathrm{N}, 150^{\circ}$. 04'30" W; (map 81).

Local name published in 1940 by USGS.

Hidden River Lake: lake, $1.3 \mathrm{mi}$. long, $1 \mathrm{mi}$. SW of Stony River $15 \mathrm{mi}$. NW of its junc. with Telaquana River, 65 mi. NW of Lake Clark, 
Lime Hills; $61^{\circ} 12^{\prime} 20^{\prime \prime} \mathrm{N}, 1^{\circ} 4^{\circ} 43^{\prime} 30^{\prime \prime} \mathrm{W}$; (map 71).

Prospectors' name published in 1951 by USGS.

Hideway, Lake: lake, 1,000 ft. long, between South Fork Cambell nad Rabbit Creeks, 8.2 mi SE of Anchorage, Chugach Mts.; $61^{\circ} 07^{\prime}$. $23^{\prime \prime} \mathrm{N}, 149^{\circ} 44^{\prime} 25^{\prime \prime} \mathrm{W}$; (map 69).

Local name reported in 1952 by USGS.

Hiding Lake: lake, $0.9 \mathrm{mi}$. long, $2 \mathrm{mi}$. NE of Elbow Lake and $11 \mathrm{mi}$. W of Beaver, Yukon Flats; $66^{\circ} 20^{\prime} \mathrm{N}, 147^{\circ} 49^{\prime} \mathrm{W}$; (map 118).

Prabably named by William Yanert who showed it on a 1916 manuscript map of the Yukon Flats (Stuck, 1917, map facing p. 122).

Hid Reef: reef, extends $1.1 \mathrm{mi}$., between Clarence Strait and Nichols Passage, off SW coast of Annette I., Alex. Arch.; 55 $04^{\prime}$ N, $131^{\circ} 40^{\prime}$ W; (map 3).

Descriptive name given in 1883 by Lt. Comdr. H. E. Nichols, USN.

Higgins, Point: point of land, between Behm Canal and Tongass Narrows, on SW coast of Revillagigedo I., Alex. Arch.; 55 $27^{\prime} 28^{\prime \prime} \mathrm{N}$, $131^{\circ} 50^{\prime} 00^{\prime \prime} \mathrm{W}$; (map 3).

Named by Capt. George Vancouver, RN, "August 12, 1793, no doubt after Ambrosio O'Higgins [de Vallenar], the Viceroy of Chile" (Wagner, 1937, p. 392). See Vallenar Point.

Highball Point: point of land, see Hammer Point.

High Bluff: bluffs, see High Bluffs.

High Bluffs: bluffs, $1,012 \mathrm{ft}$, extend $2 \mathrm{mi}$. along $N$ coast of Saint George I., $E$ of Samlalogh Ridge, in Pribilof Is.; 56 $36^{\prime} 20^{\prime \prime} \mathrm{N}$, $169^{\circ} 40^{\prime} 00^{\prime \prime}$ W; (map 38). Var. Eganuta, High Bluff.

Descriptive name reported by $H$. W. Elliott in 1873-74 (Baker, 1906, p. 236). It appears to be a translation of the Aleut name reported by Putnam (1903, p. 1014), USC\&GS, as "Ëgănǔtá [Iganata]."

High Bluffs: bluffs, see Einahnuhto Bluffs.

High Cache: locality, on $N$ bank of Desper Creek, W of Alaska Highway, $31 \mathrm{mi}$. SE of Northway Junction, Alaska Ra.; 62 $40^{\prime} \mathrm{N}$, $141^{\circ} 09^{\prime}$ W (map 84).

Local name reported in 1955 by USGS.

High Castle Island: island, $0.2 \mathrm{mi}$. long, one of Castle Is., in Duncan Canal, $13 \mathrm{mi}$. SW of Petersburg, off $\mathbf{S}$ coast of Kupreanof I., Alex. Arch.; $56^{\circ} 40^{\prime} 25^{\prime \prime} \mathrm{N}, 133^{\circ} 10^{\prime} 00^{\prime \prime} \mathrm{W}$; BGN 1933; (map 6).

Local descriptive name reported in 1933 by R. H. Sargent, USGS; so called because "this island is considerably higher than any of the other islands of the group."

High Cliff Bay: bay, see Kachemak Bay.

High Creek: stream, flows NE $14 \mathrm{mi}$. to Lava Creek $3 \mathrm{mi}$. SW of its junc. with Cinder River, on Alaska Penin., $37 \mathrm{mi}$. SW of Ugashik, Bristol Bay Low.; 57 $03^{\prime} 45^{\prime \prime} \mathrm{N}, 157^{\circ} 53^{\prime} 10^{\prime \prime}$ W; (map 36).

Descriptive name given in 1923 by $R$. H. Sargent, USGS, "because part of its course runs on a high terrace parallel to Lava Creek."

High Creek: stream, heads in Zane Hills, flows ENE $14 \mathrm{mi}$. to Hogatza River, $34 \mathrm{mi}$. WNW of Hughes, Hogatza High.; $66^{\circ} 09^{\prime}$ N, $155^{\circ} 27^{\prime}$

W; (map 116).

Named by mining engineers; recorded in 1956 by Orth.

Highfield, Point: point of land, northernmost tip of Wrangell I. at Wrangell, Alex. Arch.; $56^{\circ} 29^{\prime} 15^{\prime \prime} \mathrm{N}, 132^{\circ} 23^{\prime} 15^{\prime \prime} \mathrm{W}$; (map 6).

Named in August, 1793, by Capt. George Vancouver, RN, (Wagner, 1937, p. 392).

Highfield Anchorage: anchorage, $1.5 \mathrm{mi}$. across, between Simonof and Wrangell Is., Alex. Arch.; $56^{\circ} 29^{\prime} 20^{\prime \prime} \mathrm{N}, 132^{\circ} 22^{\prime} 00^{\prime \prime} \mathrm{W}$; (map 6). Var. Anchorage off, Labouchere Anchorage, Labouchere Bay, Point Highfield, Point Highfield Harbor.

Feature called "Anchorage off Point Highfield" in 1862 by F. O. Simpson, Master of the H.M.S. Devastation; name published as such in 1882 on Brit. Adm. Chart 2431. In 1869, it was called "Point Highfield Harbor" by Comdr. R. W. Meade, USN. The early traders of the Hudson's Bay Co. called it "Labouchere bay or anchorage" for the steamer Labouchere.

High Hill: hill, $725 \mathrm{ft}$., in S part of Umnak I. Aleutian Is.; $52^{\circ} 58^{\prime} 23^{\prime \prime} \mathrm{N}, 168^{\circ} 51^{\prime} 14^{\prime \prime} \mathrm{W}$; (map 21).

Descriptive name published by USC\&GS in the 1944 Aleutian Coast Pilot (p. 67) because it is the highest hill near the shore of Nikolski Bay.

High Island: island, $0.5 \mathrm{mi}$. long. $1 \mathrm{mi}$. S of Fawn Point Deer I., Aleutian Ra.; 54 $48^{\prime} 35^{\prime \prime} \mathrm{N}$, $162^{\circ} 19^{\prime} 20^{\prime \prime} \mathrm{W}$; BGN 1942; (map 25). Var. High Islet, Passage Island.

Local name reported in 1941 by USC\&GS. It may be the Passage Island published in 1888 by USBF.

High Island: island, $0.3 \mathrm{mi}$. across, $0.5 \mathrm{mi}$. NE of Popof I., in Shumagin Is., Aleutian Ra.; $55^{\circ} 21^{\prime} 35^{\prime \prime} \mathrm{N}, 160^{\circ} 19^{\prime} 00^{\prime \prime} \mathrm{W}$; (map 28). Var. Vesoki, Viesokoi, Visokoi.

Translation of the Russian word "Visokoi," meaning "high"; published by Capt. Tebenkov (1852, map 24); shown in 1872 by W. H. Dall, USC\&GS, as "Vesoki." The English form "High Island" appeared in 1888 USBF report.

High Island: island, $0.4 \mathrm{mi}$. across, between Clarence Strait and Kasaan Bay, on $\mathbf{E}$ coast of Prince of Wales I., E of Patterson I., Alex. Arch.; $55^{\circ} 24^{\prime} \mathrm{N}, 132^{\circ} 10^{\prime} \mathrm{W}$; (map 4).

Descriptive name given in 1880 by $W . H$. Dall, USC\&GS.

High Island: island, $1 \mathrm{mi}$. long, in Rocky Pass of Keku Strait, $30 \mathrm{mi}$. SW of Petersburg, Alex. Arch.; $56^{\circ} 44^{\prime} \mathrm{N}, 133^{\circ} 43^{\prime} \mathrm{W}$; (map 6).

Local name published by USC\&GS in 1932 Coast Pilot (p. 258).

High Island: island, see Cliff Island.

High Island: island, see Natoa Island.

High Island: island, see Zaimka Island.

High Islet: island, see High Island.

High Lake: lake, $0.4 \mathrm{mi}$. long, on Kenai Penin., $6 \mathrm{mi}$. WNW of terminus of Chernof Glacier, $36 \mathrm{mi}$. NE of Homer, Chugach Mts.; $59^{\circ} 55^{\prime} \mathrm{N}$, $150^{\circ} 44^{\prime} W(\operatorname{map} 50)$.
Local name reported and published by USGS in 1950.

High Lake: lake, $5 \mathrm{mi}$. long, $14 \mathrm{mi}$. $\mathrm{N}$ of Togiak Lake, $90 \mathrm{mi}$. NE of Goodnews, Kilbuck-Kuskokwim Mts.; 59 $59^{\prime} \mathrm{N}, 159^{\circ} 30^{\prime} \mathrm{W}$; (map 53).

Local name published in 1951 by USGS.

High Lake: lake, 1 mi. across, on Kokaina Creek $5.2 \mathrm{SE}$ of Tazlina Lake and $51 \mathrm{mi}$. N of Valdez, Chugach Mts.; $61^{\circ} 51^{\prime} 30^{\prime \prime} \mathrm{N}, 146^{\circ} 17^{\prime} 30^{\prime \prime}$. W; (map 68).

Local name published on recent USGS maps; so called because the lake is located at an elevation of 3,006 feet.

High Lake: lake, $1 \mathrm{mi}$. long, $2.5 \mathrm{mi}$. NW of junc. of Devil Creek and Susitna River, $37 \mathrm{mi}$. $\mathrm{S}$ of Cantwell, Talkeetna Mts.; 62 $51^{\prime} \mathrm{N}$, $149^{\circ} 07^{\prime} \mathrm{W}$; BGN 1966; (map. 82). Var. Swan Lake.

Named in 1962 by "Ken" Oldham, Jocal guide, "*** since it is the highest of several [lakes] in the immediate area."

High Lakes: lakes, extend $2 \mathrm{mi}$. between Egypt Mtn. and Tin Creek, $5 \mathrm{mi}$. NW of junc. of South Fork Kuskokwin and Post Rivers, 73 mi. SE of McGrath, Alaska Ra.; 62 ${ }^{\circ} 8^{\prime} \mathrm{N}$, $153^{\circ} 35^{\prime} \mathrm{W}$; (map 80).

Local descriptive name reported in 1958 by by USGS.

Highland, Point: point of land, on $\mathrm{N}$ shore of Frederick Sound, $4 \mathrm{mi}$. SE of Cape Fanshaw and $72 \mathrm{mi}$. E of Sitka, Coast Mts. ; $57^{\circ} 09^{\prime} 00^{\prime \prime}$ N, $133^{\circ} 27^{\prime} 45^{\prime \prime} \mathrm{W}$; (map 8).

Descriptive name given in 1868 by Comdr. R. W. Meade, USN; name published by USC\&GS in 1883 Coast Pilot (p. 126). The point is heavily wooded and precipitous.

Highland Creek: stream, flows N $13 \mathrm{mi}$. to Port Heiden near mouth of Meshik River, 13 mi. S of Port Heiden Airfield, Bristol Bay Low.; $56^{\circ} 47^{\prime} \mathrm{N}, 158^{\circ} 39^{\prime} \mathrm{W}$; (map 30).

Descriptive name reported in 1923 by $R$. H. Sargent, USGS.

Highland Creek: stream, on Kenai Penin., flows NW $2 \mathrm{mi}$. to Resurrection Creek, $5 \mathrm{mi}$. S of Hope, Chugach Mts. ; $60^{\circ} 50^{\prime} 35^{\prime \prime} \mathrm{N}, 149^{\circ} 37^{\prime}$ $50^{\prime \prime} \mathrm{W}$; (map 63).

Local prospectors' name; reported in 1904 by Moffit (1906, pl. 2), USGS.

Highland Creek: stream, flows NW $9 \mathrm{mi}$. to Charley River, $23 \mathrm{mi}$. SW of that stream's junc. with Yukon River, Yukon-Tanana High.; $65^{\circ} 03^{\prime} \mathrm{N}, 143^{\circ} 15^{\prime} \mathrm{W}$; (map 103).

Prospectors' name from an unpublished map by E. J. Chamberlain dated, 1902.

Highland Mountain: mountain, 3,700 ft., $4 \mathrm{mi}$. SSE of village of Eagle River and $14 \mathrm{mi}$. NE of Anchorage, Chugach Mts.; $61^{\circ} 16^{\prime} 20^{\prime \prime} \mathrm{N}$, $149^{\circ} 30^{\prime} 30^{\prime \prime}$ W; BGN 1966; (map 69).

So named in 1966 by Clifford D. Ells of Anchorage because the nearby "main road is called Highland Road."

Highland Park: village, $12 \mathrm{mi}$. SE of Fairbanks, on $\mathrm{S}$ side of Richardson Highway, $\mathrm{N}$ of North Pole, Tanana Low. ; $64^{\circ} 45^{\prime} 30^{\prime \prime} \mathrm{N}, 147^{\circ} 22^{\prime} 15^{\prime \prime}$ W; (map 100).

Local name reported in 1950 by USGS topographers. 
High Mountain: mountain, 2,070 ft., $6 \mathrm{mi}$. SE of Foggy Bay, Revillagigedo Channel, Coast Mts.; $54^{\circ} 55^{\prime} 05^{\prime \prime} \mathrm{N}, 130^{\circ} 50^{\prime} 45^{\prime \prime} \mathrm{W}$; (map 2). Descriptive name given in 1883 by Lt. Comdr. H. E. Nichols, USN.

High Mountain: mountain, 2,506 ft., on Gravina I., S of Sullivan Mtn., $3.9 \mathrm{mi}$. W of Ketchikan, Alex. Arch.; $55^{\circ} 21^{\prime} 45^{\prime \prime} \mathrm{N}, 131^{\circ} 47^{\prime} 40^{\prime \prime} \mathrm{W}$; (map 3).

Local name published in 1886 by USC\&GS.

High Point: point of land, $1.2 \mathrm{mi}$. $N$ of Tongass I., on $\mathrm{E}$ shore of Nakat Bay, on NE shore of Dixon Entrance, Coast Mts.; 54 $47^{\prime} 30^{\prime \prime} \mathrm{N}$, $130^{\circ} 44^{\prime} 25^{\prime \prime} \mathrm{W}$; (map 2).

Named in 1883 by Lt. Comdr. H. E. Nichols, USN.

High Point: point of land, on $\mathrm{E}$ coast of Dall I., at $\mathrm{S}$ entrance to Baldy Bay, Alex. Arch.; $55^{\circ} 01^{\prime} 15^{\prime \prime} \mathrm{N}, 132^{\circ} 57^{\prime} 30^{\prime \prime} \mathrm{W}$; (map 4).

Descriptive name given in 1881 by Lt. Comdr. H. E. Nichols, USN.

High Point: point of land, see Ancon Point.

Highpower Creek: stream, heads in Mount McKinley National Park, flows NW, then SW 58 mi. to Swift Fork Kuskokwim River, $55 \mathrm{mi}$. NE of Medfra, Kuskokwim Low.; $63^{\circ} 25^{\prime} \mathrm{N}$, $153^{\circ} 07^{\prime} \mathrm{W} ; B G N$ 1964; (map 89). Var. Black Creek, Hipower Creek, Slow Fork, Slow Fork Kuskokwim River, Slow Fork Swift Fork Kuskokwim River.

Local name reported in 1958 by USGS.

High Ridge Lake: lake, 1,500 ft. across, in Matanuska Valley, $2.5 \mathrm{mi}$. SW of Palmer, Cook Inlet Low.; $61^{\circ} 34^{\prime} 40^{\prime \prime} \mathrm{N}, 149^{\circ} 10^{\prime} 40^{\prime \prime}$ W; BGN 1957; (map 69). Var. Bairds Lake, Bear Lake, Fresara Lake.

So named in 1954 by $\mathrm{Mr}$. and Mrs. Fred Machetanz of Palmer, Alaska, because the lake is surrounded by high ridges.

High Rock: rock, off $\mathrm{S}$ coast of Amukta I., Aleutian Is.; $52^{\circ} 26^{\prime} 15^{\prime \prime} \mathrm{N}, 171^{\circ} 16^{\prime} 20^{\prime \prime} \mathrm{W}$; (map 20)

Descriptive name given by members of the North Pacific Exploring Expedition of 1855.

High Rock: rock, in Alitak Bay, $\mathbf{S}$ of Moser Penin., at $\mathrm{S}$ end of Kodiak I.; $56^{\circ} 58^{\prime} \mathrm{N}$, $154^{\circ} 05^{\prime} \mathrm{W}$; (map 32).

Descriptive name reported in 1900 by Lt. Comdr. J. F. Moser, USN.

High Rock: rock, see Inner Humpback Rock.

High Rock: rock, see Viesokoi Rock.

High Rock Islet: rock, see Viesokoi Rock.

High Smith Lake: lake, see Hugh Smith Lake.

High Valley, valley, extends SE $20 \mathrm{mi}$. from Maclaren River, between Denali Highway and Amphitheater Mts., $12 \mathrm{mi}$. NW of Paxson, Alaska Ra.; 630ㅇ' N, 146 ${ }^{\circ} 16^{\prime} \mathrm{W}$; (map 86).

Descriptive name given in 1955 by T. L. Péwé, USGS.

Highwater Island: island, $0.1 \mathrm{mi}$. across, in Neva Strait, $0.7 \mathrm{mi}$. S of Saint John Baptist Bay, off Baranof I., $18 \mathrm{mi}$. NW of Sitka, Alex. Arch.; $57^{\circ} 16^{\prime} 50^{\prime \prime} \mathrm{N}, 135^{\circ} 35^{\prime} 45^{\prime \prime} \mathrm{W}$; (map 9). Var. Highwater Islet.

Descriptive name given in 1884 as "Highwater Islet" by Comdr. J. B. Coghlan, USN because at low water it is no longer an island or islet, but it is then connected to the east shore.
The name was published by USC\&GS in 1891 Coast Pilot.

Highwater Islet: island, see Highwater Island.

Highway Pass: pass, 3,800 ft., on Denali Highway, in Mount McKinley National Park, 6 mi. NE of Eielson Visitor Center, Alaska Ra.; $63^{\circ} 28^{\prime} 15^{\prime \prime} \mathrm{N}, 150^{\circ} 09^{\prime} 30^{\prime \prime} \mathrm{W}$; (map 88).

Local name shown on a 1916 fieldsheet by C. E. Giffin, USGS.

Higtiguk: locality, on Agattu I. in the Near Is., Aleutian Is.; (map 13).

Former Aleut village reported as "uninhabited" by Hodge (1907, p. 549), BAE.

Hijosa, Isla de: island, see Middleton Island.

Hikers Lake: lake, 0.5 mi. long, on Kenai Penin., $1 \mathrm{mi}$. NW of Hidden Lake and $32 \mathrm{mi}$. $\mathrm{E}$ of Kenai, Cook Inlet Low.; $60^{\circ} 30^{\prime} 45^{\prime \prime} \mathrm{N}, 150^{\circ}$ 20'45" W; (map 62).

Named about 1963 by officials of Kenai National Moose Range, for administrative purposes.

Hiko-Bukta: bay, see Koyuktolik.

Hilda, Point: point of land, in Stephens Passage on S shore of Douglas I., $7 \mathrm{mi}$. SW of Juneau, Coast Mts.; $58^{\circ} 13^{\prime} 00^{\prime \prime} \mathrm{N}, 134^{\circ} 30^{\prime} 10^{\prime \prime} \mathrm{W}$; (map 11).

Named in 1890 by USC\&GS and published in 1893 on Chart 8235.

Hilda Creek: stream, on Douglas I., flowing SW $3 \mathrm{mi}$. to Stephens Passage, $0.5 \mathrm{mi}$. N of Point Hilda and $6 \mathrm{mi}$. SW of Juneau, Coast Mts.; $58^{\circ} 13^{\prime} 30^{\prime \prime} \mathrm{N}, 134^{\circ} 30^{\prime} 00^{\prime \prime} \mathrm{W}$; BGN 1930; (map 11).

Local name derived from Hilda Point; reported in 1928 by USFS.

Hilda Creek: stream, flows SW $5 \mathrm{mi}$. to North Fork Fortymile River, $40 \mathrm{mi}$. SW of Eagle, Yukon-Tanana High.; $64^{\circ} 19^{\prime} 40^{\prime \prime} \mathrm{N}, 141^{\circ} 58^{\prime}$ $50^{\prime \prime} \mathrm{W}$; (map 102).

Prospectors' name obtained in 1898 by E. C. Barnard, USGS

Hilda Creek: stream, flows NE $0.7 \mathrm{mi}$. to Nome River, $0.2 \mathrm{mi}$. downstream from Basin Creek and $12 \mathrm{mi}$. NE of Nome, Seward Penin. High.; $64^{\circ} 41^{\prime} \mathrm{N}, 165^{\circ} 18^{\prime} \mathrm{W}$; (map 94).

Prospectors' name reported on a 1900 map by S. E. King.

Hilgard Mountain: mountain, 1,500 ft., near Sandborn Harbor, Nagai I., in Shumagin Is., Aleutian Ra.; (map 28).

Named in 1872 by W. H. Dall, USC\&GS, for Julius Erasmus Hilgard, later superintendent of USC\&GS. This mountain is not identified on available sources.

Hiline Lake: lake, $2.3 \mathrm{mi}$. long, NW of Beluga Mtn., 46 mi. NW of Tyonek, Alaska Ra.; $61^{\circ}$ $44^{\prime} 20^{\prime \prime} \mathrm{N}, 151^{\circ} 23^{\prime} 00^{\prime \prime} \mathrm{W}$; (map 70).

Local name reported in 1954 by USGS

Hilksuk: locality, on Agattu I. in the Near Is., Aleutian Is. ; (map 13)

Former Aleut village reported as "uninhabited" by Hodge, (1907, p. 549), BAE.

Hill, Mount: mountain, $3,028 \mathrm{ft} ., 2 \mathrm{mi} . \mathrm{S}$ of mouth of Stag Bay, $19 \mathrm{mi}$. NW of Chichagof, on W coast of Chichag of I., Alex. Arch.; $57^{\circ}$ $54^{\prime} \mathrm{N}, 136^{\circ} 21^{\prime} \mathrm{W}$; BGN 1960; (map 9).

Named in 1955 by USGS "for Joseph Hill, a prospector living in this area for many years, who drowned in Lisianski Strait near this mountain."

Hill, Mount: peak, see Hill Peak.

Hillard Peak: mountain peak, 4,085 ft., $12 \mathrm{mi}$. $\mathrm{N}$ of Eagle, Porcupine Plat.; 64. $57^{\prime} 12^{\prime \prime} \mathrm{N}$, $141^{\circ} 03^{\prime} 30^{\prime \prime}$ W ; BGN 1965; (map 102).

Named by E. E. Brabb, USGS, for John J. Hillard, died 1962, after serving 31 years as customs agent at Eagle.

Hill Creek: stream, flows $\mathrm{N} 0.5 \mathrm{mi}$. to Gilmore Greek, $2 \mathrm{mi}$. W of Gilmore Dome and $12 \mathrm{mi}$. NE of Fairbanks, Yukon-Tanana High.; $64^{\circ}$ $58^{\prime} 45^{\prime \prime} \mathrm{N}, 147^{\circ} 26^{\prime} 00^{\prime \prime} \mathrm{W}$; (map 100).

Local name published in 1908 by the USGS.

Hill Creek: siream, flows SE $2.2 \mathrm{mi}$. to Arctic River, $8 \mathrm{mi}$. E of Ear Mtn. and $46 \mathrm{mi}$. NE of Teller, Seward Penin. High.; $65^{\circ} 54^{\prime}$ N, $165^{\circ}$ $59^{\prime} \mathrm{W}$; (map 111).

Prospectors' name reported in 1901 by T. G. Gerdine (in Collier, 1902, pl. 12), USGS.

Hill Gulch: ravine, trends NW $1 \mathrm{mi}$. to Stewart River, $22 \mathrm{mi}$. NE of Nome, Seward Penin. High.; $64^{\circ} 49^{\prime} \mathrm{N}, 165^{\circ} 23^{\prime} \mathrm{W}$; (map 94).

Prospectors' name reported in 1904 by T. G. Gerdine, USGS.

Hilliard Creek: stream, flows NW $1 \mathrm{mi}$. to Iron Creek which flows to Pilgrim River, between Sidney and Benson Creeks, $25 \mathrm{mi}$. NW of Solomon, Seward Penin. High.; 64 $54^{\prime} 45^{\prime \prime}$ N, $164^{\circ} 41^{\prime} 30^{\prime \prime} \mathrm{W}$; (map 95).

Prospectors' name reported in 1908 on a fieldsheet by P. S. Smith, USGS.

Hill Island: island, $2.5 \mathrm{mi}$. across, $9 \mathrm{mi}$. NW of Chichagof, on $W$ coast of Chichagof I., Alex. Arch.; $57^{\circ} 45^{\prime} \mathrm{N}, 136^{\circ} 17^{\prime} \mathrm{W}$; (map 9). Var. Hills Island.

Named "Hills Island" in 1787 by Capt. Nathaniel Portlock for Robert Hill, one of his traders (Wagner, 1937, p. 462). The name was published as "Hill Island" by USC\&GS in 1883 Coast Pilot (p. 183). Hill Island Light is on the south end of the island.

Hill Island: island, see Hills Island.

Hill Islets: islands, see McFarland Islands.

Hill Lake: lake, see Beaver Lake.

Hill Peak: peak 7,177 ft., on Alaska-Canada boundary, $\mathbf{N}$ of terminus of South Sawyer Glacier, $2 \mathrm{mi}$. N of Sawyer Glacier and $55 \mathrm{mi}$. ESE of Juneau, Coast Mts.; $58^{\circ} 00^{\prime} \mathrm{N}, 133^{\circ} 04^{\prime}$ W; BGN 1927; (map 8). Var. Boundary Peak 78, Mount Hill.

Named by United States and Canada in 1927 for Jesse Hill, United States Section, IBC.

Hill Point: point of land, on NE shore of Tenakee Inlet, $7 \mathrm{mi}$. E of Tenakee Springs, on E coast of Chichagof I., Alex. Arch.; $57^{\circ} 46^{\prime} 45^{\prime \prime}$ $\mathrm{N}, 135^{\circ} 01^{\prime} 15^{\prime \prime} \mathrm{W}$; (map 9).

Descriptive name given in 1925 by USC\&GS "because it is located at the foot of a high hill." The name was published in 1926 on Chart 8250.

Hill Point: hill, 3,118 ft., W of Nabesna River, $23 \mathrm{mi}$. SW of Northway, Alaska Ra.; $62^{\circ} 40^{\prime}$ $\mathrm{N}, 142^{\circ} 15^{\prime} \mathrm{W}$; (map 84$)$.

Local name reported in 1960 by USGS.

Hillside: area, in $S$ part of Anchorage, $S$ of Chester Creek, $W$ of Seward Highway, Cook 
Inlet Low.; $61^{\circ} 12^{\prime} 06^{\prime \prime} \mathrm{N}, 1^{\circ} 9^{\circ} 52^{\prime} 10^{\prime \prime} \mathrm{W}$; (map 69).

Local name reported in 1954 by the city engineer of Anchorage.

Hillside Lake: lake, $0.5 \mathrm{mi}$. long, $\mathrm{W}$ of Dog Lake, $6 \mathrm{mi}$. SE of Northway, Alaska Ra.; 62 ${ }^{\circ} 54^{\prime} \mathrm{N}$, $141^{\circ} 48^{\prime} \mathrm{W}$; (map 84).

Local name reported in 1954 by USGS.

Hills Island: island, 4 mi. long, in Yukon River, $28 \mathrm{mi}$. W of Marshall, Yukon-Kuskokwim Delta; 61 ${ }^{\circ} 54^{\prime}$ N, $162^{\circ} 59^{\prime}$ W; (map 74). Var. Hill Island.

Riverboat pilots' name shown on a 1916 fieldsheet by R. H. Sargent, USGS.

Hills Island: island, see Hill Island.

Hill Slough: stream, see Hills Slough.

Hills Slough: stream, $5 \mathrm{mi}$. long, channel of

Yukon River $\mathbf{N}$ of Hills I., $28 \mathrm{mi}$. W of

Marshall, Yukon-Kuskokwim Delta; $61^{\circ} 55^{\prime}$

N, $162^{\circ} 59^{\prime}$ W; (map 74). Var. Hill Slough.

Riverboat pilots' name shown on a 1916 fieldsheet by R. H. Sargent, USGS.

Hinauhan's Village : locality, "on Stikine River,"

Coast Mts.; (map 6).

Former "summer camp of a Stikine [Indian] chief" (Hodge, 1907, p. 550). Ivan Petroff lists a population of 31 for this locality in the 1880 Census.

Hinchinbroke, Canal de: water passage, "published on an anonymous Spanish chart dated about 1790 . See Wagner (1937, p. 355).

Hinchingbroke, Cape: point of land, see Hinchinbrook, Cape.

Hinchinbroke Island: island, see Hinchinbrook Island .

Hinchinbrok Sound: sound, published on a chart by Don Jacinto Caamaño dated 1791. See Wagner (1937, p. 355).

Hinchinbrook, Cape: point of land, on S tip of Hinchinbrook I., $35 \mathrm{mi}$. SW of Cordova, Chugach Mts. ; $60^{\circ} 14^{\prime} \mathrm{N}, 146^{\circ} 39^{\prime} \mathrm{W}$; (map 64). Var. Cape Hinchingbroke, Mys Morsky, Punta de Español, Punta de Arcadio, Punta de San Luis.

Named in 1778 by Capt. James Cook, RN, "after Viscount Hinchinbroke, John Montagu's father, and afterward used by several navigators ***". (Wagner, 1937, p. 392). This feature was called "M[ys] Morskoi," meaning "sea cape", by Capt. Tebenkov (1852, map 6), IRN. See also Español, Cabo.

Hinchinbrook Entrance: water passage, $10 \mathrm{mi}$. long, at entrance to Prince William Sound, between Hinchinbrook I. and Montague I., $40 \mathrm{mi}$. SW of Cordova, Chugach Mts.; $60^{\circ}$ $20^{\prime} \mathrm{N}, 146^{\circ} 50^{\prime} \mathrm{W}$; BGN 1905; (map 64). Var. Meiklejohn Entrance.

Mariners' name reported in 1901 by USC\&GS; so called for nearby Hinchinbrook Island. Capt. Abercrombie (in Glenn and Abercrombie, 1899 , p. 297), USA, called it "Meiklejohn Entrance" April 8, 1898, "in honor of Hon. G[eorge] D[eRue] Meiklejohn, 18571929, Assistant Secretary of War in the McKinley administration."

Hinchinbrook Island: island, $22 \mathrm{mi}$. long, at SE entrance to Prince William Sound, $15 \mathrm{mi}$. SW of Cordova, Chugach Mts.; $60^{\circ} 23^{\prime} \mathrm{N}, 146^{\circ}$ 28' W; BGN Sixth Report; (map 64). Var. Chinchinbrook Island, Hinchinbroke Island, Isla de la Magdalena, Khta-aluk Island, Nuchek Island, Ostrov Khtagalyuk, Ostrov TkhaIka, Rose Island, Santa Maria Magdalena.

Named on May 12, 1778, by Capt. James Cook, RN, for Viscount Hinchinbroke. The Island was called "Santa Maria Magdalena," or "Saint Mary Magdalen," by Don Ignacio Artega on July 22, 1779 (Wagner, 1937, p. 392). Capt. John Meares, RN, called it "Rose Island" in 1788. Capt. Tebenkov (1852, map 6) published the Eskimo name as "O[strov] Khtagalyuk," or "Khtagalyuk Island"; shown as "O[strov] Tkhalka," or "Tkhalka Island," on an 1802 Russian map. Hinckley, Mount: mountain, 4,300 ft., in Lincoln Mts., $2.7 \mathrm{mi}$. SW of Hyder, Coast Mts.; $55^{\circ} 53^{\prime} 15^{\prime \prime} \mathrm{N}, 130^{\circ} 04^{\prime} 40^{\prime \prime} \mathrm{W}$; $B G N$ 1927; (map 3).

Named by the Hyder Chamber of Commerce, after Earl Hinckley, U.S. Immigration Officer, who died in 1926 by falling from a cliff on this peak.

Hindasetukee: locality, see Gantegastaki.

Hines Greek: stream, flows NE $6.5 \mathrm{mi}$. to Riley Creek, $10 \mathrm{mi}$. S of Healy, Alaska Range; $63^{\circ} 43^{\prime} 30^{\prime \prime} \mathrm{N}, 148^{\circ} 54^{\prime} 30^{\prime \prime} \mathrm{W}$; (map 87).

Local name reported by Woodbury Abbey, U.S. Army Corps of Engineers, on the blueprint of his 1921 Mount McKinley National Park survey.

Hines River: stream, see Cannery Creek.

Hines River: stream, see Gines Creek.

Hioo Bay: bight, see Hallo Bay.

Hipower Creek: stream, see Highpower Creek. Hirst Cove: cove, see Kimshan Cove.

Hirst Mountain: mountain, 2,300 ft., $5 \mathrm{mi}$. NE of Chichagof, on $\mathrm{W}$ coast of Chichagof $\mathrm{I}$., Alex. Arch.; 57 $43^{\prime} \mathrm{N}, 136^{\circ} 00^{\prime} \mathrm{W}$; $B G N$ 1939; (map 9).

Named locally about 1935 for "Bernard Hirst of Sitka, who in 1905 discovered and staked the first mining claim on Kimshan Cove."

Hitchcock Glacier: glacier, W of Hitchcock Hills, trends SW $3 \mathrm{mi}$. to Seward Glacier, $43 \mathrm{mi}$. NW of Yakutat, St. Elias Mts.; $60^{\circ} 05^{\prime} \mathrm{N}$, $140^{\circ} 25^{\prime} \mathrm{W}$; (map 66).

Named in 1897 by His Royal Highness, Prince Luigi Amedeo di Savoia, Duke of Abruzzi (Filippi, 1900, p. 99).

Hitchcock Hills: mountain range, 7,200 ft., extends SW $8 \mathrm{mi}$. from Pinnacle Pass to Malaspina Glacier, $43 \mathrm{mi}$. NW of Yakutat, St. Elias Mts. ; $60^{\circ} 06^{\prime} \mathrm{N}, 140^{\circ} 20^{\prime} \mathrm{W}$; (map 66). Var. Hitchcock Range.

Named "Hitchcock Range" in 1890 by Russell (1891, p. 112), for Edward Hitchcock, "In acknowledgement of the services to science rendered by the first state geologist of Massachusetts."

Hitchcock Range: mountain range, see Hitchcock Hills.

Hiteshitak Mountain: mountain, 5,533 ft. $3 \mathrm{mi}$. W of Tohitkah Mtn. and $2.4 \mathrm{mi}$. SE of Mount Ashmun on Alaska-Canada boundary, $31 \mathrm{mi}$.
NW of Skagway, St. Elias Mts. ; $59^{\circ} 36^{\prime} 45^{\prime \prime} \mathrm{N}$, $136^{\circ} 08^{\prime} 40^{\prime \prime} \mathrm{W}$; (map 45).

Tlingit Indian name given by E. C. Robertson, geologist; published in 1952 by USGS. Hitts: locality, see Tuckers.

Hive Bay: bay, $1 \mathrm{mi}$. across, on $\mathrm{E}$ coast of Unalaska I., Aleutian Is.; $53^{\circ} 40^{\prime} \mathrm{N}, 166^{\circ} 23^{\prime}$ W; (map 23).

This name was published in the 1944 Aleutian Coast Pilot (p. 51).

Hive Island, island, $0.7 \mathrm{mi}$. across, between Resurrection Bay and Eldorado Narrows, 17 mi. S of Seward, Ghugach Mts.; $59^{\circ} 53^{\prime} \mathrm{N}$, $149^{\circ} 22^{\prime}$ W; BGN 1906; (map 49). Var. Sugar Loaf Island, Guard Island.

According to USC\&GS, in 1905 the local name was "Sugar Loaf Island." Surveyors of the Alaska Central RR. called it "Guard Island." The BGN "officially" named it Hive to avoid duplication.

Hive Rock: rock, $1.8 \mathrm{mi}$. NW of Round Point, off NW coast of Kanaga I., Aleutian Is.; $51^{\circ} 43^{\prime} 30^{\prime \prime} \mathrm{N}, 177^{\circ} 33^{\prime} 00^{\prime \prime} \mathrm{W}$; (map 17).

Name published by USC\&GS in 1956 on Chart 9145.

H'lit-tu-yah: bay, see Lituya Bay.

Hludasetsk: stream, see Ludaseska Creek.

Hlukkuhoan: locality, "in SE Alaska".

Former Tlingit Indian town listed in Hodge (1907, p. 554), BAE, as "Laxq! uxo-än" meaning "town where people do not sleep much." This locality may be the presentday Klukwan.

Hoagies Hole: $b a y, 0.2 \mathrm{mi}$. across, $14 \mathrm{mi}$. SW of Petersburg, at $\mathbf{S}$ end of Lindenberg Penin., Kupreanof I., Alex. Arch.; 56 $36^{\prime} 30^{\prime \prime} \mathrm{N}$, $133^{\circ} 01^{\prime} 10^{\prime \prime} \mathrm{W}$; (map 6).

Local fishermen's name reported in 1947 by USC\&GS.

Hobart, Point: point of land, on $\mathbf{E}$ shore of Stephens Passage, about $1 \mathrm{mi}$. S of Hobart Bay, $2.6 \mathrm{mi}$. SW of Entrance I. and $74 \mathrm{mi}$. $\mathrm{E}$ of Sitka, Coast Mts.; $57^{\circ} 22^{\prime} 45^{\prime \prime} \mathrm{N}, 133^{\circ} 28^{\prime} 20^{\prime \prime}$ W; (map 8). Var. Mys Khobart.

Named by Capt. George Vancouver, RN, after its discovery by Lt. Joseph Whidbey on August 13, 1794, for John Hobart, the Second Earl of Buckingham, England (Wagner, 1937, p. 392). This name was published in 1848 as "Mys Khobart," that is "Khobart Cape," by the Russian Hydrog. Dept. on Chart 1396.

Hobart Bay: bay, $6 \mathrm{mi}$. long, on $\mathbf{E}$ shore of Stephens Passage, $5 \mathrm{mi}$. SE of Rocky Point and $74 \mathrm{mi}$. NE of Sitka, Coast Mts.; $57^{\circ} 24^{\prime}$ $30^{\prime \prime} \mathrm{N}, 133^{\circ} 28^{\prime} 00^{\prime \prime} \mathrm{W}$; (map 8).

Named in 1889 by Lt. Comdr. H. B. Mansfield, USN; published by USC\&GS in the 1891 Coast Pilot (p. 146).

Hobo Bay: estuary, trends SE $1 \mathrm{mi}$. to Port Wells, $20 \mathrm{mi}$. NE of Whittier, Chugach Mts.; $60^{\circ} 57^{\prime} 00^{\prime \prime} \mathrm{N}, 148^{\circ} 13^{\prime} 30^{\prime \prime} \mathrm{W}$; (map 63).

Local name published in 1916 by USC\&GS.

Hobo Creek: stream, flows SE $3.5 \mathrm{mi}$. to Hobo Bay, $20 \mathrm{mi}$. NE of Whittier, Chugach Mts.; $60^{\circ} 57^{\prime} 35^{\prime \prime} \mathrm{N}, 148^{\circ} 14^{\prime} 15^{\prime \prime} \mathrm{W}$; (map 63).

Local name reported in 1951 by USGS; derived from Hobo Bay. 
Hobo Creek: stream, flows S $0.4 \mathrm{mi}$. to Hard Luck Creek which flows to Dome Creek, 22 mi. NW of Solomon, Seward Penin. High.; $64^{\circ} 53^{\prime} 05^{\prime \prime} \mathrm{N}, 164^{\circ} 36^{\prime} 00^{\prime \prime} \mathrm{W}$; (map 95).

Prospectors' name reported in 1908 on a fieldsheet by P. S. Smith, USGS.

Hobron, Port: bay, extends SW $7 \mathrm{mi}$. off Sitkalidak Strait on N coast of Sitkalidak I., SE of Kodiak I.; $57^{\circ} 10^{\prime} \mathrm{N}, 153^{\circ} 10^{\prime} \mathrm{W}$; (map 34).

Baker (1906, p. 307) wrote, "Apparently so named by Petrof[f] 1887 or 1888, who at that time established here a fishing station for the Alaska Coast Fishery Company * * *."

Hobson Creek: stream, flows S $4 \mathrm{mi}$. to Nome River, $16 \mathrm{mi}$. NE of Nome, Seward Penin. High.; $64^{\circ} 44^{\prime} \mathrm{N}, 165^{\circ} 17^{\prime} \mathrm{W}$; (map 94).

Prospectors' name reported in 1900 by E. C. Barnard (in Brooks, 1901, pl. 17), USGS.

Hochandochtla Mountain: mountain, 3,200 ft., $2 \mathrm{mi}$. NE of Anotleneega Mtn. at the headwaters of Dulbi River, $47 \mathrm{mi}$. NW of Birches, Kokrines-Hodzana High.; $65^{\circ} 31^{\prime} 50^{\prime \prime} \mathrm{N}$, $154^{\circ} 52^{\prime} 00^{\prime \prime} \mathrm{W}$; (map 107).

Koyukan Indian name obtained at Huslia in 1956 by Orth.

Hockley Hills: mountains, $1,887 \mathrm{ft}$., highest elevation, extends NE-SW $12 \mathrm{mi}$., $19 \mathrm{mi}$. NW of Selawik, Hogatza High.; $66^{\circ} 51^{\prime} \mathrm{N}, 160^{\circ} 18^{\prime}$ W; (map 114).

Probably named by English naval officers during the Franklin search expeditions of 1849-54 for John Hockley, one of Capt. F. W. Beechey's crew in 1825 .

Hocktaheene Cove: cove, see Hoktaheen Cove. Hocktaheene Greek: stream, see Hoktaheen Creek.

Hocktaheine Cove: cove, see Hoktaheen Cove.

Hocktaheine Creek: stream, see Hoktaheen Creek.

Hodatic River: stream, flows SW $16 \mathrm{mi}$. to Three Day Slough, $25 \mathrm{mi}$. W of Roundabout Mtn., Koyukuk Low.; $65^{\circ} 32^{\prime} \mathrm{N}, 157^{\circ} 25^{\prime} \mathrm{W}$; (map 108).

Koyukan Indian name reported in 1900 by Lt. B. H. Camden, USRCS (Cantwell, 1904, p. 244).

Hodcana: locality, see Caribou Bar.

Hodegaden Creek: stream, flows NE $7 \mathrm{mi}$. to Koyukuk River, $24 \mathrm{mi}$. NE of Nulato, Nulato Hills; $64^{\circ} 58^{\prime} \mathrm{N}, 157^{\circ} 33^{\prime} \mathrm{W}$; (map 97).

Koyukan Indian name reported in 1954 by USGS.

Hodgins Slough: lake, $0.8 \mathrm{mi}$. long, oxbow, $\mathrm{N}$ of junc. of Chena River and its South Fork, 25 mi. E of Fairbanks, Yukon-Tanana High.; $64^{\circ} 53^{\prime} 30^{\prime \prime} \mathrm{N}, 146^{\circ} 41^{\prime} 00^{\prime \prime} \mathrm{W}$; (map 101)

Local name reported in 1950 by USGS.

Hodgkins Mountain: peak, see Hodgkins Peak.

Hodgkins Peak: peak, 5,800 ft., just $S$ of Organ Pipes, $24 \mathrm{mi}$. NE of Juneau, Coast Mts.; $58^{\circ} 35^{\prime} 20^{\prime \prime} \mathrm{N}, 134^{\circ} 02^{\prime} 45^{\prime \prime} \mathrm{W} ; B G N$ 1923; (map 11). Var. Hodgkins Mountain.

Named in 1923 by USC\&GS for their man, Capt. William Chandler Hodgkins, 18541922.

Hodgkins Point: point of land, on S coast of Esther I., at $\mathrm{N}$ side of Wells Passage, $22 \mathrm{mi}$.
E of Whittier, Chugach Mts.; $60^{\circ} 47^{\prime} \mathrm{N}$, $148^{\circ} 02^{\prime} \mathrm{W}$; (map 63).

Local name reported in 1952 by USGS.

Hodikof, Cape: point of land, see Hodikof Point.

Hodikof, Cape: point of land, see Krupa Point.

Hodikof Bay: bight, $0.5 \mathrm{mi}$. across, on $\mathrm{E}$ coast Attu I., on N shore of Sarana Bay, Aleutian Is.; $52^{\circ} 53^{\prime} 10^{\prime \prime} \mathrm{N}, 173^{\circ} 17^{\prime} 10^{\prime \prime} \mathrm{E}$; (map 13). Var. Purvis Cove.

Name derived from Hodikof Point; shown as "Purvis Cove" on an AMS map published in 1948; listed as "Hodikof Bay" in the 1954 Coast Pilot (p. 475).

Hodikoff Point: point of land, see Hodikof, Point.

Hodikoff Point: point of land, see Krupa Point.

Hodikof Island: island, $0.1 \mathrm{mi}$. long, in Sarana Bay, off Attu I., Aleutian Is.; $52^{\circ} 52^{\prime} 40^{\prime \prime} \mathrm{N}$, $173^{\circ} 17^{\prime} 45^{\prime \prime} \mathrm{E}$; (map 13).

Derived from Hodikof Point; shown on USC\&GS Chart 9127 published in 1951.

Hodikof Point: point of land, on $\mathrm{E}$ coast of Attu I., $E$ of Pierucci Ridge, $1 \mathrm{mi}$. NE of Krupa Point at $\mathrm{N}$ entrance to Sarana Bay, Aleutian Is.; $52^{\circ} 53^{\prime} 30^{\prime \prime} \mathrm{N}, 173^{\circ} 17^{\prime} 55^{\prime \prime} \mathbf{E}$; $B G N$ 1965; (map 13). Var. Cape Hodikof, Hodikoff Point, Krupa Point.

This feature is shown as "Hodikoff Point" in the 1944 Aleutian Coast Pilot (p. 134) and as "Cape Hodikof" on an AMS map published in 1948.

Hodikof Point: point of land, see Krupa Point. Hodikof Reef: reef, between Hodikof Point and Hodikof I., E of Attu I., Aleutian Is. ; $52^{\circ} 52^{\prime}$ $50^{\prime \prime} \mathrm{N}, 173^{\circ} 17^{\prime} 00^{\prime \prime} \mathrm{E}$; (map 13).

This name is derived from Hodikof Point and is shown on USC\&GS Chart 9127, published in 1951.

Hodzana: locality, see Caribou Bar.

Hodzana River: stream, heads at $63^{\circ} 30^{\prime} \mathrm{N}$, $149^{\circ} 58^{\prime} \mathrm{W}$, flows SE $125 \mathrm{mi}$. to Hodzana Slough, Yukon River, 12 mi. SW of Beaver, Yukon Flats; $66^{\circ} 17^{\prime} 30^{\prime \prime} \mathrm{N}, 147^{\circ} 46^{\prime} 30^{\prime \prime} \mathrm{W}$; $B G N$ 1907; (map 118). Var. Hosiana River, Hosianna River.

Indian name meaning "male beaver" published on Edwards Track Chart of the Yukon, 1899, as "He Beaver (Hosiana)." The name was also applied to what is now called Hodzana Slough. The present spelling was recommended to BGN by Archdeacon Hudson Stuck in 1907, "as best representing local pronunciation."

Hodzana Slough: stream, channel of Yukon River, flows SW $12 \mathrm{mi}$., $16 \mathrm{mi}$. SW of Beaver, Yukon Flats; $66^{\circ} 14^{\prime} 00^{\prime \prime} \mathrm{N}, 147^{\circ} 54^{\prime} 40^{\prime \prime} \mathrm{W}$; (map 118). Var. He Beaver Slough.

Indian name reported in 1956 by R. E. Isto, USGS. See Hodzana River.

Hoelsher Creek: stream, flows $3.2 \mathrm{mi}$. E to $W$ side of Temnac Bay, southern Attu I., Aleutian Is.; $52^{\circ} 48^{\prime} 25^{\prime \prime} \mathrm{N}, 172^{\circ} 59^{\prime} 55^{\prime \prime} \mathrm{E}$; (map 13).

Named by the U.S. Army during its occupation of the island during World War II; name shown on an AMS map published in 1948.
Hoffman, Mount: mountain, see Hoffmann, Mount.

Hoffmann, Mount: mountain, 6,080 ft., $4 \mathrm{mi}$. SW of Chilkoot Pass and $15 \mathrm{mi}$. N. of Skagway; Coast Mts.; $59^{\circ} 40^{\prime} 10^{\prime \prime} \mathrm{N}, 135^{\circ} 20^{\prime} 20^{\prime \prime} \mathrm{W}$; (map 45). Var. Mount Hoffman.

Named in 1898 by J. A. Flemer, USC\&GS. Hoffmans: village, see Napaimiut.

Hoffnung: point of land, see Hope, Point.

Hofstad Creek: stream, flows SW $3.7 \mathrm{mi}$. to Vixen Inlet, on NW coast of Cleveland Penin., Alex. Arch.; 55 $46^{\prime} 45^{\prime \prime} \mathrm{N}, 132^{\circ} 00^{\prime}$ 05" W; BGN 1915; (map 4). Var. Hoftad Creek.

Local name reported in 1914 by E. Lester Jones, USBF.

Hoftad Creek: stream, see Hofstad Creek.

Hogan: locality, site of telegraph station, on Richardson Highway, $27 \mathrm{mi}$. N of Gulkana, Copper River Basin; 62 $38^{\prime} 50^{\prime \prime} \mathrm{N}, 145^{\circ} 29^{\prime}$ $00^{\prime \prime} \mathrm{W}$; (map 83).

Recorded in 1910 as Hogan Telegraph Station by D. C. Witherspoon (in Moffit, 1912, pl. 1), USGS.

Hogan, Mount: mountain, 5,453 ft., $1.8 \mathrm{mi}$. NE of Mount Shasta and $10.5 \mathrm{mi}$. NW of Valdez, Chugach Mts.; $61^{\circ} 10^{\prime} 30^{\prime \prime} \mathrm{N}, 146^{\circ} 30^{\prime} 50^{\prime \prime} \mathrm{W}$; (map 68).

Prospectors' name reported in 1911 by $\mathrm{J}$. W. Bagley and C. E. Giffin, USGS.

Hogan Bay: estuary, extends SE $2 \mathrm{mi}$. to Montague Strait, at SE end of Knight I., $10 \mathrm{mi}$. NE of Latouche I., Chugach Mts. ; $60^{\circ} 11^{\prime} 30^{\prime \prime}$ N, $147^{\circ} 44^{\prime} 15^{\prime \prime} \mathrm{W} ; B G N$ 1908; (map 63).

Named for a local miner and published by USC\&GS in 1908

Hogan Hill: hill, 2,647 ft., $2.5 \mathrm{mi}$. long, $E$ of Richardson Highway, $27 \mathrm{mi}$. N of Gulkana, Copper River Basin; $62^{\circ} 39^{\prime} \mathrm{N}, 145^{\circ} 28^{\prime} \mathrm{W}$; (map 83).

Local name taken from the name of the telegraph station; reported by Moffit (1912, pl. 1), USGS.

Hogan Island: island, $2.5 \mathrm{mi}$. long, $6 \mathrm{mi}$. NW of Chichagof, on $W$ coast of Chichagof $I$. Alex. Arch.; $57^{\circ} 43^{\prime} \mathrm{N}, 136^{\circ} 15^{\prime} \mathrm{W}$; (map 9). Var. Hogans Island, Vincent Island.

Named "Hogans Island" in 1787 by Capt. Nathaniel Portlock on his sketch map and "Vincent Island" on his general chart. Hogans Island was named for James Hoggan, surgeon on Capt. Portlock's ship King George (Wagner 1937, p. 462, 523). The name "Hogan Island" was published by USC\&GS in 1883 Coast Pilot (p. 183).

Hogan Lake: lake, $0.5 \mathrm{mi}$. across, on $\mathrm{N}$ central Baranof I., $13 \mathrm{mi}$. NE of Sitka, Alex. Arch.; $57^{\circ} 12^{\prime} 30^{\prime \prime} \mathrm{N}, 135^{\circ} 06^{\prime} 30^{\prime \prime} \mathrm{W}$; (map 9).

Local name reported in 1951 by USGS.

Hogan Point: point of land, on S tip of Hogan I., $6.5 \mathrm{mi}$. WNW of Chichagof, on $W$ coast of Chichagof I., Alex. Arch.; $57^{\circ} 11^{\prime} 30^{\prime \prime} \mathrm{N}$, $136^{\circ} 15^{\prime} 45^{\prime \prime} \mathrm{W}$; BGN 1926; (map 9).

Named in 1926 by USC\&GS; derived from Hogan Island and published in 1927.

Hogans Island: island, see Hogan Island.

Hogatiakakat: stream, see Hogatza River. Hogatiakakat River: stream, see Hogatza River. 
Hogatsikakat: stream, see Hogatzakhotak Creek. Hogatsikakat River: stream, see Hogatza River. Hogatza: locality, on Bear Creek, in Hogatza River Valley, $42 \mathrm{mi}$. WNW of Hughes, Hogatza High.; $66^{\circ} 11^{\prime} \mathrm{N}, 155^{\circ} 43^{\prime} \mathrm{W}$; (map 116). Var. Hog River.

This mining camp was established about 1940.

Hogatza Flats: swamp, $8 \mathrm{mi}$. across, along course of Hogatza River, $20 \mathrm{mi}$. NW of Hughes, Hogatza High.; $66^{\circ} 18^{\prime} \mathrm{N}, 154^{\circ} 39^{\prime} \mathrm{W}$; (map 116).

Local name recorded at Hughes in 1956 by Orth; named for the river.

Hogatza Hills: hills, 2,000 ft., extending NE-SW $20 \mathrm{mi}$. between Hughes Creek and Hogatza River, $25 \mathrm{mi}$. N of Hughes, Hogatza High.; $66^{\circ} 25^{\prime} \mathrm{N}, 154^{\circ} 10^{\prime} \mathrm{W}$; (map 116 ).

Indian name "Hogatzatgla," meaning "Hogatza Hills," recorded at Hughes in 1956 by Orth. The redundant "gla," meaning "hills," was dropped when the English generic was added during publication.

Hogatzakakat River: stream, see Hogatza River.

Hogatzakhotak Creek: stream, flows SE $8 \mathrm{mi}$. to Koyukuk River $3 \mathrm{mi}$. downstream from the mouth of Hogatza River, $35 \mathrm{mi}$. W of Hughes; $66^{\circ} 00^{\prime} \mathrm{N}, 155^{\circ} 28^{\prime} \mathrm{W}$; Var. Hogatsikakat, Little Hog River, Little Hogatza River.

Koyukan Indian name given as "Little $\mathbf{H o g}$ River" by Lt. B. H. Camden, USRCS, in 1900. The present name is from Orth in 1956.

Hogatza River: stream, heads at $66^{\circ} 57^{\prime} \mathrm{N}, 154^{\circ}$ $12^{\prime}$ W, flows SW 120 mi. to Koyukuk River, $32 \mathrm{mi}$. WSW of Hughes, Hogatza High.; $66^{\circ} 00^{\prime} \mathrm{N}, 155^{\circ} 24^{\prime}$ W; BGN 1901; (map 116). Var. Hog River, Hogatiakakat River, Hogatsikakat River, Hogatzakakat River, Hokachatna River, Hokuchatna River, Kokachatna River, Kokachutna River.

Koyukan Indian name reported in 1885 by Lt. Allen (1887, p. 103), USA. This feature appears to be the same stream that Lt. Stoney (1900, p. 42, map) refers to as "Kokachatna" or "Kokachutna."

Hogback Glacier: glacier, trends N $1.5 \mathrm{mi}$. to Corbin Glacier, $9 \mathrm{mi}$. E of Valdez, Chugach Mts.; $61^{\circ} 06^{\prime} 30^{\prime \prime} \mathrm{N}, 145^{\circ} 50^{\prime} 30^{\prime \prime} \mathrm{W}$; (map 68).

Named in 1898 by Capt. W. R. Abercrombie, USA.

Hogback Hill: hill, $272 \mathrm{ft}$, near S shore of Pastol Bay, $46 \mathrm{mi}$. SW of St. Michael, Yukon-

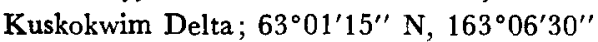
W; (map 92).

Descriptive name given in 1898 by USC\&GS "because of its shape."

Hogem Creek: stream, see Deadwood Creek.

Hog'em Gulch: stream, see Deadwood Creek.

Hogem Junction: locality, on right bank of Crooked Creek, W of Deadwood Creek, 26 mi. SW of Circle, Yukon-Tanana High.; $65^{\circ} 32^{\prime} \mathrm{N}, 144^{\circ} 38^{\prime} \mathrm{W}$; (map 104).

Name of trail junction; derived from "Hog'em Gulch," the early prospectors' nickname for Deadwood Creek. The name was reported in 1896 by USGS (Spurr, 1898, pl. 50). See Deadwood Creek.
Hoggat Bay: bay, see Hoggatt Bay.

Hoggatt Bay: bay, $0.6 \mathrm{mi}$. across, $3.5 \mathrm{mi}$. long, on $\mathrm{E}$ coast of Baranof I., Alex. Arch.; $56^{\circ} 46^{\prime} 15^{\prime \prime} \mathrm{N}, 134^{\circ} 39^{\prime} 30^{\prime \prime} \mathrm{W}$; (map 5). Var. Hoggat Bay.

Named in 1895 by Lt. Comdr. E. K. Moore, USN, for Ens. Wilford Bacon Hoggatt, 18651938, USN, a member of his party. Hoggatt was Governor of Alaska from 1906 to 1909.

Hoggatt Island: island, $0.2 \mathrm{mi}$. long, in Peril Strait, off Duffield Penin. at $\mathrm{N}$ tip of Baranof I., $23 \mathrm{mi}$. SE of Chichagof, Alex. Arch.; $57^{\circ} 33^{\prime} 10^{\prime \prime} \mathrm{N}, 135^{\circ} 30^{\prime} 30^{\prime \prime} \mathrm{W}$; (map 9).

Local name reported in 1951 by USGS.

Hoggatt Reefs: reefs, $0.3 \mathrm{mi}$. long, $\mathrm{S}$ of Hoggatt I., $\mathrm{N}$ end of Baranof I., $23 \mathrm{mi}$. SE of Chichagof, Alex. Arch.; $57^{\circ} 32^{\prime} 45^{\prime \prime} \mathrm{N}, 135^{\circ} 30^{\prime} 45^{\prime \prime}$ W; (map 9).

Named in 1895 by Lt. Comdr. E. K. Moore, USN, for Ens. Wilford Bacon Hoggatt, 18651938, a member of his party in 1895-97 and who later became Governor of Alaska, 190609. Hoggatt was born in Indiana and was a graduate of the U.S. Naval Academy. He was a navy officer, 1884-98, before becoming a mining engineer.

Hogg Bay: estuary, on $\mathrm{E}$ coast of Bainbridge I., extends W $4 \mathrm{mi}$. to Port Bainbridge, $40 \mathrm{mi}$. E of Seward, Chugach Mts.; $60^{\circ} 04^{\prime} 30^{\prime \prime} \mathrm{N}$, $148^{\circ} 17^{\prime} 30^{\prime \prime} \mathrm{W}$; (map 63).

Named for a local miner; reported in 1908 by U. S. Grant and D. F. Higgins (in Brooks and others, 1910, pl. 4), USGS.

Hogg Island: island, $0.6 \mathrm{mi}$. across, in Bluefox Bay, on $\mathrm{N}$ coast of Afognak I.; $58^{\circ} 27^{\prime} 30^{\prime \prime} \mathrm{N}$, $152^{\circ} 42^{\prime} 30^{\prime \prime} \mathrm{W}$; (map 43 ).

Name published by USC\&GS in 1928 on Chart 8573.

Hoggom Creek: stream, see Schlitz Creek.

Hogg Point: point of land, on E coast of Bainbridge $\mathrm{I}$., at $\mathrm{N}$ entrance to Hogg Bay, $16 \mathrm{mi}$. SW of Chenega, Chugach Mts.; $60^{\circ} 05^{\prime} \mathrm{N}$, $148^{\circ} 17^{\prime} \mathrm{W}$; BGN 1929; (map 63).

Named in 1929 by Capt. R. S. Patton, USC\&GS; derived from nearby Hogg Bay.

Hog Island: island, $0.4 \mathrm{mi}$. long, $3 \mathrm{mi}$. E of Afognak, between Afognak and Kodiak Is.; $58^{\circ} 00^{\prime} 15^{\prime \prime} \mathrm{N}, 152^{\circ} 41^{\prime} 10^{\prime \prime} \mathrm{W}$; (map 43). Var. Shayak Island.

Name reported in 1900 by Lt. Comdr. J. F. Moser, USN, commander of the USBF steamer Albatross, who made surveys and investigations in this area from 1897 to 1901. This island was called "O[strov] Shayak," or "Shayak Island," by Capt. Tebenkov (1852, map 23), IRN.

Hog Island: island, $0.9 \mathrm{mi}$. long, in Unalaska Bay, on NE coast of Unalaska I., Aleutian Is.; $53^{\circ} 54^{\prime} 15^{\prime \prime}$ N, $166^{\circ} 34^{\prime} 20^{\prime \prime}$ W; (map 23). Var. Ostrov Svinoy, Ostrov Uknodok, Ouknadok Island, Swinoi Island, Uknadak Island.

The Russians placed hogs on this island and the name was published as "O[strov] Svinoy," meaning "hog island," by Capt. Tebenkov (1852, map 26), IRN. Lt. Sarichev (1826, map 15), IRN, published the Aleut name as "Os[trov] Uknodok," or "Uknodok Island."
Hog Island: island, "in Muscle Cove, an indentation in the northern shore of Beaver Inlet, Unalaska Island" (Wagner, 1937, p. 462).

Hog Landing: locality, supply landing, at junc. of Hogatza and Koyukuk Rivers, $32 \mathrm{mi}$. W of Hughes, Hogatza High.; $66^{\circ} 00^{\prime} \mathrm{N}, 155^{\circ} 24^{\prime}$ W; (map 116).

Named in the 1950's when the place was established, at the south terminus of the road to Hogatza, as a river landing for supplies. "Hog" is the local name for the Hogatza River; reported in 1956 by Orth.

Hog River: locality, see Hogatza.

Hog River: stream, see Hogatza River.

Hog Rocks: reef, extends $1.5 \mathrm{mi}$., between Felice Strait and Revillagigedo Channel, $18 \mathrm{mi}$. SE of Ketchikan, NE of Ham I., Alex. Arch.; $55^{\circ} 11^{\prime} 15^{\prime \prime} \mathrm{N}, 131^{\circ} 18^{\prime} 30^{\prime \prime} \mathrm{W}$; (map 3). Var. Frog Rocks.

Named in 1883 by Lt. Comdr. H. E. Nichols, USN.

Ho-holiknuk River: stream, see Hoholitna River.

Hoholitna River: stream, heads in Whitefish Lake at $60^{\circ} 56^{\prime} \mathrm{N}, 154^{\circ} 59^{\prime} \mathrm{W}$, flows NW 165 mi. to Holitna River $13 \mathrm{mi}$. SE of its junc. with Kuskokwim River, $14 \mathrm{mi}$. S of Sleetmute, Stony River Low.; $61^{\circ} 30^{\prime} 35^{\prime \prime} \mathrm{N}, 156^{\circ} 59^{\prime} 00^{\prime \prime}$ W; BGN 1915; (map 72). Var. Agalitnak River, Ha-ha-link-nuk River, Hahalitha River, Haliknuk River, Ho-holiknuk River.

Present spelling of Indian name can be attributed to R. H. Sargent, USGS, in 1914. A name obtained in 1898 "from A. Lind, a trader" was "Haliknuk," which was said to mean "sudden (unexpected)," by J. E. Spurr and W. S. Post, USGS. Eskimo name "Agalitnak" obtained in $1842-44$ by Lt. L. A. Zagoskin, IRN.

Hokachatna: stream, see Hogatza River.

Hokachatna River: stream, see Hogatza River. Hokatena: stream, see Wild River.

Hokdoloni Hills: hills, $1,844 \mathrm{ft}$., extend N-S 8 mi. on W bank of Hughes Creek, $13 \mathrm{mi}$. NW of Hughes, Hogatza High.; $66^{\circ} 13^{\prime} \mathrm{N}, 154^{\circ} 30^{\prime}$ W; (map 116).

Indian name, reported to mean "hills above" (Lake Tokhaklanten); recorded at Hughes in 1956 by Orth.

Hokeley Gulch: ravine, extends S $1.3 \mathrm{mi}$. to Deep Creek, $4 \mathrm{mi}$. SW of Tofty and $33 \mathrm{mi}$. ESE of Tanana, Yukon-Tanana High.; $65^{\circ} 03^{\prime} 45^{\prime \prime} \mathrm{N}, 150^{\circ} 59^{\prime} 05^{\prime \prime} \mathrm{W}$; BGN 1961; (map 106). Var. Hokley Gulch; Hovley Gulch.

Prospectors' name reported in 1931 as "Hovley Gulch" by J. B. Mertie, USGS.

Hokley Gulch: ravine, Hokeley Gulch.

Hoknede Mountain: mountain, 2,969 ft., $1 \mathrm{mi}$. SW of Lake Clark and $2 \mathrm{mi}$. NW of Nondalton, Alaska Ra. ; $60^{\circ} 02^{\prime} \mathrm{N}, 154^{\circ} 53^{\prime} \mathrm{W}_{\text {; (map }}$ 61 ).

Tanaina Indian name reported in 1914 by R. H. Sargent (in Smith and others, 1917, pl. 1), USGS.

Hokotena River: stream, see Wild River.

Hoktaheen Cove: cove, $0.2 \mathrm{mi}$. across, on NW coast of Yakobi I., $1.5 \mathrm{mi}$. NW of Hoktaheen Lake, $41 \mathrm{mi}$. $\mathrm{W}$ of Hoonah, Alex. Arch.; 
$58^{\circ} 04^{\prime} 20^{\prime \prime} \mathrm{N}, 136^{\circ} 32^{\prime} 50^{\prime \prime} \mathrm{W}$; BGN 1908; (map 10). Var. Hocktaheene Cove, Hocktaheine Cove.

Tlingit Indian name reported by Lt. Comdr. Moser (1902, p. 377), USN, as Hocktaheene Cove.

Hoktaheen Creek: stream, on NW side of Yakobi I., heads in Hoktaheen Lake, flows $1.5 \mathrm{mi}$. NW to Hoktaheen Cove, $40 \mathrm{mi}$. W of Hoonah, Alex. Arch.; $58^{\circ} 04^{\prime} 20^{\prime \prime} \mathrm{N}, 136^{\circ} 32^{\prime} 30^{\prime \prime} \mathrm{W}$ $B G N$ 1908; (map 10). Var. Hocktaheene Creek, Hocktaheine Creek.

Tlingit Indian name reported by Lt. Comdr. Moser (1902, p. 377), USN, as Hocktaheene Greek.

Holstaheen Lake: lake, $0.6 \mathrm{mi}$. across, on $\mathrm{N}$ part of Yakobi I., $39 \mathrm{mi}$. W of Hoonah, Alex. Arch.; 58 $03^{\prime} 25^{\prime \prime} \mathrm{N}, 136^{\circ} 30^{\prime} 55^{\prime \prime} \mathrm{W}$; (map 10).

Local name reported by USGS in 1948 derived from Hoktaheen Creek on which it is located.

Hokuchatna: stream, see Hogatza River.

Hokuchatna River: stream, see Hogatza River. Holbrook: locality, at head of Davidson Inlet, on S. coast of Kosciusko I., Alex. Arch.; $56^{\circ} 02^{\prime} 05^{\prime \prime} \mathrm{N}, 133^{\circ} 29^{\prime} 30^{\prime \prime}$; (map 6).

This is the site of an abandoned fishing station. Named by the owners and reported in 1904 by E. F. Dickins, USC\&GS.

Holbrook Mountain: mountain, 2,648 ft., between Davidson Inlet and Tokeen Bay, on SE coast of Kosciusko I, Alex. Arch. ; 56 $6^{\circ} 01^{\prime}$ $45^{\prime \prime} \mathrm{N}, 133^{\circ} 27^{\prime} 10^{\prime \prime} \mathrm{W}$; (map 6).

Named in 1904 by E. F. Dickins, USC\&GS, "after the [Holbrook] fishery."

Holdem Creek: stream, flows NE $2.5 \mathrm{mi}$. to Ketchem Creek, $3 \mathrm{mi}$. W of Circle Hot Springs and $30 \mathrm{mi}$. SW of Gircle, Yukon-Tanana High.; $65^{\circ} 29^{\prime} \mathrm{N}, 1^{\circ} 4^{\circ} 45^{\prime} \mathrm{W}$; $B G N$ 1938; (map 104).

Local name used by prospectors in recording mining claims; reported in 1937 by USGS.

Holdeyeit Lake: lake, $1 \mathrm{mi}$. long, on $\mathrm{E}$ bank of Alatna River, $2.2 \mathrm{mi}$. NE of Allakaket, Kanuti Flats; $66^{\circ} 35^{\prime} 30^{\prime \prime} \mathrm{N}, 152^{\circ} 35^{\prime} 30^{\prime \prime} \mathrm{W}$; (map 117).

Koyukan Indian name obtained in 1956 at Allakaket by ' $\Gamma$. E. Taylor, USGS.

Hole in the Wall: locality, on E island of San Lorenzo Is., Maurelle Is., Alex. Arch.; 55 ${ }^{\circ}$. $35^{\prime} 50^{\prime \prime} \mathrm{N}, 133^{\circ} 36^{\prime} 40^{\prime \prime} \mathrm{W}$; (map 4).

Local name recorded in 1951 by USGS; shown on a 1964 USGS map as an abandoned site with several buildings remaining. USC\&GS applies this name to the channel between the two San Lorenzo Islands; "this channel is locally known as Hole in the Wall and two or three fish-buying scows anchor in the wider part of it each summer from May 1 to September 15. All necessary supplies for fishermen are available here" (USC\&GS, 1962, p. 91).

Hole in the Wall: estuary, extends E $0.8 \mathrm{mi}$. off Diver Bay, on NW coast of Dall I., Alex. Arch.; $55^{\circ} 10^{\prime} 25^{\prime \prime} \mathrm{N}, 133^{\circ} 12^{\prime} 10^{\prime \prime} \mathrm{W}$; (map 4).
Descriptive name published in 1928 by USC\&GS.

Hole in the Wall: estuary, extends SW $1.5 \mathrm{mi}$. to Sumner Strait, $6 \mathrm{mi}$. S of village of Point Baker, on $\mathrm{N}$ coast of Prince of Wales I., Alex. Arch.; $56^{\circ} 16^{\prime} 10^{\prime \prime} \mathrm{N}, 133^{\circ} 37^{\prime} 00^{\prime \prime} \mathrm{W}$; (map 6).

Named in 1886 by Lt. J. M. Helm, USN, for charting purposes; published in 1887 on USC\&GS Chart 706

Hole in the Wall Glacier: glacier, a branch of Taku Glacier, trends E $1 \mathrm{mi}$. to Taku River, $20 \mathrm{~m}$. NE of Juneau, Coast Mts.; $58^{\circ} 28^{\prime} 45^{\prime \prime}$ $\mathrm{N}, 133^{\circ} 59^{\prime} 35^{\prime \prime} \mathrm{W}$; (map 12).

Local name reported in 1951 by USGS.

Hole in the Wall Glacier: glacier, $7.5 \mathrm{mi}$. across, trends $6.8 \mathrm{mi}$. $\mathrm{N}$ to its terminus at Skolai Creek, $27 \mathrm{mi}$. NE of McCarthy, Wrangell Mts.; $61^{\circ} 39^{\prime} 30^{\prime \prime} \mathrm{N}, 142^{\circ} 12^{\prime} 31^{\prime \prime} \mathrm{W}$; (map 67).

Local name published by USGS in 1954 .

Hole in the Wall: water passage, see Piehle Passage.

Holekachucket: village, see Holikachuk.

Holes Point: point of land, see Dirovati Point. Holgate Arm: estuary, extends SE $5 \mathrm{mi}$. from Holgate Glacier to Aialik Bay, $24 \mathrm{mi}$. SW of Seward, Chugach Mts.; $59^{\circ} 49^{\prime} \mathrm{N}, 1^{149^{\circ} 45^{\prime}}$ W; BGN 1911; (map 49).

Named in 1911 by U. S. Grant, USGS, for "Dr. T. F. Holgate, Dean of the College of Liberal Arts of Northwestern University and well known educator."

Holgate Glacier: glacier, trends SE $5.3 \mathrm{mi}$. to its terminus at Holgate Arm, $24 \mathrm{mi}$. SW of Seward, Chugach Mts.; 59 $51^{\prime}$ N, $149^{\circ} 52^{\prime}$ W; BGN 1911; (map 49).

Named in 1911 by U. S. Grant, USGE, for Dr. T. F. Holgate. See Holgate Arm

Holgate Head: promontory, 1,435 ft., extends into Aialik Bay, $24 \mathrm{mi}$. SW of Seward, Chugach Mts.; $59^{\circ} 50^{\prime} \mathrm{N}, 149^{\circ} 45^{\prime} \mathrm{W}$; BGN 1930; (map 49), Var. Holgate Peninsula, Holgate Point.

Named in 1912 by USG\&GS "after adjoining Holgate Arm."

Holgate Peninsula: promontory, see Holgate Head.

Holgate Point: promontory, see Holgate Head.

Holiday Beach: beach, $0.5 \mathrm{mi}$. long, $6.2 \mathrm{mi}$. SW of Kodiak, Kodiak I. ; $57^{\circ} 42^{\prime} 20^{\prime \prime}$ N, $152^{\circ} 28^{\prime}$ $20^{\prime \prime}$ W; (map 34).

Name derived from Holiday Island and published in 1949 by USGS.

Holiday Creek: stream, flows SE $7 \mathrm{mi}$. to Hogatza River, $40 \mathrm{mi}$. NW of Hughes, Hogatza High. $66^{\circ} 18^{\prime} \mathrm{N}, 155^{\circ} 33^{\prime} \mathrm{W}$; (map 116).

Named about 1955 by mining engineers: reported in 1956 by Orth.

Holiday Island: island, $0.8 \mathrm{mi}$. long, $1 \mathrm{mi}$. $\mathrm{E}$ of Kodiak, Kodiak I.; $57^{\circ} 47^{\prime}$ N, $152^{\circ} 23^{\prime}$ W; (map 34). Var. Ostrov Prazdnichnoy, Prazdnic Island, Prazdnichnoi, Praznic Island, Praznik Island, Rocky Island.

Translation by USC\&GS in 1869 of the name "Os[trov] Prazdnichnoy," published by Sarichev (1826, map 16). In 1804, Lisianski (1814, p. 44) called it "Rocky Island."
Baker (1906, p. 510) published the name "Praznik."

Holikachek: village, see Holikachuk.

Holikachuk: village, pop. 122, on $\mathrm{W}$ bank of Innoko River, $27 \mathrm{mi}$. NE of Anvik and $49 \mathrm{mi}$. $\mathrm{N}$ of Holy Cross, Innoko Low.; 62 $54^{\prime} 40^{\prime \prime} \mathrm{N}$ $159^{\circ} 31^{\prime} 00^{\prime \prime} \mathrm{W} ; B G N$ 1941; (map 78). Var. Holekachucket, Holikachek, Holikitsak, Holokochakat, Khoughitchate, Khuligishgat, Selo Khulishganat.

There were several Ingalik Indian villages recorded in this low wetland by the Russians (see Shageluk); Holikachuk may be the one mentioned in 1861 by $P$. Tikhmeniev as "Sel[o] Khulishganat" or "Khuligishgat." The 11th Census in 1890 lists the place as "Holikitsak" with a population of 114. A post office was maintained here from 1941 to 1964 (Ricks, 1965, p. 26).

Holikachuk Slough: stream, flows E $16 \mathrm{mi}$. between Shageluk Slough and Innoko River, 1.4 mi. E of Holikachuk and $50 \mathrm{mi}$. N of Holy Cross, Innoko Low.; $62^{\circ} 55^{\prime} \mathrm{N}, 159^{\circ} 28^{\prime} \mathrm{W}$; (map 78).

Local name obtained in 1952 by USGS.

Holikitsak: village, see Holikachuk.

Holiknuk: stream, see Holitna River.

Holitna River: stream, formed by confluence of Kogrukluk River and Shotgun Creek at $60^{\circ} 49^{\prime} 30^{\prime \prime} \mathrm{N}, 157^{\circ} 51^{\prime} 00^{\prime \prime} \mathrm{W}$, flows NE 110 $\mathrm{mi}$. to Kuskokwim River, $1.5 \mathrm{mi}$. $\mathrm{S}$ of Sleetmute, Stony River Low.; $61^{\circ} 40^{\prime} 45^{\prime \prime} \mathrm{N}, 157^{\circ}$. $10^{\prime} 00^{\prime \prime}$ W; BGN 1915; (map 72). Var. Chalitnak, Cholitna, Cholitno, Chulitna, Culitna, Holiknuk, Holitno, Holitnuk, Hoolitna, Hulitna, Hulitnak, Hulitno, Khulitno, Kulitnak.

Native name published in 1826 as "Khulitna" by Lt. G. A. Sarichev, IRN; spelled "Khulitnak" in 1842-44 by Lt. L. A. Zagoskin, IRN, and "Holitnuk" on an 1898 fieldsheet by W. S. Post, USGS.

Holitno: stream, see Holitna River.

Holitnuk River: stream, see Holitna River.

Holkam Bay: bay, see Holkham Bay.

Holkham Bay: bay, $6 \mathrm{mi}$. across at mouth, with two forks, Endicott Arm and Tracy Arm, extends $\mathrm{E}$ from Stephens Passage, $45 \mathrm{mi}$. SE of Juneau, Coast Mts.; $57^{\circ} 45^{\prime} 40^{\prime \prime} \mathrm{N}, 133^{\circ} 40^{\prime}$ $30^{\prime \prime}$ W ; BGN 1964; (map 8). Var. Holkam Bay, Sum Dum, Zaliv Kholkkhem.

Named by Capt. George Vancouver, RN, after its discovery by Lt. Joseph Whidbey on August 13, 1794, for Holkham, a town in Norfolk, England (Wagner, 1937, p. 392). The Tlingit Indian name is "Sum Dum."

Holland Creek: stream, in Chigmit Mts., flows E 4 mi. to Left Fork West Glacier Creek, 5.5 mi. $\mathrm{N}$ of Chinitna Bay, Aleutian Ra.; 59 ${ }^{\circ} 6^{\prime}$ N, $153^{\circ} 18^{\prime} \mathrm{W}$; (map 51 ).

Local name published in 1958 by USGS. Holland Harbor: anchorage, see Dutch Harbor. Holligan Creek: stream, flows SW $2.2 \mathrm{mi}$. to Kuzitrin River, 21 mi. NW of Mount Bendeleben, Seward Penin. High.; $65^{\circ} 13^{\prime}$ N, $164^{\circ} 49^{\prime}$ W; (map 110).

Prospectors' name reported on the 1908 "Map of Seward Peninsula" by Arthur Gibson. 
Hollings, Cape : point of land, see Narrow Cape. Hollingworth, Mount: mountain, 4,100 ft., in Brooks Ra., $12 \mathrm{mi}$. N of Iggiruk Mts. and 36 mi. NE of Misheguk Mtn. ; $68^{\circ} 29^{\prime} \mathrm{N}, 159^{\circ} 26^{\prime}$ W; (map 131).

Named in 1960 by geologists of BP Exploration Company (Alaska) Inc. for S. E. Hollingworth, 1889-1966, who was professor of geology at University College, London University.

Hollis: village, on Hollis Anchorage, $N$ of Cat I., near center of Prince of Wales I., Alex. Arch.; $55^{\circ} 29^{\prime} 10^{\prime \prime} \mathrm{N}, 132^{\circ} 40^{\prime} 05^{\prime \prime} \mathrm{W}$; (map 4).

Local name reported in 1904 by H. C. Fassett, USBF. Hollis post office was established in 1901 and discontinued in 1942 (Ricks, 1965 , p. 26). The village "started as a mining community after the turn of the century but has now swung to logging. A research center is maintained here by the U.S. Forest Service" (Alaska Sportsman, 1962, no. 12, p. 28).

Hollis Anchorage: cove, $\mathrm{N}$ of Cat I., extends W $1.4 \mathrm{mi}$., off Twelvemile Arm Kasaan Bay, near center of Prince of Wales I., Alex. Arch.; $55^{\circ} 28^{\prime} 30^{\prime \prime} \mathrm{N}, 132^{\circ} 38^{\prime} 15^{\prime \prime} \mathrm{W}$; (map 4).

Local name reported in 1904 by $H$. C. Fassett, USBF.

Hollow Bight: cove, $0.5 \mathrm{mi}$. across, on NE coast of Kenai Penin., at SE end of Passage Canal, $6 \mathrm{mi}$. NE of Whittier, Chugach Mts.; $60^{\circ}$ $48^{\prime} 20^{\prime \prime} \mathrm{N}, 148^{\circ} 29^{\prime} 00^{\prime \prime} \mathrm{W}$; BGN 1915; (map $63)$.

Local name reported in 1914 by USC\&GS.

Holmes Creek: stream, flows $7 \mathrm{mi}$. N from Giffin Glacier to White River, $56 \mathrm{mi}$. NE of McCarthy, St. Elias Mts.; $61^{\circ} 43^{\prime} 30^{\prime \prime}$ N, $141^{\circ}$ 20'00" W; (map 67).

Local name shown on 1908 field sheet by S. R. Capps, USGS.

Holmes Creek: stream, flows SE $3.5 \mathrm{mi}$. from Holmes Pass to Clear River, $4 \mathrm{mi}$. W of Whiteface Mtn. and $32 \mathrm{mi}$. NW of Wiseman, Brooks Ra.; 67 $49^{\prime} 00^{\prime \prime} \mathrm{N}, 150^{\circ} 33^{\prime} 00^{\prime \prime} \mathrm{W}$; $B G N 1932$; (map 124).

Named in 1931 by Marshall (1956, p. 72), for "the great jurist, whom we both admired so much, and who was celebrating his ninetieth birthday at about that time." Marshall was referring to Justice Oliver Wendell Holmes, 1941-1935.

Holmes Glacier: glacier, see Giffin Glacier.

Holmes Gulch: ravine, trends $\mathrm{S} 1 \mathrm{mi}$. to Hidden Creek, $7 \mathrm{mi}$. NW of Medfra, KilbuckKuskokwim 'Mts.; $63^{\circ} 12^{\prime} \mathrm{N}, 154^{\circ} 48^{\prime} \mathrm{W}$; (map 89).

Prospectors' name obtained in 1921 by G. C. Martin (in Brooks, 1922, fig. 5), USGS.

Holmes Pass: pass, 3,600 ft. between heads of Holmes and Pyramid Creeks, $35 \mathrm{mi}$. NW of Wiseman, Brooks Ra.; $67^{\circ} 50^{\prime} 30^{\prime \prime} \mathrm{N}, 150^{\circ}$ $41^{\prime} 00^{\prime \prime} \mathrm{W}$; (map 124).

Named about 1930 by Robert Marshall for the creek which heads in the pass.

Holöatná: stream, flows $\mathrm{N}$ possibly to the Colville River; possibly it is the Colville itself, Brooks Ra.

Koyukan Indian name obtained in 1885 by Lt. Allen (1887, p. 98), USA. See Basnuná.
Holöatna: stream, see Kobuk River.

Holokak River: stream, see Holokuk River.

Holokochakat: village, see Holikachuk.

Holokuk Mountain: mountain, 3,400 ft., in Kuskokwim Mts., on E bank of Holokuk River, N of Chineekluk Creek, $41 \mathrm{mi}$. SW of Sleetmute and $44 \mathrm{mi}$. SE of Aniak, Kilbuck-Kuskokwim Mts.; $61^{\circ} 23^{\circ} \mathrm{N}, 158^{\circ} 13^{\prime} \mathrm{W}$; $B G N$ 1948; (map 72). Var. Oolokok Mountain.

Eskimo name reported in 1945 by USGS. See Holokuk River.

Holokuk River: stream, flows NE and NW $45 \mathrm{mi}$. to Kuskokwim River $31 \mathrm{mi}$. E of Aniak, Kilbuck-Kuskokwim Mts.; 61 ${ }^{\circ} 32^{\prime} 15^{\prime \prime} \mathrm{N}, 153^{\circ}$ 35'35" W; BGN 1948; (map 72). Var. Holokak River, Olokak River, Oolokok River, Ulokak River, Wloyukuk River.

Eskimo name derived from the word, variously "olo," "ulo" or "ulu," meaning "stone knife," obtained in 1898 from trader, A. Lind, and spelled "Wloyukuk" by J. E. Spurr and W. S. Post, USGS. Shown as "O-loo-kok" on a 1902 prospectors' map. The present spelling, locally used, was reported in 1945 by USGS. See Ulokak, locality.

Holonada Creek: stream, heads in Ray Mts., flows NE $30 \mathrm{mi}$. to Kanuti Kilolitna Creek 5 mi. S of its junc. with Kanuti River, $34 \mathrm{mi}$. SE of Allakaket, Kanuti Flats; $66^{\circ} 08^{\prime} \mathrm{N}$, $152^{\circ} 02^{\prime} \mathrm{W}$; (map 117).

Koyukan Indian name obtained in 1956 at Allakaket by Orth.

Holoöatná: stream, see Kobuk River.

Hŏlóstiăk-rālógg: valley, at $\mathrm{W}$ end of North Rookery, on $\mathrm{N}$ coast of Saint George $\mathrm{I}$., in Pribilof Is.; $56^{\circ} 36^{\prime} 05^{\prime \prime} \mathrm{N}, 169^{\circ} 35^{\prime} 00^{\prime \prime} \mathrm{W}$; (map 38).

Russian-Aleut name reported by Putnam (1903, p. 1014), USG\&GS, to mean "holostiak [bachelor seal] rookery," because, according to native tradition, the area was formerly occupied only by bachelor seals.

Hólóstiäk.rālōm-kiyä': ridge, at $\mathrm{W}$ end of North Rookery, on N coast of Saint George I. ; in Pribilof Is. ; $56^{\circ} 36^{\prime} 00^{\prime \prime} \mathrm{N}, 169^{\circ} 35^{\prime} 30^{\prime \prime} \mathrm{W}$; (map 38).

A Russian-Aleut name listed by Putnam (1903, p. 1014), USC\&GS, meaning "ridge where holostiaks [bachelor seals] are taken.

Holtilyet Slough: stream, anabranch of Yukon River, flows NW $5.7 \mathrm{mi}$. to Yukon River, 12 mi. NE of Nulato, Koyukuk Low.; 64.51' N, $157^{\circ} 51^{\prime} \mathrm{W}$; (map 97).

Koyukan Indian name reported in 1954 by USGS.

Holtnakatna Creek: stream, flows N $34 \mathrm{mi}$. to Dulbi River, $15 \mathrm{mi}$. S of Roundabout Mtn., Koyukuk Low.; $65^{\circ} 20^{\circ} \mathrm{N}, 156^{\circ} 30^{\prime} \mathrm{W}$; (map 108).

Koyukan Indian name reported in 1955 by USGS.

Holtz Bay: bay, 2 mi. across, formed by its East and West Arms on $\mathrm{N}$ coast of Attu I., Aleutian Is.; $52^{\circ} 56^{\prime} 30^{\prime \prime} \mathrm{N}, 173^{\circ} 10^{\prime} 45^{\prime \prime} \mathrm{E}$; BGN 1944; (map 13). Var. Bukhta Goltsovaya, Goltsovaia Bay, Goltzeb Bay, Goltzef Bay, Gotzeb Bay.
This bay was called "Goltsovaia Bay" by Capt. Lutke (1836, p. 329), IRN, possibly from the German word "holtz" meaning "wood." The Russians called it "Bukhta Goltsovaya" (Tebenkov, 1852, map 30).

Holtz Creek: stream, formed by junc. of Circle and Spruce Creeks, flows NE $10 \mathrm{mi}$. to Kugruk River, $21 \mathrm{mi}$. NE of Imuruk Lake, Seward Penin. High.; $65^{\circ} 40^{\prime} \mathrm{N}, 162^{\circ} 28^{\prime} \mathrm{W}$; (map 110).

Prospectors' name reported in 1903 by D. C. Witherspoon (in Moffit, 1905, pl. 2), USGS. Holtz Sarana Pass: pass, between Newman Peak and Prendergast Ridge, on eastern Attu Is., Aleutian Is.; $52^{\circ} 54^{\prime} 15^{\prime \prime} \mathrm{N}, 173^{\circ} 11^{\prime} 30^{\prime \prime} \mathrm{E}$; (map 13).

Named by the U.S. Army during its occupation of the island during World War II ; shown on an AMS map published in 1948.

Holy Gross: village, pop. 256 , on $W$ bank of Walker Slough, off Yukon River, $34 \mathrm{mi}$. SE of Anvik, Innoko Low.; $62^{\circ} 12^{\prime} \mathrm{N}, 159^{\circ} 46^{\prime}$ W; BGN 1944; (map 78). Var. Anilukhlukh-kat, Anilukhtak-kak, Anilukhtakpak, Askhomute, Koserefski, Kozerevsky, Nelson Askhomut, Ingrichagamut.

Lt. L. A. Zagoskin, IRN, in 1842-44, showed a native village here called "Anilukhtakpak" and "Anilukhtak-kak." Ivan Petroff in the 10th Census in 1880 lists a village called "Askhomute" and "Nelson Askhomut". A Jesuit mission and school were established here in 1886; a post office was established in 1899 under the name "Koserefski" derived from the Russian name of the old village across the river. The post office name was changed in 1912 to "Holy Cross," after the mission. In 1880 the village population was 30 Eskimo; in 1890 , with the influence of the mission, the number was 131, almost all Ingalik Indians; in 1930 its population was 337.

Holy Cross Hills: hills, $896 \mathrm{ft}$., extend SW $17 \mathrm{mi}$. from Holy Cross, $\mathbf{N}$ of Crooked Lake, Nulato Hills; $62^{\circ} 09^{\prime} \mathrm{N}, 160^{\circ} 00^{\prime} \mathrm{W}$; (map 78).

Local name reported in 1916 by G. L. Harrington and R. H. Sargent (in Harrington, 1918, pl. 1), USGS.

Holy Cross Hills: mountains, see Ilivit Mountains.

Holy Moses Creek: stream, flows NE $1.5 \mathrm{mi}$. to Big Lake, $1.5 \mathrm{mi}$. SE of village of Big Lake and $24 \mathrm{mi}$. W of Chandalar, Brooks Ra.; $67^{\circ} 29^{\prime} 30^{\prime \prime} \mathrm{N}, 149^{\circ} 24^{\prime} 15^{\prime \prime} \mathrm{W}$; (map 123).

Local name reported in 1956 by T. E. Taylor, USGS.

Holyoke Creek: stream, flows $0.8 \mathrm{mi}$. to Bourbon Creek, $2 \mathrm{mi}$. N of Nome, Seward Penin. High.; $64^{\circ} 31^{\prime} 40^{\prime \prime} \mathrm{N}, 165^{\circ} 22^{\prime} 20^{\prime \prime} \mathrm{W}$; (map 94).

Prospectors' name reported on the 1903 Campion Mining and Trading Co. map by George M. Ashford.

Holyoke Creek: stream, flows NE $4.5 \mathrm{mi}$. to Niukluk River, $32 \mathrm{mi}$. NE of Solomon, Seward Penin. High.; 64 $54^{\prime}$ N, $163^{\circ} 43$ W; (map 95). Var. Beattle Creek. 
This may be the stream shown as "Beattle" on the 1900 "Map of Nome Peninsula" by J. M. Davidson and B. D. Blakeslee.

Holyoke Glacier: glacier, trends SE $1.5 \mathrm{mi}$., on $\mathrm{W}$ bank of College Fiord, $6.8 \mathrm{mi}$. SW of College Point and $65 \mathrm{mi}$. E of Anchorage, Chugach Mts.; 61 $09^{\circ} 30^{\prime \prime} \mathrm{N}, 147^{\circ} 56^{\prime} 00^{\prime \prime} \mathrm{W}$; BGN 1910; (map 69).

Named by U.S. Grant and D. F. Higgins, USGS, in 1908. Named for Mount Holyoke College, South Hadley, Mass.

Holyoke Gulch: ravine, trends S $1 \mathrm{mi}$. to Bourbon Creek which flows to Snake River, $2 \mathrm{mi}$. NNE of Nome, Seward Penin. High.; 64 $31^{\circ}$ $30^{\prime \prime} \mathrm{N}, 165^{\circ} 22^{\prime} 30^{\prime \prime} \mathrm{W}$; (map 94).

Prospectors' name shown on the 1904 "Map of Cape Nome Precinct" by Arthur Gibson. This feature cannot be precisely identified on current maps.

Homebrew Island: island, $1.2 \mathrm{mi}$. long, in Porcupine River, $2 \mathrm{mi}$. N of Fort Yukon, Yukon Flats; $66^{\circ} 36^{\prime} \mathrm{N}, 145^{\circ} 16^{\prime} \mathrm{W}$; (map 119).

Local descriptive name obtained in 1956 by USGS.

Home Cove: cove, $0.7 \mathrm{mi}$. wide, on NW coast of Nuka I., $36 \mathrm{mi}$. ESE of Seldovia, Chugach Mts.; $59^{\circ} 23^{\prime} 30^{\prime \prime} \mathrm{N}, 150^{\circ} 42^{\prime} 15^{\prime \prime} \mathrm{W}$; (map $50)$.

Local name reported by USC\&GS in 1939 on Chart 8530.

Home Creek: stream, on S side of Alaska Penin., flows SW $2 \mathrm{mi}$. to lower Yantarni Creek, 7.5 mi. N of Cape Kunmik, Aleutian Ra.; $56^{\circ} 52^{\prime} \mathrm{N}, 157^{\circ} 10^{\prime} \mathrm{W}$; (map 31 ).

Local name reported in 1951 by USGS.

Home Creek: stream, flows N $1.2 \mathrm{mi}$. to West Fork Kuyukutuk River $12.8 \mathrm{mi}$. E of Marshall, Nulato Hills; $61^{\circ} 52^{\prime} 00^{\prime \prime} \mathrm{N}, 161^{\circ} 41^{\prime} 30^{\prime \prime} \mathrm{W}$; (map 73).

Prospectors' name reported in 1916 by Harrington (1918, map), USGS.

Home Creek: stream, heads $3 \mathrm{mi}$. SE of Fairview Mts., flows SE $16 \mathrm{mi}$. to Lake Creek, $34 \mathrm{mi}$. SW of Talkeetna, Alaska Ra.; $62^{\circ} 15^{\prime} 10^{\prime \prime} \mathrm{N}$, $161^{\circ} 09^{\prime} 30^{\prime \prime} \mathrm{W}$; (map 81).

Local name reported in 1958 by USGS.

Home Lake: lake, $1.2 \mathrm{mi}$. long, $\mathrm{S}$ of and draining into Tokositna River, $26 \mathrm{mi}$. NW of Talkeetna, Alaska, Ra.; 62 $37^{\prime} 15^{\prime \prime} \mathrm{N}, 150^{\circ} 37^{\prime} 00^{\prime \prime}$ W; (map 81).

Local name reported in 1906 by $R$. W. Porter, USGS.

Homer: town, pop. 1,247, on Kenai Penin., on $\mathrm{N}$ shore of Kachemak Bay, $16 \mathrm{mi}$. NE of Seldovia, Cook Inlet Low.; 59 38'40' N, $151^{\circ} 33^{\prime} 00^{\prime \prime} \mathrm{W}$; (map 50).

This town appears to have been established on or near Homer Spit in November 1895. Both the town and spit were named for Homer Pennock, a prospector who worked in the Cook Inlet area. A post office was established in the town in $\mathbf{1 8 9 6 .}$

Homer Spit: spit, $0.3 \mathrm{mi}$. wide, extends SE 4 mi. from Homer into Kachemak Bay, on Kenai Penin. Cook Inlet Low.; 59 $37^{\prime} \mathrm{N}$, $151^{\circ} 27^{\prime} \mathrm{W}$; (map 50).
Named by $R$. W. Stone, USGS, in 1904, for the village of Homer which was formerly located on the spit.

Homesite Park: suburb, S of Glenn Highway, E of Anchorage, Cook Inlet Low.; 61 ${ }^{\circ} 13^{\prime} 12^{\prime \prime} \mathrm{N}$, $149^{\circ} 43^{\prime} 50^{\prime \prime}$ W; BGN 1954; (map 69).

A subdivision beyond the corporate limits of Anchorage; named by Manvil H. Olson in 1953 because "the original block of land has been divided into smaller tracts which have become hornesites."

Homestake Creek: stream, flows NW $1.8 \mathrm{mi}$. to Willow Creek, $14 \mathrm{mi}$. NW of Palmer, Talkeetna Mts.; $61^{\circ} 45^{\prime} 45^{\prime \prime} \mathrm{N}, 149^{\circ} 24^{\prime} 05^{\prime \prime} \mathrm{W}$; (map 69).

Local name reported in 1913 by USGS (Brooks and others, 1914, fig. 2).

Homestake Creek: stream, flows SW $5 \mathrm{mi}$. to join Granite Creek to form Willow Creek, 32 mi. SE of Flat, Kilbuck-Kuskokwim Mts.; $62^{\circ}$ $21^{\prime} \mathrm{N}, 157^{\circ} 02^{\prime} \mathrm{W}$; (map 79).

Prospectors' name obtained in 1952 by USGS topographers.

Homestake Creek: stream, flows NE $3 \mathrm{mi}$. to Totatlanika River, $42 \mathrm{mi}$. SE of Nenana,

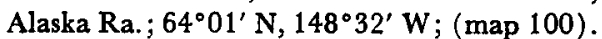

Prospectors' name reported in 1906 by L. M. Prindle (in Brooks and others, 1907, pl. 4), USGS.

Homestake Creek: stream, flows SE $4.5 \mathrm{mi}$. to Pilgrim River, $29 \mathrm{mi}$. NW of Solomon, Seward Penin. High.; $64^{\circ} 58^{\prime} \mathrm{N}, 164^{\circ} 41^{\prime} \mathrm{W}$; (map 95).

Prospectors' name reported in 1900 by E. C. Barnard (in Brooks, 1901, pl. 17), USGS.

Homestake Creek: stream, in Rampart Mts., flows NE $3 \mathrm{mi}$. to Morelock Creek $4 \mathrm{mi}$. of that stream's junc. with Yukon River, $24 \mathrm{mi}$. ENE of Tanana, Kokrines-Hodzana High.; $65^{\circ} 19^{\prime} 30^{\prime \prime} \mathrm{N}, 151^{\circ} 21^{\prime} 00^{\prime \prime} \mathrm{W}$; (map 106).

Prospectors' name reported in 1911 by $\mathrm{H}$. M. Eakin (in Brooks and others, 1912, pl. 13), USGS.

Homestake Greek: stream, flows W $3.5 \mathrm{mi}$. to Charity Creek, $68 \mathrm{mi}$. SW of Circle, YukonTanana High.; $65^{\circ} 24^{\prime} 45^{\prime \prime} \mathrm{N}, 146^{\circ} 15^{\prime} 00^{\prime \prime} \mathrm{W}$; (map 104).

Miners' name reported in 1903 by USGS and given to the creek which flows to the headwaters of Faith Creek (Prindle, 1905, pl. 13). Subsequently, the name "Charity Creek" has been reapplied through local usage to the former lower course of the stream.

Homestake Creek: stream, flows NE $4 \mathrm{mi}$. to Agiapuk River, $18 \mathrm{mi}$. NE of Teller, Seward Penin. High.; $65^{\circ} 28^{\prime} \mathrm{N}, 165^{\circ} 58^{\prime} \mathrm{W}$; (map 111).

Prospectors' name reported on the 1908 "Map of Seward Peninsula" by Arthur Gibson.

Homestake Greek: stream, flows NE $2.2 \mathrm{mi}$. to Kougarok River, $9 \mathrm{mi}$. SW of Midnight Mtn and $47 \mathrm{mi}$. NW of Imuruk Lake, Seward Penin. High.; $65^{\circ} 41^{\prime} \mathrm{N}, 164^{\circ} 48^{\prime} \mathrm{W}$; (map 110).

Prospectors' name reported in 1901 by $T$. G. Gerdine (in Gollier, 1902, pl. 12), USGS.
Homestake Gulch: ravine, trends SE $1 \mathrm{mi}$. to Casadepaga River, $0.3 \mathrm{mi}$. E of Casadepaga and $18 \mathrm{mi}$. N of Solomn, Seward Penin. High.; $64^{\circ} 48^{\prime} \mathrm{N}, 164^{\circ} 21^{\prime} \mathrm{W}$; (map 95).

Prospectors' name reported in 1907 by USGS geologists (Smith, P. S., 1910, pl. 4). Home Stream: stream, see Akalura Creek.

Honda, Cala: locality, "on the south shore of Disenchantment Bay, Yakutat Bay."

Spanish name or term published on a 1791 map by Capt. Alessandro Malaspina. See Wagner (1937, p. 462).

Honeybee Lake: lake, 2,600 ft. across, $2 \mathrm{mi}$. SW of Willow and $34 \mathrm{mi}$. $\mathrm{N}$ of Anchorage, Cook Inlet Low.; $61^{\circ} 42^{\prime} 45^{\prime \prime} \mathrm{N}, 150^{\circ} 03^{\prime} 10^{\prime \prime} \mathrm{W}$; (map 70).

Local name reported in 1958 by USGS.

Honey Creek, stream, flows W $2.7 \mathrm{mi}$. to Penny River, $11 \mathrm{mi}$. NW of Nome, Seward Penin. High.; $64^{\circ} 37^{\prime} \mathrm{N}, 165^{\circ} 39^{\prime} \mathrm{W}$; (map 94).

Prospectors' name reported in 1899 by D. C. Witherspoon (in Schrader and Brooks, 1900, map 2), USGS.

Honeymoon Creek: stream, heads on Shannon Hill, in Indian Mts., flows $N$ and $\mathbf{W} \mathbf{~ m i . ~ t o ~}$ Koyukuk River, $27 \mathrm{mi}$. NE of Hughes, Kokrines-Hodzana High.; $66^{\circ} 21^{\prime} \mathrm{N}, 153^{\circ} 39^{\prime} \mathrm{W}$; (map 116).

Local name recorded at Hughes in 1956 by Orth. Named for Honeymoon Riffle in the Koyukuk River

Honeymoon Riffle: rapids, on Koyukuk River, near mouth of Honeymoon Creek $27 \mathrm{mi}$. NE of Hughes; $66^{\circ} 21^{\prime} \mathrm{N}, 153^{\circ} 39^{\prime} \mathrm{W}$; (map 116).

Name published in 1920 by Archdeacon Hudson Stuck.

Honeymoon Slough: watercourse, $9.8 \mathrm{mi}$. long, channel of Yukon River, $\mathbf{E}$ and $\mathbf{S}$ of Bullfrog I., $45 \mathrm{mi}$. SE of Unalakleet, Innoko Low.; $63^{\circ} 41^{\prime} \mathrm{N}, 159^{\circ} 22^{\prime} \mathrm{W}$; (map 91). Var. Cunningham Slough, Ohlson Slough.

Local name reported in 1949 by USC\&GS. The variant names are found on a 1940 "Navigation Chart of the Tanana-Yukon Rivers."

Hongkong Bend: bend, of Kasilof River, on Kenai Penin. $19 \mathrm{mi}$. S of Kenai, Cook Inlet Low.; 60 $67^{\circ} 15^{\prime \prime} \mathrm{N}, 151^{\circ} 13^{\prime} 00^{\prime \prime} \mathrm{W}$; (map 62).

Local name reported in 1904 by Moffit (1906, pl. 2), USGS.

Honhosa River: stream, flows NE $43 \mathrm{mi}$. to Kateel River, $35 \mathrm{mi}$. SW of Roundabout Mtn., Nulato Hills; $65^{\circ} 28^{\prime} \mathrm{N}, 157^{\circ} 45^{\prime} \mathrm{W}$; (map 108).

Koyukan Indian name published in 1959 by USGS.

Honker Creek: stream, on Hinchinbrook I., flows NE $5.5 \mathrm{mi}$. to Fish Bay, $22 \mathrm{mi}$. SW of Cordova, Chugach Mts.; $60^{\circ} 27^{\prime} \mathrm{N}, 146^{\circ} 22^{\prime}$ W; (map 64).

Name published in 1950 by USGS.

Honolulu: locality, mile 288.7 on The Alaska RR., $12 \mathrm{mi}$. W of Honolulu Pass and $60 \mathrm{mi}$. SW of Healy, Talkeetna Mts.; $63^{\circ} 03^{\prime} 40^{\prime \prime} \mathrm{N}$, $149^{\circ} 34^{\prime} 30^{\prime \prime}$ W ; (map 87). Var. Honululu Creek.

Name of a railroad station reported by The Alaska RR. on its 1922 timetable. 
Honolulu Creek: stream, flows SW $20 \mathrm{mi}$. to Chulitna River, $60 \mathrm{mi}$. SW of Healy, Talkeetna Mts.; $63^{\circ} 03^{\prime} 15^{\prime \prime} \mathrm{N}, 149^{\circ} 35^{\prime} 30^{\prime \prime} \mathrm{W}$; (map 87).

Prospectors' name obtained in 1913 by J. W. Bagley, USGS; published by $\mathbf{S}$. R. Capps (in Martin and others, 1919, pl. 5), USGS.

Honolulu Pass: pass, 3,150 ft., trends NE-SW $1 \mathrm{mi}$., $30 \mathrm{mi}$. W of Deadman Mtn., $57 \mathrm{mi}$.

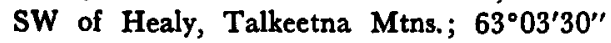
N, $149^{\circ} 11^{\prime} 45^{\prime \prime}$ W; (map 87).

Local name reported in 1913 by J. W. Bagley, USGS.

Honululu Creek: locality, see Honolulu.

Hoochinoo: islands, see Kootzanhoo Archipelago.

Hoochinoo Inlet: water passage, see Kootznahoo Inlet.

Hood Bay: locality, on $\mathrm{N}$ shore of Hood Bay, on $W$ coast of Admiralty $I$., $10 \mathrm{mi}$. SE of Angoon, Alex. Arch.; $57^{\circ} 23^{\prime} \mathrm{N}, 134^{\circ} 24^{\prime} \mathrm{W}$; (map 9). Var. Barge.

A post office of this name was established here in 1948. In 1950 the name was changed to "Barge," and in 1952 the Hood Bay Post Office was reestablished. The post office was finally discontinued in 1957 (Ricks, 1965, p. 27). The population was 50 in 1929, but in 1966 it was reported to have been abandoned.

Hood Bay: bay, $2 \mathrm{mi}$. across, $4 \mathrm{mi}$. S of Angoon, on $W$ coast of Admiralty I., Alex. Arch.; $57^{\circ} 26^{\prime} \mathrm{N}, 134^{\circ} 33^{\prime} \mathrm{W}$; BGN 1899; (map 9). Var. Hoods Bay, Hootz Bay.

Named "Hoods Bay" in 1794 by Capt. George Vancouver, RN, probably for the English Admiral and First Viscount, Samuel Hood, 1724-1816 (Wagner 1937, p. 392). Admiral Hood was second in command of Lord Rodney's North American Fleet during the Revolutionary War. There has been some confusion of the names since Capt. Vancouver's Hoods Bay apparently does not correspond to the description given by $\mathrm{Lt}$. Joseph Whidbey of Capt. Vancouver's party who visited the locality (U.S. Coast and Geodetic Survey, 1883, p. 175). The bay was called "Hootz Bay" by USC\&GS on Chart 8050 in 1899 . This name was probably derived from the Tlingit Indian word "Khuts" or "huts" meaning "bear."

Hood Canal: canal, $0.4 \mathrm{mi}$. long, connects Lake Spenard and Hood Lake, $3.9 \mathrm{mi}$. SW of Anchorage, Cook Inlet Low.; $61^{\circ} 10^{\prime} 50^{\prime \prime} \mathrm{N}$, $149^{\circ} 58^{\prime} 00^{\prime \prime} \mathrm{W}$; (map 68).

Local name reported in 1962 by USGS.

Hood Creek: stream, heads in Hood Lake, flows NE $1.2 \mathrm{mi}$. to Knik Arm, $2.3 \mathrm{mi}$. SW of Anchorage, Cook Inlet Low.; $61^{\circ} 12^{\prime} 06^{\prime \prime} \mathrm{N}$,

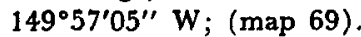

Local name reported in 1962 by USGS.

Hood Hill: hill, $330 \mathrm{ft}$., between Sargeant Cove and Andy Cove, Kiska I., Aleutian Is.; $51^{\circ} 55^{\prime} 56^{\prime \prime} \mathrm{N}, 177^{\circ} 34^{\prime} 25^{\prime \prime} \mathrm{E}$; (map 14).

An arbitrary name beginning with " $\mathrm{H}$ " to correspond to " $\mathrm{H}$ " grid used by the U.S. Army for tactical purposes during World War II; published on a 1943 Army map.
Hood Lake: lake, $0.6 \mathrm{mi}$. long, at head of Hood Creek, $3.4 \mathrm{mi}$. SW of Anchorage, Cook Inlet Low.; $61^{\circ} 10^{\prime} 58^{\prime \prime} \mathrm{N}, 1^{\circ} 9^{\circ} 58^{\prime} 15^{\prime \prime} \mathrm{W}$; (map 69).

Local name reported in 1922 by USGS.

Hoodlum Creek: stream, flows SW $4.8 \mathrm{mi}$. to Cripple River, $26 \mathrm{mi}$. NW of Imuruk Lake, Seward Penin. High.; $65^{\circ} 56^{\prime} \mathrm{N}, 163^{\circ} 42^{\prime} \mathrm{W}$; (map 110).

Prospectors' name reported in 1901 by USGS (Collier, 1902, pl. 12).

Hoodoo Gulch: ravine, trends NW $1.1 \mathrm{mi}$. to Nome River, $17 \mathrm{mi}$. NE of Nome, Seward Penin. High.; $64^{\circ} 44^{\prime} 10^{\prime \prime} \mathrm{N}, 165^{\circ} 14^{\prime} 20^{\prime \prime} \mathrm{W}$; (map 94).

Prospectors' name reported in 1904 by $T$. G. Gerdine, USGS.

Hoodoo Hill: hill, 1,536 ft., $3 \mathrm{mi}$. W of Imuruk Lake, Seward Penin. High.; $65^{\circ} 36^{\prime}$ N, $163^{\circ}$ 25' W; BGN 1952; (map 110).

Reported in 1950 by D. M. Hopkins, USGS; so named because the "summit of the hill is littered with 5- to 20-foot boulders or 'hoodoos." "

Hoodoo Island: island, see Evans Island.

Hoodoo Lake: lake, $4 \mathrm{mi}$. long, between Pavlof and Herendeen Bays, Aleutian Ra.; $55^{\circ} 41^{\prime} \mathrm{N}$, $161^{\circ} 03^{\prime} \mathrm{W}$; (map 28). Var. Hoo Doo Lake. Named "Hoo Doo Lake" in 1929 by USGS.

Hoodoo Lake: lake, see Sapsuk Lake.

Hoodoo Mountain: mountain, 3,200 ft., between Pavlof and Herendeen Bays, $3 \mathrm{mi}$. SE of Hoodoo Lake, Aleutian Ra.; $55^{\circ} 38^{\prime} 30^{\prime \prime} \mathrm{N}$, $161^{\circ} 00^{\prime} 00^{\prime \prime} \mathrm{W}$; (map 28). Var. Hoo Doo Mountain.

Named "Hoo Doo Mountain" in 1929 by USGS.

Hoodoos, The: promontory, 4,600 ft., $\mathrm{S}$ of College Glacier terminus, $13 \mathrm{mi}$. NNE of Paxson, Alaska Ra.; $63^{\circ} 13^{\prime} 30^{\prime \prime} \mathrm{N}, 145^{\circ} 26^{\prime} 40^{\prime \prime} \mathrm{W}$; (map 86).

Named about 1950 by T. L. Péwé, USGS.

Hood Point: point of land, $\mathrm{S}$ tip of Lindenberg Penin., Kupreanof I., $14 \mathrm{mi}$. S of Petersburg, Alex. Arch.; $56^{\circ} 36^{\prime} 20^{\prime \prime} \mathrm{N}, 133^{\circ} 01^{\prime} 20^{\prime \prime} \mathrm{W}$; (map 6).

Named on August 29, 1793, by Capt. George Vancouver, RN, for Adm. Samuel Hood, 1724-1816, RN.

Hoods Bay: bay, see Hood Bay.

Hoof Point: point of land, on SE tip of Ragged I., $50 \mathrm{mi}$. E of Seldovia, Chugach Mts.; $59^{\circ} 25^{\prime} \mathrm{N}, 150^{\circ} 18^{\prime} \mathrm{W}$; (map 50).

Local name reported by USC\&GS in 1939 on Chart 8530.

Hook Arm: estuary, extends W $3.8 \mathrm{mi}$. to Sea Otter Harbor, on $W$ coast of Dall I., Alex. Arch.; $55^{\circ} 06^{\prime} 45^{\prime \prime} \mathrm{N}, 133^{\circ} 11^{\prime} 00^{\prime \prime} \mathrm{W}$; (map 4).

Named in 1927 by Capt. Patton, USC\&GS, "because of the hook-like shape of this arm."

Hook Bay: bay, 1 mi. across, in N part of Bechevin Bay, $28 \mathrm{mi}$. SW of village of Cold Bay, at SW end of Alaska Penin., Bristol Bay Low.; $55^{\circ} 04^{\prime} \mathrm{N}, 163^{\circ} 24^{\prime} \mathrm{W}$; (map 29).

Name published by USC\&GS in 1963 on Chart 8701.
Hook Bay: bay, 2 mi. wide, on $S$ coast of Alaska Penin., trends SE $2 \mathrm{mi}$. to Chignik Bay, $19 \mathrm{mi}$. $\mathrm{NE}$ of Chignik, Aleutian Ra.; $56^{\circ} 30^{\prime} \mathrm{N}$, $158^{\circ} 06^{\prime} \mathrm{W}$; (map 30).

Descriptive local name reported in 1904 by R. W. Stone; applied because of the hookshaped spit on the south side.

Hook Creek: stream, heads at $E$ terminus of Hook Glacier, flows SE $7.5 \mathrm{mi}$. to Hallo Bay, on S coast of Alaska Penin., in Katmai National Monument, $36 \mathrm{mi}$. NE of Mount Katmai, Aleutian Ra.; $58^{\circ} 28^{\prime} 25^{\prime \prime} \mathrm{N}, 154^{\circ} 04^{\prime} 45^{\prime \prime}$ W; (map 42).

Named for Hook Glacier; reported in 1951 by USGS.

Hook Glacier: glacier, heads on ridge between Devils Desk and Mount Denison, trends NW $7.5 \mathrm{mi}$. to its 1951 central terminus at head of Savonoski River, on Alaska Penin., in Katmai National Monument, $25 \mathrm{mi}$. NE of Mount Katmai, Aleutian Ra.; $58^{\circ} 31^{\prime} 45^{\prime \prime} \mathrm{N}, 1^{\circ} 4^{\circ}$ 28'45" W; BGN 1925; (map 42).

So named in 1923 by $R$. H. Sargent, USGS, for "the hook-shaped ice-free area between the glacier arms."

Hook Lake: lake, 0.2 mi. across, E central Heceta I., Alex. Arch.; 55 $46^{\prime} 30^{\prime \prime}$ N, $133^{\circ} 25^{\prime} 15^{\prime \prime}$ W; (map 4).

Local name recorded in 1951 by USGS.

Hook Lake: lake, $0.9 \mathrm{mi}$. long, on Kenai Penin., $1 \mathrm{mi}$. NW of McLain Lake and $32 \mathrm{mi}$. NE of Kenai, Cook Inlet Low.; $60^{\circ} 52^{\prime} 45^{\prime \prime} \mathrm{N}$, $150^{\circ} 37^{\prime} 15^{\prime \prime} \mathrm{W}$; (map 62).

Named about 1963 by officials of Kenai National Moose Range for administrative purposes.

Hook Lake: lake, oxbow of Nixon Fork, $30 \mathrm{mi}$. W of Medfra, Kilbuck-Kuskokwim Mts.; $63^{\circ} 07^{\prime} \mathrm{N}, 155^{\circ} 40^{\prime} \mathrm{W}$; (map 89).

Local name reported in 1955 by USGS.

Hook Point: point of land, on SW coast of

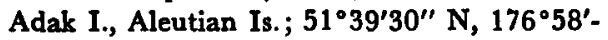
30" W; BGN 1936; (map 17).

Named by members of the U.S. Navy Aleutian Island Survey Expedition in 1934, "because it is shaped like a hook."

Hook Point: point of land, in Lake Nicholas, W of Sarana Bay, on eastern Attu I., Aleutian Is.; $52^{\circ} 52^{\prime} 45^{\prime \prime} \mathrm{N}, 173^{\circ} 15^{\prime} 00^{\prime \prime} \mathrm{E}$; (map 13).

Named by the U.S. Army during World War II; shown on an AMS map published in 1948.

Hook Point: point of land, between Dry Cove and Portage Bay, on $N$ coast of Kupreanof I., $18 \mathrm{mi}$. NW of Petersburg, Alex. Arch.; $56^{\circ} 59^{\prime} 00^{\prime \prime} \mathrm{N}, 133^{\circ} 19^{\prime} 15^{\prime \prime} \mathrm{W}$; (map 6).

Descriptive name given in 1882 by Lt. Comdr. H. E. Nichols, USN, "because of its shape."

Hook Point: point of land, on $\mathrm{N}$ shore of Spiridon Bay, on NW coast of Kodiak I.; $57^{\circ} 41^{\prime}$ $15^{\prime \prime} \mathrm{N}, 153^{\circ} 46^{\prime} 30^{\prime \prime} \mathrm{W}$; (map 34 ).

Local name reported in 1954 by USGS.

Hook Point: point of land, on E coast of Hinchinbrook I.; $23 \mathrm{mi}$. SW of Cordova, Chugach Mts.; $60^{\circ} 20^{\prime} \mathrm{N}, 146^{\circ} 15^{\prime} \mathrm{W}$; (map 64).

Name published in 1909 by USC\&GS. Hoolahoola River: river, see Hulahula River. 
Hooligan Point: point of land, southernmost tip of Limb I. in Stikine River, $12 \mathrm{mi}$. NE of Wrangell and $26 \mathrm{mi}$. SE of Petersburg, Coast Mts.; 56 $38^{\prime} 30^{\prime \prime} \mathrm{N}, 132^{\circ} 19^{\prime} 30^{\prime \prime} \mathrm{W}$; $B G N$ 1966; (map 6). Var. Euchalon Point.

Local name reported in 1961 by USFS; Tlingit Indian name "Euchalon" recorded in 1948 for this point by USGS.

Hooligan Slough: channel, extends $2.5 \mathrm{mi}$. from Farm I. to Limb I. in Stikine River, $26 \mathrm{mi}$. SE of Petersburg, Coast Mts.; 56 $38^{\prime} 25^{\prime \prime} \mathrm{N}$, $132^{\circ} 19^{\prime} 45^{\prime \prime} \mathrm{W}$; BGN 1966; (map 6). Var. Euchalon Slough.

Local name reported in 1961 by USFS; Tlingit Indian name "Euchalon" recorded in 1948 for this feature by USGS.

Hoolitna: stream, see Holitna River.

Hoonah: village, pop. 686, on $\mathrm{E}$ shore of Port Frederick, $2.5 \mathrm{mi}$. S of Point Sophia, on Icy Strait, $40 \mathrm{mi}$. SW of Juneau, Alex. Arch.;

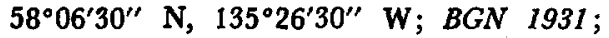
(map 11). Var. Belltown, Gaot-á-kan, Gaudah-kan, Gaudekan, Hoonah Town, Hooniah, Hoonyah, Huna, Kantukan, Koudekan.

This is the principal Huna village. The Huna (Hoonah), a Tlingit tribe in the Cross Sound area, camp in the summer from here northward to Lituya Bay. This village was called "Gaudekan [Kantukan]", meaning "bell town." Its population was 800 in 1880 , 447 in 1900,462 in 1910,402 in 1920,514 in 1930, 716 in 1939, and 563 in 1950 . The Hoonah post office was established in 1901 and thus was responsible for giving the village its present name.

Hoonah Bluff: promontory, at $\mathrm{N}$ entrance to Hoonah Harbor on $\mathrm{N}$ end of Chichagof $\mathrm{I}$., $0.5 \mathrm{mi}$. $\mathrm{N}$ of Hoonah, Alex. Arch.; 58 $8^{\circ} 07^{\prime} 30^{\prime \prime}$ N, $135^{\circ} 27^{\prime} 45^{\prime \prime} \mathrm{W}$; (map 11).

Named in 1901 by E. F. Dickins, USC\&GS, for the village of Hooniah, now spelled Hoonah. The name was published in the 1901 Coast Pilot (p. 208).

Hoonah Glacier: glacier, in Glacier Bay National Monument, trends NW $6.5 \mathrm{mi}$. to Johns Hopkins Inlet, $1.6 \mathrm{mi}$. NE of the 1961 terminus of Gilman Glacier and $78 \mathrm{mi}$. NW of Hoonah, St. Elias Mts.; $58^{\circ} 52^{\prime} 30^{\prime \prime}$ N, $137^{\circ}$ 02'15" W; BGN 1937; (map 10).

Indian name reported by the American Geographical Society in 1936. This glacier was named for the Huna (Hoonah) subdivision of the Tlingit Indians, who were located in the Cross Sound area.

Hoonah Harbor: harbor, $0.4 \mathrm{mi}$. across, at Hoonah, in Port Frederick, $40 \mathrm{mi}$. SW of Juneau, Alex. Arch.; 58 $07^{\prime} 00^{\prime \prime} \mathrm{N}, 135^{\circ} 27^{\prime}$ 45" W; BGN 1931; (map 11). Var. Hooniah Harbor, Hoonyah Harbor, Port Frederick Harbor.

Named for the Huna tribe of Tlingit Indians; published by USC\&GS as Hooniah Harbor in 1883 Coast Pilot (p. 191). Called Port Frederick Harbor in 1880 in U.S. Hydrog. Office Notice, No. 97.

Hoonah Hot Springs: village, see Tenakee Springs.
Hoonah Island: island, $0.5 \mathrm{mi}$. across, off $\mathrm{N}$ coast of Chicagof I., in Icy Strait, $5.6 \mathrm{mi}$. NW of Hoonah, Alex. Arch.; 58 ${ }^{\circ} 11^{\prime} 15^{\prime \prime} \mathrm{N}$, $135^{\circ} 29^{\prime} 30^{\prime \prime} \mathrm{W}$; BGN 1931.

Named Hooniah Island by E. F. Dickins, USC\&GS, in 1901 for the village of Hooniah, now spelled Hoonah. The name was published in the 1901 Coast Pilot (p. 202).

Hoonah Island: island, see Chichagof Island.

Hoonah Point: point of land, on $\mathrm{N}$ coast of Chichagof I., near mouth of Port Frederick, $1.2 \mathrm{mi}$. NW of Hoonah, Alex. Arch.; 58 ${ }^{\circ} 7^{\prime}$ $30^{\prime \prime} \mathrm{N}, 135^{\circ} 27^{\prime} 45^{\prime \prime} \mathrm{W}$; BGN 1931; (map 11). Var. Hooniah Point, Entrance Point.

Named Hooniah Point by E. F. Dickins, USC\&GS, in 1901 for the village of Hooniah, now spelled Hoonah. The name was published by the USC\&GS in the 1901 Coast Pilot (p. 208). Originally named Entrance Point by Lt. F. M. Symonds, USN, in 1880 and published by the USG\&GS in the 1883 Coast Pilot (p. 191).

Hoonah Sound: water passage, $5 \mathrm{mi}$. across, on $S$ coast of Chichagof I., $20 \mathrm{mi}$. E of Chichagof, Alex. Arch.; $57^{\circ} 38^{\prime} \mathrm{N}, 135^{\circ} 33^{\prime} \mathrm{W}$; $B G N 1931$; (map 9). Var. Hooniah Sound, Shekak Sound.

Name derived from the Huna, a subtribe of the Tlingit Indians. The name was published as "Hooniah" or "Hoonah Sound" by USC\&GS in the 1883 Coast Pilot (p. 164). It is reported that the Sitka Indians call it "Shekak."

Hoonah Town: village, see Hoonah.

Hooniah: village, see Hoonah.

Hooniah: village, see Tenakee Springs.

Hooniah Harbor: harbor, see Hoonah Harbor.

Hooniah Hot Springs: springs, see White Sulphur Springs.

Hooniah Point: point of land, see Hoonah Point.

Hooniah Sound: water passage, see Hoonah Sound.

Hooniah Sound Hot Springs: springs, see White Sulphur Springs.

Hooniah Warm Springs: springs, see White Sulphur Springs.

Hoonyah: village, see Hoonah.

Hoonyah Harbor: harbor, see Hoonah Harbor.

Hooper Bay: village, pop. 460, on Hooper Bay, $20 \mathrm{mi}$. S of Cape Romanzof, Yukon-Kuskokwira Delta; 61 $31^{\prime} 55^{\prime \prime} \mathrm{N}, 166^{\circ} 05^{\prime} 30^{\prime \prime} \mathrm{W}$; (map 75). Var. Askinak, Askinuk, Askinaghamiut, Naparagamiut, Askeenac.

The Eskimo name for this old village is "Askinuk," first reported by E. W. Nelson, U.S. Signal Service, in December 1878 as Askeenac. The 1880 census shows "Askinak" with 175 Eskimo and the 1890 Census shows "Askinaghamiut," numbering 138, living in 14 dwellings. A post office was established here with the name "Hooper Bay," in 1934 (Ricks, 1965 , p. 27). USC\&GS, in 1951, reported the present-day Eskimo name "Na-par-ag-amiut," (stake village people) for Hooper Bay.

Hooper Bay: bay, $11 \mathrm{mi}$. across, on coast of Bering Sea, $22 \mathrm{mi}$. S of village of Scammon Bay, Yukon-Kuskokwim Delta; $61^{\circ} 27^{\prime} \mathrm{N}$, $166^{\circ} 00^{\prime}$ W; (map 75). Var. Kanirthluk Bay.

Named by Nelson (1882, p. 666), U.S. Signal Service, in December 1878, for Capt. Galvin Leighton Hooper, USRCS, who did extensive investigations in the Bering Sea and Arctic Ocean. The Eskimo name for this bay is "Kan-ir-thluk" according to USC\&GS in 1951.

Hooper Mountains: mountains, along Arctic Ocean coast between Cape Lisburne and Barrow.

These non-existent mountains or hills were so named in 1880 by Ivan Petroff after Capt. C. L. Hooper, USRCS. Petroff may have been referring to the Brooks Range.

Hoorts, Mount: mountain, 2,088 ft., $1.5 \mathrm{mi}$. NE of Knight I., $16 \mathrm{mi}$. NNE of Yakutat, St. Elias Mts.; $59^{\circ} 45^{\prime} 05^{\prime \prime} \mathrm{N}, 139^{\circ} 31^{\prime} 45^{\prime \prime} \mathrm{W}$; (map 46).

Named by J. E. McGrath, USC\&GS, and published in USG\&GS Ann. Rept. of 1893.

Hoosier Creek: stream, flows NW $8.5 \mathrm{mi}$. to Minook Creek, between California and McDonald Bars, $4 \mathrm{mi}$. SE of Rampart, YukonTanana High.; $65^{\circ} 27^{\prime} \mathrm{N}, 150^{\circ} 07^{\prime} \mathrm{W}$; (map 106).

Prospectors' name published in 1898 by USC\&GS on Chart 3098.

Hoosier Hill : hill, $305 \mathrm{ft}$., $\mathrm{W}$ of Sargeant Cove, Kiska I., Aleutian Is.; $51^{\circ} 55^{\prime} 40^{\prime \prime} \mathrm{N}, 177^{\circ} 32^{\prime}$ $35^{\prime \prime} \mathrm{E}$; (map 14).

An arbitrary name beginning with " $\mathrm{H}$ " to correspond to " $H$ " grid used by the U.S. Army for tactical purposes during World War II; published on a 1943 Army map.

Hoosnoff: islands, see Kootznahoo Archipelago. Hoosnoff Inlet: water passage, see Kootznahoo Inlet.

Hootana: village, see Tolovana.

Hoot Island: island, $1 \mathrm{mi}$. across, in Sea Otter Sound, S of Orr I., Alex. Arch.; $55^{\circ} 53^{\prime} \mathrm{N}$, $133^{\circ} 23^{\prime} \mathrm{W}$; (map 4).

Named in 1904 by E. F. Dickins, USC\&GS, for the "Name of signal [triangulation station] Hoot."

Hootlanana: stream, see Hutlinana Creek.

Hootlinana Creek: stream, see Hutlinana Creek. Hootz Bay: bay, see Hood Bay.

Hope: village, pop. 44, on N end of Kenai Penin., near mouth of Resurrection Creek, 7 mi. NW of Sunrise, Chugach Mts. ; $60^{\circ} 55^{\prime} 15^{\prime \prime} \mathrm{N}, 149^{\circ}$ 38'30" W; (map 63). Var. Hope City.

Mining camp, called "Hope City," established about 1896. The population was 44 in $1920 ; 15$ in $1930 ; 71$ in 1939 ; and 63 in 1950. The Hope post office was established in 1897 (Ricks, 1965, p. 27).

Hope: village, see Point Hope.

Hope, Point: point of land, on E coast of Attu I., 3 mi. SE of Attu, Aleutian Is.; 52 $54^{\prime} 50^{\prime \prime}$ N, $173^{\circ} 18^{\prime} 40^{\prime \prime} \mathrm{E}$; (map 13).

Named by U.S. Army during World War II ; published in 1948 by AMS.

Hope, Point: point of land, NW tip of an island, $2.3 \mathrm{mi}$. WNW of Chichagof, off $W$ coast of 
Chichagof I., Alex. Arch.; $57^{\circ} 40^{\prime} 15^{\prime \prime} \mathrm{W}, 136^{\circ}$. $09^{\prime} 28^{\prime \prime} \mathrm{W}$; (map 9).

Name published in 1928 by USC\&GS on Chart 8258

Hope, Point: point of land, on Chukchi Sea coast, $40 \mathrm{mi}$. SW of Cape Lisburne, Arctic Slope; $68^{\circ} 20^{\prime} 20^{\prime \prime} \mathrm{N}, 166^{\circ} 50^{\prime} 40^{\prime \prime} \mathrm{W}$; (map 129). Var. Figarok, Hoffnung, Hope Point, Mys Golofnin, Mys Golovin, Mys Golovnia, Tee-kee-voga, Tiekaga, Tigara, Tigarak, Tigera, Tikarakh, Tikeh, Tikek, Tikera, Tikerak, Tikerana, Tikiqaq, Tikira, Tikirah, Tikirak, Tikirat, Tikkerak, Tkok, Ttiekigakg, Ttikigakg.

Named August 2, 1826, by Capt. Beechey (1831, p. 265), RN, who wrote, "I named it Point Hope in compliment to Sir William Johnstone Hope." According to Archdeacon Stuck (1920, p. 96) Hope was from a "wellknown house long connected with the sea." The Russians discovered this point of land late in the eighteenth century and called it "M[ys] Golovnia," or "Cape Golovnin." The Eskimo name is descriptive, "Tikarakh" or "Tikiqaq," commonly spelled "Tigara," meaning "forefinger".

Hope City: village, see Hope.

Hope Creek: stream, heads on N slope of Kulthieth Mtn., flows generally SW $7 \mathrm{mi}$. to Kaliakh River, $9 \mathrm{mi}$. from Gulf of Alaska and $100 \mathrm{mi}$. SE of Cordova, St. Elias Mts. $60^{\circ} 09^{\prime} \mathrm{N}, 142^{\circ} 47^{\prime} \mathrm{W}$; BGN 1960; (map 65).

Local name shown in an unpublished re port by G. D. Hanna and others in 1938 . Name first used by Melvin Grindle, local trapper, who, it is said, had the vain "hope" of crossing the stream without getting his feet wet.

Hope Creek: stream, flows SE $3 \mathrm{mi}$. to Faith Creek, $75 \mathrm{mi}$. SW of Circle, Yukon-Tanana High.; $65^{\circ} 19^{\prime} \mathrm{N}, 146^{\circ} 21^{\prime} \mathrm{W}$; (map 104).

Named by prospectors; reported in 1903 by T. G. Gerdine (in Prindle, 1905, pl. 13), USGS. Subsequently, the name has been applied through local usage to a stream at the headwaters of Faith Creek.

Hope Creek: stream, flows E $7 \mathrm{mi}$., joins Charity Creek to form Faith Creek, $70 \mathrm{mi}$. SW of Circle, Yukon-Tanana High.; $65^{\circ} 23^{\prime} 45^{\prime \prime} \mathrm{N}$, $146^{\circ} 16^{\prime} 00^{\prime \prime} \mathrm{W}$; (map 104). Var. Charity Greek.

This stream was originally called Charity Creek by prospectors according to T. G Gerdine, USGS, in 1903, (in Prindle, 1905, pl. 13). The present name has come into use and is published on recent USGS maps.

Hopkins Ridge: ridge, elev. 1,200 ft., on $\mathrm{E}$ coast of Attu I., extends W $2 \mathrm{mi}$. between Eckman Creek and Lake Nicholas, Aleutian Is.; $52^{\circ} 53^{\prime} 15^{\prime \prime} \mathrm{N}, 173^{\circ} 15^{\prime} 20^{\prime \prime} \mathrm{E}$; (map 13).

Named by U.S. Army during World War II ; published in 1948 by AMS.

Hoppe Island: island, $0.1 \mathrm{mi}$. long, $\mathrm{N}$ of Buchanan Head, on $\mathbf{E}$ coast of Attu I., Aleutian Is.; $52^{\circ} 51^{\prime} 20^{\prime \prime} \mathrm{N}, 173^{\circ} 26^{\prime} 00^{\prime \prime} \mathrm{E} ; B G N$ 1945; (map 13).

Name used in 1942 by U.S. Army and Navy for tactical purposes.
Hopper Creek: stream, flows SE $4 \mathrm{mi}$. to Little Chena River, $10 \mathrm{mi}$. NE of Fairbanks, Tanana Low.; 6451'45" N, $147^{\circ} 22^{\prime} 50^{\prime \prime} \mathrm{W}$; (map 100).

Local name published in 1949 by USGS.

Hopson, Point: point of land, on Beaufort Sea coast, $2 \mathrm{mi}$. W of Point Sweeney and $7 \mathrm{mi}$. W of Flaxman I., Arctic Plain; $70^{\circ} 11^{\prime} 25^{\prime \prime} \mathrm{N}$, $146^{\circ} 30^{\prime} 45^{\prime \prime} \mathrm{W}$; (map 151).

Named by Leffingwell (1919, p. 96), in 1913, "After Fred Hopson, long a resident at Barrow."

Horace Mountain: mountain, 5,446 ft., $\mathrm{N}$ of junc. of Robert and Sheep Creeks, $21 \mathrm{mi}$. NW of Chandalar, Brooks Ra.; $67^{\circ} 40^{\prime} \mathrm{N}, 1^{\prime} 49^{\circ} 08^{\prime}$ W; (map 123).

Prospectors' name reported in 1899 by Schrader (1900b, pl. 60), USGS.

Horboon Rock: rock, see Humpback Rock.

Horboon Vnutrennie: rock, see Inner Humpback Rock.

Hormigas, Las: islands, see Hermagos Islands.

Horn, Cape: point of land, on W coast of Nagai I., in Shumagin Is., Aleutian Ra.; 55 $03^{\prime} 30^{\prime \prime}$ $N, 160^{\circ} 09^{\prime} 00^{\prime} \mathrm{W}$; (map 28).

Name published by USC\&GS in an 1872 report.

Horn, Cape: point of land, on $\mathrm{E}$ bank of Kvichak River, on Alaska Penin., $19 \mathrm{mi}$. NE of Naknek, Bristol Bay Low.; 58 $59^{\prime} 40^{\prime \prime} \mathrm{N}, 156^{\circ} 52^{\prime} 30^{\prime \prime}$ W; (may 41).

Local name reported in 1952 by USGS.

Horn, Cape: point of land, on W coast of Nuka I., $35 \mathrm{mi}$. ESE of Seldovia, Chugach Mts.; $59^{\circ} 22^{\prime} \mathrm{N}, 150^{\circ} 43^{\prime} \mathrm{W}$; (map 50).

Local name published in 1953 by USGS.

Horn, Cape: point of land, see Ikatan Point.

Horn, Cape: promontory, $400 \mathrm{ft}$., on S side of Aniakchak River $5 \mathrm{mi}$. above its mouth and $16 \mathrm{mi}$. W of Cape Kunmik, on Alaska Penin., Aleutian Ra.; $56^{\circ} 47^{\prime} \mathrm{N}, 157^{\circ} 36^{\prime} \mathrm{W}$; (map 31).

Name used by trappers and reported in 1923 by R. H. Sargent, USGS, in reference to "the rough water of the Aniakchak River at this point;" shown on a 1924 USGS map.

Horn, Cape: ridge, see Horn, The.

Horn, Point: point of land, on Hinchinbrook I., SE shore of Port Etches, $32 \mathrm{mi}$. SW of Cordova, Chugach Mts.; $60^{\circ} 20^{\prime} \mathrm{N}, 146^{\circ} 34^{\prime} \mathrm{W}$; (map 64). Var. Horne Point, Punta de Espada.

Named "Horne Point" by Capt. Nathaniel Portlock (1789, map facing p. 227) for Robert Horne, carpenter of his vessel King George, while exporing the region in 1787 . It was called "Punta de Espada" (sword point) in 1779 by the Spanish exporers Don Juan de la Bodega y Quadra and Don Ignacia Arteaga on a unpublished manuscript chart called "Puerto de Santiago."

Horn, The ridge, $1,000 \mathrm{ft}$., $0.5 \mathrm{mi}$. long, on SE slope of Mount Juneau, just $W$ of Ebner Falls, $1 \mathrm{mi}$. NE of Juneau, Coast Mts.; 58 $18^{\prime} 40^{\prime \prime}$ N, $134^{\circ} 23^{\prime} 00^{\prime \prime} \mathrm{W}$; (map 11). Var. Cape Horn.
This ridge or promontory was originally called "Cape Horn" in the 1880's. The name has subsequently been shortened.

Horn Cliffs: cliffs, $8 \mathrm{mi}$. long, on SE shore of Frederick Sound, $9 \mathrm{mi}$. E of Petersburg, Coast Mts.; $56^{\circ} 47^{\prime} 40^{\prime \prime} \mathrm{N}, 132^{\circ} 40^{\prime} 00^{\prime \prime} \mathrm{W}$; (map 6).

Descriptive name given for charting purposes by USC\&GS in 1883 Coast Pilot (p. 127).

Horn Creek: stream, in Chigmit Mts., flows SE $3 \mathrm{mi}$. to Chinitna Bay, Aleutian Ra.; $59^{\circ} 52^{\prime} 25^{\prime \prime} \mathrm{N}, 153^{\circ} 04^{\prime} 00^{\prime \prime} \mathrm{W} ; B G N$ 1962; (map 51).

Local name derived from Horn Mountain; published in 1958 by USGS.

Horn Creek: stream, on Hinchinbrook I., flows W $0.7 \mathrm{mi}$. to Port Etches, $32 \mathrm{mi}$. SW of Cordova, Chugach Mts.; $60^{\circ} 20^{\prime} \mathrm{N}, 146^{\circ} 34^{\prime}$ W; (map 64).

Name published in 1950 by USGS.

Horne Point: point of land, see Horn, Point.

Horner Creek: stream, flows NW $8 \mathrm{mi}$. to Chena River, $22 \mathrm{mi}$. E of Fairbanks, Yukon-Tanana High.; $64^{\circ} 50^{\prime} 15^{\prime \prime} \mathrm{N}, 146^{\circ} 56^{\prime} 00^{\prime \prime} \mathrm{W}$; (map 101)

Local name reported in 1950 by USGS.

Horner Hot Springs: locality, on right bank of Hot Springs Slough, $23 \mathrm{mi}$. NE of Ruby, Kokrines-Hodzana High.; $64^{\circ} 54^{\prime} 55^{\prime \prime} \mathrm{N}$, $154^{\circ} 49^{\prime} 30^{\prime \prime} \mathrm{W}$; (map 98).

"Horner Hot Springs, although only threequarters of a mile from the Yukon River, appear to have been unknown to the whites until about 1913, when they were shown by an Indian to F. G. Horner, who has built a cabin and planted a small garden near them" (Waring, 1917, p. 68).

Hornet Creek: stream, flows W $2.5 \mathrm{mi}$. to $\mathrm{Ne}$ nana River, $2.4 \mathrm{mi}$. $\mathrm{N}$ of village of McKinley Park, Alaska Ra.; $63^{\circ} 46^{\prime} 00^{\prime \prime} \mathrm{N}, 148^{\circ} 54^{\prime} 28^{\prime \prime}$ W; BGN 1965; (map 87).

Named in 1965 by Alaska Dept. of Highways because "hornet nests may be found along the banks." See Iceworm Gulch.

Horney Island: island, see Morne Island.

Horn Island: island, see Morne Island.

Horn Mountain: mountain, 2,880 ft., on E shore of Frederick Sound, $2 \mathrm{mi}$. E of McDonald I. and $8 \mathrm{mi}$. NE of Petersburg, Coast Mts.; $56^{\circ} 50^{\prime} 45^{\prime \prime} \mathrm{N}, 132^{\circ} 46^{\prime} 00^{\prime \prime} \mathrm{W}$; (map 6).

Named in 1887 by Lt. Comdr. C. M. Thomas, USN.

Horn Mountain: mountain, 2,160 ft., in Glacier Bay National Monument, on coast of Gulf of Alaska, $50 \mathrm{mi}$. NW of Hoonah, St. Elias Mts.; $58^{\circ} 18^{\prime} \mathrm{N}, 136^{\circ} 46^{\prime} \mathrm{W}$; (map 10).

Descriptive name published in 1943 by USC\&GS.

Horn Mountain: mountain, 2,283 ft., at $\mathrm{SE}$ end of Knight I., $13 \mathrm{mi}$. SE of Chenega, Chugach Mts. ; $60^{\circ} 12^{\prime} 30^{\prime \prime} \mathrm{N}, 147^{\circ} 44^{\prime} 10^{\prime \prime} \mathrm{W}$; (map 63).

Local name published in 1913 by USC\&GS. Horn Mountain: peak, 2,915 ft., in Chigmit Mts., on $\mathrm{N}$ shore of Chinitna Bay, Aleutian Ra.; $59^{\circ} 53^{\prime} 30^{\prime \prime} \mathrm{N}, 153^{\circ} 06^{\prime} 50^{\prime \prime} \mathrm{W}$; (map 51).

Local name published in 1922 by USGS. 
Horn Mountain: peak, 5,010 ft., $\mathrm{N}$ of Macomb Plat., $42 \mathrm{mi}$. SE of Delta Junction, Alaska Ra.; $63^{\circ} 38^{\prime} 10^{\prime \prime} \mathrm{N}, 144^{\circ} 44^{\prime} 00^{\prime \prime} \mathrm{W}$; $B G N$ 1937; (map 86).

So named by USGS in 1936 "because of its shape, like a matterhorn."

Horn Mountains: mountains, 3,600 ft., in Kuskokwim Mts., 32 mi. NE of Aniak, KilbuckKuskokwim Mts.; $61^{\circ} 45^{\prime} \mathrm{N}, 1.58^{\circ} 31^{\prime} \mathrm{W}$; $B G N$ 1945; (map 72). Var. Chugowonu Kchugoveet.

This is a translation of the Eskimo name "Chugowonu Kchugoveet," which refers to the resemblance of the peaks to horns; reported in 1944 by USGS.

Horn Mountains: mountains, 6,000 ft., extend SW $20 \mathrm{mi}$. from Little Nelchina River to Caribou Creek, $10 \mathrm{mi}$. $\mathrm{N}$ of Tahneta Pass.; Tal keetna Mts.; $62^{\circ} 00^{\prime} \mathrm{N}, 147^{\circ} 25^{\prime} \mathrm{W}$; (map 82). Local name recorded in 1949 by USGS.

Horn Peaks, The: peaks, on a ridge, extend $W$ into Hades Highway $4.5 \mathrm{mi}$. S of Devils Paw, $33 \mathrm{mi}$. NE of Juneau, Coast Mts. ; 58 $40^{\circ} 15^{\prime \prime}$ $\mathrm{N}, 133^{\circ} 52^{\prime} 30^{\prime \prime} \mathrm{W}$; (map 12).

Local name reported in 1960 by USGS.

Horn Point: point of land, on NE coast of Goat I., 2 mi. NW of Hydaburg, Alex. Arch.; $55^{\circ} 13^{\prime} 25^{\prime \prime} \mathrm{N}, 132^{\circ} 52^{\prime} 15^{\prime \prime} \mathrm{W}$; (map 4).

Local name published in 1965 by USC\&GS.

Horn Spire: peak, 6,700 ft., in Icefall Spires; 4 mi. $W$ of The Tusk and $31 \mathrm{mi}$. $N$ of Juneau, Coast Mts.; $58^{\circ} 42^{\prime} 56^{\prime \prime} \mathrm{N}, 134^{\circ} 36^{\prime} 50^{\prime \prime} \mathrm{W}$; $B G N 1965$; (map 11).

Descriptive name given in 1965 by members of the Juneau Icefield Research Project.

Horoshiy Pogody, Mys: point of land, see Fairweather, Cape.

Horse Creek: stream, flows S $4 \mathrm{mi}$. to Copper River, $2.6 \mathrm{mi}$. E of Liberty Falls and $68 \mathrm{mi}$. NE of Valdez, Gopper River Basin; 61 ${ }^{\circ} 37^{\prime} 50^{\prime \prime}$ $\mathrm{N}, 144^{\circ} 28^{\prime} 30^{\prime \prime} \mathrm{W}$; (map 68).

Local name reported in 1907 by USGS.

Horse Creek: stream, flows SE $1.5 \mathrm{mi}$. to Hutlinana Creek, $4 \mathrm{mi}$. S of Elephant Mtn. and 7 mi. NE of Eureka, Tanana Low.; 65 $12^{\prime} 10^{\prime \prime}$ N, 149.59'57" W; BGN 1965; (map 105).

Local name reported in 1963 by Bond Taber, USGS.

Horse Creek: stream, flows NW $3 \mathrm{mi}$. to Chatanika River, $78 \mathrm{mi}$. SW of Circle, YukonTanana High.; $65^{\circ} 17^{\prime} \mathrm{N}, 146^{\circ} 28^{\prime} \mathrm{W}$; (map 104).

Named by prospectors; reported in 1908 by USGS (Covert and Ellsworth, 1909, pl. 4).

Horse Creek: stream, flows SW $5 \mathrm{mi}$. to Glacier River $0.5 \mathrm{mi}$. E of that stream's junc. with North Fork Koyukuk River and $16.5 \mathrm{mi}$. SW of Wiseman, Brooks Ra.; $67^{\circ} 19^{\prime} 45^{\prime \prime} \mathrm{N}, 150^{\circ}$ $41^{\prime} 00^{\prime \prime} \mathrm{W}$; (map 124).

Local name shown on an 1899 fieldsheet by T. G. Gerdine, USGS.

Horse Creek: stream, flows SE $5 \mathrm{mi}$. to North Fork Chandalar River, $1 \mathrm{mi}$. $\mathrm{S}$ of mouth of Goldbug Creek and $14 \mathrm{mi}$. SW of Chandalar, Brooks Ra.; $67^{\circ} 20^{\prime} 40^{\prime \prime}$ N, $148^{\circ} 50^{\prime} 00^{\prime \prime} \mathrm{W}$; (map 123).
Prospectors' name obtained in 1909 by A. G. Maddren (in Brooks and others, 1910, pl. 7), USGS.

Horsefeld: locality, on left bank of Beaver Creek, $10 \mathrm{mi}$. N of Ptarmigan Lake and $70 \mathrm{mi}$. NE of McCarthy, Alaska Ra.; $62^{\circ} 00^{\prime} \mathrm{N}, 141^{\circ} 09^{\prime}$ W; (map 67). Var. Horsfeld Roadhouse.

Roadhouse and settlement reported in 1914 by C. E. Giffin (in Capps, 1916, pl. 2), USGS.

Horsefly Creek: stream, flows NW and SW 16 mi. to Iditarod River, $30 \mathrm{mi}$. N of Flat, Kilbuck-Kuskokwim Mts.; $62^{\circ} 53^{\prime} 30^{\prime \prime}$ N, $157^{\circ}$ $56^{\prime} 10^{\prime \prime} \mathrm{W}$; (map 79).

Local name obtained in 1952 by USGS topographers.

Horse Hill: peak, 2,400 ft., at W end of Yankee Ridge, $9 \mathrm{mi}$. W of Alaska-Canada boundary and $59 \mathrm{mi}$. E of Table Mtn., Porcupine Plat.; $68^{\circ} 17^{\prime} \mathrm{N}, 141^{\circ} 21^{\prime} \mathrm{W}$; (map 137).

Local name reported in 1956 by USGS.

Horse Island: island, $1.7 \mathrm{mi}$. long, in Stephens Passage off the E coast of Mansfield Peninsula, $12 \mathrm{mi}$. SW of Juneau, Alex. Arch.; $58^{\circ} 15^{\prime} 15^{\prime \prime} \mathrm{N}, 134^{\circ} 43^{\prime} 30^{\prime \prime} \mathrm{W}$; (map 11).

Apparently named in 1890 by Lt. Comdr. H. B. Mansfield, USN, and published by USC\&GS in the 1891 Coast Pilot (p. 150).

Horse Island: island, $5 \mathrm{mi}$. long, between Big Bend Slough and Yukon River, $7.5 \mathrm{mi}$. SW of Holy Cross, Innoko Low. ; $62^{\circ} 05^{\prime} \mathrm{N}, 159^{\circ} 58^{\prime}$ W; (map 78).

Local name reported in 1916 by G. L. Harrington and R. H. Sargent (in Harrington, 1918, pl. 1), USGS.

Horse Island: island, see Cheval Island.

Horse Lake: lake, $2.5 \mathrm{mi}$. long, between The Forks and Pat Creek, $12 \mathrm{mi}$. $\mathrm{N}$ of Stevens Village, Yukon Flats; $66^{\circ} 11^{\prime} 30^{\prime \prime} \mathrm{N}, 149^{\circ} 06^{\prime}$ $00^{\prime \prime} \mathrm{W}$; (map 118).

Local name obtained in 1956 by USGS.

Horse Marine Lagoon: lagoon, $1 \mathrm{mi}$. long, at head of Moser Penin., E of Olga Bay, on S coast of Kodiak I.; $57^{\circ} 07^{\prime} 10^{\prime \prime} \mathrm{N}, 153^{\circ} 58^{\prime} 00^{\prime \prime}$ W; (map 34).

Local name used by fishermen; reported in 1900 by Lt. Comdr. J. F. Moser, USN, of the USBF steamer Albatross.

Horse Marine Lake: lake, $1 \mathrm{mi}$. long, at head of Moser Penin., between Olga and Deadman Bays, on S coast of Kodiak I.; 57 $7^{\circ} 07^{\prime} 20^{\prime \prime} \mathrm{N}$, $153^{\circ} 55^{\prime} 00^{\prime \prime} \mathrm{W}$; (map 34).

Local name used by fisherman; reported in 1900 by Lt. Comdr. J. F. Moser, USN, of the USBF steamer Albatross.

Horse Marine Stream: stream, heads at Horse Marine Lake and flows W $1 \mathrm{mi}$. to Horse Marine Lagoon $\mathbf{E}$ of Olga Bay, on $\mathbf{S}$ coast

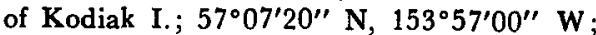
(map 34).

Local name used by fishermen; reported in 1900 by Lt. Comdr. Moser, USN, of the USBF steamer Albatross.

Horsepasture Creek: stream, flows NE $6.7 \mathrm{mi}$. to Conglomerate Creek $2 \mathrm{mi}$. $\mathrm{S}$ of its junc. with Little Oshetna River and $21 \mathrm{mi}$. NW of Tahneta Pass, Talkeetna Mts.; $62^{\circ} 09^{\prime} 50^{\prime \prime} \mathrm{N}$, $147^{\circ} 46^{\prime} 55^{\prime \prime} \mathrm{W}$; BGN 1960; (map 82).
Named in 1956 by USGS "for the grazing area through which it flows."

Horsepasture Pass: pass, 4,200 ft., between Horsepasture Creek and Little Nelchina River, 19 mi. NW of Tahneta Pass, Talkeetna Mts., $62^{\circ} 07^{\prime} 40^{\prime \prime} \mathrm{N}, 147^{\circ} 38^{\prime} 00^{\prime \prime} \mathrm{W} ; B G N$ 1960; (map 82).

Named in 1956 by USGS "because of the open grassy areas at this pass."

Horse Shoal: shoal, $0.9 \mathrm{mi}$. long, in Stephens Passage, $0.8 \mathrm{mi}$. E of Horse I. and $11 \mathrm{mi}$. SW of Juneau, Alex. Arch.; 58 $15^{\prime} 30^{\prime \prime} \mathrm{N}$, $134^{\circ} 42^{\prime} 15^{\prime \prime}$ W; (map 11). Var. Horse Shoals.

Named by Lt. Comdr. H. B. Mansfield, USN, and published by USC\&GS in the 1891 Coast Pilot (p. 149-150) as Horse Shoals.

Horse Shoals: shoal, see Horse Shoal.

Horseshoe Basin: valley, $1.5 \mathrm{mi}$. long, at head of North Fork Porterfield Creek, $12 \mathrm{mi}$. E of Wrangell, Coast Mts. ; $56^{\circ} 32^{\prime} 10^{\prime \prime} \mathrm{N}, 132^{\circ} 05^{\prime}$ $30^{\prime \prime} \mathrm{W}$; (map 6).

Local descriptive name obtained in 1953 by USGS.

Horseshoe Bay: locality, on W coast of Latouche I., S. entrance to Horseshoe Bay, $20 \mathrm{mi}$. SE of Chenega, Chugach Mts.; $60^{\circ} 01^{\prime} 10^{\prime \prime} \mathrm{N}$, $147^{\circ} 56^{\prime} 25^{\prime \prime} \mathrm{W}$; (map 63).

Local name reported in 1908 by U. S. Grant and D. F. Higgins (in Brooks and others, 1909, p. 88), USGS. It is now abandoned.

Horseshoe Bay: cove, on $\mathrm{E}$ side of Latouche Passage, $W$ coast of Latouche I., $20 \mathrm{mi}$. SE of Chenega, Chugach Mts.; $60^{\circ} 01^{\prime} 15^{\prime \prime} \mathrm{N}$, $147^{\circ} 56^{\prime} 20^{\prime \prime} \mathrm{W}$; (map 63).

Local name reported in 1907 by $F, H$. Moffit (in Brooks and others, 1908, p. 178), USGS.

Horseshoe Bend: bend, of Naknek River, at Horseshoe Point, between Chimenchun and Kanaknoli Points, on Alaska Penin., $6 \mathrm{mi}$. SE of Naknek, Bristol Bay Low.; $58^{\circ} 42^{\prime} 40^{\prime \prime} \mathrm{N}$, $156^{\circ} 49^{\prime} 45^{\prime \prime} \mathrm{W}$; (map 41).

Descriptive name given by USGS in 1962 "because of a sharp curve in the Naknek Horseshoe Bend: bend, of Ipewik River, $4.5 \mathrm{mi}$. SE of Windy Lake and $70 \mathrm{mi}$. $E$ of Point River."

Hope, Arctic Slope; $68^{\circ} 36^{\prime} 30^{\prime \prime} \mathrm{N}, 164^{\circ} 12^{\prime}$ 00" W; BGN 1965; (map 130).

Descriptive name proposed in 1965 by geologists of the B.P. Exploration Co. Inc.

Horseshoe Cove: cove, $0.7 \mathrm{mi}$. across, $1.5 \mathrm{mi}$. $\mathrm{N}$ of Pinkidulia Cove on $\mathrm{W}$ shore of Akumwarvik Bay and $33 \mathrm{mi}$. SW of Augustine I., Aleutian Ra.; $59^{\circ} 06^{\prime} \mathrm{N}, 154^{\circ} 10^{\prime} \mathrm{W}$; (map 51).

Local descriptive name reported in 1923 by K. F. Mather (in Brooks and others, 1925, pl. 3), USGS.

Horseshoe Creek: stream, flows $W 0.8 \mathrm{mi}$. to Garfield Creek which flows to Kuzitrin River, $3 \mathrm{mi}$. S of Baldy Mtn. and $38 \mathrm{mi}$. W of Imuruk Lake, Seward Penin. High.; $65^{\circ} 30^{\prime} 15^{\prime \prime} \mathrm{N}, 164^{\circ} 33^{\prime} 30^{\prime \prime} \mathrm{W}$; (map 110).

Prospectors' name shown on a map of Cape Nome gold fields by David Fox, Jr., dated 1901. 
Horseshoe Island: island, $1.4 \mathrm{mi}$. long, between Tlevak Strait and North Pass, NW of Goat I., Alex. Arch.; $55^{\circ} 13^{\prime} 00^{\prime \prime} \mathrm{N}, 132^{\circ} 56^{\prime} 30^{\prime \prime} \mathrm{W}$; (map 4).

Local name published in 1965 by USC\&GS.

Horseshoe Island: island, $1.5 \mathrm{mi}$. long, in Big John Bay, $14 \mathrm{mi}$. SE of Kake, off $\mathrm{W}$ coast of Kupreanof I., Alex. Arch.; $56^{\circ} 48^{\prime} \mathrm{N}, 133^{\circ} 44^{\prime}$ W; (map 6).

Descriptive name given for charting purposes by USC\&GS in 1932 Coast Pilot (p. 259).

Horseshoe Lake: lake, $1.6 \mathrm{mi}$. long, $\mathrm{E}$ of Little Susitna River, $13 \mathrm{mi}$. NW of Anchorage, Cook Inlet Low.; $61^{\circ} 21^{\prime} 45^{\prime \prime} \mathrm{N}, 150^{\circ} 08^{\prime} 50^{\prime \prime} \mathrm{W}$; (map 70).

Local name reported by USGS in 1958; so named because the lake has the shape of a horseshoe.

Horseshoe Lake: lake, $1.5 \mathrm{mi}$. long, $\mathrm{N}$ of Big Lake, $24 \mathrm{mi}$. $\mathrm{N}$ of Anchorage, Cook Inlet Low.; $61^{\circ} 34^{\prime} 25^{\prime \prime} \mathrm{N}, 1^{\circ} 9^{\circ} 55^{\prime} 30^{\prime \prime} \mathrm{W}$; (map 69).

Local name reported in 1950 by USGS.

Horseshoe Lake: lake, $4.5 \mathrm{mi}$. long, on left bank of Yukon River, $3.3 \mathrm{mi}$. $\mathrm{N}$ of Holy Gross, Innoko Low.; $62^{\circ} 16^{\prime} 30^{\prime \prime} \mathrm{N}, 159^{\circ} 47^{\prime} 30^{\prime \prime} \mathrm{W}$; (map 78).

Local descriptive name obtained in 1952 by USGS.

Horseshoe Lake: lake, $2 \mathrm{mi}$. long, between Ewan and Crosswind Lakes, $28 \mathrm{mi}$. NW of Glennallen, Copper River Basin; $62^{\circ} 23^{\prime} \mathrm{N}, 145^{\circ} 55^{\prime}$ W; (map 83).

Local name reported in 1951 by USGS.

Horseshoe Lake: lake, $1.2 \mathrm{mi}$. long, on $\mathrm{N}$ bank of Innoko River NW of Rennies Landing, 38 mi. NW of Ophir and $64 \mathrm{mi}$. NW of McGrath, Innoko Low.; $63^{\circ} 37^{\prime} \mathrm{N}, 157^{\circ} 06^{\prime} \mathrm{W}$; (map 90).

Local name obtained from Joseph Ferris in 1954 by R. E. Isto, USGS.

Horseshoe Lake: lake, $0.2 \mathrm{mi}$. long, $8 \mathrm{mi}$. S of Healy, Alaska, Ra.; $63^{\circ} 44^{\prime} 30^{\prime \prime} \mathrm{N}, 148^{\circ} 54^{\prime} 30^{\prime \prime}$ W; (map 87).

Local descriptive name published in 1952 by USGS.

Horseshoe Lake: lake, $1 \mathrm{mi}$. long, $1.5 \mathrm{mi}$. $\mathrm{E}$ of junc. of Tanana and Yukon Rivers and $5 \mathrm{mi}$. $\mathrm{E}$ of Tanana, Nowitna Low.; 65 ${ }^{\circ} 10^{\prime} 30^{\prime \prime} \mathrm{N}$, $151^{\circ} 54^{\prime} 30^{\prime \prime}$ W ; (Map 106).

Local name reported in 1952 by USGS.

Horseshoe Lake: lake, $1.5 \mathrm{mi}$. long, $1 \mathrm{mi}$. N of Stevens Village, Yukon Flats; $66^{\circ} 01^{\prime} 20^{\prime \prime} \mathrm{N}$, $149^{\circ} 04^{\prime} 30^{\prime \prime} \mathrm{W}$; (map 118).

Local descriptive name obtained in 1956 by USGS.

Horseshoe Lake: lake, $1.5 \mathrm{mi}$. long, $5 \mathrm{mi}$. W of Stevens Village, Yukon Flats; $66^{\circ} 02^{\prime} \mathrm{N}$, $149^{\circ} 17^{\prime} \mathrm{W}$; (map 118).

Local descriptive name obtained in 1956 by USGS.

Horseshoe Lake: lake, $1 \mathrm{mi}$. long, $1 \mathrm{mi}$. W of Sweeney Lake and $18 \mathrm{mi}$. SW of Beaver, Yukon Flats; $66^{\circ} 09^{\prime} \mathrm{N}, 147^{\circ} 48^{\prime} \mathrm{W}$; (map 118).

Local descriptive name obtained in 1956 by USGS.
Horshoe Lake: lake, an oxbow $1.5 \mathrm{mi}$. long, 4 mi. N of Bettles, Kanuti Flats; $66^{\circ} 58^{\prime} 30^{\prime \prime} \mathrm{N}$, $151^{\circ} 42^{\prime} 00^{\prime \prime} \mathrm{W}$; (map 117).

Local name reported in 1956 by T. E. Taylor, USGS.

Horseshoe Mountain: mountain, 2,369 ft., $5 \mathrm{mi}$. NE of Fortress Mtn. and $42 \mathrm{mi}$. NW of Anaktuvuk Pass, Arctic Slope; $68^{\circ} 36^{\prime} 30^{\prime \prime} \mathrm{N}$, $152^{\circ} 46^{\prime} 00^{\prime \prime} \mathrm{W}$; (map 134).

So named by USGS geologists about 1950 "because of the characteristic horseshoe shape of the feature."

Horseshoe Point: bluff, elev. $70 \mathrm{ft}$., on $\mathrm{N}$ bank of Naknek River at Horseshoe Bend, on Alaska Penin., 6.5 mi. SE of Naknek, Bristol Bay Low.; $58^{\circ} 42^{\prime} 45^{\prime \prime} \mathrm{N}, 156^{\circ} 49^{\prime} 45^{\prime \prime} \mathrm{W}$; (map 41).

Local name reported in 1952 by USGS.

Horseshoo Hill: hill, see Court House Hill.

Horsetail Creek: stream, heads in a glacier flows E $1 \mathrm{mi}$. to Mineral Creek, $4.4 \mathrm{mi}$. NW of Valdez, Chugach Mts.; $61^{\circ} 09^{\prime} 45^{\prime \prime} \mathrm{N}$, $146^{\circ} 21^{\prime} 30^{\prime \prime} \mathrm{W}$; (map 68).

Local name published in the 1950's by USGS.

Horsetail Falls Creek: stream, flows W $1 \mathrm{mi}$. to Landlocked Bay, $35 \mathrm{mi}$. NW of Cordova, Chugach Mts. ; $60^{\circ} 51^{\prime} 30^{\prime \prime} \mathrm{N}, 146^{\circ} 31^{\prime} 10^{\prime \prime} \mathrm{W}$; (map 64).

Local name reported in 1912 by $S . R$. Capps and B. L. Johnson (in Brooks and others, 1913, pl. 1), USGS. Named for the falls which occur on the stream.

Horse Trail Lake: lake, $0.2 \mathrm{mi}$. long, on Kenai Penin., between Skilak and Tustumena Lakes, $25 \mathrm{mi}$. SE of Kenai, Cook Inlet Lowr.; $60^{\circ} 20^{\prime} 20^{\prime \prime} \mathrm{N}, 150^{\circ} 42^{\prime} 40^{\prime \prime} \mathrm{W}$; (map 62).

Named about 1963 by officials of Kenai National Moose Range, for administrative purposes.

Horsfeld Creek: stream, in Nutzotin Mts., flows SE $9 \mathrm{mi}$. to Beaver Greek, $1.5 \mathrm{mi}$. SW of Braye Pass, Alaska Ra.; $62^{\circ} 00^{\prime} \mathrm{N}, 141^{\circ} 10^{\prime} \mathrm{W}$ (map 84). Var. Horsford Creek.

Local name reported by Capps (1916, pl. 17), USGS

Horsfeld Roadhouse: locality, see Horsfeld.

Horsford Creek: stream, see Horsfeld Creek.

Horton Creek: stream, flows NE $5 \mathrm{mi}$. to Fox River, $21 \mathrm{mi}$. NE of Solomon, Seward Penin. High.; $64^{\circ} 45^{\prime} \mathrm{N}, 163^{\circ} 55^{\prime} \mathrm{W}$; (map 95 ).

Prospectors' name reported in 1900 by E. C. Barnard (in Brooks, 1901, pl. 17), USGS.

Hoseanna Creek: stream, see Lignite Creek.

Hose Point: point of land, $\mathbf{N}$ point of entrance to Fitzgibbon Gove on NE side of Behm Canal, Coast Mts.; 55 $58^{\prime} 08^{\prime \prime}$ N, $1^{\prime 3} 1^{\circ} 11^{\prime} 30^{\prime \prime}$ W (map 3)

One of many arbitrary names applied to features in this area in 1891 by USC\&GS.

Hosford Creek: stream, flows W $12 \mathrm{mi}$. to Charley River, $29 \mathrm{mi}$. NW of Eagle, YukonTanana High.; $64^{\circ} 57^{\prime} \mathrm{N}, 143^{\circ} 30^{\prime} \mathrm{W}$; (map 102). Var. Cash Creek.

Prospectors' name obtained in 1905 by D. C. Witherspoon, USGS.

Hosiana River: stream, see Hodzana River. Hosianna River: stream, see Hodzana River.
Hosmer Creek: stream, flows SE $11 \mathrm{mi}$. to Nixon Fork, $17 \mathrm{mi}$. N of Medfra, Kilbuck-Kuskokwim Mts.; $63^{\circ} 21^{\prime} \mathrm{N}, 154^{\circ} 49^{\prime} \mathrm{W}$; (map 89).

Local name reported in 1924 by Joseph Stanley-Brown (in Smith, P. S., 1926, pl. 5), USGS.

Hospital Lake: lake, $25 \mathrm{mi}$. long, oxbow $0.3 \mathrm{mi}$. $\mathrm{N}$ of Fort Yukon, Yukon Flats; $66^{\circ} 34^{\prime}$ 25 $^{\prime \prime} \mathrm{N}$, $145^{\circ} 15^{\prime} 00^{\prime \prime} \mathrm{W}$; (map 119).

Local name obtained in 1956 by USGS.

Hospital Valley: valley, $0.3 \mathrm{mi}$. long, between Lake Leone and Sweeper Cove, on NE Adak I., Aleutian Is.; $51^{\circ} 51^{\prime} 00^{\prime \prime} \mathrm{N}, 176^{\circ} 38^{\prime} 24^{\prime \prime} \mathrm{W}$; (map 17).

Name published by USC\&GS in 1963 on Chart 9119

Hosyekakat: stream, see Huslia River.

Hotcake Channel: stream, anabranch $7 \mathrm{mi}$. long, in Copper River, along $\mathrm{E}$ side of Long I., 22 mi. NW of Katalla, Malaspina Coastal Plain; $60^{\circ} 27^{\prime} \mathrm{N}, 144^{\circ} 53^{\prime} \mathrm{W}$; (map 64).

Local name published in 1952 by USGS.

Hotel Gulch: ravine, trends W 0.5 mi. to Bear Creek, $4 \mathrm{mi}$. NE of Nome, Seward Penin. High.; 64 $33^{\prime} 12^{\prime \prime} \mathrm{N}, 165^{\circ} 20^{\prime} 20^{\prime \prime} \mathrm{W}$; (map 94).

Prospectors' name reported in 1904 by T. G. Gerdine, USGS.

Hotel River: stream, see Khotol River.

Hotham Inlet: bay, $50 \mathrm{mi}$. long and $8 \mathrm{mi}$. wide between Selawik Lake to its SE and Kotzebue Sound to its NW, $60 \mathrm{mi}$. WNW of Selawik, Kotzebue-Kobuk Low.; $67^{\circ} 00^{\prime \prime} \mathrm{N}, 162^{\circ} 00^{\prime}$ W; (map 114). Var. Kobuk Lake.

Named in 1826 by Capt. Beechey (1831, p. 250), RN, who wrote "we were surprised to find ourselves opposite a deep inlet which had escaped the observation of Capt. Kotzebue. I named it Hotham Inlet, in compliment to the Hon. Sir Henry Hotham, K.C.B., one of the lords of the Admiralty." Sir Henry Hotham "was concerned with the interruption of Napoleon after the battle of Water100 * *" (Stuck, 1920, p. 77). Archdeacon Stuck gave the local name as "Kobuk Lake" (Stuck, 1920, p. 75).

Hotham Peak: mountain, 1,644 ft., at head of Oksik Creek, $24 \mathrm{mi}$. NW of Selawik, Hogatza High.; $66^{\circ} 49^{\prime} \mathrm{N}, 160^{\circ} 41^{\prime} \mathrm{W}$; (map 114). Named in 1885 by Lt. Stoney (1900, map), USN.

Hot Slough: stream, flows NE $18 \mathrm{mi}$. to Birch Greek, $11.5 \mathrm{mi}$. SW of junc. of McKinley and Kantishna Rivers, Tanana Low.; $63^{\circ} 46^{\prime} 40^{\prime \prime} \mathrm{N}, 151^{\circ} 50^{\prime} 20^{\prime \prime} \mathrm{W}$; (map 88).

Local name reported in 1954 by USGS.

Hot Slough: stream, anabranch of Tanana River, $3.5 \mathrm{mi}$. long, $24 \mathrm{mi}$. SW of Fairbanks, Tanana Low.; $64^{\circ} 39^{\prime} 45^{\prime \prime} \mathrm{N}, 148^{\circ} 24^{\prime} 45^{\prime \prime} \mathrm{W}$; (map 100).

Local name reported in 1950 by USGS topographers.

Hot Spring: locality, see Chena Hot Springs. Hot Spring: spring, on W shore of Port Moller, $9 \mathrm{mi}$. SE of village of Port Moller, Bristol Bay Low. ; 55 $52^{\prime} \mathrm{N}, 160^{\circ} 30^{\prime} \mathrm{W}$; (map 28). Var. Hot Springs. 
Noted as "Hot Springs" by Atwood (1911, pl. 2), USGS, and shown as "Hot Spring" on 1953 USGS map.

Hot Spring: springs, see Hot Springs.

Hot Spring: springs, see Tolovana Hot Springs.

Hot Spring Bay: bay, see Hot Springs Bay.

Hot Spring Creek: stream, flows NE $3 \mathrm{mi}$ to Ophir Creek, $15 \mathrm{mi}$. NNE of Nyac, YukonKuskokwim Delta; $61^{\circ} 13^{\prime} \mathrm{N}, 159^{\circ} 51^{\prime} \mathrm{W}$; (map 73).

Prospectors' name reported in 1914 by A. G. Maddren (in Brooks and others, 1915, p. 332 ), USGS. So called because a hot spring "of scalding temperature at its point of issue" is located along its bank.

Hot Spring Creek: stream, see Hot Springs Creek.

Hot Spring Greek: stream, see Ophir Creek.

Hot Springs: locality, see Goddard.

Hot Springs: locality, see Serpentine Hot Springs.

Hot Springs: settlement, see Circle Hot Springs.

Hot Springs: village, see Manley Hot Springs.

Hot Springs: springs, 2 mi: SE of Hot Springs Dome and $20 \mathrm{mi}$. SW of Livengood, YukonTanana High.; $65^{\circ} 17^{\prime} \mathrm{N}, 148^{\circ} 54^{\prime} \mathrm{W}$; (map 105). Var. Hot Spring.

Local descriptive name for hot springs; published in 1907 by USGS. The springs were described by Waring $(1917$, p. 57), who stated that "the water bubbling from the springs reached temperatures $120^{\circ}$ to $130^{\circ} \mathrm{F}$ and tasted slightly alkaline."

Hot Springs: springs, see Tolovana Hot Springs.

Hot Springs Bay: bay, $1.5 \mathrm{mi}$. across, on $\mathrm{E}$ coast of Tanaga I., Aleutian Is.; $51^{\circ} 47^{\prime} 10^{\prime \prime} \mathrm{N}$, $177^{\circ} 47^{\prime} 30^{\prime \prime} \mathrm{W}$; (map 17).

Name published by USG\&GS in the 1944 Aleutian Coast Pilot (p. 118).

Hot Springs Bay: bay, $2.7 \mathrm{mi}$. across, on NE coast of Akutan I., Krenitzin Is., Aleutian Is.; $54^{\circ} 10^{\prime} 40^{\prime \prime} \mathrm{N}, 165^{\circ} 50^{\prime} 30^{\prime \prime} \mathrm{W}$; (map 24).

Named in 1901 by J. J. Gilbert, USC\&GS, for the hot springs at the head of the bay.

Hot Springs Bay: bay, 0.5 mi. across, $W$ of Goddard, on W coast of Baranof I., Alex. Arch.; $56^{\circ} 51^{\prime}$ N, $135^{\circ} 24^{\prime}$ W; (map 5). Var. Hot Spring Bay, Klucheff Bay, Kluchevoi Bay, Zaliv Klyuchevoy.

This is a translation by USC\&GS about 1882 of the name " $Z[a$ aliv] Klyuchevoy"; given in 1809 by the Russian navigator, Ivan Vasiliev the first; published by Lt. Sarichev (1826, map 19), IRN.

Hotsprings Bay: bay, 2 mi. across, on Bechevin Bay at SW end of Alaska Penin., Aleutian Ra.; $54^{\circ} 58^{\prime} \mathrm{N}, 163^{\circ} 17^{\prime} \mathrm{W}$; BGN 1965; (map 25). $V$ ar. Hot Springs Bay.

Name published in 1949 on a USGS map as "Hot Springs Bay," and in 1963 by USC\&GS as "Hotsprings Bay."

Hot Springs Cove: cove, $1.2 \mathrm{mi}$. across, in Inanudak Bay, on $W$ central coast of Umnak I., Aleutian Is.; $53^{\circ} 15^{\prime} 45^{\prime \prime} \mathrm{N}, 168^{\circ} 21^{\prime} 30^{\prime \prime} \mathrm{W}$; BGN 1940; (map 22).
Descriptive name given in 1938 by USC\&GS "because of the hot springs which exist in the valley south of this cove."

Hot Springs Creek: stream, flows $\mathrm{S} 5 \mathrm{mi}$. to Ugashik Creek, on Alaska Penin., $15 \mathrm{mi}$. NE of Kanatak, Aleutian Ra.; $57^{\circ} 40^{\prime} 05^{\prime \prime} \mathrm{N}$, $156^{\circ} 22^{\prime} 30^{\prime \prime} \mathrm{W}$; (map 36).

Named in 1921 by Capps (1923, pl. 2), USGS.

Hot Springs Creek: stream, flows W $30 \mathrm{mi}$. to Melozitna River $40 \mathrm{mi}$. W of Birches, Kokrines-Hodzana High.; $65^{\circ} 11^{\prime} 00^{\prime \prime} \mathrm{N}, 154^{\circ}$ $54^{\prime} 45^{\prime \prime} \mathrm{W}$; (map 107).

Descriptive name reported in 1915 by Waring (1917, fig. 12), USGS.

Hot Springs Creek: stream, flows NW $9.5 \mathrm{mi}$. to Little Melozitna River, $25 \mathrm{mi}$. NNE of Birches, Kokrines-Hodzana High.; $65^{\circ} 28^{\prime} 40^{\prime \prime}$ $\mathrm{N}, 153^{\circ} 20^{\prime} 00^{\prime \prime} \mathrm{W}$; (map 107).

Local name reported in 1915 by Waring (1917, fig. 12), USGS.

Hot Springs Creek: stream, flows NE $4 \mathrm{mi}$. to a swamp, $1 \mathrm{mi}$. N of Circle Hot Springs and $28 \mathrm{mi}$. SW of Circle, Yukon-Tanana High.; $65^{\circ} 29^{\prime} 40^{\prime \prime} \mathrm{N}, 144^{\circ} 37^{\prime} 40^{\prime \prime} \mathrm{W}$; BGN 1938; (map 104). Var. Grouse Creek.

Originally reported in 1915 as "Grouse Creek" by Waring (1917, fig. 7), USGS. The present name was adopted locally because the stream flows by Circle Hot Springs.

Hot Springs Creek: stream, heads in Isahaltila Mts., flows W 9 mi. to Batza Slough, S of Deniktow Ridge, 26 mi. NNW of Hochandochtla Mtn., Kokrines-Hodzana High.; $65^{\circ}$ $54^{\prime} 00^{\prime \prime} \mathrm{N}, 155^{\circ} 06^{\prime} 10^{\prime \prime} \mathrm{W}$; (map 107).

Descriptive name reported by Sam White, pilot, in 1957.

Hot Springs Creek: stream, flows NW $14 \mathrm{mi}$. to Serpentine River, $13 \mathrm{mi}$. NW of Imuruk Lake, on Seward Penin., Kotzebue-Kobuk Low.; $65^{\circ} 56^{\prime} \mathrm{N}, 164^{\circ} 54^{\prime} \mathrm{W}$; (map 110). Var. Hot Spring Greek.

Prospectors' name reported in 1901 by T. G. Gerdine (in Collier, 1902, pl. 12), USGS.

Hot Springs Dome: mountain, see Manley Hot Springs Dome.

Hot Springs Dome: mountain, see Tolovana Hot Springs Dome.

Hot Springs Landing: locality, on right bank of Tanana River, $52 \mathrm{mi}$. NE of the Bitzshtini Mts., Yukon-Tanana High.; $64^{\circ} 58^{\prime} \mathrm{N}, 150^{\circ}$ 40' $\mathrm{W}$; (map 99).

Steamboat landing established in 1902 to serve the community of Hot Springs.

Hot Spring Slough: stream, see Ketili River.

Hot Springs Slough: channel, in Yukon River, flows SW 2 mi. around N side of Fox I., 21 mi. NE of Ruby, Nowitna Low.; $64^{\circ} 55^{\prime} \mathrm{N}$, $154^{\circ} 50^{\prime} \mathrm{W}$; (map 98).

Local descriptive name; reported in 1916 by USGS.

Hot Springs Slough: channel, see Ketili River.

Hot Springs Slough: stream, heads at Baker Lake and flows SW $15 \mathrm{mi}$. to Tanana River, $50 \mathrm{mi}$. NE of Bitzshtini Mts., Yukon-Tanana

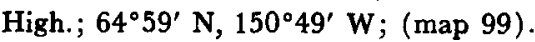

Local name reported in 1906 by D. C. Witherspoon and R. B. Oliver (in Eakin, 1913, pl. 1), USGS.

Hotspur Island: island, $3.0 \mathrm{mi}$. long, $\mathrm{NW}$ of Duke I., at $W$ end of Felice Strait, Alex. Arch.; 54.59' N, $131^{\circ} 30^{\prime} \mathrm{W}$; (map 2).

Named by local pilots; published in the 1883 Coast Pilot (p. 83).

Houchnou: islands, see Kootzanhoo Archipelago.

Houchnov Inlet: water passage, see Kootznahoo Inlet.

Houdovin, Baie: bay, see Heiden, Port.

Houghton, Port: estuary, extends W $11 \mathrm{mi}$. from its North Arm to Stephens Passage, $9 \mathrm{mi}$. N of Frederick Sound and $75 \mathrm{mi}$. E of Sitka, Coast Mts.; $57^{\circ} 19^{\prime}$ N, $133^{\circ} 30^{\prime}$ W; (map 8).

Named in August 1794, by Capt. George Vancouver, RN, for a town in Norfolk, England (Wagner, 1937, p. 392).

Hound Island: island, $1.7 \mathrm{mi}$. long, in Keku Strait, $6.5 \mathrm{mi}$. S of Kake, Alex. Arch.; $56^{\circ}$ $52^{\prime} 30^{\prime \prime} \mathrm{N}, 133^{\circ} 56^{\prime} 00^{\prime \prime} \mathrm{W}$; BGN 1901; (map 6). Var. Round Island.

Named in 1892 by Lt. W. I. Moore, USN.

Hour Creek: stream, flows SW $0.6 \mathrm{mi}$. to Noon Creek which flows to Tisuk River, $17 \mathrm{mi}$. E of Cape Douglas and $40 \mathrm{mi}$. NW of Nome, Seward Penin. High.; $65^{\circ} 00^{\prime} \mathrm{N}, 166^{\circ} 08^{\prime} \mathrm{W}$; (map 94).

Prospectors' name published on the 1908 "Map of Seward Peninsula" by Arthur Gibson. Hourglass Pass: mountain pass, $8 \mathrm{mi}$. SW of center of Okmok Caldera, on central Umnak I., Aleutian Is.; $53^{\circ} 19^{\prime} 30^{\prime \prime} \mathrm{N}, 168^{\circ} 15^{\prime} 00^{\prime \prime} \mathrm{W}$; (map 22).

Name published by Byers (1959, pl. 41), USGS.

Hourigan Point: point of land, $1 \mathrm{mi}$. W of Security Bay, on $\mathbf{N}$ coast of Kuiu I., Alex. Arch.; 56 $51^{\prime} 40^{\prime \prime} \mathrm{N}, 134^{\circ} 22^{\prime} 15^{\prime \prime} \mathrm{W}$; (map 5).

Named in 1881 by Comdr. H. Glass, USN.

Houseblock Valley: ravine, extends $S 1.5 \mathrm{mi}$. from Sevenmile Lake, near $W$ end of Amphitheater Mts., $28 \mathrm{mi}$. WNW of Paxson, Alaska Ra. ; $63^{\circ} 10^{\prime} 45^{\prime \prime} \mathrm{N}, 146^{\circ} 19^{\prime} 00^{\prime \prime} \mathrm{W}$; (map 86). So named in 1955 by T. L. Péwé, USGS, "because the valley is choked with huge rock blocks, each as large as a house."

House Mountain: mountain, 2,070 ft., on Gravina $1 ., 4 \mathrm{mi}$. W of Ketchikan, Alex. Arch.; $55^{\circ} 19^{\prime} 40^{\prime \prime} \mathrm{N}, 131^{\circ} 45^{\prime} 50^{\prime \prime} \mathrm{W}$; (map 3 ).

Named in 1883 by Lt. Comdr. H. E. Nichols, USN.

House Mountain: mountain, see Kings Mountain.

House Peak: peak, 6,070 ft., 2 mi. SE of Church Peak, $5 \mathrm{mi}$. NE of Petersburg, Coast Mts.; $56^{\circ} 55^{\prime} 45^{\prime \prime} \mathrm{N}, 132^{\circ} 32^{\prime} 30^{\prime \prime} \mathrm{W}$; (map 6).

Named in 1887 by Lt. Comdr. C. $M$ Thomas, USN, for charting purposes; published in 1888 on USC\&GS Chart 705.

House Point: point of land, on W shore of Hood Bay, $7 \mathrm{mi}$. $\mathrm{S}$ of Angoon, on $\mathrm{W}$ coast of Admiralty I., Alex. Arch.; 57 24' $20^{\prime \prime}$ N, 134 $31^{\prime}$ 35" W; (map 9).

Name published in 1917 by USC\&GS on Chart 8247. 
House Rock: rock, $300 \mathrm{ft}$. across, near E shore of Revillagigedo Channel $4.5 \mathrm{mi}$. S of Boca de Quadra, Coast Mts.; $55^{\circ} 00^{\prime} 12^{\prime \prime}$ N, $131^{\circ} 01^{\prime}$ $00^{\prime \prime} \mathrm{W}$; (map 3$)$.

Local name published in the 1925 Coast Pilot (p. 55).

Houston: RR. station, mile 174.9 on The Alaska RR., 29 mi. N of Anchorage, Cook Inlet Low.; $61^{\circ} 38^{\prime} 10^{\prime \prime} \mathrm{N}, 149^{\circ} 50^{\prime} 45^{\prime \prime} \mathrm{W}$; (map 69). Var. Houston Siding.

Name published on a 1917 blueprint map of The Alaska RR. Recent USGS maps indicate a site with two or three buildings.

Houston Pass: pass, 2,700 ft., in Ptarmigan Valley at head of Ptarmigan Creek, $93 \mathrm{mi}$. NW of Tyonek, Alaska Ra.; $62^{\circ} 03^{\prime} \mathrm{N}, 153^{\circ} 06^{\prime} \mathrm{W}$; (map 80).

Local name reported in 1940 by USGS.

Houston Siding: RR. station, see Houston.

Hove, Point: point of land, see Howe, Point.

Hovley Gulch: ravine, see Hokeley Gulch.

Howard, Mount: mountain, 2,460 ft., $7 \mathrm{mi}$. N of Cape Decision, on $\mathrm{S}$ coast of Kuiu I., Alex. Arch.; 56 $06^{\prime} 50^{\prime \prime} \mathrm{N}, 134^{\circ} 09^{\prime} 00^{\prime \prime} \mathrm{W}$; (map 5).

Named in 1886 by Lt. J. M. Helm, USN, for charting purposes; published in 1887 by USC\&GS on Chart 706.

Howard, Point: point of land, $6 \mathrm{mi}$. NW of Cape Decision, on S coast of Kuiu I., Alex. Arch.; $56^{\circ} 04^{\prime} 10^{\prime \prime} \mathrm{N}, 134^{\circ} 13^{\prime} 45^{\prime \prime} \mathrm{W}$; (map 5 ).

Named in 1890 by Lt. Comdr. H. B. Mansfield, USN, for Ens. William Lauriston Howard, USN, a member of his party.

Howard, Point: point of land, on $\mathrm{W}$ shore of Lynn Canal, $7 \mathrm{mi}$. N of Point Couverden and $23 \mathrm{mi}$. W of Juneau, St. Elias Mts.; 58 $17^{\prime} 20^{\prime \prime}$ $\mathrm{N}, 135^{\circ} 03^{\prime} 15^{\prime \prime} \mathrm{W}$; (map 11).

Named in 1890 by Lt. Comdr. H. B. Mansfield, USN, for Ens. William Lauriston Howard, USN, a member of his party.

Howard Cove: bay, $1.2 \mathrm{mi}$. across, on $\mathrm{W}$ coast of Kuiu I., $3.5 \mathrm{mi}$. NW of Cape Decision, Alex. Arch.; $56^{\circ} 03^{\prime} \mathrm{N}, 134^{\circ} 10^{\prime} \mathrm{W}$; (map 5).

Local name published by USC\&GS in 1932 Coast Pilot (p. 330).

Howard Creek: stream, flows SW $10 \mathrm{mi}$. to Niukluk River $15 \mathrm{mi}$. NW of its junc. with Casadepaga River, $31 \mathrm{mi}$. NE of Solomon, Seward Penin. High.; 64 $59^{\prime} \mathrm{N}, 164^{\circ} 07^{\prime} \mathrm{W}$; (map 95).

Prospectors' name published on the 1908 "Map of Seward Peninsula" by Arthur Gibson.

Howard Creek: stream, flows N $3.5 \mathrm{mi}$. to Minnie Creek, $7 \mathrm{mi}$. W of Poss Mtn. and $40 \mathrm{mi}$. WSW of Chandalar, Brooks Ra.; $67^{\circ} 25^{\prime} \mathrm{N}, 149^{\circ} 58^{\prime}$ W; (map 123).

Local name reported in 1956 by T. E. Taylor, USGS.

Howard Creek: stream, flows SE $1 \mathrm{mi}$. to California Creek which flows to Bonanza River, between Alta and Crush Creeks, $10 \mathrm{mi}$. NW of Solomon, Seward Penin. High.; (map 95).

Prospectors' name reported on the 1900 "Map of Nome Peninsula" by J. M. Davidson and B. D. Blakeslee. This stream cannot be precisely located on current maps.
Howard Hill: hill, $218 \mathrm{ft}$., between Amos and Andy Coves, Kiska I., Aleutian Is. ; $51^{\circ} 55^{\prime} 47^{\prime \prime}$ $\mathrm{N}, 177^{\circ} 35^{\prime} 26^{\prime \prime} \mathrm{E}$; (map 14).

An arbitrary name beginning with " $H$ " to correspond to "H" grid used by the U.S. Army for tactical purposes during World War II; published on a 1943 Army map.

Howard Hill: hill, $200 \mathrm{ft}$., $\mathrm{N}$ of Maybe Creek, at head of Ikpikpuk River, Arctic Slope $69^{\circ} 20^{\prime}$ N, 154 $34^{\prime} \mathrm{W}$; (map 142).

Named by USGS for Ens. W. L. Howard, USN, of Lt. G. M. Stoney's Naval Expedition of 1885 . They passed along the foot of this hill about May 22, 1886, on the expedition from Ft. Cosmos, on the Kobuk River, to Point Barrow. The name first appears on a fieldsheet by Gerald FitzGerald, USGS, in 1924.

Howard Hills: mountains, 4,500 ft., part of Brooks Ra., extend E and W of Howard Pass, between Ipnavik River on the $\mathrm{W}$ and Inyorurak Pass on the $\mathrm{E} ; 68^{\circ} 15^{\prime} \mathrm{N}, 156^{\circ} 50^{\prime} \mathrm{W}$; $B G N$ 1926; (map 132).

This name appears on a fieldsheet by Gerald FitzGerald in 1925, and was probably given for the pass.

Howard Lake: lake, $1 \mathrm{mi}$. long, $5 \mathrm{mi}$. W of Twentynine Mile Ridge, $21 \mathrm{mi}$. NW of Beaver, Kokrines-Hodzana High.; $66^{\circ} 38^{\prime} \mathrm{N}, 147^{\circ} 44^{\prime}$ W; (map 118).

Local name obtained in 1956 by USGS.

Howard Pass: pass, 1,700 ft., in Brooks Ra., forms divide between Aniuk and Etivluk Rivers; $68^{\circ} 13^{\prime} \mathrm{N}, 156^{\circ} 54^{\prime} \mathrm{W}$; BGN 1926; (map 132).

Named for Ens. William Lauriston Howard, 1860-1930, USN, who, while with Lt. G. M. Stoney's naval expedition to northern Alaska, made an expedition from Fort Cosmos, on the Kobuk River, to Point Barrow. Howard's route carried him through this pass on April 21, 1886 (Stoney, 1900, p. 66-77). The name first appears on a fieldsheet by Gerald FitzGerald, USGS, in 1925.

Howcan: locality, see Howkan.

Howe, Point: point of land, on $\mathrm{S}$ coast of Mitkof I., Alex. Arch.; $56^{\circ} 29^{\prime} 45^{\prime \prime} \mathrm{N}, 132^{\circ} 48^{\prime} 50^{\prime \prime}$ W; (map 6). Var. Point Hove.

Named on August 29, 1793, by Capt. George Vancouver, RN, "probably in honor of Richard Earl Howe, an admiral in the R.[oyal] N.[avy]" (Wagner, 1937, p. 392).

Howe Island: island, $1.3 \mathrm{mi}$. long, in Sagavanirktok River Delta, on Beaufort Sea coast, $29 \mathrm{mi}$. SE of Beechey Point, Arctic Plain; $70^{\circ} 19^{\prime} \mathrm{N}, 147^{\circ} 59^{\prime} \mathrm{W}$; (map 150).

Named by Leffingwell (1919, p. 96) for Dr. George P. Howe of the Anglo-American Polar Expedition, 1906-07.

Howie, Lake: lake, see Cloud Lake.

Howie Creek: stream, flows W $0.6 \mathrm{mi}$. to Candle Greek, $11 \mathrm{mi}$. SW of Candle and $33 \mathrm{mi}$. NE of Imuruk Lake, Seward Penin. High.; $65^{\circ}$ 46'30" N, 162 06'15' W; (map 110).

Prospectors' name reported on the 1908 "Map of Seward Peninsula" by Arthur Gibson. Howkan: locality, site of village on NW coast of Long I., at Howkan Narrows, Alex. Arch.; $54^{\circ} 52^{\prime} 15^{\prime \prime} \mathrm{N}, 132^{\circ} 48^{\prime} 05^{\prime \prime}$ W; (map 1). Var. Howcan, Jackson.

Tlingit Indian name reported in 1881 by Lt. Comdr. Nichols, USN. "Howkan * * * was at one time the largest village of the $\mathrm{Hyda}$ [Haida] Indians in the area. All that remains to mark this site is some evidence of clearing" (U.S. Coast and Geodetic Survey, 1962 , p. 79) * * *." This village was absorbed by the former village of Kaigani which, in turn, was abandoned when the village of Hydaburg was established in 1911 in order to centralize the school system. The Jackson post office was established at Howkan in 1882, and probably named for Sheldon Jackson, who established a mission here in 1881 . The post office name was changed to Howcan in 1886 , back to Jackson in 1890 , and back to Howcan in 1903. In 1917 the post office was discontinued and transferred to Hydaburg (Ricks, 1937, p. 27). J. R. Swanton (in Hodge, 1907, p. 573), BAE, says "Howkan (a'ok!ian, a Tlingit [Indian] word probably referring to a stone which stood up in front of the town, although some derive it from "qōwakon," deer being numerous there). A Haida town *** below which a great canoe fight took place, resulting in the occupancy of part of Prince of Wales Is. by the Kaigani Haida ** *" See Jackson Mission and Kaigani.

Howkan Narrows: water passage, extends SE 2 mi. from Channel Is., in Kaigani Strait, between Dall and Long Is., Alex. Arch.; 54 ${ }^{\circ} 52^{\prime}$ N, $132^{\circ} 48^{\prime} \mathrm{W} ; B G N$ 1939; (map 1).

Name published by USC\&GS in the 1883 Coast Pilot (p. 67); derived from former village of Howkan.

Howkan Reef: reef, 300 yds. long, between Dall and Long Is., in Kaigani Strait, Alex. Arch.; $54^{\circ} 52^{\prime} \mathrm{N}, 132^{\circ} 48^{\prime} \mathrm{W}$; (map 1). Var. HowKan Reef.

Named in 1881 by Lt. Comdr. H. E. Nichols, USN; derived from former village of Howkan.

Howkan Strait: water passage, see Kaigani Strait.

Howling Dog Canyon: canyon, extends $11 \mathrm{mi}$. along Porcupine River between Howling Dog Creek and Old Rampart, $28 \mathrm{mi}$. NE of Coleen Mtn., Brooks Ra.; 67 $09^{\prime}$ N, $141^{\circ} 46^{\prime} \mathrm{W}$; (map 121).

See Howling Dog Rock.

Howling Dog Creek: stream, flows S $8.3 \mathrm{mi}$. to Porcupine River, at Red Gate, $25 \mathrm{mi}$. NE of Coleen Mtn., Brooks Ra.; $67^{\circ} 11^{\prime} \mathrm{N}, 141^{\circ} 55^{\prime}$ W; (map 121)

Name reported by M. G. White (1952, fig. 1), USGS, in 1948. See Howling Dog Rock.

Howling Dog Rock: hill, at junc. of Porcupine River and Howling Dog Creek, $25 \mathrm{mi}$. NE of Coleen Mtn., Brooks Ra.; $67^{\circ} 11^{\prime} \mathrm{N}, 141^{\circ} 55^{\prime}$ W; (map 121).

"At the time of the Hudson's Bay Co.'s activities on the Porcupine River, the south wall of the Red Gate was known as Howling Dog Rock. The dogs used in tracking freight 
barges upstream were unable to haul loaded boats past this vertical cliff, and while the boats were being pulled up by men with long ropes the dogs had to scramble up the steep back slope of the rock and down again to join the party, or would remain behind and howl" (FitzGerald, 1944, p. 227).

Howling Hill: hill, $145 \mathrm{ft}$., W of Sargeant Cove, Kiska I., Aleutian Is. ; $51^{\circ} 55^{\prime} 06^{\prime \prime} \mathrm{N}, 177^{\circ} 33^{\prime}$ $20^{\prime \prime} \mathrm{E}$; (map 14).

An arbitrary name beginning with " $\mathrm{H}$ " to correspond to " $H$ " grid used by the U.S. Army for tactical purposes during World War II; published on a 1943 Army map.

Howling Valley: valley, $2 \mathrm{mi}$. long, branch of Granite Canyon, in Glacier Bay National Monument, $5 \mathrm{mi}$. N of Adams Inlet and $69 \mathrm{mi}$. NW of Juneau, St. Elias Mts.; $58^{\circ} 58^{\prime} 45^{\prime \prime} \mathrm{N}$, $135^{\circ} 47^{\prime} 45^{\prime \prime} \mathrm{W}$; (map 11).

Named in 1899 by John Muir (in Burroughs and others, 1902, p. 38-39) of the Harriman Alaska Expedition. Burroughs wrote that a hunting party went out to stir up the bears and there was "little doubt that the genus loci of Howling Valley would soon change its tune."

Howzerah Creek: stream, see Hawzerah Creek.

Hoya Creek: stream, flows NW $8 \mathrm{mi}$. to Bradford Canal, $10 \mathrm{mi}$. E of Ernest Sound, Coast Mts.; $56^{\circ} 11^{\prime} 15^{\prime \prime} \mathrm{N}, 131^{\circ} 42^{\prime} 20^{\prime \prime} \mathrm{W}$; (map 7).

Local name reported in 1955 by USGS.

Hoyadazzithethno Creek: stream, flows N 13 mi. from Sushgitit Hills to Mentanontli River, $34 \mathrm{mi}$. E of Hughes, Hogatza High.; $66^{\circ} 09^{\prime}$ $00^{\prime \prime} \mathrm{N}, 153^{\circ} 04^{\prime} 30^{\prime \prime} \mathrm{W}$; (map 116).

Indian name reported in 1956 by $T$. $E$. Taylor, USGS.

Hoyle, Lake: lake, $1.4 \mathrm{mi}$. long, at head of Ekolina Creek, $35 \mathrm{mi}$. E of Medfra, Kuskokwim Low.; $63^{\circ} 10^{\prime} \mathrm{N}, 153^{\circ} 36^{\prime} \mathrm{W}$; (map 89).

Named in 1899 by Lt. J. S. Herron (p. 49), USA.

Hoyt Creek: stream, flows NW $2.3 \mathrm{mi}$. to Flat Creek, $17 \mathrm{mi}$. S of junc. of Charley and Yukon Rivers, Yukon-Tanana High.; $65^{\circ} 04^{\prime} 20^{\prime \prime} \mathrm{N}$, $142^{\circ} 46^{\prime} 10^{\prime \prime} \mathrm{W}$; (map 103).

Prospectors' name from an unpublished map by E. J. Chamberlain, dated 1902.

Hozatka Lake: lake, $22 \mathrm{mi}$. S of Roundabout Mtn., Koyukuk Low.; $65^{\circ} 13^{\prime}$ N, $156^{\circ} 36^{\prime}$ W; (map 108).

Koyukan Indian name reported in 1955 by USGS.

Huaji Cliff: cliff, 1,100 ft., on SE coast of Prince of Wales I., near entrance to Clarence Strait, Alex. Arch.; $54^{\circ} 43^{\prime} 50^{\prime \prime} \mathrm{N}, 131^{\circ} 59^{\prime} 50^{\prime \prime} \mathrm{W}$; $B G N$ 1922; (map 1, 2). Var. Huajikaowas Cliff.

Tlingit Indian name given in 1922 by USC\&GS, who gives its meaning as "grizzly bear sitting down."

Huajikaowas Cliff: cliff, see Huaji Cliff.

Hub, The: peak, 1,400 ft., $14 \mathrm{mi}$. S of Ruby, Kilbuck-Kuskokwim Mts.; $64^{\circ} 32^{\prime} \mathrm{N}, 155^{\circ} 31^{\prime}$ W; (map 98). Var. Hub Hill.

Local name reported about 1952 by USGS.

Hubbard, Mount: mountain, 14,950 ft., on Alaska-Canada boundary, $2 \mathrm{mi}$. $\mathrm{S}$ of Mount
Alverstone and $59 \mathrm{mi}$. NW of Yakutat, St. Elias Mts.; $60^{\circ} 19^{\prime} 20^{\prime \prime} \mathrm{N}, 139^{\circ} 04^{\prime} 00^{\prime \prime} \mathrm{W}$; (map 66). Var. Boundary Peak 179.

Named by Russell (1891, p. 99), USGS, in 1890 for Gardiner G. Hubbard, 1822-97, founder and first president of the National Geographic Society, which, with the USGS, sponsored Russell's expedition.

Hubbard, Mount: peak, see Mooses Tooth, The. Hubbard Glacier: glacier, heads in icefield in Canada, trends SE and SW $80 \mathrm{mi}$. to its 1959 terminus at Disenchantment Bay, $34 \mathrm{mi}$. NNE of Yakutat, St. Elias Mts.; $60^{\circ} 01^{\prime} \mathrm{N}, 139^{\circ} 30^{\prime}$ W; (map 66).

Named in 1890 by Russell (1891, p. 99), USGS, for Gardiner G. Hubbard, 1822-97, Massachusetts lawyer and educator, regent of the Smithsonian Institution, and founder and first president of the National Geographic Society, which office he held from 1888 until his death. Interested in the exploration of Alaska, he helped in instigating Russell's 1890 and 1891 expeditions, which were sponsored jointly by the National Geographic Society and the U.S. Geological Survey.

Hubbard Peak: peak, 5,700 ft., $3 \mathrm{mi}$. SW of terminus of Long Glacier and $78 \mathrm{mi}$. NE of Valdez, Wrangell Mts.; $61^{\circ} 41^{\prime} 45^{\prime \prime} \mathrm{N}, 144^{\circ}$. 13'55" W; (map 68).

Name shown on a prospectors' manuscript map dated 1900.

Hub Hill : peak, see Hub, The.

Hubley, Mount: peak, 8,915 ft., in Romanzof Mts., $12 \mathrm{mi}$. E of Mount Michelson, Brooks Ra.; $69^{\circ} 16^{\prime} 30^{\prime \prime} \mathrm{N}, 143^{\circ} 47^{\prime} 55^{\prime \prime}$ W; $B G N$ 1959; (map 138).

Named in 1958 by J. E. Sater, for Richard Carleton Hubley, 1926-57, leader of the International Geophysical Year McCall Glacier party, who was killed on McCall Glacier October 28, 1957.

Hubley Glacier: glacier, heads on Mt. Hubley and trends $3 \mathrm{mi}$. NE to its terminus $12 \mathrm{mi}$. E of Mount Michelson, Brooks Ra.; 69 ${ }^{\circ} 17^{\prime} \mathrm{N}$, $143^{\circ} 44^{\prime} \mathrm{W}$; (map 138).

Named about 1959 for the mountain on which it heads.

Hub Roadhouse: locality, see Kallands.

Hub Rock: rock, in Port Chester, on W coast of Annette I., Alex. Arch.; $55^{\circ} 08^{\prime} 20^{\prime \prime} \mathrm{N}, 131^{\circ}$. $33^{\circ} 00^{\prime \prime} \mathrm{W}$; (map 3).

Named in 1883 by Lt. Comdr. H. E. Nichols, USN.

Hub Rock: rock, in El Capitan Passage, between El Capitan and Prince of Wales Is., Alex. Arch.; 55 56'35" N, $133^{\circ} 17^{\prime} 48^{\prime \prime} \mathrm{W}$; (map 4).

Named in 1903 or 1908 by E. F. Dickins, USC\&GS, who wrote "named by our party, has no local name."

Hub Rock: rock, in Aialik Bay, $0.4 \mathrm{mi}$. E of Harris Penin., 31 mi. SW of Seward, Chugach Mts.; $59^{\circ} 43^{\prime} 10^{\prime \prime} \mathrm{N}, 149^{\circ} 43^{\prime} 15^{\prime \prime} \mathrm{W}$; (map 49).

Local name reported in the early 1950's by USC\&GS.

Huckleberry Run: stream, flows W $1 \mathrm{mi}$. to Cripple River, $1.5 \mathrm{mi}$. NE of Oregon Creek and $16 \mathrm{mi}$. NW of Nome, Seward Penin. High.; $64^{\circ} 42^{\prime} \mathrm{N}, 165^{\circ} 43^{\prime} \mathrm{W}$; (map 94).

Prospectors' name shown on the 1904 "Map of Cape Nome Precinct" by Arthur Gibson.

Huddle Rocks: rocks, off SW coast of Unalaska I., at Lance Point, Aleutian Is.; 53 $19^{\prime} 30^{\prime \prime} \mathrm{N}$, $167^{\circ} 19^{\prime} 45^{\prime \prime} \mathrm{W}$; BGN 1939; (map 23). Var. South Island.

Named in 1939 by USC\&GS. These rocks were called South Island by USBF in 1888 .

Hudeuc Lake: lake, $0.3 \mathrm{mi}$. long, NE of Northway, Alaska Ra.; $62^{\circ} 58^{\prime} \mathrm{N}, 141^{\circ} 56^{\prime} \mathrm{W}$; (map 84).

Local name reported in 1954 by USGS.

Hudson Bay Creek: stream, flows NW $4 \mathrm{mi}$. to South Fork Koyukuk River, E of Jack White Ra., 26 mi. NE of Bettles, Kokrines-Hodzana High.; $66^{\circ} 58^{\prime} \mathrm{N}, 150^{\circ} 45^{\prime} \mathrm{W}$; (map 117).

Name used by prospectors and reported in 1899 by F. C. Schrader and T. G. Gerdine, USGS; probably suggested by the Hudson's Bay Company of Canada.

Hudson Bay Inlet: estuary, see Excursion Inlet. Hudson Collie: stream, see Hudson Coulee.

Hudson Coulee: stream, flows NE $4 \mathrm{mi}$. to Rock Creek $12 \mathrm{mi}$. NW of Eagle, YukonTanana High.; $64^{\circ} 52^{\prime} 20^{\prime \prime} \mathrm{N}, 141^{\circ} 32^{\prime} 00^{\prime \prime} \mathrm{W}$; (map 102). Var. Little Blanche Creek, Hudson Collie.

Prospectors' name reported in 1898 by E. C. Barnard, USGS.

Hudson Creek: stream, flows SE $2.8 \mathrm{mi}$. to Buffalo Creek, $25 \mathrm{mi}$. N of Nome, Seward Penin. High.; $64^{\circ} 52^{\prime} \mathrm{N}, 165^{\circ} 17^{\prime} \mathrm{W}$; (map 94).

Prospectors' name reported in 1904 by T. G. Gerdine, USGS.

Hudson Creek: stream, heads N of Gold Mtn., flows N $8 \mathrm{mi}$. to Little Melozitna River, 13 mi. NNW of Birches, Kokrines-Hodzana High.; $65^{\circ} 18^{\prime} 00^{\prime \prime} \mathrm{N}, 153^{\circ} 45^{\prime} 30^{\prime \prime} \mathrm{W}$; (map 107).

Local name reported in 1908 by Maddren (1910, pl. 5), USGS.

Hudson Lake: lake, $1.4 \mathrm{mi}$. across, $7 \mathrm{mi}$. $\mathrm{N}$ of Mount Carter and $57 \mathrm{mi}$. NE of Valdez, Chugach Mts.; $61^{\circ} 53^{\prime} 45^{\prime \prime} \mathrm{N}, 145^{\circ} 39^{\prime} 15^{\prime \prime} \mathrm{W}$ (map 68).

Local name published by Chapin (1918, pl. 1), USGS.

Hudsunoo: islands, see Kootzanhoo Archipelago. Hudsunoo Inlet: water passage, see Kootznahoo Inlet.

Huff Creek: stream, flows S $1.3 \mathrm{mi}$. to Big Hurrah Creek, $9 \mathrm{mi}$. NE of Solomon, Seward Penin. High.; $64^{\circ} 39^{\prime} \mathrm{N}, 164^{\circ} 13^{\prime} \mathrm{W}$; (map 95). Var. Hutt Creek.

Prospectors' name reported on a 1901 map of Cape Nome gold fields by David Fox, Jr.

Huffman Harbor: bay, $0.1 \mathrm{mi}$. across, on $\mathrm{E}$ shore of Stephens Passage, $0.6 \mathrm{mi}$. N of Pearl Harbor and $19 \mathrm{mi}$. NW of Juneau, Coast Mts.; $58^{\circ} 34^{\prime} 20^{\prime \prime} \mathrm{N}, 134^{\circ} 47^{\prime} 20^{\prime \prime} \mathrm{W}$; (map 11).

Named for James Huffman, 1868-1934, who came to Alaska from Ohio in 1887. He worked mining claims around Eagle River, and in 1911 he filed a homestead claim near the mouth of the river. He was drowned 
near here in 1934 while returning from Douglas in his motorboat (DeArmond, 1957, p. 24).

Huggins Island: island, $7 \mathrm{mi}$. long, between Mathews Slough and Koyukuk River, $60 \mathrm{mi}$. NW of Gold Mtn., Kokrines-Hodzana High.; $65^{\circ} 52^{\prime} \mathrm{N}, 154^{\circ} 27^{\prime} \mathrm{W}$; (map 107). Var. McQuister Island, McQuesten Island, McQuestion Island.

Named in 1885 by Lt. Allen (1887, p. 103), USA, for Capt. Eli Lundy Huggins, USA, "for a long time a resident of the Territory and a warm friend of the expedition." Allen also called the island "McQuesten Island" for the early Yukon River trader, "Jack" LeRoy McQuesten.

Hugh, Point: point of land, on S tip of Glass Penin. at junc. of Seymour Canal and Stephens Passage, $8 \mathrm{mi}$. SE of Pleasant Bay and $54 \mathrm{mi}$. S of Juneau, Alex. Arch.; $57^{\circ} 34^{\prime} 10^{\prime \prime} \mathrm{N}$, $133^{\circ} 48^{\prime} 30^{\prime \prime} \mathrm{W}$; (map 8).

Named by Capt. George Vancouver, RN, after its discovery by Lt. Joseph Whidbey, RN, on August 4, 1794, for Lord Hugh Seymore of England (Wagner, 1937, p. 392).

Hughes: village, pop. 69, on left bank of Koyukuk River, Hogatza High.; $66^{\circ} 03^{\prime}$ N, $154^{\circ} 15^{\prime}$ W; BGN 1944; (map 116). Var. Hughes City.

This village was established in 1910 as a riverboat landing and "port of supply" for the Indian River diggings, and was named for Charles Evans Hughes, 1862-1948, then Governor of New York. The village flourished until 1915 when the Indian River gold gave out. A store remained in existence and the town evolved into a Koyukan Indian village (Stuck, 1917, p. 324-325). See Hughes Bar. A post office was established here in 1914 , rescinded in 1916, and reestablished in 1942.

Hughes Bar: beach, on Koyukuk River, about 2 mi. upstream from Hughes, Hogatza High.; $66^{\circ} 04^{\prime} \mathrm{N}, 154^{\circ} 15^{\prime} \mathrm{W}$; (map 116).

This is the site of first gold workings in this area in 1901. Reported to be named for a prospector, Roy (or Frederick) Hughes, who came here about 1884 . The present-day village of Hughes does not seem to have been named for him.

Hughes City: village, see Hughes.

Hughes Creek: stream, heads in lake, flows SW and SE $45 \mathrm{mi}$. to Koyukuk River, $\mathrm{W}$ of Hughes, Hogatza High.; $66^{\circ} 03^{\prime} \mathrm{N}, 154^{\circ} 17^{\prime}$ W; (map 116). Var. Hatdolitna.

Local name recorded in 1956 by Orth; named for the village. The Indian name for this stream is "Hatdolitna."

Hughes Mountain: mountain, 1,665 ft., on $\mathrm{W}$ bank of Koyukuk River W of Hughes, Hogatza High.; $66^{\circ} 03^{\prime} \mathrm{N}, 154^{\circ} 25^{\prime} \mathrm{W}$; (map 116).

Local name reported in 1956 by Orth; named for the village.

Hugh Miller Fiord: water passage, see Hugh Miller Inlet.

Hugh Miller Glacier: glacier, $1.8 \mathrm{mi}$. NW of Gullied Peak, Glacier Bay National Monument, $63 \mathrm{mi}$. NW of Hoonah, St. Elias Mts.; $58^{\circ} 45^{\prime} 45^{\prime \prime} \mathrm{N}, 136^{\circ} 38^{\prime} 45^{\prime \prime} \mathrm{W}$; (map 10).
Named in 1879 by John Muir (1915, p. 147) for Hugh Miller, 1802-56, Scottish geologist. Miller was a writer and stone mason until the age of 35 when he became interested in geology. His scientific articles on "The Old Red Sandstone" and others have become classics. His elder son, Hugh Miller, 185096, was a member of the Geological Survey of England and later of Scotland. In 1879 John Muir found one large glacier at the head of Hugh Miller Inlet. By 1892 it had receded into two branches. Reid (1896, p. 428) retained the name "Hugh Miller" for the larger glacier and the other he named "Charpentier Glacier."

Hugh Miller Inlet: water passage, $5 \mathrm{mi}$. long, along SW shore of Glacier Bay, Glacier Bay National Monument, $S$ of Gilbert I., $58 \mathrm{mi}$. NW of Hoonah, St. Elias Mts. ; $58^{\circ} 45^{\prime} 30^{\prime \prime} \mathrm{N}$, $136^{\circ} 29^{\prime} 30^{\prime \prime}$ W; (map 10). Var. Hugh Miller Fiord.

Named "Hugh Miller Fiord" in 1879 by John Muir (1915, p. 312). The name was derived from Hugh Miller Glacier.

Hugh Miller Mountain: mountain, 2,765 ft., 1 mi. SW of Glacier Bay, in Glacier Bay National Monument, $56 \mathrm{mi}$. NW of Hoonah, St. Elias Mts.; $58^{\circ} 42^{\prime} 55^{\prime \prime} \mathrm{N}, 136^{\circ} 25^{\prime} 45^{\prime \prime} \mathrm{W}$; (map 10).

Name derived from the Hugh Miller inlet near which it is located. Name published in 1946 by USFS.

Hugh M. Smith Lake: lake, see Hugh Smith Lake.

Hugh Rowe Creek: stream, flows NW $1.5 \mathrm{mi}$. to Fox River opposite Guy Rowe Creek, $21 \mathrm{mi}$. NE of Solomon, Seward Penin. High.; $64^{\circ} 45^{\prime}$ N, 163⒌' W; (map 95).

Prospectors' name reported on a 1901 map of Cape Nome gold fields by David Fox, Jr. Hugh Smith Creek: stream, see Sockeye Creek.

Hugh Smith Lake: lake, $3.5 \mathrm{mi}$. long, drains W to Boca de Quadra, $1 \mathrm{mi}$. S of Marten Arm, Coast Mts. ; $55^{\circ} 06^{\prime} \mathrm{N}, 134^{\circ} 40 \mathrm{~W}$; BGN 1944; (map 3). Var. High Smith Lake, Hugh M. Smith Lake, Quadra Lake, Smith Lake.

Named in 1914 by E. Lester Jones, USBF, for Hugh McCormick Smith, 1865-1941, Commissioner, USBF. It was called Quadra Lake by Comdr. J. F. Moser, USN, in 1897.

Hugo Creek: stream, heads in Igichuk Hills and flows SW $19 \mathrm{mi}$. to Noatak River, $17 \mathrm{mi}$. NE of Kotzebue, Kotzebue-Kobuk Low.; $67^{\circ} 08^{\prime}$ N, $162^{\circ} 21^{\prime} \mathrm{W}$; (map 128). Var. Erechek River, Igachoruk River.

Local name reported in 1956 by Orth.

Huiak Island: island, see Shuyak Island.

Hukanuwu: locality, "on mainland on $\mathrm{N}$ shore of Cross Sound," St. Elias Mts.; (map 10).

Former Tlingit Indian town listed by Hodge (1907, p. 577), BAE. See Kukanuwu.

Hulahula River: stream, heads at glacier terminus in Romanzof Mts. at $69^{\circ} 06^{\prime} \mathrm{N}, 144^{\circ} 01^{\prime} \mathrm{W}$, flows $\mathrm{W}$ and $\mathrm{N} 100 \mathrm{mi}$. to Camden Bay, Arctic Plain; $70^{\circ} 04^{\prime} \mathrm{N}, 144^{\circ} 07^{\prime} \mathrm{W}$; BGN 1961; (map 151). Var. Hoolahoola River, Oolahoola River, Ulahula River.
The name "Hoolahoola," introduced by the whalers, is of Kanaka (Hawaiian) origin, meaning "a dance," and was reported in 1902 by S. J. Marsh in a communication to Alfred H. Brooks (Leffingwell, 1919).

Hulakan River: stream, see Hulakon River. Hulakin River: stream, see Hulakon River.

Hulakon River: stream, flows $\mathbf{S}$ mi. to join Unuk River at head of Burroughs Bay, Coast Mts.; $56^{\circ} 05^{\prime} 15^{\prime \prime} \mathrm{N}, 131^{\circ} 05^{\prime} 30^{\prime \prime} \mathrm{W}$; $B G N$ 1923; (map 7). Var. Hulakan River, Hulakin River.

Indian name reported in 1923 by Jesse Hill, USC\&GS, while on duty as an IBC surveyor.

Hulgothen Bluffs: bluffs, on $\mathbf{N}$ bank of Fish Creek, $6 \mathrm{mi}$. E of Fish Creek Lake, $27 \mathrm{mi}$. SE of Bettles, Kanuti Flats; $66^{\circ} 34^{\prime} \mathrm{N}, 151^{\circ} 12^{\prime} \mathrm{W}$; (map 117).

Koyukan Indian name obtained in 1956 at Allakaket by T. E. Taylor, USGS.

Hulitna: stream, see Holitna River.

Hulitnak: stream, see Holitna River.

Hulitno: stream, see Holitna River.

Hull Point: point of land, $\mathrm{W}$ point of island between Elson Lagoon and Beaufort Sea, $E$ of Elutkak Pass, $11 \mathrm{mi}$. NE of Barrow, Arctic Plain; (map 153).

Named by Comdr. Rochfort Maguire, RN, in 1853, for Master Thomas Hull, who compiled Brit. Adm. Chart 2164, "Barrow Point and Port Moore." Due to physical changes of the shore the name is no longer applied.

Hult Creek: stream, heads in Mount McKinley National Park, flows NW $13 \mathrm{mi}$. to Birch Creek, $32 \mathrm{mi}$. SSE of village of Lake Minchu. mina Tanana Low.; $63^{\circ} 28^{\prime} 25^{\prime \prime} \mathrm{N}, 151^{\circ} 51^{\prime} 00^{\prime \prime}$ $\mathrm{W}$; (map 88).

Local name reported in 1925 by $\mathbf{S}$. $R$. Capps, USGS.

Hulti Bay: bay, see LeConte Bay.

Hultulkakut: locality, see Kutul.

Hulu Bay: cove, see Casco Cove.

Humboldt Creek: stream, flows NE $1 \mathrm{mi}$. to Noxapaga River $1 \mathrm{mi}$. $\mathbf{S}$ of its junc. with Aurora Creek, $24 \mathrm{mi}$. W of Imuruk Lake, Seward Penin. High.; $65^{\circ} 38^{\prime} \mathrm{N}, 164^{\circ} 05^{\prime} \mathrm{W}$; (map 110).

Prospectors' name reported on the 1908 "Map of Seward Peninsula" by Arthur Gibson. Humboldt Creek: stream, flows $\mathrm{S}$ to Eldorado River near its head, about $25 \mathrm{mi}$. NW of Solomon, Seward Penin. High.; (map 95).

Shown on the 1900 "Map of Nome Penin." by J. M. Davidson and B. D. Blakeslee. This feature cannot be indentified on recent maps.

Humboldt Harbor: anchorage, $0.7 \mathrm{mi}$. across, on W coast of Popof I., in Shumagin Is., Aleutian Ra.; $55^{\circ} 20^{\prime} \mathrm{N}, 160^{\circ} 30^{\prime} \mathrm{W}$; (map 28).

Named in 1872 by W. H. Dall, USC\&GS, for Survey schooner Humboldt.

Humbolt Creek: stream. flows NE $20 \mathrm{mi}$. to Goodhope River, $35 \mathrm{mi}$. NW of Imuruk Lake on Seward Penin., Kotzebue-Kobuk Low.; $65^{\circ} 59^{\prime} \mathrm{N}, 164^{\circ} 02^{\prime} \mathrm{W}$; (map 110$)$.

Prospectors' name reported in 1901 by USGS (Collier, 1902, pl. 12).

Humbug, Point: point of land, on S end of Lindenberg Penin., Kupreanof I., $14 \mathrm{mi}$. S of 
Petersburg, Alex. Arch.; 56 $36^{\prime} 45^{\prime \prime} \mathrm{N}, 132^{\circ}$ $59^{\prime} 10^{\prime \prime} \mathrm{W}$; (map 6).

Named in 1869 by Comdr. R. W. Meade, USN.

Hume Island: island, $0.3 \mathrm{mi}$. long, in Carroll Inlet, $7 \mathrm{mi}$. NE of California Head, Revillagigedo I., Alex. Arch.; $55^{\circ} 23^{\prime} 45^{\prime \prime}$ N, $131^{\circ}$ $20^{\prime} 45^{\prime \prime} \mathrm{W}$; (map 3).

Local navigators' name obtained in 1904 by H. C. Fassett, USBF.

Hume Point: point of land, on NW shore of Chignik Lagoon, $9 \mathrm{mi}$. W of Chignik, Aleutian Ra.; 56 $18^{\prime} \mathrm{N}, 158^{\circ} 37^{\prime} \mathrm{W}$; (map 30).

Local name published in 1927 by USC\&GS.

Hummel Glacier: glacier, heads $4 \mathrm{mi}$. W of Ninemile Mtn., trends NW $1.5 \mathrm{mi}$. to its 1955 terminus $12.5 \mathrm{mi}$. NW of Hyder, Coast Mts.; $56^{\circ} 02^{\prime} 10^{\prime \prime} \mathrm{N}, 130^{\circ} 16^{\prime} 45^{\prime \prime} \mathrm{W}$; (map 7).

Local name reported in 1928 by USGS.

Hummer Bay: estuary, extends SE $2 \mathrm{mi}$. to Port Wells, $16 \mathrm{mi}$. NE of Whittier, Chugach Mts.; $60^{\circ} 53^{\prime} 15^{\prime \prime} \mathrm{N}, 148^{\circ} 17^{\prime} 30^{\prime \prime} \mathrm{W}$; (map 63)

Local name reported in 1916 by J. W. Bagley, USGS.

Hummer Creek: stream, flows SE $2.5 \mathrm{mi}$. to Hummer Bay, $16 \mathrm{mi}$. NE of Whittier, Chugach Mts.; $60^{\circ} 54^{\prime} 40^{\prime \prime} \mathrm{N}, 148^{\circ} 19^{\prime} 00^{\prime \prime} \mathrm{W}$; (map 63).

Local name derived from Hummer Bay; published on recent USGS maps.

Hump, The: peak, 10,300 ft., at head of Tyndall Glacier, $3 \mathrm{mi}$. SE of Mount Huxley and $71 \mathrm{mi}$. NW of Yakutat, St. Elias Mts. ; $60^{\circ} 18^{\prime}$ $40^{\prime \prime} \mathrm{N}, 141^{\circ} 05^{\prime} 30^{\prime \prime} \mathrm{W}$; BGN 1917; (map 65).

Descriptive name published by $\mathrm{H}$. W. Topham (1889, map).

Humpback, The: rock, see Humpback Rock.

Humpback Bay: bay, 1 mi. across, part of Makushin.Bay on W coast of Unalaska I., Aleutian Is.; $53^{\circ} 45^{\prime} \mathrm{N}, 166^{\circ} 53^{\prime} \mathrm{W}$; (map 23). Var. Tarasof Bay.

Descriptive name published in 1943 by USC\&GS. This bay could possibly be the same feature which Father Veniaminov (1840, v. 1, p. 171) called "Tarasovskaya" and which the USGS called "Tarasof Bay."

Humpback Bay: bight, $5 \mathrm{mi}$. across, on $\mathrm{S}$ coast of Alaska Penin., $12 \mathrm{mi}$. ENE of Stepovak Bay, Aleutian Ra.; $55^{\circ} 52^{\prime} \mathrm{N}, 159^{\circ} 20^{\prime} \mathrm{W}$; (map 27)

Local name published by USC\&GS in the 1938 Coast Pilot.

Humpback Bay: bay, see Anan Bay.

Humpback Cove: cove, $1.3 \mathrm{mi}$. across, $\mathrm{E}$ of Humpback Point, 9 mi. NE of Yakutat, Malaspina Coastal Plain; 59 $39^{\prime} \mathrm{N}, 139^{\circ} 34^{\prime} \mathrm{W}$; (map 46).

Local name published in 1959 by USGS.

Humpback Creek: stream, heads in Peabody Mts., flows W, through Humpback Lake $15 \mathrm{mi}$. to Mink Bay, Coast Mts.; $55^{\circ} 02^{\prime} \mathrm{N}, 130^{\circ} 41^{\prime}$ W; BGN 1930; (map 3$)$.

Local name reported in 1915 by $E$. Lester Jones, USC\&GS ; so named because this stream is " $a$ famous spawning place of the Humpback Salmon."

Humpback Creek: stream, on $\mathbf{N}$ part of Chichagof I., flows $11 \mathrm{mi}$. E to Port Frederick,
$3.5 \mathrm{mi}$. NE of Neka Bay and $5 \mathrm{mi}$. SW of Hoonah, Alex. Arch.; 58 $05^{\prime} 40^{\prime \prime}$ N, $135^{\circ} 34^{\prime}$ 30 " W; (map 11).

Name published in 1932 by USC\&GS on Chart 8304.

Humpback Creek: stream, heads in lake $1.4 \mathrm{mi}$. SW of Lake Redfield, flows NW $1.1 \mathrm{mi}$. to Humpback Cove, $0.4 \mathrm{mi}$. SE of Humpback Point and $8.5 \mathrm{mi}$. NE of Yakutat, Malaspina Coastal Plain; $59^{\circ} 38^{\prime} 40^{\prime \prime} \mathrm{N}, 139^{\circ} 34^{\prime} 30^{\prime \prime} \mathrm{W}$; (map 46).

Local name published in 1959 by USGS.

Humpback Creek: stream, flows W $4 \mathrm{mi}$. to Orca Inlet, $5 \mathrm{mi}$. NE of Cordova, Chugach Mts. ; $60^{\circ} 37^{\prime}$ N. $145^{\circ} 41^{\prime}$ W ; BGN 1914; (map 64). Var. Hunchback Creek.

Local name reported in 1914 by A. H. Brooks, USGS. It was formerly reported as "Hunchback Creek" in 1908 by U. S. Grant and D. F. Higgins (in Brooks and others, 1909, pl. 4), USGS.

Humpback Lake: lake, $6.3 \mathrm{mi}$. long, drains into Mink Bay by Humpback Creek, Coast Mts.; $55^{\circ} 01^{\prime} \mathrm{N}, 130^{\circ} 34^{\prime} \mathrm{W}$; BGN 1963; (map 3). Var. Bower Lake.

Named in 1923 by USFS for the "Humpback Salmon."

Humpback Point: point of land, on SE shore of Yakutat Bay, $1.4 \mathrm{mi}$. N of Redfield Cove and $8.5 \mathrm{mi}$. NE of Yakutat, Malaspina Coastal Plain: $59^{\circ} 39^{\prime} \mathrm{N}, 139^{\circ} 34^{\prime} \mathrm{W}$; (map 46).

Descriptive name published in 1959 by USGS.

Humpback Rock: rock, in Chiniak Bay, $9 \mathrm{mi}$. $\mathrm{SE}$ of Kodiak, Kodiak I. ; $57^{\circ} 42^{\prime} 30^{\prime \prime} \mathrm{N}, 152^{\circ}$. $15^{\prime} 00^{\prime \prime} \mathrm{W}$; (map 34). Var. Gorbun Rock, Horboon Rock, Kamen Gorbun Morskoy, Sugarloaf Rock, The Humpback.

A translation of the transliterated name "Horboon" [from "gorbun"], given to this feature in 1804 by Lisianski (1814, p. 142). Called "Kamen Gorbun Morskoy," meaning "humpback sea rock," by Sarichev (1826, map 16) and "The Humpback" or "Sugarloaf Rock" by USC\&GS in 1869.

Humphery Point: locality, see Humphrey Point. Humphrey Bay: bay, see Pokok Bay.

Humphrey Point: locality, on Beaufort Sea coast at Humphrey Point, $35 \mathrm{mi}$. NW of Demarcation Point, Arctic Plain; $69^{\circ} 58^{\prime} \mathrm{N}, 142^{\circ} 30^{\prime}$ W; (map 138). Var. Humphery Point, Hum. phreys Point, Humphry Point, Humphrys Point.

Eskimo camp or settlement listed in the 1940 census with a population of 24

Humphrey Point: point of land, on Arctic coast, between Beaufort Sea and Pokok Bay, $35 \mathrm{mi}$. NW of Demarcation Point, Arctic Plain; $69^{\circ} 58^{\prime} 45^{\prime \prime} \mathrm{N}, 142^{\circ} 31^{\prime} 30^{\prime \prime} \mathrm{W}$; (map 138). Var. Elurachea Point, Elurauchea Point, Humphreys Point, Point Humphrys, Imaiknaurak.

Named by Franklin (1828, p. 145) on August 3, 1826. The Eskimo name "Imaiknaurak" was reported in 1948 by USC\&GS to mean "no more water there," derived from the occurrence of the sea encroaching upon and destroying a small freshwater lake.
Humphreys Point: locality, see Humphrey Point. Humphreys Point: point of land, see Humphrey Point.

Humphry Point: locality, see Humphrey Point. Humphrys Point: locality, see Humphrey Point. Hump Island: island, $0.4 \mathrm{mi}$. across, in Cholmondeley Sound, on SE coast of Prince of Wales I., Alex., Arch.; $55^{\circ} 13^{\prime} 40^{\prime \prime}$ N, $132^{\circ} 07^{\prime}$. $00^{\prime \prime} \mathrm{W}$; (map 4). Var. Pup Island.

Local navigators' name reported in 1904 by H. C. Fassett, USBF. The name "Pup Island" was published by USC\&GS in 1901. Hump Island: island, $0.9 \mathrm{mi}$. long, in Clover Passage, between Betton and Revillagigedo Is., Alex. Arch.; $55^{\circ} 31^{\prime} 15^{\prime \prime} \mathrm{N}, 131^{\circ} 45^{\prime} 20^{\prime \prime} \mathrm{W}$; (map 3).

Named in 1885 by Lt. Ccmdr. Richardson Clover, USN.

Hump Island: island, $0.8 \mathrm{mi}$. across, on Lynn Canal, $1 \mathrm{mi}$. S of Lincoln I. and $23 \mathrm{mi}$. NW of Juneau, Alex. Arch.; 58 27'30' N, $134^{\circ}$ $59^{\prime} 00^{\prime \prime}$ W; (map 11). Var. Hump Islet.

Descriptive name given by Comdr. R. W. Meade, USN, in 1869, due to its humped appearance, and published as "Hump Inlet" by USC\&GS in the 1883 Coast Pilot (p. 194).

Hump Islet: island, see Hump Island.

Hump Knoll: mountain, 3,200 ft., on $\mathbf{S}$ end of ridge at 1961 terminus of Baird Glacier, $3 \mathrm{mi}$. $\mathrm{N}$ of Thomas Bay, and $100 \mathrm{mi}$. E of Sitka, Coast Mts.; $57^{\circ} 18^{\prime} 10^{\prime \prime} \mathrm{N}, 132^{\circ} 48^{\prime} 30^{\prime \prime} \mathrm{W}$; (map 8).

Descriptive name given in 1887 by Lt. Comdr. C. M. Thomas, USN; published in 1888 by USC\&GS.

Humpy Cove: cove, $1.2 \mathrm{mi}$. across, on $\mathrm{N}$ coast of Aliulik Penin., at S end of Kodiak I. ; 56 $51^{\circ}$ ' $30^{\prime \prime} \mathrm{N}, 154^{\circ} 01^{\prime} 00^{\prime \prime} \mathrm{W}$; (map 32 ).

Name published in 1943 by USC\&GS.

Humpy Cove: cove, $0.8 \mathrm{mi}$. across, on $\mathrm{W}$ coast of Resurrection Penin., $10 \mathrm{mi}$. SE of Seward, Ghugach Mts.; $59^{\circ} 58^{\prime} \mathrm{N}, 149^{\circ} 18^{\prime} \mathrm{W}$; (map 49).

Local name reported in the 1940 's by USC\&GS.

Humpy Creek: stream, on mainland, flows SE $8 \mathrm{mi}$. to Chickamin River, $5.5 \mathrm{mi}$. NE of Fish Point on Behm Canal, Coast Mts.; $55^{\circ} 51^{\prime} \mathrm{N}$, $130^{\circ} 52^{\prime} \mathrm{W}$; (map 3 ).

Local name reported in 1955 by USGS.

Humpy Creek: stream, on Kenai Penin., flows NW $6.5 \mathrm{mi}$. to Kachemak Bay, $14 \mathrm{mi}$. E of Homer, Chugach Mts. ; $59^{\circ} 39^{\prime} 40^{\prime \prime} \mathrm{N}, 151^{\circ} 09^{\prime}$ $00^{\prime \prime} \mathrm{W}$; (map 50).

Local name reported and published by USGS in 1950.

Humpy Point: point of land, $0.2 \mathrm{mi}$. long, extends from $\mathrm{E}$ shore of Revillagigedo Channel, Coast Mts.; $54^{\circ} 49^{\prime} 15^{\prime \prime} \mathrm{N}, 130^{\circ} 56^{\prime} 30^{\prime \prime} \mathrm{W}$; (map 2).

Local descriptive name published in 1943 by USC\&GS.

Hunchback Creek : stream, see Humpback Creek. Hunch Creek: stream, flows SW $8.4 \mathrm{mi}$. to Colorado Creek $4 \mathrm{mi}$. NE of its junc. with Innoko River, $40 \mathrm{mi}$. N of Ophir and $55 \mathrm{mi}$. NW of McGrath, Kilbuck-Kuskokwim Mts.; 63⒋ $35^{\prime \prime} \mathrm{N}, 156^{\circ} 15^{\prime} 05^{\prime \prime} \mathrm{W}$; BGN 1936; (map 90). 
Prospectors' name obtained in 1933 by J. B. Mertie, Jr. (in Smith, P. S., 1936, pl. 4), USGS.

Hunch Mountain: mountain, 1,272 ft., $\mathbf{E}$ of Innoko River, near head of Hunch Creek, 45 mi. NE of Ophir and $58 \mathrm{mi}$. NW of McGrath, Kilbuck-Kuskokwim Mts. ; $63^{\circ} 46^{\prime} \mathrm{N}, 156^{\circ} 09^{\prime}$ W; BGN 1936; (map 90).

Prospectors' name obtained in 1933 by J. B. Mertie, Jr. (in Smith, P. S., 1936, pl. 4), USGS.

Hundell Creek: stream, flows $\mathrm{N} 4 \mathrm{mi}$. to Tonsina River, $0.5 \mathrm{mi}$. SW of Lower Tonsina and 64 mi. NE of Valdez, Cooper River Basin; $61^{\circ}$. $39^{\prime} 10^{\prime \prime} \mathrm{N}, 144^{\circ} 40^{\prime} 30^{\prime \prime} \mathrm{W}$; (map 68).

Local name published since 1950 by USGS.

Hundred Mile Lake: lake, 2,100 ft. long, $\mathrm{N}$ of Glenn Highway, $44 \mathrm{mi}$. NE of Palmer, Talkeetna Mts.; $64^{\circ} 48^{\prime} 25^{\prime \prime} \mathrm{N}, 147^{\circ} 50^{\prime} 30^{\prime \prime} \mathrm{W}$; (map 69).

Local name reported in 1952 by USGS.

Hundred Thousand Creek: stream, on $\mathbf{E}$ coast of Prince of Wales I., heads in a lake, flows NE $1.4 \mathrm{mi}$. to Kasaan Bay, $5 \mathrm{mi}$. NW of

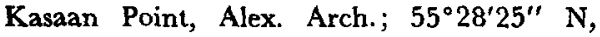
$132^{\circ} 23^{\prime} 40^{\prime \prime} \mathrm{W}$; (map 4).

Local name recorded in 1949 by USGS.

Hungarian Creek: stream, flows SE $5 \mathrm{mi}$. from Sitkum Pass to South Fork Koyukuk River, $47 \mathrm{mi}$. SW of Chandalar, Brooks Ra.; $67^{\circ} 06^{\prime}$ $30^{\prime \prime} \mathrm{N}, 149^{\circ} 57^{\prime} 00^{\prime \prime} \mathrm{W}$; (map 123).

Prospectors' name reported in 1889 by Schrader (1900b, pl. 60), USGS.

Hurigry: locality, see Whitefish Lake.

Hungry Bay: bay, $2.5 \mathrm{mi}$. across, on NW coast Amlia I., Aleutian Is. ; $52^{\circ} 07^{\prime} \mathrm{N}, 173^{\circ} 49^{\prime} \mathrm{W}$; (map 19).

Local name published on a 1951 USGS map.

Hungry Creek: stream, on Kenai Penin., flows SE $4.5 \mathrm{mi}$. to Resurrection Creek, $16 \mathrm{mi}$. SW of Hope, Chugach Mts.; $60^{\circ} 42^{\prime} 00^{\prime \prime} \mathrm{N}, 149^{\circ}$ $45^{\prime} 25^{\prime \prime} \mathrm{W}$; (map 63).

Local prospectors' name; reported in 1904 by Moffit (1906, pl. 2), USGS.

Hungry Creek: stream, flows $\mathbf{N}$, through Kutokbuna and Trout Lakes, $13 \mathrm{mi}$. to Stony River, $11 \mathrm{mi}$. NE of Tundra Lake and $84 \mathrm{mi}$. NW of Lake Clark, Lime Hills; $61^{\circ} 20^{\prime} 30^{\prime \prime} \mathrm{N}, 155^{\circ}$. $26^{\prime} 30^{\prime \prime} \mathrm{W}$; (map 71)

Local name published in 1951 by USGS.

Hungry Creek: stream, flows SW $2.5 \mathrm{mi}$. to Wilson Creek, $1.4 \mathrm{mi}$. E of Marshall, YukonKuskokwim Delta; $61^{\circ} 52^{\prime} 25^{\prime \prime} \mathrm{N}, 162^{\circ} 02^{\prime} 30^{\prime \prime}$ W; (map 74)

Local miners' name reported in 1916 by Harrington (1918, map), USGS.

Hungry Creek: stream, flows NW $2.5 \mathrm{mi}$. to Oregon Greek, $15 \mathrm{mi}$. NW of Nome, Seward Penin. High.; $64^{\circ} 41^{\prime} \mathrm{N}, 165^{\circ} 43^{\prime} \mathrm{W}$; (map 94).

Prospectors' name reported in 1900 by E. C. Barnard (in Brooks, 1901, pl. 17), USGS.

Hungry Creek: stream, flows: W $4 \mathrm{mi}$. to Roy Creek, $4.5 \mathrm{mi}$. E of Chimney Mtn. and $22 \mathrm{mi}$. $\mathrm{N}$ of Wiseman, Brooks Ra.; $67^{\circ} 43^{\prime} \mathrm{N}, 150^{\circ}$. 23' W; BGN 1932; (map 124).

Stream named by Robert Marshall in 1932.
Hungry Hollow: ravine, W of Flat Top Mtn., trends SW $7 \mathrm{mi}$. to Middle Fork Gulkana River, 12 mi. W of Paxson Lake, Alaska Ra.; $62^{\circ} 54^{\prime} \mathrm{N}, 145^{\circ} 54^{\prime} \mathrm{W}$; (map 83).

Local name reported in 1950 by USGS.

Hungry Lake: lake, $0.6 \mathrm{mi}$. long, on Kenai Penin., $3 \mathrm{mi}$. NW of Dolly Varden Lake, 17 mi. NE of Kenai, Cook Inlet Low.; $64^{\circ} 44^{\prime} \mathrm{N}$, $150^{\circ} 53^{\prime} \mathrm{W}$; (map 62).

Named about 1963 by officials of Kenai National Moose Range, for administrative purposes.

Hungryman Creek: stream, flows NE $8 \mathrm{mi}$. to Tuxedni Channel, $57 \mathrm{mi}$. SW of Kenai, Aleution Ra.; $60^{\circ} 09^{\prime} \mathrm{N}, 152^{\circ} 41^{\prime} \mathrm{W}$; (map 62).

Name reported by USGS (Brooks and others, 1922, pl. 2).

Hungryman Creek: stream, heads in lake, flows $\mathrm{S} 10 \mathrm{mi}$. to Pickle Creek $0.7 \mathrm{mi}$. $\mathrm{N}$ of its junc, with Kahiltna River, $28 \mathrm{mi}$. W of 'Talkeetna, Alaska Ra.; $62^{\circ} 17^{\prime} 50^{\prime \prime} \mathrm{N}, 150^{\circ}$ 58'40" W; (map 81).

Prospectors' named reported in 1940 by USGS.

Hungry Village: settlement, see Lime Village.

Hunker Creek: stream, flows SW $0.4 \mathrm{mi}$. to New Eldorado Creek, $13 \mathrm{mi}$. NE of Nome, Seward Penin. High.; $64^{\circ} 40^{\prime} 36^{\prime \prime} \mathrm{N}, 165^{\circ} 10^{\prime} 20^{\prime \prime} \mathrm{W}$ (map 94).

Prospectors' name reported in 1904 by T. G. Gerdine, USGS.

Hunner Creek: stream, flows SE $10 \mathrm{mi}$. to Kaviruk River, $33 \mathrm{mi}$. E of Teller, Seward Penin. High.; $65^{\circ} 17^{\prime} \mathrm{N}, 165^{\circ} 14^{\prime} \mathrm{W}$; (map 111). Var. Hunter Creek.

Prospectors' name reported in 1901 by T. G. Gerdine (in Collier, 1902, pl. 12), USGS.

Hunnings Bay: bay, see Hanning Bay.

Hunt, Lake: lake, see Harriet Hunt, Lake.

Hunt Greek: stream, flows E $1.2 \mathrm{mi}$. to Eldorado Creek which flows to Candle Creek, $29 \mathrm{mi}$. NE of Imuruk Lake, Seward Penin. High.; $65^{\circ} 42^{\prime} \mathrm{N}, 162^{\circ} 12^{\prime} \mathrm{W}$; (map 110 ).

Local name reported in 1950 by USGS.

Hunt Creek, stream, flows NW $26 \mathrm{mi}$. to Inland Lake, $14 \mathrm{mi}$. SE of Selawik, Kotzebue-Kobuk Low.; $66^{\circ} 25^{\prime} \mathrm{N}, 159^{\circ} 55^{\prime} \mathrm{W}$; (map 114).

Local name reported by the U.S. Army Corps of Engineers in 1955.

Hunter: locality, mile 40.0 on The Alaska RR. $0.5 \mathrm{mi}$. W of mouth of Moose Creek and 26 mi. SE of Sunrise, Chugach Mts.; $60^{\circ} 33^{\prime} 45^{\prime \prime}$ $\mathrm{N}, 149^{\circ} 08^{\prime} 40^{\prime \prime} \mathrm{W}$; (map 63). Var. Hunters.

Reported as "Hunters" in 1912 by Grant and Higgins (1913, pl. 1), USGS. The present spelling appears in The Alaska RR. guide of 1919.

Hunter, Mount: peak, $14,573 \mathrm{ft}$., near head of Tokositna Glacier, $10 \mathrm{mi}$. S of Denali Pass, in Mount McKinley National Park, Alaska Ra.; $62^{\circ} 57^{\prime} \mathrm{N}, 151^{\circ} 05^{\prime} \mathrm{W}$; (map 81). Var. Little McKinley, Mount Disston, Mount Hunter North Peak, Mount Roosevelt.

In 1903, Robert Dunn, reporter of the "New York Commercial Advertiser," with F. A. Cook, named a high mountain "Mount Hunter," in honor of his aunt Anna Falconnet Hunter,1855-1941, who financed his trip.
R. W. Porter, USGS, in 1906 , mistakenly applied the name to this peak, about 9 miles northwest of the one named by Dunn. Cook, in 1905, may have named this mountain "Mount Disston" for his friend Henry Disston. See Mount Huntington. Some members of Cook's 1906 party referred to this mountain as "Little McKinley" and the prospectors in the Yentna district to the south called it "Mount Roosevelt" for Theodore Roosevelt. The first ascent of Mount Hunter was July 5, 1954, by Fred Beckey, Heinrich Harrer, and Henry Meybohm (Farquhar, 1959, p. 222, 223).

Hunter Bay: estuary, extends $3 \mathrm{mi}$. E, on $\mathrm{SW}$ coast of Prince of Wales I., SE of Klakas Inlet, Alex. Arch.; 54 $52^{\prime} 45^{\prime \prime} \mathrm{N}, 132^{\circ} 21^{\prime} 30^{\prime \prime} \mathrm{W}$; (map 1).

Local name reported in 1897 by Lt. Comdr. J. F. Moser, USN.

Hunter Cove: cove, $1.4 \mathrm{mi}$. across, on W shore of Muir Inlet, in Glacier Bay National Monument, $1.5 \mathrm{mi}$. S of Rowlee Point and $60 \mathrm{mi}$. NW of Hoonah, St. Elias Mts. ; 58 $54^{\prime} 30^{\prime \prime} \mathrm{N}$, $136^{\circ} 06^{\prime} 30^{\prime \prime} \mathrm{W}$; BGN 1948; (map 10).

Name published by the American Geographical Society (Field, 1947, map). Named for Capt. J. C. Hunter of the SS City of Topeka, which brought H. F. Reid to Muir Inlet in $\mathbf{1 8 9 2 .}$

Hunter Creek: stream, flows E $1 \mathrm{mi}$. to Nome River, $S$ of Goose Creek, $9 \mathrm{mi}$. NNE of Nome, Seward Penin. High.; 64 $4^{\circ} 38^{\prime}$ N, $165^{\circ} 18^{\prime}$ W; (map 94).

Prospectors' name shown on the 1904 "Map of Cape Nome Precinct" by Arthur Gibson.

Hunter Creek: stream, heads at Hunter Creek Glacier, flows NW 8.2 mi. to Knik River, 15 mi. SE of Palmer, Chugach Mts.; 61 ${ }^{\circ} 28^{\prime} \mathrm{N}$, $148^{\circ} 48^{\prime} \mathrm{W}$; (map 69).

Local name reported in 1960 by USGS.

Hunter Creek: stream, flows SE $8.5 \mathrm{mi}$. to Flint Creek, $15 \mathrm{mi}$. NE of Long and $21 \mathrm{mi}$. SE of Ruby, Nowitna Low.; $64^{\circ} 29^{\prime} 45^{\prime \prime} \mathrm{N}, 155^{\circ} 02^{\prime}$ 50" W; (map 98).

Prospectors' name reported in 1912 by H. M. Eakin (in Brooks and others, 1913, pl. 10), USGS.

Hunter Creek: stream, heads at junc. of Fortyseven Gulch and Ninety-two Hunter Creek and flows W $6 \mathrm{mi}$. to Minook Creek, $2 \mathrm{mi}$. ESE of Rampart, Yukon-Tanana High.; $65^{\circ} 28^{\prime} \mathrm{N}$, $150^{\circ} 06^{\prime} \mathrm{W}$; (map 106).

Prospector's name reported in 1896 by J. E. Spurr, H. B. Goodrich, and F. C. Schrader, USGS. Named for William Hunter, who discovered gold here in 1896 (Prindle, 1908, p. 73).

Hunter Creek: stream, flows NW $30 \mathrm{mi}$. to Kiwalik River, $39 \mathrm{mi}$. NW of Haycock, Seward Penin. High.; $65^{\circ} 44^{\prime} \mathrm{N}, 161^{\circ} 49^{\prime} \mathrm{W}$; (map 109).

Local name shown on a 1903 fieldsheet by D. C. Witherspoon, USGS.

Hunter Creek: stream, on Seward Penin., flows NW $1 \mathrm{mi}$. to Willow Bay, $13 \mathrm{mi}$. SE of Deering, Kotzebue-Kobuk Low. ; $66^{\circ} 03^{\prime} \mathrm{N}, 162^{\circ} 16^{\prime}$ W; (map 113). 
Name used by local prospectors and reported in 1903 by D. C. Witherspoon, USGS. Hunter Creek: stream, see Hunner Creek.

Hunter Creek Glacier: glacier, trends N $6 \mathrm{mi}$. to its terminus at head of Hunter Creek $15 \mathrm{mi}$. SE of Palmer, Chugach Mts.; $61^{\circ} 22^{\prime} 20^{\prime \prime} \mathrm{N}$, 148 $43^{\prime} 15^{\prime \prime} \mathrm{W}$; (map 69).

Local name reported in 1960 by USGS.

Hunter Island Breakers: rocks, $0.2 \mathrm{mi}$. across, 7 mi. S of Dolgoi I., at SW end of Aleutian Ra.; $54^{\circ} 58^{\prime} 20^{\prime \prime} \mathrm{N}, 161^{\circ} 46^{\prime} 00^{\prime \prime} \mathrm{W}$; (map 25).

Name published in 1949 on a USGS map.

Hunter Lake: lake, $37 \mathrm{mi}$. NW of Haycock, Seward Penin. High.; $65^{\circ} 42^{\prime} \mathrm{N}, 161^{\circ} 43^{\prime} \mathrm{W}$; (map 109).

Local name published on maps after 1950.

Hunter North Peak, Mount: peak, see Hunter, Mount.

Hunters: locality, see Hunter.

Hunters Lake: lake, $0.8 \mathrm{mi}$. long, on Kenai Penin., W of Sahot Lake, $25 \mathrm{mi}$. SE of Kenai, Cook Inlet Low.; $60^{\circ} 26^{\prime} 20^{\prime \prime} \mathrm{N}, 150^{\circ} 35^{\prime} 00^{\prime \prime}$ W; (map 62).

Named about 1963 by officials of Kenai National Moose Range, for administrative purposes.

Hunters Point: point of land, see Bird Point.

Hunt Fork: stream, formed by junc. of Kevuk and Agiak Creeks, flows SE $11.5 \mathrm{mi}$. to John River, $8 \mathrm{mi}$. E of Sillyasheen Mtn. and $65 \mathrm{mi}$. NW of Wiseman, Brooks Ra.; $67^{\circ} 44^{\prime} \mathrm{N}, 152^{\circ}$ 25' W; (map 124).

Local name shown on an 1899 fieldsheet by T. G. Gerdine, USGS.

Hunting Beach: locality, see Bernirk.

Hunting Point: point of land, westernmost tip of Stuart I., $22 \mathrm{mi}$. NW of St. Michael, Yukon-Kuskokwim Delta ; 63 $3^{\circ} 5^{\prime} \mathrm{N}, 162^{\circ} 43^{\prime}$ W; (map 92).

Local descriptive name obtained in 1952 by USC\&GS. "There is a tall lookout built on this point used in the winter to spot seals on the ice."

Huntington, Mount: peak, 12,240 ft., S of West Fork Ruth Glacier, 9 mi. SE of Denali Pass, in Mount McKinley National Park, Alaska Ra.; 62 58'05" N, 150'53'50' W; (map 81). Var. Mount Disston, Mount Diston.

Named by the Browne-Parker Expedition of 1910 for Archer Milton Huntington, 1870 1955, president of the American Geographical Society "under whose asupices we had undertaken the exploration of Mt. McKinley's southern glaciers." This may be the peak F. A. Cook named "Mt. Disston" in 1906 for a friend Henry Disston. - See Hunter, Mount.

Huntington Creek: stream, heads in Klalbaimunket Lake, flows SW 2 mi. to Koyukuk River, $3 \mathrm{mi}$. $\mathbf{N}$ of Hughes, Kokrines-Hodzana High.; $66^{\circ} 05^{\prime} \mathrm{N}, 154^{\circ} 13^{\prime} \mathrm{W}$; (map 116).

Local family name; recorded at Hughes in 1956 by Orth.

Huntington Slough: stream, anabranch, flows SW, then NE, $28 \mathrm{mi}$. to Koyukuk River, 21 mi. NE of Roundabout Mtn., Koyukuk Low.; $65^{\circ} 50^{\prime} \mathrm{N}, 156^{\circ} 19^{\prime} \mathrm{W}$; (map 108).

Local family name applied to this slough; reported in 1956 by Orth.
Hunt Island: island, $0.5 \mathrm{mi}$. long, part of Sandman Reefs, 6 mi. S of Deer I., Aleutian Ra.; $54^{\circ} 45^{\prime} 25^{\prime \prime} \mathrm{N}, 162^{\circ} 15^{\prime} 00^{\prime \prime} \mathrm{W} ; B G N$ 1942; (map 25). Var. Egg Island, Iachnoi Island, Deranof Island, Yachnoy Island.

Name published in 1888 by USBF. This may be the Egg (Yachnoy) Island of Capt. M. D. Tebenkov, IRN, 1849.

Hunt Peak: mountain, $3,500 \mathrm{ft}$., at $\mathrm{E}$ end of Missionary Ra., on Lindenberg Penin., Kupreanof I., $1.3 \mathrm{mi}$. NW of Petersburg, Alex. Arch.; $56^{\circ} 58^{\prime} 35^{\prime \prime} \mathrm{N}, 133^{\circ} 08^{\prime} 30^{\prime \prime} \mathrm{W}$; (map 6).

Named in 1887 by Lt. Gomdr. C. M. Thomas, USN, for Ens. Henry J. Hunt, USN.

Hunt River: stream, heads at $67^{\circ} 40^{\prime} \mathrm{N}, 158^{\circ} 48^{\prime}$ W, flows S $43 \mathrm{mi}$. to Kobuk River, $45 \mathrm{mi}$. NW of Shungnak, Brooks Ra.; $67^{\circ} 12^{\prime} \mathrm{N}, 158^{\circ} 36^{\prime}$ W; (map 126). Var. Kon-gon-wik.

Named by Lt. Stoney (1900, map), USN, in 1885 , probably for one of his party. He recorded the Eskimo name as "Kon-gon-wik."

Hunts Creek: stream, flows N $11 \mathrm{mi}$. to Chena River, $27 \mathrm{mi}$. E of Fairbanks, Yukon-Tanana High.; $64^{\circ} 51^{\prime} 30^{\prime \prime} \mathrm{N}, 146^{\circ} 47^{\prime} 10^{\prime \prime} \mathrm{W}$; (map 101).

Local name reported in 1950 by USGS.

Hurd Creek: stream, flows NW to Pinnell River which flows to Inmachuk River between Doll and Hurd Creeks, about 13 mi. NE of Imuruk Lake, Seward Penin. High.; (map 110).

Local name published on a precinct map of Seward Peninsula by Monroe and Hutchins; corrected to June 1903 by Arthur Gibson. This stream cannot be precisely identified on current maps.

Huron Creek: stream, flows $\mathbf{N} 9 \mathrm{mi}$. to Troublesome Creek, $27 \mathrm{mi}$. W of Livengood, YukonTanana High.; $65^{\circ} 31^{\prime} 45^{\prime \prime} \mathrm{N}, 1^{\circ} 9^{\circ} 28^{\prime} 25^{\prime \prime}$ W; (map 105).

Named by prospectors; published by USGS (Covert and Ellsworth, 1909, pl. 5).

Hurricane: $R R$. station, mile 281.4 on The Alaska Railroad, $36 \mathrm{mi}$. SW of Cantwell, Talkeetna Mts.; $62^{\circ} 58^{\prime} 40^{\prime \prime} \mathrm{N}, 1^{\prime} 49^{\circ} 38^{\prime} 20^{\prime \prime}$ W; (map 82). Var. Hurricane Gulch.

This station was named in 1916 for Hurricane Gulch and has been in operation since the opening of the line.

Hurricane Gulch: ravine, trends W $5 \mathrm{mi}$. to Chulitna River, $63 \mathrm{mi}$. SW of Healy, Talkeetna

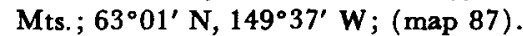

It is reported that this feature was named in 1916 by an Alaska RR. crew; however, S. R. Capps, USGS, wrote in a 1923 letter that he thought it may have been named by prospectors before that date.

Hurricane Gulch: RR. station, see Hurricane.

Hurst, Mount: mountain, $2,882 \mathrm{ft}$, on W slope of Kuskokwim Mts., $15 \mathrm{mi}$. NW of Ophir and $46 \mathrm{mi}$. NW of McGrath, Kilbuck-Kuskokwim Mts. ; 631 $13^{\prime} 30^{\prime \prime} \mathrm{N}, 156^{\circ} 57^{\prime} 45^{\prime \prime} \mathrm{W}$; (map 90). Var. Hurst Mountain.

Prospectors' name obtained in 1908 by Maddren (1910, pl. 1), USGS.

Hurst Creek: stream, heads $\mathbf{E}$ of Mount Hurst, flows NW $14 \mathrm{mi}$. to Mastodon Creek $2.8 \mathrm{mi}$. E of its junc. with Tolstoi Creek, $21 \mathrm{mi}$. NW of Ophir and $51 \mathrm{mi}$. NW of McGrath, Kilbuck-
Kuskokwim Mts.; 63 ${ }^{\circ} 21^{\prime} 35^{\prime \prime} \mathrm{N}, 156^{\circ} 59^{\prime} 00^{\prime \prime}$ W; (map 90).

Prospectors' name reported in $1917^{\circ}$ by G. L. Harrington, USGS.

Hurst Mountain: mountain, see Hurst, Mount. Hurtle Creek: stream, flows NW $10 \mathrm{mi}$. to Tonsina Lake, $34 \mathrm{mi}$. NE of Valdez, Chugach Mts. ; $61^{\circ} 26^{\prime} 35^{\prime \prime} \mathrm{N}, 145^{\circ} 31^{\prime} 45^{\prime \prime} \mathrm{W}$; (map 68).

Local name reported in 1900 by F. C. Schrader, USGS.

Husacheg: stream, see Little Delta River.

Huscroft Glacier: glacier, trends SW about 10 $\mathrm{mi}$. to its 1961 terminus, $1.5 \mathrm{mi}$. $\mathbf{E}$ of head of Crillon Inlet and $81 \mathrm{mi}$. NW of Hoonah, St. Elias Mts.; $58^{\circ} 37^{\prime} 00^{\prime \prime} \mathrm{N}, 137^{\circ} 23^{\prime} 45^{\prime \prime} \mathrm{W}$; (map 10).

Name published by members of the Harvard-Dartmouth Expeditions, 1933-34 (Washburn and Goldthwait, 1936, map).

Huskisson, Mount: mountain, not identified, in E part of Brooks Ra.; (map 138).

Named by Franklin (1828, p. 135) on July 21, 1826, for Mr. Huskisson, the "President of the Board of Trade * * *"

Huslia: village, pop. 168, on left bank of Koyukuk River, $12 \mathrm{mi}$. NE of Roundabout Mtn., Koyukuk Low.; $65^{\circ} 41^{\prime} \mathrm{N}, 156^{\circ} 24^{\prime} \mathrm{W}$; (map 108). Var. Cutoff, Cutoff Trading Post, Old Cutoff.

In the late 1940's the Koyukan Indian population at the place called "Cutoff" or "Cutoff Trading Post" moved to a new location, 4 miles away, which was named "Huslia" after the nearby stream. In 1947 a post office was established at Cutoff. In 1952 the name was changed to "Huslia" when the post office was moved to a new location on higher ground (Ricks, 1965, p. 16, 28).

Husliakakat: stream, see Huslia River.

Huslia River: stream, formed by its North and South Forks, flows SE $55 \mathrm{mi}$, to Koyukuk River, $13 \mathrm{mi}$. N of Roundabout Mtn., Koyukuk Low.; $65^{\circ} 44^{\prime} \mathrm{N}, 156^{\circ} 32^{\prime} \mathrm{W}$; (map 108). Var. Hosyekakat, Husliakakat, Hussliakatna.

Koyukan Indian name recorded by $\mathrm{Lt}$. Allen (1887, p. 105), USA, on August 16, 1885, as "Husliakakat River," meaning "mouth of the Huslia," and "Hussliakatna" (map).

Hussleakátna: locality, see Hussliakatna.

Hussliakatna: locality, "on right bank of Koyukuk River, NW of Huslia, Koyukuk." (map 108) Var. Hussleakátna.

Former Eskimo village reported in 1885 as "Hussleakátna" with a population of 14 , by Lt. H. T. Allen, USA.

Hussliakatna: stream, see Huslia River.

Hutch Creek: stream, flows NW to Kuzitrin River, about $20 \mathrm{mi}$. SW of Imuruk Lake, Seward Penin. High.; (map 110).

Prospectors' name reported on a precinct map of Seward Peninsula by Monroe and Hutchins corrected to June 1903 by Arthur Gibson. This stream cannot be precisely located on current maps.

Hutchins Bay: bay, 4.2 mi. long, just $W$ of Bearslee Is. in Glacier Bay, Glacier Bay National Monument, $55 \mathrm{mi}$. NW of Juneau, St. 
Elias Mts.; $58^{\circ} 32^{\prime} \mathrm{N}, 135^{\circ} 52^{\prime} \mathrm{W}$; BGN 1942 ; (map 11).

So named by the USC\&GS in 1942 because the bay's southern arm is the nesting place for large numbers of Hutchins geese (Branta canadensis hutchinsii).

Hutchinson Creek: stream, flows NE $17 \mathrm{mi}$. to North Fork Fortymile River, $37 \mathrm{mi}$. SW of Eagle, Yukon-Tanana High.; $64^{\circ} 24^{\prime} \mathrm{N}, 142^{\circ}$ $01^{\prime}$ W; (map 102). Var. Dewie Creek, Hutchison Creek.

Named by prospectors and reported in 1902 by Lt. Hjalmar Erickson, USA, as "Hutchison Creek"; in 1905 the name was published by USGS as "Hutchinson Creek."

Hutchinson Creek: stream, flows SW to Penny River, about $23 \mathrm{mi}$. NW of Nome, Seward Penin. High.; (map 94).

Prospectors' name reported on the 1900 "Map of Nome Peninsula" by J. M. Davidson and B. D. Blakeslee; this feature has not been positively identified.

Hutchinson Hill: hill, $99 \mathrm{ft}$., near Northeast Point, on NE coast of Saint Paul I., in Pribilof Is. ; $57^{\circ} 14^{\prime} 50^{\prime \prime} \mathrm{N}, 170^{\circ} 06^{\prime} 30^{\prime \prime} \mathrm{W}$; (map 38 ). Var. Sealion Hill.

Named for Hayward Malcolm Hutchinson, businessman, one of the first Americans to reach Sitka in 1867 . He bought the property of the Russian American Company forming Hutchinson, Kohl and Company. In 1872 it, in turn, was bought by the Alaska Commercial Company, which had secured the lease of the fur-seal rookeries of the Pribilof Islands. The name "Hutchinson Hill" is shown on Elliott's map of Saint Paul Island which was prepared in $1873-74$.

Hutchinson Point: point of land, at S point of entrance to Port Walter, $9 \mathrm{mi}$. $\mathbf{N}$ of Port Alexander, on SE coast of Baranof I., Alex. Arch.; $56^{\circ} 23^{\prime} 20^{\prime \prime} \mathrm{N}, 134^{\circ} 38^{\prime} 00^{\prime \prime} \mathrm{W}$; (map 6 ).

Local fishermen's name reported in 1947 by USC\&GS

Hutchinson Reef: reef, 1 mi. long, NE of Spruce Cape, 5 mi. NE of Kodiak, Kodiak I.; $57^{\circ} 49^{\prime}$ $45^{\prime \prime} N, 152^{\circ} 18^{\prime} 00^{\prime \prime} \mathrm{W}$; (map 34$)$.

Name published in 1881 by USC\&GS on Chart 776.

Hutchison Creek: stream, see Hutchinson Creek.

Hut Creek: stream, heads at $61^{\circ} 32^{\prime} \mathrm{N}, 163^{\circ} 08^{\prime}$

W, flows NW $30 \mathrm{mi}$. to Pitmik River, $45 \mathrm{mi}$. W of Marshall, Yukon-Kuskokwim Delta ; $61^{\circ} 45^{\prime}$ $\mathrm{N}, 163^{\circ} 23^{\prime} \mathrm{W}$; (map 74$)$.

So named by Orth in 1965 as an alternative to a long Eskimo name referring to a "sod hut."

Hutlanana Creek: stream, see Hutlinana Creek. Hutli Bay: bay, see LeConte Bay.

Hutli Glacier: glacier, see LeConte Glacier. Hutlina Creek: stream, see Hutlinana Creek.

Hutlinana Creek: stream, flows SW $28 \mathrm{mi}$. to Baker Creek, $55 \mathrm{mi}$. SE of Tanana, YukonTanana High.; $65^{\circ} 00^{\prime} \mathrm{N}, 150^{\circ} 20^{\prime} \mathrm{W}$; (map 106). Var. Hootlanana Creek, Hootlinana Creek, Hutlanana Creek, Hutlina Creek.

Tanana Indian name spelled "Hootlinana" by A. H. Brooks, USGS, in 1902.
Hutlinana Hot Springs: springs, on right bank of Hutlinana Creek, $21 \mathrm{mi}$. SE of Rampart, Yukon-Tanana High.; $65^{\circ} 13^{\prime} \mathrm{N}, 149^{\circ} 59^{\prime} \mathrm{W}$; (map 105).

Named by prospectors; reported in 1916 by USGS (Waring, 1917, fig. 10).

Hutlitakwa Creek: stream, heads at $65^{\circ} 15^{\prime} \mathrm{N}$, $149^{\circ} 33^{\prime} \mathrm{W}$, flows SW $32 \mathrm{mi}$. to Hutlinana Creek, $55 \mathrm{mi}$. SE of Tanana, Yukon-Tanana High.; $65^{\circ} 00^{\prime} \mathrm{N}, 150^{\circ} 18^{\prime} \mathrm{W}$; (map 106).

Tanana Indian name reported in 1906 by USGS.

Hut Point: point of land, on mainland, $\mathbf{N}$ point of entrance to Walker Cove, Coast Mts.; $55^{\circ} 42^{\prime} 45^{\prime \prime} \mathrm{N}, 130^{\circ} 54^{\prime} 00^{\prime \prime} \mathrm{W}$; (map 3).

Descriptive name given in 1891 by USC\&GS

Hut Point: point of land, on $\mathrm{N}$ end of Douglas I. on Gastineau Ghannel, $0.1 \mathrm{mi}$. E of Entrance Point and $7.2 \mathrm{mi}$. NW of Juneau, $58^{\circ} 20^{\prime} 05^{\prime \prime}$ N, 134 $36^{\prime} 00^{\prime \prime} \mathrm{W}$; (map 11).

Named in 1880 by Lt. F. M. Symonds, USN, because there were some Indian huts or houses on the point and a log stockade nearby (DeArmond, 1957, p. 24). Name was published by USC\&GS in the 1883 Coast Pilot (p. 173).

Hutt Creek : stream, see Huff Creek.

Huxley, Mount: mountain, 12,560 ft., $1.4 \mathrm{mi}$. NW of The Hump, at head of Tyndall Glacier and $74 \mathrm{mi}$. NW of Yakutat, St. Elias Mts.; $60^{\circ} 19^{\prime} 30^{\prime \prime} \mathrm{N}, 141^{\circ} 10^{\prime} 30^{\prime \prime} \mathrm{W}$; $B G N$ 1917; (map 65).

Named in 1886 by H. W. Topham (1889) for Thomas Henry Huxley, 1825-95, English biologist. After receiving his medical degree from the University of London, Huxley entered the Royal Navy. His interest in biology grew from a voyage of exploration in an area around Australia. In 1854 he was appointed lecturer of Natural History in the Royal School of Mines, and later to teaching posts in several other prominent institutions of learning. He was a strong supporter of Darwin's evolutionary theory.

Huxley, Mount: peak, see Haydon Peak.

Hyacks: locality, see Eyak.

Hydaberg: village, see Hydaburg.

Hydaburg: village, pop. 251, on $W$ coast of Prince of Wales I., $22 \mathrm{mi}$. SE of Craig, Alex.

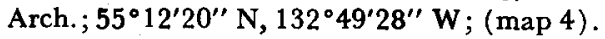
Var. Hydaberg.

Named for the "Haida" Indians, the original inhabitants of this village, who came from the village of Kaigani. Hydaburg was founded in 1911 to centralize the school system; a post office was established in 1912 (Ricks, 1965, p. 28). The village is mainly engaged in fishing and trapping and has a cooperative cannery (Alaska Sportsman, 1962, no. 12 , p. 28). See Kaigani.

Hydaburg River: stream, flows SW $6.5 \mathrm{mi}$. through Hydaburg to Sukkwan Narrows, on $W$ coast of Prince of Wales I., Alex. Arch.; $55^{\circ} 12^{\prime} 20^{\prime \prime} \mathrm{N}, 132^{\circ} 49^{\prime} 30^{\prime \prime} \mathrm{W}$; (map 4).

Local name recorded in 1948 by USGS.

Hyda Cove: bight, see Mission Cove.

Hydah Cove: bight, see Mission Cove.
Hyde Bay: estuary, see Mud Bay.

Hyde Bay River: stream, see Mud Bay River.

Hyden Canyon: canyon, see Heiden Canyon.

Hyder: village, pop. 32 , at mouth of Salmon River, on $\mathrm{W}$ bank of Portland Canal, Coast Mts. ; $55^{\circ} 55^{\prime} 00^{\prime \prime} \mathrm{N}, 130^{\circ} 01^{\prime} 30^{\prime \prime} \mathrm{W}$; (map 3 ). Var. Portland, Portland City.

This mining community, the easternmost village in Alaska, was established in 1907 and named "Portland City" because of its location. When the post office was established in 1915, the U.S. Post Office Dept. rejected this name. The village was named Hyder for Frederick Hyder, a Canadian mining engineer who was brought to Portland City in 1914 to examine some claims. "Among the claims examined by him was the Big Missouri, belonging to Daniel Lindeborg. His report on this was so favorable that Lindeborg later proposed his name * * * for the post office." The population in 1945 was 254 , mostly Indians (Colby, 1945, p. 124); in 1962 it was about 30 (Alaska Sportsman, 1962, No. 12, p. 26). The town is now practically deserted (U.S. Coast and Geodetic Survey, 1962, p. 28).

Hydra Island: island, $0.5 \mathrm{mi}$. long, $7 \mathrm{mi}$. ESE of Cape Kunmik, in Pacific Ocean, Aleutian Ra.; $56^{\circ} 45^{\prime} \mathrm{N}, 157^{\circ} 01^{\prime} \mathrm{W}$; (map 31 ). Var. Ostrov Gidra, Otter Island, Zatschra Island.

Name shown as "O[strov] Gidra," or "Hydra Island," by Capt. Tebenkov (1852, map 22) and is shown as Zatschra Island on a manuscript Russian map of Kodiak (1849). An 1888 USBF chart shows "Hydra Island," apparently identical with "Otter Island," shown on a 1900 USC\&GS chart.

Hydra Island: island, see West San Lorenzo Island.

Hyphen Gulch: ravine, extends NE $1.2 \mathrm{mi}$. from Iron Creek, $15 \mathrm{mi}$. SE of its junc. with Talkeetna River and $33 \mathrm{mi}$. E of Talkeetna, Talkeetna Mts. ; $62^{\circ} 19^{\prime} 10^{\prime \prime} \mathrm{N}, 149^{\circ} 05^{\prime} 20^{\prime \prime} \mathrm{W}$; (map 82).

Local name recorded in 1950 by USGS.

\section{I}

Iablosh Island: islands, see Apple Islands. Iachnie Island: island, see Egg Island. Iachnoi: point of land, see Egg Point. Iachnoi, Ostrov: island, see Egg Island. Iachnoi Island: island, see Guillemot Island. Iachnoi Island: island, see Hunt Island. Iaitchnoi: bay, see Egg Bay.

Iaitchnoi: point of land, see Egg Point. Iaktag, Cape: point of land, see Yakataga, Cape. Ialiasik: island, see Inner Iliasik Island. Ialiasik: island, see Outer Iliasik Island. Ialik: point of land, see Aklek, Cape. I-am-tuk: stream, see Shotgun Creek. Ianalium: point of land, see Yanaliuk, Cape. Iaslaktoli River: stream, heads in a lake at $61^{\circ}$ $55^{\prime} 15^{\prime \prime} \mathrm{N}, 164^{\circ} 44^{\prime} 00^{\prime \prime} \mathrm{W}$, flows $\mathrm{NW}$ and $\mathrm{S}$ $25 \mathrm{mi}$. to Kun River, $21 \mathrm{mi}$. E of Scammon Bay, Yukon-Kuskokwim Delta; $61^{\circ} 55^{\prime} \mathrm{N}$, $164^{\circ} 56^{\prime}$ W; (map 74). Var. North Fork Kun River.

Eskimo name reported in 1949 by USC\&GS. 
Ibach Point: point of land, on Glacier Bay, in Glacier Bay National Monument, at mouth of Reid Inlet, $72 \mathrm{mi}$. NW of Honnah, St. Elias Mts.; $58^{\circ} 52^{\prime} 45^{\prime \prime} \mathrm{N}, 136^{\circ} 47^{\prime} 45^{\prime \prime} \mathrm{W}$; $B G N$ 1962; (map 10).

Named by NPS in 1962 for Joe Ibach, who once lived on Reid Inlet and who prospected and extensively explored the area for 35 years. Ibach died in 1959.

Ibeck Creek: stream, flows SW $15 \mathrm{mi}$. to Eyak River, $4.5 \mathrm{mi}$. SE of Cordova, Chugach Mts. $60^{\circ} 31^{\prime} \mathrm{N}, 145^{\circ} 38^{\prime} \mathrm{W}$; (map 64).

"Named for a local miner," reported by U.S. Grant and D. F. Higgins (in Brooks and others, 1909, pl. 4), USGS.

Ibex Camp: locality, $3 \mathrm{mi}$. NE of West Peak and $6 \mathrm{mi}$. NE of Valdez, Chugach Mts.; $61^{\circ} 12^{\prime} 10^{\prime \prime} \mathrm{N}, 146^{\circ} 12^{\prime} 00^{\prime \prime} \mathrm{W}$; (map 68).

This mining camp was reported in 1911 by J. W. Bagley and C. E. Giffin, USGS.

Ibex Creek: stream, heads at Texas Glacier, flows S $1.5 \mathrm{mi}$. to West Fork Texas Creek, 2.5 mi. SE of Mount Jefferson Coolidge and Alaska-Canada boundary, Coast Mts.; $56^{\circ}$. $03^{\prime} 40^{\prime \prime} \mathrm{N}, 130^{\circ} 11^{\prime} 00^{\prime \prime} \mathrm{W}$; (map 7).

Local name published by A. F. Buddington (in Brooks and others, 1925, p. 85), USGS.

Ibkhikhyit: lava bed, see Ibkikwit Lava Bed.

Ibkikwit Lava Bed: lava bed, $2 \mathrm{mi}$. long, $1 \mathrm{mi}$. E of Karon Lake, $12 \mathrm{mi}$. N of Cape Mendenhall, Nunivak I.; $59^{\circ} 58^{\prime} 30^{\prime \prime} \mathrm{N}, 166^{\circ} 12^{\prime} 30^{\prime \prime}$ W; (map 55). Var. Ebcyeet, Ibkhikhyit, Ibxixyit.

Eskimo name obtained in 1949 by USC\&GS. Ibrulikhoruk Creek: stream, see Ibrulikorak Creek.

Ibrulikorak Creek: stream, flows S $0.9 \mathrm{mi}$. to Chukchi Sea, $0.2 \mathrm{mi}$. SE of Cape Thompson, Arctic Slope; $68^{\circ} 08^{\prime} 30^{\prime \prime} \mathrm{N}, 1^{\circ} 5^{\circ} 58^{\prime} 20^{\prime \prime} \mathrm{W}$; $B G N$ 1963; (map 129). Var. Eebrulikgorruk, Eegrulioruk Creek, Eeegikrattusuq Creek, Eebikruttoosook Creek, Ibrulikhoruk Creek.

Eskimo name reported about 1960 as "Eebruligorruk" by D. C. Foote in connection with Project Chariot studies. According to W. O. Pruitt, Univ. of Alaska, who spells it "Ibrulikhoruk," the name means "little sod house."

Ibxixyit: lava bed, see Ibkikwit Lava Bed.

Icathluik: stream, see Fish River.

Icathluik: stream, see Niukluk River.

Ice Bay: bight, see Palma Bay.

Iceberg Lake: lake, 2 mi. long, on Kenai Penin., in Kenai Mts., W of Skilak Glacier, $45 \mathrm{mi}$. ESE of Kenai, Chugach Mts.; $60^{\circ} 13^{\prime} \mathrm{N}$, $150^{\circ} 08^{\prime} \mathrm{W}$; (map 62).

Local descriptive name; reported in 1950 by USGS.

Iceberg Lake: lake, 2 mi. long, trends $\mathrm{EW}$ on $\mathrm{E}$ margin of Tazlina Glacier, $10 \mathrm{mi}$. S of Tazlina Lake and $34 \mathrm{mi}$. NW of Valdez, Chugach Mts.; $61^{\circ} 36^{\prime} 00^{\prime \prime} . \mathrm{N}, 146^{\circ} 29^{\prime} 15^{\prime \prime} \mathrm{W}$; (map 68).

Local name published since 1950 by USGS. Iceberg Point: point of land, on S end of Lemesurier I., in South Passage, $\mathbf{S}$ of Jacks Cove,
$25 \mathrm{mi}$. NW of Hoonah, St. Elias Mts.; $58^{\circ}-$ $15^{\prime} 50^{\prime \prime} \mathrm{N}, 136^{\circ} 04^{\prime} 30^{\prime \prime} \mathrm{W}$; (map 10).

So named by Master G. C. Hanus, USN, in 1880 "because much drift ice was stranded on the point." The name was published by USC\&GS in the 1883 Alaska Coast Pilot (p. 190).

Iceberg Point: point of land, westernmost point of Glacier I., $48 \mathrm{mi}$. NE of Whittier, Chugach Mts: ; $60^{\circ} 52^{\prime} 40^{\prime \prime} \mathrm{N}, 147^{\circ} 19^{\prime} 30^{\prime \prime} \mathrm{W}$; (map 63). Local name reported in 1951 by USGS.

Ice Greek: stream, heads S of Gustineau Peak, flows $1 \mathrm{mi}$. $\mathrm{N}$ to Silverbow Basin, $3 \mathrm{mi}$. $\mathrm{E}$ of Juneau, Coast Mts. ; $58^{\circ} 18^{\prime} 15^{\prime \prime} \mathrm{N}, 134^{\circ} 20^{\prime} 15^{\prime \prime}$ W; (map 11). Var. Southwest Fork of Gold Creek.

Local name used by early miners. Some of the earliest placer workings in the Juneau area were along this stream (DeArmond, 1957, p. 24-25).

Ice Creek: stream, flows SE $12 \mathrm{mi}$. to Lake Aleknagik, $24 \mathrm{mi}$. NW of Dillingham, KilbuckKuskokwim Mts.; $59^{\circ} 20^{\prime} \mathrm{N}, 158^{\circ} 48^{\prime} \mathrm{W}$; $B G N$ 1931; (map 52). Var. Nu-garth-pe-ak Tadi-ok.

Local name reported by USBF in 1929. The Eskimo name "Nu-garth-pe-ak Ta-di-ok" was used by H. C. Fassett, USBF, in 1910.

Icefall Lake: lake, $1.5 \mathrm{mi}$. long, $5 \mathrm{mi}$. NW of Mount Sumdum and $40 \mathrm{mi}$. SE of Juneau; $57^{\circ} 53^{\prime} 20^{\prime \prime} \mathrm{N}, 133^{\circ} 28^{\prime} 35^{\prime \prime} \mathrm{W}$; BGN 1966; (map 8).

Descriptive name given in 1965 by USGS and USFS because "ice from a nearby glacier breaks off and falls over a cliff into a small basin between the lake and the cliff."

Icefall Peak: peak, 8,000 ft., at head of College Glacier, $18 \mathrm{mi}$. NNE of Paxson, Alaska Ra.; $63^{\circ} 16^{\prime} 50^{\prime \prime} \mathrm{N}, 145^{\circ} 20^{\prime} 45^{\prime \prime} \mathrm{W}$; (map 86 ).

Named between 1948 and 1955 by T. L. Péwé, USGS.

Icefall Spires: ridge, trends SW $4 \mathrm{mi}$. from junc. of Battle and Reversed Glaciers, $30 \mathrm{mi}$. $\mathrm{N}$ of Juneau, Coast Mts. ; $58^{\circ} 43^{\prime} 15^{\prime \prime} \mathrm{N}, 134^{\circ}$. $36^{\prime} 00^{\prime \prime} \mathrm{W}$; BGN 1965; (map 11).

Descriptive name given by members of the Juneau Icefield Research Project in 1964.

Ice Gulch: ravine, trends $\mathrm{E} 0.9 \mathrm{mi}$. to Nome River, $0.1 \mathrm{mi}$. downstream from Iron Creek and $14 \mathrm{mi}$. N of Nome, Seward Penin. High.; $64^{\circ} 42^{\prime} \mathrm{N}, 165^{\circ} 19^{\prime} \mathrm{W}$; (map 94 ).

Prospectors' name reported on a map by S. E. King dated 1900.

Ice Gulch: ravine, see Icy Gulch.

Icehouse Lake: lake, $0.1 \mathrm{mi}$. across, between Telegraph Hill and Salt Lagoon, on southcentral Saint Paul I., in Pribilof Is.; 57 $08^{\prime}$ $30^{\prime \prime} \mathrm{N}, 170^{\circ} 15^{\prime} 50^{\prime \prime} \mathrm{W}$; (map 38 ).

Local name reported in 1965 by USBF. This lake, or lakes, depending on water level, was formerly the water supply for Saint Paul and so called because the village icehouse is located nearby.

Icehouse Lake: lake, $0.2 \mathrm{mi}$. long, on Woody I., $1.9 \mathrm{mi}$. E of Kodiak, Kodiak I.; $57^{\circ} 47^{\prime} \mathrm{N}$, $152^{\circ} 21^{\prime} \mathrm{W}$; (map 34). Var. Ozeno peshchanoye, Pestchanoe Lake.
Descriptive name given in late 1800 's (?) by USC\&GS. "This is the lake from which the Kodiak Ice Company obtains its ice" (Baker, 1906, p. 318). Ameigh and Chaffin (1962, p. 51) report that the Kodiak Ice Company obtained their ice from nearby Taniguak Lake. Called "Oz[ero] Peshchanoye," meaning "sandy lake," by Sarichev (1826, map 16).

Icehouse Point: point of land, on $\mathrm{W}$ coast of Woody I., $1.8 \mathrm{mi}$. E of Kodiak, Kodiak I.; $57^{\circ} 46^{\prime} 50^{\prime \prime} \mathrm{N}, 152^{\circ} 21^{\prime} 30^{\prime \prime} \mathrm{W}$; (map 34). Var. Mys Peshchanoye, Pestchanoe Point.

Descriptive name given in late 1800 's(?) by USC\&GS. See Icehouse Lake. Named "M[ys] Peschchanoye," meaning "sandy cape," by Sarichev (1826, map 16).

Ice Lake: lake, $0.6 \mathrm{mi}$. long, on Kenai Penin., $2.3 \mathrm{mi}$. SSE of Quill Lake and $23 \mathrm{mi}$. NE of Kenai, Cook Inlet Low.; $60^{\circ} 44^{\prime} \mathrm{N}, 150^{\circ} 42^{\prime}$ W; (map 62).

Named about 1963 by officials of Kenai National Moose Range, for administrative purposes.

Ice Stream Point: point of land, on coast of Beaufort Sea, on $\mathbf{S}$ shore of Smith Bay probably on Ikpikpuk River Delta, Arctic Plain; (map 148).

This name appears on Thomas Simpson's map. He describes it as "Near the middle of this [Smith] bay, a concealed reef ran far out upon which lay a stream of floating ice, * *" (Simpson, 1843, p. 137).

Ice Valley: valley, $1.5 \mathrm{mi}$. long, in Glacier Bay National Monument, $3 \mathrm{mi}$. E of Tidal Inlet and $57 \mathrm{mi}$. NW of Hoonah, St. Elias Mts.; $58^{\circ} 49^{\prime} 15^{\prime \prime} \mathrm{N}, 136^{\circ} 10^{\prime} 45^{\prime \prime} \mathrm{W}$; (map 10).

Named in 1947 by the American Geographical Society; this valley was formerly occupied by Dying Glacier and still contains some stagnant ice.

Iceworm Gulch: ravine, trends NW $2.5 \mathrm{mi}$. to Nenana River, $2.2 \mathrm{mi}$. NE of village of McKinley Park, Alaska Ra.; 63⒋ $45^{\prime} 50^{\prime \prime} \mathrm{N}$, 148 $54^{\prime 2} 5^{\prime \prime} \mathrm{W}$; BGN 1965; (map 87).

Named in 1965 by Alaska Dept. of Highways because "iceworms are the only indigenous wildlife whose name begins with an 'I.'", The naming of some features in this area was done ecologically and alphabetically.

Iceworm Peak: peak, 5,800 ft., $9 \mathrm{mi}$. S of Bradley Lake and $27 \mathrm{mi}$. ESE of Homer, Chugach Mts.; $59^{\circ} 36^{\prime} 35^{\prime \prime} \mathrm{N}, 150^{\circ} 47^{\prime} 35^{\prime \prime} \mathrm{W}$; $B G N$ 1966; (map 50).

So named in 1966 by the Mountaineering Club of Alaska because "Iceworms were noted on Nuka Glacier" by a party in 1951 .

Ichoograhloorak: locality, see Itugralurak.

Ickes Slough: channel, of the Yukon River, 5.5 mi. long, between Roosevelt I. and mainland, $12 \mathrm{mi}$. SSW of Russian Mission, YukonKuskokwim Delta; $61^{\circ} 37^{\prime} \mathrm{N}, 161^{\circ} 30^{\prime} \mathrm{W}$; (map 73).

Name shown on a 1940 navigation chart of the Yukon River. Because this chart was compiled by the Riverboat Service, The Alaska Railroad, U.S. Dept. of Interior, it may have been named for Harold L. Ickes, 1874-1952, 
Secretary of the U.S. Department of the Interior from 1933 to 1946 . See Roosevelt Island.

Icknetuk Point: point of land, on $\mathrm{N}$ shore of Norton Sound $8 \mathrm{mi}$. NW of Rocky Point and 33 mi. E of Solomon, Seward Penin. High.; $64^{\circ} 30^{\prime} \mathrm{N}, 163^{\circ} 20^{\prime} \mathrm{W}$; (map 95). Var. Ignituk Point, Iknetuk Point.

Eskimo name reported in 1899 by Schrader and Brooks (1900, map 3), USGS.

Icolick : locality, see Ikolik.

Icon Bay: bight, $1 \mathrm{mi}$. across, on SE coast of Spruce I., NE of Kodiak I.; $57^{\circ} 53^{\prime} 50^{\prime \prime}$ N, $152^{\circ} 20^{\prime} 30^{\prime \prime} \mathrm{W}$; (map 34).

Local name reported in 1949 by USGS. Icy Arm: estuary, see Taku Inlet.

Icy Basin: valley, $1.2 \mathrm{mi}$. across, snow filled, trending $\mathrm{W}$ to Taku Glacier, $12 \mathrm{mi}$. NW of Twin Glacier Lake and $25 \mathrm{mi}$. NE of Juneau, Coast Mts.; $58^{\circ} 38^{\prime} 30^{\prime \prime} \mathrm{N}, 134^{\circ} 12^{\prime} 00^{\prime \prime} \mathrm{W}$; BGN 1965; (map 11).

Descriptive name given by members of the Juneau Icefield Research Project in 1964.

Icy Bay: $b a y, 16 \mathrm{mi}$. long, at terminus of Guyot and Malaspina Glaciers, $66 \mathrm{mi}$. NW of Yakutat, Malaspina Coastal Plain ; 59 $55^{\prime} \mathrm{N}, 141^{\circ}$. $33^{\prime} \mathrm{W}$; (map 47). Var. Ledaunala, Liodianoi Bay, Lothianoi.

Explored by Joseph Whidbey June 4, 1794, and named by Capt. Vancouver (1798, v. 3, p. 204, 210, and 225), RN, but not shown on Vancouver's chart. This name was translated into Russian and is shown by Capt. Tebenkov (1852, map 7), IRN, as "Z[aliv] Ledyanoi." Early descriptions of this bay state that it was "composed of snow-ice, about thirty feet in height at the water-cliff, and probably based on a low muddy beach" (USC\&GS, 1869, p. 141-142). The bay, as seen and described in the 18th and 19th centuries, seems to have been an indentation of the Malaspina Glacier front located near where the mouth of the Yahtse River is now. The present Icy Bay was uncovered by the retreat of the glacier since 1899.

Icy Bay: bight, see Palma Bay.

Icy Bay: estuary, on $\mathbf{E}$ coast of Kenai Penin., extends NE $12 \mathrm{mi}$. from terminus of Tiger Glacier, $6 \mathrm{mi}$. W of Chenega, Chugach Mts.; $60^{\circ} 17^{\prime} \mathrm{N}, 148^{\circ} 12^{\prime} \mathrm{W}$; (map 63).

"Explored by Joseph Whidbey [of Capt. Vancouver's expedition] June 4, 1794, and named by Vancouver, but not shown on his chart" (Wagner, 1937, p. 393).

Icy Cape: locality, see Otokkok.

Icy Cape: point of land, at NW entrance to Icy Bay, $75 \mathrm{mi}$. NW of Yakutat, Malaspina Coastal Plain; 59 $56^{\prime} 45^{\prime \prime} \mathrm{N}, 141^{\circ} 42^{\prime} 00^{\prime \prime} \mathrm{W}$; (map 47). Var. Ledianoi, Ledyanoi, Punta Olavide.

This name appears to be a translation published by USC\&GS in 1868 of the Russian name shown as Ledyanoi, "M[ys]" (Cape Icy) by Capt. Tebenkov (1852, map 7), IRN. See Icy Bay. This appears to be also the "Punta Olavide" of Capt. Alessandro Malaspina, named in July 22, 1791. See Wagner (1937, p. 479).
Icy Cape: point of land, on Chukchi Sea coast, $48 \mathrm{mi}$. SW of Wainwright, Arctic Plain; $70^{\circ} 20^{\prime} \mathrm{N}, 161^{\circ} 52^{\prime} \mathrm{W} ; B$ B 1944 ; (map 146). Var. Ootookok Cape, Utukok Cape.

So named by Capt. Cook (1785, v. 2, p. 455), who wrote August 15, 1778, "The eastern extreme forms a point which was much encumbered with ice; for which reason it obtained the name of Icy Cape." This was the northern limit of Cook's discoveries. The Eskimo word "utoqaq" means "old" or "ancient" place.

Icy Cape Pass: water passage, in barrier bar between Chukchi Sea and Kasegaluk Lagoon, $2.5 \mathrm{mi}$. SW of Icy Cape, Arctic Plain; $70^{\circ} 18^{\prime}$ N, 161 ${ }^{\circ} 57^{\prime} \mathrm{W}$; (map 146).

Name published in 1955 by USGS.

Icy Channel: water passage, see Gastineau Channel.

Icy Cove: bight, $0.3 \mathrm{mi}$. across, on $\mathbf{E}$ shore of Frederick Sound, $7.5 \mathrm{mi}$. NE of Petersburg, Coast Mts.; $56^{\circ} 52^{\prime} 00^{\prime \prime} \mathrm{N}, 132^{\circ} 47^{\prime} 45^{\prime \prime} \mathrm{W}$; (map 6).

Local descriptive name reported in 1961 by USGS.

Icy Gulch: ravine, on $\mathbf{N}$ slope of Gastineau Peak, trends N $0.7 \mathrm{mi}$. to Silverbow Basin, $2.5 \mathrm{mi}$. E of Juneau, Coast Mts. ; 58 $18^{\prime} 15^{\prime \prime} \mathrm{N}$, $134^{\circ} 20^{\prime} 15^{\prime \prime} \mathrm{W}$; (map 11). Var. Ice Gulch.

Descriptive name recorded by W. M. Bennett in a mining claim in 1880. Some of the earliest placer workings in the Juneau area were here (DeArmond, 1957, p. 24-25). The name was published by W. J. Peters, USGS, in 1902.

Icy Passage: water passage, $9 \mathrm{mi}$. long, $\mathrm{N}$ of Pleasant I., in Icy Strait, $44 \mathrm{mi}$. NW of Juneau, St. Elias Mts.; $58^{\circ} 23^{\prime} \mathrm{N}, 135^{\circ} 35^{\prime} \mathrm{W}$; (map 11).

Descriptive name published by USC\&GS in the 1891 Coast Pilot (p. 194).

Icy Peak: peak, 4,500 ft., $9.5 \mathrm{mi}$. SW of Cape Kayakliut, on $S$ coast of Alaska Penin., $38 \mathrm{mi}$. SW of Ugashik, Aleutian Ra.; 57 $15^{\prime} \mathrm{N}$, $156^{\circ} 32^{\prime} \mathrm{W}$; (map 36).

Local descriptive name published by USC\&GS in the early 1880 's.

Icy Point: point of land, on $\mathrm{S}$ shore of Douglas I., $2.7 \mathrm{mi}$. SSW of Dupont and $9 \mathrm{mi}$. SW of Juneau, Coast Mts. ; $58^{\circ} 11^{\prime} 30^{\prime \prime} \mathrm{N}, 134^{\circ} 16^{\prime} 40^{\prime \prime}$ W; (map 11).

Name published by USC\&GS in 1924 on Chart 8223.

Icy Point: point of land, in Glacier Bay National Monument, at mouth of Palma Bay, 1 mi. S of mouth of Kaknau Creek and 62 mi. $\mathrm{NW}$ of Hoonah, St. Elias Mts.; 58 $23^{\prime} 10^{\prime \prime} \mathrm{N}$, $137^{\circ} 04^{\prime} 20^{\prime \prime} \mathrm{W}$; (map 10). Var. Cape Forrest, Mys Ledyanoy.

Named "M[ys] Ledyanoy" meaning "cape icy," by Capt. Tebenkov (1852, map 8) presumably because of the stranded drift ice. It has also been called "Cape Forrest" USC\&GS, 1883, Alaska Coast Pilot, p. 201).

Icy Point: point of land, see Glacier Point.

Icy Reef: barrier reef, extends $16 \mathrm{mi}$. NW from Demarcation Bay, between Beaufort Sea and mainland, Arctic Plain ; $69^{\circ} 46^{\prime} \mathrm{N}, 141^{\circ} 37^{\prime} \mathrm{W}$; (map 138).

So named August 2, 1826, by Franklin $(1828$, p. 143$)$, because of the condition of the reef.

Icy Strait: water passage, $50 \mathrm{mi}$. long, at $\mathrm{N}$ end of Chichagof I., between Chatham Strait and Cross Sound, $40 \mathrm{mi}$. W of Juneau, Alex. Arch., St. Elias Mts.; $58^{\circ} 18^{\prime} \mathrm{N}, 134^{\circ} 45^{\prime} \mathrm{W}$; (map 11). Var. Proliv Ledyanoy.

This name is a translation of the Russian name "Proliv Ledyanoy" (Tebenkov, 1852, map 8). USC\&GS published the translation in 1883 Coast Pilot (p. 118).

Icy Strait: water passage, see Cross Sound.

Ida Creek: stream, flows NW $0.6 \mathrm{mi}$. to Bonita Creek, $11 \mathrm{mi}$. NE of Nome, Seward Penin. High.; $64^{\circ} 38^{\prime} \mathrm{N}, 165^{\circ} 11^{\prime} \mathrm{W}$; (map 94). Var. Moose Creek, Morse Creek.

Prospectors' name reported in 1904 by T. G. Gerdine, USGS. Shown as "Morse" on a 1901 map of Cape Nome gold fields by David Fox, Jr. Arthur Gibson's map of 1904 shows "Ida" or "Moose."

Idagak Strait: water passage, see Udagak Strait. Ida Gulch: ravine, trends SE $0.5 \mathrm{mi}$. to Casadepaga River, between Blind and Moonlight Creeks, $15 \mathrm{mi}$. N of Solomon, Seward Penin. High.; $64^{\circ} 47^{\prime} \mathrm{N}, 164^{\circ} 28^{\prime} \mathrm{W}$; (map 95).

Prospectors' name reported in 1907 by USGS geologists (Smith, P. S., 1910, pl. 4).

Ida Gulch: ravine, trends $\mathrm{E} 3 \mathrm{mi}$. from Caribou Mtn. in Zane Hills to Bear Creek, $43 \mathrm{mi}$. WNW of Hughes, Hogatza High.; $66^{\circ} 12^{\prime} \mathrm{N}$, $155^{\circ} 45^{\prime} \mathrm{W}$; (map 116).

Named by mining engineers about 1955; reported in 1956 by Orth.

Ida Gulch: stream, $\mathrm{N}$ of Blueberry Ridge, flows $\mathrm{SE} 2.6 \mathrm{mi}$. to Illinois Creek, $3 \mathrm{mi}$. $\mathrm{N}$ of that stream's mouth, Kokrines-Hodzana High.; $65^{\circ} 13^{\prime} 20^{\prime \prime} \mathrm{N}, 153^{\circ} 07^{\prime} 30^{\prime \prime} \mathrm{W}$; (map 107).

Prospector' name reported by USGS in the 1940 's, but probably was used much earlier. Idaho Bar: bar, in Kuzitrin River, upstream of Idaho Creek, about $19 \mathrm{mi}$. W of Mount Bendeleben, Seward Penin. High.; $65^{\circ} 14^{\prime} \mathrm{N}$, $164^{\circ} 43^{\prime} \mathrm{W}$; (map 110).

Local name reported in 1901 by T. G Gerdine (in Collier, 1902, p. 12), USGS. The application of this name at this time is uncertain.

Idaho Bar: bar, see Brockways Bar.

Idaho Bar: ridge, 1,900 ft., trends SE $3 \mathrm{mi}$. from Minook Creek, between Little Minook and Hunter Creeks, 6 mi. SE of Rampart, YukonTanana High.; $65^{\circ} 28^{\prime} \mathrm{N}, 150^{\circ} 00^{\prime} \mathrm{W}$; (maps 105 and 106).

Named by prospectors; reported in 1904 by L. M. Prindle (in Brooks and others, 1905, fig. 6), USGS. The name, as used by miners, probably applied to an old stream channel now located across the ridge, but cartographic usage applies it to the whole ridge.

Idaho Creek: stream, flows SE $3.3 \mathrm{mi}$. to Little Nelchina River, $16 \mathrm{mi}$. NE of Tahneta Pass and $60 \mathrm{mi}$. SW of Gulkana, Talkeetna Mts.; $62^{\circ} 06^{\prime} 40^{\prime \prime} \mathrm{N}, 147^{\circ} 13^{\prime} 20^{\prime \prime} \mathrm{W}$; (map 82). 
Local name reported in 1917 by USGS.

Idaho Creek: stream, flows SE $4.5 \mathrm{mi}$. to Sunflower Creek, $51 \mathrm{mi}$. NW of Talkeetna, Alaska Ra.; 62 $31^{\prime} 10^{\prime \prime}$ N, $151^{\circ} 39^{\prime} 00^{\prime \prime}$ W ; BGN 1912; (map 81).

Prospectors' name reported by F. A. Cook (1908, map) .

Idaho Greek: stream, flows $\mathrm{N} 2 \mathrm{mi}$. to Creston Creek, 6 mi..NE of Cripple Creek Mts. and 51 mi. NW of Medfra, Kilbuck-Kuskokwim Mts.; $63^{\circ} 36^{\prime} \mathrm{N}, 155^{\circ} 56^{\prime} \mathrm{W}$; (map 89).

Local name reported in 1954 by USGS.

Idaho Creek: stream, flows NW $1 \mathrm{mi}$. to Alder Creek, in Bluestone River basin, $14 \mathrm{mi}$. SE of Teller, Seward Penin. High.; $65^{\circ} 05^{\prime} \mathrm{N}$, $166^{\circ} 08^{\prime} \mathrm{W}$; (map 111).

Prospectors' name reported on a map of Cape Nome goldfields by David Fox, Jr., date 1901.

Idaho Creek: stream, flows SW $4.5 \mathrm{mi}$. to Montana Creek, 48 mi. NW of Fairbanks, YukonTanana High.; $65^{\circ} 13^{\prime} 10^{\prime \prime} \mathrm{N}, 149^{\circ} 06^{\prime} 40^{\prime \prime}$ W; (map 105).

Named by prospectors; published in 1906 by USGS.

Idaho Creek: stream, flows SW $3 \mathrm{mi}$. to Kuzitrin River, $20 \mathrm{mi}$. NW of Mount Bendeleben, Seward Penin. High.; $65^{\circ} 14^{\prime} \mathrm{N}, 164^{\circ} 45^{\prime} \mathrm{W}$; (map 110).

Prospectors' name reported in 1901 by T. G. Gerdine (in Collier, 1902, pl. 12), USGS.

Idaho Creek: stream, flows S $3 \mathrm{mi}$. to McManus Creek, $68 \mathrm{mi}$. SW of Circle, Yukon-Tanana High.; $65^{\circ} 21^{\prime} \mathrm{N}, 146^{\circ} 10^{\prime} \mathrm{W}$; (map 104).

Named by prospectors and reported in 1903 by T. G. Gerdine (Prindle, 1905, pl. 13), USGS.

Idaho Creek: stream, see California Creek.

Idaho Gulch: ravine, extends $1.5 \mathrm{mi}$. $\mathrm{N}$ to Copper Creek $S$ of Lime Butte, $16 \mathrm{mi}$. SE of McCarthy, St. Elias Mts.; 61 ${ }^{\circ} 21^{\prime} 30^{\prime \prime} \mathrm{N}, 142^{\circ}$. $27^{\prime} 45^{\prime \prime} \mathrm{W}$; (map 67).

Local name published by USGS (Mendenhall and Schrader, 1903, fig. 5), taken from the sketch map of the Nizina Mining area done in 1902 by G. M. Easterly of Valdez.

Idaho Gulch: ravine, extends $\mathrm{SE} 2.2 \mathrm{mi}$. to Sullivan Creek, $35 \mathrm{mi}$. ESE of Tanana, Yukon-Tanana High.; $65^{\circ} 04^{\prime} 28^{\prime \prime} \mathrm{N}, 150^{\circ} 54^{\prime}$ 00" W; (map 106).

Prospectors' name reported in 1931 by J. B. Mertie, USGS.

Idaho Gulch: ravine, trends NW $5 \mathrm{mi}$. to Maston Creek which flows to Crosby Creek, $8 \mathrm{mi}$. SW of Ear Mtn. and $40 \mathrm{mi}$. N of Teller, Seward Penin. High.; $65^{\circ} 49^{\prime} \mathrm{N}, 166^{\circ} 17^{\prime} \mathrm{W}$; (map 111).

Prospectors' name reported in 1901 by T. G. Gerdine (in Collier, 1902, pl. 12), USGS.

Idaho Inlet: locality, on $\mathrm{E}$ shore of Idaho Inlet, $\mathrm{N}$ coast of Chichagof I., Alex. Arch.; 58 $8^{\circ} 10^{\prime}$ $\mathrm{N}, 136^{\circ} 12^{\prime} \mathrm{W}$; (map 10$)$.

Name reported in 1961.

Idaho Inlet: estuary, $9.5 \mathrm{mi}$. long, on $\mathbf{N}$ coast of Chichagof I., trends SSE from Icy Strait, Alex. Arch.; $58^{\circ} 11^{\prime} 30^{\prime \prime} \mathrm{N}, 136^{\circ} 13^{\prime} 00^{\prime \prime} \mathrm{W}$; (map 10).
Named by Capt. W. E. George for the excursion steamer Idaho which grounded near the head of the inlet (USC\&GS 1883, p. 190). Idaho Peak: mountain, see Sunset Peak.

Idaho Peak: peak, 5,000 ft., on W bank of Little Susitna River, $14 \mathrm{mi}$. N of Palmer, Talkeetna Mts. ; $61^{\circ} 48^{\prime} 15^{\prime \prime} \mathrm{N}, 149^{\circ} 08^{\prime} 20^{\prime \prime} \mathrm{W}$; (map 69).

Name reported in 1913 by USGS (Brooks and others, 1914, fig. 2).

Idaho Ridge: ridge, trends $\mathrm{W} 6 \mathrm{mi}$., $1.5 \mathrm{mi}$. W of Hunter Cove, on Muir Inlet, in Glacier Bay National Monument, $61 \mathrm{mi}$. NW of Hoonah, St. Elias Mts. ; $58^{\circ} 54^{\prime} \mathrm{N}, 136^{\circ} 14^{\prime} \mathrm{W}$; (map 10).

Name published by the American Geographical Society (Field, 1947, map).

Idaho Rock: rock, off SW coast of Revillagigedo I., in Tongass Narrows (East Channel), 800 ft. W of Saxman, Alex. Arch.; $55^{\circ} 19^{\prime} \mathrm{N}$, $131^{\circ} 36^{\prime} \mathrm{W}$; (map 3 )

Local name published by USC\&GS in the 1901 Coast Pilot (p. 51).

Idak, Cape: point of land, NE tip of Umnak I., NW end of Umnak Pass, Aleutian Is.; $53^{\circ}$ $31^{\prime} 20^{\prime \prime} \mathrm{N}, 167^{\circ} 47^{\prime} 45^{\prime \prime} \mathrm{W}$; (map 23). Var. Cape Edakh, Mys Idakh.

Name published by Capt. Tebenkov (1852, map 25), IRN, as "M[ys] Idakh" or "Cape Idak." R. H. Geoghegan believes the name to be the Aleut name "Idakug" meaning "exit or outlet."

Idak, Mount: mountain, $1,918 \mathrm{ft}$., $5 \mathrm{mi}$. N of Fort Glenn, on NE coast of Umnak I., Aleutian Is. ; $53^{\circ} 28^{\prime} 00^{\prime \prime} \mathrm{N}, 167^{\circ} 53^{\prime} 30^{\prime \prime} \mathrm{W}$; (map 23).

Name reported as Idak Peak by U.S. Army Corps of Engineers in 1942, and published as Mount Idak by USGS (Byers, 1959, pl. 41). See Idak Creek.

Idak Cove: bight, $3 \mathrm{mi}$. across, in Otter Bight, on $\mathrm{E}$ coast of Umnak I., Aleutian Is.; $53^{\circ} 26^{\prime}$ N, $167^{\circ} 50^{\prime} W$; (map 23$)$.

Name reported by the U.S. Army Corps of Engineers in 1942.

Idak Cove: bight, see Otter Bight.

Idak Creek: stream, flowing E $4 \mathrm{mi}$. to Otter Bight, $3 \mathrm{mi}$. N of Fort Glenn on NE coast of Umnak I., Aleutian Is. ; $53^{\circ} 26^{\prime} 15^{\prime \prime} \mathrm{N}, 167^{\circ}$ $51^{\prime} 30^{\prime \prime} \mathrm{W}$; (map 23).

Name published by USGS (in Byers, 1959, pl. 41). This name may have been derived from the Aleutian word, "idakuq," meaning "it leaves; it emanates from" (in Geoghegan, 1944 , p. 109), and may have been arbitrarily "clipped" for cartographic convenience.

Idakh, Mys: point of land, see Idak, Cape.

Idaliuk, Cape: point of land, see Prominence, Cape.

Idaliuk Cape: point of land, see Idaliuk Point.

Idaliuk Point: point of land, on SW coast of Umnak I., Aleutian Is.; 52 $52^{\prime} 00^{\prime \prime} \mathrm{N}$, $169^{\circ} 04^{\prime} 00^{\prime \prime} \mathrm{W}$; BGN 1942; (map 21). Var. Idaliuk Cape, Mys Idalyukh.

Aleut name published by Capt. Tebenkov (1852, map 26), IRN, as "M[ys] Idalyukh," or "Cape Idalyukh."
Idalug, Cape: point of land, on N coast of Amlia I., Aleutian Is. ; $52^{\circ} 08^{\prime} 30^{\prime \prime} \mathrm{N}, 173^{\circ} 31^{\prime} 45^{\prime \prime} \mathrm{W}$; (map 19).

Aleut name published by Capt. Tebenkov (1852, map 27), IRN, as "M[ys] Idalug" or "Cape Idalug."

Idalyukh, Cape: point of land, see Prominence, Cape.

Idalyukh, Mys: point of land, see Idaliuk Point. Idavain Lake: lake, $4.3 \mathrm{mi}$. long, $\mathrm{N}$ of Naknek Lake, on Alaska Penin., in Katmai National Monument, 37 mi. E of Naknek, Aleutian Ra.; $58^{\circ} 46^{\prime} \mathrm{N}, 155^{\circ} 56^{\prime} \mathrm{W}$; (map 42).

Reported in 1951 by USGS.

Ideal Cove: cove, extends $\mathrm{N} 1 \mathrm{mi}$. to Frederick Sound, on E coast of Mitkof I., $16 \mathrm{mi}$. NW of Wrangell, Alex. Arch.; $56^{\circ} 40^{\prime} \mathrm{N}, 132^{\circ} 38^{\prime} \mathrm{W}$; (map 6).

Named in 1887 by Lt. Comdr. C. M. Thomas, USN, for charting purposes; published in 1888 on USC\&GS Chart 705.

Ides Neck: isthmus, between Schulze Cove and Peril Strait, on NW coast of Baranof I., $27 \mathrm{mi}$. SE of Chichagof, Alex. Arch.; $57^{\circ} 24^{\prime} 15^{\prime \prime} \mathrm{N}$, $135^{\circ} 36^{\prime} 30^{\prime \prime} \mathrm{W}$; (map 9).

Named in 1884 by Comdr. J. B. Coghlan, USN, and published by USC\&GS on Chart 727.

Ididarod: locality, see Iditarod.

Ididarod River: stream, see Iditarod River.

Iditarod: locality, on E bank of Iditarod River, $7 \mathrm{mi}$. NW of Flat and $52 \mathrm{mi}$. S of Holikachuck, Kilbuck-Kuskokwim Mts.; $62^{\circ} 32^{\prime} 40^{\prime \prime}$ N, $158^{\circ} 05^{\prime} 30^{\prime \prime} \mathrm{W}$; (map 79). Var. Ididarod.

Iditarod became the supply and commercial center of the Innoko-Iditarod placer district shortly after its founding in June 1910. It was on the summer water route and winter sled trail. It had a population of about 600 or 700 persons in 1911. A post office was maintained here from 1910 to 1929 . Its population was 50 in 1920, 8 in 1930, and 1 in 1940. See Iditarod River.

Iditarod River: stream, heads at $61^{\circ} 47^{\prime} \mathrm{N}, 158^{\circ}$ $56^{\prime} \mathrm{W}$, flows $\mathrm{NE}$ and $\mathrm{W} 325 \mathrm{mi}$. to Innoko River, $25 \mathrm{mi}$. NE of Holikachuk and $66 \mathrm{mi}$. $\mathrm{NE}$ of Holy Cross, Innoko Low.; 63 ${ }^{\circ} 02^{\prime} \mathrm{N}$, $158^{\circ} 46^{\prime}$ W; BGN 1948; (map 90). Var. Haidilatna River, Haiditarod River, Ididarod River, Tachaichagat River, Yachzikatna River, Yalchikatna River, Yalchikatno River, Yath-ta-gotna River, Yuthagotna River.

Name reported in 1908 by A. G. Maddren, USGS, as "Haidilatna," which is probably an English distortion by prospectors of the name of an Ingalik Indian village on stream spelled by Father Jetté "Khadilotden." It was shortly thereafer standardized to "Iditarod" from "Haiditarod." Lt. L. A. Zagoskin, IRN, records two Indian names for the stream in 1842-44, "Yalchikatna (or Yalchikatna)" obtained from the Indians on Innoko River and "Tachaichagat" apparently obtained from Indians on Kuskokwim drainage. Both seem to be different forms of the same name. Father Jetté in 1915 spelled the Indian name for the stream "Yachzikatna." 
Igachorok Mountain: hills, see Mulik Hills. Igachoruk Mountain: hills, see Mulik Hills. Igachoruk River: stream, see Hugo Creek. Igagik: village, see Egegik.

Igagik: village, see Ugashik.

Igagik River: stream, see Egegik River.

Igagmjut: locality, see Igak.

Igak: locality, "on Afognak I., E of Afognak, Kodiak I." (map 43). Var. Igagmjut, Kaljukischwigmjut.

Former Eskimo camp or village reported by Hodge (1907, p. 595), BAE, who said "it seems to have been moved."

Igak Bay: bay, see Ugak Bay.

Igakik River: stream, see Ugashik River.

Igakskie : bay, see Ugak Bay.

Igalik Island: barrier island, $2.5 \mathrm{mi}$. long, in Plover Is., $36 \mathrm{mi}$. E of Barrow, Arctic Plain; $B G N 1916 ; 71^{\circ} 10^{\prime} \mathrm{N}, 155^{\circ} 10^{\prime} \mathrm{W}$; (map 153). Var. Igilik Island, Ikalu Island, Ikalue Island.

Eskimo name reported to mean "window," by E. de K. Leffingwell, in 1910 . Leffingwell $(1919$, p. 96) states it is "The easternmost of the Plover Islands," and "Probably the same as Ikalue on Brit. Adm. Chart No. 593."

Iganatá-koverushká: hill, see Maynard Hilll.

Igatskai: bay, see Ugak Bay.

Igatskoy, Zaliv: bay, see Ugak Bay.

Igavik: village, see Egavik.

Igavik Creek: stream, see Egavik Creek.

Igeechowrak: hill, see Iyichoruk Mountain.

Ig-gig-lah-rook Mountain: mountain, see Igiglogruk Mountain.

Iggiruk Mountains: mountains, $3,208 \mathrm{ft}$., extend NW-SE $20 \mathrm{mi}$., in De Long Mts., $45 \mathrm{mi}$. E of Misheguk Mtn., Brooks Ra.; $68^{\circ} 15^{\prime} \mathrm{N}$, $159^{\circ} 20^{\prime} \mathrm{W}$; (map 131).

Eskimo named obtained at Noatak in 1956 by USGS.

Ighauvik: village, see Egavik.

Ighelkoslende: locality, see Katagkak.

Ighiack, Cap: point of land, see Ugyak, Cape.

Ighiak: locality, see Eyak.

Ighiakchaghamiut: locality, see Igiakchak.

Ighiak Lake: lake, see Eyak Lake.

Igiagagamute: locality, see Igiak.

Igiagamute: locality, see Igiayarok.

Igiagik: village, see Egegik.

Igiagiuk, Tugat: lake, see Becharof Lake.

I-gi-ahk: locality, see Mosquito Point.

Igiak: locality, "E of Scammon Bay on $\mathbf{E}$ side of Bering Sea," Yukon-Kuskokwim Delta.; (map 75).' Var. Igiagagamute, Igiogagamut, Igragamiut.

Former Eskimo camp or settlement reported in 1878 as "Igragamiyt" by E. W. Nelson, U.S. Signal Service. Ivan Petroff listed the name as "Igiagagamute" with a population of 10 in the 1880 Census.

Igiak: locality, $5 \mathrm{mi}$. $\mathrm{N}$ of Hooper Bay, YukonKuskokwim Delta; $61^{\circ} 37^{\prime} \mathrm{N}, 165^{\circ} 5 \sigma^{\circ} \mathrm{W}$; (map 75). Var. Igiyarok, Tellamishuk.

This name has appeared on maps, but it is doubted that a village of this name was located here. It is near an archaeological site called "Tellamishuk." The name may refer to a site 20 miles NE called "Igiayarok."
Igiak: locality, see Igiayarok.

Igiak, Mys: point of land, see Ugyak, Cape. Igiak Bay: bay, see Kokechik Bay.

Igiakchak: localtiy, "in the Kuskokwim district." Var. Ighiakchaghamiut.

Former Eskimo camp or settlement listed as "Ighiakchaghamiut" with a population of 81 in the 1890 Census.

Igiak Mountains : mountains, see Askinuk Mountains.

Igiarok: locality, see Igiayarok.

Igiayarok: locality, near Kagankaguti Lake, at $E$ end of Askinuk Mts., $30 \mathrm{mi}$. NE of Hooper Bay, Yukon-Kuskokwim Delta; $61^{\circ} 43^{\prime} \mathrm{N}$, $165^{\circ} 18^{\prime} \mathrm{W}$; (map 75). Var. Igiagamute, Igiak, Igiarok, Ikragamiut.

Eskimo village consisting of two huts, visited by Nelson (1882, p. 665), U.S. Signal Service, in December 1878. He calls it "Igiagamute" on his map and "Igragamiut" in his text. The name, variously written "Ikiak," Igiagagamute," etc., has been applied to places extending from Kokechik Bay to the east end of the Askinuk Mountains. See Igiayarok Pass.

Igiayarok Pass: pass, $295 \mathrm{ft}$, in Askinuk Mts., $2 \mathrm{mi}$. SE of Castle Hill and $4.5 \mathrm{mi}$. SE of village of Scammon Bay, Yukon-Kuskokwim Delta; $61^{\circ} 49^{\prime} \mathrm{N}, 165^{\circ} 27^{\prime} \mathrm{W}$; (map 75).

Eskimo name meaning "throat" reported by USC\&GS in 1949. See Igiayarok.

Igichorak: hill, see Iyichoruk Mountain.

Igichuk Hills: range, extends NE $45 \mathrm{mi}$. from Krusenstern Lagoon to SW end of Baird Mts., $20 \mathrm{mi}$. N of Kotzebue, Arctic Slope; $67^{\circ} 14^{\prime} \mathrm{N}$, $162^{\circ} 45^{\prime} \mathrm{W}$; BGN 1962; (map 128).

Eskimo name reported in 1913 by P. S. Smith, USGS.

Igichuk River: stream, see Noatak River.

Igiglogruk Mountain: mountain, 1,617 ft., in Mulgrave Hills, $25 \mathrm{mi}$. SE of Kivalina, Arctic Slope; $67^{\circ} 41^{\prime} \mathrm{N}, 163^{\circ} 34^{\prime} \mathrm{W}$; (map 128). Var. Ig-gig-lah-rock Mountain, Igigloruk.

Eskimo name meaning "old mountain" reported in 1950 by USC\&GS.

Igigloruk: mountain, see Igiglogruk Mountain. Igigrok: mountain, see Iyikrok Mountain. Igigruk: mountain, see Iyikrok Mountain. Igikalik Creek: stream, see Thetis Creek.

Igikpak, Mount: mountain, 8,510 ft., in Schwatka Mts., at head of Noatak River, Brooks Ra.; $67^{\circ} 25^{\prime} \mathrm{N}, 154^{\circ} 58^{\prime} \mathrm{W}$; (map 125).

Eskimo name reported by Orth, USGS, in 1956 to refer in meaning to "two big peaks" and may refer to the two high rock columns that form the top of the mountain. It is the highest peak in the western Brooks Range.

Igiksukrak: mountain, see Hamlet, Mount.

Igilatvik Creek: stream, heads in lake and flows $27 \mathrm{mi}$. NE to Jago River, $5 \mathrm{mi}$. S of junc. with Okerokovik River and $23 \mathrm{mi}$. SE of Barter I., Arctic Plain; $69^{\circ} 01^{\prime} \mathrm{N}, 143^{\circ} 27^{\prime} \mathrm{W}$; (map 138).

Eskimo name recorded on Barter Island by Orth, USGS, in 1956, and reported to mean "place where parts of a house are found."

Igilerak Hill: hill, $600 \mathrm{ft}$., in Kemegrak Hills between Ilikrak and Kokirat Creeks, $10 \mathrm{mi}$.
NE of Cape Thompson, Arctic Slope; $68^{\circ} 17^{\prime}$ N, 16544' W; BGN 1963; (map 129). Var. Eegillerak Mountain.

Eskimo name recorded in 1960 by D. C. Foote in connection with Project Chariot; he spelled it "Eegillerak."

Igilik Island: barrier island, see Igalik Island.

Igiogagamut: locality, see Igiak.

Igisoogrook Mountain: hill, see Igisukruk Mountain.

Igisoogrook Mountain: mountain, see Noak, Mount.

Igisukruk Mountain: hill, $875 \mathrm{ft}$, in Igichuk Hills SE of Mount Noak, $18 \mathrm{mi}$. NW of Kotzebue, Arctic Slope ; $67^{\circ} 08^{\prime} \mathrm{N}, 162^{\circ} 55^{\prime} \mathrm{W}$; (map 128). Var. Igisoogrook Mountain.

Eskimo name meaning "big mountain" according to USC\&GS in 1950.

Igitkihn Island: island, see Igitkin Island.

Igitkilm Island: island, see Igitkin Island.

Igitkin Bank: shoal, 2 mi. long, trends $\mathrm{W}$ between Igitkin and Great Sitkin Is., Aleutian Is.; $51^{\circ} 58^{\prime} 55^{\prime \prime} \mathrm{N}, 175^{\circ} 59^{\prime} 00^{\prime \prime} \mathrm{W}$; BGN 1936 ; (map 18).

Name published by USC\&GS in the 1944 Aleutian Coast Pilot (p. 103); named for Igitkin Island by the U.S. Navy Aleutian Island Survey Expedition of 1934.

Igitkin Bight, cove, $0.3 \mathrm{mi}$. across, on $\mathrm{N}$ coast of Igitkin I., Aleutian Is.; $51^{\circ} 59^{\prime} 20^{\prime \prime} \mathrm{N}, 175^{\circ}$ 53'20' W; BGN 1936; (map 18).

Name published by the USC\&GS in the 1944 Aleutian Coast Pilot (p. 103) and named for Igitkin Island by the U.S. Navy Aleutian Island Survey Expedition of 1934.

Igitkin Island: island, $6.7 \mathrm{mi}$. long, $3 \mathrm{mi}$. SE of Great Sitkin I., between Adak and Atka Is., one of Andreanof Is., Aleutian Is.; 51 ${ }^{\circ} 59^{\prime}$ $N, 175^{\circ} 54^{\prime} \mathrm{W}$; BGN 1890; (map 18). Var. Egilka Island, Igitkihn Island, Igitkilm Island, Igitkum Island.

Aleut name recorded as "Egilka" by Commodore Joseph Billings, IRN, in 1790 and published by M. Sauer in 1802 .

Igitkin Pass: water passage, between Igitkin and Chugul Is., Aleutian Is.; $51^{\circ} 58^{\prime} \mathrm{N}, 175^{\circ} 50^{\prime}$ W; BGN 1936; (map 18).

Named for Igitkin I. by the U.S. Navy Aleutian Island Survey Expedition of 1934. It is possibly the best passage from the north and east to Kuluk Bay on Adak I. Published by the USC\&GS in the 1944 Aleutian Coast Pilot (p. 103).

Igitkin Point: point of land, W tip of Igitkin I., Aleutian Is.; $51^{\circ} 59^{\prime} 10^{\prime \prime} \mathrm{N}, 175^{\circ} 57^{\prime} 45^{\prime \prime} \mathrm{W}$; $B G N$ 1936; (map 18).

Named for Igitkin I. by the U.S. Navy Aleutian Island Survey Expedition of 1934, and published by the USC\&GS in the 1944 Aleutian Coast Pilot (p. 103).

Igitkum Island: island, see Igitkin Island.

Igitna River: stream, heads at glacier $3 \mathrm{mi}$. N of Merrill Pass, flows NE and SE $18 \mathrm{mi}$. to Kenibuna Lake, $62 \mathrm{mi}$. WNW of Tyonek, Alaska Ra.; $61^{\circ} 10^{\prime} 30^{\prime \prime} \mathrm{N}, 152^{\circ} 59^{\prime} 10^{\prime \prime} \mathrm{W}$; $B G N$ 1930; (map 71).

Tanaina Indian name reported in 1927 by USGS. 
Igiugig: village, on left bank on Kvichak River, $1 \mathrm{mi}$. SW of Iliamna Lake and $46 \mathrm{mi}$. SW of Iliamna, Bristol Bay Low.; $59^{\circ} 20^{\prime} \mathrm{N}$, $155^{\circ} 55^{\prime} \mathrm{W}$; (map 51). Var. Igiugik.

Name of a fishing village where a post office was established in 1934, discontinued in 1954 (Ricks, 1965, p. 28).

Igiugik: village, see Igiugig.

Igivachochamiut: locality, see Igivachok.

Igivachok: locality, "in Nushagak district." Var. Igivachochamiut.

Former Eskimo camp or settlement listed as "Igivachochamiut" with a population of 31 in the 1890 Census.

Igiyarok: locality, see Igiak.

Igkh-nik-toghe-mute: locality, see Iknetuk.

Igklo River: estuary, extends W $5 \mathrm{mi}$. off Kugrua Bay, $16 \mathrm{mi}$. NE of Wainwright, Arctic Plain; $70^{\circ} 47^{\prime} \mathrm{N}, 159^{\circ} 21^{\prime} \mathrm{W}$; (map 146). Var. Iklo.

Eskimo name recorded in 1956 at Wainwright by Orth, as "Iklo," meaning "large intestine."

I-gl-a-rak: locality, on right bank of Snake River, $4 \mathrm{mi}$. SE of Lake Nunavaugoluk, Bristol Bay Low.; 59 $06^{\prime} \mathrm{N}, 158^{\circ} 48^{\prime} \mathrm{W}$; (map 52). Var. Choak-ha-mut.

Eskimo village or camp shown on a 1910 manuscript map by H. C. Fassett, USBF.

Iglo Creek: stream, flows SW to Goodhope River, about $25 \mathrm{mi}$. NW of Imuruk Lake, Seward Penin. High.; (may 110).

Prospectors' name reported in 1901 by USGS (Collier, 1902, pl. 12). This stream cannot be identified on current maps.

Igloo: locality, on right bank of American River $2.5 \mathrm{mi}$. N of its junc. with Agiapuk River, 22 mi. NE of Teller, Seward Penin. High.; $65^{\circ} 28^{\prime} \mathrm{N}, 165^{\circ} 47^{\prime} \mathrm{W}$; (map 111).

Local name published in 1951 by USGS. No settlement is known to exist here.

Igloo: village, see Marys Igloo.

Igloo Creek: stream, flows NE $10 \mathrm{mi}$. to Teklanika River, $24 \mathrm{mi}$. SW of Healy, Alaska Ra.; $63^{\circ} 38^{\prime} 30^{\prime \prime} \mathrm{N}, 149^{\circ} 34^{\prime} 00^{\prime \prime} \mathrm{W}$; (map 87).

Local name reported by Woodbury Abbey, U.S. Army Corps of Engineers, on the blueprint of his 1921 Mount McKinley National Park survey.

Igloo Creek: stream, flows W $7 \mathrm{mi}$. to Bering Sea, $36 \mathrm{mi}$. NW of Nome, Seward Penin. High.; $64^{\circ} 45^{\prime} \mathrm{N}, 166^{\circ} 28^{\prime} \mathrm{W}$; (map 94).

Prospectors' name reported in 1900 by E. C. Barnard (in Brooks, 1901, pl. 17), USGS.

Igloo Creek: stream, flows SW $28 \mathrm{mi}$. to American River $1 \mathrm{mi}$. $\mathrm{N}$ of its junc. with Agiapuk River, $20 \mathrm{mi}$. NE of Teller, Seward Penin. High.; $65^{\circ} 26^{\prime} \mathrm{N}, 165^{\circ} 46^{\prime} \mathrm{W}$; (map 111). Var. Lewis River.

Prospectors' name reported in 1900 by Messrs. Kemp and David Fox (in Brooks, 1901, pl. 11).

Igloo Creek: stream, see Dewey Creek.

Igloo Creek: stream, see Eagle Creek.

Igloo Creek: stream, see Moonlight Creek.

Igloo Mountain: mountain, 4,751 ft., $3 \mathrm{mi}$. $\mathrm{N}$ of Cathedral Mtn. and $27 \mathrm{mi}$. SW of Healy,
Alaska Ra.; $63^{\circ} 36^{\prime} 30^{\prime \prime} \mathrm{N}, 149^{\circ} 36^{\prime} 30^{\prime \prime} \mathrm{W}$; (map 87).

Name taken from that of the creek which flows along its east side; published in 1954 by USGS.

Igloo Mountain: mountain, 2,675 ft., in De Long Mts., E of Raven Basin and Kukpowruk River, $28 \mathrm{mi}$. NE of Mount Kelly, Brooks Ra.; $68^{\circ} 46^{\prime} 00^{\prime \prime} \mathrm{N}, 162^{\circ} 53^{\prime} 30^{\prime \prime} \mathrm{W}$; (map 130). Var. Umiak Mountain.

Named by P. S. Smith, USGS, and shown on a 1926 fieldsheet by Gerald FitzGerald, USGS. According to Smith's notes the Eskimo call this hill Umiak, "large boat." The reason for changing the name is not clear (Chapman and Sable, 1961, p. 53).

Igloo Pass: pass, 4,300 ft., $1.1 \mathrm{mi}$. NE of Nugget Mtn. and $10 \mathrm{mi}$. NE of Juneau, Coast Mts.; $58^{\circ} 26^{\prime} 10^{\prime \prime} \mathrm{N}, 134^{\circ} 19^{\prime} 30^{\prime \prime} \mathrm{W}$; (map 11 ).

Local name reported in 1965 by D. A. Brew and $A$. B. Ford, USGS.

Igloo Point: point of land, extends NE into Eschscholtz Bay, $39 \mathrm{mi}$. SW of Selawik, KotzebueKobuk Low.; $66^{\circ} 14^{\prime} \mathrm{N}, 161^{\circ} 03^{\prime} \mathrm{W}$; (map 114).

Named by coast pilots about 1902 ; reported in 1908 by USC\&GS.

Igloopyak: reach, see Iglupiak.

Iglorak: barrier island, see Cooper Island.

Igloupack Creek: stream, see Iglupak Creek.

Igloupaek Creek: stream, see Iglupak Creek.

Iglupak Creek: stream, flows N 3 mi. to Kukpuk River, $18 \mathrm{mi}$. N of Cape Thompson, Arctic Slope; $68^{\circ} 24^{\prime} 15^{\prime \prime} \mathrm{N}, 1^{\circ} 5^{\circ} 56^{\prime} 20^{\prime \prime} \mathrm{W} ; B G N$ 1963; (map 129). Var. Igloupack Creek, Igloupaek Creek.

Eskimo name meaning "big house" recorded in 1960 by D. C. Foote in connection with Project Chariot; he spelled it "Igloupack."

Iglupiak: reach, on Omikviorok River, $23 \mathrm{mi}$. E of Kivalina, Kotzebue-Kobuk Low.; $67^{\circ} 43^{\prime}$ N, $163^{\circ} 41^{\prime} \mathrm{W}$; (map 128). Var. Igloopyak, Iglupiaq.

Eskimo name meaning "one sided"; so called because in this section of the river there is a high bank on the north side and a low bank on the south side; reported in 1966 by E. S. Burch.

Iglurak: barrier island, see Cooper Island.

Igmiumanik Creek: stream, flows SW $7 \mathrm{mi}$. to Goodnews River, $49 \mathrm{mi}$. NE of Goodnews; Kilbuck-Kuskokwim Mts.; $59^{\circ} 32^{\prime} \mathrm{N}, 160^{\circ} 28^{\prime}$ W; (map 53).

Eskimo name reported in 1954 by USGS. Ignak Creek: stream, see Ignek Creek.

Ignaluk: locality, on $\mathrm{W}$ coast of Little Diomede I., in Bering Strait, $80 \mathrm{mi}$. NW of Teller; $65^{\circ} 45^{\prime} \mathrm{N}, 168^{\circ} 56^{\prime} \mathrm{W}$; (map 111). Var. Inalik, Inalit, Igna-look.

Eskimo name recorded as Igna-look by Capt. G. L. Hooper, USRCS, in 1880; listed as "Inalit" with a population of 40 by Ivan Petroff in the 1880 Census; listed with a population of 85 in the 1890 Census.

Ignatiet Point point of land, see Mendenhall, Cape.

Ignatio Island: island, see Saint Ignace Island.
Ignekasagmi: locality, see Ignok.

Ignek Creek: stream heads between Sadlerochit and Shublik Mts., flows W $14 \mathrm{mi}$. through Ignek Valley to Canning River, $8 \mathrm{mi}$. NW of Mount Copleston and $53 \mathrm{mi}$. NW of Mount Michelson, Arctic Slope; $69^{\circ} 36^{\prime} \mathrm{N}, 146^{\circ} 18^{\prime}$ W; (map 139). Var. Ignak Greek, Ignik Creek.

Leffingwell (1919, p. 12i) writes, "The native [Eskimo] name of the stream which cut Red Hill is 'Ignek,' meaning 'fire.' The natives have assured the writer that these red beds were still smoking when their ancestors came into the country, not many years ago." Jenness (1928, p. 96) spells the name "Ignik."

Ignek Valley: valley, $30 \mathrm{mi}$. long, between Sadlerochit and Shublik Mts., $35 \mathrm{mi}$. NW of Mount Michelson, Brooks Ra.; 69 $34^{\prime} \mathrm{N}$, $145^{\circ} 30^{\prime} \mathrm{W}$; (map 139). Var. Ignak Valley, Ignik Valley.

Leffingwell $(1919$, p. 96) named the valley after Ignek Creek. He wrote (p. 137), "The Sadlerochit Glacier must have filled the eastern end of Ignek Valley, ***" (p. 137). Ignik Creek: stream, see Ignek Creek.

Ignik Valley: valley, see Ignek Valley.

Igning River: stream, flows NE $20 \mathrm{mi}$. to Noatak River, $48 \mathrm{mi}$. SW of Survey Pass, Brooks Ra.; $67^{\circ} 42^{\prime} \mathrm{N}, 155^{\circ} 53^{\prime} \mathrm{W}$; (map 125).

Eskimo name meaning "fire" or "match," recorded in Kobuk and Shungnak by Orth, USGS, in 1956.

Ignisirok Creek: stream, in De Long Mts., flows S $13 \mathrm{mi}$. to Nimiuktuk River, $34 \mathrm{mi}$. NE of .Misheguk Mtn., Brooks Ra.; $68^{\circ} 28^{\prime} \mathrm{N}$, $159^{\circ} 53^{\prime} \mathrm{W}$; (map 131).

Eskimo name meaning "material for fire," obtained at Noatak by Orth in 1956.

Ignituk: locality, see Iknetuk.

Ignituk Point: point of land, see Icknetuk Point. Ignok: locality, "on right bank of Yukon River, near Holy Cross," Innoko Low.; (map 78). Var. Ignokhatskamute, Ignokhatskomute, Ingekasagmi.

Former Eskimo village reported in 1869 as "Ingekasagmi" by Capt. C. W. Raymond, USA. Ivan Petroff listed the name as "Ignokhatskamute" with a population of 175 in the 10th Census, in 1880.

Ignokhatskamut: localtiy, "on Lower Yukon River," Yukon-Kuskokwim Delta.

Former Eskimo camp or village reported in 1900 by E. W. Nelson, U.S. Signal Service. Ignokhatskamute: locality, see Ignok.

Ignokhatskomute: locality, see Ignok.

Igognak: point of land, see Eider Point.

Igognak: point of land, see Kalekta, Cape.

Igokluk Slough: stream, flows W $14 \mathrm{mi}$. to Kwemeluk Pass, $21 \mathrm{mi}$. S of Kwiguk, YukonKuskokwim Delta; $62^{\circ} 27^{\prime} \mathrm{N}, 164^{\circ} 34^{\prime} \mathrm{W}$; (map 77).

Eskimo name obtained in 1899 by G. $R$. Putnam, USC\&GS; published in 1899 on Chart 9373.

Igouik: village, see Egavik.

Igouik Creek: stream, see Egavik Creek.

Igowik: village, see Egavik. 
Igowik Creek : stream, see Egavik Creek

Igragamiut: locality, see Igiak.

Igrahk: hill, see Igrak Hill.

Igrak Hill: hill, on shore of Chukchi Sea, 17 mi. NW of Kivalina, Kotzebue-Kobuk Low.; $67^{\circ} 55^{\prime} \mathrm{N}, 164^{\circ} 59^{\prime} \mathrm{W}$; (map 128). Var. Igrahk.

Eskimo name meaning "old hill" reported by $E$. S. Burch in 1966.

Igrarok Creek: stream, in Lisburne Hills, flows NE $6 \mathrm{mi}$. to a lagoon on Chukchi Sea coast, $9 \mathrm{mi}$. E of Cape Lisburne, Arctic Slope; $68^{\circ} 51^{\prime} 45^{\prime \prime} \mathrm{N}, 165^{\circ} 51^{\prime} 05^{\prime \prime} \mathrm{W}$; (map 129).

Eskimo name derived from that of the Igrarok Hills; reported in 1950 by USC\&GS. Igrarok Hills: hills, $500 \mathrm{ft}$., extend $5 \mathrm{mi}$. on Chukchi Sea coast, $5 \mathrm{mi}$. E of Cape Lisburne, Arctic Slope; $68^{\circ} 51^{\prime} \mathrm{N}, 165^{\circ} 57^{\prime} \mathrm{W}$; (map 129). Var. Ee-gah-rook.

Eskimo name reported to mean "low hills" by USC\&GS and spelled "Ee-gah-rook."

Igrikchum Slough: stream, flows NE $1.4 \mathrm{mi}$. to Tunurokpak Channel, W of Yukon River, 41 mi. SE of Kwiguk, Yukon-Kuskokwim Delta; $62^{\circ} 12^{\prime} 50^{\prime \prime} \mathrm{N}, 164^{\circ} 00^{\prime} 05^{\prime \prime} \mathrm{W}$; (map 77).

Eskimo name reported in 1949 by USC\&GS.

Igrooayuim Koonga: stream, see Ingrugaivik Creek.

Igrouwowalik: stream, see Igruwotalik Creek. Igruayvik: bank, see Igrugevik Bank.

Igrugaivik Bank: bank, see Igrugevik Bank.

Igrugaivik Creek: stream, distributary of Wulik River, flows SW $1 \mathrm{mi}$. to Kivalina Lagoon, 1.7 mi. E of Kivalina, Kotzebue-Kobuk Low.; $67^{\circ} 43^{\prime} \mathrm{N}, 164^{\circ} 29^{\prime} \mathrm{W}$; (map 128). Var. Igrooayuim Koonga.

Eskimo name reported in 1966 by $E$. S. Burch.

Igrugevik Bank: bank, on left side of Igrugevik Creek, $2.3 \mathrm{mi}$. E of Kivalina, Kotzebue-Kobuk Low.; $67^{\circ} 43^{\prime} \mathrm{N}, 164^{\circ} 28^{\prime} \mathrm{W}$; (map 128). Var. Igrugaivik Bank, Igruayvik.

This Eskimo name, reported in 1966 by $\mathrm{E}$. S. Burch, means "place where they put something inside." According to one story there was once a cold storage here; another story stated it was a good place for loading boats. Burch says that the name is of ten applied to a nearby hill rather than to the river bank.

Igruwotalik Creek: stream, heads in Lisburne Hills, flows SW $10 \mathrm{mi}$. to Kukpuk River, E of Kugirarok Creek, $18 \mathrm{mi}$. N of Cape Thompson, Arctic Slope; $68^{\circ} 24^{\prime} 50^{\prime \prime} \mathrm{N}, 165^{\circ} 25^{\prime} 30^{\prime \prime}$ W; (map 129). Var. Igrouwowalik.

Eskimo name spelled "Igrouwowalik" in 1960 by D. C. Foote in connection with Project Chariot studies. USGS published the name in 1964:

Igtuluwik: locality, SW of mouth of Walakpa Bay, $12 \mathrm{mi}$. SW of Barrow, Arctic Plains; $71^{\circ} 08^{\prime} \mathrm{N}, 157^{\circ} 06^{\prime} \mathrm{W}$; (map 153).

Eskimo name published by Spencer (1959, map 2).

Iguik: village, see Egavik.

Igushek River: stream, see Igushik River.

Igushik: settlement, $\mathrm{S}$ of mouth of Igushik River, $30 \mathrm{mi}$. SW of Dillingham, Bristol Bay Low.; $58^{\circ} 42^{\prime} \mathrm{N}, 158^{\circ} 53^{\prime} \mathrm{W}$; (map 40).
Eskimo village listed in the 1880 U.S. census with a population of $74 ; 28$ in 1930 ; and 16 in 1940 .

Igushik Ridge: ridge, elev. $150 \mathrm{ft}$., on $\mathrm{W}$ bank of Igushik River, extends $\mathbf{N} 7 \mathrm{mi}$. from river's mouth, $25 \mathrm{mi}$. SW of Dillingham, Bristol Bay Low.; BGN 1911; 58 $43^{\prime} \mathrm{N}, 158^{\circ} 56^{\prime} \mathrm{W}$; (map 40).

Eskimo name published in 1911 by USC\&GS; probably named after the nearby Igushik River.

Igushik River: stream, heads at Amanka Lake, fows SE $50 \mathrm{mi}$. to Nushagak Bay, $26 \mathrm{mi}$. SW of Dillingham, Bristol Bay Low.; $58^{\circ} 42^{\prime}$ N, $158^{\circ} 53^{\prime}$ W; (map 40). Var. Crooked River, Egashak River, Egashik River, Egoashik River, Egoushik River, Igushek River, Reka Iguzhak, Snake River.

Eskimo name reported by Capt. Tebenkov (1852, map 4), IRN, as "R[eka] Iguzhak." The descriptive name "Crooked River" was given in 1898 by J. E. Spurr, USGS; "Snake River" was applied in 1900 by Lt. Comdr. J. F. Moser, USN, of the USBF steamer Albatross, "because of the river's winding course." Igushik River: stream, see Snake River.

Iguzhak, Reka: stream, see Igushik River.

Igvac, Cap: promontory, see Igvak, Cape.

Igvack, Cap: promontory, see Igvak, Cape.

Igvak, Cape: promontory, between Portage and Wide Bays, on SE coast of Alaska Penin., 53 mi. E of Ugashik, Aleutian Ra.; $57^{\circ} 26^{\prime} \mathrm{N}$, $156^{\circ} 01^{\prime}$ W ; (map 36). Var. Cap Igvac, Cap Igvack, Iswak Point, Mys Igvak.

Eskimo name published in 1835 by Adm A. J. von Krusenstern, IRN, as "C[ap] Igvac" and as "C[ap] Igvack."

Igvak, Mys; promontory, see Igvak, Cape.

Ihack Bay: bay, see Ugak Bay.

Iikaagiaq: ford, see Ikagiak Shallows.

Iikhkluk Mountain: mountain, $3,650 \mathrm{ft}$. in Brooks Ra., $10 \mathrm{mi}$. SSE of Howard Pass; $68^{\circ} 05^{\prime} \mathrm{N}, 156^{\circ} 48^{\prime} \mathrm{W}$; (map 132).

Eskimo name reported by USGS in 1956 and reported to mean "rough mountain" [i-ikh-qluq].

I-im-tuck: stream, see Shotgun Creek.

Iipqagnaqtaugruk: mountain, see Ipkagnaktaugrak Mountain.

Iiveruuleviq Lake: lake, see Evrulivik Lake.

Iiwzuqtusuq: locality, see Ivruktusuk.

Ijoot: point of land, see Izhut, Cape.

$\mathrm{Ik}$ : village, see Eek.

Ik, Reka: stream, see Eek River.

Ikagiak Creek: stream, flows W $6 \mathrm{mi}$. to N end of Little Chandler Lake, $25 \mathrm{mi}$. NW of Anaktuvuk Pass, Brooks Ra.; $68^{\circ} 17^{\prime} 00^{\prime \prime} \mathrm{N}$, $152^{\circ} 39^{\prime} 00^{\prime \prime} \mathrm{W}$; (map 134).

Eskimo name obtained at Anaktuvuk Pass in 1956 by T. E. Taylor, USGS.

Ikagiak Shallows: ford, across Wulik River, 11 mi. NE of Kivalina, Kotzebue-Kobuk Low.; $67^{\circ} 48^{\prime} \mathrm{N}, 164^{\circ} 07^{\prime} \mathrm{W}$; (map 128). Var. Eekahgyak, Iikaagiaq

Eskimo name meaning "fording place" reported in 1966 by E. S. Burch.

Ikagluik, Mount: peak, 4,426 ft., on Alaska Penin., in Katmai National Monument, $15 \mathrm{mi}$.
NW of Mount Katmai, Aleutian Ra.; 58 ${ }^{\circ} 7^{\prime}$ $30^{\prime \prime} \mathrm{N}, 155^{\circ} 13^{\prime} 00^{\prime \prime} \mathrm{W}$; BGN 1924; (map 42). Var. Mount Kagluik.

Aleut name reported in 1919 by $R$. F. Griggs, National Geographic Society. Published in 1951 as "Mount Kagluik" by USGS. Ikagluik Creek, stream, heads at glacier terminus, flows NW $20 \mathrm{mi}$. to Savonoski River 1.5 mi. E of that stream's mouth at Iliuk Arm Naknek Lake, on Alaska Penin., in Katmai National Monument, $21 \mathrm{mi}$. NW of Mount Katmai, Aleutian Ra.; $58^{\circ} 31^{\prime} 40^{\prime \prime} \mathrm{N}, 155^{\circ} 17^{\prime}$. $30^{\prime \prime} \mathrm{W}$; (map 42).

Reported in 1951 by USGS.

Ikahook River: stream, see Ikalooksik River.

Ikak: locality, see Savonoski.

Ikakhtulik: stream, see Fish River.

Ikaknak Pond: lake, $0.15 \mathrm{mi}$. across, near head of Kiliguak Creek, $7.5 \mathrm{mi}$. NE of Cape Thompson, Arctic Slope; $68^{\circ} 11^{\prime} 40^{\prime \prime} \mathrm{N}, 165^{\circ} 43^{\prime} 00^{\prime \prime}$ W; BGN 1963; (map 129). Var. Eekuknuk Pond.

Eskimo name meaning "north wind" reported about 1962 by personnel of Project Chariot.

Ikaksigilak Creek: stream, see Fossil Creek.

Ikaligvigmiut: settlement, see Dogfish Village.

Ikaligvigmiut: village, see Golovin.

Ikaligvigmyut: settlement, see Dogfish Village. Ikaligwigmiut : village, see Golovin.

Ikaligwigmjut: settlement, see Dogfish Village. Ikalikhvig-myut: village, see Golovin.

Ikalikhvik: stream, see Fish River.

Ikalik Point: point of land, see Ikolik, Cape.

Ikalinigmjut: settlement, see Dogfish Village.

Ikalinkamiut: locality, see Ekiligamut.

Ikalinkamuit: locality, see Ekilik.

Ikaliukha: locality, see Ekiligamut.

Ikaliukha: locality, see Ekilik.

Ikallooksik River: stream, see Ikaloosik River Ikalloosik River: stream, see Ikalooksik River.

Ikalooksik River: stream, heads on $\mathbf{N}$ slope of Poovookpuk Mtn., flows N $10 \mathrm{mi}$. to Niyrakpak Lagoon, $16 \mathrm{mi}$. SE of Gambell, St. Lawrence I.; $63^{\circ} 36^{\prime} \mathrm{N}, 171^{\circ} 30^{\prime} \mathrm{W}, B G N$ 1951; (map 93). Var. Ekalooksik River, Ikahook River, Ikallooksik River, Ikalloosik River. Eskimo name reported in 1932 by $O$. W. Geist, Univ, of Alaska.

Ikalue Island: barrier island, see Igalik Island.

Ikalugtulik River: stream, flows NW $5 \mathrm{mi}$. to Hazen Bay, on Nelson I., $13 \mathrm{mi}$. NE of Cape Vancouver, Yukon-Kuskokwim Delta; $60^{\circ} 39^{\prime} \mathrm{N}, 165^{\circ} 06^{\prime} \mathrm{W}$; (map 57). Var. Killingupak River.

Eskimo name meaning "having humpbacked salmon" obtained at Tanunak in 1949 by USC\&GS.

Ikalu Island: barrier island, see Igalik Island.

Ikashlocktuli River: stream, see Ekashluak Creek.

Ikatak: peninsula, see Ikatan Peninsula.

Ikatan: village, on Ikatan Penin., near head of Ikatan Bay, Unimak I., Aleutian Is.; 54 45'$00^{\prime \prime} \mathrm{N}, 163^{\circ} 18^{\prime} 30^{\prime \prime} \mathrm{W}$; (map 25 ).

Name derived from Ikatan Peninsula, published in 1949 on a USGS map. 
Ikatan Bay: bay, 5 mi. across, between Ikatan and Alaska Penins., on E coast of Unimak I., Aleutian Is.; $54^{\circ} 47^{\prime} \mathrm{N}, 163^{\circ} 15^{\prime} \mathrm{W}$; (map 25).

Name derived from Ikatan Peninsula; given by W. H. Dall, USC\&GS, and published in 1882 by USC\&GS on Chart 806.

Ikatane: peninsula, see Ikatan Peninsula.

Ikatan Peninsula: peninsula, $12 \mathrm{mi}$. long, on SE coast of Unimak I., Aleutian Is.; $54^{\circ} 43^{\prime}$ $\mathrm{N}, 163^{\circ} 12^{\prime} \mathrm{W}$; (map 25). Var. Ikatak, Ikatane, Ikatok, Ikatun.

Aleut name reported by Father Ioann Veniaminov as "Ikatok" in 1830 's; shown as an island on Russian Hydrog. Dept. Chart 1379, published in 1847 .

Ikatan Point: point of land, $10 \mathrm{mi}$. SE of False Pass, on Ikatan Penin., Unimak I., Aleutian Is. ; $54^{\circ} 46^{\prime} 30^{\prime \prime} \mathrm{N}, 163^{\circ} 11^{\prime} 00^{\prime \prime} \mathrm{W}$; (map 25). Var. Cape Horn.

Named in 1901 by Ferdinand Westdahl, USC\&GS ; derived from Ikatan Peninsula.

Ikathiwik: volcanic crater, see Ikathiwik Crater.

Ikathiwik Crater: volcanic crater, $701 \mathrm{ft}$., 14 mi. $\mathbf{N}$ of Roberts Mtn. and $30 \mathrm{mi}$. NNW of Cape Mendenhall, on Nunivak I.; $60^{\circ} 14^{\prime} 10^{\prime \prime}$ $\mathrm{N}, 166^{\circ} 15^{\prime} 00^{\prime \prime} \mathrm{W}$; (map 57). Var. Ikathiwik,

Eskimo name obtained in 1949 by USC\&GS.

Ikathleewik Bay: bay, on $\mathrm{W}$ shore of Etolin Strait, $\mathbf{S}$ of Ikathleewimjingia Point, on $\mathbf{E}$ coast of Nunivak I.; $60^{\circ} 18^{\prime} \mathrm{N}, 165^{\circ} 42^{\prime} \mathrm{W}$; (map 57). Var. Ikathliwikh Bay.

Eskimo name obtained in 1949 by USC\&GS.

Ikathleewimjingia Point: point of land, extends $1.5 \mathrm{mi}$. into Etolin Strait, $18 \mathrm{mi}$. SE of Cape Etolin, on NE coast of Nunivak I.; $60^{\circ} 18^{\prime} 40^{\prime \prime}$ N, $165^{\circ} 42^{\prime} 40^{\prime \prime} \mathrm{W}$; (map 57). Var. Ikthleewimjingia Point, Ikthliwimjingia Point.

Eskimo name obtained in 1949 by USC\&GS Ikathliwikh Bay: bay, see Ikathleewik Bay. Ikathluik: stream, see Fish River.

Ikatlegomute: locality, see Ikatlek.

Ikatlek: locality, on the right bank of Yukon River between Paimiut and Ingregamiut, Nulato Hills; $61^{\circ} 58^{\prime} \mathrm{N}, 160^{\circ} 24^{\prime} \mathrm{W}$; (map 73). Var. Ikatlegomute.

The exact location of this village, which $E$. W. Nelson, U.S. Signal Service, passed through in 1879, is not known, and is undoubtedly now an abandoned site. Nelson spelled it "Ikatlegomute," i.e., "people o? Ikatlek," and placed it on his map between Paimute and Pogoreshapka [Bellkat]. The 10th Census, in 1880 , referred to a "single house" in this location, with a population of nine.

Ikatok: peninsula, see Ikatan Peninsula.

Ikatok Peak: mountain, 1,948 ft., on Ikatan Penin., Unimak I., Aleutian Is. ; $54^{\circ} 43^{\prime} 15^{\prime \prime} \mathrm{N}$, $163^{\circ} 09^{\prime} 30^{\prime \prime} \mathrm{W}$; ( $\operatorname{map} 25$ ).

Name derived from a variant of Ikatan Peninsula; applied by USC\&GS in 1926 on Chart 8701.

Ikatun: peninsula, see Ikatan Peninsula.

Ikeut, Reka: stream, see Fish River.

Ikeutpak: stream, see Fish River.

Ikgisukruk: mountain, see Hamlet, Mount.

Ikgisuqraq: mountain, see Hamlet, Mount.
Ikherkhamut: locality, "near the mouth of Copper River, Chugach Mts." (map 64).

Former Eskimo camp or settlement listed in Hodge (1907, p. 596), BAE, as being from "I-qẽr-qa-mũt," meaning "end of river people."

Ikhiak: locality, see Eyak.

Ikhiak Lake: lake, see Eyak Lake.

Ikhkelik: point of land, see Nekeelit Point.

Ikhti, Cape: point of land, see Ikti, Cape.

Ikhwok: village, see Ekwok.

Ikiak: locality, on barrier island, between Beaufort Sea and Mackay Inlet, Arctic Plain; $71^{\circ}$ $05^{\prime} 45^{\prime \prime} \mathrm{N}, 154^{\circ} 50^{\prime} 15^{\prime \prime} \mathrm{W}$; (map 153).

Eskimo name recorded at Barrow in 1951 by USC\&GS and is reported to refer to a strait. "Ikikak" is a closer rendition of the name.

Ikiakpaurak Valley: valley, drained by Cache Creek, extends E 23 mi. from Canning River, between Shublik Mts. and Third Ra., $30 \mathrm{mi}$. NW of Mount Michelson, Arctic Slope; $69^{\circ}$. $28^{\prime} \mathrm{N}, 145^{\circ} 45^{\prime} \mathrm{W}$; (map 139). Var. Ikiokpaurak Valley, Iklokpaurak Valley.

Eskimo name reported by Leffingwell (1919, p. 96) to mean "small valley."

Ikiakpuk Creek: stream, see Eagle Creek.

Ikiakpuk Creek: stream, see Ekokpuk Creek.

Ikiakpuk Valley: valley, drained by Eagle Creek, extends $\mathrm{E} 18 \mathrm{mi}$. from Canning River, between Third Ra. and Franklin Mts., $27 \mathrm{mi}$. NW of Mount Michelson, Arctic Slope; $69^{\circ} 24^{\prime} \mathrm{N}$, $145^{\circ} 40^{\prime} \mathrm{W} ; B G N$ 1960; (map 139). Var. Iklokpuk Valley.

Eskimo name "Ikiakpak" reported by Leffingwell $(1919$, p. 96) to mean "big valley." Ikiginakh, Ostrov: island, see Ikiginak Island.

Ikiginakh Island: island, see Ikiginak Island.

Ikiginak Island: island, $0.4 \mathrm{mi}$. long, between Atka and Tagalak Is., Aleutian Is. ; $51^{\circ} 58^{\prime} 45^{\prime \prime}$ N, $175^{\circ} 29^{\prime} 20^{\prime \prime}$ W; BGN 1936; (map 18). Var. Ikiginakh Island, Ikiginakh, Ostrov, Nerpchiy, Ostrov, Nerpichiy, Ostrov, Nerpitchy ilot, Seal Island.

Published as "O[strov] Ikiginakh," or "Ikiginakh Island," by Capt. Tebenkov (1852, map 27), IRN, from an Aleut name which Capt. Lutke (1836, p. 320), IRN, called "Nerpitchy ilot," or "seal island."

Ikijaktusak Creek: stream, flows S $2 \mathrm{mi}$. to Chukchi Sea, $1.4 \mathrm{mi}$. SE of Cape Thompson, Arctic Slope; $68^{\circ} 07^{\prime} 45^{\prime \prime} \mathrm{N}, 165^{\circ} 56^{\prime} 30^{\prime \prime} \mathrm{W}$; BGN 1963; (map 129). Var. Eegikruttoosook Creek, Eekheezhaktusuk Creek, Emmikroak Creek.

Eskimo name meaning "young gull" reported in 1962 by W. O. Pruitt, Univ. of Alaska, and spelled by him "Eekheezhaktusuk." USC\&GS reported a variation of this name in 1950 spelled "Eegik-rut-too-sook." Ikikiktoik: locality, see Klikitarik.

Ikikileruk Creek: stream, flows $\mathrm{N} 7 \mathrm{mi}$, to Chukchi Sea, $1.5 \mathrm{mi}$. W of Noonuklook Mtn. and $36 \mathrm{mi}$. NNW of Mount Kelly, Arctic Slope; $68^{\circ} 57^{\prime} 30^{\prime \prime} \mathrm{N}, 164^{\circ} 06^{\prime} 00^{\prime \prime} \mathrm{W}$; (map 130). Var. Mugilak Creek, Mu-gee-lu Creek.
Eskimo name reported in 1956 to mean "narrow" by T. E. Taylor, USGS.

Ikiokpaurak Creek: stream, see Cache Creek.

Ikiokpaurak Valley: valley, see Ikiakpaurak Valley.

Ikiraaluk: bay, see Moore, Port.

Ikiraaluk: water passage, see Eluitkak Pass.

Ikiut-pak: stream, see Niukluk River.

Ikkeraluk: bay, see Moore, Port.

Ikkeraluk: water passage, see Eluitkak Pass.

Ikkhagamut: locality, see Savonoski.

Ikkhagmute: locality, see Savonoski.

Ik-ku-go-ak River: stream, see Ikugoak River.

Iklauyak Creek: stream, flows SW $5 \mathrm{mi}$. to Okokmilaga River $3 \mathrm{mi}$. $\mathrm{N}$ of its head, Brooks Ra.; $68^{\circ} 10^{\prime} \mathrm{N}, 1^{\circ} 3^{\circ} 06^{\prime} \mathrm{W}$; (map 133).

Eskimo name reported in 1956 by T. E. Taylor, USGS.

Iklauyaurak Creek: stream, flows ESE $5.5 \mathrm{mi}$. to $S$ end of Chandler Lake, $27 \mathrm{mi}$. W of Anaktuvuk Pass, Brooks Ra.; 68 ${ }^{\circ} 12^{\prime} 00^{\prime \prime}$ N, $152^{\circ}$ $46^{\prime} 30^{\prime \prime}$ W; (map 134).

Eskimo name obtained at Anaktuvuk Pass in 1956 by 'T. E. Taylor, USGS.

Iklo: estuary, see Igklo River.

Iklokpaurak Valley: valley, see Ikiakpaurak Valley.

Iklokpuk Valley: valley, see Ikiakpuk Valley.

Iklut-pak: stream, see Niukluk River.

Ikmakrak Lake: lake, $2.5 \mathrm{mi}$. long, $\mathrm{W}$ of village of Meade River, Arctic Plain; $70^{\circ} 29^{\prime} \mathrm{N}$, $157^{\circ} 28^{\prime} \mathrm{W}$; (map 147)

Eskimo name obtained in 1956 at Wainwright by T. E. Taylor, USGS.

Iknetuk: locality, on W shore of Golovnin Bay, $6 \mathrm{mi}$. S of Golovin and $40 \mathrm{mi}$. ESE of Solomon, Seward Penin. High.; $64^{\circ} 28^{\prime} \mathrm{N}, 163^{\circ} 04^{\prime}$ W; (map 95). Var. Igkh-nik-toghe-mute, Ignituk, Iknutuk, Kniktag-miut, Knykhtakgmyut.

Site of an Eskimo village reported in 184244 as "Knykhtakg-myut" by Lt. L. A. Zagoskin, IRN. Ivan Petroff in the 10th Census in 1880 recorded "Ignituk" with a population of 100 . Baker (1906, p. 321), USGS, wrote "Iknetuk."

Iknetuk Point: point of land, see Icknetuk Point.

Iknivik Creek: stream, flows NW $12.5 \mathrm{mi}$. from W of Shainin Lake to Anaktuvuk River, 22 mi. NE of Anaktuvuk Pass, Arctic Slope; $68^{\circ} 21^{\prime} \mathrm{N}, 151^{\circ} 25^{\prime} \mathrm{W}$; (map 134).

Eskimo name, meaning "pointed place," published by Rausch (1951, p. .150).

Iknutak Mountain: mountain, $1,688 \mathrm{ft}$., at $\mathrm{S}$ end of penin., on W side of Golovnin Bay, $39 \mathrm{mi}$. SE of Solomon, Seward Penin. High.; $64^{\circ} 28^{\prime} \mathrm{N}, 163^{\circ} 10^{\prime} \mathrm{W}$; (map 95).

Local name reported about 1940 by USC\&GS and published on Chart 9382. See Iknetuk.

Iknutuk: locality, see Iknetuk

Iko Bay: estuary, extending S $5 \mathrm{mi}$. off Elson Lagoon, between Ross and Scott Points, 15 mi. SE of Point Barrow, Arctic Plain; $71^{\circ} 12^{\prime}$ N., $156^{\circ} 00^{\prime \prime} \mathrm{W} ;$ BGN 1964; (map 153). Var. Ahvak Bay, Mackenzie Bay, McKensie's Bay. 
Eskimo name published by Comdr. R. Maguire (1854, map facing p. 186), $\mathrm{RN}$, and reported to mean "the last one" or "the end." This feature is probably the same bay shown on Thomas Simpson's map as McKenzies Bay and named "after Chief Factor Roderick Mackenzie [sic]," of the Hudson's Bay Company (Simpson, Thomas, 1843, p. 152).

Ikogmiut: village, see Russian Mission.

Ikogmute: village, see Russian Mission.

Ikolga: locality, "on Unalaska I., Aleutian Is." (map 23)

Former Aleut camp or settlement reported by Coxe (1787, p. 164); "Consists of only one hut."

Ikolik: locality, on S shore of Gurney Bay, 23 mi. SW of Karluk, on W coast of Kodiak I.; $57^{\circ} 17^{\prime} 15^{\prime \prime} \mathrm{N}, 154^{\circ} 47^{\prime} 00^{\prime \prime} \mathrm{W}$; (map 35). Var. Icolick.

Name reported by Capt. Lisianski (1814, p. 169), IRN, as the settlement of Icolick.

Ikolik, Cape: point of land, on S shore of Gurney Bay, $23 \mathrm{mi}$. SW of Karluk, on $W$ coast of Kodiak I. ; $57^{\circ} 17^{\prime} 15^{\prime \prime} \mathrm{N}, 154^{\circ} 47^{\prime} 00^{\prime \prime} \mathrm{W}$; $B G N$ 1890; (map 35). Var. Ecolik Point, Ikalik Point, Ikolik Point, Seal Cape, Southwest Point.

Name published by the Russian Hydrog. Dept. in 1847 on Chart 1378 as "M[ys] Ikolik," or "Cape Ikolik." This feature was called "Southwest Point" by Capt. Lisianski (1814, p. 169), IRN, who reported the settlement of Icolick as being located here.

Ikongimiut: locality, at head of inlet on $\mathrm{S}$ coast of Nunivak I., $9 \mathrm{mi}$. NNE of Cape Mendenhall; $59^{\circ} 53^{\prime} 30^{\prime \prime} \mathrm{N}, 166^{\circ} 01^{\prime} 00^{\prime \prime} \mathrm{W}$; (map 55 ).

Former Eskimo village reported in 1966 by Calvin J. Lensink, USF\&WS.

Ikook Point: point of land, at NW tip of Cape Mohican, $54 \mathrm{mi}$. NW of Cape Mendenhall, Nunivak I.; $60^{\circ} 12^{\prime} 50^{\prime \prime} \mathrm{N}, 167^{\circ} 27^{\prime} 30^{\prime \prime} \mathrm{W}$; (map 57).

Name reported about 1908 by USC\&GS.

Ikooksmiut: locality, on NE coast of Cape Mohican, $17 \mathrm{mi}$. W of Nash Harbor, Nunivak I.; $60^{\circ} 12^{\prime} 30^{\prime \prime} \mathrm{N}, 167^{\circ} 26^{\prime} 00^{\prime \prime} \mathrm{W}$; (map 57). Var. Ikooxmiut, Ikukhmiut.

Eskimo summer camp reported in 1949 by USC\&GS.

Ikookstakswak Cove: cove, $8 \mathrm{mi}$. W of Iloodak Point, $44 \mathrm{mi}$. SW of Cape Etolin, on $\mathrm{N}$ coast of Nunivak I.; $60^{\circ} 13^{\prime} 30^{\prime \prime} \mathrm{N}, 167^{\circ} 20^{\prime} 00^{\prime \prime} \mathrm{W}$; (map 57). Var. Ikooxtaxwax Cove, Ikuhhtakhwakh Bay.

Eskimo name obtained in 1949 by USC\&GS.

Ikoox: peninsula, see Mochicar, Cape.

Ikooxtaxwax Cove: cove, see Ikookstakswak Cove.

fkoum'-ūngä: valley, slight depression on edge of bluffs, on $\mathbf{E}$ side of outlet for Umanangula Lake, on $\mathbf{S}$ coast of Saint George I., in Pribilof Is.; $56^{\circ} 32^{\prime} 10^{\prime \prime} \mathrm{N}, 169^{\circ} 37^{\prime} 00^{\prime \prime} \mathrm{W}$; (map 38 ).

An Aleut name listed by Putnam (1903, p. 1014), USC\&GS, and means "fox trail' *** so called because the foxes here have a trail *** over the edge of the bluff, where they go to get eggs and birds."
Ikoum-unga-Koverushka: hill, see South Hill.

Ikoygak Creek: stream, flows NE $4 \mathrm{mi}$. to Akeftapak Bay, $7 \mathrm{mi}$. SE of Gambell, N coast of St. Lawrence I.; $63^{\circ} 41^{\prime} \mathrm{N}, 171^{\circ} 38^{\prime}$ W; BGN 1951; (map 93).

Eskimo name recommended in 1949 by the Gambell village council.

Ikpek: locality, on Chukchi Sea coast, at SW end of Arctic Lagoon, $31 \mathrm{mi}$. NE of Cape Prince of Wales and $51 \mathrm{mi}$. NW of Teller, Kotzebue-Kobuk Low.; $65^{\circ} 54^{\prime}$ N, $167^{\circ} 17^{\prime}$ W; (map 111). Var. Esook.

Site of an Eskimo village or camp; shown as "Esook" on the 1908 "Map of Seward Peninsula" by Arthur Gibson. Published as "Ikpek" in 1956 by USGS.

Ikpigroak Bank: bank, on $E$ shore of Kivalina Lagoon, 2 mi. N of Kivalina, Kotzebue-Kobuk Low.; $67^{\circ} 46^{\prime} \mathrm{N}, 164^{\circ} 35^{\prime} \mathrm{W}$; (map 128).

Var. Ikpigrohck, Ikpigzaaq.

Eskimo name meaning "old riverbank" reported by E. S. Burch in 1966.

Ikpigrohck: bank, see Ikpigroak Bank.

Ikpigzaaq: bank, see Ikpigroak Bank.

Ikpik Hill: hill, $260 \mathrm{ft}$., surrounded by marsh, on W coast of Kodiak I., $36 \mathrm{mi}$. S of Karluk; $57^{\circ} 02^{\prime} 40^{\prime \prime} \mathrm{N}, 154^{\circ} 30^{\prime} 30^{\prime \prime} \mathrm{W} ; B G N$ 1934; (map 35).

Named by USC\&GS in 1934 "from an Eskimo word meaning 'bluff'."

Ikpikpuk River: stream, formed by Kigalik River and Maybe Creek at $69^{\circ} 20^{\prime} 45^{\prime \prime} \mathrm{N}$, $154^{\circ} 42^{\prime} 30^{\prime \prime} \mathrm{W}$, flows N $195 \mathrm{mi}$. to Smith Bay, Arctic Plain; $70^{\circ} 49^{\prime} 30^{\prime \prime} \mathrm{N}, 154^{\circ} 19^{\prime} 10^{\prime \prime} \mathrm{W}$; $B G N$ 1925; (map 148). Var. Chipp River, Ikpekpuk River, Ikpekpung River, Ikpikpun River, Ikpikpung River, Ikpikpungme River.

Eskimo name [Ikpikpak] meaning "big cliff or bank," originally reported by Lt. Ray (1885, p. 55, map), USA, as Ikpikpun and Ikpikpung and described as the "Third large river east of Point Barrow." Ens. W. L. Howard, USN, traveled along this stream on his trip from the Kobuk River to Point Barrow in the spring of 1886, and reported the Eskimo name as Ikpikpuk, although he also shows the name "Ik-pik-pung River" for a tributary of this stream (Stoney, 1900, p. 73 and map facing p. 66). Leffingwell (1919, p. 93, 96) explains that Ikpikpungme is a locative form meaning "at the Ikpikpuk." Lt. G. M. Stoney, USN, attempted to rename this stream Chipp River for Lt. C. W. Chipp, USN, but BGN reapplied the "Chipp River" to one of the two distributaries of the Ikpikpuk in 1925.

Ikpikpuk River Delta: delta, $8 \mathrm{mi}$. across, on $\mathrm{S}$ shore of Smith Bay, at mouth of Ikpikpuk River, Arctic Plain; $70^{\circ} 49^{\prime} \mathrm{N}, 154^{\circ} 23^{\prime} \mathrm{W}$; (map 148).

Name published by AMS in 1960.

Ikpikpun: stream, see Ikpikpuk River.

Ikpikpungme: stream, see Ikpikpuk River.

Ikpikpung River: stream, see Ikpikpuk River. Ikpik Slough: stream, flows NE $4 \mathrm{mi}$. to Elson Lagoon, $5.6 \mathrm{mi}$. E of Barrow, Arctic Plain; $71^{\circ} 17^{\prime} 45^{\prime \prime} \mathrm{N}, 156^{\circ} 31^{\prime} 30^{\prime \prime} \mathrm{W}$; (map 153). Var. Ukpik Slough.
Eskimo name meaning "cliff" or "bluff" applied for scientific purposes (Carson and Hussey, 1962).

Ikpilgok: locality, on Chukchi Sea coast, $5 \mathrm{mi}$. NE of Wainwright, Arctic Plain; $70^{\circ} 41^{\prime} 45^{\prime \prime}$ $\mathrm{N}, 159^{\circ} 54^{\prime} 00^{\prime \prime} \mathrm{W}$; (map 146).

Eskimo name published in 1958 by AMS; a camp site on the coastal trail.

Ikpilin: lake, see South Salt Lagoon.

Ikpiling : lake, see South Salt Lagoon.

Ikpiling: point of land, see Smyth, Cape.

Ikpitcheak Creek: stream, heads in lake, flows NE 11 mi. to Kuk River, $26 \mathrm{mi}$. S of Wainwright, Arctic Plain; $70^{\circ} 16^{\prime} 10^{\prime \prime} \mathrm{N}, 159^{\circ} 53^{\prime} 15^{\prime \prime}$ W; (map 146).

Eskimo name recorded in 1956 at Wainwright by Orth; reported to mean "new bank," which referred to a freshly cut bank at the stream's mouth.

Ikragamiut: locality, see Igiayarok.

Ikriktolik Lake: lake, see Kekiktalik Lake.

Ikroavik Lake: lake, $2.5 \mathrm{mi}$. long, on Chukchi Sea coast, $4.5 \mathrm{mi}$. SE of Barrow, Arctic Plain; $71^{\circ} 13^{\prime} 50^{\prime \prime} \mathrm{N}, 156^{\circ} 37^{\prime} 50^{\prime \prime} \mathrm{W}$; (map 153). Var. Ekrugavik Lake, Iksoaaviq.

Eskimo name recorded by USC\&GS about 1950 and reported to refer in meaning to "a place where one gets in a boat to travel."

Iksartaliget: locality, see Iksartolik.

Iksartolik: locality, on right bank of Kashunuk River, $3.5 \mathrm{mi}$. N of Chakaktolik, $52 \mathrm{mi}$. W of Marshall, Yukon-Kuskokwim Delta; 61 ${ }^{\circ} 49^{\prime}$ $10^{\prime \prime} \mathrm{N}, 163^{\circ} 37^{\prime} 30^{\prime \prime} \mathrm{W}$; (map 74). Var. Iksartaliget.

Eskimo name for a fish camp reported by USC\&GS in 1949. It is shown as "Iksartaliget" on a manuscript map by "Father Delon" dated 1937.

Iksiak Point: point of land, between Udamak and Naginak Coves, at head of Anderson Bay, central Unalaska I., Aleutian Is.; $53^{\circ} 39^{\prime} 40^{\prime \prime} \mathrm{N}$, 166 49'35" W; BGN 1939; (map 23).

Named by USC\&GS in 1937 . The name was derived from Iksiaktak, the Aleut name for nearby Anderson Bay. The name may be a form of the word "ixsik," meaning "burning." Iksiaktak: bay, see Anderson Bay.

Iksoaaviq: lake, see Ikroavik Lake.

Iksutpak: stream, see Fish River.

Ikthleewimjingia Point: point of land, see Ikathleewimjingia Point.

Ikthliwimjingia Point: point of land, see Ikathleewimjingia Point.

Ikti, Cape: point of land, on $\mathrm{S}$ coast of Alaska Penin., between Seal and Kuiukta Bays, $21 \mathrm{mi}$. $\mathrm{S}$ of Chignik, Aleutian Ra.; $56^{\circ} 00^{\prime} \mathrm{N}, 158^{\circ} 31^{\prime}$ W; BGN 1939; (map 27). Var. Cape Ikhti, Cape Itkbi, Cape Itkhi.

Aleut name published as "M[ys] Ikhti," or "Cape Ikhti," on Russian Hydrog. Dept. Chart 1379 in 1847, and as "M[ys] Itkhi," or "Cape Itkhi," by Capt. Tebenkov (1852, map 24).

Iktliyagak Mountain: hill, $496 \mathrm{ft}$., $5 \mathrm{mi}$. SE of Mumtrak Hill, $6.5 \mathrm{mi}$. E of Goodnews, Kilbuck-Kuskowim Mts.; $59^{\circ} 07^{\prime} \mathrm{N}, 161^{\circ} 24^{\prime} \mathrm{W}$; (map 53).

Eskimo name reported in 1954 by USGS. 
Iktua Rocks: group of rocks, in Prince of Wales Passage, off NW coast of Evans I., $12 \mathrm{mi}$. SE of Chenega, Chugach Mts.; $60^{\circ} 07^{\prime} 20^{\prime \prime} \mathrm{N}$, $148^{\circ} 02^{\prime} 05^{\prime \prime} \mathrm{W}$; (map 63).

Local name reported in 1951 by USGS.

Ikuagmiut: locality, see Akahamut.

Ikuak: locality, see Akahamut.

Ikuak: village, see Ohogamiut.

Ikugoak River: stream, flows SW $19 \mathrm{mi}$. to a lake, $11 \mathrm{mi}$. NE of Selawik, Kotzebue-Kobuk Low. ; $66^{\circ} 41^{\prime} \mathrm{N}, 159^{\circ} 40^{\prime} \mathrm{W}$; BGN 1912; (map 114). Var. Ik-ku-go-ak River.

Eskimo name reported in 1885 by Lt. Stoney (1900, map), USN.

Ikuk : village, see Ekuk.

Ikuk Creek: stream, heads in De Long Mts., on Stone Hut Mtn., flows NW 11 mi. to Pitmegea River, 17 mi. NW of Mount Kelly, Brooks Ra.; $68^{\circ} 41^{\prime} \mathrm{N}, 163^{\circ} 54^{\prime} \mathrm{W}$; (map 130).

Eskimo name obtained by John W. Kelly (Kelley) and published by Stockton (1890, p. 179).

Ikukh: peninsula, see Mohican, Cape.

Ikukhmiut: locality, see Ikooksmiut.

Ikukhtakhwakh Bay: cove, see Ikookstakswak Cove.

Ikuktlitlig Mountain: mountain, 2,588 ft., $3 \mathrm{mi}$. $\mathrm{E}$ of Explorer Mountain and $12 \mathrm{mi}$. NE of Goodnews, Kilbuck-Kuskokwim Mts.; 59 ${ }^{\circ} 16^{\prime}$ N, $161^{\circ} 27^{\prime} \mathrm{W}$; (map 53).

Eskimo name probably meaning "old end mountain" because of its end position on a ridge; obtained at Goodnews about 1951 by J. M. Hoare, USGS.

Ikutchlok: locality, see Kutchlok.

Ikwok: village, see Ekwok.

Ikwokhamut: village, see Ekwok.

Ilagia Island: island, see Nagai Island.

Ilaigutigrak Creek: stream, flows $S 20 \mathrm{mi}$. to Wulik River, $34 \mathrm{mi}$. NE of Kivalina, Brooks Ra.; $68^{\circ} 00^{\prime} \mathrm{N}, 163^{\circ} 30^{\prime} \mathrm{W}$; (map 130). Var. Ilaigutigzam Kuunga, Ilaygootigram Koonga, Ilyavlootixrut.

Eskimo name reported as "Ilyavlootixrut" in 1960 by D. C. Foote.

Ilaigutigrak Mountain: mountain, 1,823 ft., 40 mi. NE of Kivalina, Brooks Ra.; $68^{\circ} 06^{\prime} \mathrm{N}$, $163^{\circ} 28^{\prime}$ W.; (map 130). Var. Ilaigutigzaq, Ilaygootigrak, Ilyaylootixroot Mountain.

Eskimo name reported as "Ilyaylootixroot Mountain" in 1960 by D. C. Foote.

Ilaigutigzam Kuunga: stream, see Ilaigutigrak Creek.

Ilaigutigzaq: mountain, see Ilaigutigrak Mountain.

Ilak: point of land, see Ugyak, Cape.

Ilak Island: island, $1 \mathrm{mi}$. across in eastern Delarof Is., Aleutian Is.; $51^{\circ} 28^{\prime} 50^{\prime \prime} \mathrm{N}, 178^{\circ}$ $17^{\prime 20}$ " W; (map 16). Var. Illakh Island, Illiak Island, Illuk Island.

Aleut name recorded by Commodore Joseph Billings, IRN, as "Illuk," and published by Lt. Sarichev (1826, map 3), IRN, as "Illakh." The adopted form "Ilak" was published in the 1946 supplement to the 1944 Aleutian Coast Pilot.

Ilanik Lakes: lakes, $2 \mathrm{mi}$. across, $\mathrm{S}$ of mouth of Goodnews River and W of Puyulik Creek, 2 mi. S of Goodnews, Kilbuck-Kuskokwim Mts.; $59^{\circ} 06^{\prime} \mathrm{N}, 161^{\circ} 34, \mathrm{~W}$; (map 53 ).

Eskimo name reported in 1954 by USGS.

Ilaygootigrak: mountain, see Ilaigutigrak Mountain.

Ilaygootigram Koonga: stream, see Ilaigutigrak Creek.

Ildefonso, Point: point of land, SW tip of an island, between San Alberto Bay and San Christoval Channel, $1.5 \mathrm{mi}$. SE of Rosary I., Alex. Arch.; $55^{\circ} 34^{\prime} 10^{\prime \prime} \mathrm{N}, 133^{\circ} 15^{\prime} 45^{\prime \prime} \mathrm{W}$; (map 4). Var. Ildelfonso, Idelfonso Point, Punta de San Yldefonso, Punta San Ildefonso.

Named "Punta de San Yldefonso" by Don Juan de la Bodega y Quadra and Francisco Antonio Maurelle about May 24, 1779, in honor of that saint whose day is May 26.

Ildelfonso Point: point of land, see Ildefonso, Point.

Ilerun Lake: lake, $0.5 \mathrm{mi}$. long, on Kenai Penin., $1.4 \mathrm{mi}$. E of Pepper Lake and $36 \mathrm{mi}$. NE of Kenai, Cook Inlet Low.; 60 $51^{\prime} 00^{\prime \prime} \mathrm{N}$, $150^{\circ} 23^{\prime} 30^{\prime \prime} \mathrm{W}$; (map 62).

Named about 1963 by officials of Kenai National Moose Range, for administrative purposes.

Iles Creek: stream, flows NE $5 \mathrm{mi}$. to Canyon Creek, $43 \mathrm{mi}$. S of Eagle, Yukon-Tanana High; $64^{\circ} 12^{\prime} \mathrm{N}, 141^{\circ} 08^{\prime} \mathrm{W}$; (map 102).

Local name published in 1956 by USGS. Iliamna: locality, see Old Iliamna.

Iliamna: village, pop. 47, just $\mathrm{N}$ of Iliamna Lake, $56 \mathrm{mi}$. NW of Augustine I., Aleutian Ra., $59^{\circ} 45^{\prime} \mathrm{N}, 154^{\circ} 55^{\prime} \mathrm{W}$; BGN 1941; (map 51).

Eskimo village reported on a 1935 USGS map of Alaska. Before 1935 this name was applied to a village located at another site. After the move the old village became known as "Old Iliamna." Iliamna (now Old Iliamna) obtained a post office in 1901; the post office moved to the present location and retained its name.

Iliamna Bay: estuary, trends S 6 mi. to Kamishak Bay, on SE coast of Alaska Penin., 19 mi. N of Augustine I., Aleutian Ra.; $59^{\circ} 37^{\prime} \mathrm{N}$, $153^{\circ} 33^{\prime}$ W; BGN 1906; (map 51). Var. Iniskin Bay.

Local name reported in 1902 by Osgood (1904, map), USDA.

Iliamna Lake: lake, $75 \mathrm{mi}$. long and $20 \mathrm{mi}$. wide, at $\mathbf{N}$ end of Alaska Penin., between Kvichak Bay and Cook Inlet, $100 \mathrm{mi}$. W of Seldovia, Bristol Bay Low.; $59^{\circ} 30^{\prime} \mathrm{N}, 155^{\circ} 00^{\prime} \mathrm{W}$; BGN Sixth Report; (map 51). Var. Big Ilyamna Lake, Lake Chelekoff, Lake Shelekhovo, Lake Shelekof, Lámna Lake.

Native name reported as "Oz[ero] Bol[shoy] Ilyamna," meaning "Big Ilyamna Lake," on 1852 Russian Hydrog. Dept. Chart 1455. This feature was earlier called " $\mathrm{Oz}$ [ero] Shelekhovo," meaning "Lake Shelekov," on an 1802 Russian map. According to G. C. Martin, USGS, Iliamna is said to be "the name of a mythical great blackfish, supposed to inhabit this lake, which bites holes in the bidarkas of bad natives."

Iliamna Point: point of land, on $\mathrm{W}$ shore of Cook Inlet, $4 \mathrm{mi}$. S of Tuxedni Channel and
$58 \mathrm{mi}$. SW of Kenai, Aleutian Ra.; $60^{\circ} 02^{\prime} 20^{\prime \prime}$ $\mathrm{N}, 152^{\circ} 35^{\prime} 00^{\prime \prime} \mathrm{W}$; (map 62).

Name reported by USGS (Brooks and others, 1922, pl. 2).

Iliamna River: stream, heads at $59^{\circ} 55^{\prime} \mathrm{N}$, $153^{\circ} 29^{\prime} \mathrm{W}$, flows SW $28 \mathrm{mi}$. to Pile Bay, Iliamna Lake, $33 \mathrm{mi}$. NW of Augustine I., Aleutian Ra.; 59 $44^{\prime} 15^{\prime \prime} \mathrm{N}, 153^{\circ} 58^{\prime} 30^{\prime \prime} \mathrm{W}$; $B G N$ 1962; (map 51). Var. South Fork Iliamna River.

Local name reported in 1902 by W. H. Osgood, USDA. The name is derived from the lake.

Iliamna Volcano: volcano, $10,016 \mathrm{ft}$., at head of Tuxedni Glacier, $60 \mathrm{mi}$. E of Nondalton, Aleutian Ra.; $60^{\circ} 02^{\prime} \mathrm{N}, 153^{\circ} 05^{\prime} \mathrm{W}$; (map 61). Var. Burning Mountain, Montagnas Brillantes, Volcan de Miranda.

Name published by the Russians as "Sopk[a] Ilymna" (Tebenkov, 1852, map 5). Capt. M. D. Tebenkov stated that the volcano was smoking. This appears to be the volcano called "Volcan de Miranda" by the 1779 Don Ignacio Arteaga expedition; probably named in honor of Fernando Bernardo de Quirós y Miranda, the second officer of the vessel La Princesa.

Iliasik Islands. island, see Inner Iliasik Island. Iliasik Islands: island, see Outer Iliasik Island.

Iliasik Passage: water passage, between Inner and Outer Iliasik Is., $7 \mathrm{mi}$. SW of Dolgoi I., in Pavlof Is., Aleutian Ra.; $55^{\circ} 02^{\prime} \mathrm{N}, 161^{\circ} 55^{\prime}$ W; (map 28). Var. Iliasik Strait.

Feature called Iliasik Strait in 1897 by Lt. Comdr. J. F. Moser, USN, commander of USBF steamer Albatross.

Iliaviki: island, see Inner Iliasik Island.

Iliaviki: island, see Outer Iliasik Island.

Iligluruk Creek: stream, heads at $68^{\circ} 34^{\prime} \mathrm{N}, 161^{\circ}$ $20^{\prime} \mathrm{W}$, flows NW $25 \mathrm{mi}$, to Kokolik River 43 mi. NW of Misheguk Mtn., Brooks Ra.; $68^{\circ} 45^{\prime}$ N, 162 $2^{\circ} 1^{\prime}$ W; BGN 1961; (map 131).

Eskimo name referring to a "burnt-looking" area; name reported in 1925 by J. B. Mertie, Jr., and P. S. Smith, USGS.

Ilikrak Creek: stream, flows NE $13 \mathrm{mi}$. to Kukpuk River, W of Saligvik Ridge, $13 \mathrm{mi}$. NE of Cape Thompson, Arctic Slope; $68^{\circ} 17^{\prime}$ $20^{\prime \prime} \mathrm{N}, 165^{\circ} 39^{\prime} 50^{\prime \prime} \mathrm{W}$; BGN 1963; (map 129). Var. Eelikrak Creek, Imailyaktun Creek.

Eskimo name referring to the "death struggle of an animal" recorded in 1962 by W. O. Pruitt, Univ. of Alaska, who spelled it "Eelikrak."

Ilima: lake, see Clark, Lake.

Ilina Bay: bay, see Ilin Bay.

Ilin Bay: bay, $0.5 \mathrm{mi}$. across, at head of Islas Bay, $16 \mathrm{mi}$. NW of Chichagof, on $W$ coast of Chichagof I., Alex. Arch.; $57^{\circ} 50^{\prime} \mathrm{N}, 136^{\circ} 23^{\prime}$ W; (map 9). Var. Ilina Bay.

Named by the Russians in the early part of the 19th century "for the Russian mate or pilot Ilin who made a reconnaissance of it" (USC\&GS 1883, p. 182). In 1883 it was called "Ilina Bay" by USC\&GS.

Ilingnorak Ridge: ridge, 2,980 ft., extends NESW $13 \mathrm{mi}$., between Adventure and Iligluruk 
Creeks, in De Long Mts, Brooks Ra. ; 68 $43^{\prime} \mathrm{N}$, $161^{\circ} 25^{\prime} \mathrm{W}$; (map 131).

Eskimo name referring to a "burned" area, reported by USGS in 1956 .

Iliuk Arm Naknek Lake: bay, extends E $13 \mathrm{mi}$. off Naknek Lake, on Alaska Penin., in Katmai National Monument, $23 \mathrm{mi}$. NW of Mount Katmai, Aleutian Ra.; $58^{\circ} 31^{\prime} \mathrm{N}, 155^{\circ} 32^{\prime} \mathrm{W}$; (map 42). Var. East Arm Naknek Lake, Illiak Lake, Illiouk Lake, Illyuk Lake, NanvaNelhook.

Eskimo name published in 1922 by R. F. Griggs, National Geographic Society, for this very deep lake. On some Russian maps the name "Iliuk" is applied to Naknek Lake. In 1923, R. H. Sargent, USGS, reported another native name as "Nanva-Nelhook," meaning "very bad lake."

Iliuliuk: village, see Unalaska.

Iliuliuk Bay: bay, $1.3 \mathrm{mi}$. across, in Unalaska Bay between Amaknak I. and NE coast of Unalaska I., Aleutian Is.; $53^{\circ} 54^{\prime} \mathrm{N}, 166^{\circ} 30^{\prime}$ W; $B G N$ 1931; (map 23). Var. Baie de Illiuliuk, Iliuliuk Harbor, Unalaska Harbor.

Aleut name published as "Baie de Illiuliuk" by Adm. vonKrusenstern (1827, atlas), IRN. According to R. H. Geoghegan, the name is a corruption of the word "ilulaq," which means "dwelling together, harmonious," and was also the name of the chief village on Unalaska Island.

Iliuliuk Harbor: bay, see Iliuliuk Bay.

Iliuliuk Harbor: harbor, $0.35 \mathrm{mi}$. across, between Captains Bay and Iliuliuk Bay, in Unalaska Bay, on NE coast of Unalaska I., Aleutian Is.; $53^{\circ} 52^{\prime} 48^{\prime \prime} \mathrm{N}, 166^{\circ} 32^{\prime} 40^{\prime \prime} \mathrm{W}$; BGN 1931; (map 23). Var. Gavanskaia Bay, Gavanskaya, Unalaska Harbor.

Named from Iliuliuk Bay and reported as "Gavanskaya," or "harbor," by Father Veniaminov $(1840$, v. 1, p. 163).

Iliuliuk Reef: reef, at head of Iliuliuk Bay, in Unalaska Bay, on NE coast of Unalaska I., Aleutian Is.; $53^{\circ} 52^{\prime} 46^{\prime \prime} \mathrm{N}, 166^{\circ} 32^{\prime} 00^{\prime \prime} \mathrm{W}$; (map 23).

Local name taken from Iliuliuk Bay and published by USC\&GS in 1900.

Iliutagamute: locality, see Iliutak.

Iliutak: locality, "on E shore of Kuskokwim Bay,

Yukon-Kuskokwim Delta." (map 53 or 54).

Var. Lliutagamute.

Former Eskimo camp or settlement reported as "Iliutagamute" in 1869 by E. W. Nelson, U.S. Signal Service. Ivan Petroff listed Nelson's spelling of the name with a population of 40 in the 1880 Census.

Ilivit Mountains: mountains, $1,700 \mathrm{ft}$., extend NE $35 \mathrm{mi}$. from Mount Chiniklik, E of Kako Creek and Stuyahok River, $28 \mathrm{mi}$. SW of Holy Cross, Nulato Hills; $62^{\circ} 02^{\prime} \mathrm{N}, 160^{\circ} 53^{\prime} \mathrm{W}$; (map 78). Var. Holy Cross Hills, Iliwig, Iliwit.

Native name reported in $1842-44$ by Lt. L. A. Zagoskin, IRN, and shown as "Gruppa G[ora] Ilivit" or "group [of] mountains Ilivit," on 1861 map by $P$. Tikhmeniev.

Iliwig: mountains, see Ilivit Mountains.

Iliwit: mountains, see Ilivit Mountains.
Iljljuljuk: village, see Unalaska.

Ilkognak Rock: rock, between Whale and Kodiak Is., 16 mi. NW of Kodiak, Kodiak I., 57 54' $50^{\prime \prime} \mathrm{N}, 152^{\circ} 47^{\prime} 00^{\prime \prime} \mathrm{W}$; (map 34).

Russian transcription of an Eskimo name, "K[amen] Ilkognak," given in 1839 or 1840 by Sub-Lt. Mikhail Murashev, and published in 1849 on Russian Hydrog. Dept. Chart 1425.

Ilktugitak, Cape: point of land, between Amalik and Dakavak Bays, on S coast of Alaska Penin., in Katmai National Monument, $22 \mathrm{mi}$. SE of Mount Katmai, Aleutian Ra.; 58 $01^{\prime} 15^{\prime \prime}$ N, $154^{\circ} 34^{\prime} 45^{\prime \prime}$ W; (map 42). Var. Mys Iltugitak.

Native name; published in 1847 as M[ys] Iltugitak" on Russian Hydrog. Dept. Chart 1378.

Illakh Island: island, see Ilak Island.

Illak Island: island, see Ulak Island.

Illiak Island: island, see Ilak Island.

Illiak Lake: bay, see Iliuk Arm Naknek Lake.

Illinois Creek: stream, flows NW $1 \mathrm{mi}$. to the Bluestone River, $11 \mathrm{mi}$. SE of Teller, Seward Penin High.; $65^{\circ} 07^{\prime} \mathrm{N}, 166^{\circ} 10^{\prime} \mathrm{W}$; (map 111).

Prospectors' name reported on the 1908 "Map of Seward Peninsula" by Arthur Gibson.

Illinois Creek: stream, formed by confluence of Wilson and Golden Creeks, flows $S 7.5 \mathrm{mi}$. to Yukon River, at Kallands $\mathbf{N}$ of Brant $\mathbf{I}$.; Kokrines-Hodzana High.; $65^{\circ} 11^{\prime} 00^{\prime \prime} \mathrm{N}$, $153^{\circ} 04^{\prime} 30^{\prime} \mathrm{W}$; (map 107).

Prospectors' name reported in 1908 by Maddren (1910, pl. 5), USGS.

Illinois Creek: stream, flows SE to Anikovik River, about $15 \mathrm{mi}$. SE of Cape Prince of Wales, Seward Penin. High.; (map 111).

Prospectors' name shown on the 1900 "Map of Nome Peninsula" by J. M. Davidson and B. D. Blakeslee. This feature cannot be precisely identified on current maps.

Illiouk Lake: bay, see Iliuk Arm Naknek Lake. Illiuliuk: village, see Unalaska.

Illiuliuk, Baie de: bay, see Iliuliuk Bay.

Illiuliuk, Baie de: bay, see Unalaska Bay.

Illoolook: village, see Unalaska.

Illuitkuk Islands: islands, in Plover Is., extend $2 \mathrm{mi}$. SE of Plover Point and including Doctor and Deadmans Is., Arctic Plain; $71^{\circ} 21^{\prime} 35^{\prime \prime}$ N, $156^{\circ} 18^{\prime} 00^{\prime \prime} \mathrm{W}$; (map 153).

Published on the 1853 Brit. Adm. Chart 2164 of the Point Barrow area drawn by Master Thomas Hull, RN. The name is not used today.

Illuk Island : island, see Ilak Island.

Illyuk Lake: bay, see Iliuk Arm Naknek Lake.

Illyulyuk: village, see Unalaska.

Ilmalianok: point of land, see Ilmalianuk, Cape.

Ilmalianuk, Cape: point of land, on $\mathrm{W}$ coast of Umnak I., Aleutian Is.; $53^{\circ} 16^{\prime} 15^{\prime \prime}$ N. $168^{\circ}$ $35^{\prime} 30^{\prime \prime}$ W; (map 22). Var. Ilmalianok, M[ys] Ul'malyanok.

Aleut name published by Capt. Tebenkov (1852, map 25), IRN, as "M[ys] Ul'malyanok," or "Cape Ulmalyanok."

Ilmudichtchit: cove, see Udagak Bay.

Ilmudikhchit: cove, see Udagak Bay.
Ilnik: locality, on barrier beach NW of Ilnik Lake, 47 mi. SW of Port Heiden Airfield, Bristol Bay Low: ; $56^{\circ} 36^{\prime} \mathrm{N}, 159^{\circ} 37^{\prime} \mathrm{W}$; (map 30).

Eskimo camp reported in 1951 by USGS.

Ilnik Lake: lagoon, trends NE $5.5 \mathrm{mi}$. toward Seal Is. and Bristol Bay, $29 \mathrm{mi}$. NW of Mount Veniaminof, on Alaska Penin., Bristol Bay Low. ; $56^{\circ} 36^{\prime} \mathrm{N}, 159^{\circ} 37^{\prime} \mathrm{W}$; (map 30).

Local name published in 1951 by USGS ; derived from Ilnik.

Iloodak Point: point of land, $36 \mathrm{mi}$. SW of Cape Etolin, on N coast of Nunivak I.; $60^{\circ} 14^{\prime} 15^{\prime \prime}$ N, $167^{\circ} 06^{\prime} 10^{\prime \prime} \mathrm{W}$; (map 57). Var. Iloodax Point, Iludakh Point.

Eskimo name obtained in 1949 by USC\&GS. Iloodax Point: point of land, see Iloodak Point. Iloolook: village, see Unalaska.

Ilpiet Island: island, see Ilput Island.

Ilpit Island: island, see Ilput Island.

Ilput Island: island, $0.5 \mathrm{mi}$. long, off $\mathrm{W}$ coast of Baranof I., 12 mi. S of Sitka, Alex Arch.; $56^{\circ} 54^{\prime} 15^{\prime \prime} \mathrm{N}, 134^{\circ} 22^{\prime} 30^{\prime \prime} \mathrm{W}$; (map 5). Var. Ilpiet Island, Ilpit Island, Ostrov Ilpyt.

Tlingit Indian name reported in 1809 by Ivan Vasiliev the first, IRN; published by Lt. Sarichev (1826, map 19), IRN, as "O[strov] Ilpyt," or "Ilpyt Island."

Ilpyt, Ostrov: island, see Ilput Island.

Iltenleiden: locality, see Intenleiden.

Iltugitak, Mys: point of land, see Ilktugitak, Cape.

Iludakh Point: point of land, see Iloodak Point.

Iluiak Island: island, see Shuyak Island.

Iluituk Hill: hill, $810 \mathrm{ft}$., E of Tumi Creek, near shore of Chuckchi Sea, $8.5 \mathrm{mi}$. SE of Cape Thompson, Arctic Slope; $68^{\circ} 06^{\prime} \mathrm{N}, 165^{\circ} 41^{\prime}$ W; (map 129). Var. Elooweechook, Iluituq, Eeluichuk Mountain.

Eskimo name reported in 1962 as "Eeluichuk Mountain" by W. O. Pruitt, Jr., of Univ. of Alaska.

Iluituq: hill, see Iluituk Hill.

Iluyak Basin: valley, $4 \mathrm{mi}$. long, on an $\mathrm{E}$ flowing stream near the head of Kelly River, De Long Mts., Brooks Ra.; $68^{\circ} 27^{\prime} \mathrm{N}, 162^{\circ} 12^{\prime} \mathrm{W}$; (map 130).

Eskimo name means "mixing bowl"; name obtained in 1956 at Noatak by Orth.

Ilyamna: locality, see Old Iliamna.

Ilyavlootixrut: stream, see Ilaigutigrak Creek.

Ilyaylootixroot Mountain: mountain, see Ilaigutigrak Mountain.

Ilyirak Creek: stream, flows NE $7 \mathrm{mi}$, to Kukpuk River, $3 \mathrm{mi}$. NW of junc, of Ipewik River, Arctic Slope; 68 $21^{\prime} 55^{\prime \prime} \mathrm{N}, 165^{\circ} 48^{\prime} 25^{\prime \prime} \mathrm{W}$; $B G N$ 1963; (map 129). Var. Eelyeerak Creek, Eelyeerat Creek.

Eskimo name recorded in 1960 as "Eelyeerat" by D. C. Foote in connection with Project Chariot.

Imachuck River: stream, see Inmachuk River. Imagazuk: lake, see Imuruk Basin.

Imaglin Island: island, see Little Diomede Island.

Imagnak: locality, see Imagnee.

Imagnee: locality, on Summer Bay on E shore of Unalaska Bay, Unalaska I., Aleutian Is.; 
$53^{\circ} 55^{\prime} \mathrm{N}, 166^{\circ} 25^{\prime} \mathrm{W}$; (map 23). Var. Imagnak, Imagninskoe, Sinagnia, Sinagnya. Former Alecit village reported by Father Vemiaminov (1840, v. 1, p. 184) as "Imagninskoe" with a population of 32 in 1830 . The 1880 Census listed it as "Imagnak" with 34 people. Lt. Sarichev (1826, map 14), IRN, on a 1790 map, gives the village name as "Sinagyna."

Imagninskoe: locality, see Imagnee.

Imagninskoe: bay, see Summer Bay.

Imagru Bay: bay, see Clarence, Port.

Imaigenik: locality, near Anaktuvuk Pass in the Endicott Mts., Brooks Ra.; $68^{\circ} 15^{\prime} \mathrm{N}, 151^{\circ} 45^{\prime}$ W; (map 134).

Eskimo name for an archeological site reported in 1950 by Ralph Solecki (in Giddings, 1964, p. 263).

Imaiknaurak: point of land, see Humphrey Point.

Imaiknik Lake: lake, $1 \mathrm{mi}$. across, between Colville and Itkillik Rivers, $32 \mathrm{mi}$. NE of Umiat, Arctic Plain; $69^{\circ} 31^{\prime} 30^{\prime \prime} \mathrm{N}, 150^{\circ} 50^{\prime} 20^{\prime \prime} \mathrm{W}$ (map 141).

Eskimo name reported in 1956 by T. E. Taylor, USGS. It means "dried up place." Imailyaktun Creek: stream, see Ilikrak Creek. Imakhpiguak, Zaliv: bay, see Goodnews Bay. Imakhpiguak Bay: bay, see Goodnews Bay. Imaklit, Ostrov: island, see Little Diomede Island.

Imakpiguak: bay, see Goodnews Bay.

Imakruak Lake: lake, $5 \mathrm{mi}$. long, between Smith Bay and Teshekpuk Lake, Arctic Plain; $70^{\circ}$ $46^{\prime} 30^{\prime \prime} \mathrm{N}, 153^{\circ} 59^{\prime} 30^{\prime \prime} \mathrm{W}$; (map 148).

Eskimo name reported by USGS in 1956 meaning "old water."

Imaourouk: lake, see Imuruk Basin.

Imeakpun: lake, see Imikpuk Làke.

Imeakpuniglu: lagoon, see North Salt Lagoon. Imê'kpûñ: locality, see Imekpung.

Imekpung: locality, "near Point Barrow, Arctic Plain"; (map 153). Var. Imê'kpûn.

Former Eskimo camp listed by Hodge (1907, p. 600), BAE

Imelyak River: stream, heads at $67^{\circ} 34^{\prime} \mathrm{N}$, $156^{\circ} 58^{\prime} \mathrm{W}$, flows $\mathrm{NW}$ and SW $55 \mathrm{mi}$. to Cutler River, $46 \mathrm{mi}$. SW of Howard Pass, Brooks Ra.; $67^{\circ} 45^{\prime} \mathrm{N}, 158^{\circ} 10^{\prime} \mathrm{W}$; (map 126)

Descriptive Eskimo name meaning "little water," obtained at Noatak by Orth in 1956.

Imeri Lake: lake, $0.3 \mathrm{mi}$. Iong, on Kenai Penin. one of the Seven Lakes in course of East Fork Moose River, SE of Afonasi Lake, $27 \mathrm{mi}$. SW of Kenai, Cook Inlet Low.; 60 $32^{\prime} 45^{\prime \prime} \mathrm{N}$, $150^{\circ} 28^{\prime} 45^{\prime \prime} \mathrm{W}$; (map 62).

Named about 1963 by officials of Kenai National Moose Range, for administrative purposes.

Imexsaan: lake, see Emaiksoun Lake.

Imhoff Lake: lake, see Talbot Lake.

Imiak: locality, at the SE end of Aleknagik Lake near Dillingham, Kilbuck-Kuskokwim Mts.; (map 52). Var. Seleniye Imyak.

Former Eskimo village reported as "Sel[eniye] Imyak" meaning "Imyak Village," by Capt. Tebenkov (1852, map 4), IRN.
Imiaknikpak Lake: lake, $1.5 \mathrm{mi}$. across, in Killik' River valley, $17 \mathrm{mi}$. NE of Kurupa Lake, Brooks Ra.; $68^{\circ} 29^{\prime} \mathrm{N}, 154^{\circ} 03^{\prime} \mathrm{W}$; (map 133). Var. Scotty Lake.

Eskimo name meaning "big dry lake," obtained in 1956 at Anaktuvuk Pass by Orth. A 1924 fieldsheet by Gerald FitzGerald, USGS, shows "Scotty Lake," probably for George "Scotty" Clark, one of expedition's packers.

Imigrook Lagoon: lagoon, see Imikruk Lagoon. Imigrook River: stream, see Imikruk Creek.

Imigruk Creek: stream, see Imikruk Creek. Imigruk Lagoon: lagoon, see Imikruk Lagoon. Imik: locality, on Agattu I. in Near Is., Aleutian Is. ; (map 13).

Former Aleut village reported as "uninhabited" by Hodge (1907, p. 600), BAE.

Imik Lagoon: lagoon, $2 \mathrm{mi}$. long, on the Chukchi Sea coast, $25 \mathrm{mi}$. N of Krusenstern, KotzebueKobuk Low.; $67^{\circ} 29^{\prime} \mathrm{N}, 163^{\circ} 56^{\prime} \mathrm{W}$; (map 128).

Eskimo name meaning "freshwater" reported in 1962

Imikneyak Creek: stream, in DeLong Mts., flows SW $18 \mathrm{mi}$, to Kaluktavik River, $14 \mathrm{mi}$. SE of Misheguk Mtn, Brooks Ra.; $68^{\circ} 04^{\prime} \mathrm{N}, 160^{\circ} 47^{\prime}$ W; (map 131).

Eskimo name meaning "has no water," obtained at Noatak by Orth in 1956.

Imikneyak Mountains: mountains, 3,747 ft., extend NE-SW 15 mi., in DeLong Mts., between Imikneyak Creek and Kaluktavik River, 13 mi. SE of Misheguk Mtn., Brooks Ra.; $68^{\circ} 11^{\prime}$ $\mathrm{N}, 160^{\circ} 30^{\prime} \mathrm{W}$; (map 131).

Named by USGS in 1958 for the adjacent stream.

Imikpak Lake: lake, see Imikpuk Lake.

Imikpaneraluk: lagoon, see North Salt Lagoon. Imikpok: lake, see Imikpuk Lake.

Imikpuk Lake: lake, $0.7 \mathrm{mi}$. long, on Chukchi Sea coast, $3.5 \mathrm{mi}$. NE of Barrow, Arctic Plain ; $71^{\circ} 19^{\prime} 45^{\prime \prime} \mathrm{N}, 156^{\circ} 39^{\prime} 00^{\prime \prime} \mathrm{W} ;$ BGN 1966; (map 153). Var. Amikpak Lake, Emikpuk Lake, Emukpun, Imeakpun, Imikpok, Imukpung.

Eskimo name [Imikpak] meaning "big [fresh] water [lake]" originally published by Lt. Ray ( 1885 , p. 55 ), USA, as recorded in 1882 by Sgt. John Murdoch, naturalist.

Imikrak Creek: stream, flows SW $0.5 \mathrm{mi}$. to Chukchi Sea, $2.7 \mathrm{mi}$. SE of Cape Thompson, Arctic Slope; $68^{\circ} 07^{\prime} 10^{\prime \prime} \mathrm{N}, 165^{\circ} 53^{\prime} 55^{\prime \prime} \mathrm{W}$; $B G N$ 1963; (map 129). Var. Emmikroak Creek.

Eskimo name reported in 1950 by USC\&GS to mean "warm water" and spelled "Em-mikroak." The stream is reported not to freeze in winter, probably due to Cliff Spring near its mouth.

Imikruk Creek: stream, heads in a lake, and flows SW $15 \mathrm{mi}$. to Imikruk Lagoon, $7 \mathrm{mi}$. SE of Kivalina, Kotzubue-Kobuk Low.; $67^{\circ} 42^{\prime}$ $\mathrm{N}, 164^{\circ} 18^{\prime} \mathrm{W}$; (map 128). Var. Imigrook River, Imigruk Creek.

Reported in 1966 by E. S. Burch; name means "fresh water."

Imikruk Lagoon: lagoon, $6 \mathrm{mi}$. long, on Chukchi Sea coast, $4 \mathrm{mi}$. SE of Kivalina, Kotzebue-
Kobuk Low.; $67^{\circ} 40^{\prime}$ N, $164^{\circ} 20^{\prime}$ W; (map 128. Var. Imigrook Lagoon, Imigruk Lagoon.

Eskimo name for "fresh water" reported in 1966 by E. S. Burch.

Imnaaquq: bluff, see Imnakuk Bluff.

Imnaaquq Kuugauzanga: stream, see Imnakuk Creek.

Imnahkook: bluff, see Imnakuk Bluff.

Imnahkook Koogawranga: stream, see Imnakuk Creek.

Imnaitchiak Creek: stream, heads at glacier terminus, flows $\mathrm{N} 18 \mathrm{mi}$. to Oolamnagavik River, $10 \mathrm{mi}$. NE of Kurupa Lake, Brooks Ra.; $68^{\circ} 31^{\prime} \mathrm{N}, 154^{\circ} 29^{\prime} \mathrm{W}$; (map 133 ).

Eskimo name meaning "young [Dall] sheep," reported in 1956 by Orth.

Imnak Bluff: bluff, on left bank of Wulik River, at mouth of Ikalukrok River, $30 \mathrm{mi}$. NE of Kivalina, Arctic Slope; $67^{\circ} 53^{\prime} \mathrm{N}, 163^{\circ} 38^{\prime}$ W; (map 128). Var. Imnaq.

Eskimo name meaning "cliff" reported in 1966 by E. S. Burch.

Imnakpak Cliff: cliff, $600 \mathrm{ft}$., on Chukchi Sea coast, NW of Cape Thompson, Arctic Slope; $68^{\circ} 09^{\prime} \mathrm{N}, 165^{\circ} 59^{\prime} \mathrm{W}$; BGN 1963; (map 129). Var. Imnatpuk Cliff, Unukpay Cliff.

Eskimo name meaning "big cliff" reported about 1962 by W. O. Pruitt, Univ. of Alaska.

Imnakuk Bluff: bluff, extends W $4 \mathrm{mi}$. to Imnakuk Creek, on $\mathrm{N}$ side of Kivalina River, $6 \mathrm{mi}$. $\mathrm{N}$ of Kivalina, Kotzebue-Kobuk Low.; $67^{\circ}$ $48^{\prime} \mathrm{N}, 164^{\circ} 35^{\prime} \mathrm{W}$; (map 128). Var. Imnaaquq. Imnahkook.

Eskimo name reported in 1966 by E. S Burch.

Imnakuk Creek: stream, flows SW $4 \mathrm{mi}$. to Kivalina Lagoon, 8 mi. NW of Kivalina, Kotzebue-Kobuk Low.; $67^{\circ} 49^{\prime} \mathrm{N}, 164^{\circ} 40^{\prime} \mathrm{W}$; (map 128). Var. Imnaaquq Kuugauzanga, Imnahkook Koogawranga.

Eskimo name reported in 1966 by E. S. Burch.

Imnaq : bluff, see Imnak Bluff.

Imnatchiak Bluff: bluff, $200 \mathrm{ft}$., on $\mathrm{W}$ bank of Killik River $9 \mathrm{mi}$. SW of its junc. with Okokmilaga River, Brooks Ra.; $68^{\circ} 42^{\prime} \mathrm{N}, 153^{\circ} 40^{\prime}$ W; (map 133)

Eskimo name recorded by Orth in 1956, at Anaktuvuk Pass, as "Imnaitchiak," meaning "young [Dall] sheep."

Imnatpuk Cliff: cliff, see Imnakpak Cliff.

Imnauralik Clif: cliff, $10 \mathrm{mi}$. $\mathrm{N}$ of Kivalina Arctic Slope; $67^{\circ} 52^{\prime} \mathrm{N}, 164^{\circ} 38^{\prime} \mathrm{W}$; (map 128). Var. Imnauzalik, Imnowralick.

Eskimo name meaning "place of the little cliff" reported in 1966 by E. S. Burch.

Imnauzalik: cliff, see Imnauralik Cliff.

Imnavait Mountain: mountain, $3,680 \mathrm{ft}$., on $\mathrm{N}$ slope of Endicott Mts., between Kuparuk and Toolik Rivers, Arctic Slope ; $68^{\circ} 46^{\prime}$ N, $149^{\circ} 24^{\prime}$ W; (map 135).

Eskimo name reported in 1956 by USGS. Imnowralick: cliff, see Imnauralik Cliff. Imnuchuk River: stream, see Inmachuk River. Imokhtagokshuk: locality, see Imokhtegokshuk. Imokhtegokshuk: locality, on $\mathrm{N}$ coast of Norton Sound, $1 \mathrm{mi}$. NE of Cape Nome, Seward 
Penin. High.; $64^{\circ} 27^{\prime}$ N, $164^{\circ} 58^{\prime} \mathrm{W}$; (map 95). Var. Imokhtagokshuk.

Site of an Eskimo village shown as above by Ivan Petroff in the 1880 U.S. Census; listed in Petroff's text (p. 11) as "Imokhtagokshuk" with a population of 30 .

Imouroak: lake, see Imuruk Basin.

Imourouk Lake: lake, see Imuruk Lake. Imov-iack, Baie: bight, see Imuya Bay. Imoviao, Baie: bight, see Imuya Bay.

Impaghuk Point: spit, extends $\mathrm{N}$ into Koozata Lagoon from its barrier reef, $36 \mathrm{mi}$. SE of Gambell, Saint Lawrence I.; $63^{\circ} 25^{\prime} \mathrm{N}, 170^{\circ}$. 55' W; BGN 1951; (map 93).

Eskimo name recommended by the Savoonga village council; reported in 1949 by Maj. H. B. Allen, USAF.

Impassible Island: island, $0.2 \mathrm{mi}$. long, in Necker Is. S of Biorka I, $18 \mathrm{mi}$. SW of Sitka, Alex Arch.; $56^{\circ} 49^{\prime} 55^{\prime \prime} \mathrm{N}, 135^{\circ} 32^{\prime} 25^{\prime \prime} \mathrm{W}$; (map 5). Var. Neprop Island, Nepropusknoi Island, Ostrov Nepropusknoy.

This is a translation by USC\&GS of the name given in 1809 by the navigator Ivan Vasiliev the first, IRN. Lt. Sarichev (1826, map 19), IRN, published it as "O[strov] Nepropusknoy."

Imperial Passage: water passage, $1.5 \mathrm{mi}$. long, between Hill and Hogan Is., $7.5 \mathrm{mi}$. NW of Chichagof, on W coast of Chichagof I., Alex. Arch.; 57 $43^{\prime} 30^{\prime \prime} \mathrm{N}, 136^{\circ} 16^{\prime} 00^{\prime \prime} \mathrm{W}$; (map 9).

Local name published in 1910 by USC\&GS on Chart 8250.

Impnipuk River: stream, see Inmachuk River.

Impregnable Basin: valley, $0.5 \mathrm{mi}$. long, at head of Grant Creek on Douglas I., $1.5 \mathrm{mi}$. W of Juneau, Coast Mts. ; $58^{\circ} 18^{\prime} 00^{\prime \prime} \mathrm{N}, 134^{\circ} 27^{\prime} 30^{\prime \prime}$ W; (map 11).

Miners' name mentioned by DeArmond (1957, p. 23).

Imtelleiden: locality, see Intenleiden.

Imughialuk: locality, see Booshu Camp.

Imukpung: lake, see Imikpuk Lake.

Imukpunningmu: lagoon, see North Salt Lagoon.

Imukruk: lake, see Imuruk Basin.

Imurook: lake, see Imuruk Basin.

Imuruk Basin: lake, $17 \mathrm{mi}$. long, $20 \mathrm{mi}$. SE of Teller, Seward Penin. High.; $65^{\circ} 07^{\prime}$ N, $165^{\circ} 45^{\prime}$ W; (map 111). Var. Cowvinik Lake, Imagazuk, Imaourouk, Imaurook, Imau-ruk, Imoou-rouk, Imourook, Imourouk, Imukruk, Imurook, Irr-maghe-zuk, Salt Lake.

Eskimo name reported in 1826 by Capt. Beechey (1831, p. 291), RN, as "Imau-rook"; published in 1852 as "Imau-ruk" on Russian Hydrog. Dept. Chart 1455.

Imuruk Lake: lake, $8 \mathrm{mi}$. long and $5 \mathrm{mi}$. wide, $37 \mathrm{mi}$. NE of Mount Bendeleben, Seward Penin. High.; $65^{\circ} 36^{\prime} \mathrm{N}, 163^{\circ} 13^{\prime} \mathrm{W}$; $B G N$ 1952; (map 110). Var. Emuruk Lake, Imourouk Lake.

Eskimo name reported in 1901 as "Emuruk" by Mendenhall (1902, pl. 4), USGS.

Imuya Bay: bight, $4 \mathrm{mi}$. across, $4 \mathrm{mi}$. $\mathrm{S}$ of Cape Kayakliut, on SE coast of Alaska Penin., $43 \mathrm{mi}$. SE of Ugashik, Aleutian Ra.; $57^{\circ} 14^{\prime} \mathrm{N}, 156^{\circ} 20^{\prime} \mathrm{W}_{\mathrm{i}}(\operatorname{map} 36)$. Var. Baie Imoviao, Baie Imov-iat:

Eskimo name publishe in 1835 as "B[aie] Imoviao" and "B[aie] Imov-iack" by Adm. A. J. von Krusenstern, IRN.

Inaccessible Ridge: ridge, 4,000 ft., extends SWNE $7 \mathrm{mi}$., in De Long Mts., $24 \mathrm{mi}$. NW of Misheguk Mtn., Brooks Ra.; 68 $30^{\prime} \mathrm{N}$, $161^{\circ} 40^{\prime}$ W; BGN 1966; (map 131).

So called by the B. P. Exploration Company in 1965 because it consists of "A well developed hog's-back ridge which is generally difficult to climb."

Ina Gulch: ravine, trends NE $1 \mathrm{mi}$. to Slate Creek, $50 \mathrm{mi}$. SW of Eagle, Yukon-Tanana High.; $64^{\circ} 34^{\prime} \mathrm{N}, 142^{\circ} 40^{\prime}$ W; (map 102). Var. Presno Creek.

Prospectors' name obtained in 1905 by $\mathbf{D}$. C. Witherspoon, USGS.

Ina Island: island, $0.2 \mathrm{mi}$. long, on $\mathrm{N}$ shore of Expedition Harbor, Bay of Is., Adak I., Aleutian Is. ; $51^{\circ} 48^{\prime} 00^{\prime \prime} \mathrm{N}, 176^{\circ} 45^{\prime} 10^{\prime \prime} \mathrm{W}$; $B G N$ 1936; (map 17).

Named by members of the U.S. Navy Aleutian Island Survey Expedition in 1933 for the survey signal Ina.

Inakpuk: locality, on right bank of Nushagak River, $16 \mathrm{mi}$. NE of Ekwok and $60 \mathrm{mi}$. NE of Dillingham, Bristol Bay Low.; 59 $32^{\prime} \mathrm{N}$, $157^{\circ} 09^{\prime}$ W; BGN 1931; (map 52). Var. Inakpuk Village, Pitmik, Pit-mik-ha-mut.

Former Eskimo camp or village shown as "Pit-mik-ha-mut," meaning "Pitmik people," on a 1910 manuscript map by H. C. Fassett, USBF. The name "Inakpuk" was obtained in 1930 from F. H. Waskey and Beverley Polley, local inhabitants, by Gerald FitzGerald, USGS, and was published by Mertie (1938b, pl. 1), USGS.

Inakpuk Village: locality, see Inakpuk.

Inaktuli River: stream, see Inglutalik River.

Inalak: island, off coast of Unalaska I., Aleutian Is.; (map 23).

Aleut name published by Berg (1823, p. 59). Baker (1906, p. 324) says "that the island was not identified, perhaps [it is] Unalga." .The name does not appear on modern maps.

Inalik: locality, see Ignaluk.

Inalit: locality, see Ignaluk.

Inanudak Bay: bay, $2 \mathrm{mi}$. across, on $\mathrm{W}$ central coast of Umnak I., Aleutian Is.; $53^{\circ} 18^{\prime} \mathrm{N}$, $168^{\circ} 25^{\prime} \mathrm{W}$; (map 22). Var. Stepanow Bay.

Aleut name reported in 1840 by Father Ioann Veniaminov (Baker, 1906, p. 324).

Inaru River: stream, heads in Lake Itinik, at $70^{\circ} 39^{\prime} \mathrm{N}, 158^{\circ} 30^{\prime} \mathrm{W}$, flows NE $85 \mathrm{mi}$. to Kuyanak Bay, in Meade River Delta, 32 mi. SE of Barrow, Arctic Plain; $70^{\circ} 54^{\prime} \mathrm{N}$, $155^{\circ} 59^{\prime} \mathrm{W}$; (map 148). Var. Iuaru River, Kuahroo River, Kuahu River, Kuaru River.

Eskimo name reported by Capt. Ray (1885, p. 27), USA, who on March 4, 1883, wrote "we struck a stream about thirty yards wide, *** Natives gave it the name of Iuaru." Ray, however, is inconsistent, citing the name as "Kuaru, first large river east of Point Barrow" (p. 55), but spelling the name
"Kauhroo" on his map. Baker (1906, p. 324) spelled the name "Inaru," probably a misspelling of the name as reported by Ray. The name as published by Baker, however, is present-day map usage. The present-day Eskimo name for this stream is "Kugaarug" (R. F. Spencer, 1959, map 2), which is probably the same that Ray originally attempted to record.

Inayarak River: stream, see Eenayarak River.

Incarnation, Point: point of land, $\mathrm{N}$ tip of an island, at mouth of Steamboat Bay, NE coast of Noyes I., Alex. Arch.; $55^{\circ} 33^{\prime} 20^{\prime \prime} \mathrm{N}$, 133'37'15' W; BGN 1923; (map 4). Var. Punta de Jesus Maria.

The Spanish name "Punta de Jesus Maria" was given to this feature in 1775 by Don Juan de la Bodega y Quadra and Francisco Antonio Maurelle; changed to "Incarnation Point" in June 1922 by USC\&GS, to avoid names implying irreverence. Wagner (1937, p. 464) applies the Spanish name to Cape Ulitka, on the northwest coast of Noyes Island.

Inclined Mountain: mountain, 6,700 ft., between Barrenland Creek and North Fork Koyukuk River, $31 \mathrm{mi}$. SE of Anaktuvuk Pass, Brooks Ra.; $68^{\circ} 01^{\prime} \mathrm{N}, 150^{\circ} 35^{\prime} \mathrm{W}$; BGN 1932; (map 134).

Named in 1932 by Marshall (1956, p. 50) who said, "across the canyon appeared massive Inclined Mountain, with its dark, tilted strata."

Indecision Creek: stream, flows NW $11 \mathrm{mi}$. to Mother Goose Lake, on Alaska Penin., $24 \mathrm{mi}$. SE of Ugashik, Aleutian Ra.; $57^{\circ} 12^{\prime} \mathrm{N}, 157^{\circ}$ 14' W; (map 36).

Descriptive name given in 1923 by R. H. Sargent "because of its several outlets."

Independence Creek: stream, heads in glacier, flows $E$ and S $3.5 \mathrm{mi}$. to Icy Bay, $6 \mathrm{mi}$. NE of Claybluff Point and $67 \mathrm{mi}$. NW of Yakutat, St. Elias Mts. ; $60^{\circ} 00^{\prime} 55^{\prime \prime} \mathrm{N}, 141^{\circ} 24^{\prime} 30^{\prime \prime} \mathrm{W}$; (map 65).

Local name published in 1951 by USGS.

Independence Creek: stream, flows $\mathrm{N} 10 \mathrm{mi}$. to Innoko River, $8 \mathrm{mi}$. SE of Ophir and $24 \mathrm{mi}$. NW of McGrath, Kilbuck-Kuskokwim Mts.; $63^{\circ} 04^{\prime} \mathrm{N}, 156^{\circ} 19^{\prime} \mathrm{W}$; BGN 1936; (map 90).

Prospectors' name obtained in 1933 by J. B. Mertie, Jr. (in Smith, P. S., 1936, pl. 4), USGS.

Independence Creek: stream, flows SW $14 \mathrm{mi}$., joins Slate Creek to form North Fork Fortymile River, $37 \mathrm{mi}$. SW of Eagle, YukonTanana High.; $64^{\circ} 38^{\prime} \mathrm{N}, 142^{\circ} 24^{\prime} \mathrm{W}$; (map 102).

Named by prospectors and reported in 1904 by D. C. Witherspoon, USGS.

Independence Creek: stream, flows SE $4 \mathrm{mi}$. to Sinuk River, $21 \mathrm{mi}$. NW of Nome, Seward Penin. High.; $64^{\circ} 42^{\prime} \mathrm{N}, 165^{\circ} 58^{\prime} \mathrm{W}$; (map 94).

Prospectors' name reported in 1900 by E. C. Barnard (in Brooks, 1901, pl. 17), USGS. Independence Creek: stream, flows NE $1 \mathrm{mi}$. to Eldorado Creek $2 \mathrm{mi}$. $\mathbf{S}$ of its junc. with Telegram Creek, at head of Dome Creek, 21 
mi. NW of Solomon, Seward Penin. High.; $64^{\circ} 51^{\prime} \mathrm{N}, 164^{\circ} 39^{\prime} \mathrm{W}$; (map 95).

Prospectors' name reported on a map of Cape Neme gold fields by David Fox, Jr., dated 1901

Independence Creek: stream, flows N $1.5 \mathrm{mi}$. to Treasure Creek, $12 \mathrm{mi}$. N of Fairbanks, YukonTanana High.; $65^{\circ} 01^{\prime} 05^{\prime \prime} \mathrm{N}, 147^{\circ} 43^{\prime} 55^{\prime \prime} \mathrm{W}$; (map 105)

Named by prospectors; published in 1908 by USGS.

Independence Creek: stream, flows NE $1.4 \mathrm{mi}$. to Quartz Creek which flows to Kougarok Creek, $47 \mathrm{mi}$. SW of Imuruk Lake, Seward Penin. High.; $65^{\circ} 21^{\prime} \mathrm{N}, 164^{\circ} 42^{\prime} \mathrm{W}$; (map 110).

Prospectors' name reported in 1901 by T. G. Gerdine (in Collier, 1902, pl. 12), USGS.

Independence Creek: stream, flows $\mathrm{N} 5 \mathrm{mi}$, join Mastodon Creek to form Mammoth Creek, $40 \mathrm{mi}$. SW of Circle, Yukon-Tanana High.; $65^{\circ} 30^{\prime} 25^{\prime \prime} \mathrm{N}, 145^{\circ} 13^{\prime} 45^{\prime \prime} \mathrm{W}$; (map 104)

Named in 1894 by prospectors; reported in 1896 by USGS (Spurr, 1898, pl. 50)

Independence Creek: stream, flows NW $12 \mathrm{mi}$ to Holtz Creek which flows to Kugruk River, $20 \mathrm{mi}$. E of Imuruk Lake, Seward Penin. High.; $65^{\circ} 38^{\prime} \mathrm{N}, 162^{\circ} 29^{\prime} \mathrm{W}$; (map 110).

Prospectors' name reported in 1901 by $D$. L. Reaburn (in Mendenhall, 1902, pl. 4a), USGS.

Independence Gulch: ravine, trends N $2.5 \mathrm{mi}$. to Fourth of July Creek, $4 \mathrm{mi}$. SW of that 3tream's junc. with Yukon River and 32 mi. NW of Eagle, Yukon-Tanana High. $65^{\circ} 08^{\prime} 30^{\prime \prime} \mathrm{N}, 141^{\circ} 53^{\prime} 00^{\prime \prime} \mathrm{W}$; (map 103).

Local name published in 1956 by USGS.

Independence Island: island, $250 \mathrm{ft}$. long, in Steamer Bay, off $\mathrm{W}$ coast of Etolin I., Alex. Arch.; $56^{\circ} 09^{\prime} 10^{\prime \prime} \mathrm{N}, 132^{\circ} 40^{\prime} 30^{\prime \prime} \mathrm{W}$; (map 6).

Named in 1886 by Lt. Comdr, A. S. Snow, USN; published in 1887 on USC\&GS Chart 706.

Independence Lake: lake, $0.1 \mathrm{mi}$. across, $1.5 \mathrm{mi}$. $\mathrm{N}$ of Comet and $47 \mathrm{mi}$. NW of Juneau, Coast Mts.; $58^{\circ} 53^{\prime} 20^{\prime \prime} \mathrm{N}, 135^{\circ} 08^{\prime} 00^{\prime \prime} \mathrm{W}$; (map 11)

Prospectors' name reported in 1906 by $\mathbf{R}$. B. Oliver, USGS.

Independent Ridge: ridge, 4,000 ft., extends $N$ $11 \mathrm{mi}$., between Johnson and Little Gerstle Rivers, $35 \mathrm{mi}$. SE of Delta Junction, Alaska Ra.; $63^{\circ} 40^{\prime} 20^{\prime \prime} \mathrm{N}, 144^{\circ} 53^{\prime} 30^{\prime \prime} \mathrm{W}$; BGN 1937; (map 86)

Name shown on a 1927 manuscript map of the "Endicott and Haley Hunting Expedition"; so called because the ridge is nearly isolated from the Alaska Range.

Index Islet: island, see Guide Island.

Index Lake: lake, 3,500 ft. long, between Hicks Creek and Glenn Highway, $41 \mathrm{mi}$. NE of Palmer, Talkeetna Mts.; $61^{\circ} 48^{\prime} 20^{\prime \prime} \mathrm{N}, 1^{\circ} 7^{\circ}$. $57^{\prime} 20^{\prime \prime} \mathrm{W}$; (map 69).

Local name reported in 1913 by USGS.

Index Mountain: mountain, 5,411 ft., $15 \mathrm{mi}$. SW of Table Mtn. and $36 \mathrm{mi}$. NE of Arctic Vil lage, Brooks Ra. ; $68^{\circ} 15^{\prime} \mathrm{N}, 1^{\circ} 4^{\circ} 09^{\prime} \mathrm{W}$; (map 136).
Named and reported in 1926 by J. B. Mertie (in Smith, P. S., and others, 1929, pl. 1), USGS.

Indiada, Ostrov de la : island, see Indiada Island. Indiada Cove: cove, $0.5 \mathrm{mi}$. across, on $\mathrm{W}$ coast of Suemez I., at entrance to Port Santa Cruz, Alex. Arch.; $55^{\circ} 16^{\prime} 30^{\prime \prime} \mathrm{N}, 133^{\circ} 27^{\prime} 30^{\prime \prime} \mathrm{W}$; (map 4).

Named in 1923 by USC\&GS; derived from Indiada Island.

Indiada Island: island, $900 \mathrm{ft}$. long, in Indiada Cove on $\mathbf{W}$ coast of Suemez I., Alex. Arch.; $55^{\circ} 16^{\prime} 30^{\prime \prime} \mathrm{N}, 133^{\circ} 27^{\prime} 25^{\prime \prime}$ W; (map 4). Var. Isla Indiada, Isleta de la Indiada, Ostrov de la Indiada.

Spanish name given in 1779 by Don Juan de la Bodega y Quadra and Francisco Antonio Maurelle as "Isla Indiada," meaning "group-of-Indians island."

Indian: village, pop. 40 , mile 88.7 on The Alaska RR., on Seward Highway, on $\mathrm{N}$ side of Turnagain Arm, $7 \mathrm{mi}$. NW of Sunrise, Chugach Mts.; 60 $59^{\prime} 15^{\prime \prime} \mathrm{N}, 149^{\circ} 30^{\prime} 45^{\prime \prime} \mathrm{W}$; (map 63). Var. Bird Creek, Bird Settlement, New Portage.

Listed as a flag stop on the time tables of The Alaska RR. of 1922. Name derived from nearby Indian Creek. It had a population of 19 in 1958

Indian Arkipelagan: islands, see Alexander Archipelago.

Indian Bay: bay, see Summer Bay.

Indian Camp Creek: stream, heads in Latouche Glacier, flows $\mathrm{N} 2 \mathrm{mi}$. to Disenchantment Bay, $0.8 \mathrm{mi}$. E of Point Latouche and $25 \mathrm{mi}$. $\mathrm{NE}$ of Yakutat, St. Elias Mts.; $59^{\circ} 54^{\prime} 20^{\prime \prime} \mathrm{N}$, $139^{\circ} 36^{\prime} 15^{\prime \prime} \mathrm{W}$; (map 46).

Local name published in 1959 by USGS.

Indian Cove: cove, $0.3 \mathrm{mi}$. across, in Auke Bay, $\mathrm{S}$ of Fairhaven and $11 \mathrm{mi}$. NW of Juneau, Coast Mts.; 58 $22^{\prime} 20^{\prime \prime}$ N., $134^{\circ} 41^{\prime} 45^{\prime \prime}$ W; (map 11)

Local name published by USGS in 1962.

Indian Cove: estuary, see Soapstone Cove.

Indian Creek: stream, on Prince of Wales I., flows NE $5.5 \mathrm{mi}$. to Harris River Bay, $17 \mathrm{mi}$. E of Craig, Alex. Arch.; 55 $27^{\prime} 30^{\prime \prime} \mathrm{N}, 132^{\circ}$. $41^{\prime} 30^{\prime \prime} \mathrm{W}$; (map 4$)$.

Name published in 1920 by USC\&GS

Indian Creek: stream, on mainland, heads at a glacier, flows SW $4 \mathrm{mi}$. to Chickamin River $9 \mathrm{mi}$. NE of its junc. with its South Fork, Coast Mts.; $55^{\circ} 59^{\prime 25^{\prime \prime}}$ N, $130^{\circ} 39^{\prime} 20^{\prime \prime}$ W; (map 3$)$.

Local name recorded in the 1950's by USGS.

Indian Creek: stream, flows N $1.5 \mathrm{mi}$, to Whale Passage, on NE coast of Prince of Wales I., Alex. Arch.; $56^{\circ} 02^{\prime} \mathrm{N}, 132^{\circ} 58^{\prime} \mathrm{W} ; B G N$ 1915; (map 6)

Named in 1914 by E. Lester Jones, USBF

Indian Creek: stream, on Kenai Penin., heads at Indian Glacier terminus in Kenai Mts., flows W $13 \mathrm{mi}$. to Tustumena Lake, $38 \mathrm{mi}$. SE of Kenai, Chugach Mts.; $60^{\circ} 07^{\prime} \mathrm{N}, 150^{\circ} 37^{\prime} \mathrm{W}$; (map 62). Var. Indian River.

Local name reported in 1904 by Moffit and Stone (1906, pl. 2), USGS.
Indian Creek: stream, flows SW $3.5 \mathrm{mi}$. to Galena Bay, $42 \mathrm{mi}$. NW of Cordova, Chugach Mts.; $60^{\circ} 57^{\prime} 20^{\prime \prime} \mathrm{N}, 146^{\circ} 37^{\prime} 45^{\prime \prime} \mathrm{W}$; (map 64).

Local name published in 1915 by USGS; derived from.Indian River, village.

Indian Creek: stream, heads at Indian Creek Pass, flows S $7 \mathrm{mi}$. to Turnagain Arm, 6.5

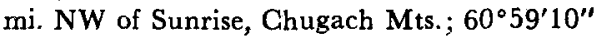
$\mathrm{N}, 149^{\circ} 30^{\prime} 00^{\prime \prime} \mathrm{W}$; (map 63).

Name used by local prospectors; reported in 1898 by Capt. Glenn (Glenn and Abercrombie, 1899, map), USA.

Indian Creek: stream, heads in Second Lake, flows SE $1.4 \mathrm{mi}$. to Cook Inlet, $\mathrm{S}$ of Tyonek, Cook Inlet Low.; 61 $01^{\circ} 45^{\prime \prime} \mathrm{N}, 151^{\circ} 08^{\prime} 25^{\prime \prime}$ W; BGN 1916; (map 70). Var. Shorty Creek, Shortys Creek.

Local name reported in 1916 by USGS.

Indian Creek: stream, flows SE $8.5 \mathrm{mi}$. to Happy River, $1 \mathrm{mi}$. NE of Rainy Pass Lodge, $85 \mathrm{mi}$. SW of Talkeetna, Alaska Ra.; $62^{\circ} 01^{\prime} \mathbf{N}$, $152^{\circ} 43^{\prime} \mathrm{W}$; (map 81)

Local name reported in 1958 by USGS.

Indian Creek: stream, flows S $22 \mathrm{mi}$. to Copper River, $9 \mathrm{mi}$. NE of Chistochina, Copper River Basin; 62 $39^{\prime} \mathrm{N}, 144^{\circ} 26^{\prime} \mathrm{W}$; (map 83). Var. Indian River, Tetelna.

Name used by prospectors and reported in 1903 by F. C. Schrader, USGS, who also noted the Indian name "Tetelna."

Indian Creek: stream, flows SW $5 \mathrm{mi}$. to Tanana River, $6 \mathrm{mi}$. NE of Big Delta, Yukon-Tanana High.; $64^{\circ} 11^{\prime} \mathrm{N}, 145^{\circ} 42^{\prime} \mathrm{W}$; (map 101).

Local name reported in 1908 by J. W. Bagley, USGS

Indian Creek: stream, flows $\mathrm{S} 7 \mathrm{mi}$. to Goodpaster River, $36 \mathrm{mi}$. NE of Big Delta, YukonTanana High.; 64 $29^{\circ} \mathrm{N}, 144^{\circ} 56^{\prime} \mathrm{W}$; (map 101).

Named by prospectors and reported in 1903 by T. G. Gerdine (in Prindle, 1913a, pl. 16), USGS.

Indian Creek: stream, flows S $4 \mathrm{mi}$. to $\mathbf{S}$ end of Chandalar Lake, $5.5 \mathrm{mi}$. SW of Chandalar, Brooks Ra.; $67^{\circ} 28^{\prime} \mathrm{N}, 148^{\circ} 41^{\prime} \mathrm{W}$; (map 123).

Local name reported in 1956 by $T$. $E$. Taylor, USGS

Indian Creek: stream, flows $\mathbf{S}$ to Moonlight Creek which flows to Anikovik River, about $16 \mathrm{mi}$. E of Cape Prince of Wales, Seward Penin. High.; (map 111).

Prospectors' name shown on the 1900 "Map of Nome Peninsula" by J. M. Davidson and B. D. Blakeslee. This feature cannot be precisely identified on current maps.

Indian Creek: stream, see Big Indian Creek.

Indian Creek: stream, see East Fork Indian Creek.

Indian Creek : stream, see Indian River

Indian Creek: stream, see Long River.

Indian Creek Pass: pass, 2,600 ft., at head of Indian Creek, $7 \mathrm{mi}$. SE of Anchorage, Chugach Mts.; 61 $04^{\prime} \mathrm{N}, 149^{\circ} 29^{\prime} \mathrm{W}$; (map 69).

Local name reported in 1960 by USGS.

Indian Creek Rapids: rapids, $0.3 \mathrm{mi}$. long, on Indian Creek, between $\mathbf{W}$ coast of Stevenson 
and NE coast of Prince of Wales Is., Alex. Arch.; $56^{\circ} 02^{\prime} \mathrm{N}, 133^{\circ} 58^{\prime} \mathrm{W}$; BGN 1915; (map 6).

Named in 1914 by E. Lester Jones, USBF Indian Glacier: glacier, on Kenai Penin., in Kenai Mts., trends NW $4.5 \mathrm{mi}$. from Harding Ice Field to the glacier's 1951 terminus at head of Indian Creek, $44 \mathrm{mi}$. SE of Kenai, Chugach Mts. ; $60^{\circ} 08^{\prime} 30^{\prime \prime} \mathrm{N}, 150^{\circ} 18^{\prime} 30^{\prime \prime} \mathrm{W}$; (map 62). Local name reported in 1951 by USGS.

Indian Grave Creek: stream, heads in Canada, flows NW across Alaska-Canada boundary 13 mi. to Kandik River, $37 \mathrm{mi}$. ENE of that stream's junc. with Yukon River, Porcupine Plat.; $65^{\circ} 37^{\prime} 15^{\prime \prime} \mathrm{N}, 141^{\circ} 23^{\prime} 00^{\prime \prime} \mathrm{W}$; (map 103).

Local name published in 1956 by USGS; named for Indian Grave Mountain.

Indian Grave Mountain: mountain, 4,385 ft., W of Alaska-Canada boundary, $55 \mathrm{mi}$. N of Eagle, Porcupine Plat.; $65^{\circ} 35^{\prime} \mathrm{N}, 141^{\circ} 01^{\prime} \mathrm{W}$; $B G N 1912$; (map 103).

Local name reported in 1910 by IBC survey.

Indian Head: point of land, on $\mathrm{W}$ shore of Belkofski Bay, $22 \mathrm{mi}$. SE of village of Cold Bay, at SW end of Alaska Penin., Aleutian Ra.; $55^{\circ} 05^{\prime} \mathrm{N}, 162^{\circ} 12^{\prime} \mathrm{W}$; (map 29)

Descriptive name published in 1926 by USC\&GS.

Indian Hill: mountain, see Larry Hill.

Indianhouse Mountain: mountain, $4,300 \mathrm{ft}$., between Falls and Indian Creeks, $18 \mathrm{mi}$. SE of Anchorage, Chugach Mts.; $61^{\circ} 00^{\prime} 30^{\prime \prime} \mathrm{N}$, 149 32'30" W ; BGN 1964; (map 69).

Named in 1963 by members of the Mountaineering Club of Alaska for "Indianhouse Roadhouse," once located nearby but now abandoned.

Indianischen Archipel: islands, see Alexander Archipelago.

Indian Island: island, $0.1 \mathrm{mi}$. across, at $\mathrm{W}$ end of Auke Bay, $0.4 \mathrm{mi}$. S of Fairhaven and 11 mi. NW of Juneau, Coast Mts.; $58^{\circ} 22^{\prime} 15^{\prime \prime}$ $\mathrm{N}, 134^{\circ} 42^{\prime} 00^{\prime \prime} \mathrm{W}$; (map 11).

Local name published in 1962 by USGS Indian Island: island, see Pyramid Island.

Indian Lake: lake, $2.4 \mathrm{mi}$. long, on Long River, $30 \mathrm{mi}$. SE of Juneau, Coast Mts. : $58^{\circ} 11^{\prime} 20^{\prime \prime}$ N, $133^{\circ} 38^{\prime} 20^{\prime \prime}$ W; (map 12). Var. Speel Lake.

Name reported in 1916 by G. H. Canfield (in Brooks and others, 1918, p. 139), USGS This feature was shown as Speel Lake in 1923 on IBC sheet 7 (1951 Atlas)

Indian Mountain: mountain, 4,234 ft., in Indian Mts., $15 \mathrm{mi}$. E of Hughes, Kokrines-Hodzana High.; $66^{\circ} 04^{\prime} \mathrm{N}, 153^{\circ} 42^{\prime} \mathrm{W}$; (map 116).

Named for the Indian River. Local name published in 1956 by USGS. The Indian name "Batzatgla," meaning "obsidian hill," was reported in 1956 by Orth.

Indian Pass: pass, 3,400 ft., near head of Porcupine Creek, $10 \mathrm{mi}$. SW of Mentasta Pass, Alaska Ra.; 62 $50^{\prime} 00^{\prime \prime} \mathrm{N}, 143^{\circ} 54^{\prime} 30^{\prime \prime} \mathrm{W}$ (map 84).

Local name reported in 1949 by USGS.
Indian Pass Creek: stream, see Isom Creek.

Indian Pass Lake: lake, $0.9 \mathrm{mi}$. long, at Indian Pass, $8 \mathrm{mi}$. $\mathrm{N}$ of junc. of Copper and Slana Rivers, Alaska Ra.; $62^{\circ} 49^{\prime} \mathrm{N}, 143^{\circ} 57^{\prime} \mathrm{W}$; (map 84).

Local name reported in 1949 by USGS.

Indian Point: point of land, on SE shore of Kanaga Bay, Kanaga I., Aleutian Is.; $51^{\circ} 42^{\prime} 22^{\prime \prime} \mathrm{N}, 177^{\circ} 11^{\prime} 25^{\prime \prime} \mathrm{W}$; (map 17).

Name published in 1957 on an AMS map.

Indian Point: point of land, $\mathrm{N}$ point of entrance to Naha Bay, on W coast of Revillagigedo I., Alex. Arch.; $55^{\circ} 57^{\prime} \mathrm{N}, 131^{\circ} 42^{\prime} \mathrm{W}$; (map 3 ). Named in 1885 by Lt. Comdr. Richardson Clover, USN, because "there are Indian graves on the point."

Indian Point: point of land, on Kupreanof $\mathrm{I}$., extending into Duncan Canal, $12 \mathrm{mi}$. SW of Petersburg, Alex. Arch.; 56 ${ }^{\circ} 45^{\prime}$ N, $133^{\circ} 15^{\prime}$ W; BGN 1933; (map 6)

Local name reported in 1933 by $R$. H. Sargent, USGS

Indian Point: point of land, on $\mathrm{S}$ end of Auke Cape in Auke Bay, $0.5 \mathrm{mi}$. SE of Fairhaven and $11 \mathrm{mi}$. NNW of Juneau, Coast Mts.; $58^{\circ}$ $22^{\prime} 20^{\prime \prime} \mathrm{N}, 134^{\circ} 41^{\prime} 30^{\prime \prime} \mathrm{W}$; BGN 1937; (map 11)

Local name reported by USGS in 1936 . Indian Point: point of land, see Green Point. Indian River: locality, "in SE Alaska."

Former summer camp of Sitka Indians listed with a population of 43 in the 1880 Census by Ivan Petroff.

Indian River: village, pop. 12, on Glenn Highway at Indian Creek, $10 \mathrm{mi}$. NE of Chisto china, Copper River Basin ; $62^{\circ} 40^{\prime} \mathrm{N}, 144^{\circ} 26^{\prime}$ W; (map 83).

Local name reported in 1952 by USGS. Indian River: stream, flows $S 5 \mathrm{mi}$. to Eastern Anchorage, $1 \mathrm{mi}$. SE of Sitka, on $W$ coast of Baranof I., Alex. Arch.; $57^{\circ} 02^{\prime} 45^{\prime \prime} \mathrm{N}, 135^{\circ}$. $18^{\prime} 30^{\prime \prime}$ W; (map 9). Var. Reka Koloshenka. Local name published by USC\&GS in $188^{2}$ Coast Pilot (p. 149). The Russians (Sarichev, 1826, map 19) called it "Reka Koloshenka" or "Koloshian River." Kolosh is the Russian name for the Tlingit Indians.

Indian River: stream, on $\mathbf{E}$ central Chichagof I.. flows SE $11 \mathrm{mi}$. to Tenakee Inlet, $1 \mathrm{mi}$. E of Tenakee Springs, Alex. Arch.; 57 $46^{\prime} 45^{\prime \prime} \mathrm{N}$, $135^{\circ} 11^{\prime} 00^{\prime \prime} \mathrm{W}$; (map 9).

Local name reported in 1951 by USGS.

Indian River: stream, heads at confluence of North and South Forks of Indian River, flows SW $4 \mathrm{mi}$. to Carter Bay at Carter, $18 \mathrm{mi}$. NW of Goodnews, Kilbuck-Kuskokwim Mts.; $59^{\circ} 17^{\prime} \mathrm{N}, 161^{\circ} 57^{\prime} \mathrm{W}$; (map 53). Var. Indian Creek.

Local name obtained in 1914 by USC\&GS reported in 1919 by G. L. Harrington (in Brooks and others, 1921, pl. 7), USGS, as "Indian Creek."

Indian River: stream, flows SW $21 \mathrm{mi}$. to Susitna River, $35 \mathrm{mi}$. NE of Talkeetna, Talkeetna Mts.; $62^{\circ} 47^{\prime} 15^{\prime \prime} \mathrm{N}, 149^{\circ} 39^{\prime} 15^{\prime \prime} \mathrm{W}$; (map 82).

Local name reported in 1951 by USGS.

Indian River: stream, heads in Indian Mts. and flows $53 \mathrm{mi}$. to Mathews Slough, E of Hug- gins I., $60 \mathrm{mi}$. NW of Gold Mtn., KokrinesHodzana High.; $65^{\circ} 52^{\prime} \mathrm{N}, 154^{\circ} 24^{\prime} \mathrm{W}$; (map 107).

Local name reported in 1913 by H. M. Eakin (1916, pl. 1), USGS.

Indian River: stream, see Indian Creek. Indian River: stream, see Itkillik River. Indian River: stream, see Nimiuktuk River. Indian River Valley: valley, extends $\mathrm{N}$ from Sitka $4 \mathrm{mi}$, along Indian River, on Baranof $I$., Alex. Arch.; $57^{\circ} 46^{\prime} 45^{\prime \prime} \mathrm{N}, 135^{\circ} 11^{\prime} 00^{\prime \prime} \mathrm{W}$; (map 9).

Name published by USC\&GS in 1883 Coast Pilot (p. 174)

Indian Rock: rock, off SE coast of Annette I. in Felice Strait, $2.2 \mathrm{mi}$. NE of Annette Point, Alex. Arch.; $55^{\circ} 01^{\prime} 55^{\prime \prime} \mathrm{N}, 131^{\circ} 00^{\prime} 20^{\prime \prime} \mathrm{W}$; (map 3).

Named in 1883 by Lt. Comdr. H. E. Nichols, USN.

Indian Rock: rock, in Security Bay, off $\mathbf{N}$ coast of Kuiu I., Alex. Arch.; 56 $50^{\circ} 35^{\prime \prime} \mathrm{N}, 134^{\circ}$. $20^{\prime} 40^{\prime \prime} \mathrm{W}$; (map 5 ).

Named in 1869 by Comdr. R. W. Meade, USN

Indian Rock: rock, in Chilkoot Inlet, $1.5 \mathrm{mi}$. E of Tanani Point and $13 \mathrm{mi}$. SW of Skagway, Coast Mts.; $59^{\circ} 16^{\prime} 55^{\prime \prime} \mathrm{N}, 135^{\circ} 23^{\prime} 55^{\prime \prime} \mathrm{W}$ (map 45)

Named by Lt. Comdr. H. E. Nichols, USN. Name was published by USC\&GS in the 1891 Coast Pilot (p. 203).

Indigo Lake: lake, $0.8 \mathrm{mi}$. across, $10 \mathrm{mi}$. SE of Sitka, on W coast of Baranof I., Alex. Arch.; $57^{\circ} 00^{\prime} 45^{\prime \prime} \mathrm{N}, 135^{\circ} 04^{\prime} 00^{\prime \prime} \mathrm{W}$; (map 9 ).

Local descriptive name reported in 1954 by R. N. DeArmond. So named because "The waters are reported to be an intense indigo blue color."

Indio, Punta del: point of land, "at the east end of what [Capt. Alessandro] Malaspina calls the 'Ensenada de Estremadura.' * * * A lone Indian came out from here in a canoe July 24, 1791" (Wagner, 1937, p. 463).

Indooli Mountain: hill, $885 \mathrm{ft} ., 11 \mathrm{mi}$. W of Roberts Mtn., $22 \mathrm{mi}$. NW of Cape Mendenhall, Nunivak 1.; $60^{\circ} 03^{\prime} \mathrm{N}, 166^{\circ} 34^{\prime} \mathrm{W}$; (map 57). Var. Indooly Butte, Induli Butte.

Eskimo name obtained in 1949 by USC\&GS. Indooly Butte: hill, sce Indooli Mountain. Induli Butte: hill, see Indooli Mountain. Indut: point of land, see Izhut, Cape.

Inerevuk Mountain: mountain, 3,440 ft., $4 \mathrm{mi}$ SE of Cosmos Mtn. and $9 \mathrm{mi}$. NE of Shungnak, Brooks Ra.; $67^{\circ} 00^{\prime} \mathrm{N}, 156^{\circ} 55^{\prime} \mathrm{W}$; (map 115)

Prospectors' name reported after 1940 by USGS.

Inerskin Bay: estuary, see Iniskin Bay.

Infante, Isla: island, see Chirik of Island.

Inferno Reef: reef, $0.5 \mathrm{mi}$. off $\mathrm{SW}$ coast of Tanaga I., Aleutian Is.; $51^{\circ} 40^{\prime} \mathrm{N}, 1^{178^{\circ} 07^{\prime}}$ W: (map 16).

Local name published on a 1954 USGS map.

Ingahamé: village, see Ingrihak.

Ingahameh: locality, see Akahamut.

Ingahameth: village, see Ingrihak. 
Ingahamiut: village, see Ingrihak.

Ingakslugwat Hills: hills, $620 \mathrm{ft}$., extend $16 \mathrm{mi}$., between Kgun Lake and Talik River, YukonKuskokwim Delta, $61^{\circ} 23^{\prime} \mathrm{N}, 164^{\circ} 01^{\prime} \mathrm{W}$; (map 74). Var. The Volcanoes.

Eskimo name reported in 1948 by USC\&GS. It is supposed to mean "little old small mountains." They are referred to as "The Volcanoes" by the "bush pilots," according to Orth, 1965 .

Ingaluat Creek: stream, flows NE $3.5 \mathrm{mi}$. to Colville River, $30 \mathrm{mi}$. NE of Umiat, Arctic Plain; $69^{\circ} 44^{\prime} \mathrm{N}, 151^{\circ} 30^{\prime} \mathrm{W}$; (map 141).

Eskimo name reported in 1956 by T. E. Taylor, USGS.

Ingamatsha: locality, see Chenega.

Ingechook Mountain: hill, see Inrichuck Hill. Ingechuk: locality, see Ingichuk.

Ingenstrem Rocks: rocks, SE of Semichi Is., Aleutian Is., $52^{\circ} 40^{\prime} \mathrm{N}, 174^{\circ} 29^{\prime} \mathrm{E}$; (map 13). Var. Ingenstern Rocks, Ingenstrom Rocks, Inghestrom Rocks, Kamni Ingenstrema.

Named by the Russians and published in 1848 as "Kamni Ingenstrema" meaning "Ingenstrem Rocks" on Russian Hydrog. Dept. Chart 1400; named for a pilot in the employ of the Russian American Company about $1829-30$. He is supposed to have visited the Andreanof Island group and spent two winters at Atka while correcting the existing hydrographic charts of this region.

Ingensterm Rocks: rocks, see Ingenstrem Rocks. Ingenstrema, Kamni: rocks, see Ingenstrem Rocks.

Ingenstrom Rocks: rocks, see Ingenstrem Rocks. Inger: locality, "on Nunivak I. in Bering Sea"; (map 55 or 57 ). Var. Ingar, Ingeramiut, Ingeramut, Ingrimiut.

Former Eskimo village reported as "Ingeramiut," meaning "mountain people," with a population of 35 in the 1890 Census.

Ingeramiut: locality, see Inger.

Ingeramiut: locality, see Ingrimiut.

Ingeramut: locality, see Inger.

Ingersol Lake: lake, see Lachbuna Lake.

Inghestrom Rocks: rocks, see Ingenstrem Rocks.

Ingichuk: locality, "in Yukon delta, YukonKuskokwim Delta." Var. Ingechuk, Inrechoa'meut.

Former Eskimo camp or settlement reported in 1878 by E. W. Nelson, U.S. Signal Service. Ivan Petroff listed a population of 8 for this locality in the 1880 Census.

Ingieguk: mountains, see Kuzilvak Mountains. Inglaliktalik River: stream, see Inglutalik River. Ingle Creek: stream, flows S $2 \mathrm{mi}$. to Mosquito Fork, $56 \mathrm{mi}$. SW of Eagle, Yukon-Tanana High.; $64^{\circ} 05^{\prime} \mathrm{N}, 142^{\circ} 02^{\prime} \mathrm{W}$; (map 102). Var. Eagle Creek.

Prospectors' name shown on a 1902 manu. script map by E. J. Chamberlain, U.S. Deputy Surveyor.

Inglestat, Point: promontory, see Bald Head.

Inglikhakh: island, see Karpa Island.

Ingloothloogramiut: locality, $0.5 \mathrm{mi}$. NW of Irwakyaruk Point, on $\mathrm{E}$ coast of Cape Mendenhall, Nunivak I.; $59^{\circ} 46^{\prime} 45^{\prime \prime} \mathrm{N}, 166^{\circ} 05^{\prime}$ - $30^{\prime \prime} \mathrm{W}$; (map 55). Var. Inglooth-lookamute, Kwigomiut.

Eskimo sealing camp reported in 1932 by USC\&GS.

Inglooth-lookamute: locality, see Ingloothloogramiut.

Inglucalik River: stream, see Inglutalik River.

Inglueakik River: stream, see Inglutalik River.

Inglutalik River: stream, heads at Traverse Peak, flows SW $80 \mathrm{mi}$. to Norton Bay, $10 \mathrm{mi}$. SE of Koyuk, Nulato Hills; $64^{\circ} 50^{\prime} \mathrm{N}, 160^{\circ} 54^{\prime} \mathrm{W}$; (map 96). Var. Inaktuli River, Inglucalik River, Inglueakik River, Inglaliktalik River.

Eskimo name reported in 1849 by Capt. M. D. Tebenkov, IRN, as "Inaktuli."

Ingolitit Cape: point of land, see Iwoonut Point.

Ingot Island: island, $5.5 \mathrm{mi}$. long, in Prince William Sound, between Knight and Eleanor Is., $22 \mathrm{mi}$. NE of Chenega, Chugach Mts.; $60^{\circ} 31^{\prime} \mathrm{N}, 147^{\circ} 38^{\prime} \mathrm{W}$; BGN 1908; (map 63).

Local name reported in 1908 by USC\&GS. Ingra: locality, see Inger.

Ingraham Bay: estuary, extends W $4 \mathrm{mi}$. from Clarence Strait, on SE coast of Prince of Wales I., Alex. Arch.; 54 58'30" N, 131 '58'$30^{\prime \prime} \mathrm{W}$; (map 2).

Named in 1879 by W. H. Dall, USC\&GS, for "Joseph Ingraham, master of the brig Hope, of Boston, 1791-92, whose unpublished hydrographic notes of this region were used in compiling the Coast Pilot of 1883."

Ingraham Creek: stream, flows W $0.9 \mathrm{mi}$. to Anvil Creek, $3 \mathrm{mi}$. NW of Nome, Seward Penin. High.; $64^{\circ} 32^{\prime} 14^{\prime \prime}$ N, $165^{\circ} 28^{\prime} 45^{\prime \prime}$ W: (map 94).

Prospectors' name reported on the 1903 Campion Mining and Trading Co. map by George M. Ashford.

Ingraham Lake: lake, see Talbot Lake.

Ingraham Point: point of land, $\mathrm{N}$ point of entrance to Ingraham Bay, on SE coast of Prince of Wales I., Alex. Arch.; 54 $59^{\prime} 00^{\prime \prime}$ N, $131^{\circ}$ $58^{\prime} 45^{\prime \prime} \mathrm{W}$; (map 2).

Local name derived from Ingraham Bay; reported in 1904 by H. C. Fassett, USBF.

Ingrakaghamiut: locality, see Ingrakaklak.

Ingrakak: locality, see Ingrakaklak.

Ingrakak: village, see Ingrihak.

Ingrakaklak: locality, on $\mathrm{W}$ coast of Tin Can Point, $13 \mathrm{mi}$. SW of Kwiguk, YukonKuskokwim Delta; $62^{\circ} 37^{\prime} \mathrm{N}, 164^{\circ} 48^{\prime} \mathrm{W}$; (map 77). Var. Ingrakaghamiut, Ingrakak.

Eskimo village reported in 1898 as "Ingrakaghamiut" by USC\&GS (Hodge, 1907, p. 609).

Ingrakaklakamiut : village, see Ingrihak.

Ingram Creek: stream, on $\mathrm{N}$ end of Kenai Penin., flows NE $8.5 \mathrm{mi}$. to Turnagain Arm, $14 \mathrm{mi}$. $\mathrm{SE}$ of Sunrise, Chugach Mts, ; $60^{\circ} 50^{\prime} 55^{\prime \prime} \mathrm{N}$, $149^{\circ} 03^{\prime} 15^{\prime \prime} \mathrm{W}$; BGN 1950; (map 63). Var. Quartz Creek

Named in 1950 by USFS for R. C. Ingram, who died in 1948, and "who was resident engineer for the Bureau of Public Roads in charge of practically all road work in the Chugach National Forest for about 25 years." Ingram Kwik: stream, see Mountain Creek. Ingram Lake: lake, see Talbot Lake.
Ingrēchōah Hill: hill, see Ingrichuak Hill

Ingregamiut: locality, on right bank of Yukon River, near upstream mouth of Tuckers Slough, $27 \mathrm{mi}$. NE of Russian Mission, YukonKuskokwim Delta; 61 $57^{\circ} \mathrm{N}, 160^{\circ} 34^{\prime} \mathrm{W}$; (map 73). Var. Mountain Village, Ruibnaia.

This is an old village site mentioned by Hrdlička (1943, p. 62). It may be the same place listed in the 1880 Census as "Ruibnaia" and having 40 inhabitants.

Ingrehak: village, see Ingrihak.

Ingresik: stream, see Ynveeghik River.

Ingri Butte: hill, $515 \mathrm{ft}$., $3.5 \mathrm{mi}$. $\mathrm{S}$ of Ingriruk Hill, $40 \mathrm{mi}$. NW of Cape Mendenhall, on SW coast of Nunivak I.; $60^{\circ} 02^{\prime} 15^{\prime \prime} \mathrm{N}, 167^{\circ} 11^{\prime}$ $15^{\prime \prime} \mathrm{W}$; (map 57). Var. Eanceec Hill, Twin Mountain.

Common Eskimo name meaning "mountain" reported in 1949 by USC\&GS.

Ingrichagamut: village, see Holy Cross.

Ingricherk Mountain: mountain, 1,557 ft., 19 mi. NW of Shungnak; $67^{\circ} 07^{\prime} \mathrm{N}, 157^{\circ} 33^{\prime} \mathrm{W}$; (map 126).

Eskimo name reported by the U.S. Army Corps of Engineers in 1955.

Ingrichuak Hill: hill, $611 \mathrm{ft}$, , on left bank of Yukon River, 42 mi. SW of Kwiguk, YukonKuskokwim Delta; $62^{\circ} 11^{\prime} \mathrm{N}, 164^{\circ} 06^{\prime} \mathrm{W}$; (map 77). Var. Gora Ingychuak, Ingechook Mountain, Ingrēchōah Hill, Ingrik Mountain, Ingrikchoa, Ingychok.

Eskimo name meaning "little mountain" obtained in $1842-44$ by Lt. L. A. Zagoskin, IRN, and recorded as "Gora Ingychuak," or "Ingychuak Mountain."

Ingrie Kwik: stream, see Mountain Creek.

Ingriguk: mountains, see Kuzilvak Mountains.

Ingrihak: village, on right bank of Yukon River, $8.5 \mathrm{mi}$. S of Marshall, Yukon-Kuskokwim Delta; $61^{\circ} 45^{\prime} 20^{\prime \prime} \mathrm{N}, 162^{\circ} 00^{\prime} 00^{\prime \prime} \mathrm{W}$; (map 74). Var. Ingrumhart, Ingrehak, Ingahamé, Ingahamiut, Ingahameth, Ingrakaklakamiut, Ingrakak.

Eskimo name published in the 1880 census as "Inghameth" and "Ingahamé" which had a population of 63 . USC\&GS reported in 1951 that " 4 or 5 native families live at Ingrihak." According to Hrdlička (1943, p. 235 ) the old village site is located farther inland.

Ingrijoak Hill: hill, $256 \mathrm{ft}$., on Cape Mendenhall, 2 mi. S of Duchikthluk Bay, Nunivak I.; $59^{\circ} 47^{\prime} 30^{\prime \prime} \mathrm{N}, 166^{\circ} 11^{\prime} 00^{\prime \prime} \mathrm{W}$; (map 55).

Eskimo name obtained in 1949 by USC\&GS. Ingrijoak Hills: hills, $500 \mathrm{ft}$., $8 \mathrm{mi}$. SW of Cape Etolin, on N Nunivak I.; $60^{\circ} 19^{\prime} \mathrm{N}, 166^{\circ} 17^{\prime}$ W ; (map 57). Var. Daniel Hills, Ingrijoax Hills, Ingrijokh Hills.

Eskimo name referring to two hills reported in 1949 by USC\&GS.

Ingrijoax Hills: hills, see Ingrijoak Hills. Ingrikchoa: hill, see Ingrichuak Hill.

Ingrik Kwik: stream, see Mountain Creek.

Ingrik Mountain: hill, see Ingrichuak Hill.

Ingrilukat Hills: hills, trend NW $5 \mathrm{mi}$. from Ingrilukat-Naskorat Hill, $29 \mathrm{mi}$. NW of Cape Mendenhall, Nunivak I.; $60^{\circ} 08^{\prime} \mathrm{N}, 166^{\circ} 30^{\prime}$ W; (map 57). 
Eskimo name meaning "small hills close together" reported in 1949 by USC\&GS.

Ingrilukat-Naskorat Hill: hill, $939 \mathrm{ft}$, in Ingrilukat Hills, $10 \mathrm{mi}$. NW of Roberts Mtn. and $28 \mathrm{mi}$. NW of Cape Mendenhall, Nunivak I. ; $60^{\circ} 07^{\prime} 40^{\prime \prime} \mathrm{N}, 166^{\circ} 24^{\prime} 50^{\prime \prime} \mathrm{W}$; (map 57).

Eskimo name meaning "head of the small hills" reported in 1949 by USC\&GS.

Ingrimiut: locality, $24 \mathrm{mi}$. NE of Cape Mendenhall, on W shore of Etolin Strait, Nunivak I.; $60^{\circ} 03^{\prime} 45^{\prime \prime} \mathrm{N}, 165^{\circ} 42^{\prime} 50^{\prime \prime} \mathrm{W}$; (map 57). Var. Ingeramiut, Ingra.

Eskimo village, now abandoned, reported in 1949 by USC\&GS. The name means "mountain people." This is probably the same place as Inger (q.v.).

Ingriruk Hill: hill, $299 \mathrm{ft}$., $5 \mathrm{mi}$. NE of Cape Mendenhall, on SE Nunivak I.; 59 $52^{\prime} 15^{\prime \prime}$ $N, 166^{\circ} 02^{\prime} 50^{\prime \prime} \mathrm{W}$; (map 55).

Eskimo name reported in 1937 by USAAF.

Ingriruk Hill: hill, $499 \mathrm{ft}$., $6 \mathrm{mi}$. WSW of Kimiksthek Hill, $42 \mathrm{mi}$. NW of Cape Mendenhall, Nunivak I.; $60^{\circ} 05^{\prime} \mathrm{N}, 167^{\circ} 12^{\prime} \mathrm{W}$; (map 57).

Eskimo name meaning "little mountain" reported in 1949 by USC\&GS.

Ingriruk Hill: hill, $550 \mathrm{ft}$., $4 \mathrm{mi}$. SW of Iookswarat Bay and $14 \mathrm{mi}$. SW of Cape Etolin, on $\mathrm{N}$ part of Nunivak I. ; $60^{\circ} 17^{\prime} 25^{\prime \prime} \mathrm{N}, 166^{\circ}$ 26'55" W; (map 57).

Eskimo name meaning "little mountain" reported in 1949 by USC\&GS

Ingrisarak Mountain: hill, $364 \mathrm{ft}$, , between Nariyauck and Ukalikchik Rivers, $27 \mathrm{mi}$. E of village of Hooper Bay, Yukon-Kuskokwim Delta; $61^{\circ} 31^{\prime} \mathrm{N}, 165^{\circ} 15^{\prime} \mathrm{W}$; (map 75). Var. Ingrishahk Hill.

Eskimo name reported in 1951 by USC\&GS. Ingrishahk Hill; hill, see Ingrisarak Mountain. Ingruksukruk Creek: stream, flows N $22 \mathrm{mi}$. to Selawik River, $40 \mathrm{mi}$. SW of Shungnak, Kotzebue-Kobuk Low.; $66^{\circ} 29^{\prime}$ N, $158^{\circ} 06^{\prime}$ W; (map 115).

Eskimo name shown on a 1927 manuscript map by the "trader at Selawik."

Ingrumhart: village, see Ingrihak.

Ingun: mountains, see Kuzilvak Mountains.

Ingvit Hill: hill, see Invut Mountain.

Ingychok: hill, see Ingrichuak Hill.

Ingychuak, Gora: hill, see Ingrichuak Hill.

Iniakuk Lake: lake, $5 \mathrm{mi}$. long, $40 \mathrm{mi}$. NW of Allakaket, Brooks Ra.; $67^{\circ} 09^{\prime} \mathrm{N}, 153^{\circ} 15^{\prime} \mathrm{W}$; (map 125).

Local name reported in 1956 by Orth, USGS. This lake drains into the Iniakuk River from which the lake received its name.

Iniam Point: bluff, elev. $48 \mathrm{ft}$., on $S$ bank of Naknek River, on Alaska Penin., $8.5 \mathrm{mi}$. SE of Naknek, Bristol Bay Low.; $58^{\circ} 42^{\prime} 45^{\prime \prime} \mathrm{N}$, $156^{\circ} 46^{\prime} 30^{\prime \prime} \mathrm{W}$; (map 41).

Local name reported in 1952 by USGS.

Inian Cove: cove, $1.6 \mathrm{mi}$. long, on $\mathrm{N}$ end of Inian Is., in North Inian Pass, 2 mi. $\mathrm{S}$ of Point Wimbledon and $36 \mathrm{mi}$. WNW of Hoonah, St. Elias Mts.; $58^{\circ} 16^{\prime} 15^{\prime \prime} \mathrm{N}$, $136^{\circ} 21^{\prime} 00^{\prime \prime} \mathrm{W}$; (map 10).
Named in 1901 by J. F. Pratt, USC\&GS, for the Inian Islands.

Inian Island: island, $3 \mathrm{mi}$. long, off $\mathrm{N}$ coast of Chichagof I., $N$ of South Inian Pass, 34 mi. $\mathrm{NW}$ of Hoonah, St. Elias Mts.; $58^{\circ} 15^{\prime} \mathrm{N}$, $136^{\circ} 19^{\prime} \mathrm{W}$; (map 10 ).

Name published in 1939 by NPS. It is the largest of the Inian Islands.

Inian Islands: islands, extends $4.5 \mathrm{mi}$., off $\mathrm{N}$ coast of Chichagof I., $\mathrm{N}$ of South Inian Pass, $34 \mathrm{mi}$. NW of Hoonah, St. Elias Mts.; $58^{\circ} 15^{\prime}$ N, $136^{\circ} 20^{\prime} \mathrm{W}$; (map 10). Var. Brian Is.

Named in 1879 by W. H. Dall, USC\&GS and published in the 1883 Alaska Coast Pilot (p. 186)

Inian Peninsula: peninsula, $7 \mathrm{mi}$. long on $\mathrm{N}$ end of Chichagof I., S of South Inian Pass, 20 mi. W of Hoonah, Alex. Arch.; 58 $10^{\prime} \mathrm{N}$, $136^{\circ} 17^{\prime} \mathrm{W}$; BGN 1960; (map 10).

Named in 1955 by Rossman (1959, map), USGS, for nearby Inian Islands.

Inigok Creek: stream, heads in lake at $69^{\circ} 58^{\prime} \mathrm{N}$, $153^{\circ} 57^{\prime} \mathrm{W}$, flows NE $75 \mathrm{mi}$. to Fish Creek, $34 \mathrm{mi}$. SW of Atigaru Point, Harrison Bay, Arctic Plain; $70^{\circ} 10^{\prime} \mathrm{N}, 152^{\circ} 35^{\prime} \mathrm{W}$; (map 149). Var. Tingmeachsiovik.

Eskimo name reported in 1956 by Orth, meaning "it goes somewhere." This may be the same stream that USC\&GS reported in 1951 as having the Eskimo name "Tingmeachsiovik."

Inikaklik Creek: stream, flows E $6.5 \mathrm{mi}$. to N end of Chandler Lake, $25 \mathrm{mi}$. WNW of Ananturak Pass, Brooks Ra.; 68 $8^{\circ} 15^{\prime} 30^{\prime \prime} \mathrm{N}$, $152^{\circ} 40^{\prime} 00^{\prime \prime} \mathrm{W}$; (map 134).

Eskimo name reported in 1950 by USGS.

Inikaklik Creek: stream, flows W $3 \mathrm{mi}$. to Okokmilaga River $12 \mathrm{mi}$. $\mathrm{N}$ of its head, Brooks Ra.; $68^{\circ} 18^{\prime} \mathrm{N}, 153^{\circ} 05^{\prime} \mathrm{W}$; (map 133).

Eskimo name meaning "camping place" reported in 1956 by T. E. Taylor, USGS.

Inikaklik Creek: stream, in Endicott Mts., heads at glacier terminus, flows NE $10 \mathrm{mi}$. to Itkillik River, Brooks Ra.; $68^{\circ} 22^{\prime} \mathrm{N}, 1^{\circ} 49^{\circ} 58^{\prime} \mathrm{W}$; (map 135).

Eskimo name reported in 1956 by USGS. Inikla Island: island, $0.7 \mathrm{mi}$. across, between Sanak and Caton Is., one of Sanak Is., Aleutian Ra.; $54^{\circ} 21^{\prime} 15^{\prime \prime} \mathrm{N}, 162^{\circ} 29^{\prime} 30^{\prime \prime} \mathrm{W}$ (map 25).

Aleut name reported by Ferdinand Westdahl, USC\&GS, commander of the Coast Survey steamer, McArthur, who made surveys in this area in 1901.

Inischen Bay: estuary, see Iniskin Bay.

Iniskin: locality, on Iniskin Penin., on $\mathrm{W}$ bank of Fitz Creek, $4 \mathrm{mi}$. $\mathrm{E}$ of Right Arm Iniskin Bay, Aleutian Ra.; $59^{\circ} 45^{\prime} \mathrm{N}, 153^{\circ} 14^{\prime} \mathrm{W}$; $(\operatorname{map} 51)$.

Local name derived from Iniskin Peninsula; published in 1958 by USGS.

Iniskin Bay: estuary, at mouth of Iniskin River extends S $10 \mathrm{mi}$. to Cook Inlet, W of Iniskin Penin., Aleutian Ra.; $59^{\circ} 39^{\prime} \mathrm{N}, 153^{\circ} 27^{\prime} \mathrm{W}$; $B G N$ 1906; (map 51). Var. Enochkin Bay, Inerskin Bay, Inischen Bay, Initskin Bay, Innerskin Bay, Inniskin Bay, Inokhin Bay.
Local name reported in 1903 as "Enochkin" by G. G. Martin (in Emmons and Hayes, 1904, p. 376), USGS; said to have been named for a Russian trader named Enochkin, "who years ago had a post in the region."

Iniskin Bay: estuary, see Iliamna Bay.

Iniskin-Chinitna Peninsula: peninsula, see Iniskin Peninsula.

Iniskin Island: island, $0.2 \mathrm{mi}$. long, in Cook Inlet, $0.8 \mathrm{mi}$. SE of Scott I. and $18 \mathrm{mi}$. N of Augustine I., Aleutian Ra.; $59^{\circ} 37^{\prime} 30^{\prime \prime} \mathrm{N}$,

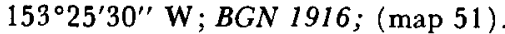

Name published in 1914 on USC\&GS Chart 3421. The name is derived from "Iniskin Peninsula," which is located nearby.

Iniskin Peninsula: peninsula, extends $15 \mathrm{mi}$ into Cook Inlet, on SE coast of Alaska Peninsula between Chinitna and Iniskin Bays, 30 mi. NE of Augustine I., Aleutian Ra.; 59 $43^{\prime}$ N, $153^{\circ} 03^{\prime}$ W; BGN 1959; (map 51). Var. Iniskin-Chinitna Peninsula.

Local name derived from Iniskin Bay and published as "Iniskin-Chinitna Peninsula" by Moffit (1927, pl. 3), USGS, but later shortened by local usage. The name has been in common usage since about 1900 .

Iniskin River: stream, heads at glacier terminus, in Chigmit Mts., flows $\mathbf{S} 8 \mathrm{mi}$. to Iniskin Bay, Aleutian Ra.; $59^{\circ} 47^{\prime} \mathrm{N}, 153^{\circ} 27^{\prime} \mathrm{W}$; $B G N$ 1916; (map 51$)$.

Local name derived from Iniskin; reported in 1914 by USC\&GS.

Iniskin Rock: rock, in Cook Inlet, $1.2 \mathrm{mi}$. SW of Scott I., and $19 \mathrm{mi}$. N of Augustine I., Aleutian Ra.; $59^{\circ} 37^{\prime} 40^{\prime \prime} \mathrm{N}, 153^{\circ} 27^{\prime} 30^{\prime \prime} \mathrm{W}$; BGN 1916; (map 51).

Name published in 1914 on USC\&GS Chart 3421. The name is derived from nearby Iniskin Peninsula.

Iniskin Shoal: shoal, in Cook Inlet, at entrance to Iniskin Bay, $1.5 \mathrm{mi}$. SW of Scott I. and 18 mi. N of Augustine I., Aleutian Ra.; $59^{\circ} 37^{\prime}$. $15^{\prime \prime} \mathrm{N}, 153^{\circ} 27^{\prime} 30^{\prime \prime} \mathrm{W} ; B C N$ 1916; (map 51 ).

Name reported in 1914 by USC\&GS. The name is derived from nearby Iniskin Peninsula

Initkilly: locality, site of an Eskimo village, on Chukchi Sea coast, near Corwin Mine, $27 \mathrm{mi}$. $\mathrm{E}$ of Cape Lisburne, Arctic Slope ; 68 ${ }^{\circ} 52^{\prime} 15^{\prime \prime}$ N, $165^{\circ} 09^{\prime} 00^{\prime \prime} \mathrm{W}$; (map 129). Var. Corwin.

Eskimo name reported in 1890 by Ivan Petroff : shown on 1890 USC\&GS chart.

Initskin Bay: estuary, see Iniskin Bay.

Injured Creek: stream, flows NE $1 \mathrm{mi}$. to Bonanza River, between Frost and Sunrise Creeks, about $13 \mathrm{mi}$. NW of Solomon, Seward Penin. High.; $64^{\circ} 46^{\prime} \mathrm{N}, 164^{\circ} 47 \mathrm{~W}$; (map 95 ).

Prospectors' name reported on the 1900 "Map of Nome Peninsula" by J. M. Davidson and B. D. Blakeslee. This stream cannot be precisely located on current maps.

Inkala River: stream, see Itkillik River.

Inland Lake: lake, $10 \mathrm{mi}$. across, $5 \mathrm{mi}$. SE of Selawik, Kotzebue-Kobuk Low.; $66^{\circ} 29^{\prime} \mathrm{N}$, $159^{\circ} 50^{\prime} \mathrm{W}$; (map 114). Var. Emogarikchoit.

Visited and named by Ensign J. L. Purcell, USN, in 1884 (Stoney, 1900, p. 12). Lt. J. C. Cantwell, USRCS, in 1884 transcribed its Eskimo name as "Emogarikchoit" with a 
meaning given as "little sea." This name spelled "E-mug-ge-row-che-uk," by Stoney is applied to a village on the lake.

Inland River: stream, see Noatak River.

Inlet Point: point of land, on W coats of Annette I., extends into Port Chester, Alex. Arch.; $55^{\circ} 09^{\prime} 20^{\prime \prime} \mathrm{N}, 131^{\circ} 33^{\prime} 00^{\prime \prime} \mathrm{W}$; (map 3 ).

Name published in 1896 by USC\&GS

Inlet Point: point of land, on NE coast of Woewodski I., $15 \mathrm{mi}$. S of Petersburg, Alex. Arch.; $56^{\circ} 35^{\prime} 45^{\prime \prime} \mathrm{N}, 132^{\circ} 59^{\prime} 15^{\prime \prime} \mathrm{W}$; (map 6 ).

Named in 1879 by W. H. Dall, USC\&GS.

Inlikak: island, see Karpa Island.

Inmachuck River: stream, see Inmachuk River.

Inmachuk River: stream, on Seward Penin., flows NE $30 \mathrm{mi}$. to Kotzebue Sound, at the village of Deering, $57 \mathrm{mi}$. SW of Kotzebue, Kotzebue-Kobuk Low.; $66^{\circ} 04^{\prime} \mathrm{N}, 162^{\circ} 42^{\prime} \mathrm{W}$; $B G N$ 1952; (map 113). Var. Imachuck River, Imnuchuk River, Impnipuk River, Impniquk River, Inmachuck River, Innuchuk River, Ipnichuk River.

Eskimo name reported in 1901 as "Ipnichuk" by Mendenhall (1902, p. 30), USGS. Mendenhall said that the name means "big cliff"; however, the present spelling of the name would indicate it may mean "new salt water."

Inner Anchorage: anchorage, $0.5 \mathrm{mi}$. across, at Kodiak, Kodiak I.; $57^{\circ} 47^{\prime} 15^{\prime \prime}$ N, $152^{\circ} 24^{\prime} 30^{\prime \prime}$ W; (map 34).

Local descriptive name reported in 1949 by USGS.

Inner Humpback Rock: rock, in Chiniak Bay $0.6 \mathrm{mi}$. S of Woody I., $3.2 \mathrm{mi}$. SE of Kodiak, Kodiak I.; $57^{\circ} 45^{\prime} 10^{\prime \prime} \mathrm{N}, 152^{\circ} 20^{\prime} 50^{\prime \prime} \mathrm{W}$; (map 34). Var. High Rock, Horbəon Vnutrennie, Kamen Gorbun Vnutrenniy.

Translation of the Russian descriptive name "Kamen Gorbun Vnutrenniy," published by Sarichev (1826, map 16).

Inner Iliasik Island: island, $3 \mathrm{mi}$. long, $7 \mathrm{mi}$. SW of Dolgoi I., in Pavlof Is., Aleutian Ra.; $55^{\circ}$ $03^{\prime} 30^{\prime \prime} \mathrm{N}, 161^{\circ} 57^{\prime} 00^{\prime \prime} \mathrm{W}$; (map 28). Var. Eliazak, Ialiasik, Iliasik Islands, Iliaviki, Iliazhek.

Native name published by Capt. Tebenkov (1852, map 24), IRN, as "O[strov] Iliaviki," and by the Russian Hydrog. Dept. as "O[strov] Iliazhek" on Chart 1379. "Inner Iliasik Island" was published in 1888 by USBF. This island along with Outer Iliasik Island comprise the Iliasik Islands.

Inner Lake George: lake, $4 \mathrm{mi}$. across, at terminus of Colony Glacier, $27 \mathrm{mi}$. SE of Palmer, Chugach Mts.; 61 ${ }^{\circ} 17^{\prime} 20^{\prime \prime} \mathrm{N}, 148^{\circ} 32^{\prime} 15^{\prime \prime} \mathrm{W}$; (map 69).

Name reported in 1951 by Stone (1963, p. 33).

Inner Nikolski Anchorage: cove, see Mueller Cove.

Inner Point: point of land, on SE coast of Prince of Wales I., in Port Johnson, Alex. Arch.; $55^{\circ} 07^{\prime} 25^{\prime \prime} \mathrm{N}, 132^{\circ} 00^{\prime} 45^{\prime \prime} \mathrm{W}$; (map 4).

Local descriptive name obtained in 1905 by E. F. Dickins, USC\&GS.

Inner Point: point of land, on E coast of Kruzof I., $9 \mathrm{mi}$. NW of Sitka, Alex. Arch.; $57^{\circ} 05^{\prime} 40^{\prime \prime}$
N, $135^{\circ} 34^{\prime} 15^{\prime \prime}$ W; BGN 1901; (map 9). Var. Inner Point of Shoals, Mys Otmeloy Vnutrenniy, Mys Otmyloy Vnutrynney, Rocky Point, Second Point.

USC\&GS about 1882 derived "Inner Point" by translating part of the name "Mys Otmyloy Vnutrynney" meaning "inner shoals cape." This name was given in 1809 by the Russian navigator Ivan Vasiliev the first to distinguish it from another point called "shoals." This feature was called "Rocky Point" in 1884 on Brit. Adm. Chart 2337.

Inner Point: point of land, on $\mathrm{W}$ shore of Kizhuyak Bay, $17 \mathrm{mi}$. NW of Kodiak, Kodiak I.; $57^{\circ} 54^{\prime} 15^{\prime \prime}$ N, $152^{\circ} 47^{\prime} 50^{\prime \prime}$ W ; (map 34). Var. Inner Cape, Mys Vnutrenniy, Vnutrennie.

Translation of the descriptive name " $M[y s]$ Vnutrenniy" given in 1839 or 1840 by Sub-Lt. Mikhail Murashev and published in 1849 on Russian Hydrog. Dept. Chart 1425.

Inner Point: point of land, in Stephens Passage, on SW coast of Douglas I., $1.8 \mathrm{mi}$. SE of Middle Point and $8 \mathrm{mi}$. SW of Juneau, Coast Mts. ; 58 $13^{\prime} 55^{\prime \prime} \mathrm{N}, 134^{\circ} 35^{\prime} 15^{\prime \prime} \mathrm{W}$; (map 11).

Name published in 1924 by USC\&GS on Chart 8235.

Inner Point of Shoals: point of land, see Inner Point.

Inner Point Sophia: point of land, at mouth of Port Frederick on $\mathrm{N}$ coast of Chichagof $\mathrm{I}$., $1.6 \mathrm{mi}$. NW of Hoonah, Alex. Arch.; $58^{\circ} 07^{\prime} 50^{\prime \prime} \mathrm{N}, 135^{\circ} 28^{\prime} 00^{\prime \prime}$. W; (map 11 ).

Named in 1901 by E. F. Dickens, USC\&GS, and published in the 1901 Coast Pilot ( $p$. 203 ).

Inner Port Walter: bay, see Little Port Walter. Inner Right Cape: point of land, near the mouth of Kiliuda Bay, on SE coast of Kodiak I.; $57^{\circ} 16^{\prime} 30^{\prime \prime} \mathrm{N}, 152^{\circ} 51^{\prime} 00^{\prime \prime} \mathrm{W}$; (map 34). Var. Arie Cape, Murre Point, Mys Ariy.

Descriptive name published in 1943 by USC\&GS. Capt. Tebenkov (1852, map 23) published the name "M[ys] Ariy," or "Ariy Cape." Baker (1906, p. 450) wrote, "Murre point, ***. Named Arie (a sea bird, the arrie or murre or guillemot, Pallas's murre, Uria lomvia arra) by Tebenkov, 1849."

Inner Rocks: rocks, in mouth of Chichagof Harbor, off NE coast of Attu 1., Aleutian Is.; $52^{\circ} 56^{\prime} 10^{\prime \prime} \mathrm{N}, 173^{\circ} 15^{\prime} 32^{\prime \prime} \mathrm{E}$; (map 13).

Descriptive name given in $1854-55$ by Lt. William Gibson, USN.

Inner Seal Rock: rock, on W coast of Kodiak I., $1.5 \mathrm{mi}$. W of Gurney Bay and $23 \mathrm{mi}$. SW of Karluk; $57^{\circ} 17^{\prime} 20^{\prime \prime} \mathrm{N}, 154^{\circ} 48^{\prime} 00^{\prime \prime} \mathrm{W}$; (map 35).

Descriptive name published by USC\&GS in 1943. See Seal Rocks.

Inner Signal: rocks, elev. $180 \mathrm{ft}$., of NE coast of Sedanka I., Aleutian Is.; $53^{\circ} 47^{\prime} 20^{\prime \prime} \mathrm{N}$, $166^{\circ} 05^{\prime} 25^{\prime \prime}$ W; (map 23). Var. Cook's Rock.

Named as one of "The Signals" by J. J. Gilbert, commander of the USC\&GS steamer Pathfinder during 1900-01.

Innerskin Bay: estuary, see Iniskin Bay.
Innesvale Gulch: ravine, extends SE $1.3 \mathrm{mi}$., at head of Deep Creek, $33 \mathrm{mi}$. ESE of Tanana, Yukon-Tanana High.; 65 ${ }^{\circ} 04^{\prime} 25^{\prime \prime} \mathrm{N}, 150^{\circ} 57^{\prime}$ 40" W; (map 106).

Prospectors' name reported in 1931 by J. B. Mertie, USGS.

Inniskin Bay: estuary, see Iniskin Bay.

Innok: stream, see Innoko River.

Innoka: locality, "on Tlegan River, Malaspina Coastal Plain."

Former Indian camp or settlement reported by Petroff (1884, p. 37).

Innoka, Reka: stream, see Innoko River.

Innoko: locality, sec Dishkakat.

Innoko River: stream, heads S of Cloudy Mtn. at $63^{\circ} 09^{\prime} \mathrm{N}, 156^{\circ} 02^{\prime} \mathrm{W}$, flows $\mathrm{NE}$ and $\mathrm{SW}$ $500 \mathrm{mi}$. to Yukon River, $1.5 \mathrm{mi}$. E of Holy Cross, Innoko Low.; $62^{\circ} 12^{\prime} \mathrm{N}, 159^{\circ} 43^{\prime} \mathrm{W}$; (map 78). Var. Legon, Chageliuk, Reka Innoka, Innok, Ittege Reka Shiltonotno.

This is probably an Ingalik Indian name recorded in $1842-44$ by Lt. L. A. Zagoskin, IRN, as "R[eka] Innoka ili Shiltonotno," meaning "Innoka or Shiltonotno River." Zagoskin wrote that Alexander Kolmakov in 1838 called it "Tlegon," but it was known to the Russian colonial administration on the Yukon as "Chagelyuk." Accordingly, Zagoskin applied the name "Tlegon" to the stream's upper course, "Innoka or Shiltonotno" to the middle course, and "Chagelyuk or Ittëge" to the lower course. These presumably were all Indian names of which "Tlegon," "Shiltonotno," and "Ittege" are no longer used. The river is now called "Innoko" (spelled that way in 1852 by the Russian Admiralty), and the name "Chagelyuk" still exist for Shageluk Slough.

Innoko Slough: stream, heads at Innoko River, flows S $25 \mathrm{mi}$. to Paimiut Slough, Innoko Low.; 62 $00^{\circ} 15^{\prime \prime} \mathrm{N}, 159^{\circ} 37^{\prime} 30^{\prime \prime} \mathrm{W}$; (map 78). Var. Paimute Slough.

Local name obtained in 1952 by USGS.

Innuchuk River: stream, see Inmachuk River.

Innupuk Rock: rock, see Inukpak Rock.

Innutat Creek: stream, see Inuktak Creek.

Innutat Creek: stream, sce Kiktoya Creek.

Inoceramus Creek: stream, heads on Sheep Mtn., flows NW $3.2 \mathrm{mi}$. to Squaw Creek, $55 \mathrm{mi}$. NE of Palmer, Talkeetna Mts.; 61 $53^{\circ} 05^{\prime \prime} \mathrm{N}$,

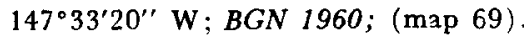

Named by USGS in 1956 "for the fossil clam belonging to the genus Inoceramus, which is abundantly found in its valley."

Inokhin Bay: estuary, sze Iniskin Bry.

Inookut: locality, see Inuktut.

Inowak Creek: stream, flows S $25 \mathrm{mi}$. to Kuskokwim River, $7.5 \mathrm{mi}$. E of Sleetmute, Stony River Low.; $61^{\circ} 42^{\prime} 40^{\prime \prime} \mathrm{N}, 156^{\circ} 56^{\prime} 15^{\prime \prime} \mathrm{W}$; (map 72).

Eskimo name obtzined in 1948 by USC\&GS.

Inqalyuk, Ostrov: island, see Little Diomede Island.

Inrechoa'meut: locality', see Ingichuk.

Inselnostlinde: locality, on Shageluk Slough, Innoko Low.; 62 ${ }^{\circ} 45^{\prime} \mathrm{N}, 159^{\circ} 45^{\prime} \mathrm{W}$; (map 78).

Former Ingalik Indian village reported in $1842-44$ by Lt. L. A. Zagoskin, IRN. See Shageluk. 
Insiachak: locality, "in the Nushagak district." Var. Insiachamiut.

Former Eskimo camp or settlement listed as "Insiachamiut," with a population of 42 , in the 1890 Census.

Insiachamiut: locality, see Insiachak.

Inside Passage: water passage, connects Tongass Narrows and Clarence Strait, between Guard I. and Vallenar Rock, off NW tip of Gravina I., Alex. Arch.; 55 $26^{\prime} \mathrm{N}, 131^{\circ} 52^{\prime} \mathrm{W}$; (map $3)$.

Named in 1885 by Lt. Comdr. Richardson Clover, USN.

Inspiration Point: point of land, on $\mathrm{E}$ shore of Ice Harbor on Favorite Passage, $0.8 \mathrm{mi}$. $\mathrm{N}$ of village of Ice Harbor and $15 \mathrm{mi}$. NW of Juneau, Coast Mts.; $58^{\circ} 25^{\prime} 30^{\prime \prime} \mathrm{N}, 134^{\circ} 45^{\prime} 20^{\prime \prime}$ W; (map 11).

Local name derived from the magnificent view from the point across Favorite Channel and Lynn Canal to the Chilkat Range (DeArmond, 1957, p. 25). Name was published by USGS in 1962.

Intankoon: hill, see Intun Cone.

Intankoon: hill, see Intungidi Hill.

Intankoon: point of land, see Chacon, Cape.

Intenleiden: locality, on Shageluk Slough; $62^{\circ}$ $4^{\prime} \mathrm{N}, 159^{\circ} 45^{\prime} \mathrm{W}$; (map 78). Var. Iltenleiden, Imtelleiden, Intenlaiden.

Ingalik Indian village reported in 1842-44 by Lt. L. A. Zagoskin, IRN. See Shageluk. Intermittent Creek: stream, in Mount McKinley National Park, flows W 2 mi. to Glacier Creek $\mathrm{E}$ of Muldrow Glacier, $4.2 \mathrm{mi}$. $\mathrm{S}$ of Eielson Visitor Center, Alaska Ra.; 63⒉ $22^{\prime} 45^{\prime \prime} \mathrm{N}$, $150^{\circ} 22^{\prime} 45^{\prime \prime} \mathrm{W}$; BGN 1932; (map 88).

So named in 1932 by USGS because the "lower course of this creek flows intermittently through the gravels at the east edge of Muldrow Glacier."

Intricate Bay: bay, $3 \mathrm{mi}$. wide, at mouth of Copper River on SE side of Iliamna Lake, $\mathrm{N}$ of Kahhonak Bay, $20 \mathrm{mi}$. SE of Iliamna, Aleutian Ra.; 59 $31^{\prime} 15^{\prime \prime} \mathrm{N}, 154^{\circ} 37^{\prime} 15^{\prime \prime} \mathrm{W}$; (map 51).

Descriptive name reported in 1911 by Martin and Katz (1912a, p. 91), USGS. "So named because the cove is full of islands."

Intun Cone: hill, $400 \mathrm{ft}$., on Cape Chacon, at $\mathrm{SE}$ tip of Prince of Wales I., Alex. Arch.; $54^{\circ} 41^{\prime} 35^{\prime \prime} \mathrm{N}, 132^{\circ} 00^{\prime} 50^{\prime \prime} \mathrm{W}$; BGN 1922; (map 1). Var. Intankoon Cone, Intuukun Cone.

Tlingit Indian name published in 1922 by USC\&GS; possibly derived from nearby Intungidi Hill. See Cape Chacon.

Intungidi Hill: hill, $500 \mathrm{ft}$., on $\mathrm{S}$ coast of Prince of Wales I., $\mathrm{N}$ of Cape Chacon, Alex. Arch.; $54^{\circ} 41^{\prime} 45^{\prime \prime} \mathrm{N}, 132^{\circ} 01^{\prime} 00^{\prime \prime} \mathrm{W}$; BGN 1922; (map 1). Var. Intankoon, Intunkun, IntunKun-Gidi Hill.

Haida Indian name published in 1922 by USC\&GS. In 1901, J. R. Swanton, BAE, reported the name "Intun-Kun-Gidi" which means "Intun(kun)'s brother."

Intunkun: hill, see Intungidi Hill.

Intun-Kun-Gidi Hill: hill, see Intungidi Hill.

Intuukun Cone: hill, see Intun Cone.
Inukpak Rock: rock, $175 \mathrm{ft}$., on $\mathrm{N}$ slope of Angayukak Hill, $5 \mathrm{mi}$. N of Cape Thompson, Arctic Slope; $68^{\circ} 12^{\prime} 55^{\prime \prime} \mathrm{N}, 166^{\circ} 00^{\prime} 35^{\prime \prime} \mathrm{W}$; BGN 1963; (map 129). Var. Innupuk Rock.

Eskimo descriptive name meaning "big man" reported about 1962 by W. O. Pruitt, Univ, of Alaska.

Inukpasugjuk Greek: stream, see Inukpasugruk Creek.

Inukpasugruk Creek: stream, flows NNW 11.5 mi., between Kollutkuk Mtn. and Three River Mtn. to John River at Anaktuvuk Pass, Brooks Ra.; $68^{\circ} 07^{\prime} 30^{\prime \prime} \mathrm{N}, 151^{\circ} 45^{\prime} 00^{\prime \prime} \mathrm{W}$; (map 134). Var. Inukpasugjuk Creek, Inukpasukruk Creek.

Eskimo name, meaning "giants' valley," published by Rausch (1951, p. 150).

Inukpasuk Hill: hill, $400 \mathrm{ft}$, , along Kivalina River, $25 \mathrm{mi}$. NE of Kivalina, Brooks Ra.; $68^{\circ} 07^{\prime} \mathrm{N}, 164^{\circ} 10^{\prime} \mathrm{W}$; (map 130). Var. Eenyookpasook.

Eskimo name meaning "there is a giant," so called because a rock on the hill resembles a large man; name reported in 1966 by $E$. S. Burch.

Inukpasukruk Greek: stream, see Inukpasugruk Creek.

Inuktak: locality, area around the $\mathrm{SE}$ end of Telavirak Hills, $12 \mathrm{mi}$. SE of Cape Thompson, Arctic Slope; $68^{\circ} 04^{\prime} \mathrm{N}, 165^{\circ} 31^{\prime} \mathrm{W}$; (map 129). Var. Inuktaq, Inyooktak.

See Inuktak Creek.

Inuktak Creek: stream, flows SW $0.8 \mathrm{mi}$. to Chukchi Sea, SE of Kisimilok Creek, $14 \mathrm{mi}$. SE of Cape Thompson, Arctic Slope; $68^{\circ} 03^{\prime} 30^{\prime \prime} \mathrm{N}, 165^{\circ} 28^{\prime} 45^{\prime \prime} \mathrm{W}$; BGN 1963; (map 129). Var. Innutat Creek, Inuktuk Creek.

Eskimo name [innutat] meaning "murder" which, according to $W$. O. Pruitt, Univ. of Alaska, refers "to a famous folktale of war between Tigaraqmiut [Point Hope people] and Kivalinaqmiut [Kivalina people] according to Lawrence Sage who lived here as a boy." Name reported in 1950 by USC\&GS. Inuktaq: locality, see Inuktak.

Inuktuk Creek: stream, see Inuktak Creek.

Inuktut: locality, on Igloo Point at $\mathrm{E}$ end of Eschscholtz Bay, Seward Penin.; 66 ${ }^{\circ} 13^{\prime} \mathrm{N}$, $161^{\circ} 04^{\prime}$ W; (map 114). Var. Inooktut, Kongigamut, Kongik.

Former Eskimo village or camp reported in 1898 by Lt. E. P. Bertholf, USRCS. See Baker (1906, p. 328).

Invut Mountain: hill, $734 \mathrm{ft}$., in low., $10 \mathrm{mi}$. $\mathrm{SW}$ of Mygha Powit Mtn., $70 \mathrm{mi}$. SE of Gambell, on Saint Lawrence I. ; $63^{\circ} 10^{\prime} \mathrm{N}, 169^{\circ} 58^{\prime} \mathrm{W}$; $B G N$ 1951; (map 93). Var. Ingvit Hill.

Eskimo name reported in 1932 by Otto $W$. Geist, Univ. of Alaska.

Inyooktak: locality, see Inuktak.

Inyooktam Koonga: stream, see Kiktoya Creek. Inyorurak Lakes: lakes, extend $\mathrm{E}-\mathrm{W} 10 \mathrm{mi}$., in upper valley of Flora Creek, $15 \mathrm{mi}$. ESE of Howard Pass, Brooks Ra.; 68 $07^{\prime}$ N, $156^{\circ} 15^{\prime}$ W ; (map 132).

Eskimo name obtained at Noatak by Orth in 1956; it is a personal name.
Inyorurak Pass: pass, 2,020 ft., in Brooks Ra., between Isikut and Koiyaktot Mts., $12 \mathrm{mi}$. ESE of Howard Pass; $68^{\circ} 11^{\prime} \mathrm{N}, 156^{\circ} 26^{\prime} \mathrm{W}$; (map 132).

Eskimo name obtained at Noatak by Orth in 1956; it is a personal name.

Inyugakuligit Creek: stream, flows E $7.5 \mathrm{mi}$. to Okokmilaga River $11 \mathrm{mi}$. S of its junc, with Fire Creek, Brooks Ra.; 68 ${ }^{\circ} 18^{\prime} \mathrm{N}, 1^{\circ} 3^{\circ} 05^{\prime}$ W; (map 133).

Eskimo name obtained in 1956 at Anaktuvuk Pass by T. E. Taylor, USGS. It means "small peoples' campsite."

Inyugiatchiak Hill: ridge, see Kimikpak Ridge. Inyuilak Creek: stream, flows SW 15 mi. to Reed River, 14 mi. S of Mount Igikpak, Brooks Ra.; $67^{\circ} 13^{\prime} \mathrm{N}, 154^{\circ} 57^{\prime} \mathrm{W}$; (map 125).

Eskimo name meaning "deserted place," reported by USGS in 1956.

Inyuraktoak Creek: stream, flows $\mathrm{SW} 3.5 \mathrm{mi}$. from Siavlat Mtn. to Nigu River, $34 \mathrm{mi}$. SE of Howard Pass, Brooks Ra.; $68^{\circ} 01^{\prime} \mathrm{N}, 155^{\circ}$ 42' W; (map 133). Var. Inyuraktoat Creek.

Eskimo name reported by Irving (1954, p. 204).

Inyuraktoat Creek: stream, see Inyuraktoak Creek.

Ioanna Bogoslova, Ostrov: island, see Bogoslof Island.

Iookswarat Bay: estuary, $2 \mathrm{mi}$. long, $9 \mathrm{mi}$. SW of Cape Etolin, on $\mathrm{N}$ coast of Nunivak I.; $60^{\circ} 21^{\prime} 30^{\prime \prime} \mathrm{N}, 166^{\circ} 22^{\prime} 45^{\prime \prime} \mathrm{W}$; (map 57). Var. Jooxwarat Bay, Jukhwarat Bay, Tsukhwarat Bay.

Eskimo name obtained in 1949 by USC\&GS.

Iork, Mys: point of land, see Cape York.

Ioulakh Island: island, see Ulak Island.

Iowa Creek: stream, fows SE $9 \mathrm{mi}$. to West Fork Little Delta River, $1.4 \mathrm{mi}$. S of that stream's junc. with East Fork and $24 \mathrm{mi}$. NW of Mount Hayes, Alaska Ra.; 63 $56^{\prime} 35^{\prime \prime} \mathrm{N}$, $146^{\circ} 56^{\prime} 10^{\prime \prime} \mathrm{W}$; (map 86).

Local name reported in 1910 by J. W. Bagley, USGS.

Iowa Creek: stream, flows S $7 \mathrm{mi}$. to Little Chena River, 14 mi. NE of Fairbanks, YukonTanana High.; $64^{\circ} 53^{\prime} 30^{\prime \prime} \mathrm{N}, 147^{\circ} 14^{\prime} 20^{\prime \prime} \mathrm{W}$; (map 100).

Name given by prospectors; reported in 1907 by C. C. Covert (in Henshaw and Covert, 1908, pI. 9), USGS.

Iowa Creek: stream, on Seward Penin., flows N $4.5 \mathrm{mi}$. to Inmachuk River, $6 \mathrm{mi}$. SW of Deering, Kotzebue-Kobuk Low.; $66^{\circ} 00^{\prime} \mathrm{N}$, $162^{\circ} 53^{\prime} \mathrm{W}$; (map 113).

Prospectors' name reported in 1908 by F. F. Henshaw (in Brooks and others, 1909, fig. 21), USGS.

Iowa Creek: stream, see Mud Creek.

Iowithla River: stream, heads in Muklung Hills and flows SE $36 \mathrm{mi}$. to Nushagak River, 26 mi. E of Dillingham, Bristol Bay Low.; $59^{\circ} 05^{\prime}$ N, 157 $45^{\prime}$ W; BGN 1937; (map 52). Var. Ai-u-wath-lok, Beaver Creek.

Eskimo name written "Ai-u-wath-lok" by H. C. Fassett, USBF, in 1910.

Ipauveerak: stream, see New Heart Creek. Ipeetahnga: hills, see Kitiram Ipitanga Hills. 
Ipewik River: stream, heads in De Long Mts. at $68^{\circ} 27^{\prime} 50^{\prime \prime} \mathrm{N}, 163^{\circ} 51^{\prime} 00^{\prime \prime} \mathrm{W}$, flows SW 85 mi. to Kukpuk River, $15 \mathrm{mi}$. NE of Cape Thompson, Arctic Slope; $68^{\circ} 20^{\prime} 30^{\prime \prime} \mathrm{N}, 165^{\circ}=$ 42'30" W; (map 129). Var. Ippewik River. Eskimo name published as "Ippewik" in 1890 by USC\&GS.

Ipewik River: stream, see Nilik River.

Iphigenia, Point: point of land, on $\mathrm{W}$ coast of Prince of Wales I., $E$ point of entrance to Port Caldera, $6.4 \mathrm{mi}$. S of Craig, Alex. Arch.; $55^{\circ} 22^{\prime} 55^{\prime \prime}$ N, $133^{\circ} 08^{\prime} 55^{\prime \prime}$ W; (map 4). Var. Mys Santa Yefigeniya, Punta de Santa Efigenia.

Name given in 1775-79 by Don Juan de la Bodega y Quadra and Francisco Antonio Maurelle as "Punta de Santa Efigenia" or "Point of Saint Efigenia."

Iphigenia Bay: bay, $30 \mathrm{mi}$. wide, between Coronation and Noyes Is., Alex. Arch.; $55^{\circ} 42^{\prime} \mathrm{N}$, $134^{\prime} 00^{\prime \prime} \mathrm{W}$; (map 4).

Named in 1867 by George Davidson, USC\&GS, for the vessel Iphigenia Nubiana, commanded by Capt. William Douglas in 1788. Davidson said "No name having been applied to this bay, we have designated it as Iphigenia Bay, after Douglas's vessel" (U.S. Coast and Geodetic Survey, 1869, p. 95).

Ipiutak: locality, near Ipiutak Lagoon, $1.8 \mathrm{mi}$. NE of Point Hope, Arctic Slope; $68^{\circ} 21^{\prime} 25^{\prime \prime}$ N, 166 $45^{\prime} 45^{\prime \prime} W$; (map 129).

Present-day Eskimo name for an early Eskimo village, now an archaeological site.

Ipiutak Lagoon: lagoon, $0.5 \mathrm{mi}$. across, on point Hope, at $W$ end of Marryat Inlet, Arctic Slope; 68 $21^{\circ} 30^{\prime \prime} \mathrm{N}, 166^{\circ} 45^{\prime} 30^{\prime \prime} \mathrm{W}$; (map 129). Var. Sipewtaq Lagoon.

Local name reported in 1956 by Orth; named after an ancient village site.

Ipkagnaktaugrak Mountain: mountain, 2,650 ft., in Wulik Mts., $55 \mathrm{mi}$. SE of Cape Sabine, Brooks Ra.; $68^{\circ} 16^{\prime} \mathrm{N}, 163^{\circ} 30^{\prime} \mathrm{W}$; (map 130). Var. Eepkagnaktowgruk, Iipqagnaqtaugruk.

Eskimo name reported in 1966 by E. S. Burch.

Ipmiluik River: stream, see Ipnelivik River.

Ipnavik River: stream, heads in Brooks Ra., flows NE $68 \mathrm{mi}$. to Colville River, $50 \mathrm{mi}$. NNE of Howard Pass, Arctic Slope ; $68^{\circ} 54^{\prime}$ N, $156^{\circ} 27^{\prime}$ W; BGN 1926; (map 132). Var. Ipnavak Greek.

Eskimo name given by USGS, referring to "the place where young Dall sheep are raised." The name first appears on a 1925 fieldsheet by Gerald FitzGerald, USGS, as "Ipnavak."

Ipnek Creek: stream, flows NE $8.5 \mathrm{mi}$. from Ipnek Mtn. to North Fork Koyukuk River opposite Delay Pass, $18 \mathrm{mi}$. W of Wiseman, Brooks Ra.; $67^{\circ} 25^{\prime} 30^{\prime \prime} \mathrm{N}, 150^{\circ} 48^{\prime} 00^{\prime \prime} \mathrm{W}$; (map 124).

This is an Eskimo word said to mean "sheep" and was given to the stream by Marshall (1956, p. 117) who wrote, "This had been an important focal point in the Wild River stampede of 1913-15. It was the point where the men coming over Jack Delay Pass from Wiseman crossed the North Fork and headed over a low pass into the Wild River drainage."

Ipnek Mountain: mountain, 5,875 ft., between North Fork Koyukuk River and Michigan Creek, $26 \mathrm{mi}$. W of Wiseman, Brooks Ra.; $67^{\circ} 20^{\prime} \mathrm{N}, 151^{\circ} 00^{\prime} \mathrm{W}$; BGN 1932; (map 124).

This is an Eskimo word, said to mean "sheep," reported in 1932 by Robert Marshall.

Ipnelivik River: stream, heads at Shishakshinovik Pass, flows N 19 mi. to Noatak River, 40 mi. SE of Howard Pass, Brooks Ra.; 67 ${ }^{\circ} 43^{\prime}$ N, $156^{\circ} 11^{\prime} \mathrm{W}$; BGN 1959; (map 126). Var. Ipmiluik River.

Eskimo name meaning "sheep raising place" derived from "imnaik" ("imnak," "cliff"), the name for the Dall sheep, (Ovis dalli); shown on 1911 fieldsheet by C. E. Giffin, 'USGS.

Ipnichuk River: stream, see Inmachuk River. Ipnot: locality, site of an Eskimo village on Chukchi Sea coast, at mouth of Isuk Creek, $3 \mathrm{mi}$. NW of Cape Thompson, Arctic Slope; $68^{\circ} 11^{\prime} \mathrm{N}, 166^{\circ} 01^{\prime} \mathrm{W}$; (map 129). Var. Impnot.

This now abandoned village or camp was reported by Ivan Petroff in the 1880 U.S. Census as "Ip-not," with a population of 40. The 1890 U.S. Census does not list the name. It is reported to mean "bird-place" and was derived from the name of the cliffs at Cape Thompson.

Ipnot: promontory, see Thompson, Cape.

Ippersua: locality, see Natirnuq.

Ippewik River: stream, see Ipewik River.

Iptugik: locality, on Agattu I. in the Near Is., Aleutian Is., (map 13).

Former Aleut village reported as "uninhabited" by Hodge (1907, p. 615), BAE.

Irak Bay: bay, see Ugak Bay.

Irak Creek: stream, flows N $11 \mathrm{mi}$. to Mikigealiak River, $25 \mathrm{mi}$. SE of Wainwright, Arctic Plain; $70^{\circ} 20^{\prime} \mathrm{N}, 159^{\circ} 24^{\prime} \mathrm{W}$; (map 146).

Eskimo word in places spelled "iyi," meaning "eye"; published in 1958 by AMS.

Irathluik: stream, see Fish River.

Irene Creek: stream, flows SW $2.4 \mathrm{mi}$. to Nome River valley, $5 \mathrm{mi}$. E of Nome, Seward Penin. High.; $64^{\circ} 29^{\prime} \mathrm{N}, 165^{\circ} 14^{\prime} \mathrm{W}$; (map 94).

Prospectors' name reported on a map by S. E. King dated 1900 .

Irene Creek: stream, flows SE $1 \mathrm{mi}$. to Bryan Creek which flows to Serpentine River, $8 \mathrm{mi}$. $\mathrm{NE}$ of Kougarok Mtn. and $34 \mathrm{mi}$. SE of Ear Mtn., Seward Penin. High.; $65^{\circ} 48^{\prime} \mathrm{N}$, $165^{\circ} 05^{\prime} \mathrm{W}$; (map 111).

Prospectors' name reported on the 1908 "Map of Seward Peninsula" by Arthur Gibson.

Irene Glacier: glacier, heads on $\mathbf{N}$ side of Mount Yeatman, trends E $3 \mathrm{mi}$. to its terminus, $9 \mathrm{mi}$. NW of Skagway, Coast Mts.; 59 $34^{\prime} 45^{\prime \prime} \mathrm{N}$, $135^{\circ} 21^{\prime} 45^{\prime \prime} \mathrm{W}$; (map 45).

Name given in 1898 by J. A. Flemer, USC\&GS.

Ireniviq: locality, area on coast between Walakpa Bay and Kuogaguruq, $15 \mathrm{mi}$. SW of Barrow, Arctic Plain; $71^{\circ} 07^{\prime} \mathrm{N}, 157^{\circ} 09^{\prime} \mathrm{W}$; (map 153). Var. Ernivwing.
Eskimo locality or camp name published by Lt. Ray (1885, p. 55), USA, as "Ernivwing" and as "Ireniviq" by Spencer (1959, map 2), BAE.

Irgkivik Creek: stream, flows NW 5 mi., around $\mathrm{N}$ side of Irgnyivik Lake to Anaktuvuk River, $25 \mathrm{mi}$. NE of Anaktuvuk Pass, Arctic Slope; $68^{\circ} 28^{\prime} \mathrm{N}, 151^{\circ} 19^{\prime} \mathrm{W}$; (map 134).

Eskimo name obtained at Anaktuvuk Pass in 1956 by T. E. Taylor, USGS.

Irgnyivik Lake: lake, $1.2 \mathrm{mi}$. long, between Irgkivik and Iknivik Creeks, $24 \mathrm{mi}$. NE of Anaktuvuk Pass, Arctic Slope; 68 ${ }^{\circ} 6^{\prime} \mathrm{N}$, $151^{\circ} 16^{\prime} \mathrm{W}$; (map 134).

Eskimo name obtained at Anaktuvuk Pass in 1956 by T. E. Taylor, USGS.

Irikaklik Creek: stream, flows E $6.5 \mathrm{mi}$. to N end of Chandler Lake, $26 \mathrm{mi}$. NW of Anaktuvuk Pass, Brooks Ra.; 68 $8^{\circ} 15^{\prime} 30^{\prime \prime} \mathrm{N}$, $152^{\circ} 41^{\prime} 00^{\prime \prime} \mathrm{W}$; (map 134).

Eskimo name obtained at Anaktuvuk Pass in 1956 by T. E. Taylor, USGS.

Irina, Lake: lake, $1 \mathrm{mi}$. long, $\mathrm{SE}$ of Redoubt Lake, $13 \mathrm{mi}$. SE of Sitka, on central Baranof I., Alex. Arch.; $56^{\circ} 54^{\prime} \mathrm{N}, 135^{\circ} 08^{\prime} \mathrm{W}$; BGN 1935; (map 5).

Named in 1935 by USFS "for the daughter of Alexander Baranof." See Baranof Island. Irinik Point: promontory, see Lewis, Cape.

Irish Channel: water passage, on Kenai Penin., in Skilak Lake, S of Lucas I., $41 \mathrm{mi}$. ESE of Kenai, Chugach Mts. ; $60^{\circ} 24^{\prime} 15^{\prime \prime} \mathrm{N}, 150^{\circ} 10^{\prime}$ $00^{\prime \prime} \mathrm{W}$; (map 62).

Local name reported in 1959 by USGS.

Irish Cove: cove, $0.7 \mathrm{mi}$. wide, on $\mathrm{S}$ shore of Port Fidalgo, Chugach Mts.; $60^{\circ} 46^{\prime} 30^{\prime \prime} \mathrm{N}$, $146^{\circ} 27^{\prime} 00^{\prime} \mathrm{W}$; BGN 1910; (map 64).

Local name reported in 1908 by Grant and Higgins (1910, pl. 2), USGS.

Irish Cove: cove, $0.5 \mathrm{mi}$. across, on $\mathrm{W}$ coast of Glacier I., $49 \mathrm{mi}$. NE of Whittier, Chugach Mts.; $60^{\circ} 53^{\prime} 15^{\prime \prime} \mathrm{N}, 147^{\circ} 17^{\prime} 45^{\prime \prime} \mathrm{W}$; (map 63).

Local name reported in 1951 by USGS.

Irish Creek: stream, on SW coast of Kupreanof I., flows W $7 \mathrm{mi}$. to Keku Strait, $28 \mathrm{mi}$. W of Petersburg, Alex. Arch.; $56^{\circ} 43^{\prime} 30^{\prime \prime}$ N, $133^{\circ}$. $41^{\prime} 15^{\prime \prime} \mathrm{W}$; (map 6).

Local name published in 1943 by USC\&GS.

Irish Creek: stream, on Iniskin Penin., flows NW $0.8 \mathrm{mi}$. to Fitz Creek, $1.7 \mathrm{mi}$. S of Chinitna Bay, Aleutian Ra.; $59^{\circ} 47^{\prime} 25^{\prime \prime} \mathrm{N}, 153^{\circ} 10^{\prime} 20^{\prime \prime}$ W; BGN 1962; (map 51).

Named by USGS in 1951 for publication purposes.

Irish Creek: stream, flows SE $2.5 \mathrm{mi}$. from Blackface Mtn. to Ernie Creek, $25 \mathrm{mi}$. SE of Anaktuvuk Pass, Brooks Ra.; $68^{\circ} 00^{\prime} \mathrm{N}, 150^{\circ} 50^{\prime} \mathrm{W}$; BGN 1932; (map 134).

Named in 1930 by Robert Marshall for a local long-time prospector, Charlie Irish, "who first explored this creek."

Irish Creek: stream, see Iron Creek.

Irish Gulch: ravine, trends NW $0.7 \mathrm{mi}$. to Scotch Gulch, $12 \mathrm{mi}$. N of Nome, Seward Penin. High.; $64^{\circ} 41^{\prime} \mathrm{N}, 165^{\circ} 23^{\prime}$ W; (map 94) Var. Scotch-Irish Creek.

Reported as "Scotch-Irish Creek" on a map by S. E. King dated 1900 . 
Irish Gulch: ravine, trends NW $0.6 \mathrm{mi}$. to Goldstream Creek, 9 mi. NE of Fairbanks, YukonTanana High.; $64^{\circ} 57^{\prime} 30^{\prime \prime} \mathrm{N}, 147^{\circ} 35^{\prime} 45^{\prime \prime} \mathrm{W}$; (map 100).

Local miner's name; published in 1908 by USGS.

Irish Gulch: ravine, extends SE $1.7 \mathrm{mi}$. to Killarney Creek, $5 \mathrm{mi}$. S of Roughtop Mtn. and $38 \mathrm{mi}$. ESE of Tanana, Yukon-Tanana High.; $65^{\circ} 07^{\prime} 33^{\prime \prime} \mathrm{N}, 150^{\circ} 44^{\prime} 45^{\prime \prime} \mathrm{W}$; BGN 1961 ; (map 106).

Prospectors' name reported in 1960 by R. G. Wayland, USGS.

Irish Gulch: ravine, trends to Charley River, about $11 \mathrm{mi}$. S of its junc. with Yukon River, Porcupine Plat.; $65^{\circ} 09^{\prime}$ N., $142^{\circ} 50^{\prime} \mathrm{W}$; (map 103).

Mentioned by Mertie (1942, p. 250), USGS; this feature has not been positively identified.

Irish Lakes: lakes, $1.5 \mathrm{mi}$. long, on left bank of Keku Creek, 22 mi. N of Point Baker, on Kupreanof I., Alex. Arch.; 56 $40^{\circ} 30^{\prime \prime} \mathrm{N}, 133^{\circ}$. $32^{\prime} 00^{\prime \prime} \mathrm{W}$; (map 6).

Local name recorded in 1960 by USGS.

Irishmans Hat: rock, off $\mathrm{N}$ coast of Unalaska $\mathrm{I}$., Aleutian Is.; $53^{\circ} 59^{\prime} 38^{\prime \prime} \mathrm{N}, 166^{\circ} 49^{\prime} 22^{\prime \prime} \mathrm{W}$; (map 23).

Descriptive name published in the 1916 Coast Pilot (p. 213).

Iris Meadows: area, $2 \mathrm{mi}$. long, in central Kruzof 1., along unnamed stream NE of Shelikof Bay, $17 \mathrm{mi}$. NW of Sitka, Alex. Arch.; $57^{\circ} 11^{\prime} \mathrm{N}$, $135^{\circ} 43^{\prime} \mathrm{W}$; ( $\operatorname{map} 9$ ).

Local name reported in 1951 by USGS.

Irivik Creek: stream, flows SE $6 \mathrm{mi}$. to Killik River $5 \mathrm{mi}$. N of its junc. with Easter Creek, Brooks Ra.; $68^{\circ} 13^{\prime} \mathrm{N}, 154^{\circ} 06^{\prime} \mathrm{W}$; (map 133).

Eskimo name meaning "place where there is a cave," obtained in 1956 at Anaktuvuk Pass by Orth.

Iron Bridge Creek: stream, flows SW $3.8 \mathrm{mi}$. to Unimak Pass, on SW coast of Unimak I., $3 \mathrm{mi}$ $\mathrm{E}$ of Scotch Cap, Aleutian Is.; $54^{\circ} 23^{\prime} 55^{\prime \prime} \mathrm{N}$, $164^{\circ} 43^{\prime} 30^{\prime \prime} \mathrm{W}$; (map 24).

Name published in 1943 by AMS

Iron Creek: locality, on NE coast of Raspberry I., $13 \mathrm{mi}$. NW of Afognak, Kodiak Island; $58^{\circ} 05^{\prime} 20^{\prime \prime} \mathrm{N}, 153^{\circ} 05^{\prime} 20^{\prime \prime} \mathrm{W}$; (map 43).

$A$ reduction and saltery plant by this name was reported in 1952 by USGS.

Iron Creek: locality, on left bank of Iron Creek $0.6 \mathrm{mi}$. S of its junc. with Pilgrim River, $25 \mathrm{mi}$. NW of Solomon, Second Penin. High.; 64 ${ }^{\circ} 58^{\prime}$ N, $164^{\circ} 39^{\prime} \mathrm{W}$; (map 95). Var. Sowik.

A road house was shown here on the 1908 "Map of Seward Peninsula" by Arthur Gibson. Name derives from Iron Creek, which was the center of a major gold mining region in the early 1900 's.

Iron Creek: stream, heads in South Channel Yakataga River $2.4 \mathrm{mi}$. NE of the river's mouth, flows SW $3 \mathrm{mi}$. to Kuktoth River, $3 \mathrm{mi}$. NW of Cape Yakataga and $103 \mathrm{mi}$. NW of Yakutat, St. Elias Mts.; $60^{\circ} 05^{\prime} 30^{\prime \prime}$ N, $142^{\circ}-$ $29^{\prime} 40^{\prime \prime} \mathrm{W}$; (map 65)

Local name published by USGS in 1951.

Iron Creek: stream, flows $5 \mathrm{mi}$. NE to Chitina
River W of Lime Creek, 43 mi. SE of McCarthy, St. Elias Mts.; $61^{\circ} 03^{\prime} 10^{\prime \prime} \mathrm{N}, 141^{\circ} 52^{\prime} 30^{\prime \prime}$ W; (map 67).

Local name reported in 1915 by F. H. Moffit, USGS.

Iron Creek: stream, heads on SW slope of Iron Mtn., flows SW $7 \mathrm{mi}$. to Kotsina River, 0.3 $\mathrm{mi}$. $\mathrm{S}$ of the mouth of Loraine Creek and 75 mi. NE of Valdez, Wrangell Mts.; $61^{\circ} 36^{\prime} 00^{\prime \prime}$ N, $144^{\circ} 12^{\prime} 25^{\prime \prime} \mathrm{W}$; (map 68).

Local name reported in 1912 by D.C. Witherspoon, USGS.

Iron Creek: stream, flows SE $1.6 \mathrm{mi}$. to Moose Creek, 12 mi NE of Palmer, Talkeetna Mts.; $61^{\circ} 46^{\prime} 10^{\prime \prime} \mathrm{N}, 149^{\circ} 30^{\prime} 00^{\prime \prime} \mathrm{W}$; (map 69).

Local name reported in 1919 by $\mathrm{A}$. $\mathrm{H}$. Brooks and G. C. Martin (in Brooks and others, 1921, pl. 7), USGS.

Iron Creek: stream, flows NW $30 \mathrm{mi}$. to Talkeetna River, $22 \mathrm{mi}$. NE of Talkeetna, Talkeetna Mts.; $62^{\circ} 26^{\prime} 30^{\prime \prime} \mathrm{N}, 149^{\circ} 28^{\prime} 06^{\prime \prime} \mathrm{W}$; (map 82).

Local name recorded in 1917 by $\mathbf{S}$. $R$. Capps, USGS.

Iron Creek: stream, flows SE $0.7 \mathrm{mi}$. to Cache Creek, $29 \mathrm{mi}$. NW of Talkeetna, Alaska Ra.; $62^{\circ} 30^{\prime} 15^{\prime \prime} \mathrm{N}, 150^{\circ} 56^{\prime} 15^{\prime \prime} \mathrm{W}$; (map 81).

Prospectors' name reported in the 1930's by USGS.

Iron Creek: stream, heads in Alaska Range in Mount McKinley National Park, flows NW $15 \mathrm{mi}$. to Slippery Creek, $16 \mathrm{mi}$. SW of Wonder Lake, Tanana Low.; $63^{\circ} 22^{\prime} 30^{\prime \prime} \mathrm{N}$, $151^{\circ} 21^{\prime} 00^{\prime \prime} \mathrm{W}$; (map 88).

Local name reported in 1925 by $S$. $R$. Capps, USGS.

Iron Creek: stream, flows NW $3 \mathrm{mi}$. to Eldorado Greek $0.4 \mathrm{mi}$. $\mathrm{E}$ of its junc. with Madison Creek, $25 \mathrm{mi}$. NW of Ophir and $53 \mathrm{mi}$. NW of McGrath, Kilbuck-Kuskokwim Mts.; $63^{\circ} 26^{\prime} 45^{\prime \prime} \mathrm{N}, 156^{\circ} 55^{\prime} 30^{\prime \prime} \mathrm{W}$; (map 90).

Prospectors' name reported in 1917 by G. L. Harrington, USGS.

Iron Creek: stream, flows NW 3.5 to Our Creek, $80 \mathrm{mi}$. SW of Eagle, Yukon-Tanana High.; $64^{\circ} 05^{\prime} 20^{\prime \prime} \mathrm{N}, 143^{\circ} 16^{\prime} 40^{\prime \prime} \mathrm{W}$; (map 102)

Local name published in 1956 by USGS.

Iron Creek: stream, flows NE $5 \mathrm{mi}$. to Totatlanika River, $34 \mathrm{mi}$. SE of Nenana, Alaska Ra.; $64^{\circ} 07^{\prime} 30^{\prime \prime} \mathrm{N}, 148^{\circ} 32^{\prime} 45^{\prime \prime} \mathrm{W}$; (map 100 ).

Local name published in 1915 on GLO [BLM] survey plats.

Iron Creek: stream, flows SE $6.8 \mathrm{mi}$. to Norton Bay, $4 \mathrm{mi}$. NE of Elim and $67 \mathrm{mi}$. NE of Solomon, Seward Penin. High.; $64^{\circ} 40^{\prime} \mathrm{N}$, $162^{\circ} 11^{\prime}$ W; (map 95). Var. Miniatulik Creek.

Prospectors' name published on the 1908 "Map of Seward Peninsula" by Arthur Gibson.

Iron Creek: stream, flows N $1.3 \mathrm{mi}$. to Garnet Creek which flows to Flambeau River, $15 \mathrm{mi}$. NE of Nome, Seward Penin. High.; 64 $42^{\prime}$ $00^{\prime \prime}$ N, $165^{\circ} 07^{\prime} 30^{\prime \prime}$ W; (map 94). Var. Triple Creek, Tripple Creek.

Prospectors' name reported in 1900 by E. C. Barnard (in Brooks, 1901, pl. 17), USGS.
Iron Creek: stream, flows SW $0.8 \mathrm{mi}$. to Nome River $0.1 \mathrm{mi}$. upstream from Ice Gulch and $14 \mathrm{mi}$. N of Nome, Seward Penin. High.; $64^{\circ} 42^{\prime} \mathrm{N}, 165^{\circ} 19^{\prime} \mathrm{W}$; (map 94).

Prospectors' name reported on a map by S. E. King dated 1900.

Iron Creek: stream, flows NE $1.7 \mathrm{mi}$. to Ivanhoe Creek, $19 \mathrm{mi}$. NE of Solomon, Seward Penin. High.; $64^{\circ} 47^{\prime} \mathrm{N}, 164^{\circ} 05^{\prime} \mathrm{W}$; (map 95).

Prospectors' name reported on a 1902 prospectors' manuscript map.

Iron Creek: stream, formed by junc. of Canyon and Dome Creeks, flows NE $6 \mathrm{mi}$. to Pilgrim River, $25 \mathrm{mi}$. NW of Solomon, Seward Penin. High.; $64^{\circ} 59^{\prime} \mathrm{N}, 164^{\circ} 39^{\prime} \mathrm{W}$; (map 95).

Prospectors' name reported in 1900 by E. C. Barnard (in Brooks, 1901, pl. 17), USGS.

Iron Creek: stream, flows SE $1 \mathrm{mi}$. to Bluestone River, $11 \mathrm{mi}$. SE of Teller, Seward Penin. High.; $65^{\circ} 08^{\prime} \mathrm{N}, 166^{\circ} 10^{\prime} \mathrm{W}$; (map 111).

Prospectors' name reported on the 1908 "Map of Seward Peninsula" by Arthur Gibson.

Iron Creek: stream, flows NE $1.6 \mathrm{mi}$. to Woodchopper Creek, $5 \mathrm{mi}$. SW of that stream's junc. with Yukon River and $41 \mathrm{mi}$. SE of Circle, Yukon-Tanana High: $65^{\circ} 17^{\prime} 40^{\prime \prime} \mathrm{N}$, $143^{\circ} 24^{\prime} 30^{\prime \prime} \mathrm{W}$; (map 103).

Prospectors' name reported by A. H. Brooks (in Brooks and others, 1907, p. 203), USGS.

Iron Creek: stream, flows W $1 \mathrm{mi}$. to Allene Creek, in Agiapuk River basin, $10 \mathrm{mi}$. NE of Teller, Seward Penin. High.; $65^{\circ} 20^{\prime}$ N, $166^{\circ}$ 03' W; (map 111).

Prospectors' name reported on the 1908 "Map of Seward Peninsula" by Arthur Gibson.

Iron Creek: stream, flows $\mathrm{N} 1.3 \mathrm{mi}$. to join French Creek, forms North Fork Kougarok River, $3 \mathrm{mi}$. SE of Harris Dome and $37 \mathrm{mi}$. W of Imuruk Lake, Seward Penin. High.; $65^{\circ}$. $36^{\prime} \mathrm{N}, 164^{\circ} 27^{\prime} \mathrm{W}$; (map 110).

'Prospectors' name reported in 1901 by T. G. Gerdine (in Collier, 1902, pl. 12), USGS.

Iron Creek: stream, flows NW $4 \mathrm{mi}$. to Eldorado Creek in American River basin, $5 \mathrm{mi}$. $\mathrm{S}$ of Kougarok Mtn. and $39 \mathrm{mi}$. NE of Teller, Seward Penin. High.; $65^{\circ} 37^{\prime} \mathrm{N}, 165^{\circ} 17^{\prime} \mathrm{W}$; (map 111)

Prospectors' name reported on the 1908 "Map of Seward Peninsula" by Arthur Gibson. Iron Creek: stream, flows $\mathrm{N} 5 \mathrm{mi}$. to join May Creek, forms Sullivan Creek which flows to Kotzebue Sound, $27 \mathrm{mi}$, N of Imuruk Lake, Seward Penin. High.; $66^{\circ} 00^{\prime} \mathrm{N}, 163^{\circ} 10^{\prime} \mathrm{W}$; (map 110). Var. Irish Creek.

Prospectors' name reported in 1903 by D. C. Witherspoon (in Moffit, 1905, pl. 2), USGS. Iron Creek: stream, see Ferrum Creek.

Iron Creek: stream, see Miniatulik River. Iron Creek: stream, see Yellow Jacket Creek.

Iron Dome: peak, 2,600 ft., near S end of Kantishna Hills, on W bank of Eldorado Creek, $3.7 \mathrm{mi}$. NW of Wonder Lake, Alaska Ra.; $63^{\circ} 31^{\prime} 25^{\prime \prime} \mathrm{N}, 150^{\circ} 59^{\prime} 10^{\prime \prime} \mathrm{W} ;$ BGN 19.32; (map 88)

Prospectors' name reported in 1932 by $F$. G. Wells and S. C. Kain, USGS.

Iron Gulch: ravine, in Kantishna Hills, extends $0.5 \mathrm{mi}$. S to Eureka Creek, $3.2 \mathrm{mi}$. NNW of 
Wonder Lake, Alaska Ra.; 63 $32^{\prime} 20^{\prime \prime}$ N, 150'55'10" W; BGN 1932; (map 88).

Name reported in 1932 by USGS.

Iron Island: island, see Segula Island.

Iron Mountain: mountain, 5,745 ft., in Takshanuk Mts., $3.4 \mathrm{mi}$. NE of Wells and $15 \mathrm{mi}$. SW of Skagway, Coast Mts.; $59^{\circ} 25^{\prime} 30^{\prime \prime} \mathrm{N}, 135^{\circ} 50^{\prime} 00^{\prime \prime} \mathrm{W}$; BGN 1957; (map 45). Var. Kahwateta Mountain, Kahwaytetay Mountain.

Local name published in 1954 by USGS. Name is derived from a large deposit of magnetite iron ore discovered in the mountain about 1869. The Tlingit name "Kahwateta" published in 1952 by the USGS, according to E. C. Robertson, means "maiden hiding place" and was based on the local Indian custom of sending the young girls of the Klukwan village at the base of the mountain up to a glacial amphitheater near the top to hide, in order to appease the angry god of the mountain who, it was believed, caused the floods and mudflows which plagued the village during the fall months.

Iron Mountain: mountain, 4,274 ft., on Kenai Penin., in Kenai Mts., $2 \mathrm{mi}$. NW of Seward, Chugach Mts.; $60^{\circ} 08^{\prime} 30^{\prime \prime} \mathrm{N}, 149^{\circ} 29^{\prime} 30^{\prime \prime} \mathrm{W}$; (map 63).

Local name reported in 1951 by USGS.

Iron Mountain: mountain, 2,250 ft., on $\mathbf{E}$ coast of Knight I., between Rua Cove and Bay of Isles, $17 \mathrm{mi}$. NE of Chenega, Chugach Mts.; $60^{\circ} 22^{\prime} \mathrm{N}, 14^{\circ} 39^{\prime} \mathrm{W}$; (map 63 ).

Local name reported in 1951 by USGS.

Iron Mountain: mountain, 6,652 ft., $4 \mathrm{mi}$. SE of Alice Peak and $81 \mathrm{mi}$. NE of Valdez, Wrangell Mts. ; $61^{\circ} 37^{\prime} 20^{\prime \prime} \mathrm{N}, 144^{\circ} 02^{\prime} 00^{\prime \prime} \mathrm{W}$; (map 68).

Local name shown on a 1912 fieldsheet by D. C. Witherspoon, USGS.

Iron Mountain: mountain, 2,300 ft., $3 \mathrm{mi}$. NE of Cosmos Mtn. and $12 \mathrm{mi}$. NE of Shungnak, Brooks Ra. ; 67 $03^{\prime}$ N, $156^{\circ} 58^{\prime}$ W ; (map 126).

Name reported by P. S. Smith (1913, p. 108), USGS.

Iron Point: point of land, on SE coast of Segula I., Rat Is., Aleutian Is.; $52^{\circ} 00^{\circ} 30^{\prime \prime} \mathrm{N}, 178^{\circ}$ 11'15" E; BGN 1937; (map 15).

Reported in 1935 by personnel of U.S.S. Oglala; the name "Iron Island" was applied in 1855 to Segula Island by the U.S. Navy North Pacific Exploring Expedition.

Irr-maghe-zuk: lake, see Imuruk Basin.

Irving, Cape: point of land, see Muzon Cape.

Irving Peak: mountain, 2,136 ft., $1.5 \mathrm{mi}$. $\mathrm{S}$ of Slocum Inlet on E shore of Stephens Passage and $20 \mathrm{mi}$. SE of Juneau, Coast Mts.; $58^{\circ}$ $06^{\prime} 10^{\prime \prime} \mathrm{N}, 134^{\circ} 03^{\prime} 15^{\prime \prime} \mathrm{W}$; (map 11).

Named by Lt. Comdr. C. M. Thomas, USN, and published by USC\&GS in 1888 on Chart 8229.

Irwakhyarak: point of land, see Irwakyaruk Point.

Irwakyaruk Point: point of land, on $\mathrm{E}$ coast of Cape Mendenhall, $4 \mathrm{mi}$. SE of Ingrijoak Hill, Nunivak I., $59^{\circ} 46^{\prime} 30^{\prime \prime} \mathrm{N}, 166^{\circ} 05^{\prime} 00^{\prime \prime} \mathrm{W}$; (map 55). Var. Irwakhyarak, Irwaxyaruk.

Eskimo name obtained in 1949 by USC\&GS Irwaxyaruk: point of land, see Irwakyaruk Point.
Isaacs: locality, see Kwik.

Isaacs, Point: promontory, see Bald Head.

Isabel, Cabo: point of land, see Elizabeth, Cape.

Isabel, Lake: lake, $0.4 \mathrm{mi}$. across, $1.8 \mathrm{mi}$. SE of Gould I., near center of Prince of Wales I., Alex. Arch.; $55^{\circ} 15^{\prime} 45^{\prime \prime} \mathrm{N}, 132^{\circ} 32^{\prime} 50^{\prime \prime} \mathrm{W}$; (map 4).

Local name reported in 1908 by C. W. Wright (in Brooks and others, 1909, pl. 3), USGS.

Isabella Creek: stream, heads in Yukon-Tanana High., flows SW $5 \mathrm{mi}$. to Noyes Slough at Lemeta, 1 mi. N of Fairbanks; $64^{\circ} 52^{\prime} 30^{\prime \prime} \mathrm{N}$, $147^{\circ} 43^{\prime} 55^{\prime \prime} \mathrm{W}$; (map 100).

Local name appeared in 1905 on a manuscript map by C. W. Joint.

Isabella Gulch: ravine, trends $1 \mathrm{mi}$. SW to Darling Creek which flows to Nome River, $17 \mathrm{mi}$. NE of Nome, Seward Penin. High.; $64^{\circ} 44^{\prime}$ N, $165^{\circ} 12^{\prime} \mathrm{W}$; ( $\operatorname{map} 94$ ).

Prospectors' name shown on the 1904 "Map of Cape Nome Precinct" by Arthur Gibson. Isabella Pass: pass, see Isabel Pass.

Isabell Creek: stream, flows S $1.5 \mathrm{mi}$. to Livengood Creek, $1 \mathrm{mi}$. NE of Livengood, YukonTanana High.; $65^{\circ} 31^{\prime} 50^{\prime \prime} \mathrm{N}, 148^{\circ} 31^{\prime} 25^{\prime \prime} \mathrm{W}$; (map 105). Var. Benner Creek, Benner Gulch.

In 1916, J. B. Mertie, USGS, reported the name of this stream to be Benner Gulch (in Brooks and others, 1918, pl. 13). However, the miners subsequently applied the name of a local prospector to the stream.

Isabelle Pass: pass, see Isabel Pass.

Isabell Pass: pass, see Isabel Pass.

Isabel Pass: pass, 3,000 ft., on Richardson Highway, $1.6 \mathrm{mi}$. $\mathrm{N}$ of Summit Lake and $11 \mathrm{mi}$. N of Paxson, Alaska Ra.; $63^{\circ} 11^{\prime} 20^{\prime \prime}$ N, $145^{\circ}$ 33'00" W; BGN 1937; (map 86). Var. Isabella Pass, Isabelle Pass, Isabell Pass.

Local name on 1909 GLO map of Alaska. It is reported to be named for Mrs. Isabella Barnette (Davies, 1965, p. 22).

Isacheluich Mountains: mountains, 3,121 ft., between Sisiak Creek and Kaluktavik River, N of Grand Canyon of Noatak River, Brooks Ra.; 68 $00^{\prime} \mathrm{N}, 160^{\circ} 43^{\prime} \mathrm{W}$; (map 127).

Eskimo name meaning "young ducks," obtained in 1956 at Noatak by Orth.

Isahultila Mountains: mountains, 1,700 ft., 10 mi. across, between Hogatza and Koyukuk Rivers, $12 \mathrm{mi}$. SW of Hughes, Hogatza High.; $66^{\circ} 00^{\prime} \mathrm{N}, 154^{\circ} 45^{\prime} \mathrm{W}$; (map 116).

Indian name obtained at Huslia by Orth in 1956 .

Isanak: water passage, see Isanotski Strait.

Isannakhskiy, Proliv: bay, see Bechevin Bay.

Isannak Islands: islands, see Sanak Islands.

Isanotskay1, Sopka: mountains, see Isanotski Peaks.

Isanotski Bay: bay, see Bechevin Bay.

Isanotski Islands: islands, $0.1 \mathrm{mi}$. across, in Bechevin Bay, SW end of Aleutian Ra.; $55^{\circ} 00^{\prime} 00^{\prime \prime} \mathrm{N}, 163^{\circ} 19^{\prime} 40^{\prime \prime} \mathrm{W}$; (map 25). Var. Issanakh Islands.

Name derived from Isanotski Strait, given by W. H. Dall, USC\&GS, and published by USC\&GS on Chart 806 in 1882
Isanotski Peaks: mountains, 8,025 ft., on SE Unimak I., Aleutian Is.; $54^{\circ} 47^{\prime} 30^{\prime \prime} \mathrm{N}$, $163^{\circ} 13^{\prime} 45^{\prime \prime} \mathrm{W}$; (map 25). Var. Isanotskaya, Sopka, Isanotski Volcano, Issanakski, Mount Devastation.

Name derived from Isanotski Strait and published by Capt. Tebenkov (1852, map 24), IRN, as "Sop[ka] Isanotskaya" meaning "Isanotski Volcano."

Isanotski Strait: water passage, $1 \mathrm{mi}$. wide and 5 mi. long, between Unimak $I$. and Alaska Penin., Aleutian Is.; $54^{\circ} 49^{\prime} 30^{\prime \prime} \mathrm{N}$, $163^{\circ} 23^{\prime} 00^{\prime \prime} W$; (map 25). Var. False Pass, Isanak, Isanotskoi, Isanotzky, Issanakskie, Issannakh, Issanotsky.

Aleut name reported by Capt. Lutke, (1836, p. 262), IRN, as "Issanakh" from the word "isanaq" which, according to $R$. $H$. Geohegan, means "tear (split or strait)." The Russian Hydrog. Dept. includes Bechevin Bay in the application of the name "Pr[oliv] Isannakhskiy" on Chart 1379 published in 1847. See Bechevin Bay.

Isanotski Volcano: mountain, see Isanotski Peaks.

Isanotskoi: volcano, see Pogromni Volcano.

Isanotskoi: water passage, see Isanotski Strait. Isanotzky: water passage, see Isanotski Strait.

Isaoktuvik Creek: stream, flows SE $7.5 \mathrm{mi}$. to Noatak River 9 mi. SW of its junc. with Nimiuktuk River, Brooks Ra.; 67 $57^{\prime} \mathrm{N}$, $160^{\circ} 14^{\prime} \mathrm{W}$; (map 127).

Eskimo name meaning "where wings are eaten," obtained in 1956 at Noatak by Orth.

Ischignik: bay, see Chignik Bay.

Isenbeck: lagoon, see Izembek Lagoon.

Isetkoak: estuary, see Esatkuat Lagoon.

Ishiuk: locality, see Issheyuk.

Ishkialik River: stream, see Kolomak River.

Ishkialik River: stream, see Lithkealik River.

Ishkowik River: stream, flows S $28 \mathrm{mi}$. to Kuskokwim Bay, $21 \mathrm{mi}$. W of Quinhagak, Yukon-Kuskokwim Delta; $59^{\circ} 59^{\prime} \mathrm{N}, 162^{\circ} 44^{\prime}$ W; (map 54).

Eskimo name reported in 1951 by USGS. Ishoot: point of land, see Izhut, Cape.

Ishoot Creek: stream, see Ishut Creek.

Ishtalitna Creek: stream, heads in Ray Mts., flows N 21 mi. to Kanuti Kilolitna River, 49 mi. SE of Allakaket, Kokrines-Hodzana High.; $65^{\circ} 59^{\prime} \mathrm{N}, 151^{\circ} 41^{\prime} \mathrm{W}$; (map 106).

Indian name obtained in 1956 at Allakaket by Orth.

Ishugid Island: island, see Herbert Island.

Ishuk : point of land, see Halkett, Cape.

Ishukpak Bluf: bluff, elev. $300 \mathrm{ft}$, on $W$ bank of Colville River, $31 \mathrm{mi}$. NE of Umiat, Arctic Plain; $69^{\circ} 47^{\prime} \mathrm{N}, 151^{\circ} 31^{\prime} \mathrm{W}$; (map 141).

Eskimo name meaning "big end one [isukpak]" reported in 1956 by T. E. Taylor, USGS. Ishuktak Creek: stream, heads at $69^{\circ} 39^{\prime} \mathrm{N}$, $156^{\circ} 20^{\prime} \mathrm{W}$, flows N $85 \mathrm{mi}$. to Topagoruk River, $40 \mathrm{mi}$. SE of village of Meade River, Arctic Plain; $70^{\circ} 11^{\prime} \mathrm{N}, 155^{\circ} 57^{\prime} \mathrm{W}$; (map 148).

Eskimo name (isoqtoq) reported by USGS in 1956, meaning "it is muddy." 
Ishut Greek: stream, flows SE $5 \mathrm{mi}$. to Anikovik River, $14 \mathrm{mi}$. SE of Cape Prince of Wales and $41 \mathrm{mi}$. NW of Teller, Seward Penin. High.; $65^{\circ} 32^{\prime} \mathrm{N}, 167^{\circ} 37^{\prime} \mathrm{W}$; (map 111). Var. Ishoot Creek, Left Fork Onokovuk River.

Eskimo name reported in 1899 as "Ishoot" by Schraeder and Brooks (1900, map 3), USGS. Reported in 1900 as "Ishut" by Brooks (1901, pl. 13 and p. 135).

Isiak, Lake: lake, $1.5 \mathrm{mi}$. long, in Noatak River valley, $40 \mathrm{mi}$. SE of Howard Pass, Brooks Ra.; $67^{\circ} 43^{\prime} \mathrm{N}, 156^{\circ} 09^{\prime} \mathrm{W}$; (map 126$)$.

Eskimo name meaning "foot" [isagak] obtained at Kobuk by Orth in 1956 .

Isidor Hill: hill, $700 \mathrm{ft}$., on SW coast of Lulu I., Alex. Arch.; $55^{\circ} 27^{\prime} 15^{\prime \prime} \mathrm{N}, 133^{\circ} 35^{\prime} 30^{\prime \prime} \mathrm{W}$; $B G N$ 1923; (map 4). Var. Isidoro.

Named in 1923 by USC\&GS; derived from "Point Saint Isidor."

Isidoro: hill, see Isidor Hill.

Isiktok Creek: stream, heads at $60^{\circ} 42^{\prime} \mathrm{N}$, $164^{\circ} 50^{\prime} \mathrm{W}$, flows $\mathrm{W} 24 \mathrm{mi}$. to Chakchak Creek, $90 \mathrm{mi}$. W of Bethel, Yukon-Kuskokwim Delta; $60^{\circ} 42^{\prime} \mathrm{N}, 164^{\circ} 24^{\prime}$ W ; (map 58).

Eskimo name meaning "he enters," reported in 1965 by Orth.

Isikut Mountain: mountain, 4,310 ft., in Brooks Ra., E of Howard Pass; $68^{\circ} 13^{\prime}$ N, $156^{\circ} 30^{\prime} \mathrm{W}$ (map 132).

Eskimo name obtained at Noatak by Orth in 1956, referring to "some kind of foot."

Isituchi : locality, on Agattu I. in Near Is., Aleutian Is.; (map 13).

Former Aluet village reported as "uninhabited" by Hodge (1907, p. 622), BAE.

Iskep, Mys: point of land, see Escape Point.

Isla, Punta de la: point of land, see Suckling, Cape.

Island Bay: bay, $2 \mathrm{mi}$. across, on $\mathrm{S}$ coast of Alaska Penin., on E shore of Stepovak Bay, Aleutian Ra.; $55^{\circ} 42^{\prime} 30^{\prime \prime} \mathrm{N}, 159^{\circ} 40^{\prime} 00^{\prime \prime} \mathrm{W}$; (map 27).

Local name published by USC\&GS in 1916 Coast Pilot.

Island Bay: bay, extends $1.8 \mathrm{mi}$. $\mathrm{N}$, off Jute Bay, on E coast of Alaska Penin., $50 \mathrm{mi}$. W of Karluk, Aleutian Ra.; $57^{\circ} 33^{\prime} 20^{\prime \prime} \mathrm{N}, 1^{\circ} 5^{\circ}$. $50^{\prime} 60^{\prime \prime} \mathrm{W}$; (map 35).

Descriptive local name obtained from J. L. McPherson of Iliamna and published by G. C. Martin (1921, pl. 10), USGS.

Island Bay: bay, extends NW $1.3 \mathrm{mi}$. on $\mathrm{N}$ coast of Spruce I., NE of Kodiak I.; $57^{\circ} 57^{\prime} 20^{\prime \prime} \mathrm{N}$, $152^{\circ} 25^{\prime} 00^{\prime \prime} \mathrm{W}$; (map 34$)$.

Descriptive local name published in 1943 by USC\&GS.

Island Bay: cove, extends $\mathrm{E} 0.8 \mathrm{mi}$., off Tlevak Strait, on $\mathbf{W}$ coast of Sukkwan I., $\mathbf{N}$ of Dunbar Inlet, Alex. Arch.; $55^{\circ} 05^{\prime} 40^{\prime \prime} \mathrm{N}, 132^{\circ}$ $52^{\prime} 10^{\prime \prime} \mathrm{W}$; (map 4).

Local name published in 1932 Coast Pilot (p. 190)

Island Butte: mountain, 2,200 ft., $7 \mathrm{mi}$. NE of Thumb Mtn. and $42 \mathrm{mi}$. NE of Goodnews, Kilbuck-Kuskokwim Mts. ; $59^{\circ} 41^{\prime} \mathrm{N}, 161^{\circ} 05^{\prime}$ W; (map 53)

Local descriptive name shown on 1898 fieldsheet by W. S. Post, USGS.
Island Cove: cove, $1 \mathrm{mi}$. across, at Cobol, in Slocum Arm, on SW coast of Chichagof I., Alex. Arch.; $57^{\circ} 29^{\prime} \mathrm{N}, 135^{\circ} 52^{\prime} \mathrm{W}$; $B G N$ 1908; (map 9).

Descriptive name given in 1908 by USC\&GS; published in 1908 Coast Pilot (p. 172). "So named because of the many small islands in the cove."

Island Creek: stream, on Kenai Penin., flows NW $2 \mathrm{mi}$. to Resurrection Creek, $6 \mathrm{mi}$. S of Hope, Chugach Mts.; $60^{\circ} 49^{\prime} 55^{\prime \prime} \mathrm{N}, 149^{\circ} 38^{\prime} 00^{\prime \prime} \mathrm{W}$; (map 63).

Local prospectors' name reported in 1904 by Moffit (1906, pl. 2), USGS.

Island Glacier: glacier, on $\mathrm{N}$ slope of Mount Veniaminof, trends $\mathrm{N} 3 \mathrm{mi}$. to its terminus at head of Fireweed Creek, $12 \mathrm{mi}$. W of Knife Peak, Aleutian Ra.; $56^{\circ} 17^{\prime} \mathrm{N}, 159^{\circ} 24^{\prime} \mathrm{W}$; (map 30).

Descriptive name reported in 1923 by $R$. H. Sargent, USGS.

Island Group: rocks, $0.1 \mathrm{mi}$. across, part of Sandman Reefs, 14 mi. SE of Deer I., Aleutian Ra.; $54^{\circ} 47^{\prime} 40^{\prime \prime} \mathrm{N}, 161^{\circ} 56^{\prime} 50^{\prime \prime} \mathrm{W}$; (map 25).

Name published in 1949 on a USGS map. Island Lake: lake, $0.5 \mathrm{mi}$. long, E central Heceta I., Alex. Arch.; $55^{\circ} 46^{\prime} 25^{\prime \prime} \mathrm{N}, 133^{\circ} 24^{\prime} 30^{\prime \prime} \mathrm{W}$; (map 4)

Local name recorded in 1951 by USGS.

Island Lake: lake, $0.2 \mathrm{mi}$. across, on Baranof $\mathrm{I}$., $9 \mathrm{mi}$. N of Port Alexander, Alex. Arch.; 56 ${ }^{\circ}$ $22^{\prime} 30^{\prime \prime} \mathrm{N}, 134^{\circ} 42^{\prime} 20^{\prime \prime} \mathrm{W}$; (map 5 )

Local descriptive name obtained in 1951 by USGS.

Island Lake: lake, $0.6 \mathrm{mi}$. long, $2.5 \mathrm{mi}$. NE of Kodiak, Kodiak I.; $57^{\circ} 49^{\prime} 05^{\prime \prime} \mathrm{N}, 152^{\circ} 21^{\prime}$ 00" W; BGN 1964; (map 34). Var. Melnitsa Lake, Ozero Melnichi.

Local name published in 1964 by USGS. Cialled "O[zero] Melnichi," meaning "mill lake," by Capt. Tebenkov (1852, map 23) because there was a mill nearby at the head of "Mill Bay."

Island Lake: lake, $500 \mathrm{ft}$. across, $3.5 \mathrm{mi}$. W of terminus of Sheridan Glacier, $10 \mathrm{mi}$. E of Cordova, Chugach Mts.; $60^{\circ} 32^{\prime} \mathrm{N}, 145^{\circ} 29^{\prime} \mathrm{W}$; (map 64).

Local descriptive name published in 1950 wy USGS.

Island Lake: lake, $1.2 \mathrm{mi}$. across, on Kenai Penin., $10 \mathrm{mi}$. N of Kenai, Cook Inlet Low.; o0 $42^{\prime} 30^{\prime \prime} \mathrm{N}, 151^{\circ} 18^{\prime} 30^{\prime \prime} \mathrm{W}$; ( $\operatorname{map} 62$ ).

Local name reported in 1964 by USGS

1sland Lake: lake, $1.6 \mathrm{mi}$. long, drains $S$ to Tolsona Creek, $17 \mathrm{mi}$. NW of Glennallen, Copper River Basin ; 62 $2^{\circ} 12^{\prime} \mathrm{N}, 146^{\circ} 02^{\prime} \mathrm{W}$; (m>p 83).

Local descriptive name reported by USGS in 1949.

Island Lake: lake, $1.2 \mathrm{mi}$. long, $\mathrm{E}$ of Alaska Highway, $30 \mathrm{mi}$. SE of Northway Junction, Alaska Ra.; $62^{\circ} 42^{\prime} \mathrm{N}, 141^{\circ} 07^{\prime} \mathrm{W}$; (map 84).

Locally named because of the island in its rnnt:r: reportad by USGS in 1955.

Island Lake: lake, $1.3 \mathrm{mi}$. long, $\mathrm{E}$ of Tetlin Lake, $18 \mathrm{mi}$. SE of Tok, Alaska Ra.; $63^{\circ} 06^{\prime} \mathrm{N}, 142^{\circ}$ $39^{\prime} \mathrm{W}$ : (map 85).

Namc reported by USGS in 1964.
Island Lake: lake, $2 \mathrm{mi}$. long, at head of Island Lake Creek, $1.8 \mathrm{mi}$. N of Stevens Village, Yukon Flats; $66^{\circ} 02^{\prime} 30^{\prime \prime} \mathrm{N}, 149^{\circ} 04^{\prime} 00^{\prime \prime} \mathrm{W}$; (map 118).

Local descriptive name obtained in 1956 by USGS.

Island Lake: lake, $1.8 \mathrm{mi}$. long, $3.5 \mathrm{mi} . \mathrm{S}$ of Beaver, Yukon Flats; $66^{\circ} 17^{\prime} \mathrm{N}, 147^{\circ} 21^{\prime} \mathrm{W}$; (map 118).

Local descriptive name obtained in 1956 by USGS.

Island Lake: lake, $0.5 \mathrm{mi}$. long, $22 \mathrm{mi} . \mathrm{N}$ of Chalkyitsik, Yukon Flats; $66^{\circ} 57^{\prime} \mathrm{N}, 143^{\circ} 46^{\prime}$ W; (map 120).

Local descriptive name reported in 1956 by R. C. Foley, USGS.

Island Lake: lake, $1.4 \mathrm{mi}$. long, $2 \mathrm{mi}$. NW of Old John Lake and $10 \mathrm{mi}$. E of Arctic Villag:, Brooks Ra.; 68 ${ }^{\circ} 07^{\prime} 30^{\prime \prime} \mathrm{N}, 145^{\circ} 08^{\prime} 00^{\prime \prime} \mathrm{W}$; (map 136).

Local descriptive name obtained in 1956 by USGS.

Island Lake Creek: stream, flows SW $4.5 \mathrm{mi}$. to Yukon River, $2 \mathrm{mi}$. NW of Stevens Village, Yukon Flats; $66^{\circ} 01^{\prime} 30^{\prime \prime} \mathrm{N}, 149^{\circ} 09^{\prime} 30^{\prime \prime} \mathrm{W}$; (map 118).

Local descriptive name obt :ined in 1956 by USGS.

Island Mountain: mountain, 2,281 ft., trends NE 7 mi. from Faro Creek $\mathrm{E}$ of Mitlak Mtn., $24 \mathrm{mi}$. N of Goodnews, Kilbuck-Kuskokwim Mts.; $59^{\circ} 27^{\prime} \mathrm{N}, 161^{\circ} 25^{\prime} \mathrm{W}$; (map 53). Var. Kikgtaguat.

Descriptive name published in 1921 by USGS. The Eskimo name is reported to be "Kikgtiguat," meaning "island like," which refers to its isolated position.

Island Number 3, 6, 11, 12, 13, 19, 20: barrier islands, on Beaufort Sea coast, NW of Flaxman I., Arctic Plain; (map 151).

These seven islands were given numbers in 1911 by Leffingwell (1919) to identify some of his surveying points. The individual islands can no longer be positively identified. Island of the Four Peaks: mountain, see Fourpeaked Mountain.

Island Point: point of land, $5.5 \mathrm{mi}$. SW of Salt Island, on $\mathbf{N}$ coast of Atka I., Aleutian Is. $52^{\circ} 07^{\prime} 00^{\prime \prime} \mathrm{N}, 174^{\circ} 45^{\prime} 05^{\prime \prime} \mathrm{W}$; (map 18 )

Descriptive name which was published by the USC\&GS in the 1944 Aleutian Coast Pilot (p. 96), was given "because a low valley between the head land and the main shore gave it the appearance of an island to ships approaching from the west."

Island Point: point of land, on Sitklan I, off $\mathrm{S}$ entrance Tongass Passage, Coast $\mathrm{Mts}$; $54^{\circ} 43^{\prime} 50^{\prime \prime} \mathrm{N}, 130^{\circ} 38^{\prime} 30^{\prime \prime} \mathrm{W}$. (map 2).

Descriptive name given in 1883 by L.t. Comdr. H. E. Nichols, USN.

Island Point: point of land, on offshore island $\mathrm{N}$ point of entrance of McLean Arm, SE coast of Prince of Wales Is., Alex. Arch. ; 54 ${ }^{\circ} 48^{\prime} 15^{\prime \prime}$ $\mathrm{N}, 131^{\circ} 57^{\prime} 15^{\prime \prime} \mathrm{W}$; (map 2).

Local descriptive name reported in 1904 by H. C. Fassett, USBF.

Island Point: point of land, $\mathrm{S}$ point of entrance to Kasaan Bay, on E coast of Prince of Wales 
I., Alex. Arch.; $55^{\circ} 22^{\prime} 25^{\prime \prime}$ N, $132^{\circ} 10^{\prime} 00^{\prime \prime} \mathrm{W}$; (map 4).

Descriptive name given in 1880 by $\mathrm{W} . \mathrm{H}$. Dall, USC\&GS.

Island Point: point of land, on Revillagigedo I., on $W$ shore of Carroll Inlet, $15 \mathrm{mi}$. NE of Ketchikan, Alex. Arch.; $55^{\circ} 27^{\prime} 15^{\prime \prime} \mathrm{N}, 131^{\circ}$ 18'45" W; (map 3).

So named in 1891 by USC\&GS because "there is an island off this point."

Island Point: point of land, on E coast of Lindenberg Penin., Kupreanof I., $10 \mathrm{mi}$. S of Petersburg, Alex. Arch.; 56 $39^{\circ} 55^{\prime \prime} \mathrm{N}, 132^{\circ}$ $55^{\prime} 00^{\prime \prime} \mathrm{W}$; (map 6).

So named in 1884 by Comdr. J. B. Coghlan, USN, "because there is an island off the point."

Island Point: point of land, on E shore of Karluk Lake, $21 \mathrm{mi}$. SE of Karluk, Kodiak I., 57 $21^{\prime} 45^{\prime \prime} \mathrm{N}, 154^{\circ} 01^{\prime} 30^{\prime \prime} \mathrm{W}$; (map 35).

Local descriptive name reported in 1952 by USGS.

Island Point: point of land, at $\mathrm{W}$ end of Peril Strait, on NW coast of Baranof I., $26 \mathrm{mi}$. NW of Sitka, Alex. Arch.; $57^{\circ} 24^{\prime} 10^{\prime \prime} \mathrm{N}, 135^{\circ}$ $36^{\prime} 45^{\prime \prime}$ W ; (map 9).

Descriptive name given in 1884 by Comdr. J. B. Coghlan, USN; published by USC\&GS in 1891 Coast Pilot (p. 182). "So called because of a small island at the end of the point."

Island Point: point of land, on E shore of Reindeer Cove, $16 \mathrm{mi}$. W of Christmas Mtn., Nulato Hills; $64^{\circ} 32^{\prime} \mathrm{N}, 161^{\circ} 05^{\prime} \mathrm{W}$; (map 96).

Local name published in 1943 by USC\&GS.

Island Rock: rock, at Nichols Point, in Isanotski Strait, Aleutian Ra. ; $54^{\circ} 51^{\prime} 25^{\prime \prime} \mathrm{N}, 163^{\circ} 23^{\prime} 20^{\prime \prime}$ W; (map 25).

Descriptive name published in 1912 by USC\&GS.

Islands, Bay of: bay, $3 \mathrm{mi}$. across, on $\mathrm{W}$ coast of Adak I., Aleutian Is.; $51^{\circ} 49^{\prime} \mathrm{N}, 176^{\circ} 49^{\prime} \mathrm{W}$; BGN 1936; (map 17).

Descriptive name given by $W . H$. Dall in 1873 and published by USC\&GS in 1875.

Islands, Bay of: $b a y$, extends NE $8 \mathrm{mi}$. off North Arm Naknek Lake, on Alaska Penin., in Katmai National Monument, $30 \mathrm{mi}$. NW of Mount Katmai, Aleutian Ra.; $58^{\circ} 39^{\prime} \mathrm{N}$, 155³2' W; BGN 1925; (map 42) Var. Elingit Lake.

Named in 1922 by R. F. Griggs, National Geographic Society. In 1923 R. H. Sargent, USGS, reported the "native name as "Elingit." Islands, Bay of: bay, see North Arm Naknek Lake.

Islands, Bay of: water passage, see Salisbury Sound.

Island Slough: stream, see Patsy Slough.

Islas Bay: bay, $1.7 \mathrm{mi}$. across, $15 \mathrm{mi}$. NW of Chichagof, on W coast of Chichagof I., Alex. Arch.; $57^{\circ} 49^{\prime} \mathrm{N}, 136^{\circ} 23^{\prime} \mathrm{W}$; (map 9).

Descriptive name given by USC\&GS ; published in 1928 on Chart 8258. The name is Spanish, meaning "islands"; so named "because of the many islands in the bay."
Isle Point: point of land, on SW coast of Etolin I., at $S$ entrance of Burnett Inlet, Alex. Arch.; $56^{\circ} 02^{\prime} \mathrm{N}, 132^{\circ} 29^{\prime} \mathrm{W} ; B$ B 1914 ; (map 6 ).

Named in 1914 by USC\&GS.

Isles, Bay of: estuary, on $\mathrm{E}$ coast of Knight I., extends NE $4 \mathrm{mi}$. to Prince William Sound, $18 \mathrm{mi}$. NE of Chenega, Chugach Mts.; $60^{\circ} 24^{\prime}$ $N, 147^{\circ} 37^{\prime} \mathrm{W}$; BGN 1908; (map 63).

Descriptive local name published in 1908 by USC\&GS.

Islet, Point: point of land, see Isleta Point.

Isleta: island, on the $\mathrm{E}$ shore of Lulu Island, Portillo Channel, in the Bucareli Bay area of SW Prince of Wales I., Alex. Arch.; $55^{\circ} 27^{\prime} \mathrm{N}$, $133^{\circ} 25^{\prime}$ W. Var. Ysleta.

Named "Ysleta," meaning "rocky island," by F. A. Maurelle and Don Juan de la Bodega y Quadra, probably in 1779 .

Isleta, Point: point of land, on W coast of Suemez I., in Port Santa Cruz, Alex. Arch.; 55 16 $30^{\prime \prime}$ N, $133^{\circ} 36^{\prime} 30^{\prime \prime} \mathrm{W}$; (map 4). Var. Mys de los Islotilos, Point Islet, Punta de la Isleta, Punta de los Yslotillos.

Spanish word meaning "rocky island" published in 1932 Coast Pilot (p. 209). In 1779, Don Juan de la Bodega y Quadra and Francisco Antonio Maurelle named this feature "Punta de la Isleta," apparently for the islet off the point.

Islet Cape: point of land, see Ostrovka Point Islet Lake: lake, $0.5 \mathrm{mi}$. long, on central Admiralty I., $2 \mathrm{mi}$. E of Hasselborg Lake and $19 \mathrm{mi}$. NE of Angoon, Alex. Arch.; 57 $39^{\prime} 10^{\prime}$ $\mathrm{N}, 134^{\circ} 10^{\prime} 30^{\prime \prime} \mathrm{W}$; (map 9).

Local name reported in 1951 by USGS.

Islet Pass: water passage, between Kanga and Redoubt Bays, $4.5 \mathrm{mi}$. N of Goddard, on W coast of Baranof I., Alex. Arch.; 56 $54^{\prime} \mathrm{N}$, $135^{\circ} 21^{\prime}$ W; (map 6). Var. Islet Passage.

Local fishermen's name reported in 1947 by USC\&GS.

Islet Passage: water passage, see Islet Pass.

Islote, Punta de los: point of land, see Islotillos, Punta de los.

Islotillos, Punta de los: point of land, just SE of Craig at the entrance to Port Bagial opposite Cape Suspiro, Alex. Arch.; $55^{\circ} 28^{\prime} \mathrm{N}, 133^{\circ} 07^{\prime}$ W. Var. Punta de los Islote

Spanish name meaning "point of the small rocky islands" given by F. A. Maurelle and Don Juan de la Bodega y Quadra in 1779 . It is called "Islote" in the text.

Islotilos, Mys de los: point of land, see Isleta Point.

Ismaeloff Strait: w'ater passage, see Sheliko Strait.

Ismailof Island: island, $1.4 \mathrm{mi}$. long, at entrance to Halibut Cove, on $\mathbf{E}$ shore of Kachemak Bay, 11 mi. ESE of Homer, Chugach Mts. $59^{\circ} 36^{\prime} \mathrm{N}, 151^{\circ} 14^{\prime} \mathrm{W}$; (map 50).

Named in 1880 by W. H. Dall, USC\&GS, for Gerassiim Grigorovich Ismailov, IRN who made explorations in Alaska in the late 18th Century. His name was spelled "Erasim Gregorieoff Sin Ismyloff" in 1788 by Capt. James Cook, RN; Capt. George Vancouver $(1798$, v. 3, p. 192), RN, called him "Mr. Smyloff."
Isom Creek: stream, flows SW $13 \mathrm{mi}$. to Yukon River, $21 \mathrm{mi}$. NE of Rampart, Yukon-Tanana High.; $65^{\circ} 45^{\prime} \mathrm{N}, 149^{\circ} 47^{\prime} \mathrm{W}$; (map 105). Var. Indian Pass Creek.

Prospectors' name reported in 1902 by $\mathbf{~ L t}$. Hjalmar Erickson, USA

Israthorak Creek: watercourse, anabranch of Kuskokwim River, heads at $61^{\circ} 19^{\prime} \mathrm{N}, 160^{\circ}$. $43^{\prime} \mathrm{W}$, and flows SW $90 \mathrm{mi}$. to the Pikmiktalik River, $29 \mathrm{mi}$. W of Tuluksak and $45 \mathrm{mi}$. SW of Russian Mission, Yukon-Kuskokwim Delta; $61^{\circ} 11^{\prime} \mathrm{N}, 161^{\circ} 49^{\prime} \mathrm{W}$; (map 73$)$.

Eskimo name reported in 1949 by USC\&GS Issanakh Islands: islands, see Isanotski Islands. Iss?nakski: mountain, see Isanotski Peaks. Issanakskie: water passage, see Isanotski Strait. Iss?nnakh: water passage, see Isanotski Strait Issannakh Bay: bay, see Bechevin Bay.

Issannak Island: island, see Sanak Island.

Issanotsky: water passage, see Isanotski Strait. Issheyuk: locality, at Howard Pass or perhaps near Lake Etivluk, Brooks Ra.; $68^{\circ} 10^{\prime} \mathrm{N}$, $156^{\circ} 30^{\prime} \mathrm{W}$; (map 132). Var. Ishiuk.

An Eskimo village visited by $\mathbf{L t}$. Stoney (1900, p. 39), USN, in December 1885 and reported by him as "a village of fifteen huts, situated near the northern limit of the mountain range." Irving (1954, p. 204) mentions an area of the Nigu River presently called "Issygok," a name comparable to Stoney's "Issheyuk." See Issygok Lake.

Issortulik Slough: stream, flows NW $8 \mathrm{mi}$. to S side of Hooper Bay, 4.5 mi. W of Keoklevik River, Yukon-Kuskokwim Delta ; 61 ${ }^{\circ} 25^{\prime} \mathrm{N}$, $165^{\circ} 55^{\prime} \mathrm{W}$; (map 75).

Eskimo name reported in 1951 by USC\&GS. Issuk Creek: stream, see Isuk Creek.

Issygok Lake: lake, $0.5 \mathrm{mi}$. across, in valley of Nigu River, $31 \mathrm{mi} \mathrm{SE}$ of Howard Pass, Brooks Ra.; $68^{\circ} 04^{\prime} \mathrm{N}, 155^{\circ} 43^{\prime} \mathrm{W}$; (map 133).

Eskimo name reported by Irving (1954, p. 204) referring to low hills WSW of Siavlat Mtn. Name was transferred to the lake by Orth in 1956. See Issheyuk.

Isthmus Bay: bay, extends $\mathrm{W} 1.7 \mathrm{mi}$. off Chiniak Bay, $\mathbf{E}$ of Isthmus Point, $11 \mathrm{mi}$. $\mathbf{S}$ of Kodiak, Kodiak I.; $57^{\circ} 37^{\prime} 30^{\prime \prime}$ N, $152^{\circ} 18^{\prime} 00^{\prime \prime} \mathrm{W}$; (map 34). Var. Peresheechnoi, Zaliv Peresheynoy.

Translation of the descriptive name " $\mathrm{Z}$ [aliv] Peresheynoy," published by Sarichev (1826, map 16).

Isthmus Cove: cove, see Brookers Lagoon.

Isthmus Island: island, $250 \mathrm{ft}$. long, in Kalsin Bay, $10 \mathrm{mi}$. S of Kodiak, Kodiak I.; $57^{\circ} 38^{\prime} 35^{\prime \prime}$ N, $152^{\circ} 25^{\prime} 20^{\prime \prime} \mathrm{W}$; (map 34). Var. Ostrov Peresheyechnoy.

Translation of the descriptive name "Os[trov] Peresheyechnoy," published by Sarichev (1826, map 19).

Isthmus Point: point of land, between Isthmus and Kalsin Bays, S shore Chiniak Bay, 11 mi. S of Kodiak, Kodiak I.; $57^{\circ} 37^{\prime} 45^{\prime \prime} \mathrm{N}$, $152^{\circ} 19^{\prime} 30^{\prime \prime} \mathrm{W}$; (map 34 ).

Descriptive name derived from Isthmus Bay and published in 1949 by USGS.

Istku Point: point of land, on NE coast of Tuxekan I., between Jinhi Bay and Tuxekan 
Narrows, $29 \mathrm{mi}$. N of Craig, Alex. Arch.; $55^{\circ} 53^{\prime} 10^{\prime \prime} \mathrm{N}, 133^{\circ} 14^{\prime} 45^{\prime \prime} \mathrm{W}$; (map 4).

Indian name published in 1964 by USC\&GS.

Istna River: stream, see South Fork Kuskokwim River.

Isto, Mount: mountain, 9,060 ft., in Romanof Mts., 12 mi. ESE of Mount Michelson, Brooks Ra.; $69^{\circ} 12^{\prime} 00^{\prime \prime} \mathrm{N}, 143^{\circ} 47^{\prime} 50^{\prime \prime} \mathrm{W}$; $B G N$ 1966; (map 38).

Named in 1966 by Earl H. Beistline, Univ. of Alaska, for Reynold E. (Pete) Isto (1913$65)$, civil engineer with the USGS, resident engineer in Alaska 1954-61, pioneer in the use of helicopters for Alaskan mapping, and head of field parties mapping the Brooks Range in 1956.

Isuk: point of land, see Halkett, Cape.

Isuk Creek: stream, flows SW $1.7 \mathrm{mi}$. to Chukchi Sea, $2.9 \mathrm{mi}$. NW of Cape Thompson, Arctic Slope; $68^{\circ} 11^{\prime} 00^{\prime \prime} \mathrm{N}, 166^{\circ} 00^{\prime} 50^{\prime \prime} \mathrm{W}$; BGN 1963; (map 129). Var. Eesook Creek, Issuk Creek.

Eskimo name meaning "end" or "last one" reported in 1950 by USC\&GS as "Ee-sook."

Isuk Creek: stream, flows NW $5.5 \mathrm{mi}$. to Chukchi Sea, $17 \mathrm{mi}$. E of Cape Lisburne, Arctic Slope; 68 $8^{\circ} 1^{\prime} 10^{\prime \prime} \mathrm{N}, 165^{\circ} 33^{\prime} 05^{\prime \prime} \mathrm{W}$; (map 129).

Var, Eesook Creek, Issuk Creek.

Eskimo name reported in 1950 by USC\&GS. Isuk Lagoon: lagoon, see Akoviknak Lagoon.

Isurik Creek: stream, flows $\mathrm{S} 5 \mathrm{mi}$. to Goodnews River, $22 \mathrm{mi}$. NE of Goodnews, KilbuckKuskokwim Mts. ; 59 $18^{\prime} \mathrm{N}, 161^{\circ} 05^{\prime} \mathrm{W}$; (map 53).

Eskimo name reported to mean "seal" or "man killed seal here"; obtained in about 1951 by J. M. Hoare, USGS, from C. B. Michael, missionary at Quinhagak.

Isutkwa: locality, at Point Barrow, Arctic Plain; (map 153).

Former Eskimo camp or settlement reported in 1892 by Sgt. John Murdoch, USA.

Isutkwa: estuary, see Esatkuat Lagoon.

Iswak Point: promontory, see Igvak, Cape.

Italian Bay: cove, extends $\mathrm{S} 0.8 \mathrm{mi}$. to Knight

I. Passage, on $S$ coast of Knight I., $8 \mathrm{mi}$. SE

of Chenega, Chugach Mts.; $60^{\circ} 13^{\prime} 30^{\prime \prime} \mathrm{N}$, 147 53'45" W ; BGN 1966; (map 63). Var. Italian Cove.

Local name reported in 1909 by USC\&GS. Italian Cove: cove, see Italian Bay.

Italio River: stream, heads $3 \mathrm{mi}$. SE of Harlequin Lake, flows W $20 \mathrm{mi}$. to Gulf of Alaska, $28 \mathrm{mi}$. SE of Yakutat Bay, Malaspina Coastal Plain; $59^{\circ} 19^{\prime} 40^{\prime \prime} \mathrm{N}, 139^{\circ} 14^{\prime} 30^{\prime \prime} \mathrm{W}$; (map 46).

Name reported by Lt. Comdr. Moser (1901, p. $386, \mathrm{pl} .43$ ), USN.

Itchadak: locality, "on one of the eastern Aleutian Is., E of Unalaska I.," Aleutian Is.

Former Aleut village reported by Coxe (1787, p. 165).

Iteriak Creek: stream, flows $\mathrm{N} 28 \mathrm{mi}$. to E Fork Etivluk River $16 \mathrm{mi}$. SE of its junc. with Etivluk River, Brooks Ra.; $68^{\circ} 38^{\prime} \mathrm{N}, 1^{155^{\circ}} 45^{\prime}$ W; BGN 1960; (map 133).

Eskimo name for ermine (Mustela erminea arctica), given by USGS geologists about 1950 "because many weasel or ermine were noted in the area by the fieldparty."

Ithagsutlek Lake: lake, $2 \mathrm{mi}$. across, $5 \mathrm{mi}$. $\mathrm{E}$ of Kwinhagak and $45 \mathrm{mi}$. $\mathrm{N}$ of Goodnews, Yukon-Kuskokwim Delta; $59^{\circ} 45^{\prime} \mathrm{N}, 161^{\circ} 45^{\prime}$ W; (map 53).

Eskimo name published in 1951 by USGS.

Itigaknit Mountain: mountain, 3,200 ft., on $\mathrm{N}$ slope of Endicott Mts. between Itkillik and Kuparuk Rivers, Arctic Slope; $68^{\circ} 44^{\prime} \mathrm{N}$, $149^{\circ} 49^{\prime} \mathrm{W}$; (map 135).

Eskimo name reported in 1956 by USGS.

Itikmalaiyak Creek: stream, flows NW $5 \mathrm{mi}$. to Anaktuvuk River, $14 \mathrm{mi}$. NE of Anaktuvuk Pass, Brooks Ra.; $68^{\circ} 19^{\prime} \mathrm{N}, 151^{\circ} 28^{\prime} \mathrm{W}$; (map 134). Var. Itikmaluruk Creek.

Eskimo name published by Rausch (1951, p. 150) as Itikmaluruk Creek; USGS reported its present spelling in 1956; it refers in meaning to "little rectum."

Itikmalakpak Creek: stream, flows NNW $18 \mathrm{mi}$. along $\mathrm{E}$ side of Mount Stuver then NW to Anaktuvuk River, $20 \mathrm{mi}$. NE of Anaktuvuk Pass, Brooks Ra.; $68^{\circ} 24^{\prime} 15^{\prime \prime}$ N, $151^{\circ} 28^{\prime} 00^{\prime \prime}$ W; (map 134). Var. Itikmalukpuk Creek.

Eskimo name, meaning "big rectum," published by Rausch (1951, p. 150) as Itikmalukpuk Creek.

Itikmalak River: stream, in Endicott Mts., heads at glacier terminus, flows NW $21 \mathrm{mi}$. to Itkillik River, $3.7 \mathrm{mi}$. N of Itkillik Lake, Arctic Slope; $68^{\circ} 28^{\prime} 30^{\prime \prime} \mathrm{N}, 149^{\circ} 59^{\prime} 00^{\prime \prime} \mathrm{W}$; (map 135).

Eskimo name reported in 1956 by USGS. Itikmalukpuk Creek: stream, see Itikmalakpak Creek.

Itikmaluruk Creek: stream, see Itikmalaiyak Creek.

Itilyiargiok Creek: stream, flows W $20 \mathrm{mi}$. to to Nigu River, $\mathbf{N}$ of Siavlat Mtn., $30 \mathrm{mi}$. SE of Howard Pass, Brooks Ra.; $68^{\circ} 05^{\prime} \mathrm{N}, 155^{\circ}$ 48' W; (map 133).

Eskimo name meaning "go to visit Indians" published by Irving (1954, p. 205) and spelled as above on his map, but given as "Itkilyiargiak" in his text (p. 204).

Itimtikrak Creek: stream, heads in Iggiruk Mts., flows SSE $14 \mathrm{mi}$. to Noatak River, $45 \mathrm{mi}$. ESE of Misheguk Mtn., Brooks Ra.; 68 $05^{\prime} \mathrm{N}$, $159^{\circ} 21^{\prime} \mathrm{W}$; (map 131)

Eskimo name obtained at Noatak by Orth in 1956.

Itinik, Lake: lake, $3.3 \mathrm{mi}$. across, at head of Inaru River, $17 \mathrm{mi}$. SE of Point Franklin, Arctic Plain; $70^{\circ} 39^{\prime} 20^{\prime \prime} \mathrm{N}, 158^{\circ} 33^{\prime} 20^{\prime \prime} \mathrm{W}$; (map 147).

Eskimo name for "rim of water around a still frozen lake," reported in 1956 by Orth.

Itiptigvik: portage, between Krusenstern Lagoon and Chukchi Sea, $3.6 \mathrm{mi}$. N of Cape Krusenstern, Kotzebue-Kobuk Low.; $67^{\circ} 11^{\prime} \mathrm{N}, 163^{\circ}$. 44' W; (map 128). Var. Eetiptigvik.

Eskimo name meaning "portage place" reported in 1966 by E. S. Burch

Itiptigvirak Neck: neck of land, between Kivalina Lagoon and Chukchi Sea, $6 \mathrm{mi}$. NW of Kivalina, Kotzebue-Kobuk Low.; 67 $58^{\prime} \mathrm{N}$, $164^{\circ} 45^{\prime} \mathrm{W}$; (map 128). Var. Eetiptigveerak.
Eskimo name meaning "little portage place" reported in 1966 by E. S. Burch.

Itiviak Pass: pass, $200 \mathrm{ft}$., in hills between Kivalina and Wulik Rivers, $8 \mathrm{mi}$. NE of Kivalina, Arctic Slope; $67^{\circ} 46^{\prime} 30^{\prime \prime} \mathrm{N}, 164^{\circ} 20^{\prime} 30^{\prime \prime} \mathrm{W}$; (map 128). Var. Ittivyak Pass.

Eskimo name meaning "portage (pass)," according to USC\&GS in 1950.

Itiviak Portage: portage, a winter shortcut across inner side of a bend on Wulik River, $22 \mathrm{mi}$. NE of Kivalina, Arctic Slope $67^{\circ} 50^{\prime} \mathrm{N}, 164^{\circ}$. $57^{\prime} \mathrm{W}$; (map 128). Var. Eetiviahk, Itiwiaac.

Eskimo name meaning "shortcut [portage" reported in 1966 by E. S. Burch.

Itivlik Lake: lake, see Etivlik Lake.

Itiwiaaq: portage, see Itiviak Portage.

Itkaling Kok: stream, see Itkillik River.

Itkaling River: stream, see Itkillik River.

Itkbi, Cape: point of land, see Ikti, Cape.

Itkhryak: island, see Deer Island.

Itkhi, Cape: point of land, see Ikti, Cape.

Itkidagula Point: point of land, between Sea Lion Point and Garden Cove, on E coast of Saint George I., in Pribilof Is.; $56^{\circ} 34^{\prime} 12^{\prime \prime}$ N, $169^{\circ} 29^{\prime} 35^{\prime \prime} \mathrm{W}$; (map 38)

An Aleut name meaning "dropping" reported by Putnam (1903, p. 1014), USC\&GS ; so named because sea lions, when being driven, "would drop off the low bluff down to the beach, where natives would hug close to the bank to allow the sea lions to pass over their heads. Two natives have been killed here by being crushed by sea-lions."

Itkilik River: stream, see Itkillik River.

Itkilikruich Ridges: hills, 2,500 ft., W of Killik River, $8 \mathrm{mi}$. NW of Imiaknikpak Lake, Brooks Ra.; $68^{\circ} 40^{\prime} \mathrm{N}, 154^{\circ} 12^{\prime} \mathrm{W}$; (map 133).

Eskimo name meaning "old Indian mountain" reported in 1956 by T. E. Taylor, USG.S

Itkillik Creek: stream, flows $\mathrm{W} 7 \mathrm{mi}$. to Hulahula River, $20 \mathrm{mi}$. SW of Mount Michelson, Brooks Range; $69^{\circ} 03^{\prime} \mathrm{N}, 144^{\circ} 36^{\prime} \mathrm{W}$ : (map 139).

Eskimo name [Itqiliq] meaning "Indian This name was published in 1956 by USGS Itkillik Lake: lake, 3 mi. long, near NE end of Endicott $M$ ts., drains $S$ to Itkillik River, 49 mi. NE of Anaktuvuk Pass, Brooks Ra.; $68^{\circ}$. $24^{\prime} \mathrm{N}, 149^{\circ} 55^{\prime} \mathrm{W}$; BGN 1960; (map 135).

Named by USGS geologists in 1951, "for the river."

Itkillik River: stream, heads near Ulo Pass in Endicott Mts. at $68^{\circ} 04^{\prime} \mathrm{N}, 150^{\circ} 01^{\prime} \mathrm{W}$, flows NE then NW $220 \mathrm{mi}$. to Colville River, 25 mi. SW of Harrison Bay, Arctic Plain; $70^{\circ} 09^{\prime}$ N, 15056' W; BGN 1916; (map 149). Var. Indian River, Inkala River, Itkaling Kok, Itkaling River, Itkilik River, Itrelik River, Itvelik River.

John Simpson (Great Britain, 1855, v. 3, p. 918 ) wrote that the Colville River receives "a large tributary at thirty miles from its mouth, called the I $t^{\prime}$-ka-ling Kök or Indian River." An Eskimo map drawn on wrapping paper by a "Colville" Eskimo at Barrow, about 1900, shows the name "It-kil-lik." Itqiliq means "Indian."

Itkilyariak Creek: stream, heads at Sunset Pass, in Sadlerochit Mts., flows NE $25 \mathrm{mi}$. to Sad- 
lerochit River $10 \mathrm{mi}$. $\mathrm{S}$ of its mouth in Camden Bay, $21 \mathrm{mi}$. SW of Barter I., Arctic Plain; $69^{\circ} 54^{\prime} \mathrm{N}, 144^{\circ} 21^{\prime}$ W; (map 139). Var. Kuselik Creek, Ooselik Creek.

S. J. Marsh reported the Eskimo name "Ooselik." Leffingwell (1919, p. 96), USGS, said the Eskimo name "Itkilyariak" means, "Route by which the Itkillik travel" or probably more correctly "Indian route."

Itkilyariak Valley: valley, $6 \mathrm{mi}$. long, at $\mathrm{E}$ end of Sadlerochit Mts., drained by Itkilyariak Creek, $24 \mathrm{mi}$. NW of Mount Michelson, Brook Ra.; 69'39' N, $144^{\circ} 14^{\prime}$ W ; (map 139).

Leffingwell (1919, p. 125), USGS, does not list this as a geographic name, but wrote, "near the east end of Sadlerochit Mountains, in Itkilyariak Valley."

Itliaruk, Mount: mountain, $3,000 \mathrm{ft}$., on left bank of Kalasik Creek, $44 \mathrm{mi}$. W of Christmas Mtn., Nulato Hills; $64^{\circ} 33^{\prime} \mathrm{N}, 159^{\circ} 06^{\prime} \mathrm{W}$; (map 96).

Eskimo name reported about 1954 by U.S. Army Corps of Engineers.

Itrelik River: stream, see Itkillik River.

Itsalik, Mount: mountain, 1,600 ft., on $\mathrm{N}$ bank of Oligavik Creek, in Lisburne Hills, $12 \mathrm{mi}$. NE of Cape Dyer, Arctic Slope ; $68^{\circ} 42^{\prime} 45^{\prime \prime} \mathrm{N}$, $165^{\circ} 47^{\prime} 30^{\prime \prime} \mathrm{W}$; (map 129).

Eskimo name published in 1964 by USGS.

Ittar Rock: rock, in W end of Kukkan Passage, $5 \mathrm{mi}$. W of Chichagof, on $W$ coast of Chichagof I., Alex. Arch.; 57 $39^{\prime} 15^{\prime \prime} \mathrm{N}$, $136^{\circ} 14^{\prime} 00^{\prime \prime}$ W; (map 9).

Name published in 1928 by USC\&GS on Chart 8280 .

Ittege: stream, see Innoko River.

Ittëge: stream, see Shageluk Slough.

Ittivyak Pass: pass, see Itiviak Pass.

Itublarak: locality, on Kukpuk River, $20 \mathrm{mi}$. NE of Point Hope, Arctic Slope; $68^{\circ} 24^{\prime} 50^{\prime \prime} \mathrm{N}$, 166'06'30" W; BGN 1963; (map 129). Var. Eetiblaeruk, Eetublaruk.

This fish camp was reported about 1962 by W. O. Pruitt, Univ. of Alaska.

Itugralurak: locality, on shore of Chukchi Sea $17 \mathrm{mi}$. NW of Kivalina, Kotzebue-Kobuk Low.; 67 $54^{\prime} \mathrm{N}, 165^{\circ} 00^{\prime} \mathrm{W}$; (map 128). Var. Ichoograhloorak, Itugzaaluuzak.

Eskimo name reported in 1966 by E. S. Burch.

Itugzaaluuzak: locality, see Itugralurak.

Itulilik: locality, on E bank of Holitna River, 22 mi. S of Sleetmute, Stony River Low.; $61^{\circ} 22^{\prime} 30^{\prime \prime} \mathrm{N}, 157^{\circ} 03^{\prime} 30^{\prime \prime} \mathrm{W}$; BGN 1948, (map 72). Var. E-tu-le-lig-a-mute.

Eskimo camp or settlement, now abandoned, shown on a manuscript map by W. R. Buckman who prospected the Chulitna valley in 1902-1903. He spelled the name "E-ti-lelig-a-mute" i.e. "people of Itulilik [Creek]." See Itulilik Creek.

Itulilik Creek: stream, flows E $24 \mathrm{mi}$ to Holitna River, $23 \mathrm{mi}$. S of Sleetmute, Stony River Low.; $61^{\circ} 22^{\prime} 30^{\prime \prime} \mathrm{N}, 157^{\circ} 04^{\prime} 00^{\prime \prime} \mathrm{W} ; B G N$ 1948; (map 72).

"This native [Eskimo] name refers to a species of small fish that inhabit the stream and from which both the stream and the native village * * * derive their name"; reported by W. R. Buckman in 1902-1903 by inference. See Itulilik.

Itvelik River: stream, see Itkillik River.

Iuaru River: stream, see Inaru River.

Iukuk Bay: bay, see Yukuk Bay.

Iulukiak: village, see Tuluksak.

Iumkraarak Slough: ivater course, see Iumkrarak Slough.

Iumkrarak Slough: water course, in Yukon Delta, extends N-S 1.5 mi. between Butomowik and Kwikluak Passes, $7 \mathrm{mi}$. E of Kwiguk, YukonKuskokwim Delta.; 62 $44^{\prime} 15^{\prime \prime} \mathrm{N}, 164^{\circ} 16^{\prime} 30^{\prime \prime}$ W; (map 77). Var. Iumkraarak Slough.

Eskimo name reported in 1899 by G. R. Putnam, USC\&GS, who spelled it "Iumkraarak."

Iuzhnie: point of land, see Cascade Point.

Iuzhnoi: point of land, see Trinity, Cape.

Ivakin Point: point of land, $2.7 \mathrm{mi}$. E of Constantine Harbor, on Amchitka I., Rat Is., Aleutian Is.; $51^{\circ} 24^{\prime} 45^{\prime \prime} \mathrm{N}, 1^{\circ} 9^{\circ} 22^{\prime} 30^{\prime \prime} \mathrm{E}$; $B G N$ 1937; (map 15)

Named "M[ys] Ivakin" by Capt. Tebenkov (1852, map 29), IRN.

Ivan: locality, at $p^{\wedge s s}$ at head of Unalakleet River drainage; $64^{\circ} 10^{\prime} \mathrm{N}, 159^{\circ} 20^{\prime} \mathrm{W}$; (map 96). Var. Ivans Barrabora.

Indian shelter cabin or small settlement on the trail between the Yukon and Unalakleet Rivers reported by W. H. Dall (1870, p. 531). Its population, according to $\mathrm{Lt}$. $\mathrm{H}$. T. Allen, USA, was 69 in 1885 .

Ivan Bay: bay, $2 \mathrm{mi}$. across, on $\mathrm{S}$ coast of Alaska Penin., the NW arm of Mitrofania Bay, 25 mi. SW of Chignik, Aleutian Ra.; $56^{\circ} 00^{\prime} \mathrm{N}$, $158^{\circ} 50^{\prime} \mathrm{W}$; (map 27).

Local name published by USC\&GS in 1916 Coast Pilot (p. 162).

Ivanhoe Greek: stream, flows NW $3.5 \mathrm{mi}$. to Big Four Creek which flows to Casadepaga River, $20 \mathrm{mi}$. NE of Solomon, Seward Penin. High.; $64^{\circ} 47^{\prime} 40^{\prime \prime} \mathrm{N}, 164^{\circ} 03^{\prime} 50^{\prime \prime} \mathrm{W}$; (map 95).

Prospectors' name reported on a 1901 map of Cape Nome goldfields by David Fox, Jr.

Ivan Island: island, $1 \mathrm{mi}$. across, in Pavlof Bay. $12 \mathrm{mi}$. NW of Cape Tolstoi, near SW end of Alaska Penin., Aleutian Ra.: 55 $31^{\prime} \mathrm{N}, 161^{\circ}$ $39^{\prime} \mathrm{W}$; (map 28).

Named in 1888 by W. H. Dall, USC\&GS. Ivanof : point of land, see Kupreanof Point.

Ivanof Bay: settlement, pop. 15, on Alaska Penin., at $\mathrm{N}$ end of Ivanof Bay, NE end of Kupreanof Penin., Aleutian Ra.; $55^{\circ} 54^{\prime} \mathrm{N}$, $159^{\circ} 29^{\prime} \mathrm{W}$; (map 27).

Cannery reported by USC\&GS in 1950 . The Ivanof post office was established in 1952, discontinued in 1954 (Ricks 1965, p. 29).

Ivanof Bay: bay, $2 \mathrm{mi}$. across, on $\mathrm{S}$ coast of Alaska Penin., $6 \mathrm{mi}$. E of Stepovak Bay and $28 \mathrm{mi}$. SW of Ivan Bay, Aleutian Ra.; $55^{\circ} 50^{\prime}$ N, $159^{\circ} 29^{\prime}$ W ; (map 27). Var. Ivanoff Bay.

Named by W. H. Dall, USC\&GS, in 1880 . Kupreanof Point, $17 \mathrm{mi}$. to the south, was called "Cap Ivanofsky" or "John's Cape," by Lutke (1836, p. 269). The name "Ivanoff
Bay" was published in 1888 on USC\&GS charts.

Ivanoff: point of land, see Kupreanof Point.

Ivanoff, Lake: lake, $1.2 \mathrm{mi}$. long, on Kenai Penin. S of Chickadee Lake, $7.5 \mathrm{mi}$. NE of Kenai, Cook Inlet Low.; $60^{\circ} 38^{\prime} 45^{\prime \prime} \mathrm{N}$, $151^{\circ} 08^{\prime} 45^{\prime \prime} \mathrm{W}$; (map 62$)$.

Named about 1963 by officials of Kenai National Moose Range for administrative purposes.

Ivanoff Bay: bay, see Ivanof Bay.

Ivanovsky, Cap: point of land, see Kupreanof Point.

Ivan River: stream, flows SE $23 \mathrm{mi}$. to Cook Inlet, $28 \mathrm{mi}$. W of Anchorage, Cook Inlet Low; $61^{\circ} 14^{\prime} 45^{\prime \prime} \mathrm{N}, 150^{\circ} 44^{\prime} 15^{\prime \prime} \mathrm{W}$; BGN 1916; (map 70). Var. Lewis River.

Local name reported in 1916 by USC\&GS. Ivans Barrabora: locality, see Ivan.

Iveagik Mountain: hills, see Iviangik Mountain. Iveetok: stream, see Aivichtik River.

Ivekan Mountain: mountain, 1,700 ft., $10 \mathrm{mi}$. NW of Southwest Cape and $28 \mathrm{mi}$. S of Gambell, St. Lawrence I.; $63^{\circ} 22^{\prime} \mathrm{N}, 171^{\circ} 43^{\prime} \mathrm{W}$; $B G N$ 1951; (map 93). Var. Aivikan Mountain, Ivikan Mountain, Mount Tvikan.

Eskimo name often written "Aivikan," with undetermined meaning. The name was recorded on an annotated map in 1944 by Lawrence Kulukhan of Gambell.

Ivektuk River: stream, see Fossil River.

Iverson Creek: stream, in Nutzotin Mts., flows NE $6.5 \mathrm{mi}$. to Beaver Creek, $8 \mathrm{mi}$. SE of Carden Hills, Alaska Ra.; $62^{\circ} 11^{\prime} 30^{\prime \prime} \mathrm{N}, 141^{\circ} 02^{\prime}$ $25^{\prime \prime} \mathrm{W}$; (map 84).

Local name reported in 1959 by USGS.

Ives Lake: lake, $0.4 \mathrm{mi}$. long, on $\mathrm{E}$ coast of Prince of Wales I., S of Coal Bay, $9 \mathrm{mi}$. NW of Kasaan Point, Alex. Arch.; $55^{\circ} 29^{\prime} 40^{\prime \prime} \mathrm{N}$, $132^{\circ} 28^{\prime} 05^{\prime \prime} \mathrm{W}$; (map 4).

Named in 1935 by USGS.

Ivey: locality, see Ivy City.

Iviagik Mountain: hills, see Iviangik Mountain.

Iviangik Mountain: hills, $922 \mathrm{ft}$, , on Chukchi Sea coast, $2.4 \mathrm{mi}$. S of Cape Dyer, Arctic Slope; 68 $8^{\circ} 37^{\prime} 05^{\prime \prime} \mathrm{N}, 166^{\circ} 13^{\prime} 25^{\prime \prime} \mathrm{W}$; (map 129). Var. Eeveagech Mountain, Iveagik Mountain, Iviagik Mountain.

Eskimo name meaning "breast," descriptive of twin hills, reported in 1950 by USC\&GS as "Ee-ve-ang-geek." USGS applied the name in error to a mountain three miles southeast.

Ivikan Mountain: mountain, see Ivekan Mountain.

Ivik Creek: stream, heads at Danger Pass and flows SE $12 \mathrm{mi}$. to Mauneluk River, Brooks Ra.; $67^{\circ} 17^{\prime} \mathrm{N}, 155^{\circ} 38^{\prime} \mathrm{W}$; (map 125).

Eskimo name meaning "grass," recorded in Kobuk and Shungnak by Orth, USGS, in 1956.

Ivisak Creek: stream, flows NE $8 \mathrm{mi}$. to Killik River $13 \mathrm{mi}$. $\mathrm{N}$ of its junc. with Easter Creek, Brooks Ra. ; $68^{\circ} 20^{\prime} \mathrm{N}, 154^{\circ} 03^{\prime} \mathrm{W}$; (map 133 ).

Eskimo name for "iron oxide paint," reported in 1956 by Orth.

Ivisaruk River: stream, heads at $69^{\circ} 45^{\prime} \mathrm{N}$, $160^{\circ} 45^{\prime} \mathrm{W}$, flows NE $78 \mathrm{mi}$. to Kuk River, 
$18 \mathrm{mi}$. S of Wainwright, Arctic Plain; $70^{\circ}$.

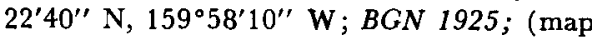
146). Var. Ivisaurk River, Ivisauruk River.

Eskimo name reported in 1923 as "Ivisaurk" by Sidney Paige, USGS; probably the same as the Eskimo "ivishaq," meaning "red paint" or "iron oxide." See Ivisak Creek and Ivishak Pass.

Ivisauruk River: stream, see Ivisaruk River.

Ivishak Pass: pass, 1,500 ft., E end of Baird Mts., between Noatak and Kobuk River drainages, 40 mi. $\mathrm{N}$ of Shungnak, Brooks Ra.; $67^{\circ} 28^{\prime} \mathrm{N}, 157^{\circ} 30^{\prime} \mathrm{W}$; (map 126).

Ivishak is an Eskimo name for iron oxide, used for making red paint; reported by Orth in 1956. See Redstone River.

Ivishak River: stream, heads in Brooks Ra. at $68^{\circ} 34^{\prime} 30^{\prime \prime} \mathrm{N}, 147^{\circ} 14^{\prime} 00^{\prime \prime} \mathrm{W}$, flows NW 95 $\mathrm{mi}$. to Sagavanirktok River, $55 \mathrm{mi}$. S of Prudhoe Bay, Arctic Plain; $69^{\circ} 30^{\prime} \mathrm{N}, 148^{\circ} 30^{\prime}$ W; BGN 1959; (map 140). Var. Evasha River, Sagavanirktok River, Tvishak River.

Eskimo name reported in 1914 by Diamond Jenness. Original BGN decision of 1916 was revised in 1949 and redescribed in 1959 according to $\mathrm{E}$. de $\mathrm{K}$. Leffingwell's application of the name. See Ivishak Pass and Ivisak Creek.

Ivishak River: stream, see Redstone River.

Ivishak River: stream, see Sagavanirktok River.

Ivor Cove: cove, $0.5 \mathrm{mi}$. across, on $\mathrm{E}$ shore of Deadman Bay, $S$ of Ivor Point, on $S$ coast of Kodiak I.; $57^{\circ} 03^{\prime} \mathrm{N}, 153^{\circ} 55^{\prime} \mathrm{W}$; (map 34).

Name derived from Ivor Point published in 1952 by USGS.

Ivor Point: point of land, on E shore of Deadman Bay, near head of Hepburn Penin., on $S$ coast of Kodiak I.; $57^{\circ} 03^{\prime} 40^{\prime \prime}$ N, $152^{\circ}$ 55'00" W; BGN 1934; (map 34).

Named in 1934 by Capt. R. R. Lukens, USC\&GS

Ivory Creek: stream, flows NE $6.7 \mathrm{mi}$., along $\mathrm{S}$ side of Hatbox Mesa to Kiruktagiak River, $2 \mathrm{mi}$. SW of Tuktu Bluff and $44 \mathrm{mi}$. NW of Anaktuvuk Pass, Arctic Slope ; $68^{\circ} 43^{\prime} 20^{\prime \prime} \mathrm{N}$, $152^{\circ} 22^{\prime} 44^{\prime \prime}$ W ; (map 134).

So named in 1950 by W. W. Patton, Jr., USGS, because of the fossil mammoth tooth found on its course.

Ivotuk Creek: stream, flows $N 27 \mathrm{mi}$. to E Fork Etivluk River $24 \mathrm{mi}$. SE of its junc. with Etivluk River, Brooks Ra.; $68^{\circ} 34^{\prime}$ N, $155^{\circ} 31^{\prime}$ W; BGN 1960; (map 133).

Eskimo name meaning "lamb;" so named about 1950 by USGS geologists, because "numerous sheep [Dall] and lambs were seen near the headwaters of the stream."

Ivotuk Hills: hills, 3,105 ft., group, $8 \mathrm{mi}$. long and $2.5 \mathrm{mi}$. wide, divided by Ivotuk Creek, $36 \mathrm{mi}$. NE of Howard Pass, Brooks Ra.; $68^{\circ}$. $28^{\prime} 15^{\prime \prime} \mathrm{N}, 1^{\circ} 5^{\circ} 33^{\prime} 00^{\prime \prime} \mathrm{W}$; BGN 1967; (map 133 ).

Named in 1966 by geologists of BP Exploration Company (Alaska) Inc.

Ivruktusuk: locality, on right bank of Wulik River, $34 \mathrm{mi}$. NE of Kivalina, Arctic Slope; $65^{\circ} 56^{\prime} \mathrm{N}, 163^{\circ} 33^{\prime} \mathrm{W}$; (map 128). Var. Eevruktoosuk, Iiwzuqtusuq.

Eskimo name meaning "place where there's lots of moss (ivrug)" reported in 1966 by E. S. Burch.

Ivwak Cape: point of land, see Eevwak Point. Ivy City: locality, on $\mathbf{S}$ bank of Yukon River, near mouth of Fourth of July Creek, 33 mi. NW of Eagle, Yukon-Tanana High.; $65^{\circ}$ $11^{\prime} 50^{\prime \prime} \mathrm{N}, 141^{\circ} 49^{\prime} 45^{\prime \prime} \mathrm{W}$; (map 103.) Var. Ivey.

Abandoned river landing for the Fourth of July Creek placer mines mentioned in 1902 by Lt. J. C. Cantwell, USRCS.

Ivy Creek: stream, flows SE $16 \mathrm{mi}$. to Nixon River, $29 \mathrm{mi}$. NW of Medfra, Kilbuck-Kuskokwim Mts.; $63^{\circ} 12^{\prime} \mathrm{N}, 155^{\circ} 36^{\prime} \mathrm{W}$; (map 89).

Local name reported in 1955 by USGS. Ivyoorigan: locality, see Iwoorigan Camp.

Ivy Ridge: ridge, $4 \mathrm{mi}$. long, trends $\mathrm{N}-\mathrm{S}$ between Hades Highway and Demorest Glacier, $29 \mathrm{mi}$. NNE of Juneau, Coast Mts.; $58^{\circ} 41^{\prime} \mathrm{N}$, $133^{\circ} 59^{\prime} \mathrm{W}$; (map 12).

Local name reported in 1960 by USGS. Ivy Wash: stream, see Glacial Fan Creek.

Iwaktok Hill: hill, $240 \mathrm{ft}$., on S bank of Manokinak River, 2 mi. $S$ of Nuskealik Lake, Yukon-Kuskokwim Delta; $61^{\circ} 25^{\prime} \mathrm{N}, 164^{\circ} 28^{\prime}$ W; (map 74).

Eskimo name obtained at Chevak by Orth in 1965, and reported to mean "game searching place."

Iwarawiramiut: locality, on W shore of a lake, $1.3 \mathrm{mi}$. N of Bangookbit Dunes and $7 \mathrm{mi}$. NW of Cape Mendenhall, Nunivak I.; 59 $52^{\prime} \mathrm{N}$, $166^{\circ} 23^{\prime} \mathrm{W}$; (map 55). Var. Ewakewigamiut, Iwikwikmute.

Eskimo summer fish camp reported in 1932 by USC\&GS.

Iwikwikmute: locality, see Iwarawiramiut.

Iwoonut Cape: point of land, see Iwoonut Point.

Iwoonut Point: point of land, $3 \mathrm{mi}$. W of Southwest Cape and $33 \mathrm{mi}$. SE of Gimbell, St. Lawrence I.; $63^{\circ} 19^{\prime} \mathrm{N}, 171^{\circ} 34^{\prime} \mathrm{W}$; $B G N$ 1951; (map 93). Var. Aikhwunat, Ingolitit Cape, Iwoonut Cape.

Eskimo name often written "Aikhwunat," but without a known meaning. Name was reported in 1944 by a survivor of a village once located at Southwest Cape.

Iwoorigan Camp: locality, on $\mathrm{N}$ coast of Saint Lawrence I., $2 \mathrm{mi}$. SE of Chibukak Point and $3 \mathrm{mi}$. SE of Gambell; $63^{\circ} 46^{\prime} \mathrm{N}, 171^{\circ} 39^{\prime} \mathrm{W}$; $B G N 1951$; Var. Ivyoorigan.

Eskimo name of camp site reported in 1932 by Otto W. Geist, Univ. of Alaska.

I.X.L. Creek: stream, see Lil Creek.

Iyagatak River: stream, see Ayugatak Creek.

Iyaggatak River: stream, see Ayugatak Creek.

Iyahuna Creek: stream, flows NE $12 \mathrm{mi}$. to Noatak River, $36 \mathrm{mi}$. SW of Survey Pass, Brooks Ra.; $67^{\circ} 33^{\prime}$ N, $155^{\circ} 13^{\prime}$ W ; (map 125)

Eskimo personal name recorded in Kobuk by Orth, USGS, in 1956.
Iyak: locality, on right bank of Kobuk River below mouth of Pah River: $66^{\circ} 48^{\prime} \mathrm{N}, 156^{\circ} 10^{\prime}$ W; (map 115).

Former Eskimo camp or village visited in 1885 by Lt. Stoney (1900, map), USN.

Iyatayet: locality, on E shore of Norton Sound between Cape Denbigh and Point Dexter, 15 mi. NW of Shaktoolik, Nulato Hills; $64^{\circ} 29^{\prime}$ $\mathrm{N}, 161^{\circ} 27^{\prime} \mathrm{W}$; (map 96).

Eskimo name for an archeological site reported in 1948 by Giddings (1964, p. 4).

Iyoukeen Cove: cove, 3 mile across, $12 \mathrm{mi}$. NE of Tenakee Springs, on E coast of Chichagof I., Alex. Arch.; $57^{\circ} 53^{\prime} \mathrm{N}, 134^{\circ} 58^{\prime} \mathrm{W}$; (map 9).

Tlingit Indian name (Iyukin) reported in 1869 by G. Davidson, USC\&GS as "I-youkeen." The name was published in 1883 Coast Pilot (p. 181)

Iyoukeen Peninsula: peninsula, $3.5 \mathrm{mi}$. long, E coast of Chichagof I. between Freshwater Bay and Iyoukeen Cove, Alex. Arch.; 57 52' N, $134^{\circ} 58^{\prime} \mathrm{W}$; (map 9).

Local name reported in 1951 by USGS.

Iyouktug Creek: stream, flows SE $7 \mathrm{mi}$. to False Bay, $17 \mathrm{mi}$. NE of Tenakee Springs, on NE coast of Chichagof I., Alex. Arch.; 57 58' 15" $\mathrm{N}, 134^{\circ} 56^{\prime} 15^{\prime \prime} \mathrm{W} ; B G N$ 1960; (map 9). Var. B saver Creek.

Tlingit Indian name said to mean "stream this side of point" reported in 1958 by USGS.

Izaviknek River: stream, heads at $61^{\circ} 32^{\prime} \mathrm{N}$, $162^{\circ} 31^{\prime} \mathrm{W}$, flows SW $80 \mathrm{mi}$. to Aropuk Like, Yukon-Kuskokwim Delta; $61^{\circ} 14^{\prime} \mathrm{N}, 163^{\circ} 32^{\prime}$ W; (map 74). Var. Izyvieknek River.

Eskimo name recorded as "Izawerknuk" by Lt. Jarvis (in Revenue Cutter Service, 1899, p. 38), who urote: "it seems to me that Izawerknuk and Kulichavak [Kvichavak] are two different names for the same stream." See Kvichavak River. The entry spelling was reported by USC\&GS in 1949.

Ixavieknik River: stream, flows SW $22 \mathrm{mi}$. to Togiak Lake, $20 \mathrm{mi}$. SE of Kagati Lake and $85 \mathrm{mi}$. NE of Goodnews, Kilbuck-Kuskokwim Mts.; $59^{\circ} 43^{\prime} \mathrm{N}, 159^{\circ} 33^{\prime} \mathrm{W}$; (map 53 ).

Eskimo name published in 1951 by USGS Izawerknuk River: stream, see Kvichavak and Izaviknek Rivers.

Izbavleniya Mys: point of land, see Escape Point Izembek Lagoon: lagoon, $12 \mathrm{mi}$. long, $10 \mathrm{mi}$. N of village of Cold Bay, at SW end of Alaska Penin., Bristol Bay Low.; $55^{\circ} 20^{\prime} \mathrm{N}, 162^{\circ} 48^{\prime}$ W; BGN 1965; (map 29). Var. Isenbeck, Izenbeck Bay, Izenbeck golfe, Izenbeka, Guba, d'Izenbek, Golfe.

Name given and published by Capt. Lutke (1836, p. 262), IRN, as "Izenbeck" for surgeon Karl Izembek, a member of his party. Izenbeka, Guba: lagoon, see Izembek Lagoon.

Izhiga Cove: bight, $1 \mathrm{mi}$. across in Inanudak Bay, on W central coast of Umnak I., Aleutian Is.; $53^{\circ} 18^{\prime} 40^{\prime \prime} \mathrm{N}, 168^{\circ} 22^{\prime} 30^{\prime \prime} \mathrm{W} ; B G N$ 1940; (map 22). Var. Northeast Anchorage.

Aleut name reported by Father Veniaminov $(1840$, v. 1, p. 146$)$ and applied to this cove after the area was surveyed in 1939 by USC\&GS. The USC\&GS field party called 
the cove "Northeast Anchorage" because it "affords a fair anchorage in northerly weather * * "

Izhut, Cape: point of land, $17 \mathrm{mi}$. NE of Afognak, at mouth of Duck Bay, on SE coast of Afognak I., $\mathrm{N}$ of Kodiak I.; $58^{\circ} 06^{\prime} 10^{\prime \prime} \mathrm{N}$, $152^{\circ} 20^{\prime} 20^{\prime \prime} \mathrm{W}$; BGN 1901; (map 43). Var. Cape Shariepof, Ijoot, Indut, Ishoot, Izhut Cape, Izhutshoi, Pentecost, Piatidesiatnitzi, Shiripof, Whitsuntide.

Native name published by Capt. Tebenkov (1852, map 23), IRN, as "M[ys] Izhut (Pyatidesyatnitsy)" or "Cape Izut (Whitsuntide)," who identifies it with the Whitsunday (Pillar Cape) of Capt. James Cook in 1778. Sub-Lt. Mikhail Murashev, IRN, called this point "M[ys] Sharypov," or "Cape Sharypov," in 1839 or 1840 and it was published as such by the Russian Hydrog. Dept. in 1849 on Chart 1425. The Russian American Company applied the name for this feature to the southern entrance to King Cove, $12.5 \mathrm{mi}$. to the $\mathrm{NE}$, in 1849.

Izhut Bay: bay, $4 \mathrm{mi}$. across, $23 \mathrm{mi}$. NE of Afognak, on SE coast of Afognak I., $\mathbf{N}$ of Kodiak I. ; $58^{\circ} 11^{\prime} \mathrm{N}, 152^{\circ} 15^{\prime} \mathrm{W}$; BGN Sixth Report; (map 43). Var. Izhutskaia Bay, Puerto de Solano, Ujut Bay, Uyut Bay, Whitsunday Bay.

Native name published by Capt. Tebenkov (1852, map 23), IRN, as "Z[aliv] Izhut" or "Izhut Bay." This, feature was named Whitsunday Bay by Capt. Cook (1785, v. 2, p. 404), RN, and "Puerto de Solano" or "harbor of east wind," by Don D. A. Galiano (1802, map 2). The Russian American Company applied the name to King Cove in 1849 . See King Cove.

Izhut Bay: bay, see King Cove.

Izigan, Cape: point of land, SW coast of Unalaska I., Aleutian Is.; $53^{\circ} 14^{\prime} 15^{\prime \prime} \mathrm{N}, 167^{\circ} 39^{\prime}$ 25" W; BGN 1939; (map 23).

Name published by Capt. Tebenkov (1852, map 26), IRN, as "M[ys] Izigan" or "Cape Izigan."

Izyvieknek River: stream, see Izaviknek River.

\section{J}

Jabbertown: locality, site of a whaling station, on Chukchi Sea coast, $3.5 \mathrm{mi}$. $\mathbf{E}$ of village of Point Hope, Arctic Slope.; 68 $20^{\prime} 30^{\prime \prime} \mathrm{N}$, $166^{\circ} 37^{\prime} 30^{\prime \prime}$ W; (map 129). Var. Cooper, Coopers.

Name shown on an 1898 manuscript map; so called because of the multiple languages of the whalers and their families. The whaling station called Cooper was located a short distance away.

Jachach, Cape: point of land, see Yakak, Cape. Jachlanissa: island, see Kochu Island.

Jack, Lake: lake, 2 mi. long, on $\mathrm{E}$ side of Kenai Penin., $1.5 \mathrm{mi}$. S of Long Bay, $16 \mathrm{mi}$. SE of Whittier, Chugach Mts.; $60^{\circ} 38^{\prime} 30^{\prime \prime} \mathrm{N}, 148^{\circ}$. $17^{\prime} 30^{\prime \prime} \mathrm{W}$; (map 63).

Local name reported in 1952 by USGS.

Jackass Canyon: ravine, in Sheep Mtn., extends $1.5 \mathrm{mi}$. NE of Glenn Highway, $52 \mathrm{mi}$. NE of Palmer, Talkeetna Mts.; $61^{\circ} 48^{\prime} 00^{\prime \prime} \mathrm{N}, 147^{\circ}$.
35'30' W; BGN 1960; (map 69). Var. Jackass Gulch.

Local name reported in 1952 by USGS.

Jackass Canyon: stream, see Gypsum Creek.

Jackass Gulch: ravine, see Jackass Canyon.

Jackass Pass: pass, $850 \mathrm{ft}$., on Gilbert Ridge, on

$E$ end of Attu I., Aleutian Is.; $52^{\circ} 51^{\prime} 25^{\prime \prime} \mathrm{N}$, $173^{\circ} 15^{\prime} 35^{\prime \prime} \mathrm{E}$; (map 13).

Name shown on an AMS map published in 1948.

Jackass Point: point of land, at $S$ tip of Akun I., Krenitzin Is., Aleutian Is.; $54^{\circ} 06^{\prime} 35^{\prime \prime} \mathrm{N}$, $165^{\circ} 33^{\prime} 50^{\prime \prime} \mathrm{W}$; (map 24$)$.

Named in 1888 by USBF.

Jack Bay: bight, $1 \mathrm{mi}$. across, off $\mathrm{SW}$ coast of Chignik Bay, $6 \mathrm{mi}$. $\mathrm{E}$ of Chignik, Aleutian Ra.; 56 $18^{\prime}$ N, $158^{\circ} 14^{\prime}$ W ; (map 30). Var. Jacks Bay.

Name reported in 1923 by R. H. S.rargent, USGS, and published in 1927 by USGS.

Jack Bay: estuary, $7 \mathrm{mi}$. long, trends $\mathbf{S}$ from Valdez Arm, $14 \mathrm{mi}$. SW of Valdez, Chugach Mts.; $61^{\circ} 02^{\prime} 30^{\prime \prime} \mathrm{N}, 146^{\circ} 39^{\prime} 30^{\prime \prime} \mathrm{W}$; (map 68). Var. Jack's Bay.

Named "Jack's Bay" in 1898 by Capt. W. R. Abercrombie, USA, presumably for W. G. Jack, a local prospector.

Jack Creek: stream, flows SE $18 \mathrm{mi}$. between Nutzotin and Wrangell Mts. to Nabesna River, $5.5 \mathrm{mi}$. NE of Nabesna, Wrangell Mts.; $62^{\circ}-$ $24^{\prime} \mathrm{N}, 142^{\circ} 51^{\prime} \mathrm{W}$; (map 84)

Name reported in 1902 by Schrader (Mendenhall and Schrader, 1903, p. 31), USGS.

Jack Creek: stream, flows S $1 \mathrm{mi}$ to Walker Fork, $50 \mathrm{mi}$. S of Eagle, Yukon-Tanana High. $64^{\circ} 05^{\prime} \mathrm{N}, 141^{\circ} 12^{\prime} \mathrm{W}$ : (map 102).

Prospectors' name shown on an 1898 manuscript map by C. A. Woodruff, Fort Cudahy, Canada.

Jack Creek: stream, flows NE $5 \mathrm{mi}$. from Jack White Ra. to Koyukuk River, $8 \mathrm{mi}$. NE of Bettles, Kanuti Flats; $66^{\circ} 58^{\prime} \mathrm{N}, 151^{\circ} 25^{\prime} \mathrm{W}$ $B G N$ 1932; (map 117). Var. Jack White Creek.

Prospectors' name in use since 1912 ; named "for Jack White, a local river man."

Jack Creek: stream, in Kallarichuk Hills of Baird Mts., flows SW $5.5 \mathrm{mi}$. to Klery Creek, $14 \mathrm{mi}$. N of Kiana, Brooks Ra.; 67 $11^{\prime} \mathrm{N}$, $160^{\circ} 24^{\prime} \mathrm{W}$; (map 127).

Name used by prospectors; reported in 1910 by P. S. Smith (in Brooks and others, 1911, pl. 13), USGS.

Jack Greek Lake: lake, see Jack Lake.

Jack Delay Pass: pass, see Delay Pass.

Jackfish Lake: lake, $0.4 \mathrm{mi}$. across, $\mathrm{S}$ of Venetie Lake, $41 \mathrm{mi}$. SW of Christian, Yukon Flats; $67^{\circ} 02^{\prime} \mathrm{N}, 146^{\circ} 20^{\prime} \mathrm{W}$; (map 122).

Local name reported in 1956 by T. E. Taylor, USGS:

Jack Frost Creek: stream, heads in Cottonwood Hills, flows NW $12 \mathrm{mi}$. to Fish River, $3 \mathrm{mi}$. S of Carey Lake and $38 \mathrm{mi}$. SSW of village of Lake Minchumina, Kuskokwim Low.; $63^{\circ}$. $21^{\prime} 30^{\prime \prime} \mathrm{N}, 152^{\circ} 36^{\prime} 00^{\prime \prime} \mathrm{W}$; (map 88)

Local name obtained in 1958 from Fabian Carey and "Val" Blackburn by USGS.
Jack Gulch: ravine, trends SW $0.8 \mathrm{mi}$. to Boulder Creek $1.7 \mathrm{mi}$. SE of its junc. with Stewart River, $20 \mathrm{mi}$. N of Nome, Seward Penin. High.; 64 $4^{\circ} 47^{\prime} \mathrm{N}, 165^{\circ} 23^{\prime} \mathrm{W}$; (map 94).

Prospectors' name reported in 1904 by T. G. Gerdine, USGS.

Jackknife Islands: islands, $0.5 \mathrm{mi}$. across, $3 \mathrm{mi}$. S of Goddard, in Necker Is., on W coast of Baranof I., Alex. Arch.; $56^{\circ} 47^{\prime} 45^{\prime \prime}$ N, $135^{\circ} 24^{\prime} 00^{\prime \prime}$ W; (map 5). Var. Jacknife Islands.

Descriptive name published in 1929 by USC\&GS; so named because of the outline of these islands on charts.

Jackknife Mountain: mountain, 2,200 ft., $1 \mathrm{mi}$. $\mathrm{N}$ of Lake Aleknagik and $28 \mathrm{mi}$. NW of Dillingham, Kilbuck-Kuskokwim Mts.; $B G N$ 1932; (map 52). Var. Jack Knife Mountain, Mount Shasta.

Name recommended by W. C. Mendenhall, USGS, in 1932 and approved by BGN over the name Mount Shasta. Jackknife Mtn. seems to have first been shown on an old manuscript sketch map made by [G. D.] Hanna, USBF. "Mount Shasta" seems to have been predominant local usage around 1930, and was so called because of the resemblance of the mountain to California's Mount Shasta.

Jack Lake: lake, $1,000 \mathrm{ft}$. long, $\mathrm{N}$ of Lake Lee, $9 \mathrm{mi}$. SW of Kodiak, Kodiak I. ; $57^{\circ} 42^{\prime} 55^{\prime \prime} \mathrm{N}$, $152^{\circ} 36^{\prime} 05^{\prime \prime} \mathrm{W}$; (map 34).

Local name reported in 1949 by USGS.

Jack Lake: lake, $0.4 \mathrm{mi}$. long, $\mathrm{W}$ of The Alaska Railroad, $1 \mathrm{mi}$. S of Willow and $35 \mathrm{mi}$. N of Anchorage, Cook Inlet Low.; 61 $43^{\prime} 40^{\prime \prime} \mathrm{N}$, 150 $01^{\prime} 40^{\prime \prime} \mathrm{W}$; BGN 1958; (map 70).

Named in 1958 by Dorace C. Thatcher of Willow; so called "because when viewing the lake and the bearer trails from the air, one is reminded of a child's jack."

Jack Lake: lake, 2 mi. long, in course of Jack Creek, $13 \mathrm{mi}$. NW of Nabesna, Wrangell Mts.; $62^{\circ} 31^{\prime} \mathrm{N}, 143^{\circ} 17^{\prime} \mathrm{W}$; BGN 1939; (map 84). Var. Jack Creek Lake.

Local name reported in 1931 by USGS.

Jacknife Islands: islands, see Jackknife Islands. Jack Point: promontory, between Castle Bay and SW coast of Chignik Bay, 8 mi. E of Chignik, Aleutian Ra.; $56^{\circ} 17^{\prime} \mathrm{N} ; 158^{\circ} 12^{\prime} \mathrm{W}$; (map $30)$.

Local name reported by a 1951 USGS field party.

Jackpot Bay: estuary, on E coast of Kenai Penin., extends NE $3.5 \mathrm{mi}$. then SE $3 \mathrm{mi}$. to $\mathrm{S}$ end of Dangerous Passage, $4.5 \mathrm{mi}$. NW of Chenega, Chugach Mts.; $60^{\circ} 19^{\prime} 30^{\prime \prime} \mathrm{N}, 148^{\circ} 11^{\prime} 00^{\prime \prime} \mathrm{W}$; (map 63).

Local name reported in 1905 by U. S. Grant, USGS.

Jackpot Creek: stream, flows SW 5 mi. to northernmost of Jackpot Lakes, $12 \mathrm{mi}$. NW of Chenega, Chugach Mts.; $60^{\circ} 25^{\prime} \mathrm{N}, 148^{\circ} 15^{\prime}$ W; (map 63). Var. Jack Pot Creek, Jack-Pot Creek.

Name used by fishermen; reported in 1897 by Lt. Comdr. J. F. Moser, USN, commander of the USBF steamer Albatross from 1897 to 
1901, who made surveys and investigations in this area.

Jackpot Island: island, in mouth of Jackpot Bay, off $\mathrm{E}$ coast of Kenai Penin., $4.5 \mathrm{mi}$. NW of Chenega, Chugach Mts.; $60^{\circ} 19^{\prime} 15^{\prime \prime} \mathrm{N}$,

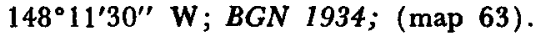

Named in 1933 by a USC\&GS field party for nearby Jackpot Bay.

Jackpot Lakes: group of lakes, along Jackpot Creek, on E coast of Kenai Penin., $8 \mathrm{mi}$. NW of Chenega, Chugach Mts.; 60 $22^{\prime} 30^{\prime \prime} \mathrm{N}$, $148^{\circ} 15^{\prime} 00^{\prime \prime} \mathrm{W}$; (map 63). Var. Jack Pot Lakes, Jack-Pot Lakes.

Name reported in 1897 by Lt. Comdr. J. F. Moser, USN, commander of the USBF steamer Albatross, while making surveys and investigations in the area.

Jackpot Point: point of land, on E coast of Kenai Penin., at $\mathrm{N}$ entrance to Jackpot Bay, $4.5 \mathrm{mi}$. NW of Chenega, Chugach Mts.; $60^{\circ} 20^{\prime} \mathrm{N}$, $148^{\circ} 10^{\prime} \mathrm{W}$; BGN 1934; (map 63).

Named in 1933 by a USC\&GS field party for nearby Jackpot Bay.

Jack Rabbit Creek: stream, see Rabbit Creek.

Jackrabbit Island: island, $0.5 \mathrm{mi}$. long, in Iliamna Lake, at mouth of Northeast Bay, $5.5 \mathrm{mi}$. E E of Iliamna, Aleutian Ra.; $59^{\circ} 45^{\prime} 30^{\prime \prime} \mathrm{N}$, $154^{\circ} 45^{\prime} 00^{\prime \prime} \mathrm{W}$; (map 51).

Local name published in 1958 by USGS.

Jack River: stream, flows NW $32 \mathrm{mi}$. to Nenana River, E of Cantwell, $28 \mathrm{mi}$. S of Healy, Talkeetna Mts.; $63^{\circ} 28^{\prime} \mathrm{N}, 148^{\circ} 49^{\prime} \mathrm{W}$; (map 87).

Named in 1898 by G. H. Eldridge and Robert Muldrow, USGS, for W. G. Jack, prospector.

Jack River: stream, see Braided Creek.

Jacks Bay: bight, see Jack Bay.

Jacks Cove: cove, on SE coast of Lemesurier I., in South Passage, SW of Willoughby Cove and $26 \mathrm{mi}$. WNW of Hoonah, St. Elias Mts.; $58^{\circ} 16^{\prime} \mathrm{N}, 136^{\circ} 04^{\prime} \mathrm{W}$; (map 10).

Local name published by USGS in the 1950's.

Jacks Creek: stream, flows SW to Dome Creek which flows to American River, about $30 \mathrm{mi}$. NE of Teller, Seward Penin. High.; (map 111).

Prospectors' name shown on a map of Cape Nome gold fields by David Fox, Jr., dated 1901. This feature cannot be precisely identified on current maps.

Jacksina Creek: stream, heads at Jacksina Glacier and flows NE $26 \mathrm{mi}$. to Nabesna River, $5 \mathrm{mi}$. $\mathrm{SE}$ of Nabesna, Wrangell Mts.; $62^{\circ} 21^{\prime} 15^{\prime \prime} \mathrm{N}$, $142^{\circ} 52^{\prime} 30^{\prime \prime} \mathrm{W}$; (map 84). Var. Di-bot-ichit-in-da.

Prospectors' name; a combined personal name with an Indian ending ( $-\mathrm{na}$ ) meaning stream or river, reported in 1902 by F. C. Schrader, USGS. Schrader gave the Indian name of the stream as "Di-bot-i-chit-in-da."

Jacksina Glacier: glacier, trends NE $10 \mathrm{mi}$. from Mount Jarvis to its terminus at head of Jacksina Creek, Wrangell Mts.; 62 ${ }^{\circ} 07^{\prime} 30^{\prime \prime} \mathrm{N}$, $143^{\circ} 23^{\prime} 30^{\prime \prime} \mathrm{W}$; (map 84).

Named for Jacksina Creek and reported in 1902 by F. C. Schrader, USGS.
Jacks Lake: lake, see Haines Lake.

Jacksmith Bay: bay, on E shore of Kuskokwim Bay, 28 mi. NW of Goodnews, Yukon-Kuskokwim Delta; $59^{\circ} 30^{\prime} \mathrm{N}, 161^{\circ} 45^{\prime} \mathrm{W}$; (map 53). Var. Jack Smith Bay, Nerviak.

Local name published in 1914 by USC\&GS. The Eskimo name is reported to be "Nerviak," meaning "place to eat." The bay is "entirely bare at low tide."

Jacksmith Creek: stream, flows W $10 \mathrm{mi}$. to Jacksmith Bay, $26 \mathrm{mi}$. NW of Goodnews, Yukon-Kuskokwim Delta, $59^{\circ} 29^{\prime} \mathrm{N}, 161^{\circ} 45^{\prime}$ W; $B G N$ 1939; (map 53). Var. Cripple Creek.

This stream was called "Cripple Creek," in 1913 by USC\&GS on Chart T-3399. It was reported as "Jacksmith Creek" in 1919 by G. L. Harrington (in Brooks and others, 1921, map 7), USGS.

Jackson: locality, see Howkan

Jackson: locality, see Jackson Mission.

Jackson, Point: point of land, on barrier beach between Breving Lagoon and Port Clarence, $8 \mathrm{mi}$. NW of Teller, Seward Penin. High.; $65^{\circ} 20^{\prime} \mathrm{N}, 166^{\circ} 36^{\prime} \mathrm{W}$; (map 111).

Named in 1827 by Capt. Beechey (1831, p. 543), RN, "in compliment to the Honorable * * Captain Samuel Jackson, C. B., *** of whom I am indebted for my earliest connexion [sic] with the voyages of Northern Discovery."

Jackson Bay: bay, see Sheep Bay.

Jackson Cove: estuary, on S coast of Glacier I., extends SE $1 \mathrm{mi}$. to Chamberlain Bay, $51 \mathrm{mi}$. NE of Whittier, Chugach Mts. ; $60^{\circ} 52^{\prime} 25^{\prime \prime} \mathrm{N}$, $147^{\circ} 12^{\prime} 45^{\prime \prime} \mathrm{W}$; (map 63)

Local name reported in 1900 by F. C. Schrader, USGS. Jackson Hole is a similar feature on the north shore.

Jackson Creek: stream, flows E $4 \mathrm{mi}$. to Copper River, $1 \mathrm{mi}$. SE of mouth of Cleave Creek and $46 \mathrm{mi}$. E of Valdez, Chugach Mts.; $61^{\circ}$. $06^{\prime} 55^{\prime \prime} \mathrm{N}, 144^{\circ} 52^{\prime} 30^{\prime \prime} \mathrm{W}$; (map 68).

Local name published since 1950 by USGS.

Jackson Creek: stream, flows NW $30 \mathrm{mi}$. to Bonasila River, $26 \mathrm{mi}$. W of Anvik and $54 \mathrm{mi}$. NW of Holy Cross, Nulato Hills; $62^{\circ} 43^{\prime} \mathrm{N}$, $161^{\circ} 01^{\prime} \mathrm{W}$; ( $\operatorname{map} 78$ ).

Local name reported in 1949 by USC\&GS. Jackson Creek: stream, flows SW $10 \mathrm{mi}$. to Bonanza River, 5 mi. W of Solomon, Seward Penin. High.; $64^{\circ} 33^{\prime} \mathrm{N}, 164^{\circ} 36^{\prime} \mathrm{W}$; (map 95). Var. East Fork Jackson Creek.

Prospectors' name reported in 1900 by $\mathrm{E}$. C. Barnard (in Brooks, 1901, pl. 17), USGS.

Jackson Creek: stream, in Rampart Mts., flows S 11 mi. to Yukon River, $8 \mathrm{mi}$. ENE of Tanana, Kokrines-Hodzana High.; $65^{\circ} 12^{\prime} 30^{\prime \prime}$ $\mathrm{N}, 151^{\circ} 50^{\prime} 00^{\prime \prime} \mathrm{W}$; (map 106).

Name taken from Edwards Track Chart of the Yukon, dated 1899; published by Cantwell (1902, p. 277), USRCS.

Jackson Hole: estuary, on $\mathrm{N}$ coast of Glacier I. extends NE $1.5 \mathrm{mi}$. to Prince William Sound, $52 \mathrm{mi}$. NE of Whittier, Chugach Mts.; $60^{\circ}$ $54^{\prime} 25^{\prime \prime} \mathrm{N} 147^{\circ} 12^{\prime} 15^{\prime \prime} \mathrm{W}$; (map 63).

Local name reported in 1908 by U. S. Grant (in Brooks and others, 1909, pl. 4), USGS.
Jackson Cove is on the south shore. This name may have been suggested by Jackson Hole, Wyoming.

Jackson Island: island, $1.2 \mathrm{mi}$. long, near head of Cordova Bay, S of Sukkwan I., Alex. Arch.; $54^{\circ} 59^{\prime} 00^{\prime \prime} \mathrm{N}, 132^{\circ} 43^{\prime} 30^{\prime \prime} \mathrm{W}$; (map 1). Var. Norcross Island.

Named in 1883 by W. H. Dall, USC\&GS, for Sheldon Jackson who established a Presbyterian mission on nearby Long Island in 1881. Jackson called this island "Norcross" in 1880 .

Jackson Island: island, $2 \mathrm{mi}$. long, in Yukon River, 36 mi. NW of Livengood, Yukon Flats; $66^{\circ} 00^{\prime} \mathrm{N}, 149^{\circ} 00^{\prime} \mathrm{W}$; (map 105).

Local name published by USGS in the 1950 's.

Jackson Lagoon: lagoon, $1.5 \mathrm{mi}$. long, on NW shore of Pavlof Bay, $3.5 \mathrm{mi}$. NW of Ivan I., Bristol Bay Low.; $55^{\circ} 34^{\prime} 15^{\prime \prime} \mathrm{N}, 161^{\circ} 39^{\prime} 15^{\prime \prime}$ W; (map 28).

Named in 1929 by USGS.

Jackson Lake: lake, $1 \mathrm{mi}$. across, $6 \mathrm{mi}$. $\mathrm{E}$ of Stevens Village, Yukon Flats; $66^{\circ} 00^{\prime} \mathrm{N}$, $148^{\circ} 54^{\prime} \mathrm{W}$; (map 105).

Local name published by USGS in the 1950's.

Jackson Mission: locality, site of Presbyterian mission and trading post, at Howkan, on W coast of Long I., Alex. Arch.; 54 $52^{\prime} 10^{\prime \prime} \mathrm{N}$, $132^{\circ} 48^{\prime} 00^{\prime \prime}$ W ; (map 1). Var. Jackson.

This mission was established in 1881 by Rev. Sheldon Jackson, and was called "Jackson" by the missionaries.

Jackson Passage: water passage, $1 \mathrm{mi}$. long, between Jackson and Sukkwan Is., near head of Cordova Bay, Alex. Arch.; 54 59'15' N, $132^{\circ} 44^{\prime} 30^{\prime \prime} \mathrm{W}$; (map 1).

Name derived from Jackson Island and published by USC\&GS in 1911.

Jackson Point: point of land, $0.4 \mathrm{mi}$. long, on $\mathrm{S}$ shore of Port Valdez, $4.2 \mathrm{mi}$. SW of Valdez Chugach Mts.; $61^{\circ} 05^{\prime} 25^{\prime \prime} \mathrm{N}, 146^{\circ} 22^{\prime} 45^{\prime \prime} \mathrm{W}$; (map 68).

Local name reported in 1901 by H. P. Ritter, USGS.

Jackson Slough: stream, anabranch of the Yukon River, $2 \mathrm{mi}$. long, $36 \mathrm{mi}$. NW of Livengood, Yukon Flats; $65^{\circ} 59^{\prime} 45^{\prime \prime} \mathrm{N}, 148^{\circ} 59^{\prime} 40^{\prime \prime} \mathrm{W}$; (map 105).

Local name published by USGS in the 1950 's.

Jacks Slough: stream, flows NW $3.3 \mathrm{mi}$. to $\mathrm{Ga}$ lena Creek, $34 \mathrm{mi}$. E of Nulato, Koyukuk Low.; $64^{\circ} 41^{\prime} \mathrm{N}, 156^{\circ} 58^{\prime} \mathrm{W}$; (map 97). Var. Last Slough.

Riverboat pilots' name shown on a 1940 "Navigation Chart of the Tanana-Yukon Rivers" published by U.S. Dept. of Interior.

Jack Uheen Slough: stream, anabranch of Yukon River, $8.5 \mathrm{mi}$. long, $4.2 \mathrm{mi}$. SE of Beaver, Yukon Flats; $66^{\circ} 20^{\prime} 20^{\prime \prime} \mathrm{N}, 147^{\circ} 14^{\prime} 30^{\prime \prime} \mathrm{W}$; (map 118). Var. Jack Wien Slough.

Local name obtained in 1956 by USGS.

Jack Wade: locality, on Wade Creek, $46 \mathrm{mi}$. S of Eagle, Yukon-Tanana High.; $64^{\circ} 09^{\prime} 00^{\prime \prime} \mathrm{N}$, $141^{\circ} 27^{\prime} 30^{\prime \prime} \mathrm{W}$; (map 102). Var. Jackwade. 
Mining camp named by miners for Jack Wade, prospector; reported in 1903 by T. G. Gerdine (in Prindle, 1905, pl. 16), USGS. A post office was established here in 1901 and maintained until 1948 (Ricks, 1965, p. 29). The population dwindled to 21 persons by 1940.

Jack Wade Creek: stream, see Wade Creek.

Jack Wade Gulch: ravine, trends SW $1 \mathrm{mi}$. to Auburn Creek which flows to American Creek, $23 \mathrm{mi}$. N of Solomon, Sewart Penin. High.; 64. $53^{\prime} 45^{\prime \prime} \mathrm{N}, 164^{\circ} 28^{\prime} 20^{\prime \prime} \mathrm{W}$; (map 95).

Name derived from Jack Wade of the "Forty Mile district." Prospectors' name reported in 1907 by USGS geologists (Smith, P. S., 1910, pl. 4).

Jack White Creek: stream, see Jack Creek.

Jack White Range: mountain range, extends NESW 16 mi., between Koyukuk River and its South Fork, $10 \mathrm{mi}$. E of Bettles, Brooks Ra; $66^{\circ} 54^{\prime} \mathrm{N}, 151^{\circ} 03^{\prime} \mathrm{W}$; (map 117).

Local name reported in 1956 by USGS.

Jack Wien Slough: channel, see Jack Uheen Slough.

Jacobieff Island: island, see Yakobi Island.

Jacobi Island: island, see Chichagof Island.

Jacob Island: island, $4.5 \mathrm{mi}$. long, $12 \mathrm{mi}$. $\mathbf{E}$ of Stepovak Bay, Aleutian Ra.; $55^{\circ} 45^{\prime} \mathrm{N}, 159^{\circ}$ 22' W; (map 27). Var. Saint Jacob.

Named by Lt. Woronkofski in 1837; published as "O[strov] Sv[yatoy] Iakova," or "St. Jacob Island," on Russian Hydrog. Dept. Chart 1379 (1847). "Jacob Island" was shown in 1888 on USC\&GS Chart 806.

Jacob Island: island, see Yakobi Island.

Jacob Point: point of land, between Yukon River and Old Lost Creek, $18 \mathrm{mi}$. NE of Stevens Village, Yukon Flats; $66^{\circ} 08^{\prime} 15^{\prime \prime} \mathrm{N}, 148^{\circ} 32^{\prime}$ $15^{\prime \prime} \mathrm{W}$; (map 118).

Local name obtained in 1956 by USGS.

Jacob Rock: rock, $0.2 \mathrm{mi}$. long, in Necker Is., W of Baranof I., $5.8 \mathrm{mi}$. SW of Goddard, Alex. Arch.; $56^{\circ} 47^{\prime} 15^{\prime \prime} \mathrm{N}, 135^{\circ} 29^{\prime} 45^{\prime \prime} \mathrm{W}$; $B G N$ 1929; (map 5).

Named in 1925 by USC\&GS. See Rogers Island.

Jacobsen Lake: lake, $0.7 \mathrm{mi}$. long, in Matanuska Valley, $14 \mathrm{mi}$. SW of Palmer, Cook Inlet Low.; 61 $34^{\prime} 45^{\prime \prime} \mathrm{N}, 149^{\circ} 32^{\prime} 15^{\prime \prime} \mathrm{W}$; (map 69).

Local name reported in 1942 by AMS.

Jacobs Mountain: mountain, 2,370 ft., near head of Kasaan Penin., on $E$ coast of Prince of Wales I., Alex. Arch.; 55 $34^{\prime} 10^{\prime \prime} \mathrm{N}, 132^{\circ} 21^{\prime}$ $45^{\prime \prime} \mathrm{W}$; (map 4).

Local name recorded in 1949 by USGS.

Jacootat Bay: bay, see Yakutat Bay.

Jade Creek: stream, heads in Jade Mts. at $67^{\circ} 14^{\prime}$ $\mathrm{N}, 158^{\circ} 01^{\prime} \mathrm{W}$, flows $\mathrm{SW} 12 \mathrm{mi}$. to Kobuk River, $33 \mathrm{mi}$. NW of Shungnak, Brooks Ra.; $67^{\circ} 07^{\prime} \mathrm{N}, 158^{\circ} 13^{\prime} \mathrm{W}$; (map 126).

Named by Mendenhall (1902, pl. 5), USGS, after the Jade Mountains.

Jade Mountain: mountains, see Jade Mountains. Jade Mountains: mountains, 3,350 ft., at SE end of Baird Mts., extend NW-SE $11 \mathrm{mi}$., $4 \mathrm{mi}$ wide, 33 mi. NW of Shungnak, Brooks Ra.; $67^{\circ} 14^{\prime} \mathrm{N}, 158^{\circ} 03^{\prime} \mathrm{W}$; (map 126). Var. Ashiganok, Green Stone Mountain, Jade Mountain.

This name is mentioned by Lt. Stoney (1900, p. 56), USN, who probably named this feature on his visit there in 1884 when he obtained samples of jade for the Smithsonian Institution. Lt. J. C. Cantwell, USRCS, called it "Ashiganok," meaning "green-stone mountain," in 1884 (Healy, 1886, p. 57). "Ashiganok" is the same as the Eskimo name "Shungnak."

Jadski Cove: cove, extends S $1 \mathrm{mi}$. to Clarence Strait, $W$ of McHenry Inlet, on SW coast of Etolin I., Alex. Arch.; 56 ${ }^{\circ} 01^{\prime} \mathrm{N}, 132^{\circ} 25^{\prime}$ W; (map 6).

Local navigators' name reported in 1904 by $H$. C. Fassett, USBF.

Jagged Boulder Plateau: plateau, 5,000 ft., near center of Granite Mtn., $22 \mathrm{mi}$. SE of Delta Junction, Alaska Ra.; $63^{\circ} 45^{\prime} \mathrm{N}, 145^{\circ} 24^{\prime} \mathrm{W}$; (map 86).

Name published on relatively recent maps.

Jagged Mountain: mountain, 2,350 ft., $5 \mathrm{mi}$. SE of tip of Cape Newenham and $35 \mathrm{mi}$. W of Hagemeister I., Kilbuck-Kuskokwim Mts.; $58^{\circ} 38^{\prime} 15^{\prime \prime} \mathrm{N}, 162^{\circ} 01^{\prime} 45^{\prime \prime} \mathrm{W}$; (map 39).

Descriptive name given in 1914 by USC\&GS; published in 1916 Coast Pilot (p. 246)

Jago Entrance: water passage, on coast of Beaufort Sea, $3.5 \mathrm{mi}$. E of Barter I., between Bernard and Jago Spits, Arctic Plain; $70^{\circ} 08^{\prime}$ N, $143^{\circ} 22^{\prime} \mathrm{W}$; (map 152)

Local name reported in 1952 by USC\&GS. The name is derived from the Jago River.

Jago Lagoon: lagoon, on coast of Beaufort Sea, extends $6.5 \mathrm{mi}$. between Manning and Martin Points, 2 mi. E of Barter I., Arctic Plain; $70^{\circ} 07^{\prime} \mathrm{N}, 143^{\circ} 22^{\prime} \mathrm{W}$; (map 152).

Local name derived from the Jago River, reported in 1952 by USC\&GS.

Jago River: stream, heads at glacier in Romanzof Mts. at $69^{\circ} 04^{\prime} 30^{\prime \prime} \mathrm{N}, 143^{\circ} 54^{\prime} 00^{\prime \prime} \mathrm{W}$, flows N $90 \mathrm{mi}$. to Jago Lagoon, $7 \mathrm{mi}$. E of Barter I., Arctic Plain; $70^{\circ} 07^{\prime} 25^{\prime \prime} \mathrm{N}, 143^{\circ} 16^{\prime} 30^{\prime \prime} \mathrm{W}$; (map 152). Var. Jags River, Jaye River.

Named by Leffingwell (1919, p. 92), USGS; derived from the name "Jags" and modified to "Jago" in order to "place the name of Lt. Jago of Collinson's [Capt. Rich. ard, RN] ship, on the map * * ." The name "Jags," according to Leffingwell, is the Eskimo attempt to pronounce "the whaler's nickname for a drunken native who first braved the devils that were supposed to dwell on that river."

Jago Spit: barrier island, $3 \mathrm{mi}$. long, on coast of Beaufort Sea, $5 \mathrm{mi}$. E of Barter I., Arctic Plain; $70^{\circ} 09^{\prime} \mathrm{N}, 143^{\circ} 16^{\prime} \mathrm{W}$; (map 152).

Local name derived from the Jago River, reported by USC\&GS in 1952.

Jag Peak: mountain, 2,880 ft., SW of Okmok Caldera, on NE part of Umnak I., Aleutian Is.; $53^{\circ} 23^{\prime} \mathrm{N}, 168^{\circ} 14^{\prime} \mathrm{W}$; (map 22).

Name published by Byers (1959, p. 313), USGS.

Jags River: stream, see Jago River.
Jaichnoi: point of land, see Egg Point.

Jaitschoi Island: island, see Egg Island.

Jake Lake: lake, $0.7 \mathrm{mi}$. long, between Peters and Twentymile Creeks, $19 \mathrm{mi}$. W of Talkeetna, Alaska Ra.; $62^{\circ} 20^{\prime} 50^{\prime \prime} \mathrm{N}, 150^{\circ} 41^{\prime} 35^{\prime \prime}$ W; (map 81).

Local name reported in 1958 by USGS.

Jaklek, Landzunge: point of land, see Aklek, Cape.

Jaklok, Landzunge: point of land, see Aklek, Cape.

Jakolof Bay: cove, 0.2 mi. wide, on Kenai Penin., at $\mathrm{S}$ end of Kasitsna Bay, $6.5 \mathrm{mi}$. NE of Seldovia, Chugach Mts.; $59^{\circ} 28^{\prime} \mathrm{N}, 151^{\circ} 32^{\prime} \mathrm{W}$; (map 50).

Local name reported by U. S. Grant, USGS, in 1915.

Jakolof Creek: stream, on Kenai Penin., flows NW $2 \mathrm{mi}$. to Jakolof Bay, $8 \mathrm{mi}$. E of Seldovia, Chugach Mts.; $59^{\circ} 27^{\prime} \mathrm{N}, 151^{\circ} 29, \mathrm{~W}$; (map 50).

Name derived from Jakolof Bay; reported by A. C. Gill, Cornell Univ., in 1918.

Jakorny: spit, see Anchor Point.

Jalamund Lake: lake, $0.4 \mathrm{mi}$. long, $\mathrm{N}$ of Black Hills, $18 \mathrm{mi}$. SE of Northway, Alaska Ra.; $62^{\circ} 43^{\prime} \mathrm{N}, 141^{\circ} 46^{\prime} \mathrm{W}$; (map 84).

Indian name reported in 1955 by USGS.

Jamboree Bay: estuary, $2 \mathrm{mi}$. long, on $\mathrm{W}$ coast of Baranof I., $25 \mathrm{mi}$. SE of Sitka, Alex. Arch.; $56^{\circ} 42^{\prime} 40^{\prime \prime} \mathrm{N}, 135^{\circ} 10^{\prime} 20^{\prime \prime} \mathrm{W}$; (map 5).

Named in 1924 by USC\&GS.

James Creek: stream, in Nutzotin Mts., flows SE $4 \mathrm{mi}$. to Carl Creek, 5.5 E of Beaver Lake, Alaska Ra.; $62^{\circ} 03^{\prime} \mathrm{N}, 141^{\circ} 37^{\prime} \mathrm{W}$; (map 84).

Local name reported in 1960 by USGS.

James Island: bar, $1.5 \mathrm{mi}$. long, trends $\mathrm{N}-\mathrm{S}$ in in NW part of Ivanof Bay, Aleutian Ra.; $55^{\circ} 52^{\prime} \mathrm{N}, 159^{\circ} 32^{\prime} \mathrm{W}$; (map 27 ).

Named by W. H. Dall, USC\&GS, and published in 1882 on Chart 806 .

James Island: island, see Bettles Island.

James Island: island, see Crow Island.

James Lagoon: lagoon, $0.5 \mathrm{mi}$. wide, on $\mathrm{W}$ shore of East Arm Nuka Bay, Kenai Penin., $40 \mathrm{mi}$. ESE of Homer, Ghugach Mts.; $59^{\circ} 34^{\prime} \mathrm{N}$, $150^{\circ} 20^{\prime} \mathrm{W}$; BGN 1911; (map 50).

Named by U. S. Grant, USGS, in 1911, "for Capt. James Bettels, of Valdez, a resident of Prince William Sound for the last 20 years."

James Lake: lake, $0.4 \mathrm{mi}$. Iong, in course of John Creek, $1.5 \mathrm{mi} \mathrm{N}$ of Port Johnson, on SE coast of Prince of Wales I., Alex. Arch.; 55 $09^{\prime} \mathrm{N}, 132^{\circ} 03^{\prime} \mathrm{W}$; (map 4).

Local name reported in 1901 by $A$. $H$. Brooks, USGS.

James Robert Glacier: glacier, in Lake Peter area, in Franklin Mts., Brooks Ra.; (map 139).

Name published by Bee and Hall (1956, p. 296).

James Robert Lake: lake, in Lake Peters area, in Franklin Mts.; Brooks Ra.; (map 139).

Name published by Bee and Hall (1956, p. 296). 
Jamestown Bay: bay, $0.6 \mathrm{mi}$. across, $1.5 \mathrm{mi}$. SE of Sitka, on W coast of Baranof I., Alex. Arch.; $57^{\circ} 02^{\prime} 40^{\prime \prime} \mathrm{N}, 135^{\circ} 17^{\prime} 30^{\prime \prime} \mathrm{W}$; (map 9).

Named in 1879 by the U.S. Navy for the U.S.S. Jamestown, which was stationed in southeastern Alaska, primarily at Sitka, where her officers, including Lt. F. M. Symonds and Master G. C. Hanus, were engaged in surveying Sitka Sound. Various islands in the sound were named after officers of the ship. The name Jamestown Bay was published by USC\&GS in 1883 Coast Pilot (p. 144).

Jamestown Hill: hill, probably on $\mathrm{N}$ slope of Mount Roberts, about $3 \mathrm{mi}$. SE of Juneau, Coast Mts. ; $58^{\circ} 18^{\prime} \mathrm{N}, 134^{\circ} 20^{\prime} \mathrm{W}$; (map 11).

Named by miners about 1885 (DeArmond, 1957, p. 37).

Jamestown Peak: peak, 3,172 ft., $9 \mathrm{mi}$. E. of Cape Fanshaw and $78 \mathrm{mi}$. E of Sitka, Coast Mts.; $57^{\circ} 10^{\prime} 40^{\prime \prime} \mathrm{N}, 133^{\circ} 19^{\prime} 35^{\prime \prime} \mathrm{W}$; (map 8).

Named in 1887 by Lt. Comdr. G. M. Thomas, USN, for the U.S.S. Jamestown, a survey ship in southeastern Alaska 1879-80; published in 1888 by USC\&GS.

Jamieson Creek: stream, flows SW to Goodhope River, about $27 \mathrm{mi}$. NW of Imuruk Lake, Seward Penin. High.; (map 110).

Prospectors' name reported in 1901 by USGS (Collier, 1902, pl. 12). This stream cannot be identified on current maps.

Jane Creek: stream, heads in Alatna Hills, flows SE 11 mi. to Koyukuk River, 2 mi. S of Bettles, Kanuti Flats; $66^{\circ} 53^{\prime} \mathrm{N}, 1^{\circ} 41^{\prime} \mathrm{W}$; (map 117 ).

Name used by prospectors and reported in 1901 by W. J. Peters (in Schrader, 1904, p. 2), USGS.

Jane Russell Peaks : peak, see Peril Peak.

Janesville Mountain: mountain, 2,567 ft., on Annette I., NE of Port Chester, Alex. Arch.; $55^{\circ} 09^{\prime} 48^{\prime \prime} \mathrm{N}, 131^{\circ} 30^{\prime} 20^{\prime \prime} \mathrm{W}$; BCN 1900; (map 3). Var. Janeville Mountain.

Named in 1883 by Lt. Comdr. H. E. Nichols, USN, after "Janesville, Wisconsin."

Janeville Mountain: mountain, see Janeville Mountain.

Jan Lake: lake, $0.4 \mathrm{mi}$. long, W of Alaska Highway, $21 \mathrm{mi}$. NW of Tanacross, Yukon-Tanana High.; $63^{\circ} 34^{\prime} \mathrm{N}, 143^{\circ} 55^{\prime} \mathrm{W}$; (map 85).

Named about 1957 by Edward Marvich of the Alaska Dept. of Fisheries for his expected daughter for whom the name "Janet" was planned. The baby was a boy.

Jan Peak: peak, see Mustang Peak.

Jansen, Point: point of land, on SE coast of Prince of Wales I., in North Arm Moira Sound, Alex. Arch.; $55^{\circ} 06^{\prime} 15^{\prime \prime} \mathrm{N}, 132^{\circ} 06^{\prime} 45^{\prime \prime}$ W; (map 4).

Local name reported in 1905 by E. F. Dickins, USC\&GS.

January Lake: lake, $1.5 \mathrm{mi}$. long, near $\mathrm{E}$ coast of Revillagigedo I., in course of North Fork Manzanita Creek, Alex. Arch.; $55^{\circ} 36^{\prime} \mathrm{N}$, $131^{\circ} 04^{\prime} \mathrm{W}$; BGN 1960; (map 3). Var. Amber Lake.

Local name reported in 1960 by USFS.

Japanese Island: island, see Japonski Island.
Japan Hills: mountains, 2,834 ft., $6.5 \mathrm{mi}$. across, between Wood River and Bonnifant Creek, 45 mi. S of Fairbanks, Alaska Ra.; $64^{\circ} 11^{\prime} \mathrm{N}$, $147^{\circ} 45^{\prime} \mathrm{W}$; (map 100). Var. Jap Hill.

Local name shown as Jap Hill in 1909 on a manuscript ARC map by Arnt Greve.

Jap Bay: $b a y, 1$ mi. across, 6 mi. NE of Kaguyak on $\mathrm{SE}$ coast of Kodiak I.; $56^{\circ} 56^{\prime} \mathrm{N}, 153^{\circ} 41^{\prime}$ W; (map 33).

Name reported in 1943 by USC\&GS.

Jap Creek: stream, flows $\mathrm{S} 3 \mathrm{mi}$. to Frederick Sound, $4 \mathrm{mi}$. NW of mouth of Le Conte Bay, $13 \mathrm{mi}$. SE of Petersburg, Coast Mts.; 56 ${ }^{\circ}$ $46^{\prime} 25^{\prime \prime} \mathrm{N}, 132^{\circ} 36^{\prime} 25^{\prime \prime} \mathrm{W}$; (map 6).

Local name recorded in 1961 by USGS.

Jap Creek: stream, heads on S side of Iron Mtn., on Kenai Penin., flows NE $3.5 \mathrm{mi}$. to Resurrection River, $1 \mathrm{mi}$. NE of Seward, Chugach Mts. ; $60^{\circ} 08^{\prime} 20^{\prime \prime} \mathrm{N}, 149^{\circ} 25^{\prime} 05^{\prime \prime} \mathrm{W}$; (map 63).

Local name reported in 1951 by USGS.

Jap Creek: stream, flows NE $4.5 \mathrm{mi}$. to Wiseman Creek, $1.4 \mathrm{mi}$. NW of mouth of that stream and $1 \mathrm{mi}$. NW of Wiseman, Brooks Ra.; $67^{\circ}$. $25^{\prime} 30^{\prime \prime} \mathrm{N}, 150^{\circ} 08^{\prime} 00^{\prime \prime} \mathrm{W}$; ( $\left.\operatorname{map} 124\right)$.

Local name obtained in 1956 by USGS topographers.

Jap Gap: pass, 1,050 ft., on E end of Attu I., between Simson and Vanderlann Peaks, 0.4 mi. SE of Lake Cories, Aleutian Is.; 52 ${ }^{\circ} 4^{\prime}$ $02^{\prime \prime} \mathrm{N}, 173^{\circ} 14^{\prime} 50^{\prime \prime} \mathrm{E}$; (map 13 ).

Named by U.S. Army during World War II; published in 1948 by AMS.

Jap Hill: mountains, see Japan Hills.

Japonski Island: island, $1 \mathrm{mi}$. across, $0.5 \mathrm{mi}$. W of Sitka, in Sitka Sound, Alex. Arch.; $57^{\circ} 03^{\prime}$ N, $135^{\circ} 22^{\prime}$ W; (map 9). Var. Japanese Island, Jeponski Island, Ostrov Yaponskoy, Yaponskoi Island.

Russian name meaning "Japanese Island" given in 1809 by the navigator Ivan Vasiliev the first; published by Lt. Sarichev (1826, map 19), IRN, as "O[strov] Yaponskoy.". This name was given because there were some shipwrecked Japanese sailors living there at the time.

Jarmin Pass: pass, $600 \mathrm{ft}$, , on E end of Attu I., at head of West Massacre Valley, Aleutian Is.; $52^{\circ} 53^{\prime} 20^{\prime \prime} \mathrm{N}, 173^{\circ} 07^{\prime} 45^{\prime \prime} \mathrm{E}$; (map 13 ).

Named by U.S. Army during World War II; published in 1948 by AMS.

Jarvis: locality, on Colville River, at mouth of Itkillik River, Arctic Plain; $70^{\circ} 09^{\prime} \mathrm{N}, 150^{\circ}$ 56' W; (map 149).

This camp was named in 1902 by $\mathrm{E}$. F. Bosqui, U.S. Commissioner, for Lt. Daniel H. Jarvis, USRCS, who conducted an overland expedition for the relief of the whaling flect at Point Barrow in 1897-98.

Jarvis, Mount: mountain, 13,421 ft., at head of Jacksina Glacier, Wrangell Mts.; 62 $01^{\prime} \mathrm{N}$, $143^{\circ} 37^{\prime} \mathrm{W}$; (map 84).

Named in 1903 by F. C. Schrader, USGS, for Capt. D. H. Jarvis, USRCS, who spent several years in Alaska.

Jarvis, Mount: mountain, 1,456 ft., E of Kivalina River, $9 \mathrm{mi}$. NE of Kivalina, Arctic Slope ; $67^{\circ} 55^{\prime} 30^{\prime \prime} \mathrm{N}, 164^{\circ} 01^{\prime} 00^{\prime \prime} \mathrm{W}$; (map 128). Var. Jarvis Mountain.
Named for Lt. Daniel H. Jarvis, USRCS, who conducted an overland expedition for the relief of the whaling fleet "frozen in" at Point Barrow. The expedition consisted of a herd of 448 reindeer which passed near this mountain about March, 1898. The mountain may have been named by P. S. Smith and J. B. Mertie, USGS, about 1925.

Jarvis Creek: stream, flows SE to Fish River, between Miller and Onekoksuk Creeks, about $37 \mathrm{mi}$. NE of Solomon, Seward Penin. High.; (map 95).

Prospectors' name reported on the 1900 "Map of Nome Peninsula" by J. M. Davidson and B. D. Blakeslee. This stream cannot be precisely located on current maps.

Jarvis Creek: stream, heads in Jarvis Glacier, flows $E 1.8 \mathrm{mi}$. to Klehini River, $37 \mathrm{mi}$. W of Skagway, St. Elias Mts.; $59^{\circ} 26^{\prime} 50^{\prime \prime} \mathrm{N}, 136^{\circ}$ $21^{\prime} 50^{\prime \prime} \mathrm{W}$; (map 45).

Local name reported by $C$. W. Wright (1904, pl. 2), USGS.

Jarvis Creek: stream, heads at $63^{\circ} 32^{\prime} \mathrm{N}, 145^{\circ}$. $41^{\prime} \mathrm{W}$, flows $\mathrm{N} 39 \mathrm{mi}$. to Delta River, $9 \mathrm{mi}$. SE of Big Delta, Alaska Ra.; $64^{\circ} 01^{\prime} \mathrm{N}, 145^{\circ}$ 45' W; (map 101).

Named by Capt. E. F. Glenn, USA in 1898 , probably for Lt. David Henry Jarvis, USRCS. The name was published in 1900 by USGS.

Jarvis Creek: stream, flows SE $1 \mathrm{mi}$. to Anikovik River, $14 \mathrm{mi}$. SE of Cape Prince of Wales and $41 \mathrm{mi}$. NW of Teller, Seward Penin. High.; $65^{\circ} 31^{\prime} \mathrm{N}, 167^{\circ} 37^{\prime} \mathrm{W}$; (map 111).

Prospectors' name shown on the 1900 "Map of Nome Peninsula" by J. M. Davidson and B. D. Blakeslee.

Jarvis Glacier: glacier, heads in Canada at $59^{\circ}$ $30^{\prime} \mathrm{N}, 136^{\circ} 39^{\prime \prime} \mathrm{W}$, trends SE $12 \mathrm{mi}$. to head of Jarvis Creek, $1.8 \mathrm{mi}$. W of Pleasant Camp and $39 \mathrm{mi}$. W of Skagway, St. Elias Mts.; $59^{\circ} 26^{\prime} 30^{\prime \prime} \mathrm{N}, 136^{\circ} 25^{\prime} 00^{\prime \prime} \mathrm{W} ; B G N 1954$; (map 45).

Local name published by A. $H$. Brooks and others $(1918, \mathrm{pl} .8)$. It was named for Inspector Jarvis of the Royal Canadian Mounted Police.

Jarvis Island: island, near entrance to Twelvemile Arm Kasaan Bay, on $\mathrm{E}$ coast of Prince of Wales I., Alex. Arch.; 55 $30^{\prime} 20^{\prime \prime} \mathrm{N}, 132^{\circ}$. $33^{\prime} 00^{\prime \prime} \mathrm{W}$; (map 4). Var. Jarvis Islands.

Named for Lt. Daniel Henry Jarvis, USRCS, commander of the revenue cutter Bear, who conducted an overland expedition for the relief of the whaling fleet imprisoned by the ice in the vicinity of Point Barrow in 1897-1898; published in 1910 by USC\&GS. Jarvis Islands: island, see Jarvis Island. Jarvis Mountain : mountain, see Jarvis, Mount. Jasper Creek : stream, flows NW $3.5 \mathrm{mi}$. to Salmon Lake, $30 \mathrm{mi}$. NE of Nome, Seward Penin. High.; 64 ${ }^{\circ} 54^{\prime} \mathrm{N}, 165^{\circ} 00^{\prime} \mathrm{W}$; (map 94). Var. Cash Creek, Bonanza Creek.

Prospectors' name reported in 1908 by $\mathbf{P}$. $\mathbf{S}$. Smith (in Brooks and others, 1909, pl. 10), USGS. Smith applied "Cash Creek" to the upper course of Jasper Creek. 
Jatahmund Lake: lake, $4 \mathrm{mi}$. long, S of Black Hills, $23 \mathrm{mi}$. $\mathrm{S}$ of Northway, Alaska Ra. $62^{\circ} 37^{\prime} \mathrm{N}, 142^{\circ} 00^{\prime} \mathrm{W}$; (map 84).

Indian name reported in 1955 by USGS.

Jaw Mountain: mountains, two, 2,400 ft., arcshaped group open to NE, $30 \mathrm{mi}$. NW of Cape Kunmik, on Alaska Penin., Aleutian Ra.; $56^{\circ} 58^{\prime} \mathrm{N}, 157^{\circ} 53^{\prime} \mathrm{W}$; (map 31 ).

Named in 1923 by R. H. Sargent, USGS, who described "its two peaks separated by a steep-side gap [like a jaw]."

Jaw Point: point of land, in Woewodski Harbor, on $E$ coast of Liesnoi I., off SE coast of Admiralty I., Alex. Arch.; $57^{\circ} 10^{\prime} 00^{\prime \prime} \mathrm{N}, 134^{\circ}$. $15^{\prime} 15^{\prime \prime} \mathrm{W}$; (map 9).

Descriptive name given in 1889 by $L t$ Comdr. H. B. Mansfield, USN ; published by USC\&GS in 1891 Coast Pilot (p. 142). Liesnoi Island is shaped somewhat like a jaw. Jaw Point marks the point of the lower jaw.

Jaw Point: point of land, on $\mathrm{E}$ shore of Taku Inlet, $3 \mathrm{mi}$. NE of Cooper Point and $12 \mathrm{mi}$. $\mathrm{W}$ of Juneau, Coast Mts.; $58^{\circ} 16^{\prime} 45^{\prime \prime} \mathrm{N}$, $134^{\circ} 04^{\prime} 45^{\prime \prime} \mathrm{W}$; (map 11).

Named by Lt. Comdr. H. B. Mansfield, USN, in 1890 and published by USC\&GS in the 1891 Coast Pilot (p. 153).

Jayalik Hill: hill, $305 \mathrm{ft}$., $22 \mathrm{mi}$. NW of Cape Mendenhall, Nunivak I.; $59^{\circ} 57^{\prime} 45^{\prime \prime} \mathrm{N}, 166^{\circ}$. $42^{\prime} 30^{\prime \prime}$ W; (map 55). Var. Chealikh Hill, Jayalix Hill.

Eskimo name for the "silver salmon" according to USC\&GS in 1949.

Jayalik Lake: lake, $0.3 \mathrm{mi}$. across, $1 \mathrm{mi}$. SW of Jayalik Hill, 22 mi. NW of Cape Mendenhall, Nunivak I.; $59^{\circ} 57^{\prime} \mathrm{N}, 166^{\circ} 43^{\prime} \mathrm{W}$; (map 55). Var. Jayalrim Kimia, Jayalrim Nanwi.

Eskimo name reported in 1949, as "Jayalrim Nanwi" meaning "silver salmon lake" according to USCi\&GS.

Jayalik River: stream, heads at Jayalik Lake, flows SW $4 \mathrm{mi}$. to Bering Sea, Nunivak I.; $59^{\circ} 55^{\prime} \mathrm{N}, 166^{\circ} 48^{\prime} \mathrm{W}$; (map 55). Var. Chealikh River, Jayalix River.

Name derived from Jayalik Lake; published in 1958 by USGS.

Jayalix Hill: hill, see Jayalik Hill

Jayalix River: stream, see Jaylik River.

Jayalrim Kamia: lake, sce Jayalik Lake.

Jayalrim Nanwi: lake, see Jayalik Lake.

Jay Creek: stream, flows W $18 \mathrm{mi}$. to Susitna

River, $19 \mathrm{mi}$. NW of junc. of Oshetna River, Talkeetna Mts. ; $62^{\circ} 46^{\prime} 40^{\prime \prime} \mathrm{N}, 147^{\circ} 53^{\prime} 08^{\prime \prime} \mathrm{W}$ (map 82).

Local name reported in 1951 by USGS.

Jay Creek: stream, flows NE $3 \mathrm{mi}$. to Ruby Creek $14 \mathrm{mi}$. NE of Shungnak; Brooks Ra.; $67^{\circ} 05^{\prime}$ N, $156^{\circ} 56^{\prime} \mathrm{W}$; (map 126 ).

Local name reported by USGS in 1956.

Jay Creek: stream, in Baird Mts., flows SW 2 mi. to Central Creek $9.5 \mathrm{mi}$. ENE of its junc with Squirrel River, $13 \mathrm{mi}$. NE of Kiana, Brooks Ra.; $67^{\circ} 08^{\prime} \mathrm{N}, 160^{\circ} 12^{\prime} \mathrm{W}$; (map 127)

Name used by prospectors; reported in 1910 by P. S. Smith (in Brooks and others, 1911 , pl. 13), USGS.
Jay Creek: stream, flows SW $2 \mathrm{mi}$, to Rye Creek, $11 \mathrm{mi}$. NW of Ipnek Mtn. and $32 \mathrm{mi}$. W of Wiseman, Brooks Ra.; 67 $24^{\prime} 30^{\prime \prime} \mathrm{N}, 1^{\circ} 1^{\circ}$. $20^{\prime} 00^{\prime \prime} \mathrm{W}$; $B G N$ 1932; (map 124).

Local name reported by Robert Marshall in 1932

Jaye River: stream, see Jago River.

Jay Lake: lake, 0.2 mi. wide, E central Heceta I, Alex. Arch.; $55^{\circ} 46^{\prime} 35^{\prime \prime} \mathrm{N}, 133^{\circ} 24^{\prime} 15^{\prime \prime} \mathrm{W}$; (map 4).

Local name recorded in 1951 by USGS.

Jay Lake: lake, $0.8 \mathrm{mi}$. long, on Kenai Penin. $\mathrm{N}$ of Muskrat Lake, $34 \mathrm{mi}$. NE of Kenai, Cook Inlet Low.; $60^{\circ} 43^{\prime} 10^{\prime \prime} \mathrm{N}, 150^{\circ} 22^{\prime} 30^{\prime \prime}$ W; $(\operatorname{map} 62)$.

Named about 1963 by officials of Kenai National Moose Range, probably for the Alaska Jay, Whiskey Jack, or Camp Robber Perisoreus canadensis fumifrons).

Jean Bogosloff Island : island, see Bogoslof Island

Jean Creek: stream, flows from Dome (hill) SW $3 \mathrm{mi}$. to Slug River, Kilbuck-Kuskokwim Mts.; 58 $42^{\prime} 30^{\prime \prime} \mathrm{N}, 161^{\circ} 38^{\prime} 00^{\prime \prime} \mathrm{W}$; (map 39).

Local name shown on a 1937 fieldsheet by J. B. Mertie, USGS

Jean Creek: stream, on Kenai Penin., in Kenai Mts., fows SE $4.5 \mathrm{mi}$. to Kenai River, $40 \mathrm{mi}$ ESE of Kenai, Chugach Mts.; $60^{\circ} 29^{\prime} \mathrm{N}$ $150^{\circ} 07^{\prime} \mathrm{W}$; (map 62)

Local name reported in 1958 by USGS.

Jeanette Island: barrier island, $0.5 \mathrm{mi}$. long, one of McClure Is. on Beaufort Sea coast, $41 \mathrm{mi}$. E of Beechey Point, Arctic Plain; $70^{\circ} 22^{\prime} \mathrm{N}$, $147^{\circ} 25^{\prime} \mathrm{W}$; (map 150).

Named in 1881 by Lt. Comdr. G. W. DeLong, USN, for his steamship, the Jeanette.

Jeanie Cove: bay, $4 \mathrm{mi}$. across, on SE coast of Montague I., $5 \mathrm{mi}$. SW of Patton Bay, $68 \mathrm{mi}$. SE of Seward, Chugach Mts.; $59^{\circ} 50^{\prime} \mathrm{N}$, $147^{\circ} 35^{\prime}$ W ; BGN 1929; (map 49). Var. Bluff Cove.

Named by USC\&GS field party in 1928 ; "name sugested by the old SS. Jeanie, which struck a rock in this cove in 1906."

Jeanie Peak: peak, 1,772 ft., $5.5 \mathrm{mi}$. NE of Cape Cleare, on Montague Island, $60 \mathrm{mi}$. SE of Seward, Chugach Mts.; $59^{\circ} 50^{\prime} 45^{\prime \prime} \mathrm{N}$, $147^{\circ} 51^{\prime} 00^{\prime \prime} \mathrm{W}$; (map 49).

Local name reported in the early 1950's by USC\&GS.

Jeanie Point: point of land, at $\mathrm{E}$ end of Jeanie Cove, on SE coast of Montague I., $68 \mathrm{mi}$. SE of Seward, Chugach Mts.; $59^{\circ} 50^{\prime} \mathrm{N}, 147^{\circ} 32^{\prime}$ W; BGN 1929; (map 49). Var. Bluff Point Named in 1928 by USC\&GS after the ship Jeanie; see Jeanie Cove.

Jean Lake: lake, $1 \mathrm{mi}$. long, in Kenai Mts., on Kenai Penin., in course of Jean Creek, $38 \mathrm{mi}$. E of Kenai, Chugach Mts.; $60^{\circ} 30^{\prime} \mathrm{N}, 150^{\circ} 10^{\prime}$ W: (map 62)

Local name reported in 1958 by USGS.

Jean Lake: lake, $1,300 \mathrm{ft}$. long, $\mathbf{E}$ of Sucker Lake, $42 \mathrm{mi}$. NE of Tyonek, Cook Inlet Low.; $61^{\circ} 39^{\prime} 50^{\prime \prime} \mathrm{N}, 150^{\circ} 48^{\prime} 55^{\prime \prime} \mathrm{W}$; (map 70).

Local name reported in 1954 by USGS

Jeannes Lake: lake, $0.5 \mathrm{mi}$. across, $8 \mathrm{mi}$. NW of Bearpaw Mtn. and $32 \mathrm{mi}$. SE of Bitzshtini
Mts., Tanana Low.; $64^{\circ} 07^{\prime} \mathrm{N}, 151^{\circ} 17^{\prime} \mathrm{W}$; (map 99).

Local name reported in 1952 by USGS. Jeep Mountain: mountain, see Cashman, Mount. Jeff Cove: cove, $0.6 \mathrm{mi}$. across, NE of Bukhti Point, S coast of Kiska I., Aleutian Is. ; $51^{\circ}$ $56^{\prime} 00^{\prime \prime} \mathrm{N}, 177^{\circ} 28^{\prime} 30^{\prime \prime} \mathrm{E}$; (map 14).

One of many arbitrary names applied to features on Kiska I. by USAAF for tactical purposes during World War II.

Jefferies Glacier: glacier, heads at $60^{\circ} 37^{\prime} \mathrm{N}$, $141^{\circ} 35^{\prime} \mathrm{W}$, trends W $30 \mathrm{mi}$. to Tana Glacier, $7 \mathrm{mi}$. S of Needle Mtn. and $40 \mathrm{mi}$. $\mathrm{N}$ of Cape Yakataga, Chugach Mts.; $60^{\circ} 37^{\prime} \mathrm{N}, 142^{\circ} 27^{\prime}$ W; BGN 1960; (map 65).

Named by USGS in 1959 for William ("Tomato Bill") Jefferies, a prospector who, with James Barkley, crossed this area in 1907 (Moffit, 1918. p. 77).

Jefferson Coolidge, Mount: mountain, 6,560 ft., on Alaska-Canada boundary, $15 \mathrm{mi}$. NW of Hyder, Coast Mts.; $56^{\circ} 06^{\prime} 45^{\prime \prime} \mathrm{N}, 130^{\circ} 14^{\prime} 40^{\prime \prime}$ W; BGN 1924; (map 7$)$.

Named in 1924 by USGS for T. Jefferson Coolidge "because of his part in BritishAmerican Joint High Commission at Quebec in August, 1898, for the discussion of the Alaska Boundary."

Jefferson Creek: stream, flows SE $2 \mathrm{mi}$. to Wade Creek, $46 \mathrm{mi}$. SW of Eagle, Yukon-Tanana High.; $64^{\circ} 09^{\prime} \mathrm{N}, 141^{\circ} 29^{\prime} \mathrm{W}$; (map 102).

Prospectors' name shown on an 1898 manuscript map by C. A. Woodruff, Fort Cudahy, Canada.

Jefferson Creek: stream, flows W $10 \mathrm{mi}$. to Yukon River, $3 \mathrm{mi}$. ENE of Circle, Porcupine Plat.; $65^{\circ} 51^{\prime} \mathrm{N}, 143^{\circ} 57^{\prime} \mathrm{W}$; (map 103)

Local name from an unpublished map by E. F. Ball, dated 1898 .

Jefferson Creek: stream, flows NE $35 \mathrm{mi}$. to Beaver Creek, $16 \mathrm{mi}$. SE of Beaver, Yukon Flats: $66^{\circ} 12^{\prime} 50^{\prime \prime} \mathrm{N}, 146^{\circ} 57^{\prime} 50^{\prime \prime} \mathrm{W}$; (map 119 !

Local name obtained in 1956 by USGS. Jefferson Creek: stream, see DeCarey Creek.

Jefferson Lake: lake, $0.4 \mathrm{mi}$. long, in course of Jefferson Creek, $18 \mathrm{mi}$. SE of Beaver, Yukon Flats; $66^{\circ} 11^{\prime} 20^{\prime \prime} \mathrm{N}, 146^{\circ} 54^{\prime} 20^{\prime \prime} \mathrm{W}$; (map 119).

Local name obtained in 1956 by USGS.

Jefferson Meadows: meadows, extend E 6 mi. from Big Meadow between Jefferson and Beaver Creeks, $14 \mathrm{mi}$. SE of Beaver, Yukon Flats; $66^{\circ} 12^{\prime} \mathrm{N}, 147^{\circ} 00^{\prime} \mathrm{W}$; (map 118).

Local name obtained in 1956 by USGS.

Jefferson Peak: mountain peak, $4,075 \mathrm{ft} . ; 7 \mathrm{mi}$. NW of Thomas Bay and $94 \mathrm{mi}$. E of Sitka, Coast Mts.; $57^{\circ} 06^{\prime} 00^{\prime \prime} \mathrm{N}, 132^{\circ} 58^{\prime} 50^{\prime \prime} \mathrm{W}$; $B G N 1935$; (map 8).

Named in 1887 by Lt. Comdr. C. M. Thomas, USN, for Thomas Jefferson, 17431826, author of the Declaration of Independence and third President of the United States, 1801-09.

Jeffery Dome: mountain, 7,000 ft., $\mathrm{W}$ of Peters Glacier, opposite mouth of Jeffery Glacier and $6.7 \mathrm{mi}$. N of summit of Mount McKinley, 
Alaska Ra.; $63^{\circ} 09^{\prime} 45^{\prime \prime} \mathrm{N}, 151^{\circ} 04^{\prime} 00^{\prime \prime} \mathrm{W}$; (map 88).

Mountain climbers' name published in 1954 by USGS.

Jeffery Glacier: glacier, heads on Wickersham Wall, E of Jeffery Point, trends NE $1.5 \mathrm{mi}$. to Peters Glacier, Alaska Ra.; $63^{\circ} 08^{\prime} 45^{\prime \prime} \mathrm{N}$, $151^{\circ} 03^{\prime} 30^{\prime \prime} \mathrm{W}$; (map 88).

Mountain climbers' name published in 1954 by USGS.

Jeffery Point: peak, 8,120 ft., between heads of Jeffery and Peters Glaciers, $5.5 \mathrm{mi}$. NW of summit of Mount McKinley, Alaska Ra.; $63^{\circ} 08^{\prime} \mathrm{N}, 151^{\circ} 06^{\prime} \mathrm{W}$; (map 88).

Mountain climbers' name published in 1954 by USGS.

Jelchhini: stream, see Kelsall River.

Jelchitni: stream, see Kelsall River.

Jellowa Island: island, see Spruce Island.

Jeltakatschkahin Greek : stream, see Little Boulder Creek.

Jendestake: locality, see Gantegastaki.

Jenkins Peak: peak, 3,325 ft., $1 \mathrm{mi}$. E of $\mathrm{W}$ Shore of Thomas Bay, $2.5 \mathrm{mi}$. W of Wind Point and $100 \mathrm{mi}$. E of Sitka, Coast Mts.; $57^{\circ} 03^{\prime} 25^{\prime \prime} \mathrm{N}, 132^{\circ} 48^{\prime} 10^{\prime \prime} \mathrm{W}$; (map 8).

Named in 1887 by Lt. Comdr. C. M. Thomas, USN, presumably for Rear Adm. Thorston Alexander Jenkins, USN.

Jenkins Rock: rock, off SW coast of Chilkat Penin., in Chilkat Inlet, $0.6 \mathrm{mi}$. NW of Letnikof Cove and $19 \mathrm{mi}$. SW of Skagway, Coast Mts. ; $59^{\circ} 11^{\prime} 20^{\prime \prime} \mathrm{N}, 135^{\circ} 25^{\prime} 00^{\prime \prime} \mathrm{W}$; (map 45).

Named and published by USC\&GS in the 1891 Coast Pilot (p. 201).

Jennie Creek: stream, flows NW $0.8 \mathrm{mi}$. to Aurora Creek which flows to Noxapaga River, $26 \mathrm{mi}$. W of Imuruk Lake, Seward Penin. High.; $65^{\circ} 39^{\prime} \mathrm{N}, 164^{\circ} 09^{\prime} \mathrm{W}$; (map 110).

Prospectors' name reported on the 1908 "Map of Seward Peninsula" by Arthur Gibson.

Jennie Greek: stream, flows S 3 mi. to Hammond River, $\mathrm{E}$ of Smith Creek Dome, $5 \mathrm{mi}$. N of Wiseman, Brooks Ra.; $67^{\circ} 29^{\prime} \mathrm{N}, 150^{\circ} 02^{\prime} \mathrm{W}$; (map 124).

Local name reported in 1939 by Marshall (1956, map).

Jennic Creek Lake: lake, $\mathrm{E}$ of and drains into Hammond River, $9.5 \mathrm{mi}$. N of Wiseman, Brooks Ra.; $67^{\circ} 33^{\prime} \mathrm{N}, 150^{\circ} 00^{\prime} \mathrm{W}$; (map 124).

Local name obtained in 1956 by USGS topographers.

Jennie M. Crossing: crossing, on Tanana River, $18 \mathrm{mi}$. downstream from mouth of Kantishna River, Nowitna Low.; 64 $4^{\circ} 56^{\prime} 15^{\prime \prime}$ N, $150^{\circ}$. $22^{\prime} 30^{\prime \prime}$ W; ( $\operatorname{map} 99$ ).

Named for the riverboat Jennie (or Jenny) $M$. Pilot's name published on a 1940 "Navigation Chart of the Tanana-Yukon Rivers" by the U.S. Dept. of Interior.

Jennie M. Island: island, $0.6 \mathrm{mi}$. long, in Tanana River, $3 \mathrm{mi}$. $\mathrm{N}$ of Junction I., Nowitna Low.; $64^{\circ} 56^{\prime} \mathrm{N}, 150^{\circ} 21^{\prime} \mathrm{W}$; (map 99).
Named by pilots for the riverboat Jennie (or Jenny) $M$; recorded on a 1940 river chart.

Jennie M. Slough: steam, see Deadman Slough. Jennie Slough: steam, see Deadman Slough.

Jenny Creek: stream, flows SW $6.5 \mathrm{mi}$. to Sitkum Creek, $4 \mathrm{mi}$. SE of Kake, on NW coast of Kupreanof I., Alex. Arch.; 56 $56^{\prime} 10^{\prime \prime} \mathrm{N}$, $133^{\circ} 52^{\prime} 00^{\prime \prime} \mathrm{W}$; (map 6).

Local name recorded in 1951 by USGS.

Jenny Creek: stream, flows NW $10 \mathrm{mi}$. to Savage River, $14 \mathrm{mi}$. SW of Healy, Alaska Ra.; $63^{\circ}$ $42^{\prime} 45^{\prime \prime} \mathrm{N}, 149^{\circ} 15^{\prime} 45^{\prime \prime} \mathrm{W}$; (map 87).

Local name published in 1953 by USGS.

Jenny Island: island, $1 \mathrm{mi}$. long, in Yukon River, $4.5 \mathrm{mi}$. SE of Fort Yukon, Yukon Flats; $66^{\circ} 31^{\prime} \mathrm{N}, 145^{\circ} 09^{\prime} \mathrm{W}$; (map 119).

Local name obtained in 1956 by USGS.

Jenny Islands: islands, $0.5 \mathrm{mi}$. long, in Prince William Sound, between Axel Lind I., and Little Axel Lind I., $34 \mathrm{mi}$. E of Whittier, Chugach Mts.; $60^{\circ} 48^{\prime} 15^{\prime \prime} \mathrm{N}, 147^{\circ} 41^{\prime} 45^{\prime \prime} \mathrm{W}$; (map 63).

Local name reported in 1951 by USGS.

Jenny M Creek: stream, flows SE $8 \mathrm{mi}$. to Chena River, 21 mi. E of Fairbanks, Tanana Low.; $64^{\circ} 50^{\prime} 45^{\prime \prime} \mathrm{N}, 147^{\circ} 00^{\prime} 20^{\prime \prime} \mathrm{W}$; (map 100).

Prospectors' name reported in 1950 by USGS topographers.

Jensens Camp: locality, 2 mi. W of Mount Distin and $18 \mathrm{mi}$. N of Nome, Seward Penin. High.; $64^{\circ} 46^{\prime} \mathrm{N}, 165^{\circ} 27^{\prime} \mathrm{W}$; (map 94).

Site of a mining camp; reported in 1951 by USGS.

Jenson Creek: stream, flows SE $8 \mathrm{mi}$. to Yukon River, 2 mi. S of Bullfrog I. and $45 \mathrm{mi}$. SE of Unalakleet, Nulato Hills; $63^{\circ} 40^{\prime} \mathrm{N}, 159^{\circ}$ $23^{\prime} \mathrm{W}$; (map 91).

Local name reported in 1949 by USC\&GS. Jeponski Island: island, see Japonski Island.

Jerome Creek: stream, flows SE $3.2 \mathrm{mi}$. to Solomon River, $4 \mathrm{mi}$. NE of Solomon, Seward Penin. High.; $64^{\circ} 37^{\prime} \mathrm{N}, 164^{\circ} 23^{\prime} \mathrm{W}$; (map 95).

Prospectors' name reported in 1900 by E. C. Barnard (in Brooks, 1901, pl. 17), USGS.

Jerome Lake: lake, $0.5 \mathrm{mi}$. long, on Kenai Penin., $1 \mathrm{mi}$. NW of junc. of Seward and Sterling Highways, $24 \mathrm{mi}$. S of Sunrise, Chugach Mts.; $60^{\circ} 32^{\prime} 45^{\prime \prime} \mathrm{N}, 149^{\circ} 34^{\prime} 30^{\prime \prime} \mathrm{W} ; B G N \quad 1960^{\circ}$ map 63). Var. Fairman Lake.

Local name reported in 1954 by USGS. In 1910 U. S. Grant, USGS, reported the name "Fairman Lake," probably after the man of that name who had a cabin nearby. Jerry Harbor: bay, $0.3 \mathrm{mi}$. across, $3.3 \mathrm{mi}$. $\mathrm{N}$ of mouth of Port Herbert, on SE coast of Baranof I., Alex. Arch.; 56 $28^{\circ} 55^{\prime \prime}$ N, $134^{\circ} 38^{\prime} 45^{\prime \prime} \mathrm{W}$; (map 6).

Local fishermen's name reported in 1947 by USC\&GS.

Jesse Creek: stream, flows NW $4.5 \mathrm{mi}$. to Norton Sound, $7 \mathrm{mi}$. S of Unalakleet, Nulato Hills; $63^{\circ} 46^{\prime} 10^{\prime \prime} \mathrm{N}, 160^{\circ} 46^{\prime} 00^{\prime \prime} \mathrm{W}$; (map 91).

Local name reported in 1952 by USG\&GS. Jesse Creek: stream, flows SE $5 \mathrm{mi}$. from Jesse Mtn. to Hammond River, $15 \mathrm{mi}$. N of Wise- man, Brooks Ra.; $67^{\circ} 38^{\prime} 00^{\prime \prime} \mathrm{N}, 150^{\circ} 04^{\prime} 30^{\prime \prime}$ W; BGN 1932; (map 124).

Named about 1930 by Marshall (1956, p. 56) for a local prospector and exploring companion, Jesse Allen, of whom he wrote, "Jesse, at 51 and despite the loss of his right arm just below the elbow in a mining accident seventeen years before, was one of the outstanding hunters and rifle shots of the region." Jesse Creek: stream, see Cheyenne Creek.

Jesse Mountain: mountain, 4,990 ft., between Glacier and Hammond Rivers, $16 \mathrm{mi} . \mathrm{N}$ of Wiseman, Brooks Ra.; 67 $7^{\circ} 38^{\prime} \mathrm{N}, 150^{\circ} 11^{\prime} \mathrm{W}$; $B G N$ 1932; (map 124).

Named about 1930 by Robert Marshall. See Jesse Creek.

Jessie Creek: stream, flows SW $4.5 \mathrm{mi}$. to Nichawak River, $16 \mathrm{mi}$. E of Katalla, Malaspina Coastal Plain; 60 $12^{\prime} \mathrm{N}, 144^{\circ} 06^{\prime} \mathrm{W}$; (map 64)

Local name reported by G. C. Martin (1920, pl. 4), USGS.

Jessie Creek: stream, see Saint Michaels Creek. Jesus Hill: hill, $820 \mathrm{ft}$., on SW part of Kiska I., Aleutian Is.; $51^{\circ} 54^{\prime} 00^{\prime \prime} \mathrm{N}, 177^{\circ} 13^{\prime} 30^{\prime \prime} \mathrm{E}$; (map 14).

An arbitrary name beginning with " $\mathrm{J}$ " to correspond to the "J" grid used by the U.S. Army for tactical purposes during World War II; published on a 1953 AMS map.

Jesus Maria, Punta de: point of land, see Incarnation, Point.

Jeter Lake: lake, see Spenard, Lake.

Jet Island: island, see Gagarin Island.

Jett Creek: stream, flows NE $3.3 \mathrm{mi}$. to Grand Central River, NE of Nome, Seward Penin High.; $64^{\circ} 54^{\prime} \mathrm{N}, 165^{\circ} 06^{\prime} \mathrm{W}$; (map 94). Var. Jet Creek, Mascotte Creek.

Local name reported in 1912 by $R$. H. Sargent, USGS. The name "Mascotte Creek" was shown on map dated 1901 of Cape Nome gold fields by David Fox, Jr.

Jette, Mount: mountain, 8,460 ft., on AlaskaCanada boundary, $8 \mathrm{mi}$. NE of Mount Stamy and $40 \mathrm{mi}$. NE of Yakutat, St. Elias Mts.; $59^{\circ} 59^{\prime} 40^{\prime \prime} \mathrm{N}, 139^{\circ} 03^{\prime} 00^{\prime \prime} \mathrm{W}$; BGN 1954; (map 46). Var. Boundary Peak 177.

Named by the USC\&GS in 1908 for Sir Louis Jetté, 1836-1920, a member of the 1903 Canadian Boundary Tribunal and Lt. Gov. of the Province of Quebec from 1898 to 1908. He was elected to the House of Commons for Montreal in 1872. In 1878 he was appointed Judge of the Supreme Court, and in 1909 became Chief Justice of the Province of Quebec. He taught at Laval Univ. and was Dean of Montreal Univ.

Jetty Lake: lake, $0.7 \mathrm{mi}$ long, on Baranof I., 3.7 mi. NW of Port Alexander, Alex. Arch.; $56^{\circ} 18^{\prime} \mathrm{N}, 134^{\circ} 40^{\prime} \mathrm{W}$; (map 5).

Local name recorded in 1951 by USGS.

Jewel Lake: lake, $0.3 \mathrm{mi}$. long, $5.7 \mathrm{mi}$. SW of Anchorage, between Campbell and Sand Lakes, Cook Inlet Low.; $61^{\circ} 08^{\prime} 25^{\prime \prime} \mathrm{N}, 149^{\circ}$. $57^{\prime} 40^{\prime \prime} \mathrm{W}$; (map 69).

Local name reported in 1942 by AMS.

Jewell Island: islands, $0.4 \mathrm{mi}$. across, at $\mathrm{W}$ end of Beecher Pass, 15 mi. S of Petersburg, Alex. 
Arch.; $56^{\circ} 36^{\prime} 10^{\prime \prime} \mathrm{N}, 133^{\circ} 01^{\prime} 30^{\prime \prime} \mathrm{W}$; (map 6).

Local fishermen's name reported in 1947 by USC\&GS.

Jewel Mountain: mountain, 4,800 ft., $4.4 \mathrm{mi}$. - $\mathrm{SE}$ of Moraine Pass and $29 \mathrm{mi}$. SE of Anchorage, Chugach Mts.; $61^{\circ} 03^{\prime} 00^{\prime \prime} \mathrm{N}, 149^{\circ} 05^{\prime} 45^{\prime \prime}$ W; (map 69).

Local name reported in 1942 by AMS. Jewett Creek : stream, see Logan Creek.

Jew Mountain: mountain, see Njoo Mountain. Jewn River: stream, anabranch flows SE $8 \mathrm{mi}$. to Tagayarak River, $3 \mathrm{mi}$. SE of Tagarayak and $48 \mathrm{mi}$. SW of Bethel, Yukon-Kuskokwim Delta; $60^{\circ} 16^{\prime} \mathrm{N}, 162^{\circ} 41^{\prime} \mathrm{W}$; (map 58). Var. June River, Ghun River.

Eskimo name reported in 1949 by USG\&GS.

Jewoak Creek: stream, flows $\mathrm{N} 4 \mathrm{mi}$. to Iookswarat Bay, $10 \mathrm{mi}$. SW of Cape Etolin, on $\mathrm{N}$ coast of Nunivak I., $60^{\circ} 20^{\prime} 10^{\prime \prime} \mathrm{N}, 166^{\circ} 24^{\prime} 30^{\prime \prime}$ W; (map 57).

Eskimo name reported in 1937 by USAAF.

Jigsaw Lake: lake, $1.5 \mathrm{mi}$. long, on Kenai Penin., $1.1 \mathrm{mi}$. W of Coyote Lake and 30 mi. NE of Kenai, Cook Inlet Low.; $60^{\circ} 44^{\prime} 30^{\prime \prime}$ $\mathrm{N}, 150^{\circ} 30^{\prime} 00^{\prime \prime} \mathrm{W}$; ( $\operatorname{map} 62$ ).

Named about 1963 by officials of Kenai National Moose Range, for administrative purposes.

Jim Creek: stream, flows SW $10 \mathrm{mi}$. to Knik River, $7.5 \mathrm{mi}$. SE of Palmer, Cook Inlet Low.; $61^{\circ} 31^{\prime} 10^{\prime \prime} \mathrm{N}, 148^{\circ} 58^{\prime} 00^{\prime \prime} \mathrm{W}$; (map 69).

Local name reported in 1925 by $K$. K. Landes (in Moffit and others, 1927, pl. 4), USGS.

Jim Creek: stream, flows E $1.5 \mathrm{mi}$. to Slate Creek, $50 \mathrm{mi}$. SW of Eagle, Yukon-Tanana High.; $64^{\circ} 34^{\prime} \mathrm{N}, 142^{\circ} 42^{\prime} \mathrm{W}$; (map 102). Var. Dim Creek.

Named by prospectors and shown on a 1905 manuscript map by Maj. W. A. Glassford, USA, as "Dim Creek." The name "Jim Creek" was published in 1906 by USGS.

Jim Creek: stream, flows W $3.2 \mathrm{mi}$. to Taylor Creek which flows to Kougarok River, $6 \mathrm{mi}$. $S$ of Midnight Mtn. and $41 \mathrm{mi}$. NW of Imuruk Lake, Seward Penin. High.; 65 ${ }^{\circ} 42^{\prime} \mathrm{N}$, $164^{\circ} 35^{\prime} \mathrm{W}$; (map 110).

Prospectors' name reported in 1900 by Brooks (1901, pl. 11), USGS.

Jim Creek: stream, see Jim River.

Jim Fish Valley: valley, $1.3 \mathrm{mi}$. long, extends from Siddens Valley to Lake Cories, on E end of Attu I., Aleutian Is.; 52 $53^{\circ} 50^{\prime \prime} \mathrm{N}$. $173^{\circ} 13^{\prime} 00^{\prime \prime} \mathrm{E}$; (map 13).

Named by the U.S. Army during its occupation of the island during World War II, shown on an AMS map published in 1948.

Jim Karse Slough: stream, a channel of the Yukon River, flows W $4 \mathrm{mi}$., $23 \mathrm{mi}$. NE of Stevens Village, Yukon Flats; $66^{\circ} 11^{\prime} 40^{\prime \prime} \mathrm{N}$. $148^{\circ} 27^{\prime} 30^{\prime \prime} \mathrm{W}$; (map 118).

Named for "a local pioneer" who in 1916 had a cabin on this channel according to William Yanert's manuscript map (Stuck, 1917 map facing p. 122). Yanert referred to the place as "Carses."
Jim Lake: lake, $0.7 \mathrm{mi}$. long, $6.6 \mathrm{mi}$. SE of Palmer, Cook Inlet Low.; $61^{\circ} 33^{\prime} 15^{\prime \prime} \mathrm{N}, 148^{\circ}$. 55'30" W; (map 69).

Local name reported in 1951 by USGS; derived from nearby Jim Creek.

Jim Lake: lake, $1.6 \mathrm{mi}$. long, $2.2 \mathrm{mi}$. NNW of village of Minchumina, Tanana Low.; 63 ${ }^{\circ} 55^{\prime}$ N, $152^{\circ} 22^{\prime}$ W ; (map 88). Var. Chilkogamina Lake.

Local name reported in 1952 by USGS. The Tanana Indian name "Chilkogamina," published by Gordon (1917, p. 84), appears to be similar to that of present day "Chilchukabena Lake."

Jimmy Brown Lake: lake, $1.1 \mathrm{mi}$. long, on $\mathrm{E}$ bank of Nabesna River, $6 \mathrm{mi}$. SW of Pickerel Lake, Alaska Ra.; $62^{\circ} 29^{\prime} \mathrm{N}, 142^{\circ} 35^{\prime} \mathrm{W}$; (map 84).

Local name reported in 1960 by USGS.

Jimmy Island: island, in Yukon River, $31 \mathrm{mi}$. NE of Nulato, Koyukuk Low.; $64^{\circ} 48^{\prime} \mathrm{N}$, $157^{\circ} 04^{\prime} \mathrm{W}$; (map 97).

Local name reported in 1954 by USGS.

Jimmy Lake: lake, $0.5 \mathrm{mi}$. long, between South Fork Kuskokwim and Styx Rivers, $84 \mathrm{mi}$. NW of Tyonek, Alaska Ra.; $61^{\circ} 43^{\prime} 30^{\prime \prime} \mathrm{N}$, $153^{\circ} 13^{\prime} 45^{\prime \prime} \mathrm{W}$; (map 71 ).

Local name reported in 1958 by USGS.

Jimmy Slough: stream, channel, flows NW $6 \mathrm{mi}$. in Yukon River, $27 \mathrm{mi}$. NE of Nulato, Koyukuk; $64^{\circ} 48^{\prime} \mathrm{N}, 157^{\circ} 12^{\prime} \mathrm{W}$; (map 97).

Riverboat pilots' name shown on a 1940 "Navigation Chart of Tanana-Yukon Rivers" published by U.S. Dept. of Interior.

Jim Pup: ravine, trends NW $2.5 \mathrm{mi}$. to Wakeup Creek, $2 \mathrm{mi}$. SW of Big Lake and $26 \mathrm{mi}$. W of Chandalar, Brooks Ra.; 67 $28^{\prime} 30^{\prime \prime} \mathrm{N}$, $149^{\circ} 28^{\prime} 30^{\prime \prime} \mathrm{W}$; (map 123).

Local name reported in 1956 by T. E. Taylor, USGS.

Jim River: stream, flows SW $60 \mathrm{mi}$. to South Fork Koyukuk River, $16 \mathrm{mi}$. SE of Bettles, Kanuti Flats; $66^{\circ} 47^{\prime} 30^{\prime \prime} \mathrm{N}, 151^{\circ} 11^{\prime} 30^{\prime \prime} \mathrm{W}$; (map 117). Var. Jim Creek.

Named by prospectors and reported as "Jim Creek" in 1899 by G. H. Wonson, Master of the steamer Dorothy, on his manuscript map of the Koyukuk River.

Jims Cove: cove, $0.2 \mathrm{mi}$. across on $\mathrm{W}$ coast of Admiralty I., $27.5 \mathrm{mi}$. $\mathrm{N}$ of Angoon, Alex. Arch.; 57 $53^{\prime} 40^{\prime \prime} \mathrm{N}, 134^{\circ} 44^{\prime} 00^{\prime \prime} \mathrm{W}$; (map 9).

Local name reported in 1951 by USGS.

Jims Creek: stream, heads in Jims Lake, flows W $2.5 \mathrm{mi}$. to Salt Lake, $11 \mathrm{mi}$. NE of Angoon, on central Admiralty I., Alex. Arch.; 57 $35^{\prime}$ $30^{\prime \prime} \mathrm{N}, 134^{\circ} 19^{\prime} 45^{\prime \prime} \mathrm{W}$; (map 9).

Local name reported in 1951 by USGS.

Jims Lake: lake, $1.8 \mathrm{mi}$. long, on central Admiralty I., empties into Jims Creek, $12.5 \mathrm{mi}$. NE of Angoon, Alex. Arch.; $57^{\circ} 34^{\prime} \mathrm{N}, 134^{\circ}$. $16^{\prime} \mathrm{W}$; (map 9).

Local name reported in 1951 by USGS.

Jimtown: locality, site of prospectors' camp, at junc. of Jim ad South Fork Koyukuk Rivers, $16 \mathrm{mi}$. SE of Bettles, Kanuti Flats; $66^{\circ} 48^{\prime} \mathrm{N}$ $151^{\circ} 11^{\prime} \mathrm{W}$; (map 117).

Name reported in 1899 by G. H. Wonson,
Master of the steamer Dorothy, on his manuscript map of the Koyukuk River. One of several temporary camps established by prospectors caught on the river during the winter of 1898-99. Named for the Jim River.

Jingeeruk Point: point of land, $7 \mathrm{mi}$. SE of Cape Etolin, on NE coast of Nunivak I.; $60^{\circ} 20^{\prime} 45^{\prime \prime}$ $\mathrm{N}, 166^{\circ} 04^{\prime} 00^{\prime \prime} \mathrm{W}$; (map 57). Var. Jingirak Point.

Eskimo name obtained in 1949 by USC\&GS.

Jingirak Point: point of land, see Jingeeruk Point.

Jinhi Bay: bay, 2 mi. long, on NE coast of Tuxekan I., $30 \mathrm{mi}$. $\mathrm{N}$ of Craig, Alex. Arch.: $5^{\circ}$. $53^{\prime} 30^{\prime \prime} \mathrm{N}, 133^{\circ} 15^{\prime} 30^{\prime \prime} \mathrm{W}$; (map 4)

Indian name published in 1964 by USC\&GS.

Jiskooksnuk Hill: hill, $503 \mathrm{ft}, 12 \mathrm{mi}$. SW of Ahding Ingrid Mtn., $34 \mathrm{mi}$. NW of Cape Mendenhall, Nunivak I.; $60^{\circ} 06^{\prime} \mathrm{N}, 166^{\circ} 56^{\prime}$ W; (map 57). Var. Jiskuksnak Hill.

Eskimo name obtained in 1949 by USC\&GS

Jiskuksnak Hill: hill, see Jiskooksnuk Hill.

Joan, Mount: mountain, in general vicinity of Womens Bay, Kodiak I.; (map 34).

This feature is reported to be named for "Mrs. Joan Bell, who, with her husband, owned and operated a dairy farm on Womens Bay. Mr. and Mrs. Bell now live in the State of Washington." Although this name is reported to be used locally, it is not shown on recent sources; the exact location of this mountain has not been established. See Bell Flats.

Joan Mountain: mountain, see John Mountain. Joanna Creek: stream, flows NE $7 \mathrm{mi}$. from Seven Dikes Mtn. to Pass Creek, $55 \mathrm{mi}$. N of Coleen Mtn., Brooks Ra., $67^{\circ} 53^{\prime}$ N, $142^{\circ} 52^{\prime}$ W; $(\operatorname{map} 121)$.

Local name reported in 1956 by T. E. Taylor, USGS.

Joaquin, Mount: mountain, 3,002 ft., in the Kuskokwim Mts., on the $E$ bank of Takotna River, $20 \mathrm{mi}$. SW of McGrath, Kilbuck-Kuskokwim Mts.; $62^{\circ} 52^{\prime} \mathrm{N}, 156^{\circ} 14^{\prime} \mathrm{W}$; (map 79).

Local name published in 1921 by USGS.

Jockeach Creek: stream, see Big Boulder Creek.

Joe Bush Creek: stream, flows S $1.1 \mathrm{mi}$. to Pioneer Creek $0.5 \mathrm{mi}$. W of that stream's head, 21 mi. S of Rampart, Yukon-Tanana High.; $65^{\circ} 12^{\prime} 15^{\prime \prime} \mathrm{N}, 150^{\circ} 07^{\prime} 10^{\prime \prime} \mathrm{W}$; (map 106).

Prospectors' name reported in 1904 by Prindle and Hess (1906, pl. 3), USGS.

Joe Creek: stream, flows NE $10 \mathrm{mi}$. joining Yacko Creek to form Sanona Creek, $22 \mathrm{mi}$. S of junc. of Oshetna and Susitna Rivers, Talkeetna Mts. ; $62^{\circ} 19^{\prime} 30^{\prime \prime} \mathrm{N}, 147^{\circ} 22^{\prime} 00^{\prime \prime} \mathrm{W}$; (map 82).

Local name reported in 1951 by USGS.

Joe Creek: stream, flows SE $3 \mathrm{mi}$. to Quartz Creek which flows to Kougarok River, $48 \mathrm{mi}$. SW of Imuruk Lake, Seward Penin. High.; $65^{\circ} 22^{\prime} \mathrm{N}, 164^{\circ} 44^{\prime} \mathrm{W}$; (map 110 ).

Prospectors' name reported in 1901 by T. G. Gerdine (in Collier, 1902, pl. 12), USGS. 
Joe Creek: stream, flows NW $5 \mathrm{mi}$. to Budd Creek which flows to American River, $9 \mathrm{mi}$. SW of Kougarok Mtn. and $35 \mathrm{mi}$. NE of Teller, Seward Penin. High.; 65³7' N, $165^{\circ}$ $30^{\prime} \mathrm{W}$; (map 111).

Propectors' name reported on a map of Cape Nome goldfields by David Fox, Jr., dated 1901.

Joe Creek: stream, heads in British Mts., flows SE $40 \mathrm{mi}$. across Alaska-Canada boundary to Firth River in Yukon, Canada, Brooks Ra.; $6^{\circ} 03^{\prime} \mathrm{N}, 140^{\circ} 27^{\prime} \mathrm{W}$; (map 137).

Local name reported in 1911 by IBC survey crew.

Joe Devlin Island: island, $2.7 \mathrm{mi}$. long, in Yukon River, $9 \mathrm{mi}$. NE of Beaver, Yukon Flats; $66^{\circ}$ $25^{\prime} \mathrm{N}, 147^{\circ} 03^{\prime} \mathrm{W}$; (map 118 ).

Local name obtained in 1956 by USGS.

Joe Ferrerra's River: stream, see Kisimilok Creek.

Joe Guay Island: island, $4 \mathrm{mi}$. long, formed by the anabranch Joe Guay Slough and the Yukon River, $1.5 \mathrm{mi}$. W of Beaver, Yukon Flats; $66^{\circ} 21^{\prime} \mathrm{N}, 147^{\circ} 28^{\prime} \mathrm{W}$; (map 118).

Locally named for Joseph Guay, a "sourdough" who had a cabin on the lower end of the island, according to a 1916 manuscript map by William Yanert (Stuck, 1917, map facing $p .122$ ). This end of the island is now separated by "New Cutoff," a channel in the Yukon River.

Joe Guay Slough: stream, an anabranch of the Yukon River, flows SW $6.5 \mathrm{mi}$. to New Cutoff, $4 \mathrm{mi}$. SW of Beaver, Yukon Flats ; $66^{\circ} 19^{\prime} 45^{\prime \prime}$ $\mathrm{N}, 147^{\circ} 30^{\prime} 00^{\prime \prime} \mathrm{W}$; (map 118).

Name derived from Joe Guay Island; re. ported in 1956 by T. E. Tayor, USGS.

Joe Gulch: ravine, trends N $0.6 \mathrm{mi}$. to Dexter Creek, $6 \mathrm{mi}$. NE of Nome, Seward Penin. High.; $64^{\circ} 35^{\prime} \mathrm{N}, 165^{\circ} 19^{\prime} \mathrm{W}$; (map 94).

Prospectors' name shown on map dated September 1901 of Cape Nome gold fields by David Fox, Jr.

Joe Island: island, $0.5 \mathrm{mi}$. long, between Port Estrella and Ulloa Channel, off $W$ coast of Prince of Wales I., Alex. Arch.; $55^{\circ} 21^{\prime}$ N., $133^{\circ} 17^{\prime} \mathrm{W}$; (map 4).

Name published in 1914 by USC\&GS.

Joe Island: island, $0.5 \mathrm{mi}$. long, in Clover Passage, between Grant and Revillagigedo Is., Alex. Arch.; 55 $32^{\prime} \mathrm{N}, 131^{\circ} 43^{\prime} \mathrm{W}$; (map 3).

Named in 1885 by Lt. Comdr. Richardson Clover, USN.

Joe Lake: lake, $1.2 \mathrm{mi}$. long, on $\mathrm{W}$ bank of $\mathrm{Ka}$ lutna River, $16.5 \mathrm{mi}$. NW of Northway Junction, Alaska Ra.; $63^{\circ} 08^{\prime} \mathrm{N}, 142^{\circ} 16^{\prime} \mathrm{W}$; (map 85).

Local name reported in 1964 by USGS.

Joe Mace Island: island, $0.5 \mathrm{mi}$. long, SW of village of Point Baker, on NW coast of Prince of Wales, Alex. Arch.; $56^{\circ} 21^{\prime} \mathrm{N}, 133^{\circ} 38^{\prime} \mathrm{W}$; (map 6).

Local name recorded in 1949 by USGS.

Joe Nort Lake: lake, $1.5 \mathrm{mi}$. long, $4.5 \mathrm{mi}$. $\mathrm{N}$ of Long Lake and $18 \mathrm{mi}$. NW of Nondalton, Alaska Ra.; $60^{\circ} 14^{\prime} \mathrm{N}, 155^{\circ} 02^{\prime} \mathrm{W}$; (map 61). Local name reported in 1954 by USGS.

Joe Reeves Slough: stream, on S coast of Alaska, flows SW 2 mi. to Gulf of Alaska, $6 \mathrm{mi}$. SE of Cordova, Malaspina Coastal Plain; 60 $28^{\prime}$ N, $145^{\circ} 40^{\prime} \mathrm{W}$; (map 64).

Local name published in 1951 by USGS.

Joe Ward Camp: village, pop. 5, on right bank of Porcupine River, $15 \mathrm{mi}$. N of Chalkyitsik, Yukon Flats; 66 $52^{\prime} \mathrm{N}, 143^{\circ} 42^{\prime} \mathrm{W}$; (map 120).

Local name published in 1951 by USGS.

Joe Ward Slough: stream, $6 \mathrm{mi}$. long, anabranch of Porcupine River, $16 \mathrm{mi}$. N of Chalkyitsik, Yukon Flats; 66 $53^{\prime} \mathrm{N}, 143^{\circ} 39^{\prime} \mathrm{W}$; (map 120).

Local name published in 1951 by USGS.

Joe Wise Creek: stream, flows SW $2 \mathrm{mi}$. to Spruce Creek, E of Glenn Gulch and $9 \mathrm{mi}$. SE of Marshall, Nulato Hills; $61^{\circ} 47^{\prime} 00^{\prime \prime} \mathrm{N}$, $161^{\circ} 53^{\prime} 30^{\prime \prime} \mathrm{W}$; (map 73).

Prospectors' name reported in 1916 by Harrington (1918, map), USGS.

Johan Bogoslow Island: island, see Bogoslof Island.

John Barleycorn Lakes: lakes, at head of Hermit Gulch, $17 \mathrm{mi}$. NW of Beaver, Kokrines-Hodzana High.; $66^{\circ} 25^{\prime} 30^{\prime \prime} \mathrm{N}, 148^{\circ} 00^{\prime} 00^{\prime \prime} \mathrm{W}$; (map 118).

Local name obtained in 1956 by USGS.

John Bay: bay, $0.5 \mathrm{mi}$. across, on NW shore of Port Conclusion, Baranof I., $2.2 \mathrm{mi}$. NW of Port Alexander, Alex. Arch.; $56^{\circ} 16^{\prime} 45^{\prime \prime} \mathrm{N}$, $134^{\circ} 40^{\prime} 30^{\prime \prime} \mathrm{W}$; (map 5).

Local name published in 1927 by USC\&GS.

John Creek: stream, flows S $2 \mathrm{mi}$. through James Lake to Dolomi Bay, $0.8 \mathrm{mi}$. N of Port Johnson, on SE coast of Prince of Wales I., Alex. Arch.; $55^{\circ} 08^{\prime} \mathrm{N}, 132^{\circ} 03^{\prime} \mathrm{W}$; (map 4 ).

Local name reported in 1901 by USGS.

John Creek: stream, flows SE $1 \mathrm{mi}$. to Twin Creek, $48 \mathrm{mi}$. W of Talkeetna, Alaska Ra.; $62^{\circ} 20^{\prime} 25^{\prime \prime} \mathrm{N}, 151^{\circ} 33^{\prime} 20^{\prime \prime} \mathrm{W}$; (map 81).

Local name reported in 1911 by S. R. Capps (1913, fig. 7), USGS.

John Creek: stream, flows NE $10 \mathrm{mi}$. to Kosina Creek, $24 \mathrm{mi}$. SW of junc. of Oshetna and Susitna Rivers, Talkeetna Mts. ; 62 ${ }^{\circ} 32^{\prime} 25^{\prime \prime} \mathrm{N}$, $148^{\circ} 05^{\prime} 20^{\prime \prime} \mathrm{W}$; (map 82).

Local name recorded in 1952 by USGS.

John Creek: stream, flows SE $1 \mathrm{mi}$. to Allene Creek, in Agiapuk River basin, $13 \mathrm{mi}$. NE of Teller, Seward Penin. High.; $65^{\circ} 22^{\prime}$ N, $166^{\circ}$ $01^{\prime} \mathrm{W}$; (map 111).

Prospectors' name reported in 1901 by T. G. Gerdine (in Collier, 1902, pl. 12), USGS.

John Creek: stream, flows S $1.7 \mathrm{mi}$. to Windy Creek which flows to Kougarok River, $49 \mathrm{mi}$. SW of Imuruk Lake, Seward Penin. High.; $65^{\circ} 27^{\prime} \mathrm{N}, 164^{\circ} 49^{\prime} \mathrm{W}$; (map 110).

Prospectors' name reported on the 1908 "Map of Seward Peninsula" by Arthur Gibson. John Creek: stream, see John R Creek.

John Fitzgerald Kennedy City: village, pop. 35, on NW shore of Knik Arm Gook Inlet, $13 \mathrm{mi}$. $\mathrm{N}$ of Anchorage, Cook Inlet Low.; 61 ' $23^{\prime} 45^{\prime \prime}$ N, $149^{\circ} 49^{\prime} 30^{\prime \prime}$ W ; (map 69). Var. Bay City.

Named on December 20,1963, by members of the Bay City council, for John Fitzgerald Kennedy, 1917-63, 35th President of the United States.

John Glacier: glacier, in Glacier Bay National
Monument $0.5 \mathrm{mi}$. long, trends $\mathrm{E}$ to its 1961 terminus, $1 \mathrm{mi}$. NW of 1961 terminus of Johns Hopkins Glacier, $80 \mathrm{mi}$. NW of Hoonah, St. Elias Mts.; $58^{\circ} 49^{\prime} 30^{\prime \prime} \mathrm{N}, 137^{\circ} 09^{\prime} 50^{\prime \prime} \mathrm{W}$; $B G N$ 1937; (map 10).

Named in 1936 by Field and Cooper (1937, p. 62) for "Stickeen John," one of the Tlingit Indians who accompanied John Muir on his visit in 1879 (Muir, 1915, p. 115)

John Hansen Creek: stream, flows S $40 \mathrm{mi}$. through John Hansen Lake, to Kantishna River, $40 \mathrm{mi}$. SE of Bitzshtini Mts., Tanana Low.; $64^{\circ} 02^{\prime} \mathrm{N}, 151^{\circ} 07^{\prime} \mathrm{W}$; (map 99).

Local name reported in 1952 by USGS.

John Hansen Lake: lake, on John Hansen Creek, $0.5 \mathrm{mi}$. W of Kantishna River and $40 \mathrm{mi}$.

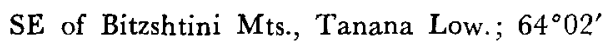
$\mathrm{N}, 151^{\circ} 10^{\prime} \mathrm{W}$; (map 99).

Local name reported in 1952 by USGS.

John Herberts Village: locality, on right bank of Porcupine River, $28 \mathrm{mi}$. NE of Chalkyitsik, Yukon Flats; $66^{\circ} 59^{\prime} \mathrm{N}, 143^{\circ} 09^{\prime} \mathrm{W}$; (map 120)

Locai name obtained in 1956 by T. E. Taylor and R. C. Foley, USGS. Recent USGS maps indicate a site with three buildings.

John Island: island, $1 \mathrm{mi}$. long, $\mathrm{W}$ of $\mathrm{N}$ part of Nagai I., in Shumagin Is., Aleutian Ra.; $54^{\circ}$ $59^{\prime} 25^{\prime \prime} \mathrm{N}, 160^{\circ} 11^{\prime} 00^{\prime \prime} \mathrm{W}$; (map 26).

Named in 1880 by W. H. Dall, USC\&GS; published by USC\&GS on an 1888 coast chart.

John Island: island, $400 \mathrm{ft}$. long, at mouth of Three Saints Bay, on SE coast of Kodiak I.; $57^{\circ} 06^{\prime} 25^{\prime \prime} \mathrm{N}, 153^{\circ} 27^{\prime} 30^{\prime \prime} \mathrm{W}$; BGN 1932; (map 34).

Named in 1931 by USC\&GS for the triangulation station John which was located on the island.

John Jay, Mount: mountain, 7,499 ft., on AlaskaCanada boundary, $22 \mathrm{mi}$. NW of Hyder, Coast Mts.; $56^{\circ} 08^{\prime} 30^{\prime \prime} \mathrm{N}, 133^{\circ} 25^{\prime} 25^{\prime \prime} \mathrm{W}$; $B G N$ 1924; ( $\operatorname{map} 7$ ).

Named in 1924 by USGS for John Jay, 1745-1820, American statesman, diplomat, and jurist.

John Kwillik Slough: stream, flows SW $3.1 \mathrm{mi}$. $S$ of Black River, 26 mi. NE of Fort Yukon, Yukon Flats; $66^{\circ} 38^{\prime} \mathrm{N}, 144^{\circ} 17^{\prime} \mathrm{W}$; (map 119).

Local name obtained in 1956 by USGS

John Lake: lake, $1.3 \mathrm{mi}$. long, $8 \mathrm{mi}$. WSW of Old Man Lake, $45 \mathrm{mi}$. W of Glennallen, Copper River Basin; $62^{\circ} 06^{\prime} 30^{\prime \prime} \mathrm{N}, 146^{\circ} 55^{\prime} 00^{\prime \prime}$ W; (map 83). Var. Kelley Lake.

Local name reported in 1949 by USGS.

John Lake: lake, $0.5 \mathrm{mi}$. long, $\mathrm{W}$ of Farewell Lake, $3 \mathrm{mi}$. W of junc. of South Fork Kuskokwim and Jones River, $67 \mathrm{mi}$. SE of McGrath, Kuskokwim Low.; $62^{\circ} 33^{\prime} 40^{\prime \prime} \mathrm{N}, 153^{\circ} 40^{\prime} 10^{\prime \prime}$ W; (map 80).

Local name obtained in 1958 by USGS.

John Mountain: mountain, 3,238 ft., on Revillagigedo I., $4.3 \mathrm{mi}$. NE of Ketchikan, Alex. Arch.; $55^{\circ} 23^{\prime} 55^{\prime \prime} \mathrm{N}, 131^{\circ} 34^{\prime} 25^{\prime \prime} \mathrm{W}$; (map 3). Var. Joan Mountain.

Local name reported in 1954 by USGS. 
Johnnie's Village: village, see Mentasta Lake. Johnnys Indians: village, see Eagle Village.

Johıny Slough: stream, flows NE $19 \mathrm{mi}$. to Barge Slough $2 \mathrm{mi}$. SW of its junc. with Holitna River, $7.8 \mathrm{mi}$. SE of Sleetmute, Stony River Low.; $61^{\circ} 35^{\prime} 45^{\prime \prime} \mathrm{N}, 157^{\circ} 05^{\prime} 30^{\prime \prime} \mathrm{W}$; $B G N$ 1948; (map 72).

Local name reported in 1945 by USGS.

Johnnys Place: locality, see Johnnys Village.

Johnnys Village: locality, on right bank of Yukon River, $10 \mathrm{mi}$. NW of Pitkas Point and $50 \mathrm{mi}$. NW of Marshall, Yukon-Kuskokwim Delta; $62^{\circ} 05^{\prime} 20^{\prime \prime} \mathrm{N}, 163^{\circ} 33^{\prime} 00^{\prime \prime} \mathrm{W}$; (map 77). Var. Johnnys Place, Liberty Landing, Takakchak.

Name of an Eskimo settlement reported in 1950 by USGS.

John R Creek: stream, flows SW $4 \mathrm{mi}$. to South Fork Koyukuk River, E of Jack White Ra., 28 $\mathrm{mi}$. NE of Bettles, Brooks Ra.; 66 $59^{\prime} 10^{\prime \prime} \mathrm{N}$, $150^{\circ} 40^{\prime} 00^{\prime \prime}$ W; (map 117). Var. John Creek.

Name reported in 1901 as "John Creek" by W. J. Peters (in Schrader, 1904, p. 2), USGS.

John Reek Creek: stream, flows E $11 \mathrm{mi}$. to Nixon Fork, $7 \mathrm{mi}$. $\mathrm{N}$ of The Forks and $30 \mathrm{mi}$. W of Medfra, Kuskokwim Low.; $63^{\circ} 07^{\prime} \mathrm{N}$, $155^{\circ} 40^{\prime} \mathrm{W}$; (map 89).

Local name published in 1955 by USGS.

John River: stream, formed by Contact and Inukpasugruk Creeks, flows S $125 \mathrm{mi}$. from Anaktuvuk Pass to Koyukuk River, $1 \mathrm{mi}$. NE of Bettles, Kanuti Flats; $66^{\circ} 55^{\prime} \mathrm{N}, 151^{\circ} 39^{\prime}$ W; (map 117). Var. Alchichna, Ascheeshna, Fickett River, Johns River, Ochesna, Old Johns River, Oschesna, Totsenbet River.

Locally named about 1898 for John Bremner who joined Lt. H. T. Allen, USA, on the Copper River in 1885 and went as far as the Koyukuk with him. Bremner prospected the John River area in 1886 and 1887, and was killed by Koyukan Indians near Dolmikaket while descending the Koyukuk River that year. The stream came to be known as "Old Johns River" or "Johns River" by prospectors. These names replaced the name "Fickett River," given in 1885 by Lt. Allen (1887, p. 101), who also wrote the Koyukan Indian name as "Ascheeshna." In 1899, T. G. Gerdine, USGS, recorded the Indian name as "Totsenbetna."

John River: stream, heads in small lake, flows $\mathrm{N} 5 \mathrm{mi}$. to lagoon, SE of Griffin Point, $18 \mathrm{mi}$. SE of Barter I., Arctic Plain; $70^{\circ} 03^{\prime} \mathrm{N}, 142^{\circ}$ 51' W; (map 152).

Local name reported in 1952 by USC\&GS.

John Roberts Lake: lake, $0.5 \mathrm{mi}$. long, $1 \mathrm{mi}$. W of Mud Canyon and $23 \mathrm{mi}$. SE of Beaver, Yukon-Tanana High.; $66^{\circ} 07^{\prime} 40^{\prime \prime} \mathrm{N}, 146^{\circ} 50^{\prime}$ $00^{\prime \prime}$ W; (map 119).

Local name obtained in 1956 by USGS.

John Rock: rock, 7 mi. SE of Dolgoi I., SW end of Aleutian Ra.; $54^{\circ} 55^{\prime} 20^{\prime \prime} \mathrm{N}, 161^{\circ} 37^{\prime} 50^{\prime \prime} \mathrm{W}$; (map 25).

Name publishd by USC\&GS in 1882 on Chart 806.
John Rock: rock, $0.1 \mathrm{mi}$. across, in the Necker Is., W of Baranof I., $5.5 \mathrm{mi}$. SW of Goddard Alex. Arch.; $56^{\circ} 46^{\prime} 20^{\prime \prime} \mathrm{N}, 135^{\circ} 27^{\prime} 45^{\prime \prime} \mathrm{W}$; BGN 1929; (map 5).

Named in 1925 by USC\&GS. See Rogers Island.

John Ross Riffle: rapids, in course of Black River, $2 \mathrm{mi}$. SE of Englishshoe Bar and $28 \mathrm{mi}$. NE of Fort Yukon, Yukon Flats; 66 $41^{\prime} 20^{\prime \prime}$ $\mathrm{N}, 144^{\circ} 13^{\prime} 00^{\prime \prime} \mathrm{W}$; (map 119).

Local name obtained in 1956 by USGS.

Johns Creek: stream, on Kenai Penin., flows W $3.5 \mathrm{mi}$. to Quartz Creek, $0.5 \mathrm{mi}$. NW of Jerome Lake and $23 \mathrm{mi}$. SSW of Sunrise, Chugach Mts.; $60^{\circ} 33^{\prime} 15^{\prime \prime} \mathrm{N}, 149^{\circ} 35^{\prime} 30^{\prime \prime} \mathrm{W}$; $B G N$ 1910; (map 63).

Local name reported in 1908 by Grant and Higgins (1910, pl. 4), USGS.

Johns Creek: stream, flows $\mathrm{N} 1.3 \mathrm{mi}$. to West Fork Kuyukutuk River, $11 \mathrm{mi}$. E of Marshall, Nulato Hills; $61^{\circ} 52^{\prime} 15^{\prime \prime} \mathrm{N}, 161^{\circ} 44^{\prime} 55^{\prime \prime} \mathrm{W}$; (map 73).

Prospectors' name reported by Harrington (1918, map), USGS, in 1916.

Johns Creek: stream, flows NE $10 \mathrm{mi}$. to Sulukna River, $46 \mathrm{mi}$. NE of Medfra, Kilbuck-Kuskokwim Mts. ; $63^{\circ} 43^{\prime} \mathrm{N}, 154^{\circ} 11^{\prime} \mathrm{W}$; (map 89). Local name reported in 1954 by USGS.

Johns Creek: stream, flows E $3 \mathrm{mi}$. to Solomon River, $13 \mathrm{mi}$. NE of Solomon, Seward Penin. High.; $64^{\circ} 44^{\prime} \mathrm{N}, 164^{\circ} 19^{\prime} \mathrm{W}$; (map 95 ).

Prospectors' name reported in 1900 by E. C. Barnard (in Brooks, 1901, pl. 17), USGS.

John Shed Creek: stream, see John Shedd Creek. John Shedd Creek: stream, flows NE $1.5 \mathrm{mi}$. to Chicago Boy Creek, $50 \mathrm{mi}$. SW of Eagle, Yukon-Tanana High.; $64^{\circ} 21^{\prime} \mathrm{N}, 142^{\circ} 34^{\prime} \mathrm{W}$; (map 102). Var. John Shed Creek.

Prospectors' name shown on an 1898 manuscript map by G. A. Woodruff, Fort Cudahy, Canada.

Johns Hopkins Fiord: estuary, see Johns Hopkins Inlet.

Johns Hopkins Glacier: glacier, in Glacier Bay National Monument, heads on $E$ slope of Lituya Mtn. and trends W $12 \mathrm{mi}$. to head of Johns Hopkins Inlet, $1 \mathrm{mi}$. SW of the terminus of Clark Glacier and $79 \mathrm{mi}$. NW of Hoonah, St. Elias Mts.; 58 $49^{\prime} 45^{\prime \prime}$ N, $137^{\circ}$ $07^{\prime} 40^{\prime \prime}$ W; (map 10).

Named in 1893 by H. F. Reid (1896, p. 423) for the Johns Hopkins University in Baltimore, Md., chartered in 1869 and opened in 1876. Johns Hopkins Inlet: estuary, heads at Johns Hopkins Glacier, trends NE $11 \mathrm{mi}$. to head of Glacier Bay, $3 \mathrm{mi}$. W of Russell I., in Glacier Bay National Monument, $77 \mathrm{mi}$. NW of Hoonah, St. Elias Mts. ; $58^{\circ} 54^{\prime} 30^{\prime \prime} \mathrm{N}, 1^{136^{\circ}} 5^{\prime}{ }^{\prime}$ 30" W; BGN 1954; (map 10). Var. Johns Hopkins Fiord, Reid Inlet.

Named by Cooper (1931, p. 61) for the Johns Hopkins Glacier which once occupied the Inlet. He also called the inlet Johns Hopkins Fiord. In 1893 Reid (1896, pl. 86), USGS, applied the name Grand Pacific Glacier at Russell I. and he called the inlet at that end of Glacier Bay, "Reid Inlet." As the glacier retreated two inlets were formed, one was called "Tarr Inlet" and the other, at the terminus of the Johns Hopkins Glacier, retained the name of "Reid Inlet." With the further retreat of the Johns Hopkins Glacier, and the lengthening of the inlet, the historical relationship to Reid Glacier became obscure and in 1954, BGN changed the name to Johns Hopkins Inlet.

Johns' House: village, see Mentasta Lake.

Johnson: locality, on Kenai Penin., near mouth of Johnson Creek, mile 33.8 on The Alaska RR., 26 mi. SE of Sunrise, Chugach Mts.; $60^{\circ} 32^{\prime} 15^{\prime \prime} \mathrm{N}, 149^{\circ} 19^{\prime} 30^{\prime \prime} \mathrm{W}$; (map 63). Var. Sunrise Station.

Local name for a flag stop published in The Alaska RR. guide of 1918.

Johnson, Mount: mountain, see Bayard, Mount. Johnson, Port: estuary, extends W $4.5 \mathrm{mi}$. off Clarence Strait, on SE coast of Prince of Wales I., Alex. Arch.; $55^{\circ} 08^{\prime} \mathrm{N}, 132^{\circ} 00^{\prime} \mathrm{W}$; (map 4).

Local name recorded in 1948 by USGS.

Johnson Bay: $b a y, 0.7 \mathrm{mi}$. across, on $\mathbf{N}$ coast of Sanak I., Aleutian Ra.; $54^{\circ} 27^{\prime} 15^{\prime \prime} \mathrm{N}, 162^{\circ}$ $37^{\prime} 40^{\prime \prime}$ W; (map 25). Var. Johnsons Bay.

Local name reported by Ferdinand Westdahl, USC\&GS, commander of the Coast Survey steamer McArthur, who made surveys in this area in 1901.

Johnson Bay: estuary, on W coast of Knight I., extends NW $2 \mathrm{mi}$. to $\mathrm{E}$ side of Knight Island Passage, 9 mi. NE of Chenega, Chugach Mts.; $60^{\circ} 21^{\prime} \mathrm{N}, 147^{\circ} 52^{\prime} \mathrm{W}$; (map 63).

Named "for a local miner"; reported in 1908 by U. S. Grant and D. F. Higgins (in Brooks and others, 1909, pl. 4), USGS.

Johnson Cove: cove, $0.6 \mathrm{mi}$. across, in Usof Bay, on $\mathrm{S}$ coast of Unalaska I., Aleutian Is.; $53^{\circ}$. $31^{\prime} 00^{\prime \prime} \mathrm{N}, 166^{\circ} 46^{\prime} 30^{\prime \prime} \mathrm{W}$; (map 23).

Name was published in the 1944 Aleutian Coast Pilot (p. 53).

Johnson Cove: cove, extends SW $0.4 \mathrm{mi}$. to Clarence Strait, on $W$ coast of Etolin I., Alex. Arch.; $56^{\circ} 05^{\prime} 55^{\prime \prime} \mathrm{N}, 132^{\circ} 41^{\prime} 20^{\prime \prime} \mathrm{W}$; $B G N$ 1917; (map 6).

Local name used by fishermen and published in 1917 by USC\&GS.

Johnson Cove: cove, $0.6 \mathrm{mi}$. long, on $\mathrm{N}$ coast of Willoughby I., in Glacier Bay, in Glacier Bay National Monument, $2.7 \mathrm{mi}$. SE of Francis I. and $42 \mathrm{mi}$. NW of Hoonah, St. Elias Mts.; $58^{\circ} 36^{\prime} 25^{\prime \prime} \mathrm{N}, 136^{\circ} 06^{\prime} 30^{\prime \prime} \mathrm{W}$; BGN 1948; (map 10).

Named in 1948 by USGS for John Johnson, a fox farmer on the island.

Johnson Cove: cove, $0.5 \mathrm{mi}$. across, on $\mathrm{E}$ coast of Evans I., on NW side of Latouche Passage, $16 \mathrm{mi}$. SE of Chenega, Chugach Mts.; $60^{\circ} 03^{\prime} 43^{\prime \prime} \mathrm{N}, 147^{\circ} 58^{\prime} 35^{\prime \prime} \mathrm{W}$; (map 63).

Local name reported in 1951 by USGS.

Johnson Cove: estuary, extends S $2.8 \mathrm{mi}$. off Moira Sound, on SE coast of Prince of Wales I., Alex. Arch.; $55^{\circ} 00^{\prime} 30^{\prime \prime} \mathrm{N}, 132^{\circ} 06^{\prime} 00^{\prime \prime} \mathrm{W}$; (map 4).

Named by local fishermen and reported in 1904 by H. C. Fassett, USBF.

Johnson Creek: stream, flows S $2 \mathrm{mi}$. to Bishop Creek at Albatross Anchorage, $16 \mathrm{mi}$. $\mathrm{N}$ of 
Unga I., near SW end of Alaska Penin., Aleutian Ra.; 55 $36^{\prime} 30^{\prime \prime} \mathrm{N}, 160^{\circ} 37^{\prime} 00^{\prime \prime} \mathrm{W}$; (map 28).

Named in 1929 by USGS.

Johnson Creek: stream, on $\mathbf{N}$ end of Douglas I., flowing $1 \mathrm{mi}$. NW to Gastineau Channel, 2.2 mi. E of Entrance Point and $5.6 \mathrm{mi}$. NW of Juneau, Coast Mts.; $58^{\circ} 20^{\prime} 25^{\prime \prime} \mathrm{N}, 134^{\circ} 32^{\prime}$ 45" W; (map 11).

Local name published by USGS in 1962. Johnson Creek: stream, $5.5 \mathrm{mi}$. long, flows $\mathrm{N}$ to Taku River, $1.5 \mathrm{mi}$. S of Twin Glacier Lake and $25 \mathrm{mi}$. NE of Juneau, Coast Mts.; $58^{\circ} 30^{\prime} 20^{\prime \prime} \mathrm{N}, 133^{\circ} 53^{\prime} 00^{\prime \prime} \mathrm{W}$; BGN 1932; (map 12).

Local name reported in 1932 by B. D. Stewart, USGS, to be "derived from the surname of the first known settler in the district who resided near the mouth of the stream."

Johnson Creek: stream, flows SE $4 \mathrm{mi}$. to Berners Bay, at mouth of Lace River, $41 \mathrm{mi}$. NW of Juneau, Coast Mts. ; $58^{\circ} 49^{\prime} 30^{\prime \prime} \mathrm{N}, 134^{\circ} 59^{\prime} 40^{\prime \prime}$ W; (map 11).

Prospector's name published by A. C. Spencer (in Emmons and Hayes, 1904, p. 38), USGS.

Johnson Creek: stream, on $\mathbf{E}$ side of Mount Ripinski, flows E $2 \mathrm{mi}$. to Tanani Bay, on Chilkoot Inlet, $0.5 \mathrm{mi}$. $\mathrm{S}$ of Tanani and 14 mi. S of Skagway, Coast Mts.; $59^{\circ} 26^{\prime} 35^{\prime \prime} \mathrm{N}$, $135^{\circ} 26^{\prime} 20^{\prime \prime} \mathrm{W}$; (map 45).

Local name published in 1954 by USGS. Johnson Creek: stream, flows SW $13 \mathrm{mi}$. to Kwethluk River, $50 \mathrm{mi}$. SE of Bethel, KilbuckKuskokwim Mts. ; $60^{\circ} 20^{\prime} \mathrm{N}, 160^{\circ} 40^{\prime} \mathrm{W}$; (map 59). Var. Grooked Creek.

Local name reported in 1955 by J. M. Hoare, USGS.

Johnson Creek: stream, heads NE of Johnson Lake, flows SW $8 \mathrm{mi}$. to stream above Johnson, $23 \mathrm{mi}$. SE of Sunrise, Ghugach Mts.; $60^{\circ} 32^{\prime} 29^{\prime \prime} \mathrm{N}, 149^{\circ} 19^{\prime} 15^{\prime \prime} \mathrm{W}$; (map 63).

Local prospectors' name; reported in 1904 by Moffit (1906, pl. 2), USGS.

Johnson Creek: stream, on $\mathbf{N}$ end of Kenai Penin., flows NW $2.5 \mathrm{mi}$. to Turnagain Arm, $5 \mathrm{mi}$. NW of Hope, Chugach Mts. ; $60^{\circ} 57^{\prime} 45^{\prime \prime}$ $N, 149^{\circ} 45^{\prime} 40^{\prime \prime} \mathrm{W}$; (map 63).

Local name reported in 1952 by USGS.

Johnson Creek: stream, flows S $1 \mathrm{mi}$. to Shoup Glacier, $1 \mathrm{mi}$. E of Midway Camp and $14 \mathrm{mi}$. NW of Valdez, Chugach Mts.; 61 ${ }^{\circ} 11^{\prime} 45^{\prime \prime} \mathrm{N}$, $146^{\circ} 38^{\prime} 20^{\prime \prime} \mathrm{W}$; (map 68).

Prospectors' name reported in 1911 by J. W. Bagley and C. E. Giffin, USGS. The Cameron-Johnson Camp was located on the stream's bank.

Johnson Creek: stream, flows $\mathrm{N} 12 \mathrm{mi}$. to Hartman River 2 mi. $S$ of its junc. with South Fork Kuskokwim River, $94 \mathrm{mi}$. NW of Tyonek, Alaska Ra.; $61^{\circ} 56^{\prime} \mathrm{N}, 153^{\circ} 20^{\prime} \mathrm{W}$; (map 71).

Local name reported in 1958 by USGS.

Johnson Creek: stream, heads at glacier $3 \mathrm{mi}$. NE of Distin Peak, flows E 45 mi. to Yentna River, $47 \mathrm{mi}$. SW of Talkeetna, Alaska Ra.; $62^{\circ} 05^{\prime} 10^{\prime \prime} \mathrm{N}, 151^{\circ} 29^{\prime} 45^{\prime \prime} \mathrm{W}$; (map 81).

Local name reported in 1945 by USGS.
Johnson Creek: stream, flows NW 2 mi. to Tibbs Creek $7.3 \mathrm{mi}$. S of that stream's junc. with Goodpaster River and $49 \mathrm{mi}$. ENE of Big Delta, Yukon-Tanana High.; 64. $21^{\prime}$ N, $144^{\circ} 16^{\prime} \mathrm{W}$; (map 101).

Local name published in 1956 by USGS.

Johnson Creek: stream, flows SE $0.6 \mathrm{mi}$. to Solomon River, $0.5 \mathrm{mi}$. SW of Shovel Creek and $5 \mathrm{mi}$. $\mathrm{N}$ of Solomon, Seward Penin. High.; $64^{\circ} 37^{\prime} 15^{\prime \prime} \mathrm{N}, 164^{\circ} 23^{\prime} 30^{\prime \prime} \mathrm{W}$; (map 95).

Prospectors' name reported on a 1902 prospectors' manuscript map.

Johnson Creek: stream, flows N $2.2 \mathrm{mi}$. to Casadepaga River, $14 \mathrm{mi}$. $\mathrm{N}$ of Solomon, Seward Penin. High.; $64^{\circ} 46^{\prime} \mathrm{N}, 164^{\circ} 30^{\prime} \mathrm{W}$; (map 95).

Prospectors' name reported in 1900 by E. C. Barnard (in Brooks, 1901, pl. 17), USGS.

Johnson Creek: stream, flows SE $1.3 \mathrm{mi}$. to join Victoria Creek to form Smallwood Creek, 13 mi. NE of Fairbanks, Yukon-Tanana High.; $64^{\circ} 57^{\prime} 27^{\prime \prime} \mathrm{N}, 147^{\circ} 21^{\prime} 00^{\prime \prime} \mathrm{W}$; (map 100).

Local name published in 1908 by USGS.

Johnson Creek: stream, flows SW $1.3 \mathrm{mi}$. to Snowball Creek which flows to Ophir Creek, 8 mi. NE of Council and $41 \mathrm{mi}$. SW of Imuruk Lake, Seward Penin. High. ; $65^{\circ} 01^{\prime}$ N, $163^{\circ} 36^{\prime}$ W; (map 110).

Prospectors' name published on the 1908 "Map of Seward Peninsula" by Arthur Gibson. Johnson Creek: stream, see Boston Creek.

Johnson Creek: stream, see Chathenda Creek. Johnson Creek: stream, see Johnston Creek. Johnson Creek: watercourse, see Talbiksok River. Johnson Creek Summit: pass, 1,450 ft., between Johnson Lake and Bench Lake, at head of Johnson Creek, $22 \mathrm{mi}$. SE of Sunrise, Chugach Mts.; $60^{\circ} 36^{\prime} 45^{\prime \prime} \mathrm{N}, 1^{\circ} 19^{\circ} 14^{\prime} 45^{\prime \prime} \mathrm{W}$; (map 63).

Local name reported in 1951 by USGS.

Johnson Glacier: glacier, trends E $5 \mathrm{mi}$. from Mount Nick to the glacier's 1958 terminus at head of Johnson River, $67 \mathrm{mi}$. SW of Kenai, Aleutian Ra.; 60 $07^{\prime} \mathrm{N}, 152^{\circ} 58^{\prime} \mathrm{W}$; (map 62).

Local name reported in 1958 by USGS; derived from the Johnson River.

Johnson Glacier: glacier, trends W $6 \mathrm{mi}$. to its terminus $2 \mathrm{mi}$. S of McPherson Glacier, 22 mi. $\mathrm{N}$ of Katalla, Chugach Mts.; $60^{\circ} 31^{\prime} \mathrm{N}$, $144^{\circ} 32^{\prime} \mathrm{W}$; (map 64).

Name published in 1959 by USGS.

Johnson Glacier: glacier, $3 \mathrm{mi}$. across, trends E $1.7 \mathrm{mi}$. to its terminus, $8.6 \mathrm{mi}$. NW of Valdez, Chugach Mts.; $61^{\circ} 14^{\prime} 20^{\prime \prime} \mathrm{N}, 146^{\circ} 19^{\prime} 50^{\prime \prime} \mathrm{W}$; (map 68).

Prospectors' name reported in 1911 by J. W. Bagley and C. E. Giffin, USGS.

Johnson Glacier: glacier, heads on M'Ladies and Sight Peaks, and trends NE $20 \mathrm{mi}$. to its terminus at head of Johnson River, $36 \mathrm{mi}$. NE of Paxson, Alaska Ra.; $63^{\circ} 28^{\prime} \mathrm{N}, 144^{\circ} 51^{\prime} \mathrm{W}$; (map 86).

Name reported in 1952 by USGS.

Johnson Gorge: canyon, extends $5 \mathrm{mi}$. along Kandik River, $12 \mathrm{mi}$. ENE of Kathul Mtn. and $50 \mathrm{mi}$. WNW of Eagle, Porcupine Plat.; $65^{\circ} 27^{\prime} 00^{\prime \prime} \mathrm{N}, 141^{\circ} 55^{\prime} 15^{\prime \prime} \mathrm{W}$; BGN 1965; (map 103).

Named in 1965 by USGS for the brothers, "Sandy" and Alfred Johnson, local trappers and prospectors, who in 1912 helped supply IBC survey.

Johnson Hill: hill, $354 \mathrm{ft}$., on W coast of Alaska Penin., $12 \mathrm{mi}$. SW of Naknek, Bristol Bay Low.; $58^{\circ} 35^{\prime} 40^{\prime \prime} \mathrm{N}, 157^{\circ} 14^{\prime} 00^{\prime \prime} \mathrm{W}$; (map 41). Var. Johnston Hill.

Local name published in 1963 by USGS; given by USC\&GS in 1916 Coast Pilot ( $p$. 236) as "Johnston Hill."

Johnson Hill Creek: stream, flows N $8 \mathrm{mi}$. around Johnson Hill to Kvichak Bay, on Alaska Penin., 11 mi. SW of Naknek, Bristol Bay Low. ; $58^{\circ} 37^{\prime} 20^{\prime \prime} \mathrm{N}, 157^{\circ} 15^{\prime} 00^{\prime \prime} \mathrm{W}$; (map 41). Var. Johnston Hill Creek.

Local name published in 1963 by USGS; shown on a 1965 USGS map as "Johnston Hill Creek."

Johnson Island: island, $2.5 \mathrm{mi}$. long, in Yukon River $4.4 \mathrm{mi}$. N of Russian Mission, YukonKuskokwim Delta; $61^{\circ} 52^{\prime} \mathrm{N}, 161^{\circ} 17^{\prime} \mathrm{W}$; (map 73).

Riverboat pilots' name shown on a 1916 fieldsheet by R. H. Sargent, USGS.

Johnson Island: island, see Berry Island.

Johnson Lake: lake, $1.3 \mathrm{mi}$. long, on SE coast of Prince of Wales I., at head of Johnson Cove, Alex. Arch.; 54 $57^{\prime} 15^{\prime \prime} \mathrm{N}, 1^{\circ} 2^{\circ} 05^{\prime} 30^{\prime \prime} \mathrm{W}$; BGN 1963; (map 1).

Named in 1961 by USFS "for nearby Johnson Gove."

Johnson Lake: lake, $0.7 \mathrm{mi}$. long, $\mathrm{E}$ of Crooked Creek, $5 \mathrm{mi}$. NW of Tustumena Lake and 17 mi. S of Kenai, Gook Inlet Low.; 60 $17^{\prime} 30^{\prime \prime}$ $\mathrm{N}, 151^{\circ} 15^{\prime} 45^{\prime \prime} \mathrm{W}$; BGN 1966; (map 62).

Local name reported in 1962 by Alaska Department of Natural Resources.

Johnson Lake: lake, $0.8 \mathrm{mi}$. long, on Kenai Penin., at head of Johnson Creek, $22 \mathrm{mi}$. SE of Sunrise, Chugach Mts.; $60^{\circ} 36^{\prime} \mathrm{N}, 149^{\circ} 15^{\prime}$ W; (map 63).

Local name reported in 1952 by USGS.

Johnson Lake: lake, 1,900 ft. long, in Matanuska Valley, $4.5 \mathrm{mi}$. SW of Palmer, Cook Inlet Low.; $61^{\circ} 34^{\prime} \mathrm{N}, 149^{\circ} 14^{\prime} \mathrm{W}$; (map 69).

Local name reported in 1942 by AMS.

Johnson Mill: locality, $0.6 \mathrm{mi}$. E of Johnson Glacier and $7.8 \mathrm{mi}$. NW of Valdez, Chugach Mts. ; $61^{\circ} 13^{\prime} 30^{\prime \prime} \mathrm{N}, 146^{\circ} 20^{\prime} 00^{\prime \prime} \mathrm{W}$; (map 68)

Local name published in the 1950's by USGS.

Johnson River: stream, heads at Johnson Glacier terminus, flows SE $15 \mathrm{mi}$. to Cook Inlet, 60 mi. SW of Kenai, Aleutian Ra.; 60 $01^{\circ} 30^{\prime \prime} \mathrm{N}$, $152^{\circ} 36^{\prime} 15^{\prime \prime} \mathrm{W}$; (map 62).

Local name reported in 1921 by Moffit (1927, pl. 1), USGS.

Johnson River: stream, heads in a lake $2 \mathrm{mi}$. W of Kukaklik Lake, at $61^{\circ} 39^{\prime} \mathrm{N}, 160^{\circ} 39^{\prime} \mathrm{W}$, flows SW $215 \mathrm{mi}$. to Kuskokwim River, $15 \mathrm{mi}$. SW of Bethel, Yukon-Kuskokwim Delta; $B G N$ 1965; 60 $38^{\prime} 30^{\prime \prime} \mathrm{N}, 1^{\circ} 2^{\circ} 05^{\prime} 30^{\prime \prime} \mathrm{W}$; (map 58). Var. Anchitaktuk River, Kvichavak River, Tundra River. 
Local name reported in 1949 by USC\&GS; possibly named for Eric Johnson, prospector. The Eskimos consider this part of the Kvichavak River.

Johnson River: stream, heads at terminus of Johnson Glacier, flows NE $25 \mathrm{mi}$. to Tanana River, $41 \mathrm{mi}$. SE of Delta Junction, Alaska Ra.; $63^{\circ} 43^{\prime} 20^{\prime \prime} \mathrm{N}, 144^{\circ} 37^{\prime} 05^{\prime \prime} \mathrm{W}$; (map 86).

Named by Lt. Allen ( 1887 , p. 82 ), USA, for Peder Johnson, Swedish miner and member of his party. Allen spells the given name "Peter" in his text, but in a letter to BGN in 1896 it was spelled "Peder."

Johnson River: stream, see Yentna River.

Johnsons Creek: stream, flows $W$ to Nome River, about $6 \mathrm{mi}$. E of Nome, Seward Penin. High.; (map 94).

Prospectors' name reported on the 1900 "Map of Nome Peninsula" by J. M. Davidson and B. D. Blakeslee; this feature has not been positively identified.

Johnson Slough: stream, heads at Big Glacier Slough, flows SW $0.5 \mathrm{mi}$. to Gulf of Alaska, $8 \mathrm{mi}$. SE of Cordova, Malaspina Coastal Plain; $60^{\circ} 27^{\prime} \mathrm{N}, 145^{\circ} 36^{\prime} \mathrm{W}$; (map 64).

Local name published in 1951 by USGS.

Johnson Slough: stream, flows SE $9 \mathrm{mi}$. to Redoubt Bay, Cook Inlet, $26 \mathrm{mi}$. WNW of Kenai; $60^{\circ} 43^{\prime} \mathrm{N}, 151^{\circ} 55^{\prime} \mathrm{W}$; (map 62).

Local name reported in 1958 by USGS.

Johnson Slough: stream, anabranch of Tanana River, flows W $9 \mathrm{mi}$., $1 \mathrm{mi}$. $\mathbf{E}$ of junc. of Johnson and Tanana Rivers, and $42 \mathrm{mi}$. SE of Delta Junction, Tanana Low.; $63^{\circ} 42^{\prime} 40^{\prime \prime}$ $\mathrm{N}, 144^{\circ} 35^{\prime} 00^{\prime \prime} \mathrm{W}$; (map 86).

Name reported in 1952 by USGS

Johnson Slough: stream, anabranch of Yukon River, flows NW $2.4 \mathrm{mi}$. around Serpentine I., $35 \mathrm{mi}$. NE of Nulato, Koyukuk Low.; $64^{\circ}$ $47^{\prime} \mathrm{N}, 157^{\circ} 00^{\prime} \mathrm{W}$; (map 97).

Local name reported in 1954 by USGS.

Johnsons Point: point of land, see Johnstone Point.

Johnsons Roadhouse: locality, on right bank of Tanana River, $16 \mathrm{mi}$. SE of Fairbanks, Tanana Low.; $64^{\circ} 43^{\prime} \mathrm{N}, 147^{\circ} 20^{\prime} \mathrm{W}$; (map 100).

Name of roadhouse on the Fairbanks-Valdez Trail; probably named for its original owner. The name was published in 1912 by USGS.

Johnsons Slough: water passage, see Middle Slough.

Johns River: stream, see John River.

John Steven Slough: lake, oxbow 2 mi. long, $\mathrm{N}$ of Black River, $24 \mathrm{mi}$. NE of Fort Yukon, Yukon Flats; $66^{\circ} 40^{\prime} 30^{\prime \prime} \mathrm{N}, 144^{\circ} 26^{\prime} 30^{\prime \prime} \mathrm{W}$; (map 119).

Local name obtained in 1956 by USGS.

Johnston Channel: channel, 6 mi. long, along E side of Herendeen Bay, Bristol Bay Low.; $55^{\circ} 51^{\prime} 00^{\prime \prime} \mathrm{N}, 160^{\circ} 47^{\prime} 15^{\prime \prime} \mathrm{W}$; (map 28).

Named in 1899 by Lt. Comdr. Z. L. Tanner, USN, for Ens. Marbury Johnston, who surveyed this channel.

Johnston Creek: stream, heads in glacier 2.6 mi. SW of Mount McPherson, flows SW 2.5 mi. to Gulf of Alaska, $1 \mathrm{mi}$. SE of Munday
Creek and $83 \mathrm{mi} \mathrm{NW}$ of Yakutat, St. Elias Mts. ; $60^{\circ} 00^{\prime} 30^{\prime \prime} \mathrm{N}, 141^{\circ} 54^{\prime} 30^{\prime \prime} \mathrm{W}$; (map 65). Var. Johnson Creek.

Named for Richard C. Johnston, who discovered petroleum in the Yakataga region about 1897. Name reported by G. C. Martin, USGS, in 1903.

Johnston Creek: stream, flows SW $5 \mathrm{mi}$. to Feather River, $28 \mathrm{mi}$. NW of Nome, Seward Penin. High.; $64^{\circ} 50^{\prime} \mathrm{N}, 165^{\circ} 59^{\prime} \mathrm{W}$; (map 94).

Prospectors' name reported in 1900 by E. C. Barnard (in Brooks, 1901, pl. 17), USGS.

Johnston Creek: stream, flows SE $7 \mathrm{mi}$. to join Coco Creek to form Kaviruk River, $38 \mathrm{mi}$. NE of Teller, Seward Penin. High.; $6^{\circ} 22^{\prime}$ N. $165^{\circ} 06^{\prime} \mathrm{W}$; (map 111). Var. Johnson Creek.

Prospectors' name reported in 1901 by $\mathrm{T}$. G. Gerdine (in Collier, 1902, pl. 12), USGS. Johnston Creek: stream, see Clara Creek.

Johnstone Bay: bay, $7 \mathrm{mi}$. across, on SE coast of Kenai Penin. between Cape Junken and Pinnacle Rock, $30 \mathrm{mi}$. SE of Seward, Chugach Mts. ; $59^{\circ} 55^{\prime} \mathrm{N}, 148^{\circ} 45^{\prime} \mathrm{W}$; BGN 1910; (map 49).

Named in 1909 by U. S. Grant, USGS, "for Vancouver's Lieut."

Johnstone Passage: water passage, $2.4 \mathrm{mi}$. long, trends $\mathrm{N}$ from Yakutat Roads to Ahduck Bay, along NE coast of Khantaak I., $2 \mathrm{mi}$. $\mathrm{N}$ of Yakutat, Malaspina Coastal Plain; 59 $36^{\prime} 00^{\prime \prime}$ $\mathrm{N}, 139^{\circ} 43^{\prime} 30^{\prime \prime} \mathrm{W}$; (map 46).

Named in 1879 by W. H. Dall, USC\&GS, for Master James Johnstone, RN, one of the companions of Capt. George Vancouver. The name was published in the 1883 Alaska Coast Pilot (p. 209).

Johnstone Point: point of land, on $\mathrm{N}$ coast of Hinchinbrook I., $30 \mathrm{mi}$. SW of Cordova, Chugach Mts.; $60^{\circ} 28^{\prime} \mathrm{N}, 146^{\circ} 37^{\prime} \mathrm{W}$; (map 64). Var. Cabo Frio, Johnsons Point, Johnston Point.

Named by Davidson (1869, p. 153), USC\&GS, while doing survey work along the south Alaska coast. Named for James Johnstone, Master of the HMS Chatham, one of the vessels in Capt. George Vancouver's expeditions to the region at the end of the 18th century. The point of land was earlier called "Cabo Frio," meaning "cold cape" in Spanish, by José Cañizares on July 22, 1779 (Wagner, 1937, p. 456).

Johnston Hill : hill, see Johnson Hill

Johnston Hill Creek: stream, see Johnson Hill Creek.

Johnston Point: point of land, see Johnstone Point.

Johns Village: village, see Eagle Village.

John's Village: village, see Mentasta Lake.

Joint Lake: lake, $0.3 \mathrm{mi}$. Jong, $5 \mathrm{mi}$. NW of White Lake and $12 \mathrm{mi}$. S of Christian, Yukon Flats; $67^{\circ} 11^{\prime} \mathrm{N}, 145^{\circ} 14^{\prime} \mathrm{W}$; (map 122).

Local name reported in 1956 by T. E. Taylor, USGS.

Jokinaugh Island: island, $2 \mathrm{mi}$. long, in Yukon River, $E$ of junction of Alfred Creek, $13 \mathrm{mi}$.
NE of Stevens Village, Yukon Flats; $66^{\circ} 06^{\prime}$ $\mathrm{N}, 148^{\circ} 39^{\prime} \mathrm{W}$; (map 118).

Local name obtained in 1956 by USGS. Jokoei Lake: lake, $0.5 \mathrm{mi}$. across, $2 \mathrm{mi}$. S of Chalkyitsik, Yukon Flats; $66^{\circ} 38^{\prime} \mathrm{N}, 143^{\circ} 45^{\prime}$ W; (map 120).

Tranjik-kutchin Indian name; obtained in 1956 by T. E. Taylor, USGS.

Jolly Gulch: ravine, extends SW 3 mi. to White Creek $0.7 \mathrm{mi}$. SW of its junc. with Rex Creek and $16 \mathrm{mi}$. SE of McCarthy, St. Elias Mts.; $61^{\circ} 17^{\prime} \mathrm{N}, 142^{\circ} 34^{\prime} \mathrm{W}$; (map 67).

Local name reported in 1902 by G. M. Esterly, of Valdez, and published by Mendenhall (1905, fig. 11), USGS.

Joly Island: island, $1.5 \mathrm{mi}$. long, near right bank of Yukon River, $20 \mathrm{mi}$. NW of Holy Cross, Nulato Hills; $62^{\circ} 28^{\prime} \mathrm{N}, 160^{\circ} 09^{\prime} \mathrm{W}$; (map 78).

Riverboat pilots' name shown on a 1940 "Navigation Chart of the T'anana-Yukon Rivers" published by U.S. Dept. of Interior.

Jonah Bay: estuary, extends W $2.7 \mathrm{mi}$. off Unakwik Inlet, $45 \mathrm{mi}$. SW of Valdez, Chugach Mts.; $61^{\circ} 00^{\prime} 30^{\prime \prime} \mathrm{N}, 147^{\circ} 36^{\prime} 15^{\prime \prime} \mathrm{W}$; $B G N$ 1910; (map 69)

Named in 1908 by U. S. Grant and D. F. Higgins, USGS.

Jones Creek: stream, heads at junc. of Middle Fork and South Fork Jones Creek, flows NW $8 \mathrm{mi}$, to East Fork Kuskokwim River, $21 \mathrm{mi}$. E of Medfra, Kuskokwim Low.; 63 $04^{\prime} \mathrm{N}$, $154^{\circ} 04^{\prime} \mathrm{W}$; (map 89).

Local name reported in 1910 by A. G. Maddren (in Brooks and others, 1911, pl. 14), USGS.

Jones Creek: stream, f.ows NW $7.7 \mathrm{mi}$. to Nixon Fork, $18 \mathrm{mi}$. N of Medfra, Kilbuck-Kuskokwim Mts.; $63^{\circ} 22^{\prime} \mathrm{N}, 154^{\circ} 46^{\prime} \mathrm{W}$; (map 89).

Local name reported in 1910 by A. G. Maddren (in Brooks and others, 1911, pl. 14), USGS.

Jones Creek: stream, flows SW $1.4 \mathrm{mi}$. to Solomon River, between Fish Creek and East Fork Solomon River, $11 \mathrm{mi}$. NE of Solomon, Seward Penin. High.; $64^{\circ} 42^{\prime} \mathrm{N}, 164^{\circ} 17^{\prime} \mathrm{W}$; (map 95)

Prospectors' name reported on a 1902 prospectors' manuscript map.

Jones Creek: stream, flows SW $10 \mathrm{mi}$. to Mettenpherg Creek, $2.5 \mathrm{mi}$. N of that stream's mouth and $71 \mathrm{mi}$. SW of Wiseman, Brooks Ra. ; $67^{\circ} 08^{\prime} \mathrm{N}, 152^{\circ} 40^{\prime} \mathrm{W}$; map 124 ).

Local name obtained in 1956 by USGS topographers.

Jones Glacier: glacier, $2.8 \mathrm{mi}$. long, in Glacier Bay National Monument, trends E to its 1961 terminus, $1 \mathrm{mi}$. NW of Johns Hopkins Inlet, $2 \mathrm{mi}$. N of terminus of Toyatte Glacier, $82 \mathrm{mi}$. $\mathrm{NW}$ of Hoonah, St. Elias Mts.; $58^{\circ} 55^{\prime} 45^{\prime \prime} \mathrm{N}$, $137^{\circ} 08^{\prime} 50^{\prime \prime} \mathrm{W}$; (map 10).

Named in 1936 by Field and Cooper (1937, p. 62) for Ernest L. Jones, 1876-1929, hydrographic and geodetic engineer and a member of the IBC. Jones was a member of the U.S. Dept. of Commercial Fisheries, 1913-15 and Superintendent and Director of USC\&GS, 1915-20. He was the author of many publications, including several on Alaska. 
Jone's Island: barrier islands, see Jones Islands. Jones Islands: barrier islands, extends NW 28 mi. from Cottle I. to Thetis I., on Beaufort Sea coast, Arctic Plain; 70 32' N, 149 $36^{\prime} \mathrm{W}$; (map 150). Var.: Jone's Island, Thetis Islands.

On July 24, 1837, P. W. Dease and Thomas Simpson reported, "a range of low islands eight miles in length, to which we attached the name of the Rev. David T. Jones, the faithful and eloquent minister at Red River" (T. Simpson, 1843, p. 129). Recent maps have extended the name West to include Thetis Island. See Thetis Island.

Jones Lake: lake, $800 \mathrm{ft}$. long, in course of Hood Creek, $3 \mathrm{mi}$. SW of Anchorage, Cook Inlet Low.; $61^{\circ} 11^{\prime} 30^{\prime \prime} \mathrm{N}, 149^{\circ} 57^{\prime} 50^{\prime \prime} \mathrm{W}$; (map 69).

Local name reported in 1962 by USGS.

Jones Mound: pingo, elev. $20 \mathrm{ft}$, , on Beaufort Sea coast, $2 \mathrm{mi}$. SW of Milne Point and $8 \mathrm{mi}$. W of Beechey Point, Arctic Plain; 70 $29^{\prime} 30^{\prime \prime}$ N, 149³1'30" W; (map 150).

Named and used as a triangulation station in 1911 by Leffingwell $(1919$, p. 41$)$, USGS.

Jones Pass: pass, 2,900 ft., $4 \mathrm{mi}$. NE of Far Mtn. and $68 \mathrm{mi}$. SW of Circle, Yukon-Tanana High.; $65^{\circ} 06^{\prime} 45^{\prime \prime} \mathrm{N}, 145^{\circ} 39^{\prime} 30^{\prime \prime} \mathrm{W}$; (map 104).

Prospectors' name reported in 1952 by USGS topographers.

Jones Point: point of land, on $\mathrm{W}$ end of spit, at $S$ end of Port Clarence, $13 \mathrm{mi}$. SW of Teller, Seward Penin. High.; 65 ${ }^{\circ} 07^{\prime}$ N, $166^{\circ} 38^{\prime} \mathrm{W}$; (map 111).

Local name reported about 1940 by USC\&GS and published on Chart 9385.

Jones Pup Creek: stream, in Darby Mts., flows E $1.5 \mathrm{mi}$. to Big Creek which flows to Tubutulik River, $42 \mathrm{mi}$. SE of Imuruk Lake, Seward Penin. High.; $65^{\circ} 04^{\prime} \mathrm{N}, 162^{\circ} 22^{\prime} \mathrm{W}$; (map 110).

Prospectors' name published on the 1908 "Map of Seward Peninsula" by Arthur Gibson.

Jones Ridge: mountain, 4,600 ft., on AlaskaGanada boundary, $25 \mathrm{mi}$. NE of Eagle, Porcupine Plat.; $65^{\circ} 07^{\prime} \mathrm{N}, 141^{\circ} 00^{\prime} \mathrm{W}$; (map 103).

It appears to have been named in 1911-12 by Cairnes (1914, map).

Jones River: stream, flows S and NW $30 \mathrm{mi}$. to South Fork Kuskokwim River, 1 mi. SE of junc. of Dillinger River, $72 \mathrm{mi}$. SE of McGrath, Kuskokwim Low.; 62 $34^{\prime} 15^{\prime \prime} \mathrm{N}$, $153^{\circ} 33^{\prime} 30^{\prime \prime} \mathrm{W}$; (map 80).

Named in 1899 by Lt. J. S. Herron, USA, for Pvt. Sam Jones, a member of his party.

Jones River: stream, see Alsek River.

Jones River: stream, see Yahtse River.

Jonesville: village, pop. 97 (1950), E of Wishbone Hill, $11 \mathrm{mi}$. NE of Palmer, Cook Inlet Low.; $61^{\circ} 43^{\circ} 50^{\prime \prime} \mathrm{N}, 148^{\circ} 56^{\prime} 00^{\prime \prime} \mathrm{W}$; (map 69).

Name of a railroad station and former mining camp listed in the 1922 Railway Guide Index. A post office establishd here in 1921 was discontinued in 1944 (Ricks, 1965, p. 29).
Jooxwarat Bay: estuary, see Iookswarat Bay.

Jordan Creek: stream, flows generally S $3 \mathrm{mi}$. to lagoon at Juneau Airport on Gastineau Channel, $7 \mathrm{mi}$. NW of Juneau, Coast Mts.; $58^{\circ} 21^{\prime} 25^{\prime \prime} \mathrm{N}, 134^{\circ} 34^{\prime} 10^{\prime \prime} \mathrm{W}$; (map 11). Var. Livingston Creek.

Named Jordan Creek by Daniel Foster and M. Y. Hurst, who filed homestead claims near the creek in 1895. Later the stream became known as Livingston Creek, probably for Arthur Livingston, who located a mining claim near its headwaters in 1887 and lived for some time near the stream. It was renamed Jordan Creek by Thomas Knudson, in 1903, who filed a homestead claim on Mendenhall Flats. Whether this name was derived from the original name or renamed for Harry Jordan, 1845-1929, who came to Juneau in 1896, is not known. Jordan operated the Glory Hole Saloon in Douglas and "he has probably grubstaked more men than anyone in this part of Alaska" (DeArmond, 1957, p. 2526). The name Jordan Creek was published by Adolph Knopf (1912, pl. 1), USGS.

Jordan Creek: stream, flows NE and N $10 \mathrm{mi}$. to Yukon River, $S$ of Senatis Mtn., 29 mi. ENE of Tanana, Yukon-Tanana High.; 65 ${ }^{\circ} 17^{\prime} 45^{\prime \prime}$ $\mathrm{N}, 150^{\circ} 07^{\prime} 30^{\prime \prime} \mathrm{W}$; (map 106). Var. Cheyenne Greek.

Name shown on a manuscript track-chart of the Yukon River, dated 1906.

Jordan Lake: lake, $0.7 \mathrm{mi}$. long, on Revillagigedo I., $3 \mathrm{mi}$. E of Naha Bay, in course of Naha River, Alex. Arch.; $55^{\circ} 36^{\prime} \mathrm{N}, 131^{\circ}$ 33' $\mathrm{W}$; (map 3).

Local name reported in 1948 by USGS. Jordon Creek: stream, flows SE to Kigezruk Creek, about $12 \mathrm{mi}$. E of Cape Prince of Wales, Seward Penin. High.; (map 111).

Prospectors' name shown on the 1900 "Map of Nome Peninsula" by J. M. Davidson and B. D. Blakeslee. This fezture cannot be precisely identifid on current maps.

Jorosa Creek: stream, flows S $1 \mathrm{mi}$. to Bangor Creek, $13 \mathrm{mi}$. N of Nome, Seward Penin. High.; $64^{\circ} 41^{\prime} \mathrm{N}, 165^{\circ} 28^{\prime} \mathrm{W}$; (map 94). Var. Gold Creek.

Prospectors' name reported in 1904 by $T$. G. Gerdine, USGS.

Joseph: locality, at junc. of Joseph Creek and Middle Fork Fortymile River, $64 \mathrm{mi}$. SW of Eagle, Yukon-Tanana High.; $64^{\circ} 22^{\prime} 31^{\prime \prime} \mathrm{N}$, $143^{\circ} 05^{\prime} 21^{\prime \prime}$ W; (map 102). Var. Joseph Village.

Settlement, now abandoned, reported in 1903 by T. G. Gerdine, USGS.

Joseph Creek: stream, heads at $64^{\circ} 25^{\prime} \mathrm{N}, 143^{\circ}$ 42' $\mathrm{W}$, flows SE $24 \mathrm{mi}$. to Middle Fork Fortymile River, $64 \mathrm{mi}$. SW of Eagle, Tanana-Yukon High.; 64. $22^{\prime} 30^{\prime \prime} \mathrm{N}, 1^{\circ} 3^{\circ}$ $05^{\prime} 20^{\prime \prime} \mathrm{W}$; (map 102).

Named by praspectors and reported in 1903 by T. G. Gerdine, USGS.

Joseph Creek: stream, flows E $2 \mathrm{mi}$. to Minook Creek 17 mi. S of Rampart, Yukon-Tanana High; $65^{\circ} 15^{\prime} 30^{\prime \prime} \mathrm{N}, 150^{\circ} 08^{\prime} 30^{\prime \prime} \mathrm{W}$; (map 106).
Prospectors' name shown on a manuscript map dated 1906; reported in 1956 by Orth. Josephine, Lake: lake, $1.3 \mathrm{mi}$. long, on Prince of Wales I., $E$ of head of Hetta Inlet, Alex. Arch.; 55 $14^{\prime} 40^{\prime \prime} \mathrm{N}, 132^{\circ} 34^{\prime} 00^{\prime \prime} \mathrm{W}$; (map 4). Var. Lake Mabel, Lake Mable.

Local name reported in 1908 by C. W. Wright (in Brooks and others, 1909, pl. 3), USGS; This feature was called "Lake Mable" in 1905 by E. F. Dickins, USC\&GS. Josephine Gulch: ravine, trends SW $0.6 \mathrm{mi}$. to Buster Creek, $9 \mathrm{mi}$. NE of Nome, Seward Penin. High.; $64^{\circ} 37^{\prime} 20^{\prime \prime} \mathrm{N}, 165^{\circ} 11^{\prime} 25^{\prime \prime} \mathrm{W}$; (map 94).

Prospectors' name reported in 1904 by T. G. Gerdine, USGS.

Joseph Village: locality, see Joseph.

Joshua Green River: stream, heads in Aleutian Ra., flows NW $15 \mathrm{mi}$. to Moffet Lagoon, 17 mi: NE of village of Cold Bay, Bristol Bay Low.; $55^{\circ} 24^{\prime} \mathrm{N}, 162^{\circ} 29^{\prime} \mathrm{W}$; (map 29).

Name published by USC\&GS in the 1964 Coast Pilot.

Josie Creek: stream, flows NW $2.4 \mathrm{mi}$. to Stewart River, $20 \mathrm{mi}$. NW of Nome, Seward Penin. High.; $64^{\circ} 48^{\prime} \mathrm{N}, 165^{\circ} 33^{\prime} \mathrm{W}$; (map 94).

Prospectors' name reported on Arthur Gibson's "Map of Cape Nome Precinct" dated 1904.

Josie Creek: stream, flows NE $2 \mathrm{mi}$. to Canyon Creek which flows to Imuruk Basin, $34 \mathrm{mi}$. NW of Nome, Seward Penin. High.; 64․ $57^{\prime} \mathrm{N}, 165^{\circ} 55^{\prime} \mathrm{W}$; (map 94).

Prospectors' name published on the 1908 "Map of Seward Peninsula" by Arthur Gibson.

Jounakh Island: island, see Kanu Island.

Jualin: locality, on Johnson Creek, $4 \mathrm{mi}$. SE of Point Sherman on Lynn Canal, $44 \mathrm{mi}$. NW of

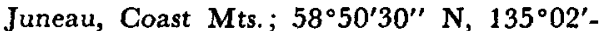
30 " W; (map 11).

Miners' name for gold mining camp located here. The name was reported by A. C. Spencer (Spencer and Wright, 1906, p. 136), USGS. The camp has been generally abandoned.

Juan de Gama Bank: reef, see Stalemate Bank.

Juanita Creek: stream, flows $\mathrm{N} \perp \mathrm{mi}$. to California Creek, $15 \mathrm{mi}$. NE of Shungnak, Brooks Ra.; $66^{\circ} 57^{\prime} 25^{\prime \prime} \mathrm{N}, 156^{\circ} 38^{\prime} 10^{\prime \prime} \mathrm{W}$; (map 115).

Prospectors' name reported after 1940 by USGS.

Jubilee Creek: stream, about $30 \mathrm{mi}$. long, heads about $68^{\circ} 35^{\prime} \mathrm{N}, 159^{\circ} 03^{\prime} \mathrm{W}$, flows NE to $\mathrm{Ki}$ ligwa River about $15 \mathrm{mi}$. upstream from its mouth, Arctic Slope; $68^{\circ} 53^{\prime} \mathrm{N}, 158^{\circ} 31^{\prime} \mathrm{W}$; $B G N$ 1960; (map 132). Var. West Fork Kiligwa River.

Named in 1955 by B. H. Kent and I. L. Teilleur, USGS.

Judd Harbor: bay, 1 mi. across, $S$ coast of Duke I., Alex. Arch.; 54 $53^{\prime} \mathrm{N}, 131^{\circ} 16^{\prime} \mathrm{W}$; (map 2).

Local name published in 1943 by USC\&GS. Judd Lake: lake, $0.9 \mathrm{mi}$. across, in course of Talachulitna Creek, $37 \mathrm{mi}$. NW of Tyonek, 
Cook Inlet Low.; $61^{\circ} 34^{\prime} 10^{\prime \prime} \mathrm{N}, 151^{\circ} 34^{\prime} 20^{\prime \prime}$ W; (map 70).

Local name reported in 1954 by USGS.

Judd Lake: lake, $1.2 \mathrm{mi}$. long, $3.7 \mathrm{mi}$. SW of Lake Louise and $37 \mathrm{mi}$. W of Glennallen, Copper River Basin; $62^{\circ} 15^{\prime} \mathrm{N}, 146^{\circ} 38^{\prime} \mathrm{W}$; (map 83).

Local name reported in 1949 by USGS.

Jude Island: island, $0.2 \mathrm{mi}$. across, in Pacific Ocean, between Unga and Wosnesenski Is., Aleutian Ra.; 55 $15^{\prime} 45^{\prime \prime} \mathrm{N}, 161^{\circ} 06^{\prime} 15^{\prime \prime} \mathrm{W}$; (map 28).

Named "O[strov] Judy" by Capt. Tebenkov (1852, map 24), IRN, and so shown on Russian Hydrog. Dept. Chart 1379; shown on inset to Chart 1379 as "O[strov] Ap[ostol] Judy" or "Apostle Jude Island." Shown as "Jude Island" on USC\&GS chart published in 1882.

Judge Creek: stream, flows SE $26 \mathrm{mi}$. to Kandik River, $9 \mathrm{mi}$. NE of that stream's junc. with Yukon River, Porcupine Plat. ; $65^{\circ} 27^{\prime} \mathrm{N}, 142^{\circ}$. 15' W; (map 103).

Local name published in 1956 by USGS.

Judy Creek: stream, heads at $69^{\circ} 29^{\prime} \mathrm{N}, 153^{\circ} 09^{\prime}$ W, flows NE $140 \mathrm{mi}$. to Fish Creek, $12 \mathrm{mi}$. S of Harrison Bay, Arctic Plain; 70 $15^{\prime} 15^{\prime \prime} \mathrm{N}$, $151^{\circ} 45^{\prime} 30^{\prime \prime} \mathrm{W}$; (map 149).

This stream appears to have been named in the 1940's by personnel of the Naval Petroleum Reserve No. 4 explorations.

Judy Hill: hill, $806 \mathrm{ft}$., on Gravina I., between Blank Inlet and Tongass Narrows, $3.2 \mathrm{mi}$. S of Ketchikan, Alex. Arch.; $55^{\circ} 17^{\prime} 40^{\prime \prime} \mathrm{N}$, $131^{\circ} 38^{\prime} 35^{\prime \prime} \mathrm{W}$; (map 3).

Named in 1885 by Lt. Comdr. Richardson Clover, USN. See 'Puppets, The.

Juel Point: point of land, between Foul Bay and Sea Otter Harbor, on $W$ coast of Dall $I$., Alex. Arch.; $55^{\circ} 07^{\prime} 30^{\prime \prime} \mathrm{N}, 133^{\circ} 13^{\prime} 45^{\prime \prime} \mathrm{W}$; (map 4).

Local name published in 1914 by USC\&GS.

Jug Island: island, $500 \mathrm{ft}$. across, in Necker Is., $20 \mathrm{mi}$. SW of Sitka, Alex. Arch.; 56 $47^{\prime} 30^{\prime \prime}$ $\mathrm{N}, 135^{\circ} 26^{\prime} 00^{\prime \prime} \mathrm{W}$; (map 5). Var. Kubieshka Island, Ostrov Kubyshka.

This is a translation by USC\&GS of the Russian name given in 1809 by the navigator Ivan Vasiliev the first, IRN. Lt. Sarichev (1826, map 19), IRN, published it as "O[strov] Kubyshka."

Jug Island: island, $300 \mathrm{ft}$. long, in Kalsin Bay, $9.5 \mathrm{mi}$. S of Kodiak, Kodiak I.; 57 $38^{\prime} 55^{\prime \prime}$ $\mathrm{N}, 152^{\circ} 25^{\prime} 10^{\prime \prime} \mathrm{W}$; (map 34). Var. Kubieshka Island, Ostrov Kubyshka.

Translation of the name "Os[trov] $\mathrm{Ku}$ byshka," published by Sarichev (1852, map 16).

Juhle, Mount: peak, 5,010 ft., on Alaska Penin., in Katmai National Monument, $10 \mathrm{mi}$. NW of Mount Katmai, Aleutian Ra.; 58 $22^{\prime} 45^{\prime \prime}$ N, 155 09'30" W; BGN 1957; (map 42).

Named in 1955 by G. O. Gates, USGS, for Rolf Werner Juhle, 1929-53, USGS geologist and vulcanologist, who apparently "lost his footing and was drowned in Knife Creek, while on a field project for National Research Council and USGS."
Jukchana: stream, see Yukon River.

Jukhwarat Bay: estuary, see Iookswarat Bay.

Julia Creek: stream, flows WSW 2 mi. to Minook Creek $E$ of that stream's junc. with Yukon River, $1.3 \mathrm{mi}$. NE of Rampart, Yukon-Tanana High.; $65^{\circ} 31^{\prime} \mathrm{N}, 150^{\circ} 08^{\prime} \mathrm{W}$; (map 106).

Prospectors' name shown on a manuscript map dated 1906; reported in 1956 by Orth.

Julian Creek: stream, flows SE $2.8 \mathrm{mi}$. to George River, $27 \mathrm{mi}$. SE of Flat, and $36 \mathrm{mi}$. N of Sleetmute, Kilbuck-Kuskokwim Mts.; $62^{\circ}$ $12^{\prime} 10^{\prime \prime} \mathrm{N}, 157^{\circ} 21^{\prime} 20^{\prime \prime} \mathrm{W}$; (map 79). Var. Middle Fork George River; Yukwonilnuk.

Local name reported in 1913 by USGS.

Julie Creek: stream, flows S $5 \mathrm{mi}$. to Zimmerman Creek 2 mi. NW of its junc. with Iditarod River, $9 \mathrm{mi}$. NW of Flat, KilbuckKuskokwirn Mts.; $62^{\circ} 32^{\prime} 35^{\prime \prime} \mathrm{N}, 158^{\circ} 12^{\prime} 40^{\prime \prime}$ W; (map 79).

Local name reported in 1913 by USGS.

Julius: $R R$. station, mile 401.3 on The Alaska RR., $9 \mathrm{mi}$. S of Nenana, Tanana Low.; $64^{\circ}$ $25^{\prime} 15^{\prime \prime} \mathrm{N}, 149^{\circ} 04^{\prime} 45^{\prime \prime} \mathrm{W}$; (map 100).

Local name derived from Julius Creek, which the railroad crosses at that point. The name was published on a timetable in 1922.

Julius Creek: stream, flows N $18 \mathrm{mi}$. to Seventeenmile Slough, $6 \mathrm{mi}$. S of Nenana, Tanana Low.; $64^{\circ} 29^{\prime} \mathrm{N}, 149^{\circ} 08^{\prime} \mathrm{W}$; (map 100).

Local name published in 1916 on a GLO [BLM] survey plat.

Julius Reef: reef, in Felice Strait, $0.2 \mathrm{mi}$. NW of Form Point, Duke I., Alex. Arch.; 54 ${ }^{\circ} 58^{\prime} 00^{\prime \prime}$ N, $131^{\circ} 25^{\prime} 45^{\prime \prime} \mathrm{W}$; (map 2).

Local name published in 1920 by USC\&GS. Julkitsik: village, see Chalkyitsik.

July Creek: stream, heads at glacier, flows NE $10 \mathrm{mi}$. to Gerstle River, $31 \mathrm{mi}$. SE of Delta Junction, Alaska Ra.; 63 $38^{\prime} 35^{\prime \prime} \mathrm{N}, 1^{\circ} 5^{\circ} 16^{\prime}$ 15" W; BGN 1937; (map 86). Var. Fourth of July Creek.

Local name shown on a 1927 manuscript map of the "Endicott and Haley Hunting Expedition."

July Creek: stream, flows E 1 mi. to Nome River, $9.3 \mathrm{mi}$. NNE of Nome, Seward Penin. High.; $64^{\circ} 37^{\prime} 30^{\prime \prime} \mathrm{N}, 165^{\circ} 18^{\prime} 00^{\prime \prime} \mathrm{W}$; (map 94).

Prospectors' name shown on the 1904 "Map of Cape Nome Precinct" by Arthur Gibson. July Creek: stream, flows SW 5 mi. to Kutuk River, $10 \mathrm{mi}$. E of Survey Pass, Brooks Ra.; $67^{\circ} 50^{\prime} \mathrm{N}, 153^{\circ} 42^{\prime} \mathrm{W}$; BGN 1932; (map 125).

Named by Robert Marshall in July, 1931, "to contrast it with the one [April Creek] across the Arctic Divide."

July Creek: stream, see Fourth of July Creek.

July Fourth Mountain: mountain, 5,007 ft., 5 mi. SE of head of Brady Glacier, Glacier Bay National Monunment, $59 \mathrm{mi}$. NW of Hoonah, St. Elias Mts.; $58^{\circ} 38^{\prime} 25^{\prime \prime} \mathrm{N}, 36^{\circ} 42^{\prime} 00^{\prime \prime} \mathrm{W}$; (map 10).

Local name reported in 1951 by USGS.

July Gulch: ravine, trends $\mathrm{W} 1 \mathrm{mi}$. to Rocky Mountain Creek which flows SW to Nome River, $20 \mathrm{mi}$. NE of Nome, Seward Penin. High.; $64^{\circ} 46^{\prime} 30^{\prime \prime} \mathrm{N}, 165^{\circ} 11^{\prime} 30^{\prime \prime} \mathrm{W}$; (map 94).
Prospectors' name shown on the 1904 "Map of Cape Nome Precinct" by Arthur Gibson. Jumbo, Mount: mountain, 3,400 ft., on NE shore of Hetta Inlet, near center of Prince of Wales I., Alex. Arch.; $55^{\circ} 15^{\prime} 10^{\prime \prime} \mathrm{N}, 132^{\circ} 36^{\prime} 45^{\prime \prime} \mathrm{W}$; (map 4).

Local name reported in 1905 by F. E. and C. W. Wright (in Brooks and others, 1906, fig. 1), USGS.

Jumbo, Mount: mountain, see Bradley, Mount. Jumbo Basin: basin, on SW coast of Prince of Wales I., $\mathbf{E}$ of head of Hetta Inlet, at head of Jumbo Creek, Alex. Arch.; 55 $14^{\prime} 32^{\prime \prime} \mathrm{N}$, $132^{\circ} 37^{\prime} 30^{\prime \prime} \mathrm{W}$; (map 4).

Local name reported in 1908 by C. W. Wright (in Brooks and others, 1909, pl. 3), USGS.

Jumbo Creek: stream, flows W $1.2 \mathrm{mi}$. to Hetta Inlet, $E$ of Jumbo I., on SW coast of Prince of Wales I., Alex. Arch.; $55^{\circ} 14^{\prime} 30^{\prime \prime} \mathrm{N}, 132^{\circ}$ $39^{\prime} 05^{\prime \prime} \mathrm{W}$; (map 4).

Local name reported in 1908 by C. W. Wright (in Brooks and others, 1909, pl. 3), USGS.

Jumbo Creek: stream, heads on Bonanza Peak, flows SW $1.8 \mathrm{mi}$. to Kennicott Glacier, $5 \mathrm{mi}$. $\mathrm{N}$ of McCarthy, Wrangell Mts.; BGN 1964; $61^{\circ} 30^{\prime} 12^{\prime \prime} \mathrm{N}, 142^{\circ} 53^{\prime} 50^{\prime \prime} \mathrm{W}$; (map 67).

Local name reported in 1908 by $D$. C Witherspoon, USGS.

Jumbo Creek: stream, heads in Mount McKinley National Park, flows NE $2 \mathrm{mi}$. to Moose Creek, $3.7 \mathrm{mi}$. E of Wonder Lake, Alaska Ra.; $63^{\circ} 30^{\prime} 50^{\prime \prime} \mathrm{N}, 150^{\circ} 46^{\prime} 10^{\prime \prime} \mathrm{W}$; BGN 1932; (map 88).

Local name reported in 1932 by F. G. Wells and S. C. Kain, USGS.

Jumbo Creek: stream, flows NW $4.5 \mathrm{mi}$ to Clear River S of Moving Mtn., $27 \mathrm{mi}$. NW of Wiseman, Brooks Ra.; $67^{\circ} 38^{\prime} 30^{\prime \prime} \mathrm{N}, 150^{\circ} 55^{\prime} 30^{\prime \prime}$ W; BGN 1932; (map 124).

Local name reported by Robert Marshall in 1932.

Jumbo Creek: stream, see Amazon Creek.

Jumbo Dome: mountain, 4,493 ft., $12 \mathrm{mi}$. SE of Rex Dome and $15 \mathrm{mi}$. NE of Healy, Alaska Ra.; $63^{\circ} 58^{\prime} 30^{\prime \prime} \mathrm{N}, 148^{\circ} 41^{\prime} 15^{\prime \prime} \mathrm{W}$; (map 87).

Local name reported in 1906 by L. M. Prindle (in Brooks and others, 1907, pl. 4), USGS.

Jumbo Island: island, $0.5 \mathrm{mi}$. long, near head of Hetta Inlet, on SW coast of Prince of Wales I., Alex. Arch.; 55 $14^{\prime} 40^{\prime \prime} \mathrm{N}, 132^{\circ} 39^{\prime} 45^{\prime \prime} \mathrm{W}$; (map 4). Var. Deer Island.

Local name reported in 1904 by E. F. Dickins, USC\&GS. The name "Deer Island" was published for this feature by USC\&GS in 1904 on chart 8100.

Jumbo Mountain: mountain, see Bradley, Mount.

Jumbo Peak: mountain, 2,000 ft., $10 \mathrm{mi}$. $\mathrm{N}$ of Medfra, Kilbuck-Kuskokwim Mts.; $63^{\circ} 15^{\prime} \mathrm{N}$, $154^{\circ} 43^{\prime} \mathrm{W}$; (map 89).

Local name reported in 1920 by G. C. Martin (in Brooks and others, 1922, fig. 5), USGS. 
Jumbo Rock: rock, in Cook Inlet, $3.4 \mathrm{mi}$. NE of Boulder Point and $17 \mathrm{mi}$. N of Kenai, Cook Inlet Low.; $60^{\circ} 47^{\prime} 45^{\prime \prime} \mathrm{N}, 151^{\circ} 10^{\prime} 10^{\prime \prime} \mathrm{W}$; (map 62).

Local name published in 1912 by USC\&GS.

Jump Creek: stream, flows NE $4.1 \mathrm{mi}$. to Candle Creek, $53 \mathrm{mi}$. NW of Haycock, Seward Penin. High.; $65^{\circ} 54^{\prime} \mathrm{N}, 161^{\circ} 57^{\prime} \mathrm{W}$; (map 109).

Local name shown on a 1903 fieldsheet by D.C. Witherspoon, USGS

Jump Off Creek: stream, see Quartz Creek.

Jumpoff Creek: stream, flows SE 3 mi. to Crooked Creek, $17 \mathrm{mi}$. SW of Circle, Yukon-Tanana High.; $65^{\circ} 37^{\prime} 45^{\prime \prime} \mathrm{N}, 144^{\circ} 26^{\prime} 40^{\prime \prime} \mathrm{W}$; (map 104). Var. Jump Off Creek.

Named by prospectors; shown on an 1898 manuscript map by E. F. Ball.

Jumpoff Icefall: icefall, in Chisana Glacier, 12 mi. above its terminus and $35 \mathrm{mi}$. NE of Mount Blackburn, Wrangell Mts.; $61^{\circ} 56^{\prime} 45^{\prime \prime}$ $\mathrm{N}, 142^{\circ} 25^{\prime} 45^{\prime \prime} \mathrm{W}$; (map 67).

Local name published by USGS in 1954.

Jumpoff Roadhouse: locality, at junc. of Jumpoff Creek and Crooked Creek, $18 \mathrm{mi}$. SW of Circle, Yukon-Tanana High.; 65 $38^{\prime} \mathrm{N}$, $144^{\circ} 20^{\prime} \mathrm{W}$; (map 104)

Name of a former roadhouse reported in 1915 by G. A. Waring, USGS.

Juna: stream, see Yukon River.

Junaka, Reka: stream, see Koyukuk River.

Junaska Island: island, see Yunaska Island.

Junco Creek: stream, flows $\mathrm{W} 1 \mathrm{mi}$. to Nenana River, $1.5 \mathrm{mi}$. N of village of McKinley Park, Alaska Ra.; $63^{\circ} 45^{\prime} 07^{\prime \prime} \mathrm{N}, 148^{\circ} 53^{\prime} 52^{\prime \prime} \mathrm{W}$; $B G N 1965$; (map 87).

Named in 1965 by the Alaska Dept. of Highways "for the bird, the junco, a species of the family Fringillidae, which is seen along the stream in the summer months." See Iceworm Gulch.

Junction Creek: stream, flows SW $4 \mathrm{mi}$. to Norton Sound, $6 \mathrm{mi}$. N of Egavik and $10 \mathrm{mi}$. E of Besboro I., Nulato Hills; 64. $09^{\prime} \mathrm{N}$, $160^{\circ} 57^{\prime} \mathrm{W}$; (map 96).

Local name published in 1950 by USC\&GS

Junction Creek: stream, flows NW $10 \mathrm{mi}$., joins Mosquito Creek to form Redmond Creek, 28 mi. NW of Big Delta, Yukon-Tanana High.; $64^{\circ} 22^{\prime} 40^{\prime \prime} \mathrm{N}, 146^{\circ} 36^{\prime} 10^{\prime \prime} \mathrm{W}$; (map 101)

Named by prospectors; reported in 1910 by C. E. Ellsworth and G. L. Parker (in Brooks and others, 1911, p. 193), USGS.

Junction Island: island, $0.1 \mathrm{mi}$. across, in central Lisianski Inlet, on NW coast of Chichagof I., $4 \mathrm{mi}$. NW of Pelican, Alex. Arch.; 57 $59^{\prime}$ $55^{\prime \prime} \mathrm{N}, 136^{\circ} 18^{\prime} 50^{\prime \prime} \mathrm{W}$; BGN 1908; (map 9). Var. Bill Island.

Descriptive name given by USC\&GS in 1908 and published in the 1908 Alaska Coast Pilot (p. 169). So named because it is near the junction of Lisianski with Lisianski Strait. The local name was Bill Island, named for superintendent of the Dundas. Bay Company in 1908.
Junction Island: island, $0.5 \mathrm{mi}$. long, off $\mathrm{N}$ tip of Chenega $\mathrm{I}$., at junction of Knight Island Passage and Dangerous Passage, $34 \mathrm{mi}$. SE of Whittier, Chugach Mts.; $60^{\circ} 23^{\prime} 30^{\prime \prime} \mathrm{N}, 147^{\circ}$. 59'30" W; BGN 1934; (map 63).

So named in 1933 by a USC\&GS field party "because it marks the junction of Dangerous Passage and Knight Island Passage."

Junction Island: island, $0.8 \mathrm{mi}$. long, in Tanana River, $12 \mathrm{mi}$. SE of the village of Manley Hot Springs, Nowitna Low.; $64^{\circ} 53^{\prime} \mathrm{N}, 150^{\circ}$ $20^{\prime} \mathrm{W}$; (map 99).

Riverboat pilots' name published on a 1940 "Navigation Chart of the Tanana-Yukon Rivers" by the U.S. Dept. of Interior.

Juncture Mountain: nunatak, see Juncture Nunatak.

Juncture Nunatak: nunatak, 4,320 ft., W of junc. of Taku Glacier and its Southwest Branch, $1.6 \mathrm{mi}$. $\mathrm{E}$ of Shoehorn Mtn. and $22 \mathrm{mi}$. NE of Juneau, Coast Mts.; 58 $36^{\prime} 15^{\prime \prime} \mathrm{N}, 134^{\circ} 15^{\prime}$ $20^{\prime \prime} \mathrm{W}$; (map 11). Var. Juncture Mountain, Juncture Peak.

Named by members of the Juneau Icefield Research Project in 1965. Published as "Juncture Peak" by USGS in 1960. It is so named because of its location at the juncture of the glaciers.

Juncture Peak: nunatak, see Juncture Nunatak. Juneau: city, pop. 6,797, on Gastineau Channel, $95 \mathrm{mi}$. N of Sitka, Coast Mts.; 58 $18^{\circ} 15^{\prime \prime} \mathrm{N}$, $134^{\circ} 24^{\prime} 30^{\prime \prime} \mathrm{W}$; (map 11). Var. Harrisburg, Juneau City, Juneau Wharf, Pilzburg, Rockwell.

The capital of Alaska since 1900; originated in 1880 as a mining camp called "Harrisburg," named for Richard H. Harris, 18331907, who with Joseph Juneau discovered gold near here on Gold Creek and staked the beach as a town site. The mining camp was also called Rockwell by the U.S. Navy in 1881 for Comdr. Charles Henry Rockwell, 18401908 , USN, who was sent with a detachment of men to the camp to maintain order. Because of the confusion of names, the miners met in 1881 and officially named the town for Joseph Juneau, 1826-99 (DeArmond, 1957, p. 23-28). The population of Juneau was 1,644 in $1910 ; 3,058$ in $1920 ; 4,043$ in $1930 ; 5,729$ in 1939 ; and 5,956 in 1950 . The Juneau post office was established in 1882 (Ricks, 1965, p. 30).

Juneau, Mount: mountain, 3,576 ft., $1.2 \mathrm{mi} . \mathrm{N}$ of Juneau, Coast Mts.; $58^{\circ} 19^{\prime} 10^{\prime \prime}$ N, i34 ${ }^{\circ} 24^{\prime}$ 15" W; (map 11). Var. Gold Mountain, Bald Mountain.

Named "Gold Mountain" by the miners in 1881. It was also called Bald Mountain as late as 1896. The name "Juneau Mountain" was first used in the mining records by Pierre ("French Pete") Erussard when he located mining claims on the mountain in 1888 (DeArmond, 1957, p. 28).

Juneau Creek: stream, heads in York Mts. and flows SW to Anikovik River, about $15 \mathrm{mi}$. SE of Cape Prince of Wales, Seward Penin. High.; (map 111).

Prospectors' name shown on a map of Cape Nome gold fields by David Fox, Jr., dated 1901. This feature cannot be precisely identified on current maps.

Juneau Creek: stream, heads on W side of Gilpatrick Mtn., drains Juneau Lake, flows SW $16 \mathrm{mi}$. to Kenai River, $32 \mathrm{mi}$. SW of Hope, Chugach Mts. ; $60^{\circ} 29^{\prime} 20^{\prime \prime} \mathrm{N}, 149^{\circ} 52^{\prime} 30^{\prime \prime} \mathrm{W}$; (map 63).

Local name reported in 1898 by Mendenhall (1900, map 16), USGS.

Juneau Creek: stream, on Kenai Penin., flows NW $4 \mathrm{mi}$. to Mills Creek, $16 \mathrm{mi}$. S of Sunrise, Chugach Mts.; $60^{\circ} 40^{\prime} 30^{\prime \prime} \mathrm{N}, 149^{\circ} 27^{\prime} 00^{\prime \prime} \mathrm{W}$; $B G N$ 1912; (map 63). Var. Junior Creek.

Local name reported in 1904 by F. H. Moffit, USGS, as being the correct name for a stream which heretofore was called "Junior Creek" (Baker, 1906, p. 339). D. H. Sleem published the name "Juneau Creek," on his map of Central Alaska, dated 1910.

Juneau Creek: stream, flows NW $1.5 \mathrm{mi}$. to Walker Fork, $50 \mathrm{mi}$. S of Eagle, YukonTanana High.; $64^{\circ} 04^{\prime} \mathrm{N}, 141^{\circ} 21^{\prime} \mathrm{W}$; (map 102).

Named for a prospector and shown on an 1898 manuscript map by E. F. Ball, prospector.

Juneau Harbor: cove, on Gastineau Ghannel, S of Juneau, Coast Mts.; $58^{\circ} 10^{\prime} 15^{\prime \prime} \mathrm{N}, 134^{\circ}$ $24^{\prime} 00^{\prime \prime} \mathrm{W}$; (map 11).

Local name derived from the city of Juneau; reported by the U.S. Navy and published by USC\&GS in the 1883 Coast Pilot (p. 225).

Juneau Icefield: icefield, $15 \mathrm{mi}$. across, $25 \mathrm{mi}$. $\mathrm{N}$ of Juneau, Coast Mts.; $58^{\circ} 37^{\prime} \mathrm{N}, 134^{\circ} 30^{\prime}$ W; (map 11). Var. Juneau Icecap.

Name reported in the 1940's.

Juneau Island: island, $0.2 \mathrm{mi}$. across, in Gastineau Channel, $2 \mathrm{mi}$. SE of Juneau, Coast $\mathrm{Mts}$; $58^{\circ} 16^{\prime} 35^{\prime \prime} \mathrm{N}, 134^{\circ} 23^{\prime} 00^{\prime \prime} \mathrm{W}$; (map 11). Var. Juneau Isle, Mayflower Island.

Local name derived from the nearby city name. Name first appeared in 1881 when N. B. Lazard located a mining claim on the island, which he called Juneau Island. The name was published by USGS in 1904. After 1900 the island was frequently called Mayflower Island, but the origin of this name is unknown. In 1912 at the first session of the Alaska Legislature a memorial was introduced by Rep. William Stubbins of Douglas "that a grant be made of the said island to the Town of Douglas, Alaska, for and to be used by the general public as a park and that the name of said island be changed to Mayflower Island." The memorial was passed but was ignored by Congress. It is believed to be the only Alaska Legislative memorial concerning an Alaska place name (DeArmond, 1957, p. 28).

Juneau Lake: lake, $1 \mathrm{mi}$. long, in Kenai Mts., coursed by Juneau Creek, $1.5 \mathrm{mi}$. NE of Trout Lake, $25 \mathrm{mi}$. SW of Hope, Chugach Mts.; $60^{\circ} 34^{\prime} 30^{\prime \prime} \mathrm{N}, 149^{\circ} 52^{\prime} 30^{\prime \prime} \mathrm{W}$; (map 63).

Local name reported in 1951 by USGS. 
Juneau Ridge: ridge, 3,500 ft., $4.5 \mathrm{mi}$. long, extending $\mathrm{E}$ from Mount Juneau to West Summit of Olds Mtn., 3 mi. NE of Juneau, Coast Mts.; $58^{\circ} 20^{\prime} \mathrm{N}, 134^{\circ} 20^{\prime} \mathrm{W}$; (map 11).

Local name reported by D. A. Brew and A. B. Ford, USGS, in 1965.

Juneau Wharf: city, see Juneau.

June Creek: stream, flows E 1 mi. to Nome River, $9 \mathrm{mi}$. NNE of Nome, Seward Penin. High.; $64^{\circ} 37^{\prime} 20^{\prime \prime} \mathrm{N}, 165^{\circ} 18^{\prime} 00^{\prime \prime} \mathrm{W}$; (map 94).

Prospectors' name shown on the 1904 "Map of Cape Nome Precinct" by Arthur Gibson.

June Creek: stream, flows N $1 \mathrm{mi}$. to Dese Creek which flows to Grantley Harbor, $8 \mathrm{mi}$. SE of Teller, Seward Penin. High.; $65^{\circ} 10^{\prime} \mathrm{N}, 166^{\circ}$ 14' W; (map 111).

Prospectors' name reported on the 1908 "Map of Seward Peninsula" by Arthur Gibson.

June Creek: stream, flows NE $3 \mathrm{mi}$. to Pinnell River, $15 \mathrm{mi}$. N of Imuruk Lake, Seward Penin. High.; $65^{\circ} 49^{\prime} \mathrm{N}, 163^{\circ} 04^{\prime} \mathrm{W} ; B G N$ 1952; (map 110).

Prospectors' name reported in 1903 by D. C. Witherspoon (in Moffit, 1905, pl. 2), USGS.

Junekakat Creek: stream, flows W $23 \mathrm{mi}$. to Yukon River, NE of Ham I., NE of Ruby, Nowitna Low.; $64^{\circ} 54^{\prime} \mathrm{N}, 154^{\circ} 49^{\prime} \mathrm{W}$; (map 98). Var. Junekaket Creek.

Indian name obtained at Ruby in 1956 by Orth.

Junekakat Slough: stream, an anabranch of Yukon River, flows W $5 \mathrm{mi}$. around Ham I., 19 mi. NE of Ruby, Nowitna Low.; $64^{\circ} 53^{\prime} \mathrm{N}$, $154^{\circ} 56^{\prime}$ W; (map 98). Var. Junekaket Slough.

Indian name obtained at Ruby in 1956 by Orth.

June Lake: lake, $1.1 \mathrm{mi}$. long, $2 \mathrm{mi}$. NE of Kinakhulantan Lake and $22 \mathrm{mi}$. NE of Ruby, Nowitna Low.; $64^{\circ} 48^{\prime} \mathrm{N}, 154^{\circ} 47^{\prime} \mathrm{W}$; (map 98).

Indian name obtained at Ruby in 1956 by Orth.

June River: stream, see Jewn River.

Jungjuk Creek: stream, heads in lake in Horn Mts., flows NE $10 \mathrm{mi}$. to Kuskokwim River, $35 \mathrm{mi}$. W. of Sleetmute, Kilbuck-Kuskokwim Mts.; $61^{\circ} 47^{\prime} 40^{\prime \prime} \mathrm{N}, 158^{\circ} 13^{\prime} 00^{\prime \prime} \mathrm{W}$; BGN 1945; (map 72). Var. Knowat Creek, Nowat Creek, Yukwonilnuk River.

Eskimo name, "Yukwonilnuk River," said to mean "river where no man is," reported on an 1898 fieldsheet by W. S. Post, USGS. In 1910 A. G. Maddren, USGS, reported the name as "Knowat River" (in Brooks and others, 1911, pl. 11), and in 1912 H. M. Eakin, USGS, reported the spelling "Nowat" (in Brooks and others, 1913, pl. 10). The present-day local name "Jungjuk Creek" was reported in 1944 by USGS.

Jungle Creek: stream, heads in Canada, flows NW across Alaska-Canada boundary, $24 \mathrm{mi}$. to Nation River, $26 \mathrm{mi}$. NNE of that stream's junc. with Yukon River and $50 \mathrm{mi}$. N of Eagle, Porcupine Plat.; $65^{\circ} 30^{\prime} 30^{\prime \prime} \mathrm{N}, 141^{\circ} 13^{\prime} 00^{\prime \prime} \mathrm{W}$; $B G N$ 1954; (map 103).

So named in 1910 by IBC survey, because of the heavy growth of vegetation in its valley.
Juninggulra Mountain: mountain, 1,830 ft., in Kuskokwim Mts., extends SW $6 \mathrm{mi}$. from Crooked Creek, $9 \mathrm{mi}$. NW of its junc. with Kuskokwim River, $42 \mathrm{mi}$. NW of Sleetmute, Kilbuck-Kuskokwim Mts.; $61^{\circ} 57^{\prime} \mathrm{N}, 158^{\circ} 22^{\prime}$ W; BGN 1945; (map 72). Var. Ju-ninggul'ra.

Native name, said to mean "crosswise" referring to its orientation to the course of Crooked Creek; reported in 1944 by USGS.

Junior Creek: stream, see Juneau Creek.

Juniper Creek: stream, flows NW $5 \mathrm{mi}$. to Chatanika River, $32 \mathrm{mi}$. NE of Fairbanks, YukonTanana High.; $65^{\circ} 13^{\prime} \mathrm{N}, 147^{\circ} 04^{\prime} \mathrm{W}$; (map 105).

Local name published in 1907 by USGS.

Juniper Creek: stream, heads in Brooks Ra. at $69^{\circ} 03^{\prime} \mathrm{N}, 146^{\circ} 23^{\prime} \mathrm{W}$, flows NW $70 \mathrm{mi}$. to join Shaviovik River, Arctic Plain; $69^{\circ} 40^{\prime} \mathrm{N}, 147^{\circ}$ $45^{\prime}$ W; BGN 1959; (map 140). Var. Shaviovik River.

Named in 1947 by G. P. Gryc, USGS for "rare growth of juniper along this stream." This is the only evergreen north of the Brooks Range.

Juniper Island: nunatak, $2.5 \mathrm{mi}$. long, at junc. of Jefferies and Tana Glaciers, $10 \mathrm{mi}$. $\mathrm{N}$ of Mount Miller and $37 \mathrm{mi}$. N of Cape Yakataga, Chugach Mts.; $60^{\circ} 36^{\prime} \mathrm{N}, 142^{\circ} 22^{\prime} \mathrm{W}$; $B G N$ 1960; (map 65).

Local name given by prospectors who crossed the Chugach Mts. between 1904 and 1907. The name was derived from the coniferous shrub which comprises the most conspicuous element of the scant vegetation on the nunatak. The name was reported by USGS in 1913.

Junjick River: stream, see Junjik River.

Junjik River: stream, flows SE $65 \mathrm{mi}$. to East Fork Chandalar River, 6 mi. $\mathrm{N}$ of Arctic Village, Brooks Ra.; $68^{\circ} 13^{\prime} \mathrm{N}, 145^{\circ} 28^{\prime} \mathrm{W}$; (map 136). Var. Junjick River.

Kutchin Indian name obtained in 1926 by J. B. Mertie, USGS.

Junken, Cape: point of land, on SE coast of Kenai Penin., at mouth of Puget Bay, 32 mi. $\mathrm{SE}$ of Seward, Chugach Mts.; $59^{\circ} 55^{\prime} \mathrm{N}$, $148^{\circ} 38^{\prime} \mathrm{W}$; (map 49).

Local name reported in 1908 by U. S. Grant, USGS.

Junnaka: stream, see Koyukuk River.

Junock River: stream, see Unuk River.

Juno Mountain: mountain, 2,600 ft., on Revillagigedo I., $2 \mathrm{mi}$. $\mathrm{N}$ of Ketchikan, Alex. Arch.; $55^{\circ} 23^{\prime} 15^{\prime \prime} \mathrm{N}, 131^{\circ} 40^{\prime} 20^{\prime \prime} \mathrm{W}$; (map 3 ).

This is one of several names given in 1883 by Lt. Comdr. Nichols, USN, which were suggested by classical mythology. Juno was an an ancient Italian (Roman) goddess, the wife of Jupiter.

Junuk River: stream, see Unuk River.

Jussila Creek: stream, flows SW $4 \mathrm{mi}$. to Noyes Slough, $2 \mathrm{mi}$. NW of Fairbanks, Tanana

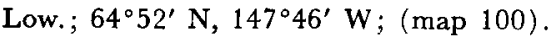

Named for Yrjo Henry Jussila, a homesteader in the area. Jussila was born in Aberdeen, Wash., in 1907 and in his youth came to Alaska where he was employed by the
Alaska RR. He died in Arizona in 1948. The name is of Finnish origin and means "John's place." The name was published in 1955 by USGS.

Justamere Ranch: area, in NE part of Anchorage, between Lawrence and Wonder Park, Cook Inlet Low.; $61^{\circ} 13^{\prime} 13^{\prime \prime} \mathrm{N}, 149^{\circ} 47^{\prime} 35^{\prime \prime} \mathrm{W}$; (map 69).

Local name reported in 1954 by the city engineer of Anchorage.

Justice Creek: stream, in Glacier Bay National Monument, heads on S slope of Mount Escures, flows $6 \mathrm{mi}$. SW to Gulf of Alaska, $4 \mathrm{mi}$. $\mathrm{NW}$ of mouth of Fourmile Creek, $94 \mathrm{mi}$. NW of Hoonah, Malaspina Coastal Plain; 58 $42^{\prime}$ $50^{\prime \prime} \mathrm{N}, 137^{\circ} 46^{\prime} 30^{\prime \prime} \mathrm{W}$; BGN 1962; (map 10). Var. Voss Creek.

So named by NPS in 1961 because it is the locale of a story by Jack London titled "The Unexpected," in which justice was provided by two prospectors who in the absence of judicial law, tried and executed a third person for a double murder. The story is based on an actual occurrence that happened in the vicinity of the creek.

Justice Creek: stream, flows SW $2 \mathrm{mi}$. to Baituk Creek, $11 \mathrm{mi}$. E of Cape Prince of Wales and $44 \mathrm{mi}$. NW of Teller, Seward Penin. High.; $65^{\circ} 34^{\prime} \mathrm{N}, 167^{\circ} 43^{\prime} \mathrm{W}$; (map 111). Var. Justida Creek.

Prospectors' name published in 1966 by USGS. Shown as "Justida Creek" on the 1908 "Map of Seward Peninsula" by Arthur Gibson.

Justida Creek: stream, see Justice Creek.

Just Island: island, $0.8 \mathrm{mi}$. long, in Fillmore Inlet, at entrance to Willard Inlet, Coast Mts.; $54^{\circ} 48^{\prime} 45^{\prime \prime} \mathrm{N}, 130^{\circ} 37^{\prime} 45^{\prime \prime} \mathrm{W}$; (map 2).

Named in 1899 by USC\&GS.

Jute Bay: bight, $4.3 \mathrm{mi}$. across, on $\mathrm{E}$ coast of Alaska Penin., $50 \mathrm{mi}$. W of Karluk, Aleutian Ra.; $57^{\circ} 32^{\prime} 30^{\prime \prime} \mathrm{N}, 155^{\circ} 51^{\prime} 00^{\prime \prime} \mathrm{W}$; (map 35).

Local name obtained from J. L. McPherson of Iliamna, reported in 1903, and published by G. C. Martin (1905, pl. 6), USGS.

Jute Creek: stream, on E coast of Alaska Penin., flows SE $2.5 \mathrm{mi}$. to Island Bay, $50 \mathrm{mi}$. W of Karluk, Aleutian Ra.; $57^{\circ} 34^{\prime} 40^{\prime \prime} \mathrm{N}, 1^{\circ}{ }^{\circ}$ $49^{\prime} 30^{\prime \prime} \mathrm{W}$; (map 35).

Local name obtained from J. L. McPherson of Iliamna; published by G. C. Martin (1921, pl. 10), USGS.

Jute Islands: islands, two, extending $0.6 \mathrm{mi}$. in Jute Bay, on E coast of Alaska Penin., 51 mi. $\mathrm{W}$ of Karluk, Aleutian Ra.; $57^{\circ} 33^{\prime} 00^{\prime \prime} \mathrm{N}$, $155^{\circ} 50^{\prime} 30^{\prime \prime} \mathrm{W}$; (map 35).

Local name reported in 1904 by G. C. Martin, USGS.

Jute Peak: peak, 2,037 ft., on E coast of Alaska Penin., $8 \mathrm{mi}$. SSW of Cape Aklek and $48 \mathrm{mi}$. $\mathrm{W}$ of Karluk, Aleutian Ra.; $57^{\circ} 34^{\prime} 30^{\prime \prime} \mathrm{N}$, $155^{\circ} 45^{\prime} 30^{\prime \prime} \mathrm{W}$; (map 35).

Local name obtained from J. L. McPherson of Iliamna; published by G. C. Martin (1921, pl. 10), USGS

Jut Ridge: ridge, trends $0.5 \mathrm{mi}$. $\mathrm{N}$ toward Bering Sea, on southwestern Kiska I., Aleutian Is.; $51^{\circ} 54^{\prime} 15^{\prime \prime} \mathrm{N}, 177^{\circ} 14^{\prime} 00^{\prime \prime} \mathrm{E}$; (map 14). 
An arbitrary name beginning with " $J$ " to correspond to the "J" grid used by the U.S. Army for tactical purposes during World War II; published on a 1953 AMS map.

JW, Mys: point of land, see Munoz, Point.

J. Woods Creek: stream, see Woods Creek.

\section{$\mathbf{K}$}

Kaaktovik: village, see Kaktovik.

Kaaktovik Island: island, see Barter Island.

Kabakof Bay: bay, see Kobakof Bay.

Kabakovskaia Bay: bay, see Kobakof Bay.

Kabkag: village, see Kalskag.

Kabuch Point: point of land, on $\mathrm{E}$ shore of Isanotski Strait, at head of Ikatan Bay, Aleutian Ra.; $54^{\circ} 49^{\prime} 00^{\prime \prime} \mathrm{N}, 163^{\circ} 21^{\prime} 30^{\prime \prime} \mathrm{W}$; (map 25). Var. Alaska Cape, Khaboutcha, Khabuch.

Aleut name published by Capt. Lutke (1836, p. 295), IRN, as "Khaboutcha." This point was also shown by Capt. Tebenkov (1852, map 24), IRN, as M[ys] Khabutch or Khabutch Cape, and by USC\&GS in 1882 as Khabucha Point on Ghart 806.

Kachauik, Mount: mountain, 2,089 ft., $10 \mathrm{mi}$. SW of Mount Arathlatuluk and $49 \mathrm{mi}$. NE of Solomon, Seward Penin. High.; $64^{\circ} 46^{\prime} \mathrm{N}$, $162^{\circ} 51^{\prime} \mathrm{W}$; (map 95).

Local name reported on the 1908 "Map of Seward Peninsula" by Arthur Gibson.

Kachauik Creek: stream, flows SW $16 \mathrm{mi}$. to Golovnin Lagoon, $5 \mathrm{mi}$. NW of Golovin and 40 mi. E of Solomon, Seward Penin. High.; $64^{\circ}$ $36^{\prime} \mathrm{N}, 163^{\circ} 07^{\prime} \mathrm{W}$; BGN 1910; (map 95). Var. Kachauik River.

This is an Eskimo name published on the 1908 "Map of Seward Peninsula" by Arthur Gibson.

Kachauik River: stream, see Kachauik Creek.

Kachegaret: locality, "at Port Clarence," Seward Penin. High.; (map 111).

Former Eskimo camp or settlement listed in the 1890 Census (p. 162).

Kachekmak Bay: bay, see Kachemak Bay.

Kachemach Mound: pingo, elev. $50 \mathrm{ft}$., $2.5 \mathrm{mi}$. E of Colville River and $13 \mathrm{mi}$. S of Harrison Bay, Arctic Plain; $70^{\circ} 10^{\prime} 10^{\prime \prime} \mathrm{N}, 150^{\circ} 38^{\prime} 15^{\prime \prime}$ W; (map 149).

Named in 1951 by Abraham and George Woods, an Eskimo father and his son, who have lived in this area most of their lives. The name was derived from that of the nearby river.

Kachemach River: stream, flows N $35 \mathrm{mi}$. to Colville River Delta, 11 mi. S of Harrison Bay; Arctic Plain; $70^{\circ} 20^{\prime} 40^{\prime \prime} \mathrm{N}, 150^{\circ} 40^{\prime} 00^{\prime \prime} \mathrm{W}$; (map 149).

Eskimo name reported in 1950 by USG\&GS ; the meaning is unknown.

Kachernak: village, pop. 43, on Kenai Penin., near Homer; (map 50).

Village incorporated in 1961.

Kachemak Bay: bay, $8 \mathrm{mi}$. wide and $40 \mathrm{mi}$. long, on SW coast of Kenai Penin., between Seldovia and Homer, Chugach Mts.; $59^{\circ} 35^{\prime} \mathrm{N}, 151^{\circ} 52^{\prime}$ W; BGN Sixth Report; (map 50). Var. Bai Tschugatschik oder Kotschekmaksky, Bukhta
Kachetmakskaya, Chugachik Bay, High Cliff Bay, Kachekmak Bay, Zaliv Chugachik, Zaliv Chugachik ili Kochekmak.

Native name published in 1847 as "Z[aliv] Chugachik ili Kochekmak" or "Chugachik or Kochekmak Bay" on Russian Hydrog. Dept. Chart 1378. According to W. H. Dall, USC\&GS, "Ka means water, chek means cliff, and mak is an intensive suffix meaning high, great, large * *."

Kachemak Glacier: glacier, trends SW $3.5 \mathrm{mi}$. from ice field in Kenai Mts. to its terminus, $32 \mathrm{mi}$. ENE of Homer, Chugach Mts.; 59 $9^{\circ}$ $43^{\prime} \mathrm{N}, 150^{\circ} 38^{\prime} \mathrm{W}$; (map 50).

Named for Kachemak Bay and reported by USGS (Martin and others, 1915, pl. 2).

Kachetmakskaya, Bukhta: bay, see Kachemak Bay.

Kachiginskaia: bay, see Kashega Bay.

Kachiksuk Bluffs: bluff, on S shore of Elson Lagoon, $2 \mathrm{mi}$. W of Christie Point, $26 \mathrm{mi}$. SE of Barrow, Arctic Plain; $71^{\circ} 11^{\prime} \mathrm{N}, 155^{\circ} 39^{\prime} \mathrm{W}$; (map 153)

Eskimo name recorded at Barrow in 1951 by USC\&GS and reported to mean "high bluffs."

Kachkahin River: stream, see Chilkoot River. Kach-Khanna: island, see Wrangell Island.

Kachutok: locality, see Kashutuk.

Kachwona Creek: stream, flows NE $10 \mathrm{mi}$., to North Fork Koyukuk River at Gates of the Arctic, $37 \mathrm{mi}$. NW of Wiseman, Brooks Ra.; $67^{\circ} 50^{\prime} 45^{\prime \prime} \mathrm{N}, 150^{\circ} 53^{\prime} 30^{\prime \prime} \mathrm{W}$; (map 124).

Probably named for an Eskimo girl of the Wiseman area. Marshall (1956, p. 83), in describing a Fourth of July celebration in Wiseman, wrote, "The big feature * * was dancing. We started at six-thirty on the evening of July 4, and at eleven next morning four Eskimo girls, Kaaruk, Ashuwaruk, Kayak, and Kachwona, were still going strong * * *"

Kackhanna, Ostrov: island, see Wrangell Island.

Kacrowtuk Lake: lake, $2 \mathrm{mi}$. long, $6 \mathrm{mi}$. SW of Selawik, Kotzebue-Kobuk Low.; $66^{\circ} 34^{\prime}$ N, $160^{\circ} 13^{\prime}$ W; (map 114). Var. Kakrotat Lake.

Eskimo name obtained in 1955 by U.S. Army Corps of Engineers.

Kadak Bay: bay, see Kadake Bay.

Kadak Creek: stream, see Kadake Creek.

Kadake Bay: bay, extends E $2 \mathrm{mi}$. to Keku Strait, W of Port Camden, on NE coast of Kuiu I., $44 \mathrm{mi}$. W of Petersburg, Alex. Arch.; $56^{\circ} 48^{\prime} 20^{\prime \prime} \mathrm{N}, 133^{\circ} 57^{\prime \prime} 20^{\prime \prime}$ W, BGN 1966; (map 6). Var. Kadak Bay.

Local name published in 1960 by USFS.

Kadake Creek: stream, flows E $12 \mathrm{mi}$. to Kadake Bay, on $\mathrm{E}$ coast of Kuiu I., Alex. Arch.; 56 . $47^{\prime} \mathrm{N}, 133^{\circ} 59^{\prime} \mathrm{W}$; (map 6). Var. Kadak Greek.

Local name published in 1943 by USC\&GS

Kadakina Creek: stream, flows W $13 \mathrm{mi}$. from Taclodahten Lake to Kanuti River, $25 \mathrm{mi}$. SE of Allakaket, Kanuti Flats; $66^{\circ} 16^{\prime} 30^{\prime \prime} \mathrm{N}$, $152^{\circ} 06^{\prime} 00^{\prime \prime} \mathrm{W}$; (map 117).

Koyukuk Indian name obtained in 1956 at Allakaket by T. E. Taylor, USGS.
Kadakina Lake: lake, $1.2 \mathrm{mi}$. long, drains $\mathrm{E}$ to Kadakina Creek, $28 \mathrm{mi}$. SE of Allakaket, Kanuti Flats; $66^{\circ} 18^{\prime} \mathrm{N}, 151^{\circ} 54^{\prime} \mathrm{W}$; (map 117).

Koyukuk Indian name obtained in 1956 at Allakaket by T. E. Taylor, USGS.

Kadashan Bay: bay, $1 \mathrm{mi}$. across, on $\mathrm{S}$ shore of Tenakee Inlet, on Chichagof I., 4 mi. S of Tenakee Springs, Alex. Arch.; $57^{\circ} 43^{\prime} \mathrm{N}$, $135^{\circ} 13^{\prime}$ W; BGN 1929; (map 9). Var. Big Bay.

Named in 1929 by USFS, "for Paul K. Kadashan, an Indian, who applied for this land as a homestead in 1915." The local descriptive name is "Big Bay."

Kadiak: town, see Kodiak.

Kadiak Cove: bay, see Camp Coogan Bay.

Kadiak Island: island, see Kodiak Island.

Kadiak Rock: rock, see Kodiak Rock.

Kadi Creek: stream, flowing N $2.5 \mathrm{mi}$. to Bering Sea, $3.2 \mathrm{~m}$. W of Cape Idak on NE tip of Umnak I., Aleutian Is.; $53^{\circ} 31^{\prime} \mathrm{N}, 167^{\circ} 52^{\prime}$ W; (map 23).

Name published by USGS (in Byers, 1959 pl. 41). This name may have been derived from the Aleutian word "kadigukuq," meaning "it stands against; it is in front of" (in Geoghegan, 1944, p. 112), and have been shortened for cartographic convenience.

Kadilotden: locality, see Khadilotden.

Kadin, Point: point of land, on NW coast of Unalaska I., Aleutian Is.; $53^{\circ} 55^{\prime} 25^{\prime \prime} \mathrm{N}$, $167^{\circ} 04^{\prime} 15^{\prime \prime}$ W ; BGN 1938; (map 23). Var. Makushin Cape.

This point was first reported as Makushin Cape by USBF in 1888. It was named Point Kadin by USC\&GS and published in the 1938 Coast Pilot (pt. 2, supp., p. 41). Kadin Island: island, $2 \mathrm{mi}$. long, in mouth of Stikine River, $4 \mathrm{mi}$. NW of Wrangell, Alex. Arch.; $56^{\circ} 32^{\prime} \mathrm{N}, 132^{\circ} 27^{\prime} \mathrm{W}$; (map 6).

Named in 1863 by surveyors from the Russian corvette Rynda for the pilot M. M. Kadin, a native of the Aleutian Islands, who was also a member of this surveying party and who drew the charts in the Tebenkov atlas in Sitka in 1848-50.

Kadischle: glacier, see Norris Glacier.

Kadishan's Village: locality, "on Stikine River," in SE Alaska, Coast Mts.

Former Stikine summer camp "of a chief named 'Katishan'" (Hodge, 1907, p. 638); listed with a population of 27 by Ivan Petroff in the 1880 Census.

Kaditskaya Bay: bay, see Birdsnest Bay.

Kadjak Island: island, see Kodiak Island.

Kadleroselik Mound: pingo, see Kadleroshilik Mound.

Kadleroselik River: stream, see Kadleroshilik River.

Kadleroshilik Mound: pingo, elev. $200 \mathrm{ft}$., on Kadleroshilik River, 12 mi. S of Foggy I., Bay, and $47 \mathrm{mi}$. SE of Beechey Point, Arctic Plain; (map 150). Var. Kadleroselik Mound.

This pingo was used as a triangulation station by Leffingwell $(1919$, p. 40,96$)$ in 1911. Eskimo name reported to mean "pos- 
sesses something on top" or "which seems to approach."

Kadleroshilik River: stream, heads at $69^{\circ} 22^{\prime} \mathrm{N}$, $147^{\circ} 34^{\prime} \mathrm{W}$, flows N $90 \mathrm{mi}$. to Foggy I. Bay, $41 \mathrm{mi}$. SE of Beechey Point, Arctic Plain; $70^{\circ} 12^{\prime} 25^{\prime \prime} \mathrm{N}, 147^{\circ} 37^{\prime} 15^{\prime \prime} \mathrm{W}$; (map 150). Var. Kalegosilik River, Kadleroselik River, Kadleroshulio River.

Named by Leffingwell (1919, p. 96) "after the mound of the same name."

Kadleroshulio River: stream, see Kadleroshilik River.

Kadruakvik Creek: stream, flows NW $3.7 \mathrm{mi}$. to Killik River $3 \mathrm{mi}$. SW of its junc. with Easter Creek, Brooks Ra.; $68^{\circ} 07^{\prime} \mathrm{N}, 154^{\circ} 14^{\prime} \mathrm{W}$; (map 133).

Eskimo name reported in 1956 by T. E. Taylor, USGS.

Kadugin: islands, see Pavlof Islands.

Kadugnak: point of land, see Kudugnak, Cape. Kadyak Island: island, see Kodiak Island.

Kadyakskaya, Bukhta: bay, see Camp Coogan Bay.

Kaetkunax Mountain: hill, see Kitkonak Hill. Kafla Golfe: bay, see Kaflia Bay.

Kaflia, Baie: bay, see Kaflia Bay.

Kaflia Bay: bay, extends W $5.5 \mathrm{mi}$. from Cape Ugyak, on E coast of Alaska Penin., in Katmai National Monument, $30 \mathrm{mi}$. E of Mount Katmai, Aleutian Ra.; $58^{\circ} 15^{\prime} \mathrm{N}, 154^{\circ} 07^{\prime} \mathrm{W}$; (map 42). Var. Baie Kaflia, Kafla Golfe, Zaliv Kaflya.

Named "Kaflia," from the Dutch "Kafel," in 1831 by Ens. Vasiliev, IRN; published in 1847 as "Z[aliv] Kaflya" on Russian Hydrog. Dept. Chart 1378.

Kaflya, Zaliv: bay, see Kaflia Bay.

Kagai Island: island, one of Shumagin Is., Aleutian Ra.; $55^{\circ} \mathrm{N}, 160^{\circ} \mathrm{W}$; (map 26$)$.

Named by Lt. Sarichev (1826, map 3), IRN, and shown as lying southwest of Nagai Island by Adm. von Krusenstern (1827, map 20), IRN. The island cannot be identified at the present time.

Kagakaglik Bank: bluff, on $\dot{N}$ bank of Wulik River, $8 \mathrm{mi}$. NE of Kivalina, KotzebueKobuk Low.; $67^{\circ} 48^{\prime} \mathrm{N}, 164^{\circ} 18^{\prime} \mathrm{W}$; (map 128). Var. Kahgakaglick, Qaagaqaglik.

Eskimo name meaning "there is 'Eskimo spinach" " reported in 1966 by E. S. Burch.

Kagak Cove: cove, $0.2 \mathrm{mi}$. across, $\mathrm{SE}$ shore of Kanaga Bay, SE Kanaga I., Aleutian Is.; $51^{\circ} 42^{\prime} 30^{\prime \prime} \mathrm{N}, 177^{\circ} 11^{\prime} 20^{\prime \prime} \mathrm{W}$; (map 17).

Name published in 1957 on an AMS map.

Kagak Unimak: island, see Cherni Island.

Kagalaksa Island: island, see Kagalaska Island.

Kagalaska Island: island, $10 \mathrm{mi}$. long, one of Andreanof Is., Aleutian Is., $51^{\circ} 48^{\prime} \mathrm{N}$, $176^{\circ} 21^{\prime} \mathrm{W} ; B G N$ 1936; (map 17). Var. Kagalaksa Island.

Aleut name published by Lutke (1835, p. 321). The Russians published it as "O[strov] Kagalaksa," or "Kagalaksa Island" (Tebenkov, 1852, map 28).

Kagalaska Strait: water passage, between Kagalaksa and Adak Is., Aleutian Is.; $51^{\circ} 48^{\prime} \mathrm{N}$, $176^{\circ} 25^{\prime} \mathrm{W} ; B G N$ 1936; (map 17).
Name derived from Kagaiaska Island, given by members of the U.S. Navy Aleutian Island Survey Expedition in 1934.

Kagalga: island, see Tigalda Island.

Kagalgin Island: island, see Uliaga Island.

Kagalis: point of land, see Kagalus, Cape.

Kagalogh: point of land, see Tolstoi Point.

Kagaluk Lake: lake, $8 \mathrm{mi}$. long, $3 \mathrm{mi}$. SE of Kagahasuk Lake and $58 \mathrm{mi}$. W of Bethel, Yukon-Kuskokwim Delta; $60^{\circ} 51^{\prime} \mathrm{N}, 163^{\circ} 30^{\prime}$ W; (map 58).

Eskimo name reported in 1949 by USC\&GS.

Kagalurpak Lake: lake, $7 \mathrm{mi}$. across, $15 \mathrm{mi}$. NW of Kagaluk Lake and $80 \mathrm{mi}$. W of Bethel, Yukon-Kuskokwim Delta; $60^{\circ} 55^{\prime} \mathrm{N}, 164^{\circ} 00^{\prime}$ W; (map 58).

Eskimo name reported in 1949 by USC\&GS to mean "river's end."

Kagalus, Cape: point of land, SE tip of Chugul I., Aleutian Is.; 51 ${ }^{\circ} 55^{\prime} 10^{\prime \prime} \mathrm{N}, 1^{\prime} 5^{\circ} 45^{\prime} 40^{\prime \prime}$ W; BGN 1936; (map 18). Var. Kagalis.

Possibly an Aleut name published as "M[ys] Kagalus" or "Cape Kagalus" by Capt. Tebenkov (1852, map 28), IRN.

Kagamila Island: island see Kagamil Island.

Kagamiliakh Island: island, see Kagamil Island. Kagamiliak Island: island, see Kagamil Island. Kagamil Island: island, $6.2 \mathrm{mi}$. long, one of Islands of Four Mountains, Aleutian Is.; $53^{\circ} 00^{\prime} \mathrm{N}, 169^{\circ} 43^{\prime} \mathrm{W}$; (map 21, 22). Var. Chamil Island, Chuginok Island, Kagamila Island, Kagamiliak Island, Kagamiliakh Island, Khogamil Island, Ostrov Kigalga.

Aleut name applied to this island by Capt. Tebenkov (1852, map 25), IRN. This island was calied "O[strov] Chuginok" or "Chuginok Island" by Lt. Sarichev (1826, map 3), IRN, and "O[strov] Kigalga," or "Kigalga Island," by the Russian Hydrog. Dept. (1847, Chart 1379). See Chuginidak and Four Mountains, Islands of.

Kagamil Pass: water passage, between Chuginadak and Kagamil Is., Aleutian Is.; $52^{\circ} 55^{\prime} \mathrm{N}$, $169^{\circ} 44^{\prime} \mathrm{W}$; (map 21).

Name derived from Kagamil Island and published by USC\&GS in 1944 Aleutian Coast Pilot (p. 72).

Kagankagati Lake: lake, $3.3 \mathrm{mi}$. long, at head of Kuttak River, $11 \mathrm{mi}$. SE of village of Scammon Bay, Yukon Kuskokwim Delta; $61^{\circ} 43^{\prime} \mathrm{N}, 165^{\circ} 18^{\prime} \mathrm{W}$; (map 75). Var. Kagankaguti Lake, Kegum Kagati.

Eskimo name reported by USC\&GS in 1951, which may mean "the source."

Kagankaguti Lake: lake, see Kagankagati Lake. Kagan Lake: lake, see Togiak Lake.

Kaga Point: point of land, on SW coast of Kagalaska I., Aleutian Is.; $51^{\circ} 44^{\prime} 20^{\prime \prime} \mathrm{N}$, $176^{\circ} 23^{\prime} 40^{\prime \prime} \mathrm{W}$; BGN 1936; (map 17).

A clipped name derived from Kagalaska Island, and given by members of the U.S. Navy Aleutian Island Survey Expedition in 1934.

Kagati Lake: lake, $4 \mathrm{mi}$. long, connected at its $\mathrm{W}$ end to Pegati Lake, $2 \mathrm{mi}$. N of Nuklunek Mtn., $75 \mathrm{mi}$. NE of Goodnews, Kilbuck-Kus- kokwim Mts.; $59^{\circ} 52^{\prime} \mathrm{N}, 160^{\circ} 05^{\prime} \mathrm{W}$; (map 53). Var. Kanektuk Lake.

Eskimo name, meaning "source," reported in 1898 by J. E. Spurr and W. S. Post, USGS. The lake is a source of Kanektuk River.

Kagati Lake: lake, see Pegati Lake.

Kagavik River: stream, see Topagoruk River. Kagayan Flats: marsh, $2.5 \mathrm{mi}$. across, between Cape Aliaksin and mainland, $10 \mathrm{mi}$. $\mathrm{N}$ of Unga I., near SW end of Alaska Penin., Aleutian Ra.; $55^{\circ} 31^{\prime} 30^{\prime \prime} \mathrm{N}, 160^{\circ} 48^{\prime} 00^{\prime \prime} \mathrm{W}$; (map 28).

Published by USC\&GS in 1916 Coast Pilot (p. 166).

Kagboo Creek: stream, flows S $6.5 \mathrm{mi}$. to Squirrel River, $\mathrm{N}$ of Kiana Hills, $15 \mathrm{mi}$. NW of Kiana, Brooks Ra.; 67 $07^{\prime} \mathrm{N}, 160^{\circ} 51^{\prime} \mathrm{W}$; (map 127).

Eskimo name obtained in 1955 by U.S. Army Corps of Engineers.

Kageehok, Cape: promontory, $2 \mathrm{mi}$. E of Gambell, on NW tip of Saint Lawrence I.; $63^{\circ}$ $47^{\prime} \mathrm{N}, 171^{\circ} 41^{\prime} \mathrm{W}$; (map 93). Var. Kagihok Point.

Eskimo name reported in 1949 by Maj. Allen, USAF.

Kaghasuk Lake: lake, $14 \mathrm{mi}$. long, $\mathrm{N}$ of Baird Inlet, and $65 \mathrm{mi}$. W of Bethel, Yukon-Kuskokwim Delta; $60^{\circ} 53^{\prime} \mathrm{N}, 163^{\circ} 42^{\prime} \mathrm{W}$; (map 58).

GS

Kaghkaghamute: locality, see Kakamut.

Kagh-Kasalik, Cape: point of land, see Tikugha Point.

Kaghkasalik, Cape: point of land, see Kaghkusalik Point.

Kagh-Kasslik, Cape: point of land, see Tikugha Point.

Kaghkusalik Point: point of land, at mouth of Muknuk River, $12 \mathrm{mi}$. SW of Savoonga, N coast of St. Lawrence 1.; $63^{\circ} 36^{\prime} \mathrm{N}, 170^{\circ}$ 48' W; BGN 1951; (map 93). Var. Cape Kaghkasalik, Kakhkasalik.

Eskimo name recorded by Orth, in 1965, as "Kakhkasalik" and refers to the "top of the head" or "crown." The name was published in 1932 as Cape Kagh-kasalik by the Univ. of Alaska.

Kaghoopalik Point: point of land, $7 \mathrm{mi}$. S of Gambell, W coast of St. Lawrence I.; $63^{\circ}$.

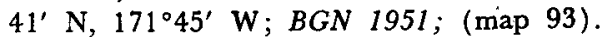
Var. Cape Kaghoopalik, Cape Kaghoopaulik, Cape Kakhupalik.

Eskimo name often written "Kakhupalik" and means "brow-like." The name was published by the Univ, of Alaska in 1932.

Kaghoopaulik, Cape: point of land, see Kaghoopalik Point.

Kagiaktak Creek: stream, see Kahgeatak Creek.

Kagigikak, Cape: point of land, on $\mathbf{S}$ coast of Adak I., Aleutian Is.; $51^{\circ} 37^{\prime} 40^{\prime \prime} \mathrm{N}, 176^{\circ}$ $43^{\prime} 20^{\prime \prime}$ W; BGN 1936; Var. Cape Kagigikhnach, Kagigikhakh, Mys.

Aleut name published by the Russians as "M[ys] Kagigikhakh," or "Cape Kagigikhakh" (Tebenkov, 1852, map 28). 
Kagigikhakh, Mys : point of land, see Kagigikak, Cape.

Kagigikhnach, Cape: point of land, see Kagigikak, Cape.

Kagigun Islands: islands, see Shumagin Islands.

Kagihok Point: promontory, see Kageehok, Cape.

Kagiluak Bight: cove, $1.3 \mathrm{mi}$. across, indents SE shore of Demarcation Bay, $3.5 \mathrm{mi}$. S of Demarcation Point, Arctic Plain; 69 $38^{\prime} \mathrm{N}$, $141^{\circ} 16^{\prime} \mathrm{W}$; (map 138).

Eskimo name recorded in 1952 by USC\&GS.

Kagiluak Creek: stream, flows $5.5 \mathrm{mi}$. NW to Kagiluak Bight, $4 \mathrm{mi}$. S of Demarcation Point, Arctic Plain; $69^{\circ} 38^{\prime} \mathrm{N}, 141^{\circ} 15^{\prime} \mathrm{W}$; (map 138).

Eskimo name recorded in 1952 by USC\&GS.

Kagloogrock: locality, see Kaglugrak Deep.

Kaglugrak Deep: locality, deep place in Wulik River, $2.5 \mathrm{mi}$. NE of Kivalina, KotzebueKobuk Low.; $67^{\circ} 44^{\prime}$ N, $164^{\circ} 27^{\prime}$ W; (map 128). Var. Kagloogrock, Kaglugzaaq.

Eskimo name meaning "old deep place" reported in 1966 by E. S. Burch.

Kaglugzaaq: locality, see Kaglugrak Deep.

Kagluik, Mount: mountain, see Ikagluik, Mount.

Kagnik: locality, see Kangik.

Kagokakat: locality, "on rightbank of Yukon River." Var. Kagokhakat, Khatnotoutze.

Former Eskimo camp or settlement reported in 1843 as "Kagokhakat," with a population of 9 , by Lt. L. A. Zagoskin, IRN; listed as "Katnotoutze" with a population of 115 by Ivan Petroff in 1880 Census.

Kagokhakat: locality, see Kagokakat.

Kagueruh Creek: stream, see Kagueruk Creek.

Kagueruk Creek: stream, on Seward Penin., flows NW $9 \mathrm{mi}$. to Arctic Lagoon, $47 \mathrm{mi}$. NW of Teller, Kotzebue-Kobuk Low.; 65 ${ }^{\circ} 53^{\prime} \mathrm{N}$, $167^{\circ} 01^{\prime} \mathrm{W}$; (map 111). Var. Kagueruh Creek, Kue-wark River.

Eskimo name published in 1956 by USGS. Reported as "Kue-wark River" on the precinct map of Seward Peninsula by Monroe and Hutchins, corrected to June 1903 by Arthur Gibson.

Kaguiak: village, see Kaguyak.

Kaguk Cove: bay, $2.2 \mathrm{mi}$. long, on $W$ coast of Prince of Wales I., 2 mi. E of Point Swift and $20 \mathrm{mi}$. NW of Craig, Alex. Arch.; $55^{\circ}$ $45^{\prime} 15^{\prime \prime} \mathrm{N}, 133^{\circ} 16^{\prime} 15^{\prime \prime} \mathrm{W}$; (map 4).

Indian name recorded in 1949 by USGS.

Kagusuk Cave: cave, on $\mathrm{N}$ slope of Mount Umagatsiak, $16 \mathrm{mi}$. N of Kivalina, Arctic Slope; $67^{\circ} 57^{\prime} \mathrm{N}, 164^{\circ} 35^{\prime} \mathrm{W}$; (map 128). $V a r$. Kahgowsuk, Qaagusuk.

According to E. S. Burch in 1966, this cave is famous in Eskimo folklore. Here Shamans were supposed to obtain their magical powers. Most of the roof has reportedly collapsed.

Kaguyak: village, at head of Kaguyak Bay, on SE coast of Kodiak I.; $56^{\circ} 51^{\prime} 40^{\prime \prime} \mathrm{N}, 153^{\circ}$. $46^{\prime} 00^{\prime \prime}$ W; BGN 1890; (map 33). Var. Aleutsk Selen Kaniyagmyut, Alsentia, Kaguiak, Kaniag-miut, Kayayak, Naouchkak.

Native name reported in 1880 as "Kaguiak" by Petroff $(1881$, p. 31$)$. This village may be "Aleutsk Selen Kaniyagmyut," meaning "Aleut village of Kaniyagmyut"; reported by the Russian American Company in 1849. In 1868 USC\&GS recorded the name "Alsentia." Kaguyak: locality, site of village on NE coast of Alaska Penin., in Katmai National Monument, $3.5 \mathrm{mi}$. $\mathrm{N}$ of Cape Chiniak, $44 \mathrm{mi}$. NE of Mount Katmai, Aleutian Ra.; 58 $34^{\prime}-$ $05^{\prime \prime} \mathrm{N}, 153^{\circ} 53^{\prime} 55^{\prime \prime} \mathrm{W}$; (map 43). Var. Douglass, Kaiayakak, Kayayak, Naouchkak.

Name publishd in 1884 by USC\&GS on Chart 960. This abandoned settlement was called "Kaiayakak" by Capt. Lutke (1836, p. 275), IRN, and "Seleniye Kayayak," "Kryayak Village," by Tebenkov (1852, map 22). In 1890, the U.S. Census Bureau called it "Douglass, after Cape Douglas" [sic] (Baker, 1906, p. 341).

Kaguyak, Cape: point of land, $3 \mathrm{mi}$. NE of Kaguyak, on SE coast of Kodiak I. ; 56 $52^{\circ} 30^{\prime \prime}$ $\mathrm{N}, 153^{\circ} 41^{\prime} 30^{\prime \prime} \mathrm{W}$; (map 33).

Name derived from village of Kaguyak; published in 1943 by USC\&GS.

Kaguyak Bay: bay, $1.5 \mathrm{mi}$. across, at Kaguyak, on SE coast of Kodiak I.; $56^{\circ} 53^{\prime}$ N, $153^{\circ} 43^{\prime}$ W; (map 33). Var. Alsentia Bay, Sbichsak Bay, Svikhchak Golfe.

Name derived from village of Kaguyak; published in 1943 by USC\&GS. This bay was called "Svikhchak" by Capt. Lutke (1835, p. 275), IRN, and was reported as "Z[aliv] Svikhshak" or "Svikhshak Bay," by Capt. Tebenkov in 1849. The name "Alsentia" was given to the bay in 1888 by USBF.

Kaguyal Crater: crater, $1.6 \mathrm{mi}$. across, near $\mathrm{S}$ coast of Alaska Penin., in Katmai National Monument, $40 \mathrm{mi}$. NE of Mount Katmai, Aleutian Ra.; 58 $37^{\prime} \mathrm{N}, 154^{\circ} 03^{\prime} \mathrm{W}$; (map 42). Var. Kaguyak Volcano.

Named in 1951 by USGS after the Eskimo village of "Kaguyak," now abandoned.

Kaguyak Volcano: crater, see Kaguyak Crater.

Kagvik Creek stream, in De Long Mts., flows SE $22 \mathrm{mi}$. to Kugururok River, $8 \mathrm{mi}$. NW of Misheguk Mtn., Brooks Ra.; 68 ${ }^{\circ} 17^{\prime} \mathrm{N}, 161^{\circ}$ $26^{\prime}$ W ; (map 131).

Eskimo name reported by USGS in 1956. Kahate River: stream, see Katete River.

Ka-hehe: stream, see Karheen Creek.

Kahgakaglick: bluff, see Kagakaglik Bank.

Kahgeatak Creek: stream, flows NW $7.5 \mathrm{mi}$. to Chukchi Sea at mouth of Amatusuk Creek, 7 mi. NE of Cape Beaufort and $48 \mathrm{mi}$. SW of Point Lay, Arctic Plain; $69^{\circ} 05^{\prime} 30^{\prime \prime} \mathrm{N}, 163^{\circ}$ 38'15" W; (map 145). Var. Kagiaktak Creek, Tolookuk Creek, Tolukak Creek.

Eskimo name reported by USC\&GS in 1949. The name "Kahgeatak" seems to be the same name as "Kahkatak," which is applied to a nearby stream.

Kahgowsuk: cave, see Kagusuk Cave.

Kah-Hehe: stream, see Karheen Creek.

Kahilitna Glacier: glacier, see Kahiltna Glacier. Kahilitna River: stream, see Kahiltna River.

Kahiltna Dome: peak, 12,525 ft., W of Kahiltna Glacier, between Mount Crosson and Mount Capps, $7.4 \mathrm{mi}$. W of summit of Mount Mc-

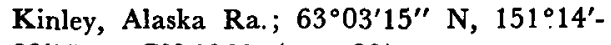
00" W; BGN 1960; (map 88).

Name reported in 1960 by Bradford Washburn.

Kahiltna Glacier: glacier, heads in icefield between Mount Foraker and Mount Hunter, trends S $30 \mathrm{mi}$. to head of Kahiltna River, 5 mi. $\mathbf{E}$ of Chelatna Lake and $35 \mathrm{mi}$. NE of Talkeetna, Alaska Ra.; $62^{\circ} 29^{\prime} \mathrm{N}, 151^{\circ} 15^{\prime}$ W; BGN 1911; (map 81). Var. Car-ilt-nu Glacier, Kahlitna Glacier, Kahilitna Glacier.

Tanaina Indian name reported in 1899 by Lt. J. S. Herron (1901, p. 45 and map), USA, as "Car-ilt-nu." The present spelling was published by Adolph Knopf and Sidney Paige (in Brooks and others, 1906, p. 118), USGS. Kahiltna Notch: pass, 11,960 ft., between East and Northeast Forks of Kahiltna Glacier, 1.9 mi. SW of summit of Mount McKinley, Alaska Ra.; $63^{\circ} 02^{\prime} 40^{\prime \prime} \mathrm{N}, 151^{\circ} 02^{\prime} 00^{\prime \prime} \mathrm{W}$; (map 88).

Mountain climbers' name published in 1954 by USGS.

Kahiltna Pass: pass, 10,400 ft., between Peters Basin and Kahiltna Glacier, E of Mount Capps and $5.4 \mathrm{mi}$. W of summit of Mount McKinley, Alaska Ra.; $63^{\circ} 05^{\prime} \mathrm{N}, 151^{\circ} 10^{\prime} \mathrm{W}$; (map 88).

Mountain climbers' name published in 1954 by USGS.

Kahiltna Peaks: peaks, W peak 12,835 ft., E peak 13,440 ft., SW of summit of Mount McKinley, between Northeast Fork and East Fork Kahiltna Glacier, Alaska Ra.; 63 ${ }^{\circ} 01^{\prime}$ $45^{\prime \prime} \mathrm{N}, 151^{\circ} 06^{\prime} 00^{\prime \prime} \mathrm{W}$; (map 88).

Mountain climbers' name published in 1954 by USGS.

Kahiltna River: stream, heads at Kahiltna Glacier at $62^{\circ} 27^{\prime} 45^{\prime \prime} \mathrm{N}, 151^{\circ} 12^{\prime} 30^{\prime \prime} \mathrm{W}$, flows SE $60 \mathrm{mi}$. to Yentna River, $53 \mathrm{mi}$. NW of Anchorage, Cook Inlet Low.; 61 $51^{\prime} 10^{\prime \prime} \mathrm{N}$, 150 46'45" W; BGN 1911; (map 70). Var. Cariltnu River, Kahilitna River, Kahlitna River, Kalidtna River, Kariltna River.

Tanaina Indian name reported in 1899 by Lt. Herron (1901, p. 45 and map), USA, as "Car-ilt-nu."

Present spelling was published by Adolph Knopf and Sidney Paige (in Brooks and others, 1906, p. 118), USGS.

Kahin: stream, see Karheen Creek.

Kahin: water passage, see Karheen Passage.

Kahini: stream, see Karheen Creek.

Kahini: water passage, see Karheen Passage.

Kahkatak Creek: stream, flows NW $7.5 \mathrm{mi}$. to Chukchi Sea at Cape Beaufort, $54 \mathrm{mi}$. SW of Point Lay, Arctic Plain; $69^{\circ} 02^{\prime} \mathrm{N}, 163^{\circ} 50^{\prime} \mathrm{W}$; (map 145). Var. Kahkatak River, Kukeatak River.

Chapman and Sable (1960, p. 53), USGS, state that this name was obtained from USC\&GS. It is the Eskimo name for Cape Beaufort.

Kahkatak River: stream, see Kahkatak Creek. Kahlchatlan: locality, "in SE Alaska," Coast Mts.

According to J. R. Swanton (in Hodge, 
1907, p. 641), BAE, this locality was "A town occupied by the Stikine [Indians] before moving to *** Wrangell * * *."

Kahlgiksuk: stream, see Kalgiksuk Creek.

Kah-lig-y-nak: village, see Koliganek.

Kahlitna Glacier: glacier, see Kahiltna Glacier.

Kahlitna River: stream, see Kahiltna River.

Kahltog: village, see Kaltag.

Kahlukhtughamiut: locality, see Kaluktuk.

Kahmiut: locality, "in the Kuskokwim district." Former Eskimo camp or settlement listed with a population of 40 in the 1890 Census.

Kahnicula Glacier: glacier, see Kanikula Glacier.

Kahnirukmiut: locality, $18 \mathrm{mi}$. SW of Cape Etolin, on N coast of Nunivak I.; $60^{\circ} 18^{\prime} 31^{\prime \prime}$ $\mathrm{N}, 166^{\circ} 36^{\prime} 10^{\prime \prime} \mathrm{W}$; (map 57). Var. Kanirak, Kanirakmiut.

Eskimo village, now abandoned, reported in 1949 by USC\&GS. Name refers to "people [village] in the corner [of the cove]."

Kahniruk River: stream, flows NW $8 \mathrm{mi}$. to Bering Sea at Kahnirukmiut, $18 \mathrm{mi}$. SW of Cape Etolin, on $\mathrm{N}$ coast of Nunivak I.; $60^{\circ}$ $18^{\prime} 31^{\prime \prime} \mathrm{N}, 166^{\circ} 36^{\prime} 10^{\prime \prime} \mathrm{W}$; (mape 57). Var. Kanirak Creek.

Eskimo name meaning "corner [of the cove]" reported in 1949 by USC\&GS.

Kahshagnak, Mount: mountain, 5,670 ft., in Takshanuk Mts., 2 mi. W of mouth of Chilkoot River, in Chilkoot Lake and $15 \mathrm{mi}$. SW of Skagway, Coast Mts. ; $59^{\circ} 22^{\prime} 40^{\prime \prime}$ N, $135^{\circ} 41^{\prime}$ $30^{\prime \prime} \mathrm{W}$; (map 45). Var. Cathedral Peak.

Local name reported by E. C. Robertson, geologist, and published in 1952 by USGS. It was called Cathedral Peak by the IBC (1923, map 9).

Kah Shakes: locality, on shore of Kah Shakes Cove, near entrance to Boca de Quadra, Coast Mts.; $55^{\circ} 02^{\prime} 30^{\prime \prime} \mathrm{N}, 130^{\circ} 58^{\prime} 30^{\prime \prime} \mathrm{W}$; (map 3). Var. Kah Shakes Cove, Kashs Village.

Former Tlingit Indian village named for Kah Shakes, the chief of the village; published as "Kah Shakes Cove," in the 1890 Census (p. 25). In the 1880 Census Petroff (1884, p. 32) reported "Kashs Village," pop. 49, located here, and "Shakes Village," pop. 38, on nearby Etolin Island. See Shakes Village.

Kah Shakes Cove: estuayy, extends E $0.7 \mathrm{mi}$., off Revillagigedo Channel, $1.4 \mathrm{mi}$. S of $\mathrm{Kah}$ Shakes Point, Coast Mts.; $55^{\circ} 02^{\prime} 40^{\prime \prime} \mathrm{N}, 130^{\circ}$. 59'15' W; (map 3).

Named for the chief of a Tlingit Indian village at the northern point of entrance to this feature. (See Kah Shakes: locality).

Kah Shakes Cove: locality, see Kah Shakes.

Kah Shakes Creek: stream, heads at Kah Shakes Lake, flows SW $1.5 \mathrm{mi}$. to Kah Shakes Lagoon, Coast Mts.; $55^{\circ} 02^{\prime} 30^{\prime \prime} \mathrm{N}, 130^{\circ} 58^{\prime} 35^{\prime \prime} \mathrm{W}$; (map 3).

Local name reported in 1901 by Comdr. J. F. Moser, USN.

Kah Shakes Lagoon: lagoon, extends $1.2 \mathrm{mi}$. from NE end of Kah Shakes Cove to mouth of Kah Shakes Creek, Coast Mts. ; 55 $02^{\prime} 25^{\prime \prime} \mathrm{N}$, $130^{\circ} 58^{\prime} 45^{\prime \prime} \mathrm{W}$; (map 3 ).

Local name reported in 1901 by Lt. Comdr. J. F. Moser, USN.
Kah Shakes Lake: lake, $0.8 \mathrm{mi}$. across, drains into Kah Shakes Cove on Revillagigedo Channel, SW of South Quadra Mtn., Coast Mts.; $55^{\circ} 03^{\prime} 30^{\prime \prime} \mathrm{N}, 130^{\circ} 56^{\prime} 15^{\prime \prime} \mathrm{W}$; BGN 1962; (map 3).

Local name reported in 1901 by Lt. Comdr. J. F. Moser, USN.

Kah Shakes Point: point of land, $\mathrm{S}$ point of entrance to Boca de Quadra, Coast Mts.; $55^{\circ}$ $04^{\prime} 50^{\prime \prime} \mathrm{N}, 130^{\circ} 59^{\prime} 20^{\prime \prime} \mathrm{W}$; (map 3).

Local navigators' name obtained in 1904 by $\mathrm{H}$. C. Fassett, USBF ; derived from village of Kah Shakes.

Kah Sheets Bay: bay, extends SE $2.5 \mathrm{mi}$. to Sumner Strait, on $S$ coast of Kupreanof I., 22 mi. SW of Petersburg, Alex. Arch.; 56 $6^{\circ} 31^{\prime} \mathrm{N}$, $133^{\circ} 06^{\prime} \mathrm{W}$; (map 6).

Tlingit Indian name obtained from local navigators; reported in 1904 by $H$. C. Fassett, USBF. See Kah Sheets Creek.

Kah Sheets Creek: stream, heads in Kah Sheets Lake, flows SE $2.5 \mathrm{mi}$. to Kah Sheets Bay, 21 mi. SW of Petersburg, on $S$ coast of Kupreanof I., Alex. Arch.; $56^{\circ} 31^{\prime} 50^{\prime \prime} \mathrm{N}, 133^{\circ} 08^{\prime} 25^{\prime \prime} \mathrm{W}$; (map 6).Var. Kah-Sheets Creek.

Tlingit Indian name given "by the fisheries" and reported in 1897 by J. F. Moser, USN, as "Kah-Sheets Creek." See Kah Sheets Bay.

Kah Sheets Island: island, $0.5 \mathrm{mi}$. long, in Kah Sheets Bay at mouth of Duncan Canal, $21 \mathrm{mi}$. SW of Petersburg, on S coast of Kupreanof $I$., Alex. Arch.; $56^{\circ} 31^{\prime} 00^{\prime \prime} \mathrm{N}, 133^{\circ} 05^{\prime} 30^{\prime \prime} \mathrm{W}$; $B G N$ 1933; (map 6).

Local name reported in 1933 by R. H. Sargent, USGS. See Kah Sheets Creek.

Kah Sheets Lake: lake, $1.5 \mathrm{mi}$. long, $20 \mathrm{mi}$. SW of Petersburg, on $S$ coast of Kupreanof $I$., Alex. Arch.; $56^{\circ} 33^{\prime} 30^{\prime \prime} \mathrm{N}, 133^{\circ} 12^{\prime} 00^{\prime \prime} \mathrm{W}$; (map 6). Var. Kah-Sheets Lake.

Tlingit Indian name "given by the fisheries" and reported in 1897 by J. F. Moser, USN, as "Kah-Sheets Lake."

Kahsitsnah: bay, see Kasitsna Bay.

Kahtete River: stream, see Katete River.

Kahuntla, Lake: lake, $0.7 \mathrm{mi}$. long, $1.5 \mathrm{mi}$. SW of Katalla, Malaspina Coastal Plain; 60 $0^{\circ} 11^{\prime}$ $\mathrm{N}, 144^{\circ} 34^{\prime} \mathrm{W}$; (map 64)

Indian name reported in 1903 by G. C. Martin, USGS.

Kahurnoi, Gape: point of land, see Kekurnoi, Cape.

Kahwateta Mountain: mountain, see Iron Mountain.

Kahwaytetay Mountain: mountain, see Iron Mountain.

Kaiakak: locality, "on right bank of Yukon River, below Nulato," Nulato Hills; (map 97).

Former Eskimo village listed with a population of 134 by Ivan Petroff in the 1880 Census.

Kaiak Cape: point of land, see Kayak Cape.

Kaiakishvigmiut: villages, see Utukok villages.

Kaiak Island: island, see Kayak Island.

Kaiaksekawik: locality, "on the $\mathrm{N}$ side of Icy Cape," Arctic Plain; (map 146). Var. Kayakshigvikg.
Former Eskimo camp or settlement reported by Lt. L. A. Zagoskin, IRN, in 1847 as "Kayakshigvikg," meaning "place for making Kayaks" (Hodge, 1907, p. 641).

Kaiaksuk Mountain: mountain, see Kayaksak Mountain.

Kaialigumiut: locality, see Kaialik.

Kaialik: locality, "in Yukon delta," YukonKuskokwim Delta. Var. Kaialigumiut, Kailwigamiut, Kialigamiut.

Former Eskimo camp or settlement reported in 1878 by E. W. Nelson, U.S. Signal Service. Ivan Petroff listed it as "Kaialigumiut," with a population of 100 , in the 1880 Census; it was listed as "Kailwigamiut" and "Kiligamiut," with a population of 157 in the 1890 Census.

Kaianak, Cape: point of land, see Battery Point. Kaiasik: island, one of Shumagin Is.; $55^{\circ} \mathrm{N}$, $160^{\circ} \mathrm{W}$; (map 27). Var. Kassik.

This Aleut name was applied by Father Veniaminov (1840, v. 1, p. 265), who described the island as high and rocky. Capt. Lutke (1836, p. 267) called it "Kassik." We are unable to identify the island at the present time.

Kaiayakak: locality, see Kaguyak.

Kaichali Island: island, see Kaiuchali Island.

Kaigahnee: point of land, see Muzon, Cape.

Kai-gah-nee Harbors: bays, see Kaigani Harbors.

Kai-gah-nee Point: point of land, see Kaigani Point.

Kaigahnee Strait: water passage, see Kaigani Strait.

Kaiganee: point of land, see Muzon, Cape.

Kaigani: locality, site of summer camp or village of Haida Indians, at SE end of Dall I., Alex. Arch.; $54^{\circ} 40^{\prime} 40^{\prime \prime} \mathrm{N}, 132^{\circ} 40^{\prime} 40^{\prime \prime} \mathrm{W}$; $B G N$ 1954; (map 1).

Haida Indian name given in 1880 by Sheldon Jackson. J. R. Swanton, BAE, says "Kaigani ***A A division of the Haida *** Their name is derived from that of a camping place or summer settlement where they were accustomed to assemble to meet incoming vessels and to trade with the whites. The Kaigani emigrated from the NW end of Queen Charlotte Is. between 150 and 200 years ago [early 1700's], drove the Tlingit (Koluschan) from the $S$ end of Prince of Wales I., and took possession of their towns. The most important of these settlements were Sukwan, Klinkwan, Howkan, and Kasaan, which bear their old Tlingit names * * Like many Tlingit tribes, but unlike other Haida, the Kaigani subdivisions took their names from the name given to some individual house * * *" (Hodge, 1907, p. 642). The villages of Howkan, Klinkwan, and Sukkwan were absorbed in the late 1800 's by the former village of Kaigani which, in turn, was abandoned in 1911 when the village of Hydaburg was established in order to centralize the school system. See Howkan, Klinkwan, and Sukkwan.

Kaigani: point of land, see Muzon, Cape. 
Kaigani Harbors: bays, collective name for North, Middle and South Kaigani Harbors, on SE Coast of Dall I., Alex. Arch.; 54 ${ }^{\circ} 45^{\prime} 30^{\prime \prime}$ N, $132^{\circ} 43^{\prime} 00^{\prime \prime} \mathrm{W}$; (map 1). Var. Kai-gahnee Harbors.

Haida Indian name recorded by A. $K$. Etolin in 1833 as "Gavan Kaigan," or "Kaigan Harbor"; published on Russian Hydrog. Dept. Chart 1396 in 1848. USC\&GS published the name "Kai-gah-nee Harbors", for these bays in the 1883 Coast Pilot (p. 66), and referred to them as North Harbor, Middle Harbor (South Harbor since 1932), and South Harbor (Datzkoo Harbor since 1932). See Datzkoo Harbor, North Harbor and South Harbor.

Kaigani Point: point of land, SW tip of Long I., Alex. Arch.; $54^{\circ} 45^{\prime} 10^{\prime \prime} \mathrm{N}, 132^{\circ} 39^{\prime} 10^{\prime \prime} \mathrm{W}$; (map 1). Var. Kai-gah-nee Point.

Name derived from Kaigani Strait and published by USC\&GS in the 1883 Alaska Coast Pilot (p. 67) as "Kai-gah-nee Point."

Kaigani Strait: water passage, extends SE 22 mi. from Tlevak Strait to mouth of Cordova Bay between Dall and Long Is., Alex. Arch.; $54^{\circ} 52^{\prime} \mathrm{N}, 132^{\circ} 48^{\prime} \mathrm{W}$; BGN 1939; (map 1). Var. Howkan Strait, Kaigahnee Strait, Kaigan Strait, Port Liscome.

Haida Indian name reported by A. K. Etolin as "Kaigan" in 1833. This appears to be the Port Liscome shown on a 1792 map by Joseph Ingraham (Wagner, 1937, p. 359).

Kaigani Strait: water passage, see Dixon Entrance.

Kaigan Strait: water passage, see Kaigani Strait.

Kaigao Cove: bay, $0.4 \mathrm{mi}$. long, in Naukati Bay on $W$ coast of Prince of Wales I., $30 \mathrm{mi}$. $\mathrm{N}$ of Craig, Alex. Arch.; $55^{\circ} 53^{\prime} 15^{\prime \prime} \mathrm{N}, 133^{\circ} 10^{\prime}$. $00^{\prime \prime} \mathrm{W}$; (map 4).

Indian name published in 1964 by USC\&GS.

Kaigo Point: point of land, on $W$ coast of Prince of Wales I., between Kaigao and Kaikli Coves, $30 \mathrm{mi}$. N of Craig, Alex. Arch.; 55 $53^{\prime} 05^{\prime \prime} \mathrm{N}$, $133^{\circ} 10^{\prime} 10^{\prime \prime} \mathrm{W}$; (map 4).

Indian name published in 1964 by USC\&GS.

Kaikli Cove: bay, $1 \mathrm{mi}$. long, off Naukati Bay, $28 \mathrm{mi}$. N of Craig, Alex. Arch.; $55^{\circ} 53^{\prime} \mathrm{N}$, $133^{\circ} 10^{\prime} \mathrm{W}$; (map 4$)$

Indian name recorded in 1949 by USGS.

Kaikshak Hill: mountain, 4,600 ft., E of Killik River, 10 mi. SE of Lake Udrivik, Brooks Ra.; $68^{\circ} 22^{\prime} \mathrm{N}, 153^{\circ} 50^{\prime} \mathrm{W}$; (map 133).

Eskimo name reported in 1956 by T. E. Taylor, USGS.

Kaiku Creek: stream, see Kako Creek.

Kailwigamiut: locality, see Kaialik.

Kaina Creek: stream, heads in glacier, flows $\mathrm{N}$ $34 \mathrm{mi}$. to Tazlina Lake, $3.4 \mathrm{mi}$. NE of mouth of Mendelina Creek and $60 \mathrm{mi}$. N of Valdez, Copper River Basin; 61 $59^{\prime} 10^{\prime \prime} \mathrm{N}, 146^{\circ} 18^{\prime}$ 50" W; (map 68).

Local name published on a 1917 USGS map.

Kaina Lake: lake, $8 \mathrm{mi}$. long, on Kaina River, $4.4 \mathrm{mi}$. W of St. Anne Lake and $51 \mathrm{mi}$. $\mathrm{N}$ of
Valdez, Chugach Mts.; 61 $51^{\prime} 00^{\prime \prime}$ N, $146^{\circ}$ $11^{\prime} 35^{\prime \prime} \mathrm{W}$; (map 68).

Local name published on a 1932 USGS map.

Kaisana: islands, see Kasiana Islands.

Kaishi Point: point of land, on $\mathrm{W}$ coast of Prince of Wales $\mathrm{I}$., $\mathrm{N}$ point of entrance to Naukati Bay, $28 \mathrm{mi}$. N of Craig, Alex. Arch.; $55^{\circ} 51^{\prime} 40^{\prime \prime} \mathrm{N}, 133^{\circ} 12^{\prime} 00^{\prime \prime} \mathrm{W}$; (map 4).

Indian name recorded in 1949 by USGS.

Kaiuchali Island: island, $500 \mathrm{ft}$. across, $1 \mathrm{mi}$. SW of Biorka I. and $18 \mathrm{mi}$. SW of Sitka, Alex. Arch.; 56 $50^{\circ} 00^{\prime \prime} \mathrm{N}, 135^{\circ} 33^{\prime} 50^{\prime \prime} \mathrm{W}$; (map 5). Var. Kaichali Island, Ostrov Kayu-chali.

Tlingit Indian name; reported in 1809 by Ivan Vasiliev the first, IRN; published by Lt. Sarichev (1826, map 19), IRN, as "O[strov] Kayu-chali," or "Kayu-chali Island."

Kaiugnak Bay: bay, extends W $8 \mathrm{mi}$. off Sitkalidak Strait, on SE coast of Kodiak I.; $57^{\circ} 02^{\prime}$ N, $153^{\circ} 30^{\prime} \mathrm{W}$; (map 34). Var. Zaliv Kayugnak.

Aleut name published as " $Z$ [aliv] Kayugnak," or "Kayugnak Bay," by Capt. Tebenkov (1852, map 23) and is perhaps derived from the word "quayuq" which, according to R. H. Geoghegan, means "berry."

Kaiuklipalik Island: island, see Kiukaplik Island.

Kaiulik Bay: bay, see Kujulik Bay.

Kaiyak: locality, see Kayak.

Kaiyak, Lake: lake, $1 \mathrm{mi}$. long, in Kugururok River Valley, in De Long Mts., $10 \mathrm{mi}$. SW of Misheguk Mtn., Brooks Ra.; $68^{\circ} 09^{\prime} \mathrm{N}, 161^{\circ}$ 26' W; (map 131).

Eskimo name reported by the U.S. Army Corps of Engineers about 1955, probably referring to the one-man canoe.

Kaiyuh Mountains: range, elev. 1,000-2,844 ft., $E$ of Yukon River, extends NE $145 \mathrm{mi}$. from Holikachuck Slough, Kilbuck-Kuskokwim Mts. ; $63^{\circ} 55^{\prime} \mathrm{N}, 158^{\circ} 30^{\prime} \mathrm{W}$; (map 90). Var. Kayuh Mts., Takaitsky.

Name reported in 1866 by Dall (1870, $p$. 53) who stated that they were named for the Ingalik Indian group who live in the flats between the mountains and the Yukon River, known as "Kaiyuhkatána" meaning "lowland people." Dall also said that the Russian name for the mountains is "Takaitsky."

Kaiyuh Slough: stream, flows SE $23 \mathrm{mi}$. to Khotol River, $19 \mathrm{mi}$. SE of Nulato, Koyukuk Low.; $64^{\circ} 26^{\prime}$ N, $157^{\circ} 57^{\prime}$ W; (map 97). Var. Kayakh, Kutulnakht.

Indian name obtained in 1866 by $W . H$. Dall $(1870$, p. 282), USC\&GS. Father Julius Jetté states that the name "Kayakh" was applied to the mountains, and the slough took its name from the mountains. The Indians here were referred to as the "Kaiyah-kho-tana" (p. 431).

Kajulik River: stream, see Kejulik River.

Kajutakrok Creek: stream, flows N $10 \mathrm{mi}$. to Camden Bay, $3 \mathrm{mi}$. E of Sadlerochit River and $15 \mathrm{mi}$. SW of Barter I., Arctic Plain; $70^{\circ} 01^{\prime}$ $50^{\prime \prime}$ N, $144^{\circ} 17^{\prime} 45^{\prime \prime} \mathrm{W}$; (map 151).

Eskimo name reported by USGS in 1956.

Kaka: locality, see Kakamut.

Kakachtoli: watercourse, see Kakahkituli Pass.
Kakagin Inlet: bay, see Basket Bay.

Kakagrak Hills: hills, $930 \mathrm{ft}$, in Igichuk Hills, extend $6 \mathrm{mi}$. S of Kilikmak Creek, on Chukchi Sea coast, $10 \mathrm{mi}$. N of Cape Krusenstern, Arctic Slope; $67^{\circ} 18^{\prime} \mathrm{N}, 163^{\circ} 39^{\prime} \mathrm{W}$; BGN 1962; (map 128). Var. Kakarak Hills, Kakaruk Hills, Kugakrak Mountains, Kukagruk Mountains.

Eskimo name obtained in 1950 by USC\&GS.

Kakahkituli Pass: watercourse, in distributary system of Yukon River, trends NW $15 \mathrm{mi}$. from Kwiguk Pass to Norton Sound, YukonKuskokwim Delta ; $62^{\circ} 51^{\prime} 15^{\prime \prime} \mathrm{N}, 164^{\circ} 50^{\prime} 00^{\prime \prime}$ W; (map 77). Var. Kakachtol.

Eskimo name recorded in 1899 as "Kakachtoli" by G. R. Putnam, USC\&GS; published in 1901 on Chart 9373.

Kakamiut: locality, see Kakamut.

Kakamut: locality, on $\mathbf{N}$ bank on Yukon River $15.5 \mathrm{mi}$. SW of Russian Mission, Yukon-Kuskokwim Delta; $61^{\circ} 37^{\prime} 30^{\prime \prime} \mathrm{N}, 161^{\circ} 40^{\prime} 30^{\prime \prime} \mathrm{W}$; (map 73). Var. Kaghkaghamute, Kaka, Kakamiut, Kochkogamute, Kochkomut, Koko, Kokok.

Eskimo name reported by Capt. C. W. Raymond, USA, in 1869, as "Kochkogamute." USC\&GS called it "Kochkomut" in 1898. This was a small settlement in 1916, consisting of about three cabins. It has the same number today.

Kakangina: stream, see Muddy Creek.

Kakanhini Creek: stream, see Muddy Creek.

Kakan River: stream, see Muddy Greek.

Kakarak Hills: hills, see Kakagrak Hills.

Kakaruk Hills: hills, see Kakagrak Hills.

Kakatkusik: point of land, see Sarichef Cape.

Kake: village, pop. 455, on NW coast of Kupreanof I., Alex. Arch.; 56 $58^{\prime} 30^{\prime \prime}$ N, 133 $56^{\prime} 30^{\prime \prime}$ W; BGN 1944; (map 6). Var. Kekou, Keku, Keq, Klukwan, S'îkanaxsā'nî, S'ikanakhse'ni.

Tlingit Indian village named for the Kake tribe living there. The original local village name was "S'ikanakhse'ni" reported to possibly mean "from a black bear town" (Hodge, 1907 , p. 644). Fishing and canning are the economic base of the town. The population was 234 in $1890 ; 232$ in $1910 ; 387$ in 1920 ; 386 in $1930 ; 419$ in 1939 ; and 376 in 1950 . The Kake post office was established in 1904 (Ricks, 1965, p. 30).

Kakechik Bay: bay, see Kokechik Bay.

Kakechik River: stream, see Kokechik River.

Kake Cove: estuary, trends S $0.6 \mathrm{mi}$., on SE tip of Chenega I., W of Knight Island Passage, $1.5 \mathrm{mi}$. E of Chenega, Chugach Mts.; $60^{\circ} 16^{\prime}$ $40^{\prime \prime} \mathrm{N}, 148^{\circ} 01^{\prime} 50^{\prime \prime} \mathrm{W}$; (map 63).

Name published in 1950 by USGS.

Kake Strait: water passage, see Keku Strait. Kakh: island, see Kak Island.

Kakhachukalik Island: island, see Kaksajookalik Island.

Kakhkasalik: point of land, see Kaghkusalik Point.

Kakhlyakhlyakakat: locality, at mouth of Gisasa River, on left bank of Koyukuk River, Koyukuk Low.; $65^{\circ} 16^{\prime} \mathrm{N}, 157^{\circ} 39^{\prime} \mathrm{W}$; (map 108). 
Koyukan Indian name obtained in 1842 by Lt. L. A. Zagoskin, IRN; applied to a camp or village.

Kakhlyakhlyakakat: locality, see Kakliaklia.

Kakhonak: village, pop. 57, on S shore of Iliamna Lake, $23 \mathrm{mi}$. S of Iliamna, Aleutian Ra.; $59^{\circ}$ $26^{\prime} \mathrm{N}, 154^{\circ} 45^{\prime} \mathrm{W}$; BGN 1911; (map 51). Var. Kakonak, Kokhanok, Kokonak, Kokonok.

Eskimo village, with a population of 28 , listed in 1890 Census by A. B. Schanz.

Kakhonak Bay: bay, 2 mi. wide, at $\mathrm{E}$ end of Iliamna Lake, $21 \mathrm{mi}$. SE of Iliamna, Aleutian Ra.; 59 $28^{\prime}$ N, $154^{\circ} 43^{\prime}$ W; BGN 1911; map 51). Var. Kakonak Bay, Kokhanok Bay, Kokonok Bay, Kokonuk Bay.

Eskimo name reported in 1891 by A. B. Schanz; derived from village of Kakhonak on the shore of the bay.

Kakhonak Lake: lake, $12 \mathrm{mi}$. long, $10 \mathrm{mi}$. N of Bruin Bay, $27 \mathrm{mi}$. NW of Augustine I., Aleutian Ra.; $59^{\circ} 30^{\prime} \mathrm{N}, 154^{\circ} 15^{\prime} \mathrm{W}$; $B G N$ 1911; (map 51). Var. Kakonak.

Name used by local prospectors; reported in 1909 by G. C. Martin, USGS. The name is derived from the nearby village of Kakhonak.

Kakhonak River: stream, heads at Kakhonak Lake, flows SW $6 \mathrm{mi}$. to Kakhonak Bay, 38 mi. W of Augustine I., Aleutian Ra.; 59 ${ }^{\circ} 7^{\prime}$ N, $154^{\circ} 29^{\prime}$ W ; BGN 1911; (map 51). Var. Kakonak River, Kokhanok River, Kokonok River.

Eskimo name reported in 1891 by A. B. Schanz. See Kakhonak.

Kakhtolinat, Mount: peak, see Katolinat, Mount.

Kakhtul River: stream, flows NW $20 \mathrm{mi}$. to Mulchatna River, $86 \mathrm{mi}$. NE of Dillingham, Bristol Bay Low.; 59 $51^{\prime}$ N, $156^{\circ} 40^{\prime}$ W ; (map 52). Var. Estu-y-a-rok, Kakhtut, Kokhtuli, Swan Creek, Swan River.

Eskimo name reported in 1890 as "Kokhtuli," meaning "woods," by A. B. Schanz in Frank Leslie's Illustrated Newspaper. The river was spelled "Kakhtul" on the 1890 Census map. It was called "Kakhtut" in 1898 by USC\&GS. W. H. Osgood (1904a, map), USDA, published it as the "Kakhtul River." More recent maps show the lower part as "Swan River."

Kakhtut: stream, see Kakhtul River.

Kakhuiyagamute: locality, see Kakuiak.

Kakhupalik, Cape: point of land, see Kaghoopalik Point.

Kakhvalga Island: island, see Kavalga Island.

Kakiagun Lake: lake, $0.5 \mathrm{mi}$. across, between Anaktuvuk and Colville Rivers, $19 \mathrm{mi}$. NE of Umiat, Arctic Plain; $69^{\circ} 29^{\prime} \mathrm{N}, 151^{\circ} 25^{\prime} \mathrm{W}$; (map 141).

Eskimo name reported in 1956 by T. E. Taylor, USGS.

Ka-ki-ak-tu-dli-ok: lake, $4 \mathrm{mi}$. $\mathrm{N}$ of Okstukuk Lake and $39 \mathrm{mi}$. $\mathrm{N}$ of Dillingham, Bristol Bay Low.; $59^{\circ} 34^{\prime} \mathrm{N}, 158^{\circ} 16^{\prime} \mathrm{W}$; (map 52).

Eskimo name reported in 1910 by $\mathrm{H}$. C. Fassett, USBF; said to mean "plenty coho" (silver salmon).
Kak Island: island, $0.3 \mathrm{mi}$. across, in Pacific Ocean, $1.7 \mathrm{mi}$. S of Nakchamik I. and $22 \mathrm{mi}$. E of Chignik, Aleutian Ra.; $56^{\circ} 17^{\prime} \mathrm{N}, 157^{\circ}$ 49' W; (map 31). Var. Kak Islet, Kakh, Katch Island, Rocky Island.

Eskimo name reported by Capt. Tebenkov (1852, map 22), IRN.

Kak Islet: island, see Kak Island.

Kakivilak Creek: stream, flows SE $17 \mathrm{mi}$. to Killik River $17 \mathrm{mi}$. SW of its junc. with Easter Creek, Brooks Ra.; $68^{\circ} 01^{\prime} \mathrm{N}, 154^{\circ} 44^{\prime}$ W; (map 133).

Eskimo name meaning "no nostrils," reported in 1956 by T. E. Taylor, USGS.

Kakkhlyakhlyakakat: locality, see Kakliaklia.

Kakliakhliakat: locality, see Kakliaklia.

Kakliaklia: locality, "on the Koyukuk River." Var. Kakhlyakhlyakakat, Kakkhlyakhlyakakat, Kakliakhliakat, Kakliakliakat, Kikliakliakakate.

Former Eskimo camp or settlement reported in $1842-44$ as "Kakhlyakhlyakakat" by Lt. L. A. Zagoskin, IRN.

Kakliakliakat: locality, see Kakliaklia.

Kaklik Naitka Greek: stream, flows NE $5 \mathrm{mi}$. to Colville River $3 \mathrm{mi}$. S of its junc. with Killik River, Brooks Ra.; $68^{\circ} 58^{\prime} \mathrm{N}, 153^{\circ} 56^{\prime} \mathrm{W}$; (map 133).

Eskimo name reported in 1956 by T. E. Taylor, USGS.

Kaklongegek Creek: stream, heads in a lake, and flows SE $4 \mathrm{mi}$. to Koozata Lagoon, 35 mi. SE of Gambell, Saint Lawrence I.; $63^{\circ} 27^{\prime}$ N, $170^{\circ} 51^{\prime}$ W; BGN 1951; (map 93).

Eskimo name recommended by the Gambell village council; reported in 1949 by Maj. H. B. Allen, USAF.

Kakna Lake: lake, $0.5 \mathrm{mi}$. long, on Kenai Penin. NE of Fire Lake, W of Skilak Lake and 25 mi. SE of Kenai, Cook Inlet Low.; $60^{\circ} 27^{\prime} \mathrm{N}$, $150^{\circ} 33^{\prime} \mathrm{W}$; (map 62).

Named about 1963 by officials of the Kenai National Moose Range, for administrative purposes.

Kaknau Creek: stream, in Glacier Bay National Monument, flows S $7 \mathrm{mi}$. to Palma Bay in Gulf of Alaska, $63 \mathrm{mi}$. NW of Hoonah, St. Elias Mts.; $58^{\circ} 24^{\prime} 00^{\prime \prime} \mathrm{N}, 137^{\circ} 04^{\prime} 30^{\prime \prime} \mathrm{W}$; $B G N 1930$; (map 10).

Tlingit Indian name suggested by USC\&GS in 1929. This is the name of an Indian village mentioned by Krause $(1956$, p. 75 ), located in this valley. The word "kaknáu" is reported to mean "grouse foot."

Kaknu Lake: lake, see Skilak Lake.

Kaknu River: stream, see Kenai River.

Kakny: stream, see Kenai River.

Kako: locality, see Kako Landing.

Kako Creek: stream, heads in Ilivit Mts., flows SW $30 \mathrm{mi}$. to Yukon River E of Arctic Island and $5 \mathrm{mi}$. $\mathrm{N}$ of Russian Mission, YukonKuskokwim Delta ; $61^{\circ} 51^{\prime} 30^{\prime \prime} \mathrm{N}, 161^{\circ} 19^{\prime} 50^{\prime \prime}$ W; (map 73). Var. Kaiku Creek.

Eskimo name shown on a 1916 field sheet by R. H. Sargent, USGS, as "Kaiku," although the name was published as "Kako," (Harrington, 1918, map).
Kako Lake: lake, $1 \mathrm{mi}$. long, at mouth of Kako Creek $4.8 \mathrm{mi}$. N of Russian Mission, YukonKuskokwim Delta ; $61^{\circ} 51^{\prime} 25^{\prime \prime} \mathrm{N}, 161^{\circ} 20^{\prime} 30^{\prime \prime}$ W; (map 73).

Local name reported by U.S. Army Corps of Engineers in 1952.

Kako Landing: locality, on $\mathrm{S}$ shore of Kako Lake $4.7 \mathrm{mi}$. N of Russian Mission, YukonKuskokwim Delta ; $61^{\circ} 51^{\prime} 15^{\prime \prime} \mathrm{N}, 161^{\circ} 20^{\prime} 30^{\prime \prime}$ W; (map 73). Var. Kako.

Local name published on a 1922 manuscript chart of the Yukon River.

Kakonak: village, see Kakhonak.

Kakonak: lake, see Kakhonak Lake.

Kakonak Bay: bay, see Kakhonak Bay.

Kakonak River: stream, see Kakhonak River.

Kakoon Lake: lake, $0.4 \mathrm{mi}$. long, on Kenai Penin. WNW of Phalarope Lake, $8 \mathrm{mi}$. SSW of Point Possession, and $38 \mathrm{mi}$. NE of Kenai, Cook Inlet Low.; $60^{\circ} 56^{\prime} 30^{\prime \prime} \mathrm{N}, 150^{\circ} 26^{\prime} 30^{\prime \prime}$ W; (map 62).

Named about 1963 by officials of Kenai National Moose Range, for administratıve purposes.

Kakovo Island: island, $0.2 \mathrm{mi}$. across, at mouth of Great Arm Whale Bay, on SW coast of Baranof I., Alex. Arch.; $56^{\circ} 37^{\prime} 00^{\prime \prime}$ N, $134^{\circ}-$ $58^{\prime} 30^{\prime \prime} \mathrm{W}$; (map 5).

Russian name meaning "how" published in 1850 by the Russian American Company.

Kakpeyak River: stream, flows SW $14 \mathrm{mi}$. to Kukpuk River, $17 \mathrm{mi}$. NE of Cape Thompson, Arctic Slope; $68^{\circ} 15^{\prime} 30^{\prime \prime} \mathrm{N}, 16^{\circ} 25^{\prime} 00^{\prime \prime} \mathrm{W}$; $B G N$ 1963; (map 129). Var. Kukpayak River.

Eskimo name reported by D. C. Foote as "Kukpayak" in connection with Project Chariot studies.

Kakrotat Lake: lake, see Kacrowtuk Lake.

Kaksajookalik Island: island, $0.2 \mathrm{mi}$. long, in Bering Sea, $0.1 \mathrm{mi}$. SW of Cape Mendenhall, Nunivak I.; $59^{\circ} 45^{\prime} 45^{\prime \prime} \mathrm{N}, 166^{\circ} 12^{\prime} 30^{\prime \prime} \mathrm{W}$; (map 55). Var. Kakhachukalik Island, Kaxajookaliy Island.

Eskimo name obtained in 1949 by USC\&GS.

Kaksu River: stream, heads in lake, flows $\mathbf{N}$ $24 \mathrm{mi}$. to Meade River, $85 \mathrm{mi}$. SE of Wainwright, Arctic Slope; $69^{\circ} 32^{\prime} \mathrm{N}, 158^{\circ} 23^{\prime} \mathrm{W}$; $B G N$ 1926; (map 143).

This Eskimo name was originally shown on a 1925 fieldsheet by Gerald FitzGerald, USGS, applied to the stream currently known as Awuna River. The name "Kaksu" somehow has migrated to the headwaters of the Meade River.

Kaksu River, stream, see Meade River.

Kaksu River: stream, see Shaningarok Creek.

Kaksurok Mountain: mountain, 1,661 ft., in Igichuk Hills, $14 \mathrm{mi}$. NE of Cape Krusenstern, Arctic Slope; $67^{\circ} 12^{\prime} \mathrm{N}, 163^{\circ} 15^{\prime} \mathrm{W}$; (map 128).

Eskimo name meaning "flat top" according to USC\&GS in 1950.

Kaktoavik: village, see Kaktovik.

Kaktoavik Island: island, see Barter Island.

Kaktoavik Lagoon: lagoon, see Kaktovik Lagoon. 
Kaktovik: village, pop. 120 , on coast of Beaufort Sea, on N coast of Barter I., Arctic Plain; $70^{\circ} 08^{\prime} \mathrm{N}, 143^{\circ} 38^{\prime} \mathrm{W}$; BGN 1961; (map 152). Var. Kaktoavik, Kaaktovik, Katovik, Barter Island.

According to Leffingwell $(1919$, p. 93), this Eskimo name, which he spells "Kaktoavik," applies to Barter I. The village takes its name from the Eskimo name of the island.

Kaktovik Lagoon: lagoon, $3.5 \mathrm{mi}$. across, on coast of Beaufort Sea, between Barter I. and mainland, Arctic Plain; $70^{\circ} 06^{\prime} \mathrm{N}, 143^{\circ} 35^{\prime}$ W; BGN 1961; (map 152). Var. Akvakniakvik Lagoon, Kaktoavik Lagoon.

Eskimo name reported by Leffingwell $(1919$, p. 93$)$ as the local name for Barter I. He spells the name "Kaktoavik" and gives Vilhjalmur Stefansson's spelling as "Kaaktovik." According to Leffingwell the name means "seining place." The application of the name to the lagoon was recommended by USG\&GS in 1960 . There is some local usage of the name "Akvakniakvik Lagoon," meaning "whaling place," so called because the Eskimo on Barter I. "would kill whales when they came into the shoal waters of the lagoon."

Kaktuli River: stream, flows NW $50 \mathrm{mi}$. to Mulchatna River, $96 \mathrm{mi}$. NE of Dillingham, Bristol Bay Low.; 59 $57^{\prime}$ N, $156^{\circ} 24^{\prime}$ W ; (map 52). Var. Kukh-du-li.

Eskimo name shown as "Kukh-du-li" on a 1910 manuscript map by H. C. Fassett, USBF.

Kakuak: village, see Koliganek.

Kakuak: village, see Nunachuak.

Kakuak: locality, see Kokwok.

Kakuak River: stream, see Kokwok River.

Kakuguk: locality, "on Agattu I. in Near Is.," Aleutian Is.; (map 13).

Former Aleut village reported as "uninhabited" by Hodge (1907, p. 645), BAE.

Kakuhan Range: mountain range, $8 \mathrm{mi}$. long, trends SE from $58^{\circ} 58^{\prime} \mathrm{N}, 135^{\circ} 07^{\prime} \mathrm{W}$ to Lions Head Mtn., $2 \mathrm{mi}$. E of Lynn Canal and 45 mi. NW of Juneau, Coast Mts.; $58^{\circ} 55^{\prime} \mathrm{N}$, $135^{\circ} 05^{\prime} \mathrm{W} ; B G N$ 1922; (map 11). Var. Kakukhan

Tlingit Indian name "Qúkúxàn [Qukukhan]" reported in 1922 by USC\&GS; published in 1923 by IBC on Sheet 10 as "Kakuhan."

Kakuiak: locality, "on Kuskokwim River." Var. Kakhuiyagamute.

Former Eskimo camp or settlement listed as "Kakhuiyagamute," with a population of 8 by Ivan Petroff in the 1880 Census.

Kakukhan: mountain range, see Kakuhan Range.

Kakuktahuk Pass: water course, in Yukon Delta extends NE $6.8 \mathrm{mi}$. from Apoon Pass to Pastol Bay, $38 \mathrm{mi}$. NE of Kwiguk, Yukon-Kuskokwim Delta ; $63^{\circ} 08^{\prime} \mathrm{N}, 163^{\circ} 38^{\prime} \mathrm{W}$; (map 92).

Eskimo name obtained in 1899 by R. L. Faris, USC\&GS; published in 1901 on Chart 9372.

Kakuktukruich Bluff: bluff, elev. 2,000 ft., extends $16 \mathrm{mi}$. on $\mathrm{E}$ bank of Sagavanirktok River, between Lupine and Ribdon Rivers,
Arctic Slope; $68^{\circ} 55^{\prime} \mathrm{N}, 148^{\circ} 42^{\prime} \mathrm{W}$; (map 135).

Eskimo name reported in 1956 by USGS.

Kakukturat Mountain: mountain, 1,730 ft., between Kuparuk and Toolik Rivers, $35 \mathrm{mi}$. SW of junc. of Ivishak and Sagavanirktok Rivers, Arctic Slope; $69^{\circ} 04^{\prime} 30^{\prime \prime} \mathrm{N}, 149^{\circ} 30^{\circ} 30^{\prime \prime} \mathrm{W}$; (map 140)

Eskimo name reported in 1956 by T. E. Taylor, USGS.

Kakul, Point: point of land, on E shore of Salisbury Sound, on Baranof I., $25 \mathrm{mi}$. NW of Sitka, Alex. Arch.; 57 $21^{\prime} 50^{\prime \prime} \mathrm{N}, 135^{\circ} 41^{\prime} 25^{\prime \prime}$ W; (map 9). Var. Mys Kakul.

Published in 1848 on Russian Hydrog. Dept. Chart 1397 as "Mys Kakul," meaning "Cape Kakul." This name may possibly be derived from the word "Kekur." See Kekur Island.

Kakul Narrows: water passage, $2 \mathrm{mi}$. long, at $\mathbf{E}$ end of Salisbury Sound, $25 \mathrm{mi}$. NW of Sitka, Alex. Arch.; $57^{\circ} 22^{\prime} \mathrm{N}, 135^{\circ} 42^{\prime} \mathrm{W}$; (map 9).

Named in 1897 by Lt. Comdr. E. K. Moore, USN, probably for Kakul Point at the mouth of the narrows.

Kakul Rock: rock, between Kakul Narrows and Salisbury Sound, off NW coast of Baranof I., Alex. Arch.; $57^{\circ} 21^{\prime} 45^{\prime \prime} \mathrm{N}, 135^{\circ} 41^{\prime} 40^{\prime \prime} \mathrm{W}$; (map 9).

Named in 1896 by Lt. Comdr. E. K. Moore, USN; published by USC\&GS in 1901 Coast Pilot (p. 192). The name was derived from nearby Kakul Point.

Kakvuiyat Bend: bend, on Colville River near mouth of Aupuk Creek, $18 \mathrm{mi}$. SE of head of Ikpikpuk River, Arctic Slope; $69^{\circ} 05^{\prime} \mathrm{N}$, $154^{\circ} 24^{\prime} \mathrm{W}$; (map 142).

Eskimo name reported in 1956 by T. E. Taylor, USGS.

Kakwan Point: point of land, on right bank of Stikine River, $16 \mathrm{mi}$. NE of Wrangell, Coast Mts. ; $56^{\circ} 41^{\prime} 50^{\prime \prime} \mathrm{N}, 132^{\circ} 12^{\prime} 30^{\prime \prime} \mathrm{W}$; (map 6).

Tlingit Indian name reported in 1877 by Joseph Hunter, Ganadian engineer and surveyor.

Kakwok River: stream, see Kokwok River.

Kala Creek: stream, flows NE $30 \mathrm{mi}$. to Kala Slough, $41 \mathrm{mi}$. E of Nulato, Koyukuk Low.; $64^{\circ} 37^{\prime} \mathrm{N}, 156^{\circ} 45^{\prime} \mathrm{W}$; (map 97). Var. Kalakaket Creek.

Local name reported in 1954 by USGS.

Kalagin: locality, see Duck Village.

Kalagin: bay, see Duck Bay.

Kalak: settlement, on right bank of Yukon River, $0.3 \mathrm{mi}$. upstream from Pilot Station, Yukon-Kuskokwim Delta; $61^{\circ} 57^{\prime} \mathrm{N}, 162^{\circ}$ 52' W; (map 74).

Eskimo name shown on a 1916 fieldsheet by R. H. Sargent, USGS. Sargent shows four cabins there in 1916, but recent maps show only one.

Kalakaket Creek: stream, see Kala Creek.

Kalarvik Point: point of land, on Nelson I. at junc. of Baird Inlet and Kolavinarak River, $80 \mathrm{mi}$. W of Bethel, Yukon-Kuskokwim Delta; $60^{\circ} 41^{\prime} \mathrm{N}, 164^{\circ} 12^{\prime} \mathrm{W}$; (map 58 ).

Eskimo name reported in 1949 by USC\&GS.

Kalasik Lake: lake, $3.1 \mathrm{mi}$. long, a cut-off meander of Johnson River, forms a circle W of river, $55 \mathrm{mi}$. $\mathrm{S}$ of Marshall, YukonKuskokwim Delta； $61^{\circ} 06^{\prime} \mathrm{N}, 162^{\circ} 15^{\prime} \mathrm{W}$; (map 74).

Eskimo name, meaning "navel," obtained by USC\&GS at Bethel in 1951.

Kala Slough: stream, anabranch of Yukon River, flows NW $14 \mathrm{mi}$. to Yukon River, $0.5 \mathrm{mi}$. S of Galena and $35 \mathrm{mi}$. E of Nulato, Koyukuk Low.; $64^{\circ} 43^{\prime} \mathrm{N}, 156^{\circ} 56^{\prime} \mathrm{W}$; (map 97). Var. Louden Slough.

Riverboat pilots' name shown on a 1940 "Navigation Chart of the Tanana-Yukon Rivers" published by the U.S. Dept. of Interior.

Kalchilasuk: locality, at $\mathrm{N}$ end of Reindeer Lake, $25 \mathrm{mi}$. SE of Barrow, Arctic Plain; $71^{\circ} 09^{\prime} 30^{\prime \prime} \mathrm{N}, 155^{\circ} 44^{\prime} 00^{\prime \prime} \mathrm{W}$; (map 153).

Eskimo name "Kakiksuk" meaning "high bluffs." See Kachiksuk Bluffs.

Kal Creek: stream, flows E $8 \mathrm{mi}$. to Canyon Creek, $45 \mathrm{mi}$. $\mathrm{S}$ of Eagle, Yukon-Tanana High.; $64^{\circ} 10^{\prime} \mathrm{N}, 141^{\circ} 08^{\prime} \mathrm{W}$; (map 102). Var. Squaw Creek.

Prospectors' name shown on an 1898 manuscript map by C. A. Woodruff, Fort Cudahy, Canada.

Kaldachabuna Lake: lake, $0.8 \mathrm{mi}$. across, on NW shore of Cook Inlet, $2.6 \mathrm{mi}$. SW of Tyonek, Cook Inlet Low.; $61^{\circ} 03^{\prime} 10^{\prime \prime} \mathrm{N}, 151^{\circ}$. $13^{\prime} 10^{\prime \prime} \mathrm{W}$; (map 70).

Tanaina Indian name reported in 1958 by USGS.

Kaldolyeit Lake: lake, $2 \mathrm{mi}$. long, $24 \mathrm{mi}$. SW of Allakaket, Kanuti Flats; $66^{\circ} 20^{\prime} \mathrm{N}, 151^{\circ} 59^{\prime}$ W; (map 117).

Koyukan Indian name obtained in 1956 at Allakaket by T. E. Taylor, USGS. There is another lake nearby with the same name.

Kaldolyeit Lake: lake, $1.4 \mathrm{mi}$. long, at head of Kanuti Chalatna Creek, $27 \mathrm{mi}$. SE of Bettles, Kanuti Flats; $66^{\circ} 32^{\prime}$ N, $151^{\circ} 16^{\prime} \mathrm{W}$; (map 117).

Koyukan Indian name obtained in 1956 at Allakaket by T. E. Taylor, USGS.

Kaleakhta: bay, see Kalekta Bay.

Kalee: village, see Point Lay.

Kalegosilik River: stream, see Kadleroshilik River.

Kaleguricheark River: stream, see Kaliguricheark River.

Kaleguricheark River: stream, see Kallarichuk River.

Kalekhta : bay, see Kalekta Bay.

Kalekhta, Cape: point of land, see Kalekta, Cape.

Kalekhtak: bay, see Kalekta Bay.

Kalekta: locality, Kalekta Bay, Unalaska I., Aleutian Is.; (map 23). Var. Selo Kalekhta. This village name was published by Lt. Sarichev (1826, map 14), IRN, as "Sel[o] Kalekhta" or "Kalekhta Village." Baker (1906, p. 345) reported it is "not now in existence."

Kalekta, Cape: point of land, NE coast of Unalaska I., Aleutian Is.; $54^{\circ} 00^{\prime} \mathrm{N}, 166^{\circ} 22^{\prime} \mathrm{W}$; (map 23). Var. Cape Kalekhta, Igognak, Priest Point. 
Aleut name published by Lt. Sarichev (1826, map 15), IRN, as "M[ys] Kalekhta" or "Cape Kalekhta." Lutke (1836, p. 281) reported that the natives called it "Igognak." It was called Priest Point by USBF in 1888.

Kalekta Bay: bay, $2.7 \mathrm{mi}$. across, NE coast of Unalaska I., Aleutian Is.; $53^{\circ} 59^{\prime} \mathrm{N}, 166^{\circ} 20^{\prime}$ W; (map 23). Var. Kaléakhta, Kalekhta, Kalekhtak.

Aleut name published by Lt. Sarichev (1826, map 14), IRN, as "Za[liv] Kalekhta," or "Kalekhta Bay."

Kalghin Island: island, see Kalgin Island.

Kalgiksuk Creek: stream, anabranch of Wulik River, $1.5 \mathrm{mi}$. long, $1.8 \mathrm{mi}$. NE of Kivalina, Kotzebue-Kobuk Low.; $67^{\circ} 44^{\prime} \mathrm{N}, 164^{\circ} 28^{\prime} \mathrm{W}$; (map 128). Var. Kahlgiksuk, Qaalgiqsuq.

Eskimo name meaning "there are whitefish" reported in 1966 by E. S. Burch.

Kalgin Island: island, $13 \mathrm{mi}$. long, in Cook Inlet, $22 \mathrm{mi}$. W of Kenai, Cook Inlet Low.; $60^{\circ}$ $28^{\prime} \mathrm{N}, 151^{\circ} 55^{\prime} \mathrm{W}$; (map 62). Var. Isla del Peligro, Kalghin Island, Ostrov Kulgiakh.

Tanaina Indian name reported in 1840 by the Russian scientist I. G. Wosnesenski. The name "Isla del Peligro," meaning "danger island," was published by Galiano (1802, map 3 ).

Kalhabuk Creek: stream, flows SSW $5.2 \mathrm{mi}$. from a lake to Hammond River, $7 \mathrm{mi}$. NW of Sukakpak Mtn. and $40 \mathrm{mi}$. WNW of Chandalar, Brooks Ra.; $67^{\circ} 40^{\prime} 40^{\prime \prime} \mathrm{N}, 149^{\circ} 56^{\prime} 00^{\prime \prime} \mathrm{W}$; (map 123).

Name reported in 1939 by Marshall (1956, p. 164).

Kalhagu Cove: cove, $0.3 \mathrm{mi}$. long, on $\mathrm{SW}$ end of Chilkat Penin., $2.6 \mathrm{mi}$. NW of Seduction Point and $24 \mathrm{mi}$. S of Skagway, Coast Mts.; $59^{\circ} 06^{\prime} 30^{\prime \prime} \mathrm{N}, 135^{\circ} 21^{\prime} 20^{\prime \prime} \mathrm{W}$; BGN 1922; (map 45). Var. Khalkhagu.

Tlingit Indian name "Khalkhagu," meaning "skunk cabbage beach," published by the IBC (1923, map 9).

Kalhvit Lake: lake, see Grosvenor, Lake.

Kali: village, see Point Lay.

Kaliada Bay: bay, see Kiliuda Bay.

Kaliakh River: stream, heads in Hanna Lake, flows SE and SW $24 \mathrm{mi}$. to Gulf of Alaska, 13 mi. NW of Cape Yakataga and $106 \mathrm{mi}$. SE of Cordova, Malaspina Coastal Plain ; $60^{\circ} 05^{\prime} 40^{\prime \prime}$ $\mathrm{N}, 142^{\circ} 48^{\prime} 30^{\prime \prime} \mathrm{W}$; (map 65). Var. Cultheeth River, Kaliekh River, Kul-thee-eth River, Kulthieth River.

Tlingit Indian name published in 1849 by Capt. M. D. Tebenkov, IRN. The 1869 Coast Pilot (p. 143) spelled it "Kaliekh." This may be the same stream labeled "small river" in Capt. George Vancouver's atlas of 1798.

Kalick: bluff, see Kalik Bluff.

Kalidge Point: point of land, see Gollie Point.

Kalidtna River: stream, see Kahiltna River.

Kaliekh River: stream, see Kaliakh River.

Kalifonsky: locality, summer pop. only, on W coast of Kenai Penin., S of Kenai, Cook Inlet Low. ; $60^{\circ} 25^{\prime} \mathrm{N}, 151^{\circ} 17^{\prime} \mathrm{W}$; BGN 1916; (map $62)$.
Tanaina Indian village reported in 1916 by USC\&GS. The name may be derived from the "Kali (fishermen)" clan of Tanaina Indians, with a Russian termination.

Kalifonsky Beach: beach, on W coast of Kenai Penin., extends N 9 mi. from Kaliíonsky on $\mathrm{E}$ shore of Cook Inlet, $2 \mathrm{mi}$. S of Kenai, Cook Inlet Low.; $60^{\circ} 27^{\prime} \mathrm{N}, 151^{\circ} 17^{\prime} \mathrm{W}$; (map 62).

Local name published in 1958 by USGS; derived from village of Kalifonsky.

Kaligagan Island: island, $1 \mathrm{mi}$. long, $\mathrm{NE}$ of Tigalda I., in Krenitzin Is., Aleutian Is.; $54^{\circ}$ $08^{\prime} 35^{\prime \prime} \mathrm{N}, 164^{\circ} 55^{\prime} 00^{\prime \prime} \mathrm{W}$; BGN 1904; (map 24). Var. Sealion Island.

Aleut name transcribed by Capt. Tebenkov (1852, map 26), IRN, as "O[strov] Kaligagan" or "Kaligagan Island."

Kalignak: village, see Koliganek.

Kaliguricheark River: stream, flows S $26 \mathrm{mi}$. to Kobuk River $5.5 \mathrm{mi}$. NE of its junc. with Salmon River, $35 \mathrm{mi}$. NE of Kiana, Brooks Ra.; $67^{\circ} 11^{\prime} \mathrm{N}, 159^{\circ} 16^{\prime} \mathrm{W}$; (map 127). Var. Kaleguricheark River, Kaligurickeark River.

Eskimo name, probably referring to "some kind of a fish," spelled "Kal-e-gu-ri-che-ark" by Lt. Stoney (1900, map), USN, in 1885 and applied the name to the present-day "Kallarichuk River." The name was reapplied to the above described stream on a 1901 fieldsheet by D. L. Raeburn, USGS, and given its present spelling.

Kaligurickeark River: stream, see Kaliguricheark River.

Kalik Bluff: $b l u f f$, on left bank of Wulik River, $25 \mathrm{mi}$. NE of Kivalina, Arctic Slope; 67 $52^{\prime}$ $\mathrm{N}, 163^{\circ} 41^{\prime} \mathrm{W}$; (map 128). Var. Kalick.

Eskimo name reported to mean "thing being towed"; so called because from the river the bluff looks like the "stem of a huge barge." Name reported in 1966 by E. S. Burch.

Kalikhsnithnukh Creek: stream, see Kaliksneethnook River.

Kalikpik River: stream, heads in lake, flows $\mathrm{NE} 40 \mathrm{mi}$. to Harrison Bay, $9 \mathrm{mi}$. SW of Atigaru Point, Arctic Plain; $70^{\circ} 27^{\prime} \mathrm{N}, 151^{\circ}$ $56^{\prime} \mathrm{W}$; (map 149).

Eskimo name reported in 1951 by USC\&GS and refers in meaning to the stream "being without banks" because "it flows through flat lands."

Kalik River: stream, on Seward Penin., flows NE $12.7 \mathrm{mi}$. to Chukchi Sea, $63 \mathrm{mi}$. NW of Deering, Kotzebue-Kobuk Low.; $66^{\circ} 33^{\prime} \mathrm{N}$, $164^{\circ} 38^{\prime} \mathrm{W}$; (map 113).

Eskimo name reported to mean "nose mucous" in 1901 by T. G. Gerdine (in Collier, 1902, pl. 12), USGS.

Kaliksneethnook River: stream, flows NE 14 mi. to Etolin Strait. $23 \mathrm{mi}$. SE of Cape Etolin, on $\mathrm{E}$ coast of Nunivak I.; $60^{\circ} 11^{\prime} 30^{\prime \prime} \mathrm{N}, 165^{\circ}$ $42^{\prime} 00^{\prime \prime} \mathrm{W}$; (map 57). Var. Kalikhsnithnukh Creek, Kalixneethlnoox River.

Eskimo name obtained in 1949 by USC\&GS. Kalinina Bay: bay, see Kalinin Bay.

Kalinina Point: point of land, see Kalinin Point. Kalinin Bay: bay, trends N 2 mi. to Salisbury Sound, on N coast of Kruzof I., $24 \mathrm{mi}$. NW of Sitka, Alex. Arch.; $57^{\circ} 20^{\prime} \mathrm{N}, 135^{\circ} 47^{\prime} \mathrm{W}$;
$B G N$ 1897; (map 9). Var. Kalinina Bay, Zaliv Kalinina.

Name published in 1848 on Russian Hydrog. Dept. Chart 1397 as "Zal[iv] Kalinina," meaning "Kalinina Bay."

Kalinin Point: point of land, on $\mathrm{N}$ coast of Kruzof I., 26 mi. NW of Sitka, Alex. Arch.; $57^{\circ} 20^{\prime} 25^{\prime \prime} \mathrm{N}, 135^{\circ} 48^{\prime} 00^{\prime \prime} \mathrm{W}$; (map 9). Var. Kalinina Point.

Named "Kalinina Point" in 1896 by Lt. Comdr. E. K. Moore, USN, probably for nearby Kalinina (Kalinin) Bay.

Kaliokhlogamute: locality, see Kaliukluk.

Kaliookhlogamute: locality, see Kaliukluk.

Kalisin Reef: reef, see Kalsin Reef.

Kalitna River: stream, see Katlitna River.

Kaliukluk: locality, near Cape Vancouver, NE of Nunivak I. in Bering Sea, Yukon-Kuskokwim Delta; (map 57). Var. Kaliokhlogamute, Kaliookhlogamute.

Former Eskimo camp or settlement reported in 1878 as "Kaliokhlogamute" by E. W. Nelson, U.S. Signal Service.

Kalixneethlnoox River: stream, see Kaliksneethnook River.

Kaljukischwigmjut: locality, see Igak.

Kalka Island: island, $2.5 \mathrm{mi}$. long, in Yukon River, $19 \mathrm{mi}$. NNE of Rampart, KokrinesHodzana High.; $65^{\circ} 46^{\prime} \mathrm{N}, 150^{\circ} 00^{\prime} \mathrm{W}$; (map 106).

Local name reported in 1956 by Orth.

Kalla: locality, on right bank of Kobuk River, 14 mi. E of Shungnak, Kotzebue-Kobuk Low.; $66^{\circ} 54^{\prime} \mathrm{N}, 156^{\circ} 38^{\prime} \mathrm{W}$; (map 115). Var. Kallamute.

Former Eskimo village visited in 1885 by Lt. G. M. Stoney, USN. He wrote the name "Kallamute," i.e. "Kalla people."

Kal-la-gu-nick: stream, see Salmon River.

Kallamute: locality, see Kalla.

Kallands: locality, on $\mathrm{N}$ shore of Yukon River, at mouth of Illinois Creek, opposite Brant I., Kokrines-Hodzana High.; $65^{\circ} 11^{\prime} 00^{\prime \prime} \mathrm{N}, 153^{\circ}$ 04'30" W; (map 107). Var. Hub Roadhouse.

Local name reported by Eakin (1913, pl. 3), USGS.

Kallareechuk River: stream, see Kallarichuk River.

Kallarichuk Hills: ridge, elev. 1,600-3,400 ft., in Baird Mts., extend SSE $15 \mathrm{mi}$. between Kallarichuk River and Klery Creek, $11 \mathrm{mi}$. NE of Kiana, Brooks Ra.; $67^{\circ} 13^{\prime} \mathrm{N}, 160^{\circ} 12^{\prime}$ W; (map 127).

Local name reported in 1955 by the U.S. Army Corps of Engineers.

Kallarichuk River: stream, heads in Kallarichuk Hills of Baird Mts., flows SE $25 \mathrm{mi}$. to Kobuk River, 21 mi. NE of Kiana, Brooks Ra.; $67^{\circ} 07^{\prime} \mathrm{N}, 159^{\circ} 43^{\prime} \mathrm{W}$; BGN 1912; (map 127). Var. Kaleguricheark River, Kallareechuk River, Reed Creek, Reed River.

Along this stream, in 1885 , Lt. Stoney (1900, map), USN, recorded the spelling "Kal-e-gu-ri-che-ark (Reed)." D. L. Raeburn's fieldsheet of 1901, USGS, retained the name "Reed River," applying the Eskimo name to a stream farther east. In 1910, P. S. 
Smith, USGS, applied the name "Kallareechuk River" to its present location.

Kalmback Lake: lake, $0.8 \mathrm{mi}$. long, one of the Meadow Lakes, in Matanuska Valley, $15 \mathrm{mi}$. NW of Palmer, Cook Inlet Low.; $61^{\circ} 36^{\prime} 30^{\prime \prime}$ N, $149^{\circ} 34^{\prime} 15^{\prime \prime}$ W ; (map 69).

Local name reported in 1950 by USGS.

Kalokut Creek: stream, flows $27 \mathrm{mi}$. N to Egaksrak Lagoon, SW of Siku Point and 17 mi. NW of Demarcation Point, Arctic Plain; $69^{\circ} 47^{\prime} \mathrm{N}, 141^{\circ} 57^{\prime} \mathrm{W}$; (map 138).

Eskimo name recorded by Leffingwell (1919, p. 96) in 1918; its meaning is uncertain.

Kalomak River: stream, see Kolomak River.

Kalooch-agoon Slough: water course, see Kaluchagun Slough.

Kaloschen Archipel: islands, see Alexander Archipelago.

Kalsin Bay: bay, extends SW $6 \mathrm{mi}$. off Chiniak Bay, $10 \mathrm{mi}$. S of Kodiak, Kodiak I.; $57^{\circ} 40^{\prime} \mathrm{N}$, $152^{\circ} 21^{\prime} \mathrm{W}$; (map 34). Var. Guba Kalsinskaya, Kalsinskaia.

Transliteration by USC\&GS in 1881 of the name "Guba Kalsinskaya," or "Kalsin Bay," published by Sarichev (1826, map 16).

Kalsin Creek: stream, flows $\mathrm{N} 4 \mathrm{mi}$. to Kalsin Bay, 13 mi. S of Kodiak, Kodiak I. ; $57^{\circ} 35^{\prime} 30^{\prime \prime}$ $\mathrm{N}, 152^{\circ} 26^{\prime} 30^{\prime \prime} \mathrm{W}$; (map 34).

Name derived from Kalsin Bay and published in 1946 by USC\&GS.

Kalsin Island: island, $1 \mathrm{mi}$. long, in Kalsin Bay, 9 mi. S of Kodiak, Kodiak I.; $57^{\circ} 39^{\prime} 45^{\prime \prime}$ N, $152^{\circ} 24^{\prime} 20^{\prime \prime} \mathrm{W}$; (map 34). Var. Kalsinskoi, Ostrov Kalsinskoy.

Transliteration by USC\&GS in 1881 of the Russian name "Os[trov] Kalsinskoy," or "Kalsin Island," published by Sarichev (1826, map 16).

Kalsin Reef: reef, in Chiniak Bay, $9 \mathrm{mi}$. SE of Kodiak, Kodiak I.; $57^{\circ} 41^{\prime} 10^{\prime \prime} \mathrm{N}, 152^{\circ} 17^{\prime} 30^{\prime \prime}$ W; (map 34). Var. Banka Kalsinskaya, Kalisin Reef.

Transliteration by USC\&GS in 1881 of the name "Banka Kalsinskaya," meaning "Kalsin Shoal," published by Sarichev (1826, map 16).

Kalsinskaia: bay, see Kalsin Bay.

Kalsinskaya, Banka: reef, see Ka'sin Reef.

Kalsinskaya, Guba: bay, see Kalsin Bay.

Kalsinskoi: island, see Kalsin Island.

Kalsinskoy, Ostrov: island, see Kalsin Island.

Kalskag: village, pop. 147 , on $\mathrm{N}$ bank of Kuskokwim River, $24 \mathrm{mi}$. $W$ of Aniak, YukonKuskokwim Delta; $61^{\circ} 32^{\prime} 20^{\prime \prime} \mathrm{N}, 160^{\circ} 18^{\prime} 20^{\prime \prime}$ W; (map 73). Var. Kabkag, Kaltchagamut, Kalthagamute, Kaltkhagamute, Kaltshak.

This village is listed as "Kaltkhagamute," with a population of 106 in the 1880 Census of I. Petroff. W. S. Post, USGS, spells the name "Kal-tchagamut" on his 1898 fieldsheet, but places the village on the right bank of a slough, 4 miles southwest of the present village called "Kalskag." The place shown by Post is now abandoned, the people have moved to Lower Kalskag and Kalskag.

Kaltag: village, pop. 165 , on right bank of Yukon River, $33 \mathrm{mi}$. SW of Nulato, Nulato Hills; $64^{\circ} 20^{\prime} \mathrm{N}, 158^{\circ} 43^{\prime} \mathrm{W}$; $B G N$ 1944; (map 97). Var. Kahltog, Kchaltak, Kkhaltel, Upper Kaltag.

Indian village called "Kaltag" by the Russtans. The 1880 Census lists two villages with this name, differentiated by "Lower" and "Upper." The present village appears to be the one called "Upper Kaltag" and the "Old Kaltag" site probably was "Lower Kaltag." The narne may refer to a species of salmon. Kaltag's population was 45 in $1880 ; 141$ in $1910 ; 89$ in $1920 ; 137$ in $1930 ; 140$ in 1940 ; and 121 in 1950 . A post office was established here in 1903 (Ricks, 1965, p. 31).

Kaltag Mountains: mountains, trend N-S in center of Nulato Hills.

So shown by Petroff in the 1880 Census.

Kaltag Portage: portage, between Old Woman and Kaltag, along Unalakleet and Kaltag Rivers, Nulato Hills; $64^{\circ} 15^{\prime} \mathrm{N}, 159^{\circ} 00^{\prime} \mathrm{W}$; (maps 96, 97).

So called in 1900 (Jackson, 1900, p. 53). Kaltag River: stream, flows NE $20 \mathrm{mi}$. to $\mathrm{Yu}$ kon River, $33 \mathrm{mi}$. SW of Nulato, Nulato Hills; $64^{\circ} 20^{\prime} \mathrm{N}, 158^{\circ} 43^{\prime} \mathrm{W}$; (map 97). Var. Chotachkakat, Khotakhkakat, Rotokakat.

Indian name reported in 1900 by Lt. J. C. Cantwell, USRCS; he also gave the name as "Rotokakat," undoubtedly obtained from Father Julius Jetté at Nulato who used the " $R$ " to express the "Kh" sound. This name would generally agree then with the Indian name "Khotakhkakat" reported in 1842-44 by Lt. L. A. Zagoskin, IRN. See Khotol River. It appears as if the present name "Kaltag River" is one of the rare cases where a village gave its name to a stream.

Kaltat: locality, "on an island in Yukon River near mouth of Koyukuk River," Nulato Hills; (map 97). Var. Khaltats Village, K-khaltat.

Former Eskimo camp or settlement reported in 1842 as "K-khaltat" with a population of 9 by Lt. L. A. Zagoskin, IRN; listed in the 1880 Census (1884, p. 37), by Ivan Petroff.

Kaltchagamut: village, see Kalskag.

Kaltchagamut: village, see Lower Kalskag.

Kalthagamute: village, see Kalskag.

Kaltkhagamute: village, see Kalskag.

Kaltkhagamute: village, see Lower Kalskag

Kaltshak: village, see Kalskag.

Kaltshak: village, see Lower Kalskag.

Kalubik Creek: stream, heads in lake, flows $\mathrm{N}$ $19 \mathrm{mi}$. to Harrison Bay, $2 \mathrm{mi}$. E of Colville River Delta, Arctic Plain; $70^{\circ} 25^{\prime} 50^{\prime \prime} \mathrm{N}$, $150^{\circ} 06^{\prime} 25^{\prime \prime} \mathrm{W}$; (map 149).

Eskimo name reported in the late 1940's by USG\&GS.

Kaluchagun: locality, on Kaluchagun I., in Norton Sound, $11.5 \mathrm{mi}$. W of Kwiguk, Yukon-Kuskokwim Delta; $62^{\circ} 42^{\prime} 30^{\prime \prime} \mathrm{N}, 164^{\circ}$ 51'30' W; (map 77).

Eskimo camp reported in 1952 by U.S. Army Corps of Engineers.

Kaluchagun Island: island, $1.5 \mathrm{mi}$. long, in Norton Sound, $11 \mathrm{mi}$. W of Kwiguk, YukonKuskokwim Delta ; $62^{\circ} 42^{\prime} 30^{\prime \prime} \mathrm{N}, 164^{\circ} 51^{\prime} 00^{\prime \prime}$ W; (map 77).
Eskimo name obtained in 1948 by USC\&GS. Kaluchagun Slough: watercourse, $0.5 \mathrm{mi}$. long, on Kaluchagun I. in Norton Sound, $11 \mathrm{mi}$. W of Kwiguk, Yukon-Kuskokwim Delta; $62^{\circ} 42^{\prime} 30^{\prime \prime} \mathrm{N}, 164^{\circ} 51^{\prime} 00^{\prime \prime} \mathrm{W}$; (map 77). Var. Kalooch-agoon Slough.

Eskimo name obtained in 1948 by USC\&GS. Kalucna River: stream, see Kalukna River.

Kaluiak: locality, on $\mathrm{S}$ shore of Chignik Bay, $E$ of Anchorage Bay and NE of Chignik, Aleutian Ra.; $56^{\circ} 25^{\prime} \mathrm{N}, 158^{\circ} 15^{\prime} \mathrm{W}$; (map 30 ).

Name listed as a "native village" by Ivan Petroff in the 10th Census, in 1880. The 11 th Census, in 1890 , reported that the only village in the area was on Mitrofania Island, though no name was given. This feature is not shown on recent maps and therefore location is approximate.

Kaluich Greek: stream, heads at $67^{\circ} 32^{\prime} \mathrm{N}$, $158^{\circ} 28^{\prime} \mathrm{W}$, flows $\mathrm{N} 22 \mathrm{mi}$. to Cutler River, $47 \mathrm{mi}$. SW of Howard Pass, Brooks Ra.; $67^{\circ} 47^{\prime} \mathrm{N}, 158^{\circ} 19^{\prime} \mathrm{W}$; (map 126).

Eskimo name meaning "lots of fish," obtained by Orth in 1956.

Kalukna River: stream, heads in Mentasta Mts. and flows $\mathrm{N} 47 \mathrm{mi}$. to Tetlin River, $20 \mathrm{mi}$. SE of Tok, Alaska Ra.; $63^{\circ} 08^{\prime} \mathrm{N}, 142^{\circ} 30^{\prime}$ W; (map 85). Var. Kalucna River, Katusna River.

Indian name obtained in 1885 by Lt. H. T. Allen (1887, map), USA.

Kalukruatchiak Point: point of land, at junc. of Okokmilaga and Killik Rivers, Brooks Ra.; $68^{\circ} 49^{\prime} \mathrm{N}, 153^{\circ} 27^{\prime} \mathrm{W}$; (map 133).

Eskimo name obtained in 1956 at Anaktuvuk Pass by T. E. Taylor, USGS

Kaluktavik River: stream, heads in lake, in DeLong Mts., flows SW $35 \mathrm{mi}$. to Noatak River W of Isacheluich Mts., $57 \mathrm{mi}$. NE of Noatak, Brooks Ra.; 67 $56^{\prime}$ N, $161^{\circ} 00^{\prime} \mathrm{W}$; (map 127).

Eskimo name meaning "place where wood is obtainable," obtained in 1956 at Noatak by Orth.

Kaluktuk: locality, "in the Kuskokwim district." Var. Kahlukhtughamiut.

Former Eskimo camp or settlement listed as "Kahlukhtughamiut" with a population of 29 in the 1890 Census.

Kalulegeet: locality, see Kalulek.

Kalulek: locality, "at Port Clarence," Seward Penin. High.; (map 111). Var. Kalulegeet.

Former Eskimo camp or settlement listed as

"Kalulegeet" in the 1890 Census (p. 162).

Kalulingmiut: locality, on Cape Douglas, $21 \mathrm{mi}$. SW of Teller, Seward Penin. High.; $65^{\circ} 00^{\prime} \mathrm{N}$, $166^{\circ} 43^{\prime} \mathrm{W}$; (map 94.). Var. Nook, Nookmute, Ongneak.

Site of an Eskimo village reported in the "Esquimaux," the newspaper published in 1866 and 1867 by personnel of the Western Union Telegraph Expedition quartered at Teller. Ivan Petroff in the 10th Census in 1880 (p. 11) listed "Nook," which means "point of land," here, with a population of 36 . He showed "Nookmute" on his map.

Kalummiktowrah: locality, see Kilimantavi. 
Kalun Lake: lake, $0.6 \mathrm{mi}$. long, on Kenai Penin. NW of Paddle Lake, $30 \mathrm{mi}$. NE of Kenai, Cook Inlet Low.; $60^{\circ} 46^{\prime} 40^{\prime \prime} \mathrm{N}, 150^{\circ} 32^{\prime} 00^{\prime \prime}$ W; (map 62). Var. Karlun Lake.

- Named about 1963 by officials of Kenai National Moose Range for administrative purposes.

Kalurivik Creek: stream, flows SW $20 \mathrm{mi}$. to Ambler River, $22 \mathrm{mi}$. N of Shungnak, Brooks Ra.; $67^{\circ} 12^{\prime} \mathrm{N}, 157^{\circ} 16^{\prime} \mathrm{W}$; (map 126).

Eskimo name reported by the U.S. Army Corps of Engineers in 1955.

Kalusul Creek: stream, flows NE $25 \mathrm{mi}$. to the South Fork Buckland River, $51 \mathrm{mi}$. NE of Haycock, Nulato Hills ; $65^{\circ} 41^{\prime} \mathrm{N}, 159^{\circ} 51^{\prime} \mathrm{W}$; (map 109).

Eskimo name reported in 1949 by the U.S. Army Corps of Engineers.

Kalutna River: stream, heads $9.5 \mathrm{mi}$. SW of Northway, W of Nabesna River, flows N 26 mi. to Tanana River, $23 \mathrm{mi}$. SE of Tok, Alaska Ra.; $63^{\circ} 10^{\prime} \mathrm{N}, 143^{\circ} 21^{\prime} \mathrm{W}$; (map 85).

Indian name reported by USGS in 1955.

Kalutna River: stream, see Cheslina River.

Kaluvarawluk Mountain: mountain, 3,000 ft., on $E$ bank of Holokuk River, $40 \mathrm{mi}$. SE of Aniak and $40 \mathrm{mi}$. SW of Sleetmute, KilbuckKuskokwim Mts.; $61^{\circ} 26^{\prime}$ N, $158^{\circ} 18^{\prime}$ W; (map 72).

Eskimo name obtained in 1948 by USC\&GS.

Kaluyut Mountain: mountains, $1,485 \mathrm{ft}$., on Nelson I., extend NE 12 mi. from Kangirlar Bay, $16 \mathrm{mi}$. E of Cape Vancouver, YukonKuskokwim Delta; $60^{\circ} 41^{\prime} \mathrm{N}, 164^{\circ} 51^{\prime} \mathrm{W}$; (map 58).

Eskimo name reported in 1949 by USC\&GS.

Kalwatta: locality, site of an Indian village, on Haines Highway, $5 \mathrm{mi}$. SE of Wells and 20 mi. SW of Skagway, Coast Mts.; $59^{\circ} 22^{\prime} 15^{\prime \prime}$ N, $135^{\circ} 50^{\prime} 00^{\prime \prime} \mathrm{W}$; (map 45). Var. Kahtkwaltoo, Katkwaahltu, Kutkwutlu, Katkwaltu, Qātq!wã'altu.

Former Tlingit Indian village listed as "Kutkwutlu," population 125, in the 1880 Census. In 1904 J. R. Swanton, BAE, spelled the name "Qātq!wā'altu" and reported its meaning as "town on point of hill." However, E. C. Robertson, USGS, in 1952, spelled it "Kahtkwaltoo," meaning "armour of wooden sticks" and stated that it "was abandoned over 60 years ago * * * during a flood."

Kalyalyakhtna: stream, see Gisasa River.

Kamaton Island: island, "one of the Aleutian chain." Var. Kanaton.

Name shown on a 1781 "anonymous" chart (Wagner, 1937, p. 346). This may be the same island called "Kanaton" on later charts.

Kambelya, Mys: point of land, see Campbell, Point.

Kambon, Mys : point of land, see Cambon, Cape.

Kamchatka, Sea of: sea, see Bering Sea.

Kamegli: locality, "on Kuskokwim River, $10 \mathrm{mi}$. upstream from Bethel," Yukon-Kuskokwim Delta; (map 59). Var. Kameglimut.

Former Eskimo camp or settlement reported in 1898 as "Kameglimut" by J. E. Spurr, USGS, who obtained the name from Rev. J. H. Kilbuck, Moravian missionary at Bethel.
Kameglimut: locality, see Kamegli.

Kamen Bylyy: rocks, see Bieli Rocks.

Kameni Point: point of land, see Kamenoi Point. Kamenistaia Bay: estuary, see Necker Bay.

Kamenistaya Bukhta: estuary, see Necker Bay. Kameniste, Ostrova: islands, see Triplets, The.

Kamenisti: rocks, volcanic rocks, between Telegraph and Bogoslof Hills, on south-central Saint Paul I., in Pribilof Is.; $57^{\circ} 09^{\prime} 40^{\prime \prime} \mathrm{N}$, $170^{\circ} 16^{\prime} 20^{\prime \prime}$ W; (map 38). Var. Kamminista, Kamninista.

A local name reported in 1965 by USBF. It is a Russian name meaning "rocky," or "stone" from the word "Kamen."

Kamenisti Lake: lake, $0.2 \mathrm{mi}$. across, $2 \mathrm{mi}$. NE of Saint Paul, on south-central Saint Paul I., in Pribilof Is.; $57^{\circ} 09^{\prime} 05^{\prime \prime} \mathrm{N}, 170^{\circ} 15^{\prime} 10^{\prime \prime} \mathrm{W}$; (map 38). Var. Kamminista Lake, Kamninista Lake.

A local Russian name meaning "rocky"; reported in 1965 by USBF.

Kamenistyy, Mys : point of land, see Rock Point.

Kamennie Point: point of land, see Kamenoi Point.

Kamennoi, Cap: point of land, see Rocky Point. Kamennoi Island: island, $0.1 \mathrm{mi}$. across, near mouth of Redoubt Bay, 8 mi. SW of Sitka, off W coast of Baranof 1., Alex. Arch.; 56 $56^{\prime} 15^{\prime \prime}$ N, $135^{\circ} 24^{\prime} 15^{\prime \prime}$ W; (map 5). Var. Ostrov Kamennoy.

Named in 1809 by the Russian navigator, Ivan Vasiliev the first; published by Lt. Sarichev (1826, map 19), IRN, as "O[strov] Kamennoy," meaning "rocky island."

Kamennoi Point: point of land, see Kamenoi Point.

Kamennoy, Mys: point of land, see Kamenoi Point.

Kamennoy, Ostrov: island, see Kamennoi Island. Kamennyy, Mys : point of land, see Rocky Point. Kamenoi Point: point of land, on $\mathrm{E}$ coast of Kruzof Island, $10 \mathrm{mi}$. NW of Sitka, Alex. Arch.; $57^{\circ} 08^{\prime} 00^{\prime \prime} \mathrm{N}, 135^{\circ} 33^{\prime} 40^{\prime \prime} \mathrm{W}$; (map 9). Var. Kameni Point, Kamennie Point, Kamennoi Point, Mys Kamennoy, Rock Point, Rocky Point.

Russian name meaning "rocky" given in 1809 by the navigator Ivan Vasiliev the first; published by Lt. Sarichev (1826, map 19), IRN, as "M[ys] Kamennoy."

Kamerchluk Slough: stream, heads in a lake, flows NE $2.5 \mathrm{mi}$. to Apoon Pass, $26 \mathrm{mi}$. NE of Kwiguk, Yukon-Kuskokwim Delta; $62^{\circ}$ 57'15" N, 1634'10' W; (map 77).

Eskimo name obtained in 1899 by $R$. $L$. Faris, USC\&GS; published in 1901 on Chart 9372.

Kame Stream: stream, heads in lake at terminus of Malaspina Glacier, flows SE $3 \mathrm{mi}$. to Yakutat Bay, $8 \mathrm{mi}$. WSW of Blizhni Point and 19 mi. NNW of Yakutat, Malaspina Coastal Plain; $59^{\circ} 47^{\prime} 30^{\prime \prime} \mathrm{N}, 139^{\circ} 58^{\prime} 30^{\prime \prime} \mathrm{W}$; (map 46).

Named in 1891 by Russell (1892, pl. 4, p. 81). A kame is a conical hill or short irregular ridge of gravel and sand deposited by glacier ice.
Kamgliuck, Pointe: point of land, see Kayakliut, Cape.

Kamguvluagvik: hill, see Mumtrak Hill.

Kamieshatskaia Bay: bay, see Kamishak Bay.

Kamieshatskoi: point of land, see Douglas, Cape.

Kamiischatskaja Bai : bay, see Kamishak Bay.

Kamiktungitak Creek: stream, flows NNE $7 \mathrm{mi}$. to Colville River, $14 \mathrm{mi}$. N of Noluck Lake, Arctic Slope; $69^{\circ} 00^{\prime} \mathrm{N}, 159^{\circ} 56^{\prime} \mathrm{W}$; (map 131).

Eskimo name reported by T. E. Taylor, USGS, in 1956.

Kamina: bluff, between Great East and Little East Rookeries, along NE coast of Saint George I., in Pribilof Is. ; $56^{\circ} 36^{\prime} 25^{\prime \prime} \mathrm{N}, 16^{\circ}$. $30^{\prime 20}$ ' W; (map 38). Var. Chunung'umal'gera.

Putnam (1903), USC\&GS, listed two names for this feature. The Aleut name, "Chunung'um-al'gera," means "seal hollow" (p. 1014), and the Russian name, "Kam'ina," means "rocky place" (p. 1015).

Kamishak: locality, on the $\mathrm{N}$ bank of McNeil River at McNeil Cove, $34 \mathrm{mi}$. SW of Augustine I., Aleutian Ra.; $59^{\circ} 07^{\prime} 30^{\prime \prime} \mathrm{N}, 154^{\circ}$ $15^{\prime} 00^{\prime \prime} \mathrm{W}$; (map 51).

Name reported in 1923 by $K$. F. Mather (in Brooks and others, 1925, pl. 3), USGS. The name derived from the bay, applied then to the cluster of buildings at the ranch of Charlie McNeil.

Kamishak Bay: bay, $30 \mathrm{mi}$. wide, on $\mathrm{E}$ coast of Alaska Penin., $88 \mathrm{mi}$. SW of Homer, Aleutian Ra.; $59^{\circ} 15^{\prime} \mathrm{N}, 153^{\circ} 50^{\circ} \mathrm{W}$; (map 51). Var. Bourdiens Bay, Bourdieus Bay, Kamieshatskaia Bay, Kamiischatskaja Bai, Kamiskuk Bay, Kamychatskoi Bay, Kamyshak Bay, Kamyshatskaya Bay.

Native name published by the early Russians as "Guba Kamyshatskaya," meaning "Kamyshatskaya Bay" (Sarichev, 1826, map 3 ). The name "Bourdieus Bay" appears on Capt. George Vancouver's map, but since the name is not mentioned in the text, it may have been given in 1787 by Capt. George Dixon (Wagner, 1937, p. 434).

Kamishak Bay: bay, see Akumwarvik Bay.

Kamishak River: stream, heads in lake at $58^{\circ}$ $46^{\prime} \mathrm{N}, 154^{\circ} 38^{\prime} \mathrm{W}$, flows NE $38 \mathrm{mi}$. to Akumwarvik Bay, $35 \mathrm{mi}$. SW of Augustine I., Aleu-

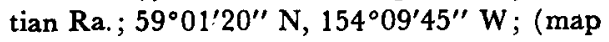
51). Var. Kamyshak River.

Native name published by Lt. Sarichev (1826, map 3), IRN, as "R[eka] Kamyshak" or "Kamyshak River."

Kamiskuk Bay: bay, see Kamishak Bay.

Kamminista: rocks, see Kamenisti.

Kamminista Lake: lake, see Kamenisti Lake.

Kamninista : rocks, see Kamenisti.

Kamninista Lake: lake, see Kamenisti Lake.

Kamuksusik: locality, "on Agattu I. in Near Is.," Aleutian Is. ; (map 13).

Former Aleut village reported as "uninhabited" by Hodge (1907, p. 649), BAE.

Kamychatskoi Bay: bay, see Kamishak Bay. Kamyshak, Ostrov: island, see Shaw Island. Kamyshak Bay: bay, see Kamishak Bay. 
Kamyshak River: stream, see Kamishak River.

Kamyshatskaya Bay: bay, see Kamishak Bay.

Kamyushkin, Mys : point of land, see East Foreland.

Kan, Ostrova: islands, see Kane Islands.

Kanaeyackdligamiut: locality, see Kanikyakstalikmiut.

Kanaga Bay: bay, $0.5 \mathrm{mi}$. across, on S Kanaga I., Aleutian Is.; $51^{\circ} 42^{\prime} 30^{\prime \prime} \mathrm{N}, 177^{\circ} 11^{\prime} 30^{\prime \prime} \mathrm{W}$; $B G N$ 1936; (map 17).

Name derived from Kanaga Island, and given by members of the U.S. Navy Aleutian Island Survey Expedition in 1934.

Kanaga Island: island, $32 \mathrm{mi}$. long, one of Andreanof Is., Aleutian Is.; $51^{\circ} 45^{\prime} \mathrm{N}, 1^{\circ} 7^{\circ}$ $22^{\prime}$ W; BGN 1944; (map 17). Var. Kanaton Island, Konega Island, Konniaga Island.

Aleut name published by G. A. Sarichev (1826, map 3) and Capt. Tebenkov (1852, map 28), IRN, as "O[strov] Kanaga," or "Kanaga Island." Baker (1906, p. 348) suggests that this may be the island called "Kanaton" by Capt. James Cook, RN, in 1778.

Kanagak: locality, "in Kuskokwim district." Var. Kanagamiut.

Former Eskimo camp or settlement listed as "Kanagamiut" with a population of 35 in the 1890 Census.

Kanagamiut: locality, see Kanagak.

Kanaga Pass: water passage, between Kanaga and Tanaga Is., Aleutian Is.; $51^{\circ} 43^{\prime} \mathrm{N}, 177^{\circ}$. 47' W; (map 17).

Name derived from Kanaga Island and published by USC\&GS in the 1944 Aleutian Coast Pilot (p. 116).

Kanaga Sound: sound, between Kanaga, Tanaga, and Bobrof Is., Aleutian Is.; $51^{\circ} 50^{\prime} \mathrm{N}, 177^{\circ}$. $30^{\prime} \mathrm{W}$; (map 17).

Name derived from Kanaga I. and published by USC\&GS in 1956 on Chart 9145.

Kanaga Volcano: volcano, $4,416 \mathrm{ft}$., on $\mathrm{N}$ tip of Kanaga I., Aleutian Is.; $51^{\circ} 55^{\prime} 30^{\prime \prime}$ N, $177^{\circ}$ $09^{\prime} 40^{\prime \prime} \mathrm{W}$; (map 17).

Name derived from Kanaga Island and published by USC\&GS in the 1944 Aleutian Coast Pilot (p. 114).

Kanagmiut: locality, see Kanak.

Kanagtatlek Creek: stream, flows SW $1 \mathrm{mi}$. to Stoggnang Creek, $50 \mathrm{mi}$. NW of Goodnews, Yukon-Kuskokwim Delta; $59^{\circ} 48^{\prime} \mathrm{N}, 161^{\circ} 57^{\prime}$ W; (map 53).

Eskimo name published in 1951 by USGS.

Kanagunut Island: island, $3.4 \mathrm{mi}$. long, in Dixon Entrance, S of Nakat Bay, Coast Mts.; $54^{\circ}$. $44^{\prime} 30^{\prime \prime} \mathrm{N}, 130^{\circ} 42^{\prime} 30^{\prime \prime} \mathrm{W}$; (map 2). Var. Kannaghunut Island, Kannagkhunut Island, Kan-na-ghu-nut Island.

Tlingit Indian name reported in 1869 by G. Davidson, USC\&GS; puhlished on USC\&GS Chart 711 as Kan-na-ghu-nut Island in 1869 .

Kanaiski Land: peninsula, see Kenai Peninsula.

Kanak: locality, "in Kuskokwim district." Var. Kanagmiut.

Former Eskimo camp or settlement listed with a population of 41 in the 1890 Census.

Kanak, Ostrov: island, see Kanak Island.

Kanakanak: village, see Dillingham.
Kanakanak: village, pop. 54 (1950), on right bank of Nushagak River at Bradford Point, 4 mi. SW of Dillingham, Bristol Bay Low.; $59^{\circ}$ $00^{\prime} 10^{\prime \prime} \mathrm{N}, 158^{\circ} 32^{\prime} 00^{\prime \prime} \mathrm{W}$; (map 52). Var. Kanakanok.

Eskimo village "which includes the former sites of Dillingham and Kanakanak ***" (U.S. Coast and Geodetic Survey, 1964, p. 250). A post office was obtained in 1929; discontinued in 1944 (Ricks, 1965, p. 31). The population was 53 in $1890 ; 145$ in 1900 ; 177 in 1930.

Kanakanak: locality, see Nelsonville.

Kanakanok: village, see Kanakanak.

Kanak Island: island, $5 \mathrm{mi}$. long, at $\mathrm{W}$ end of Controller Bay, $5 \mathrm{mi}$. SW of Bering River, and $6 \mathrm{mi}$. SE of Katalla, Malaspina Coastal Plain; $60^{\circ} 08^{\prime} \mathrm{N}, 144^{\circ} 21^{\prime} \mathrm{W}$; (map 64). Var. Ostrov Kanak.

Native name published by Capt. Tebenkov (1852, map 6) as "O[strov] Kanak" or "Kanak Island."

Kanaknoli Point: bluff, elev. $25 \mathrm{ft}$., on S bank of Naknek River, on Alaska Penin., $6 \mathrm{mi}$. SE of Naknek, Bristol Bay Low.; 58 $42^{\prime} 50^{\prime \prime} \mathrm{N}, 156^{\circ}$. $50^{\prime} 30^{\prime \prime} \mathrm{W}$; (map 41).

Eskimo name reported in 1952 by USGS.

Kanaktok Creek: stream, heads on Kanaktok Mtn., in Baird Mts., flows SE $8 \mathrm{mi}$. to Salmon River, $60 \mathrm{mi}$. NE of Kiana, Brooks Ra.; $67^{\circ}$ $47^{\prime} \mathrm{N}, 159^{\circ} 43^{\prime} \mathrm{W}$; (map 127).

Eskimo name obtained in 1956 at Noatak by Orth.

Kanaktok Mountain: mountain, 3,320 ft., in Baird Mts., at head of Kanaktok Creek, 60 mi. NE of Kiana, Brooks Ra. ; $67^{\circ} 50^{\prime} \mathrm{N}, 159^{\circ}$ 56 ' W; (map 127).

Eskimo name obtained in 1956 at Noatak by Orth.

Kanal, Mys de la: point of land, see Canal Point.

Kanalak Cape: point of land, see Kanatak Cape. Kanalkoo Bay: bay, see Kanalku Bay.

Kanalku Bay: bay, $2.5 \mathrm{mi}$. long, $5 \mathrm{mi}$. E of Angoon, on $W$ coast of Admiralty I., Alex. Arch.; 57 $30^{\prime}$ N, $134^{\circ} 26^{\prime}$ W; (map 9). Var. Kanalkoo Bay.

Tlingit Indian name published by USC\&GS in 1891 Coast Pilot (p. 159) as "Kanalkoo."

Kanalku Lake: lake, $1.5 \mathrm{mi}$. long, $8 \mathrm{mi}$. E of Angoon, on central Admiralty I., Alex. Arch.; $57^{\circ} 29^{\prime} 15^{\prime \prime} \mathrm{N}, 134^{\circ} 21^{\prime} 00^{\prime \prime} \mathrm{W}$; (map 9).

Local name derived from Kanalku Bay. The name was published in 1940 by USGS. Kanalku Mountain: mountain, 2,755 ft., $8 \mathrm{mi}$. SE of Angoon, on W coast of Baranof I., Alex. Arch.; $57^{\circ} 28^{\prime} 30^{\prime \prime} \mathrm{N}, 134^{\circ} 22^{\prime} 30^{\prime \prime} \mathrm{W}$; (map 9).

Local name reported in 1951 by USGS. Kanama Gulch: ravine, see Kanoma Gulch.

Kanapak: locality, on right bank of Kashunuk River, near mouth of Mankakvik Creek, 37 mi. W of Marshall, Yukon-Kuskokwim Delta; $61^{\circ} 50^{\prime} \mathrm{N}, 163^{\circ} 13^{\prime} \mathrm{W}$; (map 74).

Eskimo name for a fish camp reported by USC\&GS in 1949.

Kănăs-nū: locality, see Killisnoo.

Kanata Cape: point of land, see Kanatak Cape.
Kanatak: locality, at head of Portage Bay, on S coast of Alaska Penin., $53 \mathrm{mi}$. E of Ugashik, Aleutian Ra.; $57^{\circ} 34^{\prime} 05^{\prime \prime} \mathrm{N}, 156^{\circ} 02^{\prime} 15^{\prime \prime} \mathrm{W}$; (map 36).

Eskimo village listed in the 11 th Census in 1890 as having a population of 26 . Because of oil drilling activity in the 1930's, its population increased to 134 in 1940 . When this activity ceased in the 1950 's, the village was all but abandoned. It had a post office from 1922 to 1943 and from 1946 to 1954.

Kanatak: bay, see Portage Bay.

Kanatak, Lake: lake, $0.5 \mathrm{mi}$. long, in course of Kanatak Creek, $\mathbf{N}$ of Mount Becharof, on Alaska Penin., $50 \mathrm{mi}$. E of Ugashik, Aleutian Ra.; $57^{\circ} 33^{\prime} 50^{\prime \prime} \mathrm{N}, 156^{\circ} 05^{\prime} 05^{\prime \prime} \mathrm{W}$; (map 36 ).

Name reported in 1902 by J. L. McPherson of Iliamna; published by G. C. Martin (1921, pl. 10), USGS.

Kanatak Cape: point of land, between Portage and Jute Bays, on E coast of Alaska Penin., $54 \mathrm{mi}$. W of Karluk, Aleutian Ra.; 57 $32^{\prime} 10^{\prime \prime}$ N, $155^{\circ} 54^{\prime} 20^{\prime \prime}$ W ; (map 35). Var. Kanalak Cape, Kanata Cape, Cape Lgvac.

Name derived from "Kanatak Bay," the native name for Portage Bay, published on Russian Hydrog. Dept. Chart 1379 in 1847 as "Z[aliv] Kanatak." This point was called "Cape Lgvac" by Adm. von Krusenstern (1827, map 17), IRN.

Kanatak Creek: stream, flows NE through Kanatak Lake $4.2 \mathrm{mi}$. to Portage Bay $\mathrm{E}$ of Kanatak, on Alaska Penin., Aleutian Ra.; $57^{\circ} 34^{\prime} 05^{\prime \prime} \mathrm{N}$, $156^{\circ} 01^{\prime} 30^{\prime \prime} \mathrm{W}$; (map 36$)$.

Named in 1920 by G. C. Martin (1921, pl. 10). Name based on information given in 1920 by J. L. McPherson, Deputy Mineral Surveyor.

Kanatak Lagoon: estuary, extends W $2.5 \mathrm{mi}$, off Portage Bay, S of Mount Becharof, on Alaska Penin., $3 \mathrm{mi}$. $\mathrm{S}$ of Kanatak, Aleutian Ra.; $57^{\circ} 31^{\prime} \mathrm{N}, 156^{\circ} 02^{\prime} \mathrm{W}$; (map 36).

Name published in 1924 by USC\&GS on Chart 8666.

Kanatak Pass: pass, $900 \mathrm{ft}$., at Summit Lake, on route from Portage Bay to Becharof Lake, $\mathrm{N}$ of Mount Becharof, on Alaska Penin., 1.6 mi. NW of Kanatak, Aleutian Ra.; 57 $35^{\prime} 15^{\prime \prime}$ $\mathrm{N}, 156^{\circ} 04^{\prime} 00^{\prime \prime} \mathrm{W}$; (map 36).

Named in 1920 by G. C. Martin (1921, pl. 10), USGS; name based on information given in 1920 by J. L. McPherson, Deputy Mineral Surveyor.

Kanaton: island, see Kamaton.

Kanaton Island: island, see Kanaga Island.

Kanaton Ridge: ridge, $5 \mathrm{mi}$. long, $\mathrm{S}$ of Kanaga Volcano, N Kanaga I., Aleutian Is.; 59 ${ }^{\circ} 54^{\prime}$ N, $177^{\circ} 09^{\prime} \mathrm{W}$; (map 17).

Name published in 1951 on a USGS map. Kanauguk River: stream, heads in York Mts., flows SW $10 \mathrm{mi}$. to Bering Sea, $38 \mathrm{mi}$. NW of Teller, Seward Penin. High.; $65^{\circ} 27^{\prime} \mathrm{N}$, $167^{\circ} 36^{\prime} \mathrm{W}$; (map 111).

Eskimo name reported in 1900 by Brooks (1901, pl, 13 and p. 136), USGS.

Kanayat Creek: stream, in Baird Mts., flows NW $10 \mathrm{mi}$. to Sapun Creek $6 \mathrm{mi}$. SE of its junc. with Noatak River at $E$ end of its 
Grand Canyon, Brooks Ra.; 67 $50^{\prime} \mathrm{N}, 160^{\circ}$ $16^{\prime} \mathrm{W}$; (map 127).

Eskimo name obtained in 1955 by U.S. Army Corps of Engineers.

Kanayut Bluff: bluff, opposite mouth of Kanayut River, on $\mathrm{W}$ side of Anaktuvuk River, $9 \mathrm{mi}$. $\mathrm{N}$ of Table Top and $45 \mathrm{mi}$. NE of Anaktuvuk Pass, Arctic Slope; $68^{\circ} 45^{\prime} \mathrm{N}, 151^{\circ} 09^{\prime}$ W; (map 134).

Named by the USGS in 1956 for the Kanayut River mouth which faces the bluff.

Kanayut Lake: lake, see Shainin Lake.

Kanayut River: stream, heads between Mount Wachsmuth and Ear Peak, flows N $33 \mathrm{mi}$. to Anaktuvuk River at Kanayut Bluff, $8.5 \mathrm{mi}$. N of Table Top and $45 \mathrm{mi}$. NE of Anaktuvuk Pass, Arctic Slope; $68^{\circ} 44^{\prime} \mathrm{N}, 151^{\circ} 07^{\prime} \mathrm{W}$; BGN 1949; (map 134). Var. Willow Creek.

Eskimo name used by USGS geologists during the exploration of Naval Petroleum Reserve No. 4; name given in 1944.

Kancshtuk River: stream, see Kanektok River.

Kandik River: stream, heads in Canada at $65^{\circ} 48^{\prime} \mathrm{N}, 140^{\circ} 20^{\prime} \mathrm{W}$, flows SW $82 \mathrm{mi}$. to Yukon River $9 \mathrm{mi}$. NE of its junc. with Charley River, Porcupine Plat.; $65^{\circ} 22^{\prime} 30^{\prime \prime} \mathrm{N}, 142^{\circ}$ $30^{\prime} 30^{\prime \prime}$ W ; (map 103). Var. Charley Creek, Charlie Creek.

Indian name shown by Lt. Schwatka (1885b, sheet 8 ), USA. The stream is also known as Charley or Charlie Greek after Charlie Village, an Indian village which was located at its mouth.

Kanearok Creek: stream, flows N $5 \mathrm{mi}$. through a low wetland to Kobuk River $23 \mathrm{mi}$. NW of Shungnak, Brooks Ra.; $67^{\circ} 05^{\prime} \mathrm{N}, 157^{\circ} 50^{\prime} \mathrm{W}$; (map 126).

Eskimo name reported by USGS in 1956 .

Kaneetaksmiut: locality, $10 \mathrm{mi}$. SE of Cape Etolin, on NE coast of Nunivak I.; $60^{\circ} 18^{\prime} 45^{\prime \prime}$ N, $166^{\circ} 00^{\prime} 00^{\prime \prime} \mathrm{W}$; (map 57). Var. Kaneetaxmiut, Kanitakhmiut.

Eskimo summer camp reported in 1949 by USC\&GS.

Kaneetaxmiut: locality, see Kaneetaksmiut.

Kanegklikamiut: locality, see Kanelik.

Kanegtok River: stream, see Kanektok River.

Kane Islands: islands, $0.5 \mathrm{mi}$. long, at $\mathrm{N}$ end of Neva Strait, off NW coast of Baranof I., $22 \mathrm{mi}$. NW of Sitka, Alex. Arch.; $57^{\circ} 19^{\prime} 25^{\prime \prime}$ $\mathrm{N}, 135^{\circ} 40^{\prime} 00^{\prime} \mathrm{W}$; BGN 1932; (map 9). Var. Kan Islets, Kane Islets, Ostrova Kan. Named by the Russians for Capt. Kane (cnna), an "American pioneer trader on this coast at the beginning of the century" (U.S. Coast and Geodetic Survey, 1883, p. 157).

Kane Islets: islands, ser: Kane Islands.

Kanektok River: stream, heads at Kagati Lake, flows SW $75 \mathrm{mi}$. to Kuskokwim Bay, $1.5 \mathrm{mi}$. W of Kwinhagak and $46 \mathrm{mi}$. NW of Goodnews, Yukon-Kuskokwim Delta; 59 $45^{\prime} \mathrm{N}$, $161^{\circ} 56^{\prime \prime}$ W; (map 53). Var. Kancshtuk River, Kanegtok River, Kanektuk River, Kanichtuk River, Kaniktuk River, Kwina River, Quina River, Quinahak River, Quinhagak River, Quinhak River.

Eskimo name reported to mean "snow" or "snowy"; submitted in 1898 by J. E. Spurr and W. S. Post, USGS. The stream's lower course was once called "Quinhak," "Quinahak," or "Quinhagak." G. L. Harrington in 1919 stated "another explanation of the word 'Kanektok' gives it as of doubtful origin, and means 'a long way from the post,' and (though I fail to see the connection) was named from the nearby horizontal S.S. [sandstone] beds in the foothills through which the stream passes."

Kanektuk Lake: lake, see Kagati Lake.

Kanektuk Lake: lake, see Pegati Lake.

Kanektuk River: stream, see Kanektok River.

Kaňēlig'mèut: locality, see Kanelik.

Kanelik: locality, on E bank of Kanelik Pass, $11 \mathrm{mi}$. S of Kwiguk, Yukon-Kuskokwim Delta; $62^{\circ} 36^{\prime} 00^{\prime \prime} \mathrm{N}, 164^{\circ} 32^{\prime} 30^{\prime \prime} \mathrm{W}$; (map 77). Var. Kanegklikamiut, Kănēlig'mēut.

Eskimo village name written "Kanegklikamiut," meaning "Kanegklik people," in 1899 by G. R. Putnam, USC\&GS. It is now abandoned except for use as a camp.

Kanelik Pass: channel, in Yukon Delta, extends NE-SW 25 mi. between Akularak and Kwemeluk Passes, $21 \mathrm{mi}$. S of Kwiguk, Yukon-Kuskokwim Delta; $62^{\circ} 28^{\prime} \mathrm{N}, 164^{\circ} 41^{\prime} \mathrm{W}$; (map 77).

Eskimo name obtained in 1899 by G. R. Putnam, USC\&GS. Father Barnum wrote it "Kănēlǐk" in 1901.

Kaneone Peak: peak, see Kankone Peak.

Kane Peak: mountain, $3,253 \mathrm{ft}$, at $\mathrm{E}$ end of Missionary Ra., $13 \mathrm{mi}$. NW of Petersburg, on N central Lindenberg Penin., Kupreanof I., Alex. Arch.; $56^{\circ} 58^{\prime} 45^{\prime \prime} \mathrm{N}, 133^{\circ} 07^{\prime} 10^{\prime \prime} \mathrm{W}$; (map 6).

Named in 1887 by Lt. Comdr. C. M. Thomas, USN, probably for the Arctic explorer Elisha Kent Kane.

Kanga Bay: cove, $0.5 \mathrm{mi}$. across, $4 \mathrm{mi}$. $\mathrm{N}$ of Goddard, on W coast of Baranof I., Alex. Arch.; 56 $54^{\prime} \mathrm{N}, 135^{\circ} 23^{\prime} \mathrm{W}$; (map 5).

Name reported by W. H. Dall (U.S. Coast and Geodetic Survey, 1883, p. 147), USC\&GS.

Kanga Island: island, $0.8 \mathrm{mi}$. long, on $\mathrm{N}$ shore of Kanga Bay, 4.5 mi. $\mathrm{N}$ of Goddard, on $\mathrm{W}$ coast of Baranof I., Alex., Arch.; 56 $53^{\prime} 50^{\prime \prime}$ N, $135^{\circ} 21^{\prime} 30^{\prime \prime} \mathrm{W}$; (map 5). Var. Ostrov Kanga.

Named in 1809 by the Russian navigator, Ivan Vasiliev the first; published by Lt. Sarichev (1826, map 19), IRN, as "O[strov] Kanga" or "Kanga Island." According to Baker (1906, p. 349), Kanga "is an Asiatic name of the Mongolian gun."

Kangaiulouk Island : island, see Spectacle Island.

Kanganeyik Point: point of land, see Konganevik Point.

Kangea: point of land, see Tikugha Point.

Kangeakhok River: stream, flows SE $6 \mathrm{mi}$. to Powooiliak Bay, on S coast of Saint Lawrence I., $30 \mathrm{mi}$. SE of Gambell; $63^{\circ} 24^{\prime} \mathrm{N}, 171^{\circ} 15^{\prime}$ W; (map 93).

Eskimo name reported in 1949 by Maj. H. B. Allen, USAF.

Kangee Camp: locality, $\mathbf{N}$ coast of St. Lawrence I., $15 \mathrm{mi}$. SW of Savoonga ; $63^{\circ} 34^{\prime} \mathrm{N}, 170^{\circ} 53^{\prime}$
W; BGN 1951; (map 93). Var. Camp Collier, Kangi.

Eskimo name recorded by Orth in 1965 as "Kangi" and refers in meaning to "the point of a corner." The name was published by the Univ. of Alaska in 1932.

Kangeeghuk Bay: bay, 2 mi. wide, $4 \mathrm{mi}$. NW of Southeast Cape, extends N 3 ni. from Emeghee Point, on Saint Lawrence I. ; $62^{\circ} 59^{\prime} \mathrm{N}$, $169^{\circ} 45^{\prime}$ W; BGN 1951; Var. Kangighak Bay.

Eskimo name recommended by the $\mathrm{Sa}$ voonga village council; reported in 1949 by Maj. H. B. Allen, USAF.

Kangeekiksatharuk Cove: cove, $12 \mathrm{mi}$. $\mathrm{SE}$ of Cape Etolin, on NE coast of Nunivak I.; $60^{\circ}$ $20^{\prime} 15^{\prime \prime}$ N, 165 $51^{\prime} 20^{\prime \prime}$ W; (map 57): Var. Kangikikhatharak Cove.

Eskimo name meaning "small boat shelter" obtained in 1949 by USC\&GS.

Kangeekiktharuk Cove: cove, $7 \mathrm{mi}$. SW of Cape Etolin, on N coast of Nunivak I. ; $60^{\circ} 22^{\prime} 15^{\prime \prime} \mathrm{N}$, $166^{\circ} 19^{\prime} 30^{\prime \prime} \mathrm{W}$; (map 57). Var. Kangikikhatharak Cove.

See Kangeekiksatharuk Cove.

Kangeeleegowrak: stream, see Kangiligaurak Creek.

Kangekosook: village, see Koyuk.

Kang-ek-tu-nok: bay, see Golden Horn.

Kangi: locality, see Kangee Camp.

Kangianik: stream, see Colville River.

Kangighak Bay: bay, see Kangeeghuk Bay.

Kangighsak, Cape: point of land, see Kangighsak Point.

Kangighsak Camp: locality, see Lietnik.

Kangighsak Point: point of land, on $\mathrm{N}$ coast of Saint Lawrence I.; $63^{\circ} 20^{\prime} 50^{\prime \prime} \mathrm{N}, 169^{\circ} 00^{\prime} 05^{\prime \prime}$ W; (map 93). Var. Cape Kangighsak.

Eskimo name reported in 1932 by Otto W. Geist, Univ. of Alaska.

Kangigivik Point: point of land, see Konganevik Point.

Kangik: locality, at head of Kuk River, $37 \mathrm{mi}$. $\mathrm{S}$ of Wainwright, Arctic Plain; $70^{\circ} 07^{\prime} 30^{\prime \prime} \mathrm{N}$, $159^{\circ} 40^{\prime} 00^{\prime \prime} \mathrm{W}$; (map 146). Var. Kagnik, Kungik, Kungitk.

Eskimo name reported in 1923 by Sidney Paige, USGS. In 1965 Orth recorded the name as "Kangiak," meaning "river head." This may have been one of the "Killaimute" villages mentioned in the 10th Census in 1880 (1881, p. 4).

Kangikat River: stream, see Kongakut River.

Kangikikhatharak Cove: cove, see Kangeekiksatharuk Cove.

Kangikikhatharak Cove: cove, see Kangeekiktharuk Cove.

Kangik River: stream, flows NE $5 \mathrm{mi}$. to Aghnaghak Lagoon, $12 \mathrm{mi}$. S of Gambell, St. Lawrence I.; $63^{\circ} 37^{\prime} \mathrm{N}, 171^{\circ} 41^{\prime} \mathrm{W}$; $B G N$ 1951; (map 93).

Eskimo name reported by Orth in 1965 to mean "point of corner," and refers to the corner of the lagoon where the stream enters. The name was recommended for map usage by the Gambell village council in 1949.

Kangiktoolikmiut: locality, $4 \mathrm{mi}$. N of Cape Mendenhall, Nunivak I.; $59^{\circ} 52^{\prime} \mathrm{N}, 166^{\circ} 13^{\prime}$ W; (map 55). 
Eskimo name reported about 1949 by USC\&GS.

Kangiligaurak Creek: stream, flows NW $2 \mathrm{mi}$. to Kivalina Lagoon, $2 \mathrm{mi}$. SE of Kivalina, Kotzebue-Kobuk Low.; $67^{\circ} 43^{\prime} \mathrm{N}, 164^{\circ} 29^{\prime} \mathrm{W}$; (map 128). Var. Kangeeleegowrak, Qangiligauzaq.

Eskimo name meaning "little end" reported in 1966 by E. S. Burch.

Kangilipak, Lake: lake, $2 \mathrm{mi}$. long, $\mathrm{SE}$ of Okoklik Lake, in Noatak River valley, $51 \mathrm{mi}$. $\mathrm{SE}$ of Misheguk Mtn., Brooks Ra.; $68^{\circ} 00^{\prime} \mathrm{N}$, $159^{\circ} 10^{\prime} \mathrm{W}$; $(\operatorname{map} 131)$.

Eskimo name, meaning "big lake end," obtained in 1956 at Noatak by Orth.

Kangirlvar Bay: $b a y$, between Atrnak Point and Chinigyak Cape, on SW coast of Nelson I. $10 \mathrm{mi}$. SE of Cape Vancouver, Yukon-Kuskokwim Delta; $60^{\circ} 28^{\prime} \mathrm{N}, 165^{\circ} 12^{\prime} \mathrm{W}$; (map 57). Var. Tooksook Bay.

Eskimo name obtained at Tanunak in 1949 by USC\&GS.

Kangkak: bay, see Kongkok Bay.

Kangkak Basin: basin, see Kongkok Basin.

Kangkok: locality, site of village on Kongkok Bay, $27 \mathrm{mi}$. S of Gambell, on W coast of Saint Lawrence I.; $63^{\circ} 23^{\prime} \mathrm{N}, 171^{\circ} 47^{\prime} \mathrm{W}$; (map 93). Var. Kougkok.

Eskimo name reported in 1932 by Otto W. Geist, Univ, of Alaska.

Kangkok: bay, see Kongkok Bay.

Kangnakhnakh Point: point of land, see Kangnaksnak Point.

Kangnaksnak Point: point of land, $5 \mathrm{mi}$. SE of Cape Etolin on N coast of Nunivak I.; $60^{\circ} 22^{\prime}$ N, $166^{\circ} 06^{\prime} \mathrm{W}$; (map 57). Var. Kangnakhnakh Point, Kangnaxnax Point.

Eskimo name obtained in 1949 by USC\&GS.

Kangnaxnax Point: point of land, see Kangnaksnak Point.

Kangneervik: locality, sec Kangnirvik.

Kangneervim Koonga: stream, see Kangnirvik Creek.

Kangniqwim Kuunga: stream, see Kangnirvik Creek.

Kangnirvik: locality, along Kangnirvik Creek, $24 \mathrm{mi}$. NE of Kivalina, Brooks Ra.; $68^{\circ} 02^{\prime} \mathrm{N}$, $164^{\circ} 06^{\prime} \mathrm{W}$; (map 130). Var. Kangneervik, Kangnizwik, Kengneeveerax.

Eskimo name meaning "place at the end," so called because this place in the stream is head of skin boat navigation; name reported as "Kengneeveerax" in 1960 by D. C. Foote.

Kangnirvik Creek: stream, heads at $68^{\circ} 12^{\prime} \mathrm{N}$, $163^{\circ} 37^{\prime} \mathrm{W}$ and flows SW $35 \mathrm{mi}$. to Kivalina River, $18 \mathrm{mi}$. NE of Kivalina, Arctic Slope; $67^{\circ} 57^{\prime}$ N, $164^{\circ} 13^{\prime}$ W; (map 128). Var. Kangneervim Koonga, Kangniqwim Kuunga. Eskimo name reported in 1966 by E. S. Burch.

Kangnizwik: locality, see Kangnirvik.

Kangnizwim Kuunga: stream, see Kangnirvik Creek.

Kangokakh Pass: watercourse, see Kangokakli Pass.

Kangokakli Pass: watercourse, in Yukon Delta, extends NW-SE $13 \mathrm{mi}$. between Kakahkituli Pass and Norton Sound, Yukon-Kuskokwim
Delta; $62^{\circ} 51^{\prime} \mathrm{N}, 164^{\circ} 50^{\prime} \mathrm{W}$; (map 77). Var. Kangokakh Pass.

Eskimo name written "Kangokakh" in 1899 by G. R. Putnam, USC\&GS, published as "Kangokakli" in 1901 on Chart 9373.

Kangoot: locality, see Kongik.

Kangrekho, Mys: point of land, see Cangrejo, Point.

Kangukhsam Mountain: mountain, 1,820 ft., in Kinipaghulghat Mts., $9 \mathrm{mi}$. W of Northeast Cape, on Saint Lawrence I.; $63^{\circ} 18^{\prime} \mathrm{N}, 168^{\circ}$ 58' W; BGN 1951; (map 93). Var. Mount Bulova.

Eskimo name reported in 1949 by Maj. H. B. Allen, USAF.

Kanguksuk: village, see Koyuk.

Kanguksuk River: stream, see Koyuk River.

Kangusuk: village, see Koyuk.

Kangyak: stream, see Kanyak River.

Kaniag Island: island, see Kodiak Island.

Kaniag-miut: village, see Kaguyak.

Kaniakhrak Creek: stream, see Kungiakrok Creek.

Kaniat: bay, see Alitak Bay.

Kanibakhilat: mountains, see Kinipaghulghat Mountains.

Kanibukhilat Mountain: mountains, see Kinipaghulghat Mountains.

Kanichtuk River: stream, see Kanektok River. Kanicula Glacier: glacier, see Kanikula Glacier. Kaniek, Reka: stream, see Kanik River.

Kanig: locality, "on right bank of Yukon River near its mouth," Yukon-Kuskokwim Delta; (map 92). Var. Kanig-miout, Kanygmjut.

Former Eskimo camp or settlement reported in 1850 as "Kanig-miout" by Lt. L. A. Zagoskin, IRN.

Kanig-miout: locality, see Kanig.

Kanik Creek: stream, flows NE $8 \mathrm{mi}$. to East Clem Creek, 56 mi. N of Haycock, Seward Penin. High.; $66^{\circ} 00^{\prime} \mathrm{N}, 161^{\circ} 11^{\prime} \mathrm{W}$; (map 109).

Eskimo name reported in 1949 by the U.S. Army Corps of Engineers.

Kanikhluk: locality, see Kanikluk.

Kanikluk: locality, "on $\mathrm{N}$ shore of Prince William Sound," Chugach Mts. Var. Kanikhluk.

Former Eskimo camp or settlement listed as "Kanikhluk" with a population of 54 by Ivan Petroff in the 1880 Census; listed with a population of 73 in the 1890 Census.

Kanik River: stream, heads at Ualik Lake, flows SW $12 \mathrm{mi}$. to Kulukak Bay, $41 \mathrm{mi}$. SW of Dillingham, Kilbuck-Kuskokwim Mts.; 58․$56^{\prime}$ N, $159^{\circ} 37^{\prime}$ W; (map 40). Var. Reka Kaniek.

Eskimo name reported as "R[eka] Kaniek" by Capt. Tebenkov (1852, map 4), IRN.

Kaniksrak, Lake: lake, $1 \mathrm{mi}$. long, in Killik River valley, $3 \mathrm{mi}$. N of junc. of Easter Creek with Killik River, Brooks Ra.; $68^{\circ} 11^{\prime}$ N, $154^{\circ} 09^{\prime} \mathrm{W}$; (map 133).

Eskimo name meaning "has snow," obtained in 1956 at Anaktuvuk Pass by T. E. Taylor, USGS.

Kaniktuk River: stream, see Kanektok River.
Kanikula Glacier: glacier, trends SE $11 \mathrm{mi}$. to its terminus at head of Tokositna River, $37 \mathrm{mi}$. NW of Talkeetna, Alaska Ra.; 62 $42^{\prime} \mathrm{N}$, $150^{\circ} 55^{\prime}$ W; $B G N$ 1962; (map 81). Var. Kahnicula Glacier, Kanicula Glacier, Little Tokichitna Glacier.

Tanaina Indian name reported in 1906 by Belmore Browne as "Kahnicula" or "Kanicula."

Kanikyakhtalikhmiut: locality, see Kanikyakstalikmiut.

Kanikyakstalikmiut: locality, $24 \mathrm{mi}$. SE of Cape Etolin, on NE coast of Nunivak I.; $60^{\circ} 10^{\prime}$ $10^{\prime \prime} \mathrm{N}, 165^{\circ} 43^{\prime} 20^{\prime \prime} \mathrm{W}$; (map 57). Var. Kanaeyackdligamiut, Kanikyakhtalikhmiut, Kanikyaxtalixmiut, Konigiuktalikmute.

Eskimo name reported about 1949 by USC\&GS.

Kanikyaxtalixmiut: locality, see Kanikyakstalikmiut.

Kaniliak: island, one of Shumagin Is.; $55^{\circ} \mathrm{N}$, $160^{\circ} \mathrm{W}$; (map 27). Var. Khainiliakh.

This name was applied by Father Veniaminov $(1840$, v. 1, p. 255$)$ and was written "Khainiliakh" by Capt. Lutke (1836, p. 267). The exact location of this island is not known.

Kanipakhilat Mountain: mountains, see Kinipaghulghat Mountains.

Kanipakhilat Mountains: mountains, see Kinipaghulghat Mountains.

Kanirak: locality, see Kahnirukmiut.

Kanirak Creek: stream, see Kahniruk River.

Kanirakmiut: locality, see Kahnirukmiut.

Kanirthluk Bay: bay, see Hooper Bay.

Kan Islets: islands, see Kane Islands.

Kanisokrok Lake: lake, $3 \mathrm{mi}$. across, $10 \mathrm{mi}$. SE of Selawik, Kotzebue-Kobuk Low.; $66^{\circ} 33^{\prime}$ N, $159^{\circ} 40^{\prime} \mathrm{W}$; (map 114).

Eskimo name obtained by U.S. Army Corps of Engineers in 1955.

Kanitakhmiut: locality, see Kaneetaksmiut.

Kaniugi Island: island, see Koniuji Island.

Kankone Peak: peak, 4,987 ft., in Kantishna Hills, at head of Moonlight Creek, $12 \mathrm{mi}$. NW of Wonder Lake, Alaska Ra.; 63 $37^{\prime} 25^{\prime \prime}$ N, $150^{\circ} 36^{\prime} 00^{\prime \prime} \mathrm{W}$; (map 88). Var. Kaneone Peak.

Name shown as "Kaneone" on a 1916 fieldsheet by C. E. Giffin, USGS; published as "Kankone" (Capps, 1919, pl. 1).

Kanloyak: locality, on Nelson I., $2 \mathrm{mi}$. SE of Nightmute and $100 \mathrm{mi}$. SW of Bethel, YukonKuskokwim Delta; $60^{\circ} 27^{\prime} \mathrm{N}, 164^{\circ} 44^{\prime} \mathrm{W}$; (map 58).

Former Eskimo village reported in 1949 by USC\&GS. "There is presently (1949) no sign of former habitation."

Kan-na-ghu-nut Island: island, see Kanagunut Island.

Kannaghunut Island: island, see Kanagunut Island.

Kannagkhunut Island: island, see Kanagunut Island.

Kanngumavik Creek: stream, see Kongumavik Creek.

Kanoa, Mys de la: point of land, see Canoa Point. 
Kanoma Gulch: ravine, trends W $0.4 \mathrm{mi}$. to Snow Gulch, $6 \mathrm{mi}$. N of Nome, Seward Penin. High.; $64^{\circ} 35^{\prime} \mathrm{N}, 165^{\circ} 24^{\prime} \mathrm{W}$; (map 94). Var. Kanama Gulch, Kanone, Kanome Gulch. Prospectors' name reported as "Kanome" on the 1900 "Map of Nome Peninsula" by J. M. Davidson and B. D. Blakeslee.

Kanome: ravine, see Kanoma Gulch.

Kanome Gulch: ravine, see Kanoma Gulch.

Kanongiksuk Creek: stream, flows W $9 \mathrm{mi}$. to Easter Creek $3.7 \mathrm{mi}$. SE of its junc. with Killik River, Brooks Ra.; 68 ${ }^{\circ} 06^{\prime}$ N, $154^{\circ} 04^{\prime}$ W; (map 133).

Eskimo name reported in 1956 by T. E. Taylor, USGS.

Kanoolik: locality, see Kanulik.

Kanooskie Island: island, see Koniuji Island.

Kanoozhki Island: island, see Koniuji Island

Kansas Creek: stream, heading on S slope of Mount Tulik, flowing SE $3.5 \mathrm{mi}$. to Pacific Ocean, on NE coast of Umnak I., Aleutian Is. ; $53^{\circ} 20^{\prime} \mathrm{N}, 167^{\circ} 59^{\prime} \mathrm{W}$; (map 23 ).

Name published by Byers (1959, pl. 41), USGS

Kansas Creek: stream, flows NW $9 \mathrm{mi}$. to Wood River, $35 \mathrm{mi}$. E of Healy, Alaska Ra.; $63^{\circ}$ $53^{\prime} 20^{\prime \prime} \mathrm{N}, 147^{\circ} 50^{\prime} 00^{\prime \prime} \mathrm{W}$; ( $\operatorname{map} 87$ ).

Local name reported in 1910 by J. W. Bagley, USGS.

Kantangnak Creek: stream, heads on Tupikchak Mtn., flows N and NW 10 mi. to Kokolik River, Arctic Slope; $68^{\circ} 59^{\prime} \mathrm{N}, 161^{\circ} 54^{\prime} \mathrm{W}$; (map 131).

Eskimo name obtained at Point Lay in 1956 by Orth, meaning "like a basin" [qataqnak]: so called because of the deep basin-like depression along the Kokolik at the stream's mouth.

Kantishana River: stream, see Kantishna River.

Kantishna: locality, in Kantishna Hills, at junc. of Eureka and Moose Creeks, $3 \mathrm{mi}$. NW of Wonder Lake, Alaska Ra.; $63^{\circ} 31^{\prime} 30^{\prime \prime} \mathrm{N}$, $150^{\circ} 57^{\prime} 30^{\prime \prime} \mathrm{W}$; (map 88). Var. Eureka.

This mining camp was established in 1905 one of several such camps that appeared suddenly when gold was discovered in the Kantishna Hills. Most of the camps were abandoned a short time later, but this one was nearest the producing creeks. It was also referred to in the early days as "Eureka," named for the stream. A post office named "Kantishna" was established in 1905 near the mouth of the Kantishna River.

Kantishna Hills: ridge, elev. 1,000-4,987 ft., cxtends NE $50 \mathrm{mi}$. from McKinley River Alaska Ra.; $64^{\circ} 05^{\prime} \mathrm{N}, 150^{\circ} 00^{\prime} \mathrm{W}$ [NE end], $63^{\circ} 27^{\prime} \mathrm{N}, 151^{\circ} 10^{\prime} \mathrm{W}$. [SW end]; (map 88).

Local name reported in 1916 by $\mathbf{S}$. $\mathbf{R}$. Capps, USGS.

Kantishna River: stream, heads at junc. of Birch Creek and McKinley River, flows N $108 \mathrm{mi}$ to Tanana River, $32 \mathrm{mi}$. NW of Nenana, Tanana Low.; $64^{\circ} 46^{\prime} \mathrm{N}, 149^{\circ} 58^{\prime} \mathrm{W}$; (map 100). Var. Cantishna River, Con-tay-th-no, Con-tay-thno, Dugan River, Kantishana River, Toclat River.
There was considerable confusion over the application of this Indian name prior to adequate mapping. Lt. J. S. Herron, USA, in 1899 appears to have been first to show a name for the stream when he wrote both Indian names, "Toclat (Col-tay-th-no)"; recognizing the possible confusion of application with the name "Toclat River" of Lt. H. T. Allen, USA, in 1885. Herron also wrote the name as "Con-tay-thno." A. H. Brooks, USGS, called the stream "Toklat" in 1902. Lt. Gibbs, USA, in 1902 and D. L. Reaburn, USGS, in 1903 both mapped the mouth of the stream in its correct position showing it to be the same which Lt. Allen called "Dugan" in 1885 for Lt. Thomas Buchanan Dugan, USA. Gibbs wrote "Cantishna" and Reaburn "Kantishna." The name "Toklat River" is now applied to a branch of the Kantishna.

Kantukan: village, see Hoonah.

Kanuhnuktaili Slough: stream, see Kanunuk Slough.

Kanu Island: island, $1.7 \mathrm{mi}$. long, between Great Sitkin and Umak Is., Andreanof Is., Aleutian Is.; $51^{\circ} 56^{\prime} 30^{\prime \prime} \mathrm{N}, 176^{\circ} 02^{\prime} 20^{\prime \prime} \mathrm{W}$; BGN 1936; (map 17). Var. Jounakh Island, Yunakh Island, Ostrov Yunakh.

Name derived from Unak Island and given by the U.S. Navy Hydrog. Office in 1936 because ". . . There being so much similarity in the names [of nearby] Ulak I., Umak I., and Unak I., serious delay might result in sending a rescue party to one of these islands, as was brought out in the 1934 report of the expedition, and for this reason Unak I. was spelled backward ..." The name "Unak" is derived from the Aleut "unaq" meaning "wound," published by Capt. Tebenkov (1852, map 28), IRN, as "O[strov] Yunakh," or "Yunakh Island."

KanukaNanyvuk Lake: lake, $3 \mathrm{mi}$. N of Okstukuk Lake, $38 \mathrm{mi}$. $\mathbf{N}$ of Dillingham, Bristol Bay Low.; $59^{\circ} 34^{\prime} \mathrm{N}, 158^{\circ} 17^{\prime} \mathrm{W}$; (map 52).

Eskimo name shown as "Ka-nuk-a-Nan-yvuk" on a 1910 manuscript map by H. C. Fassett, USBF

Kanuktik Creek: stream, heads at Kanuktik Lake, flows NW $12 \mathrm{mi}$. to Kanektok River, $66 \mathrm{mi}$. NE of Goodnews, Kilbuck-Kuskokwim Mts.; $59^{\circ} 53^{\prime} \mathrm{N}, 160^{\circ} 28^{\prime} \mathrm{W}$; (map 53).

Eskimo name shown on an 1898 fieldsheet by W. S. Post, USGS, whose party passed by it on Sept. 4, 1898 . The name was published by Spurr (1900, map 10), USGS.

Kanuktik Lake: lake, extends N $4 \mathrm{mi}$. to headwaters of Kanuktik Creek, 60 mi. NE of Goodnews, Kilbuck-Kuskokwim Mts.; 59 $44^{\prime}$ N $160^{\circ} 19^{\prime} \mathrm{W}$; (map 53).

Eskimo name published in 1951 by USGS Kanulik: locality, at head of Nushagak Bay, 2 mi. NE of Nushagak and $6 \mathrm{mi}$. SE of Dillingham, Bristol Bay Low. ; 58 $58^{\prime} \mathrm{N}, 158^{\circ} 28^{\prime} \mathrm{W}$; (map 52). Var. Kanoolik, Karulik, Nunnungynakok.

Eskimo village reported by Ivan Petroff in 1880 Census. Its population in 1880 was 142 ; in 1890,54 ; it is now abandoned.
Kanunuk Slough: stream, in Yukon Delta, flows NE $1.8 \mathrm{mi}$. to Apoon Pass, $1.5 \mathrm{mi}$. W of Kotlik and $35 \mathrm{mi}$. NE of Kwiguk, Yukon-Kuskokwim Delta ; $63^{\circ} 02^{\prime}$ N, $163^{\circ} 36^{\prime}$ W ; (map 92). Var. Kanuhnuktaili Slough.

Eskimo name reported in 1899 by R. L. Faris, USC\&GS, as "Kanuhnuktaili."

Kanutena: stream, see Kanuti River.

Kanuti: locality, "on Koyukuk River," Hogatza High.; (map 116). Var. Konoótená, Old Man River.

Former Eskimo camp or settlement reported in 1885 as "Konoótená" with a population of 13 by Lt. H. T. Allen, USA.

Kanuti Canyon: canyon, extends $7 \mathrm{mi}$. along Kanuti River $4 \mathrm{mi}$. SE of its junc. with Mentanontli River, $17 \mathrm{mi}$. SW of Allakaket, Kokrines-Hodzana High.; $66^{\circ} 19^{\prime} 05^{\prime \prime} \mathrm{N}, 152^{\circ} 51^{\prime}$ $00^{\prime \prime} \mathrm{W}$; (map 117).

Local name reported in 1956 by T. E. Taylor, USGS.

Kanuti Chalatna Creek: stream, heads in Kaldolyeit Lake, flows SE $50 \mathrm{mi}$. through Clawanmenka Lake to Kanuti River, $22 \mathrm{mi}$. SE of Allakaket, Kanuti Flats; $66^{\circ} 17^{\prime} \mathrm{N}, 152^{\circ} 18^{\prime}$ W; (map 117).

Koyukan Indian name obtained in 1956 at Allakaket by T. E. Taylor, USGS.

Kanuti Flats: fats, of South Fork Koyukuk, Koyukuk and Kanuti Rivers, extend SW 60 mi. from Bettles and $\mathrm{E} 45 \mathrm{mi}$. from Allakaket; $66^{\circ} 32^{\prime} \mathrm{N}, 151^{\circ} 51^{\prime} \mathrm{W}$; (map 117).

Local name reported in 1956 by T. E. Taylor, USGS.

Kanuti Kilolitna Creek: stream, see Kanuti Kilolitna River.

Kanuti Kilolitna River: stream, heads in lake, in Ray Mts., flows $W$ and $N E 60 \mathrm{mi}$. to Kanuti River, $30 \mathrm{mi}$. SE of Allakaket, Kanuti Flats; $66^{\circ} 12^{\prime} 30^{\prime \prime} \mathrm{N}, 152^{\circ} 02^{\prime} 30^{\prime \prime} \mathrm{W}$; BGN 1961; (map 117). Var. Kanuti Kilolitna Creek.

Koyukan Indian name obtained in 1956 at Allakaket by Orth.

Kanuti Lake: lake, $1 \mathrm{mi}$. long, $1.7 \mathrm{mi}$. NE of Old Dummy Lake, $37 \mathrm{mi}$. SE of Allakaket, Kanuti Flats; $66^{\circ} 10^{\prime} 30^{\prime \prime} \mathrm{N}, 151^{\circ} 45^{\prime} 00^{\prime \prime} \mathrm{W}$; (map 117).

Koyukan Indian name obtained in 1956 at Allakaket by 'T. E. Taylor, USGS.

Kanuti River: stream, flows W $175 \mathrm{mi}$. to Koyukuk River, $13 \mathrm{mi}$. SW of Allakaket, Kokrines-Hodzana High.; $66^{\circ} 27^{\prime} \mathrm{N}, 153^{\circ} 00^{\prime}$ W; (map 116). Var. Kanutena, Koinooten, Konootena, Kornutena, Kornuti, Kornutna, Koznuten, Old Man Creek, Old Man River.

Koyukan Indian name obtained in 1885 by Lt. Allen (1887, p. 97), USA, who spelled it "Konootena." It is said to mean "Old Man's River," which would account for the name "old man river" used by some prospectors from 1898 to 1913.

Kanyak River: stream, flows NW $5.3 \mathrm{mi}$, to Nagosakchowik Slough, $3.2 \mathrm{mi}$. W of Sheldon Point and $21 \mathrm{mi}$. SW of Kwiguk, Yukon-Kuskokwim Delta; 62 $31^{\prime} 40^{\prime \prime} \mathrm{N}, 164^{\circ} 57^{\prime} 10^{\prime \prime} \mathrm{W}$; (map 77). Var. Kangyak, Nioklakowik Slough. 
Eskimo name obtained in 1952 by U.S Army Corps of Engineers.

Kanygmjut: locality, see Kanig.

Kanyk, Reka: stream, see Buckland River.

Kanyugi, Ostrov: island, see Koniuji Island.

Ka-o-e-che-ark: stream, see Kawichiark River.

Kaoklorokamiut: locality, see Kwikluak.

Kaolak River: stream, heads at $69^{\circ} 38^{\prime} \mathrm{N}$ $160^{\circ} 37^{\prime} \mathrm{W}$, flows NE $60 \mathrm{mi}$., joins Avalik River to form Kuk River, $37 \mathrm{mi}$. SE of Wainwright, Arctic Plain; $70^{\circ} 07^{\prime} \mathrm{N}, 159^{\circ} 41^{\prime} \mathrm{W}$; $B G N$ 1925; (map 146). Var. Kaolik River.

Eskimo name reported in 1924 by USGS.

Kaolak River: stream, see Kuk River.

Kaoledoly Slough: channel, in Yukon Delta, extends NW-SE $2.8 \mathrm{mi}$. between Kwiguk and Kwikluak Passes, $0.8 \mathrm{mi}$. N of Kwiguk, Yukon-Kuskokwim Delta; $62^{\circ} 46^{\prime} 15^{\prime \prime}$ N, $164^{\circ}$ 29'30' W ; (map 77).

Eskimo name obtained in 1899 by G. $R$. Putnam, USC\&GS. Published in 1899 on Chart 9372.

Kaolik River: stream, see Kaolak River.

Ka-ooveren River: stream, sce Kaviruk River.

Kaouakhta: island, see Kauatka.

Kapaloa: locality, see Capaloa.

Kapaloa: point of land, see Dyer, Cape.

Kapaloa Creek: stream, see Kapaloak Creek.

Kapaloak: point of land, see Dyer, Cape.

Kapaloak Creek: stream, flows SW $8.5 \mathrm{mi}$. to Chukchi Sea, $0.6 \mathrm{mi}$. S of Cape Dyer, Arctic Slope; $68^{\circ} 38^{\prime} 50^{\prime \prime} \mathrm{N}, 166^{\circ} 13^{\prime} 00^{\prime \prime} \mathrm{W} ; B G N$ 1965; (map 129). Var. Capaloa Creek, Kapaloa Creek.

Named in 1904 by Collier (1906, p. 44) who wrote, "An abandoned native settlement here bears the name Capaloa, and the name is applied by the writer to the creek near which the old houses stand." Spelling has been changd to conform with present-day pronunciation. See Capaloa and Cape Dyer.

Kapalowa: locality, see Capaloa.

Kapalowa: point of land, see Dyer, Cape.

Kapho Mountain: mountains, see Kapho Mountains.

Kapho Mountains: mountains, 4,496 ft., $5 \mathrm{mi}$. long, $2 \mathrm{mi}$. NW of head of Bradfield Canal, Coast Mts. ; $56^{\circ} 15^{\prime} \mathrm{N}, 1^{\circ} 31^{\circ} 36^{\prime} \mathrm{W}$; (map 7). Var. Kapho Mountain.

Indian name reported in 1886 by Lt. Comdr. A. S. Snow, USN; "Kapho; mountain * * said to mean 'brothers'."

Kapitanskaya Gavan: bay, see Unalaska Bay.

Kapon Creek: stream, flows NW $10 \mathrm{mi}$. to Eek River, $70 \mathrm{mi}$. SE of Bethel, Kilbuck-Kuskokwim Mts.; $60^{\circ} 10^{\prime} \mathrm{N}, 160^{\circ} 15^{\prime} \mathrm{W}$; (map 59).

Local name reported in 1955 by J. M. Hoare, USGS.

Kaponyes, Mys de: point of land, see Capones, Point.

Kapoon Creek: stream, flows SW $4 \mathrm{mi}$. from Eekayruk Mtn. to Hammond River, $29 \mathrm{mi}$ $\mathrm{N}$ of Wiseman, Brooks Ra.; $67^{\circ} 50^{\prime} \mathrm{N}, 150^{\circ}$ $08^{\prime} \mathrm{W} ; B G N$ 1932; (map 124).

Named about 1930 by Robert Marshall for an Eskimo living at Wiseman.

Kapsco Bay: $b a y$, see Wrangell Cove.

Kapsukalik Lake: lake, $2 \mathrm{mi}$. long, $19 \mathrm{mi}$. SE of Savoonga, St. Lawrence I. ; $63^{\circ} 28^{\prime} \mathrm{N}, 170^{\circ}$ $09^{\prime} \mathrm{W} ; B$ B 1951 ; (map 93).

Eskimo name reported by Orth in 1965 to mean "constricted in the middle." The name was recorded in 1949 by Maj. H. B. Allen, USAF.

Karab Cove: cove, $0.6 \mathrm{mi}$. across, in NE part of Otkriti Bay, on S coast of Agattu I., Aleutian Is., $52^{\circ} 23^{\prime} 30^{\prime \prime} \mathrm{N}, 173^{\circ} 36^{\prime} 30^{\prime \prime} \mathrm{E}$; BGN 1938; (map 13). Var. Karablin Cove, Korab Cove, Haynie Cove.

This name was proposed as "Karablin Cove," in 1938, by the Hydrog. Office of the U.S. Navy. The name was published as "Korab Cove" in 1943 on an AMS map and is shown as 'Karab ('Karablin' or 'Haynie') Cove" in the 1944 Aleutian Coast Pilot (p. 136). "Karab" has no known meaning.

Karablin: island, see Ship Rock.

Karablin Cove: cove, see Karab Cove.

Karakol, Mys de la: point of land, see Snail Point.

Karavaxarak River: stream, see Kaviavazak River.

Kardy Lake: lake, $1 \mathrm{mi}$. across, on Phipps Peninsula, $1.1 \mathrm{mi}$. SE of Ocean Cape and $3.4 \mathrm{mi}$. SW of Yakutat, Malaspina Coastal Plain; $59^{\circ} 31^{\prime} 45^{\prime \prime} \mathrm{N}, 139^{\circ} 49^{\prime} 15^{\prime \prime} \mathrm{W}$; (map 46).

Local name published in 1959 by USGS.

Karen Creek: stream, flows NE $14 \mathrm{mi}$. to Kekiktuk River 5 mi. $S$ of its junc. with the Sadlerochit River, $20 \mathrm{mi}$. NW of Mount Michelson, Brooks Ra.; 69 $29^{\prime} 15^{\prime \prime}$ N, $144^{\circ}$ 39'12" W; (map 139)

Probably named by geologists in the 1950's.

Karen Lake: lake, $0.7 \mathrm{mi}$. long, in Mentasta Mts. 9 mi. NW of Devils Mtn., Alaska Ra.; 62 ${ }^{\circ} 33^{\prime}$ N, $143^{\circ} 01^{\prime} \mathrm{W}$; (map 84).

Local name reported by USGS in 1960.

Karheen: locality, on Karheen Cove, SW coast of Tuxekan I., Alex. Arch.; $55^{\circ} 48^{\prime} 45^{\prime \prime} \mathrm{N}$, $133^{\circ} 18^{\prime} 35^{\prime \prime}$ W; (map 4). Var. Karheen Cannery.

Former village established at a cannery about 1914; named for Karheen Creek.

Karheen Cannery: locality, see Karheen.

Karheen Creek: stream, flows SW $2 \mathrm{mi}$. to Karheen Passage at Karheen, Alex. Arch.; 55 $49^{\prime}$ N, $133^{\circ} 19^{\prime}$ W; (map 4). Var. Ka-hehe, KahHehe, Kahin, Kahini, Sar-hini.

Tlingit Indian name, possibly from "ta-hin" meaning "salmon stream," reported in 1897 as "Ka-Hehe" by Lt. Comdr. J. F. Moser, USN. The present spelling was established by the name of a cannery formerly located at the stream's mouth. See Karheen.

Karheen Cove: bay, $0.2 \mathrm{mi}$. long, off Karheen Passage, on SW coast of Tuxekan I., Alex. Arch.; 55 $48^{\prime} 40^{\prime \prime} \mathrm{N}, 133^{\circ} 18^{\prime} 45^{\prime \prime} \mathrm{W}$; (map 4).

Local name published in 1925 Goast Pilot (p. 152). See Karheen.

Karheen Lakes: lakes, two, extend $1.5 \mathrm{mi}$., in course of stream, on Tuxekan I., Alex. Arch. $55^{\circ} 48^{\prime} 45^{\prime \prime} \mathrm{N}, 133^{\circ} 17^{\prime} 30^{\prime \prime} \mathrm{W}$; (map 4).

Local name recorded in 1949 by USGS.

Karheen Passage: water passage, 4 mi. long, between Heceta and Tuxekan Islands, Alex.
Arch. ; $55^{\circ} 48^{\prime} \mathrm{N}, 133^{\circ} 18^{\prime} \mathrm{W}$; (map 4). $B G N$ 1916. Var. Kahin, Kahini.

Named in 1916 by USC\&GS; derived from village of Karheen. The water passage was originally referred to as "the pass to Karheen Cannery."

Karillyukpuk Creek: stream, flows S $4 \mathrm{mi}$. from Kinnorutin Pass to Clear River, $3 \mathrm{mi}$. W of Harvey Mtn. and $33 \mathrm{mi}$. N of Wiseman, Brooks Ra.; $67^{\circ} 51^{\prime} 30^{\prime \prime} \mathrm{N}, 150^{\circ} 23^{\prime} 20^{\prime \prime} \mathrm{W}$; (map 124).

In describing this stream, Marshall (1956, p. 72) wrote, "The gulch which came in at the head of the valley *** we named Karillyukpuk, meaning 'very rugged' [in Eskimo]." Kariltna River: stream, see Kahiltna River.

Karl Creek: stream, flows $\mathrm{N} 13 \mathrm{mi}$. to Fog River, $60 \mathrm{mi}$. E of Bethel, Kilbuck-Kuskokwim Mts.; $60^{\circ} 49^{\prime} \mathrm{N}, 159^{\circ} 56^{\prime} \mathrm{W}$; (map 59).

Local name reported in 1955 by J. M. Hoare, USGS.

Karlooch: village, see Karluk.

Karloutskoi, Cap: point of land, see Karluk, Cape.

Karluk: village, pop. 129 , on E coast of Kodiak I.; $57^{\circ} 34^{\prime} 10^{\prime \prime} \mathrm{N}, 154^{\circ} 27^{\prime} 30^{\prime \prime} \mathrm{W}$; (map 35). Var. Carlook, Karlooch, Karluk Spit, Karluta, Kunakakvak.

Native name reported in 1805 by Capt. Lisianski (1814, p. 186), IRN, as "Cariook" and as "Karloock" (map, p. 169). The Russian American Company in 1849 reported a village at or near this location called "Kunakakhvak." The Karluk post office was established here in 1892 (Ricks, 1965, p. 31).

Karluk, Cape: point of land, 2 mi. W of Karluk, on $\mathrm{E}$ coast of Kodiak I. ; $57^{\circ} 35^{\prime} 10^{\prime \prime} \mathrm{N}, 154^{\circ}$ $30^{\prime} 50^{\prime \prime}$ W; (map 35). Var. Cap Karloutskoi, Karluk Head.

Name derived from village of Karluk and published by USC\&GS in 1868 . This point was called "Cape Karloutskoi" by Capt. Lutke (1836, p. 276), IRN, and Baker (1906, p. $350)$ says "locally known as 'Karluk head'."

Karluk Anchorage: bay, $3 \mathrm{mi}$. across, at Karluk, on W coast of Kodiak I.; $57^{\circ} 34^{\prime} 30^{\prime \prime} \mathrm{N}, 154^{\circ}$ 28'00" W; (map 35).

Name derived from village of Karluk and reported in 1897 by Lt. Comdr. J. F. Moser, USN, commander of the USBF steamer Albatross.

Karluk Head: point of land, see Karluk, Cape.

Karluk Island: barrier, island, $0.5 \mathrm{mi}$. long, southernmost of McClure Is., on Beaufort Sea coast, Arctic Plain; $70^{\circ} 20^{\prime} 25^{\prime \prime} \mathrm{N}, 147^{\circ} 19^{\prime} 30^{\prime \prime}$ W; (map 150). Var. Island Number 19.

It is shown on present-day maps as an unnamed island SE of Jeannette Island. It was originally named Karluk Island by Leffingwell (1919, p. 96), "after the whaling ship Karluk," which, under the command of Capt. Steven Cottle, "kindly towed the yawl halfway to Nome * * " in July 1909 (p. 15). The island was identified by Leffingwell as Island Number 19 , and was used as a triangulation station in 1910 .

Karluk Lagoon: lagoon, $2.5 \mathrm{mi}$. long, at mouth of Karluk River at Karluk, on $W$ coast of Kodiak I.; 57 $34^{\prime}$ N, $154^{\circ} 25^{\prime}$ W; (map 35). 
Name derived from village of Karluk and reported in 1897 by Lt. Comdr. J. F. Moser, USN, commander of the USBF steamer Albatross.

Karluk Lake: lake, $12 \mathrm{mi}$. long, in $\mathrm{E}$ part of Kodiak I., $20 \mathrm{mi}$. SE of Karluk; 57 $23^{\prime} \mathrm{N}$, $154^{\circ} 03^{\prime} \mathrm{W}$; (map 35$)$.

Name derived from village of Karluk and reported by USBF in 1889 .

Karluk Reef: reef, $3 \mathrm{mi}$. long, in Cook Inlet, $9 \mathrm{mi}$. SW of Kenai, Cook Inlet Low.; $60^{\circ} 27^{\prime}$ N, $151^{\circ} 24^{\prime} \mathrm{W}$; (map 62$)$.

Name published in 1900 by USC\&GS.

Karluk River: stream, heads at Karluk Lake, flows $\mathrm{N}$ and W $24 \mathrm{mi}$. through Karluk Lagoon to Shelikof Strait at Karluk, on W coast of Kodiak I. ; $57^{\circ} 34^{\prime} 20^{\prime \prime} \mathrm{N}, 154^{\circ} 27^{\prime} 45^{\prime \prime} \mathrm{W}$; (map 35).

Name derived from village of Karluk and published by USC\&GS in 1868 .

Karlukskiy, Proliv: water passage, see Kupreanof Strait.

Karluk Spit: village, see Karluk.

Karluk Strait: water passage, see Kupreanof Strait.

Karlun Lake: lake, see Kalun Lake.

Karluta: village, see Karluk.

Karmuk Point: point of land, between Kuk River and Wainwright Inlet, $4.5 \mathrm{mi}$. SE of Wainwright, Arctic Plain; $70^{\circ} 35^{\prime} 10^{\prime \prime} \mathrm{N}, 159^{\circ}$. 53'45" W; BGN 1925; (map 146).

Eskimo name reported in 1924 by USGS.

Karon Lake: lake, $1 \mathrm{mi}$. across, $12 \mathrm{mi}$. N of Cape Mendenhall, Nunivak I.; $59^{\circ} 58^{\prime} 30^{\prime \prime} \mathrm{N}$, $166^{\circ} 14^{\prime} 30^{\prime \prime} \mathrm{W}$; (map 55)

Eskimo name reported in 1949 to refer to the "river head" according to USC\&GS.

Karpa Island: island, $1.5 \mathrm{mi}$. long, $5 \mathrm{mi}$. NE of Korovin I., in Shumagin Is., Aleutian Ra.; $55^{\circ} 30^{\prime} 30^{\prime \prime} \mathrm{N}, 160^{\circ} 03^{\prime} 00^{\prime \prime} \mathrm{W} ; B G N$ 1890: (map 28). Var. Boulder, Bouldyr, Buldyr, Inglikhakh, Inlikak, Tangimak.

Published as "O[strov] Karpa," meaning "Carp Island," on Russian Hydrog. Dept. Chart 1379 (1847). The Aleut name is "Inlikak" or "Inglikhakh," according to Capt. F. P. Lutke, IRN, who also used the Russian name "Bouldyr," meaning "hovel". Boulder Island is shown on an 1890 USBF chart, while Bouldyr, Bouldir, and Karpa are shown on USC\&GS charts.

Karr Hills: mountains, see Guyot Hills.

Karshner Creek: stream, flows SE $2.3 \mathrm{mi}$. to Hot Springs Slough N of Manley Hot Springs, 44 mi. ESE of Tanana, Yukon-Tanana High.; $65^{\circ} 00^{\prime} 10^{\prime \prime} \mathrm{N}, 150^{\circ} 37^{\prime} 45^{\prime \prime} \mathrm{W}$; (map 106).

Prospectors' name reported in 1916 by USGS.

Karson Creek: stream, sec Kasson Creck.

Karstens Col: pass, 10,930 ft., between Karstens Ridge and Mount Koven, on E side of Muldrow Glacier, $6 \mathrm{mi}$. NE of Mount McKinley, Alaska Ra.; $63^{\circ} 07^{\prime} 30^{\prime \prime} \mathrm{N}, 150^{\circ} 54^{\prime} 30^{\prime \prime} \mathrm{W}$; BGN 1948; (map 88). Var. Karstens Notch.

Named in 1946 by Bradford Washburn for Harry P. Karstens. See Karstens Ridge.

Karstens Notch: pass, see Karstens Col.
Karstens Ridge: ridge, 11,000-14,000 ft., in Mount McKinley National Park, extends $\mathrm{N}$ $1.8 \mathrm{mi}$. from Harper Icefall to Karstens Col, $4.5 \mathrm{mi}$. $\mathrm{E}$ of summit of Mount McKinley, Alaska Ra.; $63^{\circ} 07^{\prime} 10^{\prime \prime} \mathrm{N}, 150^{\circ} 55^{\prime} 00^{\prime \prime} \mathrm{W}$; (map 88).

Named in 1913 by Archdeacon Stuck (1921, p. 73) for Harry P. Karstens, "in honor of the man, who with Walter's [Harper] help, cut that staircase three miles long amid the perilous complexities of its [Mount McKinley's] chaotic ice-blocks." Karstens, with Archdeacon Stuck, Walter Harper, and Robert Tatum, made the "first official ascent" of Mount McKinley (South Peak) on June 7, 1913.

Karta Bay: bay, see Kasaan Bay.

Karta Bay: estuary, extends W 1 mi., off Kasaan Bay, at mouth of Karta River, on $\mathbf{E}$ coast of Prince of Wales I., Alex. Arch.; 55 ${ }^{\circ} 34^{\prime} 15^{\prime \prime}$ N, $132^{\circ} 34^{\prime} 00^{\prime \prime}$ W; (map 4). Var. Kasa-an Anchorage.

This name was originally published as "Kasa-an" in 1883 Coast Pilot (p. 85), but due to a copying error the name appeared as "Karta" on Brit. Adm. Chart 2431, a form that has since become well established.

Karta Lake: lake, $1.5 \mathrm{mi}$. long, on Prince of Wales I., near head of Kasaan Bay, in course of Karta River, Alex. Arch.; $55^{\circ} 34^{\prime} \mathrm{N}$, $132^{\circ} 38^{\prime} \mathrm{W}$; (map 4). Var. Little Salmon Lake.

Local name reported in 1906 by Wright and Wright (1908, fig. 15), USGS. The name "Little Salmon" was published for this lake by G. H. Canfield (in Brooks and others, 1916, p. 110), USGS.

Karta River: stream, heads in Salmon Lake, on Prince of Wales I., flows $\mathrm{E}$ through Karta Lake $4 \mathrm{mi}$. to Karta Bay, Alex. Arch., $55^{\circ}$ $33^{\prime} 45^{\prime \prime}$ N, $132^{\circ} 34^{\prime} 30^{\prime \prime}$ W; (map 4). Var. Lake River, Little Salmon.

Local name reported in 1906 by Wright and Wright (1908, fig. 15), USGS

Karulik: locality, see Kanulik.

Karumnulima Creek: stream, flows S $13 \mathrm{mi}$. to Noatak River, $42 \mathrm{mi}$. WSW of Survey Pass, Brooks Ra. ; $67^{\circ} 41^{\prime} \mathrm{N}, 155^{\circ} 38^{\prime} \mathrm{W}$; (map 125). Eskimo name reported by USGS in 1956 to refer in meaning to a broken arrow.

Karvak Creek: stream, see Driftwood Creek.

Kasaan: village, pop. 36, on Kasaan Bay on SW coast of Kasaan Penin., Prince of Wales I., Alex. Arch.; $55^{\circ} 32^{\prime} 25^{\prime \prime} \mathrm{N}, 132^{\circ} 23^{\prime} 50^{\prime \prime} \mathrm{W}$; (map 4).

Village established in the 1890's when a salmon-packing plant was located here. Haida Indians from Kasaan, now "Old Kasaan," relocated here and the post office, established in 1900, was named for the old village. Its population was 129 in $1910 ; 126$ in $1920 ; 112$ in $1930 ; 85$ in 1939 ; and 47 in 1950. See Old Kasaan.

Kasaan: locality, see Old Kasaan.

Kasa-an Anchorage: estuary, see Karta Bay.

Kasaan Bay: bay, extends NW 22 mi., off Clarence Strait, on $\mathbf{E}$ coast of Prince of Wales I., Alex. Arch.; $55^{\circ} 24^{\prime} \mathrm{N}, 132^{\circ} 06^{\prime} \mathrm{W}$; BGN
1899; (map 4). Var. Casaan Bay, Karta Bay, Kasa-an Bay, Kasan Bay, Kazarn Bay, Zaliv Kazarn.

Haida Indian name published as " $\mathrm{Z}$ [aliv] Kazarn," or "Kazarn Bay," by Capt. M. D. Tebenkov (1852, map 9), IRN, who applied it to Skowl Arm, at the southeast end of this bay. The name was published as "Kasa-an Bay" in 1883 Coast Pilot (p. 85).

Kasaan Bay: locality, see Old Kasaan.

Kasa-an Bay: bay, see Karta Bay.

Kasaan Island: island, $2.5 \mathrm{mi}$. long, in Kasaan Bay, on E coast of Prince of Wales I., Alex. Arch.; $55^{\circ} 30^{\prime} \mathrm{N}, 132^{\circ} 21^{\prime} \mathrm{W}$; (map 4). Var. Long Island.

Named Long I. in 1880 by USC\&GS; USFS changed the name in 1931 "in order to avoid confusion with another Island of that name off the southwestern coast of Prince of Wales Island."

Kasaan Mountain: mountain, 2,846 ft., on E coast of Prince of Wales I., on Kasaan Penin., $\mathrm{NE}$ of Kasaan, Alex. Arch.; 55 $32^{\prime} 50^{\prime \prime} \mathrm{N}$, $132^{\circ} 21^{\prime} 30^{\prime \prime} \mathrm{W}$; (map 4).

Local name reported in 1908 by C. W. Wright (in Brooks and others, 1909, pl. 2), USGS.

Kasaan Peninsula: peninsula, on $\mathrm{E}$ coast of Prince of Wales I., extends SE 18 mi., between Clarence Strait and Kasaan Bay, Alex. Arch.; $55^{\circ} 33^{\prime} \mathrm{N}, 132^{\circ} 20^{\prime} \mathrm{W}$; (map 4).

Named in 1901 by A. H. Brooks, USGS.

Kasaan Point: point of land, on $\mathrm{E}$ coast of Prince of Wales I., between Kasaan Bay and its Skowl Arm, Alex. Arch.; $55^{\circ} 26^{\prime} 40^{\prime \prime}$ N, $132^{\circ}$ $16^{\prime} 45^{\prime \prime} \mathrm{W}$; (map 4).

Named by local fishermen and reported in 1904 by H. C. Fassett, USBF.

Kasan Bay: bay, see Kasaan Bay.

Kasatochi Island: island, $1.5 \mathrm{mi}$. across, $15 \mathrm{mi}$. NW of Atka I., Andreanof Is., Aleutian Is.; $52^{\circ} 10^{\prime} 30^{\prime \prime} \mathrm{N}, 175^{\circ} 31^{\prime} 00^{\prime \prime} \mathrm{W}$; BGN 1936; (map 18). Var. Kassatotchy Island.

Russian name published as "Kosatochyey" by Lt. Sarichev (1802, v. 2, p. 179), IRN; shown as "L'ile Kassatotchy" by Lutke (1836, p. 310), and as "O[strov] Kasatochiy" on Russian Hydrog. Dept. Chart 1400 (1848). Described by Capt. Lutke, IRN, as an extinct crater, containing a lake.

Kasaun Spit: spit, see Kason Spit.

Kasautaa: spit, see Kason Spit.

Kasegaluk Inlet: water passage, see Noakok Pass.

Kasegaluk Lagoon: lagoon, $\mathrm{N}$ end $16 \mathrm{mi}$. SW of Wainwright, extends SW $120 \mathrm{mi}$. on Chukchi Sea coast, Arctic Plain; $70^{\circ} 28^{\prime} \mathrm{N}, 160^{\circ} 29^{\prime} \mathrm{W}$ ( $\mathrm{NE}$ end) ; $69^{\circ} 16^{\prime} \mathrm{N}, 163^{\circ} 18^{\prime} \mathrm{W}$ (SW end); (map 146). Var. Kasegarlik Lagoon, Kasegarluk Lagoon, Kasegelik Lagoon.

Eskimo name reported in 1923 by USGS as "Kasegarlik" and changed in 1929 to its present spelling. In 1965, at Wainwright, Orth recorded the name as "Kasegelik," meaning "spotted seal place" or "having spotted seal."

Kasegarlik Lagoon: lagoon, see Kasegaluk Lagoon. 
Kasegarluk Lagoon: lagoon, see Kasegaluk Lagoon.

Kasegelik Lagoon: lagoon, see Kasegaluk Lagoon.

Kaseglok: village, see Kasigluk.

Kashaiagamut: locality, see Kashiagamiut

Kashaiagmut: locality, see Kashiagamiut.

Kashaiak: locality, see Káshiagamiut.

Kashaiak Mountains: mountains, $3,000 \mathrm{ft}$., in Ahklun Mts., $2 \mathrm{mi}$. NW of junc. of Nayorurun and Togiak Rivers, $56 \mathrm{mi}$. NE of Goodnews, Kilbuck-Kuskokwim Mts.; $59^{\circ} 25^{\prime} \mathrm{N}, 160^{\circ} 05^{\prime}$ W; (map 53).

Eskimo name reported in 1954 by USGS.

Kashaiak River: stream, see Nayorurun River. Kashaiyagamut: locality, see Kashiagamiut. Kashaiyak River: stream, see Gechiak Creek. Kashaiyak River: stream, see Nayorurun River. Kashaiyamut: locality, see Gechiak.

Kasheega: bay, see Kashega Bay.

Kashega: village, pop. 26, at head of Kashega Bay, on SW coast of Unalaska I., Aleutian Is.; $53^{\circ} 28^{\prime} 00^{\prime \prime} \mathrm{N}, 167^{\circ} 09^{\prime} 35^{\prime \prime} \mathrm{W}$; (map 23). Var. Kashigin, Kashuga, Koshiga, Koshigin.

Named for Kashega Bay and published by Lt. Sarichev (1826, map 14), IRN, as "S[elo] Koshiga" meaning "Koshiga Village." It was called "Kashuga" by USBF in 1888, Baker (1906, p. 352) says "in 1831 it was the headquarters of the bidarshik or foreman of the Russian American Company for the western half of Unalaska * * *,"

Kashega, Cape: point of land, see Kashega Point.

Kashega Bay: bay, $1 \mathrm{mi}$. across, SW coast of Unalaska I., Aleutian Is.; $53^{\circ} 28^{\prime} 50^{\prime \prime} \mathrm{N}, 167^{\circ}$. $10^{\prime} 30^{\prime \prime} \mathrm{W} ; B G N$ 1890; (map 23). Var. Kasheega, Kachiginskaia, Kashuga Bay, Koshigin, Koshiginskoi.

Russian name given and published by Lt. Sarichev (1826, map 14), IRN, as "Zal[iv] Koshiginskoy," or "Koshigin Bay," in honor of Yefim Koshigin who spent the winter at Unalaska in 1763 (Baker, 1906, p. 351). According to R. H. Geoghegan, the name "Kashega" is from the Greenlandic word "qagshigit" meaning "men's clubhouses."

Kashega Pinnacles: rocks, at mouth of Kashega Bay, on SW coast of Unalaska I., Aleutian Is. $53^{\circ} 29^{\prime} 40^{\prime \prime} \mathrm{N}, 167^{\circ} 08^{\prime} 30^{\prime \prime} \mathrm{W}$; BGN 1939; (map 23).

Descriptive Russian name from Kashega Bay, given by USC\&GS in 1938 .

Kashega Point: point of land, SW coast of Unalaska I., Aleutian Is. ; $53^{\circ} 31^{\prime} 25^{\prime \prime} \mathrm{N}, 167^{\circ}$. $11^{\prime} 00^{\prime \prime}$ W; (map 23). Var. Cape Kashiga, Cape Kashega, Kashuga Point.

Named for Kashega Bay and published as "M[ys] Kashiga," or "Cape Kashiga," by Capt. Tebenkov (1852, map 26), IRN. It was called "Kashuga Point" by USBF in 1888 and "Cape Kashega" by Baker (1906, p. 351).

Kasheg-e-log-e-mute: village, see Kashegelok.

Kashegelok: village, pop. 5, on right bank of Holitna River, opposite mouth of Chukowan River, $64 \mathrm{mi}$. SW of Sleetmute, KilbuckKuskokwim Mts.; $60^{\circ} 50^{\prime} \mathrm{N}, 157^{\circ} 50^{\prime} \mathrm{W}$;
$B G N$ 1948; (map 60). Var. Kasheg-e-log-emute.

Eskimo village reported as "Kasheg-e-loge-mute" by W. R. Buckman, a prospector who wintered here in 1902-03.

Kashevaroff Islands: islands, extend $14 \mathrm{mi}$. between Zarembo I. and the NW coast of Prince of Wales I., Alex. Arch.; 56 $10^{\prime} \mathrm{N}, 132^{\circ} 12^{\prime}$ W; (map 6).

Probably named in 1883 by W. H. Dall, USC\&GS; derived from Kashevarof Passage and published in the 1883 Coast Pilot (p. 89).

Kashevaroff Mountain: mountain, 2,282 ft., 12 mi. SW of Kodiak, Kodiak I.; $57^{\circ} 40^{\prime} 25^{\prime \prime} \mathrm{N}$,

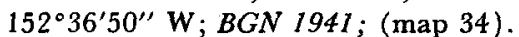

Named in 1940 by USC\&GS "for Rev. N. P. Kashevaroff who was born about 1858 in Kodiak where he was priest for many years. He died in 1935 or 1936."

Kashevaroff Passage: water passage, see Kashevarof Passage.

Kashevarof Passage: water passage, extends SE $20 \mathrm{mi}$. along $\mathrm{NE}$ coast of Prince of Wales I., from Sumner Strait to Clarence Strait, Alex. Arch.; 56 $14^{\prime} \mathrm{N}, 133^{\circ} 03^{\prime} \mathrm{W}$; (map 6). Var. Kashevaroff Passage, Kashevarow Passage, Kashvarow Passage, Kashvarow Strait, Proliv Kashevarova.

Published in 1848 on Russian Hydrog. Dept. Chart 1396 as "Proliv Kashevarova" or "Kashevarov Strait."

Kashevarova, Proliv: water passage, see Kashevarof Passage.

Kashevarow Passage: water passage, see Kashevarof Passage.

Kashiagamiut: locality, on right bank of Togiak River, $1.3 \mathrm{mi}$. E of Nayorurun River, $57 \mathrm{mi}$. NE of Goodnews, Kilbuck-Kuskokwim Mts.; $59^{\circ} 22^{\prime} \mathrm{N}$; $160^{\circ} 04^{\prime} \mathrm{W}$; (map 53). Var. Kashaiagamut, Kashaiagmut, Kashiagamut, Kashaiak, Kashaiyagamut, Kissaiakh, Kissiah, Kissiak.

Former Eskimo village or camp mentioned by Ivan Petroff in the 1880 census as "Kissiak"; published in 1884 as "Kissaiakh." It was recorded "Kashaiyagamut" on an 1898 fieldsheet by W. S. Post, but was published as "Kashaiagamut"' (Spurr, 1900, map 10), by USGS. The population in 1880 was 181 ; in 1940,33 .

Kashiagamut: locality, see Kashiagamiut.

Kashiga, Cape: point of land, see Kashega Point. Kashigalagamute: locality, see Kashigalak.

Kashigalak: locality, "on Nelson I. in Bering Sea," NE of Nunivak I.; (map 57). Var. Kashigalagamute, Kashigalogamut, Kashigalogumut.

Former Eskimo camp or settlement reported in 1878 as "Kashigalogamut" by E. W. Nelson, U.S. Signal Service; listed as "Kashigalagamute" with a population of 10 by Ivan Petroff in the 1880 Census.

Kashigalogamut: locality, see Kashigalak.

Kashigalogumut: locality, see Kashigalak.

Kashigin: village, see Kashega.

Kashkulu Khaku: point of land, see Kaskulu Point.
Kashoto Glacier: glacier, in Glacier Bay $\mathrm{Na}$ tional Monument, trends NW $2 \mathrm{mi}$. to its 1961 terminus, $0.5 \mathrm{mi}$. $\mathrm{E}$ of Johns Hopkins Inlet, $1 \mathrm{mi}$. NE of Hoonah Glacier, $79 \mathrm{mi}$. NW of Hoonah, St. Elias Mts.; 58 $53^{\prime} 15^{\prime \prime}$ N, 137'00'30" W; BGN 1937; (map 10).

Named by Field and Cooper (1937, p. 62) for Kashoto, chief of the Huna subtribe of the Tlingit Indians at the time of John Muir's visit in 1879 .

Kashs Village: locality, see Kah Shakes.

Kashuga: village, see Kashega.

Kashuga Bay: bay, see Kashega Bay.

Kashuga Point: point of land, see Kashega Point.

Kashunahmiut: locality, see Kashunuk Village. Kashunak River: stream, see Kashunuk River. Kashunok: locality, see Kashunuk Village.

Kashunuk River: stream, distributary of Yukon River, heads at junc. of Driftwood and Kashunuk Sloughs, $61^{\circ} 52^{\prime} 30^{\prime \prime} \mathrm{N}, 162^{\circ} 55^{\prime} 45^{\prime \prime} \mathrm{W}$, flows SW $225 \mathrm{mi}$. to Angyoyaravak Bay, Yukon-Kuskokwim Delta; $61^{\circ} 16^{\prime} 30^{\prime \prime} \mathrm{N}, 165^{\circ}$ $38^{\prime} 00^{\prime \prime}$ W; (map 75). Var. Kashunak River, Kashunuk Slough, Kizhunak, Kizhunok.

Eskimo name from Capt. Tebenkov (1852, map 3), IRN, who wrote it "Kizhunak." E. W. Nelson, U.S. Signal Service, crossed this stream in Dec. 1878 and gave it its present spelling.

Kashunuk Slough: stream, $2.8 \mathrm{mi}$. long, connects head of Kashunuk River at its junc. with Driftwood Slough to Yukon River, 27 mi. W of Marshall, Yukon-Kuskokwim Delta; $61^{\circ} 52^{\prime} 40^{\prime \prime} \mathrm{N}, 162^{\circ} 55^{\prime} 45^{\prime \prime} \mathrm{W}$; (map 74). Var. Keshunuk Slough.

Name shown on a fieldsheet in 1916 by R. H. Sargent, USGS.

Kashunuk Slough: stream, see Kashunuk River. Kashunuk Village: locality, at mouth of Kashunuk River, Yukon-Kuskokwim Delta; $61^{\circ} 18^{\prime} \mathrm{N}, 165^{\circ} 39^{\prime} \mathrm{W}$; (map 75). Var. Kashunahmiut, Kashunok, Old Kashunuk Village.

Abandoned Eskimo village first reported by E. W. Nelson, U.S. Signal Service, who visited there in December 1878 . He reported 20 houses and a population of $100-200$. In the 1880 Census, Petroff wrote "Kashunok" and reported a population of 125 . The 1890 Census called it "Kashunahmiut" and gave a population of 232 . In 1951 a USC\&GS field report noted this place was completely abandoned but several sod huts and the ruins of a frame church still remain on a low mound just east of the village. The triangulation station Kashu, 1951 is located in the village. The adjective "Old" is now generally used locally as part of the name.

Kashutuk: locality, "on an island in the Yukon delta," Yukon-Kuskokwim Delta; (map 77 or 92). Var. Kachutok, Kushutuk.

Former Eskimo camp or settlement listed as "Kachutok" with a population of 18 by Ivan Petroff in the 1880 Census.

Kashuvak Peninsula: peninsula, see Moser Peninsula. 
Kashvarow Passage: water passage, see Kashevarof Passage.

Kashvarow Strait: water passage, see Kashevarof Passage.

Kashvik Bay: bight, $3.3 \mathrm{mi}$. across, on $\mathrm{E}$ coast of Alaska Penin., in Katmai National Monument, $22 \mathrm{mi}$. $\mathrm{S}$ of Mount Katmai, Aleutian Ra.; $57^{\circ} 56^{\prime} \mathrm{N}, 155^{\circ} 03^{\prime} \mathrm{W}$; (map 35).

Native name published by Capt. Tebenkov (1852, map 22), IRN, as "Z[aliv] Katvik," or "Katvik Bay."'

Kashwitna: locality, mile 193.9 on The Alaska RR., $8 \mathrm{mi}$. N of Willow and $45 \mathrm{mi}$. N of Anchorage, Cook Inlet Low. ; $61^{\circ} 51^{\prime} 45^{\prime \prime} \mathrm{N}, 150^{\circ}$ $04^{\prime} 10^{\prime \prime} \mathrm{W}$; (map 70).

Tanaina Indian name listed in The Alaska Railroad Guide published in 1920. See Kashwitna River.

Kashwitna Knobs: hills, $250 \mathrm{ft}$., $1.3 \mathrm{mi}$. between tops, W of Susitna River, $47 \mathrm{mi}$. NW of Anchorage, Cook Inlet Low.; 61 ${ }^{\circ} 53^{\prime} 30^{\prime \prime} \mathrm{N}$, $150^{\circ} 13^{\prime} 30^{\prime \prime} \mathrm{W}$; (map 70).

Local name reported in 1954 by USGS; named for Kashwitna River.

Kashwitna Lake: lake, $1 \mathrm{mi}$. long, $W$ of The Alaska Railroad, $5.5 \mathrm{mi}$. N of Willow and 42 mi. NW of Anchorage, Cook Inlet Low.; $61^{\circ}$ $50^{\prime} \mathrm{N}, 150^{\circ} 05^{\prime} \mathrm{W}$; $(\operatorname{map} 70)$.

Local name reported in 1954 by USGS; named for Kashwitna River.

Kashwitna River: stream, heads at glacier in Talkeetna Mts. at $61^{\circ} 56^{\prime} 35^{\prime \prime} \mathrm{N}, 148^{\circ} 51^{\prime} 45^{\prime \prime}$ W, flows W $60 \mathrm{mi}$. to Susitna River, $12 \mathrm{mi}$. N of Willow and $49 \mathrm{mi}$. NW of Anchorage, Cook Inlet Low.; $61^{\circ} 55^{\prime} \mathrm{N}, 150^{\circ} 06^{\prime} \mathrm{W}$; BGN 1935; (map 70), Var. Kiswitno, Kochuitno.

Tanaina Indian name reported in 1906 by R. H. Sargent, USGS; adopted by miners. Lt. H. G. Learnard, of Capt. E. F. Glenn's expedition in 1898, reported two Indian names for streams in this area, "Kiswitno" and "Kochuitno," which may be variations of the name "Kashwitna."

Kasiak, Cape: point of land, between Kaiugnak and Three Saints Bays, on SE coast of Kodiak I. ; $57^{\circ} 04^{\prime} 20^{\prime \prime} \mathrm{N}, 153^{\circ} 30^{\prime} 00^{\prime \prime} \mathrm{W}$; (map 34 ). Var. Mys Kasiyak.

Eskimo name published as "M[ys] Kasiyak," "Cape Kasiyak," by Capt. Tebenkov (1852, map 23).

Kaśi-an: locality, see Old Kasaan.

Kasiana Islands: islands, $1 \mathrm{mi}$. across, $3 \mathrm{mi}$. NW of Sitka, Alex. Arch.; 57 $05^{\prime} \mathrm{N}, 135^{\circ} 24^{\prime} \mathrm{W}$; $B G N$ 1897; (map 9). Var. Apple Islands, Kaisana, Ostrova Kasyana, Ostrova Kasyany.

Named in 1809 by the Russian navigator Ivan Vasiliev the first; published by Lt. Sarichev (1826, map 19), IRN, as "O[stro]va Kasyany" or "Kasyany Islands."

Kasidaya Creek: stream, heads in a glacier at $59^{\circ} 21^{\prime} 50^{\prime \prime} \mathrm{N}, 135^{\circ} 14^{\prime} 00^{\prime \prime} \mathrm{W}$, flows NW $6 \mathrm{mi}$. to Taiya Inlet, $2.8 \mathrm{mi}$. SW of Devils Punch Bowl and $4 \mathrm{mi}$. S of Skagway, Coast Mts.; $59^{\circ} 24^{\prime} 15^{\prime \prime} \mathrm{N}, 135^{\circ} 20^{\prime} 15^{\prime \prime} \mathrm{W}$; (map 45). Var. Kasidayiya Creek, Yakutanya Creek.

Tlingit Indian name Kasidayiya, meaning "slide-front" published by the IBC (1923, map 9).
Kasidayiya Creek: stream, see Kasidaya Creek. Kasigaylick: sandbar, see Kasigiaglik Bar.

Kasigiaglik Bar: sandbar, at mouth of Wulik River, 1 mi. NE of Kivalina, Kotzebue-Kobuk Low.; $67^{\circ} 44^{\prime} \mathrm{N}, 164^{\circ} 30^{\prime} \mathrm{W}$; (map 128). Var. Kasigaylick.

Eskimo name meaning "spotted seal place" reported in 1966 by E. S. Burch.

Kasiglok: village, see Kasigluk.

Kasiglook: village, see Kasigluk.

Kasigluk: village, pop. $244,2 \mathrm{mi}$. W of Nunapitchuk and $27 \mathrm{mi}$. NW of Bethel, YukonKuskokwim Delta; BGN 1962; 60 $52^{\prime} \mathrm{N}$, $162^{\circ} 32^{\prime} \mathrm{W}$; (map 58). Var. Kaseglok, Kasigoluk, Kasiglook, Kasiglok.

Eskimo village, one of the "Tundra Villages," listed with a population of 66 in 1939 and 111 in 1950. The Kasigluk Post Office was established in 1962.

Kasigluk River: stream, heads at $60^{\circ} 23^{\prime} \mathrm{N}$, $160^{\circ} 04^{\prime} \mathrm{W}$, flows NW $60 \mathrm{mi}$. to Kuskokuak Slough, $20 \mathrm{mi}$. NE of Bethel, Yukon-Kuskokwim Delta; $60^{\circ} 50^{\prime} 45^{\prime \prime} \mathrm{N}, 161^{\circ} 14^{\prime} 00^{\prime \prime} \mathrm{W}$; (map 59). Var. Kiolemuk River.

Eskimo name reported in 1949 by J. M. Hoare, USGS.

Kasigoluk: village, see Kasigluk.

Kasik Lagoon: lagoon, $0.4 \mathrm{mi}$. long, on $\mathrm{N}$ shore of Krusenstern Lagoon, $4.5 \mathrm{mi}$. NE of Cape Krusenstern, Kotzebue-Kobuck Low. ; $67^{\circ} 10^{\prime}$ $25^{\prime \prime}$ N, 16327'15" W; (map 128).

Eskimo name meaning "shoulder blade," according to USC\&GS in 1950.

Kasilof: village, pop. 100, on $\mathrm{E}$ shore of Cook Inlet, $12 \mathrm{mi}$. S of Kenai, Cook Inlet Low.; $60^{\circ} 23^{\prime} 15^{\prime \prime} \mathrm{N}, 151^{\circ} 17^{\prime} 45^{\prime \prime} \mathrm{W}$; (map 62). Var Kassilof Saint George, Krepost Georgiyevskaya, Kussilof.

This is an agricultural settlement of Kenai Indians. In 1786 the Russian Kolomin of the Lebedef-Lastochkin Company built two $\log$ houses surrounded by a stockade at or near this site. It was called "Saint George," presumably for one of the ships of the company. An Indian fishing village grew up around this stockade. Its population in 1880 was 31 ; in 1890,117 ; in 1930,45 . A post office was obtained in 1925 (Ricks, 1965, p. 32). "In 1937 a party surveying for homesteading purposes on the Kenai Peninsula found near Kasilof the remains of a partially buried village. * * * A partial excavation showed 31 well-preserved houses, each about 15 by 22 feet and 14 feet high. The cabin walls were approximately four inches thick made of beach sand, bricks, logs and sod. Each had a fire place in the center. *** It was thought at the time to be of Eskimo origin, although Eskimos are not known to have penetrated so far south. The aboriginal inhabitants of the Peninsula are at present mostly Kenai Indians, a branch of the great Athapascan family" (Colby, 1945, p. 318). Kasilof, Cape: point of land, on $W$ coast of Kenai Penin., $14 \mathrm{mi}$. S of Kenai, Cook Inlet Low. ; $60^{\circ} 22^{\prime} \mathrm{N}, 151^{\circ} 22^{\prime} \mathrm{W}$; BGN 1925; (map 62). Var. Mys Kasilov, Cape Kassilow, Cape Kussiloff, Point Kasilof.
Name published in 1847 as "Mys Kasilov" or "Cape Kasilov," on Russian Hydrog. Dept. Chart 1378.

Kasilof, Point: point of land, see Kasilof, Cape.

Kasilof River: stream, heads at Tustumena Lake, flows NW $17 \mathrm{mi}$. to Cook Inlet at Kasilov, 12 mi. S of Kenai, Cook Inlet Low.; $60^{\circ} 23^{\prime} 15^{\prime \prime}$ $\mathrm{N}, 151^{\circ} 17^{\prime} 45^{\prime \prime} \mathrm{W}$; (map 62). Var. Kasilov River, Kassilof River, Kussilof River, Kussiloff River, Kussilowa River, Reka Kasilova, Reka Kasilovka.

This is a Russian surname reported by the scientist I. G. Wosnesenski in 1840; published by Capt. Tebenkov (1852, map 5) as " $R$ [eka] Kasilov," that is, "Kasilov River."

Kasilov, Mys: point of land, see Kasilof, Cape. Kasilova, Reka: stream, see Kasilof River. Kasilovka, Reka: stream, see Kasilof River. Kasilov River: stream, see Kasilof River.

Kasinuk Mountain: hill, $110 \mathrm{ft}$., on Nelson I., $\mathrm{E}$ of Kangirlvar Bay and $105 \mathrm{mi}$. W of Bethel, Yukon-Kuskokwim Delta; $60^{\circ} 32^{\prime} \mathrm{N}, 164^{\circ} 57^{\prime}$ $W$; $(\operatorname{map} 58)$.

Eskimo name reported in 1949 by USC\&GS. Kasitsna Bay: bay, 1.2 mi. wide, on Kenai Penin., $6.5 \mathrm{mi}$. NE of Seldovia, Chugach Mts.; $59^{\circ}$. $29^{\prime} \mathrm{N}, 151^{\circ} 32^{\prime} \mathrm{W} ; B G N$ 1944; (map 50). Var. Kahsitsnah, Kasitsne.

Kenai Indian name reported by G. C. Martin (1915, pl. 2), USGS; originally published in 1883 as "Kahsitsnah" by W. H. Dall, USC\&GS.

Kasitsne: bay, see Kasitsna Bay.

Kasiyak, Mys: point of land, see Kasiak, Cape. Kaskanak: locality, on right bank of Kvichak River, $85 \mathrm{mi}$. NE of Dillingham, Bristol Bay Low.; 59 $17^{\prime} \mathrm{N}, 156^{\circ} 11^{\prime} \mathrm{W}$; BGN 1910; (map 52). Var. Kaskanakh, Kaskanek, Kaskinakh, Koskanok.

This Eskimo village was first mentioned by Ivan Petroff in the 10th Census of 1880 as "Kaskinakh village." It was called "Kaskanakh village" in the 1890 Census. The name was spelled "Kaskanak" in 1890 by A. B. Schanz in Frank Leslie's Illustrated Newspaper. The population in 1880 was 119 ; in 1890,66 ; it is no longer permanently occupied.

Kaskanak: locality, on E bank of Tikchik Lake, $63 \mathrm{mi}$. NE of Dillingham, Kilbuck-Kuskokwim Mts.; $59^{\circ} 56^{\prime} \mathrm{N}, 158^{\circ} 12^{\prime} \mathrm{W}$; BGN 1932; (map 52). Var. Kaskanak Village, Kaskanakh, Kaskinakh.

Name of a small Eskimo village or camp obtained in 1932 by USGS; published by Mertie (1938, pl. 1), USGS. The village has no permanent population.

Kaskanak Greek: stream, heads at $59^{\circ} 45^{\prime} \mathrm{N}$, $155^{\circ} 37^{\prime} \mathrm{W}$, flows SW $40 \mathrm{mi}$. to Kuichak River, $85 \mathrm{mi}$. E of Dillingham, Bristol Bay Low.; $59^{\circ} 20^{\prime} \mathrm{N}, 156^{\circ} 04^{\prime} \mathrm{W}$; (map 52 ).

Eskimo name reported in 1931 by USGS. See Kaskanak.

Kaskanakh: locality, see Kaskanak.

Kaskanak Village: locality, see Kaskanak.

Kaskanek: locality, see Kaskanak.

Kaskinakh: locality, see Kaskanak.

Kaskulu Point: point of land, on McClellan Flats, at mouth of Chilkat River, $1.5 \mathrm{mi}$. W of 
Port Chilkoot and $17 \mathrm{mi}$. SW of Skagway, Coast Mts.; $59^{\circ} 13^{\prime} 50^{\prime \prime} \mathrm{N}, 135^{\circ} 29^{\prime} 00^{\prime \prime} \mathrm{W}$; $B G N$ 1922; (map 45). Var. Portage Point, Kashkulu Khaku, Qakulu Xagku.

Tlingit Indian name Kashkulu Khaku meaning "'man's scalp off' point" according to Louis Shotridge, and reported in 1922 by USC\&GS. It was called Portage Point by USC\&GS in the 1883 Coast Pilot (p. 197 and pl. 1819). This latter name was considered to be a misnomer.

Kaslokan Point: point of land, on $\mathrm{E}$ shore of Cold Bay, $10 \mathrm{mi}$. SE of village of Cold Bay, at SW end of Alaska Penin., Aleutian Ra.; $55^{\circ} 07^{\prime} 00^{\prime \prime} \mathrm{N}, 162^{\circ} 31^{\prime} 30^{\prime \prime} \mathrm{W}$; BGN 1925; (map 29). Var. Low Point.

Aleut name meaning "low" given by USC\&GS in 1925 (Chart 8703).

Kaslukug: locality, "on Agattu I. in Near Is.," Aleutian Is.

Former Aleut village reported as "uninhabited" by Hodge (1907, p. 663), BAE.

Kasna Creek: stream, flows N $3 \mathrm{mi}$. to Kontrashibuna Lake, $30 \mathrm{mi}$. NE of Nondalton, Aleutian Ra.; $60^{\circ} 10^{\prime} \mathrm{N}$, $154^{\circ} 00^{\prime} \mathrm{W}$; (map 61).

Tanaina Indian name reported by $\mathrm{P}$. S. Smith (1917, p. 51), USGS.

Kasnatchin: locality, at Anchor Point on $\mathrm{W}$ coast of Kenai Penin., near E point of entrance to Cook Inlet, Cook Inlet Low.; (map 50). Var. Laida, Laidennoj.

Former Athapaska Indian camp or settlement listed as "Laida" with a population of 29 by Ivan Petroff in the 1880 Census.

Kasnatchin: spit, see Anchor Point.

Kasnyku Bay: bay, 1 mi. across, $9 \mathrm{mi}$. N of Baranof, on NE coast of Baranof I., Alex. Arch.; $57^{\circ} 13^{\prime} \mathrm{N}, 134^{\circ} 51^{\prime} \mathrm{W}$; (map 9).

Tlingit Indian name reported in 1895 by Lt. Comdr. E. K. Moore, USN, and published by USC\&GS on Chart 8050 .

Kasnyku Falls: waterfall, between Kasnyku Lake and Waterfall Cove, on NE coast of Baranof I., $7 \mathrm{mi}$. $\mathrm{N}$ of Baranof, Alex. Arch.; $57^{\circ} 11^{\prime} 30^{\prime \prime}$ N, $134^{\circ} 50^{\prime} 00^{\prime \prime} \mathrm{W}$; BGN 1923; (map 9).

Named in 1922 by USFS, presumably for Kasnyku Bay.

Kasnyku Lake: lake, $1.7 \mathrm{mi}$. long, $6.5 \mathrm{mi}$. N of Baranof, on NE coast of Baranof I., Alex. Arch.; $57^{\circ} 11^{\prime} \mathrm{N}, 134^{\circ} 52^{\prime} \mathrm{W}$; BGN 1923; (map 9).

Named in 1923 by USFS, presumably for Kasnyku Bay into which it drains.

Kason Spit: spit, in Kivalina Lagoon, 2 mi. NW of Kivalina, Kotzebue-Kobuk Low.; $67^{\circ} 44^{\prime}$ N, $164^{\circ} 34^{\prime}$ W; (map 128). Var. Kasaun Spit, Kasautaa, Kasown, Nuwuksaqpaq.

Eskimo name meaning "drumstick"; so called because of its nearness to a circular sandbar called "the drum" (Kilon). Name reported in 1966 by E. S. Burch.

Kasook Inlet: estuary, extends N 3 mi. off Tlevak Strait, on $\mathbf{S}$ coast of Sukkwan I., Alex. Arch.; (map 4). Var. Kassook Inlet.

Indian name recorded in 1897 by Capt. J. F. Moser, USN; published by USC\&GS in 1899.
Kasook Lake: lake, $0.8 \mathrm{mi}$. long, on $\mathrm{S}$ coast of Sukkwan I., at head of Kasook Inlet, Alex Arch.; $55^{\circ} 03^{\prime} 15^{\prime \prime} \mathrm{N}, 132^{\circ} 49^{\prime} 30^{\prime \prime} \mathrm{W}$; (map 4). Indian name recorded in 1897 by Capt. J. F. Moser, USN; published by USC\&GS in 1899.

Kasown: spit, see Kason Spit.

Kassa Inlet: estuary, extends N $5 \mathrm{mi}$., off Cordova Bay, on SW coast of Prince of Wales I., Alex. Arch.; 545ㅇ' N, $132^{\circ} 32^{\prime} \mathrm{W}$; (map 1).

Indian name used by navigators and recorded in 1905 by E. F. Dickins, USC\&GS.

Kassa Island: island, $0.8 \mathrm{mi}$. wide, in Kassa Inlet, on SW coast of Prince of Wales I., Alex. Arch.; $54^{\circ} 56^{\prime} 40^{\prime \prime} \mathrm{N}, 132^{\circ} 29^{\prime} 45^{\prime \prime} \mathrm{W}$; (map 1)

Local name reported in 1951 by USGS.

Kassan: locality, see Old Kasaan.

Kassan Haade: locality, see Old Kasaan.

Kassan Islands: islands, extend $1 \mathrm{mi}$., between $\mathrm{El}$ Capitan and Prince of Wales Is., Alex. Arch. $55^{\circ} 55^{\prime} 30^{\prime \prime} \mathrm{N}, 133^{\circ} 16^{\prime} 20^{\prime \prime} \mathrm{W}$; (map 4).

Name published in 1962 Coast Pilot (p. 95)

Kassa Point: point of land, SE point of entrance to Kassa Inlet, on SW coast of Prince of Wales I., Alex. Arch.; 54 $55^{\prime} 25^{\prime \prime} \mathrm{N}, 132^{\circ}$ $31^{\prime} 30^{\prime \prime} \mathrm{W}$; (map 1).

Local name reported in 1951 by USGS.

Kassatotchy Island: island, see Kasatochi Island. Kassatream: stream, see Kuzitrin River.

Kassatriem: stream, see Kuzitrin River.

Kassdeparka Creek: stream, see Casadepaga River.

Kassiachamiut: locality, see Kassianmute.

Kassianmute: locality, on right bank of Togiak River, $5 \mathrm{mi}$. SW of Kashiagamiut and $50 \mathrm{mi}$. ENE of Goodnews, Kilbuck-Kuskokwim Mts.; $59^{\circ} 18^{\prime} \mathrm{N}, 160^{\circ} 12^{\prime} \mathrm{W}$; (map 53). Var. Kassiachamiut.

This Eskimo village, which had two dance houses, was first mentioned by Ivan Petroff in the 10th U.S. census. The name means "Kassian people." Its population in 1880 was 615 , in 1890 it was 50 ; it is now abandoned.

Kassik: island, see Kaiasik.

Kassilof River: stream, see Kasilof River.

Kassilof Saint George: village, see Kasilof.

Kassilow, Cape: point of land, see Kasilof, Cape.

Kasson Creek: stream, flows SW $1.7 \mathrm{mi}$. to Shovel Creek, 9 mi. N of Solomon, Seward Penin. High.; 64 $44^{\prime}$ N, $164^{\circ} 25^{\prime} \mathrm{W}$; (map 95). Var. Karson Creek.

Prospectors' name reported in 1900 by E. C. Barnard (in Brooks, 1901, pl. 17), USGS.

Kassook Inlet: estuary, see Kasook Inlet.

Kastigo, Mys de: point of land, see Punishment Point.

Kasyana, Ostrova: islands, see Kasiana Islands. Kasyany, Ostrova: islands, see Kasiana Islands. Katagkag-mïoute: locality, see Katagkak.

Katagkak: locality, "on Innoko River above its junc. with Yukon River," Innoko Low; (map 78). Var. Ighelkoslende, Katagkag-mïoute.

Former Eskimo camp or settlement reported in 1850 as "Ighelkoslende" and " $\mathrm{Ka}$ tagkag-mïoute" by Lt. L. A. Zagoskin, IRN. Katagúne: island, see Kataguni Island.
Kataguni Island: island, $1.1 \mathrm{mi}$. long, in Chilkat Is., in Lynn Canal, $0.3 \mathrm{mi}$. S of Shikosi I. and $30 \mathrm{mi}$. S of Skagway, Coast Mts.; $59^{\circ} 01^{\prime} \mathrm{N}$, $135^{\circ} 16^{\prime} \mathrm{W}$; (map 45). Var. Katagúne.

A Tlingit Indian name reported by Aurel and Arthur Krause (1883, map) as Katagúne.

Katak Creek: stream, in Franklin Mts., heads at glacier $5 \mathrm{mi}$. S of Mount Chamberlain, flows NE $15 \mathrm{mi}$. to the Hulahula River, $7.5 \mathrm{mi}$. NW of Mount Michelson, Brooks Ra.; 69. $22^{\prime} \mathrm{N}, 144^{\circ} 33^{\prime} \mathrm{W}$; BGN 1961; (map 139). Var. Katuk Creek.

Eskimo name obtained at Barter I. by USGS geologists in 1948, and reported to mean "fall" or "drop," which may refer to rapids or falls along the course of the stream. It was reported by C. L. Whittington, USGS, in 1960.

Katak Creek : stream, see Wrench Creek.

Katakturak River: stream, see Katakturuk River.

Katakturuk River: stream, heads on S slope of Sadlerochit Mts., flows W $11 \mathrm{mi}$. in valley thence $\mathrm{N}$ through mountain passes and $30 \mathrm{mi}$. $\mathrm{NE}$ to Camden Bay, $3 \mathrm{mi}$. W of Collinson Point and $25 \mathrm{mi}$. SE of Flaxman I., Arctic Plain; $69^{\circ} 59^{\prime} \mathrm{N}, 145^{\circ} 02^{\prime} \mathrm{W}$; (map 139). Var. Katakturak River, Kutukturok River.

Eskimo name reported by Leffingwell (1919, p. 96) to possibly mean "a narrow place," presumably referring to the canyon it has cut through the range. Orth was told in 1956 that the name means "many falls." USC\&GS in 1948 reported another version of the meaning, "looks open," referring to the appearance of the stream from the sea.

Katakwa Point: point of land, SE tip of Tongass I., Coast Mts.; $54^{\circ} 46^{\prime} 15^{\prime \prime} \mathrm{N}, 130^{\circ} 43^{\prime} 45^{\prime \prime} \mathrm{W}$; $B G N$ 1937; (map 2). Var. Tongass Point.

Local name derived from the Tlingit Indian name for the island, "Kut-tuk-wah," which was published in 1869 by USC\&GS. This may be the same point that Lt. Comdr. H. E. Nichols, USN, called "Tongass," published in the 1891 Coast Pilot (p. 80).

Katalahosa Lake: lake, oxbow, $0.7 \mathrm{mi}$. across, on $\mathrm{N}$ bank of Kanuti River, $24 \mathrm{mi}$. SE of Allakaket, Kanuti Flats; $66^{\circ} 17^{\prime} 30^{\prime \prime} \mathrm{N}, 152^{\circ} 08^{\prime} 30^{\prime \prime}$ W; (map 117).

Koyukan Indian name obtained in 1956 at Allakaket by T. E. Taylor, USGS.

Katalan's Rock: hill, see Castle Hill.

Katalina, Ostrov: island, see Catalina Island.

Katalla: settlement, pop. 5, on S coast of Alaska, at mouth of Katalla River, $50 \mathrm{mi}$. SE of Cordova, Malaspina Coastal Plain; 60 $12^{\prime} \mathrm{N}$, 14431' W; BGN 1906; (map 64). Var. Catalla, Catella.

Named after Katalla Bay; the village was established about 1903 as a supply point after discovery of oil in the area. The village population was 188 in $1910 ; 84$ in $1920 ; 44$ in 1930; and 23 in 1940. The Katalla post office was established in 1904 and discontinued in 1943 (Ricks, 1965, p. 32)

Katalla Bay: bay, at Katalla, extends $15 \mathrm{mi}$. from Palm Point to Strawberry Point, Malaspina Coastal Plain; $60^{\circ} 11^{\prime} \mathrm{N}, 144^{\circ} 31^{\prime} \mathrm{W} ; B G N$ 1906; (map 64). Var. Catalla Bay, Catella Bay. 
Native name meaning "bay" spelled "Catalla" by F. C. Schrader and A. C. Spencer (1901, p. 92), USGS. This name may have been given by oil prospectors.

Katalla River: stream, flows S $12 \mathrm{mi}$. to Katalla Slough, $1 \mathrm{mi}$. NE of Katalla, Malaspina Coastal Plain; $60^{\circ} 12^{\prime} \mathrm{N}, 144^{\circ} 29^{\prime} \mathrm{W}$; BGN 1906; (map 64). Var. Catalla River, Catella River.

Named after the bay; reported in 1903 by USGS. See Katalla Bay.

Katalla Slough: estuary, extends NW $3 \mathrm{mi}$. from mouth of Oil Creek to Katalla, Malaspina Coastal Plain; $60^{\circ} 12^{\prime} \mathrm{N}, 144^{\circ} 30^{\prime} \mathrm{W} ; B G N$ 1906; (map 64).

Named after the bay; reported in 1903 by USGS. See Katalla Bay.

Katcheldat River: stream, see Yentna River.

Katchin Creek: stream, flows SE $4 \mathrm{mi}$. to Redoubt Bay, Cook Inlet, $7 \mathrm{mi}$. NNW of Harriet Point and $37 \mathrm{mi}$. W of Kenai, Aleutian Ra. $60^{\circ} 29^{\prime} \mathrm{N}, 152^{\circ} 19^{\prime} \mathrm{W}$; (map 62)

Local name reported in 1958 by USGS.

Katch Island: island, see Kak Island.

Kate, Mount: mountain, $4,200 \mathrm{ft}$., $2.8 \mathrm{mi}$. SW of $\mathrm{S}$ end of Solomon Gulch, $8.4 \mathrm{mi}$. SW of Valdez, Chugach Mts.; $61^{\circ} 00^{\prime} 05^{\prime \prime} \mathrm{N}, 146^{\circ}$. $20^{\prime} 40^{\prime \prime} \mathrm{W}$; (map 68).

Named in 1898 by Capt. W. R. Abercrombie, USA.

Kate and Anna Creek: stream, flows NW $1 \mathrm{mi}$ to Canyon Creek, upstream from El Patrone Creek, $23 \mathrm{mi}$. NW of Solomon, Seward Penin. High.; $64^{\circ} 51^{\prime} \mathrm{N}, 164^{\circ} 47^{\prime} \mathrm{W}$; (map 95).

Prospectors' name reported on a map of Cape Nome goid fields by David Fox, Jr., dated 1901

Kateekhuk Island: island, see Kateekuk Island.

Kateekuk Island: island, $1 \mathrm{mi}$. across, in Semidi Is., between Aghiyuk and Chowiet Is., Aleutian Ra.; $56^{\circ} 05^{\prime} \mathrm{N}, 156^{\circ} 44^{\prime} \mathrm{W}$; (map 31). Var. Kateekhuk Island.

Eskimo name reported as "Kateekhuk Island" in 1874 by W. H. Dall, USC\&GS, and published as "Kateekuk Island" in 1916 Coast Pilot (v. 2, p. 147).

Kateel River: stream, flows NE then SE $115 \mathrm{mi}$. to Koyukuk River, $31 \mathrm{mi}$. SW of Roundabout Mtn., Koyukuk Low.; $65^{\circ} 27^{\prime} \mathrm{N}, 157^{\circ} 37^{\prime} \mathrm{W}$; (map 108). Var. Cotillakakat River, Khotylkakat, Koteelkakat.

Koyukan Indian name published in 1842 44 by Lt. L. A. Zagoskin, IRN, as "Khotylkakat" or "mouth of the Khotyl"; applied to a camp or a village at the stream's mouth. Zagoskin, however, shows the name "R[eka] Notylno" or "Notilno River" which was applied to the stream proper. Lt. Allen (1887, p. 105-106) recorded the name as "Koteelkakat" in 1885. Allen wrote "below the junction [of the Kateel and Koyukuk] is the site of the station established shortly after the transfer of the Territory ***. This is the highest point reached on the Koyukuk by Lieutenant Zagoskin, of the Russian Navy, in the winter of 1842 , though he ascended the Koteelkakat to latitude $65^{\circ} 35^{\prime}$,"
Katenai Hill: mountain, $1,344 \mathrm{ft}$., on $\mathrm{S}$ coast of Afognak 1., 5 mi. NE of Afognak, Kodiak I.; $58^{\circ} 04^{\prime} 35^{\prime \prime} \mathrm{N}, 152^{\circ} 42^{\prime} 40^{\prime \prime} \mathrm{W}$; (map 43).

Local name reported in 1952 by USGS.

Kates Needle: mountain, 10,002 ft., Boundary Peak 70 on Alaska-Canada boundary, $13 \mathrm{mi}$. SE of Devils Thumb and $126 \mathrm{mi}$. E of Sitka, Coast Mts.; $57^{\circ} 02^{\prime} 45^{\prime \prime} \mathrm{N}, 132^{\circ} 02^{\prime} 35^{\prime \prime} \mathrm{W}$ BGN 1953; (map 8). Var. Boundary Peak 70, Kates Needles.

Name published in 1893 by USC\&GS; so named because of the "very sharp peaks."

Katete River: stream, $15 \mathrm{mi}$. long, heads in Alaska about $5 \mathrm{mi}$. SW of Mount Fawcett, flows generally $\mathrm{N}$ across international boundary to Stikine River, Coast Mts.; $56^{\circ} 40^{\prime} \mathrm{N}, 131^{\circ}$ $49^{\prime}$ W; BGN 1900; (map 7). Var. Kahate River, Kahtete River, Ka-té-té River, Kwahteetah River

Tlingit Indian name reported in 1900 by Marcus Baker, USGS. This name was first published in 1883 by USC\&GS as "Kwahteetah."

Kathakne: village, on NE shore of Fish Lake, $3 \mathrm{mi}$. E of Northway, Alaska Ra.; 62 $58^{\prime} 10^{\prime \prime}$ $\mathrm{N}, 141^{\circ} 50^{\prime} 00^{\prime \prime} \mathrm{W}$; (map 84).

Indian name reported by USGS in 1955

Kathaleen Island: island, extends NE-SW $4 \mathrm{mi}$. in Yukon River, $1 \mathrm{mi}$. E of Doyle I. and 43 mi. NE of Ruby, Nowitna Low.; $64^{\circ} 59^{\prime} \mathrm{N}$, $154^{\circ} 08^{\prime} \mathrm{W}$; (map 98).

Riverboat pilots' name shown on 1940 "Navigation Chart, Tanana-Yukon Rivers" of the River Boat Service, U.S. Dept. of Interior.

Kathleen, Lake: lake, $1.7 \mathrm{mi}$. long, $28 \mathrm{mi}$. $\mathrm{N}$ of Angoon, on W coast of Admiralty I., Alex. Arch.; 57 $54^{\prime} 40^{\prime \prime} \mathrm{N}, 134^{\circ} 40^{\prime} 00^{\prime \prime} \mathrm{W}$; (map 9).

Named in 1920 by W. T. Tolch, mining engineer of Juneau.

Kathleen Creek: stream, flows $\mathrm{S} 1 \mathrm{mi}$. to Jessie Creek, 21 mi. E of Katalla, Malaspina Coastal Plain; $60^{\circ} 12^{\prime} \mathrm{N}, 144^{\circ} 02^{\prime} \mathrm{W}$; (map 64).

Local name reported by G. C. Martin (1921, pl. 4), USGS.

Kathryn, Mount: mountain, 4,305 ft., between heads of Woodchopper and Coal Creeks, Yukon-Tanana High.; $65^{\circ} 11^{\prime} 20^{\prime \prime} \mathrm{N}, 143^{\circ} 32^{\prime}$ 25" W ; BGN 1961; (map 103).

Named for Kathryn Stanton Patty, 18961961, first lady of the Univ. of Alaska from 1953 to 1960 , and who earlier, with her husband, developed gold mining operations in this area.

Kathul Mountain: mountain, 3,122 ft., $1.5 \mathrm{mi}$ $\mathrm{N}$ of Yukon River and $15 \mathrm{mi}$. NE of junc of Charley and Yukon Rivers, Porcupine Plat. $65^{\circ} 21^{\prime} 15^{\prime \prime} \mathrm{N}, 142^{\circ} 16^{\prime} 45^{\prime \prime} \mathrm{W}$; (map 103). Var. Cathul Mountain, Gathut Mountain, Kathal Mountain.

Indian name recorded in 1883 as "Cathul Mountain" by Lt. Schwatka (1885b, sheet 8 ), USA. The "Kathul" spelling was established in 1897 by USGS (1898, pl. 38).

Katie Creek: stream, on E coast of Alaska Penin., flows NE $1.7 \mathrm{mi}$. to Puale Bay, $44 \mathrm{mi}$. NW of Karluk, Aleutian Ra.; $57^{\circ} 41^{\prime} 25^{\prime \prime}$ N, $155^{\circ} 36^{\prime}$ $45^{\prime \prime} \mathrm{W}$; (map 35).
Local name obtained from J. L. McPherson of Iliamna; published by G. C. Martin (1921, pl. 10), USGS.

Katiktak Mountain: mountain, 6,320 ft., E of Rumbling Mtn., S of Kenunga Creek, $21 \mathrm{mi}$. SE of Anaktuvuk Pass, Brooks Ra.; 68 $01^{\prime} \mathrm{N}$, $150^{\circ} 58^{\prime} \mathrm{W}$; BGN 1932; (map 134).

Named by Robert Marshall in 1932. The word is reported to be an Eskimo word for "white.".

Katktuwing: locality, on coast of Beaufort Sea E of Barter I.; (map 152).

This Eskimo name is shown on John Simpson's 1853 native map. It seems to be the same name as "Kaktovik," the Eskimo name for Barter I.

Katkwaahltu: locality, "on Chilkat River, 6 mi. above its mouth," St. Elias Mts.; (map 45). Var. Katkwaltú, Kutkwutlu, Qätq!wā'łtū.

Former Tlingit Indian town listed as "Kutkwutlu" with a population of 125 in the 1880 Census by Ivan Petroff; reported in 1904 as "Qātq!wā'altū," meaning "town on the point of a hill," by J. R. Swanton, BAE.

Katkwaltn: locality, see Kalwatta.

Katkwaltú: locality, see Katkwaahitu.

Katkwaltv: locality, see Kalwatta.

Katlany's Village: locality, "in SE Alaska," Coast Mts.

Former Tlingit Indian summer camp listed with a population of 106 by Ivan Petroff in the 1880 Census.

Katlian, Mount: mountain, 4,303 ft., $8.5 \mathrm{mi}$. NE of Sitka, on W coast of Baranof I., Alex. Arch.; $57^{\circ} 09^{\prime} 15^{\prime \prime} \mathrm{N}, 135^{\circ} 12^{\prime} 00^{\prime \prime} \mathrm{W}$; BGN 1929; (map 9).

Named in 1927 by Capt. R. S. Patton, USC\&GS, "for Chief Katlian, principal chief of the Tlingit Indians at Sitka at the time of its settlement by the Russians. Under his leadership in 1802 the Indians destroyed Baranof's fort located there. It is said the name is sometimes spelled Kotian. The name is usually borne by the Chief of the Kitsadi Clan of Tlingits."

Katlian Bay: bay, $0.7 \mathrm{mi}$. across, $5 \mathrm{mi}$. long, 8 mi. N of Sitka, on NW coast of Baranof $I$., Alex. Arch.; $57^{\circ} 09^{\prime} \mathrm{N}, 135^{\circ} 23^{\prime} \mathrm{W}$; $B G N$ 1897; (map 9). Var. Bukhta Katliana, Guba Kotleana, Katliana Bay, Katlianofa Gulf, Katlians Bay, Kortleana Bay, Kotleana Bay, Kotlian Bay, Kotlians Bay.

Named in 1809 by Capt. U. F. Lisianski, IRN, for one of the Indian chiefs at Sitka.

Katlianofa Gulf: bay, see Katlian Bay.

Katlian River: stream, flows W $10 \mathrm{mi}$. to Katlian Bay, $8.5 \mathrm{mi}$. N of Sitka, on W coast of Baranof I., Alex. Arch.; 57 $10^{\prime} 15^{\prime \prime}$ N, $135^{\circ} 16^{\prime}$ $30^{\prime \prime} \mathrm{W}$; BGN 1933; (map 9).

Named in 1933 by USFS "for the Tlingit Indian chief who in 1799 sold the land upon which the settlement of Sitka was first located." It is said that in 1806 he prevented a second Indian massacre at the present site of Sitka.

Katlitna River: stream, heads in lake, flows NW $65 \mathrm{mi}$. to Kuskokwim River, $9 \mathrm{mi}$. S of Mc- 
Grath, Kuskokwim Low. ; $62^{\circ} 49^{\prime} 30^{\prime \prime} \mathrm{N}, 155^{\circ}$ $36^{\prime} 40^{\prime \prime}$ W; (map 80). Var. Kalitna River, Reka Kichotno, Reka Kitschotno.

Ingalik Indian name obtained in 1908 by Maddren (1910, pl. 1), USGS. Lt. L. A. Zagoskin, IRN, in 1842-44, applied another Indian name, "Kichotno."

Katmai: locality, site of a village near Katmai Bay, on S coast of Alaska Penin., in Katmai National Monument $16 \mathrm{mi}$. S of Mount Katmai, Aleutian Ra.; $58^{\circ} 02^{\prime} \mathrm{N}, 154^{\circ} 55^{\prime} \mathrm{W}$; $B G N$ 1954; (map 42).Var. Selo Katmay, Seleniye Katmayskoe, Village Katmay.

This once important Eskimo village was reported by von Krusenstern (1827, map 17) as "Katmay." The 10th Census in 1880 lists a population of $218 ; 11$ th Census in 1890 lists 132. Katmai was abandoned following the 1912 eruption of Mount Katmai and the people were resettled in Perryville, near Mitrofania Bay.

Katmai, Mount: volcano, 6,715 ft., with crater lake on W slope, on Alaska Penin., in Katmai National Monument, $48 \mathrm{mi}$. NW of Karluk, Aleutian Ra.; $58^{\circ} 17^{\prime} \mathrm{N}, 154^{\circ} 57^{\prime} \mathrm{W}$; $B G N$ 1966; (map 42). Var. Katmai Volcano.

Name published in 1910 as "Katmai Voicano" by USC\&GS and as "Mount Katmai" by G. C. Martin (1913, v. 28, text passim), USGS.

Katmai Bay: bay, $9 \mathrm{mi}$. across, at mouth of Katmai River, on E coast of Alaska Penin. in Katmai National Monument, $17 \mathrm{mi}$. $\mathrm{S}$ of Mount Katmai, Aleutian Ra. ; $57^{\circ} 58^{\prime} \mathrm{N}, 154^{\circ}$ $57^{\prime}$ W; (map 35). Var. Baie Katmay, Katmai Golfe, Katmaiskoi Golfe, Zaliv Katmai.

Eskimo name reported in 1828 as "Katmaiskoi golfe" by Lutke (1836, p. 276); von Krusenstern (1827, map 17), published "Baie Katmay."

Katmai Canyon: canyon, U-shaped, on Alaska Penin., extends $5 \mathrm{mi}$. along course of Katmai River, between Mount Katmai and Barrier Range, in Katmai National Monument, Aleutian Ra.; 58 $8^{\circ} 13^{\prime} \mathrm{N}, 1^{\circ} 4^{\circ} 56^{\prime} \mathrm{W}$; BGN 1924; (map 42).

Named in 1916 by R. F. Griggs, National Geographic Society, after Katmai Bay.

Katmai Creek: stream, see Katmai River.

Katmai Golfe: bay, see Katmai Bay.

Katmai Lakes: lakes, largest $0.5 \mathrm{mi}$. long, in upper Katmai River, on Alaska Penin., in Katmai National Monument, $6 \mathrm{mi}$. SE of Mount Katmai, Aleutian Ra. ; $58^{\circ} 14^{\prime}$ N, $154^{\circ}$ $50^{\prime} \mathrm{W}$; BGN 1924; (map 42).

Named in 1916 by R. F. Griggs, National Geographic Society; "field observation in $\mathbf{1 9 5 3}$ failed to show these features," according to National Park Service.

Katmai National Monument: over 4,200 sq. mi., on Alaska Penin. and adjacent islands, includes Valley of Ten Thousand Smokes, and Mount Katmai and Novarupta; site of a great volcanic eruption in June 1912, Aleutian Ra.; $58^{\circ} 25^{\prime} \mathrm{N}, 155^{\circ} 00^{\prime} \mathrm{W}$; (map 42).

Named for Mount Katmai. It was established September 24, 1918, and enlarged in 1931. In 1942 the islands off the coast were added and the monument now offers more than 4,200 sq. mi. of ocean bays, fiords and lagoons, backed by a range of glacier covered peaks and volcanic crater lakes, behind which lies an interior wilderness of forests and great lake chains.

Katmai Pass: pass, 2,600 ft., near head of Mageik Creek, on Alaska Penin., in Katmai National Monument, $7 \mathrm{mi}$. SW of Mount Katmai, Aleutian Ra.; $58^{\circ} 14^{\prime} \mathrm{N}, 155^{\circ} 10^{\prime} \mathrm{W}$; (map 42).

Named in 1898 by J. E. Spurr and W. S. Post, USGS, and "applied because of proximity to Katmai River."

Katmai Reef: reef, in Pacific Ocean, $0.25 \mathrm{mi}$. long, near middle of $\mathrm{N}$ entrance to Chignik Bay, $26 \mathrm{mi}$. NE of Chignik, Aleutian Ra.; $56^{\circ} 25^{\prime} \mathrm{N}, 157^{\circ} 49^{\prime} \mathrm{W}$; (map 31 ).

Name published by USC\&GS in the 1926 Alaska Coast Pilot (v. 2, p. 176)

Katmai River: stream, heads at glacier terminus on Alaska Penin., in Katmai National Monument, flows SW $20 \mathrm{mi}$. to Katmai Bay, $16 \mathrm{mi}$. $S$ of Mount Katmai, Aleutian Ra.; $58^{\circ} 02^{\prime}$ N, $154^{\circ} 57^{\prime}$ W; (map 42). Var. Katmai Creek, Reka Katmay.

Eskimo name reported as "R[eka] Katmay" by Capt. Tebenkov (1852, map 22) and as "Katmai River" in 1917 by R. F. Griggs, National Geographic Society.

Katmaiskoi Golfe : bay, see Katmai Bay.

Katmai Valley: valley, of Katmai River, on Alaska, Penin., in Katmai National Monument, 17 mi. S of Mount Katmai, Aleutian Ra.; $58^{\circ} 02^{\prime} \mathrm{N}, 154^{\circ} 57^{\prime} \mathrm{W}$; (map 42).

Named in 1918 by R. F. Griggs, National Geographic Society.

Katmai Volcano: volcano, see Katmai, Mount.

Katmay, Baie : bay, see Katmai Bay.

Katmay, Reka: stream, see Katmai River.

Katnu River: stream, see Big River.

Katolinat, Mount: peak, 4,730 ft., on Alaska Penin., in Katmai National Monument, 24 mi. NW of Mount Katmai, Aleutian Ra.; $58^{\circ} 27^{\prime} 50^{\prime \prime} \mathrm{N}, 1^{\circ} 25^{\prime} 20^{\prime \prime} \mathrm{W}$; (map 42). Var. Mount Kakhtolinat.

Native name reported as "Kakhtolinat" by I. Petroff in the 10th Census in 1880

Katovik : village, see Kaktovik.

Katrikiorak Creek: stream, heads in lake, flows NE $7.8 \mathrm{mi}$. to Kuk River, $34 \mathrm{mi}$. S of Wainwright, Arctic Plain; $70^{\circ} 10^{\prime} \mathrm{N}, 159^{\circ} 43^{\prime} \mathrm{W}$; (map 146).

Eskimo name published in 1958 by AMS.

Katrine Creek: stream, flows NW $7.5 \mathrm{mi}$. to Margaret Creek $1 \mathrm{mi}$. E of its junc. with Kejulik River, on Alaska Penin., $43 \mathrm{mi}$. SW of Mount Katmai, Aleutian Ra.; 57 $50^{\prime} 40^{\prime \prime} \mathrm{N}$, $155^{\circ} 42^{\prime} 40^{\prime \prime} \mathrm{W}$; (map 35).

Local name obtained from J. L. McPherson of Iliamna, and published by W. R. Smith and A. A. Baker (in Brooks and others, 1924, pl. 9), USGS.

Katschadelch : stream, see Rosaunt Creek.

Katschin River: stream, see Katzehin River.

Katschkahín River: stream, see Chilkoot River.

Katsehin River: stream, see Katzehin River.
Katsekahin River: stream, see Kicking Horse River.

Katselena: stream, see Kotsina River.

Kattag: village, see Aleut Village.

Katuk Creek: stream, see Katak Greek.

Katusna River: stream, see Kalukna River.

Katzehin River: stream, heads at terminus of Meade Glacier, flows W $12 \mathrm{mi}$. to Chilkoot Inlet, $2.4 \mathrm{mi}$. E of Battery Point and $18 \mathrm{mi}$. S of Skagway, Coast Mts. ; $59^{\circ} 12^{\prime} \mathrm{N}, 135^{\circ} 17^{\prime} \mathrm{W}$; $B G N$ 1900; (map 45). Var. Chkazhini River, Katsehin River, Katschin River.

Tlingit Indian name reported as Chkazehin by Aurel and Arthur Krause (1883, map). It was spelled Katsehin by USC\&GS in the 1891 Coast Pilot (p. 203) and Katschin on Chart 3091 in 1898.

Katz Island: island, $0.1 \mathrm{mi}$. across, in Galankin Is., $1.5 \mathrm{mi}$. S of Sitka, on W coast of Baranof I., Alex. Arch.; $57^{\circ} 01^{\prime} 50^{\prime \prime} \mathrm{N}, 135^{\circ} 19^{\prime} 00^{\prime \prime} \mathrm{W}$; (map 9).

Named in 1880 by U.S. naval officers "for Mr. Katz," USN. The name was published by USC\&GS in 1883 Coast Pilot (p. 143).

Katzzelena: stream, see Kotsina River.

Kauatka: island, one of Shumagin Is.; $55^{\circ} \mathrm{N}$, $160^{\circ}$ W; (map 27). Var. Kaouakhta, Kyuatka.

This Aleut name meaning "long, narrow, and with some stony places," was applied by Father Veniaminov (1840, v. 1, p. 255), and was published by him as "Kyuatka" (p. 265). Capt. Lutke (1836, p. 267) called the island "Kaouakhta." The exact location of this island is not known.

Kauda Point: point of land, $\mathbf{S}$ tip of Tuxekan I., $22 \mathrm{mi}$. NW of Craig, Alex. Arch.; 55 $46^{\prime}$ $28^{\prime \prime} \mathrm{N}, 133^{\circ} 15^{\prime} 30^{\prime \prime} \mathrm{W}$; (map 4).

Indian name published in 1956 by USC\&GS.

Kaufman Creek: stream, heads at Kaufman Pass and flows $4.5 \mathrm{mi}$. ESE to Temnac Bay, Attu I., Aleutian I.; $52^{\circ} 49^{\prime} 03^{\prime \prime} \mathrm{N}, 173^{\circ} 00^{\prime} 34^{\prime \prime} \mathrm{E}$; (map 13).

Named by the U.S. Army during its occupation of the island during World War II; name shown on an AMS map published in 1948.

Kaufman Gulch: ravine, extends $1.6 \mathrm{mi}$. $\mathrm{N}$ to Nizina-River, $7 \mathrm{mi}$. SE of McCarthy, Wrangell Mts.; $61^{\circ} 22^{\prime} 00^{\prime \prime} \mathrm{N}, 142^{\circ} 44^{\prime} 10^{\prime \prime} \mathrm{W}$; (map 67).

Local name obtained by USGS and published on maps since 1954.

Kaufman Pass: pass, between Kaufman Creek and Nevidiskov River, at $\mathrm{N}$ end of Theodore Ridge, southern Attu I., Aleutian Is.; 52 $50^{\prime} 15^{\prime \prime} \mathrm{N}, 172^{\circ} 54^{\prime} 00^{\prime \prime} \mathrm{E}$; (map 13).

Named by the U.S. Army during its occupation of the island during World War II; name shown on an AMS map published in 1948.

Kaugrak Deep: locality, see Kograk Deep.

Kaugzaaq: locality, see Kograk Deep.

Kauichungak Creek: stream, see Koweejoongak River.

Kauilikh Bluff: bluff, see Koweelik Bluff.

Kauk River: stream, flows NW $30 \mathrm{mi}$. to Eschscholtz Bay, 37 mi. SW of Selawik, Kotzebue- 
Kobuk Low.; $66^{\circ} 17^{\prime} \mathrm{N}, 161^{\circ} 04^{\prime} \mathrm{W}$; (map 114).

Name shown on a 1901 field sheet by D. L. Reaburn, USGS.

Kaultui Mountain: mountain, 3,743 ft., between Kaultuinjek Creek and East Fork Sheenjek River, $17 \mathrm{mi}$. E of Table Mtn., Brooks Ra.; $68^{\circ} 19^{\prime} 30^{\prime \prime} \mathrm{N}, 143^{\circ} 00^{\prime} 00^{\prime \prime} \mathrm{W}$; (map 137).

Kutchin Indian name obtained in 1956 by T. E. Taylor, USGS.

Kaultuinjek Creek: stream, flows S $20 \mathrm{mi}$. to East Fork Sheenjek River, $17 \mathrm{mi}$. SE of Table Mtn., Brooks Ra.; 68 $16^{\prime}$ N, $143^{\circ} 02^{\prime}$ W ; (map 137).

Kutchin Indian name obtained in 1956 by T. E. Taylor, USGS.

Kautas: locality, "on Koyokuk River." Var. Cawtaskákat.

Former Eskimo camp or settlement reported in 1887 as "Cawtaskákat" with a population of 10 by Lt. H. T. Allen, USA.

Kauveren River: stream, see Kaviruk River.

Kauvet Creek: stream, see Kavet Creek.

Kavachurak Creek: stream, flows N $18 \mathrm{mi}$. to Noatak River, $23 \mathrm{mi}$. S of Howard Pass, Brooks Ra.; $67^{\circ} 53^{\prime} \mathrm{N}, 156^{\circ} 52^{\prime} \mathrm{W}$; (map 126).

Eskimo name reported to mean "red hill," obtained at Noatak and Kobuk by Orth in 1956.

Kavaihazakmute: locality, see Kaviak.

Kavaksarak: locality, see Kravaksanak.

Kavaksurak Mountain: mountain, 4,425 ft., in Brooks Ra., on W side of Howard Pass; 68 ${ }^{\circ} 19^{\prime}$ N, $157^{\circ} 00^{\prime} \mathrm{W}$; (map 132).

Named by Orth in 1956 for field reference reasons. It is the Eskimo name for Howard Pass obtained at Noatak the same year and reported to mean "a little red," but also may mean "becomes red" [qavioqsirok], referring to the turning red of the vegetation in late summer and early fall.

Kavalga Island: island, $5.5 \mathrm{mi}$. long, Delarof Is., Aleutian Is. ; $51^{\circ} 33^{\prime} \mathrm{N}, 178^{\circ} 48^{\prime} \mathrm{W}$; (map 16). Var. Kakhvalga Island, Ravalga Island. Aleut name published as "Kakhvalga" by Capt. Lutke (1836, p. 323), IRN, and as "Kavalga" by Capt. Tebenkov (1852, map 28), IRN.

Kavalghak: locality, see Kavalrok.

Kavalghak Bay: bay, $3 \mathrm{mi}$. wide, between Singik Point and Kaghoopalik Point, $8 \mathrm{mi}$. S of Gambell, W coast of St. Lawrence I.; $63^{\circ} 40^{\prime} \mathrm{N}$, $171^{\circ} 46^{\prime}$ W; BGN 1951; (map 93). Var. Kayalghak Bay.

Eskimo name reported by Orth in 1965, from an informant at Gambell, to mean "sleeping place." The name is applied locally only to the coastal indentation east of Singik Point. The bay probably takes its name from a small village or camp once located here. The Gambell village council recommended the name for map usage in 1949.

Kavalghak Cape: point of land, see Singik Point. Kavalghak Creek: stream, flows W $2 \mathrm{mi}$. to Kavalghak Bay, $10 \mathrm{mi}$. S of Gambell, St. Lawrence I.; $63^{\circ} 39^{\prime} \mathrm{N}, 171^{\circ} 44^{\prime} \mathrm{W}$; $B G N$ 1951; (map 93). Var. Kavalghak River, Kovighat River.
Eskimo name reported by Orth in 1965 to mean "sleeping place." See Kavalrok.

Kavalghak River: stream, see Kavalghak Creek. Kavalina River: stream, see Kivalina River.

Kavaloonmiut: locality, see Kuvlomiut.

Kavalrok: locality, site of camp or village, 10 mi. S of Gambell, near Singik Point, $W$ coast of St. Lawrence I.; $63^{\circ} 39^{\prime} \mathrm{N}, 171^{\circ} 46^{\prime} \mathrm{W}$; (map 93). Var. Kavalghak.

This Eskimo name, sometimes spelled "Kaval-ghak," was reported by Orth in 1965 to mean "sleeping place." The variant form of the name was published by the Univ. of Alaska in 1932.

Kavalrok: point of land, see Singik Point.

Kavarok River: stream, see Kaviruk River.

Kavearak Point: point of land, on Beaufort Sea coast, $4 \mathrm{mi}$. W of Beechey Point, Arctic Plain; $70^{\circ} 30^{\prime} 15^{\prime \prime} \mathrm{N}, 149^{\circ} 19^{\prime} 20^{\prime \prime} \mathrm{W}$; (map 150).

Eskimo name reported by USC\&GS in 1951, meaning "sand" [qaviaraq].

Kaveazruk: locality, "at Port Clarence," Seward Penin: High.

Former Eskimo camp or settlement listed in the 1890 Census (p. 162).

Kavet Creek: stream, flows $10 \mathrm{mi}$. NNW to Kobuk River $7.5 \mathrm{mi}$. SE of its junc. with Kaliguricheark River, $39 \mathrm{mi}$. NE of Kiana, Brooks Ra.; $67^{\circ} 07^{\prime} 45^{\prime \prime} \mathrm{N}, 159^{\circ} 02^{\prime} 00^{\prime \prime} \mathrm{W}$; (map 127). Var. Kauvet Creek.

Eskimo name shown as "Kau-vet Creek" on a 1901 fieldsheet by D. L. Raeburn, USGS; however, the name was spelled "Kavet" when published (Mendenhall, 1902, pl. 5).

Kaviagamute: locality, see Kaviak.

Kaviagemut: locality, see Kaviak.

Kaviagmut: locality, see Kaviak.

Kaviak: locality, near head of Imuruk Basin, $25 \mathrm{mi}$. E of Teller, Seward Penin. High.; $65^{\circ}$. $09^{\prime} \mathrm{N}, 165^{\circ} 30^{\prime} \mathrm{W}$; (map 111). Var. Kavaihazakmute, Kaviagamute, Kaviagemut, Kaviagmut, Kaviarazakhmute, Kaviarazkhmute, Kaviarzakhmute.

Site of an Eskimo village. Lt. L. A. Zagoskin, IRN, 1842-44, wrote the name of the village as "Kaviag-miut" and said it meant "fox." Members of the Western Union Telegraph Expedition spelled the name variously in the "Esquimaux," their monthly newspaper published at Teller, 1866-67. In the 10th Census, in 1880, Petroff $(1884$, p. 11) listed a population of 200 Eskimo. The 11 th Census, in 1890 (1893, p. 130) included "Kaviagmiut" in the Port Clarence village. Subsequent censuses have not recorded this village.

Kaviak Creek: stream, heads on Okiotak Peak, flows NE $6.5 \mathrm{mi}$. to Sadlerochit River $7.5 \mathrm{mi}$. SW of junc. with Kekiktuk River, $23 \mathrm{mi}$. NW of Mount Michelson, Brooks Ra.; 69 $31^{\prime} \mathrm{N}$, $145^{\circ} 00^{\prime} \mathrm{W}$; BGN 1961; (map 139). Var. Fox Creek.

Eskimo name obtained in 1956 by Orth and means "red fox."

Kaviak Peninsula: peninsula, see Seward Peninsula.

Kaviarazakhmute: locality, see Kaviak.

Kaviarazkhmute: locality, see Kaviak.
Kaviarzakhmute: locality, see Kaviak.

Kaviavazak River: stream, flows SW to head of Imuruk Basin, $30 \mathrm{mi}$. E of Teller, Seward Penin. High.; (map 111). Var. Karavaxarak River.

This Eskimo name appeared on many maps between 1869 and 1898 . With the advent of the gold rush in 1899 and 1900 and the detailed mapping that accompanied it, the name was found to be unknown locally. This may be the lower, swampy portion of the Kuzitrin River, which Collier (1902, p. 60), USGS, said "is called Kaviruk by the natives, and is, in fact, the delta portion of the Kuzitrin and Kruzgamepa rivers." The stream which Collier showed as Marys River is now called "Kaviruk River." See Fish River.

Kaviavazak River: stream, see Kaviruk River.

Kaviavizak River: stream, see Kuzitrin River.

Kaviayak Baie: bay, see Glarence, Port.

Kavicksum Koogowranga: stream, see Kawiksak Creek.

Kavil River: stream, heads on Mount Salisbury at $69^{\circ} 09^{\prime} \mathrm{N}, 146^{\circ} 20^{\prime} \mathrm{W}$, flows NW $80 \mathrm{mi}$ : to Shaviovik River, $28 \mathrm{mi}$. SW of Flaxman I., Arctic Plain; $70^{\circ} 02^{\prime} 45^{\prime \prime} \mathrm{N}, 147^{\circ} 19^{\prime} 45^{\prime \prime} \mathrm{W}$; $B G N$ 1959; (map 150). Var. Spellman River.

An Eskimo word for the wolverine; the name was given in 1947 by George Gryc, USGS, "because several of the animals were seen here during the field season."

Kaviktit Mountain: mountain, 4,610 ft., in Endicott Mts., $14 \mathrm{mi}$. NE of Survey Pass, Brooks Ra.; $67^{\circ} 56^{\prime} \mathrm{N}, 153^{\circ} 37^{\prime} \mathrm{W}$; (map 125).

Eskimo name that may mean "like a quoit," recorded in Anaktuvuk Pass by Orth, USGS, in 1956.

Kavipak: bay, see Kiveepuk Bay.

Kaviruk River: stream, formed by junc, of Coco and Johnston Creeks, flows SW $17 \mathrm{mi}$. to Marys Lake, $32 \mathrm{mi}$. E of Teller, Seward Penin. High.; $65^{\circ} 13^{\prime} \mathrm{N}, 165^{\circ} 16^{\prime} \mathrm{W}$; (map 111). Var. Covearak River, Cov-vee-arak River, Fluss Cheuweren, Ka-ooveren River, Kauveren River, Kavarok River, Kaviavazak River, Kow-e-rook River, Marys River, Reka Khvuveren.

Eskimo name reported by "some of the Franklin search parties about 1850" as "Covvee-arak." It was called "Kauveren" and "Ka-ooveren" by Commodore Joseph Billings in 1790. The prospectors' name "Marys River", was reported in 1901 by T. G. Gerdine (in Collier, 1902, pl. 12), USGS. This name probably referred to the Eskimo woman who ran the roadhouse known as "Marys Igloo." Kaviyak, Zaliv: bay, see Clarence, Port.

Kavlumiut: locality', see Kuvlomiut.

Kavraurak Hill: hill, see Kavrorak Hill.

Kavrorak Hill: hill, $574 \mathrm{ft}$., on Chukchi Sea coast, $\mathrm{N}$ of Kavrorak Lagoon, $14 \mathrm{mi}$. NW of Kivalina, Arctic Slope; $67^{\circ} 53^{\prime} \mathrm{N}, 164^{\circ} 53^{\prime}$ W; BGN 1963; (map 128). Var. Covroeruk Mountain, Kavraurak Hill, Kavrowrak, Kawraugraq, Kawzauzaq. 
Eskimo name reported to refer to the "pointed part of a woman's parka," which the hill resembles; reported in 1950 by USC\&GS.

Kavrorak Lagoon: lagoon, $1.2 \mathrm{mi}$. long on Chukchi Sea coast, $13 \mathrm{mi}$. NW of Kivalina, Kotzebue-Kobuk Low.; $67^{\circ} 52^{\prime} \mathrm{N}, 164^{\circ} 54^{\prime} \mathrm{W}$; $B G N$ 1963; (map 128). Var. Covroeruk Lagoon, Kovrorak Lagoon.

Eskimo name reported in 1950 by USC\&GS ; named for the nearby hill.

Kavrorak Springs: springs, S of Kavroarak Hill, drain into Kavroarak Lagoon, $14 \mathrm{mi}$. NW of Kivalina, Kotzebue-Kobuk Low.; 67 $52^{\circ} 30^{\prime \prime}$

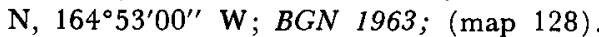
Var. Covroeruk Spring, Kevrorak Springs, Kevroruk Springs, Kovrorak Spring, Kovroruk Springs, Seekoosooweelak.

Eskimo name reported in 1950 by USC\&GS ; named for the nearby hill. E. S. Burch, in 1966, reported the Eskimo name as "Seekoosooweelak" meaning "never freezes."

Kavrowrak: hill, see Kavrorak Hill.

Kavyaak, Zaliv: bay, see Clarence, Port.

Kavyayak, Zaliv: bay, see Clarence, Port.

Kawanak Channel: water passage, in Yukon Delta on Norton Sound, extends W. from mouth of Kawanak Pass, $20 \mathrm{mi}$. N of Kwiguk, Yukon-Kuskokwim Delta; $63^{\circ} 02^{\prime} \mathrm{N}, 164^{\circ} 38^{\prime}$ W; (map 92).

Eskimo name reported in 1899 by G. R. Putnam, USC\&GS; published in 1901 on Chart 9372.

Kawanak Pass: stream, water passage in Yukon Delta, heads at Kwikpak Pass, flows NW 24 mi. to Norton Sound, Yukon-Kuskokwim Delta; $63^{\circ} 02^{\prime} \mathrm{N}, 164^{\circ} 37^{\prime} \mathrm{W}$; (map 92).

Eskimo name reported in 1899 by $G$. $R$. Putnam, USC\&GS; published in 1901 on Chart 9372.

Ka'wa-nar'a: ledge, see Kawanera.

Kawanera: ledge, projecting from shore line, at middle of Great East Rookery, on NE coast of Saint George I., in Pribilof Is.; 56 $35^{\prime} 50^{\prime \prime}$ N, $169^{\circ} 29^{\prime} 05^{\prime \prime}$ W; (map 38). Var. Ka'wanar'a.

An Aleut name listed as "Ka'wa-nar'a" by Putnam (1903, p. 1015), USC\&GS, meaning " 'sea lions' bidarra or boat." Putnam says it is a "prominent high ledge projecting from shore line to about middle of East Rookery [Great Eastern Rookery], occupied by numerous sea lions."

Kaweehnali Slough: stream, in Yukon Delta, flows $\mathrm{N} 3 \mathrm{mi}$. to Apoon Pass, $4 \mathrm{mi}$. W of Kotlik and $35 \mathrm{mi}$. NE of Kwiguk, Yukon-Kuskokwim Delta; $63^{\circ} 02^{\prime} \mathrm{N}, 163^{\circ} 40^{\prime} \mathrm{W}$; (map 92). Var. Kaweenah Slough.

Eskimo name reported in 1952 by USC\&GS as "Kaweenah Slough."

Kaweenah: stream, see Kaweehnali Slough.

Kawiakpak Creek: stream, heads on Towak Mtn., flows NE $2.8 \mathrm{mi}$. to Scammon Bay, at Point Smith $6 \mathrm{mi}$. E of Cape Romanzof, Yukon-Kuskokwim Delta; $61^{\circ} 49^{\prime} 50^{\prime \prime} \mathrm{N}, 165^{\circ}$ $55^{\prime} 00^{\prime \prime} \mathrm{W}$; (map 75).

Eskimo name reported by USC\&GS in 1949.

Kawialik Lake: lake, $3.5 \mathrm{mi}$. long, at $\mathrm{E}$ end of Askinuk Mts., between Kagankaguti and King- okakthluk Lakes, $14 \mathrm{mi}$. SE of village of Scammon Bay, Yukon-Kuskokwim Delta; $61^{\circ} 44^{\prime} \mathrm{N}$, $165^{\circ} 10^{\prime}$ W; (map 75). Var. Kowquialik Lake.

Eskimo name meaning "sandy" reported by USC\&GS in 1949.

Kawichiark River: stream, flows W $24 \mathrm{mi}$. to Kugarak River, $56 \mathrm{mi}$. SW of Shungnak, Kotzebue-Kobuk Low.; $66^{\circ} 33^{\prime} \mathrm{N}, 158^{\circ} 59^{\prime} \mathrm{W}$; $B G N$ 1902; (map 115). Var. Ka-o-e-che-ark.

Eskimo named spelled "Ka-o-e-che-ark" by Lt. Stoney (1900, map), USN, in 1886.

Kawicksahk: bluff, see Kawiksak Bluff.

Kawiksak Bluff: bluff, S of junc. of Kawiksak Creek and Kivalina River, $20 \mathrm{mi}$. NE of Kivalina, Arctic Slope; $68^{\circ} 01^{\prime} \mathrm{N}, 164^{\circ} 15^{\prime} \mathrm{W}$; (map 130). Var. Kawicksahk, Qawiqsaqq.

Eskimo name reported in 1966 by E. S. Burch.

Kawiksak Creek: stream, flows E 5 mi. to Kivalina River, $20 \mathrm{mi}$. NE of Kivalina, Arctic Slope; 68 $01^{\prime} \mathrm{N}, 164^{\circ} 15^{\prime} \mathrm{W}$; (map 130). Var. Kavicksum Koogowranga, Qawiqsam Kuugauzanga.

Eskimo name reported in 1966 by E. S. Burch.

Kawochawik: channel, see Kawokhawik Slough.

Kawochawik: water passage, see Kawokhawik Pass.

Kawockawik: channel, see Kawokhawik Slough.

Kawockawik: water passage, see Kawokhawik Pass.

Kawok: locality, see Kokwok.

Kawokhawik Island: island, $3.3 \mathrm{mi}$. long, in Yukon Delta between Kawokhawik Slough and Kwiguk Pass, $8.5 \mathrm{mi}$. W of Kwiguk, Yukon-Kuskokwim Delta ; $62^{\circ} 47^{\prime} \mathrm{N}, 164^{\circ} 49^{\prime}$ W; (map 77).

Eskimo name meaning "overnight camp" reported in 1952 by USC\&GS; so called because "in the days before outboard motors there was a camp here for overnight trips ***."

Kawokhawik Pass: water passage, $1.4 \mathrm{mi}$. long, in Yukon Delta, NW of Kawokhawik I., and $11 \mathrm{mi}$. W of Kwiguk, Yukon-Kuskokwim Delta ; $62^{\circ} 47^{\prime} \mathrm{N}, 164^{\circ} 53^{\prime} \mathrm{W}$; (map 77). Var. Akagowik Pass, Kawochawik, Kawockawik.

Eskimo name obtained in 1899 by G. R. Putnam, USC\&GS, who spelled it "Kawockawik."

Kawokhawik Slough: channel, $\mathrm{S}$ and $\mathrm{E}$ of Kawokhawik I., in Yukon Delta, rxtends 4.7 mi. between Kwiguk Pass and Nor ton Sound, $11 \mathrm{mi}$. W of Kwiguk, Yukon-'Kuskokwim Delta; 62 $46^{\prime}$ N, $164^{\circ} 52^{\prime}$ W; (map 77). Var. Kawochawik, Kawockawik.

Eskimo name obtained in 189 ) by G. R. Putnam, USC\&GS, who spelled it "Kawockawik."

Kawraugraq: hill, see Kavrorak Hill.

Kawzauzaq: hill, see Kavrorak Hill.

Kaxajookaliy Island: island, see Kaksajookalik Isiand.

Kayahtowriak: stream, see Kayz sturiak Creek. Kayaik Islands: islands, see Ka iak Islands.
Kayak: locality, site of a former village on SE coast of Wingham I., $61 \mathrm{mi}$. SE of Cordova, Malaspina Coastal Plain ; 59 $59^{\prime} 45^{\prime \prime} \mathrm{N}, 144^{\circ}$ $22^{\prime} 10^{\prime \prime} \mathrm{W}$; (map 48).

Name of a former settlement and steamer landing. A post office was established here in 1900; discontinued in 1906 (Ricks, 1965, p. 32). The place is now abandoned.

Kayak: locality, at junc. of Ipewik and Kukpuk Rivers, $15 \mathrm{mi}$. NE of Cape Thompson, Arctic Slopes; $68^{\circ} 20^{\prime} 30^{\prime \prime} \mathrm{N}, 165^{\circ} 42^{\prime} 40^{\prime \prime} \mathrm{W}$; $B G N$ 1963; (map 129). Var. Kaiyak.

This camping place was reported in 1960 by D. C. Foote, Project Chariot, as "Kaiyak," meaning "boat."

Kayak, Ostrova: islands, see Kayak Islands.

Kayak Cape: point of land, between Staraya and Protection Bays, on S coast of Unalaska I., Aleutian Is.; $53^{\circ} 35^{\prime} 00^{\prime \prime} \mathrm{N}, 166^{\circ} 30^{\prime} 40^{\prime \prime} \mathrm{W}$; (map 23). Var. Kaiak Cape, Mountain Cape, Mys Kayakh.

Aleut name recorded by Capt. Tebenkov 1852, map 26), IRN, as "M[ys] Kayakh," or "Cape Kayak." Baker (1906, p. 355) says that this name may have been given because of the possible resemblance of the word to the native skin boat. According to R. H. Geoghegan the Aleut word "qayaq" means "hill" and was incorrectly transliterated by Baker. The point was called "Mountain Cape" by USBF in 1888.

Kayak Creek: stream, flows NE $8 \mathrm{mi}$., from Fan Mtn. to Alapah Creek, $22 \mathrm{mi}$. NE of Anaktuvuk Pass, Brooks Ra.; $68^{\circ} 17^{\prime} \mathrm{N}, 150^{\circ} 59^{\prime} \mathrm{W}$; (map 134).

Named in 1932 by Robert Marshall (1956, p. 83), probably for the Eskimo girl, Kayak. In describing the Fourth of July celebration of 1931 in Wiseman, Marshall wrote, "The big feature of the festivities *** was dancing. We started at six-thirty on the evening of July 4 , and at eleven next morning four Eskimo girls, Kaaruk, Ashuwaruk, Kayak, and Kachwona, were still going strong * * *."

Kayak Entrance: water passage, in Gulf of Alaska, between Kayak I. and Windham I., $61 \mathrm{mi}$. SE of Cordova, Malaspina Coastal Plain; 59 $59^{\prime} \mathrm{N}, 144^{\circ} 21^{\prime} \mathrm{W} ; B G N$ 1908; (map 48).

Named for Kayak Island and published by USC\&GS in 1916 Coast Pilot (p. 30).

Kayakh: stream, see Kaiyuh Slough.

Kayakh, Mys : point of land, see Kayak Cape.

Kayakishvigmyut: villages, see Utukok villages.

Kayak Island: island, $20 \mathrm{mi}$. long, in Gulf of Alaska, $62 \mathrm{mi}$. SE of Cordova, Malaspina Coastal Plain; 59 $56^{\prime} \mathrm{N}, 144^{\circ} 23^{\prime} \mathrm{W}$; BGN Sixth Report; (map 48). Var. Carmen Island, Kaiak Island, Kaye's Island, Kay's Island, Kyak Island, Nuestra Señora del Carmen, Saint Elias Island, Beardslee Island.

It was called "Kayak" by the Russians (Sarichev, 1826, map 5) because of the fancied resemblance of its outline to the Eskimo skin canoe. This island, it is believed, was the one Vitus Bering saw and named Saint Elias in 1741 (Bancroft, 1886, p. 78). Capt. James Cook visited it on May 12, 1778, and 
buried a bottle with a paper and two small pieces of silver given to him by Dr. Kaye, the chaplain of King George III of England, for this purpose. Because of this, Capt. Cook gave the name "Kaye's Island" to this feature (Wagner, 1937, p. 465). It was called "Nuestra Señora del Carmen" or "Isla del Carmen," meaning "Our Lady Carmen" or "Island of [Our Lady] Carmen" by Don I. Arteaga about July 16,1779 , for the saint to whom this day was dedicated (Wagner, 1937, p. 439).

Kayak Islands: islands, $0.3 \mathrm{mi}$. across, in Galankin Is., in Sitka Sound, 2 mi. S of Sitka, Alex. Arch.; $57^{\circ} 01^{\prime} 30^{\prime \prime} \mathrm{N}, 135^{\circ} 22^{\prime} 00^{\prime \prime} \mathrm{W}$; (map 9). Var. Kayaik Islands, Kayak Islets, Kayaktch Islands, Kayatchi Islands, Ostrova Kayak.

Named in 1809 by the Russian navigator Ivan Vasiliev the first; published by Lt. Sarichev (1826, map 19), IRN, as "O[strova] Kayak," or "Kayak Islands." This is an Eskimo name for a small skin boat.

Kayak Islets : islands, see Kayak Islands.

Kayak Lake: lake, $1 \mathrm{mi}$. long, on Kenai Penin., $0.9 \mathrm{mi}$. SW of Chick Lake and $28 \mathrm{mi}$. NE of Kenai, Cook Inlet Low.; $60^{\circ} 45^{\prime} \mathrm{N}, 150^{\circ} 34^{\prime}$ W; (map 62).

Named about 1963 by officials of Kenai National Moose Range, for administrative purposes.

Kayakliut, Cape: point of land, between Imuya and Wide Bays, on SE coast of Alaska Penin., $44 \mathrm{mi}$. SE of Ugashik, Aleutian Ra.; 57 $17^{\prime}$ $35^{\prime \prime} \mathrm{N}, 156^{\circ} 19^{\prime} 00^{\prime \prime}$ W; (map 36). Var. Pointe Kamlgliuck.

Eskimo name published in 1835 as " $\mathrm{P}$ [ointe] Kamgliuck" by Adm. A. J. von Krusenstern, IRN.

Kayak Mountain: mountain, 2,498 ft., $5 \mathrm{mi}$. long, $5 \mathrm{mi}$. NW of junc. of May Creek and Nanushuk River and 51 mi. NE of Anaktuvuk Pass, Arctic Slope; $68^{\circ} 47^{\prime} \mathrm{N}, 150^{\circ} 45^{\prime} \mathrm{W}$; (map 134).

Named by USGS geologists about 1949.

Kayaksak Mountain: mountain, $1,060 \mathrm{ft}$., E of junc. of Ipewik and Kukpuk Rivers, $16 \mathrm{mi}$. NE of Cape Thompson, Arctic Slope; $68^{\circ} 20^{\prime} 40^{\prime \prime}$ N, $165^{\circ} 40^{\prime} 30^{\prime \prime} \mathrm{W}$; BGN 1963; (map 129). Var. Kaiaksuk Mountain.

Eskimo name meaning "resembles a kayak" reported in 1960 by D. C. Foote, he spelled it "Kaiaksuk."

Kayakshigvikg: locality, see Kaiaksekawik.

Kayaktch Islands: islands, see Kayak Islands.

Kayakturiak Creek: stream, flows SW $7 \mathrm{mi}$. to Kivalina Lagoon, 1 mi. N of Kivalina, Kotzebue-Kobuk Low.; $67^{\circ} 44^{\prime} \mathrm{N}, 154^{\circ} 32^{\prime} \mathrm{W}$; (map 128). Var. Kayahtowriak, Qayaqturiaq.

Eskimo name meaning "where they go with kayaks" reported in 1966 by E. S. Burch.

Kayaku Island: island, see Adak Island.

Kayalghak Bay: bay, see Kavalghak Bay.

Kayanak, Mys: point of land, see Battery Point.

Kayashek: island, see Round Island.

Kayashik: island, see Round Island.

Kayatchi Islands: islands, see Kayak Islands.

Kayayak: locality, see Kaguyak.
Kayayak: village, see Kaguyak.

Kay Creek: stream, flows SW $6.1 \mathrm{mi}$. to Buckstock River $16 \mathrm{mi}$. SE of its junc. with Aniak River, $32 \mathrm{mi}$. SE of Aniak and $20 \mathrm{mi}$. SW of Little Mountain Village, Kilbuck-Kuskokwim Mts.; $61^{\circ} 17^{\prime} \mathrm{N}, 158^{\circ} 47^{\prime \prime} \mathrm{W}$; BGN 1948; (map 72).

Prospectors' name reported in 1945 by USGS.

Kay Creek: stream, flows SW $2.5 \mathrm{mi}$. to Chukchi Sea, $2.5 \mathrm{mi}$. S of Cape Lisburne, Arctic Slope; $68^{\circ} 51^{\prime} \mathrm{N}, 166^{\circ} 13^{\prime} \mathrm{W}$; (map 129). Var. Keak Creek, Kiak Creek.

This appears to be an Eskimo name probably derived from "Keak," a name reported in 1950 by USC\&GS, or a shortened form of the name of a nearby camp called "Kayniktouk" by D. C. Foote, of Project Chariot.

Kay Creek: stream, flows $\mathrm{S}$ and $\mathrm{W} 7 \mathrm{mi}$. to Ikpikpuk River $2.5 \mathrm{mi}$. $\mathrm{N}$ of its head, Arctic Slope; $69^{\circ} 22^{\prime} 28^{\prime \prime} \mathrm{N}, 154^{\circ} 40^{\prime} 50^{\prime \prime} \mathrm{W}$; (map 142).

Named in the 1950's by Naval Petroleum Reserve No. 4 geologists "for George Frederick Kay, 1873-1943, geologist, USGS, and State Geologist of Iowa."

Kay Creek: stream, see Doestock Creek.

Kay-eghlen: bay, see Whale Bay.

Kaye's Island: island, see Kayak Island.

Kaygany, Cape: point of land, see Muzon, Cape. Kaygany, Mys: point of land, see Muzon, Cape. Kaygany Strait: water passage, see Dixon Entrance.

Kayigyalik Lake: lake, $5 \mathrm{mi}$. across, $\mathrm{E}$ of Takslesluk Lake, $30 \mathrm{mi}$. NW of Bethel, YukonKuskokwim Delta; 61 ${ }^{\circ} 04^{\prime}$ N, 162 $32^{\prime}$ W; (map 74). Var. Kyigialik Lake, Nunavak Anukslak.

Eskimo name reported by USC\&GS in 1951 . Kaymaegruk Hills: hills, see Kemegrak Hills. Kaymaegruk Lagoon: lagoon, see Kemegrak Lagoon.

Kay's Island: island, see Kayak Island.

Kayu-chali, Ostrov: island, see Kaiuchali Island.

Kayugnak, Zaliv: bay, see Kaiugnak Bay.

Kayuh Mountains: range, see Kaiyuh Mountains.

Kayuk River: stream, see Koyuk River.

Kazakof, Cape: point of land, at $W$ entrance to Kazakof Bay, $7 \mathrm{mi}$. NE of Afognak, on SE coast of Afognak I., N of Kodiak I.; $58^{\circ} 04^{\prime}$ $40^{\prime \prime} \mathrm{N}, 152^{\circ} 37^{\prime} 40^{\prime \prime} \mathrm{W}$; (map 43). Var. Kazakof Cape, Cape Kazakofskiy.

Russian name meaning "Cape Cossack" given as "M[ys] Kozakovskiy" by Sub-Lt. Mikhail Murashev, IRN, in 1839 or 1840 and published by the Russian Hydrog. Dept. in 1849 on Chart 1425 . This name was applied to Cape Kostromitinof, at east entrance to Kazakof Bay, by Capt. Tebenkov (1852, map 23), IRN. See Cape Kostromitinof.

Kazakof Bay: bay, $2 \mathrm{mi}$. across, $9 \mathrm{mi}$. NE of Afognak, on SE coast of Afognak I., $\mathbf{N}$ of Kodiak I.; $58^{\circ} 06^{\prime} \mathrm{N}, 152^{\circ} 35^{\prime} \mathrm{W}$; BGN 1935 ; (map 43). Var. Danger Bay, Opasnaia.

The name "Bukhta Onasnaya" meaning "dangerous bay" was given to this feature by
Sub-Lt. Mikhail Murashev, IRN, in 1839 or 1840 and published by the Russian Hydrog. Dept, on Chart 1425 in 1849. Baker (1906, p. 208), USGS, published the name "Danger Bay" when he translated from Murashev. In 1935 USC\&GS gave the name Kazokof Bay to this feature "as the bay is deep with practically no dangers; to conform with local usage and to eliminate the inconsistency."

Kazakofskie, Cape: point of land, see Kostromitinof, Cape.

Kazakofskiy, Cape: point of land, see Kasakof Cape.

Kazarn Bay: bay, see Kasaan Bay.

Kazhutak: locality, on left bank of Yukon River, $48 \mathrm{mi}$. SE of Kwiguk, Yukon-Kuskokwim Delta; $62^{\circ} 07^{\prime} \mathrm{N}, 163^{\circ} 57^{\prime} \mathrm{W}$; (map 77). Var. Kazhutakamiut.

Eskimo village reported in 1899 by G. $R$. Putnam, USC\&GS, who wrote it "Kazhutakamiut," meaning "Kazhutak people."

Kazhutak: locality, on left bank of Yukon River, $25 \mathrm{mi}$. WNW of Pitkas Point and $50 \mathrm{mi}$. SE of Kwiguk, Yukon-Kuskokwim Delta; 62․$07^{\prime} \mathrm{N}, 163^{\circ} 58^{\prime} \mathrm{W}$; (map 77). Var. Kazhutakamiut.

Former Eskimo village reported as "Kazhutakamiut" in 1899 by G. R. Putnam, USC\&GS. Kazhutakamiut : locality, see Kazhutak.

Kazik Hill: hill, $1,169 \mathrm{ft}$., $20 \mathrm{mi}$. W of Taylor Mts. and $60 \mathrm{mi}$. SW of Sleetmute, KilbuckKuskokwim Mts.; $60^{\circ} 56^{\prime} \mathrm{N}, 158^{\circ} 01^{\prime} \mathrm{W} ; B G N$ 1948; (map 60).

Eskimo name meaning "little house" reported in 1945 by USGS. The name refers to "the conical shape of the hill which is recognizable over a wide area and is therefore an important landmark."

Kchaltak: village, see Kaltag.

Kchisakh, Cape: point of land, see Chisak Cape. Keak Creek : stream, see Kay Creek.

Kealavik: locality, see Old Kealavik.

Kealavik River: stream, flows NW $27 \mathrm{mi}$. from Ninglick River to Azun River, $\mathbf{N}$ of Nelson I., $37 \mathrm{mi}$. NE of Cape Vancouver, Yukon-Kuskokwim Delta; $61^{\circ} 02^{\prime} \mathrm{N}, 164^{\circ} 57^{\prime} \mathrm{W}$; (map 58). Var. Kialavik River.

Eskimo name reported in 1949 by USC\&GS. Keane Gulch: ravine, trends $\mathrm{NE} 0.5 \mathrm{mi}$. to Hungry Creek which flows to Oregon Creek, a tributary to Cripple River, $15 \mathrm{mi}$. NW of Nome, Seward Penin. High.; $64^{\circ} 40^{\prime} \mathrm{N}, 165^{\circ}$ 42' W; (map 94).

Prospectors' name shown on the 1904 "Map of Cape Nome Precinct" by Arthur Gibson.

Kearney Beach: beach, $0.2 \mathrm{mi}$. long, $1.6 \mathrm{mi}$. NE of Theodore Point, southern Attu I., Aleutian Is.; $52^{\circ} 45^{\prime} 32^{\prime \prime} \mathrm{N}, 172^{\circ} 56^{\prime} 33^{\prime \prime} \mathrm{E}$; (map 13). Var. Kearny Beach.

Named by the U.S. Army during its occupation of the island during World War II; name shown as "Kearny Beach" on an AMS map published in 1948.

Kearny Beach: beach, see Kearney Beach.

Keating Creek: stream, flows NE $9 \mathrm{mi}$. to Mosquito Fork $8 \mathrm{mi}$. $\mathrm{E}$ of that stream's junc. with South Fork Koyukuk River, $44 \mathrm{mi}$. SW of 
Chandalar, Brooks Ra.; $67^{\circ} 04^{\prime} 00^{\prime \prime} \mathrm{N}, 1^{\circ} 9^{\circ}$ 31'40'" W; (map 123).

Prospectors' name obtained in 1901 by Schrader (1904, pl. 3), USGS.

Keating Range: mountain range, elev. 1,000 2,832 ft., $5 \mathrm{mi}$. long, along $W$ shore of Mosman Inlet, on $W$ coast of Etolin I., Alex. Arch.; $56^{\circ} 08^{\prime} 00^{\prime \prime} \mathrm{N}, 132^{\circ} 37^{\prime} 30^{\prime \prime} \mathrm{W}$; (map 6).

Named in 1886 by Lt. Comdr. A. S. Snow, USN; name published in 1887 on USC\&GS Chart 706.

Keche Mountains: mountain, $4.755 \mathrm{ft}$., $10 \mathrm{mi}$. $\mathrm{NW}$ of Buffalo Mtn. and $60 \mathrm{mi}$. NW of Christian, Brooks Ra.; $67^{\circ} 58^{\prime}$ N, $146^{\circ} 45^{\prime} \mathrm{W}$; (map 122).

Kutcha-kutchin Indian name obtained in 1956 by T. E. Taylor, USGS.

Kechemudluk: locality, see Cape Seppings.

Kechumstuk: locality, along Kechumstuk Creek, $1 \mathrm{mi}$. W of Mosquito Fork, $70 \mathrm{mi}$. SW of Eagle, Yukon-Tanana High.; $64^{\circ} 01^{\prime} \mathrm{N}, 142^{\circ} 33^{\prime} \mathrm{W}$; (map 102). Var. Ketchumstock, Ketchumstuck.

Settlement now abandoned, known as "Retchumstock Village" (sic) on a 1902 manuscript map by E. J. Chamberlain, U.S. Deputy Surveyor. A telegraph station, "Ketchumstock," was established here in 1915 by the U.S. Army Signal Corps. The present spelling was used in 1905 by Prindle (pl. 16). USGS.

Kechumstuk Creek: stream, heads at $64^{\circ} 04^{\prime} \mathrm{N}$, $143^{\circ} 08^{\prime} \mathrm{W}$, flows SE $25 \mathrm{mi}$. to Mosquito Fork, $70 \mathrm{mi}$. SW of Eagle, Yukon-Tanana High.; $64^{\circ} 01^{\prime} 00^{\prime \prime} \mathrm{N}, 142^{\circ} 32^{\prime} 30^{\prime \prime} \mathrm{W}$; (map 102). Var. Ketchumstock Creek, Mosquito Fork.

Prospectors' name reported in 1902 by T. G. Gerdine, USGS, as "Ketchumstock Creek."

Kechumstuk Mountain: mountain, 5,002 ft., 18 mi. W of Taylor Mtn., $75 \mathrm{mi}$. SW of Eagle, Yukon-Tanana High.; $64^{\circ} 00^{\prime} \mathrm{N}, 142^{\circ} 50^{\prime} \mathrm{W}$; (map 102). Var. Ketchumstock Mountain.

Prospectors' name obtained in 1898 by E. C. Barnard, USGS.

Keeang-ol-e-vik Pass: stream, see Kiangolevik Pass.

Kee-chat-no: stream, see Kichatna River.

Keechik: locality, see Kijik.

Keefer Creek: stream, flows NE $10 \mathrm{mi}$. to Holitna River, $12 \mathrm{mi}$. S of Sleetmute, Stony River Low.; $61^{\circ} 31^{\prime} 45^{\prime \prime} \mathrm{N}, 157^{\circ} 07^{\prime} 25^{\prime \prime} \mathrm{W}$; BGN 1948; (map 72).

Named for a prospector who worked in the area; reported in 1945 by USGS.

Keefer Cutoff: stream, anabranch on $E$ side of Nushagak River, flows S $29 \mathrm{mi}$., $28 \mathrm{mi}$. NW of Naknek, Bristol Bay Low.; $58^{\circ} 54^{\prime} 30^{\prime \prime} \mathrm{N}$,

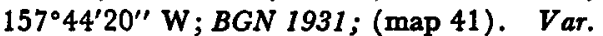
Keefer Slough.

Local name reported in 1930 by Gerald FitzGerald, USGS, based on information given by F. H. Waskey and Beverley Polley, residents of the area.

Keefer Slough: stream, see Keefer Cutoff.

Keeghik: locality, see Kijik.

Keeghik: lake, see Clark, Lake.

Keeghik River: stream, see Kijik River.
Keegragrock: locality, see Kigragrak.

Keejik: locality, see Kijik.

Keejik: mountain, see Kijik Mountain.

Keejik Creek: stream, see Kijik River.

Keejik River: stream, see Kijik River.

Kee-kik-tag-ameut: town, see Kotzebue.

Kee-kluch River: stream, see Kiklukh River.

Ke-ek-sel-hak : locality, see Nelsonville,

Ke-ek-sel-hak: village, see Dillingham.

Keektoya Creek: stream, see Kiktoya Greek.

Keelaghnuk Valley: ravine, E slope of Ivekan Mtn.; trends E $1.2 \mathrm{mi}$., SE of Wan-Mayee Creek Valley, $30 \mathrm{mi}$. SE of Gambell, St. Lawrence I.; $63^{\circ} 23^{\prime} \mathrm{N}, 171^{\circ} 40^{\prime} \mathrm{W}$; BGN 1951; (map 93).

Eskimo name reported in 1949 by Maj. $\mathrm{H}$. B. Allen, USAF.

Keele Mountains: mountian range, see Keele Range.

Keele Range: mountain range, in Alaska and Canada, extends NE $90 \mathrm{mi}$. from junc. of Black River and Salmon Fork, Porcupine Plat.; $67^{\circ} 00^{\prime} \mathrm{N}, 139^{\circ} 30^{\prime} \mathrm{W}$ [NE end], $66^{\circ} 40^{\prime} \mathrm{N}$, $142^{\circ} 45^{\prime} \mathrm{W}$ [SW end]; (maps 120 and 121). Var. Keele Mountains.

Named by Cairnes (1914, p. 26) "after Mr. Joseph Keele [1863-1923] of the Geological Survey, Canada, who has done a great amount of extremely valuable geological and exploratory work in Yukon and adjoining portions of the Northwest Territories."

Keelikhtagikh Island: island, see Kiliktagik Island.

Keelyangnak: bluff, see Kilangnak Bluff.

Keelyiktangyawk Creek: stream, see Kiliktakgot Creek.

Keelyowgorack: spit, see Kilogorak Spit.

Keenan Creek: stream, flows N $4.5 \mathrm{mi}$. to Glenn Creek $1 \mathrm{mi}$. SW of that stream's junc. with Yukon River and $43 \mathrm{mi}$. NW of Eagle, YukonTanana High.; $65^{\circ} 17^{\prime} 30^{\prime \prime} \mathrm{N}, 142^{\circ} 06^{\prime} 15^{\prime \prime} \mathrm{W}$; (map 103).

Prospectors' name from an unpublished map by E. J. Chamberlain, dated 1902.

Keene Channel: water passage, between Keene and Kupreanof Is., $14 \mathrm{mi}$. S of Petersburg, Alex. Arch.; $56^{\circ} 36^{\prime} 20^{\prime \prime} \mathrm{N}, 132^{\circ} 59^{\prime} 30^{\prime \prime} \mathrm{W}$; (map 6). Var. Keene's Channel.

Named in 1869 for charting purposes by Comdr. R. W. Meade, USN, for J. W. Keene, a local pilot.

Keene Island: island, $0.5 \mathrm{mi}$. long, at junc. of Beecher Pass and Wrangell Narrows, $14 \mathrm{mi}$. $\mathrm{S}$ of Petersburg, Alex. Arch.; $56^{\circ} 36^{\prime} 10^{\prime \prime} \mathrm{N}$, $132^{\circ} 59^{\prime} 00^{\prime \prime}$ W; (map 6). Var. Keenes Island.

Named in 1869 for charting purposes by Comdr. R. W. Meade, USN, for J. W. Keene, a local pilot.

Keene Rock: rock, in Sitka Sound, $2 \mathrm{mi}$. SW of

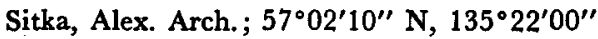
W ; (map 9). Var. Keene Rocks.

Named in 1897 by U.S. Navy for pilot J. W. Keene, who reported its presence that year (U.S. Coast and Geodetic Survey, 1883, p. 142).

Keene Rocks: rock, see Keene Rock.
Keene's Channel: water passage, see Keene Channel.

Keenes Island: island, see Keene Island.

Keengiktoorak: bank, see Kingikturak Bank.

Keenuk River: stream, see Gemuk River.

Kee River: stream, see Kuk River.

Keesaymaeruktuk Mountain: hills, see Kisaymaruktuk Mountain.

Keesaymalott Mountain: hill, see Kisimigiuktuk Hill.

Keesaymalott Mountains: mountains, see Kisimilot Mountains.

Keeseemalouk Creek: stream, see Kisimilok Creek.

Keeseemalowk Greek: stream, see Kisimilok Creek.

Keesemalouk Mountain: hill, see Kisimilok Mountain.

Keeseemalowk Mountain: hill, see Kisimilok Mountain.

Keesin-Myghook Mountain: hill, see Kessin Peak.

Keeska Island: island, see Kiska Island.

Keetavie Rookery: rookery, see Kitovi Rookery.

Keete Inlet: estuary, extends NE $5.5 \mathrm{mi}$. from Nutkwa Inlet on SW coast of Prince of Wales I., Alex. Arch.; $55^{\circ} 03^{\prime} 30^{\prime \prime} \mathrm{N}, 1^{\circ} 2^{\circ} 34^{\prime} 30^{\prime \prime} \mathrm{W}$; (map 4).

This may be an Indian name; reported in 1897 by Lt. Comdr. J. F. Moser, USN; published in 1899 by USC\&GS.

Keete Island: island, $700 \mathrm{ft}$. long, between Keete and Nutkwa Inlets, on SW coast of Prince of Wales I., Alex. Arch.; 55 $02^{\prime} 50^{\prime \prime} \mathrm{N}, 132^{\circ} 34^{\prime}$ 45" W; (map 4).

Name, possibly Indian, reported in 1951 by USGS.

Keete Point: point of land, on SW coast of Prince of Wales I., in Keete Inlet, Alex. Arch.; $55^{\circ} 03^{\prime} 05^{\prime \prime} \mathrm{N}, 132^{\circ} 33^{\prime} 15^{\prime \prime} \mathrm{W}$; (map 4).

Name, possibly Indian, reported in 1951 by USGS.

Keetovaia Bay: bay, see Whale Bay.

Keeverleek Inlet: water passage, see Kukpowruk Pass.

Keevy Peak: mountain, 7,399 ft., $21 \mathrm{mi}$. SE of Jumbo Dome and $29 \mathrm{mi}$. NE of Healy, Alaska Ra.; 63 $55^{\prime} 15^{\prime \prime} \mathrm{N}, 148^{\circ} 02^{\prime} 00^{\prime \prime} \mathrm{W}$; (map 87).

Local named obtained in 1910 by J. W. Bagley, USGS.

Keewalick: village, see Kiwalik.

Keewalik: village, see Kiwalik.

Kee-wa-lik River: stream, see Kiwalik River.

Keeyuk Creek: stream, flows N $4.1 \mathrm{mi}$. to Buckland River, $55 \mathrm{mi}$. N of Haycock, Seward Penin. Figh.; $66^{\circ} 00^{\prime} \mathrm{N}, 161^{\circ} 10^{\prime} \mathrm{W}$; (map 109).

Eskimo name reported in 1949 by the U.S. Army Corps of Engineers.

Kegan Cove: cove, extends NW 1,500 ft., off Moira Sound, on SE coast of Prince of Wales I., Alex. Arch.; $55^{\circ} 01^{\prime} \mathrm{N}, 132^{\circ} 09^{\prime} \mathrm{W}$; (map 4).

Local name reported in 1897 by Lt. Comdr. J. F. Moser, USN; see Kegan Creek.

Kegan Creek: stream, heads in Kegan Lake, flows SE 2 mi. to Kegan Cove, on SE coast of 
Prince of Wales I., Alex. Arch.; 55 $01^{\prime} 10^{\prime \prime}$ $\mathrm{N}, 132^{\circ} 09^{\prime} 30^{\prime \prime} \mathrm{W}$; (map 4).

Local name reported in 1897 by Lt.-Comdr. J. F. Moser, USN; it is the personal name of "an Indian claiming fishing rights on this salmon stream."

Kegan Lake: lake, $2.5 \mathrm{mi}$. long, on SE coast of Prince of Wales I., $\mathbf{N}$ of Moira Sound, Alex. Arch.; $55^{\circ} 02^{\prime} \mathrm{N}, 132^{\circ} 12^{\prime} \mathrm{W}$; (map 4).

Local name reported in 1897 by Lt.-Comdr.

J. F. Moser, USN; see Kegan Creek.

Keg Creek: stream, flows SW $11 \mathrm{mi}$. to West Fork Gulkana River $28 \mathrm{mi}$. NW of its junc. with Gulkana River, Alaska Ra.; 62 ${ }^{\circ} 43^{\prime} \mathrm{N}$, $146^{\circ} 26^{\prime} \mathrm{W}$; (map 83).

Local name reported by F. $H$. Moffit (in Brooks and others, 1911, p. 114), USGS.

Kegezruk Creek : stream, see Kigezruk Creek.

Keggik: locality, see Kijik.

Keghik River: stream, see Kijik River.

Kegiktowruk: locality, see Klikitarik.

Keg Lakes: lakes, $300 \mathrm{ft}$. across, on west-central Kiska I., Aleutian Is.; $51^{\circ} 56^{\prime} 05^{\prime \prime} \mathrm{N}, 177^{\circ} 21^{\prime}$ 35" E; (map 14).

An arbitrary name beginning with " $\mathrm{K}$ " to correspond to the " $\mathrm{K}$ " grid used by the U.S. Army for tactical purposes during World War II ; published on a 1953 AMS map.

Keg Point: point of land, $1 \mathrm{mi}$. N of Ham Cove, on E coast of Dall I., Alex. Arch.; 54 53' $45^{\prime \prime}$ N, 132 $51^{\prime} 10^{\prime \prime}$ W ; BGN 1928; (map 1 ).

Named in 1927 by USC\&GS after the triangulation station Keg located on an island near this point.

Keg Point: point of land, in Lake Bay, on E coast of Stevenson I., off NE coast of Prince of Wales I., Alex. Arch.; 56 $06^{\prime} 05^{\prime \prime}$ N, $132^{\circ}$ $55^{\prime} 20^{\prime \prime} \mathrm{W}$; (map 6).

Local name used by fishermen; name published in 1907 by USC\&GS.

Keguk River: stream, heads at Kegum Kagati Lake and flows S $20 \mathrm{mi}$. to Kinia River, 93 mi. SW of Bethel, Yukon-Kuskokwim Delta; $60^{\circ} 13^{\prime} \mathrm{N}, 164^{\circ} 12^{\prime} \mathrm{W}$; (map 58$)$.

Eskimo name reported in 1949 by USC\&GS. Kegulik River: stream, see Kejulik River.

Kegum Kagati : lake, see Kagankagati Lake.

Kegum Kagati Lake: lake, $6 \mathrm{mi}$. across, $15 \mathrm{mi}$. $\mathrm{S}$ of Emperor I. and $90 \mathrm{mi}$. SW of Bethel, Yukon-Kuskokwim Delta; $60^{\circ} 20^{\prime} \mathrm{N}, 164^{\circ} 20^{\prime}$ W; (map 58).

Eskimo name meaning "head of the Keguk [River]" reported in 1949 by USC\&GS.

Keith Creek: stream, see Key Creek.

Kejachu Island: island, see Adak Island.

Kejak River: stream, see Kijik River.

Kejulik Mountains: mountains, 6,000 ft., extend NE $30 \mathrm{mi}$. from Kejulik River to Mount Mageik, $7 \mathrm{mi}$. SW of Mount Katmai, Aleutian Ra.; $58^{\circ} 05^{\prime} \mathrm{N}, 155^{\circ} 30^{\prime} \mathrm{W}$; (map 35 and 42).

Name reported in 1951 by USGS.

Kejulik Pass: pass, 2,100 ft., on Alaska Penin., in Katmai National Monument, between tributaries of Gas and Takayofo Creeks, $25 \mathrm{mi}$. SW of Mount Katmai, Aleutian Ra.; 58 $04^{\prime} 40^{\prime \prime}$ $N, 155^{\circ} 32^{\prime} 00^{\prime \prime} \mathrm{W}$; (map 42$)$.
Native name reported in 1923 by $\mathbf{R}$. $\mathbf{H}$. Sargent's USGS party.

Kejulik River: stream, heads at glacier terminus, in Katmai National Monument on Alaska Penin., flows SW $44 \mathrm{mi}$. to Becharof Lake $\mathrm{N}$ of Severson Penin., $45 \mathrm{mi}$. SW of Mount Katmai, Aleutian Ra.; 57 $51^{\prime} 45^{\prime \prime} \mathrm{N}$, $155^{\circ} 57^{\prime} 30^{\prime \prime}$ W; (map 35). Var. Kajulik River, Kegulik River, Kujulik River.

Native name reported in 1904 and published by G. C. Martin (1921, pl. 9), USGS.

Kekiktalik Lake: lake, $0.7 \mathrm{mi}$. across, $\mathrm{W}$ of junc. of Tungnak Creek and Nilik River, $27 \mathrm{mi}$. E of. Cape Dyer, Arctic Slope; 68 $37^{\prime} 30^{\prime \prime} \mathrm{N}$, $165^{\circ} 08^{\prime} 50^{\prime \prime} \mathrm{W}$; (map 129). Var. Ikriktolik Lake, Kikiktalik.

Eskimo name spelled "Kikiktalik" by Orth in 1956, meaning "place with an island [in the middle]."

Kekiktuk River: stream, heads in Lake Schrader, flows NE $16 \mathrm{mi}$. to Sadlerochit River, $\mathrm{S}$ of Sunset Pass, $20 \mathrm{mi}$. NW of Mount Michelson, Brooks Ra.; 69 $33^{\prime}$ N, $144^{\circ} 43^{\prime}$ W ; (map 139). Var. Lake Fork Sadlerochit River.

Eskimo name [kikiktak] meaning "island." Leffingwell $(1919$, p. 57) wrote, "This outlet valley was followed for a few miles, and the gathering stream could be stepped across at any place. Near the main river [Sadlerochit] the Lake Fork receives several feeders from east and west so that it carries a considerable volume of water."

Keklone River: stream, see Middle Fork Kuskokwim River.

Kekou: village, see Kake.

Kekou Islets: islands, see Keku Islets.

Kekou Strait: water passage, see Keku Strait.

Kekovskoy, Proliv: water passage, see Keku Strait.

Keku : village, see Kake.

Keku Creek: stream, flows NW $11 \mathrm{mi}$. to Irish Creek, 1 mi. E of Keku Strait, on SW coast of Kupreanof I., $27 \mathrm{mi}$. W of Petersburg, Alex. Arch.; $56^{\circ} 44^{\prime} 15^{\prime \prime} \mathrm{N}, 133^{\circ} 40^{\prime} 00^{\prime \prime} \mathrm{W}$; BGN 1966; (map 6). Var. Kuku Creek.

Local name recorded in 1948 by USGS.

Keku Islets: islands, in Keku Strait, NE of Kuiu I., $45 \mathrm{mi}$. SE of Sitka, Alex. Arch.; $56^{\circ} 56^{\prime} \mathrm{N}, 134^{\circ} 06^{\prime} \mathrm{W}$; (map 5). Var. Kekou Islets, Kiku Islets.

Tlingit Indian name published in 1883 Coast Pilot (p. 118).

Kekur: rock, see Pinnacle Rock.

Kekur, Cape: point of land, see Pillar Cape.

Kekur Island: island, $300 \mathrm{ft}$. long, in Kalsin Bay, $0.6 \mathrm{mi}$. NW of Isthmus Point, $11 \mathrm{mi}$. S of Kodiak, Kodiak I. ; $57^{\circ} 38^{\prime} 25^{\prime \prime}$ N, $152^{\circ} 19^{\prime} 25^{\prime \prime}$ W; (map 34). Var. Kekurnoi, Ostrov Kekurnoy.

Transliteration of the name "Os[trov] Kekurnoy," or "Kekur Island," published by Sarichev (1826, map 16). Baker (1906, p. 357-358) wrote, "This word, spelled Kekoor, Kekour, Kekur, etc., is frequently found on Russian maps of Alaska and Eastern Siberia. It appears to be some native [sic] term adopted into the Russian and to mean any high isolated rock or rocky islet. Apparently it is an exact equivalent of the Spanish word 'Farallon'." Baker further stated that the Russian Hydrog. Dept. reported a list of words used by the promyshenniki, or fur hunters, in 1884 and "In this list occurs these two entries: Gurie (pyramid of rocks); Kekur, same as Gurie, but [more often] an isolated pillar-like rock." Petroff (in Bancroft, 1886, p. 225) wrote, "this expedition fell in with a large party of savages who had taken up a position on a Kekour, or detached cliff, near the shore, surrounded by water $* * *$. Such places, to which the Russians applied the Kamchatka name of Kekour, were often used by the natives as natural fortifications and places of refuge. War parties or hunting expeditions would leave their women and children upon such cliffs for safe-keeping till their return."

Kekur Peninsula: peninsula, $1.5 \mathrm{mi}$. long, $14 \mathrm{mi}$. NW of village of Port Alexander, on S coast of Baranof I., Alex. Arch.; 56 $23^{\prime} \mathrm{N}, 1^{\circ} 4^{\circ} 56^{\prime}$ W; BGN 1925; (map 5).

Descriptive Russian name meaning "seastack," or "pinnacle-rock," reported in 1925 by USC\&GS; probably given because "First Kekur" and "Second Kekur" are just offshore. See Kekur Island.

Kekur Point: point of land, between Kizhuyak and Sharatin Bays, $15 \mathrm{mi}$. NW of Kodiak, Kodiak I.; $57^{\circ} 51^{\prime} 30^{\prime \prime} \mathrm{N}, 152^{\circ} 47^{\prime} 00^{\prime \prime} \mathrm{W}$; $B G N$ 1909; (map 34). Var. Kekurnoi, Mys Kekurnyy, Pillar Cape.

Transliteration of the name "M[ys] Kekurnyy" given in 1839 or 1840 by Sub-Lt. Mikhail Murashev and published in 1849 on Russian Hydrog. Dept. Chart 1425. Baker (1906, p. 497) published "Pillar Cape," the translation of Murashev's name. Because of duplication, the name was changed to its present form in 1909 by USC\&GS. See Kekur Island.

Kekur Point: point of land, $\mathrm{W}$ extremity of Kekur Penin., $15 \mathrm{mi}$. NW of village of Port Alexander, on $S$ coast of Baranof I., Alex. Arch.; $56^{\circ} 23^{\prime} \mathrm{N}, 134^{\circ} 57^{\prime} \mathrm{W}$; BGN 1926; (map 5).

Descriptive Russian name meaning "pinnacle rock" given in 1925 by USC\&GS. See Kekur Isalnd.

Kekurnoi : island, see Kekur Island.

Kekurnoi : point of land, see Kekur Point.

Kekurnoi, Cape: point of land, between Alinchak and Puale Bays, on E coast of Alaska Penin., $33 \mathrm{mi}$. NW of Karluk, Aleutian Ra.; 57 $43^{\prime}$ $30^{\prime \prime} \mathrm{N}, 155^{\circ} 07^{\prime} 50^{\prime \prime} \mathrm{W}$; BGN 1901; (map 35). Var. Cape Kahurnoi, Neliupiaki, Nelupaki, Nukakalkak, Pinnacle Cape.

Russian name published by Capt. Tebenkov (1852, map 22), IRN, as "M[ys] Kekurnoy" meaning "pinnacle cape." This feature was called "Cape Nelyupiaki" by Capt. Lutke (1836, map, p. 274), IRN, and "M[ys] Nunakalkhak" on Russian Hydrog. Dept. Chart 1378 in 1847 . See Kekur Island.

Kekurnoy, Ostrov: island, see Kekur Island. Kekurnyy, Mys : point of land, see Kekur Point. Kekurnyy, Mys: point of land, see Rocky Point.

Keku Strait: water passage, $45 \mathrm{mi}$. long, between Kuiu and Kupreanof Is., Alex. Arch.; 
$56^{\circ} 30^{\prime} \mathrm{N}, 133^{\circ} 42^{\prime} \mathrm{W}$; (map 6). Var. Kake Strait, Kekou Strait, Kiku Strait, Proliv Kekovsky.

Tlingit Indian name for this feature published in 1869 Coast Pilot (p. 109).

Kelamantowruk: locality, see Kilimantavi.

Keledzhichagat: locality, on left bank of Kuskokwim River opposite mouth of George River, Kilbuck-Kuskokwim Mts.; $61^{\circ} 53^{\prime} \mathrm{N}, 157^{\circ} 42^{\prime}$ W; (map 72).

Site of an Indian summer camp reported in 1842-44 by Lt. L. A. Zagoskin, IRN.

Keledzhichagat: stream, see George River.

Kelemanturuk: locality, "near Icy Cape," Arctic Plain; (map 146).

Former Eskimo camp or settlement listed in the 1890 Census (1893, p. 162). See Kilimantavi.

Kelevatowtin: locality, see Kilimantavi.

Kelez, Mount: mountain, 3,250 ft., SE of Lake Brooks, on Alaska Penin., in Katmai National Monument, $30 \mathrm{mi}$. NW of Mount Katmai, Aleutian Ra.; $58^{\circ} 26^{\prime} 30^{\prime \prime} \mathrm{N}, 155^{\circ} 44^{\prime} 10^{\prime \prime}$ W; BGN 1957; (map 42).

Local name published in 1951 by USGS.

Kelgaya Bay: cove, $0.3 \mathrm{mi}$. across, on Chilkoot Inlet, on E coast of Chilkat Penin., $2.3 \mathrm{mi}$. SE of Port Chilkoot and $17 \mathrm{mi}$. SW of Skagway, Coast Mts.; $59^{\circ} 12^{\prime} 45^{\prime \prime} \mathrm{N}, 135^{\circ} 22^{\prime} 00^{\prime \prime} \mathrm{W}$; $B G N$ 1923; (map 45). Var. Chilkoot Inlet, Kelgaya Point, Battery Point.

Named in 1923 for adjacent point of land by BGN.

Kelgaya Point: point of land, in Chilkoot Inlet, on $\mathrm{E}$ shore of Chilkat Penin., $2.5 \mathrm{mi}$. SE of Port Chilkoot, $17 \mathrm{mi}$. SSW of Skagway, Coast Mts.; $59^{\circ} 12^{\prime} 50^{\prime \prime} \mathrm{N}, 135^{\circ} 22^{\prime} 15^{\prime \prime} \mathrm{W}$; $B G N$ 1922; (map 45). Var. Ketlgakhya Point, Ketlrachta Point.

Tlingit Indian name "Ketlgakhya" meaning "dog-howl place." Aurel and Arthur Krause (1883, map) reported the name of this and Battery 'Point as "Ketlrachta." Shown as "Kelgaya" in 1923 on IBC Sheet 9 (1951 atlas).

Kell Bay: bay, $1.5 \mathrm{mi}$. across, on $\mathrm{W}$ shore of Affleck Canal, $10 \mathrm{mi}$. $\mathrm{N}$ of Cape Decision, on S coast of Kuiu I., Alex. Arch.; $56^{\circ} 09^{\prime} 20^{\prime \prime} \mathrm{N}$, $134^{\circ} 07^{\prime} 00^{\prime \prime} \mathrm{W}$; (map 5$)$.

Name given "by the Indians"; reported in 1886 by Lt. J. M. Helm, USN.

Kelley, Mount : mountain, see Kelly, Mount.

Kelley Cove: cove, see Kelly Cove.

Kelley River: stream, see Kelly River.

Kelley River: stream, see Killey River.

Kelliher Cove: cove, $0.3 \mathrm{mi}$. across, between Point Hope and Khlebnikof Point, on $\mathbf{E}$ coast of Attu I., Aleutian Is.; $52^{\circ} 55^{\prime} 00^{\prime \prime} \mathrm{N}, 173^{\circ}$ $18^{\prime} 30^{\prime \prime} \mathrm{E}$; (map 13).

This name is listed in the 1946 supplement to the 1944 Aleutian Coast Pilot.

Kellogg Point: point of land, point of $\mathrm{N}$ entrance to Dunbar Inlet on W coast of Sukkwan I., Alex. Arch.; $55^{\circ} 06^{\prime} 05^{\prime \prime} \mathrm{N}, 132^{\circ} 52^{\prime} 30^{\prime \prime} \mathrm{W}$; (map 4).

Named in 1882 by W. H. Dall, USC\&GS, for "Miss Fannie E. Kellogg, a teacher at Sitka in 1878."
Kelly, Mount: mountain, 3,907 ft., $3 \mathrm{mi}$. NE of Rude River delta, $12 \mathrm{mi}$. NE of Cordova, Chugach Mts.; $60^{\circ} 40^{\prime} 30^{\prime \prime} \mathrm{N}, 145^{\circ} 30^{\prime} 30^{\prime \prime} \mathrm{W}$; $B G N$ 1910; (map 64). Var. Kelly Mountain.

Local name reported in 1908 by Grant and Higgins (1910, pl. 1 and 2), USGS.

Kelly, Mount: mountain, 3,152 ft., in De Long Mts., between headwaters of Kukpowruk and Kukpuk Rivers, $40 \mathrm{mi}$. SE of Cape Sabine, Brooks Ra.; 68 $28^{\prime} 30^{\prime \prime} \mathrm{N}, 163^{\circ} 37^{\prime} 30^{\prime \prime} \mathrm{W}$; (map 130). Var. Mount Kelly.

Name published in 1890 by USC\&GS. Named for "John W. Kelley a bluff, levelheaded prospector of middle age, with a fuil beard and an easy laugh" (Brower, 1944, pl. 112). Kelley (or Kelly) came to this area in 1887 and in 1891 took over the Pacific Steam Whaling Co. station at Barrow. $\mathrm{He}$ is also noted for making a vocabulary list of Eskimo words.

Kelly Cove: cove, $500 \mathrm{ft}$. across, on SE coast of Noyes I., $1.8 \mathrm{mi}$. NE of St. Nicholas Point, Alex. Arch.; $55^{\circ} 27^{\prime} 40^{\prime \prime} \mathrm{N}, 1^{\circ} 33^{\circ} 38^{\prime} 20^{\prime \prime} \mathrm{W}$; (map 4). Var. Kelley Cove.

Local name published in 1917 by USC\&GS.

Kelly Creek: stream, flows NW $11 \mathrm{mi}$. to Kala Creek, 42 mi. SE of Nulato, Koyukuk Low.; $64^{\circ} 34^{\prime} \mathrm{N}, 156^{\circ} 44^{\prime} \mathrm{W}$; (map 97).

Local name reported in 1954 by USGS.

Kelly Greek: stream, flows SE $2.6 \mathrm{mi}$. to Kwik River, $26 \mathrm{mi}$. SW of Haycock, Seward Penin. High.; $65^{\circ} 00^{\prime} \mathrm{N}, 161^{\circ} 54^{\prime} \mathrm{W}$; (map 109).

Local name published on maps after 1950.

Kelly Gulch: ravine, extends NE $2 \mathrm{mi}$. to Middle Fork Koyukuk River, $8 \mathrm{mi}$. S of Wiseman, Brooks Ra.; $67^{\circ} 18^{\prime} 00^{\prime \prime} \mathrm{N}, 150^{\circ} 11^{\prime} 30^{\prime \prime} \mathrm{W}$; (map 124).

Local name shown on an 1899 fieldsheet by T. G. Gerdine, USGS.

Kelly Lake: lake, $1 \mathrm{mi}$. long, one of the Seven Lakes, on Kenai Penin., 2 mi. NW of Hidden Lake and $30 \mathrm{mi}$. SE of Kenai, Cook Inlet Low. ; $60^{\circ} 31^{\prime} \mathrm{N}, 150^{\circ} 23 \mathrm{~W}$; ( $\left.\operatorname{map} 62\right)$.

Named about 1963 by officials of Kenai National Moose Range for administrative purposes.

Kelly Lake: lake, $0.9 \mathrm{mi}$. long, on The Alaska Railroad, $2 \mathrm{mi}$. SE of Willow and $34 \mathrm{mi}$. N of Anchorage, Cook Inlet Low.; 61 ${ }^{\circ} 42^{\prime} 50^{\prime \prime} \mathrm{N}$, $150^{\circ} 00^{\prime} 45^{\prime \prime} \mathrm{W}$; (map 70$)$.

Local name reported in 1958 by USGS.

Kelly Lake: lake, $1 \mathrm{mi}$. long, drains $\mathrm{S}$ to Little Nelchina River W of Marie Lake, $48 \mathrm{mi}$. W of Glennallen, Copper River Basin; 62 $10^{\prime} 00^{\prime \prime}$ $\mathrm{N}, 146^{\circ} 59^{\prime} 40^{\prime \prime} \mathrm{W}$; (map 83)

Local name reported in 1949 by USGS. The name has been misapplied to John Lake. Kelly Lake: lake, see John Lake.

Kelly Mountain: mountain, see Kelly, Mount.

Kelly Ridge: ridge, elev. 6,600 ft., extends SENW $2.5 \mathrm{mi}$., $1.5 \mathrm{mi}$. E of Lake Peters, Brooks Ra.; $69^{\circ} 19^{\prime} \mathrm{N}, 144^{\circ} 58^{\prime} \mathrm{W}$; (map 139).

Named by geologists in the 1950's.

Kelly River: stream, heads in De Long Mts., flows SW $45 \mathrm{mi}$. to Noatak River, $29 \mathrm{mi}$. NE of Noatak, Brooks Ra.; $67^{\circ} 55^{\prime} \mathrm{N}, 162^{\circ} 21^{\prime} \mathrm{W}$; (map 128). Var. Kelley River.
Locally named for John W. Kelley [sic] who prospected in this area in the late 1880's. See Kelly, Mount.

Kelly Rock: rock, at SW entrance point to Popof Strait, off SE coast of Unga I., in Shumagin Is., Aleutain Ra.; $55^{\circ} 11^{\prime} 40^{\prime \prime} \mathrm{N}, 160^{\circ} 27^{\prime} 25^{\prime \prime}$ W; (map 28). Var. Kellys Rock.

Local name published by USC\&GS in 1916 Coast Pilot (p. 180) as "Kellys Rock," and in 1926 Coast Pilot (p. 197) as "Kelly Rock." Kellys Rock : rock, see Kelly Rock.

Kelp Bay: bay, $1 \mathrm{mi}$. across,. on NW coast of Tigalda I., Aleutian Is.; $54^{\circ} 04^{\prime} 20^{\prime \prime} \mathrm{N}, 165^{\circ}$ 09'00" W; (map 24).

Descriptive name reported in 1901 by J. J. Gilbert, USC\&GS.

Kelp Bay: bay, $2 \mathrm{mi}$. across, on NE coast of Baranof I., $13 \mathrm{mi}$. N of Baranof, Alex. Arch.; $57^{\circ} 16^{\prime} \mathrm{N}, 134^{\circ} 50^{\prime} \mathrm{W}$; (map 9). Var. Deep Bay.

Named by W. H. Dall, USC\&GS, and published in 1883 Coast Pilot (p. 176). Kelp is a type of seaweed found along coastal areas and is locally commercially important.

Kelp Island: island, $2 \mathrm{mi}$. long, off $\mathrm{S}$ coast of Duke I., Alexander Arch; $54^{\circ} 52^{\prime} \mathrm{N}, 131^{\circ} 16^{\prime}$ W; (map 2).

Named in 1883 by Lt. Comdr. H. E. Nichols, USN.

Kelp Island Anchorage: bay, off Revillagigedo Channel, on E coast of Kelp I., S of Duke I., Alex. Arch.; $54^{\circ} 52^{\prime} 10^{\prime \prime} \mathrm{N}, 131^{\circ} 15^{\prime} 15^{\prime \prime} \mathrm{W}$; (map 2).

Name derived from Kelp Island; published in 1955 on a USGS map.

Kelp Passage: water passage, $3 \mathrm{mi}$. long, in Barrier Is., W of Middle I., Alex. Arch.; $54^{\circ} 48^{\prime} \mathrm{N}, 132^{\circ} 27^{\prime} \mathrm{W}$; (map 1).

Local descriptive name reported in 1951 by USGS.

Kelp Point: point of land, on S shore of Bay of Is., Adak I., Aleutian Is.; $51^{\circ} 47^{\prime} 25^{\prime \prime} \mathrm{N}, 176^{\circ}$. 48'20" W; BGN 1936; (map 17).

Descriptive name given by members of the U.S. Navy Aleutian Island Survey Expedition in 1934.

Kelp Point: point of land, on E shore of Nikolski Bay, on SW coast of Umnak I., Aleutian Is. ; $52^{\circ} 57^{\prime} 40^{\prime \prime} \mathrm{N}, 168^{\circ} 51^{\prime} 50^{\prime \prime} \mathrm{W}$; (map 21 ).

Name published by USC\&GS in 1944 Aleutian Coast Pilot (p. 68)

Kelp Point: point of land, on E shore of Cold Bay, at SW end of Alaska Penin., Aleutian Ra.; $55^{\circ} 06^{\prime} 50^{\prime \prime} \mathrm{N}, 162^{\circ} 31^{\prime} 20^{\prime \prime} \mathrm{W} ; B G N$ 1925; (map 29).

Named by R. R. Lukens, USC\&GS, in 1924, "because of large heavy kelp-patch on opposite side of narrow natural channel passing point."

Kelp Point: point of land, S point of entrance to McHenry Anchorage, SW Etolin I., Alex. Arch.; $55^{\circ} 57^{\prime} 45^{\prime \prime} \mathrm{N}, 132^{\circ} 27^{\prime} 00^{\prime \prime} \mathrm{W}$; (map 4).

Named in 1886 by Lt. Comdr. A. S. Snow, USN.

Kelp Point: point of land, near head of Portage Bay, on SE coast of Alaska Penin., $53 \mathrm{mi}$. NE of Ugashik, Aleutian Ra.; $57^{\circ} 33^{\prime} 45^{\prime \prime} \mathrm{N}, 156^{\circ}$ $00^{\prime} 30^{\prime \prime} \mathrm{W}$; (map 36).

Local descriptive name published in 1924 by 
USC\&GS "because of the exte--sive kelp off shore."

Kelp Point: point of land, on W shore of Port Chatham, Kenai Penin., $17 \mathrm{mi}$. SSW of Seldovia, Chugach Mts.; $59^{\circ} 12^{\prime} 40^{\prime \prime} \mathrm{N}, 151^{\circ} 48^{\prime} 00^{\prime \prime}$ W; BGN 1908; (map 50).

Named by USC\&GS in 1908 for the then numerous kelp beds.

Kelp Rocks: reef, extends $1.4 \mathrm{mi}$, in Nichols Passage, $3 \mathrm{mi}$. NW of Metlakatla, Alex. Arch.; $55^{\circ} 09^{\prime} \mathrm{N}, 131^{\circ} 39^{\prime} \mathrm{W}$; (map 3$)$.

Named in 1883 by Lt. Comdr. H. E. Nichols, USN.

Kelsall River: stream, heads in glacier $5 \mathrm{mi}$. SE of Mount Kelsall in British Columbia, flows W and SE $40 \mathrm{mi}$. to Chilkat River, $3.4 \mathrm{mi}$. W of Klutshah Mtn. and $26 \mathrm{mi}$. NW of Skagway, St. Elias Mts.; 59 $31^{\prime} 55^{\prime \prime} \mathrm{N}, 136^{\circ} 02^{\prime} 00^{\prime \prime} \mathrm{W}$; $B G N$ 1916; (map 45). Var. Bear Creek, Chilkat River, Glave Creek, Jelchhini, Jelchitni Rabenfluss, West Fork Chilkat River, Yelchthini.

Named by United States and Canada in 1916 for R. Kelsall, a member of the British Columbia-Yukon boundary surveying party in 1908. The Tlingit Indian name "Jelchhini," meaning "crow river," was published as "Jelchitni" by Aurel and Arthur Krause (1883, map). The local name was reported as "Bear Creek" by C. W. Wright (1904, pl. 2 and p. 13), USGS. The name "Kelsall River" was published in 1923 on IBC Sheet 9 (1951 atlas).

Kemamguyguok Creek: stream, flows SW $14 \mathrm{mi}$. to Kokwok River, $35 \mathrm{mi}$. NE of Dillingham, Bristol Bay Low.; 59 $30^{\prime} \mathrm{N}, 158^{\circ} 10^{\prime} \mathrm{W}$; (map 52). Var. Ke-mam-gu-y-guok.

Eskimo name shown as "Ke-mam-gu-yguok" on a 1910 manuscript map by H. C. Fassett, USBF.

Kemegrak Hills: hills, extend N $16 \mathrm{mi}$. from Cape Thompson, $W$ of Ilikrak Creek, Arctic Slope; $68^{\circ} 18^{\prime} \mathrm{N}, 165^{\circ} 54^{\prime} \mathrm{W}$; BGN 1963; (map 129). Var. Kaymaegruk Hills.

Eskimo name reported in 1960 as "Kaymaegruk" by D. C. Foote, Project Chariot.

Kemegrak Lagoon: lagoon, $2.3 \mathrm{mi}$. long, on Chukchi Sea coast, between Aiautak and Akoviknak Lagoons, $5.5 \mathrm{mi}$. NW of Cape Thompson, Arctic Slope ; $68^{\circ} 14^{\prime} \mathrm{N}, 166^{\circ} 05^{\prime}$ W; BGN 1963; (map 129). Var. Kaymaegruk Lagoon.

Eskimo name reported in 1962 by personnel of Project Chariot.

Kemik Creek: stream, heads in Brooks Ra., flows NW $15 \mathrm{mi}$. to West Fork Shaviovik River, $23 \mathrm{mi}$. SE of head of Shaviovik River, Arctic Slope; $69^{\circ} 24^{\prime} 30^{\prime \prime} \mathrm{N}, 147^{\circ} 14^{\prime} 00^{\prime \prime} \mathrm{W}$; (map 140).

Eskimo name meaning "small hill" or "mound" ["qimiq"] given in 1951 by USGS geologists.

Kemperville: locality, on right bank of Tanana River, at mouth of Hot Springs Slough $5 \mathrm{mi}$. $\mathrm{SE}$ of village of Manley Hot Springs, YukonTanana High.; 64 $59^{\prime} \mathrm{N}, 150^{\circ} 48^{\prime} \mathrm{W}$; (map 99). Var. Buckholtz Roadhouse.
Name of a roadhouse that had its origin as a trading post about 1909 .

Kempff Bay: bay, 2 mi. across, on $\mathrm{W}$ shore of Alitak Bay, at S end of Kodiak I.; $56^{\circ} 56^{\prime} \mathrm{N}$, $154^{\circ} 13^{\prime} \mathrm{W}$; (map 32 ).

Named in 1900 by Lt. Comdr. J. F. Moser, USN, commander of the Albatross, for Ens. Clarence F. Kempff, USN, a member of his party.

Kemp Hill: hill, $700 \mathrm{ft}$., on W coast of Kiska I., Aleutian Is.; $51^{\circ} 58^{\prime} 08^{\prime \prime} \mathrm{N}, 177^{\prime} 21^{\prime} 15^{\prime \prime} \mathrm{E}$; (map 14).

An arbitrary name beginning with " $\mathrm{K}$ " to correspond to the " $K$ " grid used by the U.S. Army for tactical purposes during World War II ; published on a 1953 AMS map.

Kemuk Mountain: mountain, 1,180 ft., $4 \mathrm{mi}$. E of Thorsen Mtn. and $26 \mathrm{mi}$. NE of Cape Newenham, Kilbuck-Kuskokwim Mts.; $58^{\circ}$ $54^{\prime} 40^{\prime \prime} \mathrm{N}, 161^{\circ} 39^{\prime} 30^{\prime \prime} \mathrm{W}$; (map 39).

Eskimo name recorded in 1938 by J. B. Mertie and Gerald FitzGerald, USGS; reported to mean "the one between."

Kemuk Mountain: mountain, 1,500 ft., $16 \mathrm{mi}$. NE of Okstukuk Lake and $50 \mathrm{mi}$. N. of Dillingham, Bristol Bay Low.; $59^{\circ} 42^{\prime} \mathrm{N}, 158^{\circ} 02^{\prime}$ W; BGN 1932; (map 52). Var. Kimok.

Eskimo name shown as "Kimok" on a 1910 manuscript map by H. C. Fassett, USBF.

Kemuk River: stream, heads in Nenevok Lake, flows SW $28 \mathrm{mi}$. to Togiak River, $2 \mathrm{mi}$. E of Kashiagamiut and $58 \mathrm{mi}$. NE of Goodnews, Kilbuck-Kuskokwim Mts., $59^{\circ} 22^{\prime} 30^{\prime \prime} \mathrm{N}, 160^{\circ}$ $00^{\prime} 30^{\prime \prime}$ W; (map 53). Var. Narogurum River.

Eskimo name reported in 1965 by USGS. It was also called "Narogurum," another Eskimo name, published in 1954 by USGS.

Kenachananak: locality, on mainland $\mathbf{E}$ of $\mathrm{Nu}$ nivak I., Yukon-Kuskokwim Delta; (map 58). Var. Kennachananaghmiut.

Former Eskimo camp or settlement listed as "Kennachananaghmiut," with a population of 181 in the 1890 Census.

Kenai: locality, see Lakeview

Kenai Bay: estuary, see Cook Inlet.

Kenai Junction: village, see Soldatna.

Kenai: village, pop. 778 , at mouth of Kenai River, on E shore of Cook Inlet, $65 \mathrm{mi}$. SW of Anchorage, Cook Inlet Low.; 60 $33^{\prime} \mathrm{N}$, $151^{\circ} 16^{\prime}$ W; (map 62). Var. Fort Kenai, Fort Nicholas, Kenai Rédoute, Pavlovskaya, Redaute Saint Nikolaus, Redut Svataya Nikolaya, Saint Nicholas Fort De Pawlofsk.

A fortified post, called "Redut Svataya Nikolaya," or "Fort St. Nicholas," was built in 1791 by Grigor Konovalov, commander of the St. George; of the Lebedef-Lastochkin Company. The village was also called "Paul's Fort," or "Pavlovskaya," by the Russians. In 1869 a U.S. Military Post, named "Fort Kenai" for the Indians living in the area, was established there, and in 1899 the Kenai post office was authorized (Ricks, 1965, p. 32). The population was 44 in 1880 ; in 1890,263 ; in 1910,250 ; in 1920,332; in 1930, 286.

Kenai Lake: lake, on Kenai Penin., extends SW 24 mi., from head of Kenai River to mouth of
Snow River, $22 \mathrm{mi}$. NW of Seward, Chugach Mts.; $60^{\circ} 24^{\prime} \mathrm{N}, 149^{\circ} 37^{\prime} \mathrm{W}$; (map 63). Var. Second Lake.

Local name reported in 1898 by Mendenhall (1900, map 16), USGS.

Kenai Lake: lake, see Skilak Lake.

Kenai Mountains: mountain range, maximum elevation 6,000 ft., $20 \mathrm{mi}$. wide, extends $\mathrm{NE}$ $120 \mathrm{mi}$. from $\mathrm{S}$ end of Kenai Penin., Chugach Mts.; $59^{\circ} 31^{\prime} \mathrm{N}, 151^{\circ} 00^{\prime} \mathrm{W}$; (map 50). Var. Truuli.

Name published by Grewingk (1849, p. 111), who obtained his information from $I$. G. Wosnesenski's account of a voyage to the area in 1842. The Kenai Indian name for these mountains is given as "Trüiuli."

Kenai Peninsula: peninsula, $150 \mathrm{mi}$. long and 70 mi. wide, extends SW from Turnagain Arm and Passage Canal, bounded on $E$ by Gulf of Alaska and on $W$ by Cook Inlet, Chugach Mts. and Cook Inlet Low.; $60^{\circ} \mathrm{N}, 150^{\circ} \mathrm{W}$; BGN Sixth Report; (map 63). Var. Kanaiski land, Kenay Peninsula, Tschugatsk Halbinsel.

Name published in 1868 by USC\&GS; probably derived from "Kenayskaya" the name given by the Russians in the 1790's to Cook Inlet. Commodore Joseph Billings called it "Kanaiski land" in 1802; Constantin Grewingk called it "Tschugatsk Halbinsel" or "Chugach Peninsula" in 1850.

Kenai Rédoute: village, see Kenai.

Kenai River: stream, on Kenai Penin., heads at Kenai Lake in Kenai Mts., flows W $75 \mathrm{mi}$. to Cook Inlet at Kenai, Cook Inlet Low.; 60 $33^{\prime}$ N, 151 16' W; (map 62). Var. Kaknu River, Kakny, Nik River.

Name reported in 1898 by Mendenhall (1900, map 16), USGS. The Tanaina Indian name for this stream was reported to be "Kakny [Kakna]"; the Eskimo name was "Nik [ignik]" meaning "fire," but more probably referred to the Eskimo name for the local Indians.

Kenaiskaia, Baie: estuary, see Cook Inlet.

Kenaiskaiai : estuary, see Cook Inlet.

Kenaiskichev Meerbusen: estuary, see Cook Inlet.

Kenaiskischer: estuary, see Cook Inlet.

Kenaiskoi: estuary, see Cook Inlet.

Kenaiskoi golfe: estuary, see Cook Inlet.

Kenai Strait: water passage, see Shelikof Strait.

Kenaitze Lake: lake, $0.7 \mathrm{mi}$. long, on Kenai Penin. W of Phalarope Lake, $8 \mathrm{mi}$. SSW of Point Possession and $38 \mathrm{mi}$. NE of Kenai, Cook Inlet Low.; $60^{\circ} 55^{\prime} 15^{\prime \prime} \mathrm{N}, 150^{\circ} 25^{\prime} 30^{\prime \prime}$ W; (map 62).

Named about 1963 by officials of Kenai National Moose Range, for administrative purposes.

Kenakuchuk Creek: stream, heads on Kemuk Mtn. and flows S $16 \mathrm{mi}$. to Kokwok River, 35 mi. NE of Dillingham, Bristol Bay Low.; $59^{\circ}$ $29^{\prime} \mathrm{N}, 158^{\circ} 07^{\prime} \mathrm{W}$; (map 52). Var. Ki-nuktu-cha-rok.

Eskimo name written Ki-nuk-tu-cha-rok by H. C. Fassett, USBF, in 1910. The present form of the name appears to have been established by USGS. 
Kenasnow: locality, see Killisnoo.

Kenasnow: islands, see Kootzanhoo Archipelago. Kenasnow Island: island, see Killisnoo Island.

Kenasnow Reef : rocks, see Kenasnow Rocks.

Kenasnow Rocks: rocks, in Chatham Strait, $1 \mathrm{mi}$. SW of Angoon, off W coast of Admiralty I., Alex. Arch.; $57^{\circ} 29^{\prime} 30^{\prime \prime}$ N, $134^{\circ} 36^{\prime} 00^{\prime \prime} \mathrm{W}$; (map 9). Var. Kenasnow Reef.

Named in 1869 by Lt. Comdr. R. W. Meade, USN, for Kenasnow Island, a variant of Killisnoo Island $\mathrm{N}$ off which the reef or rocks are located. Portions of the reef are always above high water. The name "Kensnow Reef" was published by USC\&GS in 1883 Coast Pilot (p. 175).

Kenay Peninsula: peninsula, see Kenai Peninsula.

Kenayskoy, Zaliv: estuary, see Cook Inlet.

Kendall Cache: locality, see Tacoma.

Kendrick Bay: estuary, extends SE $4 \mathrm{mi}$. from its West Arm to Clarence Strait, on SE coast of Prince of Wales I., Alex. Arch.; 54 ${ }^{\circ} 1^{\prime} 15^{\prime \prime}$ N, $131^{\circ} 58^{\prime} 00^{\prime \prime} \mathrm{W}$; (map 2$)$.

Named in 1879 by W. H. Dall, USC\&GS, for Capt. John Kendrick, commander of the sloop Columbia, who wintered at Nootka in 1788-89.

Kendrick Island: islands, off-shore group $2 \mathrm{mi}$. long, at mouth of Kendrick Bay off SE coast of Prince of Wales I., Alex. Arch., 54 $53^{\prime} \mathrm{N}$, $132^{\circ} 00^{\prime} \mathrm{W}$; (map 2).

Local name derived from Kendrick Bay; reported in 1904 by H. C. Fassett, USBF.

Kengneeveerax: locality, see Kangnirvik.

Kengugmiut: locality, see Kongik.

Kenibuna Lake: lake, $5 \mathrm{mi}$. long, between Alaska and Aleutian Ranges, W of Shamrock Glacier and Chakachamna Lake, $58 \mathrm{mi}$. W of Tyonek, Alaska Ra.; $61^{\circ} 10^{\prime} \mathrm{N}, 152^{\circ} 55^{\prime} \mathrm{W} ; B G N 1930$; (map 70). Var. Shallow Lake.

Tanaina Indian name reported in 1928 by USGS.

Kenmore Head: point of land, on $\mathrm{W}$ shore of Morzhovoi Bay, SW end of Alaska Penin., Aleutian Ra.; $54^{\circ} 56^{\prime} 40^{\prime \prime} \mathrm{N}, 163^{\circ} 01^{\prime} 40^{\prime \prime} \mathrm{W}$; (map 25).

Name published by USC\&GS in 1925.

Kennachananaghmiut: locality, see Kenachananak.

Kennecott: settlement, see Kennicott.

Kennedy, Point: point of land, $\mathrm{S}$ point of entrance to Saook Bay, on N coast of Baranof I., $4 \mathrm{mi}$. W of Todd, Alex. Arch.; $57^{\circ} 26^{\prime} 30^{\prime \prime} \mathrm{N}$, $135^{\circ} 09^{\prime} 15^{\prime \prime} \mathrm{W}$; (map 9).

Named in 1895 by Lt. Comdr. E. K. Moore, USN, "for Surgeon Robert Morris Kennedy USN, a member of his party." The name was published by USC\&GS on Chart 8283 .

Kennedy Creek: stream, flows S $0.8 \mathrm{mi}$. to Left Fork Dome Creek, in Pilgrim River basin, 23 mi. NW of Solomon, Seward Penin. High.; $64^{\circ} 53^{\prime} 30^{\prime \prime} \mathrm{N}, 164^{\circ} 38^{\prime} 20^{\prime \prime} \mathrm{W}$; (map 95).

Prospectors' name reported in 1908 by P. S. Smith (in Brooks and others, 1909, pl. 10), USGS.

Kennedy Creek: stream, see Midnight Creek.

Kennedy Entrance: water passage, $20 \mathrm{mi}$. wide, between Barren Is. and Chugach Is., connects
Gulf of Alaska with Cook Inlet, Kenai Penin.; $59^{\circ} 00^{\prime} \mathrm{N}, 151^{\circ} 50^{\prime} \mathrm{W}$; BGN 1966; (map 50).

Named in 1966 by the Alaska Geographic Board for John Fitzgerald Kennedy, 1917-63, 35th President of the United States.

Kennedy Lake: lake, 1,000 ft. long, in Matanuska Valley, $6.7 \mathrm{mi}$. NW of Palmer, Cook Inlet Low.; $61^{\circ} 38^{\prime} 50^{\prime \prime} \mathrm{N}, 149^{\circ} 17^{\prime} 25^{\prime \prime} \mathrm{W}$; (map 69).

Local name reported in 1942 by AMS.

Kennel Creek: stream, flows E $5 \mathrm{mi}$. to Freshwater Bay, $8.5 \mathrm{mi}$. N of Tenakee Springs, on E coast of Chichagof I., Alex. Arch.; 57 54'$00^{\prime \prime} \mathrm{N}, 135^{\circ} 09^{\prime} 20^{\prime \prime} \mathrm{W}$; BGN 1933; (map 9). Var. Canyon Creek.

Named in 1933 by USFS, "because of the large number of 'dog' salmon using it for spawning."

Kennel Lakes: lakes, $0.1 \mathrm{mi}$. across, center of Kiska I., Aleutian I.; $51^{\circ} 57^{\prime} 55^{\prime \prime}$ N, $177^{\circ}$ 21'35" E; (map 14).

An arbitrary name beginning with " $K$ " to correspond to the " $K$ " grid used by the U.S. Army for tactical purposes during World War II; published on a 1953 AMS map.

Kenney Lake: lake, $0.4 \mathrm{mi}$. across, $1.4 \mathrm{mi}$. N of mouth of Willow Creek, on Tonsina River 66 mi. NE of Valdez, Chugach Mts.; 61 ${ }^{\circ} 43^{\prime} 55^{\prime \prime}$ N, $144^{\circ} 56^{\prime} 30^{\prime \prime} \mathrm{W}$; (map 68).

Local name published in the 1950's by USGS.

Kennicott: settlement, pop. 5, on $\mathrm{N}$ bank of National Creek, $E$ of Kennicott Glacier, 3.5 mi. N of McCarthy, Wrangell Mts.; $61^{\circ} 29^{\prime}$ N, $142^{\circ} 53^{\prime}$ W; BGN 1952; (map 67). Var. Kennecott.

The "Kennecott Mines Company," which established a camp and offices here in 1906, took its name from Kennicott Glacier, but misspelled it with a second "e." The glacier was named for Robert Kennicott. In 1908, the Post Office of "Kennecott" was established and continued until 1938. (Ricks, 1965, p. -33). The town which grew to a population of 494 by 1920 , took its name from the mining company, but it has been spelled variously through the years. Present day map usage favors the original spelling honoring Robert Kennicott.

Kennicott Glacier: glacier, trends SE $27 \mathrm{mi}$. from Mount Blackburn to its terminus at head of McCarthy Creek, Wrangell Mts.; $61^{\circ} 26^{\prime}$ N, $142^{\circ} 57^{\prime}$ W; BGN 1929; (map 67).

Named in 1899 by Rohn (1900, p. 406), USGS, for Robert Kennicott, pioneer Alaska explorer and director of the scientific corps of the Western Union Telegraph Expedition in 1865.

Kennicott Pass: stream, see Fourth of July Creek.

Kennicott River: stream, flows $S 4.5 \mathrm{mi}$. from Kennicott Glacier terminus to Nizina River, $5 \mathrm{mi}$. SW of McCarthy, Wrangell Mts.; $61^{\circ}$ $22^{\prime} 35^{\prime \prime} \mathrm{N}, 143^{\circ} 00^{\prime} 00^{\prime \prime} \mathrm{W}$; BGN 1929; (map 67).

Local name derived from the glacier; reported in 1900 by T. G. Gerdine, USGS.
Kennon Island: island, $0.3 \mathrm{mi}$. long, in mouth of Chichagof Harbor, on E coast of Attu I., 0.5 mi. E of Attu Aleutian Is. ; $52^{\circ} 56^{\prime} 25^{\prime \prime} \mathrm{N}, 173^{\circ}$. $15^{\prime} 30^{\prime \prime} \mathrm{E}$; (map 13).

Named by Lt. William Gibson, July 1855 , for Lt. Beverley Kennon, USN. Lt. Kennon served with Lt. Gibson on the U.S. schooner Fenimore Cooper during the North Pacific Exploring Expedition, 1854-55, under the command of Capt. Cadwalader Ringgold and Capt. John Rodgers.

Kennoys Islands: islands, $0.4 \mathrm{mi}$. across, in Pacific Ocean, between Unga and Wosnesenski Is., Aleutian Ra.; 55 $09^{\prime} 30^{\prime \prime} \mathrm{N}, 1^{\circ} 01^{\circ} 06^{\prime}$ $00^{\prime \prime} \mathrm{W}$; (map 28).

Shown on USC\&GS charts published in or before 1902; origin of the name unknown.

Kenny Cove: bight, $1 \mathrm{mi}$. wide, at NE tip of Hinchinbrook I., $15 \mathrm{mi}$. SW of Cordova, Chugach Mts.; $60^{\circ} 25^{\prime} \mathrm{N}, 146^{\circ} 07^{\prime} \mathrm{W}$; (map 64).

Name published in 1959 by USGS.

Kenny Creek: stream, flows SW $6.7 \mathrm{mi}$. to Peters Creek, $19 \mathrm{mi}$. W of Talkeetna, Alaska Ra.; $62^{\circ} 20^{\prime} 50^{\prime \prime} \mathrm{N}, 150^{\circ} 42^{\prime} 50^{\prime \prime} \mathrm{W}$; (map 81).

Local name reported in 1958 by USGS.

Keno Creek: stream, flows SW $12 \mathrm{mi}$. to Arolik River, $30 \mathrm{mi}$. $\mathbf{N}$ of Goodnews, KilbuckKuskokwim Mts. ; 59³2' N, $161^{\circ} 22^{\prime}$ W ; (map 53).

Eskimo name reported in 1919 by G. L. Harrington (in Brooks and others, pl. 7), USGS.

Kent Creek: stream, heads $\mathrm{N}$ of Attu Mtn. at $52^{\circ} 54^{\prime} 25^{\prime \prime} \mathrm{N}, 172^{\circ} 58^{\prime} 20^{\prime \prime} \mathrm{E}$, and flows N 6 mi. to Brunette Cove in Steller Cove, $\mathrm{N}$ coast of Attu I., Aleutian Is.; 52 $58^{\prime} 23^{\prime \prime} \mathrm{N}, 172^{\circ}$ $57^{\prime} 20^{\prime \prime} \mathrm{E}$; (map 13$)$.

Named by the U.S. Army during World War II; shown on an AMS map published in 1948.

Kentucky Creek: stream, flows NE $2 \mathrm{mi}$. to Klokerblok River, $15 \mathrm{mi}$. NE of Solomon, Seward Penin. High.; 64 $39^{\prime} \mathrm{N}, 164^{\circ} 00^{\prime} \mathrm{W}$; (map 95).

Prospectors' name reported in 1900 by E. C. Barnard (in Brooks, 1901, pl. 17), USGS.

Kentucky Creek: stream, flows SW $4.8 \mathrm{mi}$. to Hutlinana Creek, $5 \mathrm{mi}$. S of Eureka Dome, 56 mi. E of Tanana, Yukon-Tanana High.; $65^{\circ}$ $09^{\prime} \mathrm{N}, 150^{\circ} 10^{\prime} \mathrm{W}$; (map 106).

Prospectors' name reported in 1906 by $L$. M. Prindle, USGS.

Kentucky Creek: stream, flows N $2.5 \mathrm{mi}$. to Louisville Creek which flows to Igloo Creek, in American River basin, $36 \mathrm{mi}$. NE of Teller, Seward Penin. High.; $65^{\circ} 28^{\prime} \mathrm{N}, 165^{\circ} 14^{\prime} \mathrm{W}$; (map 111).

Prospectors' name reported in 1900 by Messrs. Kemp and David Fox (in Brooks, 1901, pl. 11).

Kentucky Creek: stream, see Coal Creek.

Kenty Creek: stream, flows NE $6 \mathrm{mi}$. to Paint River, $2 \mathrm{mi}$. N of Middle Mtn., $37 \mathrm{mi}$. SW of Augustine I., Aleutian Ra.; $59^{\circ} 09^{\prime} 30^{\prime \prime} \mathrm{N}$, $154^{\circ} 23^{\prime} 30^{\prime \prime} \mathrm{W}$; (map 51 ). 
Local name reported by K. F. Mather, USGS, in 1923 (in Brooks and others, 1925, pl. 3).

Kenunga Creek: stream, flows E $6.5 \mathrm{mi}$., $\mathrm{N}$ of Katiktak and Blackface Mts., to Ernie Creek in Valley of Precipices, $23 \mathrm{mi}$. E of Anaktuvuk Pass, Brooks Ra.; $68^{\circ} 03^{\prime} 15^{\prime \prime} \mathrm{N}, 150^{\circ} 51^{\prime} 00^{\prime \prime}$ W; BGN 1932; (map 134).

Marshall (1956, p. 46) wrote, "I named this remarkable valley and the river which drained it Kenunga, which is Eskimo for knife edge ***." Marshall was referring to the number of knife-edge ridges he saw between Rumbling and Katiktak Mountains.

Kenunimik: locality, "on right bank of lower Yukon River," Yukon-Kuskokwim Delta; (map 77 or 92).

Former Eskimo camp or settlement reported in 1898 by USC\&GS; published on Chart 9370.

Kenunimik: locality, see Ankachak.

Kenwood Creek: stream, flows NE $17 \mathrm{mi}$. to Koyuk River, $6 \mathrm{mi}$. S of Haycock, Seward Penin. High.; $65^{\circ} 07^{\prime} \mathrm{N}, 161^{\circ} 09^{\prime} \mathrm{W}$; $B G N$ 1910; (map 109).

Local name reported in 1909 by A. H. Brooks, USGS.

Keogmute: locality, see Kuk.

Keoklevik River: stream, distributary of Kashunuk River, flows W $15 \mathrm{mi}$. to Hooper Bay, Yukon-Kuskokwim Delta; $61^{\circ} 27^{\prime} \mathrm{N}$, $165^{\circ} 47^{\prime} \mathrm{W}$; (map 75). Var. Keookthlevik, Kithlevik Slough.

Eskimo name reported by USC\&GS in 1951. Keookthlevik: stream, see Keoklevik River.

Keo Point: point of land, on $\mathrm{W}$ shore of Kuk River, $21 \mathrm{mi}$. S of Wainwright, Arctic Plain; $70^{\circ} 20^{\prime} 10^{\prime \prime} \mathrm{N}, 159^{\circ} 53^{\prime} 15^{\prime \prime} \mathrm{W}$; (map 146).

Eskimo name reported in 1956 by T. E. Tayjor, USGS.

Kepangalook: village, pop. 10, on right bank of Kuskokwim River, 6 mi. NE of Bethel, YukonKuskokwim Delta; $60^{\circ} 51^{\prime} \mathrm{N}, 161^{\circ} 37^{\prime} \mathrm{W}$; (map 59).

Eskimo camp reported in 1951 by USGS. Kepizetka River: stream, see Kokolik River. Kepizetko River: stream, see Kokolik River.

Kepler Lake: lake, 2,000 ft. long, in Matanuska Valley $4.2 \mathrm{mi}$. SW of Palmer, Cook Inlet Low.; $61^{\circ} 33^{\prime} 10^{\prime \prime} \mathrm{N}, 149^{\circ} 11^{\prime} 45^{\prime \prime} \mathrm{W}$; (map 69).

Local name reported in 1951 by USGS.

Keq : village, see Kake.

Kerchurak Creek: stream, flows NW $12 \mathrm{mi}$. to Kugarak River, $29 \mathrm{mi}$. W of Shungnak, Kotzebue-Kobuk Low. ; 66 $49^{\circ}$ N, $158^{\circ} 09^{\prime}$ W ; (map 115).

Eskimo name shown on a 1927 manuscript map by the "trader at Selawik."

Kermon Gulch: ravine, extends $1.1 \mathrm{mi} . \mathrm{N}$ to Blygh Gulch, $0.8 \mathrm{mi}$. S of head of Chititu Creek and $15 \mathrm{mi}$. SE of McCarthy, St. Elias Mts.; $61^{\circ} 17^{\prime} \mathrm{N}, 142^{\circ} 35^{\prime} \mathrm{W}$; (map 67).

Local name obtained by USGS and published on maps since 1954 .

Kern: locality, mile 70.5 on The Alaska RR., $12 \mathrm{mi}$. E of Sunrise, Chugach Mts.; $60^{\circ} 54^{\prime} 30^{\prime \prime}$ N, $149^{\circ} 04^{\prime} 30^{\prime \prime}$ W; (map 63). Var. Kern Creek Station.
Local name for a flag stop reported in 1912 by the Alaska RR. Commission (1913, pl. 11). Name derived from nearby Kern Creek.

Kern Creek: stream, flows SW $3.5 \mathrm{mi}$. to Turnagain Arm, $12 \mathrm{mi}$. E of Sunrise, Chugach Mts. ; $60^{\circ} 54^{\prime} 40^{\prime \prime} \mathrm{N}, 149^{\circ} 05^{\prime} 00^{\prime \prime} \mathrm{W}$; (map 63).

Name used by local prospectors and reported in 1899 by Lt. Herron (1901, sketch opposite p. 11), USA.

Kern Creek: stream, flows SE $12 \mathrm{mi}$. to Middle Fork Chandalar River, $25 \mathrm{mi}$. ENE of Chandalar, Brooks Ra.; $67^{\circ} 38^{\prime} 30^{\prime \prime} \mathrm{N}, 147^{\circ} 36^{\prime} 00^{\prime \prime}$ W; (map 123).

Prospectors' name obtained in 1909 by A. G. Maddren (in Brooks and others, 1910, pl. 7), USGS.

Kern Creek Station: locality, see Kern.

Kernel Cove: cove, $0.7 \mathrm{mi}$. across, in Bering Sea, $2 \mathrm{mi}$. N of Lief Cove, SW end of Kiska I., Aleutian Is.; $51^{\circ} 57^{\prime} 40^{\prime \prime} \mathrm{N}, 177^{\circ} 21^{\prime} 20^{\prime \prime} \mathrm{E}$; (map 14). Var. Norse Cove.

An arbitrary name beginning with " $K$ " to correspond to "K" grid used by U.S. Army for tactical purposes during World War II ; published on a 1953 AMS map. Variant published on a 1943 USAAF map.

Kerulu Creek: stream, flows N $24 \mathrm{mi}$. to Selawik River, $48 \mathrm{mi}$. SW of Shungnak, KotzebueKobuk Low.; $66^{\circ} 29^{\prime}$ N, $158^{\circ} 30^{\prime} \mathrm{W}$; (map 115)

Eskimo name shown on a 1927 manuscript map by the "trader at Selawik."

Keshkunuwu: locality, "in SE Alaska."

Former Tlingit Indian camp or settlement reported to be from " $Q$ !eckưnuwú," meaning "bluejayfort," by J. R. Swanton (in Hodge, 1907, p. 675).

Keshunuk Slough: stream, see Kashunuk Slough Keski Island: island, $0.4 \mathrm{mi}$. long, in El Capitan Passage, between El Capitan and Orr Is., Alex. Arch.; $55^{\circ} 55^{\prime} 50^{\prime \prime} \mathrm{N}, 133^{\circ} 20^{\prime} 10^{\prime \prime} \mathrm{W}$; BGN 1932; (map 4). Var. East Island.

Tlingit Indian name meaning "morning" given in 1932 by USC\&GS "because it is on the east or morning side of the group of small islands in this vicinity." The name "East Island" was published in 1925 Coast Pilot (p. 154).

Kessin-Nyghook, Mount: hill, see Kessin Peak.

Kessin Peak: hill, $100 \mathrm{ft}$., a cinder cone $18 \mathrm{mi}$ NW of Myghapowit Mtn. and $26 \mathrm{mi}$. SE of Savoonga, St. Lawrence I. ; $63^{\circ} 20^{\prime} \mathrm{N}, 170^{\circ} 14^{\prime}$ W; BGN 1951; (map 93). Var. KeesinMyghook Mountain, Kisin, Mount KeesinNyghook.

Eskimo name reported in 1930 by O. W. Geist, Univ. of Alaska. Orth spelled the name "Kisin" in 1965.

Kestrel Island: island, $600 \mathrm{ft}$. long, in Boca de Quadra, $1.4 \mathrm{mi}$. NW of Porpoise Point, Coast Mts. ; $55^{\circ} 06^{\prime} 25^{\prime \prime} \mathrm{N}, 130^{\circ} 47^{\prime} 50^{\prime \prime} \mathrm{W}$; (map 3 ). Var. Krestrel Island.

Named in 1891 by USC\&GS.

Keta River: stream, flows SW $20 \mathrm{mi}$. to Boca de Quadra, Coast Mts.; $55^{\circ} 20^{\prime} 10^{\prime \prime}$ N, $130^{\circ} 28^{\prime}$ 29" W ; BGN 1962; (map 3).

Indian name reported in 1961 by USFS. Ketavie Point: point of land, see Whale Point.
Ketavie Rookery: rookery, see Kitovi Rookery.

Ketchem Creek: stream, flows NE $6 \mathrm{mi}$. to Crooked Creek, $26 \mathrm{mi}$. SW of Circle, YukonTanana High.; $65^{\circ} 32^{\prime} \mathrm{N}, 144^{\circ} 37^{\prime} \mathrm{W}$; $B G N$ 1938; (map 104). Var. Ketchen Creek, Ketchum Creek.

Named by prospectors and published originally as "Ketchum Creek" by USGS (Prindle, 1906, p. 21). However, local usage has changed the name to its present spelling.

Ketchem Dome: mountain, 3,535 ft., $4.5 \mathrm{mi}$. SW of Circle Hot Springs and $33 \mathrm{mi}$. SW of Circle, Yukon-Tanana High.; $65^{\circ} 27^{\prime} 35^{\prime \prime} \mathrm{N}$, $144^{\circ} 47^{\prime} 50^{\prime \prime} \mathrm{W}$; (map 104).

Prospectors' name reported in 1955 by USGS; named for Ketchem Creek which heads on its slope.

Ketchen Creek : stream, see Ketchem Creek.

Ketchikan: city, pop. 6,483 , on $\mathrm{S}$ coast of Revillagigedo I., on $\mathbf{N}$ shore of Tongass Narrows, Alex. Arch.; 55 $20^{\prime} 30^{\prime \prime} \mathrm{N}, 131^{\circ} 38^{\prime} 45^{\prime \prime}$ W; BGN 1905; (map 3). Var. Kichikan, Kitchikan, Kitskan.

Industrial city and port of entry, established as a fishing town when a cannery was built in 1887. The town became a supply center during the gold rush period in the late 1890 's. Its population was 40 in $1890 ; 1,613$ in $1910 ; 2,458$ in $1920 ; 3,796$ in $1930 ; 4,695$ in 1939; and 5,305 in 1950. The Ketchikan post office was established in 1892. The city was named after Ketchikan Creek.

Ketchikan Harbor: anchorage, in Tongass Narrows, at Ketchikan, on SE coast of Revillagigedo I., Alex. Arch.; $55^{\circ} 20^{\prime} 30^{\prime \prime} \mathrm{N}, 131^{\circ}$ $38^{\prime} 45^{\prime \prime} \mathrm{W}$; (map 3 ).

Local name reported in 1910 by USC\&GS.

Ketchikan Lake: lake, see Lower Ketchikan Lake.

Ketchikan Creek: stream, on Revillagigedo I., heads in a lake and flows $W$ and $S$ through Ketchikan Lakes, Number One and Two, 6 mi. to Tongass Narrows at Ketchikan, Alex. Arch.; 55 $20^{\prime} 30^{\prime \prime} \mathrm{N}, 131^{\circ} 38^{\prime} 20^{\prime \prime} \mathrm{W}$; (map 3). Var. Fish Creek, Kitschkhin.

Tlingit Indian name recorded as "Kitschkhin" by Arthur or Aurel Krause in 1881, and evolved in the present name "Ketchikan." It has been suggested that the name means "eagle wing river" derived from the fact that "a boulder in the stream at the falls broke the water giving the appearance of the spread wings of an eagle." This suggested meaning has not been verified and may be a form of folklore. The name "Fish Creek" was reported as local usage in 1883 by USG\&GS.

Ketchikan Lake: lake, see Upper Ketchikan Lake.

Ketchikan Lake Number One: lake, see Lower Ketchikan Lake.

Ketchikan Lake Number Two: lake, see Upper Ketchikan Lake.

Ketchikan Lakes: lake, see Lower Ketchikan Lake.

Ketchikan Lakes: lake, see Upper Ketchikan Lake.

Ketchum Creek : stream, see Ketchem Creek.

Ketchumstock: locality, see Kechumstuk. 
Ketchumstock Creek: stream, see Kechumstuk Creek.

Ketchumstock Mountain: mountain, see Kechumstuk Mountain.

Ketchumstuck: locality, see Kechumstuk.

Ketihuvick: lake, see Brooks, Lake.

Ketik River: stream, heads at $69^{\circ} 27^{\prime} \mathrm{N}$, $159^{\circ} 56^{\prime} \mathrm{W}$, flows N $90 \mathrm{mi}$. to Avalik River $1.5 \mathrm{mi}$. E of its junc. with Kuk River, $37 \mathrm{mi}$. SE of Wainwright, Arctic Plain; $70^{\circ} 07^{\prime} \mathrm{N}$, 159³6' W; BGN 1966; (map 146).

Eskimo name reported in 1924 by W. T. Foran, USGS.

Ketik River: stream, see Avalik River.

Ketili Creek: stream, heads in Barnes Lake, flows NW $3.5 \mathrm{mi}$. to Ketili River, $4 \mathrm{mi}$. W of AlaskaCanada boundary, Coast Mts.; $56^{\circ} 41^{\prime} 30^{\prime \prime} \mathrm{N}$, $131^{\circ} 58^{\prime} 00^{\prime \prime} \mathrm{W}$; ( $\left.\operatorname{map} 7\right)$.

Tlingit Indian name reported in 1955 by USGS.

Ketili River: stream, anabranch of Stikine River, $7.5 \mathrm{mi}$. long, $20 \mathrm{mi}$. NE of Wrangell, Coast Mts.; $56^{\circ} 43^{\prime} \mathrm{N}, 132^{\circ} 04^{\prime} \mathrm{W}$; BGN 1966; (map 6). Var. Hot Springs Slough, Warm Springs Slough.

Tlingit Indian name meaning "hot (or warm spring)"; name published in 1927 on IBC sheet 5.

Ketivik Falls : waterfalls, see Brooks Falls.

Ketivik Lake: lake, see Brooks, Lake.

Ketlgakhya Point: point of land, see Kelgaya Point.

Ketlkede Creek: stream, flows SW $21 \mathrm{mi}$. to Yuki River, $48 \mathrm{mi}$. SE of Nulato, Kilbuck-Kuskokwim Mts.; $64^{\circ} 15^{\prime} \mathrm{N}, 156^{\circ} 55^{\prime} \mathrm{W}$; BGN 1961; (map 97).

Indian name shown on a 1940 map by U.S. Army Corps of Engineers. Name is probably derived from that of the hill.

Ketlkede Mountain: mountain, 1,947 ft., $49 \mathrm{mi}$. SE of Galena, SE of Nulato, Kilbuck-Kuskokwim Mts.; $64^{\circ} 29^{\prime} \mathrm{N}, 156^{\circ} 33^{\prime} \mathrm{W}$; (map 97).

Koyukan Indian name reported in 1903 by Father Julius Jetté who wrote the name "R[kh] etlela" or "Khet Mountain." The present spelling is shown on a 1940 map by U.S. Army Corps of Engineers.

Ketlrachta: point of land, see Battery Point.

Ketlrachta Point: point of land, see Kelgaya Point.

Ketngepaluk River: stream, see Kitnepaluk Creek.

Ketnik River: stream, see Kitnik River.

Ketokecheegilinguk : mountain, see Ketok Mountain.

Ketok Mountain: mountain, 1,696 ft., $42 \mathrm{mi}$ $\mathrm{E}$ of Agenuk Mtn. and $72 \mathrm{mi}$. NE of Dillingham, Kilbuck-Kuskokwim Mts.; 59 $52^{\prime} \mathrm{N}$, $157^{\circ} 18^{\prime}$ W; BGN 1931; (map 52). Var. Ketokecheegilinguk.

Eskimo name obtained in 1931 by Gerald FitzGerald, USGS. The full Eskimo name of this mountain, obtained from F. W. Waskey, a local prospector, is "Ketokecheegilinguk," which reportedly means "the mountain we can not go around." The abbreviated name was published by Mertie (1938b, p. 12 and pl. 1), USGS.
Ketoy Island: island, see Whale Island.

Kettle Cape: point of land, on SE coast of Umnak I., Aleutian Is.; $53^{\circ} 16^{\prime} 40^{\prime \prime} \mathrm{N}, 168^{\circ}$ 06'55" W; (map 22). Var. Kotelnoi, M[ys] Kotel'noy, Utmak.

Translation of Russian name published by Capt. Tebenkov (1852, map 25), IRN, as "M[ys] Kotel'noy," meaning "Kettle Cape." The Aleut name is "Utmak" and may possibly be from the word "utman," meaning "in the midst of," according to R. H. Geoghegan.

Kettle Dome: hill, 1,552 ft., $2 \mathrm{mi}$. E of Imuruk Lake, Seward Penin. High.; $65^{\circ} 35^{\prime} \mathrm{N}, 163^{\circ}$. 00' W; BGN 1952; (map 110 ).

Reported in 1950 by D. M. Hopkins, USGS; so named because at "the summit of the hill there is a hemispherical rock knob about 30 feet high. From a distance the outline of the hill and the knob suggest the top of a teakettle."

Kevinjik Creek: stream, heads at $66^{\circ} 56^{\prime} \mathrm{N}$, $141^{\circ} 45^{\prime} \mathrm{W}$, flows S $40 \mathrm{mi}$. to Salmon Fork Black River, $45 \mathrm{mi}$. SE of Chalkyitsik, Porcupine Plat.; $66^{\circ} 31^{\prime} \mathrm{N}, 142^{\circ} 05^{\prime} \mathrm{W}$; (map 120).

Tranjik-kutchin Indian name; obtained in 1956 by T. E. Taylor, USGS.

Kevrorak Springs : springs, see Kavrorak Springs. Kevroruk Springs: springs, see Kavrorak Springs. Kevuk Creek: stream, flows NE $30 \mathrm{mi}$, joins Agiak Creek to form Hunt Fork of John River, $6 \mathrm{mi}$. W of Cairn Mtn. and $73 \mathrm{mi}$. NW of Wiseman, Brooks Ra.; 67 $51^{\prime} 30^{\prime \prime} \mathrm{N}, 152^{\circ} 38^{\prime}$ $00^{\prime \prime} \mathrm{W}$; BGN 1932; (map 124).

This Eskimo name was reported by Marshall, (1956, p. 102), who wrote "The left fork called by the Eskimos 'Kevuk' (large intestines), came from the south * * *."

Kevuleek: village, see Kivalina.

Kevuleek River: stream, see Kivalina River.

Kevulik : village, see Kivalina.

Kevulik River: stream, see Kivalina River.

Kewagek Creek: stream, heads at Kiwook Pass, flows NW $3 \mathrm{mi}$. to Niyrakpak Lagoon, $18 \mathrm{mi}$. SE of Gambell, St. Lawrence I.; 63 $37^{\prime} \mathrm{N}$, $171^{\circ} 19^{\prime}$ W; $B G N$ 1951; (map 93). Var. Kiwaruk.

Eskimo name shown on a manuscript map drawn by Lawrence Kuluphan, of Gambell, in 1944. Orth recorded the name "Kiwaruk," meaning "growing river," for this stream in 1965.

Keyaluvik: locality, see Old Kealavik.

Keyaluvik: village, see Newtok.

Key Creek: stream, heads at $69^{\circ} 26^{\prime} \mathrm{N}, 153^{\circ} 21^{\prime}$ $\mathrm{W}$, flows $\mathrm{N}$ and $\mathrm{W} 75 \mathrm{mi}$. to join Wolf Creek to form Price River, $35 \mathrm{mi}$. NE of head of Ikpikpuk River, Arctic Plain; 69 $44^{\prime} 30^{\prime \prime} \mathrm{N}$, $153^{\circ} 49^{\prime} 30^{\prime \prime}$ W; BGN 1959; (map 142). Var. Keith Creek, Price River.

Name first used in 1951 by geologists on the Naval Petroleum Reserve No. 4 exploration.

Keyes Point: peninsula, $6 \mathrm{mi}$. long, in Lake Clark, $8 \mathrm{mi}$. NE of Nondalton, Alaska Ra.; $60^{\circ} 09^{\prime} \mathrm{N}, 154^{\circ} 37^{\prime} \mathrm{W}$; (map 61$)$.

Local name reported in 1954 by USGS.

Keygik: locality, see Kijik.
Key Hill: mountain, 1,200 ft., on west-central Kiska I., Aleutian Is.; $51^{\circ} 56^{\prime} 30^{\prime \prime} \mathrm{N}, 177^{\circ} 21^{\prime}$ 00" E; (map 14).

An arbitrary name beginning with " $K$ " to correspond to the " $\mathrm{K}$ " grid used by the U.S. Army for tactical purposes during World War II ; published on a 1953 AMS map.

Key Reef: reef, $0.8 \mathrm{mi}$. NW of Key Reef Rock, $5 \mathrm{mi}$. S of Zarembo I., Alex. Arch.; 56 $09^{\prime} 35^{\prime \prime}$ $\mathrm{N}, 132^{\circ} 49^{\prime} 45^{\prime \prime} \mathrm{W}$; (map 6).

Named in 1886 by Lt. Comdr. A. S. Snow, USN; name published in 1887 on USC\&GS Chart 706.

Key Reef: rock, see Key Reef Rock.

Key Reef Rock: rock, $0.8 \mathrm{mi}$. SE of Key Reef, $6 \mathrm{mi}$. S of Zarembo I., Alex. Arch.; $56^{\circ} 09^{\prime} \mathrm{N}$, $132^{\circ} 49^{\prime}$ W; (map 6). Var. Key Reef.

Local name recorded in 1949 by USGS.

Keystone Canyon: canyon, on Lowe River, extends $2 \mathrm{mi}$. N-S $1 \mathrm{mi}$. E of mouth of Bear Creek and $12 \mathrm{mi}$. SE of Valdez, Ghugach Mts.; $61^{\circ} 04^{\prime} 40^{\prime \prime} \mathrm{N}, 145^{\circ} 53^{\prime} 45^{\prime \prime} \mathrm{W}$; (map 68).

Named in 1898 by Capt. W. R. Abercrombie, USA, presumably after Pennsylvania, the Key. stone State.

Keystone Creek: stream, on W coast of Iniskin Penin., flows SW $1.2 \mathrm{mi}$. to Iniskin Bay, 2.5 mi. NE of Scott I., Aleutian Ra.; 59 $40^{\prime} 05^{\prime \prime}$ N, $153^{\circ} 23^{\prime} 20^{\prime \prime} \mathrm{W}$; BGN 1962; (map 51).

So named by USGS in 1951, because rock exposure along the stream "was the keystone to the geologic interpretation of the area."

Keystone Creek: stream, flows S $8 \mathrm{mi}$. to Shaw Creek, $10 \mathrm{mi}$. NW of Big Delta, YukonTanana High.; $64^{\circ} 16^{\prime} 30^{\prime \prime} \mathrm{N}, 146^{\prime} 04^{\prime} 15^{\prime \prime} \mathrm{W}$; (map 101).

Named by prospectors; reported in 1910 by USGS (Capps, 1912, pl. 1).

Keystone Creek: stream, flows SW $4 \mathrm{mi}$., joins Dawson Creek to form Cache Creek, $20 \mathrm{mi}$. NW of Fairbanks, Yukon-Tanana High.; $64^{\circ}$. $54^{\prime} 25^{\prime \prime}$ N, 148 $21^{\prime} 55^{\prime \prime}$ W; (map 100). Var. Dawson Creek.

Named by prospectors; published in 1906 by USGS. C. W. Joint, on a manuscript map, shows this stream as Dawson Creek and the present combined Dawson and Cache Creeks as Keystone Creek.

Keystone Creek: stream, see Cache Creek.

Keystone Creek: stream, see Dawson Creek.

Keystone Glacier: glacier, heads E of East Peak, trends SE $5.5 \mathrm{mi}$. to Bear Creek, $12 \mathrm{mi}$. E of Valdez, Chugach Mts.; $61^{\circ} 06^{\prime} 55^{\prime \prime} \mathrm{N}, 146^{\circ}$ 03'15" W; BGN 1965; (map 68). Var. Corbin Glacier.

Named in 1964 by Austin S. Post, USGS; suggested by nearby Keystone Canyon.

Kgallegak: locality, see Kialegak Village.

Kghun Lake: lake, see Kgun Lake.

Kgun Lake: lake, $15 \mathrm{mi}$. long, E of Manokinak River, $60 \mathrm{mi}$. SW of Marshall, Yukon-Kuskokwim Delta; $61^{\circ} 34^{\prime} \mathrm{N}, 163^{\circ} 45^{\prime} \mathrm{W}$; (map 74). Var. Kghun Lake, Khun Lake.

Eskimo name, meaning "source," obtained by USC\&GS from Frank Waskey at Marshall in 1949. 
Khaali Lake: lake, $2.6 \mathrm{mi}$. long, $2 \mathrm{mi}$. $\mathrm{SW}$ of Arctic Village, Brooks Ra.; $68^{\circ} 05^{\prime} \mathrm{N}, 1^{\circ} 5^{\circ} 36^{\prime}$ W; (map 136).

Kutchin Indian name obtained at Arctic Village in 1956 by T. E. Taylor, USGS.

Khaboutcha: point of land, see Kabuch Point. Khabuch: point of land, see Kabuch Point.

Khadilotden: locality, on Iditarod River, probably near the present locality of Iditarod; $62^{\circ} 33^{\prime} \mathrm{N}, 158^{\circ} 06^{\prime} \mathrm{W}$; (map 79). Var. Kadilotden, Radiolotden.

This name was reported by Father Jetté in 1915 to be the name of an Ingalik Indian village, probably from which the Iditarod River derived its name.

Khagamil Island: island, see Chuginadak Island.

Khagamil, Ostrov: island, see Chuginadak Island.

Khaigamute: locality, see Nunaikak.

Khainiliakh: island, see Kaniliak.

Khalkhagu: cove, see Kalhagu Cove.

Khallikvit, Baie : bay, see Wide Bay.

Khaltats Village: locality, see Kaltat.

Khaltsekahin River: stream, see Kicking Horse River.

Khalzekahin River: stream, see Kicking Horse River.

Khantaak Beach: beach, $5 \mathrm{mi}$. long, on NW coast of Khantaak I., $4 \mathrm{mi}$. N of Yakutat, Malaspina Coastal Plain; 59 $36^{\prime} \mathrm{N}, 139^{\circ} 45^{\prime} \mathrm{W}$; (map 46).

Named in 1906 by Tarr (1909, p. 167), USGS, for the island on which it is located.

Khantaak Island: island, $6 \mathrm{mi}$. long, on SE shore of Yakutat Bay, $1 \mathrm{mi}$. $\mathbf{N}$ of Phipps Penin., $1.8 \mathrm{mi}$. NW of Yakutat, Malaspina Coastal Plain; 59 $36^{\prime} \mathrm{N}, 139^{\circ} 46^{\prime} \mathrm{W}$; (map 46). Var. Hantak Island, Khantak Island, Kontog Island.

Tlingit Indian name recorded by Capt. Tebenkov (1852, map 7), IRN. The name is reported to mean "wooden food dish."

Khantak Island: island, see Khantaak Island.

Khask Creek: stream, see Haska Creek.

Khatnotoutze: locality, see Kagokakat.

Khatsulstit Lake: lake, see Fall Camps Lake.

Khayam Point: point of land, see Khayyam Point.

Khayyam Creek: stream, flows NE 9 mi. to Pass Creek, $7 \mathrm{mi}$. NNE of Lois Dome and $50 \mathrm{mi}$. $\mathrm{N}$ of Coleen Mtn., Brooks Ra., 67 $49^{\prime} \mathrm{N}$, $142^{\circ} 41^{\prime} \mathrm{W}$; (map 121 ).

Local name reported in 1956 by T. E. Taylor, USGS.

Khayyam Point: point of land, point of $\mathbf{E}$ entrance to McKenzie Inlet, on $\mathrm{E}$ coast of Prince of Wales I., Alex. Arch.; 55 $24^{\prime} 50^{\prime \prime}$ N, $132^{\circ}$ $21^{\prime} 00^{\prime \prime}$ W; BGN 1966; (map 4). Var. Khayam Point.

Local name reported in 1905 by E. F. Dickins, USC\&GS. The Omar Mining Company operated in this vicinity, and the Kiam mining camp was nearby. The name of the mining camp was published as "Khayyam" by Theodore Chapin (in Brooks and others, 1916, pl. 3), USGS. All these names were suggested by the name of the Persian poet, astronomer, and tentmaker Omar Khayyam, author of the "Rubaiyat."

Khaz Bay: water passage, extends NE $4 \mathrm{mi}$. from Pacific Ocean to Slocum Arm, $5 \mathrm{mi}$. S of Chichagof, on W coast of Chichagof I., Alex. Arch.; $57^{\circ} 35^{\prime} \mathrm{N}, 136^{\circ} 05^{\prime} \mathrm{W}$; BGN 1908; (map 9). Var. Zaliv Khaz.

Russian name meaning "fag end" published by Tebenkov (1852, map 8) as "Z[aliv] Khaz."

Khaz Breakers: rocks, $10 \mathrm{mi}$. S of Chichagof, on W coast of Chichagof I., Alex. Arch.; 57 $31^{\prime}$. $00^{\prime \prime}$ N, 136 $04^{\prime} 30^{\prime \prime} \mathrm{W}$; BGN 1908; (map 9). Var. Breaker No. 3 .

Named in 1908 by USC\&GS; published in 1908 Coast Pilot (p. 171). It is the outer danger in the approach to Khaz Bay for which it is named. It has also been called Breaker No. 3 by USC\&GS.

Khaz Head: point of land, on $\mathrm{N}$ tip of Khaz Penin., $9.5 \mathrm{mi}$. SSE of Chichagof, on $\mathrm{W}$ coast of Chichagof I., Alex. Arch.; 57 $31^{\prime} 45^{\prime \prime} \mathrm{N}$, $136^{\circ} 01^{\prime} 00^{\prime \prime} \mathrm{W}$; BGN 1908; (map 9).

Named in 1897 by Lt. Comdr. E. K. Moore, USN; published by the USC\&GS in 1901 Coast Pilot (p. 199). The name is derived from Khaz Bay.

Khaz Peak: mountain, 2,687 ft., on Khaz Penin., on SW coast of Chichagof I., $13 \mathrm{mi}$. SE of Chichagof, Alex. Arch.; 57 $30^{\prime} 00^{\prime \prime} \mathrm{N}, 136^{\circ}$. $57^{\prime} 30^{\prime \prime}$ W ; (map 9)

Name published in 1928 by USC\&GS on Chart 8248. The name is derived from Khaz Bay.

Khaz Peninsula: peninsula, $15 \mathrm{mi}$. long, on SW coast of Chichagof I., Alex. Arch.; $57^{\circ} 28^{\prime} \mathrm{N}$, $135^{\circ} 55^{\prime} \mathrm{W}$; BGN 1930; (map 9).

Named by USC\&GS in 1930; derived from Khaz Bay.

Khaz Point: point of land, on NW coast of Khaz Penin., $11.5 \mathrm{mi}$. SSE of Chichagof, on $W$ coast of Chichagof I., Alex. Arch.; 57 $30^{\prime} \mathrm{N}$, $136^{\circ} 00^{\prime} \mathrm{W}$; (map 9).

Named in 1897 by Lt. Comdr. E. K. Moore, USN, published by USC\&GS in the 1901 Coast Pilot (p. 198). It was probably named for Khaz Bay.

Khchakuk, Zaliv: locality, see Klchakuk.

Khgallegak: locality, see Kialegak Village.

Khiltats: locality, see Nabesna Village.

Khitkhouk, Cape: promontory, see Scotch Cap.

Khitkouk, Cape : fromontory, see Scotch Cap.

Khitrov Hills: nunataks, group extend about 15 mi. between Bering Glacier on $E$ and Steller Glacier on W, $42 \mathrm{mi}$. NW of Cape Yatataga, Chugach Mts.; $60^{\circ} 28^{\prime} \mathrm{N}, 143^{\circ} 24^{\prime} \mathrm{W}$; BGN 1960; (map 65).

Named in 1960 by USGS for Sofron Khitrov who was shipmaster and second in command as lieutenant and later captain under Vitus Bering on the Alaskan discovery voyage of the ship St. Peter in 1741.

Khituk, Cape: promontory, see Scotch Cap. Khituk, Cape: point of land, see Seal Cape. Khlawak: village, see Klawock.

Khlbnikova, Mys: point of land, see Khlebnkof Point.
Khlebnikof, Cape: point of land, see Khlebnikof Point.

Khlebnikoff, Cape: point of land, see Khlebnikof Point.

Khlebnikof Point: point of land, $2.5 \mathrm{mi}$. SE of Attu, on NE coast of Attu I., Aleutian Is.; 52 $55^{\prime} 30^{\prime \prime} \mathrm{N}, 173^{\circ} 18^{\prime} 25^{\prime \prime} \mathrm{E}$; (map 13). Var. Cape Chlebnikoff, Cape Khlebnikof, Cape Khlebnikoff, Mys Khlbnikova.

Named for the pilot, Andrei Khlebnikov, who made surveys around Kodiak in 1810; given by Adolph K. Etolin in 1827. The name was shown by the Russians as "Mys Khlbnikova" meaning "Cape of Khlebnikof" (Tebenkov, 1852, map 30). The name was published in 1943 as Cape Khlebnikof on an AMS map, and has been used in this form ever since.

Khlikakhlik Island: island, see Latouche Island. Khlikakhlit Island: island, see Latouche Island. Khobart, Mys: point of land, see Hobart, Point. Khodo: stream, see Khotol River.

Khodolkakat: stream, see Rodo River.

Khodooye: mountain, see Khotol Mountain.

Khogamil Island: island, see Kagamil Island.

Khogoltinde: locality, "on Yukon River."

Former Eskimo camp or settlement, with a population of 60 , listed by Ivan Petroff in the 1880 Census.

Kholkkhem, Zaliv: bay, see Holkham Bay.

Khotakhkakat: stream, see Kaltag River.

Khotilkakat: locality, see Kotil.

Khotilkakate: locality, see Kotil.

Khotol Mountain: mountain, 2,844 ft., $39 \mathrm{mi}$. SE of Nulato, Kilbuck-Kuskokwim Mts. ; $64^{\circ}$ $10^{\prime} \mathrm{N}, 157^{\circ} 53^{\prime} \mathrm{W}$; (map 97). Var. Hodooye, Hotel Mountain, Khodooye, Khotoldlela, Rotel Mountain, Rotoldlela.

Indian name recorded in 1903 by Father Julius Jetté of Nulato as "Khotoldlela" or "Khotol mountain." He says that the mountain is also called "Khodooye," meaning "the furthermost down the river."

Khotolno: stream, see Khotol River.

Khotol River: stream, heads at junc. of Camp Greek and Gorton Creek, flows SW $85 \mathrm{mi}$. to Yukon River, $51 \mathrm{mi}$. SW of Nulato, Koyukuk Low.; $64^{\circ} 02^{\prime} \mathrm{N}, 158^{\circ} 44^{\prime} \mathrm{W}$; (map 97). Var. Hotel River, Khodo, Khotolno, Kotol River, Kutulnakt, Rotol River.

Indian name shown as "Kutulnakt" on $P$. Tikmeniev's 1861 map; applied to Kaiyah Slough. In 1903 Father Julius Jetté of Nulato said that the Indians call the above described stream "and the lower part of the slough," "Khotolno" or "Khotol River." See Khotol Mountain and Kaltag River.

Khotylkakat: locality, on left bank of Koyukuk River, at mouth of Kateel River; Koyukuk Low.; $65^{\circ} 27^{\prime} \mathrm{N}, 157^{\circ} 37^{\prime} \mathrm{W}$; (map 108).

Koyukan Indian name shown on Lt. Zagoskin's map. He obtained the name in 1842 and applied it to a camp or village.

Khotylnakat: locality, see Kotil.

Khoudiakoff Islands: islands, see Kudiakof Islands.

Khoudobine Islands: island chain, see Kudobin Islands. 
Khoughitchate: locality, see Holikachuk.

Khozreghimená: lake, see Blackfish Lake.

Khromchenko, Cape: point of land, see Etolin, Cape.

Khta-aluk Island: island, see Hinchinbrook Island.

Khtagalyuk, Ostrov: island, see Hinchinbrook Island.

Khuchaynik Creek: stream, heads in Trimokish Hills, flows NW $24 \mathrm{mi}$. to Middle Fork Kuskokwim River $15 \mathrm{mi}$. S of junc. of its Windy Fork, $45 \mathrm{mi}$. SE of McGrath, Kuskokwim Low.; 62 $33^{\prime} 40^{\prime \prime} \mathrm{N}, 154^{\circ} 32^{\prime} 30^{\prime \prime} \mathrm{W}$; (map 80).

Native name reported in 1942 by USGS.

Khudiakoff Islands: islands, see Kudiakof Islands.

Khudobin Islands: island chain, see Kudobin Islands.

Khudsnu: locality, see Letushkwin.

Khudubin Islands: island chain, see Kudobin Islands.

Khuingshtetakhten: village, see Shageluk.

Khuligishgat: village, see Holikachuk.

Khulikakat: locality, "on Yukon River."

Former Eskimo camp or settlement reported with a population of 10 in 1844 by Lt. L. A. Zagoskin, IRN (Hodge, 1907, p. $680)$.

Khulishganat: village, see Shageluk.

Khulishganat, Selo: village, see Holikachuk.

Khulitno: stream, see Holitna River.

Khulukh Bay: bay, see Kuluk Bay.

Khunanilinde: locality, "near headwaters of Kuskokwim River," Kilbuck-Kuskokwim Mts.; (map 88 or 89 ).

Former Eskimo camp or settlement reported by Lt. L. A. Zagoskin, IRN, on an 1850 map.

Khun Lake: lake, see Kgun Lake.

Khunna Island: island, see Chicagof Island.

Khun River: stream, see Kun River.

Khushgichagat: village, see Shageluk.

Khutsnoi Island: island, see Admiralty Island. Khutulkakat: locality, see Kutul.

Khutz-nhu: water passage, see Kootznahoo Inlet. Khutz-n'hu: islands, see Kootzanhoo Archipelago.

Khutz-n'hu Island: island, see Killisnoo Island. Khvostoff Island: island, see Khvostof Island.

Khvostof Island: island, $1.8 \mathrm{mi}$. across, $4 \mathrm{mi}$. SE of Segula I., one of Rat Is., Aleutain Is.; $51^{\circ} 58^{\prime} 30^{\prime \prime} \mathrm{N}, 178^{\circ} 17^{\prime} 00^{\prime \prime} \mathrm{E}$; BGN 1890; (map 15). Var. Khvostoff Island, Khwostof Island, Khwostov Island.

Russian name probably given by Adm. von Krusenstern (1827, sheet 18), IRN, as "Khwostov," for Nikolai Alexandrovich Khwostov, a Russian naval officer, who explored Alaska in 1802-04 with G. I. Davidov. Capt. Lutke (1836, p. 326), IRN, applied the name "Khvostoff ile" to the entire group of islands that include Khvostof.

Khvostof Lake: lake, $1.4 \mathrm{mi}$. long, on $\mathrm{S}$ central Baranof I., $7 \mathrm{mi}$. SE of Whale Bay, Alex. Arch.; 56 $31^{\prime} 45^{\prime \prime} \mathrm{N}, 134^{\circ} 53^{\prime} 30^{\prime \prime} \mathrm{W}$; BGN 1933; (map 5).

Named in 1933 by USFS "for Nikolai Alexandrovich Khvostof, Lt. under Governor Bar- anof, explorer of parts of the Alaskan coast, and author of several books containing authentic records of conditions observed by him in his explorations." See Baranof Island.

Khvostof Pass: water passage, leads NE from Rat Island Pass to Bering Sea, between Segula and Khvostof Is., Rat Is., Aleutian Is.; $52^{\circ} 00^{\prime}$ N, $178^{\circ} 14^{\prime} \mathrm{E}$; BGN 1937; (map 15).

Named derived from Khvostof $I$. and given by personnel of U.S.S. Oglala of 1935 U.S. Navy Survey Expedition.

Khvuveren, Reka : stream, see Kaviruk River.

Khwain Bay: bay, see Kwain Bay.

Khwain Lake: lake, see Kwain Lake.

Khwostof Island: island, see Khvostof Island.

Khwostov Island: island, see Khvostof Island.

Kiagna River: stream, flows $26 \mathrm{mi}$. NW to Chitina River, $27 \mathrm{mi}$. SE of McCarthy, St. Elias Mts.; $61^{\circ} 06^{\prime} 30^{\prime \prime} \mathrm{N}, 142^{\circ} 31^{\prime} 55^{\prime \prime} \mathrm{W}$; (map 67).

Indian name reported in 1915 by $F$. $H$. Moffit, USGS (in Brooks and others, 1916, pl. 5).

Kiak Creek: stream, see Kay Creek.

Kialagvik Bay: bay, see Wide Bay.

Kialagvik Creek: stream, flows NE $8 \mathrm{mi}$. to Wide Bay, SE of Mount Alai, on $\mathrm{S}$ coast of Alaska Penin., $37 \mathrm{mi}$. SE of Ugashik, Aleutian Ra.; $57^{\circ} 17^{\prime} 30^{\prime \prime} \mathrm{N}, 156^{\circ} 33^{\prime} 00^{\prime \prime} \mathrm{W}$; (map 36).

Eskimo name probably derived from early name for Wide Bay; published in 1956 by USGS.

Kialagvit: bay, see Wide Bay.

Kialakvit: bay, see Wide Bay.

Kialavik: locality, see Old Kealavik.

Kialavik River: stream, see Kealavik River.

Kialegak: locality, see Kialegak Village.

Kialegak, Cape: point of land, see Kialegak Point.

Kialegak Mountains: mountains, 1,000 ft., extend $\mathrm{N} 7 \mathrm{mi}$. from Southeast Cape, Saint Lawrence I.; $62^{\circ} 59^{\prime} \mathrm{N}, 169^{\circ} 39^{\prime} \mathrm{W}$; $B G N$ 1951; (map 93). Var. Kiayalegok Mountain.

Eskimo name reported in 1932 by Otto W. Geist, Univ. of Alaska.

Kialegak Point: point of land, $4 \mathrm{mi}$. NE of Southeast Cape, St. Lawrence I. ; $62^{\circ} 59^{\prime} \mathrm{N}, 169^{\circ} 32^{\prime}$ W; BGN 1951; (map 93). Var. Cape Kialegak, Cape Kiallighak, Kialegak Cape, Southeast Cape.

Eskimo name reported by $O$. W. Geist, Univ. of Alaska, in 1932.

Kialegak Village: locality, on Kialegak Point, 4 mi. NE of Southeast Cape, St. Lawrence I.; $62^{\circ} 59^{\prime}$ N, $169^{\circ} 32^{\prime}$ W; (map 93). Var Khgallegak, Kgallegak, Kiallegak, Kialegak.

Former Eskimo camp or settlement reported as "Kgallegak" in 1849 by Capt. M. D. Tebenkov, IRN.

Kialigamiut: locality, see Kaialik.

Kiallegak: locality, see Kialegak Village.

Kiallighak, Cape: point of land, see Kialegak Point.

Kialyakvit: bay, see Wide Bay.

Kiam: locality, site of an abandoned mine, at head of McKenzie Inlet, $\mathbf{S}$ side of Skowl Arm of Kasaan Bay, Alex. Arch.; $55^{\circ} 20^{\prime} \mathrm{N}, 132^{\circ} 20^{\prime}$ W; (map 4).

The Kiam post office was established here in 1905 and was transferred to Ketchikan in 1907 or 1908 (Ricks, 1965, p. 33). This former mining camp is not shown on presentday maps. See Khayyam Point.

Kiana: village, pop. 253, on right bank of Kobuk River, 28 mi. NW of Selawik, Hogatza High.; $66^{\circ} 58^{\prime} \mathrm{N}, 160^{\circ} 26^{\prime} \mathrm{W} ; B G N$ 1945; (map 114).

Eskimo village which probably obtained its permanency as a supply center for the Squirrel River placer mines about 1909 . Reported by H. M. Eakin, USGS, in 1910 . The Kiana post office was established in 1915 . The village population was 98 in $1920 ; 115$ in 1930 ; 167 in 1939 ; and 181 in 1950.

Kiana Hills: ridge, elev. 1,100-2,600 ft., extends NW 25 mi. from Kiana, S of Squirrel River, Brooks Ra.; $67^{\circ} 02^{\prime} \mathrm{N}, 160^{\circ} 53^{\prime} \mathrm{W}$; (map 127). Var. Kyena Hills.

Name shown on a 1901 fieldsheet by D. L. Raeburn, USGS, as "Kyena Hills."

Kiangolevic Pass: stream, see Kiangolevik Pass. Kiangolevik Pass: stream, distributary of Black River, heads $4 \mathrm{mi}$. NE of Black, flows NE 20 mi. to Acharon Channel, $16 \mathrm{mi}$. NE of Black, Yukon-Kuskokwim Delta ; $62^{\circ} 32^{\prime} \mathrm{N}, 1^{\circ} 5^{\circ} 04^{\prime}$ W; (map 76). Var. Kiangolevic Pass, Keeang-ol-e-vik Pass.

Eskimo name written "Kiangolevic" by G. R. Putnam, USC\&GS, in 1899.

Kiank Island: island, see Kinuk Island.

Kiavak, Cape: point of land, $13 \mathrm{mi}$. NE of Kaguyak on SE coast of Kodiak I.; $57^{\circ} 00^{\prime}$ N, $153^{\circ} 33^{\prime}$ W; (map 33). Var. Mys Kiyavak.

Name published by Capt. Tebenkov (1852, map 23) as "M[ys] Kiyavak," or "Cape Kiyavak."

Kiavak Bay: bay, $2 \mathrm{mi}$. across, at mouth of Kaiugnak Bay, on SE coast of Kodiak I.; $57^{\circ}$ $01^{\prime}$ N, $153^{\circ} 35^{\prime}$ W; (map 34). Var. Kiawak Bay, Kiyavak Bay, Naumliack Bay, Zaliv Kiyavak.

Eskimo name published by Capt. Tebenkov (1852, map 23) as "Zaliv Kiyavak," or "Kiyavak Bay." The name "Naumliack" was recorded in 1805 by Lisianski (1814, p. 180).

Kiawak: village, see Klawock.

Kiawak Biy: bay, see Kiavak Bay.

Kiawak Inlet: water passage, see Klawak Inlet. Kiayalegok Mountain: mountain, see Kialegak Mountains.

Kiayankayagak: hill, see Lookout Mountain. Kichak: locality, see Kijik.

Kichak River: stream, see Kijik River.

Kichakuk: locality, see Klahangamut.

Ki-changamute: locality, see Klahangamut.

Kichatna Mountains: mountain range, $40 \mathrm{mi}$. long and $16 \mathrm{mi}$. wide, bounded by West Fork Yentna River on NE; Shellabarger Pass and Dillinger River on $\mathbf{N}$; Jones River on $\mathbf{W}$; and Earl River, Simpson Pass, and Kichatna River on S; centered around Cathedral Spires, 70 mi. SW of Mount McKinley, Alaska Ra.; $65^{\circ} 25^{\prime} \mathrm{N}, 152^{\circ} 43^{\prime} \mathrm{W}$; (map 8 ).

Local name derived from Kichatna River and reported in 1951 by USGS. 
Kichatna River: stream, heads at Caldwell Glacier in Cathedral Spires of Kichatna Mts., $62^{\circ} 21^{\prime} 30^{\prime \prime} \mathrm{N}, 152^{\circ} 43^{\prime} 00^{\prime \prime} \mathrm{W}$, flows SE $55 \mathrm{mi}$. to Yentna River, $47 \mathrm{mi}$. SW of Talkeetna, Alaska Ra.; $62^{\circ} 05^{\prime} 55^{\prime \prime} \mathrm{N}, 151^{\circ} 30^{\prime} 05^{\prime \prime} \mathrm{W}$; (map 81). Var. Kee-chat-no, Kichat River. Indian name for stream explored in 1899 by Lt. J. S. Herron, USA; written by him as "Kee-chat-no," meaning "Kichat river."

Kichat River: stream, see Kichatna River.

Kichik: locality, see Kijik.

Kichik: lake, see Clark, Lake.

Kichikan: city, see Ketchikan.

Kichik River: stream, see Kijik River.

Kichlulik: locality, on Talbiksok River $13.5 \mathrm{mi}$. $\mathrm{E}$ of Russian Mission, Yukon-Kuskokwim Delta; $61^{\circ} 45^{\prime} 25^{\prime \prime} \mathrm{N}, 160^{\circ} 54^{\prime} 10^{\prime \prime} \mathrm{W}$; (map 73).

This name first appears on manuscript map of Kuskokwim-Yukon Portage, dated 1919 , by R. H. Sargent, USGS. However he locates it nearer Kuskokwim on Johnson River. The name probably never applied to more than a cabin or two on the portage trail.

Kichotno, Reka: stream, see Katlitna River.

Kichtak: island, see Kodiak Island.

Kicking Horse River: stream, heads in Garrison Glacier, flows N $5 \mathrm{mi}$. to Chilkat River, $3 \mathrm{mi}$. NW of McClellan Flats and $18 \mathrm{mi}$. SW of Skagway, St. Elias Mts.; $59^{\circ} 15^{\prime} 45^{\prime \prime} \mathrm{N}, 135^{\circ}$. 37'30' W; (map 45). Var. Chalzékahin River, Khaltsekahin River, Khalzekahin River, Katsekahin River.

This name was published in 1900 on an Alaska Railroad map. The Tlingit Indian name obtained by Aurel and Aurthur Krause (1883, map) was Chalzékahin. It was given as Khalzekahin by W. H. Dall, USC\&GS, in the 1883 Coast Pilot (p. 198), Katsckahin in the 1891 Coast Pilot (p. 202), and Khaltsekahin on Chart 8300 in 1893.

Kickoojit Rocks: rocks, see Kikoojit Rocks.

Kickstep Mountain: mountain, 4,660 ft., in Kenai Mts. on Kenai Penin., $14 \mathrm{mi}$. SW of Whittier and $16 \mathrm{mi}$. SE of Sunrise, Ghugach Mts.; $60^{\circ} 45^{\prime} 10^{\prime \prime} \mathrm{N}, 149^{\circ} 05^{\prime} 40^{\prime \prime} \mathrm{W}$; $B G N$ 1964; (map 63).

Name proposed in 1962 by the Alaska Mountaineering Club for the technique of kickstepping that was used by club members in their ascent of the Mountain. This step is described as a step that is used by a mountaineer traveling up a step slope of material that is neither too hard nor too soft. He progresses by kicking a more or less level step with his foot.

Kidli Mountain: hill, see Kili Mountain.

Kidney Cove: cove, $0.2 \mathrm{mi}$. across, on $\mathrm{E}$ shore of Redoubt Bay, $10 \mathrm{mi}$. S of Sitka, on W coast of Baranof I., Alex. Arch.; 56 $54^{\prime} 20^{\prime \prime} \mathrm{N}$, $135^{\circ} 19^{\prime} 15^{\prime \prime} \mathrm{W}$; (map 6).

Local fishermen's name reported in 1947 by USC\&GS.

Kidney Creek: stream, heads in small lake, in De Long Mts., flows $\mathrm{N} 8 \mathrm{mi}$. to Driftwood Creek, $35 \mathrm{mi}$. NNE of Misheguk Mtn., Brooks
Ra.; $68^{\circ} 43^{\prime} 10^{\prime \prime} \mathrm{N}, 160^{\circ} 34^{\prime} 00^{\prime \prime} \mathrm{W} ; B G N$ 1961; (map 131).

Named by USGS geologists in 1951 "for the kidney-shaped lake at its head."

Kidney Hill: mountain, $1,800 \mathrm{ft}$., center of Kiska I., Aleutian Is.; $51^{\circ} 56^{\prime} 50^{\prime \prime} \mathrm{N}, 177^{\circ} 21^{\prime} 58^{\prime \prime}$ $\mathrm{E}$; (map 14)

An arbitrary name beginning with " $K$ " to correspond to the "K" grid used by the U.S. Army for tactical purposes during World War II ; published on a 1953 AMS map.

Kidney Island: island, $1 \mathrm{mi}$. long, one of Beards lee Is. in Glacier Bay, in Glacier Bay National Monument, $3.6 \mathrm{mi}$. NE of Strawberry I. and $56 \mathrm{mi}$. NW of Juneau, St. Elias Mts.; $58^{\circ} 32^{\prime}$ N, $135^{\circ} 53, \mathrm{~W} ; B G N 1948$; (map 11 ).

Descriptive name given in 1939 by USC\&GS because of the island's shape, and published in 1940 on their Chart 8306.

Kieegeealigamute: locality, see Kiyakyaliksamiut. Kiehzulik Bay: bay, see Kujulik Bay.

Kiektaguk: locality, see Klikitarik.

Kieogyaligamiut: locality, see Kiyakyaliksamiut. Kigalga: island, see Tigalda Island.

Kigalga, Ostrov: island, see Kagamil Island.

Kigalga Island: island, see Uliaga Island.

Kigalgin, Ostrov: island, see Carlisle Island.

Kigalgin Island: island, see Egg Island.

Kigalgin Island: island, see Uliaga Island.

Kigalik: locality, village site near head of Ikpikpuk River; $69^{\circ} 21^{\prime} \mathrm{N}, 154^{\circ} 40^{\prime} \mathrm{W}$; (map 142).

Ens. W. L. Howard stopped at this village from May 23 to 30,1886 , on his way from Ft. Cosmos to Point Barrow. The village consisted of 30 tents and 150 Eskimos (Stoney, 1900, p. 71-72). The USGS Expedition of 1924 could find no signs of this settlement (Smith and Mertie, 1930, p. 110).

Kigalik Creek: stream, see Kigalik River.

Kigalik River: stream, heads near Birthday Pass at $69^{\circ} 18^{\prime} \mathrm{N}, 156^{\circ} 47^{\prime} \mathrm{W}$, flows $\mathrm{W} 110 \mathrm{mi}$. and joins Maybe Creek to form Ikpikpuk River, Arctic Slope; $69^{\circ} 20^{\prime} 45^{\prime \prime} \mathrm{N}, 154^{\circ} 42^{\prime} 30^{\prime \prime} \mathrm{W}$, $B G N$ 1954; (map 142). Var. Kigalik Creek, Kiruilak River.

Named by the USGS Expedition of 1924 in reference to the Eskimo village of Kigalik at which Ens. W. L. Howard stopped from May 23 to 30, 1886 (Stoney, 1900, p. 71-72). The present-day Eskimo name for this stream is Kiruilak. The name first appears in 1924 on a fieldsheet by R. K. Lynt, USGS.

Kigalmilyakh Island: island, see Chuginadak Island.

Kiganghyne ile: peninsula, see Kunigiugan.

Kiganin: peninsula, see Kungiugan.

Kigchakok: bay, see Carter Bay.

Kigezruk Creek: stream, flows SW $4 \mathrm{mi}$. to Bering Sea, $12 \mathrm{mi}$. SE of Cape Prince of Wales and $43 \mathrm{mi}$. NW of Teller, Seward Penin. High.; $65^{\circ} 30^{\prime} \mathrm{N}, 167^{\circ} 44^{\prime} \mathrm{W}$; (map 111). Var. Kegezruk Creek, Kiryarzark River, Kivyearzruk Creek.

Prospectors' name reported in 1900 by Brooks (1901, pl. 13 and p. 135), USGS. In 1899 Schrader and Brooks (1900, map 3) reported the name as "Kivyearzruk" and noted (p. 25) that the gold "discovery was made in June, 1899, by Kivyearuk, a Prince of Wales native, then employed as reindeer herder by $W$. T. Lopp, a missionary in charge of a Government reindeer station."

Kightak Sichtunak: islands, see Trinity Islands. Kigigak Island: island, $5 \mathrm{mi}$. across at mouth of Ninglick River, $110 \mathrm{mi}$. W of Bethel, YukonKuskokwin Delta; $60^{\circ} 50^{\prime} \mathrm{N}, 165^{\circ} 00^{\prime} \mathrm{W}$; (map 58).

Eskimo name reported in 1949 by USC\&GS.

Kigiktowk Creek: stream, flows NW $4 \mathrm{mi}$. to Chukchi Sea, between Corwin Bluff and Cape Sabine, $W$ of Thetis Mine, $42 \mathrm{mi}$. NW of Mount Kelly, Arctic Slope; 68 $53^{\circ} 30^{\prime \prime} \mathrm{N}$, $164^{\circ} 51^{\prime} 00^{\prime \prime} \mathrm{W}$; (map 130).

Eskimo name meaning "the highest one" reported in 1950 by USC\&GS.

Kiglapak Mountains: mountains, $1,070 \mathrm{ft}$., trend W $2.5 \mathrm{mi}$. from junc. of Sphinx Creek and Tunulik River, $4 \mathrm{mi}$. NW of Goodnews, Kilbuck-Kuskokwin Mts.; $59^{\circ} 09^{\prime} 30^{\prime \prime}$ N, $161^{\circ} 37^{\prime}$. 30 " W; (map 53).

Eskimo name reported to mean "big saw tooth mountains," which refers to the rugged character of the mountains. The name was obtained about 1951 by J. M. Hoare, USGS, from C. B. Michael, missionary at Quinhagak.

Kiglowa: mountain range, see Kigluaik Mountains.

Kig-low-aie Range: mountain range, see Kigluaik Mountains.

Kiglowhite: mountain range, see Kigluaik Mountains.

Kigluaik Mountains: mountain range, highest elev. 4,714 ft., trends E-W $40 \mathrm{mi}$., $30 \mathrm{mi}$. N of Nome, Seward Penin. High.; $64^{\circ} 57^{\prime} \mathrm{N}, 165^{\circ}$. $30^{\prime} \mathrm{W}$; (map 94). Var. Kiglowa, Kig-low-aie Range, Kiglowhite, Sawtooth Range, Singatook Range.

Eskimo name reported in 1927 by Capt. F. W. Beechey, RN, as "Kig-low-aie." The present spelling was reported in 1900 by $\mathrm{E}$. C. Barnard (in Brooks, 1901, pl. 17), USGS. The 1900 "Map of Nome Peninsula" by J. M. Davidson and B. D. Blakeslee showed "Sawtooth Range," the name probably used by early prospectors.

Kikmil, Cape: point of land, see Prince of Wales, Cape.

Kigogla: locality, "on Akutan Island."

Name published on a 1783 map (Wagner, 1937 , p. 465 ).

Kigoumiut: locality, on $\mathrm{N}$ coast of Nunivak I., W of Iloodak Point, $37 \mathrm{mi}$. SW of Cape Etolin.; $60^{\circ} 13^{\prime} 50^{\prime \prime} \mathrm{N}, 167^{\circ} 07^{\prime} 00^{\prime \prime} \mathrm{W}$; (map 57).

Eskimo summer camp reported in 1932 by USC\&GS.

Kigragrak: locality, on an island in Kangnirvik Creek, 22 mi. NE of Kivalina, Brooks Ra.; $68^{\circ} 02^{\prime} \mathrm{N}, 164^{\circ} 10^{\prime} \mathrm{W}$; (map 130). Var. Keegragrock, Kiigragraaq.

Eskimo name meaning "old path cut through the willows" reported in 1966 by E. S. Burch.

Kigsitatok: locality, "on Agattu 1 in Near Is.. "Aleutian Is.; (map 13). 
Former Aleut village reported as "uninhabited" by Hodge (1907, p. 686), BAE.

Kigtsugtag Mountain: mountain, 1,702 ft., $8 \mathrm{mi}$. $\mathrm{N}$ of Beluga Hill and $9 \mathrm{mi}$. NW of Goodnews, Kilbuck-Kuskokwim Mts.; $59^{\circ} 13^{\prime} \mathrm{N}, 161^{\circ} 42^{\prime}$ W; (map 53).

Eskimo name reported in 1954 by USGS.

Kiguga, Cape: point of land, on NW coast of Adak I., Aleutian Is.; $51^{\circ} 56^{\prime} 15^{\prime \prime} \mathrm{N}, 176^{\circ}$ 48'15" W; BGN 1936; (map 17).

Aleut name published by Capt. Tebenkov (1852, map 28), IRN, as "M[ys] i Ut[yos] Kiguga," or "Kiguga Cape and Cliff."

Kigul Island: island, $0.5 \mathrm{mi}$. across, off SE coast of Umnak I., Aleutian Is.; $53^{\circ} 02^{\prime} 40^{\prime \prime}$ N, $168^{\circ} 26^{\prime} 20^{\prime \prime} \mathrm{W}$; (map 22).

Name published by USC\&GS in 1944 Aleutian Coast Pilot (p. 71).

Kigun, Cape: point of land, W tip of Atka I., Aleutian Is.; $52^{\circ} 01^{\prime} 25^{\prime \prime} \mathrm{N}, 175^{\circ} 20^{\prime} 20^{\prime \prime} \mathrm{W}$; $B G N$ 1936; (map 18). Var. Kigune, Cape

Name published as "M[ys] Kigun," "Cape Kigun," by Capt. Tebenkov (1852, map 27), IRN, possibly from the Aleut "Kiguk" or "Qiguq," meaning "diver" or "grebe," a species of duck.

Kigunak, Cape: point of land, on $\mathrm{N}$ shore of Inanudak Bay, on W coast of Umnak I., Aleutian Is.; $53^{\circ} 20^{\prime} \mathrm{N}, 168^{\circ} 25^{\prime} \mathrm{W}$; (map 22). Var. Mys Kigunakh.

Aleut name published by Capt. Tebenkov (1852, map 25), IRN, as "M[ys] Kigunakh," or "Cape Kigunakh."

Kigunakh, Mys: point of land, see Kigunak, Cape.

Kigun Bay: bay, 1 mi. across, near $W$ tip of Atka I., Aleutian Is.; $52^{\circ} 01^{\prime} 30^{\prime \prime} \mathrm{N}, 175^{\circ} 18^{\prime}$ $00^{\prime \prime} \mathrm{W}$; (map 18).

Named for Cape Kigun and published by the USC\&GS in the 1944 Aleutian Coast Pilot (p. 99).

Kigune, Cape: point of land, see Kigun, Cape.

Kigushimkada, Cape: point of land, on $\mathrm{W}$ coast of Umnak I., Aleutian Is.; $53^{\circ} 06^{\prime} 45^{\prime \prime} \mathrm{N}, 168^{\circ}$ 48'10" W; (map 22).

Aleut name published by Capt. Tebenkov (1852, map 25), IRN, as "M[ys] Kigushimkada," or "Cape Kigushimkada."

Kiialiakvit, Baie: bay, see Wide Bay.

Kiigragraaq: locality, see Kigragrak.

Kiingyak Lake: lake, $0.5 \mathrm{mi}$. across, at Howard Pass, Brooks Ra.; 68 $12^{\prime} 30^{\prime \prime}$ N, 156 $58^{\prime} 00^{\prime \prime}$ W; (map 132).

Eskimo name obtained at Noatak by Orth in 1956, meaning "face" [kinaq].

Kijik: locality, on W shore of Lake Clark near mouth of Kijik River, Alaska Ra.; $60^{\circ} 18^{\prime} \mathrm{N}$, $154^{\circ} 13^{\prime}$ W; (map 61). Var. Keechik, Keeghik, Keejik, Keggik, Keygik, Kichak, Kichik, Kilchik, Kilchikh, Lake Clark Villages, Nijik, Nikhak, Nikhkak, Old Keegik.

Former Eskimo village reported as "Kichik," population 91, by Ivan Petroff in the 1880 Census, but located on his map on the east shore of Lake Clark. According to A. B. Schanz of the 1890-91 Leslie Expedition "Kilchikh" was the permanent village, located about 9 miles up the Kijik River, and
"Nikhkak" was the salmon season fishing village on the shore of the lake. Osgood (1904 b, p. 329), USDA, recorded two spellings, "Keeghik," derived from the Eskimo name for Lake Clark, and "Nikhak." Hodge (1907, p. 682 and 687) lists "Kichik," Eskimo village, and "Kilchik," Indian village, both with the 1880 Census population of 91 ; also (1910, p. 70) "Nikhkak" population 40 in 1891 and about 25 in 1904.

Kijik: lake, see Clark, Lake.

Kijik Creek: stream, see Kijik River.

Kijik Lake: lake, $2.3 \mathrm{mi}$. long, $3 \mathrm{mi}$. SW of Kijik Mtn. and $26 \mathrm{mi}$. NE of Nondalton, Alaska Ra.; $60^{\circ} 18^{\prime} \mathrm{N}, 154^{\circ} 20^{\prime} \mathrm{W}$; (map 61).

Local name reported in 1954 by USGS; derived from nearby Eskimo village of Kijik. This was the Eskimo name for Lake Clark.

Kijik Mountain: mountain, 3,351 $\mathrm{ft}$, along the NW shore of Lake Clark, $32 \mathrm{mi}$. NE of Nondalton, Alaska Ra.; $60^{\circ} 20^{\prime} \mathrm{N}, 154^{\circ} 14^{\prime} \mathrm{W}$; (map 61). Var. Keejik.

Eskimo name reported in 1902 as "Keeghik" and "Keejik" by W. H. Osgood, USDA; de'rived from the nearby village of Kijik.

Kijik River: stream, flows SW $18 \mathrm{mi}$. to Lake Clark, $29 \mathrm{mi}$. NE of Nondalton, Alaska Ra.; $60^{\circ} 17^{\prime} 20^{\prime \prime} \mathrm{N}, 154^{\circ} 13^{\prime} 30^{\prime \prime} \mathrm{W}$; BGN 1931; (map 61). Var. Keeghik River, Keejik Creek, Keejik River, Keghik River, Kejak River, Kichak River, Kichik River, Kijik Creek, Kilchikh River, Nikhkak River.

Eskimo name reported in 1902 as "Keeghil" and "Keejik" by W. H. Osgood, USDA; derived from the native name for Lake Clark; published as "Keejik River" in 1903 by USC\&GS

Kikahe River: stream, flows N $11 \mathrm{mi}$. to Stikine River, 2 mi. W of Alaska-Canada boundary, Coast Mts.; $56^{\circ} 38^{\prime} 40^{\prime \prime} \mathrm{N}, 131^{\circ} 53^{\prime} 40^{\prime \prime} \mathrm{W}$ (map 7).

Tlingit Indian name reported in 1955 by USGS.

Kikak Creek: stream, flows NE $5 \mathrm{mi}$. to Colville River, $26 \mathrm{mi}$. NE of Umiat, Arctic Plain; $69^{\circ} 40^{\prime} 30^{\prime \prime} \mathrm{N}, 151^{\circ} 27^{\prime} 50^{\prime \prime} \mathrm{W}$; (map 141).

Eskimo name reported in 1956 by T. E. Taylor, USGS

Kikakpak Bluff: bluff, 1,000 ft. high, on E bank of Killik River $9 \mathrm{mi}$. SE of its junc. with Colville River, Brooks Ra.; $68^{\circ} 57^{\prime}$ N, $153^{\circ} 33^{\prime}$ W; (map 133).

Eskimo name reported in 1956 by T. E. Taylor, USGS.

Kikalrodik Hill, hill, $300 \mathrm{ft}$., $21 \mathrm{mi}$. W of Roberts Mtn., $28 \mathrm{mi}$. NW of Cape Mendenhall, Nunivak I.; $60^{\circ} 00^{\prime} 30^{\prime \prime} \mathrm{N}, 166^{\circ} 51^{\prime} 00^{\prime \prime} \mathrm{W}$; (map 57). Var. Kikhalradikh Hill, Kixalrodix Hill.

Eskimo name obtained in 1949 by USC\&GS.

Kikartak Rock: rock, see Kikartik Rock.

Kikartamjingia Point: point of land, $15 \mathrm{mi}$. SE of Cape Etolin, on NE coast of Nunivak I, $60^{\circ} 19^{\prime} 40^{\prime \prime} \mathrm{N}, 165^{\circ} 46^{\prime} 40^{\prime \prime} \mathrm{W}$; (map 57)

Eskimo name meaning "triangle's point" reported in 1949 by USC\&GS.

Kikartik Rock: rock, in Bering Sea, $0.7 \mathrm{mi}$. NW of Ahrayuksookwit Bluff and $12 \mathrm{mi}$. SW of
Cape Etolin, off $\mathbf{N}$ coast of Nunivak $\mathrm{I}$. $60^{\circ} 23^{\prime} 35^{\prime \prime}$ N, $166^{\circ} 29^{\prime} 00^{\prime \prime}$ W ; (map 57, Var. Kikartak Rock.

Eskimo name meaning "island" reported in 1949 by USC\&GS.

Kikchik: locality, "on Agattu I. in Near Is.," Aleutian Is.; (map 13).

Former Aleut village reported as "uninhabited" by Hodge (1907, p. 687), BAE.

Kikdooli Butte: hill, $739 \mathrm{ft}$., $16 \mathrm{mi}$. W of Roberts Mtn., $26 \mathrm{mi}$. NW of Cape Mendenhall, Nunivak I.; $60^{\circ} 03^{\prime} 15^{\prime \prime} \mathrm{N}, 166^{\circ} 43^{\prime} 00^{\prime \prime} \mathrm{W}$; (map 57). Var. Kiokhduli Hill, Kioxdooly Butte.

Eskimo name obtained in 1949 by USC\&GS.

Kikegtek Island: island, $5 \mathrm{mi}$. long, in Etolin Strait, $8 \mathrm{mi}$. NW of Cape Avinof, $10 \mathrm{mi}$. W of Kipnuk, Yukon-Kuskokwim Delta ; 59 $54^{\prime}$ N, $164^{\circ} 18^{\prime} \mathrm{W}$; (map 54).

Eskimo name reported in 1950 by USC\&GS. Kikertalik Lake: lake, $2.5 \mathrm{mi}$. long, on $\mathrm{W}$ coast of Nushagak Penin., $37 \mathrm{mi}$. SW of Dillingham, Bristol Bay Low.; $58^{\circ} 40^{\prime} \mathrm{N}, 159^{\circ} 15^{\prime} \mathrm{W}$; (map 40).

Eskimo name reported in 1952 by USC\&GS. Kikgtaguat: mountain, see Island Mountain. Kikhalradikh Hill: hill, see Kikalrodik Hill Kikhikhyakh Hill: hill, see Kikikyak Hill.

Kikhkat: locality, "on lower Yukon River," 2 mi. above Akhamut, Yukon-Kuskokwim Delta. Var. Kykhkat.

Former Eskimo camp or settlement reported as "Kykhkat" by Lt. L. A. Zagoskin, IRN, on an 1850 map.

Kikhtak: locality, on an unidentified island in Kuskokwim River, about $20 \mathrm{mi}$. NE of Bethel, Yukon-Kuskokwim Delta; (map 59). Var. Kikikhtagamiut, Kikkhtagamute, Kiktak.

Eskimo settlement, now abandoned, reported in $1878-79$ by E. W. Nelson, U.S. Signal Service. He spelled the name "Kikkhtagamute," meaning "island people." Its population was 232 in 1880 and 119 in 1890 (Kikikhtagamiut). The exact location of this place is not known.

Kikhtak: island, see Kodiak Island.

Kikhtak, Ostrov: island, see Fox Island.

Kikhtak, Ostrov: islands, see Martin Islands. Kikhtaknak: island, see Stuart Island.

Kikhtowik: island, see Kodiak Island.

Kikhtuk: locality, see Klikitarik.

Kikiakrorak River: stream, heads at $69^{\circ} 28^{\prime} \mathrm{N}$, 152:59' W, flows NE $90 \mathrm{mi}$. to Colville River, $30 \mathrm{mi}$. S of Harrison Bay, Arctic Plain; 69.$59^{\prime} 30^{\prime \prime} \mathrm{N}, 151^{\circ} 36^{\prime} 30^{\prime \prime} \mathrm{W}$; BGN 1949; (map 141)

Eskimo name reported by USGS geologists during exploration of Naval Petroleum Reserve No. 4 in 1947.

Kikiaktaurvik: locality, along Wulick River, 4 mi. NE of Kivalina, Kotzebue-Kobuk Low; $67^{\circ} 46^{\prime} \mathrm{N}, 164^{\circ} 24^{\prime} \mathrm{W}$; (map 128 ). Var. Kikiaktowrvick.

Eskimo name meaning "spear fishing place" reported in 1966 by E. S. Burch.

Kikiaktowrvick: locality, see Kikiaktaurvik. Kikikhtagamiut: locality, see Kikhtak.

Kikikhtagyut: town, see Kotzebue.

Kikiktagamute: town, see Kotzebue. 
Kikiktak: town, see Kotzebue.

Kikiktak Islands: islands, Oarlock and Tiny Is., in Dease Inlet, $33 \mathrm{mi}$. SE of Barrow, Arctic Plain; $70^{\circ} 48^{\prime} \mathrm{N}, 155^{\circ} 37^{\prime} \mathrm{W}$; (map 148).

Eskimo name (qiqiqtaq), meaning "island", reported by USC\&GS in 1951 .

Kikiktalik: lake, see Kekiktalik Lake.

Kikiktalik Rock: rock, $51 \mathrm{ft}$., $0.3 \mathrm{mi}$. NW of mouth of Ahding River and $40 \mathrm{mi}$. NW of Cape Mendenhall, in Bering Sea, off Nunivak I.; $60^{\circ} 18^{\prime} \mathrm{N}, 166^{\circ} 47^{\prime} \mathrm{W}$; (map 57).

Eskimo name reported in 1937 by USAAF. Kikiktaruk: locality, see Klikitarik.

Kikiktat Mountain: mountain, 4,126 ft., on N bank of Akmalik Creek, 9 mi. NE of Kurupa Lake, Brooks Ra.; $68^{\circ} 24^{\prime} \mathrm{N}, 154^{\circ} 17^{\prime} \mathrm{W}$; (map 133).

Eskimo name meaning "like an island" reported in 1956 by T. E. Taylor, USGS

Kikiktat Mountain: mountain, 5,000 ft., $8.5 \mathrm{mi}$. long, on $W$ bank of Hulahula River, $10 \mathrm{mi}$. NW of Mount Michelson, Brooks Ra.; 69*$26^{\prime} \mathrm{N}, 144^{\circ} 36^{\prime} \mathrm{W}$; BGN 1961; (map 139).

Eskimo name meaning "islands," and so called because "the mountain stands out like islands." This name, obtained at Barter I. in 1948 , was reported by C. L. Whittington, USGS, in 1960

Kikiktauralik Lake: lake, $0.4 \mathrm{mi}$. across, $3 \mathrm{mi}$. SE of Kivalina, Kotzebue-Kobuk Low.; $67^{\circ} 42^{\prime}$ N, $164^{\circ} 26^{\prime} \mathrm{W}$; (map 128). Var. Kikiktowralick, Qiqiqtauzalik.

Eskimo name meaning "little island place" reported in 1966 by E. S. Burch.

Kikiktausgruak Island: island, $2 \mathrm{mi}$. long, in Kuk River, $24 \mathrm{mi}$. S of Wainwright, Arctic Plain; $70^{\circ} 17^{\prime} 00^{\prime \prime} \mathrm{N}, 159^{\circ} 50^{\prime} 45^{\prime \prime} \mathrm{W}$; (map 146). Var. Kikitasugruak Island.

The Eskimo name was recorded in 1956 at Wainwright as "Kikiktasugruak" by T. E. Taylor, USGS, but was misspelled when the map was published in 1963.

Kikiktowralick: lake, see Kikiktauralik Lake.

Kikikyak Hill: hill, $763 \mathrm{ft}$., $2 \mathrm{mi}$. NE of Ahding Ingrid Mtn., $26 \mathrm{mi}$. NW of Cape Mendenhall, Nunivak I.; $60^{\circ} 08^{\prime} 30^{\prime \prime} \mathrm{N}, 166^{\circ} 31^{\prime} 50^{\prime \prime} \mathrm{W}$; (map 57). Var. Kixixyax Mountain, Kikhikhyakh Hill, Parker Hill.

Eskimo name meaning "island-like" reported in 1949 by USC\&GS.

Kikitaliorak Lake: lake, $1 \mathrm{mi}$. long, one of Inyorurak Lakes, $18 \mathrm{mi}$. ESE of Howard Pass, Brooks Ra.; $68^{\circ} 07^{\prime} 30^{\prime \prime} \mathrm{N}, 156^{\circ} 14^{\prime} 00^{\prime \prime} \mathrm{W}$; (map 132).

Eskimo name reported by USGS in 1956, meaning "has an island."

Kikitaruk Mission: town, see Kotzebue.

Kikitasugruak Island: island, see Kikiktausgruak Island.

Kikkhtagamute: locality, see Kikhtak.

Kik-khuigagamute: locality, see Kikuikak.

Kikku: locality, see Kiku.

Kikku Creek: stream, flows W 2 mi. to Kuskokwim Bay, $3 \mathrm{mi}$. S of Kwinhagak and $45 \mathrm{mi}$. NW of Goodnews, Yukon-Kuskokwim Delta ; $59^{\circ} 44^{\prime} \mathrm{N}, 161^{\circ} 55^{\prime} \mathrm{W}$; (map 53).

Eskimo name published in 1951 by USGS.
Kikliakliakakate: locality, see Kakliaklia.

KikJukh River: stream, heads $0.5 \mathrm{mi}$. S of 1950 terminus of Bering Glacier, flows $8 \mathrm{mi}$. SW to Gulf of Alaska, $8 \mathrm{mi}$. NE of Cape Suckling and $75 \mathrm{mi}$. SE of Cordova, Malaspina Coastal Plain; $60^{\circ} 00^{\prime} 20^{\prime \prime} \mathrm{N}, 143^{\circ} 50^{\prime} 00^{\prime \prime} \mathrm{W}$; (map 65). Var. Eightmile Creek, Kee-kluch River, Little Ugalentz River, Reka Malaia Ugalenka.

Tlingit Indian name obtained in 1904 by G. C. Martin, USGS, who spelied it "Keekluch." Martin also reported that the prospectors called it "Eightmile Creek." The Russians called it "R[eka] Malaia Ugalenka," meaning "little coal river." From this the 1869 Coast Pilot called it "Little Ugalentz River."

Kiklupiklak Hills: ridge, elev. 1,400 ft., extends $25 \mathrm{mi}$. between Epizetka and Kokolik Rivers, $40 \mathrm{mi}$. SE of Point Lay, Arctic Slope; $69^{\circ} 16^{\prime} \mathrm{N}, 162^{\circ} 00^{\prime \prime} \mathrm{W}$; (map 145).

Eskimo name published by USGS in 1955.

Kikmiksoot Mountain: mountain, see Kikmiksot Mountain.

Kikmiksot Mountain: mountain, 2,285 $\mathrm{ft}$., at head of Tutak Creek, in Mulgrave Hills, 16 mi. N of Noatak, Brooks Ra.; $67^{\circ} 48^{\prime} \mathrm{N}$, $163^{\circ} 09^{\prime} \mathrm{W}$; (map 128). Var. Kikmiksoot Mountain, Kikmiksut Mountain, Kimiksut Mountain.

Eskimo name meaning "resembling heels," according to USC\&GS in 1950.

Kikmiksut Mountain: mountain, see Kikmiksot Mountain.

Kikmiktalikamiut: locality, $12 \mathrm{mi}$. SE of Cape Etolin, on NE coast of Nunivak I.; 60 $10^{\prime} 15^{\prime \prime}$ N, 165 54'45" W; (map 57). Var. Kikmixtalixamiut.

Eskimo name applies to a shelter cabin; reported in 1949 by USC\&GS.

Kikmixtalixamiut: locality, see Kikmiktalikamiut.

Kikneak River: stream, heads in lake at $61^{\circ} 45^{\prime}$ $\mathrm{N}, 164^{\circ} 51^{\prime} \mathrm{W}$, flows NW $35 \mathrm{mi}$. to Kun River, $11 \mathrm{mi}$. E of village of Scammon Bay, Yukon-Kuskokwim Delta; $61^{\circ} 49^{\prime} 30^{\prime \prime} \mathrm{N}$, $165^{\circ} 18^{\prime} 30^{\prime \prime} \mathrm{W}$; (map 75).

Eskimo name reported by AMS in 1952.

Kiknik Greek: stream, flows NW $18 \mathrm{mi}$. to Holitna River, $56 \mathrm{mi}$. SW of Sleetmute, Kilbuck-Kuskokwim Mts.; $60^{\circ} 57^{\prime}$ N, $157^{\circ} 43^{\prime}$ W; BGN 1948; (map 60).

Eskimo name meaning "heel" reported in 1945 by USGS.

Kikoligarak Creek: stream, flows $\mathrm{N} 4 \mathrm{mi}$. to Chukchi Sea, $25 \mathrm{mi}$. E of Point Franklin, Arctic Plain; $70^{\circ} 53^{\prime} 30^{\prime \prime} \mathrm{N}, 157^{\circ} 42^{\prime} 30^{\prime \prime} \mathrm{W}$; (map 147). Var. Kikolikarak Creek.

Eskimo name that refers in meaning to a "seal hole," reported in 1950 by USC\&GS.

Kikolikarak Creek: stream, see Kikoligarak Creek.

Kikolik Creek: stream, flows N 4 mi. to Chukchi Sea, $23 \mathrm{mi}$. E of Point Franklin, Arctic Plain $70^{\circ} 52^{\prime} 35^{\prime \prime} \mathrm{N}, 157^{\circ} 46^{\prime} 00^{\prime \prime} \mathrm{W}$; (map 147).

Eskimo name, meaning "seal hole in the ice," obtained in 1956 at Wainwright by Orth

Kikoojit Rocks: rocks, in Bering Sea, $18 \mathrm{mi} \mathrm{SW}$ of Cape Etolin, off $\mathrm{N}$ coast of Nunivak I.; $60^{\circ} 20^{\prime}$ N, $166^{\circ} 39^{\prime}$ W; (map 57). Var. Kickoojit Rocks, Kikujit Rocks.

Eskimo name obtained in 1949 by USC\&GS.

Kikoyat Creek: stream, flows E $4 \mathrm{mi}$. to Okokmilaga River, $8.4 \mathrm{mi}$. S of mouth of Fire Creek and $39 \mathrm{mi}$. E of Kurupa Lake, Brooks Ra.; $68^{\circ} 20^{\prime} \mathrm{N}, 153^{\circ} 06^{\prime} \mathrm{W}$; (map 133).

Eskimo name reported in 1956 by T. E. Taylor, USGS.

Kiksa Island: island, see Kiska Island.

Kiktagak: locality, see Klikitarik.

Kiktaguk: locality, see Klikitarik.

Kiktaguk Bay: bay, see Klikitarik Bay.

Kiktak: locality, see Kikhtak.

Kiktak Island: island, $1.5 \mathrm{mi}$. long, in Kuskokwim River, $14 \mathrm{mi}$. NE of Bethel, YukonKuskokwim Delta; $60^{\circ} 54^{\prime} \mathrm{N}, 161^{\circ} 25^{\prime} \mathrm{W}$; (map 59).

Eskimo name reported in 1948 by USC\&GS. Kiktak Island: island, see Fox Island.

Kiktoya Creek: stream, flows S $4.5 \mathrm{mi}$. to Chukchi Sea, $13 \mathrm{mi}$. SE of Cape Thompson, Arctic Slope; $68^{\circ} 03^{\prime} 56^{\prime \prime} \mathrm{N}, 165^{\circ} 31^{\prime} 20^{\prime \prime} \mathrm{W}$ BGN 1963; (map 129). Var. Innutat Creek, Inyooktam Koonga, Keektoya Creek.

Eskimo name reported as "Keektoya" in 1952 by U.S. Army Corps of Engineers.

Kiku: locality, area between Amungna and Nunavak Bay, $3 \mathrm{mi}$. SW of Barrow, Arctic Plain; $71^{\circ} 16^{\prime} \mathrm{N}, 156^{\circ} 51^{\prime} \mathrm{W}$; (map 153). Var. Kikku.

Eskimo locality name published by $\mathbf{R}$. F. Spencer (1959, map 2) and spelled "Kikku" by Lt. P. H. Ray (1885, p. 55).

Kikuikak: locality, "at mounth of Kuskokwim River," Yukon-Kuskokwim Delta; Var. Kikkhuigagamute.

Former Eskimo camp or settlement reported by Ivan Petroff as "Kik-khuigagamute," with a population of 9 , in the 1880 Census.

Kiku Islets: islands, see Keku Islets.

Kikujit Rocks: rocks, see Kikoojit Rocks.

Kikukalen Bay: bay, see Erskine Bay.

Kikukalia Bay: bay, see Erskine Bay.

Kikukali Bay: bay, see Erskine Bay.

Kikukalya Bay: bay, see Erskine Bay.

Kikuktok Mountain: hill, $901 \mathrm{ft}$., at $E$ end of Kokechik Bay, between Kokechik and Lithkealik Rivers, $12 \mathrm{mi}$. SE of Cape Romanzof, Yukon-Kuskokwim Delta; $61^{\circ} 42^{\prime} \mathrm{N}, 165^{\circ} 47^{\prime}$ W; (map 75).

Eskimo name, meaning "like an island," obtained at Hooper Bay by USC\&GS in 1951.

Kikun: locality, "on Agattu I. in the Near Is.," Aleutian Is.; (map 13).

Former Aleut village reported as "unin. habited" by Hodge (1907, p. 687), BAE.

Kiku Strait: water passage, see Keku Strait. Kikyuktuktong: lake, see Kikyuktukturo.

Kikyuktukturo: lake, $0.2 \mathrm{mi}$. long, on Chukchi Sea coast, NE of Salt Lagoon and $5 \mathrm{mi}$. NE of Barrow, Arctic Plain; $71^{\circ} 20^{\prime} 35^{\prime \prime} \mathrm{N}, 156^{\circ}$. $36^{\prime} 00^{\prime \prime} \mathrm{W}$; (map 153). Var. Kikyuktuktong.

Eskimo name recorded in 1883 by Sgt. John Murdoch, naturalist, of Lt. P. H. Ray's Point Barrow expedition. The name is reported to mean "Island pond *** from one or two 
little islands (Kikyu'kta) near one end of it." (Murdoch, 1892, p. 28).

Kilakalik: stream, see Kisaralik River.

Kilamantavi: locality, see Kilimantavi.

Kilamantavie: locality, see Kilimantavi.

Kilametagagmiut: locality, see Kilimantavi.

Kilamitavik: locality, see Kilimantavi.

Kilangnak Bluff: bluff, extends SE $1 \mathrm{mi}$. from mouth of Tukrok River, along $N$ shore of Kotzebue Sound, $13 \mathrm{mi}$. SE of Cape Krusenstern, Kotzebue-Kobuk Low.; 67 $09^{\circ} \mathrm{N}, 163^{\circ}$ $17^{\prime} \mathrm{W}$; (map 128). Var. Keelyangnak, Qilangnaq.

Eskimo name reported in 1966 by E. S. Burch.

Kilauetawin: locality, see Kilimantavi.

Kilaugaurak Spit: spit, see Kilogorak Spit.

Kilauwitawin: locality, see Kilimantavi.

Kilbuck Glacier: glacier, see Chikuminuk Glacier.

Kilbuck Mountains: mountains, 3,000-4,000 ft., in group $95 \mathrm{mi}$. long and $25 \mathrm{mi}$. wide, trends NE-SW, bounded on S by Kwithluk Creek and Canyon Creek, on $\mathrm{E}$ by Kipchuk River, on $\mathrm{N}$ and $\mathrm{W}$ by Kuskokwim River lowlands; $61^{\circ} 20^{\prime} \mathrm{N}, 159^{\circ} 50^{\prime} \mathrm{W}$ [ $\mathrm{N}$ end], $60^{\circ} 25^{\prime} \mathrm{N}$, $161^{\circ} 00^{\prime} \mathrm{W}$ [S end]; BGN 1959; (map 59).

Named in 1898 by J. E. Spurr, USGS, after Rev. John H. Kilbuck, Moravian missionary in Alaska 1885-98 and 1921-22.

Kilchik: locality, see Kijik.

Kilchik: lake, see Clark, Lake.

Kilchikh: locality, see Kijik.

Kilchikh River: stream, see Kijik River.

Kilchikh-vona: lake, see Clark, Lake.

Kild-o-gidiinakh-ten: bend, see Long Bend.

Kiliahlik Creek: stream, see Kilikralik Creek.

Kiliahlik Point: point of land, see Kilikralik Point.

Kilialik Creek: stream, see Kilikralik Creek.

Kilialik Point: point of land, see Kilikralik Point.

Kilich Point: point of land, on E shore of Kuk River, 15 mi. S of Wainwright, Arctic Plain; $70^{\circ} 26^{\prime} \mathrm{N}, 159^{\circ} 52^{\prime} \mathrm{W}$; (map 146).

Eskimo name published in 1958 by AMS.

Ki-lick-tuk-gowt Creek: stream, see Kiliktakgot Creek.

Kiligmak: locality, see Kilikmak.

Kiligmak Inlet: water passage, between Kotlik Lagoon and Chukchi Sea, $15 \mathrm{mi}$. N of Cape Krusenstern, Kotzebue-Kobuk Low.; 67 $21^{\prime}$ $\mathrm{N}, 163^{\circ} 50^{\prime} \mathrm{W}$; (map 128). Var. Kiligmiak Inlet, Killigmack, Qiligmiak.

Eskimo name reported in 1966 by E. S. Burch.

Kiligmak River: stream, see Kilimak Creek.

Kiligmiak Inlet: water passage, see Kiligmak Inlet.

Kiliguak Creek: stream, heads W of Ikaknak Pond, flows S $3.6 \mathrm{mi}$. to Ogotoruk Creek, 7 mi. E of Cape Thompson, Arctic Slope; $68^{\circ}$ 09'10" N, 165'42'15" W; BGN 1963; (map 129). Var. Mammoth Creek.

Eskimo name meaning "carcass" refers to the remains of the Wooly or Northern Mammoth; named in 1963 by personnel of Project
Chariot after an earlier name, "Mammoth Creek," was changed because of duplication. Kili Hill: hill, $901 \mathrm{ft}$, on $\mathrm{N}$ bank of Kivalina River, 12 mi. NE of Kivalina, Arctic Slope; $67^{\circ} 52^{\prime} \mathrm{N}, 164^{\circ} 18^{\prime} \mathrm{W}$; (map 128). Var. Killee, Killi Mountain.

Eskimo name reported in 1950 by USC\&GS. Kilikak, Rochers: rocks, see Kilokak Rocks.

Kilikmak: locality, on Chukchi Sea coast, near mouth of Kilikmak Creek, $15 \mathrm{mi}$. N of Cape Krusenstern, Kotzebue-Kobuk Low.; $67^{\circ} 20^{\prime}$ $30^{\prime \prime} \mathrm{N}, 163^{\circ} 48^{\prime} 30^{\prime \prime} \mathrm{W}$; (map 128). Var. Kiligmak.

Eskimo name for a camp reported in 1926 by Gerald FitzGerald, USGS.

Kilikmak Creek: stream, heads in Igichuk Hills, flows NW $23 \mathrm{mi}$. to Kotlik Lagoon, $15 \mathrm{mi}$. N of Cape Krusenstern, Kotzebue-Kobuk Low.; $67^{\circ} 21^{\prime} \mathrm{N}, 163^{\circ} 49^{\prime} \mathrm{W}$; BGN 1962; (map 128). Var. Kiligmak River.

Eskimo name obtained in 1926 by Gerald FitzGerald, USGS.

Kilikralik Creek: stream, flows SW $2.5 \mathrm{mi}$. to Chukchi Sea, S of Kilikralik Point, $10 \mathrm{mi}$. S of Cape Dyer, Arctic Slope; $68^{\circ} 30^{\prime} 50^{\prime \prime} \mathrm{N}$, $166^{\circ} 17^{\prime} 45^{\prime \prime}$ W; (map 129). Var. Kiliahlik Creek, Kilialik Creek.

Eskimo name reported in 1950 by USC\&GS. See Kilikralik Point.

Kilikralik Point: point of land, on Chukchi Sea coast, $10 \mathrm{mi}$. S of Cape Dyer, Arctic Slope; $68^{\circ} 31^{\prime} \mathrm{N}, 166^{\circ} 18^{\prime} \mathrm{W}$; (map 129). Var. Kiliahlik Point, Kilialik Point.

Eskimo name reported in 1950 by USC\&GS to mean "corner"; they spelled it "Ki-li-ahlik." The present spelling is derived from "Killeegrallik" and was reported by D. C. Foote, in connection with Project Chariot studies.

Kiliktagik Island: island, $1.5 \mathrm{mi}$ long, in Semidi Is., $1.5 \mathrm{mi}$. NE of Chowiet I., Aleutian Ra.; $56^{\circ} 04^{\prime} \mathrm{N}, 156^{\circ} 39^{\prime} \mathrm{W}$; (map 31). Var. Keelikhtagikh Island.

Native name shown on an 1874 chart as "Keelikhtagikh" by W. H. Dall, USC\&GS.

Kiliktakgot Creek: stream, flows W $2 \mathrm{mi}$. to Chukchi Sea, $3 \mathrm{mi}$. N of Cape Dyer, Arctic Slope; 68 $41^{\prime} 10^{\prime \prime} \mathrm{N}, 166^{\circ} 09^{\prime} 55^{\prime \prime} \mathrm{W}$; (map 129). Var. Keelyiktangyawk Creek, Ki-licktuk-gowt Creek.

Eskimo name reported to mean "jointed" by USC\&GS in 1950, who spelled it "Ki-licktuk-gowt."

Kilimantavi: locality, site of Eskimo village, on Chukchi Sea coast, $14 \mathrm{mi}$. SW of Wainwright, Arctic Plain; $70^{\circ} 29^{\prime} \mathrm{N}, 160^{\circ} 26^{\prime} \mathrm{W}$; (map 146). Var. Kalummiktowrah, Kelamantowruk, Kelevatowtin, Kilamantavi, Kilamantavie, Kilamentagagmiut, Kilamitavik, Kilauetawin, Kilauwitawin, Kilimantavie, Kilimantavis, Kilimantowruk, Kilyamigtagvik, Kolumakturook, Kolumatourok, Kolmaturok.

This Eskimo name has been variously spelled by authorities for more than 100 years. The name appears first to have been recorded in Russian by Lt. L. A. Zagoskin, IRN, in $1842-44$, as "Kylyamigtagvik," and then in
1861 by $P$. Tikhmeniev as "S[elenie] Kilametagagmyut," or "Kilametagag people's village." The 1880 Census recorded the name as "Kolumakturook." John Murdoch, of Ray's "Barrow Expedition" told Marcus Baker in 1890 that the name is probably derived from that of a throwing weapon like a sling or bola. Murdoch (1892, pl. 2) spelled the name "Kilauwitawiñ" and "Kilauwitawiñmium" (p. 44), and in a letter "Ke-lev-a-towtin." With the influence of Baker's "Alaska Dictionary" in 1906 the spelling becomes more standardized in a slightly anglicized form, exemplified by the " $\mathrm{i}$ " and "ie" endings. The village is now abandoned.

Kilimantavie: locality, see Kilimantavi.

Kilimantavis: locality, see Kilimantavi.

Kilimantowruk: locality, see Kilimantavi.

Kili Mountain: hill, $900 \mathrm{ft}$., on $\mathrm{W}$ bank of Kivalina River, $11 \mathrm{mi}$. NE of Kivalina, Arctic Slope; 67 $52^{\prime} 30^{\prime \prime} \mathrm{N}, 164^{\circ} 18^{\prime} 00^{\prime \prime} \mathrm{W}$; (map 128). Var. Kidli Mountain, Killi Mountain.

Eskimo name reported in 1950 by USC\&GS; it may mean "carcass [kidli]."

Kiliouda Bay: bay, see Kiliuda Bay.

Kiliouk Bay: bay, see Kiliuda Bay.

Kiliovilik Creek: stream, flows SW $23 \mathrm{mi}$. to Selawik River, $30 \mathrm{mi}$. SW of Shungnak, Kotzebue-Kobuk Low.; $66^{\circ} 30^{\prime} \mathrm{N}, 157^{\circ} 34^{\prime} \mathrm{W}$; (map 115).

Eskimo name shown on a 1927 manuscript map by the "trader at Selawik."

Kiliovilik Range: mountains, 2,021 ft., extend E-W $26 \mathrm{mi}$. on N side of Selawik River, $\mathrm{S}$ of Sheklukshuk Ra., 22 mi. S of Shungnak, Hogatza High.; $66^{\circ} 34^{\prime} \mathrm{N}, 156^{\circ} 58^{\prime} \mathrm{W}$ [E end], $66^{\circ} 32^{\prime} \mathrm{N}, 157^{\circ} 54^{\prime} \mathrm{W}$ [W end]; $B G N$ 1966; (map 115).

Named in 1965 by W. W. Patton, USGS, for Kiliovilik Creek, which flows through the mountains.

Kiliuda: locality, site of Eskimo village, at head of Boulder Bay, on SE coast of Kodiak I.; $57^{\circ} 22^{\prime} 30^{\prime \prime} \mathrm{N}, 152^{\circ} 44^{\prime} 00^{\prime \prime} \mathrm{W}$; (map 34). Var. Killuda, Killuden, Kiluden.

Eskimo name reported as "Killuden" in 1805 by Lisianski (1814, map facing p. 169). The population was 36 in 1880 and 22 in 1890. The name may be derived from the Aleut "Kiliak" (morning) and "Uda" (bay).

Kiliuda Bay: bay, extends WNW $17 \mathrm{mi}$. off N entrance to Sitkalidak Strait, on SE coast of Kodiak I.; 57 $7^{\circ} 16^{\prime} \mathrm{N}, 152^{\circ} 54^{\prime} \mathrm{W}$; (map 34). Var. Bay of Kiluden, Kaliada Bay, Kiliouda Bay, Kiliouk Bay, Kiliudinskoi, Kiliuk Bay, Killuda Bay, Kilutsch Bay, Kilyuda Bay, Kilyudinskoy.

Native name recorded in 1805 as "Bay of Kiluden" by Lisianski (1814, map facing $p$. 169). Baker (1906, p. 365) wrote, "Perhaps it is a corruption of Kíliak, an Aleut word meaning morning, or Kiliák (early in the morning), and Uda (bay)."

Kiliuda Rock: rock, in Kiliuda Bay, at mouth of Santa Flavia Bay, on SE coast of Kodiak I., $57^{\circ} 16^{\prime} 30^{\prime \prime} \mathrm{N}, 152^{\circ} 53^{\prime} 10^{\prime \prime} \mathrm{W}$; BGN 1930; (map 34). 
Name derived from Kiliuda Bay; given in 1928 by USC\&GS.

Kiliudinskoi: bay, see Kiliuda Bay.

Kiliugmiut, Cape: point of land, see Kuliuk, Cape.

Kiliuk Bay: bay, see Kiliuda Bay.

Kiliuluk: bay, see Kuliliak Bay.

Killaimute villages: sites, the 10th Census in 1880 (1881, p. 4) recorded two Eskimo villages near the head of the Kuk River. These may be the two shown on more recent maps as "Kangik" and "Anaktuk."

Killak River: stream, flows SW $5 \mathrm{mi}$. to Kobuk River, $30 \mathrm{mi}$. SE of Shungnak, KotzebueKobuk Low.; $66^{\circ} 49^{\prime} \mathrm{N}, 156^{\circ} 05^{\prime} \mathrm{W}$; (map 115).

Eskimo name obtained in 1956 at Kobuk by Orth.

Killarney, Lake: lake, $300 \mathrm{ft}$. across, on Happy Creek at Ace Creek, $5 \mathrm{mi}$. NW of Fairbanks, Yukon-Tanana High.; 64 $52^{\prime} \mathrm{N}, 147^{\circ} 54^{\prime} \mathrm{W}$; (map 100).

This name first appears on a location map of the Tanana Mines RR. dated 1905.

Killarney Creek: stream, flows $\mathrm{S} 4.7 \mathrm{mi}$, joins Blowback Creek to form Baker Creek, $40 \mathrm{mi}$. ESE of Tanana, Yukon-Tanana High.; $65^{\circ}$ $06^{\prime} 00^{\prime \prime} \mathrm{N}, 150^{\circ} 43^{\prime} 15^{\prime \prime} \mathrm{W}$; BGN 1961; (map 106).

Prospectors' name reported in 1931 by J. B. Mertie, USGS.

Killdeer Lake: lake, $0.6 \mathrm{mi}$. long, on Kenai Penin. between Plover and Shadura Lakes, $13 \mathrm{mi}$. NE of Kenai, Cook Inlet Low.; $60^{\circ}$. $43^{\prime} 00^{\prime \prime} \mathrm{N}, 151^{\circ} 01^{\prime} 30^{\prime \prime} \mathrm{W}$; (map 62).

Named about 1963 by officials of Kenai National Moose Range, probably for the Killdeer or Noisy Plover (Oxyechus vociferus), a shore bird, "which makes itself exceedingly useful by destroying great quantities of noxious insects [notably mosquitoes]" (in Pearson, 1944, pt. 1, p. 261 ).

Killeak Lakes: lakes, on Seward Penin., the larger one $2.5 \mathrm{mi}$. long, $43 \mathrm{mi}$. NW of Deering, Kotzebue-Kobuk Low.; $66^{\circ} 20^{\prime} \mathrm{N}, 164^{\circ} 05^{\prime} \mathrm{W}$; (map 113).

Eskimo name reported in 1950 by USGS

Killee : hill, see Kili Hill.

Killem Hill: hill, $450 \mathrm{ft}$., on W coast of Kiska I., Aleutian Is.; $51^{\circ} 57^{\prime} 55^{\prime \prime} \mathrm{N}, 177^{\circ} 21^{\prime} 45^{\prime \prime} \mathrm{E}$; (map 14).

An arbitrary name beginning with " $K$ " to correspond to the " $K$ " grid used by the U.S. Army for tactical purposes during World War II; published on a 1953 AMS map.

Killer Bay: cove, $0.4 \mathrm{mi}$. across, on $\mathrm{E}$ coast of Resurrection Penin., $14 \mathrm{mi}$. SE of Seward, Chugach Mts.; $59^{\circ} 57^{\prime} \mathrm{N}, 149^{\circ} 14^{\prime} \mathrm{W}$; BGN 1929; (map 49).

Named by the 1928 USC\&GS field party; "name suggested by a fight between a whale and killer whale witnessed by us."

Killey Glacier: glacier, on Kenai Penin., in Kenai Mts., heads in Harding Icefield, trends NW $3.7 \mathrm{mi}$. to its 1951 terminus at head of Killey River, $45 \mathrm{mi}$. SE of Kenai, Chugach Mts.; $60^{\circ} 10^{\prime} \mathrm{N}, 150^{\circ} 11^{\prime} \mathrm{W}$; (map 62).
Local name reported in 1951 by USGS; derived from the name of the river.

Killey River: stream, on Kenai Penin., heads at Killey Glacier terminus, flows NW $32 \mathrm{mi}$. to Kenai River, 22 mi. ESE of Kenai, Cook Inlet Low.; $60^{\circ} 29^{\prime} \mathrm{N}, 150^{\circ} 38^{\prime} \mathrm{W}$; (map 62). Var. Kelley River.

Local name reported in 1904 by Moffit (1906, pl. 2), USGS.

Killian Creek: stream, flows SE $8 \mathrm{mi}$. to Lake Nuna Vaugaluk, $30 \mathrm{mi}$. NW of Dillingham, Kilbuck-Kuskokwim Mts.; $59^{\circ} 19^{\prime} \mathrm{N}, 159^{\circ} 05^{\prime}$ W; (map 53).

Eskimo name published in 1951 by USGS. Killianuk: point of land, see Krusenstern, Cape. Killi Creek: stream, flows N $2.3 \mathrm{mi}$. to Chukchi Sea, 22 mi. E of Point Franklin, Arctic Plain; $70^{\circ} 51^{\prime} 45^{\prime \prime} \mathrm{N}, 157^{\circ} 50^{\prime} 15^{\prime \prime} \mathrm{W}$; (map 147).

Eskimo name reported in 1950 by USC\&GS.

Killigmack: water passage, see Kiligmak Inlet. Killik Bend: bend, of Colville River $S$ of its junc. with Killik River, Brooks Ra.; 68 ${ }^{\circ} 59^{\prime}$ N, 153 $57^{\prime}$ W; BGN 1949; (map 133).

Name shown on 1924 fieldsheet by Gerald FitzGerald, USGS.

Killik Creek: stream, see Killik River.

Killik River: stream, formed by April and Kakivilak Creeks at $68^{\circ} 02^{\prime} \mathrm{N}, 154^{\circ} 30^{\prime} \mathrm{W}$, flows N $105 \mathrm{mi}$. to Colville River, $52 \mathrm{mi}$. SW of Umiat, Arctic Slope; $69^{\circ} 01^{\prime} \mathrm{N}, 153^{\circ} 55^{\prime}$ W; BGN 1925; (map 142). Var. Killik Creek.

This Eskimo name first appears about 1885 on a manuscript map drawn on wrapping paper by a Barrow Eskimo. The name was officially reported in 1901 by W. J. Peters and F. C. Schrader, USGS. The modern Eskimo pronounces the stream name "Kitlik," and the people who once lived in the stream's valley are called Kitlikmiut (Rausch, 1951, p. 150,158 ).

Killi Mountain: hill, see Kili Hill.

Killi Mountain: hill, see Kili Mountain.

Killingupak River: stream, see Ikalugtulik River. Killinupak Mountain: mountain, 1,248 ft., on W coast of Nelson I., $10 \mathrm{mi}$. NE of Cape Vancouver, Yukon-Kuskokwim Delta; $60^{\circ} 38^{\prime} \mathrm{N}$, $165^{\circ} 04^{\prime} \mathrm{W}$; (map 57). Var. The Nipple.

Eskimo name obtained at Tanunak in 1951 by USC\&GS.

Killishoo: locality, see Killisnoo.

Killisnoo: locality, on E coast of Killisnoo I., 2 mi. S of Angoon, Alex. Arch.; $57^{\circ} 28^{\prime} \mathrm{N}, 134^{\circ}$ $34^{\prime}$ W ; (map 9). Var. Kănăs-nū, Kenasnow, Killishoo.

Former village established about 1881 when members of the Hutsnuwu tribe of Tlingit Indians were brought from the villages of $\mathrm{An}$ goon and Nahltushkan to work in a fish rendering plant. The village was named for the island. Its population was 79 in $1890 ; 351$ in $1910 ; 256$ in 1920 ; and 3 in 1930 . The Killisnoo post office was established in 1882 ; discontinued in 1930 (Ricks, 1965, p. 33). Killisnoo: islands, see Kootzanhoo Archipelago. Killisnoo Harbor: bay, $0.8 \mathrm{mi}$. across, $2.5 \mathrm{mi}$. S of Angoon, on W coast of Admiralty I., Alex. Arch.; $57^{\circ} 28^{\prime} \mathrm{N}, 134^{\circ} 34^{\prime} \mathrm{W}$; (map 9).
Corruption of a Tlingit Indian word which is apparently another form of "Khutz-n'hu" meaning "bear fort." Comdr. R. W. Meade, USN, reported the Indian name for the harbor as "Koteosok" (USC\&GS, 1883, p. 176). The name probably was derived from the town of Killisnoo about 1882.

Killisnoo Island: island, $1.7 \mathrm{mi}$. long, $2 \mathrm{mi}$. S of Angoon on $\mathrm{W}$ coast of Admiralty I., Alex. Arch.; $57^{\circ} 28^{\prime} 15^{\prime \prime} \mathrm{N}, 134^{\circ} 36^{\prime} 00^{\prime \prime} \mathrm{W}$; (map 9). Var. Kenasnow Island, Khutz-n'hu Island.

Local name derived from a Tlingit Indian name, a form of the word "Khutz-n'hu," meaning "bear fort" and also the "Kenasnow Island" of Comdr. R. W. Meade, USN. This name was the former Tlingit Indian name of Admiralty Island. The name "Killisnoo Harbor" was probably derived from the town of Killisnoo established on the harbor about 1882

Killkuhn Creek: stream, see Sherrette Creek.

Killooghna Lake: lagoon, see Kiloknak Lagoon. Killuda: locality, se Kiliuda.

Killuda Bay: bay, see Kiliuda Bay.

Killuden: locality, see Kiliuda.

Kilogorak Spit: spit, in Kivalina Lagoon, $1 \mathrm{mi}$. NW of Kivalina, Kotzebue-Kobuk Low.; $67^{\circ}$. $44^{\prime}$ N, $164^{\circ} 33^{\prime}$ W ; (map 128). Var. Keelyowgorack, Kilaugaurak Spit, Qilaugauzaq, Qilaun.

Eskimo name meaning "little drum," so called because the spit is almost round, resembling a drum; reported in 1966 by E. S. Burch.

Kilo Hot Spring: spring, in Ray Mts., in headwaters of Kanuti Kilolitna River, $37 \mathrm{mi}$. NW of Rampart and $50 \mathrm{mi}$. NE of Tanana, Kokrines-Hodzana High.; $65^{\circ} 48^{\prime} 40^{\prime \prime} \mathrm{N}, 151^{\circ} 14^{\prime}$ $00^{\prime \prime} \mathrm{W}$; (map 106).

Named by Orth in 1956 for the Kanuti Kilolitna River.

Kilokak, Cape: point of land, includes offshore island, $\mathrm{S}$ point of entrance to Imuya Bay, on E coast of Alaska Penin., $47 \mathrm{mi}$. SE of Ugashik, Aleutian Ra.; $57^{\circ} 11^{\prime} 15^{\prime \prime} \mathrm{N}, 156^{\circ} 19^{\prime} 00^{\prime \prime}$ W; (map 36$)$.

Eskimo name published in 1956 by USGS; probably applied because of its nearness to Kilokak Rocks.

Kilokak Rocks: rocks, in Pacific Ocean, $\mathrm{S}$ of Cape Kilokak, on SE coast of Alaska Penin., $48 \mathrm{mi}$. SE of Ugashik, Aleutian Ra.; $57^{\circ} 10^{\prime}$ $25^{\prime \prime} \mathrm{N}, 156^{\circ} 19^{\prime} 25^{\prime \prime}$ W; (map 36). Var. Rochers Kilikak.

Eskimo name for 2 rocks published as "Roc[hers] Kilikak" by Adm. A. J. von Krusenstern, IRN, on an 1827 map corrected in 1835 ; the name "Kilokak Rocks" was published in 1900 by USC\&GS

Kiloknak Lagoon: lagoon, $8 \mathrm{mi}$. long, $8 \mathrm{mi}$. SW of Northeast Cape, SE coast of St. Lawrence I.; $63^{\circ} 11^{\prime} \mathrm{N}, 168^{\circ} 50^{\prime} \mathrm{W}$; BGN 1951; (map 93). Var. Killooghna Lake, Lake Cynthia, Tilounan Naivak.

Eskimo name shown on map annotated by Lawrence Kulukhan, of Gambell, in 1944. Orth reported the name "Tilounan Naivak," 
meaning "mainland lake," obtained at Gambell in 1965.

Kilokuyak Creek: stream, flows NE $4 \mathrm{mi}$. to Takshilik Creek, $50 \mathrm{mi}$. NE of Goodnews, Kilbuck-Kuskokwim Mts.; $59^{\circ} 42^{\prime} \mathrm{N}, 161^{\circ} 00^{\prime} \mathrm{W}$; (map 53).

Eskimo name published in 1951 by USGS.

Kilooghna: locality, on barrier reef, $\mathrm{SE}$ of Kiloknak Lagoon, $10 \mathrm{mi}$. SW of Northeast Cape, St. Lawrence I.; $63^{\circ} 10^{\prime} \mathrm{N}, 168^{\circ} 49^{\prime}$ W; (map 93).

Eskimo name reported in 1932 by $\mathrm{O}$. W Geist, Univ, of Alaska.

Kiluden: locality, see Kiliuda.

Kiluden, Bay of : $b a y$, see Kiliuda Bay.

Kilulea : $b a y$, see Dease Inlet.

Kilulikpuk Creek: stream, flows NE $13 \mathrm{mi}$. to the Buckland River, $44 \mathrm{mi}$. NE of Haycock, Seward Penin. High.; 65 $50^{\prime}$ N, $160^{\circ} 58^{\prime} \mathrm{W}$; (map 109).

Eskimo name reported in 1949 by the U.S. Army Corps of Engineers.

Kilusiktok Lake: lake, $4.5 \mathrm{mi}$. long, $22 \mathrm{mi}$. S of Barrow, Arctic Plain; $70^{\circ} 58^{\prime} \mathrm{N}, 157^{\circ} 03^{\prime} \mathrm{W}$; (map 147).

Eskimo name obtained in 1956 at Wainwright by T. E. Taylor, USGS.

Kilutsch Bay: bay, see Kiliuda Bay.

Kilyaktalik Peaks: peaks, 3,000-3,400 ft., in Maiyumerak Mts. of the Baird Mts., extend NE $10 \mathrm{mi}$. from Eli River, $33 \mathrm{mi}$. NE of Noatak, Brooks Ra.; $67^{\circ} 47^{\prime} \mathrm{N}, 161^{\circ} 40^{\prime} \mathrm{W}$; (map 127).

Eskimo name obtained in 1955 by U.S. Army Corps of Engineers.

Kilyamigtagvik : locality, see Kilimantavi.

Kilyuda Bay: bay, see Kiliuda Bay.

Kilyudinskoy: bay, see Kiliuda Bay.

Kimball, Mount: peak, 10,300 ft., at heads of Chistochina and Robertson Glaciers, $30 \mathrm{mi}$. NE of Paxson, Alaska Ra.; $63^{\circ} 14^{\prime} 15^{\prime \prime} \mathrm{N}, 144^{\circ}$. $38^{\prime 2} 25^{\prime \prime} \mathrm{W}$; (map 86).

Named in 1885 by Lt. H. T. Allen, USA.

Kimball Glacier: glacier, trends E $5 \mathrm{mi}$. to Robertson Glacier, $35 \mathrm{mi}$. NE of Paxson, Alaska Ra.; $63^{\circ} 15^{\prime} 35^{\prime \prime} \mathrm{N}, 1^{\circ} 34^{\circ} 30^{\prime} 30^{\prime \prime} \mathrm{W}$; (map 86).

Name reported in 1942 by USGS.

Kimball Pass: pass, $5 \mathrm{mi}$. NE of Ernestine and $48 \mathrm{mi}$. NE of Valdez, Chugach Mts.; $61^{\circ} 30^{\prime}$ $45^{\prime \prime} \mathrm{N}, 145^{\circ} 02^{\prime} 30^{\prime \prime} \mathrm{W}$; (map 68).

Name reported in 1898 by Capt. W. R. Abercrombie, USA.

Kimble, Mount: mountain, 2,110 ft., on SW end of Unalaska I., Aleutian Is.; $53^{\circ} 22^{\prime} 28^{\prime \prime} \mathrm{N}$, $167^{\circ} 40^{\prime} 00^{\prime \prime} \mathrm{W}$; (map 23 ).

Name published in 1951 on a USGS map.

Kimbley Creek: stream, heads on $\mathrm{S}$ slope of Cripple Creek Mts., flows SW $5.5 \mathrm{mi}$ to Canyon Creek $2 \mathrm{mi}$. E of its confluence with South Fork Folger Creek, $25 \mathrm{mi}$. NE of Ophir and $35 \mathrm{mi}$. NW of McGrath, Kilbuck-Kuskokwim Mts.; $63^{\circ} 26^{\prime} 40^{\prime \prime} \mathrm{N}, 1^{\circ} 06^{\circ} 20^{\prime \prime} \mathrm{W}$; (map 90).

Local name obtained from Joseph Ferris in 1954 by R. E. Isto, USGS.

Kimichukhakh Butte: hill, see Kimijooksuk Butte.
Kimickpak : ridge, see Kimikpak Ridge.

Kimickpayaht Koogowranga: stream, see Kimikpeyat Creek.

Kimickpayaht Kookowranga, stream, see Kumikpeyat Creek.

Kimickpowm Koogowranga : stream, see Kimikpak Creek.

Kimijooksuk Butte: hill, $735 \mathrm{ft} ., 11 \mathrm{mi}$. NE of Roberts Mtn., $26 \mathrm{mi}$. N of Cape Mendenhall, Nunivak I.; $60^{\circ} 11^{\prime} 15^{\prime \prime} \mathrm{N}, 166^{\circ} 11^{\prime} 00^{\prime \prime} \mathrm{W}$; (map 57). Var. Kimichukhakh Butte, Kimijookxux Hill.

Eskimo name meaning "two hills with the same base," according to USC\&GS in 1949.

Kimijooksuk Buttes: hills, $460 \mathrm{ft}$, $14 \mathrm{mi}$. SW of Cape Etolin, on $N$ part of Nunivak I. ; $60^{\circ} 15^{\prime}$ $30^{\prime \prime} \mathrm{N}, 166^{\circ} 21^{\prime} 10^{\prime \prime} \mathrm{W}$; (map 57 ).

See Kimijooksuk Butte.

Kimijookxux Hill: hill, see Kimijooksuk Butte. Kimikhthakh Hills: hills, see Kimikthak Hills.

Kimikhthek Hill: hill, see Kimiksthek Hill.

Kimikhthorak Hill: hill, see Kimixthoruk Hill.

Kimikpak Ridge: ridge, along Signoalik River, $23 \mathrm{mi}$. NW of Kivalina, Arctic Slope; $68^{\circ} 00^{\prime}$ N, $165^{\circ} 00^{\prime} \mathrm{W}$; (map 128). Var. Kimickpak, Qimiqpak.

Eskimo name meaning "long ridge" reported in 1966 by E. S. Burch.

Kimikpak Ridge: ridge, see Knifeblade Ridge.

Kimipak Creek: stream, flows S $3 \mathrm{mi}$. to Kivalina River, $30 \mathrm{mi}$. NE of Kivalina, Brooks Ra.; $68^{\circ} 09^{\prime} \mathrm{N}, 164^{\circ} 11^{\prime} \mathrm{W}$; (map 130). Var. Kimickpowm Koogowranga, Quimiqpaum Kuugauzanga.

Eskimo name reported in 1966 by E. S. Burch.

Kimipak Ridge: ridge, $10 \mathrm{mi}$. long, between Maybe and Weasel Creeks, $35 \mathrm{mi}$. W of Umiat, Arctic Slope; $69^{\circ} 13^{\prime} \mathrm{N}, 153^{\circ} 45^{\prime} \mathrm{W}$; (map 142). Var. Inyugiatchiak Hill.

Eskimo name meaning "big ridge" applied to Knifeblade Ridge, but given to this adjacent feature by Orth in 1956 in order to retain the name.

Kimikpaurauk River: stream, flows $5 \mathrm{mi}$. NE to Pokok Bay, SW of Humphrey Point and $36 \mathrm{mi}$. NW of Demarcation Point, Arctic Plain; 69 $57^{\prime} 30^{\prime \prime} \mathrm{N}, 142^{\circ} 34^{\prime} 30^{\prime \prime} \mathrm{W}$; (map 138).

Eskimo name recorded on Barter I. by USC\&GS in 1952 and reported to mean "big hill." Name probably refers to a large nearby pingo.

Kimikpeyat Creek: stream, flows NE $10 \mathrm{mi}$. to Kivalina River, $24 \mathrm{mi}$. NE of Kivalina, Arctic Slope; $68^{\circ} 04^{\prime} \mathrm{N}, 164^{\circ} 18^{\prime} \mathrm{W}$; (map 130). Var. Kimickpayaht Koogowranga; Qimiqpayaat Kuugauzanga.

Eskimo name meaning "short ridge" reported in 1966 by E. S. Burch.

Kimikpuk Ridge: ridge, see Knifeblade Ridge. Kimiksthek Hill: hill, $615 \mathrm{ft}$., $3.5 \mathrm{mi}$. W of Jiskooksnuk Hill, $37 \mathrm{mi}$. NW of Cape Mendenhall, Nunivak I.; $60^{\circ} 06^{\prime} 25^{\prime \prime} \mathrm{N}, 167^{\circ} 02^{\prime}-$ $00^{\prime \prime}$ W; (map 57). Var. Kimikhthek Hill, Kimixthek Hill.

Eskimo name obtained in 1949 by USC\&GS.
Kimiksut Mountain: mountain, see Kikmiksot Mountain.

Kimikthak Hills: hills, $205 \mathrm{ft}$., $5 . \mathrm{mi}$. S of Cape Etolin, on N Nunivak I.; $60^{\circ} 21^{\prime} 20^{\prime \prime} \mathrm{N}, 166^{\circ}$ $09^{\prime} 45^{\prime \prime}$ W; (map 57). Var. Kimikhthakh Hills, Kimixthax Hills.

Eskimo name obtained in 1949 by USC\&GS Kimilogchil'ogh: bluffs, see Red Bluffs.

Kimirok Hill: hill, $601 \mathrm{ft}$,, in Igichuk Hills on E bank of Milokrawlok Creek, $9 \mathrm{mi}$. E of Cape Krusenstern, Arctic Slope; $67^{\circ} 09^{\prime} \mathrm{N}$, $163^{\circ} 23^{\prime}$ W; (map 128). Var. Kimirook Hill, Kimiruk Hill.

Eskimo name meaning "ridge (long hill)" according to USC\&GS in 1950.

Kimirook Hill: hill, see Kimirok Hill.

Kimiruk Hill: hill, see Kimirok Hill.

Kimit Hills: hills, $500 \mathrm{ft}$, trend NE $6 \mathrm{mi}$. from Nariksmiut River, $16 \mathrm{mi}$. NW of Roberts Mtn., $18 \mathrm{mi}$. SW of Cape Etolin, on Nunivak I.; $60^{\circ} 13^{\prime} \mathrm{N}, 166^{\circ} 30^{\prime} \mathrm{W}$; (map 57).

Eskimo name obtained by in 1949 by USC\&GS

Kimituk: locality, "on Agattu I. in the Near Is.," Aleutian Is.; (map 13).

Former Aleut village reported as "uninhabited" by Hodge (1907, p. 689), BAE.

Kimixthax Hills: hills, see Kimikthak Hills.

Kimixthek Hill: hill, see Kimiksthek Hill.

Kimixthoruk Hill: hill, $426 \mathrm{ft}$., $33 \mathrm{mi}$. SW of Cape Etolin, on $N$ coast of Nunivak I.; $60^{\circ}$. $12^{\prime} 50^{\prime \prime} \mathrm{N}, 166^{\circ} 59^{\prime} 00^{\prime \prime} \mathrm{W}$; (map 57). Var. Kimikhthorak Hill.

Eskimo name obtained in 1949 by USC\&GS

Kimklik : locality, see Kiniklik.

Kimok: mountain, see Kemuk Mountain.

Kimouksik Lake: lake, $3.4 \mathrm{mi}$, long, $11 \mathrm{mi}$. SE of Barrow, Arctic Plain; $71^{\circ} 07^{\prime} 10^{\prime \prime} \mathrm{N}, 156^{\circ}$ $35^{\prime} 30^{\prime \prime}$ W; (map 153). Var. Kimuksuq Lake.

Eskimo personal name recorded at Barrow by Orth, USGS, in 1956.

Kimshan Cove: cove, $0.3 \mathrm{mi}$. across, $1.5 \mathrm{mi}$. N of Chichagof, on $W$ coast of Chichagof I., Alex. Arch.; $57^{\circ} 41^{\prime} 20^{\prime \prime} \mathrm{N}, 136^{\circ} 07^{\prime} 00^{\prime \prime} \mathrm{W}$; $B G N$ 1922; (map 9). Var. Hirst Cove, Mine Cove.

Named in 1920 by USC\&GS. "Kimshan" is said to be a Chinese name meaning "gold mountain," which refers to Mount Doolth near the head of the cove, on which several gold mines are located. It was originally called Hirst Cove, for Bernard Hirst, a merchant of Sitka who was the principal owner of the mine. The name was reported in 1906 by USC\&GS, but in 1908 it was changed to Mine Cove.

Kimuksuq Lake: lake, see Kimouksik Lake.

Kina Cove: estuary, extends SW $1.8 \mathrm{mi}$. off Kasaan Bay, on E coast of Prince of Wales I., Alex. Arch.; $55^{\circ} 30^{\prime} 45^{\prime \prime} \mathrm{N}, 132^{\circ} 30^{\prime} 15^{\prime \prime} \mathrm{W}$; (map 4).

Local navigators' name reported in 1900 by Lt. Comdr. J. F. Moser.

Kina Creek: stream, flows NE $6 \mathrm{mi}$. through Kina Lake to Kina Cove, on $E$ coast of Prince of Wales I., E of Twelvemile Arm Kasaan 
Bay, Alex. Arch.; $55^{\circ} 29^{\prime} 20^{\prime \prime} \mathrm{N}, 132^{\circ} 31^{\prime} 20^{\prime \prime}$ W; (map 4).

Local fisheries name reported in 1897 by Lt. Comdr. J. F. Moser, USN. It appears to be of Indian origin.

Kinagamiut: locality, see Kinak.

Kinagamute: locality, see Kinak.

Kinak: locality, on left bank of Kinak River, $96 \mathrm{mi}$. SW of Bethel, Yukon-Kuskokwim Delta ; $60^{\circ} 01^{\prime} \mathrm{N}, 164^{\circ} 03^{\prime} \mathrm{W}$; (map 58).

Former Eskimo village or camp, named for the stream; reported in 1949 by USC\&GS; "Village now deserted. Some buildings remain."

Kinak: locality, on right bank of Kuskokwim River, $4 \mathrm{mi}$. E of Tuntutuliak and $40 \mathrm{mi}$. SW of Bethel, Yukon-Kuskokwim Delta; $60^{\circ} 22^{\prime}$ $\mathrm{N}, 162^{\circ} 30^{\prime} \mathrm{W}$; (map 58). Var. Kinagamiut, Kinakamute.

Former Eskimo camp or village visited by E. W. Nelson in January 1879. Nelson reported the name to be "Kinagamiut," i.e. "Kinak River people." Its population at that time was about 175 . The 1880 Census gives the population as $60 ; 257$ in 1890; and 209 in 1900.

Kinak Bay: estuary, extends $\mathrm{N} 8 \mathrm{mi}$. from Cape Atushagvik, on S coast of Alaska Penin., in Katmai National Monument $20 \mathrm{mi}$. SE of Mount Katmai, Aleutian Ra.; $58^{\circ} 05^{\prime} \mathrm{N}$, $154^{\circ} 24^{\prime}$ W; (map 42). Var. Left Arm Amalik Bay.

Eskimo name meaning "face"; reported in 1916 by R. F. Griggs, National Geographic Society.

Kinak Bay: bay, 9 mi. across, enters Etolin Strait at mouths of Kinak and Kuguklik Rivers, 9 mi. NW of Kipnuk, Yukon-Kuskokwim Bay; $60^{\circ} 00^{\prime} \mathrm{N}, 164^{\circ} 12^{\prime} \mathrm{W}$; (map 54).

Eskimo name obtained in 1951 by USGS.

Kinakhulantan Lake: lake, extends NE-SW 1.1 $\mathrm{mi}$., $0.5 \mathrm{mi}$. S of Ham I. and $20 \mathrm{mi}$. NE of Ruby, Nowitna Low.; 64. $48^{\prime} \mathrm{N}, 154^{\circ} 51^{\prime}$ W; (map 98).

Indian name obtained at Ruby in 1956 by Orth.

Kinak River: stream, flows E $20 \mathrm{mi}$. to Kuskokwim River, $43 \mathrm{mi}$. SW of Bethel, YukonKuskokwim Delta; $60^{\circ} 20^{\prime} \mathrm{N}, 162^{\circ} 33^{\prime} \mathrm{W}$; (map 58).

Eskimo name meaning "face" reported in December 1878 by E. W. Nelson, U.S. Signal Service.

Kina Lake: lake, $0.5 \mathrm{mi}$. long, in course of Kina Creek, on Prince of Wales I., E of Twelvemile Arm Kasaan Bay, Alex. Arch.; 55 $27^{\prime} 40^{\prime \prime} \mathrm{N}$, $132^{\circ} 33^{\prime} 00^{\prime \prime} \mathrm{W}$; (map 4).

Local fisheries name reported in 1897 by Lt. Comdr. J. F. Moser, USN. See Kina Creek.

Kinani Point: point of land, at $\mathrm{N}$ end of Tuxekan Narrows on $W$ coast of Prince of Wales I., $30 \mathrm{mi}$. NW of Craig, Alex. Arch.; $55^{\circ} 53^{\prime} 28^{\prime \prime} \mathrm{N}, 133^{\circ} 14^{\prime} 55^{\prime \prime} \mathrm{W}$; (map 4).

Indian name published in 1964 by USG\&GS.

Kinarak Creek: stream, see Amadens Creek.

Kinarak Lake: lake, $4 \mathrm{mi}$. long, $2 \mathrm{mi}$. SE of mouth of Amadens Creek and $90 \mathrm{mi}$. W of
Bethel, Yukon-Kuskokwim Delta; $60^{\circ} 33^{\prime} \mathrm{N}$, $164^{\circ} 17^{\prime} \mathrm{W}$; (map 58).

Local name reported in 1965 by Orth.

Kinaruk Creek: stream, see Amadens Creek.

Kindergarten Bay: bight, $1.7 \mathrm{mi}$. across, on W coast of Etolin I., Alex. Arch.; $56^{\circ} 12^{\prime} 15^{\prime \prime} \mathrm{N}$, $132^{\circ} 42^{\prime} 30^{\prime \prime} \mathrm{W}$; (map 6).

Local name recorded in 1949 by USGS

Kineeghit Cape: point of land, see Kineeghit Point.

Kineeghit Point: point of land, $2 \mathrm{mi}$. SW of Eevwak Point, $7 \mathrm{mi}$. SW of Savoonga, $\mathrm{N}$ coast of St. Lawrence I; $63^{\circ} 39^{\prime} \mathrm{N}, 170^{\circ} 42^{\prime} \mathrm{W}$; BGN 1951; (map 93). Var. Cape Kinnit, Cape Kinnitt, Kineeghit Cape, Kinnit Cape.

Eskimo name, of unknown meaning, recommended in 1949 for map use by the Savoonga village council. $O$. W. Geist, Univ. of Alaska, reported the name "Cape Kinnit" in 1932 and Orth was told by local informants in 1965 that the name of the cliff there is "Kannit," which refers in meaning to the fact that the cliff is "near" the coast.

Kinegnagak: locality, see Razboinski.

Kinegnagmiut: locality, see Kinegnak.

Kinegnagamiut: locality, see Razboinski.

Kinegnak: locality, on S point of Cape Newenham, $39 \mathrm{mi}$. SW of Goodnews, Kilbuck-Kuskokwim Mts.; 58 $39^{\prime} \mathrm{N}, 162^{\circ} 12^{\prime} \mathrm{W}$; (map 39). Var. Kinegnagmiut, Kniegnagamute.

Eskimo village listed in the 1890 Census as "Kinegnagmiut" and "Kniegnagamute," meaning "Kinegnak people." The population in 1890 was 76 ; the inhabitants "lived in underground huts of driftwood covered with sods." The village is now abandoned. Kinegnak: village, pop. 20,1 mi. $\mathrm{N}$ of Chagvan Bay at junc. of Kinegnak River and Kookukluk Creek and $28 \mathrm{mi}$. NE of Cape Newenham, Kilbuck-Kuskokwim Mts.; $58^{\circ} 50^{\prime} \mathrm{N}$, $161^{\circ} 40^{\prime} \mathrm{W}$; BGN 1938; (map 39). Var. Old Kinegnak.

This village may have been established by Eskimos from the old village called "Kinegnak" near Cape Newenham. It was reported in 1938 by Gerald FitzGerald, USGS; the name was published by Mertie (1940, pl. 1), USGS.

Kinegnak River; stream, flows SW $18 \mathrm{mi}$. to Chagvan Bay, $27 \mathrm{mi}$. NE of tip of Cape Newenham, Kilbuck-Kuskokwim Mts.; $58^{\circ}$ 49'15" N, $161^{\circ} 40^{\prime} 45^{\prime \prime}$ W; BGN 1938; (map 39). Var. Bales Creek.

Eskimo name reported in 1938 by Gerald FitzGerald, USGS, published by Mertie (1940, pl. 1), USGS.

Kinepagelgut Mountain: mountains, see Kini paghulghat Mountains.

King, Mount: mountain, see King Mountain. Kingaghee: village, see Wales.

Kingaglia Lake: lake, $3.5 \mathrm{mi}$. across, $\mathrm{E}$ of Kgun Lake, $53 \mathrm{mi}$. SW of Marshall, Yukon-Kuskokwim Delta; 61 ${ }^{\circ} 35^{\prime} \mathrm{N}, 163^{\circ} 36^{\prime} \mathrm{W}$; (map 74).

Eskimo name obtained at Bethel by Orth in 1965, and reported to mean "last," referring to the fact that it is the last lake to the west before Kgun Lake.
Kingak Cliff: mountain, 2,255 ft., on $\mathrm{S}$ bank of Sadlerochit River, between Kekiktuk River and Arctic Creek, $18 \mathrm{mi}$. $\mathrm{N}$ of Mount Michelson, Brooks Ra.; 69³3' N, $144^{\circ} 32^{\prime}$ W ; (map 139).

Not listed by Leffingwell as a geogıaphic name but was written in his text $(1919$, $p$ 119). "The Kingak shale has been identified as at only one locality Kingak Cliff, * * * at the southeast end of Sadlerochit Mountains." It is an Eskimo name meaning "nose" and is of ten applied to the steep end of a ridge.

Kingak Cliff: mountain, see Kingak Hill.

King-a-khi: village, see Wales.

Kingak Hill: mountain, 2,260 ft., between the Hulahula and Sadlerochit Rivers, $19 \mathrm{mi} \mathrm{N}$ of Monut Michelson, Brooks Ra.; 69 $35^{\prime} \mathrm{N}$, $144^{\circ} 22^{\prime}$ W; BGN 1961; (map 139). Var. Kingak Cliff.

Eskimo name meaning "nose." See Kingak Cliff.

Kingak Mountain: mountain, 2,972 $\mathrm{ft}$., the E peak of Smith Mtn., $36 \mathrm{mi}$ NNE of Howard Pass, Arctic Slope; 68 $42^{\prime} \mathrm{N}, 156^{\circ} 24^{\prime} \mathrm{W}$; (map 132). Var. Mount Araga, Smith Mountain.

Eskimo name obtained by Orth in 1956, meaning "nose," a common topographic term used for steep-ended ridges or mountains that are of landmark value.

Kingaktakamiut: locality, on $\mathbf{N}$ coast of Cape Mendenhall, at mouth of Duchikthluk Bay, Nunivak I.; $59^{\circ} 49^{\prime} 15^{\prime \prime} \mathrm{N}, 166^{\circ} 08^{\prime} 30^{\prime \prime} \mathrm{W}$; (map 55). Var. Klingaktakamute.

Eskimo camp reported in 1942 by the USAAF.

Kingasivik Mountains: mountains, 3,410 ft., in DeLong Mts., $22 \mathrm{mi}$. ESE of Misheguk Mtn. Brooks Ra.; $68^{\circ} 10^{\prime} \mathrm{N}, 160^{\circ} 12^{\prime} \mathrm{W}$; (map 131).

Eskimo name referring to "the high place" obtained at Noatak and Kotzebue by Orth in 1956.

Kingaviksak Mountain: mountain, 3,200 ft., in De Long Mts., $12 \mathrm{mi}$. NNW of Misheguk Mtn., Brooks Ra.; 68 ${ }^{\circ} 5^{\prime}$ N, $161^{\circ} 23^{\prime}$ W ; (map 131).

Eskimo name referring to a "high place," reported by USGS in 1956.

King City: locality, on W bank of Chisana River, $3.3 \mathrm{mi}$. $\mathrm{N}$ of junc. of Sheep Creek, Alaska Ra.; 62 ${ }^{\circ} 19^{\prime} 22^{\prime \prime} \mathrm{N}, 141^{\circ} 46^{\prime} 00^{\prime \prime} \mathrm{W}$; (map 84).

Mining camp reported by USGS in 1960.

King County Creek: stream, on Kenai Penin., flows NW $10 \mathrm{mi}$. to Skilak Lake, $29 \mathrm{mi}$. ESE of Kenai, Cook Inlet Low.; $60^{\circ} 24^{\prime} 30^{\prime \prime} \mathrm{N}$, $150^{\circ} 28^{\prime} 15^{\prime \prime} \mathrm{W}$; (map 62).

Local name reported about 1911 by G. C. Martin, USGS.

King Cove: village, pop. 290, between King Cove and King Cove Lagoon, $18 \mathrm{mi}$. SE of village of Cold Bay, on SW coast of Alaska Penin., Aleutian Ra.; $55^{\circ} 03^{\prime} 20^{\prime \prime} \mathrm{N}, 162^{\circ} 19^{\prime}$ $00^{\prime \prime} \mathrm{W}$; (map 29). Var. King Cove Cannery.

Named for its founder, this fishing village has a salmon cannery and a school (Colby, 1939 , p. 331); a post office was established in 1914 (Ricks, 1965, p. 34). 
King Cove: bay, $15 \mathrm{mi}$. across, between Cold Bay and Belkofski Bay, at SW end of Alaska Penin., Aleutian Ra.; 55 $03^{\prime} \mathrm{N}, 162^{\circ} 19^{\prime} \mathrm{W}$; (map 29). Var. Kings Cove.

Local name reported by USGS in 1928 . Named "King's Cove" by USBF in 1888.

King Cove: bay, $2 \mathrm{mi}$. across, on SE coast of Afognak I., $30 \mathrm{mi}$. NE of Afognak, $\mathrm{N}$ of Kodiak I. ; $58^{\circ} 12^{\prime}$ N, $152^{\circ} 02^{\prime} \mathrm{W}$; BGN 1910; (map 43). Var. Izhut Bay, Ujut Bay.

Local name reported by USC\&GS in 1910 . "The name is used by some navigators. On some old Russian maps the names Izhut Bay and Ujut Bay were used interchangeably for this bay and one now known as Izhut Bay [ 8 miles to the southwest]. King Cove is recommended." See Izhut Bay.

King Cove: bay, see Peterson Bay.

King Cove: bay, see Salmon Bay.

King Cove: cove, see Emerald Bay

King Cove: lagoon, see King Cove Lagoon.

King Gove Cannery: village, see King Cove.

King Cove Lagoon: lagoon, $2 \mathrm{mi}$. long, $\mathrm{N}$ of King Cove, $18 \mathrm{mi}$. SE of village of Cold Bay, at SW end of Alaska Penin., Aleutian Ra.; $55^{\circ} 04^{\prime} \mathrm{N}, 162^{\circ} 19^{\prime} \mathrm{W}$; (map 29). Var. King Cove.

Name published in the 1926 Coast Pilot ( $p$ 210 ), derived from King Cove.

King Creek: stream, flows NW $10 \mathrm{mi}$. to Chickamin River, $6.5 \mathrm{mi}$. NE of Trap Point on Behm Canal, Coast Mts. ; $55^{\circ} 50^{\prime} 30^{\prime \prime} \mathrm{N}, 130^{\circ}$ $51^{\prime} 00^{\prime \prime}$ W ; (map 3 ).

Local name reported in 1955 by USGS.

King Creek: stream, flows SW $2.7 \mathrm{mi}$. to Wilson Creek, $6.8 \mathrm{mi}$. E of Marshall, Nulato Hills; $61^{\circ} 52^{\prime} 15^{\prime \prime} \mathrm{N}, 161^{\circ} 52^{\prime} 30^{\prime \prime} \mathrm{W}$; (map 73).

Prospectors' name reported by Harrington (1918, map), USGS, in 1916.

King Creek: stream, flows SE $7 \mathrm{mi}$. to North Fork Kuskokwim River, $37 \mathrm{mi}$. NE of Medfra, Kilbuck-Kuskokwim Mts. ; $63^{\circ} 26^{\prime} \mathrm{N}, 153^{\circ} 46^{\prime}$ W; (map 89).

Local name reported in 1958 by USGS.

King Creek: stream, flows NW $3 \mathrm{mi}$. to Tibbs Creek $8 \mathrm{mi}$. S of that stream's junc. with Goodpaster River and $49 \mathrm{mi}$. ENE of Big Delta, Yukon-Tanana High.; $64^{\circ} 20^{\prime} \mathrm{N}$, $144^{\circ} 16^{\prime} \mathrm{W}$; (map 101)

Local name published in 1956 by USGS.

King Creek: stream, flows SW 4 mi. to O'Brien Creek, $29 \mathrm{mi}$. S of Eagle, Yukon-Tanana High.; $64^{\circ} 21^{\prime} 30^{\prime \prime} \mathrm{N}, 141^{\circ} 25^{\prime} 00^{\prime \prime} \mathrm{W}$; (map 102).

Local name published in 1956 by USGS.

King Creek: stream, flows W 4 mi. to West Fork Chena River, $10 \mathrm{mi}$. NNW of Chena Hot Springs and $75 \mathrm{mi}$. SW of Gircle, YukonTanana High.; $65^{\circ} 12^{\prime} \mathrm{N}, 146^{\circ} 06^{\prime} \mathrm{W}$; (map 104).

Prospectors' name reported in 1954 or 1955 by USGS topographers.

King Creek: stream, flows NE $3.5 \mathrm{mi}$. to lake 1 mi. SE of Big Lake, $21 \mathrm{mi}$. W of Chandalar, Brooks Ra.; $67^{\circ} 28^{\prime} 15^{\prime \prime}$ N, $149^{\circ} 17^{\prime} 15^{\prime \prime}$ W; (map 123).

Local name reported in 1956 by T. E. Taylor, USGS.
King Greek: stream, flows SE $3.5 \mathrm{mi}$ to Hammond River, $5 \mathrm{mi}$. NE of Jesse Mtn., and $17 \mathrm{mi}$. N of Wiseman, Brooks Ra.; 67 ${ }^{\circ} 40^{\prime} 30^{\prime \prime}$ N, $150^{\circ} 00^{\prime} 30^{\prime \prime} \mathrm{W}$; BGN 1932; (map 124).

"Local name after Roy King, an early prospector of the region," reported by Robert Marshall in 1932.

Kingegan: village, see Wales.

Kingegan Mission: village, see Wales.

Kingeghee: village, see Wales.

Kinger Creek: stream, flows SW $4 \mathrm{mi}$. to Von Frank Creek, 28 mi. NE of Medfra, KilbuckKuskokwim Mts. ; $63^{\circ} 29^{\prime} \mathrm{N}, 154^{\circ} 23^{\prime} \mathrm{W}$; (map 89).

Local name reported in 1910 by A. G. Maddren (in Brooks and others, 1911, pl. 14), USGS.

Kingfisher Creek: stream, flows E $2 \mathrm{mi}$. to Casco Cove on SE coast of Attu I., Aleutian Is. $52^{\circ} 49^{\prime} 22^{\prime \prime} \mathrm{N}, 173^{\circ} 09^{\prime} 45^{\prime \prime} \mathrm{E}$; (map 13).

Named by the U.S. Army during its occupation of the island during World War II ; shown on an AMS map published in 1948.

Kingfisher Creek: stream, flows SW $1 \mathrm{mi}$. to Nenana River, $1 \mathrm{mi}$. NE of village of McKinley Park, Alaska Ra.; $63^{\circ} 44^{\prime} 24^{\prime \prime} \mathrm{N}, 148^{\circ}$. 53'20" W; BGN 1965; (map 87).

Named in 1965 by the Alaska Dept. of Highways "for the Kingfisher, the family Alcedirvidae, a bird seen in area during the summer months." See Iceworm Gulch.

Kingfisher Point: point of land, $\mathrm{E}$ tip of Igitkin I., Aleutian Is.; $51^{\circ} 59^{\prime} 20^{\prime \prime} \mathrm{N}, 175^{\circ} 48^{\prime} 25^{\prime \prime} \mathrm{W}$ BGN 1936; (map 18)

Name published by the USG\&GS in the 1944 Aleutian Coast Pilot (p. 103); named for one of the ships of the U.S. Navy Aleutian Island, Survey Expedition of 1934

King George the Third Archipelago: islands, of the Alexander Archipelago west of Chatham Strait.

Named by Capt. George Vancouver, RN, about the end of July, 1794, for the King of England (Wagner, 1937, p. 465).

Kinghiak: village, see Naknek.

Kingiak: village, see Naknek.

Kingigamute: village, see Wales.

Kingikturak Bank: bank, at $\mathrm{S}$ end of Kivalina Lagoon, $1.5 \mathrm{mi}$. SE of Kivalina, KotzebueKobuk Low.; $67^{\circ} 43^{\prime} \mathrm{N}, 164^{\circ} 29^{\prime} \mathrm{W}$; (map 128). Var. Keengiktoorak.

Eskimo name meaning "low rise in the ground" reported in 1966 by E. S. Burch.

King Island: village, see Ukivok.

King Island: island, $1,800 \mathrm{ft}$. long, in Glover Bay, on $E$ coast of Prince of Wales I., Alex. Arch.; $55^{\circ} 17^{\prime} 45^{\prime \prime} \mathrm{N}, 132^{\circ} 09^{\prime} 45^{\prime \prime} \mathrm{W}$; (map 4).

Named by local fishermen and reported in 1904 by H. C. Fassett, USBF.

King Island: island, $2 \mathrm{mi}$. across, in Bering Sea, $40 \mathrm{mi}$. W of Cape Douglas and $43 \mathrm{mi}$. S of Cape Prince of Wales, at $W$ end of Seward Penin.; 64 $58^{\prime} \mathrm{N}, 168^{\circ} 05^{\prime} \mathrm{W}$; $B G N$ 1952; (map 111). Var. Kings Island, O-kee-buck, Okiben Island, Oo-ghe-a-book I s l and Oo-ghee-a-book Island, Oooghe-a-book Island, Oukivok Island, Ukivok Island, Ukiwuk Island, Uviuvok Island.
Discovered and named by Capt. Cook (1785, v. 2, p. 442), RN, on August 6, 1778, for Lt. James King, RN, a member of his party. In 1900 the Eskimo name was reported to be "Ukiwuk" by E. W. Nelson, U.S Signal Service. Published as "Ukivok" by Lt. Sarichev (1826, map 4), IRN.

King Lake: lake, $2 \mathrm{mi}$. long, $16 \mathrm{mi}$. S of Point Possession and $29 \mathrm{mi}$. SSW of Anchorage, Cook Inlet Low. ; $60^{\circ} 49^{\prime} \mathrm{N}, 150^{\circ} 20^{\prime} \mathrm{W}$; (map 62).

Local name reported in 1951 by USGS.

Kingmetolik Creek: stream, flows N $26 \mathrm{mi}$. to Shaktoolik River, 14 mi. NE of Christmas Mtn., Nulato Hills; $64^{\circ} 41^{\prime} \mathrm{N}, 160^{\circ} 12^{\prime} \mathrm{W}$; (map 96). Var. Guingmetolik Creek.

Eskimo name reported about 1954 by U.S. Army Corps of Engineers.

King Mountain: mountain, 1,226 ft., $7 \mathrm{mi}$. NE of Nome, Seward Penin. High.; 64 $36^{\prime} \mathrm{N}$, $165^{\circ} 20^{\prime} \mathrm{W}$; (map 94). Var. Anvil Peak, Mount King.

Local name reported in 1899 as "Mt. King" by D. C. Witherspoon (in Schrader and Brooks, 1900, map 2), USGS.

King Mountain: mountain, 1,115 ft., $6 \mathrm{mi}$. NE of Mount Mordaunt and $40 \mathrm{mi}$. NE of Solomon, Seward Penin. High.; 64 $59^{\circ}$ N, $163^{\circ} 33^{\prime}$ W; (map 95)

Local name reported on the 1908 "Map of Seward Peninsula" by Arthur Gibson.

Kingokakthluk Lake: lake, 2 mi. across, at $\mathrm{E}$ end of Askinuk Mts., $\mathrm{E}$ of Kawialik Lake, $16 \mathrm{mi}$. $\mathrm{SE}$ of village of Scammon Bay, YukonKuskokwim Delta ; $61^{\circ} 44^{\prime} 30^{\prime \prime} \mathrm{N}, 165^{\circ} 06^{\prime} 00^{\prime \prime}$ W; (map 75)

Eskimo name obtained at Hooper Bay by USC\&GS in 1951

Kingooahlik Ikpick: bluff, see Kinguaglik Ikpik.

King River: stream, heads in York Mts., flows S $4.5 \mathrm{mi}$. to Bering Sea, $32 \mathrm{mi}$. NW of Teller, Seward Penin. High.; $65^{\circ} 24^{\prime} \mathrm{N}, 167^{\circ} 24^{\prime} \mathrm{W}$; (map 111)

Prospectors' name reported in 1903 by Collier (1904, pl. 2), USGS.

King Salmon: village, pop. 227, on the right bank of Naknek River, on Alaska Penin., 14 mi. SE of Naknek, Bristol Bay Low.; 58 ${ }^{\circ} 41^{\prime}$ $30^{\prime \prime} \mathrm{N}, 156^{\circ} 39^{\prime} 30^{\prime \prime} \mathrm{W}$; (map 41).

The King Salmon post office was established in 1949 at King Salmon Air Force Base.

King Salmon Bay: estuary, $2.7 \mathrm{mi}$. long, on $\mathrm{E}$ coast of Admiralty Is., trending SW from mouth of Salmon River to Seymour Canal, $22 \mathrm{mi}$. SW of Juneau, Alex. Arch.; $58^{\circ} 01^{\prime} \mathrm{N}$, $134^{\circ} 16^{\prime} \mathrm{W}$; BGN 1929; (map 11).

Local name reported in 1929 by USFS.

King Salmon Creek: stream, flows SW $47 \mathrm{mi}$. to Naknek River, on Alaska Penin., $11 \mathrm{mi}$. SE of Naknek, Bristol Bay Low.; 58 $41^{\prime} 15^{\prime \prime} \mathrm{N}$, $156^{\circ} 42^{\prime} 25^{\prime \prime} \mathrm{W}$; (map 41).

Local name reported in 1952 by USGS.

King Salmon Creek: stream, heads in lake, flows $\mathrm{S} 22 \mathrm{mi}$. to Kvichak Bay, $10 \mathrm{mi}$. NW of Naknek, Bristol Bay Low.; 58 $51^{\prime} 40^{\prime \prime} \mathrm{N}$, $157^{\circ} 08^{\prime} 30^{\prime \prime} \mathrm{W}$; (map 41).

Local name reported in 1952 by USGS. 
King Salmon Island: island, 1,900 ft. long, in Egegik River at mouth of King Salmon River, on Alaska Penin., $36 \mathrm{mi}$. SW of Naknek, Bristol Bay Low.; $58^{\circ} 13^{\prime} 45^{\prime \prime} \mathrm{N}, 157^{\circ} 20^{\prime} 05^{\prime \prime} \mathrm{W}$; (map 41).

Local name reported in 1952 by USGS.

King Salmon Lake: lake, see Mother Goose Lake.

King Salmon River: stream, on Alaska Penin., heads in Mother Goose Lake, flows NW 35 mi. to Ugashik River, $7 \mathrm{mi}$. S of Bristol Bay and $8 \mathrm{mi}$. SW of Ugashik, Bristol Bay Low.; $57^{\circ} 30^{\prime} 00^{\prime \prime} \mathrm{N}, 157^{\circ} 39^{\prime} 00^{\prime \prime} \mathrm{W}$; (map 36).

Local descriptive name reported in 1900 by Lt. Comdr. J. F. Moser, USN, of the USBF steamer Albatross.

King Salmon River: stream, on Admiralty I., flowing $E$ and SE $11 \mathrm{mi}$. to King Salmon Bay, $18 \mathrm{mi}$. S of Juneau, Alex. Arch.; 58 $02^{\prime} 30^{\prime \prime}$ $\mathrm{N}, 134^{\circ} 20^{\prime} 30^{\prime \prime} \mathrm{W}$; (map 11).

Local name published in 1951 by USGS.

King Salmon River: stream, formed by confluence of Contact and Takayofo Creeks at SW corner of Katmai National Monument, flows WNW $60 \mathrm{mi}$. to Egegik River, on Alaska Penin., $37 \mathrm{mi}$. SW of Naknek, Bristol Bay Low.; 58 $13^{\prime} 30^{\prime \prime} \mathrm{N}, 157^{\circ} 20^{\prime} 00^{\prime \prime} \mathrm{W}$; (map 41).

Named in 1902 by W. H. Osgood, USDA.

King Salmon River: stream, heads at $60^{\circ} 20^{\prime} \mathrm{N}$, $158^{\circ} 28^{\prime} \mathrm{W}$, flows E $45 \mathrm{mi}$. to Nashagak River, $100 \mathrm{mi}$. S of Sleetmute, KilbuckKuskokwim Mits.; $60^{\circ} 15^{\prime} \mathrm{N}, 157^{\circ} 17^{\prime} \mathrm{W}$; $B G N 1932$; (map 60).

Local name shown on an 1898 fieldsheet by W. S. Post, USGS.

Kings Bay: estuary, on E coast of Kenai Penin., extends NE $12 \mathrm{mi}$. to head of Port Nellie Juan, $18 \mathrm{mi}$. SE of Whittier, Chugach Mts.; $60^{\circ} 33^{\prime} 30^{\prime \prime} \mathrm{N}, 148^{\circ} 27^{\prime} 00^{\prime \prime} \mathrm{W}$; (map 63).

Local name published on recent USGS maps. Probably named for Mr. King who had a cabin at the head of the bay in 1908 .

Kings Bay: estuary, see Nellie Juan, Port.

Kings Cove: bay, see King Cove.

Kings Creek: stream, flows SW $1 \mathrm{mi}$. to Elliott Creek, $1.4 \mathrm{mi}$. NW of Iron Mtn. and $81 \mathrm{mi}$. $\mathrm{NE}$ of Valdez, Wrangell Mts.; $61^{\circ} 38^{\prime} 15^{\prime \prime} \mathrm{N}$, $144^{\circ} 03^{\prime} 50^{\prime \prime} \mathrm{W}$; (map 68).

Prospectors' name reported in 1903 by W. C. Mendenhall, USGS.

Kings Creek: stream, see Kings River.

Kings Glacier: glacier, heads in Sargent Icefield, trends $\mathbf{W} 2.5 \mathrm{mi}$. to its terminus, $2.5 \mathrm{mi}$. E of Kings Bay, $24 \mathrm{mi}$. S of Whittier, Chugach Mts.; $60^{\circ} 26^{\prime} 15^{\prime \prime} \mathrm{N}, 148^{\circ} 38^{\prime} 00^{\prime \prime} \mathrm{W}$; $B G N$ 1911; (map 63).

Named in 1908 by U.S. Grant, USGS for a prospector who lived at the mouth of Kings River.

Kings Island: island, see King Island.

Kings Lake: lake, $1.3 \mathrm{mi}$. long, in Matanuska Valley, $7.2 \mathrm{mi}$. NW of Palmer, Cook Inlet Low.; $61^{\circ} 37^{\prime} 10^{\prime \prime} \mathrm{N}, 149^{\circ} 20^{\prime} 40^{\prime \prime} \mathrm{W}$; (map 69). Var. Fishhook Lake.

Local name reported in 1950 by USGS.

Kingsley Creek: stream, heads SW of Chauik Mtn., flows SW $8.5 \mathrm{mi}$. through Grass Valley to Niukluk River, 5 mi. $S$ of Mount Bendeleben and $43 \mathrm{mi}$. SW of Imuruk Lake, Seward Penin. High.; $65^{\circ} 06^{\prime} \mathrm{N}, 164^{\circ} 02^{\prime} \mathrm{W}$; (map 110). Var. Benson Creek.

Prospectors' name published on the 1908 "Map of Seward Peninsula" by Arthur Gibson.

King Slough: water passage, $5 \mathrm{mi}$. long, from North Arm Stikine River to Dry Strait, between Farm and Dry Is., $11 \mathrm{mi}$. NW of Wrangell, Coast Mts.; $56^{\circ} 38^{\prime} \mathrm{N}, 132^{\circ} 28^{\prime} \mathrm{W}$; (map 6). Var. King Slough.

Local name recorded in 1951 by USGS.

Kingsmill Point: point of land, on NW coast of Kuiu I., $38 \mathrm{mi}$. SE of Sitka, Alex. Arch.; $56^{\circ} 50^{\prime} 00^{\prime \prime} \mathrm{N}, 134^{\circ} 25^{\prime} 10^{\prime \prime} \mathrm{W}$; (map 5).

Named by Capt. George Vancouver, RN, August 1794, "after Vice-Admiral Sir Robert Baker Kingsmill" (Wagner, 1937, p. 393394).

Kings Mountain: mountain, 5,809 $\mathrm{ft}$., on left bank of Matanuska River, $22 \mathrm{mi}$. NE of Palmer, Chugach Mts.; $61^{\circ} 44^{\prime} 55^{\prime \prime} \mathrm{N}, 148^{\circ} 30^{\prime}-$ 30" W ; BCN 1906; (map 69). Var. House Mountain.

Name used by prospectors; reported about 1905 by G. C. Martin, USGS. Named for Al King, a prospector who had a cabin at the junction of the Kings River and the Matanuska River.

King Solomon Creek: stream, flows SE $10 \mathrm{mi}$. to join Liberty Fork to form O'Brien Creek $22 \mathrm{mi}$. S of Eagle, Yukon-Tanana High.; $64^{\circ} 29^{\prime} 30^{\prime \prime} \mathrm{N}, 141^{\circ} 11^{\prime} 15^{\prime \prime} \mathrm{W}$; (map 102).

Prospectors' name obtained in 1898 by E. C. Barnard, USGS.

Kings Point: point of land, on E coast of Kenai Penin., on SE shore of Kings Bay, $22 \mathrm{mi}$. S of Whittier, Chugach Mts.; $60^{\circ} 27^{\prime} 45^{\prime \prime} \mathrm{N}$, $148^{\circ} 39^{\prime} 30^{\prime \prime} \mathrm{W}$; (map 63).

Local name published on recent USGS publications; derived from Kings River.

Kings River: stream, flows SE $10 \mathrm{mi}$. to head of Kings Bay, 23 mi. S of Whittier, Chugach Mts.; $60^{\circ} 27^{\prime} \mathrm{N}, 148^{\circ} 42^{\prime} \mathrm{W}$; $B G N$ 1910; (map 63).

Local name reported in 1908 by U.S. Grant, USGS, "for a prospector who has a cabin at the mouth."

Kings River: stream, flows S $24 \mathrm{mi}$, to Matanuska River, $15 \mathrm{mi}$. NE of Palmer, Chugach Mts.; $61^{\circ} 44^{\prime}$ N, $148^{\circ} 45^{\prime}$ W; (map 69). Var. Kings Creek.

Local name reported by USGS in 1899. Named for Al King, prospector, who had a cabin at the junction of this and the Matanuska River.

Kings Slough: stream, an anabranch of the Yukon River, flows W $5 \mathrm{mi}$., $24 \mathrm{mi}$. NE of Stevens Village, Yukon Flats; $66^{\circ} 12^{\prime} 25^{\prime \prime} \mathrm{N}$, $148^{\circ} 24^{\prime} 30^{\prime \prime} \mathrm{W}$; (map 118). Var. King's Slough.

Probably named by William Yanert who showed it on a 1916 manuscript map of the Yukon Flats (Stuck, 1917, map facing p. 122).

Kings Slough Island: island, $3 \mathrm{mi}$. long, in Yukon River S of Kings Slough, $25 \mathrm{mi}$. NE of Stevens
Village, Yukon Flats; $66^{\circ} 13^{\prime} \mathrm{N}, 148^{\circ} 21^{\prime} \mathrm{W}$; (map 118).

Local name obtained in 1956 by USGS. Kings Slough Village: locality, on $\mathrm{S}$ bank of Yukon River, $26 \mathrm{mi}$. NE of Stevens Village, Yukon Flats; $66^{\circ} 11^{\prime} 30^{\prime \prime} \mathrm{N}, 148^{\circ} 18^{\prime} 00^{\prime \prime} \mathrm{W}$; (map 118). Var. A. E. Co. Camp, Drolette's.

Site of a camp reported in 1956 by T. E. Taylor, USGS; the locality was shown as "A. E. Cio. Camp" in 1905 by L. M. Prindle, USGS.

Kinguaglik Ikpik: bluff, on right bank of Wulik River, 20 mi. NE of Kivalina, Arctic Slope; $67^{\circ} 51^{\prime} \mathrm{N}, 163^{\circ} 53^{\prime} \mathrm{W}$; (map 128). Var. Kingooahlik Ikpick.

Eskimo name meaning "closer riverbank" reported in 1966 by E. S. Burch. See Aziguglik Ikpik.

Kiniaak: village, see Naknek.

Kiniak: village, see Naknek.

Kinia River: stream, heads at Dall Lake, flows SW $30 \mathrm{mi}$. to Etolin Strait, $22 \mathrm{mi}$. S of Nightmute and $105 \mathrm{mi}$. SW of Bethel, Yukon-Kuskokwim Delta; 60 $0^{\circ} 1^{\prime} \mathrm{N}, 164^{\circ} 30^{\prime} \mathrm{W}$; (map 58). Var. Ooksokwak River, Uksukfak River. According to Orth in 1965 the Eskimo name of this stream is "Uksukfak," the same name was reported in 1949 by USC\&GS as "Ooksokwak." The name "Kinia" is unknown locally and appears to be a misapplication by USGS of the name "Kinak," which should be applied to the next large stream fifteen miles south.

Kinicklick: locality, see Kiniklik.

Kinik: village, see Knik.

Kiniklik: locality, $0.5 \mathrm{mi}$. $\mathrm{N}$ of Kiniklik I. and $37 \mathrm{mi}$. NE of Whittier, Chugach Mts.; 60 $50^{\prime}$ $55^{\prime \prime}$ N, $147^{\circ} 37^{\prime} 30^{\prime \prime}$ W; (map 63). Var. Kimklik, Kinicklick.

Eskimo name reported in 1900 by F. C. Schrader, USGS, as "Kinicklick." The village is now abandoned.

Kiniklik Island: island, $0.5 \mathrm{mi}$. across, in Prince William Sound, $36 \mathrm{mi}$. NE of Whittier, Chugach Mts.; $60^{\circ} 50^{\prime} 20^{\prime \prime} \mathrm{N}, 147^{\circ} 37^{\prime} 45^{\prime \prime} \mathrm{W}$; (map 63).

Eskimo name published on recent USGS maps; derived from the now-abandoned native village of Kiniklik on the mainland.

Kinik River: stream, see Knik River.

Kinipaghulghat Mountains: mountains, 1,820 ft., $10 \mathrm{mi}$. across, $8 \mathrm{mi}$. SW of Northeast Cape, St. Lawrence I.; $63^{\circ} 15^{\prime} \mathrm{N}, 168^{\circ} 59^{\prime}$ W; $B G N$ 1951; (map 93). Var. Kanibakhilat, Kanibukhilat Mtn., Kanipakhilat Mtn., Kanipakhilat Mts., Kinepagelgut Mtn., Kinnipaghulghat Mtn., Kinnipaghulghat Mts., Kinnipaghulhat Mts., Kinnypaghulghat Mtn., Mount Kinnipagheelghat.

Eskimo name reported in 1932 by O. W. Geist, Univ. of Alaska.

Kink, The: bend, in North Fork Fortymile River, $40 \mathrm{mi}$. SW of Eagle, Yukon-Tanana High.; $64^{\circ} 23^{\prime} \mathrm{N}, 142^{\circ} 02^{\prime} \mathrm{W}$; (map 102).

Local descriptive name reported in 1903 by T. G. Gerdine, USGS, who defined the feature as a bend in the North Fork Fortymile River. "The ridge forming the neck at its lowest 
point is 100 feet above the stream and the distance across the neck at the base is only 100 feet, while the distance around by stream is 23/4 miles. By blasting a channel through the rock barrier the waters were diverted from their former course and the stream bed was thus laid bare for mining" (Prindle, 1906, p. 25).

Kinkaid, Mount: mountain, 2,556 ft., on W coast of Baranof I., $6.5 \mathrm{mi}$. S of Sitka, Alex. Arch.; $56^{\circ} 57^{\prime} 15^{\prime \prime} \mathrm{N}, 135^{\circ} 19^{\prime} 15^{\prime \prime} \mathrm{W}$; BGN 1940; (map 5). Var. Gora Chetirekh Ugolnoi Piramidoi, Gora Chetyrekh Ugolnoy Piramidoy, Kinkaid Mountain, Pyramid Peak.

Named in 1897 by USC\&GS probably for C. A. Kinkaid, a member of the first council elected at Sitka after the transfer of Alaska to the United States. The descriptive name "G[ora] Chetyrekh Ugolnoy Piramidoy," meaning "mountain of four cornered pyramid," was applied to this feature in 1809 by Ivan Vasiliev the first, IRN, and published by Lt. Sarichev (1826, map 19), IRN.

Kinkaid Creek: stream, flows NE $15 \mathrm{mi}$. to Galena Creek, $35 \mathrm{mi}$. E of Nulato, Koyukuk Low.; $64^{\circ} 39^{\prime} \mathrm{N}, 156^{\circ} 56^{\prime} \mathrm{W}$; (map 97).

Local name reported in 1954 by USGS.

Kinkaid Mountain: mountain, see Kinkaid, Mount.

Kink Creek: stream, flows NE $4 \mathrm{mi}$. to The Kink, $40 \mathrm{mi}$. SW of Eagle, Yukon-Tanana High.; $64^{\circ} 23^{\prime} \mathrm{N}, 142^{\circ} 02^{\prime} \mathrm{W}$; (map 102 ).

Prospectors' name shown on an 1898 manuscript map by C. A. Woodruff, Fort Cudahy, Canada.

Kinky Island: island, $0.3 \mathrm{mi}$. long, $12 \mathrm{mi}$. NW of Chichagof, on W coast of Chichagof I., Alex. Arch.; $57^{\circ} 47^{\prime} 20^{\prime \prime} \mathrm{N}, 136^{\circ} 19^{\prime} 45^{\prime \prime} \mathrm{W}$; (map 9).

Named in 1925 by USC\&GS; published in 1925 Coast Pilot (p. 322).

Kinnick: village, see Knik.

Kinnipagheelghat Mount: mountains, see Kinipaghulghat Mountains.

Kinnipaghulghat Mountain: mountains, see Kinipaghulghat Mountains.

Kinnipaghulghat Mountains: mountains, see Kinipaghulghat Mountains

Kinnipaghulhat Mountains: mountains, see Kinipaghulghat Mountains.

Kinnit, Cape : point of land, see Kineeghit Point.

Kinnitt, Cape: point of land, see Kineeghit Point.

Kinnorutin Creek: stream, flows from Kinnorutin Pass $2.5 \mathrm{mi}$. E. to Hammond River $36 \mathrm{mi}$. N of Wiseman, Brooks Ra.; 67 $55^{\prime} 30^{\prime \prime}$ N, 150'13'00" W; BGN 1932; (map 124).

Marshall (1956, p. 75) wrote, "To commemorate Ernie's and my mistake I gave the name 'Kinnorutin' [Eskimo] (you are crazy) to this pass and creek which flows eastward from it into Hammond River." Their mistake was the misapprehension that a pass between the Clear and Hammond Rivers was actually the Arctic Divide.

Kinnorutin Pass: pass, $\mathrm{S}$ of Amawk Mtn., 3 mi. E of Apoon Mtn. and $36 \mathrm{mi}$. N of Wiseman, Brooks Ra.; $67^{\circ} 55^{\prime} \mathrm{N}, 150^{\circ} 22^{\prime} \mathrm{W}$; (map 124).
In 1931 Allen, Harvey, and Marshall had mistaken this pass for the Arctic Divide. See Kinnorutin Creek.

Kinnypaghulghat Mountain: mountains, see Kinipaghulghát Mountains.

Kinome Creek: stream, flows E to Nome River, about $12 \mathrm{mi}$. NE of Nome, Seward Penin. High.; (map 94).

Prospectors name reported on the 1900 "Map of Nome Peninsula" by J. M. Davidson and B. D. Blakeslee; this feature has not been positively identified.

Kinsell Slough: stream, flows SW $6 \mathrm{mi}$, to Yukon River N of Eagle I., Innoko Low.; $63^{\circ} 38^{\prime} \mathrm{N}$, $159^{\circ} 22^{\prime} \mathrm{W}$; (map 91).

Riverboat pilots' name shown on a 1940 "Navigation Chart of the Tanana-Yukon Rivers" published by the U.S. Dept. of Interior.

Kinshuda Hill: hill, 2,908 $\mathrm{ft}$., on $\mathrm{N}$ bank of Tetlin River, $17 \mathrm{mi}$. SW of Northway, Alaska Ra.; $62^{\circ} 54^{\prime} \mathrm{N}, 142^{\circ} 29^{\prime} \mathrm{W}$; (map 84).

Tetlin Indian name that means "birch hill," reported by USGS in 1962.

Kintanga Bay: bay, $8 \mathrm{mi}$. wide, extends from Kintanga Point to Akoolokok Point, $\mathbf{N}$ coast of St. Lawrence I.; $63^{\circ} 27^{\prime} \mathrm{N}, 169^{\circ} 48^{\prime} \mathrm{W}$; $B G N$ 1951; (map 93).

Eskimo name recommended by the Savoonga village council and reported in 1949 by Maj. H. B. Allen, USAF.

Kintanga Cape: point of land, see Kintanga Point.

Kintanga Point: point of land, $25 \mathrm{mi}$. SE of Savoonga, NE coast of St. Lawrence I.; $63^{\circ} 27^{\prime} \mathrm{N}, 169^{\circ} 54^{\prime} \mathrm{W}$; BGN 1951; (map 93). Var. Cape Kintange, Kintanga Cape.

Eskimo name reported in 1932 by $O$. W. Geist, Univ. of Alaska.

Kintanga Cape: point of land, see Kintanga Point.

Kintrashibuna Lake: lake, $3.5 \mathrm{mi}$. long, $30 \mathrm{mi}$. $\mathrm{NW}$ of Iliamna Volcano and $30 \mathrm{mi}$. NE of Nondalton, Aleutian Ra.; $60^{\circ} 12^{\prime}$ N, 154 03' W; BGN 1910; Var. Brooks Lake, Contlechebna Lake, Kontlalhevena, Kontleehebna Lake, Koonthrashiboona Lake, Kumthrashibuna Lake, Kunthrashiboona Lake, Kunthrashibuna Lake.

Tanaina Indian name reported in 1902 as "Koonthrashiboona" by W. H. Osgood, USDA. Early prospectors called it "Brooks Lake."

Kinuiak: village, see Naknek.

Kinuk Island: island, $3 \mathrm{mi}$. long, at mouth of Noatak River, $8 \mathrm{mi}$. NE of Kotzebue, Kotzebue-Kobuk Low.; $67^{\circ} 01^{\prime} \mathrm{N}, 162^{\circ} 29^{\prime} \mathrm{W}$; (map 128). Var. Kinak Island.

Eskimo name meaning "crazy [angry]" according to USC\&GS in 1950.

Ki-nuk-tu-cha-rok: stream, see Kenakuchuk Creek.

Kinvichavak: stream, see Kvichavak River.

Kinzarof Lagoon: lagoon, $5 \mathrm{mi}$. long, $5 \mathrm{mi}$. NE of village of Cold Bay, at head of Cold Bay, at SW end of Alaska Penin., Bristol Bay Low.; $55^{\circ} 17^{\prime} \mathrm{N}, 162^{\circ} 37^{\prime} \mathrm{W}$; (map 29).

Name reported by USC\&GS in 1925.
Kioiix Hill: hill, see Kiolik Hill.

Kiokhduli Hill: hill, see Kikdooli Butte.

Kiokluk Creek: stream, flows N $10 \mathrm{mi}$. to Chineekluk Creek $3.1 \mathrm{mi}$. E of its junc. with Holokuk River, $40 \mathrm{mi}$. SW of Sleetmute and $47 \mathrm{mi}$. SE of Anaik, Kilbuck-Kuskokwim Mts.; $61^{\circ} 22^{\prime} \mathrm{N}, 158^{\circ} 12^{\prime} \mathrm{W}$; BGN 1948; (map 72).

Eskimo name taken from mountains in which stream rises; reported in 1945 by USGS.

Kiokluk Mountains: range, 3,500 ft., in Kuskokwim Mts., SW of Chuilnuk Mts., extends EW $15 \mathrm{mi} \mathrm{E}$ of Holokuk River, $40 \mathrm{mi}$. SW of Sleetmute, Kilbuck-Kuskokwim Mts.; $61^{\circ}$. $15^{\prime} \mathrm{N}, 158^{\circ} 09^{\prime} \mathrm{W}$; BGN 1948; (map 72).

Eskimo name said to mean "rocky mountains"; reported in 1945 by USGS.

Kiolemik River: stream, see Kisaralik River.

Kiolemuk River: stream, see Kasigluk River.

Kioleralik River: stream, see Kisaralik River.

Kiolerulik River: stream, see Kisaralik River.

Kiolikh Hill: hill, see Kiolik Hill.

Kiolik Hill: hill, $425 \mathrm{ft}$., $5 \mathrm{mi}$. SW of Iookswarat Bay and $15 \mathrm{mi}$. SW of Cape Etolin, on $\mathrm{N}$ part of Nunivak I.; $60^{\circ} 17^{\prime} 30^{\prime \prime} \mathrm{N}, 166^{\circ} 29^{\prime} 45^{\prime \prime} \mathrm{W}$; (map 57). Var. Kiolikh Hill, Kiolix Hill.

Eskimo name meaning "rocky top," according to UCS\&GS in 1949.

Kiougilakh: point of land, see Kiugilak, Cape. Kiowa, Lake: lake, $800 \mathrm{ft}$. long, at mouth of Fossil Creek, $9.2 \mathrm{mi} \mathrm{NE}$ of Anchorage, Cook Inlet Low.; $61^{\circ} 17^{\prime} 54^{\prime \prime} \mathrm{N}, 149^{\circ} 40^{\prime} 10^{\prime \prime} \mathrm{W}$; (map 69).

Local name reported in 1952 by USGS.

Kioxdooly Butte: hill, see Kikdooli Butte.

Kipaiaag: ridge, see Kipaiak Ridge.

Kipaiak Ridge: ridge, trends NE $7 \mathrm{mi}$. from head of Kivalina River, $6 \mathrm{mi}$. E of Spiny Ridge and $48 \mathrm{mi}$. SE of Cape Sabine, Brooks Ra.; $68^{\circ} 18^{\prime} \mathrm{N}, 163^{\circ} 43^{\prime} \mathrm{W}$; (map 130). Var. Kipaiaag, Kipayahk.

Eskimo name reported in 1966 by E. S. Burch.

Kipayahk : ridge, see Kipaiak Ridge.

Kipchuk River: stream, flows N $60 \mathrm{mi}$. to Aniak River $38 \mathrm{mi}$. SE of Aniak, Kilbuck-Kuskokwim Mts. ; $61^{\circ} 03^{\prime} \mathrm{N}, 159^{\circ} 10^{\prime} \mathrm{W}$; (map 73). Var. Kiptsak River.

Eskimo name published as "Kiptsak River" on a 1912 manuscript map of the Kuskokwim Gold Belt by H. W. Reeth. It is reported to mean "little twisting one."

Kipisatkak River: stream, see Epizetka River. Kipisatkuk River: stream, see Epizetka River.

Kipmik, Lake: lake, $2 \mathrm{mi}$. long, drains $\mathrm{NW}$ into Lake Amitchiak, $26 \mathrm{mi}$. SE of Howard Pass, Brooks Ra.; $67^{\circ} 57^{\prime} \mathrm{N}, 156^{\circ} 09^{\prime} \mathrm{W}$; (map 126).

Eskimo name meaning "heel," reported by Orth in 1956.

Kip-nai-ak : stream, see Black River.

Kip-nee-yog-ok River: stream, see Kipniyagok River.

Kipniaguk : stream, see Black River.

Kipniak: settlement, see Black.

Kipniarak River: stream, distributary of Kipimgolak, flows NW $8 \mathrm{mi}$. to Black River, $42 \mathrm{mi}$. E of Scammon Bay, Yukon-Kuskokwim Delta; $61^{\circ} 58^{\prime} 45^{\prime \prime} \mathrm{N}, 164^{\circ} 19^{\prime} 00^{\prime \prime} \mathrm{W}$; (map 74). 
Eskimo name reported by USC\&GS in 1951. Kipniuk : settlement, see Black.

Kipniuk : stream, see Black River.

Kipniyagok River: stream, heads in lake, flows N 15 mi. to Black River at Black, YukonKuskokwim Delta; $62^{\circ} 20^{\prime} \mathrm{N}, 165^{\circ} 20^{\prime} \mathrm{W}$; (map 76). Var. Kip-nee-yog-ok River, Kripniyagok River.

Eskimo name meaning "little Kipnaiak"; reported by G. R. Putnam, USC\&GS, in 1899, as "Kripniyagok." The Black River is known in Eskimo as "Kipnaiak."

Kipnuk: village, pop. 221, on left bank of Kuguklik River, 4 mi. SE from Kinak Bay, $68 \mathrm{mi}$. W of Quinhagak, Yukon-Kuskokwim Delta; 59 $56^{\prime} \mathrm{N}, 164^{\circ} 03^{\prime} \mathrm{W}$; $B G N$ 1937; (map 54).

Eskimo name of a village reported in 1937 by the BIA. "This name has been in use 15 years." Its population was 144 in 1940 and 185 in 1950.

Kipnuktuli Creek: stream, flows S $12 \mathrm{mi}$. to Togiak River, $72 \mathrm{mi}$. NE of Goodnews, Kil-

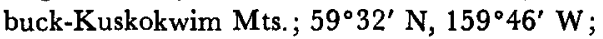
(map 53).

Eskimo name published in 1951 by USGS.

Kiptsak River: stream, see Kipchuk River.

Kipunaiak: stream, see Black River.

Kipunayak, Protoka: stream, see Black River.

Kipungolak River: stream, heads in lake at $61^{\circ} 57^{\prime} \mathrm{N}, 163^{\circ} 26^{\prime} \mathrm{W}$, flows W 80 mi. to Black River, $37 \mathrm{mi}$. E of Scammon Bay, YukonKuskokwim Delta; $61^{\circ} 59^{\prime} \mathrm{N}, 164^{\circ} 21^{\prime} \mathrm{W}$; (map 74).

Eskimo name reported by USG\&GS in 1951. Kirbas, Ostrov: island, see Kirbas Island.

Kirbas Island: island, $0.8 \mathrm{mi}$. long, $1.5 \mathrm{mi}$. SW of Goodard, in Necker Is., on W coast of Baranof I., Alex. Arch.; 56 $48^{\prime} 15^{\prime \prime} \mathrm{N}, 135^{\circ}$ 24'40" W; (map 5). Var. Ostrov Kirbas.

Named in 1809 by the Russian navigator, Ivan Vasiliev the first; published by Lt. Sarichev (1826, map 19), IRN, as "O[strov] Kirbas," or "Kirbas Island."

Kirilof Bay: bight, $2.2 \mathrm{mi}$. wide, $1 \mathrm{mi}$. NW of Constantine Harbor, on Bering Sea coast of Amchitka I., Rat Is., Aleutian Is.; $51^{\circ} 25^{\prime} 15^{\prime \prime}$ N, $179^{\circ} 15^{\prime} 00^{\prime \prime} \mathrm{E}$; BGN 1937; (map 15). Var. Kirilovskaia, Kirloff Bay.

Russian name given by the navigator Ingenstrem in 1830 . Capt. Lutke (1836, p. 324), IRN, called it "Kirilovskaia," as did Capt. Tebenkov (1852, map 30), IRN.

Kirilof Point: point of land, on NW side of Constantine Harbor, SE part of Amchitka I., Rat Is., Aleutian Is.; $51^{\circ} 25^{\prime} 15^{\prime \prime} \mathrm{N}, 179^{\circ}$ 17'50" E; BGN 1937; (map 15).

Named by personnel of U.S.S. Oglala of U.S. Navy Survey Expedition 1935; derived from Kirilof Bay.

Kirilovskaia : bight, see Kirilof Bay.

Kirinskaia Bay: stream, see Sawmill Creek

Kirinskaya Bukhta: stream, see Sawmill Creek.

Kiriushkin Island: island, see Kirushkin Island.

Kirk Creek: stream, flows NE $9 \mathrm{mi}$. to Minnehaha Creek, $6 \mathrm{mi}$. N of Candle, KotzebueKobuk Low.; $66^{\circ} 01^{\prime} \mathrm{N}, 161^{\circ} 56^{\prime} \mathrm{W}$; (map 114).
Prospectors' name reported in 1903 by D. C. Witherspoon, USGS.

Kirk Point: point of land, extends $\mathrm{S}$ between Foggy Bay and Revillagigedo Channel, Alex. Arch; $54^{\circ} 59^{\prime} 35^{\prime \prime} \mathrm{N}, 131^{\circ} 00^{\prime} 25^{\prime \prime} \mathrm{W}$; (map 2). Named in 1883 by Lt. Comdr. Nichols, USN

Kirloff Bay: bight, see Kirilof Bay.

Kirschner Lake: lake, $1 \mathrm{mi}$. across, $5 \mathrm{mi}$. E of Big Hill and $18 \mathrm{mi}$. W of Augustine I. Aleutian Ra.; $59^{\circ} 25^{\prime} 30^{\prime \prime} \mathrm{N}, 153^{\circ} 55^{\prime} 00^{\prime \prime} \mathrm{W}$; (map 51).

Name published in 1952 by USGS.

Kiruilak River: stream, see Kigalik River.

Kiruktagiak River: stream, flows NE $40 \mathrm{mi}$. to Chandler River at Tuktu Bluff, $45 \mathrm{mi}$. NW of Anaktuvuk Pass, Arctic Slope; 68 $44^{\prime} 15^{\prime \prime}$ N, $152^{\circ} 20^{\prime} 00^{\prime \prime} \mathrm{W}$; BGN 1949; (map 134).

Eskimo name used by USGS geologists during the exploration of Naval Petroleum Reserve No. 4; name given in 1944.

Kirushkin Island: island, $0.2 \mathrm{mi}$. across, connected to Japonski I., $1.8 \mathrm{mi}$. SW of Sitka, Alex. Arch.; $57^{\circ} 02^{\prime} 40^{\prime \prime} \mathrm{N}, 135^{\circ} 23^{\prime} 00^{\prime \prime} \mathrm{W}$; (map 9). Var. Kiriushkin Island, Ostrov Kiryushkin.

Named in 1809 by the Russian navigator Ivan Vasiliev the first; published by Lt. Sarichev (1826, map 19), IRN, as "O[strov] Kiryushkin," meaning "smelt island."

Kiryarzark River: stream, see Kigezruk Creek. Kiryushkin, Ostrov: island, see Kirushkin Island.

Kisaralik River: stream, heads at $60^{\circ} 11^{\prime} \mathrm{N}$, $159^{\circ} 25^{\prime} \mathrm{W}$, flows NW $100 \mathrm{mi}$. to Kuskokuak Slough, $20 \mathrm{mi}$. NE of Bethel, YukonKuskokwim Delta; $60^{\circ} 51^{\prime} 30^{\prime \prime}$ N., $161^{\circ} 14^{\prime} 00^{\prime \prime}$ W; BGN 1949; (map 59). Var. Kilakalik Kiolemik River, Kioleralik River, Kiolerulik River, Kiselalik River, Kiseralik, Kiserolik River.

Eskimo name reported in 1914 as "Kiselalik" by P. S. Smith (in Brooks, 1915, pl. 10).

Kisaymaruktuk Mountain: hills, $9 \mathrm{mi} . \mathrm{N}$ of Kivalina, Arctic Slope; $67^{\circ} 51^{\prime} \mathrm{N}, 164^{\circ} 34^{\prime} \mathrm{W}$ (map 128). Var. Keesaymaeruktuk Mountain, Seevoochyam Igaylungee, Siwutsiam Irialuni.

Eskimo name reported as "Keesaymaeruktuk Mountain" in 1960 by D. C. Foote; E. S. Burch reported the name "Seevoochyam Igaylungee" in 1966.

Kiselalik River: stream, see Kisaralik River.

Kiseralik: stream, see Kisaralik River.

Kiserolik River: stream, see Kisaralik River.

Kishbrock Island: island, $0.2 \mathrm{mi}$. across, off $\mathrm{E}$ shore of Favorite Channel, $0.3 \mathrm{mi}$. W of Dotsons Landing and $19 \mathrm{mi}$. NW of Juneau, Coast Mts.; $58^{\circ} 29^{\prime} 30^{\prime \prime} \mathrm{N}, 1^{\circ} 34^{\circ} 47^{\prime} 30^{\prime \prime} \mathrm{W}$; (map 11)

Local name published in 1962 by USGS.

Kishka Island: island, see Kiska Island.

Kishnak, Mys: point of land, see Seal Cape.

Kisimalok Mountain: hill, see Kisimilok Mountain

Kisimaloq Creek: stream, see Kisimilok Creek. Kisimeegyuktuk: hill, see Kisimigiuktuk Hill.
Kisimeelahm Koogowranga: stream, see Kisimilat Greek.

Kisimeelahm Koonga: stream, see Kisimilok Creek.

Kisimigiuktuk Hill: hill, $460 \mathrm{ft}$., S of Kivalina River, $7 \mathrm{mi}$. NE of Kivalina, Arctic Slope; $67^{\circ} 48^{\prime} \mathrm{N}, 164^{\circ} 23^{\prime} \mathrm{W}$; (map 128). Var. Kisimeegyuktuk, Kisimigiuqtuq, Keesaymalott Mountain.

Eskimo name meaning "stands alone" reported in 1960 as "Keesaymalott" by D. C. Foote.

Kisimigiuqtuk : hill, see Kisimigiuktuk Hill.

Kisimilaan Kuugauzanga: stream, see Kisimilat Creek.

Kisimilaat: mountain, see Kisimilot Mountains. Kisimilat Greek: stream, flows NW $6 \mathrm{mi}$. to Kivalina River, $20 \mathrm{mi}$. NE of Kivalina, Arctic Slope; 67 $58^{\prime} \mathrm{N}, 164^{\circ} 12^{\prime} \mathrm{W}$; (map 128). Var. Kisimeelahm Koogowranga, Kisimilaan Kuugauzanga.

Eskimo name reported in 1966 by E. S. Burch.

Kisimilok Creek: stream, heads on Sigrikpak Ridge, flows S $7 \mathrm{mi}$. to Chukchi Sea, $14 \mathrm{mi}$. SE of Cape Thompson, Arctic Slope; $68^{\circ} 03^{\prime}$ $35^{\prime \prime} \mathrm{N}, 165^{\circ} 29^{\prime} 25^{\prime \prime} \mathrm{W}$; BGN 1963; (map 129). Var. Joe Ferrerra's River, Keeseemalouk Creek, Keeseemalowk Creek, Kismaloq Creek, Kisimeelahm Koonga, Kisimiloq Creek, Kisimulowk Creek.

Eskimo name reported in 1950 by USC\&GS as "Kisimulowk", meaning "poke (bag)."

Kisimilok Mountain: hill, $585 \mathrm{ft}$., on Chukchi Sea coast, $15 \mathrm{mi}$. SE of Cape Thompson, Arctic Slope; $68^{\circ} 03^{\prime} 28^{\prime \prime} \mathrm{N}, 165^{\circ} 26^{\prime} 00^{\prime \prime} \mathrm{W}$; $B G N$ 1963; (map 129). Var. Gisamaluk Mountain, Keesemalouk Mountain, Keeseemalowk Mountain, Kisimalok Mountain, Kisimiloq Mountain.

Eskimo name meaning "stands alone"; reported in 1950 by USC\&GS.

Kisimiloq Creek: stream, see Kisimilok Creek.

Kisimiloq Mountain: hill, see Kisimilok Mountain.

Kisimilot Mountains: mountains, E of Kivalina River, $9 \mathrm{mi}$. NE of Kivalina, Arctic Slope; $67^{\circ} 56^{\prime}$ N, $164^{\circ} 02^{\prime}$ W; (map 128). Var. Keesaymalott Mountains, Kisimilaat, Kisseemeelaht.

Eskimo name meaning "stands alone" reported in 1960 as "Keesaymalott Mountains" by D. C. Foote; so called because Mount Jarvis and the hills surrounding it stand as a group.

Kisimulowk Creek: stream, see Kisimilok Creek. Kisin: hill, see Kessin Peak.

Kiska Harbor: bay, $1.5 \mathrm{mi}$. across, on E coast of Kiska I., Aleutian Is.; $51^{\circ} 58^{\prime} \mathrm{N}, 177^{\circ} 34^{\prime}$ E; BGN 1937; (map 14). Var. Kyska Harbor.

Named for Kiska Island. According to 1944 Aleutian Coast Pilot (p. 6), this is one of five sheltered harbors in the Aleutian Islands.

Kiska Island: island, $24 \mathrm{mi}$. long, one of Rat Is., Aleutian Is.; $51^{\circ} 58^{\prime} 30^{\prime \prime} \mathrm{N}, 1^{\circ} 7^{\circ} 30^{\prime} 00^{\prime \prime} \mathrm{E}$; $B G N$ 1890; (map 14). Var. Grand Kiska 
Island, Kiksa Island, Great Kysa Island, Küska, Kishka Island, Kyska, Big Kiska Island, Keeska Island, Saint Stephen, Saint Markiana, Saint Makarius.

Aleut name used by the early Russians. Baker (1906, p. 368), USGS, cites W. H. Dall, USC\&GS, as giving the meaning as "gut," but Geoghegan (1944, p. 144) gives the word "angig" with that meaning. Golder (1922, p. 199) identifies Kiska with the island seen by Vitus Bering on October 25, 1741 (O.S.), and named by him "St. Markiana (St. Makarius)." See Amchitka Island. Others have correlated Kiska with Bering's "St. Stephen." See Buldir Island.

Kiska Pass: water passage, see South Pass.

Kiska Volcano: volcano, 3,996 ft., at $\mathrm{N}$ end of Kiska I., Aleutian Is.; $52^{\circ} 06^{\prime} 35^{\prime \prime} \mathrm{N}, 177^{\circ}$ $36^{\prime 25}$ " E ; BGN 1937; (map 14).

Named after Kiska Island and published in 1943 on a USAAF map.

Kislorut Hills: hills, see Kislowrut Hills.

Kislowrut Hills: hills, in Igichuk Hills on E slope of Ingitkalik Mtn., $8 \mathrm{mi}$. E of Cape Krusenstern, Arctic Slope; $67^{\circ} 10^{\prime} \mathrm{N}, 1^{\circ} 3^{\circ} 27^{\prime} \mathrm{W}$; (map 128). Var. Kislorut Hills.

Eskimo name meaning "no cover" according to USC\&GS in 1950 . So called because these low hills are bare of trees.

Kismaliuk Bay: bay, $1.2 \mathrm{mi}$. across, SW coast of Unalaska I., Aleutian Is.; $53^{\circ} 27^{\prime} 30^{\prime \prime} \mathrm{N}$, $167^{\circ} 18^{\prime} 30^{\prime \prime} \mathrm{W}$; BGN 1938: (map 23). Var. Alimuda Bay, Middle Bay, Zaliv Kismalyuk. Aleut name reported by Lt. Sarichev (1826, map 14), IRN, as "Zal[iv] Kismalyuk," or "Kismalyuk Bay." Baker (1906, p. 93) called this feature "Alimuda Bay."

Kismalyuk, Zaliv: $b a y$, see Kismaliuk Bay.

Kissaiak: locality, on right bank of Togiak River, $9 \mathrm{mi}$. ENE of Kashiagamiut and $66 \mathrm{mi}$. NE of Goodnews, Kilbuck-Kuskokwim Mts.; $59^{\circ}$ $25^{\prime} \mathrm{N}, 159^{\circ} 50^{\prime} \mathrm{W}$; (map 53 ).

Eskimo village or camp reported by Ivan Petroff in the 10th Census in 1880. The place is no longer occupied.

Kissaiakh : locality, see Kashiagamiut.

Kisseemeelaht: mountains, see Kisimilot Mountains.

Kisselen Bay: bay, $0.8 \mathrm{mi}$. across, part of Beaver Inlet, on E coast of Unalaska I., Aleutian Is. ; $53^{\circ} 42^{\prime} 20^{\prime \prime} \mathrm{N}, 166^{\circ} 34^{\prime} 00^{\prime \prime} \mathrm{W} ; B G N$ 1904; (map 23). Var. Kissialiak Bay, Warsham Bay, Worsham Bay.

Aleut name reported by Lt. Sarichev (1826, map 14), IRN, as "Z[aliv],,Kisselen," or "Kisselen Bay," and by Father Veniaminov (1840, v. 1, p. 162) as "Kissyalyak." It was called "Worsham Bay" by USBF in 1888.

Kiss Hill: hill, 1,000 ft., on west-central Kiska I., Aleutian Is.; $51^{\circ} 56^{\prime} 22^{\prime \prime} \mathrm{N}, 177^{\circ} 22^{\prime} 00^{\prime \prime} \mathrm{E}$; (map 14).

An arbitrary name beginning with " $\mathrm{K}$ " to correspond to the " $K$ " grid used by the U.S. Army for tactical purposes during World War II; published on a 1953 AMS map.

Kissialiak Bay: bay, see Kisselen Bay.

Kissiah: locality, see Kashiagamiut.

Kissiak: locality, see Kashiagamiut.
Kisuk Creek: stream, flows NW to Kuzitrin River near its head, about $16 \mathrm{mi}$. SW of Imuruk Lake, Seward Penin. High.; (map 110).

Prospectors' name reported on a precinct map of Seward Peninsula by Monroe and Hutchins; corrected to June 1903 by Arthur Gibson. This stream cannot be precisely located on current maps.

Kiswitno: stream, see Kashwitna River.

Kita, Ostrov: island, see Kita Island.

Kitagutak: island, see Ukolnoi Island.

Kita Island: island, $0.3 \mathrm{mi}$. across, at mouth of Redoubt Bay, $9 \mathrm{mi}$. SW of Sitka, off W coast of Baranof I., Alex. Arch.; 56 55'15' N, $135^{\circ} 26^{\prime} 00^{\prime \prime} \mathrm{W}$; (map 5). Var. Ostrov Kita.

Named in 1809 by the Russian navigator, Ivan Vasiliev the first; published by $\mathrm{Lt}$. Sarichev (1826, map 19), IRN, as "O[strov] Kita," meaning "whale island."

Kitak: locality, "on Agattu I. in the Near Is.," Aleutian Is. ; (map 13)

Former Aleut village reported as "uninhabited" by Hodge (1907, p. 705), BAE.

Kitalga Island: island, see Chuginadak Island.

Kitalitna Creek: stream, flows NW $17 \mathrm{mi}$. to Grikhdalitna Greek, $1 \mathrm{mi}$. S of that stream's mouth and $16 \mathrm{mi}$ NNE of Hochandochtla Mtn., Kokrines-Hodzana High.; $65^{\circ} 45^{\prime} 20^{\prime \prime} \mathrm{N}$, $154^{\circ} 44^{\prime} 20^{\prime \prime} \mathrm{W}$; (map 107).

Koyukan Indian name obtained at Huslia in 1956 by Orth.

Kitavie Rock: rock, on top of bluff at Whale Point, SE Saint Paul I., in Pribilof Is.; 57 ${ }^{\circ}$ $07^{\prime} 30^{\prime \prime} \mathrm{N}, 170^{\circ} 15^{\prime} 20^{\prime \prime} \mathrm{W}$; (map 38).

A name reported by Elliott (1881, p. 53). See Whale Point and Kitovi Rookery.

Kitchen, The: lagoon, $0.4 \mathrm{mi}$. across, part of Caton Cove, in Sanborn Harbor, Nagai I., in Shumagin Is., Aleutian Ra.; $55^{\circ} 09^{\prime} 15^{\prime \prime} \mathrm{N}$, $159^{\circ} 59^{\prime} 45^{\prime \prime}$ W; (map 27). Var. Kitchen Anchorage, Woolly Harbor.

Named "Kitchen Anchorage" in 1888 by USBF; published as "The Kitchen" in the 1947 Coast Pilot (v. 2, p. 317).

Kitchen Anchorage: cove, $0.7 \mathrm{mi}$. across, on $\mathrm{E}$ side of Belkofski Bay, $24 \mathrm{mi}$. SE of village of Cold Bay, at SW end of Alaska Penin., Aleutian Ra.; $55^{\circ} 07^{\prime} 40^{\prime \prime}$ N, $162^{\circ} 07^{\prime} 00^{\prime \prime}$ W; (map 29). Var. Kitchen Harbor.

Name reported by USBF in 1888.

Kitchen Anchorage: lagoon, see Kitchen, The. Kitchen Harbor: cove, see Kitchen Anchorage. Kitchikan: city, see Ketchikan.

Kitchlekot: rocks, see Kitleekot Rocks.

Kiteerahm: hills, see Kitiram Ipitanga Hills.

Kite Island: island, $0.1 \mathrm{mi}$. across, in Boca de Quadra, $0.5 \mathrm{mi}$. SW of Porpoise Point, Coast Mts. ; $55^{\circ} 05^{\prime} 20^{\prime \prime} \mathrm{N}, 130^{\circ} 46^{\prime} 55^{\prime \prime} \mathrm{W}$; (map 3).

One of many arbitrary names applied to features in this area in 1891 by USC\&GS.

Kithlevik Slough: stream, see Keoklevik River. Kitilnguk: $b a y$, see Kittilngook Bay.

Kitingirak Gap: watergap, along Kivalina River, traverses Kitiram Ipitanga Hills, $17 \mathrm{mi}$. NE of Kivalina, Arctic Slope; $67^{\circ} 57^{\prime} \mathrm{N}, 164^{\circ} 12^{\prime}$ W; (map 128). Var. Kitingirock, Kitingizaaq.
Eskimo name meaning "old skin scraper" reported in 1966 by E. S. Burch.

Kitingirock: watergap, see Kitingirak Gap.

Kitingizaaq : watergap, see Kitingirak Gap.

Kitiram Ipitanga Hills: hill, trends SW $8 \mathrm{mi}$. from Kivalina River, $15 \mathrm{mi}$. NE of Kivalina, Arctic Slope; $67^{\circ} 55^{\prime} \mathrm{N}, 164^{\circ} 24^{\prime} \mathrm{W}$; (map 128). Var. Ipeetahnga, Kiteerahm, Kitizaam Ipiitaana.

Eskimo name reported as "kiteerahm Ipeetahnga" in 1966 by E. S. Burch.

Kit Island: island, extends E-W $1.8 \mathrm{mi}$. in Yukon River, $0.2 \mathrm{mi}$. N of Dasha I. and $20 \mathrm{mi}$. NE of Ruby, Nowitna Low.; $64^{\circ} 54^{\prime} \mathrm{N}, 154^{\circ}$ $56^{\prime}$ W; (map 98).

Riverboat pilots' name shown on 1940 "Navigation Chart, Tanana-Yukon Rivers" of the River Boat Service, U.S. Dept. of Interior. Kitizaam Ipiitaana: hills, see Kitiram Ipitanga Hills.

Kitkhuk, Cape: promontory, see Scotch Cap.

Kitkonak Hill: hill, $932 \mathrm{ft}$., $8 \mathrm{mi}$. long, $20 \mathrm{mi}$. E of Cape Lisburne, Arctic Slope; $68^{\circ} 49^{\prime} \mathrm{N}$, $165^{\circ} 17^{\prime} \mathrm{W}$; (map 129). Var. Kaetkunax Mountain, Kitkonuk Hill.

Eskimo name meaning "between [sea and land]" reported in 1956 by Orth.

Kitkonuk Creek: stream, see Nigiktlik Creek. Kitkonuk Hill: hill, see Kitkonak Hill.

Kitkoon Bay: lagoon, see Kitkun Bay.

Kitkuk, Cape; promontory, see Scotch Cap.

Kitkun Bay: lagoon, $4 \mathrm{mi}$. long, $1.5 \mathrm{mi}$. S of Cholmondeley Sound, on SE coast of Prince of Wales I., Alex. Arch; 55 $11^{\prime} \mathrm{N}, 132^{\circ} 09^{\prime}$ W; (map 4). Var. Kitkoon Bay.

Indian name reported in 1901 by $\mathrm{A}$. $\mathrm{H}$. Brooks, USGS.

Kit Lake: lake, $0.3 \mathrm{mi}$. long, on Kenai Penin., $0.8 \mathrm{mi}$. SW of Quill Lake, $20 \mathrm{mi}$. NE of Kenai, Cook Inlet Low.; $60^{\circ} 44^{\prime} 50^{\prime \prime} \mathrm{N}$, $150^{\circ} 46^{\prime} 00^{\prime \prime} \mathrm{W}$; (map 62).

Named about 1963 by officials of Kenai National Moose Range, for administrative purposes.

Kitleekot Rocks: rocks, $0.5 \mathrm{mi}$. N of Kookoolik Cape, 4 mi. E of Savoonga, St. Lawrence I.; $63^{\circ} 42^{\prime} \mathrm{N}, 170^{\circ} 21^{\prime} \mathrm{W}$; BGN 1951; (map 93). Var. Kitchlekot, Kukulik Mound, Seal Rocks.

Eskimo name recommended by the Savoonga village council and reported in 1949 by Maj. H. B. Allen, USAF.

Kitlik River: stream, in Baird Mts., flows SE $21 \mathrm{mi}$. to Salmon River $8 \mathrm{mi}$. NW of its junc. with Kobuk River, $28 \mathrm{mi}$. NE of Kiana, Brooks Ra. $67^{\circ} 14^{\prime} \mathrm{N}, 159^{\circ} 40^{\prime} \mathrm{W}$; (map 127).

Eskimo name obtained in 1955 by U.S. Army Corps of Engineers.

Kitluk River: stream, on Seward Penin., heads at Devil Mountain Lakes, fows NE $15 \mathrm{mi}$. to Chukchi Sea, $58 \mathrm{mi}$. NW of Deering, Kotzebue-Kobuk Low.; $66^{\circ} 35^{\prime}$ N. $164^{\circ} 23^{\prime}$ W; (map 113).

Eskimo name obtained in 1950 by USGS.

Kitnagak Bay: bay, 2 mi. wide, between Kitnagak and Seevoo Points, $\mathrm{N}$ coast of St. Lawrence I.; $63^{\circ} 20^{\prime} \mathrm{N}, 168^{\circ} 54^{\prime} \mathrm{W}$; $B G N$ 1951; (map 93). Var. Kittnighak, Kittnighnak Bay. 
Eskimo name recommended by the Gambell village council and reported in 1949 by Maj. H. B. Allen, USAF.

Kitnagak Point: point of land, $8 \mathrm{mi}$. WNW of Northeast Cape, $\mathrm{N}$ coast of St. Lawrence I.; $63^{\circ} 20^{\prime} \mathrm{N}, 168^{\circ} 56^{\prime} \mathrm{W}$; BGN 1951; (map 93).

Var. Kittnighhak Cape.

Eskimo name reported in 1932 by O. W. Geist, Univ. of Alaska.

Kitnepaluk: locality, $20 \mathrm{mi}$. S of Gambell, on. W coast of Saint Lawrence I.; $63^{\circ} 33^{\prime}$ N, $171^{\circ} 50^{\prime}$ W; (map 93). Var. Kitngeepalok, Okilerit. (map 93).

According to Orth, in 1965, the Eskimo apply the name "Kitnepaluk" to an area around Savukahuk Point which now is a coastal camp, and the site of an old village. The Eskimo call the place described above "Okilerit."

Kitnepaluk Creek: stream, flows NW $3 \mathrm{mi}$. to Bering Sea, $0.2 \mathrm{mi}$. E of Savukahuk Point and $14 \mathrm{mi}$. S of Gambell, St. Lawrence I.; $63^{\circ} 35^{\prime}$ N, $171^{\circ} 49^{\prime}$ W; BGN 1951; (map 93). Var. Ketngepaluk $R$ iver, Kitnepaluk River, Kitngeepalok.

This stream borrows its name from a camping place at its mouth. The name was shown on an annotated map made by Lawrence Kulukhan, of Gambell, in 1944.

Kitnepaluk River: stream, see Kitnepaluk Creek. Kitngeepalok: locality, see Kitnepaluk.

Kitngeepalok: stream, see Kitnepaluk Greek.

Kitnik, Gape: point of land, $17 \mathrm{mi}$. SE of Savoonga, NE coast of St. Lawrence I.; $63^{\circ} 33^{\prime} \mathrm{N}, 170^{\circ} 03^{\prime} \mathrm{W}$; (map 93). Var. Cape Kittnik.

Eskimo name reported by USC\&GS in 1925 .

Kitnik Mountain: mountain, 1,133 ft., on Nelson I., $3 \mathrm{mi}$. SE of Cape Vancouver, YukonKuskokwim Delta; $60^{\circ} 31^{\prime} \mathrm{N}, 165^{\circ} 21^{\prime} \mathrm{W}$; (map 57).

Eskimo descriptive name meaning "heel" obtained at Tanunak in 1951 by USC\&GS.

Kitnik River: stream, heads at Atuk Mtn., flows $\mathrm{N} 6 \mathrm{mi}$. to Bering Sea $2 \mathrm{mi}$. SE of Savoonga, St. Lawrence I.; $63^{\circ} 41^{\prime} \mathrm{N}, 170^{\circ} 24^{\prime} \mathrm{W}$; BGN 1951; (map 93). Var. Ketnik River, Kittnik River.

Eskimo name recommended by the Savoonga village council and reported in 1949 by Maj. H. B. Allen, USAF.

Kitoi Bay: cove, $0.5 \mathrm{mi}$. across, on SE coast of Afognak I., 20 mi. NE of Afognak, Kodiak I. $58^{\circ} 11^{\prime} 30^{\prime \prime} \mathrm{N}, 152^{\circ} 21^{\prime} 00^{\prime \prime} \mathrm{W}$; (map 43).

Local name published in 1943 by USC\&GS Kitoi Island: island, see Whale Island. Kitovaya, Bukhta: bay, see Whale Bay. Kitovey, Ostrov: island, see Whale Island. Kitovi Island: island, see Whale Island. Kitovi Point: point of land, see Whale Point.

Kitovi Rookery: rookery, on Whale Point, on SE coast of Saint Paul I., in Pribilof Is. ; 57 07'$30^{\prime \prime}$ N, $170^{\circ} 15^{\prime} 20^{\prime \prime} \mathrm{W}$; (map 38). Var. Keetavie Rookery, Ketavie Rookery.

A local Russian name "Kitovyy" meaning "of a whale" spelled "Keetavie" and "Ketavie" by Elliott (1881, p. 52-53, and Saint Paul notes). It is named for Whale (Kitovi)
Point. This seal rookery has $2,200 \mathrm{ft}$. of seamargin.

Kitoy, Ostrov: island, see Whale Island.

Kitschkhin: stream, see Ketchikan Creek.

Kitschotno, Reka: stream, see Katlitna River.

Kitskan: city, see Ketchikan.

Kitten Creek: stream, flows NW $1 \mathrm{mi}$. to Kernel Cove, west-central Kiska I., Aleutian Is.; $51^{\circ} 57^{\prime} 08^{\prime \prime} \mathrm{N}, 177^{\circ} 21^{\prime} 25^{\prime \prime} \mathrm{E}$; (map 14).

An arbitrary name beginning with " $K$ " to correspond to the " $K$ " grid used by the U.S. Army for tactical purposes during World War II; published on a 1953 AMS map.

Kitten Pass: water passage, $500 \mathrm{ft}$. wide, between Rabbit I. and Outer I., in Pye Is., 48 mi. ESE of Seldovia, Chugach Mts.; 59 21'$30^{\prime \prime} \mathrm{N}, 150^{\circ} 22^{\prime} 40^{\prime \prime} \mathrm{W} ; B G N 1929$; (map 50).

Named by USC\&GS in 1927; suggested by nearby Wildcat Pass.

Kittens, The: islands, two islands in Lynn Canal, $0.8 \mathrm{mi}$. NW of Clear Point on Mansfield Penin. and $19 \mathrm{mi}$. SW of Juneau, Alex. Arch.; 58 ${ }^{\circ} 15^{\prime}$ N, $134^{\circ} 56^{\prime} \mathrm{W}$; (map 11).

Named by Lt. Comdr. H. B. Mansfield, USN, and published by the USC\&GS in the 1891 Coast Pilot (p. 161).

Kittilngook Bay: bay, between Northwest Cape and Chibukak Point, $\mathbf{N}$ of Gambell, $\mathbf{N}$ coast of St. Lawrence I.; $63^{\circ} 48^{\prime} \mathrm{N}, 171^{\circ} 43^{\prime} \mathrm{W}$; $B G N$ 1951; (map 93). Var. Kitilnguk, MeNichol Bay.

O. W. Geist, Univ. of Alaska, shows this name on his 1932 sketch map of St. Lawrence I. Orth spelled the name "Kitilnguk" in 1965 and was told by the Eskimo at Gambell that it is an old name, now without meaning.

Kittiwake Island: island, see Whale Island.

Kittiwake Pond: lake, elev. $720 \mathrm{ft}$., $0.2 \mathrm{mi}$. across, on Buldir I., Aleutian Is.; $52^{\circ} 22^{\prime} \mathrm{N}, 175^{\circ} 55^{\prime}$ E; (map 14).

Named by Coats $(1953$, p. 8$)$, USGS, presumably for the Pacific Kittiwake (Rissa tridachyla pollicaris), a gull-like bird.

Kittnighak: $b a y$, see Kitnagak Bay.

Kittnighhak Cape: point of land, see Kitnagak Point.

Kittnighnak Bay: bay, see Kitnagak Bay.

Kittnik, Cape: point of land, see Kitnik, Cape.

Kittnik River: stream, see Kitnik River.

Kitty Lake: lake, 2,500 ft. long, NE of Coal Creek Lake, $34 \mathrm{mi}$. NW of Tyonek, Cook Inlet Low.; 61 $32^{\prime} 10^{\prime \prime} \mathrm{N}, 151^{\circ} 30^{\prime} 15^{\prime \prime} \mathrm{W}$; (map 70).

Local name reported in 1954 by USGS.

Kiuchman Rock: rock, at head of Mitchell Bay, in W central Admiralty I., $8.8 \mathrm{mi}$. NE of Angoon, Alex. Arch.; $57^{\circ} 33^{\prime} 10^{\prime \prime} \mathrm{N}, 134^{\circ} 22^{\prime} 00^{\prime \prime}$ W; (map 9).

Local name reported in 1951 by USGS.

Kiugilak, Cape: point of land, on SW coast of Great Sitkin I., Aleutian Is.; $52^{\circ} 00^{\prime} 05^{\prime \prime} \mathrm{N}$, $176^{\circ} 11^{\prime} 15^{\prime \prime} \mathrm{W}$; BGN 1936; (map 17). Var. Kiougilakh.

Aleut name reported by the North Pacific Exploring Expedition in 1855 as "Kiougilakh" and shortened to "Kiugilak" by the U.S. Navy Hydrog. Office in 1936.
Kiugtlugtulit Mountain: mountain, 1,650 ft., with 3 peaks, $4 \mathrm{mi}$. SW of Tatlignagpeke Mountain, $15 \mathrm{mi}$. N of Goodnews, KilbuckKuskokwim Mts. ; $59^{\circ} 19^{\prime} 30^{\prime \prime}$ N, $161^{\circ} 35^{\prime} 00^{\prime \prime}$ W; (map 53).

Eskimo name reported in 1954 by USGS.

Kiukhlipalik Island: island, see Kiukpalik Island.

Kiukhpalik Island: island, see Kiukpalik Island. Kiuklipalik Island; island, see Kiukpalik Island. Kiukpalik Island: island, $1.4 \mathrm{mi}$. long, in Shelikof Strait, off NE coast of Alaska Penin., in Katmai National Monument, $13 \mathrm{mi}$. NE of Cape Chiniak, and $49 \mathrm{mi}$. S of Augustine I., Aleutian Ra.; $58^{\circ} 35^{\prime} \mathrm{N}, 153^{\circ} 34$, W; BGN Sixth Report; (map 43). Var. Kaiuklipalik Island, Kiukhlipalik Island, Kiukhpalik Island, Kiuklipalik Island, Ukayukhpalyk Island.

Eskimo name transliterated by USC\&GS in 1886 from Capt. Tebenkov (1852, map 22), IRN, who published the name as "O[strov] Kayukhpalik." The Russian Hydrog. Dept. published the name as "Os[trov] Ukayukhpalyk" in 1847 on Chart 1378.

Kiuniuiu Tanani : island, see Big Koniuji Island. Kivaleek: water passage, see Kivalik Inlet.

Kivaleenahrum Tessaya: lagoon, see Kivalina Lagoon.

Kivaleena River: stream, see Kivalina River.

Kivalena: village, see Kivalina.

Kivalena River: stream, see Kivalina River.

Kivalik Inlet: water passage, between Kivalina Lagoon and Chukchi Sea, $5 \mathrm{mi}$. NW of Kivalina, Kotzebue-Kobuk Low.; $67^{\circ} 47^{\prime} \mathrm{N}, 164^{\circ}$ 41' W; (map 128). Var. Kivaleek, Kiwaliik.

Eskimo name reported in 1966 by $E$. S. Burch.

Kivalina: village, pop. 142, on barrier reef between Chukchi Sea and Kivalina Lagoon, 43 mi. NW of Noatak and $47 \mathrm{mi}$. NW of Cape Krusenstern, Kotzebue-Kobuk Low.; $67^{\circ}$ $43^{\prime} 40^{\prime \prime} \mathrm{N}, 164^{\circ} 32^{\prime} 30^{\prime \prime} \mathrm{W}$; BGN 1944; (map 128). Var. Kevuleek, Kevulik, Kivalena, Kivalinak, Kivalinyah, Kivalinagmiut, Kivelow, Kivilenya, Kuveleek, Kiveleena, Kivualinak, Kivualinagmut.

Eskimo village originally located at the north end of the lagoon; reported in 1847 by Lt. L. A. Zagoskin, IRN, who gave its name as "Kivualinagmut." The village population was 87 in 1920; 99 in 1930; 98 in 1939; and 117 in 1950 . The Kivalina post office was established in 1940.

Kivalinagmiut: village, see Kivalina.

Kivalinagmiut: locality, see Cape Seppings.

Kivalinak: village, see Kivalina.

Kivalina Lagoon: lagoon, $10 \mathrm{mi}$. long, on Chukchi Sea coast, NW of Kivalina, Kotzebue-Kobuk Low.; $67^{\circ} 47^{\prime} \mathrm{N}, 164^{\circ} 07^{\prime} \mathrm{W}$; BGN 1962; (map 128). Var. Corwin Lagoon, Kivaleenahrum Tessaya, Tasikapak.

Local name reported in 1950 by USC\&GS. It was called "Corwin Lagoon" by USC\&GS in 1884, after the Revenue Cutter Corwin.

Kivalina River: stream, heads in De Long Mts. E of Spring Ridge, flows SW $60 \mathrm{mi}$. to Kivalina Lagoon, and $6 \mathrm{mi}$. NW of Kivalina, 
Kotzebue-Kobuk Low.; $67^{\circ} 48^{\prime} \mathrm{N}, 164^{\circ} 39^{\prime} \mathrm{W}$; BGN 1905; (map 128). Var. Kavalina River, Kevuleek River, Kevulik River, Kivaleena River, Kivalena River, Kivalinyah River, Kiveleena River, Kivilenya River, Kuveleek River, Kwelow River.

Eskimo name spelled "Kuveleek" by Lt. G. M. Stoney (1900, map), USN, in 1885. A. J. Collier, USGS, reported the present spelling in 1904.

Kivalinge: locality, see Cape Seppings.

Kivalinyah: village, see Kivalina.

Kivalinyah River: stream, see Kivalina River.

Kiveepuk Bay: bay, $2 \mathrm{mi}$. across, between Kineeghit Point and Eewak Point, $7 \mathrm{mi}$. SW of Savoonga, $\mathbf{N}$ coast of St. Lawrence I.; $63^{\circ} 39^{\prime} 30^{\prime \prime} \mathrm{N}, 170^{\circ} 41^{\prime} 00^{\prime \prime} \mathrm{W}$; BGN 1951; (map 93). Var. Kavipak, Kivipak.

Eskimo name reported by Orth in 1965 as "Kavipak" and meaning "jammed" or "packed in," presumably referring to ice. The "Kiveepuk" spelling is found on a map annotated in 1944 by Lawrence Kulukhan of Gambell.

Kiveleena River: stream, see Kivalina River.

Kivellena: village, see Kivalina.

Kivelow: village, see Kivalina.

Kividlo: locality, on Seward Penin., on bar between Shishmaref Inlet and Chukchi Sea, 65 mi. NW of Deering, Kotzebue-Kobuk Low.; $66^{\circ} 32^{\prime} \mathrm{N}, 164^{\circ} 45^{\prime} \mathrm{W}$; (map 113).

Eskimo camp reported in 1950 by USGS. The name is applied to a site having two or three buildings.

Kivilenya: village, see Kivalina.

Kivilenya River: stream, see Kivalina River.

Kivipak: bay, see Kiveepuk Bay.

Kivirlik Inlet: water passage, see Kukpowruk Pass.

Kivivik Creek: stream, heads in Maiyumerak Mts. of Baird Mts., flows NW $19 \mathrm{mi}$. to Noatak River $2 \mathrm{mi}$. SE of its junc. with Kugururok River, $40 \mathrm{mi}$. NE of Noatak, Brooks Ra.; 67 $58^{\prime}$ N, $161^{\circ} 51^{\prime}$ W; (map 127).

Eskimo name meaning "going away for good," or "disappears," obtained in 1956 at Noatak by Orth. Name given because a woman and child who used this stream as a short-cut to the Eli River disappeared.

Kivliktort Mountain: mountain, 4,500 ft., in Brooks Ra., $10 \mathrm{mi}$. NE of Howard Pass; $68^{\circ} 17^{\prime} \mathrm{N}, 156^{\circ} 30^{\prime} \mathrm{W}$; (map 132).

Eskimo name obtained at Noatak by Orth in 1956, and reported to mean "real shiny."

Kivualinagmut: village, see Kivalina.

Kivualinak: village, see Kivalina.

Kivvichavak: stream, see Kvichavak River.

Kivyearzruk Creek: stream, see Kigezruk Creek. Kiwaliik: water passage, see Kivalik Inlet.

Kiwalik: village, pop. 10, on NE coast of Seward Penin., between Spafarief Bay and Kiwalik Lagoon, Kotzebue-Kobuk Low.; $66^{\circ} 02^{\prime} \mathrm{N}$, $161^{\circ} 50^{\prime} \mathrm{W}$; (map 114). Var. Keewalick, Keewalik, Kualiug-miut, Kualyugmut, Kugaluk, Kugalukmut, Kugalukmute.

Eskimo village named for the Kiwalik River, reported in 1850 as "Kualiug-muit" by Lt.
L. A. Zagoskin, IRN, and published in 1852 on Russian Hydrog. Dept. Chart 1455. Recorded in the 1880 Census as "Kugalukmute," population 12. About 1890 this village became a supply point for mining activities in the Candle area. The Keewalik post office was established in 1902 and operated intermittently until 1907 . The population, 12 in 1930 , had increased to 24 in 1940.

Kiwalik Lagoon: lagoon, at mouth of Kiwalik River, $65 \mathrm{mi}$. SW of Selawik and $4 \mathrm{mi}$. NE of Candle, Kotzebue-Kobuk Low.; $66^{\circ} 00^{\prime} \mathrm{N}$, $161^{\circ} 51^{\prime} \mathrm{W}$; (map 114).

Eskimo name derived from the river, shown on a 1902 field sheet by D. C. Witherspoon, USGS.

Kiwalik Mountain: mountain, 2,365 ft., $6 \mathrm{mi}$. S of Monument Mtn. and $26 \mathrm{mi}$. SE of Imuruk Lake, Seward Penin. High.; $65^{\circ} 36^{\prime} \mathrm{N}$, $162^{\circ} 13^{\prime} \mathrm{W}$; (map 110 ).

Prospectors' name derived from the river; reported in 1903 by D. C. Witherspoon (in Moffit, 1905, pl. 2), USGS.

Kiwalik River: stream, flows NW $58 \mathrm{mi}$. to Mud Creek Channel Kiwalik River, $55 \mathrm{mi}$. NW of Haycock, Seward Penin. High.; 65 ${ }^{\circ} 56^{\prime} \mathrm{N}$, $161^{\circ} 53^{\prime}$ W; (map 109). Var. Kee-wa-lik River.

Eskimo name published by the British Admiralty about 1880 on Chart 593, spelled "Kee-wa-lik."

Kiwaruk: stream, see Kewagek Creek.

Kiwaruk Pass: pass, see Kiwook Pass.

Kiwoak Pass: pass, see Kiwook Pass.

Kiwook Pass: pass, $510 \mathrm{ft}$., between Olngooseenuk Mtn. and Taphook Mtn., $20 \mathrm{mi}$. SE ot Gambell, St. Lawrence I.; $63^{\circ} 34^{\prime}$ N, $171^{\circ} 18^{\prime}$ W; BGN 1951; (map 93). Var. Kiwaruk Pass, Kiwoak Pass, Lowpal Pass.

Eskimo name reported in 1932 by O. W. Geist, Univ. of Alaska. The name was recorded at Gambell by Orth in 1965 as "Kiwaruk," meaning "growing river," the same name as that of the stream that heads in the pass and flows NW.

Kixalrodix Hill: hill, see Kikalrodik Hill

Kixixyax Mountain: hill, see Kikikyak Hill

Kiyakyaliksamiut: locality, on left bank of Kiyakyaliksamiut River, $32 \mathrm{mi}$. NW of Cape Mendenhall, on Nunivak I.; $59^{\circ} 59^{\prime} 45^{\prime \prime} \mathrm{N}$, $167^{\circ} 02^{\prime} 30^{\prime \prime}$ W; (map 55). Var. Kieegeealigamute, Kieogyaligamiut.

Eskimo name reported about 1949 by USC\&GS.

Kiyakyaliksamiut River: stream, flows SW 13 mi. to Bering Sea, $32 \mathrm{mi}$. NW of Cape Mendenhall, Nunivak I.; $59^{\circ} 59^{\prime} 30^{\prime \prime} \mathrm{N}, 167^{\circ} 02^{\prime}$ $30^{\prime \prime} \mathrm{W}$; (map 55). Var. KiyakyalixamiutKoweerat River.

Eskimo name obtained in 1949 by USC\&GS.

Kiyakyalixamiut-Koweerat River: stream, see Kiyakyaliksamiut River.

Kiyavak, Mys: point of land, see Kiavak, Cape. Kiyavak, Zaliv: bay, see Kiavak Bay.

Kiyavak Bay: bay, see Kiavak Bay.

Kizhuchia Creek: stream, flows NW $5.5 \mathrm{mi}$. to $\mathrm{N}$ shore of Redoubt Bay, $8 \mathrm{mi}$. S of Sitka, on
W coast of Baranof I., Alex. Arch.; 56 $56^{\prime} 10^{\prime \prime}$ N, $135^{\circ} 21^{\prime} 10^{\prime \prime}$ W; (map 5). Var. Reka Kizhuchya.

Named in 1809 by the Russian navigator, Ivan Vasiliev the first; published by Lt. Sarichev (1826, map 19), IRN, as "R[eka] Kizhuchya," or "Kizhuchya River."

Kizhuchya, Reka: stream, see Kizhuchia Creek. Kizhuitskoy, Mys: point of land, see Kizhuyak Point.

Kizhulik, Zaliv: bay, see Kujulik Bay.

Kizhunak: stream, see Kashunuk River.

Kizhunok: stream, see Kashunuk River.

Kizhutskoi: point of land, see Kizhuyak Point.

Kizhuyak Bay: bay, extends SW $20 \mathrm{mi}$. off Marmot Bay, $E$ of Whale $I$., on $N$ coast of Kodiak I.; $57^{\circ} 56^{\prime} \mathrm{N}, 152^{\circ} 40^{\prime} \mathrm{W}$; (map 34). Var. Kizhuyakskaia, Shakmanof, Zaliv Shakhmanova ili Bukhta Kizhuyakskaya.

Native name published by Capt. Tebenkov (1852, map 23), IRN, as "B[ukhta] Kizhuyak," or "Kizhuyak Bay." This name was taken from "Z[aliv] Shakhmanova ili Bukhta Kizhuyakskaya," "Shakmanor or Kizhuyak Bay," given in 1839 or 1840 by Sub Lt. Murashev, IRN, and published in 1849 on Russian Hydrog. Dept. Chart 1425.

Kizhuyak Point: point of land, E point of entrance to Kizhuyak Bay, $12 \mathrm{mi}$. NW of Kodiak I.; $57^{\circ} 55^{\prime} 15^{\prime \prime} \mathrm{N}, 152^{\circ} 36^{\prime} 30^{\prime \prime} \mathrm{W}$; (map 34). Var. Kizhutskoi, Kizhuyak Cape, Mys Kizhuitskoy, Mys Kizhuyak.

Native name published by Tebenkov (1852, map 23) as "M[ys] Kizhuyak," "Cape Kizhuyak." The name "M[ys] Kizhuitskoy" was given to this point in 1839 or 1840 by Murashev and published in 1849 on Russian Hydrog. Dept. Chart 1425.

Kizhuyakskaia: bay, see Kizhuyak Bay.

Kizhuyakskaya, Bukhta: bay, see Kizhuyak Bay. K-khaltat: locality, see Kaltat.

Kkhaltel: village, see Kaltag.

Kkholikakat: locality, see Tleket.

Klach Creek: stream, see Klak Creek.

Kladbitsha: point of land, see Graveyard Point.

Kladein Flats: tidal flats, on $\mathrm{W}$ coast of Prince of Wales I. at mouth of Staney River, $24 \mathrm{mi}$. $\mathrm{N}$ of Craig, Alex. Arch.; $55^{\circ} 49^{\prime} \mathrm{N}, 133^{\circ} 10^{\prime}$ W; (map 4).

Indian name published in 1964 by USC\&GS.

Klag Bay: bay, $2.5 \mathrm{mi}$. long, at Chichagof, on W coast of Chichagof I., Alex. Arch.; $57^{\circ} 38^{\prime}$ N, $136^{\circ} 06^{\prime} \mathrm{W} ; B G N$ 1908; (map 9). Var. Klagh Bay.

Local Tlingit Indian name reported by USC\&GS in 1908 and published in 1908 Coast Pilot (p. 173)

Klagh Bay: bay, see Klag Bay.

Klag Island: island, $1 \mathrm{mi}$. long, $3 \mathrm{mi}$. $\mathrm{S}$ of Chichagof, on $W$ coast of Chichagof I., Alex. Arch.; 57 $37^{\prime} 00^{\prime \prime} \mathrm{N}, 136^{\circ} 05^{\prime} 30^{\prime \prime} \mathrm{W}$; BGN 1908; (map 9). Var. De Groff Island.

Named in 1908 by USC\&GS probably for Klag Bay at the mouth of which it is located. The name was published by USC\&GS in 1908 Coast Pilot (p. 172). It was originally named "De Groff Island" by Lt. Comdr. E. K. Moore, 
USN, in 1897 for "De Groff, a prominent Sitka merchant."

Klahangamut: locality, $\mathrm{W}$ of Nanvakfak Lake, $16 \mathrm{mi}$. W of Goodnews, Kilbuck-Kuskokwim Mts.; 59 $08^{\prime} \mathrm{N}, 161^{\circ} 57^{\prime} \mathrm{W}$; (map 53). Var. Kichakuk, Kl-changamute.

Eskimo village first mentioned in 1880 by Ivan Petroff in the 10th Census in 1880 as "Klchangamute," meaning "Klchank people." Its population in 1880 was 18 ; in 1890,49 ; it is now abandoned.

Klahangamut: locality, see Klchakuk.

Klaheela River: stream, see Klehini River.

Klaheena River: stream, see Klahini River.

Klahena River: stream, see Klahini River.

Klahini River: stream, flows W $15 \mathrm{mi}$. to Burroughs Bay $2 \mathrm{mi}$. SW of its head at mouth of Unuk River, Coast Mts.; $56^{\circ} 02^{\prime} 30^{\prime \prime} \mathrm{N}, 131^{\circ}$ 06'00" W; BGN 1901; (map 7). Var. Glahona River, Klaheena River, Klahena River.

Indian name, meaning "Kla River," reported in 1900 by M. Baker, USGS. USG\&GS published the names "Clahona" in 1894 and "Klaheena" in 1899 for this stream.

Kláhuch Island: island, see Pyramid Island.

Klahuchtak: locality, see Chilkat.

Klakas Bay: estuary, see Klakas Inlet.

Klakas Inlet: estuary, extends $13.5 \mathrm{mi}$. N off Cordova Bay, on SW coast of Prince of Wales I., Alex. Arch.; 54 $53^{\prime} \mathrm{N}, 132^{\circ} 23^{\prime} \mathrm{W}$; (map 1). Var. Klakas Bay.

Indian name reported in 1897 by Lt. Comdr. J. F. Moser, USN.

Klakas Island: island, $1.5 \mathrm{mi}$. long, at mouth of Klakas Inlet on SW coast of Prince of Wales I., Alex. Arch.; $54^{\circ} 53^{\prime} 45^{\prime \prime} \mathrm{N}, 132^{\circ} 24^{\prime} 40^{\prime \prime} \mathrm{W}$; (map 1).

Name derived from Klakas Inlet; published by USGS in 1951.

Klakas Lake: lake, $2.5 \mathrm{mi}$. long, on SW coast of Prince of Wales I., E of Klakas Inlet, Alex. Arch.; $55^{\circ} 01^{\prime} 40^{\prime \prime} \mathrm{N}, 132^{\circ} 21^{\prime} 45^{\prime \prime} \mathrm{W}$; (map 4).

Tlingit Indian name recorded in 1897 by Lt. Comdr. J. F. Moser, USN.

Klak Creek: stream, heads at Klak Lake, flows NW $16 \mathrm{mi}$. to Kanck tok River, $55 \mathrm{mi}$. NE of Goodnews, Kilbuck-Kuskokwim Mts.; 59 ${ }^{\circ} 47^{\prime}$ N, $160^{\circ} 45^{\prime}$ W; (map 53). Var. Chlach

River, Klach Greek, Klak River.

Eskimo name shown on an 1898 fieldsheet by W. S. Post, USGS, as "Chlach River," but was published as "Klak Creek" by J. E. Spurr (1900, map 10).

Klak Lake: lake, trends SE $1.2 \mathrm{mi}$. to headwaters of Klak Creek, $1.5 \mathrm{mi}$. NW of Nagugun Lake, $60 \mathrm{mi}$. NE of Goodnews, Kilbuck-Kuskokwim Mts.; $59^{\circ} 43^{\prime} \mathrm{N}, 160^{\circ} 27^{\prime} \mathrm{W}$; (map 53).

Name derived from Klak Creek; published in 1954 by USGS.

Klak River: stream, see Klak Creek.

Klakwan: village, see Klukwan.

Klalbaimunket Lake: lake, $1 \mathrm{mi}$. across, at head of Huntington Creek, in Koyukuk River Valley, $4 \mathrm{mi}$. NE of Hughes, Kokrines-Hodzana High.; $66^{\circ} 07^{\prime} \mathrm{N}, 154^{\circ} 10^{\prime} \mathrm{W}$; (map 116).

Indian name reported to mean "grayling lake," for the fish, Arctic Grayling (Thymal- lus signifer); recorded at Hughes in 1956 by Orth.

Klaluthyiit Bluff: bluff, on right bank of Koyukuk River $43 \mathrm{mi}$. NE of Hughes; $66^{\circ}$. $28^{\prime} \mathrm{N}, 153^{\circ} 04^{\prime} \mathrm{W}$; (map 116 ).

Indian name recorded in 1956 as "Klalluth-yi-it" at Allakaket by Orth, USGS, and refers in meaning to the narrowness of the Koyukuk River Valley at that point.

Klamaskwaltin: locality, "on $\mathbf{N}$ bank of Yukon River," near mouth of Kaiyuh Slough, Koyukuk Low.; (map 97). Var. Klamasqualttin.

Former Eskimo camp or settlement reported in 1898 by USC\&GS; published as "Klamasqualttin" on Chart 3098.

Klamasqualttin: locality, see Klamaskwaltin.

Klam Creek: stream, heads in lake, flows SW $5 \mathrm{mi}$. to Klu Bay, on NW coast of Revillagigedo I., Alex. Arch.; 55 50'45" N, $131^{\circ}$ $27^{\prime} 55^{\prime \prime} \mathrm{W}$; (map 3$)$.

Local name published in 1943 by USC\&GS. Klanachargut River: stream, see Minook Creek. Klana-Kakat: stream, see Minook Creek.

Klanelneechena Creek: stream, heads at a glacier and flows NE $17 \mathrm{mi}$. to head of Tazlina Lake $2 \mathrm{mi}$. $\mathrm{N}$ of the terminus (1960) of the Tazlina Glacier and $45 \mathrm{mi}$. NW of Valdez, Chugach Mts.; $61^{\circ} 45^{\prime} 25^{\prime \prime} \mathrm{N}, 146^{\circ} 29^{\prime} 00^{\prime \prime} \mathrm{W}$; (map 68).

Indian name reported by USGS in 1960.

Klan Hill: hill, $600 \mathrm{ft}$., on $\mathrm{N}$ half of Sitklan I. Coast Mts.; $54^{\circ} 45^{\prime} 00^{\prime \prime} \mathrm{N}, 130^{\circ} 41^{\prime} 15^{\prime \prime} \mathrm{W}$; (map 2).

Indian name given in 1883 by Lt. Comdr. Nichols, USN; part of the word "Sitklan".

Klarens, Port ; bay, see Clarence, Port.

Klatakhna Creek: stream, flows W $8 \mathrm{mi}$. to Melozitna River, $45 \mathrm{mi}$. NW of Tanana, Kokrines-Hodzana High.; $65^{\circ} 43^{\prime}$ N, 152 $57^{\prime}$ W; (map 106)

Indian name obtained in 1956 at Tanana by Orth.

Klatena: stream, see Klutina River.

Klati River: stream, see Klutina River.

Klatsutachakat: stream, see Blind River.

Klatsutachakat: stream, see Klatsuta River.

Klatsutachargut: stream, see Blind River.

Klatsutachargut: stream, see Klatsuta River.

Klatsutakakat: stream, see Blind River.

Klatsutakakat: stream, see Klatsuta River.

Klatsuta River: stream, flows NW $14 \mathrm{mi}$. to Yukon River $11 \mathrm{mi}$. S of Gold Mtn., Nowitna

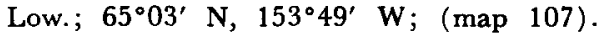
Var. Klatsutachargut, Klatsutachakat, Klatsutakakat.

Indian name reported in 1869 by Capt. C. W. Raymond; USA, as "Klatsutachargut," meaning "mouth of the Klatsuka [River]."

Klatsuta River: stream, see Blind River.

Klawack Inlet: water passage, see Klawak Inlet. Klawack Strait: water passage, see Klawak Inlet.

Klawak: village, see Klawock.

Klawak City: village, see Klawock.

Klawak Harbor: water passage, $1 \mathrm{mi}$. long, on W coast of Prince of Wales I., between Klawak I. and Klawock, Alex. Arch.; 55 $33^{\prime} \mathrm{N}$, $133^{\circ} 06^{\prime} \mathrm{W}$; (map 4).
Tlingit Indian name; published in 1925 Coast Pilot (p. 141)

Klawak Inlet: water passage, on $\mathrm{E}$ side of Wadleigh I., extends $9 \mathrm{mi}$. N of Craig, on W coast of Prince of Wales I., Alex. Arch.; $55^{\circ} 32^{\prime} \mathrm{N}, 133^{\circ} 07^{\prime} \mathrm{W}$; (map 4). Var. Kiawak Inlet, Klawack Inlet, Klawack Strait, Klawak Passage, Klawok Inlet, Kliavakhan Inlet, Tlevak Inlet, Tlevakh Inlet, Tlevakkhyn Bay, Zaliv Tlevakkhan.

Tlingit Indian name obtained by the Russians; shown on the 1853 Russian Hydrog. Dept. Chart 1493 as "Zal[iv] Tlevakkhan," or "Tlevakkhyn Bay." The 1960 Tongass National Forest map applies this name to Shinaku Inlet, on the northwest side of Wadleigh Island, and to Big Salt Lake, 4 miles to the northeast.

Klawak Inlet: estuary, see Big Salt Lake.

Klawak Island: island, 2 mi. long, W of Klawock, between Klawak Harbor and Klawak Inlet, on $W$ coast of Prince of Wales I., Alex. Arch.; $55^{\circ} 33^{\prime} 00^{\prime \prime} \mathrm{N}, 133^{\circ} 06^{\prime} 20^{\prime \prime} \mathrm{W}$; (map 4). Var. La Galera.

Local name derived from the Tlingit Indian village name; reported in 1897 by J. F. Moser, USN. This appears to be the same island called "La Galera," meaning "the galley," by the 1779 Don Ignacio Arteaga expedition.

Klawak Lake: lake, $7 \mathrm{mi}$. long, on $\mathrm{W}$ coast of Prince of Wales I., 2 mi. E of Klawock, Alex. Arch.; 55 $31^{\prime} \mathrm{N}, 132^{\circ} 59^{\prime} \mathrm{W}$; (map 4).

Local name. See Klawak Island.

Klawak Passage: water passage, see Dry Pass.

Klawak Passage: water passage, see El Capitan Passage.

Klawak Passage: water passage, see Klawak Inlet.

Klawak Reef: reef, extends $0.5 \mathrm{mi}$, between Klawak Inlet and San Alberto Bay, SW of Wadleigh I., Alex. Arch.; 55 $31^{\circ} 00^{\prime \prime} \mathrm{N}$, $133^{\circ} 10^{\prime} 30^{\prime \prime} \mathrm{W}$; (map 4).

Named in 1897 by Lt. Comdr. J. F. Moser, USN.

Klawak River: stream, heads in Klawak Lake, on $W$ coast of Prince of Wales I., flows W $2.3 \mathrm{mi}$. to Klawak Harbor, Alex. Arch.; $55^{\circ}$. $33^{\prime} 00^{\prime \prime}$ N, $133^{\circ} 05^{\prime} 40^{\prime \prime}$ W; (map 4). Var. Klawak Stream.

Local name. See Klawak Island.

Klawasena Creek: stream, see Klawasi River. Klawasina River: stream, see Klawasi River.

Klawasi River: stream, flows SW $23 \mathrm{mi}$. from glacier on Mount Drum to Copper River, at Copper Center, Copper River Basin; 61 ${ }^{\circ} 58^{\prime}$ N, $145^{\circ} 18^{\prime} \mathrm{W}$; (map 68). Var. Klawasena Creek, Klawasina River.

Indian name reported in 1885 as "Klawasina" by Lt. Allen (1887, p. 62), USA.

Klawock: village, pop. 251, on W coast of Prince of Wales I., $5 \mathrm{mi}$. N of Craig, Alex. Arch.; $55^{\circ} 33^{\prime} 15^{\prime \prime} \mathrm{N}, 133^{\circ} 05^{\prime} 45^{\prime \prime} \mathrm{W} ;$ BGN 1962; (map 4). Var. Chla-wāk-kŏn, Khlawak, Kiawak, Klawak, Klawak City, Klawok, Klawook, Kliavakhan, Kliawak, Klyavakkhan, Klyakkhan, Lawak, Thlewhakh, Tlevak, Tlewak. 
Tlingit Indian village reported in 1853 , on Russian Hydrog. Dept. Chart 1493, as "Sel[eniye] Klyakkhan," i.e. "Klyakkhan settlement," applied to a location on the west side of Shinaku Inlet. This may represent the location of the village prior to the establishment of a cannery at the present site in 1878. H. J. Holmberg referred to the village in 1855 as "Thlewhákh"; Aurel Krause reported "Chla-wak-kon," i.e. "Chla-wak people"; listed as "Klawak" in the 1890 Census. The population was 261 in 1890; 131 in $1900 ; 241$ in $1910 ; 19$ in $1920 ; 437$ in 1930; 455 in 1939; and 404 in 1950 . The Klawock post office was established in 1882 (Ricks, 1965, p. 34).

Klawok: village, see Klawock.

Klawok Inlet: water passage, see Klawak Inlet. Klawook: village, see Klawock.

Klaxermette: locality, see Tuksuk.

Klchakuk: locality, on E shore Kuskokwim Bay, $\mathbf{N}$ of Goodnews Bay, Kilbuck-Kuskokwim Mts.; (map 53). Var. Klahangamut, Klchangamute, Zaliv Khchakuk.

Former Eskimo camp or village reported by Ivan Petroff as "Kl-changamute," with a population of 18 , in the 1880 Census. This locality is shown as "Z[aliv] Khchakuk," or "Khchakuk Bay," by Lt. Sarichev (1826, map 3), IRN.

Kl-changamute: locality, see Klchakuk.

Kleguchegamiut: locality, see Kleguchek.

Kleguchek: locality, on right bank of Kuskokwim River, $3 \mathrm{mi}$. SW of Helmick Point and $45 \mathrm{mi}$. SW of Bethel, Yukon-Kuskokwim Delta; $60^{\circ} 17^{\prime} \mathrm{N}, 162^{\circ} 33^{\prime} \mathrm{W}$; (map 58). Var. Klegutshegamut, Kleguchegamiut.

Eskimo camp or small settlement reported on an 1898 fieldsheet by W. S. Post, USGS. Post and J. E. Spurr obtained the "Klegutshégamut" spelling from J. H. Kilbuck, Moravian missionary.

Klegutshegamut: locality, see Kleguchek.

Kleheena River: stream, see Klehini River.

Klehini River: stream, heads in a glacier on Nadahini Mtn. in Canada, flows SE $42 \mathrm{mi}$. to Chilkat River at Wells, 22 mi. W of Skagway, St. Elias Mts.; $59^{\circ} 24^{\prime} 45^{\prime \prime} \mathrm{N}, 135^{\circ} 55^{\prime} 30^{\prime \prime} \mathrm{W}$; BGN 1954; (map 45). Var. Klaheela River; Kleheena River, Kluheena River, Kluheeny River, Kluheny River, Kluhini River, Tlehini River.

Tlingit Indian name reported in 1880 as Kluheeny by U.S. Navy. It was published by USC\&GS in the 1883 Coast Pilot (p. 199) as T'lehini (or Kluhini) River. It is the Tlehini of Aurel and Arthur Krause (1883, map).

Klein Creek: stream, flows SE $11 \mathrm{mi}$. to Beaver Creek, $6.5 \mathrm{mi}$. W of mouth of Ptarmigan Creek and $67 \mathrm{mi}$. NE of McCarthy, Alaska Range; $61^{\circ} 58^{\prime} 45^{\prime \prime} \mathrm{N}, 141^{\circ} 14^{\prime} 00^{\prime \prime} \mathrm{W}$; (map 67).

Local name reported in 1914 by C. E. Giffin (Capps, 1916, pl. 2), USGS.

Kleiti Islands: islands, in Tuxekan Passage between Prince of Wales and Staney Is., $24 \mathrm{mi}$.
$\mathrm{N}$ of Craig, Alex. Arch.; $55^{\circ} 48^{\prime} 45^{\prime \prime} \mathrm{N}, 133^{\circ}$. $11^{\prime} 00^{\prime \prime} \mathrm{W}$; (map 4).

Indian name published in 1964 by USC\&GS.

Klery Creek: locality, on Klery Creek, W of Kallarichuk Hills and $20 \mathrm{mi}$. NE of Deviation Peak, Brooks Ra.; $67^{\circ} 09^{\prime} 30^{\prime \prime}$ N, $160^{\circ} 24^{\prime} 00^{\prime \prime}$ W; (map 127).

Name reported on a 1923 ARC map.

Klery Creek: stream, in Baird Mts., flows SW $25 \mathrm{mi}$. W of Kallarichuck Hills to Squirrel River, 12 mi. NNW of Kiana, Brooks Ra.; $67^{\circ} 06^{\prime} \mathrm{N}, 160^{\circ} 36^{\prime} \mathrm{W}$; (map 127).

According to A. H. Brooks, USGS, this stream "was prospected by some Italians who had been on Cleary Creek near Fairbanks; they named this creek after the other but spelled it phonetically not knowing the original spelling." The name was reported in 1910 by P. S. Smith, USGS.

Kletsan Creek: stream, heads at Natazhat Glacier terminus in Yukon, Canada, and flows NW $13 \mathrm{mi}$. to White River, $66 \mathrm{mi}$. NE of McCarthy, St. Elias Mts.; BGN 1954; $61^{\circ} 44^{\prime}$ $12^{\prime \prime} \mathrm{N}, 141^{\circ} 01^{\prime} 12^{\prime \prime} \mathrm{W}$; (map 67). Var. Copper Creek, Klet-san-dek Creek, Klutson Creek.

Indian name reported in 1891 by G. W. Hayes (1892, p. 143), USGS, as "Klet-sandek," meaning "copper creek."

Klet-san-dek Creek: stream, see Kletsan Creek. Kletsan Glacier: glacier, see Natazhat Glacier. Kliavakhan: village, see Klawock.

Kliavakhan Inlet: water passage, see Klawak Inlet.

Kliawak: village, see Klawock.

Klikakillah: stream, see Tlikakila River.

Klikakillah Creek: stream, see Tlikakila River.

Klikaklik Island: island, see Latouche Island.

Klikaklit Island: island, see Latouche Island.

Klikhtentotzna Creek: stream, heads in lake, $\mathbf{S}$ of Norutak Hills, flows S $30 \mathrm{mi}$. to Hogatza River, $25 \mathrm{mi}$. NW of Hughes, Hogatza High.; $66^{\circ} 21^{\prime} \mathrm{N}, 154^{\circ} 45^{\prime} \mathrm{W}$; (map 116).

Indian name "Klikh-ten-totz-na," reported to mean "bow and arrow river," recorded at Hughes in 1956 by Orth.

Klikitarik: locality, on $\mathrm{W}$ shore of Klikitarik Bay, $17 \mathrm{mi}$. E of Saint Michael, YukonKuskokwim Delta; $63^{\circ} 28^{\prime} 10^{\prime \prime} \mathrm{N}, 161^{\circ} 28^{\prime} 15^{\prime \prime}$ W; BGN 1966; (map 91). Var. Ikikiktoik, Kegiktowruk, Kiektaguk, Kikhtuk, Kikiktaruk, Kiktagak, Kiktaguk, Tlickearrik, Tlicketawik.

Reindeer camp and corral reported in 1905 by USC\&GS as "Kiktaguk." The Eskimo name "Kegiktowruk" was reported by W. $\mathbf{H}$. Dall, USC\&GS, who visited it October 8, 1866.

Klikitarik Bay: bay, 2 mi, across, off Norton Sound, $18 \mathrm{mi}$. E of Saint Michael, YukonKuskokwim Delta; $63^{\circ} 28^{\prime} \mathrm{N}, 161^{\circ} 26^{\prime} \mathrm{W}$. Var. Kiktaguk Bay.

Eskimo name reported in 1905 by USC\&GS as "Kiktaguk Bay."

Klikitarik Mountain: hill, $844 \mathrm{ft}$., E of Klikitarik River, $18 \mathrm{mi}$. SE of Saint Michael, Nulato Hills, $63^{\circ} 25^{\prime} \mathrm{N}, 161^{\circ} 26^{\prime} \mathrm{W}$; (map 91).

Eskimo name reported in 1952 by USC\&GS. Name derived from that of the nearby camp.
Klikitarik River: stream, flows N $18 \mathrm{mi}$. to Klikitarik Bay, $18 \mathrm{mi}$. E of Saint Michael, Nulato Hills; $63^{\circ} 27^{\prime} 25^{\prime \prime} \mathrm{N}, 161^{\circ} 27^{\prime} 15^{\prime \prime} \mathrm{W}$; (map 91).

Eskimo name reported in 1952 by USC\&GS. Name derived from that of the camp.

Klim Creek: stream, in De Long Mts., flows S 10 mi. to Nimiuktuk River, $15 \mathrm{mi}$. E of Thunder Mtn., Brooks 'Ra.; $68^{\circ} 25^{\prime}$ N, $159^{\circ} 51^{\prime}$ W ; BGN 1961; (map 131).

Named by a USGS exploring party in 1924 .

"So named because the only substance remaining for the [field] party at this point, was a part of a can of Klim." The product Klim was powdered milk (spelled backwards).

Klinau Island: island, $0.4 \mathrm{mi}$. long, W of Prince of Wales I., in mouth of Naukati Bay, $27 \mathrm{mi}$. $\mathrm{N}$ of Craig, Alex. Arch.; 55 $51^{\prime} 35^{\prime \prime} \mathrm{N}, 133^{\circ}$ $11^{\prime} 15^{\prime \prime} \mathrm{W}$; (map 4).

Indian name published in 1964 by USC\&GS.

Klinchef Mountain: hill, see Kliuchef, Mount. Kline Creek: stream, see Klein Creek.

Klingaktakamute: locality, see Kingaktakamiut. Klinkwan: locality, near E entrance to Klakas Inlet, on SW coast of Prince of Wales I., Alex. Arch.; $54^{\circ} 53^{\prime} 25^{\prime \prime} \mathrm{N}, 132^{\circ} 21^{\prime} 50^{\prime \prime} \mathrm{W}$; BGN 1954; (map 1).

Tlingit Indian name recorded in 1897 by Lt. Comdr. J. F. Moser, USN. A 1951 USGS map shows one building at the site of this abandoned village. According to $J$. R. Swanton (in Hodge, 1907, p. 714), BAE, "Klinkwan" is derived from the Tlingit "linqoan" meaning "shellfish town" or "town where they split yellow cedar bark into long strings." This is a "Haida town, occupied by the Yaku-lanas ***" (Hodge, 1907, p. 714).

Klinkwan: locality, see Koianglas.

Klinkwan Cove: bay, extends NE $1 \mathrm{mi}$. on SW coast of Prince of Wales I., SE of Klakas Inlet, Alex. Arch.; 54 $53^{\prime} \mathrm{N}, 132^{\circ} 21^{\prime} \mathrm{W}$; (map 1).

Name derived from the now abandoned village of Klinkwan; published by USGS in 1951.

Klinquan: locality, see Koianglas.

Klioutchevskoi : volcano, see Kliuchef, Mount.

Kliqtluaq: lake, see Canyon Lake.

Kliskan, Mount: mountain, see Kliskon, Mount.

Kliskon, Mount: mountain, 3,943 ft., at heads of Camp and Clearwater Creeks, $52 \mathrm{mi}$. NW of Talkeetna, Alaska Ra.; 62 ${ }^{\circ} 24^{\prime} 30^{\prime \prime} \mathrm{N}, 151^{\circ} 43^{\prime}$ 45" W; (map 81). Var. Mount Kliskan, Mount Tlis-kon.

Tanaina Indian name obtained in 1899 by Lt. J. S. Herron, USA, and spelled by him "Tlis-kon."

Kliuchef, Mount: hill, $820 \mathrm{ft} ., 1.4 \mathrm{mi} . \mathrm{E}$ of Goddard, on W coast of Baranof I., Alex.

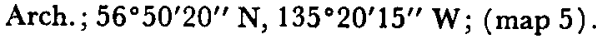
Var. Gora Klyuchevaya, Klinchef Mountain, Kliucheff Mountain, Mount Kliuchevaia, Springs Mountain.

Named in 1809 by the Russian navigator, Ivan Vasiliev the first; published by Lt. Sarichev (1826, map 19), IRN, as "G[ora] Klyuchevaya," meaning "Springs Mountain," probably because of the hot springs in the vicinity. 
Kliuchef, Mount: volcano, 3,000 ft., $2.5 \mathrm{mi}$. across, on N Atka I., Aleutian Is. ; $52^{\circ} 19^{\prime} \mathrm{N}$, $174^{\circ} 09^{\prime} \mathrm{W}$; (map 18). Var. Klioutchevskoi, Kliuchevskaia, Kljutschewskoj.

Descriptive name, from the Russian "Kliuchevskaia," meaning "springs," applied because of numerous warm springs on its west slope according to Capt. Lutke (1836, p. 318) who published the name as "Klioutchevskoi volcan," or "Kliuchef volcano." Name published as Mount Kliuchef on a 1952 USGS map.

Kliucheff Mountain: hill, see Kliuchef, Mount. Kliuchef Peninsula: peninsula, on $\mathrm{W}$ coast of Baranof I., $16 \mathrm{mi}$. S of Sitka, Alex. Arch. $56^{\circ} 49^{\prime} 40^{\prime \prime} \mathrm{N}, 135^{\circ} 22^{\prime} 20^{\prime \prime} \mathrm{W} ; B G N$ 1926; (map 5). Var. Kliuchevina.

Russian name meaning "spring," applied in 1926 by USC\&GS, which described this area as a "maze of springs, bogs, marshes, ponds, etc., sparsely wooded."

Kliuchevaia, Mount: hill, see Kliuchef, Mount. Kliuchevaya Gora: mountain, see Camel Mountain.

Kliuchevina: peninsula, see Kliuchef Peninsula. Kliuchevoi Bay: bay, $0.5 \mathrm{mi}$. long, on W coast of Baranof I., N of Goddard, $14 \mathrm{mi}$. S of Sitka, Alex. Arch.; $56^{\circ} 50^{\prime} 20^{\prime \prime}$ N, $135^{\circ} 22^{\prime} 20^{\prime \prime} \mathrm{W}$; (map 5).

Local name published in 1943 by USC\&GS See Mount Kliuchef.

Kliuchevoi Island: island, $0.1 \mathrm{mi}$. across, in Kliuchevoi Bay, on $W$ coast of Baranof $I$., $14 \mathrm{mi}$. S of Sitka, Alex. Arch.; 56 $50^{\prime} 18^{\prime \prime} \mathrm{N}$, $135^{\circ} 22^{\prime} 35^{\prime \prime} \mathrm{W}$; (map 5 ).

Local name published in 1943 by USC\&GS. See Mount Kliuchef.

Kliuchevskaia: volcano, see Kliuchef, Mount.

Kljutschewskoj: volcano, see Kliuchef, Mount. Klocheblok River: stream, see Klokerblok River. Klochkof Rock: rock, 2 or $3 \mathrm{mi}$. E of Amlia I., Aleutian Is.; $52^{\circ} 06^{\prime} \mathrm{N}, 172^{\circ} 54^{\prime} \mathrm{W}$; (map 19). Var. Klochkova, Kamen.

Named for the pilot, Klochkov, of the Russian American Company ship Chirikof, who discovered the rock in 1818 though Ingenstrem, in 1830 , denied its existence. The Aleuts called it "Siuvich," from the Russian "Sivuch," meaning "sea lion." G. Davidson's copy of Lt. G. A. Sarichev's atlas contains a manuscript note of a "rock awash." The rock is possibly part of the Agligadak Reefs.

Klochkova, Kamen: rock, see Klochkof Rock.

Kloh Kutz, Mount: mountain, 3,600 ft., in Glacier Bay National Monument, on Wachusett Inlet and $61 \mathrm{mi}$. NW of Hoonah, St. Elias Mts.; $58^{\circ} 53^{\prime} 10^{\prime \prime} \mathrm{N}, 136^{\circ} 15^{\prime} 50^{\prime \prime} \mathrm{W}$; (map 10).

Named by members of the Glacier Bay Expedition of 1941 (Field, 1947, pl. 1) for Kloh Kutz, whose name means "hole-in-thecheek," a chief of the Chilkats. In 1869, these Indians reportedly informed George Davidson, USC\&GS, of the existence of Glacier Bay.
Klokacheff, Point: point of land, see Klokachef Point.

Klokacheff Island: island, see Klokachef Island.

Klokacheff Sound: water passage, see Salisbury Sound.

Klokachef Island: island, $1.5 \mathrm{mi}$. long, $\mathrm{N}$ of Salisbury Sound, off SW coast of Chichagof I., Alex. Arch.; 57 $24^{\prime} 30^{\prime \prime} \mathrm{N}, 135^{\circ} 53^{\prime} 00^{\prime \prime} \mathrm{W}$; $B G N$ 1897; (map 9). Var. Fortuna Island, Klokacheff Island, Klokatcheff Island, Vincent Island.

Name published in 1884 on Brit. Adm. Chart 2337 as "Klokacheff Island." USC\&GS reported names "Fortuna" and "Vincent" for this island in 1883 Coast Pilot (p. 160).

Klokachef Point: point of land, on SW tip of Klokachef I., $\mathbf{N}$ of Salisbury Sound, off SW

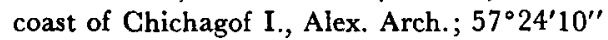

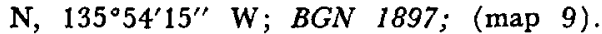
Var. Mys Klokacheva, Point Klokacheff, Point Olga.

Russian name given in 1833 by the navigator Ens. Vasiliev; published in 1848 on Russian Hydrog. Dept. Chart 1397 as "M[ys] Klokacheva."

Klokacheva, Mys: point of land, see Klokachef Point.

Klokatcheff Island: island, see Klokachef Island.

Klokblok River: stream, see Klokerblok River.

Klokerblok River: stream, flows E $26 \mathrm{mi}$. to Fish River, $32 \mathrm{mi}$. ENE of Solomon, Seward Penin. High.; 64ㅇ․ $38^{\prime} \mathrm{N}, 163^{\circ} 23^{\prime} \mathrm{W}$; (map 95). Var. Klokblok River, Kluchablok River, Klocheblok River.

Prospectors' name reported in 1900 by E. C. Barnard (in Brooks, 1901, pl. 17), USGS.

Klooch, Mount: mountain, 7,661 ft., $3.6 \mathrm{mi}$. NW of Mount Dagelet, $75 \mathrm{mi}$. NW of Hoonah, St. Elias Mts.; $58^{\circ} 36^{\prime} 40^{\prime \prime} \mathrm{N}, 137^{\circ} 16^{\prime} 15^{\prime \prime} \mathrm{W}$; (map 10).

Name published by members of the Harvard-Dartmouth Expedition, 1933-34 (Washburn and Goldthwait, 1936, map).

Klooch Glacier: glacier, heads on SW slope of Mount Klooch, trends SW $3 \mathrm{mi}$. to its 1961 terminus, $1.5 \mathrm{mi}$. SE of 1961 terminus of South Crillon Glacier and $75 \mathrm{mi}$. WNW of Hoonah, St. Elias Mts.; $58^{\circ} 35^{\prime} 05^{\prime \prime} \mathrm{N}, 137^{\circ} 21^{\prime} 15^{\prime \prime} \mathrm{W}$; (map 10).

Name reported by the Harvard-Dartmouth Expedition, 1933-34 (Washburn and Goldthwait, 1937, map).

Kloquan: village, see Klukwan.

Klotx Hills: hills, $1 \mathrm{mi}$. across, in Glacier Bay National Monument, near $\mathbf{E}$ shore of Muir Inlet, $1.6 \mathrm{mi}$. $\mathrm{N}$ of Point George, $57 \mathrm{mi}$. NW of Hoonah, St. Elias Mts.; $58^{\circ} 52^{\prime} 45^{\prime \prime} \mathrm{N}, 136^{\circ}$ $02^{\prime} 00^{\prime \prime} \mathrm{W}$; (map 10). Var. The Dumplings.

Named by members of the Glacier Bay Expedition of 1941 for Otto Julius Klotz, 18521923, of the Dominion of Canada Survey. Klotz wrote an article about the application of photo-topographic methods in the surveying of the Baird Glacier in 1895, as well as other scientific articles about Alaskan glaciers in
1899 and 1907. He was employed by the Canadian government as topographic surveyor and explorer, 1872-84. In 1885, he became Dominion Astronomer.

Kluanil Island: island, $900 \mathrm{ft}$. long, in Kasaan Bay, on $E$ coast of Prince of Wales I., $1.3 \mathrm{mi}$. SW of Patterson I., Alex. Arch.; 55 $23^{\prime} 05^{\prime \prime}$ N, $132^{\circ} 13^{\prime} 50^{\prime \prime} \mathrm{W}$; (map 4).

This may be an Indian name; published in 1927 by USC\&GS.

Klu Bay: estuary, extends NE $1.3 \mathrm{mi}$. off Shrimp Bay, on NW coast of Revillagigedo I., Alex. Arch.; $55^{\circ} 50^{\prime} 15^{\prime \prime} \mathrm{N}, 1^{\circ} 28^{\prime} 00 \mathrm{~W}$; (map 3).

Local name published in 1943 by USC\&GS. Kluchablok River: stream, see Klokerblok River. Klucheff Bay: bay, see Hot Springs Bay.

Kluchev Bay: bay, see Marsh Bay.

Kluchev Bay: lake, see Redoubt Lake.

Kluchevoi Bay: bay, see Hot Springs Bay.

Kluchman Mountain: mountain, elev. 4,940 ft., $5.2 \mathrm{mi}$. E of terminus of East Twin Glacier and $31 \mathrm{mi}$. NE of Juneau, Coast Mts.; $58^{\circ} 34^{\prime}$.. $00^{\prime \prime} \mathrm{N}, 133^{\circ} 44^{\prime} 30^{\prime \prime} \mathrm{W}$; (map 12).

Name reported in 1922 by IBC surveyors; published in 1923 on IBC sheet 8 (1951 Atlas). It is a Chinook word meaning "woman."

Klu Creek: stream, heads in lake, flows SW 4 mi. to Klu Bay, on NW coast of Revillagigedo I., Alex. Arch.; $55^{\circ} 50^{\prime} 40^{\prime \prime} \mathrm{N}, 131^{\circ} 26^{\prime} 05^{\prime \prime} \mathrm{W}$; (map 3 ).

Local name published in 1943 by USC\&GS. Kludasetsh : stream, see Ludaseska Creek.

Klughuggue: locality, "on Chichagof I.," Alex. Arch.; (map 9 or 11). Var. Chŭl-chágu.

Former Huna Tlingit Indian camp or settlement reported by Ivan Petroff, with a population of 108 , in the 1880 Census.

Klughuggue: locality, see Tlushashakian.

Kluheena River: stream, see Klehini River.

Kluheeny River: stream, see Klehini River.

Kluheny River: stream, see Klehini River.

Kluhini River: stream, see Klehini River.

Kluklaklatna River: stream, see Little Mud River.

Kluklaklatna River: stream, see Mud River.

Klukquan: village, see Klukwan.

Kluktak Creek: stream, flows NW $12 \mathrm{mi}$. to Kuskokwak Creek, 52 mi. S of Bethel, YukonKuskokwim Delta; $60^{\circ} 04^{\prime} \mathrm{N}, 161^{\circ} 44^{\prime} \mathrm{W}$; (map 59).

Eskimo name reported in 1951 by USC\&GS. Kluktoo: locality, see Kluktu.

Kluktu : locality, $0.7 \mathrm{mi}$. E of mouth of Yokeak Creek in Klehini River, $31 \mathrm{mi}$. W of Skagway, St. Elias Mountains ; $59^{\circ} 25^{\prime} 55^{\prime \prime} \mathrm{N}, 136^{\circ} 10^{\prime} 30^{\prime \prime}$ W; (map 45). Var. Kluktoo.

Name shown on a recent Canadian map.

Klukwah Mountain: mountain, 7,000 ft., $5.3 \mathrm{mi}$. NE of Klutshah Mtn. and $21 \mathrm{mi}$. NW of Skagway, Coast Mts. ; $59^{\circ} 35^{\prime} 20^{\prime \prime} \mathrm{N}, 135^{\circ} 52^{\prime} 00^{\prime \prime} \mathrm{W}$; (map 45).

Tlingit Indian name that appears to be similar to the village name Klukwan. It was published in 1954 by USGS.

Klukwan: village, pop. 112 , on $\mathbf{N}$ shore of Chilkat River, $1.4 \mathrm{mi}$. SE of Glass Point and 21 
mi. SW of Skagway, Coast Mts.; 59 $24^{\prime} 00^{\prime \prime}$ $\mathrm{N}, 135^{\circ} 53^{\prime} 30^{\prime \prime} \mathrm{W}$; (map 45). Var. Chilcat, Chilkat, Klakwan, Kloquan, Klukquan, Klukwan, Klukwan.

Originally a Tlingit Indian village the name of which, as reported by the U.S. Navy in 1880 , was "Chilcat of Klukquan," which is said to mean "the old town." W. H. Dale (U.S. Coast and Geodetic Survey, 1883, p. 198), USC\&GS, reported the inhabitants called the village "Klu-kwan." At that time it consisted of 65 houses and 560 inhabitants. Aurel and Arthur Krause (1883, map) reported the name as "Kloquan." It was listed in the 11 th Census in 1890 as "Klakwan," and it had 30 houses and 326 inhabitants, of which only three were non-Indian. The spelling "Klukwan" was adopted by the Canadian Board on Geographic Names.

Klukwan: village, see Kake.

Klumma Gutto: glacier, see Taku Glacier.

Klumū Gutta: glacier, see Taku Glacier.

Klunathkada Hill: hill, 1,950 ft., $\mathbf{N}$ of Mundthag Lake, 11 mi. $\mathrm{S}$ of Northway, Alaska Ra.; $62^{\circ}$. $48^{\prime} \mathrm{N}, 141^{\circ} 57^{\prime} \mathrm{W}$; (map 84).

Indian name reported by USGS in 1955 .

Klunistana Creek: stream, flows SW $6 \mathrm{mi}$. to Nenana River, $45 \mathrm{mi}$. SE of Healy, Alaska Ra.; $63^{\circ} 20^{\prime} 30^{\prime \prime} \mathrm{N}, 148^{\circ} 13^{\prime} 30^{\prime \prime} \mathrm{W}$; (map 87).

Tanana Indian name reported in 1910 by D. C. Witherspoon (in Moffit, 1915, pl. 1), USGS.

Klu River: stream, flows $24 \mathrm{mi}$. NE to Chakina River $8 \mathrm{mi}$. S of junc. of Chakina and Chitina Rivers, $17 \mathrm{mi}$. SW of McCarthy, Chugach Mts.; $61^{\circ} 12^{\prime} 30^{\prime \prime} \mathrm{N}, 143^{\circ} 09^{\prime} 18^{\prime \prime} \mathrm{W}$; (map 67).

Name reported in 1900 by T. G. Gerdine, USGS. This may be the Ahtena Indian word (Khlu) meaning "glacier."

Klusiktok Creek: stream, flows SE $9 \mathrm{mi}$. to the Inglutalik River, $38 \mathrm{mi}$. $\mathrm{E}$ of Haycock, Nulato Hills; $65^{\circ} 12^{\prime} \mathrm{N}, 159^{\circ} 52^{\prime} \mathrm{W}$; (map 109).

Eskimo name meaning "it is far back" reported in 1956 by Orth.

Klutagmiut: locality, see Klutak.

Klutak: locality, "in the Kuskokwim district." Var. Klutagmiut.

Former Eskimo camp or settlement listed as "Klutagmiut," with a population of 21 , in the 1890 Census.

Klutak Inlet: estuary, see Lutak Inlet.

Klutena: stream, see Klutina River.

Klutena Glacier: glacier, see Klutina Glacier.

Klutena Lake: lake, see Klutina Lake.

Klutina Glacier: glacier, heads $\mathrm{N}$ of Mount Mahlo, trends NE $6 \mathrm{mi}$. to head of Klutina River, $20 \mathrm{mi}$. N of Valdez, Chugach Mts.; $61^{\circ} 23^{\prime} 55^{\prime \prime} \mathrm{N}, 146^{\circ} 07^{\prime} 30^{\prime \prime} \mathrm{W}$; (map 68). Var. Klutena Glacier.

Local name reported in 1900 by F. C. Schrader, USGS; named for the river.

Klutina Lake: lake, 16 miles long, on Klutina River, $2.5 \mathrm{mi}$. SE of Dowling Peak and $44 \mathrm{mi}$. $\mathrm{N}$ of Valdez, Chugach Mts.; 61 ${ }^{\circ} 42^{\prime \prime} \mathrm{N}$, $145^{\circ} 58^{\prime} \quad$ W; (map 68). Var. Abercrombie Lake, Klutena Lake.
Named by several hundred prospectors who camped at this lake in 1898; derived from the river's name. It has also been locally called "Abercrombie Lake" for Capt. W. R. Abercrombie, USA, who was exploring this area at this same time.

Klutina Lake Trail: trail, heads on $\mathbf{N}$ shore of Klutina Lake, near mouth of Chultik Creek, extends $\mathrm{N} 21 \mathrm{mi}$. to Hudson Lake, $48 \mathrm{mi}$. NE of Valdez, Chugach Mts. ; $61^{\circ} 44^{\prime} 35^{\prime \prime} \mathrm{N}, 145^{\circ}$ $49^{\prime} 10^{\prime \prime} \mathrm{W}$; (map 68).

Named after lake of the same name.

Klutina River: stream, heads in Klutina Glacier, flows $63 \mathrm{mi}$. NE to Copper River at Copper Center, $66 \mathrm{mi}$. NE of Valdez, Copper River Basin; 61 $57^{\prime} 20^{\prime \prime} \mathrm{N}, 1^{\circ} 15^{\circ} 17^{\prime} 00^{\prime \prime} \mathrm{W}$; (map 68). Var. Klatena, Klati River, Klutena.

Ahtena Indian name meaning "glacier river [khlu ti-tna]" obtained in 1885 by Lt. H. T. Allen (1887, p. 61), USA, and spelled "Klatena."

Klutlan Glacier: glacier, $40 \mathrm{mi}$. long, heads in Alaska SW of Mount Natazhat, trends E across Alaska-Canada boundary to headwaters of Klutlan River, St. Elias Mts.; $61^{\circ} 27^{\prime} \mathrm{N}$, $141^{\circ} 00^{\prime} \mathrm{W}$; BGN 1954; (map 67).

Native name reported in 1891 by C. W. Hayes, USGS.

Klutshah Mountain: mountain, 6,000 ft., 3.4 mi. SE of junc. of Kelsall River with Chilkat River, $22 \mathrm{mi}$. NW of Skagway, Coast Mts.; $59^{\circ} 25^{\prime} 20^{\prime \prime} \mathrm{N}, 135^{\circ} 52^{\prime} 00^{\prime \prime} \mathrm{W}$; (map 45).

Tlingit Indian name given by E. C. Robertson, USGS, and published in 1952 by USGS.

Klutson Creek: stream, see Kletsan Creek.

Klutson Glacier: glacier, see Natazhat Glacier. Klutuk Creek: stream, heads at Kemuk Mtn. and flows SE $36 \mathrm{mi}$. to Nushagak River at Ekwok, $42 \mathrm{mi}$. NE of Dillingham, Bristol Bay Low.; 59 $22^{\prime} \mathrm{N}, 157^{\circ} 30^{\prime} \mathrm{W}$; BGN 1931; (map 52).

Eskimo name reported by Gerald FitzGerald, USGS, in 1930.

Klutuspak Creek: stream, heads at $60^{\circ} 12^{\prime} \mathrm{N}$, $158^{\circ} 08^{\prime} \mathrm{W}$, flows SE $30 \mathrm{mi}$. to Nushagak River, $115 \mathrm{mi}$. $\mathrm{S}$ of Sleetmute, KilbuckKuskokwim Mts. ; $60^{\circ} 02^{\prime} \mathrm{N}, 157^{\circ} 21^{\prime} \mathrm{W}$; (map 60). Var. Klu-tus Pah Creek, Klu-tus Pas.

Eskimo name reported in 1952 by USC\&GS as "Klu-tus Pas."

Kluvesna Glacier: glacier, trends SW $7.2 \mathrm{mi}$. to its terminus at head of Kluvesna River, 16 mi. NW of Mount Blackburn, Wrangell Mts.; $61^{\circ} 47^{\prime} \mathrm{N}, 143^{\circ} 52^{\prime} \mathrm{W}$; (map 67). Var. Kluwesna Glacier.

Prospectors' name reported in 1900 as "Kluwesna Glacier" by T. G. Gerdine, USGS; it may have been derived from the Ahtena Indian word "khly" meaning "glacier."

Kluvesna River: stream, flows SW $8 \mathrm{mi}$. from terminus of Kluvesna Glacier to Kotsina River, $22 \mathrm{mi}$. NE of Chitina, Chugach Mts.; $61^{\circ} 43^{\prime} \mathrm{N}, 144^{\circ} 03^{\prime} \mathrm{W}$; (map 68).

Indian name published in 1900 on a prospector's manuscript map.

Kluwesna Glacier: glacier, see Kluvesna Glacier. Klyakkhan: village, see Klawock.

Klyavakkhan: village, see Klawock.
Klymunget Lake: lake, $1.5 \mathrm{mi}$. across, between Besziviit Lake and mouth of Telukhti Creek, $17 \mathrm{mi}$. NW of Hochandochtla Mtn., KokrinesHodzana High: ; $65^{\circ} 40^{\prime} \mathrm{N}, 155^{\circ} 23^{\prime} \mathrm{W}$; (map 107).

Koyukan Indian name obtained at Huslia in 1956 by Orth.

Klyuchevaya, Gora: hill, see Kliuchef, Mount. Klyuchevoy, Zaliv: bay, see Hot Springs Bay.

Klyuchi: locality, see Goddard.

Knakatnuk: locality, on $\mathrm{N}$ side of Knik Arm Cook Inlet, Chugach Mts.; (map 63 or 69). Var. Knik Station.

Former Eskimo camp or settlement, with a population of 35, reported by Ivan Petroff in the 1880 Census; shown as "Knik Station" on a 1903 post route map.

Knapp Creek: stream, heads in Igichuk Hills, and flows SW $10 \mathrm{mi}$. to Noatak River, $22 \mathrm{mi}$. $\mathrm{N}$ of Kotzebue, Kotzebue-Kobuk Low. ; $67^{\circ} 13^{\prime}$ N, $162^{\circ} 28^{\prime} \mathrm{W}$; (map 128). Var. Akoblak Creek.

Name reported by the U.S. Army Corps of Engineers in 1954.

Knecktakimut: locality, see Chiukak.

Knee Bay: bay, extends SW $1.1 \mathrm{mi}$., on NE coast of Spruce I., NE of Kodiak I.; $57^{\circ} 56^{\prime}$ $\mathrm{N}, 152^{\circ} 25^{\prime} \mathrm{W}$; (map 34 ).

Local name published in 1943 by USC\&GS.

Knee Hill: mountain, $1,350 \mathrm{ft}$., west-central Kiska I., Aleutian Is.; $51^{\circ} 57^{\prime} 50^{\prime \prime} \mathrm{N}, 177^{\circ} 21^{\prime}$ 45" E. ; (map 14).

An arbitrary name beginning with " $\mathrm{K}$ " to correspond to the "K" grid used by the U.S. Army for tactical purposes during World War II; published on a 1953 AMS map.

Kneep: village, see Knik.

Kneep River: stream, see Knik River.

Knetena: stream, see Nadina River.

Knetina: stream, see Nadina River.

Kniegnagamute: locality, see Kinegnak.

Knifeblade Ridge: ridge, extends $15 \mathrm{mi}$. W of Angoyakvik Pass between Colville and Kigalik Rivers, $12 \mathrm{mi}$. S of head of Ikpikpuk River, Arctic Slope; $69^{\circ} 10^{\prime} \mathrm{N}, 154^{\circ} 48^{\prime} \mathrm{W}$; (map 142). Var. Kimikpak Ridge, Kimikpuk Ridge.

Probably named in the 1940's by the geologists on the Naval Petroleum Reserve No. 4 exploration. The Eskimo name for this ridge, "Kimikpak," has been applied to a ridge 17 miles further east by USGS.

Knife Creek: stream, on Alaska Penin., heads at central terminus of The Knife Creek Glaciers, flows NW $13 \mathrm{mi}$. to River Lethe at Three Forks, in Katmai National Monument, $16 \mathrm{mi}$. NW of Mount Katmai, Aleutian Ra.; $58^{\circ} 22^{\prime} 25^{\prime \prime} \mathrm{N}, 1^{\circ} 25^{\circ} 00^{\prime \prime} \mathrm{W}$; (map 42).

Named in 1922 by R. F. Griggs, National Geographic Society, after Knife Peak (now called Mount Griggs), which overlooks the stream on the north.

Knife Creek Glaciers, The: glaciers, on Mount Katmai, trend NW $4 \mathrm{mi}$. to a central terminus at head of Knife Creek, on Alaska Penin., in Katmai National Monument, Aleutian Ra.; $58^{\circ} 18^{\prime} \mathrm{N}, 155^{\circ} 05^{\prime} \mathrm{W}$; (map 42). 
Local name reported in 1951 by USGS.

Knife Peak: mountain, 3,000 ft., $12 \mathrm{mi}$. NE of Mount Veniaminof and $27 \mathrm{mi}$. W of Chignik, on Alaska Penin., Aleutian Ra.; $56^{\circ} 16^{\prime} \mathrm{N}$, $159^{\circ} 06^{\prime} \mathrm{W}$; (map 30).

Descriptive name reported in 1923 by $R$. H. Sargent, USGS.

Knife Peak: volcano, see Griggs, Mount.

Knife Peak Volcano: volcano, see Griggs, Mount.

Knight Creek: stream, see Sushana River.

Knight Island: island, $2.8 \mathrm{mi}$. across, on $\mathrm{E}$ shore of Yakutat Bay, $12 \mathrm{mi}$. NE of Yakutat, St. Elias Mts.; $59^{\circ} 43^{\prime} \mathrm{N}, 139^{\circ} 33^{\prime} \mathrm{W}$; (map 46). Var. Dalnie Island, Dalni Island, Dalniy Island, Knight's Island.

Named "Knight's Island" in 1794 by Lt. Peter Puget (in Vancouver, 1798, v. 3, p. 226), $R N$, probably for Sir John Knight, $R N$, who had been a fellow prisoner with Lt. W. R. Broughton, commander of the Chatham, in America in 1777, during the Revolutionary War (Wagner, 1937, p. 394). It was called "O[strov] Dalniy," meaning "distant island," by Capt. Tebenkov (1852, map 7), IRN, and "Dalni Island" by W. H. Dall in 1883 Coast Pilot (p. 210).

Knight Island: island, in Prince William Sound, trends NE-SW $26 \mathrm{mi}$., on E side of Knight Island Passage, $56 \mathrm{mi}$. ENE of Seward, Chugach Mts.; $60^{\circ} 21^{\prime} \mathrm{N}, 147^{\circ} 45^{\prime} \mathrm{W}$; (map 63). Var. Knight's Island.

Name shown on Capt. George Vancouver's chart but not mentioned in his text; no doubt named in honor of Sir John Knight. See Knight Island in Yakutat Bay.

Knight Island Passage: water passage, trends $\mathrm{S}$ $36 \mathrm{mi}$. from Prince William Sound to Montague Strait, $10 \mathrm{mi}$. NW of Montague I., Chugach Mts.; $60^{\circ} 15^{\prime} \mathrm{N}, 148^{\circ} 00^{\prime} \mathrm{W}$; (map 63 ).

Local name published in 1913 by USC\&GS; derived from nearby Knight Island.

Knight Island Passage: water passage, see Lower Passage.

Knight Mountain: mountain, 1,749 ft., $1 \mathrm{mi}$. NE of Pyramid Mtn. and $7.5 \mathrm{mi}$. SE of Goodnews, Kilbuck-Kuskokwim Mts.; 59 $01^{\prime} 30^{\prime \prime}$ $\mathrm{N}, 161^{\circ} 28^{\prime} 50^{\prime \prime} \mathrm{W}$; (map 53).

Named in 1914 by USC\&GS; published in 1915 on Chart 9103.

Knight's Island: island, see Knight Island.

Knig Slough: water passage, see King Slough.

Knik: village, pop. 40, on $W$ bank of Knik Arm Cook Inlet, $17.5 \mathrm{mi}$. NE of Anchorage, Cook Inlet Low.; $61^{\circ} 27^{\prime} 30^{\prime \prime} \mathrm{N}, 149^{\circ} 43^{\prime} 15^{\prime \prime}$ W; (map 69). Var. Kinik, Kneep, Knick, Knuyk, Kook, Kweek, Kinnick, K'niq-a-mut, Palmers Store.

Tanaina Indian village name, meaning "fire [igniq]," originally applied to a settlement of several villages at the head of Cook Inlet. The principal village (probably the one at the mouth of Knik River) was listed by Ivan Petroff as "Kinik" and "Kinnick" in 1880 U.S. Census with a population of 46 ; in 1890,160 . The total number of "Kinik" Indians living in the area in 1900 was about
250 , obtaining their subsistence by hunting, trapping and bartering. The present village called "Knik" developed around a trading post called "Palmers Store" in 1903. Its population was 118 in 1910; 40 in 1920; and 34 in 1930. The Knik post office was here from 1904 to 1919 (Ricks, 1965, p. 35). See Eklutna.

Knik Anchorage: anchorage, in Knik Arm just offshore from city of Anchorage; $61^{\circ} 13^{\prime} \mathrm{N}$, $149^{\circ} 55^{\prime} \mathrm{W}$; (map 69).

Name published in 1913 by the Alaska Coast Company on a folder.

Knik Anchorage: city, see Anchorage.

Knik Arm: estuary, $3 \mathrm{mi}$. wide, extends NE 40 mi. from Cook Inlet, $W$ of Anchorage, Cook Inlet Low.; $61^{\circ} 12^{\prime} \mathrm{N}, 150^{\circ} 13^{\prime} \mathrm{W}$; (map 70). Var. Fire River, Knik River.

Eskimo name meaning "fire [ignik]" used to identify the Tanaina Indians living on the north shore of this estuary. See Knik. The estuary name was reported in 1869 by George Davidson, USC\&GS.

Knik Glacier: glacier, heads on Mount Marcus Baker, trends W $30 \mathrm{mi}$. to its terminus near head of Knik River, $20 \mathrm{mi}$. SE of Palmer, Chugach Mts.; $61^{\circ} 24^{\prime} \mathrm{N}, 148^{\circ} 34^{\prime} \mathrm{W}$; (map 69).

Eskimo name reported in 1906 by T. G. Gerdine and R. H. Sargent, USGS.

Knik Heights: suburb, near head of Rabbit Creek, $6 \mathrm{mi}$. SE of Anchorage, Cook Inlet Low.; 61 $06^{\circ} 18^{\prime \prime} \mathrm{N}, 149^{\circ} 47^{\prime} 30^{\prime \prime} \mathrm{W}$; (map 69).

Local name reported in 1962 by USGS; derived from Knik Arm.

Knik Lake: lake, $0.5 \mathrm{mi}$. long, on W bank of Knik Arm, N of Knik, $17.5 \mathrm{mi}$. NE of Anchorage, Cook Inlet Low.; $61^{\circ} 27^{\prime} 40^{\prime \prime} \mathrm{N}$, $149^{\circ} 43^{\prime} 30^{\prime \prime} \mathrm{W}$; (map 69).

Eskimo name reported in 1911 by GLO [BLM]; name derived from the village of Knik.

Knik River: stream, heads at Knik Glacier, flows NW $25 \mathrm{mi}$. to Knik Arm, $10 \mathrm{mi}$. SW of Palmer, Cook Inlet Low.; $61^{\circ} 29^{\prime} \mathrm{N}, 149^{\circ}$. 16' W; (map 69). Var. Kinik River, Kneek River, Kneep River, Knick River, Knuyk River, Reka Knyk, Kook River, Kweek River.

Eskimo name meaning "fire [igniq]" reported by Capt. Tebenkov (1852, map 6), IRN, as "Reka Knyk." Present spelling was reported by George Davidson, USC\&GS, in 1869 Coast Pilot (p. 190).

Knik River: estuary, see Knik Arm.

Knik Station: locality, see Knakatnuk.

Kniktag-miut: locality, see Iknetuk.

K'niq-a-mut: village, see Knik.

Knob, The: hill, $700 \mathrm{ft}$., on S side of Pleasant I., in Icy Strait, $4.3 \mathrm{mi}$. W of Noon Point and $45 \mathrm{mi}$. W of Juneau, St. Elias Mts. ; 58 $20^{\prime} 30^{\prime \prime}$ $\mathrm{N}, 135^{\circ} 39^{\prime} 20^{\prime \prime} \mathrm{W}$; (map 11).

Local name published in 1948 by USGS.

Knob Creek: stream, flows SW $2 \mathrm{mi}$. to Eska Creek, $3 \mathrm{mi}$. NW of Sutton and $12 \mathrm{mi}$. NE of Palmer, Cook Inlet Low.; 61 ${ }^{\circ} 45^{\prime} 05^{\prime \prime} \mathrm{N}$, $148^{\circ} 55^{\prime} 05^{\prime \prime} \mathrm{W}$; BGN 1946; (map 69).

Local name reported about 1946 by USGS.
Knob G: mountain, 1,760 ft., on $\mathrm{W}$ side of Muir Inlet, between valleys of Morse and Plateau Glaciers, $58 \mathrm{mi}$. NW of Hoonah, St. Elias Mts.; $58^{\circ} 52^{\prime} 30^{\prime \prime} \mathrm{N}, 136^{\circ} 08^{\prime} 30^{\prime \prime} \mathrm{W}$; (map 10). Var. G, The Rat.

Named by members of the American Geographical Society's Glacier Bay Expedition of 1941 (Field, 1947, map) because H. F. Reid's triangulation station " $G$ " was established on this point in 1890 (Reid, 1892, pl. 14) and was used by many subsequent observers. It was also known as "The Rat" by tourists of the 1880's.

Knob H: peak, 1,138 ft., in Glacier Bay National Monument, $3.5 \mathrm{mi}$. SE of Point McLeod and $57 \mathrm{mi}$. NW of Hoonah, St. Elias Mts.; 58 $52^{\prime} 30^{\prime \prime} \mathrm{N}, 136^{\circ} 02^{\prime} 45^{\prime \prime} \mathrm{W}$; (map 10). Var. The Mouse.

Named by members of the American Geographical Society's Glacier Bay Expedition of 1941 (Field, 1947, map) for H. F. Reid's triangulation station " $\mathrm{H}$ " of 1890 and 1892 which was located there (Reid, 1892, pl. 14). It was also known as "The Mouse" by tourists in the 1880's.

Knob Hill: hill, see Court House Hill.

Knob Hill: mountain, $1,365 \mathrm{ft}$., on west-central Kiska I., Aleutian Is.; $51^{\circ} 56^{\prime} 05^{\prime \prime}$ N, $177^{\circ} 21^{\prime}$ $38^{\prime \prime}$ E; (map 14). Var. Siberia Hill.

An arbitrary name beginning with " $K$ " to correspond to "K" grid used by U.S. Army for tactical purposes during World War II; published on a 1953 AMS map. Variant published on a 1943 USAAF map.

Knob Hill: ridge, see Chicken Ridge.

Knob I: hill, $700 \mathrm{ft}$., in Klotz Hills, in Glacier Bay National Monument, $1.5 \mathrm{mi}$. SE of Knob $\mathrm{H}$ and $56 \mathrm{mi}$. NW of Hoonah, St. Elias Mts.; $58^{\circ} 51^{\prime} 40^{\prime \prime} \mathrm{N}, 136^{\circ} 02^{\prime} 05^{\prime \prime} \mathrm{W}$; (map 10).

Named by members of the American Geographical Society's Glacier Bay Expedition of 1941 (Field, 1947, map). This was the site of $\mathrm{H}$. F. Reid's triangulation station " $\mathrm{I}$ " in 1890 and 1892 (Reid, 1892, pl. 14).

Knob Island: island, $0.4 \mathrm{mi}$. across, in El Capitan Passage, off S coast El Capitan I., Alex. Arch.; 55 54'35" N, $133^{\circ} 20^{\prime} 15^{\prime \prime} \mathrm{W}$; (map 4).

Local name published in 1925 Coast Pilot (p. 154).

Knob Lake: lake, $0.7 \mathrm{mi}$. long, between Trail Lake and East Fork Matanuska River, $60 \mathrm{mi}$. NW-of Valdez, Copper River Basin; 61 ${ }^{\circ} 50^{\prime}$ 05" N, $147^{\circ} 20^{\prime} 20^{\prime \prime} \mathrm{W}$; BGN 1960; (map 69).

Descriptive name reported in 1956 to USGS by George Belanger. So named because of the knobby character of the terrain surrounding it.

Knob Point: promontory, on $\mathrm{E}$ coast of Amatignak I., Delarof Is., Aleutian Is. ; $51^{\circ} 15^{\prime} 10^{\prime \prime}$ $\mathrm{N}, 179^{\circ} 03^{\prime} 45^{\prime \prime} \mathrm{W}$; (map 16).

Descriptive name applied because of a conspicuous knob-shaped hill; published by USC\&GS in 1954 Coast Pilot (p. 458).

Knob Ridge: ridge, 3,450 ft., extends $\mathrm{N} 9 \mathrm{mi}$. from Bear Creek, $41 \mathrm{mi}$. NW of Tok, Alaska 
Ra.; $63^{\circ} 35^{\prime} 10^{\prime \prime} \mathrm{N}, 144^{\circ} 15^{\prime} 40^{\prime \prime} \mathrm{W}$; $B G N$ 1937; (map 86).

So named in 1937 by USGS "because of a granite knob, 70 feet high, near its center."

Knockhock: locality, on E bank of Black River, $46 \mathrm{mi}$. S of Kwiguk, Yukon-Kuskokwim Delta; $62^{\circ} 06^{\prime} 30^{\prime \prime} \mathrm{N}, 164^{\circ} 55^{\prime} 00^{\prime \prime} \mathrm{W}$; (map 77). Var. Nahk-hahk, Nakhak.

Eskimo village abandoned in favor of New Knockhock.

Knoll Bay: bay, $2 \mathrm{mi}$. across, $10 \mathrm{mi}$. NE of Kaguyak, on SE coast of Kodiak I.; $56^{\circ} 57^{\prime}$ N, $153^{\circ} 35^{\prime}$ W; (map 33).

Descriptive name given in 1933 by USC\&GS.

Knoll Head: promontory, $500 \mathrm{ft}$., $\mathrm{W}$ of mouth of Iniskin Bay, $21 \mathrm{mi}$. N of Augustine I., Aleutian Ra.; $59^{\circ} 38^{\prime} 30^{\prime \prime}$. N, $153^{\circ} 30^{\prime} 00^{\prime \prime} \mathrm{W}$; $B G N$ 1966; (map 51). Var. Back Range Head.

Descriptive name given about 1916 by USC\&GS.

Knoll Point: point of land, $8.5 \mathrm{mi}$. NE of Kaguyak, on SE coast of Kodiak I.; $56^{\circ} 56^{\prime} 10^{\prime \prime} \mathrm{N}$, $153^{\circ} 36^{\prime} 00^{\prime \prime} \mathrm{W}$; BGN 1934; (map 33).

Named in 1934 by USC\&GS "for a knoll at the end of the point."

Knoll Point: point of land, see Nichols Point. Knolls, The: hills, see Nichols Hills.

Knot Point: point of land, on NE end of Hawkins I., $3 \mathrm{mi}$. N of Cordova, Chugach Mts.; $60^{\circ} 35^{\prime} 40^{\prime \prime} \mathrm{N}, 145^{\circ} 45^{\prime} 40^{\prime \prime} \mathrm{W}$; (map 64).

Named in 1897 by Lt. Comdr. J. F. Moser, USN, while collecting hydrographic data and making harbor sketches along the coast of Alaska.

Knowat Creek: stream, see Jungjuk Creek.

Knowat River: stream, see Owhat River.

Knowl, The: peak, 5,150 ft., on edge of Taku Glacier at $\mathrm{N}$ end of the Taku Range, $1.1 \mathrm{mi}$. NW of Flower Tower and $25 \mathrm{mi}$. N of Juneau, Coast Mts.; 58 $39^{\prime} 40^{\prime \prime}$ N, $134^{\circ} 23^{\prime}$ 55" W; (map 11).

Descriptive name published in 1960 by USGS.

Knowles Bay: bight, $3.5 \mathrm{mi}$. wide, NE edge of Prince William Sound, $30 \mathrm{mi}$. NW of Cordova, Chugach Mts.; $60^{\circ} 41^{\prime} \mathrm{N}, 146^{\circ} 33^{\prime} \mathrm{W}$; (map 64).

Local name published in 1953 by USGS; derived from nearby Knowles Head.

Knowles. Creek: stream, flows SE $12 \mathrm{mi}$. to Koyuk River, $14 \mathrm{mi}$. SW of Kiwalik Mtn. and $23 \mathrm{mi}$. SE of Imuruk Lake, seward Penin. High.; $65^{\circ} 23^{\prime} \mathrm{N}, 162^{\circ} 35^{\prime} \mathrm{W}$; (map 110).

Prospectors' name reported in 1900 by W. J. Peters (in Mendenhall, 1901, pl. 20), USGS.

Knowles Head: point of land, at $\mathrm{W}$ end of Knowles Bay, $32 \mathrm{mi}$. NW of Cordova, Chugach Mts.; $60^{\circ} 41^{\prime} 00^{\prime \prime}$ N, $146^{\circ} 37^{\prime} 30^{\prime \prime}$ W; (map 64).

Named by Capt. Abercrombie (1900, map), USA, while exploring the Copper River region in 1898.
Knox Peak: mountain, 5,970 ft., in Teocalli Mts., $6 \mathrm{mi}$. SE of junc. of South Fork Kuskokwim and Tatina Rivers, $90 \mathrm{mi}$. SE of McGrath, Alaska Ra.; $62^{\circ} 13^{\prime} \mathrm{N}, 153^{\circ} 20^{\prime} \mathrm{W}$; (map 80).

Named in 1898 by J. E. Spurr and W. S. Post, USGS.

Knoxville Lake: lake, oxbow along Selawik River, 13 mi. E of Selawik, Kotzebue-Kobuk Low.; 66 $35^{\prime} \mathrm{N}, 159^{\circ} 33^{\prime} \mathrm{W}$; (map 114).

Local name reported in 1955 by the U.S. Army Corps of Engineers.

Knub Hill: mountain, 1,750 ft., on Iniskin Penin., 1 mi. W of Dry Bay, Aleutian Ra.; 59 $40^{\prime} \mathrm{N}, 153^{\circ} 10^{\prime} \mathrm{W}$; BGN 1916; (map 51). Var. Nub Hill.

Name published as "Nub Hill" by USC\&GS in 1913, but spelling was changed by BGN at the recommendation of Andrew Braid, USC\&GS.

Knudson Cove: bay, $1.2 \mathrm{mi}$. wide, on $\mathrm{W}$. coast of Revillagigedo I., at $\mathrm{S}$ entrance to Clover Passage, $35 \mathrm{mi}$. NW of Ketchikan, Alex. Arch.; $55^{\circ} 28^{\prime} 30^{\prime \prime} \mathrm{N}, 131^{\circ} 48^{\prime} 00^{\prime \prime} \mathrm{W}$; (map $3)$.

Local name recorded in 1954 by USGS.

Knudson Cove: village, see Clover Pass.

Knudson Creek: stream, see Duck Creek.

Knudson Mountain: peak, see Knutson Mountain.

Knutruin Rock: rock, in Cook Inlet, at West Foreland, $20 \mathrm{mi}$. NNW of Kenai, Cook Inlet Low.; $60^{\circ} 43^{\prime} 00^{\prime \prime} \mathrm{N}, 151^{\circ} 42^{\prime} 30^{\prime \prime} \mathrm{W}$; (map 62). Var. Knuttrain Rocks.

Reported in 1958 as Knuttrain Rocks by USGS.

Knutson Bay: bight, $6 \mathrm{mi}$. across, in Iliamna Lake, at mouth of Knutson Creek, $18 \mathrm{mi}$. E of Iliamna, Aleutian Ra.; $59^{\circ} 48^{\prime} \mathrm{N}, 154^{\circ} 15^{\prime}$ W; (map 51).

Local name reported by G. C. Martin and F. J. Katz (in Brooks and others, 1910, pl. 5), USGS. Name was apparently derived from nearby Knutson mining prospect.

Knutson Creek: stream, flows SW $11 \mathrm{mi}$. to Knutson Bay, at NE end of Iliamna Lake, Aleutian Ra.; $59^{\circ} 48^{\prime} \mathrm{N}, 154^{\circ} 09^{\prime} \mathrm{W}$; (map 51).

Local name derived from Knutson Bay; published by Martin and Katz (1912, p. 91).

Knutson Lake: lake, $0.5 \mathrm{mi}$. across, $\mathrm{S}$ of Mount Dana, 6 mi. NE of Pavlof Bay, Aleutian Ra.; $55^{\circ} 38^{\prime} \mathrm{N}, 161^{\circ} 13^{\prime} \mathrm{W}$; (map 28). Named in 1929 by USGS.

Knutson Mountain: peak, 3,880 ft., $\mathbf{N}$ of Knutson Bay, at NE end of Iliamna Lake, Aleutian Ra.; 59 $40^{\prime} \mathrm{N}, 154^{\circ} 11^{\prime} \mathrm{W}$; (map 51). Var. Knudson Mountain.

Local name published by Martin and Katz (1912, p. 91), USGS.

Knutson Valley: valley, of Knutson Creek, 3 mi. across, on NE shore of Iliamna Lake, at $\mathrm{W}$ end of Knutson Bay, Aleutian Ra.; 59 $48^{\prime}$ N, $154^{\circ} 09^{\prime} \mathrm{W}$; (map 51).

Local name published by USGS in 1952.

Knuttrain Rocks: rock, see Knutruin Rock.

Knuyk: village, see Knik.

Knuyk River: stream, see Knik River.
Knyk, Reka: stream, see Knik River.

Knykhtag-myut, Selyeniye: locality, see Iknetuk.

Knykhtakg-miut: locality, see Iknetuk.

Knykhtakg-myut: locality, see Iknetuk.

Kobakof Bay: bay, 2 mi. across, on $\mathrm{S}$ coast of Atka I., Aleutian Is.; $52^{\circ} 04^{\prime} \mathrm{N}, 174^{\circ} 30^{\prime} \mathrm{W}$; (map 18). Var. Kabakof Bay, Kabakovskaia Bay, Kobakotshaia.

Name published as "Bukh[ta] Kobakovskaia," or "Kobakovskaia Bay," on Russian Hydrog. Dept. Chart 1400 (1848). "Kabakof Bay" is said by Baker (1906, p. 340) to be named "by the pilot Ingenstrem" (cnna), about 1830 .

Kobakotshaia: 'bay, see Kobakof Bay.

Kobal: locality, see Cobol.

Kobe: railroad station, see Rex.

Kobi: railroad station, see Rex.

Kobolunuk: locality, on right bank of Yukon River, $7.7 \mathrm{mi}$. NW of Pitkas Point and $48 \mathrm{mi}$. NW of Marshall, Yukon-Kuskokwim Delta; $62^{\circ} 05^{\prime} \mathrm{N}, 163^{\circ} 30^{\prime} \mathrm{W}$; (map 77). Var. Cobolunuk.

Eskimo camp reported in 1899 by G. R. Putnam, USC\&GS, who spelled it "Cobolunuk."

Kobuk: village, pop. 54, on right bank of Kobuk River 7 mi. NE of Shungnak, KotzebueKobuk Low.; $66^{\circ} 55^{\prime} \mathrm{N}, 156^{\circ} 52^{\prime} \mathrm{W}$; (map 115). Var. Kochuk, Shungnak.

Village established about 1899 as a supply point for the mining activities in the Cosmos Hills to the north. It was then called Shungnak. Because the village was the location of a trading post, school, and Friends mission, it became primarily an Eskimo settlement by 1910 . Due to river erosion the population of Shungnak decided to relocate at a new site called "Kochuk" about 10 miles downstream in the 1920's. The few families that remained behind, and some who returned, renamed the village "Kobuk." The Shungnak post office was established in 1903; the name was changed to Kobuk in 1928. Its population was 210 in 1910 ; 95 in $1920 ; 31$ in 1939 ; and 38 in 1950.

Kobuk Creek: stream, in Ray Mts., flows SSW $10 \mathrm{mi}$. to Gishna Creek, $38 \mathrm{mi}$. NE of Tanana, Kokrines-Hodzana High.; $65^{\circ} 37^{\prime} \mathrm{N}, 151^{\circ} 20^{\prime}$ W; (map 106).

Local name obtained in 1956 at Tanana by Orth; so named because Kobuk Eskimo herded reindeer here about 50 years ago.

Kobuk Lake: lake, $0.8 \mathrm{mi}$. long, on $\mathrm{N}$ side of Chandalar River, $0.5 \mathrm{mi}$. NE of Mary Lake and $23 \mathrm{mi}$. SSE of Chandalar, Brooks Ra.; $67^{\circ} 11^{\prime} \mathrm{N}, 148^{\circ} 10^{\prime} \mathrm{W}$; (map 123).

Local name reported in 1956 by T. E. Taylor, USGS.

Kobuk River: stream, flows W $280 \mathrm{mi}$. to Hotham Inlet $25 \mathrm{mi}$. SE of Kotzebue ; $66^{\circ} 54^{\prime}$ N, 160³8' W; BGN 1905; (map 114). Var. Holöatna, Holoöatná, Koowak, Kowak, Kowuk, Kooak, Kopak, Kubuk, Kuvuk, Kubuck, Putnam.

Eskimo name meaning "big river" first transcribed by John Simpson in 1850 as "Kowuk." Explored by Lt. G. M. Stoney, 
USN, in 1883-1886, who wrote the name "Ku-buck," but proposed that it be called "Putnam" in honor of Master Charles Flint Putnam, USN, officer of the Rodgers, who was carried to sea on the ice and lost in 1880. Lt. J. C. Cantwell, USRGS, also explored the river in 1884 and 1885 and spelled the name "Koowak" on his map and "Kowak" in his text. Ivan Petroff spelled the river name "Kooak" in 1880 , and W. H. Dall spelled it "Kowak" in 1870 . Lt. H. T. Allen, USA, obtained the Koyukan Indian name in 1885 which he spelled "Holoöatna" and "Holöatna."

Kobuk River Delta: delta, extends W $32 \mathrm{mi}$. to Hotham Inlet, $35 \mathrm{mi}$. WNW of Selawik, Kotzebue-Kobuk Low.; $66^{\circ} 45^{\prime} \mathrm{N}, 161^{\circ} 45^{\prime}$ W; (map 114).

Descriptive name published in 1951 by AMS.

Kobuk Villages: localities, on lower Kobuk River. Var. Kooagamutes, Kowagamute, Kuagamut, Kubok, Ku-wung-mutes.

This name was reported in 1842-44 and spelled "Kubok" by Lt. L. A. Zagoskin, IRN. Ivan Petroff in the 1880 U.S. Census listed "Kowagamute," i.e. "Kowak people," which more than likely refers in general to the Eskimo living on the Kobuk River in camps and small settlements.

Kocacho Creek: stream, see Kokacho Creek. Kochalitno River: stream, see Swift River.

Kocheelagok: hill, see Nushkolik Mountain.

Kochek, Ostrov: island, see Middleton Island. Kochekmak, Zaliv: bay, see Kachemak Bay.

Kochilagok Hill: hill, $225 \mathrm{ft}$., W of Nungatak River, $78 \mathrm{mi}$. SW of Marshall, Yukon-Kuskokwim Delta ; 61 ${ }^{\circ} 38^{\prime}$ N, $164^{\circ} 22^{\prime}$ W; (map 74). Var. Kutchilkag Hill, Co-chee-shluck Hill.

Eskimo name that refers to the "crane" (lesser sandhill crane, Grus canadensis canadensis) and reported by USC\&GS in 1949. The name means "color body, red" (Gabrielson and Lincoln, 1959, p. 314).

Kochkogamute: locality, see Kakamut.

Kochkomut: locality, see Kakámut.

Kochlogtogpagamiut: locality, see Kukuktuk.

Kochluk Pass: water course, in Yukon Delta, heads at Kwikpak Pass, flows NW $6 \mathrm{mi}$. to Norton Sound, $27 \mathrm{mi}$. N of Kwiguk, YukonKuskokwim Delta; $63^{\circ} 09^{\prime} \mathrm{N}, 164^{\circ} 33^{\prime} \mathrm{W}$; (map 92).

Eskimo name reported in 1952 by USC\&GS. Kochrines: village, see Kokrines.

Kochu Island: island, $0.8 \mathrm{mi}$. long, in Chilkat Inlet, $1.6 \mathrm{mi}$. $\mathrm{S}$ of Letnikof Cove, on Chilkat Penin., 22 mi. SSW of Skagway, Coast Mts.; $59^{\circ} 08^{\prime} 45^{\prime \prime} \mathrm{N}, 135^{\circ} 23^{\prime} 45^{\prime \prime} \mathrm{W}$; (map 45). Var. Alexander Island, Gla-huts, Jachlanissa, Ventosa Island.

Name published by Russian Hydrog. Dept. (1848, inset dated 1838, Chart 1396) as "O[hsov]," Kochu or "Kochu Island." The island was called Ventosa Island in 1869 by Comdr. R. W. Meade, USN; the Tlingit Indian name was said to be Gla-huts (1883 Coast Pilot, p. 167). Aurel and Arthur Krause
(1883, map), however, reported the name as Jachlanissa.

Kochuitno: stream, see Kashwitna River.

Kochuk: village, see Kobuk.

Kodiac Island: island, see Afognak Island.

Kodiac Island: island, see Kodiak Island.

Kodiak: town, pop. 2,628, on NE coast of Kodiak I. ; $57^{\circ} 47^{\prime} 20^{\prime \prime}$ N, $152^{\circ} 24^{\prime} 10^{\prime \prime}$ W; BGN 1944; (map 34). Var. Gavan Saint Pavla, Kadiak, Paul's Harbor, Pavlovsky Gavan, Saint Paul, Seleniye Pavlovskoy Gavani.

Local name derived from Kodiak Island and first published by the U.S. Post Office Department when the Kodiak post office was established in 1869 (Ricks, 1965, p. 35). The post office was discontinued in 1875 and reestablished in 1888 . The town was founded in 1792 by Alexander Baranov, Manager of the Shelikov (later the Russian American) Company from 1792 to 1808 . He named it "Pavlovsk Gavan," or "Paul's Harbor." Baranov moved Shelikov's settlement from Three Saints Harbor to this location because "the land surrounding it was higher and drier *** it was surrounded by the timber needed to build boats, buildings and better fortifications * * *." (Ameigh and Chaffin, 1962 , p. 45). The 11 th Census in 1890 (1893, p. 74) reported, "The most important permanent settlement in the Second district is Kadiak, designated on our charts as St. Paul. The place was selected as a central station and headquarters of the Russian fur-trading companies in the year 1789 on account of its good harbor and close vicinity of good building timber. Previous to the establishment of New Archangel, or Sitka, on its present site, Kadiak was also the headquarters of the Russian American Company." The town was called "St. Paul" in 1805 by Lisianski (1814, p. 168), and "gavan St. Pavla" in 1849 by Capt. Tebenkov (1852, map 23). Sarichev (1826, map 16) showed it as "Seleniye Pavlovskoy Gavani," or "Settlement of Paul's Harbor."

Kodiak Harbor: bight, see Saint Paul Harbor.

Kodiak Harbor: water passage, between Kodiak and Near I., on NE coast of Kodiak I.; $57^{\circ}$ $47^{\prime} 15^{\prime \prime} \mathrm{N}, 152^{\circ} 24^{\prime} 00^{\prime \prime} \mathrm{W}$; (map 34).

Name derived from Kodiak Island and published in 1943 by USC\&GS.

Kodiak Island: island, $100 \mathrm{mi}$. long, $60 \mathrm{mi}$. across, in Gulf of Alaska, $\mathbf{S}$ of Cook Inlet; $57^{\circ} 20^{\prime} \mathrm{N}, 153^{\circ} 22^{\prime} \mathrm{W}$; BGN 1901; (map 34). Var. Cadiack Island, Codiac, Florida Blanca, Great Island, Kadiak Island, Kadjak Island, Kadyak Island, Kaniag Island, Kichtak, Kikhtak, Kikhtowik, Kodiac Island, Kuktak Island, Rodiac.

This island, the largest in Alaska, native home to the Kodiak Bear, was first discovered by Stephen Glotov in 1763. "Glotof [sic] however did not land till he reached the last and most Eastward of these islands, called by the inhabitants Kadyak." (Coxe, 1787, p. 124). According to Bancroft (1886, p. 141), "Glottof finally anchored on the 8th of September off the coast of a large and mountain- ous island, called Kikhtak by the natives, but now known as Kadiak." Petroff (in Bancroft, p. 224) says, "Kikhtak, or Kikhtowik, is the Innuit word for island. At the present day [1886] the natives of the peninsula speak of the Kodiak people simply as Kikhtagamutes, islanders. The tribal name appears to have been Kaniag and the Russian appellation now in use probably derived from both." The name "Kodiak" was first used on October 20, 1778 , by Capt. Cook (1785, v. 2, p. 504) who wrote, "It was from him [Ismyloff] that we got the name of Kodiak." During the 1800 's many spellings of the name were used and "Kadiak" was adopted as the official name in 1890, but was changed to its present spelling in 1901 because of popular local usage. This island was named "Florida Blanca" in 1788 by E. J. Martinez and Lopez de Haro (Baker, 1906, p. 375).

Kodiak Ranch: locality, $23 \mathrm{mi}$. SSE of Kodiak, on $\mathrm{E}$ coast of Kodiak I.; $57^{\circ} 28^{\prime} \mathrm{N}, 152^{\circ} 20^{\prime}$ $W$; (map 34).

Name derived from Kodiak Island and published in 1964 by USGS.

Kodiak Rock: rock, in Gulf of Alaska, $2 \mathrm{mi}$. NE of Long I., $7.5 \mathrm{mi}$. NE of Kodiak, Kodiak I.; $57^{\circ} 48^{\prime} 30^{\prime \prime} \mathrm{N}, 152^{\circ} 12^{\prime} 00^{\prime \prime} \mathrm{W}$; (map 34). Var. Kadiak Rock.

Name derived from Kodiak Island and given in 1868 by USC\&GS as "Kadiak."

Kodogh: ravine, extends $\mathrm{N}$ from Garden Cove, on SE coast of St. George I., in Pribilof Is.; $56^{\circ} 35^{\prime} 10^{\prime \prime} \mathrm{N}, 169^{\circ} 30^{\prime} 30^{\prime \prime} \mathrm{W}$; (map 38).

An Aleut name listed by Putnam (1903, p. 1015), USC\&GS, as "Ko'dogh [Ko'doch]" meaning "gulch."

Kodosin Minnkohwin Lake: lake, $3.4 \mathrm{mi}$. long, W of Konedsin Minnkohwin Lake, $22 \mathrm{mi}$. SE of Allakaket, Kanuti Flats; $66^{\circ} 22^{\prime} \mathrm{N}, 152^{\circ} 00^{\prime}$ W; (map 117).

Koyukan Indian name obtained in 1956 at Allakaket by T. E. Taylor, USGS.

Kodosin Nolitna Creek: stream, flows NE 21 mi. to Kanuti Kilolitna River $3 \mathrm{mi}$. $\mathrm{N}$ of its junc. with Holorada Creek, $31 \mathrm{mi}$. SE of Allakaket, Kanuti Flats; $66^{\circ} 10^{\prime} 30^{\prime \prime} \mathrm{N}, 152^{\circ}$ $04^{\prime} 00^{\prime \prime}$ W; (map 117).

Koyukan Indian name obtained in 1956 at Allakaket by Orth.

Koduit Lake: lake, $2 \mathrm{mi}$. long, $17 \mathrm{mi}$. NE of Fort Yukon, Yukon Flats; 66 $35^{\prime} 30^{\prime \prime} \mathrm{N}$, $144^{\circ} 38^{\prime} 00^{\prime \prime} \mathrm{W}$; (map 119$)$.

Indian name reported in 1956 by T. E. Taylor, USGS.

Koggiung: settlement, on $\mathbf{E}$ bank of Kvichak River at Graveyard Point, on Alaska Penin. $9 \mathrm{mi}$. N of Naknek, Bristol Bay Low.; 58 $52^{\prime}$ $00^{\prime \prime} \mathrm{N}, 157^{\circ} 00^{\prime} 15^{\prime \prime} \mathrm{W}$; BGN 1910; (map 41). Var. Kogiung.

Eskimo village listed by Ivan Petroff in the 1880 Census with a population of $29 ; 133$ in 1890 ; and 533 in 1900 . Its increase in population was due to the establishment of several canneries. The Koggiung post office operated from 1935 to 1946.

Kogish Mountain: mountain, near $W$ coast of Prince of Wales I., $10 \mathrm{mi}$. N of Klawock, Alex. 
Arch.; 55 $41^{\prime} 30^{\prime \prime} \mathrm{N}, 133^{\circ} 10^{\prime} 25^{\prime \prime} \mathrm{W}$; (map 4).

Named in 1904 by E. F. Dickins, USC\&GS, "after Indian chief who formally [sic] resided at Tuxekan, from information obtained from Captain [Cyrus] Orr."

Kogiukhtuli: stream, see Swan River.

Kogiung: settlement, see Koggiung.

Kogluk: locality, "at Cape Nome," Seward Penin. High.; (map 94).

Former Eskimo camp or settlement listed in the 1890 Census (p. 162).

Kogohokruk River: stream, see Henry Creek.

Kogohokruk River: stream, see Kogosukruk River.

Kogok River: stream, flows NW $35 \mathrm{mi}$. to Norton Sound, $22 \mathrm{mi}$. SW of St. Michael, YukonKuskokwim Delta; $63^{\circ} 16^{\prime} 30^{\prime \prime} \mathrm{N}, 162^{\circ} 35^{\prime} 30^{\prime \prime}$ W; (map 92).

Eskimo name reported in 1898 by USG\&GS.

Kogok River: stream, see Nunakogok River.

Kogoluk River: stream, heads at $67^{\circ} 26^{\prime} \mathrm{N}$, $156^{\circ} 09^{\prime}$ W, flows SW $52 \mathrm{mi}$. to Kobuk River, $4 \mathrm{mi}$. E of Kobuk, Brooks Ra.; $66^{\circ} 55^{\prime} \mathrm{N}$, $156^{\circ} 45^{\prime} \mathrm{W}$; (map 115). Var. El-yog-o-loktok, Koguluk River, Rocky River.

Eskimo name obtained by Lt. Stoney ( 1900 , map), USN, in 1885. The same year, Lt. J. C. Cantwell, USRCS, recorded the name as "El-yog-o-lok-tok or Rocky River" (Healy, 1887, p. 44). According to P. S. Smith and H. M. Eakin, USGS, this name means "river with falls" (in Brooks and others, 1911, p. 275).

Kogoluktuk River: stream, heads at Shishakshinovik Pass, flows SW $45 \mathrm{mi}$. to Kobuk River, $10 \mathrm{mi}$. E of Shungnak, KotzebueKobuk Low.; $66^{\circ} 55^{\prime} \mathrm{N}, 156^{\circ} 48^{\prime} \mathrm{W}$; (map 115). Var. El-yog-o-lok-tok, Koguluk River. Eskimo name written "Ko-go-luk-tuk" in 1885 by Lt. Stoney (1900, map), USN. This is probably the same stream spelled "El-yog-o-lok-tok" by Lt. J. C. Cantwell, USRCS, in 1885.

Kogomiut: locality, on Bering Sea coast, $9 \mathrm{mi}$. $\mathrm{NE}$ of Black River and $8 \mathrm{mi}$. SW of Waklarok, Yukon-Kuskokwim Delta; $62^{\circ} 28^{\prime}$ N, $165^{\circ}$ 10' W; (map 76).

Former Eskimo village reported about 1938 by USC\&GS.

Kogosukruk River: stream, heads at 69.27'30" N, $152^{\circ} 45^{\prime} 30^{\prime \prime}$ W, flows NE $80 \mathrm{mi}$. to Colville River, $41 \mathrm{mi}$. NE of Umiat, Arctic Plain; $69^{\circ} 56^{\prime} \mathrm{N}, 151^{\circ} 35^{\prime} \mathrm{W}$; BGN 1959; (map 141). Var. Kogohokruk River.

Eskimo name reported in 1946 by USG\&GS. Kogosukruk River: stream, see Henry Creek.

Kogotpak River: stream, flows $17 \mathrm{mi}$. NE to Nuvagapak Lagoon, SE of Nuvagapak Point and $26 \mathrm{mi}$. NW of Demarcation Point, Arctic Plain; 69 $52^{\prime} \mathrm{N}, 142^{\circ} 16^{\prime} \mathrm{W}$; (map 138).

Eskimo name reported by USGS in 1956.

Kogoyuk Creek: stream, flows N 12 mi. to Holokuk River $6.7 \mathrm{mi}$. SE of its junc. with Kuskokwim River, $36 \mathrm{mi}$. SE of Aniak and $46 \mathrm{mi}$. SW of Sleetmute, Kilbuck-Kuskokwim Mts.; $61^{\circ} 28^{\prime} \mathrm{N}, 158^{\circ} 28^{\prime} \mathrm{W}$; BGN 1948; (map 72). Var. Koyoyuk Creek.
Eskimo name meaning "swan" refers to the many long stretches of white water; reported in 1945 by USGS.

Kograk Deep: locality, a deep place in Wulik River, $3 \mathrm{mi}$. NE of Kivalina, Kotzebue-Kobuk Low.; 67 $45^{\prime} \mathrm{N}, 164^{\circ} 27^{\prime} \mathrm{W}$; (map 128). Var. Kaugrak Deep, Kaugzaaq, Kowgrock.

Eskimo name, so called because a young man with this name was mysteriously killed here; reported in 1966 by E. S. Burch.

Kogruak, River: estuary, see Kogru River.

Kogruak River: stream, see Canning River.

Kogruk Creek: stream, heads on Nucleus Mtn., in De Long Mts., flows W $15 \mathrm{mi}$. to join Tupik Greek to form the Utukok River, Brooks Ra.; $68^{\circ} 34^{\prime} \mathrm{N}, 161^{\circ} 06^{\prime} \mathrm{W}$; BGN 1961; (map 131)

Named by USGS geologists in 1951. It is an Eskimo name.

Kogrukluk River: stream, heads at $60^{\circ} 26^{\prime} \mathrm{N}$, $158^{\circ} 44^{\prime} \mathrm{W}$, flows NE $44 \mathrm{mi}$, joins Shotgun Creek to form Holitna River, $65 \mathrm{mi}$. SW of Sleetmute, Kilbuck-Kuskokwim Mts.; $60^{\circ}$. $49^{\prime} \mathrm{N}, 157^{\circ} 51^{\prime} \mathrm{W}$; BGN 1948; (map 60). Var. Middle Fork Holitna River.

Eskimo name spelled 'Ko-gruk-luk" in the winter of 1902-03 by W. R. Buckman, prospector.

Kogru River: estuary, extends $14 \mathrm{mi}$. W off Harrison Bay, Arctic Plain; $70^{\circ} 34^{\prime} \mathrm{N}, 152^{\circ} 00^{\prime}$ W; (map 149). Var. River Kogru, River Kogruak.

This Eskimo name first appears on Maguire's map (Great Britain, 1854, facing p. 186) as R. Kogru, and on John Simpson's map, of about the same time, it is shown as $R$. Kogruak. Kugauraq means "a creek" and Kugruak means "old river." Maguire shows this stream as an outlet for Teshekpuk Lake.

Koguklik: stream, see Middle Fork Goodnews River.

Koguluk River: stream, see Kogoluk River.

Koguluk River: stream, see Kogoluktuk River.

Kohklux: locality, $\mathbf{S}$ of Klukwan, on $\mathbf{E}$ bank of Chilkat River, $20 \mathrm{mi}$. SW of Skagway, St. Elias Mts.; $59^{\circ} 23^{\prime} 41^{\prime \prime} \mathrm{N}, 1^{\prime 35^{\circ}} 53^{\prime} 30^{\prime \prime} \mathrm{W}$; (map 45).

Tlingit Indian name for the site of a USC\&GS station during the total eclipse of the sun in 1869. Name reported in the 1883 Coast Pilot (p. 198).

Kohl Island: island, $0.2 \mathrm{mi}$. long, off $\mathrm{S}$ coast of Agattu I., $2.6 \mathrm{mi}$. W of Cape Sabak, Aleutian Is.; $52^{\circ} 21^{\prime} 00^{\prime \prime} \mathrm{N}, 173^{\circ} 39^{\prime} 20^{\prime \prime} \mathrm{E}$; $B G N$ 1938; (map 13). Var. Kuhl Island.

This island was named "for Mr. Kohl, a partner in the firm of Hutchinson, Kohl \& Co., of San Francisco, which bought the vessels and other property of the Russian American Company in 1867 and organized the Alaska Commercial Company." The name was proposed to BGN as "Kuhl" in 1938 by U.S. Navy Hydrog. Office and was approved as "Kohl" the same year. The name was published in 1944 Aleutian Coast Pilot (p. 135).

Kohlsaat Peak: mountain, 6,250 ft., $8 \mathrm{mi}$. $\mathrm{S}$ of Simpson Pass, $87 \mathrm{mi}$. W of Talkeetna, Alaska Ra.; 62 $13^{\prime} 30^{\prime \prime}$ N, $152^{\circ} 48^{\prime} 00^{\prime \prime}$ W; (map 81). Local name reported in 1958 by USGS.
Kohltiene's Village : locality, "on Stikine River" in SE Alaska, Coast Mts.

Former Stikine Indian summer camp, with a population of 28 , reported by Ivan Petroff in the 1880 Census.

Kohokachalla Mountain: hill, 1,200 ft., at NE end of Indian Mts., $33 \mathrm{mi}$. NE of Hughes, Kokrines-Hodzana High.; $66^{\circ} 22^{\prime} \mathrm{N}, 153^{\circ} 21^{\prime}$ W; (map 116).

Indian name, reported to mean "heart," recorded at Hughes in 1956 by Orth.

Koh River: stream, see Kuk River.

Koianglas: locality, site of a Haida Indian village, on SW coast of Long I., Alex. Arch.; $54^{\circ} 49^{\prime} 00^{\prime \prime} \mathrm{N}, 132^{\circ} 42^{\prime} 10^{\prime \prime} \mathrm{W}$; BGN 1929; (map 1). Var. Klinkwan, Klinquan, Korahunglus.

Name reported by Rev. Sheldon Jackson in 1880. This village, called "Klinkwan" by Baker (1906, p. 371), was absorbed by the village of Kaigani which, in turn, was abandoned in 1911 when the village of Hydaburg was established to centralize the school system. Mrs. Clara McLeod, an early teacher at Howkan wrote to USC\&GS, "The name sometimes spelled 'Koranhunglus' is said to mean 'muddy water'. Abrout 1885 two of the natives were drowned and through native superstitions the village was deserted * * *." See Kaigani and Klinkwan.

Koikpak River: stream, see Koyuk River.

Koingak: village, see Quinhagak.

Koinooten: stream, see Kanuti River.

Koipak River: stream, see Koyuk River.

Koiyaktot Mountain: mountain, $4,280 \mathrm{ft}$., in Brooks Ra., $17 \mathrm{mi}$. E of Howard Pass; 68 ${ }^{\circ} 12^{\prime}$ N, $156^{\circ} 15^{\prime} \mathrm{W}$; (map 132).

Eskimo name probably obtained at Anaktuvuk Pass by T. E. Taylor, USGS, in 1956.

Kok, Mys: point of land, see Coke, Point.

Kokachatna: stream, see Hogatza River.

Kokachatna River: stream, see Hogatza River.

Kokacho Creek: stream, heads at $67^{\circ} 30^{\prime} \mathrm{N}$, $146^{\circ} 00^{\prime} \mathrm{W}$, flows S $56 \mathrm{mi}$. to Marten Creek, $24 \mathrm{mi}$. NW of Fort Yukon, Yukon Flats; $66^{\circ} 50^{\prime} \mathrm{N}, 145^{\circ} 50^{\prime} \mathrm{W}$; (map 119). Var. Kocacho Creek.

Indian name obtained in 1956 by T. E. Taylor, USGS.

Kokachutna: stream, see Hogatza River.

Kokachutna River: stream, see Hogatza River.

Koka Island: island, $0.1 \mathrm{mi}$. across, $12 \mathrm{mi}$. S of Sitka, on W coast of Baranof I., Alex. Arch.; $56^{\circ} 54^{\prime} 20^{\prime \prime} \mathrm{N}, 135^{\circ} 23^{\prime} 00^{\prime \prime} \mathrm{W}$; (map 5). Var. Koka Islet, Ostrov Koka.

A Finnish family name applied to this island in 1809 by Ivan Vasiliev the first, IRN; published by Lt. Sarichev (1826, map 19), IRN, as "O[strov] Koka," or "Koka Island."

Koka Islet: island, see Koka Island.

Kokechik Bay: bay, $11 \mathrm{mi}$. long, on coast of Bering Sea, $10 \mathrm{mi}$. N of Hooper Bay, YukonKuskokwim Delta; $61^{\circ} 43^{\prime} \mathrm{N}, 166^{\circ} 08^{\prime} \mathrm{W}$; (map 75). Var. Igiak Bay, Kakechik Bay, Kokechik Painga.

Eskimo name, reported by USC\&GS in 1949 , meaning "has wood." It is sometimes called "Kokechik Painga" meaning "the mouth 
of that which has wood." In $1919, \mathbf{R}$. H. Sargent, USGS, gave the name as Igiak Bay, presumably derived from the nearby village called "Igiagamiut" or "Igiayarok."

Kokechik Painga: bay, see Kokechik Bay.

Kokechilk River: stream, distributary of Kashunuk River, heads at $61^{\circ} 43^{\prime} 25^{\prime \prime}$ N, $164^{\circ} 52^{\prime}$ $00^{\prime \prime} \mathrm{W}$, flows W $60 \mathrm{mi}$. to Igiak Bay, Kokechik Bay, Yukon-Kuskokwim Delta; $61^{\circ} 41^{\prime} \mathrm{N}$ $165^{\circ} 51^{\prime}$ W; (map 75). Var. Kakechik River.

Eskimo name, meaning "has wood" or "wooded," reported as Kakechik by R. H. Sargent, USGS, in 1919.

Kokhanok: village, see Kakhonak.

Kokhanok Bay: locality, $1.5 \mathrm{mi}$. E of Lookout Mtn., on N shore of Kakhonak Bay, $22 \mathrm{mi}$. SE of Iliamna, Aleutian Ra.; 59 $30^{\prime} \mathrm{N}, 154^{\circ} 34^{\prime}$ W; (map 51). Var. Kakhonak Bay.

Site of a former Eskimo village reported in 1951 by USGS. Recent USGS maps indicate one building here.

Kokhanok Bay: bay, see Kakhonak Bay.

Kokhanok River: stream, see Kakhonak River.

Kokhlokhtokhpagamute: locality, see Kukuktuk. Kokhonak Bay: locality, see Kakhonak Bay.

Kokhtuli : stream, see Kakhtul River.

Kokinhenic : locality, see Kokinhenik.

Kokinhenic Branch: stream, see Kokinhenik Branch.

Kokin Henik: locality, see Kokinhenik.

Kokin Henik: island, see Kokinhenik Island.

Kokinhenik : locality, on Kokinhenik I., at mouth of Copper River, $21 \mathrm{mi}$. NW of Katalla, Malaspina Coastal Plain; $60^{\circ} 18^{\prime} 30^{\prime \prime} \mathrm{N}, 145^{\circ}$ $05^{\prime} 00^{\prime \prime} \mathrm{W}$; (map 64). Var. Coquenhena Kokin Henik, Kokinhenic.

Indian name reported in 1897 by Lt. Comdr. J. F. Moser, USN, as "Coquenhena," later written as "Kokinhenic" and "Kokin Henik" by H. P. Ritter, USC\&GS.

Kokinhenik Bar: bar, $3.5 \mathrm{mi}$. long, off $\mathrm{S}$ coast of Alaska, $22 \mathrm{mi}$. W of Katalla, Malaspina Coastal Plain; $60^{\circ} 14^{\prime} \mathrm{N}, 1^{\circ} 05^{\circ} 09^{\prime} \mathrm{W}$; (map 64).

Name published in 1951 by USGS; derived from Kokinhenik Island.

Kokinhenik Branch: stream, distributary of Copper River, flows S $4 \mathrm{mi}$. to Gulf of Alaska, $22 \mathrm{mi}$. NW of Katalla, Malaspina Coastal Plain; $60^{\circ} 19^{\prime} \mathrm{N}, 145^{\circ} 05^{\prime} \mathrm{W}$; (map 64). Var. Coquenhena Slough, Kokinhenic Branch.

Name reported on a USC\&GS manuscript dated 1898 of the Copper River delta.

Kokinhenik Island: island, $600 \mathrm{ft}$. across, at mouth of Copper River, $21 \mathrm{mi}$. NW of Katalla, Malaspina Coastal Plain; $60^{\circ} 18^{\prime} 30^{\prime \prime} \mathrm{N}, 145^{\circ}$ $05^{\prime} 00^{\prime \prime} \mathrm{W}$; (map 64). Var. Coquenhena, Kokin Henik, Kokinhenic.

Indian name reported in 1897 by Lt. Comdr. J. F. Moser, USN, as "Coquenhena"; written by H. P. Ritter, USC\&GS, in 1898 as "Kokinhenic" and "Kokin Henik."

Kokirat Creek: stream, heads in Kemegrak Hills, flows NE $10.5 \mathrm{mi}$. to Kukpuk River 2 $\mathrm{mi}$. $\mathbf{S}$ of junc. of Ipewik River, Arctic Slope; $68^{\circ} 18^{\prime} 45^{\prime \prime} \mathrm{N}, 165^{\circ} 42^{\prime} 10^{\prime \prime} \mathrm{W}$; BGN 1963; (map 129). Var. Kokkeerat Creek, Kokkeerax Creek.

Eskimo name recorded in 1960 as "Kokkeerax" by D. C. Foote in connection with Project Chariot studies.

Kokkeerat Creek: stream, see Kokirat Creek. Kokkeerax Greek: stream, see Kokirat Creek. Koklak, Mount: mountain, 3,192 ft., in De Long Mts., W of Kelly River, $38 \mathrm{mi}$. SE of Mount Kelly, Brooks Ra.; $68^{\circ} 05^{\prime}$ N, 162 ${ }^{\circ} 32^{\prime}$ W; (map 130).

Eskimo name obtained in 1956 at Noatak by Orth.

Kokmullit: locality, see Nuwuk.

Koknuk Flats: tidal flats, at mouth of Stikine River, between Mitkoff $I$. and mainland, 7 mi. NW of Wrangell, Coast Mts.; $56^{\circ} 35^{\prime} \mathrm{N}$, $132^{\circ} 30^{\prime} \mathrm{W}$; (map 6$)$.

Local name recorded in 1951 by USGS.

Koko: locality, see Kakamut.

Kokolik: locality, E of Point Lay, near mouth of Kokolik River, Arctic Plain; (map 145).

This name was published on a chart by USC\&GS in 1899 and probably represents an Eskimo settlement that is now only a site.

Kokolik Lake: lake, $0.5 \mathrm{mi}$. across, $\mathrm{N}$ of Sulungatak Ridge, $40 \mathrm{mi}$. NW of Misheguk Mtn., Brooks Ra.; $68^{\circ} 43^{\prime} \mathrm{N}, 161^{\circ} 59^{\prime} \mathrm{W}$; (map 131).

Named for the Kokolik River by USGS about 1949.

Kokolik Pass: water passage, see Akunik Pass. Kokolik River: stream, heads in De Long Mts. at $68^{\circ} 28^{\prime} \mathrm{N}, 161^{\circ} 58^{\prime} \mathrm{W}$, flows NW $200 \mathrm{mi}$. to Kasegaluk Lagoon, $1 \mathrm{mi}$. E of Point Lay, Arctic Plain; $69^{\circ} 45^{\prime} 15^{\prime \prime}$ N, $163^{\circ} 00^{\prime} 00^{\prime \prime} \mathrm{W}$; (map 145). Var. Kepizetka River, Kepizetko River, Kokoluk River, Kokotik River.

Eskimo name reported by Lt. D. H. Jarvis, USRCS, in 1898. A. J. Collier, USGS, reported the name "Kepizetka," probably obtained from the so-called Cullinghow's map of Cape Lisburne, a manuscript map drawn by an Eskimo about 1890 . Kokolik refers to the bistort, an edible fowering plant that is abundant in the Arctic (Chapman and Sable, 1960 , p. 53). Kepizetka (qipigsatqaq) means "it twists" or "crooked."

Kokoluk River: stream, see Kokolik River.

Kokomo Creek: stream, flows NW $11 \mathrm{mi}$. to Chatanika River, $25 \mathrm{mi}$. NE of Fairbanks, Yukon-Tanana High.; $65^{\circ} 10^{\prime} 45^{\prime \prime} \mathrm{N}, 147^{\circ} 17^{\prime}$ 15" W; (map 105).

Named by prospectors; reported in 1903 by USGS (Prindle, 1905, pl. 13).

Kokonak: village, see Kakhonak.

Ko-kon-hee-ni: stream, see Muddy Creek.

Kokonok: village, see Kakhonak.

Kokonok Bay: bay, see Kakhonak Bay.

Kokonok River: stream, see Kakhonak River.

Kokonuk Bay: bay, see Kakhonak Bay.

Kokopuk Creek: stream, flows SW $11 \mathrm{mi}$. to Selawik Lake, $22 \mathrm{mi}$. NW of Selawik, Kotzebue-Kobuk Low.; $66^{\circ} 39^{\prime} \mathrm{N}, 160^{\circ} 49^{\prime} \mathrm{W}$; (map 114).

Eskimo name obtained in 1955 by U.S. Army Corps of Engineers.

Kokos, Mys: point of land, see Cocos, Point.
Kokotik River: stream, see Kokolik River.

Kokrein: village, see Kokrines.

Kokrine Mountains: mountains, see Kokrines Hills.

Kokrines: village, pop. 68, on right bank of Yukon River, $27 \mathrm{mi}$. NE of Ruby, KokrinesHodzana High.; $64^{\circ} 56^{\prime} \mathrm{N}, 154^{\circ} 42^{\prime} \mathrm{W}$; (map 98). Var. Cochranes Post, Cochrein, Kochrines, Kokrein, Kokrine Station, Newikargut.

This Indian village appears to have been named for a Russian trader, whose name Lt. Allen (1887, p. 89), USA, spells "Cochrein." Capt. Raymond (1871, p. 23), U.S. Engineers, refers to a trading village here called "Newikargut," a name borrowed from the stream on the opposite side of Yukon River. See Nowitna River.

Kokrines Hills: mountains, 3,669 ft., trend NESW $15 \mathrm{mi}$, on right bank of Yukon River, 21 mi. NE of Ruby, Kokrines-Hodzana High.; $64^{\circ} 58^{\prime} \mathrm{N}, 154^{\circ} 54^{\prime} \mathrm{W}$; (map 98). Ver. Kokrine Mountains, Suquonillá Range, Yukon Hills.

It is hard to determine when this name or an equivalent was used first. The first known reference appears to be 1902 manuscript map by A. J. Collier, USGS. These mountains are probably the same, in part, as those called "Suquonilla range of mountains" in 1869 by Capt. Raymond (1871, p. 23), USA. Named for the village of Kokrines.

Kokrine Station: village, see Kokrines.

Kok River: stream, see Kuk River.

Kokruagarok: locality, on coast of Beaufort Sea, $\mathrm{E}$ of Pitt Point, $88 \mathrm{mi}$. SE of Barrow; Arctic Plain; $70^{\circ} 55^{\prime} \mathrm{N}, 153^{\circ} 05^{\prime} \mathrm{W}$; (map 148).

This locality is an Eskimo campsite reported by USC\&GS in 1951 .

Koksetna River: stream, heads at $60^{\circ} 28^{\prime} \mathrm{N}$, $154^{\circ} 34^{\prime}$ W, flows S 45 mi. to Chulitna River, $13 \mathrm{mi}$. N of Nondalton, Alaska Ra.; $60^{\circ} 11^{\prime}$ $\mathrm{N}, 154^{\circ} 54^{\prime} \mathrm{W}$; (map 61). Var. Kok-set-no River.

Indian name published as "Kok-set-no" in the 1905 Alaska Short Line Prospectus.

Kok-set-no River: stream, see Koksetna River.

Koksukdeparga Creek: stream, see Casadepaga River.

Koksuktapaga River: stream, see Casadepaga River.

Kokumpat Creek: stream, heads in Lockwood Hills, flows $\mathrm{N} 6 \mathrm{mi}$. to Kobuk River, $30 \mathrm{mi}$. ESE of Kobuk, Kotzebue-Kobuk Low.; $66^{\circ} 46^{\prime}$ $\mathrm{N}, 155^{\circ} 48^{\prime} \mathrm{W}$; (map 116).

Eskimo name recorded at Kobuk by Orth in 1956 and reported to mean "the south one," which refers to south of the Kobuk River.

Kokwok: locality, on right bank of Nushagak River, near mouth of Kokwok River, $36 \mathrm{mi}$. NE of Dillingham, Bristol Bay Low.; $59^{\circ} 19^{\prime}$ N, 157 33' W; (map 52). Var. Kakuak, Kawok, Kok-wok-ha-mut, Kukuak.

Eskimo village or camp mentioned by Ivan Petroff in the 10th Gensus of 1880 as "Kukuak." It was called "Kok-wok-ha-mut," meaning "Kok-wok people," on a 1910 manuscript map by H. C. Fassett, USBF. F. H. Waskey, a local resident, reported in 1931 
that the name "Kokwok" was nearer the Eskimo pronunciation than "Kakuak" or "Kakwok." The population of the village was 104 in $1880 ; 45$ in 1890 . The village is now abandoned.

Kok-wok-ha-mut: locality, see Kokwok.

Kok-wok-kagati: lakes, extend $2 \mathrm{mi}$. E-W, 14 mi. $\mathrm{N}$ of Okstukuk Lake and $50 \mathrm{mi}$. $\mathrm{N}$ of Dillingham, Bristol Bay Low.; $59^{\circ} 44^{\prime}$ N, $158^{\circ} 23^{\prime}$ W; (map 52).

Eskimo name reported in 1910 by H. C. Fassett, USBF; he says name refers in meaning to "both lakes" or "twin lakes."

Kokwok River: stream, heads at Okstutuk Lake and flows SE $36 \mathrm{mi}$. to Nushagak River, $36 \mathrm{mi}$. $\mathrm{NE}$ of Dillingham, Bristol Bay Low.; 59 $18^{\prime}$ N, 157 $36^{\prime}$ W ; BGN 1931; (map 52). Var. Agutukpok River, Kakuak River, Kakwok River, Kok-Wok River, Ui-lu-gu-lum-guiguok.

Eskimo name written "Kakuak" by Ivan Petroff in the 10th Census of 1880 . The present spelling was established by $B G N$ in 1931 after being published by USBF in 1924 . Kolaktok: stream, see Lookout River.

Kolavinarak River: stream, heads at Baird Inlet, flows SW 40 mi. to Etolin Strait forming SE boundary of Nelson I., $107 \mathrm{mi}$. SW of Bethel, Yukon-Kuskokwim Delta; $60^{\circ} 17^{\prime} \mathrm{N}$, $164^{\circ} 42^{\prime}$ W; (map 58). Vax. Kolovinerak River.

Eskimo name meaning "silting;" reported in 1949 by USC\&GS.

Kolchichet Mountain: mountain, 2,000 ft., $3 \mathrm{mi}$. $\mathrm{N}$ of Nenevok Lake, $80 \mathrm{mi}$. NE of Goodnews, Kilbuck-Kuskokwim Mts.; $59^{\circ} 49^{\prime} \mathrm{N}, 159^{\circ} 48^{\prime}$ W; (map 53).

Eskimo local name shown on an 1898 fieldsheet by W. S. Post, USGS.

Kolevokharit Koygut Fails: falls, on unnamed stream, $1 \mathrm{mi}$. SW of Grant Lake and $54 \mathrm{mi}$. N of Dillingham, Kilbuck-Kuskokwim Mts.; $59^{\circ} 47^{\prime} \mathrm{N}, 158^{\circ} 34^{\prime} \mathrm{W}$; (map 52).

Eskimo name shown as "Ko-le-vok-ha-rit Ko-y-gut" on a 1910 manuscript map by $\mathrm{H}$. C. Fassett, USBF.

Koliganek: village, pop. 100 , on left bank of Nushagak River, $65 \mathrm{mi}$. NE of Dillingham, Bristol Bay Low.; $59^{\circ} 48^{\prime}$ N, $157^{\circ} 25^{\prime} \mathrm{W}$; BGN 1931; (map 52). Var. Kah-lig-y-nak, Kakuak, Kalignak.

Eskimo village listed by Ivan Petroff in the 10 th Census in 1880 as "Kalignak"; shown as "Kah-lig-y-nak" on a 1910 manuscript map by H. C. Fassett, USBF. The name "Koliganek" was obtained in 1930 from F. H. Waskey and Beverley Polley, local inhabitants, by Gerald FitzGerald, USGS. Since then the village has been moved 4 miles downstream.

Kolipsun Creek: stream, heads in lake, flows W $18 \mathrm{mi}$. to Kungok River, $20 \mathrm{mi}$. SE of Wainwright, Arctic Plain; $70^{\circ} 31^{\prime} \mathrm{N}, 159^{\circ} 16^{\prime}$ W; (map 146). Var. Ezrok River, Sungokruak Creek.

Eskimo name recorded in 1956 at Wainwright as "Kolipsiun" by Orth; refers to a "kind of clay."
Kollioksak Lake: lake, $2.5 \mathrm{mi}$. long, $20 \mathrm{mi}$. NE of Shungnak, Brooks Ra.; $66^{\circ} 59^{\prime} \mathrm{N}, 156^{\circ}$. 29' W; (map 115).

Local name reported by USGS in 1925. Named after the river.

Kollioksak River: stream, flows S $6 \mathrm{mi}$. to Kobuk River $17 \mathrm{mi}$. E of Shungnak, KotzebueKobuk Low.; $66^{\circ} 53^{\prime} \mathrm{N}, 156^{\circ} 30^{\prime} \mathrm{W}$; (map 115). Var. Kollioksok River, Kollyoksok River.

Eskimo name spelled "Kollyoksok" by P. S. Smith, USGS.

Kollioksok River: stream, see Kollioksak River. Kolloen, Mount: mountain, 2,780 ft., on E coast of Baranof 1., 3.5 mi. NW of Port Alexander, Alex. Arch.; $56^{\circ} 16^{\prime} 15^{\prime \prime} \mathrm{N}, 134^{\circ} 43^{\prime} 50^{\prime \prime}$ W; BGN 1957; (map 5$)$.

Named in 1957 by USF\&WS for Lawrence Kolloen, USF\&WS, who was killed in an airplane crash while on official duty.

Kollutarak Creek: stream, rises E of Chandler Lake, flows SE $22 \mathrm{mi}$. to Ekokpuk Creek $1 \mathrm{mi}$. $\mathrm{N}$ of that stream's mouth, $12 \mathrm{mi}$. SW of Anaktuvuk Pass, Brooks Ra.; 68 $02^{\prime} 00^{\prime \prime}$ N, $152^{\circ}$ $06^{\prime} 30^{\prime \prime} \mathrm{W}$; BGN 1932; (map 134).

This is an Eskimo name reported in 1932 by Robert Marshall.

Kollutuk Creek: stream, flows N $4 \mathrm{mi}$. from Fork Peak beside Kollutuk Mtn. to John River, $8 \mathrm{mi} \mathrm{SW}$ of Anaktuvuk Pass, Brooks Ra.; $68^{\circ} 04^{\prime} 15^{\prime \prime} \mathrm{N}, 151^{\circ} 59^{\prime} 00^{\prime \prime} \mathrm{W}$; (map 134).

Eskimo name meaning "sheep horn dipper" reported in 1930 by Robert Marshall; taken from the name of the peak, past which it flows. Kollutuk Mountain: mountain, 6,302 ft., E of John River, 6 mi. SW of Anaktuvuk Pass, Brooks Ra.; $68^{\circ} 03^{\prime} 30^{\prime \prime} \mathrm{N}, 151^{\circ} 51^{\prime} 00^{\prime \prime} \mathrm{W}$; $B G N$ 1932; (map 134).

Eskimo word, reported in 1930 by Robert Marshall ; means "sheep horn dipper" referring to the shape of the mountain.

Kollyoksok River: stream, see Kollioksak River. Kolmakof: locality, on left bank of Kuskokwim River, $21 \mathrm{mi}$. E of Aniak, Kilbuck-Kuskokwim Mts. ; $61^{\circ} 34^{\prime} 15^{\prime \prime} \mathrm{N}, 158^{\circ} 33^{\prime} 45^{\prime \prime} \mathrm{W}$; BGN 1952; (map 72). Var. Kolmakoff, Kolmakof Fort, Kolmakof Redoubt, Kolmakov Redoubt, Kolmakovski, Kvigym Painagmute, Lukeens Fort, Lukins Fort, Redut Kolmakova.

Russian American Company stockaded trading post, located by Alexander Kolmakov and built in 1832 by Ivan Simonson Lukeen (Lukin), after whom it was first named. In 1841 the post was partly destroyed by fire by Indians, rebuilt by Kolmakov, and took his name. In 1866 the garrison was withdrawn and the post dismantled. In 1885 a Moravian mission was located on the site of Kolmakof. According to Andrei Glazanov, in 1838, an Eskimo settlement called "Kvigym Painagmute" was located at the trading post.

Kolmakoff: locality, see Kolmakof.

Kolmakof Fort: locality, see Kolmakof.

Kolmakof Lake: lake, $1.5 \mathrm{mi}$. long, S of Kuskokwim River, 18 mi. E of Aniak, KilbuckKuskokwim Mts.; $61^{\circ} 33^{\prime} \mathrm{N}, 158^{\circ} 57^{\prime} \mathrm{W}$; $B G N$ 1948; (map 72).
Local name taken from the Russian trading post, now abandoned; reported in 1945 by USGS.

Kolmakof Redoubt: locality, see Kolmakof.

Kolmakof River: stream, flows S $50 \mathrm{mi}$. to Kuskokwim River opposite Kolmakof, $21 \mathrm{mi}$. $\mathrm{E}$ of Aniak, Kilbuck-Kuskokwim Mts.; $61^{\circ}$ $34^{\prime} 30^{\prime \prime} \mathrm{N}, 158^{\circ} 53^{\prime} 30^{\prime \prime} \mathrm{W}$; BGN 1945; (map 72).

Local name, derived from nearby Kolmakof; reported in 1914 by A. G. Maddren, USGS.

Kolmakova Redut: locality, see Kolmakof. Kolmakov Redoubt: locality, see Kolmakof. Kolmakovski: locality, see Kolmakof.

Kologho: cove, see Dravnoi'.

Kolomak River: stream, flows SW $15 \mathrm{mi}$, to Kokechik River, $3.2 \mathrm{mi}$. E of Igiak Bay and 12 mi. SE of Cape Romanzof, Yukon-Kuskokwim Delta; $61^{\circ} 41^{\prime} \mathrm{N}, 165^{\circ} 46^{\prime} \mathrm{W}$; (map 75). Var. Ishkialik River, Kalomak River.

Eskimo name reported by USC\&GS in 1951.

Kolomin Lake: lake, $1 \mathrm{mi}$. long, on Kenai Penin., $7 \mathrm{mi}$. S of Caribou I. in Tustumena Lake and $30 \mathrm{mi}$. SSE of Kenai, Cook Inlet Low.; $60^{\circ} 07^{\prime} 30^{\prime \prime} \mathrm{N}, 151^{\circ} 02^{\prime} 00^{\prime \prime} \mathrm{W}$; (map 62).

Named about 1963 by officials of Kenai National Moose Range, for administrative purposes.

Koloock: locality, site of Eskimo village, on Cape Kuliuk, on NW coast of Kodiak I.; $57^{\circ} 48^{\prime} \mathrm{N}, 153^{\circ} 55^{\prime} \mathrm{W}$; (map 34). Var. Kulyugmyuk.

Native name recorded in 1805 by Lisianski (1814, map facing p. 169).

Koloogrua River: stream, see Meade River.

Kolosh, Ostrov: island, see Kolosh Island.

Koloshenka, Reka: stream, see Indian River. Kolosh Island: island, $0.4 \mathrm{mi}$. across, in Hot Springs Bay, $0.5 \mathrm{mi}$. NW of Goddard, on W side of Baranof I., Alex. Arch.; 56 $50^{\prime} 30^{\prime \prime} \mathrm{N}$, $135^{\circ} 23^{\prime} 15^{\prime \prime} \mathrm{W}$; (map 5). Var. Doctor Island, Ostrov Kolosh.

Named in 1809 by the Russian navigator, Ivan Vasiliev the first; published by Lt. Sarichev (1826, map 19), IRN, as "O[strov] Kolosh," or "Kolosh Island." In 1925 it was called "Doctor Island" by USC\&GS. "Kolosh" was the Russian name for the Tlingit Indians.

Koloshskoy Strechi, Mys: point of land, see Escape Cape.

Kolotuk Creek: stream, in Romanzof Mts., heads at glacier, $2 \mathrm{mi}$. SW of Tugak Peak, flows NW $8.6 \mathrm{mi}$. to Hulahula River, $31 \mathrm{mi}$. $\mathrm{E}$ of Mount. Michelson, Brooks Ra.; 69 ${ }^{\circ} 10^{\prime}$ $\mathrm{N}, 144^{\circ} 35^{\prime} \mathrm{W}$; (map 139).

Eskimo name reported in 1960 by USGS. Kolovik: locality, on coast of Beaufort Sea, on E shore of Avatanak Bight, $5 \mathrm{mi}$. W of Pitt Point and 83 mi. SE of Barrow, Arctic Plain; $70^{\circ} 53^{\prime} 30^{\prime \prime} \mathrm{N}, 153^{\circ} 21^{\prime} 00^{\prime \prime} \mathrm{W}$; (map 148).

This name was reported to be applied to an abandoned village by USC\&GS in 1951 . Orth was told at Barrow in 1965 that the name means "tipping place (where boats are emptied of water)." 
Kolovinerak River: stream, see Kolavinarak River.

Kolugrua River: stream, see Meade River.

Kolukruak River: stream, see Meade River.

Koluktak Lakes: lakes, numerous and closely spaced, extend $40 \mathrm{mi}$. between Ikpikpuk River and Key Creek, $\mathrm{S}$ of Price River, Arctic Plain; $69^{\circ} 42^{\prime} \mathrm{N}, 154^{\circ} 00^{\prime} \mathrm{W}$; (map 142).

Eskimo name for Price River; obtained in 1956 at Anuktuvuk Pass by T. E. Taylor, USGS. The name has been transposed to the lakes just south of the Price River.

Kolumakturook: locality, see Kilimantavi.

Kolumatourok: locality, see Kilimantavi.

Kolumaturok: locality, see Kilimantavi.

Komakak Creek: stream, flows N.9 mi. to Noatak River, $41 \mathrm{mi}$. SE of Howard Pass, Brooks Ra.; $67^{\circ} 42^{\prime} \mathrm{N}, 156^{\circ} 09^{\prime} \mathrm{W}$; (map 126).

Eskimo name meaning "outgoing trail," obtained at Kobuk by Orth in 1956.

Komarof: locality, "near mouth of Yukon River," Yukon-Kuskokwim Delta; (map 77 or 92). Var. Komarov Odinotchka.

Former Eskimo camp, or settlement, and trading post reported in 1878, by E. W. Nelson, U.S. Signal Service. Ivan Petroff listed "Komarov Odinotchka," with a population of 13 , in the 1880 Census.

Komarov Odinotchka: locality, see Komarof.

Komliouck, Cap: peninsula, see Kumliun, Cape.

Komoiarak Slough: stream, flows NE $8 \mathrm{mi}$. to Kwecharak River, $14 \mathrm{mi}$. S of village of Scammon Bay, Yukon-Kuskokwim Delta ; $61^{\circ} 39^{\prime} \mathrm{N}$, $165^{\circ} 41^{\prime} \mathrm{W}$; (map 75$)$.

Eskimo name reported by USC\&GS in 1951

Kom-tok Hon: estuary, see Frederick, Port.

Kona: locality, "on Baranof I.," Alex. Arch.; (map 5 or 9 ).

Former Tlingit Indian camp or settlement reported by J. R. Swanton (in Hodge, 1907, p. 724), BAE.

Konamoxt Glacier: glacier, heads $2 \mathrm{mi}$. SW of Alaska-Canada boundary, trends NE $8 \mathrm{mi}$. into Canada to Melbern Glacier, $82 \mathrm{mi}$. W of Skagway, St. Elias Mts.; $59^{\circ} 23^{\prime} \mathrm{N}, 137^{\circ} 38^{\prime} \mathrm{W}$; (map 45).

Local name published by USGS in the 1950 's.

Konarut Mountain: mountain, 5,100 ft., $2 \mathrm{mi}$. NW of Shadow Bay, $100 \mathrm{mi}$. SE of Bethel, Kilbuck-Kuskokwim Mts. ; $60^{\circ} 02^{\prime} \mathrm{N}, 159^{\circ} 15^{\prime}$ W; BGN 1932; ( $\operatorname{map} 59$ ).

Eskimo name meaning "the source" reported in 1932 by USGS.

Kon Bay : bay, see Tebenkof Bay.

Konchanee Lake: lake, $1.1 \mathrm{mi}$. long, on Kenai Penin., $1 \mathrm{mi}$. NW of Swan Lake and $25 \mathrm{mi}$. NE of Kenai, Cook Inlet Low.; 60 $40^{\circ} 30^{\prime \prime} \mathrm{N}$, $150^{\circ} 34^{\prime} 45^{\prime \prime} \mathrm{W}$; (map 62).

Named about 1963 by officials of Kenai National Moose Range, for administrative purposes.

Konedsin Minnkohwin Lake: lake, $2 \mathrm{mi}$. long, $\mathrm{E}$ of Kodosin Minnkohwin Lake, $22 \mathrm{mi}$. SE of Allakaket, Kanuti Flats; $66^{\circ} 22^{\prime} 30^{\prime \prime} \mathrm{N}, 151^{\circ}$. 57'00' W; (map 117).

Koyukan Indian name obtained in 1956 at Allakaket, by T. E. Taylor, USGS.
Konega Island: island, see Kanaga Island.

Koness River: stream, heads at $68^{\circ} 30^{\prime} \mathrm{N}, 144^{\circ}$ 45' $\mathrm{W}$, flows SE $72 \mathrm{mi}$. to Sheenjek River, $50 \mathrm{mi}$. NE of Christian, Brooks Ra.; $67^{\circ} 44^{\prime} \mathrm{N}$, $143^{\circ} 46^{\prime} \mathrm{W}$; (map 121).

Local name reported in 1927 by J. B. Mertie, Jr. (in Smith, P. S., 1929, pl. 1), USGS. This may be "crows nest" in an altered form.

Konets Head: point of land, on SW tip of Unalaska I., Aleutian Is.; $53^{\circ} 18^{\prime} 30^{\prime \prime} \mathrm{N}, 167^{\circ} 50^{\prime}$ 00" W; BGN 1939; (map 23). Var. Southwest End, Southwest Konets.

Russian name published by Capt. Tebenkov, IRN, in 1852 as "S. W. Konets" (map 26 ), and translated by USBF in 1888 as "Southwest end."

Konetz Point: point of land, see Dalnoi Point. Kongagak River: stream, see Kongakut River. Kongakut River: stream, heads in Davidson Mts. at $68^{\circ} 49^{\prime} \mathrm{N}, 143^{\circ} 09^{\prime} \mathrm{W}$, flows $100 \mathrm{mi}$. NE to Siku Lagoon, $8 \mathrm{mi}$. NW of Demarcation Point, Arctic Plain; $69^{\circ} 46^{\prime} \mathrm{N}, 141^{\circ} 42^{\prime}$ W; BGN 1959; (map 138). Var. Kangikat River, Kongagak River, Turner River.

Eskimo name reported by Leffingwell (1919, p. 100) and meaning approximately "deer pond." See Turner River.

Konganevik Point: point of land, on Beaufort Sea coast, extending NE into Camden Bay, $21 \mathrm{mi}$. SE of Flaxman I., Arctic Plain; $70^{\circ}$. $01^{\prime} 30^{\prime \prime} \mathrm{N}, 145^{\circ} 10^{\prime} 30^{\prime \prime} \mathrm{W}$; (map 151). Var. Kanganeyik Point, Kangigivik Point, Kongangevik Point, Konyenavik Point.

Eskimo name reported in 1912 by Leffingwell $(1919$, p. 97) to mean "place where there is a deer pond."

Kongangevik Point: point of land, see Konganevik Point.

Kongeruk River: stream, flows SW $16 \mathrm{mi}$. to Johnson River, $14 \mathrm{mi}$. SW of Bethel, YukonKuskokwim Delta; $60^{\circ} 43^{\prime} \mathrm{N}, 162^{\circ} 09^{\prime} \mathrm{W}$; (map 58)

Eskimo name reported to mean "corner" in 1949 by USC\&GS

Kongigamute: locality, see Kongik.

Kongiganak: locality, on $\mathrm{W}$ shore of Kuskokwim Bay, $14 \mathrm{mi}$. SW of Kulvagavik, $34 \mathrm{mi}$ SW of Quinnagak, Yukon-Kuskokwim Delta $59^{\circ} 52^{\prime} \mathrm{N}, 163^{\circ} 02^{\prime} \mathrm{W}$; (map 54).

Name of an Eskimo village reported in 1878 by E. W. Nelson, U.S. Signal Service, as "Kongiganagamiut," i.e. "Kongiganak people."

Kongik: locality, on Buckland River, Seward Penin. High.; (map 110). Var. Kangoot, Kengugmiut, Kongigamute.

Former Eskimo camp or settlement reported as "Kongigamute," with a population of 90 , by Ivan Petroff in the 1880 Census; as "Kengugmiut," with a population of 54 , in the 1890 Census.

Kongishluk Bay: cove, $2 \mathrm{mi}$. across, on $\mathrm{S}$ shore of Scammon Bay, $10 \mathrm{mi}$. E of Cape Romanzof, Yukon-Kuskokwim Delta ; $61^{\circ} 50^{\prime} \mathrm{N}, 165^{\circ} 46^{\prime}$ W; (map 75). Var. Edmonds Cove.

Eskimo name reported by USC\&GS in 1949. The name "Edmonds Cove" was given by G. R. Putnam, USC\&GS, in 1899.
Kongkok Basin: basin, rimmed by Owalit and Ivekan Mts., 3 mi. NW of Bunnell Cape, 26 mi. S of Gambell, Saint Lawrence I.; $63^{\circ} 24^{\prime}$ N, $171^{\circ} 45^{\prime}$ W; BGN 1951; (map 93). Var. Kangkak Basin, Kongkok, Valley.

Eskimo name reported in 1949 by Maj. H. B. Allen, USAF.

Kongkok Bay: bay, $1 \mathrm{mi}$. wide, $3 \mathrm{mi}$. NW of Bunnell Cape, $27 \mathrm{mi}$. S of Gambell, W coast of St. Lawrence I.; $63^{\circ} 23^{\prime} \mathrm{N}, 171^{\circ} 47^{\prime} \mathrm{W}$; $B G N 1951$; (map 93). Var. Kangkak, Kangkok.

Eskimo name obtained from Lawrence Kulukhan, of Gambell, in 1944. Orth spelled the name "Kangkak" while there in 1965 but could not obtain a meaning for it.

Kongkok Valley: basin, see Kongkok Basin.

Konglah: locality, $\mathrm{S}$ of Rush Hill, on $\mathrm{W}$ coast of Saint Paul I., in Pribilof Is. ; $57^{\circ} 10^{\prime} 45^{\prime \prime} \mathrm{N}$, $170^{\circ} 24^{\prime} 30^{\prime \prime} \mathrm{W}$; (map 38).

Án Aleut name reported by Elliott (1881, Saint Paul map).

Kon-gon-wik: stream, see Hunt River.

Kong River: stream, see Kuk River.

Konguk: stream, see Buckland River.

Kongumavik Greek: stream, flows SE $3.5 \mathrm{mi}$. to Anaktuvuk River, $0.5 \mathrm{mi}$. N of Cache Lake and $5 \mathrm{mi}$. NE of Anaktuvuk Pass, Brooks Ra.; 68 ${ }^{\circ} 11^{\prime} 30^{\prime \prime} \mathrm{N}, 151^{\circ} 38^{\prime} 00^{\prime \prime} \mathrm{W}$; (map 134). Var. Kanngumavik Creek, Kongumavuk Creek, Kungomovik Creek.

Eskimo name, meaning "gathering place," published by Rausch (1951, p. 159) as "Kungomovik," so called because the Kobuk Eskimo of ten came here to trade with the local Tulugakmiut.

Kongumavuk Creek: stream, see Kongumavik Creek.

Koniag Glacier: glacier, heads on Koniag Peak, trends N $2.3 \mathrm{mi}$., $7 \mathrm{mi}$. W of head of Kiliuda Bay, Kodiak I. ; $57^{\circ} 22^{\prime} 00^{\prime \prime} \mathrm{N}, 153^{\circ} 19^{\prime} 10^{\prime \prime} \mathrm{W}$; (map 34).

Named in 1963 by the Kodiak and Aleutian Islands Historical Society Inc. for the Koniag Eskimo, "the oldest inhabitants of Kodiak Island."

Koniag Peak: mountain, $4,470 \mathrm{ft}, 7 \mathrm{mi}$. W of head of Kiliuda Bay, Kodiak I.; $57^{\circ} 21^{\prime} 15^{\prime \prime}$ N, 153 $19^{\prime} 20^{\prime \prime} \mathrm{W}$; BGN 1964; (map 34).

Named in 1963 by the Kodiak and Aleutian Islands Historical Society Inc. See Koniag Glacier.

Konicheskaia: mountain, see Conical Volcano.

Konicheskaya Sopka: mountain, see Conical Volcano.

Konicheskaya Sopka: mountain, see Potato Mountain.

Konichesk Volcano: mountain, see Conical Volcano.

Konigiuktalikmute: locality, see Kanikyakstalikmiut.

Koniougi Island: island, see Koniuji Island.

Konioujii: island, see Big Koniuji Island.

Koniouji Island: island, see Koniuji Island.

Koniugi: island, see Big Koniuji Island.

Koniuji Island: island, $0.8 \mathrm{mi}$. long, $10 \mathrm{mi}$. N of Atka Is., Andreanof Is., Aleutian Is.; $52^{\circ} 13^{\prime} 20^{\prime \prime} \mathrm{N}, 175^{\circ} 08^{\prime} 00^{\prime \prime} \mathrm{W}$; BGN 1890; 
(map 18). Var. Canooskie Island, Kaniugi Island, Koniougi Island, Koniouji Island, Ostrov Kanyugi, Konyuzhey.

Name applied because of the great number of crested auks which the Russians call "Kanoozhki" or "Kanooskie," and which the Aleuts call "Kunuliuk." Name published as "O[strov] Kanyugi," or "Kaniugi Island," by Lt. Sarichev (1826, map 3), IRN.

Koniuji Island: island, $400 \mathrm{ft}$. long, in Whale Passage, $18 \mathrm{mi}$. NW of Kodiak, Kodiak I.; $57^{\circ} 55^{\prime} 50^{\prime \prime} \mathrm{N}, 152^{\circ} 50^{\prime} 10^{\prime \prime} \mathrm{W}$; (map 34.) Var. Canooskie Island, Kanooskie Island, Kanoozhki Island, Ostrov Konuzhiy.

Transliteration of the name "Os[trov] Konuzhiy" given in 1839 or 1840 by Sub.-Lt. Mikhail Murashev and published in 1849 on Russian Hydrog. Dept. Chart 1425. Baker (1906, p. 378) wrote, "The name is a corruption of the Aleut name 'Kunuliuk,' meaning crested auk. Elliott spells it 'Canooskie."

Koniuji Strait: water passage, between Little and Big Koniuji Is., in Shumagin Is., Aleutian Ra.; $55^{\circ} 02^{\prime} \mathrm{N}, 159^{\circ} 30^{\prime} \mathrm{W}$; (map 27). Var. Koniushi Strait.

Named "Koniushi Strait" by W. H. Dall, USC\&GS; "Koniuji Strait" was published by USC\&GS in 1947 Alaska Coast Pilot (v. 2, p. 313 ).

Koniushi Strait: water passage, see Koniuji Strait.

Koniuzhka: island, see Big Koniuji Island.

Konke Creek : stream, see Kunk Creek.

Konke Lake: lake, see Kunk Lake.

Konnekova River: stream, see Andreafsky River.

Konniaga Island: island, see Kanaga Island.

Konogkelyokamiut: locality, see Bill Moores.

Konoo Creek: stream, see Kunuk Creek.

Konoótená: locality, see Kanuti.

Konootena: stream, see Kanuti River.

Konootená Village: locality, site of village on Kanuti River, near mouth of Mentanontli River, $18 \mathrm{mi}$. SW of Allakaket, KokrinesHodzana High.; $66^{\circ} 22^{\prime} \mathrm{N}, 153^{\circ} 00^{\prime} \mathrm{W}$; (map 117).

Koyukuk Indian village visited in 1885 by Lt. Allen (1887, p. 97), USA; consisted of "five men, three women, and five children."

Konovalof Lake: lake, $1.1 \mathrm{mi}$. long, on Kenai Penin., $4 \mathrm{mi}$. W of Beaver Lake and $8 \mathrm{mi}$. NNE of Kenai, Cook Inlet Low.; $60^{\circ} 40^{\prime} \mathrm{N}$, $151^{\circ} 09^{\prime} \mathrm{W}$; (map 62).

Named about 1963 by officials of Kenai National Moose Range for administrative purposes.

Konsena: stream, see Tiekel River.

Konsina: stream, see Tiekel River.

Konstantina, Mys: point of land, see Constantine, Cape.

Konstantina Harbor: bay, sec Constantine Harbor.

Konstantine, Fort: locality, see Nuchek.

Konstantin Harbor: lagoon, see Constantine Harbor.

Konstantinovsk: locality, see Nuchek.

Konstantinya, Mys: point of land, see Constantine, Cape.
Kontlalhevena Lake: lake, see Kontrashibuna Lake.

Kontleehebna Lake: lake, see Kontrashibuna Lake.

Kontog Island: island, see Khantaak Island.

Kontrashibuna River: stream, see Tanalian River.

Konuch Creek: stream, see Kunuk Creek.

Konuzhiy, Ostrov: island, see Koniuji Island.

Konyenavik Point: point of land, see Konganevik Point.

Konyukmute: village, see Koyuk.

Konyuzhey: island, see Koniuji Island.

Koo: locality, see Kuk.

Kooagamutes: localities, see Kobuk Villages.

Kooak: stream, see Kobuk River.

Koobuk Creek: stream, flows $W 6 \mathrm{mi}$. to the Buckland River, $53 \mathrm{mi}$. NE of Haycock, Nulato Hills; $65^{\circ} 59^{\prime} \mathrm{N}, 161^{\circ} 07^{\prime} \mathrm{W}$; (map 109).

Eskimo name meaning "big river" reported in 1923 by A. H. Brooks, USGS.

Koocheak River: stream, see Kuchiak Creek.

Koog: locality, see Kuk.

Koogacheak River: stream, see Kugachiak Creek.

Koogarak: stream, see Kugarak River.

Koogaro River: stream, see Canning River. Koogmute: locality, see Kuk.

Koogowranga: stream, see New Heart Creek. Koog River: stream, see Kuk River.

Koogrock River: stream, see Kougarok River. Koogroog River: stream, see Kugruk River.

Koogrook River: stream, see Kugrupaga River.

Kooguru River: stream, see Canning River.

Kooigamute: locality, see Kwik.

Kook: locality, see Kuk.

Kook: village, see Knik.

Kook Bay: bay, see Basket Bay.

Kookjilik Point: point of land, $10 \mathrm{mi}$. SE of Cape Etolin, on NE coast of Nunivak I.; $60^{\circ} 19^{\prime} 30^{\prime \prime} \mathrm{N}, 165^{\circ} 57^{\prime} 10^{\prime \prime} \mathrm{W}$; (map 57). Var. Kooxjiliwix Point, Kukhchiliwikh Point, Kukchivik Point.

Eskimo name obtained in 1949 by USC\&GS.

Kook Lake: lake, $2 \mathrm{mi}$. long, $7 \mathrm{mi}$. S of mouth of Tenakee Inlet, on Chichagof I., $13 \mathrm{mi}$. SE of Tenakee Springs, Alex. Arch.; $57^{\circ} 40^{\prime} \mathrm{N}$, $134^{\circ} 59^{\prime} \mathrm{W}$; (map 9).

Tlingit Indian name meaning "basket" given in 1901 by Lt. Comdr. J. F. Moser, USN.

Kookookgit Mountains: mountains, see Kookooligit Mountains.

Kookoolget Mountains, mountains, see Kookooligit Mountains.

Kookoolgit Mountains: mountains, see Kookooligit Mountains.

Kookooligit Mountains: mountains, of volcanic origin, extending E-W $21 \mathrm{mi}$. on the central part of Saint Lawrence I.; $63^{\circ} 36^{\prime} \mathrm{N}, 170^{\circ} 26^{\prime}$ W; BGN 1951; (map 93). Var. Kookoolget Mountains, Kookookgit Mountains, Kookoolgit Mountains, Kugukgit Mountains, Kugulgit Mountains, Kukulgit Mountains.

Eskimo name reported in 1921 by USC\&GS.

Kookoolik: locality, Kookoolik Cape, $4 \mathrm{mi}$. E of Savoonga, $\mathbf{N}$ coast of St. Lawrence I.; $63^{\circ} 42^{\prime} \mathrm{N}, 170^{\circ} 21^{\prime} \mathrm{W}$; BGN 1951; (map 93).

Var. Kuklik Village, Kukuliak, Kukulik.

This is an old Eskimo village site.

Kookoolik Cape: point of land, $4 \mathrm{mi}$. $\mathrm{E}$ of Savoonga, $\mathrm{N}$ coast of St. Lawrence I.; $63^{\circ} 42^{\prime} \mathrm{N}$, $170^{\circ} 21^{\prime}$ W; BGN 1951; (map 93). Var. Cape Kukuliak, Kookoolik Point, Kookooliuk Cape, Kukuliak Cape.

Eskimo name reported in 1932 by $O$. W. Geist, Univ. of Alaska. Orth spelled the name "Kukuliak," as reported by informants at Savoonga in 1965. See Kookoolik.

Kookoolik Hill: hill, $337 \mathrm{ft}$., $5 \mathrm{mi}$. SE of Savoonga, St. Lawrence I.; $63^{\circ} 40^{\prime} 30^{\prime \prime} \mathrm{N}$, $170^{\circ} 20^{\prime} 10^{\prime \prime}$ W; BGN 1951; (map 93). Var. Kukuliak Hill, Kukulik Hill, Mount Vivghaanok.

Eskímo name reported by Lawrence Kulukhan, of Gambell, in 1944. Orth spelled the name "Kukuliak," as obtained from informants at Savoonga in 1965. See Kookoolik.

Kookoolik Point: point of land, see Kookoolik Cape.

Kookooliktook River: stream, flows NE $15 \mathrm{mi}$. to lagoon on $\mathrm{N}$ coast of St. Lawrence $\mathrm{I}$, $22 \mathrm{mi}$. SE of Gambell; $63^{\circ} 36^{\prime} \mathrm{N}, 171^{\circ} 11^{\prime} \mathrm{W}$; $B G N$ 1951; (map 93). Var. Kukulikhtuk, Kukuliktook River.

Eskimo name reported in 1932 by O. W. Geist, Univ. of Alaska. Orth recorded the name in 1965 as "Kukulikhtuk," from informants at Gambell who were unable to furnish a meaning.

Kookooliuk Cape: point of land, see Kookoolik Cape.

Kookpakruk River: stream, see Kuparuk River.

Kookpoowrook River: stream, see Kukpowruk River.

Kookpowrook River: stream, see Kukpowruk River.

Kook pow ruk : stream, see Kukpowruk River. Kookpuk River: stream, see Kukpuk River.

Kook River: stream, see Knik River.

Kook River: stream, see Kuk River.

Kookroak River: stream, see Kugrua River.

Kookrook Creek: stream, see Kukruk Creek.

Kooku Beach: beach, extends SW $3 \mathrm{mi}$, along Tapaghtalghee Bay, $11 \mathrm{mi}$. NE of Southeast Cape, St. Lawrence I.; $63^{\circ} 05^{\prime} \mathrm{N}, 169^{\circ} 32^{\prime} \mathrm{W}$; $B G N$ 1951; (map 93). Var. Kuka Beach.

Eskimo name recommended by the Savoonga village Council and reported in 1949 by Maj. H. B. Allen, USAF.

Kookukluk Greek: stream, flows S $5 \mathrm{mi}$. to Kinegnak River, $28 \mathrm{mi}$. NE of Cape Newenham, Kilbuck-Kuskokwim Mts.; $58^{\circ} 50^{\prime} \mathrm{N}$, $161^{\circ} 40^{\prime} \mathrm{W}$; BGN 1938; (map 39).

Eskimo name probably best spelled "Kukaklak" and probably referring to "a small stream" reported in 1938 by J. B. Mertie and Gerald FitzGerald, USGS.

Kool-mo-gon Slough: water course, see Kulmogon Slough.

Koolokroak River: stream, see Meade River.

Koolvagavigamiut: locality, sce Kulvagavik.

Koomlangeelkuk Bay: bay, $3 \mathrm{mi}$. across, $3 \mathrm{mi}$. SW of Savoonga, N coast of St. Lawrence I.; 
$63^{\circ} 40^{\prime} \mathrm{N}, 170^{\circ} 36^{\prime} \mathrm{W}$; BGN 1951; (map 93). Var. Kumlangikhkak Bay, Kumlang-Khkak.

Eskimo name reported in 1944 by Lawrence Kulukhan, of Gambell. Orth spelled the name "Kumlang-Khkak," as spoken by informants at Savoonga in 1965.

Koongook Creek: stream, see Kunuk Creek.

Koongooyowluk: bend, see Kunguyoluk Bend.

Koonjeskie: locality, see Kunjeskie.

Koonthrashiboona Lake: lake, see Kontrashibuna Lake.

Koonthrashiboona River: stream, see Tanalian River.

Koopangoomuk Creek: stream, flows SE $2 \mathrm{mi}$. to Bering Sea, $1.3 \mathrm{mi}$. NE of Southwest Cape and $34 \mathrm{mi}$. SE of Gambell, St. Lawrence I.; $63^{\circ} 19^{\prime} \mathrm{N}, 171^{\circ} 24^{\prime} \mathrm{W}$; BGN 1951; (map 93). Var. Kupangumak.

Eskimo name reported in 1944 by Lawrence Kulukhan, of Gambell. Orth spelled the name "Kupangumak" as recorded at Gambell in 1965.

Koopowra River: stream, see Kuparuk River.

Koo River: stream, see Kuk River.

Koosetrina: stream, see Kuzitrin River.

Koot: locality, near Cape Etolin, Nunivak I.; $60^{\circ} 24^{\prime} \mathrm{N}, 166^{\circ} 06^{\prime} \mathrm{W}$; (map 57 ).

Former Eskimo camp or village listed with a population of 117 in the 1890 Census; reported as "the largest village of the Nunivagmiut [Nunivak people]" by Hodge (1907, p. 725), BAE

Koot: village, see Mekoryuk.

Kootcheak River: stream, see Kurupa River.

Koot-mahk-nak Channel: water passage, see Kutmuknuk Channel.

Kootoark River: stream, see Kutuk River.

Kootsnoo: islands, see Kootzanhoo Archipelago.

Kootsnoo Inlet: water passage, see Kootznahoo Inlet.

Kootznahoo: locality, see Letushkwin.

Kootznahoo: islands, see Kootzanhoo Archipelago.

Kootznahoo Archipelago: islands, west-central part of Admiralty I., in vicinity of Kootznahoo Inlet, Alex. Arch.; $57^{\circ} 30^{\prime} \mathrm{N}, 134^{\circ} 20^{\prime} \mathrm{W}$; (map 9). Var. Hoochinoo, Hoosnoff, Houchnou, Hudsunoo, Kenasnow, Khutz-n'hu, Killisnoo, Kootsnoo, Kootzanhoo, Koutsnou, Koutznou, Kutznou.

Named in 1869 by Comdr. R. W. Meade and published in 1881 on Hydrog. Chart 882. It was described "as a low wooded plain of great extent * * * the seat of an extensive network of inland waters not fully explored, and which from the observations of the USN, appear to wash the shores of the islands and ramifying inlet which are the seat of extensive coal fields * * *" To the interior system of canals mentioned above Meade has applied the term "Kootznahoo Archipelago." (U.S. Coast and Geodetic Survey, 1883, p. 177.) The name is derived from the Tlingit Indian word "Khutz-n 'hu" meaning "bear fort" and has a diversity of renderings. This so-called "Archipelago" by Meade is not as extensive as he thought and the name is not used on recent maps.
Kootznahoo Head: promontory, $700 \mathrm{ft}$., $1.5 \mathrm{mi}$. $\mathbf{N}$ of Angoon, on $\mathbf{W}$ coast of Admiralty $\mathrm{I}$., Alex. Arch.; $57^{\circ} 31^{\prime} 40^{\prime \prime} \mathrm{N}, 134^{\circ} 35^{\prime} 00^{\prime \prime} \mathrm{W}$; (map 9).

Obscure Tlingit Indian name meaning "bear fort" given in 1869 by Comdr. R. W. Meade, USN, and published by the USC\&GS in 1883 Coast Pilot (p. 177). Locally, the name is pronounced "Hu-che-nu." This name was also used for the rum distilled by the Indians by methods learned by them from the white soldiers in the area. "Hootch," a derivative of 'this name, has long been used as a colloquial term for "moonshine."

Kootznahoo Inlet: water passage, $6 \mathrm{mi}$. long, extends from Mitchell Bay to Chatham Strait, at Angoon, on W coast of Admiralty I., Alex. Arch.; 57 $32^{\prime}$ N, $134^{\circ} 31^{\prime} \mathrm{W}$; BGN 1899; (map 9). Var. Hoochinoo Inlet, Hoosnoff Inlet, Houchnov Inlet, Hudsunoo Inlet, Khutz-nhu, Kootsnoo Inlet, Koutsnou Inlet, Koutsnow Inlet, Kutznov Inlet.

Tlingit Indian name given in 1880 by Comdr. R. W. Meade, USN.

Kootznahoo Roads: bay, $1 \mathrm{mi}$. across, $1.5 \mathrm{mi}$. S of Angoon, on W coast of Admiralty I., Alex. Arch.; $57^{\circ} 29^{\prime} \mathrm{N}, 134^{\circ} 36^{\prime} \mathrm{W}$; (map 9).

Tlingit Indian name given in 1880 by Comdr. R. W. Meade, USN.

Koourovskaia: bay, see Kovurof Bay.

Koovghsheluk Point: point of land, see Koovukseluk Point.

Koovikoilik, Cape: point of land, see Koovukseluk Point.

Kooviksilik Gape: point of land, see Koovukseluk Point.

Koovloomute: locality, see Kuvlomiut.

Koovukseluk Cape: point of land, see Koovukseluk Point.

Koovukseluk Point: point of land, $\mathrm{N}$ coast of St. Lawrence I., $2 \mathrm{mi}$. SW of Savoonga; $63^{\circ}$ $41^{\prime} \mathrm{N}, 170^{\circ} 33^{\prime} \mathrm{W}$; BGN 1951; (map 93). Var. Cape Koovikoilik, Cape Kooviksilik, Koovghsheluk Point, Kooviksilik Cape, Koovukseluk Cape, Kuvakhselak.

Eskimo name spelled "Kooviksilik" by O. W. Geist, Univ. of Alaska, in 1932 and as "Kuvakhselak" by Orth in 1965 . Its meaning is unknown.

Koowak: stream, see Kobuk River.

Kooxjiliwix Point: point of land, see Kookjilik Point

Koozata Lagoon: lagoon, extends NW $35 \mathrm{mi}$. from Siknik Cape, $S$ coast of St. Lawrence I., $50 \mathrm{mi}$. SE of Gambell ; $63^{\circ} 21^{\prime} \mathrm{N}, 170^{\circ} 39^{\prime} \mathrm{W}$; BGN 1951; (map 93).

Locally named for Warren Koozata, formerly president of the Gambell village council. Its full Eskimo name is "Koozata Naivak." Naivak means "lake."

Koozata River: stream, flows SW $20 \mathrm{mi}$. to Koozata Lagoon, S coast of St. Lawrence I.; $63^{\circ} 24^{\prime} \mathrm{N}, 170^{\circ} 40^{\prime} \mathrm{W}$; BGN 1951; (map 93).

Locally narned for Warren Koozata, formerly president of the Gambell village council.

Kopak: stream, see Kobuk River.

Kopkakisak Island: barrier island, $15 \mathrm{mi}$. long, between Kasegaluk Lagoon and Chukchi Sea,
$6 \mathrm{mi}$. SW of Point Lay, Arctic Plain; $69^{\circ} 34^{\prime}$ N, $163^{\circ} 09^{\prime} \mathrm{W}$; (map 145). Var. Kopkukisuk Island.

Eskimo name obtained at Point Lay by Orth in 1956.

Kopkukisuk Island: barrier island, see Kopkakisak Island.

Koposo, Ostrov: island, see Coposo Island.

Koppen Creek: stream, flows SW $3.5 \mathrm{mi}$. to Sheep Bay, $12 \mathrm{mi}$. NW of Cordova, Chugach Mts.; $60^{\circ} 42^{\prime} 20^{\prime \prime} \mathrm{N}, 145^{\circ} 53^{\prime} 30^{\prime \prime} \mathrm{W}$; (map 64). Name published in 1950 by USGS.

Kopshesut Creek: stream, flows SW $6 \mathrm{mi}$. to Kobuk River, $26 \mathrm{mi}$. NW of Shungnak, Brooks Ra.; $67^{\circ} 04^{\prime} \mathrm{N}, 158^{\circ} 00^{\prime} \mathrm{W}$; (map 126).

Eskimo name reported by the U.S. Army Corps of Engineers in 1955.

Korab Cove: cove, see Karab Cove.

Korahunglus: locality, see Koianglas.

Korga Island: island, $0.4 \mathrm{mi}$. across, in Redoubt Bay, 9 mi. $S$ of Sitka, off $W$ coast of Baranof I., Alex. Arch.; 56 $55^{\circ} 45^{\prime \prime} \mathrm{N}, 135^{\circ} 23^{\prime} 00^{\prime \prime} \mathrm{W}$; $B G N$ 1929; (map 5). Var. Crow Island.

Named in 1809 by the Russian navigator, Ivan Vasiliev the first; published by Lt. Sarichev (1826, map 19), IRN, as "O[strov] Korga," meaning "crow island."

Koriga Point: point of land, on NW coast of Unalaska I., Aleutian Is.; $53^{\circ} 57^{\prime} 40^{\prime \prime} \mathrm{N}, 167^{\circ}$ $00^{\prime} 30^{\prime \prime} \mathrm{W}$; BGN 1938; (map 23).

Siberian word applied by Capt. Tebenkov (1852, atlas notes, p. 270), IRN, to describe this feature's resemblance to Gape Kovrizhka. Koriumanyi: lake, see Govorushka Lake.

Korivin, Ostrov: island, see Korovin Island.

Kornui Lake: lake, $1.5 \mathrm{mi}$. long, $4.7 \mathrm{mi}$. SW of Arctic Village, Brooks Ra.; $68^{\circ} 04^{\prime} \mathrm{N}, 145^{\circ} 39^{\prime}$ W; (map 136).

Kutchin Indian name obtained at Arctic Village in 1956 by T. E. Taylor, USGS.

Kornutena: stream, see Kanuti River.

Kornuti: stream, see Kanuti River.

Kornutna: stream, see Kanuti River.

Koronados, Los: islands, see Coronados Islands.

Koronotsii, Ostrov: island, see Coronation Island.

Koroshiy Pogodi: mountain, see Fairweather, Mount.

Korovei: point of land, see Korovin, Cape.

Korovenski: bay, Korovin Bay.

Korovin, Cape: point of land, on NW coast of Atka I., Aleutian Is.; $52^{\circ} 19^{\prime} \mathrm{N}, 174^{\circ} 27^{\prime} \mathrm{W}$ : (map 18). Var. Korovei, Korovinski.

Named for Korovin Bay, published as “M[ys] Korovei," or "Cape Korovei," by Lt. Sarichev (1826, map 13), IRN.

Korovin Bay: bay, $4.5 \mathrm{mi}$. across, on $\mathrm{N}$ coast of Atka I., Aleutian Is.; $52^{\circ} 15^{\prime} \mathrm{N}, 1^{174^{\circ} 27^{\prime}}$ W; BGN 1890; (map 18). Var. Korovenski, Korovinskaia, Korovinskoi, Korowinsky, Zaliv Korovinskoy.

Published as "Korovinskoy Zaliv," or "Korovinskoy Bay," by Lt. Sarichev (1826, map 3), IRN, probably for Capt. Ivan Korovin of the trading vessel Trinity, which was in these waters in 1762 . 
Korovin Bay: bight, $2.5 \mathrm{mi}$. across, on $\mathrm{S}$ coast of Korovin I., in Shumagin Is., Aleutian Ra.; $55^{\circ} 24^{\prime} \mathrm{N}, 160^{\circ} 15^{\prime} \mathrm{W}$; (map 28).

Named in 1915 for the island by USC\&GS; published on 1917 coast chart.

Korovin Island: island, $8 \mathrm{mi}$. long, in Shumagin Is., Aleutian Ra.; $55^{\circ} 26^{\prime} \mathrm{N}, 160^{\circ} 15^{\prime} \mathrm{W}$; (map 28). Var. Korovinskoi, Ostrov Korivin, Ostrov Korovinskiy, Ostrov Korovinskoi. Name published by Capt. Tebenkov (1852, map 24) as "O[strov] Korovinskoi" and shown on a Russian Hydrog. Dept. Chart as "O[strov] Korovinskiy," presumably for Ivan Korovin of the ship Sv. Troitzka (Holy Trinity), who explored the Aleutian Islands in 1762. The name is derived from the Russian "Korova," meaning "cow."

Korovinskaia: bay, see Korovin Bay.

Korovinskaia: volcano, see Korovin Volcano.

Korovinskaia Volcano: volcano, see Korovin Volcano.

Korovinskaya Sopka: volcano, see Korovin Volcano.

Korovinski: locality, an abandoned village, on $\mathrm{N}$ shore of Korovin Bay, Atka I., Aleutian Is.; $52^{\circ} 17^{\prime} \mathrm{N}, 174^{\circ} 21^{\prime} \mathrm{W}$; (map 18). Var. Korovinsky, Korovinsky Village, Nikolskoi, Nikolskoye, Seleniye.

Former Aleut village, called "Nikolskoi" by Capt. F. P. Lutke, IRN; residents moved to a site on Nazan Bay, according to Baker (1906, p. 379).

Korovinski: point of land, see Korovin, Cape.

Korovinskiy, Ostrov: island, see Korovin Island. Korovinskoi : volcano, see Korovin Volcano.

Korovinskoi, Ostrov: island, see Korovin Island. Korovinskoi Bay: bay, see Korovin Bay.

Korovinskoy, Zaliv: bay, see Korovin Bay.

Korovinsky: locality, see Korovinski.

Korovinsky Village : locality, see Korovinski.

Korovin Strait: water passage, between Korovin and Popof Is., in Shumagin Is., Aleutian Ra.; $55^{\circ} 23^{\prime} \mathrm{N}, 160^{\circ} 20^{\prime} \mathrm{W}$; (map 28).

Name published by USC\&GS on a 1903 coast chart.

Korovin Volcano: volcano, $4,852 \mathrm{ft}$., in $\mathrm{N}$ part of Atka I., Aleutian Is.; $52^{\circ} 23^{\prime} \mathrm{N}, 174^{\circ} 10^{\prime}$ W; (map 18). Var. Korovinskaia, Korovinskaia Volcano, Korovinskaya Sopka.

Name published as "Korovinskoi volcan" by Capt. Lutke (1836, p. 310), IRN, after Korovin Bay to the southwest.

Korowinsky: bay, see Korovin Bay.

Kortleana Bay: bay, see Katlian Bay.

Kosakuts River: stream, heads at Bering Glacier, flows S $3 \mathrm{mi}$. to Kaliakh River, $2.5 \mathrm{mi}$. E of Hanna Lake, St. Elias Mts. ; $60^{\circ} 13^{\prime} 30^{\prime \prime}$ N, $143^{\circ} 04^{\prime} 00^{\prime \prime}$ W; (map 65). Var. Cosacoots River.

Indian name reported as "Cosacoots" in 1903 by J. L. McPherson, Deputy U.S. Mineral Surveyor.

Kosciusko Island: island, extends NE-SW 26 mi., separated from Prince of Wales I. by El Capitan Passage, $W$ of Clarence Strait, Alex Arch.; $56^{\circ} 03^{\prime} \mathrm{N}, 1^{\circ} 3^{\circ} 33^{\prime} \mathrm{W}$ : (map 6).

Named in 1879 by W. H. Dall, USG\&GS probably for Tadeusz (Thaddeus) Andrzej
Bonawentura Kosciusko, 1746-1817, a Polish citizen who joined the American Revolutionary Army in 1776 as a volunteer and was appointed an engineer with the rank of colonel, later to become a major general.

Kos'era-an'ag: lake, see Upper Lake.

Koserefski: locality, see Kozherevsky.

Koserefski: village, see Holy Cross.

Koserefski River: stream, see Kozherevsky River.

Koshiga: village, see Kashega.

Koshigin: village, see Kashega.

Koshigin: bay, see Kashega Bay.

Koshiginskoi : bay, see Kashega Bay.

Koshotok Creek: stream, see Casadepaga River.

Kosina Creek: stream, flows N $35 \mathrm{mi}$. to Susitna River $21 \mathrm{mi}$. NW of its junc. with Oshetna River and $55 \mathrm{mi}$. SE of Cantwell, Talkeetna Mts.; $62^{\circ} 46^{\prime} 55^{\prime \prime} \mathrm{N}, 147^{\circ} 56^{\prime} 07^{\prime \prime}$ W; (map 82).

Indian name reported in 1951 by USGS. Kosinas, Mys: point of land, see Cosinas, Point. Koskakat: locality, see Cos Jacket.

Koskakat: stream, see Cosna River.

Koskanok: locality, see Kaskanak.

Koskatantna Creek: stream, in Hogatza River flats, flows W $11 \mathrm{mi}$. to Hogatza River, $24 \mathrm{mi}$. NW of Hughes, Hogatza High.; $69^{\circ} 16^{\prime} 30^{\prime \prime} \mathrm{N}$, $154^{\circ} 54^{\prime} 00^{\prime \prime} \mathrm{W}$; (map 116).

Indian name recorded in 1956 at Hughes by Orth.

Kosna: stream, see Cosna River.

Kosoktok Creek: stream, see Casadepaga River.

Kostromitinof, Cape: point of land, at mouth of Duck Bay, $10 \mathrm{mi}$. NE of Afognak, on SE coast of Afognak I., $\mathrm{N}$ of Kodiak I.; $58^{\circ} 05^{\prime}$ $05^{\prime \prime} \mathrm{N}, 152^{\circ} 32^{\prime} 30^{\prime \prime} \mathrm{W}$; (map 43). Var. Cape Kazakofskie.

Russian family name given as "M[ys] Kostromitinov" by Sub-Lt. Mikhail Murashev, IRN in 1839 or 1840 and published by the Russian Hydrog. Dept. in 1849 on Chart 1425 . The name "M[ys] Kazakovskiy," or "Cossack Cape," was applied to this point by Capt. Tebenkov (1852, map 23), IRN. See Cape Kazakof

Kotaglikark: stream, see Helpmejack Creek.

Kotak Point: point of land, see Kowtuk Point.

Kotalhnó River: stream, see Foraker River.

Kotelnoi: point of land, see Kettle Cape.

Kotel'noy, M[ys]: point of land, see Kettle Cape.

Kothlik Island: island, in Yukon Delta on Norton Sound, $4 \mathrm{mi}$. long, $\mathrm{W}$ of Kochluk Pass, 23 mi. N of Kwiguk, Yukon-Kuskokwim Delta $63^{\circ} 07^{\prime} \mathrm{N}, 164^{\circ} 32^{\prime} \mathrm{W}$; (map 92).

Eskimo name reported in 1899 by G. R Putnam, USC\&GS; published in 1901 on Chart 9372.

Kotil : locality, at junc. of Kateel and Koyukuk Rivers, Koyukuk Low.; $62^{\circ} 27^{\prime}$ N, $157^{\circ} 37^{\prime} \mathrm{W}$ (map 108). Var. Khotilkakat, Khotilkakate, Khotylnakat.

Former Eskimo camp or settlement reported as "Khotilkakate" on an 1850 map by Lt. L. A. Zagoskin, IRN. Ivan Petroff listed "Khotilkakat" with a population of 65 in the 1880 Census.

Kotleana, Guba: bay, see Katlian Bay.
Kotleana Bay: bay, see Katlian Bay

Kotlian Bay: bay, see Katlian Bay.

Kotlians Bay: bay, see Katlian Bay.

Kotlick: village, see Kotlik.

Kotlik: village, pop. 116, on E bank of Kotlik River, $0.3 \mathrm{mi}$. S of Apoon Pass and $35 \mathrm{mi}$. NE of Kwiguk, Yukon-Kuskokwim Delta; $63^{\circ} 02^{\prime} \mathrm{N}, 163^{\circ} 33^{\prime} \mathrm{W}$; (map 92). Var. Kotlick.

Eskimo village listed in 1880 Census with a population of 10 ; in 1890 , it was 31 ; in 1920 83 ; in 1930,14 ; in 1940,35 ; in 1950,44 ; and, although the 1960 Census lists 57 inhabitants, the BIA gives the population as 116

Kotlik Lagoon: lagoon, $4.5 \mathrm{mi}$. long, on Chukchi Sea coast, $16 \mathrm{mi}$. N of Cape Krusenstern, Kotzebue-Kobuk Low.; $67^{\circ} 23^{\prime} \mathrm{N}, 163^{\circ} 48^{\prime} \mathrm{W}$; (map 128)

This name refers in some way to "an incident that occurred a hundred years ago, when a Russian was killed here," according to USC\&GS in 1950

Kotlik River: stream, in Yukon Delta, flows $\mathbf{N}$ $30 \mathrm{mi}$. to Apoon Pass, $36 \mathrm{mi}$. NE of Kwiguk, Yukon-Kuskokwim Delta: $63^{\circ} 02^{\prime} \mathrm{N}, 163^{\circ} 33^{\prime}$ W; (map 92) .

Eskimo name from the word meaning "breeches"; probably reported in 1899 by $R$. L. Faris, USC\&GS.

Kotol River: stream, see Khotol River.

Kotovy: islands, see Pribilof Islands.

Kotschekmaksky, Bai: bay, see Kachemak Bay. Kotsena: stream, see Kotsina River.

Kotsina River: stream, heads at glacier at about $61^{\circ} 46^{\prime} \mathrm{N}, 143^{\circ} 45^{\prime} \mathrm{W}$, flows SW $42 \mathrm{mi}$. to Copper River, $2 \mathrm{mi}$. NE of Chitina and 67 mi. NE of Valdez, Copper River Basin; $61^{\circ}$ $32^{\prime} 30^{\prime \prime} \mathrm{N}, 144^{\circ} 24^{\prime} 30^{\prime \prime} \mathrm{W}$; (map 68). Var. Katselena, Katzzelena, Kotsena.

Ahtena Indian name meaning "coal river [kho-tsi-tns]," spelled Katz-zelena and Katselena in 1898 by Capt W. R. Abercrombie, USA. W. J. Peters, USGS, used the Kotsina spelling on an 1899 fieldsheet.

Kotsokhotana: stream, see Buckland River.

Kotush Mountains: mountain range, see Chilkat Range.

Kotzebue: town, pop. 1,290, on NW shore of Baldwin Penin., Kotzebue-Kobuk Low.; $66^{\circ}$ 54' N, $162^{\circ} 35^{\prime} \mathrm{W}$; BGN 1944; (map 113). Var. Kee-kik-tag-ameut, Kikikhtagyut, Kikiktagamute, Kikiktak, Kikitaruk Mission

Kotzebue was established as a permanent Eskimo village when a reindeer station was located here about 1897. Prior to then, it was a summer fish camp first mentioned by Lt. Zagoskin (1847, pt. 1, p. 74), IRN, who recorded the name as "Kikikhtagyut." The 1880 Census lists the name as "Kikiktagamute," with a population of 200 . A post office called "Kotzebue" was established here in 1899, the name being derived from Kotzebue Sound. A Society of Friends mission was founded the same year. Kotzebue's population was 193 in $1910 ; 230$ in $1920 ; 291$ in $1930 ; 372$ in 1940 ; and 623 in 1950.

Kotzebue Creek: stream, flows SW $2 \mathrm{mi}$. to Bering Sea, $29 \mathrm{mi}$. NW of Teller, Seward 
Penin. High.; $65^{\circ} 24^{\prime} \mathrm{N}, 167^{\circ} 18^{\prime} \mathrm{W}$; (map 111).

Prospectors' name reported on the 1908 "Map of Seward Peninsula" by Arthur Gibson.

Kotzebue Sound: bay, $35 \mathrm{mi}$. wide and $80 \mathrm{mi}$. long, on $\mathbf{W}$ coast of Alaska, $\mathbf{N}$ of Seward Penin., Kotzebue-Kobuk Low.; $66^{\circ} 45^{\prime} \mathrm{N}$, $163^{\circ} 00^{\prime}$ W; (map 113). Var. Kotzebue's Sound.

Named by Lt. Otto von Kotzebue for himself after discovering the bay in 1816 . He said, "In compliance with the general wish of my companions, I called this newly discovered sound by my name, Kotzebue's Sound." Kotzebue, 1787-1846, IRN, accompanied Adm. A. J. von Krusenstern on his circumnavigation of the world in 180306 and commanded two other voyages around the world, 1815-17 and 1823-26. On his second voyage he explored the northwest coast of Alaska in 1816 to find the western end of a Northwest passage.

Kotzebue's Sound: bay, see Kotzebue Sound.

Koubougakhli, Cape: point of land, see Kubugakli, Cape.

Koudekan: village, see Hoonah.

Koudiakoff Islands: islands, see Kudiakof Islands.

Kougachuk Creek: stream, on Seward Penin., flows SE $15.6 \mathrm{mi}$. to Kotzebue Sound, $34 \mathrm{mi}$. NW of Deering, Kotzebue-Kobuk Low.; $66^{\circ}$ $15^{\prime} \mathrm{N}, 163^{\circ} 50^{\prime} \mathrm{W}$; (map 113).

Eskimo name reported in 1950 by USGS.

Kougarok: locality, at junc. of Kougarok and Kuzitrin Rivers, $15 \mathrm{mi}$. NW of Mount Bendeleben, Seward Penin. High.; (map 110). Var. Checkers, Kugruk, Davidson.

In 1900 , at the beginning of gold mining on the interior of Seward Peninsula, Brooks (1901, p. 125), USGS, reported a small settlement "usually known as Checkers" had sprung up here. This was the point where loads on small boats from Marys Igloo were transferred to pack horses and then shipped to placer camps. Collier (1902, pl. 12), USGS, showed this settlement as "Kugruk," which was at that time the name of the Kougarok River. The 1901 map of Seward Peninsula goldfields by David Fox, Jr., showed "Kougarok." Subsequent maps did not name this place. The Kougarok Post Office was established in 1902 and discontinued the following year (Ricks, 1965, p. 37). A post office named "Kugarok" was established in 1905 and changed to Davidson in 1906 (ibid.); its location is unknown.

Kougarok Mountain: mountain, 2,870 ft., 34 $\mathrm{mi}$. SE of Ear Mtn. and $44 \mathrm{mi}$. NE of Teller, Seward Penin. High.; $65^{\circ} 41^{\prime} \mathrm{N}, 165^{\circ} 14^{\prime} \mathrm{W}$; (map 111). Var. Kugruk Mountains.

Local name reported as "Kugruk" in 1901 by T. G. Gerdine (in Collier, 1902, pl. 12), USGS. See Kugruk River.

Kougarok River: stream, formed by junc. of Macklin and Washington Creeks, flows S 45 mi. to Kuzitrin River, $47 \mathrm{mi}$. SW of Imuruk Lake, Seward Penin. High.; $65^{\circ} 15^{\prime} \mathrm{N}, 164^{\circ}$ -
34' W; BGN 1904; (map 110). Var. Koogrock River, Kougrok River, Kugiruk River, Kugrok River, Kugrock River, Kugruk River.

Eskimo name reported on a map of Cape Nome goldfields by David Fox, Jr., dated 1901. Reported in 1900 as "Kugruk River" by Brooks (1901, pl. 11), USGS. See Kugruk River.

Kougkok: locality, see Kangkok.

Kougrok River: stream, see Kougarok River.

Kouiak River: stream, see Koyukuk River.

Kouiou-ioukack, Cap: promontory, see Kuyuyukak, Cape.

Kou Island: island, see Kuiu Island.

Koujulik Bay: bay, see Kujulik Bay.

Koukack, Baie: estuary, see Kukak Bay.

Koukak: locality, see Kukak.

Koukak Bay: estuary, see Kukak Bay.

Koukhat: point of land, see Douglas, Cape.

Koulagayakh: island, see Kulyugayak.

Kouliliak : bay, see Kuliliak Bay.

Koulitchkow Bay: bay, see Snipe Bay.

Kouloukak Bay: bay, see Kulukak Bay.

Kouloulak Bay: bay, see Kulukak Bay.

Koulugmut, Cap: point of land, see Kuliuk, Cape.

Koumlick, Cap: promontory, see Kumlik, Cape.

Koumlick, Ile: island, see Kumlik Island.

Koumloun: peninsula, see Kumliun, Cape.

Koumlun: peninsula, see Kumliun, Cape.

Koumlune: peninsula, see Kumliun, Cape.

Kounkoun, Cap: promontory, see Kunmik, Cape.

Koupolinaia Hill: mountain, see Cupola Peak.

Kousilvak: water course, see Kwemeluk Pass.

Kousk Island: island, $0.4 \mathrm{mi}$. long, one of Keku Islets, in Keku Strait, 5 mi. SW of Kake, Alex. Arch.; 56 $54^{\prime} 30^{\prime \prime}$ N, $133^{\circ} 59^{\prime} 30^{\prime \prime} \mathrm{W}$; (map 6).

Local fishermen's name reported in 1947 by USC\&GS.

Kouskokvim Bay: gulf, see Kuskokwim Bay.

Koutousoff, Cap: promontory, see Kutuzof, Cape.

Koutouzoff, Cap: promontory, see Kutuzof, Cape.

Koutsnou: islands, see Kootzanhoo Archipelago.

Koutsnou Inlet: water passage, see Kootznahoo Inlet.

Koutsnow Inlet: water passage, see Kootznahoo Inlet.

Koutznou: islands, see Kootzanhoo Archipelago.

Kouwegok Slough: stream, flows $S 5 \mathrm{mi}$. to mouth of Unalakleet River, E of Unalakleet, Nulato Hills; $63^{\circ} 52^{\prime} 25^{\prime \prime} \mathrm{N}, 160^{\circ} 47^{\prime} 00^{\prime \prime} \mathrm{W}$; (map 91).

Eskimo name reported in 1952 by USC\&GS.

Koven, Mount: peak, 12,210 ft., in Mount McKinley National Park, E of Muldrow Glacier, $6 \mathrm{mi}$. NE of summit of Mount McKinley, Alaska Ra.; $63^{\circ} 08^{\prime} 05^{\prime \prime} \mathrm{N}, 150^{\circ} 53^{\prime} 40^{\prime \prime} \mathrm{W}$; $B G N$ 1947; ( $\operatorname{map} 88$ ).

Named for Theodore G. Koven, a member of the Rockefeller Cosmic Ray Expedition who, with Allen Carpé, was killed in May 1932 by falling into a crevasse on Muldrow Glacier. See Carpe, Mount.

Kovighat River: stream, see Kavalghak Creek.
Kovogzruk: locality, at Port Clarence, Seward Penin. High.; (map 111).

Former Eskimo camp or settlement listed in the 1890 Census (p. 162).

Kov River: stream, see Kuk River.

Kovrizhka, Cape: point of land, $9 \mathrm{mi}$. NW of Makushin Bay, on NW coast of Unalaska I., Aleutian Is.; $53^{\circ} 50^{\prime} 40^{\prime \prime} \mathrm{N}, 167^{\circ} 09^{\prime} 00^{\prime \prime} \mathrm{W}$; $B G N$ 1938; (map 23). Var. Ermoshkinskie, Cape Gatan, Cape Gattan, Cape Hatan, Cape Hattan, Makushin Cape.

Russian name reported by Lt. Sarichev (1826, map 14), IRN, as "M[ys] Gattan," or "Cape Gattan," and by Capt. Tebenkov (1852, map 26), IRN, as "M[ys] Kovrizhka," meaning "Cape Gingerbread (ginger cake)." This point was called "Makushin Cape" by USBF in 1888.

Kovrorak Hill: hill, see Kavrorak Hill.

Kovrorak Lagoon: lagoon, see Kavrorak Lagoon. Kovrorak Mountain: hill, see Kavrorak Hill.

Kovrorak Spring: springs, see Kavrorak Springs. Kovroruk Springs: springs, see Kavrorak Springs.

Kovurof Bay: bay, $1 \mathrm{mi}$. across, on $\mathbf{N}$ coast of Atka I., Aleutian Is.; $52^{\circ} 05^{\prime} \mathrm{N}, 174^{\circ} 56^{\prime} \mathrm{W}$; (map 18). Var. Koourovskaia, Kovurova.

So named by Ingenstrem (cnna) or Capt. Lutke, IRN, about 1830 and published as "Koourovskaia baie" by Lutke (1836, p. 315). Called "Zaliv Kovurova," or "Kovurova Bay," by Capt. Tebenkov (1852, map 27), IRN.

Kovurof Point: promontory, elev. 1,320 ft., on $\mathrm{N}$ coast of Atka I., Aleutian Is.; $52^{\circ} 07^{\prime} 00^{\prime \prime}$ $\mathrm{N}, 174^{\circ} 54^{\prime} 15^{\prime \prime} \mathrm{W}$; (map 18). Var. Cape Tolstoi.

Name given for Kovurof Bay to the west and published by USC\&GS in the 1944 Aleutian Coast Pilot (p. 97). It was called "Cape Tolstoi" meaning "broad," by Ingenstrem (cnna); the name was published by Capt. Lutke (1836, p. 310), IRN.

Kovurova: bay, see Kovurof Bay.

Kowagamute: localities, see Kobuk Villages.

Kowak: stream, see Kobuk River.

Kowee Greek: stream, on Douglas I., flows 2.5 mi. NE to Gastineau Channel at West Juneau, $0.5 \mathrm{mi}$. SW of Juneau, Coast Mts. ; $58^{\circ}$ $17^{\prime} 50^{\prime \prime} \mathrm{N}, 134^{\circ} 25^{\prime} 55^{\prime \prime} \mathrm{W}$; BGN 1964; (map 11). Var. Cowee Creek, Kow-eeh Creek, Kowie Creek.

Named locally for Kowee, a chief of the Auk Tlingit Indians, who reportedly had his summer home at the mouth of the creek and who is credited with having guided Joe Juneau and Dick Harris to their gold find at Silver Bow Basin in 1880. Early miners spelled the name "Kowee" or "Kow-eeh," but after the USGS mapped the area in 1903 the name was published as "Cowee Creek" (DeArmond, 1957, p. 13).

Kow-eeh Creek: stream, see Kowee Creek.

Koweejoongak River: stream, flows $\mathrm{N} 10 \mathrm{mi}$. to Bering Sea, $9 \mathrm{mi}$. SE of Cape Etolin, on NE coast of Nunivak I. ; $60^{\circ} 19^{\prime} 20^{\prime \prime} \mathrm{N}, 166^{\circ} 03^{\prime} 45^{\prime \prime}$ W; (map 57). Var. Kauichungak Creek.

Eskimo name obtained in 1949 by USC\&GS. 
Koweelik Bluff: bluff, on N coast of Nunivak I., E of Iloodak Point and $36 \mathrm{mi}$. SW of Cape Etolin; $60^{\circ} 13^{\prime} 15^{\prime \prime} \mathrm{N}, 167^{\circ} 03^{\prime} 30^{\prime \prime} \mathrm{W}$; (map 57). Var. Kauilikh Bluff, Koweelix Cliff.

Eskimo name refers to the fact that the "bluff is cut by streams"; reported in 1949 by USC\&GS.

Koweelix Cliff : bluff, see Koweelik Bluff.

Kow-e-rok: locality, on NE side of Grantley Harbor, about $2 \mathrm{mi}$. $\mathrm{N}$ of Imuruk Basin and $9 \mathrm{mi}$. E of Teller, Seward Penin. High.; (map 111).

Site of an Eskimo village reported in 1827 by Capt. Beechey (1831, map facing p. 328), RN. This may have been the village subsequently known as "Kaviak."

Kow-e-rook River: stream, see Kaviruk River.

Kowgrock: locality, see Kograk Deep.

Kowguckpak: ravine, see Kugukpak Valley.

Kowie Creek: stream, see Kowee Creek.

Kowigilikalik: locality, at headwaters of Tagayarak River, $20 \mathrm{mi}$. SW of Tuntutuliak and $60 \mathrm{mi}$. SW of Bethel, Yukon-Kuskokwim Delta; $60^{\circ} 18^{\prime} \mathrm{N}, 163^{\circ} 12^{\prime} \mathrm{W}$; (map 58).

Former small settlement or camp reported in 1949 by USC\&GS.

Kowikarurmiut: locality, on $\mathrm{N}$ shore of Duchikthluk Bay, $3 \mathrm{mi}$. N of Cape Mendenhall, Nunivak I.; $59^{\circ} 51^{\prime} \mathrm{N}, 166^{\circ} 15^{\prime} \mathrm{W}$; (map 55).

Eskimo summer fish camp reported in 1949 by USC\&GS.

Kowkow Creek: stream, flows NW $2.5 \mathrm{mi}$. to Trail Creek, $25 \mathrm{mi}$. N of Goodnews, KilbuckKuskokwim Mts.; $59^{\circ} 28^{\prime} 45^{\prime \prime} \mathrm{N}, 161^{\circ} 28^{\prime} 00^{\prime \prime}$ W; (map 53).

Eskimo name published by G. L. Harrington (in Brooks, 1921, pl. 7), USGS. Gold production along this creek started in 1913

Kownruk: canyon, see Kunruk Canyon.

Kowquialik Lake: lake, see Kawialik Lake.

Kowtuck Point: point of land, see Kowtuk Point.

Kowtuk Point: point of land, on Chukchi Sea coast, $15 \mathrm{mi}$. NE of Point Hope, Arctic Slope; $68^{\circ} 27^{\prime} 07^{\prime \prime} \mathrm{N}, 166^{\circ} 19^{\prime} 30^{\prime \prime} \mathrm{W}$; (map 129). Var. Kotak Point, Kowtuck Point.

Eskimo name reported in 1950 to mean "little point" by USC:\&GS.

Kowuk: stream, see Kobuk River.

Koyakutuk River: stream, see Kuyukutuk River.

Koyana Creek: stream, flows SE $1.9 \mathrm{mi}$. to Norton Sound, $23 \mathrm{mi}$. E of Solomon, Seward Penin. High.; 64 $34^{\prime} \mathrm{N}, 163^{\circ} 40^{\prime} \mathrm{W}$; (map 95).

Prospectors' name reported in 1900 by $\mathbf{E}$. C. Barnard (in Brooks, 1901, pl. 17), USGS

Koyoukuk River: stream, see Koyukuk River.

Koyoukut Mountain: hill, see Koyukuk Mountain.

Koyoyuk Creek: stream, see Kogoyuk Creek.

Koyuk: village, pop. 129, on right bank at mouth of Koyuk River, $31 \mathrm{mi}$. NW of Christmas Mtn., Seward Penin. High.; 64 ${ }^{\circ} 56^{\prime}$ N, $161^{\circ} 09^{\prime} \mathrm{W}$; BGN 1944; (map 96). Var. Kangekosook, Kanguksuk, Kangusuk, Konyukmute, Kuyuk Kvienkhakg-miut, Kvynkhakg-myut, Norton Bay Station.
Eskimo village reported in $1842-44$ by $\mathrm{Lt}$. L. A. Zagoskin, IRN, who recorded its name as "Kvynkhak-miut," meaning "Kvynkhak people." Baron Otto von Bendeleben, Western Union Telegraph Expedition, wrote the name "Konyukmute" in 1865 . The village became a supply center for local mining, and a trading station, called "Norton Bay Station," was established about 1900 . The population in 1930 was 110.

Koyuk Inlet: estuary, at mouth of Koyuk River, on Norton Bay, $30 \mathrm{mi}$. NW of Christmas Mtn., Seward Penin. High.; $64^{\circ} 54^{\prime} \mathrm{N}, 161^{\circ} 10^{\prime} \mathrm{W}$; (map 96).

Eskimo name reported about 1954 by U.S. Army Corps of Engineers.

Koyuk River: stream, flows SE $115 \mathrm{mi}$. to Koyuk Inlet, $30 \mathrm{mi}$. NW of Christmas Mtn., Nulato Hills; $64^{\circ} 55^{\prime} \mathrm{N}, 161^{\circ} 08^{\prime} \mathrm{W}$; $B G N$ 1952; (map 96). Var. Kanguksuk River, Kayuk River, Koikpak River, Koipak River, Kuyuk River, Kvieguk River, Left Fork Kviguk River, Reka Kvyguk, Reka Kvynkhak.

Eskimo name reported by Capt. Tebenkov (1852, map 2), IRN, as "Kvyguk." The present spelling comes from A. H. Brooks, USGS, in 1900. The Western Union Telegraph Expedition spelled the name "Koikpak," which means "big river."

Koyuktolik Bay: bay, $2 \mathrm{mi}$. wide, at $\mathrm{SW}$ tip of Kenai Penin., $16 \mathrm{mi}$. SW of Seldovia, Chugach Mts.; $59^{\circ} 14^{\prime} 30^{\prime \prime} \mathrm{N}, 151^{\circ} 56^{\prime} 30^{\prime \prime}$ W; $B G N$ 1908; (map 50). Var. Dog Salman, Dogfish, Dogsalman, Hiko-Bukta.

Eskimo name reported by USC\&GS in 1908 . The name "Hiko-Bukta" appears to be partly Russian.

Koyuktulik River: stream, see Kuiuktulik River. Koyukuk: village, pop. 128, on right bank of Yukon River, W of Koyukuk I. and $16 \mathrm{mi}$. $\mathrm{NE}$ of Nulato, Nulato Hills ; $64^{\circ} 53^{\prime} \mathrm{N}, 157^{\circ} 42^{\prime}$ W; (map 97).

A trading post and Eskimo village listed with a population of 150 by Ivan Petroff in the 1880 Census. A post office was established in 1898; discontinued in 1900 and re-opened in 1933 (Ricks, 1965, p. 37). Its population was 121 in $1910 ; 124$ in $1920 ; 143$ in 1930 ; 106 in 1940; and 79 in 1950.

Koyukuk Island: island, on Yukon River, 18 mi. NE of Nulato, Koyukuk Low.; $64^{\circ} 53^{\prime} \mathrm{N}$, $157^{\circ} 35^{\prime} \mathrm{W}$; (map 97). Var. Traders Island.

Riverboat pilots' name shown on a 1940 "Navigation Chart of the Tanana-Yukon Rivers" published by U.S. Dept. of Interior. Koyukuk Mountain: hill, $903 \mathrm{ft}$., on right bank of Yukon River, 3 mi. N of Koyukuk and 19 mi. NE of Nulato, Koyukuk Low.; 64 $54^{\prime} \mathrm{N}$, 157 $39^{\prime}$ W; BGN 1890; (map 97). Var. Benelaracher, Be-ne-le-rah-cher, Koyoukut Mountain, Koyukuk Sopka.

Name obtained in 1869 from the Russians by Capt. C. W. Raymond, U.S. Army Corps of Engineers, and written "Koyukuk Sopka" by him. A. V. Zane, USN, of Lt. ' G. M. Stoney's expedition gave in 1886 the Koyukan Indian name as "Be-ne-le-rah-cher," meaning "big mountain."
Koyukuk River: stream, heads at its Middle and North Forks, flows SW $425 \mathrm{mi}$. to Yukon River, $22 \mathrm{mi}$. NE of Nulato, Koyukuk Low.; $64^{\circ} 55^{\prime} \mathrm{N}, 157^{\circ} 32^{\prime} \mathrm{W}$; BGN 1890; (map 97). Var. Coyukuk River, Reka, Junaka, Junnaka, Kouiak River, Koyoukuk River, Reka Kuiuk, Kujupak, Kuryukak, Kuyukak, Reka Kuyaak, Tug-ga-rag-a-wick, Yunaka, Yunnaka.

Koyukan Indian name first recorded by Lt. L. A. Zagoskin, IRN, as "Kuyukak" (and "Yunaka" or "Yunnaka"). The Russians at Nulato referred to the stream as "Kuiuk" or "Kuyaak." The Western Union Telegraph Expedition spelled the name "Coyukuk." BGN standardized the present spelling. The lower part of the river was explored by Zagoskin in $1842-44$ and in 1885 , Lt. H. T. Allen, USA, explored almost its entire length.

Koyukuk Sopka: hill, see Koyukuk Mountain.

Kozakakat Slough: stream, flows NW $11 \mathrm{mi}$ to Koyukuk River, $15 \mathrm{mi}$. SW of Roundabout Mtn., Koyukuk Low.; $65^{\circ} 28^{\prime} \mathrm{N}, 157^{\circ} 02^{\prime} \mathrm{W}$; (map 108).

Koyukan Indian name, meaning "mouth of the Kosa," obtained in 1955 at Huslia by USGS.

Kozerevsky: village, see Holy Cross.

Kozherevsky: locality, on left bank of Yukon River opposite Holy Cross, Innoko Low.; $62^{\circ}$ $12^{\prime} \mathrm{N}, 159^{\circ} 43^{\prime} \mathrm{W}$; (map 78). Var. Koserefski.

Site of an Ingatik Indian village which, according to Hrdlička (1943, p. 221), was called "Kozherevsky" by the Russians. See Holy Cross.

Kozherevsky River: stream, flows SE $30 \mathrm{mi}$. to Yukon River, $7 \mathrm{mi}$. NW of Holy Cross, Innoko Low.; 62 $2^{\circ} 14^{\prime} 30^{\prime \prime}$ N, $159^{\circ} 58^{\prime} 30^{\prime \prime}$ W; (map 78). Var. Koserefski River.

Local name reported in 1916 by G. L. Harrington and R. H. Sargent (in Harrington, 1918, pl. 1), USGS; name derived from the earlier name of Holy Cross.

Kozian Reef : reef, see Cozian Reef.

Kozikakat River: stream, see Bear Creek.

Koznuten: stream, see Kanuti River.

Kradigy: hill, see Fox Castle.

Kraemer Creek: stream, flows SE $0.6 \mathrm{mi}$. to Trout Lake, $28 \mathrm{mi}$. NE of Paxson, Alaska Ra.; $63^{\circ} 07^{\prime} 50^{\prime \prime} \mathrm{N}, 144^{\circ} 38^{\prime} 32^{\prime \prime} \mathrm{W}$; (map 86).

Name published on relatively recent maps.

Kraenberi Lake: lake, $0.8 \mathrm{mi}$. long, on Kenai Penin. W of Angler Lake, $6 \mathrm{mi}$. SW of Point Possession and $41 \mathrm{mi}$. NE of Kenai, Cook Inlet Low.; $60^{\circ} 58^{\prime} \mathrm{N}, 150^{\circ} 28^{\prime} \mathrm{W}$; (map 62).

Named about 1963 by officials of Kenai National Moose Range, for administrative purposes.

Kragluchten Point: point of land, at $\mathrm{W}$ end of Little East Rookery, on NE coast of Saint George I., in Pribilof Is. ; $56^{\circ} 36^{\prime} 25^{\prime \prime}$ N, $169^{\circ}$ $31^{\prime} 20^{\prime \prime} \mathrm{W}$; (map 38).

An Aleut name listed by Putnam (1903, p. 1015), USC\&GS, as "Krag'lucht'en" meaning "squealing *** so called from the noise made by the pup seals on the rocks beneath."

Krainie Cape: point of land, see Last Point.

Krakankringa: cove, see Garden Cove. 
Krasnaia Bay: bay, see Red Bay.

Krasnaya, Bukhta: bay, see Red Bay.

Krasni Point: point of land, at $\mathrm{E}$ entrance to Temnac Bay, on S coast of Attu I., Aleutian Is.; 52 $47^{\prime} 10^{\prime \prime} \mathrm{N}, 1^{\circ} 03^{\circ} 30^{\prime \prime} \mathrm{E}$; BGN 1938; (map 13). Var. Krasni Cape, Krasnoi Cape, Point Rouge, Red Cape, Temnac Point.

Derived from a Russian name, "Krasnoy Mys," meaning "red cape," and applied to a point at the west entrance to Massacre Bay (Sarichev, 1826, map 13). The name was changed in the 1930's to its present form and location. See Murder Point.

Krasni Point: point of land, see Murder Point. Krasnoi Bay: $b a y$, see Redfish Bay.

Krasnoi Cape: point of land, see Krasni Point. Krasnoi Point: point of land, see Murder Point. Krasnoi Ribi: bay, see Redfish Bay.

Krasnoi Ribi : islands, see Redfish Islets.

Krasnoi Ribi: point of land, see Redfish Cape. Krasnoy Ryby, Bukhta: bay, see Redfish Bay. Krasnoy Ryby, Mys: point of land, see Redfish Point.

Krasnyy Rybiy: islands, see Redfish Islets.

Krasnyy Rybiy: point of land, see Redfish Cape.

Krauses Hole: cove, $0.1 \mathrm{mi}$. across, on $\mathrm{W}$ coast of Woewodski I., $19 \mathrm{mi}$. SW of Petersburg, Alex. Arch.; $56^{\circ} 32^{\prime} 20^{\prime \prime} \mathrm{N}, 133^{\circ} 03^{\prime} 20^{\prime \prime} \mathrm{W}$; (map 6).

Local fishermen's name reported in 1947 by USC\&GS.

Kravaksanak: locality, on E bank of Kwikpak Pass, $14 \mathrm{mi}$. E of Kwiguk, Yukon-Kuskokwim Delta ; $62^{\circ} 48^{\prime} 45^{\prime \prime} \mathrm{N}, 164^{\circ} 04^{\prime} 30^{\prime \prime} \mathrm{W}$; (map 77). Var. Kravaksarak.

Eskimo camp reported in 1899 by R. L. Faris, USC\&GS; written by him as "Kravaksarakamiut," meaning "Kravaksarak people."

Kravaksarak: locality, see Kravaksanak.

Kravaksarok: watercourse, see Little Apoon Pass.

Kreg'lucht'en-ang'ten-algarel'ogrey: rookery, see Little East Rookery.

Krein Lake: lake, $0.8 \mathrm{mi}$. long, on Kenai Penin., $\mathrm{N}$ of Grus Lake, $27 \mathrm{mi}$. NE of Kenai, Cook Inlet Low.; $60^{\circ} 47^{\prime} 20^{\prime \prime} \mathrm{N}, 150^{\circ} 40^{\prime} 30^{\prime \prime} \mathrm{W}$; (map 62).

Named about 1963 by officials of Kenai National Moose Range, for administrative purposes.

Krekatok Island: island, $4.5 \mathrm{mi}$. long, one of Sand Is., between Bering Sea and Scammon Bay, Yukon-Kuskokwim Delta; $62^{\circ} 02^{\prime} \mathrm{N}$, $165^{\circ} 59^{\prime} \mathrm{W}$; (map 76).

Eskimo name reported by USC\&GS in 1923

Krenitsy, Mys: point of land, see Krenitzin, Cape.

Krenitsyn: point of land, see Krenitzin, Cape.

Krenitsyna, Mys: point of land, see Krenitzin, Cape.

Krenitzin, Cape: point of land, at $\mathrm{N}$ entrance to Bechevin Bay, $14 \mathrm{mi}$. $\mathrm{N}$ of False Pass, at SW end of Alaska Penin., Bristol Bay Low.; $55^{\circ} 04^{\prime} \mathrm{N}, 163^{\circ} 25^{\prime} \mathrm{W}$; (map 29). Var. Cap Krenitsyn, Krenitzine Point, Krenytsin, Cap Krenitzyn, Mys Krenitsy, Mys Krenitsyna.

Named for Capt. Lt. Peter Kuzmich
Krenitzin, IRN, commander of the galliot Saint Catherine, who led a Russian exploring expedition to the Aleutian Is. in 1768-69. The name was published by Adm. von Krusenstern (1827, atlas map 20), IRN, as "C[ap] Krenitzyn," or "Cape Krenitzyn."

Krenitzine: point of land, see Krenitzin, Cape. Krenitzin Islands: islands, in Fox Is., Aleutian Is., consisting principally of Akutan, Akun, Rootok, Avatanak, Tigalda, Ugamak, and Aiktak Is. ; $54^{\circ} 07^{\prime} \mathrm{N}, 165^{\circ} 30^{\prime} \mathrm{W}$; (map 24). Var. Krenytsin Islands.

Probably named by Capt. Tebenkov (1852, map 26), IRN, for Capt. Lt. Peter Kuzmich Krenitzin (or Krenitsyn), IRN, who, with Lt. M. D. Levashev, IRN, in 1768-69 explored and mapped over 30 islands in the Aleutians. Capt. Tebenkov spelled the name "Ostrova Krinitsyna," or "Krinitsyn Islands."

Krenitzyn, Cap: point of land, see Krenitzin, Cape.

Krenytsin: point of land, see Krenitzin, Cape.

Krenytsin Islands: islands, see Krenitzin Islands.

Krepost Georgiyevskaya: village, see Kasilof. Kresta, Mys: point of land, see Cross, Cape.

Kresta, Mys: point of land, see Kresta Point.

Kresta Point: point of land, on NW coast of Attu I., Aleutian Is.; $53^{\circ} 00^{\prime} 10^{\prime \prime} \mathrm{N}, 172^{\circ} 38^{\prime}$ $20^{\prime \prime}$ E; BGN 1938; (map 13). Var. Cape Cross, Mys Kresta, Northwest Shoulder.

This cape was called "M[ys] Kresta," meaning "Cape Cross" (Tebenkov, 1852, map 30). Baker (1906, p. 469), USGS, calls it "Northwest Shoulder" and reports this name as being given by the North Pacific Exploring Expedition of 1854-55.

Kresta Point: point of land, on S tip of Krestof I., 9 mi. NW of Sitka, Alex. Arch.; 57 $08^{\prime} 30^{\prime \prime}$ N, $135^{\circ} 30^{\prime} 30^{\prime \prime} \mathrm{W}$; (map 9). Var. Krestof Point, Mys Kresta.

Russian name meaning "cross," given in 1833 by the navigator Ens. Vasiliev; published in 1848 on Russian Hydrog. Dept. Chart 1397 as "M[ys] Kresta."

Kresta Strait: water passage, see Cross Sound. Krestina, Ostrov: island, see Cristina Island.

Krestof, Port: bight, $0.7 \mathrm{mi}$. across, on $\mathbf{E}$ coast of Kruzof I., 12 mi. NW of Sitka, Alex. Arch.; $57^{\circ} 09^{\prime} 00^{\prime \prime} \mathrm{N}, 135^{\circ} 35^{\prime} 30^{\prime \prime} \mathrm{W}$; (map 9). Var Gavan Krestovskaya, Port Cross, Port Krestov, Zaliv Mylkoy.

Name published in 1848 on Russian $\mathrm{Hy}-$ drog. Dept. Chart 1397 as "Gavan Krestovskaya," meaning "cross harbor." It was called "Zaliv Mylkoy," meaning "shallow bay," in 1809 by the Russian navigator Ivan Vasiliev the first; published as such by Sarichev (1826, map 19).

Krestoff Island: island, see Krestof Island.

Krestoff Sound: sound, see Krestof Sound.

Krestoff Strait: sound, see Krestof Sound.

Krestof Island: island, $6 \mathrm{mi}$. long, between Kruzof and Baranof Is., $10 \mathrm{mi}$. NW of Sitka, Alex. Arch.; $57^{\circ} 11^{\prime} \mathrm{N}, 135^{\circ} 30^{\prime} \mathrm{W}$; $B G N$ 1897; (map 9). Var. Cross Island, Krestoff Island, Krestov Island, Ostrov Krestovskiy.
Published in 1848 on Russian Hydrog. Dept. Chart 1397 as "Os[trov] Krestovskiy," meaning "cross island."

Krestof Mountain: mountain, 1,631 ft., on Krestof I., $10 \mathrm{mi}$. NW of Sitka, Alex. Arch.; $57^{\circ} 11^{\prime} \mathrm{N}, 135^{\circ} 29^{\prime} \mathrm{W}$; (map 9). Var. Gora Krestovskaya.

Russian name meaning "cross" given in 1809 by the navigator Ivan Vasiliev the first published by Lt. Sarichev (1826, map 19), IRN, as "Gora Krestovskaya."

Krestof Point: point of land, see Kresta Point. Krestof Sound: sound, $4 \mathrm{mi}$. across, $3 \mathrm{mi}$. N of Sitka Sound, off NW coast of Baranof I., Alex. Arch.; $57^{\circ} 12^{\prime} \mathrm{N}, 135^{\circ} 35^{\prime} \mathrm{W} ; B G N$ 1897; (map 9). Var. Cross Sound, Krestoff Sound, Krestoff Strait, Krestov Sound, Proliv Krestovskiy.

Russian name meaning "cross," given in 1809 by the navigator Ivan Vasiliev the first, IRN; published in 1848 on Russian Hydrog. Dept. Chart 1397 as "Pr[oliv] Krestovskiy."

Krestofski Islet: island, see Guide Island.

Krestof Strait: water passage, see Olga Strait.

Krestov Island: island, see Krestof Island.

Krestov, Port: bight, see Krestof, Port.

Krestovskaya, Gavan: bight, see Krestof, Port.

Krestovskaya, Gora: mountain, see Krestof Mountain.

Krestovskin, Zaliv: cove, see Gibson Cove.

Krestovskiy, Ostrov: island, see Krestof Island.

Krestovskiy, Proliv: sound, see Krestof Sound.

Krestovskoy, Ostrov: island, see Guide Island.

Krestovskoy, Proliv: water passage, see Olga Strait.

Krestov Sound: sound, see Krestof Sound.

Krestrel Island: island, see Kestrel Island.

Kreuger Creek: stream, flows SE $7 \mathrm{mi}$. to Arctic River, $7 \mathrm{mi}$. SE of Ear Mtn. and $44 \mathrm{mi}$. NE of Teller, Seward Penin. High.; 65 $53^{\prime} \mathrm{N}$, $166^{\circ} 03^{\prime} \mathrm{W}$; (map 111).

Prospectors' name reported in 1901 by T. G. Gerdine (in Collier, 1902, pl. 12), USGS.

Krilon, Gora: mountain, see Crillon, Mount.

Kripniyagok River: stream, see Kipniyagok River.

Kripniyuk: stream, see Black River.

Krischa: glacier, see Krisha Glacier.

Krisha Glacier: glacier, $0.5 \mathrm{mi}$. long, on N slope of Takhinsha Mts., $6 \mathrm{mi}$. W of Mount Emmerick and $25 \mathrm{mi}$. SW of Skagway, St. Elias Mts.; $59^{\circ} 12^{\prime} 30^{\prime \prime} \mathrm{N}, 135^{\circ} 49^{\prime} 30^{\prime \prime} \mathrm{W}$; (map 45). Var. Krischa.

Probably a Tlingit Indian name shown as Krischa by Aurel and Arthur Krause (1883, map). Galled Krisha Glacier by USC\&GS (1883 Coast Pilot, pl. 1819).

Krishka Island: island, $1 \mathrm{mi}$. across, in Whale Bay, off SE coast of Baranof I., Alex. Arch.; $56^{\circ} 36^{\prime} 10^{\prime \prime} \mathrm{N}, 134^{\circ} 55^{\prime} 30^{\prime \prime} \mathrm{W}$; BGN 1926; (map 5). Var. Cone Island, Gasilnik Island, Gasilo Island, Zakrishka Island.

Russian word, "kryshka" meaning "cover," given in 1925 by USC\&GS because the island closes the entrance to Kritoi Basin. The descriptive name "Cone Island" was used for this island in 1924 by USC\&GS because of "its marked resemblance to an inverted cone, when seen from the northwestward." 
Krissey Island: island, see Rat Island.

Kritchek River: stream, see Kvichavak River.

Kritoi Basin: bay, $1 \mathrm{mi}$. across, enclosed by Krishka I. in Whale Bay, on SW coast of Baranof I., Alex. Arch.; 56 $35^{\prime} 45^{\prime \prime}$ N, $134^{\circ}$ 59'30" W; (map 5). Var. Zakritoi Basin.

Russian word, "krytoi" meaning "covered," given in 1926 by USC\&GS.

Kritskoi Island: island, 2 mi. long, one of Kudobin Is., $16 \mathrm{mi}$. W of village of Port Moller, Bristol Bay Low.; 56 $01^{\prime} 15^{\prime \prime} \mathrm{N}, 161^{\circ} 00^{\prime} 00^{\prime \prime}$ W; (map 28). Var. L'ile aux Loups, Wolf Island.

Named "Kritskoi ile" by Capt. Lutke (1836, p. 261), IRN. He erroneously called it "L'ile aux Loups," or "wolf island," on his Chart 14.

Krivoi Island: island, see Crooked Island.

Krivoi Island: island, see Kriwoi Island.

Krivoy, Ostrov: island, see Crooked Island.

Kriwoi Island: island, $1.2 \mathrm{mi}$. across, in Yakutat Bay, $0.6 \mathrm{mi}$. NE of Dolgoi I. and $5.5 \mathrm{mi}$. NE of Yakutat, Malaspina Coastal Plain; $59^{\circ} 37^{\prime} 30^{\prime \prime}$ N, 139 39'30' W; (map 46). Var. Crooked Island, Krivoi Island.

Named "O[strov] Krivoy," meaning "crooked island," by Capt. Tebenkov (1852, map 7), IRN.

Krogh Lake: lake, $0.3 \mathrm{mi}$. across, $\mathrm{S}$ coast of Etolin I., Alex. Arch.; 55 55'25" N, 132 ${ }^{\circ} 20^{\prime}$ $15^{\prime \prime} \mathrm{W}$; (map 4).

Named in 1886 by Lt. Comdr. A. S. Snow, USN.

Kroto: locality, site of an Indian village, at junc. of Kroto Creek and Susitna River, $36 \mathrm{mi}$. NW of Anchorage, Cook Inlet Low.; 61 $41^{\circ} 36^{\prime \prime} \mathrm{N}$, $150^{\circ} 18^{\prime} 40^{\prime \prime} \mathrm{W}$; (map 70).

Name of a former Tanaina Indian village; reported by Robert Muldrow (in Eldridge, 1900, map 3), USGS.

Kroto Creek: stream, heads in Kroto Lake, flows SE $80 \mathrm{mi}$. to Susitna River, $36 \mathrm{mi}$. NW of Anchorage, Cook Inlet Low.; 61 ${ }^{\circ} 42^{\prime} \mathrm{N}$, $150^{\circ} 19^{\prime}$ W; BGN 1961; (map 70). Var. Croto River, Deshka River.

Name reported in 1954 by USGS; derived from the name of the Indian village once located at the mouth of this stream.

Kroto Lake: lake, $0.5 \mathrm{mi}$. long, at head of Kroto Creek, 19 mi. NW of Talkeetna, Alaska Ra.; $62^{\circ} 26^{\prime} 55^{\prime \prime} \mathrm{N}, 150^{\circ} 39^{\prime} 20^{\prime \prime} \mathrm{W}$; (map 81).

Local name reported in 1958 by USGS.

Kroto Slough: stream, anabranch of Susitna River, flows SW $11 \mathrm{mi}$. to Yentna River 1.7 $\mathrm{mi}$. N of its junc. with Susitna River, $32 \mathrm{mi}$. NW of Anchorage, Cook Inlet Low.; 61 ${ }^{\circ} 35^{\prime}-$ $20^{\prime \prime} \mathrm{N}, 150^{\circ} 27^{\prime} 45^{\prime \prime} \mathrm{W}$; BGN 1962; (map 70). Var. Croto Slough.

Name published by AMS in 1947 as "Croto Slough." Present spelling reported by USGS in 1961; derived from the Indian village of Kroto which was formerly located in the vicinity.

Krugloi Island: island, $0.1 \mathrm{mi}$. long, in Peril Strait, $1 \mathrm{mi}$. NW of N coast of Duffield Penin., $\mathrm{N}$ tip of Baranof I., Alex. Arch.; 57 $33^{\prime} 45^{\prime \prime}$ N, $135^{\circ} 28^{\prime} 05^{\prime \prime} \mathrm{W}$; (map 9). Var. Krugloi Islet, Kruoloi Island, Ostrov Krugloy.
Russian name meaning "round" given in 1809 by the navigator Ivan Vasiliev the first; published by Lt. Sarichev (1826, map 19), IRN, as "O[strov] Krugloy."

Kruglni Island: island, see Agattu Island.

Krugloi Island: island, see Round Island.

Krugloi Islands: islands, $0.5 \mathrm{mi}$. across, on N shore of Salisbury Sound, off Chichagof I., 26 mi. NW of Sitka, Alex. Arch.; 57 $21^{\prime} 50^{\prime \prime} \mathrm{N}$, $135^{\circ} 43^{\prime} 30^{\prime \prime}$ W; (map 9).

Name derived from Krugloi Island, the former name of Round Island. The name was published by Baker (1906, p. 383).

Krugloi Islet: island, see Krugloi Island.

Krugloi Point: point of land, on NE tip of Agattu I., Aleutian Is.; 52 $30^{\circ} 50^{\prime \prime} \mathrm{N}, 1^{\prime} 3^{\circ}$ 46'20" E; BGN 1938; (map 13). Var. Farrar Cape, Northeast Cape, Ostrov Krugly.

Translation of "Ostrov Krugly," published in 1848 on Russian Hydrog. Dept. Chart 1400. The point was also listed as Farrar Cape in the 1944 Aleutian Coast Pilot.

Krugloi Point: point of land, on $\mathrm{S}$ tip of Halleck I., $10 \mathrm{mi}$. NW of Sitka, Alex. Arch.; $57^{\circ} 11^{\prime} \mathrm{N}, 135^{\circ} 27^{\prime} \mathrm{W}$; BGN 1897; (map 9). Var. Mys Krugloy, Round Point.

Russian name meaning "round" given in 1809 by the navigator Ivan Vasiliev the first; published by Lt. Sarichev (1826, map 19), IRN, as "M[ys] Krugloy," or "Round Cape." Krugloy, Mys: point of land, see Krugloi Point. Krugloy, Ostrov: island, see Krugloi Island.

Krugloy, Ostrov: island, see Mills Island.

Krugloy, Ostrov: island, see Round Island.

Krugly, Ostrov: point of land, see Krugloi Point.

Kruoloi Island: island, see Krugloi Island.

Krupa Point: point of land, at SE end of Hodikof Bay, in Sarana Bay, on E coast of Attu I., Aleutian Is.; $52^{\circ} 52^{\prime} 55^{\prime \prime} \mathrm{N}, 173^{\circ} 16^{\prime} 55^{\prime \prime} \mathrm{E}$; $B G N$ 1965; (map 13). Var. Hodikof Point, Hodikoff Point, Gape Hodikof.

This name was published in 1948 on an AMS map.

Krupa Point: point of land, see Hodikof Point.

Krusenstern, Cape: point of land, on Chukchi Sea coast, $\mathbf{N}$ point of entrance to Kotzebue Sound, $35 \mathrm{mi}$. NW of Kotzebue, KotzebueKobuk Low.; $67^{\circ} 08^{\prime} 00^{\prime \prime} \mathrm{N}, 163^{\circ} 44^{\prime} 45^{\prime \prime} \mathrm{W}$; (map 128). Var. Killianuk, Kruzenstern Cape, Noovowa.

On August 14, 1816, Lt. Otto von Kotzebue, IRN, wrote "we reached the promontory, which forms the north entrance to the sound, which received the name of Krusenstern." It was named for Admiral Adam Johann von Krusenstern, first Russian circumnavigator, 1803-04. Apparently the lagoon and the lowlands west of Ingitkalik Mountain were not seen at that time and Kotzebue applied the name to this promontory. The Eskimo name "Killianuk" was recorded by Rev. Stuck $(1920$, p. 85) in 1918.

Krusenstern Island: island, see Little Diomede Island.

Krusenstern Lagoon: lagoon, $7 \mathrm{mi}$. long, on Chukchi Sea coast, NE of Cape Krusenstern, Kotzebue-Kobuk Low.; $67^{\circ} 09^{\prime} \mathrm{N}, 163^{\circ} 08^{\prime} \mathrm{W}$;
$B G N 1962$; (map 128). Var. Eenyitkaleeoom Tehsaya.

Local name reported in 1942 by USC\&GS. E. S. Burch reported in 1966 that the Eskimo call it "Eenyitkaleeoom Tehsaya [Inyitkalium Teseya]."

Krusoff Island: island, see Kruzof Island.

Krusow Island: island, see Kruzof Island.

Krustoi Island: island, see Krutoi Island.

Kruto, Cape: point of land, see Steep Cape.

Krutoi, Cape: point of land, see Steep Cape.

Krutoi Island: island, $0.6 \mathrm{mi}$. across, in Yakutat Bay, $2.5 \mathrm{mi}$. NW of Humpback Point and $8.8 \mathrm{mi}$. NE of Yakutat, Malaspina Coastal Plain; $59^{\circ} 40^{\prime} 10^{\prime \prime} \mathrm{N}, 1^{\circ} 9^{\circ} 38^{\prime} 40^{\prime \prime} \mathrm{W}$; (map 46). Var. Krustoi Island, Steep Island.

Named "O[strov] Krutoy," meaning "steep island," by Capt. Tebenkov (1852, map 7), IRN.

Krutoy, Cape: point of land, see Steep Cape. Kruzenstern Cape: point of land, see Krusenstern, Cape.

Kruzenstern Island: island, see Little Diomede Island.

Kruzgamapah River: stream, see Pilgrim River. Kruzgamapa River: stream, see Pilgrim River. Kruzgamepa Hot Springs: locality, see Pilgrim Springs.

Kruzgamepa River: stream, see Pilgrim River.

Kruzof, Point: point of land, on NW tip of Kruzof 1., $27 \mathrm{mi}$. NW of Sitka, Alex. Arch.; $57^{\circ} 20^{\prime} 15^{\prime \prime} \mathrm{N}, 135^{\circ} 50^{\prime} 30^{\prime \prime} \mathrm{W}$; (map 9).

Named in 1896 by Lt. Comdr. W. I. Moore, USN. The name was published in 1900 by USC\&GS on Chart 8282 .

Kruzoff Island: island, see Kruzof Island.

Kruzof Island: island, $25 \mathrm{mi}$. long, $\mathrm{W}$ of Baranof I. and $10 \mathrm{mi}$. NW of Sitka, Alex. Arch.; $57^{\circ} 10^{\prime} \mathrm{N}, 135^{\circ} 40^{\prime} \mathrm{W}$; BGN 1896; (map 9). Var. Crooze Island, Edgecumb Island, Grooze, Krusoff Island, Krusow Island, Kruzoff Island, Kruzow Island, Pitt Island, Saint Hyacinthe, San Jacinto, Sitka Island, Tleekh.

The Tlingit Indian name for this island was recorded in 1849 by Capt. Tebenov (1852, map 7), IRN, as "O[strov] Tlikh." Atter 1775, when Don Juan de la Bodega y Quadra named Mount Edgecumbe "Montaña de San Jacinto," the island became known as San Jacinto or, as La Pérouse called it, St. Hyacinthe. In 1787 Capt. Nathaniel Portlock named it "Pitt Island" (Wagner, 1937, p. 485). The early Russian traders called it "Sitka Island," but in 1805 Capt. U. T. Lisianski, IRN, named it "Crooze Island," after a Russian admiral. In 1849 Constantin Grewingk called it "Edgecumb or Krusow Island." "Kruzof" was adopted by BGN (Baker, 1906, p. 384).

Kruzow Island: island, see Kruzof Island.

Kryci Iles: islands, see Rat Islands.

Kryci Îles: islands, see Rat Islands.

Kryci Islands: islands, see Rat Islands.

Krysi Island: island, see Rat Island.

Krysi Islands: islands, see Rat Islands.

Krysi Pass: water passage, between Sea Lion Rock and Rat I., Rat Is., Aleutian Is.; $51^{\circ} 52^{\prime} \mathrm{N}, 178^{\circ} 03^{\prime} \mathrm{E}$; (map 15). 
Russian name meaning "rat" published in 1954 Coast Pilot (p. 466).

Krysi Point: point of land, NW tip of Rat I., Aleutian Is.; $51^{\circ} 50^{\prime} \mathrm{N}, 178^{\circ} 12^{\prime} \mathrm{E}$; BGN 1937; (map 15).

Name derived from the Russian word "krysi," meaning "rat." Published on a 1935 chart by U.S. Navy Hydrog. Office.

Krysiy, Ostrova: islands, see Rat Islands.

Kshaliuk Cape: point of land, see Kshaliuk Point.

Kshaliuk Point: point of land, on $\mathrm{W}$ coast of Umnak I., Aleutian Is.; $53^{\circ} 13^{\prime} 45^{\prime \prime} \mathrm{N}, 168^{\circ}$ $40^{\prime} 30^{\prime \prime} \mathrm{W}$; BGN 1940; (map 22). Var. Bulldog Point, Kshaliuk Cape, Mys Kshalyukh.

Aleut name published by Capt. Tebenkov (1852, map 25), IRN, as "M[ys] Kshalyukh," or "Cape Kshalyukh." This feature was called "Bulldog Point" in 1939 by USC\&GS.

Kshalyukh, Mys: point of land, see Kshaliuk Point.

Kuagamut: localities, see Kobuk Villages.

Kuahroo River: stream, see Inaru River.

Kuahru: lagoon, see Tachinisok Inlet.

Kuahu River: stream, see Inaru River.

Kuakan Point: point of land, northernmost sip of Deer I., between Ernest Sound and Seward Passage, Alex. Arch.; $56^{\circ} 05^{\prime} 40^{\prime \prime}$ N, $132^{\circ} 01^{\prime}$ $50^{\prime \prime}$ W; BGN 1923; (map 6).

Tlingit Indian word from "qowakan" meaning "deer" given in 1923 by USC\&GS.

Kuakat Ridge: ridge, elev. 1,615 ft., extends N-S 8 mi.; along E side of Kuna River near its mouth, Arctic Slope; 68 $51^{\prime} \mathrm{N}, 157^{\circ} 35^{\prime}$ W; (map 132).

Eskimo name reported by T. E. Taylor, USGS, in 1956.

Kualiug-miut: village, see Kiwalik.

Kualyugmut: village, see Kiwalik.

Kuaruaipa: stream, on Beaufort Sea coast, E of Point Barrow; (map 153).

Listed in Ray's Eskimo vocabulary as meaning "The Second Kuaru" (Ray, P. H., 1885 , p. 55 ). The stream has not been identified.

Kuaruaipa: stream, see Avak Creek.

Kuaru River: stream, see Inaru River.

Kubanof Rock: rock, in Tonowek Bay, $0.7 \mathrm{mi}$. $\mathrm{N}$ of Harmony Is., Alex. Arch.; $55^{\circ} 44^{\prime} 00^{\prime \prime} \mathrm{N}$, $133^{\circ} 25^{\prime} 10^{\prime \prime} \mathrm{W}$; (map 4).

Local name recorded in 1951 by USGS.

Kubieshka Island: island, see Jug Island.

Kubok: localities, see Kobuk Villages.

Ku-buck: stream, see Kobuk River.

Kubugakhli, Cape: point of land, see Kubugakli, Cape.

Kubugakli, Cape: point of land, $\mathrm{S}$ point of entrance to Kashvik Bay, in Katmai National Monument, on $\mathrm{E}$ coast of Alaska Penin., $26 \mathrm{mi}$. S of Mount Katmai, Aleutian Ra.; 57 $53^{\prime} 50^{\prime \prime}$ N, $155^{\circ} 03^{\prime} 35^{\prime \prime}$ W; (map 35). Var. Cape Koubougakhli, Cape Kubugakhli.

Native name published by Capt. Lutke (1835, map, p. 274), IRN, as "Cape Koubougakhli" and by Capt. Tebenkov (1852, map 22), IRN, as "M[ys] Kubugakhli," or "Cape Kubugakhli."
Kubugakli, Mount: mountain, 2,900 ft., on E coast of Alaska Penin., 27 mi. SW of Mount Katmai, Aleutian Ra. ; $57^{\circ} 53^{\prime} 10^{\prime \prime}$ N, $155^{\circ} 07^{\prime}$ 55" W; (map 35).

Name derived from Cape Kubugakli, and given by USC\&GS in 1910.

Kubuk: stream, see Kobuk River.

Kubyshka, Ostrov: island, see Jug Island.

Kuchat: point of land, see Douglas, Cape.

Kuchaurak Creek: stream, flows NW $13 \mathrm{mi}$. to $\mathrm{S}$ end of Kasegaluk Lagoon, $28 \mathrm{mi}$. S of Point Lay, Arctic Plain; $69^{\circ} 21^{\prime} \mathrm{N}, 163^{\circ} 09^{\prime} \mathrm{W}$; (map 145).

Eskimo name reported by USC\&GS in 1949, meaning "new small stream."

Kucheak Creek: stream, heads in lake, flows NE $25 \mathrm{mi}$. to Inaru River, $15 \mathrm{mi}$. NW of village of Meade River, Arctic Plain; $70^{\circ} 40^{\prime} 47^{\prime \prime}$ N, 157 39'25" W; (map 147).

Eskimo name obtained in 1956 at Wainwright by T. E. Taylor, USGS

Kucher Creek: stream, flows NW $30 \mathrm{mi}$. to Colville River $5 \mathrm{mi}$. E of its junc. with Etivluk River, Brooks Ra.; $68^{\circ} 57^{\prime} \mathrm{N}, 155^{\circ} 45^{\prime} \mathrm{W}$; $B G N$ 1925; (map 133).

Name spelled "Koo-che-ak" on manuscript map made by an Eskimo about 1890. The Eskimo name probably is "Kugchiak," meaning "new river." Published by Schrader (1904, pl. 3), USGS.

Kuchiak Creek: stream, flows SE $3 \mathrm{mi}$. to Oblaron Creek, $10 \mathrm{mi}$. NW of Selawik, KotzebueKobuk Low.; $66^{\circ} 43^{\prime} \mathrm{N}, 160^{\circ} 13^{\prime} \mathrm{W}$; (map 114).

Eskimo name obtained by U.S. Army Corps of Engineers in 1955.

Kuchiak Creek: stream, flows NW $19 \mathrm{mi}$. to Chukchi Sea, $35 \mathrm{mi}$. SW of Point Lay, Arctic Plain; $69^{\circ} 15^{\prime} 30^{\prime \prime} \mathrm{N}, 163^{\circ} 20^{\prime} 00^{\prime \prime} \mathrm{W}$; (map 145). Var. Koocheak River.

Eskimo name reported by USC\&GS in 1949, meaning "new stream."

Kuch-Kan Island: island, see Kutkan Island.

Kuchuk Creek: stream, heads in Waring Mts. and flows S $16 \mathrm{mi}$. to Kugarak River, $45 \mathrm{mi}$. SW of Shungnak, Kotzebue-Kobuk Low.; $66^{\circ} 44^{\prime} \mathrm{N}, 158^{\circ} 43^{\prime} \mathrm{W}$; (map 115).

Eskimo name shown on a 1927 manuscript map by the "trader at Selawik."

Kuchyuma, Ostrov: islands, see Kutchuma Islands.

Kuckokwak Creek: stream, see Kuskokwak Creek.

Kudiakof Islands: islands, including Glen, Operl, and Neumann Islands, forming the NW boundary of Izembek and Moffet Lagoons, at SW end of Alaska Penin., Bristol Bay Low.; $55^{\circ} 22^{\prime} \mathrm{N}, 162^{\circ} 50^{\prime} \mathrm{W}$; (map 29). Var. Chimiudi Islands, Chudoekow Islands, Koudiakoff Islands, Khoudiakoff Islands, Khudiakoff Islands, Ostrova Chimyudy.

Named for a surveyor, Kudiakov (cnna), who was sent to the area by Lt. Sarichev, IRN, in 1791 (Baker, 1906, p. 384) and published by Lutke (1836, p. 291) as "Khoudiakoff." These islands were called "O[strova] Chimyudy" or "Chimyudy Islands" by Capt. Teben- kov (1852, map 24), IRN. This Aleut name may possibly be derived from the words "cimgup" and "uddag" which, according to R. H. Geoghegan, mean "small saltwater fish" [common to this area] and "bay."

Kudobin Islands: island chain, $8 \mathrm{mi}$. long, includes Walrus and Kritskoi Is., on Bering Sea coast $13 \mathrm{mi}$. W of village of Port Moller, Bristol Bay Low. ; $56^{\circ} 01^{\prime} \mathrm{N}, 160^{\circ} 55^{\prime} \mathrm{W}$; (map 28). Var. Ile aux Loups, Khudobin Islands, Khoudobine Islands, Khudubin Islands, Wolf Island.

Named "Khudobin Island" in 1882 by W. H. Dall, USC\&GS, for Andrew Khudobin, one of Capt. F. P. Lutke's naval officers in 1828. Khudobin surveyed and named the group "Ile aux Loups," or "Wolf Island," according to Lutke. Lutke (1836, p. 263) called the feature "Khoudobine."

Kudobin Peninsula: island, see Deer Island.

Kudugnak, Cape: point of land, on NE entrance point to Nazan Bay, on NE coast of

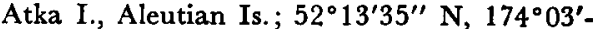
$30^{\prime \prime}$ W; (map 18). Var. Kadugnak, Kudugnake.

Aleut name, published as "M[ys] Kudugnak," or "Cape Kudugnak," by Capt. Tebenkov (1852, map 27), IRN.

Kudugnake: point of land, see Kudugnak, Cape. Kuearuk River:stream, see Steamboat Slough.

Kue-che-ark: stream, see Kuikcherk River.

Kue-ga-rack: stream, see Kugarak River.

Kuegerak: stream, see Kugarak River.

Kuethluk: stream, see Kwethluk River.

Kue-wark River: stream, see Kagueruk Creek.

Kugachiak Creek: stream, heads in lake, flows NW $20 \mathrm{mi}$. to Kasegaluk Lagoon, $20 \mathrm{mi}$. NE of Point Lay, Arctic Plain; 69 ${ }^{\circ} 56^{\prime} 30^{\prime \prime} \mathrm{N}$ $162^{\circ} 29^{\prime} 30^{\prime \prime}$ W; (map 145). Var, Koogacheak River, Kugachiak River, Kugachiakruak River.

Eskimo name reported by USGS in 1956 and means, in a sense, "new stream."

Kugachiak River: stream, see Kugachiak Greek.

Kugachiakruak River: stream, see Kugachiak Greek.

Kugachuk River: stream, see Lane River.

Kugak: locality, see Kukak.

Kugak, Mount: peak, see Kukak Volcano.

Kugakrak Mountains: hills, see Kakagrak Hills.

Kugak Volcano: peak, see Kukak Volcano.

Kugalga: island, see Tigalda Island.

Kugaluk: village, see Kiwalik.

Kugalukmut: village, see Kiwalik.

Kugalukmute: village, see Kiwalik.

Kugarak River: stream, flows SW $58 \mathrm{mi}$. to Selawik River, $27 \mathrm{mi}$. SE of Selawik, Kotzebue-Kobuk Low.; $66^{\circ} 34^{\prime} \mathrm{N}, 159^{\circ} 00^{\prime} \mathrm{W}$; $B G N$ 1912; (map 114). Var. Koogarak, Kue-garack, Kuegerak.

Eskimo name reported in 1886 as "Kue-garack" by Lt. Stoney (1900, map), USN. The present spelling was reported in 1901 by USGS.

Ku-gat-gui-gut: stream, flows $\mathrm{S} 25 \mathrm{mi}$. to $\mathrm{Ke}$ mam-gu-y-guok, $36 \mathrm{mi}$. NE of Dillingham, 
Bristol Bay Low.; $59^{\circ} 33^{\prime} \mathrm{N}, 158^{\circ} 12^{\prime} \mathrm{W}$; (map 52).

Eskimo name reported in 1910 by H. C. Fassett, USBF.

Kugat Volcano: peak, see Kukak Volcano.

Kugidach Jagutscha: volcano, see Pogromni Volcano.

Kugikukvik River: stream, see Kuskokwim River.

Kugikukwik River: stream, see Kuskokwim River.

Kugirarok Creek: stream, heads on Mount Nasak, in Lisburne Hills, flows SW $15 \mathrm{mi}$. to Kukpuk River, $18 \mathrm{mi}$. N of Cape Thompson, Arctic Slope; $68^{\circ} 24^{\prime} 30^{\prime \prime} \mathrm{N}, 165^{\circ} 56^{\prime} 30^{\prime \prime} \mathrm{W}$; (map 129). Var. Kutigrarak, Kutigraruk Creek.

Eskimo name recorded in 1956 by Orth as "Kutigrarak"; said to mean "flint arrowheads."

Kugirukak River: stream, see Noxapaga River.

Kugiruk River: stream, see Kougarok River.

Kugok River: stream, see Kungok River.

Kugoosuguru: locality, camp site on Chukchi Sea coast $8 \mathrm{mi}$. SW of Barrow, Arctic Plain; $71^{\circ} 12^{\prime} \mathrm{N}, 157^{\circ} 00^{\prime} \mathrm{W}$; (map 153$)$.

Eskimo camp name published by R. F. Spencer (1959, map 2). Lt. P. H. Ray, $(1885$, p. 55$)$, USA, spells the name "Kuosugru" and lists it as the third camp below the village at Cape Smyth.

Kugrak River: stream, flows N $20 \mathrm{mi}$. to Noatak River, $41 \mathrm{mi}$. SW of Survey Pass, Brooks Ra.; $67^{\circ} 40^{\prime} \mathrm{N}, 155^{\circ} 37^{\prime} \mathrm{W}$; (map 125).

Eskimo name meaning "old river," recorded in Kobuk by Orth, USGS, in 1956.

Kugrock River: stream, see Kougarok River.

Kugrok River: stream, see Kougarok River.

Kugrua Bay: bay, $9 \mathrm{mi}$. long, off $\mathrm{W}$ end of Peard Bay, at mouth of Kugrua River, $18 \mathrm{mi}$. NE of Wainwright, Arctic Plain; $70^{\circ} 47^{\prime} \mathrm{N}$, $159^{\circ} 08^{\prime} \mathrm{W}$; (map 146).

See Kugrua River.

Kugruak River: stream, see Canning River.

Kugrua River: stream, heads in lake, flows NW $40 \mathrm{mi}$. to Kugrua Bay, $9 \mathrm{mi}$. NE of Wainwright, Arctic Plain; $70^{\circ} 46^{\prime} 30^{\prime \prime}$ N, $159^{\circ} 17^{\prime}$. 00" W; BGN 1949; (map 146). Var. River Cogrua, Kookroak River, Kugura River, Kugurua River, Kukroak River.

Eskimo name shown as "R. Cogrua" on Brit. Adm. Chart 593, 1827-55. Lt. Ray (1885, p. 54), USA, lists the word "kug'ru," meaning "swan." However, other spellings of this name would indicate that it may be "Kukraq," meaning "creek."

Kugruk: locality, see Kougarok.

Kugruk Lagoon: lagoon, on Seward Penin., at mouth of Kugruk River, $1.2 \mathrm{mi}$. wide and 3 mi. long, $4 \mathrm{mi}$. SE of Deering, Kotzebue-Kobuk Low.; $66^{\circ} 03^{\prime} \mathrm{N}, 162^{\circ} 38^{\prime} \mathrm{W}$; (map 113).

Eskimo name reported in 1950 by USGS; derived from the Kugruk River which flows into the lagoon.

Kugruk Mountains: mountain, see Kougarok Mountain.

Kugruk River: stream, on Seward Penin., heads in Imuruk Lake, flows NE then NW $60 \mathrm{mi}$. to Kugruk Lagoon, at Kotzebue Sound, $5 \mathrm{mi}$. SE of Deering, Kotzebue-Kobuk Low.; $66^{\circ} 00^{\prime}$ N, $162^{\circ} 40^{\prime} \mathrm{W} ; B G N 1952$; (map 113). Var. Koogroog River, Mammoth River, Right Fork Kugruk River, Swan River

Eskimo name reported in 1899 as "Koogroog" by Schrader and Brooks (1900, map 3 ), USGS. This appears to be the stream that Ivan Petroff in 1880 named "Mammoth" "from the occurrence of Mammoth bones in the vicinity" (Baker, 1906, p. 424). Reported as "Swan River" in 1901 by D. L. Reaburn (in Mendenhall, 1902, pl. 42), USGS

In 1904, after USGS had completed reconnaissance mapping of Seward Peninsula, attention was called to the fact that three major rivers on the peninsula were named "Kugruk." Action was then taken to change these names. The above river was retained as Kugruk since that is the way it was used in court records. The Kugruk River which flows to the Kuzitrin River was changed to Kougarok River, because, as A. J. Collier, USGS, stated in a letter, "it has always been pronounced locally as Koogarok, and so appears on all claim notices. When I first heard the name in 1900 , I fancied that it had reference to the Rocky Mountain lion as cougar. In court records it is usually spelled 'Kougarok,' and the mining district is the Kougarok district." The Kugruk River which flows northwest to the Chukchi Sea was changed to Kugrupaga River because that was the name shown on the Monroe and Hutchin's map prepared under direction of the court in 1901. Since no gold of economic value had yet been found on this stream, it was felt this change could be effected without inconvenience.

Kugruk River: stream, see Kougarok River. Kugruk River: stream, see Kugrupaga River. Kugrukruk River: stream, see Noxapaga River. Kugrupaga Creek: stream, see Henry Creek.

Kugrupaga Inlet: $b a y$, extends $\mathbf{S} 3.3 \mathrm{mi}$., off Arctic Lagoon, at mouth of Kugrupaga River, $25 \mathrm{mi}$. SW of Shishmaref, Kotzebue-Kobuk Low.; $66^{\circ} 01^{\prime} \mathrm{N}, 166^{\circ} 49^{\prime} \mathrm{W}$; (map 112).

Named for the river; published in 1952 by AMS.

Kugrupaga River: stream, on Seward Penin. flows NW $32 \mathrm{mi}$. to Kugrupaga Inlet, on Chukchi Sea, $16 \mathrm{mi}$. NW of Ear Mtn. and 52 mi. NW of Teller, Kotzebue-Kobuk Low. $66^{\circ} 00^{\prime} \mathrm{N}, 166^{\circ} 48^{\prime} \mathrm{W}$; BGN 1905; (map 111). Var. Koogrook River, Kugruk River.

Eskimo name reported in 1901 as "Kugruk" by T. G. Gerdine (in Collier, 1902, pl. 9), USGS. See Kugruk River.

Kugukgit Mountains: mountains, see Kookooligit Mountains.

Kuguklik River: stream, flows W $30 \mathrm{mi}$. to Kinak Bay, $48 \mathrm{mi}$. W of Kulvagavik and 4 mi. NW of Kipnuk, Yukon-Kuskokwim Delta; $59^{\circ} 58^{\prime} \mathrm{N}, 164^{\circ} 08^{\prime} \mathrm{W}$; (map 54$)$.

Eskimo name reported in 1878 by E. W. Nelson, U.S. Signal Service.
Kugukpak Creek: stream, heads in lake, flows SE $14 \mathrm{mi}$. to Okokmilaga River $6 \mathrm{mi}$. $\mathrm{N}$ of its head, Brooks Ra.; $68^{\circ} 13^{\prime} \mathrm{N}, 153^{\circ} 06^{\prime} \mathrm{W}$; (map 133).

Eskimo name meaning "biggest creek," obtained in 1956 at Anaktuvuk Pass by T. E. Taylor, USGS.

Kugukpak Valley: ravine, formed by Kuropak Creek, $11 \mathrm{mi}$. SE of Point Thompson, Arctic Slope; $68^{\circ} 05^{\prime} \mathrm{N}, 165^{\circ} 35^{\prime} \mathrm{W}$; (map 129). Var. Kowguckpak.

Eskimo name meaning "big gorge"; so called because the ravine's walls are fairly steep with few breaks in them. Name reported in 1966 by E. S. Burch.

Kuguk River: stream, see Kungok River.

Kugulgit Mountains: mountains, see Kookooligit Mountains.

Kugulik Bay: bay, see Kujulik Bay.

Kugun Point: point of land, on $\mathrm{E}$ coast of Tuxekan I., 25 mi. N of Craig, Alex. Arch.; $55^{\circ} 49^{\prime} 15^{\prime \prime} \mathrm{N}, 133^{\circ} 12^{\prime} 55^{\prime \prime} \mathrm{W}$; (map 4).

Indian name recorded in 1949 by USGS.

Kugura River: stream, see Kugrua River.

Kugurua River: stream, see Kugrua River.

Kuguru River: stream, see Canning River.

Kuguyuk Lake: lake, $0.5 \mathrm{mi}$. long, on Kenai Penin. $W$ of Bird Lake, $5 \mathrm{mi}$. SW of Point Possession and $42 \mathrm{mi}$. NE of Kenai, Cook Inlet Low.; $60^{\circ} 48^{\prime} 40^{\prime \prime} \mathrm{N}, 150^{\circ} 26^{\prime} 30^{\prime \prime} \mathrm{W}$; (map 62).

Named about 1963 by officials of Kenai National Moose Range, for administrative purposes.

Ku-Henmut: locality, see Kutmiut.

Kuhl Island: island, see Kohl Island.

Kuhnteah: lake, see Mosquito Lake.

Kuhsuman Creek: stream, flows NW $13 \mathrm{mi}$ from a glacier to Nanushuk River, 37 mi. ENE of Anaktuvuk Pass, Brooks Ra.; 68 21'15" N, $150^{\circ} 35^{\prime} 00^{\prime \prime} \mathrm{W}$; (map 134).

Named by USGS geologists during the exploration of Naval Petroleum Reserve No. 4 ; name given in 1944.

Kuiagdak: island, see Poperechnoi Island

Kuiak River: stream, flows NW $25 \mathrm{mi}$. to Norton Sound, $14 \mathrm{mi}$. SW of St. Michael, YukonKuskokwim Delta; 63 $23^{\prime} \mathrm{N}, 162^{\circ} 27^{\prime} \mathrm{W}$; (map 92).

Eskimo name obtained in 1952 by USC\&GS Kuigamute: locality, see Kwik.

Kuik: locality, see Kwik.

Kuikcherk River: stream, flows NW $22 \mathrm{mi}$. to Kobuk River, 3 mi. E of Shungnak, KotzebueKobuk Low.; $66^{\circ} 53^{\prime} \mathrm{N}, 157^{\circ} 02^{\prime} \mathrm{W}$; (map 115). Var. Kue-che-ark.

Eskimo name spelled "Kue-che-ark" by Lt. Stoney (1900, map), USN, and applied by him to a stream to the east of this one. W. C. Mendenhall, USGS, reported the above spelling and application in 1901.

Kuikh: locality, see Kwik.

Kuikhlogamute: village, see Kwethluk.

Kuikhoglyuk, Reka: stream, see Ulukuk River Kuikli : locality, see Kwik.

Kui-kohk-tak Pass: water passage, see Kwikok. tuk Pass.

Kuikpak: stream, see Yukon River. 
Kuik River: stream, see Kwik River.

Kuilkluk : village, see Kwethluk.

Kuimla Reka: water course, see Kwemeluk Pass. Kuingak: stream, see Akulik River.

Kuingshtetakten: village, see Shageluk.

Kuirzinjik Lake: lake, $0.8 \mathrm{mi}$. long, on $\mathrm{E}$ bank of Sheenjek River, 7.4 mi. NW of Table Mtn. and $44 \mathrm{mi}$. NE of Arctic Village, Brooks Ra.; $68^{\circ} 23^{\prime} \mathrm{N}, 143^{\circ} 57^{\prime} \mathrm{W}$; (map 137). Var. Lobo Lake.

Kutchin Indian name obtained in 1956 by T. E. Taylor, USGS.

Kuiu Island: island, $65 \mathrm{mi}$. long, Alex. Arch.; $56^{\circ} 35^{\prime} \mathrm{N}, 134^{\circ} 00^{\prime} \mathrm{W}$; BGN 1890; (map 5). Var. Kou Island, Ostrov Kuyu.

Tlingit Indian name published in 1848 as "Ostrov Kuyu," or "Kuyu Island," on Russian Hydrog. Dept. Chart 1396.

Kuiuk, Reka: stream, see Koyukuk River.

Kuiukpak Slough: distributary, of Yukon River, extends E-W $10 \mathrm{mi}$. between Kwikluak and Alakanuk Passes, 7 mi. SW of Kwiguk, YukonKuskokwim Delta ; $62^{\circ} 43^{\prime}$ N, $164^{\circ} 43^{\prime}$ W; (map 77).

Eskimo name obtained in 1952 by U.S. Army Corps of Engineers.

Kuiukta Bay: bay, $5 \mathrm{mi}$. across, on $\mathrm{S}$ coast of Alaska Penin., $24 \mathrm{mi}$. SW of Chignik, Aleutian Ra.; $56^{\circ} 00^{\prime} \mathrm{N}, 158^{\circ} 36^{\prime} \mathrm{W}$; (map 27). Var. Dorai Bay.

Aleut name published as "Z[aliv] Kuiukta," or "Kuiukta Bay," by Capt. Tebenkov (1852, map 24) and as "Kuiukta Bay (Dorai Bay)" in USC\&GS Alaska Coast Pilot (1947, v. 2, p. 291).

Kuiuktalik: locality, on NW shore of Norton Bay near Elim, Seward Penin. High.

Site of an Eskimo village shown on the 1900 "Map of Nome Peninsula" by J. M. Davidson and B. D. Blakeslee.

Kuiuktulik Creek: stream, see Quiktalik Creek.

Kuiuktulik River: stream, flows NE $8.5 \mathrm{mi}$. to Norton Bay, $29 \mathrm{mi}$. NW of Christmas Mtn., Seward Penin. High.; $64^{\circ} 50^{\prime} \mathrm{N}, 161^{\circ} 18^{\prime} \mathrm{W}$; $B G N$ 1954; (map 96). Var. Koyuktulik River, Kuiutulik River.

Eskimo name reported in 1900 by J. J. Gilbert, USC\&GS.

Kuiukuk: locality, "on SE coast of Alaska Penin.," Aleutian Ra. Var. Kuyukak, Wrangell Bay.

Former Eskimo camp or settlement reported as "Kuyukak," with a population of 18 , by Ivan Petroff in the 1880 Census; listed as "Wrangell Bay," with a population of 62 , in the 1890 Census.

Kuiu Lake: lake, see Alecks Lake.

Kuiu Stream: stream, see Alecks Creek.

Kuiutulik River: stream, see Kuiuktulik River.

Kujulik Bay: bay, $16 \mathrm{mi}$. long, on $\mathrm{S}$ coast of Alaska Penin., $25 \mathrm{mi}$. SW of Cape Kunmik, Aleutian Ra.; $56^{\circ} 35^{\prime} \mathrm{N}, 157^{\circ} 45^{\prime} \mathrm{W}$; (map 31). Var. Kaiulik Bay, Kiehzulik Bay, Koujulik Bay, Kugulik Bay, Sitkum Bay, Zaliv Kizhulik.

Native name shown as "Z[aliv] Kizhulik" on Russian Hydrog. Dept. Chart 1379 in 1847.
Kujulik River: stream, see Kejulik River.

Kujupak: stream, see Koyukuk River.

Kuk: locality, site of Eskimo village on Chukchi Sea coast, at Point Collie, SW of Wainwright, Arctic Plain; $70^{\circ} 36^{\prime} \mathrm{N}, 160^{\circ} 07^{\prime} \mathrm{W}$; (map 146). Var. Keogmute, Koo, Koog, Koogmute, Kook, Kunmeum.

The 11th Census in 1890 (1893, p. 133) stated, "The Koog river debouches close to the village that bears its name, near Point Collie." This may be the same village with a population of 80 that Lt. Ray (1885, p. 38), USA, recorded as "Kunmeum," "near Wainwright Inlet." The Eskimo word "kuk" means "river," and "kukmiut" means "river people."

Kuk, Mys: point of land, see Coke, Point.

Kuka, Kekur: rocks, see Signals, The.

Kuka Beach : beach, see Kooku Beach.

Kuka Creek: stream, heads in lake at $61^{\circ} 21^{\prime} 15^{\prime \prime}$ $\mathrm{N}, 162^{\circ} 33^{\prime} 40^{\prime \prime} \mathrm{W}$, flows W $30 \mathrm{mi}$. to Izaviknek River, $14 \mathrm{mi}$. NE of Aropuk Lake, YukonKuskokwim Delta; $61^{\circ} 21^{\prime} 35^{\prime \prime} \mathrm{N}, 163^{\circ} 13^{\prime} 05^{\prime \prime}$ W; (map 74).

Eskimo name referring to "its middle" reported by Orth in 1965.

Kukagruk Mountains: hills, see Kakagrak Hills. Kukak: locality, on S shore of Kukak Bay, on S coast of Alaska Penin., in Katmai National Monument, $29 \mathrm{mi}$. NE of Mount Katmai, Aleutian Ra.; $58^{\circ} 19^{\prime} 05^{\prime \prime} \mathrm{N}, 154^{\circ} 11^{\prime} 15^{\prime \prime} \mathrm{W}$; (map 42). Var. Kugak, Kugat, Toujajak.

Eskimo village called "Toujajak Village" by von Langsdorff (1814, v. 2, p. 235), and "Kukak," by Ivan Petroff in the 1880 U.S. Census. Its population in 1880 was 37 . There is a historical locality of the same name four miles to the NE.

Kukak: locality, on Kukak Point, on S coast of Alaska Penin., in Katmai National Monument, $31 \mathrm{mi}$. NE of Mount Katmai, Aleutian $\mathrm{Ra}$; 58 $21^{\prime} 10^{\prime \prime} \mathrm{N}, 154^{\circ} 06^{\prime} 10^{\prime \prime} \mathrm{W}$; BGN 1925; (map 42). Var. Koukak, Kugak, Old Kukak, Selenie Kukak.

Former Eskimo village reported in 1831 by Ens. Vasiliev; published in 1847 as "Selenie Kukak" on Russian Hydrog. Dept. Chart 1378.

Kukak: peak, see Kukak Volcano.

Kukak, Guba: estuary, see Kukak Bay.

Kukak, Zaliv: estuary, see Kukak Bay.

Kukak Bay: estuary, extends SW $10 \mathrm{mi}$. from Kukak Point, on S coast of Alaska Penin., in Katmai National Monument, $25 \mathrm{mi}$. E of Mount Katmai, Aleutian Ra.; 58 $19^{\prime} \mathrm{N}$, 154 ${ }^{\circ} 6^{\prime}$ W; BGN 1925; (map 42). Var. Baie Koukack, Guba Kukak, Koukak Bay, Kukat Bay, Zaliv Kukak.

Eskimo name recorded by the early Russian explorers; published by Sarichev (1826, map 3) as "Guba Kukak."

Kukak Creek: stream, heads in lake, flows $\mathrm{N}$ $25 \mathrm{mi}$. to Nigisaktuvik River, $7.5 \mathrm{mi}$. W. of village of Meade River, Arctic Plain; 70 27' N, $157^{\circ} 43^{\prime} \mathrm{W}$; (map 147).

Eskimo name obtained in 1956 at Wainwright by T. E. Taylor, USGS.
Kukaklek Lake: lake, $14 \mathrm{mi}$. long, at head of Alagnak River, $40 \mathrm{mi}$. SW of Iliamna, Aleutian Ra.; $59^{\circ} 10^{\prime} \mathrm{N}, 155^{\circ} 20^{\prime} \mathrm{W}$; (map 51). Var. Aliknuk Lake.

Native name published by Capt. Tebenkov, IRN, on an 1849 map as "Kukaklek Oz[ero]," or "Kukaklek Lake."

Kukaklik Lake: lake, $3.7 \mathrm{mi}$. across, in YukonKuskokwim Portage, between Arhymot and Kulik Lakes, $26 \mathrm{mi}$. SE of Russian Mission, Yukon-Kuskokwim Delta; $61^{\circ} 39^{\prime} \mathrm{N}, 160^{\circ} 32^{\prime}$ W; (map 73). Var. Oakakhl, Oknakluk, Ookakhl, Ookaht, Ookakht, Ukak.

This Eskimo name was first reported in Russian, by Lt. L. A. Zagoskin, IRN, in $1842-44$, as "Ozero Kuka-Klik," or "Lake Kukaklik." Although it is shown as a large lake on Kuskokwim-Yukon Portage, its exact identity cannot be determined. R. $H$. Sargent, USGS, who traversed the portage in 1916, placed the name on the lake immediately south of Kulik Lake, in a location verified by USC\&GS in 1949. The U.S. Army Corps of Engineers, however, applied the name to Kukaklik Lake's present location in 1952. Authorities give the Eskimo name with various spellings. They may represent two names for this feature, or confusion in the application of names to the "portage lakes." Capt. R. W. Raymond, USA, called it "Ookakhl" and "Oakakhl," in 1869, and W.S. Post, USGS, called it "Oknakluk" in 1898.

Kukak Point: point of land, $\mathrm{N}$ point of entrance to Kukak Bay, on $\mathbf{S}$ coast of Alaska Penin., in Katmai National Monument, 33 mi. NE of Mount Katmai, Aleutian Ra.; $58^{\circ} 20^{\prime} 40^{\prime \prime} \mathrm{N}, 154^{\circ} 05^{\prime} 35^{\prime \prime} \mathrm{W}$; (map 42).

Local name reported in 1951 by USGS; named after Kukak Bay.

Kukaktlik River: stream, flows SW $20 \mathrm{mi}$. to Middle Fork Goodnews River, $29 \mathrm{mi}$. NE of Goodnews, Kilbuck-Kuskokwim Mts.; 59 $18^{\prime}$ $\mathrm{N}, 160^{\circ} 51^{\prime} \mathrm{W}$; (map 53).

Eskimo name reportedly meaning "middle one," obtained about 1951 at Goodnews by J. M. Hoare, USGS.

Kukaktlim Lake: lake, $1.5 \mathrm{mi}$. across, $12 \mathrm{mi}$. SE of Nagyagat Mtn. and $43 \mathrm{mi}$. NE of Goodnews, Kilbuck-Kuskokwim Mts.; $59^{\circ} 20^{\prime}$ N, $160^{\circ} 30^{\prime} \mathrm{W}$; (map 53).

Eskimo name published in 1951 by USGS.

Kukak Volcano: peak, 6,700 ft., on Alaska Penin., in Katmai National Monument, 26 mi. NE of Mount Katmai, Aleutian Ra.; $58^{\circ} 27^{\prime} 15^{\prime \prime} \mathrm{N}, 154^{\circ} 21^{\prime} 25^{\prime \prime} \mathrm{W}$; BGN 1957; (map 42). Var. Kugak Volcano, Kugat Volcano, Kukak, Mount Kugak.

Name reported in 1908 as "Kugak Volcano" by USC\&GS. The spelling was changed to agree with that of the bay.

Kukan Island: island, see Sitkalidak Island.

Kukanuwu: locality, "on the mainland, $\mathrm{N}$ of Cross Sound," St. Elias Mts.; (map 10).

Former Huna Tlingit camp or settlement reported by J. R. Swanton (in Hodge, 1907. p. 733), BAE.

Kukat Bay: estuary, see Kukak Bay. 
Kukchivik Point: point of land, see Kookjilik Point.

Kukeatak: point of land, see Beaufort, Cape.

Kukeatak River: stream, see Kahkatak Creek.

Kukhchiliwikh Point: point of land, see Kookjilik Point.

Kukh-du-li: stream, see Kaktuli River.

Kukh-Kan Island: island, see Kutkan Island.

Kukitiyak Island: island, see Avogon Island.

Kukkan Bay: bay, 1 mi. across, on $\mathrm{N}$ coast of Herbert Graves I., $5 \mathrm{mi}$. W of Chichagof, off W coast of Chichagof I., Alex. Arch.; $57^{\circ} 40^{\prime}$ N, 136 $14^{\prime} \mathrm{W}$; BGN 1926; (map 9).

Tlingit Indian name for Portlock Harbor reported by Comdr. H. E. Nichols, USN, in the USC\&GS 1891 Coast Pilot (p. 189). At that time he thought that Kakkan Bay was identical to Portlock Harbor, but this was later discovered to be incorrect. The bay was named for a Tlingit Chief, Michael Kukkan, who in 1862 was appointed by the Russian Government to be "Chief Toyon of Koloshi" (Alaska Boundary Tribunal, v. 2, p. 316).

Kukkan Bay: water passage, see Kukkan Passage. Kuk-kan Harbor: bay, see Portlock Harbor.

Kukkan Passage: water passage, $2 \mathrm{mi}$. long, along SW coast of Herbert Graves I., $10 \mathrm{mi}$. WSW of Chichagof, on W coast of Chichagof I., Alex. Arch.; $57^{\circ} 39^{\prime} \mathrm{N}, 136^{\circ} 13^{\prime} \mathrm{W}$; BGN 1926; (map 9). Var. Cape Edward Pass, Kukkan Bay.

Named in 1926 by USC\&GS for Kukkan Bay which it joins; published in 1928 on Chart 8250. Cape Edward Pass was reported as the local name, but was misapplied at the time to another feature.

Kuklik Village: locality, see Kookoolik.

Kukpak: stream, see Kukpuk River.

Kukpayak River: stream, see Kakpeyak River.

Kukpowruk: locality, site of Eskimo village on coast of Chukchi Sea, near mouth of Kukpowruk River, $10 \mathrm{mi}$. S of Point Lay, Arctic Plain; $69^{\circ} 36^{\prime} 40^{\prime \prime} \mathrm{N}, 163^{\circ} 00^{\prime} 00^{\prime \prime} \mathrm{W}$; (map 145). Var. Kookpoowrook River, Kookpowrook River, Kukpowrukuk River, Sing-i-too-rók.

In 1884 Brower (1944, p. 25) wrote: "we fairly ran to a village called Kukpowruk on a river of the same name. Nobody was home." In 1918 Archdeacon Stuck (1920, p. 182) referred to a single dwelling called "Sing-i-toorók," at the mouth of the "Ku-póu-ruk" River. The 11 th Census of 1890 (p. 158) lists a population of 52 Eskimo called "Kukpaurungmiut" on the Kukpowruk River.

Kukpowruk Inlet: water passage, see Kukpowruk Pass.

Kukpowruk Pass: water passage, between Chukchi Sea and Kasegaluk Lagoon, $6 \mathrm{mi}$. S of Point Lay, Arctic Plain; 69 $40^{\prime} 30^{\prime \prime}$ N, $163^{\circ}$ $06^{\prime} 00^{\prime \prime} \mathrm{W}$; (map 145). Var. Keeverleek Inlet, Kivirlik Inlet, Kukpowruk Inlet, Singak Inlet.

Eskimo name reported by USC\&GS in 1949; named for the nearby Kukpowruk River. This passage is, however, referred to as "Keeverleek [Kivirlik]" meaning "further in" at Point Hope and as "Singuk" at Wainwright.
Kukpowruk River: stream, heads in De Long Mts. at $68^{\circ} 26^{\prime} \mathrm{N}, 162^{\circ} 30^{\prime} \mathrm{W}$, flows $\mathrm{N} 160 \mathrm{mi}$. to Kasegaluk Lagoon, $9 \mathrm{mi}$. S of Point Lay, Arctic Plain; $69^{\circ} 37^{\prime} 30^{\prime \prime} \mathrm{N}, 163^{\circ} 02^{\prime} 45^{\prime \prime} \mathrm{W}$; BGN Sixth Report; (map 145). Var. Kookpoowrook River, Kookpowrook River, Kook pow ruk, Kukpowrukuk River, Kupouruk River.

Eskimo name listed in 11 th U.S. Census of 1890 (p. 133). "At Point Lay a river called Kukpowrukuk enters the largest of these sheets of water [Kasegaluk Lagoon]." The name probably means "fairly large stream [Kukpauraq]" or "a stream [Kugauraq]." The name's earliest published use appears to be in John W. Kelly's "Eskimo Vocabulary," 188589, where it is listed as "Kook pow ruk."

Kukpowrukuk River: stream, see Kukpowruk River.

Kukpuk: locality, on S bank of Kukpuk River near Iglupak Creek, $18 \mathrm{mi}$. N. of Cape Thompson, Arctic Slope; $68^{\circ} 24^{\prime} 30^{\prime \prime} \mathrm{N}, 165^{\circ} 55^{\prime} 15^{\prime \prime}$ W; BGN 1963; (map 129).

Site of an Eskimo camp reported in 1950 by USC\&GS. Named for the river.

Kukpuk River: stream, heads in De Long Mts. at $68^{\circ} 19^{\prime} 50^{\prime \prime} \mathrm{N}, 163^{\circ} 24^{\prime} 50^{\prime \prime} \mathrm{W}$, flows SW and NW $125 \mathrm{mi}$. to $E$ end of Marryat Inlet, 12 mi. NE of village of Point Hope, Arctic Slope; $68^{\circ} 25^{\prime} \mathrm{N}, 166^{\circ} 22^{\prime} \mathrm{W}$; (map 129). Var. Kookpuk River, Kukpak Kupuk River, Marryat Creek, Tigara River.

On September 6, 1826, Capt. Beechey (1831, p. 320 ), RN, wrote, "We noticed the water, whilst off Marryat Creek to be of very muddy colour, as if some river discharged itself there." Eskimo name "Kukpak" meaning "big river" was published in 1890 by USC\&GS as "Kookpuk."

Kukritovik Entrance: water passage, see Kuvritovik Entrance.

Kuk River: stream, formed by Avalik and Kaolak Rivers, flows N 35 mi. to Wainwright Inlet, $5 \mathrm{mi}$. SE of Wainwright, Arctic Plain; $70^{\circ} 35^{\prime} \mathrm{N}, 159^{\circ} 53^{\prime} \mathrm{W}$; BGN 1966; (map 146). Var. Kaolak River, Kee River, Koh River, Kok River, Kong River, Koo River, Koog River, Kook River, Kov River, Ku River, Tutua Wing River.

Eskimo name meaning "river." Surgeon John Simpson's native map, 1853, shows "Koh," "Kong," and "Tutua Wing," streams connecting the Colville River with Wainwright Inlet. Lt. Ray (1885, p. 55), USA, records "River at Wainwright's Inlet-Ku." His map, however, shows "Koo River." Published by USC\&GS in 1869, as "Kook." U.S. Navy Hydrog. Chart 69, 1892, shows two rivers, one called "Koo" and the other "Kee."

Kuk River Valley: valley, of Kuk River, $S$ of Wainwright, Arctic Plain; (map 146). Var. Kuk Valley.

Named in 1924 by USGS for the Kuk River

Kukroak River: stream, see Kugrua River.

Kukruk Creek: stream, flows NW $2.5 \mathrm{mi}$. to Chukchi Sea, 2 mi. E of Arrow Creek and 27 mi. E of Cape Lisburne, Arctic Slope; 68 $52^{\prime}$ - $15^{\prime \prime} \mathrm{N}, 165^{\circ} 08^{\prime} 40^{\prime \prime} \mathrm{W}$; (map 129). Var. Kookrook Creek.

Eskimo name for "creek" reported in 1950 by USC\&GS.

Kuktak Island: island, see Kodiak Island.

Kukthluk River: stream, flows SW $3 \mathrm{mi}$. to Pikmiktalik River, $14 \mathrm{mi}$. W of Bethel, YukonKuskokwim Delta; $60^{\circ} 49^{\prime} \mathrm{N}, 162^{\circ} 11^{\prime} \mathrm{W}$; (map 58).

Eskimo name reported in 1949 by USC\&GS. Kukuak: locality, see Kokwok.

Kukuak: point of land, see Douglas, Cape.

Kuku Creek: stream, see Keku Creek.

Kukukpilak Creek: stream, heads in pond in De Long Mts., flows SE $13 \mathrm{mi}$. to Nimiuktuk River, $30 \mathrm{mi}$. E of Misheguk Mtn., Brooks Ra.; $68^{\circ} 17^{\prime} \mathrm{N}, 159^{\circ} 55^{\prime} \mathrm{W}$; (map 131).

Eskimo name obtained at Noatak in 1956 by Orth.

Kukuktuk: locality, "on left bank of Kuskokwim River, about 30 mi. downstream from Kolmakof," Kilbuck-Kuskokwim Mts.; (map 72). Var. Kochlogtogpagamiut, Kokhlokhtokhpagamute.

Former Eskimo camp or settlement reported as "Kokhlokhtokhpagamute," with a population of 51 , by Ivan Petroff in the 1880 Census ; as "Kochlog togpagamiut," with a population of 20 , in the 1890 Census.

Kukulgit Mountains : mountains, see Kookooligit Mountains.

Kukuliak: locality, "on $\mathrm{N}$ shore of St. Lawrence I."; (map 93).

Former Eskimo village reported in 1849 by Capt. M. D. Tebenkov, IRN.

Kukuliak: locality, see Kookoolik.

Kukuliak Cape: point of land, see Kookoolik Cape.

Kukuliak Hill: hill, see Kookoolik Hill.

Kukulik: locality, see Kookoolik.

Kukulik Hill: hill, see Kookoolik Hill.

Kukulikhtuk: stream, see Kookooliktook River. Kukulik Mound: rocks, see Kitleekot Rocks.

Kukuliktook River: stream, see Kookooliktook River.

Kuk Valley: valley, see Kuk River Valley.

Kukwahyekukwo Mountain: mountain, see Four Winds Mountain.

Kulak Point: point of land, $\mathrm{S}$ entrance to Tanaga Bay, on SW Tanaga I., Aleutian Is.; $51^{\circ} 42^{\prime} 30^{\prime \prime} \mathrm{N}, 178^{\circ} 06^{\prime} 40^{\prime \prime} \mathrm{W}$; (map 16).

Aleut name published as "M[ys] Kkhulak," or "Cape Kulak," by Capt. Tebenkov (1852, map 28)

Kulchavak River: stream, see Kvichavak River. Kulebrina: island, see Culebrina Island. Kulgiakh, Ostrov: island, see Kalgin Island.

Kulgurak Island: barrier island, $3 \mathrm{mi}$. long, in Plover Is., E of Dease Inlet, $38 \mathrm{mi}$. SE of Barrow, Arctic Plain; $71^{\circ} 08^{\prime} 55^{\prime \prime} \mathrm{N}, 155^{\circ} 02^{\prime}$ $30^{\prime \prime} \mathrm{W}$; (map 153).

Eskimo name probably borrowed from adjacent Kulgurak Point, called Tangent Point on recent maps.

Kulgurak Point: point of land, see Tangent Point.

Kuliak, Cape: point of land, S point of entrance to Kuliak Bay, on $\mathrm{S}$ coast of Alaska 
Penin., in Katmai National Monument, 29 mi. SE of Mount Katmai, Aleutian Ra.; 58 $08^{\prime} 10^{\prime \prime} \mathrm{N}, 154^{\circ} 12^{\prime} 30^{\prime \prime} \mathrm{W}$; (map 42). Var. Mys Kuliak, Mys Kuliakuiak.

Eskino name from the early Russians; published by Capt. Tebenkov (1852, map 22) as "M[ys] Kulyak," also transliterated as "Kuliak."

Kuliak, Mys: point of land, see Kuliak Cape. Kuliak Bay: bay, $4 \mathrm{mi}$. wide, extends NW $5 \mathrm{mi}$. from Cape Kuliak, on S coast of Alaska Penin., in Katmai National Monument, $29 \mathrm{mi}$. ESE of Mount Katmai, Aleutian Ra.; $58^{\circ} 10^{\prime} \mathrm{N}$, $154^{\circ} 10^{\prime} \mathrm{W}$; (map 42).

Named in 1919 by R. F. Griggs, National Geographic Society, after Cape Kuliak, its southern entrance point.

Kuliakuiak, Mys: point of land, see Kuliak, Gape.

Kulichavak River: stream, see Kvichavak River. Kulichek, Kamen: rock, see Kulichkof Rock.

Kulichivak River: stream, see Kvichavak River. Kulichkof Bay: bay, see Snipe Bay.

Kulichkoff Island: island, see Kulichkof Island. Kulichkoff Island: rock, see Kulichkof Rock.

Kulichkof Island: island, $400 \mathrm{ft}$. long, in Woody Island Channel, $1.2 \mathrm{mi}$. SE of Kodiak, Kodiak I.; $57^{\circ} 46^{\prime} 30^{\prime \prime} \mathrm{N}, 152^{\circ} 23^{\prime} 00^{\prime \prime} \mathrm{W}$; (map 34). Var. Kulichkoff Island, Ostrov Kulichkov.

This is a transliteration by USC\&GS in 1869 of the name "Os[trov] Kulichkov," meaning "Wookcock Island," published by Sarichev (1826, map 16).

Kulichkof Island: island, $500 \mathrm{ft}$. long, off Cape Ugyak, between Kukak Bay and Shelikof Strait, on S coast of Alaska Penin., in Katmai National Monument $32 \mathrm{mi}$. E of Mount Katmai, Aleutian Ra.; 58 $17^{\prime} 15^{\prime \prime} \mathrm{N}, 154^{\circ}$. 05'50" W; (map 42).

Local name reported in 1951 by USGS. Russian name, meaning "snipe," given in 1831 by Ensign Vasiliev.

Kulichkof Rock: rock, $200 \mathrm{ft}$. across, $6 \mathrm{mi}$. SW of Sitka, off W coast of Baranof I., Alex. Arch.; 56 $59^{\prime} 30^{\prime \prime} \mathrm{N}, 135^{\circ} 26^{\prime} 30^{\prime \prime} \mathrm{W}$; BGN 1897; Var. Kamen Kulichek, Kulich Rock, Kulichkoff Island, Kulitch Rock, Kulitzkoff Island, Ostrov Kulichkov, Snipe Rock.

Named in 1809 by the. Russian navigator, Ivan Vasiliev the first; published by Lt. Sarichev (1826, map 19), IRN, as "O[strov] Kulickkov" [from Kulichok], meaning "snipe island."

Kulichkov, Ostrov: island, see Kulichkof Island. Kulichkov, Ostrov: rock, see Kulichkof Rock. Kulichkova Bukhta: bay, see Snipe Bay.

Kulich Rock: rock, see Kulichkof Rock.

Kulik, Lake: lake, $16 \mathrm{mi}$. long, $4 \mathrm{mi}$. S of Eagle Mtn., in Wood River Lakes, $55 \mathrm{mi}$. N of Dillingham, Kilbuck-Kuskokwim Mts.; 59 ${ }^{\circ} 7^{\prime}$ N, 158 58' W; BGN 1937; (map 52). Var. Ku-lik.

Eskimo name shown as "Ku-lik" on a 1910 manuscript map by H. C. Fassett, USBF; the local name "Lake Kulik" was published in 1915 by USGS

Kulik Lake: lake, $12 \mathrm{mi}$. long, near head of Alaska Penin., $45 \mathrm{mi}$. $\mathrm{N}$ of Mount Katmai,
Aleutian Ra.; $58^{\circ} 57^{\prime}$ N, $154^{\circ} 57^{\prime}$ W; $B G N$ 1937; (map 42). Var. Coolic Lake, Coolie Lake.

Local name reported in 1923 as Coolic by R. H. Sargent, USGS, and edited to Kulik in 1927.

Kulik Lake: lake, $4.5 \mathrm{mi}$. long, in Yukon-Kuskokwim Portage $19 \mathrm{mi}$. SE of Russian Mission, Yukon-Kuskokwim Delta; $61^{\circ} 42^{\prime} \mathrm{N}, 160^{\circ} 42^{\prime}$ W; (map 73)

Eskimo name published as "Ozero Kulik" by $P$. Tikhmeniev, in 1861, probably from information given by Lt. L. A. Zagoskin, IRN. Capt. C. W. Raymond, USA, spelled it Koulakh" in 1869. The application of the name "Kulik Lake" appears to be well established. See Kukaklik Lake.

Kuliliak Bay: bay, $2.1 \mathrm{mi}$. across, S coast of Unalaska I., Aleutian Is.; $53^{\circ} 26^{\prime} \mathrm{N}, 167^{\circ} 01^{\prime}$ W; (map 23). Var. Kiliuluk, Kouliliak, Kullilak, Kullilyak.

Aleut name published by Lt. Sarichev (1826, map 15, dated 1792), IRN, as "Zaliv Kul-lilyak," or "Kullilyak Bay." According to R. G. Geoghegan, this name was derived from the Aleut word "kulilak" meaning "sorrow" or "grief."

Kulinyemute, Cape: point of land, see Kuliuk, Cape.

Kulitch Bay: $b a y$, see Snipe Bay.

Kulitchok: bay, see Snipe Bay.

Kulitch Rock : rock, see Kulichkof Rock

Kulitnak: stream, see Holitna River.

Kulitzkoff Island: rock, see Kulichkof Rock.

Kuliugiak: island, see Kulyugayak.

Kuliug-miut, Cape: point of land, see Kuliuk, Cape.

Kuliugmiute, Cape: point of land, see Kuliuk, Cape.

Kuliuk, Cape: point of land, $\mathrm{N}$ point of entrance to Uyak Bay, on NW coast of Kodiak I. ; $57^{\circ}$ $48^{\prime} 10^{\prime \prime} \mathrm{N}, 153^{\circ} 55^{\prime} \mathrm{W}$; BGN 1890; (map 34). Var. Cape Kiliugmiut, Cape Kulinyemute, Cape Kuliug-miut, Cape Kuliugmiute, Cape Koulugmut, Kumelmot Point, Kumolmot Point.

Eskimo name published as "Cap Koulugmut," or "Cape of the Kuliuk people," by Capt. Lutke (1836, p. 276). Name may have been derived from a native village known as "Koloock" located at this point as recorded in 1805 by Lisianski (1814, map facing p. 169).

Kuliukak, Zaliv: bay, see Kulukak Bay.

Kuljkhlugamute: village, see Kwethluk.

Kulkana: village, see Gulkana.

Kulkana: stream, see Gulkana River.

Kullilak: $b a y$, see Kuliliak Bay.

Kullilyak: bay, see Kuliliak Bay.

Kulluk: locality, see Kulukak.

Kulluk Bay: bay, see Kulukak Bay.

Kullukuk Point: point of land, see Kulukak Bay.

Kulmogon Slough: water course, in Yukon Delta extends NE 2 mi. from Apoon Pass to Tatlalinguk Pass, $39 \mathrm{mi}$. NE of Kwiguk, YukonKuskokwim Delta; $63^{\circ} 03^{\prime} \mathrm{N}, 163^{\circ} 27^{\prime} \mathrm{W}$; (map 92). Vat. Kool-mo-gon Slough.
Eskimo name obtained in 1952 by USC\&GS ; means "counting to ten."

Kul-thee-eth River: stream, see Kaliakh River.

Kulthieth Mountain: peak, 3,437 ft., in Robinson Mts., 11 mi. NW of Cape Yakataga, St. Elias Mts.; $60^{\circ} 10^{\prime} \mathrm{N}, 142^{\circ} 40^{\prime} \mathrm{W}$; (map 65). Var. Cultheeth Mountain.

See Kultheith River.

Kulthieth River: stream, heads in Robinson Mts., flows SW $12 \mathrm{mi}$. to Kaliakh River, $18 \mathrm{mi}$. WNW of Cape Yakataga, St. Elias Mts.; $60^{\circ}$ $11^{\prime} 30^{\prime \prime} \mathrm{N}, 142^{\circ} 53^{\prime} 30^{\prime \prime} \mathrm{W}$; (map 65). Var. Cultheeth River.

Indian name "Cul-theeth" obtained in 1904 by G. C. Martin, USGS, from J. L. McPherson, Deputy U.S. Mineral Surveyor; pronounced "Kul-thee-ě'th" according to F. H. Moffitt, USGS.

Kulthieth River: stream, see Kaliakh River.

Kultuk: locality, see Nikishka No. 3.

Kulugra Ridge: ridge, $25 \mathrm{mi}$. long, between Meade River and Shaningarok Creek, $80 \mathrm{mi}$. SE of Wainwright, Arctic Slope; $69^{\circ} 35^{\prime} \mathrm{N}$, $157^{\circ} 59^{\prime} \mathrm{W}$; (map 143).

Eskimo name published in 1956 by USGS. This name was originally shown applied to what is now the Meade River on a manuscript map referred to as Cullinghow's map of Cape Lisburne, done by an Eskimo about 1890 . P. H. Ray (1885, p. 55), USA, shows "Kulugrua" for the Meade River.

Kulugrua River: stream, see Meade River.

Kulukak: locality, near head of Nushagak Penin., on W shore of Kulukak Bay, $43 \mathrm{mi}$. W of viilage of Clarks Point, Kilbuck-Kuskokwim Mts.; 58 $55^{\prime} 15^{\prime \prime} \mathrm{N}, 159^{\circ} 44^{\prime} 30^{\prime \prime}$ W; (map 40). Var. Kulluk.

Former Eskimo village or camp reported in 1880 as "Kulluk," population 65, by Petroff (1884, p. 17); population 83 in $1920 ; 28$ in 1930 ; and 55 in 1940.

Kulukak Bay: bay, extends NE $8 \mathrm{mi}$. off Bristol Bay, between Kulukak and Right Hand Points, at head of Nushagak Penin., Kilbuck-Kuskokwim Mts.; $58^{\circ} 49^{\prime} \mathrm{N}, 159^{\circ} 44^{\prime} \mathrm{W}$; (map 40). Var. Kouloukak Bay, Kouloulak Bay, Kulluk Bay, Kululak Bay, Kulukuk Bay, Kululuk Bay, Kulutuk Bay, Zaliv Kuliukak.

Eskimo name reported as "Z[aliv] Kuliukak" by Capt. Tebenkov (1852, map 4), IRN.

Kulukak Lake: lake, see Ualik Lake.

Kulukak Point: point of land, E point of entrance to Kulukak Bay, on $\mathrm{N}$ shore of Bristol Bay, $44 \mathrm{mi}$. SW of Dillingham, Kilbuck-Kuskokwim Mts.; $58^{\circ} 50^{\prime} 30^{\prime \prime} \mathrm{N}, 159^{\circ} 39^{\prime} 00^{\prime \prime} \mathrm{W}$; (map 40). Var. Kullukuk Point.

Eskimo name reported as "Kullukuk Point" by A. B. Chanz in 11 th Census in 1890 (U.S. Bureau of the Census, 1893, p. 91) and reported as "Kulukak Point" in 1953 by USGS

Kulukak River: stream, flows S $36 \mathrm{mi}$. to Kulukak Bay, $45 \mathrm{mi}$. SW of Dilingham, Kilbuck-Kuskokwim Mts.; $58^{\circ} 56^{\prime} \mathrm{N}, 159^{\circ} 44^{\prime} \mathrm{W}$ (map 40).

Eskimo name reported in 1952 by USGS.

Kuluk Bay: bay, $5 \mathrm{mi}$. across, on NE coast of Adak I., Aleutian Is., $51^{\circ} 52^{\prime} 30^{\prime \prime} \mathrm{N}, 176^{\circ} 33^{\prime}$ - 
00" W; BGN 1936; (map 17). Var. Khulukh Bay.

Transliteration by the U.S. Navy Hydrog. Office in 1936 of the Aleut name published by Capt. Tebenkov (1852, map 28), IRN, as "Z[aliv] Khulukh," or "Khulukh Bay."

Kulukbuk Hills: mountain, 1,000 ft., on W bank of Holitna River, $26 \mathrm{mi}$. S of Sleetmute, Kilbuck-Kuskokwim Mts.; $61^{\circ} 18^{\prime} \mathrm{N}, 157^{\circ} 15^{\prime} \mathrm{W}$; $B G N$ 1945; $(\operatorname{map} 72)$.

Eskimo name reported in 1944 by USGS.

Kuluk Shoal: shoal, $\mathrm{N}$ of Kuluk Bay, on NE coast of Adak I., Aleutian Is.; $51^{\circ} 55^{\prime} 05^{\prime \prime} \mathrm{N}$, $176^{\circ} 32^{\prime} 30^{\prime \prime} \mathrm{W}$; BGN 1936; (map 17).

Name derived from Kuluk Bay, and given by members of the U.S. Navy Aleutian Island Survey Expedition in 1934.

Kulukuk Bay; bay, see Kulukak Bay.

Kululak Bay: bay, see Kulukak Bay.

Kululin: locality, see Sinaruruk.

Kululuk Bay: bay, see Kulukak Bay.

Kuluruak: locality, on SE end of Icy Reef, 2.5 mi. W of Demarcation Point, Arctic Plain; $69^{\circ} 41^{\prime} 30^{\prime \prime} \mathrm{N}, 141^{\circ} 24^{\prime} 30^{\prime \prime} \mathrm{W}$; (map 138).

Eskimo name recorded on Barter I. in 1952 by USC\&GS and reported to mean "like a thumb."

Kulutuk Bay: bay, see Kulukak Bay.

Kulvagavik: locality, on W shore of Kuskokwim Bay at mouth of Ishkowik River, $24 \mathrm{mi}$. W of Quinhagak, Yukon-Kuskokwim Delta; $59^{\circ}$. $59^{\prime} \mathrm{N}, 162^{\circ} 45^{\prime} \mathrm{W}$; (map 54). Var. Koolvagavigamiut.

Eskimo village reported in 1879 by E. W. Nelson, U.S. Signal Service, as "Koolvagavigamiut," that is, "Kulvagavik people" and published by Ivan Petroff in the 10th Census in 1880. Recent U.S. Geological Survey maps indicate a site with two buildings. Its population in 1880 was 10

Kulyugayak: island, one of Shumagin Is., $55^{\circ}$ $\mathrm{N}, 160^{\circ} \mathrm{W}$; (map 27). Var. Koulagayavik Kuliugiak.

This name, meaning "round and rocky," was applied by Father Veniaminov (1840, v. 1, p. 255) to one of Shumagin Is.; Capt. Lutke (1836, p. 267) called it "Koulagayakh." The exact location of this island is not known.

Kulyugmyuk: locality, see Koloock.

Kulyukak: lake, see Ualik Lake.

Kumelmot Point: point of land, see Kuliuk, Cape.

Kumikpeyat Creek: stream, flows NE $10 \mathrm{mi}$. to Kivalina River $24 \mathrm{mi}$. NE of Kivalina, Arctic Slope; $68^{\circ} 04^{\prime} \mathrm{N}, 164^{\circ} 18^{\prime} \mathrm{W}$; (map 130). Var. Kimickpayaht Koogowranga, Qimiqpayaat Kuugauzanga.

Eskimo name reported by E. S. Burch, in 1966, to mean "short ridge."

Kumisik Point: promontory, see Kumlik, Cape.

Kumlangikhkak Bay: bay, see Koomlangeelkuk Bay.

Kumlang-Khkak : bay, see Koomlangeelkuk Bay.

Kumlik, Cape: promontory, 2,325 ft., on $\mathrm{S}$ coast of Alaska Penin., 13 mi. SW of Cape Kunmik, Aleutian Ra.; $56^{\circ} 39^{\prime} \mathrm{N}, 157^{\circ} 27^{\prime} \mathrm{W}$; (map 31). Var. Cap Koumlick, Kumisik Point, Mys Kumlik.
Native name shown in 1847 as "M[ys] Kumlik," or "Cape Kumlik," on Russian Hydrog. Dept. Chart 1379 and as "C[ap] Koumlick" by von Krusenstern (1827, map 20), IRN.

Kumlik Island: island, $1.5 \mathrm{mi}$. across, $\mathrm{S}$ of Alaska Penin., $1 \mathrm{mi}$. E of Cape Kumlik and $12 \mathrm{mi}$. SW of Cape Kunmik, Aleutian Ra.; 56 $38^{\prime}$ N, $157^{\circ} 24^{\prime}$ W ; (map 31). Var. Ile Koumlick, Ostrov Kumlik.

Native name shown as "I[le] Koumlick" by von Krusenstern (1827, map 20), IRN; published as "O[strov] Kumlick" by Russian Hydrog. Dept. in 1847 on Chart 1379.

Kumlium: peninsula, see Kumliun, Cape.

Kumliun, Cape: peninsula, extends E $12 \mathrm{mi}$. between Kujulik and Chignik Bays, on S shore of Alaska Penin., 24 mi. NE of Chignik, Aleutian Ra.; $56^{\circ} 30^{\prime} \mathrm{N}, 157^{\circ} 54^{\prime} \mathrm{W}$; (map 31). Var. Cap Komliouck, Foggy Cape, Koumloun, Koumlune, Kumlium, Kumtiak, Mys Kumliun.

Native name published as "C[ap] Komliouck" by von Krusenstern (1827, map 20), IRN, and as "Cape Kumliun" in 1888 by USBF. According to Capt. Lutke (1836, p. 277), IRN, this peninsula may be the Foggy Cape reported by Capt. James Cook, $\mathrm{RN}$, in 1798.

Kumliun, Cape : promontory, see Foggy Cape.

Kumlunak Pepninsula: peninsula, on Nelson I., formed by a bend in Ninglick River, $14 \mathrm{mi}$. NW of Pingo Lake and $105 \mathrm{mi}$. NW of Bethel, Yukon-Kuskokwim Delta; $60^{\circ} 55^{\prime} \mathrm{N}, 164^{\circ} 55^{\prime}$ W ; (map 58).

Eskimo name reported to mean "thumb" in 1949 by USC\&GS.

Kumolmot Point: point of land, see Kuliuk Cape.

Kumthrashibuna Lake: lake, see Kontrashubuna Lake.

Kumtiak: peninsula. see Kumliun, Cape.

Kunaghak Creek: stream, flows NW $4 \mathrm{mi}$. to Bering Sea, $1 \mathrm{mi}$. S of Ungyat Point and 18 mi. S of Gambell, St. Lawrence I.; $63^{\circ} 31^{\prime} \mathrm{N}$, $171^{\circ} 50^{\prime} \mathrm{W}$; $B G N$ 1951; (map 93). Var. Kunaghak River.

Eskimo name reported by Lawrence Kulukhan, of Gambell, in 1944.

Kunaghak River: stream, see Kunaghak Creek. Kunaiugiuk Island: island, see Spectacle Island. Kunakakvak: village, see Karluk.

Kunakan Island: island, see Sitkalidak Island. Kunakh: stream, see Kunuk Creek.

Kunarak Creek: stream, flows NW $4.1 \mathrm{mi}$. to Chukchi Sea, $18 \mathrm{mi}$. E of Point Franklin, Arctic Plain; $70^{\circ} 50^{\prime} \mathrm{N}, 158^{\circ} 02^{\prime} \mathrm{W}$; (map 147).

Eskimo name reported in 1950 by USC\&GS.

Kuna River: stream, heads in Brooks Ra., flows NNE $50 \mathrm{mi}$. to Colville River, $20 \mathrm{mi}$. NE of Liberator Lake; $68^{\circ} 57^{\prime} \mathrm{N}, 157^{\circ} 36^{\prime} \mathrm{W}$; $B G N$ 1926; (map 132). Var. Kayatunak.

This Eskimo name was given by P. S. Smith and J. B. Mertie, Jr. (1930, map), USGS, because of the many geese seen here. It refers to the lesser snow goose, (Chen hyperborea hyperborea), which Gabrielson and Lincoln
(1959, p. 137) list in Barrow Eskimo as "Ku-no."

Kunayosh Creek: stream, heads in a swamp, flows SW $9 \mathrm{mi}$. to Gulf of Alaska at Situk, $10 \mathrm{mi}$. SE of Yakutat, Malaspina Coastal Plain; $59^{\circ} 26^{\prime} 15^{\prime \prime} \mathrm{N}, 139^{\circ} 33^{\prime} 00^{\prime \prime} \mathrm{W}$; (map 46).

Tlingit Indian name reported by Lt. Comdr. Moser (1902, p. 385), USN.

Kungagingan: peninsula, see Kungiugan.

Kungealoruk Creek: stream, on Seward Penin. flows NE $5.3 \mathrm{mi}$. to Kotzebue Sound, $37 \mathrm{mi}$. NW of Deering, Kotzebue-Kobuck Low.; $66^{\circ} 25^{\prime} \mathrm{N}, 163^{\circ} 50^{\prime} \mathrm{W}$; (map 113). Var. Kungealarook Creek.

Eskimo name reported in 1950 by USGS.

Kungiakrok Creek: stream, flows N $8 \mathrm{mi}$. to Noatak River $1.2 \mathrm{mi}$. SE of its junc. with Kugururok River, $40 \mathrm{mi}$. NE of Noatak, Brooks Ra.; 6758' N, 161 $52^{\prime}$ ' W; (map 127). Var. Kaniakhrak Creek.

Eskimo name meaning "corral (pen)," obtained in 1956 at Noatak by Orth.

Kungik: locality, see Kangik.

Kungitak Cape: point of land, see Reef Point. Kungitakh Cape: point of land, see Reef Point. Kungitk: locality, see Kangik.

Kungkaka Lakes: lakes, group, extends S $5 \mathrm{mi}$. along valley of Martha Creek, $35 \mathrm{mi}$. NE of Hughes, Hogatza High.; $66^{\circ} 21^{\prime}$ N, 153 $3^{\circ} 5^{\prime}$ W; (map 116). Var. Kung-kaka-lav'n-tokhen.

Indian name recorded in 1956 as "Kungkaka-lav'n-tokhen" by Orth and reported to mean "lake beneath hill." The name was shortened for cartographic reasons and applied collectively to several lakes in the stream valley.

Kung-kaka-lav'n tokhen: lakes, see Kungkaka Lakes.

Kungok River: stream, heads in lake, flows W $26 \mathrm{mi}$. to Kuk River, $12 \mathrm{mi}$. S of Wainright, Arctic Plain; $70^{\circ} 29^{\prime} 30^{\prime \prime} \mathrm{N}, 159^{\circ} 44^{\prime} 15^{\prime \prime} \mathrm{W}$; (map 146). Var. Kugok River, Kuguk River.

Eskimo name reported in 1923 by Sidney Paige, USGS. The name probably refers to the snow goose (Chen hyperboreus).

Kungomovik Creek: stream, see Kongumavik Creek.

Kungsugrug River: stream, an anabranch, flows NW $7 \mathrm{mi}$. to Selawik River, $5 \mathrm{mi}$. NW of Selawik, Kotzebue-Kobuk Low.; $66^{\circ} 37^{\prime} \mathrm{N}$, $160^{\circ} 10^{\prime} \mathrm{W}$; (map 114).

Eskimo name obtained in 1955 by U.S. Army Corps of Engineers.

Kunguk Creek: stream, see Kunuk Creek.

Kúng-uk River: stream, see Buckland River.

Kunguyoluk Bend: bend, in Kivalina River, 14 mi. NE of Kivalina, Arctic Slope, 67 $7^{\circ} 53^{\prime} \mathrm{N}$, $164^{\circ} 13^{\prime} \mathrm{W}$; (map 128). Var. Koongooyowluk, Kuunguyauluk.

Eskimo name reported in 1966 by E. S. Burch.

Kuniguigan: peninsula, SW end of Big Koniuji I., in Shumagin Is., Aleutian Ra.; $55^{\circ} 02^{\prime} 30^{\prime \prime}$ $\mathrm{N}, 159^{\circ} 38^{\prime} 10^{\prime \prime}$ W; $(\operatorname{map} 27)$. Var. Kiganghyne Ile, Kiganin, Kungagingan.

Shown as a separate island given the Russian-Aleut name "O[strov] Kungiugan" by 
Capt. Tebenkov (1852, map 24), IRN. The Russian-French form, "Kiganghyne Ile," was used by Capt. Lutke (1836, p. 267), IRN, for one of the Shumagin Is., not otherwise identified. "Kungiugan" is described as part of Big Koniuji Island in the USC\&GS 1947 Coast Pilot (p. 312).

Kunjeskie: locality, "in SE Alaska;" Var. Koonjeskie.

Former Tlingit settlement reported in 1875 as "Koonjeskie" by H. W. Elliott (Hodge, 1907, p. 736).

Kunk Creek: stream, heads at Kunk Lake, flows E $1 \mathrm{mi}$. to Zimovia Strait, on E coast of Etolin I., Alex. Arch.; $56^{\circ} 17^{\prime} 00^{\prime \prime} \mathrm{N}, 132^{\circ} 23^{\prime} 30^{\prime \prime} \mathrm{W}$; (map 6). Var. Konke Creek.

Tlingit Indian name reported in 1901 by Lt. Comdr. J. F. Moser, USN, as "Konke Greek."

Kunkhogliak: locality, "on Yukon River, Alaska."

Former Eskimo camp or settlement, with a population of 11 , reported in 1844 by Lt. L. A. Zagoskin (Petroff, 1884, p. 37).

Kunk Lake: lake, $1.5 \mathrm{mi}$. long, on NE coast of Etolin I., Alex. Arch.; $56^{\circ} 16^{\prime} 40^{\prime \prime} \mathrm{N}, 132^{\circ}$ $25^{\prime} 30^{\prime \prime}$ W; (map 6). Var. Konke Lake.

Tlingit Indian name reported in 1901 by Lt. Comdr. J. F. Moser, USN, as "Konke Lake."

Kunmeum: locality, see Kuk.

Kunmik, Cape: promontory, $1,376 \mathrm{ft}$., on $\mathrm{S}$ coast of Alaska Penin. between Yantarni and Amber Bays, Aleutian Ra.; $56^{\circ} 46^{\prime} \mathrm{N}, 157^{\circ}$ 12' W; (map 31). Var. Cap Kounkoun. Named "C[ap] Kounkoun" by von Krusenstern (1827, map 20), IRN; published in 1899 as "Cape Kunmik" by USC\&GS.

Kunmudlin: locality, see Nuwuk.

Kunneyook: locality, site of Eskimo encampment, on Chukchi Sea coast, about $10 \mathrm{mi}$. S of Icy Cape, Arctic Plain; (map 146).

Eskimo name recorded by Archdeacon Stuck (1920, p. 189).

Kun River: stream, heads at $61^{\circ} 54^{\prime} \mathrm{N}, 164^{\circ} 37^{\prime}$ W, flows W 65 mi. to Scammon Bay, YukonKuskokwim Delta; $61^{\circ} 51^{\prime}$ N, $165^{\circ} 37^{\prime}$ W; (map 75). Var. Khun River, Maria Louisa. W. H. Dall (1870, p. 275) wrote "North of Cape Dyer, a small river, called by Captain [Elijah E.] Smith the 'Maria Louisa River' ('Kun of the Innuit' [Eskimo]), empties into Scammon Bay."

Kunruk Canyon: canyon, $3 \mathrm{mi}$. long, along Sapumik Greek, $38 \mathrm{mi}$. NE of Kivalina, Brooks Ra.; $68^{\circ} 14^{\prime} \mathrm{N}, 163^{\circ} 47^{\prime} \mathrm{W}$; (map 130). Var. Kownruk, Kuunruq.

Eskimo name reported in 1966 by E. S. Burch.

Kunsiniali Point: bluff, elev. $80 \mathrm{ft}$., on $\mathrm{N}$ bank of Naknek River, on Alaska Penin., $5 \mathrm{mi}$. $\mathrm{E}$ of Naknek, Bristol Bay Low.; $58^{\circ} 43^{\prime} 40^{\prime \prime}$ N, $156^{\circ}$. $52^{\prime} 20^{\prime \prime} \mathrm{W}$; (map 41).

Eskimo name reported in 1952 by USGS.

Kunthrashiboona Lake: lake, see Kontrashibuna Lake.

Kunthrashiboona River: stream, see Tanalian River.
Kunthrashibuna Lake: lake, see Kontrashibuna Lake.

Kunthrashibuna River: stream, see Tanalian River.

Kunujutanany: island, see Big Koniuji Island.

Kunuk Creek: stream, flows W $6.5 \mathrm{mi}$. to Aiautak Lagoon, $8.2 \mathrm{mi}$. NW of Cape Thompson, Arctic Slope; $68^{\circ} 14^{\prime} 45^{\prime \prime} \mathrm{N}, 166^{\circ} 08^{\prime} 10^{\prime \prime} \mathrm{W}$; BGN 1963; (map 129). Var. Konoo Creek, Konuch Creek, Koongook Creek, Kunakh, Kunguk Creek, Qoonukh Creek.

Eskimo name meaning "narrow place" or "neck", referring to the narrow slough at the end of Aiautak Lagoon; reported in 1950 by USC\&GS as "Koon-gook." Recorded as "Kunakh" at Point Hope in 1956 by Orth. Kunuliuk Tanani: island, see Big Koniuji Island. Kununak: stream, see Lucky Six Creek.

Kunuyu-tanan: island, see Big Koniuji Island.

Kunyanak Creek: stream, flows $\mathrm{E}$ and SE 18 mi. to Natmotirak Creek, $51 \mathrm{mi}$. SW of Howard Pass, Brooks Ra.; $67^{\circ} 46^{\prime} \mathrm{N}, 158^{\circ} 27^{\prime}$ W; (map 126).

Eskimo name reported by USGS in 1956

Kuogaguruq: locality, area on coast between Singaruak Creek and Ireniviq, $16 \mathrm{mi}$. SW of Barrow, Arctic Plain; $71^{\circ} 06^{\prime} \mathrm{N}, 157^{\circ} 09^{\prime} \mathrm{W}$; (map 153).

Eskimo locality or camp name, published by R. F. Spencer (1959, map 2), which probably means "small stream."

Kuosugru: locality, "inland from Point Barrow," Arctic Plain; (map 147 or 153).

Former Eskimo summer camp reported in 1892 by Sgt. John Murdoch, USA (Hodge, 1907 , p. 736).

Kupangumak: stream, see Koopangoomuk Creek.

Kuparuk Mound: pingo, elev. $30 \mathrm{ft}$., on $\mathrm{E}$ side of Fawn Creek, near Beaufort Sea coast, 12 mi. SE of Beechey Point, Arctic Plain; $70^{\circ} 20^{\prime}$ $\mathrm{N}, 148^{\circ} 40^{\prime} \mathrm{W}$; (map 150 ).

Eskimo name given by Leffingwell in 1911 $(1919$, p. 41$)$ to a pingo which he used as a triangulation station. It was named for the river.

Kuparuk River: stream, heads in lake at $68^{\circ} 32^{\prime}$ $\mathrm{N}, 149^{\circ} 12^{\prime} \mathrm{W}$, flows $\mathrm{N} 200 \mathrm{mi}$. to Gwydyr Bay, $8 \mathrm{mi}$. SE of Beechey Point, Arctic Plain; $70^{\circ} 25^{\prime} 30^{\prime \prime} \mathrm{N}, 148^{\circ} 52^{\prime} 00^{\prime \prime} \mathrm{W}$; BGN 1949; (map 150). Var. Kookpakruk River, Koopowra River, Kupaurak River, Kupowra River.

Eskimo name shown on a manuscript map drawn in 1901 by S. J. Marsh, prospector, who spelled it Koopowra and which he translated as "big river" [probably kugauraq]

Kuparuk River Delta: delta, $3 \mathrm{mi}$. across, on Beaufort Sea coast, at mouth of Kuparuk River in Gwydyr Bay, Arctic Plain; $70^{\circ} 25^{\prime} \mathrm{N}$, $148^{\circ} 53^{\prime} \mathrm{W}$; (map 150).

Name reported in 1966 by USGS.

Kupaurak River: stream, see Kuparuk River.

Kupig River: stream, see Kupigruak Channel.

Kupigruak Channel: stream, distributary of Colville River, flows NE $15 \mathrm{mi}$. to Harrison Bay, Arctic Plain; $70^{\circ} 30^{\prime} \mathrm{N}, 153^{\circ} 23^{\prime} \mathrm{W}$; (map 149). Var. Kupig River.

Schrader (1904, map), USGS, gave the name "Kupig River" for this stream.
USC\&GS reported the present form of the name in 1951. The name probably means "big old river [kugpakruaq]."

Kupik: stream, see Colville River.

Kupluruak Point: point of land, between Ivisaruk and Kuk Rivers, $18 \mathrm{mi}$. S of Wainwright, Arctic Plain; $70^{\circ} 22^{\prime} 28^{\prime \prime} \mathrm{N}, 159^{\circ} 57^{\prime} 45^{\prime \prime} \mathrm{W}$; (map 146). Var. Kuvlurak.

According to the Eskimo at Wainwright in 1965 , the name "Kuvlurak," meaning "thumb," is applied to the point of land constricting the mouth of the Ivisaruk River $S$ of Neakok I.

Kupolnaia, Gora: mountain, see Cupola Peak.

Kupolnaya, Gora: mountain, see Cupola Peak.

Kupouruk River: stream, see Kukpowruk River

Kupowra River: stream, see Kuparuk River.

Kupreanoff Island: island, see Kupreanof Island.

Kupreanoff Point: point of land, see Kupreanof Point.

Kupreanof Harbor: anchorage, $1 \mathrm{mi}$. across, between Paul and Jacob Is., $12 \mathrm{mi}$. E of Stepovak Bay, Aleutian Ra.; $55^{\circ} 46^{\prime} 30^{\prime \prime} \mathrm{N}, 150^{\circ} 22^{\prime}$ 00 " W; (map 27).

Named by Lt. Woronkofski in 1837 ; published as "G[avan] Kupreanova," or "Kupreanof Harbor," by Russian Hydrog. Dept. on Chart 1379 (1847).

Kupreanof Island: island, $56 \mathrm{mi}$. long, separated from mainland by Frederick Sound, Alex. Arch.; $56^{\circ} 45^{\prime} \mathrm{N}, 133^{\circ} 30^{\prime} \mathrm{W}$; BGN Sixth Report; (map 6). Var. Kupreanoff Island, Kupreanov Island, Kuprianoff Island, Ostrov Kupreyanova.

Published in 1848 on Russian Hydrog. Dept. Chart 1396 as "Os[trov] Kupreyanova." Named for Capt. Ivan Andreevich Kupreanov, Governor of the Russian American Colonies from 1836 to 1840 .

Kupreanof Mountain: mountain, 2,511 ft., in Bohemian Ra., on Kupreanof I., 19 mi. NW of Petersburg and $22 \mathrm{mi}$. ESE of Kake, Alex. Arch.; $56^{\circ} 55^{\prime} 30^{\prime \prime} \mathrm{N}, 133^{\circ} 24^{\prime} 00^{\prime \prime} \mathrm{W}$; (map 6).

Local name recorded in 1948 by USGS.

Kupreanof Mountain: mountain, 2,440 ft., on Kupreanof Penin., on N coast of Kodiak I.; $57^{\circ} 56^{\prime} \mathrm{N}, 153^{\circ} 05^{\prime} \mathrm{W}$; BGN 1909; (map 34).

Name derived from Kupreanof Island and given in 1909 by USC\&GS.

Kupreanof Peninsula: peninsula, $20 \mathrm{mi}$. long, forms $E$ shore of Stepovak Bay, on $S$ coast of Alaska Penin., Aleutian Ra.; $55^{\circ} 45^{\prime} \mathrm{N}, \mathbf{1 5 9}^{\circ}$. $35^{\prime} \mathrm{W}$; (map 27).

Published by USC\&GS in 1916 Alaska Coast Pilot (v. 2, p. 164).

Kupreanof Peninsula: peninsula, $15 \mathrm{mi}$. long, between Kupreanof Strait and Vickoda Bay, on $\mathrm{N}$ coast of Kodiak I. ; $57^{\circ} 55^{\prime} \mathrm{N}, 153^{\circ} 05^{\prime} \mathrm{W}$; (map 34).

Name derived from Kupreanof Island and published in 1943 by USC\&GS.

Kupreanof Point: point of land, on Alaska Penin., SE tip of Kupreanof Penin., 5 mi. E of Stepovak Bay, Aleutian Ra.; 55 $34^{\prime} \mathrm{N}, 159^{\circ} 36^{\prime} \mathrm{W}$; $B G N$ 1890; (map 27). Var. Cape Saint John, Cap Ivanovsky, Ivanof, Ivanoff, Kupreanoff Point, Point Kypreia. 
Name published as "Cap Ivanovsky," or "John's Cape," by Capt. Lutke (1836, p. 269) and as "M[ys] Kupreanova," or "Kupreanof Point," by Russian Hydrog. Dept. on Chart 1379 in 1847.

Kupreanof Strait: water passage, extends NW 22 mi. from Whale $I$., between Raspberry and Kodiak Is.; $57^{\circ} 58^{\prime} \mathrm{N}, 1^{\circ} 03^{\circ} \mathrm{O}$ W ; BGN 1901 ; (map 34). Var. Karluk Strait, Northern Strait, North Strait, Proliv Karlukskiy, Proliv Syvernoy, Sievernoi Strait.

Name derived from Kupreanof Island and published in 1849 by the Russian American Company. Called "Proliv Karlukskiy," or "Karluk Strait," [probably for village of Karluk] in 1839 or 1840 by Sub. Lt. Mikhail Murashev. The descriptive name "Proliv Syvernoy," meaning "Northern Strait," was published by Capt. Tebenkov (1852, map 23).

Kupreyanova, Ostrov: island, see Kupreanof Island.

Kupreanov Island: island, see Kupreanof Island. Kuprianoff Island: island, see Kupreanof Island. Kuptagok: locality, "on Agattu I. in Near Is.," Aleutian Is.; (map 13).

Former Aleut village reported as "uninhabited" by Hodge (1907, p. 736), BAE.

Kupuk Creek: stream, flows SW $4.5 \mathrm{mi}$. to Hammond River, $7 \mathrm{mi}$. E of Whiteface Mtn. and $26 \mathrm{mi}$. N of Wiseman, Brooks Ra.; $67^{\circ} 47^{\prime} \mathrm{N}$, $150^{\circ} 08^{\prime} \mathrm{W}$; $B G N$ 1932; (map 124).

Named in 1930 by Robert Marshall for an Eskimo living at Wiseman.

Kupuk River: stream, see Kukpuk River.

Kuregamut: locality, on right bank of Kuskokwim River, E of mouth of Gweek River, 7 mi. NE of Bethel, Yukon-Kuskokwim Delta; $60^{\circ} 51^{\prime} 30^{\prime \prime} \mathrm{N}, 161^{\circ} 34^{\prime} 30^{\prime \prime} \mathrm{W}$; (map 59).

Eskimo camp reported in 1951 by USC\&GS. Kurgorak Bay: bay, extends $5 \mathrm{mi}$. SE from Dease Inlet, $37 \mathrm{mi}$. SE of Barrow, Arctic Plain; $71^{\circ} 02^{\prime} \mathrm{N}, 155^{\circ} 15^{\prime} \mathrm{W}$; (map 153).

Eskirno name meaning "a small stream" referring to the creek at its head.

Ku River: stream, see Kuk River.

Kuropak Creek: stream, flows $S 3.5 \mathrm{mi}$. to Chukchi Sea, E of Telavirak Hills, $11 \mathrm{mi}$. SE of Cape Thompson, Arctic Slope 68 $04^{\prime} 33^{\prime \prime}$ N, 165'35'25' W; BGN 1963; (map 129). Var. Kuropuk Creek, Nayvay Creek.

Eskimo name "alluding to a big valley hidden by a narrow mouth" according to $W$. $O$. Pruitt, Univ, of Alaska, in 1962.

Kuropuk Creek: stream, see Kuropak Creek. Kursa, Mys: point of land, see Course Point. Kursoolah: locality, just NW of Zapadni Point, on SW coast of Saint Paul I., in Pribilof Is.; $57^{\circ} 09^{\prime} 25^{\prime \prime} \mathrm{N}, 170^{\circ} 21^{\prime} 30^{\prime \prime} \mathrm{W}$; (map 38 ). Var. Kursula.

A name reported by Elliott (1881, Saint Paul map), USC\&GS.

Kursula: locality, see Kursoolah.

Kurtluk River: stream, flows S $6 \mathrm{mi}$. to Togiak Bay, $4 \mathrm{mi}$. SW of Togiak, Kilbuck-Kuskokwim Mts.; $59^{\circ} 02^{\prime} \mathrm{N}, 160^{\circ} 28^{\prime} \mathrm{W}$; (map 53).

Eskino name published in 1951 by USGS.

Kuruk Creek: stream, in De Long Mts., flows SW $7 \mathrm{mi}$., to Kelly River, $22 \mathrm{mi}$. NW of Misheguk
Mtn., Brooks Ra. ; $68^{\circ} 20^{\prime}$ N, $161^{\circ} 59^{\prime}$ W; (map 131).

Eskimo name obtained by the U.S. Army Corps of Engineers about 1955.

Kurupa Creek: stream, see Kurupa River.

Kurupa Hills: mountains, $4,200 \mathrm{ft}$., in group 5 mi. long, in Brooks Ra., $1.5 \mathrm{mi}$. W of Kurupa Lake and $53 \mathrm{mi}$. NE of Howard Pass; $68^{\circ} 23^{\prime}$ N, $154^{\circ} 48^{\prime} \mathrm{W}$; (map 133).

Named in 1966 by geologists of BP Exploration Company (Alaska) Inc.

Kurupa Lake: lake, $3 \mathrm{mi}$. long, one of Kurupa Lakes, in course of Kurupa River, Brooks Ra.; $68^{\circ} 22^{\prime} \mathrm{N}, 154^{\circ} 39^{\prime} \mathrm{W}$; BGN 1960; (map 133).

Named about 1946 by USGS geologists during exploration of Naval Petroleum Reserve No. 4.

Kurupa Lakes: lakes, two, include Kurupa and Cascade Lakes, at head of Kurupa River, Brooks Ra.; $68^{\circ} 22^{\prime}$ N, $154^{\circ} 38^{\prime}$ W; $B G N$ 1949; (map 133).

Named about 1947 by geologists associated with exploration of Naval Petroleum Reserve No. 4, initiated in 1944.

Kurupa River: stream, heads in Brooks Ra. at $60^{\circ} 12^{\prime} \mathrm{N}, 154^{\circ} 32^{\prime} \mathrm{W}$, flows $\mathrm{N} 80 \mathrm{mi}$. to Colville River, $21 \mathrm{mi}$. SW of head of Ikpikpuk River, Arctic Slope; $69^{\circ} 04^{\prime} \mathrm{N}, 1^{\circ} 5^{\circ} 03^{\prime} \mathrm{W}$; $B G N$ 1949; (map 142). Var. Kootcheak River, Kurupa Creek.

Eskimo name reported in 1901 by W. J. Peters and F. C. Schrader, USGS. This may be a form of the Eskimo word "Kurugak," meaning "duck."

Kuryukak: stream, see Koyukuk River.

Kusaluck River: stream, see Kushluk River.

Kusalvak Island: island, see Kusilvak Island.

Kuselik Creek: stream, see Itkilyariak Creek.

Kushaluk River: stream, see Kushluk River.

Kushichagat: locality, see Vagitchitchate.

Kushluk: stream, see Kwethluk River.

Kushluk River: stream, heads at $60^{\circ} 35^{\prime} \mathrm{N}$, $160^{\circ} 51^{\prime} \mathrm{W}$, flows NW $25 \mathrm{mi}$. to Kwethluk River, 21 mi. E of Bethel, Yukon-Kuskokwim Delta; $60^{\circ} 46^{\prime} \mathrm{N}, 161^{\circ} 19^{\prime} \mathrm{W}$; BGN 1960; (map 59). Var. Akulikutak River, Kusaluck River, Kushaluk River, Kuskaluk River.

Eskimo name reported in 1948 by USC\&GS. Kushluk Slough: stream, see Kuskokuak Slough. Kushneaheen Creek: stream, see Kushneahin Creek.

Kushneaheen Lake: lake, see Kushneahin Lake. Kushneahin Creek: stream, heads at Kushneahin Lake, flows SW $6 \mathrm{mi}$. to Keku Strait, on S coast of Kupreanof I., $2.5 \mathrm{mi}$. N of Point Barrie, Alex. Arch.; 56 $28^{\prime} 20^{\prime \prime}$ N, $133^{\circ} 39^{\prime} 50^{\prime \prime}$ W; (map 6). Var. Kushneaheen Creek, Kusnaheen Creek.

Tlingit Indian name meaning "Kushnea River" reported in 1901 by Lt. Comdr. J. F. Moser, USN.

Kushneahin Lake: lake, $1 \mathrm{mi}$. long, $6.5 \mathrm{mi}$. NE of Point Barrie, on $\mathbf{S}$ coast of Kupreanof 1 ., Alex. Arch.; $56^{\circ} 30^{\prime} \mathrm{N}, 133^{\circ} 31^{\prime} \mathrm{W}$; (map 6). Var. Kushneaheen Lake.

Tlingit Indian name meaning "Kushnea River" reported in 1901 by Lt. Comdr. J. F. Moser, USN.
Kushtahcah Lake: lake, see Kushtaka Lake. Kushtahkah Lake: lake, see Kushtaka Lake. Kushtahkah Ridge: ridge, see Kushtaka Ridge. Kushtahka Lake: lake, see Kushtaka Lake. Kushtahka Ridge: ridge, see Kushtaka Ridge.

Kushtaka Glacier: glacier, trends S $3.5 \mathrm{mi}$. to its terminus $0.6 \mathrm{mi}$. $\mathrm{N}$ of Kushtaka Lake, $20 \mathrm{mi}$. NE of Katalla, Chugach Mts.; 60 $24^{\prime}$ $30^{\prime \prime} \mathrm{N}, 144^{\circ} 07^{\prime} 00^{\prime \prime} \mathrm{W}$; (map 64).

Local name reported in 1903 by G. C. Martin (1905, p. 17). Name derived from nearby lake.

Kushtaka Lake: lake, $3.5 \mathrm{mi}$. long, at terminus of Kushtaka Glacier, $18 \mathrm{mi}$. NE of Katalla, Chugach Mts.; $60^{\circ} 23^{\prime} \mathrm{N}, 144^{\circ} 07^{\prime} \mathrm{W}$; (map 64). Var. Kushtahcah Lake, Kushtahka Lake, Kushtahkah Lake.

Indian name reported in 1903 as "Kushtahkah," meaning "demon" or "ghost," by G. C. Martin, USGS. "The natives believe that this lake is inhabited by evil spirits who often make the water boil in the winter or break up the ice. The cause of these phenomena is the escape of coal gas from the bottom of the lake through the water. In winter it accumulates under the ice, with increasing tension till the ice gives way and is sometimes shot into the air."

Kushtaka Ridge: ridge, elev. 1,200 ft., extends 5 mi. SW of Martin River Glacier along W side of Kushtaka Lake, $20 \mathrm{mi}$. NE of Katalla, Chugach Mts.; $60^{\circ} 25^{\prime} \mathrm{N}, 144^{\circ} 09^{\prime} \mathrm{W}$; (map 64). Var. Kushtahka Ridge, Kushtahkah Ridge.

Native name reported in 1903 by G. C. Martin, USGS; name derived from Kushtaka Lake.

Kushutuk: locality, see Kashutuk.

Kusiloak: watercourse, see Kwemeluk Pass.

Kusiloff: mountains, see Kuzilvak Mountains.

Kusilov Mountain: mountains, see Kuzilvak Mountains.

Kusilvak: locality, "at mouth of Yukon River," Yukon-Kuskokwim Delta; (map 92). Var. Kusilvuk.

Former Eskimo camp or settlement reported by Ivan Petroff on an 1880 map.

Kusilvak: watercourse, see Kwemeluk Pass.

Kusilvak Island: island, one of outer islands of Yukon Delta; Var. Kusalvak Island.

Eskimo name published about 1860 . This feature cannot be identified on current maps.

Kusilvak Mountains: mountains, highest elev. $2,400 \mathrm{ft}$., extend $7 \mathrm{mi}$. along SE shore of Nunavakanuk Lake, $50 \mathrm{mi}$. S of Kwiguk, Yukon-Kuskokwim Delta ; $62^{\circ} 00^{\prime} \mathrm{N}, 164^{\circ} 34^{\prime}$ W; BGN 1966; (map 77). Var. Ingieguk, Ingriguk, Ingun, Kusiloff, Kusilov Mountain, Kusilvak Mountain, Kuzilvak Mountains.

Eskimo name reported in 1867 as "Kusilvak" by Dall (1870, p. 232). The plural form of the generic is relatively recent. The Russian maps called it "Ingieguk," undoubtedly the Eskimo name meaning "mountain."

Kusilvuk: locality, see Kusilvak.

Küska: island, see Kiska Island.

Kuskaluk River: stream, see Kushluk River. 
Kuskoguak Slough: stream, see Kuskokuak.

Kuskohkkagamiut: locality, see Kuskovak.

Kuskokuak Slough: stream, an anabranch of Kuskokwim River, heads at $60^{\circ} 52^{\prime} \mathrm{N}, 161^{\circ} 19^{\prime}$ W, flows SW $25 \mathrm{mi}$., $8 \mathrm{mi}$. E of Bethel, YukonKuskokwim Delta; $60^{\circ} 48^{\prime} \mathrm{N}, 161^{\circ} 32^{\prime} \mathrm{W}$; (map 59). Var. Kushluk Slough, Kuskoguak Slough.

Eskimo name reported in 1949 by J. M. Hoare, USGS.

Kuskokvagmute: locality, see Kuskovak.

Kuskokvakh Creek: stream, see Kuskokwak Creek.

Kuskokvim, Ryka: stream, see Kuskokwim River.

Kuskokwak Channel Kuskokwim Bay: channel, extends S $10 \mathrm{mi}$. from mouth of Kuskokwak Greek to point $7 \mathrm{mi}$. NW of Quinhagak, Yukon-Kuskokwim Delta; 59 $53^{\prime} \mathrm{N}, 162^{\circ} 15^{\prime}$ W ; (map 54).

Local name obtained in 1943 by USC\&GS; name derived from Kuskokwak Creek.

Kuskokwak Creek: stream, heads at $59^{\circ} 55^{\prime} \mathrm{N}$, $161^{\circ} 33^{\prime} \mathrm{W}$, flows NW $50 \mathrm{mi}$. to Kuskokwak Channel in Kuskokwim Bay, $55 \mathrm{mi}$. SW of Bethel, Yukon-Kuskokwim Delta; $60^{\circ} 02^{\prime} \mathrm{N}$, $162^{\circ} 14^{\prime}$ W; (map 58). Var. Kuckokwak Creek, Kuskokvakh Creek, Kuskovakh Creek. Eskimo name reported in 1914 by USC\&GS.

Kuskokwim Bay: gulf, $100 \mathrm{mi}$. wide, extends NE $60 \mathrm{mi}$. from Bering Sea to mouth of Kuskokwim River, bounded on NW by Cape Avinof and on SE by Cape Newenham; $59^{\circ}$ $00^{\prime} \mathrm{N}, 163^{\circ} 00^{\prime} \mathrm{W}$; BGN Sixth Report; (map 54). Var. Kuskoquim Bay, Kouskokvim Bay. Eskimo name obtained by Ustingov [cnna], a Russian who visited the area in 1818. The word "Kuskokwim," according to the Moravian missionary J. H. Kilbuck, is the genitive of "Kuskokwik," the last syllable meaning "river," but the rest of the name is of unknown meaning (Spurr, 1900, p. 73). The name of the bay was derived from the river name.

Kuskokwim Mountains: mountain range, $430 \mathrm{mi}$. long and $50 \mathrm{mi}$. wide, extends NE-SW between Canyon Creek and Chikuminuk Lake on $\mathrm{S}$ and Tanana River on $\mathrm{N}$; bounded on SE by Kantishna River, North Fork Kuskokwim River, Kuskokwim River, Holitna River, and Kogrukluk River, and on NW by Kaiyuh Mts. at Sulatna Crossing, Innoko River, Dishna River, Iditarod River, Russian Mts., and Kilbuck Mts.; $64^{\circ} 45^{\prime} \mathrm{N}, 151^{\circ} 30^{\prime} \mathrm{W}$ [NE end], $60^{\circ} 10^{\prime} \mathrm{N}, 159^{\circ} 40^{\prime} \mathrm{W}$ [SW end]; Var. Tanana Hills.

Reported and defined in 1898 by Spurr $(1900$, p. 239$)$, USGS. The name was derived from the Kuskokwim River which flows across the range. Spurr (p. 70) applied the name "Tanana Hills" to the low mountains at the northeast end of what are now the Kuskokwim Mountains. See Kuskokwim Bay.

Kuskokwim River: stream, heads at confluence of its East and North Forks, flows SW $500 \mathrm{mi}$. to Kuskokwim Bay; $60^{\circ} 05^{\prime} \mathrm{N}, 162^{\circ} 25^{\prime} \mathrm{W}$; BGN 1964; (map 58). Var. Chin-ana, Kugikukvik River, Kugikukwik River, Ryka Kuskokvim.
Eskimo name apparently obtained in 1818 by Ustiugov [cnna] and published by Lt. Sarichev (1826, map 3), IRN, as "Ryka Kuskokvim." According to Lt. J. S. Herron, USA, in 1899, the Tanana Indian name for the stream "was Chin-ana, now obsolete except among the old Indians." See Kuskokwim Bay.

Kuskokwim River: stream, see North Fork Kus-, kokwim River.

Kuskokwim River: stream, see South Fork Kuskokwim River.

Kuskoquim Bay: gulf, see Kuskokwim Bay.

Kuskovak: locality, on right bank of Kuskokwim River, $6 \mathrm{mi}$. SW of Eek I. and $53 \mathrm{mi}$. SW of Bethel, Yukon-Kuskokwim Delta; $60^{\circ} 07^{\prime}$ $30^{\prime \prime} \mathrm{N}, 162^{\circ} 30^{\prime} 00^{\prime \prime} \mathrm{W}$; (map 58). Var. Kuskohkkagamiut, Kuskokvagmute, Kuskokvakh, Kuskovakh.

Eskimo village reported by E. W. Nelson, U.S. Signal Service, who passed near it in January 1879; he spelled the name "Kuskovakh." Its population in 1880 was 24 . This may be the same place listed as "Kuskohkagamiut" in the 11 th Census in 1890 with 115 people, but because of another village with a similar name on the left bank of the river, it is difficult to determine which place is meant. Kuskovakh: locality, see Kuskovak.

Kuskulana Glacier: glacier, trends SW $15 \mathrm{mi}$. from Mount Blackburn to its terminus at head of Kuskulana River, $29 \mathrm{mi}$. NW of McCarthy, Wrangell Mts.; $61^{\circ} 37^{\prime} \mathrm{N}, 143^{\circ} 42^{\prime} \mathrm{W}$; (map 67).

Indian name given in 1900 by T. G. Gerdine, USGS.

Kuskulana Pass: pass, 4,500 ft., between Kuskulana and Chokosna Rivers, at head of Trail Creek, $15 \mathrm{mi}$. SW of Mount Blackburn and $25 \mathrm{mi}$. NW of McCarthy, Wrangell Mts. ; $61^{\circ}$ $33^{\prime} \mathrm{N}, 143^{\circ} 39^{\prime} \mathrm{W}$; (map 67).

Indian name reported in 1907 by $D$. C. Witherspoon, USGS (Moffit and Maddren, 1909, pl. 1).

Kuskulana River: stream, heads at Kuskulana Glacier, flows SW $21 \mathrm{mi}$. to Chitina River, $0.4 \mathrm{mi}$. NE of mouth of Nerelna Creek and $73 \mathrm{mi}$. NE of Valdez, Copper River Basin; $61^{\circ} 28^{\prime} 00^{\prime \prime} \mathrm{N}, 144^{\circ} 10^{\prime} 30^{\prime \prime} \mathrm{W}$; (map 68).

Ahtena Indian name obtained in 1899 by Oscar Rohn.

Kuskunuk: locality, "on Hooper Bay," YukonKuskokwim Delta ; (map 75).

Former Eskimo camp or settlement reported in 1899 by E. W. Nelson, U.S. Signal Service.

Kuslina Creek: stream, flows SW $5.5 \mathrm{mi}$. to Copper River, $7 \mathrm{mi}$. N of Chitina and $68 \mathrm{mi}$. ENE of Valdez, Copper River Basin; 61 ${ }^{\circ} 36^{\prime}$ $55^{\prime \prime} \mathrm{N}, 144^{\circ} 27^{\prime} 00^{\prime \prime} \mathrm{W}$; (map 68).

Ahtena Indian name obtained in 1900 by F. C. Schrader, USGS.

Kusluik: stream, see Fish River.

Kusnaheen Creek: stream, see Kushneahin Creek.

Kussan Point: point of land, on $\mathrm{W}$ coast of Prince of Wales I., in Tuxekan Passage, 25 mi. N of Craig, Alex. Arch.; $55^{\circ} 50^{\prime} 25^{\prime \prime} \mathrm{N}$, $133^{\circ} 10^{\prime} 10^{\prime \prime} \mathrm{W}$; (map 4).
Indian name recorded in 1949 by USGS.

Kussilof : village, see Kasilof.

Kussiloff, Cape: point of land, see Kasilof, Cape.

Kussiloff River: stream, see Kasilof River.

Kussilof River: stream, see Kasilof River.

Kussilowa River: stream, see Kasilof River.

Kussu Islands: islands, in Naukati Bay on W coast of Prince of Wales I., $28 \mathrm{mi}$. N of Craig, Alex. Arch.; 55 $52^{\prime} 05^{\prime \prime} \mathrm{N}, 133^{\circ} 10^{\prime} 15^{\prime \prime} \mathrm{W}$; (map 4).

Indian name published in 1964 by USC\&GS.

Kustahekdaan: locality, on Baranof I., Alex. Arch.

Former Tlingit Indian camp or settlement reported by J. R. Swanton (in Hodge, 1907, p. 738), BAE.

Kustatan: village, summer pop. only, on SW coast of West Foreland, $20 \mathrm{mi}$. NW of Kenai, Cook Inlet Low.; $60^{\circ} 43^{\prime} \mathrm{N}, 151^{\circ} 45^{\prime} \mathrm{W}$; (map 62).

Tanaina Indian name published by Petroff $(1881$, p. 29$)$ in the 10 th Census in 1880 . "The last syllable, tan, means point or cape." Kustatan Ridge: ridge, elev. $450 \mathrm{ft}$., extends $\mathrm{S}$ $9 \mathrm{mi}$. from McArthur River, on SW shore of Trading Bay, $30 \mathrm{mi}$. NW of Kenai, Cook Inlet Low.; 6053' N, $151^{\circ} 50^{\prime} \mathrm{W}$; (map 62).

Local name reported in 1958 by USGS. Name derived from Tanaina Indian village of Kustatan.

Kustatan River: stream, distributary of McArthur River, flows S $24 \mathrm{mi}$. to Redoubt Bay, $24 \mathrm{mi}$. NW of Kenai, Cook Inlet Low.; $60^{\circ} 44^{\prime} \mathrm{N}, 151^{\circ} 50^{\prime} \mathrm{W}$; (map 62).

Tanaina Indian name published by USFS on a Chugach National Forest map dated 1910. Name derived from village of Kustatan. Kutarlak Creek: stream, flows SW $3 \mathrm{mi}$. to Kogoluktuk River, $39 \mathrm{mi}$. NE of Kobuk, Brooks Ra.; $67^{\circ} 23^{\prime} \mathrm{N}, 156^{\circ} 05^{\prime} \mathrm{W}$; (map 126).

Eskimo name literally meaning "big drop," probably referring to the head-wall at the head of the stream; obtained at Kobuk by Orth in 1956.

Kutchaurak Creek: stream, heads in Brooks Ra., flows NNW $35 \mathrm{mi}$. to Etivluk River, $36 \mathrm{mi}$. NE of Howard Pass, Arctic Slope $68^{\circ} 40^{\prime} \mathrm{N}$, $156^{\circ} 14^{\prime}$ W; BGN 1960; (map 132). Var. Etivolipar Creek.

Eskimo name obtained probably in 1949 by USGS.

Kutchik River: stream, flows NE $40 \mathrm{mi}$. to Chandler River $9 \mathrm{mi}$. S of its junc. with Colville River, Arctic Slope; $69^{\circ} 19^{\prime} 30^{\prime \prime} \mathrm{N}$, $151^{\circ} 26^{\prime} 00^{\prime \prime} \mathrm{W}$; (map 141).

Eskimo name used in 1945 by USGS geologists during exploration of Naval Petroleum Reserve No. 4. The name may mean "hip [kutsik]."

Kutchilkag Hill: hill, see Kochilagok Hill.

Kutchiuma Island: islands, see Kutchuma Islands.

Kutchlok: locality, "on Unalaska Island," Aleutian Is.; (map 23). Var. Ikutchlok.

Former Aleut village reported by Coxe (1787, p. 160) 
Kutchuma Group: islands, see Kutchuma Islands.

Kutchuma Islands: islands, group $1.3 \mathrm{mi}$. long, 3 mi. S of Sitka, off $W$ coast of Baranof I., Alex. Arch.; 57 $00^{\prime} 30^{\prime \prime} \mathrm{N}, 135^{\circ} 18^{\prime} 30^{\prime \prime} \mathrm{W}$; $B G N$ 1897; (map 9). Var. Boidarkin Group, Kutchiuma Island, Kutchuma Group, Kutchuma Islets, Ostrov Boydarkin, Ostrov Kuchyuma.

This feature was originally called " $\mathrm{O}$ [strov] Boydarkin," or "Boydarkin Island," in 1809 by the Russian navigator Ivan Vasiliev the first; Capt. Tebenkov (1852, map 38), IRN, published the name "Ostrov Kuchyuma." This was transliterated about 1882 by USC\&GS.

Kutchuma Islets: islands, see Kutchuma Islands.

Kutegi Point: point of land, on $\mathrm{E}$ coast of Tuxekan I., $30 \mathrm{mi}$. N of Craig, Alex Arch.; $55^{\circ} 54^{\prime} 15^{\prime \prime} \mathrm{N}, 133^{\circ} 16^{\prime} 05^{\prime \prime} \mathrm{W}$; (map 4).

Indian name published in 1964 by USC\&GS.

Kutigraruk Creek: stream, see Kugirarok Creek.

Kutkan Island: island, $0.15 \mathrm{mi}$. across, in Galankin Is., 1 mi. S of Sitka, on W coast of Baranof I., Alex. Arch.; 57 $02^{\prime} 25^{\prime \prime} \mathrm{N}, 135^{\circ} 19^{\prime} 30^{\prime \prime}$ W; (map 9). Var. Garden Islet, Gull Island, Kuchkan Island, Kuch-Kan Island, Kukhkan Island, Kukh-Kan Island, Ostrov Stanovoy, Popoff Island, Stanovoi Islet.

Named by the Russians for a famous Indian chief who freed his slaves and embraced Christianity (U.S. Coast and Geodetic Survey, 1883 , p. 142). It was called "Ostrov Stanovoy" meaning "camp island" in 1809 by the Russian navigator Ivan Vasiliev the first.

Kutkwutlu: locality, see Katkwaahltu.

Kutlakoo Creek: stream, see Kutlaku Creek.

Kutlakoo Lake: lake, see Kutlaku Lake.

Kutlaku Creek: stream, flows NE $0.4 \mathrm{mi}$. to head of Bay of Pillars, on W coast of Kuiu I., Alex. Arch.; $56^{\circ} 37^{\prime} 10^{\prime \prime} \mathrm{N}, 134^{\circ} 07^{\prime} 00^{\prime \prime} \mathrm{W}$; (map 5). Var. Kutlakoo Creek, Point Ellis Creek. Tlingit Indian name reported in 1900 as "Kutlakoo Creek" by Lt. Comdr. J. F. Moser, USN, commander of USBF steamer Albatross.

Kutlaku Lake: lake, $1.2 \mathrm{mi}$. long, just SE of Bay of Pillars, on W coast of Kuiu I., Alex. Arch.; $56^{\circ} 36^{\prime} 40^{\prime \prime} \mathrm{N}, 134^{\circ} 08^{\prime} 00^{\prime \prime} \mathrm{W}$; (map 5). Var. Kutlakoo Lake, Point Ellis Lake.

Tlingit Indian name reported in 1900 as "Kutlakoo Lake" by Lt. Comdr. J. F. Moser, USN, commander of USBF steamer Albatross. Kutloot Island: rock, see South Island.

Kutmiut: locality, site of Eskimo village, on left bank of Kun River, $2.7 \mathrm{mi}$. east of village of Scammon Bay, Yukon-Kuskokwim Delta ; $61^{\circ}$ $51^{\prime} \mathrm{N}, 165^{\circ} 30^{\prime} \mathrm{W}$; (map 75). Var. Kutmut, Ku-Henmut.

This name is first mentioned by W. H. Dall (1870, p. 275) who wrote "Ten miles from the mouth [of the Kun] is a native settlement known as Kuttenmut." The people at Scammon Bay told Orth in 1965, the name means "people of the Kun," and the name is sometimes used locally for the village of Scammon Bay.

Kutmiut: village, see Scammon Bay.
Kutmuknuk Channel: water passage, extends W from Kwemeluk Pass to Bering Sea, $17 \mathrm{mi}$. NE of Black; 62 $2^{\circ} 4^{\prime} \mathrm{N}, 165^{\circ} 08^{\prime} \mathrm{W}$; (map 76). Var. Koot-mahk-nak Channel.

Eskimo name from USC\&GS in 1898.

Kutmut: locality, see Kutmiut.

Kutna Creek: stream, flows SE and N $7 \mathrm{mi}$. to Twentymile Slough, which flows to Yentna River, $50 \mathrm{mi}$. NW of Anchorage, Cook Inlet Low.; $61^{\circ} 48^{\prime} 35^{\prime \prime} \mathrm{N}, 150^{\circ} 48^{\prime} 20^{\prime \prime} \mathrm{W}$; (map 70). Var. Cutnu Creek, Kut River.

Tanaina Indian name reported in 1899 by Lt. J. S. Herron, USA, as "Cut-nu," or "Cut [Kut] River."

Kutoark River: stream, see Kutuk River.

Kutokbuna Lake: lake, $1 \mathrm{mi}$. across, in course of Hungry Creek, $3.3 \mathrm{mi}$. NE of Tundra Lake and $60 \mathrm{mi}$. SE of Sleetmute, Lime Hills; $61^{\circ} 16^{\prime} \mathrm{N}, 155^{\circ} 34^{\prime} \mathrm{W}$; (map 71).

Indian name published in 1951 by USGS.

Kut River: stream, see Kutna Creek.

Kuttak River: stream, heads in Kagankaguti Lake, flows SW $25 \mathrm{mi}$. to Kokechik River, 11 mi. S of village of Scammon Bay, Yukon-Kuskokwim Delta ; $61^{\circ} 41^{\prime} \mathrm{N}, 165^{\circ} 35^{\prime} \mathrm{W}$; (map 75)

Eskimo name reported in 1952 by AMS.

Kut-tuk-wah Island: island, see Tongass Island. Kutuark River: stream, see Kutuk River.

Kutukhum River: stream, heads at $60^{\circ} 44^{\prime} \mathrm{N}$ $162^{\circ} 59^{\prime} \mathrm{W}$, flows SE $35 \mathrm{mi}$. to Napatuk Creek, $36 \mathrm{mi}$. SW of Bethel, Yukon-Kuskokwim Delta; $60^{\circ} 30^{\prime} \mathrm{N}, 162^{\circ} 37^{\prime} \mathrm{W}$; (map 58).

Eskimo name reported in 1949 by USC\&GS.

Kutuk Pass: pass, 3,450 ft., in Endicott Mts. between head of April Creek to the $N$ and Unakserak and Kutuk Rivers to the S, Brooks Ra.; $67^{\circ} 52^{\prime} \mathrm{N}, 153^{\circ} 58^{\prime} \mathrm{W}$; (map 125).

Local name reported in 1931 by Robert Marshall.

Kutuk River: stream, heads at $67^{\circ} 53^{\prime} \mathrm{N}$, $153^{\circ} 49^{\prime} \mathrm{W}$, flows SW $30 \mathrm{mi}$. to Alatna River, $24 \mathrm{mi}$. S of Survey Pass, Brooks Ra.; 67 $31^{\prime}$ N, 153 '58' W; BGN 1912; (map 125). Var. Kootoark River, Kutoark River, Kutuark River.

Eskimo name first reported by Stoney (1900, map), USN, in 1886 as "Koo-too-ark" or "Koo-to-ark," but spelled "Kutuk" by P. S. Smith (1913, p. 35), USGS.

Kutuk River: stream, see Pish River.

Kutukturok River: stream, see Katakturuk River.

Kutul: locality, on Yukon River, $50 \mathrm{mi}$. upstream from Anvik, Innoko Low. Var. Hultulkakut, Khutulkakat.

Former Eskimo camp or settlement reported about 1844 as "Khutulkakat" by L. A. Zagoskin, IRN.

Kutulnakht: stream, see Kaiyuk Slough.

Kutulnakt: stream, see Khotol River.

Kutuzof, Cape: promontory, elev. $150 \mathrm{ft}$., on NW shore of Alaska Penin., $24.5 \mathrm{mi}$. NE of Port Moller, Bristol Bay Low.; 56 $18^{\prime} \mathrm{N}$, $160^{\circ} 20^{\prime}$ W; (map 30). Var. Mys Kutuzova, Cap Koutousoff, Cap Koutouzoff, Cape Kutuzoff, Gap Seniavine.
Shown as C[ap] Koutousoff in von. Krusenstern's "Atlas of the Pacific Ocean" (1827, map 20) ; it was also reported as Cap Seniavine by Capt. Lutke (1836, map 14), IRN. Confusion between the names Kutuzof and Seniavine applied to the same cape was clarified in 1890 by USBF when the name "Cape Seniavin" was applied to a promontory 10 miles to the northeast.

Kutuzoff, Cape: promontory, see Kutuzof, Cape. Kutuzova, Mys: promontory, see Kutuzof, Cape.

Kutzkatna Creek: stream, heads on Anthracite Ridge, flows SW $1.8 \mathrm{mi}$. to Mudflow Creek, E of Tukmakna Creek, $37 \mathrm{mi}$. NE of Palmer, Talkeetna Mts.; $61^{\circ} 49^{\prime} 10^{\prime \prime} \mathrm{N}, 148^{\circ} 05^{\prime} 45^{\prime \prime} \mathrm{W}$; BGN 1932; (map 69).

Tanaina Indian name meaning "canyon river" reported in 1932 by a USGS field party.

Kutznou: islands, see Kootzanhoo Archipelago.

Kutznov Inlet: water passage, see Kootznahoo Inlet.

Kuunguyauluk: bend, see Kunguyoluk Bend.

Kuunruq: canyon, see Kunruk Canyon.

Kuvakhselak: point of land, see Koovukseluk Point.

Kuveleek: village, see Kivalina.

Kuveleek River: stream, see Kivalina River.

Kuviak Lake: lake, 0.6 mi. long, on Kenai Penin., $0.5 \mathrm{mi}$. E of Leaf Lake and $31 \mathrm{mi}$. NE of Kenai, Cook Inlet Low.; $60^{\circ} 48^{\prime} \mathrm{N}, 150^{\circ} 32^{\prime}$ W; (map 62)

An Eskimo-sounding name given about 1963 by officials of Kenai National Moose Range, for administrative purposes.

Kuvirok Lake: lake, 2 mi. long, $\mathrm{E}$ of and drains into Epizetka River, $23 \mathrm{mi}$. SE of Point Lay, Arctic Plain; $69^{\circ} 31^{\prime} \mathrm{N}, 162^{\circ} 21^{\prime} \mathrm{W}$; (map 145).

Eskimo name published by USGS in 1955 .

Kuvlomiut: locality, $8 \mathrm{mi}$. SE of Cape Etolin, on NE coast of Nunivak I. ; $60^{\circ} 20^{\prime} 15^{\prime \prime} \mathrm{N}, 166^{\circ}$. 04'20" W; (map 57). Var. Kavaloonmiut, Kavlumiut, Koovloomute.

Eskimo summer fish camp and winter village reported in 1932 by USC\&GS.

Kuvlurak: point of land, see Kupluruak Point.

Kuvritovik: locality, near Barter I., on coast of Beaufort Sea, Arctic Plain; (map 152).

This is the name of a fish camp reported by USC\&GS in 1952, although its exact location is not given in the report. See Kuvritovik Entrance.

Kuvritovik Entrance: water passage, on coast of Beaufort Sea, between Arey and Barter Is. Arctic Plain; $70^{\circ} 07^{\prime} \mathrm{N}, 143^{\circ} 47^{\prime} \mathrm{W}$; $B G N$ 1961; (map 152). Var. Kukritovik Entrance.

Eskimo name reported by USC\&GS in 1952 as "Kuvritovik Ekit," meaning "Kuvritovik entrance (or inlet)."

Kuvuk: stream, see Kobuk River.

Ku-wung-mutes: localities, see Kobuk Villages.

Kuyaak, Reka: stream, see Koyukuk River.

Kuyanak Bay: estuary, extends W 5 mi. off Admiralty Bay, at mouth of Meade River, $30 \mathrm{mi}$. $\mathrm{SE}$ of Barrow, Arctic Plain ; $70^{\circ} 55^{\prime} \mathrm{N}, 156^{\circ} 05^{\prime}$ W; (map 147). 
Eskimo name obtained in 1956 at Wainwright by T. E. Taylor, USGS.

Kuyemabo, Mys: point of land, see Quemada, Point.

Kuyikanuikpul: locality, on right bank of Yukon River, below Holy Cross, Innoko Low; (map 78).

Former Eskimo camp settlement reported in 1869 by C. W. Raymond, U.S. Engineers.

Kuyikanuikpul: settlement, see Paimiut.

Kuyu, Ostrov: island, see Kuiu Island.

Kuyuk: village, see Koyuk.

Kuyukak: localiiy, see Kuiukuk.

Kuyukak: stream, see Koyukuk River.

Kuyuk River: stream, see Koyuk River.

Kuyuktuvuk Creek: stream, flows S $14.5 \mathrm{mi}$. to Dietrich River, $10 \mathrm{mi}$. NNW of Snowden Mtn. and $46 \mathrm{mi}$. NW of Chandalar, Brooks Ra.; $67^{\circ} 55^{\prime} 30^{\prime \prime} \mathrm{N}, 149^{\circ} 50^{\prime} 00^{\prime \prime} \mathrm{W}$; BGN 1939; (map 123).

Eskimo name reported in 1939 by Marshall (1956, p. 160).

Kuyukutuk River: stream, heads at junction of its South and West Forks at $61^{\circ} 52^{\prime} \mathrm{N}, 161^{\circ}$. $41^{\prime} \mathrm{W}$, flows NW $50 \mathrm{mi}$. to Five Day Slough, $17.5 \mathrm{mi}$. $\mathrm{N}$ of Marshall, Yukon-Kuskokwim Delta; $62^{\circ} 08^{\prime} \mathrm{N}, 162^{\circ} 10^{\prime} \mathrm{W}$; (map 77). Var. Koyakutuk River.

Eskimo name obtained in 1948 by USC\& GS.

Kuyungsik River: stream, heads in lake at $61^{\circ} 29^{\prime}$ $\mathrm{N}, 164^{\circ} 35^{\prime} \mathrm{W}$, flows SW $30 \mathrm{mi}$. to join Aphrewn River, $1.5 \mathrm{mi}$. S of its source, YukonKuskokwim Delta; $61^{\circ} 22^{\prime} 30^{\prime \prime} \mathrm{N}, 165^{\circ} 10^{\prime} 00^{\prime \prime}$ W; (map 75). 1949

Eskimo name reported by USC\&GS in

Kuyuyukak, Cape: promontory, on $\mathrm{S}$ coast of Alaska Penin. between Chiginagak Bay and Nakalilok Bay, $16 \mathrm{mi}$. NE of Cape Kunmik, Aleutian Ra.; $56^{\circ} 54^{\prime} \mathrm{N}, 156^{\circ} 50^{\prime} \mathrm{W}$; (map 31). Var. Cap Kouiou-ioukack.

Eskimo name published as "C[ap] Kouiouioukack" by Adm. von Krusenstern (1827, map 20), IRN, and as "Cape Kuyuyukak" by USC\&GS on an 1899 chart.

Kuzilvak: village, see Kusilvak.

Kuzitrin Flats: fat, trends NE $30 \mathrm{mi}$. from junc. of Kougarok and Kuzitrin Rivers, $25 \mathrm{mi}$. SE of Imuruk Lake, Seward Penin. High.; $65^{\circ}$ $22^{\prime} \mathrm{N}, 164^{\circ} 15^{\prime} \mathrm{W}$; (map 110).

Local name published by Henshaw and Parker (1913, p. 195), USGS.

Kuzitrin Lake: lake, extends E-W $3 \mathrm{mi}$. at head of Kuzitrin River, $15 \mathrm{mi}$. S of Imuruk Lake, Seward Penin. High.; $65^{\circ} 23^{\prime} \mathrm{N}, 163^{\circ} 13^{\prime} \mathrm{W}$; $B G N 1952$; (map 110).

Reported in 1950 by D. M. Hopkins, USGS. So named by a USGS field party in 1948 because the name "appears in the official station description of Coast and Geodetic Survey Bench Mark 'Kuzitrin,' 2 miles north of the lake *** [the lake] is used by a few commercial pilots *** [and] is the source of the Kuzitrin River."

Kuzitrin River: stream, heads in Kuzitrin Lake, $13 \mathrm{mi}$. S of Imuruk Lake, flows W $95 \mathrm{mi}$. to Imuruk Basin, $30 \mathrm{mi}$. $\mathrm{SE}$ of Teller, Seward
Penin. High.; $65^{\circ} 10^{\prime} \mathrm{N}, 165^{\circ} 25^{\prime} \mathrm{W}$; $B G N$ 1952; (map 111). Var. Kassatream, Kassatriem, Kaviavizak River, Koosetrina, Port Clarence River.

Eskimo name reported in 1900 by Brooks (1901, pl. 3), USGS.

Kvichak: village, on $\mathrm{E}$ bank of Kvichak River, on Alaska Penin., $17 \mathrm{mi}$. NE of Naknek, Bristol Bay Low.; $58^{\circ} 58^{\prime} \mathrm{N}, 156^{\circ} 56^{\prime} \mathrm{W}$; (map 41).

Eskimo name "reported by the early Russians" and published in 1898 by USGS. See Kvichak River.

Kvichak: village, see Levelock.

Kvichak Bay: bay, at head of Bristol Bay, extends NE $45 \mathrm{mi}$. from line between Etolin Point and Goose Point at $S$ entrance of Egegik River to mouth of Kvichak River at Koggiung, Bristol Bay Low. ; $58^{\circ} 26^{\prime} \mathrm{N}, 157^{\circ} 54^{\prime} \mathrm{W}$; (map 41).

Named in 1901 by Lt. Comdr. J. F. Moser, USN, commander of the USBF steamer Albatross. The name was probably derived from the Kvichak River.

Kvichak River: stream, heads in Iliamna Lake, flows SW $50 \mathrm{mi}$. to Kvichak Bay at Kogging on Alaska Penin., $9 \mathrm{mi}$. N of Naknek, Bristol Bay Low.; $58^{\circ} 52^{\prime} \mathrm{N}, 157^{\circ} 03^{\prime} \mathrm{W}$; (map 41). Var. Bristol River, Kvitchak, Reka Kviychak, Riviere Bristol.

Eskimo name reported in 1828 by Capt. Lutke (1836, map 14), IRN, as "Riviere Bristol or Kvitchak." The spelling "Kvichak" was given by USBF on an 1888 map.

Kvichak River: stream, see Kvichavak River.

Kvicharak River: stream, see Chelunginik River. Kvicharak River: stream, see Kwecharak River. Kvichavak River: stream, heads at $61^{\circ} 20^{\prime} \mathrm{N}$, $161^{\circ} 28^{\prime} \mathrm{W}$, flows $\mathrm{SW} 40 \mathrm{mi}$. to Johnson River, $30 \mathrm{mi}$. NW of Bethel, Yukon-Kuskokwim Delta; $61^{\circ} 08^{\prime} 30^{\prime \prime} \mathrm{N}, 162^{\circ} 07^{\prime} 20^{\prime \prime} \mathrm{W}$; (map 74). Var. Ankitaktuk Creek, Izawerknuk River, Kinvichavak, Kritchek River, Kulchavak River, Kulichavak River, Kulichivak River, Kvichak River, Kvichivak River, Kvinchagak River, Kwachuvak River.

Eskimo name reported by Lt. L. A. Zagoskin, IRN, in 1842-44 as "R[eka] Kvinchagak." It is shown, however, as flowing directly to the Bering Sea at about Hazen Bay and thus may refer to another stream. E. W. Nelson, U.S. Signal Service, traveled along the stream in January 1879, and gave the Eskimo name as "Kivvichavak," from which the present spelling is derived.

Kvichavak River: stream, see Johnson River.

Kvichivak River: stream, see Kvichavak River. Kvichpak: stream, see Yukon River.

Kvichvauk Pass: water course, in Yukon Delta, extends NE $5.8 \mathrm{mi}$. from Apoon Pass to Pastol Bay, $40 \mathrm{mi}$. NE of Kwiguk, Yukon-Kuskokwim Delta ; $63^{\circ} 05^{\prime} \mathrm{N}, 163^{\circ} 27^{\prime} \mathrm{W}$; (map 92).

Eskimo name [Kuiguak] meaning "slough" obtained in 1899 by R. L. Faris, USG\&GS; published in 1901 on Chart 9372.

Kvieguk River: stream, see Koyuk River.

Kvienkhakg-miut: village, see Koyuk.

Kvigathlogamute: locality, see Kvigatluk.
Kvigathluk: locality, see Kvigatluk.

Kvigatluk: locality, E of Kyigayalik Lake, $26 \mathrm{mi}$. NW of Bethel, Yukon-Kuskokwim Delta; $60^{\circ}$ $59^{\prime} \mathrm{N}, 162^{\circ} 25^{\prime} \mathrm{W}$; (map 58). Var. Kvigathlogamute, Kvigathluk.

Site of an Eskimo village or camp visited in January 1879 by E. W. Nelson, U.S. Signal Service, who spelled it "Kvigathlogamute," that is "Kvigathlok people."

Kvigmut: locality, see Kwik.

Kvigym Painagmute: locality, see Kolmakof.

Kvikhlyuak: locality, see Kwikluak.

Kvikhlyuak, Protok: stream, see Kwikluak Pass.

Kvikhlyuak, Reka: stream, see Kwikluak Pass.

Kvikhpak, Reka: stream, see Kwipak Pass.

Kvikhpakh: stream, see Yukon River.

Kvinchagak River: stream, see Kvichvak River. Kvingak: village, see Quinhagak.

Kviougmioute: locality, see $\mathrm{K}$ wik.

Kvitchak: stream, see Kvichak River.

Kviychak, Reka: stream, see Kvichak River.

Kvyguk: stream, see Akulik River.

Kvyguk, Reka: stream, see Koyuk River.

Kvynkhak, Reka: stream, see Koyuk River.

Kvynkhakg-myut: village, see Koyuk.

Kwachuvak River: stream, see Kvichavak River.

Kwahteetah River: stream, see Katete River.

Kwain Bay: bay, $1.2 \mathrm{mi}$. across, on SE coast of Annette I., Alex. Arch.; 55 $05^{\prime} 30^{\prime \prime} \mathrm{N}, 131^{\circ}$. $21^{\prime} 30^{\prime \prime} \mathrm{W}$; (map 3). Var. Khwain Bay.

Local navigators' name published in 1917 by USC\&GS; reported in 1904 as "Khwain" by H. C. Fassett, USBF.

Kwain Lake: lake, $0.5 \mathrm{mi}$. long, on Annette I., $1.4 \mathrm{mi}$. SW of Kwain Bay, Alex. Arch.; $55^{\circ} 04^{\prime}$ 45" N, 131 '24'15" W; BGN 1917; (map 3). Var. Khwain Lake.

Named in 1917 by USC\&GS.

Kwalana: stream, see Foraker River.

Kwatahein Creek: stream, flows W 6 mi, to Bay of Pillars, on W coast of Kuiu I., Alex. Arch.; $56^{\circ} 35^{\prime} 50^{\prime \prime} \mathrm{N}, 134^{\circ} 14^{\prime} 00^{\prime \prime} \mathrm{W}$; (map 5). Var. Quat-a-hein.

Tlingit Indian name reported in 1900 as "Quat-a-hein Creek," probably from "x'éitahhin," meaning "trout river," by Lt. Comdr. J. F. Moser, commander of USBF steamer $\mathrm{Al}$ batross.

Kwati Point: point of land, on NE coast of Tuxekan I., in Jinhi Bay, 29 mi. $\mathrm{N}$ of Craig, Alex. Arch,; $55^{\circ} 53^{\prime} 15^{\prime \prime} \mathrm{N}, 133^{\circ} 16^{\prime} 30^{\prime \prime} \mathrm{W}$; (map 4).

Indian name published in 1964 by USC\&GS. Kweakpak: locality, in SW Alaska, Yukon-Kuskokwim Delta; (map 74). Var. Queakhpaghamiut.

Former Eskimo camp or settlement listed as "Queakhpaghamiut" in the 1890 Census.

Kwecharak River: stream, heads in a lake, flows $\mathrm{NE}$, then NW $10 \mathrm{mi}$. to Kokechik River, $12 \mathrm{mi}$. $\mathrm{S}$ of village of Scammon Bay, Yukon-Kuskokwim Delta; 61 $40^{\circ} 20^{\prime \prime} \mathrm{N}, 165^{\circ} 41^{\prime} 10^{\prime \prime} \mathrm{W}$; (map 75). Var. Kvicharak River, Tellamishuk River.

Eskimo name reported in 1951 by USC\&GS.

Kweek: village, see Knik.

Kweek-lok-choon: water passage, see Kwiklokchun Channel. 
Kweek River: stream, see Knik River.

Kwégamut: locality, see Kwik.

Kwegamy River: stream, see Quigmy River.

Kwegugamiut: village, see Kwiguk.

Kweguk River: watercourse, see Kwiguk Pass.

Kwek: locality, see Kwik.

Kwek River: stream, see Gweek River.

Kweleluk: locality, in SW Alaska, Yukon-Kuskokwim Delta; (map 58). Var. Quelochamiut.

Former Eskimo camp or settlement listed as "Quelochamiut," with a population of 112 , in the 1890 Census.

Kwelow River: stream, see Kivalina River.

Kwemeluk Pass: water course, $30 \mathrm{mi}$. long, a distributary of Yukon River, $\mathbf{S}$ of Kwikluak Pass, Yukon-Kuskokwim Delta; $62^{\circ} 33^{\prime} \mathrm{N}$, $165^{\circ} 01^{\prime}$ W; (map 76). Var. Kousilvak, Reka Kuimla, Kusiloak, Kusilvak, Naulchi.

Eskimo name shown by $P$. Tikhmeniev as "R[eka] Kuimla" meaning, "Kuimla[k] River." The present spelling was recommended by USC\&GS in 1898

Kwethluk: village, pop. 325 , on left bank of Kwethluk River $\mathrm{E}$ of its junc. with Kuskokuak Slough, $11 \mathrm{mi}$. E of Bethel, Yukon-Kuskokwim Delta; $60^{\circ} 49^{\prime} \mathrm{N}, 161^{\circ} 26^{\prime}$ W; BGN 1938; (map 59). Var. Kuilkhlogamute, Kuilkluk, Kuljkhlugamute, Kwiklak, Kwithluk, Quithlook.

Eskimo village mentioned by Eakin (1914, pl. 1), USGS, who spelled it "Kwiklak." The spelling evolved to "Quithlook" in 1923 and to "Kwethluk" in 1938. Its population was 186 in 1939 and 242 in 1950 . The Kwethluk post office was established in 1947 (Ricks, 1965 , p. $\left.3^{8}\right)$. This may be the same village reported in 1879 by E. W. Nelson, U.S. Signal Service, as "Kuilkhlogamute," or "Kuilkhlok people." In the 1880 U.S. Census, Ivan Petroff used Nelson's spelling on his map but spelled it "Kuljkhlugamute" in the text. In 1880 , the population of the village was 75 .

Kwethluk River: stream, heads at $60^{\circ} 05^{\prime} \mathrm{N}$, $160^{\circ} 00^{\prime} \mathrm{W}$, flows NW $85 \mathrm{mi}$. to Kuskokuak Slough, $10 \mathrm{mi}$. E of Bethel, Yukon-Kuskokwim Delta; $60^{\circ} 49^{\prime} \mathrm{N}, 161^{\circ} 27^{\prime} \mathrm{W}$; BGN 1938; (map 59). Var. Kuethluk, Kushluk, Kwikli, Kwiklimut, Kwikluk, Kwithluk River, Quethluk.

Eskimo name shown as "Kwiklimut," meaning "Kwikli (river) people," and "Kwikluk" on an 1898 fieldsheet by W. S. Post, USGS, according to information obtained from $\mathrm{J}$. $\mathrm{H}$. Kilbuck, Moravian missionary. The present spelling was used by A. G. Maddren (in Brooks, 1915, p. 355 ), USGS.

Kwichlowak Pass: water course, in Yukon Delta, extends N $5 \mathrm{mi}$. from Okwega Pass to Pastol Bay, $38 \mathrm{mi}$. NE of Kwiguk, Yukon-Kuskokwim

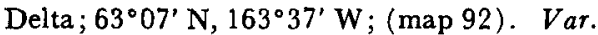
Kwikhlowak Pass.

Eskimo name [Kuigtluak] meaning "good stream" reported in 1899 by G. R. Putnam, USC\&GS.

Kwichpak: stream, see Yukon River.

Kwickpack River: stream, see Kwikpak Pass.

Kwick River: stream, see Kwik River.

Kwigalogamute: locality, see Kwigalok.
Kwigalok: locality, on Kuskokwim River, between Tuluksak and Tuklak $40 \mathrm{mi}$. NE of Bethel, Yukon-Kuskokwim Delta; $61^{\circ} 12^{\prime} \mathrm{N}$, $160^{\circ} 45^{\prime} \mathrm{W}$; (map 73). Var. Kwigalogamute, Kwikagamut, Kwikak, Queekagamut, Quiechochlogamiut.

This unidentified place is listed in the 1880 Census, on the right bank of the river, as "Kwigalogmute," having 314 inhabitants. The 1890 Census lists a place in the same area, on the left bank, as "Quiechochlogamiut," population 65 . This may be the same place shown in Russian by P. Tikhmeniev on his 1861 map as "S[eleniye] Kviguglyugmyut." Kwigamute: locality, see Kwik.

Kwigillingok: village, pop. 344 , on $W$ shore of Kuskokwim Bay, $17 \mathrm{mi}$. SW of Kulvagavik, $37 \mathrm{mi}$. SW of Kwinhagak, Yukon-Kuskokwim Delta; $59^{\circ} 51^{\prime} \mathrm{N}, 1^{\circ} 3^{\circ} 08^{\prime} \mathrm{W}$; BGN 1937; (map 54). Var. Quigillingok, Quillingok.

Eskimo village reported as "Quillingok" on a map in the 1927 Annual Report of the Governor of Alaska. Its population was 146 in 1940 and 245 in 1950.

Kwigluk Island: island, $4 \mathrm{mi}$. long, in Kuskokwim Bay, 5 mi. SE of Kipnuk, Yukon-Kuskokwim Delta; $59^{\circ} 42^{\prime} \mathrm{N}, 164^{\circ} 00^{\prime} \mathrm{W}$; (map 54).

Eskimo name obtained in 1951 by USGS.

Kwigomiut: locality, see Ingloothloogramiut.

Kwigorlak: locality, at junc. of Big and Kashunuk Rivers, $45 \mathrm{mi}$. W of Marshall, Yukon-Kuskokwim Delta; $61^{\circ} 48^{\prime} 30^{\prime \prime} \mathrm{N}$ $163^{\circ} 25^{\prime} 30^{\prime \prime} \mathrm{W}$; (map 74).

Eskimo fish camp shown on a manuscript map by "Father Delon," dated 1937; reported by USC\&GS in 1949 .

Kwiguk: village, pop. 358 , on left bank of Kwiguk Pass, $3 \mathrm{mi}$. NNW of Akumsuk, Yukon-Kuskokwim Delta; $62^{\circ} 45^{\prime} 30^{\prime \prime} \mathrm{N}, 164^{\circ}$ $30^{\prime} 00^{\prime \prime}$ W; (map 77). Var. Kwegugamiut.

Eskimo village reported in 1899 by G. $R$. Putnam, USC\&GS. A post office was established here in 1920 .

Kwiguk Pass: water course, in Yukon Delta, ex. tends NW-SE $15 \mathrm{mi}$. between Kwikluak Pass and Norton Sound, Yukon-Kuskokwim Delta; $62^{\circ} 49^{\prime} \mathrm{N}, 164^{\circ} 52^{\prime} \mathrm{W}$; (map 77). Var. Kweguk River, Kwikak Pass, Kwikuk Slough.

A common descriptive Eskimo name meaning "big stream" reported in 1898 by USC\&GS.

Kwihcherak: stream, see Goodnews River.

Kwihukhamut: locality, on $\mathrm{E}$ shore of Togiak Bay, $S$ of Nunavarchak Lake, $78 \mathrm{mi}$. NE of Cape Newenham, Kilbuck-Kuskokwim Mts.; $58^{\circ} 48^{\prime}$ N, $160^{\circ} 05^{\prime}$ W; (map 39). Var. Kwi-huk-ha-mut.

Eskimo village or camp shown on a 1910 manuscript map by H. F. Fassett, USBF. It is now abandoned.

Kwik: locality, on $\mathbf{S}$ coast of Nunivak I., $2 \mathrm{mi}$. $\mathrm{N}$ of Cape Mendenhall, Nunivak I.; $59^{\circ} 48^{\prime}$ $\mathrm{N}, 166^{\circ} 05^{\prime} \mathrm{W}$; (map 55). Var. Kweegamute, Kwigamiut.

Eskimo village, reported as "Kweegamute" with a population of 43 in the 1890 Census (1893, map) and as "Kwigamiut" (p. 111) according to Hodge (1907, p. 747), BAE.
Kwik: locality, on right bank of Kuskokwim River, W of mouth of Gweek River, $7 \mathrm{mi}$. NE of Bethel, Yukon-Kuskokwim Delta; $60^{\circ} 51^{\prime}$ N, $161^{\circ} 35^{\prime}$ W; (map 59). Var. Kooigamute, Kuigamute, Kwégamut, Kwek, Kwigamute.

Small Eskimo settlement, now abandoned, listed by Ivan Petroff in the 10th Census, in 1880 , as "Kooigamute" and "Kwigamute" with a population of 215 . The name means "river [kuik]."

Kwik: locality, at mouth of Kwik River, $3 \mathrm{mi}$. mi. $\mathbf{W}$ of Baldhead, on $\mathbf{N}$ shore of Norton Bay, Seward Penin. High.; $64^{\circ} 46^{\prime}$ N, $161^{\circ} 40^{\prime}$ W ; (map 96). Var. Isaacs, Kuik, Kuikh, Kuikli, Kwikmute, Kvigmut, Kviougmioute, Queekmute, Quick.

Site of a former Eskimo village first reported in 1865 by members of Western Union Telegra'ph Expedition as "Kwikmute." Its population was 30 in 1880 .

Kwikagamiut: locality, see Kwikak.

Kwikagamut: locality, see Kwigalok.

Kwikak: locality, on Bering Sea coast, $6.5 \mathrm{mi}$. SW of Black, Yukon-Kuskokwim Delta; $62^{\circ} 16^{\prime} \mathrm{N}, 165^{\circ} 28^{\prime} \mathrm{W}$; (map 76). Var. Kwikagamiut.

This is the site of a village reported by USC\&GS in 1898, as "Kwikagamiut," or "people of Kwikak."

Kwikak: locality, see Kwigalok.

Kwikak Pass: watercourse, see Kwiguk Pass.

Kwik Delta: delta, at mouth of Kwik Stream, between Sudden Stream and Strawberry I., $21 \mathrm{mi}$. NW of Yakutat, St. Elias Mts.; $59^{\circ} 47^{\prime} \mathrm{N}, 139^{\circ} 50^{\prime} \mathrm{W}$; (map 46).

Name published by Tarr and Martin (1912, p. 30), USGS.

Kwikh: locality, see Kiwk.

Kwikhlowak Pass: watercourse, see Kwichlowak Pass.

Kwikhpak Pass: stream, see Kwikpak Pass. Kwikhsak Pass: stream, see Kwikpak Pass.

Kwiklak: village, see Kwethluk.

Kwikli: stream, see Kwethluk River.

Kwiklimut: stream, see Kwethluk River.

Kwikliuak: stream, see Kwikluak Pass.

Kwikloaklok: locality, on left bank of Yukon River, $6 \mathrm{mi}$. W of Pitkas Point, $46 \mathrm{mi}$. NW of Marshall, Yukon-Kuskokwim Delta; $62^{\circ}$ $03^{\prime} 40^{\prime \prime} \mathrm{N}, 163^{\circ} 28^{\prime} 15^{\prime \prime} \mathrm{W}$; (map 77).

Eskimo camp reported in 1899 by $G$. $R$ Putnam, USC\&GS.

Kwiklokchun: locality, on left bank of Kwikluak Pass, Yukon Delta, $15 \mathrm{mi}$. SW of Kwiguk, Yukon-Kuskokwim Delta ; $62^{\circ} 34^{\prime} 50^{\prime \prime} \mathrm{N}, 164^{\circ}$. 49'05" W; (map 77).

Eskimo settlement or camp reported in 1899 by G. R. Putnam, USC\&GS.

Kwiklokchun Channel: water passage, in Yukon Delta, E of Munson I., extends N-S $2 \mathrm{mi}$. between Kwemeluk and Kwikluak Passes, 17 mi. SW of Kwiguk, Yukon-Kuskokwim Delta ; $62^{\circ} 34^{\prime} \mathrm{N}, 164^{\circ} 52^{\prime} \mathrm{W}$; (map 77). Var. Kweek-lok-choon

Eskimo rame meaning "fish saltry" reported in 1952 by USC\&GS

Kwiklowak Pass: stream, see Kwikluak Pass. 
Kwikltak: stream, see Kwikluak Pass.

Kwikluagamiut: locality, see Kwikluak.

Kwikluak: locality, on S bank of Kwikluak Pass, Yukon Delta, 12.5 mi. SW of Kwiguk, YukonKuskokwim Delta; $62^{\circ} 36^{\prime} \mathrm{N}, 164^{\circ} 43^{\prime} \mathrm{W}$; (map 77). Var. Kaoklorokamiut, Kvikhlyuak, Kwikluagamiut.

Eskimo village which, according to $\mathrm{Lt}$. $\mathrm{L}$. A. Zagoskin, IRN, in 1842-44, was mentioned in 1832 by Alexander Glazanov. Zagoskin spelled it "Kvikhlyuak." G. R. Putnam, USC\&GS, recorded the name "Kaoklorokamiut" in 1899.

Kwikluak Channel: water passage, in off-shore mud flats between Avogon and Flat Is., extends NW $9.5 \mathrm{mi}$. from Kwikluak Pass to Bering Sea, Yukon-Kuskokwim Delta; 62 $42^{\prime} \mathrm{N}$, $165^{\circ} 07^{\prime} \mathrm{W}$; (map 76).

Named for Kwikluak Pass; reported by USC\&GS in 1898.

Kwikluak Pass: channel, in Yukon Delta, heads at Head of Passes, flows NW and SW $40 \mathrm{mi}$. to Norton Sound $18 \mathrm{mi}$. SW of Kwiguk, YukonKuskokwim Delta; 62 $35^{\prime} \mathrm{N}, 164^{\circ} 58^{\prime} \mathrm{W}$; (map 77). Var. American Mouth, Kwikliuak Kwiklowak Pass, Kwikltak, Protok Kvikhlyuak, Reka Kvikhlyuak.

Eskimo name published in $1842-44$, by Lt. L. A. Zagoskin, IRN, as "Kvikhlyuak," with note in Russian "Krivoy, Izvilistyy," meaning "crooked, meandering." Capt. C. W. Raymond, U.S. Army Corps of Engineers, referred to it as "American Mouth" in 1869.

Kwikluk: stream, see Kwethluk River.

Kwikmute: locality, see Kwik.

Kwikoktuk Pass: water passage, S of Blind I., in offshore mud flats, extends NW $4 \mathrm{mi}$. from Avogon I. to Norton Sound, $13 \mathrm{mi}$. SW of Kwiguk, Yukon-Kuskokwim Delta ; $62^{\circ} 40^{\prime} \mathrm{N}$, 164 58' W; (map 77). Var. Blind Pass, Kui-kohk-tak Pass.

Eskimo name reported to mean "blind" (USC\&GS, 1949).

Kwikpak: locality, on $\mathrm{N}$ bank of Kwikpak Pass, $22 \mathrm{mi}$. N of Kwiguk, Yukon-Kuskokwim Delta; $63^{\circ} 04^{\prime} 15^{\prime \prime} \mathrm{N}, 164^{\circ} 24^{\prime} 15^{\prime \prime} \mathrm{W}$; (map 92). Var. Kwikpakamiut, Old Kwikpakamiut.

Eskimo village, now abandoned, reported in 1879 by USC\&GS as "Kwikpakamiut," meaning "Kwikpak people." "Kwikpak" is the Eskimo name for one of the major distributary channels of the Yukon River; it is a name often applied to the Yukon itself. This may be the same as the village of Kwikpuk reported in 1899 by USC\&GS at about $62^{\circ} 40^{\prime} \mathrm{N}, 163^{\circ}$ $55^{\prime} \mathrm{W}$.

Kwikpak: stream, see Yukon River.

Kwikpakak Slough: water course, in Yukon Delta, flows NW $19 \mathrm{mi}$. from Aproka Pass to Kawanak Pass opposite Sea Gull Point, 18.5 mi. N of Kwiguk, Yukon-Kuskokwim Delta: $63^{\circ} 01^{\prime} \mathrm{N}, 164^{\circ} 22^{\prime} \mathrm{W}$; (map 92).

Eskimo name [Kuigpakak] meaning "part of (?) the big stream," according to R. L. Faris, USG\&GS, in 1899.

Kwikpakamiut: locality, see Kwikpak.
Kwikpak Crossing: crossing, at junc. of Kwikpak and Apoon Passes, in Yukon Delta, YukonKuskokwim Delta; $62^{\circ} 55^{\prime} \mathrm{N}, 164^{\circ} 03^{\prime} \mathrm{W}$; (map 77).

Riverboat pilots' name for the crossing or bar at the junction of two Yukon distributary channels; name reported in 1899 by USRCS.

Kwikpak Pass: stream, in Yukon Delta, flows NW $50 \mathrm{mi}$. from Head of Passes to Norton Sound, $23 \mathrm{mi}$. N of Kwiguk, Yukon-Kuskokwim Delta ; $63^{\circ} 05^{\prime} \mathrm{N}, 164^{\circ} 34^{\prime} \mathrm{W}$; BGN Sixth Report; (map 92). Var. Kwickpack River, Kwikhpak Pass, Kwikhsak Pass, Reka Kvikhpak ili Yukkhana.

Eskimo name [Kuigpak] meaning "big stream" published by Capt. Tebenkov (1852, map 3 ) as "Reka Kvikhpak."

Kwikpuk: locality, see Kwikpak.

Kwikpukna River: stream, see Big River.

Kwikpuk River: stream, see Big River.

Kwik River: stream, flows SE $27 \mathrm{mi}$. to Norton Bay, 37 mi. NW of Christmas Mtn., Seward Penin. High.; $64^{\circ} 47^{\prime} \mathrm{N}, 161^{\circ} 40^{\prime} \mathrm{W}$; (map 96). Var. Kuik River, Kwick River, Quick River.

Eskimo name meaning "river" reported in 1897 by Lt. D. H. Jarvis, USRCS, as "Kuik." Kwik River: stream, see Grand Wash River.

Kwik Stream: stream, heads in Hayden Glacier, flows SE $5 \mathrm{mi}$. to Grand Wash, $7 \mathrm{mi}$. NW of Blizhni Point and $25 \mathrm{mi}$. NW of Yakutat, St. Elias Mts.; $59^{\circ} 54^{\prime} 00^{\prime \prime} \mathrm{N}, 139^{\circ} 57^{\prime} 45^{\prime \prime} \mathrm{W}$; (map 46). Var. Grand Wash.

Native name given as "R[eka] Kvik," or "Kvik River," by Capt. Tebenkov (1852, map 7), IRN. The lower part of this stream is called "Grand Wash."

Kwik Stream: stream, see Grand Wash River.

Kwiktalik Mountain: mountain, 1,707 ft., in Kwiktalik Mts., $13 \mathrm{mi}$. SE of Golovin and 19 mi. SW of Elim, Seward Penin. High; $64^{\circ} 25^{\prime}$ $\mathrm{N}, 162^{\circ} 42^{\prime} \mathrm{W}$; (map 95). Var. Quiktalik Mountain.

Eskimo name reported in 1900 by W. J. Peters (in Mendenhall, 1901, pl. 20), USGS.

Kwiktalik Mountains: mountain range, trends $\mathrm{N}-\mathrm{S} 11 \mathrm{mi}$. beween Golovnin Bay and Norton Bay, $52 \mathrm{mi}$. E of Solomon, Seward Penin. High.; $64^{\circ} 25^{\prime} \mathrm{N}, 162^{\circ} 45^{\prime} \mathrm{W}$; (map 95).

Local name published in 1956 by USGS. The name is derived from Kwiktalik Mountain. Kwikuk Slough: watercourse, see Kwiguk Pass. Kwilokuk: locality, "in the Kuskokwim district." Var. Quilochugamiut.

Former Eskimo camp or settlement listed as "Quilochugamiut," with a population of 12 , in the 1890 Census.

Kwimlilthla Slough: watercourse, in Yukon Delta, extends NW-SE 25 mi. between Kwikluak and Akularak Passes, $9 \mathrm{mi}$. SW of Kwiguk, Yukon-Kuskokwim Delta; $62^{\circ} 38^{\prime} 30^{\prime \prime} \mathrm{N}$, $164^{\circ} 20^{\prime} 10^{\prime \prime} \mathrm{W}$; (map 77).

Eskimo name possibly meaning "river without place or camp [kwimlithkok]" obtained in 1899 by G. R. Putnam, USC\&GS

Kwinak: village, see Quinhagak.

Kwina River: stream, see Kanektok River.

Kwinhagak: village, see Quinhagak.
Kwinhagamut: village, see Quinhagak.

Kwiniuk, Mount: mountain, 2,073 ft., on NW shore of Norton Bay, 6 mi. SW of Elim, Seward Penin. High.; (map 95). Var. Haystack Mountain, Kwiniuk Mountain, Quinnehuk Mountain.

Eskimo name reported in 1900 as " $\mathrm{K}$ winiuk Mt." by W. J. Peters (in Mendenhall, 1901, pl. 20), USGS.

Kwiniuk Inlet: lagoon, $6 \mathrm{mi}$. long, on $\mathrm{N}$ side of Norton Bay, 13 mi. NE of Elim, Seward Penin. High.; $64^{\circ} 45^{\prime} \mathrm{N}, 161^{\circ} 50^{\prime} \mathrm{W}$; (map 96).

Local name reported in 1955 by USGS.

Kwiniuk Mountain: mountain, see Kwiniuk, Mount.

Kwiniuk River: stream, flows NE $43 \mathrm{mi}$. to Norton Bay, at Moses Point, $72 \mathrm{mi}$. NE of Solomon, Seward Penin. High.; $64^{\circ} 42^{\prime} \mathrm{N}, 162^{\circ} 02^{\prime}$ W; (map 95). Var. Oweruk Creek, Quinnehuk River, Quinnelhock River.

Eskimo name reported as "Quinnehuk" on the 1900 "Map of Nome Peninsula" by J. M. Davidson and B. D. Blakeslee. Davidson and Blakeslee applied "Quinnehuk" to a stream to the southwest and applied "Oweruk" to this stream.

Kwinlatah Slough: stream, a distributary of the the Oaklee River, flows W $2.7 \mathrm{mi}$. to Controller Bay, $20 \mathrm{mi}$. SE of Katalla, Malaspina Coastal Plain; $60^{\circ} 02^{\prime} \mathrm{N}, 144^{\circ} 00^{\prime} \mathrm{W}$; (map 64). Var. Quinlatah Slough.

Eskimo name reported by F. H. Moffit (1914, pl. 1), USGS.

Kwinukamut: locality, on E shore of Kuskokwim Bay, $50 \mathrm{mi}$. $\mathrm{N}$ of Goodnews, Yukon-Kuskokwim Delta; $59^{\circ} 50^{\prime} \mathrm{N}, 162^{\circ} 00^{\prime} \mathrm{W}$; (map 53).

Name of Eskimo village or camp meaning "Kwinuk people" was published on a 1928 post-route map. The place is now abandoned. Kwithluk: village, see Kwethluk.

Kwitschak-Sund: gulf, see Bristol Bay.

Kwithluk River: stream, see Kwethluk River.

Kwittevunkud Lake: lake, $2 \mathrm{mi}$. long, $12 \mathrm{mi}$. SE of Christian and $12 \mathrm{mi}$. SW of Burnt Mountain, Yukon Flats; $67^{\circ} 16^{\prime} \mathrm{N}, 144^{\circ} 49^{\prime} \mathrm{W}$; (map 122).

Kutcha-kutchin Indian name; obtained in 1956 by T. E. Taylor, USGS.

Kwiyadik Creek: stream, see Arolik River.

Kwiyadik Greek: stream, see North Mouth Arolik River.

Kwygyschpainagmjut: village, see Quinhagak.

Kyagamiut: locality, on $\mathrm{N}$ shore of Duchikthluk Bay, $3 \mathrm{mi}$. N of Cape Mendenhall, Nunivak I.; $59^{\circ} 51^{\prime} 45^{\prime \prime}$ N, $166^{\circ} 11^{\prime} 45^{\prime \prime}$ W; (map 55). Var. Kyagamute.

Eskimo fish camp reported in 1942 by the USAAF.

Kyagamute: locality, see Kyagamiut.

Kyak Island: island, see Kayak Island.

Kychchogljuk River: stream, see Ulukuk River.

Kyena Hills: ridge, see Kiana Hills.

Kygane: point of land, see Muzon, Cape.

Kyigialik Lake: lake, see Kayigyalik Lake.

Kyikhgyit, Lake: lake, $0.5 \mathrm{mi}$. long, in Hogatza Flats, W of Twin Lakes, $22 \mathrm{mi}$. NW of Hughes, Hogatza High.; $66^{\circ} 19^{\prime} 30^{\prime \prime} \mathrm{N}, 154^{\circ} 39^{\prime} 00^{\prime \prime} \mathrm{W}$; (map 116). 
Indian name "K'yikh-g'yi-it," reported to mean "between (or among) the birch," recorded at Hughes in 1956 by Orth.

Kykhkat: locality, see Kikhkat.

Kypreia, Point: point of land, see Kupreanof Point.

Kyska: island, see Kiska Island.

Kyska Harbor: bay, see Kiska Harbor.

Kystotank, Mys: point of land, see West Foreland.

Kytlek Island: rock, see South Island.

Kyuatka: island, see Kauatka.

\section{L}

Labandera Rock: rock, between Bucareli Bay and Port Santa Cruz, on W coast of Suemez

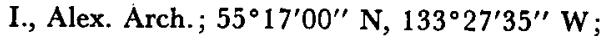
(map 4). Var. La Labandera.

Spanish name given in 1775-79 by Don Juan de la Bodega y Quadra and Francisco Antonio Maurelle as "la Labandera," meaning "the washer-woman."

Labaree Creek: stream, flows N $3 \mathrm{mi}$. to Kuzitrin River, $17 \mathrm{mi}$. NW of Mount Bendeleben, Seward Penin. High.; $65^{\circ} 13^{\prime} \mathrm{N}, 164^{\circ} 41^{\prime} \mathrm{W}$; (map 110).

Prospectors' name reported on the 1908 "Map of Seward Peninsula" by Arthur Gibson.

Labastida, Isla: island, "one of a small group of islands west of Umnak Island."

This name appears on a 1791 map of Bodega y Quadra; probably named by him for his secretary (Wagner, 1937, p. 465).

Label Reef: reef, at mouth of Eagle Bay on S coast of Unalaska I., Aleutian Is.; 53 $25^{\prime} 50^{\prime \prime}$ N, 166 57'35' W; BGN 1939; (map 23).

Descriptive name given by USC\&GS in 1937 because, "its presence is advertised by breakers at all stages of tide."

Labor Hill: hill, 550 ft., central Kiska I., Aleu$\operatorname{tian}$ Is.; $51^{\circ} 56^{\prime} 10^{\prime \prime} \mathrm{N}, 177^{\circ} 22^{\prime} 25^{\prime \prime} \mathrm{E}$; (map 14).

An arbitrary name beginning with " $L$ " to correspond to "L" grid used by the U.S. Army for tactical purposes during World War II; published on a 1953 AMS map.

Labouchere Anchorage: anchorage, see Highfield Anchorage.

Labouchere Bay: anchorage, see Highfield Anchorage.

Labouchere Bay: bay, extends SW $2 \mathrm{mi}$. to Sumner Strait, $4 \mathrm{mi}$. $\mathrm{S}$ of village of Point $\mathrm{Ba}-$ ker, on $\mathrm{N}$ coast of Prince of Wales I., Alex. Arch.; 56 $17^{\prime} 30^{\prime \prime} \mathrm{N}, 133^{\circ} 39^{\prime} 30^{\prime \prime} \mathrm{W}$; (map 6). Var. Labouchere Harbor, Port Labouchere.

Named by local traders about 1880 for the Hudson Bay Co. steamer Labouchere.

Labouchere Harbor: bay, see Labouchere Bay.

Labouchere Harbor: cove, see Pyramid Harbor.

Labouchere Island: island, $0.1 \mathrm{mi}$. long, at mouth of Labouchere Bay, $4.5 \mathrm{mi}$. S of Point Baker, on NW coast of Prince of Wales I., Alex. Arch.; $56^{\circ} 17^{\prime} 35^{\prime \prime} \mathrm{N}, 133^{\circ} 40^{\prime} 20^{\prime \prime} \mathrm{W}$; BGN 1900; (map 6). Var. Ship Island.

Published in 1891 Coast Pilot (p. 127). "Ship Island" was given to this feature in 1886 by Lt. J. M. Helm, USN.
Labret River: stream, see Tutuksuk River.

Lace Hill: hill, $600 \mathrm{ft}$., south-central Kiska I., Aleutian Is.; $51^{\circ} 56^{\prime} 25^{\prime \prime} \mathrm{N}, 177^{\circ} 23^{\prime} 05^{\prime \prime} \mathrm{E}$; (map 14)

An arbitrary name beginning with " $L$ " to correspond to "L" grid used by the U.S. Army for tactical purposes during World War II published on a 1953 AMS map.

Lace River: stream, heads at terminus of branch of Meade Glacier, $13 \mathrm{mi}$. S of Snow Top, flows S $19 \mathrm{mi}$. to Berner Bay, $42 \mathrm{mi}$. NW of Juneau, Coast Mts.; $58^{\circ} 48^{\prime} 30^{\prime \prime} \mathrm{N}, 134^{\circ} 59^{\prime} 30^{\prime \prime} \mathrm{W}$ $B G N$ 1965; (map 11).

Local name derived from the network of interlocking sloughs near the stream's mouth; reported in 1928 by USFS.

Lacey Island: island, 1,000 ft. long, near head of Cordova Bay, $1 \mathrm{mi}$. E of Jackson I., Alex. Arch.; 54 $58^{\prime} 45^{\prime \prime} \mathrm{N}, 132^{\circ} 41^{\prime} 20^{\prime \prime} \mathrm{W}$; (map 1).

Local name recorded in 1905 by E. F. Dickins, USC\&GS.

Lachbuna Lake: lake, $2.5 \mathrm{mi}$. long, at head of Kijik River, 42 mi. NE of Nondalton, Alaska Ra.; $60^{\circ} 29^{\prime} \mathrm{N}, 154^{\circ} 01^{\prime} \mathrm{W}$; BGN 1910; (map 61). Var. Ingersol Lake, Lawsbina Lake.

Indian name obtained by A. G. Maddren, USGS, in 1902. The "buna" ending means "lake." Early prospectors called it Ingersol Lake.

Lachina: stream, see Lakina River

Lackie Gulch: ravine, trends SE $1 \mathrm{mi}$. to Osborn Creek, $10 \mathrm{mi}$. NE of Nome, Seward Penin.

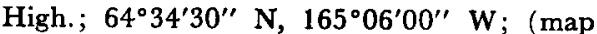
94)

Prospectors' name reported in 1904 by $T$. G. Gerdine, USGS.

Lacuna Glacier: glacier, heads $W$ of Kahiltna Glacier at junc. of three branches and trends SW $15 \mathrm{mi}$. to Yentna Glacier, $56 \mathrm{mi}$. NW of Talkeetna, Alaska Ra.; $62^{\circ} 41^{\prime} \mathrm{N}, 151^{\circ} 40^{\prime} \mathrm{W}$; (map 81).

Mountain climbers' name published in the late 1940's.

Lacy Cove: cove, $0.7 \mathrm{mi}$. across, on $\mathrm{N}$ coast of Chichagof I., $1.4 \mathrm{mi}$. E of Point Lavinia, 33 mi. NW of Hoonah, Alex. Arch.; 58 $13^{\prime} 10^{\prime \prime}$ $\mathrm{N}, 136^{\circ} 19^{\prime} 15^{\prime \prime} \mathrm{W}$; (map 10)

Local name "for a Mr. Lacy (cnna)," by USFS in 1935.

Lad Hill: mountain, 1,260 ft., center of Kiska I., Aleutian Is. ; $51^{\circ} 57^{\prime} 55^{\prime \prime} \mathrm{N}, 177^{\circ} 29^{\prime} 53^{\prime \prime} \mathrm{E}$; (map 14).

An arbitrary name beginning with " $L$ " to correspond to "L" grid used by the U.S. Army for tactical purposes during World War II ; published on a 1943 Army map.

Ladanan Creek: stream, flows SE $11 \mathrm{mi}$. to Pegeeluk Greek, $16 \mathrm{mi}$. S of Survey Pass, Brooks Ra.; $67^{\circ} 37^{\prime} \mathrm{N}, 154^{\circ} 16^{\prime} \mathrm{W}$; (map 125).

A girl's name recorded by USGS in 1956 .

Ladd: locality, on NW shore of Cook Inlet at mouth of Chuitna River, $2 \mathrm{mi}$. $\mathrm{N}$ of Tyonek, Cook Inlet Low.; $61^{\circ} 06^{\prime} 00^{\prime \prime} \mathrm{N}, 151^{\circ} 06^{\prime} 40^{\prime \prime}$ W; (map 70). Var. Chuitna, Ladds, Ladds Station.

A former trading post and fishing station on or near the site of an Indian village called
"Chuitna," named for a Mr. Ladd (cnna), the operator. The name was in use in 1895 . The place served as a base camp for Capt. E. F. Glenn, USA, in 1898 . Recent USGS maps indicate a site with one building.

Ladder Island: island, $0.5 \mathrm{mi}$. long, in Kiliuda Bay, on SE coast of Kodiak I.; $57^{\circ} 18^{\prime} 30^{\prime \prime} \mathrm{N}$, $152^{\circ} 54^{\prime} 30^{\prime \prime} \mathrm{W}$; BGN 1930; (map 34).

Descriptive name given in 1928 by USG\&GS "because there was a native's ladder for scaling the cliffs, hanging at the south end of this island."

Ladds: locality, see Ladd.

Ladds Station: locality, see Ladd.

Ladia Rocks: rocks, see Laida Rocks.

Ladron Islands: islands, see Ladrones Islands.

Ladrones Islands: islands, group, extend $2 \mathrm{mi}$. in Trocadero Bay, on $W$ coast of Prince of Wales I., Alex. Arch.; 55 $23^{\prime} \mathrm{N}, 133^{\circ} 05^{\prime} \mathrm{W}$; BGN 1922; (map 4). Var. Islas de Ladrones, Ladron Islands, Robber Islands, Yslas de Ladrones.

Name given in 1775-79 by Don Juan de la Bodega y Quadra and Francisco Antonio Maurelle as "Islas de Ladrones," meaning "islands of robbers." This name is "Only found on the maps of the Arteaga expedition of 1779 [in which Quadra and Maurelle took part], but not in the narratives, although thieving Indians in this locality are mentioned by Mourelle [sic]" (Wagner, 1937, p. 395 ).

Ladue Creek: stream, see Ladue River.

Ladue River: stream, heads $2.5 \mathrm{mi}$. NE of Tetlin Junc., flows $\mathrm{E}$ across Alaska-Canada boundary $110 \mathrm{mi}$. to White River in Yukon, Canada, Yukon-Tanana High.; $63^{\circ} 07^{\prime} 25^{\prime \prime} \mathrm{N}$, $140^{\circ} 22^{\prime} 20^{\prime \prime} \mathrm{W}$; BGN 1954; (map 85). Var. Ladue Creek, La Due River, West Fork Ladue River.

Presumably named for a prospector, La Due, who wintered on the Yukon in 1884-85.

Lady Hill: hill, $965 \mathrm{ft}$., $0.5 \mathrm{mi}$. SE of Conquer Point, Kiska I., Aleutian Is.; $52^{\circ} 00^{\prime} 13^{\prime \prime}$ N, $177^{\circ} 29^{\prime} 43^{\prime \prime}$ E ; (map 14).

An arbitrary name beginning with " $L$ " to correspond to "L" grid used by the U.S. Army for tactical purposes during World War II; published on a 1943 Army map.

Lady Island: island, in Yukon River, $\mathbf{N}$ of Burns Island, E of Lady Point, $10 \mathrm{mi}$. SW of Birches, Kokrines-Hodzana High.; 65 ${ }^{\circ} 03^{\prime}$ $45^{\prime \prime} \mathrm{N}, 153^{\circ} 52^{\prime} 00^{\prime \prime} \mathrm{W}$; (map 107).

Riverboat pilots' name shown on a 1940 "Navigation Chart of the Tanana-Yukon Rivers" published by the Department of the Interior.

Lady Point: point of land, on $\mathrm{N}$ shore of Yukon River, W of Lady I., $\mathbf{N}$ of Chokoyik I and $11 \mathrm{mi}$. WSW of Birches, Kokrines-Hodzana High.; $65^{\circ} 03^{\prime} 45^{\prime \prime} \mathrm{N}, 153^{\circ} 54^{\prime} 46^{\prime \prime} \mathrm{W}$; (map 107).

Riverboat pilots' name shown on a 1940 "Navigation Chart of the Tanana-Yukon Rivers" published by the Department of the Interior.

Lafayette Glacier: glacier, trends NW $3.5 \mathrm{mi}$ from Unakwik Peak, $4.5 \mathrm{mi}$. SE of College 
Point and $51 \mathrm{mi}$. W of Valdez, Chugach Mts. $61^{\circ} 02^{\prime} 40^{\prime \prime} \mathrm{N}, 147^{\circ} 04^{\prime} 15^{\prime \prime} \mathrm{W}$; BGN 1950 , (map 69)

Named in 1947 by Douglas Brown for Lafayette College, Easton, Penn., founded in 1826.

Lagartos, Rio de: stream, see Bering River.

Lagoma Bay: bay, $0.5 \mathrm{mi}$. wide, on $\mathrm{N}$ shore of Roller Bay, W coast of Noyes I., Alex. Arch.; $55^{\circ} 31^{\prime} 35^{\prime \prime} \mathrm{N}, 133^{\circ} 43^{\prime} 30^{\prime \prime} \mathrm{W}$; BGN 1923; (map 4). Var. Gum Bay.

Spanish name meaning "the gum," given in 1923 by USC\&GS "because the topographic station here is called Gum."

Lagoon: locality, mile 343.7 on The Alaska RR., $12 \mathrm{mi}$. S of Healy, Alaska Ra.; $63^{\circ} 41^{\prime} \mathrm{N}$, $148^{\circ} 52^{\prime} \mathrm{W}$; BGN 1945; (map 87).

Name of a railroad station reported by The Alaska RR. on its 1922 timetable.

Lagoon, The: estuary, $0.7 \mathrm{mi}$. wide, at $\mathrm{E}$ end of Galena Bay, $40 \mathrm{mi}$. NW of Cordova, Chugach Mts.; 60 $57^{\prime} 30^{\prime \prime} \mathrm{N}, 146^{\circ} 33^{\prime} 30^{\prime \prime} \mathrm{W}$; (map 64).

Local name reported in 1912 by $\mathrm{S}$. R. Capps and B. L. Johnson (in Brooks and others, 1913, pl. 4), USGS.

Lagoon, The: lagoon, $0.4 \mathrm{mi}$. long, on $\mathrm{E}$ shore of Yakutat Roads, $0.6 \mathrm{mi}$. NW of Yakutat, Malaspina Coastal Plain; 59 $33^{\prime} 30^{\prime \prime} \mathrm{N}, 139^{\circ}$ $44^{\prime} 45^{\prime \prime} \mathrm{W}$; (map 46).

Local name reported in 1964 (de Laguna and others, map 4 ).

Lagoon Creek: stream, flows SW $3 \mathrm{mi}$. to Landlocked Bay, $35 \mathrm{mi}$. NW of Cordova, Chugach Mts. ; $60^{\circ} 51^{\prime} 30^{\prime \prime} \mathrm{N}, 146^{\circ} 31^{\prime} 00^{\prime \prime} \mathrm{W}$; (map 64).

Local name reported in 1912 by Capps and Johnson (1915, pl. 1), USGS. So called because of the lagoonlike head of Landlocked Bay.

Lagoon Creek: stream, on $\mathrm{S}$ coast of Alaska, flows SE $3 \mathrm{mi}$. to Harrison Lagoon, $21 \mathrm{mi}$. NE of Whittier, Chugach Mts.; $60^{\circ} 59^{\prime} 40^{\prime \prime} \mathrm{N}$, $148^{\circ} 12^{\prime} 00^{\prime \prime} \mathrm{W}$; ( $\operatorname{map} 63$ ).

Local name reported in 1951 by USGS.

Lagoon Creek: stream, flows SE $1 \mathrm{mi}$. to lagoon on Bering Sea, $1.3 \mathrm{mi}$. E of Tin City and $49 \mathrm{mi}$. NW of Teller, Seward Penin. High.; $65^{\circ} 33^{\prime} \mathrm{N}, 167^{\circ} 54^{\prime} \mathrm{W}$; (map 111). Var. Ocean Creek.

Prospectors' name reported in 1901 by $\mathrm{T}$. G. Gerdine (in Collier, 1902, pl. 12), USGS. Lagoon Creek: stream, see Boulder Creek.

Lagoon Creek: stream, see Ocean Creek.

Lagoon Island: island, $0.3 \mathrm{mi}$. across, off $\mathrm{E}$ shore of Bartlett Cove near S entrance to Glacier Bay, $5.6 \mathrm{mi}$. NE of Point Gustavus and 54 mi. WNW of Juneau, St. Elias Mts.; $58^{\circ} 27^{\prime}$ $30^{\prime \prime} \mathrm{N}, 135^{\circ} 52^{\prime} 15^{\prime \prime} \mathrm{W}$; BGN 1962; (map 11).

Local name published in 1948 by USGS

Lagoon Lake: lagoon, see Salt Lagoon.

Lagoon Point: point of land, on $\mathrm{N}$ shore of Nelson Lagoon, $22 \mathrm{mi}$. W of village of Port Moller, on Alaska Penin., Bristol Bay Low.; $56^{\circ} 00^{\prime} 35^{\prime \prime} \mathrm{N}, 161^{\circ} 07^{\prime} 00^{\prime \prime} \mathrm{W}$; (map 28). Var. Cap Rojnoff, Rozhnof.

Named in 1882 by W. H. Dall, USC\&GS This is possibly the same as "Cap Rojnoff (Rozhnof)" of Capt. Lutke (1836, p. 261).
Shown as "Lagoon Point" on 1890 USBF chart.

Lagoon Point: point of land, on $\mathrm{N}$ coast of Sitkalidak I., between Port Hobron and McDonald Lagoon, SE of Kodiak I.; $57^{\circ}$ $11^{\prime} 15^{\prime \prime} \mathrm{N}, 153^{\circ} 04^{\prime} 00^{\prime \prime} \mathrm{W}$; (map 34).

Descriptive local name; published in 1943 by USC\&GS.

Lagoon Rookery: rookery, on N shore of Village Cove, on S coast of Saint Paul I., in Pribilof Is.; $57^{\circ} 08^{\prime} \mathrm{N}, 170^{\circ} 17^{\prime} \mathrm{W}$; (map 38$)$.

Local name for a seal rookery reported by Elliott (1881, p. 51-52).

LaGorce, Mount: mountain, $3,315 \mathrm{ft}$., on $\mathrm{N}$ shore Iliuk Arm Naknek Lake, on Alaska Penin. in Katmai National Monument, 27 mi. NW of Mount Katmai, Aleutian Ra.; $58^{\circ} 33^{\prime} 20^{\prime \prime} \mathrm{N}, 155^{\circ} 29^{\prime} 15^{\prime \prime} \mathrm{W}$; BGN 1925; (map 42).

Named in 1919 by R. F. Griggs, National Geographic Society, for John Oliver LaGorce, 1880-1959, of the National Geographic Society.

LaGorce Glacier: glacier, trends N 2 mi. to its terminus, $6 \mathrm{mi}$. $\mathrm{S}$ of junc. of Bremner and Wernicke Rivers, $38 \mathrm{mi}$. N of Katalla, Chugach Mts.; $60^{\circ} 45^{\prime} \mathrm{N}, 144^{\circ} 29^{\prime} \mathrm{W}$; (map 64).

Named in 1910 by Lawrence Martin for John O. LaGorce, 1880-1959, National Geographic Society.

Lahach-tak: locality, see Chilkat.

Laida: locality, see Kasnatchin.

Laida Point: point of land, see Nemo Point.

Laida Rocks: rocks, at tip of Kupreanof Penin. on $\mathrm{N}$ coast of Kodiak I.; $58^{\circ} 00^{\prime} 05^{\prime \prime} \mathrm{N}$, 153 $17^{\prime} 30^{\prime \prime}$ W ; BGN 1966; (map 43). Var. Ladia Rocks, Rocky Reef Point.

This name is a partial transliteration by USC\&GS of the name "M[ys] Kamenistoy Laidy," meaning "Cape Rocky Reef," given by Sub. Lt. Murashev, IRN, in 1839 or 1840 and published by the Russian Hydrog. Dept. on Chart 1425 in 1849. The Russian word "laida," meaning "bank" or "shoal," was published for this feature by Capt. Tebenkov (1852, map 7), IRN.

Laida Slough: lagoon, $1.5 \mathrm{mi}$. long, on $\mathrm{W}$ coast of Kenai Penin., $1.5 \mathrm{mi}$. NW of village of Anchor Point, $15 \mathrm{mi}$. NW of Homer, Cook Inlet Low.; 59 $48^{\prime} \mathrm{N}, 151^{\circ} 51^{\prime} \mathrm{W}$; (map 50).

Local name reported by USGS or USC\&GS in the 1940's.

Laida Spit: spit, on W coast of Kenai Penin., $1.5 \mathrm{mi}$. NNE of village of Anchor Point and $15 \mathrm{mi}$. NW of Homer, Cook Inlet Low.; $59^{\circ} 48^{\prime} \mathrm{N}, 151^{\circ} 51^{\prime} \mathrm{W}$; (map 50$)$.

Local name reported by USGS or USC\&GS in the 1940's.

Laidennoj: locality, see Kasnatchin.

Laidennoj: spit, see Anchor Point.

Laja, La: rock, or small island near San Fernando I., Prince of Wales Island, Alex. Arch. Var. La Lakha.

Named by F. A. Maurelle and Don Juan de la Bodega $x$ Quadra in 1779 . Laja is a Spanish word for a "thin flat stone."
Lake Bay: locality, on $\mathrm{E}$ shore of Lake Bay Creek on NE coast of Prince of Wales I., $\mathrm{SE}$ of Stevenson I., Alex. Arch.; $56^{\circ} 01^{\prime} 00^{\prime \prime}$ $\mathrm{N}, 132^{\circ} 55^{\prime} 30^{\prime \prime} \mathrm{W}$; (map 6).

This is the site of an abandoned fishing village; shown as an abandoned cannery on current maps. In 1890 the U.S. Census Bureau (1893, p. 29) reported this fishing station to be one of the best on Prince of Wales Island; concerning the population, it was reported that "There is a settlement here usually of about 50 natives and half a dozen white men during the fishing season, but it is wholly abandoned in the winter months." A post office operated here from 1911 to 1921 (Ricks, 1965, p. 38).

Lake Bay: bay, $3 \mathrm{mi}$. across, at $\mathbf{S}$ end of Kashevarof Passage, on NE coast of Prince of Wales I., Alex. Arch.; $56^{\circ} 03^{\prime} \mathrm{N}, 133^{\circ} 53^{\prime}$ W; BGN 1915; (map 6)

Local name reported by Lt. Comdr. J. F. Moser, USN, Commander of the USBF steamer Albatross.

Lake Bay: cove, trends NE $3 \mathrm{mi}$. to Chignik Bay, $5 \mathrm{mi}$. E of Chignik, Aleutian Ra.; $56^{\circ} 18^{\prime}$ N, $158^{\circ} 17^{\prime} \mathrm{W}$; (map 30 ).

Name reported in 1923 by R. H. Sargent, USGS; published in 1927 by USGS.

Lake Bay: estuary, on S coast of Esther I., extends SE $1.5 \mathrm{mi}$. to Wells Passage, $22 \mathrm{mi}$. E of Whittier, Chugach Mts.; 60 $47^{\circ} 15^{\prime \prime} \mathrm{N}$, $148^{\circ} 04^{\prime} 15^{\prime \prime} \mathrm{W}$; (map 63 ).

Local name reported in 1952 by USGS.

Lake Bay Creek: stream, heads at Barnes Lake, flows NE $1 \mathrm{mi}$. to Lake Bay, on NE coast of Prince of Wales I., Alex. Arch.; 56 $01^{\prime} 20^{\prime \prime}$ N, $132^{\circ} 55^{\prime} 30^{\prime \prime} \mathrm{W} ; B G N$ 1915; (map 6).

Named in 1914 by E. Lester Jones, USBF. Lake Clark Pass: pass, 1,000 ft., NE of Summit Lake, $50 \mathrm{mi}$. WNW of Kenai, Aleutian Ra.; $60^{\circ} 49^{\prime} \mathrm{N}, 152^{\circ} 44^{\prime} \mathrm{W}$; (map 62 ).

Local name reported in 1959 by USGS. "So named because it is a pass through the Aleutian Range from Cook Inlet to Lake Clark."

Lake Clark Villages: locality, see Kijik.

Lake Creek: stream, heads in Canada near boundary monument 30, flows SW $19 \mathrm{mi}$. to Unuk River, $12 \mathrm{mi}$. NE of head of Burroughs Bay, Coast Mts. ; $56^{\circ} 08^{\prime}$ N, $130^{\circ} 58^{\prime} \mathrm{W}$; (map 7).

Local descriptive name published in 1951 by USGS.

Lake Creek: stream, flows $4 \mathrm{mi}$. SE to Auke Lake, $1.2 \mathrm{mi}$. NE of village of Auke Bay and $10 \mathrm{mi}$. NW of Juneau, Coast Mts.; $58^{\circ} 23^{\prime} 30^{\prime \prime} \mathrm{N}$, $134^{\circ} 38^{\prime} 00^{\prime \prime} \mathrm{W}$; (map 11).

Local name published by Knopf (1912a, pl. 1), USGS.

Lake Creek: stream, $3.5 \mathrm{mi}$. long, flows NE to Fork Creek, $29 \mathrm{mi}$. W of Chikuminuk Lake and $73 \mathrm{mi}$. SE of Bethel, Kilbuck-Kuskokwim Mts.; $60^{\circ} 11^{\prime} \mathrm{N}, 160^{\circ} 00^{\prime} \mathrm{W}$; BGN 1959; (map $59)$.

Local name reported in 1956 by USGS.

Lake Creek: stream, flows $10 \mathrm{mi}$. N to Hanagita River $W$ of Hanagita Lake, $33 \mathrm{mi}$. SW of 
McCarthy, Chugach Mts. ; $61^{\circ} 15^{\prime} 00^{\prime \prime} \mathrm{N}, 143^{\circ}$ $49^{\prime} 45^{\prime \prime} \mathrm{W}$; (map 67).

Local name reported in 1911 by $D$. C. Witherspoon, USGS.

Lake Creek: stream, flows NW $6 \mathrm{mi}$. to Nizina River, $10 \mathrm{mi}$. SE of McCarthy, St. Elias Mts. $61^{\circ} 22^{\prime} 33^{\prime \prime} \mathrm{N}, 142^{\circ} 38^{\prime} 30^{\prime \prime} \mathrm{W}$; (map 67).

Name used by prospectors and shown on a map of the Nizina Mining District, dated 1902, by George M. Esterly of Valdez.

Lake Creek: stream, heads in Lake Nancy, flows SE $7 \mathrm{mi}$. to Little Susitna River, $29 \mathrm{mi}$. N of Anchorage, Cook Inlet Low.; $61^{\circ} 37^{\prime} 30^{\prime \prime} \mathrm{N}$, $149^{\circ} 56^{\prime} 15^{\prime \prime} \mathrm{W}$; (map 69).

Local name reported in 1942 by AMS

Lake Creek: stream, heads in a lake, flows W 5 mi. to Tatondan Lake $39 \mathrm{mi}$. NE of Palmer, Chugach Mts. ; $61^{\circ} 46^{\prime} 25^{\prime \prime} \mathrm{N}, 147^{\circ} 58^{\prime} 55^{\prime \prime} \mathrm{W}$; (map 69).

Local name reported in 1952 by USGS.

Lake Creek: stream, heads at Chelatna Lake, at $62^{\circ} 26^{\prime} 30^{\prime \prime} \mathrm{N}, 151^{\circ} 24^{\prime} 00^{\prime \prime} \mathrm{W}$, flows SE $50 \mathrm{mi}$. to Yentna River, $58 \mathrm{mi}$. NW of Anchorage, Cook Inlet Low.; $61^{\circ} 54^{\prime 2} 5^{\prime \prime} \mathrm{N}, 150^{\circ} 54^{\prime} 25^{\prime \prime}$ W; BGN 1911; (map 70). Var. Mantalik Creek, Mentalik Creek.

Prospectors' name reported by Sidney Paige and Adolph Knopf (in Brooks and others, 1906, p. 119), USGS. W. S. Post, USGS, reported in 1898 the Tanaina Indian name for this stream as "Mentalik."

Lake Creek: stream, flows SE $6 \mathrm{mi}$. to Susitna River, $80 \mathrm{mi}$. SE of Healy, Alaska Ra.; $63^{\circ}$ $01^{\prime} 15^{\prime \prime} \mathrm{N}, 147^{\circ} 22^{\prime} 00^{\prime \prime} \mathrm{W}$; (map 87).

Prospectors' name shown on a 1910 fieldsheet by D. C. Witherspoon, USGS; published by Moffit (1912, pl. 1).

Lake Creek: stream, flows SE $5.5 \mathrm{mi}$. to an oxbow lake of North Fork Kuskokwim River, $26 \mathrm{mi}$. NE of Medfra, Kilbuck-Kuskokwim Mts. ; $63^{\circ}$ $18^{\prime} \mathrm{N}, 153^{\circ} 59^{\prime} \mathrm{W}$; (map 89 ).

Local name reported in 1958 by USGS.

Lake Creek: stream, heads in Wonder Lake, flows NNW 2 mi. to Moose Creek, Alaska Ra.; $6^{\circ}$. $31^{\prime} 00^{\prime \prime} \mathrm{N}, 150^{\circ} 54^{\prime} 25^{\prime \prime} \mathrm{W}$; (map 88).

Local name reported in 1932 by USGS.

Lake Creek: stream, flows NW $2 \mathrm{mi}$. to Tisuk River, $18 \mathrm{mi}$. E of Cape Douglas and $39 \mathrm{mi}$. NW of Nome, Seward Penin. High.; 64 $4^{\circ} 9^{\prime}$ N, $166^{\circ} 05^{\prime} \mathrm{W}$; (map 94).

Prospectors' name published on the 1908 "Map of Seward Peninsula" by Arthur Gibson.

Lake Creek: stream, flows SW $4 \mathrm{mi}$. through a lake to Helpmejack Creek, $60 \mathrm{mi}$. SSE of Survey Pass, Brooks Ra.; 67 $02^{\prime} \mathrm{N}, 153^{\circ} 33^{\prime} \mathrm{W}$; (map 125).

Local name reported by Orth, USGS, in 1956.

Lake Creek: stream, flows SW $2.5 \mathrm{mi}$. from $\mathrm{N}$ of Mathews Dome to Wild Lake, $6.5 \mathrm{mi}$. N of junc. of Flat Creek and Wild River, Brooks Ra.; $67^{\circ} 28^{\prime} 30^{\prime \prime} \mathrm{N}, 151^{\circ} 35^{\prime} 00^{\prime \prime} \mathrm{W}$; (map 124).

Local name shown on an 1899 fieldsheet by T. G. Gerdine, USGS.

Lake Creek: stream, flows NW then SW $29 \mathrm{mi}$. to Coleen River, $11 \mathrm{mi}$. WNW of Rabbit Mtn. and $33 \mathrm{mi}$. N of Coleen Mtn., Brooks Ra.; $67^{\circ} 35^{\prime} \mathrm{N}, 142^{\circ} 38^{\prime} \mathrm{W}$; (map 121).
Local name reported in 1956 by T. E. Taylor, USGS.

Lake Creek: stream, flows NW $5.5 \mathrm{mi}$. from Squaw Lake to North Fork Chandalar River, $11 \mathrm{mi}$. N of Chandalar, Brooks Ra.; 67 $39^{\prime}$ $30^{\prime \prime} \mathrm{N}, 148^{\circ} 23^{\prime} 45^{\prime \prime} \mathrm{W}$; (map 123).

Prospectors' name shown on an 1899 fieldsheet by T. G. Gerdine, USGS.

Lake Creek: stream, flows SW to Turner Creek which flows to Noxapaga River, about $30 \mathrm{mi}$. SW of Imuruk Lake, Seward Penin. High. (map 110).

Prospectors' name shown on a map of Cape Nome gold fields by David Fox, Jr., dated 1901.

Lake Creek: stream, see Lone Creek.

Lake Creek: stream, see Sapsuk River.

Lake Dune: dune, $77 \mathrm{ft}$, on NE coast of Saint Paul I., in Pribilof Is.; $57^{\circ} 13^{\prime} 25^{\prime \prime}$ N, $170^{\circ}$ 08'10"' W; (map 38).

Descriptive name reported by $W$. W. Duffield, USC\&GS, in 1897.

Lake Fork Crescent River: stream, flows SE 20 mi. through Crescent Lake, joins North Fork to form Crescent River, $53 \mathrm{mi}$. SW of Kenai, Aleutian Ra.; $60^{\circ} 21^{\prime} 20^{\prime \prime} \mathrm{N}, 152^{\circ} 44^{\prime} 40^{\prime \prime} \mathrm{W}$; (map 62).

Local name reported in 1959 by USGS.

Lake Fork Crescent River: stream, flows S $10 \mathrm{mi}$. to Crescent Lake, $70 \mathrm{mi}$. NE of Nondalton, Aleutian Ra.; $60^{\circ} 24^{\prime} \mathrm{N}, 153^{\circ} 01^{\prime} \mathrm{W}$; (map 61).

Local name reported in 1958 by USGS.

Lake Fork Knik River: stream, heads in Upper Lake George, flows N $11.5 \mathrm{mi}$. to join Glacier Fork to form Knik River, $20 \mathrm{mi}$. SE of Palmer, Chugach Mts. ; $61^{\circ} 25^{\prime} 30^{\prime \prime} \mathrm{N}, 148^{\circ} 37^{\prime} 30^{\prime \prime} \mathrm{W}$; (map 69).

Local name reported in 1960 by USGS.

Lake Fork Paint River: stream, flows SE $4 \mathrm{mi}$ to Paint River, $8 \mathrm{mi}$. NE of Akjemguiga Cove, $39 \mathrm{mi}$. SW of Augustine I., Aleutian Ra.; $59^{\circ}$. $11^{\prime} \mathrm{N}, 154^{\circ} 28^{\prime} \mathrm{W}$; (map 51 ).

Local name reported by $K$. F. Mather, USGS, in 1923 (in Brooks and others, 1925, pl. 3).

Lake Fork Sadlerochit River: stream, see Carnivore Creek.

Lake Fork Sadlerochit River: stream, see Kekiktuk River.

Lake George Glacier: glacier, trends N $14 \mathrm{mi}$. to its terminus at a stream which drains into Upper Lake George, $42 \mathrm{mi}$. E of Anchorage, Chugach Mts.; $61^{\circ} 10^{\prime} 45^{\prime \prime} \mathrm{N}, 148^{\circ} 37^{\prime} 40^{\prime \prime} \mathrm{W}$; (map 69).

Local name reported in 1960 by USGS.

Lake Hill: hill, $282 \mathrm{ft}$., on central Saint Paul I., in Pribilof Is.; $57^{\circ} 10^{\prime} 40^{\prime \prime} \mathrm{N}, 170^{\circ} 14^{\prime} 50^{\prime \prime}$ W; (map 38).

A local name published in 1875 by USC\&GS; so called because a small lake is located at its foot.

Lake Kenai: locality, see Primrose

Lake Minchumina: village, pop. 30, on NW shore of Lake Minchumina, Tanana Low.; $63^{\circ} 53^{\prime} \mathrm{N}, 152^{\circ} 19^{\prime} \mathrm{W}$; (map 88). Var. Minchumina.
This is the location of an airfield, Indian village, and store. A post office was established in 1930.

Lake Point: point of land, on SW coast of Adak I., Aleutian Is. ; $51^{\circ} 37^{\prime} 40^{\prime \prime} \mathrm{N}, 176^{\circ} 59^{\prime} 00^{\prime \prime} \mathrm{W}$; $B G N 1936$; (map 17).

Named by members of the U.S. Navy Aleutian Island Survey Expedition in 1934, "because of the numerous lakes back of the point."

Lake Point: point of land, on N shore of Kvichak Bay at mouth of Supply Creek, $29 \mathrm{mi}$. W of Naknek, Bristol Bay Low.; 58 $41^{\prime} 55^{\prime \prime} \mathrm{N}, 157^{\circ}$. 47'30' W; (map 41).

Local name published in 1965 by USGS.

Lake Point: point of land, see Aiak, Cape.

Lake Point: point of land, see Lance Point.

Lake River: stream, see Karta River.

Lakekta Point: point of land, $0.15 \mathrm{mi}$. long, $\mathrm{E}$ shore of Revillagigedo Channel, Coast Mts.; $54^{\circ} 51^{\prime} 30^{\prime \prime} \mathrm{N}, 130^{\circ} 57^{\prime} 00^{\prime \prime} \mathrm{W}$; BGN 1937; (map 2).

Local name published in 1943 by USC\&GS.

Lakeshore Cone: hill, $585 \mathrm{ft}$., W of Fenner Lake, on Semisopochnoi I., Rat Is., Aleutian Is.; $51^{\circ} 57^{\prime} 40^{\prime \prime} \mathrm{N}, 179^{\circ} 37^{\prime} 25^{\prime \prime}$ E; BGN 1952; (map 15).

So named in 1950 by USGS "because of the proximity to Fenner Lake."

Lakeside Point: point of land, $5.5 \mathrm{mi}$. NW of Naga Point, on central Kanaga 1., Aleutian Is.; $51^{\circ} 50^{\prime} \mathrm{N}, 177^{\circ} 1^{\prime} 2^{\prime} \mathrm{W}$; (map 17).

Name published by USC\&GS in 1957 on Chart 9193.

Lakeside Roadhouse: roadhouse, along The Alaska RR., on W side of Bear Lake, Kenai Penin., 7 mi. $N$ of Seward, Chugach Mts.; $60^{\circ} 12^{\prime} \mathrm{N}, 149^{\circ} 22^{\prime} \mathrm{W}$; BGN 1910 vacated 1966; (map 63).

Local name reported in 1909 by Grant and Higgins (1910, pl. 2), USGS.

Lakeview, locality, on Kenai Penin., at $\mathrm{E}$ end of Kenai Lake, mile 20.0 on The Alaska RR. $16 \mathrm{mi}$. N of Seward, Chugach Mts. ; $60^{\circ} 21^{\prime} 15^{\prime \prime}$ $\mathrm{N}, 149^{\circ} 21^{\prime} 20^{\prime \prime} \mathrm{W}$; BGN 1945; (map 63). Var. Kenai.

Name of a stop on The Alaska Railroad; listed in the timetables of 1927 .

Lakina Lake: lake, $0.5 \mathrm{mi}$. long, $5 \mathrm{mi}$. SW of Long Lake and $18.5 \mathrm{mi}$. SW of McCarthy, Wrangell Mts.; BGN 1966; $61^{\circ} 20^{\prime} 40^{\prime \prime} \mathrm{N}$, $143^{\circ} 27^{\prime} 00^{\prime \prime} \mathrm{W}$; (map 67)

Name used by local airplane pilots, because of its proximity to the river of that name; reported in 1965 by $\mathrm{L}$. A. Yehle, USGS.

Lakina River: stream, flows SW $25 \mathrm{mi}$, from Lakina Glacier terminus to Chitina River, 23 mi. SW of McCarthy, Copper River Basin; $61^{\circ} 19^{\prime} 30^{\prime \prime} \mathrm{N}, 143^{\circ} 34^{\prime} 00^{\prime \prime} \mathrm{W}$; (map 67). Var. Lachina.

Oscar Rohn (1900, p. 406) spelled the Indian name "Lachina" in 1899.

Lakloey Hill: hill, $700 \mathrm{ft}$., SE of Badger Road, 5.5 mi. E of Fairbanks, Tanana Low.; $64^{\circ}-$ $49^{\prime} 30^{\prime \prime} \mathrm{N}, 147^{\circ} 30^{\prime} 30^{\prime \prime} \mathrm{W}$; (map 100).

Local name reported in 1950 by USGS topographers. 
Lakso Slough: stream, anabranch, flows SW 0.8 mi. to Khotol River, $4.3 \mathrm{mi}$. SW of Fall Camps Lake, $32 \mathrm{mi}$. SE of Nulato, Koyukuk Low. ; $64^{\circ} 17^{\prime} \mathrm{N}, 158^{\circ} 25^{\prime} \mathrm{W}$; (map 97). Var. Takuzatolatlna.

Appears to be a transiation of an Indian name; reported in 1935 by Frederica de Laguna, BAE.

La Lakha: rock, see Laja, La.

Lamande Creek: stream, flows NW $1 \mathrm{mi}$. to Discovery Creek, $22 \mathrm{mi}$. NW of Solomon, Seward Penin. High.; $64^{\circ} 51^{\prime} \mathrm{N}, 164^{\circ} 45^{\prime} \mathrm{W}$; (map 95).

Prospectors' name reported on a map of Cape Nome gold fields by David Fox, Jr., dated 1901.

Lamb Creek: stream, heads in Canada, flows NW, across Alaska-Canada boundary, $5 \mathrm{mi}$. to Baultoff Creek, in Nutzotin Mts., $6 \mathrm{mi}$. NE of Braye Pass, Alaska Ra.; $62^{\circ} 05^{\prime} 28^{\prime \prime}$ N, $141^{\circ} 01^{\prime} 38^{\prime \prime}$ W; (map 84).

Local name reported in 1959 by USGS.

Lamb Island: island, $0.5 \mathrm{mi}$. across, off mouth of Afognak Bay, $3.5 \mathrm{mi}$. NE of Afognak, on $S$ coast of Afognak I.; $58^{\circ} 02^{\prime} 35^{\prime \prime} \mathrm{N}, 152^{\circ}$ $41^{\prime} 40^{\prime \prime} \mathrm{W}$; (map 43).

Local name reported in 1900 by Lt. Comdr. Moser, USN, commander of the USBF steamer Albatross.

Lambda Rock: rock, $0.1 \mathrm{mi}$. across, in Maurelle Is., $0.6 \mathrm{mi}$. S of Twin Is., Alex. Arch.; 55 $38^{\prime}$ $35^{\prime \prime} \mathrm{N}, 133^{\circ} 40^{\prime} 00^{\prime \prime} \mathrm{W}$; (map 4).

Named in 1925 by USC\&GS; derived "from the 11 th letter of the Greek alphabet."

Lame Greek: stream, flows SE $1.6 \mathrm{mi}$. to Lazy Creek, center of Kiska I., Aleutian Is.; $51^{\circ}$. $56^{\prime} 20^{\prime \prime} \mathrm{N}, 177^{\circ} 25^{\prime} 51^{\prime \prime} \mathrm{E}$; (map 14). Var. Goffee Creek.

An arbitrary name beginning with " $L$ " to correspond to "L" grid used by U.S. Army for tactical purposes during World War II; published on a 1953 AMS map. Variant published on a 1943 USAAF map.

Lame Hill: hill, 1,600 ft., SW end of Russian Ridge, in center of Kiska I., Aleutian Is.; $51^{\circ}$. 57'30' N, 177'22'13' E; (map 14). Var. Russian Ridge.

An arbitrary name beginning with " $L$ " to correspond to "L" grid used by U.S. Army for tactical purposes during World War II; published on a 1953 AMS map. Variant published on a 1943 USAAF map.

Lámna Lake : lake, see Iliamna Lake.

Lamont: locality, on S bank of Lamont Slough, $4.5 \mathrm{mi}$. SE of Kwiguk, Yukon-Kuskokwim Delta ; 62 $42^{\prime} 25^{\prime \prime} \mathrm{N}, 164^{\circ} 23^{\prime} 50^{\prime \prime} \mathrm{W}$; (map 77). Var. Eluktuk.

This is the fish camp of an Eskimo family named Lamont; reported in 1952 by USC\&GS

Lamont Slough: watercourse, in Yukon Delta, extends NW-SE $5.6 \mathrm{mi}$. between Sunshine B3y and Kwikluak Pass, $1.5 \mathrm{mi}$. S of Kwiguk Yukon-Kuskokwim Delta; 62 ${ }^{\circ} 44^{\prime}$ N, $164^{\circ} 30^{\prime}$ W; (map 77).

"Name derived from the name of the Eskimo family whose camp (Lamont) is situated at the mouth" of this slough; reported in 1952 by USC\&GS.
Lamp Hills: hills, 1,015 ft., center Kiska I., Aleutian Is.; $51^{\circ} 58^{\prime} 17^{\prime \prime} \mathrm{N}, 177^{\circ} 29^{\prime} 44^{\prime \prime} \mathrm{E}$; (map 14).

An arbitrary name beginning with " $L$ " to correspond to "L" grid used by the U.S. Army for tactical purposes during World War II; published on a 1943 Army map.

Lamplugh Glacier: glacier, in Glacier Bay National Monument, trends N $8 \mathrm{mi}$. to its 1961 terminus in Johns Hopkins Inlet, $1.4 \mathrm{mi}$. W of Ptarmigan Creek and $76 \mathrm{mi}$. NW of Hoo. nah, St. Elias Mts.; 58 $53^{\prime} 30^{\prime \prime} \mathrm{N}, 136^{\circ} 55^{\prime} 45^{\prime \prime}$ W; BGN 1923; (map 10).

Named by Lawrence Martin, USGS, about 1912 for George W. Lamplugh, 1859-1926, English geologist who visited Glacier Bay in 1884. Lamplugh joined the Geological Survey in 1901 and was assistant director of the Geological Survey of Great Britain, 1914-20.

Lanagan Creek: stream, in Bendeleben Mts., flows SW $3.5 \mathrm{mi}$. to Pargon River, $13 \mathrm{mi}$. E of Mount Bendeleben, Seward Penin. High.; $65^{\circ} 09^{\prime} \mathrm{N}, 163^{\circ} 39^{\prime} \mathrm{W}$; (map 110). Var. Dry Creek.

Prospectors' name reported in 1909 by Smith and Eakin (1911, pl. 1), USGS. This appears to be the stream shown as "Dry" on a map of Cape Nome gold fields by David Fox, Jr., dated 1901

Lana Lake: lake, $0.5 \mathrm{mi}$. long, $19 \mathrm{mi}$. E of Chitina and $31 \mathrm{mi}$. W of McCarthy, Copper River Basin; 61 ${ }^{\circ} 30^{\prime} \mathrm{N}, 143^{\circ} 52^{\prime} \mathrm{W}$; (map 67).

Local name obtained by USGS and published on maps since 1954 .

Lancashire Rocks: rocks, on W edge of Neptune Bay, on E shore of Kachemak Bay, $8 \mathrm{mi}$. SE of Homer, Chugach Mts.; $59^{\circ} 33^{\prime}$ N, $151^{\circ} 25^{\prime}$ W; (map 50).

Named by W. H. Dall, USC\&GS, in 1880 , for Sir Thomas Hesketh's yacht Lancashire Witch, which visited Cook Inlet that year.

I Lancaster Cove: cove, extends SE $0.5 \mathrm{mi}$., off Cholmondeley Sound, on SE coast of Prince of Wales I., Alex. Arch.; 55 $13^{\prime} 15^{\prime \prime} \mathrm{N}, 132^{\circ}$ $05^{\prime} 30^{\prime \prime}$ W; (map 4).

Local name published in 1925 Coast Pilot (p. 79).

Lancaster Creek: stream, flows SE $2 \mathrm{mi}$. to Yukon River, $20 \mathrm{mi}$. W of Tanana, KokrinesHodzana High.; $65^{\circ} 12^{\prime} \mathrm{N}, 152^{\circ} 46^{\prime} \mathrm{W}$; (map 106).

Prospectors' name reported in 1911 by $\mathrm{H}$. M. Eakin, USGS.

Lance Hill: mountain, 1,315 ft., center of Kiska I., Aleutian Is.; $51^{\circ} 58^{\prime} 14^{\prime \prime} \mathrm{N}, 177^{\circ} 29^{\prime} 20^{\prime \prime} \mathrm{E}$; (map 14).

An arbitrary name beginning with " $L$ " to correspond to "L" grid used by the U.S. Army for tactical purposes during World War II; published on a 1943 Army map.

Lance Point: point of land, on $\mathrm{SW}$ coast of Unalaska I., Aleutian Is.; $53^{\circ} 20^{\prime} 10^{\prime \prime} \mathrm{N}, 167^{\circ}$ 18'40" W; BGN 1939; (map 23). Var. Lake Point.

Named for triangulation station Lance which was established on this point by USC\& GS in 1936. This point was reported as Lake
Point by USBF in 1888 , "because early charts showed a lake in the vicinity."

Lance Point: point of land, on $\mathrm{W}$ shore of Lynn Canal, at $\mathrm{N}$ entrance to William Henry Bay, $42 \mathrm{mi}$. NW of Juneau, St. Elias Mts., $58^{\circ} 44^{\prime}$ $00^{\prime \prime} \mathrm{N}, 135^{\circ} 13^{\prime} 50^{\prime \prime} \mathrm{W}$; (map 11).

Name published in 1924 by USC\&GS on Chart 8302.

Lanchas, Puerto de las: cove, "on the east side of Yakutat Bay."

Name shown on a 1791 Spanish map, but not mentioned in Capt. Alessandr Malaspina's narrative; see Wagner (1937, p. 466).

Landing, The: landing, on Wilson Greek Slough, $1.2 \mathrm{mi}$. SE of Marshall, Nulato Hills, YukonKuskokwim Delta; $61^{\circ} 52^{\prime} \mathrm{N}, 162^{\circ} 03^{\prime} \mathrm{W}$; (map 74).

The riverboat landing for the Willow Creek Mine was at the end of a "cat" road about 5 miles downstream from here. The USC\&GS reported in 1951 that this place is now used and is referred to as "The Landing."

Landlocked Bay: bay, $2.2 \mathrm{mi}$. wide, on $\mathrm{N}$ shore of Port Fidalgo, $35 \mathrm{mi}$. NW of Cordova, Chugach Mts.; $60^{\circ} 48^{\prime} 40^{\prime \prime} \mathrm{N}, 146^{\circ} 35^{\prime} 00^{\prime \prime} \mathrm{W}$; (map 64).

Local descriptive name reported in 1898 by Schrader (1900a, p. 417, map 19), USGS.

Landlocked Creek: stream, flows NW $16 \mathrm{mi}$. to lower Meshik River, $17 \mathrm{mi}$. S of Port Heiden Airfield, Bristol Bay Low.; $56^{\circ} 43^{\prime} \mathrm{N}, 158^{\circ} 33^{\prime}$ W; (map 30).

Name reported in 1923 by R. H. Sargent, USGS; published in 1927 by USGS.

Landmark Gap: water gap, elev. 3,250 ft., $5.5 \mathrm{mi}$ long, in Amphitheater Mts., at Landmark Gap Lake, $19 \mathrm{mi}$. NW of Paxson, Alaska Ra.; $63^{\circ} 08^{\prime} \mathrm{N}, 146^{\circ} 05^{\prime} \mathrm{W}$; (map 86$)$.

Descriptive name given in 1898 by W. C. Mendenhall, USGS.

Landmark Gap Lake: lake, $4 \mathrm{mi}$. long, in Landmark Gap, in Amphitheater Mts., $19 \mathrm{mi}$.

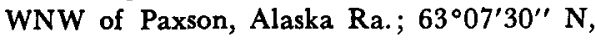
$146^{\circ} 05^{\prime} 00^{\prime \prime} \mathrm{W}$; (map 86).

Named in 1955 by Reuben Kachadoorian, USGS.

Landslide Creek: stream, flows NW $3.8 \mathrm{mi}$. to Oshetna River $31 \mathrm{mi}$. SW of its junc. with Susitna River, Talkeetna Mts.; $62^{\circ} 15^{\prime} 15^{\prime \prime} \mathrm{N}$, $147^{\circ} 52^{\prime} 10^{\prime \prime} \mathrm{W}$; BGN 1960; (map 82).

Named in 1956 by USGS "for a landslide on the east side of its valley."

Lane: locality, mi. 242 on The Alaska RR., 15 mi. N of Talkeetna, Talkeetna Mts.; $62^{\circ}$ $32^{\prime} 30^{\prime \prime} \mathrm{N}, 150^{\circ} 05^{\prime} 20^{\prime \prime} \mathrm{W}$; (map 81).

This place was listed as a flag stop in the 1922 Railroad Time Table.

Lane: city, see Anchorage.

Lane, Mount: mountain, in York Mts., about $30 \mathrm{mi}$. NW of Teller, Seward Penin. High.; (map 111).

Prospectors' name shown on the 1900 "Map of Nome Peninsula" by J. M. Davidson and B. D. Blakeslee. This feature cannot be precisely identified on current maps.

Lane Creek: stream, flows SW $11 \mathrm{mi}$. to Susitna River, 14 mi. N of Talkeetna, Talkeetna Mts.; $62^{\circ} 31^{\prime} 55^{\prime \prime} \mathrm{N}, 150^{\circ} 06^{\prime} 05^{\prime \prime} \mathrm{W}$; (map 81). 
Name reported on a 1915 railroad-location blueprint map.

Lane Creek: stream, flows NW $5 \mathrm{mi}$. to Placer Greek which flows to Goodhope River, $25 \mathrm{mi}$. NW of Imuruk Lake, Seward Penin. High.; $65^{\circ} 48^{\prime} \mathrm{N}, 164^{\circ} 00^{\prime} \mathrm{W}$; (map 110).

Prospectors' name reported on a map of Cape Nome gold fields by David Fox, Jr., dated 1901.

Lane Greek: stream, flows NW to Niukluk River, between Camp and Richter Creeks, about $6 \mathrm{mi}$. NW of Council and $30 \mathrm{mi}$. NE of Solomon, Seward Penin. High.; (map 95).

Prospectors' name reported on a prosspector's manuscript map dated 1902 . This stream cannot be precisely located on current maps. See Paterson Creek.

Lane Creek: stream, see Bennett Creek.

Lane Island: island, $800 \mathrm{ft}$. long, in Danger Passage between Felice Strait and Revillagigedo Channel, Alex. Arch.; $55^{\circ} 02^{\prime} 10^{\prime \prime} \mathrm{N}$, $131^{\circ} 13^{\prime} 00^{\prime \prime} \mathrm{W}$; (map 3).

Named in 1883 by Lt. Comdr. H. E. Nichols, USN.

Lane Ridge: ridge, $0.6 \mathrm{mi}$. long, between Mutt and Jeff Coves, center of Kiska I., Aleutian Is.; $51^{\circ} 56^{\prime} 15^{\prime \prime} \mathrm{N}, 177^{\circ} 29^{\prime} 06^{\prime \prime} \mathrm{E}$; (map 14).

An arbitrary name beginning with " $L$ " to correspond to the "L" grid used by the U.S. Army for tactical purposes during World War II ; published on a 1943 Army map.

Lane River: stream, on Seward Penin., flows NE $17 \mathrm{mi}$. to Nugnugaluktuk River, $44 \mathrm{mi}$. NW of Deering, Kotzebue-Kobuk Low.; $66^{\circ} 12^{\prime} \mathrm{N}$, $164^{\circ} 15^{\prime}$ W; (map 113). Var. Kugachuk River.

Prospectors' name reported in 1901 by T. G. Gerdine (in Collier, 1902, pl. 12), USGS.

Lanes Landing: locality, see Shelton.

Langara, Islas de: islands, "the easternmost of the Barren Islands including East and West Amatuli Islands."

Name appears on a 1779 Spanish map (Wagner, 1937, p. 466). Probably named for Juan de Lángara.

Langara, Islas de: islands, see Barren Islands.

Langdon Glacier: glacier, heads in Sargent Icefield, trends NW $4 \mathrm{mi}$. to its terminus, $2 \mathrm{mi}$. E of head of Kings Bay, $24 \mathrm{mi}$. S of Whittier, Chugach Mts.; $60^{\circ} 26^{\prime} 15^{\prime \prime} \mathrm{N}, 148^{\circ} 39^{\prime} 00^{\prime \prime} \mathrm{W}$; BGN 1911; (map 63).

Named in 1908 by U. S. Grant and D. F. Higgins, USGS; "probably named for Seth Langdon of Evanston, Illinois."

Lange: area, the $\mathrm{W}$ part of Mountain View, in Anchorage, Cook Inlet Low.; $61^{\circ} 13^{\prime} 40^{\prime \prime} \mathrm{N}$, $149^{\circ} 48^{\prime} 50^{\prime \prime} \mathrm{W}$; (map 69).

Local name reported in 1954 by the city engineer of Anchorage.

Lange Island: island, $1.6 \mathrm{mi}$. long, in Yukon River E of Clay I., $11 \mathrm{mi}$. E of Birches, Nowitna Low.; $65^{\circ} 07^{\prime} 45^{\prime \prime} \mathrm{N}, 153^{\circ} 11^{\prime} 30^{\prime \prime} \mathrm{W}$; (map 107).

Riverboat pilots' name shown on a 1940 "Navigation Chart of the Tanana-Yukon Rivers" published by the Department of the Interior.
I.angmuir, Mount: mountain, 8,648 ft., $\mathrm{N}$ of Second Branch Columbia Glacier $29 \mathrm{mi}$. NW of Valdez, Chugach Mts. ; $61^{\circ} 20^{\prime} 30^{\prime \prime}$ N, $147^{\circ}$ $00^{\prime} 45^{\prime \prime} \mathrm{W}$; (map 69).

Named for Irving Langmuir, 1881-1957, chemist; name published by Nielson (1963, p. 135).

Lanin, Cape: point of land, see Lapin, Cape.

Lankey Road House: locality, see Tatalina Roadhouse.

Lansberg Creek: stream, heads at Lake Gilbert, flows S to Morzhovoi Bay, at SW end of Alaska Penin., Bristol Bay Low.; $55^{\circ} 05^{\prime} \mathrm{N}$, $163^{\circ} 12^{\prime} \mathrm{W}$; (map 29).

Name reported by USG\&GS in 1926.

Lansing Bluff: bluff, on E coast of Long I., 5.5 mi. SE of Kodiak, Kodiak I. ; 57 $45^{\prime} 40^{\prime \prime}$ N, $152^{\circ} 16^{\prime} 05^{\prime \prime} \mathrm{W}$; (map 34 ).

Local name reported in 1949 by USGS.

Lansing Creek: stream, flows $\mathrm{E} 10 \mathrm{mi}$. to Granite Fork, $60 \mathrm{mi}$. $\mathrm{N}$ of Stevens Village, KokrinesHodzana High.; $66^{\circ} 51^{\prime} \mathrm{N}, 149^{\circ} 21^{\prime} \mathrm{W}$; (map 118).

Name reported in 1909 by A. G. Maddren (in Brooks and others, 1910, pl. 7), USGS.

Lantern Creek: stream, flowing $\mathrm{N} 1 \mathrm{mi}$. to Bluff Cove, $\mathbf{S}$ of Leo Hill, Kiska I., Aleutian Is.; $51^{\circ} 59^{\prime} 13^{\prime \prime} \mathrm{N}, 177^{\circ} 28^{\prime} 52^{\prime \prime} \mathrm{E}$; (map 14).

An arbitrary name beginning with " $L$ " to correspond to "L" grid used by the U.S. Army for tactical purposes during World War II; published on a 1943 Army map.

La Perouse, Mount: peak, 10,728 ft., in Glacier Bay National Monument, $12 \mathrm{mi}$. N of Icy Point, St. Elias Mts. ; $58^{\circ} 34^{\prime} \mathrm{N}, 137^{\circ} 05^{\prime} \mathrm{W}$; (map 10).

Named in 1874 by W. H. Dall, USC\&GS, for Jean François de Galaup de la Perouse. See La Perouse Glacier.

La Perouse Glacier: glacier, in Glacier Bay National Monument, heads on the $\mathrm{S}$ slope of Mount Crillon, trends S $15 \mathrm{mi}$, to the Gulf of Alaska $8 \mathrm{mi}$. NW of Icy Point, $71 \mathrm{mi}$. NW of Hoonah, St. Elias Mts.; $58^{\circ} 27^{\prime} \mathrm{N}, 137^{\circ} 17^{\prime} \mathrm{W}$; (map 10).

Named in 1874 by W. H. Dall, USC\&GS, for Jean François de Galaup de la Pérouse, 1741-1788, a French navigator who explored the coast in this area in 1786 . The name was published in the 1883 Coast Pilot (p. 201). La Perouse, a member of the French navy, was sent in 1782 to Canada to attack the British forts on Hudson Bay. In 1785 he was given command of an expedition of exploration by Louis XVI. With two ships, La Boussole and $L^{\prime}$ Astrolabe, he sailed in 1886 from the Sandwich Islands to the Alaska coast in the neighborhood of Mount St. Elias where he mapped the coast and studied the Indians. While returning to France, La Perouse, his two ships, and crew were lost. Parts of his ships were found in 1827 on Santa Cruz Island in the New Hebrides in the South Pacific.

Lapin, Cape: point of land, on $\mathrm{N}$ coast of Unimak I., Aleutian Is. ; $54^{\circ} 58^{\prime} 00^{\prime \prime} \mathrm{N}, 164^{\circ} 07^{\prime} 30^{\prime \prime}$ W; (map 24). Var. Gape Lanin.

Probably named for Capt. .Ivan Savich Lapin, a fur trader in this area in 1762 . Capt.
Tebenkov (1852, map 26), IRN, however, shows the name as "M[ys] Lanin."

Lapin, Cape: point of land, see Cave Point.

Lapin, Cape : point of land, see Mordvinof, Cape.

Lapin, Cape: point of land, see Oksenof Point.

Larch Bay: bay, $2 \mathrm{mi}$. across, $3 \mathrm{mi}$. NW of Cape Ommaney, on $\mathrm{S}$ coast of Baranof $\mathrm{I}$., Alex. Arch.; $56^{\circ} 12^{\prime} \mathrm{N}, 134^{\circ} 43^{\prime} \mathrm{W}$; (map 5). Var. Listvinichnaia Bay, Lisvinichnaya Bukhta, Lisvinitchny Bay.

This is an 1865 translation by the British Admiralty of the name "Lisvinichnaya Bukhta," given in 1850 by the Russian American Company.

Lard Hill: mountain, 1,600 ft., NE end of Russian Ridge, west-central Kiska I., Aleutian Is.; $51^{\circ} 57^{\prime} 40^{\prime \prime} \mathrm{N}, 177^{\circ} 22^{\prime} 30^{\prime \prime} \mathrm{E}$; (map 14).

An arbitrary name beginning with " $L$ " to correspond to "L" grid used by the U.S. Army for tactical purposes during World War II; published on a 1953 AMS map.

Lare Glacier: glacier, heads $1.8 \mathrm{mi}$. SE of Mount McPherson, trends SW $1.5 \mathrm{mi}$. to its 1950 terminus at head of Little River, $81 \mathrm{mi}$. NW of Yakutat, St. Elias Mts. ; $60^{\circ} 02^{\prime} 10^{\prime \prime} \mathrm{N}, 141^{\circ}$ $48^{\prime} 45^{\prime \prime}$ W; (map 65).

Name reported in 1913 by A. G. Maddren, USGS.

Larga, Isla: island, see Naked Island.

Large, Ile du: island, see Navy Island.

Large Bay: bay, see Starrigavan Bay.

Large Island: island, see Bolshoi Island.

Large Rock: rock, 80 yds. across, $0.4 \mathrm{mi}$. S of Ringgold I., in S part of Bay of Is., Aleutian Is. ; $51^{\circ} 47^{\prime} 37^{\prime \prime} \mathrm{N}, 176^{\circ} 48^{\prime} 15^{\prime \prime} \mathrm{W}$; (map 17).

Descriptive name published by USC\&GS in 1960 on Chart 9120.

Largo Creek: stream, flows SW $9 \mathrm{mi}$. to Berry Creek which flows to Noxapaga River, $19 \mathrm{mi}$. NW of Imuruk Lake, Seward Penin. High.; $65^{\circ} 40^{\prime} \mathrm{N}, 163^{\circ} 56^{\prime} \mathrm{W}$; BGN 1952; (map 110).

Reported in 1950 by D. M. Hopkins, USGS; named for the ridge to the south.

Largo Ridge: ridge, elev. 1,157 ft., extends E-W 10 mi., between Largo Creek and Noxapaga River, $12 \mathrm{mi}$. NW of Imuruk Lake, Seward Penin. High.; $65^{\circ} 40^{\prime} \mathrm{N}, 163^{\circ} 45^{\prime} \mathrm{W} ; B G N$ 1952; (map 110).

Reported in 1950 by D. M. Hopkins, USGS ; so named for the "'musical term 'Largo,' * * * meaning 'broad and stately.' Both of these adjectives are appropriate when applied to Largo Ridge."

Lark Hill: mountain, 1,200 ft., central Kiska I., Aleutian Is.; $51^{\circ} 57^{\prime} 55^{\prime \prime} \mathrm{N}, 177^{\circ} 24^{\prime} 40^{\prime \prime} \mathrm{E}$; (map 14).

An arbitrary name beginning with " $L$ " to correspond to "L" grid used by the U.S. Army for tactical purposes during World War II; published on a 1953 AMS map.

Lark Island: island, in Yukon River, $33 \mathrm{mi}$. NE of Nulato, Koyukuk Low.; $64^{\circ} 48^{\prime} \mathrm{N}, 157^{\circ} 00^{\prime}$ W; (map 97).

Local name reported in 1954 by USGS.

Lark Lake: lake, $1.1 \mathrm{mi}$. long; on Kenai Penin., $6 \mathrm{mi}$. SE of Moose Point and $36 \mathrm{mi}$. NE of Kenai, Cook Inlet Low.; $60^{\circ} 54^{\prime} 30^{\prime \prime} \mathrm{N}$, $150^{\circ} 31^{\prime} 00^{\prime \prime} \mathrm{W}$; (map 62). 
Named about 1963 by officials of Kenai National Moose Range, for the Pallid Horned Lark (Eremophila alpestris articola), the only lark found in Alaska.

Larratita: island, see Larzatita Island.

Larry Hill: mountain, $1,300 \mathrm{ft}$., central Kiska I., Aleutian Is.; $51^{\circ} 57^{\prime} 40^{\prime \prime} \mathrm{N}, 177^{\circ} 23^{\prime} 55^{\prime \prime} \mathrm{E}$; (map 14). Var. Indian Hill.

An arbitrary name beginning with " $L$ " to correspond to "L" grid used by U.S. Army for tactical purposes during World War II ; published on a 1953 AMS map. Variant published on a 1943 USAAF map.

Lars Island: island, $0.4 \mathrm{mi}$. across, at mouth of Berg Bay, Glacier Bay National Monument, $0.3 \mathrm{mi}$. SE of Netland I. and $38 \mathrm{mi}$. NW of Hoonah, St. Elias Mts.; $58^{\circ} 31^{\prime} 30^{\prime \prime} \mathrm{N}, 136^{\circ}$ $07^{\prime} 45^{\prime \prime}$ W ; BGN 1942; (map 10).

Named by USG\&GS in 1939 for Lars Netland, 1869-1934, member of the U.S. section of the IBC from 1904-10. Netland aided in the reconnaissance survey of Berg Bay in 1907. $\mathrm{He}$ was born in Norway and came to the United States in 1889. After going to the Klondike in 1898, he did surveying work in Dawson. From 1900 to 1903 he was chief of a Canadian exploration party in the Yukon Territory.

Larsen Bay: village, pop. 72, near mouth of Larsen Bay, on W shore of Uyak Bay, on NW coast of Kodiak I. ; $57^{\circ} 32^{\prime} 20^{\prime \prime} \mathrm{N}, 153^{\circ} 58^{\prime} 45^{\prime \prime}$ W; (map 34). Var. Larsons Bay, Uyak.

Name derived from Larsen Bay and reported in 1890 to be a native settlement "containing less than 20 people" in the 11 th Census in 1890 (1893, p. 79). The native name was "Uyak."

Larsen Bay: bay, $1.5 \mathrm{mi}$. across, on $\mathrm{E}$ coast of Nagai I., in Shumagin Is., Aleutian Ra.; $55^{\circ}$ $03^{\prime} 30^{\prime \prime} \mathrm{N}, 159^{\circ} 59^{\prime} 00^{\prime \prime} \mathrm{W}$; (map 27). Var. Pete Larssen.

Named for Peter Larson, an Unga Island furrier, hunter, and guide according to Polk's Gazetteer (1915-16, p. 543), and published on USC\&GS Chart 8700 (1917).

Larsen Bay: $b a y$, extends W 6 mi. off Uyak Bay, on NW coast of Kodiak I.; $57^{\circ} 32^{\prime} 30^{\prime \prime} \mathrm{N}$, $153^{\circ} 58^{\prime} 40^{\prime \prime} \mathrm{W}$; (map 34). Var. Larsen Harbor, Larsens Bay, Larson's Bay.

Local name reported in 1890 in the 11 th Gensus in 1890 (1893, p. 79).

Larsen Creek: stream, in Rampart Mts., flows $\mathrm{E}$ and $\mathrm{S} 7 \mathrm{mi}$. to Bear Greek $2 \mathrm{mi}$. $\mathrm{N}$ of that stream's junc. with Yukon River, $34 \mathrm{mi}$. NE of Tanana, Kokrines-Hodzana High.; 65 ${ }^{\circ} 33^{\prime}$ $30^{\prime \prime} \mathrm{N}, 151^{\circ} 01^{\prime} 00^{\prime \prime} \mathrm{W}$; (map 106). Var. Bonanza Creek.

Named in 1956 by Orth, for John Larsen, prospector, who once lived near the mouth of Bear Creek.

Larsen Harbor: bay, see Larsen Bay.

Larsen Island: island, $1.7 \mathrm{mi}$. long in Anton Larsen Bay, 11 mi. NW of Kodiak, Kodıak I.; $57^{\circ} 52^{\prime} 30^{\prime \prime} \mathrm{N}, 152^{\circ} 39^{\prime} 00^{\prime \prime} \mathrm{W}$; (map 34).

Name derived from Anton Larsen Bay; published in 1952 by USGS.

Larsen Rocks: rocks, see Latax Rocks.
Larsens Bay: bay, see Larsen Bay.

Larson Lake: lake, $3 \mathrm{mi}$. long, $6.5 \mathrm{mi}$. $\mathrm{E}$ of Talkeetna, Talkeetna Mts.; $62^{\circ} 20^{\prime} 15^{\prime \prime} \mathrm{N}$, $149^{\circ} 53^{\prime} 10^{\prime \prime} \mathrm{W}$; BGN 1963; (map 82). Var. Talkeetna Lake.

Local name reported in 1962 by USGS.

Larsons Bay: village, see Larsen Bay.

Larzatita Island: island, 1,400 ft. long, in San Christoval Channel, between Prince of Wales and San Fernando Is., Alex. Arch.; 55 $34^{\prime}$ $50^{\prime \prime} \mathrm{N}, 133^{\circ} 19^{\prime} 40^{\prime \prime} \mathrm{W}$; BGN 1908; (map 4). Var. Isla Larzatita, La Ratita, Larratita.

Spanish name given in 1775-79 by Don Juan de la Bodega y Quadra and Francisco Antonio Maurelle as "La Ratita," meaning "a short time(?)"; the name Larzatita is an alteration of Maurelle and Qudara's name (Wagner, 1937, p. 394).

Larzatita Island Reef: reef, in San Christoval Channel, N of Larzatita I., Alex. Arch.; $55^{\circ}$ $35^{\prime} 05^{\prime \prime} \mathrm{N}, 133^{\circ} 14^{\prime} 40^{\prime \prime} \mathrm{W}$; (map 4).

Named by USC\&GS and published in 1932 Coast Pilot (p. 216)

LaSalle Creek: stream, flows W $7.5 \mathrm{mi}$. from Emma Dome, $\mathrm{S}$ of Bluecloud Mtn., to Glacier River, $4 \mathrm{mi}$. S of Delay Pass, $15 \mathrm{mi}$. W of Wiseman, Brooks Ra.; 67 $23^{\prime}$ N, $150^{\circ} 39^{\prime}$ W; (map 124).

Local name obtained in 1956 by USGS topographers.

Lascano, Archipielago de: islands, see Lascano, Islas de.

Lascano, Islas de: islands, in Unimak Pass off the north end of Unalaska Island. Var. Archipielago de Lascano.

Name appears on the "Galiano map of 1802" (Wagner, 1937, p. 467).

Lash Bay: cove, $0.7 \mathrm{mi}$. across, on $\mathrm{S}$ coast of Tanaga I., Aleutian Is.; $51^{\circ} 40^{\prime} 00^{\prime \prime} \mathrm{N}, 178^{\circ}$ 02'30" W; (map 16).

Name published in the 1946 supplement to the 1944 Aleutian Coast Pilot (U.S. Coast and Geodetic Survey, 1946, p. 118).

Lash Hills: mountains, 1,400 ft., center of Kiska I., Aleutian Is.; $51^{\circ} 57^{\prime} 43^{\prime \prime} \mathrm{N}, 17^{\circ} 28^{\prime} 50^{\prime \prime} \mathrm{E}$; (map 14).

An arbitrary name beginning with " $L$ " to correspond to "L" grid used by the U.S. Army for tactical purposes during World War II; published on a 1943 Army map.

Laska Cove: cove, $0.5 \mathrm{mi}$. across, on $\mathrm{W}$ coast of Kagalaska I., Aleutian Is.; $51^{\circ} 49^{\prime} 45^{\prime \prime} \mathrm{N}$, $176^{\circ} 24^{\prime} 40^{\prime \prime} \mathrm{W}$; BGN 1936; (map 17).

A clipped name derived from Kagalaska Island, and given by members of the U.S. Navy Aleutian Island Survey Expedition in 1934.

La Spray Creek: stream, flows SE $3 \mathrm{mi}$, joins Myrtle Creek to form Flambeau River, $18 \mathrm{mi}$. NE of Nome, Seward Penin. High.; $64^{\circ} 44^{\prime}$ N, $165^{\circ} 08^{\prime} \mathrm{W}$; (map 94). Var. Babylon Creek.

Prospectors' name reported in 1904 by $T$. G. Gerdine, USGS. Shown as "Babylon Cr." on the 1902 "Map of the Nome and Snake River Country" by J. M. Davidson.

Lass Lake: lake, $150 \mathrm{yd}$. across, $0.7 \mathrm{mi}$. $\mathrm{S}$ of Beach Cove, on W central Kiska I., Aleutian Is.; $51^{\circ} 59^{\prime} 05^{\prime \prime} \mathrm{N}, 177^{\circ} 29^{\prime} 35^{\prime \prime} \mathrm{E}$; (map 14).
An arbitrary name beginning with " $L$ " to correspond to "L" grid used by the U.S. Army for tactical purposes during World War II; published on a 1943 Army map.

Lasso Hill: hill, $700 \mathrm{ft}$., on E side of Quisling Cove, W coast of Kiska I., Aleutian Is.; $51^{\circ}$ $58^{\prime} 40^{\prime \prime} \mathrm{N}, 177^{\circ} 23^{\prime} 30^{\prime \prime} \mathrm{E}$; (map 14).

An arbitrary name beginning with " $L$ " to correspond to "L" grid used by the U.S. Army for tactical purposes during World War II; published on a 1953 AMS map.

Last Chance: locality, on right bank of First Chance Creek, 5 mi. SE of Kiwalik Mtn. and $33 \mathrm{mi}$. SE of Imuruk Lake, Seward Penin. High.; $65^{\circ} 27^{\prime} \mathrm{N}, 162^{\circ} 02^{\prime} \mathrm{W}$; (map 110). Var. First Chance Cabin.

Site of a mining camp; reported in 1951 by USGS. Shown as "First Chance Cabin" on the 1908 "Map of Seward Peninsula" by Arthur Gibson.

Last Chance Basin: valley, $0.2 \mathrm{mi}$. SW of The Horn and $0.5 \mathrm{mi}$. E of Juneau, Coast Mts.; $58^{\circ} 18^{\prime} 30^{\prime \prime} \mathrm{N}, 134^{\circ} 23^{\prime} 30^{\prime \prime} \mathrm{W}$; (map 11). Var. Lost Chance Basin.

Named in 1881 by William Stewart, Squire Howe, and Oscar Cooper when they located here a group of placer claims called the "Last Chance group" (DeArmond, 1957, p. 29).

Last Chance Creek: stream, flows E $0.6 \mathrm{mi}$. to Salmon River, $26 \mathrm{mi}$. NE of Cape Newenham, Kilbuck-Kuskokwim Mts. ; 58 $56^{\prime} 15^{\prime \prime} \mathrm{N}, 161^{\circ}$ $42^{\prime} 30^{\prime \prime} \mathrm{W}$; (map 39).

Probably a prospectors' name obtained in 1948 or 1949 from John Hill, of the Goodnews Mining Co., by USGS. The name was published in 1950

Last Chance Creek: stream, heads on W slope of Red Mtn., flows $1.5 \mathrm{mi}$. W to Kuskokwim Bay, Kilbuck-Kuskokwim Mts.; $58^{\circ} 58^{\prime} \mathrm{N}$, $161^{\circ} 44^{\prime} \mathrm{W}$; BGN 1938; (map 39 ).

Local name published by Mertie (1940, pl. 2), USGS.

Last Chance Creek: stream, heads $\mathrm{N}$ of Crater Mtn., flows NE $7 \mathrm{mi}$. to Ganes Creek, $33 \mathrm{mi}$. SW of McGrath, Kilbuck-Kuskokwim Mts.; $62^{\circ} 53^{\prime} 30^{\prime \prime} \mathrm{N}, 156^{\circ} 39^{\prime} 40^{\prime \prime} \mathrm{W}$; BGN 1936; (map 79). Var. Last Chance Gulch, Spalding Creek.

Prospectors' name reported in 1908 by A. G. Maddren, USGS.

Last Chance Creek: stream, in Kantishna Hills, flows NW $2.7 \mathrm{mi}$. to Caribou Creek, $8 \mathrm{mi}$. NNE of Wonder Lake, Alaska Ra.; 63 ${ }^{\circ} 6^{\prime}$ 25 $^{\prime \prime}$ $\mathrm{N}, 150^{\circ} 48^{\prime} 35^{\prime \prime} \mathrm{W}$; (map 88).

Name shown on a 1916 fieldsheet by C. E. Giffin, USGS.

Last Chance Creek: stream, flows W $9.5 \mathrm{mi}$. to Wapoo Creek $6.2 \mathrm{mi}$. NE of its junc. with Innoko River, $48 \mathrm{mi}$. NW of Ophir and 74 mi. NW of McGrath, Innoko Low. ; 63 ${ }^{\circ} 43^{\prime} 20^{\prime \prime}$ $\mathrm{N}, 157^{\circ} 18^{\prime} 30^{\prime \prime} \mathrm{W}$; (map 90).

Local name reported in 1964 by Arthur Gervais, USGS.

Last Chance Creek: stream, flows NW $8 \mathrm{mi}$. to Moose Creek, $25 \mathrm{mi}$. NE of Healy, Alaska Ra. ; 6359'30' N, 148 $10^{\circ} 50^{\prime \prime} \mathrm{W}$; (map 87). 
Local name reported in 1906 by $L$. M. Prindle (in Brooks and others, 1907, pl. 4), USGS.

Last Chance Creek: stream, flows NE $3 \mathrm{mi}$. to Tibbs Creek $4.6 \mathrm{mi}$. $\mathrm{S}$ of that stream's junc. with Goodpaster River and $49 \mathrm{mi}$. NE of Big Delta, Yukon-Tanana High.; $64^{\circ} 25^{\prime} \mathrm{N}$, $144^{\circ} 18^{\prime} \mathrm{W}$; (map 101)

Local name reported in 1958 by USGS.

Last Chance Creek: stream, flows E $3.5 \mathrm{mi}$. to North Fork Snake River, $14 \mathrm{mi}$. NW of Nome, Seward Penin. High.; $64^{\circ} 43^{\prime} \mathrm{N}, 165^{\circ} 27^{\prime} \mathrm{W}$; (map 94).

Prospectors' name reported in 1900 by E. C. Barnard (in Brooks, 1901, pl. 17), USGS.

Last Chance Creek: stream, heads in Canada, flows W $6 \mathrm{mi}$. to Yukon River, $6 \mathrm{mi}$. NE of Eagle, Porcupine Plat.; $64^{\circ} 51^{\prime} 20^{\prime \prime} \mathrm{N}, 141^{\circ}$ 05'00" W; BGN 1954; (map 102). Var. Chance Creek, Last-Chance Creek, Lastchance Greek.

Prospectors' name obtained in 1898 by E. C. Barnard, USGS.

Last Chance Creek: stream, flows NE $1 \mathrm{mi}$. to American Creek near its head, in Niukluk River basin, $23 \mathrm{mi}$. N of Solomon, Seward Penin. High.; 64 $53^{\circ} 30^{\prime \prime}$ N, $164^{\circ} 32^{\prime} 50^{\prime \prime}$ W; (map 95).

Prospectors' name reported in 1908 by P. S. Smith (in Brooks and others, 1909, pl. 10), USGS.

Last Chance Creek: stream, flows SW $9 \mathrm{mi}$. to Bering Sea, $44 \mathrm{mi}$. NW of Nome, Seward Penin. High.; $64^{\circ} 56^{\prime} \mathrm{N}, 166^{\circ} 30^{\prime} \mathrm{W}$; (map 94).

Prospectors' name reported in 1900 by E. C. Barnard (in Brooks, 1901, pl. 17), USGS.

Last Chance Creek: stream, flows $\mathrm{N} 1 \mathrm{mi}$. to Seventymile River, $34 \mathrm{mi}$. NW of Eagle, Yukon-Tanana High.; $64^{\circ} 59^{\prime} \mathrm{N}, 142^{\circ} 14^{\prime} \mathrm{W}$; (map 102).

Prospectors' name shown on a 1902 manuscript map by E. J. Chamberlain, U.S. Deputy Surveyor.

Last Chance Creek: stream, flows NE $3 \mathrm{mi}$. to Fish Creek, $16 \mathrm{mi}$. NE of Fairbanks, YukonTanana High.; $65^{\circ} 00^{\prime} 30^{\prime \prime} \mathrm{N}, 147^{\circ} 12^{\prime} 00^{\prime \prime} \mathrm{W}$; (map 105).

So named by prospectors; published in 1908 by USGS.

Last Chance Creek: stream, flows NW $2 \mathrm{mi}$, joins Louis Creek to form Little Eldorado Creek, $17 \mathrm{mi}$. NE of Fairbanks, YukonTanana High.; $65^{\circ} 03^{\prime} 45^{\prime \prime} \mathrm{N}, 147^{\circ} 32^{\prime} 00^{\prime \prime} \mathrm{W}$; (map 105). Var. Big Eldorado Creek.

Named by prospectors; published in 1908 by USGS.

Last Chance Creek: stream, flows SE $1.2 \mathrm{mi}$. to Turner Creek which flows to Noxapaga River, $35 \mathrm{mi}$. W of Imuruk Lake, Seward Penin. High.; $65^{\circ} 33^{\prime} \mathrm{N}, 164^{\circ} 29^{\prime} \mathrm{W}$; (map 110).

Prospectors' name reported in 1901 by T. G. Gerdine (in Collier, 1902, pl. 12), USGS.

Last Chance Creek: stream, flows ENE $1.5 \mathrm{mi}$. to NW end of Big Lake, $1 \mathrm{mi}$. $\mathrm{N}$ of village of Big Lake and $25 \mathrm{mi}$. W of Chandalar, Brooks Ra.; $67^{\circ} 31^{\prime} 00^{\prime \prime} \mathrm{N}, 1^{\circ} 49^{\circ} 27^{\prime} 30^{\prime \prime} \mathrm{W}$; (map 123).
Local name reported in 1956 by T. $E$. Taylor, USGS.

Last Chance Creek: stream, flows SW to Angeles Creek which flows to Garfield Creek, about $5 \mathrm{mi}$. SE of Baldy Mtn. and $37 \mathrm{mi}$. SW of Imuruk Lake, Seward Penin. High.; (map 110).

Prospectors' name shown on a map of Cape Nome gold fields by David Fox, Jr., dated 1901. This stream cannot be precisely located on current maps.

Last Chance Creek: ravine, see Last Chance Gulch.

Last Chance Creek: stream, see North Fork Snake River.

Last Chance Gulch: ravine, trends SE $3.2 \mathrm{mi}$. to Long Creek, $2 \mathrm{mi}$. NW of Long and 21 mi. S of Ruby, Kilbuck-Kuskokwim Mts.; $64^{\circ} 26^{\prime} 45^{\prime \prime} \mathrm{N}, 155^{\circ} 31^{\prime} 45^{\prime \prime} \mathrm{W}$; (map 98). Var. Last Chance Creek.

Prospectors' name reported in 1913 by Eakin (1914, pl. 3), USGS.

Last Chance Gulch: stream, see Last Chance Creek.

Last Creek: stream, heads on E slope of Sadlerochit Mts., flows E $3 \mathrm{mi}$. to Sadlerochit River, $23 \mathrm{mi}$. N of Mount Michelson, Brooks Ra.; $69^{\circ} 38^{\prime} \mathrm{N}, 144^{\circ} 24^{\prime} \mathrm{W}$; BGN 1961; (map 139).

So named by USGS because the final fieldwork of the 1948 season in the Sadlerochit Mts. was done on this stream.

Last Lake: lake, see Ambresvajun Lake.

Last Point: point of land, at mouth of Back Bay, in Afognak Bay, $5 \mathrm{mi} . \mathbf{N}$ of Afognak, on $\mathbf{S}$ coast of Afognak I., N of Kodiak I.; 58 04'$35^{\prime \prime} \mathrm{N}, 152^{\circ} 46^{\prime} 05^{\prime \prime} \mathrm{W}$; (map 43). Var. Krainie Cape.

Translation of the name "M[ys] Krayniy," given by Sub-Lt. Mikhail Murashev, IRN, in 1839 or 1840 , and published by the Russian Hydrog. Dept. in 1849 on Chart 1425

Last Slough: stream, see Jacks Slough.

Last Tetlin Hill: hill, 2,360 ft., $\mathrm{S}$ of Tetlin Lake, $23 \mathrm{mi}$. S of Tok, Alaska Ra.; $63^{\circ} 01^{\prime} \mathrm{N}, 142^{\circ}$ $40^{\prime} \mathrm{W}$; (map 85).

Local name reported in 1963 by USGS. Named for Last Tetlin Village.

Last Tetlin Village: village, pop. 19, on $\mathrm{N}$ bank of Tetlin River, $3.3 \mathrm{mi}$. SE of Tetlin Lake, 23 mi. SE of Tok, Alaska Ra.; $63^{\circ} 02^{\prime} \mathrm{N}, 142^{\circ} 37^{\prime}$ W; (map 85)

Local name reported in 1963 by USGS.

Last Timber Cape: point of land, see Last Timber Point.

Last Timber Point: point of land, on $\mathrm{S}$ coast of Raspberry I., N of Kodiak I.; $57^{\circ} 58^{\prime} 50^{\prime \prime} \mathrm{N}$, $152^{\circ} 58^{\prime} 55^{\prime \prime} \mathrm{W}$; (map 34). Var. Last Timber Cape, Mys Poslydnyago Lysu, Posliednaho Liesu.

Translation of the descriptive name " $\mathrm{M}$ [ys] Poslydnyago Lysu" given in 1839 or 1840 by Sub-Lt. Mikhail Murashev and published in 1849 on Russian Hydrog. Dept. Chart 1425. Lastex Hill: hill, $600 \mathrm{ft}$., $\mathrm{S}$ of Bluff Cove, Kiska I., Aleutian Is.; $51^{\circ} 58^{\prime} 54^{\prime \prime} \mathrm{N}, 177^{\circ} 28^{\prime} 25^{\prime \prime} \mathrm{E}$; (map 14).

An arbitrary name beginning with " $L$ " to correspond to "L" grid used by the U.S. Army for tactical purposes during World War II; published on a 1943 Army map.

Lastova Bay: bight, see Bedard Cove.

Latax Rocks: rocks, $3 \mathrm{mi}$. long, $5 \mathrm{mi}$. N of Shuyak I. and $56 \mathrm{mi}$. N of Kodiak I.; $58^{\circ} 41^{\prime} \mathrm{N}, 152^{\circ}$ $30^{\prime}$ W; BGN 1921; (map 43). Var. Bobrovie Islands, Larsen Rocks, Sea Otter Islets, Sea-Otter Rocks.

Name given by USC\&GS in 1910 in an effore to stem the increasing duplication of "Bobrovyye," published for this feature by the Russian American Company in 1849, and "Sea Otter," the translation of Bobrovyye, applied to these rocks by Baker (1906, p. 558). In 1910 "*** A suggestion was made [to USC\&GS] * * that the Indian[?] name for Sea Otter is Latax ***." The word may possibly be from the Aleut "cngatuq" meaning "hairy sea otter" according to $R$. $H$. Geoghegan.

Latch Hill: hill, $350 \mathrm{ft}$, near S coast of Quisling Cove, on NW shore of Kiska I., Aleutian Is.; $51^{\circ} 58^{\prime} 30^{\prime \prime} \mathrm{N}, 177^{\circ} 22^{\prime} 45^{\prime \prime} \mathrm{E}$; (map 14).

An arbitrary name beginning with " $L$ " to correspond to "L" grid used by the U.S. Army for tactical purposes during World War II; published on a 1953 AMS map.

Late Point: point of land, the $\mathrm{S}$ tip of Windfall I., in Seymour Canal, $29 \mathrm{mi}$. NE of Angoon, on $\mathrm{E}$ coast of Admiralty I., Alex. Arch.; $57^{\circ}$ -

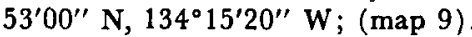

Named in 1889 by Lt. Comdr. H. B. Mansfield, USN, and published by USC\&GS on Chart 8228.

Lathrop, Mount: mountain peak, 6,190 ft., 1.4 mi. E of Usibelli Peak and $17 \mathrm{mi}$. NE of Healy, Alaska Ra.; $63^{\circ} 54^{\prime} 18^{\prime \prime} \mathrm{N}, 148^{\circ} 25^{\prime} 40^{\prime \prime} \mathrm{W}$; BGN 1965; (map 87).

Named in 1964 by USGS for Austin E. Lathrop, 1865-1950, coal-mining operator and businessman in the Healy area.

Latin Hill: hill, $900 \mathrm{ft}$., on Persian Ridge, westcentral Kiska I., Aleutian Is.; $51^{\circ} 58^{\prime} 20^{\prime \prime} \mathrm{N}$, $177^{\circ} 23^{\prime} 30^{\prime \prime} \mathrm{E}$; (map 14)

An arbitrary name beginning with " $L$ " to correspond to "L" grid used by the U.S. Army for tactical purposes during World War II; published on a 1953 AMS map.

Latouche: village, on NW coast of Latouche I., $18 \mathrm{mi}$. SE of Chenega, Chugach Mts.; $60^{\circ}$ $03^{\prime} 05^{\prime \prime} \mathrm{N}, 147^{\circ} 54^{\prime} \mathrm{W} ; B G N$ 1919; (map 63). Var. Barracks, Beatson, Beatsons Wharf

A mining village and landing on Latouche Island. A post office was established here in 1905, but was discontinued in 1955 (Ricks, 1965 , p. 39). Recent maps indicate a settlement of about 20 buildings at the site.

Latouche Glacier: glacier, heads $3 \mathrm{mi}$. SE of Point Latouche, trends N $0.9 \mathrm{mi}$. to head of Indian Camp Creek, $23 \mathrm{mi}$. NE of Yakutat, St. Elias Mts.; $59^{\circ} 52^{\prime} 30^{\prime \prime} \mathrm{N}, 1^{\circ} 9^{\circ} 35^{\prime} 40^{\prime \prime} \mathrm{W}$; $(\operatorname{map} 46)$.

Named by Tarr (1906, map 145), USGS, probably for Latouche Point.

Latouche Island: island, $13 \mathrm{mi}$. long, between Montague Strait and Latouche Passage, 55 mi. ESE of Seward, Chugach Mts. ; $60^{\circ} 00^{\prime} \mathrm{N}$, 147 $55^{\prime}$ W; BGN 1910; (map 63). Var. Foot 
Island, Isla San Antonio, Khlikakhlik Island, Ostrov Khlikakhlik.

Named in 1794 by Capt. George Vancouver, RN, probably "after the famous naval commander LaTouche-Tréville, of France" (Wagner, 1937, p. 394). It was called "Foot Island" in 1787 by Capt. Nathaniel Portlock because of its shape. Its Eskimo name was reported by Martin Sauer in 1802 as "Ostrov Khlikakhlik," i.e., "Khlikakhlik Island." The Eskimo name probably means "island."

Latouche Mountain: mountain, see Latouche Peak.

Latouche Passage: water passage, extends $16 \mathrm{mi}$ SW from Knight Island Passage to Gulf of Alaska, on $W$ side of Latouche I., Chugach Mts. ; $60^{\circ} 00^{\prime} \mathrm{N}, 148^{\circ} 00^{\prime} \mathrm{W}$; BGN 1910; (map 63).

Local name published in 1907 by USC\&GS; derived from nearby Latouche Island.

Latouche Peak: mountain, 2,200 ft., on Latouche I., $7 \mathrm{mi}$. NE of Danger I., $55 \mathrm{mi}$. SE of Seward, Chugach Mts.; 59 $59^{\prime} \mathrm{N}, 1^{\circ} 7^{\circ} 55^{\prime} \mathrm{W}$; (map 49). Var. Latouche Mountain.

Named in 1928 by USC\&GS "after the island."

Latouche Point: point of land, E point between Disenchantment and Yakutat Bays, $25 \mathrm{mi}$. N of Yakutat, St. Elias Mts.; 59 $54^{\prime} 10^{\prime \prime}$ N, $139^{\circ}$ 37'30" W; (map 46). Var. Punta de la Esperanza.

Named in 1794 by Lt. Peter Puget (in Vancouver, 1798 , v. 3, p. 224), RN, undoubtedly for Adm. La'Touche-Tréville, French naval commander (Wagner, 1937, p. 394) during the French Revolution and later under Napoleon Bonaparte. In 1791, Capt. Malaspina (Galiano, 1802, map 9) named it "Punta de la Esperanza," meaning "point of hope," alluding to his hope of finding the Northwest Passage at the end of Yakutat Bay.

Lauder, Point: point of land, $S$ point of entrance to Whale Bay, on SW coast of Baranof I., Alex. Arch.; $56^{\circ} 32^{\prime} 25^{\prime \prime} \mathrm{N}, 1^{\circ} 5^{\circ} 03^{\prime} 30^{\prime \prime} \mathrm{W}$; (map 5). Var. South Point.

Named about June 23, 1787, by Capt. George Dixon, for William Lauder, the surgeon of the vessel Queen Charlotte.

Lauf Islands: islands, $0.4 \mathrm{mi}$. across, at head of Rodman Bay, on N coast of Baranof I., $9 \mathrm{mi}$. NW of Todd, Alex. Arch.; $57^{\circ} 27^{\prime} 15^{\prime \prime} \mathrm{N}, 135^{\circ}$ 23'15' W; (map 9).

Named in 1895 by Lt. Comdr. E. K. Moore, USN, and published by USC\&GS on Chart 8283.

Laughton Glacier: glacier, trends N $2.2 \mathrm{mi}$. to its terminus, $0.2 \mathrm{mi}$. S of Skagway River, 1.6 $\mathrm{mi}$. SE of Glacier and $9 \mathrm{mi}$. NE of Skagway, Coast Mts.; $59^{\circ} 32^{\prime} 10^{\prime \prime} \mathrm{N}, 1^{\circ} 05^{\prime} 30^{\prime \prime} \mathrm{W}$; (map 45).

Local name published in 1951 by USGS.

Launch Cove: cove, $0.2 \mathrm{mi}$. across, in Peril Strait, $1 \mathrm{mi}$. N of Fish Bay, on NW coast of Baranof I., Alex. Arch.; $57^{\circ} 24^{\prime} \mathrm{N}, 135^{\circ} 37^{\prime} \mathrm{W}$; (map 9)

Named in 1884 by Comdr. J. B. Coghlan, USN; published by USC\&GS in 1891 Goast Pilot (p. 182).
Launch Passage: water passage, $1 \mathrm{mi}$. long, between Anguilla and Esquibel Is., in Maurelle Is., Alex. Arch.; $55^{\circ} 39^{\prime} \mathrm{N}, 133^{\circ} 34^{\prime} \mathrm{W}$; (map 4).

Named in 1925 by USC\&GS.

Laura Lake: lake, $3 \mathrm{mi}$. long, $3.5 \mathrm{mi}$. SW of Duck Cape, on Afognak I., $29 \mathrm{mi}$. NE of Afognak, Kodiak I.; $58^{\circ} 21^{\prime} 30^{\prime \prime} \mathrm{N}, 152^{\circ} 18^{\prime} 00^{\prime \prime}$ W; (map 43).

Local name reported in 1952 by USGS.

Laurada Creek: stream, flows W $1.3 \mathrm{mi}$. to Nome River, $5 \mathrm{mi}$. E of Nome, Seward Penin. High.; $64^{\circ} 30^{\prime} \mathrm{N}, 165^{\circ} 13^{\prime} \mathrm{W}$; (map 94).

Prospectors' name reported on a map by S. E. King dated 1900.

Lava Bight: cove, $1.4 \mathrm{mi}$. across on $\mathrm{NW}$ coast of Akutan I., Aleutian Is.; 54 $09^{\prime} 30^{\prime \prime} \mathrm{N}, 166^{\circ}$ 05'00" W; (map 23).

Name published in 1965 by USC\&GS.

Lava Cove: bight, 2 mi. across, on SE coast of Seguam I., Aleutian Is.; $52^{\circ} 17^{\prime} \mathrm{N}, 172^{\circ} 26^{\prime} \mathrm{W}$; (map 19).

Named for Lava Point, and published by USC\&GS in 1944 Aleutian Coast Pilot ( $p$. 85).

Lava Creek: stream, flows $S 10 \mathrm{mi}$. to Thorne River, $2 \mathrm{mi}$. NW of Thorne Bay, on $\mathrm{E}$ coast of Prince of Wales I., Alex. Arch.; 55 $42^{\prime} 28^{\prime \prime}$ N, 132 $36^{\prime} 30^{\prime \prime} \mathrm{W}$; BGN 1960; (map 4).

Named in 1956 by C. L. Sainsbury, USGS, "because it is eroded into a sequence of lava beds."

Lava Creek: stream, flows N $1.5 \mathrm{mi}$. to Kashevarof Passage, on $\mathrm{N}$ coast of Prince of Wales I., Alex. Arch.; $56^{\circ} 14^{\prime} 30^{\prime \prime} \mathrm{N}, 133^{\circ} 06^{\prime} 20^{\prime \prime} \mathrm{W}$; $B G N$ 1923; ( $\operatorname{map} 6$ ).

Named in 1923 by USFS.

Lava Creek: stream, flows $\mathrm{N} 21 \mathrm{mi}$. to Cinder River, on Alaska Penin., $34 \mathrm{mi}$. SW of Uga-

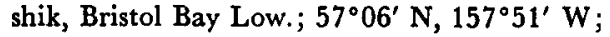
(map 36).

Descriptive name given in 1923 by $\mathbf{R}$. H. Sargent, USGS, "because of the ejecta from Aniakchak Volcano which filled its valley and which is now deeply eroded."

Lava Creek: stream, heads in Bendeleben Mts., flows SW $12 \mathrm{mi}$. to Fish River, $34 \mathrm{mi}$. S of Imuruk Lake, Seward Penin. High.; 65 ${ }^{\circ} 05^{\prime}$ N, $163^{\circ} 01^{\prime} \mathrm{W}$; (map 110).

Prospectors' name published on the 1908 "Map of Seward Peninsula" by Arthur Gibson.

Lava Creek: stream, flows NW $11 \mathrm{mi}$. to Kiwalik River, $47 \mathrm{mi}$. NW of Haycock, Seward Penin. High.; 65 $49^{\circ} \mathrm{N}, 161^{\circ} 50^{\prime} \mathrm{W}$; (map 109).

Local name shown on a 1903 fieldsheet by D. C. Witherspoon, USGS.

Lava Creek: stream, on Seward Penin., flows N $4.4 \mathrm{mi}$. to Eagle Creek, $32 \mathrm{mi}$. SW of Deering, Kotzebue-Kobuk Low.; $66^{\circ} 00^{\prime} \mathrm{N}, 163^{\circ} 51^{\prime} \mathrm{W}$; (map 113).

Local name published on the 1908 "Map of Seward Peninsula" by Arthur Gibson.

Lava Fork: stream, flows $\mathrm{S} 4.5 \mathrm{mi}$. from Canada, near boundary monument 42 , to left bank of Blue River, $1.5 \mathrm{mi}$. S of Blue Lake, Coast Mts. ; $56^{\circ} 19^{\prime} 10^{\prime \prime} \mathrm{N}, 130^{\circ} 52^{\prime} 30^{\prime \prime} \mathrm{W}$; (map 7). Local name reported in 1955 by USGS.
Lava Island: island, $0.1 \mathrm{mi}$. across, off $\mathrm{S}$ coast of Kruzof I., $14 \mathrm{mi}$. W of Sitka, Alex. Arch.; $57^{\circ} 00^{\prime} 20^{\prime \prime}$ N, $135^{\circ} 42^{\prime} 15^{\prime \prime} \mathrm{W}$; (map 9). Var. Ostrov Lava, Lava Islet.

Derived from a Russian name meaning "lava," given in 1809 by the navigator Ivan Vasiliev the first, IRN; published by Lt. Sarichev (1826, map 19), IRN, as "O[strov] Lava."

Lava Lake: lake, $2 \mathrm{mi}$. across, $19 \mathrm{mi}$. $\mathrm{W}$ of Imuruk Lake, Seward Penin. High.; $65^{\circ} 35^{\prime} \mathrm{N}$, 1635' W; BGN 1952; (map 110).

Reported in 1950 by D. M. Hopkins, USGS ; 'The name 'Lava Lake' was applied by the 11 th Weather Squadron, USAAF, to a weather station operated on the east shore of the lake in 1945."

Lava Point: point of land, on SE coast of Seguam I., Aleutian Is.; $52^{\circ} 17^{\prime} 00^{\prime \prime} \mathrm{N}, 172^{\circ} 24^{\prime} 50^{\prime \prime} \mathrm{W}$; (map 19).

Descriptive name given by a special U.S. Navy survey party because the point forms the terminus of an extensive lava-flow; published by USC\&GS in 1944 Aleutian Coast Pilot (p. 85)

Lava Point: point of land, on NW coast of Akutan I., Aleutian Is.; $54^{\circ} 10^{\prime} 20^{\prime \prime} \mathrm{N}, 166^{\circ}$ 04'45" W; (map 23). Var. Flat Top.

Descriptive name, reported by USC\&GS in 1902. It was called Flat Top by J. F. Moser, USN, in 1897.

Lavanak Point: point of land, see Twinlava Point.

Lavinia, Point: point of land, on $\mathbf{N}$ tip of Inian Penin., on Chichagof I., on S shore of South Inian Pass, $1.3 \mathrm{mi}$. $\mathrm{N}$ of Elfin Cove and 38 mi. WNW of Hoonah, Alex. Arch.; 58 $13^{\prime} 30^{\prime \prime}$ N, 136 $10^{\prime} 15^{\prime \prime}$ W; (map 10).

Named by Capt. George Vancouver, RN, in 1794 for Lady Lavinia Spencer, daughter of Margaret Bingham, Countess of Lucan (Wagner, 1937, p. 394).

Lawak: village, see Klawock.

Lawing: locality, on E shore of Kenai Lake, mile 23.3 on The Alaska RR., 1 mi. NE of Black Point, $21 \mathrm{mi}$. N of Seward, Chugach Mts.; $60^{\circ} 24^{\prime} 15^{\prime \prime} \mathrm{N}, 149^{\circ} 21^{\prime} 50^{\prime \prime} \mathrm{W}$; (map 63). Var. Roosevelt,

Listed as a station in The Alaska RR. guide of 1925. Recent USGS maps indicate a site of six or seven buildings.

Lawrence: area, in NE part of Anchorage, between Runstettler and Vanover, Cook Inlet Low.; 61 $13^{\prime} 08^{\prime \prime} \mathrm{N}, 149^{\circ} 47^{\prime} 35^{\prime \prime} \mathrm{W}$; (map 69).

Local name reported in 1954 by the city engineer of Anchorage.

Lawrence, Port: cove, $0.5 \mathrm{mi}$, across, on $\mathrm{S}$ coast of Shuyak I., $40 \mathrm{mi}$. N of Kodiak I. ; $58^{\circ} 29^{\prime}$ $30^{\prime \prime} \mathrm{N}, 152^{\circ} 36^{\prime} 20^{\prime \prime} \mathrm{W}$; (map 43).

Name published by USC\&GS in 1926.

Lawrence Creek: stream, flows SW $5 \mathrm{mi}$. through Lawrence Valley to Herendeen Bay, near SW end of Alaska Penin., Aleutian Ra.; 55 44'30" $\mathrm{N}, 160^{\circ} 39^{\prime} 00^{\prime \prime} \mathrm{W}$; ( $\operatorname{map} 28$ ).

Named in 1890 by Lt. Comdr. Z. L. Tanner, USN. 
Lawrence Creek: stream, flows SW and S 2 mi. to Gulf of Alaska, $N$ of Umbrella Reef and $87 \mathrm{mi}$. NW of Yakutat, St. Elias Mts. ; $60^{\circ} 00^{\prime}-$ $30^{\prime \prime} \mathrm{N}, 142^{\circ} 02^{\prime} 50^{\prime \prime} \mathrm{W}$; (map 65 ).

Named after Lawrence E. Barber, one of the first to locate oil in the Yakataga region in 1897. This local name was reported by G. C. Martin, USGS, in 1903 and published in 1905.

Lawrence Glacier: glacier, heads $W$ of head of Tebenkof Glacier, trends NW $2.5 \mathrm{mi}$. to Blackstone Bay, $8 \mathrm{mi}$. SE of Whittier, Chugach Mts. ; $60^{\circ} 40^{\prime} 30^{\prime \prime} \mathrm{N}, 148^{\circ} 38^{\prime} 00^{\prime \prime} \mathrm{W}$; $B G N$ 1930; (map 63).

Named in 1910 by Lawrence Martin for Lawrence College, Appleton, Wisconsin.

Lawrence Valley: valley, $5 \mathrm{mi}$. long, extends SW along course of Lawrence Creek to Herendeen Bay, between Gull and Crow Points, near SW end of Alaska Penin., Aleutian Ra.; 55 $44^{\prime} 30^{\prime \prime}$ N, $160^{\circ} 39^{\prime} 00^{\prime \prime} \mathrm{W}$; (map 28).

Named in 1890 by Lt. Comdr. Z. L. Tanner, USN.

Lawsbina Lake: lake, see Lachbuna Lake.

Lawson Creek: stream, on NE shore of Douglas I., flows $2 \mathrm{mi}$. NE to Gastineau Channel, 0.7 mi. NW of Douglas and $1 \mathrm{mi}$. S of Juneau, Coast Mts.; $58^{\circ} 17^{\prime} 12^{\prime \prime} \mathrm{N}, 134^{\circ} 24^{\prime} 36^{\prime \prime} \mathrm{W}$; (map 11).

Named for William Lawson, 1843-1932, a skilled carpenter and boatbuilder in Juneau in the 1880's. The name Lawson Creek appears first in the mining records in 1894 (DeArmond, 1957, p. 29).

Lawson Creek: stream, flows NE $8 \mathrm{mi}$, joins Munson Creek to form Clums Fork Birch Creek, $64 \mathrm{mi}$. SW of Circle, Yukon-Tanana High.; $65^{\circ} 07^{\prime} 10^{\prime \prime} \mathrm{N}, 145^{\circ} 30^{\prime} 00^{\prime \prime} \mathrm{W}$; (map 104).

Named by prospectors; reported in 1911 by USGS (Prindle, 1913, pl. 1).

Lawson Hills: mountains, 1,310 ft., center of Kiska I., Aleutian Is.; $51^{\circ} 57^{\prime} 40^{\prime \prime} \mathrm{N}, 177^{\circ}$ $25^{\prime} 06^{\prime \prime} \mathrm{E}$; (map 14).

An arbitrary name beginning with "L" to correspond to "L" grid used by the U.S. Army for tactical purposes during World War II; published on a 1943 Army map.

Lay, Point: point of land, on barrier island of Chukchi Sea coast, $43 \mathrm{mi}$. SW of Icy Cape, Arctic Plain; $69^{\circ} 45^{\prime} 45^{\prime \prime} \mathrm{N}, 163^{\circ} 03^{\prime} 05^{\prime \prime} \mathrm{W}$; (map 145). Var. Lay Point, Sloistic.

Named in September 1826 by Capt. Beechey (1831, v. 1, p. 303 ), RN, who wrote, "and to the points and inlets to the southward [of Cape Smyth] I with pleasure affixed the names of the officers of the ship, whose merits entitled them to this distinction." George Tradescant Lay was the naturalist of the expedition. Tikhmeniev's 1861 map shows the name M[ys] Sloistyy meaning "in layers."

Laydanoprodevskie: locality, see Ledyanoprolivskoe.

Layman Hill: mountain, 1,445 ft., center of Kiska I., Aleutian Is.; $51^{\circ} 58^{\prime} 07^{\prime \prime} \mathrm{N}, 177^{\circ}$ $28^{\prime} 48^{\prime \prime}$ E; (map 14).
An arbitrary name beginning with " $L$ " to correspond to "L" grid used by the U.S. Army for tactical purposes during World War II; published on a 1943 Army map.

Lazaref, Cape: point of land, on SE coast of Unimak I., Aleutian Is.; 54 $37^{\prime} 00^{\prime \prime} \mathrm{N}$, $163^{\circ} 35^{\prime} 10^{\prime \prime} \mathrm{W}$; (map 25). Var. Cape Lazareff, Touliouliaga.

Named Lazareff by Capt. Lutke (1836, p. 295), IRN, who said "that Kudiakof, 1791, reported its native name as Touliouliaga."

Lazareff, Cape : point of land, see Lazaref, Cape.

Lazaref Peak: mountain, 1,259 ft., on SE coast of Unimak I., Aleutian Is., $54^{\circ} 38^{\prime} 40^{\prime \prime} \mathrm{N}$, $163^{\circ} 31^{\prime} 30^{\prime \prime} \mathrm{W}$; (map 25).

Name derived from Cape Lazaref; reported by Ferdinand Westdahl, USC\&GS, commander of the Coast Survey steamer McArthur, who made surveys in this area in 1901.

Lazaref Reef: reef, at Cape Lazaref, on SE coast of Unimak I., Aleutian Is.; $54^{\circ} 36^{\prime} 20^{\prime \prime} \mathrm{N}$, $163^{\circ} 35^{\prime} 00^{\prime \prime} \mathrm{W}$; (map 25).

Name derived from Cape Lazaref; published by USC\&GS in 1938.

Lazaref River: stream, flows SE $10 \mathrm{mi}$. to Pacific Ocean, on SE coast of Unimak I., Aleutian Is.; $54^{\circ} 37^{\prime} 45^{\prime \prime} \mathrm{N}, 163^{\circ} 34^{\prime} 00^{\prime \prime} \mathrm{W}$; (map 25).

Name derived from Cape Lazaref; published in 1949 on a USGS map.

Lazaro, Mount: mountain, 1,710 ft., on $S$ coast of Duke I., Alex. Arch. ; $54^{\circ} 53^{\prime} \mathrm{N}, 131^{\circ} 22^{\prime} \mathrm{W}$; (map 2). Var. Mount St. Lazaro.

Named on June 8,1789 , by Capt. W. Douglas, RN, who described it as "a high mountain on the west side of the [Buccleugh] Sound." The name was shortened to its present form in 1880 by USC\&GS.

Lazier, Mount: hill, $977 \mathrm{ft}, 4 \mathrm{mi}$. NW of Katalla, Chugach Mts., $60^{\circ} 13^{\prime} \mathrm{N}, 144^{\circ} 37^{\prime} \mathrm{W}$; (map 64).

Local name reported in 1920 by G. C. Martin (1921, pl. 4), USGS.

Lazy Bay: cove, $1.5 \mathrm{mi}$. across, on $W$ shore of Alitak Bay, at S end of Kodiak I.; $56^{\circ} 53^{\prime} 30^{\prime \prime}$ N, $154^{\circ} 14^{\prime} 30^{\prime \prime} \mathrm{W}$; (map 32 ).

Name reported in 1900 by Comdr. J. F. Moser, USN.

Lazy Creek: stream, flowing $\mathrm{S} 2.1 \mathrm{mi}$. to Gertrude Cove, central Kiska I., Aleutian Is.; $51^{\circ} 56^{\prime} 36^{\prime \prime} \mathrm{N}, 177^{\circ} 25^{\prime} 38^{\prime \prime} \mathrm{E}$; (map 14). Var. Cream Brook.

An arbitrary name beginning with " $L$ " to correspond to "L" grid used by U.S. Army for tactical purposes during World War II; published on a 1953 AMS map. Variant published on a 1943 USAAF map.

Lazy Mountain: mountain, 3,720 ft., $5 \mathrm{mi}$. NE of Palmer, Chugach Mts.; $61^{\circ} 37^{\prime} 25^{\prime \prime} \mathrm{N}$, $148^{\circ} 57^{\prime} 50^{\prime \prime} \mathrm{W}$; (map 69).

Local name reported in 1951 by USGS.

Lazy Slough: stream, flows S $9 \mathrm{mi}$. to Yukon River $\mathbf{N}$ of Blackburn I., Innoko Low.; $63^{\circ} 25^{\prime} \mathrm{N}, 159^{\circ} 24^{\prime} \mathrm{W}$; (map 91).

Riverboat pilots' name shown on a 1940 "Navigation Chart of the Tanana-Yukon
Rivers" published by the U.S. Dept. of Interior.

L'chtinigé: cove, see Pyramid Harbor.

Lead Hill: hill, 1,500 ft., west-central Kiska $I$., Aleutian Is.; $51^{\circ} 58^{\prime} 11^{\prime \prime} \mathrm{N}, 177^{\circ} 22^{\prime} 13^{\prime \prime} \mathrm{E}$; (map 14).

An arbitrary name beginning with " $\mathrm{L}$ " to correspond to "L" grid used by the U.S. Army for tactical purposes during World War II; published on a 1953 AMS map.

Leader Island: island, $125 \mathrm{ft}$. elev., $0.1 \mathrm{mi}$. across, $8 \mathrm{mi}$. E of Stepovak Bay, Aleutian Ra.; $55^{\circ}$ $43^{\prime} 30^{\prime \prime} \mathrm{N}, 159^{\circ} 27^{\prime} 40^{\prime \prime} \mathrm{W}$; (map 27). Var. Provodnik.

Named "Provodnik," or "leader," by Lt. Woronkofski in 1837; published by USC\&GS in 1947 Alaska Coast Pilot (v. 2, p. 302).

Leading Point: point of land, on SW coast of Prince of Wales I., E of Barrier Is., Alex. Arch. ; $54^{\circ} 48^{\prime} 30^{\prime \prime} \mathrm{N}, 132^{\circ} 22^{\prime} 25^{\prime \prime} \mathrm{W}$; (map 1 ).

Descriptive name published in 1899 by USC\&GS.

Leading Point : point of land, see Harrison Point. Leadville Mountain: mountain, 1,750 ft., on Annette I., $2 \mathrm{mi}$. E of Metlakatla, Alex. Arch.; $55^{\circ} 07^{\prime} 30^{\prime \prime} \mathrm{N}, 131^{\circ} 31^{\prime} 30^{\prime \prime} \mathrm{W}$; (map 3).

Named in 1883 by Lt. Comdr. H. E. Nichols, USN, for "Leadville, Colorado."

Leaf Hills : mountains, 1,260 ft., center of Kiska I., Aleutian Is. ; $51^{\circ} 57^{\prime} 51^{\prime \prime} \mathrm{N}, 177^{\circ} 29^{\prime} 30^{\prime \prime}$ E; (map 14).

An arbitrary name beginning with " $L$ " to correspond to "L" grid used by the U.S. Army for tactical purposes during World War II; published on a 1943 Army map.

Leaf Lake: lake, $0.7 \mathrm{mi}$. long, on Kenai Penin., $1.5 \mathrm{mi}$. SE of Owl Lake and $31 \mathrm{mi}$. NE of Kenai, Cook Inlet Low.; $60^{\circ} 47^{\prime} 45^{\prime \prime} \mathrm{N}, 150^{\circ}$ $33^{\prime} 30^{\prime \prime} \mathrm{W}$; (map 62).

Named about 1963 by officials of Kenai National Moose Range, for administrative purposes.

Leaf Lake: lake, $1 \mathrm{mi}$. long, between Tanana River and Alaska Highway, $1.4 \mathrm{mi}$. SW of Midway Lake and $22 \mathrm{mi}$. SE of Tok, YukonTanana High.; $63^{\circ} 12^{\prime} \mathrm{N}, 142^{\circ} 21^{\prime} \mathrm{W}$; (map 85).

Local name reported in 1963 by USGS; named because the lake's outline is similar to that of a leaf.

League, Point: point of land, on $\mathrm{E}$ shore of Stephens Passage, 0.3 mi. S of Dry Bay and $53 \mathrm{mi}$. SE of Juneau, Coast Mts.; $57^{\circ} 37^{\prime} 45^{\prime \prime}$ $\mathrm{N}, 133^{\circ} 40^{\prime} 20^{\prime \prime} \mathrm{W}$; (map 8).

Named in 1868 by Lt. Comdr. R. W. Meade, USN; name published by USC\&GS in 1891 Coast Pilot (p. 147).

Leah Greek: stream, anabranch of Yukon River, flows SW $4.3 \mathrm{mi}$. to Steamboat Slough, $61 \mathrm{mi}$. SSW of Nulato, Innoko Low.; $63^{\circ} 55^{\prime} 30^{\prime \prime} \mathrm{N}$, $159^{\circ} 04^{\prime} 30^{\prime \prime} \mathrm{W}$; (map 90).

So called by riverboat pilots shortly after the riverboat Leah sank at the stream's mouth in 1906. The Leah was built by the Alaska Commercial Co. at St. Michael in 1895. She had a net tonnage of 295 tons. 
Leah Crossing: crossing, in Yukon River, downstream from Quail I., Innoko Low.; $63^{\circ} 53^{\prime}$ N, $159^{\circ} 10^{\prime} \mathrm{W}$; (map 91).

Riverboat pilots' name shown on a 1940 "Navigation Chart of the Tanana-Yukon Rivers" published by the U.S. Dept of Interior.

Leah Island: island, see Quail Island.

Leah Slough: channel, of Yukon River between Quail I. and right bank, Innoko Low.; 63 ${ }^{\circ} 55^{\prime}$ N, $159^{\circ} 03^{\prime} \mathrm{W}$; (map 91). Var. Steamboat Slough.

Riverboat pilots' name shown on a 1940 "Navigation Chart of the Tanana-Yukon Rivers" published by the U.S. Dept. of Interior. It is said to have been so named "because a river boat, probably the Leah, was wrecked in this slough many years ago."

Leak Hill: mountain, 1,225 ft., center of Kiska I., Aleutian Is.; $51^{\circ} 57^{\prime} 43^{\prime \prime} \mathrm{N}, 177^{\circ} 29^{\prime} 56^{\prime \prime} \mathrm{E}$; (map 14).

An arbitrary name beginning with " $\mathrm{L}$ " to correspond to "L" grid used by the U.S. Army for tactical purposes during World War II; published on a 1943 Army map.

Leaking Glacier: glacier, just W of Two Echo Cliffs, trends S $1 \mathrm{mi}$. to its 1962 terminus, $0.5 \mathrm{mi}$. N of terminus of Nugget Creek Glacier and $9 \mathrm{mi}$. $\mathrm{N}$ of Juneau, Coast Mts.; $58^{\circ} 26^{\circ} 20^{\prime \prime}$ $\mathrm{N}, 134^{\circ} 25^{\prime} 30^{\prime \prime} \mathrm{W}$; (map 11).

Local name reported in 1965 by D. A. Brew and A. B. Ford, USGS.

Leaky Lake: lake, $150 \mathrm{yd}$. across, south-central Kiska I., Aleutian Is.; $51^{\circ} 56^{\prime} 10^{\prime \prime} \mathrm{N}, 177^{\circ}$. $22^{\prime} 55^{\prime \prime} \mathrm{E}$; (map 14).

An arbitrary name beginning with " $L$ " to correspond to "L" grid used by the U.S. Army for tactical purposes during World War II ; published on a 1953 AMS map.

Lean Hill: hill, $661 \mathrm{ft}$, center of Kiska I., Aleutian Is.; $51^{\circ} 56^{\prime} 52^{\prime \prime} \mathrm{N}, 177^{\circ} 24^{\prime} 43^{\prime \prime} \mathrm{E}$; (map 14).

An arbitrary name beginning with " $L$ " to correspond to "L" grid used by the U.S. Army for tactical purposes during World War II; published on a 1943 Army map.

Leap Hill: hill, $610 \mathrm{ft}$., center of Kiska I., Aleutian Is.; $51^{\circ} 56^{\prime} 46^{\prime} \mathrm{N}, 177^{\circ} 24^{\prime} 38^{\prime \prime} \mathrm{E}$; (map 14).

An arbitrary name beginning with " $L$ " to correspond to "L" grid used by the U.S. Army for tactical purposes during World War II; published on a 1943 Army map.

Leare Point: point of land, on left bank of Yukon River, at junc. of Jimmy Slough and Yukon River, $32 \mathrm{mi}$. NE of Nulato; $64^{\circ} 46^{\prime} \mathrm{N}, 157^{\circ}$ 02' W; (map 97).

Local name reported in 1954 by USGS.

Learnard Glacier: glacier, at SW end of Chugach Mts., trends $S 2.5 \mathrm{mi}$. to its terminus $1.5 \mathrm{mi}$. NW of Whittier, Chugach Mts.; $60^{\circ} 47^{\prime} 35^{\prime \prime}$ N, $148^{\circ} 43^{\prime} 30^{\prime \prime} \mathrm{W} ; B G N$ 1930; (map 63).

Var. Longfellow Glacier.

Named in 1910 by Lawrence Martin for Lt. H. G. Learnard, USA, of Capt. E. F. Glenn's expedition.

Lears Point: point of land, see Eightmile Point.
Leary Creek: stream, flows SW $2 \mathrm{mi}$. to Twelvemile Creek, $50 \mathrm{mi}$. S of Eagle, Yukon-Tanana High.; $64^{\circ} 06^{\prime} \mathrm{N}, 141^{\circ} 20^{\prime} \mathrm{W}$; (map 102).

Prospectors' name shown on an 1898 manuscript map by C. A. Woodruff, Fort Cudahy, Canada.

Leask Cove: cove, $0.6 \mathrm{mi}$. across, on Revillagigedo I., near head of George Inlet, Alex. Arch.; 55 $30^{\prime} 15^{\prime \prime} \mathrm{N}, 131^{\circ} 30^{\prime} 15^{\prime \prime} \mathrm{W}$; (map 3).

Local navigators' name obtained in 1904 by H. C. Fassett, USBF.

Leask Creek: stream, $2.8 \mathrm{mi}$. long, drains Leask Lake SE into Leask Cove, near head of George Inlet, on Revillagigedo I., Alex. Arch.; 55 30'40" N, $131^{\circ} 31^{\prime} 00^{\prime \prime} \mathrm{W}$; BGN 1962; (map $3)$.

Local name reported in 1961 by USFS.

Leask Lake: lake, $0.7 \mathrm{mi}$. across, drained by Leask Creek into Leask Cove, near $\mathrm{N}$ end of George Inlet, on Revillagigedo I., Alex. Arch.; 55 $32^{\prime}$ N, $131^{\circ} 34^{\prime}$ W; BGN 1962; (map 3).

Local name reported in 1961 by USFS.

Leather Hill: hill, $750 \mathrm{ft}$., on central Kiska I., Aleutian Is.; $51^{\circ} 57^{\prime} 13^{\prime \prime} \mathrm{N}, 177^{\circ} 25^{\prime} 00^{\prime \prime} \mathrm{E}$; (map 14).

An arbitrary name beginning with " $L$ " to correspond to "L" grid used by the U.S. Army for tactical purposes during World War II ; published on a 1943 Army map.

Leather Lake: lake, 125 yd. across, center of Kiska I., Aleutian Is.; $51^{\circ} 57^{\prime} 15^{\prime \prime} \mathrm{N}, 177^{\circ}$ $25^{\prime} 00^{\prime \prime} \mathbf{E}$; (map 14).

An arbitrary name beginning with " $\mathrm{L}$ " to correspond to "L" grid used by the U.S. Army for tactical purposes during World War II; published on a 1943 Army map.

Leavitt Island: barrier island, $2 \mathrm{mi}$. long, one of Jones Is. on Beauford Sea coast, $W$ of Pingok I., Arctic Plain; $70^{\circ} 34^{\prime} \mathrm{N}, 149^{\circ} 35^{\prime} \mathrm{W}$; (map 150).

E. de K. Leffingwell (1919, p. 97) originally named "the largest of the Jones Islands, *** Leavitt Island, * * * after Capt. [George] Leavitt of the whaling fleet." Leffingwell gave its Eskimo name as "Pingok," meaning "mound," which name is applied to the largest island on present day maps.

Leavitt Island: barrier island, see Pingok Island. Lebedevski: islands, see Pribilof Islands.

Lebyazhye, Ozero: lake, see Swan Lake.

Lechner Glacier: glacier, $1.3 \mathrm{mi}$. long, $1 \mathrm{mi}$. E of Aialik Bay, $16 \mathrm{mi}$. SW of Seward, Chugach Mts.; $59^{\circ} 56^{\prime} 30^{\prime \prime} \mathrm{N}, 149^{\circ} 39^{\prime} 30^{\prime \prime}$ W ; $B G N$ 1911; (map 49).

Named in 1909 by U. S. Grant, USGS, for John Lechner, prospector, then living at Seward; Lechner and F. P. Skee "probably had more to do with the finding of lode gold north of Seward than any other two men.' See Skee Glacier.

LeConte Bay: bay, $1 \mathrm{mi}$. across, at $\mathrm{S}$ end of Frederick Sound, $17 \mathrm{mi}$. SE of Petersburg, Coast Mts.; $56^{\circ} 44^{\prime} 30^{\prime \prime} \mathrm{N}, 132^{\circ} 31^{\prime} 00^{\prime \prime} \mathrm{W}$; $B G N$ 1905; (map 6). Var. Hulti Bay, Hutli Bay, Leconte Bay, Thunder Bay.
Named in 1887 by Lt. Comdr. C. M. Thomas, USN, for Joseph LeConte, professor of geology at the University of California at that time. The Indian name is "Hutli," reported by John Muir, in 1884, for "the Tlingits' mythical thunder bird, the flapping of whose wings produces the thunder."

LeConte Glacier: glacier, trends S $6 \mathrm{mi}$. to head of LeConte Bay, $20 \mathrm{mi}$. E of Petersburg, Coast Mts.; $56^{\circ} 49^{\prime} 30^{\prime \prime} \mathrm{N}, 132^{\circ} 22^{\prime} 30^{\prime \prime} \mathrm{W} ; B G N$ 1905; (map 6). Var. Hutli Glacier, Thunder Glacier, Leconte Glacier.

Named in 1887 by Lt. Comdr. C. $M$ Thomas, USN, for Joseph LeConte, professor of geology at the University of Calif. See LeConte Bay.

Ledaunala: $b a y$, see Icy Bay.

Ledge Creek: stream, flows NW $5 \mathrm{mi}$. to Tolstoi Creek $2.7 \mathrm{mi}$. S of its junc. with Mastodon Creek, $21 \mathrm{mi}$. NW of Ophir, Kilbuck-Kuskokwim Mts.; $63^{\circ} 18^{\prime} 35^{\prime \prime} \mathrm{N}, 157^{\circ} 03^{\prime} 50^{\prime \prime} \mathrm{W}$; (map 90).

Prospectors' descriptive name published in 1921 by USGS.

Ledge Creek: stream, heads on SE slope of Sadlerochit Mts., flows $2.5 \mathrm{mi}$. to Sadlerochit River $5 \mathrm{mi}$. NE of junc. of Kekiktuk River, 21 mi. NW of Mount Michelson, Brooks Ra.; $69^{\circ} 35^{\prime} \mathrm{N}, 144^{\circ} 35^{\prime} \mathrm{W}$; (map 139).

Named by USGS geologists in the 1950's.

Ledge Island: island, in Funter Bay, on Mansfield Penin., $0.4 \mathrm{mi}$. SE of Funter and $18 \mathrm{mi}$. SW of Juncau, Alex. Arch.; $58^{\circ} 15^{\prime} 05^{\prime \prime} \mathrm{N}$, $134^{\circ} 53^{\prime} 20^{\prime \prime} \mathrm{W}$; (map 11). Var. Ledge Islet.

Named in 1890 by Lt. Comdr. H. B. Mansfield, USN; published in 1897 by USC\&GS.

Ledge Islet: island, see Ledge Island.

Ledge Lake: lake, $1 \mathrm{mi}$. long, on $\mathrm{N}$ coast of Kuiu I., just W of Saginaw Bay, Alex. Arch.; $56^{\circ} 53^{\prime} 15^{\prime \prime} \mathrm{N}, 134^{\circ} 16^{\prime} 30^{\prime \prime} \mathrm{W}$; (map 5 ).

Local name recorded in 1948 by USGS.

Ledge Point: point of land, on $\mathrm{N}$ shore of Harry Bay, at entrance into Nakat Bay, NE of Dixon Entrance, Coast Mts. ; $54^{\circ} 48^{\prime} 40^{\prime \prime}$ N, $130^{\circ} 45^{\prime}$ 45" W; (map 2).

Named in 1883 by Lt. Comdr. H. E. Nichols, USN.

Ledge Point: point of land, on mainland, $\mathrm{S}$ point of entrance to Walker Cove, Coast Mts. ; 55 $42^{\prime} 25^{\prime \prime} \mathrm{N}, 130^{\circ} 53^{\prime} 35^{\prime \prime} \mathrm{W}$; (map 3). Descriptive name given in 1891 by USC\&GS. Ledianoi: point of land, see Icy Cape.

Leduc Lake: lake, $2.5 \mathrm{mi}$. long, $3 \mathrm{mi}$. NW of junc. of Chickamin and Leduc Rivers, Coast Mts.; $55^{\circ} 56^{\prime} \mathrm{N}, 130^{\circ} 53^{\prime} \mathrm{W}$; (map 3).

Local name reported in 1955 by USGS:

Leduc River: stream, heads at a glacier in British Columbia, Canada, flows SW $30 \mathrm{mi}$. into Alaska, to Chickamin River, Coast Mts.; $55^{\circ}$ $54^{\prime} \mathrm{N}, 130^{\circ} 47^{\prime} \mathrm{W}$; (map 3). Var. Le Duc River.

Local name published in 1898 by USC\&GS Ledyanoi: point of land, see Icy Cape.

Ledyanoprolivskoe: locality, "in SE Alaska." Var. Laydanoprodevskie.

Russian name reported by Veniaminov ( 1840 , v. 2, p. 29), meaning "icy strait." Ac- 
cording to Hodge (1907, p. 761), BAE, this may be a former Tlingit Indian town, its population "numbering 200 in 1835."

Ledyanoy, Mys: point of land, see Icy Point.

Ledyanoy, Proliv: water passage, see Icy Strait.

Lee, Lake: lake, $0.3 \mathrm{mi}$. long, drains $\mathrm{E}$ through Lake Orbin to Sargent Creek, $9 \mathrm{mi}$. SW of Kodiak, Kodiak I.; $57^{\circ} 42^{\prime} 50^{\prime \prime} \mathrm{N}, 152^{\circ} 36^{\prime} 00^{\prime \prime}$ W; (map 34).

Local descriptive name; reported in 1949 by USGS.

Lee, Mount: peak, 2,650 ft., S of Burls Pass, on Alaska Penin., $45 \mathrm{mi}$. NE of Ugashik, Aleutian Ra.; $57^{\circ} 39^{\prime} 25^{\prime \prime} \mathrm{N}, 156^{\circ} 15^{\prime} 00^{\prime \prime} \mathrm{W}$; (map 36).

Local name reported in 1921 by Capps (1923, pl. 2), USGS, as being named "for an oil prospector who had a cabin at the mouth of Des Moines Creek."

Lee, Mount: peak, 6,300 ft., E of Glacier Point, $E$ of Ruth Glacier, Alaska Ra.; $62^{\circ} 53^{\prime} 30^{\prime \prime} \mathrm{N}$, $150^{\circ} 30^{\prime} 20^{\prime \prime} \mathrm{W}$; (map 81).

Mountain climbers' name probably given by members of the 1945 Mazama expedition to the area (Metcalf, 1945, map facing p. 11).

Lee Creek: stream, see Des Moines Creek.

Lee Gulch: ravine, trends SW $1.1 \mathrm{mi}$. to Hastings Creek, $10 \mathrm{mi}$. SE of Nome, Seward Penin. High.; 64 $27^{\prime} 30^{\prime \prime} \mathrm{N}, 165^{\circ} 05^{\prime} 37^{\prime \prime} \mathrm{W}$; (map 94). Var. Lees Gulch, Leo Gulch.

Prospectors' name reported in 1904 by T. G. Gerdine, USGS.

Leech Hill: hill, $760 \mathrm{ft}$., center of Kiska I., Aleutian Is.; $51^{\circ} 57^{\prime} 00^{\prime \prime} \mathrm{N}, 177^{\circ} 29^{\prime} 14^{\prime \prime} \mathrm{E}$; (map 14).

An arbitrary name beginning with " $L$ " to correspond to "L" grid used by the U.S. Army for tactical purposes during World War II; published on a 1943 Army map.

Leeper, Mount: mountain, 8,200 ft., in Robinson Mts., $8 \mathrm{mi}$. NW of Yaga Peak and $98 \mathrm{mi}$. NW of Yakutat, Chugach Mts.; $60^{\circ} 17^{\prime} 40^{\prime \prime} \mathrm{N}$, $142^{\circ} 06^{\prime} 00^{\prime \prime} \mathrm{W}$; (map 65).

Local name reported in 1943 by ARC.

Leeper Creek: stream, flows SW $1 \mathrm{mi}$. to Carbon Creek, $17 \mathrm{mi}$. NE of Katalla, Chugach Mts.; $60^{\circ} 23^{\prime} \mathrm{N}, 144^{\circ} 10^{\prime} \mathrm{W}$; (map 64).

Local name published in 1907 by USGS.

Leeper Glacier: glacier, heads $7 \mathrm{mi}$. SW of summit of Mount Leeper, trends SW $12 \mathrm{mi}$. to 1950 terminus, $4.2 \mathrm{mi}$. N of Duktoth Mtn. and $107 \mathrm{mi}$. NW of Yakutat, Chugach Mts.; $60^{\circ} 14^{\prime} 40^{\prime \prime} \mathrm{N}, 142^{\circ} 27^{\prime} 30^{\prime \prime} \mathrm{W}$; BGN 1957; (map 65).

Local name derived from Mount Leeper; published in 1964 by USGS.

Leer Hill: hill, $346 \mathrm{ft}$., NW of Mutt Cove, center of Kiska I., Aleutian Is.; 51 ${ }^{\circ} 56^{\prime} 37^{\prime \prime} \mathrm{N}$, $177^{\circ} 29^{\prime} 14^{\prime \prime} \mathrm{E}$; (map 14).

An arbitrary name beginning with " $L$ " to correspond to "L" grid used by the U.S. Army for tactical purposes during World War II; published on a 1943 Army map.

Lees, Point: point of land, on mainland, $\mathrm{E}$ of Bell I., between Anchor Pass and Behm Canal, Alex. Arch.; 55 $57^{\prime} 40^{\prime \prime} \mathrm{N}, 131^{\circ} 23^{\prime} 25^{\prime \prime}$ W; (map 3). Var. Mys Liz.
Named August 11, 1793, by Capt. George Vancouver, RN (Wagner, 1937, p. 394).

Lees Camp: locality, on right bank of Solomon River, $4 \mathrm{mi}$. NE of Solomon, Seward Penin. High.; 64 $37^{\prime} \mathrm{N}, 164^{\circ} 23^{\prime} \mathrm{W}$; (map 95).

Site of a mining camp; published in 1956 by USGS.

Lees Gulch: ravine, see Lee Gulch.

Leesia Bay: bay, see Aleutkina Bay.

Leesoffskaia Bay: bay, $0.2 \mathrm{mi}$. across, in Aleutkina Bay, $4 \mathrm{mi}$. SE of Sitka, on $W$ coast of Baranof I., Alex. Arch.; $57^{\circ} 00^{\prime} 00^{\prime \prime} \mathrm{N}, 135^{\circ} 16^{\prime} 30^{\prime \prime} \mathrm{W}$; (map 5).

Russian name meaning "fox" published in 1943 Coast Pilot (p. 357). See Aleutkina Bay.

Leesoffskaia Bay: bay, see Aleutkina Bay.

Lessy, Mys: point of land, see Fox Cape.

Leesy Island: island, see Fox Island.

Leffingwell Creek: stream, heads at Leffingwell Glacier, flows NE $3 \mathrm{mi}$. to Okpilak River, in Romanzof Mts, Brooks Ra.; 69 21' N, $144^{\circ} 03^{\prime} \mathrm{W}$; (map 139).

Name published on a map by E. G. Sable, in USGS open-file report 810, 1965. Named for Leffingwell Glacier.

Leffingwell Glacier: glacier, trends $5 \mathrm{mi}$. from $S$ side to $E$ side of Mount Michelson at head of Leffingwell Creek in Romanzof Mts., Brooks Ra.; $69^{\circ} 18^{\prime}$ N, $144^{\circ} 08^{\prime}$ W; (map 139).

Named for Ernest de Koven Leffingwell who for several years, between 1906 and 1914, explored and studied the geology and geography of northeast Alaska, culminating with his report on "The Canning River Region." The name "Leffingwell Glacier" was published in USGS Open File Report 810 , 1965, by E. G. Sable.

Lefler Creek: stream, $1.6 \mathrm{mi}$. long, flows SE to Temnac Bay, on $\mathbf{S}$ coast of Attu I., Aleutian Is.; $52^{\circ} 49^{\prime} 30^{\prime \prime} \mathrm{N}, 173^{\circ} 02^{\prime} 30^{\prime \prime} \mathrm{E}$; (map 13).

Named by the U.S. Army during its occupation of the island during World War II; shown on an AMS map published in 1948.

Left Arm: bay, see Lefthand Bay.

Left Arm Amalik Bay: estuary, see Kinak Bay.

Left Cape: point of land, W point of entrance to Kiliuda Bay, on SE coast of Kodiak I.; $57^{\circ} 15^{\prime} 30^{\prime \prime} \mathrm{N}, 152^{\circ} 57^{\prime} 00^{\prime \prime} \mathrm{W}$; (map 34). Var. Lievoi, Mys Lyvoy.

Partial translation of the descriptive name "M[ys] Lyvoy," meaning "Left-hand Cape," published by Capt. Tebenkov (1852, map 23).

Left Elk Creek: stream, flows SW $0.8 \mathrm{mi}$. to Elk Creek, $6 \mathrm{mi}$. NE of Nome, Seward Penin. High.; 64 ${ }^{\circ} 34^{\prime} 48^{\prime \prime} \mathrm{N}, 165^{\circ} 15^{\prime} 00^{\prime \prime} \mathrm{W}$; (map 94).

Prospectors' name reported on the 1903 Campion Mining and Trading Co. map by George M. Ashford.

Left Fork American River: stream, see American River.

Left Fork Banner Creek: stream, flows E $1.5 \mathrm{mi}$. to Banner Creek, $10 \mathrm{mi}: \mathrm{N}$ of Nome, Seward Penin. High.; $64^{\circ} 39^{\prime} \mathrm{N}, 165^{\circ} 20^{\prime} \mathrm{W}$; (map 94).
Prospectors' name shown on the 1902 "Map of the Nome and Snake River Country" by J. M. Davidson.

Left Fork Cache Creek: stream, flows E $8 \mathrm{mi}$. to Cache Creek, $15 \mathrm{mi}$. W of Fairbanks, YukonTanana High.; 64 $4^{\circ} 1^{\prime} 10^{\prime \prime} \mathrm{N}, 148^{\circ} 19^{\prime} 45^{\prime \prime} \mathrm{W}$; (map 100). Var. Cash Creek.

Name shown as Cash Creek by C. W. Joint on a manuscript map in 1905, but published in its present form by USGS in 1952.

Left Fork Casadepaga River: stream, see Lower Willow Creek.

Left Fork Chicken Creek: stream, flows S $2.5 \mathrm{mi}$. to Chicken Creek, $50 \mathrm{mi}$. SW of Eagle, YukonTanana High.; $64^{\circ} 07^{\prime} \mathrm{N}, 141^{\circ} 55^{\prime} \mathrm{W}$; (map 102).

Prospectors' name shown on an 1898 manuscript map by C. A. Woodruff, Fort Cudahy, Canada.

Left Fork Chicken Creek: stream, see Chicken Greek.

Left Fork Dexter Creek: stream, flows N $0.5 \mathrm{mi}$. to Dexter Creek, 6 mi. NNE of Nome, Seward Penin. High.; $64^{\circ} 34^{\prime} 42^{\prime \prime} \mathrm{N}, 165^{\circ} 20^{\prime} 25^{\prime \prime} \mathrm{W}$; (map 94).

Prospectors' name reported on a 1901 map of Cape Nome gold fields by David Fox, Jr.

Left Fork Dome Creek: stream, flows SW $1 \mathrm{mi}$. to Dome Creek, $23 \mathrm{mi}$. NW of Solomon, Seward Penin. High.; $64^{\circ} 53^{\prime} \mathrm{N}, 164^{\circ} 39^{\prime} \mathrm{W}$; (map 95). Var. Left Fork Iron Creek.

Prospectors' name reported as "Left Fork" on a map of Cape Nome gold fields by David Fox, Jr., dated 1901.

Left Fork Dry Creek: stream, heads on Newton Peak, flows SW $1.5 \mathrm{mi}$. to Dry Creek, $3 \mathrm{mi}$. NE of Nome, Seward Penin. High.; 64 $32^{\prime}$ N, $165^{\circ} 19^{\prime} \mathrm{W}$; (map 94). Var. Newton Creek, Newton Gulch No. 2.

Prospectors' name reported in 1904 by 'T. G. Gerdine, USGS. Earlier maps showed "Newton Creek" or "Newton Gulch No. 2." See Newton Gulch.

Left Fork Goose Creek: stream, flows S $2 \mathrm{mi}$. to Goose Creek, $30 \mathrm{mi}$. SE of Rampart, YukonTanana High.; $65^{\circ} 19^{\prime} 35^{\prime \prime} \mathrm{N}, 149^{\circ} 29^{\prime} 00^{\prime \prime} \mathrm{W}$; (map 105).

Local name reported in 1908 by USGS (Covert and Ellsworth, 1909, pl. 5).

Left Fork Harris Creek: stream, flows E $0.7 \mathrm{mi}$. to Harris Creek which flows to North Fork Kougarok River, W of Harris Dome and 41 mi. NW of Imuruk Lake, Seward Penin. High.; $65^{\circ} 38^{\prime} \mathrm{N}, 164^{\circ} 35^{\prime} \mathrm{W}$; (map 110).

Prospectors' name reported in 1901 by T. G. Gerdine (in Collier, 1902, pl. 12), USGS.

Left Fork Hunter Creek: stream, flows NW 7.6 mi. to Hunter Creek, 39 mi. NW of Haycock, Seward Penin. High.; $65^{\circ} 46^{\prime} \mathrm{N}, 161^{\circ} 28^{\prime} \mathrm{W}$; (map 109).

Local name reported in 1908 by USGS (Brooks and others, 1909, fig. 21).

Left Fork Iron Creek: stream, see Left Fork Dome Creek.

Left Fork Kougarok Creek: stream, see Left Fork Kougarok River. 
Left Fork Kougarok River: stream, flows NE 4 mi. to Kougarok River, $18 \mathrm{mi}$. S of Midnight Mtn. and $45 \mathrm{mi}$. W of Imuruk Lake, Seward Penin. High.; $65^{\circ} 31^{\prime} \mathrm{N}, 164^{\circ} 43^{\prime} \mathrm{W}$; (map 110). Var. Left Fork Kougarok Creek.

Prospectors' name reported in 1900 by Brooks (1901, pl. 11), USGS.

Left Fork Kougarok River: stream, see Washington Creek.

Left Fork Kviguk River: stream, see Koyuk River.

Left Fork McKinley Creek: stream, see Enterprise Creek.

Left Fork Onokovik River: stream, see Ishut Creek.

Left Fork Slate Creek: stream, flows NE $0.5 \mathrm{mi}$, joins Right Fork to form Slate Creek which flows $\mathbf{E}$ to Nome River, $13 \mathrm{mi}$. N of Nome, Seward Penin. High.; $64^{\circ} 42^{\prime} \mathrm{N}, 165^{\circ} 20^{\prime} \mathrm{W}$; (map 94).

Prospectors' name shown on the 1902 "Map of the Nome and Snake River Country" by J. M. Davidson.

Left Fork Tributary Creek: stream, flows E to Tributary Greek near its head about $10 \mathrm{mi}$. NE of Solomon, Seward Penin. High.; (map 95).

Prospectors' name reported on a prospector's manuscript map dated 1902 . This stream cannot be precisely located on current maps.

Left Fork West Glacier Creek: stream, heads at glacier terminus in Chigmit Mts., flows S 14 mi., joins Right Fork to form West Glacier Creek, $5 \mathrm{mi}$. N of Chinitna Bay, Aleutian Ra.; $59^{\circ} 55^{\prime} 40^{\prime \prime} \mathrm{N}, 153^{\circ} 17^{\prime} 20^{\prime \prime} \mathrm{W}$; (map 51).

Local name published by USGS in 1958.

Left Fork Windy Creek: stream, flows NE $4.5 \mathrm{mi}$. to Windy Creek which flows to Kougarok River, $48 \mathrm{mi}$. SW of Imuruk Lake, Seward Penin. High.; $65^{\circ} 26^{\prime} \mathrm{N}, 164^{\circ} 48^{\prime} \mathrm{W}$; (map 110). Var. Blue-Stone Creek.

Prospectors' name shown on a map of Cape Nome gold fields by David Fox, Jr., dated 1901.

Lefthand Bay: $b a y$, extends $\mathrm{W} 4 \mathrm{mi}$. inland from Balboa Bay, $10 \mathrm{mi}$. N of Unga I., on Alaska Penin., Aleutian Ra.; $55^{\circ} 32^{\prime} \mathrm{N}, 160^{\circ} 40^{\prime} \mathrm{W}$; (map 28). Var. Left Arm.

Named by Atwood (1911, pl. 2), USGS.

Left Head: bay, NE arm of Port Moller, near SW end of Alaska Penin., Aleutian Ra.; 55 $50^{\prime} 30^{\prime \prime} \mathrm{N}, 160^{\circ} 18^{\prime} 00^{\prime \prime} \mathrm{W}$; (map 28).

Named by Atwood (1911, pl. 2), USGS.

Leg Hills: hills, $500 \mathrm{ft}$., central Kiska I., Aleutian Is.; $51^{\circ} 58^{\prime} 15^{\prime \prime} \mathrm{N}, 177^{\circ} 24^{\prime} 15^{\prime \prime} \mathrm{E}$; (map 14).

An arbitrary name beginning with " $\mathrm{"} \mathrm{to}$ correspond to "L" grid used by the U.S. Army for tactical purposes during World War II; published on a 1953 AMS map.

Legend Hills: hills, $506 \mathrm{ft}$., center of Kiska I., Aleutian Is.; $51^{\circ} 56^{\prime} 30^{\prime \prime} \mathrm{N}, 177^{\circ} 25^{\prime} 00^{\prime \prime} \mathrm{E}$; (map 14).

An arbitrary name beginning with " $L$ " to correspond to "L" grid used by the U.S. Army for tactical purposes during World War II; published on a 1943 Army map.
Leghveehuk Creek: stream, heads in lake, flows SW 1 mi. to Koozata River, $1 \mathrm{mi}$. N of Koozata Lagoon and Silook Camp, St. Lawrence I.; $63^{\circ} 25^{\prime} \mathrm{N}, 170^{\circ} 40^{\prime} \mathrm{W}$; BGN 1951) (map 93). Var. Leghvihak Creek.

Eskimo name sometimes spelled "Leghvihak;" reported in 1944 by Lawrence Kulukhan, of Gambell.

Leghvihak Creek: stream, see Leghveehuk Creek. Legina Island: island, Legma Island.

Legma Island: island, $1.8 \mathrm{mi}$. long, $3 \mathrm{mi}$. W of Goddard, in Necker Is. off $W$ coast of Baranof I., Alex. Arch.; $56^{\circ} 49^{\prime} 30^{\prime \prime} \mathrm{N}, 135^{\circ} 27^{\prime} 00^{\prime \prime} \mathrm{W}$; (map 5). Var. Legina Island.

Aleut name reported to mean "calm" recorded in 1809 by Ivan Vasiliev the first, IRN. Legon: stream, see Innoko River.

Lehunua Island: island, $0.2 \mathrm{mi}$. long, in Chilkat Inlet, off SW coast of Chilkat Penin., $22 \mathrm{mi}$. SW of Skagway, Coast Mts.; $59^{\circ} 08^{\prime} 45^{\prime \prime} \mathrm{N}$, 135'22'45" W; BGN 1923; (map 45) Var. Lehunuwu Island, Tlekunuwu Island.

"Lehunua" is a Tlingit Indian name variously spelled "Lehu-nuwu" and "Tlekunuwu" and is said to mean "red-ocher fort"; reported in 1923 by IBC and published in 1924 by USC\&GS.

Lehunua Point: point of land, on SW coast of Chilkit Penin., in Chilkat Inlet, $0.4 \mathrm{mi}$. E of Kochu I. and $22 \mathrm{mi}$. SW of Skagway, Coast Mts.; $59^{\circ} 08^{\prime} 45^{\prime \prime} \mathrm{N}, 135^{\circ} 22^{\prime} 45^{\prime \prime} \mathrm{W}$; BGN 1923; (map 45). Var. Lehunuwu Point, Tlekunuwu Point.

"Lehunva" is a Tlingit Indian name variously spelled "Lehu-nuwu," "Tlekunuwu," etc. meaning "red-ocher fort," reported by IBC in 1923 and published by USC\&GS in 1924.

Lehunuwu Point: point of land, see Lehunua Point.

Leila, Lake: lake, $1.1 \mathrm{mi}$. long, in course of Eureka Creek, SE of Tahneta Pass, on Glenn Highway, $62 \mathrm{mi}$. NE of Palmer, Copper River Basin; 61 $52^{\prime} 45^{\prime \prime} \mathrm{N}, 147^{\circ} 19^{\prime} 00^{\prime \prime} \mathrm{W}$; (map 69).

Named in 1898 by Capt. E. F. Glenn, USA. Leisnoi Island: island, see Liesnoi Island.

Leland, Mount: mountain peak, see Henry Clay, Mount.

Leland Islands: islands, in group $1.5 \mathrm{mi}$. long, in Glacier Bay, Glacier Bay National Monument, $2 \mathrm{mi}$. S of Sandy Cove and $62 \mathrm{mi}$. NW of Juneau, St. Elias Mts.; $58^{\circ} 39^{\prime} 10^{\prime \prime} \mathrm{N}, 135^{\circ}$ 59'15" W; BGN 1948; (map 11).

Named in 1942 by USC\&GS.

Lemesurier Island: island, $5 \mathrm{mi}$. across, in Icy Strait, between North and South Passages, $0.7 \mathrm{mi}$. NW of Goose I. and $27 \mathrm{mi}$. NW of Hoonah, St. Elias Mts.; $58^{\circ} 17 \mathrm{~N}, 136^{\circ} 05^{\prime} \mathrm{W}$; (map 10).

Named by W. H. Dall, USC\&GS, in 1879 , for a midshipman on H.M.S. Chatham, who commanded one of Vancouver's boats during the exploration of Cross Sound in 1794. The name was published in the 1883 Alaska Coast Pilot (p. 190).

Lemesurier Island: island, see Misery Island.
Lemesurier Point: point of land, $\mathrm{W}$ tip of Cleveland Penin., Alex. Arch.; $56^{\circ} 46^{\prime} \mathrm{N}, 132^{\circ} 17^{\prime}$ W; (map 4). Var. Point Mesurier, Misery Point.

This feature was discovered by James Johnstone, RN; named August 25, 1793, for a midshipman on H.M.S. Chatham (Wagner, 1937, p. 394).

Lemesurier Point: point of land, on NE tip of Kayak I., $18 \mathrm{mi}$. SE of Katalla, Malaspina Coastal Plain, $60^{\circ} 00^{\prime} 15^{\prime \prime} \mathrm{N}, 144^{\circ} 12^{\prime} 00^{\prime \prime} \mathrm{W}$; (map 64). Var. Lemesurier Point, Mesurier Point, Punta de Navia.

Explored by Le Mesurier, RN, about June 15, 1794, and named for him by Capt. George Vancouver, RN. Spanish explorers who were in the area about the same time, called it "Punta de Navia," meaning "ship point."

Lemeta: village, pop. 1,015 , a residential suburb $1 \mathrm{mi}$. N of Fairbanks, Tanana Low.; $64^{\circ} 51^{\prime}$. $30^{\prime \prime} \mathrm{N}, 147^{\circ} 43^{\prime} 30^{\prime \prime} \mathrm{W}$; (map 100). Var. Lemeta Tract, Lemeta Subdivision.

Local name reported in 1950 by USGS topographers.

Lemeta Subdivision: village, see Lemeta.

Lemeta Tract: village, see Lemeta.

Lemley Rock: rocks, see Lemly Rocks.

Lemly Rock: rocks, see Lemly Rocks.

Lemly Rocks: rocks, offshore at Lemesurier Point, SW coast of Cleveland Penin., Alex. Arch.; $55^{\circ} 46^{\prime} 05^{\prime \prime} \mathrm{N}, 132^{\circ} 17^{\prime} 00^{\prime \prime} \mathrm{W}$; BGN 1900; (map 4). Var. Lemley Rock, Lemly Rock.

Named in 1886 by Lt. Comdr. R. Clover, USN, for "Capt. Samuel Conrad Lemly, Judge Advocate General, USN." The name was published erroneously as Lemley by Lt. Comdr. H. E. Nichols (U.S. Coast and Geodetic Survey, 1891, p. 106), USN.

Lemon Brook: stream, flows $\mathrm{S} 1 \mathrm{mi}$. to Lick Creek, on central Kiska I., Aleutian Is.; $51^{\circ} 57^{\prime} 00^{\prime \prime} \mathrm{N}, 177^{\circ} 27^{\prime} 35^{\prime \prime} \mathrm{E}$; (map 14).

Shown on a 1943 USAAF map.

Lemon Creek: stream, flows NE $0.7 \mathrm{mi}$. to Bering Sea, center of Kiska I., Aleutian Is.; $51^{\circ}$ $59^{\prime} 12^{\prime \prime} \mathrm{N}, 177^{\circ} 27^{\prime} 08^{\prime \prime} \mathrm{E}$; (map 14).

An Arbitrary name beginning with " $L$ " to correspond to " $L$ " grid used by the U.S. Army for tactical purposes during World War II; published on a 1943 Army map.

Lemon Creek: stream, floating $6 \mathrm{mi}$. SW to Gastineau Channel, $0.8 \mathrm{mi}$. E of Sunny Point and $4.8 \mathrm{mi}$. NW of Juneau, Coast Mts.; $58^{\circ}-$ $21^{\prime} \mathrm{N}, 134^{\circ} 30^{\prime} \mathrm{W}$; (map 11).

Reportedly named for John Lemon, who in 1879 did some placer mining on the creek with James Hollywood. In 1880 he joined the Edmund Bean party of prospectors who blazed a trail over Chilkoot Pass to the head. waters of the Yukon (DeArmond, 1957, p. 29-30).

Lemon Creek Glacier: glacier, $4 \mathrm{mi}$. long, trends $\mathrm{S}$ to Blackerby Ridge, $1 \mathrm{mi}$. NE of Salmon Creek Reservoir and 4 mi. NE of Juneau, Coast Mts. ; 58 $21^{\prime} 30^{\prime \prime} \mathrm{N}, 134^{\circ} 21^{\prime} 30^{\prime \prime} \mathrm{W}$; (map 11). $V a r$. Lemon Glacier.

Local name derived from Lemon Creek which drains the glacier; reported by $W . T$. Peters, and published in 1902 by USGS. 
Lemon Glacier: glacier, see Lemon Creek Glacier.

Lemon Point: point of land, at $\mathrm{N}$ point of entrance to Port McArthur, in Affleck Canal, on S coast of Kuiu I., Alex. Arch.; $56^{\circ} 04^{\prime} 20^{\prime \prime}$ N, $134^{\circ} 07^{\prime} 20^{\prime \prime} \mathrm{W}$; (map 5 ).

Named in 1886 by Lt. J. M. Helm, USN, for charting purposes; published in 1887 by USC\&GS on Chart 706.

Lemon Point Rock: rock, in Affleck Canal, near the mouth of Port McArthur, on $S$ coast of Kuiu I., Alex. Arch.; $56^{\circ} 04^{\prime}$ N, $134^{\circ} 06^{\prime} 35^{\prime \prime}$ W; (map 5).

Local name published by USC\&GS in 1932 Coast Pilot (p. 249).

Lena, Point: point of land, at S entrance to Lena Cove on Favorite Channel, $14 \mathrm{mi}$. NW of Juneau, Coast Mts. ; $58^{\circ} 23^{\prime} 45^{\prime \prime} \mathrm{N}, 134^{\circ} 46^{\prime} 45^{\prime \prime}$ W; (map 11)

Named by Capt. L. A. Beardslee, USN, in 1880 and published by USC\&GS in the 1883 Coast Pilot (p. 174).

Lena Beach: village, pop. 54, in Lena Cove, on Favorite Channel, $14 \mathrm{mi}$. NW of Juneau, Coast Mts.; $58^{\circ} 23^{\prime} 35^{\prime \prime} \mathrm{N}, 134^{\circ} 44^{\prime} 50^{\prime \prime} \mathrm{W}$; (map 11 ).

Name published in 1940 by the Bureau of the Census.

Lena Cove: cove, $0.5 \mathrm{mi}$. across, on $\mathrm{E}$ shore of Favorite Channel, $0.6 \mathrm{mi}$. S of Tee Harbor and $14 \mathrm{mi}$. NW of Juneau, Coast Mts.; $58^{\circ} 24^{\prime} \mathrm{N}, 134^{\circ} 46^{\prime} \mathrm{W}$; (map 11 ).

Named by USC\&GS for Mrs. Lena Vanderbilt DeGroff; published in 1893 on Chart 8300.

Lena Creek: stream, flows $1 \mathrm{mi}$. NW to Lena Cove on Favorite Channel, $1 \mathrm{mi}$. SE of Tee Harbor and $13 \mathrm{mi}$. NW of Juneau, Coast Mts.; $58^{\circ} 23^{\prime} 40^{\prime \prime} \mathrm{N}, 134^{\circ} 44^{\prime} 45^{\prime \prime} \mathrm{W}$; (map 11).

Name published in 1962 by USGS.

Lenant Creek: stream, flows SW $7 \mathrm{mi}$. to McCoy Creek, $29 \mathrm{mi}$. NW of Big Delta, YukonTanana High.; $64^{\circ} 29^{\prime} 30^{\prime \prime} \mathrm{N}, 146^{\circ} 21^{\prime} 00^{\prime \prime} \mathrm{W}$; (map 101)

Local name reported in 1910 by USGS (Capps, 1912, pl. 1).

Lenard Harbor: bay, $2 \mathrm{mi}$. across, on $\mathbf{E}$ side of Cold Bay, $9 \mathrm{mi}$. SE of village of Cold Bay, at SW end of Alaska Penin., Aleutian Ra.; $55^{\circ} 08^{\prime} \mathrm{N}, 162^{\circ} 27^{\prime} \mathrm{W}$; (map 29).

Named by USBF in 1888 .

Lend Ridge: ridge, $0.6 \mathrm{mi}$. long, $\mathrm{SW}$ of Quisling Cove, along Bering Sea coast of Kiska I., Aleutian Is.; $51^{\circ} 58^{\prime} 35^{\prime \prime} \mathrm{N}, 177^{\circ} 22^{\prime} 15^{\prime \prime} \mathrm{E}$; (map 14).

An arbitrary name beginning with "L" to correspond to "L" grid used by the U.S. Army for tactical purposes during World War II; published on a 1953 AMS map.

Lennan Shoal: shoal, off SW coast of Dolgoi I., Aleutian Ra.; ( $\operatorname{map} 28$ )

Named in 1880 by W. H. Dall, USC\&GS, and shown on an 1882 coast chart; the shoal has not been positively identified.

Lenora Lake: lake, $0.3 \mathrm{mi}$. long, drains $\mathrm{NW}$ into Lower Ugashik Lake, on Alaska Penin., $20 \mathrm{mi}$.
SE of Ugashik; $57^{\circ} 24^{\prime} 40^{\prime \prime} \mathrm{N}, 156^{\circ} 54^{\prime} 30^{\prime \prime} \mathrm{W}$; (map 36)

Named in 1923 by R. H. Sargent, USGS.

Lenore Hill: mountain, 3,302 ft., on $S$ coast of Alaska Penin., $9 \mathrm{mi}$ NE of entrance to Chinitna Bay and $50 \mathrm{mi}$. NW of Homer, Aleutian Ra. $59^{\circ} 58^{\prime} 45^{\prime \prime} \mathrm{N}, 152^{\circ} 47^{\prime} 00^{\prime \prime} \mathrm{W}$; (map 50).

Name reported by $F$. $H$. Moffit, USGS, in 1920 (in Brooks and others, 1922, pl. 2).

Lentil Hill: hill, $420 \mathrm{ft}$., center of Kiska I., Aleutian Is.; $51^{\circ} 56^{\prime} 09^{\prime \prime} \mathrm{N}, 177^{\circ} 25^{\prime} 24^{\prime \prime} \mathrm{E}$; (map 14).

An arbitrary name beginning with " $L$ " to correspond to "L" grid used by the U.S. Army for tactical purposes during World War II; published on a 1943 Army map.

Leo, Lake: lake, $0.5 \mathrm{mi}$. across, $1.5 \mathrm{mi}$. NE of Klokachef I., on Chichag of I., $19 \mathrm{mi}$. SE of Chichagof, Alex. Arch.; $57^{\circ} 25^{\prime} 30^{\prime \prime} \mathrm{N}, 135^{\circ}$ $51^{\prime} 00^{\prime \prime} \mathrm{W}$; BGN 1930; (map 9 )

Named in 1928 by USC\&GS for adjacent Leo Anchorage.

Leo, Point: point of land, on $\mathrm{N}$ shore of Salisbury Sound, on Chichagof I., $20 \mathrm{mi}$. SE of Chichagof, Alex. Arch.; $57^{\circ} 23^{\prime} 30^{\prime \prime} \mathrm{N}, 135^{\circ}$ $50^{\prime} 30^{\prime \prime} \mathrm{W}$; ( $\operatorname{map} 9$ ).

Named in 1896 by Lt. Comdr. E. K. Moore, USN, for adjoining Leo Anchorage. The name was published in 1900 by USC\&GS on Chart 8282.

Leo Anchorage: anchorage, $0.5 \mathrm{mi}$. across, $1 \mathrm{mi}$. NE of Klokachef I., on Chichagof I., $19 \mathrm{mi}$. SE of Chichagof, Alex. Arch.; $57^{\circ} 25^{\prime} 20^{\prime \prime} \mathrm{N}$, $135^{\circ} 51^{\prime} 30^{\prime \prime} \mathrm{W}$; (map 9).

Surveyed and named in 1884 by Comdr. J. B.. Coghlan, USN, presumably for the steamer Leo, which operated in these waters at that time. The name was published by USC\&GS in 1891 Coast Pilot (p. 180).

Leo Creek: stream, $0.1 \mathrm{mi}$. long, on Chichagof I., $1.5 \mathrm{mi}$. NE of Klokachef I., flows from Leo Lake to Leo Anchorage, $19 \mathrm{mi}$. SE of Chichagof, Alex. Arch.; 57 $25^{\prime} 30^{\prime \prime}$ N, $135^{\circ} 51^{\prime} 00^{\prime \prime}$ W; (map 9).

Local name reported in 1951 by USGS.

Leo Gulch : ravine, see Lee Gulch.

Leo Hill: hill, $132 \mathrm{ft}$., E of Bluff Cove, Kiska I., Aleutian Is.; $51^{\circ} 59^{\prime} 15^{\prime \prime} \mathrm{N}, 177^{\circ} 29^{\prime} 05^{\prime \prime} \mathrm{E}$; (map 14).

An arbitrary name beginning with " $L$ " to correspond to "L" grid used by the U.S Army for tactical purposes during World War II; published on a 1943 Army map.

Leo Island: island, $0.1 \mathrm{mi}$. across, in Klag Bay, 2 mi. S of Chichagof, of W coast of Chichagof I., Alex. Arch.; 57 $38^{\prime} 00^{\prime \prime} \mathrm{N}, 136^{\circ} 05^{\prime} 35^{\prime \prime} \mathrm{W}$; $B G N$ 1908; ( $\operatorname{map} 9$ ).

Named in 1908 by USC\&GS, probably for the steamer Leo.

Leon, Cape: point of land, see Leontovich, Cape. Leon Bay: cove, $0.5 \mathrm{mi}$. across, on $\mathrm{E}$ shore of Iliamna Lake, $0.8 \mathrm{mi}$. SE of Tommy Point and $15 \mathrm{mi}$. SE of Iliamna, Aleutian Ra.; $59^{\circ}$ $35^{\prime} \mathrm{N}, 154^{\circ} 38^{\prime} \mathrm{W}$; (map 51 ).

Local name published in 1954 by USC\&GS. Leona Lake: lake, $0.4 \mathrm{mi}$. across, on $\mathrm{E}$ coast of Baranof I., $2.4 \mathrm{mi}$. NW of Port Alexander, Alex. Arch; $56^{\circ} 16^{\prime} \mathrm{N}, 134^{\circ} 42^{\prime} \mathrm{W}$; (map 5).
Local name recorded in 1951 by USGS. Leonard Island: island, $0.7 \mathrm{mi}$. long, $0.5 \mathrm{mi}$. W of Long I., in Yukon River, $2.5 \mathrm{mi}$. SW of Tanana, Nowitna Low.; $65^{\circ} 09^{\prime} 30^{\prime \prime} \mathrm{N}, 152^{\circ}$. $10^{\prime} 00^{\prime \prime} \mathrm{W}$; ( $\operatorname{map} 106$ ).

Local name reported in 1952 by USGS.

Leonard Wood Point: point of land, see Aurora Point.

Leone, Lake: lake, $0.5 \mathrm{mi}$. across, $1 \mathrm{mi}$. SW of Kuluk Bay, on NE coast of Adak I., Aleutian Is.; $51^{\circ} 50^{\prime} 30^{\prime \prime} \mathrm{N}, 176^{\circ} 38^{\prime} 30^{\prime \prime} \mathrm{W}$; (map 17).

Local name published in 1951 on a USGS map.

Leonora Creek: stream, flows WSW $2.6 \mathrm{mi}$. to Minook Creek, $1 \mathrm{mi}$. E of Rampart and $62 \mathrm{mi}$. ENE of Tanana, Yukon-Tanana High.; $65^{\circ}$ $30^{\prime} 30^{\prime \prime} \mathrm{N}, 150^{\circ} 07^{\prime} 00^{\prime \prime} \mathrm{W}$; (map 106).

Prospectors' name shown on a manuscript map dated 1906; reported in 1956 by Orth.

Leontavitch, Cape: point or land, see Leontovich, Cape.

Leontovich, Cape: point of land, on $\mathrm{N}$ coast of Alaska Penin., $4 \mathrm{mi}$. NE of mouth of Cathedral River, $18 \mathrm{mi}$. NE of Moffet Point and 33 mi. NE of village of Cold Bay, Bristol Bay Low.; $55^{\circ} 40^{\prime} 25^{\prime \prime} \mathrm{N}, 162^{\circ} 16^{\prime} 45^{\prime \prime} \mathrm{W}$; $B G N$ 1966; (map 29). Var. Cape Leon, Cape Leontavitch, Cape Leontovitch, Starling Cape, Starling Point.

Named by Capt. Lutke (1836, p. 261) IRN, for Lt. Alexander Leontovich, IRN, a member of his party on his voyage around the world, 1826-1829.

Leontovitch, Cape: point of land, see Leontovich, Cape.

Leper Lake: lake, $0.1 \mathrm{mi}$. across, at mouth of Lazy Creek, center of Kiska I., Aleutian Is.; $51^{\circ} 56^{\prime} 25^{\prime \prime} \mathrm{N}, 177^{\circ} 26^{\prime} 00^{\prime \prime} \mathrm{E}$; (map 14).

An arbitrary name beginning with " $\mathrm{L}$ " to correspond to "L" grid used by the U.S. Army for tactical purposes during World War II; published on a 1943 Army map.

Lepping's, Cape: point of land, see Seppings, Cape.

Leroy Creek: stream, flows NW $2.4 \mathrm{mi}$. to Bluestone River, $12 \mathrm{mi}$. SE of Teller, Seward Penin. High.; 65 $07^{\prime} \mathrm{N}, 166^{\circ} 07 \mathrm{~W}$; (map 111).

Local name reported in 1900 by $E$. C Barnard (in Brooks, 1901, pl. 17), USGS

Leskoff : point of land, see Lieskof, Cape.

Lesnoi Islet : island, see Liesnoi Island.

Lesser Arm: bay, see Small Arm Whale Bay.

Lester Island: island, $3.8 \mathrm{mi}$. long, southernmost of the Beardslee Is., in Glacier Bay, in Glacier Bay National Monument, St. Elias Mts.; $58^{\circ} 28^{\prime} \mathrm{N}, 135^{\circ} 50^{\prime} \mathrm{W} ; B G N$ 1942; (map 11).

Named in 1942 by USC\&GS for Rear Adm. Lester Anthony Beardslee, 1836-1903, who as commander of the U.S.S. Jamestown, surveyed various Alaskan coves and harbors in 18791880 , and who is supposed to have been the first to apply the name "Glacier Bay."

Lester River: stream, flows NW $15 \mathrm{mi}$. to Tuxekan Passage, on $\mathrm{W}$ coast of Prince of Wales I., Alex. Arch.; $55^{\circ} 49^{\prime} 15^{\prime \prime}$ N, $133^{\circ}$. $10^{\prime} 00^{\prime \prime}$ W; (map 4). Var. Staney Creek.

Local name recorded in 1949 by USGS. 
Let Island: island, $0.2 \mathrm{mi}$. across, $4 \mathrm{mi}$. SW of Deer I., Aleutian Ra.; $54^{\circ} 50^{\prime} 15^{\prime \prime} \mathrm{N}, 162^{\circ}$ $26^{\prime} 30^{\prime \prime} \mathrm{W} ; B G N$ 1942; (map 25). Var. Big Sandy Island, Low Island Number 2.

Named by USC\&GS in 1939 for the triangulation station Let 1936 located on the island. According to USC\&GS, this island was locally called "Big Sandy Island." The USBF called it "Low Island Number 2" in 1888.

Lethe, River: stream, on Alaska Penin., in Katmai National Monument, heads in glacial lake on Mount Mageik and flows NW $14 \mathrm{mi}$. through Valley of Ten Thousand Smokes to Ukak River, 18 mi. NW of Mount Katmai, Aleutian Ra.; $58^{\circ} 23^{\prime} 45^{\prime \prime} \mathrm{N}, 155^{\circ} 24^{\prime} 00^{\prime \prime} \mathrm{W}$; $B G N$ 1924; (map 42).

Named in 1917 by R. F. Griggs, National Geographic Society; suggested by Lethe, the "river of forgetfulness" in the Hades of Greek mythology.

Letniki-Takaïak: locality, see Takaiak.

Letnikof Cove: locality, on SW shore of Letnikof Cove, Chilkat Penin., Coast Mts.; $59^{\circ} 11^{\prime}$ N, $135^{\circ} 24^{\prime} \mathrm{W}$; (map 45).

Cannery reported in 1962 by USC\&GS.

Letnikof Cove: cove, $0.5 \mathrm{mi}$. across, on $\mathrm{SW}$ coast of Chilkat Penin., $1.6 \mathrm{mi}$. N of Kochu I., in Chilkat Inlet, $19 \mathrm{mi}$. SW of Skagway, Coast Mts. ; $59^{\circ} 10^{\prime} 40^{\prime \prime} \mathrm{N}, 135^{\circ} 24^{\prime} 10^{\prime \prime} \mathrm{W}$; (map 45). Var. Letnikov Cove, Litnekof Cove.

Named "B[ukhta] Letnikov," meaning "Letnikov Cove," on the 1848 Russian Hydrog. Dept. Chart 1396. It was published as Letnikoff Cove by USC\&GS in the 1883 Coast Pilot (p. 197).

Letnikov Cove: cove, see Letnikof Cove.

Leto Point: point of land, on E shore of Kizhuyak Bay, $3.3 \mathrm{mi}$. SW of Kekur Point, $16 \mathrm{mi}$. W of Kodiak, Kodiak I.; $57^{\circ} 49^{\prime} 30^{\prime \prime} \mathrm{N}, 152^{\circ}$. $50^{\prime} 45^{\prime \prime} \mathrm{W}$; ( $\left.\operatorname{map} 34\right)$.

Local name published in 1943 by USC\&GS. Letushkwin: locality, on Admiralty I. on $\mathrm{N}$ shore of Chaik Bay, $11 \mathrm{mi}$. S of Angoon, Alex.

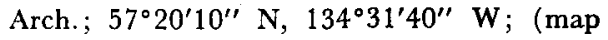
9). Var. Bear Fort, Khudsnu, Old Khootznahoo, Old Kootznahoo.

Tlingit Indian village reported by $\mathbf{W}$. $\mathbf{H}$. Dall, USC\&GS, in the 1883 Coast Pilot.

Leuel Lake: lake, 100 yd. across, south-central Kiska I., Aleutian Is. ; $51^{\circ} 56^{\prime} 15^{\prime \prime} \mathrm{N}, 177^{\circ}$ $23^{\circ} 03^{\prime \prime} \mathrm{E}$; ( $\left.\operatorname{map} 14\right)$.

An arbitrary name beginning with " $L$ " to correspond to "L" grid used by the U.S. Army for tactical purposes during World War II; published on a 1953 AMS map.

Levacheff, Port: $b a y$, see Levashef, Port.

Levashef, Port: bay, at head of Captains Bay in Unalaska Bay, on NE coast of Unalaska I., Aleutian Is.; $53^{\circ} 49^{\prime} 50^{\prime \prime} \mathrm{N}, 166^{\circ} 36^{\prime} 15^{\prime \prime} \mathrm{W}$; $B G N$ 1931; (map 23). Var. Captains Harbor, Port Levacheff, Saint Paul Harbor.

Russian name given in honor of Lt. Michael Levashev, IRN, who spent the winter here in 1768-69, by Adm. Krusenstern (1827, atlas), IRN, who changed the name from "Captains Harbor" as given by $\mathbf{L}$. Sarichev, IRN, in 1790 to distinguish it from Captains
Bay. Levashev called this feature St. Paul Harbor after his ship (Coxe, 1787, p. 222). Levashef, Port: bay, see Captains Bay.

Level Island: islands, see Level Islands.

Level Islands: islands, $2.7 \mathrm{mi}$. long, between Sumner Strait and Duncan Canal, SE coast of Kupreanof I., Alex. Arch.; $56^{\circ} 28^{\prime} \mathrm{N}, 133^{\circ}$ $05^{\prime} \mathrm{W}$; (map 6). Var. Level Island.

Descriptive name given in 1886 by Lt. Comdr. A. S. Snow, USN, because "at high water it becomes two islands."

Level Mountain: hill, $600 \mathrm{ft}$., on Revillagigedo I., 0.4 mi. $\mathrm{N}$ of Ketchikan, Alex. Arch.; $55^{\circ} 21^{\prime}$ $\mathrm{N}, 131^{\circ} 38^{\prime} \mathrm{W}$; (map 3 ).

Descriptive name given in 1883 by Lt. Comdr. H. E. Nichols, USN.

Levelock: village, pop. 88 , on right bank of Kvichak River, $58 \mathrm{mi}$. E of Dillingham, Bristol Bay Low.; $59^{\circ} 07^{\prime} \mathrm{N}, 156^{\circ} 51^{\prime} \mathrm{W}$; (map 52). Var. Kvichak, Livelock, Old Kvichak.

Eskimo village named "Kvichak" reported by early Russian explorers and mentioned in 11 th Census in 1890 . A post office called "Levelock" was established here in 1939 (Ricks, 1965, p. 39).

Levelock Creek: stream, flows SE $11 \mathrm{mi}$. to Kvichak River, $58 \mathrm{mi}$. E of Dillingham, Bristol Bay Low.; $59^{\circ} 07^{\prime} 15^{\prime \prime} \mathrm{N}, 156^{\circ} 50^{\prime} 30^{\prime \prime} \mathrm{W}$; (map 52).

Local name published by USGS in 1952. The stream takes its name from the nearby village.

Lewes River: stream, see Yukon River.

Lewis: locality, on right bank of Yukon River and $58 \mathrm{mi}$. E of Nulato, Koyukuk Low.; $64^{\circ} 43^{\prime} 30^{\prime \prime} \mathrm{N}, 156^{\circ} 09^{\prime} 00^{\prime \prime} \mathrm{W}$; (map 97). Var. Lewis' Store.

Riverboat pilots' name reported in 1908 by A. G. Maddren, USGS.

Lewis, Cape: promontory, 1,222 $\mathrm{ft}$., on Chukchi Sea coast, $29 \mathrm{mi}$. NE of village of Point Hope, Arctic Slope; $68^{\circ} 42^{\prime} 50^{\prime \prime} \mathrm{N}, 166^{\circ} 12^{\prime} 01^{\prime \prime} \mathrm{W}$; (map 129). Var. Ee-ree-nick Cape, Irinik Point.

Named in 1826 by Capt. Beechey (1831, map on p. 328), RN, for Charles Lewis of his party. According to USC\&GS in 1950, the Eskimo name is "Ee-ree-nick [Irinik]," meaning "falling rocks."

Lewis Cass, Mount: mountain, 6,864 $\mathrm{ft}$, on Alaska-Canada boundary, $23 \mathrm{mi}$. N of mouth of Unuk River, at Burroughs Bay, Coast Mts.; $56^{\circ} 24^{\prime} 25^{\prime \prime} \mathrm{N}, 131^{\circ} 05^{\prime} 00^{\prime \prime} \mathrm{W}$; BGN 1924; (map 7).

Named in 1924 by USGS for Lewis Cass, 1782-1866, American statesman, diplomat, soldier, and author.

Lewis Gulch: ravine, trends W $1.5 \mathrm{mi}$. to Crooked Creek $1 \mathrm{mi}$. $\mathrm{N}$ of its junc. with American Creek, $43 \mathrm{mi}$. NW of Sleetmute, KilbuckKuskokwim Mts.; $62^{\circ} 03^{\prime} \mathrm{N}, 158^{\circ} 14^{\prime} \mathrm{W}$; BGN 1945; (map 79). Var. Louise Gulch.

Prospectors' name obtained in 1944 by USGS ; named for a "prospector named Lewis who mined at the mouth." Called "Louise Gulch" in 1923 by Mertie and Harrington (1924, pl. 4), USGS.
Lewis Island: island, $0.3 \mathrm{mi}$. long, in Revillagigedo Channel, $0.5 \mathrm{mi}$. E of Ham I., Alex. Arch.; $55^{\circ} 11^{\prime} 45^{\prime \prime} \mathrm{N}, 131^{\circ} 21^{\prime} 50^{\prime \prime} \mathrm{W}$; (map 3). Var. Side Island, Walker Island.

Named by local pilots about 1880 ; called "Side Island" in the 1883 Coast Pilot (p. 77). This island has been confused with nearby Walker Island.

Lewis Island: island, see Walker Island.

Lewis Peak: peak, 7,800 ft., in Cathedral Spires of Kichatna Mts., $81 \mathrm{mi}$. W of Talkeetna, Alaska Ra.; $62^{\circ} 24^{\prime} \mathrm{N}, 152^{\circ} 41^{\prime} \mathrm{W}$; (map 81).

Named in 1899 by Lt. J. S. Herron, USA.

Lewis Point: locality, on Lewis Point on $\mathrm{N}$ bank of Nushagak River, $14 \mathrm{mi}$. SE of Dillingham, Bristol Bay Low.; $59^{\circ} 00^{\prime} \mathrm{N}, 158^{\circ} 06^{\prime} \mathrm{W}$; $B G N$ 1937; (map 40).

Eskimo settlement or camp reported in 1924 by USBF.

Lewis Point: point of land, on NE coast of Gravina I., 4 mi. NW of Ketchikan Harbor, Alex. Arch.; $55^{\circ} 22^{\prime} 30^{\prime \prime} \mathrm{N}, 131^{\circ} 44^{\prime} 30^{\prime \prime} \mathrm{W}$; (map 3).

Named about 1880 by local navigators; reported by USC\&GS.

Lewis Point: point of land, on $\mathrm{N}$ bank of Nushagak River, $13 \mathrm{mi}$. SE of Dillingham, Bristol Bay Low.; $59^{\circ} 00^{\prime} \mathrm{N}, 158^{\circ} 06^{\prime} \mathrm{W}$; BGN 1937; (map 40).

Local name reported in 1937 by USGS.

Lewis Reef: reef, in Tongass Narrows, extends $1,000 \mathrm{ft}$., off Lewis Point on NE coast of Gravina I., Alex. Arch.; 55 $22^{\prime} 30^{\prime \prime} \mathrm{N}, 131^{\circ} 44^{\prime} 15^{\prime \prime}$ W; (map 3).

Named about 1880 by local navigators; reported by USC\&GS.

Lewis Rich Channel: stream, distributary of Kobuk River, flows SW $7 \mathrm{mi}$. to Hotham Inlet, $52 \mathrm{mi}$. NW of Selawik, Kotzebue-Kobuk Low.; $66^{\circ} 43^{\prime} \mathrm{N}, 161^{\circ} 52^{\prime} \mathrm{W}$; (map 114).

Local name reported by the U.S. Army Corps of Engineers in 1955.

Lewis River: stream, heads on Mount Susitna, flows S $30 \mathrm{mi}$. to Cook Inlet, $30 \mathrm{mi}$. W of Anchorage, Cook Inlet Low.; $61^{\circ} 14^{\prime} \mathrm{N}, 150^{\circ}$ $48^{\prime}$ W ; BGN 1916; (map 70).

Local name reported in 1916 by USGS.

Lewis River: stream, see Igloo Creek.

Lewis River: stream, see Ivan River.

Lewis River: stream, see Yukon River.

Lewis River Slough: lake, $1 \mathrm{mi}$. long, one of Chedatna Lakes, on W bank of Ivan River, 18 mi. NE of Tyonek, Cook Inlet Low; 61 $1^{\circ} 15^{\prime}$ $45^{\prime \prime} \mathrm{N}, 150^{\circ} 46^{\prime} 10^{\prime \prime} \mathrm{W}$; (map 70).

Local name reported in 1958 by USGS; derived from nearby Lewis River.

Lewis' Store: locality, see Lewis.

Lgun, Kamen: rocks, see Liar Rocks.

Lgvac, Gape: point of land, see Kanatak Cape. Lhakatruntamená: lake, see Fish Creek Lake.

Lhookoovik, Cape: point of land, see Vngyat Point.

Lhookoovik Cape: point of land, see Shlokovik Point.

Liakik, Cape: point of land, between Three Saints Bay and Sitkalidak Strait, on SE coast of Kodiak I.; $57^{\circ} 07^{\prime} \mathrm{N}, 153^{\circ} 27^{\prime} \mathrm{W}$; (map 34). Var. Mys Lyakh, Mys Lyakhik: 
Transliteration of "M[ys] Lyakhik," published by Capt. Tebenkov (1852, map 23). Possibly derived from the Aleut word "lakh," which, according to R. H. Geoghegan, means "black-footed tundra goose," and which Father Veniaminov (1846, p. 47) published as "Lyakh."

Liakik Bay: bay, see Three Saints Bay.

Liar Rocks: rocks, $\mathrm{S}$ of Eastern Channel, Sitka Sound, $3 \mathrm{mi}$. S of Sitka, Alex. Arch.; $57^{\circ} 01^{\prime}$ $40^{\prime \prime}$ N, $135^{\circ} 21^{\prime} 50^{\prime \prime} \mathrm{W}$; (map 9). Var. False Rock, Kamen Lgun.

This is an 1882 translation by USC\&GS of the name given in 1809 by the Russian navigator Ivan Vasiliev the first; reported by Lt. Sarichev (1826, map 19), IRN, as K[amen] Lgun."

Libbey Glacier: glacier, heads on Haydon Peak, trends S 6 mi. to Agassiz Glacier, $11 \mathrm{mi}$. S of Mount St. Elias and $60 \mathrm{mi}$. NW of Yakutat, St. Elias Mts.; $60^{\circ} 08^{\prime} \mathrm{N}, 140^{\circ} 57^{\prime} \mathrm{W}$; $B G N$ 1929; (map 66). Var. Libby Glacier.

So named in 1888 by $\mathrm{H}$. W. Topham (1889) for William Libbey, Jr., 1855-1927, of Princeton Univ., scientist, geologist, geographer, writer, and soldier, who was a member of the New York Times Expedition to this area in 1886.

Libby Creek: stream, heads about $57^{\circ} 29^{\prime} \mathrm{N}$, $133^{\circ} 22^{\prime} \mathrm{W}$, flows $5 \mathrm{mi}$. SSW to Stephens Passage, $76 \mathrm{mi}$. NE of Sitka, Coast Mts.; $57^{\circ} 28^{\prime}$ $10^{\prime \prime} \mathrm{N}, 133^{\circ} 30^{\prime} 30^{\prime \prime} \mathrm{W}$; (map 8).

Local name reported in 1955 by USGS.

Libby Glacier: glacier, see Libbey Glacier.

Libby Island: island, $0.5 \mathrm{mi}$. across, at mouth of Graves Harbor, in Glacier Bay National Monument, $50 \mathrm{mi}$. NW of Hoonah, St. Elias Mts.; $58^{\circ} 16^{\prime} 40^{\prime \prime} \mathrm{N}, 136^{\circ} 46^{\prime} 45^{\prime \prime} \mathrm{W}$; (map 10).

Name published by USC\&GS in the 1901 Alaska Coast Pilot (p. 212).

Libby River: stream, heads $\mathrm{N}$ of Mount Bendeleben, flows SW $14 \mathrm{mi}$. to Niukluk River, 50 mi. SW of Imuruk Lake, Seward Penin. High.; $65^{\circ} 02^{\prime} \mathrm{N}, 164^{\circ} 14^{\prime} \mathrm{W}$; (map 110$)$.

Prospectors' name reported in 1900 by E. C. Barnard (in Brooks, 1901, pl. 17), USGS.

Libby Station: village, see Teller.

Libbysville: village, see Teller.

Libbyville: village, on $\mathrm{N}$ coast of Alaska Penin., $3.5 \mathrm{mi}$. NW of Naknek, Bristol Bay Low.; $58^{\circ}$ $46^{\prime} 40^{\prime \prime} \mathrm{N}, 157^{\circ} 03^{\prime} 20^{\prime \prime} \mathrm{W}$; (map 41).

Name published by USC\&GS in 1947 Coast Pilot (p. 521). This village is the site of a Libby, McNeill, and Libby Go. cannery.

Libel Hill: hill, $500 \mathrm{ft}$, center of Kiska I., Aleutian Is.; $51^{\circ} 57^{\prime} \mathrm{N}, 177^{\circ} 26^{\prime} \mathrm{E}$; (map 14).

An arbitrary name beginning with " $L$ " to correspond to "L" grid used by the U.S. Army for tactical purposes during World War II; published on a 1943 Army map.

Liberator Creek: stream, heads at Liberator Lake, flows NNE and E $12 \mathrm{mi}$. to Colville River, Arctic Slope; $68^{\circ} 59^{\prime} \mathrm{N}, 158^{\circ} 10^{\prime} \mathrm{W}$; $B G N$ 1960; (map 132).

Named by USGS geologists in 1950 for the lake which it drains.
Liberator Lake: lake, $1.5 \mathrm{mi}$. across, $58 \mathrm{mi}$. NW of Howard Pass, Arctic Slope; 68 $53^{\prime} \mathrm{N}$, $158^{\circ} 22^{\prime}$ W; BGN 1960; (map 132).

So named by personnel of the Naval Petroleum Reserve No. 4 explorations in the 1940's, because the lake was used as a landmark by supply-plane pilots flying converted B-24 longrange bombers called "Liberator" by the British during World War II.

Liberator Ridge: ridge, elev. 3,176 ft., trends EW $10 \mathrm{mi} \mathrm{S}$ of Liberator Lake, Arctic Slope; $68^{\circ} 50^{\prime} \mathrm{N}, 158^{\circ} 15^{\prime} \mathrm{W}$; (map 132).

Named by personnel of the Naval Petroleum Reserve No. 4 explorations in 1949 for Liberator Lake.

Liberty: locality, $\mathrm{N}$ of junc. of King Solomon Creek and Liberty Fork, $22 \mathrm{mi}$. S of Eagle,

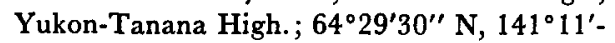
15" W; (map 102). Var. Liberty Fork.

Mining camp, now abandoned, reported in 1903 by Prindle (1905, p. 10), USGS.

Liberty Gap: point of land, see Battery Point.

Liberty Creek: stream, flows NE $13 \mathrm{mi}$. to Copper River, $4 \mathrm{mi}$. SE of Lower Tonsina and 66 mi. NE of Valdez, Copper River Basin; $61^{\circ}$ $38^{\prime} 15^{\prime \prime} \mathrm{N}, 144^{\circ} 32^{\prime} 30^{\prime \prime} \mathrm{W}$; (map 68).

Local name published in the 1950's by USGS.

Liberty Creek: stream, flows $\mathrm{N} 5 \mathrm{mi}$. to Walker Fork, $55 \mathrm{mi}$. SW of Eagle; $64^{\circ} 02^{\prime} \mathrm{N}, 141^{\circ} 34^{\prime}$ W; (map 102).

Prospectors' name shown on an 1898 manuscript map by C. A. Woodruff, Fort Cudahy, Canada.

Liberty Falls: falls, on Liberty Creek $1.2 \mathrm{mi}$. S of its mouth, on Copper River, $66 \mathrm{mi}$. NE of Valdez, Copper River Basin; 61 $37^{\circ} 20^{\prime \prime} \mathrm{N}$, $144^{\circ} 32^{\prime} 45^{\prime \prime} \mathrm{W}$; (map 68).

Local name published in the 1950's by USGS.

Liberty Fork: stream, heads in Canada, flows SW $12 \mathrm{mi}$. to join King Solomon Creek to form O'Brien Creek, $22 \mathrm{mi}$. S of Eagle, YukonTanana High.; $64^{\circ} 29^{\prime} 30^{\prime \prime} \mathrm{N}, 141^{\circ} 11^{\prime} 15^{\prime \prime} \mathrm{W}$; (map 102).

Prospectors' name reported in 1898 by E. C. Barnard, USGS. This is one of several names in the "Fortymile district" that are patriotic. Liberty Fork: locality, see Liberty.

Liberty Landing: locality, see Johnnys Village. Lick Greek: stream, heads in Nutzotin Mts., flows NE and NW $18 \mathrm{mi}$. to Nabesna River, $7.5 \mathrm{mi}$. SW of Jatahmund Lake and $29 \mathrm{mi}$. SW of Northway, Alaska Ra.; $62^{\circ} 35^{\prime} \mathrm{N}, 142^{\circ}$ $16^{\prime}$ W; BGN 1941; (map 84).

So named by USGS field party because the clays along the stream were licked by mountain sheep; reported in 1940 by P. S. Smith, USGS.

Lick Creek : stream, flows S $2.6 \mathrm{mi}$. to Gertrude Cove, central Kiska I., Aleutian Is.; $51^{\circ} 56^{\prime}$ $24^{\prime \prime}$ N, $177^{\circ} 27^{\prime} 28^{\prime \prime} \mathrm{E}$; (map 14). Var. Gin Brook, Collins Creek.

An arbitrary name beginning with "L" to correspond to "L" grid used by U.S. Army for tactical purposes during World War II; published on a 1953 AMS map.
Licking Creek: stream, on Revillagigedo I., flows SW 3.2 mi. to Carroll Inlet, E of Nigelius Point, Alex. Arch.; $55^{\circ} 33^{\prime} 20^{\prime \prime} \mathrm{N}, 131^{\circ} 20^{\prime} 10^{\prime \prime}$ W; BGN 1923; (map 3).

Named in 1921 by USFS.

Lida Island: island, $0.1 \mathrm{mi}$. across, $0.5 \mathrm{mi}$. NW of Caton I., Sanak Is.; Aleutian Ra.; $54^{\circ} 25^{\prime}$ $20^{\prime \prime} \mathrm{N}, 162^{\circ} 29^{\prime} 10^{\prime \prime} \mathrm{W}$; (map 25).

Name given in 1880 by USBF.

Lidrejana Bay; bay, see Andrew Bay.

Liebes Cove: bay, $1.2 \mathrm{mi}$. across, off Saint Michael Bay, $2 \mathrm{mi}$. SE of Saint Michael, Yukon-Kuskokwim Delta; 63 ${ }^{\circ} 27^{\prime}$ N, 161 ${ }^{\circ} 59^{\prime}$ W; (map 91).

Local name reported in 1898 by USC\&GS.

Liebigstag: locality, "on the left bank of Copper River, near $61^{\circ} 57^{\prime} \mathrm{N}, 145^{\circ} 45^{\prime}$ W." Var. Liebigstag's.

A former Ahtena Indian village reported in 1885 as "Liebigstag's" by Lt. Allen (1887, p. 120), USA.

Liebigstag River: stream, see Chetaslina River.

Liebigstag's: locality, see Liebigstag.

Lief Cove: cove, $0.8 \mathrm{mi}$. across, on $\mathrm{W}$ coast of Kiska I., Aleutian Is.; $51^{\circ} 56^{\prime} 15^{\prime \prime} \mathrm{N}, 177^{\circ} 19^{\prime}$ 20" E; (map 14).

An arbitrary name beginning with " $L$ " to correspond to "L" grid used by the U.S. Army for tactical purposes during World War II; published on a 1953 AMS map.

Liesistoi : island, see Wooded Island.

Lieskof, Cape: point of land, on $\mathrm{N}$ coast of Alaska Penin, at its SW end, $5 \mathrm{mi}$. $\mathrm{N}$ of Black Hills and $45 \mathrm{mi}$. NE of village of Cold Bay, Bristol Bay Low.; BGN 1965; (map 29). Var. Garfield Point, Leskoff, Lieskoff, Liskoff, Mys Lyskova.

Named "Mys Lyskova," or "Lyskov Cape," in 1828 by Capt. Lutke (1836, p. 261), IRN, for Lt. Arkady Lyskov, IRN, who accompanied him on his voyage around the world in 1826-29. The name was published in 1847 on Chart 1379 by the Russian Hydrog. Dept. and by Capt. Tebenkov (1852, map 24), IRN. The name "Garfield" was applied to this point in 1888 by USBF.

Lieskoff: point of land, see Lieskof, Cape.

Liesnoi Island: island, $0.5 \mathrm{mi}$. long, $4.5 \mathrm{mi}$. NW of Wrangell, Alex. Arch.; $56^{\circ} 30^{\prime} \mathrm{N}, 132^{\circ} 29^{\prime}$ W; (map 6). Var. Leisnoi Island.

Russian name meaning "wooded" given in 1863 by surveyors from the corvette Rynda. See Rynda Island.

Liesnoi Island: island, $0.4 \mathrm{mi}$. long, $4.4 \mathrm{mi}$. SW of Goddard, in Necker Is., on W coast of Baranof I., Alex. Arch.; 56 $48^{\prime} 45^{\prime \prime}$ N, $135^{\circ}$ $28^{\prime} 45^{\prime \prime}$ W; (map 5). Var. Lusnoi Island, Ostrov Lysnoy.

Named in 1809 by the Russian navigator, Ivan Vasiliev the first; published by Lt. Sarichev (1826, map 19), IRN, as "O[strov] Lysnoy," meaning "wooded island."

Liesnoi Island: island, $0.1 \mathrm{mi}$. across, off $\mathrm{S}$ coast of Kruzof I., 14 mi. SW of Sitka, Alex. Arch.; $57^{\circ} 00^{\prime} 45^{\prime \prime} \mathrm{N}, 135^{\circ} 41^{\prime} 30^{\prime \prime} \mathrm{W}$; (map 9). Var. Lesnoi Islet, Ostrov Lysnoy. 
Russian name meaning "wooded" given in 1809 by the navigator Ivan Vasiliev the first; published by Lt. Sarichev (1826, map 19), IRN, as "O[strov] Lysnoy."

Liesnoi Island: island, $1.4 \mathrm{mi}$. long, between Eliza and Woewodski Harbors, off SE coast of Admiralty I., $14 \mathrm{mi}$. NE of Tyee, Alex. Arch.; $57^{\circ} 10^{\prime} \mathrm{N}, 134^{\circ} 17^{\prime} \mathrm{W}$; (map 9). Vंar. Ostrov Lysnoy.

Named in 1838 by Capt. Lt. D. F. Zarembo; published as "Os[trov] Lysnoy" meaning "wooded island" in 1848 on Russian Hydrog. Dept. Chart 1396.

Liesnoi Island: island, $0.1 \mathrm{mi}$. across, $2.5 \mathrm{mi}$. N of Fish Bay, in Peril Strait, off NW coast of Baranof I., $24 \mathrm{mi}$. SE of Chichagof, Alex. Arch.; $57^{\circ} 25^{\prime} 10^{\prime \prime} \mathrm{N}, 135^{\circ} 36^{\prime} 20^{\prime \prime} \mathrm{W}$; (map 9). Var. Liesnoi Islet, Ostrov Lysnoy, Woody Islet.

Russian name meaning "wooded," given in 1809 by the navigator Ens. Vasiliev (cnna); published in 1848 on Russian Hydrog. Dept. Chart 1397 as "Os[trov] Lysnoy."

Liesnoi Island: island, see Makhnati Island.

Liesnoi Island: island, see Woody Island.

Liesnoi Islet: island, see Liesnoi Island.

Liesnoi Shoal: shoal, in Peril Strait, $2 \mathrm{mi}$. N of Fish Bay on Baranof I., $25 \mathrm{mi}$. SE of Chichagof, Alex. Arch.; $57^{\circ} 24^{\prime} 45^{\prime \prime} \mathrm{N}, 135^{\circ} 36^{\prime} 30^{\prime \prime}$ W; (map 9).

Named in 1884 by Comdr. J. B. Coghlan, USN, probably for Liesnoi Island, a short distance to the north. The name was published by USC\&GS in 1891 Coast Pilot (p. 182).

Lietnik: locality, $10 \mathrm{mi}$. W of Northeast Cape, NE coast of St. Lawrence I.; $63^{\circ} 20^{\prime} 10^{\prime \prime} \mathrm{N}$, $168^{\circ} 59^{\prime} 00^{\prime \prime} \mathrm{W}$; (map 93). Var. Kangighsak Camp.

Eskimo name reported by USC\&GS in 1925 . Lietnik: locality, see Litnik.

Lietnik Cape: point of land, see Lipsett Point.

Lieuy Lake: lake, $1 \mathrm{mi}$. long, in course of Dorothy Creek $1.5 \mathrm{mi}$. E of its mouth on Taku Inlet, $16 \mathrm{mi}$. ESE of Juneau, Coast Mts.; $58^{\circ}$ $14^{\prime} 25^{\prime \prime} \mathrm{N}, 134^{\circ} 00^{\prime} 15^{\prime \prime} \mathrm{W}$; BGN 1954; (map 12). Var. Lake Veronica.

Local name reported in 1947 by USFS.

Lievoi : point of land, see Left Cape.

Lighter Creek: estuary, extends NE $1.5 \mathrm{mi}$. to Davis Creek, $5 \mathrm{mi}$. E of Angoon, on $\mathrm{W}$ central Admiralty I., Alex. Arch.; $57^{\circ} 31^{\prime} 20^{\prime \prime} \mathrm{N}$, $134^{\circ} 26^{\prime} 30^{\prime \prime} \mathrm{W}$; (map 9).

Named by Comdr. R. W. Meade, USN, and published in 1869 on Hydrog. Chart 225. It was so named because near the mouth of the stream are extensive coal croppings from which considerable lignite was lightered in 1868-69 (U.S. Coast and Geodetic Survey, 1883, p. 159).

Light House Rock: rock, see Pilot Rock.

Light Point: point of land, E tip of Kalgin I., in Cook Inlet, $20 \mathrm{mi}$. SW of Kenai, Cook Inlet Low.; $60^{\circ} 29^{\prime} \mathrm{N}, 151^{\circ} 50^{\prime} \mathrm{W}$; (map 62).

Local name reported in 1959 by USGS. So named because of the navigation light on the point.

Lighthouse Point: point of land, at $\mathrm{N}$ tip of Afognak I., $34 \mathrm{mi}$. N of Afognak; $58^{\circ} 28^{\prime} 55^{\prime \prime}$
N, $152^{\circ} 39^{\prime} 00^{\prime \prime}$ W; (map 43). Var. Mys Afognaka, North Point, Mys Syvernoy.

Name published by USC\&GS in 1926 and so called because "a 60-foot high light located in a white house is situated there." In 1849 this feature was called "Mys Afognaka," or "Cape Afognak," by the Russian American Company and "Mys Syvernoy" meaning "north cape" by Capt. Tebenkov (1852, map 22), IRN.

Lighthouse Rocks: rocks, $0.2 \mathrm{mi}$. across, largest is $500 \mathrm{ft}$. long and $90 \mathrm{ft}$. high, $30 \mathrm{mi}$. SW of Chowiet I. in Semidi Is., in Pacific Ocean; Aleutian Ra.; $55^{\circ} 47^{\prime} \mathrm{N}, 157^{\circ} 24^{\prime} \mathrm{W}$; (map 31). Var. Namtschak Rock, Utes Namdak. Named in 1874 by W. H. Dall, USC\&GS. Capt. Tebenkov (1852, map 22), IRN, called them "Ut[es] Namdak," or "Namdak Crag," whereas Capt. Archimandritov, IRN, is reported to have called them "Namtschak" in 1849.

Lightning Creek: stream, flows $\mathrm{N} 2 \mathrm{mi}$. to Casadepaga River, $23 \mathrm{mi}$. NE of Solomon, Seward Penin. High.; 64 $53^{\prime}$ N, $164^{\circ} 14^{\prime}$ W; (map 95).

Prospectors' name reported on a 1902 prospectors' manuscript map.

Lignite: locality, mile 363.3 on The Alaska RR., $4 \mathrm{mi}$. N of Healy, Alaska Ra.; $63^{\circ} 54^{\prime} 30^{\prime \prime} \mathrm{N}$, $149^{\circ} 01^{\prime} 10^{\prime \prime} \mathrm{W}$; (map 87). Var. Dry Greek.

Name of a railroad station reported by The Alaska RR. on its 1922 timetable; derived from the lignite coal found in the area. This station was originally named "Dry Creek."

Lignite Creek: stream, in Nutzotin Mts., heads in Canada, flows NW $2.6 \mathrm{mi}$. to Rocker Creek, $0.3 \mathrm{mi}$. W of Alaska-Canada boundary and $70 \mathrm{mi}$. NE of McCarthy, Alaska Ra.; $61^{\circ} 52^{\prime} 30^{\prime \prime} \mathrm{N}, 141^{\circ} 00^{\prime} 30^{\prime \prime} \mathrm{W}$; (map 67).

Name used by prospectors and reported about 1908 by IBC surveyors.

Lignite Creek: stream, flows W $15 \mathrm{mi}$. to $\mathrm{Ne}$ nana River, 3.5 mi. NW of Healy, Alaska Ra.; $63^{\circ} 54^{\prime} \mathrm{N}, 149^{\circ} 00^{\prime}$. W; (map 87). BGN 1947. Var. Hoseanna Creek.

Name from prospectors; reported in 1902 by A. H. Brooks, USGS. Named for the lignite coal deposits in the area. It was called "Hoseanna Creek" in 1916.

Likes Creek: stream, on Kenai Penin., flows SW $5 \mathrm{mi}$. to Thumb Cove, $8 \mathrm{mi}$. SE of Seward, Chugach Mts.; $60^{\circ} 00^{\prime} 50^{\prime \prime} \mathrm{N}, 149^{\circ} 17^{\prime} 45^{\prime \prime} \mathrm{W}$; $B G N$ 1910; (map 63).

Local name reported in 1909 by Grant and Higgins (1910, pl. 2), USGS.

Lil Creek: stream, flows SE 1 mi. to Fox River, $24 \mathrm{mi}$. NE of Solomon, Seward Penin. High.; $64^{\circ} 46^{\prime} 45^{\prime \prime} \mathrm{N}, 163^{\circ} 48^{\prime} 10^{\prime \prime} \mathrm{W}$; (map 95). Var. "I.X.L. Creek.

Prospectors' name published in 1956 by USGS. Reported as "I.X.L." on a map of Cape Nome gold fields by David Fox, Jr., dated 1901

Lila Lake: lake, $0.4 \mathrm{mi}$. long, $\mathrm{N}$ of Glenn Highway, SW of Nikolai Lake, 36 mi. SW of Glennallen, Copper River Basin; $62^{\circ} 03^{\prime} \mathrm{N}$, $146^{\circ} 37^{\prime} \mathrm{W}$; (map 83)

Local name published by USGS in 1951 .
Lilac Hill: hill, $925 \mathrm{ft}$., center of Kiska I., Aleutian Is.; $51^{\circ} 58^{\prime} 52^{\prime \prime} \mathrm{N}, 177^{\circ} 26^{\prime} 30^{\prime \prime} \mathrm{E}$; (map 14).

An arbitrary name beginning with " $L$ " to correspond to "L" grid used by the U.S. Army for tactical purposes during World War II; published on a 1943 Army map.

Lili Creek: stream, flows N $20 \mathrm{mi}$. to Meade River, $88 \mathrm{mi}$. SE of Wainwright, Arctic Slope; $69^{\circ} 33^{\prime} \mathrm{N}, 158^{\circ} 06^{\prime} \mathrm{W}$; (map 143).

Reported to be named for the wife of a member of one of the survey crews; name published by USGS in 1956.

Lili Lake: lake, $0.6 \mathrm{mi}$. across, on Kenai Penin., $1.8 \mathrm{mi}$. WNW of the Finger Lakes and $15 \mathrm{mi}$. $\mathrm{E}$ of Kenai, Cook Inlet Low.; $60^{\circ} 39^{\prime} 30^{\prime \prime} \mathrm{N}$, $150^{\circ} 49^{\prime} 00^{\prime \prime} \mathrm{W}$; (map 62).

Named about 1963 by officials of Kenai National Moose Range, for administrative purposes.

Lilian Creek: stream, flows NW to Anvil Creek which flows to Cripple River, about $23 \mathrm{mi}$. NW of Imuruk Lake, Seward Penin. High.; (map 110).

Prospectors' name reported on a precinct map of Seward Peninsula by Monroe and Hutchins, corrected to June 1903 by Arthur Gibson. This stream cannot be precisely located on current maps.

Liljegren Passage: water passage, in Prince William Sound, extends E-W $6 \mathrm{mi}$. between Storey I. and Peak and Naked Is., $39 \mathrm{mi}$. NE of Chenega, Chugach Mts.; 60 $42^{\prime} 30^{\prime \prime} \mathrm{N}$ $147^{\circ} 25^{\prime} 30^{\prime \prime} \mathrm{W}$; (map 63$)$.

Local name reported in 1910 by USC\&GS.

Lillian Creek: stream, flows S $2.4 \mathrm{mi}$. to Buster Creek, $8 \mathrm{mi}$. NE of Nome, Seward Penin. High.; $64^{\circ} 36^{\prime} \mathrm{N}, 165^{\circ} 15^{\prime} \mathrm{W}$; (map 94).

Prospectors' name reported in 1900 by E. C. Barnard (in Brooks, 1901, pl. 17), USGS. Lillian Creek: stream, flows W $1 \mathrm{mi}$. to Livengood Creek, $48 \mathrm{mi}$. E of Rampart, YukonTanana High.; $65^{\circ} 30^{\prime} 45^{\prime \prime} \mathrm{N}, 148^{\circ} 34^{\prime} 40^{\prime \prime} \mathrm{W}$; (map 105).

This stream was prospected and named about 1914 , by N. R. Hudson, for his daughter. The name was reported in 1915 by A. H. Brooks, USGS.

Lillian Creek: stream, flows SW $2.2 \mathrm{mi}$. to Henry Creek which flows to Kougarok Creek, $13 \mathrm{mi}$. SW of Midnight Mtn. and $50 \mathrm{mi}$. W of Imuruk Lake, Seward Penin. High.; 65 ${ }^{\circ} 38^{\prime}$ $\mathrm{N}, 164^{\circ} 55^{\prime} \mathrm{W}$; (map 110).

Prospectors' name reported on the 1908 "Map of Seward Peninsula" by Arthur Gibson.

Lillian Creek: stream, flows NW to Kuzitrin River, about $25 \mathrm{mi}$. SW of Imuruk Lake, Seward Penin. High.; (map 110).

Prospectors' name reported on a precinct map of Seward Peninsula by Monroe and Hutchins, corrected to June 1903 by Arthur Gibson. This stream cannot be precisely located on current maps.

Lillian Creek: stream, see Magnet Creek.

Lillie Creek: stream, flows SE $4 \mathrm{mi}^{-}$to Lake Aleknagik, in Sunshine Valley, $37 \mathrm{mi}$. NW of 
Dillingham, Kilbuck-Kuskokwim Mts. ; $59^{\circ} 28^{\prime}$ $\mathrm{N}, 159^{\circ} 03^{\prime} \mathrm{W}$; (map 53 ).

Local name published in 1951 by USGS

Lilliput Cove: cove, $0.2 \mathrm{mi}$. across, $1.8 \mathrm{mi}$. NW of Vega Point, $\mathrm{S}$ coast of Kiska I., Aleutian Is.; $51^{\circ} 50^{\prime} 50^{\prime \prime} \mathrm{N}, 177^{\circ} 17^{\prime} 30^{\prime \prime} \mathrm{E}$; (map 14).

One of many arbitrary names applied to features on Kiska I. by USAAF for tactical purposes during World War II.

Lilliwig Creek: stream, flows SE $1 \mathrm{mi}$. to Ingle Greek, $56 \mathrm{mi}$. SW of Eagle, Yukon-Tanana High.; $64^{\circ} 05^{\prime} 30^{\prime \prime} \mathrm{N}, 142^{\circ} 01^{\prime} 45^{\prime \prime} \mathrm{W}$; (map 102).

Prospectors' name published in 1925 by ARC.

Lilly Creek: stream, flows NW $1 \mathrm{mi}$. to Bering Sea, central Kiska I., Aleutian Is.; $51^{\circ} 58^{\prime} 50^{\prime \prime}$ $\mathrm{N}, 177^{\circ} 23^{\prime} 50^{\prime \prime} \mathrm{E}$; (map 14).

An arbitrary name beginning with " $\mathrm{L}$ " to correspond to "L" grid used by the U.S. Army for tactical purposes during World War II; published on a 1953 AMS map.

Lilly Creek: stream, flows W $5 \mathrm{mi}$. to Lake Nancy, $3 \mathrm{mi}$. SE of Willow and $34 \mathrm{mi}$. N of Anchorage, Cook Inlet Low.; $61^{\circ} 42^{\prime} 10^{\prime \prime} \mathrm{N}$, $150^{\circ} 00^{\prime} 25^{\prime \prime} \mathrm{W}$; ( $\left.\operatorname{map} 70\right)$.

Local name reported in 1958 by USGS.

Lilly Lake: lake, on Kenai Penin., $0.1 \mathrm{mi}$. long, $6 \mathrm{mi}$. WSW of Ohlson Mtn. and $7 \mathrm{mi}$. NW of Homer, Cook Inlet Low.; 59 $42^{\prime} 10^{\prime \prime} \mathrm{N}, 151^{\circ}$ $42^{\prime} 10^{\prime \prime} \mathrm{W}$; (map 50).

Local name reported and published by USGS in the 1950's.

Lily Creek: stream, flows NE $10 \mathrm{mi}$. to Nenana River, $38 \mathrm{mi}$. SE of Healy, Talkeetna Mts.; $63^{\circ} 22^{\prime} 20^{\prime \prime} \mathrm{N}, 148^{\circ} 19^{\prime} 00^{\prime \prime} \mathrm{W}$; (map 87).

Local name obtained in 1951 by USGS.

Lily Lake: lake, $0.4 \mathrm{mi}$. long, on Chilkat Penin., $1.2 \mathrm{mi}$. SW of Battery Point on Chilkoot Inlet and $18 \mathrm{mi}$. SW of Skagway, St. Elias Mts.; $59^{\circ} 12^{\prime} 15^{\prime \prime} \mathrm{N}, 135^{\circ} 23^{\prime} 30^{\prime \prime} \mathrm{W}$; (map 45).

Local name obtained by USGS field personnel and published on Federal maps since 1950.

Lily Lake: lake, $0.2 \mathrm{mi}$. long, on Kenai Penin. $\mathbf{N}$ of Sterling Highway, $26 \mathrm{mi}$. $\mathbf{E}$ of Kenai, Cook Inlet Low.; 60 $32^{\prime} 10^{\prime \prime} \mathrm{N}, 150^{\circ} 30^{\prime} 15^{\prime \prime}$ W; (map 62).

Named about 1963 by officials of Kenai National Moose Range, for administrative purposes.

Lily Lake: lake, $1.2 \mathrm{mi}$. long, in course of Tyone Creek, NW of Moore Lake, $49 \mathrm{mi}$. NW of Glennallen, Copper River Basin; 62 $25^{\prime} 30^{\prime \prime}$ N, $146^{\circ} 57^{\prime} 00^{\prime \prime} \mathrm{W}$; (map 83).

Local name published in 1959 by USGS.

Lily Lake: lake, $0.7 \mathrm{mi}$. long, between Birch and Elbow Lakes, $15 \mathrm{mi}$. SW of Beaver, $\mathrm{Yu}$ kon Flats; $66^{\circ} 17^{\prime} 50^{\prime \prime} \mathrm{N}, 147^{\circ} 55^{\prime} 00^{\prime \prime} \mathrm{W}$; (map 118).

Probably named by William Yanert who recorded it on a 1916 manuscript map of the Yukon Flats (Stuck, 1917, map facing p. 122).

Lily Pad Lake: lake, see Long Lake.

Limb Island: island, $3 \mathrm{mi}$. long, Stikine River $14 \mathrm{mi}$. NE of Wrangell, Coast Mts. ; $56^{\circ} 40^{\prime} 30^{\prime \prime}$
N, $132^{\circ} 17^{\prime} 00^{\prime \prime} \mathrm{W}$; (map 6). Var. Desert Island.

Local name recorded in 1953 by USGS.

Lime Butte: ridge, elev. 5,100 ft., extends SW 2 mi. from junc. of Copper and Dan Creeks, $17 \mathrm{mi}$. SE of McCarthy, Wrangell Mts.; $61^{\circ}$ $21^{\prime} 30^{\prime \prime} \mathrm{N}, 142^{\circ} 26^{\prime} 30^{\prime \prime} \mathrm{W}$; (map 67).

Local name obtained by USGS and published on maps since 1954.

Lime Creek: stream, flows $3 \mathrm{mi}$. NE to Chitina River, E of Iron Creek, $45 \mathrm{mi}$. SE of McCarthy, St. Elias Mts. ; $61^{\circ} 02^{\prime} 30^{\prime \prime} \mathrm{N}, 141^{\circ} 50^{\prime} 30^{\prime \prime}$ W; (map 67).

Local name reported in 1915 by $F$. $H$. Moffit, USGS.

Lime Creek: stream, heads at glacier terminus, flows NW $1.5 \mathrm{mi}$. to Rock Creek, $19 \mathrm{mi}$. W of Mount Blackburn, Wrangell Mts.; 61 ${ }^{\circ} 41^{\prime} 30^{\prime \prime}$ N, 14356, 45" W; (map 67).

Local name reported in 1901 by T. G. Gerdine, USGS.

Lime Creek: stream, heads at Lime Glacier terminus and flows $7.2 \mathrm{mi}$. SE to White River, $43 \mathrm{mi}$. NE of McCarthy, Wrangell Mts.; $61^{\circ} 45^{\prime} \mathrm{N}, 141^{\circ} 47^{\prime} \mathrm{W}$; (map 67).

Local name reported in 1902 by $D$. C. Witherspoon (in Moffit and Knopf, 1910, pl 1), USGS

Lime Creek: stream, flows $\mathrm{N} 1.6 \mathrm{mi}$. to East Fork Solomon River, $14 \mathrm{mi}$. NE of Solomon, Seward Penin. High.; $64^{\circ} 42^{\prime} \mathrm{N}, 164^{\circ} 06^{\prime} \mathrm{W}$; (map 95). Var. Little Creek.

Prospectors' name reported on a 1902 prospectors' manuscript map.

Lime Creek: stream, see Bear River.

Lime Glacier: glacier, trends $11 \mathrm{mi}$. SE to its terminus at head of Lime Creek, $\mathrm{E}$ of Middle Fork Glacier and $42 \mathrm{mi}$. NE of McCarthy, Alaska Ra.; $61^{\circ} 47^{\prime} 30^{\prime \prime} \mathrm{N}, 141^{\circ} 55^{\prime} 00^{\prime \prime} \mathrm{W}$ (map 67).

Name shown on 1908 fieldsheet by S. R. Capps, USGS

Lime Gulch: ravine, trends $\mathrm{NE} 0.2 \mathrm{mi}$. to Mystery Creek, $10 \mathrm{mi}$. N of Medfra, KilbuckKuskokwim Mts. ; $63^{\circ} 15^{\prime} \mathrm{N}, 154^{\circ} 46^{\prime} \mathrm{W}$; (map 89).

Local name reported in 1920 by G. C. Martin (in Brooks and others, 1922, fig. 5), USGS

Lime Hills: mountain range, 2,000 ft., extends NE $18 \mathrm{mi}$. between Tundra Lake and Swift River, $80 \mathrm{mi}$. NW of Lake Clark, Lime Hills $61^{\circ} 21^{\prime} \mathrm{N}, 155^{\circ} 33^{\prime} \mathrm{W}$; (map 71).

So named in 1914 by P. S. Smith (1917, p. $50)$, USGS, "because they consist entirely of limestone."

Lime Peak: mountain, 5,062 ft., in White Mountains, $14 \mathrm{mi}$. NW of Mount Prindle and $80 \mathrm{mi}$ WSW of Circle, Yukon-Tanana High.; $65^{\circ} 38^{\prime}$ N, 146 $46^{\prime} \mathrm{W}$; (map 104)

Prospectors' name reported in 1954 or 1955 by USGS topographers.

Lime Point: point of land, between Hetta and Nutkwa Inlets, on SW coast of Prince of Wales I., Alex. Arch.; $55^{\circ} 03^{\prime} 15^{\prime \prime} \mathrm{N}, 132^{\circ} 37^{\prime} 50^{\prime \prime} \mathrm{W}$ (map 4).

Name reported in 1897 by Lt. Comdr. J. F. Moser, USN; published by USC\&GS in 1899.
Lime Springs Creek: stream, flows $4 \mathrm{mi}$. NW to Ghitistone River $2 \mathrm{mi}$. $E$ of junc. of Nizina River and $13 \mathrm{mi}$. E of McCarthy, Wrangell Mts. ; $61^{\circ} 27^{\prime} 00^{\prime \prime} \mathrm{N}, 142^{\circ} 30^{\prime} 30^{\prime \prime} \mathrm{W}$; (map 67).

Local name obtained by USGS and published on maps since 1954

Lime Village: settlement, pop. 15, on left bank of Stony River near junc. of Hungry Creek, 11 mi. NE of Tundra Lake and $85 \mathrm{mi}$. NW of Lake Clark, Lime Hills; $61^{\circ} 21^{\prime} 20^{\prime \prime}$ N, $155^{\circ}$ 28'00" W; BGN 1966; (map 71). Var. Hungry Village.

Native village listed in the 1939 Census as "Hungry Village" with a population of 38 ; 29 persons in 1950 . It is presently referred to as "Lime Village," named for the nearby Lime Hills.

Limestack Mountain: mountain, 6,000 ft., at head of Graylime Creek, E of Ernie Pass, 23 mi. E of Anaktuvuk Pass, Brooks Ra.; $68^{\circ}$ $06^{\prime} 30^{\prime \prime} \mathrm{N}, 150^{\circ} 50^{\prime} 54^{\prime \prime} \mathrm{W}$; (map 134).

About his naming this mountain in 1930 , Marshall (1956, p. 41) wrote, "Above me rose the last thousand feet of my mountain just a gray stack of limestone. So I called the peak 'Limestack Mountain'."

Limestone Bluffs: mountain, 3,650 ft., on $\mathrm{N}$ shore of Limestone Inlet, Stephens Passage, 25 mi. SE of Juneau, Coast Mts. ; $58^{\circ} 03^{\prime} 10^{\prime \prime} \mathrm{N}$, $133^{\circ} 58^{\prime} 30^{\prime \prime} \mathrm{W}$; (map 12).

Named in 1869 by Comdr. R. W. Meade, USN (in Baker, 1906, p. 404), who says, “* * * From a remarkable-looking streak on the side of the mountain forming the west side of the inlet I called it 'Limestone Inlet' and the mountain 'Limestone Bluff.'"

Limestone Cliffs: cliffs, extends NE-SW $3 \mathrm{mi}$. along NW coast of Norton Bay, $13 \mathrm{mi}$. SW of Elim, Seward Penin High.; 64 $30^{\prime}$ N, $162^{\circ}$ $35^{\prime} \mathrm{W}$; (map 95).

Local name published in 1956 by USGS.

Limestone Creek: stream, flows W $4 \mathrm{mi}$, to head of Limestone Inlet, $25 \mathrm{mi}$. SE of Juneau, Coast Mts.; $58^{\circ} 02^{\prime} 10^{\prime \prime} \mathrm{N}, 133^{\circ} 56^{\prime} 10^{\prime \prime} \mathrm{W}$; $B G N$ 1929; (map 12).

Name derived from Limestone Bluffs in 1929 by USFS.

Limestone Creek: stream, flows $2.7 \mathrm{mi}$. to Clear Creek, $4.5 \mathrm{mi}$. NE of terminus of Long Glacier, $84 \mathrm{mi}$. NE of Valdez, Wrangell Mts.; $61^{\circ} 45^{\prime}$ $35^{\prime \prime} \mathrm{N}, 144^{\circ} 04^{\prime} 45^{\prime \prime} \mathrm{W}$; (map 68).

Local name reported in 1900 by F. C. Schrader, USGS.

Limestone Creek: stream, flows SE, through Trout Lake, $6 \mathrm{mi}$. to Middle Fork Chistochina River, $27 \mathrm{mi}$. NE of Paxson, Alaska Ra.; $63^{\circ}$ $05^{\prime} 20^{\prime \prime} \mathrm{N}, 144^{\circ} 38^{\prime} 00^{\prime \prime} \mathrm{W}$; (map 86).

Name published on relatively recent maps. Limestone Creek: stream, flows NE $1.7 \mathrm{mi}$. to Jump Creek which flows to Candle Creek, 4.5 mi. SW of Candle and $37 \mathrm{mi}$. NE of Imuruk Lake, Seward Penin. High. ; $65^{\circ} 53^{\prime} \mathrm{N}, 162^{\circ} 04^{\prime}$ W; (map 110).

Prospectors' name reported on the 1908 "Map of Seward Peninsula" by Arthur Gibson. Limestone Creek: stream, flows S $2.5 \mathrm{mi}$. to Bettles River opposite mouth of Eightmile 
Creek, $24 \mathrm{mi}$. WNW of Chandalar, Brooks Ra.; $67^{\circ} 34^{\prime} 15^{\prime \prime} \mathrm{N}, 149^{\circ} 22^{\prime} 30^{\prime \prime} \mathrm{W}$; (map 123).

This name was reported prior to 1956 by USGS. It applied to a longer stream to the west. See Mathews River.

Limestone Creek: stream, see Mathews River.

Limestone Gap: gap, $5,025 \mathrm{ft}$., in Limestone Hills at head of Littie Nelchina River, $16 \mathrm{mi}$ NW of Tahneta Pass, Talkeetna Mts.; $62^{\circ}$. $03^{\prime} 30^{\prime \prime} \mathrm{N}, 147^{\circ} 38^{\prime} 50^{\prime \prime} \mathrm{W}$; (map 82).

Descriptive name given in 1898 by Capt. E. F. Glenn, USA.

Limestone Gulch: ravine, extends W $2.3 \mathrm{mi}$. to Billy Creek, in Limestone Hills, $16 \mathrm{mi}$. NW of

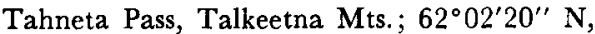
$147^{\circ} 41^{\prime} 45^{\prime \prime} \mathrm{W}$; (map 82).

Local descriptive name reported in 1931 by USGS.

Limestone Gulch: ravine, trends SW $3.5 \mathrm{mi}$. to Fossil Creek, $29 \mathrm{mi}$. SE of Livengood, YukonTanana High.; $65^{\circ} 28^{\prime} \mathrm{N}, 147^{\circ} 36^{\prime} \mathrm{W}$; (map 105).

Descriptive name applied by prospectors; published by USGS on recent maps.

Limestone Hills: mountains, 5,700 ft., extend NW-SE $10 \mathrm{mi}$. at head of Little Nelchina River, $15 \mathrm{mi}$. NW of Tahneta Pass, Talkeetna Mts.; $62^{\circ} 03^{\prime} 30^{\prime \prime} \mathrm{N}, 147^{\circ} 37^{\prime} 00^{\prime \prime} \mathrm{W}$; (map 82).

Local descriptive name reported in 1931 by USGS.

Limestone Hogback: ridge, trends NE $1 \mathrm{mi}$. from Yukon River, 1.6 mi. NW of Hillard Peak and $12 \mathrm{mi}$. NE of Eagle, Porcupine Plat.; $64^{\circ} 57^{\prime} 40^{\prime \prime} \mathrm{N}, 1^{\circ} 1^{\circ} 07^{\prime} 00^{\prime \prime} \mathrm{W} ;$ BGN 1965; (map 102).

Descriptive name published in 1956 by USGS.

Limestone Inlet: cove, $0.2 \mathrm{mi}$. across, on $\mathrm{E}$ shore of Stephens Passage, $2.5 \mathrm{mi}$. S of Taku Harbor and $25 \mathrm{mi}$. SE of Juneau, Coast Mts.; $58^{\circ} 01^{\prime}$ $50^{\prime \prime} \mathrm{N}, 133^{\circ} 59^{\prime} 30^{\prime \prime} \mathrm{W}$; (map 12).

Named in 1869 by Gomdr. R. W. Meade, USN, who (in Baker, 1906, p. 404) says, “* * * From a remarkable-looking streak on the side of the mountain forming the west side of the inlet I called it Limestone Inlet * * *."

Limestone Mountain: mountain, 2,844 ft., 13 mi. NE of Medfra, Kilbuck-Kuskokwim Mts.; $63^{\circ} 16^{\prime} \mathrm{N}, 154^{\circ} 33^{\prime} \mathrm{W}$; (map 89).

Local name reported in 1953 by USGS.

Limestone Point: point of land, between Davidson Inlet and Edna Bay, SE coast of Kosciusco I., Alex. Arch.; $55^{\circ} 56^{\prime} 50^{\prime \prime} \mathrm{N}, 133^{\circ} 36^{\prime} 50^{\prime \prime} \mathrm{W}$; $(\operatorname{map} 4)$

Local name recorded in 1951 by USGS.

Limestone Ridge: ridge, $1,100 \mathrm{ft}$., trends SW 3 mi. between headwaters of Carter and Sphinx Creeks, $8 \mathrm{mi}$. NW of Goodnews, Kilbuck-Kuskokwim Mts.; $59^{\circ} 12^{\prime} \mathrm{N}, 161^{\circ} 41^{\prime} \mathrm{W}$; (map $53)$.

Local descriptive name published in 1954 by USGS.

Limit Creek: stream, heads in Sadlerochit Mts. between Back Dog and Dodo Creeks, flows $\mathrm{S}$ $5 \mathrm{mi}$. to Fire Creek $1.5 \mathrm{mi}$. W of its junc. with Sadlerochit River, $24 \mathrm{mi}$. NW of Mount
Michelson, Brooks Ra.; $69^{\circ} 31^{\prime} 40^{\prime \prime} \mathrm{N}, 1^{\prime 4} 5^{\circ}$ $00^{\prime} 00^{\prime \prime}$ W; BGN 1961; (map 139).

Name used by USGS geologists in 1948 and reported by C. L. Whittington in 1960 .

Limpid Creek: stream, flows N $1 \mathrm{mi}$. to Quisling Cove, center of Kiska I., Aleutian Is.; $51^{\circ}$ $58^{\prime} 37^{\prime \prime} \mathrm{N}, 177^{\circ} 23^{\prime} 00^{\prime \prime} \mathrm{E}$; (map 14). Var. Martini Creek.

An arbitrary name beginning with " $L$ " to correspond to "L" grid used by U.S. Army for tactical purposes during World War II; published on a 1953 AMS map.

Lina Bay: bay, see Lituya Bay.

Lincoln, Cape: point of land, see Mordvinof, Cape.

Lincoln Anchorage: bay, $1.4 \mathrm{mi}$. across, along Favorite Channel on E coast of Lincoln I., $24 \mathrm{mi}$. NW of Juneau, Alex. Arch.; $58^{\circ} 29^{\prime} 30^{\prime \prime}$ $\mathrm{N}, 134^{\circ} 58^{\prime} 00^{\prime \prime} \mathrm{W}$; (map 11).

Local name derived from Lincoln Island; published in 1962 by USGS.

Lincoln Bay: bight, see Lincoln Bight.

Licoln Bight: bight, $1.5 \mathrm{mi}$. across, on $\mathrm{NW}$ coast of Saint Paul I., in Pribilof Is.; $57^{\circ}$ $12^{\prime} 30^{\prime \prime} \mathrm{N}, 170^{\circ} 21^{\prime} 30^{\prime \prime} \mathrm{W}$; (map 38). Var. Lincoln Bay.

Local name published in 1890 by USC\&GS as "Lincoln Bay."

Lincoln Channel: water passage, $3.5 \mathrm{mi}$. long, between Kanaganut and Sitklan Is., Coast Mts.; $54^{\circ} 44^{\prime} 30^{\prime \prime} \mathrm{N}, 130^{\circ} 41^{\prime} 40^{\prime \prime} \mathrm{W}$; (map 2). Var. Lincoln Passage.

Named in 1869 for U.S. Revenue Cutter Lincoln; reported by G. Davidson, USC\&GS.

Lincoln Creek: stream, flows SW $10 \mathrm{mi}$. to Fourth of July Creek, $6 \mathrm{mi}$. S of Crater Mtn. and $40 \mathrm{mi}$. SW of McGrath, KilbuckKuskokwim Mts.; $62^{\circ} 43^{\prime} \mathrm{N}, 156^{\circ} 47^{\prime} \mathrm{W}$; (map 79).

Prospectors' name published in 1921 by USGS

Lincoln Creek: stream, flows SE $3.2 \mathrm{mi}$. to Goldstream Creek, $16 \mathrm{mi}$. W of Fairbanks, Yukon-Tanana High.; 64. $52^{\prime} 50^{\prime \prime} \mathrm{N}, 148^{\circ}$ $13^{\prime} 40^{\prime \prime} \mathrm{W}$; (map 100).

Named by prospectors; published in 1906 by USGS.

Lincoln Creek: stream, flows NE $6 \mathrm{mi}$. to Henry Creek which flows to Kougarok Creek, $16 \mathrm{mi}$. SW of Midnight Mtn. and $51 \mathrm{mi}$. W of Imuruk Lake, Seward Penin. High.; 65 $37^{\circ}$ N, 164.58' W; (map 110).

Prospectors' name reported on the 1908 "Map of Seward Peninsula" by Arthur Gibson.

Lincoln Creek: stream, flows SE $2.5 \mathrm{mi}$. to Eldorado Creek which flows to Noxapaga River, $28 \mathrm{mi}$. NW of Imuruk Lake, Seward Penin. High.; $65^{\circ} 42^{\prime} \mathrm{N}, 164^{\circ} 13^{\prime} \mathrm{W}$; (map 110).

Prospectors' name reported on the 1908 "Map of Seward Peninsula" by Arthur Gibson.

Lincoln Creek: stream, flows NE $7 \mathrm{mi}$. to South Fork Serpentine River, $13 \mathrm{mi}$. N of Kougarok Mtn. and $27 \mathrm{mi}$. SE of Ear Mtn., Seward Penin. High.; $65^{\circ} 52^{\prime} \mathrm{N}, 165^{\circ} 18^{\prime} \mathrm{W}$; (map 111).
Prospectors' name reported on the 1908 "Map of Seward Peninsula" by Arthur Gibson. Lincoln Creek: stream, flows SE to Washington Creek which flows to Lone Mountain Creek, near head of American River, about $35 \mathrm{mi}$. NE of Teller, Seward Penin. High.; (map 111).

Prospectors' name shown on a map of Cape Nome gold fields by David Fox, Jr., dated 1901. This feature cannot be precisely identified on current maps.

Lincoln Island: island, $250 \mathrm{ft}$. long, $0.3 \mathrm{mi}$. NE of Lincoln Rock, on W coast of Etolin I., Alex. Arch.; $56^{\circ} 03^{\prime} 30^{\prime \prime} \mathrm{N}, 132^{\circ} 41^{\prime} 30^{\prime \prime} \mathrm{W}$; (map 6). Var. Lincoln Rock.

Named by USC\&GS for charting purposes; name published in 1943. See Abraham Islands.

Lincoln Island: island, $4.7 \mathrm{mi}$. long, trending NW, in Lynn Canal just $S$ of its junc. with Favorite Channel, $24 \mathrm{mi}$. NW of Juneau, Alex. Arch.; $58^{\circ} 30^{\prime} \mathrm{N}, 135^{\circ} 00^{\prime} \mathrm{W}$; (map 11).

Named in 1868 by Comdr. R. W. Meade, USN, presumably for Abraham Lincoln, 18091865, 16th President of the United States; published by the USC\&GS in the 1883 Coast Pilot (p. 194).

Lincoln Mountains: mountain range, 5,000 ft., W of Portland Canal and Salmon River, extends S $17 \mathrm{mi}$. from West Fork Texas Creek, Coast Mts.; 55 $56^{\prime} \mathrm{N}, 130^{\circ} 10^{\prime} \mathrm{W}$; (map 3). Name published in 1891 by USC\&GS

Lincoln Passage: water passage, see Lincoln Channel.

Lincoln Peak: peak, 4,750 ft., $2.5 \mathrm{mi}$. NW of Grant Peak and 86 mi. E of Sitka, Coast Mts.; $57^{\circ} 14^{\prime} 50^{\prime \prime} \mathrm{N}, 133^{\circ} 06^{\prime} 27^{\prime \prime} \mathrm{W}$; (map 8).

Named in 1887 by Lt. Comdr. C. $M$. Thomas, USN, for Abraham Lincoln, 180965 , lawyer, statesman, and the 16 th President of the United States, 1861-65.

Lincoln Rock: rock, $0.3 \mathrm{mi}$. SW of Lincoln $\mathbf{I}$., on W coast of Etolin I., Alex. Arch.; 56 $03^{\prime} 25^{\prime \prime}$ N, $132^{\circ} 41^{\prime} 50^{\prime \prime} \mathrm{W}$; (map 6).

Named in 1886 by Lt. Comdr. A. S. Snow, USN, for Abraham Lincoln. See Abraham Islands.

Lincoln Rock: island, see Lincoln Island.

lind Creek: stream, flows NW $7 \mathrm{mi}$. to Sethkokna River, 74 mi. NE of Medfra, KilbuckKuskokwim Mts.; $63^{\circ} 58^{\prime} \mathrm{N}, 153^{\circ} 17^{\prime} \mathrm{W}$; (map 89).

Local name reported in 1958 by USGS.

Lind Island: island, see Axel Lind Island.

Linda Creek: stream, flows NW $5 \mathrm{mi}$. to Hunter Creek, $39 \mathrm{mi}$. NW of Haycock, Seward Penin. High.; $65^{\circ} 44^{\prime} \mathrm{N}, 161^{\circ} 39^{\prime} \mathrm{W}$; (map 109).

Local name published on maps after 1950.

Linda Creek: stream, flows SW $5 \mathrm{mi}$. from Linda Creek Lake to Middle Fork Koyukuk River, $36 \mathrm{mi}$. W of Chandalar, Brooks Ra.; $67^{\circ} 31^{\prime} 15^{\prime \prime} \mathrm{N}, 149^{\circ} 51^{\prime} 00^{\prime \prime} \mathrm{W}$; (map 123).

Prospectors' name obtained in 1909 by $\mathrm{A}$. G. Maddren (in Brooks and others, 1910, pl. 7), USGS

Linda Creek Lake: lake, $0.1 \mathrm{mi}$. across, at head of Linda Creek, $39 \mathrm{mi}$. WNW of Chandalar. 
Brooks Ra.; $67^{\circ} 33^{\prime}$ N, $149^{\circ} 45^{\prime}$ W ; (map 123 ). Local name obtained in 1956 by USGS.

Linda Creek Pass: pass, 2,400 ft., between Bettles and Middle Fork Koyukuk Rivers by way of Linda Creek, a tributary of Middle Fork Koyukuk River, $31 \mathrm{mi}$. WNW of Chandalar, Brooks Ra.; 67 $33^{\prime} \mathrm{N}, 149^{\circ} 40^{\prime} \mathrm{W}$; (map 123).

Local name obtained in 1956 by USGS.

Lindale: area, in S part of Anchorage, between Rees and North Fork Chester Creek, Gook Inlet Low.; $61^{\circ} 12^{\prime} 18^{\prime \prime} \mathrm{N}, 149^{\circ} 51^{\prime} 15^{\prime \prime}$ W ; (map 69).

Local name reported in 1954 by the city engineer of Anchorage.

Linda Vista Greek: stream, flows N $0.6 \mathrm{mi}$. to Big Hurrah Creek, $9 \mathrm{mi}$. NE of Solomon, Seward Penin. High.; $64^{\circ} 39^{\prime} \mathrm{N}, 164^{\prime} 16^{\prime} \mathrm{W}$; (map 95).

Prospectors' name reported on a 1902 prospectors' manuscript map.

Lindblom Creek: stream, flows $1.6 \mathrm{mi}$. to Snake River, $8 \mathrm{mi}$. NW of Nome, Seward Penin. High.; $64^{\circ} 37^{\prime} \mathrm{N}, 165^{\circ} 28^{\prime} \mathrm{W}$; (map 94). Var. Lindbloom Creek.

Reported as "Lindbloom" on a map by S. E. King, dated 1900. Named for Erik C. Lindblom, one of the "three Swedes" who discovered gold in the Nome area in the summer of 1898. Lindblom, a native of Sweden, was 30 years old in 1898, and for several years had been a tailor in San Francisco. He joined the stampede to Kotzebue Sound, but ended up in Council where he met John Brynteson, a Swede, and Jafet Lindeberg, a Norwegian. These three, often called the "three Swedes," sought new territory and prospected along the coast of Norton Sound where they found gold along the Snake River (Rickard, 1909, p. 330-334).

Lindbloom Creek: stream, see Lindblom Creek. Linden River: stream, see Don River.

Lindenberg Harbor: bay, $0.5 \mathrm{mi}$. across, at Todd, on $\mathbf{S}$ coast of Chichagof I., Alex. Arch.; $57^{\circ} 27^{\prime} 30^{\prime \prime} \mathrm{N}, 135^{\circ} 01^{\prime} 40^{\prime \prime} \mathrm{W}$; (map 9). Var. Gavan Lindenberga.

Named in 1883 by the Russian navigator Ens. Vasiliev for G. Lindenberg (cnna), who made surveys in this area in 1838.

Lindenberg Head: point of land, $0.7 \mathrm{mi}$. SE of Todd, on Peril Strait, on $\mathrm{S}$ coast of Chichagof I., Alex. Arch.; $57^{\circ} 27^{\prime} 20^{\prime \prime} \mathrm{N}, 135^{\circ}$ $01^{\prime} 20^{\prime \prime} \mathrm{W}$; (map 9).

Apparently named in 1895 by Lt. Comdr. E. K. Moore, USN, for adjacent Lindenberg Harbor. The name was published by USC\&GS on Chart 8283.

Lindenberg Peninsula: peninsula, $30 \mathrm{mi}$. long, on $E$ coast of Kupreanof 1 ., separated from Mitkof I. on SE by Wrangell Narrows, $26 \mathrm{mi}$. NW of Wrangell, Alex. Arch.; 56 $48^{\circ} 30^{\prime \prime} \mathrm{N}$, $133^{\circ} 06^{\prime} 00^{\prime \prime} \mathrm{W}$; (map 6). Var. Bereg Lindenberga, Lindenberg Shore.

Named by the Russian Hydrog. Dept. in 1853, who published it on Chart 1493 as "Berg Lindenberga," i.e. "Lindenberg Shore," referring to the eastern shore. The generic "peninsula" was given by W. H. Dall,
USC\&GS, in 1883. This feature was named for the Russian, G. Lindenberg (cnna), who explored and surveyed in the Alexander Archipelago in 1838.

Lindenberg Shore: peninsula, see Lindenberg Peninsula.

Lindenberga, Bereg: peninsula, see Lindenberg Peninsula.

Lindenberga, Gavan: bay, see Lindenberg Harbor.

Linder Lakes: lakes, $1.8 \mathrm{mi}$. SW of Sawmill I. and $9 \mathrm{mi}$. N of Nenana, Tanana Low.; $64^{\circ} 42^{\prime}$ $\mathrm{N}, 149^{\circ} 11^{\prime} \mathrm{W}$; (map 100).

Local name reported in 1950 by USGS topographers.

Lindita Peak: mountain peak, 7,910 ft., $0.7 \mathrm{mi}$. SE of Tazcol Peak and $20 \mathrm{mi}$. NW of Valdez, Chugach Mts.; $61^{\circ} 20^{\prime} 38^{\prime \prime} \mathrm{N}, 146^{\circ} 36^{\prime} 22^{\prime \prime} \mathrm{W}$; (map 68).

Named about 1955 by L. E. Nielson; it is a Spanish word meaning "little beauty."

Lindman Lake: lake, $0.2 \mathrm{mi}$. long, at head of Kasaan Penin., on E coast of Prince of Wales I., Alex. Arch.; $55^{\circ} 36^{\prime} 35^{\prime \prime} \mathrm{N}, 132^{\circ} 29^{\prime} 50^{\prime \prime}$ W; (map 4).

Local name recorded in 1949 by USGS.

Line Island: island, $300 \mathrm{ft}$. across, in Sitka Sound, $1.5 \mathrm{mi}$. W of Sitka, Alex. Arch.; $57^{\circ}$ $03^{\prime} 27^{\prime \prime} \mathrm{N}, 135^{\circ} 22^{\prime} 50^{\prime \prime} \mathrm{W}$; (map 9).

Named by the U.S. Navy in 1880; published by USC\&GS in 1883 Coast Pilot (p. 142).

Liner Island: island, $1.5 \mathrm{mi}$. long, at $\mathrm{NW}$ end of Weir $\mathbf{I}$. in Yukon River, $1 \mathrm{mi}$. $\mathrm{E}$ of Birches, Nowitna Low.; $65^{\circ} 08^{\prime} 15^{\prime \prime} \mathrm{N}, 153^{\circ} 30^{\prime} 00^{\prime \prime} \mathrm{W}$; (map 107). Var. Linet Island.

Riverboat pilots' name shown on a 1940 "Navigation Chart of the Tanana-Yukon Rivers" published by the Department of the Interior.

Linet Island: island, see Liner Island.

Lingo: area, in SW Anchorage $1.5 \mathrm{mi}$. SW of City Hall, Cook Inlet Low.; $61^{\circ} 12^{\prime} 10^{\prime \prime} \mathrm{N}$, $149^{\circ} 55^{\prime} 15^{\prime \prime} \mathrm{W}$; (map 69).

Residential district in city of Anchorage reported by office of city engineer of Anchorage Link Hills: mountains, $1,365 \mathrm{ft}$., center of Kiska I., Aleutian Is.; $51^{\circ} 58^{\prime} 06^{\prime \prime} \mathrm{N}, 177^{\circ} 25^{\prime} 10^{\prime \prime}$ E; (map 14). Var. China Hills.

An arbitrary name beginning with " $L$ " to correspond to "L" grid used by U.S. Army for tactical purposes during World War II ; published on a 1953 AMS map. Variant published on a 1943 USAAF map.

Link Island: island, $1.6 \mathrm{mi}$. long, in Beardslee Islands in Glacier Bay, Glacier Bay National Monument, $4 \mathrm{mi}$. NE of Strawberry Island and $56 \mathrm{mi}$. NW of Juneau, St. Elias Mts.; $58^{\circ} 33^{\prime} 00^{\prime \prime} \mathrm{N}, 135^{\circ} 53^{\prime} 45^{\prime \prime}$ W; BGN 1948 (map 11).

So named by the USC\&GS in 1939 because two islands shown on previous charts are now linked together near the center by a narrow grass-covered isthmus.

Link Lake: lake, $0.4 \mathrm{mi}$. long, at head of Bottle Creek, $38 \mathrm{mi}$. SW of Talkeetna, Cook Inlet Low.; 62 $60^{\circ} 05^{\prime \prime} \mathrm{N}, 151^{\circ} 05^{\prime} 08^{\prime \prime} \mathrm{W}$; (map 81).

Local name reported in 1958 by USGS.
Linkum Creek: stream, heads between Jacobs and Kasaan Mts., flows SW 2 mi. to Kasaan Bay at Kasaan, on E coast of Prince of Wales I., Alex. Arch.; 55 $32^{\prime} 20^{\prime \prime} \mathrm{N}, 132^{\circ} 23^{\prime} 50^{\prime \prime} \mathrm{W}$; $B G N 1960$; (map 4).

"This stream name has reference usage since 1929. * * * used in a FPC [Federal Power Commission] license issued July 9, 1930 to Booth Fisheries * * *;" reported in 1960 by USFS.

Linquist Creek: stream, heads on Kings Mtn., flows NW $2.3 \mathrm{mi}$. to Matanuska River, $20 \mathrm{mi}$. NE of Palmer, Chugach Mts. ; 61 ${ }^{\circ} 45^{\prime} 20^{\prime \prime} \mathrm{N}$, $148^{\circ} 34^{\prime} 45^{\prime \prime} \mathrm{W}$; (map 69).

Local name reported in 1952 by USGS.

Linton Creek: stream, flows S $0.8 \mathrm{mi}$. to join Sigard Creek to form Bonanza River, $18 \mathrm{mi}$. NW of Solomon, Seward Penin. High.; $64^{\circ} 46^{\prime} 55^{\prime \prime} \mathrm{N}, 164^{\circ} 47^{\prime} 30^{\prime \prime} \mathrm{W}$; (map 95).

Prospectors' name reported on the 1900 "Map of Nome Peninsula" by J. M. Davidson and B. D. Blakeslee.

Liodianoi Bay: $b a y$, see Icy Bay.

Lion and Reliance Reef : point of land, see Lion Point.

Lion and Reliance Reef: point of land, see Reliance Point.

Lion and Reliance Reef: island, see Tigvariak Island.

Lion Bay: bay, on Beaufort Sea coast between Flaxman I. and mainland, extending $10 \mathrm{mi}$. W of Point Brownlow, Arctic Plain; $70^{\circ} 10^{\prime} \mathrm{N}$, $146^{\circ} 00^{\prime} \mathrm{W}$; (map 151).

Probably named for one of the two boats used by Sir John Franklin's party in 1826; the name, however, is recent.

Lion Bight: cove, $0.9 \mathrm{mi}$. across, on $\mathrm{SW}$ coast of Unalaska I., Aleutian Is.; $53^{\circ} 25^{\prime} 15^{\prime \prime} \mathrm{N}$, $167^{\circ} 08^{\prime} 00^{\prime \prime} \mathrm{W}$; BGN 1939; (map 23).

Named by USC\&GS in 1938, "because of its nearness to Lion Rock."

Lion Cove: cove, $0.6 \mathrm{mi}$. across, halfway between Yug and Orient Points, $S$ coast of Little Kiska I., Aleutian Is.; $51^{\circ} 57^{\prime} \mathrm{N}, 177^{\circ} 41^{\prime} \mathrm{E}$; (map 14).

This is one of the animal names arbitrarily applied to features in this area in 1943 by USAAF for tactical purposes during World War II.

Lion Creek: stream, flows N $1.1 \mathrm{mi}$. to Big Hurrah Creek, $9 \mathrm{mi}$. NE of Solomon, Seward Penin. High.; $64^{\circ} 38^{\prime} \mathrm{N}, 164^{\circ} 12^{\prime} \mathrm{W}$; (map 95).

Prospectors' name shown on Arthur Gibson's "Map of Cape Nome Precinct" dated 1904.

Lion Head: mountain, 3,195 ft., at junc. of Caribou Creek and Matanuska River, $49 \mathrm{mi}$. NE of Palmer, $61^{\circ} 47^{\prime} \mathrm{N}, 147^{\circ} 40^{\prime} \mathrm{W}$; (map 69).

Local name reported in 1952 by USGS. Lion Hills : hills, $520 \mathrm{ft}$., center Kiska I., Aleutian Is.; $51^{\circ} 56^{\prime} 15^{\prime \prime} \mathrm{N}, 177^{\circ} 24^{\prime} 56^{\prime \prime} \mathrm{E}$; (map 14).

An arbitrary name beginning with " $L$ " to correspond to "L" grid used by the U.S. Army for tactical purposes during World War II; published on a 1943 Army map.

Lion Island: island, see Tigvariak Island. 
Lion Point: point of land, NW tip of an island, was once part of Tigvariak I., at $E$ point of entrance to Foggy I. Bay, on Beaufort Sea coast, Arctic Plain; $71^{\circ} 14^{\prime} 30^{\prime \prime} \mathrm{N}, 147^{\circ} 16^{\prime} 25^{\prime \prime}$ W; (map 150). Var. Lion and Reliance Reef, Lion Reef, Point Lion.

On August 7, 1826, Franklin (1828, p. 152) named the island Lion and Reliance Reef after his two boats (the Lion was driven aground at this place). Leffingwell (1919, p. 100) adopted the Eskimo name "Tigariak" for the island, and, in his text, applied Franklin's names to the NE (Point Reliance) and NW (Point Lion) points of the island (p. 89). However Leffingwell's maps show these points as Reliance Point and Lion Point.

Lion Reef: point of land, see Lion Point.

Lion Reef: point of land, see Reliance Point.

Lion Rock: rock, in Lion Bight on SW coast of Unalaska I., Aleutian Is.; $53^{\circ} 25^{\prime} 12^{\prime \prime} \mathrm{N}$, $167^{\circ} 08^{\prime} 45^{\prime \prime} \mathrm{W}$; BGN 1939; (map 23).

Descriptive name given by USC\&GS in 1938, "because, when seen from the southwest it has the appearance of a crouching lion."

Lions Head: mountain, see Lions Head Mountain.

Lions Head Mountain: mountain, 5,400 ft., on Kakuhan Range, $3.6 \mathrm{mi}$. NE of Point Sherman on Lynn Canal and $46 \mathrm{mi}$. NW of Juneau, Coast Mts.; 58 $52^{\prime} 45^{\prime \prime}$ N, $135^{\circ} 03^{\prime}$ $40^{\prime \prime}$ W; BGN 1923; (map 11). Var. Lions Head.

Descriptive name given in 1867 by George Davidson, USC\&GS, because its "serrated profile is said to show, when seen from Chatham strait, a resemblance to a couchant lion' (Knopf, 1911, p. 10). The name was pubblished in the 1869 Coast Pilot. The mountain was charted, however, east of Berners Bay and continued to be so shown for nearly 40 years.

Lipsett Point: point of land, at mouth of Afognak Bay, $1.5 \mathrm{mi}$. NE of Afognak, on $S$ coast of Afognak I., $\mathrm{N}$ of Kodiak I.; $58^{\circ} 01^{\prime} 35^{\prime \prime} \mathrm{N}$, $152^{\circ} 45^{\prime} 05^{\prime \prime}$ W; (map 43). Var. Lietnik Cape, Point Lipsett.

Local name reported in 1900 by Lt. Comdr. J. F. Moser, USN, Commander of the USBF steamer Albatross. This point was called "M[ys] Lytnika" meaning "summer village cape" by Sub-Lt. Mikhail Murashev, IRN, in 1839 or 1840 , and published by the Russian Hydrog. Dept. in 1849 on Chart 1425.

Lira, Punta de: point of land, on $\mathbf{S}$ shore of Port Refugio on Suemez I.; Alex. Arch.; $55^{\circ} 77^{\prime} \mathrm{N}$, $133^{\circ} 18^{\prime} \mathrm{W}$; (map 4).

Spanish name given by F. A. Maurelle and Bodega y Quadra in 1779, probably for Benito de Lira, naval captain (Wagner, 1937, p. 467).

Lisa Lake: lake, $0.5 \mathrm{mi}$. long, $2 \mathrm{mi}$. SW of junc. of Johnson and Tanana Rivers and 39 mi. SE of Delta Junction, Tanana Low.; $63^{\circ} 42^{\prime} 40^{\prime \prime} \mathrm{N}, 144^{\circ} 40^{\prime} 50^{\prime \prime} \mathrm{W}$; (map 86).

Name published on relatively recent maps.

Lisa Point: point of land, on a small island between Thetis and Tebenkof Bays, on W coast of Kuiu I., Alex. Arch.; $56^{\circ} 26^{\prime} 35^{\prime \prime}$ N, $134^{\circ} 08^{\prime} 50^{\prime \prime} \mathrm{W}$; BGN 1929; (map 5). Var. Bridge Point.

Russian name meaning "fox" given in 1928 by USC\&GS; suggested by triangulation station Fox on the point.

Lisbon, Cape: promontory, see Lisburne, Cape.

Lisbon Creek: stream, flows NE $1 \mathrm{mi}$. to Bering Sea, center of Kiska I., Aleutian Is.; $51^{\circ} 59^{\prime}$. $13^{\prime \prime} \mathrm{N}, 177^{\circ} 28^{\prime} 22^{\prime \prime} \mathrm{E}$; (map 14).

An arbitrary name beginning with " $L$ " to correspond to "L" grid used by the U.S. Army for tactical purposes during World War II published on a 1943 Army map.

Lisborne, Cape : promontory, see Lisburne, Cape. Lisburn, Cape: promontory, see Lisburne, Cape. Lisburne, Cape: promontory, 1,500 ft., on Chukchi Sea coast, $40 \mathrm{mi}$. NE of village of Point Hope, Arctic Slope; $68^{\circ} 53^{\prime} \mathrm{N}, 166^{\circ} 13^{\prime}$ W; BGN 1944; (map 129). Var. Cape Lisbon, Cape Lisborne, Cape Lisburn, Uivak, Uivaq, Uivfak, Uwuk, Webuk Unasiksuk, Wevok, Wevuk.

Discovered and named by Capt. Cook (1785, p. 460), RN, on August 21, 1778, who wrote "The southern extreme seemed to form a point which was named Cape Lisburne." An early Eskimo name for the cape was "Uivaq," generally spelled "Wevuk" or "Wevok." Cape Lisburne was often referred to as "Uivac Ungasiktoq" meaning "distant cape" as opposed to "Uivaq Qanitoq" (Cape Thompson) meaning "near cape."

Lisburne Hills: range, 2,000 ft., extends SE 45 mi. from Cape Lisburne to Kakpuk River Arctic Slope; $68^{\circ} 35^{\prime} \mathrm{N}, 1^{\circ} 5^{\circ} 49^{\prime} \mathrm{W}$; (map 129). Var. Lisburne Mountain, Lisburne Range.

Named in 1904 "after the cape" by Collier (1906, p. 13), USGS.

Lisburne Mountain: range, see Lisburne Hills. Lisburne Range: range, see Lisburne Hills.

Lisburne Ridge: ridge, elev. 2,660 ft., extends WNW-ESE $11 \mathrm{mi}$. between Etivluk River and Hardway Creek, $29 \mathrm{mi}$. N of Howard Pass, Arctic Slope; $68^{\circ} 37^{\prime} \mathrm{N}, 156^{\circ} 35^{\prime} \mathrm{W}$; BGN 1960; (map 132). Var. White Ridge.

So named in 1950 by USGS because "the fifth and farthest north belt $* * *$ the Lisburne [limestone] group is exposed $* * *$ on Lisburne Ridge, a narrow *** hogback *** that coincides with a major fault" (Chapman and others, 1964, p. 342).

Liscome, Port: water passage, see Kaigani Strait.

Liscome Bay: estuary, extends N 2 mi., on S coast of Dall I.; Alex. Arch.; $54^{\circ} 41^{\prime} \mathrm{N}$, $132^{\circ} 48^{\prime} \mathrm{W}$; (map 1 ).

Named in 1792 by Ingraham (cnna) (Baker, 1906, p. 405).

Liscome Point: point of land, on SW coast of Dall I., W side of Liscome Bay, Alex. Arch.; $54^{\circ} 41^{\prime} \mathrm{N}, 132^{\circ} 51^{\prime} \mathrm{W}$; BGN 1929; (map 1).

Named in 1928 by R. S. Patton, USC\&GS.

Liscum Slough: stream, flows SE $10 \mathrm{mi}$. to Goodpaster River, $18 \mathrm{mi}$. E of Big Delta, Yukon-Tanana High.; $64^{\circ} 11^{\prime} 30^{\prime \prime} \mathrm{N}, 145^{\circ} 15^{\prime} 00^{\prime \prime}$ W; (map 101).
Local name reported in 1908 by J. W. Bagley, USGS.

Lises, Cape: point of land, on the NW coast of Little Tanaga I., Aleutian Is.; $51^{\circ} 52^{\prime} 50^{\prime \prime} \mathrm{N}$, $176^{\circ} 12^{\prime} 30^{\prime \prime} \mathrm{W}$; BGN 1936; (map 17). Var. Fox Cape.

Russian name reported by Capt. Tebenkov (1849, atlas notes, p. 119), IRN, as "Lises," probably from the word "lisa" meaning "fox" or "vixen." "C. Lises (Fox Cape)" was published by the U.S. Navy Hydrog. Office (1868, chart 8).

Lishtak: stream, see Shotgun Creek.

Lisianski Bay: bay, see Barling Bay.

Lisianski Inlet: estuary, $25 \mathrm{mi}$. long, trends SE from its mouth on Cross Sound, on NW coast of Chichagof I., $37 \mathrm{mi}$. W of Hoonah, Alex. Arch.; $58^{\circ} 07^{\prime} 30^{\prime \prime} \mathrm{N}, 136^{\circ} 27^{\prime} 30^{\prime \prime} \mathrm{W}$; $B G N$ 1908; (map 10).

Name published by USC\&GS in the 1908 Alaska Coast Pilot (p. 169).

Lisianski Peninsula: peninsula, $8 \mathrm{mi}$. N of Sitka, on NW coast of Baranof I., Alex. Arch.; $57^{\circ} 10^{\prime} \mathrm{N}, 135^{\circ} 23^{\prime} \mathrm{W}$. (map 9).

Named in 1883 by W. H. Dall, USC\&GS; published in 1883 Coast Pilot (p. 152). It was named for Capt. Urey Theodorovich Lisianski, Russian explorer, who visited this area in 1804 and 1805 .

Lisianski Point: point of land, on S tip of Lisianski Penin., $6.5 \mathrm{mi}$. N of Sitka, on NW coast of Baranof I., Alex. Arch.; 57 $08^{\prime} 35^{\prime \prime}$ $\mathrm{N}, 135^{\circ} 23^{\prime} 40^{\prime \prime} \mathrm{W}$; (map 9).

Named in 1883 by W. H. Dall, USC\&GS, for Capt. Urey Theodorovich Lisianski, Russian explorer, who visited Sitka in 1804 after the Indians had destroyed the settlement. He bombarded and destroyed the Indian village on Indian River in retaliation.

Lisianski River: stream, on Chichagof I., flows $7 \mathrm{mi}$. NW to head of Lisianski Inlet, $7 \mathrm{mi}$. SE of Pelican, Alex. Arch.; 57 $52^{\prime} \mathrm{N}, 136^{\circ} 06^{\prime}$ W; BGN 1960; (map 9).

Named in 1955 by USGS for Lisianski Inlet.

Lisianski Strait: water passage, $13 \mathrm{mi}$. long, extends $\mathrm{S}$ from Lisianski Inlet to Point Urey on NW coast of Chichagof I., $18 \mathrm{mi}$. NW of Chichagof, Alex. Arch.; 57 $50^{\prime} \mathrm{N}, 136^{\circ} 27^{\prime}$ W; (map 9). Var. Lisiansky Strait.

Named in 1879 by W. H. Dall, USG\&GS; published in 1883 Coast Pilot (p. 184). It was named for Capt. Urey Theodorovich Lisianski, Russian explorer, on whose chart this strait first appeared in 1814 .

Lisiansky Strait: water passage, see Lisianski Strait.

Liskoff: point of land, see Lieskof, Cape.

L!'isti: locality, see Tlistee.

Listvinichnaia Bay: bay, see Larch Bay.

Lisvinichnaya Bukhta: bay, see Larch Bay.

Lisvinitchny Bay: $b a y$, see Larch Bay.

Lisyy, Ostrova : island, see Fox Islands.

Lithkealik River: stream, heads in Askinuk Mts., flows SW $10 \mathrm{mi}$. to Kokechik Bay, 11 mi. SE of Cape Romanzof, Yukon-Kuskokwim Delta ; $61^{\circ} 42^{\prime} \mathrm{N}, 165^{\circ} 51^{\prime} \mathrm{W}$; Var. Ishkialik River.

Eskimo name reported by USC\&GS in 1951. 
Lithkealiktulik Slough: stream, see Owl Creek. Litnekof Cove: cove, see Letnikof Cove.

Litnik: locality, on $S$ coast of Afognak $I$. at head of Afognak Bay, $5 \mathrm{mi}$. $\mathrm{N}$ of Afognak, Kodiak I.; $58^{\circ} 05^{\prime} 00^{\prime \prime} \mathrm{N}, 152^{\circ} 48^{\prime} 20^{\prime \prime} \mathrm{W}$; (map 43). Var. Elitnik, Lietnik.

Russian name (from the words "lytniy domik" meaning "summer house") reported in 1900 by Lt. Comdr. J. F. Moser, USN. Baker (1906, p. 406) wrote that this village "is apparently the Afognak of other maps ***". In 1889 USBF applied this name to the village of Afognak. See Afognak.

Litnik: locality, see Nunalik.

Litnik Bay: estuary, see Afognak Bay.

Litnik Lake: lake, see Afognak Lake.

Litnik Mountain: mountain, 1,955 ft., $2.5 \mathrm{mi}$. NW of Afognak, on S coast of Afognak I.; $58^{\circ} 02^{\prime} 20^{\prime \prime} \mathrm{N}, 152^{\circ} 48^{\prime} 30^{\prime \prime} \mathrm{W}$; (map 43 ).

Name derived from village of Litnik and published by USC\&GS in 1910.

Litnik River: stream, see Afognak River.

Little Abraham River: stream, flows SW $1.6 \mathrm{mi}$. to Abraham Bay, Attu I., Aleutian Is.; $52^{\circ}$ $53^{\prime} 35^{\prime \prime} \mathrm{N}, 172^{\circ} 47^{\prime} 30^{\prime \prime} \mathrm{E}$; (map 13).

Name shown on an AMS map published in 1948, derived from Abraham Bay.

Little Afognak: locality, $16 \mathrm{mi}$. NE of Afognak, on SE Coast of Afognak I.; $58^{\circ} 07^{\prime} 50^{\prime \prime} \mathrm{N}$, $152^{\circ} 24^{\prime} 30^{\prime \prime}$ W; (map 43). Var. Duck Village.

Name derived from Afognak I., reported in 1900 by Lt. Comdr. J. F. Moser, USN, commander of the USBF steamer Albatross, who made surveys and investigations in this area; published by USC\&GS in 1910. Recorded in 11 th Census in $1890(1893$, p. 74$)$ as a part of greater Afognak. Sub. Lt. M. Murashev, IRN, in 1839 or 1840 , reported the name "S[eleniye] Afognakskoye" or "Afognak Village," for this locality. See Afognak.

Little Aiktalik Island: island, see Sundstrom Island.

Little Alaid Island: island, see Alaid Island.

Little Albert Creek: stream, flows SE $7 \mathrm{mi}$. to Albert Creek, $5 \mathrm{mi}$. NW of Central and $30 \mathrm{mi}$. SW of Circle, Yukon-Tanana High.; 65 $36^{\circ}$ $40^{\prime \prime} \mathrm{N}, 144^{\circ} 57^{\prime} 45^{\prime \prime} \mathrm{W}$; (map 104).

Prospectors' name reported in 1954 or 1955 by USGS topographers.

Little Anvil Creek: stream, see Silverbow Creek.

Little Apoon Pass: watercourse, in Yukon Delta, extends NE-SW $7 \mathrm{mi}$. between Chinikluk Slough and Kwikpak Pass, $20 \mathrm{mi}$. NE of Kwiguk, Yukon-Kuskokwim Delta; 62 ${ }^{\circ} 54^{\prime} \mathrm{N}$, $164^{\circ} 00^{\prime} \mathrm{W}$; (map 77). Var. Kravaksarok, Little Aproon Pass.

Name recorded as "Little Aproon" in 1899 by R. L. Faris, USG\&GS, who also obtained the Eskimo name "Kravaksarok."

Little Aproon Pass: watercourse, see Little Apoon Pass.

Little Axel Lind Island: island, $1 \mathrm{mi}$. long, in Prince William Sound, 1 mi. SE of mouth of Eaglek Bay, 36 mi. E of Whittier, Ghugach Mts.; $60^{\circ} 48^{\prime} 30^{\prime \prime} \mathrm{N}, 147^{\circ} 40^{\prime} 00^{\prime \prime} \mathrm{W}$; (map 63).
Local name published on recent USGS maps; name derived from nearby Axel Lind Island.

Little Baht Harbor: bight, $0.1 \mathrm{mi}$. across, $\mathrm{E}$ of Baht Harbor, on $\mathbf{N}$ coast of Zarembo I., Alex. Arch.; $56^{\circ} 27^{\prime} 10^{\prime \prime} \mathrm{N}, 132^{\circ} 46^{\prime} 20^{\prime \prime} \mathrm{W}$; $B G N$ 1917; (map 6).

Local name reported in 1916 by USC\&GS. Little Basket Bay: cove, $0.4 \mathrm{mi}$. across, $9.5 \mathrm{mi}$. $\mathbf{S}$ of mouth of Tenakee Inlet, on SE coast of Chichagof I., Alex. Arch.; 57 $38^{\prime} 10^{\prime \prime} \mathrm{N}$, $134^{\circ} 53^{\prime} 00^{\prime \prime} \mathrm{W}$; BGN 1935; (map 9).

Local name reported in 1935 by USFS.

Little Bay: bay, $1.3 \mathrm{mi}$. across, on $\mathrm{N}$ coast of Akun I., Aleutian Is.; $54^{\circ} 16^{\prime} 45^{\prime \prime} \mathrm{N}, 165^{\circ} 35^{\prime}$ $00^{\prime \prime} W$; (map 24). Var. Riecheshni Bay.

Descriptive name given in 1888 by USBF. "Called Riecheshni bay by [Father] Veniaminov, 1830" (Baker, 1906, p. 406).

Little Bay: bay, $0.2 \mathrm{mi}$. across, $11 \mathrm{mi}$. NW of Chichagof, on W coast of Chichagof I., Alex. Arch.; $57^{\circ} 46^{\prime} 30^{\prime \prime} \mathrm{N}, 136^{\circ} 18^{\prime} 00^{\prime \prime} \mathrm{W}$; (map 9). GS.

Descriptive name given in 1919 by USC\&

Little Bay: bay, trends SW $1.5 \mathrm{mi}$. to Knight Island Passage at $S$ end of Knight I., $12 \mathrm{mi}$. $\mathrm{SE}$ of Chenega, Chugach Mts.; $60^{\circ} 10^{\prime} 30^{\prime \prime} \mathrm{N}$, $147^{\circ} 48^{\prime} 30^{\prime \prime} \mathrm{W}$; (map 63).

Name published in 1909 by USC\&GS

Little Beach: beach, 1,700 ft. long, on $\mathrm{S}$ coast of Alaska Penin. in Katmai National Monument, $1 \mathrm{mi}$. $\mathrm{N}$ of Kukak Point and $32 \mathrm{mi}$. NE of Mount Katmai, Aleutian Ra.; $58^{\circ} 21^{\prime} 30^{\prime \prime} \mathrm{N}$, $154^{\circ} 05^{\prime} 50^{\prime \prime} \mathrm{W}$; (map 42).

Local name reported in 1955 by USC\&GS. Little Bear Creek: stream, in Kantishna Hills, flows NE $3.5 \mathrm{mi}$. to Toklat River, $2.5 \mathrm{mi}$. SW of junc. of that stream's East Fork and $38 \mathrm{mi}$. W of Healy, Alaska Ra.; $63^{\circ} 53^{\prime} 00^{\prime \prime} \mathrm{N}, 150^{\circ}$ $13^{\prime} 30^{\prime \prime} \mathrm{W}$; (map 88)

Prospectors' name shown on a 1916 fieldsheet by C. E. Giffin, USGS.

Little Bear Creek: stream, heads at $64^{\circ} 56^{\prime} 35^{\prime \prime}$ $\mathrm{N}, 160^{\circ} 20^{\prime} 00^{\prime \prime} \mathrm{W}$, flows NW $12 \mathrm{mi}$. to Inglutalik River, $24 \mathrm{mi}$. SE of Haycock, Nulato Hills; $65^{\circ} 03^{\prime} 35^{\prime \prime} \mathrm{N}, 160^{\circ} 26^{\prime} 55^{\prime \prime} \mathrm{W}$; $B G N$ 1966; (map 109).

Local name reported in 1909 by P. S. Smith, USGS

Little Bear Lake: lake, $0.1 \mathrm{mi}$. long, on Kenai Penin., $0.8 \mathrm{mi}$. SE of Bear Lake, $6 \mathrm{mi}$. NE of Seward, Chugach Mts.; $60^{\circ} 11^{\prime} 05^{\prime \prime} \mathrm{N}$, $149^{\circ} 20^{\prime} 30^{\prime \prime} \mathrm{W}$; (map 63).

Local name reported in 1951 by USGS

Little Bear Rock: rock, on W shore of Bumble Bay, 23 mi. SW of Karluk, Kodiak I.; 57 $16^{\prime}$ $15^{\prime \prime} \mathrm{N}, 154^{\circ} 44^{\prime} 00^{\prime \prime} \mathrm{W}$; (map 35).

Local name reported in 1952 by USGS.

Little Beauty Creek: stream, heads on Bean Ridge, flows NE $5 \mathrm{mi}$. to Sunde Creek $1.3 \mathrm{mi}$. $\mathrm{S}$ of that stream's junc. with Baker Creek, 44 mi. ESE of Tanana, Yukon-Tanana High.; $65^{\circ} 04^{\prime} 15^{\prime \prime} \mathrm{N}, 150^{\circ} 34^{\prime} 55^{\prime \prime} \mathrm{W}$; (map 106).

Local name reported in 1952 by USGS.

Little Beaver Creek: stream, flows SW $9 \mathrm{mi}$. to head of Nixon Fork, 24 mi. NE of Medfra,
Kilbuck-Kuskokwim Mts.; $63^{\circ} 26^{\prime} \mathrm{N}, 154^{\circ} 28^{\prime}$ W; (map 89).

Local name reported in 1910 by A. G Maddren (in Brooks and others, 1911, pl. 14), USGS.

Little Beaver Lake: lake, $0.5 \mathrm{mi}$. long, one of the Beaver Lakes, $25 \mathrm{mi}$. N of Anchorage, Cook Inlet Low.; $61^{\circ} 35^{\prime} 15^{\prime \prime} \mathrm{N}, 149^{\circ} 51^{\prime} 35^{\prime \prime}$ W; (map 69).

Local name reported in 1950 by USGS.

Little Beaver Lake: lake, $0.5 \mathrm{mi}$. long, in Nutzotin Mts., N of Beaver Lake, $11.5 \mathrm{mi}$. E of Euchre Mtn., Alaska Ra.; $62^{\circ} 03^{\prime} 30^{\prime \prime} \mathrm{N}, 141^{\circ}$ $49^{\prime} 30^{\prime \prime} \mathrm{W}$; (map 84).

Local name reported by USGS in 1960.

Little Beaver Lake: lake, 2,000 ft. across, $5 \mathrm{mi}$. $\mathrm{NW}$ of Flat Creek Lake and $24 \mathrm{mi}$. S of Beaver Yukon Flats; $66^{\circ} 01^{\prime} 15^{\prime \prime} \mathrm{N}, 147^{\circ} 10^{\prime} 30^{\prime \prime} \mathrm{W}$; (map 118)

Local name obtained in 1956 by USGS.

Little Biorka Island: island, $0.5 \mathrm{mi}$. long, NW of Biorka I., in the Necker Is., W of Baranof I., Alex. Arch.; 56 $52^{\prime} \mathrm{N}, 135^{\circ} 34^{\prime} \mathrm{W}$; (map 5).

Local name published by USC\&GS in the 1925 Coast Pilot (p. 285)

Little Black Creek: stream, flows NE $15 \mathrm{mi}$, to Kobuk River, $17 \mathrm{mi}$. NW of Shungnak, Kotzebue-Kobuk Low.; 66 $56^{\circ} \mathrm{N}, 157^{\circ} 40^{\prime} \mathrm{W}$; (map 115).

Local name reported in 1954 by the U.S. Army Corps of Engineers.

Little Black River: stream, heads at $65^{\circ} 30^{\prime} \mathrm{N}$, $143^{\circ} 30^{\prime} \mathrm{W}$, flows NNW $90 \mathrm{mi}$. to its distributaries, the Grass and Sucker Rivers, $16 \mathrm{mi}$. S of Chalkyitsik, Yukon Flats; $66^{\circ} 26^{\prime} \mathrm{N}, 143^{\circ} 49^{\prime}$ W; BGN 1959; (map 120). Var. Big Black River, Rat River.

Local name published in 1890 by USC\&GS. In the early days this stream was often confused with the Big Black (now Black) and Rat Rivers.

Little Black River: stream, see Grass River.

Little Black River: stream, see Grayling Fork Black River

Little Blanche Creek: stream, flows NE $2 \mathrm{mi}$ to Engineer Creek, $6.5 \mathrm{mi}$. NE of Fairbanks, Yukon-Tanana High.; 64 $56^{\prime} \mathrm{N}, 147^{\circ} 38^{\prime} \mathrm{W}$; $B G N 1933$; (map 100). Var. Engineer Creek.

Local name reported in 1933 by J. M. Hill USGS.

Little Blanche Creek: stream, see Hudson Coulee.

Little Blanche Creek: stream, see Rock Creek.

Little Bogus Creek: stream, heads in a lake and flows SW $8 \mathrm{mi}$. to Tuluksak River, $2.5 \mathrm{mi}$. NE of Tuluksak and $38 \mathrm{mi}$. SE of Russian Mission Yukon-Kuskokwim Delta; $61^{\circ} 07^{\prime} \mathrm{N}, 160^{\circ} 53^{\prime}$ W; (map 73 )

Local name reported by the U.S. Army Corps of Engineers in 1952.

Little Bonanza Creek: stream, flows NE $5.4 \mathrm{mi}$. to Bonanza Creek, $6 \mathrm{mi}$. SW of Monzonite Hills, Nowitna Low.; $64^{\circ} 20^{\prime} 12^{\prime \prime}$ N, $154^{\circ} 40^{\prime}$ $30^{\prime \prime} \mathrm{W}$; (map 98).

Local name reported about 1952 by USGS

Little Bonanza Creek: stream, flows E $2.5 \mathrm{mi}$ to North Fork Fortymile River, $30 \mathrm{mi}$. SW of 
Eagle, Yukon-Tanana High.; $64^{\circ} 36^{\prime} \mathrm{N}, 142^{\circ}$ $10^{\prime} \mathrm{W}$; (map 102).

Prospectors' name shown on an 1898 manuscript map by C. A. Woodruff, Fort Cudahy, Canada.

Little Bonanza Creek: stream, flows N $5 \mathrm{mi}$. to Boston Creek, $7 \mathrm{mi}$. SW of Ruby, KilbuckKuskokwim Mts.; $64^{\circ} 38^{\prime} 40^{\prime \prime} \mathrm{N}, 155^{\circ} 35^{\prime} 45^{\prime \prime}$ W; (map 98).

Local name reported in 1933 by USGS.

Little Boulder Creek: stream, heads in a glacier, $2.3 \mathrm{mi}$. W of Four Winds Mtn., flows $\mathrm{SE} 6.5 \mathrm{mi}$. to Klehini River, $3.6 \mathrm{mi}$. E of Porcupine and $29 \mathrm{mi}$. W of Skagway, St. Elias Mts.; $59^{\circ} 25^{\prime} 30^{\prime \prime} \mathrm{N}, 1^{\circ} 36^{\circ} 07^{\prime} 55^{\prime \prime} \mathrm{W}$; $B G N$ 1956; (map 45). Var. Jeltakatschkahin Creek, Teltakatschkahin Creek, Teltakhatskahin Creek, Yealthkaklatselahini, Yeltakaska Creek.

Prospectors' name reported by Wright (1904, pl. 2), USGS. It was called by its Indian name Teltakatschkahin Creek or Jeltakatschkahin by Krause (1883, map). In 1898, J. A. Flemer, USC\&GS, spelled it Teltakhatskahin. The IBC (1923, map 9) gave the native name Yeltakaska, and in 1952, C. E. Robertson, USGS, reported the full name as Yealthkaklatselahini.

Little Boulder Creek: stream, heads on Fairview Mtn., flows S $0.8 \mathrm{mi}$. to join Big Boulder Creek to form Twin Creek, $46 \mathrm{mi}$. W of Talkeetna, Alaska Ra. ; 62 $20^{\prime} 45^{\prime \prime} \mathrm{N}, 151^{\circ} 33^{\prime} 20^{\prime \prime}$ $\mathrm{W}$; (map 81).

Local name reported in 1911 by USGS.

Little Boulder Creek: stream, flows SW $9 \mathrm{mi}$. from Boulder Ridge to Boulder Creek, $28 \mathrm{mi}$. $E$ of Tanana, Yukon-Tanana High.; $65^{\circ}$ $08^{\prime} 40^{\prime \prime} \mathrm{N}, 151^{\circ} 08^{\prime} 00^{\prime \prime} \mathrm{W}$; (map 106).

Local name reported in 1952 by USGS.

Little Branch Bay: bay, $0.3 \mathrm{mi}$. across, empties into Branch Bay, $8 \mathrm{mi}$. NW of village of Port Alexander, on S coast of Baranof I., Alex. Arch.; 56 $18^{\prime} 00^{\prime \prime} \mathrm{N}, 134^{\circ} 50^{\prime} 30^{\prime \prime} \mathrm{W}$; (map 5). Var. Bukhta Maloy Strylky, Maloi Strelka.

Named published by USC\&GS in 1883 Coast Pilot (p. 132); derived from "Bukhta Maloy Strylky [from Strelka]," meaning "little arrow bay"; published by the Russian American Company in 1850.

Little Bremner River: stream, heads in glacier, flows SSW $13 \mathrm{mi}$. to Bremner River, $0.8 \mathrm{mi}$. $S$ of the mouth of MacCreel Creek, and 60 mi. W of Valdez, Chugach Mts.; $61^{\circ} 02^{\prime} 05^{\prime \prime}$ N, $144^{\circ} 26^{\prime} 30^{\prime \prime} \mathrm{W}$; (map 68).

Local name reported by F. H. Moffit (1912, pl. 5), USGS.

Little Brownson Bay: bight, $0.5 \mathrm{mi}$. across, on $S$ coast of Prince of Wales I., $E$ of Brownson Bay, Alex. Arch.; 54 $45^{\prime} 30^{\prime \prime} \mathrm{N}, 132^{\circ} 13^{\prime} 30^{\prime \prime}$ W; (map 1).

Descriptive name derived from "Brownson Bay" and published in 1923 by USC\&GS.

Little Brushman: peak, $3,810 \mathrm{ft}$., $3 \mathrm{mi}$. SE of Brushman Mtn. and $44 \mathrm{mi}$. NE of Arctic Village, Brooks Ra.; $68^{\circ} 25^{\prime} \mathrm{N}, 144^{\circ} 00^{\prime} \mathrm{W} ; B G N$ 1960; (map 136). Var. Brushman Annex.
Named in 1960 by USGS relative to Brushman Mountain.

Little Cambell Creek: stream, flows NW $8.3 \mathrm{mi}$. to Campbell Creek $4.4 \mathrm{mi}$. S of Anchorage, Cook Inlet Low.; $61^{\circ} 09^{\prime} 23^{\prime \prime} \mathrm{N}, 149^{\circ} 52^{\prime} 30^{\prime \prime}$ W; (map 69).

Local name reported in 1962 by USGS.

Little Cape Corwin: point of land, extends into Etolin Strait, $3 \mathrm{mi}$. SE of Twin Mtn. and 24 mi. NE of Cape Mendenhall, on $E$ coast of Nunivak I.; $60^{\circ} 01^{\prime} 15^{\prime \prime} \mathrm{N}, 165^{\circ} 38^{\prime} 00^{\prime \prime} \mathrm{W}$; (map 57).

Name reported about 1908 by USC\&GS.

Little Caribou Creek: stream, flows NW $6.5 \mathrm{mi}$. to Caribou Creek, $8 \mathrm{mi}$. N of Flat, $52 \mathrm{mi}$. SE of Holikachuk, Kilbuck-Kuskokwim Mts.; $62^{\circ} 34^{\prime} 10^{\prime \prime} \mathrm{N}, 158^{\circ} 03^{\prime} 40^{\prime \prime} \mathrm{W}$; (map 79).

Prospectors' name published in 1921 by USGS.

Little Caribou Creek: stream, in Kantishna Hills, flows NE $7 \mathrm{mi}$. to Crooked Creek, $3 \mathrm{mi}$. $W$ of junc. of Toklat River and its Clearwater Fork, Alaska Ra.; 63 $48^{\prime} 30^{\prime \prime} \mathrm{N}, 150^{\circ} 22^{\prime} 45^{\prime \prime}$ W; (map 88).

Local name shown on a 1916 fieldsheet by C. E. Giffin, USGS.

Little Caribou Creek: stream, flows SE $0.8 \mathrm{mi}$. to Chatanika River, $9.5 \mathrm{mi}$. WNW of Mount Ryan and $47 \mathrm{mi}$. NE of Fairbanks, YukonTanana High.; $65^{\circ} 17^{\prime} 10^{\prime \prime} \mathrm{N}, 146^{\circ} 33^{\prime} 45^{\prime \prime} \mathrm{W}$; (map 104).

Prospectors' name reported in 1954 or 1955 by USGS topographers.

Little Cedar Island: island, $0.1 \mathrm{mi}$. across, in Freshwater Bay, $8.5 \mathrm{mi}$. NE of Tenakee Springs, on $\mathrm{E}$ central Chichagof $\mathrm{I}$., Alex. Arch.; $57^{\circ} 52^{\prime} 15^{\prime \prime} \mathrm{N}, 135^{\circ} 03^{\prime} 05^{\prime \prime} \mathrm{W}$; BGN 1935 ; (map 9).

Local name reported in 1935 by USFS.

Little Champion Creek: stream, flows SW $6 \mathrm{mi}$. to Champion Creek, $25 \mathrm{mi}$. SW of Eagle, Yukon-Tanana High.; $64^{\circ} 31^{\prime} 20^{\prime \prime} \mathrm{N}, 141^{\circ}$ 35'40" W; (map 102). Var. Star Creek.

Local name published in 1956 by USGS.

Little Champion Creek: stream, flows SW 11 mi. to Champion Creek, $54 \mathrm{mi}$. NE of Fairbanks, Yukon-Tanana High.; $65^{\circ} 25^{\prime}$ N, $146^{\circ}$ 49' W; BGN 1910; (map 104).

Local name reported in 1909 by L. M. Prindle, USGS.

Little Chandler Lake: lake, $3 \mathrm{mi}$. long, adjoins Chandler Lake on $\mathbf{N}$, at head of Chandler River, 26 mi. NW of Anaktuvuk Pass, Brooks Ra.; $68^{\circ} 16^{\prime} 30^{\prime \prime} \mathrm{N}, 152^{\circ} 40^{\prime} 00^{\prime \prime} \mathrm{W}$; (map 134).

So named by the USGS in 1956 for the larger body of water it adjoins, Chandler Lake, which was named by Lt. Stoney, USN, in 1886, for William E. Chandler, 1835-1917, Secretary of the Navy.

Little Chena River: stream, heads at $65^{\circ} 11^{\prime} \mathrm{N}$, $146^{\circ} 36^{\prime} \mathrm{W}$, flows SW $45 \mathrm{mi}$. to Chena River, $9 \mathrm{mi}$. E of Fairbanks, Yukon-Tanana High.; $64^{\circ} 52^{\prime} \mathrm{N}, 147^{\circ} 25^{\prime} \mathrm{W}$; BGN 1965; (map 100). Var. Little Chenoa River.

Local name reported in 1903 by T. G. Gerdine (in Prindle, 1905, pl. 16), USGS.
Little Chena Roadhouse: locality, on Little Chena River, $14 \mathrm{mi}$. E of Fairbanks, Tanana Low.; $64^{\circ} 52^{\prime} \mathrm{N}, 147^{\circ} 15^{\prime} \mathrm{W}$; (map 100).

Name of a roadhouse published in the 1915 Polk's Gazetteer.

Little Chenoa River: stream, see Little Chena River.

Little Clearwater Creek: stream, heads in Clearwater Mts., flows S $14 \mathrm{mi}$. to Clearwater Creek, $41 \mathrm{mi}$. S of Mount Hayes, Alaska Ra.; $63^{\circ} 02^{\prime} 35^{\prime \prime} \mathrm{N}, 146^{\circ} 52^{\prime} 55^{\prime \prime} \mathrm{W}$; (map 86).

Local name reported in 1910 by $D$. C. Witherspoon, USGS.

Little Coal Bay: estuary, extends S $0.5 \mathrm{mi}$. off Kasaan Bay, $\mathbf{E}$ coast of Prince of Wales I., $0.5 \mathrm{mi}$. E of Coal Bay, Alex. Arch.; 55 $30^{\prime} 25^{\prime \prime}$ N, 132 $27^{\prime} 50^{\prime \prime} \mathrm{W}$; (map 4).

Local descriptive name recorded in 1949 by USGS.

Little Coal Creek: stream, flows NW $3.8 \mathrm{mi}$. to Chulitna River, $42 \mathrm{mi}$. NE of Talkeetna, Talkeetna Mts. ; $62^{\circ} 53^{\prime} 55^{\prime \prime} \mathrm{N}, 149^{\circ} 46^{\prime} 15^{\prime \prime} \mathrm{W}$; (map 82).

Local name reported in 1931 by USGS.

Little Cottonwood Creek: stream, flows NE 10 mi., to Noatak River, $37 \mathrm{mi}$. ESE of Misheguk Mtn., Brooks Ra.; 68 07' N, 159 $40^{\prime} \mathrm{W}$; (map 131).

Translation of an Eskimo name reported by Orth in 1956.

Little Cove: cove, $0.9 \mathrm{mi}$. across, at head of Middle Bay, on NE coast of Kodiak I; $57^{\circ}$ $39^{\prime} 20^{\prime \prime} \mathrm{N}, 152^{\circ} 30^{\prime} 05^{\prime \prime} \mathrm{W}$; (map 34). Var. Zaliv Mylkoy.

Translation by Baker (1906, p. 406) of the descriptive name "Zal[iv] Mylkoy," published by Sarichev (1826, map 16).

Little Crazy Mountains: mountains, 2,000 ft., extend $15 \mathrm{mi}$. $\mathbf{E}$ from junc. of Mule and Preacher Creeks, $25 \mathrm{mi}$. W of Circle, YukonTanana High.; $65^{\circ} 50^{\prime} \mathrm{N}, 144^{\circ} 55^{\prime} \mathrm{W}$; (map 104).

Local name reported by USGS in 1952; named in contrast to the higher Crazy Mountains three miles south.

Little Creek: locality, along Seward Penin. RR., N of Nome, Seward Penin. High.; (map 94).

Site of a RR. station established in 1905 (Cole, 1953, p. 14). Its precise location is unknown.

Little Creek: stream, flows SE $2 \mathrm{mi}$. to Red Bay, on $\mathrm{N}$ coast of Prince of Wales I., Alex. Arch.; $56^{\circ} 16^{\prime} 10^{\prime \prime} \mathrm{N}, 133^{\circ} 20^{\prime} 50^{\prime \prime} \mathrm{W}$; (map 6).

Named in 1886 by Lt. J. M. Helm, USN, for charting purposes; name published in 1887 on USC\&GS Chart 706.

Little Creek: stream, flows NW 1 mi. to Kuskokwim River $1.4 \mathrm{mi}$. N of its junc. with Oskawalik River, $33 \mathrm{mi}$. W of Sleetmute, Kilbuck-Kuskokwim Mts.; $61^{\circ} 45^{\prime} 40^{\prime \prime} \mathrm{N}, 158^{\circ}$ $10^{\prime} 20^{\prime \prime} \mathrm{W}$; (map 72).

Local descriptive name reported in 1952 by USGS.

Little Creek: stream, in Nutzotin Mts., flows SE $2.8 \mathrm{mi}$. to easternmost of Braye Lakes, $1.5 \mathrm{mi}$. NE of Braye Pass, Alaska Ra.; 62 $02^{\prime} 28^{\prime \prime} \mathrm{N}$, $141^{\circ} 06^{\prime} 00^{\prime \prime} \mathrm{W}$; (map 84).

Local name reported by USGS in 1959. 
Little Creek: stream, flows $\mathrm{N} 11 \mathrm{mi}$. to Iditarod River, $3 \mathrm{mi}$. SW of the junc. of Montana Creek, $35 \mathrm{mi}$. SE of Holy Cross, KilbuckKuskokwim Mts.; $62^{\circ} 05^{\prime} 25^{\prime \prime} \mathrm{N}, 158^{\circ} 42^{\prime} 00^{\prime \prime}$ W; BGN 1948; (map 79).

Prospectors' name obtained in 1913 by Eakin (1914, pl. 1), USGS.

Little Creek: stream, flows NW $4 \mathrm{mi}$. to Otter Greek $12 \mathrm{mi}$. E of its junc, with Iditarod River, $4.5 \mathrm{mi}$. E of Flat and $57 \mathrm{mi}$. NW of Sleetmute, Kilbuck-Kuskokwim Mts. ; $62^{\circ} 27^{\prime} 10^{\prime \prime} \mathrm{N}, 157^{\circ}$. $51^{\prime} 40^{\prime \prime} \mathrm{W}$; (map 79).

Name shown on 1910 manuscript map of "Iditarod Placer Fields."

Little Creek: stream, flows NE $6 \mathrm{mi}$. to Innoko River, $4 \mathrm{mi}$. of Ophir and $28 \mathrm{mi}$. NW of

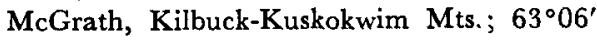
N, $156^{\circ} 26^{\prime} \mathrm{W}$; (map 90).

Prospectors' name obtained in 1908 by Maddren (1910, pl. 1), USGS.

Little Creek: stream, flows NE $3 \mathrm{mi}$. to Riley Creek, $12 \mathrm{mi}$. S of Healy, Alaska Ra.; 63 $41^{\prime}$. $45^{\prime \prime} \mathrm{N}, 148^{\circ} 55^{\prime} 30^{\prime \prime} \mathrm{W}$; (map 87).

Local descriptive name reported by USGS in 1950.

Little Creek: stream, flows NE $1.5 \mathrm{mi}$. to Trail Creek, $8 \mathrm{mi}$. E of Long and $25 \mathrm{mi}$. SSE of

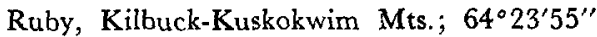
$\mathrm{N}, 155^{\circ} 13^{\prime} 15^{\prime \prime} \mathrm{W}$; (map 98$)$.

Prospectors' name reported in 1913 by Eakin $(1914$, pl. 3), USGS. The stream's identity is in doubt.

Little Creek: stream, flows SW $3 \mathrm{mi}$. to Snake River, $3 \mathrm{mi}$. NW of Nome, Seward Penin. High.; $64^{\circ} 32^{\prime} \mathrm{N}, 165^{\circ} 30^{\prime} \mathrm{W}$; (map 94). Var. Moonlight Creek.

Prospectors' name reported in 1899 by D. C. Witherspoon (in Schrader and Brooks, 1900, map 2), USGS. The 1900 "Map of Nome Peninsula" by J. M. Davidson and B. D. Blakeslee shows "Moonlight" along the lower half of the stream.

Little Creek: stream, flows NE $6 \mathrm{mi}$. to Big Creek, 9 mi. SE of Ruby, Kilbuck-Kuskokwim Mts. ; $64^{\circ} 42^{\prime} 15^{\prime \prime} \mathrm{N}, 155^{\circ} 12^{\prime} 10^{\prime \prime} \mathrm{W}$; (map 98).

Prospectors' name reported in 1933 by Mertie (1936, pl. 2), USGS.

Little Creek: stream, flows NW $1.5 \mathrm{mi}$. to Candle Creek, $9 \mathrm{mi}$. SW of Candle and $34 \mathrm{mi}$. NW of Imuruk Lake, Seward Penin. High.; $65^{\circ} 48^{\prime} \mathrm{N}$, $162^{\circ} 05^{\prime} \mathrm{W}$; (map 110).

Prospectors' name reported on the 1908 "Map of Seward Peninsula" by Arthur Gibson.

Little Creek: stream, flows N $0.8 \mathrm{mi}$. to California Creek, $14 \mathrm{mi}$. NE of Shungnak, Brooks Ra.; $66^{\circ} 57^{\prime} 20^{\prime \prime} \mathrm{N}, 156^{\circ} 39^{\prime} 00^{\prime \prime} \mathrm{W}$; (map 115).

Prospectors' name reported by USGS after 1940.

Little Creek: stream, see Lime Creek.

Little Crow Hills: mountains, 1,600 ft., extend $\mathrm{SE} 4 \mathrm{mi}$. from junc. of Kisaralik River and Quartz Creek, 55 mi. SE of Bethel, KilbuckKuskokwim Mts. ; $60^{\circ} 32^{\prime} \mathrm{N}, 160^{\circ} 15^{\prime} \mathrm{W}$; (map 59 ).

Local name reported in 1949 by USGS.

Little Dahl River: stream, see Little Dall River.
Little Daisy Creek: stream, flows NW $6 \mathrm{mi}$. to Goodhope River, $27 \mathrm{mi}$. NW of Imuruk Lake, Seward Penin. High.; $65^{\circ} 50^{\prime} \mathrm{N}, 164^{\circ} 02^{\prime} \mathrm{W}$; (map 110).

Prospectors' name reported in 1901 by USGS (Collier, 1902, pl. 12).

Little Dall River: stream, heads at Sussaymin Lakes, flows SE $30.0 \mathrm{mi}$. to Yukon River, 42 mi. NE of Rampart, Yukon Flats; $65^{\circ} 57^{\prime} \mathrm{N}$, $149^{\circ} 17^{\prime}$ W; (map 105). Var. Little Dahl River.

Local name reported in 1927 by USGS.

Little Daykoo Harbor: water passage, $0.8 \mathrm{mi}$. long, between SE coast of Dall I. and Daykoo Is., Alex. Arch.; $54^{\circ} 42^{\prime} 10^{\prime \prime} \mathrm{N}, 132^{\circ} 42^{\prime} 30^{\prime \prime}$ W; (map 1).

Local name published in 1924 by USC\&GS. Little Delta: locality, see Delta Telegraph Station.

Little Delta Creek: stream, see Delta Creek.

Little Delta River: stream, heads at junc. of East and West Forks of Little Delta River and flows $\mathrm{N} 24 \mathrm{mi}$. to Tanana River, $28 \mathrm{mi}$. NW of Big Delta, Tanana Low.; $64^{\circ} 17^{\prime} \mathrm{N}, 146^{\circ} 42^{\prime}$ W; (map 101). Var. Delta Creek, Husacheg, Silok Creek, Silokh Creek.

Lt. H. T. Allen, USA, named a stream west of the Delta River "Delta Creek," but its exact identity has been a problem to map makers. This particular stream came to be called "Little Delta River" in the early 1900's, no doubt in an effort to retain a form of Lt. Allen's name, but at the same time to differentiate it from nearby Delta River and Delta Creek. Its Indian name was "Silokh" according to A. H. Brooks, USGS, in 1898. J. T. Geoghegan, however, gives its Indian name as "Husacheg."

Little Denver Creek: stream, heads on Manley Hot Springs Dome, flows W $5.8 \mathrm{mi}$. to Cache Creek, Yukon-Tanana High.; $65^{\circ} 02^{\prime} 35^{\prime \prime} \mathrm{N}$, $150^{\circ} 54^{\prime} 30^{\prime \prime} \mathrm{W}$; (map 106).

Prospectors' name reported in 1931 by J. B. Mertie, USGS.

Little Derby Creek: stream, flows $S 0.6 \mathrm{mi}$. to Norton Sound, $6 \mathrm{mi}$. SE of Nome, Seward Penin. High.; $64^{\circ} 28^{\prime} 09^{\prime \prime} \mathrm{N}, 165^{\circ} 12^{\prime} 10^{\prime \prime} \mathrm{W}$; (map 94). Var. Minne Ha Ha Creek.

Prospectors' name reported in 1904 by T. G. Gerdine, USGS.

Little Devil Lake: lake, $1.5 \mathrm{mi}$. long, on Dall I., $\mathrm{SE}$ of Devil Lake, Alex. Arch.; $54^{\circ} 54^{\prime} 50^{\prime \prime} \mathrm{N}$, $133^{\circ} 05^{\prime} 00^{\prime \prime} \mathrm{W}$; (map 1 ).

Local descriptive name reported in 1948 by USGS.

Little Dexter Creek: stream, flows SE to Dexter Creek $0.5 \mathrm{mi}$. SW of its junc. with Nome River, $7 \mathrm{mi}$. NNE of Nome, Seward Penin. High.; 64 ${ }^{\circ} 35^{\prime} \mathrm{N}, 16^{\circ} 17^{\prime} \mathrm{W}$; (map 94).

Prospectors' name shown on the 1902 "Map of the Nome and Snake River Country" by J. M. Davidson.

Little Diomede Island: island, $2 \mathrm{mi}$. across, one of Diomede Is., in Bering Strait, $25 \mathrm{mi}$. NW of Cape Prince of Wales, Seward Penin. High.; $65^{\circ} 45^{\prime} \mathrm{N}, 168^{\circ} 55^{\prime} \mathrm{W}$; (map 111). Var. Imaglin Island, Krusenstern Island, Kruzenstern Island, Ostrov Imaklit, Ostrov Inqalyuk.
In the late 1800 's this island was commonly known as "Little Diomede," which was derived from the collective name of both islands named in 1728 by Vitus Bering. See Diomede Islands. In 1826 Capt. Beechey (1831, p. 247) named it "Krusenstern," after the Russian Adm. [Adam Johann von] Krusenstern. Its Eskimo name, reported by Martin Sauer (1802, p. 258), was "Imaglin"; Capt. Tebenkov (1852, map 1), IRN, records the name as "Ingalyuk."

Little Dixie Creek: stream, flows NW $1.4 \mathrm{mi}$. to Casadepaga River, $26 \mathrm{mi}$. NE of Solomon, Seward Penin. High.; 64 $55^{\prime} \mathrm{N}, 164^{\circ} 09^{\prime} \mathrm{W}$; (map 95). Var. Nipple Gulch.

Reported in 1907 as "Nipple Gulch" by USGS geologists (Smith, P. S., 1910, pl. 3). The geologists applied "Little Dixie Creek" to the next stream to the northeast. Prospectors' name reported on a 1902 prospectors' manuscript map.

Little Dollar Greek: stream, flows SE $1.7 \mathrm{mi}$. to Dollar Creek, $32 \mathrm{mi}$. NW of Talkeetna, Alaska Ra.; 62 $28^{\prime} 50^{\prime \prime} \mathrm{N}, 151^{\circ} 03^{\prime} 40^{\prime \prime} \mathrm{W}$; (map 81).

Prospectors' name reported in the 1930's by USGS.

Little Dome: peak, 1,030 ft., on Hermit Ridge, $20 \mathrm{mi}$. NW of Beaver, Kokrines-Hodzana High.; $66^{\circ} 26^{\prime} \mathrm{N}, 148^{\circ} 10^{\prime} \mathrm{W}$; (map 118). Local descriptive name obtained in 1956 by USGS.

Little Dome Creek: stream, flows E $8.7 \mathrm{mi}$. to Sulatna River, $13 \mathrm{mi}$. NE of Sulatna Crossing and $36 \mathrm{mi}$. SE of Ruby, Kilbuck-Kuskokwim Mts. ; 64 $4^{\circ} 15^{\prime} 45^{\prime \prime} \mathrm{N}, 155^{\circ} 02^{\prime} 45^{\prime \prime} \mathrm{W}$; (map 98).

Prospectors' name reported in 1913 by Eakin (1914, pl. 3), USGS.

Little Dome Creek: stream, flows N $0.8 \mathrm{mi}$. to Sheep Creek, $9 \mathrm{mi}$. NW of Fairbanks, YukonTanana High.; 64 $54^{\prime} 25^{\prime \prime}$ N, $147^{\circ} 59^{\prime} 15^{\prime \prime}$ W; (map 100).

Locally named relative to Dome Greek north of Goldstream Creek Valley and published on a railroad location manuscript map of 1916 or 1917.

Little Dry Creek: stream, see Cold Creek.

Little Dry Island: island, $0.8 \mathrm{mi}$. long, between Dry and Farm Is., at mouth of Stikine River, $11 \mathrm{mi}$. NW of Wrangell, Coast Mts.; 56 $37^{\prime}$ $10^{\prime \prime} \mathrm{N}, 132^{\circ} 31^{\prime} 00^{\prime \prime} \mathrm{W}$; (map 6$)$.

Local name recorded in 1948 by USGS.

Little Duncan Bay: $b a y$, extends SE $3.5 \mathrm{mi}$. to W shore of Duncan Canal, $16 \mathrm{mi}$. SW of Petersburg, on S coast of Kupreanof I., Alex. Arch.; $56^{\circ} 35^{\prime} 30^{\prime \prime} \mathrm{N}, 1^{\circ} 3^{\circ} 06^{\prime} 30^{\prime \prime} \mathrm{W}$; BGN 1933; (map 6). Var. Little Duncan Canal.

Local name used by fishermen; name published in 1932 by USC\&GS.

Little Duncan Canal: bay, see Little Duncan Bay.

Little Dutch Creek: stream, flows SE to Niukluk River, W of Ophir Creek, about $4 \mathrm{mi}$. NW of Council and $32 \mathrm{mi}$. NE of Solomon, Seward Penin. High.; ( $\operatorname{map} 95$ ).

Prospectors' name reported on the 1900 "Map of Nome Peninsula" by J. M. Davidson and B. D. Blakeslee. This stream cannot be precisely located on current maps. 
Little Eagle Lake: lake, $0.7 \mathrm{mi}$. long, on Eagle River $2.5 \mathrm{mi}$. downstream from Eagle Lake, $40 \mathrm{mi}$. SE of Wrangell, Coast Mts.; 56 $06^{\prime} 15^{\prime \prime}$ N, $131^{\circ} 31^{\prime} 30^{\prime \prime}$ W; (map 7). Var. Eagle Lake.

Local name reported in 1966 by USFS; recorded in 1929 by USFS as "Eagle Lake."

Little Eastern Rookery: rookery, see Little East Rookery.

Little East Fork George River: stream, flows SW $16 \mathrm{mi}$. to join Munther Creek to form East Fork George River, $5 \mathrm{mi}$. W of Granite $\mathrm{Mtn}$. and $38 \mathrm{mi}$. SE of Flat, Kilbuck-Kuskokwim Mts.; $62^{\circ} 18^{\prime} 20^{\prime \prime} \mathrm{N}, 156^{\circ} 53^{\prime} 00^{\prime \prime} \mathrm{W}$; (map 79).

Local name obtained in 1952 by USGS topographers.

Little East Rookery: rookery, $1.2 \mathrm{mi}$. E of village of Saint George, on $\mathbf{N}$ coast of Saint George I., in Pribilof Is.; $56^{\circ} 36^{\prime} 23^{\prime \prime} \mathrm{N}$, $169^{\circ} 30^{\prime} 40^{\prime \prime} \mathrm{W}$; (map 38). Var. Kreg'lucht'en-ang'ten-algarel'ogrey, Little Eastern Rookery.

The name is reported as "Little Eastern Rookery" by Elliott (1881, p. 61); this rookery has $750 \mathrm{ft}$. of sea-margin for seals. It was called "Little East Rookery" by Joseph Stanley-Brown, USGS, in 1891, and by W. W. Duffield, USC\&GS, in 1897. Putnam (1903, p. 1015), USC\&GS, gives the Aleut name as "Kreg'lucht'en-ang'ten-algarel'ogrey" [BGN orthography] meaning "the rookery at Kregluchten." See Kregluchten.

Little Egg Island: island, 130 yds. across, in Popof Strait, in Shumagin Is., Aleutian Ra.; $55^{\circ} 17^{\prime} 00^{\prime \prime} \mathrm{N}, 160^{\circ} 31^{\prime} 25^{\prime \prime} \mathrm{W}$; (map 28). Var. Egg Islands.

Both Egg and Little Egg Islands were named Egg Islands in 1872 by W. H. Dall, USC\&GS. The names were applied separately in USC\&GS 1916 Coast Pilot (p. 177).

Little Eightmile Island: island, in Yukon River, $41 \mathrm{mi}$. SW of Nulato, Koyukuk Low.; $64^{\circ} 11^{\prime}$ N, $158^{\circ} 40^{\prime} \mathrm{W}$; (map 97). Var. Dasger Island.

Local descriptive name reported in 1954 by USGS.

Little Eldorado Creek: stream, in Nutzotin Mts., flows S $2.2 \mathrm{mi}$. to Bonanza Creek 2.2 mi. NE of its junc. with Chathenda Creek, $12 \mathrm{mi}$. E of Euchre Mtn., Alaska Ra.; $62^{\circ}$ $06^{\prime} 15^{\prime \prime} \mathrm{N}, 141^{\circ} 50^{\prime} 00^{\prime \prime} \mathrm{W}$; (map 84).

Named by prospectors and reported by S. R. Capps (in Brooks and others, 1915, p. 222), USGS.

Little Eldorado Creek: stream, heads $\mathrm{N}$ of Lookout Mtn., flows NW $15 \mathrm{mi}$. to Bonanza Creek, $10 \mathrm{mi}$. S of Flat, Kilbuck-Kuskokwim Mts.; $62^{\circ} 18^{\prime} 40^{\prime \prime} \mathrm{N}, 158^{\circ} 05^{\prime} 40^{\prime \prime} \mathrm{W}$; (map 79).

Prospectors' name reported in 1933 by J. B. Mertie, USGS.

Little Eldorado Creek: stream, heads at junc. of Last Chance and Louis Creeks, flows NW 5.5 mi. to Chatanika River, $17 \mathrm{mi}$. N of Fairbanks, Yukon-Tanana High.; $65^{\circ} 06^{\prime} \mathrm{N}, 147^{\circ} 41^{\prime} \mathrm{W}$; $B G N$ 1933; (map 105). Var. Eldorado Creek, Big Eldorado Creek.
Named by prospectors; reported in 1903 by USGS as Eldorado Creek (Prindle, 1905, pl. 13).

Little Eldorado Creek: stream, see Nugget Creek.

Little Fairmount Island: island, $0.4 \mathrm{mi}$. long, in Prince William Sound, $0.5 \mathrm{mi}$. SW of Fairmount I., $43 \mathrm{mi}$. NE of Whittier, Chugach Mts.; $60^{\circ} 51^{\prime} 35^{\prime \prime} \mathrm{N}, 147^{\circ} 27^{\prime} 45^{\prime \prime} \mathrm{W}$; (map $63)$.

Local name published on recent USGS maps; derived from nearby Fairmount Island. Little Falls Creek: stream, flows SE $0.5 \mathrm{mi}$. to Falls Creek $0.8 \mathrm{mi}$. NW of its junc. with Gache Creek, $32 \mathrm{mi}$. NW of Talkeetna, Alaska Ra. $62^{\circ} 29^{\prime} 08^{\prime \prime} \mathrm{N}, 151^{\circ} 01^{\prime} 20^{\prime \prime} \mathrm{W}$; (map 81).

Local descriptive name reported in 1958 by USGS.

Little Fish Creek: stream, flows SW $11 \mathrm{mi}$. through Fish Lake to Fish Creek, $5 \mathrm{mi}$. NW of Tanacross, Yukon-Tanana High.; 63 $27^{\prime} \mathrm{N}$, $143^{\circ} 26^{\prime} \mathrm{W}$; (map 85).

Local name reported in 1950 by USGS.

Little Flash Lake: lake, $100 \mathrm{yd}$. across, on southern Kiska I., Aleutian Is.; $51^{\circ} 52^{\prime} 42^{\prime \prime} \mathrm{N}$, $177^{\circ} 18^{\prime} 20^{\prime \prime} \mathrm{E}$; (map 14).

An arbitrary name beginning with " $L$ " to correspond to "L" grid used by the U.S. Army for tactical purposes during World War II; published on a 1953 AMS map.

Little Fork Island: island, $0.3 \mathrm{mi}$. across, on SE coast of Shuyak I., $42 \mathrm{mi}$. N of Kodiak I.; $58^{\circ} 30^{\prime} 20^{\prime \prime} \mathrm{N}, 152^{\circ} 23^{\prime} 00^{\prime \prime} \mathrm{W}$; (map 43). Var. Maloi Krieposti.

Translation of the name "Os[trov] Mal[oy] Krypost," published in 1849 by the Russian American Company.

Little Fox Creek: stream, flows S $2 \mathrm{mi}$. to Sand Bay, Great Sitkin I., Aleutian Is.; $51^{\circ} 59^{\prime} 48^{\prime \prime}$ N, $176^{\circ} 05^{\prime} 15^{\prime \prime} \mathrm{W}$; (map 17).

Descriptive name published in 1951 on a USGS map.

Little Garfield Creek: stream, flows SE $8.5 \mathrm{mi}$. to Noxapaga River, $3 \mathrm{mi}$. S of Noxapaga and $29 \mathrm{mi}$. SW of Imuruk Lake, Seward Penin. High.; $65^{\circ} 26^{\prime} \mathrm{N}, 164^{\circ} 13^{\prime} \mathrm{W}$; (map 110).

Prospectors' name reported in 1901 by T. G. Gerdine (in Collier, 1902, pl. 12), USGS.

Little Gavanski Island: island, $0.4 \mathrm{mi}$. across, in Gavanski Is., $6 \mathrm{mi}$. NW of Sitka, Alex. Arch.; $57^{\circ} 07^{\prime} 30^{\prime \prime} \mathrm{N}, 135^{\circ} 25^{\prime} 00^{\prime \prime} \mathrm{W}$; (map 9). Var. Gavanski Islet, Little Gavanski Islet, Ostrov Gavanskoy Menshoy.

USC\&GS derived this name about 1882 from translation of part of "Ostrov Gavanskoy Menshoy," meaning "smaller harbor island"; published by Lt. Sarichev (1826, map 19), IRN; originally given in 1809 by the navigator Ivan Vasiliev the first, IRN.

Little Gavanski Islet: island, see Little Gavanski Island.

Little Gerstle River: stream, flows NE $24 \mathrm{mi}$. to Tanana River, $34 \mathrm{mi}$. SE of Delta Junction, Tanana Low.; $63^{\circ} 47^{\prime} 50^{\prime \prime} \mathrm{N}, 144^{\circ} 46^{\prime} 30^{\prime \prime} \mathrm{W}$; $B G N$ 1937; (map 86).

Local name reported in 1937 by USGS. Little Glacier: glacier, see Popof Glacier.
Little Glacier Slough: stream, on S coast of Alaska, flows S $3 \mathrm{mi}$. to Gulf of Alaska, 10 mi. SE of Cordova, Malaspina Coastal Plain; $60^{\circ} 27^{\prime} \mathrm{N}, 145^{\circ} 32^{\prime} \mathrm{W}$; ( $\left.\operatorname{map} 64\right)$.

Local name published in 1951 by USGS.

Little Goat Lake: lake, $1.5 \mathrm{mi}$. long, on mainland, drains into Big Goat Lake, $2 \mathrm{mi}$. W of Wilson Lake, Coast Mts.; $55^{\circ} 31^{\prime} \mathrm{N}, 130^{\circ} 38^{\prime} \mathrm{W}$; (map 3).

Local name reported in 1955 by USGS.

Little Gold Creek: stream, flows N $6.5 \mathrm{mi}$. to Jarvis Creek, $26 \mathrm{mi}$. S of Delta Junction,

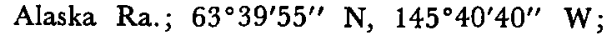
$B G N$ 1937; (map 86).

Local name reported in 1937 by USGS.

Little Gold Creek: stream, flows S $2.8 \mathrm{mi}$. to Gold Creek, $48 \mathrm{mi}$. N of Big Delta, Yukon-Tanana High.; 64 $49^{\prime} 15^{\prime \prime} \mathrm{N}, 145^{\circ} 34^{\prime} 30^{\prime \prime} \mathrm{W}$; (map 101).

Named by prospectors and reported in 1905 by D. C. Witherspoon (in Prindle, 1913a, pl. 1), USGS.

Little Goldstream: locality, see Berg.

Little Goldstream: RR. station, see Berg.

Little Goldstream Creek: stream, heads at $64^{\circ} 42^{\prime}$ $\mathrm{N}, 148^{\circ} 36^{\prime} \mathrm{W}$, flows $\mathrm{W}$ and NE $32 \mathrm{mi}$. to Goldstream Creek, $6 \mathrm{mi}$. S of Minto Lakes, Tanana Low.; $64^{\circ} 47^{\prime} \mathrm{N}, 148^{\circ} 53^{\prime} \mathrm{W}$; (map $100)$.

Local name shown on an Alaska RR. manuscript map dated 1914 .

Little Goose Bay: cove, $0.4 \mathrm{mi}$. wide, on Polk Inlet, Prince of Wales I., Alex. Arch.; 55 $24^{\prime} 45^{\prime \prime}$ N, 132 $27^{\prime} 30^{\prime \prime}$ W; BGN 1963; (map 4).

Local name reported in 1961 by USFS; so called by local loggers and fishermen, "because of its proximity to Goose Bay."

Little Goose Island: island, $0.3 \mathrm{mi}$. across, part of Sandman Reefs, 12 mi. S of Deer I., Aleutian Ra.; 54 $41^{\prime} 00^{\prime \prime} \mathrm{N}, 162^{\circ} 12^{\prime} 15^{\prime \prime} \mathrm{W}$; (map 25). Var. Goose I., Gusinnoi, Civoutchy Rocher.

Name derived from Goose Island, published in 1882 by USC\&GS on Chart 806 . See Goose Island.

Little Granite Creek: stream, flows SW $3.5 \mathrm{mi}$. to Matanuska River, 2 mi. E of Sutton and 12 mi. NE of Palmer, Chugach Mts.; 61 ${ }^{\circ} 43^{\prime} 25^{\prime \prime}$ N, 148 49'35" W; (map 69).

Local name reported in 1942 by AMS.

Little Granite Creek: stream, flows W $4 \mathrm{mi}$. to North Fork Salcha River $7 \mathrm{mi}$. N of that stream's junc. with Salcha River and $45 \mathrm{mi}$. NE of Big Delta, Yukon-Tanana High.; $64^{\circ}$ $45^{\prime} \mathrm{N}, 145^{\circ} 18^{\prime} \mathrm{W}$; (map 101).

Local name reported in 1958 by USGS.

Little Green Island: island, $0.7 \mathrm{mi}$. long, in Montague Strait, $1.5 \mathrm{mi}$. SW of Green I., 20 mi. SE of Chenega, Chugach Mts.; $60^{\circ} 12^{\prime} 20^{\prime \prime}$ N, $147^{\circ} 30^{\prime} 30^{\prime \prime} \mathrm{W}$; (map 63).

Local name published on recent USGS maps; named relative to nearby Green Island.

Little Gulch: ravine, trends W $0.5 \mathrm{mi}$. to Glacier Creek, $8 \mathrm{mi}$. N of Nome, Seward Penin. High.; $64^{\circ} 37^{\prime} 15^{\prime \prime} \mathrm{N}, 165^{\circ} 20^{\prime} 30^{\prime \prime} \mathrm{W}$; (map 94).

Prospectors' name reported on the 1903 Campion Mining and Trading Co. map by George M. Ashford. 
Little Gulch: ravine, trends NE $0.5 \mathrm{mi}$. to Nome River, $22 \mathrm{mi}$. NE of Nome, Seward Penin. High.; $64^{\circ} 48^{\prime} \mathrm{N}, 165^{\circ} 13^{\prime} \mathrm{W}$; (map 94). Var. Mays Oaks Gulch.

Prospectors' name reported as "Little or Mays Oaks Gulch" on Arthur Gibson's "Map of Cape Nome Precinct" dated 1904.

Little Gulch: ravine, see Phillips Gulch.

Little Gunnuk Creek: stream, flows W $3.5 \mathrm{mi}$. to Keku Strait, $0.5 \mathrm{mi}$. S of Keku, on NW coast of Kupreanof I., Alex. Arch.; 56 $58^{\prime} 05^{\prime \prime} \mathrm{N}$ $133^{\circ} 55^{\prime} 45^{\prime \prime} \mathrm{W}$; (map 6).

Local name recorded in 1951 by USGS.

Little Hamilton Island: island, $0.6 \mathrm{mi}$. long, in Hamilton Bay, $7.5 \mathrm{mi}$. SE of Kake, on NW coast of Kupreanof I., Alex. Arch.; 56 $53^{\prime} 40^{\prime \prime}$ N, $133^{\circ} 48^{\prime} 30^{\prime \prime} \mathrm{W}$; (map 6).

Local name recorded in 1951 by USGS.

Little Harbor: anchorage, see Fox Hole.

Little Harris Creek: stream, flows S $1 \mathrm{mi}$. to North Fork Kougarok River, E of Harris Dome, $39 \mathrm{mi}$. W of Imuruk Lake, Seward Penin. High.; $65^{\circ} 36^{\prime}$ N, $164^{\circ} 32^{\prime}$ W ; (map 110). Var. Chilly Creek.

Prospectors' name reported on the 1908 "Map of Seward Peninsula" by Arthur Gibson. This appears to be the "Chilly Creek" shown on a precinct map of Seward Peninsula by Monroe and Hutchins; corrected to 1903 by Arthur Gibson.

Little Hogatza River: stream, see Hogatzakhotak Creek.

Little Hog Butte: hill, $930 \mathrm{ft}$., $51 \mathrm{mi}$. NE of Medfra, Kilbuck-Kuskokwim Mts. ; $63^{\circ} 36^{\prime} \mathrm{N}$ $153^{\circ} 31^{\prime} \mathrm{W}$; (map 89)

Local name reported in 1958 by USGS.

Little Hog River: stream, see Hogatzakhotak Creek.

Little Honolulu Creek: stream, flows NW $4.5 \mathrm{mi}$ to Honolulu Creek, $60 \mathrm{mi}$. SW of Healy, Talkeetna Mts.; $63^{\circ} 03^{\prime} 10^{\prime \prime} \mathrm{N}, 149^{\circ} 34^{\prime} 15^{\prime \prime}$ W; (map 87).

Prospectors' name obtained in 1913 by J. W. Bagley, USGS; published by S. R. Capps (in Martin, 1919, pl. 5), USGS.

Little Humpback Lake: lake, $1 \mathrm{mi}$. long, $0.4 \mathrm{mi}$ $S$ of Humpback Lake and $48 \mathrm{mi}$. SE of Ketchikan, Coast Mts. ; $55^{\circ} 00^{\prime} 30^{\prime \prime} \mathrm{N}, 130^{\circ} 33^{\prime} 30^{\prime \prime}$ W; BGN 1963; (map 3).

Local name reported in 1961 by USFS.

Little Hurrah Creek: stream, flows N $1.3 \mathrm{mi}$. to Big Hurrah Creek, $9 \mathrm{mi}$. NE of Solomon, Seward Penin. High.; $64^{\circ} 39^{\prime} \mathrm{N}, 164^{\circ} 14^{\prime} \mathrm{W}$ (map 95)

Prospectors' name reported in 1900 by E. C. Barnard (in Brooks, 1901, pl. 17), USGS.

Little Indian Creek: stream, on $\mathrm{N}$ end of Kenai Penin, flows W $8 \mathrm{mi}$. to Chickaloon Bay, $10 \mathrm{mi}$. $\mathrm{W}$ of Hope, Cook Inlet Low.; $60^{\circ} 56^{\prime} 00^{\prime \prime} \mathrm{N}$, $149^{\circ} 55^{\prime} 30^{\prime \prime} \mathrm{W}$; (map 63 ).

Local name reported in 1895 by Becker (1898, p. 82), USGS.

Little Indian River: stream, flows NW $34 \mathrm{mi}$. to Mathews Slough, $25 \mathrm{mi}$. NNE of Hochandochtla Mtn., Kokrines-Hodzana High.; $65^{\circ}$ $51^{\prime} \mathrm{N}, 154^{\circ} 27^{\prime} \mathrm{W}$; (map 107).

Local name obtained in 1952 by USGS topographers.
Little Island: island, $0.4 \mathrm{mi}$. across, at mouth of Deep Bay, in Peril Strait, off $S$ coast of Chichagof I., $24 \mathrm{mi}$. SE of Chichagof, Alex. Arch.; $57^{\circ} 25^{\prime} 45^{\prime \prime} \mathrm{N}, 135^{\circ} 35^{\prime} 45^{\prime \prime} \mathrm{W}$; (map 9). Var. Ostrov Malyy.

This is a translation by USC\&GS about 1882 of the name given by the Russian pilot Ens. Vasiliev; published in 1848 on Russian Hydrog. Dept. Chart 1397 as "Os[trov] Malyy."

Little Island: island, in Lynn Canal, $0.4 \mathrm{mi}$. N of Ralston Island and $28 \mathrm{mi}$. NW of Juneau, Alex. Arch.; 58 $32^{\prime} 25^{\prime \prime} \mathrm{N}, 1^{\circ} 5^{\circ} 02^{\prime} 35^{\prime \prime} \mathrm{W}$; (map 11).

Descriptive name given in 1880 by Lt. F. M. Symonds, USN, and published by USC\&GS in the 1883 Coast Pilot (p. 194).

Little Jack Creek: stream, heads in Mentasta Mts., flows $\mathbf{S} 7 \mathrm{mi}$. to Jack Lake, Alaska Ra.; $62^{\circ} 31^{\prime} 20^{\prime \prime} \mathrm{N}, 143^{\circ} 18^{\prime} 40^{\prime \prime} \mathrm{W} ;$ BGN 1939 ; (map 84).

Local name reported in 1939 by USGS. Little Jack Slough: stream, heads in lake, flows SE 4 mi. to Redoubt Bay, $35 \mathrm{mi}$. W of Kenai, Cook Inlet Low.; $60^{\circ} 32^{\prime} \mathrm{N}, 152^{\circ} 16^{\prime} \mathrm{W}$; (map 62)

Local name published in 1963 by USGS

Little Jarvis Glacier: glacier, heads $2.4 \mathrm{mi}$. NE of Mount Henry Glay, trends N 2 mi. to its terminus, $1.9 \mathrm{mi}$. S of the terminus of Jarvis Glacier, and $39 \mathrm{mi}$. W of Skagway, St. Elias Mts.; $59^{\circ} 25^{\prime} \mathrm{N}, 136^{\circ} 25^{\prime} \mathrm{W} ; B G N$ 1959; (map 45). Var. Jarvis Creek.

Name published in 1954 by USGS.

Little Jessie Creek: stream, flows $\mathrm{S}$ to Niukluk River, about $6 \mathrm{mi}$. NW of Council and $32 \mathrm{mi}$. NE of Solomon, Seward Penin. High.; (map 95).

Prospectors' name reported on the 1900 "Map of Nome Peninsula" by J. M. Davidson and B. D. Blakeslee. This stream cannot be precisely located on current maps.

Little Jew Mountain: peak, see Little Njoo Mountain.

Little Joe Creek: stream, flows SE $2.3 \mathrm{mi}$, joins New York Creek to form Beaver Creek, $11 \mathrm{mi}$. SE of Ruby, Kilbuck-Kuskokwim Mts.; $64^{\circ}$. $35^{\prime} 30^{\prime \prime} \mathrm{N}, 155^{\circ} 24^{\prime} 45^{\prime \prime} \mathrm{W}$; (map 98).

Local name obtained in 1956 by Orth.

Little Joe Gulch: ravine, trends NE $1 \mathrm{mi}$. to New Eldorado Creek, $13 \mathrm{mi}$. NE of Nome, Seward Penin. High.; $64^{\circ} 40^{\prime} 36^{\prime \prime}$ N, $165^{\circ} 10^{\prime} 30^{\prime \prime}$ W; (map 94)

Prospectors' name reported in 1904 by T. G. Gerdine, USGS.

Littlejohn Lagoon: lagoon, $2 \mathrm{mi}$. long, on $\mathrm{E}$ side of Morzhovoi Bay, at SW end of Alaska Penin., Aleutian Ra.; 55 $01^{\prime} \mathrm{N}, 162^{\circ} 56^{\prime} \mathrm{W}$; (map 29)

Local name published in 1925 by USC\&GS.

Little Johnny Creek: stream, flows S $1.5 \mathrm{mi}$. to Dome Creek, 29 mi. S of Eagle, Yukon-Tanana High.; 64 $23^{\circ} 15^{\prime \prime} \mathrm{N}, 141^{\circ} 16^{\prime} 30^{\prime \prime} \mathrm{W}$; (map 102).

Local name published in 1956 by USGS.

Little Joker Island: island, $2.5 \mathrm{mi}$. long, in Yukon River, $17 \mathrm{mi}$. W of Tanana, Nowitna Low.; $65^{\circ} 14^{\prime} 30^{\prime \prime} \mathrm{N}, 152^{\circ} 40^{\prime} 00^{\prime \prime} \mathrm{W}$; (map 106).
Local name reported in 1952 by USGS.

Little Kalusuk Creek: stream, flows NW $14 \mathrm{mi}$. to Kalusuk Greek, $49 \mathrm{mi}$. NE of Haycock, Nulato Hills; $65^{\circ} 38^{\prime} \mathrm{N}, 159^{\circ} 51^{\prime} \mathrm{W}$; (map 109).

Local name published on maps after 1950 .

Little Kamishak River: stream, flows NE $18 \mathrm{mi}$ to Akumwarvik Bay, $35 \mathrm{mi}$. SW of Augustine I., Aleutian Ra.; $59^{\circ} 01^{\prime} \mathrm{N}, 154^{\circ} 11^{\prime} \mathrm{W}$; (map 51)

Local name reported in 1923 by $K$. F Mather (in Brooks and others, 1925, pl. 3), USGS.

Little Kanatak Creek: stream, flows SW $4.4 \mathrm{mi}$ to Kanatak Creek, $0.2 \mathrm{mi}$. W of its mouth at Portage Bay, on S coast of Alaska Penin., $53 \mathrm{mi}$. E of Ugashik, Aleutian Ra.; 57 $34^{\prime} 15^{\prime \prime}$ $\mathrm{N}, 156^{\circ} 01^{\prime} 55^{\prime \prime} \mathrm{W}$; (map 36).

Local name published in 1924 by USC\&GS

Little Kasigluk River: stream, flows N $14 \mathrm{mi}$. to Kasigluk River, 40 mi. SE of Bethel, KilbuckKuskokwim Mts.; $60^{\circ} 41^{\prime} \mathrm{N}, 160^{\circ} 36^{\prime} \mathrm{W}$; (map 59).

Local name reported in 1955 by $J . M$ Hoare, USGS.

Little Kayak Island: island, see Wingham Island.

Little King Salmon River: stream, flows S $25 \mathrm{mi}$. to Nuyakuk River, $65 \mathrm{mi}$. NE of Dillingham, Bristol Bay Low.; $59^{\circ} 56^{\prime} \mathrm{N}, 157^{\circ} 57^{\prime}$ W; (map 52).

Name published in 1932 by the U.S. BIA.

Little Kings Creek: stream, see Young Creek.

Little Kiska Beach: beach, 100 yds. long, facing South Pass, W coast of Little Kiska I., Aleutian Is.; $51^{\circ} 57^{\prime} 30^{\prime \prime} \mathrm{N}, 177^{\circ} 37^{\prime} 15^{\prime \prime} \mathrm{E}$; (map 14).

One of many arbitrary names applied to features on Kiska I. by USAAF for tactical purposes during World War II.

Little Kiska Head: point of land, on NW tip of Little Kiska I., Aleutian Is.; $51^{\circ} 58^{\prime} 20^{\prime \prime} \mathrm{N}$ $177^{\circ} 38^{\prime} 20^{\prime \prime} \mathrm{E} ; B$ B $N$ 1937; (map 14).

Name published on a 1905 USC\&GS chart. Little Kiska Island: island, $3.5 \mathrm{mi}$. long, $\mathrm{E}$ of Kiska I., one of Rat Is., Aleutian Is.; $51^{\circ} 57^{\prime}$ $\mathrm{N}, 177^{\circ} 39^{\prime} \mathrm{E} ; B G N$ 1937; (map 14).

So called by Capt. Lutke (1836, p. 326), IRN, to distinguish Petite Kyska Ile (Little Kiska Island) from Grande Kyska Ile (Kiska Island).

Little Kitoi Lake: lake, $0.8 \mathrm{mi}$. long, at head of Kitoi Bay on SE coast of Afognak Is., $20 \mathrm{mi}$. $\mathrm{NE}$ of Afognak, Kodiak I.; $58^{\circ} 12^{\prime} \mathrm{N}, 152^{\circ}$ $22^{\prime} \mathrm{W}$; (map 43).

Local descriptive name reported in 1952 by USGS; derived from Kitoi Bay.

Little Kobuk Sand Dunes: sand dunes, $3 \mathrm{mi}$. long and $1 \mathrm{mi}$. wide, in Kobuk River valley, $32 \mathrm{mi}$. NW of Shungnak, Brooks Ra.; $67^{\circ} 01^{\prime} \mathrm{N}$, $158^{\circ} 18^{\prime} \mathrm{W}$; (map 126)

Descriptive name given in 1956 by Orth. See Big Kobuk Sand Dunes.

Little Koniuji Island: island, $8 \mathrm{mi}$. long, in Shumagin Is., Aleutian Ra. ; $55^{\circ} 00^{\prime} \mathrm{N}, 159^{\circ} 23^{\prime} \mathrm{W}$; (map 26). Var. Ostrov Malyy Koniushi, Tangimak Island, Tankinak, Toughimik Island. 
Named "O[strov] Malyy Koniushi," meaning "little Koniushi island" by the Russian Hydrog. Dept. and Capt. Tebenkov (1853, map 24), IRN. Father Veniaminov (1840, v. 1, p. 254) used the Aleut name "Tangimak," and Capt. F. P. Lutke, IRN, called it "Tounghimik." "Little Koniuji" is shown on an 1888 USC\&GS chart.

Little Kotlik River: stream, in Yukon Delta, flows NE 15 mi. to Kotlik River opposite Kotlik, 36 mi. NE of Kwiguk, Yukon-Kuskokwim Delta; $63^{\circ} 02^{\prime} \mathrm{N}, 163^{\circ} 33^{\prime} \mathrm{W}$; (map 92).

Local name published in 1901 by USC\&GS on Chart 9372.

Little Lagoon: lagoon, $0.6 \mathrm{mi}$. long, on $\mathrm{W}$ side of Morzhovoi Bay, at SW end of Alaska Penin., Bristol Bay Low.; $55^{\circ} 03^{\prime} 30^{\prime \prime} \mathrm{N}, 163^{\circ} 13^{\prime} 30^{\prime \prime}$ W; (map 29).

Descriptive name published in 1943 on a USGS map.

Little Lagoon: lagoon, $1 \mathrm{mi}$. long, on $\mathrm{S}$ coast of Port Houghton, $2 \mathrm{mi}$. SW of Walter I. and $82 \mathrm{mi}$. E of Sitka, Coast Mts. ; $57^{\circ} 17^{\prime} 45^{\prime \prime} \mathrm{N}$, $133^{\circ} 19^{\prime} 30^{\prime \prime} \mathrm{W}$; ( $\left.\operatorname{map} 8\right)$.

Local name reported in 1955 by USGS.

Little Lake: lake, $0.7 \mathrm{mi}$. long, $2.8 \mathrm{mi}$. W of Ratz Harbor, NE Prince of Wales I., Alex. Arch.; $55^{\circ} 53^{\prime} \mathrm{N}, 132^{\circ} 41^{\prime} \mathrm{W}$; BGN 1963; (map 4).

Local descriptive name reported in 1961 by USFS.

Little Lake: lake, $765 \mathrm{ft}$. long, $52 \mathrm{mi}$. NW of Valdez, between Nelchitna and South Fork Matanuska Rivers, Chugach Mts.; $61^{\circ} 44^{\prime} 25^{\prime \prime}$ N, $147^{\circ} 13^{\prime} 00^{\prime \prime} \mathrm{W}$; (map 69).

Local name reported in 1960 by USGS.

Little Lake: lake, $0.5 \mathrm{mi}$. long, between Boulder Creek and Swift Fork Kuskokwim River, 15 mi. NW of Mount Russell, Alaska Ra.; $62^{\circ} 57^{\prime}-$ $45^{\prime \prime} \mathrm{N}, 152^{\circ} 11^{\prime} 00^{\prime \prime} \mathrm{W}$; ( $\left.\operatorname{map} 81\right)$.

Local descriptive name reported in 1958 by USGS.

Little Lake: lake, $0.4 \mathrm{mi}$. long, WSW of Harding Lake and $37 \mathrm{mi}$. NW of Big Delta, YukonTanana High.; $64^{\circ} 24^{\prime} 45^{\prime \prime} \mathrm{N}, 146^{\circ} 54^{\prime} 00^{\prime \prime} \mathrm{W}$; (map 101).

Local descriptive name; published in 1951 by USGS.

Little Lake Glark: lake, $8.5 \mathrm{mi}$. long, at NE end of Lake Clark, $44 \mathrm{mi}$. NE of Nondalton, Aleutian Ra.; $60^{\circ} 25^{\prime} \mathrm{N}, 153^{\circ} 40^{\prime} \mathrm{W}$; (map 61).

Name shown on a 1909 fieldsheet by C. E. Giffin, USGS.

Little Lake Louise: lake, $2.1 \mathrm{mi}$. long, $1 \mathrm{mi}$. W of Lake Louise and $37 \mathrm{mi}$. WNW of Glennal. len, Copper River Basin; $62^{\circ} 19^{\prime} \mathrm{N}, 46^{\circ} 40^{\prime}$ W; (map 83).

Local name reported in 1952 by USGS.

Little Level Island: island, $1.2 \mathrm{mi}$. long, one of Level Is., off SE coast of Kupreanof I., Alex. Arch.; $56^{\circ} 27^{\prime} 30^{\prime \prime} \mathrm{N}, 133^{\circ} 06^{\prime} 00^{\prime \prime} \mathrm{W}$; (map 6).

Local descriptive name reported in 1949 by USGS.

Little Lockwood Creek: stream, heads NW of Wolf Creek Mtn., flows NE $14 \mathrm{mi}$. to Hawk River, $34 \mathrm{mi}$. SW of Anvik and $46 \mathrm{mi}$. $\mathrm{N}$ of Russian Mission, Nulato Hills; $62^{\circ} 27^{\prime} 15^{\prime \prime} \mathrm{N}$, $161^{\circ} 12^{\prime} 40^{\prime \prime} \mathrm{W}$; (map 78).
Local name reported in 1949 by USC\&GS.

Little Long Lake: lake, $0.3 \mathrm{mi}$. long, $2.2 \mathrm{mi}$. SE of Big Lake and $14 \mathrm{mi}$. SW of junc. of Herron and Foraker Rivers, Tanana Low.; $63^{\circ} 30^{\prime} \mathrm{N}$, $152^{\circ} 27^{\prime} \mathrm{W}$; (map 88).

Local name reported in 1954 by USGS.

Little McKinley: peak, see Hunter, Mount.

Little Macklin Creek: stream, flows NW 2 mi. to Macklin Creek which flows to Kougarok River, $6 \mathrm{mi}$. W of Midnight Mtn. and $47 \mathrm{mi}$. NW of Imuruk Lake, Seward Penin. High.; 65 ${ }^{\circ} 45^{\prime}$ N, $164^{\circ} 47^{\prime} \mathrm{W}$; (map 110).

Prospectors' name reported on the 1908 "Map of Seward Peninsula" by Arthur Gibson.

Little McLellan Creek: stream, flows NE $3.5 \mathrm{mi}$. from McLellan Pass to McLellan Creek, $13 \mathrm{mi}$. ENE of Chandalar, Brooks Ra.; 67 $33^{\prime} \mathrm{N}$, $148^{\circ} 02^{\prime} \mathrm{W}$; (map 123). Var. McLellan Creek.

Local name reported in 1956 by T. E. Taylor, USGS.

Little Macondray Creek: stream, flows SE to Nome River, about $37 \mathrm{mi}$. NE of Nome, Seward Penin. High.; (map 94).

Prospectors' name reported on the 1900 "Map of Nome Peninsula" by J. M. Davidson and B. D. Blakeslee; this feature has not been positively identified.

Little Manila Creek: stream, flows W 3 mi., joins Chicago Boy Creek to form Manila Creek, $50 \mathrm{mi}$. SW of Eagle, Yukon-Tanana High.; $64^{\circ} 21^{\prime} 45^{\prime \prime} \mathrm{N}, 142^{\circ} 35^{\prime} 00^{\prime \prime} \mathrm{W}$; (map 102). Var. Little Manilla Creek.

Prospectors' name shown on an 1898 manuscript map by C. A. Woodruff, Fort Cudahy, Canada.

Little Manilla Creek: stream, see Little Manila Creek.

Little Martin Lake: lake, $2.3 \mathrm{mi}$. long, along S side of Martin River, $13 \mathrm{mi}$. N of Katalla, Chugach Mts.; $60^{\circ} 24^{\prime} \mathrm{N}, 144^{\circ} 29^{\prime} \mathrm{W}$; $B G N$ 1948; (map 64).

Name published in 1948 by USGS.

Little Matterhorn: peak, 5,900 ft., on Taku Range at edge of Taku Glacier, $0.7 \mathrm{mi}$. NW of Cathedral Peak and $22 \mathrm{mi}$. N of Juneau, Coast Mts.; $58^{\circ} 37^{\prime} 20^{\prime \prime} \mathrm{N}, 134^{\circ} 22^{\prime} 15^{\prime \prime} \mathrm{W}$; (map 11).

Name proposed in 1964 by the Juneau Icefield Research Program.

Little May Creek: stream, flows SE to Nome River, about $36 \mathrm{mi}$. NE of Nome, Seward Penin. High.; (map 94).

Prospectors' name reported on the 1900 "Map of Nome Peninsula" by J. M. Davidson and B. D. Blakeslee; this feature has not been positively identified.

Little Meadow Creek: stream, heads in a lake, flows SW $3.2 \mathrm{mi}$. to join Lucile Creek to form Meadow Creek, $25 \mathrm{mi}$. N of Anchorage, Cook Inlet Low.; $61^{\circ} 34^{\prime} 00^{\prime \prime} \mathrm{N}, 149^{\circ} 46^{\prime} 40^{\prime \prime} \mathrm{W}$; (map 69)

Local name reported in 1942 by AMS.

Little Melozi River: stream, see Little Melozitna River.

Little Melozitna Hot Springs: springs, on course of Hot Springs Creek $1.4 \mathrm{mi}$. SE of mouth of that stream, $24 \mathrm{mi}$. NNE of Birches, KokrinesHodzana High.; $65^{\circ} 27^{\prime} 30^{\prime \prime} \mathrm{N}, 153^{\circ} 18^{\prime} 40^{\prime \prime} \mathrm{W}$; (map 107).

So named because "they are on a tributary of Little Melozitna River, though they are about $2 \frac{1}{2} 2 \mathrm{mi}$. from that stream. ***A small cabin was built near the principal spring [of the group of 21] in 1913 by two French trappers, but it has been occupied for only short times ***." (Waring, 1917, p. 66.)

Little Melozitna River: stream, heads W of Gold Mtn., flows NE $38 \mathrm{mi}$. to Melozitna River, 37 mi. NNE of Birches, Kokrines-Hodzana High.; $65^{\circ} 38^{\prime} 25^{\prime \prime} \mathrm{N}, 153^{\circ} 11^{\prime} 20^{\prime \prime} \mathrm{W}$; (map 107). Var. Little Melozi River.

Local name reported in 1908 as "Little Melozi River" by Maddren (1910, pl. 5), USGS.

Little Merganser Lake: lake, $0.3 \mathrm{mi}$. long, on Kenai Penin. NE of Big Merganser Lake, 25 mi. NE of Kenai, Cook Inlet Low.; $60^{\circ} 43^{\prime} 20^{\prime \prime}$ $\mathrm{N}, 150^{\circ} 36^{\prime} 15^{\prime \prime} \mathrm{W}$; (map 62).

Named about 1963 by officials of Kenai National Moose Range, probably for the RedBreasted Merganser, Salt-water Shelldrake, or Sea Robin (Mergus serrator), a duck which breeds in Alaska and along the Arctic coast to Greenland.

Little Mike Point: point of land, see Murder Point.

Little Miller Creek: stream, flows S $1.5 \mathrm{mi}$. to Dome Creek, $29 \mathrm{mi}$. S of Eagle, Yukon-Tanana High.; $64^{\circ} 23^{\prime} 30^{\prime \prime} \mathrm{N}, 141^{\circ} 12^{\prime} 10^{\prime \prime} \mathrm{W}$; (map 102). Var. Miller Creek.

Prospectors' name shown on a 1902 manuscript map by E. J. Chamberlain, U.S. Deputy Surveyor.

Little Mink Lake: lake, $0.4 \mathrm{mi}$. long, on Kenai Penin. NW of Big Mink Lake, $20 \mathrm{mi}$. NE of Kenai, Cook Inlet Low.; $60^{\circ} 39^{\prime} 20^{\prime \prime} \mathrm{N}, 150^{\circ}$ $43^{\prime} 50^{\prime \prime} \mathrm{W}$; (map 62).

Named about 1963 by officials of Kenai National Moose Range, for administrative purposes.

Little Minook Creek: stream, flows NW $5 \mathrm{mi}$. to Minook Creek, between Idaho and California Bars, $3.5 \mathrm{mi}$. SE of Rampart, Yukon-Tanana High.; $65^{\circ} 27^{\prime} 30^{\prime \prime} \mathrm{N}, 150^{\circ} 06^{\prime} 00^{\prime \prime} \mathrm{W}$; (map 106).

Prospectors' name published in 1898 by USC\&GS on Chart 3098. Gold was discovered here in the early 1890's by John Minook, but the first claim was located by F. S. Langford in 1896. See Minook Creek.

Little Minook Junior Creek: stream, heads on California Bar, flows NW $2.1 \mathrm{mi}$. to Minook Creek, 4 mi. SSE of Rampart, Yukon-Tanana High.; $65^{\circ} 27^{\prime} 35^{\prime \prime} \mathrm{N}, 150^{\circ} 06^{\prime} 10^{\prime \prime} \mathrm{W}$; (map 106).

Prospectors' name reported in 1904 by Prindle and Hess (1906, pl. 3), USGS.

Little Montana Creek: stream, flows SE $1.6 \mathrm{mi}$. to Bonanza Creek, $20 \mathrm{mi}$. NE of Flat, KilbuckKuskokwim Mts.; $62^{\circ} 31^{\prime} 20^{\prime \prime} \mathrm{N}, 157^{\circ} 23^{\prime} 50^{\prime \prime}$ W; (map 79).

Prospectors' name obtained in 1952 by USGS topographers. 
Little Moose Creek: stream, flows SW $10 \mathrm{mi}$. to George River, $29 \mathrm{mi}$. SE of Flat and $41 \mathrm{mi}$. N of Sleetmute, Kilbuck-Kuskokwim Mts.; $62^{\circ}$ $17^{\prime} 40^{\prime \prime} \mathrm{N}, 157^{\circ} 11^{\prime} 30^{\prime \prime} \mathrm{W}$; (map 79).

Local name obtained in 1952 by USGS topographers.

Little Moose Creek: stream, in Kantishna Hills, flows NE $5.6 \mathrm{mi}$. to Clearwater Fork, $2.7 \mathrm{mi}$. $\mathrm{S}$ of that stream's junc. with Toklat River, $63^{\circ} 46^{\prime} 40^{\prime \prime} \mathrm{N}, 150^{\circ} 20^{\prime} 30^{\prime \prime} \mathrm{W}$; (map 88).

Local name shown on a 1916 fieldsheet by C. E. Giffin, USGS.

Little Moose Creek: stream, flows NW 2 mi. to Moose Creek, $37 \mathrm{mi}$. S of Nenana, Alaska Ra.; $64^{\circ} 02^{\prime} \mathrm{N}, 148^{\circ} 58^{\prime} \mathrm{W}$; (map 100).

Named relative to Moose Creek, published in 1915 on GLO [BLM] survey plat.

Little Moose Creek: stream, flows NW $5.4 \mathrm{mi}$. to South Fork Sulatna River, $15 \mathrm{mi}$. E of Poorman and $25 \mathrm{mi}$. SW of Monzonite Hills, Kilbuck-Kuskokwim Mts.; 64 $07^{\circ} 36^{\prime \prime}$ N, $155^{\circ} 03^{\prime} 40^{\prime \prime} \mathrm{W}$; (map 98).

Local name reported in 1952 by USGS.

Little Mosquito Creek: stream, flows SE $5 \mathrm{mi}$. to Big Mosquito Creek, $7 \mathrm{mi}$. ENE of Central and $21 \mathrm{mi}$. SW of Circle, Yukon-Tanana High.; $65^{\circ} 36^{\prime} \mathrm{N}, 144^{\circ} 34^{\prime} \mathrm{W}$; (map 104). Var. Mosquito Creek.

Name originally reported in 1915 as Mosquito Creek by Waring (1917, fig. 6), USGS.

Little Mountain: hill, $119 \mathrm{ft}$, , on $\mathbf{E}$ shore of Reindeer Cove, $16 \mathrm{mi}$. W of Christmas Mtn., Nulato Hills; $64^{\circ} 32^{\prime} \mathrm{N}, 161^{\circ} 05^{\prime} \mathrm{W}$; (map 96).

Local name reported about 1954 by U.S. Army Corps of Engineers.

Little Mountain: mountain, 4,468 ft., near head of Camp Creek, $12.5 \mathrm{mi}$. NW of Mount Russell, Alaska Ra.; $62^{\circ} 53^{\prime} 35^{\prime \prime} \mathrm{N}, 152^{\circ} 13^{\prime} 05^{\prime \prime}$ W; (map 81).

Local descriptive name reported in 1958 by USGS.

Little Mountain: mountain, see Pilot Mountain.

Little Mountain Village: locality, on right bank of Kuskokwim River, $32 \mathrm{mi}$. $\mathrm{E}$ of Aniak, Kilbuck-Kuskokwim Mts.; 61 ${ }^{\circ} 33^{\prime} 35^{\prime \prime}$ N, $158^{\circ} 32^{\prime} 15^{\prime \prime} \mathrm{W}$; (map 72).

This former Eskimo village or camp appears to have been first mentioned in 1842-44 by Lt. L. A. Zagoskin, IRN, as "Ikalikhtuli," referring to a "fishing place" 2 miles above Wloyukuk [Holokuk River]. The name "Little Mountain Village," referring to Horn Mountain[s] behind it, was reported in 1916 by R. H. Sargent, USGS. W. S. Post, USGS, does not show a village here on his 1898 fieldsheet. There are no permanent buildings here.

Little Mount Juneau: peak, see Roberts, Mount. Little Mount Susitna: mountain, 3,035 ft., W of Mt. Susitna, $31 \mathrm{mi}$. NE of Tyonek, Alaska Ra.; $61^{\circ} 30^{\prime} 45^{\prime \prime} \mathrm{N}, 150^{\circ} 56^{\prime} 30^{\prime \prime} \mathrm{W}$; (map 70).

Local name reported in 1954 by USGS; so named in contrast to the larger Mount Susitna.

Little Mud River: stream, heads on SE slope of Kaiyuh Mts. at $64^{\circ} 10^{\prime} \mathrm{N}, 157^{\circ} 17^{\prime} \mathrm{W}$, flows
SW and SE $110 \mathrm{mi}$. to Mud River $10 \mathrm{mi} . \mathrm{N}$ of its junc. with Innoko River, $60 \mathrm{mi}$. NW of Ophir and $64 \mathrm{mi}$. S of Nulato, Innoko Low.; $63^{\circ} 48^{\prime} \mathrm{N}, 157^{\circ} 46^{\prime} \mathrm{W}$; $B G N$ 1965; (map 90). Var. Kluklaklatna River.

Local name published in 1965 by USGS. Indian name "Kluklaklatna" was reported in 1908 by A. G. Maddren, USGS. See Mud River.

Little Mud River: stream, flows SW $80 \mathrm{mi}$. to Nowitna River $1.5 \mathrm{mi}$. E of its junc. with Lost River, $15 \mathrm{mi}$. NE of Monzonite Hills, Kilbuck-Kuskokwim Mts.; $64^{\circ} 29^{\prime}$ N, $154^{\circ} 12^{\prime}$ W; (map 98).

Local name reported in 1915 by Eakin (in Brooks and others, 1916, pl. 10), USGS.

Little Muklung River: stream, flows S $20 \mathrm{mi}$. to Black Slough, $7 \mathrm{mi}$. NE of Dillingham, Bristol Bay Low.; $59^{\circ} 03^{\prime} 30^{\prime \prime} \mathrm{N}, 158^{\circ} 17^{\prime} 00^{\prime \prime} \mathrm{W}$; $B G N$ 1931; (map 52). Var. Little Mukhlung River.

Eskimo name written Mukh-lung by $\mathbf{H}$. C. Fassett, in 1910, USBF.

Little Mukhlung River: stream, see Little Muklung River.

Little Mulchatna River: stream, flows W $17 \mathrm{mi}$. to the Chilikadroth River, $40 \mathrm{mi}$. NE of Nondalton, Alaska Ra.; 60 $33^{\prime} 30^{\prime \prime}$ N, $154^{\circ}$. $35^{\prime} 00^{\prime \prime} \mathrm{W}$; (map 61).

Local name reported in 1933 by USGS.

Little Mulchatna River: stream, see Mulchatna River.

Little Mummy Island: island, $300 \mathrm{ft}$. across, 1 mi. E of Mummy I. and $12 \mathrm{mi}$. SW of Cordova, Chugach Mts.; $60^{\circ} 28^{\prime} \mathrm{N}, 146^{\circ} 03^{\prime}$ W; BGN 19.33; (map 64).

Local name reported by $H$. E. Smith, USFS, in 1933. So called because of its location near Mummy Island.

Little Munson Creek: stream, flows NE $8 \mathrm{mi}$. to Munson Creek, $55 \mathrm{mi}$. N of Big Delta, YukonTanana High.; $64^{\circ} 55^{\prime} 50^{\prime \prime} \mathrm{N}, 146^{\circ} 01^{\prime} 45^{\prime \prime} \mathrm{W}$; (map 101)

Named by prospectors; reported in 1910 by USGS (Capps, 1912, pl. 1).

Little Naked Island: island, see Peak Island.

Little Naked Island: island, see Storey Island.

Little Narrows: water passage, between Miller and Kodiak Is, on W shore of Alitak Bay, at $S$ end of Kodiak I.; $56^{\circ} 58^{\prime} 00^{\prime \prime}$ N, $154^{\circ} 08^{\prime} 30^{\prime \prime}$ W; (map 32).

Descriptive name published in 1943 by USC\&GS

Little Nation Hill: mountain, 3,350 ft., $33 \mathrm{mi}$. $\mathrm{N}$ of Eagle, Porcupine Plat.; $65^{\circ} 16^{\prime} 30^{\prime \prime} \mathrm{N}$, $141^{\circ} 15^{\prime} 00^{\prime \prime} \mathrm{W}$; (map 103).

Named by J. B. Mertie, Jr. (in Smith and others, 1933, p. 356), USGS, for purposes of geographic and geologic description, but the name did not become an established map name. It was named relative to the IBC survey triangulation station Nation on a higher hill 3.5 miles to the east.

Little Naukati Bay: estuary, on W coast of Prince of Wales I., trends W 1 mi. to Tuxekan Narrows, Alex. Arch.; 55 $52^{\prime} 30^{\prime \prime} \mathrm{N}, 133^{\circ} 13^{\prime} 15^{\prime \prime}$ W; (map 4).

Indian name recorded in 1949 by USGS.
Little Nelchina River: stream, heads at $62^{\circ} 06^{\prime}$ $\mathrm{N}, 147^{\circ} 49^{\prime} \mathrm{W}$, flows SE $43 \mathrm{mi}$. to Nelchina River, $1.5 \mathrm{mi}$. $\mathrm{N}$ of Twin Lakes and $61 \mathrm{mi}$. NW of Valdez, Copper River Basin; 61 ${ }^{\circ} 57^{\prime} 10^{\prime \prime}$ $\mathrm{N}, 146^{\circ} 52^{\prime} 30^{\prime \prime} \mathrm{W}$; BGN 1915; (map 68). Var. Bubb Creek, Nelchina River, Taiklano.

E. F. Glenn named this river in 1898 "Bubb Creek" and gave its Ahtena Indian name "Taiklano." It was called "Nelchina River" in 1906 by USGS and later "Little Nelchina" River (Moffit, 1915, fig. 3).

Little Nenana River: stream, distributary, flows N 4 mi. from Nenana River to Tanana River, $0.7 \mathrm{mi}$. W of Nenana, Tanana Low.; 64 $34^{\circ}$ $00^{\prime \prime} \mathrm{N}, 149^{\circ} 07^{\prime} 15^{\prime \prime} \mathrm{W}$; (map 100). Var. Nenana Slough.

Local name derived from Nenana River and reported by USGS (Capps, 1919, pl. 1). The stream had been shown earlier as Nenana Slough on a railroad manuscript map in 1914.

Little Njoo Mountain: peak, 5,568 ft., in Philip Smith Mts., on $\mathrm{N}$ bank of Junjik River, $26 \mathrm{mi}$. NW of Arctic Village, Brooks Ra.; 68 $26^{\prime} \mathrm{N}$, $146^{\circ} 07^{\prime} \mathrm{W}$; (map 136). Var. Little Jew Mountain.

Kutchin Indian name obtained in 1926 by Mertie (in Smith, P. S., 1929, pl. 1), USGS.

Little Noatak River: stream, see Little Noatak Slough.

Little Noatak Slough: stream, a distributary of Noatak River, flows SE $10 \mathrm{mi}$. to Hotham Inlet, 12 mi. NE of Kotzebue, Kotzebue-Kobuk Low.; $67^{\circ} 00^{\prime} \mathrm{N}, 162^{\circ} 13^{\prime} \mathrm{W}$; (map 128). Var. Little Noatak River.

Local name obtained at Kotzebue in 1956 by Orth.

Little Noquashinski Bay: water passage, see Nakwasina Passage.

Little Norway: bight, west arm of Clark Bay, on W shore of Stepovak Bay, near SW end of Alaska Penin., Aleutian Ra.; 55 $46^{\prime} \mathrm{N}, 160^{\circ}$. $03^{\prime} \mathrm{W}$; (map 28).

Local name published by USC\&GS in 1916 Coast Pilot (p. 164).

Little Oshetna River: stream, heads at $62^{\circ} 08^{\prime} \mathrm{N}$, $147^{\circ} 50^{\prime} \mathrm{W}$, flows NE $27 \mathrm{mi}$. to Oshetna River, $5 \mathrm{mi}$. E of Twin Hills and $70 \mathrm{mi}$. W of Gulkana, Talkeetna Mts.; $62^{\circ} 22^{\prime} 25^{\prime \prime} \mathrm{N}, 147^{\circ} 29^{\prime}$ $30^{\prime \prime} \mathrm{W}$; (map 82).

Local name reported by F. H. Moffit (in Brooks and others, 1915, fig. 3), USGS.

Little Panguingue Creek: stream, flows NE $5 \mathrm{mi}$. to Nenana River, $7 \mathrm{mi}$. NW of Healy, Alaska Ra.; 635' $20^{\prime \prime} \mathrm{N}, 149^{\circ} 02^{\prime} 40^{\prime \prime} \mathrm{W}$; (map 87). Name reported in 1951 by USGS.

Little Pass: water passage, in Barrier Is., 1 mi. NE of Middle I., SW coast of Prince of Wales I., Alex. Arch.; 54 $44^{\circ}$ N, $132^{\circ} 24^{\prime}$ W; (map 1).

Local descriptive name reported in 1951 by USGS.

Little Pavlof: mountain, 6,762 ft., $9 \mathrm{mi}$. W of Pavlof Bay, near SW end of Alaska Penin., Aleutian Ra.; $55^{\circ} 24^{\prime} \mathrm{N}, 161^{\circ} 55^{\prime} \mathrm{W}$; (map 28).

Named in 1929 by USGS.

Little Peters Creek: stream, flows N $5 \mathrm{mi}$. to Peters Creek, $\mathrm{E}$ of Birchwood, $20 \mathrm{mi}$. NE of 
Anchorage, Cook Inlet Low.; $61^{\circ} 24^{\prime} \mathrm{N}, 149^{\circ}$ $27^{\prime} \mathrm{W}$; (map 69).

Local name reported in 1942 by AMS.

Little Peters Hills: ridge, 2,500 ft., extends 6 mi. along $W$ bank of Bear Creek, $22 \mathrm{mi}$. W of Talkeetna, Alaska Ra.; $62^{\circ} 18^{\prime} \mathrm{N}, 150^{\circ} 50^{\prime} \mathrm{W}$; (map 81).

Local name reported in 1911 by S. R. Capps (in Brooks, 1912, pl. 9), USGS.

Little Poker Creek: stream, flows SE $4.5 \mathrm{mi}$. to Caribou Creek, $22 \mathrm{mi}$. NE of Fairbanks, Yukon-Tanana High.; $65^{\circ} 09^{\prime} 15^{\prime \prime} \mathrm{N}, 147^{\circ} 29^{\prime}$ $30^{\prime \prime} \mathrm{W}$; (map 105).

Named by prospectors; reported in 1907 by C. C. Covert, USGS.

Little Polavina Rookery: rookery, see Little Polovina Rookery.

Little Pole Anchorage: estuary, see Fishermans Harbor.

Little Polly Creek: stream, flows SE $8 \mathrm{mi}$. to Polly Creek, $1.8 \mathrm{mi}$. W of Redoubt Point and $45 \mathrm{mi}$. SW of Kenai, Aleutian Ra.; $60^{\circ} 17^{\prime} 00^{\prime \prime}$ $\mathrm{N}, 152^{\circ} 27^{\prime} 30^{\prime \prime} \mathrm{W}$; (map 62).

Local name published in 1959 by USGS. Little Polovina: hill, see Little Polovina Hill.

Little Polovina Hill: hill, $308 \mathrm{ft}$., on northcentral Saint Paul I., in Pribilof Is.; $57^{\circ} 11^{\prime}$ $45^{\prime \prime} \mathrm{N}, 170^{\circ} 13^{\prime} 40^{\prime \prime} \mathrm{W}$; (map 38). Var. Little Polavina.

"Polovina" is Russian for "halfway" (Baker, 1906, p. 408). The name was reported as "Little Polavina" by Elliott (1881, St. Paul map). See Polovina Hill.

Little Polovina Rookery: rookery, $1.1 \mathrm{mi}$. N of Halfway Point, on E coast of Saint Paul I., in Pribilof Is.; $57^{\circ} 10^{\prime} 40^{\prime \prime} \mathrm{N}, 170^{\circ} 09^{\prime} 20^{\prime \prime} \mathrm{W}$; (map 38). Var. Little Polavina Rookery, Polovina Cliffs Rookery.

This seal rookery was named relative to Polovina Rookery; noted by Elliott (1881, p. 56): "There is a small rookery, which I call 'Little Polavina' * * *."

Little Port Walter: bay, $0.2 \mathrm{mi}$. across, $\mathrm{S}$ of Port Walter, $9 \mathrm{mi}$. N of village of Port Alexander, on S coast of Baranof I., Alex. Arch.; 56 ${ }^{\circ} 23^{\prime}$ $00^{\prime \prime} \mathrm{N}, 134^{\circ} 38^{\prime} 30^{\prime \prime} \mathrm{W}$; BGN 1933; (map 5). Var. Inner Port Walter.

Local name used by fishermen; published in 1925 by USC\&GS as "Inner Port Walter" and in 1927 as "Little Port Walter."

Little Potato Mountain: peak, 1,250 ft., on N side of Potato Mtn., $15 \mathrm{mi}$. NE of Cape Prince of Wales, Seward Penin. High.; $65^{\circ}$ $29^{\prime} 15^{\prime \prime} \mathrm{N}, 167^{\circ} 34^{\prime} 00^{\prime \prime} \mathrm{W}$; (map 111).

Local name reported in 1918 by Steidtmann and Cathcart (1922, fig. 14), USGS.

Little Preacher Creek: stream, flows NW $13 \mathrm{mi}$. to Preacher Creek, $0.2 \mathrm{mi}$. SE of junction of Preacher and Birch Creeks and $33 \mathrm{mi}$. SE of Fort Yukon, Yukon Flats; $66^{\circ} 07^{\prime} 50^{\prime \prime} \mathrm{N}, 144^{\circ}$ $50^{\prime} 00^{\prime \prime} \mathrm{W}$; (map 119).

Local name obtained in 1956 by USGS.

Little Ptarmigan Creek: stream, flows SE $4 \mathrm{mi}$. to Kuzitrin River, $22 \mathrm{mi}$. NE of Salmon Lake and $22 \mathrm{mi}$. W of Mount Bendeleben, Seward Penin. High.; $65^{\circ} 13^{\prime}$ N, $164^{\circ} 49^{\prime} \mathrm{W}$; (map 110). Var. Ptarmigan Creek.
Prospectors' name published in 1956 by USGS. Reported as "Ptarmigan Creek" on a 1908 "Map of Seward Peninsula" by Arthur Gibson.

Little Puffin Bay: bay, $0.9 \mathrm{mi}$. long, on $\mathrm{W}$ coast of Baranof I., $5 \mathrm{mi}$. W of Port Alexander, Alex. Arch.; $56^{\circ} 13^{\prime} 50^{\prime \prime} \mathrm{N}, 134^{\circ} 47^{\prime} 00^{\prime \prime} \mathrm{W}$; BGN 1925; (map 5).

Named in 1925 by USC\&GS; derived from Puffin Bay.

Little Pup: stream, flows NE $1 \mathrm{mi}$. to Poorman Creek, $0.8 \mathrm{mi}$. SE of Poorman and $45 \mathrm{mi}$. S

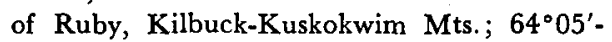

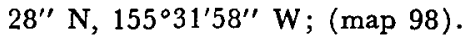

Local name reported in 1933 by USGS.

Little Pybus Bay: bay, $1 \mathrm{mi}$. across, on SE coast of Admiralty I., 5 mi. SW of Pybus Bay, Alex. Arch.; $57^{\circ} 13^{\prime} \mathrm{N}, 134^{\circ} 08^{\prime} \mathrm{W}$; (map 9).

Local name reported in 1951 by USGS.

Little Queenie Creek: stream, flows NW $3.5 \mathrm{mi}$. to Goldstream Creek, $7 \mathrm{mi}$. N of Fairbanks, Yukon-Tanana High.; 64 $56^{\prime} 20^{\prime \prime} \mathrm{N}, 147^{\circ}$. 45'15" W; (map 100).

Named by prospectors; shown in 1905 on a manuscript map by C. W. Joint.

Little Question Lake: lake, $0.1 \mathrm{mi}$. long, at head of Question Creek, $6 \mathrm{mi}$. S of Talkeetna, Cook Inlet Low.; $62^{\circ} 13^{\prime} 30^{\prime \prime} \mathrm{N}, 150^{\circ} 03^{\prime} 55^{\prime \prime} \mathrm{W}$; (map 81).

Local name reported in 1958 by USGS.

Little Rabbit Creek: stream, flows NW and W $6.2 \mathrm{mi}$. to Rabbit Creek, $9.5 \mathrm{mi}$. S of Anchorage, Cook Inlet Low.; $61^{\circ} 04^{\prime} 38^{\prime \prime} \mathrm{N}, 149^{\circ}$ 49'25" W; (map 69).

Local name published in 1912 by USC\&GS.

Little Rapids Island: island, $0.1 \mathrm{mi}$. across, $\mathrm{S}$ of Rapids I., in Sergius Channel, in Peril Strait, $26 \mathrm{mi}$. NW of Sitka, Alex. Arch.; 57 $24^{\prime} 15^{\prime \prime}$ N, 135 $37^{\prime} 40^{\prime \prime}$ W; (map 9).

Descriptive name given by Comdr. J. B. Coghlan, USN; published by USC\&GS in 1883 Coast Pilot (p. 181).

Little Raspberry Island: island, $1.7 \mathrm{mi}$. long, between Raspberry and Afognak Is., $\mathrm{N}$ of Kodiak I. ; $58^{\circ} 00^{\prime} 00^{\prime \prime} \mathrm{N}, 152^{\circ} 54^{\prime} 30^{\prime \prime} \mathrm{W}$; (map 43). Var. Maloi Malinovoi.

Translation of the name "Os[trov] Maloy Malinovoy" given by Sub-Lt. Mikhail Murashev, IRN, in 1839 or 1840 , and published by the Russian Hydrog. Dept. in 1849 on Chart 1425.

Little Raspberry Strait: water passage, see Whale Passage.

Little Ratz Creek: stream, flows NE $4 \mathrm{mi}$. to Little Ratz Harbor, NE coast of Prince of Wales I., Alex. Arch.; 55 $51^{\prime} 45^{\prime \prime} \mathrm{N}, 132^{\circ}$. 34'40" W ; BGN 1962; (map 4).

"This stream is the only drainage into Little Ratz Harbor and the name is used locally"; reported in 1961 by USFS.

Little Ratz Harbor: cove, $0.7 \mathrm{mi}$. wide, $1.5 \mathrm{mi}$. $S$ of Ratz Harbor, NE coast of Prince of Wales I., Alex. Arch.; 55 $51^{\prime} 45^{\prime \prime}$ N, $132^{\circ} 34^{\prime} 00^{\prime \prime} \mathrm{W}$; BGN 1962; (map 4).

Local name reported in 1961 by USFS.

Little River: stream, flows NW through Little River Lake $13 \mathrm{mi}$. to Shelikof Strait, $3.7 \mathrm{mi}$.
NE of Cape Kuliuk, on NW coast of Kodiak I.; $57^{\circ} 50^{\prime} 30^{\prime \prime} \mathrm{N}, 1^{\circ} 53^{\circ} 51^{\prime} 30^{\prime \prime} \mathrm{W}$; (map 34).

Descriptive name given in 1897 by Lt. Comdr. Moser, USN, of the USBF steamer Albatross.

Little River: stream, heads in Lare Glacier and Hows S $3.5 \mathrm{mi}$. to Gulf of Alaska, $5 \mathrm{mi}$. NW of Icy Cape and $79 \mathrm{mi}$. NW of Yakutat, Malaspina Coastal Plain; $59^{\circ} 59^{\prime} 20^{\prime \prime} \mathrm{N}, 141^{\circ}$ $49^{\prime} 00^{\prime \prime} \mathrm{W}$; (map 47).

Local name reported by A. G. Maddren, USGS, in 1913.

Little River Lake: lake, $1.5 \mathrm{mi}$. long, in course of Little River, on NW coast of Kodiak 1.; $57^{\circ} 46^{\prime} 20^{\prime \prime} \mathrm{N}, 153^{\circ} 39^{\prime} 00^{\prime \prime} \mathrm{W}$; (map 34).

Name derived from Little River and published in 1952 by USGS.

Little Rock: rock, $200 \mathrm{ft}$. long, in Revillagigedo Channel $3 \mathrm{mi}$. S of Mary I., Alex. Arch.; $55^{\circ} 00^{\prime} 10^{\prime \prime} \mathrm{N}, 131^{\circ} 11^{\prime} 30^{\prime \prime} \mathrm{W}$; (map 3 ).

Named about 1880 by local navigators; reported by USC\&GS.

Little Rock Mountain: mountain, 3,120 ft., 31 mi. NW of Christian and $42 \mathrm{mi}$. N of Venetie, Brooks Ra.; $67^{\circ} 37^{\prime} \mathrm{N}, 146^{\circ} 09^{\prime} \mathrm{W}$; (map 122).

Local name reported in 1956 by T. E. Taylor, USGS.

Little Rose Island: island, $0.2 \mathrm{mi}$. across, in Peril Strait, $0.5 \mathrm{mi}$. NE of Rapids Point, off NW coast of Baranof I., Alex. Arch.; 57 $27^{\prime} 30^{\prime \prime}$ N, 135'32'40" W; (map 9).

Named in 1884 by Comdr. J. B. Coghlan, USN; published by USC\&GS on Chart 727 .

Little Russian Mission: settlement, see Russian Mission.

Little Rusty Creek: stream, flows N $1.5 \mathrm{mi}$. to White Creek, $69 \mathrm{mi}$. SE of Healy, Alaska Ra.; $63^{\circ} 11^{\prime} 15^{\prime \prime} \mathrm{N}, 14^{\circ} 18^{\prime} 20^{\prime \prime} \mathrm{W}$; (map 87).

Named relative to nearby Rusty Creek; published in 1960 by USGS.

Little Saint Michael Canal: water course, extends SW $6.8 \mathrm{mi}$., from North Branch, Big St. Michael Canal to Big St. Michael Canal, $12 \mathrm{mi}$. SW of St. Michael, Yukon-Kuskokwim Delta; $63^{\circ} 24^{\prime} \mathrm{N}, 162^{\circ} 24^{\prime} \mathrm{W}$; (map 92). Var. North Branch Saint Michael Canal.

Local name obtained in 1952 by USC\&GS; the northeastern part of this feature was published as "North Branch Big Saint Michael Canal" in 1901 by USC\&GS.

Little Salchaket River: stream, see Little Salcha River.

Little Salcha River: stream, flows SW $17 \mathrm{mi}$. to Tanana River, $44 \mathrm{mi}$. NW of Big Delta, Tanana Low.; $64^{\circ} 31^{\prime} 45^{\prime \prime} \mathrm{N}, 147^{\circ} 03^{\prime} 00^{\prime \prime} \mathrm{W}$; (map 100). Var. Little Salchaket River..

Named by prospectors; published in 1906 by USGS as "Little Salchaket River." Present name reported in local usage in 1907 by Prindle (1908, pl. 4), USGS.

Little Salmon: stream, see Karta River.

Little Salmon Lake: lake, see Karta Lake.

Little Salmon River: stream, heads in a lake 1.6 mi. NE of Porcupine Peak, flows E $8.5 \mathrm{mi}$. to Tsirku River, $3.6 \mathrm{mi}$. W of Klukwan and 25 mi. SW of Skagway, St. Elias Mts.; $59^{\circ} 23^{\prime} 05^{\prime \prime}$ N, $135^{\circ} 59^{\prime} 20^{\prime \prime} \mathrm{W}$; (map 45$)$. 
Local name reported by Wright (1904, pl. 2 ), USGS. At that time the Tsirku River was called the Salmon River by the miners, therefore the name.

Little Salt Creek: stream, in Ray Mts., flows ENE $13 \mathrm{mi}$. to Yukon River, $21 \mathrm{mi}$. N of Rampart and $73 \mathrm{mi}$. NE of Tanana, Kokrines-Hodzana High.; $65^{\circ} 48^{\prime} 15^{\prime \prime} \mathrm{N}, 150^{\circ} 04^{\prime} 00^{\prime \prime} \mathrm{W}$; (map 106).

Prospectors' name reported in 1956 by Orth.

Little Saltery Island: island, $0.4 \mathrm{mi}$. across, 15 mi. SW of Petersburg, between Woewodski I. and Lindenberg Penin., Kupreanof I., Alex. Arch.; $56^{\circ} 35^{\prime} 45^{\prime \prime} \mathrm{N}, 133^{\circ} 01^{\prime} 30^{\prime \prime} \mathrm{W}$; BGN 1933; (map 6).

Local name reported in 1933 by R. H. Sargent, USGS; name obtained from G. J. Hilderbrand of Pearl Island.

Little Sandy Island: island, see Fawn Island.

Little Scottie Greek: stream, heads in lake $\mathbf{S}$ of Mount Dave in Yukon, Canada, flows NW, across Alaska-Canada boundary, $12 \mathrm{mi}$. to Scottie Creek, $36 \mathrm{mi}$. SE of Northway Junction, Alaska Ra.; 62 $38^{\prime} 15^{\prime \prime} \mathrm{N}, 141^{\circ} 00^{\prime} 15^{\prime \prime}$ W; (map 84).

Local name reported in 1955 by USGS

Little Selatna River: stream, flows W $16 \mathrm{mi}$. to Kuskokwim River, $3.3 \mathrm{mi}$. NE of junc. of Selatna River, $29 \mathrm{mi}$. S of McGrath, KilbuckKuskokwim Mts. ; $62^{\circ} 33^{\prime} \mathrm{N}, 155^{\circ} 43^{\prime} \mathrm{W}$; (map 80 ).

Local name reported in 1940 by USGS.

Little Sheep Creek: stream, $1.1 \mathrm{mi}$. long, flows SW to SW shore of Gastineau Channel, 1.5 mi. NW of Dumont and $5 \mathrm{mi}$. SE of Juneau, Coast Mts.; $58^{\circ} 14^{\prime} 40^{\prime \prime} \mathrm{N}, 134^{\circ} 17^{\prime} 30^{\prime \prime} \mathrm{W}$; (map 11).

Local name reported in 1916 by D. G. Witherspoon, USGS, and published in 1918.

Little Sheep Creek: stream, flows NE $1.5 \mathrm{mi}$. to Goldstream Creek, 9 mi. NW of Fairbanks, Yukon-Tanana High.; $64^{\circ} 55^{\prime} \mathrm{N}, 147^{\circ} 59^{\prime} \mathrm{W}$; BGN 1939; (map 100).

Local name reported in 1939 by USGS.

Little Shotgun Creek: stream, flows SE $5 \mathrm{mi}$. to Shotgun Creek, $61 \mathrm{mi}$. SW of Healy, Alaska Ra.; $63^{\circ} 02^{\prime} 40^{\prime \prime} \mathrm{N}, 149^{\circ} 48^{\prime} 00^{\prime \prime} \mathrm{W}$; (map 87).

Prospectors' name obtained in 1913 by J. W. Bagley, USGS; published by S. R. Capps (in Martin, 1919, pl. 5), USGS.

Little Silver Bow Basin: valley, see Lurvey Basin.

Little Singatook: mountain, 3,653 ft., at $\mathrm{W}$ end of Kigluaik Mts., $1 \mathrm{mi}$. N of Grand Singatook and $35 \mathrm{mi}$. NW of Nome, Seward Penin. High.; $64^{\circ} 55^{\prime} \mathrm{N}, 166^{\circ} 05^{\prime} \mathrm{W}$; (map 94).

Named in 1966 by L. G. Madland; he reported "the name 'Singatook' is the name the Eskimos living in the area use for both peaks."

Little Sitchin Island: island, see Little Sitkin Island.

Little Sitkin Island: island, $6.8 \mathrm{mi}$. across, one of Rat Is., Aleutian Is.; $51^{\circ} 57^{\prime} \mathrm{N}, 178^{\circ} 31^{\prime} \mathrm{E}$, $B G N$ 1937; (map 15). Var. Little Sitchin Island, Western Sitkin Island.

Named "Os[trov] Malyy Sitkhin," meaning "little Sitkin island" on the 1848 Russian Hydrog. Dept. Chart 1400. The name "Sit- kin" may possibly be from the Aleut word "sitxan," which, according to R. H. Geoghegan, means "from beneath or from under."

Little Sitkin Pass: water passage, between Little Sitkin and Davidof Is. in Rat Is., Aleutian Is. ; $51^{\circ} 58^{\prime} \mathrm{N}, 178^{\circ} 24^{\prime} \mathrm{E} ; \mathrm{BGN} 1937$; (map 15).

Named for Little Sitkin Island in 1936 by U.S. Hydrographic Office. See Little Sitkin Island.

Little Situk Lake: lake, see Mountain Lake.

Little Skookum Chuck: water passage, see Tonowek Narrows.

Little Smith Island: island, $0.5 \mathrm{mi}$. long, off W coast of Smith I., in Prince William Sound, $28 \mathrm{mi}$. NE of Chenega, Chugach Mts.; 60 $31^{\prime}$ $15^{\prime \prime} \mathrm{N}, 14^{\circ} 25^{\prime} 30^{\prime \prime} \mathrm{W}$; (map 63). Var. Smith Islands.

Local name reported in 1905 by U. S. Grant, USGS.

Little South Fork George River: stream, flows W $30 \mathrm{mi}$. to East Fork George River, $32 \mathrm{mi}$. N of Sleetmute, Kilbuck-Kuskokwim Mts.; $62^{\circ}$ $09^{\prime} 30^{\prime \prime} \mathrm{N}, 157^{\circ} 03^{\prime} 40^{\prime \prime} \mathrm{W}$; (map 79).

Local name obtained in 1952 by USGS topographers.

Little Specimen Gulch: ravine, trends NW 0.6 mi. to Specimen Gulch, on NE slope Anvil Mtn., 5 mi. N of Nome, Seward Penin. High.; $64^{\circ} 34^{\prime} 48^{\prime \prime} \mathrm{N}, 165^{\circ} 22^{\prime} 50^{\prime \prime} \mathrm{W}$; (map 94). Var. California Gulch.

Prospectors' name reported on the 1903 Campion Mining and Trading Co. map by George M. Ashford.

Little Spruce Creek: stream, flows SW $3 \mathrm{mi}$. to Willow Creek, $3 \mathrm{mi}$. E of junc. of Willow and Robert Creeks and $16.5 \mathrm{mi}$. NW of Chandalar, Brooks Ra.; 67 $39^{\circ} 30^{\prime \prime} \mathrm{N}, 148^{\circ} 56^{\prime} 00^{\prime \prime} \mathrm{W}$; (map 123).

Local name reported in 1956 by T. E. Taylor, USGS.

Little Squaw: settlement, see Chandalar.

Little Squaw Creek: stream, flows NE $2.5 \mathrm{mi}$. to Little Squaw Lake, $11 \mathrm{mi}$. NE of Chandalar, Brooks Ra.; $67^{\circ} 35^{\prime} 00^{\prime \prime} \mathrm{N}, 148^{\circ} 08^{\prime} 30^{\prime \prime} \mathrm{W}$; (map 123).

Prospectors' name obtained in 1909 by A. G. Maddren (in Brooks and others, 1910, pl. 7), USGS.

Little Squaw Lake: lake, $1 \mathrm{mi}$. across, $2 \mathrm{mi}$. SE of Squaw Lake, and $12 \mathrm{mi}$. NE of Chandalar, Brooks Ra.; 67 $36^{\prime}$ N, $148^{\circ} 06^{\prime}$ W ; (map 123). Local name published in 1951 by USGS.

Little Squaw Peak: peak, 5,000 ft., $3.5 \mathrm{mi}$. S of Squaw Lake and $8.5 \mathrm{mi}$. NE of Chandalar, Brooks Ra.; $67^{\circ} 33^{\prime} 00^{\prime \prime} \mathrm{N}, 148^{\circ} 11^{\prime} 30^{\prime \prime} \mathrm{W}$; (map 123).

Local name reported in 1956 by T. E. Taylor, USGS.

Little Stony Creek: stream, heads N of Gravel Mtn., flows N $4.5 \mathrm{mi}$. to Stony Creek, $2 \mathrm{mi}$. N of Stony Hill and $11.5 \mathrm{mi}$. NE of head of McKinley River, Alaska Ra.; $63^{\circ} 29^{\prime} 45^{\prime \prime} \mathrm{N}$ $150^{\circ} 15^{\prime} 00^{\prime \prime} \mathrm{W}$; (map 88).

Local name reported in 1954 by USGS

Little Supreme Bluff: bluff, on E shore of Ikpikpuk River, $18 \mathrm{mi}$. $\mathrm{N}$ of its head, Arctic Plain; $69^{\circ} 35^{\prime} \mathrm{N}, 154^{\circ} 56^{\prime} \mathrm{W}$; (map 142).
Probably named in the 1940's by the geologists on the Naval Petroleum Reserve No. 4 exploration.

Little Susitna River: stream, heads at Mint Glacier, in Talkeetna Mts. at $61^{\circ} 51^{\prime} 30^{\prime \prime} \mathrm{N}, 149^{\circ}$ $03^{\prime} 30^{\prime \prime} \mathrm{W}$, flows SW $110 \mathrm{mi}$. to Cook Inlet, $13 \mathrm{mi}$. W of Anchorage, Cook Inlet Low.; $61^{\circ} 15^{\prime} 15^{\prime \prime} \mathrm{N}, 150^{\circ} 17^{\prime} 30^{\prime \prime} \mathrm{W}$; (map 70).

Local name published in 1898 by USC\&GS.

Little Swede Creek: stream, flows E $2 \mathrm{mi}$. to Glacier River, $1.5 \mathrm{mi}$. S of mouth of Swede Creek, $11.5 \mathrm{mi}$. NW of Wiseman, Brooks Ra.; $67^{\circ}$. $31^{\prime} 45^{\prime \prime} \mathrm{N}, 150^{\circ} 24^{\prime} 30^{\prime \prime} \mathrm{W}$; (map 124).

Local name reported by Marshall (1956, map).

Little Swift Creek: stream, flows NW $14 \mathrm{mi}$. to Crooked Creek, $74 \mathrm{mi}$. SE of Bethel, KilbuckKuskokwim Mts. ; $60^{\circ} 16^{\prime} \mathrm{N}, 159^{\circ} 51^{\prime} \mathrm{W}$; (map $59)$.

Local descriptive name; reported in 1955 by J. M. Hoare, USGS.

Little Swift River: stream, see Enatalik Creek.

Little Tanaga Island: island, $10 \mathrm{mi}$. long, one of Andreanof Is., Aleutian Is.; $51^{\circ} 50^{\prime} \mathrm{N}, 176^{\circ} 08^{\prime}$ W; BGN 1936; (map 17). Var. Tanaga Island, Tannak Island.

Aleut name published by Capt. Tebenkov (1852, map 28), IRN, as "O[strov] Tanaga," or "Tanaga Island." The name was changed to Little Tanaga Island by the North Pacific Exploring Expedition in $\mathbf{1 8 5 5}$ to distinguish it from the larger Tanaga Island.

Little Tanaga Strait: water passage, between Little Tanaga and Kagalaska Is., Aleutian Is.; $51^{\circ} 48^{\prime} \mathrm{N}, 176^{\circ} 14^{\prime} \mathrm{W}$; BGN 1936; (map 17).

Name derived from Little Tanaga Island, and given by members of the U.S. Navy Aleutian Island Survey Expedition in 1934.

Little Tanana Slough: stream, anabranch of Tanana River, $\mathrm{N}$ of Tanacross, flows W $15 \mathrm{mi}$., Yukon-Tanana High.; $63^{\circ} 22^{\prime} 30^{\prime \prime} \mathrm{N}, 143^{\circ} 26^{\prime}$ $00^{\prime \prime} \mathrm{W}$; (map 85)

Name reported in 1902 by Lt. William Mitchell, U.S. Army Signal Corps.

Little Taylor Mountains: mountains, 2,200 ft., in group $8 \mathrm{mi}$. across, $5 \mathrm{mi}$. SE of Taylor Mts., Kilbuck-Kuskokwim Low.; $60^{\circ} 52^{\prime} \mathrm{N}, 157^{\circ} 12^{\prime}$ W; BGN 1948; (map 60).

Named relative to the Taylor Mountains; name reported about 1915 by USGS.

Little Togiak Lake: lake, extends SE $6 \mathrm{mi}$. to Lake Nerka, $22 \mathrm{mi}$. E of Togiak Lake and 96 mi. NE of Goodnews, Kilbuck-Kuskokwim Mts.; $59^{\circ} 34^{\prime} \mathrm{N}, 159^{\circ} 06^{\prime} \mathrm{W}$; BGN 1931; (map 53).

Name reported in 1925 by USBF.

Little Tokichitna Glacier: glacier, see Kanikula Glacier.

Little Tokio River: stream, see Little Tok River.

Little Tok River: stream, heads at glacier terminus in Mentasta Mts., flows N $32 \mathrm{mi}$. to Tok River, $22 \mathrm{mi}$. SW of Tok, Alaska Ra.; $63^{\circ} 05^{\prime}$ N, $143^{\circ} 22^{\prime}$ W; BGN 1936; (map 85). Var. Little Tokio River.

Local name reported in 1902 by Schrader, USGS (in Mendenhall and Schrader, 1903, pl. 3, p. 48). 
Little Tonsina River: stream, flows NW $20 \mathrm{mi}$. to Tonsina River, $3.3 \mathrm{mi}$. SW of Tonsina and $49 \mathrm{mi}$. NE of Valdez, Chugach Mts.; 61 $36^{\prime}$ -

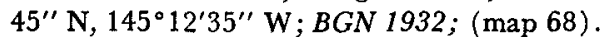
Var. Mosquito River.

Local name reported in 1932 by G. F. Feuchsel, USGS.

Little Tonzona River: stream, heads at glacier, $62^{\circ} 36^{\prime} \mathrm{N}, 152^{\circ} 56^{\prime} \mathrm{W}$, flows $\mathrm{NW} 70 \mathrm{mi}$. to South Fork Kuskokwim River, $46 \mathrm{mi}$. E of McGrath, Kuskokwim Low.; $62^{\circ} 58^{\prime} \mathrm{N}, 154^{\circ}$ $10^{\prime} \mathrm{W}$; BGN 1964; (map 81). Var. Tonzona River.

Name suggested by C. F. Herbert, Deputy Commissioner, Alaska Dept. of Natural Resources, in order to qualify the local name "Tonzona River" for this feature. Long standing map usage applies the name "Tonzona River" to another feature.

Little Totem Bay: cove, $\mathrm{W}$ arm of Totem Bay, on S coast of Kupreanof I., Alex. Arch.; 56 $28^{\prime} \mathrm{N}, 133^{\circ} 25^{\prime} \mathrm{W}$; (map 6).

Local name recorded in 1949 by USGS.

Little Tulsona Creek: stream, flows S $7 \mathrm{mi}$. to Tulsona Creek at Glenn Highway, $13 \mathrm{mi}$. SW of Chistochina, Copper River Basin; $62^{\circ}$. $26^{\prime} \mathrm{N}, 144^{\circ} 58^{\prime} \mathrm{W}$; (map 83).

Local name published by USGS in 1951.

Little Turner Creek: stream, flows $\mathrm{S}$ to Turner Creek which flows to Noxapaga River, about $34 \mathrm{mi}$. SW of Imuruk Lake, Seward Penin. High.; (map 110).

Prospectors' name shown on a map of Cape Nome gold fields by David Fox, Jr., dated 1901. This stream cannot be precisely located on current maps.

Little Ugalentz River: stream, see Kiklukh River.

Little Ugashik Creek: stream, heads between Mounts Demian and Lee, and flows W $2.2 \mathrm{mi}$. to Blue Creek $0.7 \mathrm{mi}$. NE of its junc. with Ugashik Creek, on Alaska Penin., 42 mi. NE of Ugashik, Aleutian Ra.; 57 $39^{\prime} 45^{\prime \prime} \mathrm{N}, 156^{\circ}$ $19^{\prime} 30^{\prime \prime} \mathrm{W}$; (map 36). Var. Blue Creek.

Name reported in 1920 by G. C. Martin, USGS, based on information obtained from J. L. McPherson, Deputy Mineral Surveyor, in 1902.

Little Ugashik Creek: stream, see Blue Creek.

Little Underhill Greek: stream, heads at glacier terminus, flows SW $47 \mathrm{mi}$. to Stony River $18 \mathrm{mi}$. NW of its junc. with Telaquana River, $70 \mathrm{mi}$. NW of Lake Clark, Lime Hills; $61^{\circ} 14^{\prime} 45^{\prime \prime} \mathrm{N}, 154^{\circ} 47^{\prime} 40^{\prime \prime} \mathrm{W}$; (map 71).

Prospectors' name published in 1951 by USGS.

Little Wabash Creek: stream, flows NW $4.5 \mathrm{mi}$. to lake in Nixon Fork Takotna River, $20 \mathrm{mi}$. NW of Medfra, Kilbuck-Kuskokwim Mts.; $63^{\circ} 15^{\prime} \mathrm{N}, 155^{\circ} 15^{\prime} \mathrm{W}$; (map 89).

Local name reported in 1958 by USGS.

Little Waldren Fork: stream, flows NE $14 \mathrm{mi}$. to join Moore Creek to form Takotna River, $39 \mathrm{mi}$. E of Flat, Kilbuck-Kuskokwim Mts.; $62^{\circ} 32^{\prime} 30^{\prime \prime} \mathrm{N}, 156^{\circ} 47^{\prime} 30^{\prime \prime} \mathrm{W}$; (map 79). Var. Waldren Fork.

Local name obtained in 1952 by USGS topographers.
Little Washington Creek: stream, flows SW 5 mi. to Seventymile River, $22 \mathrm{mi}$. NW of Eagle, Yukon-Tanana High.; $64^{\circ} 56^{\prime} \mathrm{N}, 141^{\circ} 51^{\prime} \mathrm{W}$; (map 102). Var. Washington Creek.

Named by prospectors and reported in 1898 by E. C. Barnard, USGS.

Little Waterfall Bay: bay, extends S $1.2 \mathrm{mi}$. off Perenosa Bay, on $\mathrm{N}$ coast of Afognak I., Kodiak I.; $58^{\circ} 24^{\prime} 00^{\prime \prime} \mathrm{N}, 152^{\circ} 29^{\prime} 30^{\prime \prime} \mathrm{W}$; (map 43).

Local descriptive name published in 1952 by USGS.

Little Whale Bay: bay, see Small Arm Whale Bay.

Little Whiteman Creek: stream, flows NW $9 \mathrm{mi}$. to McKinley Creek, $60 \mathrm{mi}$. SW of Eagle, Yukon-Tanana High.; $64^{\circ} 20^{\prime} 20^{\prime \prime} \mathrm{N}, 142^{\circ} 53^{\prime} 50^{\prime \prime}$ W; (map 102). Var. Solomon Gulch.

Local name derived from Whiteman Creek; published in 1956 by USGS.

Little Williams Slough: stream, anabranch, heads at Tanana River, flows NW $5.8 \mathrm{mi}$. to Williams Slough, $37 \mathrm{mi}$. NE of The Bitzshtini Mts., Nowitna Low.; $64^{\circ} 58^{\prime} \mathrm{N}, 151^{\circ} 28^{\prime} \mathrm{W}$; (map 99).

Riverboat pilots' name published on a 1940 "Navigation Chart of the Tanana-Yukon Rivers" by the U.S. Dept. of Interior.

Little Willow Creek: stream, flows NW and SW $36 \mathrm{mi}$. to Susitna River, $5.5 \mathrm{mi}$. NW of Willow and $42 \mathrm{mi}$. NW of Anchorage, Cook Inlet Low.; $61^{\circ} 48^{\prime} 40^{\prime \prime} \mathrm{N}, 150^{\circ} 09^{\prime} 30^{\prime \prime} \mathrm{W}$; (map 70).

Name reported in 1906 by $R$. H. Sargent and T. G. Gerdine, USGS.

Little Willow Creek: stream, flows S $1.9 \mathrm{mi}$. to Willow Creek, $30 \mathrm{mi}$. NE of Flat, KilbuckKuskokwim Mts. ; $62^{\circ} 37^{\prime} \mathrm{N}, 157^{\circ} 07^{\prime} \mathrm{W}$; (map 79). Var. Willow Creek.

Prospectors' name obtained in 1952 by USGS topographers.

Little Willow Creek: stream, flows SW 2 mi. to Chatanika River, $17 \mathrm{mi}$. N of Fairbanks, Yukon-Tanana High.; $65^{\circ} 06^{\prime} \mathrm{N}, 147^{\circ} 41^{\prime} \mathrm{W}$; (map 105). Var. Willow Creek.

Name originally published in 1908 as Willow Creek by USGS, but changed by local use to its present form.

Little Windy Creek: stream, flows SE $6 \mathrm{mi}$. to Windy Creek, $30 \mathrm{mi}$. S of Healy, Alaska Ra.; $63^{\circ} 25^{\prime} 27^{\prime \prime} \mathrm{N}, 148^{\circ} 54^{\prime} 30^{\prime \prime} \mathrm{W}$; (map 87).

Local descriptive name obtained in 1951 by USGS.

Little Windy Creek: stream, flows NW $2 \mathrm{mi}$. to Windy Creek which flows to Right Fork Bluestone River, $12 \mathrm{mi}$. S of Teller, Seward Penin. High.; $65^{\circ} 05^{\prime} \mathrm{N}, 166^{\circ} 20^{\prime} \mathrm{W}$; (map 111).

Prospectors' name reported on a map of Cape Nome goldfields by David Fox, Jr., dated 1901.

Little Windy Gulch: ravine, trends SSE $2 \mathrm{mi}$. to Salcha River, $7 \mathrm{mi}$. NE of West Point and $56 \mathrm{mi}$. SW of Circle, Yukon-Tanana High.; $65^{\circ} 01^{\prime} 30^{\prime \prime} \mathrm{N}, 144^{\circ} 29^{\prime} 30^{\prime \prime} \mathrm{W}$; (map 104).

Prospectors' name reported in 1954 or 1955 by USGS topographers.
Little Woods Creek: stream, flows SE $5.8 \mathrm{mi}$. to Mae West Lake, S of Glenn Highway, $17 \mathrm{mi}$. W of Glennallen, Copper River Basin; 62 $2^{\circ} 5^{\prime}$ $\mathrm{N}, 146^{\circ} 05^{\prime} \mathrm{W}$; (map 83).

Local name reported in 1949 by USGS.

Little Wrangell Island: island, $0.2 \mathrm{mi}$. across, in Biorka Channel, $\mathrm{S}$ of Wrangell $\mathrm{I}$. and $\mathrm{E}$ of Biorka I., $4.5 \mathrm{mi}$. WNW of Goddard, Alex. Arch.; 56 $50^{\prime} 50^{\prime \prime} \mathrm{N}, 135^{\circ} 29^{\prime} 30^{\prime \prime} \mathrm{W}$; (map 5). Var. Ostrov Malyy Vrangel.

This island was named in 1809 by the Russian navigator Ivan Vasiliev the first; Lt. Sarichev (1826, map 19), IRN, published the name as "O[strov] $\mathrm{Mal}[\mathrm{yy}]$ Vrangel" or "little Wrangell island."

Little Writer Creek: stream, heads in Dutch Hills, flows SE $1 \mathrm{mi}$. to Willow Creek, $0.5 \mathrm{mi}$. $\mathrm{N}$ of its junc. with Cottonwood Creek, $28 \mathrm{mi}$. NW of Talkeetna, Alaska Ra.; $62^{\circ} 33^{\prime} 20^{\prime \prime} \mathrm{N}$, $150^{\circ} 49^{\prime} 40^{\prime \prime} \mathrm{W}$; (map 81).

Prospectors' name reported in the 1930's by USGS.

Little Yetna River: stream, flows NE $55 \mathrm{mi}$. to join Big Yetna River to form Yetna River, 32 mi. E of Holikachuk and $32 \mathrm{mi}$. NW of Flat, Innoko Low.; $62^{\circ} 51^{\prime} 30^{\prime \prime} \mathrm{N}, 158^{\circ} 30^{\prime} 00^{\prime \prime} \mathrm{W}$; (map 79)

Local name obtained in 1952 by USGS topographers.

Lituya Bay: bay, in Glacier Bay National Monument, heads at terminus of Cascade Glacier, trends $7.5 \mathrm{mi}$. SW to Gulf of Alaska, at Harbor Point, $88 \mathrm{mi}$. NW of Hoonah, Malaspina Coastal Plain; 58 $36^{\prime} 45^{\prime \prime} \mathrm{N}, 137^{\circ} 39^{\prime} 30^{\prime \prime} \mathrm{W}$ (map 10). Var. Alituya Bay, Altona Bay, Altuya Bay, Busen Altua, Entrada de Aragon, Frenchman's Bay, H'lit-tu-yah, Lina Bay, Ltuya Bay, Port des Français, Skecter Bay.

Tlingit Indian name obtained and used by the Russians. In 1805 Capt. Lisianski (1814, p. 221), IRN, called it "L'tooa Bay." It was published in Russian as "Z[aliv] L'tua" by Capt. Tebenkov (1852, map 8), IRN, and the Russian Hydrog. Dept. Chart 1378 shows "Zal[iv] Altua ili Port Frantsuzov" meaning "Altua Bay or Port of Frenchmen." La Pérouse (1797, map 19) originally called the bay "Port des Français" meaning the "bay of the Frenchmen." Whalers knew it as Frenchman's Bay. La Perouse visited and surveyed the bay in 1786 and made observations about the Indians living there.

Lituya Glacier: glacier, in Glacier Bay National Monument, heads on SW slope of Fairweather Ra., trends SW $11 \mathrm{mi}$. to Gilbert Inlet, on Lituya Bay, $1.6 \mathrm{mi}$. NW of the terminus of Cascade Glacier and $85 \mathrm{mi}$. NW of Hoonah, St. Elias Mts.; $58^{\circ} 40^{\prime} 30^{\prime \prime} \mathrm{N}, 137^{\circ} 31^{\prime} 00^{\prime \prime} \mathrm{W}$; $B G N$ 1945; (map 10). Var. Desolation Glacier.

Named in 1917 by J. B. Mertie, Jr., USGS Lituya Mountain: mountain, 11,924 ft., in Glacier Bay National Monument, $0.8 \mathrm{mi}$. SW of Mount Salisbury, $87 \mathrm{mi}$. NW of Hoonah, St. Elias Mts.; $58^{\circ} 48^{\prime} 20^{\prime \prime}$ N, $137^{\circ} 26^{\prime} 00^{\prime \prime} \mathrm{W}$; (map 10). Var. Mount Crillon.

Name published in Russian by Capt. Tebenkov (1852, map 8), IRN, as "G[ora] 
L'tua" meaning "Lituya Mountain", named for Lituya Bay.

Livelock: village, see Levelock.

Lively Islands: islands, in Tlevak Strait, NE of Dall I., Alex. Arch.; 55 $14^{\prime} \mathrm{N}, 133^{\circ} 05^{\prime} \mathrm{W}$; (map 4). Var. Voorhees Isles.

Named in 1882 by W. H. Dall, USC\&GS, for the steam launch Lively of the Coast Survey steamer Hassler. These islands were called "Voorhees Isles" by Sheldon Jackson in 1880 .

Lively Rock: rock, in Port Chester, on W coast of Annette I., Alex. Arch.; $55^{\circ} 09^{\prime} 30^{\prime \prime} \mathrm{N}$, $131^{\circ} 35^{\prime} 00^{\prime \prime} \mathrm{W}$; (map 3).

Named in 1883 by Lt. Comdr. H. E. Nichols, USN, for the steamer Hassler's launch Lively.

Livengood: village (pop. 40), on Livengood Creek, $50 \mathrm{mi}$. NW of Fairbanks, YukonTanana High.; $65^{\circ} 31^{\prime} 30^{\prime \prime} \mathrm{N}, 148^{\circ} 32^{\prime} 45^{\prime \prime} \mathrm{W}$; BGN 1944; (map 105). Var. Brooks.

Gold was discovered on July 24, 1914, on Livengood Creek by N. R. Hudson and Jay Livengood. The village was founded near their claim as a mining camp during the winter of 1914-15 when hundreds of people came into the district. A post office was established in 1915 and discontinued in 1957 (Ricks, 1965, p. 39). The town was named for Jay Livengood.

Livengood Creek: stream, flows SW $10 \mathrm{mi}$. to Tolovana River, $5 \mathrm{mi}$. SW of Livengood, Yukon-Tanana High.; $65^{\circ} 28^{\prime} 30^{\prime \prime} \mathrm{N}, 148^{\circ}$ $34^{\prime} 10^{\prime \prime} \mathrm{W}$; (map 105).

Named by prospectors for Jay Livengood, who, with N. R. Hudson, discovered gold on July 24, 1914, on the banks of this creek. The name was reported in 1915 by USGS (Brooks and others, 1916, pl. 9).

Livengood Dome: mountain, 2,622 ft., $5 \mathrm{mi}$. NE of Livengood and $55 \mathrm{mi}$. NW of Fairbanks, Yukon-Tanana High.; $65^{\circ} 35^{\prime} 25^{\prime \prime} \mathrm{N}, 148^{\circ} 2^{\prime} 8^{\prime}$ 40 " W; (map 105).

Named for Jay Livengood, who discovered gold in the area in 1914. The name was reported in 1916 by J. B. Mertie (in Brooks and others, 1918, pl. 13), USGS.

Liver Creek: stream, flowing NE $1 \mathrm{mi}$. to Bering Sea, center of Kiska I., Aleutian Is.; 51 ${ }^{\circ} 58^{\prime} 54^{\prime \prime}$ N, $177^{\circ} 25^{\prime} 57^{\prime \prime} \mathrm{E}$; (map 14).

An arbitrary name beginning with " $L$ " to correspond to "L" grid used by the U.S. Army for tactical purposes during World War II; published on a 1943 Army map.

Liver Lakes: lakes, $0.2 \mathrm{mi}$. long, center Kiska I., Aleutian Is.; $51^{\circ} 57^{\prime} 05^{\prime \prime} \mathrm{N}, 177^{\circ} 24^{\prime} 15^{\prime \prime} \mathrm{E}$; (map 14).

An arbitrary name beginning with " $L$ " to correspond to "L" grid used by the U.S. Army for tactical purposes during World War II; published on a 1953 AMS map.

Live Trap Lake: lake, $0.5 \mathrm{mi}$. long, $8.7 \mathrm{mi}$. SSE of junc. of Foraker and Herron Rivers, Tanana Low.; $63^{\circ} 31^{\prime} 30^{\prime \prime} \mathrm{N}, 152^{\circ} 04^{\prime} 00^{\prime \prime} \mathrm{W}$; (map 88).

Local name obtained in 1958 from Fabian Carey and "Val" Blackburn by USGS.
Livingston Creek: stream, flows NW $9 \mathrm{mi}$. to Feather River, $32 \mathrm{mi}$. NW of Nome, Seward Penin. High.; $64^{\circ} 50^{\prime} \mathrm{N}, 166^{\circ} 09^{\prime} \mathrm{W}$; (map 94).

Prospectors' name reported in 1900 by E. C. Barnard (in Brooks, 1901, pl. 17), USGS.

Livingston Creek: stream, see Jordan Creek.

Liz, Mys : point of land, see Lees, Point.'

Lizzie Creek: stream, flows NE $1 \mathrm{mi}$. to Kougarok River, $16 \mathrm{mi}$. SE of Midnight Mtn. and 45 mi. W of Imuruk Lake, Seward Penin. High.; $65^{\circ} 33^{\prime} \mathrm{N}, 164^{\circ} 44^{\prime} \mathrm{W}$; (map 110 ).

Prospectors' name reported on the 1908 "Map of Seward Peninsula" by Arthur Gibson. L'Kudinaku: stream, see Rosaunt Creek.

Loaf Island: island, tied to shore, on $\mathrm{W}$ shore of Massacre Bay, on SE coast of Attu I., Aleutian Is.: $52^{\circ} 50^{\prime} 15^{\prime \prime} \mathrm{N}, 173^{\circ} 12^{\prime} 45^{\prime \prime} \mathrm{E}$; (map 13).

Named by the U.S. Army during its occupation of the island during World War II; shown on an AMS map published in 1948.

Loaf Ridge: ridge, 2 mi. long, between Nakat Mtn. and Fillmore Inlet, Coast Mts. ; 54 $51^{\circ}$ $15^{\prime \prime} \mathrm{N}, 130^{\circ} 36^{\prime} 30^{\prime \prime} \mathrm{W}$; (map 2).

Named in 1883 by Lt. Comdr. H. E. Nichols, USN

Lobo, El: island, "shown on Camacho's map of 1779 where none exists. It was possibly the north end of Shuyak Island" (Wagner, 1937, p. 468).

Lobo Lake: lake, see Kuirzinjik Lake.

Lobos, Islas de: islands, see Sealion Islands.

Lobster Creek: stream, flows NE $0.3 \mathrm{mi}$. to Bluff Cove, Kiska I., Aleutian Is.; 51 ${ }^{\circ} 59^{\prime} 08^{\prime \prime}$ N, $177^{\circ} 28^{\prime} 39^{\prime \prime} \mathrm{E}$; (map 14).

An arbitrary name beginning with " $L$ " to correspond to "L" grid used by the U.S. Army for tactical purposes during World War II; published on a 1943 Army map.

Lockanok: locality, on right bank of Alagnak River, $2.5 \mathrm{mi}$. S of Hallersville and $60 \mathrm{mi}$. E of Dillingham, Bristol Bay Low.; $59^{\circ} 00^{\prime} 30^{\prime \prime} \mathrm{N}$, $156^{\circ} 49^{\prime} 30^{\prime \prime} \mathrm{W}$; (map 52).

Eskimo name for a village and cannery recorded on the 1941 Cannery Map of Alaska. The cannery is now abandoned.

Lockenuck; stream, see Alagnak River.

Lock Island: island, $0.15 \mathrm{mi}$. across, in Portlock Harbor, $5.5 \mathrm{mi}$. NW of Chichagof, on W coast of Chichagof I., Alex. Arch.; 57 $43^{\prime} 30^{\prime \prime} \mathrm{N}$, $136^{\circ} 11^{\prime} 50^{\prime \prime} \mathrm{W}$; (map 9).

Named by USC\&GS and published in 1928 on Chart 8258. "Lock" is the last syllable of the name "Portlock," the name of the harbor. Lockwood, Point: point of land, on $\mathrm{E}$ coast of Woewodski I., $18 \mathrm{mi}$. S of Petersburg, Alex. Arch.; 56 $33^{\prime} 25^{\prime \prime} \mathrm{N}, 1^{\circ} 32^{\circ} 57^{\prime} 50^{\prime \prime}$ W; (map 6). Var. Mys Poverotnyy, Poverotni Point.

Named in 1869 by Comdr. R. W. Meade, USN; named "Mys Poverotnyy" meaning "turning point" in 1838 by the Russian surveyor, G. Lindenberg.

Lockwood Hills: mountains, 4,130 ft., extend from Pick River E and SE $60 \mathrm{mi}$. to Kokhila Hills at $66^{\circ} 29^{\prime} \mathrm{N}$., $155^{\circ} 00^{\prime} \mathrm{W}, 50 \mathrm{mi}$. NW of Hughes, Hogatza High.; $66^{\circ} 40^{\prime} \mathrm{N}, 155^{\circ} 30^{\prime}$
W; (map 116). Var. Asiksat Hills, Lockwood Mountains.

Named in 1885 by Lt. Stoney (1900, map), USN probably for Lt. J. B. Lockwood. See Lockwood Peak. The Eskimo name "Asiksat" means "bending frame."

Lockwood Lake: lake, $1.3 \mathrm{mi}$. long, E of Yentna River, $43 \mathrm{mi}$. NW of Anchorage, Gook Inlet Low.; 61 $45^{\prime} 30^{\prime \prime} \mathrm{N}, 150^{\circ} 34^{\prime} 25^{\prime \prime} \mathrm{W}$; (map 70).

Local name reported in 1954 by USGS.

Lockwood Peak: mountain, 3,300 ft., in Missionary Ra., $13 \mathrm{mi}$. NW of Petersburg, on Lindenberg Penin., Kupreanof I., Alex. Arch.; $56^{\circ} 57^{\prime} 15^{\prime \prime} \mathrm{N}, 133^{\circ} 11^{\prime} 10^{\prime \prime} \mathrm{W}$; (map 6).

Named in 1887 by Lt. Comdr. C. M. Thomas, USN, for Lt. James Booth Lockwood, USA, who died in 1883 at Cape Sabine.

Loco Creek: stream, flows NE $4 \mathrm{mi}$. to Cripple Creek, $76 \mathrm{mi}$. SE of Bethel, Kilbuck-Kuskokwim Mts.; $60^{\circ} 43^{\prime} 30^{\prime \prime} \mathrm{N}, 159^{\circ} 33^{\prime} 10^{\prime \prime} \mathrm{W}$; (map 59).

Prospectors' name reported in 1914 by A. G. Maddren (in Brooks, 1915, pl. 11), USGS.

Locust Hill: hill, $300 \mathrm{ft}$., center of Kiska I., Aleutian Is.; $51^{\circ} 56^{\prime} 33^{\prime \prime} \mathrm{N}, 177^{\circ} 26^{\prime} 17^{\prime \prime} \mathrm{E}$; (map 14).

An arbitrary name beginning with " $\mathrm{L}$ " to correspond to "L" grid used by the U.S. Army for tactical purposes during World War II; published on a 1943 Army map.

Lodestone Creek: stream, flows SW $2 \mathrm{mi}$. to Secret Creek, $4.5 \mathrm{mi}$. NE of Solomon, Seward Penin. High.; $64^{\circ} 35^{\prime} \mathrm{N}, 164^{\circ} 15^{\prime} \mathrm{W}$; (map 95).

Prospectors' name reported in 1907 by USGS geologists (Smith, P. S., 1910, pl. 3).

Lodge, Mount: mountain, 10,530 ft., in St. Elias Mts., on Alaska-Canada boundary, $6.8 \mathrm{mi}$. N of Mount Watson, $83 \mathrm{mi}$. WSW of Skagway, St. Elias Mts.; $59^{\circ} 06^{\prime} 55^{\prime \prime} \mathrm{N}, 137^{\circ} 32^{\prime} 25^{\prime \prime} \mathrm{W}$; BCN 1954; (map 45). Var. Boundary Peak 166.

Named in 1908 by USC\&GS for Senator Henry Cabot Lodge, 1850-1924, U.S. Bounddary Commissioner in 1903. Senator Lodge was born and educated in Massachusetts, taught American history at Harvard Univ., and was a literary editor before entering politics. He was a member of Congress from 1887 to 1893 and Senator from 1893 to 1924 .

Lodge Hill: hill, $850 \mathrm{ft}$., south-central Kiska I., Aleutian Is.; $51^{\circ} 56^{\prime} 35^{\prime \prime} \mathrm{N}, 177^{\circ} 23^{\prime} 15^{\prime \prime} \mathrm{E}$; (map 14).

An arbitrary name beginning with " $L$ " to correspond to "L" grid used by the U.S. Army for tactical purposes during World War II; published on a 1953 AMS map.

Lodge Island: island, $5 \mathrm{mi}$. across, $7 \mathrm{mi}$. SE of Goddard, on W coast of Baranof I., Alex. Arch.; $56^{\circ} 46^{\prime} \mathrm{N}, 135^{\circ} 13^{\prime} \mathrm{W}$; (map 5).

Named by USC\&GS for charting purposes; name published in the 1932 Coast Pilot ( $p$. 366 ).

Lodge Lake: lake, 150 yd. across, Kiska I., Aleutian Is.; $51^{\circ} 56^{\prime} 40^{\prime \prime} \mathrm{N}, 177^{\circ} 23^{\prime} 12^{\prime \prime} \mathrm{E}$; (map 14). Var. Double Lake. 
An arbitrary name beginning with " $L$ " to correspond to "L" grid used by U.S. Army for tactical purposes during World War II; published on a 1953 AMS map. Variant published on a 1943 USAAF map.

Lofty Mountain: mountain, 2,284 ft., on NE part of Unalaska I., Aleutian Is.; $53^{\circ} 56^{\prime} 38^{\prime \prime}$ N, $166^{\circ} 18^{\prime} 00^{\prime \prime}$ (map 23).

Descriptive name published in the 1944 Aleutian Coast Pilot (p. 28).

Logan, Mount: inountain, 6,300 ft., 4.4 mi. SE of Mount Cashman and $16 \mathrm{mi}$. N of Valdez, Chugach Mts.; $61^{\circ} 20^{\prime} 25^{\prime \prime} \mathrm{N}, 146^{\circ} 20^{\prime} 10^{\prime \prime} \mathrm{W}$; $B G N$ 1960; (map 68). Var. Mount Egan, Sourdough Peak.

Named by L. E. Nielsen in 1959 for "Dr. Logan who spent the winter of 1898-99 in the interior of Alaska where he saved the lives of many prospectors. About March, 1899, he died on the Valdez Glacier while trying to bring a group of prospectors with scurvy to Valdez."

Logan Beach: beach, $4 \mathrm{mi}$. long, on $\mathrm{E}$ shore of Yakutat Bay, S of Logan Bluffs, $19 \mathrm{mi}$. NE of Yakutat, St. Elias Mts. ; $59^{\circ} 49^{\prime} 00^{\prime \prime} \mathrm{N}, 139^{\circ}$ $35^{\prime} 30^{\prime \prime} \mathrm{W}$; (map 46).

Named by Tarr and Martin (1906, map), USGS. Gold, disseminated through the gravel of this beach, attracted prospectors to this area in 1905 (Tarr, 1909, p. 166-167).

Logan Bluffs: bluffs, on E shore of Yakutat Bay, extend $3 \mathrm{mi}$. S of Point Latouche and $23 \mathrm{mi}$. $\mathrm{NE}$ of Yakutat, St. Elias Mts.; $59^{\circ} 52^{\prime} 30^{\prime \prime} \mathrm{N}$, $139^{\circ} 38^{\prime} 00^{\prime \prime} \mathrm{W}$; (map 46).

Local name derived from nearby Logan Beach; published in 1959 by USGS.

Logan Creek: stream, flows NE $10 \mathrm{mi}$. to Yukon River, $43 \mathrm{mi}$. NW of Eagle, Yukon-Tanana High.; $65^{\circ} 16^{\prime} 20^{\prime \prime} \mathrm{N}, 141^{\circ} 59^{\prime} 10^{\prime \prime} \mathrm{W}$; (map 103). Var. Butter Creek, Jewett Creek.

Name used by prospectors and reported in 1905 by D. C. Witherspoon. Mertie (1930, p. 7) reports some usage of "Jewett Creek" in 1925 , which is probably derived from F. L. Jewett, one of the operators of a nearby coal mine in 1902 (Collier, 1903, p. 29).

Logan Creek: stream, flows NW to Inmachuk River near its junc. with Pinnell River, about $16 \mathrm{mi}$. N of Imuruk River, Seward Penin. High.; (map 110).

Local name published on a precinct map of Seward Peninsula by Monroe and Hutchins; corrected to June 1903 by Arthur Gibson. This stream cannot be precisely identified on current maps.

Logan Glacier: glacier, heads in Canada, $10 \mathrm{mi}$. NE of Mount Logan, trends NW $50 \mathrm{mi}$. into Alaska to Chitina Glacier, $13 \mathrm{mi}$. SW of Mount Tittmann and $115 \mathrm{mi}$. NW of Yakutat, St. Elias Mts.; $60^{\circ} 57^{\prime} 30^{\prime \prime} \mathrm{N}, 141^{\circ} 29^{\prime} 00^{\prime \prime}$ W; BGN 1960; (map 65).

Named in $1912-13$ by IBC because of its nearness to Mount Logan. Mount Logan was named by I. C. Russell in 1890, in honor of Sir William Edmond Logan, "founder and long director of the Geological Survey of Canada," who was born in Montreal and edu- cated in the British Isles. After working for a while in a copper smelting works in Swansea, he became actively interested in geology, especially the coal beds of South Wales. He was director of the Geological Survey of Canada from 1842-69. He was knighted in 1856 .

Logan Reef: reef, in outer Chiginagak Bay, 0.6 mi. S of Derickson I., near S shore of Alaska Penin., Aleutian Ra.; 56 $58^{\prime} 40^{\prime \prime}$ N, $156^{\circ} 43^{\prime}$ $10^{\prime \prime} \mathrm{W}$; (map 31$)$.

Local name published in 1953 by USC\&GS Log Cabin Inn: roadhouse, on Glenn Highway $3.6 \mathrm{mi}$. $\mathrm{S}$ of junc. of Little Tok and Tok Rivers, $23 \mathrm{mi}$. S of Tok, Alaska Ra.; 63 $01^{\circ}$ ' $30^{\prime \prime} \mathrm{N}, 143^{\circ} 21^{\prime} 00^{\prime \prime} \mathrm{W}$; (map 85).

Name reported by USGS in 1952.

Logger Gulch: ravine, extends N $1.5 \mathrm{mi}$, from $\mathrm{N}$ of Devils Thumb to Boston Creek, $7 \mathrm{mi}$. S of Ruby, Kilbuck-Kuskokwim Mts. ; $64^{\circ} 38^{\prime}$ $15^{\prime \prime} \mathrm{N}, 155^{\circ} 29^{\prime} 00^{\prime \prime} \mathrm{W}$; (map 98).

Prospectors' name reported in 1908 by A. G. Maddren, USGS.

Logging Cabin Creek: stream, heads on Mount Fairplay, flows N $15 \mathrm{mi}$. to West Fork Dennison Fork, $43 \mathrm{mi}$. NE of Tok, Yukon-Tanana High.; $63^{\circ} 52^{\prime} \mathrm{N}, 142^{\circ} 18^{\prime} \mathrm{W}$; (map 85).

Local name reported by USGS in 1956.

Logging Camp Bay: cove, $0.1 \mathrm{mi}$. across, at NE side of Passage Canal, $8.5 \mathrm{mi}$. NE of Whittier, Chugach Mts. ; $60^{\circ} 49^{\prime} 45^{\prime \prime} \mathrm{N}, 148^{\circ} 25^{\prime} 30^{\prime \prime}$ W; BGN 1915; (map 63).

Local name reported in 1914 by USC\&GS.

Logging Lake: lake, $0.7 \mathrm{mi}$. long, between Tetlin and Tetlin Lake, $19 \mathrm{mi}$. SE of Tok, Alaska Ra.; $63^{\circ} 08^{\prime} \mathrm{N}, 142^{\circ} 35^{\prime} \mathrm{W}$; (map 85).

Local name reported by USGS in 1964.

Log Island: island, see Loy Island.

Log Jam: locality, see Log Jam Road House.

Logjam Creek: stream, flows N $19 \mathrm{mi}$. to Sweetwater Lake, $\mathrm{N}$ central Prince of Wales I., Alex. Arch.; $55^{\circ} 56^{\prime} 28^{\prime \prime} \mathrm{N}, 132^{\circ} 58^{\prime} 25^{\prime \prime} \mathrm{W}$; $B G N$ 1963; (map 4).

Local name reported in 1961 by USFS; "stream has a huge log jam that has accumulated over several hundred years."

Log Jam Road House: locality, on left bank of Tolovana River, $22 \mathrm{mi}$. S of Livengood, $\mathrm{Yu}$ kon-Tanana High.; $65^{\circ} 14^{\prime} \mathrm{N}, 148^{\circ} 40^{\prime} \mathrm{W}$; (map 105). Var. Log Jam.

Former roadhouse reported in 1915 by USGS (Brooks and others, 1916, pl. 9). The name was given by prospectors because of a huge log jam there in the Tolovana River.

Log Lakes: lakes, $0.2 \mathrm{mi}$. across, center of Kiska I., Aleutian Is.; $51^{\circ} 57^{\prime} 12^{\prime \prime} \mathrm{N}, 177^{\circ} 26^{\prime} 15^{\prime \prime}$ E; (map 14).

An arbitrary name beginning with " $L$ " to correspond to "L" grid used by the U.S. Army for tactical purposes during World War II; published on a 1943 Army map.

Log Point: point of land, on N coast of Liesnoi I., in Woewodski Harbor, on Admiralty I., 26 mi. SE of Angoon, Alex. Arch.; 57 $10^{\prime} 30^{\prime \prime} \mathrm{N}$, $134^{\circ} 16^{\prime} 00^{\prime \prime} \mathrm{W}$; (map 9).

Named in 1889 by Lt. Comdr. H. B. Mansfield, USN; published by USC\&GS in 1891 Coast Pilot (p. 142).
Lohtianoi: water passage, see Cross Sound.

Lohtianoi Point: point of land, see Glacier Point.

Lois Creek: stream, heads in Davidson Mts., and flows S $20 \mathrm{mi}$. to Coleen River $14 \mathrm{mi}$. SE of Bear Mtn. and $45 \mathrm{mi}$. SE of Table Mtn., Porcupine Plat.; $68^{\circ} 12^{\prime} \mathrm{N}, 141^{\circ} 57^{\prime} \mathrm{W}$; (map 137).

Local name reported in 1956 by USGS. Lois Dome: mountain, 2,592 ft., $7 \mathrm{mi}$. W of junc. of Pass Creek with Coleen River, $43 \mathrm{mi}$. N of Coleen Mtn., Brooks Ra.; $67^{\circ} 43^{\prime} \mathrm{N}, 142^{\circ}$ $48^{\prime} \mathrm{W}$; (map 121).

Local name reported in 1956 by T. E. Taylor, USGS.

Lois Glacier: glacier, see Brilliant Glacier.

Loma Point: point of land, see Lomas, Point.

Lomas, Point: point of land, on $\mathrm{W}$ coast of Prince of Wales I., in Port Caldera, $6.8 \mathrm{mi}$. S of Craig, Alex. Arch.; $55^{\circ} 22^{\prime} 40^{\prime \prime} \mathrm{N}, 133^{\circ} 10^{\prime} 30^{\prime \prime}$ W; BGN 1922; (map 4). Var. Cabo de las Lomas, Cape Lomas, Mys de los Lomas, Point Loma.

Name given in $1775-79$ by Don Juan de la Bodega y Quadra and Francisco Antonio Maurelle as "Cabo de las Lomas," meaning "cape of the hillocks." Baker (1906, p. 411), published the name "Cape Lomas"; changed to "Point Lomas" in 1922 by USC\&GS, because "Not bold or prominent enough to be styled a Cape."

Lomauik: locality, see Lomavik.

Lomavigamute: locality, see Lomavik.

Lomavik: locality, on left bank of Kuskokwim River, $14 \mathrm{mi}$. SW of Bethel, Yukon-Kuskokwim Delta; $60^{\circ} 38^{\prime} \mathrm{N}, 161^{\circ} 59^{\prime} \mathrm{W}$; (map 59). Var. Lomauik, Lomavikmut, Lomavigamute, Lomawigamute.

Eskimo village, now abandoned, listed by Ivan Petroff in the 10th Census, in 1880, with a population of 81 . Petroff received his information from E. W. Nelson, U.S. Signal Service, who was there in January 1879 and who spelled the name "Lomavigamute," meaning "Lomavik people." In 1890 the village population was 53 , of whom 29 were Eskimos.

Lomavikmut: locality, see Lomavik.

Lomavik Slough: channel, of Kuskokwim River, $8 \mathrm{mi}$. long, $23 \mathrm{mi}$. SW of Bethel, YukonKuskokwim Delta; $60^{\circ} 33^{\prime} \mathrm{N}, 162^{\circ} 12^{\prime} \mathrm{W}$; (map 58). Var. The Canal.

Local name reported in 1949 by USC\&GS. Lomawigamute: locality, see Lomavik.

Lombard Creek: stream, flows SW $2 \mathrm{mi}$. to Sunset Creek which flows to Grantley Harbor, 6 mi. NE of Teller, Seward Penin. High.; $65^{\circ}-$ $20^{\prime} \mathrm{N}, 166^{\circ} 14^{\prime} \mathrm{W}$; (map 111).

Prospectors' name reported on the 1908 "Map of Seward Peninsula" by Arthur Gibson.

Lomen Creek: stream, flows NE $9 \mathrm{mi}$. to Mangoak River, $25 \mathrm{mi}$. SW of Selawik, KotzebueKobuk Low.; $66^{\circ} 14^{\prime} \mathrm{N}, 160^{\circ} 05^{\prime} \mathrm{W}$; (map 114).

Prospectors' name reported in 1911 by USGS. 
Lone Baldy: mountain, 1,294 ft., $2.5 \mathrm{mi}$. NW of Katalla, Chugach Mts.; $60^{\circ} 13^{\prime} \mathrm{N}, 144^{\circ} 35^{\prime}$ W; (map 64).

Name published in 1907 by USGS.

Lone Butte: mountain, 3,668 ft., $10 \mathrm{mi}$. SE of junc. of Oshetna and Susitna River and 64 mi. NW of Gulkana, Talkeetna Mts. ; 62 ${ }^{\circ} 30^{\prime}$ $\mathrm{N}, 147^{\circ} 18^{\prime} \mathrm{W}$; (map 82).

Local descriptive name reported by $F . H$. Moffit (in Brooks and others, 1915, pl. 6), USGS.

Lone Butte Creek: stream, flows N $15 \mathrm{mi}$. to Serpentine River, $33 \mathrm{mi}$. SE of Shishmaref, Kotzebue-Kobuk Low.; $66^{\circ} 02^{\prime} \mathrm{N}, 165^{\circ} 03^{\prime} \mathrm{W}$; (map 112).

Prospectors' name reported in 1901 by Collier (1902, pl. 12), USGS.

Lone Creek: stream, flows S $11.8 \mathrm{mi}$. to Chuitna River, $6 \mathrm{mi}$. NW of Tyonek, Cook Inlet Low.; $61^{\circ} 07^{\prime} 10^{\prime \prime} \mathrm{N}, 151^{\circ} 17^{\prime} 35^{\prime \prime} \mathrm{W}$; (map 70).

Local descriptive name reported in 1958 by USGS.

Lone Creek: stream, flows NW $1 \mathrm{mi}$. to Big Hurrah Creek $0.4 \mathrm{mi}$. E of its junc. with Solomon River, $7 \mathrm{mi}$. NE of Solomon, Seward Penin. High.; $64^{\circ} 39^{\prime} 10^{\prime \prime} \mathrm{N}, 164^{\circ} 18^{\prime} 00^{\prime \prime} \mathrm{W}$; (map 95).

Local name reported on a 1902 prospector's manuscript map.

Lone Creek: stream, flows SW $1.5 \mathrm{mi}$. to Sigard Creek which flows to head of Bonanza River, $18 \mathrm{mi}$. NW of Solomon, Seward Penin. High.; $64^{\circ} 46^{\prime} 55^{\prime \prime} \mathrm{N}, 164^{\circ} 47^{\prime} 30^{\prime \prime} \mathrm{W}$; (map 95).

Prospectors' name reported on the 1900 "Map of Nome Peninsula" by J. M. Davidson and B. D. Blakeslee.

Lone Creek: stream, flows NW $3.5 \mathrm{mi}$. to Igloo Creek which flows to American River, $29 \mathrm{mi}$. NE of Teller, Seward Penin. High.; $65^{\circ} 26^{\prime}$ $\mathrm{N}, 165^{\circ} 27^{\prime} \mathrm{W}$; (map 111). Var. Lake Creek, Victoria Creek.

Prospectors' name reported in 1901 by $\mathrm{T}$. G. Gerdine (in Collier, 1902, pl. 12), USGS. This appears to be the "Victoria Creek" reported in 1900 by Messrs. Kemp and David Fox (in Brooks, 1901, pl. 11).

Lone Creek: stream, see Bullion Creek.

Lone Hill: mountain, 2,060 ft., on Alaska Penin., SW of Wide Bay, 34 mi. SE of Ugashik, Aleutian Ra.; $57^{\circ} 16^{\prime} \mathrm{N}, 156^{\circ} 39^{\prime} \mathrm{W}$; (map 36).

Local descriptive name published in 1956 by USGS.

Lone Indian Mountain: mountain, 2,701 ft., 45 mi. NE of Medfra, Kilbuck-Kuskokwim Mts.; $63^{\circ} 44^{\prime} \mathrm{N}, 154^{\circ} 25^{\prime} \mathrm{W}$; (map 89).

Local name reported in 1954 by USGS.

Lone Island: island, $0.1 \mathrm{mi}$. across, in Glacier Bay, Glacier Bay National Monument, 2 mi. NE of Geike Rock and $53 \mathrm{mi}$. NW of Hoonah, St. Elias Mts. ; $58^{\circ} 43^{\prime} 10^{\prime \prime} \mathrm{N}, 136^{\circ} 17^{\prime} 40^{\prime \prime} \mathrm{W}$; (map 10).

Local name published by Reid (1896, p. 425), USGS

Lone Island: island, $2 \mathrm{mi}$. long, in Prince William Sound, between Naked and Perry Is., $30 \mathrm{mi}$. NE of Chenega, Chugach Mts.; $60^{\circ} 40^{\prime} 30^{\prime \prime} \mathrm{N}$, $147^{\circ} 45^{\prime} 30^{\prime \prime} \mathrm{W}$; BGN 1908; (map 63). Var. Long Island.
Local name reported in 1900 by USC\&GS. This island was occupied for many years after 1896 for the propagation of blue foxes.

Lone Jim Mountain: hill, $678 \mathrm{ft}$., S of Fourmile Creek, $53 \mathrm{mi}$. N of Ophir and $66 \mathrm{mi}$. NW of McGrath, Kilbuck-Kukokwim Mts.; 635'$30^{\prime \prime} \mathrm{N}, 156^{\circ} 08^{\prime} 30^{\prime \prime} \mathrm{W}$; BGN 1936; (map 90). Var. Lone Mountain.

Prospectors' name obtained in 1933 by J. B. Mertie, Jr. (in Smith, P. S., 1936, pl. 4), USGS.

Lonely Lake: lake, $0.7 \mathrm{mi}$. long, on Kenai Penin., $0.3 \mathrm{mi}$. SE of Leaf Lake and $31 \mathrm{mi}$. NE of Kenai, Cook Inlet Low. ; $60^{\circ} 47^{\prime} 25^{\prime \prime} \mathrm{N}, 150^{\circ}$ $32^{\prime} 30^{\prime \prime} \mathrm{W}$; (map 62).

Named about 1963 by officials of Kenai National Moose Range, for administrative purposes.

Lonely Lake: lake, $0.5 \mathrm{mi}$. long, $14 \mathrm{mi}$. $\mathrm{NE}$ of Shivering Mtn., Brooks Ra.; 67 $57^{\prime} 15^{\prime \prime} \mathrm{N}$, $153^{\circ} 11^{\prime} 00^{\prime \prime} \mathrm{W}$; BGN 1966; (map 125).

So named in 1966 by Mr. and Mrs. Gilbert F. Staender because when they set up a base camp at this lake they were completely isolated.

Lone Mountain: mountain, on Mansfield Peninsula, $1.8 \mathrm{mi}$. SE of Barlow Cove and $15 \mathrm{mi}$. W of Juneau, Alex. Arch.; 58 $18^{\prime} 20^{\prime \prime} \mathrm{N}, 134^{\circ}$ $50^{\prime} 00^{\prime \prime} \mathrm{W}$; BGN 1900; (map 11). Var. Barlow Mountain.

Descriptive name given in 1869 by Comdr. R. W. Meade, USN, and published in 1881 on Hydrog. Chart 883.

Lone Mountain: mountain, 3,000 ft., in Ahklun Mts., $4 \mathrm{mi}$. E of Gechiak Lake and $52 \mathrm{mi}$. NE of Goodnews, Kilbuck-Kuskokwim Mts.; 59 ${ }^{\circ}$ $22^{\prime} \mathrm{N}, 160^{\circ} 15^{\prime} \mathrm{W}$; (map 53$)$.

Descriptive name reported in 1954 by USGS.

Lone Mountain: ridge, 1,807 ft., extends N-S 7.5 mi. between Middle Fork Kuskokwim and Big Rivers, $39 \mathrm{mi}$. SE of McGrath, Kuskokwim Low.; 62 $30^{\prime} \mathrm{N}, 154^{\circ} 51^{\prime} \mathrm{W}$; (map 80).

Local name reported in 1931 by USGS

Lone Mountain: mountain, 3,452 ft., $\mathrm{S}$ of Hodzana River, $40 \mathrm{mi}$. NW of Beaver, KokrinesHodzana High.; $66^{\circ} 34^{\prime}$ N, $148^{\circ} 46^{\prime}$ W ; (map 118).

Local name published in 1951 by USGS.

Lone Mountain: mountain, near head of American River, about $20 \mathrm{mi}$. SE of Ear Mtn. and $35 \mathrm{mi}$. NE of Teller, Seward Penin. High.; (map 111).

Prospectors' name shown on a map of Cape Nome goldfields by David Fox, Jr., dated 1901. This feature cannot be precisely identified on current maps.

Lone Mountain: hill, see Lone Jim Mountain.

Lone Passage: water passage, $4 \mathrm{mi}$. long, in Prince William Sound, between Lone and Perry Is., $32 \mathrm{mi}$. SE of Whittier, Chugach Mts.; $60^{\circ}$ $43^{\prime} \mathrm{N}, 147^{\circ} 47^{\prime} \mathrm{W}$; (map 63).

Local name published on recent USGS maps; derived from nearby Lone Island.

Lone Peak: mountain, $1,847 \mathrm{ft}$., on SW end of of Unalaska I., Aleutian Is.; $53^{\circ} 19^{\prime} 25^{\prime \prime} \mathrm{N}$, $167^{\circ} 45^{\prime} 15^{\prime \prime} \mathrm{W}$; (map 23).
Name reported by U.S. Army Corps of Engineers in 1942 and published in the 1944 Aleutian Coast Pilot (p. 50).

Lone Point: point of land, on SW tip of Lone I., $30 \mathrm{mi}$. NE of Chenega, Chugach Mts.; $60^{\circ}$ $39^{\prime} 45^{\prime \prime} \mathrm{N}, 147^{\circ} 46^{\prime} 15^{\prime \prime} \mathrm{W}$; (map 63).

Local name published on recent USGS maps; derived from the name of the island.

Lone Ridge: mountain, 1,800 ft., $3.5 \mathrm{mi}$. long, 15 mi. NW of Tyonek, Alaska Ra.; $61^{\circ} 14^{\prime} \mathrm{N}$, $151^{\circ} 28^{\prime} \mathrm{W}$; BGN 1964; (map 70).

So named by USGS in 1962 "because the ridge stands alone on the surounding lowland several miles from the nearest uplands."

Lone Rock: rock, $1.5 \mathrm{mi}$. NE of Kigul I., off SE coast of Umnak I., Aluetian Is.; $53^{\circ} 03^{\prime} 45^{\prime \prime} \mathrm{N}$, $168^{\circ} 24^{\prime} 15^{\prime \prime} \mathrm{W}$; (map 22).

Name published by USC\&GS in 1944 Aleutian Coast Pilot (p. 71).

Lone Rock: rock, $0.2 \mathrm{mi}$. long, in Pacific Ocean, $E$ of Port Wrangell, $1 \mathrm{mi}$. NE of David I., on E coast of Alaska Penin., $40 \mathrm{mi}$. NE of Sutwik I., Aluetian Ra.; $57^{\circ} 03^{\prime} \mathrm{N}, 156^{\circ} 28^{\prime} \mathrm{W}$; (map 36). Var. Kamen Odinakoi, Kamen Odinakiy.

This is a translation of the Russian name "K[amen] Odinakiy," meaning "isolated (lone) rock," given by Ens. Vasiliev (cnna) in 1832 and published by Capt. Lutke (1836, p. 274), IRN.

Lone Rock: rock, 2 mi. S. Matushka I., in Gulf of Alaska, $40 \mathrm{mi}$. SW of Seward, Chugach Mts.; $59^{\circ} 34^{\prime} 30^{\prime \prime} \mathrm{N}, 149^{\circ} 37^{\prime} 25^{\prime \prime} \mathrm{W} ; B G N$ 1908; (map 49).

Local descriptive name reported in 1908 by USC\&GS.

Lone Rock: rock, see Polka Rock.

Lonesome Bay: cove, 2 mi. long, on $\mathrm{N}$ shore of Pile Bay, at $\mathrm{E}$ end of Iliamna Lake, Aleutian Ra.; $59^{\circ} 47^{\prime} \mathrm{N}, 153^{\circ} 59^{\prime} \mathrm{W}$; (map 51).

Local name published by USGS in 1954.

Lonesome Island: island, see Ninemile Island.

Lonesome Lake: lake, $0.3 \mathrm{mi}$. long, on Kenai Penin., $3 \mathrm{mi}$. E of Barabara Lake and $27 \mathrm{mi}$. SSW of Anchorage, Cook Inlet Low.; 60 $50^{\circ}$ $30^{\prime \prime} \mathrm{N}, 150^{\circ} 06^{\prime} 30^{\prime \prime} \mathrm{W}$; (map 62).

Named about 1963 by officials of Kenai National Moose Range for administrative purposes.

Lonesome Point: point of land, on NE shore of Iliamna Lake, between Lonesome and Pile Bays, Aleutian Ra.; $59^{\circ} 46^{\prime} 30^{\prime \prime} \mathrm{N}, 153^{\circ} 58^{\prime} 20^{\prime \prime}$ W; (map 51).

Local name derived from nearby Lonesome Bay; reported in 1954 by USGS.

Lonesome River: stream, see Magitchlie Creek.

Lone Spruce Rock: rock, $200 \mathrm{ft}$. long, between Tlevak and South Pass Sukkwan Strait, NW of Sukkwan I., Alex. Arch.: $55^{\circ} 10^{\prime} 00^{\prime \prime} \mathrm{N}$, $132^{\circ} 53^{\prime} 05^{\prime \prime}$ W; BGN 1908; (map 4). Var. Green Rock.

Descriptive name reported in 1907 by E. F. Dickins, USC\&GS. This feature was called Green Rock in 1903, "according to Swift, of the Albatross."

Lonestar Creek: stream, heads in Moose Lake, flows SSW, through Sprucefish Lake, $7 \mathrm{mi}$. to 
Highpower Creek, $31 \mathrm{mi}$. SSW of village of Lake Minchumina, Kuskokwim Low.; $63^{\circ} 29^{\prime}$ $30^{\prime \prime} \mathrm{N}, 152^{\circ} 37^{\prime} 20^{\prime \prime} \mathrm{W}$; (map 88).

Local name obtained in 1958 from Fabian Garey and "Val" Blackburn by USGS.

Lone Tree Islet: island, $300 \mathrm{ft}$. across, at $\mathrm{S}$ point of entrance to Whitewater Bay, on Admiralty I., $17 \mathrm{mi}$. S of Angoon, Alex Arch.; 57 $15^{\prime} 00^{\prime \prime}$ $\mathrm{N}, 134^{\circ} 38^{\prime} 15^{\prime \prime} \mathrm{W}$; (map 9).

Descriptive name given by $L t$. Comdr. H. E. Nichols, USN, and published in the 1891 Coast Pilot (p. 157). So named because of its single dead tree.

Lone Tree Point: point of land, westernmost tip of Mickey $\mathrm{I}$. in Yukon River, $0.3 \mathrm{mi}$. $\mathrm{S}$ of Hardluck I. and $30 \mathrm{mi}$. NE of Ruby, Nowitna

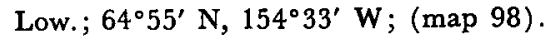

Riverboat pilots' name shown on 1940 "Navigation Chart, Tanana-Yukon Rivers" of the River Boat Service, U.S. Dept. of Interior.

Lonetree Point: point of land, on Elrington I. at SW end of Elrington Passage, $45 \mathrm{mi}$. SE of Seward, Chugach Mts. ; $59^{\circ} 59^{\prime} \mathrm{N}, 148^{\circ} 12^{\prime} \mathrm{W}$; (map 49).

Local name reported in the early 1950's by USC\&GS.

Long: settlement, pop. 28, on left bank of Long Creek, $23 \mathrm{mi}$. S of Ruby, Kilbuck-Kuskokwim Mts.; $64^{\circ} 24^{\prime} 15^{\prime \prime} \mathrm{N}, 155^{\circ} 30^{\prime} 00^{\prime \prime} \mathrm{W}$; (map 98). Var. Long City.

This mining camp developed after the discovery of gold on Long Creek in 1911. A post office was established here in 1913 and discontinued in 1932 (Ricks, 1965, p. 39).

Long, Lake: lake, $1 \mathrm{mi}$. long, NE of Spruce Lake, $7.5 \mathrm{mi}$. SE of Talkeetna, Cook Inlet Low.; $62^{\circ} 13^{\prime} 05^{\prime \prime} \mathrm{N}, 150^{\circ} 00^{\prime} 50^{\prime \prime} \mathrm{W}$; (map 81). Var. Long Lake.

Local name reported in 1958 by USGS.

Long Arm: estuary, extends NE $1.5 \mathrm{mi}$. from mouth of Moser Bay, on W coast of Revillagigedo I., Alex. Arch.; 55 $34^{\prime} 15^{\prime \prime} \mathrm{N}, 131^{\circ}$ 39'30" W; (map 3).

Local navigators' descriptive name reported in 1904 by H. C. Fassett, USBF.

Long Bay: bay, $0.5 \mathrm{mi}$. across, $3.5 \mathrm{mi}$. long, on W shore of Tenakee Inlet, on Chicagof I., $14 \mathrm{mi}$. NW of Tenakee Springs, Alex. Arch.; $57^{\circ} 52^{\prime} 30^{\prime \prime} \mathrm{N}, 135^{\circ} 35^{\prime} 00^{\prime \prime} \mathrm{W}$; BGN 1935; (map 9).

Local descriptive name; reported in 1935 by USGS.

Long Bay: estuary, on E coast of Kenai Penin., trends NE $2.5 \mathrm{mi}$. to Culross Passage, $16 \mathrm{mi}$. $\mathrm{SE}$ of Whittier, Chugach Mts.; $60^{\circ} 42^{\prime} 00^{\prime \prime} \mathrm{N}$, $148^{\circ} 15^{\prime} 10^{\prime \prime} \mathrm{W}$; (map 63).

Descriptive name reported in 1916 by J. W. Bagley, USGS.

Long Bay: estuary, extends S $6.5 \mathrm{mi}$. to Prince William Sound, $52 \mathrm{mi}$. NE of Whittier, Chugach Mts.; $60^{\circ} 55^{\prime} 30^{\prime \prime} \mathrm{N}, 147^{\circ} 13^{\prime} 00^{\prime \prime} \mathrm{W}$; (map 63).

Local name reported in 1900 by F. C. Schrader, USGS.

Long Beach: beach, $16 \mathrm{mi}$. long on $\mathrm{W}$ shore of Pavlof Bay, on Alaska Penin., Aleutian Ra.; $55^{\circ} 20^{\prime} \mathrm{N}, 161^{\circ} 47^{\prime} \mathrm{W}$; (map 28).
Published by USC\&GS in 1916 Coast Pilot (p. 183).

Long Beach: locality, on right bank of Kobuk River near Kobuk; (map 115).

This appears to have been an Eskimo camp or village near present-day Kobuk (Stuck, 1914 b, p. 88).

Long Bend: bend, of Koyukuk River, $13 \mathrm{mi}$. NE of Hughes, Hogatza High.; $66^{\circ} 14^{\prime} \mathrm{N}, 154^{\circ} 03^{\prime}$ W; (map 116).

Local name reported in 1956 by Orth as a translation of a Koyukan Indian name transcribed as "Kild-o-gidiinakh-ten."

Long Channel: water passage, trends N-S 6 mi., from Drier Bay to Knight Island Passage, on SW side of Knight I., Chugach Mts.; $60^{\circ}$ $15^{\prime} 00^{\prime} \mathrm{N}, 147^{\circ} 54^{\prime} 30^{\prime \prime} \mathrm{W}$; BGN 1908; (map $63)$.

Local name published in 1908 by USC\&GS. Long Gity: settlement, see Long.

Long Creek: stream, flows NW $3.8 \mathrm{mi}$. to Otter Creek, $8.7 \mathrm{mi}$. NE of Flat, Kilbuck-Kuskokwim Mts.; $62^{\circ} 29^{\prime} 45^{\prime \prime} \mathrm{N}, 157^{\circ} 44^{\prime} 50^{\prime \prime} \mathrm{W}$; (map 79).

Prospectors' name obtained in 1952 by USGS topographers.

Long Creek: stream, heads in Peters Hills, flows NW and SW $3.5 \mathrm{mi}$ to Gache Creek, $27 \mathrm{mi}$. NW of Talkeetna, Alaska Ra.; $62^{\circ} 30^{\prime} 50^{\prime \prime} \mathrm{N}$, $150^{\circ} 54^{\prime} 50^{\prime \prime} \mathrm{W}$; (map 81). Var. Coal Creek.

Name published by Cook (1908, map).

Long Creek: stream, between Dutch and Peters Hills, formed by junc. of Canyon and Divide Creeks, flows NE $3 \mathrm{mi}$. to Tokositna River, 27 mi. NW of Talkeetna, Alaska Ra.; 62 $37^{\prime} 25^{\prime \prime}$ $\mathrm{N}, 150^{\circ} 41^{\prime} 15^{\prime \prime} \mathrm{W}$; (map 81). Var. Dog Creek.

Prospectors' name reported in 1911 by $S$. R. Capps (in Brooks, 1912, pl. 9 and p. 196), USGS. In 1906, R. W. Porter, USGS, applied the name "Dog Creek" to the same feature.

Long Creek: siream, heads at an unnamed glacier, $63^{\circ} 12^{\prime} \mathrm{N}, 149^{\circ} 45^{\prime} \mathrm{W}$, flows SE $12 \mathrm{mi}$. to West Fork Chulitna River, $58 \mathrm{mi}$. SW of

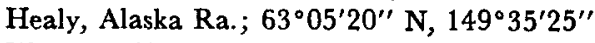
W; (map 87).

Prospectors' name obtained in 1913 by J. W. Bagley, USGS; published by S. R. Capps (in Martin, 1919, pl. 5), USGS.

Long Creek: stream, flows S $23 \mathrm{mi}$. to Sulatna River, $6.3 \mathrm{mi}$. NW of Sulatna Crossing and 33 mi. S of Ruby, Kilbuck-Kuskokwim Mts.; $64^{\circ} 15^{\prime} 36^{\prime \prime} \mathrm{N}, 155^{\circ} 35^{\prime} 30^{\prime \prime} \mathrm{W}$; (map 98).

Prospectors' name reported in 1911 by $\mathrm{A}$. G. Maddren (in Brooks and others, 1912, p. 294-296), USGS

Long Creek: stream, flows SW $6 \mathrm{mi}$. to Chatanika River, 31 mi. NE of Fairbanks, Yukon-Tanana High.; $65^{\circ} 13^{\prime} 15^{\prime \prime} \mathrm{N}, 147^{\circ} 04^{\prime} 15^{\prime \prime} \mathrm{W}$; (map 105).

Local name published by USGS in the 1950 's.

Long Creek: stream, flows SE $4 \mathrm{mi}$. to Victoria Creek, $4.4 \mathrm{mi}$. NNE of Victoria Mtn. and 80 mi. W of Circle, Yukon-Tanana High.; $65^{\circ} 51^{\prime}$ $\mathrm{N}, 146^{\circ} 52^{\prime} \mathrm{W}$; (map 104).

Prospectors' name reported in 1954 or 1955 by USGS topographers.
Long Creek: stream, flows SW $2.8 \mathrm{mi}$. to a small lake $0.8 \mathrm{mi}$. SE of Big Lake, $21 \mathrm{mi}$. W of Chandalar, Brooks Ra.; $67^{\circ} 28^{\prime} 20^{\prime \prime} \mathrm{N}, 149^{\circ} 17^{\prime} 30^{\prime \prime}$ W; (map 123).

Local name reported in 1956 by T. E. Taylor, USGS.

Long Creek: stream, flows NE to Eagle Creek which flows to Gripple River, about $30 \mathrm{mi} \mathrm{NW}$ of Imuruk Lake, Seward Penin. High.; (map 110).

Prospectors' name reported in 1901 by USGS (Collier, 1902, pl. 12). This stream cannot be identified on current maps.

Long Creek: stream, see Coal Creek.

Longfellow Glacier: glacier, see Learnard Glacier.

Long Fred Lake: lake, $0.8 \mathrm{mi}$. long, between Kalukna River and Titus Paul Hill, $22 \mathrm{mi}$.

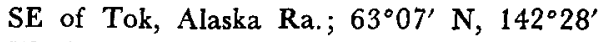
W; (map 85).

Local name reported by USGS in 1964.

Long Glacier: glacier, heads at $61^{\circ} 49^{\prime} \mathrm{N}, 144^{\circ}$ $01^{\prime} \mathrm{W}$, trends SW $9 \mathrm{mi}$. to its terminus $3 \mathrm{mi}$. NW of Hubbard Peak and $80 \mathrm{mi}$. NW of Valdez, Wrangell Mts.; $61^{\circ} 43^{\prime} 55^{\prime \prime} \mathrm{N}, 144^{\circ}$ $10^{\prime} 45^{\prime \prime} \mathrm{W}$; (map 68).

Glacier named by F. C. Schrader, USGS, in 1900 "because of its shape."

Long Island: island, $3.5 \mathrm{mi}$. long, $\mathrm{SW}$ of Sanak I., one of Sanak Is., Aleutian Ra.; 54 $24^{\prime} \mathrm{N}$, $162^{\circ} 49^{\prime} \mathrm{W}$; (map 25). Var. Clifford Island.

Name published by USC\&GS in the 1947 Alaska Coast Pilot (p. 348); called "Clifford Island" by USBF in 1890. See Clifford Island.

Long Island: island, $14 \mathrm{mi}$. long, $7 \mathrm{mi}$. wide, E of Dall I., Alex. Arch.; 54 $51^{\prime} \mathrm{N}, 132^{\circ} 41^{\prime} \mathrm{W}$; (map 1). Var. Dolgoi Island, Ostrov Dolgoy.

Translation of the name "Ostrov Dolgoy," given by the Russians; published in 1865 on Brit. Adm. Chart 2431.

Long Island: island, $1 \mathrm{mi}$. long, on $\mathrm{W}$ coast of Baranof I., $3.5 \mathrm{mi}$. S of Sitka, Alex. Arch.; $57^{\circ} 00^{\prime} \mathrm{N}, 135^{\circ} 21^{\prime} \mathrm{W}$; (map 5). Var. Dolgay Island, Dolgoi Island, Ostrov Dolgoy.

This is a translation by USC\&GS of the name given in 1809 by the navigator Ivan Vasiliev the first, IRN. Lt. Sarichev (1826, map 19), IRN, published it as "Os[trov] Dolgoy."

Long Island: island, $1 \mathrm{mi}$. long, in Southwest Is., in Pybus Bay, on Admiralty I., $25 \mathrm{mi}$. SE of Angoon, Alex. Arch.; 57 $16^{\prime} 30^{\prime \prime} \mathrm{N}, 134^{\circ}$ $03^{\prime} 30^{\prime \prime} \mathrm{W}$; (map 9).

Descriptive name given in 1869 by Comdr. R. W. Meade; published on Hydrog. Chart 225. "The island is ten times longer than wide."

Long Island: island, $0.3 \mathrm{mi}$. long, in Ugak Bay, on $\mathbf{E}$ coast of Kodiak I.; $57^{\circ} 25^{\prime} 40^{\prime \prime} \mathrm{N}, 152^{\circ}$ $34^{\prime} 10^{\prime \prime} \mathrm{W}$; (map 34).

Local descriptive name reported in 1952 by USGS.

Long Island: island, $0.4 \mathrm{mi}$. long, in Kootznahoo Inlet, $4 \mathrm{mi}$. NE of Angoon, on Admiralty I., Alex. Arch.; $57^{\circ} 32^{\prime} 10^{\prime \prime} \mathrm{N}, 134^{\circ} 30^{\prime} 00^{\prime \prime} \mathrm{W}$; (map 9). 
Descriptive name given by Comdr. R. W. Meade, USN, and published by USG\&GS in 1883 Coast Pilot (p. 177).

Long Island: island, $3.7 \mathrm{mi}$. long, between Chiniak Bay and Gulf of Alaska, 5 mi. E of Kodiak, NE of Kodiak I., $57^{\circ} 46^{\prime} \mathrm{N}, 152^{\circ} 17^{\prime}$ W; (map 34). Var. Barren Island, Dolgoi Island, Goloi Island, Ostrov Dolgoy ili Goloy.

Partial translation of the descriptive name "Os[trov] Dolgoy ili goloy," meaning "long or bare island," published by Sarichev (1826, map 16). Called "Barren Island" by Lisianski in 1804 (1814, p. 169).

Long Island: island, $0.6 \mathrm{mi}$. long, off $\mathrm{W}$ shore of Port Frederick, $1 \mathrm{mi}$. SW of Hoonah, Alex. Arch.; $58^{\circ} 05^{\prime} 50^{\prime \prime} \mathrm{N}, 135^{\circ} 28^{\prime} 00^{\prime \prime} \mathrm{W}$; (map 11).

Descriptive name given in 1880 by USN and published in 1881 on Hydrog. Chart 883.

Long Island: island, $0.6 \mathrm{mi}$. long, at mouth of Tonsina Bay, $30 \mathrm{mi}$. SE of Seldovia, Chugach Mts.; $59^{\circ} 18^{\prime} 30^{\prime \prime} \mathrm{N}, 150^{\circ} 54^{\prime} 00^{\prime \prime} \mathrm{W}$; (map 50).

Local name reported by USC\&GS in 1938 .

Long Island: island, $8 \mathrm{mi}$. long, in Copper River, $23 \mathrm{mi}$. NW of Katalla, Malaspina Coastal Plain; $60^{\circ} 28^{\prime} \mathrm{N}, 144^{\circ} 58^{\prime} \mathrm{W}$; (map 64).

Local descriptive name reported in 1912 by Grant and Higgins (1913, pl. 1), USGS.

Long Island: island, $3.1 \mathrm{mi}$. long, W of Tanana I. in Yukon River, $1 \mathrm{mi}$. S of Tanana, Nowitna Low.; $65^{\circ} 10^{\prime} \mathrm{N}, 152^{\circ} 06^{\prime} \mathrm{W}$; (map 106). Var. Bull Island.

Local name reported in 1952 by USGS

Long Island: barrier island, $5.5 \mathrm{mi}$. long, on Beaufort Sea coast, in Return Is., $2.5 \mathrm{mi}$. E of Beechey Point, Arctic Plain; $70^{\circ} 28^{\prime} 55^{\prime \prime} \mathrm{N}$, $148^{\circ} 55^{\prime} 30^{\prime \prime} \mathrm{W}$; (map 150).

Named by Leffingwell (1919, p. 97) in 1911, "After Capt. Long of the whaling fleet." Long Island: island, see Bull Island.

Long Island. island, see Clifford Island.

Long Island: island, see Dolgoi Island.

Long Island: island, see Kasaan Island.

Long Island: island, see Lone Island.

Long Island: island, see Squire Island.

Long Island: spit, see Carter Spit.

Long Island Channel: stream, anabranch of Copper River, on W side of Long I., $25 \mathrm{mi}$. NW of Katalla, Malaspina Coastal Plain; $60^{\circ} 26^{\prime} \mathrm{N}, 145^{\circ} 03^{\prime} \mathrm{W}$; (map 64).

Local descriptive name published in 1952 by USGS.

Long John: locality, on Long John Lagoon, $7 \mathrm{mi}$. NW of Dolgoi I., near SW end of Alaska Penin., Aleutian Ra.; $55^{\circ} 15^{\prime} 15^{\prime \prime} \mathrm{N}, 161^{\circ} 53^{\prime}$ $50^{\prime \prime} \mathrm{W}$; (map 28).

Reported in 1929 by USGS.

Long John Lagoon: lagoon, $2.5 \mathrm{mi}$. long, on $\mathrm{W}$ shore of Pavlof Bay, $6 \mathrm{mi}$. NW of Dolgoi I., near SW end of Alaska Penin., Aleutian Ra.; $55^{\circ} 14^{\prime} 30^{\prime \prime} \mathrm{N}, 161^{\circ} 53^{\prime} 30^{\prime \prime} \mathrm{W}$; BGN 1939; (map 28). Var. East Bay, East Bay Lagoon, Long Johns Lagoon.

W. H. Dall, USC\&GS, reported the name as "East Bay" in 1880; it was published in 1911 by USC\&GS as "Long Johns Lagoon."
A 1929 USGS map shows "Long John Lagoon."

Long Johns Lagoon: lagoon, see Long John Lagoon.

Long Lake: lake, $2.2 \mathrm{mi}$. long, on NW coast of Revillagigedo I., 3 mi. of Curlew Point, Alex. Arch.; 55 $55^{\prime}$ N, $131^{\circ} 28^{\prime} \mathrm{W}$; (map 3).

Local name repored in 1952 by USGS.

Long Lake: lake, $0.8 \mathrm{mi}$. long, on Baranof $\mathrm{I}$., among Wakefield Lakes, $26 \mathrm{mi}$. SE of Sitka, Alex. Arch.; $56^{\circ} 52^{\prime} 30^{\prime \prime} \mathrm{N}, 134^{\circ} 44^{\prime} 00^{\prime \prime} \mathrm{W}$; (map 5).

Local descriptive name obtained in 1951 by USGS.

Long Lake: lake, $0.5 \mathrm{mi}$. across, on $\mathrm{N}$ coast of Woody I., 2 mi. E of Kodiak, NE of Kodiak I. ; $57^{\circ} 47^{\prime} 10^{\prime \prime} \mathrm{N}, 152^{\circ} 20^{\prime} 00^{\prime} \mathrm{W}$; (map 34).

Local descriptive name published in 1965 by USC\&GS.

Long Lake: lake, $4 \mathrm{mi}$. long on Long River, 27 mi. SE of Juneau, Coast Mts.; $58^{\circ} 10^{\prime} 00^{\prime \prime} \mathrm{N}$, $133^{\circ} 43^{\prime} 00^{\prime \prime} \mathrm{W}$; (map 12).

Name derived from Long River; published in 1951 on a USGS map.

Long Lake: lake, $2 \mathrm{mi}$. long, $\mathrm{E}$ of Iliamna Lake, $1.7 \mathrm{mi}$. NE of Pile Bay, Aleutian Ra.; 59 $49^{\prime}$ $30^{\prime \prime} \mathrm{N}, 153^{\circ} 50^{\prime} 30^{\prime \prime} \mathrm{W}$; (map 51).

Local name published by USGS in 1954 .

Long Lake: lake, $4.5 \mathrm{mi}$. long, $12 \mathrm{mi}$. W of Lake Glark and $12 \mathrm{mi}$. NW of Nondalton, Alaska Ra.; $60^{\circ} 08^{\prime} 30^{\prime \prime} \mathrm{N}, 155^{\circ} 03^{\prime} 30^{\prime \prime} \mathrm{W}$; (map 61). Var. Portage Lake.

Named by R. H. Sargent and P. S. Smith, USGS, in 1914. The name "Portage Lake" was reported in 1914 by Thomas Hanmore, U.S. Commissioner at Iliamna.

Long Lake: lake, $0.9 \mathrm{mi}$. long, on Kenai Penin., $1.3 \mathrm{mi}$. W of Swan Lake, and $25 \mathrm{mi}$. NE of Kenai, Cook Inlet Low.; $60^{\circ} 40^{\prime} 30^{\prime \prime} \mathrm{N}, 150^{\circ}$ $35^{\prime} 20^{\prime \prime} \mathrm{W}$; (map 62).

Named about 1963 by officials of Kenai National Moose Range, for administrative purposes.

Long Lake: lake, $3 \mathrm{mi}$. long, $2.5 \mathrm{mi}$. NW of junc. of Nizina and Ghitina Rivers and 18 mi. SW of McCarthy, Cooper River Basin; $61^{\circ} 23^{\prime} \mathrm{N}, 143^{\circ} 16^{\prime} \mathrm{W}$; (map 67).

Local name published on manuscript map, 1909 , by the Copper River and Northwestern Railway, Chitina Branch Line.

Long Lake: lake, $0.9 \mathrm{mi}$. long, in Matanuska Valley, $3.5 \mathrm{mi}$. SW of Palmer, Cook Inlet Low.; $61^{\circ} 33^{\prime} 45^{\prime \prime} \mathrm{N}, 149^{\circ} 12^{\prime} 05^{\prime \prime} \mathrm{W}$; (map 69).

Local name reported in 1942 by AMS.

Long Lake: lake, $1.8 \mathrm{mi}$. long, $1.7 \mathrm{mi}$. SW of Willow and $35 \mathrm{mi}$. $\mathrm{N}$ of Anchorage, Cook Inlet Low.; $61^{\circ} 43^{\prime} 30^{\prime \prime} \mathrm{N}, 150^{\circ} 05^{\prime} 15^{\prime \prime} \mathrm{W}$; BGN 1961; (map 70). Var. Big Lake.

Local descriptive name reported in 1958 by USGS.

Long Lake: lake, $1.2 \mathrm{mi}$. long, on Glenn Highway, $32 \mathrm{mi}$. NE of 'Palmer, Talkeetna Mts.; $61^{\circ} 48^{\prime} 25^{\prime \prime} \mathrm{N}, 148^{\circ} 12^{\prime} 30^{\prime \prime} \mathrm{W}$; (map 69).

Local name reported in 1948 by USGS.

Long Lake: lake, $1.5 \mathrm{mi}$. long, drains NE to Tolsona Creek, $22 \mathrm{mi}$. NW of Glennallen, Copper River Basin ; $62^{\circ} 12^{\prime} \mathrm{N}, 146^{\circ} 10^{\prime} \mathrm{W}$; (map 83).
Local descriptive name reported by USGS in 1949.

Long Lake: lake, $0.7 \mathrm{mi}$. long, in course of Sawmill Creek, $7 \mathrm{mi}$. SW of Talkeetna, Cook Inlet Low.; $62^{\circ} 16^{\prime} 00^{\prime \prime} \mathrm{N}, 150^{\circ} 18^{\prime} 45^{\prime \prime} \mathrm{W}$; (map 81).

Local descriptive name reported in 1958 by USGS.

Long Lake: lake, $0.5 \mathrm{mi}$. long, $0.3 \mathrm{mi}$. NW of Jack Lake and $18 \mathrm{mi}$. NW of Nebesna, Wrangell Mts. ; $62^{\circ} 33^{\prime} 30^{\prime \prime} \mathrm{N}, 143^{\circ} 24^{\prime} 00^{\prime \prime} \mathrm{W}$; (map 84). Var. Lily Pad Lake.

Local descriptive name reported by USGS in 1960.

Long Lake: lake, $1.3 \mathrm{mi}$. long, $\mathrm{W}$ of Fish Lake, $1.5 \mathrm{mi}$. SE of Northway, Alaska Ra.; 62 $57^{\circ}$ $\mathrm{N}, 141^{\circ} 52^{\prime} \mathrm{W}$; (map 84).

Local descriptive name reported by USGS in 1955.

Long Lake: lake, $1.3 \mathrm{mi}$. long, between Alaska Highway and Tanana River, $\mathrm{S}$ of Midway Lake, $23 \mathrm{mi}$. SE of Tok, Yukon-Tanana High.; $63^{\circ} 12^{\prime} \mathrm{N}, 142^{\circ} 16^{\prime} \mathrm{W}$; (map 85).

Local descriptive name reported by USGS in 1964.

Long Lake: lake, $0.9 \mathrm{mi}$. long, $1 \mathrm{mi}$. SE of Sprucefish Lake, $26 \mathrm{mi}$. SSW of village of Lake Minchumina, Kuskokwim Low.; $63^{\circ} 32^{\prime} 45^{\prime \prime} \mathrm{N}$, $152^{\circ} 38^{\prime} 30^{\prime \prime} \mathrm{W}$; (map 88).

Local name obtained in 1958 from Fabian Carey and "Val" Blackburn by USGS.

Long Lake: lake, 2 mi. long, drains $\mathrm{W}$ to Patterson Creek, E of Harper Bend, $21 \mathrm{mi}$. SE of Tanana, Nowitna Low.; $65^{\circ} 00^{\prime} 30^{\prime \prime} \mathrm{N}, 151^{\circ}$ $27^{\prime} 00^{\prime \prime} \mathrm{W}$; (map 106).

Local name reported in 1952 by USGS.

Long Lake: lake, $3 \mathrm{mi}$. long, drains $\mathrm{W}$ to Hay Slough, $13 \mathrm{mi}$. ESE of Tanana, Nowitna Low.; $65^{\circ} 08^{\prime} \mathrm{N}, 151^{\circ} 36^{\prime} \mathrm{W}$; (map 106).

Local name reported in 1952 by USGS.

Long Lake: lake, $3 \mathrm{mi}$. SE of Fish Lake and 7 mi. E of Roundabout Mtn., Koyukuk Low.; $65^{\circ} 32^{\prime} \mathrm{N}, 156^{\circ} 18^{\prime} \mathrm{W}$; (map 108).

Local name obtained at Huslia by USGS in 1954 or 1955.

Long Lake: lake, $2 \mathrm{mi}$. NE of Huslia, $14 \mathrm{mi}$. NE of Roundabout Mtn., Koyukuk Low.; $65^{\circ} 43^{\prime}$ N, $156^{\circ} 19^{\prime} \mathrm{W}$; (map 108).

Descriptive local name obtained in 1956 at Huslia by Orth.

Long Lake: lake, $3 \mathrm{mi}$. long, $38 \mathrm{mi}$. NW of Midnight Hill, Porcupine Plat. ; $66^{\circ} 12^{\prime}$ N, $142^{\circ} 24^{\prime}$ W; (map 120).

Local descriptive name; reported in 1956 by R. C. Foley, USGS

Long Lake: lake, oxbow $1.4 \mathrm{mi}$. long, $0.3 \mathrm{mi}$. $\mathrm{N}$ of Beaver Creek and $17 \mathrm{mi}$. SE of Beaver, Yukon Flats; $66^{\circ} 14^{\prime} \mathrm{N}, 146^{\circ} 51^{\prime} \mathrm{W}$; (map 119).

Local descriptive name obtained in 1956 by USGS.

Long Lake: lake, $3.5 \mathrm{mi}$. long, $1 \mathrm{mi}$. NW of Devils Lake and $21 \mathrm{mi}$. SW of Beaver, Yukon Flats; $66^{\circ} 17^{\prime} \mathrm{N}, 148^{\circ} 10^{\prime} \mathrm{W}$; (map 118 ).

Local descriptive name obtained in 1956 by USGS. 
Long Lake: lake, $2 \mathrm{mi}$. long, $2 \mathrm{mi}$. W of Nelson Lake and $13 \mathrm{mi}$. NW of Beaver, Yukon Flats; $66^{\circ} 30^{\prime} \mathrm{N}, 147^{\circ} 46^{\prime} \mathrm{W}$; (map 118).

Probably named by William Yanert, who recorded it on a 1916 manuscript map of the Yukon Flats (Stuck, 1917, map facing p. 122).

Long Lake: lake, extends $\mathrm{N}-\mathrm{S} 1 \mathrm{mi}$., $4 \mathrm{mi}$. SE of Selawik, Kotzebue-Kobuk Low.; 66 $34^{\prime}$ N, $159^{\circ} 57^{\prime} \mathrm{W}$; (map 114).

Local name reported by the U.S. Army Corps of Engineers in 1955.

Long Lake: lake, see Mundthag Lake.

Long Lake: lake, see Takslesluk Lake.

Long Lake Hills: ridge, 2,500 ft., extends E-W $6 \mathrm{mi}$. between Happy and Skwentna Rivers, $78 \mathrm{mi}$. NW of Tyonek, Alaska Ra.; $62^{\circ} 00^{\prime} \mathrm{N}$, $152^{\circ} 31^{\prime} \mathrm{W}$; (map 70).

Local name reported in 1958 by USGS.

Long Lakes: lakes, $3 \mathrm{mi}$. W of Beaver Lake and Creeks, $16 \mathrm{mi}$. SE of Beaver, Yukon Flats; $66^{\circ} 11^{\prime} 20^{\prime \prime} \mathrm{N}, 146^{\circ} 57^{\prime} 00^{\prime \prime} \mathrm{W}$; (map 119).

Local descriptive name obtained in 1956 by USGS.

Longmare Lake: lake, $1.4 \mathrm{mi}$. long, on Kenai Penin., S of Sterling Highway, $13 \mathrm{mi}$. E of Kenai, Cook Inlet Low.; $60^{\circ} 30^{\prime} \mathrm{N}, 150^{\circ} 55^{\prime}$ W; BGN 1954; (map 62). Var. DeLong Lake.

Local name reported in 1954 by USGS.

Long Mountain: mountain, on penin. between Unalaska and Kalekta Bays, on $\mathbf{N}$ coast of Unalaska I., Aleutian Is., near $53^{\circ} 59^{\prime} \mathrm{N}$, $166^{\circ} 23^{\prime} \mathrm{W}$; (map 23).

Descriptive name used by the Harriman Alaska Expedition in 1899 (p. 91). The name was published by Baker (1906, p. 412), but is not shown on modern maps.

Long Mountains: mountains, $1,000 \mathrm{ft}$., on right bank of Yukon River, between Carlo and Turtle Is., $17 \mathrm{mi}$. NW of Holy Cross, Nulato Hill; $62^{\circ} 25^{\prime} \mathrm{N}, 160^{\circ} 10^{\prime} \mathrm{W}$; (map 78).

Local name reported in 1916 by G. L. Harrington and R. H. Sargent (in Harrington, 1918, pl. 1), USGS.

Long Point: point of land, on SE shore of Karluk Lake, $24 \mathrm{mi}$. SE of Karluk, Kodiak Is. ; $57^{\circ}$ $18^{\prime} 20^{\prime \prime} \mathrm{N}, 154^{\circ} 01^{\prime} 00^{\prime \prime} \mathrm{W}$; (map 35).

Local descriptive name reported in 1952 by USGS.

Long Point: point of land, at E entrance to Long Bay, $54 \mathrm{mi}$. NE of Whittier, Chugach Mts.; $60^{\circ} 55^{\prime} 55^{\prime \prime} \mathrm{N}, 147^{\circ} 10^{\prime} 45^{\prime \prime} \mathrm{W}$; (map 63).

Local name published on recent USGS maps; derived from nearby Long Bay.

Long Point: point of land, $4 \mathrm{mi}$. long, formed by a bend of Yukon River, $10 \mathrm{mi}$. NE of Stevens Village, Yukon Flats; $66^{\circ} 03^{\prime} \mathrm{N}, 148^{\circ} 45^{\prime} \mathrm{W}$; (map 118).

Local descriptive name obtained in 1956 by USGS.

Long Point 'SD': point of land, on SW coast of Kanaga I., Aleutian Is.; $51^{\circ} 41^{\prime} 42^{\prime \prime}$ N, $177^{\circ}$ $34^{\prime} 12^{\prime \prime} \mathrm{W}$; (map 17).

Name published in 1943 on an AMS map.

Long Pond: estuary, flows NW $5 \mathrm{mi}$. to Wrangell Narrows at Petersburg, on NW coast of Mitkof I., $34 \mathrm{mi}$. NW of Wrangell, Alex. Arch.; $56^{\circ} 48^{\prime} 30^{\prime \prime} \mathrm{N}, 132^{\circ} 57^{\prime} 30^{\prime \prime} \mathrm{W}$; (map 6).
Local name published in 1943 by USC\&GS. Long Portage Creek: stream, see Beaver Creek. Long Portage Creek: stream, see Goblet Creek. Long Ridge: ridge, elev. 2,200 ft., extends NE 17 mi. from Dall River, $32 \mathrm{mi} \mathrm{NW}$ of Stevens Village, Kokrines-Hodzana High.; $66^{\circ} 27^{\prime} \mathrm{N}$, $149^{\circ} 24^{\prime} \mathrm{W}$; (map 118).

Local descriptive name obtained in 1956 by USGS.

Long River: stream, flows E $12 \mathrm{mi}$. to Speel River, $30 \mathrm{mi}$. SE of Juneau, Coast Mts.; $58^{\circ} 11^{\prime} 45^{\prime \prime}$ $\mathrm{N}, 133^{\circ} 37^{\prime} 30^{\prime \prime} \mathrm{W}$; (map 12). Var. Indian Creek.

Descriptive name reported in 1916 by $G$. H. Canfield (in Brooks and others, 1918, p. 136), USGS. In 1921 this stream was shown as Indian Creek by the U.S. Federal Power Commission.

Long Sands: shoal, $4.5 \mathrm{mi}$. long, in Nushagak Bay, between Middle and Ship Channels, 19 mi. S of Dillingham, Bristol Bay Low.; 58 ${ }^{\circ}$ $44^{\prime} \mathrm{N}, 158^{\circ} 32^{\prime} \mathrm{W}$; (map 40).

Local name reported in 1950 by USCi\&GS.

Long Slough: lake, $2 \mathrm{mi}$. long, between Beaver Lake and Jefferson Creek, $18 \mathrm{mi}$. SE of Beaver, Yukon Flats; $66^{\circ} 11^{\prime} 50^{\prime \prime} \mathrm{N}, 146^{\circ} 54^{\prime} 00^{\prime \prime} \mathrm{W}$; (map 119).

Local descriptive name obtained in 1956 by USGS.

Long Slough: stream, anabranch of Koyukuk River, $6 \mathrm{mi}$. long $E$ of Long Bend, $13 \mathrm{mi}$. NE of Hughes, Hogatzu High.; 66 $6^{\circ} 14^{\prime}$ N, 154 $4^{\circ} 02^{\prime}$ W; (map 116).

Local name reported by Orth in 1956.

Long Stretch: reach, of Koyukuk River, extends N-S $12.4 \mathrm{mi}$., $43 \mathrm{mi}$. SW of Roundabout Mtn., Koyukuk Low.; $65^{\circ} 08^{\prime}$ N, $157^{\circ} 39^{\prime}$ W ; (map 108).

Descriptive name obtained in 1955 at Koyukuk by USGS.

Long Tangle Lake: lake, $4.5 \mathrm{mi}$. long, one of Tangle Lakes, near head of Delta River, 15 mi. W of Paxson, Alaska Ra.; $63^{\circ} 06^{\prime} 10^{\prime \prime} \mathrm{N}$, $145^{\circ} 57^{\prime} 40^{\prime \prime} \mathrm{W}$; (map 86).

Name published on relatively recent maps.

Lonieof Lake: lake, $2 \mathrm{mi}$. long, on Baranof I., $20 \mathrm{mi}$. NW of Port Alexander, Alex. Arch.; $56^{\circ} 30^{\prime} \mathrm{N}, 134^{\circ} 55^{\prime} \mathrm{W}$; (map 5).

Local name recorded in 1951 by USGS.

Lontana Point: point of land, S tip of Suemez I., Alex Arch.; 55 $12^{\prime} 15^{\prime \prime} \mathrm{N}, 133^{\circ} 20^{\prime} 10^{\prime \prime} \mathrm{W}$; $B G N$ 1923; (map 4).

Spanish word (from "lontanaza"), meaning "distant" or "background," given in 1923 by USC\&GS.

Look Lake: lake, $0.1 \mathrm{mi}$. across, center of Kiska I., Aleutian Is.; $51^{\circ} 57^{\prime} 40^{\prime \prime}$ N, $177^{\circ} 26^{\prime}$ $10^{\prime \prime} \mathrm{E}$; (map 14).

An arbitrary name beginning with " $L$ " to correspond to "L" grid used by the U.S. Army for tactical purposes during World War II; published on a 1943 Army map.

Lookoovik Cape: point of land, see Vngyat.

Lookout, Cape: point of land, off S point of entrance to Sea Otter Harbor, on $W$ coast of Dall I., Alex. Arch.; 55 $06^{\prime} \mathrm{N}, 133^{\circ} 14^{\prime} \mathrm{W}$; (map 4).

Name published in 1912 by USG\&GS.
Lookout, Point: point of land, on W shore of Security Bay, on N coast of Kuiu I., Alex. Arch.; $56^{\circ} 50^{\prime} 00^{\prime \prime} \mathrm{N}, 134^{\circ} 20^{\prime} 10^{\prime \prime} \mathrm{W}$; (map 5).

Named in 1869 by Comdr. R. W. Meade, USN.

Lookout, Point: point of land, on $\mathrm{E}$ shore of Stephens Passage, $0.8 \mathrm{mi}$. N of Dry Bay and $52 \mathrm{mi}$. SE of Juneau, Coast Mts.; $57^{\circ} 39^{\prime} 00^{\prime \prime}$ N, $133^{\circ} 40^{\prime} 30^{\prime \prime} \mathrm{W}$; (map 8).

Named in 1868 by Comdr. R. W. Meade, USN; name published in 1869 on Hydrog. Chart 225. Probably so named because "a very dangerous reef awash at high water, extends off this point a mile and a half" (U.S. Coast and Geodetic Survey, 1891, p. 168).

Lookout Cove: cove, $2 \mathrm{mi}$. across, on SE coast of Umnak I., Aleutian Is.; $53^{\circ} 00^{\prime} 25^{\prime \prime} \mathrm{N}$, $168^{\circ} 36^{\prime} 45^{\prime \prime} \mathrm{W}$; (map 22).

Name derived from Lookout Point; published in 1951 on a USGS map.

Lookout Glacier: glacier, heads $1.5 \mathrm{mi}$. W of Mount Klooch, trends $1.5 \mathrm{mi}$. SW to its 1961 terminus, $1.2 \mathrm{mi}$. E of 1961 terminus of South Grillon Glacier and $77 \mathrm{mi}$. NW of Hoonah, St. Elias Mts. ; $58^{\circ} 36^{\prime} \mathrm{N}, 137^{\circ} 21^{\prime} \mathrm{W}$; (map 10).

Name published by members of the Harvard-Dartmouth Expedition, 1933-34 (Washburn and Goldthwait, 1936, map).

Lookout Hill: mountain, 1,500 ft., on SE side of Attu I., Aleutian Is.; $52^{\circ} 49^{\prime} 37^{\prime \prime} \mathrm{N}, 173^{\circ}$ $07^{\prime} 30^{\prime \prime} \mathrm{E}$; (map 13).

Named by the U.S. Army during its occupation of the island during World War II; shown on an AMS map published in 1948.

Lookout Hill: hill, $700 \mathrm{ft}$. elev., $1 \mathrm{mi}$. NE of Bales Landing, on N shore of Stepovak Bay, Aleutian Ra.; $55^{\circ} 52^{\prime} \mathrm{N}, 159^{\circ} 47^{\prime} \mathrm{W}$; (map 27).

Local name published by USC\&GS in 1916 Alaska Coast Pilot (v. 2, p. 164).

Lookout Hill: mountain, 2,440 ft., NW of Rainy Pass Lodge, $86 \mathrm{mi}$. SW of Talkeetna, Alaska Ra.; $62^{\circ} 06^{\prime} 00^{\prime \prime} \mathrm{N}, 152^{\circ} 44^{\prime} 45^{\prime \prime} \mathrm{W}$; (map 81). Local name reported in 1958 by USGS.

Lookout Mountain: hill, $413 \mathrm{ft}$., $7 \mathrm{mi}$. E of Mumtrak Hill and $10 \mathrm{mi}$. NE of Goodnews, Kilbuck-Kuskokwim Mts.; $59^{\circ} 09^{\prime} 15^{\prime \prime} \mathrm{N}$, $161^{\circ} 20^{\prime} 00^{\prime \prime}$ W; (map 53). Var. Kiayankayagak.

Name published in 1951 by USGS. The Eskimo name, reported to be "Kiayankayagak," was obtained about 1951 at Goodnews by J. M. Hoare, USGS.

Lookout Mountain: hill, $528 \mathrm{ft}$., $3 \mathrm{mi}$. N Reindeer I., and $21 \mathrm{mi}$. SE of Iliamna, Aleutian Ra.; $59^{\circ} 30^{\prime} \mathrm{N}, 154^{\circ} 37^{\prime} \mathrm{W}$; (map 51 ).

Name published by USGS (in Martin and Katz, 1912, pl. 1).

Lookout Mountain: mountain, 1,622 ft., on Kenai Penin., $3 \mathrm{mi}$. NW of Kachemak Bay and $6 \mathrm{mi}$. NE of Homer, Cook Inlet Low.; $59^{\circ} 42^{\prime} 30^{\prime \prime} \mathrm{N}, 151^{\circ} 27^{\prime} 00^{\prime \prime} \mathrm{W}$; (map 50).

Local name reported and published by USGS in the 1950's.

Lookout Mountain: mountain, 2,146 ft., $23 \mathrm{mi}$. $\mathrm{S}$ of Flat and $40 \mathrm{mi}$. NW of Sleetmute, Kil- 
buck-Kuskokwim Mts.; $62^{\circ} 07^{\prime} 30^{\prime \prime} \mathrm{N}, 157^{\circ}$ $59^{\prime} 30^{\prime \prime} \mathrm{W}$; (map 79).

Local name published in 1921 on a USGS map.

Lookout Mountain: mountain, 2,965 ft., $16 \mathrm{mi}$. NW of Honolulu Pass, $50 \mathrm{mi}$. SW of Healy, Alaska Ra.; $63^{\circ} 13^{\prime} 30^{\prime \prime} \mathrm{N}, 149^{\circ} 34^{\prime} 20^{\prime \prime} \mathrm{W}$; (map 87).

Local name obtained in 1951 by USGS.

Lookout Mountain: mountain, 2,118 ft., at E end of Alatna Hills, $3.5 \mathrm{mi}$. SW of Bettles, Brooks Ra.; $66^{\circ} 53^{\prime} \mathrm{N}, 151^{\circ} 48^{\prime} \mathrm{W}$; (map 117).

Named by Lt. Allen (1887, p. 101), USA, who climbed this mountain in 1885.

Lookout Peak : hill, see Dexter Peak.

Lookout Point: point of land, on SE coast of Umnak I., Aleutian Is.; $53^{\circ} 00^{\prime} 15^{\prime \prime} \mathrm{N}, 168^{\circ}$. $36^{\prime} 50^{\prime \prime} \mathrm{W}$; (map 22).

Name published by USG\&GS in 1944 Aleutian Coast Pilot (p. 70).

Lookout Point: point of land, on SE Caton I., Sanak Is., Aleutian Ra.; 54 $23^{\prime} \mathrm{N}, 163^{\circ} 27^{\prime}$ W; (map 25).

Name reported in 1900 by USC\&GS.

Lookout Point: point of land, see Watch Point.

Lookout Ridge: ridge, extends $60 \mathrm{mi}$. E from Disappointment Creek, between Colville and Awuna River, $115 \mathrm{mi}$. SE of Wainwright, Arctic Slope; $69^{\circ} 07^{\prime} \mathrm{N}, 158^{\circ} 36^{\prime} \mathrm{W} ; B G N$ 1926; (map 143).

Name proposed by Gerald FitzGerald, USGS, in 1925, in reference to the numerous Eskimo lookout stations and frames of old camps seen there. This ridge is a convenient observation area for the Eskimo in hunting caribou.

Lookout River: stream, heads in lake, flows E 60 mi. to Awuna River, $140 \mathrm{mi}$. SE of Wainwright, Arctic Slope; 69 $03^{\prime} \mathrm{N}, 156^{\circ} 34^{\prime} \mathrm{W}$; $B G N$ 1926; (map 143). Var. Kolaktok.

So named in 1925 by Gerald FitzGerald, USGS, after Lookout Ridge. The Eskimo name for this stream is "Kolaktok."

Lookta-ek: locality, see Alaganik.

Loomis Glacier: glacier, in Glacier Bay National Monument, $2.2 \mathrm{mi}$. long, heads NE of Emerson Peaks, flows $\mathrm{N}$ to Plateau Glacier, $68 \mathrm{mi}$. NW of Hoonah, St. Elias Mts.; 58 $56^{\prime} 30^{\prime \prime}$ $\mathrm{N}, 136^{\circ} 25^{\prime} 30^{\prime \prime} \mathrm{W}$; (map 10).

Named by members of the American Geographical Society's Glacier Bay Expedition of 1941 (Field, 1947, map) for Henry B. Loomis, a companion of John Muir on his trip to the Muir Glacier in 1890.

Loon Creek: stream, flowing $\mathrm{S} 2.3 \mathrm{mi}$. to Vega Bay, Kiska I., Aleutian Is., $51^{\circ} 55^{\prime} 58^{\prime \prime}$ N, $177^{\circ}$ $24^{\prime} 20^{\prime \prime}$ E; (map 14).

An arbitrary name beginning wtih " $L$ " to correspond to "L" grid used by the U.S. Army for tactical purposes during World War II; published on a 1953 AMS map.

Loon Creek: stream, flows S $9.5 \mathrm{mi}$. through Loon Lake to Agiak Creek, $9 \mathrm{mi} . \mathrm{N}$ of Sillyasheen Mtn. and $76 \mathrm{mi}$. NW of Wiseman, Brooks Ra.; 67 $53^{\prime} 30^{\prime \prime} \mathrm{N}, 152^{\circ} 40^{\prime} 30^{\prime \prime} \mathrm{W}$; $B G N 1932$; (map 124).
Named in 1931 by Marshall (1956, p. 102) who wrote, " ** * we called it 'Loon Creek' after some loons we observed * * *."

Loon Island: island, see Gagarin Island.

Loon Lake: lake, $800 \mathrm{ft}$. long, on Revillagigedo I., $\mathrm{N}$ of Throne Arm, between Ella and Mirror Lakes, Alex. Arch.; 55 $29^{\prime} 50^{\prime \prime} \mathrm{N}, 131^{\circ} 09^{\prime} 00^{\prime \prime}$ W; (map 3).

Local name reported in 1955 by USGS.

Loon Lake: lake, $0.8 \mathrm{mi}$. long, at head of Kasaan Penin., on E coast of Prince of Wales I., Alex. Arch.; $55^{\circ} 37^{\prime} 40^{\prime \prime} \mathrm{N}, 132^{\circ} 20^{\prime} 00^{\prime \prime} \mathrm{W}$; $B G N$ 1960; (map 4).

So named by C. L. Sainsbury, USGS, in 1956 "because of the large number of loons observed on it at various times."

Loon Lake: lake, $1.8 \mathrm{mi}$. long, on Kenai Penin., $0.5 \mathrm{mi}$. SW of Swan Lake and $24 \mathrm{mi}$. NE of Kenai, Gook Inlet Low.; $60^{\circ} 39^{\prime} 15^{\prime \prime} \mathrm{N}, 150^{\circ}$ $35^{\prime} 45^{\prime \prime} \mathrm{W}$; (map 62).

Named about 1963 by officials of Kenai National Moose Range, probably for the BlackThroated Loon or Arctic Diver, (Gavia arctica), which breeds in the tundra near Kotzebue Sound. (Pearson, 1944, pt. 1, p. 14).

Loon Lake: lake, $1.2 \mathrm{mi}$. long, $2 \mathrm{mi}$. NNE of Old Man Lake and $35 \mathrm{mi}$. WNW of Glennallen, Cooper River Basin; 62 $2^{\circ} 11^{\prime} 30^{\prime \prime} \mathrm{N}$, $146^{\circ} 36^{\prime} 00^{\prime \prime} \mathrm{W}$; (map 83).

Local name reported in 1949 by USGS.

Loon Lake: lake, $1 \mathrm{mi}$. long, $13 \mathrm{mi}$. $\mathbf{N}$ of Chalkyitsik, Yukon Flats; $66^{\circ} 50^{\prime} \mathrm{N}, 143^{\circ} 45^{\prime} \mathrm{W}$; (map 120).

Local name obtained in 1956 by T. E. Taylor and R. C. Foley, USGS.

Loon Lake: lake, $1.5 \mathrm{mi}$. long, in course of Loon Creek, $13 \mathrm{mi}$. N of Sillyasheen $\mathrm{Mtn}$. and 76 mi. NW of Wiseman, Brooks Ra.; 67 $57^{\prime} 30^{\prime \prime}$ $\mathrm{N}, 152^{\circ} 37^{\prime} 00^{\prime \prime} \mathrm{W}$; (map 124).

Named about 1930 by Marshall (1956, p. 103) for the stream that flows through it; "we suddenly came upon a gorgeous lake * * fresh as at creation."

Loon Lake: lake, $1 \mathrm{mi}$. long, $0.5 \mathrm{mi}$. S of Arctic Village, Brooks Ra.; $68^{\circ} 07^{\prime} \mathrm{N}, 145^{\circ} 33^{\prime} \mathrm{W}$; (map 136).

Local name reported in 1956 by $R$. C. Foley, USGS.

Loon Lakes: lakes, $\mathrm{N}$ of Beaver Creek, $19 \mathrm{mi}$. SE of Beaver, Yukon Flats; $66^{\circ} 14^{\prime} \mathrm{N}, 146^{\circ} 49^{\prime}$ W; (map 119).

Local name obtained in 1956 by USGS.

Loon Point: point of land, at mouth of Eliza Harbor, on Admiralty I., $25 \mathrm{mi}$. SE of Angoon, Alex. Arch.; $57^{\circ} 10^{\prime} 35^{\prime \prime} \mathrm{N}, 134^{\circ} 16^{\prime} 55^{\prime \prime} \mathrm{W}$; (map 9).

Named in 1889 by Lt. Comdr. H. B. Mansfield, USN; published by USC\&GS on Chart 8216.

Loon Rock: rock, at $\mathrm{N}$ entrance to Hawkins Island Cutoff, $20 \mathrm{mi}$. SW of Cordova, Chugach Mts.; $60^{\circ} 29^{\prime} \mathrm{N}, 146^{\circ} 20^{\prime} \mathrm{W}$; (map 64).

Named in 1903 by Homer P. Ritter, USC\&GS, for the family Gaviidae, birds, which are found throughout the Northern Hemisphere.
Loop, The: lake, an oxbow of Nowitna River, 38 mi. NE of Ruby, Nowitna Low.; $64^{\circ} 46^{\prime} \mathrm{N}$, $154^{\circ} 14^{\prime} \mathrm{W}$; (map 98).

Local name obtained by Orth in 1956.

Loot Hill: hill, $675 \mathrm{ft}$., $\mathrm{N}$ of Mutt Cove, center of Kiska I., Aleutian Is.; 51 $56^{\prime} 43^{\prime \prime}$ N, $177^{\circ}$ $29^{\prime} 54^{\prime \prime} \mathbf{E}$; (map 14).

An arbitrary name beginning with " $L$ " to correspond to "L" grid used by the U.S. Army for tactical purposes during World War II; published on a 1943 Army map.

Loper Creek: stream, flows N $19 \mathrm{mi}$. to Preacher Creek, $45 \mathrm{mi}$. W of Gircle, Yukon-Tanana High.; $65^{\circ} 46^{\prime} \mathrm{N}, 145^{\circ} 37^{\prime} \mathrm{W}$; (map 104). Var. Preacher Creek.

Name originally reported in 1896 by J.E. Spurr, USGS, to be Preacher Creek. However, in 1903, T. G. Gerdine, USGS, reported the present name (in Prindle, 1905, pl. 13).

Loper Island: island, $0.4 \mathrm{mi}$. across, between Marconi Slough and Chena River at Tanana River, 6 mi. SW of Fairbanks, Tanana Low.; $64^{\circ} 47^{\prime} 45^{\prime \prime} \mathrm{N}, 147^{\circ} 55^{\prime} 00^{\prime \prime} \mathrm{W}$; (map 100).

Local name reported in 1950 by USGS topographers.

Lopp Lagoon: lagoon, $18 \mathrm{mi}$. long, on $\mathrm{NW}$ coast of Seward Penin., 2 mi. NE of Cape Prince of Wales and $52 \mathrm{mi}$. NW of Teller, Kotzebue-Kobuk Low.; $65^{\circ} 45^{\prime} \mathrm{N}, 167^{\circ} 45^{\prime} \mathrm{W}$; (map 111)

Named in 1900 by A. H. Brooks, USGS, for "Rev. William Thomas Lopp, of Indiana, a missionary to the Eskimo, who began work here in 1890" (Baker, 1906, p. 413). According to Schrader and Brooks (1900, p. 25), USGS, Lopp was in charge of a U.S. government reindeer station in 1899 and employed Kivyearzuk, the Eskimo who discovered gold in the Cape York region.

Loraine Creek: stream, flows SW $3.7 \mathrm{mi}$. to Kotsina River, $0.3 \mathrm{mi}$. N of mouth of Iron Creek and $76 \mathrm{mi}$. NE of Valdez, Wrangell Mts.; $61^{\circ} 36^{\prime} 15^{\prime \prime} \mathrm{N}, 144^{\circ} 12^{\prime} 15^{\prime \prime} \mathrm{W}$; (map 68).

Prospectors' name shown on a 1912 field sheet by D. C. Witherspoon, USGS.

Loras Harbor: harbor, see Dora Harbor

Lord Islands: islands, $2 \mathrm{mi}$. across, at mouth of Nakat Bay, Coast Mts. ; $54^{\circ} 44^{\prime} \mathrm{N}, 130^{\circ} 47^{\prime} \mathrm{W}$; (map 2).

Named in 1868 by Staff Comdr. David Pender, RN.

Lord Rock: island, $0.1 \mathrm{mi}$. across, in SW end of Lord Is. at mouth of Nakat Bay, Coast Mts.; $54^{\circ} 43^{\prime} 35^{\prime \prime} \mathrm{N}, 130^{\circ} 49^{\prime} 05^{\prime \prime} \mathrm{W}$; (map 2).

Name derived from Lord Islands; given in 1883 by Lt. Comdr. H. E. Nichols, USN.

Lords Harbor: harbor, see Dora Harbor.

Lords Lake: lake, $1 \mathrm{mi}$. long, $12 \mathrm{mi}$. N. of Eagle, Porcupine Plat.; 64 ${ }^{\circ} 57^{\prime} 30^{\prime \prime} \mathrm{N}, 141^{\circ} 18^{\prime} 00^{\prime \prime}$ W; (map 102).

Local name published in 1956 by USGS.

Lords Pocket: bay, $0.1 \mathrm{mi}$. across, $4 \mathrm{mi}$. $\mathrm{N}$ of mouth of Patterson Bay, on SE coast of Baranof I., Alex. Arch.; 56 $35^{\prime} 35^{\prime \prime}$ N, 134 $37^{\prime} 30^{\prime \prime}$ $\mathrm{W} ;(\operatorname{map} 6)$.

Local fishermen's name reported in 1947 by USC\&GS 
Lore Hill: mountain, 1,275 ft., center of Kiska I., Aleutian Is.; $51^{\circ} 58^{\prime} 20^{\prime \prime} \mathrm{N}, 177^{\circ} 26^{\prime} 30^{\prime \prime} \mathrm{E}$; (map 14). Var. Sorghum Hill.

An arbitrary name beginning with " $L$ " to correspond to "L" grid used by U.S. Army for tactical purposes during World War II; published on a 1953 AMS map. Variant published on a 1943 USAAF map.

Loren Hill: mountain, 1,600 ft., center of Kiska I., Aleutian Is.; $51^{\circ} 58^{\prime} 20^{\prime \prime} \mathrm{N}, 177^{\circ} 28^{\prime} 25^{\prime \prime} \mathrm{E}$; (map 14). Var. Panther Peak.

An arbitrary name beginning with " $L$ " to correspond to "L" grid used by U.S. Army for tactical purposes during World War II; published on a 1953 AMS map. Variant published on a 1943 USAAF map.

Lorentz River: stream, see Zitziana River.

Lorenz River: stream, see Zitziana River.

Loring: village, pop. 10, on $\mathrm{W}$ coast of Revillagigedo I., near head of Naha Bay, Alex. Arch.; 55 36 $16^{\prime \prime}$ N, $131^{\circ} 38^{\prime} 00^{\prime \prime} \mathrm{W}$; (map 3).

This fishing village was built around a salmon cannery established in 1885 and abandoned in 1930. A post office, established here in 1885 was discontinued in 1936 (Ricks, 1965, p. 40 ).

Lorna Creek: stream, flows SE $5 \mathrm{mi}$. to Aurora Creek which flows to Noxapaga River, $27 \mathrm{mi}$ W of Imuruk Lake, Seward Penin. High.; $65^{\circ} 38^{\prime} \mathrm{N}, 164^{\circ} 13^{\prime} \mathrm{W}$; (map 110). Var. Money Greek.

Prospectors' name reported on the 1908 "Map of Seward Peninsula" by Arthur Gibson. Reported as "Money Creek" in 1901 by T. G. Gerdine (in Collier, 1902, pl. 12), USGS

Lorraine, Lake: lake, $0.7 \mathrm{mi}$. long, in Elmendorf Moraine, W of Knik Arm Cook Inlet, 5.4 mi. NW of Anchorage, Cook Inlet Low.; $61^{\circ}$. $17^{\prime} 38^{\prime \prime} \mathrm{N}, 149^{\circ} 57^{\prime} 00^{\prime \prime} \mathrm{W}$; (map 69).

Local name reported in 1952 by USGS.

Losa Island: island, $0.1 \mathrm{mi}$. long, in Iphigenia Bay, $2.4 \mathrm{mi}$. SW of Cape Lynch, off NW coast of Heceta I., Alex. Arch.; $55^{\circ} 46^{\prime} 20^{\prime \prime} \mathrm{N}$, $133^{\circ} 45^{\prime} 30^{\prime \prime} \mathrm{W}$; BGN 1925; (map 4).

Spanish name meaning "flagstone," given in 1924 by USG\&GS.

Lost Butte: hill, 2,305 ft., $1.8 \mathrm{mi}$. W of Billy Lake, $17 \mathrm{mi}$. SE of Chitina and $34 \mathrm{mi}$. W of McCarthy, Copper River Basin; $61^{\circ} 26^{\prime} \mathrm{N}, 143^{\circ}$ $58^{\prime} \mathrm{W}$; (map 67).

Local name published by Moffit (1914, pl. 1), USGS.

Lost Cabin Lake: lake, $1 \mathrm{mi}$. long, at mouth of Atlasta Creek, S of Glenn Highway, $21 \mathrm{mi}$. W of Glennallen, Copper River Basin; 62 $04^{\circ}$ $30^{\prime \prime} \mathrm{N}, 146^{\circ} 11^{\prime} 00^{\prime \prime} \mathrm{W}$; (map 83).

Local name reported in 1949 by USGS.

Lost Chance Basin: valley, see Last Chance Basin.

Lost Chicken Creek: stream, flows SE $1 \mathrm{mi}$. to South Fork Fortymile River, $55 \mathrm{mi}$. SW of Eagle, Yukon-Tanana High.; $64^{\circ} 03^{\prime} \mathrm{N}, 141^{\circ}$ 53' W; (map 102).

Prospectors' name shown on a 1902 manuscript map by E. J. Chamberlain, U.S. Deputy Surveyor.
Lost Chicken Hill: mountain, 2,100 ft., $1 \mathrm{mi}$. N of junc. of Dennison and Mosquito Forks, 55 mi. SW of Eagle, Yukon-Tanana High.; $64^{\circ}$ 04' N, 141 '55' W; (map 102).

Local name published in 1956 by USGS.

Lost Cove: cove, $0.3 \mathrm{mi}$. across, near $\mathrm{S}$ end of Lisianski Strait, on Chichagof I., $12 \mathrm{mi}$. SW

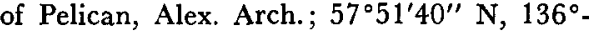
$25^{\prime} 00^{\prime \prime} \mathrm{W}$; (map 9).

Named by USC\&GS and published in 1928 on Chart 8258.

Lost Creek: stream, on Kenai Penin., heads at Lost Lake, flows S $6.5 \mathrm{mi}$. to Salmon Creek, $4.5 \mathrm{mi}$. NE of Seward, Chugach Mts.; $60^{\circ}-$ $15^{\prime} 45^{\prime \prime} \mathrm{N}, 149^{\circ} 24^{\prime} 45^{\prime \prime} \mathrm{W}$; (map 63).

Local name reported in 1909 by Grant and Higgins (1910, pls. 1, 2), USGS.

Lost Creek: stream, flows $2.5 \mathrm{mi}$. S to North Fork Bremner River, $4.5 \mathrm{mi}$. SW of Hanagita Peak and $41 \mathrm{mi}$. SW of McCarthy, Chugach Mts.; $61^{\circ} 01^{\prime} 35^{\prime \prime} \mathrm{N}, 143^{\circ} 48^{\prime} 30^{\prime \prime} \mathrm{W}$; (map 67).

Local name published by Moffit (1914, pl. 1), USGS

Lost Creek: stream, in Mentasta Mts., flows S 10 mi. to Jack Creek, 2.5 mi. SE of Jack Lake, Alaska Ra.; $62^{\circ} 30^{\prime} 00^{\prime \prime} \mathrm{N}, 143^{\circ} 10^{\prime} 45^{\prime \prime} \mathrm{W}$; (map 84).

Local name reported by Mendenhall (1905, pl. 11), USGS.

Lost Greek: stream, flows NE $2 \mathrm{mi}$. to Nome River, $6 \mathrm{mi}$. NE of Nome, Seward Penin High.; 64 $34^{\prime} \mathrm{N}, 165^{\circ} 13^{\prime} \mathrm{W}$; (map 94).

Prospectors' name reported on a map by S. E. King, dated 1900.

Lost Creek: stream, flows NW $5 \mathrm{mi}$. to Klokerblok River, $20 \mathrm{mi}$. E of Solomon, Seward Penin. High.; $64^{\circ} 39^{\prime} \mathrm{N}, 163^{\circ} 49^{\prime} \mathrm{W}$; (map 95)

Prospectors' name reported in 1900 by E. C. Barnard (in Brooks, 1901, pl. 17), USGS

Lost Creek: stream, flows SW $1.2 \mathrm{mi}$. to Kasson Creek which flows to Solomon River, $9 \mathrm{mi}$ NE of Solomon, Seward Penin. High.; 64 ${ }^{\circ}$. $41^{\prime} 40^{\prime \prime} \mathrm{N}, 164^{\circ} 23^{\prime} 45^{\prime \prime} \mathrm{W}$; (map 95).

Prospectors' name shown on Arthur Gibson's "Map of Cape Nome Precinct" dated 1904.

Lost Creek: stream, flows $\mathrm{N} 1 \mathrm{mi}$. to Lower Willow Creek which flows to Casadepaga River, $16 \mathrm{mi}$. N of Solomon, Seward Penin. High.; $64^{\circ} 48^{\prime} \mathrm{N}, 164^{\circ} 24^{\prime} \mathrm{W}$; (map 95).

Prospectors' name reported on a map of Cape Nome gold fields by David Fox, Jr. dated 1901

Lost Creek: stream, flows S $2 \mathrm{mi}$. to Mission Creek, $2 \mathrm{mi}$. NW of Eagle, Yukon-Tanana High.; 64. $48^{\prime} 30^{\prime \prime} \mathrm{N}, 141^{\circ} 16^{\prime} 20^{\prime \prime} \mathrm{W}$; (map 102.)

Local name published in 1956 by USGS.

Lost Creek: stream, flows N $3.2 \mathrm{mi}$. to Stewart River, 22 mi. N of Nome, Seward Penin. High.; 64 $49^{\prime} 24^{\prime \prime} \mathrm{N}, 165^{\circ} 21^{\prime} 50^{\prime \prime} \mathrm{W}$; (map 94). Var. Christmas Creek.

Prospectors' name reported in 1904 by $\mathrm{T}$. G. Gerdine, USGS. Shown as "Christmas Gr." on the 1902 "Map of the Nome and Snake River Country" by J. M. Davidson.

Lost Creek: stream, flows SW $20 \mathrm{mi}$. to Serpentine Creek, $62 \mathrm{mi}$. NE of Big Delta, Yukon-
Tanana High.; $64^{\circ} 51^{\prime} \mathrm{N}, 144^{\circ} 30^{\prime} \mathrm{W}$; (map 101).

Named by prospectors; reported in 1910 by USGS (Prindle 1913, pl. 1).

Lost Creek: stream, flows NW $1.3 \mathrm{mi}$. to American Creek which flows to Niukluk River, 26 mi. N of Solomon, Seward Penin. High.; $64^{\circ} 56^{\prime} \mathrm{N}, 164^{\circ} 25^{\prime} \mathrm{W}$; (map 95). Var. Game Creek.

Prospectors' name reported in 1907 by USGS geologists (Smith, P. S., 1910, pl. 4).

Lost Creek: stream, flows SW $2.6 \mathrm{mi}$. to Tubutulik River, $28 \mathrm{mi}$. N of Elim and $50 \mathrm{mi} \mathrm{SE}$ of Imuruk Lake, Seward Penin. High.; $65^{\circ} 00^{\prime}$ $\mathrm{N}, 162^{\circ} 06^{\prime} \mathrm{W}$; (map 110)

Prospectors' name reported in 1900 by W. J. Peters (in Mendenhall, 1901, pl. 20), USGS.

Lost Creek: stream, flows $\mathrm{S} 1 \mathrm{mi}$. to Chatanika River, $11 \mathrm{mi}$. NE of Twin Buttes and $45 \mathrm{mi}$ NE of Fairbanks, Yukon-Tanana High.; $65^{\circ}$ $16^{\prime} 30^{\prime \prime} \mathrm{N}, 146^{\circ} 41^{\prime} 15^{\prime \prime} \mathrm{W}$; (map 104). Var. Nome Creek.

Originally reported in 1903 as "Nome Creek" by Prindle (1905, pl. 13), USGS However, the name was later changed by local usage, probably because there is a Nome Creek a few miles north of this stream.

Lost Greek: stream, flows W $3 \mathrm{mi}$. to Minook Creek, 15 mi. S of Rampart, Yukon-Tanana High; $65^{\circ} 17^{\prime} \mathrm{N}, 150^{\circ} 06^{\prime} \mathrm{W}$; (map 106).

Prospectors' name reported in 1904 by L. M. Prindle, USGS

Lost Creek: stream, flows SW $15 \mathrm{mi}$. to West Fork Tolovana River, $8 \mathrm{mi}$. SW of Livengood, Yukon-Tanana High.; $65^{\circ} 29^{\prime} \mathrm{N}, 148^{\circ} 49^{\prime} \mathrm{W}$ (map 105).

Named by prospectors; reported in 1915 by Brooks (Brooks and others, 1916, pl. 9), USGS.

Lost Creek: stream, flows NW $2 \mathrm{mi}$. to Portage Creek which flows to American River, $12 \mathrm{mi}$. NW of Kougarok Mtn. and $22 \mathrm{mi}$. SE of Ear Mtn., Seward Penin. High.; $65^{\circ} 46^{\prime} \mathrm{N}$,

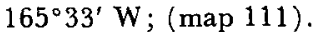

Prospectors' name reported on the 1908 "Map of Seward Peninsula" by Arthur Gibson. Lost Creek: stream, heads at $65^{\circ} 52^{\prime} \mathrm{N}, 147^{\circ} 35^{\prime}$ $\mathrm{W}$, flows NW $37 \mathrm{mi}$. to Tincan Lake, $20 \mathrm{mi}$. $\mathrm{SW}$ of Beaver, Yukon Flats.; $66^{\circ} 09^{\prime} 45^{\prime \prime} \mathrm{N}$, $147^{\circ} 55^{\prime} 00^{\prime \prime} \mathrm{W}$; (map 118).

Named by prospectors and reported in 1902 by Lieut. H. Erickson, USA.

Lost Creek: stream, see Crescent Creek

Lost Creek: stream, see Lost River.

Lost Creek: stream, see Panamaroff Creek.

Lost Creek: stream, see Serpentine Creek.

Lost Harbor: bay, $1.5 \mathrm{mi}$. across, on W coast of Akun I., Krenitzen Is., Aleutian Is.; 54 $13^{\prime}$ $45^{\prime \prime} \mathrm{N}, 165^{\circ} 36^{\prime} 30^{\prime \prime} \mathrm{W}$; (map 24).

Named in 1901 by J. J. Gilbert, USC\&GS.

Lost Harbor: locality, at Lost Harbor on $\mathrm{W}$ coast of Akun I., Aleutian Is.; (map 24).

Name of a former mining camp that was located on the island in the 1920's. The camp contained a smelter, tramway, machine shop, commissary and other buildings for the operation of a sulphur mine. 
Lost Horse Greek: stream, flows SW $5.5 \mathrm{mi}$. to Washington Creek, $22 \mathrm{mi}$. N of Fairbanks, Yukon-Tanana High.; $65^{\circ} 09^{\prime} 45^{\prime \prime} \mathrm{N}, 147^{\circ}$ $49^{\prime} 20^{\prime \prime}$ W; (map 105).

Local name published by USGS in the 1950's.

Lost Jim Cone: hill, 1,536 ft., in lava, $3 \mathrm{mi}$. NW of Sandy Lake and 5 mi. S of Imuruk Lake, Seward Penin. High.; $65^{\circ} 29^{\prime}$ N, $163^{\circ} 18^{\prime}$ W; $B G N$ 1952; (map 110).

Reported in 1950 by D. M. Hopkins, USGS; so named because while "mapping the [lava] flow in 1947, a member of the Geological Survey field party was separated from the remainder of the group and lost for nearly a day."

Lost Lake: lake, $0.2 \mathrm{mi}$. across, $\mathrm{N}$ of Pierucci Ridge, on E end of Attu I., Aleutian Is.; $52^{\circ}$ $54^{\prime} 03^{\prime \prime} \mathrm{N}, 173^{\circ} 17^{\prime} 15^{\prime \prime} \mathrm{E}$; (map 13).

Named by the U.S. Army during its occupation of the island during World War II; shown on an AMS map published in 1948.

Lost Lake: lake, on Kenai Penin., $1.5 \mathrm{mi}$. long, at head of Lost Creek, $10 \mathrm{mi}$. $\mathrm{N}$ of Seward, Chugach Mts.; $60^{\circ} 16^{\prime} \mathrm{N}, 149^{\circ} 26^{\prime} \mathrm{W}$; $B G N$ 1910; (map 63).

Local name reported in 1909 by Grant and Higgins (1910, pls. 1, 2), USGS.

Lost Lake: lake, $0.7 \mathrm{mi}$. long, on Kenai Penin. $\mathrm{SW}$ of Woods Lake, $32 \mathrm{mi}$. NE of Kenai, Cook Inlet Low.; $60^{\circ} 48^{\prime} 40^{\prime \prime} \mathrm{N}, 150^{\circ} 30^{\prime} 15^{\prime \prime}$ W; (map 62).

Named about 1963 by officials of Kenai National Moose Range, for administrative purposes.

Lost Lake: lake, $1.2 \mathrm{mi}$. long, W of Knik Arm Cook Inlet, $8.4 \mathrm{mi}$. NW of Anchorage, Cook Inlet Low.; $61^{\circ} 20^{\prime} 10^{\prime \prime} \mathrm{N}, 149^{\circ} 59^{\prime} 40^{\prime \prime} \mathrm{W}$; (map 69).

Local name reported in 1952 by USGS.

Lost Lake: lake, $0.2 \mathrm{mi}$. across, $1 \mathrm{mi}$. NE of Chitina and $56 \mathrm{mi}$. NE of Valdez, Chugach Mts.; $61^{\circ} 31^{\prime} 45^{\prime \prime} \mathrm{N}, 144^{\circ} 25^{\prime} 45^{\prime \prime} \mathrm{W}$; (map 68).

Local name published in the 1950's by USGS.

Lost Lake: lake, $0.5 \mathrm{mi}$. long, WSW of Quartz Lake and $3.3 \mathrm{mi}$. N of Big Deita, YukonTanana High.; 64 $12^{\prime}$ N, $145^{\circ} 51^{\prime}$ W ; (map 101).

Local name published in 1951 by USGS.

Lost Lake: lake, $0.6 \mathrm{mi}$. long, $0.4 \mathrm{mi}$. S of mouth of Dome Creek and $29 \mathrm{mi}$. NW of Birches, Kokrines-Hodzana High.; $65^{\circ} 30^{\prime} 30^{\prime \prime} \mathrm{N}, 154^{\circ}$. $03^{\prime} 00^{\prime \prime} \mathrm{W}$; (map 107).

Local name obtained in 1954 by USGS topographers.

Lost Lake: lake, $0.7 \mathrm{mi}$. long, $1 \mathrm{mi}$. SW of Sweeney Lake and $18 \mathrm{mi}$. SW. of Beaver, Yukon Flats; $66^{\circ} 08^{\prime} 20^{\prime \prime} \mathrm{N}, 147^{\circ} 47^{\prime} 00^{\prime \prime} \mathrm{W}$; (map 118).

Local name obtained in 1956 by USGS.

Lost Lake: lake, see Crescent Lake.

Lost River: stream, flows SW $5 \mathrm{mi}$. to Gulf of Alaska, 7 mi. SE of Yakutat, Malaspina Coastal Plain.; 59 $27^{\prime} 20^{\prime \prime} \mathrm{N}, 139^{\circ} 36^{\prime} 30^{\prime \prime} \mathrm{W}$; BGN 1962; (map 46). Var. Lost Creek, Tha-ghean, Thaghian Creek, Thaghian River.
Local name reported as early as 1903 ; a general translation of the stream's Tlingit Indian name was reported in 1901 by Lt. Comdr. J. F. Moser, USN, as "Tha-ghe-an."

Lost River: stream, flows NE $46 \mathrm{mi}$. to Nowitna River, $14 \mathrm{mi}$. NE of Monzonite Hills, KilbuckKuskokwim Mts.; $64^{\circ} 30^{\prime} \mathrm{N}, 154^{\circ} 15^{\prime} \mathrm{W}$; (map 98).

Local name reported in 1915 by H. M. Eakin (in Brooks and others, 1916, pl. 10), USGS.

Lost River: stream, heads in York Mts., flows S $9 \mathrm{mi}$. to Bering Sea, $24 \mathrm{mi}$. NW of Teller, Seward Penin. High.; $65^{\circ} 23^{\prime} \mathrm{N}, 167^{\circ} 09^{\prime} \mathrm{W}$; (map 111).

Prospectors' name reported in 1903 by Collier (1904, pl. 2), USGS.

Lost River: locality, on Bering Sea coast, near mouth of Lost River, about $2 \mathrm{mi}$. S of York Mts. and $25 \mathrm{mi}$. NW of Teller, Seward Penin. High.; (map 111).

Site of a mining camp and landing listed in the 1915-16 Polk's Gazetteer. In 1903 A. J. Gollier, USGS, accompanied three miners to Lost River, where he discovered the first lode tin in the York district (Steidtmann and Gathcart, 1922, p. 14). This area remained an important source of tin for many years. It appears a resident population was never established at this site.

Lost Rocker Falls: waterfall, somewhere along Sheep Creek, about $5 \mathrm{mi}$. SE of Juneau, Coast Mts.; $58^{\circ} 16^{\prime} \mathrm{N}, 134^{\circ} 19^{\prime} \mathrm{W}$; (map 11).

Miners' name reported by DeArmond (1957, p. 39).

Lost Slough: stream, distributary of Nenana River, flows N $12 \mathrm{mi}$. to Seventeenmile Slough, $9 \mathrm{mi}$. S of Nenana, Tanana Low.; $64^{\circ} 27^{\prime} 30^{\prime \prime}$ N, $149^{\circ} 10^{\prime} 20^{\prime \prime} \mathrm{W}$; (map 100).

Local name published by USGS in 1919.

Lost Temper Creek: stream, heads on Monument Ridge, flows $\mathrm{N} 17 \mathrm{mi}$. to Colville River, Arctic Slope; $68^{\circ} 54^{\prime} \mathrm{N}, 157^{\circ} 25^{\prime} \mathrm{W}$; (map 132).

Named in 1950 by B. H. Kent, USGS geologist connected with the Naval Petroleum Reserve No. 4 explorations because of a camp incident. Name was published by USGS in 1951.

Lothianoi: bay, see Icy Bay.

Lotus Island: island, $0.15 \mathrm{mi}$. long, between Nizki and Shemya Is., Semichi Is., Aleutian Is.; $52^{\circ} 43^{\prime} 40^{\prime \prime} \mathrm{N}, 174^{\circ} 02^{\prime} 40^{\prime \prime} \mathrm{E}$; (map 13).

Name published in 1948 on USC\&GS Chart 9130.

Louden: locality, on right bank of Yukon River, $43 \mathrm{mi}$. E of Nulato, Koyukuk Low.; $64^{\circ} 38^{\prime}$ $\mathrm{N}, 156^{\circ} 41^{\prime} \mathrm{W}$; (map 97). Var. Lowden, Sachertelontin, Saghadellautin, Sakadelontin, Sakatalan, Sakataloden, Sakedelontin, Sar-duLoten, Zakatlatan.

Telegraph station established in 1903 by the U.S. Army Signal Corps. Former Indian village or camp, which Frederick Whymper (1869, p. 226) reported as "Sachertelontin;" Petroff (1881, p. 62) listed "Sakatalan," population 25 ; the 1890 Census recorded "Sakatạloden," population 39; "Sar-du-Loten" was shown in 1899 on Edwards' Track Chart of the Yukon. Since the origin of the name Louden has not been determined, it is of interest to note the various endings of the Indian names, from which the name Louden may have been derived.

Louden Slough: stream, anabranch of Yukon River, $40 \mathrm{mi}$. E of Nulato, Koyukuk Low.; $64^{\circ} 40^{\prime} \mathrm{N}, 156^{\circ} 46^{\prime} \mathrm{W}$; (map 97).

Riverboat pilots' name shown on a 1940 "Navigation Chart of the Tanana-Yukon Rivers" published by the U.S. Dept. of Interior.

Louden Slough: stream, see Kala Slough.

Loud Hill: hill, 1,307 ft., center of Kiska I., Aleutian Is., $51^{\circ} 58^{\prime} 20^{\prime \prime} \mathrm{N}, 177^{\circ} 27^{\prime} 23^{\prime \prime} \mathrm{E}$; (map 14). Var. Tobacco Hill.

An arbitrary name beginning with " $L$ " to correspond to "L" grid used by U.S. Army for tactical purposes during World War II; published on a 1953 AMS map. Variant published on a 1943 USAF map.

Louie Creek: stream, flows SW $14 \mathrm{mi}$. to Koyukuk River, $7 \mathrm{mi}$. W of Roundabout Mtn., Koyukuk Low.; $65^{\circ} 33^{\prime}$ N, $156^{\circ} 47^{\prime} \mathrm{W}$; (map 108).

Local name obtained at Huslia by USGS in 1954 or 1955.

Louie Lake: lake, $0.8 \mathrm{mi}$. long, $3 \mathrm{mi}$. ENE of Tetlin and $21 \mathrm{mi}$. SE of Tok, Alaska Ra.; $63^{\circ} 09^{\prime} \mathrm{N}, 142^{\circ} 25^{\prime} \mathrm{W}$; (map 85).

Local name reported by USGS in 1964.

Louie Pup: stream, flows NW $2 \mathrm{mi}$. to Boulder Creek, $7 \mathrm{mi}$. SW of Central and $35 \mathrm{mi}$. SW of Circle, Yukon-Tanana High.; $65^{\circ} 31^{\prime} \mathrm{N}$, $145^{\circ} 00^{\prime} \mathrm{W}$; (map 104).

Prospectors' name reported in 1954 or 1955 by USGS topographers.

Louies Corner: locality, on S coast of Alaska Penin. at head of Stepovak Bay, Aleutian Ra.; $55^{\circ} 51^{\prime} 10^{\prime \prime} \mathrm{N}, 159^{\circ} 47^{\prime} 00^{\prime \prime} \mathrm{W}$; (map 27).

Local name published by USC\&GS in 1916 Coast Pilot.

Louisa, Point: point of land, on E shore of Stephens Passage, $0.8 \mathrm{mi}$. SW of Fairhaven and $12 \mathrm{mi}$. NW of Juneau, Coast Mts.; $58^{\circ}$ $22^{\prime} 25^{\prime \prime} \mathrm{N}, 134^{\circ} 43^{\prime} 30^{\prime \prime} \mathrm{W}$; (map 11).

Named in 1880 by Capt. L. A. Beardslee, USN, for the great aunt of Oliver J. Vanderbilt; local miner; published by USC\&GS in the 1883 Coast Pilot (p. 174).

Louisa Creek: stream, flows W $1.2 \mathrm{mi}$. to Kougarok River, $18 \mathrm{mi}$. S of Midnight Mtn. and $45 \mathrm{mi} \mathrm{SW}$ of Imuruk Lake, Seward Penin.

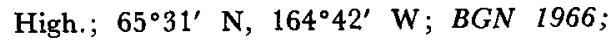
(map 110). Var. Louise Creek.

Prospectors' name reported in 1901 by $\mathbf{T}$. G. Gerdine (in Collier, 1902, pl. 12), USGS.

Louis Bay: estuary, at NE end of Knight I., extends NE $1 \mathrm{mi}$. to Lower Passage, in Prince William Sound, $42 \mathrm{mi}$. SE of Whittier, Chugach Mts. ; $60^{\circ} 28^{\prime} 45^{\prime \prime} \mathrm{N}, 147^{\circ} 40^{\prime} 00^{\prime \prime} \mathrm{W} ; B G N$ 1908; (map 63).

Local name reported in 1908 by Grant and Higgins (1909, pl. 4), USGS.

Louis Creek: stream, flows NW 8 mi. to Yanert Fork, $28 \mathrm{mi}$. SE of Healy, Alaska Ra.; 63$36^{\prime} 20^{\prime \prime} \mathrm{N}, 148^{\circ} 10^{\prime} 00^{\prime \prime} \mathrm{W}$; (map 87). 
Local name obtained in 1913 by J. W. Bagley, USGS; published by Moffit (1915, pl. 1). Louis Greek: stream, flows $\mathrm{N} 0.8 \mathrm{mi}$. to Little Eldorado Creek, $16 \mathrm{mi}$. NE of Fairbanks, Yukon-Tanana High.; $65^{\circ} 03^{\prime} 35^{\prime \prime} \mathrm{N}, 147^{\circ}$ $32^{\prime} 00^{\prime \prime} \mathrm{W}$; (map 105).

Named by prospectors; published in 1908 by USGS.

Louis Creek: stream, see California Creek.

Louise, Lake: lake, $0.5 \mathrm{mi}$. long, drains $\mathrm{S}$ to Buskin River, 4 mi. SW of Kodiak, Kodiak I. ; $57^{\circ} 45^{\prime} 40^{\prime \prime} \mathrm{N}, 152^{\circ} 30^{\prime} 00^{\prime \prime} \mathrm{W}$; (map 34). Local name reported in 1949 by USGS.

Louise, Lake: lake, $8.5 \mathrm{mi}$. long, $32 \mathrm{mi}$. NW of Glennallen, Copper River Basin; 62 $2^{\circ} 20^{\prime} \mathrm{N}$, $146^{\circ} 32^{\prime} \mathrm{W}$; (map 83).

Local name reported in 1898 by Capt. E. F. Glenn (in Glenn and Abercrombie, 1889, p. 63), USGS.

Louise, Point: point of land, on the mainland, S point of entrance to Rudyerd Bay, Behm Canal, Coast Mts.; 55 $32^{\prime} 42^{\prime \prime}$ N, $130^{\circ} 52^{\prime} 05^{\prime \prime}$ W; (map 3). Var. Cape New Eddystone, Mys Novoeddiston, New Eddystone Point.

Name published in 1899 by USC\&GS; originally named "New Eddystone Point" by Capt. George Vancouver, RN, August 9, 1793, "for a supposed resemblance to Eddystone [lighthouse off the coast of Cornwall] in England ***" (Wagner, 1937, p. 399-400).

Louise Cove: cove, on SE coast of Kuiu I., trends SE $1 \mathrm{mi}$. to Sumner Strait, $18 \mathrm{mi}$. SW of village of Point Baker, Alex. Arch.; 56 $11^{\prime} 30^{\prime \prime}$ N, $133^{\circ} 57^{\prime} 00^{\prime \prime} \mathrm{W}$; BGN 1966; (map 6).

Local name published by USC\&GS in 1917 Coast Pilot (p. 126).

Louise Cove: cove, $0.8 \mathrm{mi}$. across, in Kakul Narrows, on NW coast of Baranof I., $26 \mathrm{mi}$. NW of Sitka, Alex. Arch.; $57^{\circ} 22^{\prime} 10^{\prime \prime}$ N, $135^{\circ} 40^{\prime} 00^{\prime}$ W ; (map 9). Var. Rodman Cove.

Probably a local name; reported in 1896 by Lt. Comdr. E. K. Moore, USN, and published in 1900 by USC\&GS on Chart 8282.

Louise Creek: stream, flows $\mathrm{S} 1.5 \mathrm{mi}$. to Lignite Creek, $5 \mathrm{mi}$. NE of Healy, Alaska Ra.; $63^{\circ} 54^{\prime} 55^{\prime \prime} \mathrm{N}, 148^{\circ} 52^{\prime} 15^{\prime \prime} \mathrm{W}$; (map 87).

Local name reported in 1950 by USGS.

Louise Creek: stream, see Louisa Creek.

Louise Gulch : ravine, see Lewis Gulch.

Louise Island: island, see Blackburn Island.

Louis Lake: lake, $5 \mathrm{mi}$. NE of Bucket Lake, and $26 \mathrm{mi}$. SW of Roundabout Mtn., Koyukuk Low.; $65^{\circ} 14^{\prime} \mathrm{N}, 157^{\circ} 01^{\prime} \mathrm{W}$; (map 108).

Local name obtained at Huslia by USGS in 1954 or 1955.

Louisville Creek: stream, flows NW $3 \mathrm{mi}$. to Igloo Creek which flows to American River, $35 \mathrm{mi}$. NE of Teller, Seward Penin. High.; $65^{\circ} 29^{\prime} \mathrm{N}, 165^{\circ} 16^{\prime} \mathrm{W}$; (map 111).

Prospectors' name reported in 1901 by T. G. Gerdine (in Collier, 1902, pl. 12), USGS.

Lou Lake: lake, $2 \mathrm{mi}$. across, $2 \mathrm{mi}$. $\mathrm{W}$ of Kagalurpak Lake and $83 \mathrm{mi}$. W of Bethel, Yukon-Kuskokwim Delta; $60^{\circ} 56^{\prime} \mathrm{N}, 164^{\circ} 12^{\prime}$ W; (map 58).

Name reported about 1965 by personnel of Clarence Rhode National Wildlife Range.
Loups, Ile aux: island chain, see Kudobin Islands.

Loups, L'ile aux: island, see Kritskoi Island.

Louse Greek: stream, flows $\mathrm{N} 2.2 \mathrm{mi}$. to Bluff Cove through Middle Pass, Kiska I., Aleutian Is.; $51^{\circ} 59^{\prime} \mathrm{N}, 177^{\circ} 29^{\prime} \mathrm{E}$; (map 14). Var. Swallow Creek.

An arbitrary name beginning with " $L$ " to correspond to "L" grid used by U.S. Army for tactical purposes during World War II; published on a 1953 AMS map. Variant published on a 1943 USAAF map.

Lousy Creek: stream, flows $\mathrm{N} 2 \mathrm{mi}$. to Middle Fork Fortymile River, $45 \mathrm{mi}$. SW of Eagle, Yukon-Tanana High.; $64^{\circ} 27^{\prime} 45^{\prime \prime} \mathrm{N}, 142^{\circ}$ $31^{\prime} 50^{\prime \prime} \mathrm{W}$; (map 102).

Prospectors' name shown on an 1898 manuscript map by C. A. Woodruff, Fort Cudahy, Canada.

Lousy Hill: mountain, 1,300 ft., center of Kiska I., Aleutian Is.; $51^{\circ} 57^{\prime} 33^{\prime \prime} \mathrm{N}, 177^{\circ} 28^{\prime} 22^{\prime \prime} \mathrm{E}$; (map 14).

An arbitrary name beginning with " $L$ " to correspond to "L" grid used by the U.S. Army for tactical purposes during World War II; published on a 1943 Army map.

Lovelace Creek: stream, flows NW $5.5 \mathrm{mi}$. to Keku Strait, on SW coast of Kupreanof I., 14 mi. N of Point Baker, Alex. Arch.; 56 ${ }^{\circ} 33^{\prime} 15^{\prime \prime}$ $\mathrm{N}, 133^{\circ} 39^{\prime} 20^{\prime \prime} \mathrm{W}$; (map 6).

Local name recorded in 1960 by USGS.

Love Lakes: lakes, $0.2 \mathrm{mi}$. across, center of Kiska I., Aleutian Is.; $51^{\circ} 56^{\prime} 37^{\prime \prime} \mathrm{N}, 177^{\circ}$ 24'55" E; (map 14).

An arbitrary name beginning with " $L$ " to correspond to "L" grid used by the U.S. Army for tactical purposes during World War II; published on a 1943 Army map.

Lovers Cove: bay, $0.2 \mathrm{mi}$. across, on $\mathrm{N}$ shore of Big Port Walker, $10 \mathrm{mi}$. N of village of Port Alexander, on S coast of Baranof I., Alex. Arch.; $56^{\circ} 23^{\prime} 20^{\prime \prime} \mathrm{N}, 134^{\circ} 43^{\prime} 00^{\prime \prime} \mathrm{W}$; (map 6).

Local fishermen's name reported in 1947 by USC\&GS.

Low Bluff: point of land, $1.2 \mathrm{mi}$. SE of Chitka Point, on $\mathrm{N}$ coast of Amchitka I., Aleutian Is.; $51^{\circ} 34^{\prime} 52^{\prime \prime} \mathrm{N}, 178^{\circ} 59^{\prime} 30^{\prime \prime} \mathrm{E}$; $B G N$ 1937; (map 15).

Name recorded by the U.S. Navy North Pacific Exploring Expedition of 1855.

Low Bluffs: bluffs, between Zapadni and Southwest Points, on SW coast of Saint Paul I., in Pribilof Is.; $57^{\circ} 09^{\prime} 30^{\prime \prime} \mathrm{N}, 170^{\circ} 23^{\prime} 00^{\prime \prime} \mathrm{W}$; (map 38)

A local descriptive name reported in 1965 by USBF.

Low Cape: point of land, $13 \mathrm{mi}$. NW of Alitak Bay, on SW coast of Kodiak I.; 56 $59^{\prime} 35^{\prime \prime} \mathrm{N}$, $154^{\circ} 31^{\prime} 10^{\prime \prime} \mathrm{W}$; (map 32). Var. Mys Nizmennoi, Nizmenno Point.

Translation by USC\&GS in 1868 of the Russian "M[ys] Nizmennoi," published by Capt. Tebenkov (1852, map 22), IRN.

Low Cape: point of land, on $\mathrm{W}$ shore near head of Kizhuyak Bay, on $\mathbf{N}$ coast of Kodiak I.; $57^{\circ} 44^{\prime} 30^{\prime \prime} \mathrm{N}, 152^{\circ} 52^{\prime} 30^{\prime \prime} \mathrm{W}$; (map 34). Var. Nizmennie.
Baker (1906 p. 414) published this name as a translation of Sub-Lt. Mikhail Murashev's "Nizmennie," which is an error in location, since Murashev's application of the name was to the E shore of the bay. See Dovolno Point. Low Cape: point of land, see Narrow Cape.

Low Greek: stream, on Iniskin Penin., flows N 2 mi. to Trail Creek, Aleutian Ra.; $59^{\circ} 48^{\prime} \mathrm{N}$, $153^{\circ} 16^{\prime} \mathrm{W}$; BGN 1962; (map 51).

Local name published by USGS in 1958. Low Creek: stream, see Trail Creek.

Lowden: locality, see Louden.

Lowe, Point: point of land, on $\mathrm{N}$ shore of Valdez Arm, $11 \mathrm{mi}$. W of Valdez, Chugach Mts.; $61^{\circ} 02^{\prime} 35^{\prime \prime} \mathrm{N}, 146^{\circ} 45^{\prime} 50^{\prime \prime} \mathrm{W}$; (map 68).

Named by Capt. W. R. Abercrombie, USA, in 1898, for Lt. Percival G. Lowe, USA, a member of his exploring party.

Lowell Creek: stream, on Kenai Penin., heads between Marathon Mtn. and Bear Mtn., flows E $2.5 \mathrm{mi}$. to an aqueduct $\mathrm{W}$ of Seward, Chugach Mts.; $60^{\circ} 06^{\prime} 10^{\prime \prime} \mathrm{N}, 149^{\circ} 27^{\prime} 00^{\prime \prime} \mathrm{W}$; (map 63).

Local name published by D. H. Sleem on his map of Central Alaska dated 1910. Probably named for Capt. Lowell who, with his family, were the first white settlers in the area, arriving there in 1884 .

Lowell Glacier: glacier, in Kenai Mts. on Kenai Penin., trends NE $5 \mathrm{mi}$. to head of Placer Creek, 14 mi. NW of Seward, Chugach Mts.; $60^{\circ} 14^{\prime} 59^{\prime \prime} \mathrm{N}, 149^{\circ} 44^{\prime} 30^{\prime \prime} \mathrm{W}$; BGN 1966; (map 63). Var. Placer River Glacier.

Name reported in 1915 by USGS; probably named "for Mr. Lowell the first white settler in Seward."

Lowell Glacier: glacier, trends NE 2 mi. to its terminus, $3 \mathrm{mi}$. SE of Carmen Lake and $5 \mathrm{mi}$. $\mathrm{N}$ of Whittier, Chugach Mts. ; $60^{\circ} 51^{\prime} \mathrm{N}, 148^{\circ}$. 41' W; (map 63).

Named by USC\&GS in 1915 for James Russell Lowell, 1819-91, American poet, essayist, editor, and dramatist.

Lowell Glacier: glacier, in Dora Keen Ra., trends W $4 \mathrm{mi}$. to Harvard Glacier, $46 \mathrm{mi}$. NW of Valdez, Chugach Mts.; $61^{\circ} 18^{\prime} 30^{\prime \prime} \mathrm{N}, 147^{\circ}$ 37'30' W; BGN 1930; (map 69).

Named by Lawrence Martin in 1910 for Abbot Lawrenice Lowell, 1856-1943, educator and president of Harvard Univ., Cambridge, Mass.

Lowell Island, island, see Renard Island.

Lowell Point: point of land, at NW side of Resurrection Bay, on Kenai Penin., $2 \mathrm{mi}$. S of Seward, Chugach Mts.; $60^{\circ} 04^{\prime} 15^{\prime \prime}$ N, $149^{\circ}$ $26^{\prime} 00^{\prime \prime}$ W; BGN 1906; (map 63).

Local name reported in 1905 by USC\&GS.

Lowenstern, Cape: point of land, $\mathrm{E}$ entrance point to Shishmaref Inlet, $6 \mathrm{mi}$. E of Shishmaref, Kotzebue-Kobuk Low.; $66^{\circ} 14^{\prime} \mathbf{N}$, $165^{\circ} 52^{\prime} \mathrm{W}$; (map 112).

Named in August 1816, by Lt. Otto von Kotzebue, IRN.

Lower Arm Cabin Cove: cove, $0.4 \mathrm{mi}$. across, on $\mathrm{E}$ coast of Kagalaska I., Aleutian Is.; $51^{\circ}$ $49^{\prime} 20^{\prime \prime} \mathrm{N}, 176^{\circ} 18^{\prime} 00^{\prime \prime} \mathrm{W}$; BGN 1936; (map 17). Var. South Arm Cabin Cove.

Descriptive name given by members of the 
U.S. Navy Aleutian Island Survey Expedition in 1934 .

Lower Basin: valley, on lower part of Nugget Creek, $0.2 \mathrm{mi}$. E of 1962 terminus of Mendenhall Glacier and $9 \mathrm{mi}$. NW of Juneau, Coast Mts.; $58^{\circ} 25^{\prime} 30^{\prime \prime} \mathrm{N}, 134^{\circ} 30^{\prime} 45^{\prime \prime} \mathrm{W}$; (map 11).

Local name published by USGS (Knopf, 1912, pl. 1).

Lower Beluga Lake: lake, $3 \mathrm{mi}$. long, in course of Beluga River, $20 \mathrm{mi}$. NW of Tyonek, Cook Inlet Low.; $61^{\circ} 21^{\prime} 30^{\prime \prime} \mathrm{N}, 1^{\circ} 1^{\circ} 21^{\prime} 30^{\prime \prime} \mathrm{W}$; (map 70).

Local name published in 1954 by USGS.

Lower Birch Creek Slough: stream, anabranch of Yukon River, flows SW $15 \mathrm{mi} ., 44 \mathrm{mi}$. SW of Fort Yukon, Yukon Flats; $66^{\circ} 27^{\prime} \mathrm{N}, 146^{\circ}$. 50' W; (map 119).

Local name obtained in 1956 by USGS.

Lower Boulder Creek: stream, flows NW $9 \mathrm{mi}$. to Salcha River $9.5 \mathrm{mi}$. E of that stream's junc. with its North Fork and $46 \mathrm{mi}$. NE of Big Delta, Yukon-Tanana High.; $64^{\circ} 39^{\prime} \mathrm{N}, 145^{\circ}$ $00^{\prime} \mathrm{W}$; (map 101).

Local name reported in 1958 by USGS.

Lower Checats Lake: lake, $0.7 \mathrm{mi}$. long, $1 \mathrm{mi}$. NE of Winstanley $\mathrm{I}$. in Behm Canal, $32 \mathrm{mi}$. NE of Ketchikan, Coast Mts.; $55^{\circ} 27^{\prime} 50^{\prime \prime} \mathrm{N}, 130^{\circ}$. $52^{\prime} 10^{\prime \prime} \mathrm{W}$; (map 3 ).

Local name recorded in 1955 by USGS. See Checats Point.

Lower Cohoe Lake: lake, $0.8 \mathrm{mi}$. long, one of the Cohoe Lakes, on $\mathrm{W}$ coast of Kenai Penin., 16 mi. SW of Kenai, Cook Inlet Low.; 60 $0^{\circ} 19^{\prime}$ $35^{\prime \prime} \mathrm{N}, 151^{\circ} 20^{\prime} 30^{\prime \prime} \mathrm{W} ; B G N$ 1966; (map 62).

D. F. Smith, Anchorage, proposed this name in 1965 to differentiate the Cohoe Lakes.

Lower Dewey Lake: lake, $0.8 \mathrm{mi}$. long, $1.4 \mathrm{mi}$. W of Upper Dewey Lake and $2 \mathrm{mi}$. SE of Skagway, Coast Mts.; $59^{\circ} 26^{\prime} 30^{\prime \prime} \mathrm{N}, 135^{\circ} 19^{\prime}$ $00^{\prime \prime} \mathrm{W}$; (map 45)

Local name obtained by USGS field personnel and published on Federal maps since 1950.

Lower Doame Lake: lake, $0.6 \mathrm{mi}$. long, on Doame River, $3 \mathrm{mi}$. S of Gateway Knob, in Alsek River, $62 \mathrm{mi}$. SE of Yakutat, St. Elias Mts.; $59^{\circ} 08^{\prime} 50^{\prime \prime} \cdot \mathrm{N}, 138^{\circ} 09^{\prime} 25^{\prime \prime} \mathrm{W}$; (map 46).

Local name published in 1959 by USGS.

Lower Ella Lake: lake, $1 \mathrm{mi}$. long, on $\mathrm{E}$ coast of Revillagigedo I., in course of Ella Creek, $2 \mathrm{mi}$. $\mathrm{W}$ of Behm Canal, Alex. Arch.; $55^{\circ} 30^{\prime} 15^{\prime \prime} \mathrm{N}$, $131^{\circ} 02^{\prime} 55^{\prime \prime} \mathrm{W}$; (map 3 ).

Local name reported in 1952 by USGS

Lower Engineers Camp: locality, pop. 60, on The Alaska RR., on Kenai Penin., at $\mathrm{E}$ end of Turnagain Arm, Chugach Mts.; 60 $49^{\prime} \mathrm{N}$, $148^{\circ} 58^{\prime} \mathrm{W}$; (map 63 )

Railroad camp reported in 1953 by USGS.

Lower Falls: falls, on Kisaralik River, $4.5 \mathrm{mi}$. NW of Quicksilver Creek, $65 \mathrm{mi}$. SE of Bethel, Kilbuck-Kuskokwim Mts.; $60^{\circ} 25^{\prime} 30^{\prime \prime} \mathrm{N}$, $160^{\circ} 05^{\prime} 30^{\prime \prime} \mathrm{W}$; (map 59).

Local name reported in 1949 by USGS.

Lower Fire Lake: lake, $0.4 \mathrm{mi}$. long, one of the Fire Lakes, at head of Fire Creek, $15 \mathrm{mi}$. NE of Anchorage, Cook Inlet Low.; 61 $21^{\prime} 20^{\prime \prime}$
N, $149^{\circ} 32^{\prime} 30^{\prime \prime}$ W; (map 69). Var. Fire Lake.

Local name reported in 1942 as Fire Lake by AMS.

Lower Fish Lake: lake, $1 \mathrm{mi}$ long, in course of Fish Creek, 4 mi. NE of Paxson, Alaska Ra.; $63^{\circ} 05^{\prime} 15^{\prime \prime} \mathrm{N}, 145^{\circ} 25^{\prime} 00^{\prime \prime} \mathrm{W}$; (map 86).

Name published on relatively recent maps.

Lower Fork Twelvemile Creek: stream, flows S $3 \mathrm{mi}$. to Twelvemile Creek, $3 \mathrm{mi}$. NNE of Twelvemile Mtn. and $17 \mathrm{mi}$. SW of Wiseman, Brooks Ra.; $67^{\circ} 11^{\prime} 30^{\prime \prime} \mathrm{N}, 150^{\circ} 24^{\prime} 00^{\prime \prime} \mathrm{W}$; (map 124).

Local name reported in 1956 by T. E. Taylor, USGS.

Lower Halfway Lake: lake, $1.2 \mathrm{mi}$. long, $0.7 \mathrm{mi}$. $\mathrm{S}$ of Gas Lake and $23 \mathrm{mi}$. SE of Beaver, Yukon-Tanana High.; $66^{\circ} 05^{\prime} \mathrm{N}, 146^{\circ} 57^{\prime} \mathrm{W}$; (map 119).

Local descriptive name obtained in 1956 by USGS.

Lower Herring Bay: estuary, on NW coast of Knight I., extends SW $4.5 \mathrm{mi}$, to Knight Island Passage, $10 \mathrm{mi}$. NE of Chenega, Chugach Mts.; $60^{\circ} 22^{\prime} 45^{\prime \prime} \mathrm{N}, 147^{\circ} 51^{\prime} 15^{\prime \prime} \mathrm{W}$; (map 63).

Local name published in 1908 by USC\&GS. So named because it is south of Herring Bay.

Lower Horseshoe Lake: lake, $2 \mathrm{mi}$. long, $\mathrm{E}$ of Big Rat Lake, $21 \mathrm{mi}$. SW of Beaver, Yukon Flats; $66^{\circ} 15^{\prime} 30^{\prime \prime} \mathrm{N}, 148^{\circ} 09^{\prime} 00^{\prime \prime} \mathrm{W}$; (map 118). Var. Lower Horseshoe.

Probably named by William Yanert, who recorded it on a 1916 manuscript map of the Yukon Flats (Stuck, 1917, map facing p. 122).

Lower Icefall: icefall, in Muldrow Glacier, NW of Mount Tatum, in Carpé Ridge, on NE slopes of Mount McKinley, Alaska Ra.; $63^{\circ} 12^{\prime} 30^{\prime \prime} \mathrm{N}, 150^{\circ} 51^{\prime} 00^{\prime \prime} \mathrm{W}$.; (map 88)

Mountain climbers' name published in 1954 by USGS

Lowe River: stream, heads in Deserted Glacier, flows W $28 \mathrm{mi}$. to head of Port Valdez, 1.6 mi. S of Valdez, Chugach Mts. ; $61^{\circ} 05^{\prime} 30^{\prime \prime} \mathrm{N}$, $146^{\circ} 15^{\prime} 30^{\prime \prime} \mathrm{W}$; (map 68)

Named by Capt. W. R. Abercrombie, USA, in 1898 , for Lt. Percival G. Lowe, a member of his exploring party.

Lower Kalskag: village, pop. 122, on right bank of Kuskokwim River $2.2 \mathrm{mi}$. SW of Kalskag and $27 \mathrm{mi}$. W of Aniak, Yukon-Kuskokwim Delta; $61^{\circ} 30^{\prime} 50^{\prime \prime} \mathrm{N}, 160^{\circ} 21^{\prime} 30^{\prime \prime} \mathrm{W}$; (map 73). Var. Kaltchagamut, Kaltkhagamute, Kaltshak.

This name is listed as "Kaltkhagamute," having a population of 106 , in the 10th Census, in 1880. W. S. Post, USGS, spells the name "Kal-tchagamut" on his 1898 field sheet, but places the village on the right bank of a slough 1.5 miles west of the present village called "Lower Kalskag." The place shown by Post is now abandoned; the people have moved to Lower Kalskag and Kalskag. The Russian (Greek) Orthodox Church maintains a mission here which probably accounts for its separation from Kalskag.

Lower Ketchikan Lake: lake, $1.8 \mathrm{mi}$. long, in course of Ketchikan Creek, $1 \mathrm{mi}$. N of Ketchi- kan, Revillagigedo I., Alex. Arch.; 55 $22^{\prime} 15^{\prime \prime}$ N, 131 37'30' W; BGN 1966; (map 3). Var. Ketchikan Lake, Ketchikan Lakes, Ketchikan Lake Number One.

Local name reported in 1911 as "Ketchikan Lake" by USFS.

Lower Khudsnu Bay: bay, see Whitewater Bay. Lower Kobuk Canyon: canyon, on Kobuk River, $9 \mathrm{mi}$. W of Norutak Lake, Kotzebue-Kobuk Low.; $66^{\circ} 49^{\prime} \mathrm{N}, 154^{\circ} 42^{\prime} \mathrm{W}$; (map 116).

Name published by USGS in 1956 . Referred to as the "lower gorge of the Kowak" by Mendenhall (1902, p. 25).

Lower Kootznahoo Bay: bay, see Whitewater Bay.

Lower Koutsnow Bay: bay, see Whitewater Bay.

Lower Lagoon, The: bend, of Naknek River 0.6 mi. wide, $\mathbf{S}$ of Grassy Point, on Alaska Penin., $15 \mathrm{mi}$. SE of Naknek, Bristol Bay Low.; $58^{\circ}$. $39^{\prime} 45^{\prime \prime} \mathrm{N}, 156^{\circ} 39^{\prime} 00^{\prime \prime} \mathrm{W}$; (map 41).

Descriptive name given by USGS in 1962 "because of the wide bend in the Naknek River."

Lower Lake: lake, see Dolgoi Lake.

Lower Lake George: lake, $2.7 \mathrm{mi}$. long, $27 \mathrm{mi}$. SE of Palmer, between Inner Lake George and Knik Glacier, Chugach Mts.; $61^{\circ} 19^{\prime} \mathrm{N}$, $148^{\circ} 30^{\prime} \mathrm{W}$; (map 69).

Local name reported in 1951 by Stone (1963, p. 33).

Lower Malina Lake: lake, $1.5 \mathrm{mi}$. long, $17 \mathrm{mi}$ NW of Afognak, on W coast of Afognak I.; $58^{\circ} 09^{\prime} 30^{\prime \prime} \mathrm{N}, 153^{\circ} 08^{\prime} 00^{\prime \prime} \mathrm{W}$; (map 43).

Name derived from Malina Bay; published by USGS in 1952 .

Lower Mountain: mountain, 5,462 ft., on $\mathrm{N}$ bank of Beaver Creek, $18 \mathrm{mi}$. N of Pingpong Mtn. and $65 \mathrm{mi}$. NE of McCarthy, Alaska Ra.; $62^{\circ} 00^{\prime} \mathrm{N}, 141^{\circ} 21^{\prime} \mathrm{W}$; (map 67)

Local name obtained by USGS and published on maps since 1954.

Lower Mouth Birch Creek: stream, distributary, flows NW $50 \mathrm{mi}$. from Birch Creek to Lower Birch Creek Slough, $39 \mathrm{mi}$. SW of Fort Yukon, Yukon Flats; $66^{\circ} 27^{\prime} \mathrm{N}, 146^{\circ} 38^{\prime} \mathrm{W}$; (map 119).

Local name published in 1951 by USGS.

Lower Mouth Porcupine River: stream, distributary of Porcupine River, flows SW $6.4 \mathrm{mi}$. to Yukon River, $5 \mathrm{mi}$. W of Fort Yukon, Yukon Flats; $66^{\circ} 34^{\prime} 40^{\prime \prime} \mathrm{N}, 145^{\circ} 26^{\prime} 00^{\prime \prime} \mathrm{W}$; (map 119).

Local name obtained in 1956 by USGS.

Lower Niklaremut Creek: stream, flows SW 2.3 mi. to Yukon River, $5 \mathrm{mi}$. NW of Ruby, Kokrines-Hodzana High.; $64^{\circ} 44^{\prime} 30^{\prime \prime} \mathrm{N}, 155^{\circ}$ $35^{\prime} 40^{\prime \prime}$ W; (map 98). Var. Necklaremont River.

Riverboat pilots' name shown on 1940 "Navigation Chart, Tanana-Yukon Rivers" of the Riverboat Service, U.S. Dept. of Interior.

Lower Noatak Canyon: canyon, $8 \mathrm{mi}$. long, course of Noatak River through Igichuk Hills, $21 \mathrm{mi}$. N of Kotzebue, Arctic Slope; 67 $14^{\prime}$ $\mathrm{N}, 162^{\circ} 33^{\prime} \mathrm{W}$; (map 128). Var. Amortak Canyon, Amortuk Canyon.

Local name reported in 1956 by Orth. The 
Eskimo name "Amortak" means "canyon."

Lower Ohmer Lake: lake, $0.9 \mathrm{mi}$. long, on Kenai Penin., $1 \mathrm{mi}$. $\mathrm{N}$ of Skilak Lake and $33 \mathrm{mi}$. ESE of Kenai, Chugach Mts.; $60^{\circ} 27^{\prime} 20^{\prime \prime}$ N, $150^{\circ}$ $18^{\prime} 50^{\prime \prime} \mathrm{W} ; B G N 1966$; (map 62). Var. Alcatraz Lake.

Local name reported in 1966 by USGS. Named for the late Earl N. Ohmer, former chairman of the Territorial Game Commission. "Alcatraz Lake" was a local name reported in 1958 by USGS.

Lower Paradise Lake: lake, extends NE-SW 1.5 $\mathrm{mi}$., at SW end of Paradise Lakes, $20 \mathrm{mi}$. NE of Seward, Chugach Mts.; $60^{\circ} 20^{\prime} 30^{\prime \prime} \mathrm{N}$, $149^{\circ} 04^{\prime} 30^{\prime \prime} \mathrm{W}$; (map 63).

Local name reported in 1951 by USGS.

Lower Passage: water passage, trends SE-NW 6 mi., between Knight and Disk Is., in Prince William Sound, $40 \mathrm{mi}$. SE of Whittier, Chugach Mts.; $60^{\circ} 30^{\prime} \mathrm{N}, 147^{\circ} 40^{\prime} \mathrm{W}$; BGN 1908; (map 63). Var. Knight Island Passage.

Local name reported in 1908 by USC\&GS.

Lower Ramparts: bluffs, $300 \mathrm{ft}$. high, extend 4 mi. along banks of Porcupine River, $35 \mathrm{mi}$. NE of Chalkyitsik, Porcupine Plat.; $66^{\circ} 59^{\prime} \mathrm{N}$, $142^{\circ} 46^{\prime} \mathrm{W}$; ( $\left.\operatorname{map} 120\right)$.

Descriptive name published in 1895 by USC\&GS.

Lower Ramparts : canyon, see Rampart Gorge.

Lower Ruby Greek: stream, flows SW $1.6 \mathrm{mi}$. to Cache Creek, opposite Hansen Bar, $31 \mathrm{mi}$. NW of Talkeetna, Alaska Ra.; $62^{\circ} 26^{\prime} 32^{\prime \prime} \mathrm{N}, 151^{\circ}$ 03'00" W; (map 81).

Prospectors' name reported in the 1930's by USGS.

Lower Russian Lake: lake, on Kenai Penin., 1.5 mi. long, coursed by Russian River, $6 \mathrm{mi}$. NW of Upper Russian Lake, $29 \mathrm{mi}$. NW of Seward, Chugach Mts.; $60^{\circ} 26^{\prime} 30^{\prime \prime} \mathrm{N}, 1^{\circ} 9^{\circ}$ $59^{\prime} 00^{\prime \prime} \mathrm{W}$; ( $\left.\operatorname{map} 63\right)$.

Local name published by USGS (Martin and others, 1915, pl. 2).

Lower Silvis Lake: lake, $0.8 \mathrm{mi}$. long, on Revillagigedo I., W of George Inlet, in course of Beaver Falls Creek, Alex. Arch.; $55^{\circ} 23^{\prime} 00^{\prime \prime} \mathrm{N}$, $131^{\circ} 30^{\prime} 30^{\prime \prime} \mathrm{W}$; (map 3). Var. Silvis Lake. Local name reported in 1919 by USGS.

Lower Sucker Creek: stream, heads in Sucker Lake, flows SE 13 mi. to Alexander Creek, 6.5 mi. NW of Susitna and $33 \mathrm{mi}$. NW of Anchorage, Cook Inlet Low.; $61^{\circ} 36^{\prime} 50^{\prime \prime} \mathrm{N}, 150^{\circ} 39^{\prime}$ $30^{\prime \prime} \mathrm{W}$; $(\operatorname{map} 70)$

Local name reported in 1958 by USGS.

Lower Summit Lake: lake, $0.5 \mathrm{mi}$. long, on Kenai Penin., along Canyon Creek, $16 \mathrm{mi}$. S of Sunrise, Chugach Mts. ; $60^{\circ} 39^{\prime} 45^{\prime \prime} \mathrm{N}, 149^{\circ} 28^{\prime} 40^{\prime \prime}$ W; (map 63).

Local name reported about 1914 by USGS (Martin and others, 1915, pls. 2, 4).

Lower Sweetheart Lake: lake, $5 \mathrm{mi}$. long, on Sweetheart Creek, 2 mi. from Gilbert Bay and $38 \mathrm{mi}$. ESE of Juneau, Coast Mts.; $57^{\circ}$ $56^{\prime} 45^{\prime \prime} \mathrm{N}, 133^{\circ} 38^{\prime} 05^{\prime} \mathrm{W}$; (map 8). Var. Gilbert Lake, Sweetheart Lake.

Local name reported in 1955 by USGS; named "Sweetheart Lake; not Gilbert Lake" in 1923 by USFS.
Lower Talarik Creek: stream, flows SSW $10 \mathrm{mi}$. to Iliamna Lake $24 \mathrm{mi}$. SW of Iliamna, Bristol Bay Low.; $59^{\circ} 37^{\prime} 25^{\prime \prime} \mathrm{N}, 155^{\circ} 32^{\prime} 00^{\prime \prime} \mathrm{W}$; (map 51).

Name published in 1957 by USGS.

Lower Tangle Lake: lake, $2 \mathrm{mi}$. long, one of Tangle Lakes, near head of Delta River, 16 mi. NW of Paxson, Alaska Ra.; $63^{\circ} 08^{\prime} 20^{\prime \prime}$ $\mathrm{N}, 145^{\circ} 57^{\prime} 30^{\prime \prime} \mathrm{W}$; (map 86).

Name published on relatively recent maps.

Lower Tazimina Lake: lake, $6 \mathrm{mi}$. long, in course of Tazimina River, $10 \mathrm{mi}$. E of Nondalton and $20 \mathrm{mi}$. NE of Iliamna, Aleutian Ra.; $50^{\circ}$. $00^{\prime} \mathrm{N}, 154^{\circ} 28^{\prime} \mathrm{W}$; BGN 1910; (map 51). Var. Lower Taschemna Lake, Nohutno Lake, Nulkutno Lake, Tazhemina Lake, Taziminah Lake.

Tanaina Indian name reported in 1902 as "Taziminah Lakes" by A. G. Maddren, USGS. The present spelling was shown on a 1909 fieldsheet by D.C. Witherspoon, USGS.

Lower Telida Lake: lake, $1 \mathrm{mi}$. long, $52 \mathrm{mi}$. NE of Medfra, Kuskokwim Low.; $63^{\circ} 25^{\prime} \mathrm{N}, 153^{\circ}$ $14^{\prime} \mathrm{W}$; (map 89).

Local name derived from the village name; reported in 1958 by USGS.

Lower Tonsina: locality, $1 \mathrm{mi}$. NW of junc. of Tonsina River with Copper River, $64 \mathrm{mi}$. $\mathrm{NE}$ of Valdez, Copper River Basin; 61 $39^{\prime} 20^{\prime \prime}$ $\mathrm{N}, 144^{\circ} 40^{\prime} 30^{\prime \prime} \mathrm{W}$; (map 68).

This probably was little more than a roadhouse; first reported by F. H. Moffit, USGS, in 1914.

Lower Trail Lake: lake, extends N $1.5 \mathrm{mi}$. from head of Trail River to Upper Trail Lake, 22 mi. N of Seward, Chugach Mts. ; $60^{\circ} 26^{\prime} 30^{\prime \prime}$ $\mathrm{N}, 149^{\circ} 21^{\prime} 45^{\prime \prime} \mathrm{W}$; (map 63).

Local name reported in 1951 by USGS.

Lower Ugashik Lake: lake, $11 \mathrm{mi}$. across, in course of Ugashik River, $\mathrm{S}$ of Upper Ugashik Lake, on Alaska Penin., $14 \mathrm{mi}$. E of Ugashik, Aleutian Ra.; 57 $31^{\prime} \mathrm{N}, 156^{\circ} 54^{\prime} \mathrm{W}$; (map 36). Var. Ugashik Lakes.

Local name reported in 1903 as "Ugashik Lakes" for both Upper and Lower Ugashik Lakes by G. C. Martin (1905, pl. 6), USGS. The name "Lower Ugashik Lake" is applied separately on 1956 USGS map.

Lower Willow Creek: stream, flows SE $7.5 \mathrm{mi}$. to Casadepaga River, $18 \mathrm{mi}$. NE of Solomon, Seward Penin. High.; $64^{\circ} 49^{\prime}$ N, $164^{\circ} 21^{\prime}$ W; (map 95). Var. Alert Creek, First Fork Koksuktapaga, Left Fork Casadepaga River, Willow Creek.

Prospectors' name reported in 1905 by T. G. Gerdine, USGS. It was reported in 1900 as "Left Fork" by E. C. Barnard (in Brooks, 1901, pl. 17), USGS. It was shown as "Left Fork" on the lower course and as "Willow" at the head on a map of Cape Nome gold fields by David Fox, Jr., dated 1901.

Lower Wolf Lake: lake, $0.7 \mathrm{mi}$. long, drains into Moser Bay, on W coast of Revillagigedo I., Alex. Arch.; 55 $33^{\prime} 30^{\prime \prime} \mathrm{N}, 131^{\circ} 37^{\prime} 00^{\prime \prime} \mathrm{W}$; $B G N$ 1962; (map 3).

Local name reported in 1961 by USFS.
Low Hill: hill, $407 \mathrm{ft}$, just S of North Hill, on north-central Saint Paul I., in Pribilof Is.; $57^{\circ} 11^{\prime} 50^{\prime \prime} \mathrm{N}, 170^{\circ} 18^{\prime} 30^{\prime \prime} \mathrm{W}$; (map 38).

Named by Elliott (1881, Saint Paul map).

Low Island: island, $0.1 \mathrm{mi}$. across, in Sitka Sound, $10 \mathrm{mi}$. SW of Sitka, Alex. Arch.; $57^{\circ} 00^{\prime} 40^{\prime \prime}$ $\mathbf{N}, 135^{\circ} 36^{\prime} 35^{\prime \prime} \mathrm{W}$; (map 9). Var. Low Islets, Ostrov Nizmennoy, Ostrov Nizmynnoy.

This is an 1882 translation by USC\&GS of the name given in 1809 by the Russian navigator Ivan Vasiliev the first; reported by Lt. Sarichev (1826, map 19) IRN, as "O[strov] Nizmynnoy."

Low Island: island, $0.5 \mathrm{mi}$. long, $0.8 \mathrm{mi}$. W of Entrance Point, at NW end of Narrow Strait, on $\mathrm{N}$ coast of Kodiak I.; $57^{\circ} 54^{\prime} 45^{\prime \prime} \mathrm{N}, 152^{\circ}$ $33^{\prime} 20^{\prime \prime} \mathrm{W}$; (map 34). Var. Nizmennie, Ostrov Nizmennyy.

Translation of the descriptive name "O[strov] Nizmennyy" given in 1839 by SubLt. Mikhail Murashev and published in 1849 on Russian Hydrog. Dept. Chart 1425.

Low Island Anchorage: anchorage, $1 \mathrm{mi}$. across, between Low I. and Shakmanof Point, $11 \mathrm{mi}$. NW of Kodiak, on $\mathrm{N}$ coast of Kodiak I.; $57^{\circ} 55^{\prime} \mathrm{N}, 152^{\circ} 34^{\prime} \mathrm{W}$; (map 34).

Name derived from Low Island; published in 1943 by USC\&GS.

Low Island Number One: island, Sozavarika Island.

Low Island Number Two: island, see Let Island.

Low Islets: group of islands, $0.5 \mathrm{mi}$. across, in Sitka Sound, $1 \mathrm{mi}$. E of Shoals Point, on Kruzof I., $11 \mathrm{mi}$. W of Sitka, Alex Arch.; $57^{\circ} 00^{\prime} 41^{\prime \prime} \mathrm{N}, 135^{\circ} 36^{\prime} 30^{\prime \prime} \mathrm{W}$; (map 9).

Descriptive name published by USC\&GS in 1883 Coast Pilot (p. 138). They are "low rocky islets, wooded and with some rocks * * *” (U.S. Coast and Geodetic Survey, 1891, p. 168).

Low Islets: island, see Low Island.

Low Lake: lake, $0.6 \mathrm{mi}$. long, on Revillagigedo I., in course of Fish Creek, at head of Thorne Arm, Alex. Arch.; 55 $23^{\prime} 50^{\prime \prime} \mathrm{N}, 131^{\circ} 11^{\prime} 40^{\prime \prime}$ W; (map 3).

Local name reported in 1949 by USGS.

Iow Lake: lake, $0.7 \mathrm{mi}$. long, between Farewell Lake and junc. of South Fork Kuskokwim River and Tin Creek, $71 \mathrm{mi}$. SE of McGrath, Kuskokwim Low.; 62 $33^{\prime} 00^{\prime \prime} \mathrm{N}, 153^{\circ} 36^{\prime} 20^{\prime \prime}$ W; (map 80).

Local descriptive name reported in 1958 by USGS.

Lowlying Point: point of land, see Nismeni Point.

Lowpal Pass; pass, sec Kiwook Pass.

Low Point: point of land, on E shore of Bay of Waterfalls, on $\mathrm{S}$ coast of Adak I., Aleutian Is.; $51^{\circ} 41^{\prime} 20^{\prime \prime} \mathrm{N}, 176^{\circ} 50^{\prime} 20^{\prime \prime} \mathrm{W}$; $B G N$ 1936; (map 17).

Descriptive name given by Lt. William Gibson, USN, commander of the schooner Fenimore Cooper, during the North Pacific Exploring Expedition in 1855.

Low Point: point of land, $\mathrm{N}$ point of entrance to Mine Harbor, on SE shore of Herendeen 
Bay, on Alaska Penin., Aleutian Ra.; 55 46$15^{\prime \prime} \mathrm{N}, 160^{\circ} 42^{\prime} 00^{\prime \prime} \mathrm{W}$; (map 28).

Named in 1890 by Lt. Comdr. Z. L. Tanner, USN.

Low Point: point of land, on E shore of St. John Harbor, on NW coast of Zarembo I., Alex. Arch.; $56^{\circ} 27^{\prime} \mathrm{N}, 132^{\circ} 57^{\prime} \mathrm{W}$; (map 6).

Named in 1886 by Lt. Comdr. A. S. Snow, USN; name published in 1887 on USC\&GS Chart 706

Low Point: point of land, on E shore of Chilkoot Inlet, $2.3 \mathrm{mi}$. SW of Mount Villard, $14 \mathrm{mi}$ $\mathrm{S}$ of Skagway, Coast Mts.; $59^{\circ} 15^{\prime} 50^{\prime \prime} \mathrm{N}$, $135^{\circ} 22^{\prime} 10^{\prime \prime}$ W; BGN 1929; (map 45).

Local descriptive name published in 1914 by USC\&GS. The point is marked by Low Point Light, a white wooden house, 35 feet above high tide, built in 1915 .

Low Point: point of land, see Broken Point.

Low Point: point of land, see Kaslokan Point.

Low Point: rock, on $\mathrm{W}$ shore of Bay of Waterfalls, on SW coast of Adak I., Aleutian Is.; $51^{\circ} 41^{\prime} 25^{\prime \prime} \mathrm{N}, 176^{\circ} 50^{\prime} 45^{\prime \prime} \mathrm{W}$; (map 17).

Descriptive name published by USC\&GS in 1956 on Chart 9145.

Low Ridge: moraine, $4 \mathrm{mi}$. long, $27 \mathrm{mi}$. SE of Palmer, between Inner and Lower Lakes George, Chugach Mts; $61^{\circ} 18^{\prime} 45^{\prime \prime} \mathrm{N}, 148^{\circ}$ $31^{\prime} 00^{\prime \prime} \mathrm{W}$; (map 69).

Descriptive name reported in 1951 by Stone (1963, p. 33).

Lowrie Island: island, $0.6 \mathrm{mi}$. long, in Pacific Ocean, $1.2 \mathrm{mi}$. N of Forrester I., Alex.'Arch.; $54^{\circ} 51^{\prime} 30^{\prime \prime} \mathrm{N}, 133^{\circ} 32^{\prime} 15^{\prime \prime} \mathrm{W}$; (map 1).

Named in 1879 by Dall, USC\&GS, for "Captain Lowrie, of the [vessel] * * * Captain Cook, in 1786, who was perhaps the first English-speaking navigator to visit [the] Queen Charlotte Islands, and possibly the first who saw this island."

Low Rock: rock, in Hook Arm Sea Otter Harbor, $0.1 \mathrm{mi}$. S of Channel Island, on $W$ coast of Dall I., Alex Arch.; 55 $07^{\prime} 30^{\prime \prime}$ N, $133^{\circ} 09^{\prime} 52^{\prime \prime}$ W; (map .4).

Descriptive name given by USC\&GS in 1924.

Loyal Hills: mountains, $1,325 \mathrm{ft}$, center of Kiska I., Aleutian Is. ; $51^{\circ} 57^{\prime} 30^{\prime \prime}$ N, $177^{\circ} 28^{\prime}$ $46^{\prime \prime} \mathrm{E}$; (map 14).

An arbitrary name beginning with " $L$ " to correspond to " $L$ " grid used by the U.S. Army for tactical purposes during World War II; published on a 1943 Army map.

Loyd Hill: mountain, 1,340 ft., center of Kiska I., Aleutian Is.; $51^{\circ} 57^{\prime} 53^{\prime \prime} \mathrm{N}, 177^{\circ} 28^{\prime} 47^{\prime \prime} \mathrm{E}$; (map 14).

An arbitrary name beginning with " $L$ " to correspond to "L" grid used by the U.S. Army for tactical purposes during World War II; published on a 1943 Army map.

Loy Island: island, $1,700 \mathrm{ft}$. across, in Twelvemile Arm Kasaan Bay, near center of Prince of Wales I., Alex. Arch.; $55^{\circ} 29^{\prime}$ N, $132^{\circ} 37^{\prime}$ W; (map 4). Var. Log Island.

Local descriptive name; reported in 1905 by E. F. Dickins, USC\&GS. A loy is a long, narrow spade once used for stony soil.

Lozi-koket: village, see Ruby.
Ltua, Mys: point of land, see Fairweather, Cape.

Ltuya Bay: 'bay, see Lituya Bay.

Lubbe Creek: stream, flows $3 \mathrm{mi}$. W to McCarthy Creek $10 \mathrm{mi}$. NE of McCarthy, Wrangell Mts. ; $61^{\circ} 32^{\prime} 45^{\prime \prime} \mathrm{N}, 142^{\circ} 47^{\prime} 10^{\prime \prime} \mathrm{W}$; (map 67).

Local name obtained by USGS and published on maps since 1954.

Lucan, Point: point of land, on $\mathrm{N}$ tip of Althorp Penin., on Chichagof I., $0.8 \mathrm{mi}$. SE of Three Hill I., $34 \mathrm{mi}$. W of Hoonah, Alex. Arch.; $58^{\circ} 09^{\prime} \mathrm{N}, 136^{\circ} 22^{\prime} \mathrm{W}$; (map 10).

Named in 1794 by Capt. George Vancouver, $\mathrm{RN}$, probably for the Countess of Lucan. Lucan was also the family name of the wife of the second Earl of Spencer (Wagner, 1937, p. 395).

Lucan, Point: point of land, see Column Point.

Lucas Island: island, $0.8 \mathrm{mi}$. long, in Skilak Lake on Kenai Penin., $41 \mathrm{mi}$. ESE of Kenai, Chugach Mts.; $60^{\circ} 24^{\prime} 30^{\prime \prime} \mathrm{N}, 150^{\circ} 10^{\prime} 00^{\prime \prime} \mathrm{W}$; (map 62).

Local name reported in 1959 by USGS.

Luce Island: island, $0.1 \mathrm{mi}$. across, in Kutchuma Is., $3 \mathrm{mi}$. S of Sitka, off W coast of Baranof I., Alex. Arch.; $57^{\circ} 00^{\prime} 40^{\prime \prime} \mathrm{N}, 135^{\circ} 19^{\prime} 20^{\prime \prime} \mathrm{W}$; $(\operatorname{map} 9)$.

Named in 1880 by U'S. Navy "for Mr. Luce, USN, one of the men on the U.S.S. Jamestown at Sitka that year." The name was published by USC\&GS in 1883 Coast Pilot (p. 144).

Luce Island: island, see Emgeten Island.

Luchek Mountain: mountain, 1,699 ft., on W shore of Moser Bay, on SW coast of Kodiak I., $41 \mathrm{mi}$. S of Karluk; $57^{\circ} 00^{\prime} 20^{\prime \prime} \mathrm{N}, 154^{\circ} 10^{\prime} 00^{\prime \prime}$ W; BGN 1934; (map 35)

Named by USC\&GS in 1934 from the "Eskimo word meaning 'signal' because the summit forms a natural signal for navigation."

Lucia Glacier: glacier, heads at $60^{\circ} 05^{\prime} \mathrm{N}$, $140^{\circ} 00^{\prime} \mathrm{W}$, and trends SE and $\mathrm{S} 15 \mathrm{mi}$. to 1961 terminus, $4 \mathrm{mi}$. NW of Blizhni Point and 23 mi. NW of Yakutat, St. Elias Mts.; $59^{\circ} 52^{\prime} \mathrm{N}$, $139^{\circ} 53^{\prime} \mathrm{W}$; (map 46).

Named in 1891 for Lucia Kerr, the mother of Mark B. Kerr, USGS topographer, who accompanied Russell on his expedition to this area.

Lucia Nunatak: nunatak, 1,400 ft., in Lucia Glacier, $2 \mathrm{mi}$. E of Floral Pass and $30 \mathrm{mi}$. NW of Yakutat, St. Elias Mts. ; $59^{\circ} 58^{\prime} 30^{\prime \prime} \mathrm{N}, 1^{\prime 39^{\circ}}$ $54^{\prime} 30^{\prime \prime} \mathrm{W}$; (map 46).

Named in 1906 by Tarr (1909, p. 79), USGS, for Lucia Glacier.

Lucile Creek: stream, heads in Lucile Lake, flows W $11 \mathrm{mi}$. and joins Little Meadow Creek to form Meadow Creek, $22 \mathrm{mi}$. W of Palmer, Cook Inlet Low.; $61^{\circ} 34^{\prime} 00^{\prime \prime} \mathrm{N}, 149^{\circ} 46^{\prime} 45^{\prime \prime}$ W; (map 69).

Local name published by The Alaska Railroad on a 1918 blueprint map.

Lucile Gulch: stream, see Lucille Greek.

Lucile Lake: lake, $1.7 \mathrm{mi}$. long, in Matanuska Valley, $W$ of Wasilla, $11 \mathrm{mi}$. SW of Paimer, Cook Inlet Low.; $61^{\circ} 34^{\prime} 30^{\prime \prime} \mathrm{N}, 149^{\circ} 28^{\prime} 30^{\prime \prime}$
W; (map 69). Var. Wassillas Lake, Lucille Lake.

Named in 1898 by Capt. E. F. Glenn, USA, and published by him on a map of military expeditions of the route from Knik Arm to Tanana River.

Lucille Creek: stream, flows N $0.6 \mathrm{mi}$. to Livengood Creek, $3 \mathrm{mi}$. NE of Livengood, YukonTanana High.; $65^{\circ} 32^{\prime} 25^{\prime \prime} \mathrm{N}, 148^{\circ} 27^{\prime} 10^{\prime \prime} \mathrm{W}$; (map 105). Var. Lucile Gulch.

Name originally reported in 1916 by J. B. Mertie, USGS, as Lucile Gulch (in Brooks and others, 1918, pl. 13), but local usage has applied the name to the stream as shown on recent USGS maps.

Lucille Lake: lake, see Lucile Lake.

Luck Creek: stream, flows $\mathrm{N} 7.5 \mathrm{mi}$. to Luck Lake, on NE coast of Prince of Wales I., Alex. Arch.; 55 $55^{\prime} 42^{\prime \prime} \mathrm{N}, 132^{\circ} 45^{\prime} 51^{\prime \prime} \mathrm{W}$; $B G N$ 1963; (map 4).

Local name recorded in 1949 by USGS; derived from Luck Point.

Luck Lake: lake, 2 mi. long, NE coast of Prince of Wales I., Alex. Arch.; 55 $56^{\prime} \mathrm{N}, 132^{\circ} 46^{\prime}$ W; (map 4).

Local name recorded in 1949 by USGS; derived from Luck Point.

Luck-Luc Creek : stream, flows SW to Noxapaga River, about $15 \mathrm{mi}$. W of Imuruk Lake, Seward Penin. High.; (map 110).

Prospectors' name reported on a precinct map of Seward Peninsula by Monroe and Hutchins; corrected to June 1903 by Arthur Gibson. The stream cannot be precisely located on current maps.

Luck Point: point of land, $2.4 \mathrm{mi}$. NE of Luck Lake, on NE coast of Prince of Wales I., Alex. Arch.; 55 59' N, $132^{\circ} 44^{\prime}$ W; (map 4).

Named in 1886 by Lt. Comdr. A. S. Snow, USN.

Lucky Bay: estuary, extends SW $1.5 \mathrm{mi}$. to Knight Island Passage, at SW end of Knight I., $8.5 \mathrm{mi}$. SE of Chenega, Chugach Mts.; $60^{\circ} 13^{\prime} 00^{\prime \prime} \mathrm{N}, 147^{\circ} 52^{\prime} 15^{\prime \prime} \mathrm{W}$; (map 63).

Local name reported in 1909 by USC\&GS.

Lucky Chance Lakes: lakes, on Baranof I., W of Lucky Chance Mountain, $12 \mathrm{mi}$. SE of Sitka, Alex. Arch.; $56^{\circ} 57^{\prime} 10^{\prime \prime} \mathrm{N}, 1^{\circ} 5^{\circ} 03^{\prime} 00^{\prime \prime}$ W; (map 5).

Local name recorded in 1951 by USGS.

Lucky Chance Mountain: mountain, 3,240 ft., on Baranof I., 13 mi. SE of Sitka, Alex. Arch.; $56^{\circ} 57^{\prime} 00^{\prime \prime} \mathrm{N}, 135^{\circ} 02^{\prime} 30^{\prime \prime} \mathrm{W}$; (map 5).

Local name recorded in 1951 by USGS

Lucky Cove: estuary, $0.2 \mathrm{mi}$. long, on S coast of Revillagigedo I., $3.4 \mathrm{mi}$. NW of Point Alaya, Alex. Arch.; $55^{\circ} 12^{\prime} 45^{\prime \prime} \mathrm{N}, 131^{\circ} 16^{\prime} 00^{\prime \prime} \mathrm{W}$; (map 3).

Local navigators' name obtained in 1904 by H. C. Fassett, USBF.

Lucky Creek: stream, flows S $2 \mathrm{mi}$. to Cache Creek, between Iron and Rambler Creeks, 29 mi. NW of Talkeetna, Alaska Ra.; $62^{\circ} 29^{\prime} 50^{\prime \prime}$ $\mathrm{N}, 150^{\circ} 27^{\prime} 15^{\prime \prime} \mathrm{W}$; (map 81).

Prospectors' name reported in 1911 by Capps (1913, fig. 5), USGS.

Lucky Creek: stream, flows NW $2 \mathrm{mi}$. to Livengood Creek, 4 mi. NE of Livengood, Yukon- 
Tanana High.; $65^{\circ} 33^{\prime} 05^{\prime \prime} \mathrm{N}, 148^{\circ} 25^{\prime} 35^{\prime \prime} \mathrm{W}$; (map 105). Var. Goodluck Creek.

Name originally reported in 1916 as Goodluck Greek by J. B. Mertie (in Brooks and others, 1918, pl. 13), USGS; however, local usage has shortened it to the present form shown on recent USGS maps.

Lucky Greek: stream, flows SW $1.7 \mathrm{mi}$. to join Shasta Creek to form Harris Creek which flows to North Fork Kougarok River, 5 mi. NE of Harris Dome and $37 \mathrm{mi}$. NW of Imuruk Lake, Seward Penin. High.; $65^{\circ} 41^{\prime}$ N, $164^{\circ}$ $27^{\prime} \mathrm{W}$; (map 110).

Prospectors' name reported in 1901 by T. G. Gerdine (in Collier, 1902, pl. 12), USGS.

Lucky Creek: stream, flows $\mathrm{S}$ to Sinuk River, about $39 \mathrm{mi}$. NW of Nome, Seward Penin. High.; (map 94).

Prospectors' name reported on the 1900 "Map of Nome Peninsula" by J. M. Davidson and B. D. Blakeslee; this feature has not been positively identified.

Lucky Dick Creek: stream, see Lucky Ditch Creek.

Lucky Ditch Creek: stream, flows NW $1.4 \mathrm{mi}$. to Grantley Harbor, $4 \mathrm{mi}$. SE of Teller, Seward Penin. High.; 65 $5^{\circ} 15^{\prime}$ N, 166 $16^{\circ} 14^{\prime}$ W; (map 111). Var. Lucky Dick Creek.

Prospectors' name reported on the 1908 "Map of Seward Peninsula" by Arthur Gibson.

Lucky Dog Creek: stream, flows SW $5 \mathrm{mi}$. to Pilgrim River, $18 \mathrm{mi}$. W of Mount Bendeleben and $56 \mathrm{mi}$. SW of Imuruk Lake, Seward Penin. High.; $65^{\circ} 07^{\prime} \mathrm{N}, 164^{\circ} 43^{\prime} \mathrm{W}$; (map 110). Var. Williams Creek.

Prospectors' name reported on a map of Cape Nome gold fields by David Fox, Jr., dated 1901. Fox appears to have applied the name "Williams" to this stream and "Lucky Dog" to the next stream south.

Lucky Gulch: ravine, trends $\mathrm{E} 2 \mathrm{mi}$. to Faro Creek, $25 \mathrm{mi}$. N of Goodnews, Kilbuck-Kuskokwim Mts.; $59^{\circ} 27^{\prime} 30^{\prime \prime} \mathrm{N}, 161^{\circ} 31^{\prime} 00^{\prime \prime} \mathrm{W}$; (map 53).

Probably a prospector's name reported in 1919 by G. L. Harrington (in Brooks, 1921, pl. 7), USGS. Gold was discovered in this area about 1900 .

Lucky Gulch: ravine, trends NW $1 \mathrm{mi}$. to Valdez Creek, $70 \mathrm{mi}$. SE of Healy, Alaska Ra.; $63^{\circ} 12^{\prime}$ $30^{\prime \prime} \mathrm{N}, 147^{\circ} 17^{\prime} 00^{\prime \prime} \mathrm{W}$; (map 87).

Prospectors' name reported in 1908 by $F$. H. Moffit (in Brooks and others, 1909, p. 159), USGS.

Lucky Gulch: ravine, in Kantishna Hills, extends S $0.5 \mathrm{mi}$. to Eureka Creek, $3.5 \mathrm{mi}$. N of Won-

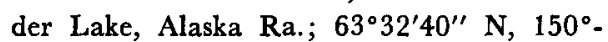
53'30" W; BGN 1932; (map 88).

Prospectors' name reported in 1932 by F. G. Wells and S. C. Kain, USGS.

Lucky Gulch: ravine, trends SW $3.1 \mathrm{mi}$. to Monument Creek, 11 mi. S of Long, KilbuckKuskokwim Mts.; $64^{\circ} 15^{\prime} \mathrm{N}, 155^{\circ} 30^{\prime} \mathrm{W}$; (map 98).

Prospectors' name reported by Mertie and Harrington (1924, p. 97), USGS.
Lucky Gulch: ravine, trends SE $2.5 \mathrm{mi}$. to Fox Creek, $15 \mathrm{mi}$. NW of Eagle, Yukon-Tanana High.; 64.57' N, 141 ${ }^{\circ} 34^{\prime} \mathrm{W}$; (map 102).

Prospectors' name shown on an 1898 manuscript map by C. A. Woodruff, Fort Cudahy, Canada.

Lucky Gulch: ravine, trends N 5 mi. to Fourth of July Creek, $33 \mathrm{mi}$. NW of Eagle, YukonTanana High.; $65^{\circ} 09^{\prime} 45^{\prime \prime} \mathrm{N}, 141^{\circ} 50^{\prime} 00^{\prime \prime} \mathrm{W}$; (map 103).

Prospectors' name reported in 1902 by Lt. Hjalmar Erickson and William Yanert, USA. Lucky Gulch: stream, see Bullion Creek.

Lucky Hill: mountain, 5,200 ft., $70 \mathrm{mi}$. SE of Healy, Alaska Ra., $63^{\circ} 11^{\prime} 25^{\prime \prime} \mathrm{N}, 147^{\circ} 14^{\prime} 50^{\prime \prime}$ W; (map 87).

Name taken from the name of the ravine which heads on its western flank; reported in 1960 by USGS.

Lucky Point: point of land, between Finger and Sweeper Coves, on SW shore of Kuluk Bay, on NE coast of Adak I., Aleutian Is.; 51 51'$20^{\prime \prime} \mathrm{N}, 176^{\circ} 35^{\prime} 00^{\prime \prime} \mathrm{W}$; BGN 1936; (map 17).

Named by members of the U.S. Navy Aleutian Island Survey Expedition in 1934, for the survey signal $L u k$, located on this point. Lucky Point: point of land, on left bank of Yukon River, $\mathbf{S}$ of Horseshoe Lake, $3 \mathrm{mi}$. NW of Holy Cross, Innoko Low.; 62 $14^{\prime} 20^{\prime \prime}$ $\mathrm{N}, 159^{\circ} 48^{\prime} 50^{\prime \prime} \mathrm{W}$; (map 78).

Local name obtained in 1952 by USGS.

Lucky Shot: village, see Lucky Shot Landing Lucky Shot Landing: village, pop. 10 (1940), at junc. of Grubstake and Willow Creeks, $15 \mathrm{mi}$. NW of Palmer, Talkeetna Mts.; 61 ${ }^{\circ} 46^{\prime} 30^{\prime \prime}$ N, $149^{\circ} 24^{\prime} 30^{\prime \prime}$ W; (map 69). Var. Lucky Shot.

Name of a mining camp reported in 1942 by AMS. A post office was established here in 1933, using just the name Lucky Shot, but was discontinued in 1942 (Ricks, 1965, p. 40). Recent USGS maps indicate an airfield and five or six buildings at this site. The name is derived from the nearby Lucky Shot mine.

Lucky Six Creek: stream, flows SW $7 \mathrm{mi}$. from Gull Pass to Noatak River, Brooks Ra.; $67^{\circ}$ $32^{\prime} \mathrm{N}, 154^{\circ} 57^{\prime} \mathrm{W}$; (map 125). Var. Kununak.

Gold was discovered on this stream in 1898 and the stream was probably named at that time. The place was so inaccessible, however, that the miners spent only a few days there. Not only was the area inaccessible but it was also difficult to prospect because of lack of timber. It is reported that the planks used for sluice boxes were whipsawed by hand on the Reed River, $30 \mathrm{mi}$. away, and hauled by dogs and men to the "Lucky Six." The Eskimo name for it is "Kununak," reported by Orth, USGS, in 1956 to mean "waterfall."

Lucky Strike Creek: stream, flows S $4.5 \mathrm{mi}$. to Bluestone River, $11 \mathrm{mi}$. SE of Teller, Seward Penin. High.; $65^{\circ} 08^{\prime} \mathrm{N}, 166^{\circ} 09^{\prime} \mathrm{W}$; (map 111).
Local name reported in 1900 by E. C. Barnard (in Brooks, 1901, pl. 17), USGS.

Lucy, Port: bay, $1 \mathrm{mi}$. across, extends NE $5 \mathrm{mi}$., $6 \mathrm{mi}$. $\mathrm{N}$ of the village of Port Alexander, on $S$ coast of Baranof I., Alex. Arch.; 56 ${ }^{\circ} 0^{\prime}$ N, $134^{\circ} 39^{\prime} \mathrm{W}$; (map 5).

Named for charting purposes; name published in 1901 by USC\&GS.

Lucy Lake: lake, 1,700 ft. long, in Matanuska Valley, $16 \mathrm{mi}$. SW of Palmer, Cook Inlet Low.; $61^{\circ} 31^{\prime} \mathrm{N}, 149^{\circ} 34^{\prime} \mathrm{W}$; (map 69).

Local name reported in 1950 by USGS.

Lucy Lake: lake, $1.6 \mathrm{mi}$. long, near Eldridge Glacier terminus, $40 \mathrm{mi}$. N of Talkeetna, Alaska Ra.; $62^{\circ} 53^{\prime} 40^{\prime \prime} \mathrm{N}, 149^{\circ} 53^{\prime} 15^{\prime \prime} \mathrm{W}$; (map 82).

Local name reported in 1951 by USGS.

Ludaseska Creek: stream, flows E $1 \mathrm{mi}$. to Ghilkat Inlet, $3 \mathrm{mi}$. NW of Glacier Point and $23 \mathrm{mi}$. SW of Skagway, St. Elias Mts.; $59^{\circ}$ $07^{\prime} 45^{\prime \prime} \mathrm{N}, 135^{\circ} 27^{\prime} 00^{\prime \prime} \mathrm{W}$; BGN 1922; (map 45). Var. Hludasetsk, Kludasetsh, Tikudasetzk.

"Ludaseska" is a Tlingit Indian name published in 1923 on IBC Sheet 9 (1951 atlas). The variant names are also reported to be Indian.

Ludvik Lake: lake, $0.4 \mathrm{mi}$. across, on Baranof I., $9 \mathrm{mi}$. N of Port Alexander, Alex. Arch.; 56 $22^{\prime} 40^{\prime \prime} \mathrm{N}, 134^{\circ} 42^{\prime} 00^{\prime \prime} \mathrm{W}$; (map 5).

Local name recorded in 1951 by USGS.

Luebner Lake: lake, $0.3 \mathrm{mi}$. across, on Kenai Penin., $10 \mathrm{mi}$. SW of Whittier, Chugach Mts.; $60^{\circ} 45^{\prime} 30^{\prime \prime} \mathrm{N}, 148^{\circ} 59^{\prime} 15^{\prime \prime} \mathrm{W}$; (map 63).

Local name reported in 1952 by USGS.

Lufin Point: point of land, see Manning Point

Lug Point: point of land, SE tip of Lane Ridge, between Mutt and Jeff Coves, on SE coast of Kiska I., Aleutian Is.; $51^{\circ} 56^{\prime} 00^{\prime \prime} \mathrm{N}, 177^{\circ}$ 29'20" E; (map 14). Var. Walrus Point.

Name shown on a 1943 AMS map; variant name shown on a 1943 USAAF map.

Luisa Creek: stream, flows SW to Coarse Gold Creek which flows to Penny River, about 8 mi. N of Solomon, Seward Penin. High.; (map 95).

Prospectors' name shown on Arthur Gibson's "Map of Cape Nome Precinct" dated 1904. This stream cannot be precisely located on current maps.

Lukanin Bay: bay, $1.5 \mathrm{mi}$. across, between Lukanin and Tonki Points, on SE coast of Saint Paul I., in Pribilof Is.; $57^{\circ} 08^{\prime} 30^{\prime \prime} \mathrm{N}$, $170^{\circ} 14^{\prime} 00^{\prime \prime} \mathrm{W}$; (map 38). Var. Lukannon Bay.

See Lukanin Rookery.

Lukanin Hill: hill, $90 \mathrm{ft}$, , on $\mathrm{S}$ coast of Saint Paul I., in Pribilof Is.; $57^{\circ} 07^{\prime} 40^{\prime \prime} \mathrm{N}, 170^{\circ}$ $15^{\prime} 40^{\prime \prime}$ W.; (map 38). Var. Lukannon Hill. See Lukanin Rookery.

Lukanin Point: point of land, just NE of Saint Paul, on SE coast of Saint Paul I., in Pribilof Is.; $57^{\circ} 07^{\prime} 50^{\prime \prime} \mathrm{N}, 170^{\circ} 15^{\prime} 15^{\prime \prime} \mathrm{W}$; (map 38). Var. Lukannon Point.

See Lukanin Rookery.

Lukanin Rookery: rookery, on Lukanin Point, on S coast of Saint Paul I., in Pribilof Is.; 
$57^{\circ} 04^{\prime} 50^{\prime \prime} \quad$ N, $170^{\circ} 15^{\prime} 15^{\prime \prime}$ W; (map 38). Var. Lukannon Rookery.

Elliott (1881, p. 164) wrote “ ' Lukannon'; so named after one of the Russian pioneers, a sailor, who is said to have taken from St. Paul Island in 1787 , over 5,000 seaotter, aided by another promyshlenik, named Kaiekov; * * *." According to Petroff (Bancroft, 1886, p. 183) Ivan Lukanin was "the peredovchik [senior officer] with Ismailof."

Lukannon Bay: bay, see Lukanin Bay.

Lukannon Hill: hill, see Lukanin Hill.

Lukannon Point: point of land, see Lukanin Point.

Lukannon Rookery: rookery, see Lukanin Rookery.

Lukas Creek: stream, see Lumber Creek.

Luke Creek: stream, flows S $2.5 \mathrm{mi}$. to Luke Lake, $16 \mathrm{mi}$. W of Beaver, Yukon Flats; $66^{\circ}$ $22^{\prime} 30^{\prime \prime} \mathrm{N}, 147^{\circ} 59^{\prime} 00^{\prime \prime} \mathrm{W}$; (map 118).

Local name obtained in 1956 by USGS.

Lukeens Fort: locality, see Kolmakof.

Luke Lake: lake, $0.7 \mathrm{mi}$. across, $\mathbf{E}$ of Doctor Cook Lake, $16 \mathrm{mi}$. W of Beaver, Yukon Flats; $66^{\circ} 22^{\prime} 30^{\prime \prime} \mathrm{N}, 147^{\circ} 59^{\prime} 00^{\prime \prime} \mathrm{W}$; (map 118). Var. Third Lake.

Local name reported in 1956 by USGS; in 1916, William Yanert recorded the lake as "Third Lake" on a manuscript map. It was so called because the lake is third in a series of lakes.

Luke Point: point of land, between Grace Harbor and Vesta Bay on $\mathrm{E}$ coast of Dall I., Alex. Arch.; $54^{\circ} 55^{\prime} 45^{\prime \prime} \mathrm{N}, 132^{\circ} 53^{\prime} 35^{\prime \prime} \mathrm{W}$; $B G N$ 1929; (map 1). Var. Grace Point.

Named in 1928 by USC\&GS "in honor of Frank Luke, aviator in World War I, who made a brilliant record in the few weeks he served before being killed in action * **." The name "Grace Point" was proposed for this feature in 1927 by Capt. R. S. Patton, USC\&GS.

Lukins Fort: locality, see Kolmakof.

Lukluksukwik Lake: lake, $0.9 \mathrm{mi}$. across, $2.6 \mathrm{mi}$. W of Seemalik Butte, $45 \mathrm{mi}$. NW of Cape Mendenhall, Nunivak I.; $60^{\circ} 09^{\prime} \mathrm{N}, 167^{\circ} 14^{\prime}$ W; (map 57).

Eskimo name reported in 1942 by the USAAF.

Lukthlukrit Marsh: marsh, $1 \mathrm{mi}$. across, $2 \mathrm{mi}$. N of Kimiksthek Hill and $38 \mathrm{mi}$. NW of Cape Mendenhall, Nunivak I.; $60^{\circ} 09^{\prime} \mathrm{N}, 167^{\circ} 00^{\prime}$ W; (map 57).

Eskimo name refers to "molting place of geese," according in 1949 to USC\&GS.

Lulanna: locality, "in SE Alaska." Var. Sulan-na.

Former Haida Indian town reported in 1836-41 by Work (cnna) (Hodge, 1907, p. 778).

Lull, Point: point of land, on $\mathbf{E}$ shore of Echo Cove at $\mathrm{S}$ tip of Catherine I., $16 \mathrm{mi}$. SW of Angoon, Alex. Arch.; $57^{\circ} 18^{\prime} 00^{\prime \prime} \mathrm{N}, 1^{\prime 3} 4^{\circ}$ $48^{\prime} 45^{\prime \prime} W$; (map 9).

Named in 1883 by W. H. Dall, USC\&GS, for Capt. Phelps Lull, USN, a hydrographic inspector for USC\&GS ; published by USC\&GS in 1883 Coast Pilot (map, p. 122).

Lulu Creek: stream, flows NW $2 \mathrm{mi}$. to Cleary Creek, $20 \mathrm{mi}$. NE of Fairbanks, Yukon-Tanana High.; $65^{\circ} 06^{\prime} 30^{\prime \prime} \mathrm{N}, 147^{\circ} 29^{\prime} 00^{\prime \prime} \mathrm{W}$; (map 105). Var. Cora Gulch.

Local name originally reported in 1909 by L. M. Prindle (in Brooks and others, 1910, fig. 4), USGS, as Cora Gulch; however, through local usage the present name was adopted and published on recent maps.

Lulu Creek: stream, flows NW $1 \mathrm{mi}$. to Allene Creek, in Agiapuk River basin, $11 \mathrm{mi}$. NE of Teller, Seward Penin. High.; $65^{\circ} 21^{\prime} \mathrm{N}$, $166^{\circ} 02^{\prime} \mathrm{W}$; (map 111).

Prospectors' name reported on the 1908 "Map of Seward Peninsula" by Arthur Gibson.

Lulu Creek: stream, see Benson Creek.

Lulu Hill: mountain, 1,275 ft., center of Kiska I., Aleutian Is.; $51^{\circ} 58^{\prime} 20^{\prime \prime} \mathrm{N}, 177^{\circ} 24^{\prime} 54^{\prime \prime} \mathrm{E}$; (map 14).

An arbitrary name beginning with " $L$ " to correspond to "L" grid used by the U.S. Army for tactical purposes during World War II; published on a 1943 Army map.

Lulu Island: island, $7 \mathrm{mi}$. across, between Noyes and San Fernando Is., Alex. Arch.; 55 $28^{\prime}$ N, $133^{\circ} 30^{\prime} \mathrm{W}$; BGN 1922; (map 4).

Named in 1915 by Theodore Chapin (in Brooks and others, 1916, pl. 3), USGS, for his sister.

Lumber Bay: bight, $1.5 \mathrm{mi}$. across, on S coast of Alaska Penin., Aleutian Ra.; 55 $31^{\prime} 30^{\prime \prime} \mathrm{N}$, $160^{\circ} 27^{\prime} 00^{\prime \prime}$ W; (map 28). Var. Rough Beach.

Published as "Lumber Bay, or Rough Beach as it is called locally" by USC\&GS in 1916 Coast Pilot (p. 165).

Lumber Bay: bight, $1 \mathrm{mi}$. across, on $\mathrm{SW}$ coast of Chignik Bay and $4 \mathrm{mi}$. NE of Chignik, Aleutian Ra.; $56^{\circ} 19^{\prime} \mathrm{N}, 158^{\circ} 18^{\prime} \mathrm{W}$; (map 30).

Name reported in 1923 by R. H. Sargent, USGS; published in 1927 by USGS.

Lumber Cove: cove, $0.3 \mathrm{mi}$. across, at $\mathrm{S}$ end of Lisianski Strait, on Chichagof I., $17 \mathrm{mi}$. SW of Chichagof, Alex. Arch.; $57^{\circ} 50^{\prime} \mathrm{N}, 136^{\circ}$ 25' W; (map 9).

Descriptive name given by USC\&GS; published in 1925 Coast Pilot (p. 325). So named "because of the high trees in this area." Lumber Creek: stream, flows SW $1 \mathrm{mi}$. to Niukluk River, $1 \mathrm{mi}$. SW of Council and 32 mi. NE of Solomon, Seward Penin. High.; $64^{\circ} 53^{\prime} \mathrm{N}, 163^{\circ} 39^{\prime} \mathrm{W}$; (map 95). Var. Lukas Creek.

Prospectors' name published in 1956 by USGS ; reported as "Lukas Cr." on the 1908 "Map of Seward Peninsula" by Arthur Gibson.

Lump Island: island, $0.1 \mathrm{mi}$. across, in entrance to Pavlof Bay, Aleutian Ra.; $55^{\circ} 24^{\prime} 25^{\prime \prime} \mathrm{N}$, $161^{\circ} 37^{\prime} 40^{\prime \prime} \mathrm{W}$; (map 28)

Named in 1924 by USC\&GS.

Lump Mountain: mountain, 1,270 ft., $3 \mathrm{mi}$. NE of Beluga Hill and $10 \mathrm{mi}$. NW of Goodnews, Kilbuck-Kuskokwim Mts.; $59^{\circ} 09^{\prime} \mathrm{N}, 161^{\circ} 43^{\prime}$ W; (map 53).

Descriptive name given in 1914 by USC\& GS; published in 1915 on Chart 9103.
Lunatic Lake: lake, $0.5 \mathrm{mi}$. across, $\mathrm{N}$ of Jeff Cove, center of Kiska I., Aleutian Is, ; $51^{\circ}$ $56^{\prime} 25^{\prime \prime} \mathrm{N}, 177^{\circ} 28^{\prime} 15^{\prime \prime} \mathrm{E}$; (map 14).

An arbitrary name beginning with " $\mathrm{L}$ " to correspond to " $L$ " grid used by the U.S. Army for tactical purposes during World War II; published on a 1943 Army map.

Lunch Creek: stream, heads in a lake, flows SW and NW 4 mi. to Clover Passage, on W coast of Revillagigedo I., Alex. Arch.; 55 $30^{\prime} 45^{\prime \prime}$ $\mathrm{N}, 131^{\circ} 43^{\prime} 20^{\prime \prime} \mathrm{W}$; BGN 1962; (map 3).

Local name reported in 1961 by USFS.

Lunch Gulch: ravine, in Peters Hills, trends SE $2.6 \mathrm{mi}$. to South Fork Martin Creek, $25 \mathrm{mi}$. NW of Talkeetna, Alaska Ra.; $62^{\circ} 25^{\prime} 30^{\prime \prime} \mathrm{N}$, $150^{\circ} 52^{\prime} 00^{\prime \prime} \mathrm{W}$; (map 81).

Prospectors' name reported in the 1930's by USGS.

Lunch Lake: lake, $2 \mathrm{mi}$. long, $5 \mathrm{mi}$. SW of Minto, Tanana Low.; $64^{\circ} 52^{\prime} \mathrm{N}, 149^{\circ} 19^{\prime} \mathrm{W}$; (map 100).

Local name reported in 1950 by USGS topographers.

Lung Island: island, $1 \mathrm{mi}$. long, at mouth of Duncan Canal, on S coast of Kupreanof I., $21 \mathrm{mi}$. SW of Petersburg, Alex. Arch.; 56 ${ }^{\circ}$ $30^{\prime} 45^{\prime \prime} \mathrm{N}, 133^{\circ} 04^{\prime} 15^{\prime \prime} \mathrm{W}$; (map 6).

Named in 1887 by Lt. Comdr. C. M. Thomas, USN, for charting purposes; published in 1888 on USG\&GS Chart 705.

Lupine River: stream, heads in Brooks Ra., flows NW $45 \mathrm{mi}$. to Sagavanirktok River $30 \mathrm{mi}$. SW of its junc. with Ivishak River, Arctic Slope; $69^{\circ} 05^{\prime} \mathrm{N}, 148^{\circ} 44^{\prime} \mathrm{W}$; (map 140).

Named about 1951 by USGS geologists.

Lure Lake: lake, $0.4 \mathrm{mi}$. long, on Kenai Penin. NW of Paddle Lake, $31 \mathrm{mi}$. NE of Kenai, Cook Inlet Low.; $60^{\circ} 46^{\prime} 45^{\prime \prime} \mathrm{N}, 150^{\circ} 31^{\prime} 20^{\prime \prime}$ W; (map 62).

Named about 1963 by officials of Kenai National Moose Range, for administrative purposes.

Lurvey Basin: valley, near head of Lurvey Greek on NW slope of Sheep Mtn., $3 \mathrm{mi}$. E of Juneau, Coast Mts.; $58^{\circ} 18^{\prime} \mathrm{N}, 134^{\circ} 19^{\prime} \mathrm{W}$; (map 11). Var. Dix Bow Basin, Little Silver Bow Basin, Upper Silver Bow Basin.

Locally named for W. L. Lurvey who mined in this valley about 1883 . The miners also called it "Dix Bow Basin" for John Dix, one of the early miners at Juneau in 1881 (DeArmond, 1957, p. 30).

Lurvey Creek: stream, heads in glacier on NW slope of Sheep Mtn., flows $1 \mathrm{mi}$. NW to Gold Creek, $2.5 \mathrm{mi}$. E of Juneau, Coast Mts.; $58^{\circ}$ $18^{\prime} 35^{\prime \prime} \mathrm{N}, 134^{\circ} 19^{\prime} 50^{\prime \prime} \mathrm{W}$; (map 11). Var. Dix Creek, Dix Gulch.

Locally named for W. L. Lurvey, who mined along the creek about 1883 . The creek was also called "Dix Creek" and "Dix Gulch" by the miners working for John Dix (DeArmond, 1957, p. 30).

Lush Creek: stream, flows SE $25 \mathrm{mi}$. to East Fork Chandalar River $30 \mathrm{mi}$. W of Christian, Brooks Ra.; 67 $32^{\prime}$ N, $146^{\circ} 13^{\prime}$ W; (map 122).

Local name reported in 1927 by J. B. Mertie, Jr., USGS. In his notes one finds 
the notation "name of pike, trans[lation] of Ind[ian]."

Lush Lake: lake, $1.3 \mathrm{mi}$. long, on $\mathrm{W}$ bank of Yukon River, $3 \mathrm{mi}$. N of Rampart, $61 \mathrm{mi}$. ENE of Tanana, Kokrines-Hodzana High.; $65^{\circ} 33^{\prime} \mathrm{N}, 150^{\circ} 10^{\prime} \mathrm{W}$; (map 106).

Local name reported in 1956 by Orth.

Lusnoi Island: island, see Liesnoi Island.

Lutak Inlet: estuary, $4.5 \mathrm{mi}$. long, trends NW from head of Chilkoot Inlet to outlet of Chilkoot Lake, $0.5 \mathrm{mi}$. S of Chilkoot and $13 \mathrm{mi}$. SW of Skagway, Coast Mts.; 59 $17^{\prime} 15^{\prime \prime} \mathrm{N}$, $135^{\circ} 22^{\prime} 30^{\prime \prime} \mathrm{W}$; (map 45). Var. Klutak Inlet, West Arm Chilkoot Inlet.

Tlingit Indian name published in 1923 on IBC Sheet 9 (1951 atlas).

Luther Creek: stream, flows E $6.5 \mathrm{mi}$. to American River, $31 \mathrm{mi}$. NE of Teller, Seward Penin. High.; $65^{\circ} 36^{\prime} \mathrm{N}, 165^{\circ} 39^{\prime} \mathrm{W}$; (map 111).

Prospectors' name reported on a map by George M. Ashford dated August 1907.

Lutke, Cape: point of land, on $\mathbf{S}$ central coast of Unimak I., Aleutian Is.; $54^{\circ} 29^{\prime} 10^{\prime \prime} \mathrm{N}$, $164^{\circ} 20^{\prime} 15^{\prime \prime} \mathrm{W}$; (map 24). Var. Cape Promontory, Mys Sivuchiy, Sealion Cape, Siuchi.

Named by the Russian Hydrog. Dept. (1847, chart 1379) for Capt. Feodor Petrovitch Lutke who, in command of the corvette Seniavine, named many features in the Aleutian Islands while on a voyage around the world in 1826-29, and published an account of the voyage in 1836 which was used quite extensively in the preparation of this dictionary. This point was called M[ys] Sivuchiy meaning "sealion cape" by Capt. Tebenkov (1852, map 26) and Cape Promontory by USBF in 1888.

L! uxâ' caiyîk-ān: locality, see Tluhashaiyikan. Lyakh, Mys: point of land, see Liakik, Cape.

Lyakhik, Mys: point of land, see Liakik, Cape.

Lyakhik, Zaliv: bay, see Three Saints Bay.

Lydick Creek: stream, heads in Robinson Mts. and flows SW $2.5 \mathrm{mi}$. to Gulf of Alaska, 4.5 mi. NW of Icy Cape and $79 \mathrm{mi}$. NW of Yakutat, Malaspina Coastal Plain; $59^{\circ} 59^{\prime} 20^{\prime \prime} \mathrm{N}$, $141^{\circ} 48^{\prime} 20^{\prime \prime} \mathrm{W}$; (map 47).

Local name published in 1948 by USGS.

Lydick Slough: stream, flows SW $2 \mathrm{mi}$. to Eyak River, $4 \mathrm{mi}$. SE of Cordova, Malaspina Coastal Plain; 60 $30^{\prime} 15^{\prime \prime} \mathrm{N}, 145^{\circ} 40^{\prime} 00^{\prime \prime} \mathrm{W}$; (map 64).

Local name published in 1951 by USGS.

Lydonia, Mount: mountain, 3,262 ft., $4.5 \mathrm{mi}$. NNW of Chichagof, on W coast of Chichagof I., Alex. Arch.; $57^{\circ} 43^{\prime} 45^{\prime \prime} \mathrm{N}, 136^{\circ} 08^{\prime} 00^{\prime \prime} \mathrm{W}$; $B G N$ 1920; (map 9).

Named in 1920 by the USC\&GS for the U.S.S. Lydonia, a USC\&GS vessel, which was used in a reconnaissance of this region about this time.

Lydonia, Point: point of land, $\mathrm{N}$ point of entrance to Black Bay, $4 \mathrm{mi}$. NW of Chichagof, on $W$ coast of Chichagof I., Alex. Arch.; 57 $42^{\prime} 35^{\prime \prime} \mathrm{N}, 136^{\circ} 09^{\prime} 15^{\prime \prime} \mathrm{W}$; BGN 1926; (map 9).

Named in 1926 by USC\&GS. See Mount Lydonia and Lydonia Island.
Lydonia Island: island, $0.7 \mathrm{mi}$ long, $4 \mathrm{mi}$. NW of Chichagof, on $\mathrm{W}$ coast of Chichagof $\mathrm{I}$., Alex. Arch.; $57^{\circ} 42^{\prime} 40^{\prime \prime} \mathrm{N}, 136^{\circ} 10^{\prime} 00^{\prime \prime} \mathrm{W}$; BGN 1926; (map 9).

Named in 1926 by USC\&GS for the USC\&GS steamer Lydonia, which anchored near the foot of Mount Lydonia, just northwest of the island, a few years before.

Lyeel-ghit Cliff: cliff, $4 \mathrm{mi}$. SW of Savoonga, Koomlangeelkuk Bay, $\mathbf{N}$ coast of St. Lawrence I.; $63^{\circ} 40^{\prime} \mathrm{N}, 170^{\circ} 36^{\prime} \mathrm{W}$; (map 93).

Eskimo name reported in 1932 by $O$. W. Geist, Univ, of Alaska.

Lymam Rock: rock, see Lyman Rock.

Lyman Anchorage: anchorage, $1.2 \mathrm{mi}$. across, on E coast of Prince of Wales I., between Figgins and Lyman Points, on Kasaan Penin., Alex. Arch.; $55^{\circ} 33^{\prime} \mathrm{N}, 132^{\circ} 17^{\prime} \mathrm{W}$; (map 4). Var. Port Hadley.

Named in 1901 by USC\&GS for "Charles Lyman, second watch officer of the Coast Survey steamer Gedney, engaged in Coast Pilot work in 1900."

Lyman Creek: stream, see Sockeye Falls.

Lyman Point: point of land, on $\mathrm{E}$ coast of Prince of Wales I., E point of entrance to Lyman Anchorage on Kasaan Peninsula, Alex. Arch.; $55^{\circ} 32^{\prime} 30^{\prime \prime} \mathrm{N}, 132^{\circ} 16^{\prime} 35^{\prime \prime} \mathrm{W}$; (map 4).

Named and described in the 1901 Alaska Coast Pilot (p. 84).

Lyman Rock: rock, in Lyman Anchorage, on E coast of Prince of Wales I., on Kasaan Penin., Alex. Arch.; $55^{\circ} 32^{\prime} 25^{\prime \prime} \mathrm{N}, 132^{\circ} 17^{\prime} 25^{\prime \prime} \mathrm{W}$; (map 4). Var. Lymam Rock.

Named and described in the 1901 Alaska Coast Pilot (p. 84).

Lynch, Cape: point of land, $\mathrm{S}$ of Cone Bay, on NW coast of Heceta I., Alex. Arch.; 55 ${ }^{\circ} 47^{\prime}$ $\mathrm{N}, 133^{\circ} 42^{\prime} \mathrm{W}$; (map 4).

Local navigators' name recorded by $\mathrm{Lt}$. Comdr. H. E. Nichols (U.S. Coast and Geodetic Survey, 1891, p. 122) USN.

Lynden Creek: stream, flows W $2.4 \mathrm{mi}$. to Herendeen Bay, $14 \mathrm{mi}$. SW of Village of Port Moller, near SW end of Alaska Penin., Aleutian Ra.; $55^{\circ} 49^{\prime} \mathrm{N}, 160^{\circ} 45^{\prime} \mathrm{W}$; (map 28 ).

Name shown on 1963 USC\&GS chart.

Lynn Brothers: islands, in chain about $3.5 \mathrm{mi}$. long, on W side of Lynn Canal in St. James Bay, 35 mi. NW of Juneau, St. Elias Mts.; $58^{\circ} 36^{\prime} 30^{\prime \prime} \mathrm{N}, 135^{\circ} 12^{\prime} 00^{\prime \prime} \mathrm{W}$; (map 11). Var. Brothers, The Brothers.

Named "The Brothers" in 1868 by Comdr. R. W. Meade, USN; published by USC\&GS in the 1883 Coast Pilot (p. 195). The name was modified to Lynn Brothers in the 1891 Coast Pilot (p. 119). See Lynn Sisters.

Lynn Canal: water passage, $60 \mathrm{mi}$. long, trends $\mathrm{S}$ from Chilkat Is. to Chatham Strait, $22 \mathrm{mi}$. $\mathrm{W}$ of Juneau; $58^{\circ} 10^{\prime} \mathrm{N}, 134^{\circ} 58^{\prime} \mathrm{W}$; $B G N$ 1933; (map 11). Var. Lynn Channel.

Examined by Joseph Whidbey and named in July 1794 , by Capt. Vancouver (1798, v. 3, p. 249), RN, for his birthplace, King's Lynn, Norfolk, England (Wagner, 1937, p. 395).

Lynn Channel: water passage, see Lynn Canal.
Lynn Creek: stream, flows W $1 \mathrm{mi}$. to Snake River, $5 \mathrm{mi}$. NW of Nome, Seward Penin. High.; $64^{\circ} 35^{\prime} \mathrm{N}, 165^{\circ} 28^{\prime} \mathrm{W}$; (map 94).

Prospectors' name reported in 1899 by $D$. C. Witherspoon (in Schrader and Brooks, 1900 , map 2), USGS.

Lynne Lake: lake, 3,300 ft. long, $2 \mathrm{mi}$. S of Willow and $34 \mathrm{mi}$. N of Anchorage, Cook Inlet Low.; $61^{\circ} 42^{\prime} 40^{\prime \prime} \mathrm{N}, 150^{\circ} 02^{\prime} 20^{\prime \prime} \mathrm{W}$; (map 70).

Local name reported in 1958 by USGS.

Lynn Sisters: islands, both are $0.2 \mathrm{mi}$. long, off W shore of Lynn Canal $5.5 \mathrm{mi}$. S of Point Whidbey and $29 \mathrm{mi}$. NW of Juneau, St. Elias Mts.; $58^{\circ} 30^{\prime} 00^{\prime \prime} \mathrm{N}, 135^{\circ} 07^{\prime} 15^{\prime \prime} \mathrm{W}$; (map 11). Var. The Sisters.

Named "The Sisters" in 1868 by Comdr. R. W. Meade, USN, and later modified to "Lynn Sisters." The present name was published by USC\&GS in the 1883 Coast Pilot (p. 194). See Lynn Brothers.

Lynx Creek: stream, on Kenai Penin., flows N $3 \mathrm{mi}$. to Center Creek, $14 \mathrm{mi}$. SE of Sunrise, Chugach Mts.; $60^{\circ} 43^{\prime} 00^{\prime \prime} \mathrm{N}, 149^{\circ} 17^{\prime} 35^{\prime \prime} \mathrm{W}$; (map 63).

Local name published in 1899 by USGS.

Lynx Creek: stream, in Teocalli Mts., flows SE $5 \mathrm{mi}$. to Tatina River, $2.5 \mathrm{mi}$. $\mathbf{E}$ of junc. with South Fork Kuskokwim River, $85 \mathrm{mi}$. SE of McGrath, Alaska Ra.; $62^{\circ} 17^{\prime} 45^{\prime \prime} \mathrm{N}$, $153^{\circ} 18^{\prime} 20^{\prime \prime} \mathrm{W}$; (map 80).

Local name obtained in 1958 by USGS.

Lynx Creek: stream, flows SW $1 \mathrm{mi}$. to Nenana River, $1.4 \mathrm{mi}$. E of village of McKinley Park, Alaska Ra.; $63^{\circ} 43^{\prime} 58^{\prime \prime} \mathrm{N}, 148^{\circ} 52^{\prime} 20^{\prime \prime} \mathrm{W}$; BGN 1965; (map 87).

Named in 1965 by the Alaska Dept. of Highways for the "many lynx which live in the area." See Iceworm Gulch.

Lynx Creek: stream, heads in Kuskokwim Mts., flows SSE $12 \mathrm{mi}$. to North Fork Kuskokwim River, $11 \mathrm{mi}$. W of village of Lake Minchumina, Kuskokwim Low.; $63^{\circ} 52^{\prime} 05^{\prime \prime} \mathrm{N}, 152^{\circ}$ $50^{\prime} 45^{\prime \prime} \mathrm{W}$; (map 88).

Local name obtained in 1958 from Fabian Carey and "Val" Blackburn by USGS.

Lynx Creek: stream, flows SW $2 \mathrm{mi}$. to McAdam Creek, $40 \mathrm{mi}$. SE of Nenana, Alaska Ra.; $64^{\circ} 02^{\prime} 10^{\prime \prime}$ N, $148^{\circ} 40^{\prime} 45^{\prime \prime}$ W ; (map 100).

Prospectors' name reported in 1950 by USGS topographers.

Lynx Creek: stream, flows NE $18 \mathrm{mi}$. to Kantishna River, $44 \mathrm{mi}$. SE of Bitzshtini Mts., 'Tanana Low.; $64^{\circ} 19^{\prime} \mathrm{N}, 150^{\circ} 34^{\prime} \mathrm{W}$; (map 99).

Local name reported in 1952 by USGS.

Lynx Creek: stream, flows S $5 \mathrm{mi}$. to Grant Creek $2 \mathrm{mi}$. N of that stream's junc. with Yukon River, $25 \mathrm{mi}$. W of Tanana, KokrinesHodzana High.; $65^{\circ} 13^{\prime} 15^{\prime \prime} \mathrm{N}, 152^{\circ} 56^{\prime} 00^{\prime \prime}$ W; (map 106).

Prospectors' name reported in 1911 by H. M. Eakin, USGS.

Lynx Creek: stream, flows NE $16 \mathrm{mi}$. to Hess Creek, $20 \mathrm{mi}$. NE of Rampart, Yukon-Tanana High.; $65^{\circ} 41^{\prime}$ N, $149^{\circ} 34^{\prime}$ W; (map 105). 
Named by prospectors; reported in 1902 by Lt. H. Erickson, USA. The name was published by USGS (Prindle, 1905, pl. 16).

Lynx Creek: stream, on Seward Penin., flows NW $9 \mathrm{mi}$. to Lopp Lagoon, $11 \mathrm{mi}$. NE of Cape Prince of Wales and $51 \mathrm{mi}$. NW of Teller, Kotzebue-Kobuk Low.; $65^{\circ} 41^{\prime} \mathrm{N}, 167^{\circ} 49^{\prime} \mathrm{W}$; (map 111). Var. Potato Creek.

Prospectors' name reported in 1901 by T. G. Gerdine (in Collier, 1902, pl. 12), USGS.

Lynx Creek: stream, flows SW $2 \mathrm{mi}$. to Kogoluktuk River, $13 \mathrm{mi}$. NE of Shungnak, Brooks Ra.; 66 $58^{\prime}$ N, $156^{\circ} 44^{\prime}$ W; (map 115).

Prospectors' name reported by USGS after 1940.

Lynx Dome: mountain, 1,952 ft., $\mathrm{N}$ of Yukon River, $27 \mathrm{mi}$. WNW of Tanana, KolrinesHodzana High.; $65^{\circ} 16^{\prime} \mathrm{N}, 152^{\circ} 59^{\prime} \mathrm{W}$; (map 106).

Prospectors' name reported in 1956 by R. M. Chapman, USGS.

Lynx Lake: lake, 2 mi. long, S of Frog Mts. and Lake Nerka, $35 \mathrm{mi}$. NW of Dillingham, Kilbuck-Kuskokwim Mts.; $59^{\circ} 30^{\prime} \mathrm{N}, 158^{\circ} 53^{\prime} \mathrm{W}$; $B G N$ 1931; (map 52). Var. Chu-du-lung. Local name published by USBF in 1929 . The Eskimo name "Chu-du-lung" was used in 1910 by H. C. Fassett, USBF, and is reported to mean "a lot of trout."

Lynx Lake: lake, $0.5 \mathrm{mi}$. long, one of the Swanson Lakes, on Kenai Penin. S of Birch Tree Lake, $36 \mathrm{mi}$. NE of Kenai, Cook Inlet Low.; $60^{\circ} 51^{\prime} 10^{\prime \prime} \mathrm{N}, 150^{\circ} 23^{\prime} 55^{\prime \prime} \mathrm{W}$; (map 62).

Named about 1963 by officials of Kenai National Moose Range, for administrative purposes.

Lynx Lake: lake, $1.8 \mathrm{mi}$. long, $6 \mathrm{mi}$. S of Willow and $28 \mathrm{mi}$. N of Anchorage, Cook Inlet Low.; $61^{\circ} 38^{\prime} 00^{\prime} \mathrm{N}, 150^{\circ} 03^{\prime} 20^{\prime \prime} \mathrm{W}$; (map 70).

Local name reported in 1958 by USGS.

Lynx Mountains: mountain, see Sawtooth Mountain

Lyon Creek: stream, on Kenai Penin., flows NW $5 \mathrm{mi}$. to Tincan Creek, $11 \mathrm{mi}$. SE of Sunrise, Chugach Mts.; $60^{\circ} 46^{\prime} 50^{\prime \prime} \mathrm{N}, 149^{\circ} 13^{\prime} 00^{\prime \prime} \mathrm{W}$; (map 63).

Local name reported in 1909 by Grant and Higgins (1913, pl. 1), USGS.

Lysistoy, Ostrov: island, see Wooded Island.

Lyskova, Mys: point of land, see Lieskof Cape. Lysnoy, Ostrov: island, see Liesnoi Island.

Lysnoy, Ostrov: island, see Woody Island.

Lyvoy, Mys: point of land, see Left Cape.

\section{$\mathbf{M}$}

Mabe Gulch: ravine, trends NW $0.4 \mathrm{mi}$. to Lost Creek which flows to Nome River, $6 \mathrm{mi}$. NE of Nome, Seward Penin. High.; 64 $34^{\circ} 33^{\prime} 15^{\prime \prime}$ N, $165^{\circ} 14^{\prime} 20^{\prime \prime} \mathrm{W}$; (map 94).

Prospectors' name reported on the 1903 Campion Mining and Trading Co. map by George M. Ashford.

Mabel Bay: bay, extends SE 3 mi., off Cordova Bay, on SW coast of Prince of Wales I., $E$ of Point Webster, Alex. Arch.; 54 $59^{\prime} 40^{\prime \prime}$ N, $132^{\circ} 36^{\prime} 30^{\prime \prime} \mathrm{W}$; (map 1 ).

Local name published in 1924 by USC\&GS; derived from Mabel Island.
Mabel Creek: stream, flows N $8 \mathrm{mi}$. to Rocky Bay, 2 mi. SW of Thorne I., on $\mathrm{N}$ coast of Prince of Wales I., Alex. Arch.; $56^{\circ} 02^{\prime} \mathrm{N}$, $133^{\circ} 04^{\prime} \mathrm{W}$; (map 6).

Local name reported in 1949 by USGS; derived from Mable Island.

Mabel Creek: stream, flows SE $5 \mathrm{mi}$. to Mascot Creek in Noxapaga River basin, $33 \mathrm{mi}$. SW of Imuruk Lake, Seward Penin. High.; $65^{\circ} 27^{\prime}$ $\mathrm{N}, 164^{\circ} 23^{\prime} \mathrm{W}$; (map 110).

Prospectors' name reported in 1901 by T. G. Gerdine (in Collier, 1902, pl. 12), USGS.

Mabel Island: island, $0.7 \mathrm{mi}$. long, between Mabel and Cordova Bays, on SW coast of Prince of Wales I., Alex. Arch.; 54 ${ }^{\circ} 59^{\prime} 30^{\prime \prime}$ $\mathrm{N}, 132^{\circ} 35^{\prime} 45^{\prime \prime} \mathrm{W}$; (map 1).

Local name recorded in 1905 by E. F. Dickins, USC\&GS.

Mable Island: island, $0.4 \mathrm{mi}$. long, in Dewey Anchorage, between Etolin and Onslow Is., Alex. Arch.; $55^{\circ} 55^{\prime} 10^{\prime \prime} \mathrm{N}, 132^{\circ} 24^{\prime} 40^{\prime \prime} \mathrm{W}$; (map 4). Var. Mable Island.

Named in 1886 by Lt. Comdr. A. S. Snow, USN.

Mabel Island: island, $1 \mathrm{mi}$. long, in Whale Passage, between Thorne and Prince of Wales Is., $40 \mathrm{mi}$. SW of Wrangell, Alex. Arch.; 56 $03^{\prime} 00^{\prime \prime} \mathrm{N}, 133^{\circ} 04^{\prime} 30^{\prime \prime} \mathrm{W}$; (map 6).

Local name published in 1943 by USC\&GS.

Mabel, Lake: lake, see Josephine, Lake.

Mab Island: island, $3 \mathrm{mi}$. long, off $\mathbf{E}$ shore of Lynn Canal, $3 \mathrm{mi}$. SE of Point Bridget and $30 \mathrm{mi}$. NW of Juneau, Coast Mts.; $58^{\circ} 38^{\prime} 00^{\prime \prime}$ $\mathrm{N}, 134^{\circ} 57^{\prime} 15^{\prime \prime} \mathrm{W}$; (map 11).

Named in 1890 by Lt. Comdr. H. B. Mansfield, USN, and published in 1897 by USC\&GS on Chart 8302.

Mable, Lake: lake, see Josephine, Lake.

Mable Island: island, see Mabel Island.

Thichtam Creek: stream, flows SW $4.2 \mathrm{mi}$. to Tisuk River, $40 \mathrm{mi}$. NW of Nome, Seward Penin. High.; $64^{\circ} 59^{\prime} \mathrm{N}, 166^{\circ} 11^{\prime} \mathrm{W}$; (map 94).

Prospectors' name reported in 1900 by E. G. Barnard (in Brooks, 1901, pl. 17), USGS

McAdam Creek: stream, flows NW $3 \mathrm{mi}$. to California Creek, $38 \mathrm{mi}$. SE of Nenana, Alaska Ra. ; $64^{\circ} 02^{\prime} 25^{\prime \prime} \mathrm{N}, 148^{\circ} 42^{\prime} 30^{\prime \prime} \mathrm{W}$; (map 100).

Local name published in 1915 on a GLO[BLM] survey plat.

McAlister Creek: stream, see McAllister Creek. McAllister Creek: stream, flows E $2.5 \mathrm{mi}$. to Shoup Bay, $0.5 \mathrm{mi}$. SE of Palmer Creek and $11 \mathrm{mi}$. W of Valdez, Chugach Mts.; $61^{\circ} 08^{\prime}$ $05^{\prime \prime} \mathrm{N}, 146^{\circ} 35^{\prime} 45^{\prime \prime} \mathrm{W}$; (map 68). Var. McAlister Creek.

Local name published in 1912 by USGS

McAllister Gulch: ravine, trends NE $1 \mathrm{mi}$. to Arizona Creek which flows to Kougarok Creek, $15 \mathrm{mi}$. SW of Midnight Mtn. and 48 mi. W of Imuruk Lake, Seward Penin High.; $65^{\circ} 36^{\prime} \mathrm{N}, 164^{\circ} 52^{\prime} \mathrm{W}$; (map 110).

Prospectors' name reported on the 1908 "Map of Seward Peninsula" by Arthur Gibson.

McAntee Creek: stream, flows SE $7.5 \mathrm{mi}$. to Yukon River, $13 \mathrm{mi}$. NE of Ruby, Kokrines-

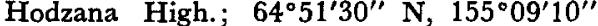
W; (map 98).

Local name obtained in 1956 by Orth.

Macaroni Creek: stream, flows S $6.3 \mathrm{mi}$. to Indian River, $S$ of Indian Mts., $40 \mathrm{mi}$. NE of Hochandochtla Mtn., Kokrines-Hodzana High.; $65^{\circ} 54^{\prime} 15^{\prime \prime} \mathrm{N}, 153^{\circ} 46^{\prime} 30^{\prime \prime} \mathrm{W}$; (map 107).

Local name obtained in 1954 by USGS topographers.

McArthur, Mount: mountain, 2,150 ft., $6 \mathrm{mi}$. $\mathrm{N}$ of Cape Decision, on $\mathbf{S}$ coast of Kuiu I., Alex. Arch.; $56^{\circ} 05^{\prime} 00^{\prime \prime} \mathrm{N}, 134^{\circ} 11^{\prime} 15^{\prime \prime} \mathrm{W}$; (map 5).

Named in 1886 by Lt. J. M. Helm, USN, for the Coast Survey steamer McArthur, which he commanded in 1886 .

McArthur, Port: bay, $0.6 \mathrm{mi}$. across, in Affeck Canal, on S coast of Kuiu I., Alex. Arch.; $56^{\circ} 04^{\prime} 00^{\prime \prime} \mathrm{N}, 134^{\circ} 07^{\prime} 30^{\prime \prime} \mathrm{W}$; (map 5).

Named in 1886 by Lt. J. M. Helm, USN, for the Coast Survey steamer McArthur, which he commanded in 1886.

McArthur Cove: cove, $0.5 \mathrm{mi}$. wide, on $\mathrm{N}$ coast of Ragged I., in Pye Is., $48 \mathrm{mi}$. E of Seldovia, Chugach Mts.; $59^{\circ} 22^{\prime} 30^{\prime \prime} \mathrm{N}, 150^{\circ} 21^{\prime} 30^{\prime \prime} \mathrm{W}$; $B G N$ 1929; (map 50).

Named by USC\&GS in 1927, probably for nearby McArthur Pass.

McArthur Creek: stream, flows N $23 \mathrm{mi}$. to Ladue River, W of Moosehorn Ridge, $30 \mathrm{mi}$. $\mathrm{NE}$ of Northway Junction, Yukon-Tanana High.; $63^{\circ} 16^{\prime} \mathrm{N}, 141^{\circ} 02^{\prime} \mathrm{W}$; $B G N$ 1912; (map 85).

Probably named in 1912 for J. J. McArthur of the IBC.

McArthur Flats: flats, extend NE $8 \mathrm{mi}$. from Kustatan Ridge at mouth of McArthur River, $30 \mathrm{mi}$. NW of Kenai, Cook Inlet Low.; $60^{\circ} 55^{\prime}$ $N$, $151^{\circ} 43^{\prime} \mathrm{W}$; (map 62).

Local name reported in 1958 by USGS.

McArthur Glacier: glacier, in Chigmit Mts. trends E $6.2 \mathrm{mi}$. to its terminus at head of McArthur River, $33 \mathrm{mi}$. W of Tyonek, Aleutian Ra.; 61 $06^{\circ} 50^{\prime \prime} \mathrm{N}, 152^{\circ} 21^{\prime} 00^{\prime \prime} \mathrm{W}$; (map 70).

Local name reported in 1958 by USGS.

McArthur Pass: water passage, on approach to Kiska Harbor from Bering Sea, between McArthur Reef and NE coast of Kiska I., Aleutian Is.; $52^{\circ} 04^{\prime} \mathrm{N}, 177^{\circ} 46^{\prime} \mathrm{E}$; (map 14).

Name published in the 1954 Coast Pilot (p. 466).

McArthur Pass: water passage, $0.5 \mathrm{mi}$. wide, N of Ragged I., connecting East Arm Nuka Bay with Gulf of Alaska, $48 \mathrm{mi}$. E of Seldovia, Chugach Mts.; $59^{\circ} 27^{\prime} 30^{\prime \prime} \mathrm{N}, 150^{\circ} 21^{\prime} 00^{\prime \prime} \mathrm{W}$; (map 50).

Named by USC\&GS in 1906 for Coast Survey steamer McAtthur which was used for surveys in this area during 1906-07.

McArthur Reef: reef, $0.8 \mathrm{mi}$. across, in Bering Sea, $11.5 \mathrm{mi}$. ESE of Kiska Volcano, Kiska I., Aleutian Is.; $52^{\circ} 03^{\prime} 45^{\prime \prime} \mathrm{N}, 177^{\circ} 52^{\prime} 10^{\prime \prime} \mathrm{E}$; $B G N$ 1937; (map 14)

Named for USC\&GS steamer McArthur and published on a 1906 USC\&GS chart. 
McArthur Reef: reef, in Sumner Strait, between Zarembo, Prince of Wales and Kupreanof Is., Alex. Arch.; $56^{\circ} 23^{\prime} 45^{\prime \prime} \mathrm{N}, 133^{\circ} 10^{\prime} 30^{\prime \prime} \mathrm{W}$; (map 6).

Named in late 1880 's by USC\&GS for its steamer McArthur.

McArthur Reef: rock, see Westdahl Rock.

McArthur River: stream, heads at McArthur Glacier terminus, flows SE $33 \mathrm{mi}$. to Trading Bay, $30 \mathrm{mi}$. NW of Kenai, Cook Inlet Low.; $60^{\circ} 55^{\prime} \mathrm{N}, 151^{\circ} 43^{\prime} \mathrm{W}$; BGN 1916; (map 62).

Named in 1910 by USC\&GS for the steamer McArthur.

McBann Creek: stream, flows NW $1.5 \mathrm{mi}$. to Gold Run Creek which flows to Casadepaga River, $23 \mathrm{mi}$. NE of Solomon, Seward Penin. High.; $64^{\circ} 51^{\prime} \mathrm{N}, 164^{\circ} 05^{\prime} \mathrm{W}$; (map 95).

Prospectors' name reported on a 1902 prospectors' manuscript map.

McBlaine Lake: lake, see Sadie Lake.

McBride Glacier: glacier, in Glacier Bay National Monument, heads on S slope of Takhinsha Mts., trends S $14 \mathrm{mi}$. to Muir Inlet, $4 \mathrm{mi}$. N of Sealers I., and $42 \mathrm{mi}$. SW of Skagway, St. Elias Mts.; $59^{\circ} 02^{\prime} 00^{\prime \prime} \mathrm{N}, 136^{\circ} 08^{\prime} 30^{\prime \prime}$ W; (map 45). Var. Second North Tributary.

Named in 1890 by Reid (1896, pl. 86) for $\mathrm{H}$. McBride, a member of his party in 1890. On the map dated 1890, Reid (1892, pl. 14) had named the glacier "Second North Tributary Muir Glacier," but later he changed the name to McBride Glacier.

McCall Creek: stream, heads at McCall Glacier in Romanzof Mts., flows NE $8 \mathrm{mi}$. to Jago River, $18 \mathrm{mi}$. NE of Mt. Michelson, Brooks Ra.; $69^{\circ} 25^{\prime} \mathrm{N}, 143^{\circ} 36^{\prime} \mathrm{W}$; BGN 1959; (map 138).

Named in 1958 by R. E. Isto, USGS, "after McCall Glacier."

McCall Glacier: glacier, heads on Mt. Hubley in Romanzof Mts., trends $\mathbf{N} 5 \mathrm{mi}$. to its terminus at head of McGall Greek, $10 \mathrm{mi}$. $\mathrm{E}$ of Mt. Michelson, Brooks Ra.; 69 $20^{\prime} \mathrm{N}$, $143^{\circ} 49^{\prime}$ W; BGN 1960; (map 138).

Named in 1956 by R. C. Hubley for John Gill McCall, glaciologist, University of Alaska, who died in 1954.

McCallie Creek: stream, flows E $3 \mathrm{mi}$. to Ohio Creek, $60 \mathrm{mi}$. SW of Healy, Alaska Ra.; $63^{\circ}$. $06^{\prime} \mathrm{N}, 149^{\circ} 49^{\prime} \mathrm{W}$; (map 87).

Local name reported in 1925 by S. R. Capps (in Moffit and others, 1927, pl. 2), USGS.

McCallum Creek: stream, heads at glacier near head of West Gulkana Glacier, flows SW $6 \mathrm{mi}$. to Phelan Creek, 2 mi. N of Fielding Lake and $14 \mathrm{mi}$. NW of Paxson, Alaska Ra.; $63^{\circ}$ $13^{\prime} 22^{\prime \prime} \mathrm{N}, 145^{\circ} 40^{\prime} 00^{\prime \prime} \mathrm{W}$; (map 86).

Named for the McCallum telegraph station; local name reported about 1913 by U.S. Army Signal Corps personnel.

McCally Creek: stream, heads on Barometer Mtn., flows NE $2.8 \mathrm{mi}$. to Kuskokwim River, $0.6 \mathrm{mi}$. $\mathrm{N}$ of Red Devil and $7 \mathrm{mi}$. NW of Sleetmute, Kilbuck-Kuskokwim Mts.; 61 ${ }^{\circ} 46^{\prime}$ $15^{\prime \prime} \mathrm{N}, 157^{\circ} 19^{\prime 2} 20^{\prime \prime} \mathrm{W}$; BGN 1943; (map 72).

Locally named "for a prospector" according to USGS in 1942

McCamant Creek: stream, flows SW $6 \mathrm{mi}$. to
Allen River, 6.5 mi. S of Gunsight Mtn. and $50 \mathrm{mi}$. W of Wiseman, Brooks Ra.; $67^{\circ} 23^{\prime}$ N, 151 $59^{\prime} \mathrm{W}$; BGN 1932; (map 124).

Named in 1931 by Robert Marshall "for an old prospector in the area, 'Mac' McCamant."

McCann Creek: stream, flows NE $1 \mathrm{mi}$. to Smalls River, $29 \mathrm{mi}$. NE of Cape Newenham, Kilbuck-Kuskokwim Mts.; $58^{\circ} 58^{\prime} 50^{\prime \prime} \mathrm{N}, 161^{\circ}$ $42^{\prime} 40^{\prime \prime}$ W; BGN 1938; (map 39).

Local name published in a 1933 .U.S. Dept. of Interior mining report.

McCann Hill: mountain, 4,275 ft., on AlaskaCanada boundary, $11 \mathrm{mi}$. NE of Eagle, Porcupine Plat.; $64^{\circ} 55^{\prime} \mathrm{N}, 141^{\circ} 00^{\prime} \mathrm{W}$; (map 102).

Named in 1914 by CPGGN for W. S. McCann, member of 1912 Canadian Geological Survey party under D. D. Gain nes.

McCartey, Point: point of land, on an island in Bronaugh Is., at mouth of Nichols Passage, Alex. Arch.; $55^{\circ} 05^{\prime} 50^{\prime \prime} \mathrm{N}, 131^{\circ} 42^{\prime} 15^{\prime \prime} \mathrm{W}$; (map 3). Var. McCarty Point.

Named in 1883 by Lt. Comdr. H. E. Nichols, USN.

McCarthy: settlement, at mouth of McCarthy Greek near Kennicott Glacier, $12 \mathrm{mi}$. NE of the junc. of the Nizina and Chitina Rivers, Wrangell Mts.; $61^{\circ} 26^{\prime} 00^{\prime \prime} \mathrm{N}, 142^{\circ} 55^{\prime} 30^{\prime \prime} \mathrm{W}$; (map 67). Var. Shushanna Junction.

Mining camp named for nearby stream. Established about 1908; population of 127 in $1920 ; 115$ in 1930 ; and 49 in 1939 . The McCarthy post office operated from 1912 to 1943. See Kennicott.

McCarthy: village, see Big Delta.

McCarthy, Mount: mountain, see McCarty, Mount.

McCarthy Creek: stream, flows $S$ and W $18 \mathrm{mi}$. from McCarthy Glacier terminus to Kennicott River at McCarthy, Wrangell Mts.; $61^{\circ}$ $25^{\prime} 45^{\prime \prime} \mathrm{N}, 142^{\circ} 56^{\prime} 00^{\prime \prime} \mathrm{W}$; (map 67).

Local name reported in 1900 by T. G. Gerdine (in Mendenhall and Schrader, 1903, pl. 3), USGS.

McCarthy Creek Glacier: glacier trends S 1.9 mi. to its terminus at head of McCarthy Creek, $11 \mathrm{mi}$. NE of McCarthy, Wrangell Mts.; $61^{\circ}$. $36^{\prime} \mathrm{N}, 142^{\circ} 49^{\prime} \mathrm{W}$; (map 67).

Named for the creek; reported by Moffit and Capps (1911, p. 48), USGS.

McGarthy Glacier: glacier, see McCarty Glacier. McCarthys Marsh: basin, $25 \mathrm{mi}$. long, at junc of Pardon and Fish Rivers, $\mathbf{S}$ of Bendeleben Mts. and $W$ of Darby Mts., Seward Penin. High.; $65^{\circ} 05^{\prime} \mathrm{N}, 163^{\circ} 10^{\prime} \mathrm{W}$; (map 110). Var. Upper Fish River Basin.

Local name published in 1956 by USGS; referred to as "Upper Fish River Basin" by Mendenhall (1901, p. 125), USGS.

McCarthy Telegraph Station: village, see Big Delta.

Macartney, Point: point of land, between Frederick Sound and Keku Strait, on NW coast of Kupreanof Island, $38 \mathrm{mi}$. SE of Angoon, Alex. Arch.; $57^{\circ} 01^{\prime} 30^{\prime \prime} \mathrm{N}, 134^{\circ} 02^{\prime} 50^{\prime \prime} \mathrm{W}$; (map 9).

Named in 1794 by Capt. Vancouver (1798, v. 3, p. 292) for George, Earl Macartney,
English Governor of the Windward Islands in the Caribbean and later Governor of Madras, India (Wagner, 1937, p. 395). It was discovered in 1794 by James Johnstone, a member of Capt. Vancouver's party.

McCarty: village, see Big Delta.

McCarty, Mount: mountain, 3,519 ft., $2.6 \mathrm{mi}$. SE of Mount Alexander and $26 \mathrm{mi}$. NE of Yukatat, St. Elias Mts.; $59^{\circ} 53^{\prime} \mathrm{N}, 139^{\circ} 24^{\prime}$ W; (map 46). Var. Mount McCarthy.

Named in 1905 by Tarr and Martin, (1906, map), USGS, for Neil McCarty, one of I. C. Russell's assistants on his 1891 expedition.

McCarty Glacier: glacier, heads in Kenai Mts. and trends $\mathrm{S} 7 \mathrm{mi}$. to its terminus at East Arm Nuka Bay, $45 \mathrm{mi}$. E of Homer, Chugach Mts. ; $59^{\circ} 44^{\prime} 00^{\prime \prime} \mathrm{N}, 150^{\circ} 13^{\prime} 30^{\prime \prime} \mathrm{W}$; $B G N$ 1911; (map 50).

Named for William McCarty of Seward and reported by USGS in 1911.

McCarty Glacier: glacier, heads $0.2 \mathrm{mi}$. W of summit of Mount McCarty, trends SE $1.6 \mathrm{mi}$. to 1961 terminus, $2.7 \mathrm{mi}$. NW of Cape Enchantment and $25 . \mathrm{mi}$. NE of Yakutat, St. Elias Mts.; 59 $51^{\prime} 45^{\prime \prime} \mathrm{N}, 139^{\circ} 23^{\prime} 10^{\prime \prime} \mathrm{W}$; $B G N$ 1911; (map 46). Var. McCarthy Glacier.

Named in 1905 by R. S. Tarr and G. C. Martin, USGS. See McCarty, Mount.

McCarty Lagoon: lagoon, $0.5 \mathrm{mi}$. wide, on $\mathrm{E}$ shore of East Arm Nuka Bay, Kenai Penin., $43 \mathrm{mi}$. ESE of Homer, Chugach Mts.; 59 32' $\mathrm{N}, 150^{\circ} 21^{\prime} \mathrm{W}$; BGN 1911; (map 50).

Local name reported by USGS iii 1911 as being "named for William McCarty of Seward."

McCarty Point: point of land, see McCartey, Point.

McCarty Roadhouse: village, see Big Delta.

McCarty Telegraph Station: village, see Big Delta.

McClellan Flats: tidal flat, $2.2 \mathrm{mi}$. across, at mouth of Chilkat River on Chilkat Inlet, 1 $\mathrm{mi}$. $\mathrm{N}$ of Pyramid Harbor and $17 \mathrm{mi}$. SW of Skagway, Coast Mts. ; $59^{\circ} 13^{\prime} \mathrm{N}, 135^{\circ} 29^{\prime} \mathrm{W}$; (map 45).

Published by USG\&GS in the 1891 Coast Pilot (p. 201). This flat was named by the U.S. Navy for Lt. E. P. McClellan, USN, who visited the locality in 1880

McClellan Group: islands, $0.1 \mathrm{mi}$. across, in Galankin Is., Sitka Sound, $1.5 \mathrm{mi}$. S of Sitka, Alex. Arch.; $57^{\circ} 01^{\prime} 40^{\prime \prime} \mathrm{N}, 135^{\circ} 20^{\prime} 30^{\prime \prime} \mathrm{W}$; (map 9).

Named in 1880 by U.S. Navy for Lt. E. P. McClellan, USN, and published by USC\&GS in the 1883 Coast Pilot (p. 143).

McClellan Rock: rock, $0.7 \mathrm{mi}$. SE of Todd, in Peril Strait, off S coast of Chichagof I., Alex. Arch.; $57^{\circ} 27^{\prime} 10^{\prime \prime} \mathrm{N}, 135^{\circ} 01^{\prime} 30^{\prime \prime} \mathrm{W}$; (map 9). Var. McLellan.

Named in 1880 by U.S. Navy for its discoverer Lt. E. P. McClellan, USN (U.S. Coast and Geodetic Survey, 1883, p. 166).

McCloud Creek: stream, flows NW $4 \mathrm{mi}$. to Murphy Creek, $17 \mathrm{mi}$. NW of Fairbanks, Yukon-Tanana High.; $65^{\circ} 00^{\prime} \mathrm{N}, 148^{\circ} 07^{\prime} \mathrm{W}$; (map 105). 
Named by prospectors; reported in 1908 by USGS (Covert and Ellsworth, 1909, pl. 2).

McCloud Creek: stream, see McLeod Creek.

McCloud Head: promontory, on E tip of Attu I., Aleutian Is. ; $52^{\circ} 49^{\prime} 50^{\prime \prime} \mathrm{N}, 173^{\circ} 25^{\prime} 40^{\prime \prime} \mathrm{E}$; (map 13).

Named by the U.S. Army during World War II; map published in 1948 by AMS.

McCloud Lake: lake, see McLeod Lake.

McCloud Ranch Creek: stream, flows SE $1.6 \mathrm{mi}$. to Hot Springs Slough, $52 \mathrm{mi}$. NE of Bitzshtini Mts., Yukon-Tanana High.; $64^{\circ} 59^{\prime} \mathrm{N}$, $150^{\circ} 43^{\prime} \mathrm{W}$; (map 99).

Local name reported in 1952 by USGS.

McClure Bay: estuary, on E coast of Kenai Penin., extends N $8 \mathrm{mi}$. to Port Nellie Juan, $24 \mathrm{mi}$. SE of Whittier, Chugach Mts. ; $60^{\circ} 34^{\prime}$ $00^{\prime \prime} \mathrm{N}, 148^{\circ} 10^{\prime} 30^{\prime \prime} \mathrm{W}$; BGN 1910; (map 63).

Named in 1910 by U. S. Grant, USGS.

McClure Islands: barrier islands, extends $6.5 \mathrm{mi}$. on Beaufort Sea coast, $8 \mathrm{mi}$. N of Foggy I. Bay and $28 \mathrm{mi}$. NW of Flaxman I., Arctic Plain; $70^{\circ} 22^{\prime} \mathrm{N}, 147^{\circ} 25^{\prime} \mathrm{W}$; (map 150).

Named by Leffingwell $(1919$, p. 97$)$ after Capt. Robert McClure, RN, who discovered, in August 1850, "the long chain of islands that extend from the Midways to Flaxman Island * * *"

MacColl Ridge: ridge, elev. 5,500 ft., $26 \mathrm{mi}$. long, between Chitina River and Young Creek, $15 \mathrm{mi}$. SE of McCarthy, St. Elias Mts.; $61^{\circ} 09^{\prime} \mathrm{N}, 142^{\circ} 12^{\prime} \mathrm{W}$ (SE end), 61 $11^{\circ} 18^{\prime} \mathrm{N}$ $142^{\circ} 54^{\prime} \mathrm{W}$ (NW end); $\dot{B} G N 1962$; (map 67).

Named in 1962 by USGS for Robert S. MacColl, 1933-61, USGS geologist, who lost his life in the Kiagna River while mapping in this area.

McConnell Ridge: ridge, $3 \mathrm{mi}$. long, in Glacier Bay National Monument, extends W from McBride Glacier to Muir Inlet, $4 \mathrm{mi}$. $\mathrm{N}$ of Sealers I. and $40 \mathrm{mi}$. SW of Skagway, St. Elias Mts.; $59^{\circ} 03^{\prime} \mathrm{N}, 136^{\circ} 07^{\prime} \mathrm{W}$; (map 45).

Named in 1947 for R. G. McConnell, 18571942, Canadian geologist, who visited Muir Inlet in 1913. McConnell was a member of the Canadian Geological Survey and was famous for his geological investigations of the Klondike and Yukon areas of Canada.

McCord: locality, site of former village, on $\mathrm{E}$ shore of McCord Bay, at head of Port Hobron, on $N$ coast of Sitkalidak I., SE of Kodiak I.; $57^{\circ} 08^{\prime} 30^{\prime \prime} \mathrm{N}, 153^{\circ} 11^{\prime} 45^{\prime \prime} \mathrm{W}$; (map 34).

The McCord post office was established in 1929 and moved to Old Harbor in 1931.

McCord Bay: bay, $0.5 \mathrm{mi}$. across, at head of Port Hobron, on N coast of Sitkalidak I., SE of Kodiak I.; $57^{\circ} 08^{\prime} 30^{\prime \prime} \mathrm{N}, 153^{\circ} 12^{\prime} 00^{\prime \prime} \mathrm{W}$; (map 34).

Local name published in 1943 by USC\&GS.

McCord Creek: stream, flows E $11 \mathrm{mi}$. to McElfish Creek $W$ of Alaska-Canada boundary, $49 \mathrm{mi}$. NE of Northway Junction, Yukon-Ta-

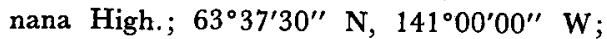
(map 85).

Local name reported in 1956 by USGS.

McCord Creek: stream, flows SW $5.5 \mathrm{mi}$. to Tolovana Rjver, $8 \mathrm{mi}$. SE of Livengood, Yu-
kon-Tanana High.; $65^{\circ} 28^{\prime} 40^{\prime \prime} \mathrm{N}, 148^{\circ} 12^{\prime} 45^{\prime \prime}$ W; (map 105).

Named by prospectors for a local miner; reported in 1915 by USGS (Brooks and others, 1916, pl. 9).

McCoy Creek: stream, flows NW $22 \mathrm{mi}$. to Salcha River, $31 \mathrm{mi}$. NW of Big Delta, YukonTanana High.; 64. $30^{\prime} 55^{\prime \prime} \mathrm{N}, 146^{\circ} 23^{\prime} 45^{\prime \prime} \mathrm{W}$; BGN 1964; (map 101). Var. Flat Creek.

Name originally applied by mistake by USGS to the stream now known as Flat Creek (Capps, 1912, pl. 1).

McCoy Creek: stream, see Flat Creek.

MacCreel Creek: stream, heads in glacier, flows SE $2.6 \mathrm{mi}$. to Little Bremner River, $60 \mathrm{mi}$. E of Valdez, Chugach Mts.; $61^{\circ} 02^{\prime} 45^{\prime \prime} \mathrm{N}, 144^{\circ}$ $26^{\prime} 25^{\prime \prime} \mathrm{W}$; (map 68).

Local name reported by Moffit (1914, pl. 1), USGS.

McCulloch Rock: rock, at mouth of Chapel Cove, on SW coast of Adak I., Aleutian Is.; $51^{\circ} 38^{\prime} 52^{\prime \prime} \mathrm{N}, 176^{\circ} 48^{\prime} 44^{\prime \prime} \mathrm{W}$; (map 17).

Name published by USC\&GS in the 1954 Coast Pilot.

McCumber Creek: stream, heads $1.6 \mathrm{mi}$. N of St. Anthony Pass, flows NW $13 \mathrm{mi}$. to Jarvis Creek, $21 \mathrm{mi}$. S of Delta Junction, Alaska Ra.; $63^{\circ} 44^{\prime} 55^{\prime \prime} \mathrm{N}, 145^{\circ} 39^{\prime} 10^{\prime \prime} \mathrm{W}$; BGN 1937; (map 86).

Name recorded in 1937 by USGS.

McCune Glacier: glacier, trends N $4 \mathrm{mi}$. to its terminus $1.5 \mathrm{mi}$. S of Honey Glacier, $50 \mathrm{mi}$. NW of Katalla, Chugach Mts.; $60^{\circ} 54^{\prime} 00^{\prime \prime} \mathrm{N}$, $144^{\circ} 48^{\prime} 30^{\prime \prime} \mathrm{W}$; (map 64).

Named by Lawrence Martin in 1910 for "McCune of the Copper River and Northwestern Railroad."

McCurdy Creek: stream, flows N $4.5 \mathrm{mi}$. to Chitina River, $3 \mathrm{mi}$. SW of Gibraltar Hill and $35 \mathrm{mi}$. SE of McCarthy, St. Elias Mts.; $61^{\circ}$ $05^{\prime} \mathrm{N}, 142^{\circ} 11^{\prime} \mathrm{W}$; (map 67).

Local name reported in 1915 by F. H. Moffit, USGS.

McGush Lake: lake, see Mendenhall Lake.

McDame Creek: stream, flows NE $1 \mathrm{mi}$. to Gold Run which flows to Bluestone River, $14 \mathrm{mi}$. SE of Teller, Seward Penin. High.; 65 ${ }^{\circ} 04^{\prime} 00^{\prime \prime}$ $\mathrm{N}, 166^{\circ} 12^{\prime} 00^{\prime \prime} \mathrm{W}$; (map 111).

Prospectors' name reported on the 1908 "Map of Seward Peninsula" by Arthur Gibson.

McDermott Creek: stream, flows N $12 \mathrm{mi}$. to Yukon River, $15 \mathrm{mi}$. NE of Rampart, YukonTanana High.; $65^{\circ} 38^{\prime} 45^{\prime \prime} \mathrm{N}, 149^{\circ} 48^{\prime} 50^{\prime \prime} \mathrm{W}$; (map 105).

Named by prospectors; reported in 1902 by Lt. Hjalmar Erickson, USA. The name was published by USGS (Prindle, 1905, pl. 16).

McDoel Peak: mountain, 5,111 ft, $3 \mathrm{mi}$. NE of junc. of Happy and Skwentna Rivers, $74 \mathrm{mi}$. SW of Talkeetna, Alaska Ra.; $62^{\circ} 01^{\prime} 10^{\prime \prime} \mathrm{N}$, $152^{\circ} 18^{\prime} 20^{\prime \prime} \mathrm{W}$; $(\operatorname{map} 81)$.

Named in 1898 by W. S. Post, USGS.

McDonald: locality, see Yes Bay.

McDonald, Lake: lake, $4.5 \mathrm{mi}$. long, on Cleveland Penin., $N$ of Yes Bay, Alex. Arch.; $55^{\circ}$ $58^{\prime} \mathrm{N}, 131^{\circ} 50^{\prime} \mathrm{W}$; (map 3 ).
Local navigators' name obtained in 1904 by H. C. Fassett, USBF.

McDonald, Mount: mountain, $2,157 \mathrm{ft}$., E of Anvik River, $40 \mathrm{mi}$. S of Unalakleet, Nulato Hills; $63^{\circ} 17^{\prime} 30^{\prime \prime} \mathrm{N}, 160^{\circ} 28^{\prime} 00^{\prime \prime} \mathrm{W}$; (map 91).

Local name reported in 1949 by USC\&GS.

McDonald Arm: bay, $3.5 \mathrm{mi}$. long, at head of Duncan Canal, on Kupreanof I., $11 \mathrm{mi}$. E of Petersburg, Alex. Arch.; 56 $47^{\prime} 30^{\prime \prime} \mathrm{N}$, $133^{\circ} 15^{\prime} 30^{\prime \prime} \mathrm{W}$; (map 6).

Local name recorded in 1951 by USGS.

McDonald Bar: ridge, elev. 2,600 ft., extends S $3 \mathrm{mi}$. from junc. of Hoosier and Minook Creeks, $5.5 \mathrm{mi}$. SSE of Rampart, YukonTanana High.; $65^{\circ} 25^{\prime} 30^{\prime \prime} \mathrm{N}, 150^{\circ} 05^{\prime} 30^{\prime \prime} \mathrm{W}$; (map 106). Var. MacDonald Bar.

Prospectors' name reported in 1904 by L. M. Prindle, USGS.

McDonald Bay: cove, see McDonald Cove.

McDonald Bay: estuary, see Yes Bay.

McDonald Cove: cove, $0.6 \mathrm{mi}$. across, $\mathrm{S}$ of Monolith Point, on E coast of Agattu I., Aleutian Is.; $52^{\circ} 27^{\prime} 40^{\prime \prime} \mathrm{N}, 173^{\circ} 42^{\prime} 00^{\prime \prime} \mathrm{E} ; B G N$ 1938; (map 13). Var. McDonald Bay.

Named in 1896 by USBF to honor Marshall McDonald, who was U.S. Commissioner of Fish and Fisheries before his death in 1895.

McDonald Creek: stream, flows W $14 \mathrm{mi}$. to Anvik River, $32 \mathrm{mi}$. SE of Unalakleet, Nulato Hills; $63^{\circ} 28^{\prime} \mathrm{N}, 160^{\circ} 17^{\prime} \mathrm{W}$; (map 91).

Local name reported in 1949 by USC\&GS.

McDonald Creek: stream, flows SE $2.2 \mathrm{mi}$. to Nome River, $5 \mathrm{mi}$. E of Nome, Seward Penin. High.; $64^{\circ} 30^{\prime} \mathrm{N}, 165^{\circ} 14^{\prime} \mathrm{W}$; (map 94).

Prospectors' name reported in 1900 by $\mathrm{E}$. C. Barnard (in Brooks and others, 1901, pl. 17), USGS. This stream may have been named for "Alex" McDonald, who claimed Polte Gulch on Cripple Creek.

McDonald Creek: stream, flows S $1 \mathrm{mi}$. to Discovery Creek which flows to Flambeau River, $13 \mathrm{mi}$. NE of Nome, Seward Penin. High. $64^{\circ} 38^{\prime} \mathrm{N}, 165^{\circ} 05^{\prime} \mathrm{W}$; (map 94).

Prospectors' name shown on the 1904 "Map of Cape Nome Precinct" by Arthur Gibson.

McDonald Island: island, $0.2 \mathrm{mi}$. long, in Frederick Sound, $6 \mathrm{mi}$. NE of Petersburg, Alex. Arch.; $56^{\circ} 50^{\prime} 50^{\prime} \mathrm{N}, 132^{\circ} 49^{\prime} 00^{\prime \prime} \mathrm{W}$; (map 6).

Named in 1887 by Lt. Comdr. C. M Thomas, USN, for Ens. John McDonald, USN, a member of his party.

McDonald Lagoon: lagoon, $4 \mathrm{mi}$. long, on $\mathrm{E}$ central Sitkalidak I., SE of Kodiak I.; $57^{\circ}$. $09^{\prime} \mathrm{N}, 153^{\circ} 05^{\prime} \mathrm{W}$; ( $\operatorname{map} 34$ ).

Local name published in 1943 by USC\&GS.

McDonald Point: point of land, on $\mathbf{E}$ coast of Agattu I., Aleutian Is.; 52 $26^{\prime} 00^{\prime \prime} \mathrm{N}, 173^{\circ}$ $42^{\prime} 20^{\prime \prime} \mathrm{E} ; B G N 1938$; (map 13).

Name derived from McDonald Cove; proposed by the U.S. Navy Hydrog. Office in 1938.

McDonald Rock: rock, in Stephens Passage W of Hobart Bay, about $3 \mathrm{mi}$. W of The Twins and $71 \mathrm{mi}$. NE of Sitka, Coast Mts.; $57^{\circ} 25^{\prime} \mathrm{N}$, $133^{\circ} 38^{\prime} \mathrm{W}$; (map 8).

Name published in 1895 by USC\&GS. 
MacDonald Spit: spit, $1 \mathrm{mi}$. long, on Kenai Penin., at $W$ edge of Kasitsna Bay, $5 \mathrm{mi}$. NE of Seldovia, Chugach Mts. ; $59^{\circ} 29^{\prime} \mathrm{N}, 151^{\circ} 35^{\prime}$ W; (map 50).

Local name published by USGS in 1951 .

McDonalds Trading Post: locality, on $\mathrm{S}$ bank of Kuskokwim River, $3 \mathrm{mi}$. NW of Sleetmute, Kilbuck-Kuskokwim Mts.; 61 $44^{\prime} 30^{\prime \prime} \mathrm{N}$, $157^{\circ} 13^{\prime} 10^{\prime \prime} \mathrm{W}$; (map 72).

Published in 1950 by USGS.

McDonell, Mount: mountain, 5,481 ft., on Alaska-Canada boundary, $4 \mathrm{mi}$. NW of Pleasant Camp and $41 \mathrm{mi}$. W of Skagway, St. Elias Mts.; $59^{\circ} 28^{\prime} 00^{\prime \prime} \mathrm{N}, 136^{\circ} 28^{\prime} 30^{\prime \prime} \mathrm{W}$; $B G N$ 1952; (map 45). Var. Boundary Peak 150 , Mount McDonnell.

Named in 1950 by the IBC for Inspector A. E. C. McDonell (died 1938) of the Royal Mounted Police. Inspector McDonell, in 1904, was commanding officer and assistant surgeon of the Mounted Police at Pleasant Camp; he later became superintendent of this camp.

McDonnell, Mount: mountain, see McDonell, Mount.

McDonough Peak: mountain, 2,700 ft., on S part of Douglas I., $5.2 \mathrm{mi}$. E of Point Hilder on Stephens Passage and $6 \mathrm{mi}$. S of Juneau, Coast Mts.; $58^{\circ} 13^{\prime} 25^{\prime \prime} \mathrm{N}, 134^{\circ} 21^{\prime} 25^{\prime \prime} \mathrm{W}$; (map 11).

Named in 1893 by USC\&GS and published on Chart 8235.

McDougal: locality, $\mathrm{E}$ of junc. of Lake Creek and Yentna River, $57 \mathrm{mi}$. NW of Anchorage, Cook Inlet Low.; $61^{\circ} 54^{\prime} 05^{\prime \prime} \mathrm{N}, 150^{\circ} 52^{\prime} 30^{\prime \prime}$ W; (map 70). Var. McDougall.

Local name reported in 1911 by USGS. In 1912 S. R. Capps, USGS, reported the locality as McDougall, "possibly named for a local businessman."

McDougall: locality, see McDougal.

MacDougall Creek: stream, flows NW $4.2 \mathrm{mi}$. to Kuskulana River, 17 mi. SW of Mt. Blackburn and $31 \mathrm{mi}$. NW of McCarthy, Wrangell Mts.; $61^{\circ} 33^{\prime} 45^{\prime \prime} \mathrm{N}, 143^{\circ} 50^{\prime} 00^{\prime \prime} \mathrm{W}$; (map 67).

Local name reported in 1912 by $D$. C. Witherspoon, USGS.

McDougall Creek: stream, flows NE $3.5 \mathrm{mi}$. to Flat Creek, $12 \mathrm{mi}$. NW of Tahneta Pass and $70 \mathrm{mi}$. SW of Gulkana, Talkeetna Mts.; $62^{\circ}$ $03^{\prime} \mathrm{N}, 147^{\circ} 27^{\prime} \mathrm{W}$; (map 82).

Local name reported in 1917 by USGS.

McElfish Creek: stream, flows SE, across AlaskaCanada boundary, $15 \mathrm{mi}$. to North Ladue River in Yukon, Canada, $48 \mathrm{mi}$. NE of Northway Junction, Yukon-Tanana High.; $63^{\circ} 36^{\prime}$ $45^{\prime \prime} \mathrm{N}, 140^{\circ} 59^{\prime} 30^{\prime \prime} \mathrm{W}$; BGN 1954; (map 85).

Name reported in 1912 by Thomas Riggs, IBC.

McFadden Creek: stream, see Buffalo Creek.

McFarland Islands: islands, extend $4 \mathrm{mi}$. in Tlevak Strait off W coast of Sukkwan I., Alex. Arch.; $55^{\circ} 04^{\prime} \mathrm{N}, 132^{\circ} 55^{\prime} \mathrm{W}$; (map 4). Var. Hill Islets.

Named in 1882 by W. H. Dall, USC\&GS, for "Mrs. A. R. McFarland, a missionary and teacher who began work in Alaska in 1877."
These islands were called "Hill Islets" by Jackson (1880, p. 376).

McGilvery Creek: stream, heads on Pin Peak, near center of Prince of Wales I., flows NE 6 $\mathrm{mi}$. to Salmon Lake, $15 \mathrm{mi}$. E of Klawock, Alex. Arch.; $55^{\circ} 34^{\prime} 13^{\prime \prime} \mathrm{N}, 132^{\circ} 42^{\prime} 50^{\prime \prime} \mathrm{W}$; (map 4).

Local name recorded in 1949 by USGS.

McGinnis, Mount: mountain, see McGinnis Mountain.

McGinnis Creek: stream, flows SW $3 \mathrm{mi}$. to Montana Creek, $2.5 \mathrm{mi}$. NW of Mendenhall Lake and $12.5 \mathrm{mi}$. NW of Juneau, Coast Mts. $58^{\circ} 26^{\prime} 30^{\prime \prime} \mathrm{N}, 134^{\circ} 38^{\prime} 40^{\prime \prime} \mathrm{W}$; (map 11). Var. McInnis River, McKinnis Creek.

Named "McInnis River" in 1881 by John McInnis and Edward Brennan who staked claims there (DeArmond, 1957, p. 30). The name "McGinnis Greek" was reported in 1903 by A. C. Spencer and C. W. Wright, USGS.

McGinnis Glacier: glacier, heads on McGinnis Peak, trends NE $8 \mathrm{mi}$., in two arms which join $2 \mathrm{mi}$. W of its 1951 terminus NW of Mount Pillsbury, $19 \mathrm{mi}$. E of Mount Hayes, Alaska Ra.; $63^{\circ} 35^{\prime} 30^{\prime \prime}$ N, $146^{\circ} 05^{\prime} 35^{\prime \prime}$ W; (map 86).

Name published on relatively recent maps. McGinnis Mountain: mountain, 4,228 ft., 1.6 mi. NW of Mendenhall Lake and $12 \mathrm{mi}$. NW of Juneau, Coast Mts.; $58^{\circ} 27^{\prime} 10^{\prime \prime} \mathrm{N}, 134^{\circ}$ 35'45' W; BGN 1930; (map 11). Var. Mount McGinnis.

Local name reported in 1912 by the USFS and published by USGS (Knopf, 1912, pl. 1). McGinnis Peak: peak, 11,400 ft., at head of McGinnis Glacier, $14 \mathrm{mi}$. SE of Mount Hayes, Alaska Ra.; $63^{\circ} 32^{\prime} 45^{\prime \prime} \mathrm{N}, 146^{\circ} 18^{\prime} 00^{\prime \prime} \mathrm{W}$; (map 86)

Name published on relatively recent maps.

McGinty Point: point of land, $\mathrm{W}$ entrance point to Beaver Bay, $10 \mathrm{mi}$. NW of Unga I., on Alaska Penin., Aleutian Ra.; 55 $27^{\prime} 30^{\prime \prime} \mathrm{N}$, $160^{\circ} 59^{\prime} 00^{\prime \prime} \mathrm{W}$; (map 28). Var. McGintys Point.

Published as McGintys Point in USC\&GS 1916 Coast Pilot (p. 182) and as McGinty Point in 1926 Coast Pilot (v. 2, p. 201). McGintys Point: point of land, see McGinty Point.

McGonagall Mountain: peak, 6,560 ft., in Mount McKinley National Park, W of Muldrow Glacier, $14 \mathrm{mi}$. NE of Mount McKinley, Alaska Ra.; $63^{\circ} 14^{\prime} 10^{\prime \prime} \mathrm{N}, 150^{\circ} 44^{\prime} 20^{\prime \prime} \mathrm{W}$; (map 88).

Named for Charles McGonogal; spelling was changed in publication. See McGonagall Pass.

McGonagall Pass: pass, 5,600 ft., in Mount McKinley National Park, $\mathrm{N}$ of Muldrow Glacier, between McGonagall and Oastler Mts., 14 mi. NE of Mount McKinley, Alaska Ra.; $63^{\circ}$ $14^{\prime} \mathrm{N}, 150^{\circ} 43^{\prime} \mathrm{W}$; (map 88). BGN 1948. Var. Glacier Pass, McGonigal Pass, McGonnagal Pass, McGonogal Pass, McGonogill Pass.

Named about 1916 for Charles McGonogal, prospector, who was one of the first to discover this pass; spelling was changed in pub- lication. He almost reached the north summit of Mount McKinley, April 3, 1910, but stopped a few hundred feet below while his partners, "Pete" Anderson and "Billy" Taylor, made the first ascent.

McGonigal Pass: pass, see McGonagall Pass. McGonnagal Pass: pass, see McGonagall Pass. McGonogal Pass: pass, see McGonagall Pass. McGonogill Pass: pass, see McGonagall Pass.

McGrath: town, pop. 241, on left bank of Kuskokwim River opposite junc. of Takotna River, Kuskokwim Low.; 62 ${ }^{\circ} 57^{\prime} 30^{\prime \prime} \mathrm{N}, 155^{\circ} 35^{\prime} 30^{\prime \prime}$ W; BGN 1944; Var. Old McGrath.

A small trading post was established here in the spring of 1907 for the new diggings on the Innoko River. The town was named for Peter McGrath, U.S. Deputy Marshall for the area who established headquarters here the same year. A post office was established in 1913. Its population in 1920 was 90 ; in 1930,112 ; in 1940,138; and in 1950, 175. The original townsite, now called "Old McGrath" was on the right bank of the river.

McHenry Anchorage: bay, $1.7 \mathrm{mi}$. long, sW coast of Etolin I., Alex. Arch.; 55 $58^{\prime}$ N, $132^{\circ}$. 27' W; (map 4).

Named in 1886 by Lt. Comdr. A. S. Snow, USN, for John McHenry, a member of his party.

McHenry Inlet: estuary, extends SW $3 \mathrm{mi}$. to Glarence Strait, on SW coast of Etolin I., 32 mi. S of Wrangell, Alex. Arch.; 56 $00^{\prime} 30^{\prime \prime} \mathrm{N}$, $132^{\circ} 24^{\prime} 30^{\prime \prime} \mathrm{W}$; (map 6).

Named in 1886 by Lt. Comdr. A. S. Snow, USN, for John McHenry, a member of his party.

McHenry Lake: lake, $0.7 \mathrm{mi}$. long, $\mathrm{E}$ of Navy Peak, on Etolin I., $28 \mathrm{mi}$. S of Wrangell, Alex. Arch.; $56^{\circ} 03^{\prime} 45^{\prime \prime} \mathrm{N}, 132^{\circ} 20^{\prime} 30^{\prime \prime} \mathrm{W}$; $B G N$ 1923; (map 6).

Named in 1923 by USFS; derived from McHenry Inlet.

McHenry Ledge: shoal, $1 \mathrm{mi}$. NW of Lemesurier Point, W coast of Cleveland Penin., Alex. Arch.; $55^{\circ} 46^{\prime} 45^{\prime \prime} \mathrm{N}, 132^{\circ} 18^{\prime} 00^{\prime \prime} \mathrm{W}$; (map 4).

Named in 1886 by Lt. Comdr. R. Clover, USN.

Machewik Mountain: hill, $730 \mathrm{ft}$., $4 \mathrm{mi}$. NE of Beluga Hill and $3 \mathrm{mi}$. NW of Goodnews, Kilbuck-Kuskokwim Mts. ; $59^{\circ} 08^{\prime} \mathrm{N}, 161^{\circ} 40^{\prime}$ W; (map 53).

Eskimo name reported in 1954 by USGS. Machie Creek: stream, flows NE $5 \mathrm{mi}$. to Fox River, $30 \mathrm{mi}$. NE of Solomon, Seward Penin. High.; $64^{\circ} 48^{\prime} \mathrm{N}, 163^{\circ} 38^{\prime} \mathrm{W}$; (map 95).

Prospectors' name published on the 1908 "Map of Seward Peninsula" by Arthur Gibson.

Machin Island: islands, see Magoun Islands.

McHugh Creek: stream, heads in lake, NE of Suicide Peak, flows SW $5 \mathrm{mi}$. to Turnagain Arm Cook Inlet, $15 \mathrm{mi}$. S of Anchorage, Chugach Mts.; 61 $01^{\prime} 00^{\prime \prime} \mathrm{N}, 149^{\circ} 43^{\prime} 40^{\prime \prime} \mathrm{W}$; (map 69).

Local name published in 1912 by USC\&GS. 
McHugh Creek: stream, flows NW $11 \mathrm{mi}$. to Hess Creek, $14 \mathrm{mi}$. NW of Livengood, YukonTanana High.; $65^{\circ} 43^{\prime} \mathrm{N}, 148^{\circ} 42^{\prime} \mathrm{W}$; (map 105).

Named by prospectors; reported in $1916 \mathrm{by}$ J. B. Mertie (in Brooks and others, 1918, pl. 13), USGS.

McHugh Peak: mountain, 3,500 ft., on $\mathrm{N}$ bank of McHugh Creek, $14 \mathrm{mi}$. SE of Anchorage, Chugach Mts.; $61^{\circ} 02^{\prime} 05^{\prime \prime} \mathrm{N}, 1^{\circ} 49^{\circ} 41^{\prime} 50^{\prime \prime} \mathrm{W}$. (map 69).

Local name reported in 1942 by AMS.

McIntosh: locality, roadhouse on Mineral Creek, $5.4 \mathrm{mi}$. NW of Valdez, Chugach Mts, ; $61^{\circ}$ $11^{\prime} 00^{\prime \prime} \mathrm{N}, 146^{\circ} 20^{\prime} 30^{\prime \prime} \mathrm{W}$; (map 68). Var. McIntoshs Road House, McIntosh Property.

Local name for a former roadhouse; published in 1912 by USGS.

McIntosh Peak: peak, 4,000 ft., in Robinson Mts. on SW side of Bering Glacier, $25 \mathrm{mi}$. NW of Cape Yakataga, St. Elias Mts.; $60^{\circ} 18^{\prime} \mathrm{N}$, $142^{\circ} 55^{\prime} \mathrm{W}$; BGN 1960; (map 65).

Named in 1960 by USGS for "Scotty" McIntosh, who, after surviving a Royal Canadian Air Force plane crash in about 1943, was drowned while attempting to cross the Kosakuts River.

McIntosh Property: locality, see McIntosh.

McIntoshs Road House: locality, see McIntosh.

McIntyre, Point: point of land, $\mathrm{W}$ point of entrance to Prudhoe Bay, on Beaufort Sea coast, $15 \mathrm{mi}$. SE of Beechey Point, Arctic Plain; $70^{\circ}$. $24^{\prime} \mathrm{N}, 148^{\circ} 35^{\prime} \mathrm{W}$; (map 150).

Named by Leffingwell (1919, p. 15, 97). "After Samuel [Scotty] McIntyre, who worked for the writer for 3 years."

McIver Bight: cove, $1.2 \mathrm{mi}$. across, on SW coast of Unalaska I., Aleutian Is.; $53^{\circ} 30^{\prime} 20^{\prime \prime} \mathrm{N}$, $167^{\circ} 10^{\prime} 30^{\prime \prime} \mathrm{W}$; (map 23).

Name published as being "locally known" in the 1944 Aleutian Coast Pilot (p. 47).

McKay Creek: stream, flows S $4 \mathrm{mi}$. to Chatanika River, $30 \mathrm{mi}$. NE of Fairbanks, YukonTanana High.; $65^{\circ} 13^{\prime} 20^{\prime \prime} \mathrm{N}, 147^{\circ} 09^{\prime} 30^{\prime \prime} \mathrm{W}$ (map 105).

Named by prospectors; published in 1907 by USGS.

MeKay Inlet: bay, $5 \mathrm{mi}$. long and $2 \mathrm{mi}$. wide, extends $S$ from Fatigue Bay, $3 \mathrm{mi}$. SE of Tangent Point at mouth of Dease Inlet and $44 \mathrm{mi}$. SE of Barrow, Arctic Plain; $71^{\circ} 07^{\prime} 20^{\prime \prime}$ N, $154^{\circ} 59^{\prime} 25^{\prime \prime} \mathrm{W} ; B G N$ 1966; (map 153). Var. Fatigue Bay, Mackay Inlet, M'Kay Inlet. Named in 1837 by Thomas Simpson in honor of one of his guides, James McKay.

Mackay Inlet: lagoon, see Fatigue Bay.

Mackay Inlet: bay, see McKay Inlet.

McKay Inlet: lagoon, see Fatigue Bay.

M'Kay Inlet: bay, see McKay Inlet.

M'Kay Inlet: lagoon, see Fatigue Bay.

McKelvie Creek: stream, in Bendeleben Mts., flows NE $3.2 \mathrm{mi}$. to Pargon River, $31 \mathrm{mi}$. SW of Imuruk Lake, Seward Penin. High.; $65^{\circ}$ $11^{\prime} \mathrm{N}, 163^{\circ} 42^{\prime} \mathrm{W}$; (map 110). Var. Warnecke Creek.

Prospectors' name published on the 1908 "Map of Seward Peninsula" by Arthur Gibson. This appears to be the stream shown as
"Warnecke" on a map of Cape Nome gold fields by David Fox, Jr, dated 1901.

McKensie's Bay:- estuary, see Iko Bay.

MacKenzie, Point: point of land, on $\mathrm{S}$ shore of Knik Arm, $3.4 \mathrm{mi}$. NW of Anchorage, Cook Inlet Low.; $61^{\circ} 14^{\prime} 18^{\prime \prime} \mathrm{N}, 149^{\circ} 59^{\prime} 00^{\prime \prime} \mathrm{W}$; (map 69). Var. Point Mackinzie.

Named by Joseph Whidbey of Capt. Vancouver's party on May 4, 1794 for the Rt. Hon. James Stuart Mackenzie (Wagner, 1937, p. 395).

Mackenzie Bay: estuary, see Iko Bay.

McKenzie Creek: stream, flows NE $2 \mathrm{mi}$. to Chichagof Harbor, NE Attu Is., Aleutian Is, ; $52^{\circ} 55^{\prime} 43^{\prime \prime} \mathrm{N}, 173^{\circ} 14^{\prime} 15^{\prime \prime} \mathrm{E}$; (map 13).

Named by the U.S. Army during World War II; published in 1948 by AMS.

McKenzie Greek: stream, flows W $1.8 \mathrm{mi}$. to Susitna River, $3.5 \mathrm{mi}$. SW of Curry and 17 mi. N of Talkeetna, Talkeetna Mts. ; $62^{\circ} 34^{\prime}$ $00^{\prime \prime} \mathrm{N}, 150^{\circ} 03^{\prime} 20^{\prime \prime} \mathrm{W}$; (map 81).

Prospectors' name reported in 1922 by USGS.

McKenzie Inlet: estuary, extends S $6 \mathrm{mi}$. off Skowl Arm, on E coast of Prince of Wales I. Alex. Arch.; 55 ${ }^{\circ} 25^{\prime} \mathrm{N}, 132^{\circ} 22^{\prime} \mathrm{W}$; (map 4).

Local navigators' name reported in 1901 by A. H. Brooks, USGS.

McKenzie Rock: rock, $300 \mathrm{ft}$. long, between McKenzie Inlet and Skowl Arm Kasaan Bay, on E coast of Prince of Wales I., Alex. Arch.; $55^{\circ} 24^{\prime} 45^{\prime \prime} \mathrm{N}, 132^{\circ} 22^{\prime} 00^{\prime \prime} \mathrm{W}$; (map 4).

Local navigators' name reported in 1901 by A. H. Brooks, USGS.

McKeon Flats: flats, at $\mathrm{E}$ edge of lagoon in back of Neptune Bay, on S shore of Kachemak Bay, on Kenai Penin., 9 mi. SE of Homer, Chugach Mts.; 59 $32^{\prime} 15^{\prime \prime} \mathrm{N}, 151^{\circ} 21^{\prime} 30^{\prime \prime} \mathrm{W}$; (map 50).

Local name reported by USGS or USC\&GS in the 1940 's.

McKeon Rock: rock, at entrance to Neptune Bay, on E shore of Kachemak Bay, on Kenai Penin., $8 \mathrm{mi}$. SE of Homer, Chugach Mts.; $59^{\circ} 33^{\prime} \mathrm{N}, 151^{\circ} 24^{\prime} \mathrm{W}$; (map 50).

Local name reported by USGS or USC\&GS in the 1940's.

Mackey Creek: stream, see Fred Creek.

Mackeys Lakes: lakes, group extends $4.5 \mathrm{mi}$. NW of Soldatna, on Kenai Penin., $10 \mathrm{mi}$. E of Kenai, Cook Inlet Low.; $60^{\circ} 01^{\prime} 30^{\prime \prime} \mathrm{N}, 151^{\circ}$ $00^{\prime} 00^{\prime \prime} \mathrm{W}$; (map 62).

Local name reported in 1965 by USGS.

McKinley: locality, see Denali.

McKinley, Mount: mountain, highest elev. on North American Continent, consists of two summit peaks, South Peak, 20,320 ft., and North Peak, 19,470 ft., collectively called Churchill Peaks, in Mount McKinley National Park, Alaska Ra.; $63^{\circ} 04^{\prime} 15^{\prime \prime}$ N, $151^{\circ} 00^{\prime} 20^{\prime \prime}$ W. Var. Bulshaia Gora, Bulshaya Gora, Densmores Peak, Denali, Din-al-ee, Din-az-ee, Doleika, Doleyka, Mount Denali, Mount Doleika, Tennaly, To-lah-gah, Traleika, Traleyka.

Named in 1896 by William A. Dickey, prospector, "after William McKinley of Ohio, who had been nominated for the presidency, and that fact was the first news we received on our way out of that wonderful wilderness." McKinley, 1843-1901, was the 25th President of the United States.

The first mention of the Mount McKinley massif is by Capt. George Vancouver, who, after seeing it from Cook Inlet in 1794, referred to the "stupendous snow mountains." The Russians descriptively called the mountain "Bolshaya (Bulshaia) Gora" or "big mountain." Alfred Mayo and Arthur Harper, pioneer Alaska traders, after a trip up the Tanana in 1878, reported an enormous ice mountain to the south but did not name it. A prospector, Frank Densmore, spoke so enthusiastically after seeing the mountain from Lake Minchumina in 1889, that it was known for years among prospectors as "Densinores Peak." The Tanana Indian name was reported as "Denali," and the Tanaina Indian name is given as "Doleika" or "Traleika." Each of these names is said to mean "the big one" or "the high one."

North Peak was first reached on April 3, 1910, by two prospectors, Peter Anderson and William Taylor. South Peak, the higher was first "conquered" on June 7, 1913, by Archdeacon Hudson Stuck, Walter Harper, Robert Tatum and Harry Karstens (later park superintendent).

McKinley Bar: bar, in headwaters of McKinley River in Mount McKinley National Park, extends W $18 \mathrm{mi}$. from Muldrow Glacier terminus to Eagle Gorge, Alaska Ra.; $63^{\circ} 25^{\prime} \mathrm{N}$, $150^{\circ} 50^{\prime}$ W.; (map 88).

Local name reported in 1954 by USGS.

McKinley Creek: stream, flows SE to Boulder Creek which flows to Snake River, about 25 mi. NW of Nome, Seward Penin. High.; (map 94).

Prospectors' name reported on the 1900 "Map of Nome Peninsula" by J. M. Davidson and B. D. Blakeslee; this feature has not been positively identified.

McKinley Creek: srteam, heads in a glacier, 1.5 $\mathrm{mi}$. S of Porcupine Creek, flows NW $5 \mathrm{mi}$. to Porcupine Creek, $2 \mathrm{mi}$. S of Porcupine and $33 \mathrm{mi}$. SW of Skagway, St. Elias Mts.; $59^{\circ} 23^{\prime}$ $35^{\prime \prime} \mathrm{N}, 136^{\circ} 14^{\prime} 50^{\prime \prime} \mathrm{W}$; (map 45).

Probably named by prospectors. Name was reported in 1899 by USGS.

McKinley Creek: stream, flows NW $15 \mathrm{mi}$. from Halfway Mtn. to South Fork Hoholitna River, $65 \mathrm{mi}$. NW of Nondalton, Lime Hills; $60^{\circ}$ $50^{\prime \prime} 00^{\prime \prime} \mathrm{N}, 155^{\circ} 35^{\prime} 30^{\prime \prime} \mathrm{W}$; (map 61).

Local name reported in 1950 by USC\&GS.

McKinley Creek: stream, flows NW $6 \mathrm{mi}$. to Walker Fork, $53 \mathrm{mi}$. S of Eagle, YukonTanana High.; $64^{\circ} 03^{\prime} \mathrm{N}, 141^{\circ} 23^{\prime} \mathrm{W}$; (map 102).

Named by prospectors and shown on an 1898 manuscript map by E. F. Ball, prospector. McKinley Creek: stream, flows N $8 \mathrm{mi}$. to Middle Fork Fortymile River, $58 \mathrm{mi}$. SW of Eagle, Yukon-Tanana High.; $64^{\circ} 23^{\prime} \mathrm{N}, 142^{\circ} 53^{\prime} \mathrm{W}$; (map 102). 
Named by prospectors; shown on a 1902 manuscript map by E. J. Chamberlain, U.S. Deputy Surveyor.

McKinley Creek: stream, flows W $4 \mathrm{mi}$. to O'Brien Creek, $24 \mathrm{mi}$. S of Eagle, YukonTanana High.; $64^{\circ} 27^{\prime} \mathrm{N}, 141^{\circ} 17^{\prime} \mathrm{W}$; (map 102).

Named by prospectors; reported in 1903 by L. M. Prindle (1905, pl. 16), USGS.

McKinley Creek: stream, flows SW $7 \mathrm{mi}$. to Golovnin Bay, $5 \mathrm{mi}$. SE of Golovin and 47 mi. SE of Solomon, Seward Penin. High.; $64^{\circ} 30^{\prime} \mathrm{N}, 162^{\circ} 53^{\prime} \mathrm{W}$; (map 95).

Prospectors' name shown on a precinct map of Seward Peninsula by Monroe and Hutchins, corrected up to June 1903 by Arthur Gibson.

McKinley Creek: stream, flows $3.5 \mathrm{mi}$. to Rhode Island Creek $0.3 \mathrm{mi}$. N of that stream's junc. with Omega Creek, $26 \mathrm{mi}$. S of Rampart, Yukon-Tanana High.; $65^{\circ} 07^{\prime} 45^{\prime \prime} \mathrm{N}, 150^{\circ}$ 20'15" W; (map 106).

Prospectors' name reported in 1931 by $\mathrm{J}$. B. Mertie, USGS.

McKinley Creek: stream, flows SW $3 \mathrm{mi}$. to Grantley Harbor, $9 \mathrm{mi}$. E of Teller, Seward Penin. High.; $65^{\circ} 15^{\prime} \mathrm{N}, 166^{\circ} 04^{\prime} \mathrm{W}$; (map 111). Var. Dewey Greek.

Prospectors' name reported in 1901 by $\mathrm{T}$. G. Gerdine (in Collier, 1902, pl. 12), USGS.

McKinley Creek: stream, flows N $11 \mathrm{mi}$. to Preacher Creek, $60 \mathrm{mi}$. SW of Circle, YukonTanana High.; $65^{\circ} 33^{\prime} \mathrm{N}, 146^{\circ} 02^{\prime} \mathrm{W}$; (map 104).

Named by prospectors; reported in 1903 by T. G. Gerdine (in Prindle, 1905, pl. 13), USGS.

McKinley Creek: stream, flows NE $4 \mathrm{mi}$. to Bryan Creek which flows to Serpentine River, $8 \mathrm{mi}$. NE of Kougarok Mtn. and $33 \mathrm{mi}$. SE of Ear Mtn., Seward Penin. High.; $6^{\circ} \mathbf{4 7}^{\prime}$ N, $165^{\circ} 07^{\prime} \mathrm{W}$; (map 111).

Prospectors' name reported on the 1908 "Map of Seward Peninsula" by Arthur Gibson. McKinley Creek: stream, flows SE $10 \mathrm{mi}$. to John River, $5.5 \mathrm{mi}$. S of Gunsight Mtn. and $51 \mathrm{mi}$. W of Wiseman, Brooks Ra.; $67^{\circ} 24^{\prime} 00^{\prime \prime}$ $\mathrm{N}, 152^{\circ} 03^{\prime} 30^{\prime \prime} \mathrm{W}$; BGN 1932; (map 124).

Local name reported by Robert Marshall in 1932.

McKinley Fork: stream, see McKinley River.

McKinley Fork: stream, see Swift Fork.

McKinley Fork Kuskokwim River: stream, see Swift Fork Kuskokwim River.

McKinley Glacier: glacier, see Muldrow Glacier.

McKinley Lake: lake, $1.2 \mathrm{mi}$. long, $4 \mathrm{mi}$. W of Copper River, $1 \mathrm{mi}$. N of Copper River Highway, $20 \mathrm{mi}$. SE of Cordova, Chugach Mts. ; $60^{\circ} 28^{\prime} \mathrm{N}, 145^{\circ} 11^{\prime} \mathrm{W}$; (map 64).

Local name reported in 1909 by Grant and Higgins (1910, pl. 2), USGS.

McKinley Park: settlement, pop. 28, and RR. station, mi. 347.9 on the Alaska RR., 9 mi. S of Healy, Alaska Ra.; $63^{\circ} 43^{\prime} 45^{\prime \prime}$ N, $148^{\circ} 55^{\prime}$ 00" W; (map 87). Var. Riley Creek, Riley.

Settlement reported in 1920 as Riley Creek, perhaps in a slightly different location than the present place. The Riley post office was established in 1922 and its name changed to McKinley Park the same year (Ricks, 1965, p. 40). Its population was listed as 49 in the 1930 census.

McKinley Peak: mountain, 2,351 ft., $18 \mathrm{mi}$. SE of Cordova, Chugach Mts.; $60^{\circ} 28^{\prime} \mathrm{N}, 145^{\circ}$ $13^{\prime} \mathrm{W}$; (map 64).

Local name reported by Moffit (1914, pl. 1), USGS.

McKinley Range: mountain range, that part of Alaska Ra., including Mount McKinley, which extends $\mathrm{SW}$ from the Chulitna-Cantwell divide; (map 88).

So defined in 1899 by Lt. J. S. Herron, USA, but not used on subsequent maps.

McKinley River: stream, heads at Muldrow Glacier terminus, flows NW 58 mi., joins Birch Creek to form Kantishna River, $23 \mathrm{mi}$. $\mathrm{E}$ of village of Lake Minchumina, Alaska $\mathrm{Ra}$; 6352' N, 151 $33^{\prime} \mathrm{W}$; BGN 1947; (map 88). Var. McKinley Fork.

Named in 1902 "McKinley Fork" by A. H. Brooks; shown as "McKinley River" on a 1905 manuscript map of "Kantishna Gold Fields," by A. Friedrich, prospector.

McKinney Lake: lake, $2 \mathrm{mi}$. long, on centrảl Admiralty I., empties into Hasselborg Lake, $15 \mathrm{mi}$. NE of Angoon, Alex. Arch. ; $57^{\circ} 40^{\prime} 30^{\prime \prime}$ N, 134 $18^{\prime} 30^{\prime \prime}$ W; (map 9).

Local name reported in 1951 by USGS.

McKinsey Valley: valley, trends SE $3 \mathrm{mi}$. to Chignik Bay, 11.5 mi. N of Chignik, Aleutian Ra.; 56 27'30' N, 158 $24^{\prime} 00^{\prime \prime}$ W; (map 30). , Local name published in 1927 by USC\&GS.

Mackinzie, Point: point of land, see MacKenzie, Point.

Macklin Creek: stream, flows SW $6.5 \mathrm{mi}$. to join Washington Creek, forms Kougarok River, 8 1 mi. SW of Midnight Mtn. and $49 \mathrm{mi}$. NW of

Imuruk Lake, Seward Penin. High.; $65^{\circ} 44^{\prime}$ N, 164.51' W; (map 110).

Prospectors' name reported in 1901 by $\mathrm{T}$. G. Gerdine (in Collier, 1902, pl. 12), USGS. McKorryok: village, see Mekoryuk.

Macks Bay: bay, see Tanaskan Bay.

Macks Head: point of land, in Sanborn Harbor on W coast of Nagai I., in Shumagin Is., Aleutian Ra.; $55^{\circ} 07^{\prime} 20^{\prime \prime}$ N, $160^{\circ} 00^{\prime} 30^{\prime \prime}$ W; (map 28). Var. Mack's Head.

Local name shown on a USC\&GS chart about 1900.

Macks Head Island: island, $300 \mathrm{ft}$. across, in Sanborn Harbor, on W coast of Nagai I., in Shumagin Is., Aleutian Ra.; $55^{\circ} 07^{\prime} 25^{\prime \prime} \mathrm{N}, 160^{\circ}$ $01^{\prime} 00^{\prime \prime}$ W; (map 28). Var. Mack's Head Island.

Local name published in 1872 by W. $\mathrm{H}$. Dall, USC\&GS.

McLain Greek: stream, see McLean Creek.

McLain Lake: lake, 1 mi. long, on Kenai Penin., $1 \mathrm{mi}$. SE of Hook Lake, $32 \mathrm{mi}$. NE of Kenai, Cook Inlet Low. ; $60^{\circ} 52^{\prime} \mathrm{N}, 150^{\circ} 35^{\prime} \mathrm{W}$; (map 62).

Local name reported in 1958 by USGS.

McLane Creek: stream, flows E $3 \mathrm{mi}$. to Faro Creek, $25 \mathrm{mi}$. N of Goodnews, Kilbuck-Kuskokwim Mts.; 59 $28^{\prime} \mathrm{N}, 161^{\circ} 31^{\prime} \mathrm{W}$; (map 53). Var. McLean Creek.
Probably a prospector's name reported in 1919 by G. I. Harrington (in Brooks, 1921, pl. 7), USGS.

McLanes Creek: stream, heads in Babantaltlin Hills, flows SE and SW $19 \mathrm{mi}$. to Hogatza River, $30 \mathrm{mi}$. W of Hughes, Hogatza High.; $66^{\circ} 00^{\prime} \mathrm{N}, 155^{\circ} 19^{\prime} \mathrm{W}$; (map 116).

Local name obtained in 1956 at Hogatza by Orth.

Maclaren Glacier: glacier, trends W and S 13 mi. to its 1951 terminus at head of Maclaren River, $24 \mathrm{mi}$. SE of Mount Hayes, Alaska Ra.; $63^{\circ} 17^{\prime} \mathrm{N}, 146^{\circ} 31^{\prime} \mathrm{W}$; (map 86).

Local name shown on 1910 fieldsheet by C. E. Giffin, USGS.

Maclaren River: stream, heads at Maclaren Glacier in Clearwater Mts., flows SW $55 \mathrm{mi}$. to Susitna River, $16 \mathrm{mi}$. NE of junc. of Oshetna River, Alaska Ra.; $62^{\circ} 50^{\prime} 15^{\prime \prime} \mathrm{N}, 147^{\circ} 07^{\prime} 20^{\prime \prime}$ W; (map 82).

Local name reported in 1909 by USGS.

McLean Arm: estuary, extends $5.5 \mathrm{mi}$. W from Clarence Strait, SE coast of Prince of Wales I., Alex. Arch.; 54 $47^{\prime} 45^{\prime \prime}$ N, $131^{\circ} 57^{\prime} 15^{\prime \prime}$ W; (map 2). Var. McLeans Arm.

Named in 1885 by Lt. Comdr. R. Clover, USN, for Ens. Walter McLean, USN, a member of his party.

McLean Creek: stream, flows NW $8 \mathrm{mi}$. to Colorado Greek $0.2 \mathrm{mi}$. $\mathrm{E}$ of its junc. with Innoko River, $38 \mathrm{mi}$. N of Ophir and $54 \mathrm{mi}$. NW of McGrath, Innoko Low.; $63^{\circ} 40^{\prime} 25^{\prime \prime} \mathrm{N}, 156^{\circ}$ 21'10" W; (map 90).

Prospectors' name reported in 1933 by USGS.

McLean Creek: stream, flows NW 6 mi. to Birch Creek, 12 mi. SSE of Mastodon Dome and $50 \mathrm{mi}$. SW of Circle, Yukon-Tanana High.; $65^{\circ} 18^{\prime} 20^{\prime \prime} \mathrm{N}, 145^{\circ} 02^{\prime} 00^{\prime \prime} \mathrm{W}$; (map 104). Var. McLain Creek.

Named by prospectors and reported in 1910 by C. E. Ellsworth and G. L. Parker (in Brooks and others, 1911, p. 195), USGS.

McLean Creek: stream, flows SE $1 \mathrm{mi}$. to Eldorado Creek which flows to Noxapaga River, $27 \mathrm{mi}$. NW of Imuruk Lake, Seward Penin. High.; $65^{\circ} 43^{\prime} \mathrm{N}, 164^{\circ} 12^{\prime} \mathrm{W}$; (map 110).

Prospectors' name reported on the 1908 "Map of Seward Peninsula" by Arthur Gibson. McLean Creek : stream, see McLane Creek.

McLean Point: point of land, S point of entrance to McLean Arm, SE coast of Prince of Wales I., Alex. Arch.; 54 $47^{\prime} 30^{\prime \prime}$ N, $131^{\circ} 57^{\prime}$ $15^{\prime \prime} \mathrm{W}$; (map 2$)$.

Local name derived from McLean Arm; reported in 1904 by H. C. Fassett, USBF.

McLeans Arm: estuary, see McLean Arm.

McLees Lake: lake, $1.7 \mathrm{mi}$. long, on $\mathrm{N}$ coast of Unalaska I., Aleutian Is.; $53^{\circ} 59^{\prime} 00^{\prime \prime} \mathrm{N}, 166^{\circ}$ 43'35" W; BGN 1937; (map 23).

Named for George T. M. McLees, quartermaster, USC\&GS, who drowned September 26, 1936 , off the coast near this lake during a survey of the locality.

McLellan: rock, see McClellan Rock.

McLellan Creek: stream, flows SW $1 \mathrm{mi}$. to Deep Canyon Creek which flows $S$ to Nome River, 
$28 \mathrm{mi}$. NNE of Nome, Seward Penin. High.; $64^{\circ} 53^{\prime} \mathrm{N}, 165^{\circ} 15^{\prime} \mathrm{W}$; (map 94).

Prospectors' name shown on the 1904 "Map of Cape Nome Precinct" by Arthur Gibson.

McLellan Creek: stream, flows NE 5 mi., E of McLellan Peak, joins Slate Creek to form Grave Creek, $15 \mathrm{mi}$. ENE of Chandalar, Brooks Ra.; $67^{\circ} 34^{\prime} 30^{\prime \prime}$ N, $147^{\circ} 58^{\prime} 00^{\prime \prime}$ W; (map 123).

Local name reported in 1923 by USGS and applied in part to Little McLellan Creek.

McLellan Creek: stream, see Little McLellan Creek.

McLellan Pass: pass, 3,800 ft., between Crystal Peak and McLellan Peak, 9 mi. ENE of Chandalar, Brooks Ra.; 67 $32^{\prime} \mathrm{N}, 148^{\circ} 09^{\prime} \mathrm{W}$; (map 123).

Local name reported in 1956 by T. E. Taylor, USGS.

McLellan Peak: peak, 5,320 ft., SE of McLellan Pass, 9 mi. ENE of Chandalar, Brooks Ra.; $67^{\circ} 31^{\prime} 15^{\prime \prime} \mathrm{N}, 148^{\circ} 08^{\prime} 30^{\prime \prime} \mathrm{W}$; (map 123).

Local name reported in 1956 by T. E. Taylor, USGS.

McLeod, Point: point of land, on $\mathrm{W}$ shore of Muir Inlet, in Glacier Bay National Monument, at mouth of Hunter Cove, $61 \mathrm{mi}$. NW of Hoonah, St. Elias Mts. ; $58^{\circ} 54^{\prime} 50^{\prime \prime} \mathrm{N}, 136^{\circ}$ 06'25" W; (map 10).

Named by members of the American Geographical Society's Glacier Bay Expedition of 1941 (Field, 1947, map) for "Capt. McLeod" of the SS Princess Maquinna which brought members of an excursion of the Twelfth International Geological Congress to Glacier Inlet in 1913.

McLeod Bay: bay, $1.5 \mathrm{mi}$. across, on SE coast of Dall I., Alex. Arch.; $54^{\circ} 41^{\prime} 30^{\prime \prime} \mathrm{N}, 132^{\circ} 41^{\prime} 40^{\prime \prime}$ W; (map 1).

Local name published by USC\&GS in 1911. McLeod Greek: stream, heads at glacier terminus in Mount McKinley National Park, flows $\mathrm{N} 20 \mathrm{mi}$. to McKinley River at $\mathrm{W}$ end of Eagle Gorge, $11 \mathrm{mi}$. W of Wonder Lake, Tanana Low.; $64^{\circ} 28^{\prime} 10^{\prime \prime} . \mathrm{N}, 151^{\circ} 14^{\prime} 45^{\prime \prime} \mathrm{W}$; (map 88). Var. McCloud Creek.

Named by prospectors for John McLeod a member of Judge James Wickersham's McKinley Expedition in 1903. "The Circle philologer, the interpreter for Da-yin-num, the medicine man of too-whun-na. $\mathrm{He}$ is a hunter, a canoeman, a trapper who knows the wilderness life like his foster brothers, the [Tena] Indians." (From Wickersham's notes printed in the Fairbanks News-Miner July 17, 1963). Name reported as "McCloud" by S. R. Capps, USGS, in 1925.

MacLeod Harbor: bay, $3 \mathrm{mi}$. long, on NW coast of Montague Island, $8 \mathrm{mi}$. NE of Cape Cleare, $60 \mathrm{mi}$. SE of Seward, Chugach Mts.; $59^{\circ} 53^{\prime}$ $\mathrm{N}, 147^{\circ} 15^{\prime} \mathrm{W}$; (map 49). Var. Macleod Harbor, McLeods Harbour.

Named "McLeods Harbour" in 1789 by Capt. Nathaniel Portlock (1789, pp. 260211), for William McLeod, one of the mates of the King George (Wagner, 1937, p. 468). Portlock was anchored here from April 24 to May 1, 1787.
McLeod Lake: lake, 1,000 ft. across, in Matanuska Valley, $2.5 \mathrm{mi}$. SW of Palmer, Cook Inlet Low.; 61 $33^{\prime} 55^{\prime \prime} \mathrm{N}, 149^{\circ} 09^{\prime} 00^{\prime \prime} \mathrm{W}$; (map 69).

Local name reported in 1942 by AMS.

McLeod Lake: lake, $0.9 \mathrm{mi}$. long, between McLeod Creek and Muddy River, $4 \mathrm{mi}$. SW of

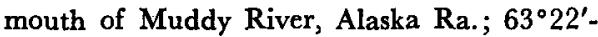
$30^{\prime \prime} \mathrm{N}, 151^{\circ} 05^{\prime} 00^{\prime \prime} \mathrm{W}$; (map 88). Var. McGloud Lake.

Local name reported in 1954 by USGS.

McLeod Point: point of land, on coast of Beaufort Sea, 4 mi. E of Smith Bay, Arctic Plain; $70^{\circ} 53^{\prime} \mathrm{N}, 153^{\circ} 46^{\prime} \mathrm{W}$; (map 148). Var. M'Leod Point, Macleod Point.

The exact identity of several points of land, in this area, named in 1837 by P. W. Dease and Thomas Simpson, are difficult to determine. These points, from east to west, are McLeod, McPherson, and Drew. It seems the Point McLeod of current maps is applied to what Dease and Simpson named Point McPherson, and their Point McLeod is applied to a small point $3 \mathrm{mi}$. to the east (Simpson, Thomas, 1843, pp. 136-137).

M'Leod Point: point of land, see McLeod Point McLeods Harbour: bay, see MacLeod Harbor. McLoughlin Rocks: reef, see Yukon Reef.

McLoughlins Point: point of land, see Petrof, Point.

McLoughlins Rocks: reef, see Yukon Reef.

McMahon Creek: stream, flows W $1 \mathrm{mi}$. to Butte Creek, $30 \mathrm{mi}$. SW of Eagle, Yukon-Tanana High.; $64^{\circ} 42^{\prime} \mathrm{N}, 142^{\circ} 02^{\prime} \mathrm{W}$; (map 102).

Prospectors' name shown on an 1898 manuscript map by C. A. Woodruff, Fort Cudahy, Canada.

McManus Creek: stream, flows SW 14 mi., joins Smith Creek to form Chatanika River, $76 \mathrm{mi}$. SW of Circle, Yukon-Tanana High.; $65^{\circ} 17^{\prime}$ $30^{\prime \prime} \mathrm{N}, 146^{\circ} 20^{\prime} 50^{\prime \prime} \mathrm{W}$; (map 104).

Named by prospectors; reported in 1903 by T. G. Gerdine (in Prindle, 1905, pl. 13), USGS.

McMullen Gove: cove, on $\mathrm{E}$ coast of Harris Penin., $28 \mathrm{mi}$. SW of Seward, Chugach Mts.; $59^{\circ} 46^{\prime} \mathrm{N}, 149^{\circ} 46^{\prime} \mathrm{W}$; BGN 1930; (map 49).

Named by the 1912 USC\&GS field party "in honor of Capt. McMullen, a veteran pilot, who commanded the steamer Dora."

McNair Island: island, see Grand Island.

McNairy Point: point of land, at S limit of entrance to Steamboat Bay, $1 \mathrm{mi}$. NE of Whitney I. and $61 \mathrm{mi}$. E of Sitka, Coast Mts. ; $57^{\circ}$ $15^{\prime} 45^{\prime \prime} \mathrm{N}, 133^{\circ} 32^{\prime} 00^{\prime \prime} \mathrm{W}$; (map 8).

Named in 1887 by Lt. Comdr. C. M Thomas, USN; published in 1888 by USC\&GS.

McNally Creek: stream, flows $\mathrm{N} 1.4 \mathrm{mi}$. to Ugashik Creek, on Alaska Penin., $42 \mathrm{mi}$. NE of Ugashik, Aleutian Ra.; $57^{\circ} 37^{\prime} 45^{\prime \prime} \mathrm{N}, 156^{\circ}$ $16^{\prime} 50^{\prime \prime} \mathrm{W}$; (map 36).

Prospector's name reported in 1921 by Capps (1923, pl. 2), USGS.

Macnamara Point: point of land, on $\mathrm{W}$ coast of Zarembo I., $28 \mathrm{mi}$. SW of Wrangell, Alex. Arch.; 56 $19^{\prime} 50^{\prime \prime}$ N, $133^{\circ} 03^{\prime} 45^{\prime \prime}$ W; (map 6). Var. McNamara Point.
Named on September 1, 1793, by Capt. George Vancouver, RN, "no doubt in honor of James Macnamara, who served under Hood and was later Rear-Admiral in the RN" (Wagner, 1937, p. 395).

McNaughton Point: point of land, near head of Big John Bay, $13.5 \mathrm{mi}$. SE of Kake, on W coast of Kupreanof I., Alex. Arch.; 56 ${ }^{\circ} 50^{\prime}$ $10^{\prime \prime} \mathrm{N}, 133^{\circ} 41^{\prime} 40^{\prime \prime} \mathrm{W}$; (map 6).

Local fishermen's name reported in 1947 by USC\&GS.

McNears: locality, on $\mathrm{S}$ bank of Goldstream Creek, $5 \mathrm{mi}$. NW of Fairbanks, Yukon-Tanana High.; 64 ${ }^{\circ} 55^{\prime} \mathrm{N}, 147^{\circ} 48^{\prime} \mathrm{W}$; (map 100).

Name of a railroad station of the now defunct Chatanika Branch of The Alaska RR. (formerly Tanana Valley RR.); published on a timetable in 1922.

McNeil Canyon: canyon, on Kenai Penin., trends S $2 \mathrm{mi}$. in course of McNeil Greek to Kachemak Bay, $12 \mathrm{mi}$. NE of Homer, Cook Inlet Low.; $59^{\circ} 43^{\prime} \mathrm{N}, 151^{\circ} 15^{\prime} \mathrm{W}$; (map 50).

Local name reported and published by USGS in the 1950's.

McNeil Cove: bay, $3 \mathrm{mi}$. across, on $\mathrm{W}$ shore of Kamishak Bay, $32 \mathrm{mi}$. SW of Augustine I., Aleutian Ra.; $59^{\circ} 08^{\prime} 30^{\prime \prime} \mathrm{N}, 154^{\circ} 11^{\prime} 30^{\prime \prime} \mathrm{W}$; (map 51).

Named for Charlie McNeil, a rancher in the area, and reported by R. H. Sargent, USGS, in 1923. The name was published by K. F. Mather (in Brooks and others, 1925, pl. 3).

McNeil Creek: stream, on Kenai Penin., flows S $3 \mathrm{mi}$. to Kachemak Bay, $12 \mathrm{mi}$. NE of Homer, Cook Inlet Low.; $59^{\circ} 43^{\prime} \mathrm{N}, 151^{\circ} 15^{\prime}$ W; (map 50).

Local name reported by W. H. Dall, USGS, in 1895.

McNeil Head: promontory, on E shore of Kamishak Bay, $1.5 \mathrm{mi}$. N of Horseshoe Cove, $32 \mathrm{mi}$. SW of Augustine I., Aleutian Ra.; $59^{\circ} 07^{\prime} 20^{\prime \prime} \mathrm{N}, 154^{\circ} 10^{\prime} 30^{\prime \prime} \mathrm{W}$; (map 51 ).

Local name published by USGS in 1951 . Charlie McNeil was a rancher in the area in the early 1920's.

McNeil Islet: island, $45 \mathrm{ft}$. high, in Kamishak Bay, $0.7 \mathrm{mi}$. NE of McNeil Head, $31 \mathrm{mi}$. SW of Augustine I., Aleutian Ra.; $59^{\circ} 07^{\prime} 40^{\prime \prime} \mathrm{N}$, $154^{\circ} 09^{\prime} 30^{\prime \prime} \mathrm{W}$; (map 51 ).

Local name published by USGS in 1951 . Charlie McNeil was a rancher in the area in the early 1920's.

McNeill Creek: stream, flows $\mathbf{S} 5 \mathrm{mi}$., between Faith and Joe Wise Creeks, to Spruce Creek, $10.3 \mathrm{mi}$. SE of Marshall, Nulato Hills; $61^{\circ}$ $46^{\prime} 45^{\prime \prime} \mathrm{N}, 161^{\circ} 50^{\prime} 45^{\prime \prime} \mathrm{W}$; (map 73).

Prospectors' name reported by Harrington (1918, map), USGS, in 1916.

McNeil River: stream, heads at a glacier at $58^{\circ} 56^{\prime} \mathrm{N}, 154^{\circ} 40^{\prime} \mathrm{W}$, and flows NE $22 \mathrm{mi}$. to McNeil Cove, $34 \mathrm{mi}$. SW of Augustine I., Aleutian Ra.; $59^{\circ} 07^{\prime} 20^{\prime \prime} \mathrm{N}, 154^{\circ} 15^{\prime} 00^{\prime \prime} \mathrm{W}$; (map 51).

Named for Charlie McNeil, a rancher in the area, and reported by R. H. Sargent, USGS, in 1923. The name was published by 
K. F. Mather (in Brooks and others, 1925, pl. 3).

McNett Fork: stream, flows $2 \mathrm{mi}$. E to Squaw Creek $2 \mathrm{mi}$. S of Squaw Lake, $9.5 \mathrm{mi}$. NE of Chandalar, Brooks Ra.; 67 ${ }^{\circ} 34^{\prime} 30^{\prime \prime}$ N, $148^{\circ}$ $11^{\prime} 30^{\prime \prime} \mathrm{W}$; (map 123).

Local name reported in 1956 by T. E. Taylor, USGS.

McNew Hill: ridge, (elev. 1,050 ft.), on $E$ end of Attu I., Aleutian Is.; $52^{\circ} 50^{\prime} 15^{\prime \prime} \mathrm{N}, 173^{\circ}$ 23'00" W; BGN 1945; (map 13).

Proposed in 1944 to honor Sgt. John B. McNew, USA, who was killed in action on Attu I., May 30, 1943.

McNichol Bay: bay, see Kittilngook Bay.

Macomb Plateau: plateau, 4,490 ft., at head of Dry Creek, $45 \mathrm{mi}$. SE of Delta Junction, Alaska Ra.; $63^{\circ} 36^{\prime} 30^{\prime \prime} \mathrm{N}, 144^{\circ} 41^{\prime} 00^{\prime \prime} \mathrm{W}$; BGN 1937; (map 86).

Local name shown on a 1927 manuscript map of the "Endicott and Haley Hunting Expedition."

Macooshino: settlement, see Makushin.

McPherson, Mount: mountain, 6,461 ft., in Robinson Mts., $4.3 \mathrm{mi}$. E of Munday Peak and 82 mi. NW of Yakutat, Chugach Mts.; $60^{\circ} 04^{\prime} 15^{\prime \prime}$ N, 141 ${ }^{\circ} 49^{\prime} 45^{\prime \prime}$ W; (map 65).

Probably named for J. L. McPherson, Deputy U.S. Mineral Surveyor. Name reported in 1913 by A. C. Maddren, USGS, and published in 1921 by G. C. Martin (pl. 6). USGS.

McPherson Bay: bay, on N coast of Naked I., extends $\mathrm{N} 2 \mathrm{mi}$. to McPherson Passage, 38 mi. NE of Chenega, Chugach Mts.; $60^{\circ} 40^{\prime}$ $30^{\prime \prime} \mathrm{N}, 147^{\circ} 22^{\prime} 30^{\prime \prime} \mathrm{W}$; (map 63).

Local name published on recent USGS maps; derived from nearby $\mathrm{McPherson}$ Passage.

McPherson Glacier: glacier, trends W $6 \mathrm{mi}$. to its terminus at a Lake, $1.5 \mathrm{mi}$. S of Goat Mtn., 27 mi. N of Katalla, Chugach Mts.; ' $60^{\circ} 40^{\prime}$ $\mathrm{N}, 144^{\circ} 39^{\prime} \mathrm{W}$; (map 64$)$.

Name published in 1959 by USGS.

McPherson Passage: water passage, in Prince William Sound, extends NW-SE $6 \mathrm{mi}$. between Peak and Naked Is., $38 \mathrm{mi}$. NE of Chenega, Chugach Mts.; $60^{\circ} 40^{\prime} 45^{\prime \prime} \mathrm{N}, 147^{\circ}$ $22^{\prime} 30^{\prime \prime} \mathrm{W}$; (map 63).

Local name published in 1910 by USC\&GS.

McPherson Point: point of land, on coast of Beaufort Sea, near Point McLeod, Arctic Plain; (map 148). Var. M'Pherson Point, McPherson.

Named by P. W. Dease and Thomas Simpson July 27, 1837. See McLeod Point.

M'Pherson Point: point of land, see McPherson Point.

McQuesten Creek: stream, heads in Ray Mts., flows S $15 \mathrm{mi}$. to Tozitna River, $28 \mathrm{mi}$. NNE of Tanana, Kokrines-Hodzana High.; $65^{\circ}$ $32^{\prime} 47^{\prime \prime} \mathrm{N}, 151^{\circ} 42^{\prime} 40^{\prime \prime} \mathrm{W}$; BGN 1961; (map 106). Var. McQuisten Creek, McQuistern Greek.

Named in 1956 by Orth for Napoleon Leroy "Jack" McQuesten, one of the first prospectors and fur traders on the Yukon. $\mathrm{He}$ was born in New Hampshire in 1836 and came to Alaska in 1872. See Harpers Bend.

McQuesten Island: island, see Huggins Island. McQuestion Island: island, see Huggins Island. McQuisten Creek: stream, see McQuesten Creek.

McQuister Island: island, see Huggins Island. McQuistern Greek: stream, see McQuesten Greek.

Mac's Pond: lake, see Ned Pond.

Mc'Tarish Point: point of land, see McTavish Point.

McTavish Point: point of land, on W shore between Admiralty Bay and Dease Inlet, Arctic Plain; $70^{\circ} 57^{\prime} 35^{\prime \prime} \mathrm{N}, 155^{\circ} 49^{\prime} 15^{\prime \prime} \mathrm{W}$; (map 148). Var. McTarish Point, Point McThvisk.

This name originated on Maguire's chart (Great Britain, 1854, facing p. 186) as " $\mathrm{Pt}$. McThvisk." This spelling was considered an error, and published on British Admiralty Chart No. 593 as "McTavish Point."

McThvisk, Point: point of land, see McTavish Point.

MacVicar, Mount: mountain, 6,600 ft., $4 \mathrm{mi}$. SE of $S$ end of Chandler Lake and $15 \mathrm{mi}$. NW of headwater of John River, Brooks Ra.; $68^{\circ} 10^{\prime} \mathrm{N}, 152^{\circ} 37^{\prime} \mathrm{W}$; BGN 1959; (map 134).

Named in 1958 by John M. Campbell of Yale Univ, for Donald George MacVicar who drowned in Chandler Lake while doing geologic studies in the area in 1956.

Madan, Point: point of land, $\mathrm{W}$ entrance to Madan Bay, $\mathrm{N}$ of Wrangell I., $11 \mathrm{mi}$. SE of Wrangell, Coast Mts.; $56^{\circ} 22^{\prime} 45^{\prime \prime} \mathrm{N}, 132^{\circ}$ $09^{\prime} 45^{\prime \prime} \mathrm{W}$; (map 6).

Named on August 27, 1793, by Capt. George Vancouver, RN, "possibly after Bishop Spencer Madan" (Wagner, 1937, p. 395).

Madan Bay: bay, 2 mi. long, at $\mathrm{S}$ end of Eastern Passage, $\mathrm{N}$ of Wrangell I., $12 \mathrm{mi}$. SE of Wrangell, Coast Mts.; $56^{\circ} 23^{\prime} \mathrm{N}, 132^{\circ} 09^{\prime} \mathrm{W}$; $B G N$ 1936; (map 6).

Named in 1935 by USFS; derived from Point Madan.

Madean Peak: mountain peak, $8,190 \mathrm{ft}$., $0.8 \mathrm{mi}$. SE of Tazlina Tower and $25 \mathrm{mi}$. NW of Valdez, Chugach Mts.; $61^{\circ} 23^{\prime} 00^{\prime \prime} \mathrm{N}, 146^{\circ} 44^{\prime} 30^{\prime \prime}$ W; BGN 1965; (map 68).

Named about 1955 by L. E. Nielsen (1963, p. 135).

Made Creek: stream, flows SW $0.6 \mathrm{mi}$. to Osborn Creek, $11 \mathrm{mi}$. NE of Nome, Seward Penin. High.; $64^{\circ} 36^{\prime} 30^{\prime \prime} \mathrm{N}, 165^{\circ} 07^{\prime \prime} 30^{\prime \prime} \mathrm{W}$; (map 94).

Prospectors' name reported in 1904 by $T$. G. Gerdine, USGS.

Madeira Creek: stream, flows W $0.3 \mathrm{mi}$. to Slate Creek which flows to Pilgrim River, $25 \mathrm{mi}$. NW of Solomon, Seward Penin. High.; $64^{\circ}$ $53^{\prime} 00^{\prime \prime} N, 164^{\circ} 49^{\prime} 45^{\prime \prime}$ W; (map 95).

Prospectors' name reported in 1908 by $P$. S. Smith (in Brooks and others, 1909, pl. 10), USGS.

Mad Hill: hill, $315 \mathrm{ft}$, between Kilignak and Niyiklik Creeks, $8 \mathrm{mi}$. E of Cape Thompson, Arctic Slope; $68^{\circ} 09^{\prime} 50^{\prime \prime} \mathrm{N}, 165^{\circ} 40^{\prime} 35^{\prime \prime} \mathrm{W}$; BGN 1963; (map 129).
Named about 1962 by personnel of Project Chariot.

Madhouse, The: locality, see Phoenix.

Madison Creek: stream, flows NE to Adams Creek which flows to Shovel Creek, $W$ of Button Creek, $10 \mathrm{mi}$. N of Solomon, Seward Penin. High.; (map 95).

Prospectors' name reported on a prospector's manuscript map dated 1902. This stream cannot be precisely located on current maps.

Madison Creek: stream, flows SE to Anikovik River, about $15 \mathrm{mi}$. SE of Cape Irince of Wales, Seward Penin. High.; (map 111).

Prospectors' name shown on the 1900 "Map of Nome Peninsula" by J. M. Davidson and B. D. Blakeslee. This feature cannot be precisely identified on current maps.

Madison Creek: stream, heads on $N$ slope of Madison Mtn., flows NW and SW $23 \mathrm{mi}$. to Tolstoi Creek $6 \mathrm{mi}$. SE of its junc. with Dishna River, $26 \mathrm{mi}$. NW of Ophir and 55 mi. NW of McGrath, Kilbuck-Kuskokwim Mts.; $63^{\circ} 23^{\prime} 40^{\prime \prime} \mathrm{N}, 157^{\circ} 07^{\prime} 00^{\prime \prime} \mathrm{W}$; (map 90).

Prospectors' name reported in 1907 by USGS.

Madison Creek: stream, flows NE $8 \mathrm{mi}$. to Wild River, $5 \mathrm{mi}$. $\mathrm{N}$ of Twoday Mtn. and $36 \mathrm{mi}$. W of Wiseman, Brooks Ra.; 67. $21^{\prime} 30^{\prime \prime} \mathrm{N}$, $151^{\circ} 27^{\prime} 30^{\prime \prime} \mathrm{W}$; BGN 1932; (map 124).

Local name reported by Robert Marshall in 1932.

Madison Gulch: ravine, heads on Mount Brynteson, trends E $0.5 \mathrm{mi}$. to Glacier Creek, $9 \mathrm{ml}$. $\mathrm{N}$ of Nome, Seward Penin. High.; $64^{\circ} 38^{\prime} 18^{\prime \prime}$ $\mathrm{N}, 165^{\circ} 20^{\prime} 40^{\prime \prime} \mathrm{W}$; (map 94). Var. Mountain Gulch.

Prospectors' name reported on Arthur Gibson's "Map of Cape Nome Precinct" dated 1904. Reported as "Mt. Gul." on the 1902 "Map of the Nome and Snake River Country" by J. M. Davidson.

Madison Mountain: mountain, 1,958 ft., on $\mathrm{W}$ slope of Kuskokwim Mts., at heads of Fourmile and Madison Creeks, 19 mi. NW of Ophir and $47 \mathrm{mi}$. NW of McGrath, Kilbuck-Kuskokwim Mts. ; $63^{\circ} 23^{\prime} \mathrm{N}, 156^{\circ} 47^{\prime} \mathrm{W}$; (map 90).

Prospectors' name reported in 1933 by USGS.

Madjujuinuk: locality, on $\mathrm{E}$ shore of Norton Sound between Cape Denbigh and Point Dexter, $14 \mathrm{mi}$. NW of Shaktoolik, Nulato Hills; $64^{\circ} 28^{\prime} 30^{\prime \prime} \mathrm{N}, 161^{\circ} 28^{\prime} 30 \mathrm{~W}$; (map 96).

Eskimo name for an archeological site reported in 1950 by Geddings (1964, p. 9).

Madre de Deos, Ostrov de la: island, see Madre de Dios Island.

Madre de Dios, Isla: island, see Madre de Dios Island.

Madre de Dios, Isla de la: island, see Madre de Dios Island.

Madre de Dios Island: island, $1.8 \mathrm{mi}$. long, between Bucareli and Trocadero Bays, on W coast of Prince of Wales I., Alex. Arch.; 55 $23^{\prime} 40^{\prime \prime} \mathrm{N}, 133^{\circ} 08^{\prime} 00^{\prime \prime} \mathrm{W}$; (map 4). Var. Isla de la Madre de Dios, Isla Madre de Dios, Ostrov de la Madre de Deos. 
Name "Isla de la Madre de Dios" or "Mother of God Island" was given to this island June 1, 1779, by Francisco Antonio Maurelle (Wagner, 1937, p. 395).

Madson Mountain: mountain, 5,269 ft., on Kenai Penin., $24 \mathrm{mi}$. N of Seward, Chugach Mts.; $60^{\circ} 27^{\prime} 30^{\prime \prime} \mathrm{N}, 149^{\circ} 25^{\prime} 45^{\prime \prime} \mathrm{W}$; BGN 1910; (map 63).

Local name reported in 1909 by Grant and Higgins (1910, pls. 1, 2), USGS.

Mae West Lake: lake, $0.6 \mathrm{mi}$. long, S of Glenn Highway, $17 \mathrm{mi}$. W of Glennallen, Copper River Basin; 62 $05^{\prime} 30^{\prime \prime} \mathrm{N}, 146^{\circ} 04^{\prime} 30^{\prime \prime} \mathrm{W}$; (map 83).

Local name published in 1964 by USGS.

Mafsorak: stream, sce Mapsorak Creek.

Mafsorak Hill: hill, see Mapsorak Mountain.

Mafsorak Mountain: hill, see Mapsorak Hill.

Magaktlek Creek: stream, flows SW $10 \mathrm{mi}$. to Bessie Creek, $43 \mathrm{mi}$. N of Goodnews, YukonKuskokwim Delta; $59^{\circ} 58^{\prime} \mathrm{N}, 161^{\circ} 37^{\prime} \mathrm{W}$; (map 53).

Local Eskimo name published in 1951 by USGS.

Magazine Ridge: ridge, $2.5 \mathrm{mi}$. long, $\mathrm{N}$ of Fort Glenn, between Teal and Thirty Three Creeks, NE coast of Umnak I., Aleutian Is. ; 53 ${ }^{\circ} 5^{\prime}$ $\mathrm{N}, 167^{\circ} 55^{\prime} \mathrm{W}$; (map 23).

Name published by Byers (1959, Pl. 41), USGS. This name is one of many given to local features during and after World War II, by U.S. military personnel.

Magdalena, Cape: point of land, $\mathrm{N}$ point of entrance to Port Bazan, on SW coast of Dall I., Alex. Arch.; $54^{\circ} 50^{\prime} 10^{\prime \prime} \mathrm{N}, 133^{\circ} 00^{\prime} 30^{\prime \prime} \mathrm{W}$; (map 1). Var. Cabo de Santa Maria Mag. delena.

According to Baker (1906, p. 421), “* * * Either this cape or Cape Muzon was named 'Cabo de Santa Maria Magdalena' [Cape of St. Mary Magdalen] by [Juan] Perez, 1774."

Magdalena, Isla de la: island, see Hinchinbrook Island.

Mageik, Mount: mountain, 7,250 ft., on Alaska Penin., in Katmai National Monument $11 \mathrm{mi}$. SW of Mount Katmai, Aleutian Ra.; $58^{\circ}$ 11'45' N, $155^{\circ} 15^{\prime} 10^{\prime \prime}$ W; BGN 1966; (map 42). Var. Mageik Mountain, Mageik Volcano.

Native name reported in 1917 by R. F. Griggs, National Geographic Society, as Mageik Volcano (map) and as Mount Mageik (text).

Mageik Creek: stream, on Alaska Penin., in Katmai National Monument, heads near Katmai Pass, flows SE $10 \mathrm{mi}$. to Katmai River, 7 mi. S of Mount Katmai, Aleutian Ra.; $58^{\circ}$ $09^{\prime} 10^{\prime \prime} \mathrm{N}, 155^{\circ} 01^{\prime} 00^{\prime \prime} \mathrm{W}$; BGN 1924; (map 42).

Named in 1916 by R. F. Griggs, National Geographic Society, probably after Mount Mageik.

Mageik Landslide: slope, along upper course of Martin Creek, on Alaska Penin., in Katmai National Monument, $12 \mathrm{mi}$. SW of Mount Katmai, Aleutian Ra.; $58^{\circ} 07^{\prime} 30^{\prime \prime} \mathrm{N}, 155^{\circ}$. $12^{\prime} 00^{\prime \prime} \mathrm{W}$; (map 42).
Named in 1917 by R. F. Griggs, National Geographic Society, to designate this unusual slide of boulders, soil, peat, and other debris triggered by the Mount Katmai eruption.

Mageik Mountain: mountain, see Mageik, Mount.

Mageik Volcano: mountain, see Mageik, Mount.

Maggie Creek: stream, flows W to Agiapuk River, about $18 \mathrm{mi}$. N of Teller, Seward Penin. High.; (map 111).

Prospectors' name reported on a precinct map of Seward Peninsula gold fields by Monroe and Hutchins, corrected up to June 1903 by Arthur Gibson. This feature cannot be precisely identified on current maps.

Maggie Creek: stream, in Rampart Mts., flows S $3 \mathrm{mi}$. to Morelock Creek, NW of Bonanza Creek, 23 mi. ENE of Tanana, Kokrines-Hodzana High.; $65^{\circ} 20^{\prime} \mathrm{N}, 151^{\circ} 23^{\prime} \mathrm{W}$; (map 106)

Prospectors' name reported in 1911 by $\mathrm{H}$. M. Eakin, USGS.

Maghi Point: point of land, see Tangent Point. Magician Creek: stream, flows SW $0.5 \mathrm{mi}$. to Mutt Cove, Kiska I., Aleutian Is.; 51 '55'52' $\mathrm{N}, 177^{\circ} 30^{\prime} 30^{\prime \prime} \mathrm{E}$; (map 14)

An arbitrary name beginning with " $M$ " to correspond to " $M$ " grid used by U.S. Army for tactical purposes during World War II ; published on a 1943 Army map.

Magician Hill: hill, $470 \mathrm{ft}$., E of Mutt Cove, Kiska I., Aleutian Is.; $51^{\circ} 56^{\prime} 02^{\prime \prime}$ N, $177^{\circ} 30^{\prime}$ $33^{\prime \prime} \mathrm{E}$; (map 14).

An arbitrary name beginning with " $M$ " to correspond to "M" grid used by U.S. Army for tactical purposes during World War II; published on a 1943 Army map.

Magic Mountain: mountain, 1,260 ft., central Kiska.I., Aleutian Is.; $51^{\circ} 57^{\prime} 27^{\prime \prime} \mathrm{N}, 177^{\circ} 30^{\prime}$ $18^{\prime \prime} \mathrm{E}$; (map 14). Var. Stubble Ridge.

An arbitrary name beginning with "M" to correspond to "M" grid used by U.S. Army for tactical purposes during World War II; published on a 1953 AMS map. Variant published on a 1943 USAAF map.

Magitchlie Creek: stream, heads on E slope of the Magitchlie Range, flows S $90 \mathrm{mi}$. to Innoko River, $60 \mathrm{mi}$. NW of Ophir and $60 \mathrm{mi}$. $\mathrm{NE}$ of Holikachuck, Innoko Low.; 63 $32^{\prime} 30^{\prime \prime}$ N, 158 $12^{\prime} 30^{\prime \prime} \mathrm{W}$; (map 90). Var. Lonesome River.

Local name obtained from Joseph Ferris in 1954 by R. E. Isto, USGS.

Magitchlie Range: mountain range, cxtends $\mathrm{N}-\mathrm{S}$ $15 \mathrm{mi}$., $39 \mathrm{mi}$. SW of Nulat, Kilbuck-Kuskokwim Mts. ; $64^{\circ} 08^{\prime} \mathrm{N}, 158^{\circ} 24^{\prime} \mathrm{W}$; (map 97). Var. Black River Mountain, Sistdlila.

Ingalik Indian name reported in 1939 by USGS. It was referred to in 1935 as "Black Bear Mountain" by Frederica de Laguna.

Magnet Creek: stream, flows S $3 \mathrm{mi}$. to Cache Greek, on coast of Norton Sound, $7 \mathrm{mi}$. E of Solomon, Seward Penin. High.; 64 $34^{\prime}$ N, $164^{\circ} 13^{\prime} \mathrm{W}$; (map 95). Var. Lillian Creek.

Prospectors' name shown on Arthur Gibson's "Map of Cape Nome Precinct" dated 1904.
Magnet Creek: stream, flows S $1.3 \mathrm{mi}$. to North Fork Kougarok River, $2 \mathrm{mi}$. SW of Harris Dome and $42 \mathrm{mi}$. W of Imuruk Lake, Seward Penin. High.; $65^{\circ} 36^{\prime} \mathrm{N}, 164^{\circ} 37^{\prime} \mathrm{W}$; (map 110).

Prospectors' name reported in 1901 by T. G. Gerdine (in Collier, 1902, pl. 12), USGS.

Magnet Creek: stream, flows NE $5.7 \mathrm{mi}$. to Pinnell River, $14 \mathrm{mi}$. NE of Imuruk Lake, Seward Penin. High.; $65^{\circ} 47^{\prime} \mathrm{N}, 163^{\circ} 02^{\prime} \mathrm{W}$; $B G N 1952$; (map 110).

Prospectors' name reported in 1903 by $\mathrm{D}$. C. Witherspoon (in Moffit, 1905, pl. 2), USGS.

Magnet Creek: stream, flows $2.5 \mathrm{mi}$. N from N of Poss Mtn. to Gold Creek, $33 \mathrm{mi}$. W of Chandalar, Brooks Ra.; $67^{\circ} 31^{\prime} \mathrm{N}, 149^{\circ} 43^{\prime} \mathrm{W}$; (map 123).

Local name reported in 1956 by T. E. Taylor, USGS.

Magnetic Island: island, 1 mile long, in Tuxedni Bay, W of Rusty Mount, $59 \mathrm{mi}$. SW of Kenai, Aleutian Ra.; $60^{\circ} 14^{\prime} 30^{\prime \prime}$ N, $152^{\circ}$ $51^{\prime} 00^{\prime \prime} \mathrm{W}$; (map 62).

Local name reported in 1958 by USGS.

Magnetic Point: point of land, E point of entrance to Union Bay, $W$ coast of Cleveland Penin., Alex. Arch.; 55 $47^{\circ} 00^{\prime \prime} \mathrm{N}, 132^{\circ} 11^{\prime}$ $15^{\prime \prime} \mathrm{W}$; (map 4).

Local name published in 1943 by USC\&GS.

Magnet Rock: rock, in Cook Inlet, $0.5 \mathrm{mi}$. W of SW end of Kenai Penin., $14 \mathrm{mi}$. SW of Seldovia, Chugach Mts.; $59^{\circ} 18^{\prime} 30^{\prime \prime}$ N, $152^{\circ} 00^{\prime}$ $00^{\prime \prime} \mathrm{W}$; BGN 1908; (map 50).

Local name published in 1908 by USC\&GS.

Magnificent, Mount: mountain, 4,285 ft., $5 \mathrm{mi}$. $\mathrm{E}$ of the village of Eagle River and $18 \mathrm{mi}$. NE of Anchorage, Chugach Mts.; 61 $1^{\circ} 19^{\prime} \mathrm{N}$, $149^{\circ} 24^{\prime}$ W; BGN 1959; (map 69). Var. My Mountain.

Descriptive name given in 1953 by Mrs. Ollie A. Trower of Anchorage.

Magnolia Creek: stream, flows NW to Snake River, about $31 \mathrm{mi}$. NE of Nome, Seward Penin. High.; (map 94).

Prospectors' name reported on the 1900 "Map of Nome Peninsula" by J. M. Davidson and B. D. Blakeslee; this feature has not been positively identified.

Magnolia Greek: stream, flows S $5 \mathrm{mi}$. to Igloo Creek which flows to American River, $32 \mathrm{mi}$. NE of Teller, Seward Penin. High.; $65^{\circ} 28^{\prime}$ $\mathrm{N}, 165^{\circ} 22^{\prime} \mathrm{W}$; (map 111).

Prospectors' name reported in. 1900 by Messrs. Kemp and David Fox (in Brooks, 1901, pl. 11).

Magnolia Gulch: ravine, trends SW $0.7 \mathrm{mi}$. to Grouse Creek which flows to Goldbottom Creek, $15 \mathrm{mi}$. N of Nome, Seward Penin.

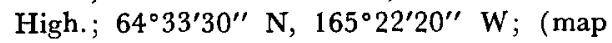
94).

Prospectors' name reported on the 1903 Gampion Mining and Trading Co. map by George M. Ashford.

Magoffin Lake: lake, see Volkmar Lake.

Magoghyik River: stream, see Maghoweyik River. 
Magot Point: point of land, $\mathrm{E}$ of mouth of Susitna River, $22 \mathrm{mi}$. NW of Anchorage, Cook Inlet Low.; $61^{\circ} 17^{\prime} \mathrm{N}, 150^{\circ} 32^{\prime} \mathrm{W}$; (map 70). Local name reported in 1958 by USGS.

Magoun Islands: islands, $1.5 \mathrm{mi}$. long, between Krestof and Sitka Sounds, $11 \mathrm{mi}$. NW of Sitka, Alex. Arch.; $57^{\circ} 10^{\prime} \mathrm{N}, 135^{\circ} 34^{\prime} \mathrm{W}$; (map 9). Var. Machin Island, Magun Island, Ostrov Magun.

Named by the Russians in the 1840's for Capt. Magoun (cnna), an early trader.

Magpie Creek: stream, flows SW $1.5 \mathrm{mi}$. to Elliott Creek, $2.3 \mathrm{mi}$. SE of Hubbard Peak and $78 \mathrm{mi}$. NE of Valdez, Wrangell Mts.; $61^{\circ}$ $40^{\prime} 05^{\prime \prime} \mathrm{N}, 144^{\circ} 11^{\prime} 20^{\prime \prime} \mathrm{W}$; (map 68).

Name published by USGS (Moffit and Maddren, 1909, fig. 2).

Magpie Creek: stream, see Camp Creek.

Magtok: locality, "on Agattu I. in Near Is.," Aleutian Is.

Former Aleut village reported as "uninhabited" by Hodge (1907, p. 785), BAE.

Maguire Creek: stream, flows S $18 \mathrm{mi}$. to Little Susitna River, $15 \mathrm{mi}$. NW of Anchorage, Cook Inlet Low.; $61^{\circ} 16^{\prime} 25^{\prime \prime} \mathrm{N}, 150^{\circ} 19^{\prime} 00^{\prime \prime} \mathrm{W}$; (map 70).

Local name reported in 1958 by USGS.

Maguire Islands: barrier islands, on Beaufort Sea coast W of Flaxman I., extends 9 mi. between Challenge and Mary Sachs Entrances, Arctic Plain; $70^{\circ} 14^{\prime} \mathrm{N}, 146^{\circ} 30^{\prime} \mathrm{W}$; (map 151).

Named in 1910 by Leffingwell (1919, p. 97) for Comdr. Rochfort Maguire, RN.

Magun, Ostrov: islands, see Magoun Islands.

Maguriak Creek: stream, heads in lake, flows $\mathbf{N}$ $15 \mathrm{mi}$. to Kungok River, $19 \mathrm{mi}$. SE of Wainwright, Arctic Plain; $70^{\circ} 31^{\prime} \mathrm{N}, 159^{\circ} 17^{\prime} \mathrm{W}$; (map 146).

Eskimo name obtained at Wainwright in 1956 by T. E. Taylor, USGS; probably means (Magurok) "it howls."

Mahid Island: island, see Maid Island.

Mahlo, Mount: mountain, 6,300 ft., $0.5 \mathrm{mi}$. SE of Mount Brookfield and $17 \mathrm{mi}$. N of Valdez, Chugach Mts.; $61^{\circ} 21^{\prime} 20^{\prime \prime} \mathrm{N}, 146^{\circ} 16^{\prime} 20^{\prime \prime} \mathrm{W}$; BGN 1960; (map 68).

Named in 1898 for Emil Mahlo, a topographer with Capt. W. R. Abercrombie, who with F. C. Schrader, USGS, made the first topographic map of the Valdez Glacier area.

Mahlo River: stream, heads on E slope of Bence Mtn., flows NNE $16 \mathrm{mi}$. to Klutina Lake, 48 mi. NE of Valdez, Chugach Mts.; $61^{\circ} 44^{\prime} 10^{\prime \prime}$ $\mathrm{N}, 145^{\circ} 44^{\prime} 30^{\prime \prime} \mathrm{W}$; (map 68).

Named in 1898 by Capt. W. R. Abercrombie, USA, for Emil Mahlo, a member of his party.

Mahon: locality, $4 \mathrm{mi} . \mathrm{N}$ of Nenana, Tanana Low.; 64.37' N, $149^{\circ} 04^{\prime} \mathrm{W}$; (map 100).

Railroad station name published in 1923 railway guide and on a USGS map in 1924.

Mahoney Lake: lake, $0.7 \mathrm{mi}$. across, on Revillagigedo I., on W bank of George Inlet, $7 \mathrm{mi}$. $\mathrm{NE}$ of Ketchikan, Alex. Arch.; $55^{\circ} 25^{\prime} 15^{\prime \prime} \mathrm{N}$, $131^{\circ} 31^{\prime} 15^{\prime \prime} \mathrm{W}$; (map 3).

Local name published in 1943 by USC\&GS.

Mahoney Mountain: mountain, 3,350 ft., on Revillagigedo I., between Mahoney and Up- per Silvis Lakes, $5 \mathrm{mi}$. NE of Ketchikan, Alex. Arch.; $55^{\circ} 23^{\prime} 50^{\prime \prime} \mathrm{N}, 131^{\circ} 32^{\prime} 40^{\prime \prime} \mathrm{W}$; (map 3).

Local name published in 1943 by USC\&GS. Mahtkweengak Slough: water course, see Mahtkwingak Slough.

Mahtkwingak Slough: water course, in Yukon Delta, flows N 20 mi. from Kwikpak Pass to Norton Sound, $34 \mathrm{mi}$. N of Kwiguk, YukonKuskokwim Delta; $63^{\circ} 14^{\prime} \mathrm{N}, 164^{\circ} 21^{\prime} \mathrm{W}$; (map 92). Var. Mahtkweengak Slough, Malitqweengak Slough.

Eskimo name reported in 1899 by G. R. Putnam, USC\&GS; published in 1901 on Chart 9372.

Mahutzu River: stream, see Delta Creek.

Maiachnoi Island: island, see Signal Island.

Maiden Creek: stream, flows N $1.7 \mathrm{mi}$. to Spruce Creek, $3.5 \mathrm{mi}$. S of Ophir and $32 \mathrm{mi}$. NW of

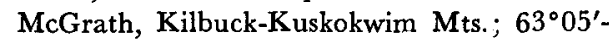
$30^{\prime \prime} \mathrm{N}, 156^{\circ} 31^{\prime} 30^{\prime \prime} \mathrm{W}$; (map 90).

Prospectors' name reported in 1912 by $\mathrm{H}$. M. Eakin, USGS.

Maiden Creek: stream, flows SE $3 \mathrm{mi}$. to Salcha River $11 \mathrm{mi}$. E of that stream's junc. with its North Fork and $45 \mathrm{mi}$. NE of Big Delta, Yukon-Tanana High.; $64^{\circ} 39^{\prime} \mathrm{N}, 144^{\circ} 56^{\prime} \mathrm{W}$; (map 101).

Local name reported in 1958 by USGS.

Maiden Lake: lake, $100 \mathrm{ft}$. long, S of Kiska Harbor, on E coast of Kiska I.; Aleutian Is.; $51^{\circ} 56^{\prime} 50^{\prime \prime} \mathrm{N}, 177^{\circ} 35^{\prime} 30^{\prime \prime} \mathrm{E}$; (map 14).

An arbitrary name beginning with " $\mathrm{M}$ " to correspond to "M" grid used by U.S. Army for tactical purposes during World War II; published on a 1943 Army map.

Maiden Mountain: hill, $300 \mathrm{ft}$., on eastern Kiska I., near South Pass, Aleutian Is.; $51^{\circ}$ $56^{\prime} 50^{\prime \prime}$ N, $177^{\circ} 35^{\prime} 45^{\prime \prime} \mathrm{E}$; (map 14).

An arbitrary name beginning with " $M$ " to correspond to " $M$ " grid used by the U.S. Army for tactical purposes during World War II ; published on a 1953 AMS map.

Maiden Pup: stream, flows W $1.5 \mathrm{mi}$. to North Fork Harrison Creek, $15 \mathrm{mi}$. SW of Circle Hot Springs and $42 \mathrm{mi}$. SW of Circle, YukonTanana High.; $65^{\circ} 23^{\prime} 20^{\prime \prime} \mathrm{N}, 145^{\circ} 07^{\prime} 10^{\prime \prime} \mathrm{W}$; (map 104).

Prospectors' name reported in 1954 or 1955 by USGS topographers.

Maid Island: island, $0.7 \mathrm{mi}$. long, in Necker Is. $16 \mathrm{mi}$. S of Sitka, Alex. Arch.; 56 $50^{\circ} 10^{\prime \prime} \mathrm{N}$, $135^{\circ} 27^{\prime} 45^{\prime \prime} \mathrm{W}$; BGN 1940; (map 5). Var. Mahid Island, Maïd Island, Ostrov Mayd.

Tlingit Indian name reported in 1809 by Ivan Vasiliev the first; published by Lt. Sarichev (1826, map 19), IRN, as "O[strov] Mayd" or "Mayd Island."

Maid Lake: lake, $0.9 \mathrm{mi}$. long, on $\mathrm{E}$ bank of Susitna River, $23 \mathrm{mi}$. NW of Anchorage, Cook Inlet Low.; $61^{\circ} 25^{\prime} 25^{\prime \prime} \mathrm{N}, 150^{\circ} 26^{\prime} 40^{\prime \prime} \mathrm{W}$; (map 70).

Local name reported in 1958 by USGS.

Mailboat Cove: cove, $0.5 \mathrm{mi}$. across, on $\mathrm{S}$ shore of Chernofski Harbor, on SW coast of Unalaska I., Aleutian Is.; $53^{\circ} 23^{\prime} 35^{\prime \prime} \mathrm{N}, 167^{\circ}$ $32^{\prime 2} 5^{\prime \prime}$ W; BGN i940; (map 23). Var. West Bight.
Named by USC\&GS in 1939 because "the mailboat on its regular calls generally anchors in this cove." The cove was first called West Bight in 1937 by a USC\&GS field party.

Mailbox Creek: stream, flows S $3 \mathrm{mi}$. from Twelvemile Mtn. to Middle Fork Koyukuk River, $23 \mathrm{mi}$. S of Wiseman, Brooks Ra.; $67^{\circ} 06^{\prime} 20^{\prime \prime} \mathrm{N}, 150^{\circ} 28^{\prime} 30^{\prime \prime} \mathrm{W}$; (map 124). Var. Branson Creek.

This stream was reported as Branson Creek in 1899 by T. G. Gerdine, USGS, but in 1956 USGS reported "Mailbox Creek" to be local usage.

Mail Slough: stream, an anabranch of Yukon River, flows W $16 \mathrm{mi}$., $4 \mathrm{mi}$. NE of Stevens Village, Yukon Flats; $66^{\circ} 03^{\prime} \mathrm{N}, 149^{\circ} 00^{\prime} \mathrm{W}$; (map 118).

Local name obtained in 1956 by USGS.

Main Bay: estuary, on E coast of Kenai Penin., extends NE 3.5 mi. to Prince William Sound, $20 \mathrm{mi}$. N of Chenega, Chugach Mts.; $60^{\circ} 33^{\prime}$ N, $148^{\circ} 02^{\prime} \mathrm{W}$; $B G N$ 1914; (map 63).

Descriptive name given in 1913 by USC\&GS.

Main Creek: stream, flows S $14 \mathrm{mi}$. to Amber Bay, 12 mi. NW of Cape Kunmik, near S shore of Alaska Penin., Aleutian Ra.; 56 $51^{\prime} \mathrm{N}$, $157^{\circ} 28^{\prime} \mathrm{W}$; (map 31).

Local name published in 1951 by USGS.

Main Creek: stream, heads on Yuki Mtn., flows N $26 \mathrm{mi}$. to Ruby Slough, $12 \mathrm{mi}$. W of Ruby, Kilbuck-Kuskokwim Mts.; 64 ${ }^{\circ} 42^{\prime}$ $45^{\prime \prime} \mathrm{N}, 155^{\circ} 52^{\prime} 45^{\prime \prime} \mathrm{W}$; (map 98).

Prospectors' name reported in 1908 by A. G. Maddren (in Brooks and other, 1909, p. 230), USGS.

Main Lake: lake, former glacier lake in Glacier Bay National Monument, extending S $4 \mathrm{mi}$. from present mouth of Berg Creek, $64 \mathrm{mi}$. $\mathrm{NW}$ of Juneau, St. Elias Mts.; $58^{\circ} 50^{\prime} 00^{\prime \prime} \mathrm{N}$, $135^{\circ} 45^{\prime} 30^{\prime \prime}$ W; (map 11). Var. Endicott Lake.

Named in 1890 by H. F. Reid (1892, pl. 14) for the valley in which the lake was located. Later he changed the name to Endicott Lake for the river which drained it. Reid's map shows the lake at the terminus of Muir Glacier. Since 1900 the glacier has retreated $6 \mathrm{mi}$. to the $\mathrm{N}$, a condition resulting in the lake's disappearance. The name Endicott Lake is now given to a small lake $2 \mathrm{mi}$. SW of the outlet of the original lake.

Main Lake: lake, see Endicott Lake.

Main Valley: valley, $7 \mathrm{mi}$. long, in Glacier Bay National Monument, extending $\mathbf{N}$ from Endicott Gap, $60 \mathrm{mi}$. NW of Juneau, St. Elias Mts. ; $58^{\circ} 52^{\prime} \mathrm{N}, 135^{\circ} 43^{\prime} \mathrm{W}$; (map 11). Var. Endicott Valley.

Named in 1882 by John Muir when the valley was occupied by a branch of Muir Glacier. In 1890 H. F. Reid (1892, pl. 114) showed "Main Valley" as the ice-filled portion NW of Main Lake. Later Reid (1896, p. 86 and 90), named the entire valley "Endicott Valley" because it drained into the Endicott River. With the retreat of the Muir Glacier after 1890, the entire valley was uncovered. The northern part of the 
valley now drains into Muir Inlet, and the southern part drains into the Endicott River. Main Valley: lake, see Endicott Lake.

Main Valley: valley, see Endicott Valley.

Maiogagaluk: locality, see My-og-g-a-gal-look.

Maiyumerak Creek: stream, in Baird Mts., at $\mathrm{N}$ end of Maiyumerak Mts., flows NE $8 \mathrm{mi}$. to Noatak River, $55 \mathrm{mi}$. NE of Noatak, Brooks Ra.; $67^{\circ} 59^{\prime} \mathrm{N}, 161^{\circ} 12^{\prime} \mathrm{W}$; (map 127).

Named for the mountains; reported in 1956 by Orth.

Maiyumerak Mountains: mountains, $\mathbf{1 , 0 0 0 - 4 , 0 0 0}$ $\mathrm{ft}$, in Baird Mts., extend W $45 \mathrm{mi}$. from Nakolik River, between Eli and Noatak Rivers, $15 \mathrm{mi}$. NE of Noatak, Brooks Ra.; $67^{\circ} 50^{\prime} \mathrm{N}$, $161^{\circ} 27^{\prime} \mathrm{W}$; (map 127).

Eskimo name meaning "all the mountains are steep," obtained in 1956 at Noatak by Orth.

Major Creek: stream, $1.4 \mathrm{mi}$. long, flows SE to Sargeant Cove on E coast of Kiska I., Aleutian Is.; $51^{\circ} 56^{\prime} 02^{\prime \prime} \mathrm{N}, 177^{\circ} 33^{\prime} 23^{\prime \prime} \mathrm{E}$; (map 14). Var. Brandy Creek.

An arbitrary name beginning with " $M$ " to correspond to "M" grid used by U.S. Army for tactical purposes during World War II; published on a 1953 AMS map. Variant published on a 1943 USAAF map.

Majority Creek: stream, flowing SE $1 \mathrm{mi}$. to Trout Lagoon, W of Kiska Harbor, Kiska I., Aleutian Is.; $51^{\circ} 58^{\prime} 34^{\prime \prime} \mathrm{N}, 177^{\circ} 31^{\prime} 25^{\prime \prime} \mathrm{E}$; (map 14). Var. Trout Creek.

An arbitrary name beginning with " $M$ " to correspond to " $M$ " grid used by U.S. Army for tactical purposes during World War II; published on a 1953 AMS map. Variant published on a 1943 USAAF map.

Major Ridge: ridge, $1 \mathrm{mi}$. long, extending from Mason Hill to Kiska Harbor, Kiska I., Aleutian Is.; $51^{\circ} 57^{\prime} 25^{\prime \prime} \mathrm{N}, 177^{\circ} 31^{\prime} 40^{\prime \prime} \mathbf{E}$; (map 14).

An arbitrary name beginning with " $M$ " to correspond to " $M$ " grid used by U.S. Army for tactical purposes during World War II; published on a 1943 Army map.

Makagamute: locality, see Makak.

Makag'mut: locality, see Makak.

Makak: locality, "on right bank of Yukon River below Anvik." Var. Akka, Makagamute, Makag'mut, Makeymut, Makka, Makki, Manki.

Former Eskimo camp or settlement reported in 1861 as "Makka" by P. Tikhmeniev. Ivan Petroff listed the name as "Makeymute" with a population of 121 in the 1880 Census; its population was 50 in 1890 .

Makaka Point: point of land, at NW end of Hawkins I., $20 \mathrm{mi}$. W of Cordova, Chugach Mts. ; $60^{\circ} 31^{\prime} 00^{\prime \prime} \mathrm{N}, 146^{\circ} 17^{\prime} 20^{\prime \prime} \mathrm{W}$; (map 64).

This is presumably a "native" name reported in 1898 by Capt. Abercrombie (1900, map), USA, while exploring the Copper River region.

Makaktuk Lake: lake, $1.5 \mathrm{mi}$. long, in Anaktuvuk River valley, $11 \mathrm{mi}$. NE of Anaktuvuk Pass, Brooks Ra.; 68 $17^{\prime}$ N, $151^{\circ} 32^{\prime}$ W ; (map 134).
Eskimo name obtained at Anaktuvuk Pass in 1956 by T. E. Taylor, USGS.

Makarius Bay: bay, 2 mi. across, on SW-facing coast of Amchitka I., Aleutian Is. ; $51^{\circ} 23^{\prime} 15^{\prime \prime}$ $\mathrm{N}, 179^{\circ} 12^{\prime} 00^{\prime \prime} \mathrm{E}$; (map 15). Var. Saint Makarius Bay.

Name shown on a 1951 USGS map; shown as "St. Makarius Bay" on a 1955 AMS map. Makeymut: locality, see Makak.

Makhnak, Ostrov: rock, see Black Rock.

Makhnashka, Mys: point of land, see Rocky Point.

Makhnashka, Zaliv: bay, see Monashka Bay.

Makhnati Island: island, $0.1 \mathrm{mi}$. across, connected to Japonski I., in Sitka Sound, $2 \mathrm{mi}$. SW of Sitka, Alex. Arch.; $57^{\circ} 02^{\prime} 25^{\prime \prime} \mathrm{N}, 135^{\circ}$. 23'15" W; BGN 1932; (map 9). Var. Liesnoi Island, Mokhnatoi Island, Moknatoi Island, Ostrov Mokhnatoy, Ostrov Mokhnatyy, Wooded Island.

Russian name meaning "rough" given in 1809 by the navigator Ivan Vasiliev the first; published by Lt. Sarichev (1826, map 19), IRN, as "Os[trov] Makhnatyy."

Makhnati Islands: islands, $0.8 \mathrm{mi}$. across, near head of Whale Bay, on SW coast of Baranof I., Alex. Arch.; $56^{\circ} 38^{\prime} \mathrm{N}, 135^{\circ} 01^{\prime} \mathrm{W}$; (map 5). Var. Makhnatoi Islet, Ostrov Makhnatoy.

Russian name from "mokhnatyy," meaning "rough" or "rugged," published in 1850 by the Russian American Company as "Ostrov Makhnatoy."

Makhnati Rock: rock, sunken rock SW of Makhnati I., in Sitka Sound, $2.5 \mathrm{mi}$. SW of Sitka, Alex. Arch.; $57^{\circ} 02^{\prime} 10^{\prime \prime}$ N, $135^{\circ} 23^{\prime} 30^{\prime \prime}$ W; (map 9). Var. Beacon Rock.

Named in 1883 by USC\&GS and published in the 1883 Alaska Coast Pilot (p. 141). Name was derived from Makhnati Island.

Makhnatoi Islet: islands, see Makhnati Islands.

Makhnatoy, Ostrov: islands, see Makhnati Islands.

Makingiyeek Bay: cove, $1 \mathrm{mi}$. across, between Taphook Point and base of Pungokosit Spit $19 \mathrm{mi}$. SE of Gambell, $N$ coast of St. Lawrence I.; $63^{\circ} 37^{\prime} \mathrm{N}, 171^{\circ} 16^{\prime} \mathrm{W}$; $B G N$ 1951; (map 93). Var. Makiugiyuk Bay.

Eskimo name reported in 1932 by $\mathrm{O}$. W. Geist, Univ. of Alaska.

Makiugiyuk Bay: cove, see Makingiyeek Bay.

Makka: locality, sec Makak.

Makki: locality, see Makak.

Maknak Creek: stream, see Muknuk River.

Maknashka Bay: bay, see Monashka Bay.

Makhnashkina, Mys: point of land, see Miller Point.

Maknashkina Cape: point of land, see Miller Point.

Maknek River: stream, heads at Soomaghat Mtn., flows S $12 \mathrm{mi}$. to Bering Sea, on St. Lawrence I.; $63^{\circ} 08^{\prime} \mathrm{N}, 169^{\circ} 24^{\prime} \mathrm{W} ; B G N$ 1951; (map 93).

Eskimo name recommended by the Gambell village council and reported in 1949 by Maj. H. B. Allen, USAF.

Maknighak, Camp: locality, Eskimo camp, on barrier beach, $\mathrm{S}$ of Maknik Lagoon, $20 \mathrm{mi}$.
SW of Northeast Cape, St. Lawrence I.; $63^{\circ}$ $10^{\prime} \mathrm{N}, 169^{\circ} 18^{\prime} \mathrm{W}$; (map 93).

Eskimo name reported in 1932 by $\mathrm{O}$. W. Geist, Univ, of Alaska.

Maknik Lagoon: lagoon, $7 \mathrm{mi}$. long, $16 \mathrm{mi}$. SW of Northeast Cape, on S coast of St. Lawrence I.; $63^{\circ} 11^{\prime} \mathrm{N}, 169^{\circ} 15^{\prime} \mathrm{W}$; BGN 1951; (map 93). Var. Lake Cynthia.

Eskimo name recommended by the Gambell village council and reported in 1949 by Maj. H. B. Allen, USAF.

Makpik, Lake: lake, $1.7 \mathrm{mi}$. long, NE of Aiautak Lagoon, $15 \mathrm{mi}$. E of Point Hope, Arctic Slope; $68^{\circ} 20^{\prime} \mathrm{N}, 166^{\circ} 12^{\prime} \mathrm{W}$; (map 129). Var. Lake Mukpik.

Eskimo name reported in 1956 by Orth. See Makpik Creek. It was originally applied to the short stream which connects Makpik Lake to another lake to the north.

Makpik Creek: stream, heads in DeLong Mts., flows SSW $38 \mathrm{mi}$. through Feniak Lake to Noatak River, $47 \mathrm{mi}$. WSW of Howard Pass, Brooks Ra.; 68 $01^{\prime} 30^{\prime \prime} \mathrm{N}, 158^{\circ} 39^{\prime} 00^{\prime \prime} \mathrm{W}$; (map 132).

Eskimo name obtained at Noatak by Orth in 1956, and reported to mean "mouth of a small stream" or "outlet."

Maktak Mountain: mountain, $1,128 \mathrm{ft}$., on S bank of Ipewik River, $10 \mathrm{mi}$. NE of its junc. with Kukpuk River, Arctic Slope; $68^{\circ} 25^{\prime} \mathrm{N}$, $165^{\circ} 26^{\prime} \mathrm{W}$; (map 129).

Eskimo name meaning "whale skin" reported in 1956 by Orth.

Makuschkin Volcano: volcano, see Makushin Volcano.

Makushi: bay, see Makushin Bay.

Makushi, Cape: point of land, see Makushin Point.

Makushin: settlement, pop. 10 (1940), on N shore of Makushin Bay, on $\mathrm{W}$ coast of Unalaska I., Aleutian Is.; 53 $46^{\prime} 15^{\prime \prime} \mathrm{N}, 166^{\circ}$ 59'05" W; Var. Macooshino, Makushinskoe.

Named after Makushin Bay and published by Lt. Sarichev (1826, map 14), IRN, as "Makushinskoe Seleniye" meaning "Makushin village." The location of Makushin Village on Sarichev's map is $4 \mathrm{mi}$. NW of the location applied on modern maps.

Makushin Bay: bay, $2.4 \mathrm{mi}$. across, $W$ coast of Unalaska I., Aleutian Is.; $53^{\circ} 44^{\prime} \mathrm{N}, 167^{\prime} 00^{\prime}$ W; BGN 1890; (map 23). Var. Guba Makushinskaya, Makushi, Makushinskoi, Makyshinskaia.

Russian name given by Capt. P. K. Krenitzin and Lt. M. Levashev (Coxe, 1787, p. 222), IRN, and was transliterated as "Makyshinskaia Bay" by Rev. Coxe (1787, p. 205). This name may have been taken from the Russian word "makushka," meaning "the crown (of the head)" or "top," possibly referring to Makushin Volcano. Lt. Sarichev (1826, map 14, dated 1792), IRN, published the name "Guba Makushinskaya," meaning "Makushin Bay."

Makushin Cape: point of land, see Kovrizhka, Cape.

Makushin Cape: point of land, see Makushin Point. 
Makushin Cape: point of land, see Point Kadin. Makushinck, Cape: point of land, see Makushin Point.

Makushin Point: point of land, $\mathrm{N}$ shore of Makushin Bay, W coast of Unalaska I., Aleutian Is.; $53^{\circ} 45^{\prime} 30^{\prime \prime} \mathrm{N}, 167^{\circ} 01^{\prime} 20^{\prime \prime} \mathrm{W}$; $B G N$ 1938; (map 23). Var. Cape Makushi, Cape Makushinck, Cape Makushinski, Makushin Cape, Mys Makushinskoy.

According to Lt. Sarichev (1802, v. 2, p. 82), IRN, this name was published by the Russians as "M[ys] Makushinskoy" or "Cape Makushin." The USBF used the generic "Point" in 1888.

Makushin Volcano: volcano, 6,680 ft., northcentral Unalaska I., Aleutian Is.; $53^{\circ} 53^{\prime} 15^{\prime \prime}$ $\mathrm{N}, 166^{\circ} 55^{\prime} 00^{\prime \prime} \mathrm{W}$; (map 23). Var. Aigagin, Aiyagin, Ajagisch, Ayagish, Ayyagyh, Gheerful Mountain, Makuschkin Volcano, Ognedieshutshai Gora, Ognedyshushchaya Gora, Wesselow.

Russian name, probably derived from the word "makushka," meaning "the crown (of the head)" or "top," and applied to this feature because it is the highest point on Unalaska Island. This volcano was called "Ognedyshushchaya Gora" meaning "burning mountain" by Sarichev (1826, map 14, dated 1792), IRN. Sarichev also called it "Ayyagyh" (1802, v. 2., p. 132). Rev. Coxe $(1787$, p. 210) wrote "there is a burning mountain here called 'Ayagish." " These native names are probably derived from the Aleutian word "ayaq" which, according to R. H. Geoghegan, is the name applied to Makushin Volcano on Unalaska I. This Aleut word may possibly come from the words "aigay" meaning "greater, larger," and "kigusiq," meaning "volcano." Bank (1956, p. 24) reported "an old Aleut legend which told of a great battle that had occurred between the Makushin and Recesnoi, one of the volcanoes on the next island to the west. As the legend relates, Makushin still smokes a little, resting and waiting while the other volcano is quiet, extinguished in the duel."

Makushinskaya, Guba: bay, see Makushin Bay.

Makushinski, Cape: point of land, see Makushin Point.

Makushinskoe: settlement, see Makushin.

Makushinskoi: bay, see Makushin Bay.

Makushinskoy, Mys: point of land, see Makushin Point.

Makushin Valley: valley, extends E $4.5 \mathrm{mi}$. to Unalaska Bay, on NE coast of Unalaska I., Alcutian Is.; $53^{\circ} 54^{\prime} 50^{\prime} \mathrm{N}, 166^{\circ} 38^{\prime} 20^{\prime \prime} \mathrm{W}$; (map 23). Var. Glacier Valley.

Named for Makushin Bay. Reported by George Davidson, USC\&GS, in 1869; called "Glacier Valley" by W. H. Dall in 1873.

Makyshinskaia: bay, see Makushin Bay.

Malaia Ugalenka, Reka: stream, see Kiklukh River.

Malalolik Creek: stream, see Melatolik Creek.

Malamute Creek: ravine, see Malamute Gulch.

Malamute Fork Alatna River: stream, flows SW

$35 \mathrm{mi}$. to Alatna River, $6.5 \mathrm{mi}$. SW of mouth of Iniakuk River, Brooks Ra.; $67^{\circ} 02^{\prime} 00^{\prime \prime} \mathrm{N}$, $153^{\circ} 15^{\prime} 45^{\prime \prime} \mathrm{W}$; (map 125). Var. Mettenpherg Creek.

Local name reported in 1930 by USGS.

Malamute Fork John River: stream, flows SE $40 \mathrm{mi}$. to John River, $\mathrm{W}$ of Ninemile Hills, $37.5 \mathrm{mi}$. SW of Wiseman, Brooks Ra.; $67^{\circ}$. $02^{\prime} 10^{\prime \prime} \mathrm{N}, 151^{\circ} 48^{\prime} 45^{\prime \prime} \mathrm{W}$; (map 124). Var. Malamute River.

Local name reported in 1899 as "Malamute River" by T. G. Gerdine, USGS.

Malamute Gulch: ravine, trends $\mathrm{S} 0.8 \mathrm{mi}$. to Otter Creek, $3 \mathrm{mi}$. E of Flat, Kilbuck-Kuskokwim Mts.; $62^{\circ} 28^{\prime} \mathrm{N}, 157^{\circ} 56^{\prime} \mathrm{W}$; (map 79). Var. Malamute Creek, Malamute Pup.

Prospectors' name reported in 1933 by J. B. Mertie, USGS.

Malamute Pup: ravine, see Malamute Gulch.

Malamute River: stream, see Malamute Fork John River.

Malaspina Glacier: glacier, $30 \mathrm{mi}$. across, heads $8 \mathrm{mi}$. S of Alaska-Canada boundary, trends S $28 \mathrm{mi}$. to Gulf of Alaska, $38 \mathrm{mi}$. NW of Yakutat, St. Elias Mts.; $59^{\circ} 42^{\prime} 30^{\prime \prime}$ N, $140^{\circ}$ 37'30" W; BGN 1944; (map 46). Var. Malaspina Plateau.

Named Malaspina Plateau in 1874 by W. H. Dall, USC\&GS, who at the time did not recognize its true character because of its cover of morainal material. Named for Capt. Don Alessandro Malaspina, Italian navigator and explorer in the service of Spain, who explored the NW coast of North America in 1791. A closer approach to the glacier was made in 1880 and its true character was seen. Since then it has been known as the Malaspina Glacier (U.S. Coast and Geodetic Survey, 1883, p. 211)

Malay Creek: stream, see Maylay Creek.

Malay Hill: mountain, $1,025 \mathrm{ft}$., $0.5 \mathrm{mi}$. E of Beach Cove, Kiska I., Aleutian Is.; 51 ${ }^{\circ} 59^{\prime} 35^{\prime \prime}$ $\mathrm{N}, 177^{\circ} 30^{\prime} 10^{\prime \prime} \mathrm{E}$; (map 14).

An arbitrary name beginning with " $M$ " to correspond to "M" grid used by U.S. Army for tactical purposes during World War II; published on a 1943 Army map.

Malburn Creek: stream, flows NE $7 \mathrm{mi}$. to Birch Creek, $57 \mathrm{mi}$. SW of Circle, Yukon-Tanana High.; $65^{\circ} 16^{\prime} 30^{\prime \prime} \mathrm{N}, 145^{\circ} 32^{\prime} 00^{\prime \prime} \mathrm{W}$; (map 104).

Named by prospectors; reported in 1911 by USGS (Prindle, 1913, pl. 1).

Malchatna: locality, see Mulchatna.

Malchatna: stream, see Mulchatna River.

Malcolm River: stream, heads in British Mts., $14.5 \mathrm{mi}$. E of Mount Greenough, flows NE, across Alaska-Canada boundary, $56 \mathrm{mi}$. to Beaufort Sea, $5.5 \mathrm{mi}$. W of Herschel I., Yukon, Canada, Arctic Plain; $69^{\circ} 33^{\prime} \mathrm{N}, 139^{\circ} 32^{\prime} \mathrm{W}$; BGN 1953; (map 138). Var. Firth River, Sir Pulteney Malcolm River.

Named "Sir Pulteney Malcolm River" by Sir John Franklin, July 23, 1826.

Male Creek: stream, see Mule Creek.

Male Hill: hill, $843 \mathrm{ft}$., $1.3 \mathrm{mi}$. W of Kiska Harbor, Kiska I., Aleutian Is.; $51^{\circ} 58^{\prime} 25^{\prime \prime} \mathrm{N}$, $177^{\circ} 30^{\prime} 25^{\prime \prime} \mathrm{E}$; (map 14).

An arbitrary name beginning with " $M$ " to correspond to "M" grid used by U.S. Army for tactical purposes during World War II; published on a 1943 Army map.

Malemute Riffle: rapids, in Koyukuk River at Allakaket, Kanuti Flats; $66^{\circ} 34^{\prime} \mathrm{N}, 152^{\circ} 40^{\prime}$ W; (map 117).

This name was reported by Archdeacon Stuck (1917, p. 329), because the riffle is opposite Alatna, "a little village of Eskimos, or 'Malemutes' as the Indians call them, from the Kobuk [River] * * *."

Male Point: point of land, SW tip of Fillmore I., Coast Mts. ; $54^{\circ} 47^{\prime} 40^{\prime \prime} \mathrm{N}, 130^{\circ} 36^{\prime} 55^{\prime \prime} \mathrm{W}$; (map 2).

Named in 1891 by USC\&GS.

Maley Roukav: bay, see Small Arm Whale Bay. Malga Bay: bay, $0.8 \mathrm{mi}$. across, on NW coast of Unalga I., Aleutian Is.; $53^{\circ} 59^{\prime} 30^{\prime \prime} \mathrm{N}, 166^{\circ}$ $10^{\prime} 40^{\prime \prime} \mathrm{W}$; (map 23). Var. Unalga Cove.

Named "Unalga Cove" by J. J. Gilbert, commander of the USC\&GS steamer Pathfinder during 1900-01. Published as "Malga Bay" in the 1916 Coast Pilot (pt. 2, p. 205).

Malikfik Bay: bay, on Norton Sound, $24 \mathrm{mi}$. SW of Christmas Mtn., Nulato Hills; $64^{\circ} 24^{\prime}$ $\mathrm{N}, 161^{\circ} 17^{\prime} \mathrm{W}$; (map 96). Var. Malikvik Bay.

Eskimo name reported about 1954 by U.S. Army Corps of Engineers.

Malikvik Bay: bay, see Malikfik Bay.

Malina Bay: bay, $4 \mathrm{mi}$. across, $18 \mathrm{mi}$. NW of Afognak, on W coast of Afognak I.; $58^{\circ} 13^{\prime}$ N, 15305' W; BGN 1913; (map 43). Var. Alimvoak Bay.

Local Russian name meaning "raspberry" reported by G. C. Martin, USGS, in 1912. The Russian American Company published the native name "Zal[iv] Alimvoak," or "Alimvoak Bay," for this feature in 1849.

Malina Creek: stream, heads at Upper Malina Lake, flows W $4.5 \mathrm{mi}$. to Shelikof Strait, 20 mi. NW of Afognak, on W coast of Afognak I.; $58^{\circ} 10^{\prime} 30^{\prime \prime} \mathrm{N}, 153^{\circ} 12^{\prime} 45^{\prime \prime} \mathrm{W}$; (map 43).

Name derived from Malina Bay; published in 1952 on a USGS map.

Malina Point: point of land, $22 \mathrm{mi}$. W of Afognak, on W coast of Raspberry I.; $58^{\circ}$ $02^{\prime} 20^{\prime \prime} \mathrm{N}, 153^{\circ} 21^{\prime} 45^{\prime \prime} \mathrm{W}$; BGN 1909; (map 43). Var. Cape Malinoff, Cape Ustya, Raspberry Cape.

Russian name meaning "raspberry," given in 1909 by USC\&GS. Sub-Lt. Mikhail Murashev, IRN, applied the name "M[ys] Malinovoy," "cape raspberry," to this feature in 1839 or 1840 and the Russian American Company called it "M[ys] Ustya," "Cape Ustya," in 1849. See Raspberry Cape and Ustia Point. Malinoff, Cape : point of land, see Malina Point. Malinoff, Cape: point of land, see Raspberry Cape.

Malinoff Island: island, see Raspberry Island. Malinof Island: island, see Raspberry Island.

Malinovoi: point of land, see Raspberry Cape. Malinovoi Strait: water passage, see Raspberry Strait.

Malinovskie lietnik: locality, see Nunalik village. Malinovskie lietnik: point of land, see Nuniliak, Cape.

Malinovski Litnik: locality, see Nunalik village. 
Malinovskiy Lytnik: locality, see Nunalik.

Malinovskoi, Gape: point of land, see Nuniliak, Cape.

Malıtqweengak Slough: water course, see Mahtkwingak Slough.

Malka Bay: bay, $0.5 \mathrm{mi}$. across, Malina Bay, 15 mi. NW of Afognak, on W coast of Afognak I., $\mathrm{N}$ of Kodiak I.; $58^{\circ} 11^{\prime} 30^{\prime \prime} \mathrm{N}, 153^{\circ} 00^{\prime} 00^{\prime \prime}$ W; $B G N$ 1923; (map 43).

Named by USC\&GS in 1923 ; suggested by the Russian name meaning "bevel" for a nearby village "found on an 1849 Russian map."

Mallard Bay: estuary, trends $1.6 \mathrm{mi}$. to Clarence Strait, SE coast of Prince of Wales I., Alex. Arch.; 54 $46^{\prime} 30^{\prime \prime} \mathrm{N}, 131^{\circ} 59^{\prime} 30^{\prime \prime} \mathrm{W}$; (map 2).

Name published by P. S. Smith (in Brooks and others, 1914, p. 82), USGS, who says "according to local usage this name correctly applies to the next bay south which is called on the charts Stone Rock Bay * * *." See Stone Rock Bay.

Mallard Bay: estuary, on W coast of Knight I., extends N $1.5 \mathrm{mi}$. to Drier Bay, $9 \mathrm{mi}$. $\mathrm{E}$ of Chenega, Chugach Mts.; $60^{\circ} 18^{\prime} 10^{\prime \prime} \mathrm{N}, 147^{\circ}$ $49^{\prime} 00^{\prime \prime} \mathrm{W}$; (map 63).

Local name published in 1910 by USC\&GS. Mallard Bay: bay, see Stone Rock Bay.

Mallard Bay: cove, see Mallard Cove.

Mallard Cove: cove, $0.5 \mathrm{mi}$. across, on $\mathrm{E}$ shore of Port Snettisham, $0.4 \mathrm{mi}$. W of Fannie I. and $29 \mathrm{mi}$. SE of Juneau, Coast Mts.; $58^{\circ} 02^{\prime}-$ $45^{\prime \prime} \mathrm{N}, 133^{\circ} 48^{\prime} 10^{\prime \prime} \mathrm{W}$; BGN 1930; (map 12). Var. Mallard Bay.

Local name reported in 1921 by USFS.

Mallard Duck Bay: estuary, on S shore of Alaska Penin., trends NW $4 \mathrm{mi}$. to head of Chignik Lagoon, $9 \mathrm{mi}$. W of Chignik, Aleutian Ra.; $56^{\circ} 16^{\prime} \mathrm{N}, 158^{\circ} 37^{\prime} \mathrm{W}$; (map 30).

Local name reported in 1908 by W. D. Atwood, USGS.

Mallard Head: point of land, on $\mathrm{W}$ coast of Knight I., on S side of Drier Bay, between Cathead Bay and Mallard Bay, $8.5 \mathrm{mi}$. $\mathrm{E}$ of Chenega, Chugach Mts.; $60^{\circ} 18^{\prime} 10^{\prime \prime} \mathrm{N}, 147^{\circ}$ $49^{\prime} 45^{\prime \prime} \mathrm{W}$; (map 63).

Local name published in 1910 by USC\&GS.

Mallard Lake: lake, $0.5 \mathrm{mi}$. long, on Kenai Penin., $1 \mathrm{mi}$. N of Swan Lake and $27 \mathrm{mi}$. NE of Kenai, Cook Inlet Low.; $60^{\circ} 42^{\prime} 45^{\prime \prime} \mathrm{N}$, $150^{\circ} 32^{\prime} 00^{\prime \prime} \mathrm{W}$; (map 62).

Named about 1963 by officials of Kenai National Moose Range, for the Mallard (Anas platyrhynchos), "the one duck most important to the human race."

Mallard Lake: lake, $1.5 \mathrm{mi}$. long, $\mathrm{N}$ of $\mathrm{Big}$ Grass Lake, $16 \mathrm{mi}$. W of Beaver, Yukon Flats; $66^{\circ} 20^{\prime} \mathrm{N}, 147^{\circ} 59^{\prime} \mathrm{W}$; (map 118).

Probably named by William Yanert, who recorded it on a 1916 manuscript map of the Yukon Flats (Stuck, 1917, map facing p. 122).

Mallard Lake: lake, see Millard Lake.

Mallard Rocks: rocks, see Northeast Rocks.

Malmesbury, Port: estuary, $6 \mathrm{mi}$. long, on W coast of Kuiu I., $15 \mathrm{mi}$. E of Port Alexander, Alex. Arch.; $56^{\circ} 01^{\prime} 30^{\prime \prime} \mathrm{N}, 134^{\circ} 16^{\prime} 00^{\prime \prime} \mathrm{W}$ (map 5). Var. Port Malmsbury.
Named by Capt. George Vancouver, RN, on August 4 or 6, 1794, "no doubt in honor of James Harris, first Earl of Malmsbury" (Wagner, 1937, p. 396).

Malmsbury, Port: estuary, see Malmesbury, Port.

Maloi Krieposti: island, see Little Fort Island. Maloi Malinovoi: island, see Little Raspberry Island.

Maloi Rukov: bay, see Small Arm Whale Bay.

Maloi Strelka: bay, see Little Branch Bay.

Maloney Creek: stream, flows NW to Goodhope River near its head, about $16 \mathrm{mi}$. NW of Imuruk Lake, Seward Penin. High.; (map 110).

Prospectors' name reported on a precinct map of Seward Peninsula by Monroe and Hutchins; corrected to June 1903 by Arthur Gibson. This stream cannot be precisely located on current maps.

Maloy Malinovoy, Proliv: water passage, see Narrow Strait.

Maloy Malinovoy Proliv: water passage, see Whale Passage.

Maloy Rukav: bay, see Small Arm Whale Bay.

Maloy Strylky, Bukhta: bay, see Little Branch Bay.

Malpelo, Bajo del: shoals, off S end of Kayak I. Name shown on a 1779 chart by Josef Camacho. It may represent a transposition of "pelo malo" meaning "bird's down" (Wagner, 1937, p. 470).

Malyy, Ostrov: island, see Little Island.

Malyy Koniushi, Ostrov: island, see Little Koniuji Island.

Malyy Vrangel, Ostrov: island, see Little Wrangell Island.

Mamagnak Mountains: hills, $500 \mathrm{ft}$., extend 4 mi. at $\mathrm{N}$ end of Poovookpuk Mtn., $20 \mathrm{mi}$. S of Gambell, St. Lawrence I.; $63^{\circ} 31^{\prime}$ N, $171^{\circ}$ $34^{\prime}$ W; BGN 1951; (map 93). Var. Momag. hunk Mountains.

Eskimo descriptive name reported in 1965 by Orth, to mean "like breasts."

Mamalak Creek: stream, see Mamelak Creek. Mamelak Creek: stream, heads in Igichuk Hills, and flows SE $9 \mathrm{mi}$. to Noatak River, $18 \mathrm{mi}$. N of Kotzebue, Kotzebue-Kobuk Low.; $67^{\circ}$ $10^{\prime} 30^{\prime \prime} \mathrm{N}, 162^{\circ} 06^{\prime} 30^{\prime \prime} \mathrm{W}$; (map 128). Var. Mamalak Creek, Mumayluk Creek.

Eskimo name meaning "stink" (mamaqtoq"it smells bad") according to USC\&GS in 1950.

Mamelak Mountain: hill, $699 \mathrm{ft} ., 1.5 \mathrm{mi}$. NW of junc. of Noatak River and Mamelak Greek, $18 \mathrm{mi}$. N of Kotzebue, Arctic Slope; 67 $7^{\circ} 10^{\prime}$ $30^{\prime \prime} \mathrm{N}, 162^{\circ} 39^{\prime} 30^{\prime \prime} \mathrm{W} ;$ Var. Mumayluk Mountain

Eskimo name, probably derived from the nearby stream, reported in 1950 by USC\&GS.

Mammary Peak: peak, 6,800 ft., $3 \mathrm{mi}$. NE of Avalanche Canyon between Gilkey Glacier and Matthes Glacier, and $16 \mathrm{mi}$. NE of Juneau, Coast Mts.; $58^{\circ} 49^{\prime} 00^{\prime \prime} \mathrm{N}, 134^{\circ} 16^{\prime} 00^{\prime \prime} \mathrm{W}$; (map 11). Var. Mammary Point.

Descriptive name proposed in 1964 by members of the Juneau Icefield Research Project.
Mammoth Creek: stream, flows SW $1.3 \mathrm{mi}$. to Mastodon Creek, $20 \mathrm{mi}$. NW of Ophir and $50 \mathrm{mi}$. NW of McGrath, Kilbuck-Kuskokwim Mts.; $63^{\circ} 22^{\prime} \mathrm{N}, 156^{\circ} 56^{\prime} \mathrm{W}$; (map 90).

Prospectors' name published in 1921 by USGS

Mammoth Creek: stream, flows NE $4 \mathrm{mi}$. joins Porcupine Creek to form Crooked Creek, 37 mi. SW of Gircle, Yukon-Tanana High.; $65^{\circ}$ $33^{\prime} 20^{\prime \prime} \mathrm{N}, 145^{\circ} 09^{\prime} 00^{\prime \prime} \mathrm{W}$; (map 104).

Named by prospectors; reported in 1896 by USGS (Spurr, 1898, pl. 1). So named because fossil remains of mammoths, mastodons and several other prehistoric animals have been found near the stream.

Mammoth Creek: stream, see Kiliguak Creek. Mammoth Gulch: ravine, trends W 1 mi. to Bluff Creek which flows to Arctic Creek, a tributary of Cripple River, $12 \mathrm{mi}$. NW of Nome, Seward Penin. High.; $64^{\circ} 37^{\prime} 30^{\prime \prime}$ N, $165^{\circ} 45^{\prime} 00^{\prime \prime} \mathrm{W}$; (map 94).

Prospectors' name shown on the 1904 "Map of "Cape Nome Precinct" by Arthur Gibson. Mammoth House: locality, see Miller House. Mammoth River: stream, see Kugruk River.

Mamtrelich: town, see Bethel.

Manayagavik Slough: stream, flows W $2.3 \mathrm{mi}$. to Bering Sea, $3.5 \mathrm{mi}$. NW of village of Hooper Bay, Yukon-Kuskokwim Delta; $61^{\circ} 34^{\prime} \mathrm{N}$, $166^{\circ} 11^{\prime} \mathrm{W}$; (map 75).

Eskimo name reported by USC\&GS in 1951 to refer to the "place where fish are hooked." Manby, Cape: point of land, see Manby, Point. Manby, Point: point of land, at mouth of Yakutat Bay, $4 \mathrm{mi}$. S of Malaspina Glacier and $23 \mathrm{mi}$. NW of Yakutat, Malaspina Coastal Plain; 59 $41^{\prime} 30^{\prime \prime} \mathrm{N}, 140^{\circ} 18^{\prime} 15^{\prime \prime} \mathrm{W}$; BGN Sixth Report; (map 46). Var. Bolshoi Point, Cape Manby, Cape Saint Elias, Pointe de la Boussole.

Named by Capt. Vancouver $(1798$, v. 3 , p. 205), RN, for Thomas Manby, master's mate of the H.M.S. Discovery. The point is apparently identical with Pointe de la Boussole of La Pérouse, 1786 (U.S. Coast and Geodetic Survey, 1883, p. 206).

Manby Stream: stream, at terminus of Malaspina Glacier, flows S $3.5 \mathrm{mi}$. to Yakutat Bay, $1.5 \mathrm{mi}$. $W$ of Point Manby and $23 \mathrm{mi}$. NW of Yakutat, Malaspina Coastal Plain; $59^{\circ} 41^{\prime} 35^{\prime \prime} \mathrm{N}, 140^{\circ} 20^{\prime} 00^{\prime \prime} \mathrm{W}$; (map 46).

Named in 1891 by Russell (1892, pl. 4), USGS, for Point Manby.

Mancha Creek: stream, flows SE $30 \mathrm{mi}$. across Alaska-Canada boundary to Firth River in Yukon, Canada, Brooks Ra.; $68^{\circ} 40^{\prime} \mathrm{N}, 140^{\circ}$ 57' W; (map 137).

Name reported in 1911 by IBC survey crew. Mandarin Hill : hill, $447 \mathrm{ft} ., 1.5 \mathrm{mi}$. E of Conquer Point, Kiska I., Aleutian Is.; $52^{\circ} 00^{\prime} 20^{\prime \prime} \mathrm{N}$, $177^{\circ} 31^{\prime} 03^{\prime \prime} \mathrm{E}$; (map 14).

An arbitrary name beginning with " $M$ " to correspond to the " $M$ " grid used by U.S. Army for tactical purposes during World War II ; published on a 1943 Army map.

Mandarin Rock: rock, at head of Zachary Bay, on $\mathrm{N}$ coast of Unga I., in Shumagin Is., Aleutian Ra. 
Named in 1872 by W. H. Dall, USC\&GS; not identified on present maps.

Manelak River: stream, see Mauneluk River.

Maneuver Hills: hill, $458 \mathrm{ft}$., $1 \mathrm{mi}$. W of Salmon Lagoon, center Kiska I., Aleutian Is. ; $52^{\circ} 00^{\prime}$ $10^{\prime \prime} \mathrm{N}, 177^{\circ} 31^{\prime 2} 0^{\prime \prime} \mathrm{E}$; (map 14).

An arbitrary name beginning with " $M$ " to correspond to " $M$ " grid used by U.S. Army for tactical purposes during World War II; published on a 1943 Army map.

Mangoak River: stream, flows NW $34 \mathrm{mi}$. to Selawik Lake, $15 \mathrm{mi}$. SW of Selawik, Kotzebue-Kobuk Low.; $66^{\circ} 25^{\prime} \mathrm{N}, 160^{\circ} 13^{\prime} \mathrm{W}$; (map 114). Var. Man-go-ak.

Name reported in 1886 as "Man-go-ak" by Lt. Stoney (1900, map), USN.

Mangy Hill: hill, $410 \mathrm{ft}$., $\mathrm{E}$ of Moron Lake, 1.5 mi. E of Conquer Point, Kiska I., Aleutian Is.; $52^{\circ} 00^{\prime} 27^{\prime \prime} \mathrm{N}, 177^{\circ} 31^{\prime} 13^{\prime \prime} \mathrm{E}$; (map 14).

An arbitrary name beginning with " $M$ " to correspond to " $M$ " grid used by U.S. Army for tactical purposes during World War II; published on a 1943 Army map.

Manhattan Arm Sea Otter Harbor: estuary, extends E $2.5 \mathrm{mi}$, off Sea Otter Harbor, on W coast of Dall I., Alex. Arch.; $55^{\circ} 06^{\prime} 30^{\prime \prime} \mathrm{N}$, $133^{\circ} 11^{\prime} 15^{\prime \prime} \mathrm{W}$; (map 4).

Named in 1923 by USC\&GS after the nearby Manhattan Copper Mine.

Manhattan Creek: stream, flows S $1.2 \mathrm{mi}$. to Jeff Cove, on south-central coast of Kiska I., Aleutian Is.; $51^{\circ} 56^{\prime} 18^{\prime \prime} \mathrm{N}, 177^{\circ} 28^{\prime} 30^{\prime \prime} \mathrm{E}$; (map 14).

An arbitrary name beginning with " $M$ " to correspond to "M" grid used by U.S. Army for tactical purposes during World War II ; published on a 1943 Army map.

Manhattan Lake: lake, $0.6 \mathrm{mi}$. long, on W coast of Dall I., near head of Manhattan Arm Sea Otter Harbor, Alex. Arch.; $55^{\circ} 05^{\prime} 20^{\prime \prime} \mathrm{N}$, $133^{\circ} 08^{\prime} 30^{\prime \prime} \mathrm{W}$; (map 4).

Named in 1923 by USC\&GS.

Maniac Hill: mountain, 1,220 ft., center of Kiska I., Aleutian Is. ; $51^{\circ} 57^{\prime} 30^{\prime \prime} \mathrm{N}, 177^{\circ} 30^{\prime} 35^{\prime \prime} \mathrm{E}$; (map 14).

An arbitrary name beginning with " $\mathrm{M}$ " to correspond to "M" grid used by U.S. Army for tactical purposes during World War II; published an a 1943 Army map.

Manigam Kunga: stream, see Manikam Creek. Manikam Creek: stream, flows E $1 \mathrm{mi}$. to Kangnirvik Creek, $25 \mathrm{mi}$. NE of Kivalina, Brooks Ra.; $68^{\circ} 02^{\prime} \mathrm{N}, 163^{\circ} 55^{\prime} \mathrm{W}$; (map 130). Var. Maniqam Kunga, Moneykam Koonga. Eskimo name reported in 1966 by E. S. Burch.

Manila Creek: stream, flows S $1 \mathrm{mi}$. to Salmon Lagoon, Kiska I., Aleutian Is.; $52^{\circ} 00^{\prime} 20^{\prime \prime} \mathrm{N}$, $177^{\circ} 33^{\prime} 00^{\prime \prime} \mathrm{E}$; (map 14).

An arbitrary name beginning with " $M$ " to correspond to " $M$ " grid used by the U.S. Army for tactical purposes during World War II; published on a 1953 AMS map.

Manila Creek: stream, flows NW $7 \mathrm{mi}$. to Middle Fork Fortymile River, $54 \mathrm{mi}$. SW of Eagle, Yukon-Tanana High.; $64^{\circ} 25^{\prime} 20^{\prime \prime} \mathrm{N}, 142^{\circ}$ $45^{\prime} 40^{\prime \prime}$ W; (map 102). Var. Manilla Creek.
Named by prospectors for Manila Bay, Philippine Islands, where the United States destroyed the Spanish fleet in 1898 at the end of the Spanish-American War. The name is shown on an 1898 manuscript map by C. A. Woodruff.

Manila Creek: stream, flows SE $1.8 \mathrm{mi}$. to Solomon River, 2 mi. NE of Solomon, Seward Penin. High.; $64^{\circ} 35^{\prime} \mathrm{N}, 164^{\circ} 25^{\prime} \mathrm{W}$; (map 95). Var. Manilla Creek, Mannilla Creek. Prospectors' name reported in 1900 by E. C. Barnard (in Brooks, 1901, pl. 17), USGS. Manila Creek: stream, flows SE $1.8 \mathrm{mi}$. to Hobson Creek, $17 \mathrm{mi}$. NE of Nome, Seward Penin High.; $64^{\circ} 45^{\prime} \mathrm{N}, 165^{\circ} 17^{\prime} \mathrm{W}$; (map 94). Var. Manilla Creek.

Prospectors' name reported in 1900 by $\mathrm{E}$. C. Barnard (in Brooks, 1901, pl. 17), USGS Manilla Creek: stream, see Manila Creek.

Maningdlik River: stream, see Maninglik River.

Maninglik River: stream, flows $W 6.4 \mathrm{mi}$. to Kashunuk River, 15 mi. N of Kgun Lake and $58 \mathrm{mi}$. W of Marshall, Yukon-Kuskokwim Delta; 61 ${ }^{\circ} 49^{\prime} \mathrm{N}, 163^{\circ} 50^{\prime} \mathrm{W}$; (map 74). Var. Maningdlik River.

Eskimo name shown on a manuscript map by "Father Delon" dated 1937.

Maniqam Kunga: stream, see Manikam Creek. Mankakvik Creek: stream, flows SW $4 \mathrm{mi}$, to Kashunuk River, W of Takonak Creek, $37 \mathrm{mi}$. W of Marshall, Yukon-Kuskokwim Delta ; $61^{\circ}$ $50^{\prime} 15^{\prime \prime} \mathrm{N}, 163^{\circ} 12^{\prime} 45^{\prime \prime} \mathrm{W}$; (map 74).

Eskimo name reported by USC\&GS in 1951.

Manker Creek: stream, flows NE $20 \mathrm{mi}$. to Klutina River, $1 \mathrm{mi}$. SW of The Gorge and $49 \mathrm{mi}$. NE of Valdez, Chugach Mts. ; $61^{\circ} 45^{\prime}$ $55^{\prime \prime} \mathrm{N}, 145^{\circ} 38^{\prime} 40^{\prime \prime} \mathrm{W}$; (map 68). Var. Grayling Creek.

Named in 1898 by Capt. W. R. Abercrombie, USA.

Mankomen Lake: lake, $3.7 \mathrm{mi}$. long, at head of East Fork Chistochina River, $30 \mathrm{mi}$. NE of Chistochina, Alaska Ra.; $63^{\circ} 00^{\prime} \mathrm{N}, 144^{\circ} 32^{\prime}$ W; (map 83).

Indian name, applied by prospectors and reported by USGS (in Mendenhall and Schrader, 1903, map)

Manley Hot Springs: village, pop. 72 , on Hot Springs Slough, $54 \mathrm{mi}$. NE of the Bitzshtini Mts., Yukon-Tanana High.; $65^{\circ} 00^{\prime} \mathrm{N}, 150^{\circ}$ 38' W; (map 99). Var. Hot Springs, Baker Hot Springs.

J. F. Karshner located a homestead here in 1902, about the same time the U.S. Army Signal Corps established a telegraph station nearby; the place soon became known as Baker Hot Springs after Baker Creek. In 1907 Frank Manley (Hilliard B. Knowles) built a four-story Hot Springs Resort Hotel (Sims, 1965, p. 14). The village population became 101 in $1910 ; 29$ in $1920 ; 45$ in 1930; 39 in 1939; and 29 in 1950. The Hot Springs post office was established in 1907; name changed to Manley Hot Springs in 1957 (Ricks, 1965, p. 27, 41).

Manley Hot Springs Dome: mountain, 2,649 ft., on Bean Ridge, $3.5 \mathrm{mi}$. NW of village of Manley Hot Springs, $40 \mathrm{mi}$. ESE of Tanana,
Yukon-Tanana High.; $65^{\circ} 01^{\prime} 50^{\prime \prime} \mathrm{N}, 150^{\circ} 44^{\prime}-$ $30^{\prime \prime}$ W; BGN 1962; (map 106). Var. Hot Springs Dome.

Prospectors' name, generally referred to locally as "Hot Springs Dome." The name "Manley" was added to differentiate from a similarly named feature.

Manleyville: locality, $1 \mathrm{mi}$. E of Baranof, on $\mathbf{E}$ coast of Baranof I., Alex. Arch.; 57 ${ }^{\circ} 05^{\prime} 35^{\prime \prime}$ $\mathrm{N}, 134^{\circ} 48^{\prime} 30^{\prime \prime} \mathrm{W}$; (map 9).

This locality, shown with two cabins, was reported in 1966 by USGS.

Manna Creek: stream, on Seward Penin., flows NNW $7.5 \mathrm{mi}$. to Lynx Creek which flows to Lopp Lagoon, $11 \mathrm{mi}$. NE of Cape Prince of Wales and $50 \mathrm{mi}$. NW of Teller, KotzebueKobuk Low.; $65^{\circ} 41^{\prime} \mathrm{N}, 167^{\circ} 47^{\prime} \mathrm{W}$; (map 111).

Prospectors' name reported in 1901 by T. G. Gerdine (in Collier, 1902, pl. 12), USGS.

Mannilla Creek: stream, see Manila Creek.

Manning, Cape: promontory, $20 \mathrm{mi}$. SE of Cape Etolin, on E coast of Nunivak I.; $60^{\circ} 16^{\prime} 30^{\prime \prime}$ N, $165^{\circ} 40^{\prime} 30^{\prime \prime} \mathrm{W}$; (map 57).

Name reported about 1908 by USC\&GS. Manning, Point: island, see Barter Island.

Manning Lake: lake, $0.1 \mathrm{mi}$. across, on $\mathrm{W}$ end of Agattu I. at head of Miner Creek, $2.5 \mathrm{mi}$. NE of Gillon Point, Aleutian Is.; $52^{\circ} 25^{\prime} 20^{\prime \prime} \mathrm{N}$, $173^{\circ} 25^{\prime} 15^{\prime \prime}$ W; BGN 1946; (map 13).

Proposed in 1944 to honor Pfc. Ned H. Manning, USA, who was killed in action on Attu I., May 29, 1943.

Manning Point: point of land, at mouth of Kismaliuk Bay, on SW coast of Unalaska I., Aleutian Is.; $53^{\circ} 27^{\prime} 20^{\prime \prime} \mathrm{N}, 167^{\circ} 20^{\prime} 00^{\prime \prime} \mathrm{W}$; BGN 1938; (map 23). Var. Lufin Point.

Named by USC\&GS in 1937 for the USCG steamer Manning.

Manning Point: point of land, on coast of Beaufort Sea, $8 \mathrm{mi}$. E of Barter I., between Jago and Kaktovik Lagoons, Arctic Plain; $70^{\circ} 07^{\prime}$ N, $143^{\circ} 30^{\prime} \mathrm{W}$; (map 152). Var. Manning Spit, Nanning Point, Nuwaak Point, Nuwuak Point, Point Manning.

On August 4, 1826, Sir John Franklin (1828, p. 146), applied the name "Point Manning" to the $E$ point of an island, which now is, by local usage, called "Barter I." John Simpson's 1853 native map seems to apply the Eskimo name "Nu-wa-ak Point [the place of barter]"; however, Leffingwell (1919, p. 94) applies the similar Eskimo name "Nuwuak" to Collinson Point, although these two names may be of entirely separate origins. Leffingwell is probably responsible for the present application of the name "Manning Point."

Manning Rock: rock, see Manning Rocks.

Manning Rocks: rock, in Prince William Sound, $2 \mathrm{mi}$. E of Bay of Isles off E coast of Knight I., $20 \mathrm{mi}$. NE of Chenega, Chugach Mts.; $60^{\circ} 24^{\prime}$ N, $147^{\circ} 34^{\prime} \mathrm{W}$; BGN 1966; (map 63). Var. Manning Rock.

Name reported in 1908 by USC\&GS. "Named for the U.S. Revenue Cutter Manning which struck here in 1907."

Manning Spit: point of land, see Manning Point. 
Man-of-War Peak: peak, 2,800 ft., N of Frederick Sound, $1 \mathrm{mi}$. W of Alaska Peak and 77 mi. E of Sitka, Coast Mts.; $57^{\circ} 08^{\prime} 30^{\prime \prime} \mathrm{N}$, $133^{\circ} 20^{\prime} 15^{\prime \prime} \mathrm{W}$; (map 8).

Named in 1887 by Lt. Comdr. C. M. Thomas, USN; name published in 1888 by USC\&GS.

Manokenak River: stream, see Manokinak River.

Manokinak River: stream, distributary of Kashunuk River, heads at $61^{\circ} 48^{\prime} \mathrm{N}, 163^{\circ} 53^{\prime}$ $W$, flows SW $140 \mathrm{mi}$. to Hazen Bay, YukonKuskokwim Delta; $61^{\circ} 08^{\prime} \mathrm{N}, 165^{\circ} 12^{\prime} \mathrm{W}$; $B G N$ 1965; (map 75). Var. Manokenak River, Manokinok River, Manopiknak River. Eskimo name reported by E. W. Nelson $(1882$, v. 4, p. 667) as "Manopiknak" in his text and "Manokinak" on his map. Nelson crossed this stream in December 1878.

Manokinok River: stream, see Manokinak River.

Manokotak: village, pop. 149, on left bank of Igushik River, $22 \mathrm{mi}$. SW of Dillingham, Kilbuck-Kuskokwim Mts. ; 58 $58^{\prime} 50^{\prime \prime}$ N, $159^{\circ} 03^{\prime}$ 25" W; (map 40). Var. Manokutuk.

Eskimo village reported in 1948 by USC\& GS. Its population was 120 in 1950 ; a post office was established here in 1960 (Ricks, 1965, p. 41)

Manokutuk: village, see Manokotak.

Manook Creek: stream, see Minook Creek.

Manopiknak River: stream, see Manokinak River.

Mansfield: village, see Mansfield Village.

Mansfield, Cape: point of land, on Kenai Penin., at $W$ end of Whidbey Bay, $20 \mathrm{mi}$. SE of Seward, Chugach Mts.; $59^{\circ} 57^{\prime} \mathrm{N}, 149^{\circ} 01^{\prime} \mathrm{W}$; $B G N$ 1910; (map 49).

Named in 1908 by U. S. Grant, USGS, for Lt. Comdr. Henry Buckingham Mansfield, USN. See sources in the Introduction.

Mansfield, Lake: lake, $3 \mathrm{mi}$. long, $\mathrm{N}$ of Mansfield Village, $7 \mathrm{mi}$. $\mathrm{N}$ of Tanacross, YukonTanana High.; $63^{\circ} 30^{\prime} \mathrm{N}, 143^{\circ} 25^{\prime} \mathrm{W}$; (map 85).

Named in 1890 by E. H. Wells, of Frank Leslie's Illustrated Newspaper, for Lt. Comdr. Henry Buckingham Manśfield, USN.

Mansfield, Point: point of land, in Sitklan Passage, on $\mathbf{N}$ coast of Sitklan $\mathbf{I}$., Coast Mts.; $54^{\circ} 45^{\prime} 50^{\prime \prime} \mathrm{N}, 130^{\circ} 40^{\prime} 30^{\prime \prime} \mathrm{W}$; (map 2).

Named for Lt. Comdr. Henry Buckingham Mansfield, USN, who made surveys in this vicinity in 1889-91; published in 1943 by USC\&GS.

Mansfield Creek: stream, flows SW $31 \mathrm{mi}$. to Lake Mansfield, $7 \mathrm{mi}$. $\mathrm{N}$ of Tanacross, YukonTanana High.; $62^{\circ} 29^{\prime} \mathrm{N}, 143^{\circ} 26^{\prime} \mathrm{W}$; (map 85).

Named by E. H. Wells, of Frank Leslie's Illustrated Newspapers, in 1890.

Mansfield Peninsula: peninsula, on $\mathbf{N}$ end of Admiralty $I$. extending from Point Retreat $23 \mathrm{mi}$. S to Hawk Point, $14 \mathrm{mi}$. W of Juneau, Alex. Arch.; $58^{\circ} 15^{\prime} \mathrm{N}, 134^{\circ} 50^{\prime} \mathrm{W}$; (map 11).

Named in 1893 by USC\&GS for Lt. Comdr. Henry Buckingham Mansfield, USN, 18461918. As commander of the USC\&GS steamer Patterson, he made coast and hydro- graphic surveys of Alaska waters from 1889 to 1891 .

Mansfield Village: village, pop. 39, S of Lake Mansfield, $6 \mathrm{mi}$. NW of Tanacross, YukonTanana High.; $63^{\circ} 28^{\prime} \mathrm{N}, 143^{\circ} 26^{\prime} \mathrm{W} ; B G N$ 1944; (map 85). Var. Mansfield.

Named for the lake.

Manslaughter Creek: stream, flows S $12 \mathrm{mi}$. to Khotol River, $2 \mathrm{mi}$. SE of junc. of Khotol River and Ground Surface Slough, $22 \mathrm{mi}$. SE of Nulato, Koyukuk Low; $64^{\circ} 24^{\prime}$ N, $158^{\circ} 13^{\prime}$ W; (map 97). Var. Tenadziladlakatna.

Appears to be a translation of an Indian name; reported in 1935 by Frederica de Laguna.

Mantalik Creek: stream, see Lake Creek.

Mantaschlano: stream, see Stony River.

Mantashtano: stream, see Stony River.

Mantas River: stream, see Mentasta Creek.

Manuilyisat Hills: hills, $960 \mathrm{ft}$., extend $5 \mathrm{mi}$. on right bank of Ambler River $5 \mathrm{mi}$. NNE of its junc. with Kobuk River, Brooks Ra.; $67^{\circ} 10^{\prime}$ $\mathrm{N}, 157^{\circ} 43^{\prime} \mathrm{W}$; (map 126 ).

Eskimo name reported in 1965 by Wilfried Zibell.

Manzanita Bay: estuary, extends SW $2 \mathrm{mi}$. off Behm Canal, between Skirt and Wart Points, on E coast of Revillagigedo I., Alex. Arch.; $55^{\circ} 35^{\prime} \mathrm{N}, 130^{\circ} 58^{\prime} \mathrm{W}$; BGN 1929; (map 3).

Local name reported in 1928 by USFS to have been given for "the lighthouse tender Manzanita, detailed on the International boundary work in 1901."

Manzanita Creek: stream, $2 \mathrm{mi}$. long, drains Manzanita Lake into Manzanita Bay, on $E$ coast of Revillagigedo I., $32 \mathrm{mi}$. NE of Ketchikan, Alex. Arch.; 55 $35^{\prime} 50^{\prime \prime} \mathrm{N}, 130^{\circ} 58^{\prime} 20^{\prime \prime}$ W; BGN 1923; (map 3).

Named in 1923 by USFS.

Manzanita Island: island, $1.2 \mathrm{mi}$. long, in Behm Canal, $\mathbf{E}$ of Wart Point on $\mathbf{E}$ coast of Revillagigedo I., Alex. Arch.; 55 $35^{\prime}$ N, $130^{\circ} 56^{\prime}$ W; (map 3).

Named in 1891 by USC\&GS. See Manzanita Bay.

Manzanita Lake: lake, $6 \mathrm{mi}$. long, in course of Manzanita Greek, on $\mathrm{E}$ coast of Revillagigedo I., Alex. Arch.; 55 $34^{\prime} \mathrm{N}, 131^{\circ} 03^{\prime} \mathrm{W}$; (map

3). Var. Ella Lake, Lake Manzanita.

Name reconded in 1926 by R. H. Sargent and F. H. Moffit (in Smith and others, 1929 pl. 5), USGS. See Manzanita Bay.

Manzanita Lake: lake, see Ella Lake.

Manzanita Peak: mountain, 2,481 ft., on $\mathrm{E}$ coast of Mitkof I., $12 \mathrm{mi}$. NW of Wrangell, Alex. Arch.; $56^{\circ} 35^{\prime} 30^{\prime \prime} \mathrm{N}, 132^{\circ} 39^{\prime} 00^{\prime \prime} \mathrm{W}$; (map 6).

Named in 1887 by Lt. Comdr. C. M. Thomas, USN, for charting purposes; name published in 1888 on USC\&GS Chart 705.

Manzoni, Lake: lake, $2.4 \mathrm{mi}$. long, on mainland, S of Walker Cove, at head of Granite Creek, Alex. Arch.; $55^{\circ} 39^{\prime} \mathrm{N}, 130^{\circ} 46^{\prime} \mathrm{W}$; $B G N$ 1963; (map 3).

Named by the Ketchikan Chamber of Commerce and USFS in 1962 for Carl Anthony Manzoni, 1928-62, a local bush pilot who, in cooperation with USFS, helped in selecting sites and in planning multiple type recreational facilities in and adjacent to the lakes, streams, and bays of the Tongass National Forest.

Map Hill: mountain, 1,227 ft., at head of Moose Creek, central Kiska I., Aleutian Is.; 51 ${ }^{\circ} 57^{\prime}$ $40^{\prime \prime} \mathrm{N}, 177^{\circ} 30^{\prime} 58^{\prime \prime} \mathrm{E}$; (map 14).

An arbitrary name beginning with " $M$ " to correspond to " $M$ " grid used by U.S. Army for tactical purposes during World War II; published on a 1943 Army map.

Mapsa, Lake: lake, $1 \mathrm{mi}$. long, on $\mathrm{S}$ bank of Noatak River, $37 \mathrm{mi}$. NE of Noatak, Brooks Ra.; 67 $57^{\prime} \mathrm{N}$, 161 ${ }^{\circ} 57^{\prime} \mathrm{W}$; (map 127).

Eskimo name meaning "spleen" reported in 1956 by Orth.

Mapsorak Creek: stream, flows S 5 mi. to Mapsorak Lagoon, between Mapsorak Mtn. and Tinguk Ridge, $18 \mathrm{mi}$. SE of Cape Thompson, Arctic Slope; $68^{\circ} 02^{\prime} \mathrm{N}, 165^{\circ} 20^{\prime} \mathrm{W}$; $B G N$ 1963; (map 129). Var. Mafsorak, Mapsorrak Creek, Singdolik Creek, Singoolik Creek.

Eskimo name reported in 1962 by Project Chariot personnel; named after the hill.

Mapsorak Hill: hill, $152 \mathrm{ft}$, E of Mapsorak Lagoon, $19 \mathrm{mi}$. SE of Cape Thompson, Arctic Slope; $68^{\circ} 02^{\prime} 05^{\prime \prime} \mathrm{N}, 165^{\circ} 19^{\prime} 30^{\prime \prime} \mathrm{W}$; $B G N$ 1963; (map 129). Var. Mafsorak Mountain, Mapsorrak Mountain, Mapsorrax Mountain, Mupsorut Hill.

Eskimo descriptive name meaning "overhanging," reported in 1950 by USC\&GS. See Mapsorak Mountain.

Mapsorak Lagoon: lagoon, $2 \mathrm{mi}$. long, on Chukchi Sea coast, $17 \mathrm{mi}$. SE of ${ }_{\text {Cape Thomp- }}$ son, Arctic Slope; $68^{\circ} 02^{\prime} 11^{\prime \prime} \mathrm{N}, 165^{\circ} 22^{\prime} 00^{\prime \prime}$ W; BGN 1963; (map 129). Var. Mapsorrak Lagoon, Mupsorut Lagoon.

Named "Mapsorrak Lagoon" in 1960 by Project Chariot personnel "for the hill." Spelling changed to conform with that of the hill."

Mapsorak Mountain: hill, $740 \mathrm{ft}$, between Kisimilok and Mapsorak Creeks, $17 \mathrm{mi}$. SE of Cape Tompson, Arctic Slope ; $68^{\circ} 04^{\prime} \mathrm{N}, 165^{\circ}$ $21^{\prime}$ W; (map 129). Var. Mafsorak Hill, Mapsorrax Mountain, Mup-so-rut Hill.

Eskimo name reported in 1950 by USC\&GS as "Mup-so-rut." W. O. Pruitt, Univ. of Alaska, spelled the name "Mafsorak" and gives its meaning as "overhanging." The name is derived from the low hill located just to the south.

Mapsorrak Creek: stream, see Mapsorak Creek. Mapsorrak Lagoon: lagoon, see Mapsorak Lagoon.

Mapsorrak Mountain: hill, see Mapsorak Hill. Mapsorrax Mountain: hill, see Mapsorak Hill. Mapsorrax Mountain: hill, see Mapsorak Mountain.

Maquinna Cove: cove, $0.2 \mathrm{mi}$. across, in Glacier Bay National Monument, on Muir Inlet, 0.5 mi. N of Point George and $57 \mathrm{mi}$. NW of Hoonah, St. Elias Mts.; 58 51'45" N, 136 $03^{\prime} 15^{\prime \prime} \mathrm{W}$; (map 10).

Named by members of the American Geographical Society's Glacier Bay Expedition of 1941 (Field, 1947, map) for the SS Princess 
Maquinna, which anchored there on an excursion of the Twelfth International Geological Congress in 1913.

Marabilla, Point: point of land, on NW coast of Lulu I., Alex. Arch.; 55 $30^{\prime} 20^{\prime \prime}$ N, 133 $32^{\prime}$ $30^{\prime \prime}$ W; (map 4). Var. Mys de la Mirabilya, Punta de la Marabilla, Punta Maravilla.

Spanish name given in 1779 by Don Juan de la Bodega y Quadra and Francisco Antonio Maurelle as "Punta Maravilla" or "point marigold."

Marabilla, Punta de la: point of land, see Marabilla, Point.

Marabilla, Ysla de la: island, see Marabilla Island.

Marabilla Island: island, $0.4 \mathrm{mi}$. long, in Saint Nicholas Channel, off NW coast of Lulu I., Alex. Arch.; $55^{\circ} 31^{\prime} 00^{\prime \prime} \mathrm{N}, 1^{\circ} 33^{\circ} 32^{\prime} 30^{\prime \prime} \mathrm{W}$; (map 4). Var. Isla Maravilla, Ostrov de la Mirabilya, Ysla de la Marabilla.

Spanish name given in 1779 by Don Juan de la Bodega y Quadra and Francisco Antonio Maurelle as "Isla Maravilla" or "marigold island."

Marack Lake: lake, $0.6 \mathrm{mi}$. long, in course of Meadow Creek, $24 \mathrm{mi}$. W of Beaver, Yukon Flats; $66^{\circ} 17^{\prime} 40^{\prime \prime} \mathrm{N}, 148^{\circ} 16^{\prime} 00^{\prime \prime} \mathrm{W}$; (map 118).

Local name obtained in 1956 by USGS.

Marathon Mountain: mountain, 4,603 ft., in Kenai Mts., on Kenai Penin., $2 \mathrm{mi}$. W of Seward, Chugach Mts. ; $60^{\circ} 07^{\prime} \mathrm{N}, 149^{\circ} 30^{\prime} \mathrm{W}$; (map 63).

Named for the marathon races that are run on the mountain each year. The first "mountain marathon" race was run in 1915. The marathon consists of a race to the top of the mountain and back (Currier, 1966, p. 1013).

Maravilla, Isla: island, see Marabilla Island.

Maravilla, Punta: point of land, see Marabilla, Point.

Marble Bluffs: bluffs, $1,000 \mathrm{ft}$., $17 \mathrm{mi}$. NW of Angoon, on $\mathrm{W}$ coast of Admiralty I., Alex.

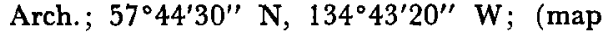
$9)$.

Descriptive local name published by USC\&GS in the 1883 Coast Pilot (p. 179). This may be a misnomer because the USGS shows this area covered by plutonic rocks.

Marble Cliffs: cliffs, on SE side of Mount Kwiniuk, on NW coast of Norton Bay, $6 \mathrm{mi}$. SW of Elim, Seward Penin. High.; $64^{\circ} 34^{\prime}$ N, $162^{\circ} 26^{\prime} \mathrm{W}$; (map 95).

Local name published in 1956 by USGS.

Marble Cove: cove, $0.1 \mathrm{mi}$. across, $13 \mathrm{mi}$. NW of Angoon, on W coast of Admiralty I., Alex. Arch.; 57 $41^{\prime} 15^{\prime \prime} \mathrm{N}, 134^{\circ} 41^{\prime} 50^{\prime \prime} \mathrm{W}$; (map 9).

Descriptive name reported in 1919 by USGS and published by Chapin $(1920$, p. 50$)$. The marble here is of "considerable scientific interest and possibly some commercial value."

Marble Creek: stream, on Revillagigedo I., flows SW $5 \mathrm{mi}$. to Carroll Inlet, $3 \mathrm{mi}$. $\mathrm{N}$ of Island Point, Alex. Arch.; 55 $29^{\prime} 45^{\prime \prime} \mathrm{N}, 131^{\circ} 18^{\prime} 00^{\prime \prime}$ W; (map 3).
Local name recorded in 1915 by Theodore Chapin (in Brooks and others, 1916, fig. 6), USGS.

Marble Creek: stream, flows SW $4 \mathrm{mi}$. to Shakan Bay, on NW coast of Prince of Wales I., 15 mi. SE of Point Baker, Alex. Arch.; 56 $10^{\prime}$ $30^{\prime \prime} \mathrm{N}, 133^{\circ} 28^{\prime} 00^{\prime \prime} \mathrm{W}$; (map 6).

Local name obtained from Capt. Cyrus Orr, of Shaken in 1904 by E. F. Dickins, USG\&GS.

Marble Creek: stream, on Chichagof I., flows W $4 \mathrm{mi}$. to Black River, $4 \mathrm{mi}$. NE of Chichagof, Alex. Arch.; $57^{\circ} 42^{\prime} 45^{\prime \prime} \mathrm{N}, 136^{\circ} 01^{\prime} 45^{\prime \prime} \mathrm{W}$; (map 9).

Descriptive local name reported in 1939 by USGS. So named because "a band of white marble is exposed near its mouth."

Marble Creek: stream, $6 \mathrm{mi}$. long, in Tongass National Forest, on Chichagof I., heads in series of small lakes on $\mathrm{N}$ slope of Tarn Mtn., flows circuitously $\mathrm{N}$ to Idaho Inlet, Alex. Arch.; $58^{\circ} 04^{\prime} 30^{\prime \prime} \mathrm{N}, 136^{\circ} 09^{\prime} 00^{\prime \prime} \mathrm{W}$; $B G N$ 1960; (map 10).

Named in 1955 by Rossman (1959, map), USGS, because it flows through an area underlain by marble.

Marble Creek: stream, heads in glacier, on $\mathrm{N}$ slope of Mount Gage, flows N 5 mi. to Chitina River, $68 \mathrm{mi}$. NE of Cape Yakataga, Chugach Mts.; $60^{\circ} 59^{\prime} 10^{\prime \prime} \mathrm{N}, 140^{\circ} 42^{\prime} 00^{\prime \prime} \mathrm{W}$; (map 65).

Name derived from a 1915 fieldsheet by F. H. Moffit, USGS.

Marble Hill: hill, $100 \mathrm{ft}$., W of Kiska Harbor, Kiska I., Aleutian Is. ; $51^{\circ} 58^{\prime} 15^{\prime \prime} \mathrm{N}, 177^{\circ} 31^{\prime}$ $55^{\prime \prime} \mathrm{E}$; (map 14).

An arbitrary name beginning with " $\mathrm{M}$ " to correspond to " $M$ " grid used by U.S. Army for tactical purposes during World War II ; published on 1943 Army map.

Marble Island: island, $4 \mathrm{mi}$. across, NE Davidson Inlet, Alex. Arch.; 55 58' N, $133^{\circ} 27^{\prime} \mathrm{W}$; $B G N$ 1906; (map 4). Var. Fox Island.

Named in 1904 by E. F. Dickins, USC\&GS, "at request of President of Great American Marble Company whose quarry is on the island * * *. This island was discovered by R. L. Fox which he earlier named after himself before being surveyed."

Marble Islands: islands, two small islands, $0.3 \mathrm{mi}$. and $1.6 \mathrm{mi}$. across, in Glacier Bay, Glacier Bay National Monument, $45 \mathrm{mi}$. NW of Hoonah, St. Elias Mts. ; $58^{\circ} 39^{\prime} \mathrm{N}, 136^{\circ} 03^{\prime} \mathrm{W}$; (map 10). Var. Marble Islets.

So named by Capt. W. E. George in 1883 "because the islands are composed largely of marble" (USC\&GS, 1883, p. 189).

Marble Islet: island, $0.1 \mathrm{mi}$. long, $7 \mathrm{mi}$. NE of Gape Decision, in Affleck Canal, on $\mathbf{S}$ coast of Kuiu I., Alex. Arch.; 56 $06^{\prime} 05^{\prime \prime}$ N, $134^{\circ} 05^{\prime}$ $10^{\prime \prime} \mathrm{W}$; (map 5 )

Descriptive name given in 1886 by Lt. Comdr. A. S. Snow, USN, "from its [geological] formation."

Marble Islets: islands, see Marble Islands.

Marble Mountain: mountain, 3,364 ft., in Glacier Bay National Monument, $0.7 \mathrm{mi}$. E of Shag Cove and $48 \mathrm{mi}$. NW of Hoonah, St. Elias Mts.; 58 $38^{\prime} 30^{\prime \prime} \mathrm{N}, 136^{\circ} 18^{\prime} 15^{\prime \prime} \mathrm{W}$; (map 10). Local name reported by USGS in 1951.
Marble Passage: water passage, $1.5 \mathrm{mi}$. long, between Marble and Orr Is., Alex. Arch.; $55^{\circ} 57^{\prime} 30^{\prime \prime} \mathrm{N}, 132^{\circ} 25^{\prime} 30^{\prime \prime} \mathrm{W}$; (map 4).

Name published in 1914 by USC\&GS.

Marble Point: point of land, on $\mathbf{E}$ shore of Herendeen Bay, $16 \mathrm{mi}$. SW of village of Port Moller, near SW end of Alaska Penin., Aleutian Ra.; $55^{\circ} 47^{\prime} 15^{\prime \prime} \mathrm{N}, 160^{\circ} 45^{\prime} 00^{\prime \prime} \mathrm{W}$; (map 28).

Named in 1890 by Lt. Comdr. Z. L. Tanner, USN, "because of the white marble-like appearance of the rock on the point."

Marble Point: point of land, E entrance to Mosman Inlet, on SW coast of Etolin I., $29 \mathrm{mi}$. S of Wrangell, Alex. Arch.; 56 $04^{\prime} 45^{\prime \prime} \mathrm{N}$, $132^{\circ} 31^{\prime} 45^{\prime \prime} \mathrm{W}$; BGN 1917; (map 6).

Named in 1916 by USC\&GS.

Marble Point: point of land, on SW shore of Russell Fiord, $4.5 \mathrm{mi}$. SE of Osier I. and 29 mi. NE of Yakutat, St. Elias Mts.; $59^{\circ} 56^{\prime} 20^{\prime \prime}$ $\mathrm{N}, 139^{\circ} 23^{\prime} 55^{\prime \prime} \mathrm{W}$; (map 46).

Descriptive name given in 1905 by Tarr (1906, map and p. 165), USGS, because of a mile-long band of white marble on the point.

Marchainville, Mount: mountain, 4,067 ft., in Glacier Bay National Monument, $2.7 \mathrm{mi}$. N of Palma Bay and $62 \mathrm{mi}$. NW of Hoonah, St. Elias Mts.; $58^{\circ} 26^{\prime} 55^{\prime \prime} \mathrm{N}, 137^{\circ} 01^{\prime} 30^{\prime \prime} \mathrm{W}$; (map 10).

Name published by USC\&GS in 1943.

Marcia Cove: estuary, see Marsha Bay.

Marconi Slough: stream, distributary, flows SW $0.3 \mathrm{mi}$. from Chena River to Tanana River, $5.5 \mathrm{mi}$. SW of Fairbanks, Tanana Low.; $64^{\circ}$ $47^{\prime} 45^{\prime \prime} \mathrm{N}, 147^{\circ} 55^{\prime} 10^{\prime \prime} \mathrm{W}$; (map 100).

So named for the inventor of the telegraph, Guglielmo Marconi, 1874-1937, because the Fairbanks-Nenana telegraph line followed the right bank of stream. The name is published on recent USGS maps.

Marcus Baker, Mount: mountain, 13,176 ft., at head of Knik and Matanuska Glaciers, $47 \mathrm{mi}$. $\mathrm{SE}$ of Palmer, Chugach Mts.; $61^{\circ} 26^{\prime} 15^{\prime \prime} \mathrm{N}$, $147^{\circ} 45^{\prime} 00^{\prime \prime} \mathrm{W}$; BGN 1924; (map 69). Var. Mount Saint Agnes.

Named in 1924 by A. H. Brooks, USGS, for Marcus Baker, 1849-1903, cartographer with USC\&GS and USGS.

Marcus Baker Glacier: glacier, heads on Mount Marcus Baker, trends W $23 \mathrm{mi}$. to its terminus at head of Glacier Fork, $29 \mathrm{mi}$. SE of Palmer, Chugach Mts.; $61^{\circ} 27^{\prime} \mathrm{N}, 148^{\circ} 17^{\prime} \mathrm{W}$; (map $69)$.

Name reported in 1960 by USGS.

Mardow Creek: stream, flows SE $13 \mathrm{mi}$. to Kandik River, $7 \mathrm{mi}$. NE of that stream's junc. with Yukon River, Porcupine Plat. ; $65^{\circ} 26^{\prime} \mathrm{N}, 142^{\circ}$ 19' W; (map 103).

Local name published in 1956 by USGS

Mardow Lake: lake, $1.5 \mathrm{mi}$. long, $24 \mathrm{mi}$. SW of Chalkyitsik, Yukon Flats; $66^{\circ} 19^{\prime} \mathrm{N}, 143^{\circ} 56^{\prime}$ W; (map 120).

Local name obtained in 1956 by $T$. E. Taylor and R. C. Foley, USGS.

Marelock Creek: stream, see Morelock Creek. Margaret, Mount: mountain, 5,059 ft., $11 \mathrm{mi}$. W of Mount Healy and $14 \mathrm{mi}$. SW of Healy, 
Alaska Ra.; $63^{\circ} 45^{\prime} 10^{\prime \prime}$ N, $149^{\circ} 21^{\prime} 00^{\prime \prime}$ W; (map 87).

Name reported and perhaps given by Woodbury Abbey on his 1921 survey of the boundaries of McKinley National Park.

Margaret Bay: bay, $0.15 \mathrm{mi}$. across, $0.6 \mathrm{mi}$. NW of Unalaska, in Unalaska Bay on NE coast of Unalaska I., Aleutian Is.; 53 $53^{\prime} 02^{\prime \prime} \mathrm{N}$, $166^{\circ} 32^{\prime} 48^{\prime \prime} \mathrm{W}$; (map 23).

Name published by USC\&GS in 1965 on Chart 9008.

Margaret Creek: stream, on Revillagigedo I., flows NW, through Margaret Lake, $6 \mathrm{mi}$. to Traitors Cove, Alex. Arch.; 55 $41^{\prime} 40^{\prime \prime} \mathrm{N}$, $131^{\circ} 37^{\prime} 30^{\prime \prime} \mathrm{W}$; BGN 1962; (map 3).

Local name reported in 1961 by USFS.

Margaret Creek: stream, flows SW $17 \mathrm{mi}$. to Kejulik River, on Alaska Penin., $8 \mathrm{mi}$. E of Becharof Lake and $40 \mathrm{mi}$. SW of Mount Katmai, Aleutian Ra.; 57 $51^{\prime} 10^{\prime \prime}$ N, $155^{\circ} 44^{\prime} 15^{\prime \prime}$ W; (map 35).

Local name obtained from J. L. McPherson of Iliamna, and published by W. R. Smith and A. A. Baker (in Brooks and others, 1924, pl. 9), USGS.

Margaret Lake: lake, $1 \mathrm{mi}$. long, in course of Margaret Creek, on W coast of Revillagigedo I., Alex. Arch.; 55 $41^{\prime} \mathrm{N}, 131^{\circ} 36^{\prime} \mathrm{W}$; $B G N$ 1962; (map 3).

Local name reported in 1961 by USFS.

Margaret Lake: lake, see Catherine, Lake.

Margaretta Creek: stream, flows NW to Big Hurrah Creek, E of Little Hurrah Creek, about $9 \mathrm{mi}$. NE of Solomon, Seward Penin. High.; (map 95).

Prospectors' name reported on a prospector's manuscript map dated 1902. This stream cannot be precisely located on current maps.

Marge, Lake: lake, $0.6 \mathrm{mi}$. across, on Prince of Wales I., E of Hetta Inlet, S of Summit Lake, Alex. Arch.; $55^{\circ} 13^{\prime} \mathrm{N}, 132^{\circ} 31^{\prime} \mathrm{W}$; (map 4).

Local name reported in 1908 by C. W. Wright (in Brooks and others, 1909, pl. 3), USGS.

Margerie Glacier: glacier, heads on S slope of Mount Root, on Alaska-Canada boundary, trends NE $21 \mathrm{mi}$. to Tarr Inlet, $1 \mathrm{mi}$. SE of the terminus of Grand Pacific Glacier and $87 \mathrm{mi}$ NW of Hoonah, St. Elias Mts.; $59^{\circ} 02^{\prime} 12^{\prime \prime}$ N, 137 $04^{\prime} 00^{\prime \prime}$ W; BGN 1923; (map 45).

Named by Lawrence Martin, USGS, in 1923 for Emmanuel de Margerie, 1862-1953, French geologist, who visited Glacier Bay in 1913. Margerie was a famous geographer and geologist, who published many scientific papers including several on the geology of North America.

Margot Creek: stream, flows NW $24 \mathrm{mi}$. to Iliuk Arm Naknek Lake, on Alaska Penin., in Katmai National Monument, $27 \mathrm{mi}$. NW of Mount Katmai, Aleutian Ra.; $58^{\circ} 29^{\prime} 15^{\prime \prime} \mathrm{N}$, $155^{\circ} 34^{\prime} 10^{\prime \prime} \mathrm{W}$; (map 42).

Local name reported in 1951 by USGS.

Margret Creek: stream, on $\mathrm{N}$ part of Chichagof I., heads in lake $0.4 \mathrm{mi}$. $\mathrm{N}$ of Mount Althorp, flows $4 \mathrm{mi}$. $\mathrm{N}$ to Port Althorp, $1.8 \mathrm{mi}$. SE of Point Lucan, $33 \mathrm{mi}$. W of Hoonah, Alex.
Arch.; $58^{\circ} 07^{\prime} \mathrm{N}, 136^{\circ} 20^{\prime} \mathrm{W} ; B G N \quad 1960$ (map 10).

Local name reported in an application for a power license dated 1927.

Marguerite Creek: stream, flows NW $9 \mathrm{mi}$., joins with Emma Creek to form California Creek, $41 \mathrm{mi}$. SE of Nenana, Alaska Ra.; $64^{\circ} 01^{\prime}$ $\mathrm{N}, 148^{\circ} 44^{\prime} \mathrm{W}$; (map 100).

Local name reported by USGS (Capps, 1912, pl. 1).

Marhlan Creek: stream, see Marlan Creek.

Maria, Point: point of land, on E coast of Baker I., NE point of entrance to Port Asumcion, Alex. Arch.; $55^{\circ} 22^{\prime} 00^{\prime \prime} \mathrm{N}, 133^{\circ} 29^{\prime} 30^{\prime \prime} \mathrm{W}$; (map 4). Var. Mys Maria Khosefa, Punta de Maria Josefa, Punta Maria Josefa.

Name given in $1775-79$ by Don Juan de la Bodega y Quadra and Francisco Antonio Maurelle as "Punta de Maria Josefa," i.e. "Point of Mary Josephine." "Maria Josefa was one of the daughters of Charles III" (Wagner, 1937, p. 470)

Maria Antonia, Punta: point of land, on S side of San Juan Bautista Island, Bucareli Bay, Alex. Arch.; 55 $24^{\prime}$ N, $133^{\circ} 18^{\prime}$ W; (map 4).

Named by the 1779 Don Ignacio Arteaga expedition. "One of the children of Fernando IV, King of Naples, bore this name" (Wagner, 1937, p. 470).

Maria Creek: stream, flows NW $8 \mathrm{mi}$. to Kugrupaga River, $7 \mathrm{mi}$. SW of Ear Mtn. and $40 \mathrm{mi}$. N of Teller, Seward Penin. High.; $65^{\circ} 50^{\prime} \mathrm{N}, 166^{\circ} 24^{\prime} \mathrm{W}$; (map 111).

Prospectors' name reported in 1901 by $\mathrm{T}$. G. Gerdine (in Collier, 1902, pl. 12), USGS.

Mariagamiut: village, see Scammon Bay.

Maria Josefa, Punta: point of land, see Maria, Point.

Maria Josefa, Punta de: point of land, see Maria, Point.

Mariakamut: village, see Scammon Bay.

Maria Khosefa, Mys: point of land, see Maria, Point.

Maria Louisa : stream, see Kun River.

Marian Creek: stream, see Mariner Creek.

Marie, Point: point of land, $\mathrm{S}$ point of entrance to Ushk Bay, in Peril Strait, on Chichagof I., $21 \mathrm{mi}$. SE of Chichagof, Alex. Arch.; 57 $33^{\prime}$ N, $135^{\circ} 34^{\prime} \mathrm{W}$; (map 9)

Named in 1895 by Lt. Comdr. Moore, USN, and published in 1900 by USC\&GS on Chart 8282.

Marie Creek: stream, flows W to Nome River, about $20 \mathrm{mi}$. NE of Nome, Seward Penin. High.; (map 94).

Prospectors' name reported on the 1900 "Map of Nome Peninsula" by J. M. Davidson and B. D. Blakeslee; this feature has not been positively identified.

Marie Creek: stream, flows $12 \mathrm{mi}$. SW to Becharof Lake, on Alaska Penin., $1 \mathrm{mi}$. $\mathrm{N}$ of Kejulik River and $44 \mathrm{mi}$. SW of Mount Katmai, Aleutian Ra.; $57^{\circ} 53^{\prime} 05^{\prime \prime}$ N, $155^{\circ} 56^{\prime} 00^{\prime \prime}$ W; (map 35).

Local name reported in 1923 by $R$. $H$. Sargent, USGS, and published by W. R. Smith (in Brooks and others, 1925, pl. 4), USGS.
Marie Creek: stream, flows SE 2 mi. to Walker Fork, $54 \mathrm{mi}$. SW of Eagle, Yukon-Tanana High.; $64^{\circ} 03^{\prime} 00^{\prime \prime} \mathrm{N}, 141^{\circ} 26^{\prime} 30^{\prime \prime} \mathrm{W}$; (map 102).

Named by prospectors and shown on an 1898 manuscript map by E. F. Ball, prospector. Marie Creek: stream, flows NE $3 \mathrm{mi}$. to Bonanza Creek, $10 \mathrm{mi}$. SE of junc. of Charley and Yukon Rivers, Yukon-Tanana High.; 65 ${ }^{\circ} 12^{\prime}$ N, $142^{\circ} 35^{\prime} \mathrm{W}$; (map 103).

Prospectors' name from an unpublished map by E. J. Chamberlain, dated 1902.

Marie Lake: lake, $0.9 \mathrm{mi}$. long, in course of Mendeltna Creek, $46 \mathrm{mi}$. WNW of Glennallen, Copper River Basin; 62 ${ }^{\circ} 10^{\prime} \mathrm{N}, 146^{\circ} 57^{\prime} \mathrm{W}$; (map 83).

Local name reported in 1949 by USGS.

Marie Mountain: mountain, 4,350 ft., in Romanzof Mts., between McCall Creek and Jago River, $15 \mathrm{mi}$. NE of Mt. Michelson, Brooks Ra.; $69^{\circ} 24^{\prime} \mathrm{N}, 143^{\circ} 41^{\prime} \mathrm{W}$; (map 138).

Named about 1959 by members of the International Geophysical Year McCall Glacier expedition.

Marilyns Twins: peak, see Peril Peak.

Marina, Port de la: water passage, see Real Marina, Port.

Marine Creek: stream, flows NW $1.3 \mathrm{mi}$. to Taylor Creek which flows to Kougarok River, $4 \mathrm{mi}$. SE of Midnight Mtn. and $39 \mathrm{mi}$. NW of Imuruk Lake, Seward Penin. High.; $65^{\circ}$ $45^{\prime} \mathrm{N}, 164^{\circ} 29^{\prime} \mathrm{W}$; (map 110).

Prospectors' name reported on the 1908 "Map of Seward Peninsula" by Arthur Gibson.

Mariner Creek: stream, flows NE $7.5 \mathrm{mi}$. to Canyon Creek, $40 \mathrm{mi}$. S of Eagle, YukonTanana High.; $64^{\circ} 14^{\prime} \mathrm{N}, 141^{\circ} 08^{\prime} \mathrm{W}$; BGN 1954; (map 102). Var. Marian Creek, Marion Creek, Merriam Creek.

Prospectors' name obtained in 1898 by E. C. Barnard, USGS.

Marin Range: ridge, elev. $1,800 \mathrm{ft}$., $5 \mathrm{mi}$. long, 16 mi. S of Kodiak, Kodiak I.; $57^{\circ} 33^{\prime} \mathrm{N}$, $152^{\circ} 23^{\prime} \mathrm{W}$; (map 34).

Local name reported in 1949 by USGS.

Marion, Lake: lake, $0.8 \mathrm{mi}$. long, S of Big Lake, $20 \mathrm{mi}$. $\mathrm{N}$ of Anchorage, Cook Inlet Low.; $61^{\circ} 30^{\prime} 35^{\prime \prime} \mathrm{N}, 149^{\circ} 54^{\prime} 20^{\prime \prime} \mathrm{W}$; BGN 1960; (map 69). Var. Oscar Lake.

Named "in memoriam" in 1960 by a petition of friends of Marion Calvert Suomela, who died in 1955.

Marion Creek: stream, flows NW 3 mi. to American Creek, $5 \mathrm{mi}$. SW of Eagle, Yukon-Tanana High.; $64^{\circ} 43^{\prime} 45^{\prime \prime} \mathrm{N}, 141^{\circ} 15^{\prime} 30^{\prime \prime} \mathrm{W}$; (map 102).

Named by prospectors; reported in 1898 by E. C. Barnard, USGS.

Marion Creek: stream, flows W $17.5 \mathrm{mi}$. to Middle Fork Koyukuk River, 7 mi. S of Wiseman, Brooks Ra.; $67^{\circ} 19^{\prime} 12^{\prime \prime} \mathrm{N}, 150^{\circ} 10^{\prime} 00^{\prime \prime} \mathrm{W}$; (map 124).

Local name shown on an 1899 fieldsheet by T. G. Gerdine, USGS.

Marion Creek: stream, see Mariner Creek.

Marion Gulch: ravine, trends NW $0.5 \mathrm{mi}$. to Darling Creek which flows to Nome River, 17 
mi. NE of Nome, Seward Penin. High.; 64$44^{\prime} \mathrm{N}, 165^{\circ} 12^{\prime} \mathrm{W}$; (map 94).

Prospectors' name shown on the 1904 "Map of Cape Nome Precinct" by Arthur Gibson.

Mariposa Creek: stream, flows N $1.5 \mathrm{mi}$. to Yankee River which flows to Mint River, 35 mi. NW of Teller, Seward Penin. High.; $65^{\circ}-$ $38^{\prime} \mathrm{N}, 167^{\circ} 10^{\prime} \mathrm{W}$; (map 111).

Prospectors' name reported on the 1908 "Map of Seward Peninsula" by Arthur Gibson.

Mariposa Gulch: ravine, trends NE to American Creek which flows to Niukluk River, $W$ of Game Creek and $26 \mathrm{mi}$. N of Solomon, Seward Penin. High.; (map 95).

Prospectors' name reported in 1908 by USGS (Smith, P. S., 1910, p. 206). This feature cannot be precisely identified on current maps.

Mariposa Reef: reef, S of Strait I. in Sumner Strait, between Kupreanof, Kuiu, and Prince of Wales Is., 3 mi. NW of Point Baker, Alex. Arch.; $56^{\circ} 22^{\prime} 45^{\prime \prime} \mathrm{N}, 133^{\circ} 42^{\prime} 00^{\prime \prime} \mathrm{W}$; (map 6). Local name recorded in 1948 by USGS.

Mariposa Rock: rock, at entrance to Steamer Bay, on W coast of Etolin I., $24 \mathrm{mi}$. SW of Wrangell, Alex. Arch.; 56 $10^{\circ} 40^{\prime \prime} \mathrm{N}, 132^{\circ}$ 44'15' W; (map 6).

Spanish word meaning "butterfly" given in 1918 by USC\&GS.

Mariuk: village, see Scammon Bay.

Mariy, Port: $b a y$, see Shelikof Bay.

Marka Bay: estuary, extends NW $1 \mathrm{mi}$., on S coast of Afognak I., $6 \mathrm{mi}$. NE of Afognak, Kodiak I.; $58^{\circ} 04^{\prime} 00^{\prime \prime}$ N, $152^{\circ} 39^{\prime} 15^{\prime \prime}$ W; (map 43).

Local name published in 1943 by USC\&GS.

Mark Greek: stream, anabranch of Chisana River, flows $\mathrm{N} 11 \mathrm{mi}$. to its mouth $1 \mathrm{mi}$. SE of Northway Junction, Alaska Ra.; $63^{\circ}$ $00^{\prime} \mathrm{N}, 141^{\circ} 47^{\prime} \mathrm{W}$; (map 84).

Local name reported in 1955 by USGS.

Marks Creek: stream, flows NE $3.3 \mathrm{mi}$., joins Orthmer Greek to form Flat Creek, $19 \mathrm{mi}$. $S$ of junc. of Charley and Yukon Rivers, Yukon-Tanana High.; $65^{\circ} 03^{\prime} \mathrm{N}, 142^{\circ} 50^{\prime} \mathrm{W}$; (map 103).

Prospectors' name from an unpublished map by E. J. Chamberlain dated 1902.

Marlan Creek: stream, flows NE $5 \mathrm{mi}$. to Niukluk River valley, $3.5 \mathrm{mi}$. SE of Council and 32 mi. NE of Solomon, Seward Penin. High.; $64^{\circ} 51^{\prime} \mathrm{N}, 163^{\circ} 37^{\prime} \mathrm{W}$; (map 95). Var. Marhlan Creek.

Prospectors' name published as "Marhlan Cr." on the 1908 "Map of Seward Peninsula" by Arthur Gibson.

Marmion Island: island, $0.2 \mathrm{mi}$. across, SE of Douglas I. at $\mathbf{S}$ end of Gastineau Channel, $9 \mathrm{mi}$. SE of Juneau, Coast Mts.; 58 $11^{\prime} 55^{\prime \prime}$ N, $134^{\circ} 15^{\prime} 20^{\prime \prime} \mathrm{W}$; (map 11).

Named and published by W. H. Dall, USC\&GS, in the 1883 Coast Pilot (p. 171). The name was taken from the title of a narrative poem by Sir Walter Scott (DeArmond, 1957, p. 31).

Marmot Bay: bay, extends E $25 \mathrm{mi}$. from Whale I., between Afognak and Kodiak Is.; $58^{\circ} 00^{\prime}$
N, $152^{\circ} 06^{\prime} \mathrm{W}$; (map 34). Var. Chigik, Evershichie Bay, Ewatschitze Bay, Tsalk, Tschijschi, Ulnik, Whitsuntide Bay, Zaliv Yevvashichey.

Translation by USC\&GS of the name "Zaliv Yevvashichey," derived from an early name for Marmot I., published by Capt. Tebenkov (1852, map 22), IRN. Capt. Cook (1785, v. 2, p. 404), RN, called it "Whitsuntide Bay" in 1778[?]. See Izhut Bay.

Marmot Cape: point of land, on S tip of Marmot I., at mouth of Marmot Bay, $\mathrm{N}$ of Kodiak I.; $58^{\circ} 10^{\prime} 00^{\prime \prime} \mathrm{N}, 151^{\circ} 51^{\prime} 50^{\prime \prime} \mathrm{W}$; BGN 1910; (map 43).

Name derived from Marmot Island and given by USC\&GS in 1910 .

Marmot Island: island, $6 \mathrm{mi}$. long, $3 \mathrm{mi}$. E of Afognak I., N of Kodiak I.; $58^{\circ} 13^{\prime} \mathrm{N}, 151^{\circ}$. $50^{\prime} \mathrm{W}$; (map 43). Var. Evrashichie Island, Isla de Camacho, St. Hermogenes Island.

Translation by USG\&GS of "Os[trov] Yevrashichey," from the Russian "Yevrashka," published by Sarichev (1826, map 5). Otto von Kotzebue (in Baker, 1906, p. 426) says "An animal in many respects similar to the squirrel; but it is much larger and lives in the earth; it is called in Siberia 'Gewraschka.' The Americans call it 'Tschikschi' [probably from the Eskimo 'Sikrik' or 'Siksik' meaning 'ground squirrel']." In 1890 the U.S. Census Bureau (11th Census, 1893, p. 73) reports "The only land animals [on Marmot Island] are the foxes and myriads of ground squirrels (spermophilus), ***. These rodents are called 'yevrashka' in Russian. This word our mapmakers erroneously translated 'marmot,' and thus misnamed the island * * *." Father Veniaminov (1846,p. 63) published the Aleut name "Uhnik" [for Yevrashka] from "ulngiq" which according to R. H. Geoghegan, means "ground squirrel." This island was named "St. Hermogenes" on May 25, 1778, by Capt. Cook $(1785$, v. 2, p. 384) and "Isla de Camacho" in 1779 by Don Juan Francisco de la Bodega y Quadra and Francisco Antonio Maurelle (Baker, 1906, p. 426). Wagner (1937, p. 437) says, "Afognak Island is drawn so out of place on Camacho's map that I have grave doubts about this being Marmot Island, as identified by Baker. It has more the appearance of being Afognak Island proper." The name given by Quadra and Maurelle was probably for the navigator Josef Camacho who copied their map.

Marmot Strait: water passage, between Afognak and Marmot Is., $\mathbf{N}$ of Kodiak I.; 58 $8^{\circ} 5^{\prime} \mathrm{N}$, $151^{\circ} 55^{\prime}$ W; (map 43). Var. Evarashichiche.

Translation of "Pr[oliv] Yevrashichiy" from an early name for Marmot Island, published by the Russian American Company in 1849 .

Marmot Valley: valley, $1.5 \mathrm{mi}$. long, near head of Rhine Creek, $0.5 \mathrm{mi}$. SW of North Rhine Peak and $8 \mathrm{mi}$. SE of Juneau, Coast Mts.; $58^{\circ} 15^{\prime} 00^{\prime \prime} \mathrm{N}, 134^{\circ} 11^{\prime} 25^{\prime \prime} \mathrm{W}$; (map 11)

Local name reported in 1965 by D. A. Brew and A. B. Ford, USGS. Named for the hoary marmot (Marmota caligata).
Maroonitch : locality, see Marunich.

Marquette Glacier: glacier, on Kenai Penin., trends NW $2.5 \mathrm{mi}$. to its terminus $\mathrm{E}$ of SE side of Blackstone Bay, $8 \mathrm{mi}$. SE of Whittier, Chugach Mts.; $60^{\circ} 39^{\prime} 40^{\prime \prime} \mathrm{N}, 148^{\circ} 39^{\prime} 20^{\prime \prime} \mathrm{W}$; $B G N 1930$; (map 63).

Named in 1910 by Lawrence Martin for Marquette Univ., Milwaukee, Wis.

Marr, Mount: mountain, 2,211 ft., in Coleen Hills, 4 mi. SW of Coleen Mtn., Brooks Ra.; $67^{\circ} 05^{\prime} \mathrm{N}, 142^{\circ} 56^{\prime} \mathrm{W}$; (map 121).

Local name reported in 1939 by FitzGerald (1944, p. 234), USGS.

Marr, Mount: mountain, 2,283 ft., $3 \mathrm{mi}$. S of Helm Bay, on SE coast of Gleveland Penin., Alex. Arch.; 55 $33^{\prime} 30^{\prime \prime}$ N, $131^{\circ} 58^{\prime} 55^{\prime \prime} \mathrm{W}$; (map 3).

Named in 1886 by USC\&GS for Robert Athelston Marr, USC\&GS.

Marryat Creek: stream, see Kukpuk River.

Marryat Inlet: lagoon, on Chukchi Sea coast, extends NE $10 \mathrm{mi}$. from Point Hope, Arctic

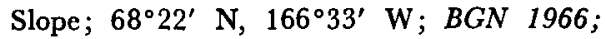
(map 129). Var. Marrayatt Inlet, Marriet Inlet, Marryatt Inlet.

Discovered by Lt. Edward Belcher in September 1827 and named by Capt. Beechey (1831, v. 2, p. 549 ), RN, who wrote "This cove, which I have named after his (Lieut. Belcher's) relation, Captain Marryat, R.N., is the estuary of a river which has no doubt contributed to throw up the point [Point Hope]." Captain Marryat was a famous sailor and novelist.

Marsan: village, see Alatna.

Marsden, Point: point of land, on $\mathrm{W}$ coast of Admiralty I. in Chatham Strait, $2 \mathrm{mi}$. $\mathrm{S}$ of mouth of Hawk Inlet and $22 \mathrm{mi}$. SW of

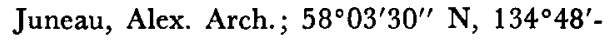
$25^{\prime \prime} \mathrm{W}$; (map 11).

Joseph Whidbey in 1794 passed by the point which was later named by Capt. Vancouver, RN (1801, v. 15, p. 439), either for William Marsden or Samuel Marsden of Paramatta, New South Wales (Wagner, 1937, v. 2, p. 396).

Marsh, Point: point of land, on an island, E point of entrance to Cordova Bay, on SW coast of Prince of Wales I., Alex. Arch.; 54 ${ }^{\circ}$. $43^{\prime} 15^{\prime \prime} \mathrm{N}, 132^{\circ} 19^{\prime} 05^{\prime \prime} \mathrm{W}$; (map 1).

Named in 1885 by Lt. Comdr. R. Clover, USN, for Ens. Charles C. Marsh, USN, a member of his party.

Marsh, Point: point of land, on the Chukchi Sea coast, at $S$ point of entrance to Wainwright Inlet $2.5 \mathrm{mi}$. S of Wainwright, Arctic Plain; $70^{\circ} 36^{\prime} 25^{\prime \prime} \mathrm{N}, 160^{\circ} 07^{\prime} 00^{\prime \prime} \mathrm{W}$; (map 146).

Named by Capt. Beechey (1831, p. 303), RN, in September, 1826, for George Marsh, ship's purser.

Marsh Bay: bay, $0.4 \mathrm{mi}$. across, at $\mathrm{S}$ end of Redoubt Lake, $0.4 \mathrm{mi}$. NE of Goddard on western Baranof I., Alex. Arch.; 56 $50^{\circ} 50^{\prime \prime}$ N, $135^{\circ} 20^{\prime} 00^{\prime \prime} \mathrm{W}$; (map 5). Var. Kluchev Bay.

The 1848 Russian Hydrog. Dept. Chart 1397 applied the name "Zaliv Klyuchevoy" to a bay on the coast about two miles to the 
southwest. In 1880 the British Admiralty translated the Russian name as "Marsh Bay," but misapplied it to this feature. Subsequent maps have followed the British Admiralty application.

Marsha Bay: estuary, on E coast of Knight I., extends SE $2 \mathrm{mi}$. to Prince William Sound, 15 mi. ENE of Chenega, Chugach Mts.; $60^{\circ} 19^{\prime}$. $30^{\prime \prime} \mathrm{N}, 147^{\circ} 39^{\prime} 30^{\prime \prime}$.W ; BGN 1908; (map 63). Var. Marcia Cove.

Local name published in 1908 by USC\&GS. Marshall: village, pop. 166, on E bank of Poltes Slough, $\mathbf{N}$ of Arbor I., on right bank of Yukon River, Yukon-Kuskokwim Delta; $61^{\circ} 53^{\prime} \mathrm{N}$, $162^{\circ} 05^{\prime} \mathrm{W}$; (map 74). Var. Marshall Landing, Fortuna Ledge.

On July 15, 1913, gold was discovered on Wilson Creek by E. L. Mack and Joe Mills and Marshall quickly became a placer mining camp with the ensuing stampede. The camp was located on a channel of the Yukon River because of the convenience for a riverboat landing. A post office called "Fortuna Ledge" was established here 1915 (Ricks, 1965, p. 21). The camp was named for Thomas Riley Marshall, 1854-1925, Vice President of the United States in the Woodrow Wilson administration, 1913-21 (Stuck, 1917, p. 197). See Wilson Creek.

Marshall Creek: stream, flows NW $8 \mathrm{mi}$. to Yukon River, $10 \mathrm{mi}$. W of Rampart, YukonTanana High.; $65^{\circ} 29^{\prime} \mathrm{N}, 150^{\circ} 29^{\prime} \mathrm{W}$; (map 106).

Riverboat pilots' name shown on Edwards Track Chart of the Yukon, dated 1899.

Marshall Glacier: glacier, trends N $5 \mathrm{mi}$. to its terminus, $2 \mathrm{mi}$. SW of Marshall Pass and 25 mi. E of Valdez, Chugach Mts.; $61^{\circ} 04^{\prime} 45^{\prime \prime} \mathrm{N}$, $145^{\circ} 31^{\prime} 30^{\prime \prime} \mathrm{W}$; (map 68).

Local name published in the 1950's by USGS.

Marshall Gulch: ravine, trends W $1.7 \mathrm{mi}$. to Little Eldorado Creek, $15 \mathrm{mi}$. NE of Fairbanks, Yukon-Tanana High.; $65^{\circ} 04^{\prime} 30^{\prime \prime} \mathrm{N}$, 147'32'15" W; (map 105).

Named by prospectors; published in 1908 by USGS.

Marshall Island: island, $0.1 \mathrm{mi}$. across, in Thimbleberry Bay, $2.5 \mathrm{mi}$. SE of Sitka, on $W$ coast of Baranof I., Alex. Arch.; 57 $02^{\prime} 00^{\prime \prime}$ N, $135^{\circ} 15^{\prime} 10^{\prime \prime} \mathrm{W}$; (map 9). Var. Marshall Islet.

Named in 1880 by the U.S. Navy and published by USC\&GS in the 1883 Coast Pilot (p. 144).

Marshall Islet: island, see Marshall Island.

Marshall Lake: lake, $1 \mathrm{mi}$. long, on Mount Doonerak, $37 \mathrm{mi}$. NW of Wiseman, Brooks Ra.; $67^{\circ} 54^{\prime} \mathrm{N}, 150^{\circ} 35^{\prime} \mathrm{W}$; BGN 1954; (map 124).

Named in 1956 by USGS for Robert Marshall, 1901-39, woodsman, explorer, and author.

Marshall Landing: village, see Marshall.

Marshall Mountain: mountain, 5,200 ft., 5.6 mi. SE of Powell Peak and $41 \mathrm{mi}$. NE of Valdez, Chugach Mts. ; $61^{\circ} 41^{\prime} 15^{\prime \prime} \mathrm{N}, 145^{\circ} 53^{\prime} 55^{\prime \prime}$ W; (map 68).
Named in 1898 by Capt. W. R. Abercrombie, USA.

Marshall Pass: pass, 4 mi. E of Heiden Canyon and $26 \mathrm{mi}$. E of Valdez, Chugach Mts.; $61^{\circ} 06^{\prime} 15^{\prime \prime} \mathrm{N}, 145^{\circ} 28^{\prime} 30^{\prime \prime} \mathrm{W}$; (map 68).

Named in 1898 by Capt. W. R. Abercrombie, USA.

Marshall Reese, Mount: mountain, 1,930 ft., on $\mathrm{N}$ coast of Unalaska I., Aleutian Is.; 54 $59^{\prime}$ $05^{\prime \prime} \mathrm{N}, 166^{\circ} 49^{\prime} 00^{\prime \prime} \mathrm{W}$; (map 23).

Name derived from Reese Bay and published in 1951 by USGS.

Marsha Peak: mountain, 4,525 ft., $14 \mathrm{mi}$. E of Wrangell, Coast Mts.; $56^{\circ} 29^{\prime} 20^{\prime \prime} \mathrm{N}, 132^{\circ}$ $02^{\prime} 00^{\prime \prime} \mathrm{W}$; (map 6).

Local name recorded in 1955 by USGS.

Marsh Creek: stream, flows NE $7 \mathrm{mi}$. to Otter Bight, on NE coast of Umnak I., Aleutian Is.; $53^{\circ} 25^{\prime} 42^{\prime \prime} \mathrm{N}, 167^{\circ} 51^{\prime} 20^{\prime \prime} \mathrm{W}$; (map 23).

Name published in 1958 by AMS.

Marsh Creek: stream, flows SE $0.8 \mathrm{mi}$. to Marsh Lake, E central Heceta I., Alex. Arch.; 55 ${ }^{\circ}$ $45^{\prime} 55^{\prime \prime} \mathrm{N}, 133^{\circ} 25^{\prime} 15^{\prime \prime} \mathrm{W}$; (map 4).

Local name recorded in 1951 by USGS.

Marsh Creek: stream, in Chigmit Mts., flows S 2 mi. to Chinitna Bay, Aleutian Ra.; $59^{\circ} 49^{\prime}$ $50^{\prime \prime} \mathrm{N}, 153^{\circ} 16^{\prime} 30^{\prime \prime} \mathrm{W}$; BGN 1961; (map 51).

Local name published by USGS in 1922. The name was originally applied to what is now known as Glearwater Greek.

Marsh Creek: stream, heads $\mathrm{N}$ of Mount Weller, in the Sadlerochit Mts., flows N $28 \mathrm{mi}$. to Camden Bay, 3 mi. E of Collinson Point and $27 \mathrm{mi}$. SW of Barter I., Arctic Plain; 69 $59^{\prime}$ N, $144^{\circ} 48^{\prime}$ W; (map 139). Var. Marsh River, Nuvoak Creek.

Named by Leffingwell (1919, p. 97) for the prospector, S. J. Marsh, who spent many years in northern Alaska. In 1948 USC\&GS reported the Eskimo name "Nuvoak [nuvuk]" meaning "point of land" or "cape."

Marsh Creek: stream, see Clearwater Creek.

Marsh Fork Canning River: stream, heads at glacier in Philip Smith Mts., flows N $50 \mathrm{mi}$. to Canning River, $11 \mathrm{mi}$. NE of Mount Salisbury and $40 \mathrm{mi}$. W of Mount Michelson, Brooks Ra.; $69^{\circ} 12^{\prime} \mathrm{N}, 145^{\circ} 51^{\prime} \mathrm{W}$; (map 139). Var. Right Fork Channing River, Right Fork Kooguru River.

In 1903 S. J. Marsh, who explored and sketched this stream, called it "Right Fork," after the manner of prospectors who term the tributaries right and left when ascending the stream. "Marsh Fork" first appears in Baker's Dictionary, 1906.

Marsh Island: island, $0.4 \mathrm{mi}$. long, off $\mathrm{W}$ coast of Etolin I., $27 \mathrm{mi}$. SW of Wrangell, Alex. Arch.; $56^{\circ} 07^{\prime} \mathrm{N}, 132^{\circ} 43^{\prime} \mathrm{W}$; (map 6).

Named in 1886 by Lt. Comdr. A. S. Snow, USN.

Marsh Lake: lake, $0.2 \mathrm{mi}$. long, E central Heceta I., Alex. Arch.; $55^{\circ} 45^{\prime} 55^{\prime \prime} \mathrm{N}, 133^{\circ} 25^{\prime} 00^{\prime \prime} \mathrm{W}$; $(\operatorname{map} 4)$.

Local name recorded in 1951 by USGS.

Marsh Lake: lake, 1 mi. long, on Kenai Penin., $2.5 \mathrm{mi}$. $\mathrm{N}$ of Skilak Lake and $28 \mathrm{mi}$. SE of Kenai, Cook Inlet Low.; $60^{\circ} 30^{\prime}$ N, $150^{\circ} 27^{\prime}$ $\mathrm{W}$; (map 62).
So named about 1963 by officials of Kenai National Moose Range, because the lake is located in a low wetland or marsh.

Marsh Lake: lake, $0.4 \mathrm{mi}$. long, in Ptarmigan Valley, $1 \mathrm{mi}$. S of Houston Pass and $92 \mathrm{mi}$. NW of Tyonek, Alaska Ra.; $62^{\circ} 01^{\prime} 45^{\prime \prime} \mathrm{N}$, $153^{\circ} 07^{\prime} 20^{\prime \prime} \mathrm{W}$; (map 80).

Local name obtained in 1958 by USGS.

Marsh Lake: lake, $0.5 \mathrm{mi}$. long, $7.5 \mathrm{mi}$. WSW of Lake Louise and $40 \mathrm{mi}$. WNW of Glennallen, Copper River Basin; $62^{\circ} 15^{\prime} \mathrm{N}, 146^{\circ} 45^{\prime} \mathrm{W}$; (map 83).

Local name reported in 1959 by USGS.

Marshmallow Mountain: mountain, 7,000 ft., between Nanushuk River and Alapah Creek, $\mathrm{N}$ of Alapah Mtn., $24 \mathrm{mi}$. NE of Anaktuvuk Pass, Brooks Ra.; $68^{\circ} 13^{\prime} 00^{\prime \prime} \mathrm{N}, 150^{\circ} 50^{\prime} 30^{\prime \prime}$ W; BGN 1932; (map 134).

So named by Robert Marshall in 1930 "because the appearance of its summit looked like a marshmallow."

Marsh Mountain: mountain, 1,600 ft., E of Aleknagik Lake and $17 \mathrm{mi}$. $\mathbf{N}$ of Dillingham, Kilbuck-Kuskokwim Mts.; $59^{\circ} 17^{\prime} \mathrm{N}, 158^{\circ} 31^{\prime}$ W; BGN 1932; (map 52).

Local name reported in 1932 by Gerald FitzGerald, USGS.

Marsh Peak: peak, 4,000 ft., $2 \mathrm{mi}$. W of head of Thomas Bay and $98 \mathrm{mi}$. E of Sitka, Coast Mts.; $57^{\circ} 07^{\prime} 30^{\prime \prime} \mathrm{N}, 132^{\circ} 52^{\prime} 05^{\prime \prime} \mathrm{W}$; (map 8).

Named in 1887 by Lt. Comdr. C. M. Thomas, USN, presumably for O. C. Marsh, 1831-99, vertebrate paleontologist. He was professor of paleontology at Yale Univ., 1866-99. He headed numerous scientific expeditions to the Rocky Mountain Area, and in 1887 he was made honorary curator in vertebrate paleontology at the U.S. National Museum. His best known work dealt with the evolution of the horse.

Marsh River: stream, see Marsh Creek.

Marten Arm: estuary, extends $7 \mathrm{mi}$. NE off Boca: de Quadra, Coast Mts.; $55^{\circ} 07^{\prime} \mathrm{N}$, $130^{\circ} 42^{\prime} \mathrm{W}$; (map 3$)$.

Named in 1891 by USC\&GS.

Marten Arm Lake: lake, $2 \mathrm{mi}$. long, $1 \mathrm{mi}$. N of Marten Arm and $4 \mathrm{mi}$. NE of Bactrian Point, Coast Mts.; $55^{\circ} 09^{\prime} 10^{\prime \prime} \mathrm{N}, 130^{\circ} 36^{\prime} 00^{\prime \prime} \mathrm{W}$; (map 3).

Local name recorded in 1955 by USGS.

Marten Creek: stream, heads in Upper Marten Lake, flows $5 \mathrm{mi}$. $\mathrm{S}$ through Marten and Clay Lakes to Bradfield Canal, Coast Mts.; $56^{\circ}$ $14^{\prime} \mathrm{N}, 131^{\circ} 53^{\prime} \mathrm{W}$; $B G N$ 1923; (map 7).

Named in 1923 by USFS.

Marten Creek: stream, in Kantishna Hills, flows SE $3.5 \mathrm{mi}$. to Crooked Creek, $4 \mathrm{mi}$. W of junc. of Toklat River and its Clearwater Fork, Alaska Ra.; $63^{\circ} 48^{\prime} 40^{\prime \prime} \mathrm{N}, 153^{\circ} 25^{\prime} 00^{\prime \prime} \mathrm{W}$; (map 88)

Local name shown on a 1916 fieldsheet by C. E. Giffin, USGS.

Marten Creek: stream, flows WSW $8 \mathrm{mi}$. to South Fork Chena River $7 \mathrm{mi}$. SW of that stream's junc. with Chena River and $35 \mathrm{mi}$. E of Fairbanks, Yukon-Tanana High.; $64^{\circ} 49^{\prime}$ N, $146^{\circ}$ $30^{\prime} \mathrm{W}$; (map 101).

Local name published in 1956 by USGS. 
Marten Creek: stream, heads at $67^{\circ} 28^{\prime} \mathrm{N}$, $145^{\circ} 43^{\prime} \mathrm{W}$, flows $S 68 \mathrm{mi}$. to Cutoff Slough, Yukon River, $18 \mathrm{mi}$. NW of Fort Yukon, Yukon Flats; $66^{\circ} 39^{\prime} 45^{\prime \prime} \mathrm{N}, 145^{\circ} 53^{\prime} 45^{\prime \prime} \mathrm{W}$; (map 119).

Local name obtained in 1956 by USGS.

Marten Creek: stream, flows SE $20 \mathrm{mi}$. to Coleen River $11 \mathrm{mi}$. NNE of its junc. with Strangle Woman Creek, $66 \mathrm{mi}$. NE of Coleen Mtn., Brooks Ra. ; $67^{\circ} 59^{\prime} \mathrm{N}, 142^{\circ} 04^{\prime} \mathrm{W}$; (map 121). Local name reported in 1956 by $T$. E. Taylor, USGS.

Marten Island: island, $8 \mathrm{mi}$. long, in Yukon River $\mathbf{N}$ of Marten Slough, $20 \mathrm{mi}$. SW of Beaver, Yukon Flats; $66^{\circ} 13^{\prime} \mathrm{N}, 148^{\circ} 06^{\prime} \mathrm{W}$; (map 118).

Local name obtained in 1956 by USGS.

Marten Lake: lake, $1.8 \mathrm{mi}$. long, in course of Marten Creek, 2 mi. N of Bradfield Canal, Coast Mts.; $56^{\circ} 16^{\prime} \mathrm{N}, 131^{\circ} 51^{\prime} \mathrm{W}$; BGN 1923 ; (map 7$)$.

Named in 1923 by USFS.

Marten Lake: lake, $0.6 \mathrm{mi}$. long, $\mathrm{N}$ of Heart Lake, $15 \mathrm{mi}$. W of Beaver, Yukon Flats; $66^{\circ}$. $21^{\prime} \mathrm{N}, 147^{\circ} 57^{\prime} \mathrm{W}$; (map 118).

Probably named by William Yanert, who recorded it on a 1916 manuscript map of the Yukon Flats (Stuck, 1917, map facing p. 122)

Marten Lake: lake, $0.5 \mathrm{mi}$. long, $0.7 \mathrm{mi}$. SW of Chalkyitsik, Yukon Flats; $66^{\circ} 39^{\prime} \mathrm{N}, 143^{\circ} 45^{\prime}$ W; (map 120).

Local name obtained in 1956 by T. E. Taylor and R. C. Foley, USGS.

Marten River: stream, heads at glacier, in Peabody Mts., flows SW $23 \mathrm{mi}$. to Marten Arm, Coast Mts.; $55^{\circ} 09^{\prime} 30^{\prime \prime} \mathrm{N}, 130^{\circ} 31^{\prime} 45^{\prime \prime} \mathrm{W}$; $B G N$ 1963; (map 3).

Local name reported in 1961 by USFS.

Marten Slough: stream, an anabranch of Yukon River, flows W $9 \mathrm{mi}$., $21 \mathrm{mi}$. SW of Beaver, Yukon Flats; $66^{\circ} 12^{\prime} \mathrm{N}, 148^{\circ} 15^{\prime} \mathrm{W}$; (map 118).

Local name obtained in 1956 by USGS.

Marten Stand Mountain: peak, 3,810 ft., $7.5 \mathrm{mi}$. SW of Arctic Village, Brooks Ra.; $68^{\circ} 01^{\prime} 30^{\prime \prime}$ $\mathrm{N}, 1^{\circ} 36^{\circ} 30^{\prime \prime} \mathrm{W}$; (map 136).

Local name reported in 1956 by $R$. C. Foley, USGS.

Marten Upper Lake; lake, see Upper Marten Lake.

Martha Creek: stream, flows NW $3.7 \mathrm{mi}$. to Tisuk River, $18 \mathrm{mi}$. E of Cape Douglas and $38 \mathrm{mi}$. NW of Nome, Seward Penin. High.; 64 $59^{\circ}$ N, $166^{\circ} 04^{\prime} \mathrm{W}$; (map 94).

Prospectors' name published on the 1908 "Map of Seward Peninsula" by Arthur Gibson.

Martha B Creek: stream, flows N $7.5 \mathrm{mi}$. to Koyukuk River, E of Kohokachalla Mtn., 36 mi. NE of Hughes, Hogatza High.; $66^{\circ} 23^{\prime} \mathrm{N}$, $153^{\circ} 17^{\prime} \mathrm{W}$; (map 116).

Name reported by Orth in 1956.

Martin: $R R$. station, on The Alaska RR., $15 \mathrm{mi}$. NW of Fairbanks, Yukon-Tanana High.; $64^{\circ}$ $54^{\prime} \mathrm{N}, 148^{\circ} 11^{\prime} \mathrm{W}$; (map 100). Var. Spinach Creek.

Local name listed on a timetable in 1922. It had been formerly called Spinach Creek as the stream by that name enters Goldstream Creek nearby.

Martin, Cape: point of land, see Martin Point. Martin, Mount: volcano, 6,050 ft., on Alaska Penin., in Katmai National Monument, 16 mi. SW of Mount Katmai, Aleutian Ra.; $58^{\circ} 10^{\prime}$ N, 155²1' W; BGN 1966; (map 42). Var. Martin Mountain, Martin Volcano.

Named in 1919 by R. F. Griggs, National Geographic Society, for George C. Martin, USGS, who wrote the first authoritative report of the eruption of Mount Katmai.

Martin, Point: point of land, at NW end of Controller Bay, $0.5 \mathrm{mi}$. $\mathrm{N}$ of Whale $\mathrm{I}$. and 2.7 mi. SW of Katalla, Malaspina Coastal Plain; $60^{\circ} 11^{\prime} \mathrm{N}, 144^{\circ} 36^{\prime} \mathrm{W}$; (map 64). Var. Cape Martin, Punta de Eguia, Punta Nodales.

Named in 1794 by Capt. Vancouver (1798, v. 3, p. 217), RN, who wrote, there are "two rocky islets lying off the northwest point of Controllers Bay which after Sir Henry Martin, I called Point Martin * * *." It was called "Punta de Eguia" by Don Jacinto Arteaga in July, 1779, probably for "Manuel de Eguia, a brigadier in the Spanish navy who wrecked in 1787 in the San Pedro Alcántara, while enroute from Callao to Cadiz" (Wagner, 1937, p. 449). The "Punta Nodales" of Capt. Alessandro Malaspina appears to be this point of land also. He named it thus July 16 , 1791.

Martin Creek: stream, on Alaska Penin., in Katmai National Monument, flows SE through Mageik Landslide $10 \mathrm{mi}$. to Katmai River, $11 \mathrm{mi}$. SW of Mount Katmai, Aleutian Ra.; $58^{\circ} 06^{\prime} 25^{\prime \prime} \mathrm{N}, 155^{\circ} 03^{\prime} 10^{\prime \prime} \mathrm{W}$; $B G N$ 1925; (map 42).

Named in 1916 by R. F. Griggs, National Geographic Society, for Mount Martin.

Martin Creek: stream, on Kenai Penin., flows SW 6 mi. to Resurrection River, $12 \mathrm{mi}$. NW of Seward, Chugach Mts.; $60^{\circ} 14^{\prime} 30^{\prime \prime} \mathrm{N}, 149^{\circ}$ $38^{\prime} 45^{\prime \prime} \mathrm{W}$; (map 63).

Local name reported in 1912 by Grant and Higgins (1913, pl. 1), USGS.

Martin Creek: stream, heads in Slender Lake, flows generally NE $7 \mathrm{mi}$. to Kiagna River, 119 $\mathrm{mi}$. NE of Cordova, Chugach Mts.; 60 $57^{\circ}$. $40^{\prime \prime} \mathrm{N}, 142^{\circ} 19^{\prime} 30^{\prime \prime} \mathrm{W}$; (map 65).

Name published by F. H. Moffit (1918, pl. 6), USGS.

Martin Creek: stream, heads in Peters Hills, flows SE $8 \mathrm{mi}$. to Peters Creek, $20 \mathrm{mi}$. W of Talkeetna, Alaska Ra.; $62^{\circ} 30^{\prime} 40^{\prime \prime}$ N, $150^{\circ} 44^{\prime}$ 15" W; (map 81).

Prospectors' name reported in 1911 by S. R. Capps (in Brooks, 1912, pl. 9), USGS.

Martin Creek: stream, flows SW 1 mi. to Norton Sound, $0.5 \mathrm{mi}$. E of Peluk Creek and $2 \mathrm{mi}$. E of Nome, Seward Penin. High.; 64 $29^{\prime}$ N, $165^{\circ} 20^{\prime} \mathrm{W}$; (map 94).

Prospectors' name shown on the 1902 "Map of the Nome and Snake River Country" by J. M. Davidson.

Martin Creek: stream, flows SW $4 \mathrm{mi}$. to Goldstream Creek, $6 \mathrm{mi}$. NE of Livengood, YukonTanana High.; 65 $32^{\prime} 50^{\prime \prime}$ N, $148^{\circ} 21^{\prime} 20^{\prime \prime} \mathrm{W}$; (map 105). Var. Cash Creek.
Named by prospectors; reported in 1915 by Brooks (Brooks and others, 1916, pl. 9), USGS.

Martin Creek: stream, in Baird Mts., flows SE $2.5 \mathrm{mi}$. to Klery Creek, $18 \mathrm{mi}$. N of Kiana, Brooks Ra.; $67^{\circ} 13^{\prime} 40^{\prime \prime} \mathrm{N}, 160^{\circ} 24^{\prime} 00^{\prime \prime} \mathrm{W}$; (map 127).

Name used by prospectors; reported in 1910 by P. S. Smith (in Brooks and others, 1911, pl. 13), USGS.

Martinez, Punta de: point of land, see East Forland.

Martinez Mountain: mountain, 3,000 ft., between Temnac River and O'Donnell Creek, on E central Attu I., Aleutian Is.; $52^{\circ} 52^{\prime} 25^{\prime \prime} \mathrm{N}$, $173^{\circ} 03^{\prime} 25^{\prime \prime} \mathrm{E}$; (map 13).

Named by the U.S. Army during World War II; published in 1948 by AMS.

Martin Glacier: glacier, on W slope of Brabazon Ra., trends W $2.4 \mathrm{mi}$. to 1961 terminus at head of Gines Creek, $0.8 \mathrm{mi}$. W of Tanis Lake and $47 \mathrm{mi}$. SE of Yakutat, St. Elias Mts.; $59^{\circ} 16^{\prime} 45^{\prime \prime} \mathrm{N}, 138^{\circ} 30^{\prime} 00^{\prime \prime} \mathrm{W}$; (map 46).

Named by Blackwelder (1907, p. 417, 426), USGS, for E. R. Martin, who was in charge of the U.S. Boundary Survey party that surveyed this area in 1906.

Martin Harbor: bay, $0.9 \mathrm{mi}$. across, on SE side of Korovin Bay, on NW coast of Atka I., Aleutian Is.; $52^{\circ} 13^{\prime} 40^{\prime \prime} \mathrm{N}, 174^{\circ} 17^{\prime} 00^{\prime \prime} \mathrm{W}$; (map 18). Var. Pestchanaia, Peschani, Sand Bay, Sand Harbor.

Named for Capt. Martin Klinkofstrom of the Russian American Company, who first used the bay, according to Dall (1873, p. 114). It was called "Peshtchanaia anse," meaning "sandy bay," by Capt. Lutke (1836, p. 313), IRN.

Martini Creek: stream, see Limpid Creek.

Martin Island: island, $0.1 \mathrm{mi}$. across, in Kutchuma Is., 3 mi. S of Sitka, off W coast of Baranof I., Alex. Arch.; 57 $00^{\prime} 18^{\prime \prime}$ N, $135^{\circ}$ $18^{\prime} 05^{\prime \prime} \mathrm{W}$; (map 9). Var. Gravel Island, Pesiak.

Local name reported in 1898 by USC\&GS. It was called "Pesiak," a Russian name meaning "gravel," by Ivan Vasiliev the first, in 1809.

Martin Island: barrier island, $4 \mathrm{mi}$. long, $\mathrm{E}$ of Cooper I., in Plover Is., $27 \mathrm{mi}$. E of Barrow, Arctic Plain; $71^{\circ} 13^{\prime} \mathrm{N}, 155^{\circ} 30^{\prime} \mathrm{W} ; B G N$ 1916; (map 153). Var. Shiningarok.

Named in 1850 by Comdr. Moore, RN, after one of his officers. Comdr. Maguire (Great Britain, 1854, map facing p. 186), RN, shows it as the first island $E$ of Point Barrow, now named Doctor Island. Leffingwell (1919, p. 97) applied the name to the present day Cooper I. and reported the Eskimo name "Shiningarok," meaning "he slept."

Martin Islands: islands, off S coast of Alaska, 0.5 mi. S of Cape Martin, $2.7 \mathrm{mi}$. SW of Katalla, Malaspina Coastal Plain; $60^{\circ} 10^{\prime} \mathrm{N}, 144^{\circ} 36^{\prime}$ W; (map 64). Var. Anglicé Island, Fox Islands, Ostrov Kikhtak.

Name published in 1904 by USC\&GS. Capt. Tebenkov (1852, map 6) showed one island here called "Ostrov Kikhtak," or "Kik- 
tak island." It was an Eskimo name meaning "island."

Martin Lake: lake, $4.2 \mathrm{mi}$. long, drains NW to Martin River E of Ragged Mtn., $10 \mathrm{mi}$. N of Katalla, Chugach Mts.; $60^{\circ} 22^{\prime} \mathrm{N}, 144^{\circ} 32^{\prime}$ W; BGN 1948; (map 64). Var. Big Martin Lake.

Originally named "Big Martin Lake" in 1938 by geologists of the Iniskin Drilling Company; changed, in 1948, to its present form by USGS.

Martin Lake: lake, $0.7 \mathrm{mi}$. long, one of the Canoe Lake Chain, on Kenai Penin., $23 \mathrm{mi}$. NW of Kenai, Cook Inlet Low.; $60^{\circ} 41^{\prime} 40^{\prime \prime} \mathrm{N}, 150^{\circ}$ $30^{\prime} 00^{\prime \prime} \mathrm{W}$; (map 62).

Named about 1963 by officials of the Kenai National Moose Range, for administrative purposes.

Martin Mountain: volcano, see Martin, Mount.

Martin Point: paint of land, on coast of Beaufort Sea, $8 \mathrm{mi}$. E of Barter I., between Jago and Tapkaurak Lagoons, Arctic Plain; $70^{\circ} 07^{\prime} 50^{\prime \prime}$ N, $143^{\circ} 15^{\prime} 30^{\prime \prime} \mathrm{W}$; BGN 1944; (map 152). Var. Point Sir Henry Martin.

Named Point Sir Fenry Martin by Sir John Franklin (1828, p. 146), August 4, 1826. The original location is doubtful; however, the name was definitely applied to this point by Leffingwell $(1919$, p. 97) in 1912.

Martin River: stream, on Kenai Penin., flows N $7 \mathrm{mi}$. to Kachemak Bay, $20 \mathrm{mi}$. NE of Homer, Chugach Mts.; $59^{\circ} 45^{\prime} 45^{\prime \prime} \mathrm{N}, 151^{\circ}$. $00^{\prime} 00^{\prime \prime} \mathrm{W}$; (map 50).

Local name reported and published by USGS in the 1950 's.

Martin River: stream, heads at terminus of Martin River Glacier, flows W $22 \mathrm{mi}$. to Copper River, $19 \mathrm{mi}$. NW of Katalla, Malaspina Coastal Plain; $60^{\circ} 24^{\prime} \mathrm{N}, 144^{\circ} 53^{\prime} \mathrm{W}$; (map 64).

Named by Capt. Abercrombie (Glenn and Abercrombie, 1899, map), USA.

Martin River Glacier: glacier, trends SW $25 \mathrm{mi}$. to its terminus at head of Martin River, 20 mi. NE of Katalla, Chugach Mts.; $60^{\circ} 28^{\prime} \mathrm{N}$ $144^{\circ} 20^{\prime} \mathrm{W}$; (map 64).

Local name reported in 1905 by G. C. Martin (1906, pl. 12), USGS.

Martin River Slough: stream, distributary of Martin River, flows S $12 \mathrm{mi}$. to Gulf of Alaska, $8 \mathrm{mi}$. NW of Katalla, Malaspina Coastal Plain; $60^{\circ} 17^{\prime} \mathrm{N}, 144^{\circ} 42^{\prime} \mathrm{W}$; $B G N$ 1948; (map 64)

Local name reported about 1947 by USGS.

Martin Rock: rock, in Port Chester, on W coast of Annette I., Alex. Arch.; $55^{\circ} 08^{\prime} 30^{\prime \prime} \mathrm{N}$, 131'33'15" W; (map 3).

Named in 1883 by Lt. Comdr. H. E. Nichols, USN.

Martin Volcano: volcano, see Martin, Mount. Martins Bar: island, see Henry Martin Island. Marukta Mountain: hill, $1.5 \mathrm{mi}$. E of Sevuokuk Mtn., $0.5 \mathrm{mi}$. SE of Sevooghak Mtn. and 3 mi. SE of Gambell, St. Lawrence I., $63^{\circ} 46^{\prime}$ N, $171^{\circ} 39^{\prime}$ W; BGN 1951; (map 93). Var. Mount Marukta, Mount Merukta.
Eskimo name reported by Orth in 1965 ; name derived from that of an unidentified point of land.

Marunich: locality, just SE of North Point, on N Coast of Saint Paul I., in Pribilof I's.; 57 ${ }^{\circ} 12^{\prime}$ $50^{\prime \prime} \mathrm{N}, 170^{\circ} 17^{\prime} 20^{\prime \prime} \mathrm{W}$; (map 38). Var. Maroonitch, Marunichen.

Elliott (1881, St. Paul notes) wrote "Maroonitch, the site of a pioneer village, established by one Maroon."

Marvel Creek: stream, flows SE $6 \mathrm{mi}$. to Eagle Creek, $73 \mathrm{mi}$. E of Bethel, Kilbuck-Kuskokwim Mts.; 60 $53^{\prime}$ N, $159^{\circ} 36^{\prime}$ W; (map 59).

Prospectors' name reported in 1914 by A. G. Maddren (in Brooks, 1915, pl. 11), USGS.

Marvel Dome: mountain, 4,500 ft., $72 \mathrm{mi}$. NE of Bethel, in Kilbuck Mts., Kilbuck-Kuskokwim Mts.; 6058' N, 159 $41^{\prime} \mathrm{W}$; (map 59).

Local name reported in 1914 by A. G. Maddren (in Brooks, 1915, pl. 11), USGS.

Marvine Glacier: glacier, heads on Mount Cook and trends SW $12 \mathrm{mi}$. to Malaspina Glacier, $49 \mathrm{mi}$. NW of Yakutat, St. Elias Mts. ; $60^{\circ} 03^{\prime}$ $\mathrm{N}, 140^{\circ} 12^{\prime} \mathrm{W}$; (map 66).

Named by Russell (1891, p. 112), for Archibald Robertson Marvine, 1848-76, American geologist.

Mary, Lake: lake, in course of Old Franks Creek, on Prince of Wales I., NW of Skowl Arm Kasaan Bay, Alex. Arch.; 55 $26^{\prime} 40^{\prime \prime}$ N, 132 $30^{\prime}$ ' $20^{\prime \prime} \mathrm{W}$; (map 4).

Name published in 1927 by USC\&GS

Mary, Lake: lake, see Bart Lake.

Mary, Mount: mountain, 2,920 ft., at SW end of Lake Schrader-Lake Peters Channel, in Franklin Mts., Brooks Ra.; $69^{\circ} 20^{\prime} \mathrm{N}, 1^{\circ} 5^{\circ} 08^{\prime} \mathrm{W}$; (map 139). 295)

Name published by Bee and Hall (1956, p. Mary, Mount: hill, see Tomname Mountain.

Mary, Point: point of land, at $\mathrm{N}$ entrance to Shelikof Bay, on Kruzof I., $20 \mathrm{mi}$. NW of Sitka, Alex. Arch.; 57 $10^{\prime} 10^{\prime \prime}$ N, $135^{\circ} 49^{\prime} 30^{\prime \prime}$ W; (map 9).

Name published in 1899 by USG\&GS on Chart 8050

Mary, Port: bay, see Shelikof Bay.

Mary Anderson Bay: cove, extends N $1.4 \mathrm{mi}$. off Duck Bay, on SE coast of Afognak I., $15 \mathrm{mi}$. NE of Afognak, Kodiak I.; $58^{\circ} 08^{\prime} 00^{\prime \prime} \mathrm{N}$, $152^{\circ} 27^{\prime} 30^{\prime \prime} \mathrm{W}$; (map 43).

Local name reported in 1952 by USGS.

Mary Bay: bay, see Mary, Port.

Mary Creek: stream, see Marys Creek.

Mary Creek: stream, see Marys Slough.

Mary Ellen Creek: stream, flows SW $10 \mathrm{mi}$. to Killik River $11 \mathrm{mi}$. SW of its junc. with Easter Creek, Brooks Ra.; 68 $02^{\prime} \mathrm{N}, 154^{\circ} 30^{\prime} \mathrm{W}$; (map 133).

Name reported in 1956 by Orth.

Mary Frances Anchorage: bay, see Orel Anchorage.

Mary Gulch: ravine, at head of Mountain Creek, trends W $0.7 \mathrm{mi}$. to Snake River valley, $6 \mathrm{mi}$. NW of Nome, Seward Penin. High.; 64 $4^{\circ} 35^{\prime}$ N, $165^{\circ} 27^{\prime} \mathrm{W}$; (map 94).

Prospectors' name reported in 1904 by T. G. Gerdine, USGS.
Mary Island: island, $0.3 \mathrm{mi}$. long, one of Sanak Is., Aleutian Ra.; $54^{\circ} 20^{\prime} 40^{\prime \prime} \mathrm{N}, 162^{\circ} 38^{\prime} 00^{\prime \prime}$ W; (map 25)

Name reported by Ferdinand Westdahl, USC\&GS, commander of the Coast Survey steamer McArthur, who made surveys in this area in 1901.

Mary Island: island, $5 \mathrm{mi}$. long, between Felice Strait and Revillagigedo Channel, $25 \mathrm{mi}$. SE of Ketchikan, Alex. Arch.; $55^{\circ} 05^{\prime} \mathrm{N}, 131^{\circ}$. $12^{\prime} \mathrm{W}$; (map 3). Var. Saint Mary Island.

Named in 1880 by W. E. George, a local pilot. The British Admiralty erroneously called it "Saint Mary Island" on Chart 2431 published in 1882

Mary Island: locality, on NE coast of Mary I., on W shore of Revillagigedo Channel, $25 \mathrm{mi}$. SE of Ketchikan, Alex. Arch.; $55^{\circ} 06^{\prime} 00^{\prime \prime} \mathrm{N}$, $131^{\circ} 10^{\prime} 08^{\prime \prime} \mathrm{W}$; (map 3 ).

This is the site of an abandoned settlement which had a post office from 1892-1900 (Ricks, 1965, p. 41).

Mary Island: island, $0.4 \mathrm{mi}$. long, in Womens Bay, 7 mi. SW of Kodiak, Kodiak I.; $57^{\circ} 42^{\prime}$ $25^{\prime \prime} \mathrm{N}, 152^{\circ} 32^{\prime} 00^{\prime \prime} \mathrm{W}$; (map 34).

Local name published in 1943 by USC\&GS. Mary Island Anchorage: bay, on $\mathrm{N}$ coast of Mary I. Revillagigedo Channel, Alex. Arch.; 55 $06^{\prime} 40^{\prime \prime} \mathrm{N}, 131^{\circ} 11^{\prime} 45^{\prime \prime} \mathrm{W}$; (map 3).

Local name published in 1883 by USC\&GS

Mary Lake: lake, $0.8 \mathrm{mi}$. long, $\mathrm{N}$ of Chandalar River, $5.5 \mathrm{mi}$. W of Caro and $23 \mathrm{mi}$. SSE of Chandalar, Brooks Ra.; $67^{\circ} 10^{\prime} 40^{\prime \prime} \mathrm{N}, 148^{\circ}$ $14^{\prime} 00^{\prime \prime} \mathrm{W}$; (map 123).

Local name reported in 1956 by T. E. Taylor, USGS.

Mary Lake: lake, see Bart Lake.

Maryland Creek: stream, flows N 1 mi. to North Fork Kougarok River, $1.5 \mathrm{mi}$. SE of Harris Dome and $38 \mathrm{mi}$. W of Imuruk Lake, Seward Penin. High.; $65^{\circ} 37^{\prime} \mathrm{N}, 164^{\circ} 30^{\prime} \mathrm{W}$; (map 110). Var. Napoleon Creek.

Prospectors' name reported on the 1908 "Map of Seward Peninsula" by Arthur Gibson.

Mary Lou Gulch: ravine, trends SE $4 \mathrm{mi}$. to Granite Creek, 58 mi. NE of Bethel, KilbuckKuskokwim Mts.; $60^{\circ} 59^{\prime} 40^{\prime \prime} \mathrm{N}, 160^{\circ} 05^{\prime} 30^{\prime \prime}$ W; (map 59).

Local name reported in 1955 by J. M. Hoare, USGS.

Mary Louise Fork: stream, flows NE $1 \mathrm{mi}$. to Ketchem Creek, $4 \mathrm{mi}$. SW of Circle Hot Springs and $32 \mathrm{mi}$. SW of Circle, YukonTanana High.; $65^{\circ} 27^{\prime} 29^{\prime \prime} \mathrm{N}, 144^{\circ} 45^{\prime} 25^{\prime \prime} \mathrm{W}$; (map 104).

Prospectors' name reported in 1954 or 1955 by USGS topographers.

Mary Mountain: hill, see Soomaghat Mountain. Mary Mountain: hill, see Tomname Mountain. Mary Range: mountains, 7,700 ft., extend N 18 mi. from crest of Brooks Ra. to the mouth of Whistler Creek, between Whistler Creek on $\mathrm{W}$ and Carnivore Creek on $\mathrm{E}$, in Franklin Mts., Brooks Ra.; $69^{\circ} 15^{\prime} \mathrm{N}, 145^{\circ} 10^{\prime} \mathrm{W}$; (map 139).

Name published by Bee and Hall (1956, p. 295). 
Mary Sachs Entrance: water passage, on Beaufort Sea coast between Flaxman I. and Maguire Is., Arctic Plain; $70^{\circ} 13^{\prime} \mathrm{N}, 146^{\circ} 15^{\prime} \mathrm{W}$; (map 151).

Named by Leffingwell (1919, p. 97) after the schooner Mary Sachs, of the Canadian Arctic Expedition, which first passed through this entrance in August 1913.

Mary Sachs Island: island, now part of Flaxman I. on Beaufort Sea coast; (map 151).

"First sand island west of Flaxman Island" (Leffingwell, 1919, p. 97). See Mary Sachs Entrance.

Marys Bay: cove, $0.7 \mathrm{mi}$. wide, on Rugged I., 19 mi. S of Seward, Chugach Mts.; 59 $51^{\prime} \mathrm{N}$, $149^{\circ} 23^{\prime} \mathrm{W}$; (map 49).

Local name reported in the early 1950's by USC\&GS.

Marys Creek: stream, flows S $1.5 \mathrm{mi}$. to Puffy Slough, $6 \mathrm{mi}$. E of Katalla, Malaspina Coastal Plain; $60^{\circ} 12^{\prime} \mathrm{N}, 144^{\circ} 20^{\prime} \mathrm{W}$; (map 64). Var. Mary Creek.

Local name reported in 1903 by G. C. Martin (1905, p. 12), USGS.

Marys Igloo: village, pop. 5, in Kuzitrin River basin, $2 \mathrm{mi}$. NW of Marys Mtn. and $40 \mathrm{mi}$. SE of Teller, Seward Penin. High.; 65 $09^{\prime} \mathrm{N}$, $165^{\circ} 04^{\prime} \mathrm{W}$; (map 111). Var. Igloo.

Miners' name popularly applied to the Eskimo settlement at the head of steamboat navigation on the Kuzitrin River; reported as "Marys Igloo" by Brooks (1901, p. 11), USGS, in 1900, the first year of gold prospecting in this area. At this place, goods were transferred to flat-bottomed river boats that were towed upstream to the gold fields along the Kougarok and Kuzitrin Rivers or to the railway at Lanes Landing (Collier and others, 1908 , p. 59). Balcom (1965, p. 16) attributes the name to an "Eskimo woman named Mary who held open house there for visiting miners, trappers and other travelers, who never arrived too late or too early for snacks and coffee at Mary's house, or 'igloo,' the Eskimo word for 'shelter.' " Balcom (ibid.) also notes that in "1952 the Alaska Native School was closed for lack of students by the teacher, the only white man left in the place." In 1952 the post office of Igloo, which had been in continuous operation since 1901, was discontinued. The population in 1910 was 141 ; in 1930, 113; and in 1950, 64 .

Marys Lake: lake, $0.5 \mathrm{mi}$. across, at mouth of Kaviruk River, $\mathrm{N}$ of Lake Omiaktalik, $32 \mathrm{mi}$. $\mathrm{E}$ of Teller, Seward Penin. High.; $65^{\circ} 13^{\prime} \mathrm{N}$, $165^{\circ} 15^{\prime} \mathrm{W}$; (map 111).

Local name published in 1956 by USGS.

Marys Mountain: hill, $\mathbf{5 5 0} \mathrm{ft}$., between Kuzitrin and Pilgrim Rivers, $40 \mathrm{mi}$. SE of Teller, Seward Penin. High.; $65^{\circ} 08^{\prime} \mathrm{N}, 165^{\circ} 01^{\prime} \mathrm{W}$; (map 111).

Prospectors' name reported on the 1908 "Map of Seward Peninsula" by Arthur Gibson.

Marys River: stream, see Kaviruk River.

Marys Slough: stream, flows $1.1 \mathrm{mi}$. NW to Unalakleet River, $1.1 \mathrm{mi}$. S of Unalakleet, $\mathrm{Nu}$ - lato Hills; $63^{\circ} 51^{\prime} 25^{\prime \prime} \mathrm{N}, 160^{\circ} 46^{\prime} 15^{\prime \prime} \mathrm{W}$; (map 91). Var. Mary Creek.

Local name reported in 1952 by USC\&GS; named for "Sinrock Mary, an Eskimo woman famed for her part as interpreter in the first reindeer purchase in Siberia."

Mascot Greek: stream, flows SE $4 \mathrm{mi}$. to North Fork Salcha River $3 \mathrm{mi}$. $\mathrm{N}$ of that stream's junc. with Salcha River and $42 \mathrm{mi}$. NE of Big Delta, Yukon-Tanana High.; $64^{\circ} 41^{\prime}$ N, $145^{\circ}$ 18' W; (map 101).

Local name reported in 1958 by USGS.

Mascot Creek: stream, flows N4 mi. to East Fork Chena River, $63 \mathrm{mi}$. SW of Circle, Yukon-Tanana High.; $65^{\circ} 03^{\prime} \mathrm{N}, 145^{\circ} 10^{\prime} \mathrm{W}$; (map 104),

Named by prospectors; reported in 1911 by USGS (Prindle, 1913, pl. 1).

Mascot Creek: stream, flows SE $7.2 \mathrm{mi}$. to Little Garfield Creek which flows to Noxapaga River, $31 \mathrm{mi}$. SW of Imuruk Lake, Seward Penin. High.; $65^{\circ} 26^{\prime} \mathrm{N}, 164^{\circ} 16^{\prime} \mathrm{W}$; (map 110). Var. Tina Creek.

Prospectors' name reported in 1901 by T. G. Gerdine (in Collier, 1902, pl. 12), USGS. Gerdine showed the upper course of the stream as "Tina Creek."

Mascot Creek: stream, flows SE $2 \mathrm{mi}$. to Magnolia Creek which flows to Igloo River, in American River basin, $32 \mathrm{mi}$. NE of Teller, Seward Penin. High.; $65^{\circ} 28^{\prime} \mathrm{N}, 165^{\circ} 23^{\prime} \mathrm{W}$; (map 111).

Prospectors' name reported in 1901 by T. G. Gerdine (in Collier, 1902, pl. 12), USGS.

Mascot Creek: stream, flows N $11 \mathrm{mi}$. to Beaver Creek, $80 \mathrm{mi}$. W of Circle, Yukon-Tanana High.; $65^{\circ} 44^{\prime} 30^{\prime \prime} \mathrm{N}, 146^{\circ} 53^{\prime} 10^{\prime \prime} \mathrm{W}$; (map 104).

Named by prospectors; published in 1906 by USGS.

Mascot Creek: stream, flows S $8.5 \mathrm{mi}$. to Glacier River, $4 \mathrm{mi}$. E of Delay Pass and $12.5 \mathrm{mi}$. W of Wiseman, Brooks Ra.; $67^{\circ} 27^{\prime}$ N, $150^{\circ} 34^{\prime}$ W; (map 124).

Local name shown on an 1899 fieldsheet by T. G. Gerdine, USGS.

Mascot Creek: stream, flows SW to Dome Creek which flows to American River, about $30 \mathrm{mi}$. NE of Teller, Seward Penin. High.; (map 111).

Prospectors' name shown on a map of Cape Nome gold fields by David Fox, Jr., dated 1901. This feature cannot be precisely identified on current maps.

Mashik: village, see Port Heiden.

Mashik: village, see Port Moller.

Mashikh: village, see Port Moller.

Mashooshalluk Creek: stream, flows S $15 \mathrm{mi}$. from Pamichtuk Lake to John River, $8.5 \mathrm{mi}$. NW of Gunsight Mtn. and $57 \mathrm{mi}$. W of Wiseman, Brooks Ra.; $67^{\circ} 35^{\prime} \mathrm{N}, 152^{\circ} 12^{\prime} \mathrm{W}$; BGN 1932; (map 124).

Robert Marshall reported this in 1932 as an "Eskimo name, the first part being the Eskimo word for the root of the wild potato plant."

Masked Bay: estuary, on N end of Chenega I., extends NW $2 \mathrm{mi}$. to Dangerous Passage, 36 mi. SE of Whittier, Chugach Mts.; 60 $22^{\prime} 30^{\prime \prime}$ N, 148 $03^{\prime} 00^{\prime \prime} \mathrm{W}$; BGN 1934; (map 63).

Named in 1933 by a USC\&GS field party "because the entrance to the bay is masked by a group of small islands."

Mason Creek: stream, flows SE $2.8 \mathrm{mi}$. to Goldbottom Creek which flows to Niukluk River, $32 \mathrm{mi}$. NE of Solomon, Seward Penin. High.; $64^{\circ} 58^{\prime} \mathrm{N}, 163^{\circ} 54^{\prime} \mathrm{W}$; (map 95).

Prospectors' name published on the 1908 "Map of Seward Peninsula" by Arthur Gibson.

Mason Creek: stream, flows SE $10 \mathrm{mi}$. to Mason Slough, $7.5 \mathrm{mi}$. WSW of Kallands, KokrinesHodzana High.; $65^{\circ} 10^{\prime} \mathrm{N}, 153^{\circ} 19^{\prime} \mathrm{W}$; (map 107).

Prospectors' name reported in 1908 by Maddren (1910, pl. 5), USGS.

Mason Hill: mountain, $1,275 \mathrm{ft}$., center of Kiska I., Aleutian Is.; $51^{\circ} 56^{\prime} 57^{\prime \prime}$ N, $177^{\circ} 31^{\prime}$ 12" E; (map 14).

An arbitrary name beginning with " $M$ " to correspond to "M" grid used by U.S. Army for tactical purposes during World War II; published on a 1943 Army map.

Mason Narrows: reach, on Tanana River, extends $4 \mathrm{mi}$. S of Goodpaster River and $7 \mathrm{mi}$. E of Big Delta, Tanana Low.; $64^{\circ} 07^{\prime} \mathrm{N}, 145^{\circ}$ $48^{\prime}$ W; (map 101). Var. Mason's Narrows.

Named in 1885 by Lt. Allen (1887, p. 84), USA, for Otis Tufton Mason of the Smithsonian Institution.

Mason Slough: stream, anabranch of Yukon River, extends $11 \mathrm{mi}$. from W end of Flora $I$. to $E$ end of Clay I., $5 \mathrm{mi}$. $E$ of Birches, Kokrines-Hodzana High.; $65^{\circ} 07^{\prime} 30^{\prime \prime} \mathrm{N}, 153^{\circ}$ $18^{\prime} 00^{\prime \prime}$ W; (map 107). Var. Herman Slough.

Riverboat pilots' name shown on a 1940 "Navigation Chart of the Tanana-Yukon Rivers" published by the Department of the Interior.

Mason's Narrows: reach, see Mason Narrows.

Massacre Bay: bay, $4 \mathrm{mi}$. across, on SE coast of Attu I., Aleutian Is.; $52^{\circ} 50^{\prime} \mathrm{N}, 173^{\circ} 14^{\prime} \mathrm{E}$; BGN 1944; (map 13). Var. Gavan Ubiennaya, Gavan Ubiennykh, Gavan Ubiyennykh, Gaven Ubiyennaya, Massacre Harbor, Oubiennaia Bay, Subienna Bay, Ubiennoi Bay, Uniyenna Bay, Ubiyenna Harbor.

This name was given by G. I. Davidov in 1802 , presumably referring to the killing of 15 Aleut by promyshlenniki in 1745 . See Attu Island. The Russians called it "Gavan Ubiyennykh" and "Gavan Ibiyennaya" meaning "massacre harbor" (Sarichev, 1826, map 13), IRN. This bay was also called "Oubiennaia" by Capt. F. P. Lutke (1836, p. 329) and "Subienna" by Grewingk (1849, p. 235).

Massacre Beach: beach, $0.9 \mathrm{mi}$. long, on SE coast of Attu I., on N shore of Massacre Bay, Aleutian Is.; $52^{\circ} 51^{\prime} 15^{\prime \prime} \mathrm{N}, 173^{\circ} 12^{\prime} 40^{\prime \prime} \mathrm{E}$; (map 13).

Name derived from Massacre Bay; published in 1948 by AMS.

Mastadon Creek: stream, flows $\mathbf{N} 4 \mathrm{mi}$. to Chena River, $7 \mathrm{mi}$. WNW of Granite Tors and 56 mi. NW of Big Delta, Yukon-Tanana High.; $64^{\circ} 53^{\prime} 45^{\prime \prime} \mathrm{N}, 146^{\circ} 24^{\prime} 45^{\prime \prime} \mathrm{W}$; (map 101). 
Local name reported in 1958 by USGS. "Named for the mastodon bones found in the frozen muck while mining."

Masters Creek: stream, flows SE $2.8 \mathrm{mi}$. to Sulatna River $\mathrm{E}$ of Tamarack Bluff, $7.5 \mathrm{mi}$. SE of Sulatna Crossing, Kilbuck-Kuskokwim Mts.; $64^{\circ} 10^{\prime} 15^{\prime \prime} \mathrm{N}, 155^{\circ} 13^{\prime} 30^{\prime \prime} \mathrm{W}$; (map 98).

Prospectors' name reported in 1913 by Eakin (1914, pl. 3), USGS.

Mastic Rock: rock, in Revillagigedo Channel, between Bold and Revillagigedo Is., near mouth of Coho Cove, Alex. Arch.; 55 ${ }^{\circ} 15^{\prime} 31^{\prime \prime} \mathrm{N}$, $131^{\circ} 24^{\prime} 00^{\prime \prime}$ W; (map 3). Var. Mastick Rock, Mystic Rock.

Name published "as Mastick Rock" in 1883 Coast Pilot (p. 78). "A vessel named Mastick struck on this rock in July, 1882."

Mastodon: locality, on Mastodon Creek, $40 \mathrm{mi}$. SW of Circle, Yukon-Tanana High.; $65^{\circ} 30^{\prime} \mathrm{N}$, $145^{\circ} 14^{\prime} \mathrm{W}$; (map 104).

Name of an early mining camp, derived from the name Mastodon Creek. A post office was maintained here from 1902 to 1906 (Ricks, 1965, p. 41).

Mastodon Creek: stream, flows W $11 \mathrm{mi}$. to Tolstoi Creek, $23 \mathrm{mi}$. NW of Ophir and $53 \mathrm{mi}$. NW of McGrath, Kilbuck-Kuskokwim Mts.; $63^{\circ} 21^{\prime} \mathrm{N}, 157^{\circ} 04^{\prime} \mathrm{W}$; (map 90).

Prospectors' name reported in 1917 by G. L. Harrington (in Martin and others, 1919, pl. 9), USGS.

Mastodon Creek: stream, flows SW $11 \mathrm{mi}$. to Nowitna River $14 \mathrm{mi}$. SW of its junc. with Titna River, Kilbuck-Kuskokwim Mts.; $64^{\circ} 13^{\prime} 30^{\prime \prime} \mathrm{N}, 153^{\circ} 54^{\prime} 48^{\prime \prime} \mathrm{W}$; (map 98).

Local name reported in 1915 by $H$. M. Eakin (in Brooks and others, 1916, pl. 10), USGS.

Mastodon Creek: stream, flows NE $6 \mathrm{mi}$., joins Independence Creek to form Mammoth Greek, $40 \mathrm{mi}$. SW of Circle, Yukon-Tanana High.; $65^{\circ} 30^{\prime} 25^{\prime \prime} \mathrm{N}, 145^{\circ} 13^{\prime} 45^{\prime \prime} \mathrm{W}$; (map 104).

Named in 1894 by prospectors; name reported in 1896 by USGS (Spurr, 1898, pl. 50). So called because "fossil mastodon bones were found in the muck along the creek."

Mastodon Creek: stream, flows S $10 \mathrm{mi}$. to Fish Greek, $20 \mathrm{mi}$. NW of Livengood, YukonTanana High.; $65^{\circ} 41^{\prime} \mathrm{N}, 149^{\circ} 04^{\prime} \mathrm{W}$; (map 105).

Local name published by USGS (Mertie, 1937, pl. 1).

Mastodon Creek: stream, flows NW $1 \mathrm{mi}$, to Columbia Creek in Kougarok River basin, $12 \mathrm{mi}$. SW of Midnight Mtn. and $53 \mathrm{mi}$. NW of Imuruk Lake, Seward Penin. High.; $65^{\circ} 43^{\prime} \mathrm{N}$, $165^{\circ} 00^{\prime} \mathrm{W}$; (map 110$)$.

Prospectors' name reported on the 1908 "Map of Seward Peninsula" by Arthur Gibson. Mastodon Dome: mountain, 4,418 ft., $46 \mathrm{mi}$. SW of Circle, Yukon-Tanana High.; 65 ${ }^{\circ} 25^{\prime} 45^{\prime \prime}$ N, $145^{\circ} 20^{\prime} 40^{\prime \prime} \mathrm{W}$; (map 104).

Named by prospectors; reported in 1896 by USGS (Spurr, 1898, pl. 39).

Mastodon Fork Eagle Creek: stream, flows NW 2.2 mi., joins Miller Fork to form Eagle Greek, $46 \mathrm{mi}$. SW of Circle, Yukon-Tanana High.; $65^{\circ} 27^{\prime} \mathrm{N}, 145^{\circ} 25^{\prime} \mathrm{W}$; (map 104).
Named by prospectors; name reported in 1896 by USGS (Spurr, 1898, pl. 50).

Mastoid Hill: mountain, $1,380 \mathrm{ft}$., center of Kiska I., Aleutian Is.; $51^{\circ} 56^{\prime} 36^{\prime \prime} \mathrm{N}, 177^{\circ} 31^{\prime}$ 40" E; (map 14).

An arbitrary name beginning with " $M$ " to correspond to "M" grid used by U.S. Army for tactical purposes during World War II; published on a 1943 Army map.

Maston Creek: stream, flows NW $5.5 \mathrm{mi}$. to Crosby Creek which flows to Kugrupaga River, $6 \mathrm{mi}$. SW of Ear Mtn. and $42 \mathrm{mi}$. N of Teller, Seward Penin. High.; $65^{\circ} 51^{\prime} \mathrm{N}$, $166^{\circ} 23^{\prime} \mathrm{W}$; (map 111).

Prospectors' name reported in 1901 by T. G. Gerdine (in Collier, 1902, pl. 12), USGS.

Masu Creek: stream, flows SE $11 \mathrm{mi}$. to Kollutarak Creek $1 \mathrm{mi}$. N of its junc. with Ekokpuk Creek, $11 \mathrm{mi}$. SW of Anaktuvuk Pass, Brooks Ra.; $68^{\circ} 03^{\prime} \mathrm{N}, 152^{\circ} 07^{\prime} \mathrm{W}$; (map 134).

Eskimo name published by Rausch (1951, p. 150)

Masukatalik Creek: stream, flows NW $18 \mathrm{mi}$. to West Fork Buckland River, Nulato Hills; $65^{\circ}$ $43^{\prime} \mathrm{N}, 160^{\circ} 33^{\prime} \mathrm{W}$; (map 109).

Eskimo name reported in 1949 by the U.S. Army Corps of Engineers.

Matach Bay: cove, $0.6 \mathrm{mi}$. across, between Kresta Point and Cape Wrangell, on NW coast of Attu I., Aleutian Is.; 52 $2^{\circ} 7^{\prime} 30^{\prime \prime} \mathrm{N}$, $172^{\circ} 31^{\prime} 30^{\prime \prime} \mathrm{E}$; (map 13).

This name was shown on a manuscript map by L. M. Turner in the 1880's.

Mataktook Creek: stream, see Mataktuk.

Mataktuk Creek: stream, flows NW $2 \mathrm{mi}$. to Chukchi Sea, between Tulugak and Kahkatak Creeks, Arctic Plain; $69^{\circ} 01^{\prime}$ N., $163^{\circ} 52^{\prime}$ W; (map 145). Var. Mataktook Creek.

Eskimo name reported by USC\&GS in 1949, meaning "without parka." There is another stream with this name about $15 \mathrm{mi}$. to the sw.

Matanooski River: stream, see Matanuska River.

Matanuska: village, pop. 50, mile 150.7 on The Alaska RR., in Matanuska Valley, $5.5 \mathrm{mi}$. SW of Palmer, Cook Inlet Low.; $61^{\circ} 32^{\prime} 30^{\prime \prime} \mathrm{N}$, $149^{\circ} 13^{\prime} 45^{\prime \prime} \mathrm{W}$; (map 69).

Village established as a railroad station about 1914 and named for the Matanuska River. A townsite was surveyed here in 1916 because this was the junction of the main railroad line and the Matanuska Branch to the coal fields.

Matanuska: locality, on E shore of Old Man Lake, $21 \mathrm{mi}$. W of junc. of Tolsona Creek and Tazlina River, Copper River Basin; $62^{\circ} 08^{\prime} \mathbf{N}$, $146^{\circ} 38^{\prime} \mathrm{W}$.

Former Indian village reported in 1898 by Capt. E. F. Glenn, USA. See Miduuski.

Matanuska Glacier: glacier, trends NW $27 \mathrm{mi}$. to its terminus at a stream which drains into $\mathrm{Ma}$ tanuska River, $46 \mathrm{mi}$. NE of Palmer, Chugach Mts.; $61^{\circ} 46^{\prime} 35^{\prime \prime} \mathrm{N}, 147^{\circ} 46^{\prime} 00^{\prime \prime} \mathrm{W}$; (map $69)$.

Named in 1898 by Mendenhall (1900, p. 299 and 327), USGS ; derived from the Matanuska River.
Matanuska Lake: lake, 3,000 ft. long, in Matar nuska Valley, $4.5 \mathrm{mi}$. SW of Palmer, Cook Inlet Low.; 61 $33^{\prime} 20^{\prime \prime} \mathrm{N}, 149^{\circ} 13^{\prime} 40^{\prime \prime} \mathrm{W}$; (map 69)

Name published on a 1918 blueprint map of The Alaska RR.

Matanuska River: stream, formed by its East and South Forks at $61^{\circ} 47^{\prime} 30^{\prime \prime} \mathrm{N}, 147^{\circ} 30^{\prime} 15^{\prime \prime}$ W, flows SW $75 \mathrm{mi}$. to the Knik Arm Cook Inlet, $9.5 \mathrm{mi}$. SW of Palmer, Cook Inlet Low.; $61^{\circ} 29^{\prime} 40^{\prime \prime} \mathrm{N}, 149^{\circ} 16^{\prime} 00^{\prime \prime} \mathrm{W}$; (map 69). Var. Matanooski River, Mednofski River, Mednorechka River, Mednoviska River, Miduuski River.

Name derived from the Russian term for the "copper river people" spelled Matanooski, Mednofski, Miduuski, Mednoviska, etc. It appears to be the same name used by the Russians for the Ahtena Indians on the Copper River, and may have originally been used in the 19th century to imply a route from Cook Inlet to the Copper River. The present spelling was used by USC\&GS in 1897

Matanuska Valley: valley, of Matanuska River, extends SW $60 \mathrm{mi}$. from terminus of Matanuska Glacier to Knik Arm Cook Inlet, $25 \mathrm{mi}$. NE of Anchorage, Cook Inlet Low.; $61^{\circ} 40^{\prime}$ $\mathrm{N}, 149^{\circ} 06^{\prime} \mathrm{W}$; (map 69).

Name reported in 1898 by Mendenhall (1899, p. 46), USGS, while he was exploring the Matanuska River region under the command of Capt. E. F. Glenn, USA.

Matcharak, Lake: lake, $2 \mathrm{mi}$. long, in Noatak River valley, $37 \mathrm{mi}$. SE of Howard Pass, Brooks Ra.; $67^{\circ} 45^{\prime}$ N, $156^{\circ} 12^{\prime}$ W; (map 126).

Eskimo name reported by USGS in 1956.

Mather, Mount: peak, 12,123 ft. in Mount McKinley National Park, $20 \mathrm{mi}$. NE of Mount McKinley, Alaska Ra.; 631 $11^{\prime} 45^{\prime \prime} \mathrm{N}, 150^{\circ} 26^{\prime}$. 00" W; BGN 1947; (map 88).

Named in 1947 by NPS in honor of Stephen T. Mather, Director of the National Park Service from May 16, 1917, to January 8, 1929.

Mathews Dome: mountain, 4,710 ft., $3 \mathrm{mi}$. E of Wild Lake and $37 \mathrm{mi}$. W of Wiseman, Brooks Ra.; $67^{\circ} 28^{\prime} \mathrm{N}, 151^{\circ} 28^{\prime} \mathrm{W}$; BGN 1932; (map 124).

Robert Marshall reported this local name in 1932, "given by the prospectors for the late Joe Mathews, who made the first gold strike on the Wild River."

Mathews River: stream, flows S $22 \mathrm{mi}$. from N of Snowden Mtn. to Bettles River S of Wiehl Mtn., $27 \mathrm{mi}$. WNW of Chandalar, Brooks $\mathrm{Ra}$; $67^{\circ} 33^{\prime} 30^{\prime \prime} \mathrm{N}, 149^{\circ} 30^{\prime} 00^{\prime \prime} \mathrm{W}$; (map 123). Var. Limestone Creek.

This stream was reported as Limestone Creek in 1899 by T. G. Gerdine (in Maddren, 1913, pl. 1), USGS, and in 1901 by W. J. Peters (Schrader, 1904, pl. 2), USGS. This present name was published in 1956 by USGS.

Mathews Slough: stream, an anabranch of Koyukuk River, flows SW 16 mi. on $S$ and E side of Huggins I., $24 \mathrm{mi}$. NNE of Hochandochtla Mtn., Kokrines-Hodzana High.; 65 $51^{\prime} 15^{\prime \prime}$ N, $154^{\circ} 33^{\prime} 00^{\prime \prime} \mathrm{W}$; (map 107). 
Local name obtained in 1954 by USGS topographers.

Matin Peak: peak, $4,700 \mathrm{ft}$., $2 \mathrm{mi}$. NW of Olds Mtn. and $7 \mathrm{mi}$. NE of Juneau, Coast Mts.; $58^{\circ} 21^{\prime} 45^{\prime \prime} \mathrm{N}, 134^{\circ} 19^{\prime} 35^{\prime \prime} \mathrm{W}$; (map 11).

Local name reported in 1965 by D. A. Brew and A. B. Ford, USGS. It may be from the French word meaning "morning."

Matogak River: stream, heads at $59^{\circ} 12^{\prime} \mathrm{N}, 160^{\circ}$ $40^{\prime} \mathrm{W}$, flows SW $28 \mathrm{mi}$. to Hagemeister Strait, $10 \mathrm{mi}$. N of Hagemeister I., Kilbuck-Kuskokwim Mts.; $58^{\circ} 53^{\prime} \mathrm{N}, 160^{\circ} 57^{\prime} \mathrm{W}$; (map 39). Var. Matuwalk River.

Eskimo name obtained about 1947 from Frank Waskey, trader and prospector, by USGS. He states "This stream is well known to former prospectors as 'Matuwalk'."

Matsnu: island, see Moose Island.

Matson Creek: stream, flows SE $2 \mathrm{mi}$. to Garnet Creek which flows to Flambeau River, $15 \mathrm{mi}$. NE of Nome, Seward Penin. High.; 64 $4^{\circ} 1^{\prime}$ N, $165^{\circ} 07^{\prime} \mathrm{W}$; (map 94).

Prospectors' name reported on a 1901 map of Cape Nome gold fields by David Fox, Jr.

Matson Creek: stream, flows NW $1.2 \mathrm{mi}$. to East Fork Solomon River, $11 \mathrm{mi}$. NE of Solomon, Seward Penin. High.; $64^{\circ} 41^{\prime} 30^{\prime \prime}$ N, 164 $4^{\circ} 12^{\prime}$ $45^{\prime \prime} \mathrm{W}$; (map 95).

Prospectors' name shown on Arthur Gibson's "Map of Cape Nome Precinct" dated 1904.

Matsutuak River: stream, flows NW $8 \mathrm{mi}$. to Ekaluakat River SE of its junc. with Egaksrak River, $19 \mathrm{mi}$. W of Demarcation Point, Arctic Plain; 69 $44^{\prime} \mathrm{N}, 142^{\circ} 04^{\prime} \mathrm{W}$; (map 138).

Eskimo name recorded on Barter I. in 1952 by USC\&GS and refers to a kind of tuber used for food.

Matthes Branch : glacier, see Matthes Glacier.

Matthes Glacier: glacier, heads at Alaska-Canada boundary, $3 \mathrm{mi}$. SE of Mount Ogilvie, and trends SW $12 \mathrm{mi}$. to Taku Glacier, $27 \mathrm{mi}$. NE of Juneau, Coast Mts.; $58^{\circ} 41^{\prime} \mathrm{N}, 138^{\circ} 17^{\prime} \mathrm{W}$; $B G N 1965$; (map 11). Var. Matthes Branch, North Branch Taku Glacier, Upper Taku Névé.

Named in 1964 by members of the Juneau Icefield Research Program for Dr. François Emile Matthes, 1874-1948, topographer and glaciologist.

Matthes Glacier: glacier, see Bucher Glacier.

Matthews Creek: stream, flows NW $1.5 \mathrm{mi}$. to

Pilgrim River, $28 \mathrm{mi}$. NW of Solomon, Seward Penin. High.; 64 $56^{\prime} 35^{\prime \prime}$ N, $164^{\circ} 45^{\prime} 30^{\prime \prime}$ W; (map 95). Var. Mattis Creek.

Reported as "Mattis" in 1906 by P. S. Smith (in Brooks and others, 1907, fig. 8).

Matthews Mountain: mountain, 1,710 ft., $3 \mathrm{mi}$. $W$ of Chirikof Point, on E coast of Attu I., Aleutian Is.; $52^{\circ} 51^{\prime} 06^{\prime \prime} \mathrm{N}, 173^{\circ} 21^{\prime} 03^{\prime \prime} \mathrm{E}$; BGN 1945; (map 13).

This name was proposed in 1944 to honor Capt. Ralph D. Matthews, USAAF, killed December 26, 1943; published in 1951 on USC\&GS Chart 9127.

Mattis Creek: stream, see Matthews Creek.
Mattress Hill: mountain, $1,370 \mathrm{ft}$, central Kiska I., Aleutian Is.; 51 ${ }^{\circ} 56^{\prime} 43^{\prime \prime} \mathrm{N}, 177^{\circ} 31^{\prime}$ 17"'E; (map 14).

An arbitrary name beginning with " $M$ " to correspond to " $\mathrm{M}$ " grid used by U.S. Army for tactical purposes during World War II; published on a 1943 Army map.

Matushka Island: island, $1.2 \mathrm{mi}$. long, among Chiswell Is., $36 \mathrm{mi}$. SW of Seward, Chugach Mts.; $59^{\circ} 37^{\prime} \mathrm{N}, 149^{\circ} 37^{\prime} \mathrm{W}$; BGN 1930; (map 49).

Named by the 1912 USC\&GS field party; it is "a Russian word meaning 'mother."."

Matuwalk River: stream, see Matogak River.

Matwi Island: island, see Saint Matthew Island.

Maud Creek: stream, heads in Kigluaik Mts., flows NE $1 \mathrm{mi}$. to Golden Gate Creek, $3.5 \mathrm{mi}$. SW of that stream's junc. with Pilgrim River, $12 \mathrm{mi}$. NE of Salmon Lake and $22 \mathrm{mi}$. SW of Mount Bendeleben, Seward Penin. High.; $65^{\circ} 02^{\prime} 45^{\prime \prime} \mathrm{N}, 164^{\circ} 45^{\prime} 30^{\prime \prime} \mathrm{W}$; (map 110).

Prospectors' name reported on a map of Cape Nome gold fields by David Fox, Jr., dated 1901.

Maud Creek: stream, flows NE $8 \mathrm{mi}$. to Derwent Creek, $12 \mathrm{mi}$. SE of junc. of Charley and Yukon Rivers, Yukon-Tanana High.; 65 ${ }^{\circ} 10^{\prime}$ N, $142^{\circ} 34^{\prime} \mathrm{W}$; (map 103).

Prospectors' name from an unpublished map by E. J. Chamberlain dated 1902.

Maude, Lake: lake, $1 \mathrm{mi}$. long, on Cleveland Penin., E of Bailey Bay, $4 \mathrm{mi}$. N of Bell Island Hot Springs, Alex. Arch.; 55 $58^{\prime} \mathrm{N}, 131^{\circ} 39^{\prime}$ W; (map 3).

Local name published in 1943 by USC\&GS.

Maudheim: locality, site of settlement at entrance to Wainwright Inlet, $3 \mathrm{mi}$. SW of Wainwright, Arctic Plain; $70^{\circ} 36^{\prime} \mathrm{N}, 160^{\circ} 06^{\prime} \mathrm{W}$; (map 146).

Roald Engelbregt Gravning Amundsen, 1872-1928, explorer, established a small settlement here when investigating airplane navigation prior to his flight over the North Pole in 1925. Named for the expedition's ship Maud (Smith and Mertie, 1930, p. 104).

Maud Point: point of land, on S shore of Kimsham Cove, $2 \mathrm{mi}$. NW of Chichagof, on W coast of Chichagof I., Alex. Arch.; 57 $41^{\prime} 10^{\prime \prime}$ $\mathrm{N}, 136^{\circ} 07^{\prime} 30^{\prime \prime} \mathrm{W}$; (map 9).

Name published in 1928 by USC\&GS on Chart 8258. Reported to be named for Amundsen's ship. See Maudheim.

Mauneluk River: stream, heads in Schwatka Mts., flows SW $50 \mathrm{mi}$. to Kobuk River, $23 \mathrm{mi}$. E of Shungnak, Kotzebue-Kobuk Low.; $66^{\circ} 52^{\prime}$ $\mathrm{N}, 156^{\circ} 18^{\prime} \mathrm{W}$; (map 115). Var. Mau-neluck, Manelak River.

Eskimo name written "Mau-ne-luck" by Lt. Stoney (1900, map), USN, in 1885.

Maurelle Islands: islands, extend $7 \mathrm{mi}$. W, off Gulf of Esquibel, W coast of Prince of Wales I. Alex. Arch.; $55^{\circ} 39^{\prime} \mathrm{N}, 133^{\circ} 37^{\prime} \mathrm{W}$; (map 4).

Named by W. H. Dall, USC\&GS, in 1879, for the Spanish navigator Don Francisco Antonio Maurelle who, under the command of Don Juan de la Bodega y Quadra, made and took part in surveys in this region from 1775 to 1779 .

Maury Peak: peak, 5,452 ft., $2.5 \mathrm{mi}$. E of Farragut Lake, $97 \mathrm{mi}$. E of Sitka, Coast Mts.; $57^{\circ} 16^{\prime} 00^{\prime \prime} \mathrm{N}, 132^{\circ} 53^{\prime} 40^{\prime \prime} \mathrm{W}$; (map 8).

Named in 1895 by USC\&GS for Capt. M. F. Maury, USN. The name was published in 1895 by USC\&GS on Chart 8050 .

Mausolus, Mount: mountain, 9,170 ft., NW of Stony Glacier, between headquarters of Stony and Swift Rivers, $100 \mathrm{mi}$. NW of Tyonek, Alaska Ra.; $61^{\circ} 37^{\prime} 30^{\prime \prime} \mathrm{N}, 153^{\circ} 51^{\prime} 20^{\prime \prime} \mathrm{W}$; (map 71).

Name shown on a manuscript map, probably done by a prospector, dated 1917. He must have been a classicist, because several of his names come from classical history. Mausolus, ruler of Caria (now Turkey) about 353 B.C., was commemorated by a magnificent tomb at Halicarnassus.

Mauze Gulch: ravine, trends SW $2 \mathrm{mi}$. to Kougarok River $13 \mathrm{mi}$. N of its junc. with Kuzitrin River, $45 \mathrm{mi}$. SW of Imuruk Lake, Seward Penin. High.; $65^{\circ} 26^{\prime} \mathrm{N}, 164^{\circ} 40^{\prime} \mathrm{W}$; (map 110). Var. Moses Gulch.

Prospectors' name reported on the 1908 "Map of Seward Peninsula" by Arthur Gibson. Reported as "Moses Gulch" in 1906 by A. H. Brooks (in Collier and others, 1908, pl. 9), USGS.

Mavis Island: island, $0.3 \mathrm{mi}$. long, in Eyak Lake, $2 \mathrm{mi}$. E of Cordova, Chugach Mts.; 60 $32^{\prime}-$ $45^{\prime \prime} \mathrm{N}, 145^{\circ} 41^{\prime} 30^{\prime \prime} \mathrm{W} ;$ BGN 1937; (map 64).

Named for Miss Mavis Fields of Cordova, who was killed in an airplane accident near this island on May 19, 1935; reported in 1936 by USGS.

Max Cove: estuary, extends SE 3 mi. off Klakas Inlet, on SW coast of Prince of Wales I., Alex. Arch. ; 54 57'15" N, 132 $24^{\prime} 15^{\prime \prime} \mathrm{W}$; (map 1).

Local name published by USC\&GS in 1911.

Maxeys-Cache: locality, near junc. of North Fork Goodpaster River and Eisenmenger Fork, 51 mi. ENE of Big Delta, Yukon-Tanana High.; $64^{\circ} 28^{\prime} \mathrm{N}, 144^{\circ} 14^{\prime} \mathrm{W}$; (map 101).

Local name published in 1943 by USGS.

Max Hill: hill, $980 \mathrm{ft}$., center of Kiska I., Aleutian Is.; $51^{\circ} 56^{\prime} 57^{\prime \prime} \mathrm{N}, 177^{\circ} 30^{\prime} 30^{\prime \prime} \mathrm{E}$; (map 14).

An arbitrary name beginning with " $\mathrm{M}$ " to correspond to "M" grid used by U.S. Army for tactical purposes during World War II; published on a 1943 Army map.

Max Lake: lake, 3,000 ft. long., in Tordrillo Mts., $12 \mathrm{mi}$. NW of Chakachamna Lake and $61 \mathrm{mi}$. NW of Tyonek, Alaska Ra.; 61 ${ }^{\circ} 22^{\prime} 25^{\prime \prime} \mathrm{N}$, $152^{\circ} 52^{\prime} 25^{\prime \prime} \mathrm{W}$; (map 70).

Local name reported in 1958 by USGS.

Maxon Lake: lake, see Maxson Lake.

Maxson Lake: lake, $1 \mathrm{mi}$. across, $13 \mathrm{mi}$. SW of Lake Louise, $45 \mathrm{mi}$. NW of Glennallen, Copper River Basin; $62^{\circ} 12^{\prime} 30^{\prime \prime} \mathrm{N}, 146^{\circ} 5^{\prime} 00^{\prime \prime}$ W; (map 83). Var. Maxon Lake.

Local name reported in 1959 by USGS.

Maxwell Creek: stream, flows W 1.5 mi. to Shepherd Creek, $18 \mathrm{mi}$. NE of Katalla, Chugach Mts.; $60^{\circ} 24^{\prime} \mathrm{N}, 144^{\circ} 12^{\prime} \mathrm{W}$; (map 64). 
Name used by local prospectors and reported in 1905 my G. C. Martin, USGS.

Mayachnoy, Ostrov: island, see Signal Island. Mayastetchnoi Island: island, see Signal Island.

Maybe Creek: stream, flows NW $5 \mathrm{mi}$. to Moose Creek, $8 \mathrm{mi}$. SE of its junc. with Billy Goat Creek and $33 \mathrm{mi}$. NE of Flat, KilbuckKuskokwim Mts.; $62^{\circ} 45^{\prime} 10^{\prime \prime} \mathrm{N}, 157^{\circ} 11^{\prime} 30^{\prime \prime}$ W; (map 79).

Prospectors' name obtained in 1952 by USGS topographers.

Maybe Creek: stream, heads in lake at $69^{\circ} 15^{\prime} 30^{\prime \prime}$ $\mathrm{N}, 153^{\circ} 26^{\prime} 00^{\prime \prime} \mathrm{W}$, flows W $55 \mathrm{mi}$. to join Kigalik River to form Ikpikpuk River, Arctic Slope; $69^{\circ} 20^{\prime} 45^{\prime \prime} \mathrm{N}, 154^{\circ} 42^{\prime} 30^{\prime \prime} \mathrm{W}$; BGN 1925; (map 142).

Named by members of USGS Expedition of 1924 , because "when searching for a portage, we were doubtful where this [stream] led."

Maybeso Creek: stream, flows E $6.4 \mathrm{mi}$. to Hollis Anchorage, near center of Prince of Wales I., $\mathrm{N}$ of Cat I., Alex Arch.; $55^{\circ} 29^{\prime} 10^{\prime \prime} \mathrm{N}, 132^{\circ}$ $39^{\prime} 55^{\prime \prime} \mathrm{W}$; (map 4).

Name published by Wright and Wright (1908, fig. 15), USGS.

May Creek: locality, on Dan Creek Road at May Creek crossing, $9 \mathrm{mi}$. SE of McCarthy, St. Elias Mts. ; $61^{\circ} 21^{\prime} 00^{\prime \prime} \mathrm{N}, 142^{\circ} 41^{\prime} 40^{\prime \prime} \mathrm{W}$; (map 67).

Local name obtained by USGS and published on maps since 1954

May Creek: stream, between Chititu and Young Creeks, flows $\mathrm{N} 8 \mathrm{mi}$. to Nizina River, $9 \mathrm{mi}$. SE of McCarthy, St. Elias, Mts.; 61 ${ }^{\circ} 22^{\prime} 00^{\prime \prime}$ N, $142^{\circ} 41^{\prime} 40^{\prime \prime} \mathrm{W}$; (map 67).

Local name recorded in 1902 by G. M. Easterly of Valdez.

May Creek: stream, flows NE $6.2 \mathrm{mi}$. to Sulatna River, $9 \mathrm{mi}$. E of Sulatna Crossing, KilbuckKuskokwim Mts. ; $64^{\circ} 11^{\prime} \mathrm{N}, 155^{\circ} 10^{\prime} \mathrm{W}$; (map 98).

Local name reported about 1952 by USGS:

May Creek: stream, flows SW $1.5 \mathrm{mi}$. to Bear Creek, $28 \mathrm{mi}$. N of Haycock, Seward Penin. High.; $65^{\circ} 37^{\prime} \mathrm{N}, 161^{\circ} 09^{\prime} \mathrm{W}$; (map 109).

Local name shown on a 1903 fieldsheet by D. C. Witherspoon, USGS.

May Creek: stream, flows E $5.6 \mathrm{mi}$. to join Iron Creek to form Sullivan Creek which flows to Kotzebue Sound, $27 \mathrm{mi}$. N of Imuruk Lake, Seward Penin. High.; $66^{\circ} 00^{\prime} \mathrm{N}, 163^{\circ} 10^{\prime} \mathrm{W}$; (map 110).

Prospectors' name reported in 1901 by $D$. L. Reaburn (in Mendenhall, 1902, pl. 4a), USGS.

May Creek: stream, flows NW $31 \mathrm{mi}$. around E and $\mathrm{N}$ sides of Arc Mtn. to Nanushuk River, $15 \mathrm{mi}$. NE of Table Top and $52 \mathrm{mi}$. NE of Anaktuvuk Pass, Arctic Slope; $68^{\circ} 45^{\prime} \mathrm{N}$, 150³4' W; BGN 1949; (map 134).

Named in 1944 by USGS geologists during the exploration of Naval Petroleum Reserve No. 4 during the month of May.

May Creek: stream, see Sullivan Creek.

Mayd, Ostrov: island, see Maid Island.

Mayeral, Gavan: water passage, see Mayoral, Port.
Mayer Peak: mountain peak, 5,100 ft., $4.2 \mathrm{mi}$. SE of Terrace Mt. and $32 \mathrm{mi}$. N of Valdez, Chugach Mts.; $61^{\circ} 33^{\prime} 45^{\prime \prime} \mathrm{N}, 146^{\circ} 01^{\prime} 30^{\prime \prime} \mathrm{W}$; (map 68). Var. Meyer Peak.

Named in 1898 by Capt. W. R. Abercrombie, USA.

Mayflower Creek: stream, flows NE $1 \mathrm{mi}$. to Kalsin Bay, 10 mi. S of Kodiak, Kodiak I.; $57^{\circ}$ $38^{\prime} 45^{\prime \prime} \mathrm{N}, 152^{\circ} 25^{\prime} 45^{\prime \prime} \mathrm{W}$; BGN 1966; (map 34)

Local name reported in 1966 by the Alaska State Geographic Board.

Mayflower Island: island, see Juneau Island.

May Gulch: ravine, trends NW $0.5 \mathrm{mi}$. to Hungry Creek which flows to Oregon Creek, a tributary of Cripple River, $14 \mathrm{mi}$. NW of Nome, Seward Penin. High.; $64^{\circ} 39^{\prime} 40^{\prime \prime} \mathrm{N}, 165^{\circ} 40^{\prime}$ 20" W; (map 94).

Prospectors' name shown on the 1904 "Map of Cape Nome Precinct" by Arthur Gibson.

May Gulch: ravine, trends W $1 \mathrm{mi}$. to Heine Creek, 5 mi. NE of Livengood, Yukon-Tanana High.; 65 $33^{\prime} 30^{\prime \prime} \mathrm{N}, 148^{\circ} 24^{\prime} 50^{\prime \prime} \mathrm{W}$; (map 105).

Local name published by USGS in the 1950's.

May Lake: lake, $0.8 \mathrm{mi}$. across, at head of Canoe Creek, between Canoe Hills and Fortress Creek, $47 \mathrm{mi}$. NW of Anaktuvuk Pass, Arctic Slope; $68^{\circ} 37^{\prime} 30^{\prime \prime} \mathrm{N}, 1^{\circ} 3^{\circ} 00^{\prime} 00^{\prime \prime} \mathrm{W}$; (map 134.)

Named in 1944 by W. W. Patton, USGS, for a May camp during the exploration of Naval Petroleum Reserve No. 4.

Maylay Creek: stream, flowing N $1.1 \mathrm{mi}$. to Bering Sea, $0.5 \mathrm{mi}$. NE of Conquer Point, Kiska I., Aleutian Is.; 52 $00^{\prime} 35^{\prime \prime}$ N, $177^{\circ} 30^{\prime}$ 03" E; (map 14). Var. Bourbon Creek, Malay Creek.

An arbitrary name beginning with " $M$ " to correspond to " $M$ " grid used by U.S. Army for tactical purposes during World War II ; published on a 1953 AMS map.

Maynard Glacier: glacier, $3 \mathrm{mi}$. long, in Glacier Bay National Monument, heads on Goat Ridge, trends NE to its 1950 terminus $1.4 \mathrm{mi}$. W of Charpentier Inlet, $58 \mathrm{mi}$. NW of Hoonah, St. Elias Mts.; 58 $42^{\prime} 15^{\prime \prime} \mathrm{N}, 136^{\circ} 33^{\prime} 00^{\prime \prime}$ W; BGN 1937; (map 10).

Named by W. O. Field and W. S. Cooper for Rear Adm. Washburn Maynard, 18441913, USN, who was in command of the U.S.S. Pinta when he took H. F. Reid to Muir Glacier in 1892 .

Maynard Hill: hill, $380 \mathrm{ft}$, on west-central Saint George I., in Pribilof Is. ; 56 $35^{\prime} 25^{\prime \prime} \mathrm{N}, 1^{\circ} 9^{\circ}$ $41^{\prime} 00^{\prime \prime}$ W; (map 39). Var. Eganutá-koverushka', Iganatá-koverushka', Maynards Hill.

This feature was named in 1891 by Joseph Stanley-Brown, USGS, probably for Lt. Washburn Maynard, USN, who accompanied H. W. Elliott in 1874. According to Putnam (1903, p. 1014), USC\&GS, "Eganutá-koverushka' is the Aleut-Russian name meaning "hill near Eganuta."

Maynard Mountain: mountain, 4,000 ft., in Chugach Mts., 3 mi. NW of Whittier, Chugach
Mts.; $60^{\circ} 48^{\prime} 12^{\prime \prime} \mathrm{N}, 148^{\circ} 44^{\prime} 40^{\prime \prime} \mathrm{W} ; B G N$ 1965; (map 63).

Named by R. G. Warns, USA, for Robert L. Maynard, U.S. Army helicopter pilot, who was killed in April 1964, while aiding victims of the Good Friday earthquake.

Maynards Hill: hill, see Maynard Hill.

Mayoeak River: stream, flows N $5 \mathrm{mi}$. to Elson Lagoon, $5 \mathrm{mi}$. SE of Barrow, Arctic Plain; $71^{\circ} 16^{\prime} \mathrm{N}, 156^{\circ} 24^{\prime} \mathrm{W}$; (map 153). Var. Belle Vue River, Bellevue River, Bellvue River, Mayoria.

Eskimo name reported in 1950 by USC\&GS meaning "to ascend," [meokiak], referring to step-like ponds along its course. The name was first recorded as "Mayoria" by Comdr. Maguire (Great Britain, 1854, map facing p. 186), RN. Thomas Simpson (1843 p. 152) named the stream "Bellevue" in expression of delight on seeing his goal, Point Barrow.

Mayoral, Port: water passage, $3 \mathrm{mi}$. long, between Baker and Saint Ignace Is., Alex. Arch.; $55^{\circ} 24^{\prime}$ N, $133^{\circ} 27^{\prime}$ W; (map 4). Var. Gavan Mayeral, Mayoral Cover, Puerto de Mayoral.

Name "Puerto de Mayoral" or "port of steward" was given on May 20, 1779, by Francisco Antonio Maurelle (Wagner, 1937, p. 396).

Mayoral, Puerto: water passage, see Mayoral, Port.

Mayoral Cove: water passage, see Moyoral, Port.

Mayoria: stream, see Mayoeak River.

Mayoriak: stream, see Miguakiak River.

Mayoriak River: stream, heads in Imakruak Lake, flows N $5 \mathrm{mi}$. to Smith Bay, Arctic Plain; $70^{\circ} 48^{\prime} \mathrm{N}, 1^{\circ} 4^{\circ} 03^{\prime} \mathrm{W}$; (map 148). Var. Miguakiak River.

Eskimo name atributed to Stefánsson by Leffingwell (1919, p. 97). Reported as an outlet of Teshekpuk Lake, this feature is probably the same stream shown on Maguire's chart (Great Britain, 1854, facing p. 186) as "R. Miguakiak" (see Miguakiak River)

Maypole Hill: mountain, 1,724 ft., $16 \mathrm{mi}$. NE of Rampart, Kokrines-Hodzana High.; $65^{\circ} 41^{\prime}$ $45^{\prime \prime} \mathrm{N}, 149^{\circ} 52^{\prime} 10^{\prime \prime} \mathrm{W}$; (map 105)

Local name published by USGS in the 1950's.

Maysi, Cabo: point of land, in Port Refugio, Bucareli Bay, Alex. Arch.

Spanish name probably given by Francisco Antonio Maurelle in 1779 "after a cape of that name at the east end of Cuba as he had seen service in the Caribbean" (Wagner, 1937, p. 471).

Mays Oaks Gulch: ravine, see Little Gulch.

Mayuasanik Greek: stream, flows $\mathrm{N} 10 \mathrm{mi}$. to Colville River $1.2 \mathrm{mi}$. S of its junc. with Killik River, Brooks Ra.; 68 $59^{\prime}$ N, $153^{\circ} 58^{\prime}$ W; (map 133).

Eskimo name reported in 1956 by T. E Taylor, USGS

Mayukuit Mountain: mountain, 6,200 ft., E of junc. of Easter Creek and Killik River, Brooks Ra.; $68^{\circ} 10^{\prime}$ N, $154^{\circ} 00^{\prime} \mathrm{W}$; (map 133). 
Eskimo name referring to "hunting [Dall] sheep with dogs," and reported in 1956 by T. E. Taylor, USGS.

Mazama, Mount: peak, 6,860 ft., $4 \mathrm{mi}$. NE of Glacier Point, E of Ruth Glacier, Alaska Ra.; $62^{\circ} 54^{\prime} 50^{\prime \prime} \mathrm{N}, 150^{\circ} 29^{\prime} 30^{\prime \prime} \mathrm{W}$; (map 81).

Mountain climbers' name probably given by members of the 1945 Mazama expedition to the area (Metcalf, 1945, map facing p, 11).

Mazarredo, Puerto: estuary, see Fidalgo, Port.

Mazuma Creek: stream, flows SW $6 \mathrm{mi}$. to Caribou Creek, $20 \mathrm{mi}$. NW of Tahneta Pass, Talkeetna Mts.; $62^{\circ} 01^{\prime} 25^{\prime \prime} \mathrm{N}, 147^{\circ} 52^{\prime} 20^{\prime \prime} \mathrm{W}$; (map 82).

Local name published by G. C. Martin and J. B. Mertie (in Brooks and others, 1914, pl. 11), USGS.

Mead Creek: stream, heads in Horn Mts., flows N $3 \mathrm{mi}$. to Flat Creek, $2 \mathrm{mi}$. SW of its junc. with Little Nelchina River and $13 \mathrm{mi}$. N of Tahneta Pass, Talkeetna Mts.; $62^{\circ} 04^{\prime} 20^{\prime \prime} \mathrm{N}$, 147 21'50' W; BGN 1960; (map 82). Var. Placer Creek.

Local name reported in 1956 by USGS.

Meade Glacier: glacier, heads $5 \mathrm{mi}$. W of Mount Poletica on Alaska-Canada boundary, trends NW $27 \mathrm{mi}$. to its terminus at head of Katzehin River, $8 \mathrm{mi}$. $\mathbf{E}$ of Chilkoot Inlet and $17 \mathrm{mi}$. SE of Skagway, Coast Mts.; $59^{\circ} 14^{\prime} 15^{\prime \prime} \mathrm{N}$, $135^{\circ} 05^{\prime} 00^{\prime \prime} \mathrm{W}$; (map 45).

Named by the USC\&GS, probably for Rear Adm. R. W. Meade, 1870-1933, USN, who as commander of the U.S.S. Saginaw made a reconnaissance voyage through the Alex. Arch. in the winter of 1868-69.

Meade Mountain: mountain range, see Brooks Range.

Meade Point: point of land, on Kuiu I., at entrance to Security Bay, $38 \mathrm{mi}$. SE of Sitka, Alex. Arch.; 56 $53^{\prime} 30^{\prime \prime} \mathrm{N}, 1^{\circ} 4^{\circ} 21^{\prime} 00^{\prime \prime} \mathrm{W}$; (map 5).

Named in late 1880's by USC\&GS for Rear Adm. Richard Worsam Meade, USN, who made surveys in this vicinity in 1868-69. See Meade Glacier.

Meade River: village, pop. 30, on W bank of the Meade River near Imakrak Lake, $58 \mathrm{mi}$. SW of Barrow, Arctic Plain; $70^{\circ} 28^{\prime} \mathrm{N}, 157^{\circ} 24^{\prime}$ W; BGN 1965; (map 147). Var. Atkasak, Atkasuk, Mead River, Meade River Village, Tikikluk, Tikilook, Tikiluk.

The Eskimo name for this place is "Atkasak" according to 1923 fieldsheet by E. C. Guerin, USGS, although another Eskimo name, "Tikiluk," was reported in 1951. A post office was established there in 1951 with the name "Meo.de River"; it was discontinued in 1957.

Meade River: stream, heads on Kulugra Ridge at $69^{\circ} 23^{\prime} \mathrm{N}, 158^{\circ} 40^{\prime} \mathrm{W}$, flows NE $250 \mathrm{mi}$. to Admiralty Bay, Arctic Plain; $70^{\circ} 52^{\prime} \mathrm{N}, 155^{\circ}$ 55' W; BGN 1893; (map 148). Var. Cogtua River, Kaksu River, Koloogrua River, Kolukruak River, Koolokroak River, Kulugrua River, Mead River, Meads River.

This river was explored by Capt. P. H. Ray (1885, p. 27), USA, in April 1883. Ray name the river "presumably after an ad- miral of the U.S. Navy [Richard Worsam Meade] who was engaged *** in survey work in southwest Alaska * * *" (Stuck, 1920, p. 263-264). The Eskimo name, according to John Murdoch of Ray's party, was 'Kulugrua, second large river east of Point Barrow (Meade)" (Ray, p. 55). On a 1925 fieldsheet by Gerald FitzGerald, USGS, the name Kaksu River is shown applied to present-day Awuna River. This name [Kaksu] somehow migrated to the headwaters of the Meade River, and is so applied on current maps.

Meade River Delta: delta, $11 \mathrm{mi}$. across, on W shore of Admiralty Bay, $30 \mathrm{mi}$. SE of Barrow, Arctic Plain, $70^{\circ} 52^{\prime} \mathrm{N}, 156^{\circ} 07^{\prime} \mathrm{W}$; (map 148).

Name published by USGS in 1955 .

Meade River Mountains: mountain range, see Brooks Range.

Meade River Village: village, see Meade River. Meadow Creek: stream, $6 \mathrm{mi}$. long, on Chichagof $I .$, heads in lake, flows generally $W$ to Lisianski Inlet, $30 \mathrm{mi}$. W of Hoonah, Alex. Arch.; $B G N$ 1960; $55^{\circ} 01^{\prime} 00^{\prime \prime} \mathrm{N}, 136^{\circ} 18^{\prime} 15^{\prime \prime} \mathrm{W}$; (map 10)

Named in 1955 by USGS and published in 1959 (Rossman, 1959, map). So named "because the lower part of this stream flows through a low-lying park or meadow-like area."

Meadow Creek: stream, flows NE $2.5 \mathrm{mi}$. to Karluk Lake, 24 mi. SE of Karluk, Kodiak I.; $57^{\circ} 18^{\prime} 00^{\prime \prime} \mathrm{N}, 154^{\circ} 02^{\prime} 25^{\prime \prime} \mathrm{W}$; (map 35).

Local name reported in 1952 by USGS.

Meadow Creek: stream, heads on Mount Adair, in Kenai Mts., flows NE $3.5 \mathrm{mi}$. to Kenai Lake, $20 \mathrm{mi}$. N of Seward, Ghugach Mts.; $60^{\circ} 23^{\prime} 45^{\prime \prime} \mathrm{N}, 149^{\circ} 25^{\prime} 45^{\prime \prime} \mathrm{W}$; (map 63).

Local name reported in 1951 by USGS.

Meadow Creek: stream, flows W $8.5 \mathrm{mi}$. to Eagle River $S$ of village of Eagle River, $12 \mathrm{mi}$. $\mathrm{NE}$ of Anchorage, Chugach Mts.; $61^{\circ} 18^{\prime} 45^{\prime \prime}$ $\mathrm{N}, 149^{\circ} 34^{\prime} 30^{\prime \prime} \mathrm{W}$; (map 69).

Local name reported in 1960 by USGS.

Meadow Creek: stream, formed by Little Meadow and Lucille Creeks, flows SW $5 \mathrm{mi}$. to Big Lake, $23 \mathrm{mi}$. N of Anchorage, Cook Inlet Low.; $61^{\circ} 33^{\prime} 00^{\prime \prime} \mathrm{N}, 1^{\circ} 9^{\circ} 52^{\prime} 30^{\prime \prime} \mathrm{W}$; (map 69).

Local name reported in 1914 by GLO [BLM].

Meadow Creek: stream, flows SE $1.7 \mathrm{mi}$. to Purinton Creek, $35 \mathrm{mi}$. NE of Palmer, Talkeetna Mts.; $61^{\circ} 49^{\prime} 00^{\prime \prime} \mathrm{N}, 148^{\circ} 08^{\prime} 30^{\prime \prime} \mathrm{W}$; BGN 1932; (map 69).

So named in 1931 by a USGS field party because the stream flows through several meadows.

Meadow Creek: stream, flows NE $5 \mathrm{mi}$. to Brushkana Creek, $50 \mathrm{mi}$. SE of Healy, Talkeetna Mts.; $63^{\circ} 13^{\prime} \mathrm{N}, 148^{\circ} 25^{\prime} \mathrm{W}$; (map 87).

Local name obtained in 1913 by J. W. Bagley, USGS; published by Moffit (1915, pl. 1), USGS.

Meadow Creek: stream, flows N $33 \mathrm{mi}$. to Nowitna River, $41 \mathrm{mi}$. N of Medfra, KilbuckKuskokwim Mts.; $63^{\circ} 49^{\prime}$ N, $154^{\circ} 46^{\prime}$ W; (map 89).
Local name obtained in 1924 by J. S. Brown (in Smith, P. S., and others, 1926, pl. 5), USGS.

Meadow Creek: stream, heads at Roaring Bear Lake, flows SW $41 \mathrm{mi}$. to Gamble Slough, $13 \mathrm{mi}$. NE of Stevens Village, Yukon Flats; $66^{\circ} 10^{\prime} \mathrm{N}, 148^{\circ} 51^{\prime} \mathrm{W}$; (map 118).

Local name obtained in 1956 by USGS.

Meadow Island: island, $0.5 \mathrm{mi}$. long, at $\mathrm{S}$ end of Keku Strait, between Kupreanof and Kuiu Is., $1.1 \mathrm{mi}$. NW of Baker Point, Alex. Arch.; $56^{\circ} 29^{\prime} 40^{\prime \prime} \mathrm{N}, 133^{\circ} 42^{\prime} 50^{\prime \prime} \mathrm{W}$; (map 6).

Descriptive name given for charting purposes by USC\&GS in 1932 Coast Pilot (p. 257).

Meadow Lake: lake, $4 \mathrm{mi}$. long, $5 \mathrm{mi}$. S of Pile Bay and $29 \mathrm{mi}$. NW of Augustine I., Aleutian Ra.; 59 $38^{\prime}$ N, $154^{\circ} 02^{\prime}$ W; (map 51). Var. Medow Lake.

This name first appears in 1907 on a blueprint manuscript map drawn by W. E. Smith, Chief Engineer, Alaska Short Line Railway.

Meadow Lake: lake, $0.6 \mathrm{mi}$. long, on Kenai Penin., $0.7 \mathrm{mi}$. SW of Rock Lake and $21 \mathrm{mi}$. $\mathrm{NE}$ of Kenai, Cook Inlet Low.; $60^{\circ} 38^{\prime} 30^{\prime \prime} \mathrm{N}$, $150^{\circ} 40^{\prime} 15^{\prime \prime} \mathrm{W}$; (map 62).

Named about 1963 by officials of Kenai National Moose Range for administrative purposes.

Meadow Lake: lake, $650 \mathrm{ft}$. long, $4.2 \mathrm{mi}$. SW of Anchorage, Cook Inlet Low.; 61 ${ }^{\circ} 10^{\prime} 03^{\prime \prime} \mathrm{N}$, $149^{\circ} 57^{\prime} 35^{\prime \prime} \mathrm{W}$; (map 69).

Name published on a 1918 blueprint map of The Alaska RR.

Meadow Lakes: lake, approximately $10 \mathrm{mi}$. long, between Little Susitna River and The Alaska RR., 5 mi. NW of Wasilla, Cook Inlet Low.; $61^{\circ} 37^{\prime} \mathrm{N}, 149^{\circ} 38^{\prime} \mathrm{W}$; (map 69).

Local name reported in 1942 by AMS.

Mead Point: point of land, see Heald Point.

Mead River: stream, see Meade River.

Mead River: village, see Meade River.

Meads River: stream, see Meade River.

Meakerville: village, pop. 48 , on Odiak Slough, $0.5 \mathrm{mi}$. S of Cordova, Chugach Mts.; 60 $32^{\prime}-$ $30^{\prime \prime} \mathrm{N}, 145^{\circ} 00^{\prime} 30^{\prime \prime} \mathrm{W}$.

Name of a settlement reported in 1955 by Rand McNally.

Mean Rock: rock, part of Sandman Reefs, 4.5 mi. S of Deer I., Aleutian Ra.; $54^{\circ} 46^{\prime} 25^{\prime \prime} \mathrm{N}$, $162^{\circ} 22^{\prime} 05^{\prime \prime} \mathrm{W} ; B G N$ 1942; (map 25).

Named by USC\&GS in 1941 "because the waters surrounding it are generally rough." Meares, Port: $b a y$, "in Prince William Sound." Named by Capt. William Douglas on August 14, 1788 (Wagner, 1937, p. 472).

Meares, Port: bay, see Bazan, Port.

Meares Glacier: glacier, heads between Aspero Peak and Mount Michelson, trends SW 15 $\mathrm{mi}$. to Unakwik Inlet, $42 \mathrm{mi}$. W of Valdez, Chugach Mts.; $61^{\circ} 09^{\prime} \mathrm{N}, 147^{\circ} 31^{\prime} \mathrm{W}$; BGN 1910; (map 69). Var. Brooks Glacier.

Named in 1909 by U. S. Grant and D. F. Higgins, USGS, for Capt. John Meares, 17561809, British explorer and trader. Capt. Meares, while on a trading expedition aboard the English vessel Nootka, spent the winter of 1786-87 in Prince William Sound. 
Meares Island: island, $0.9 \mathrm{mi}$. long, in Meares Passage $1^{\circ} \mathrm{mi}$. N of Dall I., Alex. Arch.; 55 $16^{\prime} 15^{\prime \prime} \mathrm{N}, 133^{\circ} 10^{\prime} 30^{\prime \prime} \mathrm{W}$; (map 4).

Named in 1907 by E. F. Dickins, USC\&GS.

Meares Passage: water passage, $6 \mathrm{mi}$. long, between Dall and Suemes Is., Alex. Arch.; $55^{\circ}$ $14^{\prime} \mathrm{N}, 133^{\circ} 14^{\prime} \mathrm{W}$; (map 4). Var. Sea Otter Bay.

Name published by W. H. Dall, USC\&GS, in the 1883 Coast Pilot (p. 97). This feature was named for Capt. John Meares, who visited this vicinity in 1788 while on a trading cruise.

Meares Point: point of land, southernmost point on Perry I., SW entrance to South Bay, 26 mi. NE of Chenega, Chugach Mts. ; 60'39'15" N, 147 55'45" W; BGN 1966; (map 63). Var. South Point.

Name published in 1954 by USGS; undoubtedly named for Capt. John Meares who explored the region in 1788 .

Meat Mountain: mountain, 2,900 ft., near head of Colville River, $49 \mathrm{mi}$. NNE of Misheguk Mtn., Arctic Slope; $68^{\circ} 56^{\prime} \mathrm{N}, 160^{\circ} 45^{\prime} \mathrm{W}$; $B G N$ 1926; (map 131). Var. Nikipak Mountain.

Named by the 1925 USGS exploring expedition, "derived from the Eskimo name, 'Nikipak, which means 'meat" (Chapman and Sable, 1960, p. 54).

Mechakamiut: locality, on a stream flowing to Bering Sea, $8 \mathrm{mi}$. NW of Cape Mendenhall, Nunivak I.; $59^{\circ} 51^{\prime} 40^{\prime \prime} \mathrm{N}, 166^{\circ} 25^{\prime} 15^{\prime \prime} \mathrm{W}$; (map 55).

Eskimo camp reported in 1949 by USC\&GS.

Mechanic Creek: stream, in DeLong Mts., flows NE $9 \mathrm{mi}$. to Singayoak Creek, $54 \mathrm{mi}$. NE of Misheguk Mtn., Brooks Ra.; 68 $8^{\circ} 43^{\prime}$ N, $159^{\circ}$ 27' W; BGN 1960; (map 131).

Named in 1953 by I. L. Tailleur, USGS, "for mechanical work on vehicles."

Mecklenberg Creek: stream, see Mettenpherg Creek.

Meddler Creek: stream, flows SE $1 \mathrm{mi}$. to Minnesota Creek which flows to Penny Creek, 0.1 mi. NE of Sapphire Creek and $8 \mathrm{mi}$. N of Solomon, Seward Penin. High.; 64 $40^{\circ} 35^{\prime \prime} \mathrm{N}$, $164^{\circ} 21^{\prime} 20^{\prime \prime} \mathrm{W}$; (map 95).

Prospectors' name reported in 1907 by USGS geologists (Smith, P. S., 1910, pl. 3).

Medfra: village, pop. 8, on right bank of Kuskokwim River, $29 \mathrm{mi}$. SW of Mystery Mts.,

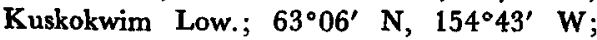
BGN 1937; (map 89). Var. Berrys Landing.

Medfra may have been a small Indian camp, but more likely owes its existence to the establishment early in the 20th century of a trading post here and of a landing originally called "Berrys Landing." In 1930 the settlement had a population of 24 . A post office was maintained here from 1922 to 1955 (Ricks, 1965, p. 41).

Medial Creek: stream, heads between the two parts of Smith Mtn., flows $\mathrm{N} 7 \mathrm{mi}$. to Ipnavik River, $41 \mathrm{mi}$. N of Howard Pass, Arctic Slope; $68^{\circ} 47^{\prime} \mathrm{N}, 156^{\circ} 31^{\prime} \mathrm{W}$; (map 132).

Named by geologists connected with the Naval Petroleum Reserve No. 4 explorations; name published by USGS in 1951.
Medicine Creek: stream, flows SW $3 \mathrm{mi}$. to Salmon River, $27 \mathrm{mi}$. NE of Cape Newenham, Kilbuck-Kuskokwim Mts.; $58^{\circ} 55^{\prime} 40^{\prime \prime} \mathrm{N}, 161^{\circ}$ $42^{\prime} 30^{\prime \prime} \mathrm{W}$; (map 39).

Local name published in a 1933 U.S. Dept. of Interior mining report.

Medicine Creek: stream, flows SW $16 \mathrm{mi}$. to Kuskokwim River, $0.4 \mathrm{mi}$. upstream from Medfra, Kilbuck-Kuskokwim Mts.; $63^{\circ} 06^{\prime} \mathrm{N}$, 154 $42^{\prime}$ W ; (map 89).

Local name reported in 1933 by J. B. Mertie (in Smith, P. S. and others, 1936, pl. 4), USGS.

Medicine Creek: stream, flows SW $0.8 \mathrm{mi}$. to Chatanika River, $4 \mathrm{mi}$. downstream from mouth of Sourdough Creek, $45 \mathrm{mi}$. NE of Fairbanks, Yukon-Tanana High.; $65^{\circ} 16^{\prime} 30^{\prime \prime}$ N, 146 $37^{\prime} 00^{\prime \prime} \mathrm{W}$; (map 104).

Prospectors' name reported in 1954 or 1955 by USGS topographers.

Medicine Lake: lake, $1.2 \mathrm{mi}$. across, $3 \mathrm{mi}$. NE of Circle Hot Springs and $26 \mathrm{mi}$. SW of Circle, Yukon-Tanana High.; $65^{\circ} 30^{\prime} \mathrm{N}, 144^{\circ} 30^{\prime}$ W; (map 104).

Named by prospectors; reported in 1896 by USGS (Spurr, 1898, pl. 39).

Medicineman Creek: stream, flows SW $12 \mathrm{mi}$. to Red Slough, 54 mi. NE of Medfra, Kuskokwim Low.; $63^{\circ} 34^{\prime} \mathrm{N}, 153^{\circ} 20^{\prime} \mathrm{W}$; (map 89).

Local name reported in 1958 by USGS.

Medicine Man Creek: stream, heads at glacier terminus in Nutzotin Mts. and flows SE $4 \mathrm{mi}$. to Cross Creek near its junc. with Chisana River, Alaska Ra.; $62^{\circ} 10^{\prime} 30^{\prime \prime}$ N, $142^{\circ} 06^{\prime} 00^{\prime \prime}$ W; (map 84).

Local name reported by USGS in 1960.

Mednofski River: stream, see Matanuska River. Mednorechka River: stream, see Matanuska River.

Mednoviska River: stream, see Matanuska River. Medow Lake: lake, see Meadow Lake.

Medvednaia: locality, "on left bank of Yukon River."

Former Eskimo camp or settlement reported with a population of 15 by Ivan Petroff in the 1880 Census.

Medvednikova: bay, see Bear Bay.

Medvejie Lake: lake, $1 \mathrm{mi}$. long, drains into Silver Bay, $8 \mathrm{mi}$. SE of Sitka, on $W$ coast of Baranof I., Alex Arch.; 57 $01^{\prime} 30^{\prime \prime}$ N, $135^{\circ}$ 07'00" W; BGN 1935; (map 9). Var. Bear Lake.

Russian word meaning "bear" reported as a local name in 1934 by USFS; USFS published the name "Bear Lake" for this feature in 1929.

Medvetcha River: stream, see Sawmill Creek.

Medviezhi, Ostrova: island, see Woewodski Island.

Medvydnik, Mys: point of land, see Bear Cape. Medvydnikova, Zaliv: bay, see Bear Bay.

Medvyzhiy, Mys: point of land, see Bear Cape. Medvyzhya, Reka: stream, see Sawmill Greek.

Meehan: locality, $1.5 \mathrm{mi}$. N of Fairbanks Creek Camp, on left bank of Fairbanks Creek, 22 mi. NE of Fairbanks, Yukon-Tanana High.; $65^{\circ} 04^{\prime} 20^{\prime \prime} \mathrm{N}, 147^{\circ} 09^{\prime} 45^{\prime \prime} \mathrm{W}$; (map 105). Var. Alder Creek Camp, Meehan City, Mehan.
Name published in 1907 by USGS as Mehan, a former mining camp. The settlement began about 1905 (Kitchener, 1954, p. 297) and was named by prospectors for an early miner, Pat Meehan. A post office was established here in 1906 and maintained until 1942 (Ricks, 1965, p. 41).

Meehan City: locality, see Meehan.

Meek, Mount: mountain, 3,000 ft., on $\mathrm{N}$ end of Douglas I., $2.5 \mathrm{mi}$. S of Entrance Point and $8 \mathrm{mi}$. W of Juneau, Coast Mts.; $58^{\circ} 17^{\prime} 55^{\prime \prime} \mathrm{N}$, 134'36'40' W; BGN 1959; (map 11).

Named by USF\&WS for Joseph Robert Meek, 1909-54, a pilot for the Service. The mountain peak overlooks the Juneau airport from which he operated.

Meeks Pond: lake, $500 \mathrm{ft}$. long, $2.5 \mathrm{mi}$. W of terminus of Sheridan Glacier and $10 \mathrm{mi}$. E of Cordova, Chugach Mts.; $60^{\circ} 31^{\prime} 45^{\prime \prime} \mathrm{N}, 145^{\circ}$ $26^{\prime} 30^{\prime \prime} \mathrm{W}$; (map 64).

Name published in 1950 by USGS.

Meela-toal-ik Slough: stream, see Melatolik Creek.

Mee-sulk-mah-nee: lake, see Big Lake.

Megotsol Island: island, on Yukon River, $13 \mathrm{mi}$. NE of Nulato, Koyukuk Low.; 64 $51^{\prime} \mathrm{N}$, $157^{\circ} 46^{\prime}$ W; (map 97). Var. Split Tip Island.

Riverboat pilots' name shown on a 1940 "Navigation Chart of the Tanana-Yukon Rivers" published by U.S. Dept. of Interior.

Mehan: locality, see Meehan.

Meiers: locality, on Richardson Highway, $4 \mathrm{mi}$. SE of Paxson Lake, Copper River Basin; $62^{\circ}$ $49^{\prime} \mathrm{N}, 145^{\circ} 29^{\prime} \mathrm{W}$; (map 83). Var. Meiers Roadhouse, Myers.

Local name of a station or roadhouse reported in 1910 by D. C. Witherspoon, USGS; named for C. J. Meiers, the proprietor.

Meiers Roadhouse: locality, see Meiers.

Meigs Peak: peak, 2,661 ft., on Snettisham Penin., $4 \mathrm{mi}$. E of Midway Is., and $40 \mathrm{mi}$. SE of Juneau, Coast Mts. ; $57^{\circ} 51^{\prime} 15^{\prime \prime} \mathrm{N}, 133^{\circ} 42^{\prime}$ 15" W; BGN 1935; (map 8).

Named in 1887 by Lt. Comdr. C. M. Thomas, USN, for Gen. Montgomery Cunningham Meigs, 1816-92, USA, who was in charge of building the Potomac Aqueduct and other structures in Washington, D.C., including parts of the Capitol.

Meiklejohn Entrance: water passage, see Hinchinbrook Entrance.

Meiklejohn Pass: pass, 4,500 ft., in Mentasta Mts., between Little Tok and Nebesna Rivers, $25 \mathrm{mi}$. E of Mentasta Lake, Alaska Ra.; $62^{\circ}$ $59^{\prime} 30^{\prime \prime} \mathrm{N}, 143^{\circ} 00^{\prime} 00^{\prime \prime} \mathrm{W}$; (map 84).

Named in 1898 by Lt. P. G. Lowe, USA, in honor of the Assistant Secretary of War, the Honorable George DeRoe Meiklejohn, 18571929.

Meinzer Creek: stream, flows NE $11.7 \mathrm{mi}$. to Fairhaven Creek, $50 \mathrm{mi}$. N of Haycock, Seward Penin. High.; $65^{\circ} 55^{\prime} \mathrm{N}, 161^{\circ} 07^{\prime} \mathrm{W}$; (map 109).

Local name published on maps after 1950. Mejillones, Punta de los: point of land, see Miliflores, Point.

Meketchum Creek: stream, flows SW $2.1 \mathrm{mi}$. to Sulatna River, $14 \mathrm{mi}$. SE of Long, Kilbuck- 
Kuskokwim Mts.; $64^{\circ} 12^{\prime} 15^{\prime \prime} \mathrm{N}, 1^{\circ} 5^{\circ} 28^{\prime} 55^{\prime \prime}$ W; BGN 1936; (map 98).

Prospectors' name reported in 1933 by Mertie (1936, pl. 2), USGS.

Mekorryok: village, see Mekoryuk.

Mekoryok: village, see Mekoryuk.

Mekoryuk: village, pop. 242, at mouth of Shoal Bay, $2.7 \mathrm{mi}$. SSW of Cape Etolin, Nunivak I.; $60^{\circ} 23^{\prime} 20^{\prime \prime} \mathrm{N}, 166^{\circ} 11^{\prime} 00^{\prime \prime} \mathrm{W}$; BGN 1952; (map 57). Var. Koot, Mekorryok, McKorryok, Mekoryok.

Eskimo village shown on a 1937 manuscript map of Nunivak Island. USC\&GS reported a summer camp here in 1874, and it may be the same place shown on early maps as "Koot."

Mekoryuk River: stream, heads at $60^{\circ} 04^{\prime} \mathrm{N}$, $166^{\circ} 21^{\prime} \mathrm{W}$, flows NE $32 \mathrm{mi}$. to Shoal Bay at Mekoryuk, $3 \mathrm{mi}$. $\mathrm{S}$ of Cape Etolin, on $\mathrm{N}$ coast of Nunivak I.; $60^{\circ} 23^{\prime} \mathrm{N}, 166^{\circ} 11^{\prime} \mathrm{W}$; (map 57).

Eskimo name reported in 1937 by USAAF. Melalolic: stream, see Melatolik Creek.

Melanson Lake: lake, $1.2 \mathrm{mi}$. long, on Annette I., $2 \mathrm{mi}$. NE of Metlakatla, Alex. Arch.; 55 $08^{\prime}$ $10^{\prime \prime} \mathrm{N}, 131^{\circ} 30^{\prime} 30^{\prime \prime} \mathrm{W}$; (map 3 ).

Named in 1897 by USC\&GS.

Melatolic: stream, see Melatolik Creek.

Melatolik Creek: stream, flows NW $30 \mathrm{mi}$. to Bering Sea, $28 \mathrm{mi}$. NE of Cape Romanzof, 16 mi. SW of Black, Yukon-Kuskokwim Delta; $62^{\circ} 09^{\prime} \mathrm{N}, 165^{\circ} 08^{\prime} \mathrm{W}$; (map 76). Var. Malalolik Creek, Melalolic, Melatolic, Muganolowik, Meela-toal-ik Slough.

Eskimo name published by Dall (1870, p. 275) as "Muganolowik" and reported by G. R. Putnam, USC\&GS, in 1899, as "Melatolic."

Melba Creek: stream, flows N $1 \mathrm{mi}$. to Monte Cristo Creek, $15 \mathrm{mi}$. NE of Fairbanks, YukonTanana High.; $64^{\circ} 59^{\prime} 55^{\prime \prime} \mathrm{N}, 147^{\circ} 20^{\prime} 55^{\prime \prime} \mathrm{W}$; $B G N$ 1933; (map 100).

Name reported in 1913 by Theodore Chapin, USGS (in Brooks and others, 1914, p. 330).

Melboune Creek: stream, flows $W$ to Cripple River, about $31 \mathrm{mi}$. NW of Nome, Seward Penin. High.; (map 94).

Prospectors' name reported on the 1900 "Map of Nome Peninsula" by J. M. Davidson and B. D. Blakeslee; this feature has not been positively identified.

Meli, Point: point of land, see Green Point.

Meliktahkvik: locality, see Mitliktavik.

Melkouodiya, Mys: point of land, see Dolphin Point.

Melkowadia, Mys: point of land, see Dolphin Point.

Mellen, Lake: lake, 1 mi. long, on Prince of Wales I., E of Hetta Inlet, in course of Reynolds Creek, Alex. Arch.; 55 $13^{\prime} \mathrm{N}, 132^{\circ} 34^{\prime} \mathrm{W}$; (map 4).

Local name reported in 1905 by E. F. Dickins, USC\&GS.

Mellen Rock: rock, in Cordova Bay, off SE coast of Sukkwan I., $2.4 \mathrm{mi}$. SW of Lime Point, Alex. Arch.; 55 $01^{\prime} 35^{\prime \prime} \mathrm{N}, 132^{\circ} 39^{\prime} 55^{\prime \prime} \mathrm{W}$; (map 4).

Named in 1905 by E. F. Dickins, USC\&GS; derived from Lake Mellen.
Mellicks Trading Post: locality, on W bank of Kuskokwim River $1 \mathrm{mi}$. S of Sleetmute, Kilbuck-Kuskokwim Mts.; 61 $41^{\prime} 05^{\prime \prime} \mathrm{N}, 157^{\circ}$ $10^{\prime} 45^{\prime \prime} \mathrm{W}$; (map 72). Var. Smeaton's Trading Post.

Named for the owner, "Nick" R. Mellick, former postmaster at Sleetmute. In 1923 the Alaska Road Commission reported Smeaton's Trading Post here. William M. Smeaton was postmaster at Sleetmute from 1926 to 1933.

Mellow Creek: stream, flows N $2 \mathrm{mi}$. to Phoebe Creek, $2 \mathrm{mi}$. NW of the more northern Twin Lake and $18 \mathrm{mi}$. WNW of Chandalar, Brooks Ra.; $67^{\circ} 34^{\prime} 30^{\prime \prime}$ N, $149^{\circ} 08^{\prime} 15^{\prime \prime}$ W; (map 123 ).

Local name reported in 1956 by T. E. Taylor, USGS.

Melnichi, Ozero: lake, see Island Lake.

Melnichnoi: point of land, see Miller Point.

Melnichnoy, Mys: point of land, see Miller Point.

Melnitsa Lake: lake, see Island Lake.

Melokoshar Point: bluff, $25 \mathrm{ft}$., on N bank of Naknek River opposite Smelt I., on Alaska Penin., $10 \mathrm{mi}$. SW of Naknek, Bristol Bay Low.; $58^{\circ} 41^{\prime} 30^{\prime \prime} \mathrm{N}, 156^{\circ} 44^{\prime} 00^{\prime \prime} \mathrm{W}$; (map 41).

Eskimo name reported in 1952 by USGS.

Meloy Creek: stream, flows N $10 \mathrm{mi}$. to Cinder River, on Alaska Penin., $37 \mathrm{mi}$. NW of Sutwik I., Aleutian Ra.; 57 $01^{\prime} 25^{\prime \prime} \mathrm{N}, 157^{\circ} 48^{\prime}$ $30^{\prime \prime} \mathrm{W}$; (map 36).

Named in 1923 by R. H. Sargent, USGS, for "Joe Meloy," a packer for Sargent and for earlier USGS expeditions.

Meloze: stream, see Melozitna River.

Melozecargut: stream, see Melozitna River.

Melozekargut: stream, see Melozitna River.

Melozi: locality, on right bank of Yukon River, $8 \mathrm{mi}$. NW of Ruby, Kokrines-Hodzana High.; $64^{\circ} 46^{\prime} \mathrm{N}, 155^{\circ} 45^{\prime} \mathrm{W}$; (map 98).

Former riverboat landing and telegraph station. This may be the same place as the Melozi Landing mentioned in early records as being at the mouth of the Melozitna River.

Melozi Creek: stream, flows N 0.8 mi. to Yukon River, $1.5 \mathrm{mi}$. NE of Ruby, Kilbuck-Kuskokwim Mts.; $64^{\circ} 45^{\prime} \mathrm{N}, 155^{\circ} 27^{\prime} \mathrm{W}$; (map 98).

Prospectors' name reported in 1908 by A. G. Maddren, USGS.

Melozi Hot Springs: springs, in course of Hot Springs Creek $3.5 \mathrm{mi}$. E of its mouth, $26 \mathrm{mi}$. NNW of Hochandochtla Mtn., KokrinesHodzana High.; $65^{\circ} 54^{\prime} 30^{\prime \prime} \mathrm{N}, 154^{\circ} 59^{\prime} 30^{\prime \prime}$ W; (map 107).

Local name reported in 1954 by USGS.

Melozi Island: island, in Yukon River, $6 \mathrm{mi}$. NW of Ruby, Kokrines-Hodzana High.; $64^{\circ} 46^{\prime} \mathrm{N}$, $155^{\circ} 40^{\prime} \mathrm{W}$; (map 98). Var. Woodchopper Island.

Named for the Melozi telegraph station on the river shore nearby; reported in 1956 by Orth.

Melozi Landing : locality, at mouth of Melozitna River, 2 mi. NE of Ruby, Kilbuck-Kuskokwim Mts.; $64^{\circ} 46^{\prime} \mathrm{N}, 155^{\circ} 28^{\prime} \mathrm{W}$; (map 98).

Former riverboat landing and telegraph station.
Melozimoran Creek: stream, heads on Moran Dome and flows NW 21 mi. to Little Melozitna River, $39 \mathrm{mi}$. NNE of Birches, KokrinesHodzana High. ; $65^{\circ} 36^{\prime} 03^{\prime \prime} \mathrm{N}, 153^{\circ} 10^{\prime} 30^{\prime \prime} \mathrm{W}$; (map 107).

Prospectors' name derived from parts of the names "Little Melozitna River" and "Moran Dome"; reported by USGS in the 1940's.

Melozi River: stream, see Melozitna River.

Melozi Springs: springs, S shore of Hot Springs Creek, $0.7 \mathrm{mi}$. NE of mouth of Glacier Creek, $33 \mathrm{mi}$. W of Birches, Kokrines-Hodzana High.; $65^{\circ} 07^{\prime} 45^{\prime \prime} \mathrm{N}, 154^{\circ} 41^{\prime} 30^{\prime \prime} \mathrm{W}$; (map 107).

Group of 20 springs is so called "because they are on a tributary of Melozitna (or Big Melozi) River, though they are fully $10 \mathrm{mi}$. from the main stream.

"In December, 1911, a two-room cabin and a dog house were built. *** Two small log bath houses, apparently of somewhat earlier construction on either side of the spring have furnished bathing facilities * * * (Waring, 1917, p. 67-68).

Melozikakat: locality, on $\mathrm{N}$ bank of Yukon River N of Ruby, at mouth of Melozitna River, Kokrines-Hodzana High.; $64^{\circ} 45^{\prime} \mathrm{N}, 155^{\circ} 28^{\prime}$ W; (map 98).

Former Indian village or camp reported in 1880 Census, with a population of 30 , by Petroff (1884 p. 12).

Melozikakat: stream, see Melozitna River.

Melozitna Canyon: canyon, extends NE-SW 13 mi. along Melozitna River, $7 \mathrm{mi}$. N of Ruby, Kokrines-Hodzana High.; $64^{\circ} 51^{\prime} \mathrm{N}, 155^{\circ} 30^{\prime}$ W; (map 98).

Local name obtained in 1956 by Orth.

Melozitna River: stream, flows SW $135 \mathrm{mi}$. to Yukon River, $2 \mathrm{mi}$. NE of Ruby, KokrinesHodzana High.; $64^{\circ} 46^{\prime} \mathrm{N}, 155^{\circ} 28^{\prime} \mathrm{W}$; (map 98). Var. Meloze, Melozecargut, Melozekargut, Melozikakat, Melozi River, Melozoi River, Melzoi River, Reka Molekostna.

Indian name recorded in 1867 by the Western Union Telegraph Expedition as "Melozecargut," or "mouth of the Meloze." The river appears to be the same stream reported as "R[eka] Molekostna" in 1842-44 by Lt. Zagoskin, IRN. Present-day usage is "Melozi River."

Melozoi River: stream, see Melozitna River.

Melsing Creek: stream, flows SW $8.5 \mathrm{mi}$. to Niukluk River at Council, $33 \mathrm{mi}$. NE of Solomon, Seward Penin. High.; 64 $54^{\prime} \mathrm{N}, 163^{\circ} 40^{\prime} \mathrm{W}$; (map 95).

Prospectors' name reported in 1899 by Schrader and Brooks (1900, map 3), USGS. Named for L. S. Melsing, one of those who found gold in this area.

Melsing Creek Divide: ridge, $15 \mathrm{mi}$. long, divides drainage of Pargon River to $\mathrm{N}$ and Niukluk River to S, $8 \mathrm{mi}$. NE of Council and $40 \mathrm{mi}$. NE of Solomon, Seward Penin. High.; $64^{\circ}$. $57^{\prime} \mathrm{N}, 163^{\circ} 25^{\prime} \mathrm{W}$; (map 95).

Local name reported in 1906 by USGS.

Melvin Channel: stream, distributary of Kobuk River, flows SW $45 \mathrm{mi}$. to Hotham Inlet, 53 mi. NW of Selawik, Kotzebue-Kobuk Low.; $66^{\circ} 48^{\prime} \mathrm{N}, 161^{\circ} 51^{\prime} \mathrm{W}$; (map 114). 
Local name reported by the U.S. Army Corps of Engineers in 1955.

Mely, Mys: point of land, see Green Point.

Melzoi River: stream, see Melozitna River.

Mememdez, Ensenada de: bay, see Sheep Bay.

Memorial Creek: stream, flows NE $18 \mathrm{mi}$. to Ipnavik River, $17 \mathrm{mi}$. NNW of Howard Pass, Brooks Ra.; $68^{\circ} 26^{\prime} \mathrm{N}, 157^{\circ} 12^{\prime} \mathrm{W}$; (map 132).

So named in 1951 by I. L. Tailleur, USGS, "for a traverse on May 30 [Memorial Day]."

Memorial Point: point of land, on $\mathrm{E}$ shore of Kanaga Bay, and SE coast of Kanaga I., Aleutian Is.; $51^{\circ} 42^{\prime} 55^{\prime \prime} \mathrm{N}, 177^{\circ} 11^{\prime} 55^{\prime \prime} \mathrm{W}$; (map 17).

Name published in 1957 by AMS.

Memory Lake: lake, $0.6 \mathrm{mi}$. across, in Matanuska Valley, $10 \mathrm{mi}$. NW of Palmer, Cook Inlet Low.; 61 $37^{\prime} 45^{\prime \prime} \mathrm{N}, 149^{\circ} 25^{\prime} 15^{\prime \prime} \mathrm{W}$; $B G N$ 1958; (map 69). Var. Swamp Lake.

Named by C. C. Shrock, of Wasilla, in 1957 because "Swamp Lake," the former name, "was not appropriate for the feature" and because a school for children was about to be established on the lake frontage and $\mathrm{Mr}$. Shrock wished the students to leave the school with "happy memories."

Menace Creek: stream, flows SE $0.6 \mathrm{mi}$. to Salmon Lagoon, Kiska I., Aleutian Is.; 52 ${ }^{\circ} 00^{\prime}$ 05" N, 177 32'22" E; (map 14).

An arbitrary name beginning with " $M$ " to correspond to " $M$ " grid used by the U.S. Army for tactical purposes during World War II; published on a 1943 Army map.

Menafee Anchorage: bay, see Menefee Anchorage.

Menafee Inlet: inlet, see Menefee Inlet.

Menchikoff, Cap: bluff, see Menshikof, Cape.

Menchikoff, Cape: bluff, see Menshikof, Cape.

Mendaña, Isla: island, "in about $57^{\circ} 32^{\prime}$ N." Probably named by Capt. Alessandro Malaspina in 1791 for Alvaro de Mendaña, the discoverer of the Solomon Islands (Wagner, 1937, p. 472).

Mendeltna Creek: stream, heads in Cat Lake, flows SE through Marie and Old Man Lakes, $40 \mathrm{mi}$. to Tazlina Lake, $30 \mathrm{mi}$. SW of Glenallen, Copper River Basin; 61 ${ }^{\circ} 58^{\prime} \mathrm{N}, 146^{\circ}$. $25^{\prime} \mathrm{W}$; (map 68).

Indian name reported by USGS (in Moffit, 1915, pl. 6).

Mendeltna Lodge: locality, near Mendeltna Creek, SW of Glennallen, Copper River Basin; $62^{\circ} 00^{\prime} \mathrm{N}, 146^{\circ} 30^{\prime} \mathrm{W}$; (map 83).

Name reported in 1961 (Rand McNally, 1961, p. 57).

Mendeltna Springs: springs, in course of Mendeltna Creek, $4 \mathrm{mi}$. NW of Old Man Lake and $40 \mathrm{mi}$. WNW of Glennallen, Copper River Basin; $62^{\circ} 11^{\prime} \mathrm{N}, 146^{\circ} 46^{\prime} \mathrm{W}$; (map 83).

Local name reported in 1949 by USGS

Mendenhall, Cape: point of land, protrudes SE $5 \mathrm{mi}$. into Bering Sea from SE coast of Nunivak I.; $59^{\circ} 45^{\prime} \mathrm{N}, 166^{\circ} 10^{\prime} \mathrm{W} ; B G N$ 1944; (map 55). Var. Ignatiet Point.

Named for Thomas C. Mendenhall, Supt. of USC\&GS and listed by Baker (1906, p. 431), USGS
Mendenhall Glacier: glacier, heads just $\mathbf{N}$ of Mendenhall Towers and trends $\mathrm{S} 10 \mathrm{mi}$. to its terminus (1962) at Mendenhall Lake, $10 \mathrm{mi}$. NW of Juneau, Coast Mts.; $58^{\circ} 25^{\prime} 30^{\prime \prime} \mathrm{N}$, $134^{\circ} 33^{\prime} 30^{\prime \prime}$ W; (map 11). Var. Auke Glacier.

The feature was called Auke Glacier by John Muir in 1879, and this name was used by the early miners (DeArmond, 1957, p. 31). USC\&GS renamed the glacier for its Superintendent, Prof. Thomas Corwin Mendenhall, $1841-1924$, in 1892.

Mendenhall Lake: lake, $1.8 \mathrm{mi}$. across, at 1962 terminus of Mendenhall Glacier, $3 \mathrm{mi}$. N of the Juneau Airport, Coast Mts.; 58 $24^{\prime} 30^{\prime \prime}$ N, $134^{\circ} 34^{\prime} 30^{\prime \prime}$ W; (map 11). Var. McCush Lake.

Local name derived from the Mendenhall Glacier and published in 1962 by USGS. In 1909 the lake was called McCush Lake by miners because Neil McCush had mining property near it (DeArmond, 1957, p. 31).

Mendenhall Peninsula: peninsula, $2.6 \mathrm{mi}$. long, trending $\mathrm{S}$ from $\mathrm{N}$ shore of Auke Bay, $9 \mathrm{mi}$. NW of Juneau, Coast Mts.; $58^{\circ} 22^{\prime} \mathrm{N}, 134^{\circ}$. 38' W; BGN 1929; (map 11).

Named by USFS in 1928 for Prof. Thomas Corwin Mendenhall, 1841-1924, Superintendent of USC\&GS, 1889-94. See Mendenhall Glacier.

Mendenhall River: stream, heads in Mendenhall Lake, flows $4 \mathrm{mi}$. S to Gastineau Channel at Juneau Airport, $8 \mathrm{mi}$. NW of Juneau, Coast Mts.; $58^{\circ} 21^{\prime} 30^{\prime \prime} \mathrm{N}, 134^{\circ} 36^{\prime} 00^{\prime \prime} \mathrm{W}$; (map 11). Var. Glacier River.

Local name reported in 1903 by A. C. Spencer and C. W. Wright, USGS, and derived from Mendenhall Glacier. Early miners about 1885 called this stream Glacier River (DeArmond, 1957, p. 32).

Mendenhall Towers: ridge, with a series of peaks, trending E-W $1.5 \mathrm{mi}$., $2.5 \mathrm{mi}$. SW of Emperor Peak and $21 \mathrm{mi}$. $\mathrm{N}$ of Juneau, Coast Mts.; $58^{\circ} 32^{\prime} 00^{\prime \prime}$ N, $134^{\circ} 29^{\prime} 05^{\prime \prime}$ W; BGN 1965; (map 11). Var. The Towers.

Descriptive name given in 1964 by members of the Juneau Icefield Research Project. The name is derived from nearby Mendenhall Glacier.

Mendenhaven: locality, $2 \mathrm{mi}$. $\mathrm{N}$ of Juneau Airport and $8 \mathrm{mi}$. NW of Juneau, Coast Mts.; $58^{\circ} 23^{\prime} 30^{\prime \prime} \mathrm{N}, 134^{\circ} 34^{\prime} 00^{\prime \prime} \mathrm{W}$; (map 11).

Local name published in 1962 by USGS.

Menefee Anchorage: bay, $1 \mathrm{mi}$. across, near S entrance to Moira Sound, on SE coast of Prince of Wales I., Alex. Arch.; 55 $02^{\prime} 15^{\prime \prime} \mathrm{N}$, $132^{\circ} 01^{\prime} 00^{\prime \prime}$ W; (map 4). Var. Menafee Anchorage, Menefes Anchorage.

Named in 1885 by Lt. Comdr R. Clover, USN, "for Ensign Daniel Preston Menefee," USN, a member of his party. This name was published erroneously as "Menafee" in 1891 Coast Pilot (p. 87).

Menefee Inlet: inlet, extends SE $8 \mathrm{mi}$. to Ernest Sound, on E coast of Etolin I., $29 \mathrm{mi}$. S of Wrangell, Alex. Arch.; 56 $03^{\prime} 30^{\prime \prime} \mathrm{N}, 132^{\circ} 09^{\prime}$ $30^{\prime \prime} \mathrm{W}$; (map 6). Var. Menafee Inlet, Menefes Inlet.
Named in 1886 by Lt. Comdr. A. S. Snow, USN, for Ens. Daniel Preston Menefee, USN, a member of his party.

Menefee Islands: islands, extend $1 \mathrm{mi}$. in Menefee Anchorage, on SE coast of Prince of Wales I., near entrance to Moira Sound, Alex. Arch.; $55^{\circ} 02^{\prime} 00^{\prime \prime} \mathrm{N}, 132^{\circ} 01^{\prime} 30^{\prime \prime} \mathrm{W}$; (map 4).

Local name published in 1925 Coast Pilot (p. 76).

Menefee Point: point of land, $\mathrm{S}$ entrance to Menefee Inlet, SE coast of Etolin I., $30 \mathrm{mi}$. $\mathrm{S}$ of Wrangell, Alex. Arch.; $56^{\circ} 02^{\prime} 45^{\prime \prime} \mathrm{N}$, $132^{\circ} 10^{\prime} 00^{\prime \prime} \mathrm{W}$; (map 6).

Named in 1924 by USC\&GS.

Menefes Anchorage: bay, see Menefee Anchorage.

Menefes Inlet: inlet, see Menefee Inlet.

Menotl Creek: stream, heads in Kaiyuh Mts., flows S $15 \mathrm{mi}$. to Hather Creek, $51 \mathrm{mi}$. NE of Holikachuck and $68 \mathrm{mi}$. SE of Unalakleet,

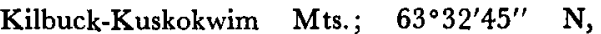
$158^{\circ} 42^{\prime} 00^{\prime \prime} \mathrm{W}$; (map 90).

Indian name reported in 1954 by USGS.

Menshikof, Cape: bluff, $25 \mathrm{ft}$., on $\mathrm{N}$ coast of Alaska Penin., SW of Ugashik Bay and $16 \mathrm{mi}$. W of Ugashik, Bristol Bay Low.; 57 $31^{\prime} 20^{\prime \prime}$ N, $157^{\circ} 49^{\prime} 15^{\prime \prime}$ W; (map 36). Var. Cap du Prince Menshikoff, Cap Menchikoff, Cape Menchikoff, Mys Menshikova.

Named "M[ys] Menshikova," meaning "Menshikov's Cape," by Capt. Lutke (1836, map 14), IRN, probably for a Russian prince. Menshikova, Mys: bluff, see Menshikof, Cape.

Mensis Point: point of land, at SW end of Chignik Lagoon, $10 \mathrm{mi}$. W of Chignik, Aleutian Ra.; 56 $17^{\prime \prime} \mathrm{N}, 158^{\circ} 38^{\prime} \mathrm{W}$; (map 30).

Local name published in 1927 by USC\&GS. Mentalik Creek: stream, see Lake Creek.

Mentanontle, Lake: lake, see Todatonten, Lake. Mentanóntlekákat: stream, Mentanontli River. Mentanontlekakat Lake: lake, see Todatonten, Lake.

Mentanontle River: stream, see Mentanontli River.

Mentanontli, Lake: lake, see Todatonten, Lake. Mentanóntli Creek: stream, see Mentanontli River.

Mentanontli River: stream, flows $\mathrm{N} 17 \mathrm{mi}$. from Lake Todatonten to Kanuti River $6.5 \mathrm{mi}$. S of its junc. with Kobuk River, $53 \mathrm{mi}$. SW of Bettles, Kokrines-Hodzana High.; $66^{\circ} 21^{\prime} 15^{\prime \prime} \mathrm{N}$ $152^{\circ} 58^{\prime} 30^{\prime \prime} \mathrm{W}$; (map 117). Var. Mentanóntlekákat, Mentanontle River, Mentanóntli Creek, Mentantlekakat.

Name reported in 1901 as "Mentanóntli Creek" by D. L. Reaburn (in Mendenhall, 1902, pl. 4a), USGS. In a sense, Lt. Allen (1887, p. 96), USA, reported this name in 1885 when he referred to the outlet of "Lake Todatonten (Tatatontly)" as "Mentanóntlekákat," or "mouth of the Mentanóntle."

Mentantlekakat: stream, see Mentanontli River. Mentantlekakat Lake: lake, see Todatonten, Lake.

Mentasta: village, see Mentasta Lake.

Mentasta Creek: stream, flows S $1.1 \mathrm{mi}$. from Mentasta Lake to Slana River, $37 \mathrm{mi}$. SW of Tok, Alaska Ra.; $62^{\circ} 54^{\prime} 20^{\prime \prime} \mathrm{N}, 143^{\circ} 46^{\prime} 00^{\prime \prime}$ 
W; BGN 1952; (map 84). Var. Mantas River.

Named for the lake; reported by USGS in 1929.

Mentasta Creek: stream, see Station Creek.

Mentasta Lake: village, pop. 40, on shore of Mentasta Lake, on W side of Mentasta Pass, $38 \mathrm{mi}$. SW of Tok, Alaska Ra.; 62 $54^{\prime} 50^{\prime \prime} \mathrm{N}$, $143^{\circ} 45^{\prime} 10^{\prime \prime}$ W; BGN 1952; (map 84). Var. Johnnie's Village, John's House, John's Village, Mentasta, Mentasta Telegraph Station, Mentasta Village, Montasta Lake.

This appears to be an early Indian settlement site which has been located in more than one place around Mentasta Lake. P. G. Lowe in 1898 reported near the lake an Indian's house which he called John's House or John's Village, after the Indian occupant. The U.S. Army Signal Corps established a telegraph station in the pass in 1902. Mendenhall $(1905$, p. 23$)$, USGS, noted that this area has been the best known route of native migration across the Alaska Range since the first native settlements here. The Mentasta Lake post office was established in 1947 and discontinued in 1951 (Ricks, 1965, p. 42). The 1940 U.S. Census reported "Montasta Lake native village" with a population of 15 .

Mentasta Lake: lake, $3.3 \mathrm{mi}$. long, $3 \mathrm{mi}$. W of Mentasta Pass and $36 \mathrm{mi}$. SW of Tok, Alaska Ra.; $62^{\circ} 55^{\prime} \mathrm{N}, 143^{\circ} 46^{\prime} \mathrm{W}$; $B G N$ 1952; (map 84).

Indian name reported in 1885 by Lt. Allen (1887, p. 72), USA.

Mentasta Lake Pass: pass, see Mentasta Pass. Mentasta Mountains: mountain range, elev. 4,000-7,000 ft., $40 \mathrm{mi}$. long and $25 \mathrm{mi}$. wide, bounded by Slana River on W, Jack Creek on S, Nabesna River on E, and Station and Tuck Creeks on N, Alaska Ra.; 62 $30^{\prime} \mathrm{N}$, $142^{\circ} 40^{\prime} \mathrm{W}$ [SE end], $62^{\circ} 50^{\prime} \mathrm{N}, 143^{\circ} 35^{\prime} \mathrm{W}$ [NW end]; (map 84).

Indian name used in 1902 by D. C. Witherspoon (in Mendenhall, 1905, pl. 11), USGS; derived from Mentasta Pass at the NW end of the range. See Mentasta Pass.

Mentasta Pass: pass, 2,280 ft., on Glenn Highway, at NW end of Mentasta Mts., $35 \mathrm{mi}$. SW of Tok, Alaska Ra.; $62^{\circ} 55^{\prime} \mathrm{N}, 143^{\circ} 40^{\prime} \mathrm{W}$; (map 84).

Indian name reported in 1885 by Lt. Allen (1887, Tanana River map), USA. In 1905 F. C. Schrader, USGS, observed that the name "Mentasta" appears to be a corruption of the name "Mantasna," i.e. "Mantas River." See Mentasta Lake : village.

Mentasta Telegraph Station: village, see Mentasta Lake.

Mentasta Village: village, see Mentasta Lake. Mentokakat: locality, "on left bank of Yukon River." Var. Minkhotliatno, Montekakat.

Former Eskimo camp or settlement reported in 1844 as "Minkhotliatno" with a population of 46 by Lt. L. A. Zagoskin, IRN. Ivan Petroff listed the entry name with a population of 20 in the 1880 Census.
Menu Hill: hill, $280 \mathrm{ft}$., E side of Kiska I., Aleutian Is.; $51^{\circ} 56^{\prime} 16^{\prime \prime} \mathrm{N}, 177^{\circ} 34^{\prime} 03^{\prime \prime} \mathrm{E}$; (map 14).

An arbitrary name beginning with " $M$ " to correspond to " $\mathrm{M}$ " grid used by U.S. Army for tactical purposes during World War II; published on a 1943 Army map.

Menzies Cape: point of land, see Ommaney, Cape.

Menzies Strait: water passage, see Chatham Strait.

Menzies' Strait: water passage, see Chatham Strait.

Merchandise Peaks: hills, $491 \mathrm{ft}$., E side of Kiska I., Aleutian Is.; $51^{\circ} 56^{\prime} 45^{\prime \prime}$ N, 177 $35^{\prime}$ $00^{\prime \prime} \mathrm{E}$; (map 14).

An arbitrary name beginning with " $M$ " to correspond to "M" grid used by U.S. Army for tactical purposes during World War II; published on 1943 Army map.

Mercy Hill: hill, $704 \mathrm{ft} ., \mathrm{W}$ of Kiska Harbor, Kiska I., Aleutian Is.; 51 ${ }^{\circ} 58^{\prime} 55^{\prime \prime} \mathrm{N}, \mathbf{1 7 7}^{\circ} 31^{\prime}$ 28" E; (map 14).

An arbitrary name beginning with " $M$ " to correspond to "M" grid used by U.S. Army for tactical purposes during World War II; published on a 1943 Army map.

Meri, Port: bay, see Shelikof Bay.

Meridian Creek: stream, heads near Noluck Lake, flows N 13 mi. to Colville River, Arctic Slope; $69^{\circ} 00^{\prime} \mathrm{N}, 159^{\circ} 56^{\prime} \mathrm{W}$; BGN 1925; (map 131).

So named by the 1924 USGS field party, "because it runs close to and nearly parallel to the 160 th meridian."

Meridian Island: island, $1.5 \mathrm{mi}$. long, in Tanana River, $5 \mathrm{mi}$. SE of Fairbanks, Tanana Low.; $64^{\circ} 47^{\prime} \mathrm{N}, 147^{\circ} 38^{\prime} \mathrm{W}$; (map 100).

Named for the Fairbanks meridian that crosses the west end of the island. The name was published in 1949 by the USGS.

Meroyuk River: stream, see Napatuk Creek.

Merriam, Mount: mountain, 5,083 ft., in Glacier Bay National Monument, $0.6 \mathrm{mi}$. N of head of Twin Glacier, $66 \mathrm{mi}$. NW of Hoonah, St. Elias Mts. ; $58^{\circ} 54^{\prime} 05^{\prime \prime} \mathrm{N}, 136^{\circ} 26^{\prime} 00^{\prime \prime} \mathrm{W}$; (map 10).

Named by members of the 1941 Glacier Bay Expedition for Dr. Clinton Hart Merriam, 1855-1942, Chief of the USDA Biological Survey. He was with the Harriman Expedition in 1899 and was editor of the Harriman Alaska Series of the Smithsonian Institution. Merriam was born in New York and practiced medicine 1879-85. He became chief of the U.S. Biological Survey in 1885 , a position he held until 1910 . In 1891 he visited Alaska as a member of the U.S. Bering Sea Seal Commission. He was a founder of the National Geographical Society and the Chairman of the U.S. Geographic Board, 1917-25. He was also the author of numerous publications.

Merriam Creek: stream, see Mariner Creek.

Merrifield Bay: cove, $0.2 \mathrm{mi}$. across, on $\mathrm{N}$ coast of Prince of Wales I., $1.5 \mathrm{mi}$. E of Point Baker, Alex. Arch.; $56^{\circ} 21^{\prime} 00^{\prime \prime} \mathrm{N}, 133^{\circ} 35^{\prime} 20^{\prime \prime}$ W; (map 6).
Local name recorded in 1949 by USGS.

Merrill Pass: pass, 3,180 ft., in Alaska Ra., at head of Merrill River, $10 \mathrm{mi}$. W of Kenibuna Lake and $73 \mathrm{mi}$. NW of Tyonek; $61^{\circ} 12^{\prime} \mathrm{N}$, $153^{\circ} 18^{\prime} \mathrm{W}$; BGN 1930; (map 71).

Named in 1929 by USGS "for R. H. Merrill, pioneer aviator of Alaska, who discovered this pass, and who was killed in 1929 while flying near Anchorage."

Merrill River: stream, heads at Merrill Pass, flows NW $10 \mathrm{mi}$. to Necons River, $7.4 \mathrm{mi}$. NE of Two Lakes and $84 \mathrm{mi}$. NW of Tyonek, Alaska Ra.; $61^{\circ} 13^{\prime} 20^{\prime \prime} \mathrm{N}, 153^{\circ} 36^{\prime} 30^{\prime \prime} \mathrm{W}$; (map 71).

Named in 1929 by USGS. See Merrill Pass.

Merry Christmas Creek: stream, flows SE $3 \mathrm{mi}$. to Slate Creek, $40 \mathrm{mi}$. SW of Eagle, YukonTanana High.; $64^{\circ} 37^{\prime} \mathrm{N}, 142^{\circ} 29^{\prime} \mathrm{W}$; (map 102).

'Prospectors' name shown on a 1902 manuscript map by E. J. Ghamberlain, U.S. Deputy Surveyor.

Mertz Island: island, $0.1 \mathrm{mi}$. across, $\mathrm{N}$ of Long I., $3.5 \mathrm{mi}$. S of Sitka, Alex. Arch.; $57^{\circ} 00^{\prime} 02^{\prime \prime} \mathrm{N}$, $135^{\circ} 21^{\prime} 15^{\prime \prime}$ W; (map 9). Var. Mertz Islet.

Named in 1880 by the U.S. Navy for Lt. Albert Mertz, USN, and published by USC\&GS in the 1883 Coast Pilot (p. 143).

Mertz Islet: island, see Mertz Island.

Merukhta: point of land, see Meruwtu Point.

Merukta, Mount: hill, see Marukta Mountain.

Meruwtu Cape: point of land, see Meruwtu Point.

Meruwtu Point: point of land, $4 \mathrm{mi}$. SE of Gambell, $\mathrm{N}$ coast of St. Lawrence I.; 63 $45^{\prime} \mathrm{N}$, $171^{\circ} 38^{\prime}$ W; BGN 1951; (map 93). Var. Cape Noovookiak, Merukhta, Meruwtu Cape.

Eskimo name reported in 1949 by Maj. H. B. Allen, USAF; recorded in 1965 as "Merukhta" by Orth.

Mesa Creek: stream, flows $\mathbf{N} 9 \mathrm{mi}$. to Jacksina Creek, $10 \mathrm{mi}$. NE of Jacksina Glacier terminus, Wrangell Mts. ; $62^{\circ} 14^{\prime} 30^{\prime \prime} \mathrm{N}, 143^{\circ} 12^{\prime} 30^{\prime \prime}$ W; (map 84).

Named in 1902 by F. C. Schrader, USGS, "because its source is in the lava mesa of the locality."

Mesa Lake: lake, $1.8 \mathrm{mi}$. long, on Revillagigedo I., in course of Gokachin Creek, $2 \mathrm{mi}$. E of head of Thorne Arm, Alex. Arch.; 55 $23^{\prime} 45^{\prime \prime} \mathrm{N}$, $131^{\circ} 07^{\prime} 20^{\prime \prime} \mathrm{W}$; (map 3).

Local name reported in 1949 by USGS.

Mesa Mountain: mountain, 3,200 ft., $2 \mathrm{mi}$. E of Tutna Lake and $28 \mathrm{mi}$. NW of Nondalton, Alaska Ra.; $60^{\circ} 22^{\prime} 30^{\prime \prime} \mathrm{N}, 1^{\circ} 15^{\circ} 12^{\prime} 00^{\prime \prime} \mathrm{W}$; (map 61). Var. Cornforth Peak.

Descriptive name given by $R$. H. Sargent and P. S. Smith, USGS, in 1914. It was called Cornforth Peak by early prospectors.

Mesa Rocks: rocks, between Uganik Bay and Uganik Passage, on N coast of Kodiak I.; $57^{\circ}$ $50^{\prime} 35^{\prime \prime} \mathrm{N}, 153^{\circ} 28^{\prime} 40^{\prime \prime} \mathrm{W}$; (map 34).

Descriptive local name; published in 1943 by USC\&GS.

Meshagak: locality, see Nushagak.

Meshik: village, see Port Heiden. 
Meshik Lake: lake, $1.3 \mathrm{mi}$. long, at head of Meshik River, in a low pass through Aleutian Ra., on S side of Pinnacle Mtn., $28 \mathrm{mi}$. W of Cape Kunmik, on Alaska Penin., Aleutian Ra.; $56^{\circ} 47^{\prime}$ N, $157^{\circ} 57^{\prime}$ W; (map 31). Var. Mishik Lake.

Presumably an Eskimo name used by local fishermen; published as Mishik in 1905 by USGS.

Meshik River: stream, on Alaska Penin., heads in Meshik Lake, flows W $31 \mathrm{mi}$. to Port Heiden, $34 \mathrm{mi}$. NNW of Chignik, Bristol Bay Low.; $56^{\circ} 46^{\prime} \mathrm{N}, 158^{\circ} 38^{\prime} \mathrm{W}$; (map 30). Var. Mishik River.

Probably an Eskimo name adopted by the fishermen. It is shown as Mishik River on a 1905 USGS map and reported as Meshik River by A. G. Maddren, USGS.

Messy Slough: stream, flows W $16 \mathrm{mi}$. from Koyukuk River to Cutoff Slough, $42 \mathrm{mi}$. NW of Hochandochtla Mtn., Kokrines-Hodzana High.; $65^{\circ} 55^{\prime} 45^{\prime \prime} \mathrm{N}, 155^{\circ} 59^{\prime} 45^{\prime \prime} \mathrm{W}$; (map 107).

Local name obtained in 1954 by USGS topographers.

Mesurier Point: point of land, see Lemesurier Point.

Metal Creek: stream, heads at Metal Creek Glacier, flows SW $15 \mathrm{mi}$. to Glacier Fork Knik River, $23 \mathrm{mi}$. SE of Palmer, Chugach Mts.; $61^{\circ} 26^{\prime} 28^{\prime \prime} \mathrm{N}, 148^{\circ} 30^{\prime} 45^{\prime \prime} \mathrm{W}$; (map 69).

Named by local prospectors; reported in 1906 by T. G. Gerdine and R. H. Sargent, USGS.

Metal Creek Glacier: glacier, trends W $5.7 \mathrm{mi}$. to its terminus at head of Metal Creek, 23 mi. E of Palmer, Chugach Mts.; 61 ${ }^{\circ} 38^{\prime} \mathrm{N}$, $148^{\circ} 25^{\prime}$ W; (map 69)

Local name reported in 1960 by USGS.

Metal Hill: hill, $866 \mathrm{ft}$., $W$ of Minute Hill, center Kiska I., Aleutian Is., $51^{\circ} 56^{\prime} 42^{\prime \prime} \mathrm{N}$, $177^{\circ} 32^{\prime} 30^{\prime \prime} \mathrm{E}$; (map 14).

An arbitrary name beginning with " $M$ " to correspond to "M" grid used by U.S. Army for tactical purposes during World War II; published on 1943 Army map.

Meteor Hill: hill, $455 \mathrm{ft}$., $\mathrm{S}$ of Kiska Harbor, Kiska I., Aleutian Is.; $51^{\circ} 57^{\prime} 12^{\prime \prime} \mathrm{N}, 177^{\circ}$. $33^{\prime} 20^{\prime \prime} \mathrm{E}$; (map 14).

An arbitrary name beginning with " $M$ " to correspond to " $M$ " grid used by U.S. Army for tactical purposes during World War II published on a 1943 Army map.

Meteorite Mountain: mountain, 6,565 ft., $15 \mathrm{mi}$. NE of Mount Denson, $32 \mathrm{mi}$. NW of Cordova, Chugach Mts.; $60^{\circ} 59^{\prime} \mathrm{N}, 145^{\circ} 58^{\prime} \mathrm{W}$; (map 64).

Local name published in 1953 by USGS.

Meteor Peak: peak, 8,574 ft., near head of Black Rapids Glacier, $14 \mathrm{mi}$. SE of Mount Hayes, Alaska Ra.; $63^{\circ} 27^{\prime} 05^{\prime \prime} \mathrm{N}, 146^{\circ} 27^{\prime} 00^{\prime \prime} \mathrm{W}$; (map 86).

Name published on relatively recent maps.

Meter Bight: bight, $5 \mathrm{mi}$. across, on $\mathrm{E}$ coast of Zarembo I., $14 \mathrm{mi}$. SW of Wrangell, Alex. Arch.; $56^{\circ} 21^{\prime} \mathrm{N}, 132^{\circ} 40^{\prime} \mathrm{W}$; BGN 1917; (map 6).

Named in 1916 by J. A. Daniels, USC\&GS.
Metervik Bay: bay, extends NW 2 mi. off Kulukak Bay, 4 mi. NE of Right Hand Point and $48 \mathrm{mi}$. SW of Dillingham, Kilbuck-Kuskokwim Mts.; 58 $49^{\prime} \mathrm{N}, 159^{\circ} 46^{\prime} \mathrm{W}$; (map 40). Native name reported in 1952 by USGS.

Metlah-Catlah: town, see Metlakatla.

Metlahkatlah: town, see Metlakatla.

Metlakahtla: town, see Metlakatla.

Metlakatla: town, pop. 830 , on $\mathrm{W}$ coast of Annette I., $15 \mathrm{mi}$. S of Ketchikan, Alex. Arch.; $55^{\circ} 07^{\prime} 45^{\prime \prime} \mathrm{N}, 131^{\circ} 34^{\prime} 30^{\prime \prime} \mathrm{W}$; BGN 1957; (map 3). Var. Metlah-Catlah, Metlahcatlah, Metlahkatlah, Metla-katla, Metlakahtla, New Metlakahta, New Metlakatla, Port Chester.

Tsimshian Indian town established in 1887 when Rev. William Duncan, who established a mission of the Ghurch of England at [Old] Metlakatla in British Columbia in 1857, moved here with most of the Indians in his charge due to differences with his superiors over the conduct of his work. The Annette Island location was first called New Metlakatla and "sometimes Port Chester by outsiders." The 1890 census listed a population of 823 ; 465 in $1900 ; 602$ in $1910 ; 574$ in $1920 ; 466$ in $1930 ; 674$ in 1939 ; and 817 in 1950 . The Metlakahtla post office was established in 1888 , discontinued in 1889 . It was reestablished as New Metlakahtla in 1892; spelling changed to Metlakahtla in 1895 and again changed in 1904 to its present form (Ricks, 1965 , p. 42,45 ).

Metlatavik: locality, see Mitliktavik.

Metletukeruk: locality, see Mitletukeruk.

Mettenpherg Creek: stream, flows S $25 \mathrm{mi}$. to Malamute Fork Alatna River, $32 \mathrm{mi}$. NW of Bettles, Brooks $\mathrm{Ra} ; 67^{\circ} 06^{\prime} \mathrm{N}, 152^{\circ} 44^{\prime} \mathrm{W}$; $B G N$ 1959; (map 124). Var. Mecklenberg Creek.

Reported as "Mecklenberg Creek" by P. S. Smith (1913, p. 143), USGS. The present spelling was recommended about 1930 by Robert Marshall after his work in the region.

Mettenpherg Creek: stream, see Malamute Fork Alatna River.

Metukatoak: locality, "at Port Clarence," Seward Penin. High.

Former Eskimo camp or settlement listed in the 1890 Census (p. 162).

Metzdorf Slough: stream, anabranch on left side of Yukon River, flows SW $17 \mathrm{mi}$. E of Quail I., Innoko Low.; $63^{\circ} 54^{\prime} \mathrm{N}, 159^{\circ} 00^{\prime} \mathrm{W}$; (map 90).

Riverboat pilots' name shown on 1940 "Navigation Chart of the Tanana-Yukon Rivers," U.S. Dept. of Interior.

Mexico Point: point of land, on an island at $\mathrm{S}$ entrance to Eureka Channel, on SW coast of Prince of Wales I., Alex. Arch.; $54^{\circ} 45^{\prime} 20^{\prime \prime} \mathrm{N}$, $132^{\circ} 22^{\prime} 30^{\prime \prime} \mathrm{W}$; (map 1 ).

Local name published by USC\&GS in 1899. Meyer Creek: stream, heads in Horn Mts., flows NW $1.7 \mathrm{mi}$. to Flat Creek, $2 \mathrm{mi}$. SW of its junc. with Little Netchina River and $13 \mathrm{mi}$. $\mathrm{N}$ of Tahneta Pass, Talkeetna Mts.; $62^{\circ} 04^{\prime}$ $25^{\prime \prime} \mathrm{N}, 147^{\circ} 21^{\prime} 30^{\prime \prime} \mathrm{W}$; (map 82).

Local name reported in 1917 by USGS.
Meyer Peak: mountain peak, see Mayer Peak. Meyers Chuck: cove, on E side of Clarence Strait, on SW side of Lemesurier Point, on Gleveland Penin., Alex. Arch.; 55 $44^{\prime} 30^{\prime \prime}$ N, $132^{\circ} 15^{\prime} 45^{\prime \prime}$ W; BGN 1965; (map 4). Var. Meyerschuck, Myers Chuck.

Local name published in 1917 by USC\&GS; see Salt Chuck, village.

Meyers Chuck: village, pop. 27, on Clarence Strait, at SW end of Cleveland Penin., Alex Arch.; 55 $44^{\prime} 30^{\prime \prime} \mathrm{N}, 132^{\circ} 15^{\prime} 15^{\prime \prime} \mathrm{W}$; $B G N$ 1965; (map 4). Var. Myers Chuck.

Fishing village reported to be named for "a prospector named Meyer who found his food in the woods" (Alaska Sportsman, 1962, No. 12, p. 26). A post office was established here in 1922 and discontinued in 1945 (Ricks, 1965, p. 44). See Salt Chuck, village.

Meyers Creek: stream, flows S $2 \mathrm{mi}$. to Butte Creek, $22 \mathrm{mi}$. W of Eagle, Yukon-Tanana High.; 64 $4^{\circ} 5^{\prime} \mathrm{N}, 141^{\circ} 55^{\prime} \mathrm{W}$; (map 102).

Prospectors' name shown on a 1898 manuscript map by C. A. Woodruff, Fort Cudahy, Canada.

Meyers Island: island, $1,600 \mathrm{ft}$. long, in Clarence Strait, W of village of Meyers Chuck, on SW coast of Gleveland Penin., Alex. Arch.; 55 ${ }^{\circ}$ $44^{\prime} 25^{\prime \prime} \mathrm{N}, 132^{\circ} 15^{\prime} 40^{\prime \prime} \mathrm{W}$; BGN 1965; (map 4).

Named by local fishermen and reported in 1904 by H. C. Fassett, USBF.

Meyers Stream: stream, flows NW $0.7 \mathrm{mi}$. to Meyers Chuck, on SW coast of Cleveland Penin., Alex. Arch.; 55 $44^{\prime} 13^{\prime \prime}$ N, 132 $14^{\prime} 40^{\prime \prime}$ W; BGN 1965; (map 4).

Name reported in 1900 by Lt. Comdr. J. F. Moser, USN; so named because "it is fished by Mr. Meyers."

Miam, Lake: lake, $1 \mathrm{mi}$. long, drains $\mathrm{SW}$ to Portage Bay, on $\mathrm{N}$ shore of Ugak Bay, on E coast of Kodiak I.; $57^{\circ} 30^{\prime} 30^{\prime \prime}$ N, $152^{\circ}$ $34^{\prime} 00^{\prime \prime}$ W; (map 34).

Local name reported in 1949 by USGS.

Mice Creek: stream, flows E $11 \mathrm{mi}$. to Bear Creek, $6.3 \mathrm{mi}$. S of Tetlin Lake and $32 \mathrm{mi}$. S of Tok, Alaska Ra.; $62^{\circ} 58^{\prime} \mathrm{N}, 142^{\circ} 42^{\prime \prime} \mathrm{W}$; (map 84).

Local name reported by USGS in 1960.

Michael Bay: cove, see Steller Cove.

Michael Creek: stream, flows SW $3 \mathrm{mi}$. to Delta River, crosses Richardson Highway, $29 \mathrm{mi}$. NW of Paxson, Alaska Ra.; 63 ${ }^{\circ} 5^{\prime} 55^{\prime \prime} \mathrm{N}$, $145^{\circ} 47^{\prime} 00^{\prime \prime} \mathrm{W}$; (map 86).

Name published on relatively recent maps. Michaelovski: village, see Saint Michael.

Michaelovski Island: island, see Saint Michael Island.

Michael Point: point of land, see Mikhail Point. Michaels Sword: peak, 6,840 ft., on Hades Highway, $1.2 \mathrm{mi}$. W of Devils Paw, $36 \mathrm{mi}$. NW of Juneau, Coast Mts.; $58^{\circ} 43^{\prime} 30^{\prime \prime} \mathrm{N}$, $133^{\circ} 52^{\prime} 30^{\prime \prime} \mathrm{W}$; (map 12$)$.

Local name reported in 1960 by USGS.

Michel Lake: lake, $0.7 \mathrm{mi}$. long, among Loon Lakes, $48 \mathrm{mi}$. SW of Fort Yukon, Yukon Flats; $66^{\circ} 14^{\prime} \mathrm{N}, 146^{\circ} 47^{\prime} \mathrm{W}$; (map 119).

Local name obtained in 1956 by USGS. 
Michelson, Mount: mountain, $8,975 \mathrm{ft}$. at head of Meares Glacier, $34 \mathrm{mi}$. NW of Valdez, Chugach Mts. ; $61^{\circ} 16^{\prime} 50^{\prime \prime} \mathrm{N}, 147^{\circ} 13^{\prime} 40^{\prime \prime} \mathrm{W}$; (map 69).

Named about 1957 by members of the Chugach Mountains Expedition sponsored by the Arctic Institute of North America (Nielsen, 1963, p. 135). Named for Albert Abraham Michelson, 1852-1931, American physicist.

Michelson, Mount: mountain, 8,855 ft., in Romanzof Mts., between Hulahula and Okpilak Rivers, $56 \mathrm{mi}$. SW of Barter I., Brooks Ra.; $69^{\circ} 19^{\prime} \mathrm{N}, 144^{\circ} 15^{\prime} \mathrm{W}$; BGN 1961; (map 139).

Named by Leffingwell $(1919$, p. 97) for Albert Abraham Micheison, 1852-1931, American scientist.

Michigan Creek: stream, flows SE $24 \mathrm{mi}$. to George River, $27 \mathrm{mi}$. SE of Flat and $37 \mathrm{mi}$. $\mathbf{N}$ of Sleetmute, Kilbuck-Kuskokwim Mts.; $62^{\circ} 13^{\prime} 40^{\prime \prime} \mathrm{N}, 157^{\circ} 18^{\prime} 30^{\prime \prime} \mathrm{W}$; (map 79).

Prospectors' name obtained in 1913 by Eakin (1914, pl. 1), USGS.

Michigan Creek: stream, flows NW 8 mi. to South Fork Goodpaster River, $35 \mathrm{mi}$. E of Big Delta, Yukon-Tanana High.; $64^{\circ} 11^{\prime} 15^{\prime \prime} \mathrm{N}, 144^{\circ} 41^{\prime}$ $00^{\prime \prime} \mathrm{W}$; (map 101).

Local name reported in 1955 by USGS.

Michigan Creek: stream, flows N $14 \mathrm{mi}$. to Yukon River, $30 \mathrm{mi}$. SE of junc. of Charley River, Yukon-Tanana High.; $65^{\circ} 12^{\prime} \mathrm{N}, 141^{\circ} 48^{\prime} \mathrm{W}$; (map 103). Ball.

Prospectors' name reported in 1898 by E. F.

Michigan Creek: stream, flows SW $20 \mathrm{mi}$. to Wild River, E of Twoday Mtn. and $35 \mathrm{mi}$. SW of Wiseman, Brooks Ra.; $67^{\circ} 16^{\prime} 15^{\prime \prime} \mathrm{N}$, $151^{\circ} 24^{\prime} 00^{\prime \prime} \mathrm{W}$; (map 124).

Local name shown on an 1899 fieldsheet by T.G. Gerdine, USGS.

Mickey Creek: stream, flows NE $6 \mathrm{mi}$. to Chandalar River, $3.5 \mathrm{mi}$. W of Caro and $25 \mathrm{mi}$. SSE of Chandalar, Brooks Ra. ; $67^{\circ} 09^{\prime} 30^{\prime \prime} \mathrm{N}$, $148^{\circ} 08^{\prime} 30^{\prime \prime} \mathrm{W}$; (map 123).

Prospectors' name obtained by A. G. Maddren, USGS, in 1909 (in Brooks and others, 1910, pl. 7).

Mickey Island: island, extends E-W $2.5 \mathrm{mi}$., in Yukon River, $2 \mathrm{mi}$. W of Edith I. and $32 \mathrm{mi}$. NE of Ruby, Nowitna Low.; $64^{\circ} 55^{\prime} \mathrm{N}, 154^{\circ}$. $31^{\prime} \mathrm{W}$; (map 98).

Riverboat pilots' name shown on 1940 "Navigation Chart, Tanana-Yukon Rivers" of the River Boat Service, U.S. Dept. of Interior.

Midarm Island: island, $0.2 \mathrm{mi}$. long, on SE coast of Afognak I., in W arm Izhut Bay at mouth of Kitoi Bay, $20 \mathrm{mi}$. NE of Afognak, Kodiak I.; $58^{\circ} 11^{\prime} 10^{\prime \prime} \mathrm{N}, 152^{\circ} 19^{\prime} 40^{\prime \prime} \mathrm{W}$; (map 43).

Local name published in 1943 by USC\&GS.

Midas Camp: site, mining camp $0.5 \mathrm{mi}$. $\mathrm{S}$ of Solomon Gulch, $7 \mathrm{mi}$. S of Valdez, Chugach Mts.; $61^{\circ} 00^{\prime} 55^{\prime \prime} \mathrm{N}, 146^{\circ} 16^{\prime} 30^{\prime \prime} \mathrm{W}$; (map 68).

Local name reported in 1911 by USGS.

Midas Creek: stream, flows NW $3 \mathrm{mi}$. to South Fork Avolik River, $28 \mathrm{mi}$. NE of Goodnews,
Kilbuck-Kuskokwim Mts.; $59^{\circ} 28^{\prime} \mathrm{N}, 161^{\circ} 19^{\prime}$ W; (map 53).

Local name reported in 1954 by USGS.

Midas Creek: stream, flows $\mathbf{N} 8 \mathrm{mi}$. to Sixtymile Creek, $5 \mathrm{mi}$. W of that stream's mouth and $56 \mathrm{mi}$. W of Wiseman, Brooks Ra.; $67^{\circ} 20^{\prime} 45^{\prime \prime} \mathrm{N}, 152^{\circ} 13^{\prime} 30^{\prime \prime} \mathrm{W}$; (may 124).

Local name shown on a 1899 fieldsheet by T. G. Gerdine, USGS.

Midas Creek: stream, heads at $67^{\circ} 56^{\prime} \mathrm{N}, 155^{\circ} 36^{\prime}$ W, flows SW $27 \mathrm{mi}$. to Noatak River, $27 \mathrm{mi}$. SE of Howard Pass, Brooks Ra.; 67 $51^{\prime}$ N, $156^{\circ} 27^{\prime} \mathrm{W}$; (may 126 ).

Prospectors' name probably given around 1900 when a small amount of placer gold was found in the stream's gravel. The name was reported by P. S. Smith (1913, p. 141), USGS, in 1911. The Eskimo name for this stream is "Ningyak" meaning "cottonwood," reported by Orth in 1956.

Midday Creek: stream, flows SW to Penny River, about $27 \mathrm{mi}$. NW of Nome, Seward Penin. High.; (map 94).

Prospectors' name reported on the 1900 "Map of Nome Peninsula" by J. M. Davidson and B. D. Blakeslee; this feature has not been positively identified.

Middle Arm: cove, $0.8 \mathrm{mi}$. long, on E shore of Eyak Lake, $3.5 \mathrm{mi}$. E of Cordova, Chugach Mts. ; $60^{\circ} 33^{\prime} 30^{\prime \prime} \mathrm{N}, 145^{\circ} 38^{\prime} 30^{\prime \prime} \mathrm{W}$; (map 64).

Local descriptive name published in 1951 by USGS.

Middle Arm Kelp Bay: bay, $1 \mathrm{mi}$. across, $5 \mathrm{mi}$. long, empties into Kelp Bay, on Baranof I., $10 \mathrm{mi}$. SE of Todd, Alex. Arch.; 57 $20^{\prime} \mathrm{N}$, $134^{\circ} 57^{\prime} \mathrm{W}$; (map 9).

Named in 1895 by Lt. Comdr. E. K. Moore, USN, and published by USC\&GS on Chart 8050.

Middle Arm Perenosa Bay: bay, see Delphin Bay.

Middle Arm Three Arm Bay: bay, $0.7 \mathrm{mi}$. across, part of Three Arm Bay, on W coast of Adak I., Aleutian Is.; $51^{\circ} 45^{\prime} 00^{\prime \prime} \mathrm{N}, 176^{\circ} 51^{\prime} 20^{\prime \prime} \mathrm{W}$; BGN 1936; (map 17).

Descriptive name given by Lt. William Gibson, USN. See Low Point.

Middle Basin: valley, on Nugget Creek, $2 \mathrm{mi}$. E of terminus of Mendenhall Glacier and $9 \mathrm{mi}$. NW of Juneau, Coast Mts.; $58^{\circ} 25^{\prime} 45^{\prime \prime} \mathrm{N}$, $134^{\circ} 28^{\prime} 30^{\prime \prime} \mathrm{W}$; (map 11). Var. Sunrise Basin.

Local name published in 1962 by USGS. The original name used by miners was "Sunrise Basin."

Middle Bay: bay, extends SW $5 \mathrm{mi}$. off Chiniak Bay between Broad and Cliff Points, $8 \mathrm{mi}$. S of Kodiak, Kodiak I.; $57^{\circ} 41^{\prime} \mathrm{N}, 152^{\circ} 27^{\prime} \mathrm{W}$; (map 34). Var. Guba Srednyaya, Srednaia.

Translation by USC\&GS in 1881 of the name "Guba Srednyaya," published by Sarichev (1826, map 16).

Middle Bay: bay, see Alimuda Bay.

Middle Bay: bay, see Kismaliuk Bay.

Middle Bluff: bluff, $110 \mathrm{ft}$., on W coast of Alaska Penin., $29 \mathrm{mi}$. SW of Naknek, Bristol Bay Low.; $58^{\circ} 24^{\prime} 20^{\prime \prime} \mathrm{N}, 157^{\circ} 31^{\prime} 15^{\prime \prime} \mathrm{W}$; (map 41).
Local name published in 1958 by USGS Middle Branch Norris Glacier: glacier, heads E of Nugget Mtn., trends NE $5.5 \mathrm{mi}$. to Death Valley Branch Morris Glacier, $13 \mathrm{mi}$. NE of Juneau, Goast Mts.; $58^{\circ} 28^{\prime} \mathrm{N}, 134^{\circ} 15^{\prime} \mathrm{W}$; (map 11).

Local name reported in 1965 by D. A. Brew and A. B. Ford, USGS.

Middle Branch South Fork Chester Creek: stream, flows SW $2.7 \mathrm{mi}$. through De Barr Vista, Nunaka Valley, and Bonibrook, joins South Branch to form South Fork Chester Creek in Anchorage, Cook Inlet Low.; 61. $11^{\prime}$. $23^{\prime \prime}$ N, $149^{\circ} 47^{\prime} 05^{\prime \prime}$ W; (map 69).

Local name reported in 1962 by USGS.

Middle Breaker: rocks, $10 \mathrm{mi}$. S of Chichagof, on W coast of Chichagof I., Alex. Arch.; 57 $31^{\prime}$ $00^{\prime \prime} \mathrm{N}, 136^{\circ} 04^{\prime} 40^{\prime \prime} \mathrm{W}$; BGN 1908; (map 9).

Named in 1908 by USC\&GS and published in the 1908 Coast Pilot (p. 167). Named presumably because the rocks are halfway between the reefs off the West coast of Khaz Peninsula and the Khaz Breakers.

Middle Cape: point of land, on S shore of Halibut Bay, on W coast of Kodiak I., $18 \mathrm{mi}$. SW of Karluk ; $57^{\circ} 22^{\prime} \mathrm{N}, 154^{\circ} 46^{\prime} \mathrm{W}$; BGN 1931; (map 35). Var. Middle Headland.

Named by USC\&GS in 1929 "because of its central location with respect to other prominent points or capes." The USC\&GS survey of 1919 called it "Middle Headland."

Middle Cape: point of land, see Seredni Point.

Middle Channel: channel, $10 \mathrm{mi}$. long, in $\mathrm{Nu}$ shagak Bay, between Long Sands and Big Sands, $22 \mathrm{mi} \mathrm{S}$ of Dillingham, Bristol Bay Low.; $58^{\circ} 40^{\prime} \mathrm{N}, 158^{\circ} 30^{\prime} \mathrm{W}$; (map 40).

Local name reported in 1950 by USC\&GS. The Nushagak Bay channels are constantly changing in location and navigability.

Middle Channel: stream, $6 \mathrm{mi}$. long, anabranch of Porcupine River $14 \mathrm{mi}$. N of Chalkyitsik, Yukon Flats; $66^{\circ} 54^{\prime} \mathrm{N}, 143^{\circ} 36^{\prime} \mathrm{W}$; (map 120).

Local name published in 1951 by USGS.

Middle Channel: water passage, $2.5 \mathrm{mi}$. long, along NW coast of Beauchamp I., W of Baranof I., $8.5 \mathrm{mi}$. SE of Goddard, Alex. Arch.; $56^{\circ} 43^{\prime} 00^{\prime \prime} \mathrm{N}, 135^{\circ} 17^{\prime} 30^{\prime \prime} \mathrm{W}$; (map 5).

Local name published by USC\&GS in 1932 Coast Pilot (p. 376).

Middle Channel: water passage, in Sitka Sound, extends NE $1.5 \mathrm{mi}$. to Sitka, Alex. Arch.; $57^{\circ} 02^{\prime} \mathrm{N}, 135^{\circ} 21^{\prime} \mathrm{W}$; (map 9). Var. Farvater Sredniy.

An 1882 translation by USC\&GS of name "Farv[ater] Sredniy" published by Capt. Teb. enkov (1852, map 38).

Middle Channel Kiwalik River: stream, a distributary of Kiwalik River, heads at Mud Greek Channel, flows NE $0.8 \mathrm{mi}$. to Kiwalik Lagoon, $56 \mathrm{mi}$. NW of Haycock, Seward Penin. High.; $65^{\circ} 58^{\prime} \mathrm{N}, 161^{\circ} 52^{\prime} \mathrm{W}$; (map 109).

Local name published on maps after 1950. Middle Chugach Island: island, see Perl Island. Middle Craig Point: point of land, on NE coast of Zarembo I., $11 \mathrm{mi}$. SE of Wrangell, Alex. 
Arch.; $56^{\circ} 26^{\prime} 15^{\prime \prime} \mathrm{N}, 132^{\circ} 39^{\prime} 20^{\prime \prime} \mathrm{W}$; (map 6).

Local name used by fishermen; name published in 1923 by USC\&GS.

Middle Creek: stream, flows N 6 mi. to W shore of Duncan Canal, on $\mathbf{S}$ coast of Kupreanof I., $16 \mathrm{mi}$. SW of Petersburg, Alex. Arch.; 56 $38^{\circ}$ $20^{\prime \prime} \mathrm{N}, 133^{\circ} 14^{\prime} 50^{\prime \prime} \mathrm{W}$; (map 6).

Local descriptive name obtained in 1951 by USGS.

Middle Creek: stream, flows NW $8 \mathrm{mi}$. to East Fork Matanuska River, $59 \mathrm{mi}$. NE of Palmer, Copper River Basin, 61 $41^{\circ} 15^{\prime \prime} \mathrm{N}, 147^{\circ} 21^{\prime}$ 30" W; BGN 1960; (map 69).

Local descriptive name reported in 1956 by USGS.

Middle Creek: stream, heads $\mathrm{N}$ of Slow Fork Hills, flows SW $26 \mathrm{mi}$. to Slow Fork Kuskokwim River, $42 \mathrm{mi}$. E of Medfra, Kuskokwim Low.; $63^{\circ} 16^{\prime} \mathrm{N}, 153^{\circ} 27^{\prime} \mathrm{W}$; (map 89).

Local name reported in 1958 by USGS.

Middle Dome: mountain, 2,117 ft., in Glacier Bay National Momument, on $\mathrm{W}$ side of $\mathrm{La}$ Perouse Glacier, $3 \mathrm{mi}$. NE of Gulf of Alaska and $73 \mathrm{mi}$. NW of Hoonah, St. Elias Mts.; $58^{\circ} 31^{\prime} 10^{\prime \prime} \mathrm{N}, 137^{\circ} 16^{\prime} 15^{\prime \prime} \mathrm{W}$; (map 10).

Local name published by USGS in the 1950's.

Middle Finger Lake: lake, longest of the Finger Lakes, on Kenai Penin., $1.7 \mathrm{mi}$. long, $13 \mathrm{mi}$. NE of Kenai, Cook Inlet Low.; $60^{\circ} 38^{\prime} 45^{\prime \prime} \mathrm{N}$, $150^{\circ} 53^{\prime} 45^{\prime \prime} \mathrm{W}$; (map 62).

Named about 1963 by officials of Kenai National Moose Range, for administrative purposes.

Middle Fork Bremner River: stream, heads at a glacier terminus, flows NW $14 \mathrm{mi}$, joins North Fork to form Bremner River, $42 \mathrm{mi}$. SSE of Chitina, Chugach Mts.; $60^{\circ} 57^{\prime} \mathrm{N}$, $143^{\circ} 53^{\prime} \mathrm{W}$; (map 65).

Name published by Moffit (1914, fig. 2), USGS.

Middle Fork Buckland River: stream, flows SW $25 \mathrm{mi}$. to the Buckland River, $50 \mathrm{mi}$. NE of Haycock, Nulato Hills; $65^{\circ} 44^{\prime} \mathrm{N}, 160^{\circ} 00^{\prime}$ W; (map 109).

Local name published in 1951 by USGS.

Middle Fork Chandalar River: stream, flows SW $102 \mathrm{mi}$., joins North Fork Chandalar River to form Chandalar River, $23 \mathrm{mi}$. SSE of Chandalar, Brooks Ra.; $67^{\circ} 10^{\prime} \mathrm{N}, 148^{\circ} 18^{\prime}$ W; (map 123).

Prospectors' name reported in 1899 by Schrader (1900b, pl. 60), USGS.

Middle Fork Chester Creek: stream, heads in Russian Jack Springs, flows SW $2.6 \mathrm{mi}$., joins South Fork to form Chester Creek in Anchorage, Cook Inlet Low.; 61 ${ }^{\circ} 11^{\prime} 58^{\prime \prime} \mathrm{N}$, $149^{\circ} 49^{\prime} 55^{\prime \prime} \mathrm{W}$; (map 69).

Local name reported in 1962 by USGS.

Middle Fork Chistochina River: stream, flows SW $20 \mathrm{mi}$. from $\mathrm{E}$ terminus of Chistochina Glacier to Chistochina River, $30 \mathrm{mi}$. NW of Slana, Alaska Ra.; $62^{\circ} 54^{\prime} \mathrm{N}, 144^{\circ} 47^{\prime} \mathrm{W}$; (map 83).

Local name reported by USGS (in Mendenhall and Schrader, 1903).
Middle Fork Chulitna River: stream, heads at $63^{\circ} 18^{\prime} \mathrm{N}, 148^{\circ} 50^{\prime} \mathrm{W}$, flows SW $28 \mathrm{mi}$. to join East Fork Chulitna River to form Chulitna River, $55 \mathrm{mi}$. SW of Healy, Talkeetna Mts.; $63^{\circ} 06^{\prime} 30^{\prime \prime} \mathrm{N}, 1^{\circ} 31^{\prime} 30^{\prime \prime} \mathrm{W}$; (map 87).

Name reported in 1913 by J. W. Bagley, USGS.

Middle Fork Copper Creek: stream, flows N 3 mi. to Copper Creek, $1.4 \mathrm{mi}$. S of Kotsina River, $82 \mathrm{mi}$. NE of Valdez, Wrangell Mts.; $61^{\circ} 41^{\prime} 20^{\prime \prime} \mathrm{N}, 144^{\circ} 03^{\prime} 15^{\prime \prime} \mathrm{W}$; (map 68).

Local name shown on a 1912 fieldsheet by D. C. Witherspoon, USGS.

Middle Fork Eek River: stream, heads at $60^{\circ} 03^{\prime}$ $\mathrm{N}, 160^{\circ} 30^{\prime} \mathrm{W}$, flows NW $44 \mathrm{mi}$. to the Eek River, $46 \mathrm{mi}$. S of Bethel, Yukon-Kuskokwim Delta ; $60^{\circ} 09^{\prime} \mathrm{N}, 161^{\circ} 35^{\prime} \mathrm{W}$; (map 59).

Local name reported in 1935 by USGS.

Middle Fork Eldorado Creek: stream, heads on NE side of East Peak of Ear Mtn., flows E 1.5 mi. to Eldorado Creek, in Arctic River basin, $2.8 \mathrm{mi}$. E of The Ears, Seward Penin. High.; $65^{\circ} 56^{\prime} 05^{\prime \prime} \mathrm{N}, 166^{\circ} 08^{\prime} 50^{\prime \prime} \mathrm{W}$; BGN 1954; (map 111).

Named in 1945 by a USGS field party.

Middle Fork Fortymile River: stream, heads at $64^{\circ} 01^{\prime} \mathrm{N}, 144^{\circ} 50^{\prime} \mathrm{W}$, flows NE $60 \mathrm{mi}$. to North Fork Fortymile River, $38 \mathrm{mi}$. SW of Eagle, Yukon-Tanana High.; $64^{\circ} 27^{\prime} 40^{\prime \prime} \mathrm{N}$, $142^{\circ} 13^{\prime} 00^{\prime \prime} \mathrm{W}$; (map 102). Var. Granite Fork, Middle Fork North Fork Fortymile River, Two White Men Creek.

Named by prospectors and shown in 1902 on a manuscript map by E. J. Chamberlain, U.S. Deputy Surveyor. The name was reported in 1898 as "Granite Fork" by C. A. Woodruff, Fort Cudahy, Canada.

Middle Fork George River: stream, see Julian Creek.

Middle Fork Glacier: glacier, trends E $9.6 \mathrm{mi}$. to its terminus at head of Middle Fork White River, $39 \mathrm{mi}$. NE of McCarthy, Wrangell Mts.; $61^{\circ} 46^{\prime} \mathrm{N}, 141^{\circ} 59^{\prime} \mathrm{W}$; (map 67).

Local name reported by Capps (1916, pl. 1), USGS.

Middle Fork Glacier Creek: stream, flows SW $2 \mathrm{mi}$. to join the Glacier Fork to form Glacier Creek, $8 \mathrm{mi}$. N of Nome, Seward Penin. High.

Prospectors' name published in 1900 by Schrader (1900c, p. 16), USGS. Subsequent maps show a different drainage pattern at the head of Glacier Creek.

Middle Fork Goodnews River: stream, flows SW $44 \mathrm{mi}$. to Goodnews River, $4 \mathrm{mi}$. E of Goodnews, Kilbuck-Kuskokwim Mts.; $59^{\circ} 08^{\prime} \mathrm{N}$, $161^{\circ} 29^{\prime} \mathrm{W}$; (map 53). Var. Koguklik.

Name published by G. L. Harrington (in Brooks 1921, pl. 7), USGS. Harrington reports that the Eskimo name of the fork is "Koguklik," meaning "having the middle."

Middle Fork Gulkana River: stream, flows E through Dickey Lake $29 \mathrm{mi}$. to Gulkana River, $2.5 \mathrm{mi}$. SW of Paxson Lake, Alaska Ra.; 62 $51^{\prime} \mathrm{N}, 145^{\circ} 40^{\prime} \mathrm{W}$; (map 83).

Local name reported by USGS (in Moffit, 1912, pl. 1).
Middle Fork Holitna River: stream, see Kogrukluk River.

Middle Fork Iron Creek: stream, flows W $8 \mathrm{mi}$. to Iron Creek, $14 \mathrm{mi}$. SE of its junc. with Talkeetna River and $32 \mathrm{mi}$. E of Talkeetna, Talkeetna Mts.; $62^{\circ} 20^{\prime} 15^{\prime \prime} \mathrm{N}, 149^{\circ} 07^{\prime} 30^{\prime \prime}$ W; (map 82).

Local name recorded in 1917 by $S . R$. Capps (in Brooks and others, 1919, pl. 4), USGS.

Middle Fork Jones Creek: stream, flows W $6 \mathrm{mi}$. to Jones Creek $10 \mathrm{mi}$. SE of its junc. with East Fork Kuskokwim River and $30 \mathrm{mi}$. SE

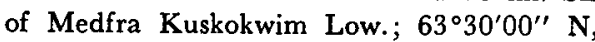
$153^{\circ} 45^{\prime} 30^{\prime \prime} \mathrm{W}$; (map 89).

Local name reported in 1958 by USGS.

Middle Fork Koyukuk River: stream, heads from junc. of Bettles and Dietrich Rivers, flows SW $62 \mathrm{mi}$. to join North Fork, to form Koyukuk River, $26 \mathrm{mi}$. SW of Wiseman, Brooks Ra.; $67^{\circ} 02^{\prime} 30^{\prime \prime} \mathrm{N}, 151^{\circ} 04^{\prime} 00^{\prime \prime} \mathrm{W}$; (map 124).

Local name shown on an 1899 fieldsheet by T. G. Gerdine, USGS.

Middle Fork Koyukuk River: stream, see Dietrich River.

Middle Fork Kuskokwim River: stream, heads SW of Trimokish Hills at $62^{\circ} 07^{\prime} 40^{\prime \prime} \mathrm{N}, 154^{\circ}$ $24^{\prime} 00^{\prime \prime}$ W, flows NW $130 \mathrm{mi}$. to Kuskokwim River, $21 \mathrm{mi}$. E of McGrath, Alaska Ra.; 62 ${ }^{\circ}$ $59^{\prime} \mathrm{N}, 154^{\circ} 58^{\prime} \mathrm{W}$; (map 80). Var. Keklone River.

Local name reported in 1905 by $\mathrm{A}$. H. Brooks, USGS. The native name was "Keklone" according to Gordon (1917, map).

Middle Fork Lake: lake, $1.5 \mathrm{mi}$. long, on Middle Fork Goodnews River, $6 \mathrm{mi}$. W of Gechiak Lake and $42 \mathrm{mi}$. NE of Goodnews, KilbuckKuskokwim Mts.; $59^{\circ} 24^{\prime} \mathrm{N}, 160^{\circ} 36^{\prime} \mathrm{W}$; (map 53).

Local name reported in 1954 by USGS.

Middle Fork Montana Creek: stream, flows SW $19 \mathrm{mi}$. joining the North Fork to form Montana Greek, $11 \mathrm{mi}$. SE of Talkeetna, Cook Inlet Low.; 62 $11^{\prime} 25^{\prime \prime} \mathrm{N}, 149^{\circ} 57^{\prime} 00^{\prime \prime} \mathrm{W}$; (map 82).

Local name recorded in 1950 by USGS.

Middle Fork North Fork Fortymile River: stream, see Middle Fork Fortymile River.

Middle Fork of the West Fork Tozitna River: stream, see Banddana Creek.

Middle Fork Okpikruak River: stream, heads at glacier terminus, flows $\mathrm{N} 20 \mathrm{mi}$. to Okpikruak River $11 \mathrm{mi}$. SW of its junc. with Okokmilaga River, Brooks Ra.; 68 $35^{\prime}$ N, $153^{\circ} 29^{\prime}$ W; (map 133).

So named in 1949 by W. W. Patton, USGS, during exploration of Naval Petroleum Reserve No. 4.

Middle Fork Paint River: stream, flows N 1.5 mi., joins South Fork Paint River to form Paint River, $8 \mathrm{mi}$. SE of Spectacle Lake, 47 mi. SW of Augustine I., Aleutian Ra.; 59 ${ }^{\circ} 7^{\prime}$ $15^{\prime \prime} \mathrm{N}, 154^{\circ} 38^{\prime} 10^{\prime \prime} \mathrm{W}$; (map 51).

Local name reported by $K$. F. Mather, USGS, in 1923 (in Brooks and others, 1925, pl. 3). 
Middle Fork Salcha River: stream, see Salcha River.

Middle Fork Tozitna River: stream, see Banddana Creek.

Middle Fork Tuentna River: stream, see West Fork Nixon Fork.

Middle Fork White River: stream, heads at Middle Fork Glacier, flows SE $8 \mathrm{mi}$. to White River, $42 \mathrm{mi}$. NE of McCarthy, Wrangell Mts.; $61^{\circ} 45^{\prime} \mathrm{N}, 141^{\circ} 18^{\prime} \mathrm{W}$; (map 67).

Local name reported in 1908 by D. C. Witherspoon (Moffit and Knopf, 1910, pl. 2), USGS.

Middle Fork Willow Creek: stream, flows S 1.7 mi. to Willow Creek, $18 \mathrm{mi}$. N of Fairbanks, Yukon-Tanana High.; $65^{\circ} 07^{\prime} \mathrm{N}$; $147^{\circ} 44^{\prime} \mathrm{W}$; (map 105).

Local name published by USGS in the 1950 's.

Middle Glacier: glacier, see Gascade Glacier.

Middle Glacier Greek: stream, heads at glacier terminus, flows S $5.5 \mathrm{mi}$. to Chinitna Bay, Aleutian Ra.; $59^{\circ} 52^{\prime} \mathrm{N}, 153^{\circ} 09^{\prime} \mathrm{W}$; BGN 1906; (map 51).

Local name published by G. G. Martin (1905, pl. 4), USGS.

Middle Ground Shoal: shoal, $4 \mathrm{mi}$. long, in Orca Bay, NW of Hawkins I.; $20 \mathrm{mi}$. W of Cordova, Chugach Mts.; $60^{\circ} 31^{\prime} 30^{\prime \prime} \mathrm{N}, 146^{\circ} 20^{\prime} 00^{\prime \prime} \mathrm{W}$; BGN 1933; ( $\operatorname{map} 64$ ).

Local name reported in 1908 by Grant and Higgins (1909, pl. 4), USGS.

Middle Ground Shoal: shoal, $3.5 \mathrm{mi}$. long, in Gompertz Channel of Cook Inlet, $12 \mathrm{mi}$. $\mathrm{N}$ of East Foreland and $24 \mathrm{mi}$. NW of Kenai, Cook Inlet Low.; $60^{\circ} 53^{\prime} \mathrm{N}, 151^{\circ} 23^{\prime} \mathrm{W}$; (map 62).

Local descriptive name; published in 1943 by USC\&GS.

Middle Harbor Kai-gah-nee Harbors: bay, see South Kaigani Harbor.

Middle Headland: point of land, see Middle Cape.

Middle Hill: hill, $650 \mathrm{ft}$., center of Kiska I., Aleutian Is.; $51^{\circ} 56^{\prime} 46^{\prime \prime} \mathrm{N}, 177^{\circ} 34^{\prime} 10^{\prime \prime} \mathrm{E}$; (map 14). Var. Elephant Hill.

An arbitrary name beginning with " $M$ " to correspond to " $M$ " grid used by U.S. Army for tactical purposes during World War II; pub. lished on a 1953 AMS map. Variant name was published on a 1943 USAAF map.

Middle Hill: hill, $125 \mathrm{ft}$., $2 \mathrm{mi}$. N of Saint Paul, Saint Paul I., in Pribilof Is.; $57^{\circ} 09^{\prime} \mathrm{N}, 170^{\circ}$ 17 ' W ; (map 38).

Local name published in 1897 by $W . W$. Duffield, USC\&GS.

Middle Island: island, $2.3 \mathrm{mi}$. long, largest of Barrier Is., in Cordova Bay, off SW coast of Prince of Wales I., Alex. Arch.; $54^{\circ} 48^{\prime} \mathrm{N}$, $132^{\circ} 26^{\prime} \mathrm{W}$; (map 1$)$.

Local descriptive name reported in 1951 by USGS.

Middle Island: island, $700 \mathrm{ft}$. long, in Sakie Bay, on W coast of Dall I., Alex. Arch.; 55 ${ }^{\circ} 03^{\prime} 35^{\prime \prime}$ N, $133^{\circ} 11^{\prime} 30^{\prime \prime} \mathrm{W}$; (map 4).

Descriptive name published in 1924 by USC\&GS.

Middle Island: island, $0.5 \mathrm{mi}$. across, in Natzuhini Bay, $1.5 \mathrm{mi}$. $\mathrm{N}$ of Hydaburg, on $\mathrm{W}$ coast of Prince of Wales I., Alex. Arch.; 55 $14^{\prime} \mathrm{N}$, $132^{\circ} 51^{\prime} \mathrm{W}$; (map 4).

Local descriptive name published in 1965 by USC\&GS.

Middle Island: island, $2 \mathrm{mi}$. long, in Shakan Bay, between Kosciusko and Prince of Wales Is., $14 \mathrm{mi}$. $\mathrm{S}$ of Point Baker, Alex. Arch.; 56 ${ }^{\circ}$. $10^{\prime} \mathrm{N}, 133^{\circ} 32^{\prime} \mathrm{W}$; (map 6$)$.

Named in 1886 by Lt. J. M. Helm, USN, for charting purposes; name published in 1887 on USC\&GS chart 706.

Middle. Island: island, $2 \mathrm{mi}$. across, in Sitka Sound, $5.5 \mathrm{mi}$. NW of Sitka, Alex. Arch.; $57^{\circ} 06^{\prime} \mathrm{N}, 135^{\circ} 27^{\prime} \mathrm{W}$; (map 9). Var. Ostrov Sredney, Ostrov Yabloshny.

This is an 1882 translation by USC\&GS of the name given in $\mathbf{1 8 0 9}$ by the Russian navigator Ivan Vasiliev the first; reported by Lt. Sarichev (1826, map 19), IRN, as "Os[trov] Sredney." The name "Ostrov Yabloshny," meaning "apple island," was published for this island in 1848 by the Russian Hydrog. Dept. on Chart 1397.

Middle Island: island, $200 \mathrm{ft}$. long, in Kalsin Bay, on E coast of Kodiak I, ; $57^{\circ} 38^{\prime} 30^{\prime \prime} \mathrm{N}$, $152^{\circ} 21^{\prime} 51^{\prime \prime}$ W; (map 34). Var. Ostrov Sredney, Srednie Island.

Translation of the name "Os[trov] Sredney" published by Sarichev (1826, map 16).

Middle Island: island, $0.2 \mathrm{mi}$. across, $11 \mathrm{mi}$. NW of Chichagof, on $W$ coast of Chichagof I., Alex. Arch.; $57^{\circ} 46^{\prime} 55^{\prime \prime} \mathrm{N}, 136^{\circ} 19^{\prime} 20^{\prime \prime} \mathrm{W}$; (map 9).

Named in 1925 by USC\&GS and published in the 1925 Coast Pilot (p. 322). Presumably named because it is at the middle of the mouth of Davison Bay.

Middle Island: islands, see Apple Islands.

Middle Islands: islands, see Vitskari Island.

Middle Islands: islands, $2.5 \mathrm{mi}$. long, in Kashevarof Is., off NE coast of Prince of Wales I., $30 \mathrm{mi}$. SW of Wrangell, Alex. Arch.; 56 ${ }^{\circ} 11^{\prime}$ $\mathrm{N}, 132^{\circ} 57^{\prime} \mathrm{W}$; (map 6$)$.

Descriptive name given in 1886 by Lt. Comdr. A. S. Snow, USN, because of their location.

Middle Islands: islands, group in north arm of Lake Nerka, $1 \mathrm{mi}$. NE of Anvil Bry and 38 mi. NW of Dillingham, Kilbuck-Kuskokwim Mts.; $59^{\circ} 35^{\prime} \mathrm{N}, 158^{\circ} 45^{\prime} \mathrm{W} ; B G N$ 1931; (map 52).

Local name obtained in 1930 from F. $H$. Waskey and Beverley Polley, local inhabitants, by Gerald FitzGerald, USGS; published in 1938 by J. B. Mertie, USGS.

Middle Island Sankhat: island, see San Island. Middle Kaigani Harbor: bay, see South Kaigani Harbor.

Middle Kiska Lake: lake, $0.5 \mathrm{mi}$. across, between East and West Kiska Lakes, north-central Kiska I., Aleutian Is.; $52^{\circ} 03^{\prime} 45^{\prime \prime} \mathrm{N}, 177^{\circ}$ $34^{\prime} 00^{\prime \prime} \mathrm{E}$; (map 14).

One of many arbitrary names applied to features on Kiska I. by USAAF during World War II.

Middle Lagoon: lagoon, $1.5 \mathrm{mi}$. long, on $\mathrm{W}$ side of Morzhovoi Bay, at SW end of Alaska Penin.,
Bristol Bay Low.; $55^{\circ} 04^{\prime} 30^{\prime \prime} \mathrm{N}, 163^{\circ} 13^{\prime} 00^{\prime \prime}$ W; (map 29).

Descriptive name published in the 1926 Coast Pilot (p. 215).

Middle Lake: lake, $0.3 \mathrm{mi}$. long, $3 \mathrm{mi}$. $\mathrm{W}$ of terminus of Sheridan Glacier, $10 \mathrm{mi}$. E of Cordova, Chugach Mts.; $60^{\circ} 32^{\prime} \mathrm{N}, 145^{\circ} 23^{\prime} \mathrm{W}$; (map 64).

Local descriptive name published in 1950 by USGS.

Middle Lake: lake, 2,100 ft. across, E of Little Susitna River, $14 \mathrm{mi}$. NW of Anchorage, Cook Inlet Low.; $61^{\circ} 23^{\prime} 00^{\prime \prime} \mathrm{N}, 150^{\circ} 09^{\prime} 30^{\prime \prime} \mathrm{W}$; $(\operatorname{map} 70)$.

Local descriptive name reported in 1958 by USGS.

Middle Lake: lake, $3.4 \mathrm{mi}$. long, $\mathrm{N}$ of Ewan Lake, $27 \mathrm{mi}$. NW of Glennallen, Copper River Basin; $62^{\circ} 29^{\prime} \mathrm{N}, 145^{\circ} 44^{\prime} \mathrm{W}$; (map 83).

Local name reported in 1950 by USGS.

Middle Ledge: rocks, extending W $0.3 \mathrm{mi}$. toward middle of Tanaga Bay, Tanaga I., Aleutian Is.; $51^{\circ} 45^{\prime} 50^{\prime \prime} \mathrm{N}, 177^{\circ} 57^{\prime} 00^{\prime \prime} \mathrm{W}$; (map 17).

Descriptive name published by USC\&GS in 1957 on Chart 9146.

Middle Mountain: mountain, 1,760 ft., near E coast of Annette I., between Blunt and Narrows Mts., Alex. Arch.; 55 $09^{\circ} 30^{\prime \prime} \mathrm{N}$, $131^{\circ} 24^{\prime} 25^{\prime \prime} \mathrm{W}$; (map 3).

Descriptive name given in 1883 by $L t$. Comdr. H. E. Nichols, USN.

Middle Mountain: mountain, $3,328 \mathrm{ft}$., on Admiralty I., $7 \mathrm{mi}$. NE of Soapberry Mtn. and 49 mi. NE of Sitka, Alex. Arch.; 57 $27^{\prime} 17^{\prime \prime}$ N, 134 $16^{\prime} 00^{\prime \prime} \mathrm{W}$; BGN 1962; (map 9).

Local name reported in 1962 by USFS. Named for the middle arm of Pybus Bay, which trends toward it. "The Indians have called it by this name for many years."

Middle Mountain: mountain, 1,000 ft., $5.5 \mathrm{mi}$. $\mathrm{W}$ of McNeil Cove, $39 \mathrm{mi}$. SW of Augustine I., Aleutian Ra.; $59^{\circ} 08^{\prime} \mathrm{N}, 154^{\circ} 25^{\prime} \mathrm{W}$; (map 51).

Local name reported by K. F. Mather, USGS, in 1923 (in Brooks and others, 1925, pl. 3).

Middle Pass: pass, between Bluff Cove and Kiska Harbor, Kiska I., Aleutian Is.; $51^{\circ} 59^{\prime} 00^{\prime} \mathrm{N}$, $177^{\circ} 29^{\prime} 35^{\prime \prime}$ E ; (map 14). Var. Windy Pass.

An arbitrary name beginning with " $M$ " to correspond to " $M$ " grid used by U.S. Army for tactical purposes during World War II; published on a 1943 USAAF map.

Middle Peak: peak, 2,050 ft., on E end of Attu I., $2 \mathrm{mi}$. W of Point Hope, Aleutian Is. ; 52 ${ }^{\circ} 54^{\prime}$ $47^{\prime \prime} \mathrm{N}, 173^{\circ} 16^{\prime} 07^{\prime \prime} \mathrm{E}$; (map 13).

Descriptive name given in $1854-55$ by Lt. William Gibson, USN.

Middle Peak: peak, $3,722 \mathrm{ft}$., $0.6 \mathrm{mi}$. SW of Hawthorne Peak, $3 \mathrm{mi}$. SE of Thane on Gastineau Channel, and $7 \mathrm{mi}$. SE of Juneau, Coast Mts.; $58^{\circ} 15^{\prime} 20^{\prime \prime} \mathrm{N}, 134^{\circ} 15^{\prime} 00^{\prime} \mathrm{W}$; (map 11).

Descriptive name given in 1916 by D. C. Witherspoon, USGS, and published in 1918. Middle Point: point of land, on $\mathrm{E}$ shore of Bay of Waterfalls, at Chapel Cove, on SW coast 
of Adak I., Aleutian Is.; $51^{\circ} 39^{\prime} 15^{\prime \prime} \mathrm{N}, 176^{\circ}$ 49'20" W; BGN. 1936; (map 17).

Named by U.S. Navy officers in 1893 ; published by the U.S. Navy Hydrog. Office in 1895.

Middle Point: point of land, in Ham Cove, on $\mathrm{E}$

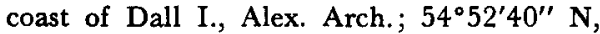
$132^{\circ} 51^{\prime} 15^{\prime \prime} \mathrm{W}$; (map 1).

Local descriptive name reported in 1951 by USGS.

Middle Point: point of land, on SW shore of Port Moller, near SW end of Alaska Penin., Aleutian Ra.; $55^{\circ} 51^{\prime} 30^{\prime \prime} \mathrm{N}, 160^{\circ} 41^{\prime} 00^{\prime} \mathrm{W}$; (map 28).

Name shown on a 1963 USG\&GS chart. Middle Point: point of land, $4 \mathrm{mi}$. $\mathbf{N}$ of Fish Bay, on $\mathrm{N}$ coast of Baranof I., $27 \mathrm{mi}$. $\mathrm{N}$ of

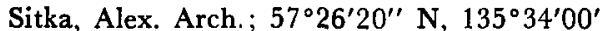
W; (map 9). Var. Mid Point, Mys Sredniy, Srednie Point.

This is a translation by USC\&GS about 1882 of the name given by the Russian pilot Ens. Vasiliev; published in 1848 on Russian Hydrog. Dept. Chart 1397 as "M [ys] Sredniy."

Middle Point: point of land, in Stephens Passage on the $W$ coast of Douglas Island, 2 mi. NW of Inner Point and $9 \mathrm{mi}$. SW of Juneau, Coast Mts.; $58^{\circ} 15^{\prime} 00^{\prime \prime} \mathrm{N}, 1^{\prime} 4^{\circ} 37^{\prime} 30^{\prime \prime} \mathrm{W}$; (map 11).

Local name published in 1942 by USGS.

Middle Point: point of land, on N coast of Montague I., between Rocky Bay and Zaikof Bay, $39 \mathrm{mi}$. E of Chenega, Chugach Mts.; $60^{\circ} 20^{\prime}$ $40^{\prime \prime} \mathrm{N}, 147^{\circ} 00^{\prime} 00^{\prime \prime} \mathrm{W}$; (map 63). Var. Punta de Carrillo.

Descriptive name given in 1902 by Ferdinand Westdahl, USC\&GS. Named "Punta de Carrillo" about August 1, 1779, by Don Ignacio Arteaga "perhaps after one of the Carrillos then in California" (Wagner, 1937, p. 440).

Middle Point: point of land, see Bear Cape.

Middle Point: point of land, see Center Point Middle Point: point of land, see Sennett Point.

Middle Point: point of land, see Vincennes Point.

Middle Punuk Island: island, in Punuk Islands, $16 \mathrm{mi}$. S of Northeast Cape, St. Lawrence I. $63^{\circ} 05^{\prime} \mathrm{N}, 168^{\circ} 49^{\prime} \mathrm{W}$; (map 93)

Descriptive name; see Punuk Islands.

Middle Reef: reef, in Pacific Ocean, 22 mi. S of Buldir I. and $50 \mathrm{mi}$. W of Kiska I., Aleutian Is.; $51^{\circ} 59^{\prime} \mathrm{N}, 176^{\circ} 01^{\prime} \mathrm{E}$; (map 14).

Local name reported in the 1944 Aleutian Coast Pilot (p. 129)

Middle Reef: reef, 3 mi. long, in middle of Alitak Bay, at $S$ end of Kodiak I.; $56^{\circ} 54^{\prime} \mathrm{N}, 154^{\circ}$ $03^{\prime} \mathrm{W}$; (map 32 ).

Descriptive name reported in 1900 by Comdr. J. F. Moser, USN.

Middle River: stream, distributary of Chakachatna River, flows SE $10 \mathrm{mi}$. to Trading Bay, $32 \mathrm{mi}$. NW of Kenai, Cook Inlet Low. $60^{\circ} 58^{\prime} \mathrm{N}, 151^{\circ} 35^{\prime} \mathrm{W}$; (map 62).

Local descriptive name; reported in 1958 by USGS.
Middle Rock: island, see Prolewy Rocks.

Middle Rock: rock, in Bay of Waterfalls, on SW coast of Adak I., Aleutian Is.; $51^{\circ} 40^{\prime} 15^{\prime \prime} \mathrm{N}$, 176 51'35" W; BGN 1936; (map 17).

Descriptive name given by Lt. William Gibson, USN. See Low Point.

Middle Rock: rock, $1 \mathrm{mi}$. N of Legma I., in Necker Is., $16 \mathrm{mi}$. SW of Sitka, Alex. Arch.; $56^{\circ} 50^{\prime} 55^{\prime} \mathrm{N}, 135^{\circ} 26^{\prime} 00^{\prime \prime} \mathrm{W}$; (map 5). Var Srednie Rock, Kamen Sredney.

This is a translation by USC\&GS of the name given in 1809 by the navigator Ivan Vasiliev the first, IRN. Lt. Sarichev (1826, map 19), IRN, published it as "K[amen] Sredney."

Middle Rock: rock, in Valdez Narrows, at en trance to Port Valdez, $13 \mathrm{mi}$. SW of Valdez Chugach Mts.; $61^{\circ} 04^{\prime} 55^{\prime \prime} \mathrm{N}, 146^{\circ} 39^{\prime} 00^{\prime \prime} \mathrm{W}$; (map 68)

Name published in 1911 by the USC\&GS on Chart 5519; so called because of its position in the channel.

Middle Rocks: rocks, E of Kennon I., in mouth of Chichagof Harbor, on NE coast of Attu I., Aleutian Is.; $52^{\circ} 55^{\prime} 22^{\prime \prime} \mathrm{N}, 173^{\circ} 15^{\prime} 55^{\prime \prime} \mathrm{E}$; (map 13).

Descriptive name given in $1854-55$ by $\mathrm{Lt}$. William Gibson, USN.

Middle Rocks: rocks, see Vistskari Rocks.

Middle Salt Lagoon: lagoon, $1 \mathrm{mi}$. across, on Chukchi Sea coast, at mouth of Beaded Creek, 2 mi. NE of Barrow, Arctic Plain; $71^{\circ} 19^{\prime} \mathrm{N}, 156^{\circ} 41^{\prime} \mathrm{W}$; (map 153). Var. Sinnyu, Sinnyuli.

Named for scientific purposes (Carson and Hussey, 1962). This is probably the same lagoon that Lt. P. H. Ray $(1885$, p. 55) recorded as Sinnyu, meaning "thong" or "shoestring."

Middle Slough: watercourse, $4.5 \mathrm{mi}$. long, a channel of Yukon River, in Devils Elbow, W of Blade I. and $25 \mathrm{mi}$. SW of Russian Mission, Yukon-Kuskokwim Delta; 61 ${ }^{\circ} 36^{\prime} \mathrm{N}$, $162^{\circ} 00^{\prime} \mathrm{W}$; (map 73 ).

Riverboat pilots' descriptive name shown on a 1916 field sheet by R. H. Sargent, USGS.

Middle Slough: water passage, on $\mathbf{N}$ coast of Blacksand I. at mouth of Situk River, $10 \mathrm{mi}$. $\mathrm{SE}$ of Yakutat, Malaspina Coastal Plain; $59^{\circ}$. $26^{\prime} 40^{\prime \prime} \mathrm{N}, 139^{\circ} 33^{\prime} 10^{\prime \prime} \mathrm{W}$; (map 46). Var. Johnsons Slough.

Local name published in 1959 by USGS. Middle Spit: point of land, see Cutter Point. Middleton, Mount: mountain, 5,266 ft., on Alaska-Canada boundary, $34 \mathrm{mi}$. NW of Hyder, Coast Mts., $56^{\circ} 16^{\prime} 00^{\prime \prime} \mathrm{N}, 130^{\circ} 37^{\prime} 20^{\prime \prime}$ W; BGN 1924; (map 7)

Named in 1924 by USGS for Henry Middleton, 1771-1846, U.S. minister to Russia, 1820-1830, who "negotiated treaty with Russia, 1824, regulating trade and fisheries in the Pacific Ocean and northwest coast of America, and establishing the line of $54^{\circ} 40^{\prime}$ as the southern limit of Russian settlement." Middleton Island: island, $19 \mathrm{mi}$. long, in Gulf of Alaska, $80 \mathrm{mi}$. SW of Cordova, Malaspina Coastal Plain; $59^{\circ} 26^{\prime} \mathrm{N}, 146^{\circ} 20^{\prime} \mathrm{W}$; (map 48). Var. Achakoo Island, Achek Island,
Atchaka Island, Galiano Island, Isla de Hijosa, Middletons Island, Ostrov Kocheck, Rasa Island.

Named in 1794 by Capt. George Vancouver, RN, "probably after Sir Charles Middleton, a rear admiral and comptroller of the navy. In 1788 it had been discovered by [E.J.] Martínez who named it 'Hijosa.' In 1791 Malaspina first named it 'Rasa' but soon changed this to 'Galiano'" (Wagner, 1937, p. 397398). The Eskimo name "Achakoo" was published for this island by Bancroft (1886, p. 268); Capt. Tebenkov (1852, map 6), IRN, called it "Ostrov Ochek" or "Ochek Island," probably from "ochekanit," meaning "to chisel (or carve) round," because of its shape.

Middletons Island: island, see Middleton Island.

Middle Yoke Creek: stream, flows SE $2 \mathrm{mi}$. to Yoke Bay, on SE coast of Great Sitkin I., Aleutian Is. ; $52^{\circ} 01^{\prime} 24^{\prime \prime} \mathrm{N}, 176^{\circ} 02^{\prime} 28^{\prime \prime} \mathrm{W}$ (map 17).

Descriptive name published in 1951 by USGS.

Middy Point: point of land, E tip of Ham I., at $\mathrm{N}$ entrance to Felice Strait, Alex. Arch.; $55^{\circ}$. $10^{\prime} 15^{\prime \prime} \mathrm{N}, 131^{\circ} 19^{\prime} 30^{\prime \prime} \mathrm{W}$; (map 3 ).

Named in 1883 by Lt. Comdr. H. E. Nichols, USN; "named for the [U.S. Naval] Academy middies."

Midnight Cove: cove, $0.3 \mathrm{mi}$. wide, on $\mathrm{N}$ shore of Moonlight Bay, on SE coast of Kenai Penin., $43 \mathrm{mi}$. ESE of Homer, Chugach Mts.; $59^{\circ} 30^{\prime}$ $40^{\prime \prime} \mathrm{N}, 150^{\circ} 20^{\prime} 15^{\prime \prime} \mathrm{W} ;$ BGN 1929; (map 50 ).

Named by USG\&GS field party in 1927 .

Midnight Creek: stream, flows SW $5.6 \mathrm{mi}$. to Long Creek, $8 \mathrm{mi}$. W of Long and $31 \mathrm{mi}$. SW of Ruby, Kilbuck-Kuskokwim Mts. ; 64 $4^{\circ} 18^{\prime} 12^{\prime \prime}$ $\mathrm{N}, 155^{\circ} 37^{\prime} 45^{\prime \prime} \mathrm{W}$; (map 98)

Prospectors' name reported in 1911 by A. G. Maddren (in Brooks and others, 1912, p. 294296), USGS.

Midnight Creek: stream, heads NE of Midnight Mtn., flows SE $5 \mathrm{mi}$. to Taylor Creek which flows to Kougarok River, $38 \mathrm{mi}$. NW of Imuruk Lake, Seward Penin. High.; 65 ${ }^{\circ} 45^{\prime}$ $\mathrm{N}, 164^{\circ} 28^{\prime} \mathrm{W}$; (map 110). Var. Kennedy Creek.

Prospectors' name reported in 1901 by T. G. Gerdine (in Collier, 1902, pl. 12), USGS.

Midnight Creek: stream, heads in Canada, flows NW across Alaska-Canada boundary $15 \mathrm{mi}$. to Bull Creek, $50 \mathrm{mi}$. NE of junc. of Charley and Yukon Rivers, Porcupine Plat.; $65^{\circ} 58^{\prime} 30^{\prime \prime}$ $\mathrm{N}, 141^{\circ} 12^{\prime} 45^{\prime \prime} \mathrm{W}$; (map 103).

Local name published in 1956 by USGS

Midnight Dome: mountain, $3,600 \mathrm{ft}$., $1.5 \mathrm{mi}$. S of Smith Creek Dome and $3.5 \mathrm{mi}$. N of Wiseman, Brooks Ra.; $67^{\circ} 27^{\prime} 30^{\prime \prime} \mathrm{N}, 150^{\circ} 09^{\prime} 00^{\prime \prime}$ W; BGN 1932; (map 124).

Local name reported in 1932 by Robert Marshall, "because it is a spot to which the inhabitants climb on June 22, to see the midnight sun."

Midnight Hill: mountain, $3,180 \mathrm{ft} ., 3 \mathrm{mi}$. W of Alaska-Canada boundary and $84 \mathrm{mi}$. SE of 
Chalkyitsik, Porcupine Plat.; $66^{\circ} 03^{\prime}$ N, $141^{\circ}$ 06' W; (map 120).

Local name obtained in 1956 by T. E. Taylor and R. C. Foley, USGS.

Midnight Mountain: mountain, 2,720 ft., $11 \mathrm{mi}$. N. of Harris Dome and $40 \mathrm{mi}$. NW of Imuruk Lake, Seward Penin. High'; $65^{\circ} 46^{\prime}$ N, $164^{\circ}$ 35' W; (map 110).

Local name reported in 1900 by Brooks (1901, pl. 11), USGS.

Midnight Mountain: mountain, 6,000 ft., $2 \mathrm{mi}$. $\mathrm{S}$ of Mount Doonerak and $36 \mathrm{mi}$. NW of Wiseman, Brooks Ra.; $67^{\circ} 53^{\prime} 00^{\prime \prime}$ N, $150^{\circ} 36^{\prime}$ $30^{\prime \prime} \mathrm{W}$; (map 124).

Named in 1939 by Marshall (1956, p. 148) who wrote, "we spent more than an hour, equally distributed around midnight, on the summit, and called our peak Midnight Mountain."

Mid Point: point of land, between Scabbard and Finger Bays, on S shore of Kuluk Bay, on NE coast of Adak I., Aleutian Is.; $51^{\circ} 50^{\prime} 40^{\prime \prime} \mathrm{N}$, $176^{\circ} 33^{\prime} 00^{\prime \prime} \mathrm{W}$; BGN 1936; (map 17).

So named by members of the U.S. Navy Aleutian Island Survey Expedition in 1934, "because it is midway between Lucky Point and Thunder Point."

Mid Point: point of land, see Middle Point.

Mid Reef: reef, in Amlia Pass, between Atka and Amlia Is., Aleutian Is.; $52^{\circ} 07^{\prime} 47^{\prime \prime} \mathrm{N}, 174^{\circ}$ 04'15" W; (map 18).

Name published by the USC\&GS in the 1944 Aleutian Coast Pilot (p. 90). So called because "it is midway between the islands."

Midsitena: stream, see Canoe Portage Creek.

Midtimber River: stream, heads in lake at 1950 terminus of Bering Glacier, flows $\mathrm{SE}$ and $\mathrm{W}$ $8 \mathrm{mi}$. to Gulf of Alaska, $13 \mathrm{mi}$. NE of Cape Suckling, Malaspina Coastal Plain; $60^{\circ} 05^{\prime} 30^{\prime \prime}$ $\mathrm{N}, 143^{\circ} 24^{\prime} 50^{\prime \prime} \mathrm{W}$; (map 65).

Name published by F. H. Moffit (1914, pl. 1), USGS.

Midun Island: island, $0.5 \mathrm{mi}$. across, $4 \mathrm{mi}$. SE of Deer I., SW end of Aleutian Ra.; 54 $50^{\circ}$ $30^{\prime \prime} \mathrm{N}, 162^{\circ} 10^{\prime} 20^{\prime \prime} \mathrm{W}$; (map 25).

Name reported by W. H. Dall, USC\&GS, and published in 1882 by USC\&GS on Chart 806.

Miduuski: locality, "on E bank of Copper River." Former Athapascan Indian camp or settlement listed by Hodge (1907, p. 859).

Miduuski River: stream, see Matanuska River.

Midway Bay: bay, extends NW 2 mi., off Sitkalidak Strait, $W$ of Bush Point, on SE coast of Kodiak I.; $57^{\circ} 13^{\prime} 30^{\prime \prime} \mathrm{N}, 153^{\circ} 14^{\prime} 00^{\prime \prime} \mathrm{W}$; BGN 1930; (map 34). Var. Sheep Bay.

Descriptive name given in 1930 by USC\&GS, "because this bay is about midway of the length of Sitkalidak Strait * * *", The name "Sheep Bay" was suggested in 1928 by a USC\&GS field party.

Midway Camp: locality, 2 mi. S of Mount Cameron and $15 \mathrm{mi}$. NW of Valdez, Chugach Mts.; $61^{\circ} 10^{\prime} 45^{\prime \prime} \mathrm{N}, 146^{\circ} 40^{\prime} 30^{\prime \prime} \mathrm{W}$; (map 68).

Former mining camp name reported in 1911 by USGS
Midway Island: island, $300 \mathrm{ft}$. long, in Tlevak Strait, between Dall and Prince of Wales Is., Alex. Arch.; $55^{\circ} 15^{\prime} 15^{\prime \prime} \mathrm{N}, 133^{\circ} 05^{\prime} 55^{\prime \prime} \mathrm{W}$; (map 4).

Local descriptive name; published in 1925 Coast Pilot (p. 138).

Midway Island: island, $0.2 \mathrm{mi}$. across, in Redfish Bay, $10 \mathrm{mi}$. NW of village of Port Alexander, on $\mathrm{S}$ coast of Baranof I., Alex. Arch.; $56^{\circ}$ $19^{\prime} 40^{\prime \prime} \mathrm{N}, 134^{\circ} 52^{\prime} 10^{\prime \prime} \mathrm{W}$; (map 5).

Named in 1897 by Lt. Comdr. J. F. Moser, USN, commander of USBF steamer Albatross.

Midway Island: island, $0.1 \mathrm{mi}$. across, in S part of Port Frederick, $10 \mathrm{mi}$. SW of Hoonah, on N central Chichagof I., Alex. Arch.; 57 59'$50^{\prime \prime} \mathrm{N}, 135^{\circ} 36^{\prime} 30^{\prime \prime} \mathrm{W}$; (map 9).

Descriptive name published in 1926 by USC\&GS on Chart 8304. Presumably so named because the island is in the center of The Narrows.

Midway Island: rock, see Hague Rock.

Midway Islands: barrier islands, consist of Argo and Reindeer Is., extend $3 \mathrm{mi}$. on Beaufort Sea coast, $7 \mathrm{mi}$. N of Prudhoe Bay, and 18.5 mi. E of Beechey Point, Arctic Plain; 70 27' N, $148^{\circ} 16^{\prime} \mathrm{W}$; (map 150$)$.

Name reported in 1889 by Capt. C. $R$. Stockton, RN.

Midway Islands: islands, $1 \mathrm{mi}$. across, in $\mathbf{N}$ part of Pybus Bay, on SE coast of Admiralty I., Alex. Arch.; 57 $19^{\prime} \mathrm{N}, 134^{\circ} 05^{\prime} \mathrm{W}$; (map 9).

Name published in 1947 by USC\&GS on Chart 8218.

Midway Islands: islands, in Stephens Passage between Snettisham Penin. and Admiralty I., 4 mi. NE of Point Glass and $37 \mathrm{mi}$. SE of Juneau, Coast Mts.; $57^{\circ} 50^{\prime} 15^{\prime \prime}$ N., $133^{\circ} 48^{\prime} 45^{\prime \prime} \mathrm{W}$; (map 8).

Named by Comdr. R. W. Meade, USN; name published in 1869 on Hydrog. Chart 225 ; so named because "they are nearly in the middle of Stephens Passagè."

Midway Lake: lake, $3.4 \mathrm{mi}$. long, $\mathrm{S}$ of Alaska Highway, $22 \mathrm{mi}$. E of Tok, Yukon-Tanana High.; $63^{\circ} 13^{\prime} \mathrm{N}, 142^{\circ} 17^{\prime} \mathrm{W}$; (map 85).

Local name published by USGS in 1950 .

Midway Lakes: lakes, extend NW-SE $1.5 \mathrm{mi}$ between East and West Forks Yentna River, $59 \mathrm{mi}$. W of Talkeetna, Alaska Ra.; $62^{\circ} 21^{\prime} 25^{\prime \prime}$ $\mathrm{N}, 151^{\circ} 56^{\prime} 40^{\prime \prime} \mathrm{W}$; (map 81).

Local descriptive name reported in 1958 by USGS

Midway Point: point of land, $\mathrm{E}$ point of entrance to Isthmus Bay, on S shore of Chiniak Bay, $13 \mathrm{mi}$. SE of Kodiak, Kodiak I.; 57 $37^{\prime}$ $30^{\prime \prime} \mathrm{N}, 152^{\circ} 15^{\prime} 00^{\prime \prime} \mathrm{W}$; (map 34$)$.

Local descriptive name; reported in 1949 by USGS.

Midway Point: point of land, on E coast of Glass Penin., $5 \mathrm{mi}$. S of Point Glass and $42 \mathrm{mi}$. S of Juneau, Alex. Arch.; $57^{\circ} 44^{\prime} 00^{\prime \prime} \mathrm{N}, 1^{\circ} 3^{\circ} 52^{\prime}$ 25" W; (map 8)

Named in 1889 by Lt. Comdr. H. B. Mansfield, USN; published in 1892 by USC\&GS Midway Reef: reef, in Mine Harbor, in SE arm of Herendeen Bay, near SW end of Alaska
Penin., Aleutian Ra.; $55^{\circ} 45^{\prime} 50^{\prime \prime} \mathrm{N}, 160^{\circ} 41^{\prime}$ $40^{\prime \prime} \mathrm{W}$; (map 28).

Named in 1890 by Lt. Comdr. Z. L. Tanner, USN, and shown on a 1963 USC\&GS chart. Midway Reef: reef, at E end of Peril Strait, 2 mi. S of Chichagof I., $11 \mathrm{mi}$. SW of Angoon, Alex. Arch.; $57^{\circ} 26^{\prime} 00^{\prime \prime} \mathrm{N}, 134^{\circ} 50^{\prime} 40^{\prime \prime} \mathrm{W}$; (map 9).

Named by W. H. Dall, USC\&GS, and published in 1883 Coast Pilot (p. 167).

Midway Rock: rock, between Ukolnoi and Wosnesenski Is., $10 \mathrm{mi}$. NE of Dolgoi I., Aleutian Ra.; 55 $12^{\prime} 15^{\prime \prime} \mathrm{N}, 161^{\circ} 28^{\prime} 30^{\prime \prime} \mathrm{W}$; (map 28).

Name shown on a USC\&GS chart published in 1964.

Midway Rock: rock, at S end of Wrangell Narrows, $19 \mathrm{mi}$. $\mathrm{S}$ of Petersburg, Alex. Arch.; $56^{\circ} 31^{\prime} 50^{\prime \prime} \mathrm{N}, 132^{\circ} 57^{\prime} 45^{\prime \prime} \mathrm{W}$; (map 6). Var. Polivnoi Rock, Polivnoy.

Named in 1869 by Comdr. R. W. Meade, USN; named "Polivnoy" meaning "awash" in 1838 by the Russian surveyor, G. Lindenberg.

Midway Rock: rock, in Peril Strait, $2.5 \mathrm{mi}$. N of Fish Bay, off NW coast of Baranof I., Alex. Arch.; $57^{\circ} 25^{\prime} 00^{\prime \prime} \mathrm{N}, 135^{\circ} 36^{\prime} 20^{\prime \prime} \mathrm{W}$; (map 9). Var. Kamen Sredniy.

This is a translation by USC\&GS about 1882 of the name given by the Russian pilot Ens. Vasiliev; published in 1848 on Russian Hydrog. Dept. Chart 1397 as "Kam[en] Sredniy."

Midway Rocks: rocks, in Port Frederick on Chichagof I., $1.6 \mathrm{mi}$. S of Chimney Rock and $0.5 \mathrm{mi}$. SW of Hoonah, Alex. Arch.; $58^{\circ} 00^{\prime}$ -

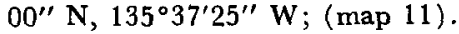

Local name published in 1950 by USC\&GS on Chart 8304

Miednaia: stream, see Copper River.

Mielkie Point: point of land, see Rock Point.

Mielkoi Cove: bay, $0.2 \mathrm{mi}$. across, $6.5 \mathrm{mi}$. $\mathrm{S}$ of Sitka, on W coast of Baranof I., Alex. Arch.; $56^{\circ} 57^{\prime} 45^{\prime \prime} \mathrm{N}, 135^{\circ} 22^{\prime} 30^{\prime \prime} \mathrm{W}$; (map 5).

Russian word "melkoi," meaning "shallow," published in 1929 by USC\&GS.

Mieshak, Zaliv: bay, see Missak Bay.

Miesof: point of land, see Black Point.

Miesofski: point of land, see Black Point.

Miga, Cape: point of land, on $\mathrm{N}$ coast of Kanaga I., Aleutian Is.; $51^{\circ} 56^{\prime} 20^{\prime \prime} \mathrm{N}, 177^{\circ} 10^{\prime} 50^{\prime \prime} \mathrm{W}$; $B G N$ 1936; (map 17). Var. Mys Miga.

Russian name published by Capt. Tebenkov (1852, map 28), IRN, as "M[ys] Miga," or "Cape Miga," from the word "mig," meaning "wink" or "twinkling of an eye."

Migrant Lakes: lakes, $16 \mathrm{mi}$. WSW of Liberator Lake, Arctic Slope ; $68^{\circ} 49^{\prime} 30^{\prime \prime} \mathrm{N}, 158^{\circ} 58^{\prime} 00^{\prime \prime}$ W; BGN 1960; (map 132).

Named in. 1953 by I. L. Tailleur, USGS, "for migration of lake beds."

Miguakiak River: stream, distributary of Ikpikpuk River, flows E $20 \mathrm{mi}$. to Teshekpuk Lake, Arctic Plain; $70^{\circ} 39^{\prime} \mathrm{N}, 154^{\circ} 06^{\prime} \mathrm{W}$; (map 148). Var. Mayoriak.

Eskimo name that first appeared on Maguire's chart (Great Britain, 1854, facing p. 186) as "R. Miguakiak." This feature is probably the same stream spelled "Mayoriak" by Stefánsson (Leffingwell, 1919, p. 97). 
Miguakiak River: stream, see Mayoriak River.

Mijillones, Punta de los: point of land, see Miliflores, Point.

Mikchalk Lake: lake, extends SE $1.6 \mathrm{mi}$. from mouth of Wind River to head of Peace River, $51 \mathrm{mi}$. NW of Dillingham, Kilbuck-Kuskokwim Mts.; $59^{\circ} 45^{\prime} \mathrm{N}, 158^{\circ} 52^{\prime} \mathrm{W}$; BGN 1931; (map 52). Var. Fourth Lake, Nan-viuk-kanuk.

The Eskimo name of this lake was reported as "Nan-viuk-ka-nuk" on a 1910 manuscript map by H. C. Fassett, USBF; called "Fourth Lake" in 1925 by the U.S. Commissioner of Fisheries because it is the fourth one from Nushagak Bay. The descriptive Eskimo name "Mikchalk," meaning "small lake," was recorded in 1931 by Gerald FitzGerald, USGS ; published by Mertie (1938b, pl. 1), USGS.

Mike Creek: stream, heads at Leak Hill, flows SE $2 \mathrm{mi}$. to Mutt Cove, center of Kiska I., Aleutian Is.; $51^{\circ} 56^{\prime} 20^{\prime \prime} \mathrm{N}, 177^{\circ} 30^{\prime} 14^{\prime \prime} \mathrm{E}$; (map 14). Var. Sidecar Creek.

An arbitrary name beginning with " $M$ " to correspond to " $M$ " grid used by U.S. Army for tactical purposes during World War II; published on a 1953 AMS map. Variant published on a 1943 USAAF map.

Mike Hess Creek: stream, see Hess Creek.

Mike Hill: hill, $350 \mathrm{ft}$., E of Mutt Cove, center Kiska I., Aleutian Is.; $51^{\circ} 56^{\prime} 30^{\prime \prime} \mathrm{N}$, $177^{\circ} 30^{\prime} 15^{\prime \prime}$ E (map 14).

An arbitrary name beginning with " $M$ " to correspond to " $M$ " grid used by U.S. Army for tactical purposes during World War II ; published on a 1943 Army map.

Mike Point: point of land, between Raymond and Wadding Coves, on $\mathbf{E}$ coast of Cleveland Penin., Alex. Arch.; 55 $37^{\prime} 15^{\prime \prime}$ N, $131^{\circ}$. 52'40" W.; (map 3).

Local navigators' name obtained in 1904 by H. C. Fassett, USBF.

Mikes Bay; cove, $0.5 \mathrm{mi}$. wide, on $\mathrm{W}$ coast of Nuka I., 36 mi. ESE of Seldovia, Ghugach Mts.; $59^{\circ} 21^{\prime} 30^{\prime \prime} \mathrm{N}, 150^{\circ} 43^{\prime} 00^{\prime \prime} \mathrm{W}$; (map 50).

Local name published by USGS in 1953.

Mikfik Creek: stream, flows N 5 mi. to McNeil River, $35 \mathrm{mi}$. SW of Augustine I., Aleutian Ra.; 59 $9^{\circ} 7^{\prime} \mathrm{N}, 154^{\circ} 15^{\prime}$ W ; (map 51).

Native name reported by $\mathrm{K}$. F. Mather, USGS, in 1923 (in Brooks and others, 1925, pl. 3).

Mikhaila, Ostrov: island, see Saint Michael Island.

Mikhailovosk: locality, see Fort Saint Michael. Mikhailovsk: locality, see Old Sitka.

Mikhail Point: point of land, between Abraham and Etienne Bays, on SW coast of Attu I., Aleutian Is.; $52^{\circ} 52^{\prime} \mathrm{N}, 172^{\circ} 37^{\prime} \mathrm{E}$; BGN 1938; (map 13). Var. Michael Point, Portage Point.

Named for Capt. Mikhail Dmitrievich Tebenkov, 1831-50, early explorer of the North Pacific, director of the Russian American Company and Governor of Russian America from 1845-50. Shown as "Portage Point" on a manuscript map by $L$. M. Turner in the 1880 's. The name "Michael Point" was pro- posed in 1938 by U.S. Navy Hydrog. Office and was subsequently approved as "Mikhail Point" by BGN.

Mikigealiak River: stream, heads in Takrak Lake, flows N $25 \mathrm{mi}$. to Kungok River, $17 \mathrm{mi}$. SE of Wainwright, Arctic Plain; $70^{\circ} 30^{\prime} \mathrm{N}$ $159^{\circ} 25^{\prime}$ W; (map 146). Var. Mikigialek River.

Eskimo name reported as "Mikigialek" in 1924 by USGS.

Mikigialek River: stream, see Mikigealiak River. Mikisagimiut: locality, on $\mathbf{N}$ coast of Nunivak I., $7 \mathrm{mi}$. NW of Seemalik Butte, $42 \mathrm{mi}$. SW of Cape Etolin.; $60^{\circ} 13^{\prime} 15^{\prime \prime} \mathrm{N}, 167^{\circ} 16^{\prime} 30^{\prime \prime} \mathrm{W}$; (map 57).

Eskimo summer camp reported in 1932 by USC\&GS.

Mikischkin, Gap: promontory, see East Foreland.

Mikkelsen Bay: bay, 9 mi. across, on Beaufort Sea coast, between Bullen Point and Tigvariak I., $15 \mathrm{mi}$. W of Flaxman I., Arctic Plain; $70^{\circ} 11^{\prime} \mathrm{N}, 147^{\circ} 04^{\prime} \mathrm{W}$; (map 150).

Named by Leffingwell (1919, p. 97) for his associate, Capt. Ejnar Mikkelsen of the Anglo-American Polar Expedition, 1906.

Milady Island: island, off left bank of Yukon River, $\mathrm{S}$ of Koyukuk and between Megotsol and Koyukuk I., Koyukuk Low.; $64^{\circ} 50^{\prime} \mathrm{N}$, 157 $43^{\prime} \mathrm{W}$; (map 97).

Riverboat pilots' name shown on a 1940 "Navigation Chart of the Tanana-Yukon Rivers" published by U.S. Dept. of Interior. Mile Creek: stream, flows SE $1 \mathrm{mi}$. to Shovel Creek near its head, $12 \mathrm{mi}$. $\mathrm{N}$ of Solomon, Seward Penin. High.; $64^{\circ} 43^{\prime} 30^{\prime \prime} \mathrm{N}, 165^{\circ} 26^{\prime}$ $00^{\prime \prime} \mathrm{W}$; (map 95).

Prospectors' name reported on a 1902 prospectors' manuscript map.

Miles Glacier: glacier, trends W $30 \mathrm{mi}$. to its terminus at Miles Lake, $2 \mathrm{mi}$. N of Goat Mtn. and $33 \mathrm{mi}$. N of Katalla, Chugach Mts.; $60^{\circ} 40^{\prime} \mathrm{N}, 144^{\circ} 37^{\prime} \mathrm{W}$; (map 64).

Named in 1885 by Lt. Allen (1887, pl. 5), USA, during his Alaska expedition, for Maj. Gen. Nelson A. Miles, 1839-1925, USA. "He entered the Army as a volunteer in 1861, attaining the rank of Maj. General of Volunteers, grade by grade, and at age of 25 commanded an army corps. He entered regular army at close of Civil War, rose by regular grades to be Maj. General, succeeding to command of USA on retirement of Gen. Schofield. He conducted several campaigns against hostile Indians on the Western frontiers, notably that against Apaches under Geronimo and Natchez, who surrendered in 1886." (Who's Who in America, 1899, p. 491).

Miles Lake: lake, $3.5 \mathrm{mi}$. across, in Copper River, at terminus of Miles Glacier, $33 \mathrm{mi}$. $\mathrm{N}$ of Katalla, Chugach Mts.; $60^{\circ} 41^{\prime} \mathrm{N}, 144^{\circ} 40^{\prime} \mathrm{W}$; (map 64)

Local name published by the Alaska Railroad Commission (1913, pl. 5). Name derived from nearby Miles Glacier.

Miles Pass: pass, see Suslota Pass.

Mile Twenty: locality, see Bluff.
Miliak Cove: estuary, see Soapstone Cove

Miliflores, Point: point of land, SE tip of San Juan Bautista I., in Bucareli Bay, Alex. Arch.; $55^{\circ} 24^{\prime} 30^{\prime \prime}$ N, $133^{\circ} 15^{\prime} 05^{\prime \prime}$ W; (map 4). Var. Miliflores Point, Punta de los Mejillones, Punta de los Mijillones, Punta de los Milillores, Thousand Flowers Point.

This point was originally called "Punta de Mejillones" meaning "mussel (or clam) point" by the 1779 Don Ignacio Arteaga expedition. Its present name was derived from a mistake in reading the original Spanish map and recording "Milflores (Miliflores)," i.e. "thousand flowers."

Miliffores Point: point of land, see Miliflores, Point.

Milillores, Punta de los: point of land, see Miliflores, Point.

Military Creek: stream, flows NW $0.8 \mathrm{mi}$. to Birch Creek, which flows to Big Four Creek, $19 \mathrm{mi}$. NE of Solomon, Seward Penin. High.; $64^{\circ} 49^{\prime} \mathrm{N}, 164^{\circ} 10^{\prime} \mathrm{W}$; (map 95). Var. Milton Creek.

Prospectors' name published in 1956 by USGS. Reported as "Milton" on a prospectors' manuscript map dated 1902.

Militia Hill: hill, $325 \mathrm{ft}$, on eastern Kiska I., near South Pass, Aleutian Is.; $51^{\circ} 56^{\prime} 15^{\prime \prime} \mathrm{N}$, $177^{\circ} 36^{\prime} 10^{\prime \prime} \mathrm{E}$; (map 14).

An arbitrary name beginning with " $M$ " to correspond to " $M$ " grid used by the U.S. Army for tactical purposes during World War II; published on a 1953 AMS map.

Milk Creek: stream, flows SW $5 \mathrm{mi}$. to lower Alec River, $3 \mathrm{mi}$. E of Black Lake, Aleutian Ra.; $56^{\circ} 27^{\prime}$ N, $158^{\circ} 52^{\prime}$ W ; (map 30).

Name reported in 1923 by R. H. Sargent, USGS; published in 1927 by USGS.

Milk Creek: stream, $22 \mathrm{mi}$. long, flows NE from Heart Lake to Chikuminuk Lake, $98 \mathrm{mi}$. SE of Bethel, Kilbuck-Kuskokwim Mts.; $60^{\circ} 12^{\prime} \mathrm{N}$, $159^{\circ} 09^{\prime} \mathrm{W}$; (map 59 ).

Descriptive name given in 1954 by J. M. Hoare and W. L. Conrad, USGS; "Chikuminuk Glacier drains into this creek causing it to appear white."

Milk Creek: stream, heads at Milk Glacier, flows SW $0.9 \mathrm{mi}$. to Crow Creek, $29 \mathrm{mi}$. SE of Anchorage, Chugach Mts.; $61^{\circ} 01^{\prime} 35^{\prime \prime} \mathrm{N}, 149^{\circ}$ 06'30" W; BGN 1932; (map 69).

Local name reported in 1932 by W. G. Carson and C. F. Park, USGS.

Milk Glacier: glacier, heads between Goat and Summit Mts., trends SW 2 mi. to its terminus at Milk Creek, $29 \mathrm{mi}$. SE of Anchorage, Chugach Mts.; 61 $02^{\prime} 15^{\prime \prime} \mathrm{N}, 149^{\circ} 06^{\prime} 10^{\prime \prime} \mathrm{W}$; $B G N$ 1932; (map 69).

Local name reported in 1932 by W. G. Carson and C. F. Park, USGS.

Millard Creek: stream, flows NW 5 mi. to Galena Bay, $40 \mathrm{mi}$. NW of Cordova, Chugach Mts.; $60^{\circ} 55^{\prime} 30^{\prime \prime} \mathrm{N}, 146^{\circ} 35^{\prime} 30^{\prime \prime} \mathrm{W}$; (map 64).

Local name reported in 1912 by Capps and Johnson (in Brooks and others, 1913, p. 88), USGS; possibly named for B. F. Millard, an officer of the Granite Gold Mining Co. 
Millard Lake: lake, $0.7 \mathrm{mi}$. long, $2.5 \mathrm{mi}$. $\mathrm{N}$ of Copper Mtn., $38 \mathrm{mi}$. NW of Cordova, Chugach Mts.; $60^{\circ} 54^{\prime} 30^{\prime \prime} \mathrm{N}, 146^{\circ} 34^{\prime} 30^{\prime \prime} \mathrm{W}$; (map 64). Var. Mallard Lake.

Reported in 1912 as "Mallard" by R. H. Sargent and C. E. Giffin, USGS, but was published in 1918 as "Millard Lake" by USC\&GS.

Millar Rocks: rocks, extend $0.6 \mathrm{mi}$., between Meares Passage and Pacific Ocean, $S$ of Suemez I., Alex. Arch.; $55^{\circ} 11^{\prime} 50^{\prime \prime}$ N, $133^{\circ}$ $15^{\prime} 45^{\prime \prime} \mathrm{W}$; (map 4).

Name published as "Millars Reef" in 1914 by USC\&GS; possibly named for Craig Millar, a cannery man for whom the village of Craig was named. See Craig.

Mill Bay: bay, extends SW $1.4 \mathrm{mi}$., between Miller Point and Spruce Cape, $3 \mathrm{mi}$. NE of Kodiak, Kodiak I. ; $57^{\circ} 49^{\prime} 30^{\prime \prime}$ N, $152^{\circ} 20^{\prime} 30^{\prime \prime}$ W; BGN 1933; (map 34). Var. Bukhta Popovskaya, Popof Bay, Popotskaia, Popogg Bay, Priest Bay.

Local name reported in 1933 by Gerald FitzGerald, USGS; "given because there was an old Russian flour mill, now in ruins, at the head of this bay." Sub-Lt. Mikhail Murashev in 1839 or 1840 named it "Bukhta Popovskaya," meaning "Popov bay." Baker (1906, p. 504) wrote, "Vasili and Ivan Popof were pioneer traders and fur hunters in Alaska in 1762-63."

Mill Creek: stream, heads at Virginia Lake, flows SW $0.7 \mathrm{mi}$. to Eastern Passage, $7 \mathrm{mi}$. NE of Wrangell, Coast Mts.; $56^{\circ} 27^{\prime} 30^{\prime \prime} \mathrm{N}, 132^{\circ}$ $12^{\prime} 20^{\prime \prime} \mathrm{W}$; (map 6).

Local name reported in 1914 by $\mathrm{E}$. Lester Jones, USBF.

Mill Creek: stream, heads in a series of lakes, flows SW $2 \mathrm{mi}$. to marsh along Stuart Creek, $4 \mathrm{mi}$. W of Mount Tiekel and $29 \mathrm{mi}$. NE of Valdez, Chugach Mts.; $61^{\circ} 17^{\prime} 40^{\prime \prime}$ N, $145^{\circ}$ $28^{\prime} 20^{\prime \prime} \mathrm{W}$; (map 68).

Local name published in the 1950's by USGS:

Mill Creek: stream, flows SE $4.8 \mathrm{mi}$. to Lakina River, $2.5 \mathrm{mi}$. SW of Lakina Glacier terminus, $17 \mathrm{mi}$. NW of McCarthy, Wrangell Mts.; $61^{\circ}$. $32^{\prime} \mathrm{N}, 143^{\circ} 23^{\prime} \mathrm{W}$; (map 67).

Local name reported in 1900 by T. G. Gerdine, USGS.

Miller, Mount: mountain, $11,000 \mathrm{ft}$., near W end of Barkley Ridge, $13 \mathrm{mi}$. NW of Mount Leeper and $110 \mathrm{mi}$. NW of Yakutat, Chugach Mts. $60^{\circ} 27^{\prime} \mathrm{N}, 142^{\circ} 19^{\prime} \mathrm{W}$; (map 65).

Name reported by F. H. Moffit (1914, pl. 1), USGS, for a prospector who accompanied James Barkley on his trip across this area in 1906 or possibly 1905 (Moffit, 1918, p. 77). Miller Cape: point of land, see Miller Point.

Miller Creek: stream, heads in Miller Glacier, trends $S$ and $W 9 \mathrm{mi}$. to Ahrnklin River, $4 \mathrm{mi}$. $\mathrm{W}$ of Harlequin Lake and $22 \mathrm{mi}$. SE of Yakutat, Malaspina Coastal Plain; $59^{\circ} 27^{\prime} 00^{\prime \prime}$ $\mathrm{N}, 139^{\circ} 06^{\prime} 50^{\prime \prime} \mathrm{W}$; (map 46).

Name published in 1928 by IBC.

Miller Creek: stream, heads in Robinson Mts., flows $3 \mathrm{mi}$. SW to North Channel Yakataga River, $4.5 \mathrm{mi}$. $\mathrm{N}$ of Cape Yakataga and 102 mi. NW of Yakutat; St. Elias Mts. ; $60^{\circ} 07^{\prime} 40^{\prime \prime}$ N, $142^{\circ} 24^{\prime} 30^{\prime \prime} \mathrm{W}$; BGN 1945; (map 65).

Probably named for J. B. Miller, a prospector in this region about 1907.

Miller Creek: stream, flows SE $5.5 \mathrm{mi}$. to Lake Clark, $32 \mathrm{mi}$. NE of Nondalton, Alaska Ra.; $60^{\circ} 19^{\prime} 30^{\prime \prime} \mathrm{N}, 154^{\circ} 09^{\prime} 30^{\prime \prime} \mathrm{W}$; (map 61).

Local name reported in 1954 by USGS.

Miller Creek: stream, heads in Vogel Lake, flows NW $4 \mathrm{mi}$. to Cook Inlet, $25 \mathrm{mi}$. SW of Anchorage, Cook Inlet Low.; $61^{\circ} 00^{\prime} 18^{\prime \prime} \mathrm{N}, 150^{\circ}$ $30^{\prime} 30^{\prime \prime} \mathrm{W}$; (map 70).

Local name reported in 1933 by USGS.

Miller Creek: stream, heads at Canwell Glacier terminus, flows W $3 \mathrm{mi}$. to Delta River, crossing Richardson Highway $25 \mathrm{mi}$. NW of Paxson, Alaska Ra. ; $63^{\circ} 22^{\prime} 35^{\prime \prime} \mathrm{N}, 145^{\circ} 45^{\prime} 00^{\prime \prime}$ W; (map 86).

Name reported in 1952 by USGS.

Miller Creek: stream, flows SE $6.5 \mathrm{mi}$. to Fish Creek, $28 \mathrm{mi}$. NE of Fairbanks, Yukon-Tanana High.; $65^{\circ} 03^{\prime} 40^{\prime \prime} \mathrm{N}, 146^{\circ} 58^{\prime} 00^{\prime \prime} \mathrm{W}$; (map 104).

Named by prospectors; reported in 1903 by T. G. Gerdine (M. Prindle, 1905, pl. 13), USGS.

Miller Creek: stream, flows NE $4 \mathrm{mi}$. to Troublesome Creek, $15 \mathrm{mi}$. E. of Rampart, YukonTanana High.; $65^{\circ} 26^{\prime} 40^{\prime \prime} \mathrm{N}, 149^{\circ} 42^{\prime} 00^{\prime \prime} \mathrm{W}$; (map 105).

Named by prospectors; reported in 1908 by USGS (Covert and Ellsworth, 1909, pl. 5).

Miller Creek: stream, flows SW $3 \mathrm{mi}$. to Hunter Creek, $0.5 \mathrm{mi}$. E of that stream's junc. with Minook Creek and $3 \mathrm{mi}$. SE of Rampart, Yukon-Tanana High.; $65^{\circ} 29^{\prime} \mathrm{N}, 150^{\circ} 05^{\prime} \mathrm{W}$; (map 106).

Prospectors' name reported in 1931 by J. B. Mertie, USGS.

Miller Creek: stream, flows NE $5 \mathrm{mi}$. to Mammoth Creek, $40 \mathrm{mi}$. SW of Circle, YukonTanana High.; $65^{\circ} 31^{\prime} 20^{\prime \prime} \mathrm{N}, 1^{\circ} 15^{\circ} 13^{\prime} 10^{\prime \prime} \mathrm{W}$; (map 104).

Named for O. C. Miller, who discovered the creek and prospected there in 1894; reported in 1896 by USGS (Spurr, 1898, p. 349).

Miller Creek: stream, flows SW $4 \mathrm{mi}$. to Goldstream Creek, $6 \mathrm{mi}$. E of Livengood, YukonTanana High.; $65^{\circ} 31^{\prime} 25^{\prime \prime} \mathrm{N}, 148^{\circ} 20^{\prime} 10^{\prime \prime} \mathrm{W}$; (map 105).

Local name reported in 1915 by Brooks (Brooks and others, 1916, pl. 9), USGS.

Miller Creek: stream, flows $S$ to Fish River between Bourne and Jarvis Creeks, about $40 \mathrm{mi}$. NE of Solomon, Seward Penin. High.; (map 95).

Prospectors' name reported on the 1900 "Map of Nome Peninsula" by J. M. Davidson and B. D. Blakeslee. This stream cannot be precisely located on current maps.

Miller Creek: stream, see Little Miller Creek.

Miller Fork Eagle Creek: stream, flows SW 2.6 mi., joins Mastodon Fork to form Eagle Creek, $46 \mathrm{mi}$. SW of Circle, Yukon-Tanana High.; $65^{\circ} 27^{\prime} \mathrm{N}, 145^{\circ} 25^{\prime} \mathrm{W}$; (map 104).
Named by prospectors; reported by USGS in 1896 (Spurr, 1898, pl. 50).

Miller Glacier: glacier, heads on S slope of Crescent Mtn., trends S $4 \mathrm{mi}$. to 1961 terminus at head of Miller Creek, $26 \mathrm{mi}$. E of Yakutat, St. Elias Mts.; $59^{\circ} 31^{\prime} 50^{\prime \prime} \mathrm{N}, 139^{\circ} 00^{\prime} 10^{\prime \prime} \mathrm{W}$; (map 46).

Name published in 1928 by IBC.

Miller Glacier: glacier, trends SE $5 \mathrm{mi}$. to its 1959 terminus near head of Disenchantment Bay, $36 \mathrm{mi}$. NNE of Yakutat, St. Elias Mts.; $60^{\circ} 03^{\prime} \mathrm{N}, 139^{\circ} 31^{\prime} \mathrm{W}$; (map 66).

Named by Lt. Comdr. J. F. Moser, USN, in 1901 for Ens. Cyrus R. Miller, USN, a member of his party.

Miller Gulch: ravine, extends NE $0.8 \mathrm{mi}$. to Slate Creek $1.5 \mathrm{mi}$. E of its junc. with Chistochina River 23 mi. NE of Paxson, Alaska Ra.; $63^{\circ}-$ $10^{\prime} 02^{\prime \prime} \mathrm{N}, 144^{\circ} 49^{\prime} 40^{\prime \prime} \mathrm{W}$; (map 86).

Named about 1900 by prospectors for Jack Miller, who first found gold here; reported by W.C. Mendenhall, USGS.

Miller Gulch: ravine, extends SE $3 \mathrm{mi}$. to Sullivan Creek, $34 \mathrm{mi}$. ESE of Tanana, YukonTanana High.; $65^{\circ} 03^{\prime} 30^{\prime \prime}$ N, $150^{\circ} 55^{\prime} 20^{\prime \prime} \mathrm{W}$; (map 106).

Prospectors' name reported in 1931 by J. B. Mertie, USGS.

Miller House: locality, pop. 20, on right bank of Mammoth Creek, $40 \mathrm{mi}$. SW of Circle, YukonTanana High.; $65^{\circ} 31^{\prime} 30^{\prime \prime}$ N, $145^{\circ} 13^{\prime} 00^{\prime \prime} \mathrm{W}$; (map 104). Var. Mammoth House, Miller House Post Office.

Local name reported in 1903 by T. G. Gerdine (in Prindle, 1905, pl. 13), USGS. The name was previously reported as "Mammoth House" in 1896 by Spurr (1898, pl. 50), USGS.

Miller House: locality, see Millers Camp.

Miller Island: island, $1 \mathrm{mi}$. across, at mouth of Moser Bay, in Alitak Bay, $\mathrm{S}$ end of Kodiak I.; $56^{\circ} 57^{\prime} 30^{\prime \prime} \mathrm{N}, 154^{\circ} 08^{\prime} 00^{\prime \prime} \mathrm{W}$; (map 32).

Named in 1900 by Comdr. J. F. Moser, USN, commander of the Albatross, for Ens. Cyrus R. Miller, USN, a member of his party. Miller Lake: lake, $2.5 \mathrm{mi}$. long, on Prince of Wales I., N of Eudora Mts., Alex. Arch.; 55 ${ }^{\circ}$ $08^{\prime} 45^{\prime \prime} \mathrm{N}, 132^{\circ} 13^{\prime} 30^{\prime \prime} \mathrm{W}$; (map 4). Var. Mitten Lake, Mitter Lake.

Named in 1885 by Lt. Comdr. R. C. Clover, USN, for Gen. John F. Miller, senator from California, his wife's father.

Miller Lake: lake, see Situk Lake.

Miller Peak: peak, 3,556 ft., in Glacier Bay National Monument, $3 \mathrm{mi}$. NE of Sandy Cove on $\mathrm{E}$ shore of Glacier Bay and $61 \mathrm{mi}$. NW of Juneau, St. Elias Mts.; 58 $43^{\prime} 05^{\prime \prime} \mathrm{N}$, $135^{\circ} 53^{\prime} 45^{\prime \prime} \mathrm{W}$; BGN 1957; (map 11).

Named by NPS in 1956 for Ben C. Miller, 1898-1953, first Superintendent of Sitka National Monument and the first NPS official in charge of Glacier Bay National Monument. and Old Kasaan National Monument.

Miller Point: point of land, between Mill and Monashka Bays, $3.5 \mathrm{mi}$. NE of Kodiak, Kodiak I. ; $57^{\circ} 50^{\prime} 15^{\prime \prime} \mathrm{N}, 152^{\circ} 21^{\prime} 10^{\prime \prime} \mathrm{W}$; (map 34). Var. Maknashkina Cape, Melnichnoi, Mil- 
ler Cape, Millers Cape, Mys Makhnashkina, Mys Melnichnoy, Popof Cape, Popofskie.

"M[ys] Melnichnoy," which literally means "mill cape," was published by Capt. Tebenkov (1852, map 23). Called "M[ys] Makhnashkina," or "Makhnashkina Cape," in 1839 or 1840 by Sub-Lt. Mikhail Murashev and published in 1849 on Russian Hydrog. Dept. Chart 1425.

Millers Camp: locality, on $\mathrm{N}$ bank of Yukon River, $0.5 \mathrm{mi}$. NW of junc. of Tatonduk River and $15 \mathrm{mi}$. $\mathrm{N}$ of Eagle, Porcupine Plat.; $65^{\circ}$ $00^{\prime} 15^{\prime \prime} \mathrm{N}, 141^{\circ} 20^{\prime} 40^{\prime \prime} \mathrm{W}$; (map 103). Var. Miller House, Millers Roadhouse.

A roadhouse name published in 1925 by ARC.

Millers Landing: locality, on N shore of Kachemak Bay, on Kenai Penin., $4 \mathrm{mi}$. NW of Homer, Cook Inlet Low.; $59^{\circ} 40^{\prime}$ N., $151^{\circ} 26^{\prime}$ W; (map 50).

Local name reported and published by USGS in the 1950's.

Millers Roadhouse: locality, see Millers Camp.

Mill Hill: hill, $310 \mathrm{ft}$., $0.9 \mathrm{mi}$. E of Conquer Point, Kiska I., Aleutian Is: ; $52^{\circ} 00^{\prime} 30^{\prime \prime} \mathrm{N}$, $177^{\circ} 30^{\prime} 40^{\prime \prime} \mathrm{E}$; (map 14).

An arbitrary name beginning with " $M$ " to correspond to " $M$ " grid used by the U.S. Army for tactical purposes during World War II; published on a 1953 AMS map.

Millichetah Greek: stream, flows SW $10 \mathrm{mi}$. to Alatna River, $25 \mathrm{mi}$. NE of Walker Lake, Brooks Ra.; $67^{\circ} 22^{\prime}$ N, $153^{\circ} 38^{\prime}$ W; BGN 1932; (map 125). Var. Akoblooiek River, A-koo-loo-ik River.

Indian name of unknown meaning reported by Robert Marshall in 1931. The Eskimo name "Akoblooiek" reported by Mendenhall (1902, pl. 4), USGS, or "A-koo-loo-ik" reported by Stoney (1900, map), USN, is similar to the present-day name "Akabluak" for a nearby pass.

Million Creek: stream, flows W $4 \mathrm{mi}$. to Windy Greek which flows to Budd Creek, in American River basin, $10 \mathrm{mi}$. SW of Kougarok Mtn. and $33 \mathrm{mi}$. NE of Teller, Seward Penin. High.; $65^{\circ} 34^{\prime} \mathrm{N}, 165^{\circ} 27^{\prime} \mathrm{W}$; (map 111).

Prospectors' name reported on a map by George M. Ashford dated August 1907.

Million Creek: stream, see Windy Creek.

Mill Lake: lake, see Virginia Lake.

Millowcrawlook Mountain: mountain, see Milokrawlok Mountain.

Mills, Mount: mountain, 3,205 ft., in Kenai Mts., $13 \mathrm{mi}$. SE of Seldovia, Chugach Mts. $59^{\circ} 17^{\prime} \mathrm{N}, 151^{\circ} 32^{\prime} \mathrm{W}$; BGN 1910; (map 50).

Named by U. S. Grant and D. F. Higgins, USGS, in 1909, for Sanford J. Mills, a local prospector.

Mills Bay: cove, extends $\mathrm{N} 0.5 \mathrm{mi}$. off Kasaan Bay, on E Coast of Prince of Wales I., Alex. Arch.; 55 $35^{\prime} 10^{\prime \prime} \mathrm{N}, 132^{\circ} 29^{\prime} 30^{\prime \prime} \mathrm{W}$; (map 4).

Local name recorded in 1949 by USGS.

Mills Creek: stream, on Kenai Penin., flows N 10 mi. to Canyon Creek, $16 \mathrm{mi}$. S of Sunrise, Chugach Mts.; $60^{\circ} 40^{\prime} 25^{\prime \prime} \mathrm{N}, 149^{\circ} 28^{\prime} 15^{\prime \prime} \mathrm{W}$; (map 63).
Name used by local miners and reported in 1895 by Becker (1898, p. 82), USGS,

Mills Creek: stream, heads at junction of Wagner Gulch and Squirrel Creek, flows SE $8 \mathrm{mi}$. to Camp Creek, $40 \mathrm{mi}$. W of Talkeetna, Alaska Ra.; 62 $20^{\circ} 45^{\prime \prime} \mathrm{N}, 151^{\circ} 21^{\prime} 00^{\prime \prime} \mathrm{W}$; (map 81).

Prospectors' name reported in 1906 by $R$. W. Porter, USGS.

Mills. Island: island, $0.1 \mathrm{mi}$. across, in Krestof Sound, $12 \mathrm{mi}$. NW of Sitka, Alex. Arch.; $57^{\circ}$. $11^{\prime} 10^{\prime \prime} \mathrm{N}, 135^{\circ} 34^{\prime} 00^{\prime \prime} \mathrm{W}$; (map 9). Var. Mills Islet, Ostrov Krugloy.

This feature was named "Mills Islet" in 1897 by Comdr. E. K. Moore, USN, for a prominent Sitka merchant. It was originally called "Ostrov Krugloy," meaning "round island," in 1809 by the Russian navigator Ivan Vasiliev the first.

Mills Islet: island, see Mills Island.

Milne Point: point of land, on Beaufort Sea coast, $7 \mathrm{mi}$. W of Beechey Point, Arctic Plain; $70^{\circ}$. $31^{\prime} 00^{\prime \prime} \mathrm{N}, 149^{\circ} 27^{\prime} 30^{\prime \prime} \mathrm{W}$; (map 150). Var. Point Milne.

Named "Point Milne" by P. W. Dease and Thomas Simpson on July 24, 1837 (in Simpson, 1843, p. 129). Leffingwell (1919, p. 89) writes, "Point Milne has been placed [by Leffingwell] on a conspicuous point on the mainland in the approximate position indicated by the Dease and Simpson map."

Milocrawluk Mountain: mountain, see Milok. rawlok Mountain.

Milokrawlok Creek: stream, heads on Milokrawlok Mtn. in Igichuk Hills, and flows S $9 \mathrm{mi}$. to Situkuyok River, $10 \mathrm{mi}$. SE of Cape Krusenstern, Kotzebue-Kobuk Low.; $67^{\circ} 05^{\prime} 30^{\prime \prime}$ N, $163^{\circ} 22^{\prime} 30^{\prime \prime} \mathrm{W}$; (map 128). Var. Millowcrawlook River, Milowcrawluk Creek.

Eskimo name obtained in 1950 by USC\&GS.

Milokrawlok Mountain: mountain, $1,000 \mathrm{ft}$., in Igichuk Hills at head of Milokrawlok Creek, $10 \mathrm{mi}$. NE of Cape Krusenstern, Arctic Slope; $67^{\circ} 12^{\prime} \mathrm{N}, 163^{\circ} 26^{\prime} \mathrm{W}$; (map 128). Var. Millowcrawlook Mountain, Milocrawluk Mountain.

Eskimo name obtained in 1950 by USC\&GS.

Milowcrawluk Greek: stream, see Milokrawlok Creek.

Milroy Creek: stream, flows SE $2.3 \mathrm{mi}$. to Hannum Creek which flows to Inmachuk River, 22 mi. N of Imuruk Lake, Seward Penin. High.; $65^{\circ} 55^{\prime} \mathrm{N}, 163^{\circ} 17^{\prime} \mathrm{W}$; (map 110).

Prospectors' name reported in 1903 by USGS (Collier, 1902, pl. 12).

Milton Greek: stream, flows E $0.8 \mathrm{mi}$. to North Pass Kiska Harbor, $\mathrm{S}$ of Model Cove, Kiska I., Aleutian Is; $51^{\circ} 59^{\prime} 10^{\prime \prime} \mathrm{N}, 177^{\circ} 34^{\prime} 26^{\prime \prime} \mathrm{E}$; (map 14).

An arbitrary name beginning with " $M$ " to correspond to " $M$ " grid used by U.S. Army for tactical purposes during World War II; published on a 1943 Army map.

Milton Greek: stream, see Military Creek.

Milton Lake: lake, $0.5 \mathrm{mi}$. long, $1 \mathrm{mi}$. $\mathrm{E}$ of lower arm of Simpson Bay, $6 \mathrm{mi}$. N of Cordova,
Chugach Mts.; $60^{\circ} 38^{\prime} \mathrm{N}, 145^{\circ} 48^{\prime} \mathrm{W}$; (map 64).

Local name published in 1951 by USGS.

Miluet Creek: stream, flows S $25 \mathrm{mi}$. to Ambler River, $25 \mathrm{mi}$. NW of Shungnak, Brooks Ra.; $67^{\circ} 08^{\prime} \mathrm{N}, 157^{\circ} 47^{\prime} \mathrm{W}$; (map 126).

Probably an Eskimo name, reported by the U.S. Army Corps of Engineers in 1955.

Miluveach River: stream, heading at $69^{\circ} 57^{\prime} \mathrm{N}$, $150^{\circ} 18^{\prime} \mathrm{W}$, flows $\mathrm{N} 50 \mathrm{mi}$. to Colville River Delta, Arctic Plain; $70^{\circ} 23^{\prime} \mathrm{N}, 150^{\circ} 31^{\prime} \mathrm{W}$; (map 149).

Eskimo name reported in 1951 by USC\&GS.

Mimosa Hill: hill, $296 \mathrm{ft}$., on east-central Kiska I., Aleutian Is.; $51^{\circ} 56^{\prime} 25^{\prime \prime} \mathrm{N}, 177^{\circ} 35^{\prime} 46^{\prime \prime}$ E; (map 14). Var. Minosa Hill.

An arbitrary name beginning with " $M$ " to correspond to " $M$ " grid used by U.S. Army for tactical purposes during World War II; published on a 1953 AMS map. Variant published on a 1943 USAAF map.

Mina Creek: stream, flows SW, then NW, 8.8 mi. to Kugruk River, $24 \mathrm{mi}$. NE of Imuruk Lake, Seward Penin. High.; $65^{\circ} 46^{\prime} \mathrm{N}, 162^{\circ}$ 26' W; (map 110). Var. Torrance Creek.

Prospectors' name reported in 1903 by D. C. Witherspoon (in Moffit, 1905, pl. 2), USGS. This appears to be the Torrance Creek noted on a precinct map of Seward Peninsula by Monroe and Hutchins; corrected up to June 1903 by Arthur Gibson.

Minchumina: village, see Lake Minchumina.

Minchumina, Lake: lake, $9 \mathrm{mi}$. long, $66 \mathrm{mi}$. NNW of Mount McKinley, Tanana Low.; $63^{\circ} 53^{\prime} 30^{\prime \prime} \mathrm{N}, 152^{\circ} 14^{\prime} 00^{\prime \prime} \mathrm{W}$; (map 88).

Tanana Indian name meaning "clear lake," reported in 1899 by Lt. J. S. Herron, USA.

Mindalina Island: island, $0.1 \mathrm{mi}$. long, at $\mathrm{S}$ entrance to Squid Bay, on $\mathbf{S}$ coast of Yakobi I., $11 \mathrm{mi}$. SW of Pelican, Alex. Arch.; 57 $52^{\prime} 20^{\prime \prime}$ N, 136 $29^{\prime} 35^{\prime \prime}$ W; $B G N$ 1928; (map 9).

Russian word meaning "almond" given in 1928 by USC\&GS "on account of its shape." Mine Cove: cove, see Kimshan Cove.

Mine Harbor: cove, $1 \mathrm{mi}$. across, on SE arm of Herendeen Bay, $16 \mathrm{mi}$. SW of village of Port Moller, near SW end of Alaska Penin., Aleutian Ra.; 55 $45^{\prime} 50^{\prime \prime}$ N, $160^{\circ} 42^{\prime} 20^{\prime \prime}$ W; (map 28). Var. Coal Harbor.

Named in 1890 by USBF "for a coal mine opened in the vicinity in 1888."

Mine Mountain: mountain, 2,500 ft., on Chichagof $\mathrm{I} ., 4 \mathrm{mi}$. $\mathrm{N}$ of head of Goulding Harbor, $13 \mathrm{mi}$. $\mathrm{N}$ of Chichagof, Alex. Arch.; 57 $50^{\prime}$ $30^{\prime \prime} \mathrm{N}, 136^{\circ} 10^{\prime} 30^{\prime \prime} \mathrm{W}$; (map 9).

Name reported by Rossman (1959, p. 209), USGS. So named because of the gold mine on the west side, which was opened in 1921.

Mineral, Punta de: point of land, see Mineral Point.

Mineral Creek: stream, flows SW $1 \mathrm{mi}$. to Gulf of Alaska, $1.5 \mathrm{mi}$. NW of mouth of Crillon River, $80 \mathrm{mi}$. WNW of Hoonah, Malaspina Coastal Plain ; $58^{\circ} 32^{\prime} 25^{\prime \prime} \mathrm{N}, 137^{\circ} 27^{\prime} 10^{\prime \prime} \mathrm{W}$; (map 10). 
Name published by the Harvard-Dartmouth Expedition, 1933-34 (Washburn and Goldthwaite, 1936, map).

Mineral Creek: stream, heads in Mineral Creek Glacier, flows S $11 \mathrm{mi}$. to Port Valdez, 4.7 mi. NW of Valdez, Chugach Mts. ; $61^{\circ} 07^{\prime} 45^{\prime \prime}$ N, $146^{\circ} 24^{\prime} 05^{\prime \prime} \mathrm{W}$; (map 68).

This is presumably a local name published in 1898.

Mineral Creek: stream, flows NW $1.7 \mathrm{mi}$. to Kluvesna River, $18 \mathrm{mi}$. NW of Mount Blackburn, Wrangell Mts.; $61^{\circ} 45^{\prime} \mathrm{N}, 143^{\circ} 55^{\prime} \mathrm{W}$; (map 67).

Name reported by USGS in 1923.

Mineral Creek: stream, flows SW $1.7 \mathrm{mi}$. to Nome River, $12 \mathrm{mi}$. NE of Nome, Seward Penin. High.; $64^{\circ} 40^{\prime} \mathrm{N}, 165^{\circ} 18^{\prime} \mathrm{W}$; (map 94).

Local name published in 1900 on USC\&GS Chart 9380.

Mineral Creek: stream, flows N $2 \mathrm{mi}$. to Woodchopper Creek, $4 \mathrm{mi}$. SSW of that stream's junc. with Yukon River and $41 \mathrm{SE}$ of Circle, Yukon-Tanana High.; $65^{\circ} 18^{\prime} 20^{\prime \prime}$ N, $143^{\circ} 22^{\prime}$ 40" W ; (map 103).

Prospectors' name reported by A. H. Brooks (in Brooks and others, 1907, p. 203), USGS. This stream was "staked" as early as 1898 , and by 1906 was the principal placer goldmining site on Woodchopper Creek.

Mineral Creek Glacier: glacier, heads $3.5 \mathrm{mi}$. S of Mount Logan, trends S $2 \mathrm{mi}$. to its terminus, $3 \mathrm{mi}$. $\mathrm{N}$ of Smith Mill on Mineral Creek and $10 \mathrm{mi}$. $\mathrm{N}$ of Valdez, Chugach Mts.; $61^{\circ}$. $15^{\prime} 25^{\prime \prime} \mathrm{N}, 146^{\circ} 18^{\prime} 30^{\prime \prime} \mathrm{W}$; (map 68). Var. Mineral Glacier.

Local name published in 1915 by USGS.

Mineral Creek Islands: islands, $1 \mathrm{mi}$. across, at $\mathrm{E}$ end of Port Valdez, $2 \mathrm{mi}$. NW of Valdez, Chugach Mts.; $61^{\circ} 07^{\prime} 35^{\prime \prime} \mathrm{N}, 1^{-} 46^{\circ} 19^{\prime} 00^{\prime \prime} \mathrm{W}$; (map 68).

Local name published in the 1950 's by USGS.

Mineral Glacier: glacier, see Mineral Greek Glacier.

Mineral Hill: hill, probably on N slope of Mount Roberts, about $3 \mathrm{mi}$. SE of Juneau, Coast Mts.; $58^{\circ} 18^{\prime} \mathrm{N}, 134^{\circ} 20^{\prime} \mathrm{W}$; (map 11).

Named about 1885 by miners (DeArmond, 1957, p. 37):

Mineral Hill: mountain, $2,050 \mathrm{ft}, 0.7 \mathrm{mi}$. W of Alaska-Canada boundary and $8.5 \mathrm{mi}$. N. of Hyder, Coast Mts. ; $56^{\circ} 02^{\prime} 30^{\prime \prime} \mathrm{N}, 130^{\circ} 03^{\prime} 15^{\prime \prime}$ W; (map 6).

Local descriptive name published by USGS in 1928.

Mineral Island: island, see Spuhn Island.

Mineral Lake: lake, $1.2 \mathrm{mi}$. across, in course of Station Creek, in Mentasta Mts., $29 \mathrm{mi}$. S of Tok, Alaska Ra.; $62^{\circ} 56^{\prime} \mathrm{N}, 143^{\circ} 22^{\prime} \mathrm{W}$; $B G N$ 1936; (map 84).

Local name reported in 1936 by USGS.

Mineral Mountain: mountain, 3,400 ft., on Chichagof I., $2 \mathrm{mi}$. $\mathrm{N}$ of mouth of Phonograph Creek, on Lisianski Inlet, $3.8 \mathrm{mi}$. SE of Pelican, Alex. Arch.; 57 $56^{\prime} 07^{\prime \prime} \mathrm{N}, 136^{\circ} 08^{\prime} 00^{\prime \prime}$ W; BGN 1960; (map 9).
So named in 1955 by D. L. Rossman, USGS, "because of the presence of wellformed minerals in several localities on its slopes."

Mineral Point: point of land, on $\mathbf{E}$ coast of Baker I., in Port San Antonio, Alex. Arch.; 55 $21^{\prime}$ $00^{\prime \prime} \mathrm{N}, 133^{\circ} 35^{\prime} 30^{\prime \prime} \mathrm{W}$; (map 4). Var. Punta de Mineral.

Spanish name given in 1775-79 by Don Juan de la Bodega y Quadra and Francisco Antonio Maurelle as "Punta de Mineral," i.e., "mineral point."

Miner Cove: bay, $0.2 \mathrm{mi}$. across, $4 \mathrm{mi}$. N of village of Port Alexander, on $\mathrm{S}$ coast of Baranof I., Alex. Arch.; $56^{\circ} 18^{\prime} 30^{\prime \prime} \mathrm{N}, 134^{\circ} 38^{\prime} 10^{\prime \prime} \mathrm{W}$; (map 5).

Local name used by fishermen; published in 1927 by USC\&GS.

Miner Creek: stream, on SW coast of Agattu I., heads at Manning Lake, flows S $2 \mathrm{mi}$. to the Pacific Ocean W of Nile Point, Aleutian Is.; $52^{\circ} 23^{\prime} 45^{\prime \prime} \mathrm{N}, 173^{\circ} 24^{\prime} 40^{\prime \prime} \mathrm{E}$; (map 13).

Name published in 1953 by USGS.

Miner Hill: point of land, on S shore of Nelson Lagoon, $19 \mathrm{mi}$. W of village of Port Moller, on Alaska Penin., Bristol Bay Low.; 55 ${ }^{\circ} 8^{\prime}$ N, $161^{\circ} 08^{\prime} \mathrm{W}$; (map 28).

Named in 1929 by USGS.

Miner Island: island, $0.3 \mathrm{mi}$. across, off $\mathrm{E}$ coast of Yakobi I., on Lisianski Inlet, $0.5 \mathrm{mi}$. N of Rock Point, $34 \mathrm{mi}$. SW of Hoonah, Alex. Arch.; $58^{\circ} 00^{\prime} 40^{\prime \prime} \mathrm{N}, 136^{\circ} 20^{\prime} 15^{\prime \prime} \mathrm{W}$; $B G N$ 1908; (map 10).

Named by USC\&GS in 1908 and published in the 1908 Alaska Coast Pilot (p. 169).

Miner River: stream, see Miners Creek.

Miners Bay: estuary, extends E $1.5 \mathrm{mi}$. off Unakwik Inlet, Prince William Sound, 40 mi. W of Valdez, Chugach Mts.; $61^{\circ} 04^{\prime} \mathrm{N}$, $147^{\circ} 31^{\prime} \mathrm{W}$; (map 69).

Local name reported in 1898 by Capt. Glenn (Glenn and Abercrombie, 1899, p. 24), USA.

Miners Creek: stream, heads at Pedro Glacier, flows SW $6.7 \mathrm{mi}$., through Miners Lake, to Miners Bay, $40 \mathrm{mi}$. W of Valdez, Chugach Mts.; 61 $04^{\circ}$ N, $147^{\circ} 29^{\prime}$ W; BGN 1910; (map 69). Var. Miner River.

Local name reported in 1897 by Lt. Comdr. J. F. Moser (1899c, p. 138), USN, while collecting hydrographic data for USBF.

Miners Lake: lake, $2.2 \mathrm{mi}$. long, $\mathrm{E}$ of Unakwik Inlet, in course of Miners Creek, $38 \mathrm{mi}$. W of Valdez, Chugach Mts. ; 61 $04^{\prime} 45^{\prime \prime}$ N, 147 $26^{\circ}$ 30" W; BGN 1910; (map 69). Var. Boot Lake.

Local name reported in 1897 by Lt. Comdr. J. F. Moser, USN, while doing survey work in the area aboard the USBF steamer Albatross.

Miners Point: point of land, $\mathrm{W}$ point of entrance to Uganik Bay, on NW coast of Kodiak I.; $57^{\circ} 54^{\prime} 00^{\prime \prime} \mathrm{N}, 153^{\circ} 43^{\prime} 20^{\prime \prime} \mathrm{W}$; BGN 1910; (map 34).

Named in 1908 by W. C. Hodgkins, USC\&GS
Minerva Mountain: mountain, 2,602 ft., on Revillagigedo I. 2 mi. $\mathbf{N}$ of Ketchikan, Alex.

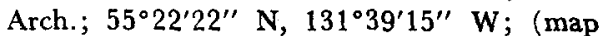
$3)$.

This is one of several names given in 1883 by Lt. Comdr. H. E. Nichols, USN, which were suggested by classical mythology.

Minett Island: island, $150 \mathrm{ft}$. across, in Jamestown Bay, $1.5 \mathrm{mi}$. SE of Sitka, on W coast of

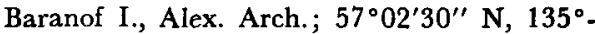
$17^{\prime} 30^{\prime \prime} \mathrm{W}$; (map 9). Var. Minett Islet.

Named in 1880 by the U.S. Navy, presumably for Lt. Henry Minett, USN. The name was published by USC\&GS in 1883 Coast Pilot (p. 144).

Mingkoket, Lake: lake, $1 \mathrm{mi}$. long, $\mathrm{N}$ of Niitltoktalogi Mtn., drains N to Siruk Creek, $38 \mathrm{mi}$. $\mathrm{NE}$ of Hughes, Hogatza High.; $66^{\circ} 31^{\prime} \mathrm{N}$, $153^{\circ} 36^{\prime} \mathrm{W}$; (map 116).

Indian descriptive name, meaning "big lake," recorded at Allakaket in 1956 by Orth. Minga, Lake: lake, see Sinclair Lake.

Mingkoket Lake: lake, $1.8 \mathrm{mi}$. long, drains $\mathrm{E}$ to Koyukuk River, $15 \mathrm{mi}$. SE of Allakaket, $\mathrm{Ka}$ nuti Flats; $66^{\circ} 30^{\prime} \mathrm{N}, 152^{\circ} 07^{\prime} \mathrm{W}$; (map 117).

Koyukan Indian name meaning "big lake," obtained in 1956 at Allakaket by Orth.

Mingogut Lake: lake, $0.3 \mathrm{mi}$. $\mathrm{N}$ of Huslia, $12 \mathrm{mi}$. NE of Roundabout Mtn., Koyukuk Low.; $65^{\circ}$ $42^{\prime} \mathrm{N}, 156^{\circ} 24^{\prime} \mathrm{W}$; (map 108).

Koyukan Indian name meaning "big lake [mingkokat]," reported in 1955 by USGS.

Miniatulik Creek: stream, flows NE $4 \mathrm{mi}$. to Iron Creek which flows to Norton Bay, $4 \mathrm{mi}$. N of Elim and $66 \mathrm{mi}$. E of Solomon, Seward Penin. High.; $64^{\circ} 41^{\prime} \mathrm{N}, 162^{\circ} 15^{\prime} \mathrm{W}$; (map 95).

This is an Eskimo name reported in 1909 by Smith and Eakin (1911, pl. 1), USGS.

Miniatulik Creek: stream, see Iron Creek.

Miniatulik River: stream, flows E $9.8 \mathrm{mi}$. to Koyuk Inlet, $30 \mathrm{mi}$. NW of Christmas Mtn., Seward Penin. High.; 64 ${ }^{\circ} 55^{\prime} \mathrm{N}, 161^{\circ} 12^{\prime} \mathrm{W}$; $B G N$ 1910; (map 96). Var. Iron Creek, Neechuck River.

Eskimo name reported in 1900 by J. J. Gilbert, USC\&GS.

Mink Bay: estuary, extends S $5.4 \mathrm{mi}$. from Boca de Quadra, $3 \mathrm{mi}$. E of Vixen Bay and $40 \mathrm{mi}$. SE of Ketchikan, Coast Mts. ; $55^{\circ} 05^{\prime} 30^{\prime \prime} \mathrm{N}$, $130^{\circ} 43^{\prime} 30^{\prime \prime} \mathrm{W}$; (map 3).

One of many arbitrary names applied to features in this area in 1891 by USC\&GS.

Mink Creek: stream, $0.5 \mathrm{mi}$. long, drains Mink Lake into Tonovek Creek, E central Heceta I., Alex. Arch.; $55^{\circ} 46^{\prime} 25^{\prime \prime} \mathrm{N}, 133^{\circ} 23^{\prime} 55^{\prime \prime} \mathrm{W}$; (map 4).

Local name recorded in 1951 by USGS.

Mink Creek: stream, on S side of Mount Ripinski, flows E $1 \mathrm{mi}$. to Tanani Bay at Tanani, $14 \mathrm{mi}$. SW of Skagway, Coast Mts.; $59^{\circ} 16^{\prime}$ $00^{\prime \prime} \mathrm{N}, 135^{\circ} 26^{\prime} 30^{\prime \prime} \mathrm{W}$; (map 45).

Local name obtained by USGS field personnel and published on Federal maps since 1950.

Mink Creek: stream, heads on W slope of Watson Peak and flows generally SW $4.5 \mathrm{mi}$. to Gulf of Alaska, $1.4 \mathrm{mi}$. NW of Cape Yakataga and 
$102 \mathrm{mi}$. NW of Yakutat, St. Elias Mts.; $60^{\circ}$ $04^{\prime} 35^{\prime \prime} \mathrm{N}, 142^{\circ} 27^{\prime} 45^{\prime \prime} \mathrm{W}$; BGN 1945; (map $65)$.

Local name reported in 1945 by USGS.

Mink Creek: stream, heads in a lake, flows $W$ $1.9 \mathrm{mi}$. to Fire Creek, $17 \mathrm{mi}$. NE of Anchorage, Cook Inlet Low:; $61^{\circ} 23^{\prime} 30^{\prime \prime} \mathrm{N}, 149^{\circ} 32^{\prime} 15^{\prime \prime}$ W; (map 69).

Local name reported in 1942 by AMS.

Mink Creek: stream, flows S $5.7 \mathrm{mi}$. to Kaiyuh Slough, $0.5 \mathrm{mi}$. W of The Forks, $20 \mathrm{mi}$. SE of Nulato, Koyukuk Low.; $64^{\circ} 26^{\prime}$ N, $157^{\circ}$ $58^{\prime} \mathrm{W}$; (map 97).

Local name reported in 1935 by Frederica de Laguna.

Mink Creek: stream, flows W $4 \mathrm{mi}$. to Squirrel River, $3.2 \mathrm{mi}$. NE of Kiana, Brooks Ra.; $67^{\circ} 01^{\prime} \mathrm{N}, 160^{\circ} 23^{\prime} \mathrm{W}$; (map 127).

Name used by prospectors; reported in 1910 by P. S. Smith (in Brooks and others, 1911, pl. 13), USGS.

Mink Creek Lake: lake, $0.6 \mathrm{mi}$. long, on Kenai Penin. at head of Mink Creek, $14 \mathrm{mi}$. NE of Kenai, Cook Inlet Low.; $60^{\circ} 41^{\prime} \mathrm{N}, 150^{\circ} 53^{\prime}$ W; (map 62).

Named about 1963 by officials of Kenai National Moose Range for administrative purposes.

Mink Lake: lake, $0.2 \mathrm{mi}$. long, $\mathrm{E}$ central Heceta I., Alex. Arch.; $55^{\circ} 45^{\prime} 50^{\prime \prime} \mathrm{N}, 133^{\circ} 23^{\prime} 45^{\prime \prime} \mathrm{W}$; (map 4).

Local name recorded in 1951 by USGS.

Mink Lake: lake, $1 \mathrm{mi}$. long, $2 \mathrm{mi}$. WNW of Graphite Lake and $21 \mathrm{mi}$. W of Coleen Mtn., Yukon Flats; $67^{\circ} 06^{\prime} \mathrm{N}, 143^{\circ} 34^{\prime} \mathrm{W}$; (map 121).

Local name reported in 1956 by T. E. Taylor, USGS.

Minkokhwin Lake: lake, see Minnkohwin Lake.

Minkoshchaliton Lake: lake, $3 \mathrm{mi}$. long, $1.5 \mathrm{mi}$. NW of Abraham Lake and $12 \mathrm{mi}$. N of Stevens Village, Yukon Flats; $66^{\circ} 11^{\prime} \mathrm{N}, 148^{\circ} 59^{\prime} \mathrm{W}$; (map 118)

Kutchin Indian name obtained in 1956 by T. E. Taylor, USGS.

Mink Point: point of land, between South and East Arms Uganik Bay, on N coast of Kodiak I. ; $57^{\circ} 43^{\prime} 00^{\prime \prime} \mathrm{N}, 153^{\circ} 25^{\prime} 50^{\prime \prime} \mathrm{W}$; (map 34).

Named in 1897 by Lt. Gomdr. J. F. Moser, USN, of the USBF steamer Albatross.

Mink Slough: stream, flows SW $6 \mathrm{mi}$. to Yukon River, Innoko Low.; $63^{\circ} 17^{\prime} \mathrm{N}, 159^{\circ} 38^{\prime} \mathrm{W}$; (map 91).

Riverboat pilots' name shown on a 1940 "Navigation Chart of the Tanana-Yukon Rivers" published by the U.S. Dept. of Interior.

Minnehaha Creek: stream, flows NE $9 \mathrm{mi}$. to Kiwalik Lagoon, $7 \mathrm{mi}$. $\mathbf{N}$ of Candle, Kotzebue-Kobuk Low.; $66^{\circ} 03^{\prime} \mathrm{N}, 161^{\circ} 56^{\prime} \mathrm{W}$; (map 114).

Prospectors' name reported in 1901 by W. C. Mendenhall and D. L. Reaburn, USGS.

Minnesota Creek: stream, flows NE $4 \mathrm{mi}$. to Arolik River, $32 \mathrm{mi}$. N of Goodnews, KilbuckKuskokwim Mts. ; 59³4' N, $161^{\circ} 29^{\prime} \mathrm{W}$; (map $53)$.
Name published by Harrington (in Brooks, 1921, pl. 7), USGS.

Minnesota Creek: stream, flows SW $2 \mathrm{mi}$. to Penny Creek, $7 \mathrm{mi}$. NE of Solomon, Seward Penin. High.; $64^{\circ} 40^{\prime} \mathrm{N}, 164^{\circ} 23^{\prime} \mathrm{W}$; (map 95).

Prospectors' name reported on a 1901 map of Cape Nome gold fields by David Fox, Jr.

Minnesota Creek: stream, flows W $5 \mathrm{mi}$. from O'Keefe Hills to South Fork Koyukuk River, $25 \mathrm{mi}$. WSW of Chandalar, Brooks Ra.; $67^{\circ}$ $21^{\prime} \mathrm{N}, 149^{\circ} 23^{\prime} \mathrm{W}$; (map 123).

Local name reported in 1956 by T. E. Taylor, USGS.

Minnesota Ridge: ridge, in Glacier Bay National Monument, trends NW $5 \mathrm{mi}$. from Curtis Hills, on Muir Inlet, $67 \mathrm{mi}$. NW of Hoonah, St. Elias Mts.; $58^{\circ} 59^{\prime} 30^{\prime \prime} \mathrm{N}, 136^{\circ} 13^{\prime} 30^{\prime \prime} \mathrm{W}$; (map 10).

Named by members of the American Geographical Society's Glacier Bay Expedition of 1941 (Field, 1947, map) for the Univ. of Minnesota in recognition of the studies carried on in Muir Inlet since 1916 by W. S. Cooper of the Botany Department.

Minnie Bay: estuary, on SW coast of Prince of Wales I., extends NE $0.5 \mathrm{mi}$. off Minnie Cutoff, E of Point March, Alex. Arch.; 54 ${ }^{\circ} 43^{\prime} 15^{\prime \prime}$ $\mathrm{N}, 132^{\circ} 18^{\prime} 30^{\prime \prime} \mathrm{W}$; (map 1$)$.

Local name published by USC\&GS in 1923.

Minnie Creek: stream, flows NE $17 \mathrm{mi}$. to Takotna River, $34 \mathrm{mi}$. SW of McGrath, KilbuckKuskokwim Mts.; $62^{\circ} 41^{\prime} 05^{\prime \prime}$ N, $156^{\circ} 32^{\prime} 00^{\prime \prime}$ W; (map 79) .

Local name obtained in 1952 by USGS topographers.

Minnie Creek: stream, flows NW 5 mi. to Hidden Greek, $9 \mathrm{mi}$. NW of Medfra, Kilbuck-Kuskokwim Mts.; $63^{\circ} 12^{\prime} \mathrm{N}, 154^{\circ} 52^{\prime} \mathrm{W}$; (map 89).

Local name reported in 1958 by USGS.

Minnie Creek: stream, heads in Bendeleben Mts. flows NW $20 \mathrm{mi}$. to Kuzitrin River, $25 \mathrm{mi}$. SW of Imuruk Lake, Seward Penin. High.; $65^{\circ} 26^{\prime}$ N, $164^{\circ} 02^{\prime}$ W; BGN 1952; (map 110). Var. South Fork Kuzitrin River.

Prospectors' name reported in 1901 by $\mathrm{T}$. G. Gerdine (in Collier, 1902, pl. 12), USGS. Minnie Creek: stream, flows W $14.5 \mathrm{mi}$. from S of Poss Mtn. to Middle Fork Koyukuk River at Wiseman, Brooks Ra.; $67^{\circ} 25^{\prime} \mathrm{N}, 150^{\circ} 06^{\prime}$ W; (map 124).

Local name shown on an 1899 fieldsheet by T. G. Gerdine, USGS.

Minnie Creek Lake: lake, $0.7 \mathrm{mi}$. long, drains into Minnie Creek, $4 \mathrm{mi}$. W of Poss Mtn. and $36 \mathrm{mi}$. WSW of Chandalar, Brooks Range; $67^{\circ} 27^{\prime} 15^{\prime \prime} \mathrm{N}, 149^{\circ} 52^{\prime} 00^{\prime \prime} \mathrm{W}$; (map 123).

Local name reported in 1956 by T. E. Taylor, USGS.

Minnie Cutoff: water passage, $1 \mathrm{mi}$. long, between SW coast of Prince of Wales $I$. and Point Marsh, Alex. Arch.; 54 $44^{\circ} 00^{\prime \prime} \mathrm{N}$, $132^{\circ} 18^{\prime} 15^{\prime \prime} \mathrm{W}$; (map 1).

Name reported in 1948 by USGS; derived from Minnie Bay.

Minnie Reef: reef, N of Lydonia I., in Portlock Harbor, $4.5 \mathrm{mi}$. NW of Chichagof, on W coast of Chichagof I., Alex. Arch.; 57 $43^{\prime} 10^{\prime \prime} \mathrm{N}$; $136^{\circ} 10^{\prime} 15^{\prime \prime} \mathrm{W}$; (map 9 ).

Name published by USC\&GS in 1925 Coast Pilot (p. 320). The Minnie Reef Light is located here.

Minnkohwin Lake: lake, $0.7 \mathrm{mi}$. across, $2 \mathrm{mi}: \mathrm{N}$ of Katalahosa Lake, $21 \mathrm{mi}$. SE of Allakaket, Kanuti Flats; $66^{\circ} 19^{\prime} 45^{\prime \prime} \mathrm{N}, 152^{\circ} 08^{\prime} 30^{\prime \prime} \mathrm{W}$; (map 117). Var. Minkokhwin Lake.

Koyukan Indian name obtained in 1956 at Allakaket by T. E. Taylor, USGS.

Mino Creek: stream, flows SE $9 \mathrm{mi}$. to Pacific Ocean, $12 \mathrm{mi}$. W of Unga I., on Alaska Penin., Aleutian Ra.; $55^{\circ} 23^{\prime} 50^{\prime \prime} \mathrm{N}, 1^{\prime 6} 1^{\circ} 08^{\prime}$ $00^{\prime \prime}$ W; (map 28).

Named in 1929 by USGS.

Minook Creek: stream, heads on Eureka Dome and flows $\mathrm{N} 22 \mathrm{mi}$. to Yukon River, $1 \mathrm{mi}$. N of Rampart, Yukon-Tanana High.; $65^{\circ} 31^{\prime} \mathrm{N}$, $150^{\circ} 08^{\prime} \mathrm{W}$; (map 106). Var. Clanachargut, Klanachargut River, Klana-Kakat, Manook Creek, Minuk Creek, Munook Creek, Mynook Greek.

Named in the early 1890 's by prospectors for John Minook, "Russian halfbreed," who is reported to have found gold on Little Minook Creek about 1893. The Indian name for this stream, reported by Capt. Raymond (1871, p. $113)$, USA, was "Clanachargut" "KlanaKakat, or mouth of the Kla River."

Minook Island: island, $1.5 \mathrm{mi}$. long, in Yukon River, 2 mi. NNE of Rampart, KokrinesHodzana High.; $65^{\circ} 32^{\prime}$ N, $150^{\circ} 08^{\prime} \mathrm{W}$; (map 106).

Local name reported in 1956 by Orth.

Minor Creek: stream, flows SE $1.2 \mathrm{mi}$. to Major Creek, $\mathbf{N}$ of Sargeant Cove, Kiska I., Aleutian Is.; $51^{\circ} 56^{\prime} 09^{\prime \prime} \mathrm{N}, 177^{\circ} 33^{\prime} 20^{\prime \prime} \mathrm{E}$; (map 14). Var. Vermouth Brook.

An aribtrary name beginning with " $M$ " to correspond to " $\mathrm{M}$ " grid used by U.S. Army for tactical purposes during World War II; published on a 1953 AMS map. Variant published on a 1943 USAAF map.

Minosa Hill: hill, see Mimosa Hill.

Minotocloga Lake: lake, $0.3 \mathrm{mi}$. long, on $\mathrm{W}$ bank of Alatna River, $1 \mathrm{mi}$. N of Allakaket, Kanuti Flats; $66^{\circ} 34^{\prime} 45^{\prime \prime} \mathrm{N}, 152^{\circ} 39^{\prime} 00^{\prime \prime} \mathrm{W}$; (map 117).

Koyukan Indian name obtained in 1956 at Allakaket by T. E. Taylor, USGS.

Mint Greek: stream, flows E to Solomon River, S of Gem Creek, about $9 \mathrm{mi}$. NE of Solomon, Seward Penin. High.; (map 95).

Prospectors' name reported on a prospector's manuscript map dated 1902 . This stream cannot be prescisely located on current maps.

Mint Glacier: glacier, on Montana Peak, extends S $1.5 \mathrm{mi}$. to its terminus at head of Little Susitna River, $18 \mathrm{mi}$. $\mathrm{N}$ of Palmer, Talkeetna Mts.; $61^{\circ} 51^{\prime} 30^{\prime \prime} \mathrm{N}, 149^{\circ} 03^{\prime} 30^{\prime \prime} \mathrm{W}$; (map 69).

Local name reported in 1942 by AMS.

Minto: village, pop. 161 , on $\mathrm{E}$ bank of Tanana River, $44 \mathrm{mi}$. W of Fairbanks, Tanana Low.; $64^{\circ} 53^{\prime} 15^{\prime \prime} \mathrm{N}, 149^{\circ} 11^{\prime} 00^{\prime \prime} \mathrm{W}$; BGN 1944; (map 100). Var. Minto Landing, Minto Roadhouse, Minto Telegraph Station, Munto. 
Name derived from Minto Lakes and reported by the Chief Signal Officer, U.S. Army, 1909 as Minto Telegraph Station and published in 1911 by the USGS (Brooks and others, pl. 12).

Mintokh Lake: lakes, see Minto Lakes.

Minto Lake: lakes, see Minto Lakes.

Minto Lakes: lakes, near mouth of Goldstream Greek, 34 mi. NW of Fairbanks, Tanana Low.; $64^{\circ} 53^{\prime} \mathrm{N}, 148^{\circ} 49^{\prime} \mathrm{W}$; 'map 100). Var. Mintokh Lake, Minto Lake, Mintu Lake.

This is a Tanana Indian name published in 1861 by $\mathrm{P}$. Tikhmeniev as "Oz[ero] Mintokh" or "Lake Mintokh." Although early maps apply the name to a vaguely shown single lake, present-day usage applies the name to all the lakes in this lowland area. R. H. Geoghegan spells the name "Mintu," the first syllable, "min," meaning "lake."

Minto Landing: village, see Minto.

Minton Creek: stream, flows NW $5 \mathrm{mi}$, to McCoy Greek, $23 \mathrm{mi}$. NW of Big Delta, YukonTanana High.; $64^{\circ} 25^{\prime} 45^{\prime \prime} \mathrm{N}, 146^{\circ} 15^{\prime} 00^{\prime \prime} \mathrm{W}$; (map 101).

Prospectors' name; reported in 1910 by USGS (Capps, 1912, pl. 1).

Minto Roadhouse: village, see Minto.

Minto Telegraph Station: village, see Minto.

Mint River: stream, on Seward Penin., heads in York Mts., flows NW $23 \mathrm{mi}$. to Lopp Lagoon, 47 mi. N!V of Teller, Kotzebue-Kobuk Low.; $65^{\circ} 45^{\prime} \mathrm{N}, 167^{\circ} 30^{\prime} \mathrm{W}$; (map 111$)$.

Prospectors' name reported in 1900 by Brooks (1901, pl. 13), USGS.

Mintu Lake: lakes, see Minto Lakes.

Minuk Creek: stream, see Minook Creek.

Minute Hill: hill, $875 \mathrm{ft}$., between Major and Minor Creeks, center of Kiska I., Aleutian Is.; $51^{\circ} 56^{\prime} 40^{\prime \prime} \mathrm{N}, 177^{\circ} 32^{\prime} 40^{\prime \prime} \mathrm{E}$; (map 14). Var. Clover Spur.

An arbitrary name beginning with " $M$ " to correspond to " $M$ " grid used by U.S. Army for tactical purposes during World War II; published on a 1953 AMS map. Variant published on a 1943 USAAF map.

Minx Islands: islands, extend $0.5 \mathrm{mi}$., at head of Thorne Arm off $\mathrm{S}$ coast of Revillagigedo I., Alex. Arch.; $55^{\circ} 23^{\prime} 10^{\prime \prime} \mathrm{N}, 131^{\circ} 15^{\prime} 35^{\prime \prime} \mathrm{W}$; (map 3).

Arbitrary name given in 1891 by USC\&GS.

Minya Peak: peak, 7,700 ft., S of Canwell Glacier, $18 \mathrm{mi}$. $\mathrm{N}$ of Paxson, Alaska Ra.; $63^{\circ}$ $17^{\prime} 45^{\prime \prime} \mathrm{N}, 145^{\circ} 28^{\prime} 00^{\prime \prime} \mathrm{W}$; (map 86).

Named between 1948 and 1955 by T. L. Péwé, USGS.

Mirabales, Mys: point of land, see Miraballes, Point.

Miraballes, Point: point of land, between Port Saint Nicholas and Trocadero Bay, on $W$ coast of Prince of Wales I., Alex. Arch.; 55 ${ }^{\circ} 25^{\prime} 50^{\prime \prime}$ $\mathrm{N}, 133^{\circ} 05^{\prime} 05^{\prime \prime} \mathrm{W}$; (map 4). Var. Mys Mirabales, Punta de Miraballes, Punta de Miravalles.

Spanish name given in 1779 by Don Juan de la Bodega y Quadra and Francisco Antonio Maurelle as "Punta de Miraballes," meaning "sunflower point."
Mirabilya, Mys de la: point of land, see Marabilla, Point.

Mirabilya, Ostrov de la: island, see Marabilla Island.

Miramar, Mount: mountain, 2,001 ft., highest point on Baker I., Alex. Arch.; 55 $5^{\circ} 9^{\prime} 25^{\prime \prime} \mathrm{N}$, $133^{\circ} 36^{\prime} 00^{\prime \prime} \mathrm{W}$; BGN 1923; (map 4).

Spanish word meaning "seaview," given in 1923 by USC\&GS because this feature "commands a magnificent view of the sea."

Miranda, Volcan de: mountain, see Iliamna Volcano.

Miranda, Volcan de: volcano, see Redoubt Volcano.

Miravalles, Punta de: point of land, see Miraballes, Point.

Mirror Bay: bay, extends NE 2 mi. to Nuyakuk Lake, $105 \mathrm{mi}$. NE of Goodnews, KilbuckKuskokwim Mts.; 59 $54^{\prime}$ N, $159^{\circ} 05^{\prime}$.W ; $B G N$ 1932; (map 53).

So named in 1932 by Gerald FitzGerald, USGS, because "the bay gives a remarkable reflection of the surrounding mountain tops."

Mirror Creek: stream, on Attu I., flows N 1.3 mi. to McKenzie Creek, $1.2 \mathrm{mi}$. SW of Attu, Aleutian Is.; $52^{\circ} 55^{\prime} 27^{\prime \prime} \mathrm{N}, 173^{\circ} 13^{\prime} 50^{\prime \prime} \mathrm{E}$; (map 13).

Named by the U.S. Army during World War II; published in 1948 by AMS.

Mirror Creek: stream, heads in Yukon, Canada, flows NW across Alaska-Canada boundary 13 mi. to Chisana River, $37 \mathrm{mi}$. SE of Northway Junction, Alaska Ra.; $62^{\circ} 36^{\prime} \mathrm{N}, 141^{\circ} 18^{\prime} \mathrm{W}$; BGN 1952; (map 84).

Named in 1898 by W. J. Peters and A. H. Brooks, USGS, "because of the exceptional clear character of the water for this region."

Mirror Harbor: bay, $0.2 \mathrm{mi}$. across, $12 \mathrm{mi}$. NW of Chichagof, on $W$ coast of Chichagof I., Alex. Arch.; $57^{\circ} 47^{\prime} 45^{\prime \prime} \mathrm{N}, 136^{\circ} 19^{\prime} 00^{\prime \prime} \mathrm{W}$; (map 9).

Descriptive name published by USC\&GS in 1925 Coast Pilot (p. 322).

Mirror Lake: lake, $0.2 \mathrm{mi}$. across, on NE coast of Attu I., $2 \mathrm{mi}$. SW of Attu, Aleutian Is.; $52^{\circ} 54^{\prime} 43^{\prime \prime} \mathrm{N}, 173^{\circ} 13^{\prime} 35^{\prime \prime} \mathrm{E}$; (map 13).

Named by U.S. Army during World War II, published in 1948 by AMS.

Mirror Lake: lake, $4.5 \mathrm{mi}$. long, on Revillagigedo I., $6 \mathrm{mi}$. $\mathrm{N}$ of Thorne Arm, in course of Fish Creek, Alex. Arch.; 55 $31^{\prime} \mathrm{N}, 131^{\circ} 09^{\prime} \mathrm{W}$; (map 3).

Local name reported in 1916 by USGS.

Mirror Lake: lake, $1.6 \mathrm{mi}$. long, on Funnel Creek, $3 \mathrm{mi}$. NE of Spectacle Lake, $37 \mathrm{mi}$. S of Iliamna, Aleutian Ra.; $59^{\circ} 14^{\prime} \mathrm{N}, 154^{\circ} 45^{\prime} \mathrm{W}$; (map 51).

Local name reported by K. F. Mather, USGS, in 1923 (in Brooks and others, 1925 pl. 3).

Mirror Lake: lake, $0.5 \mathrm{mi}$. across, $2 \mathrm{mi}$. NE of Birchwood and $21 \mathrm{mi}$. NE of Anchorage, Cook Inlet Low.; $61^{\circ} 25^{\prime} 30^{\prime \prime} \mathrm{N}, 149^{\circ} 24^{\prime} 40^{\prime \prime}$ W; BGN 1962; (map 69). Var. Bear Lake. Local name reported in 1960 by USGS.

Mirror Lake: lake, $0.6 \mathrm{mi}$. long, between Flat and Big Lakes, $22 \mathrm{mi}$. N of Anchorage, Cook
Inlet Low.; $61^{\circ} 32^{\prime} 05^{\prime \prime} \mathrm{N}, 1^{\circ} 49^{\circ} 58^{\prime} 45^{\prime \prime} \mathrm{W}$; $B G N$ 1958; (map 69). Var. Mud Lake.

Named in 1958 by Mrs. Margaret Almdale because "the former name 'Mud Lake' implies that the water is muddy, while it is clear and has a sandy, rocky bottom. 'Mirror Lake' would be more appropriate since the lake itself is small in size and reflects the trees surrounding the lake along the water's edge."

Mirror Lake: lake, $1.3 \mathrm{mi}$. long, in Broad Pass, $37 \mathrm{mi}$. S of Healy, Talkeetna Mts.; $63^{\circ} 20^{\prime} \mathrm{N}$, $149^{\circ} 07^{\prime} \mathrm{W}$; (map 87).

Local descriptive name reported in 1953 by USGS.

Mirror Slough: stream, flows NW $6.5 \mathrm{mi}$. to Gulf of Alaska, $6 \mathrm{mi}$. NW of Katalla, Malaspina Coastal Plain; $60^{\circ} 16^{\prime} \mathrm{N}, 144^{\circ} 41^{\prime} \mathrm{W}$; (map 64).

Local name reported in 1904 by G. C. Martin, USGS

Misery Creek: stream, on Alaska Penin., flows 2 mi. SE to lower Yantarni Creek, $7.5 \mathrm{mi}$. N of Cape Kunmik, Aleutian Ra.; 56 $52^{\prime}$ N, $157^{\circ}$. 11' W; (map 31).

Local name published in 1951 by USGS.

Misery Island: island, $0.6 \mathrm{mi}$. long, in Clarence Strait, W of Lemesurier Point on SW coast of Cleveland Penin., Alex. Arch.; 55 $45^{\prime} 00^{\prime \prime} \mathrm{N}$, $132^{\circ} 16^{\prime} 30^{\prime \prime} \mathrm{W}$; (map 4). Var. Lemesurier Island.

Local name reported in 1904 by H. C. Fassett, USBF. This name is derived from the French name "Lemesurier" and has been "folk etymologized" to its present form.

Misery Point: point of land, see Lemesurier Point.

Mishap Creek: stream, flows SW $5.7 \mathrm{mi}$. to Unimak Pass, on SW coast of Unimak I., Aleutian Is.; $54^{\circ} 25^{\prime} 40^{\prime \prime} \mathrm{N}, 164^{\circ} 50^{\prime} 52^{\prime \prime} \mathrm{W}$; BGN 1939; (map 24). Var. Big Loss Creek, Big River.

USC\&GS reports that the name "Big Loss Creek" was derived "from an incident ***. A lightkeeper attempting to swim the creek, when finding the foot bridge washed out, tried to throw his clothes ahead across the creek. Misjudging the distance, his bundle of clothes fell short of the far bank and were washed down stream." When USC\&GS recommended a name for this feature, they chose "Mishap Creek."

Misheguk Mountain: mountain, 4,500 ft., in De Long Mts., Brooks Ra.; $68^{\circ} 15^{\prime} \mathrm{N}, 161^{\circ} 03^{\prime} \mathrm{W}$; $B G N 1961$; (map 131).

Named by the 1925 USGS exploring expedition. An Eskimo named Misheguk helped the USGS field party, and the mountain may have been named for him.

Mishevik Slough: stream, flows SW $23 \mathrm{mi}$. to Kuskokwim River, $3.3 \mathrm{mi}$. NE of Akiak and $23 \mathrm{mi}$. NE of Bethel, Yukon-Kuskokwim Delta ; $60^{\circ} 56^{\prime} 30^{\prime \prime} \mathrm{N}, 161^{\circ} 07^{\prime} 40^{\prime \prime} \mathrm{W}$; (map 59).

Eskimo name reported in 1948 by USC\&GS Mishik: village, see Port Heiden.

Mishik Lake: lake, see Meshik Lake.

Mishik River: stream, see Meshik River.

Mishuk Creek: stream, flows NNE $8 \mathrm{mi}$. through a low wetland to Kobuk River, $24 \mathrm{mi}$. NW of 
Shungnak, Brooks Ra.; $67^{\circ} 04^{\prime} \mathrm{N}, 157^{\circ} 54^{\prime} \mathrm{W}$; (map 126).

Eskimo name reported by the U.S. Army Corps of Engineers in 1955.

Missak Bay: bay, extends N $5 \mathrm{mi}$. from Cape Atushagvik, on $\mathrm{E}$ coast of Alaska Penin., in Katmai National Monument, $25 \mathrm{mi}$. SE of Mount Katmai, Aleutian Ra.; $58^{\circ} 06^{\prime}$ N., $154^{\circ} 16^{\prime} \mathrm{W}$; $B G N$ 1924; (map 42). Var. Baie Tehivilh-Kyd, Zaliv Mieshak.

Aleutian name published in 1847 as "Z[aliv] Mieshak' on Russian Hydrog. Dept. Chart 1379. In 1919 R. F. Griggs, National Geographic Society, reported the present spelling.

Missionary Range: mountain range, elev. 1,000$3,253 \mathrm{ft} ., 8 \mathrm{mi}$. long, on Lindenberg Penin., Kupreanof I., $10 \mathrm{mi}$. NW of Petersburg, Alex. Arch.; $56^{\circ} 58^{\prime} \mathrm{N}, 133^{\circ} 15^{\prime} \mathrm{W}$; (map 6).

Named in 1887 by Lt. Comdr. C. M. Thomas, USN, for charting purposes; name published in 1888 on USC\&GS Chart 705.

Mission Cove: bight, extends SE $800 \mathrm{ft}$. off Howkan Narrows, on W coast of Long I., Alex. Arch.; 54 $4^{\circ} 52^{\prime} 25^{\prime \prime} \mathrm{N}, 132^{\circ} 48^{\prime} 10^{\prime \prime} \mathrm{W}$; (map 1 ). Var. Hyda Cove, Hydah Cove.

Descriptive name given in 1882 by $\mathrm{W} . \mathrm{H}$. Dall, USC\&GS, probably for the Presbyterian mission at Howkan village. According to Baker (1906, p. 440) this cove "has also been named 'Hydah' by Sheldon Jackson."

Mission Creek: stream, heads in Russian Mts. and flows S $8.5 \mathrm{mi}$. to Kuskokwim River $11 \mathrm{mi}$. E of Aniak, Kilbuck-Kuskokwim Mts.; 61 ${ }^{\circ}$ $34^{\prime} 15^{\prime \prime} \mathrm{N}, 159^{\circ} 11^{\prime} 00^{\prime \prime} \mathrm{W}$; BGN 1948; (mảp 73).

Local name reported by A. G. Maddren, USGS, in 1914; so called for the Russian (Greek) Orthodox Mission at its mouth.

Mission Creek: stream, heads at $64^{\circ} 38^{\prime} \mathrm{N}$, $141^{\circ} 40^{\prime} \mathrm{W}$, flows NE $27 \mathrm{mi}$. to Yukon River, $\mathrm{N}$ of Eagle, Yukon-Tanana High.; 64 $47^{\circ} 45^{\prime \prime}$ $\mathrm{N}, 141^{\circ} 12^{\prime} 00^{\prime \prime} ;(\operatorname{map} 102)$. Var. Tatotlinda, Tototlindu.

Prospectors' name reported in 1896 by Spurr (1898, pl. 48), USGS; so called because a "small temporary mission" was located at the stream's mouth. Its Indian name was recorded by Lt. Schwatka (1885, map 7), USA, as "Tototlindu" and his text "Tatotlinda."

Mission Creek: stream, in Rampart Mts., flows SW $8 \mathrm{mi}$. to Yukon River, $\mathrm{E}$ of Mission Hill, $4 \mathrm{mi}$. NE of Tanana, Kokrines-Hodzana High.; $65^{\circ} 11^{\prime} 30^{\prime \prime} \mathrm{N}, 151^{\circ} 58^{\prime} 00^{\prime} \mathrm{W}$; (map 106).

Local name reported in 1956 by Orth; so named because St. James Episcopal Mission was located nearby.

Mission Creek: stream, flows $\mathrm{N} 10 \mathrm{mi}$. to Arctic River, $15 \mathrm{mi}$. NE of Ear Mtn. and $53 \mathrm{mi}$. NE of Teller, Seward Penin. High.; 65 $59^{\prime} \mathrm{N}$, $165^{\circ} 45^{\prime} \mathrm{W}$; (map 111 )

Prospectors' name reported in 1901 by T. G. Gerdine (in Collier, 1902, pl. 12), USGS.

Mission Creek: stream, flows $\mathrm{W}$ to Anikovik River, about $15 \mathrm{mi}$. ESE of Cape Prince of Wales, Seward Penin. High.; (map 111).

Prospectors' name reported on a precinct map of Seward Peninsula gold fields by Monroe and Hutchins, corrected up to June 1903 by Arthur Gibson. This feature cannot be precisely identified on current maps.

Mission Creek : stream, see Bear Creek.

Mission Creek : stream, see Dupont Creek.

Mission Creek : stream, see Shelman Creek.

Mission Creek : stream, see Village Creek.

Mission Hill: hill, $852 \mathrm{ft}$., on $\mathrm{N}$ bank of Yukon River, $3 \mathrm{mi}$. ENE of Tanana, KokrinesHodzana High.; $65^{\circ} 11^{\prime} \mathrm{N}, 151^{\circ} 59^{\prime} \mathrm{W}$; (map 106). Var. Misson Hill.

Local name shown on a 1930(?) manuscript chart of junction of Yukon and Tanana Rivers; named for St. James Episcopal Mission.

Mission Hill: mountain, 1,270 ft., between Minor and Hatch Creeks, center Kiska I., Aleutian Is.; $51^{\circ} 56^{\prime} 25^{\prime \prime} \mathrm{N}, 177^{\circ} 31^{\prime} 55^{\prime \prime} \mathrm{E}$; (map 14).

An arbitrary name beginning with " $M$ " to correspond to " $M$ " grid used by U.S. Army for tactical purposes during World War II; published on a 1943 Army map.

Mission Island: island, $1 \mathrm{mi}$. across, in Yukon River, $\mathbf{S}$ of Mission Hill, $3 \mathrm{mi}$. $\mathrm{E}$ of Tanana, Nowitna Low.; $65^{\circ} 10^{\prime} \mathrm{N}, 151^{\circ} 58^{\prime} \mathrm{W}$; (map 106).

Local name reported in 1952 by USGS.

Mission Warehouse: locality, see Shiniak.

Misson Hill: hill, see Mission Hill.

Missoula Creek: stream, flows NE $1 \mathrm{mi}$. to Fish Creek, $58 \mathrm{mi}$. SW of Eagle, Yukon-Tanana High.; $64^{\circ} 20^{\prime} 45^{\prime \prime} \mathrm{N}, 142^{\circ} 45^{\prime} 00^{\prime \prime} \mathrm{W}$; (map 102).

Prospectors' name shown on an 1898 manuscript map by C. A. Woodruff, Fort Cudahy, Canada.

Missouri Creek: stream, flows SE $5 \mathrm{mi}$. to the Pacific Ocean, on NE coast of Umnak I., $6 \mathrm{mi}$. SE of Okmak Caldera, Aleutian Is.; $53^{\circ} 19^{\prime} 30^{\prime \prime} \mathrm{N}, 167^{\circ} 59^{\prime} 45^{\prime \prime} \mathrm{W}$; (map 23).

Name published by Byers (1959, pl. 41), USGS.

Missouri Creek: stream, flows NE $6 \mathrm{mi}$. to John River, W of Threetime Mtn., $13 \mathrm{mi}$. N of mouth of Timber Creek and $51 \mathrm{mi}$. W of Wiseman, Brooks Ra.; $67^{\circ} 14^{\prime} 30^{\prime \prime} \mathrm{N}, 151^{\circ} 58^{\prime} 30^{\prime \prime}$ W; (map 124).

Local name reported in 1939 by Marshall (1956, map).

Missouri Creek: stream, flows NW to Anikovik River, about $15 \mathrm{mi}$. E. of Cape Prince of Wales, Seward Penin. High.; (map 111).

Prospectors' name shown on the 1900 "Map of Nome Peninsula" by J.M. Davidson and B. D. Blakeslee. This feature cannot be precisely identified on current maps.

Mist Cove: $b a y, 0.6 \mathrm{mi}$. across, at $W$ point of entrance to Patterson Bay, $19 \mathrm{mi}$. $\mathrm{N}$ of village of Port Alexander, on SE coast of Baranof I., Alex. Arch.; $56^{\circ} 31^{\prime} 20^{\prime \prime} \mathrm{N}, 134^{\circ} 40^{\prime} 00^{\prime \prime} \mathrm{W}$; $B G N$ 1937; (map 5). Var. Deep Cove.

Descriptive name given in 1928 by USC\&GS because "a high waterfall into the cove causes a heavy mist at all times"; previously named "Deep Cove" by USFS in 1923.

Mist Creek: stream, heads E of Fillmore Peak, flows S $1.5 \mathrm{mi}$. to $\mathrm{N}$ shore of Port Snettisham,
$2 \mathrm{mi}$. NE of Point Styleman and $30 \mathrm{mi}$. SE of Juneau, Coast Mts.; $57^{\circ} 59^{\prime} 35^{\prime \prime} \mathrm{N}, 133^{\circ}$ 51'00'' W; (map 8).

Name derived from Mist Island near its mouth; reported in 1921 by USFS.

Mist Harbor: cove, $0.6 \mathrm{mi}$. across, on $\mathrm{E}$ coast of Nagai I., in Shumagin Is., Aleutian Ra.; $55^{\circ}$ $08^{\prime} \mathrm{N}, 159^{\circ} 51^{\prime} \mathrm{W}$; (map 27).

Name published by USC\&GS in 1882 .

Mist Island: island, $0.1 \mathrm{mi}$. across, in Port Snettisham, $0.5 \mathrm{mi}$. SE of mouth of Mist Creek and $30 \mathrm{mi}$. SE of Juneau, Coast Mts. ; $57^{\circ} 59^{\prime}$. $20^{\prime \prime} \mathrm{N}, 133^{\circ} 50^{\prime} 40^{\prime \prime} \mathrm{W}$; (map 8).

Name published in 1895 by USC\&GS.

Misty, Cape: point of land, on SW coast of Amlia I., Aleutian Is.; $52^{\circ} 03^{\prime} \mathrm{N}, 173^{\circ} 50^{\prime} \mathrm{W}$; (map 19).

Descriptive name published on a 1951 USGS map.

Misty Creek: stream, see Mystery Creek.

Misty Mountain: mountain, $6,010 \mathrm{ft}$., $12 \mathrm{mi}$. NW of Arctic Village, Brooks Ra.; $68^{\circ} 15^{\prime} \mathrm{N}, 145^{\circ}$ 54' W; (map 136).

Descriptive name given by USGS party; reported in 1926 by Mertie (in Smith, P. S., and others, 1929, pl. 1), USGS.

Mitchel Creek: stream, see Mitchell Creek.

Mitchell Bay: bay, $3.5 \mathrm{mi}$. across, $7 \mathrm{mi}$. NE of Angoon, on $W$ central Admiralty I., Alex. Arch.; $57^{\circ} 33^{\prime} \mathrm{N}, 134^{\circ} 24^{\prime} \mathrm{W}$; (map 9).

Named in 1869 by Comdr. R. W. Meade, USN, for his classmate Lt. Comdr. John Gardner Mitchell, USN. The name was published by USC\&GS in 1883 Coast Pilot (p. 177).

Mitchell Creek: stream, flows SW $2 \mathrm{mi}$. to East Fork Solomon River $1 \mathrm{mi}$. E of its mouth and $11 \mathrm{mi}$. NE of Solomon, Seward Penin. High.; $64^{\circ} 41^{\prime} \mathrm{N}, 164^{\circ} 15^{\prime} \mathrm{W}$; (map 95).

Prospectors' name reported on a 1902 prospectors' manuscript map.

Mitchell Creek: stream, flows NE $6 \mathrm{mi}$. to Agiapuk River, $22 \mathrm{mi}$. NE of Teller, Seward Penin. High.; $65^{\circ} 24^{\prime} \mathrm{N}, 165^{\circ} 44^{\prime} \mathrm{W}$; (map 111). Var. Mitchel Creek.

Prospectors' name reported in 1901 by $\mathrm{T}$. G. Gerdine (in Collier, 1902, pl. 12), USGS. Mitchell Point: point of land, E entrance to Douglas Bay, on $\mathbf{S}$ coast of Kupreanof I., 26 mi. SW of Petersburg, Alex. Arch.; $56^{\circ} 27^{\prime} \mathrm{N}$, $133^{\circ} 12^{\prime} \mathrm{W}$; (map 6).

Named on August 31, 1793, by Capt. George Vancouver, RN, "after Captain William Mitchell, RN" (Wagner, 1937, p. 398).

Mitchell Rock: rock, in Galankin Is., in Sitka Sound, $0.8 \mathrm{mi}$. S of Sitka, Alex. Arch.; $57^{\circ} 02^{\prime} 40^{\prime \prime} \mathrm{N}, 135^{\circ} 20^{\prime} 15^{\prime \prime} \mathrm{W}$; (map 9).

Named in 1880 by the U.S. Navy; published in 1883 Coast Pilot (p. 142).

Mitchells Island: island, see Wingham Island.

Mitchell Slough: estuary, on Kupreanof I., extends NW $1 \mathrm{mi}$. to Duncan Canal, $11 \mathrm{mi}$. SW of Petersburg, Alex. Arch.; $56^{\circ} 44^{\prime} 10^{\prime \prime} \mathrm{N}$, $133^{\circ} 12^{\prime} 30^{\prime \prime} \mathrm{W}$; BGN 1961; (map 6). Var. Ohmer Slough.

Local name reported in 1960 by USFS. See Ohmer Slough. 
Mitcher Creek: stream, flows SE $1 \mathrm{mi}$. to Redwood Creek, $4 \mathrm{mi}$. E of Katalla, Chugach Mts. ; $60^{\circ} 11^{\prime} \mathrm{N}, 144^{\circ} 25^{\prime} \mathrm{W}$; BGN 1946; (map 64).

Local name reported in 1945 by USGS; "named for the Mitcher group of oil fields near the head of the creek."

Mite Cove: cove, $0.2 \mathrm{mi}$. across, on $\mathrm{N}$ coast of Yakobi I., on Lisianski Inlet, $1.3 \mathrm{mi}$. SE of Ewe Ledge and $37 \mathrm{mi}$. W of Hoonah, Alex. Arch.; $58^{\circ} 04^{\prime} 15^{\prime \prime} \mathrm{N}, 136^{\circ} 26^{\prime} 20^{\prime \prime} \mathrm{W}$; (map 10).

Named by J. F. Pratt, USC\&GS, in 1901 and published in the 1901 Alaska Coast Pilot (p. 205).

Mite Island: island, $0.1 \mathrm{mi}$. across at mouth of Mite Cove, in Lisianski Inlet, on Yakobi I., $1.2 \mathrm{mi}$. SE of Ewe Ledge, $37 \mathrm{mi}$. W of Hoonah, Alex. Arch.; 58 $04^{\prime} 25^{\prime \prime} \mathrm{N}$, $136^{\circ} 26^{\prime} 50^{\prime \prime}$ W; (map 10). Var. Mite Islet.

Named by J. F. Pratt, USC\&GS, in 1901 and published in the 1901 Alaska Coast Pilot.

Mite Islet: island, see Mite Island.

Mitgoff Island: island, see Mitkof Island.

Mitik Creek: stream, flows W $2.5 \mathrm{mi}$. to Ogotoruk Creek, S of Conglomerate Creek, 6.5 mi. SE of Cape Thompson, Arctic Slope; $68^{\circ} 06^{\prime} 40^{\prime \prime} \mathrm{N}, 165^{\circ} 44^{\prime} 30^{\prime \prime} \mathrm{W}$; BGN 1963; (map 129).

Eskimo name meaning "eider duck" given in 1963 by personnel of Project Chariot. An earlier name, "Duck Creek," was changed to avoid duplication.

Mitkoff Island: island, see Mitkof Island.

Mitkof Island: island, $17 \mathrm{mi}$. long, separated from Kupreanof and Woewodski Is. by Wrangell Narrows, $12 \mathrm{mi}$. NW of Wrangell, Alex. Arch.; $56^{\circ} 40^{\prime} \mathrm{N}, 132^{\circ} 50^{\prime} \mathrm{W}$; $B G N$ 1890; (map 6). Var. Mitgoff Island, Mitkoff Island, Mittkoff Island, Ostrov Mitkova.

Published in 1848 on Russian Hydrog. Dept. Chart 1396 as "Os[trov] Mitkova" for a Capt. Mitkov (cnna).

Mitkova, Ostrov: island, see Mitkof Island.

Mitlak Mountain: mountain, $1,800 \mathrm{ft}$., $15 \mathrm{mi}$. NE of Tooth Mtn. and $22 \mathrm{mi}$. N of Goodnews, Kilbuck-Kuskokwim Mts.; $59^{\circ} 26^{\prime} \mathrm{N}$, $161^{\circ} 32^{\prime} \mathrm{W}$; (map 53).

Eskimo name published in 1951 by USGS.

Mitlak Mountain: mountain, 2,900 ft., in Ahklun Mts., $53 \mathrm{mi}$. NE of Goodnews, KilbuckKuskokwim Mts.; $59^{\circ} 36^{\prime} \mathrm{N}, 160^{\circ} 21^{\prime} \mathrm{W}$; (map $53)$.

Eskimo name reported in 1954 by USGS. Mit-Le-Topik: locality, see Mitletukeruk.

Mitletukeruk: locality, on spit at NE end of Lopp Lagoon, on Chukchi Sea coast, $22 \mathrm{mi}$. NE of Cape Prince of Wales, at $\mathrm{W}$ end of Seward Penin., Kotzebue-Kobuk Low.; 65 ${ }^{\circ} 49^{\prime}$ N, $167^{\circ} 33^{\prime} \mathrm{W}$; (map 111). Var. Mit-Le-Topik, Metletukeruk.

Site of an Eskimo village or campground; name obtained in 1901 by T. G. Gerdine (in Collier, 1902, pl. 12), USGS, The name "Mit-Le-Topik" was shown on the 1908 "Map of Seward Peninsula" by Arthur Gibson.

Mitliktavik: locality, site of an Eskimo village, on Chukchi Sea coast, on Kasegaluk Lagoon,
$21 \mathrm{mi}$. SW of Wainwright, Arctic Plain; $70^{\circ}-$ $25^{\prime} \mathrm{N}, 160^{\circ} 38^{\prime} \mathrm{W}$; (map 146). Var. Metlatavik, Meliktahkvik.

Eskimo name recorded as "Me-lik-tahk-vik" by Archdeacon Stuck (1920, p. 192). Orth was told at Wainwright in 1965 that this is a place where canoes are built. "Mitlik" means "adz", or "place where the adz is used."

Mitre, The: peak, 6,600 ft., $5.5 \mathrm{mi}$. S of Eklutna Lake and $30 \mathrm{mi}$. E of Anchorage, Chugach Mts.; $61^{\circ} 15^{\prime} 52^{\prime \prime} \mathrm{N}, 148^{\circ} 57^{\prime} 12^{\prime \prime} \mathrm{W}$; $B G N$ 1966; (map 69).

Named in 1965 by members of the Mountaineering Club of Alaska. "In Europe mitre is the term used for a sharp, symmetrical, rock peak such as this one."

Mitrofa Island: island, see Mitrofania Island.

Mitrofania: locality, between Kuiukta and Mitrofania Bays, on $S$ coast of Alaska Penin., $24 \mathrm{mi}$ SW of Chignik, Aleutian Ra.; $55^{\circ} 59^{\prime} \mathrm{N}, 158^{\circ}$ 43' W; (map 27).

Native village, shown on a USBF Chart (1890) and reported as abandoned in USC\&GS Alaska Coast Pilot (1947, v, 2, p. 293).

Mitrofania Bay: bay, $6 \mathrm{mi}$. across, on S coast of Alaska Penin., 25 mi. SW of Chignik, Aleutian Ra.; $55^{\circ} 55^{\prime} \mathrm{N}, 158^{\circ} 48^{\prime} \mathrm{W}$; (map 27).

Named for Mitrofania Island; published in 1888 by USBF.

Mitrofania Harbor: anchorage, on $\mathrm{E}$ side of Mitrofania Bay, $24 \mathrm{mi}$. SW of Chignik, Aleutian Ra.; $55^{\circ} 59^{\prime} \mathrm{N}, 158^{\circ} 43^{\prime} \mathrm{W}$; (map 27).

Named in 1888 by USBF.

Mitrofania Island: island, $8 \mathrm{mi}$. across, $33 \mathrm{mi}$. E of Stepovak Bay, Aleutian Ra.; $55^{\circ} 53^{\prime} \mathrm{N}$, $158^{\circ} 50^{\prime} \mathrm{W}$; BGN 1890; (map 27). Var. Mitrofa Island, Saint Mitrofania Island, Saint Mitrophan.

Name published as "St. Mitrophan" by Grewingk (1850, p. 49), and as "Os[trov] Sv[iataya] Mitrofania," or "St. Mitrofania Island," on Russian Hydrog. Dept. Chart 1455 (1852). "Os[trov] Mitrofania," or "Mitrofania Island" is shown by Capt. Tebenkov (1852, map 24), IRN.

Mitten Creek: stream, flows $\mathrm{N} 7 \mathrm{mi}$. to Colville River, $13 \mathrm{mi}$. NW of Liberator Lake, Arctic Slope; $68^{\circ} 59^{\prime} \mathrm{N}, 158^{\circ} 46^{\prime} \mathrm{W}$; BGN 1960; (map 132).

Named in 1951 by H. N. Reiser, USGS, "for mitten lost on this creek."

Mitten Hill: hill, 4,300 ft., on S bank of Beaver Creek, $11 \mathrm{mi}$. N of Rock Lake and $66 \mathrm{mi}$. NE of McCarthy, Alaska Ra.; 61 ${ }^{\circ} 58^{\prime} 30^{\prime \prime} \mathrm{N}$, $141^{\circ} 14^{\prime} 25^{\prime \prime} \mathrm{W}$; (map 67).

Local name obtained by USGS and published on maps since 1954 .

Mitten Lake: lake, see Miller Lake.

Mitter Lake: lake, see Miller Lake.

Mittkoff Island: island, see Mitkof Island.

Mitt Lake: lake, $0.1 \mathrm{mi}$. across, $0.5 \mathrm{mi}$. SW of Sweeper Cove, Kuluck Bay, on NE coast of Adak I, Aleutian Is; $51^{\circ} 50^{\prime} 37^{\prime \prime} \mathrm{N}, 176^{\circ} 39^{\prime}$ 24" W; (map 17).

Name published by USC\&GS in 1961 on Chart 9141.
Miyghapak, Cape: point of land, see Niyghapak Point.

Miykhapakhit Mountain: mountain, see Myghapowit Mountain.

Miyook Mountain: hill, see Owalit Mountain.

Mizofek Point: point of land, see Black Point.

Mkleetokumenah: mountain, see Schwatka, Mount.

M'Ladies Mountain: peak, 8,880 ft., near head of Fels Glacier, $24 \mathrm{mi}$. N of Paxson, Alaska Ra.; $63^{\circ} 22^{\prime} 35^{\prime \prime} \mathrm{N}, 145^{\circ} 25^{\prime} 00^{\prime \prime} \mathrm{W}$; (map 86).

Name published on relatively recent maps.

Model Cove: cove, $1.4 \mathrm{mi}$. across, on $\mathrm{E}$ coast of Kiska I., Aleutian Is.; 52 $00^{\prime} \mathrm{N}, 177^{\circ} 35^{\prime} \mathrm{E}$; (map 14). Var. Crawfish Cove.

An arbitrary name beginning with " $M$ " to correspond to " $M$ " grid used by the U.S. Army for tactical purposes during World War II; published on a 1943 Army map.

Model Creek: stream, flows SE $1.8 \mathrm{mi}$. to Model Cove, on eastern Kiska I., Aleutian Is. ; $52^{\circ}$ $00^{\prime} 32^{\prime \prime} \mathrm{N}, 177^{\circ} 34^{\prime} 50^{\prime \prime} \mathrm{E}$; (map 14).

An arbitrary name beginning with " $M$ " to correspond to " $M$ " grid used by the U.S. Army for tactical purposes during World War II ; published on a 1953 AMS map.

Model Hill: hill, $300 \mathrm{ft}$., NW of Model Cove, on Kiska I., Aleutian Is. ; $52^{\circ} 00^{\prime} 35^{\prime \prime}$ N, $177^{\circ}$ 34'15" E; (map 14).

An arbitrary name beginning with " $\mathrm{M}$ " to correspond to " $M$ " grid used by the U.S. Army for tactical purposes during World War II; published on a 1953 AMS map.

Modesta Creek: stream, flows SE to Don River, $6 \mathrm{mi}$. SE of Cassiterite Peak and $17 \mathrm{mi}$. NW of Teller, Seward Penin. High.; (map 111). Var. Modesty Creek.

Prospectors' name shown on the 1900 "Map of Nome Peninsula" by J. M. Davidson and B. D. Blakeslee. This feature cannot be precisely identified on current maps.

Modesty Creek: stream, see Modesta Creek.

Modoc Creek: stream, flows NW $4.5 \mathrm{mi}$. to Chatanika River, $45 \mathrm{mi}$. NE of Fairbanks, Yukon-Tanana High.; $65^{\circ} 16^{\prime} 45^{\prime \prime}$ N, $146^{\circ} 34^{\prime}$ $30^{\prime \prime} \mathrm{W}$; (map 104).

Named by prospectors; reported in 1908 by USGS (Covert and Ellsworth, 1909, pl. 4). Mofeta, Mys: point of land, see Moffet Point. Moffet, Cape: point of land, see Moffett, Cape. Moffet, Mount: volcano, see Moffett, Mount.

Moffeta, Mys: point of land, see Moffet Point. Moffet Bay: lagoon, see Moffet Lagoon.

Moffet Cove: lagoon, see Moffet Lagoon.

Moffet Lagoon: lagoon, $7 \mathrm{mi}$. long, $15 \mathrm{mi}$. NE of village of Cold Bay, at SW end of Alaska Penin., Bristol Bay Low., $55^{\circ} 24^{\prime}$ N, $162^{\circ} 35^{\prime}$ W; BGN 1965; (map 29). Var. Moffet Bay, Moffet Cove, Neumann Bay, Sloss Bay.

Name derived from Moffet Point and given by W. H. Dall, USC\&GS, in 1882. This lagoon was given the names "Neumann and Sloss Bays" by USBF in 1888 and was called "Moffet Cove" by USC\&GS in 1890 (chart 806).

Moffet Point: point of land, at $\mathrm{N}$ end of Moffet Lagoon, $19 \mathrm{mi}$. $\mathrm{N}$ of village of Cold Bay, SW end of Alaska Penin., Bristol Bay Low.; 55 ${ }^{\circ}$ 
$27^{\prime} 20^{\prime \prime} \mathrm{N}, 162^{\circ} 32^{\prime} 00^{\prime \prime} \mathrm{W} ; \mathrm{B} G N$ 1966; (map 29). Var. Mys Mofeta, Mys Moffeta, Neumann Point.

Named by Capt. Lutke (1836, p. 262), IRN, for Midshipman Samuel Moffet, a member of his crew on the sloop Moller during his voyage around the world from 1826-29. This point was called "Neumann" by USBF in 1888.

Moffett, Cape: point of land, on NW coast of Adak I., Aleutian Is.; $51^{\circ} 57^{\prime} 25^{\prime \prime} \mathrm{N}, 176^{\circ} 47^{\prime}$ $10^{\prime \prime}$ W; BGN 1936; (map 17). Var. Cape Moffet.

Named by the U.S. Navy Hydrog. Office in 1936 for Rear-Adm. William Adger Moffett, 1869-1933, USN, who was lost with the U.S.S. Akron on April 4, 1933, off Barnegat, N.J.

Moffett, Mount: volcano, 3,924 ft., on N Adak I., Aleutian Is.; $51^{\circ} 56^{\prime} 18^{\prime \prime} \mathrm{N}, 176^{\circ} 44^{\prime} 22^{\prime \prime} \mathrm{W}$; BGN 1936; (map 17). Var. Mount Moffet. Named by the U.S. Navy Hydrog. Office in 1936 for Rear-Adm. William Adger Moffett, 1869-1933, USN. See Moffett, Cape.

Moffit, Mount: peak, 13,020 ft., near head of Trident Glacier, $11 \mathrm{mi}$. SE of Mount Hayes, Alaska Ra.; $63^{\circ} 34^{\prime} 08^{\prime \prime} \mathrm{N}, 146^{\circ} 23^{\prime} 50^{\prime \prime} \mathrm{W}$; $B G N$ 1960; (map 86).

Named in 1950 by USGS for Fred Howard Moffit, 1874-1958, USGS, who worked in Alaska for 40 years and authored over fifty publications on Alaskan geology and mining.

Mogak Creek: stream, heads in lake at $61^{\circ} 25^{\prime} \mathrm{N}$, $162^{\circ} 33^{\prime} \mathrm{W}$, flows SE $35 \mathrm{mi}$. to Putu Creek $6 \mathrm{mi}$. NW of its junc. with Johnson River, Yukon-Kuskokwim Delta; $61^{\circ} 18^{\prime} 30^{\prime \prime} \mathrm{N}, 162^{\circ}$ $11^{\prime} 45^{\prime \prime} \mathrm{W}$; (map 74).

Eskimo name reported by Orth in 1965 , as "Morak" meaning "wood," but misspelled on a recent USGS map.

Moghoweyik River: stream, flows NW $12 \mathrm{mi}$. to Bering Sea, 22 mi. S of Gambell, St. Lawrence $1 . ; 63^{\circ} 28^{\prime} \mathrm{N}, 171^{\circ} 51^{\prime} \mathrm{W}$; BGN 1951; (map 93). Var. Magoghyik River, Mogoghyik River, Mookyik River.

Eskimo name reported in 1944 by Lawrence Kulukhan of Gambell.

Mogilnoi Island: island, $250 \mathrm{ft}$. across, connected to Japonski I., in Sitka Sound, $2 \mathrm{mi}$. W of Sitka, Alex. Arch.; $57^{\circ} 02^{\prime} 35^{\prime \prime} \mathrm{N}, 135^{\circ} 23^{\prime} 00^{\prime \prime}$ W; (map 9). Var. Ostrov Mogilnoy, Shell Island.

Russian name meaning "grave" given in 1809 by the navigator Ivan Vasiliev the first, IRN, published by Lt. Sarichev (1826, map 19), IRN, as "O[strov] Mogilnoy."

Mogilnoy, Ostrov: island, see Mogilnoi Island.

Mogoghyik River: stream, see Moghoweyik River.

Mogtalik: locality, see Mukialik.

Mogul Creek: stream, flows NE $19 \mathrm{mi}$, to Seventymile River, $18 \mathrm{mi}$. NW of Eagle, Yukon-Tanana High.; $64^{\circ} 40^{\prime} \mathrm{N}, 141^{\circ} 42^{\prime} \mathrm{W}$; (map 102).

Prospectors' name obtained in 1898 by E. C. Barnard, USGS.

Mohican, Cape: peninsula, on Nunivak I., extends NW $2 \mathrm{mi}$. into Bering Sea, $53 \mathrm{mi}$. NW of Cape Mendenhall ; $60^{\circ} 12^{\prime} \mathrm{N}, 167^{\circ} 25^{\prime} \mathrm{W}$; $B G N$ 1902; (map 57). Var. Ikoox, Ikukh, Mys Boil.

Name reported about 1899 by USC\&GS. Capt. M. D. Tebenkov, IRN, in 1849 named it "Mys Boil" for Lt. Roman Boil, who was in the party when Capt. Lt. M. N. Vasiliev, IRN, discovered Nunivak Island in 1821.

Mohler Lake: lake, $0.5 \mathrm{mi}$. long, $11 \mathrm{mi}$. SW of Lake Louise, $\mathrm{E}$ of Nicholson Lake, $45 \mathrm{mi}$. WNW of Glennallen, Copper River Basin; $62^{\circ} 13^{\prime} 30^{\prime \prime} \mathrm{N}, 146^{\circ} 54^{\prime} 00^{\prime \prime} \mathrm{W}$; (map 83). Var. Moyler Lake.

Local name reported in 1949 by USGS.

Moira Island: island, $0.8 \mathrm{mi}$. long, at mouth of Moira Sound, on SE coast of Prince of Wales I., Alex. Arch.; $55^{\circ} 03^{\prime} 45^{\prime \prime} \mathrm{N}, 132^{\circ} 00^{\prime} 45^{\prime \prime} \mathrm{W}$; (map 4).

Named in 1886 by. Lt. Comdr. R. C. Glover USN.

Moira Rock: rock, $0.1 \mathrm{mi}$. long, at mouth of Moira Sound, on SE coast of Prince of Wales I., Alex. Arch.; $55^{\circ} 05^{\prime} 00^{\prime \prime} \mathrm{N}, 131^{\circ} 59^{\prime} 45^{\prime \prime} \mathrm{W}$; $B G N$ 1966; (map 3). Var. Moira Rocks.

Named in 1885 by Lt. Comdr. Richardson Glover, USN.

Moira Rocks: rock, see Moira Rock.

Moira Sound: estuary, extends from junc. of its South and West Arms $10 \mathrm{mi}$. NE to Glarence Strait, on SE coast of Prince of Wales I., Alex. Arch.; $55^{\circ} 05^{\prime} \mathrm{N}, 132^{\circ} 00^{\prime} \mathrm{W}$; (map 4).

Named by Capt. Vancouver (1798, v. 2, p. 206), RN, in August 1793, "after the noble Earl of that title." See Apodaca, Bocas de.

Mojovy Island: island, see Hall Island.

Moke Rock: rock, near water level, SE of Maurelle Is., Alex. Arch.; $55^{\circ} 36^{\prime} 30^{\prime \prime} \mathrm{N}, 133^{\circ} 34^{\prime}$ $55^{\prime \prime} \mathrm{W}$; (map 4).

Local name published in 1925 by USC\&GS. Mokhnatoi Island: island, see Makhnati Island. Mokhnatoy, Ostrov: island, see Makhnati Island.

Mokhnatyy, Ostrov: island, see Makhnati Island.

Mokhoweyik Camp: locality, see Booshu Camp. Moknatoi Island: island, see Makhnati Island. Mokrovskoi: bay, see Pumicestone Bay.

Mokrovskoi, Cape: point of land, see Spray Cape.

Molchatna: locality, see Mulchatna.

Molchatna: stream, see Mulchatna River.

Moldy Lake: lake, oxbow lake of Koyukuk River, $10 \mathrm{mi}$. NW of Roundabout Mtn., Koyukuk Low.; $65^{\circ} 41^{\prime} \mathrm{N}, 156^{\circ} 36^{\prime} \mathrm{W}$; (map 108).

Local name obtained at Huslia by USGS in 1954 or 1955

Mole Harbor: bay, $1.3 \mathrm{mi}$. across, in Seymour Ganal, on Admiralty I., $24 \mathrm{mi}$. NE of Angoon, Alex. Arch.; 57 $40^{\prime} \mathrm{N}, 134^{\circ} 03^{\prime} \mathrm{W}$; (map 9).

Named in 1889 by Lt. Comdr. H. B. Mansfield, USN; published by USC\&GS in 1891 Coast Pilot (p. 144).

Molekostna, Reka: stream, see Melozitna River. Mole River: stream, flows E $3 \mathrm{mi}$. to Mole Harbor Admiralty I., $20 \mathrm{mi}$. NE of Angoon, Alex.
Arch.; $57^{\circ} 38^{\prime} 50^{\prime \prime} \mathrm{N}, 134^{\circ} 06^{\prime} 00^{\prime \prime} \mathrm{W}$; (map 9).

Local name reported in 1951 by USGS

Moller, Port: bay, $3 \mathrm{mi}$. across, trends NW 18 mi. toward Bristol Bay, near SW end of Alaska Penin., Aleutian Ra.; 55 ${ }^{\circ} 53^{\prime} \mathrm{N}, 160^{\circ}$ 28' W; BGN 1944; (map 28).

Named by Capt. M. N. Staniukovich, of Capt. F. P. Lutke's expedition, for the sloop Moller, in which he explored the bay in 1828 .

Moller Island: barrier island, one of Kudobin Is., about $20 \mathrm{mi}$. W of village of Port Moller, Bristol Bay Low.; $56^{\circ} 01^{\prime} \mathrm{N}, 161^{\circ} 05^{\prime} \mathrm{W}$; (map 28). Var. Möller Island.

This name was reported in 1882 by W. $\mathrm{H}$. Dall, USC\&GS; shown as Möller Island on an 1890 USBF chart. Subsequent changes in the shore line make it impossible to identify this feature at present.

Molly Creek: stream, flows NW $13 \mathrm{mi}$. to Middle Frok Fortymile River, $80 \mathrm{mi}$. SW of Eagle, Yukon-Tanana High.; $64^{\circ} 11^{\prime} 40^{\prime \prime}$ N, $143^{\circ} 28^{\prime}$ $20^{\prime \prime} \mathrm{W}$; (map 102).

Local name published in 1956 by USGS.

Molybdenum Mountain: mountain, 1,705 ft., on W bank of Owhat River $19 \mathrm{mi}$. NE of Aniak, Kilbuck-Kuskokwim Mts.; $61^{\circ} 49^{\prime} \mathrm{N}, 161^{\circ} 15^{\prime}$ W; (map 73).

Prospectors' name reported by USC\&GS in 1948.

Molybdenum Ridge: ridge, elev. 5,900 ft., extends 5.5 mi., between East Fork Little Delta River and Delta Creek, $14 \mathrm{mi}$. N of Mount Hayes, Alaska Ra.; $63^{\circ} 49^{\prime} 15^{\prime \prime} \mathrm{N}, 146^{\circ} 39^{\prime} 00^{\prime \prime}$ $\mathrm{W}$; (map 86).

Name published on relatively recent maps. Momaghnuk Mountains: hills, see Mamagnak Mountains.

Monahan Creek: stream, flows NE $18 \mathrm{mi}$. to Chakina River, $7 \mathrm{mi}$. N of Goodlata Peak and $18 \mathrm{mi}$. SW of McCarthy, Chugach Mts.; $61^{\circ}$ $10^{\prime} \mathrm{N}, 143^{\circ} 07^{\prime} \mathrm{W}$; (map 67).

Local name reported in 1911 by D. C. Witherspoon, USGS.

Monahan Greek: stream, heads N of Butte Lake, flows NNW $19 \mathrm{mi}$. to Brushkana Creek, on S side of Monahan Flats, $46 \mathrm{mi}$. SE of Healy, Talkeetna Mts. ; $63^{\circ} 19^{\prime} 00^{\prime \prime} \mathrm{N}, 148^{\circ} 04^{\prime} 20^{\prime \prime} \mathrm{W}$; (map 87).

Name reported in 1966 by USGS.

Monahan Flat: flat, extends SW $18 \mathrm{mi}$. from West Fork Glacier to junc. of Canyon Creek and Nenana River, 50 mi. SE of Healy, Alaska Ra.; $63^{\circ} 20^{\prime} \mathrm{N}, 147^{\circ} 50^{\prime} \mathrm{W}$; (map 87).

Named locally for George Monahan, prospector; name reported in 1913 by J. W. Bagley, USGS.

Monarch Creek: stream, flows NE $8 \mathrm{mi}$. to North Fork Chandalar River, $9.5 \mathrm{mi}$. W of Caro and $22 \mathrm{mi}$. S of Chandalar, Brooks Ra.; $67^{\circ} 10^{\prime} 30^{\prime \prime}$ $\mathrm{N}, 148^{\circ} 22^{\prime} 00^{\prime \prime} \mathrm{W}$; (map 123).

Prospectors' name obtained in 1909 by $\mathrm{A}$. G. Maddren (in Brooks and others, 1910, pl. 7), USGS.

Monarch Slough: stream, channel of Yukon River, extends N 2 mi. to Poltes Slough 2.2 mi. NW of Marshall, Yukon-Kuskokwim Delta; $61^{\circ} 54^{\prime} \mathrm{N}, 162^{\circ} 09^{\prime} \mathrm{W}$; (map 74). 
Riverboat pilots' name shown on a fieldsheet by R. H. Sargent, USGS, in 1916.

Monashka Bay: bay, $1.2 \mathrm{mi}$. N of Kodiak, extends SW 3 mi., between Miller and Termination Points, Kodiak I.; $57^{\circ} 50^{\prime} \mathrm{N}, 152^{\circ} 25^{\prime}$ W; BGN 1933; (map 34). Var. Chernieshef, Devils Bay, Maknashka Bay, Sycamore Bay, Zaliv Chernysheva, Zaliv Makhnashka.

Local name reported in 1933 by Gerald FitzGerald, USGS, derived from the name "Z[aliv] Makhnashka" [from Monakhinya], meaning "nun bay," published by Capt. Tebenkov (1852, map 23). This feature was called "Zaliv Chernysheva" [from Chernichie] meaning "sycamore bay," by Sub-Lt. Mikhail Murashev in 1839 or 1840 . USC\&GS called it "Devils Bay" in 1881 and later in 1910, "Sycamore Bay."

Monashka Creek: stream, flows NE $3.8 \mathrm{mi}$. to Monashka Bay, $3.7 \mathrm{mi}$. NW of Kodiak, Kodiak I.; $57^{\circ} 50^{\prime} 15^{\prime \prime} \mathrm{N}, 152^{\circ} 26^{\prime} 30^{\prime \prime} \mathrm{W}$; (map 34).

Name derived from Monashka Bay and published in 1952 by USGS.

Monashka Mountain: mountain, $1,814 \mathrm{ft}$., $\mathrm{N}$ of Monashka Bay, 4.7 mi. NW of Kodiak, Kodiak I.; $57^{\circ} 51^{\prime} 20^{\prime \prime} \mathrm{N}, 152^{\circ} 27^{\prime} 15^{\prime \prime} \mathrm{W}$; (map 34).

Name derived from Monashka Bay and published in 1943 by USC\&GS.

Monday Creek: stream, flows S $1.8 \mathrm{mi}$. to Grant Creek $4.5 \mathrm{mi}$. NE of that stream's junc. with Yukon River, $23 \mathrm{mi}$. WNW of Tanana, Kokrines-Hodzana High.; $65^{\circ} 14^{\prime} 08^{\prime \prime} \mathrm{N}, 152^{\circ}$ 57'25" W; (map 106).

Prospectors' name reported in 1956 by $R$. M. Chapman, USGS.

Monday Creek: stream, flows $\mathrm{W}$ to Anikovik River, about $15 \mathrm{mi}$. SE of Cape Prince of Wales, Seward Penin. High.; (map 111). Var. Right Fork Ono-ko-vuk River.

Prospectors' name shown on the 1900 "Map of Nome Peninsula" by J. M. Davidson and B. D. Blakeslee. This stream cannot be precisely identified on current maps.

Mondragones, Los: islands, see Ballena Islands.

Money Creek: stream, see Lorna Creek.

Money Gulch: ravine, trends to Albert Creek, $8 \mathrm{mi}$. $\mathrm{N}$ of Tahneta Pass, $62^{\circ} 00^{\prime} \mathrm{N}, 147^{\circ} 20^{\prime}$ W; (map 82).

Local name published by Theodore Chapin (in Brooks and others, 1915, p. 128), USGS.

Moneykam Koonga: stream, see Manikam Creek.

Money Knob: mountain, 1,800 ft., $1.5 \mathrm{mi}$. SE of Livengood, Yukon-Tanana High.; 65 $30^{\prime} 15^{\prime \prime}$ $\mathrm{N}, 148^{\circ} 31^{\prime} 30^{\prime \prime} \mathrm{W}$; (map 105).

Local name published by USGS in the 1950's.

Monie Lake: lake, $1 \mathrm{mi}$. long, on $\mathrm{E}$ coast of Prince of Wales I., W of Doctor Point, Alex. Arch.; 55 $19^{\prime} 25^{\prime \prime} \mathrm{N}, 132^{\circ} 10^{\prime} 20^{\prime \prime} \mathrm{W}$; (map 4).

Name published in 1927 by USC\&GS.

Monja, La : rock, see Perl Rock.

Monkey Ridge: ridge, $0.5 \mathrm{mi}$. long, $0.5 \mathrm{mi}$. W of Kiska Harbor, Kiska I., Aleutian Is.; $51^{\circ} 58^{\prime} 10^{\prime \prime} \mathrm{N}, 177^{\circ} 31^{\prime} 20^{\prime \prime} \mathrm{E}$; (map 14).
An arbitrary name beginning with " $M$ " to correspond to "M" grid used by the U.S. Army for tactical purposes during World War II; published on a 1943 Army map.

Monocline Bluff: promontory, $628 \mathrm{ft}$., on right bank of Yukon River, in Paimiut Hills, $16 \mathrm{mi}$. SW of Holy Cross, Nulato Hills; $62^{\circ} 05^{\prime} \mathrm{N}$, $160^{\circ} 02^{\prime} \mathrm{W}$; (map 78).

Riverboat pilots' name shown on a 1940 "Navigation Chart of the Tanana-Yukon Rivers" published by U.S. Dept. of Interior.

Monolith Point: point of land, on $\mathbf{E}$ coast of Agattu I., $\mathrm{N}$ point of entrance to McDonald Cove, $3.7 \mathrm{mi}$. SW of Krugloi Point, Aleutian Is.; $52^{\circ} 28^{\prime} 00^{\prime \prime} \mathrm{N}, 173^{\circ} 42^{\prime} 05^{\prime \prime} \mathrm{E}$; (map 13).

This name was published in the USBF Annual Report for 1893-94 (1896, p. 223).

Monolith Point: point of land, on $\mathrm{W}$ shore of Albatross Anchorage, at head of Balboa Bay, $28 \mathrm{mi}$. S of village of Port Moller, on Alaska Penin., Aleutian Ra.; $55^{\circ} 35^{\prime} 00^{\prime \prime} \mathrm{N}, 160^{\circ} 36^{\prime}$ 45" W; (map 28).

Name published in 1893 by U.S. Navy Hydrog. Office.

Monopoly Creek: stream, flows SE $8 \mathrm{mi}$. to Fish Greek, $25 \mathrm{mi}$. NE of Fairbanks, Yukon-Tanana High.; $65^{\circ} 03^{\prime} \mathrm{N}, 147^{\circ} 02^{\prime} \mathrm{W}$; (map 105).

Local name published in 1940 by USGS.

Monotis Creek: stream, flows NE $4.5 \mathrm{mi}$. to Kiruktagiak River, $13 \mathrm{mi}$. S of Castle Mtn. and 33 mi. WNW of Anaktuvuk Pass, Brooks Ra.; 68 ${ }^{\circ} 24^{\prime}$ N, $152^{\circ} 49^{\prime} \mathrm{W}$; (map 134).

Named in 1944 by USGS geologists during the exploration of Naval Petroleum Reserve No. 4 for the fossil, Monotis subcircularis, abundant on the creek.

Monrak: locality, $\mathrm{S}$ of mouth of Monrak River on left bank of Kolavinarak River, 92 mi. SW of Bethel, Yukon-Kuskokwim Delta; $60^{\circ} 29^{\prime}$ $\mathrm{N}, 164^{\circ} 26^{\prime} \mathrm{W}$; (map 58). Var. Munroke.

Former Eskimo camp or village reported in 1949 by USC\&GS.

Monrak: locality, see Agiukchuk.

Monrak River: stream, flows SW $4 \mathrm{mi}$. to Kolavinarak River, $6 \mathrm{mi}$. SE of Emperor I. and $92 \mathrm{mi}$. SW of Bethel, Yukon-Kuskokwim Delta ; $60^{\circ} 29^{\prime} \mathrm{N}, 164^{\circ} 26^{\prime} \mathrm{W}$; (map 58). Var. Munroke River.

Eskimo name reported in 1949 by USC\&GS

Monroe Bay: bay, $0.7 \mathrm{mi}$. across, on $\mathrm{W}$ coast of Kanaga I., Aleutian Is. ; $51^{\circ} 42^{\prime} 20^{\prime \prime}$ N, $177^{\circ}$ $41^{\prime} 30^{\prime \prime} \mathrm{W}$; (map 17).

Name published in 1951 by USGS.

Monroke: locality, see Agiukchuk.

Monsoon Lake: lake, $0.1 \mathrm{mi}$. long, $\mathrm{S}$ of Kiska Harbor on east-central Kiska I., Aleutian Is.,

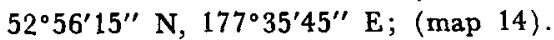

An arbitrary name beginning with " $M$ " to correspond to " $M$ " grid used by the U.S. Army for tactical purposes during World War II; published on a 1943 Army map.

Monsoon Lake: lake, $2.1 \mathrm{mi}$. long, $15 \mathrm{mi}$. E of junc. of MacLaren and Susitna Rivers, Alaska Ra.; $62^{\circ} 50^{\prime} \mathrm{N}, 146^{\circ} 37^{\prime} \mathrm{W}$; (map 83).

Local name reported by USGS in 1959.

Montagnas Brillantes: mountain, see Iliamna Volcano.
Montague Island: island, trends NE-SW $50 \mathrm{mi}$, in Prince William Sound, $76 \mathrm{mi}$. E of Seward, Chugach Mts.; $60^{\circ} 10^{\prime} \mathrm{N}, 147^{\circ} 15^{\prime} \mathrm{W}$; BGN 1900; (map 63). Var. Isla de Quiros, Montagu Island, Ostrov Tsukli, Tsukli Island.

This island was named "Montagu" by Capt. James Cook, RN, on May 18, 1778, for John Montagu, Earl of Sandwiche, the son of Viscount Hinchinbroke (Wagner, 1937, p. 398). It was called "Isla de Quiros" or "Quiros' Island" by the Spaniards in the late 1700's. The Eskimo name, published by Lt. Sarichev (1826, map 5), IRN, was "Ostrov Tsukli," or "Tsukli Island."

Montague Peak: mountain, 2,160 ft., at NE end of Montague I., $37 \mathrm{mi}$. E of Chenega, Chugach Mts.; $60^{\circ} 14^{\prime} 59^{\prime \prime} \mathrm{N}, 147^{\circ} 00^{\prime} 45^{\prime \prime} \mathrm{W}$; (map 63).

Named in 1903 by Ferdinand Westdahl, USC\&GS.

Montague Point: point of land, on $\mathrm{N}$ tip of Montague I., above NW entrance to Rocky Bay, $36 \mathrm{mi}$. ENE of Chenega, Chugach Mts.; $60^{\circ} 22^{\prime} 30^{\prime \prime} \mathrm{N}, 147^{\circ} 05^{\prime} 15^{\prime \prime} \mathrm{W}$; (map 63). Var. Punta de Aliaga.

Named in 1902 by Ferdinand Westdahl, USC\&GS. It was called "Punta de Aliaga" by Don Ignacio Arteaga in 1779.

Montague Strait: water passage, $5 \mathrm{mi}$. wide, between Montague and Latouche Is., at SW edge of Prince William Sound, $20 \mathrm{mi}$. SE of Chenega, Chugach Mts.; $60^{\circ} 00^{\prime} \mathrm{N}, 147^{\circ} 45^{\prime}$ W; (map 63).

Local name reported in 1909 by Grant and Higgins (1910, pl. 2), USGS. Name derived from nearby Montague Island.

Montagu Island: island, see Montague Island. Montana: village, pop. 39, mile 209.3 on The Alaska Railroad, $17 \mathrm{mi}$. S of Talkeetna, Cook Inlet Low.; $62^{\circ} 04^{\prime} 47^{\prime \prime} \mathrm{N}, 150^{\circ} 04^{\prime} 15^{\prime \prime} \mathrm{W}$; (map 81). Var. Montana Creek.

This place orignated as a railroad construction camp and was so named in 1919 by the builders. Homesteaders settled here in fall of 1957.

Montana Bill Creek: stream, distributary of South Fork Big River, flows E $13 \mathrm{mi}$. to Redoubt Bay, $28 \mathrm{mi}$. W of Kenai, Cook Inlet Low.; $60^{\circ} 38^{\prime} 15^{\prime \prime} \mathrm{N}, 152^{\circ} 04^{\prime} 30^{\prime \prime} \mathrm{W}$; (map 62).

Local name reported in 1958 by USGS.

Montana Creek: village, see Montana.

Montana Creek: ravine, see Montana Gulch.

Montana Creek: stream, flowing $8 \mathrm{mi}$. SE to the Mendenhall River, 1 mi. $\mathrm{N}$ of Juneau Airport and $8 \mathrm{mi}$. NW of Juneau, Coast Mts.; $58^{\circ}$ $22^{\prime} 55^{\prime \prime} \mathrm{N}, 134^{\circ} 36^{\prime} 00^{\prime \prime} \mathrm{W}$; (map 11). Var. Brennan River.

The origin of the name is unknown. The name was in use in the 1880 's, but the stream was called Brennan River in 1881 by Edward J. Brennan who with John McInnis located placer claims along the stream (DeArmond, 1957, p. 32).

Montana Creek: stream, formed by its North and Middle Forks, flows SW $9.2 \mathrm{mi}$. to Susitna River, $15 \mathrm{mi}$. S of Talkeetna, Cook Inlet 
Low.; $62^{\circ} 06^{\prime} 18^{\prime \prime} \mathrm{N}, 150^{\circ} 04^{\prime} 20^{\prime \prime} \mathrm{W}$; $B G N$ 1954; (map 81). Var. Sunshine Creek.

Prospectors' name reported in 1898 by Capt. E. F. Glenn, USA.

Montana Creek: stream, heads on Juninggulra Mtn., flows NW 22 mi. to Iditarod River, 24 mi. NW of village of Crooked Creek and 37 mi. SE of Holy Cross, Kilbuck-Kuskokwim Mts.; $62^{\circ} 06^{\prime} 45^{\prime \prime} \mathrm{N}, 158^{\circ} 38^{\prime} 00^{\prime \prime} \mathrm{W}$; BGN 1945; (map 79).

Prospectors' name reported in 1933 by Mertie (1936, p. 243), USGS.

Montana Creek: stream, heads near Black Pass, flows S $2.4 \mathrm{mi}$. to Bonanza Creek, $2 \mathrm{mi}$. SW of Camelback Mtn. and $20 \mathrm{mi}$. NE of Flat, Kilbuck-Kuskokwim Mts.; 62 $31^{\prime} 15^{\prime \prime} \mathrm{N}$, $157^{\circ} 22^{\prime} 30^{\prime \prime} \mathrm{W}$; (map 79).

Prospectors' name published in 1921 by USGS.

Montana Creek: stream, flows N $4 \mathrm{mi}$. to Creston Creek, $5.5 \mathrm{mi}$. N of Cripple Creek Mts. and $52 \mathrm{mi}$. NW of Medfra, Kilbuck-Kuskokwim Mts.; $63^{\circ} 36^{\prime} \mathrm{N}, 155^{\circ} 58^{\prime} \mathrm{W}$; (map 89).

Local name reported in 1954 by. USGS.

Montana Creek: stream, flows W $6 \mathrm{mi}$. to Nenana River, 10 mi. S of Healy, Alaska Ra.; 63 $43^{\prime}$ $30^{\prime \prime} \mathrm{N}, 148^{\circ} 53^{\prime} 00^{\prime \prime} \mathrm{W}$; (map 87).

Local name reported in 1923 by The Alaska R.R. on a manuscript map.

Montana Creek: stream, flows $\mathrm{E} 3 \mathrm{mi}$. to Hutchinson Creek, $47 \mathrm{mi}$. SW of Eagle, YukonTanana High.; $64^{\circ} 19^{\prime} 15^{\prime \prime} \mathrm{N}, 142^{\circ} 19^{\prime} 00^{\prime \prime} \mathrm{W}$; (map 102).

Prospectors' name shown on an 1898 manuscript map by C. A. Woodruff, Fort Cudahy, Canada.

Montana Creek: stream, flows SE $1.6 \mathrm{mi}$. to Solomon River, $15 \mathrm{mi}$. NE of Solomon, Seward Penin. High.; $64^{\circ} 46^{\prime} \mathrm{N}, 164^{\circ} 19^{\prime} \mathrm{W}$; (map 95).

Prospectors' name reported on a 1902 prospectors' manuscript map.

Montana Creek: stream, flows SE $3 \mathrm{mi}$. to Seventymile River, $40 \mathrm{mi}$. NW of Eagle, Yukon-Tanana High.; $64^{\circ} 58^{\prime} \mathrm{N}, 142^{\circ} 40^{\prime} \mathrm{W}$; (map 102).

Named by prospectors and shown on a 1902 manuscript map by E. J. Chamber, U.S Deputy Surveyor.

Montana Creek: stream, flows $\mathrm{S} 2.3 \mathrm{mi}$. to East Fork Chena River, $67 \mathrm{mi}$. SW of Circle, Yukon-Tanana High.; $65^{\circ} 02^{\prime} 15^{\prime \prime} \mathrm{N}, 145^{\circ} 23^{\prime}$. $50^{\prime \prime} \mathrm{W}$; (map 104).

Named by prospectors and reported in 1911 by USGS (Prindle, 1913, pl. 1).

Montana Creek: stream, flows S $7.5 \mathrm{mi}$. to Yukon River, $\mathrm{E}$ of Birches and $14 \mathrm{mi}$. WSW of Kallands, Kokrines-Hodzana High.; $65^{\circ} 08^{\prime}$ $15^{\prime \prime} \mathrm{N}, 153^{\circ} 33^{\prime} 00^{\prime \prime} \mathrm{W}$; (map 107).

Local name obtained in 1952 by USGS topographers.

Montana Creek: stream, flows SW $21 \mathrm{mi}$. to Tolovana River, $50 \mathrm{mi}$. NW of Fairbanks, Tanana Low.; $65^{\circ} 10^{\prime}$ N, $149^{\circ} 16^{\prime}$ W. (map 105).

Named by prospectors; published in 1906 by USGS.

Montana Creek: stream, flows S $3 \mathrm{mi}$. to McManus Creek, $67 \mathrm{mi}$. SW of Circle, Yukon.
Tanana High.; $65^{\circ} 21^{\prime} 30^{\prime \prime} \mathrm{N}, 146^{\circ} 05^{\prime} 10^{\prime \prime} \mathrm{W}$; (map 104).

Named by prospectors; reported in 1903 by T. G. Gerdine (Prindle, 1905, pl. 13), USGS. Montana Creek: stream, flows NE $5 \mathrm{mi}$. to Beaver Creek, $26 \mathrm{mi}$. E of Livengood, Yukon-Tanana High.; $65^{\circ} 30^{\prime} \mathrm{N}, 147^{\circ} 39^{\prime} \mathrm{W}$; (map 105).

Local name published by USGS in the 1950's.

Montana Creek: stream, flows NW $1 \mathrm{mi}$. to South Fork Grouse Creek, in Mint River basin, 41 mi. NW of Teller, Seward Penin. High.; $65^{\circ}$ $35^{\prime} \mathrm{N}, 167^{\circ} 31^{\prime} \mathrm{W}$; (map 111).

Prospectors' name reported on the 1908 "Map of Seward Peninsula" by Arthur Gibson.

Montana Creek: stream, flows W $8.6 \mathrm{mi}$. to Kugruk River, $26 \mathrm{mi}$. NE of Imuruk Lake, Seward Penin. High.; $65^{\circ} 49^{\prime} \mathrm{N}, 162^{\circ} 26^{\prime} \mathrm{W}$; (map 110). Var. Trace Creek.

Prospectors' name reported in 1903 by $D$. C. Witherspoon (in Moffit, 1905, pl. 2), USGS. This appears to be the Trace Greek noted on a precinct map of Seward Peninsula by Monroe and Hutchins; corrected up to June 1903 by Arthur Gibson.

Montana Creek: stream, see Polly Creek.

Montana Creek: stream, see Sheep Creek.

Montana Gulch: ravine, extends E $1.9 \mathrm{mi}$. to Minook Creek, $3 \mathrm{mi}$. SSE of Rampart, YukonTanana High.; $65^{\circ} 27^{\prime} 50^{\prime \prime} \mathrm{N}, 150^{\circ} 06^{\prime} 20^{\prime \prime} \mathrm{W}$; (map 106). Var. Montana Creek.

Prospectors' name reported in 1904 by Prindle and Hess (1960, pl. 3), USGS.

Montana Peak: peak, 6,900 ft., $20 \mathrm{mi}$. N of Palmer, at head of Mint Glacier, Talkeetna Mts.; 61 $53^{\prime} 00^{\prime \prime} \mathrm{N}, 149^{\circ} 03^{\prime} 30^{\prime \prime} \mathrm{W}$; (map 69 ).

Local name reported in 1942 by AMS.

Montasta Lake: village, see Mentasta Lake.

Montauk Bluff: bluff, 2,643 ft., extends $1 \mathrm{mi}$. on $\mathbf{N}$ bank of Yukon River, $23 \mathrm{mi}$. NNW of Eagle, Porcupine Plat.; $65^{\circ} 06^{\prime} 30^{\prime \prime} \mathrm{N}, 141^{\circ}$ $29^{\prime} 00^{\prime \prime} \mathrm{W}$; (map 103). Var. Montauk Point.

Local name published in 1956 by USGS. Probably the "Montauk Point" reported in 1900 by Lt. J. C. Cantwell, USRCS, although Baker (1906, p. 442) states that the point is on the left bank.

Montauk Creek: stream, flows NE $6 \mathrm{mi}$. to Yukon River, opposite Montauk Bluff, $23 \mathrm{mi}$. NNW of Eagle, Yukan-Tanana High.; $65^{\circ} 06^{\prime} \mathrm{N}$, $141^{\circ} 31^{\prime} \mathrm{W}$; (map 103).

Local name published in 1956 by USGS.

Monte Carlo Creek: stream, flows SE $1 \mathrm{mi}$. to Star Creek in Pargon River basin, $12 \mathrm{mi}$. NE of Council and $18 \mathrm{mi}$. SE of Mount Bendeleben, Seward Penin. High.; $65^{\circ} 03^{\prime} \mathrm{N}, 163^{\circ}$ 32' W; (map 110).

Prospectors' name reported on a map of Cape Nome gold fields by David Fox, Jr., dated 1901.

Monte Carlo Island: island, $0.7 \mathrm{mi}$. long, between Kuiu and Kupreanof Is., $13 \mathrm{mi}$. NW of Point Baker, Alex. Arch.; 56 $36^{\circ} 2^{\prime} 00^{\prime \prime}$ N, $133^{\circ}$. $46^{\prime} 15^{\prime \prime} \mathrm{W}$; (map 6).

Named by USC\&GS for charting purposes; name publised in 1932 Coast Pilot (p. 257).
Monte Cristo Creek: stream, heads on Mount Gordon, flows NE $9.5 \mathrm{mi}$. to Nabesna River $11 \mathrm{mi}$. SE of Nabesna, Wrangell Mts.; $62^{\circ}$ $14^{\prime} \mathrm{N}, 142^{\circ} 54^{\prime} \mathrm{W}$; (map 84). Var. Na-un-da. Named by prospectors and reported in 1902 by F. C. Schrader, USGS, who states that the Indian name is "Na-un-da."

Monte Cristo Creek: stream, flows SW $7 \mathrm{mi}$. to McCoy Creek, $24 \mathrm{mi}$. NW of Big Delta, Yukon-Tanana High. ; $64^{\circ} 26^{\prime} 15^{\prime \prime} \mathrm{N}, 146^{\circ} 17^{\prime} 30^{\prime \prime}$ W; (map 101).

Named by prospectors; reported in 1910 by USGS (Capps, 1912, pl. 1).

Monte Cristo Creek: stream, flows SW $1 \mathrm{mi}$., joins Alfield Creek to form Sulphur Creek, 23 mi. NE of Nome, Seward Penin. High.; $64^{\circ}$ $49^{\prime} 00^{\prime \prime} \mathrm{N}, 165^{\circ} 11^{\prime} 40^{\prime \prime} \mathrm{W}$; (map 94).

Prospectors' name reported in 1904 by $\mathrm{T}$. G. Gerdine, USGS.

Monte Cristo Creek: stream, flows S $1 \mathrm{mi}$. to O'Connor Creek, $10 \mathrm{mi}$. NW of Fairbanks, Yukon-Tanana High.; $64^{\circ} 58^{\prime} 15^{\prime \prime} \mathrm{N}, 147^{\circ}$ 50'45" W; (map 100).

Local name published in 1908 by USGS.

Monte Gristo Creek: stream, flows NE $1.5 \mathrm{mi}$. to Barnes Creek, $16 \mathrm{mi}$. NE of Fairbanks, Yukon-Tanana High.; $65^{\circ} 01^{\prime} \mathrm{N}, 147^{\circ} 21^{\prime} \mathrm{W}$; BGN 1933; (map 105). Var. Fish Creek.

This stream was originally considered part of Fish Creek; the present name was reported in 1917 by Theodore Chapin (in Martin, G. C., and others, 1919, fig. 13), USGS.

Montekakat: locality, see Mentokakat.

Monterde, Isla : island, "one of a group of islands west of Umnak," Aleutian Is.

Name shown on a 1791 map by Don Juan de la Bodega y Quadra probably to honor José Maria de Monterde, one of the royal officials at San Blas at this time (Wagner, 1937, p. 474).

Monterey Creek: stream, flows SW $1.5 \mathrm{mi}$. to California Creek which flows to Pargon River, $13 \mathrm{mi}$. NE of Council and $25 \mathrm{mi}$. SE of Mount Bendeleben, Seward Penin. High.; $65^{\circ} 00^{\prime} \mathrm{N}$, $163^{\circ} 18^{\prime} \mathrm{W}$; (map 110).

Prospectors' name reported on a map of Cape Nome gold fields by David Fox, Jr., dated 1901.

Montgomery Bay: cove, $0.6 \mathrm{mi}$. across, on NW coast of Latouche I., $4.3 \mathrm{mi}$. NE of Danger I., $5.2 \mathrm{mi}$. SE of Seward, Chugach Mts.; $59^{\circ} 58^{\prime}$ $45^{\prime \prime} \mathrm{N}, 148^{\circ} 01^{\prime} 20^{\prime \prime} \mathrm{W}$; (map 49).

Local navigators' name published in 1907 by USC\&GS on Chart 8522.

Monti, Baie de: $b a y$, see Yakutat Bay.

Monti Bay: bay, $3.5 \mathrm{mi}$. long on SE shore of Yakutat Bay, S of Khantaak I., W of Yakutat, Malaspina Coastal Plain; $59^{\circ} 34^{\prime} \mathrm{N}, 139^{\circ} 50^{\prime}$ W; (map 46). Var. Bahia de Monti, Bahie de Monti, Baie de Monti, De Monti Bay.

The name "Baie de Monti" was given in 1786 to Yakutat Bay or a part of it by Capt. La Pérouse. It was named for Lt. de Monti who was the first officer of L'Astolabe, one of La Pérouse's ships, and the first to reconnoiter the bay. It was called De Monti Bay by USC\&GS. Since 1945 the name has been contracted to Monti Bay, although the name De Monti Bay is still used on some maps. 
Monument Creek: stream, flows S $1.5 \mathrm{mi}$. to Skowl Arm Kasaan Bay, on E coast of Prince of Wales I., Alex. Arch.; 55 $26^{\prime} 10^{\prime \prime} \mathrm{N}, 132^{\circ}-$ $23^{\prime} 40^{\prime \prime} \mathrm{W}$; BGN 1963 ; (map 4).

Local name reported in 1961 by USFS; given "because of its proximity to Old Kasaan National Monument * * *."

Monument Greek: stream, heads at glacier, flows NE $5.5 \mathrm{mi}$. to Matanuska River, $37 \mathrm{mi}$. NE of Palmer, Chugach Mts.; 61 $46^{\prime} 25^{\prime \prime}$ N, 148 02'45" W; (map 69).

Local name reported in 1913 by USGS.

Monument Creek: stream, flows SW $9 \mathrm{mi}$. to Sulatna River, $3.6 \mathrm{mi}$. NW of Sulatana crossing and $35 \mathrm{mi}$. $\mathrm{S}$ of Ruby, Kilbuck-Kuskokwim Mts.; $64^{\circ} 13^{\prime} 48^{\prime \prime} \mathrm{N}, 155^{\circ} 32^{\prime} 10^{\prime \prime} \mathrm{W}$; (map 98).

Prospectors' name reported in 1913 by Eakin (1914, pl. 3), USGS.

Monument Greek: stream, flows SE $3 \mathrm{mi}$. to Snake River, $6 \mathrm{mi}$. NW of Nome, Seward Penin. High.; $64^{\circ} 35^{\prime} \mathrm{N}, 165^{\circ} 28^{\prime} \mathrm{W}$; (map 94).

Prospectors' name reported in 1900 by E. C. Barnard (in Brooks, 1901, pl. 17), USGS. This appears to be the stream labeled "Peacer Creek" by Schrader (1900c, p. 16), USGS.

Monument Creek: stream, flows NE $1.3 \mathrm{mi}$. to Casadepaga River, $15 \mathrm{mi}$. NE of Solomon, Seward Penin. High.; $64^{\circ} 47^{\prime} \mathrm{N}, 164^{\circ} 24^{\prime} \mathrm{W}$; (map 95).

Prospectors' name reported on a 1902 prospectors' manuscript map.

Monument Creek: stream, flows WSW $10 \mathrm{mi}$. to North Fork Chena River, $1.3 \mathrm{mi}$. NW of Ghena Hot Springs and $78 \mathrm{mi}$. SW of Circle, YukonTanana High.; $65^{\circ} 04^{\prime} \mathrm{N}, 146^{\circ} 05^{\prime} \mathrm{W}$; (map 104).

Named by prospectors and reported in 1914 by Ellsworth and Davenport (1915b, pl. 12), USGS.

Monument Creek: stream, flows NW $1.6 \mathrm{mi}$. to North Fork Kougarok River, $2 \mathrm{mi}$. SW of Harris Dome and $41 \mathrm{mi}$. W of Imuruk Lake, Seward Penin. High.; $65^{\circ} 36^{\prime}$ N, $164^{\circ} 37^{\prime}$ W; (map 110).

Prospectors' name reported in 1901 by T. G. Gerdine (in Collier, 1902, pl. 12), USGS.

Monument Creek: stream, flows SE $36 \mathrm{mi}$. to Sheenjek River, $4 \mathrm{mi}$. W of Grayling Lake and $63 \mathrm{mi}$. NW of Coleen Mtn., Brooks Ra:; $67^{\circ} 59^{\prime} \mathrm{N}, 143^{\circ} 16^{\prime} \mathrm{W}$; (map 121).

Prospectors' name reported in 1927 by J. B. Mertie, Jr., USGS.

Monument Hill: mountain, 1,050 ft., between Beach Cove and Kiska Harbor, Kiska I., Aleutian Is. ; $51^{\circ} 59^{\prime} 32^{\prime \prime} \mathrm{N}, 177^{\circ} 30^{\prime} 27^{\prime \prime} \mathrm{E}$; (map 14).

An arbitrary name beginning with " $M$ " to correspond to " $M$ " grid used by U.S. Army for tactical purposes during World War II; published on a 1943 Army map.

Monument Mountain: mountain, 2,667 ft., 24 mi. NE of Katalla, Chugach Mts.; $60^{\circ} 26^{\prime} \mathrm{N}$, $144^{\circ} 01^{\prime} \mathrm{W}$; (map 64).

So named after a GLO (BLM) monument on its top; name reported in 1905 by G. C. Martin (1908, pl. 335), USGS.
Monument Mountain: mountain, 2,400 ft., $6 \mathrm{mi}$. $\mathbf{N}$ of Kiwalik Mtn. and $25 \mathrm{mi}$. $\mathbf{E}$ of Imuruk Lake, Seward Penin. High.; $65^{\circ} 36^{\prime}$ N, $162^{\circ} 13^{\prime}$ W; (map 110).

Prospectors' name reported in 1903 by D. C. Witherspoon (in Moffit, 1905, pl. 2), USGS.

Monument Mountain: mountain, see Monument Rock.

Monument Ridge: ridge, elev. 2,000 ft., extends E-W 12 mi., divided by Cutaway Creek, 20 mi. SE of Liberator Lake, Arctic Slope; $68^{\circ}$ $41^{\prime} \mathrm{N}, 157^{\circ} 40^{\prime} \mathrm{W}$; (map 132).

So named in 1949 by USGS geologists "because the eroded hogback forms freestanding monuments."

Monument Rock: mountain, 1,447 ft., $1.7 \mathrm{mi}$. $\mathrm{N}$ of Sunset and $7 \mathrm{mi}$. NW of Nome, Seward Penin. High.; $64^{\circ} 36^{\prime} \mathrm{N}, 165^{\circ} 33^{\prime} \mathrm{W}$; (map 94). Var. Monument Mountain.

Local name reported on Arthur Gibson's "Map of Cape Nome Precinct" dated 1904. Shown as "Mounment Mountain" on the 1903 Campion Mining and Trading Co. map by George M. Ashford.

Monument Rocks: rocks, elev. 1,405 ft., on mountain at head of Flint Creek, $10 \mathrm{mi}$. NE of Sulatna Crossing and $28 \mathrm{mi}$. SE of Ruby, Kilbuck-Kuskokwim Mts.; $64^{\circ} 20^{\prime} \mathrm{N}, 155^{\circ} 27^{\prime}$ W; (map 98).

Local name reported about 1952 by USGS.

Monzonite Creek: stream, heads in Monzonite Hills, flows NE $10 \mathrm{mi}$. to Sulatna River, Nowitna Low.; $64^{\circ} 32^{\prime} \mathrm{N}, 154^{\circ} 35^{\prime} \mathrm{W}$; (map 98).

Local name reported about 1952 by USGS.

Monzonite Hills: hills, extend E-W $11 \mathrm{mi}$., on right bank of Sulatna River, $33 \mathrm{mi}$. SE of Ruby, Nowitna Low.; $64^{\circ} 25^{\prime} \mathrm{N}, 154^{\circ} 30^{\prime} \mathrm{W}$; (map 98).

Local name reported about 1952 by USGS. Moody: locality, mile 353.2 on The Alaska RR., $4 \mathrm{mi}$. S of Healy, Alaska Ra.; $63^{\circ} 47^{\prime} 45^{\prime \prime} \mathrm{N}$, $148^{\circ} 56^{\prime} 00^{\prime \prime} \mathrm{W}$; (map 87).

Name of a flag stop reported on a 1922 timetable by the Alaska RR.

Moody Creek: stream, flows NW $21 \mathrm{mi}$. to Healy River, $2.5 \mathrm{mi}$. E of Healy, Alaska Ra.; $63^{\circ} 51^{\prime}$ $\mathrm{N}, 148^{\circ} 53^{\prime} \mathrm{W}$; (map 87).

Local name reported in 1910 by J. W. Bagley (in Capps, 1912, pl. 2), USGS.

Mookyik River: stream, see Moghoweyik River. Moon Creek: stream, flows SE $2.3 \mathrm{mi}$. to Peace River, 4 mi. NW of Haycock, Seward Penin. High.; $65^{\circ} 15^{\prime} \mathrm{N}, 161^{\circ} 14^{\prime} \mathrm{W}$; (map 109).

Local name reported in 1917 by G. L. Harrington, USGS

Moon Lake: lake, $0.5 \mathrm{mi}$. across, on Kenai Penin. W of Aspen Lake, $11 \mathrm{mi}$. S of Point Possession and $38 \mathrm{mi}$. NE of Kenai, Cook Inlet Low.; $60^{\circ} 52^{\prime} 45^{\prime \prime} \mathrm{N}, 150^{\circ} 22^{\prime} 00^{\prime \prime} \mathrm{W}$; (map 62).

Named about 1963 by officials of Kenai National Moose Range, for administrative purposes.

Moon Lake: lake, $0.9 \mathrm{mi}$. long, between Alaska Highway and Tanana River, $6 \mathrm{mi}$. W of Tanacross, Alaska Ra.; $63^{\circ} 23^{\prime} \mathrm{N}, 143^{\circ} 23^{\prime} \mathrm{W}$; (map 85)

Local name reported by USGS in 1964.
Moon Lake: lake, $2.5 \mathrm{mi}$. long, $1 \mathrm{mi}$. SW of Gamble Slough, 9 mi. NE of Stevens Village, Yukon Flats; $66^{\circ} 08^{\prime} \mathrm{N}, 148^{\circ} 56^{\prime} \mathrm{W}$; (map 118).

Local name obtained in 1956 by USGS.

Moonlight Bay: cove, $0.7 \mathrm{mi}$. wide, on SE coast of Kenai Penin., $5 \mathrm{mi}$. SW of Black Mtn. and $42 \mathrm{mi}$. ESE of Homer, Chugach Mts.; 59 $30^{\prime}$ $15^{\prime \prime} \mathrm{N}, 150^{\circ} 22^{\prime} 00^{\prime \prime} \mathrm{W}$; BGN 1929; (map 50).

Named by USC\&GS in 1928.

Moonlight Creek: stream, in Kantishna Hills, heads on Kankone Peak, flows NE $6.4 \mathrm{mi}$. to Glearwater Fork Toklat River, $17 \mathrm{mi}$. N of Eielson Visitor Center, Alaska Ra.; $63^{\circ} 40^{\prime} \mathrm{N}$, $150^{\circ} 24^{\prime} \mathrm{W}$; (map 88)

Prospectors' name shown on a 1916 fieldsheet by C. E. Giffin, USGS.

Moonlight Creek: stream, heads in Moonlight Springs, flows S $0.7 \mathrm{mi}$. to Little Creek, 3.2 mi. $\mathbf{N}$ of Nome, Seward Penin. High.; $64^{\circ}$ $32^{\prime} 48^{\prime \prime} \mathrm{N}, 165^{\circ} 24^{\prime} 40^{\prime \prime} \mathrm{W}$; (map 94).

Prospectors' name published on the 1900 "Map of Nome Peninsula" by J. M. Davidson and B. D. Blakeslee.

Moonlight Creek: stream, flows NE $2.5 \mathrm{mi}$. to Eldorado River, $20 \mathrm{mi}$. NW of Solomon, Seward Penin. High.; $64^{\circ} 44^{\prime} \mathrm{N}, 164^{\circ} 58^{\prime} \mathrm{W}$; (map 95)

Prospectors' name reported in 1900 by E. C. Barnard (in Brooks, 1901, pl. 17), USGS.

Moonlight Creek: stream, flows S $1.5 \mathrm{mi}$. to Casadepaga River, $15 \mathrm{mi}$. N of Solomon, Seward Penin. High.; $64^{\circ} 47^{\prime} \mathrm{N}, 164^{\circ} 27^{\prime} \mathrm{W}$; (map 95). Var. Alert Creek.

Prospectors' name reported in 1905 by T. G. Gerdine, USGS. Shown as "Alert" on a prospector's 1902 manuscript map.

Moonlight Creek: stream, flows SW $3 \mathrm{mi}$. to Tubutulik River in Death Valley, $38 \mathrm{mi}$. SE of Imuruk Lake, Seward Penin. High. ; 65 ${ }^{\circ} 09^{\prime}$ N, 162'17' W; (map 110).

Prospectors' name published on the 1908 "Map of Seward Peninsula" by Arthur Gibson.

Moonlight Creek: stream, heads on Eva Mtn., flows SW $5.5 \mathrm{mi}$. to Grantley Harbor, $5 \mathrm{mi}$. NE of Teller, Seward Penin. High.; $65^{\circ} 18^{\prime} \mathrm{N}$, $166^{\circ} 13^{\prime} \mathrm{W}$; (map 111). Var. Igloo Creek.

Local name reported in 1900 by $E$. C. Barnard (in Brooks, 1901, pl. 17), USGS.

Moonlight Creek: stream, heads in York Mts., flows NW $2 \mathrm{mi}$. to Anikovik River, $15 \mathrm{mi}$. E of Cape Prince of Wales and $41 \mathrm{mi}$. NW of Teller, Seward Penin. High.; $65^{\circ} 33^{\prime}$ N, $167^{\circ}$ $34^{\prime} \mathrm{W}$; (map 111).

Prospectors' name shown on the 1900 'Map of Nome Peninsula" by J. M. Davidson and B. D. Blakeslee.

Moonlight Creek: stream, flows NE $5.6 \mathrm{mi}$. to Humboldt Creek which flows to Goodhope River, $38 \mathrm{mi}$. NW of Imuruk Lake on Seward Penin., Kotzebue-Kobuk Low.; $65^{\circ} 59^{\prime}$ N, $164^{\circ} 07^{\prime} \mathrm{W}$; (map 110$)$

Prospectors' name reported in 1901 by USGS (Collier, 1902, pl. 12).

Moonlight Creek: stream, see Little Creek. 
Moonlight Point: point of land, S tip of Nevensky I., in Yukon River, $1.5 \mathrm{mi}$. SW of Marshall, Yukon-Kuskokwim Delta ; $61^{\circ} 51^{\prime} 40^{\prime \prime} \mathrm{N}, 162^{\circ}$ $07^{\prime} 00^{\prime \prime} \mathrm{W}$; (map 74).

Riverboat pilots' name shown on a fieldsheet by R. H. Sargent, USGS, in 1916.

Moonlight Springs: springs, $0.3 \mathrm{mi}$. SE of Perkinsville and $4 \mathrm{mi}$. $\mathrm{N}$ of Nome, Seward Penin. High.; 64 $33^{\circ} 20^{\prime \prime} \mathrm{N}, 165^{\circ} 24^{\prime} 25^{\prime \prime} \mathrm{W}$; (map 94).

Prospectors' name reported on the 1903 Campion Mining and Trading Co. map by George M. Ashford.

Moonshine Creek: stream, flows NW $2.5 \mathrm{mi}$ to Frederick Sound, $10 \mathrm{mi}$. SE of Petersburg, Coast Mts.; $56^{\circ} 48^{\prime} 50^{\prime \prime}$ N, $132^{\circ} 42^{\prime} 22^{\prime \prime}$ W; (map 6).

Local name recorded in 1961 by USGS.

Moonshine Creek: stream, flows W $5.3 \mathrm{mi}$, to Nizina River, $4.5 \mathrm{mi}$. E of Nizina Mtn. and $20 \mathrm{mi}$. NE of McCarthy, Wrangell Mts.; $61^{\circ}$ $36^{\prime} \mathrm{N}, 142^{\circ} 26^{\prime} \mathrm{W}$; (map 67).

Local name reported in 1922 by Moffitt (in Smith and others, 1930, pl. 3), USGS.

Moonshine Creek: stream, flows SE $1 \mathrm{mi}$. to Birch Creek which flows to Big Four Creek, $20 \mathrm{mi}$. NE of Solomon, Seward Penin. High.; $64^{\circ} 49^{\prime} \mathrm{N}, 164^{\circ} 09^{\prime} \mathrm{W}$; (map 95).

Prospectors' name reported on a 1902 prospectors' manuscript map.

Moore, Mount: peak, 7,410 ft., $0.8 \mathrm{mi}$. SW of Elephant Promontory and $37 \mathrm{mi}$. $\mathrm{N}$ of Juneau,

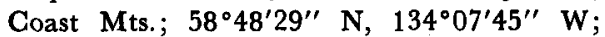
BGN 1965; (map 11).

Named in 1964 by members of the Juneau Icefield Research Program.

Moore, Port: $b a y, 3.5 \mathrm{mi}$. across, SE side of Point Barrow at $\mathrm{W}$ end of Elson Lagoon, Arctic Plain; $71^{\circ} 22^{\prime} \mathrm{N}, 156^{\circ} 27^{\prime} \mathrm{W}$; (map 153). Var. Ikiraaluk, Ikkeraluk, Moore Harbour, Moore's Harbour.

Comdr. Rochfort Maguire (Great Britain, 1854, map facing p. 188) applied the name "Moore's Harbour" to the area just S of Plover Point where he wintered the H.M.S. Plover in 1852-53. The subsequent 1853 Brit. Adm. Chart 2164 used the name "Port Moore." It commemorates Comdr. Thomas E. L. Moore, RN (Leffingwell, 1919, p. 97).

Moore Channel: water passage, see Eluitkak Pass.

Moore City: locality, on Ganes Creek, at mouth of Last Chance Gulch, $38 \mathrm{mi}$. SW of McGrath, Kilbuck-Kuskokwim Mts. ; 62 $53^{\prime} 30^{\prime \prime}$ N, $156^{\circ}$ $39^{\prime} 40^{\prime \prime} \mathrm{W}$; (map 79).

Mining camp and recording office established in 1907; local name reported in 1908 by A. G. Maddren, USGS. Probably abandoned in 1908 .

Moore Creek: locality, on Moore Creek, $7.5 \mathrm{mi}$. NE of Camelback Mtn. and $30 \mathrm{mi}$. E of Iditarod, Kilbuck-Kuskokwim Mts.; 62 ${ }^{\circ} 36^{\prime} 00^{\prime \prime}$ N, 157 $09^{\prime} 10^{\prime \prime} \mathrm{W}$; (map 79).

Name reported in 1947 by USGS.

Moore Creek: stream, flows NW $10 \mathrm{mi}$. to Crooked Creek, $5 \mathrm{mi}$. E of its mouth at Upper Ugashik Lake, on Alaska Penin., $35 \mathrm{mi}$. NE of Ugashik, Aleutian Ra.; $57^{\circ} 37^{\prime} 05^{\prime \prime} \mathrm{N}, 156^{\circ}$ $30^{\prime} 00^{\prime \prime} \mathrm{W}$; (map 36$)$.

Local name reported in 1923 by $R$. H. Sargent, USGS.

Moore Creek: stream, heads $2 \mathrm{mi}$. SE of Camelback Mtn., flows E $25 \mathrm{mi}$. to join Little Waldren Fork to form Takotna River, $39 \mathrm{mi}$. E of Flat, Kilbuck-Kuskokwim Mts. ; 62 $32^{\prime} 30^{\prime \prime} \mathrm{N}$, 156 $32^{\prime} 30^{\prime \prime}$ W; (map 79).

Prospectors' name reported in 1910 by A. G. Maddren, USGS.

Moore Creek: stream, flows NW $2 \mathrm{mi}$. to Woodchopper Creek, $3 \mathrm{mi}$. $\mathrm{S}$ of that stream's junc. with Yukon River and $41 \mathrm{mi}$. SE of Circle, Yukon-Tanana High.; $65^{\circ} 19^{\prime} \mathrm{N}, 143^{\circ} 21^{\prime} \mathrm{W}$; (map 103).

Local name published in 1956 by USGS.

Moore Creek: stream, flows N $12 \mathrm{mi}$. to Mosquito Fork, $9.5 \mathrm{mi}$. E of Eagle Cliff and $42 \mathrm{mi}$. SW of Chandalar, Brooks Ra. ; $67^{\circ} 04^{\prime} 15^{\prime \prime} \mathrm{N}, 149^{\circ}$ $37^{\prime} 00^{\prime \prime} \mathrm{W}$; (map 123).

Prospectors' name obtained in 1901 by Schrader (1904, pl. 3), USGS.

Moore Harbour: bay, see Moore, Port.

Moore Icefall: icefall, of 2,200 ft., extends WNW $1.8 \mathrm{mi}$. from Icefall Peak, at head of Gulkana Glacier, $18 \mathrm{mi}$. NNE of Paxson, Alaska Ra.; $63^{\circ} 17^{\prime} \mathrm{N}, 145^{\circ} 22^{\prime} \mathrm{W}$; (map 86). Var. Moores Icefall.

Named between 1948 and 1955 by T. L. Péwé, USGS.

Moore Island: island, in Koyukuk River, about $7 \mathrm{mi}$. S of Bettles, Kanuti Flats; $66^{\circ} 48^{\prime} \mathrm{N}$, $151^{\circ} 45^{\prime} \mathrm{W}$; ( $\operatorname{map} 117$ ).

This island, named in 1885 by Lt. Allen (1887, p. 100), USA, cannot be identified.

Moore Lake: lake, $2.3 \mathrm{mi}$. Iong, in course of Tyone Creek, $6 \mathrm{mi}$. W of Susitna Lake and 46 mi. NW of Glennallen, Copper River Basin; $62^{\circ} 24^{\prime} \mathrm{N}, 146^{\circ} 54^{\prime} \mathrm{W}$; (map 83).

Local name reported in 1959 by USGS.

Moore Mountains: mountains, $30 \mathrm{mi}$. long, on central Chichagof I., $38 \mathrm{mi}$. $\mathbf{N}$ of Sitka, Alex. Arch.; $57^{\circ} 38^{\prime} \mathrm{N}, 135^{\circ} 20^{\prime} \mathrm{W}$; (map 9).

Named in 1895 by USC\&GS for Lt. Comdrs. Edwin King Moore and William Irwin Moore, USN.

Moore Nunatak: nunatak, $1,000 \mathrm{ft}$., at junc. of Agassiz Glacier and Malaspina Glacier, $5 \mathrm{mi}$. SW of Samovar Hills and $57 \mathrm{mi}$. NW of Yakutat, St. Elias Mts. ; $60^{\circ} 06^{\prime} 30^{\prime \prime} \mathrm{N}, 140^{\circ} 55^{\prime} 30^{\prime \prime}$ W; (map 66).

Named by I. C. Russell, in 1891, presumably for Will C. Moore, a member of his party, who was drowned while landing at Icy Bay on June 6, 1891.

Moore Ridge: ridge, $1 \mathrm{mi}$. long, between West and East Arms Holtz Bay, Attu I., Aleutian Is.; $52^{\circ} 55^{\prime} 20^{\prime \prime} \mathrm{N}, 173^{\circ} 09^{\prime} 00^{\prime \prime} \mathrm{E}$; (map 13).

Named by the U.S. Army during World War II ; published in 1948 by AMS.

Moores Channel: water passage, see Eluitkak Pass.

Moore's Harbour: bay, see Moore, Port.

Moores Icefall: icefall, see Moore Icefall.

Moorovskoy: bay, see Pumicestone Bay.

Moose Creek: locality, along Richardson Highway, $20 \mathrm{mi}$. SE of Fairbanks, Tanana Low.; $62^{\circ} 42^{\prime} 30^{\prime \prime} \mathrm{N}, 147^{\circ} 08^{\prime} 30^{\prime \prime} \mathrm{W}$; (map 100 )

Local name derived from Moose Creek that flows north of the locality. The name has appeared on recent maps.

Moose Creek: settlement, pop. 10, on Alaska RR., on $\mathbf{N}$ bank of Matanuska River, $\mathrm{E}$ of Moose Creek, $5.8 \mathrm{mi}$. NE of Palmer, Cook Inlet Low.; $61^{\circ} 40^{\prime} 30^{\prime \prime} \mathrm{N}, 1^{\circ} 9^{\circ} 01^{\prime} 45^{\prime \prime} \mathrm{W}$; (map 69).

Name of a station on The Alaska RR. that had its beginning about 1916. A post office was established here in 1917; discontinued in 1922 (Ricks, 1965, p. 43). Recent USGS maps indicate a site with four or five buildings.

Moose Creek: village, see Stony River.

Moose Creek: stream, flows NE $1.1 \mathrm{mi}$. to Kiska Harbor, on east-central Kiska I., Aleutian Is.; $51^{\circ} 58^{\prime} 06^{\prime \prime} \mathrm{N}, 177^{\circ} 32^{\prime} 07^{\prime \prime} \mathrm{E}$; (map 14). Var. Whiskey Creek.

An arbitrary name beginning with " $M$ " to correspond to " $M$ " grid used by the U.S. Army for tactical purposes during World War II; published on a 1943 Army map.

Moose Creek: stream, flows SW $3.4 \mathrm{mi}$. to Taku River, $1.7 \mathrm{mi}$. E of outlet of Twin Glacier Lake and $25 \mathrm{mi}$. NE of Juneau, Coast Mts.; $58^{\circ} 31^{\prime} 45^{\prime \prime} \mathrm{N}, 133^{\circ} 50^{\prime} 30^{\prime \prime} \mathrm{W}$; BGN 1932; (map 12)

Local descriptive name reported in 1932 by B. D. Stewart, USGS, to have been given because "moose abound in the vicinity *** [and this area] is the moose hunting ground of [the] natives and the people of Juneau."

Moose Creek: stream, on Kenai Penin., flows SE $3.5 \mathrm{mi}$. to Fox Creek $0.8 \mathrm{mi}$. N of $\mathrm{NE}$ end of Kachemak Bay, $21 \mathrm{mi}$. NE of Homer, Cook Inlet Low.; $59^{\circ} 48^{\prime} 20^{\prime \prime} \mathrm{N}, 151^{\circ} 03^{\prime} 00^{\prime \prime} \mathrm{W}$; (map 50).

Local name reported and published by USGS in the 1950's.

Moose Creek: stream, on Kenai Penin., in Kenai Mts., flows W $11 \mathrm{mi}$. to Tustumena Lake, 35 mi. SE of Kenai, Cook Inlet Low.; $60^{\circ} 09^{\prime} \mathrm{N}$, $150^{\circ} 42^{\prime} \mathrm{W}$; (map 62).

Local name reported about 1911 by USGS. Moose Creek: stream, on Kenai Penin., flows NE $3 \mathrm{mi}$. to Resurrection River, $18 \mathrm{mi}$. NW of Seward, Chugach Mts.; $60^{\circ} 18^{\prime} 00^{\prime \prime} \mathrm{N}, 149^{\circ}$. $45^{\prime} 20^{\prime \prime} \mathrm{W}$; (map 63).

Local name reported in 1912 by Grant and Higgins (1913, pl. 1), USGS.

Moose Creek: stream, on Kenai Penin., flows SE $3 \mathrm{mi}$. to Upper Trail Lake, $27 \mathrm{mi}$. $\mathrm{N}$ of Seward, Chugach Mts.; $60^{\circ} 30^{\prime} 15^{\prime \prime} \mathrm{N}, 149^{\circ}-$ 25'15' W ; (map 63).

Local prospectors' name; reported in 1904 by Moffit (1906, pl. 2), USGS.

Moose Creek: stream, heads in Kenai Mts. $9 \mathrm{mi}$. $S$ of Grandview, flows NW to Trail Creek, $0.5 \mathrm{mi}$. E of Hunter, $26 \mathrm{mi}$. SE of Sunrise, Chugach Mts.; $60^{\circ} 33^{\prime} 50^{\prime \prime}$ N, $149^{\circ} 07^{\prime} 30^{\prime \prime} \mathrm{W}$; (map 63).

Local name reported in 1951 by USGS.

Moose Creek: stream, on Kenai Penin., flows E $3 \mathrm{mi}$. to Resurrection Creek, $14 \mathrm{mi}$. SSW of Hope, Chugach Mts. ; 60 $43^{\prime} 25^{\prime \prime}$ N, 149 $43^{\prime}$ $30^{\prime \prime} \mathrm{W}$; (map 63). 
Local prospectors' name; reported in 1904 by Moffit (1906, pl. 2), USGS.

Moose Creek: stream, on Kenai Penin., flows W $1.5 \mathrm{mi}$. to Canyon Creek, $11 \mathrm{mi}$. S of Sunrise, Chugach Mts.; $60^{\circ} 43^{\prime} 55^{\prime \prime} \mathrm{N}, 149^{\circ} 27^{\prime} 00^{\prime \prime} \mathrm{W}$; (map 63).

Local name reported by G. F. Becker (1898, p. 82), USGS.

Moose Creek: stream, heads at glacier on Montana Peak, in Talkeetna Mts., flows S $18 \mathrm{mi}$. to Matanuska River, $5.5 \mathrm{mi}$. NE of Palmer, Cook Inlet Low.; $61^{\circ} 40^{\prime} 30^{\prime \prime} \mathrm{N}, 149^{\circ} 02^{\prime} 05^{\prime \prime}$ W; BGN 1910; (map 69). Var. Tsadaka Greek.

Local name obtained in 1910 by USGS. In 1898 Capt. Glenn (in Glenn and Abercrombie, 1899 , p. 52), USA, referred to the stream as "Tsadaka," which appears to be either a Tanaina Indian word or a combination of Indian and Russian words meaning "moose."

Moose Creek: stream, flows S $7.8 \mathrm{mi}$. to Yentna River, $52 \mathrm{mi}$. NW of Anchorage, Cook Inlet Low.; $61^{\circ} 47^{\prime} 30^{\prime \prime} \mathrm{N}, 150^{\circ} 41^{\prime} 45^{\prime \prime} \mathrm{W}$; (map $70)$.

Local name reported in 1954 by USGS.

Moose Creek: stream, flows S $40 \mathrm{mi}$. to Kuskokwim River, $18 \mathrm{mi}$. NE of Sleetmute, Stony River Low.; $61^{\circ} 47^{\prime} 40^{\prime \prime} \mathrm{N}, 156^{\circ} 39^{\prime} 15^{\prime \prime} \mathrm{W}$; (map 72).

Local name obtained in 1952 by USGS.

Moose Creek: stream, heads in a lake at $62^{\circ} 29^{\prime} 30^{\prime \prime} \mathrm{N}, 150^{\circ} 24^{\prime} 00^{\prime \prime} \mathrm{W}$, flows S $52 \mathrm{mi}$. to Kroto Creek, $20 \mathrm{mi}$. NW of Willow and 56 mi. NW of Anchorage, Cook Inlet Low.; $61^{\circ}$ $59^{\prime} 10^{\prime \prime} \mathrm{N}, 150^{\circ} 23^{\prime} 45^{\prime \prime} \mathrm{W}$; BGN 1961; (map 70). Var. Deshka River.

Local name reported in 1954 by USGS.

Moose Creek: stream, heads in Twin Lakes, flows SE through Glennallen, $17 \mathrm{mi}$. to Tazlina River, Copper River Basin; 62 $02^{\circ} 40^{\prime \prime} \mathrm{N}$. $145^{\circ} 28^{\prime} 35^{\prime \prime} \mathrm{W}$; (map 83).

Local name reported by USGS (in Moffit, 1915, pl. 6).

Moose Creek: stream, heads in a lake, flows SW, through Moose Creek Lake, $8 \mathrm{mi}$. to Happy River, 86 mi. W of Talkeetna, Alaska Ra.; $62^{\circ} 08^{\prime} 15^{\prime \prime} \mathrm{N}, 152^{\circ} 44^{\prime} 20^{\prime \prime} \mathrm{W}$; BGN 1962; (map 81).

Named in 1902 by A. H. Brooks, USGS.

Moose Creek: stream, heads on Granite Mtn., flows SW $18 \mathrm{mi}$. to East Fork George River, $36 \mathrm{mi}$. $\mathrm{N}$ of Sleetmute, Kilbuck-Kuskokwim Mts.; $62^{\circ} 12^{\prime} 45^{\prime \prime} \mathrm{N}, 156^{\circ} 56^{\prime} 30^{\prime \prime} \mathrm{W}$; (map 79).

Local name obtained in 1952 by USGS topographers.

Moose Creek: stream, flows NW $8 \mathrm{mi}$. to Bonanza Creek, $9.4 \mathrm{mi}$. SE of Flat and $51 \mathrm{mi}$. NW of Sleetmute, Kilbuck-Kuskokwim Mts.; $62^{\circ}$ $22^{\prime} 25^{\prime \prime}$ N, $157^{\circ} 46^{\prime} 00^{\prime \prime}$ W ; (map 79).

Prospectors' name obtained in 1952 by USGS topographers.

Moose Creek: stream, flows S $7 \mathrm{mi}$. to West Fork Gulkana River $32 \mathrm{mi}$. NW of that streams junc. with Gulkana River, Alaska Ra.; $62^{\circ} 44^{\prime} \mathrm{N}, 146^{\circ} 33^{\prime} \mathrm{W}$; (map 83 ).
Local name reported by F. H. Moffit (1912, p. 114), USGS.

Moose Creek: stream, flows NW $30 \mathrm{mi}$. to Iditarod River, $20 \mathrm{mi}$. N of Flat and $50 \mathrm{mi}$. SE of Holikachuck, Kilbuck-Kuskokwim Mts.; $62^{\circ} 45^{\prime} 15^{\prime \prime} \mathrm{N}, 157^{\circ} 59^{\prime} 00^{\prime \prime} \mathrm{W}$; (map 79).

Prospectors' name reported in 1912 by $\mathrm{H}$. M. Eakin, USGS.

Moose Creek: stream, flows NW $18 \mathrm{mi}$. to join Billy Goat Creek to form California Creek, 35 mi. NE of Flat, Kilbuck-Kuskokwim Mts.; $62^{\circ} 50^{\prime} 50^{\prime \prime} \mathrm{N}, 157^{\circ} 19^{\prime} 50^{\prime \prime} \mathrm{W}$; (map 79).

Local name obtained in 1952 by USGS topographers.

Moose Creek: stream, flows SE $5 \mathrm{mi}$. to Tuck Greek, $23 \mathrm{mi}$. SE of Mentasta Pass, Alaska Ra.; $62^{\circ} 52^{\prime} \mathrm{N}, 142^{\circ} 56^{\prime} \mathrm{W}$; BGN 1936; (map 84).

Local name reported by USGS in 1933.

Moose Creek: stream, heads in Black Hills $2 \mathrm{mi}$. $\mathrm{N}$ of Jatahmund Lake, flows $\mathrm{N}$ through many lakes $45 \mathrm{mi}$. to Chisana River, at Northway Junction, Alaska Ra.; $63^{\circ} 01^{\prime} \mathrm{N}, 141^{\circ} 49^{\prime} \mathrm{W}$; (map 84).

Local name reported by USGS in 1954.

Moose Creek: stream, flows NW $17 \mathrm{mi}$. to Yanert Fork, $17 \mathrm{mi}$. SE of Healy, Alaska Ra.; $63^{\circ} 40^{\prime}$ $\mathrm{N}, 148^{\circ} 38^{\prime} \mathrm{W}$; (map 87 ).

Local name reported in 1913 by J. W. Bagley (in Brooks, 1914, pl. 12), USGS.

Moose Creek: stream, heads in Mount McKinley National Park, flows W and N $50 \mathrm{mi}$. to Bearpaw River, $18 \mathrm{mi}$. E of Chilchukabena Lake, Tanana Low.; 63 ${ }^{\circ} 53^{\prime} 15^{\prime \prime} \mathrm{N}, 150^{\circ} 54^{\prime} 05^{\prime \prime} \mathrm{W}$; (map 88).

Name shown on a 1905 manuscript map of "Kantishna Gold Fields," by A. Friedrich, prospector.

Moose Creek: stream, flows NW $10 \mathrm{mi}$. to its junc. with Sheep Creek to form Tatlanika Creek, $46 \mathrm{mi}$. SE of Nenana, Alaska Ra.; $64^{\circ} 01^{\prime} \mathrm{N}, 148^{\circ} 12^{\prime} \mathrm{W}$; (map 100$)$.

Named by prospectors; reported in 1906 by L. M. Prindle (in Brooks and others, 1907, pl. 4), USGS

Moose Creek: stream, flows SW $1.9 \mathrm{mi}$. to Poorman Creek, $14 \mathrm{mi}$. SW of Poorman, KilbuckKuskokwim Mts.; $64^{\circ} 01^{\prime} 20^{\prime \prime} \mathrm{N}, 155^{\circ} 48^{\prime \prime} 55^{\prime \prime}$ W; BGN 1936; (map 98).

Propectors' name reported in 1935 by USGS.

Moose Creek: stream, flows W $9 \mathrm{mi}$. to Nenana River, $23 \mathrm{mi}$. $\mathrm{S}$ of Nenana, Alaska Ra.; $64^{\circ} 03^{\prime} 45^{\prime \prime} \mathrm{N}, 149^{\circ} 09^{\prime} 30^{\prime \prime} \mathrm{W}$; (map 100)

Local name reported in 1910 by $S$. R Capps (in Brooks and others, 1911, pl. 10), USGS.

Moose Creek: stream, flows NW $9.3 \mathrm{mi}$. to South Fork Sulatna River $13 \mathrm{mi}$. E of Poorman and $27 \mathrm{mi}$. SW of Monzonite Hills, Kilbuck-Kuskokwim Mts.; $64^{\circ} 05^{\prime} \mathrm{N}, 155^{\circ} 06^{\prime} \mathrm{W}$; (map 98). Var. Big Moose Creek.

Local name reported as Big Moose Creek by Mertie and Harrington (1924, pl. 1), USGS.

Moose Creek: stream, heads in Canada, flows NW $13 \mathrm{mi}$. to Fortymile River, $36 \mathrm{mi}$. SE of
Eagle, Yukon-Tanana High.; $64^{\circ} 17^{\prime} 15^{\prime \prime} \mathrm{N}$, $141^{\circ} 01^{\prime} 30^{\prime \prime} \mathrm{W}$; (map 102).

Named by prospectors and reported in 1896 by Spurr (1898, pI. 46), USGS.

Moose Creek: stream, flows SE $5 \mathrm{mi}$. to Mosquito Fork, $58 \mathrm{mi}$. SW of Eagle, Yukon-Tanana High.; $64^{\circ} 17^{\prime} 30^{\prime \prime} \mathrm{N}, 142^{\circ} 16^{\prime} 00^{\prime \prime} \mathrm{W}$; (map 102).

Local name reported in 1956 by USGS.

Moose Creek: stream, flows W $23 \mathrm{mi}$. to Piledriver Slough, $17 \mathrm{mi}$. SE of Fairbanks, Tanana Low.; $64^{\circ} 43^{\prime} \mathrm{N}, 147^{\circ} 13$, W; (map 100).

Local name reported in 1903 by T. G. Gerdine (in Prindle, 1905, pl. 16), USGS.

Moose Creek: stream, flows NW $2.3 \mathrm{mi}$. to Stewart River, $20 \mathrm{mi}$. NW of Nome, Seward Penin. High.; $64^{\circ} 47^{\prime} \mathrm{N}, 165^{\circ} 36^{\prime} \mathrm{W}$; (map 94).

Prospectors' name published on the 1900 "Map of Nome Peninsula" by J. M. Davidson and B. D. Blakeslee.

Moose Creek: stream, flows'S $1.5 \mathrm{mi}$. to Seventymile River, 15 mi. NW of Eagle, Yukon-

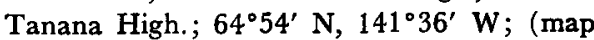
102).

Named by prospectors and reported in 1903 by Prindle (1905, pl. 16), USGS.

Moose Creek: stream, flows SW $8.5 \mathrm{mi}$. to Goldstream Creek, $12 \mathrm{mi}$. NW of Fairbanks, YukonTanana High.; $64^{\circ} 55^{\prime} 30^{\prime \prime} \mathrm{N}, 148^{\circ} 04^{\prime} 40^{\prime \prime} \mathrm{W}$; (map 100).

Local name shown on a location map of the Tanana Mines RR. dated 1905.

Moose Creek: stream, flows E $1 \mathrm{mi}$. to Steel Creek, $8 \mathrm{mi}$. NE of Fairbanks, Yukon-Tanana High.; $64^{\circ} 56^{\prime} \mathrm{N}, 147^{\circ} 29^{\prime} \mathrm{W}$; BGN 1933 ; (map 100).

Local name reported in 1933 by J. M. Hill, USGS; "many mining claims have been recorded under this name."

Moose Creek: stream, flows SE $1 \mathrm{mi}$. to Fairbanks Creek, $20 \mathrm{mi}$. NE of Fairbanks, YukonTanana High.; $65^{\circ} 04^{\prime} 10^{\prime \prime} \mathrm{N}, 147^{\circ} 16^{\prime} 10^{\prime \prime} \mathrm{W}$; (map 105).

Local name reported in 1903 by T. G. Gerdine (Prindle, 1905, pl. 13), USGS.

Moose Creek: stream, flows S $3.5 \mathrm{mi}$. to Boulder Creek, $24 \mathrm{mi}$. E of Tanana, Yukon-Tanana High.; $65^{\circ} 08^{\prime} 30^{\prime \prime} \mathrm{N}, 151^{\circ} 14^{\prime} 30^{\prime \prime} \mathrm{W}$; (map 106)

Local name reported in 1952 by USGS.

Moose Creek: stream, flows SW $3 \mathrm{mi}$. to Chatanika River, $4.5 \mathrm{mi}$. $\mathrm{N}$ of Twin Buttes and $40 \mathrm{mi}$. NE of Fairbanks, Yukon-Tanana High.; $65^{\circ} 13^{\prime} 30^{\prime \prime} \mathrm{N}, 146^{\circ} 56^{\prime} 30^{\prime \prime} \mathrm{W}$; (map 104).

Prospectors' name reported in 1954 or 1955 by USGS topographers.

Moose Creek: stream, flows SW $6 \mathrm{mi}$. to Wickersham Creek, $30 \mathrm{mi}$. N of Fairbanks, YukonTanana High.; $65^{\circ} 16^{\prime} 30^{\prime \prime} \mathrm{N}, 147^{\circ} 48^{\prime} 20^{\prime \prime} \mathrm{W}$; (map 105).

Local name published by USGS in the 1950's.

Moose Creek: stream, flows SW $7 \mathrm{mi}$. to Nome Creek, $4.5 \mathrm{mi}$. SE of Table Top Mtn. and $48 \mathrm{mi}$. NE of Fairbanks, Yukon-Tanana High.; $65^{\circ} 20^{\prime} \mathrm{N}, 146^{\circ} 49^{\prime} \mathrm{W}$; (map 104). 
Prospectors' name reported in 1954 or 1955 by USGS topographers.

Moose Creek: stream, flows NE $10 \mathrm{mi}$. to Starvation Creek, $30 \mathrm{mi}$. SE of Rampart, Yukon Tanana High.; $65^{\circ} 20^{\prime} 05^{\prime \prime}$ N, $149^{\circ} 17^{\prime} 10^{\prime \prime}$ W; (map 105)

Named by prospectors; reported in 1908 by USGS (Covert and Ellsworth, 1909, pl. 5).

Moose Creek: stream, heads in Rampart Mts., flows S $12 \mathrm{mi}$. to Yukon River, $2 \mathrm{mi}$. $\mathrm{N}$ of Garnet I., $15 \mathrm{mi}$. WSW of Rampart, Kokrines-Hodzana High.; $65^{\circ} 28^{\prime} \mathrm{N}, 150^{\circ} 40^{\prime} \mathrm{W}$; (map 106).

Local name reported in 1956 by Orth.

Moose Creek: stream, flows NW $12 \mathrm{mi}$. to South Fork Hess Creek, $12 \mathrm{mi}$. NE of Livengood, Yukon-Tanana High.; $65^{\circ} 40^{\prime} 30^{\prime \prime} \mathrm{N}, 148^{\circ} 20^{\prime}$ 45" W; (map 105).

Local name reported in 1915 by Brooks (Brooks and others, 1916, pl. 9), USGS.

Moose Creek: stream, flows NE $7 \mathrm{mi}$. to Beaver Creek, $9.5 \mathrm{mi}$. ENE of Victoria Mtn. and 72 mi. W of Circle, Yukon-Tanana High.; $65^{\circ}$ $49^{\prime} 50^{\prime \prime} \mathrm{N}, 146^{\circ} 34^{\prime} 10^{\prime \prime} \mathrm{W}$; (map 104).

Prospectors' name reported in 1954 or 1955 by USGS topographers.

Moose Creek: stream, flows E $4.5 \mathrm{mi}$. from Emma Dome to Middle Fork Koyukuk River, $3 \mathrm{mi}$. $\mathrm{S}$ of Wiseman, Brooks Ra.; 67 $22^{\prime} 15^{\prime \prime} \mathrm{N}$, $150^{\circ} 08^{\prime} 30^{\prime \prime} \mathrm{W}$; BGN 1932; (map 124).

Local name reported by Robert Marshall in 1932.

Moose Creek: stream, see Happy River.

Moose Creek: stream, see Ida Creek.

Moose Creek: stream, see Moose Creek Number One.

Moose Creek: stream, see Moose Creek Number Two.

Moose Creek: stream, see Vault Creek.

Moose Creek Bluff: hill, $805 \mathrm{ft}$., NE of junc. of Moose Creek and Piledriver Slough, $13 \mathrm{mi}$. SE of Fairbanks, Tanana Low.; $64^{\circ} 44^{\prime} \mathrm{N}$, $147^{\circ} 12^{\prime} \mathrm{W}$; (map 100).

Name derived from Moose Creek; published on recent maps.

Moose Creek Lake: lake, $0.6 \mathrm{mi}$. long, near head of Moose Creek, $83 \mathrm{mi}$. W of Talkeetna, Alaska Ra.; $62^{\circ} 13^{\prime} 40^{\prime \prime} \mathrm{N}, 152^{\circ} 40^{\prime} 40^{\prime \prime} \mathrm{W}$; (map 81).

Local name reported in 1958 by USGS.

Moose Creek Number One: stream, flows N 1.5 mi. to Dome Creek, $13 \mathrm{mi}$. N of Fairbanks, Yukon-Tanana High.; $65^{\circ} 02^{\prime} \mathrm{N}, 147^{\circ} 38^{\prime} \mathrm{W}$; (map 105). Var. Moose Creek.

Originally published in 1908 by USGS; as Moose Creek, however, local usage has applied the present name to the stream's lower course, including its west fork; "Moose Creek Number Two" applies to the east fork.

Moose Creek Number Two: stream, flows NW 1 mi. to Moose Creek Number One, $12 \mathrm{mi}$. N of Fairbanks, Yukon-Tanana High.; $65^{\circ} 01^{\prime}$ $20^{\prime \prime} \mathrm{N}, 147^{\circ} 37^{\prime} 20^{\prime \prime} \mathrm{W}$; (map 105). Var. Moose Creek.

Originally published in 1908 by USGS as Moose Creek; however, when local usage applied the name Moose Creek Number One to lower course of the stream, the present name was applied to this tributary.

Moose Gulch: ravine, trends S $0.9 \mathrm{mi}$. to Ester Creek, $10 \mathrm{mi}$. W of Fairbanks, Yukon-Tanana High.; 64 $50^{\circ} 50^{\prime \prime} \mathrm{N}, 148^{\circ} 03^{\prime} 55^{\prime \prime} \mathrm{W}$; (map 100).

Local name reported in 1913 by $P$. S. Smith, USGS.

Moosehead Lake: lake, 2 mi. long, $\mathbf{S}$ of Lake George, $41 \mathrm{mi}$. SE of Delta Junction, Tanana Low.; $63^{\circ} 45^{\prime} \mathrm{N}, 144^{\circ} 32^{\prime} \mathrm{W}$; (map 86).

Name published on relatively recent maps.

Moosehead Rack: bluff, elev. $600 \mathrm{ft}$., on $\mathrm{S}$ bank of Yukon River, at mouth of Cheyenne Creek, $25 \mathrm{mi}$. ENE of Tanana, Yukon-Tanana High.; $65^{\circ} 15^{\prime} \mathrm{N}, 151^{\circ} 16^{\prime} \mathrm{W}$; (map 106).

Riverboat pilots' name shown on a Yukon River track chart manuscript dated 1906.

Moosehead Rapids: rapids, in Kasilof River on Kenai Penin., $18 \mathrm{mi}$. S of Kenai, Cook Inlet Low.; $60^{\circ} 18^{\prime} \mathrm{N}, 151^{\circ} 13^{\prime} \mathrm{W}$; (map 62). Var. Moose Rapids.

Reported by D. H. Sleem as "Moose Rapids" on his 1910 map of Central Alaska. The present name was reported about 1911 by USGS.

Mooseheart Mountain: mountain, 2,136 ft., 34 mi. NE of Bitzshtini Mts., Kilbuck-Kuskokwim Mts.; $64^{\circ} 45^{\prime} \mathrm{N}, 151^{\circ} 03^{\prime} \mathrm{W}$; (map 99).

Local name reported in 1937 by USGS.

Moose Hill: hill, $925 \mathrm{ft}$., $24 \mathrm{mi}$. SW of Medfra, Kuskokwim Low.; $63^{\circ} 04^{\prime} \mathrm{N}, 153^{\circ} 57^{\prime} \mathrm{W}$; (map 89).

Local name reported in 1958 by USGS.

Moosehorn Island: island, $2 \mathrm{mi}$. long, in Yukon River, W of Bonasila I., and $23 \mathrm{mi}$. NW of Holy Cross, Innoko Low.; $62^{\circ} 30^{\prime} \mathrm{N}, 160^{\circ} 07^{\prime}$ W; (map 78).

Riverboat pilots' name shown on a 1940 "Navigation Chart of the Tanana-Yukon Rivers" published by the U.S. Dept. of Interior.

Moosehorn Lake: lake, $1.1 \mathrm{mi}$. long, on Kenai Penin., $1 \mathrm{mi}$. SW of Swan Lake and $24 \mathrm{mi}$. NE of Kenai, Cook Inlet Low.; $60^{\circ} 38^{\prime} 40^{\prime \prime} \mathrm{N}$, $150^{\circ} 34^{\prime} 00^{\prime \prime} \mathrm{W}$; (map 62).

Named about 1963 by officials of Kenai National Moose Range for administrative purposes.

Moosehorn Lake: lake, $0.4 \mathrm{mi}$. across, $24 \mathrm{mi}$. N of Chalkyitsik, Yukon Flats; $66^{\circ} 59^{\prime} \mathrm{N}, 143^{\circ}$ 48' W; (map 120).

Local name obtained in 1956 by T. E. Taylor and R. C. Foley, USGS.

Moosehorn Mountain: ridge, see Moosehorn Ridge.

Moosehorn Mountains: ridge, see Moosehorn Ridge.

Moosehorn Ridge: ridge, elev. 3,400 to $4,400 \mathrm{ft}$., $14 \mathrm{mi}$. long, extends across Alaska-Canada boundary $S$ of Ladue River, $61 \mathrm{mi}$. E of Tok, Yukon-Tanana High.; 63 $08^{\circ} \mathrm{N}, 140^{\circ} 58^{\prime} \mathrm{W}$; BGN 1954; (map 85). Var. Moosehorn Mountain, Moosehorn Mountains.

Named "Moosehorn Mountain" in 1898 by A. H. Brooks (1900a, p. 434), USGS.
Moose Island: island, $0.4 \mathrm{mi}$. across, in entrance to Giles Bay, in Lake Minchumina; $63^{\circ} 51^{\prime} 45^{\prime \prime}$ $\mathrm{N}, 152^{\circ} 19^{\prime} 30^{\prime \prime} \mathrm{W}$; (map 88). Var. Matsnu. Local named reported about 1952 by "Val" Blackburn of village of Lake Minchumina. The Tanana Indian name was reported to be "Matsnu," meaning "gull island."

Moose Island: island, $3.5 \mathrm{mi}$. long, in Yukon River, $20 \mathrm{mi}$. NE of Stevens Village, Yukon Flats; $66^{\circ} 13^{\prime} \mathrm{N}, 148^{\circ} 30^{\prime} \mathrm{W}$; (map 118). Local name obtained in 1956 by USGS.

Moose Lake: lake, $3 \mathrm{mi}$. long, $8 \mathrm{mi}$. SE of Pile Bay and $26 \mathrm{mi}$. NW of Augustine I., Aleutian Ra.; $59^{\circ} 35^{\prime} \mathrm{N}, 154^{\circ} 00^{\prime} \mathrm{W}$; (map 51).

Local name reported by Martin and Katz (1912a, pl. 1), USGS.

Moose Lake: lake, $1 \mathrm{mi}$. long, on Kenai Penin., SW of Grouse Lake, $35 \mathrm{mi}$. NE of Kenai, Cook Inlet Low.; $60^{\circ} 45^{\prime} \mathrm{N}, 150^{\circ} 19^{\prime} \mathrm{W}$; (map 62).

Named about 1963 by officials of Kenai National Moose Range for administrative purposes.

Moose Lake: lake, $1.3 \mathrm{mi}$. long, drains $\mathrm{E}$ to Tolsona Creek N of Glenn Highway, $17 \mathrm{mi}$. W of Glennallen, Copper River Basin; 62 $08^{\prime} \mathrm{N}$, $146^{\circ} 04^{\prime} \mathrm{W}$; (map 83).

Local name reported by USGS in 1949.

Moose Lake: lake, $0.9 \mathrm{mi}$. long, at head of Lonestar Creek, NE of Sprucefish Lake, $23 \mathrm{mi}$. SSW of village of Lake Minchumina, Kuskokwim Low.; $63^{\circ} 35^{\prime} 15^{\prime \prime} \mathrm{N}, 152^{\circ} 41^{\prime} 30^{\prime \prime} \mathrm{W}$; (map 88).

Local name obtained in 1958 from Fabian Garey and "Val" Blackburn by USGS.

Moose Lake: lake, $1.2 \mathrm{mi}$. long, SW of Healy Lake, $29 \mathrm{mi}$. SE of Delta Junction, Tanana

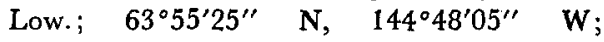
(map 86).

Name published on relatively recent maps.

Moose Lake: lake, 1,000 ft. long, on $\mathrm{N}$ bank of Yukon River, $17 \mathrm{mi}$. E of Tanana, KokrinesHodzana High.; $65^{\circ} 12^{\prime} 20^{\prime \prime}$ N, $151^{\circ} 29^{\prime} 30^{\prime \prime}$ W; (map 106).

Local name reported in 1956 by Orth.

Moose Lake: lake, $1 \mathrm{mi}$. $\mathrm{N}$ of Crow Lake and 19 mi. NW of Roundabout Mtn., Koyukuk Low.; $65^{\circ} 47^{\prime} \mathrm{N}, 156^{\circ} 48^{\prime} \mathrm{W}$; (map 108).

Local name obtained at Huslia by USGS in 1954 or 1955.

Moose Pass: village, pop. 136, mile 29.3 on The Alaska RR. on Seward Highway, on SW shore of Upper Trail Lake, $26 \mathrm{mi}$. $\mathrm{N}$ of Seward, Chugach Mts.; $60^{\circ} 29^{\prime} 20^{\prime \prime} \mathrm{N}, 149^{\circ}$. $22^{\prime} 00^{\prime \prime} \mathrm{W}$; (map 63).

Name of a station on The Alaska RR. reported in 1912 by A. H. Brooks, USGS. It is reported that the village originally got the name Moose Pass because "in 1903, a mail carrier driving a team of dogs had considerable trouble gaining the right-of-way from a giant moose * * *." A post office was established here in 1928 (Ricks, 1965, p. 43).

Moose Pass: pass, on Kenai Penin., between Mud and Upper Trail Lakes, $28 \mathrm{mi}$. N of Seward, Chugach Mts.; $60^{\circ} 31^{\prime} \mathrm{N}, 149^{\circ} 28^{\prime} \mathrm{W}$; (map 63).

Local name reported in 1952 by USGS.

Moose Pasture Lake: lake, $0.5 \mathrm{mi}$. long, on Kenai Penin., $4 \mathrm{mi}$. NW of Trapper Joe Lake and 
$30 \mathrm{mi}$. SSW of Anchorage, Cook Inlet Low.; $60^{\circ} 48^{\prime \prime} \mathrm{N}, 150^{\circ} 08^{\prime} \mathrm{W}$; (map 62).

Named about 1963 by officials of Kenai National Moose Range for administrative purposes.

Moose Pasture Pass: pass, $5 \mathrm{mi}$. SW of junc. of North Fork Tlikadila and Tlikadila Rivers, at head of Chokotonk River, $70 \mathrm{mi}$. NE of Nondalton, Aleutian Ra.; (map 61).

Local name reported in 1958 by USGS.

Moose Point: locality, on right bank of Yukon River, $33 \mathrm{mi}$. NE of Ruby, Kokrines-Hodzana High.; $64^{\circ} 57^{\prime} \mathrm{N}, 154^{\circ} 27^{\prime} \mathrm{W}$; (map 98). Var. Mouse Point.

Settlement reported in 1917 by USGS; now abandoned.

Moose Point: point of land, NW coast of Kenai Penin., $12 \mathrm{mi}$. WSW of Point Possession and $35 \mathrm{mi}$. NE of Kenai, Cook Inlet Low.; $60^{\circ}$ $57^{\prime} 15^{\prime \prime} \mathrm{N}, 150^{\circ} 41^{\prime} 00^{\prime \prime} \mathrm{W}$; (map 62).

Local name published in 1933 by USGS.

Moose Point Shoal: shoal, extends NE-SW $5 \mathrm{mi}$., in Cook Inlet, $1.8 \mathrm{mi} \mathrm{NW}$ of Moose Point, Kenai Penin., $27 \mathrm{mi}$. SW of Anchorage, Cook Inlet Low.; $61^{\circ} 00^{\prime} \mathrm{N}, 150^{\circ} 39^{\prime} \mathrm{W}$; (map 70). Local name reported in 1952 by USGS.

Moose Rapids : rapids, see Moosehead Rapids.

Moose River: stream, on Kenai Penin., flows SW $23 \mathrm{mi}$. to Kenai River at Sterling, $18 \mathrm{mi}$. E of Kenai, Cook Inlet Low.; $60^{\circ} 32^{\prime} 15^{\prime \prime} \mathrm{N}, 150^{\circ}$ $45^{\prime} 30^{\prime \prime} \mathrm{W}$; (map 62).

Local name reported in 1904 by Moffit (1906, pl. 2), USGS

Moose Slough: stream, see Hardluck Slough.

Mooses Tooth, The: peak, 10,335 ft., near head of Buckskin Glacier, $15 \mathrm{mi}$. SE of Mount McKinley, Alaska Ra.; 62 ${ }^{\circ} 58^{\prime} 15^{\prime \prime}$ N, 150 $36^{\prime}$ 45" W; (map 81). Var. Mount Hubbard.

A translation of the original Athabaskan Indian name obtained in 1953 by USGS; originally named "Mt. Hubbard" in 1910 by the Browne-Parker Expedition for Thomas H. Hubbard, then president of the Peary Arctic Club.

Moose Valley: valley, $2 \mathrm{mi}$. long, between Klehini River and Mosquito Lake, $3 \mathrm{mi} \mathrm{NW}$ of Wells, $25 \mathrm{mi}$. W of Skagway, St. Elias Mts.; $59^{\circ} 26^{\prime} 30^{\prime \prime} \mathrm{N}, 136^{\circ} 01^{\prime} 15^{\prime \prime} \mathrm{W}$; (map 45).

Local name obtained by USGS field personnel and published on Federal maps since 1950.

Moose Village: locality, on right bank of Kuskokwim River at mouth of Moose Creek, $17 \mathrm{mi}$. NE of Sleetmute, Stony River Low.; 61 ${ }^{\circ} 47^{\prime}$ $40^{\prime \prime} \mathrm{N}, 156^{\circ} 40^{\prime} 00^{\prime \prime} \mathrm{W}$; (map 72). Var. Stony River Village.

Trading post and riverboat landing reported by the Alaska Road Commission on its 1923 map. This may have been the original site of the Indian village prior to the development of nearby Stony River.

Moose Village: village, see Stony River.

Moowookyik Camp: locality, see Booshu Camp. Mop Point: point of land, on N shore of Thorne Arm on $\mathrm{S}$ coast of Revillagigedo I., Alex. Arch.; 55 $22^{\prime} 55^{\prime \prime} \mathrm{N}, 131^{\circ} 14^{\prime} 20^{\prime \prime} \mathrm{W}$; (map 3 ).

Arbitrary name given in 1891 by USC\&GS. Moquawkie: locality, see Tobona.
Moquawkie: village, see Tyonek.

Moraine: locality, mile 7.1 on the Whittier branch of The Alaska RR., $4 \mathrm{mi}$. WNW of Whittier, Chugach Mts.; $60^{\circ} 47^{\prime} \mathrm{N}, 148^{\circ} 52^{\prime}$ W; (map 63).

Name of a railroad engineering camp reported in 1951 by USGS.

Moraine Creek: stream, flows NW $4 \mathrm{mi}$. to Karluk Lake, $17 \mathrm{mi}$. SE of Karluk, Kodiak I.; $57^{\circ} 26^{\prime} 00^{\prime \prime} \mathrm{N}, 154^{\circ} 04^{\prime} 30^{\prime \prime} \mathrm{W}$; (map 35 ).

Local name reported in 1952 by USGS.

Moraine Creek: stream, heads at $59^{\circ} 05^{\prime} \mathrm{N}$, $154^{\circ} 47^{\prime} \mathrm{W}$, flows NW $23 \mathrm{mi}$. to Kukaklek Lake, $14 \mathrm{mi}$. S of Big Mtn., $41 \mathrm{mi}$. SW of Iliamna, Aleutian Ra.; $59^{\circ} 11^{\prime} 30^{\prime \prime} \mathrm{N}, 155^{\circ} 11^{\prime}-$ $00^{\prime \prime} \mathrm{W}$; (map 51).

Named in 1923 by K. F. Mather (in Brooks, and others, 1925, pl. 3), USGS.

Moraine Creek: stream, at Russell Glacier terminus, flows N $1.7 \mathrm{mi}$. to White River, 42 mi. NE of McGarthy, St. Elias Mts.; 61 ${ }^{\circ} 42^{\prime}$ $\mathrm{N}, 141^{\circ} 47^{\prime} \mathrm{W}$; (map 67).

Name reported in 1908 by F. H. Moffit, USGS; so named because of its relationship to moraine of Russell Glacier.

Moraine Creek: stream, flows NW $4 \mathrm{mi}$. to Crescent Creek, $80 \mathrm{mi}$. W of Eagle, Yukon-Tanana High.; 64 $48^{\prime} \mathrm{N}, 143^{\circ} 55^{\prime} \mathrm{W}$; (map 102).

Local name reported in 1912 by USGS.

Moraine Creek: stream, heads on Caribou Mtn. in Zane Hills, flows E $5 \mathrm{mi}$. to Bear Creek, $39 \mathrm{mi}$. WNW of Hughes, Hogatza High.; $66^{\circ} 10^{\prime} 30^{\prime \prime} \mathrm{N}, 155^{\circ} 37^{\prime} 00^{\prime \prime} \mathrm{W}$; (map 116).

Named about 1955 by mining engineers; reported in 1956 by Orth.

Moraine Island: island, $0.7 \mathrm{mi}$. long, $0.4 \mathrm{mi}$. from $\mathrm{S}$ shore of Icy Bay, Malaspina Coastal Plain; $59^{\circ} 55^{\prime} 30^{\prime \prime} \mathrm{N}, 141^{\circ} 23^{\prime} 00^{\prime \prime} \mathrm{W}$; (map 47).

Descriptive name published by USC\&GS in 1923. This island is a part of the moraine of Malaspina Glacier.

Moraine Pass: pass, 4,000 ft., at head of North Fork Ship Creek, $25 \mathrm{mi}$. SE of Anchorage, Chugach Mts.; $61^{\circ} 05^{\prime} 30^{\prime \prime} \mathrm{N}, 149^{\circ} 11^{\prime} 50^{\prime \prime} \mathrm{W}$; $B G N$ 1964; (map 69).

So named in 1963 by members of the Mountaineering Club of Alaska because "the surface of the pass consists of morainal material."

Moraine Reef: reef, extends $1 \mathrm{mi}$. along S shore of Icy Bay, $0.5 \mathrm{mi}$. SW of Moraine I., Malaspina Coastal Plain; $59^{\circ} 55^{\prime} \mathrm{N}, 141^{\circ} 25^{\prime} \mathrm{W}$; (map 47).

Descriptive name published by USC\&GS in 1923. The reef is a part of a moraine of Malaspina Glacier.

Morakas Point: bluff, elev. $122 \mathrm{ft}$, on S bank of Naknek River, on Alaska Penin., $2.5 \mathrm{mi}$. E of Naknek, Bristol Bay Low.; $58^{\circ} 44^{\prime} \mathrm{N}$, $156^{\circ} 56^{\prime} \mathrm{W}$; (map 41).

Local name reported in 1952 by USGS.

Moran Creek: stream, flows W $0.8 \mathrm{mi}$. to Solomon River, $4 \mathrm{mi}$. NE of Solomon, Seward Penin. High.; 64 $37^{\circ} 15^{\prime \prime} \mathrm{N}, 164^{\circ} 23^{\prime} 20^{\prime \prime} \mathrm{W}$; (map 95).

Prospectors' named reported in 1903 or 1904 on a location map of Council City \& Solomon River Railroad.
Moran Creek: stream, flows NW $19 \mathrm{mi}$. to Little Melozitna River, $22 \mathrm{mi}$. N of Birches, Kokrines-Hodzana High.; $65^{\circ} 26^{\prime} 40^{\prime \prime} \mathrm{N}, 153^{\circ} 31^{\prime}$ 30 " W; (map 107).

Name from prospectors, reported in 1908 by Maddren (1910, pl. 5), USGS.

Moran Dome: mountain, 3,608 ft., at head of Melozimoran Creek, $28 \mathrm{mi}$. NW of Tanana, Kokrines-Hodzana High.; $65^{\circ} 23^{\prime} \mathrm{N}, 1^{152^{\circ}} 5^{\prime}$ W; (map 106).

Named about 1908 by prospectors for Moran Creek.

Mordaunt, Mount: hill, $662 \mathrm{ft} ., 1 \mathrm{mi}$. NE of junc. of Ophir Creek and Niukluk River and 34 mi. NE of Solomon, Seward Penin. High.; $64^{\circ} 56^{\prime} \mathrm{N}, 163^{\circ} 43^{\prime} \mathrm{W}$; (map 95).

Local name reported on the 1908 "Map of Seward Peninsula" by Arthur Gibson. See Mordaunt Creek.

Mordaunt Creek: stream, flows NE to Niukluk River, between Alice Creek and Casadepaga River, $31 \mathrm{mi}$. NE of Solomon, Seward Penin. High.; (map 95).

Prospectors' name reported on a prospector's manuscript map dated 1902 . This stream cannot be precisely located on current maps. Probably named for A. P. Mordaunt, one of the party that found gold along Melsing and Ophir Creeks in early 1898 (Collier and others, 1908, p. 15).

Mordvinof, Cape: point of land, on NW coast of Unimak I., Aleutian Is.; 54 $56^{\prime} 45^{\prime \prime}$ N, $164^{\circ}$ 26'00" W; BGN 1942; (map 24). Var. Cape Lapin, Cape Lincoln, Mys Mordvinova, Mys Oksenova, Noisak, Oksenof.

Russian name given as M[ys] Mordvinova, probably from the word morda meaning "muzzle" or "snout," [the point does look like the snout of an animal] by Capt. Staniukovich (cnna), in 1828. This point was called M[ys] Mordvinova (M[ys] Oksenova) by Capt. Tebenkov (1852, map 26), IRN. It was also called Cape Lincoln by USBF in 1888 .

Mordvinof, Cape; point of land, see Oksenof Point.

Mordvinova, Mys : point of land, see Mordvinof, Cape.

Mordvinove, Mys: paint of land, see Oksenof Point.

More Creek: stream, flows SE $0.3 \mathrm{mi}$. to Clear Creek, $24 \mathrm{mi}$. NE of Katalla, Chugach Mts.; $60^{\circ} 25^{\prime} 30^{\prime \prime} \mathrm{N}, 144^{\circ} 00^{\prime} 05^{\prime \prime} \mathrm{W}$; (map 64).

Local name published in 1951 by USGS.

Morelock Creek: stream, in Rampart Mts., flows SE $14 \mathrm{mi}$. to Yukon River, $23 \mathrm{mi}$. ENE of Tanana, Kokrines-Hodzana High.; $65^{\circ} 16^{\prime} \mathrm{N}$, $151^{\circ} 18^{\prime}$ W; (map 106). Var. Marelock Greek.

Prospectors' or riverboat pilots' name shown on Edwards Track Chart of the Yukon, dated 1899; published by Cantwell (1902, p. 277), USRCS.

Morgan, Cape: point of land, S tip of Akutan I., Aleutian Is.; $54^{\circ} 02^{\prime} 50^{\prime \prime} \mathrm{N}, 166^{\circ} 02^{\prime} 30^{\prime \prime} \mathrm{W}$; (map 23).

Name given by the USBF in 1888 .

Morgan Creek: stream, flows W $1.2 \mathrm{mi}$. to Cache Creek $3 \mathrm{mi}$. E of its junc, with Kahiltna River, 
$30 \mathrm{mi}$. W of Talkeetna, Alaska Ra.; $62^{\circ} 23^{\prime} 30^{\prime \prime}$ $\mathrm{N}, 151^{\circ} 02^{\prime} 30^{\prime \prime} \mathrm{W}$; (map 81).

Prospectors' name reported in the 1930's by USGS.

Morgan Gulch: ravine, trends S $1 \mathrm{mi}$. to Glacier Creek which flows to Snake River, $7 \mathrm{mi}$. N of Nome, Seward Penin. High.; 64 $36^{\prime} \mathrm{N}$, $165^{\circ} 24^{\prime} \mathrm{W}$; (map 94).

Prospectors' name shown on the 1904 map of Cape Nome Precinct by Arthur Gibson.

Morgan Hill: hill, $850 \mathrm{ft}$., $1.7 \mathrm{mi}$. NE of Conquer Point, Kiska I., Aleutian Is.; $52^{\circ} 01^{\prime} 00^{\prime \prime} \mathrm{N}$, $177^{\circ} 31^{\prime 2} 5^{\prime \prime} \mathrm{E}$; (map 14).

An arbitrary name beginning with " $M$ " to correspond to " $\mathrm{M}$ " grid used by the U.S. Army for tactical purposes during World War II; published on a 1953 AMS map.

Morgan Island: island, $0.9 \mathrm{mi}$. long, in Yukon River opposite Stink Creek, $56 \mathrm{mi}$. SW of Nulato and $57 \mathrm{mi}$. E of Unalakleet, Innoko Low.; $63^{\circ} 59^{\prime} \mathrm{N}, 158^{\circ} 55^{\prime} \mathrm{W}$; (map 90).

Name shown on 1940 "Navigation Chart of the Tanana-Yukon Rivers" U.S. Dept. of Interior.

Morgan Island: island, $0.7 \mathrm{mi}$. long, in Tanana River, E of mouth of Chena River and $6 \mathrm{mi}$. SW of Fairbanks, Tanana Low.; 64 ${ }^{\circ} 47^{\prime} 30^{\prime \prime} \mathrm{N}$, $147^{\circ} 51^{\prime} 45^{\prime \prime} \mathrm{W}$; (map 100).

Local name reported in 1950 by USGS topographers.

Morgan Point: point of land, at $\mathrm{W}$ entrance to King Cove, on SW end of Alaska Penin., 18 mi. SE of village of Cold Bay, Aleutian Ra.; $55^{\circ} 02^{\prime} 20^{\prime \prime} \mathrm{N}, 162^{\circ} 20^{\prime} 00^{\prime \prime} \mathrm{W}$; (map 29).

Name reported by USC\&GS in 1927.

Morjevskaia: bay, see Morzhovoi Bay.

Morjevskoi Pic: peak, see North Walrus Peak.

Morjovi: island, see Walrus Island.

Morjovi Island: island, see Hall Island.

Morkovskoi: bay, see Pumicestone Bay.

Morkovskoi, Cape: point of land, see Spray Cape.

Morne Island: island, $0.1 \mathrm{mi}$. across, in Galankin Is., $1 \mathrm{mi}$. $\mathrm{S}$ of Sitka, on $\mathrm{W}$ coast of Baranof I., Alex. Arch.; $57^{\circ} 02^{\prime} 15^{\prime \prime} \mathrm{N}, 135^{\circ} 19^{\prime} 15^{\prime \prime} \mathrm{W}$; (map 9). Var. Horn Island, Horney Island, Ostrov Rogova, Rogova Island, Rokhova Island.

This name may be a misspelled translation of the Russian name "Rogova," meaning "horn," given in 1809 by Ivan Vasiliev the first, IRN. The " $\mathrm{M}$ " may represent a typographical error.

Morning Call Creek: stream, flows N $2.7 \mathrm{mi}$. to Grand Central River, $29 \mathrm{mi}$. NE of Nome, Seward Penin. High. ; $64^{\circ} 54^{\prime} \mathrm{N}, 165^{\circ} 06^{\prime} \mathrm{W}$; (map 94).

Prospectors' name reported in 1900 by E. C. Barnard (in Brooks, 1901, pl. 17), USGS

Morning Cove: cove, $0.3 \mathrm{mi}$. wide, on $\mathrm{NE}$ coast of Ragged I., in Pye Is., $50 \mathrm{mi}$. E of Seldovia, Chugach Mts.; $59^{\circ} 27^{\prime} 30^{\prime \prime} \mathrm{N}, 150^{\circ} 18^{\prime} 00^{\prime \prime} \mathrm{W}$ $B G N$ 1929; (map 50). Var. Morning Sun Cove.

Named "Morning Sun Cove" by USC\&GS in 1927; shortened to "Morning Cove" by BGN.
Morningstar Creek: stream, flows NW $7 \mathrm{mi}$. to McCumber Creek, $24 \mathrm{mi}$. SE of Delta Junction, Alaska Ra.; $63^{\circ} 42^{\prime}$ N, $145^{\circ} 33^{\prime}$ W ; BGN 1937; (map 86).

Local name reported in 1937 by USGS.

Morning Star Creek: stream, flows NE to Goodhope River, about $17 \mathrm{mi}$. NW of Imuruk Lake, Seward Penin. High.; (map 110).

Prospectors' name shown on a map of Cape Nome gold fields by David Fox, Jr., dated 1901. This stream cannot be precisely located on current maps.

Morning Sun Cove: cove, see Morning Cove.

Moron Lake: lake, $0.2 \mathrm{mi}$. across, $1.1 \mathrm{mi}$. E of Conquer Point, on West-central Kiska I., Aleutian Is.; $52^{\circ} 00^{\prime} 25^{\prime \prime} \mathrm{N}, 177^{\circ} 30^{\prime} 50^{\prime \prime} \mathrm{E}$; (map 14).

An arbitrary name beginning with " $\mathrm{M}$ " to correspond to " $M$ " grid used by the U.S. Army for tactical purposes during World War II; published on a 1943 Army map.

Moroyak: locality, on right bank of Tagayarak River, $18 \mathrm{mi}$. SW of Tuntutuliak and $58 \mathrm{mi}$. SW of Bethel, Yukon-Kuskokwim Delta; $60^{\circ} 17^{\prime} \mathrm{N}, 163^{\circ} 07^{\prime} \mathrm{W}$; (map 58).

Former Eskimo camp or small settlement reported in 1949 by USC\&GS. The exact location of this site is in doubt; however, the name is similar to "Mcroyuk," a variant name of Napatuk Creek.

Morozofa Bay: bay, see Cold Bay.

Morozoffski Bay: bay, see Cold Bay.

Morozova Bay: bay, see Cold Bay.

Morozovskie Bay: bay, see Cold Bay.

Morozovskiy, Zaliv: bay, see Cold Bay.

Morris, Lake: lake, $1.5 \mathrm{mi}$. long, $13.5 \mathrm{mi}$ : NW of Chichagof, on W coast of Chichagof I., Alex. Arch.; $57^{\circ} 50^{\prime} \mathrm{N}, 136^{\circ} 17^{\prime} \mathrm{W}$; (map 9).

Named in 1917 by USGS and published by R. M. Overbeck (in Martin and others, 1919, pl. 2), USGS.

Morris Cove: cove, $0.3 \mathrm{mi}$. across, in Summer Bay, on E shore of Unalaska Bay, on NE coast of Unalaska I., Aleutian Is.; $53^{\circ} 55^{\prime} 00^{\prime \prime} \mathrm{N}$, $166^{\circ} 26^{\prime} 10^{\prime \prime} \mathrm{W}$; (map 23).

Name published by USC\&GS in 1966 on Chart 9007.

Morris Creek: stream, heads at glacier E of Simpson Pass, flows SE $8 \mathrm{mi}$. to Kichatna River, $83 \mathrm{mi}$. W of Talkeetna, Alaska Ra.; $62^{\circ} 18^{\prime} \mathrm{N}$, $152^{\circ} 41^{\prime} \mathrm{W}$; (map 81).

Named in 1899 by Lt. J. S. Herron, USA.

Morris Creek: stream, flows NE $5 \mathrm{mi}$. to Fox River, $31 \mathrm{mi}$. NE of Solomon, Seward Penin. High.; $64^{\circ} 48^{\prime} \mathrm{N}, 163^{\circ} 33^{\prime} \mathrm{W}$; (map 95). Var. Dewey Creek.

Prospectors' name published on the 1908 "Map of Seward Peninsula" by Arthur Gibson. Reported in 1900 as "Dewey Cr." by E. C. Barnard (in Brooks, 1901, pl. 17), USGS.

Morris Reef: reef, at mouth of Sitkoh Bay, off SE tip of Chichagof I., 8 mi. E of Todd, Alex. Arch.; $57^{\circ} 28^{\prime} 30^{\prime \prime} \mathrm{N}, 134^{\circ} 50^{\prime} 30^{\prime \prime} \mathrm{W}$; (map 9).

Named in 1880 by the U.S. Navy for William Gouverneur Morris, U.S. Collector of Customs at Sitka (U.S. Coast and Geodetic Survey, 1883, p. 167).
Morse Cove: estuary, 2 mi. long, E coast of Duke I., Alex. Arch.; $54^{\circ} 55^{\prime} 45^{\prime \prime}$ N, $131^{\circ} 14^{\prime} 15^{\prime \prime} \mathrm{W}$; (map 2).

Named in 1883 by Lt. Comdr. H. E. Nichols, USN, for Fremont Morse, a member of his party.

Morse Creek: stream, see Ida Creek.

Morse Glacier: glacier, in Glacier Bay National Monument, heads $2 \mathrm{mi}$. N of Tidal Inlet, trends $\mathrm{E} 5 \mathrm{mi}$. to its 1948 terminus, $3 \mathrm{mi}$. W of Muir Inlet, $58 \mathrm{mi}$. NW of Hoonah, St. Elias Mts.; $58^{\circ} 51^{\prime} 50^{\prime \prime} \mathrm{N}, 136^{\circ} 11^{\prime} 00^{\prime \prime} \mathrm{W}$; (map 10). Var. West Tributary Muir Glacier.

Named in 1892 by Reid (1896, p. 440) for J. F. Morse, one of his companions on his trip to this area in 1890 . Reid originally called it "West Tributary" (1892, map).

Morse Island: island, see Bendel Island.

Morse Lake: lake, $65 \mathrm{yd}$ across, $1.3 \mathrm{mi}$. W of Kiska Harbor, Kiska I., Aleutian Is.; 51 ${ }^{\circ}$ $59^{\prime} 03^{\prime \prime} \mathrm{N}, 177^{\circ} 30^{\prime} 40^{\prime \prime} \mathrm{E}$; (map 14).

An arbitrary name beginning with " $M$ " to correspond to " $\mathrm{M}$ " grid used by U.S. Army for tactical purposes during World War II; published on a 1943 Army map.

Morse Peak: mountain, 3,554 ft., on Glass Penin., $33 \mathrm{mi}$. NE of Angoon, on $\mathrm{E}$ coast of Admiralty I., Alex. Arch.; $57^{\circ} 51^{\prime} 15^{\prime \prime} \mathrm{N}$, $134^{\circ} 02^{\prime} 20^{\prime \prime} \mathrm{W}$; BGN 1934; (map 9).

Named in 1887 by Lt. C. M. Thomas, USN, for Samuel Finley Breese Morse, 17911872, American inventor and artist, who invented the electric telegraph in 1832.

Morse Rock: rock, in Port Chester, on W coast of Annette I., Alex. Arch.; 55 $09^{\prime} 15^{\prime \prime}$ N, $131^{\circ} 34^{\prime} 05^{\prime \prime} \mathrm{W}$; (map 3$)$.

Named in the 1880 's by USC\&GS, probably for Fremont Morse, USC\&GS; published in 1891 Coast Pilot (p. 93).

Morserovia: island, see Walrus Island.

Morsezovia: island, see Walrus Island.

Morshevoi: bay, see Morzhovoi Bay.

Morshovoi: bay, see Morzhovoi Bay.

Morskiy Ostrov: island, see Navy Island.

Morskoi, Cape: peninsula, see Phipps Peninsula.

Morskoi, Cape: point of land, see Ocean Cape.

Morskoi, Ostrov: island, see Navy Island.

Morskoi Rock: rock, $2 \mathrm{mi}$. off NW tip of Kruzof I. and $28 \mathrm{mi}$. NW of Sitka, Alex. Arch.; $57^{\circ}$ $20^{\prime} 30^{\prime \prime} \mathrm{N}, 135^{\circ} 54^{\prime} 00^{\prime \prime} \mathrm{W}$; BGN Sixth Report; (map 9). Var. Kamen Morskoy, Ostrov Morskoy, Sea Rock.

Russian name meaning "sea," given in 1833 by the navigator Ens. Vasiliev; published in 1848 on Russian Hydrog. Dept. Chart 1397 as "Os[trov] Morskoy."

Morskoy, Kamen: rock, see Morskoi Rock.

Morskoy, Mys: point of land, see Ocean Cape.

Morsky, Mys: point of land, see Hinchinbrook, Cape.

Morzhevskoy Pik: peak, see North Walrus Peak. Morzhovia : village, see Morzhovoi.

Morzhovoi: village, pop. 17 , on $\mathrm{S}$ shore of Traders Cove, on Bechevin Bay, Aleutian Ra.; $54^{\circ} 54^{\prime} 35^{\prime \prime} \mathrm{N}, 163^{\circ} 18^{\prime} 10^{\prime \prime} \mathrm{W}$; BGN 1890; (map 25). Var. Morzhovia, New Morzhovoi, Old Morzhovoi, Protassof, Selo Morzhovskoe. 
Name published in 1847 on Chart 1379 of the Russian Hydrog. Dept. as "S[elo] Morzhovskoe" (walrus village).

Morzhovoi: island, see Walrus Island.

Morzhovoi Bay: bay, $5 \mathrm{mi}$. across, on SW end of Alaska Penin., Aleutian Ra.; $55^{\circ} \mathrm{N}, 163^{\circ}$ W; BGN 1890; (map 25). Var. Adamagan, Morjevskaia, Morshevoí, Morshovoi, Morzovia Bay.

Transliteration of the Russian name published by Capt. Tebenkov (1852, map 24), IRN, as "Za[liv] Morzhovoi," meaning "walrus island." Baker (1906, p. 445) reports "Its Aleut name as Adamagan."

Morzhovoi Island: island, see Hall Island.

Morzhovoy, Ostrov: island, see Hall Island.

Morzhovoy, Ostrov: island, see Walrus Island.

Morzovia Bay: bay, see Morzhovoi Bay.

Moser Bay: bay, $1.5 \mathrm{mi}$. across, on NW shore of Alitak Bay, at $\mathrm{S}$ end of Kodiak I.; $56^{\circ} 59^{\prime} \mathrm{N}$, $154^{\circ} 08^{\prime} \mathrm{W}$; (map 32 ).

Named by USBF in 1901 for Lt. Comdr. Jefferson F. Moser, 1848-1934, USN, commander of the USBF steamer Albatross from 1897 to 1901. Moser made a reconnaissance of the Alitak Bay area in 1900 and named many features along the south coast of Alaska.

Moser Bay: estuary, extends SE 3 mi., off Behm Canal, on W coast of Revillagigedo I., $3 \mathrm{mi}$. S of Naha Bay, Alex. Arch.; 55 $34^{\prime}$ N, $131^{\circ} 41^{\prime}$ W; (map 3).

Named in 1886 by USC\&GS for Lt. Comdr. Jefferson Franklin Moser, USN.

Moser Creek: stream, heads in Moser Glacier, flows $\mathrm{S} 6 \mathrm{mi}$. to Ahrnklin River, $4.2 \mathrm{mi}$. $\mathrm{S}$ of Slate Peak and $22 \mathrm{mi}$. E of Yakutat, St. Elias Mts. ; $59^{\circ} 30^{\prime} 00^{\prime \prime} \mathrm{N}, 139^{\circ} 06^{\prime} 30^{\prime \prime} \mathrm{W}$; (map 46).

Name published in 1928 by IBC.

Moser Glacier: glacier, heads on S slope of Crescent Mtn., trends W $1.4 \mathrm{mi}$. to 1961 terminus at head of Moser Creek, $24 \mathrm{mi}$. E of Yakutat, St. Elias Mts.; 59 $34^{\prime} 20^{\prime \prime}$ N, $139^{\circ}$ $03^{\prime} 15^{\prime \prime} \mathrm{W}$; (map 46).

Named by USBF for Lt. Comdr. Jefferson Franklin Moser, USN, 1848-1934, who, as commander of the USBF steamer Albatross, made a reconnaissance trip to this region in 1901.

Moser Island: island, $0.5 \mathrm{mi}$. long, between Behm Canal and Moser Bay on W coast of Revillagigedo I., $16 \mathrm{mi}$. N of Ketchikan, Alex. Arch.; $55^{\circ} 34^{\prime} 30^{\prime \prime} \mathrm{N},{ }^{\prime} 131^{\circ} 41^{\prime} 00^{\prime \prime} \mathrm{W}$; (map 3 ).

Local navigator's name reported in 1904 by $\mathbf{H}$. C. Fassett, USBF.

Moser Island: island, $6 \mathrm{mi}$. long, separating North and South Arms Hoonah Sound on Chichagof I., $17 \mathrm{mi}$. E of Chichagof, Alex. Arch.; 57 $41^{\prime} \mathrm{N}, 135^{\circ} 40^{\prime} \mathrm{W}$; (map 9).

Named by USC\&GS for Lt. Comdr. Jefferson Franklin Moser, 1848-1934, USN, who later became Rear Adm. He was in command of the USBF steamer Albatross which explored salmon streams in Alaska. The results of these studies were published in 1899 and 1902.

Moser Peninsula: peninsula, $13 \mathrm{mi}$. long, between Deadman Bay and Moser Bay, at head of Alitak Bay, $S$ end of Kodiak I.; $57^{\circ} 04^{\prime}$ N, $154^{\circ} 00^{\prime} \mathrm{W}$; BGN 1934; (map 32, 34, 35). Var. Kashuvak Peninsula.

Named by USC\&GS in 1934 for Lt. Comdr. Jefferson F. Moser. "Kashuvak" is the name of a former native village located on this peninsula. See Moser Bay.

Moser Point: point of land, at $\mathbf{S}$ tip of Moser Penin., between Moser and Alitak Bays, at $\mathbf{S}$ end of Kodiak I.; $56^{\circ} 58^{\prime} 10^{\prime \prime} \mathrm{N}, 154^{\circ} 05^{\prime} 35^{\prime \prime}$ W; BGN 1934; (map 32).

Named by USC\&GS in 1935 for Lt. Comdr. Jefferson F. Moser., See Moser Bay.

Moses: village, see Moses Point.

Moses, Point: point of land, on W shore of Hanus Bay, on NE coast of Baranof I., $3 \mathrm{mi}$. S of Todd, Alex. Arch.; $57^{\circ} 25^{\prime} 15^{\prime \prime} \mathrm{N}, 135^{\circ} 03^{\prime} 40^{\prime \prime}$ W; (map 9).

Named in 1895 by Lt. Comdr. E. K. Moore, USN, for asst. engineer Stanford Elwood Moses, a member of his party.

Moses Gulch: ravine, see Mauze Gulch.

Moses Point: village, pop. 15 (1958), at mouth of Kwiniuk River on N shore of Norton Bay, $8 \mathrm{mi}$. NE of Elim, Seward Penin. High; $64^{\circ}$ $42^{\prime} \mathrm{N}, 162^{\circ} 02^{\prime} \mathrm{W}$; (map 95). Var. Moses, Roadhouse Moses.

Shown as "Moses" on the 1900 "Map of Nome Peninsula" by J. M. Davidson and B. D. Blakeslee.

Moses Point: point of land, on $\mathrm{N}$ side of Norton Bay, NE tip of bar on SE shore of Kwiniuk Inlet, $20 \mathrm{mi}$. NE of Elim, Seward Penin. High.; $60^{\circ} 45^{\prime} 30^{\prime \prime} \mathrm{N}, 161^{\circ} 45^{\prime} 00^{\prime \prime} \mathrm{W}$; $B G N$ 1910; (map 96).

Local name reported in 1910, derived from Moses Roadhouse to the southwest.

Moses Rocks: rocks, off Coal Bay, $8 \mathrm{mi}$. E of Pavlof Bay, near SW end of Alaska Penin., Aleutian Ra.; $55^{\circ} 21^{\prime} \mathrm{N}, 161^{\circ} 20^{\prime} \mathrm{W}$; (map 28).

Local name reported in 1897 by Lt. Comdr. J. F. Moser, USN, commander of the USBF steamer Albatross from 1897 to 1901, who surveyed and investigated this area.

Moses Village: locality, see Arctic City.

Mosheim Dome: mountain, 6,450 ft., on AlaskaCanada boundary, 23 mi. NE of mouth of Unuk River at Burroughs Bay, Coast Mts.; $56^{\circ} 22^{\prime} 15^{\prime \prime} \mathrm{N}, 131^{\circ} 49^{\prime} 00^{\prime \prime} \mathrm{W}$; (map 7).

Named by IBC for Adolph Mosheim, one of the U.S. Boundary Commission surveyors who worked in this area in 1905 . The name was published in 1927 on IBC sheet 3.

Mosk Cape: point of land, see Moss Cape.

Mosman Inlet: estuary, extends SE $6 \mathrm{mi}$. to Clarence Strait, on SW coast of Etolin I., 28 mi. SW of Wrangell, Alex. Arch.; 56 $04^{\prime} 30^{\prime \prime}$ N, $132^{\circ} 32^{\prime} 00^{\prime \prime} \mathrm{W}$; (map 6).

Named in 1879 by W. H. Dall, USC\&GS, for Alonzo Tyler Mosman, USC\&GS, who made surveys in Alaska in 1867.

Mosman Island: island, $1 \mathrm{mi}$. long, at mouth of Mosman Inlet, on SW coast of Etolin I., 30 mi. SW of Wrangell, Alex. Arch.; 56 $04^{\prime} \mathrm{N}$, $132^{\circ} 33^{\prime} \mathrm{W}$; (map 6 ).

Local name recorded in 1953 by USGS.

Mosman Point: point of land, on S coast of Mosman I., off SW coast of Etolin I., $30 \mathrm{mi}$. SW of
Wrangell, Alex. Arch.; $56^{\circ} 03^{\prime} 15^{\prime \prime} \mathrm{N}, 132^{\circ}$ $32^{\prime} 15^{\prime \prime}$ W; BGN 1914; (map 6). Var. Reef Point.

Named in 1914 by USC\&GS.

Mosquito Creek: stream, flows SW $25 \mathrm{mi}$. to Mulchatna River, $100 \mathrm{mi}$. SE of Sleetmute, Kilbuck-Kuskokwim Mts.; $60^{\circ} 19^{\prime}$ N, $156^{\circ} 13^{\prime}$ W; (map 60).

Local name reported in 1952 by USC\&GS. Mosquito Creek: stream, flows SW $2.5 \mathrm{mi}$., joins Ernestine Creek to form Tiekel River, $1 \mathrm{mi}$. NE of mouth of Fall Creek and $44 \mathrm{mi}$. NE of Valdez, Chugach Mts.; $61^{\circ} 26^{\prime} 05^{\prime \prime} \mathrm{N}, 145^{\circ}$. $07^{\prime} 00^{\prime \prime} \mathrm{W}$; (map 68).

Local name published in the 1950's by USGS.

Mosquito Greek: stream, flows NE $4 \mathrm{mi}$., joins Junction Creek to form Redmond Creek, 28 mi. NW of Big Delta, Yukon-Tanana High.; $64^{\circ} 22^{\prime} 40^{\prime \prime} \mathrm{N}, 146^{\circ} 36^{\prime} 10^{\prime \prime} \mathrm{W}$; (map 101 ).

Prospectors' name; reported in 1910 by C. E. Ellsworth and G. L. Parker (in Brooks and others, 1911, p. 193), USGS.

Mosquito Creek: stream, formed by junc. of its North and South Forks, flows NW to Telephone Creek, $0.7 \mathrm{mi}$. E of its junc. with Fish River, $25 \mathrm{mi}$. NW of Council and $34 \mathrm{mi}$. S of Imuruk Lake, Seward Penin. High.; $65^{\circ}$ $05^{\prime} \mathrm{N}, 162^{\circ} 57^{\prime} \mathrm{W}$; (map 110).

Prospectors' name reported in 1900 by E. C. Barnard (in Brooks, 1901, pl. 17), USGS.

Mosquito Creek: stream, flows SE $1.3 \mathrm{mi}$. to Eldorado Creek which flows to Candle Creek, $0.4 \mathrm{mi}$. SW of Tunnel Creek and $33 \mathrm{mi}$. NE of Imuruk Lake, Seward Penin. High.; $65^{\circ}$ $43^{\prime} \mathrm{N}, 162^{\circ} 05^{\prime} \mathrm{W}$; (map 110).

Local name reported in 1950 by USGS.

Mosquito Creek: stream, see Little Mosquito Creek.

Mosquito Flats: swamp, $13 \mathrm{mi}$. across, at junc. of Wolf Creek and Mosquito Fork, $33 \mathrm{mi}$. N of Tok, Yukon-Tanana High.; $63^{\circ} 52^{\prime} \mathrm{N}$, $142^{\circ} 55^{\prime} \mathrm{W}$; (map 85).

Named by Lt. William Mitchell, U.S. Army Signal Corps, in 1902.

Mosquito Fork: stream, heads at $63^{\circ} 58^{\prime} \mathrm{N}$, $143^{\circ} 47^{\prime} \mathrm{W}$, flows NE $86 \mathrm{mi}$., joins Dennison Fork to form South Fork Fortymile River, Yukon-Tanana High.; $64^{\circ} 03^{\prime} 20^{\prime \prime} \mathrm{N}, 141^{\circ} 54^{\prime}$ 40" W; (map 102). Var. Mosquito Fork South Fork Fortymile River.

Prospectors' name obtained in 1898 by E. C. Barnard, USGS.

Mosquito Fork: stream, see Kechumstuk Creek.

Mosquito Fork South Fork Fortymile River: stream, see Mosquito Fork.

Mosquito Islands: islands, $0.3 \mathrm{mi}$. long, on NW coast of Kupreanof I., $1.3 \mathrm{mi}$. W of Kake, Alex. Arch.; 56 $58^{\prime} 15^{\prime \prime} \mathrm{N}, 133^{\circ} 58^{\prime} 15^{\prime \prime} \mathrm{W}$; (map 6).

Local name recorded in 1951 by USGS.

Mosquito Lake: lake, $1 \mathrm{mi}$. long, on SW side of Chilkat River, $4.6 \mathrm{mi}$. NW of Wells and 25 mi. W of Skagway, St. Elias Mts. ; $59^{\circ} 28^{\prime} 00^{\prime \prime}$ N, $136^{\circ} 01^{\prime} 45^{\prime \prime}$ W; (map 45). Var. Kuhnteah.

Locil name "reported by E. C. Robertson and published in 1952 by USGS. It was 
called "Kuhnteah" by the Indians. A road was cut to it in the summer of 1951 for recreational purposes.

Mosquito Lake: lake, $0.8 \mathrm{mi}$. long, on Kenai Penin. SW of Silver Lake, $15 \mathrm{mi}$. ENE of Kenai, Cook Inlet Low.; $60^{\circ} 38^{\prime} \mathrm{N}, 150^{\circ} 49^{\prime}$ W; (map 62).

Named about 1963 by officials of Kenai National Moose Range, for administrative purposes.

Mosquito Mountain: mountain, 2,474 ft., W of Iditarod River, $29 \mathrm{mi}$. SE of Holy Cross, Kilbuck-Kuskokwim Mts. ; $62^{\circ} 05^{\prime} \mathrm{N}, 158^{\circ} 54^{\prime} \mathrm{W}$; (map 79).

Local name obtained in 1945 by USGS topographers.

Mosquito Pass: pass, in Kigluaik Mts., between Windy Creek and Cobblestone River, $30 \mathrm{mi}$. $\mathrm{N}$ of Nome, Seward Penin. High.; 64 $4^{\circ} 56^{\prime} \mathrm{N}$, $165^{\circ} 28^{\prime} \mathrm{W}$; (map 94).

Local name reported in 1912 by $R$. $H$. Sargent, USGS.

Mosquito Point: locality, N of Aleknagik, at SE end of Lake Aleknagik, $18 \mathrm{mi}$. N of Dillingham, Kilbuck-Kuskokwim Mts.; 59 $18^{\prime} \mathrm{N}$, 158 $37^{\prime}$ W; BGN 1937; (map 52). Var. I-gi-ahk.

Former Eskimo village called "I-gi-ahk"; recorded on a 1910 manuscript map by $H$. C. Fassett, USBF. The local name "Mosquito Point" was reported in 1937 by USGS and published by Mertie (1938, pl. 1), USGS. In 1937 this village consisted of 40 white people.

Mosquito River: stream, see Little Tonsina River.

Moss: locality, where The Alaska RR. crosses Moose Creek, $3 \mathrm{mi}$. N of Ferry and $36 \mathrm{mi}$. $\mathrm{S}$ of Nenana, Alaska Ra.; $64^{\circ} 03^{\prime} \mathrm{N}, 149^{\circ} 08^{\prime}$ W; (map 100).

Former RR. station listed on a 1922 timetable.

Moss Cape: point of land, $4 \mathrm{mi}$. NE of Belkofski, near SW end of Alaska Penin., Aleutian Ra.; $55^{\circ} 07^{\prime} 30^{\prime \prime} \mathrm{N}, 161^{\circ} 57^{\prime} 00^{\prime \prime} \mathrm{W}$; (map 28). Var. Mosk Cape.

Local name reported in 1880 by W. H. Dall, USC\&GS.

Moss Creek: ravine, see Moss Gulch.

Moss Creek: stream, flows E $1.4 \mathrm{mi}$. to Moose Creek, W of Kiska Harbor, Kiska I., Aleutian Is. ; $51^{\circ} 57^{\prime} 51^{\prime \prime} \mathrm{N}, 177^{\circ} 31^{\prime} 57^{\prime \prime} \mathrm{E}$; (map 14). Var. Rum Brook.

An arbitrary name beginning with " $M$ " to correspond to " $\mathrm{M}$ " grid used by the U.S. Army for tactical purposes during World War II; published on a 1943 Army map.

Moss Creek: stream, heads at a glacier, flows SE $3 \mathrm{mi}$. to Chickaloon River, $38 \mathrm{mi}$. NE of Palmer, Talkeetna Mts.; $61^{\circ} 59^{\prime} 15^{\prime \prime} \mathrm{N}, 148^{\circ}$ 18'00" W; (map 69).

Named in 1898 by guide John Bagg of Capt. E. F. Glenn's expedition.

Moss Gulch: ravine, trends SW $1 \mathrm{mi}$. to Nome River, 5 mi. E of Nome, Seward Penin. High.; $64^{\circ} 31^{\prime} \mathrm{N}, 165^{\circ} 13^{\prime} \mathrm{W}$; (map 94). Var. Moss Creek.
Prospectors' name reported in 1899 as "Moss Creek" by D.C. Witherspoon (in Schrader and Brooks, 1900, map 2), USGS Witherspoon appears to have applied the name to Osborn Creek. "Moss Gulch" was shown on a 1901 map of Cape Nome gold fields by David Fox, Jr.

Moss Island: island, $0.8 \mathrm{mi}$. long, in Douglas Bay, on S coast of Kupreanof I., $27 \mathrm{mi}$. SW of Petersburg, Alex. Arch.; 56 $27^{\prime} 30^{\prime \prime} \mathrm{N}$, $133^{\circ} 18^{\prime} 00^{\prime \prime} \mathrm{W}$; ( $\left.\operatorname{map} 6\right)$.

Named in 1887 by Lt. Comdr. C. M. Thomas, USN, for charting purposes; published in 1888 on USC\&GS Chart 705.

Moss Point: point of land, on E coast of Umak I., Aleutian Is. ; $51^{\circ} 53^{\prime} 40^{\prime \prime} \mathrm{N}, 175^{\circ} 57^{\prime} 25^{\prime \prime} \mathrm{W}$; $B G N$ 1936; (map 18).

Named by a member of the U.S. Navy Aleutian Island Survey Expedition of 1934, and shown on a 1952 USGS map.

Moss Point: point of land, $\mathrm{W}$ point of entrance to Tamgas Harbor, on $S$ coast of Annette I., 22 mi. S of Ketchikan, Alex. Arch.; $55^{\circ} 01^{\prime} 15^{\prime \prime} \mathrm{N}$, $131^{\circ} 33^{\prime} 30^{\prime \prime} \mathrm{W}$; (map 3).

Name published in 1891 by USC\&GS.

Moss Point: point of land, on SE coast of Prince of Wales I., in Port Johnson, Alex. Arch.; 55 $07^{\prime} 15^{\prime \prime} \mathrm{N}, 132^{\circ} 02^{\prime} 45^{\prime \prime} \mathrm{W}$; (map 4).

Local name published in 1943 by USC\&GS.

Moss Point: point of land, on SE coast of Kenai Penin., at entrance to North Arm Nuka Bay, $34 \mathrm{mi}$. SE of Homer, Chugach Mts.; 59०. $32^{\prime} 30^{\prime \prime} \mathrm{N}, 150^{\circ} 36^{\prime} 30^{\prime \prime} \mathrm{W}$; BGN 1929; (map $50)$.

Descriptive local name reported by USC\&GS in 1927. So named "because of a close-by cluster of moss covered rocks."

Moth Bay: estuary, extends N $1.7 \mathrm{mi}$. from Thorne Arm, on $\mathrm{S}$ coast of Revillagigedo I., Alex. Arch.; $55^{\circ} 16^{\prime} \mathrm{N}, 131^{\circ} 20^{\prime} \mathrm{W} ; B G N$ 1917; (map 3).

Named in 1917 by USC\&GS; derived from Moth Point.

Mother Goose Glacier: glacier, on Kenai Penin., heads $1.5 \mathrm{mi}$. W of Snow River Pass, trends W $2.5 \mathrm{mi}$. to its terminus at head of Victor Creek, $18 \mathrm{mi}$. NE of Seward, Chugach Mts.; $60^{\circ} 21^{\prime} 00^{\prime \prime} \mathrm{N}, 149^{\circ} 14^{\prime} 30^{\prime \prime} \mathrm{W}$; (map 63).

Local name reported in 1951 by USGS.

Mother Goose Lake: lake, $6.4 \mathrm{mi}$. long, at head of King Salmon River, on Alaska Penin., 21 mi. $S$ of Ugashik, Aleutian Ra.; $57^{\circ} 13^{\prime} \mathrm{N}$, $157^{\circ} 22^{\prime}$ W; (map 36). Var. King Salmon Lake.

Named in 1923 by R. H. Sargent, USGS; "suggested by its goose-like shape." According to Sargent, the local name was King Salmon Lake.

Motherwood Point: point of land, on Seward Penin., extends into Spafarief Bay, $16 \mathrm{mi}$. E of Deering, Kotzebue-Kobuk Low.; 66 $04^{\circ} \mathrm{N}$, $162^{\circ} 02^{\prime} \mathrm{W}$; (map 113).

Local name reported in 1950 by USGS.

Moth Point: point of land, between Moth Bay and Thorne Arm, on $\mathrm{S}$ coast of Revillagigedo I., Alex. Arch.; $55^{\circ} 15^{\prime} 55^{\prime} \mathrm{N}, 131^{\circ} 19^{\prime} 35^{\prime \prime} \mathrm{W}$; (map 3).

Arbitrary name given in 1891 by USC\&GS.
Mound Hill: hill, $900 \mathrm{ft}$, on S coast of Revillagigedo I., $3.3 \mathrm{mi}$. NW of Point Alava, Alex. Arch.; 55 $13^{\prime} 50^{\prime \prime} \mathrm{N}, 131^{\circ} 14^{\prime} 05^{\prime \prime} \mathrm{W}$; (map 3 ). Descriptive name given in 1883 by Lt. Comdr. H. E. Nichols, USN.

Moundhill Point: point of land, on $\mathrm{E}$ coast of Seguam I., Aleutian Is.; $52^{\circ} 20^{\prime} 00^{\prime \prime}$ N, $172^{\circ}$ $18^{\prime} 30^{\prime \prime} \mathrm{W}$; (map 19).

Descriptive name published by USC\&GS in 1944 Aleutian Coast Pilot (p. 85).

Mound Point: point of land, $\mathrm{N}$ point of entrance to Karta Bay, on $\mathbf{E}$ coast of Prince of Wales I., Alex. Arch.; $55^{\circ} 34^{\prime} 30^{\prime \prime}$ N, $132^{\circ} 33^{\prime} 55^{\prime \prime} \mathrm{W}$; (map 4).

Descriptive name given in 1886 by $L t$. Comdr. R. C. Clover, USN.

Mountain: village, see Mountain Village.

Mountian Bay: bay, see Uniktali Bay.

Mountain Cape: point of land, see Gori Point.

Mountain Cape: point of land, see Kayak Cape.

Mountain Creek: stream, on Alaska Penin., flows SW $4 \mathrm{mi}$. to Northeast Greek $2 \mathrm{mi}$. above that stream's mouth on Amber Bay, $11 \mathrm{mi}$. NW of Cape Kunmik, Aleutian Ra.; $56^{\circ} 50^{\prime} \mathrm{N}, 157^{\circ}$ 23' W ; (map 31).

Local name published in 1951 by USGS.

Mountain Creek: stream, flows NW $7 \mathrm{mi}$. to Fork Creek, $11 \mathrm{mi}$. E of Eek Lake and $71 \mathrm{mi}$. SE of Bethel, Kilbuck-Kuskokwim Mts.; 60 $13^{\prime}$ $30^{\prime \prime} \mathrm{N}, 160^{\circ} 01^{\prime} 00^{\prime \prime} \mathrm{W}$; (map 59 ).

Local descriptive name; reported in 1955 by J. M. Hoare, USGS.

Mountain Creek: stream, heads in Paimiut Mts., flows NW and SW $25 \mathrm{mi}$. to Tuckers Slough, 36 mi. $\mathrm{N}$ of Base I. in Yukon River and 27 mi. NE of Russian Mission, Nulato Hills; $62^{\circ} 00^{\prime} 25^{\prime \prime} \mathrm{N}, 160^{\circ} 40^{\prime} 00^{\prime \prime} \mathrm{W}$; (map 78). Var. Ingram Kwik, Ingrie Kwik, Ingrik Kwik.

Name translated from the Eskimo and reported in 1916 by G. L. Harrington and R. H. Sargent (Harrington, 1918, pl. 1), USGS. Mountain Creek: stream, heads in Mary Gulch, flows W $1.5 \mathrm{mi}$. to Gold Creek, $6 \mathrm{mi}$. NW of Nome, Seward Penin. High.; 64 $35^{\prime} \mathrm{N}$, $165^{\circ} 28^{\prime} \mathrm{W}$; (map 94).

Prospectors' name reported in 1899 by D. C. Witherspoon (in Schrader and Brooks, 1900, map 2), USGS.

Mountain Creek: stream, flows NE $1 \mathrm{mi}$. to Bonanza River, between Frost and Sunrise Creeks, about $13 \mathrm{mi}$. NW of Solomon, Seward Penin. High.; $64^{\circ} 46^{\prime} \mathrm{N}, 164^{\circ} 48^{\prime} \mathrm{W}$; (map 95).

Prospectors' name reported on the 1900 "Map of Nome Peninsula" by J. M. Davidson and B. D. Blakeslee. This stream cannot be precisely located on current maps.

Mountain Creek: stream, flows NW $1.4 \mathrm{mi}$. to Stewart River, $20 \mathrm{mi}$. NW of Nome, Seward Penin. High.; $64^{\circ} 48^{\prime} \mathrm{N}, 165^{\circ} 29^{\prime} \mathrm{W}$; (map 94).

Prospectors' name reported in 1900 by $\mathbf{E}$. C. Barnard (in Brooks, 1901, pl. 17), USGS. Mountain Creek: stream, flows SW $5 \mathrm{mi}$. to a lagoon on Port Clarence, $3 \mathrm{mi}$. SE of Teller Mission and $4 \mathrm{mi}$. $\mathrm{N}$ of Teller, Seward Penin. High.; $65^{\circ} 19^{\prime} \mathrm{N}, 166^{\circ} 23^{\prime} \mathrm{W}$; (map 111). 
Local name reported in 1900 by E. C. Barnard (in Brooks, 1901, pl. 17), USGS.

Mountain Creek: stream, flows NE $7 \mathrm{mi}$. to Black River, $8 \mathrm{mi}$. E of Bear $\mathbf{M} \mathrm{tn}$. and 39 mi. W of Midnight Hill, Porcupine Plat.; $66^{\circ} 05^{\prime} \mathrm{N}, 142^{\circ} 19^{\prime} \mathrm{W}$; (map 120).

Local descriptive name; reported in 1956 by R. C. Foley, USGS.

Mountain Creek: stream, flows S $9 \mathrm{mi}$. to Chandalar River $\mathbf{E}$ of Funchion Creek, $38 \mathrm{mi}$. SE of Chandalar, Brooks Ra.; $67^{\circ} 07^{\prime} \mathrm{N}$, $147^{\circ} 28^{\prime} \mathrm{W}$; (map 123).

Prospectors' name obtained in 1909 by A. G. Maddren (in Brooks and others, 1910, pl. 7), USGS.

Mountain Greek: stream, flows SE to Flambeau River, about $13 \mathrm{mi}$. E of Nome, Seward Penin. High.; (map 94).

Prospectors' name reported on the 1900 "Map of Nome Peninsula" by J. M. Davidson and B. D. Blakeslee; this feature has not been positively identified.

Mountain Creek: stream, fows E to Frederick Creek which flows to Hungry Creek, about $33 \mathrm{mi}$. NW of Nome, Seward Penin. High.; (map 94).

Prospectors' name reported on the 1900 "Map of Nome Peninsula" by J. M. Davidson and B. D. Blakeslee; this feature has not been positively identified.

Mountaineers Pass: pass, 8,700 ft., between 2 arms of Nabesna Glacier, $6 \mathrm{mi}$. NE of Mount Blackburn and $26 \mathrm{mi}$. NW of McCarthy, Wrangell Mts. ; $61^{\circ} 46^{\prime} 45^{\prime \prime} \mathrm{N}, 143^{\circ} 13^{\prime} 30^{\prime \prime} \mathrm{W}$ $B G N$ 1966; (map 67).

Named in 1965 by the Mountaineering Club of Alaska, "because it can be reached only by glacier travel and is likely to be used only by mountaineers."

Mountain Gulch : ravine, see Madison Gulch.

Mountain Head: point of land, in Peril Strait $2 \mathrm{mi}$. N of Fish Bay, on Baranof I., $26 \mathrm{mi}$. NW of Sitka, Alex. Arch.; 57 $24^{\prime} 35^{\prime \prime}$ N, $135^{\circ} 35^{\prime}$ $15^{\prime \prime} \mathrm{W}$; (map 9).

Descriptive name given in 1884 by Comdr. J. B. Coghlan, USN; published by USC\&GS in 1891 Coast Pilot (p. 182).

Mountain Lake: lake, $1.9 \mathrm{mi}$. long, $16 \mathrm{mi}$. NE of Yakutat, St. Elias Mts.; $59^{\circ} 40^{\prime} 00^{\prime \prime} \mathrm{N}, 1^{\circ} 9^{\circ} 20^{\prime}$ 45" W; BGN 1962; (map 46). Var. Little Situk Lake.

Local name reported by USGS in 1959 . It is also known locally as Little Situk Lake.

Mountain Men, River of the: stream, see Tanana River.

Mountain Peak, Cape: point of land, see Upright, Cape.

Mountain Point: suburb, pop. 372, on S coast of Revillagigedo I. at Mountain Point, $5 \mathrm{mi}$. SE of Ketchikan, Alex. Arch.; $55^{\circ} 17^{\prime} 45^{\prime \prime} \mathrm{N}$, $131^{\circ} 32^{\prime} 00^{\prime \prime} \mathrm{W}$; (map 3$)$.

Local name for this residential district of Ketchikan reported in 1960 by the U.S. Census Bureau.

Mountain Point: point of land, on $\mathrm{S}$ tip of Nagai I., in Shumagin Is., Aleutian Ra.; 54 $52^{\prime} \mathrm{N}$, $160^{\circ} 13^{\prime}$ W; (map 26). Var. Golova, Mountain Cape.
Named M[ys] Golova, meaning "chief (head) point," by Capt. Tebenkov (1852, map 24), IRN

Mountain Point: point of land, E point of entrance to Carroll Inlet, on S coast of Revillagigedo I., Alex. Arch.; 55 $17^{\prime} 35^{\prime \prime} \mathrm{N}, 131^{\circ}$ $32^{\prime} 20^{\prime \prime} \mathrm{W}$; (map 3).

So named in 1883 by Lt. Comdr. H. E. Nichols, USN, "because of the view of the mountains to the northwest of this point."

Mountain Point: point of land, on $\mathbf{E}$ coast of Lindenberg Penin., Kupreanof I., W shore of Wrangell Narrows, $5 \mathrm{mi}$. S of Petersburg, Alex. Arch.; $56^{\circ} 44^{\prime} 15^{\prime \prime} \mathrm{N}, 132^{\circ} 57^{\prime} 30^{\prime \prime} \mathrm{W}$; (map 6). Var. Cove Point.

Named in 1884 by Comdr. J. B. Coghlan, USN; published in 1883 Coast Pilot (p. 115) as "Cove Point." This point is possibly "Mys Vodopada" meaning "waterfall cape," or "Mys Kritoy," meaning "steep cape"; given in 1838 by the Russian surveyor, G. Lindenberg.

Mountain Point: point of land, on $\mathrm{E}$ coast of Kruzof I., $10 \mathrm{mi}$. NW of Sitka, Alex. Arch.; $57^{\circ} 07^{\prime} N, 135^{\circ} 34^{\prime} \mathrm{W}$; (map 9)

Name published in 1932 by USGS.

Mountain Point: point of land, on $\mathrm{W}$ coast of Knight I., at $\mathrm{W}$ point of entrance to Port Audrey, at head of Drier Bay, $11 \mathrm{mi}$. NE of Chenega, Chugach Mts.; $60^{\circ} 20^{\prime} 00^{\prime \prime} \mathrm{N}, 147^{\circ}$. $21^{\prime} 15^{\prime \prime} \mathrm{W}$; (map 63).

Local name published in 1908 by USC\&GS. Mountain Slough: stream, distributary of Eyak River, flows SW $4 \mathrm{mi}$. to Gulf of Alaska, $5 \mathrm{mi}$. $S$ of Cordova, Malaspina Coastal Plain; $60^{\circ}$ $28^{\prime} 30^{\prime \prime} \mathrm{N}, 145^{\circ} 44^{\prime} 00^{\prime \prime} \mathrm{W}$; (map 64).

Local name reported in 1897 by Lt. Comdr. J. F. Moser, USN, commander of the USBF steamer Albatross in 1897-1901.

Mountain View: area, in NE section of Anchor-

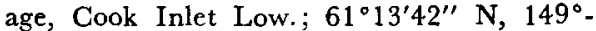
$48^{\prime} 25^{\prime \prime} \mathrm{W}$; (map 69).

Local name reported in 1941 by AMS.

Mountain View: locality, at the junc. of Fish and Skookum Creeks, $4.5 \mathrm{mi}$. $\mathrm{N}$ of Hyder, Coast Mts.; $55^{\circ} 59^{\prime} 10^{\prime \prime} \mathrm{N}, 130^{\circ} 03^{\prime} 00^{\prime \prime} \mathrm{W}$ (map 3).

Settlement referred to as a camp in 1949 by USFS.

Mountain Village: locality, see Ingregamiut.

Mountain Village: village, pop. 300 , on $\mathrm{N}$ bank of Yukon River, $52 \mathrm{mi}$. SE of Kwiguk, YukonKuskokwim Delta; $62^{\circ} 05^{\prime} \mathrm{N}, 163^{\circ} 43^{\prime} \mathrm{W}$; (map 77). Var. Mountain.

Eskimo village listed with a population of 136 in 1920; 76 in $1930 ; 128$ in 1939; and 221 in 1950. So called because "it is located at the foot of the first mountain met with going up the Yukon."

Mount Andrew: locality, on Kasaan Penin., on $\mathrm{E}$ coast of Prince of Wales I., Alex. Arch.; $55^{\circ} 30^{\prime} \mathrm{N}, 132^{\circ} 20^{\prime} \mathrm{W}$; (map 4).

Former mining camp operated by the Andrew mining company; reported by Brooks (1902, p. 13), USGS, in 1901.

Mount Edgecumbe: locality, pop. 1,884, on E coast of Japonski I., $0.5 \mathrm{mi}$. W of Sitka, Alex. Arch.; $57^{\circ} 03^{\prime} \mathrm{N}, 135^{\circ} 21^{\prime} \mathrm{W}$; (map 9).
Name derived from Mount Edgecumbe The place, formerly a USN center, is now a hospital and a boarding school for Alaska natives. The vocational school operated by the BIA had an enrollment of 650 in 1962 The hospital consisting of a tuberculosis sanitorium and an orthopedic hospital is operated by the U.S. Public Health Service. A post office was established here in 1947 but was discontinued in 1959 (Ricks, 1965, p. 44).

Mount Fairweather Range: mountain range, see Fairweather Range.

Mount McKinley National Park: 3,030 sq. mi. of subarctic wilderness, on $\mathrm{N}$ slope of Alaska Ra., extends SW 115 mi. from Nenana River, E of Mount Healy, to Mount Russell; it includes Mount McKinley, highest peak on North American Continent; $63^{\circ} 20^{\prime} \mathrm{N}, 150^{\circ} 20^{\prime}$ W; (map 88).

Charles Sheldon, 1867-1928, noted hunternaturalist, visited the Mount McKinley area in 1906,1907 , and 1908 to study Dall sheep and other wildlife. He believed the outstanding wilderness wonders of the area should be protected, and worked unrelentingly toward that goal. He was the prime figure in Mount $\mathrm{Mc}$ Kinley's establishment as a National Park on February 26, 1917.

Mouse, The : peak, see Knob H

Mouse Creek: stream, heads in lake and flows ESE $2.5 \mathrm{mi}$. to Alfred Creek, $4 \mathrm{mi}$. upstream from Caribou Greek, $56 \mathrm{mi}$. NE of Palmer, Talketna Mts.; $61^{\circ} 57^{\prime} 00^{\prime \prime} \mathrm{N}, 147^{\circ} 33^{\prime} 30^{\prime \prime} \mathrm{W}$; BGN 1960; (map 69).

Named in 1956 by USGS for the small rodent.

Mouse Point: locality, see Moose Point

Mouse Point: point of land, extends into Kagalurpak Lake, 2 mi. $\mathrm{N}$ of Blair Inlet and 80 mi. W of Bethel, Yukon-Kuskokwim Delta; $60^{\circ} 54^{\prime} \mathrm{N}, 164^{\circ} 05^{\prime} \mathrm{W}$; (map 58).

Name used by personnel of Clarence Rhode National Wildlife Range; reported in 1965.

Mouse Point: point of land, easternmost tip of Mickey I., in Yukon River, $33 \mathrm{mi}$. NE of Ruby, Nowitna Low.; $64^{\circ} 56^{\prime} \mathrm{N}, 154^{\circ} 29^{\prime} \mathrm{W}$; (map 98).

Riverboat pilots' name shown on 1940 "Navigation Chart, Tanana-Yukon Rivers" of the River Boat Service, U.S. Dept. of Interior.

Movie Lake: lake, $0.8 \mathrm{mi}$. long, northern lake of Trinity Lakes, $39 \mathrm{mi}$. NW of Tyonek, Cook Inlet Low.; $61^{\circ} 37^{\prime} 30^{\prime \prime} \mathrm{N}, 151^{\circ} 27^{\prime} 00^{\prime \prime} \mathrm{W}$; (map 70).

Local name reported in 1954 by USGS

Moving Mountain: mountain, $3,600 \mathrm{ft}$., $5 \mathrm{mi}$. S of Redstar Mts. and $27 \mathrm{mi}$. NW of Wiseman, Brooks Ra.; $67^{\circ} 40^{\prime} \mathrm{N}, 150^{\circ} 54^{\prime} \mathrm{W}$; BGN 1932 ; (map 124)

According to Marshall (1956, p. 12), "there had been large landslides on the sides of this mountain which accounted for our naming it 'Moving Mountain','

Mox Lake: lake, $0.5 \mathrm{mi}$. long, on Kenai Penin., $0.7 \mathrm{mi} . \mathrm{N}$ of Hidden Lake and $33 \mathrm{mi}$. $\mathrm{E}$ of Kenai, Cook Inlet Low.; $60^{\circ} 30^{\prime} 45^{\prime \prime} \mathrm{N}, 150^{\circ}$ $18^{\prime} 30^{\prime \prime} \mathrm{W}$; (map 62). 
Named about 1963 by officials of Kenai National Moose Range, for administrative purposes.

Moyler Lake: lake, see Mohler Lake.

Mucha Lake: lake, $1.7 \mathrm{mi}$. long, $9 \mathrm{mi}$. $\mathrm{N}$ of Bearpaw Mtn., 37 mi. SE of Bitzshtini Mts., Tanana Low.; $64^{\circ} 13^{\prime} \mathrm{N}, 150^{\circ} 54^{\prime} \mathrm{W}$; (map 99).

Local name reported in 1952 by USGS.

Muck-A-Charley Mountain: mountain, see Mukacharni Mountain.

Mucker Hill: hill, $890 \mathrm{ft}$, $1.2 \mathrm{mi}$. W of Kiska Harbor, Kiska I., Aleutain Is. ; $51^{\circ} 58^{\prime} 16^{\prime \prime} \mathrm{N}$; $177^{\circ} 30^{\prime} 30^{\prime \prime} \mathrm{E}$; (map 14).

An arbitrary name beginning with " $M$ " to correspond to " $M$ " grid used by the U.S. Army for tactical purposes during World War II; published on a 1943 Army map.

Mudbank, The: bank, on Hodzana River, $35 \mathrm{mi}$. NW of Beaver, Kokrines-Hodzana High.; $66^{\circ} 41^{\prime} \mathrm{N}, 148^{\circ} 21^{\prime} \mathrm{W}$; (map 118).

Local descriptive name obtained in 1956 by USGS.

Mud Bay: suburb, pop. 35, on W coast of Revillagigedo I., $5.5 \mathrm{mi}$. NW of Ketchikan, Alex. Arch.; $55^{\circ} 25^{\prime} 15^{\prime \prime} \mathrm{N}, 131^{\circ} 46^{\prime} 00^{\prime \prime} \mathrm{W}$; (map 3). Var. Totem Lodge, Totem Village.

This is a residential suburb of Ward Cove, recorded in 1954 by USGS.

Mud Bay: bay, $0.5 \mathrm{mi}$. across, on SE shore of Hetta Inlet, on SW coast of Prince of Wales I., Alex. Arch.; 55 $05^{\prime} \mathrm{N}, 132^{\circ} 38^{\prime} \mathrm{W}$; (map 4).

Local name recorded in 1951 by USGS.

Mud Bay: $b a y$, SW arms of Port Moller, extends S $3.5 \mathrm{mi}$. inland, near SW end of Alaska Penin., Aleutian Ra.; 55 $49^{\prime} \mathrm{N}, 160^{\circ} 27^{\prime} \mathrm{W}$; (map 28).

Named by Atwood (1911, pl. 2), USGS.

Mud Bay: bay, $0.8 \mathrm{mi}$. across, on $\mathrm{N}$ coast of Chichagof I. on Icy Strait, $1 \mathrm{mi}$. SE of Goose I. and $20 \mathrm{mi}$. NW of Hoonah, Alex. Arch.; $58^{\circ} 11^{\prime} 30^{\prime \prime} \mathrm{N}, 135^{\circ} 59^{\prime} 00^{\prime \prime} \mathrm{W}$; (map 11).

Descriptive name given in 1880 by Master G. C. Hanus, USN, and published by USC\&GS in the 1883 Coast Pilot (p. 190).

Mud Bay: cove, $0.4 \mathrm{mi}$. wide, on $\mathrm{W}$ coast of Revillagigedo I., on $\mathrm{E}$ shore of Tongass Narrows, $5 \mathrm{mi}$. NW of Ketchikan, Alex. Arch.; $55^{\circ} 25^{\prime} 15^{\prime \prime} \mathrm{N}, 131^{\circ} 46^{\prime} 00^{\prime \prime} \mathrm{W}$; (map 3).

Local name published in 1932 Coast Pilot (p. 104)

Mud Bay: cove, $0.2 \mathrm{mi}$. across, $8.5 \mathrm{mi}$. $\mathrm{W}$ of Wrangell, on S coast of Vank I., Alex. Arch.; $56^{\circ} 27^{\prime} 10^{\prime \prime} \mathrm{N}, 132^{\circ} 36^{\prime} 10^{\prime \prime} \mathrm{W}$; (map 6).

Local name published by USC\&GS in 1925 Coast Pilot (p. 205).

Mud Bay: cove, $0.5 \mathrm{mi}$. across, on $\mathbf{E}$ coast of Kruzof I., 13.5 mi. NW of Sitka, Alex. Arch.; $57^{\circ} 10^{\prime} 45^{\prime \prime} \mathrm{N}, 135^{\circ} 36^{\prime} 30^{\prime \prime} \mathrm{W}$; (map 9).

Descriptive name published in 1900 by USC\&GS.

Mud Bay: cove, see Flat Bay.

Mud Bay: estuary, trends NE $6 \mathrm{mi}$. past extensive mud flats, to Chignik Bay, $6 \mathrm{mi}$. NW of Chignik, on S shore of Alaska Penin., Aleutian Ra.; $59^{\circ} 19^{\prime} \mathrm{N}, 158^{\circ} 25^{\prime} \mathrm{W}$; (map 30). Var. Doris Bay.
Local name reported in 1899 by Lt. Comdr. J. F. Moser, USN, Commander of the USBF steamer Albatross.

Mud Bay: estuary, $0.5 \mathrm{mi}$. wide, on $\mathrm{N}$ shore of Orca Inlet, on Hawkins I., 3 mi. W of Cordova, Chugach Mts.; 60 $33^{\prime} 30^{\prime \prime} \mathrm{N}, 145^{\circ}$ $50^{\prime} 00^{\prime \prime}$ W ; BGN 1961; (map 64). Var. Hyde Bay.

Local descriptive name reported in 1960 by USFS.

Mud Bay: lagoon, $0.5 \mathrm{mi}$. wide, at NW end of Homer Spit, on N shore of Kachemak Bay, on Kenai Penin., $0.5 \mathrm{mi}$. E of Homer, Cook Inlet Low.; $59^{\circ} 38^{\prime} 15^{\prime \prime} \mathrm{N}, 1^{\circ} 1^{\circ} 29^{\prime} 30^{\prime \prime} \mathrm{W}$; (map 50).

Local name reported by USGS or USC\&GS in the 1940's.

Mud Bay: lagoon, see Guyot Bay.

Mud Bay River: stream, on $\mathrm{N}$ end of Chichagof I., flowing $\mathrm{N} 10 \mathrm{mi}$. to Mud Bay on Icy Strait, $19 \mathrm{mi}$. NW of Hoonah, Alex. Arch.; $58^{\circ} 10^{\prime} 30^{\prime \prime} \mathrm{N}, 135^{\circ} 57^{\prime} 30^{\prime \prime} \mathrm{W}$; BGN 1960; (map 11). Var. Hyde Bay River.

Local name derived from Mud Bay published by USGS in 1948.

Mud Canyon: canyon, trends N $4.6 \mathrm{mi}$., $4.5 \mathrm{mi}$. SW of Abraham Lake and $21 \mathrm{mi}$. SE of Beaver, Yukon-Tanana High.; $66^{\circ} 09^{\prime} 00^{\prime \prime} \mathrm{N}$, $146^{\circ} 47^{\prime} 30^{\prime \prime} \mathrm{W}$; (map 119).

Local descriptive name obtained in 1956 by USGS.

Mud Creek: stream, flows S $0.5 \mathrm{mi}$. to Red Bay, on $\mathrm{N}$ coast of Prince of Wales $\mathrm{I}$., $12 \mathrm{mi}$. $\mathrm{E}$ of Point Baker, Alex. Arch.; 56 $18^{\circ} 55^{\prime \prime} \mathrm{N}, 133^{\circ}$ $20^{\prime} 40^{\prime \prime} \mathrm{W}$; (map 6).

Named in 1886 by Lt. J. M. Helm, USN, for charting purposes; name published in 1887 on USC\&GS Chart 706.

Mud Creek: stream, flows NE $1 \mathrm{mi}$. to Snake River along Norton Sound coast, $5 \mathrm{mi}$. W of Nome, Seward Penin. High.; $64^{\circ} 36^{\prime}$ N, $165^{\circ}$. $34^{\prime} \mathrm{W}$; (map 94)

Prospectors' name reported on the 1900 "Map of Nome Peninsula" by J. M. Davidson and B. D. Blakeslee; this feature has not been positively identified.

Mud Creek: stream, flows NW $1.2 \mathrm{mi}$. to Ruby Creek which flows to Casadepaga River, 17 mi. NE of Solomon, Seward Penin. High.; $64^{\circ} 48^{\prime} \mathrm{N}, 164^{\circ} 17^{\prime} \mathrm{W}$; (map 95). Var. Iowa Creek.

Prospectors' name reported in 1905 by T. G. Gerdine, USGS. The variant name "Iowa" was reported in 1907 by USGS geologists (P. S. Smith, 1910, pl. 4).

Mud Greek: stream, flows SE $0.5 \mathrm{mi}$. to Mystery Creek 2 mi. upstream from its junc. with Niukluk River, $34 \mathrm{mi}$. NE of Solomon, Seward Penin. High.; $64^{\circ} 52^{\prime} \mathrm{N}, 163^{\circ} 31^{\prime} \mathrm{W}$; (map 95).

Prospectors' name reported in 1903 by USGS (Collier and others, 1908, p. 240).

Mud Creek: stream, flows NE, then SE $5.2 \mathrm{mi}$. to Mud Creek Channel Kiwalik River, $57 \mathrm{mi}$. NW of Haycock, Seward Penin. High.; $65^{\circ}$ $58^{\prime} \mathrm{N}, 161^{\circ} 54^{\prime} \mathrm{W}$; (map 109).

Local name reported in 1908 by USGS (Brooks and others, 1909, fig. 21).
Mud Greek: stream, flows SW 10 mi. to Koyukuk River, $10 \mathrm{mi}$. ESE of Ninemile Hills and 43 mi. SW of Wiseman, Brooks Ra.; $67^{\circ} 00^{\prime} 30^{\prime \prime}$ N, $151^{\circ} 19^{\prime} 30^{\prime \prime} \mathrm{W}$; BGN 1932; (map 124).

Local name reported by Robert Marshail in 1932.

Mud Creek: watercourse, anabranch of Kuskokwim River, heads at Lower Kalskag and flows W $9 \mathrm{mi}$., $30 \mathrm{mi}$. W of Aniak, Yukon-Kuskokwim Delta ; $61^{\circ} 30^{\prime} \mathrm{N}, 160^{\circ} 27^{\prime} \mathrm{W}$; (map 73).

Local name shown on a 1919 field sheet by R. H. Sargent, USGS.

Mud Creek Channel Kiwalik River: stream, a distributary of Kiwalik River, flows NW $3 \mathrm{mi}$. to Kiwalik Lagoon, $57 \mathrm{mi}$. NW of Haycock, Seward Penin. High.; 65 59' N, 161 $54^{\prime} \mathrm{W}$; (map 109).

Local name published on maps after 1950.

Mud Creek Ditch: ditch, flows NE, then SE 4.4 mi. to Kiwalik River, 54 mi. NW of Haycock, Seward Penin. High.; $65^{\circ} 56^{\prime} \mathrm{N}, 161^{\circ} 55^{\prime} \mathrm{W}$; (map 109).

Local name published on maps after 1950.

Muddy Creek: stream, distributary of Ustay River, flows SE $3 \mathrm{mi}$. to Dry Bay, at mouth of Clear Creek, $47 \mathrm{mi}$. SE of Yakutat, Malaspina Coastal Plain; 59 $09^{\prime} 45^{\prime \prime} \mathrm{N}, 138^{\circ} 37^{\prime} 45^{\prime \prime} \mathrm{W}$; $B G N$ 1962; (map 46). Var. Kakangina, Kakanhini Creek, Kakan River, Ko-kon-heeni, Stickleback Creek.

Local descriptive name reported in 1927 by USGS. Capt. Tebenov (1852, map 7), IRN, shows five outlets of the Alsek River and one he recorded as "Kakangina [Kakanhini]," meaning "stickleback river." Lt. Comdr. J. F. Moser, USN, found the Alsek to have only three main outlets. Just west of these is the "Ko-kon-hee-ni" an outlet of the Ustay River. It is this latter application that is now called "Muddy Creek."

Muddy Creek: stream, heads on Anthracite Ridge, flows S $4.2 \mathrm{mi}$. to Matanuska River, 38 mi. NE of Palmer, Talkeetna Mts. ; 61 ${ }^{\circ} 47^{\prime} 00^{\prime \prime}$ $\mathrm{N}, 148^{\circ} 00^{\prime} 35^{\prime \prime} \mathrm{W}$; (map 69).

Descriptive name reported in 1913 by USGS.

Muddy Creek: stream, flows NE $5 \mathrm{mi}$. to Skwentna River, $8 \mathrm{mi}$. NE of Mount Estelle and $76 \mathrm{mi}$. NW of Tyonek, Alaska Ra.; $61^{\circ}$ $54^{\prime} \mathrm{N}, 152^{\circ} 41^{\prime} \mathrm{W}$; (map 70).

Local descriptive name reported by $S$. R. Capps (in Smith and others, 1929, pl. 1), USGS.

Muddy Lake: lake, $0.7 \mathrm{mi}$. long, in Kenai Mts., on Kenai Penin., in distributary of Skilak River, $0.8 \mathrm{mi}$. E of Skilak Lake and $42 \mathrm{mi}$. ESE of Kenai, Ghugach Mts. ; $60^{\circ} 24^{\prime} \mathrm{N}, 150^{\circ}$. $06^{\prime} \mathrm{W}$; (map 62$)$.

Local name reported in 1959 by USGS.

Muddy Lake: lake, $1 \mathrm{mi}$. long, $\mathrm{W}$ of Jefferson Creek and $19 \mathrm{mi}$. $\mathrm{S}$ of Beaver, Yukon Flats; $66^{\circ} 05^{\prime} 35^{\prime \prime} \mathrm{N}, 147^{\circ} 09^{\prime} 20^{\prime \prime} \mathrm{W}$; (map 118 ).

Local descriptive name obtained in 1956 by USGS.

Muddy River: stream, flows NW $18 \mathrm{mi}$. to Frederick Sound, $8 \mathrm{mi}$. NE of Petersburg, Coast Mts.; $56^{\circ} 54^{\prime} 10^{\prime \prime} \mathrm{N}, 132^{\circ} 49^{\prime} 05^{\prime \prime} \mathrm{W}$; $B G N$ 1923 ; (map 6). 
Descriptive name given in 1923 by USFS.

Muddy River: stream, in Mount McKinley National Park, flows N $14 \mathrm{mi}$. from Peters Glacier terminus to McKinley River, $6 \mathrm{mi}$. WSW of Wonder Lake, Tanana Low.; $63^{\circ} 25^{\prime} 30^{\prime \prime} \mathrm{N}$, $151^{\circ} 02^{\prime} 30^{\prime \prime}$ W; BGN 1947 (map 88). Var. Nichutalinó, The Great Muddy.

Descriptive name reported in 1913 by Belmore Browne as "The Great Muddy." The present form of the name was given in 1925 by S. R. Capps, USGS; the Indian name is "Nichutalinó."

Muddy River: stream, flows E $25 \mathrm{mi}$. from Lake Minchumina to Birch Creek, $2 \mathrm{mi}$. SW of Chilchukabena Lake, Tanana Low.; 63⒌ $3^{\prime} 10^{\prime \prime}$ $\mathrm{N}, 151^{\circ} 35^{\prime} 50^{\prime \prime} \mathrm{W}$; (map 88).

Local descriptive name reported in 1925 by USGS. Once considered to be the head of the Kantishna River.

Mudflow Greek: stream, heads on Anthracite Ridge, flows SW 3 mi. to Purinton Creek, 36 mi. NE of Palmer, Talkeetna Mts.; 61 ${ }^{\circ} 49^{\prime} 10^{\prime \prime}$ N, 148 07'30' W; BGN 1932; (map 69).

So named by a 1932 USGS field party because of "large mudflow in middle course of stream."

Mud Fork: stream, flows NE $18 \mathrm{mi}$. to Troublesome Creek, $24 \mathrm{mi}$. NW of Livengood, YukonTanana High.; $65^{\circ} 35^{\prime} \mathrm{N}, 149^{\circ} 20^{\prime} \mathrm{W}$; (map 105).

Named by prospectors; reported in 1908 by USGS (Covert and Ellsworth, 1909, pl. 5).

Mud Fork: stream, heads on Dall Mtn., flows NE $32 \mathrm{mi}$. to Hodzana River, $49 \mathrm{mi}$. NW of Beaver, Kokrines-Hodzana High.; $66^{\circ} 42^{\prime} \mathrm{N}$, $148^{\circ} 58^{\prime} \mathrm{W}$; (map 118).

Local name reported in 1909 by Maddren $(1910$, pl. 7), USGS.

Mud Lake: lake, $1 \mathrm{mi}$. long, on Kenai Penin., $26 \mathrm{mi}$. S of Sunrise, Chugach Mts. ; $60^{\circ} 31^{\prime} 50^{\prime \prime}$ iv, $149^{\circ} 32^{\prime} 30^{\prime \prime} \mathrm{W}$; (map 63).

Local name reported in 1952 by USGS.

Mud Lake: lake, $1.4 \mathrm{mi}$. long, $\mathrm{N}$ of Glenn Highway, $12 \mathrm{mi}$. W of Glennallen, Copper River Basin; $62^{\circ} 08^{\prime} \mathrm{N}, 145^{\circ} 56^{\prime} \mathrm{W}$; (map 83).

Local name reported in 1951 by USGS.

Mud Lake: lake, $1.3 \mathrm{mi}$. across, $1 \mathrm{mi}$. W of Little Lake Louise and 4. mi. NW of Glennallen, Copper River Basin; 62 ${ }^{\circ} 19^{\prime} \mathrm{N}, 146^{\circ} 43^{\prime}$ W; (map 83).

Local name reported in 1959 by USGS.

Mud Lake: lake, $0.7 \mathrm{mi}$. long, $14 \mathrm{mi}$. NE of Chalkyitsik, Yukon Flats; $66^{\circ} 50^{\prime} \mathrm{N}, 143^{\circ} 32^{\prime}$ W; (map 120).

Local descriptive name; reported in 1956 by R. G. Foley, USGS.

Mud Lake: lake, $1.3 \mathrm{mi}$. long, $1 \mathrm{mi}$. NE of Khaali Lake and $0.9 \mathrm{mi}$. S of Arctic Village, Brooks Ra.; $68^{\circ} 06^{\prime} 30^{\prime \prime} \mathrm{N}, 145^{\circ} 32^{\prime} 00^{\prime \prime} \mathrm{W}$; (map 136).

Local descriptive name obtained in 1956 by USGS.

Mud Lake: lake, see Flat Horn Lake.

Mud Lake: lake, see Mirror Lake.

Mud Lakes: lakes, at head of Ed Berg Slough, $7 \mathrm{mi}$. SE of Beaver, Yukon Flats; $66^{\circ} 19^{\prime} \mathrm{N}$, $147^{\circ} 00^{\prime} \mathrm{W}$; (map 118).
Local descriptive name obtained in 1956 by USGS.

Mud River: stream, heads in Tlatl Hills at $64^{\circ} 04^{\prime} \mathrm{N}, 156^{\circ} 55^{\prime} \mathrm{W}$, flows SW $100 \mathrm{mi}$. to Innoko River, $52 \mathrm{mi}$. NW of Ophir and 74 mi. S of Nulato, Innoko Low.; $63^{\circ} 40^{\prime} \mathrm{N}$, $157^{\circ} 42^{\prime}$ W; BGN 1965; (map 90). Var. Kluklaklatna River.

Local name published by USGS in 1965: The Indian name "Kluklaklatna" was reported in 1908 by A. G. Maddren, USGS. See Little Mud River.

Mudslide Creek: stream, $0.7 \mathrm{mi}$. long, in Glacier Bay National Monument, flows NW to Lituya Bay $1 \mathrm{mi}$. SW of Crillon Inlet and $84 \mathrm{mi}$. NW of Hoonah, St. Elias Mts.; $58^{\circ} 30^{\prime} 55^{\prime \prime} \mathrm{N}$, $137^{\circ} 39^{\prime} 00^{\prime \prime} \mathrm{W}$; BGN 1959; (map 10).

Local name reported by Mertie (1930, fig. 4), USGS.

Mudslide Creek : stream, see Fall Creek.

Mudyutok River: stream, distributary of Fish River, flows SE $8 \mathrm{mi}$. to Golovnin Lagoon, $37 \mathrm{mi}$. NE of Solomon, Seward Penin. High.; $64^{\circ} 36^{\prime} \mathrm{N}, 163^{\circ} 14^{\prime} \mathrm{W}$; (map 95).

Local name reported about 1940 by USC\&GS and published on Chart 9382.

Mueller Cove: cove, $0.4 \mathrm{mi}$. across, in SE part of Nikolski Bay, on SW coast of Umnak I., Aleutian Is.; $52^{\circ} 56^{\prime} 35^{\prime \prime} \mathrm{N}, 168^{\circ} 52^{\prime} 00^{\prime \prime} \mathrm{W}$; BGN 1940; (map 21). Var. Inner Nikolski Anchorage.

- Named in 1938 by USC\&GS for Karl Mueller, UCS\&GS, a coxswain on a survey party who was killed on May 28, 1938, when his boat struck a rzef at the entrance to the cove. See Rudisell Reef.

Mueller Cove: estuary, extends SE $1.5 \mathrm{mi}$. to W side of Unakwik Inlet, $38 \mathrm{mi}$. NE of Whittier, Chugach Mts.; $60^{\circ} 53^{\prime} 15^{\prime \prime} \mathrm{N}, 147^{\circ} 35^{\prime} 30^{\prime \prime} \mathrm{W}$; (map 63).

Local name reported in 1951 by USGS.

Mueller Mountain: hill, $945 \mathrm{ft}$., $50 \mathrm{mi}$. E of Nulato, Kokrines-Hodzana High.; $64^{\circ} 44^{\prime} \mathrm{N}$, $156^{\circ} 25^{\prime} \mathrm{W}$; (map 97).

Local name reported in 1954 by USGS.

Muerta Island: island, 1,100 ft. across, in Port Real Marina, on NE coast of Baker, I., Alex. Arch.; 55 $25^{\prime} 10^{\prime \prime}$ N, $133^{\circ} 29^{\prime} 15^{\prime \prime}$ W; (map 4). Var. Isla del Muerto, Ysla del Muerta.

Name "Isla del Muerto," meaning "island of the dead," was probably given to this island in 1779 by Francisco Antonio Maurelle. "[Juan] Pantoja in his account of the 1779 exploration of the bay [Bucareli] describes finding a dead male Indian on an island in the Puerto Real Marina * * *" (Wagner, 1937, p. 398).

Muerto, Isla del: island, see Muerta Island.

Muffin Islands: islands, extend $1.2 \mathrm{mi}$. in SW Ernest Sound, $0.4 \mathrm{mi}$. E of Eagle I., Alex Arch.; $55^{\circ} 52^{\prime} 30^{\prime \prime} \mathrm{N}, 132^{\circ} 17^{\prime} 30^{\prime \prime} \mathrm{W}$; (map 4).

Named in 1886 by Lt. Comdr. Snow, USN. Muganolowik: stream, see Melatolik Creek.

Mu-gee-lu Creek: stream, Ikikileruk Greek.

Mugilak Creek: stream, see Ikikileruk Creek.

Mugisitokiwik: locality, on bar between Lopp Lagoon and Chukehi Sea, $12 \mathrm{mi}$. NE of Cape Prince of Wales, at $\mathrm{W}$ end of Seward Penin.,
54 mi. NW of Teller, Kotzebue-Kobuk Low.; $65^{\circ} 44^{\prime} \mathrm{N}, 167^{\circ} 52^{\prime} \mathrm{W}$; (map 111).

Site of an Eskimo village or camp reported about 1940 by USC\&GS and published on Chart 9380 .

Mugum-Nyagha: hill, see Mugum Peak.

Mugum Peak: hill, $370 \mathrm{ft}$., $4 \mathrm{mi}$. $\mathrm{E}$ of Taphook Mtn. and $23 \mathrm{mi}$. SE of Gambell, St. Lawrence I.; $63^{\circ} 34^{\prime} 30^{\prime \prime} \mathrm{N}, 171^{\circ} 09^{\prime} 00^{\prime \prime} \mathrm{W}$; BGN 1951; (map 93). Var. Mount Niivouk, Mount Nyghook No. 1, Mugum-Nyagha, Nairak, Naiwak.

Eskimo name reported in 1944 by Lawrence Kulukhan, of Gambell. Orth, recorded local usage in 1965 as "Naiwak" or "Nairak," meaning "high mound" or "mount."

Muir, Mount: mountain, 7,605 ft., NW of Harriman Fiord, 8 mi. NW of Point Doran and 50 mi. E of Anchorage, Chugach Mts. ; $61^{\circ} 06^{\prime} 30^{\prime \prime}$ N, 148 $22^{\prime} 45^{\prime \prime} \mathrm{W} ; B G N$ 1910; (map 69).

Name reported in 1908 by Grant and Higgins (1910, pl. 2), USGS. Probably named for John Muir, 1838-1914, American naturalist and writer who traveled in Alaska. See Muir Inlet.

Muir Glacier: glacier, in Glacier Bay National Monument, heads about $9 \mathrm{mi}$. S of Mount Harris, trends SE $12 \mathrm{mi}$. to Muir Inlet, $6 \mathrm{mi}$. NW of Westdahl Point and $77 \mathrm{mi}$. NW of Hoonah, St. Elias Mts.; $69^{\circ} 00^{\prime} \mathrm{N}, 136^{\circ} 10^{\prime}$ W; (map 10).

Named about 1880 for John Muir, 18341918, the American naturalist who discovered this glacier on his 1879 trip to Alaska. See Muir Inlet.

Muir Inlet: estuary, in Glacier Bay National Monument, heads in Muir Glacier, extends S $21 \mathrm{mi}$. to Glacier Bay, $51 \mathrm{mi}$. NW of Hoonah, St. Elias Mts.; $58^{\circ} 45^{\prime} \mathrm{N}, 136^{\circ} 05^{\prime} \mathrm{W}$; (map $10)$.

Named in 1883 by USC\&GS for John Muir, 1834-1918, an American naturalist who visited this area in 1890. Born in Scotland, he came to the United States in 1849 and settled in California in 1868. He was a conservationist and crusader for national parks and made extended trips throughout the United States and Alaska.

Muir Island: island, see Sealers Island.

Muir Point: point of land, at mouth of Adams Inlet, on Muir Inlet, in Glacier Bay National Monument, $2 \mathrm{mi}$. SSW of Point George, 55 mi. NW of Hoonah, St. Elias Mts.; $58^{\circ} 49^{\prime} 40^{\prime \prime}$ N, $136^{\circ} 04^{\prime} 35^{\prime \prime}$ W; BGN 1948; (map 10). Var. Cabin Point, Camp Muir, White Mans Point.

Camp Muir was named in 1890 by Reid (1892, p. 21). "On July 1st the George W. Elder cast anchor in Muir Inlet, not far from the glacier, and landed our instruments, tents, personal baggage, and provisions on the eastern shore. We found Professor Muir and Mr. Loomis encamped there $* * *$. This was our base-camp, and, in honor of Professor Muir we named it Camp Muir." The point of land was named for the camp. It was known by the Huna Indians as "White Mans Point," probably because of the tourists who landed there. 
Muisofski Island: island, see Saint Lazaria Islands.

Mukacharni Mountain: mountain, 1,426 ft., 1 mi. W of Eva Mtn. and $8 \mathrm{mi}$. NE of Teller, Seward Penin. High.; $65^{\circ} 21^{\prime} \mathrm{N}, 166^{\circ} 11^{\prime} \mathrm{W}$; (map 111). Var. Muck-A-Charley Mountain. Prospectors' name reported on the 1908 "Map of Seward Peninsula" by Arthur Gibson. This appears to be the feature reported in 1896 as "Muck-A-Charley Mountain" (Jackson, 1896, p. 45).

Mukachiak Greek: stream, flows $\mathrm{N} 4 \mathrm{mi}$. to Noatak River, $2 \mathrm{mi}$. $\mathrm{E}$ of its junc. with Kalluktarik River, $59 \mathrm{mi}$. NE of Noatak, Brooks Ra.; $67^{\circ} 55^{\prime} \mathrm{N}, 160^{\circ} 56^{\prime} \mathrm{W}$; (map 127).

Eskimo name meaning "baby diaper," obtained in 1956 at Noatak by Orth.

Mukhak: locality, near mouth of Kun River, Yukon-Kuskokwim Delta; 61 $1^{\circ} 51^{\prime} \mathrm{N}, 165^{\circ} 37^{\prime}$ W, (map 75).

Reported in 1949 by USC\&GS to be the name of a fish camp, but its location is unverified.

Mukh-lung River: stream, see Muklung River.

Mukialik: locality, on left bank of Yukon River, $49 \mathrm{mi}$. SE of Kwiguk, Yukon-Kuskokwim Delta ; $62^{\circ} 06^{\prime} \mathrm{N}, 163^{\circ} 55^{\prime} \mathrm{W}$; (map 77). Var. Mogtalik.

Eskimo camp name obtained in 1899 by G. R. Putnam, USC\&GS. Published in 1901 on Chart 9370.

Mukluk Creek: stream, flows S $12.4 \mathrm{mi}$. through Nulato to Mukluk Slough, Nulato Hills; $64^{\circ}$ $43^{\prime} \mathrm{N}, 158^{\circ} 06^{\prime} \mathrm{W}$; ( $\left.\operatorname{map} 97\right)$.

Local name reported in 1954 by USGS.

Mukluk Creek: stream, flows $\mathrm{N} 4 \mathrm{mi}$. to Schlitz Creek which flows to Serpentine River, $11 \mathrm{mi}$. $\mathrm{NW}$ of Midnight Mtn. and $53 \mathrm{mi}$. NW of Imuluk Lake, Seward Penin. High.; 65 $52^{\prime} \mathrm{N}$, $164^{\circ} 54^{\prime} \mathrm{W}$; (map 110).

Prospectors' name reported on the 1908 "Map of Seward Peninsula" by Arthur Gibson.

Mukluk Slough: channel, on Yukon River, flows SW $3.2 \mathrm{mi}$. around Nulato I., Nulato Hills; $64^{\circ} 42^{\prime} \mathrm{N}, 158^{\circ} 08^{\prime} \mathrm{W}$; (map 97).

Local name reported in 1954 by USGS.

Mukluktulik River: stream, flows NE $12 \mathrm{mi}$. to Koyuk Inlet, $31 \mathrm{mi}$. NW of Christmas I, Seward Penin. High.; $64^{\circ} 55^{\prime} \mathrm{N}, 161^{\circ} 12^{\prime} \mathrm{W}$; $B G N$ 1910; (map 96). Var. Mukluktuluk River.

Eskimo name reported in 1900 by J. J. Gilbert, USC\&GS.

Mukluktuluk River: stream, see Mukluktulik River.

Muklung Hills: mountains, 2,526 ft., trend SE $14 \mathrm{mi}$., $10 \mathrm{mi}$. E of Marsh Mtn. and $22 \mathrm{mi}$. NE of Dillingham, Kilbuck-Kuskokwim Mtns.; $59^{\circ} 20^{\prime} \mathrm{N}, 158^{\circ} 20^{\prime} \mathrm{W}$; BGN 1937; (map 52).

Local name published by USGS in 1934; named for the Muklung River.

Muklung River: stream, flows S $24 \mathrm{mi}$. to Wood River, $9 \mathrm{mi}$. N of Dillingham, Bristol Bay Low.; $59^{\circ} 10^{\prime} \mathrm{N}, 158^{\circ} 32^{\prime} \mathrm{W}$; BGN 1931; (map 52), Var. Mukh-lung River.

Eskimo name written in 1910 as "Mukhlung" by H. C. Fassett, USBF.
Muknuk River: stream, heads in Kookooligit Mts., flows W $5 \mathrm{mi}$. to Bering Sea, $12 \mathrm{mi}$. SW of Savoonga, St. Lawrence I.; $63^{\circ} 36^{\prime} \mathrm{N}, 170^{\circ}$ $48^{\prime}$ W; BGN 1951; (map 93). Var. Maknak Creek.

Eskimo descriptive name reported in 1965 by Orth as "Maknak," meaning "a drainage." The spelling recommended by the Savoonga village council in 1949, was "Muknuk."

Mukpik, Lake: stream, see Makpik, Lake.

Mukslulik Greek: stream, flows SE $20 \mathrm{mi}$. to Holitna River $4 \mathrm{mi}$. $\mathrm{N}$ of its junc. with Chukowan River, $59 \mathrm{mi}$. SW of Sleetmute, Kilbuck-Kuskokwim Mts. ; $60^{\circ} 54^{\prime} \mathrm{N}, 157^{\circ} 47^{\prime} \mathrm{W}$; BGN 1948; (map 60).

Eskimo name reported in 1945 by USGS to mean "dirty water."

Mukugnuk: locality, "on Agattu I. in Near Is.," Aleutian Is.

Former Aleut village reported as "uninhabited" by Hodge (1907, p. 955), BAE.

Mukuksok Channel: stream, heads at Nazuruk Channel, Kobuk River, flows SE $7 \mathrm{mi}$. to Selawik Lake, $33 \mathrm{mi}$. NW of Selawik, Kotzebue-Kobuk Low. ; $66^{\circ} 35^{\prime}$ N, $161^{\circ} 12^{\prime}$ W; (map 114).

Eskimo name obtained by U.S. Army Corps of Engincers in 1955.

Mukuksok Point: point of land, extends into Selawik Lake, $33 \mathrm{mi}$. W of Selawik, KotzebueKobuk Low.; 66 $35^{\prime} \mathrm{N}, 161^{\circ} 13^{\prime} \mathrm{W}$; (map 114).

Eskimo name obtained by U.S. Army Corps of Engineers in 1955.

Mulchatna: locality, "near Nushagak River," Bristol Bay Low. Var. Malachatna, Molchatna.

Former Eskimo camp or settlement listed as "Molchatna" with a population of 180 by Ivan Petroff in the 1880 Census.

Mulchatna River: stream, heads at Turquoise Lake, flows SW $160 \mathrm{mi}$. to Nushagak River, $65 \mathrm{mi}$. NE of Dillingham, Bristol Bay Low.; $59^{\circ} 40^{\prime} \mathrm{N}, 157^{\circ} 07^{\prime} \mathrm{W}$; (map 52). Var. Little Mulchatna River, Malchatna, Molchatna, Pahls-chat-nok.

Native name reported as "Molchatna" by Ivan Petroff in the 1880 U.S. census; shown as "Pahls-chat-nok" by H. C. Fassett, USBF, on a 1910 manuscript map. "Mulchatn?" reportedly conforms to the local pronunciation. Muldrow Glacier: glacier, in Mount Mcisinley National Park, trends NE $30 \mathrm{mi}$. from foot of Harper Icefall to its 1952 terminus at head of McKinley River, Alaska Ra.; 632 $24^{\prime} \mathrm{N}$, $150^{\circ} 33^{\prime}$ W ; BGN 1947; (map 88). Var. McKinley Glaciex.

Named in 1902 by A. H. Brooks, USGS, for Robert Muldrow, 1864-1946, USGS topographer, who with George Homans Eldridge made a reconnaissance in the Susitna River basin in 1898.

Mule Creek: stream, heads in a lake, flows SE $3 \mathrm{mi}$. to Knik Arm, $7.5 \mathrm{mi}$. N of Anchorage, Cook Inlet Low.; 61 $19^{\prime} 30^{\prime \prime} \mathrm{N}, 149^{\circ} 55^{\prime} 00^{\prime \prime}$ W; (map 69).

Local name reported in 1942 by AMS.
Mule Creek: stream, flows NW $13 \mathrm{mi}$. to Preacher Creek, $32 \mathrm{mi}$. NW of Circle, YukonTanana High.; $65^{\circ} 55^{\prime}$ N, $145^{\circ} 20^{\prime}$ W; (map 104).

Prospectors' name reported in 1952 by USGS topographers.

Mule Creek: stream, flows S $3 \mathrm{mi}$. to Bettles River, $3.8 \mathrm{mi}$. SW of junc. of Phoebe and Robert Creeks and $23 \mathrm{mi}$. WNW of Chandalar, Brooks Ra.; $67^{\circ} 34^{\prime} 45^{\prime \prime} \mathrm{N}, 149^{\circ} 21^{\prime} 00^{\prime \prime} \mathrm{W}$; (map 123). Var. Male Creek.

Name reported in 1931 by Marshall (USGS, 1934, pl. 6).

Mule Creek: stream, see Big Spruce Creek.

Mule Rock: rock, in Tamgas Harbor, on $\mathbf{S}$ coast of Annette I., Alex. Arch., $55^{\circ} 01^{\prime} 20^{\prime \prime} \mathrm{N}$, $131^{\circ} 30^{\prime} 40^{\prime \prime} \mathrm{W}$; (map 3).

Named in 1883 by Lt. Comdr. H. E. Nichols, USN.

Mulgrave, Cape: mountains, see Mulgrave Hills. Mulgrave, Point: mountains, see Mulgrave Hills. Mulgrave, Port: cove, $0.9 \mathrm{mi}$. long, on $\mathbf{S}$ end of Khantaak I., N of Graveyard Cove, 1.8 mi. NW of Yakutat, Malaspina Coastal Plain; $59^{\circ} 33^{\prime} 45^{\prime \prime}$ N, $139^{\circ} 46^{\prime} 40^{\prime \prime}$ W; (map 46). Var. Foggy Harbor, Rurik Harbor.

Named in 1787 by Capt. George Dixon, RN, (Vancouver, 1798, v. 3, p. 170) for Constantine John Phipps, the Baron Mulgrave, an English Arctic explorer. The cove, the harbor, and adjacent waters were called "Rurik Harbor" by Capt. C. V. Kromchenko in 1823 (U.S. Coast and Geodetic Survey, 1883, p. 208) presumably for the brig of the Russian American Company by this name. Capt. James Colnett, RN, called it "Foggy Harbor" in 1788 (de Laguna and others, 1964, p. 20). See Phipps Peninsula.

Mulgrave Hills: mountains, $1,800 \mathrm{ft}$., extend $\mathrm{N}$ $37 \mathrm{mi}$. between Noatak and Wulik Rivers, Arctic Slope; $67^{\circ} 42^{\prime} \mathrm{N}, 163^{\circ} 24^{\prime} \mathrm{W}$; $B G N$ 1962; (map 128). Var. Cape Mulgrave, Mulgrave Range, Mulgrove Hills, Point Mulgrave.

Named on July 31,1826 , by Capt. F. W. Beechey, $\mathrm{RN}$; derived from name given on August 14, 1778, by Capt. James Cook, RN, who wrote $(1785$, p. 453$)$ "The coast here forms a point, named Point Mulgrave * * *." Beechey (1831, p. 262) observed "a low range of hills terminating about four miles from the sea, which must be the Cape [sic] Mulgrave of Capt. Cook, who navigated this part of the coast at too great a distance to sec the land in front of the hills which *** after passing the Mulgrave Range, forms an extensive plain ***." Beechey's chart shows Mulgrave Hills. Rev. Stuck (1920, p. 89) says that they were named for Lord Mulgrave who was "the Captain Constantine Phipps who made a noted voyage to the North Pole in 1772 and reached a latitude of $80^{\circ} 48^{\prime}$ off the coast of Spitzbergen ***."

Mulgrave Island: island, "at $\mathrm{N}$ point of Montague Island, where none exists."

Name given by Capt. Nathaniel Portlock on May 1, 1787. See Wagner (1937, p. 474). 
Mulgrave Range: mountains, see Mulgrave Hills.

Mulgrove Hills: mountains, see Mulgrave Hills. Mulik Hills: hills, $800 \mathrm{ft}$, in Igichuk Hills, extend $\mathrm{N} 5 \mathrm{mi}$. from junc. of Noatak River and Hugo Creek, $18 \mathrm{mi}$. NE of Kotzebue, Brooks Ra.; $67^{\circ} 10^{\prime} \mathrm{N}, 162^{\circ} 19^{\prime} \mathrm{W}$; (map 128). Var, Erecheck Mountain, Igachorok Mountain, Igachoruk Mountain, Twin Mountain.

Eskimo name obtained by U.S. Army Corps of Engineers in 1954.

Mullen Slough: stream, anabranch, flows SW 2 $\mathrm{mi}$, to Chena River, $20 \mathrm{mi}$. E of Fairbanks, Tanana Low.; $64^{\circ} 49^{\prime} 50^{\prime \prime} \mathrm{N}, 147^{\circ} 02^{\prime} 30^{\prime \prime} \mathrm{W}$; (map 100).

Local name reported in 1950 by USGS topographers.

Muller Creek: stream, flows NW $4.3 \mathrm{mi}$. to St. Joe Creek, $4.5 \mathrm{mi}$. SE of Blackburn I. in Yukon River, $58 \mathrm{mi}$. SE of Unalakleet, Innoko Low.; $63^{\circ} 19^{\prime} 30^{\prime \prime} \mathrm{N}, 159^{\circ} 21^{\prime} 00^{\prime \prime} \mathrm{W}$; (map 91).

Local name reported in 1949 by USC\&GS.

Mulligan Creek: stream, flows SW $4.2 \mathrm{mi}$. to Eldorado River, $16 \mathrm{mi}$. NW of Solomon, Seward Penin. High.; 64. $41^{\prime} \mathrm{N}, 164^{\circ} 54^{\prime} \mathrm{W}$; (map 95).

Prospectors' name reported in 1900 by E. C. Barnard (in Brooks, 1901, pl. 17), USGS.

Mull Lake: lake, $1.7 \mathrm{mi}$. long, on Kenai Penin., one of the Bedlam Lakes, at head of Bedlam Creek, $8 \mathrm{mi}$. S of Point Possession and 25 mi. SW of Anchorage, Cook Inlet Low.; 60 ${ }^{\circ} 55^{\prime}$ $\mathrm{N}, 150^{\circ} 20^{\prime} \mathrm{W}$; (map 62).

Local name reported in 1961 by USGS.

Mumayluk Creek: stream, see Mamelak Creek.

Mumayluk Mountain: hill, see Mamelak Mountain.

Mumik Lake: lake, $3 \mathrm{mi}$. long, $3 \mathrm{mi}$. E of Tunusiktok Lake, $25 \mathrm{mi}$. SE of Point Lay, Arctic Plain; $69^{\circ} 35^{\prime} \mathrm{N}, 162^{\circ} 03^{\prime} \mathrm{W}$; (map 145). Var. Mumiq.

Eskimo name "Mumiq", meaning "drumstick" obtained at Point Lay in 1956 by Orth.

Mumiq Lake: lake, see Mumik Lake.

Mummy Bay: estuary, trends SW $3.5 \mathrm{mi}$. to Knight I. Passage, at $S$ end of Knight I., $10 \mathrm{mi}$. SE of Chenega, Chugach Mts.; 60 $12^{\prime}$ $30^{\prime \prime} \mathrm{N}, 147^{\circ} 51^{\prime} 15^{\prime \prime} \mathrm{W}$; (map 63).

Local name reported in 1905 by U.S. Grant, USGS.

Mummy Island: island, in Knight Island Passage, extends N-S $1.5 \mathrm{mi}$., off $W$ coast of Knight I., $5.5 \mathrm{mi}$. E of Chenega, Chugach Mts.; $60^{\circ} 17^{\prime} 00^{\prime \prime} \mathrm{N}, 147^{\circ} 54^{\prime} 30^{\prime \prime} \mathrm{W}$; (map 63).

Local name published in 1908 by USC\&GS.

Mummy Island: island, $1 \mathrm{mi}$. long, at $\mathrm{S}$ entrance to Orca Inlet, $10 \mathrm{mi}$. SW of Cordova, Chugach Mts.; $60^{\circ} 28^{\prime} \mathrm{N}, 146^{\circ} 00^{\prime} \mathrm{W}$; (map $64)$.

Local name reported by H. P. Ritter, USC\&GS, in 1899.

Mumsuk: locality, see Akumsuk.

Mumtrahahamut: locality, see Mumtrak.

Mumtrahamiut: locality, see Mumtrak.
Mumtrahamut: locality, see Mumtrak.

Mumtrahamute: locality, see Mumtrak.

Mumtrak: locality, on Goodnews Bay at mouth of Goodnews River, $0.2 \mathrm{mi}$. SE of Goodnews, Kilbuck-Kuskokwim Mts.; 59 $07^{\prime} \mathrm{N}, 161^{\circ}$ 35' W; (map 53). Var. Mumtrahahamut, Mumtrahamiut, Mumtrahamut, Mumtrahamute, Mumtrakmut.

This Eskimo village was first mentioned by Ivan Petroff in the 10th Census in 1880 as "Mumtrahamute" or "Mumtrah people." Its population in 1880 was 162 ; it was the same in 1890. It was abandoned about 1930 after the people moved to Goodnews.

Mumtrak: village, see Goodnews.

Mumtrak Creek: stream, see South Fork Goodnews River.

Mumtrak Hill: hill, $773 \mathrm{ft}$., $1.5 \mathrm{mi}$. NE of Goodnews, $3 \mathrm{mi}$. SE of Kiglapak Mts., KilbuckKuskokwim Mts. ; $59^{\circ} 08^{\prime} 30^{\prime \prime} \mathrm{N}, 161^{\circ} 32^{\prime} 30^{\prime \prime}$ W; (map 53). Var. Boots Mountain, Kamguvluagvik.

Named in 1914 by USC\&GS for the Eskimo village of Mumtrak at its base. The name was published in 1915 on Chart 9103. The Eskimo name of the hill, "Kamguvluagvik," was obtained at Goodnews about 1951, by J. M. Hoare, USGS.

Mumtrakmut: locality, see Mumtrak.

Mumtreckhlagamute: town, see Bethel.

Mumtrekhlagamute: town, see Bethel.

Mumtrekkhlogamute: town, see Bethel.

Mumtrelega: town, see Bethel.

Mumtrelegamut: town, see Bethel.

Muncaster Creek: stream, flows $2.5 \mathrm{mi}$. S to a point $0.2 \mathrm{mi}$. $\mathrm{N}$ of Klehini River, $4.5 \mathrm{mi}$. W of Wells and $26 \mathrm{mi}$. W of Skagway; St. Elias Mts.; $59^{\circ} 25^{\prime} 20^{\prime \prime} \mathrm{N}, 136^{\circ} 03^{\prime} 20^{\prime \prime} \mathrm{W}$; (map 45).

Local name obtained by USGS field personnel and published on Federal maps since 1950.

Munday Creek: stream, heads in glacier $1.4 \mathrm{mi}$. $\mathrm{S}$ of Munday Peak, flows $3.5 \mathrm{mi}$. to Gulf of Alaska, $3.8 \mathrm{mi}$. SE of Umbrella Reef and 84 mi. WNW of Yakutat, St. Elias Mts. ; $60^{\circ} 00^{\prime}$ $50^{\prime \prime} \mathrm{N}, 141^{\circ} 56^{\prime} 20^{\prime \prime} \mathrm{W}$; (map 65).

Name derived from Munday Peak, published in 1951 by USGS.

Munday Peak: peak, 4,800 ft., in Robinson Mts., $4.7 \mathrm{mi}$. NE of Umbrella Reef on Gulf of Alaska and $86 \mathrm{mi}$. NW of Yakutat, Chugach Mts.; $60^{\circ} 04^{\prime} 30^{\prime \prime} \mathrm{N}, 141^{\circ} 57^{\prime} 10^{\prime \prime} \mathrm{W}$; (map 65).

Named by J. L. McPherson, Deputy U.S. Mineral Surveyor, for Charles F. Munday, one of the first to locate petroleum lands in the Yakataga region about 1897 . The name was reported in 1903 by G. C. Martin, USGS.

Mundcho Lake: lake, $0.8 \mathrm{mi}$. long, $3.5 \mathrm{mi}$. SE of Tetlin, SW of Titus Paul Hill, $21 \mathrm{mi}$. W of Northway Junction, Alaska Ra.; 63 ${ }^{\circ} 06^{\prime} \mathrm{N}$, $142^{\circ} 26^{\prime} \mathrm{W}$; (map 85 ).

Indian name reported by USGS in 1964 .

Mundthag Lake: lake, $1.4 \mathrm{mi}$. long, at $\mathrm{N}$ end of Black Hills, $12 \mathrm{mi}$. $\mathrm{S}$ of Northway, Alaska Ra.; $62^{\circ} 47^{\prime} \mathrm{N}, 141^{\circ} 58^{\prime} \mathrm{W}$; BGN 1962; (map 84). Var. Long Lake.
Indian name reported by USGS in 1955.

Munina: village, see Ninilchik.

Munook Creek: stream, see Minook Greek.

Muñoz, Cabe de: point of land, see Muzon, Cape.

Munoz, Point: point of land, on SW coast of Khantaak I., $2.2 \mathrm{mi}$. NE of Point Carrew and $3.5 \mathrm{mi}$. NW of Yakutat, Malaspina Coastal Plain: $59^{\circ} 35^{\prime} 10^{\prime \prime} \mathrm{N}, 139^{\circ} 48^{\prime} 10^{\prime \prime} \mathrm{W}$; (map 46). Var. Mys JW, Southwest Point.

Named in 1791 by Capt. Alessandro Malaspina, probably for a Spanish naval officer named Muñoz Goosens (Wagner, 1937, p. 399). Capt. Tebenkov (1852, map 7), IRN, called the point "Mys JW," which was interpreted by Baker (1906, p. 449) to mean "Southwest Point."

Muñoz Goosens, Cabo de: point of land, see Muzon, Cape.

Muñoz Gorens, Gabo de: point of land, see Muzon, Gape.

Munro Glacier: glacier, see Boundary Glacier.

Munroke: locality, see Monrak.

Munroke River: stream, see Monrak River.

Mun-sat-lee Ridge: ridge, see Munsatli Ridge.

Munsatli Ridge: ridge, elev. $1,900 \mathrm{ft}$., extends NE 18 mi. from the Telida Mts., between Fish Creek and North Fork Kuskokwim River, Tanana Low., $63^{\circ} 45^{\prime} \mathrm{N}, 153^{\circ} 00^{\prime} \mathrm{W}$; (map 89). Var. Mun-sat-lee Ridge.

Tanana Indian name obtained in 1899 by Lt. J. S. Herron, USA, who wrote it "Munsat-lee."

Munson Creek: stream, flows NW $17 \mathrm{mi}$. to East Fork Chena River, $56 \mathrm{mi}$. N of Big Delta, Yukon-Tanana High.; $64^{\circ} 57^{\prime} \mathrm{N}, 146^{\circ} 04^{\prime} \mathrm{W}$; (map 101).

Named by prospectors; reported in 1909 by T. W. Bagley (in Capps, 1912, pl. 1), USGS.

Munson Creek: stream, flows NE $8 \mathrm{mi}$, joins Lawson Creek to form Clums Fork Birch Creek, $64 \mathrm{mi}$. SW of Gircle, Yukon-Tanana High.; $65^{\circ} 07^{\prime} 10^{\prime \prime} \mathrm{N}, 145^{\circ} 30^{\prime} 00^{\prime \prime} \mathrm{W}$; (map 104).

Named by prospectors; reported in 1911 by USGS (Prindle, 1913, pl. 1).

Munson Island: island, $3.4 \mathrm{mi}$. long, in offshore islands of Yukon Delta, between Kwemeluk and Kwikluak Passes, $17 \mathrm{mi}$. SW of Kwiguk, Yukon-Kuskokwim Delta; $62^{\circ} 33^{\prime} \mathrm{N}$, $165^{\circ} 55^{\prime} \mathrm{W}$; (map 77).

Local name obtained in 1948 by USC\&GS. Munsons: settlement, see Aurora Lodge.

Munther Creek: stream, flows SE $3.2 \mathrm{mi}$. to join Little East Fork to form Little East Fork George River, $5 \mathrm{mi}$. W of Granite Mtn., $38 \mathrm{mi}$. SE of Flat, Kilbuck-Kuskokwim Mts.; $62^{\circ} 18^{\prime} 20^{\prime \prime} \mathrm{N}, 156^{\circ} 53^{\prime} 00^{\prime \prime} \mathrm{W}$; (map 79).

Prospectors' name obtained in 1952 by USGS topographers.

Munto: village, see Minto.

Mupsorut Hill: hill, see Mapsorak Hill.

Mup-so-rut Hill: hill, see Mapsorak Mountain. Mupsorut Lagoon: lagoon, see Mapsorak Lagoon.

Muravief, Mount: mountain, 3,330 ft., $19 \mathrm{mi}$. $\mathrm{N}$ of village of Port Alexander, on $\mathrm{S}$ central 
Baranof I., Alex. Arch.; 56 $31^{\prime} 15^{\prime \prime}$ N, $134^{\circ}-$ 45'20' W; BGN 1933; (map 5). Var. Muravief Peak.

Named in 1933 by USGS for Matrei Ivanovich Muraviev, Fourth Russian Governor of Alaska, 1820-1825.

Muravief Peak: mountain, see Muravief, Mount. Murchison, Mount: mountain, 6,263 ft., on S edge of Sheridan Glacier, $35 \mathrm{mi}$. NW of Katalla, Chugach Mts. ; $60^{\circ} 37^{\prime} \mathrm{N}, 145^{\circ} 07^{\prime} \mathrm{W}$; (map 64).

Local name published in 1951 by USGS.

Murder Cove: bay, $0.7 \mathrm{mi}$ across, on $\mathrm{S}$ tip of Admiralty I., $11 \mathrm{mi}$. SE of Baranof, Alex. Arch.; 57 $01^{\prime} 30^{\prime \prime} \mathrm{N}, 134^{\circ} 28^{\prime} 30^{\prime \prime} \mathrm{W}$; (map 9).

Named presumably by Comdr. R. W. Meade, USN, in 1869 because "traders occasionally anchor here and one small party, while asleep on the beach, were murdered by natives, their boat rifled and bodies left to be destroyed by wild animals." (U.S. Coast and Geodetic Survey, 1883, p. 131).

Murder Point: point of land, at $\mathrm{W}$ entrance to Massacre Bay, on SE coast of Attu I., Aleu$\operatorname{tian}$ Is.; $52^{\circ} 47^{\prime} 40^{\prime \prime} \mathrm{N}, 173^{\circ} 10^{\prime} 45^{\prime \prime} \mathrm{E}$; (map 13). Var. Akachaga Head, Krasni Point, Krasnoi Point, Little Mike Point.

Name published in 1943 by AMS and shown as "Murder (Little Mike) Point" in the 1944 Aleutian Coast Pilot (p. 133); originally named by the Russians "Krasnoy Mys" meaning "red cape" (Sarichev, 1826, map 13). See Krasni Point.

Murdo Island: island, in Port Chester, on W coast of Annette I., Alex. Arch.; 55 $09^{\prime} \mathrm{N}$, $131^{\circ} 35^{\prime} \mathrm{W}$; (map 3 ).

Named in 1883 by Lt. Comdr. H. E. Nichols, USN.

Murie, Mount: mountain, see Tugak Peak.

Murie Islets: islands, $1 \mathrm{mi}$. long, NW of Simeonof I., in Shumagin Is., Aleutian Ra.; $54^{\circ} 54^{\prime} 30^{\prime \prime}$ $\mathrm{N}, 159^{\circ} 20^{\prime} 00^{\prime \prime} \mathrm{W}$; BGN 1964; (map 26).

Named for Olaus J. Murie, 1889-1963, ecologist and biologist.

Murk Bay: bay, $1 \mathrm{mi}$. across, on $\mathrm{N}$ side of Graves Harbor, in Glacier Bay National Monument, $49 \mathrm{mi}$. NW of Hoonah, St. Elias Mts.; $58^{\circ} 17^{\prime}$ $15^{\prime \prime} \mathrm{N}, 136^{\circ} 44^{\prime} 45^{\prime \prime} \mathrm{W}$; BGN 1930; (map 10).

Named by USC\&GS in 1926 and published in 1929.

Murphy Bay: bay, $3 \mathrm{mi}$. across, between Southwest Cape and Iwoonut Point, SW coast of St. Lawrence I.; $63^{\circ} 20^{\prime} \mathrm{N}, 171^{\circ} 30^{\prime} \mathrm{W} ; B G N$ 1954; (map 93).

Name published by USC\&GS in 1921.

Murphy Cove: cove, $0.8 \mathrm{mi}$. long, in Glacier Bay National Monument, on S side of Graves Harbor, $2 \mathrm{mi}$. E of Libby I. and $48 \mathrm{mi}$. NW of Hoonah, St. Elias Mts.; $58^{\circ} 16^{\prime} 30^{\prime \prime} \mathrm{N}$, $136^{\circ} 43^{\prime} 15^{\prime \prime} \mathrm{W}$.

Name published by USC\&GS in 1901 Alaska Coast Pilot (p. 212).

Murphy Creek: stream, heads $\mathrm{N}$ of Murphy Dome, flows NE $12 \mathrm{mi}$. to Chatanika River, $18 \mathrm{mi}$. NW of Fairbanks, Yukon-Tanana High.; $65^{\circ} 02^{\prime} 20^{\prime \prime} \mathrm{N}, 148^{\circ} 05^{\prime} 30^{\prime \prime} \mathrm{W}$; (map 105).
Named by prospectors; reported in 1908 by USGS. (Covert and Ellsworth, 1909, pl. 2). Murphy Creek: stream, flows S to Stoney Creek which flows to Noxapaga River, about $25 \mathrm{mi}$. W of Imuruk Lake, Seward Penin. High.; (map 110).

Prospectors' name shown on a map of Cape Nome gold fields by David Fox, Jr., dated 1901. This stream cannot be precisely located on current maps.

Murphy Dome: mountain, 2,930 ft., $20 \mathrm{mi}$. NW of Fairbanks, Yukon-Tanana High.; 64 ${ }^{\circ} 57^{\prime}$ N, $148^{\circ} 21^{\prime}$ W; (map 100).

Local name published in 1949 by USGS.

Murphys Mint Creek: stream, flows SE to Cripple River, about $24 \mathrm{mi}$. NW of Nome, Seward Penin. High.; (map 94).

Prospectors' name reported on the 1900 "Map of Nome Peninsula" by J. M. Davidson and B. D. Blakeslee; this feature has not been positively identified.

Murray, Cape: point of land, see Chacon, Cape. Murray, Cape: point of land, see Nunez Point. Murray Creek: stream, flows NW $3.5 \mathrm{mi}$. to Otter Creek, 6 mi. E of Flat, Kilbuck-Kuskokwim Mts.; 62 $28^{\prime} \mathrm{N}, 157^{\circ} 48^{\prime} \mathrm{W}$; (map 79).

Prospectors' name obtained in 1952 by USGS topographers.

Murray Creek: stream, flows SW $1 \mathrm{mi}$. to Dome Greek, $13 \mathrm{mi}$. N of Fairbanks, Yukon-Tanana High.; $65^{\circ} 02^{\prime} \mathrm{N}, 147^{\circ} 36^{\prime} \mathrm{W}$; (map 105).

Named by prospectors; published in 1908 by USGS.

Murray Gulch: ravine, extends N 2 mi. to New York Creek $1.5 \mathrm{mi}$. N of its junc. with Kuskokwim River, $1 \mathrm{mi}$. NW of Little Mountain Village, Kilbuck-Kuskokwim Mts.; $61^{\circ} 34^{\prime} 15^{\prime \prime}$ N, 158 $35^{\prime} 00^{\prime \prime} \mathrm{W} ; B G N$ 1948; (map 72).

Prospectors' name reported in 1914 by Maddren (in Brooks and others, 1915, p. 353), USGS.

Murray Island: island, $1.5 \mathrm{mi}$. long, in Tanana River, at $W$ end of Harper Bend, $17 \mathrm{mi}$. SE of Tanana, Nowitna Low.; $65^{\circ} 00^{\prime} \mathrm{N}, 151^{\circ}$ $40^{\prime} \mathrm{W}$; (map 106).

Riverboat pilots' name shown on a 1940 Navigation Chart, Tanana-Yukon Rivers.

Murray Lake: lake, $3 \mathrm{mi}$. long, on Alaska Penin., in course of American Creek, SE of Hammersly Lake, $34 \mathrm{mi}$. $\mathrm{N}$ of Mount Katmai, Alcutian Ra.; $58^{\circ} 47^{\prime} \mathrm{N}, 155^{\circ} 04^{\prime} \mathrm{W}$; (map 42).

Local name reported in 1951 by USGS.

Murre Point: point of land, see Inner Right Cape.

Murre Rocks: rocks, off SE coast of Big Koniuji I., in Shumagin Is., Aleutian Ra.; $55^{\circ} 05^{\prime} 30^{\prime \prime}$ N, $159^{\circ} 30^{\prime} 00^{\prime \prime} \mathrm{W}$; (map 27$)$.

Named in July 1874 by W. H. Dall, USC\&GS, "because of the large number of these birds in the vicinity." This probably pertains to the North Pacific Murre (Uria aalge inornata).

Musatchie Nose: point of land, see Chacon, Cape.

Muscle Cove: bay, see Agamgik Bay.

Muse Island: island, $0.4 \mathrm{mi}$. long, in Gambier Bay, on $\mathbf{E}$ coast of Admiralty $\mathrm{Y}$., $0.8 \mathrm{mi}$. NW of Church Point and $60 \mathrm{mi}$. NW of Sitka, Alex. Arch.; $57^{\circ} 27^{\prime} 25^{\prime \prime} \mathrm{N}, 133^{\circ} 57^{\prime} 10^{\prime \prime} \mathrm{W}$; (map 8).

Named in 1889 by Lt. Comdr. H. B. Mansfield, USN; published in 1892 by USC\&GS.

Mushevik Point: bluff, elev. $3 \mathrm{ft}$, at E, or upstream end, of Lower Lagoon on Naknek River, on Alaska Penin., $15 \mathrm{mi}$. SE of Naknek, Bristol Bay Low.; $58^{\circ} 40^{\prime} \mathrm{N}, 156^{\circ} 37^{\prime} \mathrm{W}$; (map 41).

Eskimo name reported in 1952 by USGS.

Mush Lake: lake, $1.3 \mathrm{mi}$. long, between South and East Arms Uganik Bay, on $\mathrm{N}$ coast of Kodiak I.; $57^{\circ} 41^{\prime} \mathrm{N}, 153^{\circ} 27^{\prime} \mathrm{W}$; (map 34).

Local name reported in 1954 by USGS.

Mushroom Island: island, $0.5 \mathrm{mi}$. across, in Sukkwan Strait, $0.6 \mathrm{mi}$. NW of Hydaburg, on W coast of Prince of Wales I., Alex. Arch.; $55^{\circ} 12^{\prime} 40^{\prime \prime} \mathrm{N}, 132^{\circ} 50^{\prime} 45^{\prime \prime} \mathrm{W}$; (map 4).

Local name published in 1965 by USC\&GS.

Mushroom Islets: islands, group of 5 , at entrance to Iniskin Bay, $20 \mathrm{mi}$. N of Augustine I., Aleutian Ra., $59^{\circ} 38^{\prime} 35^{\prime \prime} \mathrm{N}, 153^{\circ} 26^{\prime} 30^{\prime \prime}$ W; BGN 1916; (map 51).

Descriptive name published in 1914 on USC\&GS Chart 3421.

Mushroom Reef: reef, on W coast of Kodiak I., $13 \mathrm{mi}$. NW of Ayakulik and $20 \mathrm{mi}$. SW of Karluk; $57^{\circ} 20^{\prime} 00^{\prime \prime} \mathrm{N}, 154^{\circ} 47^{\prime} 12^{\prime \prime} \mathrm{W}$; BGN 1931; (map 35).

Named by USC\&GS in 1929 "because of the mushroom shape of the reef."

Mushukhli, Ostrov: island, see Fire Island.

Mushukli Island: island, see Fire Island.

Muskeg: locality, on The Alaska RR., $20 \mathrm{mi}$. W of Fairbanks, Yukon-Tanana High.; 64․ $49^{\prime} \mathrm{N}$, $148^{\circ} 28^{\prime} \mathrm{W}$; (map 100).

This is the name of a former railroad station reported on a timetable in 1922 . The name is derived from a Chippewa word meaning "grassy swamp" and describes the character of the Goldstream Creek valley.

Muskeg Creek: stream, heads in lake, flows NW $22 \mathrm{mi}$. to Stony River $10 \mathrm{mi}$. SE of its junc. with Kuskokwin River, 26 mi. E of Sleetmute, Stony River Low. ; $61^{\circ} 39^{\prime} 40^{\prime \prime}$ N, $156^{\circ} 23^{\prime} 35^{\prime \prime}$ W; (map 72).

Local name reported in 1914 by R. H. Sargent (in Smith, P. S., 1917, pl. 5), USGS.

Muskellunge Creek: stream, flows NW $10 \mathrm{mi}$. to Noxapaga River, $17 \mathrm{mi}$. W of Imuruk Lake, Seward Penin. High.; $65^{\circ} 37^{\prime} \mathrm{N}, 163^{\circ} 52^{\prime} \mathrm{W}$; $B G N$ 1952; (map 110).

Reported in 1950 by D. M. Hopkins, USGS; so named because "the creek abounds with muskellunge, a large game fish."

Muskomee Bay: bay, extends E $1.8 \mathrm{mi}$. off Raspberry Strait on SW coast of Afognak I., $13 \mathrm{mi}$. NW of Afognak, Kodiak I.; $58^{\circ} 06^{\prime} 20^{\prime \prime} \mathrm{N}$, $153^{\circ} 04^{\prime} 00^{\prime \prime} \mathrm{W}$; (map 43).

Local name reported in 1952 by USGS.

Muskrat Creek: stream, flows NW $9 \mathrm{mi}$. to Basket Creek $8.2 \mathrm{mi}$. SE of its junc. with Holitna River, 15 mi. SE of Sleetmute, Stony River Low.; $61^{\circ} 36^{\prime} 00^{\prime \prime} \mathrm{N}, 156^{\circ} 45^{\prime} 20^{\prime \prime} \mathrm{W}$; (map 72).

Local name obtained in 1952 by USGS. 
Muskrat Lake: lake, $0.6 \mathrm{mi}$. long, on Kenai Penin., $2.6 \mathrm{mi}$. SW of Moose Lake and $34 \mathrm{mi}$. NE of Kenai, Cook Inlet Low.; $60^{\circ} 42^{\prime} 40^{\prime \prime} \cdot \mathrm{N}$, $150^{\circ} 22^{\prime} 25^{\prime \prime} \mathrm{W}$; (map 62).

Named about 1963 by officials of Kenai National Moose Range for administrative purposes.

Muskrat Lake: lake, $1.2 \mathrm{mi}$. long, in course of Dora Creek 2 mi. $\mathrm{N}$ of that stream's junc. with Chitina River and $30 \mathrm{mi}$. SW of McCarthy, Copper River Basin; 61 $24^{\prime} 45^{\prime \prime}$ N, $143^{\circ} 51^{\prime}$ 00" W; (map 67).

Local name obtained by USGS and published on maps since 1954.

Muskwa Village: locality, on Kenai Penin. along Seward Highway, $21 \mathrm{mi}$. N of Seward, Chugach Mts.; $60^{\circ} 24^{\prime} 15^{\prime \prime} \mathrm{N}, 149^{\circ} 21^{\prime} 30^{\prime \prime} \mathrm{W}$; (map 63).

Recent USGS maps indicate a site with five buildings.

Mussel Cove: bay, see Agamgik Bay.

Mussel Point: point of land, on E shore of Redfish Bay, $9.8 \mathrm{mi}$. NW of village of Port Alexander, on $S$ coast of Baranof I., Alex. Arch.; $56^{\circ} 19^{\prime} 35^{\prime \prime} \mathrm{N}, 134^{\circ} 51^{\prime} 35^{\prime \prime} \mathrm{W}$; (map 5).

Named commander of USBF steamer $\mathrm{Al}$ batros in 1897 by Lt. Comdr. J. F. Moser, USN.

Mussel Point: point of land, see Fern Point.

Mustang Peak: peak, 6,720 ft., $0.8 \mathrm{mi}$. SE of Dike Mtn. and $25 \mathrm{mi}$. N of Juneau, Coast Mts.; $58^{\circ} 38^{\prime} 45^{\prime \prime} \mathrm{N}, 134^{\circ} 34^{\prime} 40^{\prime \prime} \mathrm{W}$; $B G N$ 1965; (map 11). Var. Jan Peak.

Named in 1964 by members of the Juneau Icefield Research Program.

Mutaktuk Creek: stream, flows NW $7.5 \mathrm{mi}$. to Chukchi Sea, E of Agiak Lagoon, $37 \mathrm{mi}$. NW of Mount Kelly, Arctic Slope; 68 $55^{\prime} \mathrm{N}$, $164^{\circ} 25^{\prime} \mathrm{W}$; (map 130). Var. Punuk Creek.

Eskimo name reported to mean "no parka" by USGS (Chapman and Sable, 1960, p. 54).

Muth Glacier: glacier, trends SW $1.5 \mathrm{mi}$. to its terminus at head of stream which drains into Coghill Lake, Chugach Mts.; $61^{\circ} 06^{\prime} 30^{\prime \prime} \mathrm{N}$, $147^{\circ} 14^{\prime} 15^{\prime \prime} \mathrm{W}$; (map 69).

Named in 1908 by U. S. Grant and D. F. Higgins, USGS.

Mutnaia Gulch: ravine, on Kenai Penin., trends W $0.5 \mathrm{mi}$. along course of Travers Creek to NW entrance to Kachemak Bay, $11 \mathrm{mi}$. NW of Homer, Cook Inlet Low.; 59 $43^{\prime} 40^{\prime \prime} \mathrm{N}$, $151^{\circ} 50^{\prime} 00^{\prime \prime} \mathrm{W}$; (map 50).

Named "Mutnaya", meaning "muddy", about 1840 by I. G. Wosnesenski.

Mutt Cove: cove, $0.6 \mathrm{mi}$. across, $\mathrm{E}$ of Jeff Cove, on $\mathrm{S}$ coast of Kiska I., Aleutian Is.; $51^{\circ} 56^{\prime}$ N, $177^{\circ} 30^{\prime} \mathbf{E}$; (map 14).

An arbitrary name beginning with " $M$ " to correspond to " $\mathrm{M}$ " grid used by the U.S. Army for tactical purposes during World War II; published on a 1943 Army map.

Mutton Cove: cove, $0.3 \mathrm{mi}$. across, on $\mathrm{N}$ shore of Chernofski Harbor, SW coast of Unalaska I., Alcutian Is.; $53^{\circ} 24^{\prime} 15^{\prime \prime} \mathrm{N}, 167^{\circ} 31^{\prime} 00^{\prime \prime} \mathrm{W}$; BGN 1940; (map 23). Var. East Cove.

Descriptive name given in 1937 by USC\&GS, because, "Wool and mutton were shipped out of this locality by the sheep ranchmen, the only inhabitants." The field party first called it "East Cove."

Muzon, Cape: point of land, SE tip of Dall I., Alex. Arch.; $54^{\circ} 39^{\prime} 50^{\prime \prime}$ N, $132^{\circ} 41^{\prime} 30^{\prime \prime} \mathrm{W}$; (map 1). Var. Cabo de Muñoz, Cabo de Muñoz Goosens, Cabo de Muñoz Gorens, Cape Caiganee, Cape Irving, Cape Kaygany, Cape Pitt, Kaigahnee, Kaiganee, Kaigani, Kygane, Mys Kaygany.

Baker (1960, p. 450) says "It is highly probable that this is Cabo de Muñoz or Muñoz Goosens or Muñoz Gorens of [Don Jacinto] Caamaño, in 1792, and that [G.] Vancouver, in copying from Caamaño, transposed two letters, making "Muzon." In this form it has come into general use and is well established." In 1787 this point was called "Cape Pitt" by Capt. George Dixon and "Cape Irving" by Capt. William Douglas. The native name was published in Russian as "M[ys] Kaygany (Muzon)," i.e. "Cape Kaygany (Muzon)," by Capt. Tebenkov (1852, map 9).

Myak Rock: rock, $471 \mathrm{ft}$., just $\mathrm{N}$ of Ananongutka, $1 \mathrm{mi}$. E of Suskaralogh Point, on NW coast of Saint George I., in Pribilof Is. ; $56^{\circ}$ $36^{\prime} 40^{\prime \prime} \mathrm{N}, 169^{\circ} 43^{\prime} 10^{\prime \prime} \mathrm{W}$; (map 38).

Aleut name reported by Putnam (1903, p. 1015), USC\&GS, meaning " 'pile of rock or landmark' * * * remarkable crag 471 feet in elevation, standing in front of a bluff [Ananongutka] and visible along almost the entire north shore of the isiand. The same word [Myak] is applied by the natives to the numerous cairns or piles of rocks, erected by them over the island, which serve as guide posts to them when caught out in thick and foggy weather ***."

Myaughee, Cape: promontory, on NE coast of St. Lawrence I., $9 \mathrm{mi}$. SE of Savoonga; $63^{\circ}$ $39^{\prime} \mathrm{N}, 170^{\circ} 12^{\prime} \mathrm{W}$; (map 93).

Eskimo name reported in 1932 by $O$. W. Geist, University of Alaska. Orth in 1965 recorded the name as "Maiyure," meaning "cling."

My Creek: stream, flows W $7 \mathrm{mi}$. to Molly Creek, $80 \mathrm{mi}$. SW of Eagle, Yukon-Tanana High.; $64^{\circ} 06^{\prime} 45^{\prime \prime} \mathrm{N}, 143^{\circ} 23^{\prime} 00^{\prime \prime} \mathrm{W}$; (map 102).

Local name published in 1956 by USGS.

Mydnaya Ryka: stream, see Copper River.

Myers: locality, see Meiers.

Myers Chuck: village, see Meyers ${ }^{*}$ Chuck.

Myers Chuck: cove, see Meyers Chuck.

Myers Creek: stream, flows $\mathrm{N} 1 \mathrm{mi}$. to Little Caribou Creek, $3 \mathrm{mi}$. W of the junc. of Clearwater Fork, Toklat River with the Toklat River, Tanana Low.; $63^{\circ} 48^{\prime} 15^{\prime \prime} \mathrm{N}, 150^{\circ} 22^{\prime}$ $50^{\prime \prime} \mathrm{W}$; (map 88).

Local name reported in 1954 by USGS.

Myers Creek: stream, flows E $2.5 \mathrm{mi}$. to Lower Willow Creek which flows to Casadepaga River, $18 \mathrm{mi}$. NW of Solomon, Seward Penin. High.; 64 $49^{\prime} \mathrm{N}, 164^{\circ} 31^{\prime} \mathrm{W}$; (map 95).

Prospectors' name reported on a 1901 map of Cape Nome gold fields by David Fox, Jr. Mycrs Creek: stream, see Myers Fork.

Myers Creek: stream, see Ridgeway Creek.

Myers Fork: stream, flows SE $4 \mathrm{mi}$. to Chicken
Creek, $55 \mathrm{mi}$. SW of Eagle, Yukon-Tanana High.; $64^{\circ} 05^{\prime} \mathrm{N}, 141^{\circ} 55^{\prime} \mathrm{W}$; (map 102). Var. Myers Creek.

Named by prospectors and reported in 1896 by Spurr (1898, p. 332), USGS.

My-Ghapawit Mountain: mountain, see Myghapowit Mountain.

Myghapowit Mountain: mountain, 1,453 ft., 32 mi. SW of Northeast Cape, on Saint Lawrence I.; $63^{\circ} 13^{\prime} \mathrm{N}, 169^{\circ} 40^{\prime} \mathrm{W}$; BGN 1951; (map 93). Var. Miykhapakhit, Miykhapakhit Mountain, Mount Ghapawit, Mount Rosoff, My-Ghapawit Mountain.

Eskimo name recorded in 1931 by Otto W. Geist, Univ. of Alaska.

My Lake: lake, $0.6 \mathrm{mi}$. long, $\mathrm{E}$ of Little Susitna River, $17 \mathrm{mi}$. NW of Anchorage, Gook Inlet Low.; $61^{\circ} 27^{\prime} 00^{\prime \prime} \mathrm{N}, 150^{\circ} 06^{\prime} 25^{\prime \prime} \mathrm{W}$; (map $70)$.

Local name reported in 1958 by USGS.

Mylkiy, Mys : point of land, see Rock Point.

Mylkoy, Zaliv: bight, see Krestof, Port.

Mylkoy, Zaliv: cove, see Little Cove.

My Mountain: mountain, see Mount Magnificent.

Mynook Creek: stream, see Minook Creek.

My-o-ga-a-gal-uk: locality, see My-og-g-a-gallook.

My-og-arg-a-look: locality, see My-og-g-a-gallook.

My-og-g-a-gal-look: locality, probably near head of Easter Creek, Brooks Ra.; 67 $56^{\prime} \mathrm{N}, 153^{\circ}$ $28^{\prime} \mathrm{W}$; (map 125). Var. Maiogagaluk, Myo-ga-a-gal-uk, My-og-arg-a-look, Maiogagaluk.

The exact location of this Eskimo village or camp, reported by Lt. G. M. Stoney, USN, in 1886 , is conjectural, but it must have been located somewhere on Easter Creek near its headwaters. He spells the name variously and its meaning is unknown. Baker (1906, p. 422) spelled the name "Maiogagaluk."

Myriad Islands: islands, $2.3 \mathrm{mi}$. long, $5 \mathrm{mi}$. WSW of Chichagof, on $W$ coast of Chichagof I., Alex. Arch.; $57^{\circ} 38^{\prime} \mathrm{N}, 136^{\circ} 13^{\prime} \mathrm{W} ; B G N$ 1926; (map 9).

Descriptive name given in 1925 by USC\&GS; published in 1927 Coast Pilot (supp. p. 27), The numerous (myriad) islands include rocks and islands as much as 1 mi. long.

Myrtle, Mount: mountain, 1,402 ft., $24 \mathrm{mi}$. S of Karluk, on W coast of Kodiak I. ; $57^{\circ} 13^{\prime} 30^{\prime \prime}$ $\mathrm{N}, 154^{\circ} 28^{\prime} 20^{\prime \prime} \mathrm{W}$; (map 35).

Local name published in 1943 by USC\&GS. Myrtle Creek: stream, heads on NW side of Marin Ra., flows $\mathrm{N}$ to $\mathrm{E}$ side of Kalsin Bay, $13 \mathrm{mi}$. S of Kodiak, Kodiak I.; $57^{\circ} 36^{\prime} 30^{\prime \prime} \mathrm{N}$, $152^{\circ} 24^{\prime} 20^{\prime \prime} \mathrm{W}$; BGN 1966; (map 34).

Local name reported in 1966 by the Alaska State Geographic Board.

Myrtle Creek: stream, flows NW $3.6 \mathrm{mi}$. to Bear Creek $7.5 \mathrm{mi}$. NE of Nyac and $37 \mathrm{mi}$. SW of Aniak, Kilbuck-Kuskokwim Mts.; 61 ${ }^{\circ} 03^{\prime} 45^{\prime \prime}$ N, 159 $45^{\prime} 15^{\prime \prime} \mathrm{W}$; (map 73).

Prospectors' name shown on a 1914 fieldsheet by A. G. Maddren, USGS

Myrtle Creek: stream, in Kantishna Hills, flows E $5.5 \mathrm{mi}$. from Spruce Peak to Clearwater 
Fork Toklat River, $13 \mathrm{mi}$. NNE of Eielson Visitor Center, Alaska Ra.; $63^{\circ} 35^{\prime} 30^{\prime \prime} \mathrm{N}$, $150^{\circ} 31^{\prime} 00^{\prime \prime} \mathrm{W}$; (map 88).

Local name obtained in 1913 by Archdeacon Stuck (1921, p. 15).

Myrtle Creek: stream, flows S $1 \mathrm{mi}$. to join La Spray Creek to form Flambeau River, $18 \mathrm{mi}$. NE of Nome, Seward Penin. High.; 64 $44^{\prime}$. $09^{\prime \prime} \mathrm{N}, 165^{\circ} 07^{\prime} 40^{\prime \prime} \mathrm{W}$; (map 94). Var. Abbie Creek.

Prospectors' name reported in 1904 by $T$. G. Gerdine, USGS. Shown as "Abbie" on a map of Cape Nome gold fields by David Fox, Jr., dated 1901.

Myrtle Creek: stream, flows NW $1.6 \mathrm{mi}$. to Casadepaga River, $21 \mathrm{mi}$. NE of Solomon, Seward Penin. High.; 64 $51^{\circ} \mathrm{N}, 164^{\circ} 19^{\prime} \mathrm{W}$; (map 95).

Prospectors' name reported on a map of 1901 Cape Nome gold fields by David Fox, Jr.

Myrtle Creek: stream, flows SW $4 \mathrm{mi}$. to Livengood Creek, $0.3 \mathrm{mi}$. W of Livengood, YukonTanana High.; $65^{\circ} 31^{\prime} 30^{\prime \prime} \mathrm{N}, 148^{\circ} 33^{\prime} 15^{\prime \prime} \mathrm{W}$; (map 105).

Named by prospectors; name reported in 1915 by (Brooks and others, 1916, pl. 9), USGS.

Myrtle Creek: stream, flows SW $8 \mathrm{mi}$. to Slate Creek, $5 \mathrm{mi}$. SE of that stream's junc. with Middle Fork Koyukuk River and $13.5 \mathrm{mi}$. $\mathrm{S}$ of Wiseman, Brooks Ra.; $67^{\circ} 13^{\prime} \mathrm{N}, 150^{\circ}$ 03' W ; (map 124).

Local name shown on an 1899 fieldsheet by T. G. Gerdine, USGS.

Myrtle Lake: lake, $0.8 \mathrm{mi}$. long, on SE coast of Prince of Wales I., near head of Niblack Anchorage, Alex., Arch.; $55^{\circ} 04^{\prime} 30^{\prime \prime} \mathrm{N}, 132^{\circ}$ $08^{\prime} 30^{\prime \prime}$ W; (map 4).

Local name reported in 1901 by $\mathrm{A}$. $\mathrm{H}$. Brooks, USGS.

Mysovskoy, Mys: point of land, see Bleck Pnint: Mysovskoy, Ostrov: islands, see Saint Islands.

Mystery Creek: stream, on Alaska Penin., nows SE $4 \mathrm{mi}$. to Aniakchak River, $20 \mathrm{mi}$. W of Cape Kunmik; Aleutian Ra. ; $56^{\circ} 48^{\prime} \mathrm{N}, 157^{\circ}$ $43^{\prime} \mathrm{W}$; (map 31 ).

Local name obtained from trappers in 1923 by $R$. H. Sargent, USGS.

Mystery Creek: stream, on Kenai Penin., heads $\mathrm{N}$ of Round Mtn., flows NW $21 \mathrm{mi}$. to Chickaloon $38 \mathrm{mi}$. ENE of Kenai, Cook Inlet Low.; $60^{\circ} 45^{\prime} \mathrm{N}, 150^{\circ} 15^{\prime} \mathrm{W}$; (map 62).

Local name reported about 1911 by USGS (Martin, G. C., and others, 1915, pl. 2).

Mystery Creek: stream, flows NW $7 \mathrm{mi}$. to Nixon Fork Takotna River, $14 \mathrm{mi}$. NW of Medfra, Kilbuck-Kuskokwim Mts.; $63^{\circ} 17^{\prime}$ N, $154^{\circ}$ 53' W; (map 89).

Local name reported in 1920 by G. C. Martin (in Brooks and others, 1922, fig. 5), USGS.

Mystery Creek: stream, flows $3 \mathrm{mi}$. SE to Shovel Creek, $6 \mathrm{mi}$. N of Solomon; $64^{\circ} 38^{\prime} \mathrm{N}, 164^{\circ}$ 25' W; (map 95). Var. Misty Creek.

Prospectors' name reported in 1900 by E. C. Barnard (in Brooks, 1901, pl. 17), USGS.
Mystery Creek: stream, flows SW $3 \mathrm{mi}$. to Niukluk River, $5 \mathrm{mi}$. SE of Council and 33 mi. NE of Solomon, Seward Penin. High. $64^{\circ} 50^{\prime} \mathrm{N}, 163^{\circ} 33^{\prime} \mathrm{W}$; (map 95).

Prospectors' name reported in 1899 by Schrader and Brooks (1900, map 3), USGS.

Mystery Creek: stream, flows SW $7 \mathrm{mi}$. to Cripple River, $23 \mathrm{mi}$. NW of Imuruk Lake, Seward Penin. High.; $65^{\circ} 55^{\prime} \mathrm{N}, 163^{\circ} 35^{\prime} \mathrm{W}$; (map 110).

Prospectors' name reported in 1901 by USGS (Collier, 1902, pl. 12).

Mystery Creek: stream, flows S to Sinuk River, about $30 \mathrm{mi}$. NW of Nome, Seward Penin. High.; (map 94).

Prospectors' name reported on the 1900 "Map of Nome Peninsula" by J. M. Davidson and B. D. Blakeslee; this feature has not been positively identified.

Mystery Mountain : peak, see Deception, Mount. Mystery Mountains: mountains, 3,850 ft., trend N-S $9 \mathrm{mi}$., $30 \mathrm{mi}$. $\mathrm{N}$ of Medfra, KilbuckKuskokwim Mts.; $63^{\circ} 31^{\prime} \mathrm{N}, 154^{\circ} 34^{\prime} \mathrm{W}$; (map 89).

Local name reported in 1924 by USGS.

Mystic Creek: stream, flows E $6.5 \mathrm{mi}$. to Wood River, $36 \mathrm{mi}$. NE of Healy, Alaska Ra.; $63^{\circ}$ $57^{\prime} 30^{\prime \prime} \mathrm{N}, 147^{\circ} 47^{\prime} 40^{\prime \prime} \mathrm{W}$; (map 87).

Prospectors' name reported in 1906 by $\mathrm{L}$. M. Prindle (in Brooks and others, 1907, pl. 4), USGS.

Mystic Creek: stream, flows SE $4 \mathrm{mi}$. to Inmachuck River, $27 \mathrm{mi}$. NE of Imuruk, Seward Penin. High.; $65^{\circ} 59^{\prime} 10^{\prime \prime} \mathrm{N}, 162^{\circ} 56^{\prime} 45^{\prime \prime} \mathrm{W}$; (map 110).

Prospectors' name reported in 1901 by D. L. Reaburn (in Mendenhall, 1902, pl. 4a), USGS.

Mystic Mountain: mountain, 5,111 ft., $35 \mathrm{mi}$. NE of Healy and $25 \mathrm{mi}$. E of Jumbo Mtn., Alaska Ra.; $63^{\circ} 58^{\prime} 50^{\prime \prime} \mathrm{N}, 147^{\circ} 50^{\prime} 30^{\prime \prime} \mathrm{W}$; (map 87).

Name taken from the name of the stream that flows on its south side; published in 1963 by USGS.

Mrstic Pass: pass, 2,800 ft., between head of Tonzona and West Fork Yentna Rivers, 80 mi. NW of Talkeetna, Alaska Ra.; $62^{\circ} 38^{\prime} 30^{\prime \prime}$ $\mathrm{N}, 152^{\circ} 32^{\prime} 00^{\prime \prime} \mathrm{W}$; (map 81).

Local name reported in 1925 by S. R. Capps (in Moffit, 1927), USGS.

Mystic Rock: rock, see Mastic Rock.

\section{$\mathbf{N}$}

Nabaksyalik Point: point of land, $7 \mathrm{mi}$. SW of Cape Etolin, on $\mathrm{N}$ coast of Nunivak I.; $60^{\circ}$ $22^{\prime} 20^{\prime \prime}$ N, $166^{\circ} 18^{\prime} 45^{\prime \prime}$ W ; (map 57). Var Nabaxyalix Point.

Eskimo name obtained in 1949 by USC\&GS.

Nabangoyak Rock: rock, $6 \mathrm{mi}$. SE of Cape Mohican off $W$ coast of Nunivak I.; $60^{\circ} 08^{\prime} \mathrm{N}$, $167^{\circ} 21^{\prime} \mathrm{W}$; (map 57).

Eskimo name obtained in 1949 by USC\&GS. Nabaxyalix Point: point of land, see Nabaksyalik Point.

Nabesna: village, pop. $41, \mathrm{~W}$ of Nabesna River, at base of White Mtn., $84 \mathrm{mi}$. NE of Glennallen, Wrangell Mts.; $62^{\circ} 22^{\prime} \mathrm{N}, 143^{\circ} 00^{\prime} \mathrm{W}$; BCN 1939; (map 84).
This village began as a camp of the $\mathrm{Na}$ besna Mining Co., from which its name was derived. Its first post office was established in 1909 (Ricks, 1965, p. 44).

Nabesna Glacier: glacier, trends $\mathrm{E}$ and NE 50 mi. from Mount Wrangell to its 1957 terminus at head of Nabesna River, Wrangell Mts.; $62^{\circ} 00^{\prime} \mathrm{N}, 143^{\circ} 00^{\prime} \mathrm{W}$; (map 84).

Named in 1902 by F. C. Schrader, USGS, for the Nabesna River.

Nabesna River: stream, heads at Nabesna Glacier and flows NE $73 \mathrm{mi}$. to join the Chisana River to form the Tanana River, $41 \mathrm{mi}$. SE of Tok, Alaska Ra.; $63^{\circ} 03^{\prime} \mathrm{N}, 141^{\circ} 52^{\prime} \mathrm{W}$; $B G N$ 1960; (map 84).

Named by W. J. Peters and A. H. Brooks, USGS, in 1898; derived from the local Indian name for the upper Tanana River (Allen, 1887 , p. 136)

Nabesna Slough: stream, anabranch of Nabesna River, flows NE $8 \mathrm{mi}$., $7 \mathrm{mi}$. SW of Northway Junction, Alaska Ra.; $62^{\circ} 57^{\prime} 45^{\prime \prime} \mathrm{N}, 141^{\circ}$ $58^{\prime} 00^{\prime \prime}$ W; (map 84).

Local name reported by USGS in 1955.

Nabesna Village: locality, on $\mathrm{W}$ bank of Nobesna River $6 \mathrm{mi}$. SW of Northway Junction, Alaska Ra.; $62^{\circ} 59^{\prime} \mathrm{N}, 141^{\circ} 58^{\prime} \mathrm{W}$; (map 84). Var. Khiltats.

Nabesna Indian village reported by USGS in 1945. This may represent the same people that once occupied a village called "Khiltats" at the mouth of the Nabesna River (Hodge, 1907 , p. 679).

Nachalney, Ostrov: island, see Nachalni Island. Nachalnie: point of land, see Entrance Point.

Nachalnie Point: point of land, see Nachalni Point.

Nachalni Island: island, $0.5 \mathrm{mi}$. long, between Afognak and Kupreanof Straits, S of Raspberry I., 6 mi. SW of Afognak, Kodiak I., $57^{\circ}$ $58^{\prime} 40^{\prime \prime} \mathrm{N}, 152^{\circ} 55^{\prime} 30^{\prime \prime} \mathrm{W}$; (map 34). Var. Ostrov Nachalney.

Named "Ostrov Nachalney," i.e. "beginning island," in 1809 by the Russian navigator Ivan Vasiliev the first; published as such by Lt. Sarichev (1826, map 19), IRN.

Nachalni Point: point of land, $\mathrm{S}$ tip of Nachalni I., in Kupreanof Strait, $23 \mathrm{mi}$. NW of Kodiak, Kodiak I.; $57^{\circ} 58^{\prime} 30^{\prime \prime} \mathrm{N}, 152^{\circ} 55^{\prime} 45^{\prime \prime} \mathrm{W}$; BGN 1909; (map 34). Var. Entrance Point, Mys Nachalnyy, Nachalnie Paint.

Transliteration of "M[ys] Nachalnyy" meaning "point of entrance," the name given to this point by Sub-Lt. Mikhail Murashev in 1839 or 1840 and published in 1849 on Russian Hydrog. Dept. Chart 1425. Baker (1906, p. 244) published "Entrance Point," as the translation of Murashev's name. Because of duplication this name was changed to its present form by USC\&GS in 1909.

Nachalny, Mys: point of land, see Entrance Point.

Nachalnyy, Mys: point of land, see Nachalni Point.

Nachlezhnia: bay, see Camp Coogan Bay.

Nachliwagimiut: locality, see Nakhliwak.

Nachliwagimiut: village, see Chaniliut.

Nacholchaviamut: locality, see Nakolkavik. 
Nachralik Pass: pass, 2,250 ft., in De Long Mts., between head of Cairn Creek and Utukok River drainage, Brooks Ra. ; 68 ${ }^{\circ} 33^{\prime} \mathrm{N}, 161^{\circ} 06^{\prime}$ W; (map 131).

Eskimo name published by USGS in 1962. Nachramkunga Greek: stream, see Contact Creek.

Nackchamik Island: island, see Nakchamik Island.

Nack-tchamick, Ile: island, see Nakchamik Island.

Nacooytoolecmiut: locality, see Nakooytoolekmiut.

Nadezhda Island: islands, $0.6 \mathrm{mi}$. across, in Kresta Sound, $14 \mathrm{mi}$. NW of Sitka, Alex. Arch.; 57 $12^{\prime} \mathrm{N}, 135^{\circ} 36^{\prime} \mathrm{W}$; (map 9). Var. Ostrova Nadezhdy.

Russian name meaning "hope," given in 1833 by the navigator Ens. Vasiliev (cnna); published in 1848 on Russian Hydrog. Dept. Chart 1397 as "O[stro]va Nadezhdy." It was named for Adm. A. J. von Krusenstern's vessel the Nadezhda.

Nadezhdy, Ostrova: islands, see Nadezhda Island.

Nadina Glacier: glacier, heads on Mount Drum and trends SW $9 \mathrm{mi}$. to its terminus at head of Nadina River, Wrangell Mts.; 62 ${ }^{\circ} 00^{\prime} 30^{\prime \prime}$ N, 144.49'00" W; (map 83).

Local name reported by USGS (in Menden. hall and Schrader, 1903, p. 63); named for the river.

Nadina River: stream, heads at Nadina Glacier, flows $18 \mathrm{mi}$. SW to Copper River, $3.3 \mathrm{mi}$. NE of the locality of Willow Creek, $62 \mathrm{mi}$. NE of Valdez, Copper River Basin; 61 $51^{\circ} 20^{\prime \prime} \mathrm{N}$, $145^{\circ} 09^{\prime} 50^{\prime \prime}$ W; (map 68). Var. Knetena, Knetina.

Ahtena Indian name spelled Knetena by Capt. W. R. Abercrombie, USA, in 1898. T. G. Gerdine and W. C. Mendenhall, USGS, introduced the present spelling in 1902.

Nadiwen Lake: lake, see Butte Lake.

Nadviktak Creek: stream, flows NW $8 \mathrm{mi}$. to Kivalina River, $21 \mathrm{mi}$. NE of Kivalina, Arctic Slope; $67^{\circ} 59^{\prime} \mathrm{N}, 164^{\circ} 12^{\prime} \mathrm{W}$; (map 128). Var. Nadviktak Koogowrak, Nazwiztaq Kuugauzaq.

Eskimo name reported in 1966 by E. S. Burch.

Nadviktak Koogowrak: stream, see Nadviktak Creek.

Nadviktak Lakes: lakes, $25 \mathrm{mi}$. NE of Kivalina, Arctic Slope; $68^{\circ} 00^{\prime} \mathrm{N}, 164^{\circ} 00^{\prime} \mathrm{W}$; (map 130). Var. Nazwiqtaq.

Eskimo name reported in 1966 by E. S. Burch.

Nadzaheen Cove: estuary, $0.8 \mathrm{mi}$. long, on NE coast of Annette I., Alex. Arch.; 55 ${ }^{\circ} 13^{\prime} 45^{\prime \prime} \mathrm{N}$, $131^{\circ} 28^{\prime} 00^{\prime \prime} \mathrm{W}$; (map 3).

Tlingit Indian name [Nadzahin] meaning "Nadza River"; published in 1911 by USC\&GS.

Naerie Rock: rock, near mouth of Hot Springs Bay, $1.4 \mathrm{mi}$. NW of Goddard, on $W$ coast of Baranof I., Alex. Arch.; 56 50'53" N, 135 $24^{\prime} 00^{\prime \prime}$ W; (map 5). Var. Kamen Nayery.

Named in 1804 by the Russian navigator,
Ivan Vasiliev the first; published by Lt. Sarichev (1826, map 19), IRN as "K[amen] Nayery" or "Nayery Rock."

Naga: rocks, see Nagai Rocks.

Nagahut Rocks: rocks, $2 \mathrm{mi}$. SW of Perl and 24 mi. SW of Seldovia, Chugach Mts.; $59^{\circ} 11^{\prime} \mathrm{N}$, $151^{\circ} 46^{\prime}$ W; BGN 1908; (map 50). Var. Los Frailes.

Indian name reported by USC\&GS in 1908. These rocks were called "Los Frailes" meaning "the brothers," on an unpublished Spanish map by Francisco Antonio Maurelle, Don Ignacio Arteaga, and Don Juan Francicso de la Bodega y Quadra in 1779.

Nagai Island: island, $31 \mathrm{mi}$. long, one of largest of Shumagin Is., Aleutian Ra.; $55^{\circ} 05^{\prime} \mathrm{N}$, $160^{\circ} 00^{\prime} \mathrm{W}$; $B G N$ 1890; (map 28). Var. Ilagia Island, Nagay Island.

This native name was reported in English by Sauer (1802, p. 166); reported in French as "Ile Nagay" by Capt. Lutke (1836, map 24). According to the log of V. Bering's ship St. Peter for August 31, 1741, a sailor named Shumagin died and was buried here, and his name was given to the group of islands.

Nagai Rocks: rocks, 2 mi. W of Chirikof I., 100 mi. SW of Kodiak I., Kodiak Is.; $55^{\circ} 49^{\prime} 30^{\prime \prime}$ $\mathrm{N}, 155^{\circ} 46^{\prime} 00^{\prime \prime} \mathrm{W}$; (map 32). Var. Kamen Nagay, Naga, Nagau.

Named "by Kashevarof about 1830 * * *" (Baker, 1906, p. 451) and published by Capt. Lutke (1836, p. 278), IRN.

Naganak: cove, see Naginak Cove.

Naganakh: cove, see Naginak Cove.

Naga Point: point of land, on $\mathrm{E}$ coast of Kanaga I., Aleutian Is. ; $51^{\circ} 46^{\prime} 20^{\prime \prime} \mathrm{N}, 177^{\circ} 06^{\prime} 50^{\prime \prime} \mathrm{W}$; BGN 1936; (map 17).

A clipped name derived from Kanaga Island, and given by members of the U.S. Navy Aleutian Island Survey Expedition in 1934.

Nagasay Cove: cove, $0.4 \mathrm{mi}$. long, $\mathrm{N}$ coast of Esquibel I. in Maurelle Is., Alex. Arch.; 55 ${ }^{\circ}$ $38^{\prime} 45^{\prime \prime} \mathrm{N}, 133^{\circ} 33^{\prime} 50^{\prime \prime} \mathrm{W}$; BGN 1925; (map $4)$.

Tlingit Indian name, meaning "blue fox," given in 1924 by USC\&GS because of a foxfarm on the $W$ shore of this Cove.

Nagau: rocks, see Nagai Rocks.

Nagay, Kamen: rocks, see Nagai Rocks.

Nagay Island: island, see Nagai Island.

Nagchamik, Ostrov: island, see Nakchamik Island.

Nageesluk River: stream, see Nageethluk River.

Nageethluk River: stream, heads at $62^{\circ} 17^{\prime} \mathrm{N}$ $161^{\circ} 08^{\prime} \mathrm{W}$, flows $\mathrm{W} 90 \mathrm{mi}$. to Atchuelinguk River, $31 \mathrm{mi}$. $\mathbf{N}$ of Marshall, YukonKuskokwim Delta; 62 $20^{\prime} \mathrm{N}, 162^{\circ} 08^{\prime} \mathrm{W}$; (map 77). Var. Nageesluk River, Nagislak River.

Eskimo name meaning "place of snares," according to a 1948 field report by USC\&GS. Naghaikhlavigamute: locality, see Nakolkavik. Naghikhlavigamute: locality, see Nakolkavik.

Naginak Cove: cove, $0.7 \mathrm{mi}$. across, in Anderson Bay, part of Makushin Bay, $W$ coast of Unalaska I., Aleutian Is.; $53^{\circ} 39^{\prime} \mathrm{N}, 166^{\circ} 51^{\prime}$ W; (map 23). Var. Naganak, Naganakh.
Aleut name published by Lt. Sarichev (1802, v. 2, p. 139), IRN, as "Naganakh" from the word "naganak" which, according to R. H. Geoghegan, means "sickness." The name was later published as "Naginak" by Father Veniaminov (1840, v. 1, p. 164).

Nagishlamina River: stream, heads in lake, flows NE and SE $23 \mathrm{mi}$. to Chakachamna Lake, 45 mi. NW of Tyonek, Alaska Ra.; 61 ${ }^{\circ} 14^{\prime} \mathrm{N}$, $152^{\circ} 27^{\prime}$ W; BGN 1930; (map 70).

Tanaina Indian name reported in 1927 by S. R. Capps (in Smith and others, 1930, p. 146), USGS.

Nagislak River: stream, see Nageethluk River. Naglatuk Hill: hill, 931 ft., highest point in Kakagrak Hills, at W end of Igichuk Hills, 12 mi. $\mathbf{N}$ of Cape Krusenstern, Arctic Slope; $67^{\circ} 18^{\prime} \mathrm{N}, 163^{\circ} 39^{\prime} \mathrm{W}$; BGN 1962; (map 128). Var. Naglatuk Mountain, Naglutook Mountain.

Eskimo name meaning "restless," according to USC\&GS in 1950.

Naglatuk Mountain: hill, see Naglatuk Hill.

Nagle Creek: stream, flows $S$ to Anikovik River, about $15 \mathrm{mi}$. E of Cape Prince of Wales, Seward Penin. High.; (map 111).

Prospectors' name shown on the 1900 "Map of Nome Peninsula" by J. M. Davidson and B. D. Blakeslee. This feature cannot be precisely identified on current maps.

Naglutook Mountain: hill, see Naglatuk Hill.

Nag-Miout: locality, see Nak.

Nagokchik: locality, see Naguchik.

Nagosakchowik: locality, on S bank of Kwemeluk Pass $4 \mathrm{mi}$. W of Sheldon Point and $21 \mathrm{mi}$. SW of Kwiguk, Yukon-Kuskokwim Delta; $62^{\circ}-$ $31^{\prime} 45^{\prime \prime} \mathrm{N}, 164^{\circ} 57^{\prime} 40^{\prime \prime} \mathrm{W}$; (map 77). Var. Nahr-go śak-chokó wik, Nargosakchokowik, Narosigak, Narosigagamieut.

Fish camp reported in 1952 by USC\&GS. Former Eskimo village recorded in 1899 as "Narosigagamieut" by G. R. Putnam, USC\&GS.

Nagosakchowik Slough: stream, heads in lake, flows N $9.5 \mathrm{mi}$. to Kwemeluk Pass, $4 \mathrm{mi}$. W of Sheldon Point and $21 \mathrm{mi}$. SW of Kwiguk, Yukon-Kuskokwim Delta; $62^{\circ} 32^{\prime}$ N, $164^{\circ} 57^{\prime}$ W; (map 77). Var. Nargosakchokowik Slough, Narosigak Slough, Nioklakowik Slough.

Eskimo name obtained by USC\&GS in 1952. Probably the same as "Nioklakowik" recorded in 1899 by G. R. Putnam, USC\&GS.

Nagotligageivik Mountain: mountain, 1,305 ft., $4 \mathrm{mi}$. W of Tatlinagpeke Mtn. and $20 \mathrm{mi}$. N of Goodnews, Kilbuck-Kuskokwim Mts.; 59 ${ }^{\circ} 23^{\prime}$ N, $161^{\circ} 34^{\prime} \mathrm{W}$; (map 53 ).

Eskimo name reported in 1954 by USGS. Nagounalaska: island, see Unalaska Island.

Naguchik: locality, on $\mathrm{E}$ bank of Apoon Pass, $24 \mathrm{mi}$. NE of Kwiguk, Yukon-Kuskowim Delta ; $62^{\circ} 55^{\prime} 40^{\prime \prime} \mathrm{N}, 163^{\circ} 49^{\prime} 15^{\prime \prime} \mathrm{W}$; (map 77). Var. Nagokchik.

Eskimo fish camp reported in 1952 by USC\&GS.

Nagugun Creek: stream, heads at Nagugun Lake, flows SE $5 \mathrm{mi}$. to Nayorurun River, $58 \mathrm{mi}$. NE 
of Goodnews, Kilbuck-Kuskokwim Mts.; 59 ${ }^{\circ}$ $36^{\prime} \mathrm{N}, 160^{\circ} 16^{\prime} \mathrm{W}$; (map 53).

Eskimo name reported to mean "river that others meet," obtained in 1951 by J. M. Hoare, USGS, from C. B. Michael, missionary at Quinhagak.

Nagugun Lake: lake, extends SE $5 \mathrm{mi}$. to headwaters of Nagugun Creek, $58 \mathrm{mi}$. NE of Goodnews, Kilbuck-Kuskokwim Mts.; 59 $39^{\prime} \mathrm{N}$, $160^{\circ} 21^{\prime} \mathrm{W}$; (map 53)

Name derived from Nagugun Creek of which it is the source; published in 1951 by USGS.

Nagunalaska: island, see Unalaska Island.

Nagyagat Mountain: mountain, 2,600 ft., in Ahklum Mts., $10 \mathrm{mi}$. SW of Goodnews Lake and $33 \mathrm{mi}$. NE of Goodnews, Kilbuck-Kuskokwim Mts.; $59^{\circ} 22^{\prime} \mathrm{N}, 160^{\circ} 48^{\prime} \mathrm{W}$; (map 53).

Eskimo name reported to mean "place to smell bear," obtained about 1951 at Goodnews by J. M. Hoare, USGS.

Nagzamik Island: island, see Nakchamik Island.

Naha Bay: estuary, extends E $3 \mathrm{mi}$., off Behm Canal, on W coast of Revillagigedo I., Alex. Arch.; $55^{\circ} 36^{\prime} \mathrm{N}, 131^{\circ} 41^{\prime} \mathrm{W}$; (map 3).

Tlingit Indian name reported in 1883 by W. H. Dall, USC\&GS.

Naha River: stream, on Revillagigedo I., flows SW through several lakes $17 \mathrm{mi}$. to Naha Bay, Alex. Arch.; $55^{\circ} 35^{\prime} 45^{\prime \prime} \mathrm{N}, 131^{\circ} 38^{\prime} 00^{\prime \prime} \mathrm{W}$; (map 3).

Name reported in 1897 by Lt. Comdr. J. F. Moser, USN. See Naha Bay.

Nahihmood: locality, see Nahimud.

Nahimud: locality, site of Eskimo village, on $\mathbf{S}$ shore of Kiliuda Bay, SE coast of Kodiak I.; $57^{\circ} 18^{\prime} \mathrm{N}, 153^{\circ} 06^{\prime} \mathrm{W}$; (map 34 ). Var. Nahihmood.

Native name recorded in 1805 as "Nahihmood" by Lisianski (1814, map facing p. 169).

Nahk-hahk: locality, see Knockhock.

Nahku Bay: estuary, $1 \mathrm{mi}$. long and $0.2 \mathrm{mi}$. wide, at head of Taiyu Inlet, $1 \mathrm{mi}$. W of Skagway, Coast Mts.; $59^{\circ} 27^{\prime} 45^{\prime \prime}$ N, $135^{\circ} 20^{\prime} 15^{\prime \prime} \mathrm{W}$; (map 45).

Tlingit Indian name published in 1923 on IBC Sheet 9 (1951 atlas).

Nahku Portage: portage, $1.5 \mathrm{mi}$. long, between Mud Bay and Letnikof Cove, on Chilkat Penin., $20 \mathrm{mi}$. S of Skagway, Coast Mts. ; 59 ${ }^{\circ}$ $10^{\prime} 00^{\prime \prime} \mathrm{N}, 135^{\circ} 21^{\prime} 30^{\prime \prime} \mathrm{W}$; (map 45).

Indian name published by the IBC (1923, map 9).

Nahltushkan: locality, see Neltushkin.

Nahn-var-ahn-ak Slough: stream, see Nanvaranak Slough.

Nah-park-lu-lik : locality, see Napaklulik.

Nahr-gó sak-chokó wik: locality, see Nagosakchowik.

Nahsayvernia: point of land, see North Point.

Nah Speel: rookery, NW of Saint Paul, near West Landing, on Saint Paul I., Pribilof Is.; 57 $07^{\prime} 30^{\prime \prime} \mathrm{N}, 170^{\circ} 16^{\prime} 40^{\prime \prime} \mathrm{W}$; (map 38). Var. Nah Speetsah.

Elliott (1881, p. 164 and 174) says this is an Aleut "corruption" of the Russian name "Nah Speetsah" meaning "on the point."
This term in turn is derived from "Spitsa," meaning "a pointed stick," which is of German derivation.

Nahtuk Mountain: mountain, 5,980 ft., in Endicott Mts., $32 \mathrm{mi}$. SE of Survey Pass, Brooks Ra.; 673' N, $153^{\circ} 07^{\prime} \mathrm{W}$; BGN 1932; (map 125).

Eskimo name reported by Robert Marshall in 1931. So named because it is at the head of the Nahtuk River. Nahtuk [Natak] means "owl."

Nahtuk River: stream, heads on $N$ slope of Nahtuk Mtn., and flows SW $23 \mathrm{mi}$. to Alatna River, $27 \mathrm{mi}$. SE of Survey Pass, Brooks Ra.; $67^{\circ} 25^{\prime} \mathrm{N}, 153^{\circ} 43^{\prime} \mathrm{W}$; BGN 1912; (map 125). Var. Akoblueik, Akuluik, Nuhluk River, Nuluk River.

Eskimo name reported by Stoney (1900, map), USN, in 1886 as "Nuhluk," but spelled "Nahtuk" by Mendenhall (1902, pl. 4) in 1901 as conforming more to local pronunciation. Nahtuk [Natak] means "owl."

Nahulkavik: lake, see Coville Lake.

Nahwazúk: lake, see Salmon Lake.

Naimak Islet: island, see Chernabura Island.

Nain Creek: stream, tributary to the Kuskokwim River.

Name mentioned as a note on an 1898 fieldsheet by W. S. Post, USGS; however, he noted that the exact location was undetermined. The name was probably derived from that of a Moravian mission built in 1757 in Pennsylvania which in turn was named for a biblical town in Galilee (Luke 7: 11-17).

Nairak: hill, see Mugum Peak.

Naiwak: hill, see Mugum Peak.

Najwarwak: lake, see Chandler Lake.

Nak: locality, on right bank of Kuskokwim River, near the Yukon-Kuskokwim Portage; (map 73). Var. Nag-Miout.

Former Eskimo village recorded as "Nagmiout" on an 1850 map by Lt. L. A. Zagoskin, IRN (Hodge, 1910, p. 12). This may be the same place as Uknavik; shown on some maps as "Ok[nag]amiut."

Nakahkpuk: stream, see Wattamuse Creek:

Nakailingak Creek: stream, flows SE $4 \mathrm{mi}$. to Kanektok River, $60 \mathrm{mi}$. NE of Goodnews, Kilbuck-Kuskokwim Mts.; $59^{\circ} 51^{\prime} \mathrm{N}, 160^{\circ} 45^{\prime} \mathrm{W}$; (map 53).

Eskimo name published in 1951 by USGS.

Nakaktuk Lakes: lakes, extend $5 \mathrm{mi}$., W of Kutchik River, $8.5 \mathrm{mi}$. S of Umiat, Arctic Slope; $69^{\circ} 14^{\prime} \mathrm{N}, 152^{\circ} 18^{\prime} \mathrm{W}$; (map 141).

Eskimo name referring to stones or turf "lined up" to point to something or as a barrier against caribou; name reported in 1956 by T. E. Taylor, USGS.

Nakalilok Bay: bay, $4 \mathrm{mi}$. long, on $\mathrm{S}$ coast of Alaska Penin., 16 mi. NE of Cape Kunmik, Aleutian Ra.; $56^{\circ} 55^{\prime} \mathrm{N}, 156^{\circ} 56^{\prime} \mathrm{W}$; (map 31). Var. Nakkhalilok Bay, Zaliv Nakkhalilok.

Eskimo name shown in 1847 as "Z[aliv] Nakkahalilok" on Russian Hydrog. Dept. Chart 1379.

Nakat Bay: bay, $5 \mathrm{mi}$. across, extends NE $5 \mathrm{mi}$. from Cape Fox on mainland, Coast Mts.; $54^{\circ} 46^{\prime}$ N, $130^{\circ} 47^{\prime} \mathrm{W}$; BGN 1916; (map 2). Var. Bukhta Nakat, Nakat Inlet.

Tlingit Indian name published in 1853 on Russian Hydrog. Dept. Chart 1493 as "Bukh[ta] Nakat" meaning "Nakat Bay."

Nakat Harbor: bay, $4.3 \mathrm{mi}$. long, E of and parallel to Nakat Inlet, Coast Mts.; $54^{\circ} 50^{\prime} \mathrm{N}$, $130^{\circ} 42^{\prime} \mathrm{W}$; (map 2).

Name derived from Nakat Inlet; given in 1888 by Lt. Gomdr. H. E. Nichols, USN.

Nakat Inlet: estuary, extends N $11 \mathrm{mi}$. from Ledge Point, at head of Nakat Bay, Coast Mts.; $54^{\circ} 48^{\prime} 30^{\prime \prime} \mathrm{N}, 130^{\circ} 44^{\prime} 30^{\prime \prime} \mathrm{W}$; (map 2).

Tlingit Indian name possibly derived from the word "Nakatse" meaning "fox" (Krause, 1956, p. 256). Lt. Comdr. H. E. Nichols, USN, writes in the USC\&GS Alaska Coast Pilot (1891, p. 79) "The body of water between Cape Fox and Tongass is sometimes called Nakat Inlet, but that name really applies only to the inlet proper," whose southern limit is at Ledge Point.

Nakat Inlet: estuary, see Fillmore Inlet.

Nakat Inlet: $b a y$, see Nakat Bay.

Nakat Lake: lake, $1.5 \mathrm{mi}$. long, between Nakat and Willard Inlets, Coast Mts.; 54 $4^{\circ} 5^{\prime} 15^{\prime \prime} \mathrm{N}$, $130^{\circ} 42^{\prime} 45^{\prime \prime}$ W; BGN 1962; (map 2).

Name derived from Nakat Inlet; given in 1962 by USFS.

Nakat Mountain: mountain, 2,875 ft., on mainland between Filmore and Willard Inlets, Coast Mts.; 54 $52^{\prime} 15^{\prime \prime} \mathrm{N}, 130^{\circ} 38^{\prime} 20^{\prime \prime} \mathrm{W}$; (map 2).

Name derived from Nakat Inlet; given in 1883 by Lt. Comdr. H. E. Nichols, USN.

Nakchamik, Ostrov: island, see Nakchamik Island.

Nakchamik Island: island, $3.5 \mathrm{mi}$. across, $\mathrm{S}$ of Alaska Penin., $7.3 \mathrm{mi}$. S of Cape Kumliun, Aleutian Ra.; $56^{\circ} 20^{\prime} \mathrm{N}, 157^{\circ} 49^{\prime} \mathrm{W}$; (map 31). Var. Ile Nack-tchamick, Nackchamik Island, Nagzamik Island, Ostrov Nagchamik, Ostrov Nakchamik.

Eskimo name shown in 1847 as "Os[trov] Nakchamik" on Russian Hydrog. Dept. Chart 1379.

Naked Island: island, in Lynn Canal, $1.3 \mathrm{mi}$. NW of Clear Point on Mansfield Peninsula and 19 mi. SW of Juneau, Alex. Arch.; 58 $15^{\prime} 20^{\prime \prime} \mathrm{N}$, $134^{\circ} 56^{\prime} 30^{\prime \prime} \mathrm{W}$; (map 11).

Descriptive name given in 1890 by $L t$. Comdr. H. B. Mansfield, USN, and published by USC\&GS in the 1883 Coast Pilot (p. 161).

Naked Island: island, $8 \mathrm{mi}$. across, in Prince William Sound, $32 \mathrm{mi}$. NE of Chenega, Chugach Mts.; 60 $40^{\prime} \mathrm{N}, 147^{\circ} 25^{\prime} \mathrm{W}$; (map 63). Var. Big Naked Island, Isla Larga.

Named in 1898 by Capt. W. R. Abercrombie, USA, who applied the name to a group of three islands. F. C. Schrader, USGS, in 1900 reported the largest of these islands as Naked Island. John Goodell of Valdez states, "the islands are called 'Naked,' so it is said, from the fact that the natives once found on them a naked woman, who was crazy." This appears to be the Isla Larga named by the 1779 Don Ignacio Arteaga expedition. 
Nakedrixo: locality, see Akilloaq.

Nakeduxo: locality, see Akilloaq.

Nakee Creek: stream, flows SW 2 mi. to Kuskokwim Bay, $3 \mathrm{mi}$. SW of Kwinhagak and 45 mi. NW of Goodnews, Yukon-Kuskokwim Delta; $59^{\circ} 44^{\prime} \mathrm{N}, 161^{\circ} 55^{\prime} \mathrm{W}$; (map 53).

Eskimo name published in 1951 by USGS. Nakeen: village, on $\mathrm{W}$ bank of Kvichak River, $1.5 \mathrm{mi}$. $\mathrm{N}$ of Telephone Point and $14 \mathrm{mi}$. N of Naknek, Bristol Bay Low.; $58^{\circ} 46^{\prime} 10^{\prime \prime} \mathrm{N}$, $157^{\circ} 02^{\prime} 15^{\prime \prime} \mathrm{W}$; (map 41).

Local name published by USC\&GS in 1954 Coast Pilot (p. 505).

Nakhak: locality, see Knockhock.

Nakhapagak: stream, see Noxapaga River.

Nakhliwak: locality, on $\mathrm{S}$ bank of Apoon Pass, $1 \mathrm{mi}$. W of Pastol Bay and $40 \mathrm{mi}$. NE of Kwi-

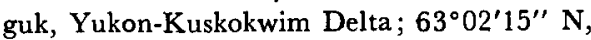
$163^{\circ} 23^{\prime} 00^{\prime \prime} \mathrm{W}$; (map 92). Var. Nachliwagimiut.

Eskimo village, now abandoned, reported in 1899 by R. L. Faris, USC\&GS, as "Nachliwagimiut." This name is often applied to nearby Chaniliut, but cartographic usage has reapplied the name to a few existing cabins in the described location.

Nakhliwak: village, see Chaniliut.

Nakkhalilok, Zaliv: bay, see Nakalilok Bay.

Nakkhalilok Bay: bay, see Nakalilok Bay.

Nakmaktuak: stream, see Ambler River.

Nakmaktuak Pass: pass, 2,450 ft., between Noatak River (Nushralutak Creek) and Kobuk River (Ambler River) drainages, Brooks Ra.; 67 $38^{\prime}$ N, $156^{\circ} 27^{\prime}$ W; (map 126).

Named by Orth in 1956 and derived from the Eskimo name for the Ambler River. The risme means "backpacking place" and refers in a sense to a "pass or to a short-cut." The name appears to be similar to Natmotirak [Creek].

Nakneck, Fleuve: stream, see Naknek River.

Nakneck, Riviere de: stream, see Naknek River.

Naknek: village, pop. 249 , on $\mathrm{N}$ bank of Naknek River near its mouth, on- $N$ coast of Alaska Penin., $56 \mathrm{mi}$. SE of Dillingham, Bristol Bay Low.; $58^{\circ} 43^{\prime} 40^{\prime \prime} \mathrm{N}, 157^{\circ} 00^{\prime} 45^{\prime \prime} \mathrm{W}$; $B G N$ 1948 ; (map 41). Var. Fort Souworoff, Fort Suvaroff, Fort Suworof, Kinghiak, Kingiak, Kiniaak, Kiniak, Kinuiak, Naugvik, Pawik, Suvarov, Suwarof, Suworof.

Originally an Eskimo village reported about 1821 by Capt. Lt. M. N. Vasiliev, IRN, who gave its name as "Naugeik." Lt. Sarichev (1826, map 3), IRN, reported it as "Naugvik." Spelled "Naknek" by Capt. Tebenkov (1852, map 4), IRN. The Russians built a post called "Fort Suvarov" at or near the village, named after the nearby point of land. The 1880 Census lists the village name as "Kinghiak." Its population in 1890 was 51 ; 111 in $1920 ; 173$ in $1930 ; 152$ in 1939 ; and 174 in 1950. The Naknek post office was established in 1907. Naknek is noted for its "Red Salmon" canneries. See Suworof, Cape. Naknek: village, see South Naknek.

Naknek, Reka: stream, see Naknek River.

Naknek Lake: lake, $20 \mathrm{mi}$. long, at head of
Naknek River, on Alaska Penin, intersected by western boundary of Katmai National Monument, $22 \mathrm{mi}$. E of Naknek, Aleutian Ra.; $58^{\circ} 38^{\prime} \mathrm{N}, 155^{\circ} 52^{\prime} \mathrm{W}$; (map 42). Var. Agulogak Lake, Akougak, Akulogak, Lac Acoulogack, Lake Walker.

Eskimo name published in 1836 by F. P. Lutke. Ens. Vasiliev, IRN, reported the lake name to be "Akulogak" in 1831. Ivan Petroff named it "Lake Walker" for Francis A. Walker, Superintendent of the 1880 census. Naknek River: stream, heads in Naknek Lake, flows W $35 \mathrm{mi}$. to Kvichak Bay, on Alaska Penin., 2 mi. W of Naknek, Bristol Bay Low.; $58^{\circ} 43^{\prime} \mathrm{N}, 157^{\circ} 04^{\prime} \mathrm{W}$; (map 41). Var. Agulogak River, Fleuve Nakneck, Naknek Riviere, Naknik River, Reka Naknek, Riviere de Nakneck.

Eskimo name published as "Naknek Riviere" by Capt. Lutke (1836, p. 257). It was shown as "R[eka] Naknek" by Capt. Tebenkov (1852, map 4).

Naknek Riviere: stream, see Naknek River.

Naknik River: stream, see Naknek River.

Nakochelik Creek: stream, flows NW $11 \mathrm{mi}$. to Kobuk River, 35 mi. NW of Shungnak, Brooks Ra.; $67^{\circ} 05^{\prime} \mathrm{N}, 158^{\circ} 19^{\prime} \mathrm{W}$; (map 126).

Eskimo name reported by the U.S. Army Corps of Engineers in 1955.

Nakochna River: stream, heads in lake, flows SE $24 \mathrm{mi}$. to Kichatna River, $54 \mathrm{mi}$. SW of Talkeetna, Alaska Ra.; $62^{\circ} 09^{\prime} 25^{\prime \prime} \mathrm{N}, 151^{\circ}$ 45'00" W; (map 81).

Tanaina Indian name obtained in 1899 by Lt. J. S. Herron, USA, and spelled by him "Na-Koch-nu," or "Nakoch River,"

Nakolik Mountain: mountain, 2,200 ft., at $\mathrm{E}$ end of Maiyumerak Mts., in Baird Mts., $59 \mathrm{mi}$. NE of Noatak, Brooks Ra.; $67^{\circ} 51^{\prime} \mathrm{N}, 160^{\circ} 52^{\prime}$ W; (map 127).

Eskimo name meaning "it has a head," obtained in 1956 at Noatak by Orth.

Nakolik River: stream, in Baird Mts., flows N 20 mi. to Noatak River $7 \mathrm{mi}$. E of its junc. with Kaluktavik River, Brooks Ra. ; $67^{\circ} 53^{\prime} \mathrm{N}, 160^{\circ}$. $46^{\prime} \mathrm{W}$; (map 127).

Named for the nearby mountain; reported in 1956 by Orth.

Nakolikurok Creek: stream, in Baird Mts., flows NW $24 \mathrm{mi}$. to Nakolik River $4.5 \mathrm{mi}$. S of its junc. with Noatak River, $59 \mathrm{mi}$. N of Kiana, Brooks Ra.; $67^{\circ} 50^{\prime} \mathrm{N}, 160^{\circ} 42^{\prime} \mathrm{W}$; (map 127).

Eskimo name meaning "little Nakolik," obtained in 1956 at Noatak by Orth.

Nakolkavik: locality, on left bank of Kuskokwim River near its mouth, Yukon-Kuskokwim Delta; (map 58). Var. Nacholchavigamut, Naghaikhlavigamute, Naghikhlavigamute.

Former Eskimo village, recorded as "Naghaikhlavigamute" in 1878 by E. W. Nelson, U.S. Signal Service, and on an 1880 map by Ivan Petroff, who also reported "Naghikhlavigamute" with a population of 193 in his text. In 1898 the spelling "Nacholchavigamut" was obtained from a Moravian missionary, J. H. Kilbuck, by J. E. Spurr and W. S. Post, USGS.
Nakooytoolekmiut: locality, $20 \mathrm{mi}$. NE of Cape Mendenhall, on SE coast of Nunivak I.; $59^{\circ}$. $53^{\prime} 30^{\prime \prime} \mathrm{N}, 164^{\circ} 42^{\prime} 10^{\prime \prime} \mathrm{W}$; (map 55). Var. Nacooytoolecmiut, Nakuitulekmiut.

Eskimo camp reported in 1949 by USC\&GS.

Naksrak Pass: pass, 1,200 ft., at head of Cutler River and Apkugagruk Creek, $25 \mathrm{mi}$. NNE of

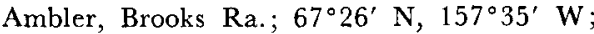
(map 126). Var. Naqsraq.

Eskimo name meaning "pass" reported in 1965 by Wilfried Zibell. This is the best pass between the Ambler-Redstone drainage and the Noatak-Cutler drainage.

Nakuitulekmiut: locality, see Nakooytoolekmiut. Nakvasina, Guba: sound, see Nakwasina Sound.

Nakvasinskaya, Guba: water passage, see Nakwasina Passage.

Nakvassin Lake: lake, $0.7 \mathrm{mi}$. long, near head of Port Herbert, $14.5 \mathrm{mi}$. NW of Port Alexander, on S coast of Baranof I., Alex. Arch.; $56^{\circ} 27^{\prime} 00^{\prime \prime} \mathrm{N}, 134^{\circ} 44^{\prime} 15^{\prime \prime} \mathrm{W}$; BGN 1933; (map 5).

Named in 1923 by USFS "for a Russian hunter who was killed in the massacre at the first site of Sitka," in 1802.

Nakwasina Bay: bay, $2 \mathrm{mi}$. across, at head of Nakwasina Sound, on Baranof I., $13 \mathrm{mi}$. N of Sitka, Alex. Arch.; 57 $15^{\prime} 00^{\prime \prime} \mathrm{N}, 135^{\circ}$ $20^{\prime} 30^{\prime \prime} \mathrm{W}$; (map 9).

Local name reported in 1929 by USFS. Name is derived from Nakwasina Sound.

Nakwasina Passage: water passage, $6 \mathrm{mi}$. long, between $\mathrm{N}$ coast of Halleck I., and Baranof I., 14 mi. N of Sitka, Alex, Arch.; $57^{\circ} 15^{\prime} \mathrm{N}$, $135^{\circ} 30^{\prime}$ W; BGN 1940; (map 9). Var. Guba Nakvasina, Guba Nakvasinskaya, Little Noquashinski Bay, Nakvasina Creek, Nakwasinskaia Bay, Noquashinski Bay, West Arm Nakwasina Passage.

Russian name meaning "fermented" given in 1809 by the navigator Ivan Vasiliev the first; published by Lt. Sarichev (1826, map 19), IRN, as "Guba Nakvasinskaya." This name was applied to both the water passage and the sound until 1929, when USC\&GS made a distinction between the two features.

Nakwasina Sound: sound, between Baranof I. and $\mathrm{E}$ coast of Halleck I., $11 \mathrm{mi}$. N of Sitka, Alex. Arch.; $57^{\circ} 12^{\prime} \mathrm{N}, 135^{\circ} 24^{\prime} \mathrm{W}$; $B G N$ 1940; (map 9). Var. Eastern Arm Nakwasina Passage, Guba Nakvasina, Guba Nakvasinskaya, Nakwasina Passage, Squashinski Bay.

Russian name meaning "fermented," given in 1809 by the navigator Ivan Vasiliev the first; published by Lt. Sarichev (1826, map 19), IRN, as "Guba Nakvasinskaya." See Nakwasina Passage.

Nakwasinskaia Bay: water passage, see Nakwasina Passage.

Nalageavik: barrier island, see Arey Island.

Nalakachak Creek: stream, flows SW $6.5 \mathrm{mi}$. to Aiautak Lagoon, $10 \mathrm{mi}$. NW of Cape Thompson, Arctic Slope; $68^{\circ} 15^{\prime} 55^{\prime \prime} \mathrm{N}, 166^{\circ} 09^{\prime} 25^{\prime \prime}$ W; BGN 1963; (map 129). Var. Nalakacheak Creek. 
Eskimo name recorded in 1960 as "Nalakacheak" by D. C. Foote in connection with Project Chariot studies.

Nalakacheak Creek: stream, see Nalakachak Greek.

Nalikaurak: locality, on Kangnirvik Creek, 35 mi. NW of Kivalina, Brooks Ra.; $68^{\circ} 02^{\prime} \mathrm{N}$, $164^{\circ} 05^{\prime} \mathrm{W}$; (map 130). Var. Nalikauzaq, Nellikowrak.

Eskimo name referring to a willow grove reported in 1966 by E. S. Burch who relates that it was named for an Eskimo woman who hung herself here.

Nalikauzaq: locality, see Nailikaurak.

Nalimiu Point: point of land, see Nalimiut Point.

Nalimiut Point: point of land, on SE shore of Peard Bay, $10 \mathrm{mi}$. SE of Franklin Point, Arctic Plain ; $70^{\circ} 48^{\prime} 30^{\prime \prime} \mathrm{N}, 158^{\circ} 26^{\prime} 45^{\prime \prime} \mathrm{W}$; (map 147). Var. Nalimiu Point.

Eskimo name reported in 1950 by USC\&GS.

Naltuck-an: locality, see Neltushkin.

Naluakruk Lake: lake, $3 \mathrm{mi}$. across, between Teshekpuk Lake and Beaufort Sea, Arctic Plain; $70^{\circ} 49^{\prime} 30^{\prime \prime} \mathrm{N}, 153^{\circ} 33^{\prime} 30^{\prime \prime} \mathrm{W}$; (map 148).

Eskimo name (nalukraq?) reported by USGS in 1956, refers in meaning to "a place where swimming caribou are hunted."

Naluk Greek: stream, flows NE $10 \mathrm{mi}$. to Kobuk River, 26 mi. NW of Selawik, Hogatza High.; $66^{\circ} 59^{\prime} \mathrm{N}, 160^{\circ} 06^{\prime} \mathrm{W}$; (map 114).

Eskimo name obtained by U.S. Army Corps of Engineers in 1955.

Nalvaruk Lake: lake, see Narvakrak, Lake.

Namdak, Utes: rocks, see Lighthouse Rocks.

Nameless Creek: stream, flows NE $10 \mathrm{mi}$. to Kokwok River, $33 \mathrm{mi}$. NE of Dillingham, Bristol Bay Low.; 59 $29^{\prime} \mathrm{N}, 158^{\circ} 04^{\prime} \mathrm{W}$; (map 52).

Local name reported by USC\&GS in 1950.

Nameless Island: island, $0.2 \mathrm{mi}$. long, in Necker Is. W of Baranof I., $20 \mathrm{mi}$. S of Sitka, Alex. Arch.; $56^{\circ} 47^{\prime} 10^{\prime \prime} \mathrm{N}, 135^{\circ} 27^{\prime} 30^{\prime \prime} \mathrm{W}$; (map 5). Var. Beziemiamnnoi Island, Ostrov Bezymyannoy.

Translation in 1929 by USC\&GS of the name given in 1809 by the navigator Ivan Vasiliev the first, IRN. Lt. Sarichev (1826, map 19), IRN, published "O[strov] Bezymyannoy."

Namtschak Rock: rocks, see Lighthouse Rocks. Nanana River: stream, see Nenana River.

Nanava-ak Lake: lake, see Nenevok Lake.

Nanavochtshak Lake: lake, 2 mi. long, just $\mathrm{W}$ of Togiak Lake and $75 \mathrm{mi}$. NE of Goodnews, Kilbuck-Kuskokwim Mts.; 59 $39^{\prime}$ N, $159^{\circ} 39^{\prime}$ W; (map 53).

Eskimo name shown on an 1898 fieldsheet by W. S. Post, USGS.

Nancy: locality, mile 180.7 on The Alaska RR., $33 \mathrm{mi} . \mathrm{N}$ of Anchorage, Cook Inlet Low.; $61^{\circ} 41^{\prime} 40^{\prime \prime} \mathrm{N}, 149^{\circ} 59^{\prime} 00^{\prime \prime} \mathrm{W}$; (map 69).

Name of station stop on The Alaska Railroad published in 1919 Railway Guide Index; derived from nearby Lake Nancy. Recent USGS maps indicate a site with one building.
Nancy, Lake: lake, $3.5 \mathrm{mi}$. long, at Nancy, on The Alaska Railroad, $31 \mathrm{mi}$. N of Anchorage, Cook Inlet Low.; 61 $41^{\prime} \mathrm{N}, 1^{\circ} 9^{\circ} 59^{\prime} \mathrm{W}$; (map 69).

Name reported about 1917 by builders of The Alaska Railroad on a railroad blueprint. Nancy Lee Creek: stream, flows SW $0.6 \mathrm{mi}$. to New Eldorado Creek, at head of Osborn Creek, $12 \mathrm{mi}$. NE of Nome, Seward Penin. High.; $64^{\circ} 38^{\prime} \mathrm{N}, 165^{\circ} 10^{\prime} \mathrm{W}$; (map 94).

Prospectors' name reported in 1904 by $\mathbf{T}$. G. Gerdine, USGS.

Nandell: locality, on Tetlin River near Tetlin Lake, Yukon-Tanana High; (map 85). Var. Nandellas, Nandell's Village.

Former Indian village or camp. Called "Nandell's Village," named for its chief, reported to have a population of 86 in 1885 , by Lt. H. T. Allen, USA.

Nandellas: locality, see Nandell.

Nandell's Village: locality, see Nandell.

Nando River: stream, see South Fork Kuskokwim River.

Nangmut: locality, between Kagati Lake and Kolchichet Mtn., $75 \mathrm{mi}$. NE of Goodnews, Kilbuck-Kuskokwim Mts.; $59^{\circ} 51^{\prime}$ N, $160^{\circ} 12^{\prime}$ W; (map 53).

Eskimo name shown on an 1898 fieldsheet by W. S. Post, USGS.

Nanikakaya Point: point of land, see Alexai Point.

Nanikax: locality, on E coast of Attu I., probably on Alexai Point, Aleutian Is.; 52 $49^{\prime} \mathrm{N}$, $173^{\circ} 18^{\prime} \mathrm{E}$; (map 13).

Archaeological site reported to be an old Aleutian village. It was one of three sites excavated on Attu Island in 1909-10 (Jochelson, 1925, p. 24).

Naniksrak Mountain: hill, 1,800 ft., $\mathrm{S}$ of junc. of Kanayut and Anaktuvuk Rivers, $43 \mathrm{mi}$. NE of Anaktuvuk Pass, Arctic Slope; 68 ${ }^{\circ} 42^{\prime}$ $30^{\prime \prime} \mathrm{N}, 151^{\circ} 08^{\prime} 00^{\prime \prime} \mathrm{W}$; (map 134).

Eskimo name obtained at Anaktuvuk Pass in 1956 by T. E. Taylor, USGS.

Nanimak, Ostrov: island, see Chernabura Island.

Naniratkohort Creek: stream, flows SW $8 \mathrm{mi}$. to Ambler River, $20 \mathrm{mi}$. N of Shungnak, Brooks Ra.; $67^{\circ} 11^{\prime} \mathrm{N}, 157^{\circ} 08^{\prime} \mathrm{W}$; (map 126).

Eskimo name reported by the U.S. Army Corps of Engineers in 1955.

Nankahkwik Creek: stream, flows from Driftwood Slough to Kashunuk River, $37 \mathrm{mi}$. E of Marshall, Yukon-Kuskokwim Delta; 61 ${ }^{\circ} 51^{\prime}$ $\mathrm{N}, 163^{\circ} \cdot 15^{\prime} \mathrm{W}$; (map 74).

Eskimo name shown on a manuscript map of the Kashunuk River by "Father Delon" dated 1937.

Nanning Point: point of land, see Manning Point.

Nanook Creek: stream, heads in Shublik Mts., flows NW $17 \mathrm{mi}$. to Canning River, $7 \mathrm{mi}$. NW of Mount Copleston and $53 \mathrm{mi}$. NW of Mount Michelson, Arctic Slope; $69^{\circ} 34^{\prime} 30^{\prime \prime} \mathrm{N}, 146^{\circ}$ 16'30" W; (map 139).

"Nanoq" is the Eskimo name for the "polar bear." The name probably was applied by USGS geologists in the 1950's.
Nanouan Toughat Lac: lake, see Becharof Lake.

Nantok River: stream, part of distributary system of Yukon River, heads at $61^{\circ} .58^{\prime} \mathrm{N}, 163^{\circ} 17^{\prime}$ W, flows SW $50 \mathrm{mi}$. to Kashunuk River, 18 $\mathrm{mi}$. N of Kgun Lake and $58 \mathrm{mi}$. W of Marshall, Yukon-Kuskokwim Delta; 61 $51^{\prime} 15^{\prime \prime} \mathrm{N}$, $163^{\circ} 51^{\prime} 30^{\prime \prime} \mathrm{W}$; (map 74).

Eskimo name found on a manuscript map by "Father Delon" and reported by USC\&GS in 1951.

Nanuk Lake: lake, $1.5 \mathrm{mi}$. long, between Nechelik and Sakoonang Channels, in Colville River Delta, Arctic Plain; $70^{\circ} 19^{\prime} \mathrm{N}$, $151^{\circ} 01^{\prime} \mathrm{W}$; (map 149).

Eskimo name reported in 1951 by USG\&GS as "Nanuk Narivanga" meaning "polar bear lake," because "the bears frequent this area to catch fish on the [channel] bars."

Nanuktuk Creek: stream, flows NW $18 \mathrm{mi}$. to Kukaklek Lake, $47 \mathrm{mi}$. SW of Iliamna, Aleutian Ra. ; $59^{\circ} 08^{\prime} 29^{\prime \prime} \mathrm{N}, 155^{\circ} 28^{\prime} 29^{\prime \prime} \mathrm{W}$; (map 51).

Local name published on 1951 USGS map.

Nanushuk Lake: lake, $0.7 \mathrm{mi}$. across, $2 \mathrm{mi}$. S of the junc. of Nanushuk River and Kuhsuman Creek, 35 mi. NE of Anaktuvuk Pass, Brooks Ra.; 68²4' N, $150^{\circ} 35^{\prime}$ W; (map 134).

Eskimo name used by USGS geologists during the exploration of Naval Petroleum Reserve No. 4 ; name given in 1944.

Nanushuk River: stream, heads at a glacier, in Endicott Mts., $68^{\circ} 07^{\prime} 30^{\prime \prime} \mathrm{N}, 150^{\circ} 45^{\prime} 05^{\prime \prime} \mathrm{W}$, flows N $100 \mathrm{mi}$. to Anaktuvuk River, $28 \mathrm{mi}$. $\mathrm{E}$ of Umiat, Arctic Slope; $69^{\circ} 18^{\prime} \mathrm{N}, 151^{\circ} 00^{\prime}$ W; BGN 1949; (map 141).

Eskimo name reported in 1901 by Peters and Schrader (1904, p. 79), USGS. Schrader named an "Upper Cretaceous" rock series for this stream.

Nanvak Bay: bay, extends S $4 \mathrm{mi}$. from mouth of Slug River to Bristol Bay, $25 \mathrm{mi}$. W of Hagemeister I., Kilbuck-Kuskokwim Mts.; $58^{\circ} 35^{\prime} \mathrm{N}, 161^{\circ} 45^{\prime} \mathrm{W}$; (map 39).

Eskimo name from Frank Waskey, trader and prospector; published in 1948 by USGS.

Nanvakfak Lake: lake, $2.5 \mathrm{mi}$. across, $1 \mathrm{mi}$. NW of Goodnews Bay and $13 \mathrm{mi}$. W of Goodnews, Kilbuck-Kuskokwim Mts.; 59॰08' N, $161^{\circ} 54^{\prime}$ W; (map 53). Var. Big Lake, Great Lake.

Eskimo name meaning "big lagoon" reported in 1902 by USC\&GS field party. The local name "Big Lake" was reported about 1940 by USC\&GS. It is also known as "Great Lake."

Nanva-Nelhook: bay, see Iliuk Arm Naknek Lake.

Nanvaranak Choa: lake, $1.7 \mathrm{mi}$. across, in course of Kashunuk River, $2.6 \mathrm{mi}$. N of Nuigalak Lake and $36 \mathrm{mi}$. E of Hooper Bay, YukonKuskokwim Delta ; $61^{\circ} 36^{\prime} \mathrm{N}, 164^{\circ} 43^{\prime} \mathrm{W}$; (map 74).

Eskimo name referring to "little lake in course of river"; reported by USC\&GS in 1951.

Nanvaranak Lake: lake, $5 \mathrm{mi}$. long, in course of Kashunuk River, W of Nuigalak Lake, YukonKuskokwim Delta; $61^{\circ} 35^{\prime} \mathrm{N}, 164^{\circ} 45^{\prime} \mathrm{W}$; (map 74). Var. Sohy Bay. 
Eskimo name that refers to "lake in course of river"; reported by USC\&GS in 1951.

Nanvaranak Slough: stream, heads in lake, flows NW $7 \mathrm{mi}$. to Kwikpak Pass, $18 \mathrm{mi}$. W of Kwiguk, Yukon-Kuskokwim Delta; 62 $43^{\prime} 40^{\prime \prime}$ N, $163^{\circ} 56^{\prime} 15^{\prime \prime} \mathrm{W}$; (map 77). Var. Nahnvar-ahn-ak Slough.

Eskimo name obtained in 1948 by USC\&GS. Nanvaranok: locality, see New Hamilton.

Nanvarnaluk: locality, see Nanvarnarluk.

Nanvarnarluk: locality, $8 \mathrm{mi}$. NW of Nunavakpak Lake and $40 \mathrm{mi}$. NW of Bethel, YukonKuskokwim Delta; $60^{\circ} 55^{\prime} \mathrm{N}, 162^{\circ} 54^{\prime} \mathrm{W}$; (map 58). Var. Nanvarnaluk.

Eskimo camp reported in 1949 by USC\&GS. Nanvarnok: locality, see New Hamilton.

Nan-viuk-ka-nuk: lake, see Mikchalk Lake.

Nanvogalokhlagamute: locality, see Nanvogaloklak.

Nanvogaloklak: locality, on lake which drains to Kvichavak River, Yukon-Kuskokwim Delta; (map 74). Var. Nanvogalokhlagamute, Nauvogalokhlagamute, Nauwogalokhlagamute, Nunavoknakchlugamiut.

Former Eskimo village or camp reported in 1879 as "Nanvogalokhlagamute" by E. W. Nelson, U.S. Signal Service. In the 1880 Census Ivan Petroff recorded "Nauvogalokhlagamute" with a population of 100 , but spelled it "Nauwogalokhlagamute" on his map. The 1890 Census lists Nunavoknakchlugamiut, population 107.

Nanwakhchiak Crater: crater, see Nanwaksjiak Crater.

Nanwakhthak Lake: lake, see Nanwaksthak Lake.

Nanwaksjiak Crater: crater, $15 \mathrm{mi}$. $\mathrm{N}$ of Cape Mendenhall, $13 \mathrm{mi}$. W of Twin Mtn., Nunivak I. ; $60^{\circ} 01^{\prime} 45^{\prime \prime} \mathrm{N}, 166^{\circ} 05^{\prime} 00^{\prime \prime} \mathrm{W}$; (map 57). Var. Nanwakhchiak Crater, Nanwaxjiak Crater.

Eskimo name meaning "deep hole" refers to this deep crater; reported in 1949 by USC\&GS.

Nanwaksthak Lake: lake, $0.5 \mathrm{mi}$, across, $5 \mathrm{mi}$. SW of Cape Etolin, on $\mathrm{N}$ coast of Nunivak I.; $60^{\circ} 22^{\prime} 30^{\prime \prime} \mathrm{N}, 166^{\circ} 16^{\prime} 30^{\prime \prime} \mathrm{W}$; (map 57). Var. Nanwakhthak Lake, Nanwaxthak Lake.

Eskimo name reported to mean "big lake" in 1949 by USC\&GS.

Nanwaxjiak Grater: crater, see Nanwaksjiak Crater.

Nanwaxthak Lake: lake, see Nanwaksthak Lake.

Nanwhyenuk Lake: lake, see Nonvianuk Lake.

Nan-y-vuk-cho-ak: lake, see Grant Lake.

Nan-y-vuk-hak Lake: lake, see Nunavaugaluk Lake.

Nan-y-vuk-ha-luk Lake: lake, see Nunavaugaluk Lake.

Naokok: locality, site of Eskimo village on coast of Chukchi Sea, on point of land, near S end of Kasegaluk Lagoon, 19 mi. $\mathbf{S}$ of Point Lay, Arctic Plain; $69^{\circ} 29^{\prime} . \mathrm{N}, 163^{\circ} 05^{\prime} \mathrm{W}$; (map 145.) Var. Neakok.

Eskimo name reported by USGS in 1923. According to a USC\&GS field report this place [Neakok] was an old whaling post, now abandoned, consisting in 1949 of two old buildings. The name means "head."

Naokok Pass: water passage, between Chukchi Sea and Kasegaluk Lagoon, $21 \mathrm{mi}$. S of Point Lay, Arctic Plain; $69^{\circ} 27^{\prime} 30^{\prime \prime} \mathrm{N}, 163^{\circ} 08^{\prime} 30^{\prime \prime}$ W; (map 145). Var. Kasegaluk Inlet.

Name published by USGS in 1955; named for nearby Naokok. USC\&GS reports that the Eskimo refer to it as Kasegaluk, the same name as that of the lagoon.

Naouchkak: locality, see Kaguyak.

Naouchlágamut: locality, see Nauklak.

Napachiakachagamut: locality, see Napakiak.

Napachiakáchagamut: village, see Napakiak.

Na-pac-took-took Mountain: hill, see Napaktuktuk Mountain.

Napahaiagamut: locality, see Napakiak. Napahaiagamut: village, see Napakiak. Napahaiagamute: village, see Napaiskak. Napahayagamiut: locality, see Napakiak.

Napahayagamiut: village, see Napakiak.

Napahayagamute: locality, see Napakiak.

Napahayagamute: village, see Napaisiak.

Napai : village, see Napaimiut.

Napaimiut: village, pop. 10 , on right bank of Kuskokwim River, $28 \mathrm{mi}$. E of Aniak, KilbuckKuskokwim Mts.; $61^{\circ} 32^{\prime} 30^{\prime \prime}$ N, $158^{\circ} 41^{\prime} 30^{\prime \prime}$ W; BGN 1945; (map 72). Var. Hoffmans, Napai, Napaimut, Napaimute, Napamiute, Napamute.

Eskimo and Indian village listed in the 1880 Census with a population of 60 ; its population was 23 in 1890 ; and 111 in 1930 . The name is reported to mean "forest people."

Napaimiut: locality, see Napaimute.

Napaimut: village, see Napaimiut.

Napaimute: locality, on south shore of Iliamna Lake $1 \mathrm{mi}$. W of Kakhonak and $22 \mathrm{mi}$. S of Iliamna, Aleutian Ra.; $59^{\circ} 26^{\prime} \mathrm{N}, 154^{\circ} 52^{\prime} \mathrm{W}$; (map 51). Var. Napai, Napaimiut.

Former Eskimo village or camp reported in the 1890 Census as "Napaimiut" with a population of 11 .

Napaimute: village, see Napaimiut.

Napaishak: village, see Napaiskak.

Napaiskagamut: village, see Napaiskak.

Napaiskak:1 village, pop. 154, on left bank of Kuskokwim River at mouth of Napaiskak Slough, $6 \mathrm{mi}$. S of Bethel, Yukon-Kuskokwim Delta; 60 $42^{\prime} 30^{\prime \prime} \mathrm{N}, 161^{\circ} 54^{\prime} 30^{\prime \prime} \mathrm{W}$; $B G N$ 1941; (map 59). Var. Napahaiagamute, Napaishak, Napaiskagamut, Napasheagamiut, Napasiak, Napaiskeagamiut, Napaskiagamut, Napaskiagamute, Napaskiak, Napiakmut.

Eskimo village shown on an 1867 USC\&GS map as "Napasiak" located on the right bank of the Kuskokwim River. In the 1880 Census Ivan Petroff lists "Napaskiagamute" with a population of 196 . In 1890, "Napasheagamiut" contained 97 persons; in 1939,67; and in 1950,121 . The present spelling of the name was first used in 1898 by J. H. Kilbuck, Moravian missionary. In 1956 the village had a Russian Orthodox church, school and about 30 dwellings (Oswalt, 1963, map and p. 11).

Napaiskak Slough: stream, anabranch of Tupuknuk Slough, flows SW $3.5 \mathrm{mi}$. to Kuskokwim
River, $9 \mathrm{mi}$. S of Bethel, Yukon-Kuskokwim Delta; $60^{\circ} 42^{\prime} 40^{\prime \prime} \mathrm{N}, 161^{\circ} 46^{\prime} 30^{\prime \prime} \mathrm{W}$; (map 59).

Eskimo name reported in 1948 by USC\&GS.

Napakiak: locality, on right bank of Johnson River near its mouth, $14 \mathrm{mi}$. SW of Bethel, Yukon-Kuskokwim Delta; $60^{\circ} 41^{\prime} \mathrm{N}, 162^{\circ} 07^{\prime}$ W; (map 58). Var. Napachiakachagamut, Napahaiagamut, Napahaiagamute, Napahayagamiut, Napahayagamute.

Former Eskimo village or camp recorded in 1878 as "Napahaiagamut" by E. W. Nelson, U.S. Signal Service. In the 1880 Census Ivan Petroff reported "Napahaiagamute" with a population of 98 , and in $1898 \mathrm{~W}$. S. Post recorded "Napachiakachagamut."

Napakiak: village, pop. 190, on right bank of Kuskokwim River, $10 \mathrm{mi}$. SW of Bethel, Yukon-Kuskokwim Delta; $60^{\circ} 42^{\prime} \mathrm{N}, 161^{\circ} 57^{\prime}$ W; (map 59). Var. Napachiakáchagamut, Napahaiagamut, Napahaiagamute, Napahayagamiut, Napahayagamute, Napakiakáchagamut, Napakiakamute, Napakiarek.

Eskimo village reported as "Napahaiagamute" by E. W. Nelson, U.S. Signal Service, in December 1878; the 1880 Census gave the village population as 98 . The name was spelled "Napahayagamiut" in the 1890 Census, but J. E. Spurr and W. S. Post, USGS, showed the name as "Napachiakachagamut" from information received from J. H. Kilbuck, a Moravian missionary. The village population had increased to 139 in 1950 and the Napakiak post office was established in 1951 (Ricks, 1965, p. 44). Today, the village has a church, a school and about 12 dwellings. Napakiakáchagamut: village, see Napakiak.

Napakiakamute: village, see Napakiak.

Napakiarek: village, see Napakiak.

Napaklulik: locality, on Mangoak River, SE of Selawik Lake, Kotzebue-Kobuck Low.; $66^{\circ}$ $20^{\prime} \mathrm{N}, 160^{\circ} 20^{\prime} \mathrm{W}$; (map 14). Var. Nahpark-lu-lik.

Former Eskimo village or camp recorded in 1886 as "Nah-park-lu-lik" by Lt. G. M. Stoney, USN.

Napaktualuit Lake: lake, $0.7 \mathrm{mi}$. long, at western base of Napaktualuit Mtn., 5 mi. NE of Anaktuvuk Pass, Brooks Ra.; $68^{\circ} 10^{\prime}$ N, $151^{\circ} 34^{\prime}$ W; (map 134).

Eskimo name obtained at Anaktuvuk Pass in 1956 by T. E. Taylor, USGS.

Napaktualuit Mountain: mountain, 5,840 ft., E of Anaktuvuk River, $6 \mathrm{mi}$. NE of Anaktuvuk Pass, Brooks Ra.; $68^{\circ} 10^{\prime} \mathrm{N}, 151^{\circ} 30^{\prime} \mathrm{W}$; (map 134).

Eskimo name obtained at Anaktuvuk Pass in 1956 by T. E. Taylor, USGS.

Napaktuktuk Mountain: hill, 436 ft., N.W of Noatak River delta, $13 \mathrm{mi}$. N of Kotzebue, Kotzebue-Kobuk Low.; $67^{\circ} 05^{\prime} \mathrm{N}, 162^{\circ} 41^{\prime} \mathrm{W}$; (map 128). Var. Na-pac-took-took Mountain.

Eskimo name meaning "many trees" according to USC\&GS in 1950.

Napamiute: village, see Napaimiut.

Napamute: village, see Napaimiut.

I The spelling "Napaskiak" should be used to conform to present-day local usage. 
Napanik Creek: stream, flows N $7 \mathrm{mi}$. to Avalik River, $43 \mathrm{mi}$. SE of Wainwright, Arctic Plain; $73^{\circ} 05^{\prime} \mathrm{N}, 159^{\circ} 10^{\prime} \mathrm{W}$; (map 146).

Eskimo name recorded at Wainwright in 1956 by T. E. Taylor, USGS. Orth was told in 1965 that "Napanik" is the name of the man who died at the mouth of the stream "long ago."

Naparagamiut: village, see Hooper Bay.

Napareayak Slough: stream, flows $S 5 \mathrm{mi}$. past village of Hooper Bay to Hooper Bay, YukonKuskokwim Delta ; $61^{\circ} 31^{\prime} 40^{\prime \prime} \mathrm{N}, 166^{\circ} 05^{\prime} 15^{\prime \prime}$ W; (map 75).

Eskimo name, meaning "little stakes," reported by USC\&GS in 1951.

Naparuacheak: locality, site of Eskimo village on Chukchi Sea coast, on barrier reef $15 \mathrm{mi}$. NE of Point Lay; Arctic Plain; 69 ${ }^{\circ} 7^{\prime} \mathrm{N}$, $162^{\circ} 45^{\prime} \mathrm{W}$; (map 145).

Eskimo name reported by USGS in 1923.

Napasiak: village, see Napaiskak.

Napaskeagamiut: village, see Napaiskak.

Napaskiagamiut: village, see Napaiskak.

Napaskiagamut: village, see Napaiskak.

Napaskiagamute; village, see Napaiskak.

Napaskiak: village, see Napaiskak.

Napatolik Creek: stream, flows SW $11 \mathrm{mi}$. to Selawik Lake, $14 \mathrm{mi}$. W of Selawik, KotzebueKobuk Low.; $66^{\circ} 37^{\prime} \mathrm{N}, 160^{\circ} 30^{\prime} \mathrm{W}$; (map 114).

Eskimo name obtained by U.S. Army Corps of Engineers in 1955.

Napatorak Greek: stream, in De Long Mts., flows SSE $20 \mathrm{mi}$. to Kelly River, $40 \mathrm{mi}$. SE of Mount Kelly, Brooks Ra.; $68^{\circ} 12^{\prime} \mathrm{N}, 162^{\circ} 13^{\prime} \mathrm{W}$; (map 130).

Eskimo name, means "small trees"; name obtained in 1956 at Noatak by Orth.

Napatuk Creek: stream, heads at $60^{\circ} 33^{\prime} \mathrm{N}$, $163^{\circ} 00^{\prime} \mathrm{W}$, flows SE $36 \mathrm{mi}$. to Kuskokwim River, $20 \mathrm{mi}$. NW of Eek and $35 \mathrm{mi}$. SW of Bethel, Yukon-Kuskokwim Delta; $60^{\circ} 25^{\prime} \mathrm{N}$, $162^{\circ} 25^{\prime} \mathrm{W}$; (map 58). Var. Meroyuk River.

Eskimo name reported in 1925 by USGS. The name "Meroyuk" was reported as local usage by USC\&GS in 1949.

Napautokik Creek: stream, flows $S 5 \mathrm{mi}$. to Kobuk River, 26 mi. N of Selawik, KotzebueKobuk Low.; $66^{\circ} 58^{\prime} \mathrm{N}, 160^{\circ} 11^{\prime} \mathrm{W}$; (map 114).

Eskimo name obtained by U.S. Army Corps of Engineers in 1955.

Napawrax: locality, area on Chuchi Sea coast between Kugoosuguru and Natirnuq, $9 \mathrm{mi}$. SW of Barrow, Arctic Plain; $71^{\circ} 1^{\prime}$ N, $157^{\circ}$. 01' W; (map 153). Var. Nunaktuau.

Eskimo locality or camp name published by Spencer (1959, map 2) in the same general area as "Nunaktuau," listed by Lt. P. H. Ray (1885, p. 55). Hodge (1910, p. 97) lists "Nunaktuau * * * Eskimo summer village," which he locates near Walakpa Bay.

Napean, Point: point of land, at entrance to Eliza Harbor, on SE coast of Admiralty 1., $22 \mathrm{mi}$. SE of Angoon, Alex. Arch.; 57 $08^{\prime} 35^{\prime \prime} \mathrm{N}$, $134^{\circ} 16^{\prime} 45^{\prime \prime}$ W; (map 9). Var. Nepean Point, Nepen Point, Nepken Point.
Named in 1794 by Capt. George Vancouver, RN, for Evan Nepean of the British Admiralty (Wagner, 1937, p. 399). Lt. Joseph Whidbey of Vancouver's party explored the point on August 3, 1794. On Vancouver's original chart and the French copy of it, the name was spelled "Nepean," and this form was widely used. However, in his text, Capt. Vancouver spelled it "Napean."

Napi: locality, see Napaimute.

Napiakmut: village, see Napaiskak.

Napoleon Creek: stream, flows SW $7 \mathrm{mi}$. to South Fork Fortymile River, $50 \mathrm{mi}$. SW of Eagle,

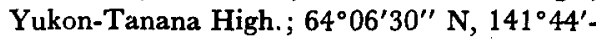
30" W; (map 102). Var. Napolean Gulch.

Named by prospectors and reported in 1896 by Spurr (1898, pl. 47), USGS. "Napolean Gulch, named after the Frenchman who located it, is rich in nuggets"' (Ogilvie, 1897, p. 8).

Napoleon Creek: stream, see Maryland Creek. Napoleon Gulch: stream, see Napoleon Creek.

Napotoli Creek: stream, flows E $20 \mathrm{mi}$. to Nushagak River, $65 \mathrm{mi}$. NE of Dillingham, Bristol Bay Low.; $59^{\circ} 48^{\prime} \mathrm{N}, 1^{\circ} 7^{\circ} 25^{\prime} \mathrm{W}$; BGN 1931 : (map 52).

Eskimo name obtained in 1930 from F. H. Waskey and Beverly Polley, local inhabitants, by Gerald FitzGerald, USGS.

Nappy Creek: stream, flows NE $0.5 \mathrm{mi}$. to Ophir Creek which flows to Niukluk River, $11 \mathrm{mi}$. N of Council and $15 \mathrm{mi}$. SE of Mount Bendeleben, Seward Penin. High.; $65^{\circ} 03^{\prime} \mathrm{N}, 163^{\circ} 41^{\prime}$ W; (map 110).

Prospectors' name reported on a map of Cape Nome gold fields by David Fox, Jr., dated 1901.

Naptowne: suburb, of Sterling on Sterling Highway, $1.5 \mathrm{mi}$. ESE of Sterling, $19 \mathrm{mi}$. ESE of Kenai, Cook Inlet Low.; $60^{\circ} 30^{\prime} 30^{\prime \prime}$ N. $150^{\circ}$ 43'30' W; (map 62). Var. Naptowne Lodge.

Name published in 1965 by USGS. This village was reported in 1959 by USGS as Naptowne Lodge.

Naptowne: village, see Sterling.

Naptowne Lodge: suburb, see Naptowne.

Nargosakchokowik: locality, see Nagosakchowik.

Nargosakchokowik: stream, see Nagosakchowik Slough.

Nariksmiut: locality, at mouth of Nariksmiut River, $40 \mathrm{mi}$. NW of Cape Mendenhall, Nunivak I.; $60^{\circ} 24^{\prime} \mathrm{N}$; $166^{\circ} 43^{\prime} \mathrm{W}$; (map 57). Var. Narixmiut.

Eskimo camp reported in 1949 by USC\&GS. Nariksmiut River: stream, heads in Ingrilukat Hills, flows NW $16 \mathrm{mi}$. to Bering Sea at Nariksmiut, $40 \mathrm{mi}$. NW of Cape Mendenhall, on $\mathrm{N}$ coast of Nunivak I.; $60^{\circ} 24^{\prime} \mathrm{N}, 166^{\circ} 43^{\prime}$ W; (map 57). Var. Narixmiut River.

Eskimo name obtained in 1949 by USC\&GS. Naringolapak Slough: distributary, in Yukon Delta, extends N-S $12 \mathrm{mi}$. between Kwikluak and Kwikpak Passes, $14 \mathrm{mi}$. E of Kwiguk, Yukon-Kuskokwim Delta; $62^{\circ} 48^{\prime} 10^{\prime \prime} \mathrm{N}, 164^{\circ}$. 05'10" W; (map 77).

Eskimo name obtained in 1899 by G. R. Putnam, USC\&GS. Published in 1901 on Chart 9372.
Naringolapak Slough: watercourse, see Takwaklanuk Slough.

Narivakvak: lake, see Chandler Lake.

Narivakvuk: lake, see Chandler Lake.

Narivukpuk Lake: lake, see Neruokpuk Lakes.

Narixmiut: locality, see Nariksmiut.

Narixmiut River: stream, see Nariksmiut River.

Nariyauck River: stream, heads in lake, flows SW $15 \mathrm{mi}$. to Kashunuk River, $29 \mathrm{mi}$. E of. village of Hooper Bay, Yukon-Kuskokwim Deita; $61^{\circ} 26^{\prime} \mathrm{N}, 165^{\circ} 15^{\prime} \mathrm{W}$; (map 75).

Eskimo name reported by USC\&GS in 1951. Naro'am-an'yi: lake, see Atka Lake.

Naro'am-unga: bluff, just E of Rush Point, on SW coast of Saint George I., in Pribilof Is.; $56^{\circ} 35^{\prime} 15^{\prime \prime} \mathrm{N}, 169^{\circ} 43^{\prime} 30^{\prime \prime} \mathrm{W}$; (map 38).

Aleut name, meaning "Atka natives' trail," reported by Putnam (1903, p. 1015), USC\&GS. "The tradition is that natives of Atka who had been taken to Saint Paul by the Russians left Saint Paul in their bidarkas, intending to return to Atka. They landed on the beach below this point, not knowing where they were, and hauled their bidarkas up on the bluff and spent the night on top. They then went to Zapadni where they lived for a time, and were later taken to Atka by the Russians. This place does not seem to offer a safe place of descent at present."

Narogurum River: stream, see Kemuk River

Narokachik River: stream, heads in a lake at $61^{\circ} 01^{\prime} \mathrm{N}, 164^{\circ} 15^{\prime} \mathrm{W}$, flows $\mathrm{NW} 40 \mathrm{mi}$. to Azun River, 2 mi. E of Hazen Bay, YukonKuskokwim Delta; 61 $05^{\circ} \mathrm{N}, 164^{\circ} 51^{\prime} \mathrm{W}$; (map 74). Var. Narokachuk Creek.

Eskimo name reported by USC\&GS in 1949.

Narokachuk Creek: stream, see Narokachik Creek.

Naros Bay: bight, see Beyer Bay.

Narosigagamieut: locality, see Nagosakchowik.

Narosigak: locality, see Nagosakchowik.

Narosigak: stream, see Nagosakchowik Slough.

Narrow Cape: point of land, $\mathrm{E}$ point of entrance to Ugak Bay, $3 \mathrm{mi}$. N of Ugak I., on $\mathbf{E}$ coast of Kodiak I., $57^{\circ} 25^{\prime} 30^{\prime \prime} \mathrm{N}, 152^{\circ} 20^{\prime} 00^{\prime \prime} \mathrm{W}$; (map 34). Var. Cape Hollings, Low Cape, Mys Tonkie, Mys Tonkiy, Tonkeye, Tonkie.

Named "Cape Hollings" in 1788 or 1789 by Meares (1790, p. 304). See Wagner (1937, p. 462). In 1804 Lisianski (1814, p. 169) gave the descriptive name "Narrow Cape." About 1808-10 Lt. G. A. Sarichev published "Mys Tonkiy," a Russian translation of the present name. In 1869 USC\&GS identified it as "Low Cape."

Narrow Cape: spit, see Unga Spit.

Narrow Cove: cove, $5 \mathrm{mi}$. long, at $\mathrm{E}$ end of Kukaklek Lake, $42 \mathrm{mi}$. S of Iliamna, Aleutian Ra.; $59^{\circ} 09^{\prime} \mathrm{N}, 155^{\circ} 05^{\prime} \mathrm{W}$; (map 51).

Descriptive name published by USGS in 1926.

Narrow Creek: stream, flows NW $0.6 \mathrm{mi}$. to Red Bay, on N coast of Prince of Wales I., Alex. Arch.; $56^{\circ} 16^{\prime} 35^{\prime \prime} \mathrm{N}, 133^{\circ} 19^{\prime} 15^{\prime \prime} \mathrm{W}$; (map 6).

Named in 1886 by Lt. J. M. Helm, USN, for charting purposes; name published in 1887 on USC\&GS Chart 706. 
Narrow Pass: water passage, $1.2 \mathrm{mi}$. long, off Behm Canal, between Revillagigedo and Rudyerd Is., Alex. Arch.; 55 $18^{\prime} 00^{\prime \prime} \mathrm{N}, 131^{\circ}$ 02'45" W; (map 3).

Descriptive name given in 1891 by USC\&GS.

Narrow Point: point of land, on $\mathrm{E}$ coast of Prince of Wales $1 ., 8 \mathrm{mi}$. W of Lemesurier Point, Alex. Arch.; $55^{\circ} 47^{\prime} 30^{\prime \prime} \mathrm{N}, 132^{\circ}$ 28'30" W; (map 4). Var. Mys Tonkiy, Point Tonkey, Tonki Point.

This is a translation of "M[ys] Tonkiy"; published in 1853 on Russian Hydrog. Dept. Chart 1493.

Narrow Point: point of land, see Tonki Point.

Narrow Point: point of land, see Uzkosti Point.

Narrows, The: water passage, $1 \mathrm{mi}$. long, between SW coast of Prince of Wales $I$. and NE islands of Barrier Is., Alex. Arch.; 54 $49^{\prime} \mathrm{N}$, $132^{\circ} 22^{\prime} \mathrm{W}$; (map 1 ).

Named by Lt. Comdr. J. F. Moser, USN, in 1897.

Narrows, The: water passage, between Blake Channel and Eastern Pasage, on $\mathrm{E}$ coast of Wrangell I., Alex. Arch.; $56^{\circ} 22^{\prime} \mathrm{N}, 132^{\circ} 06^{\prime}$ W; (map 6).

Named in 1917 by USC\&GS.

Narrows, The: water passage, $1 \mathrm{mi}$. long, on Windham Bay, $5 \mathrm{mi}$. E of Point Windham and $60 \mathrm{mi}$. SW of Juneau, Coast Mts. ; $57^{\circ} 35^{\prime} 10^{\prime \prime}$ $\mathrm{N}, 133^{\circ} 26^{\prime} 45^{\prime \prime} \mathrm{W}$; (map 8).

Local name reported in 1951 by USGS.

Narrows, The: water passage, in $\mathbf{S}$ part of Port Frederick, $11 \mathrm{mi}$. SW of Hoonah, on $\mathrm{N}$ central Chichagof I., Alex. Arch.; 57 $59^{\prime} 20^{\prime \prime}$ N, $135^{\circ}$ $38^{\prime} 30^{\prime \prime} \mathrm{W}$; (map 9).

Descriptive name published by USC\&GS in the 1943 Coast Pilot (p. 417).

Narrows, The: water passage, between Little Raspberry and Afognak Is., Kodiak I.; $58^{\circ}$ $00^{\prime} \mathrm{N}, 152^{\circ} 53^{\prime} \mathrm{W}$; (maps 34,43 ).

Local descriptive name reported in 1952 by USGS.

Narrows, The: water passage, $0.1 \mathrm{mi}$. wide, $\mathrm{S}$ of Ismailof $I$., connecting Halibut Cove and Kachemak Bay, 11 mi. SE of Homer, Chugach Mts.; $59^{\circ} 35^{\prime} 45^{\prime \prime} \mathrm{N}, 151^{\circ} 14^{\prime} 00^{\prime \prime} \mathrm{W}$; (map $50)$.

Local name reported by USGS or USC\&GS in the 1940's.

Narrows, The: water passage, NW of $\mathrm{N}$ tip of Hawkins I., $5 \mathrm{mi}$. NW of Cordova, Chugach Mts.; $60^{\circ} 37^{\prime} \mathrm{N}, 145^{\circ} 47^{\prime} \mathrm{W}$; (map 64).

Named in 1897 by Lt. Cmdr. J. F. Moser, USN, while doing hydrographic studies along the coast of Alaska.

Narrows, The: watercourse, $0.3 \mathrm{mi}$. wide, in Galena Bay, $42 \mathrm{mi}$. NW of Cordova, Chugach Mts.; $60^{\circ} 57^{\prime} \mathrm{N}, 146^{\circ} 39^{\prime} \mathrm{W}$; (map 64).

Local name reported in 1912 by Capps and Johnson (1913, pl. 4), USGS.

Narrows, The: water gap, of Hodzana River, 32 mi. NW of Beaver, Kokrines-Hodzana High.; $66^{\circ} 39^{\prime} \mathrm{N}, 143^{\circ} 17^{\prime} \mathrm{W}$; (map 118).

Local descriptive name obtained in 1956 by USGS.

Narrows, The: water passage, see Olga Narrows.
Narrows, The: water passage, see Sitkalidak Passage.

Narrows Mountain: mountain, 2,075 ft., on Annette I., W of Cascade Inlet, Alex. Arch.; $55^{\circ} 10^{\prime} 50^{\prime \prime} \mathrm{N}, 131^{\circ} 24^{\prime} 25^{\prime \prime} \mathrm{W}$; (map 3 ).

Named in 1883 by Lt. Cmdr. H. E. Nichols, USN; derived from Tongass Narrows.

Narrows Peak: peak, 2,600 ft., on SW side of Petersburg Mtn. on Lindenberg Penin., Kupreanof 1., $2.2 \mathrm{mi}$. NW of Petersburg, Alex. Arch.; $56^{\circ} 50^{\prime} 18^{\prime \prime} \mathrm{N}, 132^{\circ} 59^{\prime} 00^{\prime \prime} \mathrm{W}$; (map 6).

Named in 1887 by Lt. Cmdr. C. M. Thomas, USN, for charting purposes; published in 1888 on USC\&GS Chart 705.

Narrows Point: point of land, on NE coast of Little Tanaga I., Aleutian Is.; $51^{\circ} 51^{\prime} 15^{\prime \prime} \mathrm{N}$, $176^{\circ} 04^{\prime} 05^{\prime \prime} \mathrm{W}$; BGN 1936; (map 17).

Descriptive name given by members of the U.S. Navy Aleutian Island Survey Expedition in 1934 .

Narrows Point: point of land, see Uzkosti Point.

Narrow Strait: water passage, $7 \mathrm{mi}$. long, between Spruce I. and NE coast of Kodiak I.; $57^{\circ} 54^{\prime} \mathrm{N}, 152^{\circ} 27^{\prime} \mathrm{W}$; (map 34). Var. Elovoi Strait, Proliv Maloy Malinovoy, Proliv Uzenkiy, Proliv Uzenkoy ili Yelovoy, Prolivchik Uzinkoy, Spruce Strait, Usinka Narrows, Uzenkoi Strait.

Partial translation of the name "Proliv Uzenkoy ili Yelovoy," meaning "narrow or spruce strait" given by Sub-Lt. M. Murashev, IRN, in 1839 or 1840 and published in 1849 on Russian Hydrog. Dept. Chart 1425.

Narvakrak, Lake: lake, $3 \mathrm{mi}$. long, in Noatak River Valley, $3 \mathrm{mi}$. $\mathrm{N}$ of Noatak Canyon, $43 \mathrm{mi}$. NE of Noatak, Brooks Ra.; $68^{\circ} 00^{\prime} \mathrm{N}$, $161^{\circ} 43^{\prime}$ W; (map 127). Var. Nalvaruk Lake.

Eskimo name meaning "great old lake," obtained in 1956 at Noatak by Orth.

Narvaqpak Lake: lakes, see Neruokpuk Lakes. Narwhal Island: barrier island, $2 \mathrm{mi}$. long on Beaufort Sea coast, northern island of McClure Is., $38 \mathrm{mi}$. E of Beechey Point, Arctic Plain, $70^{\circ} 23^{\prime} 45^{\prime \prime} \mathrm{N}, 147^{\circ} 28^{\prime} 50^{\prime \prime} \mathrm{W}$; (map 150).

Named by Leffingwell (1919, p. 14, 97) after the whaleship Narwhal, on which he "returned to civilization in the fall of 1908, as the guest of Capt. George Leavitt."

Nasak, Mount: peak, 2,126 ft., in Lisburne Hills, $13 \mathrm{mi}$. SE of Cape Dyer, Arctic Slope; $68^{\circ}$ $34^{\prime} 30^{\prime \prime} \mathrm{N}, 165^{\circ} 45^{\prime} 50^{\prime \prime} \mathrm{W}$; (map 129).

Eskimo descriptive name meaning "cap" reported in 1956 by Orth.

Nasanki Harbor: anchorage, see Pavlof Harbor. Nasaugluk: village, see Togiak.

Nasaurak Mountain: mountain, 2,979 ft., on W side of Anaktuvuk River, $14 \mathrm{mi}$. N of Anaktuvuk Pass, Brooks Ra.; $68^{\circ} 20^{\prime}$ N, $151^{\circ} 37^{\prime}$ W; (map 134).

Eskimo name obtained at Anaktuvuk Pass in 1956 by T. E. Taylor, USGS.

Nasauzaq: hill, see Nasorak Hill.

Naseleniya, Mys: point of land, see Possession, Point.
Nashak Lake: lake, $6.5 \mathrm{mi}$. long, on $\mathrm{S}$ bank of Kuyungsik River, SE of Nuigalak Lake, Yukon-Kuskokwim Delta; 61 ${ }^{\circ} 26^{\prime} \mathrm{N}, 164^{\circ} 48^{\prime}$ W; (map 74).

Eskimo name referring to a "coat (or parka) hood"; obtained at Chevak by Orth in 1965.

Nash Harbor: village, pop. 49 (1950), on SW shore of Nash Harbor, $32 \mathrm{mi}$. SW of Gape Etolin, on Nunivak I.; $60^{\circ} 12^{\prime} 15^{\prime \prime} \mathrm{N}, 166^{\circ}$ $56^{\prime} 15^{\prime \prime} \mathrm{W}$; (map 57).

Eskimo village shown on a 1937 manuscript map of Nunivak Island; name derived from that of the cove.

Nash Harbor: bay, $3 \mathrm{mi}$. across from Cape Alonquin to Chingeruk Point, $25 \mathrm{mi}$. SW of Cape Etolin, on $\mathrm{N}$ coast of Nunivak I., $60^{\circ}$ $15^{\prime} 00^{\prime \prime} \mathrm{N}, 166^{\circ} 52^{\prime} 30^{\prime \prime} \mathrm{W}$; (map 57).

Local name reported in 1902 by USC\&GS. Nasikach Island: island, see Twoheaded Island. Nasikan Island: island, see Twoheaded Island.

Naskak Camp: locality, on Bering Sea coast, near W end of Niyrakpak Lagoon, $12 \mathrm{mi}$. SE of Gambell, St. Lawrence I.; $63^{\circ} 39^{\prime} \mathrm{N}, 171^{\circ} 29^{\prime}$ W; BGN 1951; (map 93). Var. Naskok.

Eskimo name reported in 1932 by $O$. W. Geist, Univ. of Alaska. Its meaning is unknown.

Naskok: locality, see Naskak Camp.

Naskonat Peninsula: peninsula, extends into Bering Sea, just $\mathrm{N}$ of Ningaluk River, $110 \mathrm{mi}$. W of Bethel, Yukon-Kuskokwim Delta; $61^{\circ} 00^{\prime}$ $\mathrm{N}, 165^{\circ} 00^{\prime} \mathrm{W}$; (map 57$)$.

Eskimo name meaning "small hand" obtained at Tanunak in 1951 by USC\&GS.

Naskowhak, Point: point of land, at $\mathrm{W}$ entrance to Seldovia Bay, $1.5 \mathrm{mi}$. NW of Seldovia, Chugach Mts.; $59^{\circ} 27^{\prime} 30^{\prime \prime} \mathrm{N}, 151^{\circ} 44^{\prime} 30^{\prime \prime} \mathrm{W}$; $B G N$ 1908; (map 50).

Kenai Indian name reported by USC\&GS in 1908.

Nasoaruk Creek: stream, see Nasorak Creek.

Nasorak Creek: stream, flows SW $4 \mathrm{mi}$. to Chukchi Sea, $1.4 \mathrm{mi}$. W of Crowbill Point and $4 \mathrm{mi}$. SE of Cape Thompson, Arctic Slope; $68^{\circ} 06^{\prime} 30^{\prime \prime} \mathrm{N}, 165^{\circ} 51^{\prime} 05^{\prime \prime} \mathrm{W}$; BGN 1963; (map 129). Var. Nasoaruk Creek, Nusoaraq Creek, Nusoaruk Creek.

Eskimo name reported as "Nu-soa-ruk" in 1950 by USC\&GS.

Nasorak Hill: hill, $610 \mathrm{ft}$, $7 \mathrm{mi}$. S of Jarvis Mtn. and $12 \mathrm{mi}$. NE of Kivalina, Arctic Slope; $67^{\circ} 49^{\prime} \mathrm{N}, 164^{\circ} 06^{\prime} \mathrm{W}$; (map 128). Var. Nasauzaq, Nasowrak.

Eskimo name meaning "little hood" reported in 1966 by E. S. Burch.

Nasowrak: hill, see Nasorak Hill.

Nassau Fiord: estuary, on E coast of Kenai Penin., trends SE $4 \mathrm{mi}$. to Icy Bay, $8.5 \mathrm{mi}$. SW of Chenega, Chugach Mts.; 60 $14^{\prime} 30^{\prime \prime}$ N, 148 20'00" W; BGN 1910; (map 63).

Named about 1910 by G. W. Perkins (possibly of the Alaska Steamship Company).

Nataga Creek: stream, heads on E side of Mount Seltat, on Alaska-Canada boundary, flows SE $11 \mathrm{mi}$. to Kelsall River, $28 \mathrm{mi}$. NW of Skagway, St. Elias Mts.; $59^{\circ} 32^{\prime} 20^{\prime \prime} \mathrm{N}, 136^{\circ} 06^{\prime} 00^{\prime \prime}$ 
W; BGN 1922; (map 45). Var. Natagehin Greek.

Tlingit Indian name reported as Natagehin by Aurel and Arthur Krause (1883, map). The "hin" or "hini" termination means "creek."

Natagehin: stream, see Nataga Creek.

Natalia Bay: bay, extends NE $3.5 \mathrm{mi}$. off Sitkalidak Strait, on SW coast of Sitkalidak I., SE of Kodiak I.; $57^{\circ} 04^{\prime} \mathrm{N}, 153^{\circ} 21^{\prime} \mathrm{W}$; $B G N$ 1934; (map 34).

Named in 1934 by USC\&GS, "in honor of Madame Natalia Shelikov, wife of Capt. Grigori Ivanovich Shelikov, and his companion in all his travels ***. After Shelikov's death in 1795, Madame Natalia succeeded him as manager of the Russian American Company."

Natalia Island: island, 2,000 ft. long, between Soda Bay and Tlevak Strait, on $\mathrm{W}$ coast of Prince of Wales I., Alex. Arch.; 55 ${ }^{\circ} 14^{\prime} 15^{\prime \prime} \mathrm{N}$,

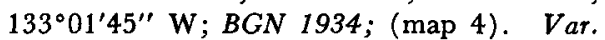
Nathalie Island, Natalie Island.

Named in 1928 by USFS for Natalia Shelikov, wife of Grigori Ivanovich Shelikov. See Natalia Bay and Shelikov Strait.

Natalia Peninsula: peninsula, 4 mi. long, on SW coast of Sitkalidak I., SE of Kodiak I.; $57^{\circ} 05^{\prime}$ $\mathrm{N}, 153^{\circ} 22^{\prime} \mathrm{W}$; BGN 1934; (map 34).

Named in 1934 by USC\&GS, "in honor of Madame Natalia Shelikov * * *." See Natalia Bay.

Natalia Point: point of land, $\mathbf{S}$ point of entrance to Soda Bay, on W coast of Prince of Wales I., Alex. Arch.; 55 $14^{\prime} 00^{\prime \prime} \mathrm{N}, 133^{\circ} 02^{\prime} 20^{\prime \prime} \mathrm{W}$; $B G N$ 1934; (map 4). Var. Nathalie Point. Named in 1928 by USFS for Natalia Shelikov, wife of Grigori Ivanovich Shelikov. See Natalia Bay and Shelikov Strait.

Natalia Point: point of land, $\mathrm{S}$ tip of Natalia Penin. on SW coast of Sitkalidak I., SE of Kodiak I.; $57^{\circ} 04^{\prime}$ N, $153^{\circ} 23^{\prime} \mathrm{W}$; BGN 1934; (map 34).

Named in 1934 by USC\&GS, "in honor of Madame Natalia Shelikov * * *." See Natalia Bay.

Natalie, Mount: mountain, see Nathlie Mountain.

Natalie Island: island, see Natalia Island.

Nataroarok Creek: stream, heads in lake and flows N $25 \mathrm{mi}$. to Camden Bay, $3 \mathrm{mi}$. SW of mouth of Hulahula River and $12 \mathrm{mi} \mathrm{SW}$ of Barter I., Arctic Plain; $70^{\circ} 02^{\prime} 10^{\prime \prime} \mathrm{N}, 144^{\circ}$ $10^{\prime} 40^{\prime \prime} \mathrm{W}$; (map 151).

Eskimo name reported by USGS in 1956.

Natat Creek: stream, heads in Mentasta Mts., flows NW $14 \mathrm{mi}$. to Slana River $3.2 \mathrm{mi}$. NE of its junc. with Copper River, Alaska Ra.; $62^{\circ} 43^{\prime} \mathrm{N}, 143^{\circ} 52^{\prime} \mathrm{W}$; (map 84).

Indian name reported in 1903 by F. C. Schrader, USGS.

Natat Creek: stream, see Rufus Creek.

Natazhat, Mount: peak, 13,435 ft., at head of Natazhat Glacier, $61 \mathrm{mi}$. NE of McCarthy, St. Elias Mts.; $61^{\circ} 31^{\prime} \mathrm{N}, 141^{\circ} 06^{\prime} \mathrm{W}$; $B G N$ 1917; (map 67).

Indian name reported in 1891 by Hayes (1892, sheet 2), USGS.
Natazhat Glacier: glacier, 4 mi. long, trends NE from Mount Natazhat, Alaska, to head of Kletsan Creek, Canada, St. Elias Mts.; $61^{\circ}$ $33^{\prime} \mathrm{N}, 141^{\circ} 55^{\prime} \mathrm{W}$; BGN 1953; (map 67). Var. Kletsan Glacier, Klutson Glacier.

Named in 1912 by Thomas Riggs, Jr., IBC; named after Mount Natazhat.

Natcheck: locality, see Nuchek.

Natcheek : locality, see Nuchek.

Nateekin: locality, at the head of Nateekin Bay in Unalaska Bay, Unalaska I., Aleutian Is. (map 23). Var. Natiekinskoe, Selo Natyka, Natieka.

Former Aleut name published as "Sel[o] Natyka" or "Natyka village" by Lt. Sarichev (1826, map 14), IRN. Father Veniaminov (Baker, 1906, p. 455) reported "Natiekinskoe," and says it consists of two huts (yourts) and 15 people."

Nateekin Bay: bay, $1 \mathrm{mi}$. across, in Unalaska Bay, N coast of Unalaska I., Aleutian Is.; $53^{\circ} 53^{\prime}$ N, $166^{\circ} 36^{\prime}$ W; (map 23). Var. Natiekinshaia, Natykin, Natykinskaya.

Aleut name recorded by Father Veniaminov $(1840$, v. 1 , p. 163$)$ as "Natykinskaya" or "Natykin." It was published in 1875 with the present spelling by USC\&GS.

Nathalie Island: island, see Natalia Island.

Nathalie Mountain: mountain, see Nathlie Mountain.

Nathalie Point: point of land, see Natalia Point. Nathlie Mountain: mountain, 6,910 ft., N of Sanford Glacier, $10 \mathrm{mi}$. SW of Mount Sanford and $33 \mathrm{mi}$. SE of Gulkana, Wrangell Mts.; $62^{\circ} 09^{\prime} \mathrm{N}, 144^{\circ} 24^{\prime} \mathrm{W}$; (map 83). Var. Mount Natalie, Nathalie Mountain.

Name reported in 1898 as "Mount Natalie" by Capt. W. F. Abercrombie (1899, p. 312), USA. The "Nathlie" spelling was published by Schrader (1900, map 20), USGS.

Natieka: village, see Nateekin.

Natiekinshaia: bay, see Nateekin Bay.

Natiekinskoe: village, see Nateekin.

Natinakunit Pass: pass, 1,650 ft., in De Long Mts., between Nimiuktuk and Anisak Rivers, Brooks Ra.; $68^{\circ} 26^{\prime} \mathrm{N}, 159^{\circ} 42^{\prime} \mathrm{W}$; (map 131).

Eskimo name reported by USGS in 1956.

Nation: locality, on $\mathbf{S}$ bank of Yukon River, $2.2 \mathrm{mi}$. below mouth of Nation River, YukonTanana High.; $65^{\circ} 12^{\prime} 10^{\prime \prime} \mathrm{N}, 141^{\circ} 47^{\prime} 20^{\prime \prime} \mathrm{W}$; (map 103). Var. Nation City.

Former mining settlement and river landing for the Fourth of July Creek placer mining area. As early as 1900, Lt. John Cantwell reported the existence of the settlement, but it never developed into a large permanent population.

National Creek: stream, flows W $2.6 \mathrm{mi}$. to Kennicott Glacier, $4 \mathrm{mi}$. NE of McCarthy, Wrangell Mts.; $61^{\circ} 29^{\prime} \mathrm{N}, 142^{\circ} 53^{\prime} \mathrm{W}$; (map 67).

Local name published on a manuscript map of the Copper River and Northwestern Railway, Chitina Branch Line, dated 1909.

Nation City: locality, see Nation.
Nation Point: point of land, NW tip of Coronation I., Alex. Arch.; 55 $55^{\prime} 45^{\prime \prime}$ N, $134^{\circ} 20^{\prime}$ $05^{\prime \prime} \mathrm{W}$; (map 4).

Named in 1886 by Lt. Cmdr. Snow, USN. Nation Reef: island, 2 mi. long, in Yukon River at mouth of Fourth of July Creek, $34 \mathrm{mi}$. NNW of Eagle, Yukon-Tanana High.; $65^{\circ} 12^{\prime}$ $\mathrm{N}, 141^{\circ} 50^{\prime} \mathrm{W}$; (map 103). Var. Rock of Ages.

Local name published in 1956 by USGS. The generic "reef" may refer to rock stratum that extends into or across the Yukon River at this point and may be the same stratum that J. B. Mertie, Jr., USGS, called "Rock of Ages" in 1937.

Nation River: stream, heads in Canada at $65^{\circ} 35^{\prime}$ $\mathrm{N}, 140^{\circ} 23^{\prime} \mathrm{W}$, flows SW $50 \mathrm{mi}$. to Yukon River, $32 \mathrm{mi}$. NW of Eagle, Porcupine Plat.; $65^{\circ} 12^{\prime} \mathrm{N}, 141^{\circ} 43^{\prime} \mathrm{W}$; (map 103). Var. Tahkandik River, Tahkandit River, Takondit River.

Lt. Schwatka (1885, sheet 8), USA, first mapped this stream in 1883 using the Indian name "Tahkandik." Spurr (1898, pl. 38), USGS, spelled the name "Tahkandit," but the English name, reported as early as 1896 by F. C. Schrader, USGS, soon became fixed. The stream had some prominence from 1897 to 1898 because of a coal mine located near its mouth.

Natirnuq: locality, area on Chukchi Sea coast between Walakpa Bay and Napawrax, $10 \mathrm{mi}$. SW of Barrow, Arctic Plain; $71^{\circ} 10^{\prime} \mathrm{N}$, $157^{\circ} 03^{\prime} \mathrm{W}$; (map 153). Var. Ippersua.

Eskimo locality or camp name published by Spencer (1959, map 2). It is in the same general area that Lt. P.H. Ray (1885, p. 55) lists the name "Ippersua."

Native Creek: stream, flows S $4 \mathrm{mi}$. to Barnum Creek, $13 \mathrm{mi}$. NE of Goodnews, Kilbuck-Kuskokwim Mts. $59^{\circ} 16^{\prime} \mathrm{N}, 161^{\circ} 23^{\prime} \mathrm{W}$; (map 53).

Local name published in 1954 by USGS.

Native Creek: stream, flows NW $0.8 \mathrm{mi}$. to Ophir Creek which flows to Niukluk River, 3 mi. NNW of Council and $35 \mathrm{mi}$. NE of Solomon, Seward Penin. High.; $64^{\circ} 56^{\prime} \mathrm{N}, 163^{\circ}$ $42^{\prime} \mathrm{W}$; (map 95).

Prospectors' name reported on the 1900 "Map of Nome Peninsula" by J. M. Davidson and B. D. Blakeslee.

Native Hill: hill, $408 \mathrm{ft}$., $2 \mathrm{mi}$. SE of Newton Peak and $6 \mathrm{mi}$. NE of Nome, Seward Penin. High ; $64^{\circ} 33^{\prime} \mathrm{N}, 165^{\circ} 15^{\prime} \mathrm{W}$; (map 94).

Local name published in 1956 by USGS.

Natlavtlen River: stream, flows SW $44 \mathrm{mi}$. to Nikolai Slough, $40 \mathrm{mi}$. SW of Roundabout Mtn., Koyukuk Low. ; $65^{\circ} 02^{\prime} \mathrm{N}, 157^{\circ} 10^{\prime} \mathrm{W}$; (map 108).

Koyukan Indian name reported in 1955 by USGS.

Natmotirak Creek: streaim, heads at $67^{\circ} 36^{\prime} \mathrm{N}$, $159^{\circ} 00^{\prime} \mathrm{W}$, flows NE $24 \mathrm{mi}$, to Kaluich Creek, $48 \mathrm{mi}$. SW of Howard Pass, Brooks Ra.; $67^{\circ}$ $46^{\prime} \mathrm{N}, 158^{\circ} 24^{\prime} \mathrm{W}$; (map 126)

Eskimo name meaning "old pack route," as reported to Orth at Noatak in 1956. This name is similar to the Eskimo name for the Ambler River. 
Natnohoka Creek: stream, in the Dulbi Flats, $2 \mathrm{mi}$. E of Boatmakers Creek, flows NW $6 \mathrm{mi}$. to Nayuka River, $24 \mathrm{mi}$. WNW of Hochandochtla Mtn., Kokrines-Hodzana High.; $65^{\circ} 38^{\prime} \mathrm{N}, 155^{\circ} 40^{\prime} \mathrm{W}$; (map 107).

Koyukan Indian name obtained at Huslia in 1956 by Orth.

Natoa Island: island, $1.5 \mathrm{mi}$. long, $2 \mathrm{mi}$. SE of Harbor I., in Gulf of Alaska, $34 \mathrm{mi}$. S of Seward, Chugach Mts.; $59^{\circ} 38^{\prime} 30^{\prime \prime}$ N, $149^{\circ}$ $36^{\prime} 30^{\prime \prime}$ W; BGN 1930; (map 49). Var. High Island.

Named by the 1912 USC\&GS field party; it is an "Eskimo word meaning 'summit,' this being the highest spot on any island in this vicinity."

Natohona Creek: stream, flows W $10 \mathrm{mi}$. to Tok River $11 \mathrm{mi}$. NW of its junc. with Little Tok River and $25 \mathrm{mi}$. SW of Tok, Alaska Ra.; $63^{\circ} 07^{\prime} 30^{\prime \prime} \mathrm{N}, 143^{\circ} 41^{\prime} 00^{\prime \prime} \mathrm{W}$; BGN 1936; (map 85).

Indian name reported by USGS in 1936.

Natoma Bay: bay, extends NW $2.3 \mathrm{mi}$. off Cordova Bay, on $E$ coast of Long I., Alex. Arch.; $54^{\circ} 52^{\prime} \mathrm{N}, 132^{\circ} 38^{\prime} \mathrm{W}$; BGN 1929; (map 1).

Named in 1928 by USC\&GS for the steamer Natoma, used for surveys in this area.

Natoma Point: point of land, $\mathrm{N}$ point of entrance to Natoma Bay, on $\mathbf{E}$ coast of Long I., Alex. Arch.; 54 $52^{\prime} 15^{\prime \prime} \mathrm{N}, 132^{\circ} 37^{\prime} 28^{\prime \prime} \mathrm{W}$; BGN 1929; (map 1).

Named in 1928 by USC\&GS for the steamer Natoma.

Natrahazuivun Lake: lake, $1.5 \mathrm{mi}$. long, $1 \mathrm{mi}$. $S$ of Black River and $23 \mathrm{mi}$. NE of Fort Yukon, Yukon Flats; $66^{\circ} 38^{\prime} 20^{\prime \prime} \mathrm{N}, 144^{\circ} 27^{\prime}$ 00" W; (map 119).

Kutchin Indian name obtained in 1956 by T. E. Taylor, USGS.

Natravak Lake: lake, see Galbraith Lake.

Natural Arch: natural bridge, 50-ft. arch, composed of volcanic rock, at $S$ edge of point where Bering Glacier heads at Bagley Icefield, $30 \mathrm{mi}$. N of Cape Yakataga, St. Elias Mts.; $60^{\circ} 29^{\prime} 30^{\prime \prime} \mathrm{N}, 142^{\circ} 23^{\prime} 30^{\prime \prime} \mathrm{W} ; B G N$ 1960; (map 65).

Name recorded on field notes in 1913 by A. G. Maddren, USGS.

Natural Bridge: natural bridge, with opening about $20 \mathrm{ft}$. in diameter, $1.5 \mathrm{mi}$. W of Nimrod Peak and $19 \mathrm{mi}$. N of Eagle, Porcupine Plat.; $65^{\circ} 04^{\prime} 07^{\prime \prime} \cdot \mathrm{N}, 141^{\circ} 07^{\prime} 00^{\prime \prime} \mathrm{W}$; $B G N$ 1965; (map 103).

Name proposed in 1965 by Earl Brabb, USGS.

Natural Hill: hill, $300 \mathrm{ft}$, on north-central Little Kiska I., Aleutian Is.; $51^{\circ} 57^{\prime} 45^{\prime \prime} \mathrm{N}$, $177^{\circ} 38^{\prime} 35^{\prime \prime} \mathrm{E}$; (map 14).

An arbitrary name beginning with " $N$ " to correspond to "N" grid used by the U.S. Army for tactical purposes during World War II; published on a 1953 AMS map.

Natvakrak Lakes: lakes, two, largest of which is $1 \mathrm{mi}$. long, between Ivisaruk and Kaolak Rivers, 45 mi. S of Wainwright, Arctic Plain; $70^{\circ} 00^{\prime} \mathrm{N}, 160^{\circ} 25^{\prime} \mathrm{W}$; (map 146).

Eskimo name recorded at Wainwright in 1956 by T. E. Taylor, USGC; means "lakes."
Natvakruak Creek: stream, flows NW $20 \mathrm{mi}$. from Natvakruak Lake to Siksikpuk River, $36 \mathrm{mi}$. N of Anaktuvuk Pass, Arctic Slope; $68^{\circ} 38^{\prime} 15^{\prime \prime} \mathrm{N}, 152^{\circ} 00^{\prime} 30^{\prime \prime} \mathrm{W}$; (map 134).

Named in 1950 by W. W. Patton and A. S. Keller, USGS, for the lake at the stream's head.

Natvakruak Lake: locality, near Anaktuvuk Pass, in the Endicott Mountains, Brooks Ra.; $68^{\circ} 15^{\prime} \mathrm{N}, 151^{\circ} 45^{\prime} \mathrm{W}$; (map 134).

Eskimo name for an archeological site reported in 1950 by Ralph Solecki (in Giddings, 1964, p. 263).

Natvakruak Lake: lake, $1.3 \mathrm{mi}$. across, at head of Natvakruak Creek, $3 \mathrm{mi}$. NW of Nasaurak Mtn. and $11 \mathrm{mi}$. N of Anaktuvuk Pass, Arctic Slope; $68^{\circ} 22^{\prime} \mathrm{N}, 151^{\circ} 42^{\prime} \mathrm{W}$; (map 134).

Eskimo name, meaning "old lake [narvakruak]," reported in 1945 by USGS.

Natvaksukruk Hill: mountain, see Outpost Mountain.

Natvatchiak Hill: mountain, elev, $1,355 \mathrm{ft}$., between Chandler and Kutchik Rivers, $13 \mathrm{mi}$. $S$ of Umiat, Arctic Slope; $69^{\circ} 11^{\prime} \mathrm{N}, 151^{\circ} 53^{\prime}$ W; (map 141).

Eskimo name reported in 1956 by T. E. Taylor, USGS.

Natyka: village, see Nateekin.

Natykin: bay, see Nateekin Bay.

Natykinskaya: bay, see Nateekin Bay.

Natzuhini Bay: estuary, extends N $4.3 \mathrm{mi}$. off Sukkwan Strait, on $W$ coast of Prince of Wales I. N of Hydaburg, Alex. Arch.; 55 ${ }^{\circ}$. $13^{\prime} \mathrm{N}, 132^{\circ} 51^{\prime} \mathrm{W}$; (map 4).

Indian name published in 1965 by USC\&GS.

Naugeik: village, see Naknek.

Naugolka Point: point of land, between Viekoda Bay and $E$ end of Uganik Passage, on $N$ coast of Kodiak I.; $57^{\circ} 53^{\prime} 30^{\prime \prime} \mathrm{N}, 152^{\circ} 13^{\prime} 40^{\prime \prime} \mathrm{W}$; (map 34).

Native name published in 1943 by USC\&GS.

Naugvik: village, see Naknek.

Naukatee Bay: bay, see Naukati Bay.

Naukati Bay: bay, $2.4 \mathrm{mi}$. long, off Tuxekan Passage, W coast of Prince of Wales I., Alex. Arch.; $55^{\circ} 51^{\prime} 20^{\prime \prime} \mathrm{N}, 133^{\circ} 11^{\prime} 00^{\prime \prime} \mathrm{W}$; (map 4). Var. Naukatee Bay.

Named "Naukatee Bay" in 1904 by E. F. Dickins, USC\&GS, who wrote "Indian name for this inlet from information given by Capt. Cyrus Orr."”

Naukati Creek: stream, heads in lake, flows W 3.5 mi. to Naukati Bay, $W$ coast of Prince of Wales I., Alex. Arch.; $55^{\circ} 53^{\prime} 18^{\prime \prime} \mathrm{N}, 133^{\circ}$ $08^{\prime} 45^{\prime \prime} \mathrm{W}$; (map 4).

Local name recorded in 1949 by USGS.

Nauklagamut: locality, see Nauklak.

Nauklak: locality, on Alaska Penin., in Katmai National Monument, about $15 \mathrm{mi}$. E of Naknek Lake, Aleutian Ra.; $58^{\circ} 35^{\prime}$ N, $154^{\circ} 56^{\prime}$ W; (map 42). Var. Naouchlágamut, Nauklagamut.

Former Eskimo village recorded in 1898 as "Naouchlágamut" by J. E. Spurr and W. S. Post, USGS, who obtained their information from the chief of Savonoski.
Naulchi: water course, see Kwemeluk Pass.

Naumliack: locality, site of Eskimo village, on Kiavak Bay, on SE shore of Kodiak I. ; $57^{\circ} 01^{\prime}$ $\mathrm{N}, 153^{\circ} 35^{\prime} \mathrm{W}$; (map 34$)$.

Native name recorded in 1805 by Lisianski (1814, p. 180).

Naumliack Bay: bay, see Kiavak Bay.

Na-un-da: stream, see Monte Cristo Creek.

Nautilus Creek: stream, flows NW $3 \mathrm{mi}$. to North Fork Indian River, $14 \mathrm{mi}$. NW of Goodnews, Kilbuck-Kuskokwim Mts.; $59^{\circ} 17^{\prime}$ $\mathrm{N}, 161^{\circ} 42^{\prime} \mathrm{W}$; (map 53).

Local name published in 1951 by USGS.

Nauvogalokhlagamute: locality, see Nanvogaloklak.

Nauwogalokhlagamute: locality, see Nanvogaloklak.

Navarak: lake, see Feniak Lake.

Navashak Lake: lake, $1.5 \mathrm{mi}$. across, in Noatak River valley, $8 \mathrm{mi}$. SE of Feniak Lake, Brooks Ra.; 68 $07^{\circ} \mathrm{N}, 158^{\circ} 10^{\prime} \mathrm{W}$; (map 132).

Eskimo name obtained at Noatak in 1956 by Orth, and reported to refer in meaning "to call for," in reference to the lake.

Navia, Punta de: point of land, see Lemesurier Point.

Navia, Punta de: point of land, see Saint Elias, Cape.

Navisok: locality, on Agattu I., Aleutian Is.; $52^{\circ} 26^{\prime} \mathrm{N}, 173^{\circ} 36^{\prime} \mathrm{E}$; (map 13 ).

Former Aleut village or camp listed by Hodge (1910, p. 46).

Navvook Lake: lake, see Troutman Lake.

Navy Cove: cove, $0.7 \mathrm{mi}$. across, SE of Little Kiska Head on $N$ coast of Little Kiska I., Aleutian Is.; $51^{\circ} 57^{\prime} 50^{\prime \prime} \mathrm{N}, 177^{\circ} 38^{\prime} 40^{\prime \prime} \mathrm{E}$; (map 14). Var. Tiger Cove.

Name shown on a 1957 AMS map; variant shown on 1943 USAAF map.

Navy Cove: bight, $0.4 \mathrm{mi}$. across, on SE coast of Attu I., on NW shore of Massacre Bay, Aleutian Is.; $52^{\circ} 50^{\prime} 30^{\prime \prime} \mathrm{N}, 173^{\circ} 12^{\prime} 25^{\prime \prime} \mathrm{E}$; (map 13).

Named by U.S. Army during World War II ; published in 1948 by AMS.

Navy Hill: hill, see Court House Hill.

Navy Island: island, $0.3 \mathrm{mi}$, across, smallest and most southerly of three islands east of Port Wrangell, in the Pacific Ocean, $22 \mathrm{mi}$. SE of Mount Chiginagak; Aleutian Ra.; 56 $59^{\prime} 40^{\prime \prime}$ $\mathrm{N} ; 156^{\circ} 27^{\prime} 30^{\prime \prime} \mathrm{W}$; (map 31). Var. Ile du Large, Navy Islet, Ostrov Morskiy, Ostrov Morskoi.

Named "Ostrov Morskoi," i.e. "sea island," by Ens. Vasiliev, IRN, in 1832 . This name was translated by USC\&GS as "Navy Island" probably intentionally changing the meaning somewhat. Lutke (1836, p. 274) called it "Ile du Large."

Navy Islet, island, see Navy Island.

Navy Lake: lake, $1 \mathrm{mi}$. long, $1.5 \mathrm{mi}$. $\mathrm{E}$ of Burnett Inlet, on Etolin I., Alex. Arch.; $56^{\circ} 04^{\prime} 15^{\prime \prime} \mathrm{N}, 132^{\circ} 25^{\prime} 30^{\prime \prime} \mathrm{W}$; (map 6).

Local name recorded in 1953 by USGS.

Navy Peak: mountain, 3,665 ft., $2.5 \mathrm{mi}$. N of McHenry Inlet, on Etolin I., Alex. Arch.; $56^{\circ} 04^{\prime} 10^{\prime \prime} \mathrm{N}, 132^{\circ} 23^{\prime} 00^{\prime \prime} \mathrm{W}$; (map 6). 
Named in 1886 by Lt. Comdr. A. S. Snow, USN; name published in 1887 on USG\&GS Chart 706.

Navy Town: locality, on SE coast of Attu I., on $W$ shore of Massacre Bay, Aleutian Is.; $52^{\circ} 50^{\prime} 20^{\prime \prime} \mathrm{N}, 173^{\circ} 11^{\prime} 45^{\prime \prime} \mathrm{E}$; (map 13).

Named during the military occupation of the island in World War II; published in 1948 by AMS.

Nayery, Kamen: rock, see Naerie Rock.

Nayorurun River: stream, flows S $27 \mathrm{mi}$. to Togiak River, $1 \mathrm{mi}$. W of Kashiagamiut, 56 mi. NE of Goodnews, Kilbuck-Kuskokwim Mts.; $59^{\circ} 22^{\prime} 12^{\prime \prime} \mathrm{N}, 160^{\circ} 06^{\prime} 07^{\prime \prime} \mathrm{W}$; (map 53). Var. Kashaiak River, Kashaiyak River.

Eskimo name reported in 1956 by USGS. The name of the river was reported as "Kashaiyak" on an 1898 fieldsheet by W. S. Post, USGS.

Nayrak Lake: lake, see Troutman Lake.

Nayuka River: stream, in Dulbi Flats, heads NW of Dulbatna Mtn., flows N $24 \mathrm{mi}$. then WSW $22 \mathrm{mi}$. to Dulbi Slough, $32 \mathrm{mi}$. W of Hochandochtla Mtn., Kokrines-Hodzana High.; $65^{\circ}$ $38^{\prime} 20^{\prime \prime} \mathrm{N}, 155^{\circ} 57^{\prime} 30^{\prime \prime} \mathrm{W}$; (map 107).

Koyukan Indian name obtained at Huslia in 1956 by Orth.

Nayvay Creek: stream, see Kuropak Greek.

Nazan: village, see Atka.

Nazan Cape: point of land, see Agony Point. Nazan, Zaliv: bay, see Chisak Bay.

Nazan Bay: bay, 4 mi. across, on NE coast of Atka I., Aleutian Is.; $52^{\circ} 12^{\prime} \mathrm{N}, 174^{\circ} 06^{\prime} \mathrm{W}$; (map 18). Var. Baie de l'Est, East Bay, Zaliv Nazan.

Apparently named as "Z[aliv] Nazan," or "Nazan Bay," by Capt. Tebenkov (1852, map 27), IRN. It was called "Baie de l'Est," or "east bay," by Capt. Lutke (1836, p. 313), IRN.

Nazan Bay: bay, see Chisak Bay.

Nazi Creek: stream, flowing SE $0.7 \mathrm{mi}$. to Pacific Ocean, Little Kiska I., Aleutian Is. ; 51 '56'52' N, $177^{\circ} 40^{\prime} 20^{\prime \prime} \mathrm{E}$; (map 14).

An arbitrary name beginning with " $N$ " to correspond to "N" grid used by the U.S. Army for tactical purposes during World War II; published on a 1953 AMS map.

Nazikak Island: island, see Twoheaded Island. Nazikak Point: island, see Twoheaded Island.

Nazowlakdalak: stream, see Girl Creek.

Nazuruk Channel: stream, a distributary of Kobuk River, heads at Melvin Channel Kobuk River, and flows SW $41 \mathrm{mi}$. to Hotham Inlet, $39 \mathrm{mi}$. WSW of Selawik, KotzebueKobuk Low.; $66^{\circ} 31^{\prime} \mathrm{N}, 161^{\circ} 24^{\prime} \mathrm{W}$; (map 114).

Eskimo name reported in 1926 by USGS.

Nazwiqtaq: lake, see Nadviktak Lake,

Nazwiztaq Kuugauzaq: stream, see Nadviktak Greek.

NC Creek: stream, flows SW $6 \mathrm{mi}$. to Yukon River at Tanana, Kokrines-Hodzana High.; $65^{\circ} 10^{\prime} \mathrm{N}, 152^{\circ} 04^{\prime} \mathrm{W}$; (map 106).

Local name reported in 1952 by USGS; named for the N[orthern] C[ommercial] Company which maintained a store at Tanana.
Neacola River: stream, heads in lake $2 \mathrm{mi}$. E of Telaguana Pass, flows NE $21 \mathrm{mi}$. to Kenibuna Lake, $60 \mathrm{mi}$. W of Tyonek, Alaska Ra.; $61^{\circ} 09^{\prime} 40^{\prime \prime} \mathrm{N}, 152^{\circ} 55^{\prime} 30^{\prime \prime} \mathrm{W}$; BGN 1930; (map 70).

Tanaina Indian name reported in 1928 by S. R. Capps and Gerald FitzGerald (in Smith and others, 1930b, pl. 2), USGS.

Neak Creek: stream, see Niak Creek.

Nea-kluk: stream, see Niukluk River.

Neakok: locality, see Naokok.

Neakok Island: island, $05 \mathrm{mi}$. across, in mouth of Ivisaruk River, $18 \mathrm{mi}$. S of Wainwright, Arctic Plain; $70^{\circ} 22^{\prime} 58^{\prime \prime} \mathrm{N}, 159^{\circ} 59^{\prime} 15^{\prime \prime} \mathrm{W}$; (map 146).

Eskimo name recorded at Wainwright in 1956 by Orth; means "head."

Neal Point: point of land, $8.5 \mathrm{mi}$. W of Wrangell, southernmost tip of Vank I., Alex. Arch.; $56^{\circ} 27^{\prime} \mathrm{N}, 132^{\circ} 36^{\prime} \mathrm{W}$; (map 6).

Local name used by fishermen and published in 1920 by USCRGS.

Nealruk Mountain: hill, $774 \mathrm{ft}$., on Nelson I., 9 mi. E of Cane Vancouver, Yukon-Kuskokwim Delta: $60^{\circ} 33^{\prime}$ N. $165^{\circ} 09^{\prime} \mathrm{W}$; (mas 57).

Eskimo name obtained at Tanunak in 1951 by USC\&GS

Near Island: island, 1,289 ft. elev., $1.5 \mathrm{mi}$. long, $3 \mathrm{mi}$. SE of Nagai I., in Shumagin Is., Aleutian Ra.; $54^{\circ} 56^{\prime} 30^{\prime \prime}$ N, $160^{\circ} 03^{\prime} 00^{\prime \prime}$ W; (map 26). Var. Blizhni, Ostrov Blizhniy.

This is a translation of "Orstrov' Blizhn'y" published by Capt. Tebenkov (1852, map 24), IRN.

Near Island: island, $1.5 \mathrm{mi}$. long, in Saint Paul Harbor, $0.5 \mathrm{mi}$. S of Kodiak. Kodiak I.; $57^{\circ} 47^{\prime}$ N. $152^{\circ} 24^{\prime}$ W: BGN 19.39: (man 34). Var. Bliskie Island. Blisnie Island. Bliski Island, Blizkiy Island, Close Island, Ostrov Blizkiy. Pogibshi Island.

The name "Ostrov Blizkiv." or "close island" was recorded in 1805 bv Lisianski (1814. map facing p. 169). The Russian word "pogibshiy" meaning "perishing" was applied to this island by W. H. Dall (in Emerson and others. 1904, p. 52).

Near Islands: islands, chain combrising west end of Aleutian Is., extend from Inoenstrem Rocks, westward about $95 \mathrm{mi}$. to Peaked I., off Cape Wrangell ; principal islands are Attu, Agattu, and Semichi Is. (Alaid. Nizki, and Shemva): $59^{\circ} 55^{\prime} \mathrm{N}, 172^{\circ} 28^{\prime} \mathrm{F}$, lwost end? $52^{\circ} 37^{\prime}$ N. $174^{\circ} 32^{\prime}$ E least end7; BGN 1963; Var. Blinies Islands, Bliihi Islands. Blizhnie Islands, Blizhniye Islands, Plishnie Ostrova, Rat Islands.

This is a translation of the descrintive name "Plishnie Ostrova," published bv G. H. von Langsdorff (1813-14, v. 2, p. 13). Lt. G. A. Sarichev (1826, map 1), IRN, published the name as "O/strolva Blizhniye." This name was given by early Russian explorers because these are the nearest of the Aleutian Islands to Asia. See Aleutian Islands.

Near Point: point of land, on W coast of Piper I., in Fish Bay, on Baranof I., $25 \mathrm{mi}$. NW of
Sitka, Alex. Arch.; 57 $23^{\prime} 30^{\prime \prime} \mathrm{N}, 135^{\circ} 35^{\prime} 45^{\prime \prime}$ W; (map 9).

Named in 1880 by U.S. Navy and published by USC\&GS on Chart 727 .

Near Point: point of land, on $\mathrm{N}$ coast of Whale I., $2.3 \mathrm{mi}$. SW of Afognak, $\mathrm{N}$ of Kodiak I.; $57^{\circ} 58^{\prime} 30^{\prime \prime}$ N, $152^{\circ} 49^{\prime} 20^{\prime \prime}$ W; (map 34). Var. Blizhnie Cape, Mys Blizhniy.

Translation of the descriptive name " $M[y s]$ Blizhniy" given by Sub-Lt. Mikhail Murashev in 1839 or 1840 and published in 1849 on Russian Hydrog. Dept. Chart 1425.

Nebel Island: island, see Shuyak Island.

Necessity Cove: cove, 1 mi. across, on $\mathrm{S}$ shore of Alaska Penin., on SE shore of Castle Cape NE of Ship Mtn., Aleutian Ra.; $56^{\circ} 09^{\prime} \mathrm{N}$, $158^{\circ} 21^{\prime} \mathrm{W}$; (map 30).

Local name published by USC\&GS in 1916 Coast Pilot (p. 160).

Nechelik Channel: stream, distributary of Colville River, flows $\mathbf{N} 22 \mathrm{mi}$. to Harrison Bay, Arctic Plain.; $70^{\circ} 27^{\prime} \mathrm{N}, 151^{\circ} 04^{\prime} \mathrm{W}$; (map 149). Var. Ne-ohi-lik River.

Eskimo name reported in 1951 by USC\&GS meaning "new deep channel."

Nechraje: rock, see Eldred Rock.

Necker, Port: estuary, see Necker Bay.

Necker Bay: estuary, $10 \mathrm{mi}$. long, on $\mathrm{W}$ coast of Baranof I., $35 \mathrm{mi}$. NW of Port Alexander, Alex. Arch.; 56 $40^{\prime} \mathrm{N}, 135^{\circ} 05^{\prime} \mathrm{W}$; (map 5). Var. Kamenistaia Bay, Kamenistaya Bukhta, Port Necker, Port Neker, Rocky Bay, Stone Bay, Stony Bay.

Originally named "Port Necker" in 1786 by La Pérouse in honor of Jacques Necker, French minister of finance; published in 1850 by Russian American Company as "Kamenistaya Bukhta," meaning "rocky bay."

Necker Islands: islands, extend SE $12 \mathrm{mi}$. from Biorka and Little Biorka Is., to Bachek I., off W coast of Baranof I., Alex. Arch.; 56 $46^{\circ} \mathrm{N}$, $135^{\circ} 27^{\prime} \mathrm{W}$; (map 5).

Name published in the 1883 Coast Pilot (p. 136). Named on September 5, 1786, by La Pérouse.

Necker Isles: islands, see Guibert Islets.

Neck Lake: lake, $0.15 \mathrm{mi}$. across, on northwestern Little Kiska I., Aleutian Is.; $51^{\circ} 58^{\prime} \mathrm{N}, 177^{\circ}$. $38^{\prime} \mathrm{E}$; (map 14).

An arbitrary name beginning with " $N$ " to correspond to "N" grid used by the U.S. Army for tactical purposes during World War II; published on a 1953 AMS map.

Neck Lake: lake, $3 \mathrm{mi}$. long, on Prince of Wales I., Alex. Arch.; $56^{\circ} 06^{\prime} \mathrm{N}, 133^{\circ} 11^{\prime} \mathrm{W}$; (map $6)$.

Local name recorded in 1949 by USGS.

Necklaremont River: stream, see Lower Niklaremut Creek.

Necklaremont River: stream, see Upper Niklaremut Creek.

Neck Point: point of land, on $\mathrm{N}$ coast of Chichagof I., $3.4 \mathrm{mi}$. SE of Point Sophia on Icy Strait and $4 \mathrm{mi}$. E of Hoonah, Alex. Arch.; $58^{\circ} 07^{\prime} 10^{\prime \prime} \mathrm{N}, 135^{\circ} 20^{\prime} 00^{\prime \prime} \mathrm{W}$; (map 11).

Descriptive name given in 1901 by E. F. Dickins, USC\&GS, and published in the 1901 Coast Pilot (p. 204). 
Neck Point: point of land, on SE coast of Montague I., $9 \mathrm{mi}$. NE of Cape Cleare, $66 \mathrm{mi}$. SE of Seward, Chugach Mts. ; $59^{\circ} 48^{\prime} \mathrm{N}, 147^{\circ} 41^{\prime}$ W; (map 49).

Local name reported in the early 1950's by USC\&GS.

Neckshortka Lake: lake, $1.3 \mathrm{mi}$. long, on Kenai Penin., $4.8 \mathrm{mi}$. S of Point Possession and 43 mi. NE of Kenai, Cook Inlet Low.; 60 $57^{\circ}$ $30^{\prime \prime} \mathrm{N}, 150^{\circ} 23^{\prime} 30^{\prime \prime} \mathrm{W}$; (map 62).

Named about 1963 by officials of Kenai National Moose Range, for administrative purposes.

Necodayno: stream, see Nikadavna Creek.

Necons River: stream, heads in glacier lake, flows SW $40 \mathrm{mi}$., through Two Lakes to Stony River, $47 \mathrm{mi}$. N of Lake Clark and $100 \mathrm{mi}$. W of Tyonek, Alaska Ra.; $61^{\circ} 01^{\prime} 30^{\prime \prime} \mathrm{N}, 154^{\circ}$ 05'30' W; BGN 1930; (map 71).

Local name reported in 1928 by S. R. Capps and Gerald FitzGerald, USGS.

Ned Pond: lake, $0.4 \mathrm{mi}$. across, NE of Big Lake and $18 \mathrm{mi}$. SW of Beaver, Yukon Flats; $66^{\circ}$ $17^{\prime} \mathrm{N}, 148^{\circ} 01^{\prime} \mathrm{W}$; (map 118. Var. Mac's Pond.

Local name obtained in 1956 by USGS; shown as "Mac's Pond" on William Yanert's 1916 manuscript map (Stuck, 1917, map facing p. 122).

Neds Lake: lake, $0.8 \mathrm{mi}$. long, $3.5 \mathrm{mi}$. SE of Allakaket, Kanuti Flats; $66^{\circ} 31^{\prime} 30^{\prime \prime} \mathrm{N}, 152^{\circ}$ $32^{\prime} 45^{\prime \prime} \mathrm{W}$; (map 117).

Local name reported in 1956 by T. E. Taylor, USGS.

Neeaxtouwik Mountain: mountain, see Niaktuvik, Mount.

Neechuck River: stream, see Miniatulik River.

Necdle, The: rock, about $260 \mathrm{ft}$. across, in Montague Strait, $8 \mathrm{mi}$. SW of S tip of Green I., Chugach Mts. ; $60^{\circ} 06^{\prime} 40^{\prime \prime} \mathrm{N}, 147^{\circ} 36^{\prime} 00^{\prime \prime} \mathrm{W}$; $B G N$ 1908; (map 63).

Descriptive name reported in 1908 by USG\&GS.

Needle Island: island, $0.9 \mathrm{mi}$. long, in Yukon River W of Garden I., 2 mi. N of Anvik, Nulato Hills; $62^{\circ} 41^{\prime} \mathrm{N}, 160^{\circ} 12^{\prime} \mathrm{W}$; (map 78).

Riverboat pilots' name shown on a 1940 "Navigation Chart of the Tanana-Yukon River" published by U.S. Dept. of Interior.

Needle Mountain: mountain, $8,000 \mathrm{ft}$., on Thompson Ridge, $3 \mathrm{mi}$. SE of Barkley Lake and $110 \mathrm{mi}$. E of Cordova, St. Elias Mts.; $60^{\circ} 41^{\prime} 00^{\prime \prime} \mathrm{N}, 142^{\circ} 31^{\prime} 30^{\prime \prime} \mathrm{W}$; (map 65).

Local name reported by F. H. Moffit (1918, pl. 6), USGS.

Needle Peak: mountain, 1,960 ft., highest point on Coronation I., Alex. Arch.; 55 $52^{\prime} 25^{\prime \prime} \mathrm{N}$, $134^{\circ} 15^{\prime} 50^{\prime \prime} \mathrm{W}$; (map 4).

Descriptive name given in 1886 by Lt. Comdr. A. S. Snow, USN.

Needle Peak: peak, 4,540 ft., on Kenai Penin., at head of Petrof Glacier, $30 \mathrm{mi}$. ENE of Seldovia, Chugach Mts.; $59^{\circ} 30^{\prime} 30^{\prime \prime} \mathrm{N}$, $150^{\circ} 47^{\prime} 30^{\prime \prime} \mathrm{W}$; (map 50$)$.

Descriptive name reported by USC\&GS in 1912. So named "because of its pointed appearance."
Needle Peak: mountain, 7,586 ft., in Nutzotin Mts., on W bank of Snag Creek $4 \mathrm{mi}$. SW of junc. with its East Fork, Alaska Ra.; $62^{\circ} 11^{\prime} \mathrm{N}$, $141^{\circ} 33^{\prime} \mathrm{W}$; (map 84).

Descriptive name given in 1898 by W. J. Peters and A. H. Brooks, USGS.

Needle Rock: rock, off NW coast of Amaknak I., in Unalaska Bay, on NE coast of Unalaska I., Aleutian Is. ; $53^{\circ} 55^{\prime} 31^{\prime \prime} \mathrm{N}, 166^{\circ} 31^{\prime} 46^{\prime \prime} \mathrm{W}$; (map 23).

Descriptive name given by W. H. Dall, USC\&GS, in 1874. A 1791 map by John Henry Cox shows this name applied to another rock near here. See Wagner (1937, p. 475).

Needle Rock: mountain, 2,900 ft., $8 \mathrm{mi}$. E of Jumbo Dome and $20 \mathrm{mi}$. NE of Healy, Alaska Ra.; $63^{\circ} 58^{\prime} 50^{\prime \prime} \mathrm{N}, 148^{\circ} 29^{\prime} 45^{\prime \prime} \mathrm{W}$; (map 87).

Descriptive name published in 1952 by USGS.

Neekahueena: lake, see Nikabuna Lake.

Neekahweena: lake, see Nikabuna Lake.

Neeksigalik Lake: lake, see Tulugak, Lake.

Neenana: locality, see North Nenana.

Neenana River: stream, see Nenana River

Neenivik River: stream, see Golsovia River.

Neets Bay: estuary, extends E $9 \mathrm{mi}$. from Behm Canal, along NW coast of Revillagigedo I., Alex. Arch.; $55^{\circ} 46^{\prime}$ N., $131^{\circ} 42^{\prime}$ W ; (map 3 ).

Arbitrary name given in 1891 by USC\&GS.

Neets Creek: stream, flows W, through Bluff Lake, $5 \mathrm{mi}$. to Neets Bay, on NW coast of Revillagigedo I., Alex Arch.; 55 $47^{\prime} 15^{\prime \prime} \mathrm{N}$, $131^{\circ} 29^{\prime} 20^{\prime \prime} \mathrm{W}$; BGN 1923; (map 3).

Named in 1923 by USFS.

Neets Lake: lake, $0.6 \mathrm{mi}$. long, drains into Neets Creek $E$ of Neets Bay, on NW coast of Revillagigedo I., Alex. Arch.; 55 $45^{\prime} 50^{\prime \prime}$ N. $131^{\circ}$. 28'30" W; BGN 1923; (map 3).

Named in 1923 by USFS.

Neeyiklik Creek: stream, see Niyiklik Creek.

Negaleh: locality: see Nigalik.

Negheling River: stream, see Newhalen River.

Negotsena Creek: stream, flows SW $8 \mathrm{mi}$. to Yukon River, $12 \mathrm{mi}$. NE of Nulato, Nulato Hills; $64^{\circ} 52^{\prime} \mathrm{N}, 157^{\circ} 54^{\prime} \mathrm{W}$; (map 97).

Koyukan Indian name reported in 1954 by USGS.

Negra, Punta: point of land, "E of Cape Suckling."

Spanish name meaning "black" shown on a 1791 map of Capt. Alessandro Malaspina. Negrillos, Rocas: rocks, "at the south end of Hinchinbrook Island."

Name recorded in Capt. Alessandro Malaspina's journal written about 1791 .

Negritos, Los: rocks, see Porpoise Rocks.

Negro, Cabo: point of land, "on Prince of Wales Island, in east part of Bucareli Bay."

Descriptive Spanish name meaning "black cape" given by members of the 1779 Don Ignacio Arteaga expedition.

Negro Creek: stream, heads near summit of Dahlgren Peak, flows N $4.5 \mathrm{mi}$. to Port Houghton, $75 \mathrm{mi}$. E of Sitka, Coast Mts.; $57^{\circ} 17^{\prime} \mathrm{N}, 133^{\circ} 25^{\prime} \mathrm{W}$; (map 8).

Local name reported in 1955 by USGS.
Negro Lake: lake, $0.5 \mathrm{mi}$. across, $2 \mathrm{mi}$. SW of Alexey Lake and $7 \mathrm{mi}$. NE of Iliamna, Aleutian Ra.; $59^{\circ} 51^{\prime} \mathrm{N}, 154^{\circ} 49^{\prime} \mathrm{W}$; (map 51).

Local name published by USGS in 1954 .

Negromoon Creek: stream, flows E to Inglutalik River, NE of Norton Bay, Nulato Hills; (map 109).

Local name reported in 1910 by $A$. $H$. Brooks, USGS.

Negsue Creek: stream, flows SW $2 \mathrm{mi}$. to Penny River, $9 \mathrm{mi}$. W of Nome, Seward Penin. High.; $64^{\circ} 33^{\prime} \mathrm{N}, 165^{\circ} 41^{\prime} \mathrm{W}$; (map 94).

Prospectors' name reported in 1899 by D. C. Witherspoon (in Schrader and Brooks, 1900, map 2), USGS.

Negukthlik River: stream, heads at $59^{\circ} 09^{\prime} \mathrm{N}$, $159^{\circ} 55^{\prime} \mathrm{W}$, flows SW $25 \mathrm{mi}$. to Ungalikthluk River, 12 mi. SE of Togiak, Kilbuck-Kuskokwim Mts.; $58^{\circ} 56^{\prime} \mathrm{N}, 160^{\circ} 08^{\prime} \mathrm{W}$; (map 39). Var. Ungalikthluk River, Ungalukthluk River, Ungalukuk River, Ungulukthluk River.

Eskimo name reported as "Ungulukthluk River" in 1951 by USGS. Name changed to present spelling on recent maps.

Negvelnuk: stream, see Golsovia River.

Nehenta Bay: cove, extends NE $0.6 \mathrm{mi}$. from Clarence Strait, on SW coast of Gravina I., Alex Arch.; $55^{\circ} 09^{\prime} 25^{\prime \prime} \mathrm{N}, 131^{\circ} 47^{\prime} 45^{\prime \prime} \mathrm{W}$; $B G N$ 1923; (map 3). Var. Copper Bay.

Tlingit Indian word meaning "copper ore;" name given in 1922 by USC\&GS because the "Field-party of $1921 * * *$ reported the existence of copper-prospects there."

Neh-leel-ahk: point of land, see Nililak Point.

Nehlutahalik Slough: stream, see Nelutahalik Creek.

Neil Lake: lake, $0.9 \mathrm{mi}$. long, W of Kroto Creek, $52 \mathrm{mi}$. NW of Anchorage, Cook Inlet Low.; $61^{\circ} 56^{\prime} 00^{\prime \prime} \mathrm{N}, 150^{\circ} 22^{\prime} 40^{\prime \prime} \mathrm{W}$; (map 70).

Local name reported in 1954 by USGS

Neilson Canyon: canyon, $0.5 \mathrm{mi}$. long, on Kenai Penin., $5 \mathrm{mi}$. NE of Homer, Cook Inlet Low.; $59^{\circ} 41^{\prime} 30^{\prime \prime} \mathrm{N}, 151^{\circ} 25^{\prime} 00^{\prime \prime} \mathrm{W}$; (map 50).

Local name reported and published by USGS in the 1950's.

Neilson Greek: stream, on $\mathrm{N}$ end of Douglas I., flowing $1.6 \mathrm{mi}$. NE to Gastineau Channel, $3.7 \mathrm{mi}$. NW of Juneau, Coast Mts. ; 58 $19^{\prime} 5^{\prime \prime}$ $\mathrm{N}, 134^{\circ} 30^{\prime} 00^{\prime \prime} \mathrm{W}$; (map 11).

Local name published in 1962 by USGS.

Neka Bay: bay, extends W $6.5 \mathrm{mi}$. off Port Frederick, Chichagof I., $8 \mathrm{mi}$. SW of Hoonah, Alex. Arch.; $58^{\circ} 02^{\prime} 30^{\prime \prime} \mathrm{N}, 1^{\circ} 35^{\circ} 38^{\prime} 00^{\prime \prime} \mathrm{W}$; (map 11).

Name published in 1951 by USGS.

Neka Island: island, $0.3 \mathrm{mi}$. across, in Port Frederick at mouth of Neka Bay on Chichagof I., $8.8 \mathrm{mi}$. SW of Hoonah, Alex. Arch.; $58^{\circ} 02^{\prime}$ $00^{\prime \prime} \mathrm{N}, 135^{\circ} 38^{\prime} 15^{\prime \prime} \mathrm{W}$; (map 11).

Name published in 1951 by USGS.

Nekakte Creek: stream, heads at $67^{\circ} 29^{\prime} \mathrm{N}$, $158^{\circ} 19^{\prime} \mathrm{W}$, flows SSW 19 mi. to Akillik River, 45 mi. NW of Shungnak, Brooks Ra.; $67^{\circ} 16^{\prime}$ N, $158^{\circ} 29^{\prime} \mathrm{W}$; (map 126)

Eskimo name reported by USGS in 1956 .

Neka Mountain: mountain, 2,972 ft., on Chichagof I., $0.9 \mathrm{mi}$. N of Neka Bay on Port Frederick and $8 \mathrm{mi}$. SW of Hoonah, Alex. 
Arch.; $58^{\circ} 04^{\prime} 00^{\prime \prime} \mathrm{N}, 135^{\circ} 38^{\prime} 30^{\prime \prime} \mathrm{W} ; B G N$ 1959; (map 11).

Local name published in 1951 by USGS.

Neka River: stream, on Chichagof I., flows SE 7 mi. to Neka Bay on Port Frederick, $13 \mathrm{mi}$. SW of Hoonah, Alex. Arch.; $58^{\circ} 03^{\prime} 30^{\prime \prime} \mathrm{N}$, $135^{\circ} 47^{\prime} 15^{\prime \prime} \mathrm{W}$; BGN 1959; (map 11).

Local name published in 1951 by USGS.

Nekeelit Point: point of land, $5.5 \mathrm{mi}$. S of Gambell, W coast of St. Lawrence I.; $63^{\circ} 42^{\prime} \mathrm{N}$, $171^{\circ} 45^{\prime} \mathrm{W}$; BGN 1951; (map 93). Var. Ikhkelik, Nekiylit.

Eskimo name reported in 1932 by O. W. Geist. In 1965 Orth recorded the name as "Ikhkelik," meaning "like a visor."

Neker, Port: estuary, see Necker Bay.

Neketa Bay: bay, $0.5 \mathrm{mi}$. across, on $W$ coast of Shuyak I., $43 \mathrm{mi}$. $\mathrm{N}$ of Kodiak I.; 58 $31^{\prime} 30^{\prime \prime}$ $\mathrm{N}, 152^{\circ} 38^{\prime} 00^{\prime \prime} \mathrm{W}$; (map 43).

Name published by USC\&GS on Chart 8555 in 1927.

Neketa Creek: stream, flows E $6 \mathrm{mi}$. to Chignik Bay, $10.5 \mathrm{mi}$. $\mathrm{N}$ of Chignik, Aleutian Ra.; $56^{\circ} 27^{\prime} \mathrm{N}, 158^{\circ} 25^{\prime} \mathrm{W}$; (map 30 ).

Native name reported by a 1951 USGS field party.

Nekiylit: point of land, see Nekeelit Point.

Nekula Gulch: ravine, trends NW $0.6 \mathrm{mi}$. to Anvil Creek $\mathrm{N}$ of Dexter Peak and $6 \mathrm{mi}$. N of Nome, Seward Penin. High.; 64 $35^{\prime} 29^{\prime \prime}$ N, $165^{\circ} 20^{\prime} 50^{\prime \prime}$ W; (map 94). Var. Nikkala Gulch, Nickala Creek.

Prospectors' name of Finnish origin published on the 1902 "Map of the Nome and Snake River Country" by J. M. Davidson. In 1916, Polk's Gazetteer showed a mining camp along the ravine, calling the camp "Nickala Gulch."

Nekutak Lake: lake, $0.8 \mathrm{mi}$. long, on Kenai Penin. N of Embryo Lake, $34 \mathrm{mi}$. NE of Kenai, Cook Inlet Low.; $60^{\circ} 48^{\prime} \mathrm{N}, 150^{\circ} 26^{\prime} \mathrm{W}$; (map 62).

An Eskimo-sounding name given about 1963 by officials of Kenai National Moose Range, for administrative purposes.

Nelchina: locality, at the junc. of Little Nelchina River and Crooked Creek, $16 \mathrm{mi}$. NE of Tahneta Pass, Talkeetna Mts., $62^{\circ} 06^{\prime} 15^{\prime \prime} \mathrm{N}$,

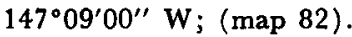

Former mining settlement established about 1913; reported by Theodore Chapin (in Brooks, 1915, p. 122), USGS.

Nelchina Bench Lake: lake, $0.5 \mathrm{mi}$. long, at SW end of Heavenly Ridge, $57 \mathrm{mi}$. NW of Valdez, Copper River Basin ; 61 ${ }^{\circ} 52^{\prime} 30^{\prime \prime}$ N, 146 $56^{\circ} 30^{\prime \prime}$ W; (map 68).

Local name published in the 1950's by USGS.

Nelchina Glacier: glacier, heads on Mount Willard Gibbs, trends N $23 \mathrm{mi}$. to its terminus at head of Nelchina River, $49 \mathrm{mi}$. NW of Valdez, Chugach Mts.; $61^{\circ} 43^{\prime} \mathrm{N}, 147^{\circ} 05^{\prime} \mathrm{W}$; BGN 1915; (map 69).

Local name reported in 1914 by USGS (Brooks and others, 1915, pl. 6).

Nelchina River: stream, heads in Nelchina Glacier, flows $\mathrm{N}$ and SE $28 \mathrm{mi}$. to Tazlina Lake, $1.6 \mathrm{mi}$. SW of mouth of Mendeltna
Creek and $58 \mathrm{mi}$. N of Valdez, Copper River Basin; $61^{\circ} 56^{\prime} 30^{\prime \prime} \mathrm{N}, 146^{\circ} 26^{\prime} 30^{\prime \prime} \mathrm{W} ; B G N$ 1915; (map 68). Var. Tazlina River.

Indian name adopted by miners. This stream was originally the upper part of the Tazlina River. The name "Nelchina" was applied to a tributary now called Little Nelchina River.

Nelchina River: stream, see Little Nelchina River.

Neliupiaki: point of land, see Kekurnoi, Cape. Nellag Island: island, $0.7 \mathrm{mi}$. long, between Hook and Manhattan Arms, at head of Sea Otter Harbor, off W coast of Dall I., Alex. Arch.; $55^{\circ} 06^{\prime} 45^{\prime \prime}$ N, $133^{\circ} 10^{\prime} 30^{\prime \prime}$ W; (map 4). Var. Goose Island.

Local name recorded in 1920 by USC\&GS. Nellie, Lake: lake, $1.3 \mathrm{mi}$. long, $1.5 \mathrm{mi}$. W of Reflection Lake, $12 \mathrm{mi}$. S of Bradfield Canal, Alex. Arch.; $56^{\circ} 01^{\prime} 00^{\prime \prime} \mathrm{N}, 131^{\circ} 37^{\prime} 45^{\prime \prime} \mathrm{W}$; $(\operatorname{map} 7)$.

Local name reported in 1955 by USGS.

Nellie Gulch: ravine, trends NW $0.8 \mathrm{mi}$. to Mountain Creek, $6 \mathrm{mi}$. NW of Nome, Seward Penin. High.; $64^{\circ} 35^{\prime} 10^{\prime \prime} \mathrm{N}, 165^{\circ} 26^{\prime} 40^{\prime \prime} \mathrm{W}$; (map 94).

Prospectors' name reported in 1904 by $T$. G. Gerdine, USGS.

Nellie Juan, Port: estuary, trends NE $18 \mathrm{mi}$. from mouth of Kings Bay to Prince William Sound, on E coast of Kenai Penin., 24 mi. SE of Whittier, Chugach Mts.; $60^{\circ} 38^{\prime} \mathrm{N}, 148^{\circ}$ 05' W; (map 63). Var. Kings Bay, Port Nell Juan, Port Nelly Juan.

Discovered and named in 1887 by Samuel Applegate, for his schooner, the Nellie Juan. This spelling is from Applegate's map.

Nellie Juan Bay: bay, see Aspid Bay.

Nellie Juan Cape: point of land, see Aspid Cape.

Nellie Juan Glacier: glacier, on E side of Kenai Penin., heads in Sargent Icefield, trends NE 2 mi. to Derickson Bay, $26 \mathrm{mi}$. SE of Whittier, Chugach Mts.; $60^{\circ} 28^{\prime} \mathrm{N}, 148^{\circ} 21^{\prime} \mathrm{W}$; (map 63).

Named in 1910 by U. S. Grant, USGS, "for Samuel Applegate's schooner Nellie Juan."

Nellie Juan Lake: lake, on Kenai Penin., trends $\mathrm{N} 4 \mathrm{mi}$. to head of Nellie Juan River, $14 \mathrm{mi}$. NE of Seward, Chugach Mts.; $60^{\circ} 14^{\prime} \mathrm{N}$, $149^{\circ} 03^{\prime}$ W; BGN 1960; (map 63). Var. Snow Lake.

Local name reported in 1959 by USGS.

Nellie Juan River: stream, heads at Nellie Juan Lake, flows NE $20 \mathrm{mi}$. to Kings Bay, $24 \mathrm{mi}$. S of Whittier, Chugach Mts.; $60^{\circ} 26^{\prime} 30^{\prime \prime} \mathrm{N}$, $148^{\circ} 42^{\prime} 30^{\prime \prime} \mathrm{W}$; (map 63).

Named in 1910 by U. S. Grant, USGS.

Nellie Martin River: stream, flows NE $5 \mathrm{mi}$. to Patton Bay, $70 \mathrm{mi}$. SE of Seward, Chugach Mts.; 59.55' N, $147^{\circ} 30^{\prime} \mathrm{W}$; (map 49).

Local name reported in the early 1950's by USC\&GS.

Nellikowrak: locality, see Nalikaurak.

Nell Juan, Port: estuary, see Nellie Juan, Port. Nelly Juan, Port: estuary, see Nellie Juan, Port. Nelsaluk: locality, near end of spit that extends
E from Barter I. into Bernard Harbor, Arctic Plain; 70 08' N, $143^{\circ} 34^{\prime} \mathrm{W}$; (map 152).

Eskimo name reported by USC\&GS in 1952 to mean in general, "big Nelsons place."

Nelsaluk Pass: water passage, on coast of Beaufort Sea, between Barter I. and Manning Point, Arctic Plain; 70 07'30' N, 143 ${ }^{\circ} 02^{\prime}$ 45" W; (map 152). Var. Nelsaluk Passage.

Local Eskimo name reported by USC\&GS in 1952.

Nelsaluk Passage: water passage, see Nelsaluk Pass.

Nels Klevens: area, NE part of Mountain View, in Anchorage, Cook Inlet Low.; $61^{\circ} 13^{\prime} 52^{\prime \prime} \mathrm{N}$, $149^{\circ} 47^{\prime} 55^{\prime \prime} \mathrm{W}$; (map 69).

Local name reported in 1954 by the city engineer of Anchorage.

Nels Miller Slough: stream, flows SE $3 \mathrm{mi}$. to Copper River, $45 \mathrm{mi}$. N of Katalla, Chugach Mts.; $60^{\circ} 51^{\prime} \mathrm{N}, 144^{\circ} 36^{\prime} \mathrm{W}$; (map 64).

Name published in 1959 by USGS.

Nelson, Point: point of land, $\mathrm{S}$ point of entrance to Smeaton Bay, on E bank of Behm Canal, Coast Mts.; $55^{\circ} 18^{\prime} 05^{\prime \prime} \mathrm{N}, 130^{\circ} 55^{\prime} 30^{\prime \prime} \mathrm{W}$; (map 3).

Named by Capt. George Vancouver, RN, "August 7, 1793, after Captain Horatio Nelson [later, Lord Nelson], RN, * * *" (Wagner, 1937, p. 399).

Nelson Askhomut: village, see Holy Cross.

Nelson Bay: bay, $0.7 \mathrm{mi}$. across, $10 \mathrm{mi}$. SE of Baranof, off $\mathrm{E}$ coast of Baranof I., Alex. Arch.; $56^{\circ} 57^{\prime} \mathrm{N}, 134^{\circ} 44^{\prime} \mathrm{W}$; (map 5).

Local name used by fishermen; published in 1901 by USC\&GS.

Nelson Bay: bay, $1.5 \mathrm{mi}$. wide, at delta of Rude River, $9 \mathrm{mi}$. NE of Cordova, Chugach Mts.; $60^{\circ} 40^{\prime} \mathrm{N}, 145^{\circ} 39^{\prime} \mathrm{W}$; (map 64).

Name published in 1959 by USGS; derived from the proposed townsite of Nelson, which was never built.

Nelson Bluff: bluff, $250 \mathrm{ft}$. high, extends 1.5 mile along left bank of Black River, $25 \mathrm{mi}$. $\mathrm{E}$ of Chalkyitsik, Porcupine Plat.; $66^{\circ} 38^{\prime} \mathrm{N}, 142^{\circ}$ $50^{\prime} \mathrm{W}$; (map 120).

Local name obtained in 1956 by $T$. $E$. Taylor and R. C. Foley, USGS.

Nelson Butte: hill, see Army Peak.

Nelson Cove: cove, extends SE $0.3 \mathrm{mi}$. from Clarence Strait, on SW coast of Gravina I., $6 \mathrm{mi}$. NW of Dall Head, Alex. Arch.; 55 $12^{\prime}$ $15^{\prime \prime} \mathrm{N}, 131^{\circ} 49^{\prime} 45^{\prime \prime} \mathrm{W}$; (map 3 ).

Local name recorded in 1921 by USC\&GS "named for an early prospector."

Nelson Creek: stream, heads in a glacier, flows $3 \mathrm{mi}$. $\mathbf{E}$ to Taiya River $1 \mathrm{mi}$. above its mouth on Taiya Inlet, $3.3 \mathrm{mi}$. NW of Skagway, Coast Mts.; 59 $29^{\prime} 55^{\prime \prime} \mathrm{N}, 135^{\circ} 21^{\prime} 40^{\prime \prime} \mathrm{W}$; (map 45).

Local name obtained by USGS field personnel and published on Federal maps since 1950.

Nelson Creek: stream, on Kenai Penin., flows NW $1.5 \mathrm{mi}$. to Sixmile Creek, $4.5 \mathrm{mi}$. S of Sunrise, Ghugach Mts. ; 60 $48^{\prime} 55^{\prime \prime} \mathrm{N}, 149^{\circ} 25^{\prime}$ 35" W; (map 63).

Local prospectors' name; reported about 1914 by B. L. Johnson (in Martin and others, 1915, pl. 2), USGS. 
Nelson Creek: stream, in Nutzotin Mts., flows SW $2 \mathrm{mi}$. to Chavolda Creek $4.5 \mathrm{mi}$. SE of its junc. with Chisana River, Alaska Ra.; $62^{\circ} 08^{\prime} \mathrm{N}, 142^{\circ} 01^{\prime} \mathrm{W}$; (map 84).

Local name reported in 1960 by USGS.

Nelson Creek: stream, flows E $1.3 \mathrm{mi}$. to Lower Willow Creek which flows to Casadepaga River, $19 \mathrm{mi}$. N of Solomon, Seward Penin. High.; $64^{\circ} 50^{\prime} \mathrm{N}, 164^{\circ} 32^{\prime} \mathrm{W}$; (map 95).

Prospectors' name reported on a map of Cape Nome gold fields by David Fox, Jr., dated 1901.

Nelson Creek: stream, flows SE $0.6 \mathrm{mi}$. to Old Glory Creek in Immachuk River basin, $17 \mathrm{mi}$. NW of Imuruk Lake, Seward Penin. High.; $65^{\circ} 51^{\prime} \mathrm{N}, 163^{\circ} 11^{\prime} \mathrm{W}$; (map 110).

Local name published on a precinct map of Seward Peninsula by Monroe and Hutchins; corrected to June 1903 by Arthur Gibson.

Nelson Glacier: glacier, heads on S slope of Mount Waters, trends SE $3.5 \mathrm{mi}$. to its 1955 terminus $1.5 \mathrm{mi}$. N of Berg Mtn., $16 \mathrm{mi}$. E of Wrangell, Coast Mts. ; $56^{\circ} 28^{\prime} 30^{\prime \prime} \mathrm{N}, 131^{\circ} 59^{\prime}$ $30^{\prime \prime} \mathrm{W}$; (map 7).

Local name reported by F. E. Wright and C. W. Wright (1908, p. 189), USGS.

Nelson Island: island, $0.4 \mathrm{mi}$. long, in Narrow Strait, between Spruce I. and NE coast of Kodiak I.; $57^{\circ} 53^{\prime} 35^{\prime \prime}$ N, $152^{\circ} 24^{\prime} 40^{\prime \prime} \mathrm{W}$; $B G N 1909$; (map 34).

Named in 1909 by Capt. Hodgkins, USC\&GS, "probably * * * after Assistant John Nelson * * *, USC\&GS."

Nelson Island: island, $40 \mathrm{mi}$. long, between Baird Inlet and Etolin Strait, between Kolovinerak and Ningaluk Rivers, $90 \mathrm{mi}$. W of Bethel, Yukon-Kuskokwim Delta ; $60^{\circ} 40^{\prime} \mathrm{N}, 164^{\circ} 45^{\prime}$ W; (map 58).

Named in 1880 by Henry Gannett for Edward William Nelson, who spent about 5 years in this area as an observer for the U.S. Signal Service and collector for the Smithsonian Institution. '

Nelson Island: island, $2 \mathrm{mi}$. long, in the Kuskokwim River 2 mi. N of Tuluksak, Yukon-Kuskokwim Delta; 61 ${ }^{\circ} 08^{\prime} \mathrm{N}, 160^{\circ} 56^{\prime} \mathrm{W}$; (map 73).

Name shown on 1898 field sheet by W. S. Post, USGS.

Nelson Lagoon: lagoon, $20 \mathrm{mi}$. long, $20 \mathrm{mi} \mathrm{W}$ of village of Port Moller, on Alaska Penin., Bristol Bay Low.; $56^{\circ} 00^{\prime} \mathrm{N}, 161^{\circ} 00^{\prime} \mathrm{W}$; (map 28).

Named in 1882 by W. H. Dall, USC\&GS, for Edward William Nelson, U.S. Signal Service, who explored the Yukon Delta region in 1877-81.

Nelson Lake: lake, $2 \mathrm{mi}$. long, $2 \mathrm{mi}$. E of Long Lake and $12 \mathrm{mi}$. NW of Beaver, Yukon Flats; $66^{\circ} 29^{\prime} 30^{\prime \prime} \mathrm{N}, 147^{\circ} 42^{\prime} 00^{\prime \prime} \mathrm{W}$; (map 118).

Probably named by William Yanert who showed it on a 1916 manuscript map of the Yukon Flats (Stuck, 1917, map facing p. 122).

Nelson Lake: lake, $1 \mathrm{mi}$. long, $20 \mathrm{mi}$. E of Chalkyitsik, Porcupine Plat.; $66^{\circ} 40^{\prime} \mathrm{N}, 142^{\circ}$ 59' W; (map 120).

Local name obtained in 1956 by T. E. Taylor and R. C. Foley, USGS.
Nelson Mountain: peak, 5,457 ft., $5.5 \mathrm{mi}$. N of Hanagita Lake and $31 \mathrm{mi}$. SW of McCarthy, Chugach Mts.; $61^{\circ} 19^{\prime} 45^{\prime \prime} \mathrm{N}, 143^{\circ} 49^{\prime} 30^{\prime \prime} \mathrm{W}$; (map 67).

Local name obtained by USGS and published on maps since 1954.

Nelson Mountain: mountain, 2,044 ft., $29 \mathrm{mi}$. NW of Beaver, Kokrines-Hodzana High.; $66^{\circ} 41^{\prime} \mathrm{N}, 148^{\circ} 05^{\prime} \mathrm{W}$; (map 118).

Local name obtained in 1956 by USGS.

Nelson Reef: reef, in N part of Alitak Bay, at S end of Kodiak I.; $56^{\circ} 56^{\prime} 30^{\prime \prime} \mathrm{N}, 154^{\circ} 02^{\prime} 30^{\prime \prime}$ W; (map 32).

Name published in 1943 by USC\&GS.

Nelsons Camp: locality, see Sooghmeghat.

Nelsonville: locality, on right bank of Nushagak River, $3 \mathrm{mi}$. SW of Dillingham, Bristol Bay Low.; $59^{\circ} 00^{\prime} 30^{\prime \prime} \mathrm{N}, 158^{\circ} 32^{\prime} 00^{\prime \prime} \mathrm{W}$; (map 52). Var. Dillingham, Kanakanak, Ke-eksel-hak.

Named about 1944 for Senator Knute Nelson, 1843-1923, Governor of Minnesota 189395, and U.S. Senator, 1895-1923. Nelson, as a member of Senator Dillingham's subcommittee, made an extensive tour of Alaska in 1903. This location, which was then called "Dillingham," and an Eskimo village called "Keek-sel-hak" was recorded on a 1910 manuscript map by H. C. Fassett, USBF. In 1944 the name "Dillingham" was transferred to Snag Point where the Dillingham post office had been since 1904; the name "Nelsonville" came into use about this time. The place is now a section of Kanakanak.

Nelsonville: village, see Dillingham.

Neltuschk-an: locality, see Neltushkin.

Neltushkin: locality, on $\mathbf{N}$ shore of Whitewater Bay, on W coast of Admiralty I., Alex. Arch.; $57^{\circ} 15^{\prime} 30^{\prime \prime} \mathrm{N}, 134^{\circ} 36^{\prime} 15^{\prime \prime}$ W; (map 9). Var. Nahltushkan, Naltuck-an, Neltuschk-an, Scutshon.

Tlingit Indian village reported as "Neltuschk-an," meaning "town on outside of point," in 1885 by Aurel Krause. It was called "Scutskon" by I. Petroff in the 10th Census in 1880. In 1880 the population was 246 "but subsequently they moved to Killisnoo" (Hodge, 1910, p. 11). The BAE recorded the name as "Naltūck-ān."

Nelupaki : point of land, see Kekurnoi, Cape.

Nelutahalik Creek: stream, in Yukon Delta, flows $\mathrm{N} 4 \mathrm{mi}$. to Apoon Pass, $3.5 \mathrm{mi}$. E of Pastol Bay and $38 \mathrm{mi}$. NE of Kwiguk, Yukon-Kuskokwim Delta; $63^{\circ} 02^{\prime} \mathrm{N}, 163^{\circ} 28^{\prime} \mathrm{W}$; (map 92). Var. Nehlutahalik Slough.

Eskimo name obtained in 1899 by $R$. L. Faris, USC\&GS, who reported it as "Nehlutahalik."

Nemod Creek: stream, see Davis Creek.

Nemo Point: point of land, $13 \mathrm{mi} \mathrm{S}$ of Wrangell, on $W$ coast of Wrangell I., Alex. Arch.; 56 $17^{\prime} 00^{\prime \prime} \mathrm{N}, 132^{\circ} 21^{\prime} 40^{\prime \prime} \mathrm{W}$; BGN 1923; (map 6). Var. Duga Point, Laida Point, Wren Point.

Named in 1923 by USC\&GS for the triangulation station on the north side of the point.
Nenana: village, pop. 286 , mile 411.7 on The Alaska RR., on left bank of Tanana River, E of mouth of Nenana River, $45 \mathrm{mi}$. SW of Fairbanks, Tanana Low.; $64^{\circ} 34^{\prime} \mathrm{N}, 1^{\circ} 9^{\circ} 05^{\prime} \mathrm{W}$; $B G N$ 1944; (map 100). Var. Nenana Indian Mission, Saint Marks Indian Mission.

Nenana, named for the nearby stream, became a base for railroad construction in 1916 near the location of the Nenana Indian Mission (also called St. Marks Indian Mission), established in 1907 . On July 15, 1923, President Warren Harding drove the golden spike at the north end of the 700-foot steel bridge over the Tanana River, marking the completion of the railroad. The population of the village was 190 in $1910 ; 634$ in $1920 ; 291$ in 1930 ; 231 in 1939; and 242 in 1950 . The Nenana post office was established in 1908 (Ricks, 1965, p. 45). See Tortella.

Nenana: locality, see North Nenana.

Nenana Glacier: glacier, heads at $63^{\circ} 32^{\prime} \mathrm{N}$, $147^{\circ} 36^{\prime} \mathrm{W}$, trends SW $7 \mathrm{mi}$. to head of $\mathrm{Ne}$ nana River, $44 \mathrm{mi}$. SE of Healy, Alaska Ra.; $63^{\circ} 29^{\prime} 30^{\prime \prime} \mathrm{N}, 147^{\circ} 47^{\prime} 45^{\prime \prime} \mathrm{W}$; (map 87).

Local name obtained in 1913 by J. W. Bagley, USGS; published by Moffit (1915, pl. 1).

Nenana Indian Mission: village, see Nenana.

Nenana Mountain: mountain, 7,881 ft., $37 \mathrm{mi}$. $\mathrm{NE}$ of Cantwell and $42 \mathrm{mi}$. SE of Healy,

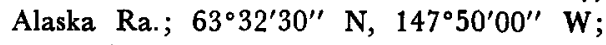
(map 87).

Name taken from the glacier and river which heads on it; reported in 1951 by USGS.

Nenana River: stream, heads at Nenana Glacier, in Alaska Ra., flows N $140 \mathrm{mi}$. to Tanana River at Nenana, Tanana Low.; 64 $33^{\prime} 50^{\prime \prime} \mathrm{N}$, $149^{\circ} 06^{\prime} 20^{\prime \prime} \mathrm{W}$; (map 100). Var. Cantwell River, Nanana River, Neenana River, Tutlut River.

Originally named Cantwell River by Lt. Allen (1887, map), USA, in 1885 for Lt. John C. Cantwell, of the Revenue-Cutter Service, who explored the Kobuk River region in 1884 and 1885 . In 1898, W. J. Peters and A. H. Brooks, USGS, reported that the native name was "Tutlut," but Lt. J. C. Castner, USA (in Glenn and Abercrombie, 1899, p. 233), stated in 1898: "The largest, of twenty cabins, was opposite the mouth of the Nanana (Lieutenant Allen's Cantwell) River." The Tanana Indian name was spelled "Nenana" by Lt. Herron (1901, p. 48), USA. Local usage adopted the latter spelling. According to Father Julius Jette, S. J., the name "remains unexplained and seems as much a puzzle to them [the Indians] as it is to me."

Nenana River: village, see Ferry.

Nenana Slough: stream, see Little Nenana River. Nenevok Lake: lake, $4 \mathrm{mi}$. long, extends NW-SE $8 \mathrm{mi}$., NW of Togiak Lake, $78 \mathrm{mi}$. NE of Goodnews, Kilbuck-Kuskokwim Mts.; 59 $45^{\prime}$ $\mathrm{N}, 159^{\circ} 48^{\prime} \mathrm{W}$; (map 53). Var. Nanava-ak Lake, Nenevokuk Lake, Nunava-ak Lake.

Eskimo name probably meaning "lake" shown on a 1898 fieldsheet by W. S. Post, USGS, whose party camped on its shore, September 10 of that year. The name was 
published as "Nenevokuk" by Spurr (1900, map 10), USGS.

Nenevokuk Lake: lake, see Nenevok Lake.

Neniltschik oder Sunit, Cape: point of land, see Ninilchik, Cape.

Ne-ohi-lik River: stream, see Nechelik Channel. Nepean Point: point of land, see Napean, Point. Nepen Point: point of land, see Napean, Point. Nepken Point: point of land, see Napean, Point. Nepoverotni Rocks: rocks, see Nepovorotni Rocks.

Nepovorotni Rocks: rocks, in Sitka Sound, between Middle and Western Channels, $1.3 \mathrm{mi}$. SW of Sitka, Alex. Arch.; 57 $02^{\prime} 22^{\prime \prime}$ N, $135^{\circ}$ $21^{\prime} 45^{\prime \prime} \mathrm{W}$; (map 9). Var. Kamen Nepovorotnoy, Nepoverotni Rocks.

Russian name meaning "not turning," given in 1809 by the navigator Ivan Vasiliev the first, published by Lt. Sarichev (1826, map 19), IRN, as "K[amen] Nepovorotnoy."

Nepovorotnoy, Kamen: rocks, see Nepovorotni Rocks.

Neprokhodnaya, Guba: $b a y$, see No Thorofare Bay.

Neprop Island: island, see Impassible Island.

Nepropusknoi Island: island, see Impassible Island.

Nepropusknoy, Ostrov: island, see Impassible Island.

Neptune Bay: bight, $1.5 \mathrm{mi}$. wide, on $\mathrm{E}$ shore of Kachemak Bay, on Kenai Penin., 9 mi SE of Homer, Chugach Mts. ; $59^{\circ} 33^{\prime} \mathrm{N}, 151^{\circ} 24^{\prime}$ W; (map 50).

Local name reported by USGS or USC\&GS in the 1940's.

Neptune Island: island, $0.3 \mathrm{mi}$. long, in Blake Channel, on $\mathrm{E}$ coast of Wrangell I., Alex. Arch.; $56^{\circ} 20^{\prime} 50^{\prime \prime} \mathrm{N}, 132^{\circ} 00^{\prime} 15^{\prime \prime} \mathrm{W}$; (map 6).

Named by USC\&GS for charting purposes; name published in 1924 .

Neptune Point: point of land, on NE coast of Kenai Penin., at E entrance to Shotgun Cove, $5.5 \mathrm{mi}$. NE of Whittier, Chugach Mts. ; $60^{\circ} 48^{\prime}$ N, $148^{\circ} 32^{\prime}$ W ; BGN 1915; (map 63).

Named in 1914 by USC\&GS.

Neragon Island: barrier island, $7.5 \mathrm{mi}$. long, one of Sand Is. between Bering Sea and Scammon Bay, Yukon-Kuskokwim Delta; 61 ${ }^{\circ} 55^{\prime} \mathrm{N}$, $165^{\circ} 59^{\prime} \mathrm{W}$; (map 75).

Name reported by R. H. Sargent, USGS, in 1919.

Nerelna Creek: stream, heads in lake, flows NE 9 mi. to Chitina River, $0.3 \mathrm{mi}$. SW of delta of Kuskulana River and $72 \mathrm{mi}$. NE of Valdez, Chugach Mts.; $61^{\circ} 27^{\prime} 40^{\prime \prime} \mathrm{N}, 144^{\circ} 10^{\prime} 30^{\prime \prime} \mathrm{W}$; (map 68).

Ahtena Indian name from an unpublished prospectors' map made in 1900 .

Nerka, Lake: lake, $36 \mathrm{mi}$, long, extends $\mathrm{S}$ from Akulukpak River to River Bay, $30 \mathrm{mi}$. N of Dillingham, Kilbuck-Kuskokwim Mts.; 59³2' N, 15900' W; BGN 1931; (map 52). Var. Agouloukpak, Agulukok, Agulukpak, Agulukpok Lake, Akuliukhpak Lake, Cho-kwokstchu-luk, Chung-nok-du-li, Pamiek Lake.

So named in 1910 by USBF because the lake is a great spawning ground of the red or blue- back salmon (Nerka). The Eskimo name of the lake, "Agulukpak," meaning "big aguluk," was obtained in 1898 as "Agouloukpak" from A. Mittendorf, a local trader, by J. E. Spurr and W. S. Post, USGS. This is probably the same lake called "Pamiek" by Capt. Tebenkov (1852, map 4).

Nerpchiy, Ostrov: island, see Ikiginak Island.

Nerpichie: point of land, see Seal Cape.

Nerpichie Bay: bay, see Seal Bay.

Nerpichie Islets: islands, see Seal Islands.

Nerpichiy, Ostrov: island, see Ikiginak Island. Nerpitchy Island: island, see Ikignak Island. Neruokpuk Lake: lakes, see Neruokpuk Lakes. Neruokpuk Lakes: lakes, include Lake Peters and Lake Schrader, in Franklin Mts., extend 9.5 mi. at head of Kekiktuk River, $19 \mathrm{mi}$. W of Mount Michelson, Brooks Ra.; 69 $21^{\prime} \mathrm{N}$, $145^{\circ} 00^{\prime} \mathrm{W}$; (map 139). Var. Narivukpuk Lake, Narvaqpak Lake, Neruokpuk Lake.

Eskimo name reported by Leffingwell $(1919$, p. 98$)$ to mean "big lake." Diamond Jenness spells it "Narivukpuk" and Orth recorded it as "Narvaqpak" in 1965.

Neruokpuk Lakes: lake, see Peters, Lake.

Neruokpuk Lakes: lake, see Schrader, Lake.

Nerviak: bay, see Jacksmith Bay.

Nesbit, Point: point of land, see Nesbitt, Point. Nesbit Creek: stream, flows SW $6.5 \mathrm{mi}$. to Kingsley Creek, $7 \mathrm{mi}$. SE of Mount Bendeleben and $41 \mathrm{mi}$. SW of Imuruk Lake, Seward Penin. High.; $65^{\circ} 06^{\prime} \mathrm{N}, 163^{\circ} 56^{\prime} \mathrm{W}$; (map 110).

Prospectors' name published on the 1908 "Map of Seward Peninsula" by Arthur Gibson.

Nesbitt, Point: point of land, southernmost tip of Zarembo I., Alex. Arch.; $56^{\circ} 14^{\prime} \mathrm{N}, 132^{\circ} 52^{\prime}$ W; (map 6). Var. Point Nesbit.

Named in September 1793, by Capt. George Vancouver, RN (Wagner, 1937, p. 399). It was discovered by James Johnstone September 1 .

Nesbitt Reef: reef, 0.2 mi. long, off Point Nesbitt at $S$ tip of Zarembo I., Alex. Arch.; 56 $13^{\prime} 30^{\prime \prime}$ $\mathrm{N}, 132^{\circ} 51^{\prime} 30^{\prime \prime} \mathrm{W}$; (map 6$)$.

Named in 1886 by Lt. Comdr. A. S. Snow, USN; name published in 1887 on USC\&GS Chart 706.

Ness Creek: stream, flows N $4 \mathrm{mi}$. to Canoe Bay, $\mathbf{E}$ of Pavlof Bay, near SW end of Alaska Penin., Aleutian Ra.; $55^{\circ} 32^{\prime} 20^{\prime \prime}$ N, $161^{\circ}$ $16^{\prime} 40^{\prime \prime} \mathrm{W}$; (map 28).

Named in 1929 by USGS.

Nesselrode, Mount: mountain, 8,105 ft., on Alaska-Canada boundary, $2.8 \mathrm{mi}$. NE of Mount Bressler and $46 \mathrm{mi}$. N of Juneau, Coast Mts.; 58 $57^{\prime} 45^{\prime \prime} \mathrm{N}, 134^{\circ} 18^{\prime} 45^{\prime \prime} \mathrm{W}$; BGN 1923; (map 11). Var. Boundary Peak 98.

Named in 1924 by Lawrence Martin, Department of State, for Count Karl Robert Nesselrode, 1780-1862, Russian Minister of Foreign Affairs, 1816-56, and a plenipotentiary in 1824 in negotiations with the United States regarding the Alaskan boundary.

Nest Greek: stream, flows N $3.5 \mathrm{mi}$. to Bering Sea, $1.5 \mathrm{mi}$. NE of Cape Chagak, on N coast of Umnak I., Aleutian Is. ; $53^{\circ} 32^{\prime} \mathrm{N}, 168^{\circ} 12^{\prime}$ W; (map 22).

Name published by Byers (1959, pl. 41), USGS.

Nest Island: island, $500 \mathrm{ft}$. long, in Kiliuda Bay, on SE coast of Kodiak I.; $57^{\circ} 17^{\prime} 40^{\prime \prime} \mathrm{N}, 152^{\circ}$ 53'30" W; BGN 1930; (map 34). Var. Parrot Island.

Descriptive name given in 1930 by USC\&GS, "Because of duplications of the name Parrot ***. The field party *** called the group of islands located here Parrot Islands because hundreds of sea-parrots have the top of this island honeycombed with burrows * * *."

Nest Lake: lake, $0.5 \mathrm{mi}$. long, on Kenai Penin., $0.8 \mathrm{mi}$. S of Kayak Lake and $27 \mathrm{mi}$. NE of Kenai, Cook Inlet Low.; $60^{\circ} 44^{\prime} 10^{\prime \prime} \mathrm{N}, 150^{\circ}$ $34^{\prime} 30^{\prime \prime} \mathrm{W}$; (map 62).

Named about 1963 by officials of Kenai National Moose Range, for administrative purposes.

Nest Rock: rock, in Kuliliak Bay, on $\mathrm{S}$ coast of Unalaska I., Aleutian Is.; $53^{\circ} 27^{\prime} 42^{\prime \prime} \mathrm{N}$, $167^{\circ} 01^{\prime} 50^{\prime \prime}$ W; BGN 1939; (map 23).

Descriptive name given by USC\&GS in 1938 because of the "large number of birds which nest on the islet during the summer months."

Nethkahati Creek: stream, heads in Ray Mts., flows W $15 \mathrm{mi}$. to Slokhenjikh Creek $2.5 \mathrm{mi}$. ENE of that stream's junc. with Melozitna River, Kokrines-Hodzana High.; $65^{\circ} 48^{\prime} 10^{\prime \prime} \mathrm{N}$, $152^{\circ} 50^{\prime} 00^{\prime \prime} \mathrm{W}$; (map 106).

Koyukan Indian name referring to "stream junction" obtained in 1956 at Hughes by Orth.

Netholzende Lake: lake, $5.5 \mathrm{mi}$. SE of Long Lake, 13 SE of Roundabout Mtn., Koyukuk Low.; $65^{\circ} 31^{\prime} \mathrm{N}, 156^{\circ} 06^{\prime} \mathrm{W}$; (map 108).

Koyukan Indian name obtained in 1955 at Huslia by USGS.

Netland Glacier: glacier, heads $2 \mathrm{mi}$. S of AlaskaCanada boundary, trends N $3 \mathrm{mi}$. to its 1964 terminus in Canada, $5 \mathrm{mi}$. W of junc. of Tatshenshi and Alsek Rivers and $92 \mathrm{mi}$. W of Skagway, St. Elias Mts.; $59^{\circ} 25^{\prime} \mathrm{N}, 137^{\circ}$. $53^{\prime} \mathrm{W}$; (map 45).

Local name published by USGS in the 1950's.

Netland Island: island, $1 \mathrm{mi}$. across, at mouth of Berg Bay, Glacier Bay National Monument, $0.3 \mathrm{mi}$. NW of Lars I. and $39 \mathrm{mi}$. NW of Hoonah, St. Elias Mts.; $58^{\circ} 32^{\prime} 15^{\prime \prime} \mathrm{N}, 136^{\circ}$ $08^{\prime} 45^{\prime \prime}$ W; BGN 1942; (map 10).

Named by USC\&GS in 1939 for Lars Netland, 1869-1934, a member of the U.S. section of the IBC from 1904-10. Netland aided in the reconnaissance survey of Berg Bay in 1907.

Netletna River: stream, flows N $45 \mathrm{mi}$. to Innoko River, $20 \mathrm{mi}$. NE of Holikachuck, Innoko Low.; $63^{\circ} 01^{\prime} \mathrm{N}, 158^{\circ} 75^{\prime} 00^{\prime \prime} \mathrm{W}$; (map 90).

Indian name reported in 1954 by USGS. Netsekawik: locality, on Golovnin Bay, on $\mathrm{N}$ shore of Norton Sound, Seward Penin. High.; $64^{\circ} 26^{\prime} \mathrm{N}, 162^{\circ} 57^{\prime} \mathrm{W}$; (map 95). 
Former Eskimo village or camp recorded in the 1890 Census (p. 162).

N. E. Twin: peak, see Northeast Twin.

Neuberger Mount: mountain, 6,747 ft., $8 \mathrm{mi}$. $\mathrm{S}$ of Tanacross, Alaska Ra.; $63^{\circ} 16^{\prime} \mathrm{N}, 143^{\circ}$ $26^{\prime} \mathrm{W}$; BGN 1961; (map 85).

Named for Richard Lewis Neuberger, 191260 , who, as a member of the U.S. Senate from Oregon, was a strong supporter of legislation that led to statehood for Alaska.

Neukeluk River: stream, see Niukluk River.

Neukluk River: stream, see Niukluk River.

Neumann Bay: lagoon, see Moffet Lagoon.

Neumann Island: island, $3 \mathrm{mi}$. long, easternmost of Kudiakof Is., near NW shore of Moffett Lagoon, $17 \mathrm{mi}$. N of village of Cold Bay at SW end of Alaska Penin., Bristol Bay Low.; 55 ${ }^{\circ}$ 26'00' N, 162 $36^{\prime} 30^{\prime \prime}$ W; BGN 1966; (map 29). Var. Moffet Point.

Named by USBF, 1888, for Rudolph Neumann, a member of the Alaska Commercial Company.

Neumann Point: point of land, see Moffet Point.

Neva Bay: bay, $0.3 \mathrm{mi}$. across, on $\mathrm{SW}$ coast of

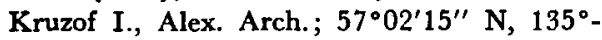
$50^{\prime} 40^{\prime \prime}$ W; (map 9). Var. Bukhta Neva.

Named "Bukhta Neva," or "Neva Bay," about 1849 by the Russian American Company, after the ship Neva.

Neva Channel: water passage, see Neva Strait.

Neva Cove: cove, extends S $0.6 \mathrm{mi}$., between Entrance and Otmeloi Points, at NW end of Narrow Strait, on N coast of Kodiak I.; $57^{\circ}$ $54^{\prime} 30^{\prime \prime} \mathrm{N}, 152^{\circ} 31^{\prime} 15^{\prime \prime} \mathrm{W}$; (map 34).

Local name published in 1943 by USC\&GS.

Neva Creek: stream, flows SW $4 \mathrm{mi}$. to Kougarok River, $15 \mathrm{mi}$. $\mathrm{N}$ of its junc. with Kuzitrin River, $45 \mathrm{mi}$. SW of Imuruk Lake, Seward Penin. High.; $65^{\circ} 28^{\prime} \mathrm{N}, 164^{\circ} 42^{\prime} \mathrm{W}$; (map 110).

Prospectors' name reported in 1901 by T. G. Gerdine (in Collier, 1902, pl. 12), USGS.

Nevada Creek: stream, $1.7 \mathrm{mi}$. long, on the $\mathrm{W}$ end of Douglas I., flowing NE to Gastineau Channel, $6.5 \mathrm{mi}$. SE of Juneau, Coast Mts.; $58^{\circ} 13^{\prime} 50^{\prime \prime} \mathrm{N}, 134^{\circ} 18^{\prime} 15^{\prime \prime} \mathrm{W}$; (map 11).

Local name reported in 1902 by W. J. Peters, USGS.

Nevada Creek: stream, flows W $0.7 \mathrm{mi}$. to Carbon Creek, $17 \mathrm{mi}$. NE of Katalla, Chugach Mts.; $60^{\circ} 23^{\prime} \mathrm{N}, 144^{\circ} 12^{\prime} \mathrm{W}$; (map 64).

Prospectors' name published in 1907 by USGS.

Nevada Creek: stream, flows SE $5.1 \mathrm{mi}$. to Poorman Creek, $3.3 \mathrm{mi}$. SW of Poorman, Kilbuck-Kuskokwim Mts.; $64^{\circ} 05^{\prime} \mathrm{N}, 155^{\circ} 39^{\prime}$ W; (map 98).

Prospectors' name reported in 1921 by USGS.

Nevada Creek: stream, flows S $1.8 \mathrm{mi}$. to Flambeau River, $17 \mathrm{mi}$. NE of Nome, Seward Penin. High.; $64^{\circ} 43^{\prime} \mathrm{N}, 165^{\circ} 05^{\prime} \mathrm{W}$; (map 94).

Prospectors' name reported on Arthur Gibson's "Map of Cape Nome Precinct" dated 1904.
Nevada Cireek: stream, flows SW $0.5 \mathrm{mi}$. to California Creek, 7 mi. S of Rampart, YukonTanana High.; $65^{\circ} 24^{\prime} 00^{\prime \prime} \mathrm{N}, 150^{\circ} 06^{\prime} 40^{\prime \prime} \mathrm{W}$; (map 106).

Prospectors' name shown on a manuscript map dated 1906; reported in 1956 by Orth Nevada Creek: stream, flows NW to North Fork Kougarok River near its mouth, about $14 \mathrm{mi}$. SW of Midnight Mtn. and $45 \mathrm{mi}$. W of Imuruk Lake, Seward Penin. High.; (map 110).

Prospectors' name shown on a map of Cape Nome gold fields by David Fox, Jr., dated 1901. This stream cannot be precisely located on current maps.

Neva Island: island, $0.1 \mathrm{mi}$. across, $2.5 \mathrm{mi}$. W of Sitka, in Sitka Sound, Alex. Arch.; 57 $03^{\prime}$ $30^{\prime \prime} \mathrm{N} 135^{\circ} 24^{\prime} 20^{\prime \prime} \mathrm{W}$; (map 9). Var. Nevi Island, Ostrov Nevy.

Named in 1809 by the Russian navigator Ivan Vasiliev the first; published by Lt. Sarichev (1826, map 19), IRN, as "Os[trov] Nevy," or "Nevy Island." See Nevski Island.

Neva Point: point of land, between Nakwasina Passage and Neva Strait, $15 \mathrm{mi}$. NW of Sitka, on NW coast of Baranof I., Alex. Arch.; $57^{\circ} 14^{\prime} 10^{\prime \prime} \mathrm{N}, 135^{\circ} 33^{\prime} 00^{\prime \prime} \mathrm{W}$; (map 9).

Apparently named for Neva Strait by W. H. Dall, USC\&GS, in the 1883 Coast Pilot (p. 153)

Neva Strait: water passage, $16 \mathrm{mi}$. NW of Sitka, between Partishkof I. and NW coast of Baranof I., Alex. Arch.; $57^{\circ} 15^{\prime} \mathrm{N}, 135^{\circ} 34^{\prime} \mathrm{W}$; (map 9). Var. Neva Channel, Olga Strait. Named in 1804 by Capt. U. T. Lisianski, IRN, for his vessel the Neva. It was called "Ogla Strait" by I. Vasiliev in 1809 and included the water now known as "Olga Strait." "The present Neva Strait is the Olga Strait of the Russian chart of 1809 , but not of M. D. Tebenkov." (U.S. Coast and Geodetic Survey, 1883, p. 156.)

Nevat Point: point of land, an S shore of Kasegaluk Lagoon, $13 \mathrm{mi}$. SE of Icy Cape, Arctic Plain; $70^{\circ} 15^{\prime} \mathrm{N}, 161^{\circ} 21^{\prime} \mathrm{W}$; (map 146).

Eskimo name obtained by Orth in 1956 .

Nevensky Island: island, $4.5 \mathrm{mi}$. long, in Yukon River, between Arbor and Spangle Is. $W$ of Marshall, Yukon-Kuskokwim Delta; $61^{\circ} 54^{\prime} \mathrm{N}$, $162^{\circ} 07^{\prime} \mathrm{W}$; (map 74).

Name shown on a 1940 navigation chart of the Yukon River.

Never-Never Lake: lake, $0.7 \mathrm{mi}$. long, $\mathrm{W}$ of Big Lake, $21 \mathrm{mi}$. N of Anchorage, Cook Inlet Low.; 61 $31^{\prime} 25^{\prime \prime}$ N, $149^{\circ} 58^{\prime} 10^{\prime \prime}$ W; BGN 1957; (map 69).

So named in 1956 by Lloyd E. Farley, because, "[since] the lake is isolated from roads and connecting lakes or streams, it appears as if it belonged to Never-Never Land."

Nevertolemute: locality, see Nvortulermiut.

Nevidiskov Bay: bay, $3.6 \mathrm{mi}$. across, formed by its $E$ and $W$ arms, on $S$ coast of Attu I., Aleutian Is.; $52^{\circ} 46^{\prime} 45^{\prime \prime} \mathrm{N}, 172^{\circ} 51^{\prime} 00^{\prime \prime} \mathrm{E}$; $B G N$ 1938; (map 13). Var. Helughi Bay.

Named for Michael Nevidiskov, navigator of the Russian vessel Yevdokia. Nevidiskov may have been the first Caucasian to land on Attu Island in 1745. He took a native islander, called "Temnac," home with him in order to learn the language spoken on the islands (Coxe, 1787, p. 30). Bancroft (1886, p. 111), spelled the name "Nevodchikof."

Nevidiskov Creek: stream, on S coast of Attu I., flows S $1.3 \mathrm{mi}$. to West Arm Nevidiskov Bay, Aleutian Is.; $52^{\circ} 48^{\prime} 20^{\prime \prime} \mathrm{N}, 172^{\circ} 49^{\prime} 20^{\prime \prime} \mathrm{E}$; (map 13)

Name derived from Nevidiskov Bay; published in 1948 by AMS.

Nevidiskov River: stream, on $S$ coast of Attu I., flows S $4.7 \mathrm{mi}$. to Nevidiskov Bay, Aleutian Is.; $52^{\circ} 48^{\prime} 00^{\prime \prime} \mathrm{N}, 172^{\circ} 52^{\prime} 05^{\prime \prime} \mathrm{E}$; (map 13).

Name derived from Nevidiskov Bay; published in 1948 by AMS.

Nevi Island: island, see Neva Island.

Nevski Island: island, $0.1 \mathrm{mi}$. across, tied to Japonski I., in Sitka Sound, $1.3 \mathrm{mi}$. SW of Sitka, Alex. Arch.; $57^{\circ} 02^{\prime} 40^{\prime \prime} \mathrm{N}, 135^{\circ} 21^{\prime} 50^{\prime \prime}$ W; (map 9). Var. Nevskoi Island, Ostrov Nevskoy.

Named in 1809 by the Russian navigator Ivan Vasiliev the first; published by Lt. Sarichev (1826, map 19), IRN, as "O[strov] Nevskoy," or "Nevskoy Island." This island was presumably named for the Russian warship Neva which was at Sitka in 1804. Nevski is also a Russian family name.

Nevskoi Island: island, see Nevski Island.

Nevskoy, Ostrov: island, see Nevski Island.

Nevy, Ostrov: island, see Neva Island.

New Andreafski: village, see Andreafsky.

New Andreafsky: village, see Andreafsky.

New Archangel: locality, see Fort Saint Michael.

New Archangel: town, see Sitka.

New Balaam: village, see Uzinki.

New Bogoslof Island: island, see Fire Island.

New Bonanza Creek: stream, flows SW $0.8 \mathrm{mi}$. to Bonita Creek, $11 \mathrm{mi}$. NE of Nome, Seward Penin. High.; $64^{\circ} 38^{\prime} 20^{\prime \prime} \mathrm{N}, 165^{\circ} 12^{\prime} 40^{\prime \prime} \mathrm{W}$ (map 94).

Prospectors' name reported in 1904 by T. G. Gerdine, USGS.

New Boston: locality, site of town near Grant Creek on Douglas I., $1 \mathrm{mi}$. W of Juneau, Coast Mts. ; $58^{\circ} 18^{\prime} \mathrm{N}, 134^{\circ} 27^{\prime} \mathrm{W}$; (map 11). Var. Union City.

Name of a short-lived town mentioned by DeArmond (1957, p. 23).

New Chevak: village, see Chevak.

Newchuklichargut: stream, see Grant Creek.

Newchuklikaket: stream, see Grant Creek.

Newcomer Creek: stream, see Cache Creek.

New Cornwall: area, extending from Pt. Staniforth in Canada to Pt. Rothsay in southeast Alaska.

Named by Capt. George Vancouver, RN, about September 20, 1793, in honor of the English county.

New Cóttonwood Creek: stream, flows SSW 17 mi. to Noatak River, $5 \mathrm{mi}$. E of confluence of Noatak and Nimiuktuk Rivers, Brooks Ra.; $68^{\circ} 08^{\prime} \mathrm{N}, 159^{\circ} 42^{\prime} \mathrm{W}$; (map 131).

Translation of an Eskimo name reported by Orth in 1956 . 
New Cutoff: channel, of Yukon River, $3.5 \mathrm{mi}$. SW of Beaver, Yukon Flats; $66^{\circ} 19^{\prime} 30^{\prime \prime} \mathrm{N}$, $147^{\circ} 30^{\prime} 45^{\prime \prime} \mathrm{W}$; (map 118.)

Local name obtained in 1956 by USGS.

New Eddystone Cape: point of land, see Louise, Point.

New Eddystone Islands: islands, extend $1.4 \mathrm{mi}$. off mainland, in Behm Canal, $3 \mathrm{mi}$. $\mathrm{N}$ of Winstanley I., Coast Mts.; 55 $31^{\prime}$ N, $130^{\circ} 54^{\prime} \mathrm{W}$; (map 3$)$

Named about 1865 by the British Admiralty; derived from New Eddystone Rock.

New Eddystone Point: point of land, see Louise, Point.

New Eddystone Rock: rock, elev. $230 \mathrm{ft} ., 500 \mathrm{ft}$. long, in Behm Canal, E of Revillagigedo I., $3 \mathrm{mi}$. N of Winstanley I., Coast Mts.; $55^{\circ} 30^{\prime}$ $15^{\prime \prime} \mathrm{N}, 130^{\circ} 56^{\prime} 10^{\prime \prime} \mathrm{W}$; (map 3).

So named in 1793 by Capt. Vancouver, RN (1798, v. 4, p. 159) because of its resemblance to the lighthouse rock off Plymouth, England.

New Eldorado Creek: stream, flows SE $3.8 \mathrm{mi}$., joins Bonita Creek to form Osborn Creek, 12 mi. NE of Nome, Seward Penin. High.; $64^{\circ}$ $38^{\prime} \mathrm{N}, 165^{\circ} 10^{\prime} \mathrm{W}$; (map 94).

Prospectors' name reported in 1900 by E. C. Barnard (in Brooks, 1901, pl. 17), USGS.

Newenham, Cape: point of land, in Bering Sea between Kuskokwim and Bristol Bays, $40 \mathrm{mi}$. W of Hagemeister I., Kilbuck-Kuskokwim Mts.; $58^{\circ} 39^{\prime} 00^{\prime \prime} \mathrm{N}, 162^{\circ} 10^{\prime} 30^{\prime \prime} \mathrm{W}$; (map 39).

Named July 16, 1778 , by Lt. Williamson, RN, when he was sent ashore by Capt. James Cook, RN, for reconnaissance reasons. $\mathrm{He}$ "landed on the point, and, having climbed the highest hill *** took possession of the country in his Majesty's name, and left on the hill a bottle, in which was described, on a piece of paper, the names of the ships, and the date of discovery" (Cook, 1785, v. 2, p. 432). Capt. Lutke (1836, p. 252-6) IRN, said that "Cap Newnham" is called "Black by the natives on account of its appearance."

New Fort Hamilton: locality, see New Hamilton.

Newhalen: village, pop. 63 , an $\mathrm{N}$ shore of Iliamna Lake, at mouth of Newhalen River, $2.5 \mathrm{mi}$. S of Iliamna, Bristol Bay Low.; 59 ${ }^{\circ}$ $43^{\prime} 20^{\prime \prime} \mathrm{N}, 154^{\circ} 54^{\prime} 00^{\prime \prime} \mathrm{W}$; BGN 1910; (map 51). Var. Newhalen Village, Newrailing Village, Nogheling, Noghelingamiut, Noghelingamute, Nuwhalen Village.

Eskimo name of a village listed in the 1890 Census as "Noghelingamute" or "people of the Noghelin," population 16. (1893, p. 164). The present spelling is an anglicization of the name. There evidently were two villages of these people on Newhalen River in 1890; see Noghelin Painga.

Newhalen River: stream, heads at Sixmile Lake, flows S $22 \mathrm{mi}$. to Iliamna Lake, $3 \mathrm{mi}$. S of Iliamna, Aleutian Ra.; $59^{\circ} 43^{\prime} \mathrm{N}, 154^{\circ} 53^{\prime} \mathrm{W}$; $B G N$ 1910; (map 51). Var. Negheling River, Newrailing River, New-Whalen River, Newwhalin River, New-Whrailing River, New-
Whraling River, Noálen River, Nogheling River, Noghelin Painga, Noghelin River, Nogholem River, Nuwhalen River.

Eskimo name reported in 1891 as "Noghelin Painga," meaning "mouth of the Noghelin," by A. B. Schanz in the 1890 Census. The present spelling was reported in 1900 by $A$. G. Maddren, USGS, and represents pronunciation of the Eskimo name by English-speaking prospectors.

Newhalen Village: village, see Newhalen.

New Halfway Lakes: lakes, $4 \mathrm{mi}$. SE of Muddy Lake and $22 \mathrm{mi}$. SE of Beaver, Yukon Flats; $66^{\circ} 05^{\prime} \mathrm{N}, 147^{\circ} 02^{\prime} \mathrm{W}$; (map 118).

Local name obtained in 1956 by USGS.

Newhall, Mount: mountain, 1,651 ft., on SE shor: of Unalaska Bay, on NE coast of Unalaska I., Aleutian Is.; 53 $52^{\prime} 39^{\prime \prime} \mathrm{N}, 166^{\circ}-$ $29^{\prime} 56^{\prime \prime} \mathrm{W}$; (map 23 ).

Local name published in 1951 on a USGS map.

New Hamilton: locality, on right bank of Nanvaranak Slough near its mouth on Kwikpak Pass, $18 \mathrm{mi}$. E of Kwiguk, Yukon-Kuskokwim Delta; 62 ${ }^{\circ} 43^{\prime} 45^{\prime \prime} \mathrm{N}, 163^{\circ} 5^{\prime} 10^{\prime \prime} \mathrm{W}$; (map 77). Var. Elutuc, Nanvaranok, Nanvarnok, New Fort Hamilton, Ninvaug, Ninvok.

The North American Transportation and Trading Company in 1899 established a supply depot here at a small Eskimo settlement called "Nanvaranok" after the adjacent stream. The trading company, however, called its depot and trading post "New Fort Hamilton." See Hamilton. In 1842-44 Lt. L. A. Zagoskin, IRN, showed an Eskimo village at or near this place called "Ninvaug." New Harbor: bay, see Baralof Bay.

New Harbor: estuary, see Freshwater Bay.

New Heart Creek: stream, flows W $6.5 \mathrm{mi}$. to Ipiavik Lagoon, $14 \mathrm{mi}$. SE of Kivalina, Kotzebue-Kobuk Low.; $67^{\circ} 37^{\prime} \mathrm{N}, 164^{\circ} 08^{\prime} \mathrm{W}$; (map 128). Var. Ahsiglirahgim, Ipauveerak, Koogowranga.

Local name reported in 1950 by USC\&GS. Newi-cargut: locality, see Nowi.

Newicargut: stream, see Nowitna River.

New Igloo: locality, on right bank of Pilgrim River $2.5 \mathrm{mi}$. SE of its junc. with Kuzitrin River and $36 \mathrm{mi}$. SE of Teller, Seward Penin. High.; $65^{\circ} 08^{\prime} \mathrm{N}, 165^{\circ} 10^{\prime} \mathrm{W}$; (map 111).

Local name published in 1965 by USGS; named relative to Igloo to the north and Marys Igloo to the east.

Newikargut: locality, see Nowi.

Newikargut: village, see Kokrines.

Newikargut: stream, see Nowitna River.

New Jersey Creek: stream, flows $\mathrm{E}$ and $\mathrm{N} 7 \mathrm{mi}$. to Bering Sea, on $\mathrm{N}$ coast of Umnak I., Aleutian Is., $53^{\circ} 33^{\prime} 30^{\prime \prime} \mathrm{N}, 168^{\circ} 35^{\prime} 15^{\prime \prime} \mathrm{W}$; (inap 22).

Name published by Byers (1959, pl. 41), USGS.

New Kealavik: village, see Newtok.

New Knockhock: village, on right bank of Black River, $45 \mathrm{mi}$. S of Kwiguk, Yukon-Kuskokwim Delta; $62^{\circ} 07^{\prime} 45^{\prime \prime} \mathrm{N}, 164^{\circ} 53^{\prime} 40^{\prime \prime} \mathrm{W}$; (map 77). Var. New Nakhak, Newnockhock.
Eskimo village with a population of 122 in 1950. See Knockhock.

New Koliganek: locality, on left bank of Nushagak River, $8 \mathrm{mi}$. SE of Koliganek and $70 \mathrm{mi}$. NE of Dillingham, Bristol Bay Low.; 59 $45^{\prime}$ $\mathrm{N}, 157^{\circ} 10^{\prime} \mathrm{W}$; (map 52).

Eskimo village or camp name published in 1954 by USGS.

Newktok: village, see Newtok.

New Lake: lake, $0.9 \mathrm{mi}$. long, $2 \mathrm{mi}$. $\mathrm{S}$ of Big Lake and $23 \mathrm{mi}$. SW of Beaver, Yukon Flats; $66^{\circ} 09^{\prime} \mathrm{N}, 148^{\circ} 02^{\prime} \mathrm{W}$; (map 118).

Local name obtained in 1956 by USGS.

New Lakes: lakes, Little Kiska I., Aleutian Is.; $51^{\circ} 55^{\prime} 12^{\prime \prime} \mathrm{N}, 177^{\circ} 39^{\prime} 10^{\prime \prime} \mathrm{E}$; (map 14).

An arbitrary name beginning with " $N$ " to correspond to "N" grid used by the U.S. Army for tactical purposes during World War II; published on a 1953 AMS map.

Newland Cape: point of land, on SW coast of Shuyak I., $42 \mathrm{mi}$. $N$ of Kodiak I.; $58^{\circ} 30^{\prime} 30^{\prime \prime}$ N, $152^{\circ} 39^{\prime} 00^{\prime \prime} \mathrm{W}$; (map 43).

Name published in 1926 by USC\&\&GS.

Newlands Creek: stream, flows SE $2.5 \mathrm{mi}$. to Quartz Creek, $10 \mathrm{mi}$. SE of Long and $30 \mathrm{mi}$. SSE of Ruby, Kilbuck-Kuskokwim Mts.; $64^{\circ} 19^{\prime} \mathrm{N}, 155^{\circ} 15^{\prime} \mathrm{W}$; (map 98).

Prospectors' name reported in 1913 by Eakin (1914, pl. 3), USGS. The stream's identity is in doubt.

Newlin Ridge: ridge, $0.5 \mathrm{mi}$. long, on southwestern Little Kiska I., Aleutian Is.; $51^{\circ} 57^{\prime}$ $15^{\prime \prime} \mathrm{N}, 177^{\circ} 38^{\prime} 10^{\prime \prime} \mathrm{E}$; (map 14).

An arbitrary name beginning with " $N$ " to correspond to "N" grid used by the U.S. Army for tactical purposes during World War II; published on a 1953 AMS map.

New Lowden: locality, on right bank of Yukon River, about $6 \mathrm{mi}$. NE of Louden and $48.5 \mathrm{mi}$. E of Nulato, Koyukuk Low, ; $64^{\circ} 40^{\prime} 00^{\prime \prime} \mathrm{N}$, $156^{\circ} 28^{\prime} 30^{\prime \prime} \mathrm{W}$; (map 97).

Riverboat pilots' name shown on a 1940 "Navigation Chart of the Tanana-Yukon Rivers" published by U.S. Dept. of Interior. Newman Bay: bay, extends NE $3.5 \mathrm{mi}$., on SW coast of Sitkalidak I., SE of Kodiak I.; $57^{\circ} 06^{\prime}$ $\mathrm{N}, 153^{\circ} 22^{\prime} \mathrm{W}$; (map 34$)$.

Local name published in 1943 by USC\&GS. Newman Creek: stream, flows $\mathbf{N} 7 \mathrm{mi}$. to Dry Creek, $52 \mathrm{mi}$. NE of Healy, Alaska Ra.; $64^{\circ} 00$, $\mathrm{N}, 147^{\circ} 15^{\prime} \mathrm{W}$; (map 87 ).

Prospectors' name shown on a 1910 fieldsheet by J. W. Bagley, USGS; published by Capps (1912, pl. 1), USGS.

Newmann Island: island, see Operl Island.

Newman Peak: mountain, 2,000 ft., on Attu Is., $2.5 \mathrm{mi}$. SW of Attu, Aleutian Is.; 52 $54^{\prime} 35^{\prime \prime}$ $\mathrm{N}, 173^{\circ} 12^{\prime} 07^{\prime \prime} \mathrm{E}$; (map 13).

Named by U.S. Army during World War II. Published in 1948 by AMS.

New Metlakahta: town, see Metlakatla. New Metlakatla: town, see Metlakatla. New Morzhovoi: village, see Morzhovoi. New Nakhak: village, see New Knockhock. New Norfolk: area, extending from New Cornwall to Cross Sound in southeast Alaska.

Named by Capt. George Vancouver, RN, in honor of English county, after possession was 
taken by Joseph Whidbey and James Johnstone on August 16, 1794.

Newport Entrance: water passage, between McClure and Stockton Is., on Beaufort Sea coast, $22 \mathrm{mi}$. NW of Flaxman I., Arctic Plain; $70^{\circ}$ $19^{\prime} 18^{\prime \prime} \mathrm{N}, 147^{\circ} 12^{\prime} 30^{\prime \prime} \mathrm{W}$ (map 150).

So named by Leffingwell $(1919$, p. 98$)$ "After the whale ship Newport, which is reported to have entered the lagoon at this place."

Newport Island: island, in Newport Entrance, on Beaufort Sea coast, W of Pole I., Arctic Plain ; (map 150).

Named by Leffingwell (1919, p. 98). "After the whaleship Newport." This island is no longer shown on topographic maps.

New Port Walter: locality, on $\mathrm{N}$ shore of Port Walter, $10 \mathrm{mi}$. $\mathrm{N}$ of Port Alexander, on $\mathbf{E}$ coast of Baranof I., Alexander Arch.; 56 ${ }^{\circ}$ $23^{\prime} 40^{\prime \prime} \mathrm{N}, 134^{\circ} 39^{\prime} 00^{\prime \prime} \mathrm{W}$; (map 5). Var. New Walter, Port Walter.

Site of an abandoned saltery (herring packing plant) and fertilizer plant, probably built between 1917 and 1920. The Port Walter post office was established here in 1918; discontinued in 1921 (Ricks, 1965, p. 53).

Newrailing River: stream, see Newhalen River. Newrailing Village: village, see Newhalen.

New Reef: reefs, 2 reefs $0.1 \mathrm{mi}$. long, in Disenchantment Bay, $1.5 \mathrm{mi}$. $\mathrm{N}$ of Haenke I., and $31 \mathrm{mi}$. N of Yakutat, St. Elias Mts. ; $59^{\circ} 59^{\prime}$ $30^{\prime \prime} \mathrm{N}, 139^{\circ} 32^{\prime} 00^{\prime \prime} \mathrm{W}$; (map 46).

Named by Tarr (1906, map facing p. 145), USGS. These reefs appeared after the earthquake of 1899, which caused an uplift of 1719 feet in this area (in Tarr and Martin, 1912, p. 21-22).

New Reefs: reefs, $0.2 \mathrm{mi}$. across near head of Eleanor Cove, $14 \mathrm{mi}$. NE of Yakutat, St. Elias Mts.; $59^{\circ} 42^{\prime} \mathrm{N}, 139^{\circ} 29^{\prime} \mathrm{W}$; (map 46).

Named by Tarr and Martin (1912, map 14 and p. 21), USGS. These reefs were created during the 1899 earthquake; they are not shown, however, on USC\&GS Chart 8455, published in 1965.

New River Bay: bay, extends S $1.3 \mathrm{mi}$. on S shore of Lake Minchumina, Tanana Low.; $63^{\circ} 51^{\prime} 15^{\prime \prime} \mathrm{N}, 152^{\circ} 14^{\prime} 45^{\prime \prime} \mathrm{W}$; (map 88).

Local name reported in 1954 by USGS.

New Russia: locality, see Glory of Russia.

New Shoal: rock, see Westdahl Rock.

New Stuyahok: village, pop. 145, on right bank of Nushagak River, $10 \mathrm{mi}$. NE of Ekwok and $52 \mathrm{mi}$. NE of Dillingham, Bristol Bay Low.; $59^{\circ} 29^{\prime} \mathrm{N}, 157^{\circ} 20^{\prime} \mathrm{W}$; (map 52). Var. New Stuyarok.

Located on the site of the Eskimo village of "Stuyarok." The name "New Stuyahok" first appeared in the 1950 Census with a population of 88. A post office was established here in 1961. (Ricks 1965, p. 45).

Newtak: village, see Newtok.

Newtok: village, pop. 129 , on Kealavik River N of Nelson I., $36 \mathrm{mi}$. NE of Cape Vancouver, Yukon-Kuskokwim Delta; $60^{\circ} 56^{\prime} \mathrm{N}, 164^{\circ} 38^{\prime}$ W; (map 58). Var. Keyaluvik, New Kealavik, Newtok, Newtak, Niuftak.
Newly established Eskimo village reported in 1949 by USC\&GS. Its population in 1950 was 69 . See Old Kealavik.

New Tokeen: village, see Tokeen.

Newton Creek: stream, flows SE $1.5 \mathrm{mi}$. to American River, $25 \mathrm{mi}$. NE of Teller, Seward Penin. High.; $65^{\circ} 31^{\prime} \mathrm{N}, 165^{\circ} 45^{\prime} \mathrm{W}$; (map 111).

Prospectors' name reported in 1901 by $\mathrm{T}$. G. Gerdine (in Collier, 1902, pl. 12), USGS.

Newton Creek: stream, see Left Fork Dry Creek.

Newton Creek: ravine, see Newton Gulch.

Newton Gulch: ravine, heads on S side of Newton Peak, trends S $15 \mathrm{mi}$. to Dry Creek, $3 \mathrm{mi}$. NE of Nome, Seward Penin. High.; 64 $31^{\circ} 50^{\prime \prime}$ N, $165^{\circ} 19^{\prime} 30^{\prime \prime} \mathrm{W}$; (map 94). Var. Newton Creek, Newton Gulch No. 1.

Prospectors' name reported in 1900 as "Newton Cr." by E. C. Barnard (in Brooks, 1901, pl. 17), USGS. Reported in 1904 as "gulch" and applied as above by T. G. Gerdine, USGS. See Left Fork Dry Creek.

Newton Gulch Number One: ravine, see Newton Gulch.

Newton Gulch Number Two: stream, see Left Fork Dry Creek.

Newton Peak: mountain, 1,152 ft., $4 \mathrm{mi}$. NE of Nome, Seward Penin. High.; $64^{\circ} 33^{\prime} \mathrm{N}, 165^{\circ}$ 19' W; (map 94). Var. Dry Creek Mountain, Eagle Peak, Newton Rock.

Local name reported in 1904 by T. G. Gerdine, USGS

Newton Rock: mountain, see Newton Peak.

New Trinity Island: island, "one of the Trinity Islands S of Kodiak Island."

Name shown on Capt. John Meares' 1790 chart.

New Walter: locality, see New Port Walter.

New-Whalen River: stream, see Newhalen River.

Newwhalin River: stream, see Newhalen River. New Whrailing River: stream, see Newhalen River.

New-Whraling River: stream, see Newhalen River.

New Year Gulch: ravine, trends SE $0.7 \mathrm{mi}$. to Anvil Creek, $6 \mathrm{mi}$. NE of Nome, Seward Penin. High.; $64^{\circ} 35^{\prime} 20^{\prime \prime} \mathrm{N}, 16^{\circ} 22^{\prime} 20^{\prime \prime} \mathrm{W}$; (map 94). Var. New Years Gulch.

Reported as "New Years Gul." on the 1902 "Map of the Nome and Snake River Country" by J. M. Davidson.

New Year Islands: islands, extend N-S $0.6 \mathrm{mi}$, off W coast of Knight I., on E side of Knight Island Passage, $6 \mathrm{mi}$. NE of Chenega, Chugach Mts.; $60^{\circ} 19^{\prime} 00^{\prime \prime} \mathrm{N}, 147^{\circ} 54^{\prime} 45^{\prime \prime} \mathrm{W}$; (map 63)

Name published in 1910 by USG\&GS.

New Years Gulch: ravine, see New Year Gulch.

New York Creek: stream, flows $4 \mathrm{mi}$. N to Bering Sea, E of Fox Point, on $\mathrm{N}$ coast of Umnak I., Aleutian Is.; $53^{\circ} 33^{\prime} 00^{\prime \prime} \mathrm{N}, 168^{\circ} 16^{\prime} 45^{\prime \prime} \mathrm{W}$; (map 22).

Name published by Byers (1959, pl. 41), USGS.

New York Creek: stream, flows SE $3.3 \mathrm{mi}$. to Kuskokwim River $0.9 \mathrm{mi}$. N of its junc. with Holokuk River, $0.5 \mathrm{mi}$. W of Little Mountain
Village, Kilbuck-Kuskokwim Mts.; 61 ${ }^{\circ} 33^{\prime} \mathrm{N}$, 158 $35^{\prime}$ W; BGN 1948; (map 72).

Prospectors' name reported in 1914 by $A$. G. Maddren (in Brooks and others, 1915, p. 353), USGS.

New York Creek: stream, flows NE $4 \mathrm{mi}$., joins Little Joe Creek to form Beaver Creek, 11 mi. SE of Ruby, Kilbuck-Kuskokwim Mts.; $64^{\circ} 35^{\prime} 30^{\prime \prime} \mathrm{N}, 155^{\circ} 24^{\prime} 45^{\prime \prime} \mathrm{W}$; BGN 1936; (map 98).

Prospectors' name reported in 1908 by A. G. Maddren (in Brooks and others, 1909, p. 230), USGS.

New York Creek: stream, flows SW $10 \mathrm{mi}$. to North Fork Baker Creek, $45 \mathrm{mi}$. E of Tanana, Yukon-Tanana High.; $65^{\circ} 07^{\prime} 25^{\prime \prime}$ N, $150^{\circ} 29^{\prime}$ 40 " W; (map 106).

Prospectors' name reported in 1904 by Prindle and Hess (1906, pl. 3), USGS.

New York Gulch: ravine, extends SW $1.3 \mathrm{mi}$. to American Creek, $27 \mathrm{mi}$. ESE of Tanana, Yukon-Tanana High.; $65^{\circ} 06^{\prime} 10^{\prime \prime} \mathrm{N}, 151^{\circ} 10^{\prime}$ 15" W; (map 106).

Prospectors' name reported in 1931 by $\mathrm{J}$. B. Mertie, USGS.

Nexeura: point of land, see Niksirok Point.

Niagara Creek: stream, flows SW $2.2 \mathrm{mi}$. to Kougarok River $11 \mathrm{mi}$. $\mathrm{N}$ of its junc. with Kuzitrin River, $44 \mathrm{mi}$. SW of Imuruk Lake, Seward Penin. High.; $65^{\circ} 25^{\prime} \mathrm{N}, 164^{\circ} 38^{\prime} \mathrm{W}$; (map 110).

Prospectors' name reported on the 1908 "Map of Seward Peninsula" by Arthur Gibson.

Niaghapok Cape: point of land, see Niyghapak Point.

Niak: locality, site of an Eskimo campground, on Chukchi Sea coast, $4 \mathrm{mi}$. S of Cape Lisburne, Arctic Slope; $68^{\circ} 49^{\prime} \mathrm{N}, 166^{\circ} 11^{\prime} \mathrm{W}$; (map 129).

Eskimo name reported in 1904 by J. B. Driggs, a Point Hope missionary. The name may mean "head."

Niak Greek: stream, flows SW $4 \mathrm{mi}$. to Chukchi Sea, $5 \mathrm{mi}$. S of Cape Lisburne, Arctic Slope; $68^{\circ} 49^{\prime} \mathrm{N}, 166^{\circ} 12^{\prime} \mathrm{W}$; (map 129). Var. Neak Creek.

Eskimo name reported in 1904 by J. B. Driggs, a Point Hope missionary. See Niak. Niakogon Buttes: mountain, $1,325 \mathrm{ft}$., between Chandler and Tuluga Rivers, $25 \mathrm{mi}$. SE of Umiat, Arctic Plain; $69^{\circ} 01^{\prime} \mathrm{N}, 151^{\circ} 42^{\prime} \mathrm{W}$; $B G N 1949$; (map 141).

Eskimo name reported in 1949 by USGS Niakogon Mountain: mountain, 1,603 ft., $23 \mathrm{mi}$. SE of junc. of Colville and Killik Rivers, Brooks Ra.; 68 $53^{\prime}$ N, $153^{\circ} 03^{\prime}$ W; (map 133).

Eskimo name reported about 1950 by USGS geologists during exploration of Naval Petroleum Reserve No. 4.

Delta, near Heald Point, on Beaufort Sea coast, Arctic Plain; (map 150).

Niako Island: island, in Sagavanirktok River This name first appears on Surgeon John Simpson's 1853 native map on which he notes "First sleeping place of the natives of $\mathrm{Pt}$. Barrow, travelling from Colville $\mathrm{R}$. to $\mathrm{Pt}$. 
Berens." Leffingwell (1919, p. 91) refers to it as "a small island at Heald Point ***." This place cannot be definitely identified, but may refer to present-day Niakuk Is. near Heald Point.

Niako Island: islands, see Niakuk Islands.

Niaktuvik, Mount: mountain, 1,300 ft., in Lisburne Hills, $15 \mathrm{mi}$. SE of Cape Dyer, Arctic Slope; 68 $29^{\prime} 30^{\prime \prime} \mathrm{N}, 165^{\circ} 50^{\prime} 55^{\prime \prime} \mathrm{W}$; (map 129). Var. Neeaxtouwik Mountain.

Eskimo name reported by Orth in 1956.

Niaktuvik Creek: stream, heads in Waring Mts. at $66^{\circ} 59^{\prime} \mathrm{N}, 158^{\circ} 50^{\prime} \mathrm{W}$, flows NE $20 \mathrm{mi}$. to Kobuk River, $41 \mathrm{mi}$. NW of Shungnak, Brooks Ra.; $67^{\circ} 10^{\prime} 30^{\prime \prime} \mathrm{N}, 158^{\circ} 27^{\prime} 00^{\prime \prime} \mathrm{W}$; (map 126).

Eskimo name reported by Orth in 1956.

Niakuk Islands: islands, off-shore group, extends $1.2 \mathrm{mi}$. W of Heald Point, at mouth of Prudhoe Bay, on Beaufort Sea coast, $23 \mathrm{mi}$. SE of Beechey Point, Arctic Plain; $70^{\circ} 22^{\prime} \mathrm{N}, 148^{\circ}$. 14' W; (map 150). Var. Niako Island.

Eskimo name meaning "head" [neaqoq]; reported by USC\&GS in 1949. This name may be the same as that reported by Surgeon John Simpson on his 1853 native map as Niako. See Niako I.

Niblack: locality, at head of Niblack Anchorage, on SE coast of Prince of Wales I., Alex. Arch.; $55^{\circ} 04^{\prime} 00^{\prime \prime} \mathrm{N}, 132^{\circ} 08^{\prime} 45^{\prime \prime} \mathrm{W}$; (map 4).

The Niblack post office was established at this former mining camp in 1901 but was transferred in 1909 to Ketchikan (Ricks, 1965, p. 45). This site is shown as an abandoned mine on a 1957 USGS map.

Niblack Anchorage: estuary, extends W $2.5 \mathrm{mi}$. off Moira Sound, on SE coast of Prince of Wales I., Alex. Arch.; $55^{\circ} 04^{\prime} \mathrm{N}, 132^{\circ} 05^{\prime} \mathrm{W}$; (map 4). Var. Niblick Anchorage.

Named in 1885 by Lt. Comdr. R. C. Clover, USN, for Ens. Albert Parker Niblack, USN, a member of his party. This name was later shown erroneously as "Niblick" on Brit. Adm. Chart 2431.

Niblack Hollow: ravine, $1 \mathrm{mi}$. long, on $\mathrm{SW}$ coast of Cleveland Penin., Alex. Arch.; 55 $34^{\prime} 55^{\prime \prime}$ $\mathrm{N}, 132^{\circ} 10^{\prime} 00^{\prime \prime} \mathrm{W}$; (map 4).

Local name published in 1927 by USC\&GS; derived from Niblack Point.

Niblack Islands: islands, $2 \mathrm{mi}$. long, in Ernest Sound between Deer and Etolin Is., $34 \mathrm{mi}$. SE of Wrangell, Alex. Arch.; $56^{\circ} 02^{\prime} \mathrm{N}$, $132^{\circ} 06^{\prime} \mathrm{W}$; (map 6).

Named in 1886 by Lt. Gomdr. A. S. Snow, USN, for Ens. Albert Parker Niblack, USN, a member of his party.

Niblack Point: point of land, on SW coast of Cleveland Penin., Alex. Arch.; 55 $33^{\prime} \mathrm{N}$, $132^{\circ} 07^{\prime} \mathrm{W}$; (map 4). Var. Niblick Point.

Named in 1885 by Lt. Comdr. R. C. Clover, USN, for Ens. Albert Parker Niblack, USN, a member of his party. This name was later shown erroneously as "Niblick" on Brit. Adm. Chart 2431.

Niblick Anchorage: estuary, see Niblack Anchorage.

Niblick Point: point of land, see Niblack Point.

Nichawak Mountain: mountain, 1,600 ft., $3 \mathrm{mi}$. $\mathrm{W}$ of Mount Campbell and $65 \mathrm{mi}$. SE of
Cordova, Malaspina Coastal Plain; $60^{\circ} 14^{\prime} \mathrm{N}$, $143^{\circ} 58^{\prime} \mathrm{W}$; (map 65). Var. Mount Nichawak, Nitchavak Mountain, Nitchawak Mountain.

Native name reported in 1903 by G. G. Martin, USGS.

Nichawak River: stream, flows SW $12 \mathrm{mi}$. to Controller Bay, $12 \mathrm{mi}$. E of Katalla, Malaspina Coastal Plain; $60^{\circ} 12^{\prime} \mathrm{N}, 144^{\circ} 11^{\prime} \mathrm{W}$; (map 64).

Local name published in 1907 by USGS.

Nichenthraw Mountain: mountain, 6,461 ft., on W bank of East Fork Chandalar River, 20 mi. N of Arctic Village, Brooks Ra.; $68^{\circ} 25^{\prime}$ N, 145'22' W; (map 136).

Kutchin Indian name reported in 1926 by J. B. Mertie, Jr. (in Smith, P. S., and others, 1929, pl. 1), USGS.

Nichin Cove: bay, $0.7 \mathrm{mi}$. long, on $\mathbf{E}$ coast of Tuxekan I., $26 \mathrm{mi}$. N. of Craig, Alex. Arch.; $55^{\circ} 51^{\prime} 15^{\prime \prime} \mathrm{N}, 133^{\circ} 13^{\prime} 30^{\prime \prime} \mathrm{W}$; (map 4).

Indian name published in 1964 by USC\&GS.

Nichlson Creek: stream, flows $3 \mathrm{mi}$. NW to Chagvan Bay, 21 mi. NE of Cape Newenham, Kilbuck-Kuskokwim Mts.; $58^{\circ} 46^{\prime} \mathrm{N}$, $161^{\circ} 40^{\prime} \mathrm{W}$; (map 39).

Local name shown on a 1937 fieldsheet by J. B. Mertie, USGS.

Nicholas Lake: lake, $1.6 \mathrm{mi}$. long, $\mathrm{W}$ of Sarana Bay, eastern Attu I., Aleutian Is.; 52 ${ }^{\circ} 2^{\prime} 30^{\prime \prime}$ $\mathrm{N}, 173^{\circ} 15^{\prime} 00^{\prime \prime} \mathrm{E}$; (map 13).

So named by the U.S. Army during its occupation of the island during World War II; name shown on an AMS map published in 1948.

Nicholas Island: island, see Green Island.

Nicholas Islands: islands, see Nichols Islands.

Nicholls Hills: hills, see Nichols Hills.

Nichols Bay: estuary, extends NW $5 \mathrm{mi}$. from Dixon Entrance, on $\mathbf{S}$ coast of Prince of Wales I., Alex. Arch.; 54 ${ }^{\circ} 41^{\prime} 30^{\prime \prime} \mathrm{N}, 1^{\circ} 2^{\circ} 04^{\prime} 45^{\prime \prime} \mathrm{W}$; (map 1).

Named in 1880 by USC\&GS for Lt. Comdr. Henry Ezra Nichols, USN.

Nichols Hills: hills, $116 \mathrm{ft}$., on E coast of Nushagak Penin., W of Nichols Spit, $36 \mathrm{mi}$. SW of Dillingham, Bristol Bay Low.; 58 $34^{\prime} \mathrm{N}$, $158^{\circ} 47^{\prime} \mathrm{W}$; (map 40). Var. Nicholls Hills, The Knolls, Ushki Hills.

Named in 1890 by USBF probably for Lt. Comdr. Henry Ezra Nichols, USN, of the USC\&GS steamer Hassler, who wrote a revised edition of the 1891 Coast Pilot. A descriptive name "Ushki," meaning "ears," was given by Capt. Tebenkov (1852, map 4), IRN.

Nichols Islands: islands, offshore chain, extends $2.5 \mathrm{mi}$. in Tlevak Strait, between Dall and Goat Is., Alex. Arch.; $55^{\circ} 10^{\prime} \mathrm{N}, 132^{\circ} 59^{\prime} \mathrm{W}$; $B G N$ 1966; (map 4). Var. Nicholas Islands, Sentinel Islands.

Named in 1882 by W. H. Dall, USC\&GS, for Lt. Comdr. Henry E. Nichols, USN, who reconnoitered this region in 1881 . Nearby are The Sentinels. Nichols called the entire group "Sentinel Islands" in 1881.
Nichols Lake: lake, $1.3 \mathrm{mi}$. long, at head of Nichols Bay, on S coast of Prince of Wales I., Alex. Arch.; 54 $45^{\prime} 15^{\prime \prime} \mathrm{N}, 132^{\circ} 11^{\prime} 30^{\prime \prime} \mathrm{W}$; (map 1).

Name derived from Nichols Bay; published by USC\&GS in 1923 .

Nichols Mountain: mountain, $1,830 \mathrm{ft}$, on $\mathrm{S}$ coast of Prince of Wales I., Alex. Arch.; $54^{\circ}$ $43^{\prime} 35^{\prime \prime} \mathrm{N}, 132^{\circ} 11^{\prime} 05^{\prime \prime} \mathrm{W}$; (map 1).

Name derived from Nichols Bay; published by USG\&GS in 1943.

Nicholson Lake: lake, $0.6 \mathrm{mi}$. long, $9 \mathrm{mi}$. NW of Old Man Lake and $45 \mathrm{mi}$. WNW of Glennallen, Copper River Basin; $62^{\circ} 13^{\prime} 30^{\prime \prime} \mathrm{N}, 146^{\circ}$ $55^{\prime} 30^{\prime \prime} \mathrm{W}$; (map 83). Var. Nickolson Lake. Local name reported in 1949 by USGS.

Nicholson Rocks: rocks, in Western Channel, in Sitka Sound, 2 mi. $W$ of Sitka, Alex. Arch.; $57^{\circ} 02^{\prime} 39^{\prime \prime} \mathrm{N}, 135^{\circ} 24^{\prime} 15^{\prime \prime} \mathrm{W}$; (map 9).

Named in 1880 by USN, and published by USC\&GS in the 1883 Coast Pilot (p. 142).

Nichols Pass: water passage, see Nichols Passage.

Nichols Passage: water passage, extends N 15 mi. from Clarence Strait to Revillagigedo Channel, between Annette and Gravina Is., Alex. Arch.; $55^{\circ} 05^{\prime} \mathrm{N}, 131^{\circ} 42^{\prime} \mathrm{W}$; (map 3 ). Var. Nichols Pass.

Named by USC\&GS for Lt. Comdr. Henry E. Nichols, USN, who made extensive surveys in this vicinity from 1881 to 1883 while in command of the survey steamer Hassler; published in 1883 Coast Pilot (p. 79) as "Nichols Pass."

Nichols Point: point of land, on $\mathrm{E}$ shore of Isanotski Strait, Aleutian Ra.; 54 $51^{\prime} 30^{\prime \prime} \mathrm{N}$, $163^{\circ} 23^{\prime} 00^{\prime \prime} \mathrm{W}$; BGN 1926; (map 25). Var. Knoll Point.

Named by USC\&GS in 1926 for Joseph R. Nichols, who died in 1925, and was responsible for the establishment of the cannery which formed the nucleus of the settlement of False Pass.

Nichols Spit: spit, $2.2 \mathrm{mi}$. long, on $\mathrm{E}$ coast of Nushagak Penin., $6 \mathrm{mi}$. NW of Protection Point and $33 \mathrm{mi}$. SW of Dillingham, Bristol Bay Low.; $58^{\circ} 35^{\prime} \mathrm{N}, 158^{\circ} 46^{\prime} \mathrm{W}$; (map 40).

Named in 1910 by USC\&GS probably for Lt. Comdr. Henry Ezra Nichols, USN, of the USC\&GS steamer Hassler.

Nichta: village, see Nightmute.

Nichtmut: village, see Nightmute.

Nichutalinó: stream, see Muddy River.

Nick, Mount: mountain, 5,364 $\mathrm{ft}$., at head of Johnson Glacier, $60 \mathrm{mi}$. NE of Nondalton, Aleutian Ra.; $60^{\circ} 05^{\prime} \mathrm{N}, 153^{\circ} 03^{\prime} \mathrm{W}$; (map 61).

Local name reported in 1920 on a USGS manuscript map. The name was possibly obtained originally from a USC\&GS manuscript sheet.

Nickala Creek: ravine, see Nekula Gulch.

Nickel: locality, on $\mathbf{N}$ tip of Fleming I., 12 mi. NW of Ghichagof, on W coast of Chichagof I., Alex. Arch.; 57 $47^{\prime} 40^{\prime \prime}$ N, $136^{\circ} 19^{\prime} 10^{\prime \prime}$ W; (map 9).

Local name of a former mining camp reported by R. M. Overbeck (in Martin and 
others, 1919, pl. 2), USGS, which was established about 1911. A description of this nickel mining locality is given by W. T. Pecora (in Kesler and others, 1944, p. 230), USGS. The camp was abandoned about 1942 when the workings were flooded.

Nickel Creek: stream, heads in lake, flows N 23 mi. to Tazlina River, $5 \mathrm{mi}$. SW of Glennallen, Copper River Basin; $62^{\circ} 05^{\prime} \mathrm{N}, 145^{\circ} 41^{\prime} \mathrm{W}$; (map 83).

Local name reported by USGS (in Chapin, 1918, pl. 1).

Nicklason Lake: lake, $0.3 \mathrm{mi}$. across, in Matanuska Valley, $5.4 \mathrm{mi}$. NW of Palmer, Cook Inlet Low.; $61^{\circ} 37^{\prime} 45^{\prime \prime} \mathrm{N}, 1^{\circ} 9^{\circ} 16^{\prime} 00^{\prime \prime} \mathrm{W}$; (map 69).

Local name reported in 1942 by AMS.

Nickle Creek: stream, flows NW $4 \mathrm{mi}$. to Port Clarence, $10 \mathrm{mi}$. SW of Teller, Seward Penin. High.; $65^{\circ} 08^{\prime} \mathrm{N}, 166^{\circ} 32^{\prime} \mathrm{W}$; (map 111).

Prospectors' name reported on the 1908 "Map of Seward Peninsula" by Arthur Gibson.

Nickle Creek: stream, flows NW $2.3 \mathrm{mi}$. to North Creek which flows to Agiapuk River, $14 \mathrm{mi}$. NE of Teller, Seward Penin. High.; $65^{\circ} 23^{\prime}$ $\mathrm{N}, 165^{\circ} 27^{\prime} \mathrm{W}$; (map 111).

Prospectors' name reported in 1901 by T. G. Gerdine (in Collier, 1902, pl. 12), USGS.

Nickoli Lake: lake, $1.5 \mathrm{mi}$. long, $\mathrm{N}$ of Glenn Highway, W of Mendeltna Creek, $35 \mathrm{mi}$. W of Glennallen, Copper River Basin ; 62 ${ }^{\circ} 04^{\prime} 30^{\prime \prime}$ N, $146^{\circ} 33^{\prime} 00^{\prime \prime}$ W; (map 83). Var. Nikolai Lake.

Local name reported as "Nikolai Lake" by USGS in 1949.

Nickolson Lake: lake, see Nicholson Lake.

Nicolai's Village: locality, see Skolai.

Nicolet Creek: stream, flows W $1 \mathrm{mi}$. to Three Mile Bay, on S shore of Orca Inlet, $2 \mathrm{mi}$. SW of Cordova, Chugach Mts.: $60^{\circ} 32^{\prime} \mathrm{N}, 145^{\circ}$ 47' W; BGN 1961; (map 64).

Named by USFS in 1936 for "Ralph Nicolet, son of a pioneer family of Cordova, who was killed in 1929 while hunting in the vicinity."

Nicolie Greek: stream, flows NE $4.5 \mathrm{mi}$. to Tyone Creek, $21 \mathrm{mi}$. NE of Tahneta Pass, Talkeetna Mts.; $62^{\circ} 11^{\prime} 20^{\prime \prime} \mathrm{N}, 147^{\circ} 11^{\prime} 50^{\prime \prime} \mathrm{W}$; BGN 1960; (map 82).

Named in 1956 by USGS "for an Athapascan Indian.

Nicoloffsky: locality, see Nikolaief.

Nicolo Point: point of land, see Saint Nicholas Point.

Nido Peak, El: mountain, 3,358 ft., between Stag Bay and Lisianski Inlet, on W coast of Chichagof I., 4 mi. W of Pelican, Alex. Arch.; $57^{\circ} 57^{\prime} 40^{\prime \prime} \mathrm{N}, 136^{\circ} 20^{\prime} 15^{\prime \prime} \mathrm{W}$; (map 9).

Local name reported in 1951 by USGS; of Spanish derivation meaning "the nest." It probably was named after the El Nido gold mine, 2.5 miles to the east, which was opened in 1921. No mining has been done here since 1939 (Roseman, 1959, p. 200).

Niegieklik: stream, see Andreafky River.

Niegvielnuk: point of land, see Black Point.

Nigag Mountain: mountain, 1,861 ft., $8 \mathrm{mi}$. SW of Nagugun Lake and $50 \mathrm{mi}$. NE of Goodnews, Kilbuck-Kuskokwim Mts.; 59 $34^{\prime} \mathrm{N}$, $160^{\circ} 29^{\prime} \mathrm{W}$; (map 53).

Eskimo name reported in 1954 by USGS.

Nigaktoviakvik Creek: stream, flows W 6 mi. to Killik River $10 \mathrm{mi}$. N of its junc. with Easter Creek, Brooks Ra.; $68^{\circ} 17^{\prime} \mathrm{N}, 154^{\circ} 03^{\prime} \mathrm{W}$; (map 133).

Eskimo name reported in 1956 by T. E. Taylor, USGS.

Nigaktukvik Creek: stream, flows NW 3 mi. from Mayukuit Mtn. to Killik River, Brooks Ra.; $68^{\circ} 12^{\prime} \mathrm{N}, 154^{\circ} 07^{\prime} \mathrm{W}$; (map 133).

Eskimo name meaning "place where [Dall] sheep are snared," reported in 1956 by T. E. Taylor, USGS.

Nigalek: locality, see Nigalik.

Nigalik: locality, at mouth of Colville River, Arctic Plain; $70^{\circ} 25^{\prime} \mathrm{N}, 150^{\circ} 30^{\prime} \mathrm{W}$; (map 149). Var. Goosetown, Negaleh, Nigalek, Nigaluk, Nigamak, Nighali, Nikilik, Nirlik.

Formerly one of the most famous Eskimo trading sites in northern Alaska for the coastal and inland Eskimo, who met here each spring to hunt and trade. Recorded in 1853 by Comdr. R. Maguire as "Nighali" and "Nigamak" and by John Simpson, as "Nigalek" (Leffingwell, 1919, p. 98). W. H. Dall's map of 1877 shows it as Nig-a-lek; the 10th Census of 1880 lists "Nigaluk." The name "Nikilik" is derived from Nikilivik, the Eskimo name for the Pacific white-fronted goose ( $A n$ ser albifrons frontalis) (Rausch, 1951, p. 158). See Nunatunga.

Nigaluk: locality, see Nigalik.

Nigamak: locality, see Nigalik.

Nigato: stream, see Yukon River.

Nigatuk Creek: stream, flows NE $6 \mathrm{mi}$. to Tolishden Slough, $7 \mathrm{mi}$. SW of Roundabout Mtn., Koyukuk Low.; $65^{\circ} 27^{\prime} \mathrm{N}, 156^{\circ} 38^{\prime} \mathrm{W}$; (map 108).

Koyukan Indian name reported in 1955 by USGS.

Nigelius Point: point of land, on W bank, near head of Carroll Inlet on Revillagigedo I., Alex. Arch.; $55^{\circ} 33^{\prime} 30^{\prime \prime} \mathrm{N}, 131^{\circ} 21^{\prime} 00^{\prime \prime} \mathrm{W}$; (map 3).

Local navigators' name reported in 1904 by $H$. C. Fassett, USBF.

Nigeruk Creek: stream, flows $8.5 \mathrm{mi}$. to Kobuk River $1 \mathrm{mi}$. W of its junc. with Kaliguricheark River, $34 \mathrm{mi}$. NE of Kiana, Brooks Ra.; $67^{\circ} 11^{\prime} \mathrm{N}, 159^{\circ} 18^{\prime} \mathrm{W}$; (map 127).

Eskimo name shown on a 1901 fieldsheet by D. L. Raeburn, USGS.

Nighali: locality, see Nigalik.

Nighmut: village, see Nightmute.

Nighmute: village, see Nightmute.

Nightmute: village, pop. 127, on Nelson I., Yukon-Kuskokwim Delta; $60^{\circ} 28^{\prime} 50^{\prime \prime} \mathrm{N}$, $164^{\circ} 44^{\prime} 00^{\prime \prime} \mathrm{W}$; BGN 1965; (map 58). Var. Nichta, Nichtmut, Nighmute, Nightmut, Nigmute, Nigtmuit, Nigtmute, Nikhta.

Eskimo village listed in the 1939 Census with a population of $78 ; 27$ in 1950 ; and 237 in 1960. In 1964 many of the people moved west to a new location named Toksook Bay.
Nights Lodging Cape: point of land, see Nochlega Point.

Nigiakturik River; stream, see Nigisaktuvik River.

Nigiaktuvik River: stream, see Nigisaktuvik River.

Nigiklik: locality, at junc. of Andreafsky and Yukon Rivers, Yukon-Kuskokwim Delta; $62^{\circ}$ $02^{\prime} \mathrm{N}, 163^{\circ} 15^{\prime} \mathrm{W}$; (map 77). Var. Nigiklikmiout, Nigiklik-miut, Nygykligmjut.

Former Eskimo village or camp published in 1850 as "Nigiklik-miout" by Lt. L. A. Zagoskin, IRN; his map locates it at or near Pitkas Point.

Nigiklik-miout: locality, see Nigiklik.

Nigiklik-miut: locality, see Nigiklik.

Nigikmigoon River: stream, flows SW $23 \mathrm{mi}$. to the Inglutalik River, $22 \mathrm{mi}$. SE of Haycock, Nulato Hills; $65^{\circ} 05^{\prime} \mathrm{N}, 160^{\circ} 28^{\prime} \mathrm{W}$; (map 109).

Eskimo name reported in 1949 by the U.S. Army Corps of Engineers.

Nigikmiut Creek: stream, flows NW $6 \mathrm{mi}$. to Bering Sea, $1 \mathrm{mi}$. E of Kahnirukmiut and 18 mi. SW of Cape Etolin, on $\mathbf{N}$ coast of Nunivak I.; $60^{\circ} 18^{\prime} 32^{\prime \prime} \mathrm{N}, 166^{\circ} 35^{\prime} 30^{\prime \prime} \mathrm{W}$; ( $\left.\operatorname{map} 57\right)$.

Eskimo name reported in 1937 by USAAF.

Nigiktlik Creek: stream, heads on Kitkonak Hill, flows SW $9.5 \mathrm{mi}$. to Oligavik Creek, $21 \mathrm{mi}$. $\mathrm{SE}$ of Cape Lisburne, Arctic Slope ; $68^{\circ} 45^{\prime} 10^{\prime \prime}$ $\mathrm{N}, 165^{\circ} 27^{\prime} 25^{\prime \prime} \mathrm{W}$; (map 129). Var. Kitkonuk Creek.

Eskimo name reported in 1956 by Orth.

Nigisakfogvik River: stream, see Nigisaktuvik River.

Nigisak River: stream, see Nigisaktuvik River. Nigisaltuvik River: stream, heads in lake at $69^{\circ} 55^{\prime} 30^{\prime \prime} \mathrm{N}, 157^{\circ} 46^{\prime} 00^{\prime \prime} \mathrm{W}$, flows $\mathrm{N} 90 \mathrm{mi}$. to the Meade River, $6 \mathrm{mi}$. NW of village of Meade River, Arctic Plain; $70^{\circ} 33^{\prime}$ N, $157^{\circ} 30^{\prime}$ W; BGN 1949; (map 147). Var. Nigiakturik River, Nigiaktuvik River, Nigisak River, Nigisakfogvik River.

Eskimo name, reported to mean "place where east wind blows," shown on a 1923 field sheet by E. C. Guerin, USGS, as "Nigisakfogvik River."

Niglaktak Lake: lake, $2 \mathrm{mi}$. across, $0.1 \mathrm{mi}$. E of Selawik, Kotzebue-Kobuk Low.; $66^{\circ} 36^{\prime} \mathrm{N}$, $159^{\circ} 57^{\prime} \mathrm{W}$; (map 114).

Eskimo name obtained by U.S. Army Corps of Engineers in 1955.

Nigmute: village, see Nightmute.

Nigtmuit: village, see Nightmute.

Nigtmute: village, see Nightmute.

Nigtun Lake: lake, $1.5 \mathrm{mi}$. long, in Howard Pass, Brooks Ra.; 68 $13^{\prime} 30^{\prime \prime}$ N, $156^{\circ} 53^{\prime} 00^{\prime \prime}$ W; (map 132).

Eskimo name obtained at Noatak by Orth in 1956, meaning "drill" or "bit" [niogtun]. See Tukuto Lake.

Niguanak Ridge: ridge, elev. $300 \mathrm{ft}$., $6 \mathrm{mi}$. long, between Jago and Niguanak Rivers, $12 \mathrm{mi}$. $\mathrm{SE}$ of Barter I., Arctic Plain; $69^{\circ} 57^{\circ} \mathrm{N}$, $143^{\circ} 13^{\prime} \mathrm{W}$; (map 138).

Eskimo name recorded on Barter I. in 1952 by USC\&GS and refers in meaning to an "attempt to see animals." 
Niguanak River: stream, flows N $35 \mathrm{mi}$. to Oruktalik Lagoon, $15 \mathrm{mi}$. SE of Barter I., Arctic Plain; $70^{\circ} 04^{\prime} \mathrm{N}, 142^{\circ} 59^{\prime} \mathrm{W}$; (map 152).

Local name derived from Niguanak Ridge, reported by USC\&GS in 1952.

Nigu Bluff: bluff, on right bank of Nigu River, $2.5 \mathrm{mi}$. above its mouth and $22 \mathrm{mi}$. NE of Howard Pass, Arctic Slope; $68^{\circ} 29^{\prime}$ N, $156^{\circ}$ 26' W; BGN 1960; (map 132). Var. Rainbow Bluff.

Named in 1925 by Gerald FitzGerald, USGS, for the multi-colored chert in the bluff. "Nigu" is an Eskimo word for "rainbow."

Nigu Hills: hills, 3,000 ft., $5 \mathrm{mi}$. long and $4 \mathrm{mi}$. wide, in Brooks Ra., $\mathrm{N}$ of Howard Hills, 10 mi. NE of Howard Pass; $68^{\circ} 23^{\prime} \mathrm{N}, 156^{\circ} 33^{\prime}$ W; (map 132).

Named in 1966 by geologists of BP Exploration Company (Alaska) Inc.

Nigu Lake: lake, see Etivlik Lake.

Nigu River: stream, heads in Imakturok Pass, flows NW $70 \mathrm{mi}$. to Etivluk River, $25 \mathrm{mi}$. NW of Howard Pass, Brooks Ra.; 68 $32^{\prime}$ N, $156^{\circ}$ 28' W; BGN 1926; (map 132).

Named in 1925 by Gerald FitzGerald (in Smith and Mertie, 1930, pl. 1), USGS, for a multi-colored chert bluff near the stream's mouth. See Nigu Bluff.

Nigvilnak: point of land, see Black Point.

Niitiltoktalogi Mountain: mountain, see Niitltoktalogi Mountain.

Niitltoktalogi Mountain: mountain, 2,050 ft., on $\mathrm{N}$ bank of Koyukuk River, $32 \mathrm{mi}$. NNE of Hughes, Hogatza High.; $66^{\circ} 25^{\prime} \mathrm{N}, 153^{\circ} 40^{\prime}$ W; (map 116). Var. Niitiltoktalogi Mountain.

Indian name published in 1956 by USGS. Niivouk, Mount: hill, see Mugum Peak.

Nijik: locality, see Kijik.

Nijunjak: island, see Chernabura Island.

Nikabuna Lake: lake, $2.5 \mathrm{mi}$. long, on Chulitna River, $23 \mathrm{mi}$. NW of Nondalton, Alaska Ra.; $60^{\circ} 06^{\prime} \mathrm{N}, 155^{\circ} 26^{\prime} \mathrm{W}$; BGN 1916; (map 61). Var. Neekahueena, Neekahweena, Nikawina, Robinson Lake.

Tanaina Indian name reported in 1902 as "Nikawina" by W. H. Osgood, USDA.

Nikabuna Lakes: lakes, a group of lakes $8 \mathrm{mi}$. long, on the Chulitna River, $22 \mathrm{mi}$. NW of Nondalton, Alaska Ra.; $60^{\circ} 05^{\prime} \mathrm{N}, 155^{\circ} 25^{\prime}$ W; (map 61).

Local name reported in 1909 by USGS.

Nikadavna Creek: stream, flows $\mathrm{N} 6 \mathrm{mi}$. to the Chilchitna River, $40 \mathrm{mi}$. NW of Nondalton, Alaska Ra.; $60^{\circ} 28^{\prime} \mathrm{N}, 155^{\circ} 28^{\prime} \mathrm{W}$; (map 61). Var. Chau-off-pad-le-rok, Necodayno, Nikadavno.

Tanaina Indian name reported in 1914 as "Nikadavno" by R. H. Sargent and P. S. Smith, USGS. H. C. Fassett, USBF, seems to have recorded the Eskimo name of this stream as "Chau-off-pad-le-rok."

Nikadavno: stream, see Nikadavna Creek.

Nikawina: lake, see Nikabuna Lake.

Nikhak: locality, see Kijik.

Nikhkak: locality, see Kijik.

Nikhkak River: stream, see Kijik River.
Nikhta: village, see Nightmute.

Nikhtagmut: locality, see Niktak.

Nikilik: locality, see Nigalik.

Nikipak Mountain: mountain, see Meat Mountain.

Nikishka: locality, see Nikishka No. 2.

Nikishka Bay: bight, extends SW $4 \mathrm{mi}$. from Boulder Point, along SE shore of Gompertz Channel, $14 \mathrm{mi}$. N of Kenai, Cook Inlet Low.; $60^{\circ} 45^{\prime} \mathrm{N}, 151^{\circ} 18^{\prime} \mathrm{W}$; BGN 1952; (map 62). Var. Nikishki Bay, Nikiska Bay.

Name published in 1943 Coast Pilot (p. 99) ; derived from village of Nikishka, which was formerly located here.

Nikishka No. 1: locality, see Nikiski Wharf.

Nikishka No. 2: locality, on NW coast of Kenai Penin., $3.2 \mathrm{mi}$. SW of Boulder Point and 12 mi. N of Kenai, Cook Inlet Low.; $60^{\circ} 44^{\prime} 20^{\prime \prime}$ $\mathrm{N}, 151^{\circ} 19^{\prime} 30^{\prime \prime} \mathrm{W}$; (map 62). Var. Nikishka, Nikishki.

Former Tanaina Indian Village and boat landing. The 1964 USC\&GS Coast Pilot (p. 78) stated it is now a barge wharf; recent USGS maps indicate a site with two or three buildings. See Nikishka No. 3 .

Nikishka No. 3: locality, on NW coast of Kenai Penin., $6 \mathrm{mi}$. E of Boulder Point and $16 \mathrm{mi}$. NNE of Kenai, Cook Inlet Low.; (map 62). Var. Kultuk, Titukilsk.

Former Tanaina Indian village reported in 1930 by de Laguna (1934, p. 134). The names "Titukilsk and Nikishka" are combined in Ivan Petroff's 1880 Census and pertain to two small villages that had a total population of 57. Correlation of these two names with the present names, "Nikiski Wharf," "Nikishka No. 2," and "Nikishka No. 3," has not been possible. It appears that the name "Nikishka" was applied several villages north of Kenai, of which Titukilsk may have been one.

Nikishki: locality, see Nikishka No. 2.

Nikishki Bay: bight, see Nikishka Bay.

Nikiska Bay: bight, see Nikishka Bay.

Nikiski Wharf: locality, on $\mathrm{W}$ coast of Kenai Penin., $10 \mathrm{mi}$. NNW of Kenai, Cook Inlet Low.; $60^{\circ} 41^{\prime} \mathrm{N}, 151^{\circ} 24^{\prime} \mathrm{W}$; (map 62). Var. Nikishka No. 1.

Former Tanaina Indian village and boat landing reported as "Nikishka No. 1" in 1912 by USC\&GS. The village is now known primarily as a wharf and petroleum-handling facility, according to the 1964 USC\&GS Coast Pilot (p. 78). See Nikishka No. 3.

Nikkala Gulch: ravine, see Nekula Gulch.

Niklavik Creek: stream, heads in swampland NW of Tunusiktok Lake and fows NW $25 \mathrm{mi}$. to Kokolik River, $10.5 \mathrm{mi}$. E of Point Lay, Arctic Plain; $69^{\circ} 45^{\prime} \mathrm{N}, 162^{\circ} 37^{\prime} \mathrm{W}$; (map 145).

Eskimo name appearing on a field sheet by Gerald FitzGerald, USGS, dated 1923.

Niklavik Creek: stream, heads in lake, flows $\mathrm{E}$ $18 \mathrm{mi}$. to Inaru River, $29 \mathrm{mi}$. S of Barrow, Arctic Plain; $70^{\circ} 52^{\prime} 10^{\prime \prime} \mathrm{N}, 156^{\circ} 57^{\prime} 30^{\prime \prime} \mathrm{W}$; (map 147).

Eskimo name obtained in 1956 at Wainwright by T. E. Taylor, USGS.
Nikok River: stream, flows E $15 \mathrm{mi}$. to Salmon River, $36 \mathrm{mi}$. NE of Kizna, Brooks Ra.; $67^{\circ} 25^{\prime}$ $\mathrm{N}, 159^{\circ} 48^{\prime} \mathrm{W}$; (map 127).

Eskimo name obtained in 1955 by U.S. Army Corps of Engineers.

Nikolai : locality, see Skolai.

Nikolai: village, pop. 86, at junc. of South Fork Kuskokwim and Little Tonzona Rivers, $46 \mathrm{mi}$. $\mathrm{E}$ of McGrath, Kuskokwim Low.; 62 ${ }^{\circ} 58^{\prime} 10^{\prime \prime}$ $\mathrm{N}, 154^{\circ} 09^{\prime} 30^{\prime \prime} \mathrm{W}$; (map 80). Var. Old Nikolai.

Ingalik Indian village located at its present site about 1925, previously was situated several miles up the South Fork (Hosley, 1961, p. 95). In 1960 Hosley reported the village consisted of 12 cabins, 2 school buildings, and a Greek Gatholic-Russian Orthodox church. The old village site up-river is now called "Old Nikolai."

Nikolai Bay: bay, $2 \mathrm{mi}$. across, in Tustumena Lake, $S$ of Caribou I., on Kenai Penin., 25 mi. SSE of Kenai, Cook Inlet Low.; $60^{\circ} 13^{\prime} \mathrm{N}$, $151^{\circ} 01^{\prime} \mathrm{W}$; (map 62).

Local name reported in 1904 by F. H. Moffitt, USGS; derived from Nikolai Creek.

Nikolai Butte: peak, 6,000 ft., NW of Lime Butte, $16 \mathrm{mi}$. SE of McCarthy, Wrangell Mis.; $61^{\circ} 23^{\prime} \mathrm{N}, 142^{\circ} 27^{\prime} \mathrm{W}$; (map 67).

Named for Nikolai, the tyone or chief of the Copper River area, reported in 1908 by D. C. Witherspoon, USGS (in Moffit and Capps, 1911, pl. 2).

Nikolai Cove: cove, $1 \mathrm{mi}$. across, on SE shore of Castle Cape, $11 \mathrm{mi}$. SE of Chignik, Aleutian Ra.; $56^{\circ} 13^{\prime} \mathrm{N}, 158^{\circ} 12^{\prime} \mathrm{W}$; (map 30). Var. Nikoli Cove.

Name reported in 1923 by R. H. Sargent, USGS; published in 1927 by USGS.

Nikolai Creek: stream, on Kenai Penin., flows N $18 \mathrm{mi}$. to Tustumena Lake, $27 \mathrm{mi}$. SSE of Kenai, Cook Inlet Low.; $60^{\circ} 11^{\prime} 45^{\prime \prime} \mathrm{N}, 151^{\circ}$ $00^{\prime} 30^{\prime \prime} \mathrm{W}$; ( $\left.\operatorname{map} 62\right)$.

Local name published by $D$. $H$. Sleem on his map of Central Alaska dated 1910.

Nikolai Creek: stream, heads in lake, flows SE $38 \mathrm{mi}$. to Trading Bay, $12 \mathrm{mi}$. SW of Tyonek, Cook Inlet Low.; $61^{\circ} 00^{\prime} 45^{\prime \prime} \mathrm{N}, 151^{\circ} 28^{\prime} 55^{\prime \prime}$ W; (map 70).

Local name reported in 1927 by S. R. Capps (in Smith and others, 1930, pl. 3), USGS.

Nikolai Creek: stream, flows $4 \mathrm{mi}$. W to McCarthy Creek, $5 \mathrm{mi}$. E of McCarthy, Wrangell Mts. ; $61^{\circ} 26^{\prime} 45^{\prime \prime} \mathrm{N}, 142^{\circ} 46^{\prime} 30^{\prime \prime} \mathrm{W}$; (map 67).

The name was reported in 1900 by T. G. Gerdine, USGS. See Nikolai Butte.

Nikolaief : locality, on $\mathrm{S}$ coast of Alaska Penin. at Dushkin Lagoon, $11 \mathrm{mi}$. NNE of Belkofski, Aleutian Range; 55 $14^{\prime} \mathrm{N}, 161^{\circ} 26^{\prime} \mathrm{W}$; (map 28). Var. Nicoloffsky, Nikolaievsky.

Former Aleut village or camp, presumably named by the Russians after Tsar Nikolas; reported in the 1880 Census as "Nikolaievsky," population 43, by Petroff (1884, p. 29).

Nikolaievsky: locality, see Nikolaief.

Nikolai Gulch: ravine, trends $1 \mathrm{mi}$. SW to Dan Creek, $0.1 \mathrm{mi}$. W of junc. of Copper and 
Dan Creeks, SW of Nikolai Butte and $15 \mathrm{mi}$. $\mathrm{SE}$ of McCarthy, Wrangell Mts.; $61^{\circ} 22^{\prime} \mathrm{N}$, $142^{\circ} 29^{\prime} \mathrm{W}$; (map 67).

The name was reported in 1908 by D. C. Witherspoon, USGS (in Moffit and Capps, 1911, pl. 2). See Nikolai Butte.

Nikolai Lake: lake, $0.6 \mathrm{mi}$. long, on Kenai Penin., $2 \mathrm{mi}$. S of Caribou I. in Tustumena Lake and $25 \mathrm{mi}$. S of Kenai, Cook Inlet Low.; 60 $0^{\circ} 11^{\prime}$ $50^{\prime \prime} \mathrm{N}, 151^{\circ} 02^{\prime} 00^{\prime \prime} \mathrm{W}$; (map 62).

Named about 1963 by officials of Kenai National Moose Range, for administrative purposes.

Nikolai Lake: lake, see Nickoli Lake.

Nikolai Pass: pass, 3,700 ft., at head of Nikolai Creek, $10 \mathrm{mi}$. NE of McCarthy, Wrangell Mts.; $61^{\circ} 26^{\prime} \mathrm{N}, 142^{\circ} 39^{\prime} \mathrm{W}$; (map 67).

Local name obtained by USGS and published on maps since 1964. See Nikolai Butte. Nikolai Slough: stream, anabranch, heads at Koyukuk River, flows SE $23 \mathrm{mi}$. to Bear Creek, $35 \mathrm{mi}$. NE of Nulato, Koyukuk Low.; $64^{\circ} 52^{\prime} \mathrm{N}, 157^{\circ} 00^{\prime} \mathrm{W}$; (map 97).

Local name reported in 1954 by USGS.

Nikolas Reef: reef, Cozian Reef.

Nikolay, Ostrov: island, see Green Island.

Nikoli Cove: cove, see Nikolai Cove.

Nikolski: village, pop. 92, on Nikolski Bay, on SW coast of Umnak I., Aleutian Is.; $52^{\circ} 56^{\prime}$ 23" N, 168'51'35" W; BGN 1890; (map 21). Var. Nikolskoje, Nikolsky, Oomnak, Recheshnaia, Recheshnoe, Retchechnoi, Riecheshno, Riechesnoe, Rjätscheschnoje, Rychesnoi, Umnak.

Russian name published in 1868 by the U.S. Navy Hydrog. Office. Recorded in 1834 as "Recheshnoe," meaning "river," popuIation 83 , by Father Veniaminov (1840, v. 1 , p. 151). Shown as "Nikolsky" on Petroff's 1880 Census map, and recorded with a population of 127 . The population was 94 in $1890 ; 109$ in $1929 ; 97$ in 1939 , and 64 in 1950.

Nikolski Anchorage: $b a y$, see Nikolski Bay.

Nikolski Bay: bay, $4.5 \mathrm{mi}$. across, on SW coast of Umnak I., Aleutian Is.; $52^{\circ} 57^{\prime} 30^{\prime \prime} \mathrm{N}$, $168^{\circ} 4^{\prime} 00^{\prime \prime}$ W; BGN 1940; (map 21). Var. Nikolski Anchorage, Nikolski Harbor.

Named in 1939 by USC\&GS, "from the village of Nikolski on Umnak Island." Nikolski Harbor: bay, see Nikolski Bay.

Nikolskoi: locality, see Korovinski.

Nikolskoje: village, see Nikolski.

Nikolskoye, Seleniye: locality, see Korovinski.

Nikolsky: village, see Nikolski.

Nikonda Creek: stream, heads at Nikonda Glacier terminus, flows NW $7 \mathrm{mi}$. to Nabesna River, $11 \mathrm{mi}$. S of Devils Mtn., Wrangell Mts.; 62 $11^{\prime} \mathrm{N}, 142^{\circ} 51^{\prime} \mathrm{W}$; (map 84).

Indian name reported in 1902 by $\mathrm{D}$. C. Witherspoon, USGS.

Nikonda Glacier: glacier, extends N 6 mi. to its terminus at head of Nikonda Creek, $18 \mathrm{mi}$. W of Euchre Mtn., E of Nabesna Glacier, Wrangell Mts.; $62^{\circ} 03^{\prime} \mathrm{N}, 142^{\circ} 44^{\prime} \mathrm{W}$; (map 84).

Local name reported in 1959 by USGS. Nik River: stream, see Kenai River.
Niksirok Point: point of land, at NW end of Elson Bay, $2.5 \mathrm{mi}$. SW of Point Barrow, Arctic Plain; $71^{\circ} 21^{\prime} 15^{\prime \prime} \mathrm{N}, 156^{\circ} 31^{\prime} 45^{\prime \prime} \mathrm{W}$; (map 153). Var. Nexeura.

Eskimo name recorded in 1965 at Barrow by Orth, USGS, and means "becoming hook." The Brit. Adm. Chart 2165 drawn in 1853 by Master Thomas Hull spells the name "Nexeura."

Niktak: locality, on Cape Prince of Wales, Kotzebue-Kobuk Low.; $65^{\circ} 35^{\prime} \mathrm{N}, 168^{\circ} 03^{\prime} \mathrm{W}$; (map 111). Var. Nikhtagmut.

Former Eskimo village or camp recorded as "Nikhtagmut" by Lt. Zagoskin (1847, p. 73), IRN.

Nilak: locality, see Nililak.

Nilak Point: point of land, see Nililak Point.

Nil Desperandum Gulch: ravine, trends SE 0.9 mi. to Lost Creek, $5 \mathrm{mi}$. NE of Nome, Seward Penin. High.; $64^{\circ} 33^{\prime} 20^{\prime \prime} \mathrm{N}, 165^{\circ} 14^{\prime} 00^{\prime \prime} \mathrm{W}$; (map 94).

Prospectors' name reported on the 1903 Campion Mining and Trading Co. map by George M. Ashford.

Nile Point: point of land, on SW coast of Agattu I., Aleutian Is.; $52^{\circ} 23^{\prime} 25^{\prime \prime} \mathrm{N}, 173^{\circ}$ $24^{\prime} 50^{\prime \prime}$ E; (map 13).

Named by U.S. Army during World War II.

Nilikluguk: village, pop. 40 (1950), on NW coast of Nelson I., $12 \mathrm{mi}$. NE of Cape Vancouver, Yukon-Kuskokwim Delta.; 60³9' N, $165^{\circ} 09^{\prime} \mathrm{W}$; (map 57 ).

Eskimo village reported in 1937 by USC\&GS.

Nilik River: stream, heads on North Aluk Hill, flows SW $30 \mathrm{mi}$. to Ipewik River, $28 \mathrm{mi}$. SE of Cape Dyer, Arctic Slope; $68^{\circ} 30^{\prime} 30^{\prime \prime} \mathrm{N}$, $165^{\circ} 12^{\prime} 05^{\prime \prime} \mathrm{W}$; (map 129). Var. Ipewik River, North Kukpuk River, Savailok River.

Eskimo name meaning "to pass wind" reported in 1955 by U.S. Army corps of Engineers.

Nililak: locality, on $\mathbf{S}$ bank of Kwikluak Pass, Yukon Delta, $14 \mathrm{mi}$. SW of Kwiguk, YukonKuskokwim Delta; 62 $35^{\prime} 25^{\prime \prime} \mathrm{N}, 164^{\circ} 47^{\prime} 05^{\prime \prime}$ W; (map 77). Var. Nilak.

Eskimo campsite reported in 1952 by USC\&GS

Nililak Point: point of land, in Yukon Delta between Kwemuluk Pass and Kwiklokchum Channel, $0.5 \mathrm{mi}$. N of Sheldon Point and 18 mi. SW of Kwiguk, Yukon-Kuskokwim Delta; $62^{\circ} 32^{\prime} 30^{\prime \prime} \mathrm{N}, 164^{\circ} 51^{\prime} 00^{\prime \prime} \mathrm{W}$; (map 77). Var. Nilak Point, Neh-leel-ahk.

Eskimo name obtained in 1948 by USC\&GS. Nilimut Creek: stream, see Nilumat Creek. Nilkoka River: stream, see Tolovana River. Nillik: locality, an left bank of Selawik River, $21 \mathrm{mi}$. E of Selawik, Kotzebue-Kobuk Low.; $66^{\circ} 36^{\prime} \mathrm{N}, 159^{\circ} 15^{\prime} \mathrm{W}$; (map 114).

Eskimo camp reported in 1954 by the U.S. Army Corps of Engineers.

Nilumat Creek: stream, on W slope of Towak Mtn., flows SW $3 \mathrm{mi}$. to Kokechik Bay, 3.5 mi. S of Cape Romanzof, Yukon-Kuskokwim Delta; $61^{\circ} 46^{\prime} \mathrm{N}, 166^{\circ} 03^{\prime} \mathrm{W}$; (map 75). Var. Nilimut Creek, Nilumut River.
Eskimo name reported by USC\&GS in 1949. Nilumut River: stream, see Nilumat Creek.

Nilunorat Hills: hills, 1,945 ft., SE of Angayucham Mts. and $60 \mathrm{mi}$. NNW of Hughes, Hogatza High.; $66^{\circ} 21^{\prime} \mathrm{N}, 155^{\circ} 07^{\prime} \mathrm{W}$; (map 116).

Name reported in 1956 by USGS.

Nimgun Creek: stream, heads at Nimgun Lake, flows S $22 \mathrm{mi}$. to Goodnews River, $38 \mathrm{mi}$. NE of Goodnews, Kilbuck-Kuskokwim Mts.; $59^{\circ}$ $27^{\prime} \mathrm{N}, 160^{\circ} 47^{\prime} \mathrm{W}$; (map 53).

Eskimo descriptive name reported to mean "to wind around," obtained about 1951 at Goodnews by J. M. Hoare, USGS.

Nimgun Lake: lake, $0.8 \mathrm{mi}$. long, $9 \mathrm{mi}$. NW of Goodnews, Kilbuck-Kuskokwim Mts.; 59 $34^{\prime}$ $\mathrm{N}, 160^{\circ} 45^{\prime} \mathrm{W}$; (map 53$)$.

Name derived from Nimgun Creek; published in 1951 by USGS.

Nimiuk Point: point of land, on Baldwin Penin., extends into Hotham Inlet, $18 \mathrm{mi}$. SE of Kotzebue, Kotzebue-Kobuk Low.; $66^{\circ} 47^{\prime} \mathrm{N}$, $162^{\circ} 01^{\prime} \mathrm{W}$; (map 113). Var. Nimyuk, Ninvok, Ninvook.

Eskimo name reported in 1884 by Lt. G. M. Stoney, USN, who says it signifies the cottonwood tree.

Nimrod Hill: ridge, elev. 1,560 ft., extends NWSE $3 \mathrm{mi}$. on $E$ side of Imuruk Lake, Seward Penin. High.; $65^{\circ} 37^{\prime}$ N, $163^{\circ} 05^{\prime} \mathrm{W}$; (map $110)$.

Local name reported in 1951 by USGS.

Nimrod Peak: peak, 5,075 ft., $2 \mathrm{mi}$. W of Squaw Mtn. and $19 \mathrm{mi}$. N of Eagle, Porcupine Plat.; $65^{\circ} 04^{\prime} 12^{\prime \prime} \mathrm{N}, 141^{\circ} 04^{\prime} 00^{\prime \prime} \mathrm{W}$; BGN 1965 ; (map 103).

Named in 1965 by USGS, for Edwin E. Robertson . (died 1941), who was known locally as "Nimrod."

Nimyuk: locality, probably near head of Unakserak River, Brooks Ra.; $67^{\circ} 52^{\prime}$ N, $153^{\circ} 54^{\prime}$ W; (map 125).

Stoney (1900, map), USN, reports an Eskimo village consisting of two huts here in 1886 , inhabited by three men, two women, and some children. It was probably not a permanent village but rather a convenient place for hunting and trading parties to camp. Stoney's text states that he traveled up the Kutuk [Koo-to-ark] River; however, his manuscript map locates Nimyuk at the head of the Unakserak River, which he does not name. If his text is correct, Nimyuk should be located near the head of July Creek. "Nimyuk [Ningyak]" is an Eskimo name meaning "cottonwood."

Nimyuk: point of land, see Nimiuk Point.

Nina Cove: cove, $1 \mathrm{mi}$. long, $\mathrm{S}$ of Coning Inlet, on E coast of Long I., Alex. Arch.; 54 $49^{\prime} 30^{\prime \prime}$ N, 132 39'10' W; BGN 1929; (map 1).

Named in 1928 by USC\&GS whose "field party suggested 'Ning' from the last syllable of 'Coning [Inlet]' but for the sake of euphony, the change to 'Nina' is recommended."

Ninagiak Island: island, $1.2 \mathrm{mi}$. long, in Hallo Bay, on S coast of Alaska Penin., in Katmai National Monument, $37 \mathrm{mi}$. NE of Mount Katmai, Aleutian Ra.; $58^{\circ} 27^{\prime} 30^{\prime \prime}$ N, $154^{\circ} 00^{\prime}$ - 
00" W; (map 42). Var. Ile Pina-ghiack, Ostrov Ninagiak.

Eskimo name published by Capt. Tebenkov (1852, map 22), IRN.

Ninagiak River: stream, flows SE $10 \mathrm{mi}$. to Hallo Bay, on E coast of Alaska Penin., in Katmai National Monument, $36 \mathrm{mi}$. NE of Mount Katmai, Aleutian Ra.; $58^{\circ} 28^{\prime} 35^{\prime \prime} \mathrm{N}$, $154^{\circ} 04^{\prime} 30^{\prime \prime} \mathrm{W}$; (map 42).

Reported in 1951 by USGS; probably named for Ninagiak Island.

Ninefoot Shoal: shoal, in Khaz Bay, $5.5 \mathrm{mi}$. S of Chichagof, on W coast of Chichagof I., Alex. Arch.; 57 $34^{\prime} 45^{\prime \prime} \mathrm{N}, 136^{\circ} 05^{\prime} 30^{\prime \prime} \mathrm{W}$; (map 9).

Descriptive name given in 1917 by USC\&GS and published in the 1917 Coast Pilot (p. 221).

Ninemile: locality, on left bank of Salmon River, $7.5 \mathrm{mi}$. NW of Hyder, Coast Mts.; 56 $01^{\prime} 15^{\prime \prime}$ $\mathrm{N}, 130^{\circ} 04^{\prime} 25^{\prime \prime} \mathrm{W}$; (map 7).

Name published in 1920 by L. G. Westgate (in Brooks and others, 1922, fig. 1), USGS. Ninemile Camp: locality, on left bank of Yukon River, at junc. of Ninemile Slough and Yukon River, $9 \mathrm{mi}$. SW of Nulato, Koyukuk Low.; $64^{\circ} 36^{\prime} \mathrm{N}, 158^{\circ} 17^{\prime} \mathrm{W}$; (map 97).

Local descriptive name reported in 1954 by USGS.

Ninemile Creek: stream, on $\mathbf{N}$ end of Douglas I., flowing $0.7 \mathrm{mi}$. NW to Gastineau Channel, $1.2 \mathrm{mi}$. E of Entrance Point and $6.4 \mathrm{mi}$. $\mathrm{NW}$ of Juneau, Coast Mts.; $58^{\circ} 20^{\prime} 10^{\prime \prime} \mathrm{N}$, $134^{\circ} 34^{\prime} 30^{\prime \prime} \mathrm{W}$; (map 11).

Local name published in 1962 by USGS.

Ninemile Creek: stream, heads at a glacier and flows NE $4.6 \mathrm{mi}$. to Matanuska River, $33 \mathrm{mi}$. NE of Palmer, Chugach Mts.; 61 ${ }^{\circ} 47^{\prime} 15^{\prime \prime} \mathrm{N}$, $148^{\circ} 12^{\prime} 15^{\prime \prime} \mathrm{W}$; (map 69).

Local name reported in 1948 by USGS.

Ninemile Creek: stream, heads in Scotty Lake, flows S $12 \mathrm{mi}$. to Moose Creek, $13 \mathrm{mi}$. SW of Talkeetna, Cook Inlet Low.; $62^{\circ} 11^{\prime} 30^{\prime \prime} \mathrm{N}$, $150^{\circ} 23^{\prime} 50^{\prime \prime} \mathrm{W}$; (map 81).

Local descriptive name reported in 1958 by USGS.

Ninemile Creek: stream, heads at glacier terminus, in Nutzotin Mts., flows NW $5 \mathrm{mi}$. to Cooper Creek $7 \mathrm{mi}$. SE of its junc. with $\mathrm{Na}$ besna River; $62^{\circ} 21^{\prime} \mathrm{N}, 142^{\circ} 35^{\prime} \mathrm{W}$; (map 84).

Local name reported by USGS in 1960 . So named because it is about nine miles upstream from the mouth of Cooper Creek.

Ninemile Creek: stream, flows SW $9 \mathrm{mi}$. from Ninemile Hills to John River, $53 \mathrm{mi}$. SW of Wiseman, Brooks Ra.; $67^{\circ} 00^{\prime} 20^{\prime \prime} \mathrm{N}, 151^{\circ}$ 47'00' W; (map 124).

Local name reported in 1956 by USGS; probably so called because the mouth of the creek is about nine miles from Bettles.

Ninemile Hills: hills, 3,000 ft., 9 mi. across, between Timber Creek and Wild River, on S side of Death Valley, $45 \mathrm{mi}$. SW of Wiseman, Brooks Ra. ; 67 $04^{\prime} \mathrm{N}, 151^{\circ} 38^{\prime} \mathrm{W}$; (map 124).

Local name reported in 1956 by USGS; so called because Ninemile Creek heads in them.

Ninemile Island: island, in Yukon River, $7 \mathrm{mi}$. SW of Nulato, Koyukuk Low.; 64 $38^{\prime} \mathrm{N}$, $158^{\circ} 13^{\prime} \mathrm{W}$; (map 97). Var. Center Island. Local descriptive name reported in 1954 by USGS.

Ninemile Island: island, exends NE-SW $4.8 \mathrm{mi}$. in Yukon River, $10 \mathrm{mi}$. NE of Ruby, Nowitna Low.; 64 $50^{\prime} \mathrm{N}, 155^{\circ} 12^{\prime} \mathrm{W}$; (map 98). Var. Lonesome Island.

Local name reported about 1952 by USGS.

Ninemile Lake: lake, $1.3 \mathrm{mi}$. across, $22 \mathrm{mi}$. SE of Beaver, Yukon Flats; $66^{\circ} 11^{\prime} 30^{\prime \prime} \mathrm{N}, 146^{\circ}$. 39'30" W; (map 119).

Local name obtained in 1956 by USGS.

Ninemile Lake: lake, $0.7 \mathrm{mi}$. long, $7 \mathrm{mi}$. NE of Beaver, Yukon Flats; $66^{\circ} 27^{\prime} 10^{\prime \prime} \mathrm{N}, 147^{\circ} 15^{\prime}$ 20" W; (map 118).

Local name obtained in 1956 by USGS; name derived from the distance to Beaver via a year-round trail.

Ninemile Lake: lake, $0.8 \mathrm{mi}$. long, $8 \mathrm{mi}$. SE of Fort Yukon, Yukon Flats; $66^{\circ} 30^{\prime} 00^{\prime \prime} \mathrm{N}, 145^{\circ}$. 02'30" W; (map 119).

Local name reported in 1956 by USGS; so called because the lake is about 9 miles up the Yukon River from Fort Yukon.

Ninemile Lake: lake, $0.5 \mathrm{mi}$. across, between Ninemile Hills and Ninemile Creek, $4 \mathrm{mi}$. E of mouth of Ninemile Creek and $49 \mathrm{mi}$. SW of Wiseman, Brooks Ra.; $67^{\circ} 01^{\prime} 15^{\prime \prime} \mathrm{N}, 151^{\circ}$. $38^{\prime} 00^{\prime \prime} \mathrm{W}$; (map 124).

Local name reported in 1956 by USGS; probably so called because it lies between Ninemile Creek and Ninemile Hills.

Ninemile Mountain: mountain, 6,335 ft., 7.5 mi. NW of Hyder, Coast Mts. ; $56^{\circ} 00^{\prime} 45^{\prime \prime} \mathrm{N}$, $130^{\circ} 08^{\prime} 00^{\prime \prime} \mathrm{W}$; (map 7 ).

Local descriptive name published in 1928 by USGS.

Ninemile Point: point of land, on right bank of Yukon River, between Straight and Ninemile Is., 7 mi. NE of Ruby, Nowitna Low.; 64' $49^{\prime}$ $\mathrm{N}, 155^{\circ} 19^{\prime} \mathrm{W}$; (map 98 ).

Local name reported about 1952 by USGS. Ninemile Point: point of land, on $\mathrm{N}$ shore of Yukon River between Burns and Youngs Is., $9 \mathrm{mi}$. SW of Birches, Kokrines-Hodzana High.; $65^{\circ} 04^{\prime} \mathrm{N}, 153^{\circ} 48^{\prime} \mathrm{W}$; (map 107).

Local name obtained by USGS topographers in 1952. So named because it is 9 miles from Birches.

Ninemile Point: point of land, on Seward Penin., extends into Kotzebue Sound, $7 \mathrm{mi}$. E of Deering, Kotzebue-Kobuk Low.; $66^{\circ} 04^{\prime}$ N, $162^{\circ}$ $27^{\prime} \mathrm{W}$; (map 113).

Local name reported in 1950 by USGS.

Ninemile River: stream, flows NE $22 \mathrm{mi}$. to Yukon River, $8 \mathrm{mi}$. SW of Nulato, Nulato Hills; $64^{\circ} 38^{\prime} \mathrm{N}, 158^{\circ} 18^{\prime} \mathrm{W}$; (map 97).

Local descriptive name reported in 1954 by USGS.

Ninemile Slough: channel, in Yukon River, flows SW $5.2 \mathrm{mi}$. around $\mathrm{E}$ side of Ninemile I., 8 mi. NE of Ruby, Nowitna Low.; $64^{\circ} 50^{\prime} \mathrm{N}$, $155^{\circ} 12^{\prime} \mathrm{W}$; (map 98).

Local name reported about 1952 by USGS. Ninemile Slough: stream, anabranch, flows SW $6 \mathrm{mi}$. around Ninemile I. to Yukon River, 9 mi. SW of Nulato, Koyukuk Low.; $64^{\circ} 36^{\prime} \mathrm{N}$, $158^{\circ} 17^{\prime} \mathrm{W}$; (map 97).
Local descriptive name reported in 1954 by USGS.

Ninemile Slough: stream, an anabranch of Porcupine River, flows SW $5 \mathrm{mi} .39 \mathrm{mi}$. NE of Fort Yukon, Yukon Flats; $66^{\circ} 49^{\prime} \mathrm{N}, 144^{\circ} 00^{\prime}$ W; (map 119).

Local name obtained in 1956 by USGS.

Nine Pup: stream, flows NW $1 \mathrm{mi}$. to Deadwood Creek, $36 \mathrm{mi}$. SW of Circle, Yukon-Tanana High.; $65^{\circ} 27^{\prime} 25^{\prime \prime} \mathrm{N}, 144^{\circ} 56^{\prime} 10^{\prime \prime} \mathrm{W}$; (map 104).

Named "Nine Pup" by prospectors; reported in 1909 by B. L. Johnson (in Brooks and others, 1910, fig. 5), USGS.

Nineteenmile: locality, $9.5 \mathrm{mi}$. SE of Bearpaw and $55 \mathrm{mi}$. SE of Bitzshtini Mts., Tanana Low.; $64^{\circ} 04^{\prime} \mathrm{N}, 150^{\circ} 25^{\prime} \mathrm{W}$; (map 99).

A shelter station on the winter sled trail; reported in 1932 by USGS.

Ninetyeight Creek: stream, flows E $11 \mathrm{mi}$. to Salcha River, $30 \mathrm{mi}$. NW of Big Delta, YukonTanana High.; 64 $33^{\prime} \mathrm{N}, 146^{\circ} 16^{\prime} \mathrm{W}$; '(map 101). Var. Ninety-eight Creek.

Local name published in 1956 by USGS.

Ninetyeight Pup: stream, flows N $4 \mathrm{mi}$. to Preacher Creek, $15 \mathrm{mi}$. NW of Porcupine Dome and $50 \mathrm{mi}$. SW of Circle, Yukon-Tanana High.; $65^{\circ} 43^{\prime} \mathrm{N}, 145^{\circ} 47^{\prime} \mathrm{W}$; (map 104).

Prospectors' name reported in 1952 by USGS topographers.

Ninety-two Hunter Creek: stream, flows $\mathbf{N} 7 \mathrm{mi}$. to Hunter Creek at $W$ end of Forty-seven Gulch, $8 \mathrm{mi}$. SE of Rampart, Yukon-Tanana High.; 65 $28^{\prime}$ N, $149^{\circ} 49^{\prime}$ W; (map 105).

Local name published by USGS (Mertie, 1937, pl. 1).

Ninetytwo Pup: stream, flows N $1.7 \mathrm{mi}$. to Hoosier Creek, $11 \mathrm{mi}$. SSE of Rampart, Yukon-Tanana High.; $65^{\circ} 21^{\prime} 20^{\prime \prime} \mathrm{N}, 150^{\circ} 01^{\prime} 40^{\prime \prime}$ W; (map 106).

Prospectors' name shown on a manuscript map dated 1906; reported in 1956 by Orth. Ningalingfuk River: stream, see Ninglikfak River.

Ningaluk River: channel, see Ninglick River.

Ningeehak: locality, site of camp, $2 \mathrm{mi}$. NW of Aghnaghak Lagoon and $9 \mathrm{mi}$. SE of Gambell, $\mathrm{N}$ coast of St. Lawrence I.; $63^{\circ} 41^{\prime} \mathrm{N}, 171^{\circ} 36^{\prime}$ W; (map 93). Var. Ningehak.

Eskimo name recorded in 1965 by Orth, as "Ninehak," meaning "little camp." The name was first reported by $O$. W. Geist in 1932.

Ningeehak Beach: beach, extends SE $4 \mathrm{mi}$. from Ikoygak Creek, along shore of Akeftapak Bay, $9 \mathrm{mi}$. SE of Gambell, St. Lawrence I.; $63^{\circ} 42^{\prime}$ N, 171 $34^{\prime}$ W; BGN 1951; (map 93). Var. Ningehak Beach.

Eskimo name often spelled "Ningehak" and meaning "little camp."

Ningehak : locality, see Ningeehak.

Ningehak Beach: beach, see Ningeehak Beach.

Ninghak: lake, see Troutman Lake.

Ningikfak River: stream, see Ninglikfak River. Ninglick River: channel, flows W $44 \mathrm{mi}$. from Baird Inlet to Bering Sea, just N of Nelson I., $110 \mathrm{mi}$. W of Bethel, Yukon-Kuskokwim 
Delta; $60^{\circ} 53^{\prime} \mathrm{N}, \cdot 165^{\circ} 04^{\prime} \mathrm{W}$; (map 57). Var. Ningaluk River, Ninglik Pass.

Eskimo name obtained from the Rev. Jules Convert as "Ningaluk" in 1949 by USC\&GS.

Ninglikfak River: stream, flows SW $20 \mathrm{mi}$. to Hooper Bay, 2 mi. N of Keoklivik River, Yukon-Kuskokwim Delta; $61^{\circ} 29^{\prime} \mathrm{N}, 165^{\circ} 45^{\prime}$ W; (map 75). Var. Ningalingfuk River, Ningikfak River.

Eskimo name obtained at Hooper Bay by USC\&GS in 1949.

Ninglik Pass: channel, see Ninglick River.

Ningolik Valley: valley, extends $\mathrm{N} 9 \mathrm{mi}$. along the Chandler River from junc. of Ayiyak and Jiksikpuk Rivers, Brooks Ra.; 68 ${ }^{\circ} 55^{\prime} \mathrm{N}$, $151^{\circ} 53^{\prime} \mathrm{W}$; (map 134).

Eskimo name obtained at Anaktuvuk Pass in 1956 by T. E. Taylor, USGS; it means "has cottonwood [ningok]."

Ningyoyak Creek: stream, flows SW $6 \mathrm{mi}$. to Midas Creek, $28 \mathrm{mi}$. SE of Howard Pass, Brooks Ra.; 67 $51^{\prime} \mathrm{N}, 156^{\circ} 22^{\prime} \mathrm{W}$; (map 126).

Eskimo name meaning "little cottonwood" relative to Midas Creek which is called "Ningyak" or "cottonwood"; recorded at Kobuk by Orth in 1956.

Ninilchik: village, pop. 169 , on W coast of Kenai Penin., $38 \mathrm{mi}$. SW of Kenai, Cook Inlet Low.; $60^{\circ} 03^{\prime} \mathrm{N}, 151^{\circ} 40^{\prime} \mathrm{W}$; BGN 1944; (map 62). Var. Munina.

This is an agricultural settlement, formerly a fur-farming and fishing village. Ivan Petroff (U.S. Bureau of the Census, 1884, p. 27), wrote "A number of 'colonial citizens,' or superannuated employe's [sic] of the old Russian Company, were ordered to settle some fifty or sixty [1820 or 1830] years ago at Ninilchik, and their descendants live there still." Its population in 1880 was 53 ; in 1890,81 ; in 1920,87 ; in 1930,124 . A post office was obtained in the early 1940's.

Ninilchik, Cape: point of land, $1.5 \mathrm{mi}$. SW of Ninilchik and $39 \mathrm{mi}$. SW of Kenai, Cook Inlet Low. ; $60^{\circ} 02^{\prime} \mathrm{N}, 151^{\circ} 42^{\prime} \mathrm{W}$; (map 62). Var. Cape Neniltschik oder Sunit, Mys Ninilchika.

Native name published by Capt. Tebenkov (1852, map 5), IRN, as "M[ys] Ninilchika" or "Cape Ninilchik." See Ninlchik, village.

Ninilchika, Mys: point of land, see Ninilchik, Cape.

Ninilchika, Reka: stream, see Ninilchik River. Ninilchik Dome: hill, 1,956 ft., on Kenai Penin., $9 \mathrm{mi}$. W of Caribou Lake and $20 \mathrm{mi}$. NE of Homer, Cook Inlet Low.; $59^{\circ} 54^{\prime} 30^{\prime \prime} \mathrm{N}$, $151^{\circ} 25^{\prime} 30^{\prime \prime} \mathrm{W}$; (map 50).

Local name reported and published by USGS in the 1950's.

Ninilchik River: stream, flows SW $21 \mathrm{mi}$. to Cook Inlet at Ninilchik, $38 \mathrm{mi}$. SW of Kenai, Cook Inlet Low.; $60^{\circ} 03^{\prime} \mathrm{N}, 151^{\circ} 40^{\prime} \mathrm{W}$; (map 62). Var. Reka Ninilchika.

Native name published by Capt. Tebenkov (1852, map 5), IRN, as "R[eka] Ninilchika" or "Ninilchik River." See Ninilchik, village. Niniua-Tugat: lake, see Becharof Lake.

Ninivahut Lake: lake, $0.4 \mathrm{mi}$. across, $0.7 \mathrm{mi}$. S of Troutman Lake, $3 \mathrm{mi}$. S of Gambell, Saint
Lawrence I., $63^{\circ} 44^{\prime} \mathrm{N}, 171^{\circ} 43^{\prime} \mathrm{W}$; (map 93).

Eskimo name reported in 1943 by USC\&GS.

Nin Ridge: interfluve, between Kichatna and Nakochna Rivers, $55 \mathrm{mi}$. SW of Talkeetna, Alaska Ra.; $62^{\circ} 09^{\prime} 30^{\prime \prime} \mathrm{N}, 151^{\circ} 53^{\prime} 00^{\prime \prime} \mathrm{W}$; (map 81).

Tanaina Indian name obtained in 1899 by Lt. J. S. Herron, USA

Ninuluk Bluff: ridge, $600 \mathrm{ft}$., $5 \mathrm{mi}$. long, between Colville River and Ninuluk Creek, $28 \mathrm{mi}$. SW of Umiat, Arctic Slope, $69^{\circ} 09^{\prime} \mathrm{N}, 153^{\circ} 15^{\prime}$ W; BGN 1960; (map 142).

Name proposed in 1956 by USGS for use in geologic mapping; derived from the name of the stream.

Ninuluk Creek: stream, heads at $69^{\circ} 02^{\prime} \mathrm{N}$, $152^{\circ} 35^{\prime} \mathrm{W}$, flows $\mathrm{W}, \mathrm{N}$, and $\mathrm{NE} 45 \mathrm{mi}$. to Colville River, $20 \mathrm{mi}$. SW of Umiat, Arctic Slope; 69 $14^{\prime} \mathrm{N}, 152^{\circ} 52^{\prime} \mathrm{W}$; BGN 1949; (map 141). Var. Noviovak River.

Eskimo name reported in 1901 by Peters and Schrader (1904, pl. 2), USGS.

Ninuluk Creek: stream, see Chandler River.

Ninvaug: locality, see New Hamilton.

Ninvok: locality, see New Hamilton.

Ninvok: point of land, see Nimiuk Point.

Ninvook: point of land, see Nimiuk Point.

Nioklakowik Slough: stream, see Kanyak River.

Nioklakowik Slough : stream, see Nagosakchowik Slough.

Nioktun Lake: lake, see Tukuto Lake.

Nip Hill: hill, $200 \mathrm{ft}$., on S end of Little Kiska I., Aleutian Is.; $51^{\circ} 56^{\prime} 49^{\prime \prime} \mathrm{N}, 177^{\circ} 40^{\prime} 10^{\prime \prime} \mathrm{E}$; (map 14).

An arbitrary name beginning with " $N$ " to correspond to "N" grid used by the U.S. Army for tactical purposes during World War II; published on a 1953 AMS map.

Nipper Cove: cove, $0.5 \mathrm{mi}$. across, $\mathrm{E}$ of Oksenof Point, on NW coast of Unimak I., Aleutian Is. ; 54 $53^{\prime} 50^{\prime \prime} \mathrm{N}, 1^{\circ} 4^{\circ} 31^{\prime} 30^{\prime \prime} \mathrm{W}$; BGN 1942; (map 24).

Named by USC\&GS for "Nipper, a horse used by the 1939 field party on the island. The horse was accidently killed during the season."

Nipper Creek: stream, flows N $3.5 \mathrm{mi}$. to Nipper Cove, $E$ of Oksenof Point, on NW coast of Unimak I., Aleutian Is.; $54^{\circ} 53^{\prime} 45^{\prime \prime} \mathrm{N}$, 164'31'00" W; BGN 1942; (map 24).

Named in 1940 by USC\&GS “ * * * for Nipper Cove."

Nipple, The: mountain, see Killinupak Mountain.

Nipple Butte: mountain, 2,500 ft., on Prince of Wales I., near head of McKenzie Inlet, Alex. Arch.; $55^{\circ} 18^{\prime} 35^{\prime \prime} \mathrm{N}, 132^{\circ} 19^{\prime} 25^{\prime \prime} \mathrm{W}$; (map 4).

Local name published in 1943 by USC\&GS. Nipple Gulch: stream, see Little Dixie Creek.

Nipple Mountain: mountain, 2,096 ft., on E coast of Gravina I., $3.9 \mathrm{mi}$. NW of Blank Point, Alex. Arch.; 55 $18^{\prime} \mathrm{N}, 131^{\circ} 43^{\prime} \mathrm{W}$; (map 3 ).

Descriptive name given in 1883 by Lt. Comdr. H. E. Nichols, USN.

Nipple Mountain: mountain, see Dixon, Mount.
Nipples, The: mountains, $3,104 \mathrm{ft}$., on $\mathrm{N}$ coast of Kosciusko I., Alex. Arch:; 56 $06^{\prime} 55^{\prime \prime} \mathrm{N}$, $133^{\circ} 28^{\prime} 15^{\prime \prime}$ W; (map 6). Var. Shakan Nipples.

Local name used by fishermen and published by USC\&GS in 1883 Coast Pilot (p. 101) as "Shakan Nipples"; as "The Nipples" in 1925 Coast Pilot (p. 198).

Niquette Harbor: estuary, $1.4 \mathrm{mi}$. long, $\mathrm{N}$ coast of Duke I., Alex. Arch. $i 54^{\circ} 58^{\prime} 30^{\prime \prime}$ N, $131^{\circ}$ 23'00" W; BGN 1917; (map 2).

Local name reported in 1917 by USC\&GS. Nirlik: locality, see Nigalik.

Nishlik Lake: lake, 6 mi. long, among Tikchik Lakes, $5 \mathrm{mi}$. $\mathrm{N}$ of Upnuk Lake and $105 \mathrm{mi}$. SW of Sleetmute, Kilbuck-Kuskokwim Mts.; $60^{\circ} 27^{\prime} \mathrm{N}, 158^{\circ} 52^{\prime} \mathrm{W}$; BGN 1932; (map 60).

Eskimo name reported in 1915 by USBF.

Nish-thla-tot-li: bluff, see Unatlotly.

Nismeni Cove: cove, $0.5 \mathrm{mi}$. across, on Duffield Penin., N tip of Baranof I., $35 \mathrm{mi}$. N of Sitka, Alex. Arch.; $57^{\circ} 33^{\prime} 45^{\prime \prime} \mathrm{N}, 135^{\circ} 24^{\prime} 00^{\prime \prime} \mathrm{W}$; (map 9).

Named in 1895 by Lt. Comdr. E. K. Moore, USN, and published by USC\&GS on Chart 8283.

Nismeni Point: point of land, on $\mathrm{N}$ coast of Duffield Penin., $\mathbf{N}$ tip of Baranof I., Alex. Arch.; 57 $33^{\prime} 45^{\prime \prime} \mathrm{N}, 135^{\circ} 25^{\prime} 00^{\prime \prime} \mathrm{W}$; (map 9). Var. Lowlying Point, Mys Nizmennyy, Nismenna Point.

Russian name meaning "low," given in 1833 by the navigator Ens. Vasiliev (cnna), IP.N; published in 1848 on Russian Hydrog. Dept. Chart 1397 as "M[ys] Nizmennyy."

Nismenna Point: point of land, see Nismeni Point.

Nisua River: stream, flows SE $8 \mathrm{mi}$. to Matogak River, $1 \mathrm{mi}$. N of Hagemeister Strait and 9.4 mi. NW of Hagemeister I., Kilbuck-Kuskokwim Mts.; $58^{\circ} 58^{\prime} \mathrm{N}, 160^{\circ} 56^{\prime} \mathrm{W}$; (map 39).

Local name obtained in 1948 from Frank Waskey, trader and prospector; and published in 1951 by USGS. "Nisua" means "wheat [or wheat-roll]" in Finnish.

Nitak: locality, on E shore of Knik Arm, Cook Inlet, near Anchorage, Cook Inlet Low.; $61^{\circ}$. $20^{\prime} \mathrm{N}, 149^{\circ} 50^{\prime} \mathrm{W}$; (map 69). Var. Nitakh.

Former Indian village or camp listed in the 1880 Census as "Nitakh," population 15 , by Petroff (1884, p. 29).

Nitakh: locality, see Nitak.

Nitalikh Island: island, see Great Sitkin Island. Nitchavak Mountain: mountain, see Nichawak Mountain.

Nitchawak Mountain: mountain, see Nichawak Mountain.

Nitdlqaitaldatdlna: stream, see Wounded Cub Creek.

Nitrof Point: point of land, $\mathrm{S}$ tip of Amatignak I., Delarof Is., Aleutian Is.; $51^{\circ} 13^{\prime} 05^{\prime \prime} \mathrm{N}$, $179^{\circ} 07^{\prime} 30^{\prime \prime} \mathrm{W}$; (map 16).

Southernmost point of the Aleutian Isalnds; name published by the USC\&GS in 1954 Coast Pilot (p. 458).

Niuftak: village, see Newtok.

Niukluk River: stream, heads $5 \mathrm{mi}$. NE of Mount Bendeleben, flows SW, then SE, $52 \mathrm{mi}$. to Fish 
River, $34 \mathrm{mi}$. NE of Solomon, Seward Penin. High.; 64. $49^{\prime} \mathrm{N}, 163^{\circ} 27^{\prime} \mathrm{W}$; BGN 1911; (map 95). Var. East Fork Neukluk River, Eaton River, Fish River, Icathluik, Ikiut-pak, Iklut-pak, Nea-kluk River, Neukeluk River, Neukluk River, North Fork Niukluk River, Shoestring Creek.

This stream was considered the main fork of the Fish River and a route of travel between Golovnin Bay and Grantley Harbor until gold prospectors arrived in 1899 and detailed maps were constructed. Schrader and Brooks (1900, map 3), USGS, reported the "Neukluk" as tributary to the Fish River in 1899. The following year E. C. Barnard (in Brooks, 1901, pl. 17), USGS, reported and established the present spelling.

Niunak: island, see Chernabura Island.

Niunyak: island, see Chernabura Island.

Nivalghat Beach: beach, $1.5 \mathrm{mi}$. W of Seepanpak Inlet, on $\mathrm{N}$ coast of Saint Lawrence I., $63^{\circ} 21^{\prime}$ N, $169^{\circ} 18^{\prime}$ W; BGN 1951; (map 93).

Eskimo name recommended by the Savoonga village council; reported in 1949 by $\mathrm{Maj}$. H. B. Allen, USAF.

Nixon Fork: stream, flows SW $75 \mathrm{mi}$. to Takotna River, $30 \mathrm{mi}$. SW of Medfra, Kilbuck-Kuskokwim Mts.; $63^{\circ} 02^{\prime} \mathrm{N}, 1^{\circ} 40^{\prime} \mathrm{W}$; BGN 1964 ; (map 89). Var. Nixon River, Nixon Fork Takotna River, Nixons Fork, Tuentna River. Local name obtained in 1908 by A. G. Maddren, USGS. Alexander Kolmakov, in 1838, followed by Lt. L. A. Zagoskin, IRN, in 1842-44 gave the Indian name "Nochotno." A. G. Maddren, in 1908, called it by another Indian name "Tuentna."

Nixon Fork Takotna River: stream, see Nixon Fork.

Nixon River: stream, see Nixon Fork.

Nixons Fork: stream, see Nixon Fork.

Nixon Shoal: shoal, in Peril Strait, on W coast of Duffield Penin., Baranof I., $30 \mathrm{mi}$. N of Sitka, Alex. Arch.; $57^{\circ} 28^{\prime} 10^{\prime \prime}$ N, $135^{\circ} 32^{\prime} 00^{\prime \prime}$ W; (map 9).

Name published by USC\&GS in the 1901 Coast Pilot (p. 191).

Niyan-kiya: point of land, see Cascade Point. Niyghak Lake: lake, see Troutman Lake.

Niyghakpak Gliff: cliff, $0.5 \mathrm{mi}$. long, $\mathrm{E}$ of Aghnaghak Lagoon, $10 \mathrm{mi}$. SE of Gambell, on N coast of Saint Lawrence I.; $63^{\circ} 39^{\prime} 30^{\prime \prime} \mathrm{N}$, $171^{\circ} 31^{\prime} 20^{\prime \prime} \mathrm{W}$; BGN 1951; (map 93). Var. Cliff Niyghak-pak, Cliff Niyghapek, NiyghakPak Cliff.

Eskimo name recommended by the Gambell village council; reported in 1949 by Maj. H. B. Allen, USAF.

Niyghapak Point: point of land, formed by spur of Kinipaghulghat Mts., $4.3 \mathrm{mi}$. S of Northeast Cape, on $E$ coast of Saint Lawrence I.; $63^{\circ} 13^{\prime} 30^{\prime \prime} \mathrm{N}, 168^{\circ} 44^{\prime} 30^{\prime \prime} \mathrm{W}$; BGN 1951; (map 93). Var. Cape Miyghapak, Cape Niyghapak, Niaghapok Cape, Niyghapak Cape.

Eskimo name reported in 1932 by Otto W. Geist, Univ. of Alaska.

Niyghapek, Cliff: cliff, see Niyghapak Cliff.
Niyiklik Creek: stream, flows SW $4.4 \mathrm{mi}$. to Ogotoruk Creek, E of Mad Hill, $8 \mathrm{mi}$. E of Cape Thompson, Arctic Slope; $68^{\circ} 09^{\prime} 30^{\prime \prime} \mathrm{N}$, $165^{\circ} 40^{\prime} 35^{\prime \prime} \mathrm{W}$; BGN 1963; (map 129). Var. Neeyiklik Creek.

Eskimo name reported in 1962 by personnel of Project Chariot.

Niykhapakhit Lake: lake, $3 \mathrm{mi}$. long, on S edge of Myghapowit Mtn., on Saint Lawrence I.; $63^{\circ} 11^{\prime} \mathrm{N}, 169^{\circ} 44^{\prime} \mathrm{W}$; BGN 1951; (map 93).

Eskimo name reported in 1949 by Maj. H. B. Allen, USAF.

Niyrakpak Lagoon: lagoon, extends SE $7 \mathrm{mi}$. from Naskok Camp, along $N$ coast of Saint Lawrence I., $14 \mathrm{mi}$. SE of Gambell; 63 $33^{\circ}$ N, $171^{\circ} 25^{\prime}$ W; BGN 1951; (map 93). Var. Big Lake, Navvookpuk, Niyghak-puk.

Eskimo name meaning "big lake" [naivakhpak].

Nizena Glacier: glacier, see Nizina Glacier.

Nizhni Lake: lake, see Dolgoi Lake.

Nizhniye, Ozero: lake, see Dolgoi Lake.

Nizina: locality, on Chititu Creek, $5 \mathrm{mi}$. SE of the junc. of Chititu Creek and the Nizina River, $14 \mathrm{mi}$. SE of McCarthy, St. Elias Mts.; $61^{\circ} 18^{\prime} 40^{\prime \prime} \mathrm{N}, 142^{\circ} 37^{\prime} 30^{\prime \prime} \mathrm{W}$; (map 67).

Mining camp established in 1902 . The Nizina post office operated from 1903 to 1926 . Nizina Glacier: glacier, formed by Rohn and Regal Glaciers, trends $7 \mathrm{mi}$. $\mathrm{S}$ to its terminus at head of Nizina River, $18 \mathrm{mi}$. NE of McCarthy, Wrangell Mts.; $61^{\circ} 35^{\prime} \mathrm{N}, 142^{\circ} 29^{\prime}$ W; (map 67). Var. Nizena Glacier.

Indian name applied in 1899 by Rohn (1900, p. 407), USGS.

Nizina Mountain: mountain, 7,535 ft., between Nizina and West Fork Glaciers, $17 \mathrm{mi}$. NE of McCarthy, Wrangell Mts.; $61^{\circ} 36^{\prime} 45^{\prime \prime} \mathrm{N}$, $142^{\circ} 34^{\prime} 45^{\prime \prime} \mathrm{W}$; (map 67).

Named for nearby river and glacier.

Nixina River: stream, flows $37 \mathrm{mi} . S$ and $W$ from Nizina Glacier to Chitina River, $12 \mathrm{mi}$. SW of McCarthy, Wrangell Mts.; $61^{\circ} 21^{\prime} \mathrm{N}, 143^{\circ}$. 14' W; (map 67). Var. Nizzenah River.

Indian name reported by Hayes (1892, p. 124): "We * * camped on a stream flowing into the Pacific. This was the Nizzenah, a tributary of the Chittenah (Chitina), or eastern branch of Copper river."

Nizina River: stream, see Chitistone River.

Nizki Cove: cove, $1.1 \mathrm{mi}$. across, between Alaid and Nizki Is., Semichi Is., Aleutian Is.; 52 ${ }^{\circ}$ $44^{\prime} 50^{\prime \prime} \mathrm{N}, 173^{\circ} 56^{\prime} 40^{\prime \prime} \mathrm{E}$; (map 13).

Name derived from Nizki I.

Nizki Island: island, $3 \mathrm{mi}$. long, middle island of Semichi Is., Aleutian Is.; 52 ${ }^{\circ} 44^{\prime} 10^{\prime \prime} \mathrm{N}, 173^{\circ}$ 59'00" E; BGN 1938; (map 13). Var. Oubeloi Island.

Derived from Russian word [Nizkiy] meaning "low" and probably given by the U.S. Army; published by AMS in 1943. The island was shown in 1956 as "Oubeloi" by USGS.

Nizkoy, Ostrov: island, see Crooked Island.

Nizmennie: island, see Low Island.

Nizmennie: point of land, see Low Cape.

Nizmennie Kamennie: island, see Treeless Island.
Nizmennoi : point of land, see Riou, Point. Nizmennoi, Mys: point of land, see Low Cape. Nizmenno Point: point of land, see Low Cape. Nizmennoy, Ostrov: island, see Low Island. Nizmenny, Ostrov: island, see Low Island.

Nizmennyy, Mys: point of land, see Dovolno Point.

Nizmennyya, Mys: point of land, see Shoals Point.

Nizmennyy, Mys: point of land, see Nismeni Point.

Nizmennyy Kamennyy, Ostrov: island, see Treeless Island.

Nizmynnoy, Ostrov: island, see Low Island.

Nizzenah River: stream, see Nizina River.

Njoo Mountain: mountain, $45 \mathrm{mi}$. NW of Arctic Village, Brooks Ra.; $68^{\circ} 30^{\prime} \mathrm{N}, 147^{\circ} 00^{\prime} \mathrm{W}$; (map 136). Var. Jew Mountain, Nju Mountain.

Kutchin Indian name obtaind in 1928 by Gerald FitzGerald, USGS.

Nju Mountain: mountain, see Njoo Mountain. N Mys: point of land, see North Cape.

No, Mys: point of land, see Northeast Point.

Noah Lake: lake, $1 \mathrm{mi}$. long, $2 \mathrm{mi}$. W of Tinjik Lake and $13 \mathrm{mi}$. NE of Arctic Village, Brooks Ra.; $68^{\circ} 18^{\prime} \mathrm{N}, 145^{\circ} 25^{\prime} \mathrm{W}$; (map 136).

Local name reported in 1956 by $R$. C. Foley, USGS.

Noak, Mount: mountain, 2,010 ft., in Igichuk Hills, $19 \mathrm{mi}$. NE of Cape Krusenstern, Arctic Slope; $67^{\circ} 10 \mathrm{~N}, 163^{\circ} 03^{\prime} \mathrm{W}$; BGN 1962; (map 128). Var. Igisoogrook Mountain.

Eskimo name meaning "headland" obtained at Kotzebue in 1956 by Orth.

Noálen River: stream, see Newhalen River.

Noatak: village, pop. 275 , on right bank of Noatak River, $37 \mathrm{mi}$. NE of Cape Krusenstern, Arctic Slope; $67^{\circ} 34^{\prime} \mathrm{N}, 162^{\circ} 58^{\prime} \mathrm{W}$; (map 128).

Eskimo village listed by Ivan Petroff in the 1880 Census as "Noatagamute," i.e. "Noatak [River] people." The population was 121 in' $1910 ; 164$ in $1920 ; 212$ in $1930 ; 336$ in 1939 ; and 326 in 1950 . The Noatak post office was established in 1940 (Ricks, 1965, p. 46).

Noatak Canyon: canyon, of the Noatak River, $4 \mathrm{mi}$. long, $\mathrm{N}$ of Maiyumerak Mts., $40 \mathrm{mi}$. NE of Noatak, Brooks Ra.; $67^{\circ} 57^{\prime}$ N, $161^{\circ} 39^{\prime}$ W; (map 127). Var. Grand Ganyon.

The Noatak was first explored in July 1885, by S. B. McLenegan, USRCS, who referred to this feature as the first of "the Grand Canõns of the Noatak *** Here the perpendicular walls rose hundreds of feet on either side, seldom offering a foothold along the bases **" (Healy, 1887, p. 64). The first use of the name "Noatak Canyon" appears to have been by P. S. Smith (1930, pl. $5)$. The name "Grand Canyon" has been relegated to the broader valley area upstream.

Noatak River: stream, heads on Mount Igikpak in Schwatka Mts. at $67^{\circ} 25^{\prime} \mathrm{N}, 154^{\circ} 53^{\prime} \mathrm{W}$, flows SW $425 \mathrm{mi}$. to Kotzebue Sound at mouth of Hotham Inlet, $7 \mathrm{mi}$. $\mathrm{N}$ of Kotzebue, Brooks Ra.; $67^{\circ} 00^{\prime} \mathrm{N}, 162^{\circ} 30^{\prime} \mathrm{W}$; $B G N$ 1944; (map 128). Var. Igichuk River, Inland River, Noatok River, Noatuk River, 
Notoark River, Noyatag River, Nuatok River, Nunatak River, Nunatok River, Nunulak River.

The early English name "Inland River" published by surgeon John Simpson, $R N$, on his 1853 "Native Map," appears to be a general translation of the Eskimo name "Nunulak" which he also recorded. The name "Nunatak" could also mean "new land" or "belong to the land."

Noatok River: stream, see Noatak River.

Noatuk River: stream, see Noatak River.

Noaukta Slough: stream, distributary of Chakachatna River, flows SW 5 mi. to McArthur River, $24 \mathrm{mi}$. W of Tyonek, Cook Inlet Low.; $61^{\circ} 02^{\prime} 10^{\prime \prime} \mathrm{N}, 151^{\circ} 50^{\prime} 45^{\prime \prime} \mathrm{W}$; (map 70).

Tanaina Indian name reported in 1958 by USGS.

Nobhill Creek: stream, flows NW $0.8 \mathrm{mi}$. to Kasson Creek which flows to Solomon River, $9 \mathrm{mi}$. NE of Solomon, Seward Penin. High.; $64^{\circ} 41^{\prime} 40^{\prime \prime} \mathrm{N}, 164^{\circ} 23^{\prime} 30^{\prime \prime} \mathrm{W}$; (map 95). Var. Nob Hill Creek.

Prospectors' name shown on Arthur Gibson's "Map of Cape Nome Precinct" dated 1904.

Nochak: locality, on Holitna River, Stony River Low. ; $61^{\circ} \mathrm{N}, 157^{\circ} \mathrm{W}$; (map 72). Var. Nohchamiut.

Former Eskimo village or camp recorded "Noh-chamiut," population 28, in the 1890 Census (p. 164).

Nochlega Point: point of land, on $\mathrm{S}$ coast of Afognak I., $3.2 \mathrm{mi}$. SW of Afognak, N of Kodiak I.; $57^{\circ} 59^{\prime} 40^{\prime \prime}$ N, $152^{\circ} 51^{\prime} 30^{\prime \prime}$ W; (map 34). Var. Mys Nochlega, Nights Lodging Cape.

Transliteration of "M[ys] Nochlega" a name given by Sub-Lt. Mikhail Murashev in 1839 or 1840 , and published in 1849 on Russian Hydrog. Dept. Chart 1425. Baker (1906, p. 461) published "Nights Lodging Cape," the translation of Murashev's name. This name was changed to its present form in 1909 by USC\&GS.

Nocotocargut: stream, see Beaver Creek.

No Creek: stream, flows NW $34 \mathrm{mi}$. to Big Salmon Fork Little Tonzona River $1.5 \mathrm{mi}$ SE of its junc. with Little Tonzona River, $55 \mathrm{mi}$. E of McGrath, Kuskokwim Low.; 62 $56^{\prime} 20^{\prime \prime}$ $\mathrm{N}, 153^{\circ} 53^{\prime} 40^{\prime \prime} \mathrm{W}$; (map 80).

Local name obtained in 1958 by USGS.

Noctocargut: stream, see Birch Creek.

Nodales, Punta: point of land, see Martin Point.

Nododehon Lake: lake, $2.2 \mathrm{mi}$. long, in Dulbi Flats, $\mathrm{S}$ of Nogoyalna Slough and $36 \mathrm{mi}$. NW of Hochandochtla Mtn., Kokrines-Hodzana High.; $65^{\circ} 48^{\prime} \mathrm{N}, 155^{\circ} 55^{\prime} \mathrm{W}$; (map 107).

Koyukan Indian name obtained at Huslia in 1956 by Orth.

Nogadaneoda Lake: lake, $19 \mathrm{mi}$. SW of Roundabout Mtn., Koyukuk Low.; $65^{\circ} 26^{\prime}$ N, $157^{\circ}$. $10^{\prime} \mathrm{W}$; (map 108).

Koyukan Indian name reported in 1955 by USGS.

Nogahabara Sand Dunes: dunes, $5 \mathrm{mi}$. across, 28 mi. NW of Roundabout Mtn., Koyukuk Low.; $65^{\circ} 41^{\prime} \mathrm{N}, 157^{\circ} 57^{\prime} \mathrm{W}$; (map 108).
Koyukan Indian name reported in 1955 at Huslia by USGS.

Nogak Creek: stream, flows $\mathrm{N} 28 \mathrm{mi}$. to Kurupa River, $26 \mathrm{mi}$. WNW of Kurupa Lake, Brooks Ra.; $68^{\circ} 43^{\prime} \mathrm{N}$; $155^{\circ} 09^{\prime} \mathrm{W}$; BGN 1960; (map 133).

Eskimo name for the "caribou calf;" used by USGS geologists in 1950, during exploration of the Naval Petroleum Reserve No. 4.

Nogamut: locality, on E bank of Holitna River, $50 \mathrm{mi}$. SW of Sleetmute, Kilbuck-Kuskokwim Mts. ; $61^{\circ} 01^{\prime} \mathrm{N}, 157^{\circ} 40^{\prime} \mathrm{W}$; BGN 1948; (map $72\}$.

Eskimo settlement or camp, now abandoned, reported as "Noga-mute" by W. R. Buckman, a local prospector, on his 19021903 manuscript map.

Nogeling: village, see Newhalen.

Noggai: locality, on Yukon River probably near junc. of Koyukuk River, Koyukuk Low.; $64^{\circ}$ $57^{\prime} \mathrm{N}, 157^{\circ} 33^{\prime} \mathrm{W}$; (map 97).

Former Indian village or camp, population 10 , recorded in 1844 by Lt. L. A. Zagoskin, IRN (Hodge, 1910, p. 80).

Nogheling: village, see Newhalen.

Noghelingamiut: village, see Newhalen.

Noghelingamute: village, see Newhalen.

Nogheling River: stream, see Newhalen River.

Nogheling Village: village, see Newhalen.

Noghelin Painga: locality, at mouth of Newhalen River, 3 mi. S of Iliarnna, Aleutian Ra.; $59^{\circ} 43^{\prime} \mathrm{N}, 154^{\circ} 53^{\prime} \mathrm{W}$; (map 51 ).

Former Eskimo village or camp listed in the 1890 Census.

Noghelin Painga: village, see Newhalen.

Noghelin Painga: stream, see Newhalen River. Noghelin River: stream, see Newhalen River.

Nogholem River: stream, see Newhalen River

Nogoyalna Slough: stream, flows W $26 \mathrm{mi}$. to Cutoff Slough, $28 \mathrm{mi}$. NE of Roundabout Mtn., Koyukuk Low.; $65^{\circ} 54^{\prime}$ N, $156^{\circ} 02^{\prime}$ W; (map 108).

Koyukan Indian name obtained in 1955 at Huslia by USGS.

Nogrilenten, Lake: lake, $1.3 \mathrm{mi}$. long, on $\mathrm{N}$ bank of Koyukuk River, $35 \mathrm{mi}$. NE of Hughes, Hogatza High.; $66^{\circ} 24^{\prime} \mathrm{N}, 153^{\circ} 21^{\prime} \mathrm{W}$; (map 116).

Indian name, reported to mean "falls lake," recorded at Hughes in 1956 by Orth. The water level of the lake is above that of the river, and the lake's outlet is a waterfall.

No Grub Creek: stream, flows SW $2 \mathrm{mi}$. to Salcha River, $37 \mathrm{mi}$. NE of Big Delta, YukonTanana High.; 64 $40^{\prime} \mathrm{N}, 145^{\circ} 37^{\prime} \mathrm{W}$; (map 101).

Named by prospectors and reported in 1910 by Ellsworth and Parker (in Brooks and others, 1911, p. 167), USGS.

Noh-chamiut: locality, see Nochak.

Nohoolchíntna: locality, site of a village, on $\mathrm{N}$ bank of South Fork Koyukuk River 3 mi. upstream from its junc. with Koyukuk River, Kanuti Flats; $66^{\circ} 35^{\prime} \mathrm{N}, 151^{\circ} 51^{\prime} \mathrm{W}$; (map 117). Var. Nohulchinta.

Koyukan Indian village or camp of six families, reported in 1885 by Lt. Allen (1887, p. 100), USA; from the Indian name for the
South Fork Koyukuk River, which Lt. Allen also reported.

Nohoolchintna: stream, see South Fork Koyukuk River.

Nohulchinta: locality, see Nohoolchíntna.

Nohutno Lake: lake, see Lower Tazimina Lake. Noisak: point of land, see Mordvinof, Cape.

Noisy Cape: point of land, NW tip of Uganik I., E of Noisy Is. at mouth of Uganik Bay, Kodiak I.; $57^{\circ} 55^{\prime} 30^{\prime \prime} \mathrm{N}, 153^{\circ} 32^{\prime} 30^{\prime \prime} \mathrm{W}$; (map 34).

Name derived from Noisy Islands, reported in 1867 by USC\&GS.

Noisy Islands: islands, two, each $0.5 \mathrm{mi}$. long, extend $1.2 \mathrm{mi}$. between Uganik Bay and Shelikof Strait, W of Uganik I., N of Kodiak I.; 57 $55^{\prime} 30^{\prime \prime} \mathrm{N}, 153^{\circ} 33^{\prime} 15^{\prime \prime} \mathrm{W}$; BGN 1931; (map 34). Var. Ostrova Sodomnyya, Sodomniia Islands, Zotschomnia Islands.

Translation by USC\&GS in 1867 of "O[strova] Sodomnyya," published by Capt. Tebenkov (1852, maps 22 and 23).

Noisy Mountain: ridge, 4,500 ft., extends NE $5.5 \mathrm{mi}$. from Katmai Canyon, on Alaska Penin., in Katmai National Monument, 4 mi. $\mathrm{E}$ of Mount Katmai, Aleutian Ra.; $58^{\circ} \mathbf{1 5}^{\prime}$ $\mathrm{N}, 154^{\circ} 50^{\prime} \mathrm{W}$; (map 42).

Descriptive name reported in 1917 by $R$. F. Griggs, National Geographic Society, on account of the frequent rockfalls which kept the party awake.

Noisy Passage: water passage, $1.4 \mathrm{mi}$. long, between Noisy Is. and Uganik I., $\mathbf{N}$ of Kodiak I. $57^{\circ} 55^{\prime} 30^{\prime \prime} \mathrm{N}, 153^{\circ} 32^{\prime} 30^{\prime \prime} \mathrm{W}$; BGN 1931 ; (map 34).

Name derived from Noisy Islands and given in 1931 by USC\&GS.

Nok: locality, on $\mathrm{W}$ bank of Koyukuk River, above islands near its mouth, Koyukuk Low. $64^{\circ} 55^{\prime} \mathrm{N}, 157^{\circ} 35^{\prime} \mathrm{W}$; (map 97). Var. Nokchakat, Nokhakate, Nokkahat, Nok-khakat.

Former Indian village or camp, reported as "Nokhakate," population 50 in 1844, by Lt. L. A. Zagoskin, IRN (Hodge, 1910, p. 80). Nokak: locality, see Nokogamiut.

Nokatlek River: stream, see Nokotlek River.

Nokchakat: locality, see Nok.

Nokhakate: locality, see Nok.

Nokhulchitna: stream, see South Fork Koyukuk River.

Nokkakat: locality, see Nok.

Nok-khakat: locality, see Nok.

Nokliche: locality, see Nukleet.

Nokogamiut: locality, on E coast of Nokogamiut I., near mouth of Kawanak Pass and $20 \mathrm{mi}$. $\mathrm{N}$ of Kwiguk, Yukon-Kuskokwim Delta; $63^{\circ}$. $02^{\prime} 45^{\prime \prime} \mathrm{N}, 164^{\circ} 33^{\prime} 10^{\prime \prime} \mathrm{W}$; (map 92). Var. Nokak, Nokok.

Eskimo village, now abandoned, reported in 1899 by R. L. Faris, USC\&GS.

Nokogamiut Island: island, in Yukon Delta, 2 mi. long, at mouth of Kawanak Pass, 19 mi. $\mathrm{N}$ of Kwiguk, Yukon-Kuskokwim Delta; $63^{\circ}$ $03^{\prime} \mathrm{N}, 164^{\circ} 35^{\prime} \mathrm{W}$; (map 2).

Eskimo name recorded in 1952 by USGS. Nokok: locality, see Nokogamiut.

Nokotlek Point: point of land, on Kasegaluk Lagoon, W point of entrance to Nokotlek 
River, 31 mi. SW of Wainwright, Arctic Plain; $70^{\circ} 20^{\prime} \mathrm{N}, 161^{\circ} 01^{\prime} \mathrm{W}$; (map 146).

So named locally because of its relation to the Nokotlek River.

Nokotlek River: stream, flows NW $18 \mathrm{mi}$. to Kasegaluk Lagoon, $16 \mathrm{mi}$. E of Icy Cape and $31 \mathrm{mi}$. SW of Wainwright, Arctic Plain; $70^{\circ}$ $19^{\prime} \mathrm{N}, 160^{\circ} 59^{\prime} \mathrm{W}$; (map 146). Var. Nokatlek River.

Eskimo name reported in 1923 by USGS.

Nokratamiut: locality, see Nokrot.

Nokrot: locality, on Norton Sound, $2.2 \mathrm{mi}$. NE of Point Romanof and $29 \mathrm{mi}$. SW of St. Michael, Yukon-Kuskokwim Delta; 63 ${ }^{\circ} 13^{\prime}$ N, $162^{\circ} 46^{\prime} \mathrm{W}$; (map 92). Var. Azachagyamut, Nokratamiut, Nokrotmiut.

Former Eskimo village, reported as "Nokrotmiut," meaning "Nokrot people," in 1898 by USC\&GS.

Nokrotmiut: locality, see Nokrot.

No Lake Creek: stream, flows SW $20 \mathrm{mi}$. to Ongivinuck River, $72 \mathrm{mi}$. NE of Goodnews, Kilbuck-Kuskokwim Mts.; $59^{\circ} 23^{\prime} \mathrm{N}, 159^{\circ} 40^{\prime}$ W; (map 53).

Local name published in 1951 by USGS.

Nolan: locality, pop. 5, at junc. of Nolan and Wiseman Creeks, W of Midnight and Smith Greek Domes and $5.5 \mathrm{mi}$. NW of Wiseman, Brooks Ra.; $67^{\circ} 28^{\prime} 30^{\prime \prime} \mathrm{N}, 150^{\circ} 13^{\prime} 30^{\prime \prime} \mathrm{W}$; (map 124). Var. Nolan Creek.

This mining camp was named for the creek on which it is located; reported in 1928 by USGS. See Wiseman.

Nolan: village, see Wiseman.

Nolan Creek: stream, flows NW $1.5 \mathrm{mi}$. to Tisuk River, $40 \mathrm{mi}$. NW of Nome, Seward Penin. High.; 64 $56^{\prime} \mathrm{N}, 166^{\circ} 17^{\prime} \mathrm{W}$; (map 94).

Prospectors' name reported on Arthur Gibson's "Map of Cape Nome Precinct" dated 1904.

Nolan Creek: stream, $4 \mathrm{mi}$. long, flows $S$ through Nolan to Wiseman Creek, Brooks Ra.; $67^{\circ} 27^{\prime} 30^{\prime \prime} \mathrm{N}, 150^{\circ} 14^{\prime} 00^{\prime \prime} \mathrm{W}$; BGN 1932; (map 124).

Local name reported in 1909 by A. G. Maddren (in Brooks and others, 1910, pl. 7), USGS.

Nolan Creek Lake: lake, $0.2 \mathrm{mi}$. long, $\mathrm{W}$ of junc. of Nolan and Wiseman Creeks, W of Midnight Dome and $5 \mathrm{mi}$. NW of Wiseman, Brooks Ra.; $67^{\circ} 28^{\prime}$ N, $150^{\circ} 15^{\prime}$ W; (map 124).

Local name obtained in 1956 by USGS topographers.

Nolitna Creek: stream, heads at North Fork Lake, flows NW $13 \mathrm{mi}$. to Narten Slough, 14 mi. SW of Beaver, Yukon Flats; $66^{\circ} 12^{\prime} \mathrm{N}$, $147^{\circ} 58^{\prime} \mathrm{W}$; (map 118).

Indian name obtained in 1956 by T. E. Taylor, USGS.

Nolitna Creek: stream, flows NE $25 \mathrm{mi}$. to Kanuti River $3 \mathrm{mi}$. S of its junc. with Kadakina Creek, $27 \mathrm{mi}$. SE of Allakaket, Kanuti Flats; $66^{\circ} 14^{\prime} \mathrm{N}, 152^{\circ} 07^{\prime} \mathrm{W}$; (map 117).

Indian name obtained by Orth in 1956.

Noluck Lake: lake, $2.5 \mathrm{mi}$. long, on $\mathrm{N}$ slope of De Long Mts., $17 \mathrm{mi}$. $\mathrm{N}$ of Thunder Mtn.,
Brooks Ra.; $68^{\circ} 47^{\prime} 30^{\prime \prime} \mathrm{N}, 160^{\circ} 00^{\prime} 00^{\prime \prime} \mathrm{W}$; $B G N$ 1961; (map 131). Var. Lake Noruk. Named by the 1924 USGS exploring party "because of a disappointment, no luck."

Noluk, Lake: lake, see Noluck Lake.

No Man Creek: stream, see No Mans Creek.

No Mans Creek: stream, flows NW $4.5 \mathrm{mi}$. to Casadepaga River E of Big Four Creek, $26 \mathrm{mi}$. $\mathrm{NE}$ of Solomon, Seward Penin. High.; $64^{\circ} 55^{\prime}$ $\mathrm{N}, 164^{\circ} 10^{\prime} \mathrm{W}$; (map 95). Var. No Man Creek.

Prospectors' name reported in 1900 by E. C. Barnard (in Brooks, 1901, pl. 17), USGS.

Nome: town, pop. 2,316, on $S$ coast of Seward Penin., on Norton Sound, Seward Penin. High.; $64^{\circ} 30^{\prime} \mathrm{N}, 165^{\circ} 25^{\prime} \mathrm{W}$; BGN 1944; (map 94). Var. Anvil City, Nome City.

Schrader and Brooks (1900, p. 11), USGS, who visited the town in October 1899, spoke of the "thriving young city of Nome, first called Anvil City, now officially Nome." Gold was found in the area in the summer of 1898 and the town got its start in October 1898 when six men met at the mouth of the Snake River and formed the Cape Nome mining district. The short-lived name "Anvil City" was derived from Anvil Creek, where the first major gold was found. In June, 1899, gold was found on the beaches of Nome and by August a number of men were prospecting the beaches. The news of the gold strike was carried to the States that winter and in early summer 1900 the rush was on. At the peak that summer there were 30,000 people at Nome, but 16,000 left in 13 weeks (Rickard, 1909, p. 308-337). Nome incorporated on April 9, 1901. The population was 12,488 in $1900 ; 2,600$ in $1910 ; 852$ in $1920 ; 1,213$ in $1930 ; 1,559$ in 1939 ; and 1,876 in 1950 . A post office was established here in 1899 (Ricks, 1965, p. 47-48). The city is now the commercial hub of northwestern Alaska and has also become a center for Eskimo handicrafts.

Nome, Gape: point of land, on Norton Sound, 12 mi. SE of Nome and $20 \mathrm{mi}$. SW of Solomon, Seward Penin. High.; $64^{\circ} 26^{\prime} \mathrm{N}, 1^{\circ} 5^{\circ} 00^{\prime} \mathrm{W}$; (map 95). Var. Mys Sredniy, Mys Tolstoy, Mys Tolstyy.

Named "M[ys] Tolstoy" meaning "blunt" or "broad" in 1833 by Capt. M. D. Tebenkov, IRN. The 1852 Russian Hydrog. Dept. Chart 1455 shows "M[ys] Sredniy (Tolstyy)," or "cape middle (broad)." "C[ape] Nome" appears on the 1853 Brit. Adm. Chart 2172. Its origin is generally attributed to an Admirality draftsman's misinterpretation of "? name" annotated on a manuscript chart constructed on board the H.M.S. Herald about 1850-1852. The "?" mark was taken' as a " $\mathrm{C}$ " and the " $\mathrm{a}$ " was thought to be an "o." This is the explanation given by the Chief Cartographer of the British Admirality in 1900.

Nome City: town, see Nome.

Nome Creek: stream, flows SW $23 \mathrm{mi}$. to Beaver Creek, $48 \mathrm{mi}$. NE of Fairbanks, Yukon-Tanana
High.; $65^{\circ} 23^{\prime} 30^{\prime \prime} \mathrm{N}, 147^{\circ} 08^{\prime} 00^{\prime \prime} \mathrm{W}$; (map 105).

Name published by USGS (Henshaw and Covert, 1908, pl. 9).

Nome Creek: stream, see Lost Creek.

Nome Mountains: mountains, in group, $75 \mathrm{mi}$. long and $20 \mathrm{mi}$. wide, enclosed by Norton Sound, Bering Sea, Imuruk Basin, Pilgrim River, and Niukluk River, Seward Penin. High.; $64^{\circ} 50^{\prime} \mathrm{N}, 165^{\circ} 00^{\prime} \mathrm{W}$; (map 94).

Name used by Schrader and Brooks (1900, map 3), USGS, after a cursory investigation of the area in 1899 . In 1900 this area was well surveyed and the name was omitted from subsequent maps.

Nome Peninsula: peninsula, see Seward Peninsula.

Nome River: stream, heads $4.5 \mathrm{mi}$. W of Salmon Lake, flows S $40 \mathrm{mi}$. to Norton Sound, $4 \mathrm{mi}$. SE of Nome, Seward Penin. High.; 64 $29^{\prime}$ N, $165^{\circ} 18^{\prime} \mathrm{W}$; (map 94).

Prospectors' name derived from Cape Nome and reported in 1899 by D. G. Witherspoon (in Schrader and Brooks, 1900, map 2), USGS.

Nome River: locality, on Nome River, about 4 mi. E of Nome, Seward Penin. High.; (map 94).

Site of a mining camp listed in the 1915-16 Polk's Gazetteer. The site cannot be accurately located.

Nome Stake Creek: stream, flows SW $4 \mathrm{mi}$. to Fisher Creek, $12 \mathrm{mi}$. SE of junc. of Charley and Yukon Rivers, Yukon-Tanana High.; $65^{\circ} 11^{\prime} \mathrm{N}, 142^{\circ} 32^{\prime} \mathrm{W}$; (map 103).

Prospectors' name from an unpublished map by E. J. Chamberlain, dated 1902.

No Name Bay: bay, extends E $4 \mathrm{mi}$. to Keku Strait, on E coast of Kuiu I., $15 \mathrm{mi}$. NW of Point Baker, Alex. Arch.; 56 ${ }^{\circ} 30^{\prime} \mathrm{N}, 133^{\circ} 35^{\prime}$ W; (map 6).

Local name recorded in 1948 by USGS.

No Name Cove: cove, $0.7 \mathrm{mi}$. across, on SW coast of Unalaska I., Aleutian Is.; $53^{\circ} 23^{\prime} 15^{\prime \prime}$ $\mathrm{N}, 167^{\circ} 40^{\prime} 00^{\prime \prime} \mathrm{W}$; (map 23).

Name reported by U.S. Army Corps of Engineers in 1942, and published in the 1944 Aleutian Coast Pilot (p. 50).

No Name Creek: stream, flows S $1.2 \mathrm{mi}$. to Moose Creek, at Upper Canyon, $1.8 \mathrm{mi}$. N of Wonder Lake, Alaska Ra.; $63^{\circ} 30^{\prime} 50^{\prime \prime}$ N, 150 $52^{\prime}$ 45" W; (map 88).

Local name reported in 1954 by USGS

No Name Creek: stream, flows SE $1.5 \mathrm{mi}$. to Chatanika River, 8 mi. WNW of Mount Ryan and $48 \mathrm{mi}$. NE of Fairbanks, Yukon-Tanana High.; $65^{\circ} 17^{\prime} 30^{\prime \prime} \mathrm{N}, 146^{\circ} 30^{\prime} 10^{\prime \prime} \mathrm{W}$; (map 104).

Prospectors' name reported in 1954 or 1955 by USGS topographers.

No Name Lake: lake, $1.5 \mathrm{mi}$. long, $1 \mathrm{mi}$. $\mathrm{E}$ of Soule Glacier, in course of North Fork Soule River, $7 \mathrm{mi}$. W of Hyder, Coast Mts. ; 55 ${ }^{\circ} 3^{\prime}$ $30^{\prime \prime} \mathrm{N}, 130^{\circ} 12^{\prime} 30^{\prime \prime} \mathrm{W}$; (map 3).

Lncal name reported in 1955 by USGS.

No Name Lake: lake, $6 \mathrm{mi}$. NE of Grayling Hill, $53 \mathrm{mi}$. NE of Medfra, Kuskokwim Low.; $63^{\circ}$ $19^{\prime} \mathrm{N}, 153^{\circ} 07^{\prime} \mathrm{W}$; (map 89). 
Local name reported in 1958 by USGS.

No Name River: stream, see Penny River.

Nondalton: village, pop. 205, on $\mathrm{W}$ shore of Sixmile Lake, $15 \mathrm{mi}$. N of Iliamna, Alaska Ra.; 59 58' N, $154^{\circ} 51^{\prime}$ W ; BGN 1910; (map 51). Var. Nondalton Village, Noondalty Village.

Tanaina Indian namé recorded on a 1909 field sheet by D. C. Witherspoon, USGS. Nondalton post office was established in 1938 (Ricks, 1965, p. 47). See Sixmile Lake.

Nondalton Lake: lake, see Sixmile Lake.

Nondalton Village: village, see Nondalton.

Nondalty Lake: lake, see Sixmile Lake.

Nonvalnuk River: stream, see Nunavulnuk River.

Nonvianuk Lake: lake, $17 \mathrm{mi}$. long, near head of Alaska Penin., 48 mi. NW of Mount Katmai and $54 \mathrm{mi}$. NE of Naknek, Aleutian Ra.; 59 ${ }^{\circ}$ $00^{\prime \prime} \mathrm{N}, 155^{\circ} 20^{\prime} \mathrm{W}$; BGN 1957; (map 42). Var. Nanwhyenuk Lake.

Eskimo name reported in 1951 by USGS.

Nonvianuk River: stream, heads at Nonvianuk Lake, flows W $11 \mathrm{mi}$. to Alagnak River, 48 mi. SW of Kakhonak, Aleutian Ra.; $59^{\circ} 01^{\prime} 20^{\prime \prime}$ N, 155 $51^{\prime} 00^{\prime \prime}$ W; (map 51 ).

Eskimo name published in 1951 by USGS. Noobooa: island, see Barter Island.

Noocheck: bay, see Etches, Port.

Noocheek: locality, see Nuchek.

Noocleet: locality, see Nukleet.

Noocleet, Cape: point of land, see Denbigh, Cape.

Noodor Dome: mountain, 2,954 ft., $20 \mathrm{mi}$. SW of Mount Schwatka and $26 \mathrm{mi}$. NE of Livengood, Yukon-Tanana High.; $65^{\circ} 48^{\prime} 30^{\prime \prime}$ N, $147^{\circ} 56^{\prime}$ 00" W; (map 105).

Local name published by USGS in the 1950 's.

Nook: locality, see Kalulingmiut.

Nook: village, see Teller.

Nookak River: stream, see Reindeer River.

Nookati Greek: stream, heads in Kiana Hills, flows NE $7 \mathrm{mi}$. to Squirrel River, $8 \mathrm{mi}$. NNW of Deviation Peak and $25^{-} \mathrm{mi}$. NW of Kiana, Brooks Ra.; $67^{\circ} 10^{\prime} 30^{\prime \prime} \mathrm{N}, 161^{\circ} 10^{\prime} 30^{\prime \prime} \mathrm{W}$; (map 127).

Eskimo name obtained in 1955 by U.S. Army Corps of Engineers.

Nooke: village, see Teller.

Nookmut: village, see Teller.

Nookmute: locality, see Kalulingmiut.

Nookmute: village, 'see Teller.

Noolagvim Tessaya: lagoon, see Nulagvik Lagoon.

Nooluk River: stream, see Nuluk River.

Noo-na: locality, see Nuna.

Noona-agamute: locality, see Nuna.

Noonaghak Rock: rock, southernmost one of the Stolbi Rocks, in Bering Sea, $52 \mathrm{mi}$. SE of Gambell, NE of Saint Lawrence I.; $63^{\circ} 38^{\prime} \mathrm{N}$, $170^{\circ} 06^{\prime}$ W; (map 93). Var. Nunaghak Rock.

Eskimo name reported by Otto W. Geist, Univ. of Alaska, in 1932.

Noonaghak: rocks, see Stolbi Rocks.

Noona-mekrot: point of land, see Sheldon Point. Noon Creek: stream, flows SW $2.5 \mathrm{mi}$. to Tisuk
River, $16 \mathrm{mi}$. E of Cape Douglas and $40 \mathrm{mi}$. NW of Nome, Seward Penin. High.; 64 $59^{\prime}$ N, $166^{\circ} 10^{\prime} \mathrm{W}$; (map 94).

Prospectors' name published on the 1908 "Map of Seward Peninsula" by Arthur Gibson.

Noondalty Lake: lake, see Sixmile Lake.

Noondalty Village: village, see Nondalton.

Noon Gulch: ravine, trends to Albert Creek, 8 mi. N of Tahneta Pass, $62^{\circ} 00^{\prime} \mathrm{N}, 147^{\circ} 20^{\prime} \mathrm{W}$; (map 82).

Local name published by Theodore Chapin (in Brooks and others, 1915, p. 128), USGS.

Noon Point: point of land, $\mathrm{S}$ tip of Jacob I., 11 mi. E of Stepovak Bay, Aleutian Ra.; 55 $43^{\prime}$ $00^{\prime \prime}$ N, $159^{\circ} 23^{\prime} 30^{\prime \prime}$ W; (map 27). Var. Mys Poludennie.

Named by Lt. Woronkofski in 1837; published as "M[ys] Poludennie," or "noon point," on Russian Hydrog. Dept. Chart 1379 (1847). USC\&GS published the translated name in 1888.

Noon Point: point of land, E tip of Pleasant I., in Icy Strait, $40 \mathrm{mi}$. W of Juneau, St. Elias Mts.; $58^{\circ} 20^{\prime} 30^{\prime \prime} \mathrm{N}, 135^{\circ} 32^{\prime} 00^{\prime \prime} \mathrm{W}$; (map 11).

Name published by USC\&GS in the 1883 Coast Pilot (p. 190).

Noon Point: point of land, see Eightmile Point.

Noo-nuk-look: mountain, see Noonuklook Mountain.

Noonuklook Mountain: mountain, 1,000 ft., between Ikikileruk and Akulik Creeks, $5 \mathrm{mi}$. S of Chukchi Sea coast, $31 \mathrm{mi}$. NNW of Mount Kelly, Arctic Slope; $68^{\circ} 54^{\prime} \mathrm{N}, 164^{\circ} 00^{\prime} \mathrm{W}$; (map 130). Var. Noo-nuk-look.

Eskimo name reported in 1950 by USC\&GS as Noo-nuk-look [Nunakluk]. It may mean "bad land (country)."

Nooravloaksmiut Island: island, $0.2 \mathrm{mi}$. long, in Etolin Strait, $0.5 \mathrm{mi}$. off $\mathrm{E}$ coast of Nunivak I. ; $60^{\circ} 12^{\prime} 30^{\prime \prime} \mathrm{N}, 165^{\circ} 40^{\prime} 00^{\prime \prime} \mathrm{W}$; (map 57). Var. Nooravloaxmiut Island, Nuravloakh Island.

Eskimo name obtained in 1949 by USC\&GS,

Nooravloaxmiut Island: island, see Nooravloaksmiut Island.

Noorvik: village, pop. 384 , on right bank of Nazuruk Channel Kobuk River, $33 \mathrm{mi}$. NW of Selawik, Kotzebue-Kobuk Low.; $66^{\circ} 50^{\prime} \mathrm{N}$, $161^{\circ} 03^{\prime}$ W; BGN 1944; (map 114). Var. Nurvik, Oksik.

Eskimo village, at or near a camp or village, called "Oksik" on a manuscript map dated 1908 , by an unknown author. The Noorvik post office was established in 1937. Its population was 280 in $1920 ; 198$ in $1930 ; 211$ in 1939; and 248 in 1950.

Nooscha: bay, see Etches, Port.

Noovookiak, Cape: point of land, see Meruwtu Point.

Noovookiak Cape: point of land, see Agtapuk Point.

Noovougahlawk Point: point of land, see Nuvugalak Point.

Noowoo: locality, see Nuwuk.

Noowooh: locality, see Nuwuk.

Noowooh: point of land, see Barrow Point.
Noowook: locality, see Nuwuk.

Noowook: point of land, see Barrow Point.

Nooyakaglik: lakes, see Nuyakaglik Lakes.

Nooya Lake: lake, $2 \mathrm{mi}$. long, on mainland, 2 mi NE of Rudyerd Bay, Coast Mts.; $55^{\circ} 37^{\prime}$ N, $130^{\circ} 45^{\prime} \mathrm{W}$; (map 3).

Local name reported in 1955 by USGS.

Noquashinski Bay: water passage, see Nakwasina Passage.

Nora Creek: stream, flows NW $3 \mathrm{mi}$. to Flat Creek, $19 \mathrm{mi}$. $S$ of junc. of Charley and Yukon Rivers, Yukon-Tanana High.; 65 ${ }^{\circ} 03^{\prime}$ N, $142^{\circ} 48^{\prime}$ W; (map 103).

Prospectors' name from an unpublished map by E. J. Chamberlain, dated 1902 .

Norak Lake: lake, $0.9 \mathrm{mi}$. long, on Kenai Penin. SW of Phalarope Lake, $9.3 \mathrm{mi}$. SSW of Point Possession and $38 \mathrm{mi}$. NE of Kenai, Cook Inlet Low.; $60^{\circ} 54^{\prime} \mathrm{N}, 150^{\circ} 25^{\prime} \mathrm{W}$; (map 62).

Named about 1963 by officials of Kenai National Moose Range, for administrative purposes.

Norberg Creek: stream, flows NW $1.3 \mathrm{mi}$. to Macklin Creek, $7 \mathrm{mi}$. SW of Midnight Mtn. and $48 \mathrm{mi}$. NW of Imuruk Lake, Seward Penin. High.; $65^{\circ} 45^{\prime}$ N, $164^{\circ} 49^{\prime}$ W; (map 110). Var. Stevens Creek.

Prospectors' name published in 1955 by USGS. Reported as "Stevens Creek" on the "Map of Seward Peninsula" by Monroe and Hutchins, corrected up to 1903 by Arthur Gibson.

Norcross Island: island, see Jackson Island.

Nord, Cap du haut-fond: point of land, see Romanof Point.

Nord Island: island, $0.5 \mathrm{mi}$. across, in Gulf of Alaska, northernmost of Barren Is., $1.5 \mathrm{mi}$. off NE coast of Ushagat I., $72 \mathrm{mi}$. NE of Afognak, Chugach Mts. ; 58 $58^{\prime} 15^{\prime \prime} \mathrm{N}, 152^{\circ}$ $09^{\prime} 00^{\prime \prime} \mathrm{W}$; (map 43).

Named in 1908 and published in 1910 by USC\&GS. It is a French word meaning "north."

Nordyke Island: island, $0.5 \mathrm{mi}$. across, largest of Nordyke Is., in Kamishak Bay, $27 \mathrm{mi}$. SW of Augustine I., Aleutian Ra.; $59^{\circ} 10^{\prime} 45^{\prime \prime} \mathrm{N}$, $154^{\circ} 05^{\prime} 15^{\prime \prime} \mathrm{W}$; (map 51).

Name published by USGS in 1927.

Nordyke Islands: group of islands, in Kamishak Bay, $5 \mathrm{mi}$. NE of McNeil Head, $27 \mathrm{mi}$. SW of Augustine I., Aleutian Ra.; $59^{\circ} 10^{\prime} 40^{\prime \prime} \mathrm{N}$, $154^{\circ} 05^{\prime} 15^{\prime \prime} \mathrm{W}$; (map 51).

Local name reported by K. F. Mather, USGS, in 1923 (in Brooks and others, 1925, pl. 3).

Norfolk Sound: water passage, see Sitka Sound.

Noriega, Punta: point of land, "south side of San Juan Bautista Island in Bucareli Bay," Alex. Arch.; $55^{\circ} 24^{\prime} \mathrm{N}, 133^{\circ} 18^{\prime} \mathrm{W}$; (map 4).

Named by members of the 1779 Don Ignacio Arteaga expedition probably for a chaplain aboard the vessel La Princesa.

Norma Lagoon: bay, $3 \mathrm{mi}$. across, at $\mathrm{SW}$ end of Izembek Lagoon, $13 \mathrm{mi}$. W of village of Cold Bay, Bristol Bay Low.; $55^{\circ} 12^{\prime} \mathrm{N}, 163^{\circ} 02^{\prime} \mathrm{W}$; $B G N$ 1965; (map 29). 
Named in 1888 by USBF.

Norris Glacier: glacier, heads in North Branch Norris Glacier, trends $8 \mathrm{mi}$. SE to Grizzly Bar on Taku Inlet, $2.4 \mathrm{mi}$. W of Taku Point and $14 \mathrm{mi}$. NE of Juneau, Coast Mts. ; $58^{\circ} 24^{\prime} 15^{\prime \prime}$ $\mathrm{N}, 134^{\circ} 05^{\prime} 00^{\prime \prime} \mathrm{W}$; $B G N$ 1905; (map 11). Var. Kadischle, Sitth Kadischle, Windom Glacier.

Probably named in 1886 by navy officers for Dr. Basil Norris, surgeon, USN. In 1890 USC\&GS called it "Windom Glacier" for William Windom, 1827-91, lawyer and statesman, who was congressman and senator from Ohio and Secretary of the Treasury under Presidents Garfield and Harrison. The report by C. W. Wright, USGS, that the name "Norris Glacier" represented local usage, persuaded BGN to rule in its favor in 1905 . Miss E. R. Scidmore $(1899$, p. 81$)$ gives the Indian name as "Kadischle."

Norris Mountain: mountain, 4,125 ft., near 1962 terminus of Norris and Taku Glaciers, $3.4 \mathrm{mi}$. NW of Grizzly Bar on Taku Inlet and 14 mi. NE of Juneau, Coast Mts. ; $58^{\circ} 26^{\prime} 50^{\prime \prime} \mathrm{N}$, $134^{\circ} 08^{\prime} 20^{\prime \prime} \mathrm{W}$; (map 11).

Name proposed in 1964 by members of the Juneau Icefield Research Project; derived from No:ris Glacier.

Norris Outwash: moraine, see Grizzly Bar.

Norris-Taku Ridge: ridge, $11 \mathrm{mi}$. long, extending from Taku Inlet $\mathbf{N}$ to Taku Glacier, $3 \mathrm{mi}$. $\mathrm{SE}$ of Juncture Peak and $17 \mathrm{mi}$. NE of Juneau, Coast Mts.; $58^{\circ} 30^{\prime} \mathrm{N}, 134^{\circ} 08^{\prime} \mathrm{W}$; (map 11).

Local name reported in 1965 by $D$. A. Brew and A. B. Ford, USGS.

Norse Cove: cove, see Kernel Gove.

Norseman Lake: lake, $0.6 \mathrm{mi}$. across, just $\mathrm{W}$ of Asigyukpak Spit near the shore of Bristol Bay, $2 \mathrm{mi}$. W of Hagemeister I., Kilbuck-Kuskokwim Mts.; 58 $39^{\prime} 30^{\prime \prime}$ N, $161^{\circ} 24^{\prime} 30^{\prime \prime} \mathrm{W}$; (map 39).

Local name published in 1952 by USGS; probably named for a kind of airplane.

Norseman Lake: lake, $0.5 \mathrm{mi}$. long, $\mathrm{W}$ of junc. of Stokhenjikh Creek and Melozitna River, $50 \mathrm{mi}$. NW of Tanana, Kokrines-Hodzana High.; $65^{\circ} 47^{\prime} 30^{\prime \prime} \mathrm{N}, 152^{\circ} 56^{\prime} 00^{\prime \prime} \mathrm{W}$; (map 106).

Local name reported in 1956 by Orth; so named because a Norseman (airplane) landed here.

Nor-tah-rok-tah: lake, see Nutuvukti Lake.

North, Cape: point of land, see Barrow Point.

North Alak Hills: mountain, see North Aluk Hill.

North Aluk Hill: mountain, 1,198 ft., at head of Nilik River, $28 \mathrm{mi}$. ESE of Cape Lisburne, Arctic Slope; $68^{\circ} 46^{\prime} 55^{\prime \prime} \mathrm{N}, 165^{\circ} 06^{\prime} 50^{\prime \prime} \mathrm{W}$; (map 129). Var. North Alak Hills.

See South Aluk Hill.

North Anchorage: anchorage, off Saint George, on $\mathbf{N}$ coast of Saint George I., in Pribilof Is. $56^{\circ} 36^{\prime} 20^{\prime \prime} \mathrm{N}, 169^{\circ} 33^{\prime} 00^{\prime \prime} \mathrm{W}$; (map 38).

A local name reported in 1875 by USC\&GS.

North Arcuate Ridge: ridge, on N side of Okmok Caldera, on NE part of Umnak I., Aleutian Is.; $54^{\circ} 29^{\prime} \mathrm{N}, 168^{\circ} 09^{\prime} \mathrm{W}$; (map 22).

Name published by Byers (1959, pl. 41), USGS.
North Arm: bay, $1 \mathrm{mi}$. across, extends N $3 \mathrm{mi}$. from Farragut Bay, $2.5 \mathrm{mi}$. NW of Read I. $81 \mathrm{mi}$. E of Coast Mts. ; $57^{\circ} 10^{\prime} \mathrm{N}, 133^{\circ} 15^{\prime} \mathrm{W}$ (map 8).

Local name reported in 1951 by USGS.

North Arm: estuary, see West Arm Bay of Isles. North Arm Bay of Pillars: bay, see Rowan Bay. North Arm Cabin Cove: cove, see Upper Arm Cabin Cove.

North Arm Creek: stream, flows SE $5 \mathrm{mi}$. to North Arm Stikine River opposite Limb I., $15 \mathrm{mi}$. N of Wrangell, Coast Mts. ; $56^{\circ} 41^{\prime} 00^{\prime \prime}$ $\mathrm{N}, 132^{\circ} 18^{\prime} 30^{\prime \prime} \mathrm{W}$; (map 6).

Local name recorded in 1953 by USGS.

North Arm Duncan Canal: estuary, $5 \mathrm{mi}$. long, at head of Duncan Canal, $12 \mathrm{mi}$. W of Petersburg, on Kupreanof I., Alex. Arch.; 56 $48^{\prime}$ $\mathrm{N}, 133^{\circ} 17^{\prime} \mathrm{W}$; (map 6$)$.

Local name recorded in 1960 by USGS.

North Arm Hood Bay: estuary, 5 mi. across, entering Hood Bay, $11 \mathrm{mi}$. SE of Angoon, on Admiralty I., $1 \mathrm{i} \mathrm{mi}$. SE of Angoon, Alex. Arch.; $57^{\circ} 23^{\prime} \mathrm{N}, 134^{\circ} 23^{\prime} \mathrm{W}$; (map 9).

Name published in 1910 by USC\&GS on Chart 8247.

North Arm Hoonah Sound: estuary, $1.5 \mathrm{mi}$. across, $12 \mathrm{mi}$. long, on Chichagof I., $19 \mathrm{mi}$. E of Chichagof, Alex. Arch.; $57^{\circ} 40^{\prime} \mathrm{N}, 135^{\circ} 35^{\prime}$ W; (map 9).

Named in 1899 by USC\&GS and published on Chart 8050

North Arm Moira Sound: estuary, extends NW $4 \mathrm{mi}$., off Moira Sound, on SE coast of Prince of Wales I., Alex. Arch.; $55^{\circ} 04^{\prime} 30^{\prime \prime}$ N; $132^{\circ}$. 04'30" W; (map 4).

Named in 1894 by USC\&GS.

North Arm Naknek Lake: $b a y$, extends E $20 \mathrm{ml}$. off Naknek Lake, on Alaska Penin., in Katmai National Monument, $33 \mathrm{mi}$. NW of Mount Katmai, Aleutian Ra.; $58^{\circ} 39^{\prime} \mathrm{N}, 155^{\circ} 47^{\prime} \mathrm{W}$; (map 42). Var. Bay of Islands.

Local name reported in 1951 by USGS.

North Arm Nuka Bay: estuary, $1.5 \mathrm{mi}$. wide, on SE coast of Kenai Penin., $35 \mathrm{mi}$. ESE of Homer, Chugach Mts. ; 59 $32^{\prime} \mathrm{N}, 150^{\circ} 35^{\prime} \mathrm{W}$; (map 50).

Local name reported by U. S. Grant and D. F. Higgins, USGS, in 1909 (in Brooks and others, 1910, pl. 3).

North Arm Stikine River: stream, flows W $11 \mathrm{mi}$. from Stikine River to Frederick Sound, $8 \mathrm{mi}$. SE of Petersburg, Coast Mts.; 56 $41^{\prime} 30^{\prime \prime} \mathrm{N}$, $132^{\circ} 32^{\prime} 00^{\prime \prime} \mathrm{W}$; (map 6$)$.

Local name recorded in 1951 by USGS.

North Arm Three Arm Bay: bay, $0.4 \mathrm{mi}$. across, part of Three Arm Bay, on W coast of Adak I., Aleutian Is.; $51^{\circ} 45^{\prime} 40^{\prime \prime} \mathrm{N}, 176^{\circ} 51^{\prime} 40^{\prime \prime} \mathrm{W}$; BGN 1936; (map 17).

Descriptive name given by Lt. William Gibson, USN. See Low Point.

North Baird Glacier: glacier, heads at $57^{\circ} 20^{\prime} \mathrm{N}$, $132^{\circ} 35^{\prime} \mathrm{W}$, trends $\mathrm{S} 15 \mathrm{mi}$. to Baird Glacier, $3 \mathrm{mi}$. NE of Thomas Bay and $95 \mathrm{mi}$. $E$ of Sitka, Coast Mts.; $57^{\circ} 08^{\prime} \mathrm{N}, 132^{\circ} 47^{\prime} \mathrm{W}$; (map 8).

Name published in 1952 by USC\&GS.

North Bay: cove, extends SW $1.8 \mathrm{mi}$. from Tlevak Strait, on NE coast of Dall I., Alex.
Arch.; 55 $13^{\prime} \mathrm{N}, 133^{\circ} 06^{\prime} \mathrm{W}$; (map 4).

Descriptive name given in 1881 by Lt. Comdr. H. E. Nichols, USN.

North Bay: bay, 5 mi. across, on $\mathbf{N}$ coast of Saint Paul I., in Pribilof Is.; $57^{\circ} 13^{\prime} \mathrm{N}, 170^{\circ} 13^{\prime} \mathrm{W}$; (map 38).

A local name reported in 1890 by USC\&GS. North Bay: bight, $2.6 \mathrm{mi}$. across, on $\mathbf{N}$ coast of Stuart I., $16 \mathrm{mi}$. NW of St. Michael, YukonKuskokwim Delta; 63 $38^{\prime} \mathrm{N}, 162^{\circ} 28^{\prime} \mathrm{W}$; (map 92).

Named in 1898 by USC\&GS.

North Beach: beach, $4 \mathrm{mi}$. long, on $\mathrm{N}$ coast of Saint Paul I., in Pribilof Is.; $57^{\circ} 12^{\prime} 40^{\prime \prime} \mathrm{N}$, $170^{\circ} 13^{\prime} 20^{\prime \prime} \mathrm{W}$; (map 38).

A local name reported in 1965 by USBF.

North Bight: $b a y, 0.5 \mathrm{mi}$. across, on $W$ shore of Port Frederick, Chichagof I., just S of Neka Bay and $9.3 \mathrm{mi}$. SW of Hoonah, Alex. Arch.; $58^{\circ} 01^{\prime} 45^{\prime \prime} \mathrm{N}, 135^{\circ} 38^{\prime} 45^{\prime \prime} \mathrm{W}$; (map 11).

Descriptive local name published in 1942 by USGS.

North Bradfield River: stream, see North Fork Bradfield River.

North Branch Norris Glacier: glacier, heads $\mathrm{N}$ of Guardian Mtn. and trends S $4 \mathrm{mi}$. to form Norris Glacier, $12 \mathrm{mi}$. NE of Juneau, Coast Mts.; $58^{\circ} 30^{\prime} \mathrm{N}, 134^{\circ} 12^{\prime} \mathrm{W} ; B G N$ 1965; (map 11).

Named in 1964 by members of the Juneau Icefield Research Project.

North Branch Saint Michael Canal: water course, see Little Saint Michael Canal.

North Branch South Fork Chester Creek: stream, flows SW 1 mi. to South Fork Chester Creek in Anchorage, Cook Inlet Low.; 61 $11^{\circ} 07^{\prime \prime} \mathrm{N}$, $149^{\circ} 47^{\prime} 56^{\prime \prime}$. W; (map 69).

Local name published in 1954 by Northwest Mapping Service, Seattle, Wash.

North Branch Steelhead Creek: stream, see Topsy Creek.

North Branch Taku Glacier: glacier, see Matthes Glacier.

North Branch Trimble Glacier: glacier, in Tordrillo Mts., heads on Mount Gerdine, trends NE 15 mi., joins South Branch Trimble Glacier to form Trimble Glacier, $55 \mathrm{mi}$. NW of Tyonek, Alaska Ra.; $61^{\circ} 42^{\prime} 30^{\prime \prime} \mathrm{N}$, $152^{\circ} 06^{\prime} 30^{\prime \prime} \mathrm{W}$; BGN 1963; (map 70). Var. Hayes Glacier.

Named in 1961 by USGS. See Trimble Glacier.

North Burnett Island: island, $0.4 \mathrm{mi}$. long, on $\mathrm{E}$ shore of Burnett Inlet, on SW coast of Etolin I., Alex, Arch.; $56^{\circ} 04^{\prime} 20^{\prime \prime} \mathrm{N}, 132^{\circ} 27^{\prime} 30^{\prime \prime} \mathrm{W}$; BGN 1917; (map 6).

Named by USC\&GS for charting purposes; name published in 1916 .

North Buttress: mountain, $9,828 \mathrm{ft}$, , near headwaters of Big River, $93 \mathrm{mi}$. SE of McGrath, Alaska Ra.; $61^{\circ} 48^{\prime} 10^{\prime \prime}$ N, $154^{\circ} 08^{\prime} 40^{\prime \prime} \mathrm{W}$; (map 71).

Local name reported in 1958 by USGS.

North Cape: point of land, on $\mathrm{N}$ tip of Kanaga I., Aleutian Is.; $51^{\circ} 56^{\prime} 30^{\prime \prime} \mathrm{N}, 177^{\circ} 09^{\prime} 20^{\prime \prime} \mathrm{W}$; $B G N$ 1936; (map 17).

Descriptive name given by Lt. William Gibson, USN. See Low Point. 
North Cape: point of land, on $\mathbf{N}$ tip of Atka I., Aleutian Is.; $52^{\circ} 25^{\prime} \mathrm{N}, 174^{\circ} 09^{\prime} \mathrm{W}$; (map 18). Var. Sievernoi.

Name published as "M[ys] Sievernoi," meaning "north cape," by Capt. Tebenkov (1852, map 27) IRN.

North Cape: point of land, $\mathbf{N}$ point of entrance to Whale Bay, on SW coast of Baranof I., Alex. Arch.; $56^{\circ} 35^{\prime} 45^{\prime \prime} \mathrm{N}, 135^{\circ} 08^{\prime} 15^{\prime \prime} \mathrm{W}$; (map 5). Var. N Mys.

Name published by USC\&GS in 1883 Coast Pilot (p. 133) ; derived from "N Mys" published in 1850 by the Russian American Company.

North Cape: point of land, $\mathrm{N}$ tip of Spruce I., $\mathrm{NE}$ of Kodiak I.; $57^{\circ} 58^{\prime} 00^{\prime \prime} \mathrm{N}, 152^{\circ} 25^{\prime} 30^{\prime \prime}$ W; (map 34). Var. Mys Syvernyy, Sievernie.

Translation of the descriptive name "M[ys] Syvernyy" given by Sub-Lt. Mikhail Murashev in 1839 or 1840 and published in 1849 on Russian Hydrog. Dept. Chart 1425.

North Cape: point of land, see Hall, Cape.

North Cape: point of land, see North Head.

North Cape: point of land, see Savoonga Point. North Cape: point of land, see Stag Point.

North Capps Creek: stream, flows NE $5 \mathrm{mi}$. to Capps Creek, $25 \mathrm{mi}$. NW of Tyonek, Cook Inlet Low.; $61^{\circ} 19^{\prime} 00^{\prime \prime} \mathrm{N}, 151^{\circ} 40^{\prime} 50^{\prime \prime} \mathrm{W}$; $B G N$ 1964; (map 70). Var. North Fork Capps Creek.

Named in 1963 by USGS.

North Channel Kiwalik River: stream, a distributary of Kiwalik River, flows NE $3 \mathrm{mi}$. to Kiwalik Lagoon, $56 \mathrm{mi}$. NW of Haycock, Seward Penin. High; $65^{\circ} 58^{\prime} \mathrm{N}, 161^{\circ} 50^{\prime} \mathrm{W}$; (map 109).

Local name published on maps after 1950 .

North Channel Yakataga River: stream, heads at terminus of Yakataga Glacier, flows W and SW 9 mi. to Duktoth River, $4 \mathrm{mi}$. NW of Cape Yakataga and $104 \mathrm{mi}$. NW of Yakutat, St. Elias Mts.; $60^{\circ} 06^{\prime} 00^{\prime \prime} \mathrm{N}, 142^{\circ} 30^{\prime} 30^{\prime \prime}$ W; (map 65). Var. Yakataga River.

Local name published in 1951 by the USGS.

North Cove: cove, $1 \mathrm{mi}$. across, $\mathrm{N}$ Kagamil $\mathrm{I}$., $40 \mathrm{mi}$. W of Umnak I., Aleutian Is.; $53^{\circ} 01^{\prime}$ 35" N, $169^{\circ} 43^{\prime} 30^{\prime \prime}$ W; (map 22).

Descriptive name published by USC\&GS in 1944 Aleutian Coast Pilot (p. 74).

North Creek: stream, flows $\mathrm{N}$ from Shishaldin Volcano $13 \mathrm{mi}$. to Bering Sea, on $\mathrm{N}$ central coast of Unimak I., Aleutian Is.; $54^{\circ} 54^{\prime} 23^{\prime \prime}$ $\mathrm{N}, 163^{\circ} 59^{\prime} 00^{\prime \prime} \mathrm{W}$; (map 25).

Descriptive name published in 1949 on a USGS map.

North Creek: stream, heads in Horn Mts., flows $\mathrm{SE} 3 \mathrm{mi}$. to Crooked Creek, $8.5 \mathrm{mi}$. $\mathrm{N}$ of Tahneta Pass, Talkeetna Mts.; 62 $00^{\circ} 36^{\prime \prime} \mathrm{N}$, $147^{\circ} 17^{\prime} 00^{\prime \prime} \mathrm{W}$; (map 82).

Local name recorded in 1949 by USGS.

North Creek: stream, flows NE $13 \mathrm{mi}$. to Agiapuk River, $20 \mathrm{mi}$. NE of Teller, Seward Penin. High.; $65^{\circ} 27^{\prime} \mathrm{N}, 165^{\circ} 50^{\prime} \mathrm{W}$; (map 111).

Prospectors' name reported in 1901 by T. G. Gerdine (in Collier, 1902, pl. 12), USGS.
North Crillon Glacier: glacier, in Glacier Bay National Monument, heads on $\mathrm{W}$ slope of Fairweather Ra., trends SW 9 mi. to its 1961 terminus on Crillon Inlet, $80 \mathrm{mi}$. NW of Hoonah, St. Elias Mts.; $58^{\circ} 38^{\prime} 45^{\prime \prime} \mathrm{N}, 137^{\circ}$ $27^{\prime} 30^{\prime \prime}$ W; BGN 1945; (map 10). Var. Crillon Glacier, North Eastern Glacier.

Called "Crillon Glacier" by W. H. Dall, USC\&GS, in 1874 for Mount Crillon. At that time, Crillon Glacier was much more extensive and joined La Perouse Glacier near the latter's terminus. Since 1874 the Crillon Glacier has retreated, uncovering the valley now occupied by Crillon Lake. The glacier has dwindled to become two smaller glaciers; the one on the $\mathrm{N}$, terminating in Crillon Inlet, is called North Crillon Glacier.

North Dawes Glacier: glacier, heads on Alaska Canada boundary at $57^{\circ} 40^{\prime} \mathrm{N}, 132^{\circ} 50^{\prime} \mathrm{W}$, trends SW to Endicott Arm, $5 \mathrm{mi}$. WNW of Dawes Glacier and $95 \mathrm{mi}$. NE of Sitka, Coast Mts.; $57^{\circ} 34^{\prime} \mathrm{N}, 133^{\circ} 01^{\prime} \mathrm{W}$; (map 8).

Local name reported in 1961 by USGS.

North Deception Lake: lake, $1 \mathrm{mi}$. long, in Glacier Bay National Monument, alongside Brady Glacier, $1 \mathrm{mi}$. N of South Deception Lake and $53 \mathrm{mi}$. NW of Hoonah, St. Elias Mts.; $58^{\circ} 23^{\prime} 45^{\prime \prime} \mathrm{N}, 136^{\circ} 46^{\prime} 30^{\prime \prime} \mathrm{W}$; BGN 1962; (map 10).

Named by NPS in 1961 because it is a "selfdumping" lake, and for a period once each year it disappears.

North Dome: mountain, 2,700 ft., in Glacier Bay National Monument, $0.9 \mathrm{mi}$. E of Crillon Lake and $76 \mathrm{mi} \mathrm{NW}$ of Hoonah, St. Elias Mts.; $58^{\circ} 33^{\prime} 35^{\prime \prime} \mathrm{N}, 137^{\circ} 20^{\prime} 40^{\prime \prime} \mathrm{W}$; (map 10).

Name published by the Harvard-Dartmouth expedition, 1933-34, Washburn and Goldthwait, 1936, map).

Northeast Anchorage: cove, see Izhiga Cove.

North East Arm: estuary, see Nunatak Fiord.

Northeast Arm: estuary, trends SW $1 \mathrm{mi}$. to Mummy Bay, at $\mathrm{S}$ end of Knight I., $11 \mathrm{mi}$. SE of Chenega, Chugach Mts.; $60^{\circ} 13^{\prime} 45^{\prime \prime} \mathrm{N}$, $147^{\circ} 47^{\prime} 30^{\prime \prime} \mathrm{W}$; (map 63).

Descriptive name published in 1911 by USC\&GS

Northeast Arm Uganik Bay: bay, extends inland SE 8.5 mi., on $N$ coast of Kodiak I.; $57^{\circ} 47^{\prime}$ $\mathrm{N}, 153^{\circ} 29^{\prime} \mathrm{W}$; (map 34).

Descriptive name given in 1897 by Lt. Comdr. J. F. Moser, USN, of the USBF steamer Albatross.

Northeast Bay: $b a y, 1.7 \mathrm{mi}$. across, on $\mathrm{N}$ shore of Iliamna Lake, $5 \mathrm{mi}$. E of Iliamna, Aleutian Ra.; 59 $46^{\prime} \mathrm{N}, 154^{\circ} 46^{\prime} \mathrm{W}$; (map 51 ).

Local name published in 1954 by USGS.

Northeast Bight: bay, $2 \mathrm{mi}$. across, on NE coast of Nagai I., in Shumagin Is., Aleutian Ra.; $55^{\circ} 10^{\prime} \mathrm{N}, 159^{\circ} 53^{\prime} \mathrm{W}$; (map 27). Var. North East Bight.

Named in 1916 by USC\&GS.

Northeast Bluff: promontory, $500 \mathrm{ft}$., $3.5 \mathrm{mi}$. long, between Austin Cove and Holtz Bay, on $\mathrm{N}$ coast of Attu I., Aleutian Is. ; $52^{\circ} 59^{\prime} 40^{\prime \prime}$ N, 173 $07^{\prime} 30^{\prime \prime} \mathrm{E}$; (map 13).

Name given by Lt. William Gibson, USN, who commanded the schooner U.S.S. Feni- more Cooper, during the North Pacific Exploring Expedition in 1855.

Northeast Branch Taku Glacier: glacier, see Demorest Glacier.

Northeast Cape: locality, pop. 20, on Northeast Cape, at E end of St. Lawrence I.; 63 ${ }^{\circ} 18^{\prime}$ N, 168 $42^{\prime}$ W; (map 93). Var. North East Gape.

Local name reported in 1961 as "North East Cape" (Rand McNally, 1961, p. 58).

Northeast Cape: point of land, about $2 \mathrm{mi}$. NE of base of Seevookhan Mtn. at E end of St. Lawrence I.; $63^{\circ} 18^{\prime} \mathrm{N}, 168^{\circ} 42^{\prime} \mathrm{W} ; B G N$ 1951; (map 93). Var. Cape Anderson, Cape Chichmareff, Cape Seevooka, Cape Sevookak, Cape Sevuokuk, Cape Shishmaref, Cape Shishmarev, Sevooka Cape, Sevuokaa Cape, Sevuokok Cape, Sevuokuk Point.

Descriptive name given in 1849 by Capt. Tebenkov (1852, map 3), IRN. Russian Hydrog. Dept. Chart 1455 (edition of 1852) shows it as "Cape Anderson," thus attempting to preserve the name Capt. James Cook, RN, gave to St. Lawrence Island in 1778. Adm. A. J. von Krusenstern, IRN, in his Hydrographic Memoirs, named it "Shishmarev," for Capt. Lt. Glieb Semeonovich Shishmarev, who surveyed St. Lawrence Island in 1821.

North East Cape: locality, see Northeast Cape.

Northeast Cape: point of land, see Krugloi Point.

Northeast Cove: estuary, on W coast of Knight I., extends NW $0.5 \mathrm{mi}$. to Drier Bay, $12 \mathrm{mi}$. $\mathrm{NE}$ of Chenega, Chugach Mts. ; $60^{\circ} 19^{\prime} 20^{\prime \prime} \mathrm{N}$, $147^{\circ} 44^{\prime} 45^{\prime \prime} \mathrm{W}$; (map 63).

Descriptive name reported in 1908 by U. S. Grant and D. F. Higgins (in Brooks and others, 1909, pl. 4), USGS.

Northeast Creek: stream, on Alaska Penin., flows SW $5 \mathrm{mi}$. to Amber Bay, $10.5 \mathrm{mi}$. NW of Cape Kunmik, Aleutian Ra.; $56^{\circ} 52^{\prime} \mathrm{N}, 157^{\circ} 24^{\prime}$ W; (map 31).

Local descriptive name reported in 1951 by USGS.

North Eastern Glacier: glacier, see North Crillon Glacier.

Northeast Fork Kahiltna Glacier: glacier, trends W $4 \mathrm{mi}$. on $\mathbf{N}$ side of Kahiltna Peaks from Kahiltna Notch to Kahiltna Glacier, Alaska Ra.; 63 ${ }^{\circ} 02^{\prime} \mathrm{N}, 151^{\circ} 10^{\prime} \mathrm{W}$; (map 88).

Mountain climbers' name published in 1954 by USGS.

Northeast Harbor: harbor, $1 \mathrm{mi}$. across, on SE coast of Sanak I., in Sanak Is., Aleutian Ra.; $54^{\circ} 26^{\prime} 30^{\prime \prime} \mathrm{N}, 162^{\circ} 35^{\prime} 00^{\prime \prime} \mathrm{W}$; (map 25).

Descriptive name reported by Ferdinand Westdahl, USC\&GS commander of the Coast Survey steamer McArthur, who made surveys in this area in 1901.

Northeast Harbor: bay, $3 \mathrm{mi}$. across, on $\mathrm{W}$ coast of Little Koniuji I., in Shumagin Is., Aleutian Ra.; $55^{\circ} 00^{\prime} \mathrm{N}, 159^{\circ} 26^{\prime} \mathrm{W}$; (map 26 ).

Local name published in 1875 by $W$. $H$. Dall, USC\&GS.

Northeast Harbor: bay, $1.5 \mathrm{mi}$. across, on W coast of Kodiak I., $5.5 \mathrm{mi}$. NE of Karluk; $57^{\circ} 37^{\prime} 50^{\prime \prime} \mathrm{N}, 154^{\circ} 21^{\prime} 00^{\prime \prime} \mathrm{W}$; (map 35). 
Descriptive name reported in 1899 by $\mathrm{Lt}$. Comdr. Jefferson F. Moser, USN, commander of the USBF steamer Albatross.

Northeast Point: point of land, on NE coast of Semisopochnoi I., Aleutian Is.; $52^{\circ} 00^{\prime} 40^{\prime \prime} \mathrm{N}$, $179^{\circ} 41^{\prime} 00^{\prime \prime} \mathrm{E}$; (map 15).

Name published on a 1943 U.S. Army Corps of Engineers map.

Northeast Point: point of land, on $\mathbf{N}$ shore of Northeast Harbor, on SE coast of Sanak I., in Sanak Is., Aleutian Ra.; $54^{\circ} 27^{\prime} \mathrm{N}, 162^{\circ} 35^{\prime}$ W; (map 25).

Descriptive name given by $W$. H. Dall, USC\&GS, and published in 1882 on USC\&GS Chart 806.

Northeast Point: point of land, on NE tip of Saint Paul I., in Pribilof Is., Aleutian Is.; $57^{\circ}$. $14^{\prime} 50^{\prime \prime} \mathrm{N}, 170^{\circ} 05^{\prime} 50^{\prime \prime} \mathrm{W}$; (map 38). Var. Mys Vostochnyy, Vostochnie Point.

Local descriptive name published by Tikhmeniev (1861, map) as "M[ys] Vostochnyy" meaning "east cape," and by USC\&GS in 1875 as "Northeast Point."

Northeast Point: point of land, on NE tip of Khantaak I., in Yakutat Bay, 2 mi. W of Oatmeal $\mathrm{I}$. and $6 \mathrm{mi}$. $\mathrm{N}$ of Yakutat, Malaspina Coastal Plain; $59^{\circ} 38^{\prime} 20^{\prime \prime} \mathrm{N}, 139^{\circ} 43^{\prime} 05^{\prime \prime} \mathrm{W}$; (map 46). Var. Mys NO.

Named "Mys NO" by Capt. Tebenkov (1852 map 7) and interpreted by Baker (1906, p. 468) to mean "northeast cape."

Northeast Rocks: rocks, elev. $115 \mathrm{ft}$., in Bering Sea on NE coast of Kiska I,, 3 mi. E of Kiska Volcano, Aleutian Is.; $52^{\circ} 05^{\prime} 50^{\prime \prime} \mathrm{N}, 177^{\circ}$ $40^{\prime} 45^{\prime \prime} \mathrm{E}$; (map 14). Var. Mallard Rocks.

Name shown on a 1943 AMS map; variant shown on a 1943 USAAF map.

North East Rookery: rookery, see Vostochnie Rookery.

Northeast Twin: peak, 2,185 ft., on Twin Mtn., $9 \mathrm{mi}$. N of Tooth Mtn. and $20 \mathrm{mi}$. N of Goodnews, Kilbuck-Kuskokwim Mts.; 59 $23^{\prime} \mathrm{N}$, $161^{\circ} 42^{\prime} \mathrm{W}$; (map 53). Var. N. E. Twin.

Descriptive name given in 1914 by USC\&GS, published in 1915 on Chart 9103.

North Entrance: water passage, on $\mathrm{W}$ coast of Prince of Wales I., connects Big Salt Lake and Shinaku Inlet, $3.5 \mathrm{mi}$. N of Klawock, Alex. Arch.; $55^{\circ} 36^{\prime} 30^{\prime \prime} \mathrm{N}, 133^{\circ} 07^{\prime} 30^{\prime \prime} \mathrm{W}$; (map 4).

Local name recorded in 1949 by USGS.

Northerly Island: island, $0.3 \mathrm{mi}$. Iong, in St. John Harbor, on NW coast of Zarembo I., Alex. Arch.; $56^{\circ} 26^{\prime} 50^{\prime \prime} \mathrm{N}, 132^{\circ} 58^{\prime} 20^{\prime \prime} \mathrm{W}$; (map 6).

Descriptive name given in 1884 by officers of U.S.S. Adams.

Northern Strait: water passage, see Kupreanof Strait.

North Flat: tidal flat, $1 \mathrm{mi}$. long, in Wrangell Narrows, on W coast of Mitkof I., $8 \mathrm{mi}$. S of Petersburg, Alex. Arch.; 56 $41^{\circ} 30^{\prime \prime} \mathrm{N}$, $132^{\circ} 56^{\prime} 30^{\prime \prime} \mathrm{W}$; (map 6). Var. Wrangell North Flat.

This feature was originally called "Wrangell North Flat" in 1869 by Comdr. R. W. Meade, USN. Local usage shortened the name.
North Foreland: point of land, on NW shore of Cook Inlet, $2 \mathrm{mi}$. $\mathrm{S}$ of Tyonek, Cook Inlet Low.; $61^{\circ} 02^{\prime} 50^{\prime \prime} \mathrm{N}, 151^{\circ} 09^{\prime} 40^{\prime \prime} \mathrm{W}$; (map 70).

Named April 18, 1794, by Capt. George Vancouver, $\mathbf{R N}$.

North Fork: locality, see Fortymile.

North Fork Anchor River: stream, on Kenai Penin., flows W $15 \mathrm{mi}$. to Anchor River at village of Anchor Point, $14 \mathrm{mi}$. NW of Homer, Cook Inlet Low.; $59^{\circ} 46^{\prime} 30^{\prime \prime} \mathrm{N}, 151^{\circ}$ $50^{\prime} 00^{\prime \prime} \mathrm{W}$; (map 50).

Local name published on maps after 1950. North Fork Aniakchak River: stream, on Alaska Penin., flows $S 9 \mathrm{mi}$., joins the main stream $7 \mathrm{mi}$. above its mouth, $18 \mathrm{mi}$. W of Cape Kunmik, Aleutian Ra.; $56^{\circ} 48^{\prime} \mathrm{N}, 1^{\circ} 7^{\circ} 39^{\prime} \mathrm{W}$; (map 31).

Local name reported in 1924 by $R, H$. Sargent, USGS, and shown on a 1924 USGS map.

North Fork Baker Creek: stream, flows SE 13 mi. to Baker Creek, $5 \mathrm{mi}$. NW of Baker Lake, $47 \mathrm{mi}$. ESE of Tanana, Yukon-Tanana High.; $65^{\circ} 06^{\prime} \mathrm{N}, 150^{\circ} 27^{\prime} \mathrm{W}$; (map 106).

Prospectors' name reported in 1906 by USGS (Prindle, 1908, pl. 5).

North Fork Big River: stream, heads at glacier terminus NE of Lake Clark Pass, flows SE 13 mi. to Big River, $37 \mathrm{mi}$. NW of Kenai, Cook Inlet Low.; $60^{\circ} 46^{\prime} \mathrm{N}, 152^{\circ} 13^{\prime} \mathrm{W}$; (map 62).

Local name reported in 1958 by USGS.

North Fork Big River: stream, flows SW $23 \mathrm{mi}$. to Big River, $77 \mathrm{mi}$. SE of McGrath, Alaska Ra.; $61^{\circ} 58^{\prime} \mathrm{N}, 154^{\circ} 37^{\prime} \mathrm{W}$; (map 71).

Local name reported in 1958 by USGS.

North Fork Bradfield River: stream, heads W of Mount Pounder at $56^{\circ} 25^{\prime} 55^{\prime \prime} \mathrm{N}, 131^{\circ} 16^{\prime} 45^{\prime \prime}$ W, flows SW $20 \mathrm{mi}$. to join the East Fork to form Bradfield River, $2 \mathrm{mi}$. $\mathrm{E}$ of head of Bradfield Canal, Coast Mts.; $56^{\circ} 14^{\prime} \mathrm{N}, 131^{\circ}$ 27' W; BGN 1959; (map 7). Var. Bradfield River, North Bradfield River.

Named by IBC and published in 1927 on IBC sheet 5 .

North Fork Bremner River: stream, heads at Bremner Glacier, flows W $24 \mathrm{mi}$. to join South Fork Bremner River to form Bremner River, at $S$ end of Twelvemile Canyon, $68 \mathrm{mi}$. NE of Cordova, Chugaçh Mts.; $60^{\circ} 59^{\prime} 40^{\prime \prime} \mathrm{N}$, $143^{\circ} 57^{\prime} 00^{\prime \prime} \mathrm{W}$; (map 65). Var. Bremner River.

Local name reported by F. H. Moffit (1912, pl. 5), USGS.

North Fork Buckland River: stream, flows SW $33 \mathrm{mi}$. to the Buckland River, $50 \mathrm{mi}$. NE of Haycock, Nulato Hills ; $65^{\circ} 45^{\prime} \mathrm{N}, 160^{\circ} 02^{\prime} \mathrm{W}$; (map 109).

Local name published in 1951 by USGS. North Fork Campbell Creek: stream, heads in Chugach Mts., flows NW $13 \mathrm{mi}$., through Campbell Creek Canyon, to join South Fork to form Campbell Creek, $3.8 \mathrm{mi}$. SE of Anchorage, Cook Inlet Low.; $61^{\circ} 10^{\prime} 39^{\prime \prime} \mathrm{N}$, $149^{\circ} 49^{\prime} 20^{\prime \prime} \mathrm{W}$; (map 69).

Local name reported in 1942 by AMS.

North Fork Canyon Creek: stream, in Kantishna Hills, flows E $5.7 \mathrm{mi}$. to Canyon Creek, 19 mi. NNW of Eielson Visitor Center, Alaska Ra. ; $63^{\circ} 41^{\prime} 40^{\prime \prime} \mathrm{N}, 150^{\circ} 27^{\prime} 40^{\prime \prime} \mathrm{W}$; (map 88).

Name shown on a 1916 fieldsheet by C. E. Giffin, USGS.

North Fork Capps Creek: stream, see North Capps Creek.

North Fork Chandalar River: stream, flows SE $104 \mathrm{mi}$., through Chandalar Lake, joins Middle Fork Chandalar River to form Chanaalar River, $23 \mathrm{mi}$ SSE of Chandalar, Brooks Ra.; $67^{\circ} 10^{\prime} \mathrm{N}, 148^{\circ} 18^{\prime} \mathrm{W}$; (map 123).

Prospectors' name obtained in 1909 by $A$. G. Maddren (in Brooks and others, 1910, pi. 7), USGS.

North Fork Chena River: stream, flows SW 20 mi., joins West Fork Chena River to form Chena River, $49 \mathrm{mi}$. NE of Fairbanks, YukonTanana High.; $65^{\circ} 03^{\prime} 12^{\prime \prime} \mathrm{N}, 146^{\circ} 11^{\prime} 00^{\prime \prime} \mathrm{W}$; BGN 1965; (map 104). Var. West Fork Chena River.

Local name reported in 1903 by USGS (Prindle, 1905, pl. 16).

North Fork Chester Creek: stream, flows SW 1.3 mi. to Chester Creek in Anchorage, Cook Inlet Low. ; 61 $11^{\prime} 07^{\prime \prime} \mathrm{N}, 149^{\circ} 51^{\prime} 10^{\prime \prime} \mathrm{W}$; (map 69).

Local name published in 1954 by Northwest Mapping Service, Seattle, Wash.

North Fork Chuitna River: stream, see Chuit Creek.

North Fork Crescent River: stream, flows SE 15 mi., joins Lake Fork to form Crescent River, $53 \mathrm{mi}$. SW of Kenai, Aleutian Ra.; $60^{\circ} 21^{\prime} 20^{\prime \prime}$ $\mathrm{N}, 152^{\circ} 44^{\prime} 40^{\prime \prime} \mathrm{W}$; (map 62).

Local name reported in 1958 by USGS.

North Fork Dagislakhna Creek: stream, in Ray Mts., flows SW $15 \mathrm{mi}$. to Dagislakhna Creek $11 \mathrm{mi}$. NW of that stream's junc. with Tozitna River, $35 \mathrm{mi}$. NNW of Tanana, KokrinesHodzana High.; $65^{\circ} 40^{\prime} \mathrm{N}, 152^{\circ} 23^{\prime} \mathrm{W}$; $B G N$ 1960; (map 106). Var. Siskokhtanten.

Name reported by Orth in 1956 . The Indian name "Siskokhtanten" means "bear signs (dung)."

North Fork Deep Creek: stream, on Kenai Penin., flows SW $12 \mathrm{mi}$. to Deep Creek, $8 \mathrm{mi}$. NE of Ninilchik Dome and $26 \mathrm{mi}$. NE of Homer, Cook Inlet Low.; $59^{\circ} 59^{\prime} \mathrm{N}, 151^{\circ} 15^{\prime}$ W; (map 50).

Local name published on maps after 1950. North Fork East Fork Chandalar River: stream, heads at $68^{\circ} 00^{\prime} \mathrm{N}, 147^{\circ} 28^{\prime} \mathrm{W}$, flows SE 54 mi. to East Fork Chandalar River $44 \mathrm{mi}$. W of Christian, Brooks Ra.; $67^{\circ} 19^{\prime} \mathrm{N}, 146^{\circ} 50^{\prime}$ W; (map 122).

Local name published in 1951 by USGS. North Fork Elsie Creek: stream, see Eva Creek. North Fork Emma Creek: stream, flows NE $5 \mathrm{mi}$. to Emma Creek, $40 \mathrm{mi}$. S of Nenana, Alaska Ra.; $64^{\circ} 00^{\prime} 45^{\prime \prime} \mathrm{N}, 148^{\circ} 44^{\prime} 10^{\prime \prime} \mathrm{W}$; (map 100).

Named published in 1915 by GLO [BLM] survey plat.

North Fork Fortymile River: stream, heads at junc. of Independence and Slate Creeks, flows SE $44 \mathrm{mi}$. to join South Fork to form Fortymile River, $42 \mathrm{mi}$. SW of Eagle, Yukon- 
Tanana High.; $64^{\circ} 14^{\prime} \mathrm{N}, 141^{\circ} 45^{\prime} \mathrm{W}$; (map 102).

Local designation used as early as 1886 ; published in 1890 by USC\&GS.

North Fork Fox Creek: stream, flows SE $3.6 \mathrm{mi}$. to Fox Creek, $21 \mathrm{mi}$. NE of Nome, Seward Penin, High.; $64^{\circ} 46^{\prime} \mathrm{N}, 165^{\circ} 03^{\prime} \mathrm{W}$; (map 94).

Prospectors' name reported in 1900 by $\mathrm{E}$. C. Barnard (in Brooks, 1901, pl. 17), USGS.

North Fork Freshwater Creek: stream, flows SE $6.5 \mathrm{mi}$. to Freshwater Creek, $11 \mathrm{mi}$. $\mathrm{N}$ of Tenakee Springs, on $\mathbf{E}$ coast of Chichagof I., Alex. Arch.; 57 $56^{\prime} 30^{\prime \prime} \mathrm{N}, 135^{\circ} 13^{\prime} 30^{\prime \prime} \mathrm{W}$; $B G N$ 1960; (map 9).

Named in 1960 by USGS

North Fork George River: stream, flows SE 28 mi. to George River, $12 \mathrm{mi}$. NE of its junc with Kuskokwim River and $28 \mathrm{mi}$. NW of Sleetmute, Kilbuck-Kuskokwim Mts.; $62^{\circ} 03^{\prime}$ $\mathrm{N}, 157^{\circ} 35^{\prime} \mathrm{W}$; (map 79).

Local name reported in 1915 by J. B. Mertie and G. L. Harrington, USGS.

North Fork Goodpaster River: stream, see Goodpaster River.

North Fork Harrison Creek: stream, flows SE $10 \mathrm{mi}$., joins South Fork Harrison Creek to form Harrison Creek, $44 \mathrm{mi}$. SW of Circle, Yukon-Tanana High.; $65^{\circ} 21^{\prime} 45^{\prime \prime} \mathrm{N}, 1^{\circ} 5^{\circ}$ 07'30" W; (map 104).

Local name reported in 1896 by USGS (Spurr, 1898, pl. 50).

North Fork Hess Creek: stream, flows SW 21 mi. to join South Fork Hess Creek to form Hess Creek, $14 \mathrm{mi}$. NE of Livengood, YukonTanana High. ; $65^{\circ} 42^{\prime} 30^{\prime \prime}$ N, $148^{\circ} 21^{\prime} 30^{\prime \prime}$ W; (map 105).

Local name reported in 1903 by USGS (Prindle, 1905, pl. 16).

North Fork Hot Springs Creek: stream, heads S of Wolf Mtn., flows SW 8.5 mi. to Hot Springs Creek, $24 \mathrm{mi}$. WNW of Birches, KokrinesHodzana High.; $65^{\circ} 13^{\prime} 10^{\prime \prime} \mathrm{N}, 154^{\circ} 21^{\prime} 00^{\prime \prime} \mathrm{W}$; (map 107).

Local name obtained in 1954 by USGS topographers.

North Fork Huslia River: stream, flows SE 40 mi. to join South Fork Huslia River to form Huslia River, $38 \mathrm{mi}$. NE of Roundabout Mtn., Koyukuk Low.; $65^{\circ} 53^{\prime} \mathrm{N}, 157^{\circ} 36^{\prime} \mathrm{W}$; (map 108).

Local name obtained at Huslia in 1954 or 1955 by USGS.

North Fork Huslia River: stream, see Billy Hawk Creek.

North Fork Indian Creek: stream, see North Fork Indian River.

North Fork Indian River: stream, flows SW 12 mi. to join South Fork Indian River to form the Indian River, $16 \mathrm{mi}$. NW of Goodnews, Kilbuck-Kuskokwim Mts.; $59^{\circ} 18^{\prime} \mathrm{N}, 161^{\circ} 51^{\prime}$ W; (map 53). Var. North Fork Indian Creek.

Name published as "North Fork Indian Creek" by G. L. Harrington (in Brooks, 1921, pl. 7), USGS

North Fork Innoko River: stream, heads on W slope of Kuskokwim Mts. at $63^{\circ} 44^{\prime} 15^{\prime \prime} \mathrm{N}$, $155^{\circ} 35^{\prime} 30^{\prime \prime} \mathrm{W}$, flows $\mathrm{NW}$ and SW $100 \mathrm{mi}$. to Innoko River, $48 \mathrm{mi}$. $\mathrm{N}$ of Ophir and $64 \mathrm{mi}$. $\mathrm{S}$. of Galena, Innoko Low.; $63^{\circ} 49^{\prime} 20^{\prime \prime} \mathrm{N}$, 156 37'15" W; BGN 1963; (map 90). Var. Reka Ttachegno, Takhakna, Tango Creek.

Local name obtained in 1908 by A. G. Maddren, USGS. Indian name, apparently obtained in 1838 by Alexander Kolmakov; was written in 1842-44 as "R[eka] Ttachegno" by Lt. L. A. Zagoskin, IRN; later written by Father Jetté in 1915 as "Takhakna."

North Fork Jones Creek: stream, heads in a lake, flows NW $35 \mathrm{mi}$. to Jones Creek $3 \mathrm{mi}$. SE of its junc. with East Fork Kuskokwim River, $51 \mathrm{mi}$. $\mathrm{E}$ of McGrath, Kuskokwim Low.; $63^{\circ} 02^{\prime} \mathrm{N}$, $153^{\circ} 59^{\prime} \mathrm{W}$; BGN 1964; (map 89).

Local name reported in 1958 by USGS.

North Fork Kashwitna River: stream, heads in Talkeetna Mts. and flows SW $22 \mathrm{mi}$. to Kashwitna River, $36 \mathrm{mi}$. NW of Palmer, Cook Inlet Low.; $61^{\circ} 59^{\prime} 10^{\prime \prime} \mathrm{N}, 149^{\circ} 50^{\prime} 45^{\prime \prime} \mathrm{W}$; $B G N$ 1937; (map 69).

Local name reported about 1933 by USGS.

North Fork Kisaralik River: stream, $17 \mathrm{mi}$. long, flows SW through North Fork Lakes to Kisaralik River, $76 \mathrm{mi}$. SE of Bethel, Kilbuck-Kuskokwim Mts. ; $60^{\circ} 23^{\prime} \mathrm{N}, 159^{\circ} 41^{\prime} \mathrm{W}$; BGN 1960 ; (map 59). Var. Quicksilver Creek.

Local name reported in 1956 by USGS.

North Fork Kougarok River: stream, heads at junc. of French and Iron Creeks, flows SW 10 mi. to Kougarok River, $45 \mathrm{mi}$. W of Imuruk Lake, Seward Penin. High.; $65^{\circ} 35^{\prime}$ N, $164^{\circ} 44^{\prime}$ W; (map 110).

Prospectors' name reported in 1900 by Brooks (1901, pl. 11), USGS.

North Fork Koyukuk River: stream, flows S 90 mi. from Als Mtn. to Koyukuk River, $36.5 \mathrm{mi}$. SW of Wiseman, Brooks Ra. ; $67^{\circ} 03^{\prime} \mathrm{N}, 151^{\circ}$. 04' W; (map 124).

Local name shown on an 1899 fieldsheet by T. G. Gerdine, USGS.

North Fork Kugrukruk River: stream, see Eldorado Creek.

North Fork Kun River: stream, see Iaslaktoli River.

North Fork Kuskokwim River: stream, flows SW $210 \mathrm{mi}$. to Kuskokwim River, $4.5 \mathrm{mi}$. E of Medfra, Kuskokwim Low.; $63^{\circ} 07^{\prime} \mathrm{N}, 154^{\circ} 34^{\prime}$ W; BGN 1964; (map 89). Var. Kuskokwim River, Tichininik River.

This stream was considered the "Kuskokwim River" by Lt. J. S. Herron, USA, in 1899. It is shown as "North Fork Kuskokwim River" on a map prepared in 1910 by A. G. Maddren, USGS. Its Indian name reported by Gordon (1917, p. 105) in 1907 was "Tichininik."

North Fork Kuzitrin River: stream, flows SW 7.5 mi. to Kuzitrin River, $18 \mathrm{mi}$. SW of Imuruk Lake, Seward Penin. High.; $65^{\circ} 27^{\prime} \mathrm{N}, 163^{\circ}$ 49' W; (map 110).

Prospectors ${ }^{2}$ name reported on a precinct map of Seward Peninsula by Monroe and Hutchins; corrected to June 1903 by Arthur Gibson.

North Fork Kwiniuk River: stream, flows SW 7 mi. to Kwiniuk River, $8 \mathrm{mi}$. NW of Elim, Se- ward Penin. High.; $64^{\circ} 41^{\prime} \mathrm{N}, 162^{\circ} 30^{\prime} \mathrm{W}$; (map 95).

Prospectors' name shown on a precinct map of Seward Peninsula by Monroe and Hutchins, corrected up to June 1903 by Arthur Gibson.

North Fork Ladue River: stream, see North Ladue River.

North Fork Lake: lake, $1.9 \mathrm{mi}$. long, at head of Nolitna Creek, $15 \mathrm{mi}$. SW of Beaver, Yukon Flats; $66^{\circ} 10^{\prime} 40^{\prime \prime} \mathrm{N}, 147^{\circ} 42^{\prime} 30^{\prime \prime} \mathrm{W}$; (map 118).

Probably named by William Yanert who showed it on a 1916 manuscript map of the Yukon Flats (Stuck, 1917, map facing p. 122).

North Fork Lakes: lakes, two, $1.6 \mathrm{mi}$. and 0.75 mi. long, $7.5 \mathrm{mi}$. $\mathrm{N}$ of Kisaralik Lake and 83 mi. SE of Bethel, Kilbuck-Kuskokwim Mts. $60^{\circ} 27^{\prime} \mathrm{N}, 159^{\circ} 22^{\prime} \mathrm{W}$; (map 59).

Local name reported in 1955 by J. M. Hoare, USGS.

North Fork Manzanita Creek: stream, on E coast of Revillagigedo I., heads in a lake, flows SE, through January Lake, $4.5 \mathrm{mi}$. to Manzanita Creek, Alex. Arch.; $55^{\circ} 35^{\prime} 20^{\prime \prime} \mathrm{N}, 131^{\circ} 00^{\prime} 10^{\prime \prime}$ W; (map 3).

Local name reported in 1955 by USGS.

North Fork Montana Creek: stream, flows SW $14 \mathrm{mi}$. joining the Middle Fork to form Montana Creek, $11 \mathrm{mi}$. SE of Talkeetna, Cook Inlet Low.; $62^{\circ} 11^{\prime} 25^{\prime \prime} \mathrm{N}, 149^{\circ} 57^{\prime} 00^{\prime \prime} \mathrm{W}$; (map 82).

Local name recorded in 1950 by USGS.

North Fork Moose Creek: stream, in Kantishna Hills, flows NW $11 \mathrm{mi}$. to Moose Creek, $5 \mathrm{mi}$. ENE of Wonder Lake, Alaska Ra.; $63^{\circ} 31^{\prime} 10^{\prime \prime}$ $\mathrm{N}, 150^{\circ} 44^{\prime} 00^{\prime \prime} \mathrm{W}$; (map 88).

Local name reported in 1905 by L. M. Prindle, USGS.

North Fork Mosquito Creek: stream, heads in Darby Mts., flows SW $6.3 \mathrm{mi}$. to Mosquito Creek, in Fish River basin, $39 \mathrm{mi}$. SE of Imuruk Lake, Seward Penin. High.; $65^{\circ} 02^{\prime} \mathrm{N}$, $162^{\circ} 43^{\prime} \mathrm{W}$; (map 110).

Prospectors' name published on the 1908 "Map of Seward Peninsula" by Arthur Gibson.

North Fork Niukluk River: stream, see Niukluk River.

North Fork Noxapaga River: stream, see Eldorado Creek.

North Fork Nuluk River: stream, flows SW 11 mi. to join South Fork Nuluk River to form Nuluk River, $26 \mathrm{mi}$. N of Teller, Seward Penin. High.; $65^{\circ} 38^{\prime} \mathrm{N}, 166^{\circ} 15^{\prime} \mathrm{W}$; (map 111).

Prospectors' name reported on the 1908 "Map of Seward Peninsula" by Arthur Gibson.

North Fork O'Brien Creek: stream, flows S $4 \mathrm{mi}$. to Liberty Fork, $21 \mathrm{mi}$. S of Eagle, YukonTanana High.; $64^{\circ} 30^{\prime} \mathrm{N}, 141^{\circ} 10^{\prime} \mathrm{W}$; (map 102).

Prospectors' name shown on an 1898 manuscript map by C. A. Woodruff, Fort Cudahy, Canada. 
North Fork Ophir Creek: stream, see Ophir Creek.

North Fork Otter Creek: stream, flows SW 7.5 mi. to join South Fork to form Otter Creek, $10 \mathrm{mi}$. NE of Flat, Kilbuck-Kuskokwim Mts.; $62^{\circ} 31^{\prime} \mathrm{N}, 157^{\circ} 43^{\prime} \mathrm{W}$; (map 79).

Local name obtained in 1952 by USGS topographers.

North Fork Paint River: stream, flows E $6 \mathrm{mi}$. to Paint River, $45 \mathrm{mi}$. SW of Augustine I.; $59^{\circ} 10^{\prime} \mathrm{N}, 154^{\circ} 35^{\prime} \mathrm{W}$; (map 51).

Local name reported in 1923 by $R$. H. Sargent, USGS, and published by $\mathrm{K}$. F. Mather (in Brooks and others, 1925, pl. 3).

North Fork Pioneer Creek: stream, flows SW $2.6 \mathrm{mi}$, joins Deadwood Creek to form Pioneer Creek, $20 \mathrm{mi} \mathrm{S}$ of Rampart, Yukon-Tanana High.; $65^{\circ} 12^{\prime} 20^{\prime \prime} \mathrm{N}, 150^{\circ} 06^{\prime} 00^{\prime \prime} \mathrm{W}$; (map 106).

Prospectors' name reported in 1905 by ARC surveyors.

North Fork Porterfield Greek: stream, flows SE $2.5 \mathrm{mi}$. to Porterfield Creek, $12 \mathrm{mi}$. E of Wrangell, Coast Mts.; $56^{\circ} 31^{\prime} 20^{\prime \prime} \mathrm{N}, 132^{\circ} 04^{\prime}$ 45" W ; (map 6).

Local name recorded in 1953 by USGS.

North Fork Preacher Creek: stream, heads E of Lime Peak, flows NW $33 \mathrm{mi}$. to Preacher Greek, $48 \mathrm{mi}$. SW of Circle, Yukon-Tanana High.; $65^{\circ} 44^{\prime} 30^{\prime \prime} \mathrm{N}, 145^{\circ} 43^{\prime} 30^{\prime \prime} \mathrm{W}$; (map 104).

Name reported by D. C. Witherspoon (in Prindle, 1906, pl. 1), USGS.

North Fork Quartz Creek: stream, flows SE 3.5 mi. to Quartz Creek which flows to Kougarok River, $47 \mathrm{mi}$. SW of Imuruk Lake, Seward Penin. High.; $65^{\circ} 22^{\prime} \mathrm{N}, 164^{\circ} 43^{\prime} \mathrm{W}$; (map 110). Var. Right Fork Quartz Creek.

Prospectors' name reported in 1901 by $T$. G. Gerdine (in Collier, 1902, pl. 12), USGS.

North Fork Rainy Creek: stream, heads at glacier terminus, flows SW $5.8 \mathrm{mi}$., joins West Fork to form Rainy Creek, $22 \mathrm{mi}$. NW of Paxson, Alaska Ra.; $63^{\circ} 17^{\prime} 30^{\prime \prime} \mathrm{N}, 145^{\circ} 53^{\prime} 35^{\prime \prime} \mathrm{W}$; (map 86).

Local name reported in 1910 by C. E. Giffin, USGS.

North Fork Rex Creek: stream, flows $N$ and SE $4.3 \mathrm{mi}$. and joins the South Fork to form Rex Creek, on $\mathbf{E}$ coast of Alaska Penin., 2 mi. NW of Dry Bay and $51 \mathrm{mi}$. W of Karluk, Aleutian Ra.; 57 $39^{\prime} 35^{\prime \prime} \mathrm{N}, 155^{\circ} 49^{\prime} 00^{\prime \prime} \mathrm{W}$; (map 35).

Descriptive local name obtained from J. L. McPherson of Iliamna and published by $\mathbf{G}$. C. Martin (1921, pl, 10), USGS.

North Fork Ruth Glacier: glacier, trends S $6 \mathrm{mi}$. from Mount Silverthrone to Ruth Amphitheater, between Mount Dan Beard and Explorers Peak, Alaska Ra.; $63^{\circ} 03^{\prime} \mathrm{N}, 150^{\circ} 40^{\prime}$ W; (map 88).

Mountain climbers' name published in 1954 by USGS.

North Fork Sakvailak River: stream, see Sakvailak River.

North Fork Salcha River: stream, heads at $64^{\circ} 59^{\prime} \mathrm{N}, 144^{\circ} 45^{\prime} \mathrm{W}$, flows SW $36 \mathrm{mi}$. to Salcha River, 38 mi. NE of Big Delta, Yukon-
Tanana High.; $64^{\circ} 39^{\prime} \mathrm{N}, 145^{\circ} 21^{\prime} \mathrm{W}$; (map 101).

Named by prospectors and reported in 1903 by USGS (Prindle, 1913a, pl. 16).

North Fork Serpentine River: stream, flows NW $31 \mathrm{mi}$. to Serpentine River, $26 \mathrm{mi}$. SE of Shishmaref, Kotzebue-Kobuk Low.; $66^{\circ} 07^{\prime} \mathrm{N}$, $165^{\circ} 14^{\prime} \mathrm{W}$; (map 112).

Prospectors' name published by Collier (1902, pl. 12), USGS.

North Fork Ship Creek: stream, flows NW $10 \mathrm{mi}$. to Ship Creek, $15 \mathrm{mi}$. SE of Anchorage, Chugach Mts.; $61^{\circ} 08^{\prime} 40^{\prime \prime} \mathrm{N}, 149^{\circ} 27^{\prime} 50^{\prime \prime} \mathrm{W}$; (map 69).

Local name reported in 1951 by USGS.

North Fork Slug River: stream, 5 mi. long, flows SSW to Slug River, $22 \mathrm{mi}$. E of Cape Newenham, Kilbuck-Kuskokwim Mts. ; $58^{\circ} 42^{\prime} 30^{\prime \prime} \mathrm{N}$, $161^{\circ} 38^{\prime} 30^{\prime \prime} \mathrm{W}$; (map 39).

Local name shown on a 1937 fieldsheet by J. B. Mertie, USGS.

North Fork Snake River: stream, flows SE 5.5 mi. to join Goldbottom Creek to form Snake River, $13 \mathrm{mi}$. N of Nome, Seward Penin. High.; $64^{\circ} 42^{\prime} \mathrm{N}, 165^{\circ} 24^{\prime} \mathrm{W}$; (map 94). Var. Last Chance Creek, Saint Michael Creek, Waterfall Creek.

Local name reported in 1899 by Schrader (1900c, p. 16), USGS. E. C. Barnard (in Brooks, 1901, pl. 17), USGS, applied "Waterfall Creek" to the head of this stream and extended Last Chance Greek along its lower course.

North Fork Snake River: stream, see Goldbottom Creek.

North Fork Soule River: stream, heads at a glacier, in Lincoln Mts., flows SE through No Name Lake, $9 \mathrm{mi}$. to Soule River, $3 \mathrm{mi}$. NE of Glacier Point, Coast Mts. ; $55^{\circ} 50^{\prime} 10^{\prime \prime}$ $\mathrm{N}, 130^{\circ} 10^{\prime} 45^{\prime \prime} \mathrm{W}$; (map 3).

Local name reported in 1955 by USGS.

North Fork Squirrel River: stream, in Baird Mts., flows S $35 \mathrm{mi}$. to Squirrel River, $27 \mathrm{mi}$. NW of Kiana, Brooks Ra.; 67 $14^{\prime} \mathrm{N}, 161^{\circ}$ 10' W; (map 127). Var. Omanha River.

Local name in use as early as 1910.

North Fork Sulatna River: stream, flows S 14 mi. to Sulatna River, $14 \mathrm{mi}$. NW of Sulatna Crossing and $32 \mathrm{mi}$. SW of Ruby, KilbuckKuskokwim Mts.; $64^{\circ} 18^{\prime} \mathrm{N}, 155^{\circ} 48^{\prime \prime} \mathrm{W}$; (map 98).

Local name reported about 1952 by USGS.

North Fork Swift River: stream, heads at glacier $15 \mathrm{mi}$. NW of Mount Mausolus, flows SW $40 \mathrm{mi}$. to Swift River, $28 \mathrm{mi}$. NE of Tundra Lake and $85 \mathrm{mi}$. NW of Lake Clark, Lime Hills; $61^{\circ} 29^{\prime} \mathrm{N}, 155^{\circ} 01^{\prime} \mathrm{W}$; (map 71).

Prospectors' name published in 1951 by USGS.

North Fork Texas Creek: stream, heads at E terminus of Texas Glacier, flows $\mathrm{S} 2 \mathrm{mi}$. to join the West Fork to form Texas Creek, $5 \mathrm{mi}$. S of Mount Bayard and the AlaskaCanada boundary, Coast Mts. ; 56 $03^{\circ} 10^{\prime \prime} \mathrm{N}$, $130^{\circ} 05^{\prime} 30^{\prime \prime} \mathrm{W}$; (map 7).

Local name reported in 1928 by USGS.

North Fork Thumb River: stream, heads in lake and flows SW $3.5 \mathrm{mi}$. to East Fork Thumb
River, $\mathbf{E}$ of Karluk Lake on $\mathbf{W}$ central Ko: diak I.; $57^{\circ} 21^{\prime} 00^{\prime \prime} \mathrm{N}, 153^{\circ} 57^{\prime} 45^{\prime \prime} \mathrm{W}$; (map 34).

Local name reported in 1954 by USGS.

North Fork Tlikakila River: stream, flows SE $10 \mathrm{mi}$. to the Tlikakila River, $75 \mathrm{mi}$. NE of Nondalton, Aleutian Ra.; $60^{\circ} 40^{\prime} 30^{\prime \prime} \mathrm{N}, 153^{\circ}$ $08^{\prime} 30^{\prime \prime} \mathrm{W}$; (map 61).

Local name reported in 1958 by USGS.

North Fork Trail Creek: stream, see Trail Creek.

North Fork Twelvemile Creek: stream, flows SE $8 \mathrm{mi}$. to Twelvemile Creek, $56 \mathrm{mi}$. SW of Circle, Yukon-Tanana High.; $65^{\circ} 24^{\prime} \mathrm{N}, 145^{\circ}$ 43' W; (map 104). Var. East Fork Twelvemile Creek.

Name originally published in 1905 as "East Fork Twelvemile Creek" by USGS, but local usage has since shown a preference for the present name.

North Fork Unalakleet River: stream, heads at $64^{\circ} 25^{\prime} \mathrm{N}, 159^{\circ} 22^{\prime} \mathrm{W}$ and flows SW $40 \mathrm{mi}$. to Unalakleet River, $26 \mathrm{mi}$. NE of Unalakleet, Nula to Hills; $63^{\circ} 58^{\prime} 50^{\prime \prime} \mathrm{N}, 159^{\circ} 58^{\prime} 30^{\prime \prime} \mathrm{W}$; (map 91).

Local name reported in 1898 by USC\&GS.

North Fork White River: stream, flows SE 22 mi. to White River, $50 \mathrm{mi}$. NE of McCarthy, Alaska Ra.; $61^{\circ} 45^{\prime} \mathrm{N}, 141^{\circ} 34^{\prime} \mathrm{W}$; (map 67).

Local name reported in 1908 by D. C. Witherspoon (in Moffit and Knopf, 1910, pl. 2), USGS.

North Fork Yantarni Creek: stream, on Alaska Penin., flows S $2 \mathrm{mi}$. to Yantarni Creek, $3 \mathrm{mi}$. above that stream's mouth and $9 \mathrm{mi}$. $\mathrm{N}$ of Cape Kunmik, Aleutian Ra. ; 56 $54^{\prime}$ N, $157^{\circ}$. $12^{\prime} \mathrm{W}$; (map 31 ).

Local name reported in 1951 by USGS.

North Gland Lake: lake, $0.2 \mathrm{mi}$. across, E of Vega Bay, Kiska I., Aleutian Is.; 51 ${ }^{\circ} 55^{\prime} 35^{\prime \prime}$ N, $177^{\circ} 28^{\prime} 00^{\prime \prime}$ E.; (map 14).

Named by the U.S. Army during its occupation of the island during World War II; published in 1943 by AMS. It was considered one of the "G" names in the "G" grid used for tactical purposes.

North Harbor: anchorage, see Coal Harbor.

North Harbor Kai-gah-nee Harbors: bay, see North Kaigani Harbor.

North Hather Creek: stream, heads in Kaiyuh Mts., flows S $36 \mathrm{mi}$. to Hather Creek $5.7 \mathrm{mi}$. $\mathrm{W}$ of its junc. with Magitchlie Creek, $56 \mathrm{mi}$. NE of Holikachuck and $68 \mathrm{mi}$. NW of Ophir, Innoko Low.; $63^{\circ} 34^{\prime} 20^{\prime \prime} \mathrm{N}, 158^{\circ} 28^{\prime} 40^{\prime \prime} \mathrm{W}$; (map 90).

Name published in 1965 by USGS.

North Head: point of land, $\mathrm{N}$ of Kiska Harbor on $\mathbf{E}$ coast of Kiska I., Aleutian Is.; $51^{\circ} 58^{\prime}$ $40^{\prime \prime} \mathrm{N}, 177^{\circ} 34^{\prime} 30^{\prime \prime} \mathrm{E}$; BGN 1937; (map 14).

Local name recorded by USC\&GS in 1905 .

North Head: point of land, on $\mathrm{N}$ coast of Semisopochnoi I., Aleutian Is.; $52^{\circ} 01^{\prime} 40^{\prime \prime} \mathrm{N}, 179^{\circ}$. $37^{\prime} 30^{\prime \prime} \mathrm{E}$; (map 15).

Name published on a 1943 U.S. Army Corps of Engineers map.

North Head: point of land, on $\mathrm{N}$ coast of Akutan I., Krenitzin Is., Aleutian Is.; 54 $13^{\prime} 30^{\prime \prime} \mathrm{N}$, 
165'51'05" W; BGN 1904; (map 24). Var. Mys Sigakh, North Cape, Sigak Cape.

Local descriptive name reported by USBF in 1888. Capt. Tebenkov (1852, map 26) published the name as M[ys] Sigakh, or "Cape Sigakh."

North Head: point of land, $\mathrm{N}$ point of entrance of Coal Harbor on E shore of Zachary Bay, $\mathbf{N}$ coast of Unga I., in Shumagin Is., Aleutian Ra. ; $55^{\circ} 22^{\prime} 00^{\prime \prime} \mathrm{N}, 160^{\circ} 36^{\prime} 30^{\prime \prime} \mathrm{W}$; (map 28).

Probably named in 1865 by Western Union Telegraph Expedition.

North Head: promontory, on E shore of Iliamna Bay, at Kamishak Bay, Alaska Penin., $20 \mathrm{mi}$. $\mathrm{N}$ of Augustine I., Aleutian Ra.; 59 $37^{\prime} 30^{\prime \prime}$ N, 153 $33^{\prime} 30^{\prime \prime} \mathrm{W}$; BGN 1916; (map 51).

Name published in 1913 on USC\&GS Chart 3420. It was so named because it lies at north entrance to Iliamna Bay.

North Hill: hill, $422 \mathrm{ft}$, SW of North Point, on $\mathrm{N}$ coast of Saint Paul I., in Pribilof Is.; $57^{\circ} 12^{\prime}$ N, $170^{\circ} 20^{\prime} \mathrm{W}$; (map 38).

Presumably a local name published in 1875 by USC\&GS.

North Hill: hill, 1,642 ft., on NE side of Ear Mtn., $47 \mathrm{mi}$. N of Teller, Seward Penin. High.; $65^{\circ} 56^{\prime} 30^{\prime \prime} \mathrm{N}, 166^{\circ} 12^{\prime} 00^{\prime \prime} \mathrm{W}$; (map 111).

Descriptive name given in 1945 by a USGS field party.

North Inian Pass: water passage, $6 \mathrm{mi}$. long, between Icy Strait and Cross Sound, just $\mathbf{N}$ of Inian Is., $35 \mathrm{mi}$. NW of Hoonah, St. Elias Mts.; $58^{\circ} 17^{\prime} \mathrm{N}, 136^{\circ} 22^{\prime} \mathrm{W}$; (map 10).

Named in 1901 by J. F. Pratt, USC\&GS and published in the 1901 Alaska Coast Pilot.

North Island: island, $0.7 \mathrm{mi}$. long, on $\mathrm{W}$ coast of Adak I., at E entrance to Bay of Islands, Aleutian Is.; $51^{\circ} 50^{\prime} 10^{\prime \prime} \mathrm{N}, 176^{\circ} 47^{\prime} 40^{\prime \prime} \mathrm{W}$; $B G N$ 1936; (map 17).

Descriptive name given in 1934 by members of the U.S. Navy Aleutian Island Survey Expedition.

North Island: island, $0.9 \mathrm{mi}$. long, in El Capitan Passage, between El Capitan and Prince of Wales Is., Alex. Arch.; 55 $57^{\prime} 30^{\prime \prime}$ N, $133^{\circ} 18^{\prime}$ 45" W; (map 4).

Descriptive name given in 1881 by Comdr. Henry Glass, USN.

North Island: island, $0.2 \mathrm{mi}$. across, at mouth of Port McArthur, in Affleck Canal, on $\mathbf{S}$ coast of Kuiu I., Alex. Arch.; 56 04' N, $134^{\circ} 06^{\prime}$ W; (map 5).

Named in 1886 by Lt. J. M. Helm, USN, for charting purposes; published in 1887 by USC\&GS on Chart 706.

North Island: island, in Whitewater Bay, on Admiralty I., $17 \mathrm{mi}$. S of Angoon, Alex. Arch.; $57^{\circ} 14^{\prime} 27^{\prime \prime} \mathrm{N}, 134^{\circ} 33^{\prime} 45^{\prime \prime} \mathrm{W}$; (map 9).

Named in 1881 by Comdr. Henry Glass, USN, and published by USC\&GS in the 1883 Coast Pilot (p. 175). So named because "it is off the 'North' Coast of Whitewater Bay."

North Island: island, $0.4 \mathrm{mi}$. long, off E shore of Favorite Channel, $1.2 \mathrm{mi}$. SW of Yankee Cove and $27 \mathrm{mi}$. NW of Juneau, Coast Mts.; $58^{\circ} 34^{\prime} 35^{\prime \prime} \mathrm{N}, 134^{\circ} 55^{\prime} 40^{\prime \prime} \mathrm{W}$; (map 11).

Named in 1880 either by Capt. L. A. Beardslee, USN, or by Comdr. R. W. Meade,
USN, in 1869. Name was published by USC\&GS in the 1883 Coast Pilot (p. 195).

North Island: island, $0.5 \mathrm{mi}$. long, $1 \mathrm{mi}$. NE of $\mathrm{NE}$ tip of Hawkins I. and $5 \mathrm{mi}$. $\mathrm{N}$ of Cordova, Chugach Mts. ; $60^{\circ} 37^{\prime} 30^{\prime \prime} \mathrm{N}, 145^{\circ} 43^{\prime} 30^{\prime \prime} \mathrm{W}$; (map 64).

Named in 1897 by Lt. Comdr. J. F. Moser, USN, while collecting hydrographic data and making harbor sketches along the coast of Alaska; probably so named because it is the northernmost island of a chain of islands.

North Island: island, see Raspberry Island.

North Island: island, see Singa Island.

North Junction: locality, see Big Timber.

North Kai-gah-nee Harbor: $b a y$, see North Kaigani Harbor.

North Kaigani Harbor: bay, extends NW $1 \mathrm{mi}$. off Kaigani Strait, on SE coast of Dall I., Alex. Arch.; 54 $45^{\prime} 30^{\prime \prime} \mathrm{N}, 1^{\circ} 2^{\circ} 42^{\prime} 50^{\prime \prime} \mathrm{W}$; (map 1). Var. North Harbor Kai-gah-nee Harbors, North Kai-gah-nee Harbor.

Haida Indian name published in 1883 by USC\&GS Coast Pilot (p. 66) as "North Harbor Kai-gah-nee Harbors." See Kaigani Harbors.

North Kolomin Lake: lake, $0.5 \mathrm{mi}$. lang, on Kenai Penin., $6.5 \mathrm{mi}$. S of Caribou I. in Tustumena Lake and $30 \mathrm{mi}$. S of Kenai, Cook Inlet Low.; $60^{\circ} 08^{\prime} \mathrm{N}, 151^{\circ} 03^{\prime} \mathrm{W}$; (map 62).

Named about 1963 by officials of Kenai National Moose Range, for administrative purposes.

North Kukpuk River: stream, see Nilik River.

North Ladue River: stream, heads $\mathbf{S}$ of Divide Mtn., flows $E$ across Alaska-Canada boundary to Ladue River in Yukon, Ganada, YukonTanana High.; $63^{\circ} 16^{\prime} \mathrm{N}, 140^{\circ} 53^{\prime} \mathrm{W}$; $B G N$ 1954; (map 85). Var. North Fork Ladue River.

Named "North Fork Ladue River" by the IBC survey crew, 1907-09.

North Lake: lake, $800 \mathrm{ft}$. long, on Prince of Wales I., near head of Kasaan Bay, $0.8 \mathrm{mi}$. $\mathbf{N}$ of village of Salt Chuck, Alex. Arch.; $55^{\circ} 38^{\prime} 25^{\prime \prime} \mathrm{N}, 132^{\circ} 33^{\prime} 25^{\prime \prime} \mathrm{W}$; (map 4).

Local descriptive name recorded in 1949 by USGS.

Northland Glacier: glacier, heads in Kenai Mts., trends NE $5.5 \mathrm{mi}$. to its terminus, $6 \mathrm{mi}$. S of Whittier, Chugach Mts. ; $60^{\circ} 41^{\prime} 15^{\prime \prime} \mathrm{N}, 148^{\circ}$ 41'30" W; BGN 1930; (map 63).

Named in 1910 by Lawrence Martin for Northland College, Ashland, Wis.

North Ledge: rock, in Wrangell Narrows, between Mitkof I. and Lindenberg Penin., $12 \mathrm{mi}$. S of Petersburg, Alex. Arch.; 56 $37^{\prime} 45^{\prime \prime} \mathrm{N}$, $132^{\circ} 56^{\prime} 45^{\prime \prime} \mathrm{W}$; (map 6).

Descriptive name given in 1869 by Comdr. R. W. Meade, USN.

North Ledge: rock, in Lynn Canal, $1.5 \mathrm{mi}$. NW of Clear Point on Mansfield Peninsula and 19. mi. SW of Juneau, Alex. Arch.; 58 ${ }^{\circ} 15^{\prime} 35^{\prime \prime}$ $\mathrm{N}, 134^{\circ} 56^{\prime} 45^{\prime \prime} \mathrm{W}$; (map 11).

Named in 1890 by Lt. Comdr. H. B. Mansfield, USN, and published by USC\&GS in the 1891 Coast Pilot (p. 162).
North Marble Island: island, in Glacier Bay National Monument, in Glacier Bay, northernmost of Marble Is., $45 \mathrm{mi}$. NW of Hoonah, St. Elias Mts.; $58^{\circ} 40^{\prime} 15^{\prime \prime} \mathrm{N}, 136^{\circ} 03^{\prime} 45^{\prime \prime} \mathrm{W}$; (map 10).

Name published by the IBC (1923, map 10).

North Meadow Lake: lake, $0.3 \mathrm{mi}$. across, $2.8 \mathrm{mi}$. $\mathrm{NE}$ of Barrow, Arctic Plain; $71^{\circ} 18^{\prime} 30^{\prime \prime} \mathrm{N}$, $156^{\circ} 39^{\prime} 00^{\prime \prime} \mathrm{W}$; (map 153).

Named about 1956 for scientific purposes.

North Mountain: mountain, 1,848 ft., $14 \mathrm{mi}$. NW of Chichagof, on W coast of Chichagof 1 ., Alex. Arch.; $57^{\circ} 49^{\prime} 30^{\prime \prime} \mathrm{N}, 136^{\circ} 19^{\prime} 00^{\prime \prime} \mathrm{W}$; (map 9).

Name published in 1919 by R. M. Overbeck (in Martin and others, 1919, pl. 2), USGS. North Mouth Arolic River: stream, see North Mouth Arolik River.

North Mouth Arolik River: stream, N distributary of Arolik River, heads at $59^{\circ} 38^{\prime} \mathrm{N}$, $161^{\circ} 36^{\prime} \mathrm{W}$, flows NW $12 \mathrm{mi}$. to Kuskokwim Bay, $43 \mathrm{mi}$. N of Goodnews, Yukon-Kuskokwim Delta ; $59^{\circ} 42^{\prime} \mathrm{N}, 161^{\circ} 53^{\prime} \mathrm{W}$; (map 53). Var. Kwiyadik Creek, North Mouth Arolic River.

Originally called by its Eskimo name "Kwiyadik Creek" in 1898 by J. E. Spurr and W. S. Post, USGS. It was named "North Mouth Arolic River" in 1914 by USC\&GS; the present name was published in 1915 on Chart 9103.

North Nenana: locality, mi. 415.4 on The Alaska RR., on right bank of Tanana River opposite mouth of Nenana River, mi. NW of Nenana, Tanana Low.; $64^{\circ} 34^{\prime} 30^{\prime \prime} \mathrm{N}, 149^{\circ} 06^{\prime} 45^{\prime \prime} \mathrm{W}$; (map 100). Var. Nenana, Neenana.

In 1903 the U.S. Army Signal Corps established the Nenana telegraph station near here borrowing the Indian name from the stream debouching on the opposite side of the Tanana. The name "Nenana," however, was later used for a mission and town on the south bank of Tanana so that when a railroad station was established in this area on the north bank of the river in 1919, it was by necessity called "North Nenana." The Nenana post office, established in 1908, may have originally been located here, but more likely it was located at the Nenana Indian Mission across the river.

North Newton Peak: mountain, $1,060 \mathrm{ft} ., 0.7$ mi. N of Newton Peak and $5 \mathrm{mi}$. NE of Nome, Seward Penin. High.; $64^{\circ} 34^{\prime} \mathrm{N}, 165^{\circ} 19^{\prime} \mathrm{W}$; (map 94).

Local name published in 1956 by USGS. North-northeast Bight: bight, $1 \mathrm{mi}$. across, on NE coast of Semisopochnoi I., Aleutian Is.; $52^{\circ} 01^{\prime} 10^{\prime \prime} \mathrm{N}, 179^{\circ} 39^{\prime} 20^{\prime \prime} \mathrm{E}$; (map 15).

Name published on a 1943 U.S. Army Corps of Engineers map.

North-northwest Bight: bight, $0.5 \mathrm{mi}$. across, on NW coast of Semisopochnoi I., Aleutian Is.; $52^{\circ} 01^{\prime} 30^{\prime \prime} \mathrm{N}, 179^{\circ} 35^{\prime} 50^{\prime \prime} \mathrm{E}$; (map 15).

Name published on a 1943 U.S. Army Corps of Engineers map. 
North-northwest Head: point of land, on NW coast of Semisopochnoi I., Aleutian Is. ; $52^{\circ} 01^{\prime}$ N, $179^{\circ} 34^{\prime} \mathrm{E}$; (map 15).

Name published on a 1943 U.S. Army Corps of Engineers map.

North Nugget Spire: peak, 5,500 ft., $0.5 \mathrm{mi}$. N of Nugget Mtn. and $9 \mathrm{mi}$. N of Juneau, Coast Mts.; $58^{\circ} 26^{\prime} 00^{\prime \prime} \mathrm{N}, 134^{\circ} 21^{\prime} 10^{\prime \prime} \mathrm{W}$; (map 11).

Local name reported in 1965 by D. A. Brew and A. B. Ford, USGS.

North Olga Lake: lake, see Akalura Lake.

North Olga Stream: stream, see Akalura Creek.

North Pass: pass, between head of Peaceful River and George Creek on SE side of Attu I., Aleutian Is.; $52^{\circ} 50^{\prime} 40^{\prime \prime} \mathrm{N}, 173^{\circ} 05^{\prime} 00^{\prime \prime} \mathrm{E}$; (map 13).

Named by the U.S. Army during its occupation of the island during World War II; shown on an AMS map published in 1948.

North Pass: water passage, navigable width about $1.3 \mathrm{mi}$., forms NE approach to Kiska Harbor, between Kiska and Little Kiska Is., Aleutian Is. ; $51^{\circ} 58^{\prime} 20^{\prime \prime} \mathrm{N}, 177^{\circ} 36^{\prime} 30^{\prime \prime} \mathrm{E}$; (map 14). Name shown on a 1943 AMS map.

North Pass: water passage, between Tlevak Strait and South Pass, formed by Goat and Prince of Wales Is., Alex. Arch.; $55^{\circ} 14^{\prime} \mathrm{N}, 132^{\circ} 54^{\prime}$ W; BGN 1916; (map 4).

Named in 1916 by USC\&GS.

North Pass: water passage, $1 \mathrm{mi}$. long, between Saginaw Channel and Favorite Channel at $\mathrm{N}$ end of Shelter I., $22 \mathrm{mi}$. NW of Juneau, Alex. Arch.; $58^{\circ} 28^{\prime} 30^{\prime \prime} \mathrm{N}, 134^{\circ} 56^{\prime} 00^{\prime \prime} \mathrm{W}$; (map 11).

Local descriptive name published in 1962 by USGS.

North Passage: water passage, between $\mathrm{N}$ coast of Liesnoi I. and Admiralty I., at mouth of Eliza Harbor, $25 \mathrm{mi}$. SE of Angoon, Alex. Arch. ; $57^{\circ} 10^{\prime} 30^{\prime \prime} \mathrm{N}, 134^{\circ} 16^{\prime} 30^{\prime \prime} \mathrm{W}$; (map 9).

Descriptive name given in 1889 by Lt. Comdr. H. B. Mansfield, USN, and published by USC\&GS in the 1891 Coast Pilot (p. 143).

North Passage: water passage, $6 \mathrm{mi}$. long, in Icy Strait just $\mathrm{N}$ of Lemesurier I., $3 \mathrm{mi}$. S of mouth of Glacial Bay, $28 \mathrm{mi}$. NW of Hoonah, St. Elias Mts.; $58^{\circ} 19^{\prime} \mathrm{N}, 136^{\circ} 06^{\prime} \mathrm{W}$; (map 10).

Name published by USC\&GS in 1904 on Chart 8304.

North Passage Point: point of land, between Freshwater Bay and Iyoukeen Cove, on Chichagof I., $11 \mathrm{mi}$. NE of Tenakee Springs, Alex. Arch.; $57^{\circ} 51^{\prime} \mathrm{N}, 134^{\circ} 56^{\prime} \mathrm{W}$; (map 9).

Named "North Point" in 1869 by Comdr. R. W. Meade, USN, and published as "North Passage Point" by USC\&GS in the 1883 Coast Pilot (p. 179).

North Pass Sukkwan Strait: water passage, $5 \mathrm{mi}$. long, connecting Sukkwan and Tlevak Straits, $\mathrm{N}$ of Goat I., Alex. Arch.; 55 $13^{\prime} 30^{\prime \prime} \mathrm{N}, 132^{\circ}$ $54^{\prime} 00^{\prime \prime}$ W ; BGN 1916; (map 4).

Local name reported in 1916 by USC\&GS.

North Peak: mountain, elev. 1,755 ft., between Andreafsky River and its East Fork, $48 \mathrm{mi}$. $\mathrm{N}$ of Marshall, Nulato Hills; $62^{\circ} 33^{\prime} 30^{\prime \prime} \mathrm{N}$, $162^{\circ} 24^{\prime} 00^{\prime \prime} \mathrm{W}$; (map 77).

Local name reported in 1916 by USGS.
North Peak: mountain, 5,745 ft., $28 \mathrm{mi}$. SE of Mount Sorenson, $29 \mathrm{mi}$. W of Eagle, YukonTanana High.; $64^{\circ} 48^{\prime} 45^{\prime \prime} \mathrm{N}, 142^{\circ} 08^{\prime} 48^{\prime \prime} \mathrm{W}$ (map 102). Var. North Point.

Local name shown as "North Point" on a 1905 manuscript map by E. J. Chamberlain, U.S. Deputy Surveyor. Local usage has changed the name to its present form.

North Peak Mount McKinley: mountain, 19,470 ft., one of Churchill Peaks, 2 mi. N of South Peak, in Mount McKinley National Park, Alaska Ra.; $63^{\circ} 06^{\prime} \mathrm{N}, 151^{\circ} 00^{\prime} \mathrm{W}$; (map 88).

This descriptive name for the lower of Mount McKinley's two high peaks was used as early as 1910. See Mount McKinley.

North Pinnacle Rock: rock, at Cape Lazaref, on SE coast of Unimak I., Aleutian Is.; 54 $36^{\prime}$. $30^{\prime \prime} \mathrm{N}, 163^{\circ} 35^{\prime} 00^{\prime \prime} \mathrm{W}$; (map 25).

Descriptive name reported in 1926 by USC\&GS.

North Point: mountain, see North Peak.

North Point: point of land, N point of entrance to Pond Bay, on SE coast of Dall I., Alex. Arch.; $55^{\circ} 49^{\prime} \mathrm{N}, 132^{\circ} 45^{\prime} \mathrm{W}$; (map 1).

Local descriptive name reported in 1951 by USGS.

North Point: point of land, $13 \mathrm{mi}$. S of Petersburg, on SE coast of Kupreanof I., Alex. Arch.; 56 $37^{\circ} 45^{\prime \prime}$ N, $132^{\circ} 57^{\prime} 30^{\prime \prime}$ W; (map 6).

Named in 1879 by W. H. Dall, USC\&GS.

North Point: point of land, on $\mathrm{N}$ coast of St. Paul I., in Pribilof Is., Aleutian Is.; 57 $13^{\prime}$ N, $170^{\circ} 18^{\prime} \mathrm{W}$; (map 38). Var. Nahsayvernia, Severnoye Point

This is a translation of the Russian name Mys Severnoy meaning north cape, reported by $\mathrm{H}$. W. Elliott (1881, St. Paul notes) as "Nahsayvernia" meaning "on the north shore,' from Russian 'sayvernie." "

North Point: point of land, $\mathrm{N}$ point of entrance to Kasnyku Bay, $9 \mathrm{mi}$. N of Baranof, on NE coast of Baranof I., Alex. Arch.; 57 ${ }^{\circ} 13^{\prime} 25^{\prime \prime}$ N, $134^{\circ} 50^{\prime} 30^{\prime \prime} \mathrm{W}$; (map 9).

Descriptive name given in 1869 by Comdr. R. W. Meade, USN, and published by USC\&GS in the 1883 Coast Pilot (p. 177).

North Point: point of land, $\mathrm{N}$ point of entrance to Kelp Bay, on S tip of Catherine I., off Baranof I., $14 \mathrm{mi}$. SE of Todd, Alex. Arch.; $57^{\circ} 17^{\prime} 40^{\prime \prime} \mathrm{N}, 134^{\circ} 49^{\prime} 45^{\prime \prime} \mathrm{W}$; (map 9).

Descriptive name given in 1895 by Lt. Comdr. E. K. Moore, USN, and published by USC\&GS in the 1901 Coast Pilot (p. 160).

North Point: point of land, on $\mathrm{N}$ shore between Mitchell bay and Kootznahoo Inlet, $5.5 \mathrm{mi}$. NE of Angoon, on Admiralty I., Alex. Arch.; $57^{\circ} 32^{\prime} 50^{\prime \prime} \mathrm{N}, 134^{\circ} 27^{\prime} 20^{\prime \prime} \mathrm{W}$; (map 9).

Named in 1869 by Comdr. R. W. Meade, USN, and published by USC\&GS in the 1883 Coast Pilot (p. 177).

North Point: point of land, NE point of Fire I., $9 \mathrm{mi}$. SW of Anchorage, Cook Inlet Low.; $61^{\circ} 10^{\prime} 30^{\prime \prime} \mathrm{N}, 150^{\circ} 09^{\prime} 30^{\prime \prime} \mathrm{W}$; BGN 1916; $(\operatorname{map} 70)$.

Local descriptive name reported in 1916 by USC\&GS.
North Point: point of land, northernmost tip of Stuart I., $16 \mathrm{mi}$. NW of St. Michael, YukonKuskokwim Delta; 63⒊ $38^{\prime} \mathrm{N}, 162^{\circ} 26^{\prime} \mathrm{W}$; (map 92)

Local descriptive name obtained in 1952 by USC\&GS.

North Point: point of land, see Lighthouse Point.

North Point Baker: point of land, see Baker, Point.

North Pole: village, pop. 615, along Richardson Highway 12 mi. SE of Fairbanks, Tanana Low.; $64^{\circ} 45^{\prime} \mathrm{N}, 147^{\circ} 21^{\prime} \mathrm{W}$; (map 100).

Local name of a community incorporated in 1953.

North Pole Hill: hill, $700 \mathrm{ft}$,, on Prince of Wales I., near head of Kasaan Bay, $1.5 \mathrm{mi}$. NW of village of Salt Chuck, Alex. Arch.; $55^{\circ} 38^{\prime} \mathrm{N}, 132^{\circ} 36^{\prime} \mathrm{W}$; BGN 1960; (map 4).

Named by C. L. Sainsbury, USGS, in 1956, "because of the strong magnetic attraction centering near the hill."

North Punuk Island: island, in Punuk Is. group, $16 \mathrm{mi}$. S of Northeast Cape, off Saint Lawrence I.; $63^{\circ} 05^{\prime} \mathrm{N}, 168^{\circ} 49^{\prime} \mathrm{W}$; (map 93).

Local name published in 1923 by USC\&GS.

North Pustoi Bay: cove, $0.8 \mathrm{mi}$. across, $0.6 \mathrm{mi}$. NW of Pustoi I., at Fort Glenn, on NE coast of Umnak I., Aleutian Is.; 53 $24^{\prime} 05^{\prime \prime}$ $\mathrm{N}, 167^{\circ} 50^{\prime} 30^{\prime \prime} \mathrm{W}$; (map 23).

Name derived from Pustoi I.; reported by U.S. Army Corps of Engineers in 1942.

North Quadra Mountain: mountain, 2,861 ft., on N shore of Boca de Quadra, NE of Quadra Point, Coast Mts.; $55^{\circ} 06^{\prime} 45^{\prime \prime} \mathrm{N}, 130^{\circ} 56^{\prime} 50^{\prime \prime}$ W; (map 3).

Named in 1883 by Lt. Comdr. H. E. Nichols, USN.

North Rapid: rapids, in Rose Channel, in Peril Strait, $25 \mathrm{mi}$. SE of Chichagof, Alex. Arch.; $57^{\circ} 28^{\prime} 00^{\prime \prime} \mathrm{N}, 135^{\circ} 33^{\prime} 10^{\prime \prime} \mathrm{W}$; (map 9). Var. First Rapid.

Name published by USC\&GS in the 1883 Coast Pilot (p. 163). "At this point, at certain stages of the tide, the so-called First or Northern Rapid is formed, consisting of a race of great force and velocity."

North Rhine Peak: peak, 3,307 ft., $1.7 \mathrm{mi}$. E of Hawthorne Peak and $9 \mathrm{mi}$. NW of Juneau, Coast Mts.; $58^{\circ} 15^{\prime} 50^{\prime \prime} \mathrm{N}, 134^{\circ} 11^{\prime} 40^{\prime \prime} \mathrm{W}$; (map 11).

Local name reported in 1965 by D. A. Brew and A. B. Ford, USGS.

North Ridge: ridge, $0.8 \mathrm{mi}$. long, extends $\mathrm{N}$ from $\mathrm{E}$ end of Pierucci Ridge, Attu I., Aleutian Is.; $52^{\circ} 54^{\prime} 15^{\prime \prime} \mathrm{N}, 173^{\circ} 17^{\prime} 45^{\prime \prime} \mathrm{E}$; (map 13).

Named by U.S. Army during its occupation of the island during World War II, shown on an AMS map published in 1948.

North River: stream, heads at $64^{\circ} 30^{\prime} \mathrm{N}, 159^{\circ} 40^{\prime}$ $\mathrm{W}$, and flows SW $60 \mathrm{mi}$. to Unalakleet River, $3.8 \mathrm{mi}$. E of Unalakleet, Nulato Hills; $63^{\circ} 52^{\prime}$ N, $160^{\circ} 40^{\prime} \mathrm{W}$; (map 91)

Local name reported in 1906 by USC\&GS. North Rock: rock, on $\mathrm{S}$ coast of Amaknak I., in Unalaska Bay, Unalaska I., Aleutian Is.; $53^{\circ} 52^{\prime} 53^{\prime \prime} N, 166^{\circ} 32^{\prime} 06^{\prime \prime} \mathrm{W}$; (map 23). 
Named by W. H. Dall, USC\&GS, in 1871 and published on USC\&GS Chart 8901 in 1875

North Rock: rock, $7 \mathrm{mi}$. SW of Goddard; in Necker Is., off W coast of Baranof I., Alex. Arch.; 56 $44^{\prime} 35^{\prime \prime} \mathrm{N}, 135^{\circ} 25^{\prime} 55^{\prime \prime} \mathrm{W}$; (map 5).

Local name used by fishermen; published in 1929 by USC\&GS.

North Rock: rock, in Orca Inlet, $4.5 \mathrm{mi}$. N of Cordova, Chugach Mts.; $60^{\circ} 36^{\prime} 40^{\prime \prime} \mathrm{N}, 145^{\circ}$ 43'20" W; (map 64).

Named in 1897 by Lt. Comdr. J. F. Moser, USN, while collecting hydrographic data and making harbor sketches along the coast of Alaska; probably named for nearby North Island.

North Rocks: rocks, S of North I., Bay of Is., Adak I., Aleutian Is.; $51^{\circ} 50^{\prime} 10^{\prime \prime} \mathrm{N}, 176^{\circ} 47^{\prime}$ 35" W; BGN 1936; (map 17).

Descriptive name given in 1934 by members of the U.S. Navy Aleutian Island Survey Expedition.

North Rocks: rocks, extend $0.8 \mathrm{mi}$. in Pacific Ocean, $3 \mathrm{mi}$. $\mathrm{N}$ of Forrester I., Alex. Arch.; $54^{\circ} 52^{\prime} 30^{\prime \prime} \mathrm{N}, 133^{\circ} 33^{\prime} 45^{\prime \prime} \mathrm{W}$; (map 1 ).

Local descriptive name published by USC\&GS in 1943.

North Rookery: rookery, $1 \mathrm{mi}$. W of Saint George, on N coast of Saint George I., in Pribilof Is.; $56^{\circ} 36^{\prime} 10^{\prime \prime} \mathrm{N}, 169^{\circ} 34^{\prime} 20^{\prime \prime} \mathrm{W}$; (map 38). Var. Alga-anatorol'og.

This seal rookery is mentioned by Elliott (1881, p. 60-61) as having $750 \mathrm{ft}$. of seamargin. The Aleut name is "Alga-anatorol'og," meaning "*** a place where the seals do not go up *** name being due to the ridge near the center of this rookery where there are no seals" (Putnam, 1903, p. 1013).

North Saddle Lake: lake, $0.8 \mathrm{mi}$. long, on Revillagigedo I. W of Carroll Inlet, $1.3 \mathrm{mi}$. SW of Nigelius Point, Alex. Arch.; $55^{\circ} 32^{\prime} 30^{\prime \prime} \mathrm{N}$, $131^{\circ} 22^{\prime} 40^{\prime \prime} \mathrm{W}$; (map 3 ).

Named in 1923 by USFS.

North Salt Lagoon: lagoon, $0.8 \mathrm{mi}$. across, between Elson Lagoon and Chukchi Sea, $4 \mathrm{mi}$. NE of Barrow, Arctic Plain; $71^{\circ} 20^{\prime} \mathrm{N}, 156^{\circ}$. $37^{\prime} \mathrm{W}$; (map 153). Var. Imeakpuniglu, Imikpaneraluk, Imukpunningmu.

Named for scientific purposes (Carson and Hussey, 1962). This feature is probably the same lagoon recorded by Sgt. John Murdoch and published as "Imeakpuniglu" by Lt. P. H. Ray (1885, p. 55), USA, and reported by them to mean "big water, too." The Eskimo name is more closely rendered "Imikpaneraluk."

North Sandy Cove: cove, $1 \mathrm{mi}$. across, in Glacier Bay National Monument, on E shore of Glacier Bay, $1.5 \mathrm{mi}$. NE of Sturgess I. and $48 \mathrm{mi}$. NW of Hoonah, St. Elias Mts.; $58^{\circ} 44^{\prime} \mathrm{N}$, $136^{\circ} 01^{\prime} \mathrm{W}$; (map 10)

Name published in 1959 by NPS.

North Sealion Hill: hill, $645 \mathrm{ft}$., SW of Tolstoi Point, on $E$ coast of Saint George $I$, in Pribilof Is.; $56^{\circ} 35^{\prime} 20^{\prime \prime} \mathrm{N}, 169^{\circ} 29^{\prime} 50^{\prime \prime} \mathrm{W}$; (map 38). Var. Alogh'-koverushka'.
Local name reported in 1891 by Joseph Stanley-Brown, USGS. Putnam (1903, p. 1014), USC\&GS, gives the Aleut-Russian name "Alogh'-koverushka" meaning "middle hill," that is, between Gull and South Sealion Hills.

North Semidi: island, see Aghiyuk Island.

North Snohomish Lake: lake, $0.6 \mathrm{mi}$. long, $\mathrm{N}$ of Lake Snohomish, $9 \mathrm{mi}$. SW of village of Lake Minchumina, Tanana Low.; $63^{\circ} 46^{\prime} 45^{\prime \prime}$ N, $152^{\circ} 29^{\prime} 30^{\prime \prime}$ W; (map 88). Var. Lake Tukomina.

Local name reported in 1954 by USGS.

North Spit: point of land, extends SE $3.5 \mathrm{mi}$. between Goodnews and Kuskokwim Bays, 10 mi. SW of Goodnews, Kilbuck-Kuskokwim Mts.; 59 $04^{\prime} \mathrm{N}, 161^{\circ} 50^{\prime} \mathrm{W}$; (map 53 ).

Descriptive name reported by G. L. Harrington (in Brooks, 1921, pl. 7), USGS.

North Spit: spit, on $\mathrm{N}$ shore of Shagak Bay, on $\mathrm{NW}$ coast of Adak I., Aleutian Is., $51^{\circ} 52^{\prime} 40^{\prime \prime}$ $\mathrm{N}, 176^{\circ} 44^{\prime} 30^{\prime \prime} \mathrm{W}$; BGN 1936; (map 17).

Descriptive name given in 1934 by members of the U.S. Navy Aleutian Island Survey Expedition.

North Star Creek: stream, flows SW $3.3 \mathrm{mi}$. to Windy Creek, $26 \mathrm{mi}$. N of Nome, Seward Penin. High.; $64^{\circ} 53^{\prime} \mathrm{N}, 165^{\circ} 27^{\prime} \mathrm{W}$; (map 94).

Prospectors' name reported in 1900 by E. C. Barnard (in Brooks, 1901, pl. 17), USGS.

North Star Island: barrier island, $1.5 \mathrm{mi}$. long, on Beaufort Sea coast, in Maguire Is., $3 \mathrm{mi}$. NW of Flaxman Is., Arctic Plain; $70^{\circ} 13^{\prime} 30^{\prime \prime}$ $\mathrm{N}, 146^{\circ} 20^{\prime} 00^{\prime \prime} \mathrm{W}$; (map 151).

Named by Leffingwell $(1919$, p. 98) about 1913 after the schooner North Star of the Canadian Arctic Expedition.

North Strait: water passage, see Kupreanof Strait.

North Summit Ear Mountain: peak, see Ears Peak.

North Trick Lake: lake, $1.3 \mathrm{mi}$. across, in Glacier Bay National Monument, near terminus of Brady Glacier, $2.5 \mathrm{mi}$. NE of Torch Bay and $50 \mathrm{mi}$. WNW of Hoonah, St. Elias Mts.; $58^{\circ} 22^{\prime} 05^{\prime \prime} \mathrm{N}, 136^{\circ} 42^{\prime} 10^{\prime \prime} \mathrm{W} ;$ BGN 1962 ; (map 10).

So named in 1961 by NPS because the lake empties itself annually.

North Tuman Point: point of land, see Tuman Point

North Twin: peak, 7,703 ft., in Chigmit Mts., $2.5 \mathrm{mi}$. S of Iliamna Volcano, Aleutian Ra.; $59^{\circ} 59^{\prime} 45^{\prime \prime} \mathrm{N}, 153^{\circ} 04^{\prime} 25^{\prime \prime} \mathrm{W}$; (map 51).

Local descriptive name published in 1912 by USC\&GS.

North Twin Bay: bay, $1.3 \mathrm{mi}$. across, $1 \mathrm{mi}$. N of South Twin Bay on SW end of Elrington I., $45 \mathrm{mi}$. SE of Seward, Chugach Mts; $59^{\circ} 58^{\prime}$ N, $148^{\circ} 13^{\prime} \mathrm{W}$; BGN 1929; (map 49).

Descriptive name given in 1927 by USG\&GS "because it is one of two bays of nearly equal size separated by a high headland." See South Twin Bay.

North Twin Creek: stream, flows SE $5.2 \mathrm{mi}$. to North Fork Chandalar River, $10 \mathrm{mi}$. NNE of
Chandalar, Brooks Ra.; 67 $38^{\prime} 30^{\prime \prime} \mathrm{N}, 148^{\circ}$. $25^{\prime} 00^{\prime \prime}$ W; (map 123).

Local name reported in 1956 by T. E. Taylor, USGS.

North Twin Glacier: glacier, in Tordrillo Mts., trends SW $10 \mathrm{mi}$. to its terminus at Skwentna River, $59 \mathrm{mi}$. NW of Tyonek, Alaska Ra.; $61^{\circ} 26^{\prime} 15^{\prime \prime} \mathrm{N}, 152^{\circ} 44^{\prime} 30^{\prime \prime} \mathrm{W}$; (map 70).

Local descriptive name published in 1933 by USGS.

North Twin Peak: mountain, 1,494 ft., one of Twin Peaks, on W shore of Alitak Bay, at S end of Kodiak I.; $56^{\circ} 54^{\prime} 40^{\prime \prime} \mathrm{N}, 154^{\circ} 13^{\prime} 30^{\prime \prime}$ W; (map 32).

Descriptive name published in 1943 by USC\&GS.

Northumberland, Cape: point of land, $\mathrm{S}$ tip of Duke I., Alex. Arch.; $54^{\circ} 51^{\prime} 30^{\prime \prime}$ N, $131^{\circ} 20^{\prime}$ $30^{\prime \prime} \mathrm{W}$; (map 2).

Named "by [Capt. G.] Vancouver, RN, August 14, 1793, in honor of the Duke of Northumberland" (Wagner, 1937, p. 400). North Walrus Peak: peak, 2,930 ft., between Morzhovoi Bay and Thinpoint Cove, in Aleutian Ra., at SW end of Alaska Penin., $24 \mathrm{mi}$ NE of False Pass, Aleutian Ra.; 54 ${ }^{\circ} 58^{\prime} 55^{\prime \prime} \mathrm{N}$, $162^{\circ} 51^{\prime} 10^{\prime \prime} \mathrm{W}$; BGN 1966; (map 25). Var. Morjecskoi pik, Morzhevskoy pik, Walrus Peak.

Named "Morzhevskoy pik" meaning "walrus peak" by Capt. Lutke (1836, p. 272), IRN.

Northway: village, pop. 196, on E bank of Nabesna Slough, $5.5 \mathrm{mi}$. SW of Northway Junction, Alaska Ra.; $62^{\circ} 58^{\prime} \mathrm{N}, 141^{\circ} 56^{\prime} \mathrm{W}$; (map 84).

Northway was first built as a link in the Northwest Staging Route during World War II, and still serves as an important airport.

Northway Indian Village: village, between Nabesna River and Skate Lake, $1.5 \mathrm{mi}$. N of Northway, Alaska Ra.; $62^{\circ} 59^{\prime} \mathrm{N}, 141^{\circ} 57^{\prime} \mathrm{W}$; (map 84).

Indian village reported in 1954 by USGS. Northway Junction: locality, on Alaska Highway, $5.5 \mathrm{mi}$. NE of Northway, Yukon-Tanana High.; $63^{\circ} 01^{\prime} \mathrm{N}, 141^{\circ} 48^{\prime} \mathrm{W}$; (map 85).

Northway, established as a link in the Northwest Staging Route during World War II, brought nearby Northway Junction into being because the site is at a road junction on the Alaska Highway.

Northwest Arm Castle Bay: estuary, trends E 4 mi. to Castle Bay, 6 mi. SE of Chignik, Aleutian Ra.; 56 $13^{\circ} 30^{\prime \prime} \mathrm{N}, 158^{\circ} 18^{\prime} 10^{\prime \prime} \mathrm{W}$; (map $30)$.

Local name reported in 1923 by R. H. Sargent, USGS.

Northwest Bay: bay, on NW side of Eleanor I., extends NW $2 \mathrm{mi}$. to Prince William Sound, $26 \mathrm{mi}$. NE of Chenega, Chugach Mts.; $60^{\circ}$. $34^{\prime} 15^{\prime \prime} \mathrm{N}, 147^{\circ} 36^{\prime} 00^{\prime \prime} \mathrm{W}$; (map 63).

Local name published in 1910 by USC\&GS. Northwest Branch Taku Glacier: glacier, see West Branch Taku Glacier.

Northwest Cape: point of land, at NW tip of St. Lawrence I. about $1.7 \mathrm{mi}$. W of base of Sevuokuk Mtn., $63^{\circ} 47^{\prime} \mathrm{N}, 171^{\circ} 45^{\prime} \mathrm{W}$; $B G N$ 
1951: (map 93). Var. Cape Sevookak, Cape Sevuokok, Cape Sevuokuk, Sevuokok Cape, Sevuokuk Cape, Sevuokuk Point.

Descriptive name given in 1849 by Capt. M. D. Telenkov (1852, map 3), IRN. See Chibukak, Cape.

Northwest Cape: point of land, see Chibukaka Point.

Northwest Cape: point of land, see Sajaka, Gape.

Northwest Cape: point of land, see Sarichef Cape.

Northwest Gove: cove, see William Cove.

Northwestern Glacier: glacier, heads in Kenai Mts., trends S $5.5 \mathrm{mi}$. to its terminus at Northwestern Lagoon, $55 \mathrm{mi}$. NE of Homer, Chugach Mts.; $59^{\circ} 47^{\prime} 30^{\prime \prime} \mathrm{W}$; $150^{\circ} 03^{\prime} 00^{\prime \prime}$ W; BGN 1910; (map 50).

Name reported by U. S. Grant, USGS (in Brooks and others, 1910, pl. 3). Narned for Northwestern Univ., Evanston, Ill.

Northwestern Lagoon: lagoon, extends SE 4.5 mi. from Northwestern Glacier to Harris Bay, 32 mi. SW of Seward, Chugach Mts.; 59 . $44^{\prime} \mathrm{N}, 149^{\circ} 55^{\prime} \mathrm{W}$; (map 49). Var. Harris Bay.

Published in 1956 by USGS.

Northwest Fivefinger: island, see Akusha Island.

Northwest Fork Ruth Glacier: glacier, trends 4 mi. $\mathbf{E}$, from between $\mathbf{S}$ and $\mathbf{E}$ Buttresses on Mount McKinley to Mount Dan Beard then S 2 mi. to join W Fork Ruth Glacier, Alaska

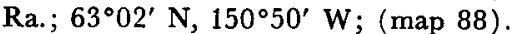

Local name reported in 1954 by USGS.

Northwest Harbor: bay, 2 mi. across, on $\mathrm{N}$ coast of Little Koniuji I., in Shumagin Is., Aleutian Ra.; $55^{\circ} 03^{\prime} 50^{\prime \prime} \mathrm{N}, 159^{\circ} 25^{\prime} 00^{\prime \prime} \mathrm{W}$; (map 27). Var. Agughum udda.

Local name published on an 1888 USC\&GS chart. Possibly the same bay called by the Aleut "Agughum udda" meaning "bay of the creator," or "God's bay," according to Father Veniaminov (1840, v. 1, p. 263).

Northwest Head: point of land, on NW coast of Little Sitkin I., Aleutian Is.; $51^{\circ} 59^{\prime} 15^{\prime \prime} \mathrm{N}$, $178^{\circ} 27^{\prime} 45^{\prime \prime} \mathrm{E}$; (map 15).

Name published on a 1943 U.S. Army Corps of Engineers map.

Northwest Point: point of land, on NW coast of Kanaga I., Aleutian Is.; $51^{\circ} 44^{\prime} 10^{\prime \prime} \mathrm{N}, 177^{\circ}$ 38'05" W; (map 17).

Descriptive name published by USC\&GS in 1956 on Chart 9145.

Northwest Point: point of land, on Buldir I., Aleutian Is.; $52^{\circ} 22^{\prime} 30^{\prime \prime} \mathrm{N}, 175^{\circ} 53^{\prime} 00^{\prime \prime} \mathrm{E}$; (map 14).

Name shown on a 1950 AMS map.

Northwest Point: point of land, on NW coast of Saint Paul I., in Pribilof Is. ; $57^{\circ} 12^{\prime} \mathrm{N}, 170^{\circ} 23^{\prime}$ W; (map 38)

Name published on USC\&GS Chart 886 (1890).

Northwest Point: point of land, $\mathrm{N}$ tip of Kalgin I., in Cook Inlet, $23 \mathrm{mi}$. WSW of Kenai, Cook Inlet Low.; 60³1' N, 151 $56^{\circ} \mathrm{W}$; (map 62). Local name reported in 1958 by USGS.

Northwest Reef: reef, off W coast of Otter I., in Pribilof Is.; $57^{\circ} 02^{\prime} 50^{\prime \prime} \mathrm{N}, 170^{\circ} 25^{\prime} 00^{\prime \prime} \mathrm{W}$; (map 38).

Descriptive name published in 1908 by USC\&GS

Northwest Shoulder: point of land, see Kresta Point.

Northwest Tributary: glacier, see Cushing Glacier.

North Yoke Mountain: peak, 2,539 ft., one of two peaks on Yoke Mtn., $4 \mathrm{mi}$. E of Jacksmith Bay, $28 \mathrm{mi}$. $\mathrm{N}$ of Goodnews, KilbuckKuskokwim Mts.; $59^{\circ} 30^{\prime}$ N, $161^{\circ} 38^{\prime}$ W; (map 53).

Named in 1914 by USC\&GS; published in 1915 on Chart 9103.

Norton Bay: $b a y$, extends NE $50 \mathrm{mi}$. from NE end of Norton Sound; it is defined on $\mathrm{S}$ by line between Cape Darby and Cape Denbigh; $64^{\circ} 30^{\prime} \mathrm{N}, 162^{\circ} 00^{\prime} \mathrm{W}$; (map 69).

Name derived from Norton Sound; published by USC\&GS in $\mathbf{1 8 8 4}$.

Norton Bay Station: village, see Koyuk.

Norton Sound: gulf, $125 \mathrm{mi}$. long and $70 \mathrm{mi}$. wide, extends $\mathrm{E}$ off Bering Sea, between Seward Penin. on $\mathrm{N}$ and Yukon Delta on $\mathrm{S}$; $64^{\circ} \mathrm{N}, 164^{\circ} \mathrm{W} ; B G N$ 1944. Var. Norton Baie.

Discovered in 1778 by Capt. Cook (1785, p. 485), RN, and named by him "in honour of Sir Fletcher Norton [later Lord Grantley], Speaker of the House of Commons.'

Norton Sound Settlements: localities, on shores of Norton Sound, $64^{\circ} \mathrm{N}, 153^{\circ} \mathrm{W}$.

The 1890 Census combined the population of villages and camps in the area under this name.

Nor-to-rok-tee: lake, see Nutuvukti Lake.

Norutak Hills: hills, extends $23 \mathrm{mi}$. long, $\mathrm{S}$ of Kobuk River and $3 \mathrm{mi}$. NE of Lockwood Hills, Hogatza High.; $66^{\circ} 38^{\prime}$ N, $154^{\circ} 20^{\prime}$ W [E end]; $66^{\circ} 45^{\prime} \mathrm{N}, 155^{\circ} 07^{\prime} \mathrm{W}$ [W end]; $B G N$ 1966; (map 116).

Named in 1965 for Norutak Lake by W. W. Patton, Jr., USGS.

Norutak Lake: lake, $4.5 \mathrm{mi}$. long, on divide between Hogatza and Kobuk Rivers, $51 \mathrm{mi}$. N of Hughes, Hogatza High.; $66^{\circ} 48^{\prime}$ N, $154^{\circ} 18^{\prime}$ W; (map 116). Var. Now-get-to-ark (Gull Lake).

Eskimo name reported by Lt. J. C. Cantwell, USRCS, in 1885 as "Nor-u-tak" and by Lt. Stoney (1900, p. 53), who reported it as "Now-get-to-ark (Gull Lake)." W. C. Mendenhall (1902, p. 25) established the present spelling.

Norvell Creek: stream, flows NW 9 mi. to Molly Creek, $80 \mathrm{mi}$. SW of Eagle, Yukon-Tanana High.; $64^{\circ} 09^{\prime} 30^{\prime \prime} \mathrm{N}, 143^{\circ} 26^{\prime} 00^{\prime \prime} \mathrm{W}$; (map 102).

Local name published in 1956 by USGS

Norway Point: point of land, on NE shore of Gastineau Channel, $1 \mathrm{mi}$. N of Juneau, Coast Mts.; $58^{\circ} 18^{\prime} 30^{\prime \prime} \mathrm{N}, 134^{\circ} 26^{\prime} 15^{\prime \prime} \mathrm{W}$; (map 11).

The name which first appeared in print in 1917 , was reportedly derived from a temporary encampment of Norwegian fishermen in the area (DeArmond, 1957, p. 33).
Nose Point: point of land, between Brow and Chin Points on NW coast of Revillagigedo I., Alex. Arch.; $55^{\circ} 48^{\prime} 20^{\prime \prime} \mathrm{N}, 131^{\circ} 42^{\prime} 28^{\prime \prime} \mathrm{W}$; (map 3).

Named in 1891 by USC\&GS; Brow and Chin Points are nearby.

Nosovskoi: locality, site of a village, $6 \mathrm{mi}$. NW of Scotch Cap, on SW coast of Unimak I., Aleutian Is.; $54^{\circ} 29^{\prime} \mathrm{N}, 164^{\circ} 53^{\prime} \mathrm{W}$; (map 24). Var. Nosovskoy.

Russian name reported in 1828 by Capt. F. P. Lutke. Its precise location is not known.

Nossuk Anchorage: anchorage, in Nossuk Bay, W coast of Prince of Wales I., Alex. Arch.; $55^{\circ} 44^{\prime} \mathrm{N}, 133^{\circ} 20^{\prime} \mathrm{W}$; BGN 1914; (map 4).

Indian name given in 1914 by USC\&GS.

Nossuk Bay: estuary, $2 \mathrm{mi}$. long, off Tonowek Bay, $W$ coast of Prince of Wales I., Alex. Arch.; $55^{\circ} 43^{\prime} \mathrm{N}, 133^{\circ} 20^{\prime} \mathrm{W}$; BGN 1914; (map 4).

Indian name given in 1914 by USC\&GS.

Notakok Mountain: mountain, 2,490 f, $27 \mathrm{mi}$. SW of Nulato, Nulato Hills; $64^{\circ} 26^{\prime} \mathrm{N}$, $158^{\circ} 44^{\prime} \mathrm{W}$; (map 97).

Native name reported in 1939 by U.S. Army Corps of Engineers.

Notch, The: $g a p$, in high bank on $\mathrm{N}$ side of Thorofare River, Mount McKinley National Park, N of Muldrow Glacier, Alaska Ra.; $63^{\circ} 24^{\prime} 40^{\prime \prime} \mathrm{N}, 150^{\circ} 25^{\prime} 12^{\prime \prime} \mathrm{W}$; BGN 1932; (map 88).

Local name reported in 1932 by J. C. Reed and S. N. Stoner, USGS

Notch, The: canyon, narrow and V-shaped, cut into a ridge on upper Kiruktagiak River, 11 $\mathrm{mi}$. S of Castle Mtn. and $34 \mathrm{mi}$. NW of Anaktuvuk Pass, Arctic Slope; $68^{\circ} 25^{\prime} 30^{\prime \prime} \mathrm{N}$, $152^{\circ} 48^{\prime} 00^{\prime \prime} \mathrm{W}$; (map 134).

Named by USGS geologists, about 1950 , as "a good descriptive name for this unusual topographic feature."

Notch Creek: stream, flows SE $14 \mathrm{mi}$. to Cross Creek $3 \mathrm{mi}$. SW of its junc. with Chisana River, Wrangell Mts.; $62^{\circ} 09^{\prime} 30^{\prime \prime} \mathrm{N}, 142^{\circ}$ $10^{\prime} 25^{\prime \prime} \mathrm{W}$; (map 84).

Name applied in 1902 by F. C. Schrader, USGS, as a contraction of an Indian name, "Not-chit-in-da."

Notch Creek: stream, flows NE $7.4 \mathrm{mi}$. to Kiruktagiak River, N of The Notch, $9.5 \mathrm{mi}$. $\mathrm{S}$ of Castle Mtn. and $34 \mathrm{mi}$. NW of Anaktuvuk Pass, Arctic Slope; $68^{\circ} 27^{\prime}$ N, $152^{\circ} 46^{\prime}$ W; (map 134).

Name derived from the notch, at the stream's mouth; given in 1949 by W. W. Patton, USGS.

Notch Mountain: mountain, 2,200 ft., on E shore of Thorne Arm, on S coast of Revillagigedo I., Alex. Arch.; 55 $16^{\prime} 25^{\prime \prime} \mathrm{N}, 131^{\circ}$ $14^{\prime} 25^{\prime \prime} \mathrm{W}$; (map 3)

Descriptive name given in 1883 by Lt. Comdr. H. E. Nichols, USN.

No Thorofare Bay: bay, $1.5 \mathrm{mi}$. long, $4.5 \mathrm{mi}$. SE of Sitka, on W coast of Baranof I., Alex. Arch.; $57^{\circ} 01^{\prime} \mathrm{N}, 135^{\circ} 14^{\prime} \mathrm{W}$; (map 9). Var. Boroshki Bay, Bukhta Poroshki, Guba Neprokhodnaya, Paroshki Bay, Poroshki Bay. 
This is an 1882 translation by USG\&GS of the name given in 1809 by the Russian navigator Ivan Vasiliev the first; reported by Lt. Sarichev (1826, map 19), IRN, as "Guba Neprokhodnaya."

No Thorofare Point: point of land, on NE coast of Woewodski I., $15 \mathrm{mi}$. S of Petersburg, Alex. Arch.; $56^{\circ} 35^{\prime} 20^{\prime \prime} \mathrm{N}, 132^{\circ} 58^{\prime} 40^{\prime \prime} \mathrm{W}$; (map 6). Var. No-thoroughfare Point.

Named in 1869 by Comdr. R. W. Meade, USN.

No-thoroughfare Point: point of land, see No Thorofare Point.

Notliagepia-ta: stream, see Patsy Slough.

Notoark River: stream, see Noatak River.

Notochargut River: stream, see Dall River.

Notochaugat River: stream, see Dall River.

Notokakat River: stream, see Dall River.

Notoniono Creek: stream, heads in Indian Mts., flows E $25 \mathrm{mi}$. to Mentanontli River, $35 \mathrm{mi}$. ENE of Hughes, Kokrines-Hodzana High. $66^{\circ} 12^{\prime} \mathrm{N}, 153^{\circ} 06^{\prime} \mathrm{W}$; (map 116).

Indian name recorded at Hughes in 1956 by Orth. The name "Mentna-gle-glau" was recorded at Allakaket, for the same stream, and was reported to mean "head of waters below."

Nouchagak River: stream, see Nushagak River. Nough-chack, Cap: point of land, see Nukshak, Cape.

Nounivak Island: island, see Nunivak Island.

Nounivok Island: island, see Nunivak Island.

Nourse River: stream, heads in a lake at $59^{\circ}$ $44^{\prime} 20^{\prime \prime} \mathrm{N}, 135^{\circ} 25^{\prime} 20^{\prime \prime} \mathrm{W}$, flows SE $7 \mathrm{mi}$. to Taiya River, $10 \mathrm{mi}$. N of Skagway, Coast Mts.; $59^{\circ} 35^{\prime} 30^{\prime \prime} \mathrm{N}, 135^{\circ} 20^{\prime} 00^{\prime \prime} \mathrm{W}$; (map 45).

Name published in 1923 by the IBC on sheet 9.

No Use Ledge: cliff, on W shore of Lynn Canal near its junc. with Icy Strait, $0.6 \mathrm{mi}$. $\mathrm{N}$ of Ansley I. and $26 \mathrm{mi}$. W of Juneau, St. Elias Mts.; $58^{\circ} 13^{\prime} 25^{\prime \prime} \mathrm{N}, 1^{\circ} 5^{\circ} 07^{\prime} 30^{\prime \prime} \mathrm{W}$; (map 11).

Named in 1890 by USC\&GS and published in the 1891 Coast Pilot (p. 195).

Novaia: locality, "on lower Yukon River."

Former Indian village or camp, population 52 in 1880 , reported by Ivan Petroff.

Novaia Harbor: estuary, see Freshwater Bay.

Novakakat: locality, see Nowi.

Novakaket Island: island, $2.7 \mathrm{mi}$. long, bounded by East Channel Yukon River, Novakaket Slough and Nowitna River, $37 \mathrm{mi}$. NE of Ruby, Nowitna Low.; $64^{\circ} 55^{\prime} \mathrm{N}, 154^{\circ} 18^{\prime} \mathrm{W}$; (map 98).

Local name reported about 1952 by USGS. This island was probably the location of the Indian village of Nowi. See Nowi.

Novakaket Slough: stream, distributary of Nowitna River, flows W and N $3.4 \mathrm{mi}$. around Novakaket I. to East Channel Yukon River, $36 \mathrm{mi}$. NE of Ruby, Nowitna Low.; $64^{\circ} 55^{\prime}$ N, $154^{\circ} 19^{\prime} \mathrm{W}$; (map 98).

Local name reported about 1952 by USGS

Novales, Punta: point of land, "this may be present-day Cape Sitkagi."

Discovered and named July 24, 1791 by Capt. Alessandro Malaspina for Manuel No- vales, one of the officers of the Descubierta (Wagner, 1937, p. 478).

Novarassi: locality, see Glory of Russia.

Novarupta: volcano, "of typical form and character which has arisen in the floor of the Valley [of Ten Thousand Smokes] between Broken Mountain and Trident," $7.5 \mathrm{mi}$. W of Mount Katmai in Katmai National Monument, on Alaska Penin., Aleutian Ra.; 58 ${ }^{\circ} 16^{\prime}$ N, 15509' W; BGN 1966; (map 42). Var. Novarupta Volcano.

Descriptive name (meaning new eruption) given in 1916 by R. F. Griggs, National Geographic Society, for this new volcano.

Novarupta Volcano: volcano, see Novarupta.

Novastoshnah: locality, see Vostochnie.

Novastoshnah Rookery: rookery, see Vostochnie Rookery.

Novatak Glacier: glacier, heads at $59^{\circ} 33^{\prime} \mathrm{N}$, $138^{\circ} 40^{\prime} \mathrm{W}$ and trends SE $16 \mathrm{mi}$. to its 1961 terminus, $3 \mathrm{mi}$. W of Alsek River and $50 \mathrm{mi}$. SE of Yakuta; St. Elias Mts.; 59 23'45" N, $138^{\circ} 19^{\prime} 30^{\prime \prime} \mathrm{W}$; (map 46).

Name given by USGS in 1962 . With the retreat of Nunatak Glacier during 1950-60, a new nunatak, or glacier island, appeared at $59^{\circ} 38^{\prime} 30^{\prime \prime} \mathrm{N}, 138^{\circ} 41^{\prime} 00^{\prime \prime} \mathrm{W}$. For this reason this glacier, which heads near the nunatak, was named "Novatak [new nunatak] Glacier."

Novaya Gaban: estuary, see Freshwater Bay.

Novie Balaam: village, see Uzinki.

Novikakat: locality, see Nowi.

Novikakat: stream, see Nowitna River.

Novi Mountain: mountain, 3,396 ft., $72 \mathrm{mi}$. NE of Medfra, Kilbuck-Kuskokwim Mts.; 63⒌ $59^{\prime}$ $\mathrm{N}, 153^{\circ} 27^{\prime} \mathrm{W}$; (map 89$)$

Local name reported in 1958 by USGS.

Noviovak River: stream, see Ninuluk Creek.

Novi River: stream, see Nowitna River.

Novo Arkhangelsk: locality, see Fort Saint Michael.

Novoarkhangelsk: town, see Sitka.

Novoeddiston Mys: point of land, see Louise, Point.

Novokhtolahamiut: locality, see Novoktolak.

Novotolak: locality, "in Kuskokwim district." Var. Novokhtolahamiut.

Former Eskimo village or camp reported in the 1890 Census as "Novokhtolahamiut," population 55.

Novy: islands, see Pribilof Islands.

Nowall Point: point of land, see Nowell, Point. Nowat Creek: stream, see Jungjuk Creek.

Nowater Creek: stream, flows S $3.5 \mathrm{mi}$. to Susitna River, $80 \mathrm{mi}$. SE of Healy, Alaska Ra.; $63^{\circ}$. $01^{\prime} 30^{\prime \prime} \mathrm{N}, 147^{\circ} 21^{\prime} 30^{\prime \prime} \mathrm{W}$; BGN 1959; (map 87).

Named in 1954 by USGS. "The name is descriptive because the lower course of the stream disappears in alluvial fan gravels except during periods of heavy runoff"

Nowat River: stream, see Crooked Creek.

Nowat River: stream, see Owhat River.

Nowel Peak: peak, see Eshamy Peak.

Nowell, Point: point of land, on E coast of Kenai Penin., at NW end of Knight Island Passage, $12 \mathrm{mi}$. NE of Chenega, Ghugach Mts.; $60^{\circ}$ - $26^{\prime} 15^{\prime \prime} \mathrm{N}, 147^{\circ} 56^{\prime} 05^{\prime \prime} \mathrm{W}$; (map 63). Var. Nowall Point.

Named by Capt. George Vancouver, RN, after Joseph Whidbey's examination June 5, 1794 (Wagner, 1937, p. 400).

Now-get-to-ark: lake, see Norutak Lake.

Nowhere Creek: stream, flows NE $9 \mathrm{mi}$. to the Oshetna River, $30 \mathrm{mi}$. NW of Tahneta Pass, Talkeetna Mts.; $62^{\circ} 14^{\prime} 15^{\prime \prime} \mathrm{N}, 147^{\circ} 54^{\prime} 20^{\prime \prime} \mathrm{W}$; $B G N 1960$; (map 82).

Named in 1956 by USGS "because this stream leads to very difficult passes."

Nowi: locality, on $\mathrm{S}$ bank of Yukon River at mouth of Nowitna River, Nowitna Low.; $64^{\circ}$ $55^{\prime} \mathrm{N}, 154^{\circ} 17^{\prime} \mathrm{W}$; (map 98). Var. Newicargut, Newikargut, Novakakat, Novikakat, Nowikakat, Noya-kakat, Noyokakat.

Former Ingalik Indian village or camp reported in 1867 by the Western Union Telegraph Expedition as "Newicargut." Ivan Petroff recorded three spellings, "Nowikakat," "Noya-kakat," and in the 1880 Census, "Noyokakat," population 107, (p. 12).

Nowikakat: locality, see Nowi.

Nowikakat: stream, see Nowitna River.

Nowikaket: stream, see Nowitna River.

Nowi River: stream, see Nowitna River.

Nowiskay Cove: cove, $0.6 \mathrm{mi}$. long, near head of North Arm Moira Sound, on SE coast of Prince of Wales I., Alex. Arch.; $55^{\circ} 07^{\prime} 15^{\prime \prime}$ N, $132^{\circ} 08^{\prime} 30^{\prime \prime} \mathrm{W}$; (map 4). Var. Nowisk-Kay.

Name reported as "Nowisk-Kay" in 1897 by Lt. Comdr. J. F. Moser, USN, as being the name of an Indian who claimed mineral rights on the stream flowing into this cove.

Nowisk-Kay: cove, see Nowiskay Cove.

Nowitna River: stream, flows NE $250 \mathrm{mi}$. to East Channel Yukon River, $38 \mathrm{mi}$. NE of Ruby, Nowitna Low.; $64^{\circ} 56^{\prime} \mathrm{N}, 154^{\circ} 16^{\prime} \mathrm{W}$; $B G N$ 1907; (map 98). Var. Newicargut, Newikargut, Novikakat, Novi River, Nowikakat, Nowikaket, Nowi River, Noyakakat.

Indian name, often locally referred to as "The Novi" or "Novi River," reported in 1867 by the Western Union Telegraph Expedition as "Newicargut." The termination "-cargut," often written "-kakat," means "mouth [of a stream]."

Now-tow-vuck-toy: lake, see Nutuvukti Lake.

Nowuk: locality, see Nuwuk.

Nowuk: point of land, see Barnow Point.

Noxapaga: locality, on left bank of Noxapaga River, $32 \mathrm{mi}$. SW of Imuruk Lake, Seward Penin. High.; $65^{\circ} 29^{\prime} \mathrm{N}, 164^{\circ} 14^{\prime} \mathrm{W}$; (map 110).

Site of a mining camp established about 1901 at the begining of gold mining in the region; reported that year by T. G. Gerdine (in Collier, 1902, pl. 12), USGS.

Noxapaga River: stream, heads $9.5 \mathrm{mi}$. W of Imuruk Lake, flows SW $56 \mathrm{mi}$. to Kuzitrin River, $15 \mathrm{mi}$. NNW of Mount Bendeleben, Seward Penin. High.; $65^{\circ} 23^{\prime} \mathrm{N}, 164^{\circ} 16^{\prime} \mathrm{W}$; (map 110). Var. Kugirukak River, Kugrukruk River, Nakhapagak.

Eskimo name shown on a 1900 "Map of Nome Peninsula" by J. M. Davidson and B. D. Blakeslee. Reported as "Kugrukruk 
River" in the 1900 by Brooks (1901, pl. 11), USGS.

No-yah-lik Peak: hill, see Noyalik Peak.

Noya-kakat: locality, see Nowi.

Noyakakat: stream, see Nowitna River.

Noyalik Peak: hill, $400 \mathrm{ft}$., on Chukchi Sea, S of Okpilatok Bluff, $9 \mathrm{mi}$. S of Cape Lisburne, Arctic Slope; $68^{\circ} 45^{\prime} 20^{\prime \prime} \mathrm{N}, 166^{\circ} 11^{\prime} 30^{\prime \prime} \mathrm{W}$; (map 129). Var. No-yah-lik Peak.

Eskimo descriptive name reported in 1950 by USGS to mean "like a sea gull."

Noyatag River: stream, see Noatak River.

Noyes Creek: stream, flows SW $5.5 \mathrm{mi}$. to Cottonwood Creek which flows to Goodhope River, $16 \mathrm{mi}$. NW of Imuruk Lake, Seward Penin. High.; $65^{\circ} 48^{\prime} \mathrm{N}, 163^{\circ} 33^{\prime} \mathrm{W}$; $B G N$ 1952; (map 110).

Prospectors' name reported in 1901 by USGS (Collier, 1902, pl. 12)

Noyes Island: island, $7 \mathrm{mi}$. across, SW of Gulf of Esquibel, Alex. Arch.; $55^{\circ} 30^{\prime} \mathrm{N}, 133^{\circ} 40^{\prime}$ W; (map 4).

Named in 1879 by W. H. Dall, USC\&GS, for William M. Noyes, USC\&GS, stationed in Alaska from 1873 to 1880 .

Noyes Mountain: mountain, $8,147 \mathrm{ft}$., in Mentasta Mts., $10 \mathrm{mi}$. NE of Jack Lake and 50 mi. S of Tok, Alaska Ra.; $62^{\circ} 39^{\prime} \mathrm{N}, 143^{\circ} 10^{\prime}$ W; BGN 1966; (map 84).

Named in 1966 by U.S. Bureau of Public Roads for Gen. John R. Noyes, 1902-56, former Commanding General of the Alaska National Guard, and head of the Alaska Road Commission.

Noyes Peak: mountain, 2,500 ft., highest point on Noyes I., Alex Arch.; 55 $31^{\prime} 55^{\prime \prime} \mathrm{N}, 133^{\circ}$ $39^{\prime} 40^{\prime \prime} \mathrm{W}$; (map 4).

Named in 1923 by USC\&GS.

Noyes Roadhouse: locality, site of roadhouse, on $\mathrm{N}$ bank of Yukon River, NW of mouth of Kandik River, Porcupine Plat.; $65^{\circ} 23^{\prime} \mathrm{N}$, 142'32' W; (map 103).

Name recorded in 1903 by T. G. Gerdine and $\mathbf{R}$. B. Oliver, USGS.

Noyes Slough: stream, anabranch of Chena River, flows W $7 \mathrm{mi}$. around Garden I. and returns to $2 \mathrm{mi}$. W of Fairbanks, Tanana Low.; $64^{\circ} 50^{\prime} 30^{\prime \prime} \mathrm{N}, 147^{\circ} 48^{\prime} 30^{\prime \prime} \mathrm{W}$; (map 100).

Locally named for a "Mr. Noyes" (cnna) who had a sawmill on this stream. The name was shown on a manuscript map of the Fairbanks Mining District by C. W. Joint in 1905 .

Noyokakat: locality, see Nowi.

Nuatok River: stream, see Noatak River.

Nubbins Mountain: mountain, 1,900 ft., on Annette I., $\mathrm{N}$ of Bingo Mtn., $7.2 \mathrm{mi}$. of Metlakatla, Alex. Arch.; $55^{\circ} 14^{\prime} 10^{\prime \prime}$ N, 131 ${ }^{\circ} 32^{\prime}$ 45" W; (map 3)

Named in 1883 by Lt. Comdr. H. E. Nichols, USN.

Nubble Point: point of land, at NE end of MacDonald Spit on Kenai Penin., 6 mi. NE of Seldovia, Chugach Mts.; $59^{\circ} 29^{\prime} 15^{\prime \prime}$ N, $151^{\circ}$. $34^{\prime} 00^{\prime \prime} \mathrm{W}$; (map 50).

Named by W. H. Dall, USC\&GS, in 1880

Nub Hill: mountain, see Knub Hill.

Nubviakchugaluk: locality, on $\mathrm{N}$ shore of Norton Bay near mouth of Kwik River, Seward
Penin. High.; $64^{\circ} 47^{\prime}$ N, $161^{\circ} 42^{\prime} \mathrm{W}$; (map

96). Var. Nubviakhchugaluk.

Former Eskimo village or camp reported as "Nubviakhchugaluk," population 30 , in the 1880 Census by Ivan Petroff.

Nubviakhchugaluk: locality, see Nubviakchugaluk.

Nuchalawoia: locality, see Nuklukayet.

Nu-cha-la-woy-ya: locality, see Nuklukayet.

Nuchek: locality, on Hinchinbrook I., on N shore of Port Etches, $35 \mathrm{mi}$. SW of Cordova, Chugach Mts.; $60^{\circ} 20^{\prime} \mathrm{N}, 146^{\circ} 39^{\prime} \mathrm{W}$; (map 64) Var. Fort Konstantine, Helena, Konstantinovsk, Natchek, Natcheek, Noocheek, Nutschek.

Site of an abandoned Eskimo village (Hodge, 1910, p. 90). The Russians built a stockade post here about 1793 called "Fort Konstantine" probably named for Grand Duke Constantine, the younger brother of Czar Alexander II. The population in 1880 was 74 , in $1890,145$.

Nuchek: bay, see Etches, Port.

Nuchek Greek: stream, on Hinchinbrook I., flows $4.5 \mathrm{mi}$. SW to Port Etches, $28 \mathrm{mi}$. SW of Cordova, Chugach Mts.; $60^{\circ} 22^{\prime} \mathrm{N}, 146^{\circ} 29^{\prime}$ W; (map 64).

Name published in 1950 by USGS; derived from the nearby village of Nuchek.

Nuchek Harbor: lagoon, see Constantine Harbor.

Nuchek Island: island, see Hinchinbrook Island.

Nuchklunek Mountain: mountain, see Nuk. lunek Mountain.

Nuchljuagmjut: locality, see Nukluak.

Nuchluk River: stream, see Nukluk Creek.

Nuchtschak, Cape: point of land, see Nukshak, Cape.

Nucksack Creek: stream, flows W to Kuzitrin River near its head, about $25 \mathrm{mi}$. SW of Imuruk Lake, Seward Penin. High.; (map 110).

Prospectors' name shown on a map of Cape Nome gold fields by David Fox, Jr., dated 1901. This stream cannot be precisely located on current maps.

Nuck-vuck-to-ark: stream, see Ambler River.

Nucleet: locality, see Nukleet.

Nucleet, Cape: point of land, see Denbigh, Cape.

Nucleus Creek: stream, heads on Nucleus Mtn., in DeLong Mts., flows NW and N $15 \mathrm{mi}$. to Driftwood Creek, Brooks Ra.; 68 $43^{\prime} 30^{\prime \prime} \mathrm{N}$, $160^{\circ} 36^{\prime} 00^{\prime \prime} \mathrm{W} ; B G N$ 1961; (map 131).

Named in 1951 by USGS geologists for Nucleus Mtn.

Nucleus Mountain: mountain, 4,250 ft., in DeLong Mts., $7 \mathrm{mi}$. W of Thunder Mtn., Brooks Ra.; $68^{\circ} 33^{\prime} 30^{\prime \prime} \mathrm{N}, 160^{\circ} 34^{\prime} 00^{\prime \prime} \mathrm{W}$; $B G N$ 1961; (map 131).

Named in 1951 by USGS geologists because "it served as a landmark feature for field parties."

Nuclucayette: locality, see Nuklukayet.

Nuclue, Point: point of land, see Denbigh, Cape. Nuclukayette: locality, see Nuklukayet.

Nude Creek: stream, flows NE to Burnt River which flows to Kugruk River, about $15 \mathrm{mi}$. NE of Imuruk Lake, Seward Penin. High.; (map 110 ).

Local name published on a precinct map of Seward Peninsula by Monroe and Hutchins ; corrected to June 1903 by Arthur Gibson. This stream cannot be precisely identified on current maps.

Nude Hill: hill, $304 \mathrm{ft}$., on eastern Little Kiska I., Aleutian Is.; $51^{\circ} 57^{\prime} 10^{\prime \prime} \mathrm{N}, 177^{\circ} 42^{\prime} 00^{\prime \prime} \mathrm{E}$; (map 14).

An arbitrary name beginning with "N" to correspond to "N" grid used by the U.S. Army for tactical purposes during World War II ; published on a 1953 AMS map.

Nudrewok Lake: lake, see Selby, Lake.

Nu-dru-vuk-puk: locality, site of an Eskimo village, at $\mathbf{N}$ end of Chandler Lake, at mouth of Inikaklik Creek, $26 \mathrm{mi}$. WNW of Anaktuvuk Pass, Brooks Ra.; $68^{\circ} 15^{\prime} \mathrm{N}, 152^{\circ} 38^{\prime} \mathrm{W}$; (map 134).

Name reported in March 1886 by Lt. Stoney (1900, map), USN.

Nuekshat Island: island, $2 \mathrm{mi}$. long, S of Anachlik I., in Colville River Delta, Arctic Plain; $70^{\circ} 24^{\prime} 30^{\prime \prime} \mathrm{N}, 150^{\circ} 26^{\prime} 30^{\prime \prime} \mathrm{W}$; (map 149).

Eskimo name meaning "winter fishing place," reported in 1951 by USC\&GS.

Nue-le-ar-gu-wick: stream, see Nuleargowik River.

Nuestra Señora de Dolores, Puerto: water passage, Lt. Don Jacinto Caamaño gave this name July 23, 1792, to what appears to be the entrance to Kaigani Strait between Dall and Long Islands, Alex. Arch. See Wagner (1937, p. 478)

Nuestra Señora del Carmen: island, see Kayak Island.

Nuestra Señora del Carmen, Entrada de: water passage, see Clarence Strait.

Nuestra Señora de Regla, Ensenada de: bay, see Chatham, Port.

Nu-garth-pe-ak Ta-di-ok: stream, see Ice Creek. Nugget Greek: ravine, see Nugget Gulch.

Nugget Creek: stream, heading in Nugget Creek Glacier and flowing generally W $5.5 \mathrm{mi}$. to end of Mendenhall Glacier, $9 \mathrm{mi}$. NW of Juneau, Coast Mts. ; $58^{\circ} 25^{\prime} 30^{\prime \prime} \mathrm{N}, 1^{\circ} 34^{\circ} 32^{\prime} 00^{\prime \prime}$ W; (map 11). Var. Goat Creek.

Name first appeared in the records of Sam E. Butts who located the "Lucky Sam" placer claim along the creek in 1900 (DeArmond, 1957 , p. 33). The name was reported in 1903 by A. C. Spencer and C. W. Wright, USGS.

Nugget Creek: stream, heads in a glacier, 2.7 mi. SE of Porcupine Peak, flows $2.3 \mathrm{mi}$. SE to Tsirku River, $1.8 \mathrm{mi}$. $\mathrm{E}$ of terminus of Le Blondeau Glacier, and $31 \mathrm{mi}$. SW of Skagway, St. Elias Mts.; $59^{\circ} 17^{\prime} 15^{\prime \prime} \mathrm{N}, 136^{\circ} 10^{\prime} 25^{\prime \prime}$ W; (map 45)

Prospectors' named reported by Wright (1904, p. 63), USGS.

Nugget Creek: stream, flows SW $6 \mathrm{mi}$. to Tuluksak River $4.6 \mathrm{mi}$. N of Nyac and $37 \mathrm{mi}$. SW of Aniak, Kilbuck-Kuskokwim Mts.; $61^{\circ} 04^{\prime} 30^{\prime \prime} \mathrm{N}, 159^{\circ} 57^{\prime} 00^{\prime \prime} \mathrm{W}$; (map 73).

Prospectors' name reported by A. G. Maddren, USGS, in 1914. 
Nugget Creek: stream, heads at glacier terminus, flows SE $5 \mathrm{mi}$. to Kuskulana River, $18 \mathrm{mi}$. SW of Mount Blackburn, Wrangell Mts.; $61^{\circ} 37^{\prime} \mathrm{N}, 143^{\circ} 43^{\prime} \mathrm{W}$; (map 67).

So named in 1901 by T. G. Gerdine, USGS, because he found a large block of native copper near it.

Nugget Creek: stream, heads in Dutch Hills, flows SE $6 \mathrm{mi}$. to Cache Creek, $29 \mathrm{mi}$. NW of Talkeetna, Alaska Ra.; $62^{\circ} 30^{\prime} 38^{\prime \prime} \mathrm{N}, 150^{\circ}$ 55'00" W; (map 81).

Prospectors' name reported in 1906 by $R$. W. Porter, USGS.

Nugget Creek: stream, flows E $1 \mathrm{mi}$. to Hastings Creek about $9 \mathrm{mi}$. E of Nome, Seward Penin. High.; $64^{\circ} 28^{\prime} \mathrm{N}, 165^{\circ} 06^{\prime} \mathrm{W}$; (map 94). Var. Taylor Creek.

Prospectors' name shown as "Nugget or Taylor Cr." on the 1904 "Map of Cape Nome Precinct" by Arthur Gibson. This feature cannot be precisely identified on current maps.

Nugget Creek: stream, flows NW $0.8 \mathrm{mi}$. to Solomon River near its head, $0.6 \mathrm{mi}$. SW of Conway Creek and $15 \mathrm{mi}$. NE of Solomon, Seward Penin. High.; 64ㅇ․ $46^{\prime} 30^{\prime \prime}$ N, $164^{\circ}$ $17^{\prime} 30^{\prime \prime} \mathrm{W}$; (map 95).

Prospectors' name reported in 1907 by USGS geologists (Smith, P. S., 1910, pl. 4).

Nugget Creek: stream, flows W $3 \mathrm{mi}$. to South Fork Chena River $5.5 \mathrm{mi}$. S of that stream's junc. with Chena River and $34 \mathrm{mi}$. E of Fairbanks, Yukon-Tanana High.; 64 ${ }^{\circ} 50^{\prime} 30^{\prime \prime} \mathrm{N}$, $146^{\circ} 31^{\prime} 00^{\prime \prime} \mathrm{W}$; (map 101).

Local name reported in 1950 by USGS.

Nugget Creek: stream, flows NE 2 mi. to American Creek which flows to Niukluk River, 26 mi. NW of Solomon, Seward Penin., High.; $64^{\circ} 54^{\prime} \mathrm{N}, 164^{\circ} 33^{\prime} \mathrm{W}$; (map 95).

Prospectors' name reported on a 1901 map of Cape Nome gold fields by David Fox, Jr.

Nugget Creek: stream, flows SW $4.4 \mathrm{mi}$. to Grand Central River, $29 \mathrm{mi}$. NE of Nome, Seward Penin. High.; 64 $54^{\circ} \mathrm{N}, 165^{\circ} 08^{\prime} \mathrm{W}$; (map 94).

Prospectors' name reported in 1900 by E. C. Barnard (in Brooks, 1901, pl. 17), USGS.

Nugget Creek: stream, flows NW $3 \mathrm{mi}$. to Goldstream Creek, $14 \mathrm{mi}$. NW of Fairbanks, Yukon-Tanana High.; 64 $4^{\circ} 55^{\prime} 00^{\prime \prime} \mathrm{N}, 148^{\circ} 07^{\prime}$ $50^{\prime \prime} \mathrm{W}$; (map 100).

Named by prospectors; shown in 1905 on a manuscript map by C. W. Joint.

Nugget Creek: stream, flows SE $3 \mathrm{mi}$. to Smallwood Creek, $13 \mathrm{mi}$. NE of Fairbanks, YukonTanana High.; $64^{\circ} 57^{\prime} \mathrm{N}, 147^{\circ} 21^{\prime} \mathrm{W}$; (map 100).

Named by prospectors; reported in 1903 by T. G. Gerdine as flowing to the Little Chena River (in Prindle, 1905, pl. 16), USGS.

Nugget Creek: stream, flows NE $1.7 \mathrm{mi}$. to Seventymile River, $35 \mathrm{mi}$. NW of Eagle, Yukon-Tanana High.; 64 $58^{\prime} 55^{\prime \prime} \mathrm{N}, 142^{\circ} 15^{\prime}$ 20" W; (map 102).

Prospectors' name shown on a 1902 manuscript map by E. J. Chamberlain, U.S. Deputy Surveyor.
Nugget Creek: stream, flows NE $3 \mathrm{mi}$. to Washington Creek, $17 \mathrm{mi}$. SE of junc. of Charley and Yukon Rivers, Yukon-Tanana High.; $65^{\circ}$ $12^{\prime} \mathrm{N}, 142^{\circ} 18^{\prime} \mathrm{W}$; (map 103). Var. Nuggett Gulch.

Prospectors' name recorded by D. G. Witherspoon, USGS, in 1904-05 and published by Prindle (1906), USGS. Brooks (1907, p. 201), USGS, referred to the feature as Nugget Gulch.

Nugget Creek: stream, flows S $1 \mathrm{mi}$. to Eureka Creek, $2.4 \mathrm{mi}$. E of Eureka Dome and $19 \mathrm{mi}$. $\mathrm{S}$ of Rampart, Yukon-Tanana High.; $65^{\circ} 13^{\prime}$ $09^{\prime \prime} \mathrm{N}, 150^{\circ} 09^{\prime} 10^{\prime \prime} \mathrm{W}$; BGN 1965; (map 106).

Prospectors' name reported in 1963 by Bond Taber, USGS.

Nugget Creek: stream, flows SE $2.5 \mathrm{mi}$. to Quail Creek, $15 \mathrm{mi}$. SE of Rampart, Yukon-Tanana High.; $65^{\circ} 21^{\prime} 30^{\prime \prime} \mathrm{N}, 149^{\circ} 47^{\prime} 00^{\prime \prime} \mathrm{W}$; (map 105). Var. Little Eldorado Creek.

Name originally reported in 1904 as "Little Eldorado Creek" by L. M. Prindle and F. L. Hess (in Brooks and others, 1905, fig. 6) USGS. Subsequently, local usage has changed the name to "Nugget."

Nugget Creek: stream, flows NW $1.9 \mathrm{mi}$. to Coarse Gold Creek which flows to Kougarok River, $17 \mathrm{mi}$. SW of Midnight Mtn. and 47 mi. W of Imuruk Lake, Seward Penin. High.; $65^{\circ} 34^{\prime} \mathrm{N}, 164^{\circ} 49 \mathrm{~W}$; (map 110).

Prospectors' name reported on the 1908 "Map of Seward Peninsula" by Arthur Gibson.

Nugget Creek: stream, flows SW $3 \mathrm{mi}$. to Fox Creek which flows to Arctic River, $9 \mathrm{mi}$. SE of Ear Mtn. and $43 \mathrm{mi}$. NE of Teller, Seward Penin. High.; $65^{\circ} 51^{\prime} \mathrm{N}, 165^{\circ} 59^{\prime} \mathrm{W}$; (map 111).

Prospectors' name reported in 1901 by T. G. Gerdine (in Collier, 1902, pl. 12), USGS.

Nugget Creek: stream, flows $5.5 \mathrm{mi}$. NW from Poss Mtn. to Middle Fork Koyukuk River, 37 mi. W of Chandalar, Brooks Ra.; 67 $29^{\prime} 30^{\prime \prime}$ N, $149^{\circ} 53^{\prime} 00^{\prime \prime} \mathrm{W}$; (map 123).

Prospectors' name obtained in 1901 by Schrader (1904, pl. 3), USGS.

Nugget Creek: stream, see Blind Creek.

Nugget Creek Glacier: glacier, branch of Norris Glacier, heads $\mathrm{N}$ of Nugget Mtn. and trends W $2 \mathrm{mi}$. to head of Nugget Creek, $8.5 \mathrm{mi}$. N of Juneau, Coast Mts. ; $58^{\circ} 25^{\prime} 45^{\prime \prime} \mathrm{N}, 134^{\circ} 25^{\prime}$ 15" W; BGN 1930; (map 11). Var. Nugget Glacier.

Name reported by Adolph Knopf (1912a, pls. 1, 2, and 5), USGS.

Nugget Glacier: glacier, see Nugget Creek Glacier.

Nugget Gulch: ravine, trends NE about $0.5 \mathrm{mi}$. to Gold Creek, at Silverbow Basin, $2.7 \mathrm{mi}$. E of Juneau, Coast Mts. ; $58^{\circ} 18^{\prime} 45^{\prime \prime}$ N, $134^{\circ} 20^{\prime}$ $45^{\prime \prime} \mathrm{W}$; (map 11).

Probably a local mining name; published in 1906 by USGS (Spencer, A. C., pl. 17).

Nugget Gulch: ravine, trends S $4 \mathrm{mi}$. to Fortymile River, $37 \mathrm{mi}$. S of Eagle, Yukon-Tanana High.; $64^{\circ} 15^{\prime} 30^{\prime \prime} \mathrm{N}, 141^{\circ} 12^{\prime} 15^{\prime \prime} \mathrm{W}$; (map 102).
Named by prospectors and reported in 1896 by Spurr (1898, pl. 46), USGS.

Nugget Gulch: ravine, trends SE $1.8 \mathrm{mi}$. to Teddys Fork, $10 \mathrm{mi}$. SW of Eagle, YukonTanana High.; $64^{\circ} 40^{\prime} 15^{\prime \prime} \mathrm{N}, 141^{\circ} 23^{\prime} 30^{\prime \prime} \mathrm{W}$; (map 102).

Prospectors' name obtained in 1898 by E. C. Barnard, USGS.

Nugget Gulch: ravine, trends SW $0.9 \mathrm{mi}$. to New Eldorado Creek, $14 \mathrm{mi}$. NE of Nome, Seward Penin. High.; $64^{\circ} 40^{\prime} 20^{\prime \prime} \mathrm{N}, 165^{\circ} 09^{\prime} 40^{\prime \prime} \mathrm{W}$; (map 94).

Prospectors' name reported in 1904 by T. G. Gerdine, USGS.

Nugget Gulch: ravine, trends NW $2.2 \mathrm{mi}$. to Oregon Creek, $14 \mathrm{mi}$. NW of Nome, Seward Penin. High.; $64^{\circ} 41^{\prime} \mathrm{N}, 165^{\circ} 40^{\prime} \mathrm{W}$; (map 94). Var. Nugget Creek.

Prospectors' name reported in 1900 by E. C. Barnard (in Brooks, 1901, pl. 17), USGS.

Nugget Gulch: ravine, trends SW $0.8 \mathrm{mi}$. to Bottom Dollar Creek, $2.4 \mathrm{mi}$. S of Ketchem Dome and $35 \mathrm{mi}$. SW of Circle, YukonTanana High.; $65^{\circ} 25^{\prime} 40^{\prime \prime} \mathrm{N}, 144^{\circ} 49^{\prime} 30^{\prime \prime} \mathrm{W}$; (map 104).

Prospectors' name reported in 1954 or 1955 by USGS topographers.

Nuggett Gulch: stream, see Nugget Creek.

Nugget Hill: hill, $320 \mathrm{ft}$., on NW tip of Little Kiska I., Aleutian Is.; $51^{\circ} 58^{\prime} 23^{\prime \prime}$ N, $177^{\circ}$ $38^{\prime} 24^{\prime \prime} \mathrm{E}$; (map 14).

An arbitrary name beginning with " $\mathrm{N}$ " to correspond to " $N$ " grid used by the U.S. Army for tactical purposes during World War II; published on a 1953 AMS map.

Nugget Mountain: mountain, 5,587 ft., $\mathrm{S}$ of head of Nugget Glacier, $5.4 \mathrm{mi}$. E of Bullard Mtn. and $9 \mathrm{mi}$. NE of Juneau, Coast Mts.; $58^{\circ} 25^{\prime} 40^{\prime \prime} \mathrm{N}, 134^{\circ} 21^{\prime} 15^{\prime \prime} \mathrm{W}$; (map 11).

Local name published in 1962 by USGS.

Nugget Towers: ridge, with series of peaks, extending $2 \mathrm{mi}$. NE from Bullard Mtn., $10 \mathrm{mi}$. $\mathrm{N}$ of Juneau, Coast Mts.; $58^{\circ} 27^{\prime} \mathrm{N}, 134^{\circ} 28^{\prime}$ W; (map 11).

Local name reported in 1965 by D. A. Brew and A. B. Ford, USGS.

Nuggyklik, Reka: stream, see Andreafsky River. Nugnugaluktuk River: stream, on Seward Penin., flows E $26 \mathrm{mi}$. to Goodhope Bay, $37 \mathrm{mi}$. NW of Deering, Kotzebue-Kobuk Low.; 66 ${ }^{\circ} 12^{\prime}$ N, $164^{\circ} 06^{\prime} \mathrm{W}$; (map 113).

Eskimo name obtained in 1903 by D. C. Witherspoon, USGS.

Nuhinik Creek: stream, heads in lake, flows NE $9.5 \mathrm{mi}$. to Easter Creek $11 \mathrm{mi}$. SE of its junc. with Killik River, Brooks Ra.; 68 $03^{\circ} \mathrm{N}$, $153^{\circ} 50^{\prime} \mathrm{W}$; (map 133).

Eskimo name reported in 1956 by Orth. Nuhkahllanny: mountain, see Gold Mountain. Nuhluk River: stream, see Nahtuk River.

Nuigalak Lake: lake, $5.5 \mathrm{mi}$. across, between Kashunuk and Manokinak Rivers, $27 \mathrm{mi}$. NE of Hazen Bay, Yukon-Kuskokwin Delta; $61^{\circ} 32^{\prime} \mathrm{N}, 164^{\circ} 38^{\prime} \mathrm{W}$; (map 74). Var. Nuigaluk Lake.

Eskimo name reported by USC\&GS as "Nu-ig-ga-luk" in 1951.

Nuigaluk Lake: lake, see Nuigalak Lake. 
Nuka, Guba: estuary, see Nuka Bay.

Nuka, Zaliv: estuary, see Nuka Bay

Nuka Bay: estuary, $10 \mathrm{mi}$. wide, on $\mathrm{E}$ coast of Kenai Penin., $40 \mathrm{mi}$. E of Seldovia, Chugach Mts.; $59^{\circ} 19^{\prime} \mathrm{N}, 150^{\circ} 33^{\prime} \mathrm{W}$; (map 50). Var. Guba Nuka, Zaliv Nuka.

Eskimo name published by Lt. Sarichev (1826, map 5) as "Guba Nuka," or "Nuka Bay"; derived from "nukaq" which refers to a "young bull caribou."

Nuka Island: island, $9 \mathrm{mi}$. long, $1 \mathrm{mi}$. off SE coast of Kenai Penin., $36 \mathrm{mi}$. ESE of Seldovia, Chugach Mts.; $59^{\circ} 22^{\prime} \mathrm{N}, 150^{\circ} 40^{\prime} \mathrm{W} ; B G N$ 1908; (map 50).

Named in 1908 by USC\&GS. See Nuka Bay.

Nuka Island Pass: water passage, see Nuka Passage.

Nuka Island Passage: stream, see Nuka River.

Nuka Island Passage: water passage, see Nuka Passage.

Nukakalkak: point of land, see Kekurnoi, Cape.

Nuka Passage: water passage, $12 \mathrm{mi}$. long, between Kenai Penin. and Nuka I., $35 \mathrm{mi}$. ESE of Seldovia, Chugach Mts.; $59^{\circ} 24^{\prime} \mathrm{N}, 150^{\circ} 44^{\prime}$ W; BGN 1931; (map 50). Var. Nuka Island Pass, Nuka Island Passage.

Name reported in 1909 by U. S. Grant and

D. F. Higgins (in Brooks and others, 1910, pl. 3), USGS. See Nuka Bay.

Nuka Point: point of land, at S tip of Nuka I., $37 \mathrm{mi}$. SE of Seldovia, Chugach Mts.; $59^{\circ} 17^{\prime}$. $30^{\prime \prime} \mathrm{N}, 150^{\circ} 43^{\prime} 00^{\prime \prime} \mathrm{W}$; BGN 1929; (map 50). Var. South Point. Bay.

Named in 1928 by USC\&GS. See Nuka

Nuka Ridge: ridge, extends NW-SE $5 \mathrm{mi}$., on N slope of DeLong Mts., $52 \mathrm{mi}$. NE of Misheguk Mtn., Brooks Ra.; $68^{\circ} 38^{\prime} \mathrm{N}, 159^{\circ} 18^{\prime}$ W; BGN 1960; (map 131).

Named in 1952 by E. G. Sable, USGS, "for location in Nuka [River] drainage system."

Nuka River: stream, on Kenai Penin., flows S $11 \mathrm{mi}$. to Beauty Bay, at NW end of West Arm Nuka Bay, 32 mi. ESE of Homer, Chugach Mts.; $59^{\circ} 33^{\prime}$ N, $150^{\circ} 38^{\prime}$ W; BGN 1929; (map 50). Var. Nuka Island Passage.

Named in 1929 by USC\&GS. See Nuka Bay.

Nuka River: stream, heads in DeLong Mts. on Thunder Mtn. and flows NE $50 \mathrm{mi}$. to Colville River, $17 \mathrm{mi}$. NW of Liberator Lake, Arctic Slope; $69^{\circ} 01^{\prime} \mathrm{N}, 158^{\circ} 54^{\prime} \mathrm{W}$; $B G N$ 1961; (map 132). Var. Putkuruk Creek, Tripod Creek.

Name shown on a 1925 fieldsheet by Gerald FitzGerald, USGS.

Nuka Rock: rock, in Gulf of Alaska, $0.5 \mathrm{mi}$. S of Nuka I. and $37 \mathrm{mi}$. SE of Seldovia, Chugach Mts.; $59^{\circ} 17^{\prime} \mathrm{N}, 150^{\circ} 43^{\prime}$ W; BGN 1931; (map 50). Var. South Rock.

Named in 1931 by USC\&GS for Nuka Point. See Nuka Bay.

Nukatpiat Mountain: mountain, 3,650 ft., S of Nigu River, $27 \mathrm{mi}$. SE of Howard Pass, Brooks Ra.; 68 $02^{\prime} \mathrm{N}, 155^{\circ} 56^{\prime} \mathrm{W}$; (map 133). Eskimo name reported in 1956 by Orth.
Nukdik Point: point of land, on Chilkoot Inlet, $0.5 \mathrm{mi}$. NE of Haines and $16 \mathrm{mi}$. SW of Skagway, Coast Mts.; $59^{\circ} 14^{\prime} 40^{\prime \prime}$ N, $135^{\circ}-$ 25'30' W; (map 45).

Tlingit Indian name meaning "young grouse," published in 1923 on IBC Sheet 9 (1951 atlas).

Nukhl-iuag-miut: locality, see Nukluak.

Nukhluagmiut: locality, see Nukluak.

Nukhshak, Mys: point of land, see Nukshak, Cape.

Nu-klac-i-yat: locality, see Nuklukayet.

Nuklakyet: locality, see Nuklukayet.

Nuklauket Pass: pass, $900 \mathrm{ft}$., $5 \mathrm{mi}$. E of junc. of Klatakhna Creek and Melozitna River, 41 mi. NW of Tanana, Kokrines-Hodzana High.; $65^{\circ} 41^{\prime} 30^{\prime \prime} \mathrm{N}, 152^{\circ} 46^{\prime} 00^{\prime \prime} \mathrm{W}$; (map 106).

Indian name obtained in 1956 at Tanana by Orth. It refers in some way to the old Indian trading area "Nuklukayet" located at the junc. of the Tanana and Yukon Rivers. Nukleet: locality, on Cape Denbigh, at E end of Norton Sound, $12 \mathrm{mi}$. NW of Shaktoolik, Nulato Hills; $64^{\circ} 24^{\prime} \mathrm{N}, 161^{\circ} 30^{\prime} \mathrm{W}$; (map 96). Var. Noocleet, Noklich, Nucleet, Nuklit. Eskimo name recorded in 1849 by Capt. M. D. Tebenkov, IRN. According to Baker $(1906$, p. 214), this is the Eskimo name for Cape Denbigh.

Nuklit: locality, see Nukleet.

Nuklit, Cape: point of land, see Denbigh, Cape. Nukliuatmiut: locality, see Nukluak.

Nukluag-miout: locality, see Nukluak.

Nuluak: locality, on S bank of Yukon River, S of Hills I., Yukon-Kuslokwim Delta; $61^{\circ} 53^{\prime}$ $\mathrm{N}, 162^{\circ} 56^{\prime} \mathrm{W}$; (map 74). Var. Nuchljuagmjut, Nukhl-iuag-miut, Nukhluagmiut, Nukliuatmiut, Nuklag-miout.

Former Eskimo village or camp reported in 1844 by Lt. L. A. Zagoskin (map, 1850), IRN. Nuklúkahyét: locality, see Nuklukayet.

Nuklukaiet: locality, see Nuklukayet.

Nuklugaluk Creek: stream, flows NW $8 \mathrm{mi}$. to Nukluk Creek, $48 \mathrm{mi}$. NE of Goodnews, Kilbuck-Kuskokwim Mts. ; 59 $41^{\prime} \mathrm{N}, 160^{\circ} 54^{\prime} \mathrm{W}$; (map 53).

Eskimo name published in 1951 by USGS. Nuklukayet: locality, at junc. of Tanana and Yukon Rivers; $65^{\circ} 10^{\prime} \mathrm{N}, 152^{\circ} 00 \mathrm{~W}$; (map 106). Var. Nuchalawoia, Nu-cha-la-woy-ya, Nuclucayette, Nuclukayette, Nu-klac-i-yat, Nuklakyet, Nuklukahyet, Nuklukoyet, Nuklukyeto, Nuklukyet, Nuklukaiet, Tuklukyet.

Former Indian trading camp and settlement located on the right bank of the Yukon River near the junction of the Tanana River, usually between the Tozitna River and Mission Hill; reported by Dall $(1870$, p. 57$)$ as "Nuklukahyet." With the establishment of a trading station, about 1869 , the area became a more permanent settlement. See Tanana.

The name "Nuklukayet," and its variant spellings appear to be derived from the pronunciation (and possible spelling) of the Indian name as interpreted by Arthur Harper who named his trading post "Nuklukyet." However, Archdeacon Stuck (1917, p. 140) reports that the Indians said, "there was never such a name" and it is more correctly given as "Nu-cha-la-woy-ya [Nuchalawoia]," meaning "between the rivers."

In the 1880 Census Petroff (1884, p. 12) listed "Nuklukaiet," population 27; 120 in 1890.

Nukluk Creek: stream, flows NW $16 \mathrm{mi}$. to Kanektok River, $48 \mathrm{mi}$. NE of Goodnews, Kilbuck-Kuskokwim Mts.; $59^{\circ} 43^{\prime} \mathrm{N}, 160^{\circ} 58^{\prime} \mathrm{W}$; (map 53). Var. Nuchluk River.

Eskimo name reported as "Nuchluk River" on an 1898 fieldsheet by W. S. Post, USGS; published as "Nukluk Creek" (Spurr, 1900, map 10).

Nukluk Creek: stream; flows NW $16 \mathrm{mi}$. to Kisaralik River, $45 \mathrm{mi}$. SE of Bethel, YukonKuskokwim Delta; $60^{\circ} 44^{\prime} \mathrm{N}, 160^{\circ} 23^{\prime} \mathrm{W}$; (map 59).

Eskimo name reported in 1955 by J. M. Hoare, USGS.

Nukluk Mountain: mountain, 1,342 ft., $6 \mathrm{mi}$. $\mathrm{N}$ of Spein Mountain, $44 \mathrm{mi}$. SE of Bethel, Kilbuck-Kuskokwim Mts. ; $60^{\circ} 41^{\prime} 45^{\prime \prime} \mathrm{N}, 160^{\circ}$ $26^{\prime} 00^{\prime \prime} \mathrm{W}$; (map 59).

Eskimo name reported in 1955 by J. M. Hoare.

Nuklukoyet: locality, see Nuklukayet.

Nuklukyet: locality, see Nuklukayet.

Nuklukyeto: locality, see Nuklukayet.

Nuklunek Mountain: mountain, 3,679 ft., $12 \mathrm{mi}$. SE of Eek Mts. and $75 \mathrm{mi}$. NE of Goodnews, Kilbuck-Kuskokwim Mts.; $59^{\circ} 48^{\prime} \mathrm{N}, 160^{\circ} 08^{\prime}$ W; (map 53). Var. Nuchklunek Mountain.

Eskimo name reported in 1898 by J. E. Spurr and W. S. Post, USGS.

Nukmiute: village, see Teller.

Nukshak, Cape: point of land, S point of entrance to Hallo Bay, on $S$ coast of Alaska Penin., in Katmai National Monument, 38 mi. NE of Mount Katmai, Aleutian Ra.; 58 $23^{\prime} 30^{\prime \prime} \mathrm{N}, 153^{\circ} 58^{\prime} 45^{\prime \prime} \mathrm{W}$; (map 43). Var. Cap Nough-chack, Cape Nuchtschak, Mys Nukhshak.

Eskimo name reported as "C[ap] Noughchack" by von Krusenstern (1827, map 17) and published in 1847 as "M[ys] Nukhshak" on Russian Hydrog. Dept. Chart 1378.

Nukshak Island: island, $0.5 \mathrm{mi}$. long, in Shelikof Strait, E of Cape Nukshak, on E coast of Alaska Penin., in Katmai National Monument, $38 \mathrm{mi}$. NE of Mount Katmai, Aleutian Ra.; 58 $23^{\prime} 25^{\prime \prime}$ N, $153^{\circ} 57^{\prime} 15^{\prime \prime}$ W; (map 43).

Local name reported in 1951 by USGS; probably named after Cape Nukshak.

Nulagito: village, see Nulato.

Nulagvik Lagoon: lagoon, on shore of Chukchi Sea, $17 \mathrm{mi}$. NW of Kivalina, Kotzebue-Kobuk Low. ; $67^{\circ} 54^{\prime} \mathrm{N}, 164^{\circ} 59^{\prime} \mathrm{W}$; (map 128). Var. Noolagvim Tessaya, Nulagwim Tasia.

Eskimo name meaning "camping place" reported in 1966 by E. S. Burch.

Nulagwim Tasia: lagoon, see Nulagvik Lagoon. Nulahtuk: locality, see Nulatok.

Nulakhtolagamute: locality, see Nuloktolok.

Nularvik River: stream, heads in Sadlerochit Mts., flows NW $18 \mathrm{mi}$. to Katakturuk River $17 \mathrm{mi}$. SW of its mouth in Camden Bay, 32 
mi. SE of Flaxman I., Arctic Plain; $69^{\circ} 46^{\prime}$ $\mathrm{N}, 145^{\circ} 19^{\prime} \mathrm{W}$; (map 139).

Eskimo name reported in 1956 by Orth to mean "place where a tent stood."

Nulato: village, pop. 283, on right bank of Yukon River, $25 \mathrm{mi}$. W of Galena, Nulato Hills; $64^{\circ} 43^{\prime} \mathrm{N}, 158^{\circ} 06^{\prime} \mathrm{W}$; (map 97). Var. Nulagito, Odinotchka.

Nulato, named for the nearby stream, was founded in 1838 by the "Russian Creole" Malakhov (or Nalakov) when he built a small trading post, without a stockade, consisting of a few small buildings. When he temporarily left for a few months, the Indians burned it. In 1839 the same thing happened. In 1841 Vasili Derzhavin (Derabin) was sent by the Russian American Company to the post. Again, in 1842, it was built and consisted of several detached log houses without a stockade. In the spring of 1851 the post was surprised by Koyukan Indians and most of its inhabitants killed, including Derzhavin and an English naval officer from the H.M.S. Enterprise, Lt. Barnard, who was sent inland in search for information about Sir John Franklin and his party. A new fort surrounded by a stockade was built 2 or 3 years later at the village's present location 2 miles up the Yukon (Bancroft, 1886, 572-574).

Nulato's population was 168 in $1880 ; 118$ in $1890 ; 230$ in $1910 ; 258$ in $1920 ; 204$ in $1930 ; 113$ in 1940 ; and 176 in 1950 . A post office was established in 1897 .

Nulato Hills: mountains, in group, $300 \mathrm{mi}$. long and $80 \mathrm{mi}$. wide, bounded on $S$ and $E$ by Yukon River, on $\mathbf{N}$ by lowlands of Selawik River and Selawik Lake, and on $W$ by Norton Bay and Norton Sound; $66^{\circ} 15^{\prime} \mathrm{N}, 159^{\circ} 00^{\prime} \mathrm{W}$ [N end], $62^{\circ} 00^{\prime} \mathrm{N}, 163^{\circ} 00^{\prime} \mathrm{W}$ [S end].

General term derived from the village and river of the same name.

Nulato Island: island, in Yukon River, $1 \mathrm{mi}$. SE of Nulato, Koyukuk Low.; $64^{\circ} 43^{\prime} \mathrm{N}, 158^{\circ} 05^{\prime}$ W; (map 97).

Riverboat pilots' name shown on a 1940 "Navigation Chart of the Tanana-Yukon Rivers" published by U.S. Dept. of Interior.

Nulatok: locality, on right bank of Nayorurun River, $5 \mathrm{mi}$. N of its junc. with Togiak River and $56 \mathrm{mi}$. NE of Goodnews, Kilbuck-Kuskokwim Mts.; $59^{\circ} 26^{\prime} \mathrm{N}, 160^{\circ} 08^{\prime} \mathrm{W}$; (map 53). Var. Nulahtuk.

Former Eskimo village, population 211, reported by Ivan Petroff in the 10th Census in 1880.

Nulato River: stream, flows NE $71 \mathrm{mi}$. to Yukon River, $1 \mathrm{mi}$. SW of Nulato, Nulato Hills; $64^{\circ}$ $42^{\prime} \mathrm{N}, 158^{\circ} 08^{\prime} \mathrm{W}$; (map 97).

Koyukan Indian name reported in 184244 as "R[eka] Nulata" by Lt. L. A. Zagoskin, IRN.

Nulavik: locality, on Chukchi Sea coast, $21 \mathrm{mi}$. SW of Barrow, Artic Plain; $71^{\circ} 01^{\prime} 35^{\prime \prime} \mathrm{N}$, $157^{\circ} 17^{\prime} 40^{\prime \prime} \mathrm{W}$; (map 153). Var. Siinaat Kivalik.

Eskimo name recorded by USC\&GS about 1950 , meaning "camping place."
Nuleargowik River: stream, flows SW $9 \mathrm{mi}$. to a lake, $11 \mathrm{mi}$. NE of Selawik, KotzebueKobuk Low.; $66^{\circ} 41^{\prime} \mathrm{N}, 159^{\circ} 39^{\prime} \mathrm{W}$; (map 114). Var. Nue-le-ar-gu-wick, Nu-le-ar-gowik, Nuteargowik.

Eskimo name obtained in 1886 by Lt. Stoney (1900, p. 101), USN, who wrote "The eleventh moon, Nue-le-ar-gu-wick, because the deer cohabit (nuele, wife, arguwick, deer)." Nulhutno Creek: stream, see Tazimina River. Nulhutno Lake: lake, see Lower Tazimina Lake. Nulhutno River: stream, see Tazimina River.

Nulitna River: stream, flows NE $28 \mathrm{mi}$. to Huslia River, $20 \mathrm{mi}$. NW of Roundabout Mtn., Koyukuk Low.; $65^{\circ} 49^{\prime}$ N, $156^{\circ} 42^{\prime}$ W ; (map 108).

Koyukan Indian name obtained at Huslia in 1955 by USGS.

Nuloktolgamute: locality, see Nuloktolok.

Nuloktolok: locality, on S part of Nelson I., between Baird Inlet and Bering Sea, YukonKuskokwim Delta; $60^{\circ} 30^{\prime} \mathrm{N}, 164^{\circ} 45^{\prime} \mathrm{W}$; (map 58). Var. Nulakhtolagamute, Nuloktolgamute, Nulukhtulogumut.

Former Eskimo village or camp visited in 1878 by E. W. Nelson, U.S. Signal Service, and recorded as "Nulukhtulogumut." In the 1880 Census Ivan Petroff lists "Nulakhtolagamute," population 25.

Nulukhtulogumut: locality, see Nuloktolok.

Nuluk River: stream, on Seward Penin., heads at junc. of its North and South Forks, flows NW $32 \mathrm{mi}$. to Arctic Lagoon, on Chukchi Sea, $48 \mathrm{mi}$. NW of Teller, Kotzebue-Kobuk Low.; 6556' N, $166^{\circ} 52^{\prime} \mathrm{W}$; (map 111). Var. Nooluk River.

Eskimo name reported in 1901 as "Nooluk" by T. G. Gerdine (in Collier, 1902, pl. 12), USGS.

Nuluk River: stream, see Nahtuk River.

Nulvororok Channel: stream, distributary of Kobuk River, heads at Melvin Channel, Kobuk River, flows NW $5 \mathrm{mi}$. to Nulvororok Lake, $48 \mathrm{mi}$. NW of Selawik, Kotzebue-Kobuk Low.; 66 $52^{\prime} \mathrm{N}, 161^{\circ} 38^{\prime} \mathrm{W}$; (map 114).

Eskimo name obtained in 1955 by U.S. Army Corps of Engineers.

Nulvororok Lake: lake, $4 \mathrm{mi}$. long, $49 \mathrm{mi}$. NW of Selawik, Kotzebue-Kobuk Low.; 66 ${ }^{\circ} 53^{\prime}$ $\mathrm{N}, 161^{\circ} 39^{\prime} \mathrm{W}$; (map 114).

Eskimo name obtained in 1955 by U.S. Army Corps of Engineers.

Number Four, Creek: stream, flows W $0.5 \mathrm{mi}$. to Red Bay, on N coast of Prince of Wales I., Alex. Arch.; $56^{\circ} 16^{\prime} 45^{\prime \prime} \mathrm{N}, 133^{\circ} 17^{\prime} 50^{\prime \prime} \mathrm{W}$; (map 6). Var. Number Four Creek.

Local descriptive name reported in 1949 by USGS.

Number Nineteen, Island: barrier island, see Karluk Island.

Number One, Creek: stream, flows W $0.5 \mathrm{mi}$. to Red Bay, on $\mathrm{N}$ coast of Prince of Wales I., Alex. Arch.; $56^{\circ} 17^{\prime} 10^{\prime \prime} \mathrm{N}, 133^{\circ} 18^{\prime} 20^{\prime \prime} \mathrm{W}$; (map 6). Var. Number One Creek.

Local descriptive name reported in 1949 by USGS.

Number One, Lake: lake, $1.6 \mathrm{mi}$. long, at terminus of Anderson Glacier, $18 \mathrm{mi}$. W of Val- dez, Chugach Mts. ; $61^{\circ} 07^{\prime} 45^{\prime \prime} \mathrm{N}, 146^{\circ} 48^{\prime} 20^{\prime \prime}$

W; (map 68).

Local name published in the 1950's by USGS.

Number One Creek: stream, flows S $2.2 \mathrm{mi}$. to Spruce Creek, $6.8 \mathrm{mi}$. SE of Marshall, Nulato Hills ; $61^{\circ} 47^{\prime} 20^{\prime \prime} \mathrm{N}, 161^{\circ} 59^{\prime} 30^{\prime \prime} \mathrm{W}$; (map 73).

Prospectors' name reported by Harrington (1918, map), USGS, in 1916; so called because the creek was considered the first stream tributary to Spruce Creek.

Number Six Hill: ridge, see Chicken Ridge.

Number Three, Creek: stream, flows W 0.5 mi. to Red Bay, on N coast of Prince of Wales I., Alex. Arch.; $56^{\circ} 16^{\prime} 55^{\prime \prime} \mathrm{N}, 133^{\circ} 17^{\prime} 55^{\prime \prime} \mathrm{W}$; (map 6). Var. Number Three Creek.

Local descriptive name reported in 1949 by USGS.

Number Three, Lake: lake, $0.4 \mathrm{mi}$. long, on Prince of Wales I., near head of Kasaan Bay, $0.8 \mathrm{mi}$. NW of village of Salt Chuck, Alex. Arch.; 55 38' $15^{\prime \prime} \mathrm{N}, 132^{\circ} 34^{\prime} 40^{\prime \prime} \mathrm{W}$; (map 4).

Name recorded in 1907-1908; and published in 1911 on a USGS map.

Number Three Bay: bight, $3 \mathrm{mi}$. across, on NW coast of Kenai Penin., $18 \mathrm{mi}$. NNE of Kenai, Cook Inlet Low.; $60^{\circ} 47^{\prime} 30^{\prime \prime} \mathrm{N}, 151^{\circ} 03^{\prime} 30^{\prime \prime}$ W; BGN 1916; (map 62).

Local name reported in 1916 by USC\&GS.

Number Two, Bluff: bluff, at junc. of Alder Creek and Chatanika River, $25 \mathrm{mi}$. NE of Fairbanks, Yukon-Tanana High.; 65 ${ }^{\circ} 10^{\prime}$ $\mathrm{N}, 147^{\circ} 16^{\prime} \mathrm{W}$; (map 105).

Local name published by USGS in the 1950's.

Number Two, Creek: stream, flows W $0.5 \mathrm{mi}$. to Red Bay, on $\mathbf{N}$ coast of Prince of Wales $\mathbf{I}$., Alex. Arch.; $56^{\circ} 17^{\prime} \mathrm{N}, 133^{\circ} 18^{\prime} \mathrm{W}$; (map 6). Var. Number Two Creek.

Local descriptive name reported in 1950 by USGS.

Number Two, Lake: lake, see Ellen, Lake.

Numuk: locality, see Nuwuk.

Numuk: point of land, see Barrow Point.

Nuna: locality, on Point Hope, Arctic Slope; $68^{\circ} 21^{\prime} \mathrm{N}, 166^{\circ} 47^{\prime}$; (map 129). Var. Noona, Noona-agamute.

Former Eskimo village or camp recorded as "Noo-na," by W. H. Dall (1877, p. 11), USC\&GS. Petroff (1884, p. 4) lists "Noonaagamute," population 74 , in the 1880 Census. Nuna means "land, earth."

Nunabiklu Slough: water course, $1.2 \mathrm{mi}$. long, in Yukon Delta, E of Nunachik Pass at Hamilton and $21 \mathrm{mi}$. NE of Kwiguk, Yukon-Kuskokwim Delta; $62^{\circ} 53^{\prime} 45^{\prime \prime} \mathrm{N}, 163^{\circ} 53^{\prime} 15^{\prime \prime} \mathrm{W}$; (map 77).

Eskimo name obtained in 1948 by USC\&GS. Nunachanaghamiut: locality, see Nunochok.

Nunachăra ğămut: locality, see Nunochok.

Nunachik Pass: watercourse, in Yukon Delta, extends NE-SW $6.3 \mathrm{mi}$. between Apoon and Little Apoon Passes, $21 \mathrm{mi}$. NE of Kwiguk, Yukon-Kuskokwim Delta ; $62^{\circ} 53^{\prime} 45^{\prime \prime} \mathrm{N}, 163^{\circ}$ 53'20" W; (map 77).

Eskimo name obtained in 1899 by $R$. L. Faris, USC\&GS. 
Nunachogumut: locality, see Nunochok.

Nunachok: locality, see Nunachuk.

Nunachuak: village, pop. 50 (1940), on left bank of Nushagak River below its junc. with Nunachuak Creek, 64. mi. NE of Dillingham, Bristol Bay Low.; $59^{\circ} 38^{\prime} \mathrm{N}, 157^{\circ} 04^{\prime} \mathrm{W}$; BGN 1931; (map 52). Var. Kakuak.

Eskimo village reported in the 1930 Census.

Nunachuak Creek: stream, flows NW $25 \mathrm{mi}$. to Nushagak River at Nunachuak, $64 \mathrm{mi}$. NE of Dillingham, Bristol Bay Low.; $59^{\circ} 38^{\prime} \mathrm{N}, 157^{\circ}$. 04' W; BGN 1931; (map 52).

Eskimo name reported in 1931 by USGS.

Nunachuk: locality, 2 mi. E of Kyigayalik Lake and $30 \mathrm{mi}$. NW of Bethel, Yukon-Kuskokwim Delta; 60 $59^{\prime} \mathrm{N}, 162^{\circ} 29^{\prime} \mathrm{W}$; (map 58). Var. Nunachok.

Listed with a population of 44 in the 1950 Census.

Nuna Creek: stream, flows SW $19 \mathrm{mi}$. to Akillik River, $43 \mathrm{mi}$. NW of Shungnak, Brooks Ra.; $67^{\circ} 17^{\prime} \mathrm{N}, 158^{\circ} 22^{\prime} \mathrm{W}$; (map 126).

Eskimo name meaning "land" reported by Orth in 1956.

Nunaghak Rock: rock, see Noonaghak.

Nunaikagamute: locality, see Nunaikak.

Nunaikagumute: locality, see Nunaikak.

Nunaikak: locality, on W bank of Yukon River, at or near Holy Cross, Innoko Low.; 62 ${ }^{\circ} 12^{\prime}$ $\mathrm{N}, 159^{\circ} 17^{\prime} \mathrm{W}$; (map 78). Var. Khaigamute, Nunaikagamute, Nunaikagumute, Ookagamute, Ukagamut, Ukak, Yukagamut, Yukagamute.

Former Eskimo village or camp reported in 1869 as "Nunaikagumute" by-Raymond (1871, p. 25), U.S. Engineers. Baker (1906, p. 474) wrote, "May be identical with Khaigamute, or perhaps Ookagamute of Petroff, 1880." Hodge (1910, p. 97) wrote, “*** perhaps identical with Ukak."

Nunaka Valley: suburb, pop. 1,442, E of Anchorage, Cook Inlet Low.; $61^{\circ} 12^{\prime} 24^{\prime \prime}$ N, $149^{\circ}$ $46^{\prime} 05^{\prime \prime} \mathrm{W}$; (map 69).

Local name reported in 1954 by the city engineer of Anchorage.

Nunakhtagamute: locality, see Nunaktak.

Nunakogok River: stream, flows N $20 \mathrm{mi}$. to Kogok River, $21 \mathrm{mi}$. SW of St. Michael, Yukon-Kuskokwim Delta; $63^{\circ} 11^{\prime} 30^{\prime \prime} \mathrm{N}, 162^{\circ}$ 17'30" W; (map 92). Var. Kogok River.

Eskimo name obtained in 1952 by USC\&GS.

Nunakolak: locality, on Nelson I., just $\mathrm{N}$ of Kangirlvar Bay, $11 \mathrm{mi}$. E of Cape Vancouver, Yukon-Kuskokwim Delta; $60^{\circ} 32^{\prime} \mathrm{N}, 165^{\circ} 06^{\prime}$ W; (map 57).

This place was once an Eskimo summer camp and is no longer used since establishment of village of Toksook Bay; reported in 1949 by USC\&GS.

Nunaktak: locality, on right bank of Yukon River about $30 \mathrm{mi}$. above Anvik, Innoko Low.; $63^{\circ} 03^{\prime} \mathrm{N}, 159^{\circ} 21^{\prime} \mathrm{W}$; (map 91). Var. Nunakhtagamute.

Former Eskimo village or camp reported in 1878-79 as "Nunakhtagamute," by E. W. Nelson, U.S. Signal Service.

Nunaktuau: locality, see Napawrax.
Nunaktuk Island: island, at mouth of Kwikpak Pass, in Yukon Delta on Norton Sound, $2.8 \mathrm{mi}$. long, $27 \mathrm{mi}$. N of Kwiguk, Yukon-Kuskokwim Delta; $63^{\circ} 05^{\prime} \mathrm{N}, 164^{\circ} 37^{\prime} \mathrm{W}$; (map 92).

Eskimo name recorded in 1952 by USGS.

Nunalik: locality, on W coast of Afognak I., at Cape Nuniliak, Kodiak I.; $58^{\circ} 09^{\prime} 45^{\prime \prime} \mathrm{N}$, $153^{\circ} 13^{\prime} 00^{\prime \prime}$ W; (map 43). Var. Litnik, Malinovskie lietnik, Malinovski, Malinovskiy Lytnik, Nuniliak, Nunilyak.

Former Eskimo summer camp published by Capt. Tebenkov (1852, map 23), IRN, as "S[eleniye] Nunalik," or "Nunalik Village;" reported in 1839 or 1840 by Sub-Lt. Mikhail Murashev, IRN, as "Malinovskiy Lytnik" or "Raspberry summer village," and published as such by the Russian American Company in 1849.

Nunalik: point of land, see Nuniliak, Cape.

Nunalyugak, Ostrov: island, see Crooked Island. Nunamekrot: point of land, see Sheldon Point. Nunamiut: locality, on $\mathrm{W}$ shore of Three Saints Bay, on SE coast of Kodiak I.; $57^{\circ} 07^{\prime} 20^{\prime \prime} \mathrm{N}$, $153^{\circ} 30^{\prime} 30^{\prime \prime} \mathrm{W}$; (map 34). Var. Nunjagmut, Nunochogamute, Old Harbor, Starri-gavan, Staruigavan, Three Saints Harbor, Ziatitz.

Former Eskimo village name meaning "land people," published as "Nunochogamute," population 160, in the 10th Census (1884, p. 11). Early Russian sources included this village in their descriptions of the settlement 1.5 miles to the southeast established by Shelikov in 1784. See Three Saints Harbor, locality.

Nunamiut: locality, see Three Saints Harbor.

Nunamiut: village, see Old Harbor.

Nunapitchuk: village, on right bank of Johnson River, $26 \mathrm{mi}$. NW of Bethel, Yukon-Kuskokwim Delta; $60^{\circ} 53^{\prime} \mathrm{N}, 162^{\circ} 29^{\prime} \mathrm{W}$; $B G N$ 1937; (map 58).

Eskimo village listed with a population of 121 in 1939 and 125 in 1950 . This village has two groups of buildings sometimes referred to as Nunapitchuk No. 1 and Nunapitchuk No. 2.

Nunapitsinchak: locality, on right bank of Kwethluk River, 13 mi. E of Bethel, YukonKuskokwim Delta ; $60^{\circ} 47^{\prime} 45^{\prime \prime} \mathrm{N}, 161^{\circ} 22^{\prime} 30^{\prime \prime}$ W; (map 59).

Eskimo settlement, of about 10 buildings, reported in 1951 by USC\&GS.

Nunaria: locality, near Point Belcher, $13 \mathrm{mi}$. NE of Wainwright, Arctic Plain; (map 146).

Eskimo village abandoned when Sidaru was established; reported on British Admiralty chart 593 (1827-54). It was already deserted in 1883.

Nunaria: locality, see Nunatunga.

Nunaria: locality, see Sidaru.

Nuna-runga: locality, see Nunatunga.

Nuna Slough: stream, anabranch, flows SE $8 \mathrm{mi}$. to Huslia River, $15 \mathrm{mi}$. NW of Roundabout Mtn. Koyukuk Low.; $65^{\circ} 45^{\prime}$ N, $156^{\circ} 36^{\prime}$ W; (map 108).

Local name reported in 1955 by USGS.

Nunatak, The: mountain, 1,205 ft., $0.7 \mathrm{mi}$. N of Nunatak Cove, on Muir Inlet, Glacier Bay National Monument, $65 \mathrm{mi}$. NW of Hoonah,
St. Elias Mts.; $58^{\circ} 59^{\prime} 15^{\prime \prime} \mathrm{N}, 136^{\circ} 10^{\prime} 55^{\prime \prime} \mathrm{W}$; (map 10). Var. Nunatak Knob.

Local name reported by USGS (Twenhofel and others, 1946, pl. 1). This mountain was a nunatak from 1911 to 1929 . It was called "Nunatak Knob" by members of the Glacier Bay Expedition of 1941 (Field, 1947, map). Nunatak, The: mountain, 1,516 ft., near S shore of Nunatak Fiord, $2.3 \mathrm{mi}$. NE of Mount Draper and $31 \mathrm{mi}$. NE of Yakutat, St. Elias Mts.; $59^{\circ} 49^{\prime} 45^{\prime \prime} \mathrm{N}, 139^{\circ} 02^{\prime} 00^{\prime \prime} \mathrm{W}$; (map 46).

Named in 1899 by the Harriman Alaska Expedition (in Gilbert, 1904, p. 60).

Nunatak Cove: cove, $0.5 \mathrm{mi}$. long, on $\mathrm{E}$ shore of Muir Inlet, Glacier Bay National Monument, $1 \mathrm{mi}$. $\mathrm{N}$ of Sealers I., and $65 \mathrm{mi}$. NW of Hoonah, St. Elias Mts.; $58^{\circ} 58^{\prime} 40^{\prime \prime} \mathrm{N}, 136^{\circ}$ $06^{\prime} 45^{\prime \prime}$ W; (map 10). Var. Ankorage Cove.

Name derived from "The Nunatak" mountain; published by USGS (Twenhofel and others, 1946, pl. 2). The name "Ankorage Cove" was given by members of the Glacier Bay Expedition of 1941 (Field, 1947, map), because since 1931 the cove has offered the best anchorage in the area.

Nunatak Fiord: estuary, heads at East Nunatak Glacier, extends NW $13 \mathrm{mi}$. to Russell Fiord, $15 \mathrm{mi}$. E of Yakutat Bay, St. Elias Mts.; $59^{\circ} 51^{\prime} \mathrm{N}, 139^{\circ} 16^{\prime} \mathrm{W}$; (map 46). Var. North East Arm.

Named in 1899 by Harriman Alaska Expedition (in Gilbert, 1904, p. 58). It was called "North East Arm" by Lt. Comdr. Moser (1901, pl. 43), USN.

Nunatak Knob: mountain, 4,100 ft., in Glacier Bay National Monument, $2.6 \mathrm{mi}$. S of Red Mtn., and $5 \mathrm{mi}$. $\mathrm{N}$ of the 1954 terminus of Casement Glacier, $40 \mathrm{mi}$. SW of Skagway, St. Elias Mts.; $59^{\circ} 10^{\prime} \mathrm{N}, 135^{\circ} 55^{\prime} \mathrm{W}$; (map 45).

Local name obtained by USGS field personnel and published on Federal maps since 1950.

Nunatak Knob: mountain, see Nunatak, The. Nunatak River: stream, see Noatak River.

Nunathloogagamiut: locality, $3 \mathrm{mi}$. NE of Ingriruk Hill, $8 \mathrm{mi}$. NE of Cape Mendenhall, Nunivak I.; $59^{\circ} 53^{\prime} 30^{\prime \prime} \mathrm{N}, 1^{\circ} 5^{\circ} 58^{\prime} 00^{\prime \prime} \mathrm{W}$; (map 55). Var. Nunathlugagamiut.

Eskimo camp reported in 1942 by the U.S. Army Air Force.

Nunathloogagamiutbingoi Dunes: sand dunes, extend NE $3 \mathrm{mi}$. along SE coast of Nunivak I., from a point $1 \mathrm{mi}$. $\mathrm{N}$ of Cape Mendenhall; $59^{\circ} 50^{\prime} \mathrm{N}, 166^{\circ} 05^{\prime} \mathrm{W}$; (map 55). Var. Nunathlugagamiut Dunes.

Eskimo name reported in 1937 by USAAF.

Nunathlugagamiut: locality, see Nunathloogagamiut.

Nunathlugagamiut Dunes: sand dunes, see Nunathloogagamiutbingoi Dunes.

Nunatok River: stream, see Noatak River.

Nunatuk Glacier: glacier, see East Nunatak Glacier and West Nunatak Glacier.

Nunatunga: locality, on $\mathrm{E}$ side of Colville River Delta, Arctic Plain; $70^{\circ} 26^{\prime} \mathrm{N}, 150^{\circ} 15^{\prime} \mathrm{W}$; (map 149). Var. Nunaria, Nuna-runga. Shown on Maguires map (Great Britain, 
1854, facing p. 186) as "Nuna-runga," and probably refers to a camp site. John Simpson's map, of the same period, would indicate that it is a form of the name "Nunamiut" [inland Eskimo], for at "Nigalek" he notes: "Where Point Barrow natives meet the Nunutang-meun or Inland Esquimaux annually in July." See Nigalik.

Nunava: estuary, see Nunavak Bay.

Nunava-ak Lake: lake, see Nenevok Lake.

Nunavachak Lake: lake, 1.3 i. long, on $\mathrm{N}$ shore of Bristol Bay, $17 \mathrm{mi}$. SE of Togiak, KilbuckKuskokwim Mts.; 58 $53^{\prime} 30^{\prime \prime} \mathrm{N}, 160^{\circ} 03^{\prime} 00^{\prime \prime}$ W; (map 39). Var. Nunavarchak Lake.

Eskimo name meaning "small lake" obtained about 1948 by USGS from Frank Waskey, local trader and prospector; erroneously published as "Nunavarchak Lake."

Nunavakanukakslak Lake: lake, $5 \mathrm{mi}$. long, along Johnson River, 3 mi. NE of Nunapitchuk and $22 \mathrm{mi}$. NW of Bethel, Yukon-Kuskokwim Delta; $60^{\circ} 57^{\prime} \mathrm{N}, 162^{\circ} 21^{\prime} \mathrm{W}$; (map 58). GS.

Eskimo name reported in 1949 by USC\&

Nunavakanuk Lake: lake, $9 \mathrm{mi}$. long and $7 \mathrm{mi}$. wide, NW of Kuzilvak Mts. and $45 \mathrm{mi}$. S of Kwiguk, Yukon-Kuskokwim Delta; $62^{\circ} 04^{\prime} \mathrm{N}$, $164^{\circ} 40^{\prime} \mathrm{W}$; (map 77).

Eskimo name obtained in 1948 by USC\& GS.

Nunavak Anukslak: lake, see Kayigyalik Lake.

Nunavakanuthluk: locality, on Johnson River, at $\mathrm{N}$ end of Nunavakanukakslak Lake, $25 \mathrm{mi}$. NW of Bethel, Yukon-Kuskokwim Delta; $60^{\circ} 59^{\prime} \mathrm{N}, 162^{\circ} 21^{\prime} \mathrm{W}$; (map 58). Var. Nunvagalovluk.

Eskimo camp or small settlement that may now be abandoned. Its exact location is in doubt and may apply to a place closer to $60^{\circ} 56^{\prime} \mathrm{N}, 162^{\circ} 35^{\prime} \mathrm{W}$

Nunavak Bay: estuary, with $\mathrm{N}$ and $\mathrm{S}$ arms extending $3 \mathrm{mi}$. off Chukchi Sea, $3 \mathrm{mi}$. S of Barrow, Arctic Plain; $71^{\circ} 15^{\prime} \mathrm{N}, 156^{\circ} 53^{\prime} \mathrm{W}$; (map 153). Var. Nunava.

Eskimo name recorded by USC\&GS about 1950 and means "big land." P. H. Ray $(1885$, p. 55$)$ records the locality name "Nunava."

Nunavakpak Lake: lake, $11 \mathrm{mi}$. long, $20 \mathrm{mi}$. NW of Fowler I. and 25 mi. W of Bethel, YukonKuskokwim Delta; $60^{\circ} 48^{\prime} \mathrm{N}, 162^{\circ} 36^{\prime} \mathrm{W}$; (map 58). Var. Big Lake.

Eskimo name reported in 1949 by USC\& GS.

Nunavarchak Lake: lake, see Nunavachak Lake. Nunavarok: lake, see Baird Inlet.

Nunavaroke: lake, see Baird Inlet.

Nunavaugaluk Lake: lake, extends SE $16 \mathrm{mi}$. to Snake River, $18 \mathrm{mi}$. NW of Dillingham, Kilbuck-Kuskokwim Mts. ; $59^{\circ} 09^{\prime} \mathrm{N}, 158^{\circ} 22^{\prime} \mathrm{W}$; BGN 1932; (map 52). Var. Nan-y-vuk-hak Lake, Nan-y-vuk-ha-luk Lake.

Eskimo name recorded by $H$. C. Fassett, USBF, on a 1910 manuscript map as "Nan-yvuk-ha-luk"; named "Lake Nunavaugaluk" by Mertie (1938b, pl. 1), USGS

Nunaviksak Greek: stream, in De Long Mts., flows SSE $16 \mathrm{mi}$. to Kugururok River, $10 \mathrm{mi}$.
NW of Misheguk Mtn., Brooks Ra.; $68^{\circ} 23^{\prime} \mathrm{N}$, $161^{\circ} 27^{\prime} \mathrm{W}$; (map 131).

Eskimo name reported in 1956 by USGS. Nunavoknakchlugamiut: locality, see Nanvogaloklak.

Nunavulnuk River: stream, flows NW $30 \mathrm{mi}$. to Big St. Michael Canal, $11 \mathrm{mi}$. SW of St. Michael, Yukon-Kuskokwim Delta; $63^{\circ} 23^{\prime} \mathrm{N}$, $162^{\circ} 19^{\prime}$ W; (map 92). Var. Nonvalnuk River.

Descriptive Eskimo name obtained in 1952 by USC\&GS meaning "river which widens to form a lake."

Nundalti Lake: lake, see Sixmile Lake.

Nundei Cove: bay, $0.5 \mathrm{mi}$. long, in Tuxekan Passage on W coast of Prince of Wales I., 22 mi. $\mathrm{N}$ of Craig, Alex. Arch.; $55^{\circ} 47^{\prime} 30^{\prime \prime} \mathrm{N}$, $133^{\circ} 12^{\prime} 45^{\prime \prime} \mathrm{W}$; (map 4).

Indian name published in 1964 by USC\&GS.

Nuneevack Island: island, see Nunivak Island. Nunevack Island: island, see Nunivak Island. Nunez Point: point of land, SE tip of Bean I., off $S$. coast of Prince of Wales I., near entrance to Nichols Bay, Alex. Arch.; 54 $41^{\prime} 05^{\prime \prime} \mathrm{N}$, $132^{\circ} 05^{\prime} 30^{\prime \prime} \mathrm{W}$; (map 1). Var. Cape Murray, Point Nunez, Punta de Nunez.

Spanish name given on July 23, 1792, by Don Jacinto Caamaño. This point was called "Cape Murray" by some of the early traders. Nungatak River: stream, probable anabranch of Kashunuk River, heads at $61^{\circ} 48^{\prime} \mathrm{N}, 163^{\circ} 55^{\prime}$ W, flows SW 60 mi. to Kashunuk River, $\mathrm{N}$ of Nuigalak Lake, Yukon-Kuskokwim Delta; $61^{\circ} 34^{\prime} \mathrm{N}, 164^{\circ} 44^{\prime} \mathrm{W}$; (map 74). Var. Sohy Bay Slough.

Eskimo name reported in 1949 by USC\&GS.

Nuniak: island, see Chernabura Island.

Nunik: island, see Chernabura Island.

Nuniliak: locality, see Nunalik village.

Nuniliak, Cape: point of land, $20 \mathrm{mi}$. NW of Afognak, on $\mathrm{W}$ coast of Afognak 1., $\mathrm{N}$ of Kodiak 1.; $58^{\circ} 09^{\prime} 45^{\prime \prime} \mathrm{N}, 153^{\circ} 13^{\prime} 00^{\prime \prime} \mathrm{W}$; (map 43). Var. Cape Malinovskoi, Malinovskie lietnik, Nunalik.

Eskimo name reported by Sub-Lt. Mikhail Murashev in 1839 or 1840 who also called it "Malinovskoy," i.e. "raspberry"; it was called "M[ys] Malinovskoy (Nunilyak)," or "cape raspberry (Nunilyak)," by the Russian American Company in 1849.

Nunilyak: locality, see Nunalik village.

Nunivachak Island: island, $1 \mathrm{mi}$. long, $2 \mathrm{mi}$. NW of Kigigak I., at mouth of Ninglick River, 110 mi. W of Bethel, Yukon-Kuskokwim Delta; $60^{\circ} 51^{\prime} \mathrm{N}, 165^{\circ} 05^{\prime} \mathrm{W}$; (map 57).

Eskimo name obtained at Tanunak in 1951 by USC\&GS.

Nunivak Bar: island, 2 mi. across, in Kuskokwim River, $31 \mathrm{mi}$. SW of McGrath, KilbuckKuskokwim Mts. ; $62^{\circ} 31^{\prime} \mathrm{N}, 155^{\circ} 52^{\prime}$ W ; (map 79).

Eskimo name published in 1954 by USGS. Nunivak Island: island, $60 \mathrm{mi}$. across, in Bering Sea, separated from Yukon-Kuskokwim Delta by Etolin Strait; $60^{\circ} 00^{\prime} \mathrm{N}, 166^{\circ} 00^{\prime} \mathrm{W} ; B G N$ 1895; (map 57). Var. Nounivak Island,
Nounivok Island, Nuneevack Island, Nunevack Island, Nuniwak Island, Otkritie.

Discovered on July 21, 1821, by Capt. Lt. M. N. Vasiliev, IRN, and named after his ship Otkritie (Discovery). A. K. Etolin and Khromchenko of the Russian American Company found the island about the same time. Capt. F. P. Lutke stated that the native name "Nounivak" [sic] had been properly retained on charts and added, had this course been followed in other cases, much confusion and embarrassment would have been avoided.

Nunivak Slough: stream, anabranch of Tanana River, $2 \mathrm{mi}$. long, $7 \mathrm{mi}$. N of Nenana, Tanana Low.; $64^{\circ} 40^{\prime} \mathrm{N}, 149^{\circ} 08^{\prime} \mathrm{W}$; (map 100).

Probably named for the U.S. Revenue steamer Nunivak that plied the Yukon from 1899 to 1901 . The name is published on recent USGS maps.

Nuniwak Island: island, see Nunivak Island.

Nunjagmut: locality, see Nunamiut.

Nun Mountain: mountain, 4,329 ft., $4.8 \mathrm{mi}$. W of Lynn Sisters in Lynn Canal and $33 \mathrm{mi}$. NW of Juneau, St. Elias Mts.; $58^{\circ} 30^{\prime} 15^{\prime \prime} \mathrm{N}, 135^{\circ}$. $15^{\prime} 15^{\prime \prime}$ W; (map 11). Var. Dome Peak.

Name published in 1924 by USC\&GS on Chart 8302 . So named because of the fancied resemblance to a nun. The 1883 Coast Pilot (p. 182) shows a mountain called Dome Peak, named in 1869 by Comdr. R. W. Meade, USN, in the position of Nun Mtn.

Nunnungynakok: locality, see Kanulik.

Nunochogamute: locality, see Nunamiut.

Nunochogamute: locality, see Nunochok.

Nunochogmute: locality, see Nunochok.

Nunochok: locality, in the Big Lake region, Yukon-Kuskokwim Delta; $60^{\circ} 30^{\prime} \mathrm{N}, 163^{\circ} 00^{\prime \prime}$ $W$; (map 74). Var. Nunachanaghamiut, Nunachāra gămut, Nunachogumut, Nunochogamute, Nunochogmute.

Former Eskimo village or camp reported in 1879 as "Nunachogumut" by E. W. Nelson, U.S. Signal Service. In the $1880 \mathrm{Cen}-$ sus Petroff (1884, p. 11) lists "Nunochogamute," population $40 ; 135$ in 1890 .

Nunovalnak Bay: bay, see Nunovulnuk Harbor.

Nunovulnuk Harbor: cove, $0.4 \mathrm{mi}$. across, on Norton Sound, E of Black Point, $24 \mathrm{mi}$. SW of Unalakleet, Nulato Hills; $63^{\circ} 33^{\prime} \mathrm{N}, 161^{\circ}$. 05' W; (map 91). Var. Nunovalnak Bay.

Eskimo name reported in 1950 by USC\&GS.

Nunsatuk River: stream, heads in Black Mts., flows NE $35 \mathrm{mi}$. to Kuskokwim River, $50 \mathrm{mi}$. SW of McGrath, Kilbuck-Kuskokwim Mts.; $62^{\circ} 17^{\prime} 45^{\prime \prime} \mathrm{N}, 156^{\circ} 12^{\prime} 45^{\prime \prime} \mathrm{W}$; (map 79).

Eskimo name reported in 1954 by USGS.

Nuntragut Slough: stream, distributary of Porcupine River, flows SW $34 \mathrm{mi}$. to Yukon River $11 \mathrm{mi}$. NW of Fort Yukon, Yukon Flats; $66^{\circ} 36^{\prime} 40^{\prime \prime} \mathrm{N}, 145^{\circ} 39^{\prime} 00^{\prime \prime} \mathrm{W}$; (map 119).

Kutchin Indian name obtained in 1956 by T. E. Taylor, USGS.

Nunulak River: stream, see Noatak River.

Nunuthlhamut: locality, on left bank of Wood River, $13 \mathrm{mi}$. $\mathrm{N}$ of Dillingham, Bristol Bay 
Low.; $59^{\circ} 15^{\prime} \mathrm{N}, 158^{\circ} 32^{\prime} \mathrm{W}$; (map 52). Eskimo village or camp shown as "Nuhuthl-ha-mut" on a 1910 manuscript map by H. C. Fassett, USBF.

Nunvagalovluk: locality, see Nunavakanuthluk. Nunvarok: lake, see Baird Inlet.

Nunvogulukhluguk: locality, in the Big Lake region, Yukon-Kuskokwim Delta; $60^{\circ} 30^{\prime} \mathrm{N}$, $163^{\circ} 00^{\prime} \mathrm{W}$; (map 74).

Former Eskimo village or camp reported in 1879 to mean "big lake" by E. W. Nelson, U.S. Signal Service.

Nunvotchuk Lake: lake, $1.7 \mathrm{mi}$. long, on W bank of Yukon River SW of Russian Mission, Yukon-Kuskokwim Delta; $61^{\circ} 46^{\prime} 40^{\prime \prime} \mathrm{N}, 161^{\circ}$ $20^{\prime} 30^{\prime \prime} \mathrm{W}$; (map 73).

Eskimo name reported by USC\&GS in 1949.

Nunvuk Mountain: mountain, $1 \mathrm{mi}$. SW of Aleknagik Lake and $30 \mathrm{mi}$. NW of Dillingham, Kilbuck-Kuskokwim Mts.; $59^{\circ} 23^{\prime} \mathrm{N}$, $158^{\circ} 59^{\prime} \mathrm{W}$; (map 52).

Eskimo name shown as "Nun-vuk" on a 1910 manuscript map by H. C. Fassett, USBF. Nuogmiut Spit: point of land, see Nuok Spit.

Nuok Spit: point of land, W point of entrance to Hooper Bay, Yukon-Kuskokwim Delta; $61^{\circ}$ $30^{\prime} \mathrm{N}, 166^{\circ} 03^{\prime} \mathrm{W}$; (map 75). Var. Nuogmiut Spit.

Eskimo name derived from the name of a settlement once located on the spit; reported by USC\&GS in 1951 .

Nuravloakh Island: island, see Nooravloaksmiut Island.

Nurse Lagoon: lagoon, $1.5 \mathrm{mi}$. long, near village of Cold Bay, at SW end of Alaska Penin. Bristol Bay Low.; $55^{\circ} 11^{\prime} 30^{\prime \prime} \mathrm{N}, 162^{\circ} 39^{\prime} 00^{\prime \prime}$ W; (map 29).

Name published in 1943 on a USGS map.

Nurukomarot Channel: channel, in offshore mudflats of Yukon Delta, extends W $3.5 \mathrm{mi}$. from Kaluchagun I. to Norton Sound, $12 \mathrm{mi}$. W of Kwiguk, Yukon-Kuskokwim Delta; $62^{\circ}$ $42^{\prime} \mathrm{N}, 164^{\circ} 54^{\prime} \mathrm{W}$; (map 77).

Eskimo name obtained in 1899 by G. R. Putnam, USC\&GS. Published in 1899 on Chart 9373.

Nurukomarot Channel: water passage, see Caseys Channel.

Nurvik: village, see Noorvik.

Nushagak: locality, at Nushagak Point, on E shore of Nushagak Bay, $6 \mathrm{mi}$. S of Dillingham, Bristol Bay Low.; $58^{\circ} 57^{\prime} \mathrm{N}, 158^{\circ} 29^{\prime} \mathrm{W}$; (map 40). Var. Aleksandrovskiy, Alexander, Alexandra, Alexandroffsk, Alexandrovsk, Alexandrovski, Fort Alexander, Fort Alexandra, Fort Alexandrofskaia, Meshagak, Nushegak, Odinochka Aleksandrovskaia, Selenie, Aleksandrovskaia, Tuviarok.

Former Eskimo village established as a trading post about 1819 , called by the Russians "Aleksandrovsk," probably for Alexander Baranov, Governor, under whose orders the post was founded. After the transfer of Alaska to the United States the settlement was referred to as "Fort" or "Redoubt Alexander" until a post office, called "Nushagak" after the river, was established in $1899.1 .5 \mathrm{mi}$.
$\mathrm{N}$ of here at Carmel. The post office was discontinued in 1935 (Ricks, 1965, p. 48). The village population was 178 in $1880 ; 268$ in $1890 ; 74$ in $1910 ; 16$ in $1920 ; 43$ in 1930 ; and 7 in 1958 . Nushagak was the principal village of several located nearby. See Bradford, Carmel, Kanulik, and Millerton.

Nushagak: village, see Dillingham.

Nushagak: lake, see Tikchik Lake.

Nushagak, Lake: lake, see Beverley, Lake.

Nushagak, Reka: stream, see Nushagak River.

Nushagak, Zaliv: bay, see Nushagak Bay.

Nushagak Bay: bay, at mouth of Nushagak River, extends S $40 \mathrm{mi}$. to Bristol Bay, E of Nushagak Penin., Bristol Bay Low.; $58^{\circ} 30^{\prime}$ N, $158^{\circ}$ $30^{\prime} \mathrm{W}$; (map 40). Var. Lower Nushagak River, Zaliv Nushagak.

Eskimo name reported as "ZaI[iv] Nushagak" by Capt. Tebenkov (1852, map 4), IRN.

Nushagak Hills: mountains, $1,400-2,400 \mathrm{ft}$., in group $35 \mathrm{mi}$. across, $70 \mathrm{mi}$. S of Sleetmute, Kilbuck-Kuskokwim Mts. ; $60^{\circ} 35^{\prime} \mathrm{N}, 157^{\circ} 10^{\prime}$ W; BGN 1937; (map 60).

Eskimo name reported by USGS in 1934 ; so called because they are at the head of the Nushagak River.

Nushagak Peninsula: peninsula, $35 \mathrm{mi}$. long, 15 mi. wide, trends SE between Bristol and Nushagak Bays, $20 \mathrm{mi}$. SW of Dillingham, Bristol Bay Low.; $58^{\circ} 39^{\prime} \mathrm{N}, 159^{\circ} 03^{\prime} \mathrm{W}$; (map 40). Named in 1910 by USC\&GS after Nushagak Bay.

Nushagak Point: promontory, $250 \mathrm{ft}$., on $\mathrm{E}$ shore of Nushagak Bay, $6 \mathrm{mi}$. S of Dillingham; Bristol Bay Low.; 58 $57^{\prime} \mathrm{N}, 158^{\circ} 29^{\prime} \mathrm{W}$; (map 40).

Eskimo name reported in 1909 by USC\&GS ; published in 1911 on Chart 9050.

Nushagak River: stream, heads at $60^{\circ} 35^{\prime} \mathrm{N}$, $156^{\circ} 06^{\prime} \mathrm{W}$ and flows SW $242 \mathrm{mi}$. to head of Nushagak Bay at Grassy I., 3 mi. S of Dillingham, Bristol Bay Low.; $59^{\circ} 03^{\prime} \mathrm{N}, 158^{\circ} 23^{\prime} \mathrm{W}$; $B G N$ 1906; (map 52). Var. Bristol River, Cook River, Nouchagak River, Nushegak River, Reka Nushagak, Reka Nushegak.

Named about 1809 by the Russian navigator, Ivan Vasiliev the first; published as "Reka Nushegak" or "Nushegak River," by Lt. Sarichev (1826, map 3), IRN. This feature was called "Bristol River" by Capt. James Cook, RN, in 1778.

Nushakantna River: stream, see Zitziana River. Nushegak: locality, see Nushagak.

Nushegak, Reka: stream, see Nushagak River. Nushegak River: stream, see Nushagak River. Nushkolik Mountain: hill, $635 \mathrm{ft}$., on W bank of Kashunuk River, $7 \mathrm{mi}$. W of Nuigalak Lake, Yukon-Kuskokwim Delta; 61 ${ }^{\circ} 33^{\prime} \mathrm{N}$, $164^{\circ} 56^{\prime} \mathrm{W}$; (map 74). Var. Nuskolik Hill, Kocheelagok.

Eskimo name reported in 1951 by USC\&GS. Nushralutak Creek: stream, heads at Nakmaktuak Pass, flows NE $11 \mathrm{mi}$. to Noatak River, $37 \mathrm{mi}$. SE of Howard Pass, Brooks Ra.; $67^{\circ}$. $45^{\prime} \mathrm{N}, 156^{\circ} 15^{\prime} \mathrm{W}$; (map 126).

Eskimo name literally meaning "rough divide in the mountains," reported in 1956 by Orth.
Nuskealik Lake: lake, $2.5 \mathrm{mi}$. across, on W bank of Manokinak River, $5 \mathrm{mi}$. SE of Nuigalak Lake, Yukon-Kuskokwim Delta; $61^{\circ} 28^{\prime} \mathrm{N}$, $164^{\circ} 27^{\prime} \mathrm{W}$; (map 74).

Eskimo name obtained from "Charlie Peterson," trader, at Hooper Bay, in 1951 by USC\&GS.

Nuskolik Hill: hill, see Nushkolik Mountain. Nusluik: stream, see Fish River.

Nusoaraq Creek: stream, see Nasorak Creek.

Nusoaruk Creek: stream, see Nasorak Creek.

Nutchitalichaket: stream, see Birch Creek.

Nuteargowik: stream, see Nuleargowik River.

Nuthatch Lake: lake, $0.3 \mathrm{mi}$. long, on Kenai Penin., S of Lynx Lake, $36 \mathrm{mi}$. NE of Kenai, Cook Inlet Low.; $60^{\circ} 50^{\prime} 40^{\prime \prime} \mathrm{N}, 150^{\circ} 23^{\prime} 30^{\prime \prime}$ W; (map 62).

Named about 1963 by officials of Kenai National Moose Range, for the Red-Breasted Nuthatch (Sitta canadensis), a bird rarely found in Alaska (Gabrielson and Lincoln, 1959 , p. 633).

Nutirwik Creek: stream, flows N $5.5 \mathrm{mi}$. then W $4.5 \mathrm{mi}$. to Dietrich River, $10 \mathrm{mi}$. NNW of Snowden Mtn. and $46.5 \mathrm{mi}$. NW of Chandalar, Brooks Ra.; $67^{\circ} 56^{\prime} \mathrm{N}, 149^{\circ} 50^{\prime} \mathrm{W}$; (map 123).

Named and reported in 1939 by Robert Marshall (1956, map) for his Eskimo friend and hunting companion, Nutirwik, or Harry Snowden.

Nut Island: island, $400 \mathrm{ft}$. long, in Sitkalidak Strait, $0.8 \mathrm{mi}$. W of Cathedral I., on SE coast of Kodiak I.; $57^{\circ} 12^{\prime} 15^{\prime \prime} \mathrm{N}, 153^{\circ} 09^{\prime} 30^{\prime \prime} \mathrm{W}$; $B G N$ 1930; (map 34).

Descriptive name given by USC\&GS in 1928, "because of the [nutlike] appearance of the island ***."

Nutkwa Falls: waterfall, on Prince of Wales I., between Nutkwa Inlet and Nutkwa Lagoon, Alex. Arch.; $55^{\circ} 07^{\prime} 10^{\prime \prime} \mathrm{N}, 132^{\circ} 32^{\prime} 20^{\prime \prime} \mathrm{W}$; (map 4).

Name, possibly Indian, reported in 1951 by USGS.

Nutkwa Inlet: estuary, extends NE $6 \mathrm{mi}$. off Hetta Inlet, on SW coast of Prince of Wales I., Alex. Arch.; 55 $02^{\prime} \mathrm{N}, 132^{\circ} 36^{\prime} \mathrm{W}$; (map 4). Var. Nutqua Inlet.

Indian name recorded in 1897 as "Nutqua" by Lt. Comdr. J. F. Moser, USN.

Nutkwa Lagoon: lagoon, $4 \mathrm{mi}$. long, on SW coast of Prince of Wales I., at head of Nutkwa Inlet, Alex. Arch.; $55^{\circ} 08^{\prime} \mathrm{N}, 132^{\circ} 30^{\prime} \mathrm{W}$; (map 4). Var. Nutqua Lagoon.

Indian name recorded in 1897 as Nutqua by Lt. Comdr. J. F. Moser, USN.

Nutkwa Point: point of land, between Keete and Nutkwa Inlets, on SW coast of Prince of Wales I., Alex. Arch.; $55^{\circ} 04^{\prime} 15^{\prime \prime} \mathrm{N}, 132^{\circ} 34^{\prime} 05^{\prime \prime} \mathrm{W}$; (map 4).

Name, possibly Indian, reported in 1951 by USGS.

Nutmoyuk Creek: stream, flows NE $5.3 \mathrm{mi}$. to Timber Creek, $13 \mathrm{mi}$. S of Kiwalik Mtn. and 32 mi. SE of Imuruk Lake, Seward Penin. High.; $65^{\circ} 19^{\prime} \mathrm{N}, 162^{\circ} 17^{\prime} \mathrm{W}$; (map 110).

Local name published on a precinct map of Seward Peninsula by Monroe and Hutch- 
ins; corrected to June 1903 by Arthur Gibson. Nutqua Inlet: estuary, see Nutkwa Inlet.

Nutqua Lagoon: lagoon, see Nutkwa Lagoon.

Nutschek: locality, see Nuchek.

Nutschek: bay, see Etches, Port.

Nutty Cove: bay, see Shakmanof Cove.

Nutuvukti Lake: lake, $6 \mathrm{mi}$. long, NE of Akoliakruich Hills and $60 \mathrm{mi}$. NNW of Hughes, Brooks Ra.; $67^{\circ} 00^{\prime} \mathrm{N}, 1^{\circ} 4^{\circ} 38^{\prime} \mathrm{W}$; (map 116). Var. Nor-tah-rok-tah, Nor-torok-tee, Now-tow-vuck-toy, Nutuwukti.

Eskimo name reported in 1885 by Lt. Stoney (1900, p. 53), USN, as "Now-towvuk-toy" and by Lt. J. C. Cantwell (in Healy, 1887, p. 34), USRGS, as "Nor-to-rok-tee" and "Nor-tah-rok-tah." Mendenhall (1902, p. 25), USGS, established the spelling as "Nutuvukti."

Nutuwukti: lake, see Nutuvukti Lake.

Nut-vuck-to-wo-ark: stream, see Ambler River.

Nutzotin Mountains: mountain range, 5,000$8,000 \mathrm{ft} . .70 \mathrm{mi}$. long and $25 \mathrm{mi}$. wide, between Nabesna River at NW end and White River in Canada at SE end; bounded on SW by Cooper Creek, Notch Creek, and Geohenda Creek; Alaska Ra.; $61^{\circ} 50^{\prime} \mathrm{N}, 140^{\circ} 50^{\prime} \mathrm{W}$ [SE end], $62^{\circ} 30^{\prime} \mathrm{N}, 142^{\circ} 30^{\prime} \mathrm{W}$ [NW end]; (map 84).

Brooks (1900a, p. 446), USGS, and W. J. Peters note: "These snow-clad mountains, which seem to be distinct from the Saint Elias chain, we have called the Nutzotin Mountains." Named after the Nutzotin Indians of this region.

Nuvagapak Lagoon: bay, $4 \mathrm{mi}$. across, between Nuvagapak Point and Aichilik River delta, 23 mi. NW of Demarcation Point, Arctic Plain; $69^{\circ} 52^{\prime} \mathrm{N}, 142^{\circ} 12^{\prime} \mathrm{W}$; (map 138).

Eskimo name recorded on Barter I. in 1952 by USC\&GS. It takes its name from the nearby point of land.

Nuvagapak Point: point of land, on SW shore of Beaufort Lagoon, $20 \mathrm{mi}$. NW of Demarcation Point, Arctic Plain; $69^{\circ} 53^{\prime} \mathrm{N}, 142^{\circ} 18^{\prime}$ W; (map 138).

Eskimo name recorded on Barter I. in 1952 by USC\&GS and means "big point."

Nuvoak Creek: stream, see Marsh Creek.

Nuvugalak Point: point of land, extends $\mathrm{E}$ into Marryat Lagoon from the spit, $9 \mathrm{mi}$. NE of Point Hope, Arctic Slope; $68^{\circ} 23^{\prime} 45^{\prime \prime}$ N, $166^{\circ}$ $30^{\prime} 25^{\prime \prime}$ W ; (map 129). Var. Noovougahlawk Point, Nuvugalaq Point.

Eskimo name reported in 1950 by USC\&GS to mean "point of land" and spelled "Noovou-gah-lawk."

Nuvugalaq Point: point of land, see Nuvugalak Point.

Nuvuk: locality, see Nuwuk.

Nuvuk: point of land, see Barrow Point.

Nuvurarak Point: point of land, see Agtapuk Point.

Nuvwa: point of land, see Seppings, Cape.

Nuwaak: point of land, see Collinson Point.

Nuwaak Point: point of land, see Manning Point.

Nu-wayn-yuk: locality, see Golsovia.

Nuwhalen River: stream, see Newhalen River.
Nuwhalen Village: village, see Newhalen.

Nu-wu-ak: island, see Barter Island.

Nuwuak: locality, on coast of Beaufort Sea, at Manning Point, Arctic Plain; 70 07' N, $143^{\circ} 30^{\prime} \mathrm{W}$; (map 152).

Former Eskimo village or camp recorded by W. H. Dall (1877, map), USC\&GS. The name means "point of land."

Nuwuak: point of land, see Collinson Point.

Nuwuak Point: point of land, see Manning Point.

Nuwuk: locality, on Arctic Coast, at Point Barrow, Arctic Plain; $71^{\circ} 23^{\prime} 10^{\prime \prime} \mathrm{N}, 156^{\circ} 28^{\prime} 10^{\prime \prime}$ W; BGN Sixth Report; (map 153). Var. Kokmullit, Kunmudlin, Noowoo, Noó wooh, Noowook, Nowuk, Numuk, Nuvuk.

Former Eskimo village reported in 1.853 by John Simpson (1885, p. 237), who wrote, "signifies emphatically "The Point." The population was 309 and the village consisted of 54 inhabited houses. In 1882 Lt. Ray (1885, p. 38 ), USA, reported a population of 150 .

Nuwuk: point of land, see Barrow Point.

Nuwuk Lake: lake, $0.15 \mathrm{mi}$. across, on Arctic Coast at Point Barrow, Arctic Plain; $71^{\circ}$ $23^{\prime} 20^{\prime \prime} \mathrm{N}, 156^{\circ} 28^{\prime} 20^{\prime \prime} \mathrm{W}$; (map 153). Var. Tuseraru.

This feature was a fresh water lake and the main water supply for the now abandoned village of Nuwuk.

Nuwuksaqpaq: spit, see Kason Spit.

Nuyakaglik Lakes: lakes, $4 \mathrm{mi}$. E of Kivalina, Kotzebue-Kobuk Low.; $67^{\circ} 43^{\prime} \mathrm{N}, 164^{\circ} 22^{\prime} \mathrm{W}$; (map 128). Var. Nooyakaglik, Nuyaqaglik

Eskimo name meaning "sea gull place" reported in 1966 by E. S. Burch.

Nu-ya-kok: lake, see Nuyakuk Lake.

Nu-ya-kok: lake, see Tikchik Lake.

Nu-ya-kok: stream, see Nuyakuk River.

Nu-ya-kok Nun-vuk: lake, see Tikchik Lake.

Nuyakuk Lake: lake, extends E $20 \mathrm{mi}$. from junc. of Portage Arm and Mirror Bay to Tikchik Lake, $65 \mathrm{mi}$. N of Dillingham, KilbuckKuskokwim Mts.; $59^{\circ} 52^{\prime} \mathrm{N}, 159^{\circ} 00^{\prime} \mathrm{W}$; $B G N$ 1932; (map 52). Var. Nu-ya-kok, Second Nuyakuk Lake, Tikchik Lake.

Eskimo name shown as "Nu-ya-kok" on a 1910 manuscript map by H. C. Fassett, USBF ; called "Second Nuyakuk Lake" in 1925 by USBF.

Nuyakuk River: stream, heads at Tikchik Lake, flows SE $36 \mathrm{mi}$. to Nushagak River, $65 \mathrm{mi}$. $\mathrm{NE}$ of Dillingham, Bristol Bay Low.; $59^{\circ} 50^{\prime}$ N, 157 27' W; BGN 1931; (map 52). Var. Nu-ya-kok, Tichik River.

The Eskimo name "Tikchik River" was published in 1898 by USC\&GS; recorded as "Nu-ya-kok or [Tik-chik]" on a 1910 manuscript map by H. C. Fassett, USBF.

Nuyaqaglik: lakes, see Nuyakaglik Lakes.

Nuyukuk: lake, see Tikchik Lake.

Nuziamundcho Lake: lake, $2.1 \mathrm{mi}$. long, on $\mathrm{E}$ bank of Kalutna River, $14 \mathrm{mi}$. NW of Northway Junction, Alaska Ra.; $63^{\circ} 06^{\prime} \mathrm{N}, 142^{\circ} 12^{\prime}$ W; (map 85).

Indian named published in 1965 by USGS. Nuziamund Lake: lake, $0.8 \mathrm{mi}$. long, $5 \mathrm{mi}$. SE of
Tetlin Lake, $\mathrm{S}$ of Old Albert Lake, $25 \mathrm{mi}$. SE of Tok, Alaska Ra.; $63^{\circ} 02^{\prime} \mathrm{N}, 142^{\circ} 31$, W; (map 85).

Indian name published in 1965 by USGS.

Nvortulermiut: locality, on Nelson I., $7 \mathrm{mi}$. S of Nightmute and $100 \mathrm{mi}$. SW of Bethel, Yukon-Kuskokwim Delta; $60^{\circ} 23^{\prime} \mathrm{N}, 164^{\circ} 44^{\prime}$ W; (map 58). Var. Nevertolemute, Nvortulermuit.

Former Eskimo village; according to USC\&GS in 1951 "now abandoned * * two or three sod huts *** used occasionally as a fish camp." Its population was 10 in 1939.

Nvortulermuit: locality, see Nvortulermiut. Nyac: village, pop. 54, on right bank of Tuluksak River, $40 \mathrm{mi}$. SW of Aniak, Kilbuck-Kuskokwim Mts.; $61^{\circ} 00^{\prime} 20^{\prime \prime} \mathrm{N}, 159^{\circ} 56^{\prime} 45^{\prime \prime} \mathrm{W}$; (map 73).

This mining camp, established about 1915 , received a post office, named "Nyac," in 1926 (Ricks, 1965, p. 48). The name is derived from the initials of the New York Alaska [Gold Dredging] Corporation.

Nyctea Hills: hills, $417 \mathrm{ft}$., on Nelson I., $11 \mathrm{mi}$. $\mathrm{N}$ of Kinarak Lake, and $87 \mathrm{mi}$. W of Bethel, Yukon-Kuskokwim Delta; $60^{\circ} 43^{\prime} \mathrm{N}, 164^{\circ} 20^{\prime}$ W; (map 58).

Name used by personnel of Clarence Rhode National Wildlife Range; reported in 1965. Nye Lake: lake, $0.7 \mathrm{mi}$. long, $8.5 \mathrm{mi}$. NW of Old Man Lake and $43 \mathrm{mi}$. NW of Glennallen, Copper River Basin; 62 $14^{\prime} \mathrm{N}, 146^{\circ} 52^{\prime} \mathrm{W}$; (map 83).

Local name reported in 1949 by USGS.

Nyghook Number One, Mount: hill, see Mugum Peak.

Nygook Number Two, Mount: hill, $658 \mathrm{ft}$, in Kookooligit Mts., $15 \mathrm{mi}$. SW of Savoonga, $33 \mathrm{mi}$. SE of Gambell, on Saint Lawrence I.; $63^{\circ} 33^{\prime} \mathrm{N}, 170^{\circ} 48^{\prime} \mathrm{W}$; (map 93).

Eskimo name reported in 1932 by Otto W. Geist, Univ. of Alaska.

Nyguilnuk, Reka: stream, see Golsovia River. Nygvylnuk, Reka: stream, see Golsovia River. Nygykligmjut: locality, see Nigiklik.

Nygyklik: stream, see Andreafsky River.

Nykhta, Mys: point of land, see Prince of Wales, Cape.

Nyman Peninsula: peninsula, extends SW 1.8 mi., in Womens Bay, $5.5 \mathrm{mi}$. SW of Kodiak, Kodiak I.; $57^{\circ} 44^{\prime}$ N, $152^{\circ} 30^{\prime} \mathrm{W}$; (map 34). Local name published in 1943 by USC\&GS. Nyman Spit: spit, extends SE $0.3 \mathrm{mi}$. from Nyman Penin., in Womens Bay, $6 \mathrm{mi}$. SW of Kodiak, Kodiak I.; $57^{\circ} 43^{\prime} 00^{\prime \prime}$ N, $152^{\circ} 30^{\prime} 40^{\prime \prime}$ W; (map 34).

Local name published in 1943 by USC\&GS.

\section{o}

Oakakhl: lake, see Kukaklik Lake.

Oakland Creek: stream, flows NE $0.5 \mathrm{mi}$. to Discovery Creek which flows to Dome Creek, 22 mi. NW of Solomon, Seward Penin. High.; $64^{\circ} 50^{\prime} 45^{\prime \prime} \mathrm{N}, 164^{\circ} 44^{\prime} 45^{\prime \prime} \mathrm{W}$; (map 95).

Prospectors' name reported in 1908 by P. S. Smith (in Brooks and others, 1909, pl. 10), USGS. 
Oakland Creek: stream, on Seward Penin., heads on Potato Mtn., flows NW $4.5 \mathrm{mi}$. to Lopp Lagoon, $15 \mathrm{mi}$. NE of Cape Prince of Wales and $48 \mathrm{mi}$. NW of Teller, Kotzebue-Kobuk Low.; $65^{\circ} 43^{\prime} \mathrm{N}, 167^{\circ} 38^{\prime} \mathrm{W}$; (map 111).

Prospectors' name reported on the 1908 "Map of Seward Peninsula" by Gibson.

Oak-pi-lah-took Bluff: hill, see Okpilatok Bluff. Oakpisoorook: locality, see Okpiksugruk.

Oakpisoorook River: stream, see Okpiksugruk Creek.

Oakpisoorook River: stream, see Umarachek Creek.

Oakwroorut Creek: stream, see Okrurat Creek. Oallek Lake: lake, see Ualik Lake.

Oarlock Island: island, $2 \mathrm{mi}$. across, between Admiralty Bay and Dease Inlet, $\mathrm{S}$ island of Kikiktak Is., $34 \mathrm{mi}$. SE of Barrow, Arctic Plain; $70^{\circ} 57^{\prime} \mathrm{N}, 155^{\circ} 40^{\prime} \mathrm{W}$; BGN 1925; (map 148).

Named by USGS in 1924 "because the charted outline resembles an oarlock."

Oasis, The: point of rock, on $\mathrm{W}$ side of Oasis Glacier $0.6 \mathrm{mi}$. N of its junc. with Baird Glacier and $102 \mathrm{mi}$. E of Sitka, Coast Mts.; 57 $11^{\prime} 05^{\prime \prime} \mathrm{N}, 132^{\circ} 38^{\prime} 50^{\prime \prime} \mathrm{W}$; (map 8).

So named because of a small group of trees here, from which the name Oasis Glacier also is derived. Name reported in 1960 by USGS.

Oasis Glacier: glacier, trends S $8 \mathrm{mi}$. to Baird Glacier, $103 \mathrm{mi}$. E of Sitka, Coast Mts.; $57^{\circ}$ $11^{\prime} \mathrm{N}, 132^{\circ} 38^{\prime} \mathrm{W}$; BGN 1966; (map 8).

So named in 1965 by A. S. Post, USGS, because of a small group of trees on the west side of the valley. "These are the only large trees in the immediate region which is otherwise a desolate area of bare rock and ice."

Oastler Mountain: mountain, $6,370 \mathrm{ft} ., 1 \mathrm{mi} . \mathrm{E}$ of McGonagall Mtn. and $14 \mathrm{mi}$. NE of Mount McKinley, Alaska Ra.; $63^{\circ} 14^{\prime} 15^{\prime \prime} \mathrm{N}, 150^{\circ} 42^{\prime}$ $00^{\prime \prime} \mathrm{W}$; (map 88).

Mountain climbers' name published in 1954 by USGS. See Oastler Pass.

Oastler Pass: pass, 5,400 ft., in Mount McKinley National Park, $\mathrm{N}$ of Muldrow Glacier, $16 \mathrm{mi}$. NE of Mount McKinley, Alaska Ra.; 63 ${ }^{\circ} 4^{\prime}$ $30^{\prime \prime} \mathrm{N}, 150^{\circ} 40^{\prime} 00^{\prime \prime} \mathrm{W} ; B G N$ 1948; (map 88).

Named by NPS in the 1930's for Frank Richard Oastler, "naturalist and advocate of the National Park Service."

Oatcoosekruk Mountain: hill, see Utkusikrak Hill.

Ober Creek: stream, flows NE $17 \mathrm{mi}$. to Jarvis Greek, $16 \mathrm{mi}$. S of Delta Junction, Alaska Ra.; $63^{\circ} 49^{\prime} 20^{\prime \prime} \mathrm{N}, 145^{\circ} 40^{\prime} 20^{\prime \prime} \mathrm{W}$; BGN 1937; (map 86).

Local name reported on 1908 fieldsheet by J. W. Bagley, USGS.

Oberlin Ridge: ridge, in Glacier Bay National Monument, trends W 5 mi., S of Morse Glacier, $60 \mathrm{mi}$. NW of Hoonah, St. Elias Mts.; $58^{\circ} 51^{\prime} 30^{\prime \prime} \mathrm{N}, 136^{\circ} 15^{\prime} 00^{\prime \prime} \mathrm{W}$; (map 10).

Named by members of the American Geographical Society Glacier Bay Expedition of 1941 (Field, 1947, map) for Oberlin College, Ohio, because G. F. Wright was a member of the faculty of this college when he made his geological studies of the Muir Glacier in 1886.
Obernoi Point: point of land, E shore of Captains Bay, in Unalaska Bay, on NE coast of Unalaska I., Aleutian Is.; $53^{\circ} 51^{\prime} 25^{\prime \prime} \mathrm{N}, 166^{\circ} 33^{\prime}$ $40^{\prime \prime} \mathrm{W}$; (map 23).

Named by W. H. Dall in 1872 , from the Russian "Ober" meaning "upper."

Obesukrak River: stream, see Okpiksugruk Creek.

Obgorelyy, Ostrov: island, see Burnt Island.

Obgorielie Island: island, see Burnt Island.

Obi, Isla: island, see Ubi Island.

Oblaron Creek: stream, flows SW $10 \mathrm{mi}$. to Selawik River, $7 \mathrm{mi}$. NW of Selawik, Kotzebue-Kobuk Low.; $66^{\circ} 38^{\prime} \mathrm{N}, 160^{\circ} 14^{\prime} \mathrm{W}$; (map 114)

Eskimo name obtained in 1955 by U.S. Army Corps of Engineers.

O'Brien Creek: stream, flows SW $2.5 \mathrm{mi}$. to Knik Arm Cook Inlet, $1.3 \mathrm{mi}$. NE of Knik and $19 \mathrm{mi}$. NE of Anchorage, Cook Inlet Low.; $61^{\circ} 28^{\prime} 05^{\prime \prime} \mathrm{N}, 149^{\circ} 41^{\prime} 50^{\prime \prime} \mathrm{W}$; (map 69).

Local name reported in 1951 by USGS

O'Brien Creek: stream, flows E 13 mi. to Copper River, $0.8 \mathrm{mi}$. N of Taral and $65 \mathrm{mi}$. NE of Valdez, Chugach Mts.; $61^{\circ} 29^{\prime} 00^{\prime \prime} \mathrm{N}, 144^{\circ}$. 27'10" W; (map 68). Var. Obrien Creek.

Prospectors' name from a manuscript map of railroad surveys dated 1909.

O'Brien Creek: stream, flows NW $1.7 \mathrm{mi}$. to Matanuska River, $39 \mathrm{mi}$. NE of Palmer, Chugach Mts.; $61^{\circ} 46^{\prime} 30^{\prime \prime} \mathrm{N}, 148^{\circ} 01^{\prime} 45^{\prime \prime} \mathrm{W}$ (map 69)

Local name reported in 1913 by USGS.

O'Brien Creek: stream, flows SW 20 mi. to Buck Creek, $34 \mathrm{mi}$. $\mathrm{S}$ of Eagle, Yukon-Tanana High.; $64^{\circ} 19^{\prime} \mathrm{N}, 141^{\circ} 25^{\prime} \mathrm{W}$; (map 102). Var. O'Brine Creek.

Named by prospectors and reported in 1896 by Spurr (1898, pl. 46), USGS.

O'Brien Creek: stream, flows SE $0.7 \mathrm{mi}$. to Willow Creek $0.8 \mathrm{mi}$. E of its junc. with Osborn Creek, $9 \mathrm{mi}$. NE of Nome, Seward Penin. High.; $64^{\circ} 37^{\prime} \mathrm{N}, 165^{\circ} 10^{\prime} \mathrm{W}$; (map 94).

Prospectors' name reported in 1904 by $\mathrm{T}$. G. Gerdine, USGS.

O'Brien Creek: stream, flows NE $3 \mathrm{mi}$. to Klokerblok River, $14 \mathrm{mi}$. NE of Solomon, Seward Penin. High.; $64^{\circ} 39^{\prime} \mathrm{N}, 164^{\circ} 01^{\prime} \mathrm{W}$; (map 95). Var. Obrien Creek.

Prospectors' name reported in 1900 by $\mathrm{E}$. C. Barnard (in Brooks, 1901, pl. 17), USGS. O'Brien Creek: stream, flows SW $9 \mathrm{mi}$. to Tatalina River, $16 \mathrm{mi}$. SE of Livengood, YukonTanana High.; $65^{\circ} 20^{\prime} \mathrm{N}, 148^{\circ} 17^{\prime} \mathrm{W}$; (map 105).

Local name published by USGS in the 1950's.

O'Brien Creek: stream, flows SW $16 \mathrm{mi}$. to Beaver Creek, $38 \mathrm{mi}$. SE of Livengood, Yukon-Tanana High.; $65^{\circ} 23^{\prime} 30^{\prime \prime} \mathrm{N}, 147^{\circ} 17^{\prime} 00^{\prime \prime}$ W; (map 105). Var. Bryan Creek.

Name originally published in 1906 as "Bryan Creek" by USGS, but according to a report by L. M. Prindle, USGS, in 1909, the prospectors had changed the name to O'Brien Creek.
O'Brien Creek: stream, flows $\mathrm{N} 1 \mathrm{mi}$. to Candle Creek, $13.5 \mathrm{mi}$. SW of Candle and $31 \mathrm{mi}$. NE of Imuruk Lake, Seward Penin. High.; $65^{\circ} 45^{\prime}$ $\mathrm{N}, 162^{\circ} 10^{\prime} \mathrm{W}$; (map 110$)$.

Prospectors' name reported on the 1908 "Map of Seward Peninsula" by Arthur Gibson.

Obrien Creek: stream, see O'Brien Creek

O'Brine Creek: stream, see O'Brien Creek.

Obsechki Island: island, $200 \mathrm{ft}$. across, $6.5 \mathrm{mi}$ SW of Sitka, on W coast of Baranof I., Alex. Arch.; $56^{\circ} 58^{\prime} 05^{\prime \prime} \mathrm{N}, 135^{\circ} 25^{\prime} 20^{\prime \prime} \mathrm{W}$; (map 5). Var. Obsetchiki Island, Obsetchka Island, Ostrov Obsechki.

Named in 1809 by the Russian navigator, Ivan Vasiliev the first; published by Lt. Sarichev (1826, map 19), IRN, as "O[strov] Obsechki," meaning "misfire island."

Observation Island: island, $1.7 \mathrm{mi}$. long, at W entrance to Steamer Bay, on $\mathrm{W}$ coast of Etolin I., Alex. Arch.; 56 $10^{\circ} 00^{\prime \prime}$ N, $132^{\circ} 43^{\prime} 30^{\prime \prime}$ W; (map 6).

Named in 1886 by Lt. Comdr. A. S. Snow, USN, whose astronomical station was near the north end of this island.

Observation Island: island, $0.7 \mathrm{mi}$. long, in Orca Inlet, off $\mathrm{NE}$ end of Hawkins I., $4 \mathrm{mi}$. $\mathrm{N}$ of Cordova, Chugach Mts. ; $60^{\circ} 37^{\prime} \mathrm{N}, 145^{\circ} 44^{\prime}$ W; (map 64).

Named in 1897 by Lt. Comdr. J. F. Moser, USN, while collecting hydrographic data and making harbor sketches along the coast of Alaska.

Observation Islet: island, see Simonof Island.

Observation Mountain: mountain, 3,260 ft., on Alaska Penin., in Katmai National Monument, $8 \mathrm{mi}$. SW of Mount Katmai, Aleutian Ra.; $58^{\circ} 10^{\prime} 15^{\prime \prime} \mathrm{N}, 155^{\circ} 07^{\prime} 35^{\prime \prime} \mathrm{W}$; $B G N$ 1924; (map 42).

So named in 1916 by R. F. Griggs, National Geographic Society "because of the view of Mount Katmai."

Observation Peak: peak, 4,935 ft., on $\mathrm{E}$ end of Blackerby Ridge, at the head of Lemon Creek Glacier, $1.6 \mathrm{mi}$. NE of Salmon Creek Reservoir and $1.5 \mathrm{mi}$. NE of Juneau, Coast Mts.; $58^{\circ} 21^{\prime} 20^{\prime \prime} \mathrm{N}, 134^{\circ} 20^{\prime} 15^{\prime \prime} \mathrm{W}$; (map 11).

Local name published in 1962 by USGS Observation Point: point of land, on $\mathrm{N}$ shore of Shearwater Bay, $\mathrm{N}$ of Kiliuda Bay, on SE coast of Kodiak I.; $57^{\circ} 20^{\prime} 40^{\prime \prime} \mathrm{N}, 152^{\circ} 03^{\prime} 30^{\prime \prime}$ W; (map 34).

Descriptive name given by USC\&GS in 1926 because, "Astronomical observations for a survey of Shearwater Bay, in 1904, were made from this point."

Observation Point: point of land, on NE coast of Stuart I., $14 \mathrm{mi}$. NW of St. Michael; YukonKuskokwim Delta; $63^{\circ} 37^{\prime} 30^{\prime \prime} \mathrm{N}, 162^{\circ} 22^{\prime} 00^{\prime \prime}$ W; (map 92).

Named in 1898 by USC\&GS.

Observation Rock: island, $200 \mathrm{ft}$. long, in Nakat Harbor, at entrance into Nakat Inlet, Coast Mts. ; $54^{\circ} 49^{\prime} 20^{\prime \prime} \mathrm{N}, 130^{\circ} 42^{\prime} 20^{\prime \prime} \mathrm{W}$; (map 2)

Named by Lt. Comdr. Nichols, USN (USC\&GS, 1891, p. 79). 
Observatory Island: island, see Pyramid Island.

Observatory Point: point of land, in Chernofski Harbor, on SW coast of Unalaska I., Aleutian Is. ; $53^{\circ} 24^{\prime} 02^{\prime \prime} \mathrm{N}, 167^{\circ} 31^{\prime} 15^{\prime \prime} \mathrm{W}$; $B G N$ 1939; (map 23).

Descriptive name published in the 1931 Coast Pilot (pt. 2, p. 287).

Observatory Point: point of land, see Tent Point.

Obsetchiki Island: island, see Obsechki Island. Obsetchka Island: island, see Obsechki Island.

Obsiekaiushie, Cape: point of land, see Drying Point.

Obsikhaiuschchi, Cape: point of land, see Drying Point.

Obsykhayushchiy, Mys: point of land, see Drying Point.

Ocalee Spit: spit, see Okalee Spit.

Occident Point: point of land, $\mathrm{W}$ tip of Whale I., N or Kodiak I.; $57^{\circ} 57^{\prime} 25^{\prime \prime} \mathrm{N}, 152^{\circ} 51^{\prime} 30^{\prime \prime}$ W; (map 34).

Local name published in 1943 by USC\&GS.

Ocean Bay: bight, $4.5 \mathrm{mi}$. across, on SE coast of Sitkalidak I., SE of Kodiak I.; $57^{\circ} 05^{\prime} \mathrm{N}$, $153^{\circ} 10^{\prime} \mathrm{W}$; (map 34).

Local name published in 1943 by USC\&GS.

Ocean Beach: beach, $1 \mathrm{mi}$. long, on $\mathbf{S}$ coast of Unga I., in Shumagin Is., Aleutian Ra.; $55^{\circ}$ $09^{\prime} 40^{\prime \prime} \mathrm{N}, 160^{\circ} 32^{\prime} 30^{\prime \prime} \mathrm{W}$; (map 28).

Name shown on 1963 USC\&GS chart.

Ocean Cape: point of land, in Gulf of Alaska, at W tip of Phipps Penin., $4.6 \mathrm{mi}$. W of Yakutat, Malaspina Coastal Plain: $59^{\circ} 32^{\prime} 30^{\prime \prime} \mathrm{N}, 139^{\circ}$ $51^{\prime} 30^{\prime \prime} \mathrm{W}$; (map 46). Var. Cape Morskoi, Cape Phipps, Mys Morskoy.

Named "M[ys] Morskoy," meaning "maritime cape," by Capt. Tebenkov (1852, map 7), IRN. In 1875 it was called "Ocean Cape" on USC\&GS Chart 751. This cape was also called "Cape Phipps" on early charts.

Ocean Cape: peninsula, see Phipps Peninsula.

Ocean Creek: stream, flows SW $3 \mathrm{mi}$. to Bering Sea, $2 \mathrm{mi}$. E of Tin City and $48 \mathrm{mi}$. NW of Teller, Seward Penin. High.; $65^{\circ} 33^{\prime}$ N, $167^{\circ}$ 53' W; (map 111). Var. Lagoon Creek.

Local name reported in 1900 by Brooks (1901, pl. 13), USGGS.

Occan Creek: stream: see Lagoon Creek.

Oceanic: locality, at $\mathrm{W}$ end of Thumb Bay, on $S$ coast of Knight I., $7 \mathrm{mi}$. SE of Chenega, Chugach Mts.; $60^{\circ} 12^{\prime} 30^{\prime \prime} \mathrm{N}, 147^{\circ} 49^{\prime} 10^{\prime \prime} \mathrm{W}$; (map 63).

Name of a settlement published in 1951 by USGS.

Ocean Point: point of land, on Colville River, 25 mi. S of Harrison Bay, Arctic Plain; $70^{\circ} 04^{\prime}$ N, $151^{\circ} 22^{\prime} \mathrm{W}$; (map 149).

Named by W. J. Peters and W. C. Schrader in 1901.

Ochesna: stream, see John River.

Ocolaksuk Lake: lake, $1.2 \mathrm{mi}$. long, on $\mathrm{W}$ bank of Yukon River $1.2 \mathrm{mi}$. NW of Russian Mission, Yukon-Kuskokwim Delta ; 61 ${ }^{\circ} 48^{\prime} 15^{\prime \prime}$ $\mathrm{N}, 161^{\circ} 21^{\prime} 30^{\prime \prime} \mathrm{W}$; (map 73). Var. Okolaksak Lake.

Eskimo name reported by USC\&GS in 1949. O-co-mon-e-look: locality, see O-con-o-ne-look.
O'Connell Lake: lake, $0.3 \mathrm{mi}$. long, $\mathrm{E}$ of Spenard, in Anchorage, Cook Inlet Low.; 61 ${ }^{\circ}$ $11^{\prime} 36^{\prime \prime} \mathrm{N}, 149^{\circ} 52^{\prime} 45^{\prime \prime} \mathrm{W}$; (map 69).

Local name reported in 1942 by AMS.

O'Connor Creek: stream, flows SW $10 \mathrm{mi}$. to Goldstream Creek, $6 \mathrm{mi}$. NW of Fairbanks, Yukon-Tanana High.; $64^{\circ} 53^{\prime} 40^{\prime \prime} \mathrm{N}, 147^{\circ} 52^{\prime}$ $50^{\prime \prime} \mathrm{W}$; (map 100).

Named by prospectors; reported in 1903 by T. G. Gerdine (in Prindle, 1905, pl. 16), USGS.

O-con-o-ne-look: locality, probably located on Agiak Creek, Brooks Ra.; $67^{\circ} 58^{\prime}$ N, $153^{\circ} 07^{\prime}$ W; (map 125). Var. O-co-mon-e-look.

The exact location of this Eskimo village or camp reported by Lt. Stoney $(1900$, p. 44$)$, USN, in 1886 is conjectural, but the above position fits his description: "we came to O-co-mon-e-look after crossing a pass ***. The road then lay in the gorges $* * *$. When ten miles Northeast *** I crossed another pass *** and reached a chain of lakes [Chandler Lake] ***"

Octallee Spit: spit, see Okalee Spit.

Octillee Spit: spit, see Okalee Spit.

Odd Fellows, Cape: point of land, see Starichkof, Cape.

Odgavigamut: locality, see Uknavik.

Odgovigamut: locality, see Uknavik.

Odiak Channel: water passage, $3 \mathrm{mi}$. long, between Hawkins and Observation Is., $3 \mathrm{mi}$. N of Cordova, Chugach Mts.; $60^{\circ} 35^{\prime} \mathrm{N}, 145^{\circ} 30^{\prime \prime}$ W; (map 64).

Named in 1897 by Lt. Comdr. J. F. Moser, USN, while collecting hydrographic data and making harbor sketches along the coast of Alaska.

Odiak Lake: lake, see Eyak Lake.

Odiak Slough: tidal flat, $0.8 \mathrm{mi}$. long, at S edge of Cordova, Chugach Mts.; $60^{\circ} 32^{\prime} 30^{\prime \prime} \mathrm{N}$, $145^{\circ} 46^{\prime} 00^{\prime \prime} \mathrm{W}$; ( $\operatorname{map} 64$ ).

Local name published in 1951 by USGS. Odinakiy, Kamen: rock, see Lone Rock.

Odinakoi, Kamen: rock, see Lone Rock.

Odinochka: locality, see Old Iliamna.

Odinochka: village, see English Bay.

Odinochka Aleksandrovskaia: locality, see Nushagak.

Odinochka Chinik: locality, see Chinik.

Odinotchka: locality, see Alexeiev.

Odinotchka: village, see Nulato.

O'Donnel Creek: stream, flows SE $1 \mathrm{mi}$. to Allene Creek, in Agiapuk River basin, $10 \mathrm{mi}$. NE of Teller, Seward Penin. High.; $65^{\circ} 20^{\prime} \mathrm{N}$, $166^{\circ} 04^{\prime} \mathrm{W}$; (map 111).

Prospectors' name reported on the 1908 "Map of Seward Peninsula" by Arthur Gibson.

O'Donnell Creek: stream, flows $7.5 \mathrm{mi}$. NE to East Arm Holtz Bay, Attu I., Aleutian Is. ; $52^{\circ} 55^{\prime} 05^{\prime \prime} \mathrm{N}, 173^{\circ} 09^{\prime} 20^{\prime \prime} \mathrm{E}$; (map 13).

Named by the U.S. Army during its occupation of the island during World War II; shown on an AMS map published in 1948.

O'Donnell Valley: valley, $5 \mathrm{mi}$. long, formed by O'Donnell Creek, Attu I., Aleutian Is.; $52^{\circ} 55^{\prime} 05^{\prime \prime} \mathrm{N}, 173^{\circ} 09^{\prime} 20^{\prime \prime} \mathrm{E}$; (map 13).
Name shown on an AMS map published in 1948.

Odor Creek: stream, flows SW $5 \mathrm{mi}$. from Robinson Mts. to Kaliakh River, $W$ of Sunshine Point, $17 \mathrm{mi}$. NW of Cape Yakataga, Malaspina Coastal Plain; $60^{\circ} 10^{\prime} 30^{\prime \prime} \mathrm{N}, 142^{\circ}-$ $52^{\prime} 30^{\prime \prime}$ W; BGN 1960; (map 65).

So named in 1947 by USGS because a persistent odor of petroleum was noticed along the stream.

Oern Creek: stream, see Oerns Creek.

Oerns Creek: stream, flows NW $8 \mathrm{mi}$. to Aaron Creek, $3 \mathrm{mi}$. NE of Blake Channel, $13 \mathrm{mi}$. N of mouth of Bradfield Canal, Coast Mts.; $56^{\circ} 23^{\prime} 00^{\prime \prime} \mathrm{N}, 131^{\circ} 56^{\prime} 30^{\prime \prime} \mathrm{W}$; (map 7). Var. Oern Greek.

Name published as "Oern Creek" in 1927 on IBC sheet 5.

Oerns Creek: stream, see Aaron Creek.

Oesta de la Entrada del Principe, Punta: point of land, see Ommaney, Cape.

Oeufs, L'ile des: island, see Egg Island.

Offield Creek: stream, flows NW $2 \mathrm{mi}$. to Coal Creek which flows to Solomon River, $15 \mathrm{mi}$. NE of Solomon, Seward Penin. High.; 64 ${ }^{\circ} 44^{\prime}$ $\mathrm{N}, 164^{\circ} 08^{\prime} \mathrm{W}$; (map 95).

Prospectors' name reported on a 1902 prospectors' manuscript map.

Offield Greek: stream, flows SW $5 \mathrm{mi}$. to Grantley Harbor, 9 mi. SE of Teller, Seward Penin. High.; $65^{\circ} 15^{\prime} \mathrm{N}, 166^{\circ} 03^{\prime} \mathrm{W}$; (map 111).

Prospectors' name reported in 1901 by T. G. Gerdine (in Collier, 1902, pl. 12), USGS.

Ogalvick: locality, see Uknavik.

Ogalvik: locality, see Uknavik.

Ogangen Island: island, $2 \mathrm{mi}$. long, in Raven Bay, on $\mathrm{S}$ coast of Unalaska I., Aleutian Is.; $53^{\circ} 26^{\prime} 45^{\prime \prime} \mathrm{N}, 166^{\circ} 52^{\prime} 30^{\prime \prime} \mathrm{W}$; (map 23).

This name was published in the 1944 Aleutian Coast Pilot (p. 54).

Ogavik: locality, see Uknavik.

Ogchul Island: island, $0.5 \mathrm{mi}$. across, $4.5 \mathrm{mi}$. SE of Amos Bay, on $S$ coast of Umnak I., Aleutian Is.; $52^{\circ} 59^{\prime} 50^{\prime \prime} \mathrm{N}, 168^{\circ} 24^{\prime} 25^{\prime \prime} \mathrm{W}$; (map 21).

Name published by USC\&GS in 1944 Aleutian Coast Pilot (p. 71).

Ogden, Mount: mountain, elev. 7,484ft., Boundary Peak 86 on Alaska-Canada boundary, 12 mi. SE of terminus of Wright Glacier and 39 mi. ENE of Juneau, Coast Mts.; 58 $25^{\prime} 50^{\prime \prime}$ $\mathrm{N}, 133^{\circ} 22^{\prime} 30^{\prime \prime} \mathrm{W} ; B G N$ 1923; (map 12). Var. Boundary Peak 86.

Named by Lawrence Martin in 1923 by USC\&GS for Herbert G. Ogden, USC\&GS.

Ogden Passage: water passage, $4 \mathrm{mi}$. long, $3 \mathrm{mi}$. SW of Chichagof, on W coast of Chicagof I., Alex. Arch.; $57^{\circ} 38^{\prime} \mathrm{N}, 136^{\circ} 10^{\prime} \mathrm{W} ; B G N 1908$; (map 9).

Named in 1908 by A. Braid, USC\&GS, for Herbert Gouverneur Ogden, born 1846, a charter member of the Board on Geographic Names. Herbert Ogden was appointed to USC\&GS in 1863 where he served as expert on topography and cartography on various expeditions. In 1863 he was in charge of a party to locate the boundary between British Columbia and Alaska. 
Oggrurak Creek: stream, see Okrurat Creek. Ogilvie, Mount: mountain, 7,780 ft., on AlaskaCanada boundary, on Storm Ridge, $1.1 \mathrm{mi}$. NW of Gate Peak and $39 \mathrm{mi}$. N of Juneau, Coast Mts.; $58^{\circ} 51^{\prime} 45^{\prime \prime} \mathrm{N}, 134^{\circ} 15^{\prime} 20^{\prime \prime} \mathrm{W}$; $B G N$ 1954; (map 11). Var. Boundary Peak 95.

Named in 1923 by Lawrence Martin for William Ogilvie, Canadian official whose surveys in 1893-95 helped establish the AlaskaCanada boundary.

Ogilvie Mountains: mountains, in Alaska and Canada, extend SE $250 \mathrm{mi}$. from $30 \mathrm{mi}$. SE of Circle; drained by Kandik, Nation, and Tatonduk Rivers; Porcupine Plat.; 65 $30^{\prime} \mathrm{N}$, $143^{\circ} 30^{\prime} \mathrm{W}$ [W end], $64^{\circ} 30^{\prime} \mathrm{N}, 136^{\circ} 00^{\prime} \mathrm{W}$ [E end]. Var. Ogilvie Range.

Keele (1910, p. 13) noted the name Ogilvie range had been applied in former reports. The mountains were probably named for William Ogilvie, 1864-1912, Ganadian explorer of the upper Yukon River.

Ogilvie Range: mountains, see Ogilvie Mountains.

Ogilvik: locality, see Uknavik.

Ogive Mountain: peak, 7,100 ft., W of Gulkana Glacier, $17 \mathrm{mi}$. N of Paxson, Alaska Ra.; $63^{\circ}$ $16^{\prime} 25^{\prime \prime} \mathrm{N}, 145^{\circ} 27^{\prime} 10^{\prime \prime} \mathrm{W}$; (map 86).

Named between 1948 and 1955 by T. L. Péwé, USGS.

Oglala Island: island, see Eddy Island.

Oglala Pass: pass, between Rat and Amchitka Is., Aleutian Is.; $51^{\circ} 42^{\prime} \mathrm{N}, 178^{\circ} 30^{\prime} \mathrm{E}$; BGN 1937; (map 15).

Named by the U.S. Navy for the U.S.S. Oglala in 1935.

Oglala Point: point of land, on NE coast of Kagalaska I., Aleutian Is.; $51^{\circ} 52^{\prime} 15^{\prime \prime} \mathrm{N}$, $176^{\circ} 17^{\prime} 30^{\prime \prime} \mathrm{W}$; BGN 1936; (map 17). Var. Oglalla Point.

Named by members of the U.S. Navy Aleutian Island Survey Expedition in 1934, for the U.S.S. Oglala.

Oglala Point: point of land, see Argonne Point. Ogalla Point: point of land, see Oglala Point. Ogliouga Island: island, see Ogliuga Island.

Ogliuga Island: island, $3 \mathrm{mi}$. across, Delarof Is., Aleutian Is.; $51^{\circ} 36^{\prime} \mathrm{N}, 178^{\circ} 39^{\prime} \mathrm{W}$; $B G N$ 1944; (map 16). Var. Ogliouga Island, Ogloga Island.

Name published by Capt. Lutke (1836, p. $323)$ as "Ogloga Ile" and, with Skagul Island, called the Delarof Islands. The adopted form "Ogliuga" was published by the USC\& GS in the 1944 Aleutian Coast Pilot (p. 120).

Ogliuga Pass: water passage, NE of Sea Otter Pass and SW of Ogliuga I., Delarof Is., Aleutian Is.; $51^{\circ} 35^{\prime} \mathrm{N}, 178^{\circ} 41^{\prime} \mathrm{W}$; (map 16).

Name published in the 1946 supplement to the 1944 Aleutian Coast Pilot (U.S. Coast and Geodetic Survey, 1946, p. 119). Named for the island.

Oglodak Island: island, $1.2 \mathrm{mi}$. across, $\mathrm{W}$ of Atka Pass, between Atka and Tagalak Is., Aleutian Is.; $51^{\circ} 59^{\prime} \mathrm{N}, 175^{\circ} 27^{\prime} \mathrm{W}$; $B G N$ 1936; (map 18). Var. Oglodok Island, Ogmodak Island, Ogmodakh Island.

Name published by Capt. Lutke (1836, p.
320-21), possibly derived from the Aleut word "Agligak," meaning "albatross."

Oglodok Island: island, see Oglodak Island.

Ogloga Island: island, see Ogliuga Island.

Ogmodakh Island: island, see Oglodak Island. Ogmodak Island: island, see Oglodak Island. Ognedieshutshai Gora: volcano, see Makushin Volcano.

Ognedyshushchaya Gora: volcano, see Makushin Volcano.

Ogotoraq Creek: stream, see Ogotoruk Creek.

Ogotoruk Creek: stream, heads on Sigrikpak Ridge, flows W and SW $11 \mathrm{mi}$. to Chukchi Sea, $6.7 \mathrm{mi}$. SE of Cape Thompson, Arctic Slope; 68 $05^{\prime} 52^{\prime \prime} \mathrm{N}, 165^{\circ} 45^{\prime} 15^{\prime \prime} \mathrm{W}$; $B G N$ 1963; (map 129). Var. Akhotoruk Creek, Alhodoruk Creek, Augutorux Creek, Ogotoraq Creek, Owgootówram Koonga.

Eskimo name meaning "poke (bag)" reported in 1950 by USC\&GS. Name derived from nearby Augutaurak (bluff); it is a variant spelling of the same name.

Ogotoruk Seavalley: sea valley, continuation of Ogotoruk Valley, in Chukchi Sea, $7 \mathrm{mi} \mathrm{SE}$ of Cape Thompson, Arctic Slope; $68^{\circ} 04^{\prime} \mathrm{N}$, $165^{\circ} 45^{\prime} \mathrm{W}$; BGN 1959; (map 129).

Name reported and probably given in 1959 by D. W. Scholl, USGS. Named for Ogotoruk Creek. It is a drowned extension of this stream.

Ogotoruk Valley: valley, extends NE $7.3 \mathrm{mi}$. from Chukchi Sea, E of Saligvik Ridge, $7 \mathrm{mi}$. SE of Cape Thompson, Arctic Slope; $68^{\circ} 09^{\prime}$ N, $165^{\circ} 43^{\prime} \mathrm{W}$; BGN 1963; (map 129).

Named about 1962 by personnel of Project Chariot.

Ogowinagak: locality, at mouth of Mukluktulik River on $\mathrm{N}$ shore of Norton Bay, $1.3 \mathrm{mi} \mathrm{SW}$ of Koyuk and $20 \mathrm{mi}$. NW of Christmas Mtn., Seward Penin. High.; $64^{\circ} 55^{\prime} \mathrm{N}, 161^{\circ} 13^{\prime} \mathrm{W}$; (map 96). Var. Ogowinanagak.

Eskimo village or camp listed by Ivan Petroff in the 10th Census in 1880 as having a population of 20 . It is now abandoned.

Ogowinanagak: locality, see Ogowinagak.

Ogriveg River: stream, distributary of Kobuk River, heads at Melvin Channel, Kobuk River, flows NW, then E, $10 \mathrm{mi}$. to Ekichuk Lake, $48 \mathrm{mi}$. NW of Selawik, Kotzebue-Kobuk Low.; $66^{\circ} 56^{\prime} \mathrm{N}, 161^{\circ} 31^{\prime} \mathrm{W}$; (map 114).

Eskimo name obtained by U.S. Army Corps of Engineers in 1955.

Ogrooruk : bluff, see Ugrurak Bluff.

Ogsachak: locality, at junc. of Ogsachak Creek and Kukpuk River, $17 \mathrm{mi}$. N of Cape Thompson, Arctic Slope; $68^{\circ} 22^{\prime} 45^{\prime \prime}$. N, $165^{\circ} 49^{\prime} 00^{\prime \prime}$ W; BGN 1963; (map 129). Var. Ogsaghaek.

Fish camp reported in 1960 by D. C. Foote in connection with Project Chariot studies; he spelled it "Ogsaghaek."

Ogsachak Creek: stream, flows SW $3.5 \mathrm{mi}$. to Kukpuk River, W of Ogsachak Mtn., $17 \mathrm{mi}$. $\mathrm{N}$ of Cape Thompson, Arctic Slope; $68^{\circ} 22^{\prime}$ $45^{\prime \prime} \mathrm{N}, 165^{\circ} 49^{\prime} 00^{\prime \prime} \mathrm{W}$; BGN 1963; (map 129). Var. Ogsaghaek Creek.
Eskimo name recorded in 1960 as "Ogsaghaek" by D. C. Foote in connection with Project Chariot studies.

Ogsachak Mountain: mountain, 1,330 ft., in Lisburne Hills, $\mathbf{N}$ of junc. of Ipewik and Kukpuk Rivers, $18 \mathrm{mi}$. N of Cape Thompson, Arctic Slope; $68^{\circ} 23^{\prime} \mathrm{N}, 166^{\circ} 15^{\prime} \mathrm{W} ; B G N$ 1963; (map 129). Var. Ogsaghaek Mountain.

Eskimo name recorded in 1960 as "Ogsaghaek" by D. C. Foote in connection with Project Chariot studies.

Ogsaghaek: locality, see Ogsachak.

Ogsaghaek Creek: stream, see Ogsachak Creek. Ogsaghaek Mountain: mountain, see Ogsachak Mountain.

Ogsit Cape: point of land, see Aghsit Point.

Oguohaydok Ridge: ridge, 1,200 ft., in Kuskokwim Mts., extends $7 \mathrm{mi}$. W from Kuskokwim River between Jungjuk and Village Creeks, $32 \mathrm{mi}$. NW of Sleetmute, Kilbuck-Kuskokwim Mts.; $61^{\circ} 49^{\prime} 30^{\prime \prime} \mathrm{N}, 158^{\circ} 13^{\prime} 00^{\prime \prime} \mathrm{W}$; $B G N$ 1945; (map 72).

Eskimo name said to mean "woman fell off mountain," referring to a local legend; reported in 1944 by USGS.

Oh-hagamiut: locality, see Oknagamut.

Ohio Creek: stream, in Kenai Mts., flows W 2.5 $\mathrm{mi}$. to Bench Lake, $21 \mathrm{mi}$. SE of Sunrise, Chugach Mts. ; $60^{\circ} 37^{\prime} 30^{\prime \prime} \mathrm{N}, 149^{\circ} 38^{\prime} 50^{\prime \prime} \mathrm{W}$; (map 63).

Local name reported in 1951 by USGS.

Ohio Creek: stream, heads at glacier terminus, flows SE $18 \mathrm{mi}$. to Chulitna River, $37 \mathrm{mi}$. SW of Cantwell, Talkeetna Mts.; $62^{\circ} 58^{\prime} 20^{\prime \prime}$ N, $149^{\circ} 42^{\prime} 00^{\prime \prime} \mathrm{W}$; (map 82).

Local name reported in 1917 by $\mathrm{S}$. $\mathbf{R}$. Capps and J. B. Mertie, Jr. (in Brooks and others, 1919, pl. 2), USGS.

Ohio Creek: stream, flows SE $4 \mathrm{mi}$. to Jackson Creek which flows to Bonanza River, $4 \mathrm{mi}$. NW of Solomon, Seward Penin. High.; $64^{\circ} 34^{\prime} \mathrm{N}, 164^{\circ} 35^{\prime} \mathrm{W}$; (map 95)

Prospectors' name reported in 1900 by E. C. Barnard (in Brooks, 1901, pl. 17), USGS.

Ohio Creek: stream, flows SE $0.8 \mathrm{mi}$. to Hot Springs Slough, at village of Manley Hot Springs, $43 \mathrm{mi}$. ESE of Tanana, YukonTanana High.; $65^{\circ} 00^{\prime} 03^{\prime \prime} \mathrm{N}, 150^{\circ} 38^{\prime} 30^{\prime \prime} \mathrm{W}$; (map 106).

Name published by G. A. Waring (1917, fig. 11), USGS.

Ohio Creek: stream, flows NW $5.5 \mathrm{mi}$. to East Fork Chena River, 12 mi. ESE of Far Mtn. and $66 \mathrm{mi}$. SW of Circle, Yukon-Tanana High.; $65^{\circ} 02^{\prime} 15^{\prime \prime} \mathrm{N}, 145^{\circ} 24^{\prime} 00^{\prime \prime} \mathrm{W}$; (map 104).

Prospectors' name reported in 1954 or 1955 by USGS topographers.

Ohio Creek: stream, flows SE $1.7 \mathrm{mi}$. to Hutlinana Creek, $18 \mathrm{mi}$. SE of Rampart, YukonTanana High.; $65^{\circ} 16^{\prime} 50^{\prime \prime}$ N, $149^{\circ} 54^{\prime} 10^{\prime \prime}$ W.; (map 105)

Named by prospectors; reported in 1908 by USGS (Covert and Ellsworth, 1909, pl. 5). Ohio Creek: stream, see Trilby Creek. 
Ohio Rock: rock, in Tongass Narrows, off $\mathrm{N}$ coast of Gravina I., opposite Ward Cove, Alex. Arch.; $55^{\circ} 23^{\prime} 50^{\prime \prime} \mathrm{N}, 131^{\circ} 46^{\prime} 10^{\prime \prime} \mathrm{W}$; (map 3).

Local name published in the 1932 Goast Pilot (p. 104).

Ohkaleeksout: stream, see Rabbit Creek. Ohkalichsuk: stream, see Rabbit Creek.

Ohlegek Creek: stream, flows NW $2.5 \mathrm{mi}$. to Niyrakpak Lagoon, $17 \mathrm{mi}$. SE of Gambell, St. Lawrence I.; $63^{\circ} 36^{\prime} \mathrm{N}, 171^{\circ} 24^{\prime} \mathrm{W}$; $B G N$ 1951 ; (map 93). Var. Ohlegek River, Olegek Creek.

Eskimo name recommended by the Gambell village council and reported in 1949 by Maj. H. B. Allen, USAF.

Ohlegek River: stream, see Ohlegek Creek.

Ohlick: water passage, see Singauk Entrance.

Ohlson Mountain: mountain, $1,513 \mathrm{ft}$., on Kenai Penin., $5 \mathrm{mi}$. N of Homer, Cook Inlet Low.; $59^{\circ} 43^{\prime} \mathrm{N}, 151^{\circ} 32^{\prime} \mathrm{W}$; (map 50 ).

Local name reported and published by USGS in the 1950's.

Ohlson Slough: watercourse, see Honeymoon. Ohmalik Creek: stream, see Omilak Creek.

Ohman Falls: waterfall, in Power Creek, $7 \mathrm{mi}$. $\mathrm{NE}$ of Cordova, Chugach Mts.; $60^{\circ} 35^{\prime} 30^{\prime \prime} \mathrm{N}$, $145^{\circ} 35^{\prime} 00^{\prime \prime} \mathrm{W}$; (map 64).

Local name published in 1951 by USGS.

Ohmer Slough: estuary, $0.7 \mathrm{mi}$. long, off Duncan Canal, $0.5 \mathrm{mi}$. S of Duncan Creek, on W coast of Lindenberg Penin., Kupreanof $I$., Alex. Arch.; 56 $46^{\prime} \mathrm{N}, 133^{\circ} 13^{\prime} \mathrm{W}$; BGN 1961; (map 6).

Local name reported in 1933 by R. H. Sargent, USGS, who misapplied it to Mitchell Slough 4 miles to the southeast. The name is said to have been given for Earl Ohmer, a former resident of Petersburg who died about 1952.

Ohmer Slough: estuary, see Mitchell Slough.

Ohnak: locality, see Onak.

Ohogamiut: village, pop. 50, on right bank of Yukon River $22 \mathrm{mi}$. SE of Marshall, YukonKuskokwim Delta; 61 $34^{\prime} \mathrm{N}, 1^{\circ} 61^{\circ} 52^{\prime} \mathrm{W}$ (map 73). Var. E-ko-go-mute, Ikuak, Ohogamut.

Eskimo name "Okhnagamiut," meaning "village (people) on other side (of river)." The name is shown as "Ohogamut" on a 1916 field sheet by R. H. Sargent, USGS. See Akahamut. See Oknagamut.

Ohogamiut: locality, see Akahamut.

Ohogamut: village, see Ohogamiut.

Ohpeelatuk: hills, see Aupilatuk Hills.

Ohtig Lake: lake, $3 \mathrm{mi}$. long, $5 \mathrm{mi}$. S of Chalkyitsik, Yukon Flats; $66^{\circ} 35^{\prime} \mathrm{N}, 143^{\circ} 44^{\prime} \mathrm{W}$; (map 120).

Tranjik-kutchin Indian name; obtained in 1956 by T. E. Taylor, USGS.

Ohwat River: stream, see Owhat River.

Oil Bay: bay, extends N 3 mi. off Cook Inlet, on $S$ coast of Iniskin Penin., Aleutian Ra.; $59^{\circ} 38^{\prime} \mathrm{N}, 153^{\circ} 17^{\prime} \mathrm{W}$; BGN 1906; (map 51).

Local name published by G. C. Martin (1905, pl. 4), USGS.

Oil Creek: stream, flows SE $5.7 \mathrm{mi}$. to Shelakof Strait, on E coast of Alaska Penin., 5 mi. SW of Cape Aklek and $47 \mathrm{mi}$. W of Karluk, Aleutian Ra.; $57^{\circ} 38^{\prime} 40^{\prime \prime} \mathrm{N}, 155^{\circ} 41^{\prime} 40^{\prime \prime} \mathrm{W}$; (map 35).

Descriptive local name obtained from J. L. McPherson of Iliamna and published by Martin (1921, pl. 10), USGS.

Oil Creek: stream, on S slope of Brower Ridge, flows S $1.5 \mathrm{mi}$. to Gulf of Alaska, $2.8 \mathrm{mi}$. NW of mouth of White River and $96 \mathrm{mi}$. NW of Yakutat, St. Elias Mts.; $60^{\circ} 03^{\prime} 25^{\prime \prime} \mathrm{N}$, $142^{\circ} 18^{\prime} 00^{\prime \prime} \mathrm{W}$; (map 65 ).

Local name reported by G. C. Martin, USGS, in 1904. So named because of oil discoveries made here about 1897.

Oil Creek: stream, flows W $0.5 \mathrm{mi}$. to Katalla Slough, $3 \mathrm{mi}$. SE of Katalla, Malaspina Coastal Plain; $60^{\circ} 11^{\prime} \mathrm{N}, 144^{\circ} 26^{\prime} \mathrm{W}$; (map 64).

Local name reported in 1904 by USGS.

Oil Lake: lake, $1.5 \mathrm{mi}$. long, between Nechelik Channel Colville River and Ublutuoch River, $5 \mathrm{mi}$. S of Harrison Bay, Arctic Plain; $70^{\circ} 18^{\prime}$ N, $151^{\circ} 09 \mathrm{~W}$; (map 149).

Presumably named by personnel of the Naval Petroleum Reserve No. 4 explorations in the late 1940's.

Oil Point: point of land, at mouth of Oil Bay, $20 \mathrm{mi}$. NE of Augustus I., Aleutian Ra.; $59^{\circ} 38^{\prime} \mathrm{N}, 153^{\circ} 14^{\prime} \mathrm{W}$; (map 51 ).

Name published in 1916 by USC\&GS.

Oil Reef: reef, at mouth of Oil Bay, $19 \mathrm{mi}$. N of Augustine I., Aleutian Ra.; $59^{\circ} 37^{\prime} 20^{\prime \prime} \mathrm{N}$, $153^{\circ} 18^{\prime} 00^{\prime \prime} \mathrm{W}$; BGN 1916; (map 51).

Name published in 1913 on USC\&GS Chart 3420.

Oiluluk Lake: lake, $0.4 \mathrm{mi}$. across, $1 \mathrm{mi}$. W of Okstukuk Lake and $23 \mathrm{mi}$. N of Dillingham, Bristol Bay Low.; $59^{\circ} 33^{\prime} \mathrm{N}, 158^{\circ} 20^{\prime} \mathrm{W}$; (map 52).

Eskimo name shown as "Oi-lu-luk" on a 1910 manuscript map by $H$. C. Fassett, USBF.

Oily Lake: lake, $5 \mathrm{mi}$. long, on Malaspina Glacier, S of Samovar Hills and $53 \mathrm{mi}$. NW of Yakutat, St. Elias Mts. ; $60^{\circ} 08^{\prime} \mathrm{N}, 140^{\circ} 40^{\prime} \mathrm{W}$; (map 66).

Name published by USGS in 1959. A lake this size does not appear on the USGS 1951 map, therefore it may be relatively new or intermittent.

Oinak Point: point of land, see Ooynik Point.

Oinathluk Point: point of land, in Lake Beverly at entrance to Silver Horn, $46 \mathrm{mi}$. NW of Dillingham, Kilbuck-Kuskokwim Mts. ; $59^{\circ} 41^{\prime}$ $\mathrm{N}, 158^{\circ} 50^{\prime} \mathrm{W}$; (map 52).

Eskimo name shown on a 1910 manuscript map as "Oi-na-thluk Point" by H. C. Fassett, USBF.

Oinuklagowik: locality, see Uinuk.

Okak Bend: bend, in Noatak River, $15 \mathrm{mi}$. SW of Feniak Lake, Brooks Ra.; $68^{\circ} 03^{\prime} \mathrm{N}, 158^{\circ}$ $33^{\prime} \mathrm{W}$; (map 132).

Eskimo name meaning "tongue" [oqaq] reported by P. S. Smith (1913, p. 45), USGS. He also mentions an abandoned Eskimo village located on the $\mathrm{N}$ side of the river on the bend.

Okalee Channel: channel, $4 \mathrm{mi}$. long, between Kanak I. and Wingham I., $10 \mathrm{mi}$. SE of
Katalla, Malaspina Coastal Plain; $60^{\circ} 05^{\prime} \mathrm{N}$, $144^{\circ} 20^{\prime} \mathrm{W}$; (map 64).

Named in 1903 by J. F. Pratt, USC\&GS for nearby Okalee Spit.

Okalee River: stream, flows SW $13 \mathrm{mi}$, to Controller Bay, $20 \mathrm{mi}$. SE of Katalla, Malaspina Coastal Plain; $60^{\circ} 03^{\prime} \mathrm{N}, 144^{\circ} 01^{\prime} \mathrm{W}$; (map 64).

Local name reported by F. H. Moffit (1914, pl. 1), USGS.

Okalee Spit: spit, extends $9 \mathrm{mi}$. into SE end of Controller Bay, $15 \mathrm{mi}$. SE of Katalla, Malaspina Coastal Plain; 66 $02^{\prime} \mathrm{N}, 144^{\circ} 15^{\prime} \mathrm{W}$; (map 64). Var. Ocalee Spit, Octallee Spit, Octillee Spit, Okali Spit.

Local name reported in 1903 by G. C. Martin (1905, pl. 3), USGS. It was also reported in 1903 as Ocalee Spit on a USC\&GS preliminary chart.

Okalik Lake: lake, $5 \mathrm{mi}$. long, between Teshekpuk Lake and Beaufort Sea, Arctic Plain; $70^{\circ} 49^{\prime} 15^{\prime \prime} \mathrm{N}, 153^{\circ} 23^{\prime} 30^{\prime \prime} \mathrm{W}$; (map 148).

Eskimo name (oqaqlik) reported by USGS in 1956, meaning "having tongue."

Okali Spit: spit, see Okalee Spit.

Okaveenok: village, see Teller Mission.

Okavigamut: locality, see Uknavik.

OK Creek: stream, flows SE $3.7 \mathrm{mi}$. to Jackson Creek which flows to Bonanza River, $5 \mathrm{mi}$. NW of Solomon, Seward Penin. High.; $64^{\circ}$. $37^{\prime} \mathrm{N}, 164^{\circ} 33^{\prime} \mathrm{W}$; (map 95). Var. West Fork Jackson Creek.

Prospectors' name shown on Arthur Gibson's "Map of Cape Nome Precinct" dated 1904.

Okee Bay: bay, 2 mi. across, on SW coast of Umnak I., Aleutian Is.; $53^{\circ} 01^{\prime} 30^{\prime \prime} \mathrm{N}$, $168^{\circ} 49^{\prime} 15^{\prime \prime} \mathrm{W}$; (map 22).

Local name reported in 1938 by USC\&GS. O-kee-buck: island, see King Island.

O'Keefe Hills: mountain, highest elev. 4,830 ft., between headwaters of Crooked Creek and South Fork Koyukuk River, $20 \mathrm{mi}$. WSW of Chandalar, Brooks Ra.; $67^{\circ} 22^{\prime}$ N, $149^{\circ} 13^{\prime}$ W; (map 123).

Local name reported in 1956 by T. E. Taylor, USGS.

Okeekuk Mountain: mountain, see Okikak Mountain.

Okee Point: point of land, an SW coast of Uinnak I., Aleutian Is.; $53^{\circ} 01^{\prime} 00^{\prime \prime} \mathrm{N}$, $168^{\circ} 51^{\prime} 30^{\prime \prime} \mathrm{W}$; BGN 1940; (map 22).

Name given in 1938 by USC\&GS, "because the sheep station in the bay to the east is known locally as Okee Bay."

Okerokovik Creek: stream, see Okerokovik River.

Okerokovik River: stream, heads in Romanzof Mts. at $69^{\circ} 23^{\prime} \mathrm{N}, 143^{\circ} 16^{\prime} \mathrm{W}$, flows $40 \mathrm{mi}$. N to Jago River, $18 \mathrm{mi}$. SE of Barter I., Arctic Plain; $69^{\circ} 51^{\prime} \mathrm{N}, 143^{\circ} 25^{\prime} \mathrm{W}$; BGN 1959; (map 138). Var. Okerokovik Creek, Okrokovik River, Ukerukuvik River.

Eskimo name reported by Leffingwell (1919, p. 98) to mean "place where there is a blubber cache." Diamond Jenness spells it "Ukerukuvik." 
Okfauchavuk Slough: watercourse, in Yukon Delta, extends E-W 2.6 mi. between Kwikpak Pass and Naringolapak Slough, $17 \mathrm{mi}$. E of Kwiguk, Yukon-Kuskokwim Delta ; 62 ${ }^{\circ} 42^{\prime} 15^{\prime \prime}$ N, 163 $58^{\prime} 00^{\prime \prime}$ W; (map 77). Var. Okpfauchakuk Slough.

Eskimo name obtained by R. L. Faris, USC\&GS, in 1899 .

Okhagamute: locality, see Oknagamut.

Okhkan Nayra Lagoon: lagoon, see Ongoveyuk

Lagoon.

Okhnagamiut: locality, see Akahamut.

Okhnagamiut: locality, see Oknagamut.

Oknagamiut: locality, see Uknavik.

Okhogamute: locality, see Oknagamut.

Okiben Island: island, see King Island.

Okikak Mountain: mountain, $1,076 \mathrm{ft}$., $36 \mathrm{mi}$.

SE of Savoonga, on St. Lawrence I.; $63^{\circ} 21^{\prime} \mathrm{N}$, $169^{\circ} 39^{\prime}$ W; BGN 1951; (map 93). Var.

Mount Ookikok, Okeekuk Mountain:

Eskimo name reported in 1932 by O. W. Geist, Univ. of Alaska.

Okilerit: locality, see Kitnepaluk.

Okinoyoktokawik: locality, on $\mathrm{N}$ shore of Norton Sound, about $19 \mathrm{mi}$. W of Nome, Seward Penin. High.; $64^{\circ} 34^{\prime} \mathrm{N}, 166^{\circ} 04^{\prime} \mathrm{W}$; (map 94).

Former Eskimo village or camp reported in the 1890 Census (1893, p. 162).

Okiotak Creek:- stream, in Baird Mts., flows NE $11 \mathrm{mi}$. to Akikukchiak Creek $6 \mathrm{mi}$. S of its junc. with Noatak River, $60 \mathrm{mi}$. NE of Noatak, Brooks Ra.; 67 $52^{\prime}$ N, $161^{\circ} 02^{\prime} \mathrm{W}$; (map 127).

Eskimo name obtained in 1955 by U.S. Army Corps of Engineers.

Okiotak Peak: mountain, 5,320 ft., on E bank of Sadlerochit River, $3 \mathrm{mi}$. NW of Lake Schrader and $23 \mathrm{mi}$. NW of Mount Michelson, Brooks Ra.; $69^{\circ} 26^{\prime} \mathrm{N}, 145^{\circ} 08^{\prime} \mathrm{W}$; BGN 1961; (map 139).

Local name reported in 1960 by USGS. "Okiotak," the Eskimo name for the American gyrfalcon, is reported to mean "one that stays all winter."

Okipiksuk River: stream, see Okpiksak River.

Okivaki : rock, see Fairway Rock.

Okkutweek River: stream, see Owhat River.

Oklashok: stream, see Alatna River.

Oklighiat Hill: hill, $300 \mathrm{ft}$., $2.5 \mathrm{mi}$. NE of Southwest Cape, $2 \mathrm{mi}$. SE of Oongayuk Hill and $33 \mathrm{mi}$. SE of Gambell, St. Lawrence I.; $63^{\circ} 20^{\prime} \mathrm{N}, 171^{\circ} 23^{\prime} \mathrm{W}$; BGN 1951; (map 93). Var. Oklighiat Peak.

Eskimo name reported in 1949 by Maj. $\mathrm{H}$. B. Allen, USAF.

Oklighiat Peak: hill, see Oklighiat Hill.

Oklune Mountains: mountains, see Ahklun Mountains.

Okmok, Mount: mountain, 3,519 ft., at NW end, Umnak I., Aleutiar. Is.; $53^{\circ} 24^{\prime} \mathrm{N}$, $168^{\circ} 08^{\prime}$ W; BGN 1966; (map 22). Var. Okmok Volcano.

Local name reported in 1946 by USGS.

Okmok Caldera: crater, $3,400 \mathrm{ft}$., $6.5 \mathrm{mi}$. across, on NE part of Umnak I., Aleutian Is.; $53^{\circ} 26^{\prime}$ N, $168^{\circ} 07^{\prime} \mathrm{W}$; BGN 1966; (map 22). Var. Okmok Volcano.
Name reported in 1946 by USGS.

Okmok Volcano: crater, see Okmok Caldera. Okmok Volcano: mountain, see Okmok, Mount.

Oknagak: locality, see Oknagamut.

Oknagamut: locality, on $\mathrm{N}$ bank of Kuskokwim River $1.8 \mathrm{mi}$. E. of Kalskag and $18 \mathrm{mi}$. W of Aniak, Yukon-Kuskokwim Delta; 61 $33^{\prime} 30^{\prime \prime}$ $\mathrm{N}, 160^{\circ} 04^{\prime} 30^{\prime \prime} \mathrm{W}$; (map 73). Var. Ohhagamiut, Okhagamute, Okhnagamiut, Okhogamute, Oknagak, Oknagamute, Ookhogamute, Ukhagmiut.

Former Eskimo village, meaning "people [village] on the other side of the river;" reported as "Ukhagmyut," by Lt. L. A. Zagoskin, IRN, in 1842-44. In 1879 W. E. Nelson, U.S. Signal Service, recorded "Okhagamute." Ivan Petroff's 1880 Census report lists a population of 130 . The spelling "Oknagamut" was established by USC\&GS in 1897 on the authority of Rev. J. H. Kilbuck, Moravian missionary. See Ohogamiut. Oknakluk: lake, see Kukaklik Lake.

Oknakuchak River: stream, see Anerkochik River.

Oknavigamut: locality, see Uknavik.

Okoklik Lake: lake, $2 \mathrm{mi}$. long, NW of Lake Kangilipak, in Noatak River Valley, $49 \mathrm{mi}$. SE of Misheguk Mtn., Brooks Ra.; $68^{\circ} 01^{\prime} \mathrm{N}$, $159^{\circ} 16^{\prime} \mathrm{W}$; (map 131)

Eskimo name meaning "it is warm" reported by USGS in 1956.

Okokmilaga River stream, formed by Sulugiak and Agiagiak Creeks, flows N $50 \mathrm{mi}$. to Killik River $18 \mathrm{mi}$. SE of its junc. with Colville River, Brooks Ra.; $68^{\circ} 49^{\prime} \mathrm{N}, 153^{\circ} 26^{\prime} \mathrm{W}$; (map 133). Var. Chandler River.

Name reported about 1946 by USGS geologists during exploration of Naval Petroleum Reserve No. 4. This stream is shown as "Chandler River" on 1924 fieldsheet by Gerald FitzGerald, USGS, because it was thought to drain Lt. Stoney's "Chandler Lake."

Okok Point: locality, on right bank of Kobuk River, $28 \mathrm{mi}$. NW of Selawik, KotzebueKobuk Low.; $66^{\circ} 56^{\prime} \mathrm{N}, 160^{\circ} 30^{\prime} \mathrm{W}$; (map 114).

Former trading post reported in 1927 by USGS.

Okok River: stream, flows SE $8 \mathrm{mi}$. to Bering Sea, $3 \mathrm{mi}$. NE of Southwest Cape, St. Lawrence I.; $63^{\circ} 20^{\prime} \mathrm{N}, 171^{\circ} 22^{\prime} \mathrm{W}$; BGN 1951; (map 93). Var. Ookook River.

Eskimo name meaning "tongue" [oqaq], reported in 1949 by Maj. H. B. Allen, USAAF. Okolaksak Lake: lake, see Ocolaksuk Lake.

Okonagun Creek: stream, flows $\mathrm{N} 7 \mathrm{mi}$. to Middle Fork Okpikruak River $4.5 \mathrm{mi}$. S of its junc. with Okpikruak River, Brooks Ra.; $68^{\circ} 31^{\prime} \mathrm{N}, 153^{\circ} 29^{\prime} \mathrm{W}$; (map 133 ).

Eskimo name shown on location label attached to mineral claim stake. Claim reads "Kamik claim. East bank of Okonagoon Creek *** Noatak-Kobuk Mining district. Billy Morry." Reported about 1950 by USGS geologists.
Okonchatelnie: point of land, see Termination Point.

Okonchatelnyy, Mys: point of land, see Termination Point.

Okotak Creek: stream, in DeLong Mts., flows SW $20 \mathrm{mi}$. to Trail Creek SW of Misheguk Mtn., Brooks Ra.; $68^{\circ} 12^{\prime} 15^{\prime \prime} \mathrm{N}, 161^{\circ} 18^{\prime} 00^{\prime \prime}$ W; BGN 1961; (map 131$)$.

Eskimo name obtained at Noatak in 1956 by Orth, meaning "sheltered" or "protected from the wind" [oqotaq]

Okpeluk River: stream, see Okpilak River.

Okpfauchakuk Slough: watercourse, see Okfauchavuk Slough.

Okpikruak River: stream, flows NE $43 \mathrm{mi}$. to Okokmilaga River $6 \mathrm{mi}$. S of its junc. with Killik River, Brooks Ra.; $68^{\circ} 44^{\prime} \mathrm{N}, 153^{\circ} 20^{\prime}$ W; (map 133).

Eskimo name reported in 1951 by USGS geologists during exploration of Naval Petroleum Reserve No. 4.

Okpiksak River: stream, flows N $17 \mathrm{mi}$. to the Meade River, $42 \mathrm{mi}$. S of Barrow, Arctic Plain; $70^{\circ} 41^{\prime} 45^{\prime \prime} \mathrm{N}, 156^{\circ} 37^{\prime} 30^{\prime \prime} \mathrm{W}$; (map 147). Var. Okpiksook River, Okipiksuk River, Okpiksuk River.

Eskimo name referring to the "owl [ukpik]," shown on a 1923 fieldsheet by E. C. Guerin, USGS, as "Okpiksook River."

Okpiksook River: stream, see Okpiksak River.

Okpiksugruk: locality, an left bank of Okpiksugruk Creek, $14 \mathrm{mi}$. NW of Kivalina, Kotzebue-Kobuk Low.; 67 $52^{\prime}$ N, 164 $51^{\prime}$ W; (map 128). Var. Ookpiksoogruk, Uqpiqsuqzuq, Oakpisoorook.

Eskimo name meaning "there are lots of willows" reported in 1966 by E. S. Burch.

Okpiksugruk Creek: stream, flows $\mathrm{S} 11.5 \mathrm{mi}$. to Asikpak Lagoon, $12 \mathrm{mi}$. NW of Kivalina, Kotzebue-Kobuk Low. ; 67 $51^{\prime} 20^{\prime \prime} \mathrm{N}, 164^{\circ} 51^{\prime} 00^{\prime \prime}$ W; BGN 1963; (map 128). Var. Oakpisoorook River, Obesukrak River, Okpiksurok Creek, Okpisoorook River, Okpisuruk Creek, Okpisuruk River, Ookpiksoogrum Koonga, Uqpiqsugzum Kunga, West Fork Oakpisoorook River.

Eskimo name meaning "there are lots of willows," reported in 1950 by USC\&GS.

Okpiksuk River: stream, see Okpiksak River.

Okpiktalik: locality, see Opiktulik.

Okpiktolik: locality, see Opiktulik.

Okpilak Glacier: glacier, $6 \mathrm{mi}$. long, in Romanzof Mts., at head of Okpilak River, $9 \mathrm{mi}$. S of Mount Michelson, Brooks Ra.; 69 $09^{\prime} \mathrm{N}$, $144^{\circ} 12^{\prime}$ W ; BGN 1961; (map 139).

Leffingwell does not list this as a geographic name, but his text (1919, pl. 18) includes photographs of Okpilak Glacier. Named for the stream that heads at its foot.

Okpilak Lake: lake, $0.5 \mathrm{mi}$. long, on $\mathrm{E}$ bank of Okpilak River, $9 \mathrm{mi}$. NE of Mount Michelson, Brooks Ra.; $69^{\circ} 25^{\prime} \mathrm{N}, 144^{\circ} 03^{\prime} \mathrm{W}$; $B G N$ 1961; (map 139).

Name published in USGS Open File Report 498 , dated 1959 . It was named for the Okpilak River.

Okpilak River: stream, heads at Okpilak Glacier in Romanzof Mts. and flows N $70 \mathrm{mi}$. to 
Camden Bay, Arctic Plain; $70^{\circ} 04^{\prime}$ N, $144^{\circ} 03^{\prime}$ W; BGN 1961; (map 151). Var. Okpeluk River, Okpilok River.

Eskimo name meaning "no willows," reported by Leffingwell (1919, p. 98), who explored to the stream's head in May 1907 with H. T. Arey.

Okpilak Valley: valley, $15 \mathrm{mi}$. long, in N slope of Romanzof Mts., $6 \mathrm{mi}$. NE of Mount Michelson, Brooks Ra.; $69^{\circ} 28^{\prime} \mathrm{N}, 144^{\circ} 00^{\prime} \mathrm{W}$; (map 139).

Leffingwell does not list this but wrote $(1919$, p. 134) of "the deepening of the Okpilak Valley * * *."

Okpilatok Bluff: hill, $600 \mathrm{ft}$., on Chukchi Sea coast, $8 \mathrm{mi}$. S of Cape Lisburne, Arctic Slope; $68^{\circ} 46^{\prime} \mathrm{N}, 166^{\circ} 11^{\prime} \mathrm{W}$; (map 129). Var. Oak-pi-lah-took Bluff.

Eskimo descriptive name reported in 1950 by USGS to mean "red appearing" and spelled "Oak-pi-lah-took."

Okpilok River: stream, see Okpilak River.

Okpirourak Creek: stream, heads at glacier near Fox Point, in Romanzof Mts., flows $36 \mathrm{mi}$. $\mathrm{NE}$ to Jago River, $24 \mathrm{mi}$. S of Barter I., Arctic Plain ; $69^{\circ} 44^{\prime \prime} \mathrm{N}, 143^{\circ} 37^{\prime} \mathrm{W}$; (map 138).

Eskimo name reported by Leffingwell $(1919$, p. 98) to mean "a few willows."

Okpisoorook River: stream, see Okpiksugruk Creek.

Okpisuruk Creek: stream, see Okpiksugruk Creek.

Okpisuruk River: stream, see Okpiksugruk Creek.

Okroknakpak Lakes: lakes, on left bank of Colville River, $32 \mathrm{mi}$. $\mathbf{E}$ of Liberator Lake, Arctic Slope; $68^{\circ} 53^{\prime} \mathrm{N}, 157^{\circ} 00^{\prime} \mathrm{W}$; (map 132).

Eskimo name reported by T. E. Taylor, USGS, in 1956. It means "place of the big lemming" and is supposed to refer to the legend of the "huge lemming that ate people." This area was once a popular hunting and fishing area.

Okrokovik River: stream, see Okerokovik River.

Okrurat Creek: stream, flows $2 \mathrm{mi}$. W to Chukchi Sea, $5.8 \mathrm{mi}$. S. of Cape Dyer, Arctic Slope; 68 $34^{\prime} 08^{\prime \prime} \mathrm{N}, 166^{\circ} 13^{\prime} 50^{\prime \prime} \mathrm{W}$; (map 129). Var. Oakwroorut Creek, Oggrurak Greek.

Eskimo descriptive name reported in 1950 by USGS to mean "white rocks" and spelled "Oak-wroo-rut."

Oksenof: point of land, see Mordvinof, Cape.

Oksenof Bay: beach, see Oksenof Beach.

Oksenof Beach: beach, $4.5 \mathrm{mi}$. long, between Cave Point and Oksenof Point, on NW coast of Unimak I., Aleutian Is.; $54^{\circ} 49^{\prime} 00^{\prime \prime} \mathrm{N}$, 164'34'30" W; BGN 1942; (map 24). Var. Bukhta Oksenova, Oksenof Bay.

Russian name reported by Father Veniaminov (1840, v. 2, p. 213) as "Bukh[ta] Oksenova"; i.e., "Oksenova Bay" and published as Oksenof Bay by Baker (1906, p. 479). The name Oksenof Beach was given by USG\&GS in 1940 to eliminate the misleading term "bay."
Oksenof Point: point of land, $5 \mathrm{mi}$. SW of Cape Mordvinof, on NW coast of Unimak I., Aleu$\operatorname{tian}$ Is.; $54^{\circ} 53^{\prime} \mathrm{N}, 164^{\circ} 33^{\prime} \mathrm{W}$; BGN 1942; (map 24). Var. Cape Lapin, Cape Mordvinof, Mys Mordvinove, Mys Oksenova, Ragged Point.

Named in 1940 by USC\&GS. The Russians called this point "Mys Mordvinove (Oksenova)"; i.e., "Cape Mordvinov (Oksenov)" (Capt. Tebenkov, 1852, map 25). Baker (1906, pl. 445) calls it Cape Mordvinof.

Oksenova, Bukhta: beach, see Oksenof Beach. Oksenova, Mys: point of land, see Mordvinof, Cape.

Oksenova, Mys: point of land, see Oksenof Point.

Okshokuhewhik Pass: watercourse, see Okshokwewhik Pass.

Okshokwewhik Pass: watercourse, in Yukon Delta, flows NE $20 \mathrm{mi}$. from Kwikpak Pass to Norton Sound, Yukon-Kuskokwim Delta; $63^{\circ} 13^{\prime} \mathrm{N}, 163^{\circ} 50^{\prime} \mathrm{W}$; (map 92). Var. Okshokuhewhik Pass.

Eskimo name reported in 1899 by G. $R$. Putnam, USC\&GS; published in 1901 on Chart 9372.

Oksik: locality, see Tenmile Post.

Oksik: village, see Noorvik.

Oksik Channel: stream, distributary of Kobuk River, flows W $10 \mathrm{mi}$. to Nazuruk Channel, Kobuk River, 32 mi. NW of Selawik, Kotzebue-Kobuk Low. ; $66^{\circ} 54^{\prime}$ N, $160^{\circ} 54^{\prime}$ W ; (map 114).

Eskimo name obtained in 1955 by U.S. Army Corps of Engineers.

Oksik Creek: stream, flows NW $12 \mathrm{mi}$. to Oksik Channel, Kobuk River, 29 mi. NW of Selawik, Kotzebue-Kobuk Low.; $66^{\circ} 52^{\prime} \mathrm{N}$, $160^{\circ} 48^{\prime} \mathrm{W}$; (map 114).

Eskimo name obtained in 1955 by U.S. Army Corps of Engineers.

Oksotalik Creek: stream, flows SE $25 \mathrm{mi}$. to Chukowan River $12 \mathrm{mi}$. W of its junc. with Holitna River, $67 \mathrm{mi}$. SW of Sleetmute, Kilbuck-Kuskokwim Mts.; $60^{\circ} 51^{\prime} \mathrm{N}, 158^{\circ} 11^{\prime} \mathrm{W}$; $B G N$ 1948; (map 60).

Eskimo name reported in 1945 by USGS to mean "place of heads."

Oksrukuyik: locality, on Sagavanirktok River, at mouth of Ribdon River, Arctic Slope; $68^{\circ} 49^{\prime}$ $\mathrm{N}, 148^{\circ} 48^{\prime} \mathrm{W}$; (map 135).

Eskimo name reported in 1956 by USGS.

Okstukuk Lake: lake, $2 \mathrm{mi}$. long, $16 \mathrm{mi}$. SW of Kemuk Mountain and $35 \mathrm{mi}$. N of Dillingham, Bristol Bay Low.; $59^{\circ} 33^{\prime} \mathrm{N}, 158^{\circ} 18^{\prime} \mathrm{W}$; $B G N$ 1931; (map 52). Var. Ok-su-kok.

Eskimo name shown as "Ok-su-kok" on a 1910 manuscript map by H. C. Fassett, USBF.

Oksuguokok Lake: lake, $1.6 \mathrm{mi}$. lang, $5 \mathrm{mi}$. $\mathrm{N}$ of Okstukuk Lake, and $41 \mathrm{mi}$. N of Dillingham, Bristol Bay Low.; $59^{\circ} 37^{\prime} \mathrm{N}, 158^{\circ} 20^{\prime} \mathrm{W}$; (map 52).

Eskimo name shown as "Ok-su-guok-ok" on a 1910 manuscript map by H. C. Fassett, USBF.

Ok-su-kok: lake, see Okstukuk Lake.

Okulak Lagoon: lagoon, see Aukulak Lagoon.
Okumiak, Mount: mountain, 1,565 ft., on a ridge between Wilson and Spruce Creeks $6 \mathrm{mi}$. SE of Marshall, Nulato Hills; $61^{\circ} 50^{\prime} \mathrm{N}, 161^{\circ} 55^{\prime}$ W; (map 73).

Eskimo name reported by Harrington (1918, map), USGS, in 1916.

Okwega Pass: watercourse, in Yukon Delta, extends NE 7.5 mi. from Apoon Pass to Pastol Bay, 40 mi. NE of Kwiguk, Yukon-Kuskokwim Delta; $63^{\circ} 07^{\prime} \mathrm{N}, 163^{\circ} 31^{\prime} \mathrm{W}$; (map 92).

Eskimo name obtained in 1898 by USC\&GS; published on Chart 9370.

Olaf Lake: lake, $1 \mathrm{mi}$. long, $18 \mathrm{mi}$. SE of Beaver, Yukon Flats; $66^{\circ} 12^{\prime} 20^{\prime \prime} \mathrm{N}, 146^{\circ} 52^{\prime} 00^{\prime \prime} \mathrm{W}$; (map 119).

Local named obtained in 1956 by USGS.

Olai, Gora: peak, see Alai, Mount.

Olai, Mount: peak, see Alai, Mount.

Olavide, Punta: point of land, see Icy Cape.

Olav Mountain: peak, see Alai, Mount.

Old Albert Lake: lake, $1.8 \mathrm{mi}$. long, $\mathrm{SE}$ of Dathlalmund Lake, $22 \mathrm{mi}$. S of Tok, Alaska Ra.; $63^{\circ} 04^{\prime} \mathrm{N}, 142^{\circ} 33^{\prime} \mathrm{W}$; (map 85).

Local name published by USGS in 1965.

Old Andreafsky: locality, on right bank of Yukon River, $3.5 \mathrm{mi}$. NW of Pitkas Point and $44 \mathrm{mi}$. NW of Marshall, Yukon-Kuskokwim Delta; $62^{\circ} 03^{\prime} 45^{\prime \prime} \mathrm{N}, 163^{\circ} 22^{\prime} 45^{\prime \prime} \mathrm{W}$; (map 77). Var. Andreafski, Andreafski Redoubt, Andreavski Redut, Andreafsky, Andreaivsky, Andreievsky.

The surname "Andreyevskaya," i.e., "Andrew's," was applied to a fort established by the Russians about 1853. The redoubt was "built in the form of a square, the buildings making two of the sides, and a stockade the other two. It contained barracks, a store, magazine, cook-house and bath-house" (Dall, 1870, p. 231). It was the site of an Indian massacre in August 1855.

Andreyevski Redoubt was located at or near the Eskimo village shown on early maps as Andreafski (or Andreafsky), but after a village of the same name was established on the Andreafsky River, the qualifying "Old" was added. See Andreafsky.

Old Auke Village: locality, see Auke.

Old Bogoslof Island: island, see Fire Island.

OId Buckland: village, see Buckland.

Old Cache Lake: lake, $1.5 \mathrm{mi}$. long, $\mathrm{E}$ of Spectacle Lake and $6 \mathrm{mi}$. SW of junc. of Herron and Foraker Rivers, Tanana Low.; 63 $35^{\prime} 30^{\prime \prime}$ $\mathrm{N}, 152^{\circ} 20^{\prime} 00^{\prime \prime} \mathrm{W}$; (map 88).

Local name reported in 1954 by USGS.

Old Camp: locality, on S bank of Porcupine River, at mouth of Salmon Trout River, 31 mi. NE of Coleen Mtn., Porcupine Plat.; $67^{\circ}$ $10^{\prime} \mathrm{N}, 141^{\circ} 40^{\prime} \mathrm{W}$; (map 121).

Name reported in 1956 by USGS, for a place consisting of two cabins.

Old Channel Creek: stream, flows SW $2.5 \mathrm{mi}$. to McCumber Creek, $26 \mathrm{mi}$. SE of Delta Junction, Alaska Ra.; $63^{\circ} 42^{\prime} 05^{\prime \prime} \mathrm{N}, 145^{\circ} 32^{\prime} 40^{\prime \prime}$ W; $B G N 1937$; (map 86).

Local name reported in 1937 by USGS.

Old Chatanika: settlement, see Chatanika.

Old Chevak: locality, on $\mathrm{N}$ bank of Keoklevik River, $9 \mathrm{mi}$. E of village of Hooper Bay, Yu- 
kon-Kuskokwim Delta; $61^{\circ} 26^{\prime} \mathrm{N}, 1^{\circ} 5^{\circ} 31^{\prime} \mathrm{W}$; (map 75).

This site was a village called "Chevak," until about 1950 when the Eskimo population moved to a new site also called "Chevak." The original site was abandoned because of occasional flooding from high storm-tides. The name "Chevak" refers in meaning to "a connecting slough."

Old Creek: stream, flows NW $25 \mathrm{mi}$. to King Salmon River, on Alaska Penin., $20 \mathrm{mi}$. SW of Ugashik, Bristol Bay Low.; 57 $17^{\prime} 15^{\prime \prime} \mathrm{N}$, $157^{\circ} 42^{\prime} 30^{\prime \prime} \mathrm{W}$; (map 36).

Named in 1923 by R. H. Sargent, USGS, for "Sidney Old, one of his packers and packer with previous USGS expeditions."

Old Crow River: stream, heads at $\mathrm{E}$ end of Davidson Mts., flows SE $175 \mathrm{mi}$. across Alaska-Canada boundary to Porcupine River in Yukon, Canada, Porcupine Plat.; 67 $34^{\prime}$ $30^{\prime \prime} \mathrm{N}, 139^{\circ} 50^{\prime} 00^{\prime \prime} \mathrm{W}$; (map 137).

Name reported in 1895 by USC\&GS

Old Cutoff : village, see Huslia.

Old Cutoff Trading Post: locality, on left bank of Koyukuk River, $4 \mathrm{mi}$. SW of Whitefish Lake and $15 \mathrm{mi}$. NE of Roundabout Mtn., Koyukuk Low.; $65^{\circ} 45^{\prime} \mathrm{N}, 156^{\circ} 23^{\prime} \mathrm{W}$; (map 108).

Trading post, now abandoned in favor of Huslia.

Old Dummy Lake: lake, $1.7 \mathrm{mi}$. long, $6.5 \mathrm{mi}$. SE of junc. of Kanuti Kilolitna and Kanuti Rivers, $24 \mathrm{mi}$. SE of Allakaket, Kanuti Flats; $66^{\circ} 08^{\prime} \mathrm{N}, 151^{\circ} 51^{\prime} \mathrm{W}$; (map 117).

Local name published in 1951 by USGS; the lake is said to have been named for a deaf-mute Indian.

Old Fort Hamilton: village, see Hamilton.

Old Franks Creek: stream, flows NE through Old Franks Lake and Lake Mary $14 \mathrm{mi}$. to Skowl Arm Kasaan Bay, on E coast of Prince

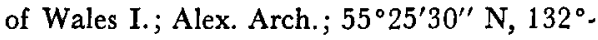
$28^{\prime} 00^{\prime \prime}$ W; (map 4).

Local name published in 1920 by USC\&GS.

Old Franks Lake: lake, $1.5 \mathrm{mi}$. long, in course of Old Franks Creek, on Prince of Wales I., NW of Skowl Arm Kasaan Bay, Alex. Arch.; $55^{\circ} 26^{\prime} 20^{\prime \prime} \mathrm{N}, 132^{\circ} 32^{\prime} 00^{\prime \prime} \mathrm{W}$; (map 4).

Local name published in 1920 by USC\&GS.

Old Glory Creek: stream, flows NE $7.3 \mathrm{mi}$. to Pinnell River which flows to Inmachuk River, $17 \mathrm{mi}$. of Imuruk Lake, Seward Penin.

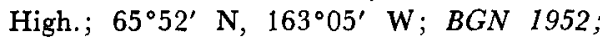
(map 110).

Prospector's name reported in 1901 by USGS (Collier, 1902, pl. 12).

Old Grouchtop: mountain, $1,268 \mathrm{ft}$., $\mathrm{W}$ of Dishna River, $35 \mathrm{mi}$. NW of Ophir and 65 mi. NW of McGrath, Kilbuck-Kuskokwim Mts.; $63^{\circ} 19^{\prime} \mathrm{N}, 157^{\circ} 35^{\prime} \mathrm{W}$; (map 90).

Name published in 1965 by USGS.

Old Hamilton: village, see Hamilton.

Old Harbor: village, pop. 193, on $W$ shore of Sitkalidak Strait, $56 \mathrm{mi}$. SW of Kodiak, Kodiak I.; $57^{\circ} 12^{\prime} 15^{\prime \prime} \mathrm{N}$, $153^{\circ} 18^{\prime} 00^{\prime \prime} \mathrm{W}$; (map 34). Var. Nunamiut, Staruigavan, Three Saints Harbor.

Name reported in the 11 th Census in 1890 (1893, p. 77) as "Old Harbor, named Starui- gavan by the Russians and Nunamiut by the natives $* * *$. This settlement, containing now less than 100 people, was once an important station of the Russian Fur Company * * *." The Old Harbor post office was established in 1931 (Ricks, 1965, p. 48). See Three Saints Harbor, locality.

Old Harbor: locality, see Nunamiut.

Old Harbor: locality, see Three Saints Harbor.

Old Harbor: bay, see Barling Bay.

Old Harbor: bay, see Staraya Bay.

Old Harbor: cove, $\mathrm{N}$ side of Makushin Bay, $\mathrm{W}$ coast of Unalaska I., Aleutian Is.; (map 23). Var. Stary Gavan.

Translation of the Russian "Star[y] Gavan," or "old harbor," by Capt. Tebenkov (1852, map 26), IRN. The name does not appear on modern maps. Baker $(1906$, p. 479$)$ reported "the present settlement of Makushin is on its shores."

Old Harbor: cove, see Three Saints Harbor.

Old Harbor Bay: bay, see Starrigavan Bay.

Old Iliamna: locality, site of village, at $\mathrm{E}$ end of Iliamna Lake, on $\mathrm{N}$ bank of Iliamna River, $30 \mathrm{mi}$. E of Iliamna, Aleutian Ra.; $59^{\circ} 45^{\prime} \mathrm{N}$, 15353' W; BGN 1941; (map 51). Var. Iliamna, Ilyamna, Odinochka.

Eskimo village reported by Ivan Petroff as "Ilyamna" in the 10th Census in 1880 (1884, p. 17). This site became known as "Old Iliamna" about 1935 after the people moved to a new location. Capt. Tebenkov (1852, map 5), IRN, recorded the name of "Odinochka," which is derived from "odinochnyy," meaning "isolated" or, possibly, "lone house."

Old John Lake: lake, $5 \mathrm{mi}$. long, at head of Vanticlese Creek, $11 \mathrm{mi}$. SE of Arctic Village, Brooks Ra.; 68 $04^{\prime} \mathrm{N}, 145^{\circ} 03^{\prime} \mathrm{W}$; (map 136).

Local name for "an old Indian who lived on the lake"; name shown on a 1926 fieldsheet by Gerald FitzGerald, USGS.

Old John Mountain: mountain, '3,720 ft., $4 \mathrm{mi}$. $\mathrm{N}$ of Old John Lake and $14 \mathrm{mi}$. E of Arctic Village, Brooks Ra.; 68 $08^{\prime} \mathrm{N}, 144^{\circ} 59^{\prime} \mathrm{W}$; (map 136).

Local name reported in 1956 by R. C. Foley, USGS.

Old Johns River: stream, see John River.

Old Kaguyak Bay: bay, $0.7 \mathrm{mi}$. across, $1.5 \mathrm{mi} . \mathrm{S}$ of Kaguyak, on SE coast of Kodiak I.; $56^{\circ} 50^{\prime}$ $20^{\prime \prime} \mathrm{N}, 153^{\circ} 46^{\prime} 00^{\prime \prime} \mathrm{W}$; (map 33).

Name derived from village of Kaguyak; published in 1943 by USC\&GS.

Old Kaltag: locality, on right bank of Yukon River, $53 \mathrm{mi}$. SW of Nulato and $21 \mathrm{mi}$. S of Kaltag, Nulato Hills; $64^{\circ} 01^{\prime} \mathrm{N}, 158^{\circ} 49^{\prime} \mathrm{W}$; (map 97).

Riverboat pilots' name shown on a 1940 "Navigation Chart of the Tanana-Yukon Rivers" published by U.S. Dept. of Interior. This may be the site of "Lower Kaltag" listed in 1880 Census. See Kaltag.

Old Kasaan: locality, on $\mathrm{N}$ shore of Skowl Arth on SE coast of Prince of Wales I., Alex. Arch.; $55^{\circ} 26^{\prime} \mathrm{N}, 132^{\circ} 23^{\prime} \mathrm{W}$; (map 4). Var. Chatchee-nie, Gasan, Kasaan, Kasaan Bay, KaSian, Kasi-an, Kassan, Kassan Haade, Skowl.
Former Haida Indian village possibly established before 1800. "Chat-chee-nie" shown in John Work's list of 1836-41 may represent the Haida name for the town. The Tlingit Indian name, Kasaan, derived from "Kaśian" meaning "pretty town," came into local usage; pronounced "GAsa'n" by the Haida (Hodge, 1907, p. 660), and so named because of the large number of ornate totems located in the village. Listed by Ivan Petroff in the 1880 Census as Kasaan (and "Skowl"), population 173, which decreased to 46 in 1890 . With the establishment in the 1890's of a salmon-packing plant on Kasaan Bay 8 miles to the north, this place was abandoned. The Haida settlement, that grew around the cannery, was known as "Kasaan," especially after the Kasaan post office was established in 1900, and the earlier site became "Old Kasaan." In 1916 , this village site was part of Old Kasaan National Monument. The National Monument status was abolished in 1955 and the village site is now part of Old Kasaan Village Historical Area, administered by the U.S. Forest Service.

Old Kashunuk Village: locality, see Kashunuk Village.

Old Kealavik: locality, on Kealavik River near Newtok, Yukon-Kuskokwim Delta; $61^{\circ} 00^{\prime} \mathrm{N}$, $164^{\circ} 45^{\prime}$ W (map 58). Var. Kealavik, Keyaluvik.

Former Eskimo village reported in 1949 by USC\&GS as "A sod hut village on the Kealavik River very recently abandoned in favor of New Kealavik. See Newtok."

Old Keegik : locality, see Kijik.

Old Khootznahoo: locality, see Letushkwin.

Old Kinegnak: village, see Kinegnak.

Old Knik: village, see Eklutna.

Old Kotzebue: locality, near mouth of Kobuk River, about $30 \mathrm{mi}$. E of Kotzebue, KotzebueKobuk Low.; near $66^{\circ} 50^{\prime} \mathrm{N}, 161^{\circ} 00^{\prime} \mathrm{W}$; (map 114).

Site of an Eskimo village reported in 1953 by J. W. Van Stone.

Old Kukak: locality, see Kukak.

Old Kvichak: village, see Levelock.

Old Kwikpakamiut: locality, see Kwikpak.

Old Lost Creek: stream, flows W $20 \mathrm{mi}$. to Yukon

River, $18 \mathrm{mi}$. NE of Stevens Village, Yukon Flats; $66^{\circ} 08^{\prime} 10^{\prime \prime} \mathrm{N}, 148^{\circ} 32^{\prime} 40^{\prime \prime} \mathrm{W}$; (map 118).

Local name obtained in 1956 by USGS.

Old McGrath: town, see McGrath.

Old Man Creek: stream, flows S $17 \mathrm{mi}$. to Mulchatna River, $85 \mathrm{mi}$. NE of Dillingham, Bristol Bay Low.; $59^{\circ} 52^{\prime} \mathrm{N}, 156^{\circ} 42^{\prime} \mathrm{W}$; (map 52).

Local name published in 1951 by USGS.

Old Man Creek: stream, heads at glacier, in Tordrillo Mts., flows NE $11 \mathrm{mi}$. to Skwentna River, $71 \mathrm{mi}$. NW of Tyonek, Alaska Ra.; 61 ${ }^{\circ} 57^{\prime} 30^{\prime \prime}$ $\mathrm{N}, 152^{\circ} 12^{\prime} 45^{\prime \prime} \mathrm{W}$; (map 70).

Local name reported in 1958 by USGS.

Old Man Creek: stream, flows NE $11 \mathrm{mi}$. to Little Nelchina River, $47 \mathrm{mi}$. W of Glennallen, Copper River Basin; $62^{\circ} 03^{\prime} \mathrm{N}, 146^{\circ} 59^{\prime} \mathrm{W}$; $B G N, 1960$; (map 83). 
Local name reported in 1935 by USGS.

Old Man Creek: stream, in Romanzof Mts., heads on Mount Michelson, flows $12 \mathrm{mi}$. to Hulahula River, Brooks Ra.; $69^{\circ} 29^{\prime}$ N, $144^{\circ}$ $23^{\prime}$ W ; BGN 1961; (map 139). Var. Angayukasrakvik Creek.

A translation of an Eskimo name used by USGS geologists in 1948. The Eskimo name "Angayukasrakuvik" refers to "old man" in its meaning, but was thought to be too long for map usage.

Old Man Creek: stream, see Kanuti River.

Old Man Lake: lake, $3.4 \mathrm{mi}$. long, in course of Mendeltna Creek, $36 \mathrm{mi}$. NW of Glennallen, Copper River Basin; 62 $08^{\prime} \mathrm{N}, 146^{\circ} 40^{\prime} \mathrm{W}$; (map 83).

Local name reported by USGS (in Moffit, 1915, pl. 6).

Old Man Lake: lake, $1.5 \mathrm{mi}$. long, oxbow of Black River Slough, $13 \mathrm{mi}$. NE of Fort Yukon, Yukon Flats; $66^{\circ} 37^{\prime} 25^{\prime \prime} \mathrm{N}, 144^{\circ} 47^{\prime} 00^{\prime \prime} \mathrm{W}$; (map 119).

Local name obtained in 1956 by USGS.

Old Man Lake: lake, $0.7 \mathrm{mi}$. long, $6 \mathrm{mi}$. SE of Peter John Mtn. and $22 \mathrm{mi}$. SE of Arctic Village, Brooks Ra.; 68 $01^{\prime} 35^{\prime \prime} \mathrm{N}, 144^{\circ} 43^{\prime} 30^{\prime \prime}$ W; (map 136).

Local name reported in 1956 by R. C. Foley, USGS.

Old Man River: locality, see Kanuti.

Old Man River: stream, see Kanuti River.

Old Man Rocks: rocks, off NE tip of Sedanka I., in Fox Is., Aleutian Is.; 53 52'15"' N, $166^{\circ} 04^{\prime} 45^{\prime \prime} \mathrm{W}$; (map 23).

Name given by J. J. Gilbert, commander of the USC\&GS steamer Pathfinder during 1900-01.

Oldmans Bay: bay, $3 \mathrm{mi}$. across, on $\mathrm{W}$ coast of Kalgin I., in Cook Inlet, $30 \mathrm{mi}$. WSW of Kenai, Cook Inlet Low.; $60^{\circ} 23^{\prime} \mathrm{N}, 152^{\circ} 02^{\prime}$ W; (map 62).

Local name reported in 1958 by USGS.

Old Morzhovoi: village, see Morzhovoi.

Old Nikolai: village, see Nikolai.

Old Ninilchik: locality, pop. 20, near Ninilchik on W coast of Kenai Penin., $38 \mathrm{mi}$. SW of Kenai, Cook Inlet Low.; $60^{\circ} 05^{\prime} \mathrm{N}, 151^{\circ} 40^{\prime}$ W; (map 62).

This is an earlier site of Ninilchik. See Ninilchik.

Old Pastolik: locality, near Pastolik along Pastolik River $40 \mathrm{mi}$. NE of Kwiguk, YukonKuskokwim Delta ; (map 77).

This is probably an earlier site of Pastolik. See Pastolik.

Old Rampart: settlement, pop. 6, on right bank of Porcupine River opposite mouth of Salmon Trout River, $31 \mathrm{mi}$. ENE of Coleen Mtn., Porcupine Plat. ; $67^{\circ} 10^{\prime} \mathrm{N}, 141^{\circ} 40^{\prime} \mathrm{W}$; (map 121). Var. Old Village.

FitzGerald (1944, p. 241), USGS, wrote in 1939 "Old Rampart, one of the largest settlements on the Porcupine River west of the 141st meridian *** a population of about $30 * * *$ has a small trading store and several well-built log cabins."

Old Red River: stream, see Ayakulik River.
Old Roadhouse Lake: lake, $0.7 \mathrm{mi}$. long, $\mathrm{N}$ of Iliamna Lake, $3 \mathrm{mi}$. NE of Iliamna, Aleutian Ra.; $59^{\circ} 48^{\prime} \mathrm{N}, 154^{\circ} 51^{\prime} \mathrm{W}$; (map 51).

Local name published in 1954 by USGS.

Old Saltery: locality, along Snake River about $3 \mathrm{mi}$. N of its mouth on Nushagak Bay, $9 \mathrm{mi}$. NW of Ekuk, Bristol Bay Low.; 58 $55^{\prime} \mathrm{N}$, $158^{\circ} 46^{\prime} \mathrm{W}$; (map 40).

Local name reported during the 1930's by USGS.

Old Saulich: locality, on The Alaska Railroad, 17 mi. W of Fairbanks, Tanana-Yukon High.; $64^{\circ} 51^{\prime} \mathrm{N}, 148^{\circ} 16^{\prime} \mathrm{W}$; (map 100).

Former railroad station. See Saulich.

Old Settlement: locality, see Staraya Artil.

Old Sitka: locality, on NW coast of Baranof I., on Starrigavan Bay, $5.5 \mathrm{mi}$. $\mathrm{N}$ of Sitka, Alex. Arch.; $57^{\circ} 07^{\prime} 50^{\prime \prime} \mathrm{N}, 135^{\circ} 22^{\prime} 20^{\prime \prime} \mathrm{W}$; (map 9). Var. Starri-gavan, Fort Archangel Gabriel, Mikhailovsk.

Site of the Russian fort and settlement founded in 1799 by A. A. Baranov, called "Mikhailovsk," because it was put under the patronage of Saint Michael Archangel. The fort was destroyed by Tlingit Indians in June 1802, and when Russian settlement was reestablished in 1804 the fort, built in a new location, was called New Archangel. See Sitka. The old site became known to the Russians as "Starri-gavan" meaning "old harbor." This may be the same place listed in the 1880 census as "Old Sitka," population 73 (1884, p. 32).

Old Sitka Harbor: bay, see Starrigavan Bay.

Old Sitka Rocks: rocks, $5 \mathrm{mi}$. NW of Sitka, off NW coast of Baranof I., Alex. Arch.; $57^{\circ} 06^{\prime}$ $45^{\prime \prime} \mathrm{N}, 135^{\circ} 24^{\prime} 00^{\prime \prime} \mathrm{W}$; (map 9).

Name published by USC\&GS in the 1891 Coast Pilot (p. 177). They were named for Old Sitka, 2 miles to the north.

Old Skwentna Roadhouse: locality, on W bank of Skwentna River, $56 \mathrm{mi}$. NW of Tyonek, Alaska Ra.; $61^{\circ} 52^{\prime} 50^{\prime \prime} \mathrm{N}, 1^{\circ} 21^{\circ} 20^{\prime} 45^{\prime \prime} \mathrm{W}$; $(\operatorname{map} 70)$.

Site of a former roadhouse shown on a 1954 USGS map. This roadhouse was probably one of several built about 1915 to accommodate miners who traveled the winter trail from the Susitna River to the mining camps at Innoko and Iditarod (Smith and others, 1929, p. 69).

Olds Mountain: mountain, 4,400 ft., $3 \mathrm{mi}$. N of Sheep Mtn. and $5 \mathrm{mi}$. NE of Juneau, Coast Mts.; $58^{\circ} 20^{\prime} 05^{\prime \prime} \mathrm{N}, 134^{\circ} 18^{\prime} 00^{\prime \prime} \mathrm{W}$; (map 11).

Named for John Olds, 1850-1910, pioneer, Juneau miner, and hotel man. He went to Alaska from England in 1877 and did prospecting and mining around Wrangell and Sitka before going to Juneau in 1880 with the first group of miners to leave from Sitka (DeArmond, 1957, p. 33). The name "Olds Mountain" was published by W. J. Peters, USGS, in 1902.

Old Snowy: peak, 9,700 ft., W of Gerstle Glacier, $31 \mathrm{mi}$. N of Paxson, Alaska Ra.; $63^{\circ} 28^{\prime} 40^{\prime \prime} \mathrm{N}, 145^{\circ} 23^{\prime} 35^{\prime \prime} \mathrm{W}$; (map 86).

Name published on relatively recent maps.
Olds River: stream, heads in lake and flows NE $5.3 \mathrm{mi}$. to Kalsin Bay, $13 \mathrm{mi}$. S of Kodiak, Kodiak I.; $57^{\circ} 35^{\prime} 30^{\prime \prime} \mathrm{N}, 152^{\circ} 26^{\prime} 30^{\prime \prime} \mathrm{W}$; (map 34).

Local name reported in 1949 by USGS.

Old Station Island: island, see Station Island.

Old Telida: village, see Telida.

Old Tokeen: locality, on NW end of Marble I., $38 \mathrm{mi}$. NW of Craig, Alex. Arch.; 55 $59^{\prime} 45^{\prime \prime}$ N, $133^{\circ} 27^{\prime} 55^{\prime \prime} \mathrm{W}$; (map 4). Var. Tokeen, Tok-Hene, Tokhin, Tokhini.

Site of an abandoned marble quarry; shown as "Tokeen" on a 1951 USGS map. A post office was maintained here from 1909 to 1938 (Ricks, 1965 , p. 65-66). Name is derived from the Tlingit Indian name "Tokhin," or "Tokhini," meaning "Tok River," which was applied to a stream on nearby Kosciusko Island. It was recorded in 1897 as "Tok-Hehe" and in 1901 as "Tok-Hene" by Lt. Comdr. J. F. Moser, USN, commander of the USBF steamer Albatross. See Tokeen.

Old Tom Creek: stream, flows $\mathrm{N} 3 \mathrm{mi}$. to mouth of McKenzie Inlet, on $\mathrm{E}$ coast of Prince of Wales I., S of Skowl Arm Kasaan Bay, Alex. Arch.; 55 $24^{\prime} 15^{\prime \prime} \mathrm{N}, 132^{\circ} 23^{\prime} 30^{\prime \prime} \mathrm{W}$; (map 4).

Local name recorded in 1897 by Lt. Comdr. J. F. Moser, USN.

Old Tyonek: settlement, on NW shore of Cook Inlet, $4.5 \mathrm{mi}$. SW of Tyonek, Cook Inlet Low.; $61^{\circ} 02^{\prime} 20^{\prime \prime} \mathrm{N}, 151^{\circ} 17^{\prime} 00^{\prime \prime} \mathrm{W}$; BGN 1952; (map 70). Var. Toyoniek, Toyonok, Tyonek Station.

Tanaina Indian village reported by USGS about 1898.

Old Tyonek Creek: stream, flows SE $11.8 \mathrm{mi}$. to Beshta Bay, $6 \mathrm{mi}$. SW of Tyonek, Cook Inlet Low.; $61^{\circ} 01^{\prime} 50^{\prime \prime} \mathrm{N}, 151^{\circ} 18^{\prime} 20^{\prime \prime} \mathrm{W}$; (map 70).

Local name reported in 1958 by USGS.

Old Valdez: locality, on $\mathrm{N}$ shore of Port Valdez, $4 \mathrm{mi}$. W of Valdez, Chugach Mts.; $61^{\circ} 07^{\prime} 45^{\prime \prime} \mathrm{N}, 146^{\circ} 21^{\prime} 20^{\prime \prime} \mathrm{W}$; (map 68). Var. Copper City.

Former landing and mining camp called originally "Copper City"; established in 1897 as an outfitting point for miners. A post office was established here in 1899 and the town was incorporated July 1, 1901. In 1903 the town was moved to the delta at the head of Port Valdez. After the destructive earthquake of 1964 , plans were made to move Valdez back to this, its original site.

Old Village: locality, on right bank of Telaquana River, $0.5 \mathrm{mi}$. W of Lake Telaquana and $72 \mathrm{mi}$. NE of Nondalton, Alaska Ra.; $60^{\circ} 57^{\prime} 45^{\prime \prime} \mathrm{N}, 154^{\circ} 02^{\prime} 00^{\prime \prime} \mathrm{W}$; (map 61).

Name of a former native village; reported by Capps (1935, pl. 2), USGS. Recent USGS maps indicate an abandoned site with three or four buildings.

Old Village: settlement, see Old Rampart.

Old Village Stream: stream, see Thoms Creek. Old Woman: locality, on $\mathrm{N}$ side of Old Woman Mtn., $35 \mathrm{mi}$. NE of Unalakleet, Nulato Hills; $64^{\circ} 03^{\prime} \mathrm{N}, 159^{\circ} 48^{\prime} \mathrm{W}$; (map 96). Var. Old Woman Cabin. 
Site of a telegraph station established in 1903 by the Signal Corps, USA.

Old Woman Cabin: locality, see Old Woman.

Old Woman Creek: stream, on $\mathrm{N}$ end of Kenai Penin., flows NE $2.5 \mathrm{mi}$. to Sixmile Creek, 3 mi. S of Sunrise, Chugach Mts.; $60^{\circ} 50^{\prime} 35^{\prime \prime} \mathrm{N}$, $149^{\circ} 25^{\prime} 50^{\prime \prime} \mathrm{W}$; (map 63).

Local name reported in 1952 by USGS.

Old Woman Creek: stream, flows N 6 mi. to Lake Minchumina, between Giles and New River Bays, Tanana Low.; $63^{\circ} 51^{\prime} 30^{\prime \prime} \mathrm{N}, 152^{\circ} 17^{\prime} 00^{\prime \prime}$ W; (map 88).

Local name reported in 1954 by USGS. Old Woman Creek: stream, heads in lake, flows SE $40 \mathrm{mi}$. to Sheenjek River, $7 \mathrm{mi}$. W of Table Mtn. and $40 \mathrm{mi}$. NE of Arctic Village, Brooks Ra.; $68^{\circ} 22^{\prime} \mathrm{N}, 143^{\circ} 56^{\prime} \mathrm{W}$; (map 137).

Prospectors' name reported in 1926 by J. B. Mertie, USGS.

Old Woman Creek: stream, heads on Kikiktat Mtn., flows NE $5.5 \mathrm{mi}$. to Hulahula River, 13 mi. NW of Mount Michelson, Brooks Ra.; $69^{\circ} 29^{\prime} 30^{\prime \prime} \mathrm{N}, 144^{\circ} 26^{\prime} 00^{\prime \prime} \mathrm{W} ; B G N$ 1961; (map 139). Var. Akuasrakuvik Creek.

A translation of an Eskimo name used by USGS geologists in 1948. The Eskimo name "Akuasrakuvik" refers to "old woman" in its meaning.

Old Woman Creek: stream, see Sunaghun Creek.

Old Woman River: stream, heads at $63^{\circ} 28^{\prime} 30^{\prime \prime}$ $\mathrm{N}, 159^{\circ} 54^{\prime} 50^{\prime \prime} \mathrm{W}$, flows $\mathrm{N} 50 \mathrm{mi}$. to Unalakleet River, $31 \mathrm{mi}$. NE of Unalakleet, YukonKuskokwim Delta; $64^{\circ} 01^{\prime} 45^{\prime \prime} \mathrm{N}, 159^{\circ} 49^{\prime} 50^{\prime \prime}$ W; (map 96)

Local name reported about 1954 by U.S. Army Corps of Engineers.

Old Womens Mountain: mountain, $1,300 \mathrm{ft}$, , N of Womens Bay, $6.5 \mathrm{mi}$. SW of Kodiak, Kodiak I. ; 57 $44^{\prime}$ N, $152^{\circ} 33^{\prime}$ W; (map 34).

Local name published in 1943 by USC\&GS.

Ole Creek: stream, heads at Reindeer Lake, flows NW $16 \mathrm{mi}$. to Kvichak River, $85 \mathrm{mi}$. E of Dillingham, Bristol Bay Low.; 59 $18^{\prime} \mathrm{N}$, $156^{\circ} 04^{\prime}$ W ; (map 52). Var. Pecks Creek.

Local name published in 1956 by USGS.

Ole Creek: stream, flows SE $10 \mathrm{mi}$. to Independence Creek, $38 \mathrm{mi}$. SW of Eagle, YukonTanana High.; $64^{\circ} 38^{\prime} 45^{\prime \prime} \mathrm{N}, 142^{\circ} 24^{\prime} 00^{\prime \prime} \mathrm{W}$ (map 102).

Named by prospectors and reported in 1904 by D. C. Witherspoon, USGS.

Olegek Creek: stream, see Ohlegek Creek.

Oleny Island: island, see Deer Island.

Olga Point: point of land, see Georgiana, Cape Olga, Point: point of land, see Klokachef Point. Olga Bay: bay, 19 mi. long, in SW part of Kodiak I., $33 \mathrm{mi}$. S of Karluk ; $57^{\circ} 05^{\prime} \mathrm{N}, 154^{\circ} 25^{\prime} \mathrm{W}$; (map 35).

Russian "given-name" published in the 11 th Census of 1890 (1893, p. 78).

Olga Creek: stream, flows W $1 \mathrm{mi}$. to $\mathrm{SW}$ shore of Olga Bay, $35 \mathrm{mi}$. S of Karluk, on SW coast of Kodiak I.; BGN 1939; (map 35). Var. Red Salmon Creek, South Olga Stream.

Named in 1939 by USC\&GS. USC\&GS reported the name Red Salmon Creek for this feature in 1930. The name South Olga Stream was reported in 1900

Olga Islands: islands, two, extend $1.2 \mathrm{mi}$. in Dolgoi Harbor, off Dolgoi I., Aleutian Ra.; $55^{\circ} 06^{\prime} 30^{\prime \prime} \mathrm{N}, 161^{\circ} 47^{\prime} 40^{\prime \prime} \mathrm{W}$; (map 28).

Local name reported in 1880 by W. H. Dall, USC\&GS, and shown on 1882 coast chart.

Olga Narrows: water passage, between Moser and Olga Bays, in SW part of Kodiak I., 38 mi. SE of Karluk; $57^{\circ} 03^{\prime} 20^{\prime \prime} \mathrm{N}, 1^{\circ} 4^{\circ} 06^{\prime} 40^{\prime \prime}$ W; $B G N$ 1934; (map 35), Var. The Narrows

Named for Olga Bay by USC\&GS in 1934. It was called "The Narrows" in the 1931 Alaska Coast Pilot (pt. 2, p. 197).

Olga Point: point of land, on N tip of Krestof $\mathrm{I}$. $14 \mathrm{mi}$. NW of Sitka, Alex. Arch.; 57 $13^{\prime} 40^{\prime \prime}$ N, $135^{\circ} 32^{\prime} 00^{\prime \prime}$ W ; (map 9). Var. Mys Olga.

Name published in 1848 on Russian Hydrog. Dept. Chart 1397 as "M[ys] Olga," meaning "Cape Olga."

Olga Rock: rock, $10 \mathrm{mi}$. SE of Dolgoi I., at SW

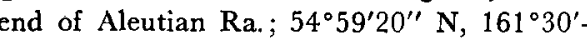
$40^{\prime \prime} \mathrm{W}$; (map 25).

Name reported by W. H. Dall, USC\&GS, and published in 1882 on USC\&GS Chart 806.

Olga Rock: rock, 2 mi. W of Klokachef I., $3 \mathrm{mi}$. $\mathrm{N}$ of Salisbury Sound, off SW coast of Chichagof I., $18 \mathrm{mi}$. S of Chichagof, Alex. Arch.; $57^{\circ} 24^{\prime} 40^{\prime \prime}$ N, $135^{\circ} 56^{\prime} 30^{\prime \prime}$ W ; (map 9).

Named by USC\&GS and published in 1899 on Chart 8050.

Olga Sound: water passage, see Salisbury Sound. Olga Strait: water passage, between Halleck and Krestof Is., $11 \mathrm{mi}$. NW of Sitka, Alex. Arch.; $57^{\circ} 11^{\prime} \mathrm{N}, 135^{\circ} 27^{\prime} \mathrm{W}$; (map 9). Var. Krestof Strait, Proliv Krestovskoy, Proliv Olgi.

Russian name given in 1833 by the navigator Ens. Vasiliev (cnna), IRN; published in 1848 on Russian Hydrog. Dept. Chart 1397 as "Pr[oliv] Olgi." This feature was called "Proliv Krestovskoy," meaning "cross strait," in 1809 by Lt. Sarichev (1826, map 19), IRN. Olga Strait: water passage, see Neva Strait.

Olga Strait: water passage, see Salisbury Sound. Olgi, Mys: point of land, see Georgiana, Cape. Olgi, Proliv: water passage, see Olga Strait.

Olgi, Proliv: water passage, see Salisbury Sound. Olgonik: village, see Wainwright.

Olie Creek: stream, flows NW to Inmachuk River about $17 \mathrm{mi}$. N of Imuruk Lake, Seward Penin. High.; (map 110).

Prospectors' name reported in 1901 by USGS (Collier, 1902, pl. 12). This stream cannot be identified on current maps.

Oligavik Creek: stream, heads on Mt. Buckland in Lisburne Hills, flows NE and SE $30 \mathrm{mi}$. to Tungnak Creek, $26 \mathrm{mi}$. E of Cape Dyer, Arctic Slope; $68^{\circ} 38^{\prime} \mathrm{N}, 165^{\circ} 12^{\prime} \mathrm{W}$; (map 129). Var. Olikvik Creek, Oolikvik River, Tugnnuk Creek, Tungnak Creek, Tungnaq Creek.

Eskimo name reported to mean "flood" in 1955 by U.S. Army Corps of Engineers.

Olikatuk Channel: stream, distributary of Kobuk River, heads at Riley Channel and flows SW $20 \mathrm{mi}$. to Hotham Inlet, $49 \mathrm{mi}$. NW of
Selawik, Kotzebue-Kobuk Low.; $66^{\circ} 40^{\prime} \mathrm{N}$, $161^{\circ} 47^{\prime} \mathrm{W}$; (map 114)

Eskimo name obtained in 1955 by U.S Army Corps of Engineers.

Oliktok Point: point of land, E point of entrance to Harrison Bay, on Beaufort Sea coast, 16 mi. W of Beechey Point, Arctic Plain; $70^{\circ}$ $30^{\prime} 45^{\prime \prime} \mathrm{N}, 149^{\circ} 51^{\prime} 30^{\prime \prime} \mathrm{W}$; (map 150). Var. Beechey Point, Olikto Point, Oliktone Point, Point Berens.

Eskimo name reported by Lt. W. J. S. Pullen, RN, as "Olikto," meaning "it shakes or trembles." On July 24, 1837, P. W. Dease and Thomas Simpson named it "Point Berens," after one of the directors of the Hudson's Bay Company (Simpson, 1843, p. 129). At variance with Sir John Franklin's text; some of the earlier charts show this to be Beechey Point. E. de K. Leffingwell (1919, p. 93) writes, "the locative plural case, Oligtone, is used *** by white men who have lived among the natives for many years."

Oliktone Point: point of land, see Oliktok Point Olikto Point: point of land, see Oliktok Point. Olikvik Creek: stream, see Oligavik Creek. Olikvik Creek: stream, see Sakvelak Creek.

Olive, Mount: hill, $862 \mathrm{ft}$., on right bank of Yukon River $5.5 \mathrm{mi}$. SSW of Russian Mission, Yukon-Kuskokwim Delta; $61^{\circ} 42^{\prime} \mathrm{N}, 161^{\circ} 21^{\prime}$ W; (map 73).

Riverboat pilots' name shown on 1922 manuscript chart of the Yukon River.

Olive Cove: cove, extends $\mathrm{N} 1 \mathrm{mi}$. to Zimovia Strait, $22 \mathrm{mi}$. S of Wrangell, on $\mathrm{E}$ coast of Etolin I., Alex. Arch.; 56 $6^{\circ} 11^{\prime} 30^{\prime \prime}$ N, $132^{\circ} 19^{\prime}$. $00^{\prime \prime} \mathrm{W}$; (map 6).

Local navigators' name reported in 1904 by H. C. Fassett, USBF.

Olive Creek: stream, flows E $3.5 \mathrm{mi}$. to Olive Cove, $22 \mathrm{mi}$. S of Wrangell and $4 \mathrm{mi}$. SE of Anita I., on E coast of Etolin I., Alex. Arch.; $56^{\circ} 10^{\prime} 45^{\prime \prime} \mathrm{N}, 132^{\circ} 19^{\prime} 30^{\prime \prime} \mathrm{W} ; B G N 1930$ (map 6).

Local name reported in 1929 by USFS.

Olive Creek: stream, flows $\mathbf{S} 3 \mathrm{mi}$. to Tolovana River, $3 \mathrm{mi}$. $\mathrm{S}$ of Livengood, Yukon-Tanana High.; $65^{\circ} 28^{\prime} 30^{\prime \prime} \mathrm{N}, 148^{\circ} 31^{\prime} 00^{\prime \prime} \mathrm{W}$; (map 105).

Prospected and named by Jay Livengood; reported in 1915 by USGS (Brooks and others, 1916, pl. 9)

Oliver Hill: hill, $500 \mathrm{ft}$, , between Klikitarik Bay and Klikitarik Mtn., $18 \mathrm{mi}$. E of St. Michael, Nulato Hills; $63^{\circ} 27^{\prime} \mathrm{N}, 161^{\circ} 26^{\prime} \mathrm{W}$; (map 91).

Local name reported in 1950 by USC\&GS. Oliver Inlet: estuary, $3 \mathrm{mi}$. long, at $\mathrm{N}$ end of Glass Penin., trends NW to Stephens Passage $5 \mathrm{mi}$. SW of False Arden and $11 \mathrm{mi}$. SE of

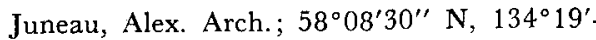
45" W; (map 11).

Named in 1890 by Lt. Comdr. H. B Mansfield, USN, and published by USC\&GS in the 1891 Coast Pilot (p. 150).

Olivers Place: locality, see Shakan.

Ollaga Island: island, see Carlisle Island.

Olnes: locality, $16 \mathrm{mi}$. $\mathrm{N}$ of Fairbanks, YukonTanana High.; $65^{\circ} 04^{\prime} 30^{\prime \prime} \mathrm{N}, 147^{\circ} 40^{\prime} 10^{\prime \prime} \mathrm{W}$ 
(map 105). Var. Olness, Dome.

Mining supply village and former RR. station on the Tanana Valley RR, reported in 1907 by USGS. The OIness post office was established in 1908, discontinued in 1910, and then reestablished as "Olnes" in 1922; finally discontinued in 1925. According to USGS it was named for a miner who spelled his name "Olnes" [cnna].

Olness: locality, see Olnes.

Olngooseenuk Mountain: mountain, 1,005 ft., $3.5 \mathrm{mi}$. long, in Poovoot Ra., $20 \mathrm{mi}$. SE of Gambell, St. Lawrence I.; 63⒊ $\mathrm{N}$, $171^{\circ} 20^{\prime} \mathrm{W}$; BGN 1951; (map 93). Var. Yaghmelugak Mountain.

Eskimo name reported in 1949 by Maj. H. B. Allen, USAF. According to Orth, 1965 , the name is best rendered "otnosirnak"; sirnak means "walrus stomach."

Olokak River: stream, see Holokuk River.

Olor Island: island, $0.6 \mathrm{mi}$. across, in Baird Inlet, $3 \mathrm{mi}$. S of Kagalurpak Lake and 80 mi. W of Bethel, Yukon-Kuskokwim Delta; $60^{\circ} 50^{\prime} 15^{\prime \prime} \mathrm{N}, 164^{\circ} 05^{\prime} 30^{\prime \prime} \mathrm{W}$; (map 58).

Name used by personnel of Clarence Rhode National Wildlife Range; reported in 1965. Olrona: bay, sec Wainwright Inlet.

Olsen Bay: bay, 2 mi. wide, at $\mathrm{N}$ edge of Port Gravina, $20 \mathrm{mi}$. NW of Cordova, Chugach Mts.; $60^{\circ} 43^{\prime} 20^{\prime \prime} \mathrm{N}, 146^{\circ} 12^{\prime} 30^{\prime \prime} \mathrm{W}$; (map 64).

Local name reported in 1908 by U. S. Grant and D. F. Higgins (in Brooks and others, 1909, pl. 4), USGS.

Olsen Cove: estuary, on $\mathrm{S}$ coast of Alaska, extends E $0.8 \mathrm{mi}$. to Prince William Sound, 38 mi. NE of Whittier, Chugach Mts. ; 60 $52^{\prime} 15^{\prime \prime}$ N, 147 $35^{\prime} 15^{\prime \prime} \mathrm{W}$; (map 63).

Local name reported in 1951 by USGS.

Olsen Creek: stream, heads in Fire Lake and flows $\mathrm{N}$ through Olsen Lake $1.4 \mathrm{mi}$. to Kenai River, on Kenai Penin., $25 \mathrm{mi}$. SE of Kenai, Cook Inlet Low.; $60^{\circ} 27^{\prime} 30^{\prime \prime} \mathrm{N}, 150^{\circ} 32^{\prime} 30^{\prime \prime}$ W; (map 62).

Named about 1963 by officials of Kenai National Moose Range, for administrative purposes.

Olsen Island: island, $1 \mathrm{mi}$. across, in Prince William Sound, $3.5 \mathrm{mi}$. W of Fairmount I., 38 mi. NE of Whittier, Chugach Mts. ; $60^{\circ} 52^{\prime} 15^{\prime \prime}$ N, 1473' $30^{\prime \prime} \mathrm{W}$; (map 63).

Local name reported in 1905 by U. S. Grant. So named because "a Mr. Olsen has a fox ranch here."

Olsen Lake: lake, $0.3 \mathrm{mi}$. long, on Kenai Penin. W of Skilak Lake, $25 \mathrm{mi}$. SE of Kenai, Cook Inlet Low.; $60^{\circ} 26^{\prime} 45^{\prime \prime} \mathrm{N}, 150^{\circ} 32^{\prime} 30^{\prime \prime} \mathrm{W}$; (map 62).

Named about 1963 by officials of Kenai National Moose Range, for administrative purposes.

Olson Creek: stream, flows SE $9 \mathrm{mi}$. to Beluga River, $12 \mathrm{mi}$. N of Tyonek, Cook Inlet Low.; $61^{\circ} 14^{\prime} 30^{\prime \prime} \mathrm{N}, 151^{\circ} 03^{\prime} 50^{\prime \prime} \mathrm{W}$; (map 70). Local name reported in 1958 by USGS.

Olsons Lake: lake, $0.8 \mathrm{mi}$. long, on $\mathrm{S}$ bank of Kanuti River, $6 \mathrm{mi}$. E of Caribou Mtn. and $47 \mathrm{mi}$. SE of Bettles, Kokrines-Hodzana
High.; $66^{\circ} 24^{\prime} 30^{\prime \prime} \mathrm{N}, 150^{\circ} 28^{\prime} 30^{\prime \prime} \mathrm{W}$; (map 117).

Local name reported in 1956 by T. $E$. Taylor, USGS.

Olsons Roadhouse: locality, see Tolstoi

Olugooseenuk Mountain: hill, see Yaghmelngak Mountain.

Olumagwilute River: stream, flows S $6 \mathrm{mi}$. to Kanektok River, $52 \mathrm{mi}$. NE of Goodnews, Kilbuck-Kuskokwim Mts.; $59^{\circ} 45^{\prime} \mathrm{N}, 160^{\circ} 51^{\prime}$ W; (map 53). Var. Olumagwilute Creek.

Eskimo name shown on an 1898 fieldsheet by W. S. Post, USGS ; published as "Olumagwilute Creek" (Spurr, 1900, map 10).

Olympia Creek: stream, flows SE $7 \mathrm{mi}$. to West Fork Chena River, 7 mi. ENE of Chena Dome and $80 \mathrm{mi}$. SW of Circle, Yukon-Tanana High.; $65^{\circ} 07^{\prime} \mathrm{N}, 146^{\circ} 14^{\prime} \mathrm{W}$; (map 104).

Named by prospectors and reported in 1913 by C. E. Ellsworth (in Ellsworth and Davenport, 1915b, pl. 12), USGS.

Olympic Creek: stream, flows S $4 \mathrm{mi}$. to Slate Creek, $21 \mathrm{mi}$. NE of Goodnews, KilbuckKuskokwim Mts.; $59^{\circ} 20^{\prime}$ N, $161^{\circ} 12^{\prime}$ W. (map 53).

Local name reported in 1948 or 1949 by Sam Marshall and John Haroldsen of Goodnews.

Omakstalia Point: bluff, elev. $25 \mathrm{ft}$., on $\mathrm{S}$ bank of Naknek River, on Alaska Penin., $9.3 \mathrm{mi}$ SE of Naknek, Bristol Bay Low.; 58 $42^{\prime} 15^{\prime \prime}$ $\mathrm{N}, 156^{\circ} 45^{\prime} 15^{\prime \prime} \mathrm{W}$; (map 41).

Eskimo name reported in 1952 by USGS.

Omalik Cireek: stream, flows NW $9 \mathrm{mi}$. to Chukchi Sea S of Omalik Lagoon, $44 \mathrm{mi}$ SW of Point Lay, Arctic Plain; $69^{\circ} 08^{\prime} 30^{\prime \prime} \mathrm{N}$, $163^{\circ} 32^{\prime} 00^{\prime \prime} \mathrm{W}$; (map 145). Var. Aumalik Creek.

Eskimo name reported by USC\&GS in 1949, and may mean "chief, amber, or cinders." It could also be a family name.

Omalik Creek: stream, see Omilak Creek.

Omalik Hill: hill, $400 \mathrm{ft}$., in Igichuk Hills, E of Noatak River, $21 \mathrm{mi}$. NE of Kotzebue, Brooks Ra.; $67^{\circ} 12^{\prime} \mathrm{N}, 162^{\circ} 25^{\prime} \mathrm{W}$; (map 128). Var. Oomalik Hill.

Eskimo name to refer to a "rich man," obtained at Kotzebue by Orth in 1956. See Omalik Creek.

Omalik Lagoon: lagoon, $1.5 \mathrm{mi}$. long, on coast of Chukchi Sea, $11 \mathrm{mi}$. NE of Cape Beaufort and $42 \mathrm{mi}$. SW of Point Lay, Arctic Plain, $69^{\circ} 09^{\prime} \mathrm{N}, 163^{\circ} 30^{\prime} \mathrm{W}$; (map 145). Var. Aumalik Lagoon.

Eskimo name reported by USC\&GS in 1949 . See Omalik Creek.

Omalik River: stream, heads in lake, flows $\mathrm{N}$ and $\mathrm{W} 11 \mathrm{mi}$. to Kuk River, $23 \mathrm{mi}$. S of Wainwright, Arctic Plain; $70^{\circ} 18^{\prime} 30^{\prime \prime} \mathrm{N}, 159^{\circ}$ 49'55" W; BGN 1925; (map 146). Var. Aumalik River.

Eskimo name, meaning "chief," obtained in 1924 by USGS. Orth was told at Wainwright in 1965 that the name meant "amber."

O'Malley Lake: lake, $2 \mathrm{mi}$. long, at head of O'Malley River, S of Karluk Lake, Kodiak I. $57^{\circ} 15^{\prime} 30^{\prime \prime} \mathrm{N}, 153^{\circ} 58^{\prime} 00^{\prime \prime} \mathrm{W}$; (map 34).

Local name reported in 1954 by USGS.
O'Malley River: stream, heads at O'Malley Lake, flows NW $0.5 \mathrm{mi}$. to Karluk Lake, Kodiak I.; $57^{\circ} 16^{\prime} 40^{\prime \prime} \mathrm{N}, 153^{\circ} 59^{\prime} 40^{\prime \prime} \mathrm{W}$; (map 34).

Local name reported in 1954 by USGS.

Omaluruk Creek: stream, flows NE $6 \mathrm{mi}$. through a low wetland to Kobuk River, $29 \mathrm{mi}$. NW of Shungnak, Brooks Ra. ; $67^{\circ} 04^{\prime} \mathrm{N}, 158^{\circ}$ $06^{\prime} \mathrm{W}$; (map 126).

Eskimo name reported by the U.S. Army Corps of Engineers in 1955.

Omanaca, Isla de: island, see Umnak Island.

Omanha River: stream, see North Fork Squirrel River.

Omanha River: stream, see Omar River.

Omar Creek: stream, flows N $2 \mathrm{mi}$. to head of McKenzie Inlet, on Prince of Wales I., S of Skowl Arm Kasaan Biy, Alex. Arch.; 55 $19^{\prime}$ $30^{\prime \prime} \mathrm{N}, 132^{\circ} 21^{\prime} 25^{\prime \prime} \mathrm{W}$; (map 4).

Name published in 1943 by USG\&GS; undoubtedly given because the [Omar] Khayyam mine was located in this vicinity.

Omar Creek: stream, flows NE $3 \mathrm{mi}$. to Khayyam Creek, $3.5 \mathrm{mi}$. NW of Lois Dome and $46 \mathrm{mi}$. NW of Coleen Mtn., Brooks Ra.; $67^{\circ}$ $45^{\prime} \mathrm{N}, 142^{\circ} 53^{\prime} \mathrm{W}$; (map 121).

Local name reported in 1956 by T. E. Taylor, USGS.

Omar River: stream, in Baird Mts., flows SW $35 \mathrm{mi}$. to Squirrel River, $16 \mathrm{mi}$. NW of Kiana, Brooks Ra.; $67^{\circ} 10^{\prime} \mathrm{N}, 161^{\circ} 00^{\prime} \mathrm{W}$; (map 127). Var. Omanha River.

Reported in 1939 by USGS.

Omega Creek: stream, flows S $9 \mathrm{mi}$. to Baker Creek, $28 \mathrm{mi}$. SSW of Rampart, Yukon-Tanana High.; $65^{\circ} 06^{\prime} 10^{\prime \prime} \mathrm{N}, 150^{\circ} 19^{\prime} 45^{\prime \prime} \mathrm{W}$; BGN 1961; (map 106). Var. Alpha Creek.

Prospectors' name reported in 1904 by Prindle and Hess (1906, p. 91), USGS. Gold was discovered here in 1899.

Omega Gulch: ravine, trends W $1.6 \mathrm{mi}$. to Crooked Creek $11.5 \mathrm{mi}$. NE of its junc. with Kuskokwim River, $42 \mathrm{mi}$. NW of Sleetmute, Kilbuck-Kuskokwim Mts. ; $62^{\circ} 01^{\prime} 20^{\prime \prime} \mathrm{N}, 158^{\circ}$. 15'05" W ; BGN 1945; (map 79)

Local name obtained in 1944 by USGS.

Omega Island: island, $5 \mathrm{mi}$. NE of Wosnesenski I. and $19 \mathrm{mi}$. NE of Dolgoi I., Aleutian Ra.; 55 $14^{\prime} 35^{\prime \prime} \mathrm{N}, 161^{\circ} 14^{\prime} 30^{\prime \prime} \mathrm{W}$; (map 28).

Shown on a 1963 USGS map.

Omega Point: point of land, $3.6 \mathrm{mi}$. SW of East Cape, on SW coast of Amchitka I., Aleutian Is.; $51^{\circ} 22^{\prime} 00^{\prime \prime} \mathrm{N}, 179^{\circ} 22^{\prime} 30^{\prime \prime} \mathrm{E}$; (map 15). Name shown on a 1955 AMS map.

Omeghok: locality, $3 \mathrm{mi}$. SE of Taphook Point, 22 mi. SE of Gambell, N coast of St. Lawrence I.; $63^{\circ} 36^{\prime} \mathrm{N}, 171^{\circ} 11^{\prime} \mathrm{W}$; (map 93).

Eskimo name reported in 1932 by $\mathrm{O}$. W. Geist, Univ, of Alaska.

Omiaktalik, Lake: lake, $1 \mathrm{mi}$. across, at mouth of Kaviruk River, $32 \mathrm{mi}$. $\mathbf{E}$ of Teller, Seward Penin. High.; 65 ${ }^{\circ} 12^{\prime}$ N, $163^{\circ} 16^{\prime}$ W; (map 111).

Eskimo name reported on the 1908 "Map of Seward Peninsula" by Arthur Gibson.

Omicron Hill: mountain, $1,100 \mathrm{ft}$., $8 \mathrm{mi}$. W of Eskimo Hill and $86 \mathrm{mi}$. S of Wainwright, 
Arctic Slope; $69^{\circ} 23^{\prime} \mathrm{N}, 160^{\circ} 12^{\prime} \mathrm{W}$; (map 144).

So named by USGTS geologists in 1950 "because this designation was used for their triangulation marker [USC\&GS] situated atop this hill" (Chapman and Sable, 1960, p. 54).

Omik: locality, on Agattu I., Aleutian Is.; $52^{\circ} 25^{\prime} \mathrm{N}, 173^{\circ} 35^{\prime} \mathrm{E}$; (map 13).

Former Aleut village or camp (Hodge, 1910, p. 121).

Omikmak Creek: stream, flows W $3.7 \mathrm{mi}$. to Kuk River, $6.5 \mathrm{mi}$. SE of Wainwright, Arctic Plain; $70^{\circ} 35^{\prime} \mathrm{N}, 159^{\circ} 50^{\prime} \mathrm{W}$; (map 146).

Eskimo name published in 1955 by AMS.

Omikmuktusuk River: stream, flows N $45 \mathrm{mi}$. to Kaolik River, $48 \mathrm{mi}$. S of Wainwright Arctic Plain; 69 $54^{\prime} \mathrm{N}, 159^{\circ} 57^{\prime} \mathrm{W}$; (map 144).

Eskimo name reported in 1956 by T. E. Taylor, USGS.

Omilak: locality, on right bank South Fork Mosquito Creek in Fish River basin, $42 \mathrm{mi}$. SE of Imuruk Lake, Seward Penin. High.; $65^{\circ} 02^{\prime} \mathrm{N}, 162^{\circ} 41^{\prime} \mathrm{W}$; (map 110). Var. Oonilak, Unilak.

Site of a former mining camp. John C. Green of San Francisco "organized a small company, and in 1881 he and several others were landed at Golofnin Bay. Guided by the natives, they found a deposit of galena ore, which they called the Omilak, in the Fish River basin. There was started the first lodemining enterprise in Alaska, except for the little done at Sitka. Work was continued for a number of years, but for one reason or another the venture was not successful" (Brooks, 1953 , p. 373). The Omilak Post Office was established in 1908 and discontinued the fol. lowing year (Ricks, 1965, p. 48).

Omilak Creek: stream, heads in Darby Mts., flows NW $20 \mathrm{mi}$. to Fish River, $22 \mathrm{mi}$. NE of Council and $37 \mathrm{mi}$. S of Imuruk Lake, Seward Penin. High.; $65^{\circ} 02^{\prime} \mathrm{N}, 163^{\circ} 02^{\prime} \mathrm{W}$; $B G N$ 1910; (map 110). Var. Ohmalik Creek, Omalik Creek, Umalik.

Eskimo name used by prospectors reported in 1900 by E. C. Barnard (in Brooks, 1901, pl. 17), USGS.

Omilak Mountain: mountain, 2,671 ft., in Darby Mts., between North Fork and South Fork Mosquito River, $42 \mathrm{mi}$. SE of Imuruk Lake, Seward Penin. High.; $65^{\circ} 03^{\prime} \mathrm{N}, 162^{\circ} 37^{\prime} \mathrm{W}$; (map 110).

Local name reported in 1900 by Mendenhall (1901, pl. 18), USGS.

Ommaney, Cape: point of land, southern tip of Baranof I., $4.5 \mathrm{mi}$. SSW of Port Alexander, Alex. Arch.; 56 $10^{\circ} 00^{\prime \prime} \mathrm{N}, 134^{\circ} 40^{\prime} 20^{\prime \prime} \mathrm{W}$; (map 5). Var. Cape Chirikoff, Menzies Cape, Punta Oesta de la Entrada del Principe, South Point, Tschirikow.

Named in 1789 by James Colnett, English fur trader. La Pérouse called it "Tschirikow;" for Capt. Alexie Ilich Chirikov, IRN, the Russian navigator who he thought landed in this area July 1741. Capt. Alessandro Malaspina, in 1791, called it "Punta Oesta de la Entrada del Principe," meaning "west point of the prince's (chief's) entrance." In 1796-99 local traders called it "Menzie's Cape"; Capt. U. T. Lisianski called it "South Cape" in 1804.

Ommaney Bay: bay, $1 \mathrm{mi}$. across, at $\mathrm{S}$ tip of Baranof I., at SW point of entrance to Chatham Strait, Alex. Arch.; $56^{\circ} 10^{\prime} 20^{\prime \prime} \mathrm{N}, 134^{\circ}$ $41^{\prime} 00^{\prime \prime} \mathrm{W}$; BGN 1925; (map 5).

Named in 1925 by USC\&GS; name derived from Cape Ommaney.

Ommaney Peak: mountain, 2,005 ft., at $\mathrm{S}$ tip of Baranof I., Alex. Arch.; $56^{\circ} 11^{\prime} 00^{\prime \prime} \mathrm{N}$, $134^{\circ} 40^{\prime} 45^{\prime \prime} \mathrm{W}$; BGN 1925; (map 5).

Named in 1925 by USC\&GS; name derived from Cape Omnaney.

Onak: locality, along $\mathrm{N}$ bank of Wulik River, 7 mi. NE of Kivalina, Kotzebue-Kobuk Low.; $67^{\circ} 47^{\prime} \mathrm{N}, 164^{\circ} 22^{\prime} \mathrm{W}$; (map 128). Var. Aunak, Aunaq, Ohnak.

Eskimo name meaning "rotten fish" (or "rotten meat"), so called because fish stored here in early fall rot quickly, possibly due to a lack of permafrost. Name reported in 1966 by E. S. Burch.

Onasnoy, Mys: point of land, see Dangerous Cape.

Onatznoj: point of land, see Dangerous Cape. Onatzo: point of land, see Dangerous Cape.

Onatzno Point: point of land, see Dangerous Cape.

One, Lake: lake, 1,800 ft. long, between Halfway Lake and Lake Two, $8 \mathrm{mi}$. S of Talkeetna, Cook Inlet Low.; $62^{\circ} 12^{\prime} 25^{\prime \prime} \mathrm{N}, 150^{\circ} 03^{\prime} 00^{\prime \prime}$ W; (map 81).

Local descriptive name reported in 1958 by USGS.

O'Neel, Mount: mountain, 6,411 ft., at head of Grinnell Glacier, $37 \mathrm{mi}$. N of Katalla, Chugach Mts.; $60^{\circ} 42^{\prime} \mathrm{N}, 144^{\circ} 50^{\prime} \mathrm{W}$; BGN 1930; (map 64).

Named about 1910 by Lawrence Martin, for A. C. O'Neel, "Chief Bridge Engineer, Copper River and Northwestern Railroad, who built a $\$ 1,500,000$ steel bridge near the base of this mountain in 1909-1910 across the Copper River, which is as large as the Mississippi at New Orleans, and never lost a man."

Onega Creek: stream, see Oniga Creek.

One Hundred Ninety-seven and One-half Mile Creek: stream, see 1971/2 Mile Creek (end of alphabet).

One Hundred Ninety-six Mile Creek: stream, see 196 Mile Creek (end of alphabet).

One Hundred Seventy-two Degree Pass: water passage, see Amukta Pass.

Oneida Rock: rock, $7.5 \mathrm{mi}$. SW of Sanak I., in Sanak Is., Aleutian Ra.; $54^{\circ} 28^{\prime} 20^{\prime \prime} \mathrm{N}, 162^{\circ}$ $55^{\prime} 40^{\prime \prime}$ W; (map 25).

Name reported by Ferdinand Westdahl, USC\&GS, commander of the Coast Survey steamer McArthur, who made surveys in this area in 1901

Oneita Creek: stream, see Anita Creek.

Onekoksuk Creek: stream, flows S to Fish River, between Jarvis Creek and Niukluk River, about $36 \mathrm{mi}$. NE of Solomon, Seward Penin. High.; (map 95).
Prospectors' name reported on the 1900 "Map of Nome Peninsula" by J. M. Davidson and B. D. Blakeslee. This stream cannot be precisely located on current maps.

Onelow Point: point of land, see Onslow Point. Onemile Creek: stream, flows W $3.5 \mathrm{mi}$. to Delta River, crosses Richardson Highway, $35 \mathrm{mi}$. S of Delta Junction, Alaska Ra.; $63^{\circ} 32^{\prime} 25^{\prime \prime} \mathrm{N}$, $145^{\circ} 51^{\prime} 55^{\prime \prime} \mathrm{W}$; $B G N$ 1938; (map 86).

Local name reported in 1938 by USGS; given because "the mouth of the stream is about one mile below Rapids Roadhouse."

One Ninety-seven and One-half Mile Creek: stream, see 1971/2 Mile Creek (end of alphabet).

One Ninety-six Mile Creek: stream, see 196 Mile Creek (end of alphabet).

Onestone Lake: lake, $1.7 \mathrm{mi}$. long, between Shell Lake and Skwentna River, $59 \mathrm{mi}$. NW of Tyonek, Alaska Ra.; $61^{\circ} 55^{\prime} 05^{\prime \prime} \mathrm{N}, 151^{\circ} 31^{\prime} 45^{\prime \prime}$ W; (map 70).

Local name reported in 1954 by USGS.

One Thousand Eight Hundred Forty-eight Hill: mountain, see 1848 Hill (end of alphabet).

Onetree Rock: rock, on E shore of Redfish Bay, $9.3 \mathrm{mi}$. NW of village of Port Alexander, on $S$ coast of Baranof I., Alex. Arch.; 56 $6^{\circ} 17^{\prime} 45^{\prime \prime}$ $\mathrm{N}, 134^{\circ} 51^{\prime} 30^{\prime \prime} \mathrm{W}$; (map 5). Var. One Tree Rock.

Named in 1897 by Lt. Comdr. J. F. Moser, USN, commander of USBF steamer Albatross. Ongivinuck River: stream, heads at Ongivinuk Lake, flows SW $25 \mathrm{mi}$. to Togiak River, $66 \mathrm{mi}$. NE of Goodnews, Kilbuck-Kuskokwim Mts.; $59^{\circ} 24^{\prime}$ N, 159 $49^{\prime}$ W; (map 53). Var. Anavinguk River, Anvaniek River, Reka Anvanyk.

Eskimo name reported in 1898 by W. S. Post, USGS; Capt. Tebenkov (1852, map 4), IRN, published it as "R[eka] Anvanyk," meaning "Anvanyk River."

Ongivinuk Lake: lake, $1.5 \mathrm{mi}$. across, at headwaters of Ongivinuck River, $9 \mathrm{mi}$. E of Togiak Lake and $85 \mathrm{mi}$. NE of Goodnews, Kilbuck-Kuskokwim Mts.; $59^{\circ} 35^{\prime} \mathrm{N}, 1^{\circ} 9^{\circ}$. $21^{\prime} \mathrm{W}$; (map 53 ).

Eskimo name published in 1951 by USGS. Ongneak: locality, see Kalulingmiut.

Ongneak: point of land, see Douglas, Cape.

Ongoke River: stream, flows SE $20 \mathrm{mi}$. to Amanka Lake, $60 \mathrm{mi}$. NE of Hagemeister I., Kilbuck-Kuskokwim Mts.; $59^{\circ} 06^{\prime}$ N, $159^{\circ} 17^{\prime}$ W; (map 53).

Eskimo name reported in 1948 or 1949 by Frank Waskey, local trader and prospector Ongolgham Lagoon: lagoon, see Ongoveyuk Lagoon.

Ongorakvik River: stream, flows N $12 \mathrm{mi}$. to Nokotlek River, $31 \mathrm{mi}$. SW of Wainwright, Arctic Plain; $70^{\circ} 18^{\prime} \mathrm{N}, 160^{\circ} 59^{\prime} \mathrm{W}$; (map 146). Var. Onguraakvik.

Eskimo name recorded as "Ongura-akvik" at Wainwright in 1956 by Orth; reported to mean "driving place," or "place where birds were driven to be caught during molting."

Ongoveguk Lagoon: lagoon, see Ongoveyuk Lagoon. 
Ongovehenok: locality, near Point Barrow, Arctic Plain; $71^{\circ} 23^{\prime} \mathrm{N}, 156^{\circ} 28^{\prime} \mathrm{W}$; (map 153).

Former Eskimo village or camp reported in the 1890 Census (1893, p. 162).

Ongoveyuk Lagoon: lagoon, $4 \mathrm{mi}$. long, at mouth of Ongoveyuk River, $27 \mathrm{mi}$. SE of Savoonga, $N$ coast of St. Lawrence I.; $63^{\circ} 26^{\prime}$ N, $169^{\circ} 48^{\prime}$ W; BGN 1951; (map 93). Var. Okhkan Nayra Lagoon, Ongolgham Lagoon, Ongoveguk Lagoon.

Eskimo name reported in 1949 by Maj. H. B. Allen, USAF.

Ongoveyuk River: stream, flows N $15 \mathrm{mi}$. to Ongoveyuk Lagoon, $28 \mathrm{mi}$. SE of Savoonga, St. Lawrence I. ; $63^{\circ} 26^{\prime} \mathrm{N}, 169^{\circ} 48^{\prime} \mathrm{W}$; $B G N$ 1951; (map 93).

Eskimo name reported in 1949 by Maj. H. B. Allen, USAF.

Onguraakvik: stream, see Ongorakvik River.

Ongutvak Mountain: mountain, 2,000 ft., $4 \mathrm{mi}$. $\mathrm{S}$ of Chikuminuk Lake, $125 \mathrm{mi}$. SW of Sleetmute, Kilbuck-Kuskokwim Mts.; 60 $06^{\prime} \mathrm{N}$, $158^{\circ} 40^{\prime}$ W; $B G N$ 1932; (map 60).

Eskimo name obtained in 1932 by Gerald FitzGerald, USGS.

Onieda Creek: stream, see Oniga Creek.

Oniga Creek: stream, flows SE $0.9 \mathrm{mi}$. to Bonita Creek, $11 \mathrm{mi}$. NE of Nome, Seward Penin. High.; $64^{\circ} 38^{\prime} \mathrm{N}, 1^{\circ} 15^{\prime} \mathrm{W}$; (map 94). Var. Onega Creek, Onieda Creek.

Prospectors' name shown on map dated September 1901 of Cape Nome gold fields by David Fox, Jr.

Onihitsk: locality, site of village, on $\mathrm{E}$ end of Sitkalidak I., SE of Kodiak I.; $57^{\circ} 09^{\prime} \mathrm{N}$, $152^{\circ} 52^{\prime}$ W; (map 34). Var. Anihitsk.

Name was recorded in 1805 by Lisianski (1814, map facing p. 169).

Onion Bay: cove, $0.5 \mathrm{mi}$. across, $17 \mathrm{mi}$. NW of Afognak, on SW coast of Raspberry I.; Kodiak Is.; $58^{\circ} 04^{\prime} \mathrm{N}, 153^{\circ} 15^{\prime} \mathrm{W}$; $B G N$ 1909; (map 43).

Local name reported in 1909 and published on Chart 8570 in 1910 by USC\&GS.

Onion Portage: portage, across a neck of a meander of Kobuk River, $35 \mathrm{mi}$. NW of Shungnak, Brooks Ra.; $67^{\circ} 07^{\prime} \mathrm{N}, 158^{\circ} 18^{\prime} \mathrm{W}$; (map 126).

Local name reported by Orth in 1956 .

Onklat Creek: stream, flows $1 \mathrm{mi}$. SW to Redfield Cove, $2.3 \mathrm{mi}$. S of Humpback Point and $7 \mathrm{mi}$. NE of Yakutat, Malaspina Coastal Plain; $59^{\circ} 36^{\prime} 50^{\prime \prime} \mathrm{N}, 139^{\circ} 34^{\prime} 35^{\prime \prime} \mathrm{W}$; (map 46).

Tlingit Indian name reported by $L t$. Comdr. Moser (1902, p. 384), USN.

Onman, Cape: point of land, see Romanof Point.

Onnuteschuik Creek: stream, heads in York Mts., flows SW $2.6 \mathrm{mi}$. to Bering Sea, $20 \mathrm{mi}$. $\mathrm{SE}$ of Cape Prince of Wales and $36 \mathrm{mi}$. NW of Teller, Seward Penin. High.; $65^{\circ} 26^{\prime} \mathrm{N}$, $167^{\circ} 31^{\prime} \mathrm{W}$; (map 111). Var. Onuntasekwik Creek.

Eskimo name published as "Onuntasekwik" on the 1908 "Map of Seward Peninsula" by Arthur Gibson.

Onokoruk River: stream, see Anikovik River.
Onokovuk River: stream, see Anikovik River.

Onolavik Lake: lake, $2 \mathrm{mi}$. long, on W bank of Yukon River, $3 \mathrm{mi}$. NW of Russian Mission, Yukon-Kuskokwim Delta; $61^{\circ} 49^{\prime} 15^{\prime \prime} \quad \mathrm{N}$, $161^{\circ} 23^{\prime} 00^{\prime \prime} \mathrm{W}$; (map 73).

Eskimo name reported by USC\&GS in 1949.

Onslow Island: island, $4 \mathrm{mi}$. long, in Clarence Strait, $S$ of Etolin I., Alex. Arch.; 55 $52^{\prime} 30^{\prime \prime}$ N, $132^{\circ} 22^{\prime} 00^{\prime \prime} \mathrm{W}$; (map 4). Var. Onslow Rock.

Named in 1887 by USG\&GS; derived from Onslow Point.

Onslow Point: point of land, on a small island, at mouth of Ernest Sound, $5.5 \mathrm{mi}$. S of Etolin I., Alex. Arch.; $55^{\circ} 50^{\prime} 20^{\prime \prime} \mathrm{N}, 132^{\circ} 18^{\prime} 30^{\prime \prime} \mathrm{W}$; (map 4). Var. Onelow Point.

This feature was discovered on August 25, 1793, by James Johnstone, RN; named by Capt. George Vancouver, RN, "in honor of George, first Earl of Onslow, one of the friends of the Prince of Wales" (Wagner, 1937, p. 401).

Onslow Rock: island, see Onslow Island.

Onúg-anúgemut: locality, see Onuganuk.

Onuganuk: locality, on Yukon Delta, at mouth of Kwikluak Pass, Yukon-Kuskokwim Delta; $62^{\circ} 35^{\prime} \mathrm{N}, 164^{\circ} 45^{\prime} \mathrm{W}$; (map 77). Var. Onúganúgemut.

Former Eskimo village or camp reported as "Onúg-anúgemut" by W. H. Dall (1870, p 264).

Onuntasekwik Creek: stream, see Onnuteschuik Creek.

Ooagalga Island: island, see Ugamak Island.

Ooailik: locality, see Ualik.

Ooallígamut: locality, see Ualik.

Ooallikh: locality, see Ualik.

Oogahik: village, see Ugashik.

Oogahik: stream, see Ugashik River.

Oogahluk Creek: stream, see Ugalak Creek.

Ooganak: locality, see Uganik.

Ooganak Bay: bay, see Uganik Bay.

Ooganok: bay, see Uganik Bay.

Oogashak: stream, see Ugashik River.

Oogashik: village, see Ugashik.

Oogashik: stream, see Ugashik River.

Oogavigmute: locality, see Uknavik.

Oo-ghe-a-book Island: island, see King Island. Oo-ghee-a-book Island: island, see King Island. Oo-ghee-ak: rock, see Fairway Rock.

Ooglaamie : town, see Barrow.

Ooglamie: town, see Barrow.

Ooglovia: locality, see Uglovaia.

Oogovigamute: locality, see Uknavik.

Oogovik: locality, see Uknavik.

Oogowigamute: locality, see Uknavik.

Oohack : bay, see Ugak Bay.

Oohack Island: island, see Ugak Island.

Oohaiack: locality, see Uhaiak.

Oohaiack: village, see Akhiok.

Oohanick: locality, see Uganik.

Oohanick: island, see Uganik Island.

Oohaskeck: locality, see Uhaskek.

Oohiack, Bay of : bay, see Uyak Bay.

Ooiak: village, see Uyak.

Ooiak Bay: bay, see Uyak Bay.

Ooiatsk: village, see Uyak.
Oo-innakhtagowik: locality, see Uinuk.

Ooinukhlagowik: locality, see Uinuk.

Ooinuklagowik: locality, see Uinuk.

Ooinuktagowik: locality, see Uinuk.

Ookagamute: locality, see Nunaikak.

Ookakhl: lake, Kukaklik Lake.

Ookakht: lake, see Kukaklik Lake.

Ookamok: island, see Chirikof Island.

Ookeeok : rock, see Fairway Rock.

Ookevok: village, see Ukivok.

Ookhogamute: locality, see Oknagamut.

Ookikok, Mount: mountain, see Okikak Mountain.

Ookivok: locality, see Ukivok.

Ooklik Dunes: sand dunes, on W coast of Cape Etolin, $26 \mathrm{mi}$. SW of Cape Vancouver, on Nunivak I.; $60^{\circ} 24^{\prime} \mathrm{N}, 166^{\circ} 10^{\prime} \mathrm{W}$; (map 57). Var. Uklik Dunes.

Eskimo name reported in 1937 by USAAF. Ookook River: stream, see Okok River.

Ookpicksook: locality, see Ukpiksuk.

Ookpiksoogruk: locality, see Ukpiksugruk.

Ookpiksoogrum Koonga: stream, see Okpiksugruk Creek.

Ooksokwak River: stream, see Kinia River.

Ookwroorat Bluff: bluff, see Ugrurak Bluff.

Oolah Mountain: mountain, 7,500 ft., NW of Oolah Pass, on $E$ side of Ulo Valley, $49 \mathrm{mi}$. $\mathrm{N}$ of Wiseman, Brooks Ra.; $68^{\circ} 06^{\prime} 30^{\prime \prime} \mathrm{N}$, $150^{\circ} 08^{\prime} 00^{\prime \prime} \mathrm{W} ; B G N$ 1932; (map 134). Var. Ulo Mountain.

Named in 1932 by Marshall (1956, p. 160) : "I pointed to the mountain just beyond the pass and said it looked exactly like an oolah [an Eskimo tool, used for scraping hides] ***."

Oolahoola River: river, see Hulahula.

Oolah Pass: pass, 4,500 ft., between Kuyuktuvuk Creek and headwaters of Itkillik River, in Ulo Valley, SE of Oolah Mtn., $46 \mathrm{mi}$. N of Wiseman, Brooks Ra.; 68 $04^{\prime} 30^{\prime \prime} \mathrm{N}, 150^{\circ}$ 02'00" W; BGN 1932; (map 134). Var. Ulo Pass.

Name taken from the neighboring mountain; reported by Marshall (1956, p. 160)

Oolahpuk Mountain: mountain, $1,000 \mathrm{ft}$., in Kialegak Mts., $5 \mathrm{mi}$. $\mathrm{N}$ of Southeast Cape and $86 \mathrm{mi}$. SE of Gambell, St. Lawrence I.; $63^{\circ} 00^{\prime} \mathrm{N}, 169^{\circ} 37^{\prime} \mathrm{W}$; BGN 1951; (map 93).

Eskimo name meaning "big ula" [ulapak] reported in 1949 by Maj. H. B. Allen, USAF. The ula or ulu is a curved knife used for scraping; the mountain is so called because its shape resembles the ula.

Oolah Valley: valley, extends NE $17 \mathrm{mi}$. along Itkillik River from Snowheel Mtn., Brooks Ra.; $68^{\circ} 08^{\prime} 30^{\prime \prime} \mathrm{N}, 150^{\circ} 17^{\prime} 00^{\prime \prime} \mathrm{W}$; (map 134). Var. Ulo Valley.

Local name for the nearby mountain; reported in 1956 by USGS.

Oolakaiya Hill: hill, see Ulakaia Hill.

Oolakukkogavik: village, see Utukakarvik.

Oolamnagavik River: stream, flows NE $38 \mathrm{mi}$. to Colville River $3.5 \mathrm{mi}$. SW of its junc. with Killik River, Brooks Ra.; $68^{\circ} 59^{\prime} \mathrm{N}, 154^{\circ} 02^{\prime}$ W; BGN 1949; (map 133).

Eskimo name reported about 1946 by geol- 
ogists during exploration of Naval Petroleum Reserve No. 4.

Oolamushak Hill: hill, $870 \mathrm{ft}$., at $\mathrm{N}$ end of Kialegak Mts., $6 \mathrm{mi}$. $\mathrm{N}$ of Southeast Cape, on Saint Lawrence I.; $63^{\circ} 02^{\prime} \mathrm{N}, 169^{\circ} 37^{\prime} \mathrm{W}$ $B G N$ 1951; (map 93). Var. Oolamushak Mountain, Ulamashak Mountain.

Eskimo name reported in 1949 by Maj. H. B. Allen, USAF.

Oolamushak Mountain: hill, see Oolamushak Hill.

Ooliktome Islands: barrier islands, see Return Islands.

Oolikvik River: stream, see Oligavik Creek.

Oolokok Mountain: mountain, see Holokuk Mountain.

Oolokok River: stream, see Holokuk River.

Oomagahchyak: mountain, see Umagatsaiak Mountain.

Oomagahchyak: mountain, see Umagatsiak Hill.

Oomagahchyam Koogowranga: stream, see Umagatsiak Creek.

Oomagveerak: locality, see Umagvirak.

Oomalik Hill: hill, see Omalik Hill.

Oomanak Island: island, sec Umnak Island.

Oomarachek Creek: stream, see Umarachek Creek.

Oomeyak: bend, see Umiak Bend.

Oomeyaluk Bay: bay, extends SE $4 \mathrm{mi}$. from Emekyalok Point to Gheena Point, $67 \mathrm{mi}$. $\mathrm{SE}$ of Gambell, $\mathrm{S}$ coast of St. Lawrence I.; $63^{\circ} 10^{\prime} \mathrm{N}, 170^{\circ} 06^{\prime} \mathrm{W} ; B G N$ 1951; (map 93).

Eskimo name recommended by the Savoonga village council and reported in 1949 by Maj. H. B. Allen, USAF.

Oommahahtchek Creek: stream, see Umahachek Creek.

Oomnak: village, see Nikolski.

Oomnak Island: island, see Umnak Island.

Oomyousik Cape: point of land, see Oomyousik Point.

Oomyousik Point: point of land, $24 \mathrm{mi}$. SE of Savoonga, NE coast of St. Lawrence I.; $63^{\circ} 28^{\prime 2} 5^{\prime \prime} \mathrm{N}, 169^{\circ} 56^{\prime} 30^{\prime \prime} \mathrm{W}$; BGN 1951; (map 93). Var. Cape Oomyousik, Cape

Oonyousik, Oomyousik Cape, Oomyousit Cape, Oonyousik Cape, Oonyousik Point.

Eskimo name reported in 1932 by O. W. Geist, Univ. of Alaska, as "Oonyousik Point."

Oomyousit Gape: point of land, see Oomyousik Point.

Oonakagamute: locality, see Unakak.

Oonakhtolik: locality, see Ungalik.

Oonalakleet: village, see Unalakleet.

Oonalakleet River: stream, see Unalakleet River.

Oonalaklik: village, see Unalakleet.

Oonalashka: island, see Unalaska Island.

Oonalaska: village, see Unalaska.

Oonalga: locality, see Unalga.

Oonalgenskoi: locality, see Unalga.

Oonalgi, Ostrov: island, see Unalga Island.

Oonangashik: locality, see Unangashik.

Oone-agun: islands, see Four Mountains, Island of.

Oonella Island: island, see Unalga Island.

Oonemak Island: island, see Unimak Island.

Oongalambingoi Dunes: dunes, trend NE $4 \mathrm{mi}$, along SE coast of Nunivak I, $4 \mathrm{mi}$. E of
Ingriruk Hill, $8 \mathrm{mi}$. NE of Gape Mendenhall; $59^{\circ} 53^{\prime} \mathrm{N}, 165^{\circ} 52^{\prime} \mathrm{W}$; (map 55). Var. Ungalambingoi.

Eskimo name obtained in 1949 by USC\&GS. Oongayuk Hill: hill, $748 \mathrm{ft}$, $3 \mathrm{mi}$. N of Southwest Cape, St. Lawrence I.; $63^{\circ} 21^{\prime} \mathrm{N}, 171^{\circ}$ 26' W; BGN 1951; (map 93). Var. Oongayuk Peak, Ungayak Hill.

Eskimo name reported in 1949 by Maj. H. B. Allen, USAF.

Oongayuk Peak: hill, see Oongayuk Hill.

Oongenskoi: village, see Unga.

Oongooriak Camp: locality, see Unguriak Camp.

Oongooviak Camp: locality, see Unguriak Camp.

Oonilak: locality, see Omilak.

Oonimak Island: island, see Unimak Island

Oonongashik: locality, see Unangashik.

Oonyousik Cape: point of land, see Oomyousik Point.

Oonyousik Point: point of land, see Oomyousik Point.

Oosak: locality, see Usak.

Ooselik Creek: stream, see Itkilyariak Creek.

Ootivakh: town, see Barrow.

Ootiwakh : town, see Barrow.

Ootka, Lake: lake, $0.7 \mathrm{mi}$. long, on Kenai Penin. $W$ of Shadura Lake, $12 \mathrm{mi}$. NE of Kenai, Cook Inlet Low; $60^{\circ} 42^{\prime} \mathrm{N}, 151^{\circ} 03^{\prime} \mathrm{W}$; (map 62).

Named about 1963 by officials of Kenai National Moose Range, for administrative purposes.

Ootkaiowik : town, see Barrow

Ootkeavic: town, see Barrow.

Ootkeawie: town, see Barrow.

Ootkiavie : town, see Barrow.

Ootokok: locality, see Otokkok.

Ootokok River: stream, see Utukok River.

Ootookok: locality, see Otokkok.

Ootookok: villages, see Utukok villages.

Ootookok Cape: point of land, see Icy Cape.

Ootookok River: stream, see Utukok River.

Oowik: watercourse, see Uwik Slough.

Ooyak Bay: bay, see Uyak Bay.

Ooyarockseevick: hill, see Uyaraksivik Hill.

Ooynik, Cape: point of land, see Ooynik Point.

Ooynik Point: point of land, $5 \mathrm{mi}$. S of Gambell, W coast of St. Lawrence I.; $63^{\circ} 43^{\prime} \mathrm{N}, 171^{\circ}$ 44' W; BGN 1951; (map 93). Var. Cape Ooynik, Cape Goynk, Oinak Point.

Eskimo name reported in 1932 by $\mathrm{O}$. W. Geist, Univ. of Alaska.

Oozinkee: village, see Uzinki.

Oozinkie: village, see Uzinki.

Opagyarak River: stream, distributary of Aprothluk River, flows S $7.8 \mathrm{mi}$. to mouth of Hazen Bay, Yukon-Kuskokwim Delta; $61^{\circ} 04^{\prime} \mathrm{N}$, $165^{\circ} 27^{\prime} \mathrm{W}$; (map 75).

Eskimo name obtained at Chevak by USC\&GS in 1951

Opasnaia : bay, see Kazakof Bay.

Opasni Cape: point of land, see Opasni Point. Opasnie: point of land, see Dangerous Cape.

Opasnic Cape: point of land, see Opasni Point. Opasni Point: point of land, on NE coast of Whale I., 3 mi. SE of Afognak, $N$ of Kodiak
I.; $57^{\circ} 58^{\prime} 35^{\prime \prime} \mathrm{N}, 152^{\circ} 43^{\prime} 10^{\prime \prime} \mathrm{W}$; BGN 1909; (map 34). Var. Dangerous Cape, Mys Opasnyy, Opasni Cape, Opasnie Cape.

Transliteration of "M[ys] Opasnyy," the name given to this point by Sub-Lt. Mikhail Murashev in 1839 or 1840 and published in 1849 on Russian Hydrog. Dept. Chart 1425. Baker (1906, p. 208) published "Dangerous Cape," the translation of Murashev's name. Because of duplication, the name was changed to its present form in 1909 by USC\&GS.

Opasnyy, Mys: point of land, see Dangerous Cape.

Opasnyy, Mys: point of land, see Opasni Point. Open Bay: bay, $1.5 \mathrm{mi}$. across, on $\mathrm{S}$ coast of Unalaska I., Aleutian Is.; $53^{\circ} 26^{\prime} 45^{\prime \prime} \mathrm{N}, 166^{\circ}$. 47'30" W; (map 23).

Descriptive name given by USBF in 1888 .

Open Bight: cove, $1.3 \mathrm{mi}$. across, on $\mathrm{N}$ coast of Akutan I., E of North Head, Krenitzin Is., Aleutian Is. ; $54^{\circ} 13^{\prime} \mathrm{N}, 165^{\circ} 55^{\prime} \mathrm{W}$; (map 24).

Descriptive name reported in 1901 by $\mathrm{J} . \mathrm{J}$. Gilbert, USC\&GS.

Open Creek: stream, flows NE $6 \mathrm{mi}$. to Tuxedni Bay, $62 \mathrm{mi}$. SW of Kenai, Aleutian Ra.; $60^{\circ}$. $14^{\prime} \mathrm{N}, 152^{\circ} 54^{\prime} \mathrm{W}$; (map 62).

Local name reported in 1958 by USGS.

Open Creek: stream, heads at lake, flows NW $2.4 \mathrm{mi}$. to Fish Lake, $4.2 \mathrm{mi}$. SE of Northway, Alaska Ra.; $62^{\circ} 56^{\prime} 15^{\prime \prime} \mathrm{N}, 141^{\circ} 48^{\prime} 40^{\prime \prime} \mathrm{W}$; (map 84)

Local name published in 1955 by USGS.

Operl Island: island, $8 \mathrm{mi}$. long, one of Kudiakof Is., off SW end of Alaska Penin., Bristol Bay Low.; $55^{\circ} 23^{\prime} \mathrm{N}, 162^{\circ} 46^{\prime} \mathrm{W}$; BGN 1966; (map 29). Var. Newmann Island.

Named by USBF in 1888.

Operl Island: island, see Glen Island.

Ophelia Creek: stream, flows NW $3.5 \mathrm{mi}$. to Wade Creek, $48 \mathrm{mi} \mathrm{SW}$ of Eagle, YukonTanana High.; 64.0 $07^{\prime} 30^{\prime \prime} \mathrm{N}, 141^{\circ} 32^{\prime} 00^{\prime \prime} \mathrm{W}$; (map 102).

Local name published in 1956 by USGS.

Ophir: settlement, on W bank of Innoko River, near mouth of Ophir Creek and $35 \mathrm{mi}$. NW of McGrath, Kilbuck-Kuskokwim Mts.; $63^{\circ}$. $10^{\prime} \mathrm{N}, 156^{\circ} 31^{\prime} \mathrm{W}$; (map 90).

Prospectors' name reported in 1908 by A. G. Maddren, USGS. Discovery of gold along Ophir Creek early in 1908 led to the establishment of a recording office in early summer 1908. Ophir post office was operated at intervals from 1909 to 1957 . Its population in 1910 was 122 ; in 1920,22 ; in 1930,19 ; and in 1960,68 .

Ophir Creek: stream, flows NW to Cripple River, about $25 \mathrm{mi}$. NW of Imuruk Lake, Seward Penin. High.; (map 110).

Prospectors' name reported on a precinct map of Seward Peninsula by Monroe and Hutchins; corrected to June 1903 by Arthur Gibson. This stream cannot be precisely located on current maps.

Ophir Creek: stream, flows NW to Kuzitrin River, about $17 \mathrm{mi}$. N of Mount Bendeleben, Seward Penin. High.; (map 110).

Prospectors' name shown on a map of Cape Nome gold fields by David Fox, Jr., dated 
1901. This stream cannot be precisely located on current maps.

Ophir Creek: stream, flows E $1 \mathrm{mi}$. to Ransburg Creek which flows to Hastings Creek, $10 \mathrm{mi}$. E of Nome, Seward Penin. High.; 64 $29^{\prime} 30^{\prime \prime}$ N, $165^{\circ} 03^{\prime} 30^{\prime \prime} \mathrm{W}$; (map 94).

Prospectors' name shown on the 1904 "Map of Cape Nome Precinct" by Arthur Gibson. This feature cannot be precisely identified on current maps.

Ophir Creek: stream, flows $1 \mathrm{mi}$. SW into Sherman Creek, $1 \mathrm{mi}$. E of Comet, on Lynn Canal and $46 \mathrm{mi}$. NW of Juneau, Coast Mts.; $58^{\circ}$. $52^{\prime} 00^{\prime \prime} \mathrm{N}, 135^{\circ} 06^{\prime} 30^{\prime \prime} \mathrm{W}$; (map 11).

Local name reported by $R$. B. Oliver, USGS, in 1906 and published in 1908.

Ophir Creek: stream, heads $0.1 \mathrm{mi}$. S of Sawmill Cove, flows SW $6 \mathrm{mi}$. to Summit Lake, $2.5 \mathrm{mi}$. SW of Yakutat, Malaspina Coastal Plain; $59^{\circ} 30^{\prime} 50^{\prime \prime} \mathrm{N}, 139^{\circ} 45^{\prime} 30^{\prime \prime} \mathrm{W}$; (map 46).

Local name published in 1959 by USGS.

Ophir Creek: stream, heads at Rockpile Pass and flows NW $14 \mathrm{mi}$. to Whitefish Lake 22 mi. SW of Aniak, Yukon-Kuskokwim Delta; $61^{\circ} 20^{\prime} \mathrm{N}, 160^{\circ} 00^{\prime} \mathrm{W}$; (map 73). Var. Hot Spring Creek.

Prospectors' name shown on a 1914 field sheet by A. G. Maddren, USGS. It is reported that gold was discovered on this stream during the "Yellow River stampede" of the winter of 1901-02.

Ophir Creek: stream, flows $13 \mathrm{mi}$. $\mathrm{N}$ to Beaver Creek, $18 \mathrm{mi}$. N of Pingpong Mtn. and $62 \mathrm{mi}$ NE of McCarthy, Alaska Ra.; $62^{\circ} 00^{\prime} \mathrm{N}$, $141^{\circ} 27^{\prime} \mathrm{W}$; (map 67).

Local name obtained by USGS and published on maps since 1954.

Ophir Creek: stream, flows NW $4.8 \mathrm{mi}$. to Donlin Creek, $2.4 \mathrm{mi}$. NE of its junc. with Flat Creek, $16 \mathrm{mi}$. N of village of Crooked Creek and $43 \mathrm{mi}$. NW of Sleetmute, Kilbuck-Kuskokwim Mts.; 62 $05^{\prime} 50^{\prime \prime} \mathrm{N}, 158^{\circ} 09^{\prime} 30^{\prime \prime} \mathrm{W}$; $B G N$ 1944; (map 79).

Prospectors' name obtained in 1913 by Eakin (1914, pl. 1), USGS.

Ophir Creek: stream, flows NE $6 \mathrm{mi}$. to Innoko River at Ophir, $32 \mathrm{mi}$. NW of McGrath, Kilbuck-Kuskokwim Mts.; $63^{\circ} 08^{\prime} 45^{\prime \prime} \mathrm{N}$, $156^{\circ} 31^{\prime} 05^{\prime \prime} \mathrm{W}$; (map 90).

'Prospectors' name obtained in 1908 by Maddren (1910, pl. 1), USGS.

Ophir Creek: stream, flows SW $7.6 \mathrm{mi}$. to Sulatna River, $1.5 \mathrm{mi}$. NW of Sulatna Crossing and $13 \mathrm{mi}$. S of Long Kilbuck-Kuskokwim Mts.; $64^{\circ} 12^{\prime} 30^{\prime \prime} \mathrm{N}, 155^{\circ} 30^{\prime} 20^{\prime \prime} \mathrm{W}$; (map 98).

Prospectors' name reported in 1921 by USGS.

Ophir Creek: stream, flows SW $19 \mathrm{mi}$. to Niukluk River, $2.8 \mathrm{mi}$. NW of Council and 33 mi. NE of Solomon, Seward Penin. High.; $64^{\circ} 55^{\prime} \mathrm{N}, 163^{\circ} 45^{\prime} \mathrm{W}$; (map 95).

Prospectors' name reported in 1899 by Schrader and Brooks (1900, map 3), USGS.

Ophir Creek: stream, flows NE $15 \mathrm{mi}$. to Nome Creek, 42 mi. NE of Fairbanks, Tanana-Yukon
High.; $65^{\circ} 22^{\prime} \mathrm{N}, 147^{\circ} 05^{\prime} \mathrm{W} ; B G N$ 1945; (map 105).

Prospectors' name published by USC\&GS (Henshaw and Covert, 1908, pl. 9).

Ophir Creek: stream, flows N $2.4 \mathrm{mi}$. to Yankee River which flows to Mint River, $40 \mathrm{mi}$. NW of Teller, Seward Penin. High.; $65^{\circ} 41^{\prime} \mathrm{N}$, $167^{\circ} 16^{\prime} \mathrm{W}$; (map 111).

Prospectors' name reported on the 1908 "Map of Seward Peninsula" by Arthur Gibson.

Ophir Gulch: ravine, trends SW to Ophir Creek, about $4 \mathrm{mi}$. NW of Council and $35 \mathrm{mi}$. NE of Solomon, Seward Penin. High.; $64^{\circ} 57^{\prime} \mathrm{N}$, $163^{\circ} 40^{\prime} \mathrm{W}$; (map 95).

Prospectors' name published in January 1900 by Schrader (1900c, p. 16), USGS.

Opiktillik: locality, see Opiktulik.

Opiktulik: locality, on N shore of Norton Sound, $8 \mathrm{mi}$. E of Solomon, Seward Penin. High. $64^{\circ} 34^{\prime} \mathrm{N}, 164^{\circ} 10^{\prime} \mathrm{W}$; (map 95). Var. Apiktalluk, Okpiktalik, Okpiktolik, Opiktillik, Oukviktoulia, Ukvikhtulig-mut, Ukvikhtuligmyut, Ukviktulik, Upiktalik.

Former Eskimo village or camp reported in 1842-44 as "Oukviktoulia" and "Ukvikhtulig-mut" by Lt. L. A. Zagoskin, IRN. In the 1880 Census Petroff (1884, p. 11) listed "Okpiktolik," population 12, but showed "Opiktalik" on his maps. The 1890 Census (p. 162) listed "Upiktalik" and included the population in the Norton Sound Settlements.

Oracle Mountain: mountain, $1,014 \mathrm{ft}$, $1.4 \mathrm{mi}$. SE of Jagged Mtn. and $6.5 \mathrm{mi}$. SE of tip of Cape Newenham, Kilbuck-Kuskokwim Mts.; $58^{\circ} 37^{\prime} 28^{\prime \prime} \mathrm{N}, 162^{\circ} 00^{\prime} 28^{\prime \prime} \mathrm{W}$; (map 39).

Local name published in 1951 by USGS.

Orange Creek: stream, see Black River.

Orange Creek: stream, see Grayling Fork Black River.

Orange Fork: stream, see Grayling Fork Black River.

Orange Glacier: glacier, heads $1.5 \mathrm{mi}$. NE of Mount Stamy, trends NW $4 \mathrm{mi}$. to 1961 terminus $1 \mathrm{mi}$. SE of terminus of Variegated Glacier and $34 \mathrm{mi}$. NE of Yakutat, St. Elias Mts.; 59 58'50" N, $139^{\circ} 16^{\prime} 45^{\prime \prime} \mathrm{W}$; (map 46).

Descriptive name given by Tarr (1906, p. 145), USGS, "because of the orange color of the morainal debris."

Orange Hill: hill, $3,510 \mathrm{ft}$, at terminus of Nabesna Glacier and $16 \mathrm{mi}$. S of Devils Mtn., Wrangell Mts.; $62^{\circ} 12^{\prime} 00^{\prime \prime} \mathrm{N}, 142^{\circ} 50^{\prime} 15^{\prime \prime} \mathrm{W}$ $B G N$ 1939; (map 84).

So named in 1902 by F. C. Schrader, USGS, "from its orange-red color, due to mineralization of the rocks."

Orange River: stream, see Grayling Fork Black River.

Oratia, Mount: mountain, 5,400 ft., $5 \mathrm{mi}$. N of Kagati Lake, $80 \mathrm{mi}$. NE of Goodnews, Kilbuck-Kuskokwim Mts.; 59 55' N, $160^{\circ}$ 01' W; (map 53). Var. Ouchklune Peak.

This mountain may have been named in 1898 by J. E. Spurr and W. S. Post, USGS.

Orazaba Reef: reef, see Orizaba Reef.

Orbin, Lake: lake, $0.3 \mathrm{mi}$. long, drains $\mathrm{E}$ to Sargent Creek, $8.5 \mathrm{mi}$. SW of Kodiak, Kodiak
I.; $57^{\circ} 42^{\prime} 40^{\prime \prime} \mathrm{N}, 152^{\circ} 35^{\prime} 00^{\prime \prime} \mathrm{W}$; (map 34 ). Local name reported in 1949 by USGS.

Orca: locality, on SE shore of Orca Inlet, 2.5 mi. NE of Cordova, Chugach Mts.; $60^{\circ} 39^{\prime} 50^{\prime \prime}$ $\mathrm{N}, 145^{\circ} 43^{\circ} 00^{\prime \prime} \mathrm{W}$; (map 64).

Named for a fishing vessel of the Pacific Steam Whaling Co. which opened a cannery here at the end of the 19 th century. A post office was established here in July 1804, but discontinued in 1909 (Ricks, 1965, p. 49 ).

Orca Bay: bay, $14 \mathrm{mi}$. wide at $\mathrm{W}$ end of Prince William Sound, $30 \mathrm{mi}$. $W$ of Cordova, Chugach Mts.; $60^{\circ} 36^{\prime} \mathrm{N}, 146^{\circ} 36^{\prime} \mathrm{W}$; $B G N$ 1906; (map 64). Var. Puerto Cordova.

Named in 1906 by Andrew Braid, USC\&GS. The name was derived from the Orca Cannery of the Pacific Steam Whaling Co. The cannery was in turned named for one of the company's vessels. The bay was originally named "Puerto Cordova," by Señor Don Salvador Fidalgo who visited the region in 1790. The name "Cordova" was adopted by Capt. Vancouver, RN, during his exploration of the Prince William Sound region in 1794. This name was in common use until the BGN, at Braid's suggestion, changed it to "Orca Bay" to avoid confusion with the Cordova Bay in Dixon Entrance (Wagner, 1937, p. 444).

Orca Channel: water passage, $1.5 \mathrm{mi}$. long, E of Observation I., $4 \mathrm{mi}$. $\mathrm{N}$ of Cordova, Chugach Mts.; $60^{\circ} 37^{\prime} 00^{\prime \prime} \mathrm{N}, 145^{\circ} 43^{\prime} 30^{\prime \prime} \mathrm{W}$; (map 64).

Named in 1897 by Lt. Comdr. J. F. Moser, USN.

Orca Creek: stream, on Hawkins I., flows W $1.5 \mathrm{mi}$. to Orca Bay, $6 \mathrm{mi}$. NW of Cordova, Chugach Mts.; $60^{\circ} 35^{\prime} \mathrm{N}, 145^{\circ} 54^{\prime} \mathrm{W}$; (map 64).

Name published in 1950 by USGS.

Orca Inlet: water passage, $15 \mathrm{mi}$. long, E of Hawkins I. and W of Cordova, Chugach Mts.; $60^{\circ} 31^{\prime} \mathrm{N}, 145^{\circ} 52^{\prime} \mathrm{W}$; (map 64).

Local name reported in 1909 by Grant and Higgins (1910, pl. 2), USGS.

Orca Point: point of land, on S shore of Boca de Quadra, at $\mathrm{N}$ tip of Peninsula Ridge, Coast Mts.; $55^{\circ} 07^{\prime} 10^{\prime \prime} \mathrm{N}, 130^{\circ} 51^{\prime} 15^{\prime \prime} \mathrm{W}$; (map 3).

Arbitrary name given in 1891 by USC\&GS.

Orchard Creek: stream, flows W, through Orchard Lake, $19 \mathrm{mi}$. to Shrimp Bay on NW coast of Revillagigedo I., Alex. Arch.; 55 $49^{\prime}$ $45^{\prime \prime} \mathrm{N}, 131^{\circ} 28^{\prime} 00^{\prime \prime} \mathrm{W}$; (map 3).

Local name reported in 1920 by USFS

Orchard Lake: lake, $3.5 \mathrm{mi}$. long, near mouth of Orchard Creek, on NW coast of Revillagigedo I., Alex. Arch.; 55 $49^{\prime} \mathrm{N}, 131^{\circ} 25^{\prime} \mathrm{W}$; (map 3).

Local name reported in 1920 by USFS

Ordonez, Isla: island, "one of the Aleutian Islands west of Umnak Island."

Name shown on a 1791 chart of Don Juan de la Bodega y Quadra. "In 1788 Francisco Ordoñez was captain de navio" (Wagner, 1937, p. 480).

Oreel Rocks: rocks, see Shag Rocks 
Oreelie Rocks: rocks, see Shag Rocks.

Oregon: locality, at junc. of Nugget Gulch and Oregon Creek, $15 \mathrm{mi}$. NW of Nome, Seward Penin. High.; $64^{\circ} 41^{\prime} \mathrm{N}, 165^{\circ} 40^{\prime} \mathrm{W}$; (map 94).

Site of a mining camp; reported in 1951 by USGS

Oregon Greek: stream, flows NE $2 \mathrm{mi}$. to Mission Creek, $15 \mathrm{mi}$. SW of Eagle, Yukon-Tanana High.; 64 ${ }^{\circ} 39^{\prime} \mathrm{N}, 141^{\circ} 32^{\prime} \mathrm{W}$; (map 102).

Named by prospectors and reported by $\mathrm{C}$.

E. Ellsworth and R. W. Davenport, USGS.

Oregon Creek: stream, flows SW $5.3 \mathrm{mi}$. to Cripple River, $15 \mathrm{mi}$. NW of Nome, Seward Penin. High.; $64^{\circ} 41^{\prime} \mathrm{N}, 165^{\circ} 45^{\prime} \mathrm{W}$; (map 94).

Prospectors' name reported in 1900 by E. C. Barnard (in Brooks, 1901, pl. 17), USGS.

Oregon Creek: stream, heads in Bendeleben Mts., flows SE $14 \mathrm{mi}$. to Boston Creek which flows to Fish River, $33 \mathrm{mi}$. S of Imuruk Lake, Seward Penin. High.; $65^{\circ} 06^{\prime} \mathrm{N}, 163^{\circ} 12^{\prime} \mathrm{W}$; (map 110).

Prospectors' name reported on a map of Cape Nome gold fields by David Fox, Jr., dated 1901

Oregon Creek: stream, flows SW $4 \mathrm{mi}$. to join Mystery Creek from SE, in Cripple River basin, $23 \mathrm{mi}$. NW of Imuruk Lake, Seward Penin High.; $65^{\circ} 56^{\prime} \mathrm{N}, 163^{\circ} 29^{\prime} \mathrm{W}$; (map 110)

Prospectors' name reported in 1901 by USGS (Collier, 1902, pl. 12)

Oregon River: stream, see Pargon River.

Orel Anchorage: bay, $0.5 \mathrm{mi}$. across, surrounded by islands, between Thetis and Petrof Bays, in $S$ part of Tebenkof Bay, on $W$ coast of Kuiu I., Alex. Arch.; $56^{\circ} 25^{\prime} \mathrm{N}, 134^{\circ} 08^{\prime} \mathrm{W}$ $B G N$ 1929; (map 5). Var. Mary Frances Anchorage.

Russian word "orël," meaning "eagle," given in 1928 by USC\&GS.

Orel Rocks: reef, see Pamplona, Bajo.

Orensic: stream, see Hadweenzic River.

Orensik: stream, see Hadweenzic River.

Orenzik: stream, see Hadweenzic River.

Orevilla, Puenta de: point of land, see Whitshed, Point.

Organ Creek: stream, flows NE $5 \mathrm{mi}$. to Sixtymile Creek, $13 \mathrm{mi}$. W of that stream's mouth and $62 \mathrm{mi}$. W of Wiseman, Brooks Ra.; $67^{\circ}$. $24^{\prime} 00^{\prime \prime} \mathrm{N}, 152^{\circ} 26^{\prime} 15^{\prime \prime} \mathrm{W}$; (map 124).

Local name obtained in 1956 by USGS topographers.

Organ Mountain: mountain, 6,980 ft., $3.2 \mathrm{mi}$. NW of Moraine Pass and $22 \mathrm{mi}$. SE of Anchorage, Chugach Mts.; $61^{\circ} 08^{\prime} 00^{\prime \prime} \mathrm{N}$, $149^{\circ} 14^{\prime} 25^{\prime \prime} \mathrm{W}$; $B G N$ 1952; (map 69).

Descriptive name reported in 1932 by USGS because "a line of several high rock pinnacles on the crest of this mountain give it the appearance from below of an organ."

Organ Pipes: peaks, along N ridge of Hodgkins Mtn., 25 mi. NW of Juneau, Coast Mts. ; 58 $8^{\circ}$ $36^{\prime} \mathrm{N}, 134^{\circ} 03^{\prime} \mathrm{W}$; (map 11).

Local name published by USGS in 1960 . Orient Point: point of land, easternmost point of Little Kiska I., Aleutian Is.; 51 ${ }^{\circ} 57^{\prime} 07^{\prime \prime}$ $\mathrm{N}, 177^{\circ} 42^{\prime} 25^{\prime \prime} \mathrm{E} ;$ BGN 1937; (map 14). Var. East Point.

Name published on a 1905 USC\&GS chart. Orient Point: point of land, on E coast of Whale I., $5 \mathrm{mi}$. SE of Afognak, $\mathbf{N}$ of Kodiak I.; $57^{\circ} 56^{\prime} 30^{\prime \prime} \mathrm{N}, 152^{\circ} 44^{\prime} 15^{\prime \prime} \mathrm{W}$; BGN 1909; (map 34). Var. East Point, Mys Vostochnyy, Vostochni.

Descriptive name "M[ys] Vostochnyy" given by Sub-Lt. Mikhail Murashev in 1839 or 1840 and published on Russian Hydrog. Dept. Chart 1425. Baker (1906, p. 223) published "East Point," the translation of Murashev's name. Because of duplication the name was changed to "Orient Point" in 1909 by USC\&GS.

Orieshik Island: island, see Egg Island.

Orin Gulch: ravine, extends NW 4,000 ft., between Big Skookum Creek and Chicago Gulch, near head of Mills Creek, $45 \mathrm{mi}$. W of Talkeetna, Alaska Ra.; 62 $21^{\prime} 30^{\prime \prime} \mathrm{N}$, $151^{\circ} 30^{\prime} 55^{\prime \prime} \mathrm{W}$; (map 81).

Prospectors' name reported in 1911 by Capps (1913, fig. 7), USGS.

Orizaba Reef: reef, off Rock Point, on Norton Sound, $1 \mathrm{mi}$. $\mathbf{N}$ of St. Michael, YukonKuskokwim Delta; $63^{\circ} 31^{\prime} 10^{\prime \prime} \mathrm{N}, 162^{\circ} 01^{\prime} 50^{\prime \prime}$ W; (map 92). Var. Orazaba Reef.

Local name obtained in 1952 by USC\&GS "derived from an old sailing vessel which foundered on it during a storm in days of Russian ownership of the territory."

Or-kim-ya-nook: stream, see Colville River.

Orlinie Cape: point of land, see Eagle Cape.

Orlova: locality, see Eagle Harbor.

Orlovsk: locality, see Eagle Harbor.

Orlovsk, Seleniye: locality, see Eagle Harbor.

Ormante, Mer d': sea, see Bering Sea.

Oro Fino Creek: stream, flows SE $1.3 \mathrm{mi}$. to Adams Creek which flows to Shovel Creek, $10 \mathrm{mi}$. NW of Solomon, Seward Penin. High.; $64^{\circ} 42^{\prime} \mathrm{N}, 164^{\circ} 29^{\prime} \mathrm{W}$; (map 95)

Prospectors' name reported on a 1902 prospector's manuscript map.

Oro Grande Creek: stream, in Kigluaik Mts., flows NE $8 \mathrm{mi}$. to Cobblestone River, $30 \mathrm{mi}$. $\mathrm{SE}$ of Teller, Seward Penin. High.; $65^{\circ} 01^{\prime} \mathrm{N}$, $165^{\circ} 30^{\prime} \mathrm{W}$; (map 111).

Local name reported about 1905 by USGS (Collier and others, 1908, pl. 8).

Oronikowaktalik Rock: rock, $20 \mathrm{ft}$., $600 \mathrm{ft}$. long, in Bering Sea, off $\mathrm{N}$ coast of Nunivak I.; $60^{\circ}$. $21^{\prime} 50^{\prime \prime} \mathrm{N}, 166^{\circ} 33^{\prime} 40^{\prime \prime} \mathrm{W}$; (map 57). Var Oronixowaxtalik Rock

Eskimo name obtained in 1949 by USC\&GS Oronixowaxtalik Rock: rock, see Oronikowaktalik Rock.

Orphan Greek: stream, flows S $1 \mathrm{mi}$. to East Fork Solomon River, $14 \mathrm{mi}$. NE of Solomon, Seward Penin. High.; $64^{\circ} 42^{\prime} \mathrm{N}, 164^{\circ} 07^{\prime} \mathrm{W}$; (map 95).

Prospectors' name reported on a 1902 prospectors' manuscript map.

Orphan Creek: stream, flows W $2 \mathrm{mi}$. to Troubelsome Creek, $15 \mathrm{mi}$. SE of Rampart, Yukon-Tanana High.; $65^{\circ} 22^{\prime} \mathrm{N}, 149^{\circ} 44^{\prime} \mathrm{W}$; (map 105)
Named by prospectors; reported in 1904 by L. M. Prindle and F. L. Hess (in Brooks and others, 1905, fig. 6), USGS.

Orr Island: island, $7.5 \mathrm{mi}$. long, between Marble and Prince of Wales Is., Alex. Arch.; 55 ${ }^{\circ} 57^{\prime}$ N, $133^{\circ} 24^{\prime} \mathrm{W}$; (map 4$)$.

Named in 1904 by E. F. Dickins, USC\&GS, "after Captain Cyrus Orr, who resides at Shakan and gave us considerable information about this locality."

Orthmer Creek: stream, flows NE $4 \mathrm{mi}$, joins Marks Creek to form Flat Creek, $19 \mathrm{mi}$. S of junc. of Charley and Yukon Rivers, YukonTanana High.; $65^{\circ} 03^{\prime} \mathrm{N}, 142^{\circ} 50^{\prime \prime} \mathrm{W}$; (map 103). Var. Othmer Creek.

Prospectors' name shown as "Othmer" on an unpublished map by E. J. Chamberlain, dated 1902.

Orton Lake: lake, $0.9 \mathrm{mi}$. long, on Revillagigedo I., near head of Naha River, $8 \mathrm{mi}$. NE of Loring, Alex. Arch.; 55 $39^{\prime} 20^{\prime \prime} \mathrm{N}, 131^{\circ} 26^{\prime}$. $00^{\prime \prime} \mathrm{W}$; (map 3).

Local name reported in 1948 by USGS.

Oruktalik Entrance: water passage, connecting Oruktalik Lagoon and Beaufort Sea, $17 \mathrm{mi}$. SW of Barter I., Arctic Plain; $70^{\circ} 04^{\prime} 25^{\prime \prime} \mathrm{N}$, $142^{\circ} 55^{\prime} 30^{\prime \prime} \mathrm{W}$; BGN 1961; (map 152). Var. Orutalik Entrance.

Local name derived from the Eskimo name for Griffin Point, reported by USC\&GS in 1952.

Oruktalik Lagoon: lagoon, $3 \mathrm{mi}$. across, on coast of Beaufort Sea, $15 \mathrm{mi}$. SE of Barter I., Arctic Plain; $70^{\circ} 04^{\prime} \mathrm{N}, 142^{\circ} 56^{\prime} \mathrm{W} ; B G N$ 1961; (map 152). Var. Orutalik Lagoon.

Local name derived from the Eskimo name for Griffin Point, reported by USC\&GS in 1952.

Oruktalik Nuvugak: point of land, see Griffin Point.

Orum Creek: stream, flows W $10 \mathrm{mi}$. to Stevens Creek, $3.6 \mathrm{mi}$. $\mathrm{N}$ of Roughtop $\mathrm{Mtn}$. and 37 mi. ENE of Tanana, Yukon-Tanana High.; $65^{\circ} 14^{\prime} 12^{\prime \prime} \mathrm{N}, 150^{\circ} 50^{\prime} 20^{\prime \prime} \mathrm{W}$; BGN 1961 ; (map 106). Var. Stevens Greek.

Prospectors' name reported in 1906 by USGS (Prindle, 1908, pl. 5).

Orutalik Entrance: water passage, see Oruktalik Entrance.

Orutalik Lagoon: lagoon, sec Oruktalik Lagoon.

Orville, Mount: peak, 10,495 ft., in Glacier Bay National Monument, in Fairweather Ra., 80 mi. NW of Hoonah, St. Elias Mts.; $58^{\circ} 44^{\prime} 15^{\prime \prime}$ N, 137 16'15" W; BGN 1962; (map 10).

Name proposed to NPS by Senator Ernest Gruening in 1961 to honor Orville Wright, 1871-1948, who with his brother Wilbur, designed the first successful airplane. Air transportation has contributed greatly to the development of Alaska.

Orzenoy: $b a y$, see Orzinski Bay.

Orzinski Bay: bay, between Elephant and Waterfall Points, extends W $0.7 \mathrm{mi}$. inland from Stepovak Bay, near SW end of Alaska Penin., Aleutian Ra.; $55^{\circ} 43^{\prime} \mathrm{N}, 160^{\circ} 04^{\prime} \mathrm{W}$; (map 28). Var. Orzenoy, Ozernoi. 
Local name published by USC\&GS on a 1909 chart. A cannery called "Ozernoi," possibly from the Russian adjective meaning "lake," was established here in 1889, according to Lt. Comdr. J. F. Moser, USN.

Osar Creek: stream, heads W of Crazy Notch, flows SW $10 \mathrm{mi}$. along Denali Highway to Clearwater Creek, $41 \mathrm{mi}$. S of Mount Hayes, Alaska R.; $63^{\circ} 02^{\prime} 10^{\prime \prime} \mathrm{N}, 146^{\circ} 53^{\prime} 12^{\prime \prime} \mathrm{W}$; $B G N$ 1959; (map 86).

Named in 1954 by USGS geologists. "The name is the plural of the Swedish word for esker, and the stream parallels an esker through its entire upper course."

Osar Lake: lake, $2.2 \mathrm{mi}$. long, $26 \mathrm{mi}$. W of Paxson, Alaska Ra.; $63^{\circ} 00^{\prime} 15^{\prime \prime} \mathrm{N}, 146^{\circ} 20^{\prime} 00^{\prime \prime}$ W; (map 86).

Named "Asar Lake" in 1955 by T. L. Péwé, USGS, but published in 1959 by USGS as "Osar." "Asar" is the Scandinavian word for a esker.

Osar Stream: stream, heads in lake at terminus of Malaspina Glacier and flows S and E $5 \mathrm{mi}$. to Yakutat Bay, $4 \mathrm{mi}$. NE of Point Manby and $20 \mathrm{mi}$. NW of Yakutat, Malaspina Coastal Plain; 59 $42^{\prime} 30^{\prime \prime} \mathrm{N}, 140^{\circ} 11^{\prime} 10^{\prime \prime} \mathrm{W}$; (map 46). Var. Forney River.

Named in 1891 by Russell (1892, pl. 4, p. 81). This is a Swedish term for what we now call an esker-a long narrow ridge of gravel and sand associated with a retreated glacier.

Osborn, Mount: mountain, 4,714ft., in Kigluaik Mts., $4.5 \mathrm{mi}$. N of Tigaraha Mtn. and $39 \mathrm{mi}$. NE of Nome, Seward Penin. High.; $65^{\circ} 00^{\prime} \mathrm{N}$, $165^{\circ} 20^{\prime} \mathrm{W}$; (map 94).

Prospectors' name reported in 1900 by $\mathbf{E}$. C. Barnard (in Brooks, 1901, pl. 17), USGS.

Osborn Creek: stream, formed by junc. of Bonita and New Eldorado Creeks, flows SW $10 \mathrm{mi}$. to Nome River, $6 \mathrm{mi}$. NE of Nome, Seward Penin.

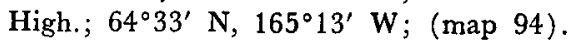

Prospectors' name reported in 1899 by D. C. Witherspoon (in Schrader and Brooks, 1900, map 2), USGS.

Osborn Dome: mountain, 1,660 ft., E of New Eldorado Creek, $13 \mathrm{mi}$. NE of Nome, Seward Penin. High.; $64^{\circ} 40^{\prime} \mathrm{N}, 165^{\circ} 11^{\prime} \mathrm{W}$; (map 94).

Local name shown on the 1902 "Map of Nome and Snake River Country" by J. M. Davidson.

Oscar Creek: stream, flows E $1 \mathrm{mi}$. to Cripple Creek which flows to Lower Willow Creek, 16 mi. W of Solomon, Seward Penin. High.; $64^{\circ}$ $48^{\prime} \mathrm{N}, 164^{\circ} 31^{\prime} \mathrm{W}$; (map 95).

Prospectors' name reported on a map of Cape Nome gold fields by David Fox, Jr., dated 1901.

Oscar Island: island, $4.6 \mathrm{mi}$. long, formed by Beaver Creek and the Yukon River, $14 \mathrm{mi}$. SW of Beaver, Yukon Flats; $66^{\circ} 14^{\prime} \mathrm{N}, 147^{\circ}$. $48^{\prime} \mathrm{W}$; (map 118 ).

Local name obtained by USGS; probably named for Oscar Reinoski who had a cabin here, according to a 1916 manuscript map by William Yanert (Stuck, 1917, map facing p. 122).
Oscar Lake: lake, $0.2 \mathrm{mi}$. long, $1 \mathrm{mi}$. E of Tanana, Kokrines-Hodzana High.; $65^{\circ} 10^{\prime} 30^{\prime \prime}$ $\mathrm{N}, 152^{\circ} 02^{\prime} 00^{\prime \prime} \mathrm{W}$; (map 106).

Local name reported in 1952 by USGS.

Oscar Lake: lake, see Marion, Lake.

Oscarville: village, pop. 51 , on right bank of Kuskokwim River, $5 \mathrm{mi}$. S of Bethel, YukonKuskokwim Delta; $60^{\circ} 43^{\prime} 30^{\prime \prime} \mathrm{N}, 161^{\circ} 46^{\prime} 00^{\prime \prime}$ W; (map 59).

About 1908 Oscar Samuelson settled at Napaiskak for a few years and then moved across the river where he opened a store and remained as a trader until his death in 1953. After the Oscarville store opened, a few Eskimo families settled near it, forming a village (Oswalt, 1963, p. 10). The village population was 11 in 1939 and 27 in 1950.

Oschesna: stream, see John River.

Oserski Bay: bay, see Redoubt Bay.

Oshetna River: stream, flows NE $55 \mathrm{mi}$. to Susitna River, $52 \mathrm{mi}$. N of Tahneta Pass and $72 \mathrm{mi}$. NW of Gulkana, Copper River Basin; $62^{\circ} 38^{\prime} 30^{\prime \prime} \mathrm{N}, 147^{\circ} 23^{\prime} 00^{\prime \prime} \mathrm{W}$; (map 82).

Indian name adopted by the miners; reported in 1906 by USC\&GS.

Oshibki, Ostrov: island, see Error Island.

Oshibki Islet: island, see Error Island.

Oshinpi Island: island, see Error Island.

Oshipki Island: island, see Error Island.

Osier Island: island, $0.3 \mathrm{mi}$. long, in Disenenchantment Bay, at mouth of Russell Fiord, $32 \mathrm{mi}$. NE of Yakutat, St. Elias Mts.; 59 ${ }^{\circ}$ $59^{\prime} 45^{\prime \prime} \mathrm{N}, 139^{\circ} 28^{\prime} 15^{\prime \prime} \mathrm{W}$; (map 46).

So named in 1891 by Russell $(1892$, p. 84 ), USGS, because "it is covered with a dense growth of willows." Osier is a name for various kinds of willows.

Oskawalik: locality, on right bank of Kuskokwim River opposite mouth of Oskawalik River, $8 \mathrm{mi}$. SW of village of Crooked Creek and $34 \mathrm{mi}$. W of Sleetmute, Kilbuck-Kuskokwim Mts.; 61 ${ }^{\circ} 44^{\prime} 30^{\prime \prime} \mathrm{N}, 158^{\circ} 11^{\prime} 30^{\prime \prime} \mathrm{W}$; $B G N$ 1948; (map 72). Var. Oskawalit, Oskwalit.

Eskimo or Indian camp (Eskimo name) reported in 1913 by Brooks and Eakin (1914, pl. 1), USGS, as "Oskawalit."

Oskawalik River: stream, heads in Chuilnuk Mts., flows NE and NW 55 mi. to Kuskokwim River, $9 \mathrm{mi}$. S of village of Crooked Creek and $33 \mathrm{mi}$. W of Sleetmute, Kilbuck-Kuskokwim Mts.; $61^{\circ} 44^{\prime} 45^{\prime \prime} \mathrm{N}, 158^{\circ} 10^{\prime} 30^{\prime \prime} \mathrm{W}$; $B G N$ 1948; (map 72). Var. Oskowalit River. Eskimo name spelled "Oskawalit" on 1898 fieldsheet by W. S. Post, USGS, with the note "obtained from A. Lind, a trader." USGS reported the present spelling in 1945 and gave the meaning as "shoe-string or thong." Oskawalit: locality, see Oskawalik.

Oskowalit River: stream, see Oskawalik River. Oskuvalowik Creek: stream, flows W $0.5 \mathrm{mi}$. to Koozata River, 2 mi. N of Koozata Lagoon, St. Lawrence I. ; $63^{\circ} 25^{\prime} \mathrm{N}, 170^{\circ} 40^{\prime} \mathrm{W} ; B G N$ 1951; (map 93).

Eskimo name recommended by the Savoonga village council and reported in 1949 by Maj. H. B. Allen, USAF.

Oskwalit: locality, see Oskawalik.
Ospook Creek: stream, flows NW $8 \mathrm{mi}$. to Kontrashibuna Lake, $34 \mathrm{mi}$. NE of Nondalton, Aleutian Ra.; 60 $00^{\prime} 30^{\prime \prime} \mathrm{N}, 153^{\circ} 53^{\prime} 00^{\prime \prime} \mathrm{W}$; (map 61).

Local name reported in 1954 by USGS.

Osprey, Lake: lake, $1.3 \mathrm{mi}$. long, $10 \mathrm{mi}$. N of village of Port Alexander, on SE coast of Baranof I., Alex. Arch.; 56 $24^{\prime}$ N, $134^{\circ} 40^{\prime} \mathrm{W}$; $B G N$ 1935; (map 5).

Named in 1935 by USFS, "for an English ship that came to the rescue of the distressed white population of Sitka in 1879, Capt. A. Holmes A' Court in command."

Ossipee Channel: water passage, between Bushy and Shrubby Is., off NE coast of Prince of Wales I., Alex. Arch.; $56^{\circ} 05^{\prime} 40^{\prime \prime}$ N, $132^{\circ}$. $59^{\prime} 00^{\prime \prime} \mathrm{W}$; (map 6).

Named in 1895 by USC\&GS for U.S.S. Ossipee.

Osten Island: island, $0.7 \mathrm{mi}$. long, in Garroll Inlet, $2.5 \mathrm{mi}$. S of Island Point, on Revillagigedo I., Alex. Arch.; 55 $24^{\prime} 45^{\prime \prime}$ N, $131^{\circ}$ $19^{\prime} 28^{\prime \prime} \mathrm{W}$; (map 3$)$.

Local navigators' name obtained in 1904 by H. C. Fassett, USBF.

Ostovia Island: island, see Otstoia Island.

Ostraia Mountain: mountain, see Barometer Mountain.

Ostraya, Gora: mountain, see Barometer Mountain.

Ostrof Point: point of land, on island $\mathrm{N}$ of Icon Bay, on $E$ coast of Spruce I., off NE coast of Kodiak I.; $57^{\circ} 54^{\prime} 10^{\prime \prime} \mathrm{N}, 152^{\circ} 19^{\prime} 30^{\prime \prime} \mathrm{W}$. (map 34).

Descriptive Russian name "ostrov" meaning "island" reported in 1949 by USGS.

Ostrovka Point: point of land, between Dry Spruce Bay and Kupreanof Strait, $24 \mathrm{mi}$. NW of Kodiak, Kodiak I.; 57 $55^{\prime} 45^{\prime \prime}$ N, $153^{\circ}$ 00'00" W; BGN 1939; (map 34). Var. Islet Cape.

Transliteration of "M[ys] Ostrovka" meaning "cape of the little island," the name given by Sub.Lt. M. Murashev, IRN, in 1839 or 1840 and published in 1849 on Russian Hydrog. Dept. Chart 1425. Baker (1906, p. 330) published "Islet Cape" as the translation of Murashev's name. Because of duplication the name was changed to its present form in 1937 by USC\&GS.

Ostrovski: locality, on W coast of Kenai Penin., on Kachemak Bay, Cook Inlet Low.; $59^{\circ} 35^{\prime}$ N, $151^{\circ} 30^{\prime} \mathrm{W}$; (map 50).

Russian name for a former Eskimo village reported with a population of 74 in the 1880 census (Petroff, 1884, p. 29).

Ostrovski: islands, see Pribilof Islands.

Ostrovskoi Point: point of land, see East Cape.

Ostupleniya, Mys: point of land, see Retreat, Point.

Osvackamute: locality, see Aziavik.

Osviak: locality, on right bank of Osviak River $5 \mathrm{mi}$. W of Estus Point, Kilbuck-Kuskokwim Mts.; $58^{\circ} 49^{\prime} \mathrm{N}, 161^{\circ} 18^{\prime} \mathrm{W}$; (map 39). Var. Azeviuk, Aziavigamut, Aziavigokhamiut, Aziavik, Osvackamute.

This is probably the same Eskimo village listed in this dictionary as Aziavik." "Os- 
viak" and "Osvachamute" appear to be more recent transcriptions of this abandoned village's name, "Osvachamute," shown on a 1937 fieldsheet by J. B. Mertie, Jr., USGS.

Osviak: locality, see Aziavik.

Osviak River: stream, heads at $59^{\circ} 06^{\prime} \mathrm{N}$, $161^{\circ} 00^{\prime} \mathrm{W}$, flows SW $36 \mathrm{mi}$. to Hagemeister Strait at Estus Point, $27 \mathrm{mi}$. SE of Platinum, Kilbuck-Kuskokwim Mts.; 58 $47^{\prime} \mathrm{N}, 161^{\circ} 12^{\prime}$ W; (map 39). Var. Aziavik, Azvichviak, Azvichvyak, Uzavigiak.

Eskimo name reported in 1849 by Capt. Tebenkov (1852, map 4) as $R$ [eka] Azvichvyak. In 1880 Ivan Petroff reported the name of the Eskimo village at its mouth as "Aziavik." According to Frank Waskey, local trader and prospector, "Uzavigiak" is a variation. The local name "Osviak River," reported in 1947 by USGS, was derived from this name.

Otai, Mount: peak, see Alai, Mount.

Otcheredin, Mys: point of land, see Acheredin Point.

Otchyeryedinskiy, Mys: point of land, see Acheredin Point.

Othmer Creek: stream, see Orthmer Creek.

Otirgon Creek: stream, flows SW 5 mi. to Nigu River, $23 \mathrm{mi}$. SE of Howard Pass, Brooks Ra.; $68^{\circ} 07^{\prime} \mathrm{N}, 155^{\circ} 57^{\prime} \mathrm{W}$; (map 133).

Eskimo name meaning "backward creek," published by Irving (1954, p. 205).

Otis, Lake: lake, $0.2 \mathrm{mi}$. long, $1.1 \mathrm{mi}$. NW of confluence of North and South Forks Campbell Creek, in Anchorage, Cook Inlet Low.; 61 $11^{\prime} 32^{\prime \prime} \mathrm{N}, 149^{\circ} 50^{\prime} 35^{\prime \prime} \mathrm{W}$; (map 69).

Local name reported in 1942 by AMS.

Ot-ke-a-vik: town, see Barrow.

Otkiawik: town, see Barrow.

Ot-ki-a-wing: town, sec Barrow.

Otkiovik: town, sec Barrow.

Otkiwik: town, see Barrow.

Otkriti Bay: bay, $2.1 \mathrm{mi}$. across, on $\mathrm{S}$ coast of Agattu I., Aleutian Is.; 52 $23^{\prime} \mathrm{N}, 173^{\circ} 35^{\prime} \mathrm{E}$; $B G N$ 1938; (map 13). Var. Atkritoi Bay, Gannon Bay.

Descriptive Russian name, "Otkrytyy", meaning "open", and possibly taken from the nautical term "otkryed," meaning "open roadstead." This name was proposed by the U.S. Navy Hydrog. Office as "Atkritoi Bay" in 1938. BGN approved the form "Otkriti" and it was published in the 1944 Aleutian Coast Pilot as "Otkviti [Gannon] Bay" (p. 136).

Otkritie: island, see Nunivak Island.

Otkroy Glaza: rock, see Eye Opener, The.

Otkryt Kamen: rocks, see Discovery Rocks.

Otkurak Creek: stream, flows S $4 \mathrm{mi}$. to Noatak River, $35 \mathrm{mi}$. SW of Survey Pass, Brooks Ra.; $67^{\circ} 39^{\prime} \mathrm{N}, 155^{\circ} 20^{\prime} \mathrm{W}$; (map 125).

Eskimo name referring to a certain kind of pot [Utkusik], recorded in Kobuk by Orth, USGS, in 1956.

Otkusekrak Mountain: hill, see Utkusikrak Hill.

Otma: island, see Attu Island.

Otmeli, Mys: point of land, see Otmeloi Point. Otmeloi Island: island, $0.5 \mathrm{mi}$. across, in Yakutat
Bay, $0.2 \mathrm{mi}$. N of Kriwoi I. and $6.5 \mathrm{mi}$. NE of Yakutat, Malaspina Coastal Plain; 59 $38^{\prime} 15^{\prime \prime}$ N, $139^{\circ} 39^{\prime} 15^{\prime \prime} \mathrm{W}$; (map 46). Var. Ostrov Otmyloy, Shoals Island.

So named "O[strov] Otmyloy," meaning "reef (or shoal) island" by Capt. M. D. Tebenkov (1852, may 7), IRN, because of a shoal extending off the island for nearly a mile. It was called "Shoals Island" in the 1883 Coast Pilot (p. 209).

Otmeloi Point: point of land, $9.3 \mathrm{mi}$. NW of Kodiak, on N coast of Kodiak I.; 57 $54^{\prime} 30^{\prime \prime}$ $\mathrm{N}, 152^{\circ} 30^{\prime} 50^{\prime \prime} \mathrm{W}$; (map 34). Var. Mys Otmeli, Shoal Cape.

Transliteration of the name "M[ys] Otmeli," given to this point by Sub-Lt. Mikhail Murashev in 1839 or 1840 and published in 1849 on Russian Hydrog. Dept. Chart 1425. Baker (1906, p. 572) published "Shoal Cape," the translation of Murashev's name. Because of duplication the name was changed to its present form in 1909 by USC\&GS.

Otmeloy Vnutrenniy, Mys: point of land, see Inner Point.

Otmeloy Vnyshniy, Mys: point of land, see Shoals Point.

Otmieloi Cape: point of land, see Shoal Point. Otmyloy, Mys: point of land, see Shoal Point. Otmyloy Vnutrynney, Mys: point of land, see Inner Point.

Otmyloy Vnyschey, Mys: point of land, see Shoals Point.

Otokkok: locality, on Chukchi Sea coast, at Icy Cape, $48 \mathrm{mi}$. SW of Wainwright, Arctic Plain; (map 146). Var. Icy Cape, Ootokok, Ootookok, Otok-kok, Otukah, Utoqaq, Utuka, Utukok.

Former Eskimo village or camp, listed as "Otok-kok," population 50, by Petroff (1884, p. 59) ; population 48 in 1890 . In 1923 Sidney Paige, USGS, reported a population of 40 at "Icy Cape." The Eskimo word, "utoqaq," means "old" or "ancient" place.

Otokkok: villages, see Utukok villages.

Otokok: villages, see Utukok villages.

Otokok River: stream, see Utukok River.

Otokumuthamut: locality, on $\mathrm{E}$ shore of Togiak Bay, about $5 \mathrm{mi}$. NW of Rocky Point and 70 mi. NE of Cape Newenham, Kilbuck-Kuskokwim Mts.; $58^{\circ} 57^{\prime} \mathrm{N}, 160^{\circ} 42^{\prime} \mathrm{W}$; (map 39). Var. O-tok-u-mut-ha-mut.

Eskimo village or camp shown on 1910 manuscript map by H. C. Fassett, USBF. It is now abandoned.

Otookok: villages, see Utukok villages.

Otrubistoi : point of land, see Crag Point.

Otrubistoi Point: point of land, Afognak Bay, $1.8 \mathrm{mi}$. $\mathrm{N}$ of Afognak, on S. coast of Afognak I., $\mathrm{N}$ of Kodiak I.; $58^{\circ} 48^{\prime} 00^{\prime \prime} \mathrm{N}, 152^{\circ} 45^{\prime} 30^{\prime \prime}$ W; (map 43). Var. Bluff Cape.

Russian name from the word "Otrubnyy" given by Sub-Lt. Mikhail Murashev, IRN, in 1839 or 1840 , and published by the Russian Hydrog. Dept. in 1849 on Chart 1425. Baker (1906, p. 139), USGS, translates the name for this feature as "Bluff Cape."

Otrubistoy, Mys: point of land, see Crag Point.
Otstoia Island: island, $0.2 \mathrm{mi}$. across, in Peril Strait, off $\mathrm{N}$ coast of Duffield Penin., on Baranof I., $17 \mathrm{mi}$. NW of Todd, Alex. Arch.; $57^{\circ} 33^{\prime} 45^{\prime \prime} \mathrm{N}, 135^{\circ} 26^{\prime} 45^{\prime \prime} \mathrm{W}$; (map 9). Var. Distant Island, Ostovia Island, Ostrov Otstoya.

Russian name meaning "distant," given in 1833 by the navigator Ens. Vasiliev (cnna), IRN; published in 1848 on Russian Hydrog. Dept. Chart 1397 as "Os[trov] Otstoya."

Otstoya, Ostrov: island, see Otstoia Island.

Otstuplenie: point of land, see Retreat, Point.

Otter: locality, between Otter Creek and Iditarod River, $6.7 \mathrm{mi}$. W of Flat and $53 \mathrm{mi}$. NW of Holy Cross, Kilbuck-Kuskokwim Mts.; $62^{\circ}$. $27^{\prime} 50^{\prime \prime} \mathrm{N}, 158^{\circ} 13^{\prime} 20^{\prime \prime} \mathrm{W}$; (map 79). Var. Otter City.

Local name for a mining camp; name derived from Otter Creek. Reported in 1910 by A. G. Maddren, USGS. Population was about 50 at that time; the settlement was a distribution center for the mines.

Otters, Sea of: sea, see Bering Sea.

Otter Bay: bay, on S coast of Alaska Penin., W of Cape Aliaksin, on west shore of Beaver Bay, Aleutian Ra.; $55^{\circ} 30^{\prime} \mathrm{N}, 160^{\circ} 54^{\prime} \mathrm{W}$; (map 28). Var. Beaver Bay, Zaliv Babrovyy.

Name translated from the Russian "Z[aliv] Bobrovyy," meaning "sea otter bay," published in 1847 on Russian Hydrog. Dept. Chart 1379, and shown as "Otter Bay" on an 1890 USBF chart. This feature has not been positively identified.

Otter Bay: bay, see Beaver Bay.

Otter Bight: bight, $2.6 \mathrm{mi}$. across, on NE coast of Umnak I., Aleutian Is.; $53^{\circ} 26^{\prime} 30^{\prime \prime} \mathrm{N}, 167^{\circ}$ 51'00" W; BGN 1937; (map 23). Var. Idak Cove.

So named by USC\&GS in 1937 "because of its association with Otter Point."

Otter Cove: bay, $5 \mathrm{mi}$. across, on SE coast of Unimak I., Aleutian Is. ; $54^{\circ} 41^{\prime} \mathrm{N}, 163^{\circ} 20^{\prime} \mathrm{W}$; (map 25).

Name reported by Ferdinand Westdahl, USC\&GS, commander of the Coast Survey steamer McArthur, who made surveys in this area in 1901.

Otter Creek: stream, flows SE to Cripple River, about $20 \mathrm{mi}$. NW of Nome, Seward Penin. High.; (map 94).

Prospectors' name reported on the 1900 "Map of Nome Peninsula" by J. M. Davidson and B. D. Blakeslee; this feature has not been positively identified.

Otter Creek : village, see Otter.

Otter Creek: stream, flows NW 7 mi. to Becharof Lake, on Alaska Penin., $49 \mathrm{mi}$. NE of Ugashik, Aleutian Ra.; $57^{\circ} 38^{\prime} 35^{\prime \prime} \mathrm{N}, 156^{\circ} 07^{\prime} 10^{\prime \prime} \mathrm{W}$; (map 36).

Local name reported in 1902 by J. L. McPherson of Iliamna; published by G. C. Martin (1921, pl. 10), USGS.

Otter Creek: stream, flows SW $7 \mathrm{mi}$. to Gompertz Channel of Cook Inlet, 26 mi. NE of Kenai, Cook Inlet Low.; $60^{\circ} 52^{\prime} 15^{\prime \prime} \mathrm{N}, 150^{\circ}$ $51^{\prime} 55^{\prime \prime} \mathrm{W}$; (map 62).

Local name reported in 1939 by USGS 
Otter Creek: stream, heads at $60^{\circ} 53^{\prime} \mathrm{N}$, $159^{\circ} 58^{\prime} \mathrm{W}$, flows NW $-20 \mathrm{mi}$. to Tuluksak River, $45 \mathrm{mi}$. NE of Bethel, Kilbuck-Kuskokwim Mts.; $60^{\circ} 58^{\prime} \mathrm{N}, 160^{\circ} 26^{\prime} \mathrm{W}$; (map 59). var. Bear Creek.

Local name reported in 1955 by J. M. Hoare, USGS.

Otter Creek: stream, heads at junc., of its North and South Forks, flows SW $20 \mathrm{mi}$. to Iditarod River, $7 \mathrm{mi}$. W of Flat and $53 \mathrm{mi}$. NE of Holy Cross, Kilbuck-Kuskokwim Mts.; $62^{\circ} 28^{\prime} \mathrm{N}$, $158^{\circ} 14^{\prime} \mathrm{W}$; (map 79).

Prospectors' name reported in 1910 by $A$ G. Maddren, USGS.

Otter Creek: stream, flows NE $8 \mathrm{mi}$. to Gakona River $38 \mathrm{mi}$. $\mathrm{N}$ of its junc, with Copper River, Copper River Basin; $62^{\circ} 51^{\prime} \mathrm{N}, 1^{\circ} 5^{\circ}$. $09^{\prime} \mathrm{W}$; (map 83).

Local name reported by USGS in 1949.

Otter Creek: stream, heads at $63^{\circ} 05^{\prime} \mathrm{N}$ $161^{\circ} 15^{\prime} \mathrm{W}$ and flows NE $30 \mathrm{mi}$. to Anvik River, $43 \mathrm{mi}$. SE of Unalakleet, Nulato Hills; $63^{\circ} 14^{\prime} 30^{\prime \prime} \mathrm{N}, 160^{\circ} 41^{\prime} 50^{\prime \prime} \mathrm{W}$; (map 91).

Local name reported by USC\&GS in 1950.

Otter Creek: stream, heads in Kantishna Hills, flows NW $14 \mathrm{mi}$. to Bearpaw River, $20 \mathrm{mi}$. $\mathrm{E}$ of Chilchukabena Lake, Tanana Low.; $63^{\circ} 55^{\prime} 40^{\prime \prime} \mathrm{N}, 150^{\circ} 50^{\prime} 00^{\prime \prime} \mathrm{W}$; (map 88).

Prospectors' name reported in 1905 by L. M. Prindle, USGS.

Otter Creek: stream, flows SE $3.6 \mathrm{mi}$. to Nome River, $4 \mathrm{mi}$. SE of Nome, Seward Penin. High.; $64^{\circ} 29^{\prime} \mathrm{N}, 165^{\circ} 17^{\prime} \mathrm{W}$; (map 94).

Prospectors' name reported in 1899 by $D$ C. Witherspoon (in Schrader and Brooks, 1900, map 2), USGS.

Otter Creek: stream, heads in Darby Mts., flows NE 5.2 mi. to Tubutulik River in Death Valley, $40 \mathrm{mi}$. SE of Imuruk Lake, Seward Penin. High.; $65^{\circ} 08^{\prime} \mathrm{N}, 162^{\circ} 17^{\prime} \mathrm{W}$; (map 110).

Prospectors' name published on 1908 "Map of Seward Peninsula" by Arthur Gibson.

Otter Creek: stream, in Baird Mts., flows W 5 mi. to Canyon Creek $3.5 \mathrm{mi}$. SSE of its junc. with Squirrel River, $5.5 \mathrm{mi}$. NNE of Kiana, Brooks Ra.; 67 $03^{\prime} \mathrm{N}, 160^{\circ} 24^{\prime} \mathrm{W}$; (map 127).

Name used by prospectors; reported in 1910 by P. S. Smith (in Brooks and others, 1911, pl. 13), USGS.

Otter Creek: stream, heads at $67^{\circ} 45^{\prime} \mathrm{N}$, $144^{\circ} 37^{\prime} \mathrm{W}$, flows SW $30 \mathrm{mi}$. to Christian River $11 \mathrm{mi}$. NW of Christian, Brooks Ra.; $67^{\circ} 31^{\prime} \mathrm{N}, 145^{\circ} 21^{\prime} \mathrm{W}$; (map 122).

Local name reported in 1956 by $T$. E. Taylor, USGS.

Otter Island: island, $0.8 \mathrm{mi}$ long, $7 \mathrm{mi} . \mathrm{S}$ of St. Paul I., Pribilof Is.; $57^{\circ} 02^{\prime} 45^{\prime \prime}$ N, $170^{\circ}$ $24^{\prime} 00^{\prime \prime}$ W; (map 38). Var. Bober, Bobrovi, Bobrovia, Bobrovoi, Sea Otter Island.

Translation from the Russian O[strov] Bobrovoy meaning "otter island" and published by Capt. Lt. Vasiliev (1829, map 3), IRN.

Otter Island: island, see Hydra Island.

Otter Lake: lake, $3 \mathrm{mi}$, long, on Chichagof I.,

$11 \mathrm{mi}$. SE of Pelican, Alex. Arch.; $57^{\circ} 48^{\prime} 30^{\prime \prime}$ N. $136^{\circ} 08^{\prime} 00^{\prime \prime} \mathrm{W} ; B G N 1960$; (map 9).
Named in 1955 by USGS; published by Rossman (1959, map). It was so named because "its shores are the home of numerous otter families."

Otter Lake: lake, $0.6 \mathrm{mi}$. across, on $\mathrm{N}$ end of Chichagof I., $3.8 \mathrm{mi}$. SE of Mud Bay and $19 \mathrm{mi}$. NW of Hoonah, Alex. Arch.; $58^{\circ} 08^{\prime} 15^{\prime \prime}$ N, $135^{\circ} 53^{\prime} 15^{\prime \prime} \mathrm{W}$; BGN 1960; (map 11).

Local name reported by USGS in 1958 and published in 1962

Otter Lake: lake, on NE end of Knight I., $\mathrm{N}$ of Bay of Isles, $18 \mathrm{mi}$. NE of Chenega, Chugach Mts.; $60^{\circ} 25^{\prime} 30^{\prime \prime} \mathrm{N}, 147^{\circ} 38^{\prime} 30^{\prime \prime} \mathrm{W}$; (map 63).

Local name reported in 1951 by USGS.

Otter Lake: lake, $0.7 \mathrm{mi}$. long, $5 \mathrm{mi}$. $\mathrm{N}$ of Little Lake Clark and $48 \mathrm{mi}$. NE of Nondalton, Aleutian Ra.; $60^{\circ} 29^{\prime} \mathrm{N}, 153^{\circ} 47^{\prime} \mathrm{W}$; (map 61 .

Local name reported in 1954 by USGS.

Otter Lake: lake, $1 \mathrm{mi}$. long, on Kenai Penin., $0.6 \mathrm{mi}$. NW of Rock Lake and $22 \mathrm{mi}$. NE of Kenai, Gook Inlet Low.; $60^{\circ} 40^{\prime} 15^{\prime \prime} \mathrm{N}, 150^{\circ}$ $40^{\prime} 00^{\prime \prime} \mathrm{W}$; (map 62).

Named about 1963 by officials of Kenai National Moose Range for administrative purposes.

Otter Lake: lake, $0.5 \mathrm{mi}$. across, $1.1 \mathrm{mi}$. E of Sixmile Lake and $7 \mathrm{mi}$. NE of Anchorage, Cook Inlet Low.; $61^{\circ} 17^{\prime} 24^{\prime \prime} \mathrm{N}, 149^{\circ} 44^{\prime} 00^{\prime \prime}$ W; (map 69).

Local name reported in 1906 by T. G. Gerdine and R. H. Sargent, USGS.

Otter Lake: lake, $0.4 \mathrm{mi}$. long, $\mathrm{S}$ of Gakona Glacier terminus, 9 mi. NE of Paxson, Alaska Ra.; $63^{\circ} 05^{\prime} 20^{\prime \prime}$ N, $145^{\circ} 13^{\prime} 30^{\prime \prime}$ W; (map 86).

Name published on relatively recent maps.

Otter Lake: lake, 2 mi. long, NW of Big Lake, $25 \mathrm{mi}$. SSW of village of Lake Minchumina,

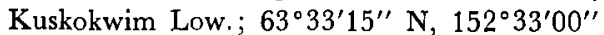
W; (map 88).

Local name obtained in 1958 from Fabian Carey and "Val" Blackburn by USGS.

Otter Point: point of land, at Fort Glenn, in NE part of Umnak I., Aleutian Is.; $53^{\circ} 24^{\prime} 50^{\prime \prime} \mathrm{N}$, $167^{\circ} 50^{\prime} 35^{\prime \prime} \mathrm{W}$; (map 23). Var. Sheep Point. Named by USC\&GS in 1937. It was called "Sheep Point" by the U.S. Army Corps of Engineers in 1942.

Otter Point: point of land, $20 \mathrm{mi}$. NW of False Pass, on the NE coast of Unimak I., Aleutian Is.; $55^{\circ} 03^{\prime} \mathrm{N}, 163^{\circ} 47^{\prime} \mathrm{W}$; (map 29).

Local name published by USC\&GS in 1902.

Otter Point Greek: stream, flows N $3.5 \mathrm{mi}$. to Bering Sea, $20 \mathrm{mi}$. NW of False Pass, on NW coast of Unimak I., Aleutian Is.; $55^{\circ} 03^{\prime} 00^{\prime \prime}$ N, 163 $47^{\prime} 45^{\prime \prime} \mathrm{W}$; (map 29).

Name derived from Otter Point and reported by USC\&GS in 1947.

Otter Pond: lake, $0.3 \mathrm{mi}$. long, $\mathrm{N}$ of Bear Lake, $17 \mathrm{mi}$. SW of Beaver, Yukon Flats; $66^{\circ} 17^{\prime} 20^{\prime \prime}$ N, 147 58 $30^{\prime \prime} \mathrm{W}$; (map 118$)$.

Probably named by William Yanert who showed it on a 1916 manuscript map of the Yukon Flats (Stuck, 1917, map facing p. 122).

Otters, Bay of: bay, see Beaver Inlet.

Otter Sound: bay, see Sea Otter Sound.
Otter Strait: water passage, between Bird and Chernabura Is., in Shumagin Is., Aleutian Ra.; $54^{\circ} 48^{\prime} \mathrm{N}, 159^{\circ} 40^{\prime} \mathrm{W}$; (map 26).

Named in 1882 by W. H. Dall, USC\&GS.

Ottertail Creek: stream, flows SW $11 \mathrm{mi}$. to East Fork Chena River, $56 \mathrm{mi}$. N of Big Delta, Yukon-Tanana High.; $64^{\circ} 57^{\prime} 15^{\prime \prime} \mathrm{N}, 145^{\circ}$. $52^{\prime} 45^{\prime \prime} \mathrm{W}$; (map 101).

Named by prospectors; reported in 1909 by USGS (Capps, 1912, pl. 1).

Ottertail Creek: stream, flows SE $40 \mathrm{mi}$. to East Fork Chandalar River, $8.5 \mathrm{mi}$. SW of Arctic Village, Brooks Ra.; $68^{\circ} 02^{\prime} \mathrm{N}, 145^{\circ} 47^{\prime} \mathrm{W}$; (map 136).

Local name reported in 1926 by J. B. Mertie, Jr. (in Smith, P. S., and others, 1929, pl. 1), USGS.

Ottertail Ridge: ridge, elev. 3,270 ft., extends S $5 \mathrm{mi}$. on W bank of Ottertail Creek, $11 \mathrm{mi}$. $\mathrm{E}$ of Arctic Village, Brooks Ra.; $68^{\circ} 07^{\prime} \mathrm{N}$ $145^{\circ} 58^{\prime} \mathrm{W}$; (map 136).

Local name "descriptive of the shape of the ridge"; reported in 1926 by Mertie, (in Smith, P. S., and others, 1929, pl. 1), USGS. Otto Lake: lake, $0.8 \mathrm{mi}$. long, $3 \mathrm{mi}$. SW of Healy, Alaska Ra.; $63^{\circ} 50^{\prime} 30^{\prime \prime} \mathrm{N}, 149^{\circ} 02^{\prime} 00^{\prime \prime}$ W; BGN 1960; (map 87). Var. Finn Lake, Ottos Lake.

Named for Otto Maki, a Finnish homesteader upon whose land the lake stands; reported in 1959 by USGS.

Otto Lake: lake, $0.4 \mathrm{mi}$. long, $1 \mathrm{mi}$. E of Jenny I. and $6 \mathrm{mi}$. SE of Fort Yukon, Yukon Flats; $66^{\circ} 30^{\prime} 30^{\prime \prime} \mathrm{N}, 145^{\circ} 06^{\prime} 00^{\prime \prime} \mathrm{W}$; (map 119).

Local name obtained in 1956 by USGS.

Ottos Lake: lake, see Otto Lake.

Ottoway Valley: valley, $3 \mathrm{mi}$. long, on Chultikana Creek, 2 mi. NW of its mouth, on Klutina Lake, $49 \mathrm{mi}$. NE of Valdez, Chugach Mts.; $61^{\circ} 46^{\prime} 45^{\prime \prime} \mathrm{N}, 145^{\circ} 49^{\prime} 30^{\prime \prime} \mathrm{W}$; (map $68)$.

Named in 1898 by Capt. W. R. Abercrombie, USA.

Otukah: locality, see Otokkok.

Otukah: villages, see Utukok villages.

Otuk Creek: stream, flows $\mathrm{N} 21 \mathrm{mi}$. to Iteriak Creek $4 \mathrm{mi}$. S of its junc. with E Fork Etivluk River, Brooks Ra.; $68^{\circ} 35^{\prime} \mathrm{N}, 155^{\circ} 46^{\prime} \mathrm{W}$; $B G N$ 1960; (map 133).

Eskimo name used about 1950 by USGS geologists during exploration of the Naval Petroleum Reserve No. 4.

Otviesnoi, Cape: point of land, see Upright, Cape.

Otvysnoy, Mys: point of land, sec Upright, Cape. Oubeloi Island: island, see Nizki Island.

Oubiennaia Bay: bay, see Massacre Bay.

Ouchklune Peak: mountain, see Oratia, Mount. Ouchklune Range: mountain range, $5,000 \mathrm{ft}$., trends NW $6 \mathrm{mi}$. from Atmugiak Creek, 75 mi. NE of Goodnews, Kilbuck-Kuskokwim Mts.; 59 $54^{\prime} \mathrm{N}, 160^{\circ} 01^{\prime} \mathrm{W}$; (map 53).

Eskimo name shown on a 1898 fieldsheet by W. S. Post, USGS

Ouchtishich-cha-ga-mut: locality, on right bank of Kanektok River, 7 mi. NE of Kwinhagak, $48 \mathrm{mi}$. $\mathrm{N}$ of Goodnews, Yukon-Kuskokwim Delta; $59^{\circ} 47^{\prime} \mathrm{N}, 161^{\circ} 41^{\prime} \mathrm{W}$; (map 53). 
Eskimo name shown on a 1898 fieldsheet by W. S. Post, USGS, with a note "name of a locality only no houses seen."

Oudagakh Strait: water passage, see Udagak Strait.

Ouektock: island, see Aiktak Island.

Ouektock: island, see Rootok Island.

Ougadakh Harbor: anchorage, see Dutch Harbor.

Ougagik: village, see Egegik.

Ougagouck, Fleuve: stream, see Egegik River.

Ougagouk: village, see Egegik.

Ougamantamuk Creek: stream, flows S $5 \mathrm{mi}$. to Nanavochtshak Lake, $75 \mathrm{mi}$. NE of Goodnews, Kilbuck-Kuskokwim Mts.; $59^{\circ} 40^{\prime} \mathrm{N}$, $159^{\circ} 39^{\prime} \mathrm{W}$; ( $\operatorname{map} 53$ ).

Eskimo name shown on a 1898 fieldsheet by W. S. Post, USGS, who, with J. E. Spurr, camped along the stream, September 16, 1898. Ougatchik Riviere: stream, see Ugashik River.

Ougavik: locality, see Uknavik.

Ouglovaia : locality, see Uglovaia.

Ougnagok: village, see Unga.

Oukamok: island, see Chirikof Island.

Oukevok: locality, see Ukivok.

Oukitshagamut: locality, on right bank of Kanektok River, $10 \mathrm{mi}$. W of Amakatatee Creek, 64 mi. NE of Goodnews, Kilbuck-Kuskokwim Mts.; $59^{\circ} 51^{\prime} \mathrm{N}, 160^{\circ} 38^{\prime} \mathrm{W}$; (map 53 ).

Eskimo name meaning "Oukitshak people" shown as one cabin on a 1898 fieldsheet by W. S. Post, USGS.

Oukivak: village, see Ukivok.

Oukivok Island : island, see King Island.

Ouknadok: locality, see Uknodok.

Ouknadok Island: island, see Hog Island.

Oukviktoulia: locality, see Opiktulik.

Oukwak: locality, see Ukivok.

Oulliaghin Island: island, see Carlisle Isiand. Oumakh Island: island, see Umak Island.

Oumalik Lakes: lakes, widely scattered group extending $18 \mathrm{mi}$. between Ikpikpuk and Oumalik Rivers, Arctic Plain; $69^{\circ} 45^{\prime} \mathrm{N}$, $155^{\circ} 15^{\prime} \mathrm{W}$; (map 142).

Named in the 1940's by the geologists on the Naval Petroleum Reserve No. 4 exploration; derived from the name of the Oumalik River.

Oumalik River: stream, heads at $69^{\circ} 38^{\prime} \mathrm{N}$, $156^{\circ} 16^{\prime} \mathrm{W}$, flows NE $140 \mathrm{mi}$. to Chipp River, $34 \mathrm{mi}$. S of Smith Bay, Arctic Plain; 70²2'$20^{\prime \prime} \mathrm{N}, 154^{\circ} 58^{\prime} 40^{\prime \prime} \mathrm{W}$; (map 148).

This Eskimo name, meaning "chief, amber, or ashes," seems to have been first used by geologists of the Naval Petroleum Reserve No. 4 probably in the late 1940's or.early 1950's. See Omalik names.

Oumnakh Island: island, see Umnak Island. Oumnak Island: island, see Umnak Island.

Ounag-touti: locality, see Ungalik.

Ounalachka: island, see Unalaska Island.

Ounalakleet: village, see Unalakleet.

Ounalaklik: village, see Unalakleet.

Ounalaklik River: stream, see Unalakieet River.

Ounalaska: village, see Unalaska.

Ounalga Isle: island, see Unalga Island.

Ounalga Pass: water passage, see Unalga Pass.

Ounalima: peak, see Angutikada Peak.
Ouna-nigh-mack, Ile: island, see Unavikshak Island.

Ounga: village, see Unga.

Ounga: rock, see Pinnacle Rock.

Ounga Island: island, see Unga Island.

Oungaklitalik River: stream, see Ungalik River. Ounimak, Ile de: island, see Unimak Island.

Ounimak Detroit: water passage, see Unimak Pass.

Oupuk Creek: stream, see Aupuk Creek.

Ourand, Mount: mountain, 6,080 ft., $1 \mathrm{mi}$. NE of Mount Evans, $21 \mathrm{mi}$. N of Valdez, Chugach Mts.; $61^{\circ} 25^{\prime} 30^{\prime \prime} \mathrm{N}, 146^{\circ} 08^{\prime} 00^{\prime \prime} \mathrm{W}$; $B G N$ 1931; (map 68).

Named in 1898 by Capt. W. R. Abercrombie, USA, for Major Charles H. Ourand, USA.

Our Creek: stream, flows W $1.3 \mathrm{mi}$. to Wilson Creek Slough, $4 \mathrm{mi}$. S of Marshall, YukonKuskokwim Delta; $61^{\circ} 49^{\prime} 20^{\prime \prime} \mathrm{N}, 162^{\circ} 02^{\prime} 45^{\prime \prime}$ W; (map 74).

Miners' name published by Harrington (1918, map), USGS.

Our Creek: stream, flows W $16 \mathrm{mi}$. to North Fork Innoko River, $61 \mathrm{mi}$. NW of Medfra, Kilbuck-Kuskokwim Mts.; $63^{\circ} 50^{\prime} \mathrm{N}, 155^{\circ} 50^{\prime}$ W; BGN 1963; (map 89).

Local name reported in 1954 by USGS.

Our Creek: stream, heads in Sischu Mts., flows N $16 \mathrm{mi}$. to Nowitna River, $28 \mathrm{mi}$. SE of Monzonite Hills, Kilbuck-Kuskokwim Mts.; $64^{\circ} 01^{\prime} 36^{\prime \prime} \mathrm{N}, 154^{\circ} 22^{\prime} 40^{\prime \prime} \mathrm{W}$; (map 98).

Local name reported in 1915 by $\mathrm{H}$. M. Eakin (in Brooks and others, 1916, pl. 10), USGS.

Our Creek: stream, flows W $7 \mathrm{mi}$. to Molly Creek, $80 \mathrm{mi}$. SW of Eagle, Yukon-Tanana High.; $64^{\circ} 05^{\prime} 45^{\prime \prime} \mathrm{N}, 143^{\circ} 22^{\prime} 50^{\prime \prime} \mathrm{W}$; (map 102).

Local name published in 1956 by USGS.

Our Creek: stream, flows NE $8.5 \mathrm{mi}$. to Chatanika River, $15 \mathrm{mi}$. NW of Fairbanks, YukonTanana High.; $65^{\circ} 03^{\prime} 15^{\prime \prime} \mathrm{N}, 147^{\circ} 54^{\prime} 15^{\prime \prime} \mathrm{W}$; (map 105).

Named by prospectors; published in 1907 by USGS.

Our Creek: stream, flows NW $7 \mathrm{mi}$. to North Fork Chandalar River, S of Bend Mtn., and $19 \mathrm{mi}$. NNE of Chandalar, Brooks Ra.; $67^{\circ}$ $45^{\prime} 45^{\prime \prime} \mathrm{N}, 148^{\circ} 17^{\prime} 00^{\prime \prime} \mathrm{W}$; (map 123).

Prospectors' name obtained in 1909 by A. G. Maddren (in Brooks and others, 1910, pl. 7), USGS.

Ouserdie Point: point of land, see Zeal Point.

Outchitak-Mioute: locality, see Uchitak.

Outer Iliasik Island: island, $3 \mathrm{mi}$. long, $7 \mathrm{mi}$. SW of Dolgoi I., in Pavlof Is., Aleutian Ra.; $55^{\circ} 00^{\prime} \mathrm{N}, 161^{\circ} 53^{\prime} \mathrm{W}$; (maps 25, 28). Var. Big Iliazhek, Eliazik, Ialiasik, Iliasik Islands, Iliaviki.

Native name published in 1847 as "O[strov] Bol[shoi] Iliazhek" or "big Iliazhek island" on Russian Hydrog. Dept. Chart 1379. Outer and Inner Iliasik Islands comprise the Iliasik Islands; called "Eliazik" by Capt. Lutkc (1836, p. 271), IRN, and "Ialiasik" by Capt. Tebenkov (1852, map 24), IRN.
Outer Island: island, 2 mi. long, in Pye Is., at $\mathrm{S}$ entrance to Nuka Bay, $46 \mathrm{mi}$. ESE of Seldovia, Chugach Mts.; $59^{\circ} 21^{\prime}$ N, $150^{\circ} 25^{\prime}$ W; BGN 1929; (map 50). Var. Outer Pye Island.

Descriptive name given by USC\&GS in 1927 and so named because it is the last or outermost (farthest off-shore) of the Pye Islands. Outer Point: point of land, at $\mathrm{W}$ tip of Baker I., $4 \mathrm{mi}$. N of Granite Point, Alex. Arch.; $55^{\circ}$ $22^{\prime} 25^{\prime \prime} \mathrm{N}, 133^{\circ} 40^{\prime} 30^{\prime \prime} \mathrm{W}$; (map 4).

Local name recorded in 1948 by USGS.

Outer Point: point of land, between Twelvemile Arm Kasaan Bay and Kina Cove, on $\mathbf{E}$ coast of Prince of Wales I., Alex. Arch.; 55 $31^{\prime} 15^{\prime \prime}$ N, $132^{\circ} 31^{\prime} 25^{\prime \prime} \mathrm{W}$; (map 4).

Descriptive name published in 1911 by USC\&GS.

Outer Point: point of land, at mouth of Freshwater Bay, on $E$ coast of Chichagof I., $9 \mathrm{mi}$. NE of Tenakee Springs, Alex. Arch.; $57^{\circ}$ $50^{\prime} 00^{\prime \prime}$ N, $134^{\circ} 59^{\prime} 15^{\prime \prime} \mathrm{W}$; (map 9). Var. Bluff Point.

Descriptive name given in 1881 by Comdr. Henry Glass, USN, and published by USC\&GS in the 1883 Coast Pilot (p. 180).

Outer Point: point of land, $\mathrm{W}$ tip of Douglas I., in Stephens Passage, $4 \mathrm{mi}$. NW of Middle Point and $10 \mathrm{mi}$. W of Juneau, Coast Mts.; 58 $18^{\prime} 05^{\prime \prime} \mathrm{N}, 134^{\circ} 41^{\prime} 15^{\prime \prime} \mathrm{W}$; (map 11).

Descriptive name given by Lt. F. M. Symonds, USN, in 1880 and published by USC\&GS in the 1883 Coast Pilot (p. 173).

Outer Point of Shoals: point of land, see Shoals Point.

Outer Pye Island: island, see Outer Island.

Outer Right Cape: point of land, east point of entrance to Kiliuda Bay, on SE coast of Kodiak I.; $57^{\circ} 16^{\prime}$ N, $152^{\circ} 49^{\prime}$ W; (map 34). Var. Mys Pravoy, Pravoi Cape, Right Cape, Starboard Cape.

Descriptive name published in 1943 by USC\&GS. Capt. Tebenkov (1852, map 23) published the name "M[ys] Pravoy," meaning "right hand cape." Baker (1906, p. 528) called this point "Right Cape" and (p. 596) "Starboard Cape."

Outer Rock: rock, in Nazan Bay, off E coast of Atka I., Aleutian Is., 52 $11^{\prime} \mathrm{N}, 174^{\circ} 07^{\prime}$ W; (map 18). Var. Vnechni Rock, Vnyshniy, Kamen.

Name published as "K[amen] Vnyshniy," meaning "outer rock," by Capt. Tebenkov (1852, map 27), IRN. Not named on recent USGS maps or USC\&GS charts.

Outer Rock: rock, awash at low tide, between Hodikof and Sarana Bays, off eastern Attu I., $1.4 \mathrm{mi}$. E of Hodikof Point, Aleutian Is.; $52^{\circ} 52^{\prime} 40^{\prime \prime} \mathrm{N}, 173^{\circ} 19^{\prime} 00^{\prime \prime} \mathrm{E}$; (map 13).

Descriptive name listed in the 1944 Aleutian Coast Pilot.

Oufer Rock: rocks, see Outer Rocks.

Outer Rocks: rocks, at W entrance to Khar Bay, $7.5 \mathrm{mi}$. SW of Chichagof, on W coast of Chichagof I., Alex. Arch.; 57 $33^{\prime} 30^{\prime \prime}$ N, $136^{\circ} 09^{\prime} 30^{\prime \prime}$ W ; BGN 1908; (map 9). Var. Outer Rock. 
Descriptive name given in 1897 as "Outer Rock" by Lt. Comdr. E. K. Moore, USN, to one of the rocks. The name was applied to the group by USC\&GS in 1908 and published in the 1908 Coast Pilot (p. 167) as "Outer Rocks."

Outer Seal Rock: rock, $3 \mathrm{mi}$. W of Gurney Bay and $24 \mathrm{mi}$. SW of Karluk, on $W$ coast of Kodiak I.; $57^{\circ} 18^{\prime} 10^{\prime \prime} \mathrm{N}, 154^{\circ} 50^{\prime} 20^{\prime \prime} \mathrm{W}$; (map 35).

Descriptive name published by USC\&GS in 1943. See Seal Rocks.

Outer Signal: rocks, elev, $50 \mathrm{ft}$., off NE coast of Sedanka I., Aleutian Is.; $53^{\circ} 48^{\prime} 15^{\prime \prime} \mathrm{N}$, $166^{\circ} 02^{\prime} 20^{\prime \prime} \mathrm{W}$; (map 23). Var. Cook's Rock.

Named as one of "The Signals" by J. J. Gilbert, comdr. of the USC\&GS steamer Pathfinder during 1900-01.

Outlet Cape: point of land, tip of Kupreanof Penin., between Kupreanof Strait and Viekoda Bay, on N coast of Kodiak I.; 57 $59^{\prime} 55^{\prime \prime} \mathrm{N}$ $153^{\circ} 17^{\prime} 00^{\prime \prime} \mathrm{W}$; (map 34). Var. Mys Vykhoda, Mys Vykhodnoy, Viekhoda.

Translation of the descriptive name " $M[y s]$ Vykhoda" given by Sub-Lt. Mikhail Murashev in 1839 or 1840 and published in 1849 on Russian Hydrog. Dept. Chart 1425.

Outlet Glacier: glacier, on $\mathrm{N}$ slope of Mount Veniaminof, trends N $3 \mathrm{mi}$. to its terminus at head of Blueberry Creek, $10 \mathrm{mi}$. W of Knife Peak, Aleutian Ra.; $56^{\circ} 17^{\prime} \mathrm{N}, 159^{\circ} 21^{\prime} \mathrm{W}$; (map 30).

Name reported in 1923 by $R$. H. Sargent, USGS; published in 1927 by USGS.

Outlook Point: mountain, 1,451 ft., $17 \mathrm{mi}$. SE of Burnt Mtn. and $30 \mathrm{mi}$. SE of Christian, Yukon Flats; $67^{\circ} 17^{\prime} \mathrm{N}, 144^{\circ} 05^{\prime} \mathrm{W}$; (map 122).

Local name reported in 1927 by J. B Mertie, USGS.

Outpost Creek: stream, heads on Outpost Mtn., flows $\mathrm{W}, \mathrm{NE}$, and $\mathrm{W} 18 \mathrm{mi}$. to Chandler River, Arctic Slope; $69^{\circ} 13^{\prime} \mathrm{N}, 151^{\circ} 25^{\prime} \mathrm{W}$ $B G N$ 1960; (map 141).

Named by USGS geologists during exploration of Naval Petroleum Reserve No. 4 between 1944-53, for Outpost Mountain.

Outpost Island: island, $0.1 \mathrm{mi}$. long, in Prince William Sound, $1.5 \mathrm{mi}$. S of Fairmount I., $42 \mathrm{mi}$. NE of Whittier, Chugach Mts.; $60^{\circ}$ $50^{\prime} 40^{\prime \prime} \mathrm{N}, 147^{\circ} 27^{\prime} 30^{\prime \prime} \mathrm{W}$; (map 63).

Local name reported in 1951 by USGS.

Outpost Mountain: mountain, 1,305 ft., at head of Outpost Creek, $25 \mathrm{mi}$. SE of Umiat, Arctic Slope; $69^{\circ} 09^{\prime} \mathrm{N}, 151^{\circ} 13^{\prime} \mathrm{W} ; B G N$ 1964; (map 141). Var. Natvaksukruk Hill.

Named by USGS geologists in 1945 during exploration of Naval Petroleum Reserve No. 4. The Eskimo name according to T. E. Taylor, USGS, is Natvaksukruk.

Outside Bay: bay, on SW coast of Naked I., trends SW $2 \mathrm{mi}$, to Prince William Sound, $32 \mathrm{mi}$. NE of Chenega, Chugach Mts.; $60^{\circ} 38^{\prime} \mathrm{N}, 147^{\circ} 29^{\prime} \mathrm{W}$; (map 63). Var. Outside Harbor.

Name published in 1943 by USC\&GS.

Outside Harbor: bay, see Outside Bay.

Outuchiwenat Mountain: mountain, 4,000 ft., 1 mi. SE of Mount Oratia, $80 \mathrm{mi}$. NE of Good- news, Kilbuck-Kuskokwim Mts.; 59 54' N, $160^{\circ} 00^{\prime} \mathrm{W}$; (map 53).

Eskimo name shown on a 1898 fieldsheet by W. S. Post, USGS.

Outwash Creek: stream, flows N $40 \mathrm{mi}$. to Kurupa River $25 \mathrm{mi}$. S of its junc. with Colville River, Brooks Ra.; $68^{\circ} 43^{\prime} \mathrm{N}, 155^{\circ} 03^{\prime} \mathrm{W}$; $B G N 1960$; (map 133).

So named about 1950 by USGS geologists during exploration of Naval Petroleum Reserve No. 4, because "stream runs through a belt of terraced gravel that is part of an outwash plain from one of the glacial advances."

Ouzinkie: village, pop. 214, on $\mathrm{W}$ coast of Spruce I., NE of Kodiak I.; $57^{\circ} 55^{\prime} 30^{\prime \prime} \mathrm{N}$, 152 ${ }^{\circ} 29^{\prime} 50^{\prime \prime} \mathrm{W}$; BGN 1960; (map 34). Var. New Balaam, Novie Balaam, Oozinkee, Oozinkie, Starling, Seleniye Ruskiy i Kreolovy, Skvortsova, Usinka, Uzinkee, Uzinki, Uzinkie.

Transliteration by Baker (1906, p. 657) of "Uzenkiy," from "uzkiy," meaning "very narrow," derived from the Russian name given to Narrow Strait, upon which the village is located. The name was reported as "Oozinkie, where there are 15 creoles ***," by Petroff (1881, p. 29). In 1849 the Russian American Company published the name "Selen[iye] Rus[kiy] i Kreolovy," meaning "village of Russians and creoles." "S[eleniye] Skvortsova," meaning "starling village" was published by Capt. Tebenkov (1852, map 23), IRN. Ouzinkie post office was established in 1927.

Oval Island: island, see Easterly Island.

Oval Mountain: hill, $901 \mathrm{ft} ., 1 \mathrm{mi}$. N of mouth of Ayakulik River, $25 \mathrm{mi}$. SW of Karluk, on W coast of Kodiak I. ; $57^{\circ} 12^{\prime} 20^{\prime \prime}$ N, $154^{\circ} 31^{\prime}$. $25^{\prime \prime} \mathrm{W}$; (map 35).

Descriptive local name published in 1943 by USC\&GS

Oval Rock: rock, in Khaz Bay, $6 \mathrm{mi}$. SW of Chichagof, off $\mathrm{W}$ coast of Chichag of $\mathrm{I}$., Alex. Arch.; $57^{\circ} 35^{\prime} 00^{\prime \prime} \mathrm{N}, 136^{\circ} 08^{\prime} 30^{\prime \prime} \mathrm{W}$; BGN 1908; (map 9). Var. Egg Rock.

Descriptive name given in 1908 by USC\&GS, and published in 1909 on Chart 8280.

Over Creek: stream, flows NW 2 mi., from NW of Minnie Creek Lake to Middle Fork Koyukuk River, $3 \mathrm{mi}$. SSW of mouth of Gold Creek and $38 \mathrm{mi}$. W of Chandalar, Bnooks Ra.; $67^{\circ}$. $29^{\prime} 00^{\prime \prime} \mathrm{N}, 149^{\circ} 55^{\prime} 30^{\prime \prime} \mathrm{W}$; BGN 1932; (map 123).

Name reported in 1931 by Marshall (USGS, 1934, pl. 6).

Overhang Point: point of land, at head of Redfish Bay, 10.5 mi. NW of village of Port Alexander, Alex. Arch.; $56^{\circ} 20^{\prime} 40^{\prime \prime} \mathrm{N}, 134^{\circ} 51^{\prime} 30^{\prime \prime}$ W; (map 5)

Named in 1897 by Lt. Comdr. J. F. Moser, USN

Overland Bluff: bluff, elev. $910 \mathrm{ft}$., $\mathrm{W}$ of junc. of Eureka and Baker Creeks, $29 \mathrm{mi}$. S of Rampart, Yukon-Tanana High.; $65^{\circ} 05^{\prime} 30^{\prime \prime} \mathrm{N}$, $150^{\circ} 17^{\prime} 30^{\prime \prime} \mathrm{W}$; BGN 1965; (map 106).
Name reported in 1963 by Bond Taber, USGS, as having "long local usage."

Overland Roadhouse: locality, $4 \mathrm{mi}$. S of Harding Lake and $34 \mathrm{mi}$. NW of Big Delta, YukonTanana High.; 64 $22^{\prime} \mathrm{N}, 146^{\circ} 52^{\prime} \mathrm{W}$; (map 101)

Name of a former roadhouse; reported in 1910 by USGS (Capps, 1912, pl. 1).

Overland Roadhouse: locality, see Fox Farm Lodge.

Oversight Creek: stream, flows NW to join Dividend Greek to form Telegram Creek, in Pilgrim River basin, 21 mi. N of Solomon, Seward Penin. High.; 64 $51^{\circ} 45^{\prime \prime}$ N, $164^{\circ}$. $34^{\prime} 00^{\prime \prime} \mathrm{W}$; (map 95)

Prospectors' name reported in 1908 by P. S. Smith (in Brooks and others, 1909, pl. 10), USGS

Over-The-Hill Portage: portage, $1.5 \mathrm{mi}$. long, across neck of bend in Koyukuk River, $46 \mathrm{mi}$. SW of Roundabout Mtn., Koyukuk Low.; $65^{\circ} 01^{\prime} \mathrm{N}, 157^{\circ} 35^{\prime} \mathrm{W}$; (map 108)

Local name obtained at Huslia by USGS in 1954 or 1955 .

Ovkekok: locality, see Ukivok.

Owalit Mountain: hill, $914 \mathrm{ft} ., 5 \mathrm{mi}$. NW of Bunnell Cape, St. Lawrence I.; $63^{\circ} 26^{\prime} \mathrm{N}$, $171^{\circ} 48^{\prime} \mathrm{W}$; BGN 1951; (map 93). Var. Miyook Mountain.

Eskimo name reported in 1949 by Maj. $\mathrm{H}$. B. Allen, USAF. According to Orth, in 1965, it means "the north one."

Owen, Mount: mountain, 7,820 ft., $9 \mathrm{mi}$. SE of Mount Augusta and $51 \mathrm{mi}$. NW of Yakutat, St. Elias Mts. ; $60^{\circ} 13^{\prime} 30^{\prime \prime} \mathrm{N}, 140^{\circ} 15^{\prime} 00^{\prime \prime} \mathrm{W}$; (map 66).

Named by Russell (1891, p. 139), USGS, for David Dale Owen, 1807-60, American geologist.

Owens: village, see Togiak.

Owens Cabins: locality, on left bank of Coleen River, $11 \mathrm{mi}$. NW of Rabbit Mtn. and 34 mi. $\mathrm{N}$ of Coleen Mtn., Brooks Ra.; 67 ${ }^{\circ} 35^{\prime}$ N, $142^{\circ} 37^{\prime} \mathrm{W}$; (map 121).

Name reported in 1939 by FitzGerald (1944 p. 231), USGS.

Owens Ridge: ridge, $1.5 \mathrm{mi}$. long, on NE side of Attu I., $1.2 \mathrm{mi}$. NE of Winter Lake, Aleutian Is.; $52^{\circ} 56^{\prime} 55^{\prime \prime} \mathrm{N}, 173^{\circ} 01^{\prime} 20^{\prime \prime} \mathrm{E}$; (map 13)

Named by the U.S. Army during its occupation of the island during World War II; name shown on an AMS map published in 1948.

Oweruk Greek: stream, see Kwiniuk River.

Owgootówram Koonga: stream, see Ogotoruk Creek.

Owgootowruk: bluff, see Augutaurak.

Owhat River: stream, heads $\mathrm{N}$ of Molybdenum Mtn. and flows SW $40 \mathrm{mi}$. to Kuskokwim River 3.8 mi. E of Aniak, Kilbuck-Kuskokwim Mts. ; $61^{\circ} 36^{\prime} \mathrm{N}, 159^{\circ} 25^{\prime} \mathrm{W}$; BGN 1948; (map 73). Var. Knowat River, Nowat River, Ohwat River, Okkutweek River, Yukwonilnuk River.

Native name reported by A. G. Maddren, USGS, in 1914. 
Owl Creek: stream, flows SW $1 \mathrm{mi}$. to Zone Creek $7.2 \mathrm{mi}$. SE of Marshall, Nulato Hills; $61^{\circ} 47^{\prime} 25^{\prime \prime} \mathrm{N}, 161^{\circ} 57^{\prime} 45^{\prime \prime} \mathrm{W}$; (map 73).

Prospectors' name reported by Harrington (1918. map), USGS, in 1916.

Owl Creek: stream, anabranch of Yukon River, heads W of Arbor I, flows NW $4.5 \mathrm{mi}$. to Center Slough, $8 \mathrm{mi}$. W of Marshall, YukonKuskokwim Delta; $61^{\circ} 52^{\prime} 30^{\prime \prime} \mathrm{N}, 162^{\circ} 20^{\prime} 00^{\prime \prime}$ W; (map 74). Var. Lithkealiktulik Slough.

This is a partial transiation of an Eskimo name "Lith-ke-a-lik-tu-lik," meaning "many owls," reported by USC\&GS in 1951.

Owl Creek: streamp flows NE $2 \mathrm{mi}$. to Crow Creek, $54 \mathrm{mi}$. S of Eagle, Yukon-Tanana High.; $64^{\circ} 01^{\prime} \mathrm{N}, 141^{\circ} 12^{\prime} \mathrm{W}$; (map 102). Prospectors' name reported in 1903 by T. G. Gerdine, USGS. On early maps the stream is shown flowing to Cherry Creek.

Owl Creek: stream, flows NW $3 \mathrm{mi}$. to Grayling Fork Black River, $34 \mathrm{mi}$. NW of Midnight Hill, Porcupine Plat.; $66^{\circ} 08^{\prime} \mathrm{N}, 142^{\circ} 17^{\prime} \mathrm{W}$ (map 120).

Local name obtained in 1956 by T. $\mathbf{E}$. Taylor and R. C. Foley, USGS.

Owl Creek: stream, flows E $10 \mathrm{mi}$. to Hodzana River $4.5 \mathrm{mi}$. NW of Beaver, Yukon Flats; $66^{\circ} 29^{\prime} 15^{\prime \prime} \mathrm{N}, 147^{\circ} 58^{\prime} 40^{\prime \prime} \mathrm{W}$; (map 118).

Prospectors' name reported in 1902 by Lt. H. Erickson, USA.

Owl Gulch: ravine, extends SE $1.2 \mathrm{mi}$. to Fourth of July Creek, $7 \mathrm{mi}$. SW of that stream's junc. with Yukon River and $33 \mathrm{mi}$. NW of Eagle, Yukon-Tanana High.; $65^{\circ} 07^{\prime} 30^{\prime \prime} \mathrm{N}, 142^{\circ}$. $01^{\prime} 00^{\prime \prime} \mathrm{W}$; (map 103).

Local name published in 1956 by USGS.

Owl High: hills, extend $\mathrm{W} 10 \mathrm{mi}$. just $\mathrm{N}$ of Owl Creek, $23 \mathrm{mi}$. NW of Beaver, KokrinesHodzana High.; $66^{\circ} 29^{\prime} \mathrm{N}, 148^{\circ} 12^{\prime} \mathrm{W}$; (map 118).

Local name obtained in 1956 by USGS

Owl Island: island, $0.8 \mathrm{mi}$. across, in Sea Otter Sound, Alex. Arch.; $55^{\circ} 53^{\prime} \mathrm{N}, 133^{\circ} 25^{\prime} \mathrm{W}$; (map 4)

Named in 1904 by E. F. Dickins, USC\&GS, "for a signal station called Owl located here."

Owl Lake: lake, 0.5 mi. across, on Kenai Penin., $2.6 \mathrm{mi}$. SW of Swanson Lake and $30 \mathrm{mi}$. NE of Kenai, Cook Inlet Low.; $60^{\circ} 48^{\prime} 20^{\prime \prime} \mathrm{N}$, $150^{\circ} 36^{\prime} 30^{\prime \prime} \mathrm{W}$; (map 62).

Named about 1963 by officials of Kenai National Moose Range, probably for Richardson's Owl or the Arctic Saw-whet (Cryptoglaux funerea richardsoni), an owl known to Alaskan Eskimos as "the blind one," because it is almost completely blinded by sunlight (Pearson, 1944, pt. 2, p. 106)

Owl Village: settlement, on right bank of a bend in Kashunuk River, $70 \mathrm{mi}$. W of Marshall, Yukon-Kuskokwim Delta; $61^{\circ} 46^{\prime} \mathrm{N}$, $164^{\circ} 13^{\prime} \mathrm{W}$; (map 74). Var. Anepoungwagavik, Anepangwagavigamiut, Anipaunorovik.

This is a partial translation of an Eskimo village name reported by USC\&GS in 1949. The name is rendered two ways: "Ane-poungwa-ga-vik," reportedly meaning "place like an owl," and "Anepangwagavigamiut," reportedly meaning "people of the owl's place."
Owpuk Creek: stream, see Aupuk Creek.

Oxadak Mountain: mountain, 7,410 ft., $\mathbf{N}$ head of Alinement Creek, $8.5 \mathrm{mi}$. $\mathrm{N}$ of Apoon Mtn., and $43 \mathrm{mi}$. N of Wiseman, Brooks Ra.; $68^{\circ}$. $01^{\prime} 30^{\prime \prime} \mathrm{N}, 150^{\circ} 14^{\prime} 00^{\prime \prime} \mathrm{W}$.

Named in 1939 by Marshall (1956, p. 162) who wrote, "Even more impressive ${ }^{*} *$ was the black mountain *** which I had taken to be Oolah Mtn. Actually it turned out to be a different peak, which we named Oxadak, after a venerable oldster of the Arctic Eskimos."

Oxide Creek: stream, flows NE $2.4 \mathrm{mi}$. to Ophir Creek, $12 \mathrm{mi}$. N of Council and $41 \mathrm{mi}$. SW of Imuruk Lake, Seward Penin. High.; 65 . $04^{\prime} \mathrm{N}, 163^{\circ} 42^{\prime} \mathrm{W}$; (map 110).

'Prospectors' name reported in 1900 by E. C. Barnard (in Brooks, 1901, pl. 17), USGS.

Ox Point: point of land, on Whiting River, 2.6 mi. NE of Port Snettisham and $34 \mathrm{mi}$. SE of Juneau, Coast Mts.; $58^{\circ} 01^{\prime} 30^{\prime \prime}$ N, 133 $39^{\circ}$ $25^{\prime \prime} \mathrm{W}$; (map 12).

Named in 1888 by Lt. Comdr. C. $M$. Thomas, USN.

Oyāgamut: locality, see Oyak.

Oyagaruk Creek: stream, heads in lake, flows SW $5 \mathrm{mi}$. to Avalik River $6.5 \mathrm{mi}$. E of its junc. with Kuk River, $38 \mathrm{mi}$. SE of Wainwright, Arctic Plain; $70^{\circ} 07^{\prime} \mathrm{N}, 159^{\circ} 24^{\prime} \mathrm{W}$; (map 146). Var. Oyararuk.

Eskimo name recorded at Wainwright in 1956 as "Oyararuk," meaning "rocky," by Orth.

Oyagatut Creek: stream, flows NW $2.6 \mathrm{mi}$. to Chukchi Sea, $19 \mathrm{mi}$. E of Point Franklin, Arctic Plain; $70^{\circ} 50^{\prime} 40^{\prime \prime} \mathrm{N}, 157^{\circ} 56^{\prime} 45^{\prime \prime} \mathrm{W}$; (map 147).

Eskimo name reported in 1950 by USC\&GS.

Oyak: locality, on E shore of Kuskokwim Bay at mouth of Oyak Creek, Yukon-Kuskokwim Delta; $59^{\circ} 47^{\prime} \mathrm{N}, 161^{\circ} 57^{\prime} \mathrm{W}$; (map 53). Var. Oyágamut.

Former Eskimo village name, "Oyágamut," obtained in 1898 from missionary John $\mathbf{H}$. Kilbuck by J. E. Spurr and W. S. Post, USGS.

Oyak Creek: stream, distributary, heads at Kanektok River, flows W $25 \mathrm{mi}$. to Kuskokwim Bay, $50 \mathrm{mi}$. NW of Goodnews, YukonKuskokwim Delta; $59^{\circ} 48^{\prime}$ N, $161^{\circ} 57^{\prime} \mathrm{W}$; (map 53).

Name derived from former Eskimo village of Oyak; published in 1951 by USGS.

Oyararuk : stream, see Oyagaruk Creek.

Oyster Rock: rock, on W coast of Kuiu I., in Tebenkof Bay, Alex. Arch.; $56^{\circ} 25^{\prime} 00^{\prime \prime} \mathrm{N}$, $134^{\circ} 09^{\prime} 40^{\prime \prime} \mathrm{W}$; BGN 1929; (map 5).

Named in 1928 by USC\&GS because "oysters were found here at low tide."

Oyukak Creek: stream, heads on $\mathrm{W}$ side of Oyukak Mtn., flows $\mathrm{N} 7 \mathrm{mi}$. to Noatak River, Brooks Ra.; $67^{\circ} 40^{\prime} \mathrm{N}, 155^{\circ} 30^{\prime} \mathrm{W}$; (map 125).

Local name recorded in Kobuk by Orth, USGS, in 1956. It is named for the mountain.

Oyukak Mountain: mountain, $7,310 \mathrm{ft}$., in Schwatka Mts., $18 \mathrm{mi}$. NW of Mount Igikpak,
Brooks Ra.; 67 $34^{\prime}$ N, $155^{\circ} 30^{\prime \prime}$ W; (map 125).

Eskimo name reported to refer in meaning to the glacier or snow cap that covers the top of the mountain. Reported by USGS in 1956.

Oywoonat: point of land, see Chibukak Point Ozernoi: bay, see Orzinski Bay.

Ozerskoy Redut: locality, see Redoubt, The.

\section{$\mathbf{P}$}

Paba, Isla de: island, see Fish Egg Island.

Pablof Harbor: anchorage, see Pavlof Harbor. Pachtolik: locality, see Pastoliak.

Pachtolik: locality, see Pastolik.

Pacific Glacier: glacier, see Grand Pacific Glacier.

Pacific Shoal: shoal, on coast of Beaufort Sea, 5 mi. E of Cape Halkett, at mouth of Harrison Bay, Arctic Plain; $70^{\circ} 46^{\prime} 30^{\prime \prime} \mathrm{N}, 151^{\circ}$ $56^{\prime} 30^{\prime \prime} \mathrm{W}$; (map 149).

Named in 1889 by Capt. C. H. Stockton, USN, for the whaling ship Pacific, whose master, Capt. Knowles, first reported this shoal (Leffingwell, 1919, p. 83-84).

Pack Creek: stream, flows E $8 \mathrm{mi}$. to Seymour Canal, at mouth of Windfall Harbor, on Admiralty I., $27 \mathrm{mi}$. S. of Juneau, Alex. Arch. $57^{\circ} 54^{\prime} 15^{\prime \prime} \mathrm{N}, 134^{\circ} 17^{\prime} 20^{\prime \prime} \mathrm{W}$; (map 9).

Named by USFS in 1939 for Charles Lathrop Pack, "editor of Nature Magazine and president of The American Tree Association." Packer Creek: stream, see Parker Creek.

Packers Creek: stream, heads in lake, flows NW 2 mi. to Naknek River at South Naknek, on Alaska Penin., $1 \mathrm{mi}$. SE of Naknek, Bristol Bay Low.; $58^{\circ} 43^{\prime} 05^{\prime \prime} \mathrm{N}, 156^{\circ} 59^{\prime} 40^{\prime \prime}$ W.; (map 41).

Local name reported in 1952 by USGS.

Packers Creek: stream, heads in Packers Creek Lake, on Kalgin I., flows SE $1 \mathrm{mi}$. to Cook Inlet, $23 \mathrm{mi}$. WSW of Kenai, Cook Inlet Low.; $60^{\circ} 26^{\prime} 30^{\prime \prime} \mathrm{N}, 151^{\circ} 53^{\prime} 50^{\prime \prime} \mathrm{W}$; (map 62)

Local name reported in 1958 by USGS.

Packers Creek Lake: lake, $2 \mathrm{mi}$. long, at head of Packers Creek on Kalgin I., 23 mi. WSW of Kenai, Cook Inlet Low.; $60^{\circ} 28^{\prime} \mathrm{N}, 151^{\circ} 55^{\prime}$ W ; (map 62).

Local name reported in 1958 by USGS.

Packers Spit: spit, $0.8 \mathrm{mi}$. long, at mouth of East Arm Uganik Bay, on $\mathrm{N}$ coast of Kodiak I.; $57^{\circ} 44^{\prime} 30^{\prime \prime} \mathrm{N}, 153^{\circ} 30^{\prime} 00^{\prime \prime} \mathrm{W}$; (map 34). Var. Uganuk Spit.

Descriptive name published in 1943 by USC\&GS. A fish-packing plant was located here in the late 1800 's. This feature was called "Uganuk Spit" [for Uganik Island] in 1897 by Lt. Comdr. J. F. Moser, USN, of the USRF steamer Albatross.

Pack Gulch: ravine, extends $1.2 \mathrm{mi}$. NE to Nizina River W of its junc. with Chitistone River, $11 \mathrm{mi}$. E of McCarthy, Wrangell Mts.; $61^{\circ} 27^{\prime} 00^{\prime \prime} \mathrm{N}, 142^{\circ} 36^{\prime} 35^{\prime \prime} \mathrm{W}$; (map 67)

Local name obtained by USGS and published on maps since 1954

Pack Lake: lake, $0.5 \mathrm{mi}$. long, on Kenai Penin., $\mathrm{N}$ of Skilak Lake, $0.9 \mathrm{mi}$. W of Engineer Lake 
and $30 \mathrm{mi}$. E of Kenai, Cook Inlet Low.; $60^{\circ} 28^{\prime} 45^{\prime \prime} \mathrm{N}, 150^{\circ} 21^{\prime} 15^{\prime \prime} \mathrm{W}$; (map 62).

Named about 1963 by officials of Kenai National Moose Range, for administrative purposes.

Pack River: stream, see Ambler River.

Pack Sack Creek: stream, flows SE $9 \mathrm{mi}$. to Buckland River, $47 \mathrm{mi}$. NE of Haycock, Nulato Hills; $65^{\circ} 50^{\prime} \mathrm{N}, 160^{\circ} 36^{\prime} \mathrm{W}$; (map 109).

Local name published on maps after 1950.

Packsaddle Gulch: ravine, extends $2 \mathrm{mi}$. up $\mathrm{S}$ slope of Strelshla Mtn., $40 \mathrm{mi}$. NE of Palmer, Talkeetna Mts.; $61^{\circ} 48^{\prime} 25^{\prime \prime} \mathrm{N}, 147^{\circ} 58^{\prime} 45^{\prime \prime}$ W; (map 69).

Local name reported in 1931 by USGS.

Packsaddle Island: nunatak, 5,640 ft., in Kennicott Glacier, $16 \mathrm{mi}$. NW of McCarthy, Wrangell Mtns.; BGN 1966; $61^{\circ} 38^{\prime} 45^{\prime \prime} \mathrm{N}$, $143^{\circ} 07^{\prime} 30^{\prime \prime} \mathrm{W}$; (map 67).

Named in 1965 by the Mountaineering Club of Alaska, "because its shape resembles a crosstree packsaddle used by pioneer miners."

Packwood Lake: lake, $300 \mathrm{ft}$., long, on Kenai Penin., $0.8 \mathrm{mi}$. S of Eagle Lake and $19 \mathrm{mi}$. NE of Homer, Gook Inlet Low.; 59 $48^{\circ} 50^{\prime \prime}$ N, $151^{\circ} 08^{\prime} 15^{\prime \prime} \mathrm{W}$; (map 50).

Local name reported and published by USGS in the 1950's.

Paddle Creek: stream, flows E $10 \mathrm{mi}$. to Little Black River, 48 mi. SE of Chalkyitsik, Porcupine Plat.; $66^{\circ} 02^{\prime} 30^{\prime \prime} \mathrm{N}, 143^{\circ} 04^{\prime} 00^{\prime \prime} \mathrm{W}$; (map 120).

Local name obtained in 1956 by T. E. Taylor and R. C. Foley, USGS.

Paddle Lake: lake, 1.1 mi. long, on Kenai Penin. between Chick and Channel Lakes, $30 \mathrm{mi}$. $\mathrm{NE}$ of Kenai, Cook Inlet Low.; $60^{\circ} 46^{\prime} 00^{\prime \prime} \mathrm{N}$, $150^{\circ} 30^{\prime} 20^{\prime \prime} \mathrm{W}$; (map 62).

Named about 1963 by officials of Kenai National Moose Range, for administrative purposes.

Paddle Lake: lake, $1 \mathrm{mi}$. long, $3 \mathrm{mi}$. NW of junc. of Ishuktak Creek and Topagoruk River, $36 \mathrm{mi}$. SE of village of Meade River, Arctic Plain; $70^{\circ} 11^{\prime} \mathrm{N}, 156^{\circ} 05^{\prime} \mathrm{W}$; (map 147).

Name published in 1966 by USGS.

Paddle Mountain: peak, 4,720 ft., $4 \mathrm{mi}$. NW of Arctic Village, Brooks Ra.; $68^{\circ} 09^{\prime} \mathrm{N}, 145^{\circ} 42^{\prime}$ W; (map 136).

Local name reported in 1956 by $R$. C. Foley, USGS.

Paddy Bay: estuary, on E coast of Kenai Penin., extends SE $2.5 \mathrm{mi}$. to Dangerous Passage, 7.5 mi. N of Chenega, Chugach Mts.; 60 $23^{\prime} 15^{\prime \prime}$ $\mathrm{N}, 148^{\circ} 04^{\prime} 30^{\prime \prime} \mathrm{W}$; (map 63).

Local name reported in 1905 by U.S. Grant, USGS.

Paddy Point: point of land, on an island at mouth of Paddy Bay, on W side of Dangerous Passage, $7.5 \mathrm{mi}$. N of Chenega, Chugach Mts.; $60^{\circ} 23^{\prime} 15^{\prime \prime} \mathrm{N}, 148^{\circ} 04^{\prime} 00 \mathrm{~W}$; BGN 1934; (map 63).

Named in 1933 by a USCi\&GS field party for nearby Paddy Bay.

Pad Island: island, $0.5 \mathrm{mi}$. across, on $\mathbf{S}$ coast of Alaska Penin., off E shore of Stepovak Bay, Aleutian Ra.; $55^{\circ} 44^{\prime} 20^{\prime \prime} \mathrm{N}, 159^{\circ} 41^{\prime} 00^{\prime \prime} \mathrm{W}$; (map 27).
Local name published by USC\&GS in 1947 Coast Pilot (v. 2, p. 305)

Page Mountain: mountain, $3,315 \mathrm{ft}$., $32 \mathrm{mi}$. NW of Medfra, Kilbuck-Kuskokwim Mts.; $63^{\circ} 22^{\prime}$ $N, 155^{\circ} 35^{\prime} \mathrm{W}$; (map 89).

Local name reported in 1954 by USGS.

Pagilak River: stream, heads E of Whale Mtn., flows $15 \mathrm{mi}$. NW to Kongakut River, $23 \mathrm{mi}$. SW of Demarcation Point, Brooks Ra.; $69^{\circ} 22^{\prime}$. N, $141^{\circ} 33^{\prime} \mathrm{W}$; (map 138).

Eskimo name recorded on Barter I. in 1952 by USC\&GS.

Pagomawik Pass: watercourse, see Bugomowik Pass.

Paguna Arm: bay, $2.7 \mathrm{mi}$. wide and $5 \mathrm{mi}$. long, on SE coast of Kenai Penin., $50 \mathrm{mi}$. E of Homer, Chugach Mts.; $59^{\circ} 36^{\prime} 30^{\prime \prime}$ N, $150^{\circ}$ $04^{\prime} 00^{\prime \prime} \mathrm{W}$; BGN 1930; (map 50).

Local Indian name reported by USC\&GS, in 1930, to mean "black bear."

Pah: locality, on Kobuk at mouth of Pah River; $66^{\circ} 46^{\prime} \mathrm{N}, 156^{\circ} 03^{\prime} \mathrm{W}$; (map 115). Var. Par.

Former Eskimo village or camp spelled "Par" in 1885 by Lt. Stoney (1900, map), USN, and the same year spelled "Pah" by Lt. Cantwell (1885, p. 31), USRCS. See Pah River.

Pahls-chat-nok: stream, see Mulchatna River. Pah Rapids: rapids, in the Kobuk River at mouth of Pah River; $66^{\circ} 46^{\prime} \mathrm{N}, 156^{\circ} 03^{\prime} \mathrm{W}$; (map 115). Var. Par Rapids.

Name reported, and probably given, by $L t$. J. C. Cantwell, USRCS, in 1885. See Pah River.

Pah River: stream, heads at $66^{\circ} 34^{\prime} \mathrm{N}, 155^{\circ} 09^{\prime}$ W, flows W $55 \mathrm{mi}$. to Kobuk River $32 \mathrm{mi}$. SE of Shungnak, Kotzebue-Kobuk Low.; $66^{\circ} 46^{\prime} \mathrm{N}, 156^{\circ} 03^{\prime} \mathrm{W}$; (map 115). Var. Chok-way-chok, Par River, Shok-ah-bokshegiak.

Eskimo name meaning "stream mouth [pang, pai]" probably applied to the stream by Lt. G. M. Stoney, USN, in 1885 , and spelled by him "Par." According to Lt. Cantwell (1885, p. 31), USRCS, the Eskimo name for the stream was "Chok-way-chok" (also spelled "Shok-ah-bok-shegiak") which he says refers to the "rapid current" at the stream's mouth. See Pah Rapids.

Pah River Flats: swamp, $10 \mathrm{mi}$ across, in basin between Zane and Lockwood Hills, $50 \mathrm{mi}$. NW of Hughes, Hogatza High.; $66^{\circ} 25^{\prime} \mathrm{N}$, $155^{\circ} 50^{\prime} \mathrm{W}$; (map 116).

Locally named for the river and published by USGS in 1956.

Pahron Creek: stream, flows $14 \mathrm{mi}$. NW to Meade River, 95 mi. SE of Wainwright, Arctic Slope; $69^{\circ} 33^{\prime} \mathrm{N}, 157^{\circ} 32^{\prime} \mathrm{W}$; BGN 1949; (map 143).

Eskimo name reported by USGS in 1949. Paiiqaaglim Kuugaqzanga: stream, see Payikaglim Creek.

Paimiut: locality, on Kokechik Bay, on $E$ bank at mouth of Lithkealik River, 11 mi. SE of Cape Romanzof, Yukon-Kuskokwim Delta; $61^{\circ} 42^{\prime} \mathrm{N}, 165^{\circ} 50^{\prime} \mathrm{W}$; (map 75).

Eskimo name referring to the "people of the stream's mouth" reported by USC\&GS in
1951. At that time the name applied to "two groups of two or three frame houses each, about a quarter of a mile apart."

Paimiut: locality, see Bimiut.

Paimiut: locality, see Paimute.

Paimiut: settlement, on $\mathrm{N}$ bank of Yukon River, $22 \mathrm{mi}$. SW of Holy Cross, Nulato Hills; $61^{\circ}$. $58^{\prime} \mathrm{N}, 160^{\circ} 14^{\prime} \mathrm{W}$; (map 73). Var. Kuyikanuikpul, Paimjut, Paimut, Paimute, Pimute.

This is a common Eskimo name, meaning "people of the stream's mouth," published in Russian in 1861 by P. Tikhmeniev, presumably from information received from Lt. $L$. A. Zagoskin, IRN, in 1842-44. Ivan Petroff lists "Paimute," population.50, in the 1830 Census. It may be the same place Capt. Raymond (1871, p. 25), USA, calls "Kuyikanuikpul." The village was originally located across the river, but was moved to higher ground about 1915. Hrdlicka (1943, p. 225) reports four villages with this name, in this vicinity, occupied at different seasons.

Paimute: locality, on right bank of Kuskokwim River, about $22 \mathrm{mi}$. NE of Bethel, YukonKuskokwim Delta; (map 59). Var. Paimiut, Paimut.

Eskimo camp or settlement reported by the Russians who recorded the name as "Paimut." See Piamiut above. In 1861, P. Tikhmeniev, historian of the Russian Amelican Company, placed the settlement on the left bank of the river. Its exact location is unknown. The population was 30 in 1880 ; but was probably abandoned shortly thereafter.

Paimiut Hills: ridge, 1,200 ft., extends $20 \mathrm{mi}$. along right bank of Yukon River, between Big Bend and Tuckers Sloughs, $12 \mathrm{mi}$. SW of Holy Cross, Nulato Hills; $62^{\circ} 00^{\prime} \mathrm{N}, 160^{\circ} 13^{\prime}$ W; (map 78).

Local name reported in 1916 by G. L. Harrington and R. H. Sargent (in Harrington, 1918, pl. 1), USGS.

Paimiut Island: island, $4.8 \mathrm{mi}$. long, in Yukon River, 17 mi. SW of Holy Cross, Innoko Low.; $61^{\circ} 58^{\prime} \mathrm{N}, 160^{\circ} 05^{\prime} \mathrm{W}$; (map 73). Var. Great Paimiut Island.

Named for the village; shown on a 1916 field sheet by R. H. Sargent, USGS.

Paimiut Mountain: hill, $671 \mathrm{ft}$, , on right bank of Yukon River, $\mathrm{E}$ of Paimiut and $40 \mathrm{mi}$. ENE of Russian Mission, Nulato Hills; 61 ${ }^{\circ} 58^{\prime} \mathrm{N}$, $160^{\circ} 13^{\prime} \mathrm{W}$; (map 73).

Riverboat pilots' name shown on a 1922 manuscript chart of Yukon River.

Paimiut Slough: watercourse, distributary of Innoko River, flows SW $70 \mathrm{mi}$. to Yukon River SW of Great Paimiut I. and $21 \mathrm{mi}$. SW of Holy Cross, Innoko Low.; 61 ${ }^{\circ} 56^{\prime} 25^{\prime \prime} \mathrm{N}$, $160^{\circ} 08^{\prime} 35^{\prime \prime} \mathrm{W}$; (map 73 ).

Named for the village; shown on Edwards' Track Chart of the Yukon, 1899, as "Pimute." Paimiut Slough: watercourse, see Summer Slough.

Paimjut: settlement, see Paimiut.

Paimut: locality, see Paimute.

Paimut: settlement, see Paimiut.

Paimute: settlement, see Paimiut.

Paimute Slough: stream, see Innoko Slough. 
Pain du Sucre: promontory, see Sugarloaf Mountain.

Paingakmeut: settlement, on left bank of Johnson River, $\mathrm{N}$ of mouth of Pikmiktalik River and $17 \mathrm{mi}$. W of Bethel, Yukon-Kuskokwim Delta; $60^{\circ} 45^{\prime} 45^{\prime \prime} \mathrm{N}, 162^{\circ} 14^{\prime} 45^{\prime \prime} \mathrm{W}$; (map 58).

Eskimo camp or small settlement listed in the 1950 Census with a population of 44 .

Painorouyun Slough: stream, flows NW $4.5 \mathrm{mi}$. to Hooper Bay, $4.3 \mathrm{mi}$. W of Keoklevik River, Yukon-Kuskokwim Delta ; $61^{\circ} 25^{\prime} \mathrm{N}, 165^{\circ} 54^{\prime}$ W; (map 75).

Eskimo name reported by USC\&GS in 1951. Painted Mountain: mountain, see Painted Peak. Painted Mountain: peak, 2,920 ft., on E bank of Soluka Creek, on Alaska Penin. in Katmai National Monument, $11 \mathrm{mi}$. SE of Mount Katmai, Aleutian Ra.; $58^{\circ} 07^{\prime} 00^{\prime \prime} \mathrm{N}, 154^{\circ} 51^{\prime}$ $30^{\prime \prime} \mathrm{W}$; BGN 1924; (map 42).

So named in 1916 by R. F. Griggs, National Geographic Society, "because of its varied colors."

Painted Peak: mountain, 1,500 ft., on Revillagigedo I., $1 \mathrm{mi}$. E of Carroll Inlet and $5 \mathrm{mi}$. $\mathrm{N}$ of Thorne Arm, Alex. Arch., 55 $27^{\prime} 45^{\prime \prime} \mathrm{N}$, $131^{\circ} 15^{\prime} 25^{\prime \prime} \mathrm{W}$; BGN 1923; (map 3). Var. Painted Mountain.

Named in 1923 by USFS.

Painter Creek: stream, flows NW $13 \mathrm{mi}$. to King Salmon River, $1 \mathrm{mi}$. W of Mother Goose Lake, on Alaska Penin., $22 \mathrm{mi}$. S of Ugashik, Bristol Bay Low.; $57^{\circ} 13^{\prime} 20^{\prime \prime} \mathrm{N}, 157^{\circ} 25^{\prime} 15^{\prime \prime} \mathrm{W}$; (map 36).

Named in 1923 by R. H. Sargent, USGS, for "Al Painter," cook for Sargent's and earlier USGS expeditions.

Painter Point: point of land, at the confluence of Mason and Clayhill Sloughs, $\mathrm{N}$ of Clay I., $10 \mathrm{mi}$. E of Birches, Kokrines-Hodzana High.; $65^{\circ} 07^{\prime} 45^{\prime \prime} \mathrm{N}, 153^{\circ} 13^{\prime} 00^{\prime \prime} \mathrm{W}$; (map 107).

Riverboat pilots' name shown on a 1940 "Navigation Chart of the Tanana-Yukon Rivers" published by the Department of Interior.

Painter Slough: stream, flows W $1 \mathrm{mi}$. from Yukon River to Mason Slough, $\mathrm{N}$ of Painter Point and $10 \mathrm{mi}$. E of Birches, KokrinesHodzana High.; $65^{\circ} 09^{\prime} 00^{\prime \prime} \mathrm{N}, 1^{\circ} 3^{\circ} 13^{\prime} 30^{\prime \prime}$ W; (map 107).

Riverboat pilots' name shown on a 1940 "Navigation Chart of the Tanana-Yukon Rivers" published by the Department of the Interior.

Paint River: stream, formed by its Middle and South Forks, flows E $17 \mathrm{mi}$. to Akjemguiga Cove in Kameshak Bay, $27 \mathrm{mi}$. SE of Kakhonak, Aleutian Ra.; 59 $09^{\prime} 30^{\prime \prime} \mathrm{N}, 154^{\circ} 14^{\prime}$ $30^{\prime \prime} \mathrm{W}$; (map 51).

Name published by K. F. Mather (in Brooks and others, 1925, pl. 3), USGS.

Paiyun Creek: stream, flows SE $12 \mathrm{mi}$. to Kanektok River, $70 \mathrm{mi}$. NE of Goodnews,

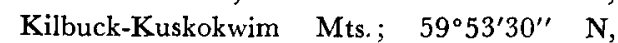
$160^{\circ} 23^{\prime} 05^{\prime \prime} \mathrm{W}$; (map 53).

Eskimo name published in 1951 by USGS.
Pajara Creek: stream, flows SW $6 \mathrm{mi}$. to Eldorado River, 15 mi. NW of Solomon, Seward Penin. High.; $64^{\circ} 40^{\prime} 30^{\prime \prime} \mathrm{N}, 164^{\circ} 54^{\prime} 00^{\prime \prime} \mathrm{W}$; (map 95). Var. Pajaro Creek.

Prospectors' name reported in 1900 by E. C. Barnard (in Brooks, 1901, pl. 17), USGS. Pajara Creek: stream, see Rabbit Creek.

Pajaro Creek: stream, see Pajaro Creek.

Pakenham Point: point of land, between Barry Arm Port Wells and College Fiord, $63 \mathrm{mi}$. SE of Anchorage, Chugach Mts.; 61 ${ }^{\circ} 20^{\prime} \mathrm{N}$, $148^{\circ} 04^{\prime} \mathrm{W}$; (map 69).

Named in 1794 by Capt. George Vancouver, RN, probably for Sir Thomas Pakenham, the commander of the West Indies station in 1786, while Vancouver was serving there (Wagner, 1937, p. 401).

Palarzook: locality, see Pelazuk.

Palazruk: locality, sec Pelazuk.

Paldo Creek: stream, flows NW $17 \mathrm{mi}$. to Salcha River $1.2 \mathrm{mi}$. SW of junc. of Lost Greek and $60 \mathrm{mi}$. NE of Big Delta, Yukon-Tanana High.; $64^{\circ} 49^{\prime} \mathrm{N}, 144^{\circ} 33^{\prime} \mathrm{W}$; (map 101).

Local name reported in 1958 by USGS.

Palisade Cliffs: cliffs, on N shore of Ikatan Bay, Aleutian Ra.; $54^{\circ} 48^{\prime} 40^{\prime \prime} \mathrm{N}, 163^{\circ} 20^{\prime} 00^{\prime \prime} \mathrm{W}$; (map 25).

Name published in 1912 by USC\&GS.

Palisade Island: island, $0.5 \mathrm{mi}$. across, in San Christoval Channel, $\mathrm{N}$ of San Fernando I., Alex. Arch.; 55 $34^{\prime} 15^{\prime \prime}$ N, $133^{\circ} 22^{\prime} 15^{\prime \prime}$ W; (map 4).

Name published in 1925 Coast Pilot (p. 146); derived from Palisade Point.

Palisade Lagoon: lagoon, $0.2 \mathrm{mi}$. wide, at $\mathrm{N}$ end of Surprise Bay, on SE coast of Kenai Penin., $38 \mathrm{mi}$. ESE of Homer, Chugach Mts.; $59^{\circ}$ $31^{\prime} \mathrm{N}, 150^{\circ} 29^{\prime} \mathrm{W}$; BGN 1929; (map 50).

So named by USC\&GS in 1927 , for nearby Palisade Peak.

Palisade Peak: peak, 3,442 ft., in Kenai Mts., $38 \mathrm{mi}$. ESE of Homer, Chugach Mts.; 59 ${ }^{\circ}$ $33^{\prime} \mathrm{N}, 150^{\circ} 29^{\prime} \mathrm{W}$; BGN 1929; (map 50).

Named by USC\&GS in 1927 as a suitable name for the peak because it "is a rugged peak and shows prominently."

Palisade Point: point of land, $\mathrm{N}$ tip of island in San Christoval Channel, $\mathbf{N}$ of Palisade I., on $\mathrm{N}$ coast of San Fernando I., Alex. Arch.; $55^{\circ} 34^{\prime} 30^{\prime \prime} \mathrm{N}, 133^{\circ} 22^{\prime} 00^{\prime \prime} \mathrm{W}$; (map 4). Var. Mys de la Yempalizda, Punta de la Empalizada, Punta Empalizada.

Translation of the name "Punta de la Empalizada" given in $1775-79$ by Don Juan de la Bodega y Quadra and Francisco Antonio Maurelle.

Palisades, The: bluffs, on left bank of Yukon River, extend E from Weir I. to Lange I., 9 mi. SW of Kallands, Nowitna Low.; $65^{\circ} 06^{\prime}$ $30^{\prime \prime} \mathrm{N}, 153^{\circ} 20^{\prime} 00^{\prime \prime} \mathrm{W}$; (map 107).

Named in 1885 by Lt. H. T. Allen, USA. Palisades Point: point of land, on $\mathrm{N}$ shore of Nazan Bay, on $\mathrm{E}$ coast of Atka I., Aleutian Is. ; $52^{\circ} 13^{\prime} 35^{\prime \prime} \mathrm{N}, 174^{\circ} 09^{\prime} 15^{\prime \prime} \mathrm{W}$; (map 18). Descriptive name published by the USC\&GS in the 1944 Aleutian Coast Pilot (p. 100), applied because of the point's "prominent, rocky bluffs."

Palley Creek: stream, flows S $12 \mathrm{mi}$. to Nushagak River, $88 \mathrm{mi}$. S of Sleetmute, KilbuckKuskokwim Mts.; $60^{\circ} 29^{\prime}$ N, 156 $59^{\prime}$ W; (map 60).

Local name reported in 1952 by USC\&GS.

Palma Bay: bight, $7 \mathrm{mi}$. across, in Glacier Bay National Monument, on Gulf of Alaska, between Icy Point and Boussole Bay, $60 \mathrm{mi}$. NW of Hoonah, St. Elias Mts.; $58^{\circ} 23^{\prime} \mathrm{N}, 137^{\circ} 00^{\prime}$ W; (map 10). Var. Ice Bay, Icy Bay.

Named "Baia de Palma" in 1792 by Capt. Alessandro Malaspina (U.S. Coast and Geodetic Survey, 1883, p. 201). See Wagner (1937, p. 481).

Palmer: town, pop. 1,181, in Matanuska Valley, $37 \mathrm{mi}$. NE of Anchorage, Cook Inlet Low.; $61^{\circ} 36^{\prime} 00^{\prime \prime}$ N, $149^{\circ} 06^{\prime} 30^{\prime \prime}$ W; (map 69). Var. Farmington, Palmer Siding, Warton.

Agricultural supply town, established as a railroad station on the Matanuska Branch of The Alaska RR. about 1916. The Palmer post office was established in 1917; discontinued in 1925. The Warton post office operated here from 1931 to 1935 , and was then changed back to Palmer in 1935 (Ricks, 1965, p. $49,50,70)$. The town became the center of the Alaska Rural Rehabilitation Corporation administered by the U.S. Dept. of the Interior, the supply center of a colony of about 180 farm families from midwest United States in the 1930's. Its population was 150 in 1939 and 890 in 1950 . It is thought to have been named for George Palmer, trader in the Knik Arm area in the late 1800's.

Palmer, Mount: mountain, 6,940 ft., E of Hunter Creek Glacier, $25 \mathrm{mi}$. SE of Palmer, Chugach Mts.; $61^{\circ} 19^{\prime} 15^{\prime \prime} \mathrm{N}, 148^{\circ} 39^{\prime} 20^{\prime \prime} \mathrm{W}$; (map 69).

Local name reported in 1960 by USGS.

Palmer Greek: stream, on Kenai Penin., flows $\mathrm{S} 2.5 \mathrm{mi}$. to a marsh $1 \mathrm{mi}$. NE of Beluga Lake, 3 mi. NE of Homer, Cook Inlet Low.; 59 $39^{\prime}$ $\mathrm{N}, 151^{\circ} 28^{\prime} \mathrm{W}$; (map 50 ).

Local name reported and published by USGS since 1950.

Palmer Creek: stream, on Kenai. Penin., flows NW $11 \mathrm{mi}$. to Resurrection Creek, $4.5 \mathrm{mi}$. S of Hope, Chugach Mts.; $60^{\circ} 51^{\prime} 15^{\prime \prime} \mathrm{N}, 149^{\circ}$ $37^{\prime} 55^{\prime \prime} \mathrm{W}$; (map 63).

Local name reported in 1895 by Becker (1898, p. 82), USGS.

Palmer Creek: stream, flows E $1 \mathrm{mi}$. to Shoup Bay, $0.1 \mathrm{mi}$. S of terminus of Shoup Glacier, $11.6 \mathrm{mi}$. NW of Valdez, Chugach Mts.; $61^{\circ}$ $08^{\prime} 25^{\prime \prime} \mathrm{N}, 146^{\circ} 36^{\prime} 25^{\prime \prime} \mathrm{W}$; (map 68).

Prospectors' name reported in 1911 by USGS.

Palmer Creek: stream, flows S $5.8 \mathrm{mi}$. to Knik River, $\mathrm{E}$ of Glenn Highway, $7 \mathrm{mi}$. SE of Palmer, Cook Inlet Low.; $61^{\circ} 31^{\prime} 10^{\prime \prime}$ N, $148^{\circ} 58^{\prime}$ 05" W; (map 69).

Local name reported in 1942 by AMS.

Palmer Creek: stream, flows NW 5 mi. to East Fork Chena River, $69 \mathrm{mi}$. SW of Circle, Yukon-Tanana High.; $65^{\circ} 01^{\prime} 45^{\prime \prime} \mathrm{N}, 145^{\circ} 29^{\prime} 10^{\prime \prime}$ W; (map 104). 
Named by prospectors; reported in 1911 by E. A. Porter (in Brooks and others, 1912, p. 244), USGS.

Palmer Creek: stream, see Coeur d'Alene Creek. Palmer Siding: town, see Palmer.

Palmer Slough: stream, flows SW $8 \mathrm{mi}$. from junc. of Rabbit Slough and Spring Greek to N shore of Knik Arm, Cook Inlet Low. ; 61 ' 30' $\mathrm{N}, 149^{\circ} 27^{\prime} \mathrm{W}$; (map 69).

Local name published on D. H. Sleem's 1910 map of central Alaska; derived from Palmer's trading post that was in the area.

Palmers Store: village, see Knik.

Palmito, Punta: point of land, "on the south side of San Juan Bautista Island, Bucareli Bay," Alex. Arch.; $55^{\circ} 24^{\prime} \mathrm{N}, 133^{\circ} 17^{\prime} \mathrm{W}$; (map 4).

Spanish name meaning "little palm point" shown on a "plano" probably by José de Cañizares in 1779. See Wagner (1937, p. 481).

Palm Point: point of land, on S coast of Alaska, on $W$ end of Katalla Bay, $1.7 \mathrm{mi}$. SW of Katalla, Malaspina Coastal Plain; $60^{\circ} 11^{\prime} \mathrm{N}$, $144^{\circ} 33^{\prime} \mathrm{W}$; (map 64).

Local name reported in 1904 by Martin (1905, pl. 3), USGS.

Palmtree Islands: islands, $0.2 \mathrm{mi}$. across, off $\mathrm{W}$ shore of Islas Bay, $16 \mathrm{mi}$. NW of Chichagof, off $W$ coast of Chichagof I., Alex. Arch.; $57^{\circ}$ $49^{\prime} 10^{\prime \prime} \mathrm{N}, 136^{\circ} 24^{\prime} 30^{\prime \prime} \mathrm{W}$; (map 9).

Name published in 1928 by USC\&GS on Chart 8258.

Palo Alto Heights: ridge, see Chicken Ridge. Palo Cano, Punta: point of land, "in Bucareli Bay, east side of San Fernando Island," Alex. Arch.; (map 4).

Spanish name shown on a "plano" probably by José de Gañizares in 1779 . See Wagner (1937, p. 481).

Paloma Pass: water passage, $0.7 \mathrm{mi}$. long, near W end of Port Real Marina, between Lulu and Pigeon Is., Alex. Arch.; 55 $26^{\prime}$ N, $133^{\circ} 33^{\prime}$ W; BGN 1923; (map 4).

Spanish word meaning "pigeon" given in 1923 by USC\&GS.

Palomas, Isla: island, see Pigeon Island.

Palomas, Ostrov de: island, see Pigeon Island.

Palonoi Point: point of land, "on the mainland, very near Point Rothsay, at mouth of Stikine river. Named Palonoi (fired) by Basargin, of the Rynda party, 1836" (Baker, 1906, p. 488).

Paltchikatno: locality, on Innoko River near junc. of Dishna River, Innoko Low.; $63^{\circ} 36^{\prime} \mathrm{N}$, $157^{\circ} 17^{\prime} \mathrm{W}$; (map 90). Var. Tichaïchachass.

Former Indian village reported in 1850 as "Paltchikatno ou Tichaïchachass" on Lt. L. A. Zagoskin's map.

Paltusey, Mys: point of land, see Halibut Point. Pamatairutmut: locality, on left bank of Kanektok River, $10 \mathrm{mi}$. E of Kwinhagak and $48 \mathrm{mi}$. $\mathrm{N}$ of Goodnews, Yukon-Kuskokwim Delta $59^{\circ} 48^{\prime} \mathrm{N}, 161^{\circ} 38^{\prime} \mathrm{W}$; (map 53).

Eskimo name was shown as a locality on an 1898 fieldsheet by W. S. Post, USGS.

Pamela, Mount: Peak, see Brooks, Mount.

Pamichtuk Lake: laké, $1 \mathrm{mi}$. long, at head of Mashooshalluk Creek, $7 \mathrm{mi}$. SE of Cairn Mtn. and $61 \mathrm{mi}$. NW of Wiseman, Brooks Ra.; $67^{\circ}$ $46^{\prime} \mathrm{N}, 152^{\circ} 12^{\prime} \mathrm{W}$; BGN 1932; (map 124).

An Eskimo word said to mean "other" reported by Robert Marshall in 1932.

Pamiek Lake: lake, see Nerka, Lake.

Pamplona, Bajo: reef, in Gulf of Alaska, off Mt. Elias; (map 47). Var. Orel Rocks, Pamplona Bank, Pamplona Rocks, Roca Pamplona.

This reef seems to have been first reported July 15, 1779, by José de Cañizares. Several other diaries of the Spanish expedition also mention the reef although Don Ignacio Arteaga and one of the others expressed opinions that it was only some white wood floating on the water. On Camacho's map of the expedition, the shoal appears at about $59^{\circ} 10^{\prime} \mathrm{N}$ off Mount St. Elias (Wagner, 1937, p. 481). Capt. Vancouver, (1798, v. 3, p. 225), RN, refers to it as "Roca Pamplona of the Spaniards." Capt. Tebenkov, IRN, relates that Talin, mate of the Russian vessel Orel, meaning "Eagle," saw it in 1794 and named it "Orel" after his ship (Baker, 1906, p. 488). This feature was never subsequently found and what was seen may have been a tide rip and discolored water, which is common in this area, or a grounded mass of ice from Malaspina Glacier, which was more extensive then.

Pamplona Bank: reef, see Pamplona, Bajo.

Pamplona Rocks: reef, see Pamplona, Bajo.

Panamaroff Creek: stream, heads in lake, flows $\mathrm{NE} 1 \mathrm{mi}$. to head of Womens Bay, $8.5 \mathrm{mi}$. SW of Kodiak, Kodiak I. ; $57^{\circ} 42^{\prime} 00^{\prime \prime}$ N, $152^{\circ}$ $33^{\prime} 50^{\prime \prime}$ W; BGN 1965; (map 34). Var. Lost Creek.

Probably named for Cornelius Panamaroff, 1880[?]-1930, a native of Kodiak.

Panaphahgrock: mountain, see Panapkagrak Mountain.

Panapkagrak Mountain: mountain, 2,460 ft., $\mathrm{W}$ of Wulik River, $40 \mathrm{mi}$. NE of Kivalina, Brooks Ra.; $68^{\circ} 05^{\prime} \mathrm{N}, 163^{\circ} 19^{\prime} \mathrm{W}$; (map 130). Var. Panaphahgrock, Panapkarroak Mountain. Descriptive Eskimo name meaning "old tent" reported as "Panapkarroak Mountain" in 1960 by D. C. Foote.

Panapkarroak Mountain: mountain, see Panapkagrak Mountain.

Pancake Creek: stream, see Pennant Creek.

Pancake Rock: island, $0.4 \mathrm{mi}$. across, $3 \mathrm{mi}$. W of Cape Starr, on W coast of Umnak I., Aleutian Is.; $52^{\circ} 56^{\prime} 07^{\prime \prime} \mathrm{N}, 169^{\circ} 01^{\prime} 45^{\prime \prime} \mathrm{W}$; $B G N$ 1940; (map 21).

Descriptive name given in 1938 by USC\&GS.

Pan de Azucar: mountain, see Augustine Volcano.

Pandora Peak: mountain peak, 6,214 ft., $2 \mathrm{mi}$ $\mathrm{SE}$ of Flandreau Mountain and $22 \mathrm{mi}$. NW of Valdez, Chugach Mts.; $61^{\circ} 19^{\prime} 34^{\prime \prime} \mathrm{N}, 146^{\circ} 43^{\prime}$. 18" W; BGN 1965; (map 68)

Named about 1959 by Nielson (1963, p. 135) for Pandora of Greek mythology; a woman given a box by Zeus from which all human ills escaped when she opened it.

Pandorga, Punta de: point of land, in the Prince William Sound area.
Spanish name meaning "fat (bulky) point" shown on an unidentified manuscript map presumably copied from a Spanish map. The name is found on no other source.

Pangengi Creek: stream, see Panguingue Creek.

Pangokepuk River: stream, see Pungokepuk Creek.

Pangokeput: lake, see Pungokepuk Lake.

Pangokeput River: stream, see Pungokepuk Creek.

Panguingue Creek: stream, flows NE $8 \mathrm{mi}$. to Nenana River, $6 \mathrm{mi}$. NW of Healy, Alaska Ra.; 6356 $30^{\prime \prime}$ N, 149 $03^{\prime} 25^{\prime \prime} \mathrm{W}$; (map 87). Var. Pangengi Creek.

Named for the Philippine card game; reported in 1952 as "Pangengi Creek" by USGS.

Panhandle Island: island, in South Pass, $\mathbf{S}$ of Signal I., Alex. Arch.; $55^{\circ} 11^{\prime} 35^{\prime \prime} \mathrm{N}, 132^{\circ} 51^{\prime}$ $40^{\prime \prime} \mathrm{W}$; (map 4).

Local name published in 1965 by USC\&GS.

Panhat Point: point of land, on NE coast of Bainbridge I., on W side of Prince of Wales Passage, $6 \mathrm{mi}$. $\mathrm{S}$ of Chenega, Chugach Mts.; $60^{\circ} 09^{\prime} 00^{\prime \prime} \mathrm{N}, 148^{\circ} 03^{\prime} 30^{\prime \prime} \mathrm{W}$; (map 63).

Local name reported in 1951 by USGS.

Panic Creek: stream, flows NW $7 \mathrm{mi}$. to Kiligwa River, $5 \mathrm{mi}$. SW of Liberator Lake, Arctic Slope; $68^{\circ} 49^{\prime} 30^{\prime \prime} \mathrm{N}, 158^{\circ} 31^{\prime} 00^{\prime \prime} \mathrm{W} ; B G N$ 1960; (map 132).

Named in 1950 by B. H. Kent, USGS, "for concern for overdue personnel."

Panikpiak Creek: stream, flows NW $8 \mathrm{mi}$. to Chukchi Sea, 7.5 mi. NE of Cape Beaufort and $47 \mathrm{mi}$. SW of Point Lay, Arctic Plain; $69^{\circ}$ $06^{\prime} 10^{\prime \prime} \mathrm{N}, 163^{\circ} 37^{\prime} 30^{\prime \prime} \mathrm{W}$; (map 145).

Eskimo name given to this stream by USC\&GS in 1949. It was the name of an Eskimo that once lived in the area, and the name came to be applied to the locality, in a "possessive" sense, because it was there that mailsleds from Barrow and Kotzebue generally met.

Pankof, Cape: point of land, on SE tip of Ikatan Penin., on SE coast of Unimak I., Aleutian Is.; 54 $40^{\prime} \mathrm{N}, 163^{\circ} 04^{\prime} \mathrm{W}$; (map 25). Var. Pankoff, Pankova.

Russian name published in 1847 as "M[ys] Paknova" or "Pankof's Cape" by the Russian Hydrog. Dept. on Chart 1379. The USBF used the two "f" spelling of the name for this point in 1888.

Pankof Breaker: reef, $3 \mathrm{mi}$. NE of East Anchor Cove, Ikatan Penin., on SE coast of Unimak I., Aleutian Is. ; $54^{\circ} 42^{\prime} 30^{\prime \prime} \mathrm{N}, 163^{\circ} 00^{\prime} 30^{\prime \prime} \mathrm{W}$; (map 25).

Name derived from Cape Pankof; reported by Ferdinand Westdahl, USC\&GS, commander of the Coast Survey steamer McArthur, who made surveys in this area in 1901.

Pankoff: point of land, see Pankof, Cape.

Pankova: point of land, see Pankof, Cape.

Pannell River: stream, see Pinnell River.

Panorama Mountain: mountain, 5,778 ft., 12 mi. SE of Fang Mtn. and $27 \mathrm{mi}$. SE of Healy, Alaska Ra.; $63^{\circ} 28^{\prime} 45^{\prime \prime} \mathrm{N}, 148^{\circ} 47^{\prime} 15^{\prime \prime} \mathrm{W}$; (map 87).

Local descriptive name obtained in 1951 by USGS. 
Panoramic Greek: stream, heads on Panoramic Peak of Granite Mtn., flows NE $6.4 \mathrm{mi}$. to Arrow Creek, $22 \mathrm{mi}$. SE of Delta Junction, Alaska Ra.; $63^{\circ} 52^{\prime} 35^{\prime \prime}$ N, $145^{\circ} 19^{\prime} 57^{\prime \prime}$ W; (map 86).

Named between 1948 and 1955 by T. L. Péwé, USGS.

Panoramic Peak: peak, 5,150 ft., on N slope of Granite Mtn., $19 \mathrm{mi}$. SE of Delta Junction, Alaska Ra.; 63 $48^{\prime} 50^{\prime \prime} \mathrm{N}, 145^{\circ} 23^{\prime} 50^{\prime \prime} \mathrm{W}$; (map 86).

Named between 1848 and 1955 by T. L. Péwé, USGS.

Panowat Spit: spit, $6 \mathrm{mi}$. long, between Kokechik Bay and Bering Sea, $1.6 \mathrm{mi}$. S of Cape Romanzof, Yukon-Kuskokwim Delta; 61 ${ }^{\circ} 43^{\prime}$ N, $166^{\circ} 09^{\prime} \mathrm{W}$; (map 75). Var. Pungohat Spit.

Eskimo name meaning "at the end of the hills," reported by USG\&GS in 1951.

Panther Peak: mountain, see Loren Hill.

Papan River: stream, see Pargon River.

Papa Willie Creek: stream, flows S $40 \mathrm{mi}$. to Yokontoh Slough, SE of Blackburn I. and $53 \mathrm{mi}$. SE of Unalakleet, Innoko Low.; $63^{\circ} 23^{\prime}$ N, 159 23' W; BGN 1960; (map 91). Var. Sisdlartna River.

Local name reported in 1951 by U.S. Army Corps of Engineers.

Papa Willie Creek: watercourse, see Yokontoh Slough.

Papiak Point: bluff, elev. $50 \mathrm{ft}$., on $\mathrm{N}$ bank of Naknek River, on Alaska Penin., 9 mi. SE- of Naknek, Bristol Bay Low.; 58 $42^{\prime} 40^{\prime \prime} \mathrm{N}$, $156^{\circ} 45^{\prime} 40^{\prime \prime} \mathrm{W}$; (map 41).

Eskimo name reported in 1952 by USGS.

Papigak Creek: stream, flows NE and N $6 \mathrm{mi}$. to Chukchi Sea, $15 \mathrm{mi}$. E of Point Franklin, Arctic Plain; $70^{\circ} 49^{\prime} 15^{\prime \prime} \mathrm{N}, 158^{\circ} 10^{\prime} \mathrm{W}$; (map 147).

Eskimo name reported in 1950 by USC\&GS. Papin River: stream, see Pargon River.

Papiok, Mount: mountain, 6,530 ft., $12 \mathrm{mi}$. N of Mount Igikpak, Brooks Ra. ; $67^{\circ} 35^{\prime} \mathrm{N}, 154^{\circ}$ $57^{\prime} \mathrm{W}$; (map 125).

Eskimo name recorded in Kobuk by Orth, USGS, in 1956 and reported to mean "tail of a fish."

Papka: locality, on N shore of Kuskokwim Bay, $10 \mathrm{mi}$. SW of Eek I. and $57 \mathrm{mi}$. SW of Bethel, Yukon-Kuskokwim Delta; $60^{\circ} 03^{\prime} \mathrm{N}, 162^{\circ}$. $28^{\prime} \mathrm{W}$; (map 58). Var. Pápkamut.

Former Eskimo camp or village reported by J. E. Spurr and W. S. Post, USGS, based on information received in 1898 from J. H. Kilbuck, Moravian missionary, who spelled it "Pápkamut," i.c. "Papka people." This appears to be the same name as "Popokamiut."

Pápkamut: locality, see Papka.

Papkes Landing: locality, on W coast of Mitkot I., 9 mi. S of Petersburg, Alex. Arch.; 56 $40^{\prime}$ $30^{\prime \prime} \mathrm{N}, 132^{\circ} 55^{\prime} 55^{\prime \prime} \mathrm{W}$; (map 6).

Local name recorded in 1953 by USGS Current maps show a dock and three cabins here.

Papoose Cove: cove, $0.5 \mathrm{mi}$. across, extends $\mathrm{E}$ to $W$ side of Squaw Bay, $30 \mathrm{mi}$. NE of Whit- tier, Chugach Mts. ; $60^{\circ} 50^{\prime} 15^{\prime \prime} \mathrm{N}, 147^{\circ} 50^{\prime} 00^{\prime \prime}$ W; (map 63).

Local name reported in 1952 by USGS.

Papoose Creek: stream, heads on Syncline Mtn. flows N $1.7 \mathrm{mi}$. to Alfred Creek, $58 \mathrm{mi}$. NE of Palmer, Chugach Mts.; 61 $57^{\circ} 00^{\prime \prime} \mathrm{N}$, $147^{\circ} 29^{\prime} 35^{\prime \prime} \mathrm{W}$; (map 69)

Local name reported in 1952 by USGS.

Papoose Twins: lakes, each $1 \mathrm{mi}$. long, $\mathrm{E}$ of Little Susitna River, $23 \mathrm{mi}$. N of Anchorage, Cook Inlet Low.; $61^{\circ} 32^{\prime} 10^{\prime \prime} \mathrm{N}, 150^{\circ} 05^{\prime} 00^{\prime \prime}$ W; (map 70).

Local name reported in 1958 by USGS.

Paps, The: hills, $500 \mathrm{ft}$., two small rounded hills, in Glacier Bay National Monument, $0.7 \mathrm{mi}$. NE of Harbor Point, at mouth of Lituya Bay, $87 \mathrm{mi}$. NW of Hoonah, Malaspina Coastal Plain; $58^{\circ} 37^{\prime} \mathrm{N}, 137^{\circ} 38^{\prime} \mathrm{W}$; (map 10).

Descriptive name published in 1875 by USC\&GS on Chart 742. The first use of name is unknown.

Par: locality, see Pah.

Paradise: locality, $\mathrm{W}$ of Carlo I., on right bank of Yukon River, $17 \mathrm{mi}$. NW of Holy Cross, Nulato Hills; $62^{\circ} 25^{\prime} \mathrm{N}, 160^{\circ} 03^{\prime} \mathrm{W}$; (map 78). Var. Bonasila.

Site of old native village shown on a 1902 fieldsheet by A. J. Collier, USGS. Both names, "Paradise" and "Bonasila," were used by the riverboat pilots from 1898 to 1910 . The name "Bonasila" is derived from the nearby Bonasila River.

Paradise Camp: locality, at head of Slate Creek, $4.5 \mathrm{mi}$. NE of Twin Mtn. and $13 \mathrm{mi}$. N of Nome, Seward Penin. High.; 64. $42^{\prime} \mathrm{N}$, $165^{\circ} 21^{\prime} \mathrm{W}$; (map 94).

Site of a mining camp shown on the 1902 "Map of the Nome and Snake River Country" by J. M. Davidson.

Paradise Cove: cove, $0.5 \mathrm{mi}$. wide, in Three Hole Bay, $26 \mathrm{mi}$. SW of Seward, Chugach Mts.; $59^{\circ} 45^{\prime} 30^{\prime \prime} \mathrm{N}, 149^{\circ} 36^{\prime} 30^{\prime \prime} \mathrm{W}$; $B G N$ 1930; (map 49).

Named by Capt. McMullen [cnna] of the steamer Dora who applied the name to all of Three Hole Bay. The 1912 USC\&GS field party restricted the application to this cove.

Paradise Greek: stream, on Kenai Penin., flows N $7.5 \mathrm{mi}$. to Resurrection River, $7 \mathrm{mi}$. NW of Seward, Chugach Mts. ; $60^{\circ} 11^{\prime} 30^{\prime \prime} \mathrm{N}, 149^{\circ} 35^{\prime}$ $10^{\prime \prime} \mathrm{W}$; (map 63).

Local name reported about 1914 by B. L. Johnson (in Martin and others, 1915, pl. 2), USGS.

Paradise Creek: stream, heads in a glacial lake, flows NW $4.8 \mathrm{mi}$. to Metal Creek, $23 \mathrm{mi}$. SE of Palmer, Chugach Mts.; 61 $21^{\circ} 30^{\prime \prime} \mathrm{N}$, $148^{\circ} 27^{\prime} 45^{\prime \prime} \mathrm{W}$; (map 69).

Local name reported in 1960 by USGS.

Paradise Creek: stream, heads on Bonasila Dome, flows $W$ and NE $34 \mathrm{mi}$. to Bonasila Slough 3 mi. W of its junc. with Yukon River, $26 \mathrm{mi}$. NW of Holy Cross, Nulato Hills; $62^{\circ} 30^{\prime} \mathrm{N}$, $160^{\circ} 14^{\prime}$ W; (map 78). Var. Stanstrom Creek.

Local name obtained in 1952 by USGS.

Paradise Creek: stream, see Bottley Creek.
Paradise Flats: tidal fats, $0.5 \mathrm{mi}$. across, at head of Saook Bay, on $\mathrm{N}$ coast of Baranof $\mathrm{I}$., $7 \mathrm{mi}$. SW of Todd, Alex. Arch; $57^{\circ} 25^{\prime} 15^{\prime \prime} \mathrm{N}$, $135^{\circ} 12^{\prime} 45^{\prime \prime} \mathrm{W}$; (map 9).

Named in 1895 by Lt. Comdr. E. K. Moore, USN, and published on Chart 8283.

Paradise Fork: stream, flows NE $16.6 \mathrm{mi}$. to Sethkokna River, $73 \mathrm{mi}$. NE of Medfra, Kilbuck-Kuskokwim Mts. ; $63^{\circ} 57^{\prime} \mathrm{N}, 153^{\circ} 19^{\prime} \mathrm{W}$; (map 89).

Local name reported in 1958 by USGS.

Paradise Hill: hill, E of Alaska Highway, $23 \mathrm{mi}$. $\mathrm{SE}$ of Northway Junction, Alaska Ra.; 62 ${ }^{\circ} 47^{\prime}$ $\mathrm{N}, 141^{\circ} 16^{\prime} \mathrm{W}$; (map 84).

Local name reported by USGS in 1952.

Paradise Lake: lake, 2,000 ft. long, in the Matanuska Valley, $8.7 \mathrm{mi}$. NW of Palmer, Cook Inlet Low.; $61^{\circ} 37^{\prime} 30^{\prime \prime} \mathrm{N}, 1^{\circ} 9^{\circ} 22^{\prime} 30^{\prime \prime} \mathrm{W}$; (map 69).

Local name reported in 1914 by GLO (BLM).

Paradise Lakes: lakes, extend NE-SW $4.5 \mathrm{mi}$. in Paradise Valley, $22 \mathrm{mi}$. NE of Seward, Chugach Mts.; $60^{\circ} 21^{\prime} 30^{\prime \prime} \mathrm{N}, 149^{\circ} 01^{\prime} 30^{\prime \prime} \mathrm{W}$; (map 63).

Local name reported in 1951 by USGS.

Paradise Pass: pass, 1,400 ft., between heads of Sethkokna River and Eden Creek, $28 \mathrm{mi}$. NW of Telida, Kilbuck-Kuskokowim Mts. ; $63^{\circ} 45^{\prime}$ $30^{\prime \prime} \mathrm{N}, 153^{\circ} 38^{\prime} 00^{\prime \prime} \mathrm{W}$; (map 89).

Local name reported in 1958 by USGS.

Paradise Valley: valley, extends NE-SW $7.5 \mathrm{mi}$. on Kenai Penin., coursed by Snow River, 20 mi. NE of Seward, Chugach Mts.; $60^{\circ} 20^{\prime} \mathrm{N}$, $149^{\circ} 05^{\prime} \mathrm{W}$; (map 63).

Local name reported in 1951 by USGS.

Paragon River: stream, see Pargon River.

Parakhodnaya, Bukhta: bay, see Steamer Bay. Parakhotnia Bay: bay, see Steamer Bay.

Parallel Creek: stream, flows E $4.5 \mathrm{mi}$. to Chignik Lagoon, $7 \mathrm{mi}$. W of Chignik, on S shore of Alaska Penin., Aleutian Ra.; 56 ${ }^{\circ} 19^{\prime}$ N, $158^{\circ} 35^{\prime} \mathrm{W}$; (map 30$)$.

Named in 1923 by R. H. Sargent, USGS; so called because "its course is near and parallel to the $56^{\circ} 20^{\prime} \mathrm{N}$ line."

Paralysis Point: point of land, $\mathrm{W}$ point of entrance to Security Bay, on N coast of Kuiu I., Alex. Arch.; $56^{\circ} 51^{\prime} 50^{\prime \prime} \mathrm{N}, 134^{\circ} 22^{\prime} 45^{\prime \prime} \mathrm{W}$; (map 5). Var. South Point.

Named in 1881 by Comdr. H. Glass, USN in 1869 called "South Point" by Comdr. R. W Meade, USN.

Paramano Bay: bay, see Paramanof Bay.

Paramanof, Cape: point of land, $23 \mathrm{mi}$. NW of Afognak, on $\mathrm{W}$ coast of Afognak I., $\mathrm{N}$ of Kodiak I. ; $58^{\circ} 18^{\prime} 20^{\prime \prime} \mathrm{N}, 153^{\circ} 03^{\prime} 30^{\prime \prime} \mathrm{W}$; (map 43). Var. Paramanoff, Paramonof, Paramonoff, Tanaak.

Name derived from Paramanof Bay and published by the Russian American Company in 1849 as "M[ys] Paramonovskoy (Tanaak)." The Russian Hydro. Dept. published the Aleut name "M[ys] Tanaak," or "Cape Tanaak," for this feature in 1847 on Chart 1378, perhaps from the word "tanaq" which, according to R. H. Geoghegan, means "land" or "place." 
Paramanof Bay: bay, $3 \mathrm{mi}$. across, $22 \mathrm{mi}$. NW of Afognak, on $W$ coast of Afognak I., $N$ of Kodiak I., $58^{\circ} 18^{\prime}$ N, $152^{\circ} 55^{\prime}$ W ; (map 43). Var. Paramano Bay, Paramanoff Bay, Paramanofskaia.

Russian family (?) name given as "Paramonovskaya Bukhta" by the Russian American Company in 1849 and spelled "Paramanoff" by USC\&GS and USBF.

Paramanoff: point of land, see Paramanof, Cape.

Paramanoff Bay: bay, see Paramanof Bay.

Paramanof Mountain: mountain, 2,175 ft., 17 mi. N of Afognak, on central Afognak $I$., $\mathbf{N}$ of Kodiak I., $58^{\circ} 14^{\prime} \mathrm{N}$; $152^{\circ} 40^{\prime} \mathrm{W}$; (map 43 ).

Name derived from Paramanof Bay and published in 1952 on a USGS map.

Paramanofskaia: bay, see Paramanof Bay.

Paramonof: point of land, see Paramanof, Cape. Paramonoff: point of land, see Paramanof, Cape. Paran Lakes: lakes, two, near head of Pargon River, Seward Penin. High.; (map 110).

Local name shown on the 1900 "Map of Nome Peninsula" by J. M. Davidson and B. D. Blakeslee. The lakes cannot be identified on subsequent maps.

Paran River: stream, see Pargon River.

Parantulik River: stream, see Pargon River.

Para Point: point of land, SW point of Pearl I., in Yukon River $17 \mathrm{mi}$. NE of Russian Mission, Yukon-Kuskokwim Delta ; 61 ${ }^{\circ} 55^{\prime} 20^{\prime \prime} \mathrm{N}$, $160^{\circ} 52^{\prime} 15^{\prime \prime} \mathrm{W}$; (map 73). Var. Pats Island.

The origin of this name is unknown. It may represent a misreading of the name "Pats Island" shown on a 1916 fieldsheet by $\mathbf{R}$. H. Sargent, USGS, which, because of filling, is now part of Pearl Island.

Parent Roadhouse: locality, see Parents Trading Post.

Parent Roadhouse: village, see Crooked Creek. Parents: village, see Crooked Creek.

Parents Mountains: mountains, $1,281 \mathrm{ft}$., extend NE 12 mi. from Chukchi Sea coast, between Kavroarak and Tasikpak Lagoons, $14 \mathrm{mi}$. NW of Kivalina, Arctic Slope; $67^{\circ} 57^{\prime} \mathrm{N}, 164^{\circ} 48^{\prime}$ W; (map 128). Var. Angeyukangak, Ungayukaukurnik.

Named in 1950 by USC\&GS; it is a translation of the Eskimo name for the mountains transcribed as "Ungayukaukurnik."

Parents Trading Post: locality, at mouth of Crooked Creek, $33 \mathrm{mi}$. WNW of Sleetmute, Kilbuck-Kuskokwim Mts.; 61 ${ }^{\circ} 52^{\prime} 30^{\prime \prime}$ N, $158^{\circ} 06^{\prime} 30^{\prime \prime}$ W; (map 72). Var. Parent Roadhouse, Portage Village.

The trading post was reported in 1910 as "Portage Village" by .C. G. Anderson (in Eakin, 1914, pl. 1), USGS. The name "Parent R. H." was reported for the same location on the 1923 map by the Alaska Road Commission.

Parents Trading Post: village, see Crooked Creek.

Pargan River: stream, see Pargon River.

Pargon River: stream, heads in Bendeleben Mts., flows SE $32 \mathrm{mi}$. to Fish River, $50 \mathrm{mi}$. NE of Solomon, Seward Penin. High.; 64 $59^{\prime}$ N, $163^{\circ} 06^{\prime} \mathrm{W}$; BGN 1910; (map 95). Var. Anaconda Creek, Oregon River, Papan River,
Papin River, Paragon River, Paran River, Parantulik River, Pargan River.

Local name derived from an Eskimo name and standardized in 1910 by BGN on the basis of local use. Reported as "Papin" in 1899 by Schrader and Brooks (1900, map 3), USGS. The variant names were used on subsequent mining and USGS maps.

Parida Island: island, 1,250 ft., long, in San Alberto Bay, $5 \mathrm{mi}$. NW of Craig, Alex. Arch.; $55^{\circ} 31^{\prime} 10^{\prime \prime}$ N, $133^{\circ} 14^{\prime} 30^{\prime \prime}$ W; (map 4). Var. Isla Partida, La Parida.

Spanish name given in $1775-79$ by Don Juan de la Bodega y Quadra and Francisco Antonio Maurelle as "Isle Partida" or "divided island." According to Wagner (1937, p. 481-482), the word "parida" is a corruption of "partida."

Parida Island Reef: reef, in San Alberto Bay, 0.6 mi. S of Parida I., Alex. Arch.; 55 $30^{\prime} 30^{\prime \prime}$ $\mathrm{N}, 133^{\circ} 14^{\prime} 30^{\prime \prime} \mathrm{W}$; (map 4).

Named by USC\&GS and published in 1925 Coast Pilot (p. 143).

Paris Creek: stream, on Douglas I., flowing 1.5 mi. NE to Glory Hole, $0.3 \mathrm{mi}$. NW of Treadwell and $2.7 \mathrm{mi}$. SE of Juneau, Coast Mts.; $58^{\circ} 16^{\prime} 35^{\prime \prime} \mathrm{N}, 134^{\circ} 22^{\prime} 50^{\prime \prime} \mathrm{W}$; (map 11). Var. French Pete's Creek, Hayes Creek. Parris Creek.

Probably named by Pierre Erussard. The name is spelled Parris in a placer claim filed by him with M. A. Hayes and Henry Borien in 1881. The early miners called the stream both Hayes Creek for Michael Angelo Hayes, one of the locators, and French Pete's Creek for Pierre Erussard (DeArmond, 1957, p. 34). The name Paris Creek was published in 1893 by USC\&GS.

Park: locality, see Parks.

Parka Creek: stream, see Scandinavian Creek.

Park Creek: stream, on Iniskin Penin., flows NE $5 \mathrm{mi}$. to Chinitna Bay, Aleutian Ra.; $59^{\circ} 49^{\prime} 40^{\prime \prime} \mathrm{N}, 153^{\circ} 05^{\prime} 45^{\prime \prime} \mathrm{W}$; (map 51).

Named in 1921 by F. H. Moffit, USGS, because of the park-like view up the stream valley, when seen from a point near the shore of Chinitna Bay.

Parker Creek: stream, flows NE $8 \mathrm{mi}$. to Lake Minchumina, $1.7 \mathrm{mi}$. SW of village of Lake

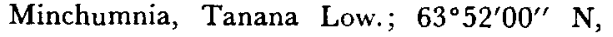
$152^{\circ} 21^{\prime} 40^{\prime \prime}$ W; (map 88). Var. Packer Creek.

Local name reported in 1954 by USGS.

Parker Creek: stream, see Poker Creek.

Parker Group: islands, $0.5 \mathrm{mi}$. across, in Sitka Sound, $3 \mathrm{mi}$. W of Sitka, Alex. Arch.; $57^{\circ} 03^{\prime}$ $40^{\prime \prime} \mathrm{N}, 135^{\circ} 25^{\prime} 00^{\prime \prime} \mathrm{W}$; (map 9)

Named in 1880 by the U.S. Navy and published by USC\&GS in the 1883 Coast Pilot (p. 140).

Parker Hill : hill, see Kikikyak Hill.

Parker Lake: lake, $0.8 \mathrm{mi}$. long, $\mathrm{W}$ of Kroto Creek, $23 \mathrm{mi}$. SW of Talkeetna, Cook Inlet Low.; 62 $02^{\prime} 15^{\prime \prime} \mathrm{N}, 150^{\circ} 29^{\prime} 15^{\prime \prime} \mathrm{W}$; (map 81 ).

Local name reported in 1958 by USGS.

Parker Pass: pass, 14,500 ft., in Mount McKinley National Park, between Harper Glacier and Harper Icefall, $3 \mathrm{mi}$. NE of summit of Mount McKinley, Alaska Ra.; $63^{\circ} 06^{\prime} 10^{\prime \prime} \mathrm{N}$, $150^{\circ} 56^{\prime} 30^{\prime \prime}$ W; BGN 1947; (map 88).

Named in 1913 by Archdeacon Stuck (1921, p. 73) for Herschel Clifford Parker, 18671931, physicist and mining engineer, who accompanied Belmore Browne on the expedition which nearly succeeded in reaching the summit of Mount McKinley in 1912.

Parker Point: point of land, $8 \mathrm{mi}$. NW of Angoon, on W coast of Admiralty I., Alex. Arch.; $57^{\circ} 36^{\prime} 45^{\prime \prime} \mathrm{N}, 134^{\circ} 40^{\prime} 30^{\prime \prime} \mathrm{W}$; (map 9).

Discovered by Lt. Joseph Whidbey, RN, July 20, 1794, and named by Capt. George Vancouver, RN, probably for Sir Peter Parker of the British Admiralty (Wagner, 1937, p. 401).

Park Peak: mountain, 4,800 ft., in British Mts. $2 \mathrm{mi}$. W of Alaska-Canada boundary and 46 mi. S of Demarcation Point, Brooks Ra.; $69^{\circ} 02^{\prime} \mathrm{N}, 141^{\circ} 06^{\prime} \mathrm{W}$; (map 138).

Name reportedly contained in IBC survey notes; published on a 1944 Canadian topographic map.

Parks: locality, on $\mathrm{N}$ bank of Kuskokwim River at mouth of Parks Creek, $2.7 \mathrm{mi}$. NW of village of Red Devil and $8.8 \mathrm{mi}$. NW of Sleetmute, Kilbuck-Kuskokwim Mts.; 61 ${ }^{\circ} 47^{\prime} 45^{\prime \prime}$ N, 157 $21^{\prime} 10^{\prime \prime} \mathrm{W}$; (map 72). Var. Park, Parks Cinnabar Ledge, Parks Prospect, Tliagenadëden, Tliagenalëden.

Trading post and supply point named for Eugene W. Parks when a post office was located here from 1909 to 1910 with Parks as postmaster. A population of 11 was recorded here in 1940, but the more recent census does not list the place.

Parks Cinnabar Ledge: locality, see Parks.

Parks Creek: stream, flows NW $3 \mathrm{mi}$. to Mink Creek SW of Birchwood, $17 \mathrm{mi}$. NE of Anchorage, Cook Inlet Low.; $61^{\circ} 23^{\prime} \mathrm{N}, 149^{\circ} 31^{\prime}$ W; (map 69).

Local name reported in 1960 by USGS.

Parks Creek: stream, flows SW $1.3 \mathrm{mi}$. to Kuskokwim River, $2.7 \mathrm{mi}$. NW of Red Devil and $8.7 \mathrm{mi}$. NW of Sleetmute, Kilbuck-Kuskokwim Mts.; $61^{\circ} 47^{\prime} 45^{\prime \prime} \mathrm{N}, 157^{\circ} 21^{\prime} 10^{\prime \prime} \mathrm{W}$; $B G N$ 1943; (map 72).

Locally narned for E. W. Parks. Reported in 1943 by USGS. See Parks.

Parks Prospect: locality, see Parks.

Parlor Harbor: anchorage, see Pavlof Harbor.

Paroshki Bay: bay, see No Thorofare Bay.

Par Rapids : rapids, see Pah Rapids.

Parris Creek: stream, see Paris Creek.

Par River; stream, see Pah River.

Parrot Beach: beach, 50 yds. long, on Sredni Bight, on NE coast of Kiska I., Aleutian Is.; $52^{\circ} 04^{\prime} 00^{\prime \prime} \mathrm{N}, 177^{\circ} 38^{\prime} 03^{\prime \prime} \mathrm{E}$; (map 14).

One of the "bird names" arbitrarily applied to features on Kiska I. in 1943 by USAAF for tactical purposes during World War II.

Parrot Island: island, $0.1 \mathrm{mi}$. across, at mouth of Kazakof Bay, $9 \mathrm{mi}$. NE of Afognak, on SE coast of Afognak I.; $58^{\circ} 05^{\prime} 20^{\prime \prime} \mathrm{N}, 152^{\circ} 34^{\prime} 35^{\prime \prime}$ W; BGN 1910; (map 43).

Named by C. G. Quillian, USC\&GS, who surveyed the locality in 1909 . 
Parrot Island: island, see Nest Island.

Parrot Lake: lake, $1 \mathrm{mi}$. long, on S end of Dall I., N of Essowah Lakes, Alex. Arch.; 54 ${ }^{\circ} 49^{\prime}$ N, 132 $52^{\prime}$ W; BGN 1935; (map 1 ).

So named in 1935 by USGS "because of its proximity to Parrot Point."

Parrot Point: point of land, on W coast of Dall I., 2 mi. $S$ of Port Bazan, Alex. Arch.; 54․ $47^{\prime} 00^{\prime \prime} \mathrm{N}, 132^{\circ} 56^{\prime} 30^{\prime \prime} \mathrm{W}$; BGN 1929; (map 1).

Name derived from Parrot Rock; given by USC\&GS in 1928.

Parrot Rock: island, $0.1 \mathrm{mi}$. long, $0.8 \mathrm{mi}$. SE of Parrot Point on SW coast of Dall I., Alex. Arch.; $54^{\circ} 46^{\prime} 40^{\prime \prime} \mathrm{N}, 132^{\circ} 55^{\prime} 30^{\prime \prime} \mathrm{W}$; (map 1).

Name published by USC\&GS in the 1925 Alaska Coast Pilot (p. 164).

Parry Lake: lake, $0.8 \mathrm{mi}$. long, on E coast of Baranof I., N of Patterson Bay, Alex. Arch.; $56^{\circ} 39^{\prime} \mathrm{N}, 134^{\circ} 41^{\prime} \mathrm{W}$; BGN 1917; (map 5).

Named in 1917 by USC\&GS for Will $\mathrm{H}$ Parry, 1864-1917, "a member of the Federal Trade Commission who had an interest in Alaska."

Parshas: locality, on $\mathrm{N}$ shore of Port Gravina, $19 \mathrm{mi}$. NW of Cordova, Ghugach Mts.; $60^{\circ}$. 44' N, 146 $08^{\prime} \mathrm{W}$; BGN 1910; (map 64). Var. Parshas Settlement.

Local name for a small Indian settlement, reported in 1908 by Grant and Higgins (1910, pl. 1 and 2), USGS. Present maps show one building at this site.

Parshas Bay: cove, $0.8 \mathrm{mi}$. wide, at $\mathrm{N}$ edge of Port Gravina, $19 \mathrm{mi}$. NW of Cordova, Chugach Mts.; $60^{\circ} 43^{\prime} 45^{\prime \prime} \mathrm{N}, 146^{\circ} 08^{\prime} 30^{\prime \prime} \mathrm{W}$; (map 64).

Local name derived from "Parshas Settlement" on east point of entrance; published by USC\&GS in 1918

Parshas Point: point of land, on N shore of Port Gravina, $19 \mathrm{mi}$. NW of Cordova, Chugach Mts. ; $60^{\circ} 44^{\prime} \mathrm{N}, 146^{\circ} 08^{\prime} \mathrm{W}$; (map 64).

Local name derived from "Parshas Settlement" on this point; published by USC\&GS in 1918.

Parshas Settlement: locality, see Parshas.

Parson Falls Creek: stream, flows S $6 \mathrm{mi}$. to Rude River, $10 \mathrm{mi}$. NE of Cordova, Chugach Mts.; $60^{\circ} 40^{\prime} 30^{\prime \prime} \mathrm{N}, 145^{\circ} 33^{\prime} 00^{\prime \prime} \mathrm{W}$; (map 64).

Local name reported in 1913 by B. L. Johnson (in Brooks and others, 1914, pl. 7), USGS.

Parsons Peak: peak, 6,600 ft., $2.2 \mathrm{mi}$. W of head of Taiya Inlet, $4 \mathrm{mi}$. NW of Skagway, Coast Mts.; $59^{\circ} 28^{\prime} 40^{\prime \prime} \mathrm{N}, 135^{\circ} 25^{\prime} 40^{\prime \prime} \mathrm{W}$; (map 45).

Named in 1897 by USC\&GS (Baker, 1906 , p. 489).

Partennoi, Point: point of land, between Ilin Bay and head of Islas Bay, $16 \mathrm{mi}$. NW of Chichagof, on W coast of Chichagof I., Alex. Arch.; 57 $50^{\prime} 10^{\prime \prime} \mathrm{N}, 136^{\circ} 23^{\prime} 20^{\prime \prime} \mathrm{W}$; (map 9).

Russian name meaning "party" given by Staff-Capt. P. I. Ilin early in the 19th Century.

Partida, Isla: island, see Parida Island.
Partie Cape: point of land, see Party Cape.

Partin Creek: stream, heads at glacier terminus, flows $\mathrm{S} 12 \mathrm{mi}$. to Fountain River at Eldridge Glacier terminus, $41 \mathrm{mi}$. $N$ of Talkeetna, Alaska Ra.; 62 $54^{\prime}$ N, $149^{\circ} 57^{\prime}$ W; (map 82). Local name reported in 1951 by USGS.

Partition Cove: bight, $1 \mathrm{mi}$. across, on SE coast of Sitkalidak I., SE of Kodiak I.; $57^{\circ} 06^{\prime} \mathrm{N}$, 1530.5' W; BGN 1934; (map 34).

Descriptive name given in 1934 by USC\&GS, because the "cove is partitioned or bisected through its center by an islet and tombolo: the beach at its head is an isthmus, only 50 to 200 meters across, forming a partition between the cove and McDonald Lagoon."

Partof Bay: cove, see Partov Cove.

Partoffshikoff Island: island, see Partofshikof Island.

Partoffshikoff Island: island, see Partofshikof Island.

Partof Point: point of land, on $\mathrm{S}$ tip of Partofshikof I., between Kruzof and Baranof Is., Alex. Arch.; $57^{\circ} 13^{\prime} 45^{\prime \prime} \mathrm{N}, 135^{\circ} 34^{\prime} 00^{\prime \prime} \mathrm{W}$; (map 9).

Named in 1897 by Lt. Comdr. E. K. Moore, USN; first part of island name.

Partofs-Chikof Island: island, sec Partofshikof Island.

Partofshikof Island: island, $8 \mathrm{mi}$. long, between Kruzof and Baranof Is., Alex. Arch.; 57 ${ }^{\circ} 15^{\prime}$ N, $135^{\circ} 36^{\prime}$ W; (map 9). Var. Partovshchikov, Ostrov Partovshikov, Partoffschikof Island, Partoffshikoff Island, Partofs-Chikof Island, Partotovstchikoff Island, Partovschikoff Island, Partovshikov Island.

Name published in 1848 on Russian $\mathrm{Hy}$ drog. Dept. Chart 1397 as "Os[trov] Partovshchikov," meaning "Partovshchikov Island." This is probably a Russian proper name.

Partotovstchikoff Island: island, see Partofshikof Island.

Partovaia: cove, see Partov Cove.

Partovaya Bay: cove, see Partov Cove.

Partov Bay: cove, see Partov Cove.

Partov Cove: bay, $1 \mathrm{mi}$. across, on $\mathrm{E}$ coast of Umnak I., Aleutian Is.; $53^{\circ} 12^{\prime} 25^{\prime \prime} \mathrm{N}, 168^{\circ}$ 19'00" W; BGN 1939; (map 22). Var. Glubokaia Bay, Glubokoi, Partof Bay, Partov Bay, Partovaia, Partovaya Bay.

Russian name [from the French] published by Capt. Tebenkov (1852, map 25), IRN, as "Bukh[ta] Partovaya," meaning "party cove." This feature was called "Glubokaya," meaning "deep," by Capt. Lutke (1836, p. 298), IRN. The name was changed to "Partov Cove" in 1938 by USC\&GS

Partovschikoff Island: island, see Partofshikof Island.

Partovshchikov, Ostrov: island, see Partofshikof Island.

Partovshikov, Ostrov: island, see Partofshikof Island.

Partway Lake: lake, $2 \mathrm{mi}$. across, $8 \mathrm{mi}$. NE of Kgun Lake and $48 \mathrm{mi}$. SW of Marshall, Yukon-Kuskokwim Delta; $61^{\circ} 38^{\prime} \mathrm{N}, 163^{\circ} 28^{\prime}$ W; (map 74)

Local name published by USGS in 1966 .
Party Cape: point of land, on NW coast of Shuyak I., $50 \mathrm{mi}$. N of Kodiak I. ; $58^{\circ} 37^{\prime} 10^{\prime \prime}$ $\mathrm{N}, 152^{\circ} 34^{\prime} 00^{\prime \prime} \mathrm{W}$; (map 43). Var. Partie Cape.

Translation of the name "M[ys] Partiy," from the French "partie," published in 1849 by the Russian American Company.

Pasagshak Bay: $b a y$, extends NE $3 \mathrm{mi}$., off Ugak Bay $\mathbf{N}$ of Pasagshak Point, on $\mathbf{E}$ coast of Kodiak I.; $57^{\circ} 26^{\prime} \mathrm{N}, 152^{\circ} 30^{\prime} \mathrm{W}$; (map 34). Native name published in 1943 by USC\&GS.

Pasagshak Point: point of land, E point of entrance to Pasagshak Bay on $\mathrm{N}$ shore of Ugak Bay, on E coast of Kodiak I.; $57^{\circ} 25^{\prime} 30^{\prime \prime} \mathrm{N}$, $152^{\circ} 08^{\prime} 30^{\prime \prime} \mathrm{W}$; (map 34).

Native name published in 1943 by USC\&GS.

Paschtol: locality, see Pastoliak.

Paschtol: locality, see Pastolik.

Paschtolik: locality, see Pastoliak.

Paschtolik: locality, sce Pastolik.

Pasco Creek: stream, flows SW $5 \mathrm{mi}$. to Salcha River, $2 \mathrm{mi}$. ESE of Caribou and $37 \mathrm{mi}$. NE of Big Delta, Yukon-Tanana High.; 64 ${ }^{\circ} 39^{\prime}$ $\mathrm{N}, 145^{\circ} 33^{\prime} \mathrm{W}$; (map 101)

Local name reported in 1958 by USGS

Pasco Pass: pass, between the valleys of Glacier River and Wiseman Creek, N of Glacier Pass, $7.5 \mathrm{mi}$. NW of Wiseman, Brooks Ra.; $67^{\circ} 28^{\prime}$ $\mathrm{N}, 150^{\circ} 21^{\prime} \mathrm{W}$; (map 124)

Prospectors' name reported by F. C. Schrader, USGS, in 1899.

Pashtol: locality, sec Pastoliak.

Pashtol: locality, see Pastolik.

Pashtolik, Reka: stream, see Pastoliak River.

Pashtolyak, Reka: stream, see Pastoliak River.

Paso Point: point of land, on SW coast of Unalaska I., Aleutian Is.; $53^{\circ} 23^{\prime} 10^{\prime \prime} \mathrm{N}, 167^{\circ}$ $41^{\prime} 00^{\prime \prime} \mathrm{W}$; (map 23)

Name given by USBF in 1888 .

Passage Arm: estuary, see Passage Canal.

Passage Bay: cove, see Shotgun Cove.

Passage Canal: estuary, on NE coast of Kenai Penin., trends NE $14 \mathrm{mi}$. from Whittier to $\mathrm{S}$ end of Port Wells, $36 \mathrm{mi}$. NW of Chenega, Chugach Mts.; $60^{\circ} 47^{\prime} \mathrm{N}, 148^{\circ} 21^{\prime} \mathrm{W}$; BGN 1915; (map 63). Var. Passage Arm, Passage Channel, Portage Bay.

Named in 1794 by Capt. Vancouver (1798, vl. 3 , p. 181), presumably because this body of water leads to a portage connecting Prince William Sound with Gook Inlet.

Passage Channel: estuary, see Passage Canal.

Passage Island: island, see High Island.

Passage Island: island, $0.9 \mathrm{mi}$. long, in South Pass, $0.5 \mathrm{mi}$. NE of Whisker Point, Alex. Arch.; $55^{\circ} 10^{\prime} 35^{\prime \prime} \mathrm{N}, 132^{\circ} 52^{\prime} 30^{\prime \prime} \mathrm{W}$; (map 4).

Local name published in 1965 by USC\&GS Passage İsland: island, $200 \mathrm{ft}$. across, between Mitchell Bay and Davis Creek, $6 \mathrm{mi}$. NE of Angoon, on $W$ central Admiralty I., Alex. Arch.; 57 $31^{\prime} 45^{\prime \prime} \mathrm{N}, 134^{\circ} 26^{\prime} 00^{\prime \prime} \mathrm{W}$; (map 9). Var. Passage Islet.

Named in 1869 by Comdr. R. W. Meade, USN. 
Passage Island: island, $0.5 \mathrm{mi}$. long, at entrance to Port Graham, on SW end of Kenai Penin., $8 \mathrm{mi}$. SW of Seldovia, Chugach Mts.; $59^{\circ}-$ 22'15" N, 151 $53^{\prime} 00^{\prime \prime}$ W; (map 50).

So named by Capt. Portlock (1789, p. 106) in 1786 , because the island was at the entrance to what was erroneously thought to be a "strait [Port Graham] leading out to sea ***",

Passage Islands: islands, $0.2 \mathrm{mi}$. across, in Middle Channel, Sitka Sound, 2 mi. SW of Sitka, Alex. Arch.; $57^{\circ} 01^{\prime} 45^{\prime \prime} \mathrm{N}, 135^{\circ} 22^{\prime} 00^{\prime \prime} \mathrm{W}$; (map 9). Var. Goloi Isles, Ostrov Goloy, Ostrov Prokhoda, Prokhoda Islands.

This is an 1882 translation by USC\&GS of the name given in 1809 by the Russian navigator Ivan Vasiliev the first; reported by Lt. Sarichev (1826, map 19), IRN, as "O[strov] Prokhoda." These islands were called "Goloy," meaning "bare" by Capt. Tebenkov (1852, map 38), IRN.

Passage Islet: island, see Passage Island.

Passage Point: point of land, on NE coast of Tanaklak I., Aleutian Is.; $51^{\circ} 57^{\prime} 50^{\prime \prime} \mathrm{N}, 176^{\circ}-$ 05'30' W; BGN 1936; (map 17).

Named by members of the U.S. Navy Aleutian Island Survey Expedition in 1934.

Passage Point: point of land, on W central Admiralty I., between Mitchell Bay and NW point of entrance to Davis Creek, $5.8 \mathrm{mi}$. NE of Angoon, Alex. Arch.; 57 $31^{\prime} 45^{\prime \prime}$ N, $134^{\circ}$ $26^{\prime} 30^{\prime \prime} \mathrm{W}$; (map 9 )

Local descriptive name reported in 1869 by Comdr. R. W. Meade, USN.

Passage Point: point of land, northernmost point of Knight I., at NW entrance to Lower Passage, $22 \mathrm{mi}$. NE of Chenega, Chugach Mts.; $60^{\circ} 30^{\prime} 55^{\prime \prime} \mathrm{N}, 147^{\circ} 41^{\prime} 40^{\prime \prime} \mathrm{W}$; (map 63).

Local name published in 1909 by USC\&GS; derived from nearby Lower Passage.

Passage Point: promontory, on the $\mathrm{W}$ coast of Sedanka Island, at the narrowest point on Udagak Strait, Aleutian Is.; $53^{\circ} 45^{\prime} \mathrm{N}, 166^{\circ}$. 15' W; (map 23)

Named July 22, 1786 by Capt. Nathaniel Portlock (Wagner, 1937, p. 482).

Passage Rock: rock, $0.4 \mathrm{mi}$. across, $\mathrm{N}$ of Tongass I., in Nakat Bay, Coast Mts. ; $54^{\circ} 46^{\prime} 52^{\prime \prime}$ $\mathrm{N}, 130^{\circ} 44^{\prime} 32^{\prime \prime} \mathrm{W}$; (map 2).

Named in 1891 by Lt. Comdr. H. E. Nichols, USN, published in the 1891 Coast Pilot (p. 79)

Passage Rock: rock, at mouth of Lituya Bay, Glacier Bay National Monument, $0.1 \mathrm{mi}$. NW of Harbor Point and $88 \mathrm{mi}$. NW of Hoonah, Malaspina Coastal Plain; $58^{\circ} 36^{\prime} 45^{\prime \prime} \mathrm{N}, 137^{\circ}$. $39^{\prime} 30^{\prime \prime} \mathrm{W}$; (map 10).

Named in 1874 by W. H. Dall, USC\&GS; published in the 1883 Alaska Coast Pilot (p. 202).

Pass Creek: stream, flows SE 7 mi. to Wide Bay, So of Mount Shannon, on S coast of Alaska Penin., $41 \mathrm{mi}$. SE of Ugashik, Aleutian Ra. $57^{\circ} 24^{\prime} 05^{\prime \prime} \mathrm{N}, 156^{\circ} 21^{\prime} 25^{\prime \prime} \mathrm{W}$; (map 36).

Local name reported in 1921 by Capps (1923, pl. 2), USGS.

Pass Creek: stream, on Kenai Penin., flows NE $21 \mathrm{mi}$. to Canyon Creek, $11 \mathrm{mi}$. S of Sunrise,
Chugach Mts.; $60^{\circ} 43^{\prime} 55^{\prime \prime} \mathrm{N}, 149^{\circ} 27^{\prime} 00^{\prime \prime} \mathrm{W}$; (map 63).

Local prospectors' name; reported in 1904 by Moffit (1906, pl. 2), USGS.

Pass Creek: stream, on Kenai Penin., flows NW $6 \mathrm{mi}$. to Resurrection Creek, $10 \mathrm{mi}$. SW of Hope, Chugach Mts.; $60^{\circ} 46^{\prime} 30^{\prime \prime}$ N, 149'41'$00^{\prime \prime} \mathrm{W}$; (map 63).

Local descriptive name reported in 1895 by Becker (1898, fig. 6), USGS.

Pass Creek: stream, flows NW $11 \mathrm{mi}$. to Salmon River, $7 \mathrm{mi}$. SE of Mount Plummer and 77 mi. NE of Bethel, Kilbuck-Kuskokwim Mts.; $60^{\circ} 55^{\prime} 30^{\prime \prime} \mathrm{N}, 159^{\circ} 30^{\prime} 00^{\prime \prime}$ W ; (map 59).

Local name reported in 1955 by J. M. Hoare, USGS.

Pass Creek: stream, flows SW $2.6 \mathrm{mi}$. to Canyon Creek, $0.1 \mathrm{mi}$. N of mouth of Divide Creek, $65 \mathrm{mi}$. NE of Valdez, Chugach Mts.; $61^{\circ} 22^{\prime}$ $30^{\prime \prime} \mathrm{N}, 144^{\circ} 22^{\prime} 30^{\prime \prime} \mathrm{W}$; (map 68).

Local name published in 1914 by USGS.

Pass Creek: stream, flows NW $4.5 \mathrm{mi}$. to Kotsina River, 2 mi. E of mouth of Clear Creek, 83 mi. NE of Valdez, Wrangell Mts.; 61 ${ }^{\circ} 42^{\prime} 50^{\prime \prime}$ $\mathrm{N}, 144^{\circ} 02^{\prime} 50^{\prime} \mathrm{W}$; (map 68$)$.

Descriptive name given in 1900 by F. C. Schrader, USGS.

Pass Creek: stream, heads at Belanger Pass, flows W $3.3 \mathrm{mi}$. to Alfred Creek, $61 \mathrm{mi}$. NE of Palmer, Talkeetna Mts.; 61 ${ }^{\circ} 57^{\prime} 50^{\prime \prime}$ N, $147^{\circ}$ $25^{\prime} 30^{\prime \prime} \mathrm{W}$; (map 69).

Local name reported in 1952 by USGS.

Pass Creek: stream, heads near Rainy Pass, in Teocalli Mts., flows SE 10 mi. to Happy River, $91 \mathrm{mi}$. SW of Talkeetna, Alaska Ra.; $62^{\circ} 10^{\prime}$ $15^{\prime \prime} \mathrm{N}, 152^{\circ} 55^{\prime} 20^{\prime \prime} \mathrm{W}$; BGN 1965; (map 81) Var. Happy River.

Local name reported in 1958 by USGS; so called because it heads just south of Rainy Pass.

Pass Creek: stream, flows NW $5 \mathrm{mi}$. to Goat Creek, $3.3 \mathrm{mi}$. S of Tanada Lake, Wrangell Mts.; $62^{\circ} 20^{\prime} \mathrm{N}, 143^{\circ} 21^{\prime} \mathrm{W}$; (map 84).

Local name reported by USGS in 1960.

Pass Creek: stream, heads on Fairview Mtn., flows NE $5.3 \mathrm{mi}$. to Camp Creek, $45 \mathrm{mi}$. W of Talkeetna, Alaska Ra.; $62^{\circ} 24^{\prime} 10^{\prime \prime} \mathrm{N}, 151^{\circ} 30^{\prime}$ $40^{\prime \prime} \mathrm{W}$; (map 81 ).

Prospectors' name reported in 1906 by R. W. Porter, USGS.

Pass Creek: stream, heads in Dutch Hills, flows SE $1 \mathrm{mi}$. to Cottonwood Creek, $27 \mathrm{mi}$. NW of Talkeetna, Alaska Ra.; 62 $34^{\prime} 10^{\prime \prime} \mathrm{N}, 150^{\circ}$ $47^{\prime} 00^{\prime \prime} \mathrm{W}$; (map 81).

Prospectors' name reported in the 1930 's by USGS.

Pass Creek: stream, heads at Summit Lake in Chulitna Pass, flows W $5.7 \mathrm{mi}$. to Chulitna River, $42 \mathrm{mi}$. NE of Talkeetna, Talkeetna Mts.; $62^{\circ} 54^{\prime} 08^{\prime \prime} \mathrm{N}, 149^{\circ} 46^{\prime} 15^{\prime \prime} \mathrm{W}$; (map 82).

Local descriptive name reported by $\mathrm{S}, \mathrm{R}$. Capps and J. B. Mertie, Jr., USGS, in 1917.

Pass Creek: stream, heads in Clearwater Mts., flows E $10 \mathrm{mi}$. to Clearwater Creek, $8 \mathrm{mi}$. N of Denali Highway and $34 \mathrm{mi}$. SW of Mount
Hayes, Alaska Ra.; $63^{\circ} 09^{\prime} 25^{\prime \prime} \mathrm{N}, 146^{\circ} 58^{\prime} 30^{\prime \prime}$ W; (map 86).

Name published on relatively recent maps. Pass Creek: stream, flows N $4.6 \mathrm{mi}$. to Browns Fork Sulukna River, $52 \mathrm{mi}$. NE of Medfra, Kilbuck-Kuskokwim Mts.; $63^{\circ} 45^{\prime} \mathrm{N}, 153^{\circ} 54^{\prime}$ W; (map 89).

Local name reported in 1958 by USGS.

Pass Creek: stream, flows S $5 \mathrm{mi}$. to Tatonduk

River, $16 \mathrm{mi}$. N of Eagle, Porcupine Plat.; $65^{\circ} 01^{\prime} 30^{\prime \prime} \mathrm{N}, 141^{\circ} 10^{\prime} 00^{\prime \prime} \mathrm{W}$; BGN 1931; (map 103).

So named in 1930 by J. B. Mertie, Jr., USGS, because it affords an easy route over the divide from the Tatonduk River to Hard Luck Greek.

Pass Creek: stream, flows SE $5 \mathrm{mi}$. from $\mathrm{E}$ of Ernie Lake to Mettenpherg Creek, $2 \mathrm{mi}$. S of Colorado Creek and $70.5 \mathrm{mi}$. W of Wiseman, Brooks Ra.; $67^{\circ} 21^{\prime} 30^{\prime \prime} \mathrm{N}, 152^{\circ} 46^{\prime} 00^{\prime \prime} \mathrm{W}$; (map 124).

Local descriptive name obtained in 1956 by USGS topographers.

Pass Creek: stream, flows S $4 \mathrm{mi}$. W of Eroded Mtn., to Tinayguk River, $3.5 \mathrm{mi}$. NW of mouth of that stream and $25 \mathrm{mi}$. NW of Wiseman, Brooks Ra.; $67^{\circ} 36^{\prime} 30^{\prime \prime} \mathrm{N}, 151^{\circ} 08^{\prime}$ $00^{\prime \prime} \mathrm{W}$; (map 124).

Local descriptive name obtained in 1956 by USGS topographers.

Pass Creek: stream, flows SE $34 \mathrm{mi}$. to Coleen River, $7 \mathrm{mi}$. E of Lois Dome and $44 \mathrm{mi}$. N of Coleen Mtn., Brooks Ra.; $67^{\circ} 43^{\prime}$ N, $142^{\circ}$ $32^{\prime} \mathrm{W}$; (map 121).

Local name reported in 1956 by T. E. Taylor, USGS

Pass Creek: stream, see Happy River.

Pass Fork Dalzell Creek: stream, heads at Rainy Pass, in Teocalli Mts., flows NW 5 mi. to Dalzell Creek, $92 \mathrm{mi}$. SE of McGrath, Alaska Ra.; $62^{\circ} 14^{\prime} 20^{\prime \prime} \mathrm{N}, 153^{\circ} 12^{\prime} 15^{\prime \prime} \mathrm{W}$; (map 80).

Local name reported in 1931 by USGS.

Pass Fork Hartman River: stream, heads at glacier E of Sled Pass, flows NE $6.7 \mathrm{mi}$. to Hartman River, $94 \mathrm{mi}$. NW of Tyonek, Alaska Ra.; $61^{\circ} 41^{\prime} 50^{\prime \prime} \mathrm{N}, 153^{\circ} 37^{\prime} 30^{\prime \prime} \mathrm{W}$; (map 71).

Local name reported in 1958 by USGS.

Pass Island: island, $0.1 \mathrm{mi}$. across, off NE coast of Mummy I., at $\mathrm{N}$ end of Long Channel, $6.5 \mathrm{mi}$. NE of Chenega, Chugach Mts.; $60^{\circ}$ $17^{\prime} 45^{\prime \prime} \mathrm{N}, 147^{\circ} 53^{\prime} 59^{\prime \prime} \mathrm{W}$; (map 63).

Local name published in 1908 by USC\&GS

Passless Creek: stream, flows SW $4 \mathrm{mi}$. to Kutuk River, $9 \mathrm{mi}$. E of Survey Pass, Brooks Ra.; $67^{\circ} 51^{\prime} \mathrm{N}, 153^{\circ} 46^{\prime} \mathrm{W}$; BGN 1932; (map 125).

Named by Robert Marshall in 1931 because a reported pass did not materialize.

Pastol Bay: bight, $28 \mathrm{mi}$. across, off Norton Sound, $30 \mathrm{mi}$. SW of St. Michael, YukonKuskokwim Delta; $63^{\circ} 12^{\prime} \mathrm{N}, 163^{\circ} 15^{\prime} \mathrm{W}$; (map 92). Var. Guba Pastol, Pastole Bay, Pastoli Bay, Pastolik Bay, Zaliv Pastol.

Name published by Sarichev (1826, map 4) as "Guba Pastol" or "Pastol Bay"; named for an early explorer or trader of the area. Petroff (U.S. Bur. Census, 1880, map) reported the name as "Pastoli." 
Pastole Bay: bight, see Pastol Bay.

Pastoliak: locality, on right bank of Pastolik River a few miles $\mathrm{N}$ of Pastolik, Yukon-Kusko-

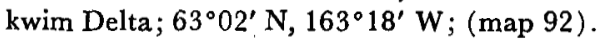
Var. Pastoliakh, Pachtolik, Paschtol, Paschtolik, Pashtol.

Former Eskimo village or camp reported as "Pastoliakh" in 1849 by Capt. M. D. Tebenkov, IRN. The original site of the village is now called "Old Pastolik."

Pastoliakh: locality, see Pastoliak.

Pastoliak River: stream, in Yukon Delta, flows NW $30 \mathrm{mi}$. to Pastol Bay, $48 \mathrm{mi}$. SW of St. Michael, Yukon-Kuskokwim Delta; $63^{\circ} 02^{\prime} \mathrm{N}$, $163^{\circ} 14^{\prime}$ W ; (map 92). Var. Pastolik River, Pastol River, Reka Pashtolik, Reka Pashtolyak, Reka Pastol, Reka Pastolyagak, Reka Pastolyak.

This is a diminutive form of the name "Pastolik" published by Lt. Sarichev (1826, map 4), IRN, as "R[eka] Pashtolyak."

Pastolik: village, on right bank of Pastolik River, $40 \mathrm{mi}$. NE of Kwiguk, Yukon-Kuskokwim Delta; 62 $59^{\prime} 50^{\prime \prime} \mathrm{N}, 163^{\circ} 18^{\prime} 15^{\prime \prime} \mathrm{W}$; (map 77).

Eskimo settlement reported in $1842-44$ by Lt. L. A. Zagoskin, IRN; it was recorded by him as "Pashtol." Dall (1870, p. 236) gives the name in 1867 as "Pastolik". The village population in 1890 was 113 . The original village site is now called "Old Pastolik."

Pastolik Bay: bight, see Pastol Bay.

Pastolik River: stream, in Yukon Delta, flows N $65 \mathrm{mi}$. to Pastol Bay at Apoon Mouth, 41 mi. NE of Kwiguk, Yukon-Kuskokwim Delta; $63^{\circ} 02^{\prime} \mathrm{N}, 163^{\circ} 20^{\prime} \mathrm{W}$; (map 92). Var. Reka Pastol.

Name published by Capt. Tebenkov (1852, map 2) as "Reka Pastol" or "Pastol River." See Pastol Bay.

Pastolik River: stream, see Pastoliak River.

Pastol River: stream, see Pastoliak River.

Pastolyagak, Reka: stream, see Pastoliak River. Pastolyak, Reka: stream, see Pastoliak River.

Pataktak: point of land, see Demarcation Point. Pataktuk: point of land, see Demarcation Point. Patch Creek: stream, see Sam Patch Creek.

Patching Lake: lake, $3.3 \mathrm{mi}$. long, on Revillagigedo I., in course of Naha River, $6 \mathrm{mi}$. E of Loring, Alex. Arch.; $55^{\circ} 36^{\prime} \mathrm{N}, 131^{\circ} 29^{\prime} \mathrm{W}$; BGN 1962; (map 3). Var. Fortman Lake.

Named for Fred Patching who was drowned in the Naha River; recorded in 1948 by USGS.

Pat Creek: stream, flows W $4 \mathrm{mi}$. through Trout Lake to Zimovia Strait, $8.5 \mathrm{mi}$. S of Wrangell, on NW coast of Wrangell I., Alex. Arch.; $56^{\circ} 20^{\prime} 30^{\prime \prime} \mathrm{N}, 132^{\circ} 20^{\prime} 20^{\prime \prime} \mathrm{W}$; (map 6).

Local name recorded in 1953 by USGS.

Pat Creek: stream, flows $\mathrm{S} 1 \mathrm{mi}$. to Tom Creek, $2 \mathrm{mi}$. NW of Gilmore Dome and $13 \mathrm{mi}$. NE of Fairbanks Yukon-Tanana High.; 64 $59^{\circ}$ $30^{\prime \prime} \mathrm{N} ; 147^{\circ} 26^{\prime} 00^{\prime \prime} \mathrm{W}$; (map 100).

Local name published in 1908 by USGS.

Pat Creek: stream, heads at Twin Lakes and flows SW $30 \mathrm{mi}$. to Dall River, $7 \mathrm{mi}$. NW of Stevens Village, Yukon Flats; $66^{\circ} 06^{\prime} \mathrm{N}, 149^{\circ}$ 03' W; (map 118).

Local name obtained in 1956 by USGS.
Paterson Creek: stream, flows NE $1 \mathrm{mi}$. to Niukluk River, between Camp and Richter Creeks, $6 \mathrm{mi}$. NW of Council and $30 \mathrm{mi}$. NE of Solomon, Seward Penin. High.; (map 95). Var. Peterson Creek.

Prospectors' name shown as "Peterson" on the 1900 "Map of Nome Peninsula" by J. M. Davidson and B. D. Blakeslee, and as "Paterson" on a 1902 prospectors' manuscript map. This stream cannot be precisely located on current maps. See Lane Creek.

Pathfinder Channel: water passage, see Avatanak Strait.

Patricia Bight: cove, $1.2 \mathrm{mi}$. across, on $\mathrm{N}$ coast of Agattu Is., Aleutian Is.; $52^{\circ} 30^{\prime} 00^{\prime \prime} \mathrm{N}, 173^{\circ}-$ 38'30" E; BGN 1938; (map 13).

This name was proposed in 1938 by the U.S. Navy Hydrog. Office, and was published in 1943 on an AMS map.

Patricia Creek: stream, flows NE $9 \mathrm{mi}$. from Seven Dikes Mtn. to Pass Creek, $53 \mathrm{mi} \mathrm{NW}$ of Goleen Mtn., Brooks Ra.; $67^{\circ} 51^{\prime}$ N, $142^{\circ} 49^{\prime}$ W; (map 121).

Local name reported in 1956 by T. E. Taylor, USGS.

Patricia Point: point of land, at $W$ entrance to Patricia Bight, on $\mathrm{N}$ coast of Agattu Is., Aleutian Is.; $52^{\circ} 30^{\prime} 20^{\prime \prime} \mathrm{N}, 173^{\circ} 37^{\prime} 25^{\prime \prime} \mathrm{E}$; $B G N$ 1938; (map 13).

This name was proposed in 1938 by the U.S. Navy Hydrog. Office, and was published in 1943 on an AMS map.

Patron Alonzo, Punta de: point of land, on Baker Island in Port Asumcion, Alex. Arch. (map 4).

Named by Francisco Antonio Maurelle about May 19, 1779. The man in charge of a launch party was called a patron and Alonzo Moreno was the patron of one of those under Maurelle (Wagner, 1937, p. 482). See Alonzo, Point.

Pats Island: point of land, see Para Point.

Patsys Cabin: locality, on right bank of Yukon River, $41 \mathrm{mi}$. SE of Kwiguk, Yukon-Kuskokwim Delta; 62 ${ }^{\circ} 15^{\prime} \mathrm{N}, 163^{\circ} 51^{\prime} \mathrm{W}$; (map 77). Var. Patsys Village.

This small settlement consisting of one or two cabins was reported in 1939 by USC\&GS.

Patsy Slough: stream, anabranch, of Yukon River E of Big Island, flows SW $5 \mathrm{mi} .3 \mathrm{mi}$. NE of Nulato, Koyukuk Low.; 64 ${ }^{\circ} 45^{\prime} \mathrm{N}$, $158^{\circ} 00^{\prime} \mathrm{W}$; (map 97). Var. Island Slough, Notliagepia-ta.

Local name reported in 1954 by USGS. Name puublished as "Island Slough" in 1898 by USC\&GS. Lt. L. A. Zagoskin, IRN, reported the Indian name, "Notliagepia-ta," in 1842-44.

Patsys Village: locality, see Patsys Cabin.

Pattern Creek: stream, flows ENE $2.5 \mathrm{mi}$. to Utukok River, $3 \mathrm{mi}$. downstream from mouth of Driftwood Creek, Arctic Slope; 68 ${ }^{\circ} 52^{\prime} 40^{\prime \prime}$ N, 161'11'00' W; BGN 1961; (map 131).

Named by USGS geologists in 1950 "because its drainage pattern may indicate geological structure."
Patterson Bay: bay, $1 \mathrm{mi}$. across, $4 \mathrm{mi}$. long, empties into South Arm Hoonah Sound, $12 \mathrm{mi}$. $E$ of Chichagof, on $S$ central Chichagof $I$., Alex. Arch.; $57^{\circ} 40^{\prime} \mathrm{N}, 135^{\circ} 45^{\prime} \mathrm{W}$; (map 9).

Name published in 1900 by USC\&GS on Chart 8000 ; probably named for the survey steamer Patterson.

Patterson Bay: bay, see Deep Cove.

Patterson Bay: estuary, $6 \mathrm{mi}$. long, on E coast of Baranof I., $20 \mathrm{mi}$. N of Port Alexander, Alex. Arch.; 56 $33^{\prime} 00^{\prime \prime} \mathrm{N}, 134^{\circ} 39^{\prime} 30^{\prime \prime} \mathrm{W}$; (map 5).

Named in 1895 by USC\&GS for its steamer Patterson.

Patterson Chutes: rapids, of Tanana River, along SE side of Vachon I., near mouth of Cosna River, Nowitna Low.; 64.51'20' N, $151^{\circ} 20^{\prime} 00^{\prime \prime} \mathrm{W}$; (map 99).

Riverboat pilots' name published on a 1940 "Navigation Chart of the Tanana-Yukon Rivers" by the U.S. Dept. of Interior.

Patterson Creek: stream, formed by junc. of Sullivan and Cache Creeks, flows W $26 \mathrm{mi}$. to Tanana River $\mathrm{E}$ of Harper Bend, Nowitna Low.; $65^{\circ} 01^{\prime} 30^{\prime \prime} \mathrm{N}, 151^{\circ} 31^{\prime} 25^{\prime \prime} \mathrm{W}$; $B G N$ 1965; (map 106). Var. Gache Creek.

Named in 1902 by Lt. G. S. Gibbs, U.S. Army Signal Corps, for H. W. Patterson who assisted him in making a map of the Tanana. Patterson Creek: stream, flows NW $3.5 \mathrm{mi}$. to South Fork Hess Creek, $10 \mathrm{mi}$. NE of Livengood, Yukon-Tanana High.; 65 $39^{\prime} 30^{\prime \prime} \mathrm{N}$, $148^{\circ} 22^{\prime} 45^{\prime \prime} \mathrm{W}$; (map 105).

Named by prospectors; reported in 1916 by J. B. Mertie (in Brooks and others, 1918, pl. 13), USGS.

Patterson Creek: stream, flows E $3.8 \mathrm{mi}$. to Candle Creek at Camp 19, $6.2 \mathrm{mi}$. SW of Candle and $37 \mathrm{mi}$. NE of Imuruk Lake, Seward Penin. High.; $65^{\circ} 50^{\prime} \mathrm{N}, 162^{\circ} 02^{\prime} \mathrm{W}$; (map 110).

Prospectors' name reported in 1903 by D. C. Witherspoon (in Moffit, 1905, pl. 2), USGS.

Patterson Glacier: glacier, heads $5 \mathrm{mi}$. NE of Twin Peaks, trends SW $15 \mathrm{mi}$. to head of Patterson River, $15 \mathrm{mi}$. NE of Petersburg, Coast Mts.; $56^{\circ} 57^{\prime} 00^{\prime \prime} \mathrm{N}, 132^{\circ} 41^{\prime} 25^{\prime \prime} \mathrm{W}$; (map 6).

Named by W. H. Dall, USC\&GS, in 1879 , for Carlile P. Patterson, then Superintendent of USC\&GS.

Patterson Island: island, $1.5 \mathrm{mi}$. long, between Clarence Strait and Kasaan Bay, on E coast of Prince of Wales I., Alex. Arch.; 55 24'15'" $\mathrm{N}, 132^{\circ} 11^{\prime} 45^{\prime \prime} \mathrm{W}$; (map 4).

Named in 1886 by Lt. Comdr. R. Clover, USN, "for the Coast Survey [USG\&GS] steamer Patterson."

Patterson Mountains: mountains, see Sisters, The.

Patterson Peaks: ridge, 4,780 ft., 2 mi. NW of Patterson Glacier, $16 \mathrm{mi}$. NE of Petersburg, Coast Mts.; 56 $58^{\prime} 32^{\prime \prime} \mathrm{N}, 132^{\circ} 40^{\prime} 20^{\prime \prime} \mathrm{W}$; (map 6).

Named in 1887 by Lt. Comdr. C. M. Thomas, USN, for charting purposes; name published in 1888 on USC\&GS Chart 705. 
Patterson Point: point of land, NE entrance point to Williwaw Cove, on $\mathrm{N}$ coast of Little Sitkin I., Aleutian Is.; $51^{\circ} 59^{\prime} 15^{\prime \prime} \mathrm{N}, 178^{\circ}$ $30^{\prime} 15^{\prime \prime}$ E; BGN 1937; (map 15).

Reported by personnel of the U.S.S. Oglala in 1935; named for the USC\&GS ship Patterson which was in these waters in 1904.

Patterson Point: point of land, E point of entrance to Patterson Bay, on SE coast of Baranof I., Alex. Arch.; 56 $32^{\prime} 30^{\prime \prime}$ N, 134 $38^{\prime} 20^{\prime \prime}$ W; (map 5).

Local name used by fishermen; published in 1901 by USC\&GS.

Patton Bay: bay, $4 \mathrm{mi}$. wide, on SE coast of Montague I., $70 \mathrm{mi}$. SE of Seward, Chugach Mts.; 59 $56^{\prime} \mathrm{N}, 147^{\circ} 25^{\prime} \mathrm{W}$; BGN 1937; (map 49).

Named in 1937 by USC\&GS for Rear Adm. Raymond Stanton Patton, 1882-1937, who began his service in USC\&GS in 1904. As commanding officer of the USC\&GS steamer Explorer in 1914, he made surveys in Prince William Sound. In 1915 he was appointed chief of the Coast Pilot Section in the Washington Office, and during World War I served as Lieutenant and Lieutenant Commander in the Navy. He served as a member of the U.S. Geographic Board from December 1926 to June 1934. Rear Adm. Patton was appointed director of the U.S. Coast \& Geodetic Survey in 1929, in which office he served continuously until his death on November 25, 1937.

Patton Cove: cove, $1.5 \mathrm{mi}$. long, on $\mathrm{SE}$ coast of Ulak I., Delarof Is., Aleutian Is.; $51^{\circ} 20^{\prime} 45^{\prime \prime}$ N, $178^{\circ} 57^{\prime} 00^{\prime \prime} \mathrm{W}$; (map 16).

Name published in the 1946 supplement to the 1944 Aleutian Coast Pilot (U.S. Coast and Geodetic Survey, 1946, p. 120).

Patton Glacier: glacier, about $1.2 \mathrm{mi}$. long, in Glacier Bay National Monument, on NE slope of Mount Cadell, trends N to its 1947 terminus $1.5 \mathrm{mi}$. S of the Plateau Glacier, $63 \mathrm{mi}$. NW of Hoonah, St. Elias Mts.; $58^{\circ} 54^{\prime} \mathrm{N}$, $136^{\circ} 18^{\prime} \mathrm{W}$; (map 10).

Named by members of the Glacier Bay Expedition of 1941 (Field, 1947, map) for J. L. Patton, one of G. F. Wright's companions on Muir Glacier in 1886.

Patton Island: island, $0.2 \mathrm{mi}$. long, $4 \mathrm{mi} . \mathrm{E}$ of Deer I., at SW end of Aleutian Ra.; $54^{\circ}$ $54^{\prime} 20^{\prime \prime} \mathrm{N}, 162^{\circ} 08^{\prime} 20^{\prime \prime} \mathrm{W}$; BGN 1943; (map 25).

Named in 1940 by USC\&GS for Admiral Raymond S. Patton 1882-1937, USC\&GS, who explored the Prince William Sound area in 1914 and served as director of USC\&GS from 1929 until his death in 1937.

Paugausailuk Hill: hill, see Pogoseluk Hill.

Paugausailuk Lagoon: lagoon, see Pusaluk Lagoon.

Paugausailum Tasia: lagoon, see Paugausailuk Lagoon.

Paugwik: village, see South Naknek.

Paulaluk Creek: stream, see Paulaluk River.

Paulaluk River: stream, flows $7 \mathrm{mi}$. NW to Kongakut River, $20 \mathrm{mi}$. SW of Demarcation
Point, Brooks Ra.; $69^{\circ} 25^{\prime} \mathrm{N}, 141^{\circ} 31^{\prime} \mathrm{W}$; (map 138). Var. Paulaluk Creek.

Eskimo name recorded on Barter I. in 1952 by USC\&GS.

Paul Bight: bight, $0.6 \mathrm{mi}$. across, on Prince of Wales I., between McKenzie Inlet and Skowl Arm Kasaan Bay, Alex. Arch.; 55 $24^{\prime} 30^{\prime \prime} \mathrm{N}$, $132^{\circ} 23^{\prime} 30^{\prime \prime} \mathrm{W}$; BGN 1930; (map 4).

Named in 1930 by USFS "for Paul Young, a Kasaan native."

Paul Creek: stream, on Hawkins I., flows N 1.2 mi. to a lagoon on Orca Bay, $10 \mathrm{mi}$. W of Cordova, Chugach Mts.; $60^{\circ} 33^{\prime} \mathrm{N}, 146^{\circ} 01^{\prime}$ W; (map 64).

Name published in 1950 by USGS.

Paulina Creek: stream, heads on Cape Mtn., flows SE $1 \mathrm{mi}$. to Bering Sea, $0.8 \mathrm{mi}$. W of Tin City and $51 \mathrm{mi}$. NW of Teller, Seward Penin. High.; $65^{\circ} 34^{\prime} \mathrm{N}, 167^{\circ} 59^{\prime} \mathrm{W}$; (map 111).

Prospectors' name reported on the 1908 "Map of Seward Peninsula" by Arthur Gibson.

Paulina Island: island, $0.4 \mathrm{mi}$. long, in Klag Bay, $1.8 \mathrm{mi}$. S of Chichagof, on $\mathrm{W}$ coast of Chichagof, I., Alex. Arch.; 57 $38^{\prime} 15^{\prime \prime} \mathrm{N}$, $136^{\circ} 05^{\prime} 20^{\prime \prime} \mathrm{W}$; (map 9).

Name published in 1928 by USC\&GS on Chart 8280.

Pauline Creek: stream, flows NW $3.7 \mathrm{mi}$. to Holtz Creek which flows to Kugruk River, 19 mi. E of Imuruk Lake, Seward Penin. High.; $65^{\circ} 34^{\prime} \mathrm{N}, 162^{\circ} 31^{\prime} \mathrm{W}$; (map 110$)$.

Prospectors' name reported in 1903 by D. C. Witherspoon (in Moffit, 1905, pl. 2), USGS.

Pauline Lakes: lakes, two, each $0.7 \mathrm{mi}$. long, E of Nabesna River, $2 \mathrm{mi}$. NE of Northway, Alaska Ra.; $63^{\circ} 00^{\prime}$ N, 141'53' W; (map 84). Local name reported by USGS in 1954 .

Paul Island: island, $4 \mathrm{mi}$. long, $13 \mathrm{mi}$. $\mathrm{E}$ of Stepovak Bay, Aleutian Ra.; $55^{\circ} 47^{\prime} \mathrm{N}, 159^{\circ}$ $19^{\prime} \mathrm{W}$; (map 27). Var. Ostrov Sviatoy Paula.

Named by Lt. Woronkofski in 1837; published as "O[strov] Sv[iatoy] Paula," or "St. Paul Island," on Russian Hydrog. Dept. Chart 1379 (1847). "Paul Island" was published in 1888 by USC\&GS

Paul Lake: lake, $2 \mathrm{mi}$. long, $1.3 \mathrm{mi}$. $\mathrm{N}$ of Port Johnson, on SE coast of Prince of Wales I., Alex. Arch.; $55^{\circ} 08^{\prime} 35^{\prime \prime} \mathrm{N}, 132^{\circ} 05^{\prime} 00^{\prime \prime} \mathrm{W}$; (map 4).

Local name reported in 1901 by $\mathrm{A}$. H. Brooks, USGS. "This is the place where gold was first discovered in the Dolomi region. The discovery was made by Paul Johnson, an Indian boy, who first found the bright particles of gold on the shore of the lake" (Brooks, 1902, p. 84).

Pauloff Harbor: village, pop. 77, on $\mathrm{W}$ shore of Pavlof Harbor, on $\mathbf{N}$ central coast of Sanak I., $50 \mathrm{mi}$. SE of False Pass, Aleutian Ra.; 54 ${ }^{\circ}-$ $27^{\prime} 45^{\prime \prime} \mathrm{N}, 162^{\circ} 41^{\prime} 30^{\prime \prime} \mathrm{W}$; (map 25). Var. Pavloff Harbor, Pavlof Harbor.

A post office was established here in 1949, and probably is responsible for establishing the present spelling of the name which varies from that of the adjacent harbor.
Pauloff Harbor: harbor, see Pavlof Harbor.

Pauls Bay: bight, $0.7 \mathrm{mi}$. across, on $\mathrm{E}$ shore of Perenosa Bay, on $\mathrm{N}$ coast of Afognak I., Kodiak I.; $58^{\circ} 23^{\prime} 40^{\prime \prime} \mathrm{N}, 152^{\circ} 21^{\prime} 00^{\prime \prime} \mathrm{W}$; (map 43).

Local name reported in 1952 by USGS.

Pauls Creek: stream, heads in lake, flows SW $34 \mathrm{mi}$. to Naknek River, on Alaska Penin., 8.6 mi. SE of Naknek, Bristol Bay Low.; 58 $43^{\prime}$ $\mathrm{N}, 156^{\circ} 46^{\prime} \mathrm{W}$; (map 41).

Local name reported in 1952 by USGS.

Pauls Harbor: town, see Kodiak.

Pauls Harbor: bight, see Saint Paul Harbor.

Pauls Lake: lake, 1 mi. long, on $\mathrm{N}$ coast of Afognak I. SE of Pauls Bay, $31 \mathrm{mi}$. NE of Afognak, Kodiak I.; $58^{\circ} 23^{\prime} \mathrm{N}, 152^{\circ} 20^{\prime} \mathrm{W}$; (map 43).

Local name reported in 1952 by USGS.

Paulson Creek: stream, in Nutzotin Mts., Hows W $0.7 \mathrm{mi}$. to Glacier Creek $1.5 \mathrm{mi}$. SW of its junc. with Chavolda Creek, $6 \mathrm{mi}$. NW of Beaver Lake, Alaska Ra.; $62^{\circ} 07^{\prime} 30^{\prime \prime} \mathrm{N}, 141^{\circ}$. 52'50' W ; (map 84).

Local name published in 1915 by USGS.

Paul Young Creek: stream, heads in a lake, flows E $5.5 \mathrm{mi}$. to Kasaan Bay, on E coast of Prince of Wales I., Alex. Arch.; $55^{\circ} 35^{\prime} 30^{\prime \prime} \mathrm{N}$, $132^{\circ} 34^{\prime} 40^{\prime \prime} \mathrm{W}$; (map 4).

Local name recorded in 1949 by USGS.

Paunagaktuk Bluff: bluff, elev. 1,000 ft., $S$ tip of Natvatchiak Hill, on $\mathrm{N}$ bank of Chandler River, $18 \mathrm{mi}$. SE of Umiat, Arctic Slope; $69^{\circ}$. $08^{\prime} \mathrm{N}, 151^{\circ} 48^{\prime} \mathrm{W}$; (map 141).

Eskimo name reported in 1956 by T. E. Taylor, USGS.

Paunraquiizak: hill, see Ponrakvirak Hill.

Paveloff Creek: stream, flows SW $2 \mathrm{mi}$. to Bowser Creek, $1 \mathrm{mi}$. N of Oil Bay and $23 \mathrm{mi}$. N of Augustine I., Aleutian Ra.; $59^{\circ} 41^{\prime} 10^{\prime \prime} \mathrm{N}$, $153^{\circ} 18^{\prime} 50^{\prime \prime} \mathrm{W}$; BGN 1962; (map 51).

Named in 1951 by USGS for an early Russian prospector "who sampled oil seeps in the area in 1882."

Paviak Peak: peak, see Pistuk Peak.

Pavlof: locality, on Settlement Point, on E shore of Pavlof Bay, near SW end of Alaska Penin., Aleutian Ra.; $55^{\circ} 29^{\prime} 30^{\prime \prime} \mathrm{N}, 161^{\circ} 28^{\prime} 00^{\prime \prime} \mathrm{W}$; (map 28). Var. Pavlooskoi, Pavlovsk Pavlovskoe, Pawlowskoje, Selenie.

Former Aleut village or camp shown as "Seleniye," meaning "village," in 1852 by Capt. M. D. Tebenkov, IRN. Recorded as "Pavlovskoe" by Father Veniaminov (1840, v. 2, p. 203). An unnamed village was shown on Selenie Point on an 1890 USBF chart. USC\&GS notes in 1925 Coast Pilot (p. 183) that no settlements or commercial enterprises existed on Pavlof Bay.

Pavlof Bay: bay, extends N 21 mi. off Pacific Ocean, on $S$ coast of Alaska Penin., Aleutian Ra.; $55^{\circ} 20^{\prime} \mathrm{N}, 161^{\circ} 38^{\prime} \mathrm{W}$; (map 28). Var. Pavlofskie, Pavlovskaia Baie, Pavlovskie, Pawlowskaja Guba, Tachik, Tatschik.

Russian name reported in French by Capt. Lutke (1836, p. 270), IRN, as "Pavlovskaia baie," meaning "Paul's bay." Father Veniaminov (1840, v. 1, p. 227) recorded "Pavlovskoy Zaliv" and gave the Aleut name as 
"Tachik." Ivan Petroff refers to Pavlof Bay in the 1880 Census.

Pavloff Cove: harbor, see Pavlof Harbor. Pavloff Harbor: village, see Pauloff Harbor. Pavloff Harbor: harbor, see Pavlof Harbor. Pavloff Volcano: volcano, see Pavlof Volcano. Pavlof Harbor: village, see Pauloff Harbor.

Pavlof Harbor: anchorage, $0.5 \mathrm{mi}$. across, in Freshwater Bay, $8.5 \mathrm{mi}$. NE of Tenakee Springs, on $\mathbf{E}$ coast of Chichagof I., Alex. Arch.; 57 50 $45^{\prime \prime}$ N, $135^{\circ} 01^{\prime} 30^{\prime \prime}$ W ; (map 9). Var. Freshwater Bay, Gavan Pavlova, Nasanki Harbor, Pablof Harbor, Parlor Harbor.

Named "Gavan Pavlova," meaning "Paul's Harbor," in 1849 by Capt. Tebenkov (1852, map 8). In 1869 Comdr. R. W. Meade, USN, called it "Freshwater Bay." Baker (1906, p. 491) says "Its native [Indian] name is said to be Nasanki."

Pavlof Harbor: harbor, $0.3 \mathrm{mi}$. across, on $\mathrm{N}$ central coast of Sanak I., $50 \mathrm{mi}$. SE of False Pass, Aleutian Ra.; $54^{\circ} 27^{\prime} 40^{\prime \prime} \mathrm{N}, 162^{\circ} 41^{\prime}$ $30^{\prime \prime}$ W; (map 25). Var. Pauloff Harbor, Pavloff Cove, Pavloff Harbor.

Named "Pavloff Harbor" by USBF in 1888. The USC\&GS published the name using the one " $f$ " spelling in 1909.

Pavlof Islands: islands, group of seven, $23 \mathrm{mi}$. across, near SW end of Alaska Penin., Aleutian Ra.; 55 ${ }^{\circ} 07^{\prime} \mathrm{N}, 161^{\circ} 40^{\prime} \mathrm{W}$; (map 28). Var. Kadugin.

Name reported by Father Veniaminov (1840, v. 1, p. 252), as "Pavlovskiye Ostrova" or "Pavlov [Paul] Islands." The Aleut name was "Kadugin," meaning "narrow," according to Veniaminov.

Pavlof Lake: lake, $0.7 \mathrm{mi}$. across, on E coast of Chichagof I., in course of Pavlof River, 7.5 mi. NE of Tenakee Springs, Alex. Arch.; 57 . $50^{\prime} 30^{\prime \prime} \mathrm{N}, 135^{\circ} 03^{\prime} 00^{\prime \prime} \mathrm{W}$; BGN 1933; (map 9).

Local name derived from Pavlof Bay; reported in 1933 by USFS.

Pavlof Mountain: volcano, see Pavlof Volcano.

Pavlof River: stream, on E coast of Chichagof I., flows $\mathrm{E} 8 \mathrm{mi}$. to Pavlof Harbor, $8 \mathrm{mi}$. NE of Tenakee Springs, Alex. Arch.; 57 $50^{\prime} 30^{\prime \prime}$ $\mathrm{N}, 135^{\circ} 03^{\prime} 00^{\prime \prime} \mathrm{W}$; (map 9).

Local name reported in 1933 by USFS; named for Gerasin Vasilovich Pavlov, first assistant to the Russian Governor at the time of transfer of Alaska to the United States in 1867.

Pavlof Sister: volcano, active, 7,028 ft., NE satellite of Pavlof Volcano, on W side of Pavlof Bay, near SW end of Alaska Penin., Aleutian Ra. ; 55 $27^{\prime} 30^{\prime \prime} \mathrm{N}, 161^{\circ} 51^{\prime} 00^{\prime \prime} \mathrm{W}$; (map 28).

Named in 1929 by USGS.

Pavlofskie: $b a y$, see Pavlof Bay.

Pavlof Volcano: volcano, 8,905 ft., on $\mathrm{W}$ side of Pavlof Bay, near SW end of Alaska Penin., Aleutian Ra.; 55 $25^{\prime} 20^{\prime \prime} \mathrm{N}, 161^{\circ} 53^{\prime} 30^{\prime \prime} \mathrm{W}$; (map 28). Var. Pavloff Volcano, Pavlof Mountain, Pavlovskaya Sopka, Pavlovskoi Volcan, Pavlov Volcano.
Russian name, meaning "Paul" or "Saint Paul", published as Pavlovskoi Volcan by Capt. Lutke (1836, p. 269), IRN; published as Pavlovskaya Sopka on a Russian Hydrog. Dept. Chart 1847. "Pavlov Volcano (smoking)" is shown on an 1890 USBF chart.

Pavlooskoi: locality, see Pavlof.

Pavlova, Gavan: anchorage, see Pavlof Harbor. Pavlovsk: locality, see Pavlof.

Pavlovskaia Baie: bay, see Pavlof Bay.

Pavlovskaya: village, see Kenai.

Pavlovskaya Sopka: volcano, see Pavlof Volcano. Pavlovsk Gaven: bight, see Saint Paul Harbor. Pavlovskie : bay, see Pavlof Bay.

Pavlovskoe: locality, see Pavlof.

Pavlovskoi Volcan: volcano, see Pavlof Volcano.

Pavlovsky Gavan: town, see Kodiak.

Pavlov Volcano: volcano, see Pavlof Volcano.

Paw Cape: point of land, on SW coast of Deer I., at SW end of Aleutian Ra.; $54^{\circ} 51^{\prime} 50^{\prime \prime} \mathrm{N}$, $162^{\circ} 23^{\prime} 30^{\prime \prime} \mathrm{W}, B G N 1942$; (map 25).

So named by USC\&GS in 1939 "because it resembles a paw in shape."

Pawgowsaylum Tessaya: lagoon, see Paugausailuk Lagoon.

Pawik: village, see Naknek.

Pawlowskaja Guba: bay, see Pavlof Bay.

Pawlowskoje: locality, see Pavlof.

Paxson: locality, on Richardson Highway, $3 \mathrm{mi}$. SE of Summit Lake and 62 mi. N of Gulkana, Alaska Ra.; $63^{\circ} 02^{\prime} 00^{\prime \prime} \mathrm{N}, 1^{\circ} 25^{\circ} 29^{\prime} 35^{\prime \prime} \mathrm{W}$; (map 86). Var. Paxson's Road House, Paxton, Paxtons.

Name reported as "Paxson's Road House" on a 1910 fieldsheet by C. E. Giffin, USGS

Paxson Lake: lake, $10 \mathrm{mi}$. long, in the course of Gulkana River, $20 \mathrm{mi}$. N of its junc. with its West Fork, Alaska Ra.; 62 ${ }^{\circ} 55^{\prime}$ N, $145^{\circ} 32^{\prime} \mathrm{W}$; $B G N$ 1952; (map 83). Var. Goolkana Lake, Gulkana Lake, Paxsons Lake.

Named for the operator of a roadhouse at the north end of the lake about 1906; reported by the U.S. Army Signal Corps.

Paxson Mountain: mountain, 5,200 ft, at E end of Amphitheater Mts., $3 \mathrm{mi}$. WSW of Paxson, Alaska Ra.; $63^{\circ} 00^{\prime} 45^{\prime \prime} \mathrm{N}, 145^{\circ} 35^{\prime} 00^{\prime \prime} \mathrm{W}$; (map 86).

Named between 1948 and 1955 by T. L. Péwé, USGS.

Paxsons Lake: lake, see Paxson Lake.

Paxton: locality, see Paxson.

Paxtons: locality, see Paxson

Pay Dirt Creek: stream, flows S to Sinuk River, about $37 \mathrm{mi}$. NW of Nome, Seward Penin. High.; (map 94).

Prospectors' name reported on the 1900 "Map of Nome Peninsula" by J. M. Davidson and B. D. Blakeslee; this feature has not been positively identified.

Payikaglim Creek: stream, flows SW $7 \mathrm{mi}$. to Sapumik Creek, $30 \mathrm{mi}$. NE of Kivalina, Brooks Ra.; 68 $08^{\prime} \mathrm{N}, 163^{\circ} 57^{\prime} \mathrm{W}$; (map 130). Var. Payikahglimb Koogowranga, Paiiqaaglim Kuugaqzanga.

Eskimo name meaning "rainbow fish [Dolly Varden trout: Salvelinus malma spectabilits]" reported in 1966 by E. S. Burch.
Payikahglimb Koogowranga: stream, see Payikaglim Creek.

Paystreak Creek: stream, heads in Kigluaik Mts., flows NW $4 \mathrm{mi}$. to Pilgrim River, $13 \mathrm{mi}$. $\mathrm{N}$ of Salmon Lake and $60 \mathrm{mi}$. SW of Imuruk Lake, Seward Penin. High.; $65^{\circ} 06^{\prime} \mathrm{N}, 164^{\circ}$ 54' W; (map 110).

Prospectors' name reported on a map of Cape Nome gold fields by David Fox, Jr., dated 1901.

Paystreak Creek: stream, flows NW $2.5 \mathrm{mi}$. to Moose Creek, $13 \mathrm{mi}$. NE of Livengood, Yukon-Tanana High.; $65^{\circ} 37^{\prime} 50^{\prime \prime} \mathrm{N}, 148^{\circ} 10^{\prime} 45^{\prime \prime}$ W; (map 105).

Named by prospectors, reported in 1916 by J. B. Mertie (in Brooks and others, 1918, pl. 13), USGS.

Peabody Mountains: mountain range, extends NE-SW 35 mi., W of pearse and Portland Canals and $\mathrm{E}$ of Marten River, Coast Mts.; $55^{\circ} 12^{\prime} \mathrm{N}, 130^{\circ} 18^{\prime} \mathrm{W}$; (map 3).

Named in 1868 by Staff Comdr. David Pender, RN.

Peaceful River: stream, heads at North Pass and flows $4.8 \mathrm{mi}$. SE to Pyramid Cove, on SE coast of Attu I., Aleutian Is.; $52^{\circ} 49^{\prime} 37^{\prime \prime} \mathrm{N}$, $173^{\circ} 11^{\prime} 07^{\prime \prime} \mathrm{E}$; (map 13).

Named by the U.S. Army during its occupation of the island during World War II; shown on an AMS map published in 1948.

Peaceful Valley: valley, $2.5 \mathrm{mi}$. long, formed by Peaceful River, on SE side of Attu I., Aleutian Is.; $52^{\circ} 49^{\prime} 37^{\prime \prime} \mathrm{N}, 173^{\circ} 11^{\prime} 07^{\prime \prime} \mathrm{E}$; (map 13).

Name shown on an AMS map published in 1948 .

Peace Island: island, $1 \mathrm{mi}$. long, in Yukon River $\mathrm{N}$ of Marten I., $21 \mathrm{mi}$. SW of Beaver, Yukon Flats; $66^{\circ} 14^{\prime} 30^{\prime \prime} \mathrm{N}, 148^{\circ} 06^{\prime} 00^{\prime \prime} \mathrm{W}$; (map 118).

Local name obtained in 1956 by USGS.

Peace River: stream, heads in Mikchalk Lake, flows S $2 \mathrm{mi}$. to Lake Beverly, $49 \mathrm{mi}$. NW of Dillingham, Kilbuck-Kuskokwim Mts.; 59०$43^{\prime} \mathrm{N}, 158^{\circ} 51^{\prime} \mathrm{W}$; $B G N$ 1931; (map 52) Var. Gui-guok-lok.

Local name obtained in 1931 from F. H. Waskey and Beverley Polley by Gerald FitzGerald, USGS. The Eskimo name "Guiguok-lok" was recorded on a 1910 manuscript map by H. C. Fassett, USBF.

Peace River: stream, flows SW $30 \mathrm{mi}$. to Koyuk River, $8 \mathrm{mi}$. SW of Haycock, Seward Penin. High.; $65^{\circ} 09^{\prime} \mathrm{N}, 161^{\circ} 25^{\prime} \mathrm{W}$; BGN 1910; (map 109).

Local name reported in 1909 by P. S. Smith, USGS.

Peacock Creek: stream, flows $1 \mathrm{mi}$. NW to Kotsina River $\mathrm{S}$ of Surprise Creek, $36 \mathrm{mi}$. NW of McCarthy, Wrangell Mts.; 61 $44^{\prime} \mathrm{N}$, $143^{\circ} 48^{\prime} \mathrm{W}$; (map 67).

Local name reported in 1900 by F. C. Schrader (Mendenhall and Schrader, 1903, pl. 3 ), USGS.

Peacock Island: island, near head of McKenzie Inlet, on Prince of Wales I., S of Skowl Arm Kasaan Bay, Alex. Arch.; $55^{\circ} 20^{\prime} 15^{\prime \prime} \mathrm{N}-432^{\circ}$ $21^{\prime} 30^{\prime \prime} \mathrm{W}$; (map 4). 
Local name reported in 1905 by E. F. Dickins, USC\&GS.

Peacock Point: point of land, on SW coast of Unalaska Is., Aleutian Is. ; $53^{\circ} 23^{\prime} 40^{\prime \prime} \mathrm{N}, 167^{\circ}-$ $36^{\prime} 10^{\prime \prime} \mathrm{W}$; BGN 1939; (map 23 ).

This descriptive name given by USC\&GS in 1939 because of the resemblance of the feature "to that of the head and breast of a strutting peacock."

Peak, Cape: point of land, see Upright, Cape.

Peaked Island: island, $0.2 \mathrm{mi}$. across, W of Cape Wrangell, off W coast of Attu I., Aleutian Is.; $52^{\circ} 55^{\prime} 20^{\prime \prime} \mathrm{N}, 172^{\circ} 26^{\prime} 35^{\prime \prime} \mathrm{E}$; (map 13).

Name probably given by Lt. William Gibson, USN, who commanded the schooner U.S.S. Fenimore Cooper during the North Pacific Exploring Expedition of 1854-55.

Peak Island: island, $2 \mathrm{mi}$. across, in Prince William Sound, off $\mathrm{N}$ coast of Naked I., $36 \mathrm{mi}$. $\mathrm{NE}$ of Chenega, Chugach Mts.; $60^{\circ} 42^{\prime} \mathrm{N}$, $147^{\circ} 23^{\prime} \mathrm{W}$; (map 63). Var. Little Naked Island.

Local descriptive name published in 1900 by USC\&GS. "So called because it was leased for blue-fox propagation under the name 'Peak' because of a high point of land."

Peak Rock: pinnacle, 5,505 ft., $2.5 \mathrm{mi}$. NE of Glacier Point, E of Ruth Glacier, Alaska Ra.; $62^{\circ} 55^{\prime} 08^{\prime \prime} \mathrm{N}, 150^{\circ} 32^{\prime} 40^{\prime \prime} \mathrm{W}$; (map 81).

Mountain climbers' name probably given by members of the 1945 Mazema Expedition to the area (Metcalf, 1945, map facing p. 11).

Peak Point: point of land, "on the north shore of St. Matthew island, near its eastern end. Named Pik (peak) by Sarichef in his atlas of 1826" (Baker, 1906, p. 492). Var. Mys Pik.

Peanut Lake: lake, $1 \mathrm{mi}$. long, $29 \mathrm{mi}$. $\mathrm{N}$ of Angoon, on $\mathrm{W}$ coast of Admiralty I., Alex. Arch.; 57 $55^{\prime} \mathrm{N}, 134^{\circ} 43^{\prime} \mathrm{W}$; BGN 1929; (map 9).

Descriptive name given in 1920 by USFS. "So named because of its shape."

Peard Bay: bay, $20 \mathrm{mi}$. across, on Chukchi Sea coast, S of Point Franklin, Arctic Plain; $70^{\circ}$ $51^{\prime} \mathrm{N}, 158^{\circ} 48^{\prime} \mathrm{W}$; (map 147). Var. Pearl Bay, Pedrl Bay.

Capt. Beechey (1831, p. 306), RN., wrote "a bay on which I bestowed the name of my first lieutenant, Mr. Peard [Lt. George Peard, RN.]."

Peard Cliff: cliff, elev. $50 \mathrm{ft}$., on $\mathrm{S}$ shore of Peard Bay, 10 mi. S of Point Franklin, Arctic Plain; $70^{\circ} 47^{\prime} \mathrm{N}, 158^{\circ} 50^{\prime} \mathrm{W}$; (map 147).

Name recorded on Brit. Adm. Chart 593, 1827-55.

Pear Lake: lake, $0.5 \mathrm{mi}$. long, one of the Beaver Lakes, $26 \mathrm{mi}$. $\mathrm{N}$ of Anchorage, Cook Inlet Low; $61^{\circ} 35^{\prime} 30^{\prime \prime}$ N. $149^{\circ} 53^{\prime} 50^{\prime \prime}$ W ; (map 69). Local name reported in 1951 by USGS.

Pearl Bay: bay, see Peard Bay.

Pearl Creek: stream, flows SW $0.7 \mathrm{mi}$. to Blue Creek, S of Featherly Pass, on Alaska Penin., $45 \mathrm{mi}$. NE of Ugashik, Aleutian Ra.; $57^{\circ}$ $40^{\prime} 45^{\prime \prime} \mathrm{N}, 156^{\circ} 18^{\prime} 35^{\prime \prime} \mathrm{W}$; (map 36).

Name reported in 1902 by J. L. McPherson of Iliamna; published by G. C. Martin (1921, pl. 10), USGS.
Pearl Creek: stream, flows SE $3.8 \mathrm{mi}$. to Noyes Slough at Totem Park, $2.3 \mathrm{mi}$. NW of Fairbanks, Tanana Low.; $64^{\circ} 52^{\prime} \mathrm{N}, 147^{\circ} 47^{\prime} \mathrm{W}$; (map 100).

Local name reported in 1950 by USGS topographers.

Pearl Creek: stream, flows N 2 mi., joins Barnes Creek to form Fish Creek, $2.5 \mathrm{mi}$. NE of Gilmore Dome, 16 mi. NE of Fairbanks, YukonTanana High.; $65^{\circ} 01^{\prime} \mathrm{N}, 147^{\circ} 18^{\prime} \mathrm{W} ; B G N$ 1933; (map 105).

Named by prospectors; published in 1907 by USGS.

Pearl Creek: stream, flows $W$ to North Fork Koyukuk River; $67^{\circ} 25^{\prime} \mathrm{N}, 150^{\circ} 45^{\prime} \mathrm{W}$; (map 134).

Prospectors' name reported in 1909 by Maddren (1910, pl. 7), USGS.

Pearl Creek: stream, see Yellow Pup.

Pearl Harbor: bay, $0.5 \mathrm{mi}$. across, on E shore of Favorite Channel, $1 \mathrm{mi}$. S of Dotsons Landing and $18 \mathrm{mi}$. NW of Juneau, Coast Mts.; $58^{\circ} 28^{\prime} 30^{\prime \prime} \mathrm{N}, 134^{\circ} 47^{\prime} 15^{\prime \prime} \mathrm{W}$; BGN 1930; (map 11). Var. Lake Harbor.

The source of the name is unknown. In 1903 it was known as Lake Harbor and was first called Pearl Harbor in 1905 in a mining claim by John Peterson (DeArmond, 1957, p. 34).

Pearl Island: island, $0.4 \mathrm{mi}$. long, between Duncan Canal and Beecher Pass, $15 \mathrm{mi}$. SW of Petersburg, on $\mathrm{S}$ coast of Kupreanof I., Alex. Arch.; $56^{\circ} 36^{\prime} 00^{\prime \prime} \mathrm{N}, 133^{\circ} 02^{\prime} 30^{\prime \prime} \mathrm{W}$; $B G N$ 1933; (map 6).

Local name reported in 1933 by $R$. H. Sargent, USGS; name obtained from G. J. Hilderbrand, who lives on this island.

Pearl Island: island, $5 \mathrm{mi}$. long, in Yukon River $17 \mathrm{mi}$. NE of Russian Mission, Yukon-Kuskokwim Delta; 61 ${ }^{\circ} 56^{\prime} \mathrm{N}, 160^{\circ} 48^{\prime} \mathrm{W}$; (map 73). Var. Buzzy Island.

Riverboat pilots' name shown on a 1916 field sheet by R. H. Sargent, USGS. This name is applied to a small island northwest of, but now joined to, the above described land.

Pearl Island: island, see Perl Island.

Pearl Point: point of land, see Perlas Point.

Pearl Rock : rock, see Perl Rock.

Pearse Canal: water passage, extends NE $26 \mathrm{mi}$. forms part of Alaska-Canada boundary, from Tongass Passage to Portland Canal, Coast

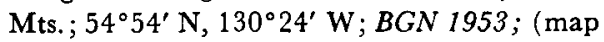
2). Var. Pearse Inlet.

Named in 1868 by David Pender, RN.

Pearse Canal: water passage, see Portland Canal.

Pearse Channel: water passage, see Portland Ganal.

Peary Creek: stream, flows SW $3.2 \mathrm{mi}$. to Flat Creek, $17 \mathrm{mi}$. NW of the village of Crooked Creek and $45 \mathrm{mi}$. NW of Sleetmute, KilbuckKuskokwim Mts.; $62^{\circ} 06^{\prime} 15^{\prime \prime} \mathrm{N}, 158^{\circ} 14^{\prime} 00^{\prime \prime}$ W; BGN 1945; (map 79).

Local name obtained in 1944 by USGS.

Pease Inlet: $b a y$, see Dease Inlet.

Peasely Creek: stream, see Peasley Creek.

Pease, Mount: peak, see Pease Peak.

Pease Peak: peak, 7,750 ft. W of Pittock Pass, 12 mi. SE of Denali Pass in Mt. McKinley
National Park, Alaska Ra.; 62 $57^{\prime} 00^{\prime \prime}$ N, $150^{\circ} 45^{\prime} 30^{\prime \prime} \mathrm{W}$; (map 81). Var. Mount Pease.

Mountain climbers' name published in the late 1940's.

Peasley Creek: stream, flows W $4 \mathrm{mi}$. to American River, $27 \mathrm{mi}$. NE of Teller, Seward Penin.; $65^{\circ} 32^{\prime} \mathrm{N}, 165^{\circ} 44^{\prime} \mathrm{W}$; (map 111). Var Peasely Creek.

Prospectors' name reported on the 1908 "Map of Seward Peninsula" by Arthur Gibson.

Peavey: locality, site of mining camp, on $\mathrm{N}$ bank of Koyukuk River $3.8 \mathrm{mi}$. W of its junc. with South Fork, $17 \mathrm{mi}$. E of Allakaket, Kanuti Flats; $66^{\circ} 35^{\prime} \mathrm{N}, 152^{\circ} 03^{\prime} \mathrm{W}$; (map 117). Var. Peavy, Peavy Trading Post.

Name reported in 1899 by G. H. Wonson, Master of the steamer Dorothy, on his map of the Koyukuk River. Archdeacon Stuck (1917, p. 346) wrote, "whenever a steamboat tied up, a few cabins were built *** some sort of official from the General Land Office *** laid out a town site with church and school and courthouse $* * *$ the town was named Peavey, and blue-prints of it looked quite imposing."

Peavey Creek: stream, flows SE $12 \mathrm{mi}$. to Koyukuk River, $20 \mathrm{mi}$. SW of Bettles, Kanuti Flats; $66^{\circ} 37^{\prime} 30^{\prime \prime} \mathrm{N}, 151^{\circ} 52^{\prime} 30^{\prime \prime} \mathrm{W} ; B G N$ 1932; (map 117)

Local name in use since 1898; reported by Robert Marshall in 1931.

Peavey Slough: stream, anabranch, $4 \mathrm{mi}$. long, on $\mathrm{N}$ bank of Koyukuk River $1.2 \mathrm{mi}$. W of junc. with its South Fork, $16 \mathrm{mi}$. $\mathrm{E}$ of Allakaket, Kanuti Flats; $66^{\circ} 35^{\prime} \mathrm{N}, 152^{\circ} 01^{\prime} \mathrm{W}$; (map 117).

In 1890 the temporary settlement of "Peavey" was located on this slough. Change in course of the river has made the slough the main channel of the Koyukuk River at this point.

Peavy: locality, see Peavey.

Peavy Trading Post: locality, see Peavey.

Pecks Creek: stream, flows W $22 \mathrm{mi}$. to Kvichak River, $87 \mathrm{mi}$. E of Dillingham, Bristol Bay Low.; $59^{\circ} 18^{\prime} \mathrm{N}, 156^{\circ} 00^{\prime} \mathrm{W}$; (map 52).

Local name published in 1956 by USGS.

Pecks Creek: stream, see Ole Creek.

Pedersen Point: bluff, see Pederson Point.

Pedersen Point: point of land, SE tip of Moser I., in Hoonah Sound, off $\mathrm{S}$ coast of Chichagof I., Alex. Arch.; 57 $39^{\prime} 30^{\prime \prime} \mathrm{N}, 135^{\circ} 35^{\prime} 30^{\prime \prime} \mathrm{W}$; (map 9). Var. Pederson Point.

Named in 1895 by Lt. Comdr. Moore, USN.

Pederson Glacier: glacier, trends E $3.2 \mathrm{mi}$. to its terminus at Aialik Bay, $20 \mathrm{mi}$. SW of Seward, Chugach Mts.; $59^{\circ} 53^{\prime} \mathrm{N}, 149^{\circ} 45^{\prime} \mathrm{W} ; B G N$ 1910; (map 49).

Named in 1908 by U. S. Grant, USGS.

Pederson Hill: hill, $450 \mathrm{ft}$., on $\mathrm{N}$ end of Mendenhall Periin., 0.6 mi. $\mathrm{S}$ of Auke Lake and 9.5 mi. NW of Juneau, Coast Mts. ; 58 $22^{\prime} 25^{\prime \prime}$ $\mathrm{N}, 134^{\circ} 38^{\prime} 00^{\prime \prime} \mathrm{W}$; (map 11 ).

Presumably named for Albert Pederson, 1859-1929, who operated a nearby dairy (DeArmond, 1957, p. 34). 
Pederson Point: bluff, elev. $60 \mathrm{ft}$., on $\mathbf{E}$ shore of Kvichak Bay, on Alaska Penin., 3 mi. NW of Naknek, Bristol Bay Low.; 58 $46^{\prime} 15^{\prime \prime} \mathrm{N}$, $157^{\circ} 03^{\prime} 45^{\prime \prime}$ W; (map 41). Var. Cape Suworof, Pedersen Point.

Local name published by USBF in 1901 for "L. A. Pedersen, who established a cannery near here in 1890."

Pederson Point: point of land, see Pedersen Point.

Pediment Creek: stream, flows NW $20 \mathrm{mi}$. to Okokmilaga River $4 \mathrm{mi}$. SE of its junc. with Killik River, Brooks Ra.; $68^{\circ} 46^{\prime}$ N, $153^{\circ} 19^{\prime}$ W; (map 133).

Named in 1949 by W. W. Patton, USGS, associated with exploration of Naval Petroleum Reserve No. 4.

Pedmar, Mount: peak, 2,825 ft., N of Katmai Bay, on E coast of Alaska Penin., in Katmai National Monument, $16 \mathrm{mi}$. SE of Mount Katmai, Aleutian Ra.; 58 $02^{\prime} 20^{\prime \prime} \mathrm{N}, 154^{\circ} 49^{\prime} 05^{\prime \prime}$ W; BGN 1924; (map 42).

Named in 1916 by R. F. Griggs, National Geographic Society.

Pedrl Bay: bay, see Peard Bay.

Pedro: locality, in the Goldstream Creek valley, 14 mi. W of Fairbanks, Yukon-Tanana High.; $64^{\circ} 50^{\prime} \mathrm{N}, 148^{\circ} 20^{\prime} \mathrm{W}$; (map 100).

Local name of a roadhouse shown in Polk's Gazetteer in 1916. The roadhouse no longer exists.

Pedro: locality, see Pedro Camp.

Pedro: village, see Pedro Bay.

Pedro Bay: village, pop. 53, at head of Pedro Bay, $38 \mathrm{mi}$. NW of Augustine I., Aleutian Ra.; $59^{\circ} 47^{\prime} 15^{\prime \prime}$ N, $154^{\circ} 06^{\prime} 30^{\prime \prime}$ W; (map 51). Var. Pedro.

Village listed in 1950 Census with a population of 44. A post office was established here in 1936 (Ricks, 1965, p. 50).

Pedro Bay: water passage, $5 \mathrm{mi}$. long, in Iliamma Lake $\mathrm{N}$ of Porcupine $21 \mathrm{mi}$. $\mathrm{E}$ of Iliamna, Aleutian Ra.; $59^{\circ} 42^{\prime} 30^{\prime \prime} \mathrm{N}, 154^{\circ} 13^{\prime} 30^{\prime \prime} \mathrm{W}$; (map 51).

Named published in 1912 on USC\&GS Chart 8554.

Pedro Camp: locality, on right bank of Pedro Creek, $12 \mathrm{mi}$. NE of Fairbanks, YukonTanana High.; $65^{\circ} 00^{\prime} \mathrm{N}, 147^{\circ} 31^{\prime} \mathrm{W}$; (map 105). Var. Pedro.

Local name of a mining camp reported to have existed by 1905 (Kitchener, 1954, p. 297). The name was derived from Pedro Creek, which in turn was named for Felix Pedro who discovered gold in the valley.

Pedro Creek: locality, on Pedro Creek, $10 \mathrm{mi}$. NE of Fairbanks, Yukon-Tanana High.; $64^{\circ}$ $59^{\prime} \mathrm{N}, 147^{\circ} 33^{\prime} \mathrm{W}$; (map 100).

This former mining settlement derived its name from the stream on which it is located. The name was first shown in the 1915-16 Polk's Gazetteer.

Pedro Creek: stream, heads on Swinging Dome, flows SW and SE $6 \mathrm{mi}$. to Iditarod River, 15 mi. SE of Flat, Kilbuck-Kuskokwim Mts.; $62^{\circ} 16^{\prime} 40^{\prime \prime} \mathrm{N}, 158^{\circ} 18^{\prime} 10^{\prime \prime} \mathrm{W}$; (map 79).

Prospectors' name obtained in 1952 by USGS topographers.
Pedro Creek: stream, flows SW $6.7 \mathrm{mi}$. joins Gilmore Creek to form Goldstream Creek 10 mi. NE of Fairbanks, Yukon-Tanana High.; $64^{\circ} 59^{\prime} \mathrm{N}, 147^{\circ} 33^{\prime} \mathrm{W}$; (map 100).

Named for Felix Pedro who discovered gold while prospecting in the valley in July, 1902, thereby starting the stampede to the area. Name reported in 1903 by T. G. Gerdine (in Prindle, 1905, pl. 16), USGS.

Pedro Creek: stream, flows SE $4 \mathrm{mi}$. to South Fork Hess Creek, $9 \mathrm{mi}$. NNE of Livengood, Yukon-Tanana High.; $65^{\circ} 38^{\prime} 45^{\prime \prime} \mathrm{N}, 148^{\circ}$. 25'20" W; (map 105).

Prospectors' name derived from the creek near Fairbanks that was named for Felix Pedro. Name reported in 1915 by Brooks (Brooks and others, 1916, pl. 9), USGS.

Pedro Dome: mountain, 2,600 ft., $15 \mathrm{mi}$. NE of Fairbanks, Yukon-Tanana High.; $65^{\circ} 02^{\prime} \mathrm{N}$, $147^{\circ} 30^{\prime} \mathrm{W}$; (map 105).

Local name derived from Pedro Greek, reported in 1903 by T. G. Gerdine (Prindle, 1905, pl. 13), USGS.

Pedro Glacier: glacier, trends SW $3 \mathrm{mi}$. to its terminus at head of stream which drains into Miners Lake, $35 \mathrm{mi}$. W of Valdez, Chugach Mts.; $61^{\circ} 07^{\prime} 30^{\prime \prime} \mathrm{N}, 147^{\circ} 22^{\prime} 40^{\prime \prime} \mathrm{W} ; B G N$ 1910; (map 69).

Name reported in 1908 by Grant and Higgins (1910, pl. 2), USGS.

Pedro Gulch: ravine, trends $\mathrm{W}$ to head of $\mathrm{Big}$ Creek, E of Chandalar River; $67^{\circ} 30^{\prime} \mathrm{N}, 148^{\circ}$ $05^{\prime} \mathrm{W}$.

Prospectors' name reported about 1923 by Mertie (1925, fig. 11), USGS.

Pedro Mountain: mountain, $1,581 \mathrm{ft}$., on penin. between Knutson and Pedro Bays, at $\mathrm{E}$ end of Iliamna Lake, $26 \mathrm{mi}$. E of Iliamna, Aleutian Ra.; $59^{\circ} 46^{\prime} 30^{\prime \prime} \mathrm{N}, 154^{\circ} 10^{\prime} 00^{\prime \prime} \mathrm{W}$; (map 51 ).

Local name derived from Pedro Bay; published by USGS in 1954 .

PEEIN-E-LUK Island: island, see Pieneluk Island.

Peel Island: island, see Herbert Graves Island.

Peeluk Creek: stream, see Peluk Creek.

Peenyiksahm Koonga: stream, see Shorty River.

Peep Rock: rock, in Karheen Passage, off SW coast of Tuxekan I., Alex. Arch.; 55 $49^{\prime} 10^{\prime \prime}$ $\mathrm{N}, 133^{\circ} 19^{\prime} 45^{\prime \prime} \mathrm{W}$; (map 4).

Name published in 1923 by USC\&GS

Peer Island: island, $200 \mathrm{ft}$. across, in Imperial Passage, $8 \mathrm{mi}$. NW of Chichag of, on W coast of Chichagof I., Alex. Arch.; 57 $43^{\prime} 45^{\prime \prime} \mathrm{N}$, $136^{\circ} 16^{\prime} 00^{\prime \prime} \mathrm{W}$; $B G N$ 1926; (map 9).

Named in 1926 by USC\&GS for geographic point "Peer" which is located on the island.

Peerleshin: mountain, see Pereleshin Mountain.

Pegati Lake: lake, 4 mi. long, joins Kagati Lake at its $\mathrm{W}$ terminus, $1 \mathrm{mi}$. $\mathrm{N}$ of Nuklunek Mtn. and $75 \mathrm{mi}$. NE of Goodnews, Kilbuck-Kuskokwim Mts.; $59^{\circ} 52^{\prime}$ N, $160^{\circ} 05^{\prime}$ W; (map 53) Var. Kagati Lake, Kanektuk Lake.

Eskimo name shown on an 1898 fieldsheet by W. S. Post, USGS; published by Spurr (1900, map 10) as "Kagati Lake." Both Pegati and Kagati Lakes were called "Kanektuk Lake" in 1923 on a U.S. Bureau of Education map.
Pegeeluk Creek: stream, flows S $12 \mathrm{mi}$. to Alatna River, $19 \mathrm{mi}$. S of Survey Pass, Brooks Ra.; $67^{\circ} 35^{\prime} \mathrm{N}, 154^{\circ} 18^{\prime} \mathrm{W}$; BGN 1932; (map 125 ).

Eskimo name meaning "not very good," reported by Robert Marshall in 1931.

Peggy Lake: lake, $0.9 \mathrm{mi}$. long, between Little Jack and Trail Creeks, $15 \mathrm{mi}$. NW of Devils Mtn., Alaska Ra.; 62 $34^{\prime} \mathrm{N}, 143^{\circ} 18^{\prime} \mathrm{W}$; (map 84).

Local name reported in 1951 by USGS.

Pegmatite Creek: stream, flows E and NW 8 mi. to Little Gerstle River $11 \mathrm{mi}$. SW of that stream's junc. with Tanana River and $36 \mathrm{mi}$ $\mathrm{SE}$ of Delta Junction, Alaska Ra.; $63^{\circ} 39^{\prime} 05^{\prime \prime}$ N, $144^{\circ} 57^{\prime} 00^{\prime \prime} \mathrm{W}$; BGN 1937; (map 86).

Local name reported in 1937 by USGS. Pegmatite is a coarse-grained igneous rock usually found in dikes.

Pegmatite Glacier: glacier, trends SW $1 \mathrm{mi}$. between College and Gulkana Glaciers, $16 \mathrm{mi}$ NNE of Paxson, Alaska Ra.; $63^{\circ} 15^{\prime} 40^{\prime \prime} \mathrm{N}$, $145^{\circ} 24^{\prime} 10^{\prime \prime} \mathrm{W}$; (map 86).

Named between 1948 and 1955 by T. L. Péwé, USGS.

Peirce, Cape: point of land, 2 mi. S of Nanvak Bay and $25 \mathrm{mi}$. W of Calm Point on Hagemeister I., Kilbuck-Kuskokwim Mts.; $58^{\circ} 33^{\prime}$ $15^{\prime \prime} \mathrm{N}, 161^{\circ} 46^{\prime} 00^{\prime \prime} \mathrm{W}$; (map 39). Var. Calm Point, Gave Point.

Named in 1869 by USC\&GS for Benjamin Peirce, then superintendent of the "Coast Survey." Capt. Tebenkov (1852, map 4), IRN, called it "M[ys] Peschera," meaning "cave point." This may be the "Calm Point" named by Capt. Cook (1785, v. 2, p. 431), RN, "from our having calm weather when off it."

Peirce, Mount: mountain, 2,000 ft., on N part of Nagai I., Shumagin Is., Aleutian Ra.; (map 27).

Named by W. H. Dall, USC\&GS, for Benjamin Peirce, 1809-80, a leading American mathematician and Superintendent of the U.S. Coast Survey (USC\&GS) from 1867-74.

Peisar Island: island, $1.3 \mathrm{mi}$. long, $4 \mathrm{mi}$. NW of Goddard, on W coast of Baranof I., Alex Arch.; 56 $53^{\prime} \mathrm{N}, 135^{\circ} 26^{\prime} \mathrm{W}$; BGN 1897; (map 5). Var. Ostrov Peysar, Peisar Islet.

Named in 1809 by the Russian navigator, Ivan Vasiliev the first; published by Lt. Sarichev (1826, map 19), IRN, as "O[strov] Peysar," meaning "writer island."

Peisar Islet: island, see Peisar Island.

Pekalok Cape: promontory, see Southwest Cape. Pekaluk Cape: promontory, see Southwest Cape Pekaluk Point: promontory, see Southwest Cape. Pektotolik Slough: distributary, in Yukon Delta, extends N-S $15 \mathrm{mi}$. between Tunurokpak Channel and Kwikluak Pass, $19 \mathrm{mi}$. SE of Kwiguk, Yukon-Kuskokwim Delta; $62^{\circ} 35^{\prime} \mathrm{N}$, $164^{\circ} 01^{\prime} \mathrm{W}$; (map 77).

Eskimo name obtained in 1899 by G. R. Putnam, USC\&GS. Published in 1901 on Chart 9372.

Pelazuk: locality, on coast of Bering Sea, $8 \mathrm{mi}$. SW of Cape Prince of Wales and $48 \mathrm{mi}$. NW of Teller, Seward Penin. High.; 65 $32^{\prime} \mathrm{N}$, 
$167^{\circ} 50^{\prime} \mathrm{W}$; (map 111). Var. Palarzook Palazruk.

Site of an Eskimo village reported in 1907 as "the old native village Palazruk" (Collier and others, 1908, p. 59). Although no population can be associated with the village, the 1954 USC\&GS Coast Pilot stills refer to "The native village of Pelazuk" (p. 551). See Polaraskh-mute.

Pelazuk: locality, see Polaraskh-mute.

Pelenga, Mys: point of land, see Azimuth Point.

Pelenga Bay: bight, $0.5 \mathrm{mi}$. across, between Azimuth and Termination Points $5 \mathrm{mi}$. $\mathrm{N}$ of Kodiak, Kodiak I. ; $57^{\circ} 51^{\prime} 35^{\prime \prime} \mathrm{N}, 152^{\circ} 25^{\prime} 00^{\prime \prime}$ W; (map 34)

Transliteration of a Russian name meaning "magnetic azimuth" published in 1943 by USC\&GS ; name derived from Azimuth Point. See Azimuth Point.

Peler Creek: stream, flows SE to Cripple River, about $26 \mathrm{mi}$. NW of Nome, Seward Penin. High.; (map 94).

Prospectors' name reported on the 1900 "Map of Nome Peninsula" by J. M. Davidson and B. D. Blakeslee; this feature has not been positively identified.

Pelfroy Creek: stream, flows NW to Kuzitrin River, about $17 \mathrm{mi}$. N of Mount Bendeleben, Seward Penin. High.; (map 110).

Prospectors' name shown on a map of Cape Nome gold fields by David Fox, Jr., dated 1901. This stream cannot be precisely located on current maps.

Pelican: village, pop. 135, on Lisianski Inlet, in NW part of Chicagof I., Alex. Arch.; 57 $57^{\prime}$ $30^{\prime \prime} \mathrm{N}, 136^{\circ} 13^{\prime} 30^{\prime \prime} \mathrm{W}$; BGN 1960; (map 9). Var. Pelican City.

Named for a fishing boat The Pelican owned by Charles Raatikainen, a founder of the town. The corporate name of the town is "Pelican," although it is frequently called "Pelican City." In 1943 there was a cannery, a small sawmill, a school, and a hotel here. A post office was first established here in 1939 (Ricks, 1965, p. 50).

Pelican City: village, see Pelican.

Pelican Creek: stream, on Chichagof I., flows SW $5 \mathrm{mi}$. to Lisianski Inlet at Pelican, Alex.

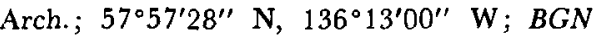
1960; (map 9)

Named in 1955 by D. L. Rossman, USGS, for the town of Pelican.

Pelican Harbor: bay, $0.3 \mathrm{mi}$. across, at Pelican, on $\mathrm{E}$ shore of Lisianski Inlet, in NW part of

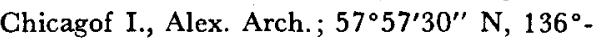
13'30" W; (map 9).

Named for the town of Pelican; published in 1961 by USC\&GS on Chart 8260 .

Peligro, Isla del: island, see Kalgin Island.

Pellew, Point: point of land, at $\mathrm{E}$ side of entrance to Eaglek Bay, $35 \mathrm{mi}$. NE of Whittier, Chugach Mts.; $60^{\circ} 50^{\prime} 30^{\prime \prime} \mathrm{N}, 147^{\circ} 39^{\prime} 45^{\prime \prime} \mathrm{W}$; (map 63).

Named in 1794 by Capt. Vancouver (1798, v. 3, p. 184), "for Edward Pellew, admiral and first Viscount Exeter (Wagner, 1937, p. 401)."
Pelly Mountains: mountain range, reported to lie $S$ of Harrison Bay, $W$ of Colville River Delta, Arctic Plain; (map 149). Var. Pelly's Mountains.

On July 24, 1837, Thomas Simpson (1843, p. 129) wrote, "In honour of the publicspirited Governor of the Hudson's Bay Company, this chain was called Pelly's Mountains." John Simpson, RN, wrote of Erk-sin-ra, an Eskimo from whom he obtained much information for his native map, "whilst his description of the coast agreed so minutely in many particulars with the narrative and chart of Messrs. Dease and Simpson, he denied the existence of the Pelly Mountains, and maintained most positively that there are no hills on the west side of the Colville visible from the sea;" (Great Britain, 1855, p. 937). On August 9, 1889, Capt. Stockton (1890, p. 184), USN, wrote: "The first important error found in the charts and maps of this region was found here by the observation of the nonexistence of the Pelly Mountains ***. The mountains certainly do not exist where placed by the charts, ***."

Pelly Mountains: mountains, see Romanzof Mountains.

Pelly River: stream, see Stikine River.

Pelly's Mountains: mountain range, see Pelly Mountains.

Peluk Creek: stream, flows SW $8 \mathrm{mi}$. to Bearing Sea, $6 \mathrm{mi}$. SE of Cape Douglas and $46 \mathrm{mi}$. NW of Nome, Seward Penin. High.; 64.57' N, 166 $32^{\prime}$ W; (map 94). Var. Peeluk Creek.

Eskimo name reported as "Peeluk" on the 1902 "Map of the Nome and Snake River Country" by J. M. Davidson. Subsequent maps show "Peluk."

Peluck Creek: stream, flows SW $0.6 \mathrm{mi}$. to West Fork Buck Creek, in Mint River basin, 1 mi. $\mathrm{NE}$ of Potato Mtn. and $16 \mathrm{mi}$. NE bf Cape Prince of Wales, Seward Penin. High.; $65^{\circ}$. $39^{\prime} 25^{\prime \prime} \mathrm{N}, 167^{\circ} 02^{\prime} 20^{\prime \prime} \mathrm{W}$; (map 111).

Prospectors' name reported in 1918 by Steidtmann and Cathcart (1922, fig. 14), USGS.

Peluk Creek: stream, in Baird Mts., flows S 4.5 mi. to Klery Creek $3 \mathrm{mi}$. NE of its junc. with Squirrel River, 12 mi. NNW of Kiana, Brooks Ra.; $67^{\circ} 08^{\prime}$ N, $160^{\circ} 33^{\prime} \mathrm{W}$; (map 127).

Name used by prospectors; reported in 1910 by P. S. Smith (in Brooks and others, 1911, pl. 13), USGS

Peluk Greek: stream, flows NW to Kuzitrin River near its head, about $15 \mathrm{mi}$. SW of Imuruk Lake, Seward Penin. High.; (map 110)

Prospectors' name reported on a precinct map of Seward Peninsula by Monroe and Hutchins; corrected to June 1903 by Arthur Gibson. This stream cannot be precisely located on current maps.

Peluk Creek: stream, flows SW to Noxapaga River near its head, about $15 \mathrm{mi}$. W of Imuruk Lake, Seward Penin High.; (map 110).
Prospectors' name reported in 1900 by Brooks (1901, pl. 11), USGS. This feature cannot be precisely identified on current maps. Peluk Creek: stream, flows NW to Anikovik River, about $15 \mathrm{mi}$. E of Cape Prince of Wales, Seward Penin. High.; (map 111).

Prospectors' name shown on the 1900 "Map of Nome Peninsula" by J. M. Davidson and B. D. Blakeslee. This feature cannot be precisely identified on current maps.

Pendant Point: point of land, S of Cape Sudak, on $\mathrm{E}$ coast of Tanaga I., Aleutian Is.; $51^{\circ}$ $50^{\prime} 00^{\prime \prime} \mathrm{N}, 177^{\circ} 37^{\prime} 30^{\prime \prime} \mathrm{W}$; (map 17).

Name published by USC\&GS in 1956 on Chart 9145

Pendergast Pup: stream, flows E $1.8 \mathrm{mi}$. to Coal Creek, $1.5 \mathrm{mi}$. S of that stream's junc. with Yukon River and $44 \mathrm{mi}$. SE of Circle, YukonTanana High.; $65^{\circ} 20^{\prime} \mathrm{N}, 143^{\circ} 06^{\prime} \mathrm{W}$; (map 103).

Local name reported in 1936 by Mertie (1938a, pl. 5), USGS.

Pendleton, Mount: mountain, 7,800 ft., in Mount McKinley National Park, $3 \mathrm{mi}$. N of Easy Pass and $35 \mathrm{mi}$. SW of confluence of Yanert Fork and Nenana River, Alaska Ra.; $63^{\circ} 24^{\prime} 56^{\prime \prime} \mathrm{N}, 1^{\circ} 49^{\circ} 42^{\prime} 15^{\prime \prime} \mathrm{W} ; B G N$ 1961; (map 87)

Named in 1961 by USGS for Thomas Percy Pendleton, 1886-1954, USGS, who, in 1919 , as topographic engineer, mapped in this area.

Penelope Creek: stream, flows NW $4.5 \mathrm{mi}$. to Casadepaga River, $23 \mathrm{mi}$. NE of Solomon, Seward Penin. High.; $64^{\circ} 53^{\prime} \mathrm{N}, 164^{\circ} 16^{\prime} \mathrm{W}$; (map 95).

Prospectors' name reported in 1900 by E. C. Barnard (in Brooks, 1901, pl. 17), USGS.

Pengnok: locality, on Chukchi Sea coast near Cape Smyth, Arctic Plain; $71^{\circ} 17^{\prime}$ N, $156^{\circ} 47^{\prime}$ W; (map 153).

Former Eskimo village or camp reported in the 1890 Census (1893, p. 162).

Penguin Creek: stream, flows W $12 \mathrm{mi}$. to Bird Creek, $0.5 \mathrm{mi}$. N of Turnagain Arm, $5.5 \mathrm{mi}$ NW of Sunrise, Chugach Mts.; $60^{\circ} 58^{\prime} 45^{\prime \prime} \mathrm{N}$, $149^{\circ} 27^{\prime} 15^{\prime \prime} \mathrm{W}$; (map 63).

Local name reported in 1899 by Lt. Herron (1901, sketch opposite p. 11), USA.

Penikl: island, see Pinnacle Island.

Peninsula, The: ridge, $3.7 \mathrm{mi}$. long, trends NW on $\mathrm{E}$ bank of Copper River, $6 \mathrm{mi}$. SE of mouth of Cleave Creek, $52 \mathrm{mi}$. E of Valdez, Chugach Mts.; $61^{\circ} 02^{\prime} 00^{\prime \prime} \mathrm{N}, 144^{\circ} 44^{\prime} 45^{\prime \prime} \mathrm{W}$ (map 68).

Named in 1898 by Capt. W. R. Abercrombie, USA. It was called Cottonwood Island in 1885 by Lt. H. T. Allen, USA.

Peninsula Island: island, elev. $1,190 \mathrm{ft}$, $1.5 \mathrm{mi}$. long, between Big Koniuji and Nagai Is., in Shumagin Is., Aleutian Ra.; 55 $11^{\prime} \mathrm{N}$, $159^{\circ} 40^{\prime} \mathrm{W}$; (map 27).

Named by W. H. Dall, USC\&GS, in 1875 and published in 1888 by the USBF.

Peninsula Lake: lake, $700 \mathrm{ft}$. long, on Nyman Penin., 6 mi. SW of Kodiak, Kodiak I.; $57^{\circ}$ $43^{\prime} 20^{\prime \prime} \mathrm{N}, 152^{\circ} 30^{\prime} 45^{\prime \prime} \mathrm{W}$; (map 34$)$. 
Local descriptive name reported in 1949 by USGS.

Peninsula Point: settlement, pop. 47, on Peninsula Point, S of Ward Cove, on SW coast of Revillagigedo I., Alex. Arch.; $55^{\circ} 23^{\prime} \mathrm{N}, 131^{\circ}$ $44^{\prime} \mathrm{W}$; (map 3$)$.

This is an extension of the Ketchikan settlement area northwest along the highway.

Peninsula Point: point of land, S of Ward Cove, on SW coast of Revillagigedo I., Alex. Arch.; $55^{\circ} 23^{\prime} \mathrm{N}, 131^{\circ} 44^{\prime} \mathrm{W}$; (map 3$)$.

Named about 1880 by local navigators; reported by USC\&GS.

Peninsula Ridge: ridge, extends $\mathrm{S} 20 \mathrm{mi}$. from Boca de Quadra to Dixon Entrance, on $E$ shore of Revillagigedo Channel, Coast Mts.; $54^{\circ} 55^{\prime} \mathrm{N}, 130^{\circ} 49^{\prime} \mathrm{W}$; (maps 2, 3).

Descriptive name given in 1883 by $\mathrm{Lt}$. Comdr. Nichols, USN.

Peninsular Point: point of land, $3 \mathrm{mi}$. N of Peril Strait, on Chichag of I., $8 \mathrm{mi}$. E of Todd, Alex. Arch.; $57^{\circ} 30^{\prime} 30^{\prime \prime}$ N, 134 $50^{\circ} 00^{\prime \prime} \mathrm{W}$; (map 9).

Descriptive name published by USC\&GS in the 1891 Coast Pilot (p. 162). It is on the south point of a peninsula in Chatham Arm.

Pen Island: island, $350 \mathrm{ft}$. across, near head of Kasaan Bay, on E coast of Prince of Wales I., Alex. Arch.; 55 $34^{\prime} 35^{\prime \prime} \mathrm{N}, 132^{\circ} 30^{\prime} 05^{\prime \prime} \mathrm{W}$; (map 4).

Local name recorded in 1949 by USGS.

Pennant Creek: stream, flows NE $1.3 \mathrm{mi}$. to Niukluk River, $2 \mathrm{mi}$. W of Council and 32 mi. NE of Solomon, Seward Penin. High.; $64^{\circ} 54^{\prime} \mathrm{N}, 163^{\circ} 44^{\prime} \mathrm{W}$; (map 95). Var. Pancake Creek.

Prospectors' name published in 1956 by USGS. Shown as "Pancake" on the 1900 "Map of Nome Peninsula" by J. M. Davidson and B. D. Blakeslee.

Penney Creek: stream, see Penny Creek.

Penniman Glaciers: glaciers, two, trend E $1 \mathrm{mi}$. from head of Baker glacier, $52 \mathrm{mi}$. SE of Anchorage, Chugach Mts.; 61 ${ }^{\circ} 05^{\prime} 30^{\prime \prime} \mathrm{N}$, $148^{\circ} 19^{\prime} 45^{\prime \prime} \mathrm{W}$; BGN 1929; (map 69).

Named in 1914 by Dora Keen Handy for "the Penniman brothers of Philadelphia; James $H$., philanthropist, and Josiah $H$., president and provost of the Univ. of Pennslyvania."

Pennington Creek: stream, flows N $3 \mathrm{mi}$. to Walker Fork, $50 \mathrm{mi}$. $\mathrm{S}$ of Eagle, YukonTanana High.; $64^{\circ} 04^{\prime} 30^{\prime \prime} \mathrm{N}, 141^{\circ} 15^{\prime} 00^{\prime \prime} \mathrm{W}$; (map 102).

Prospectors' name shown on a 1898 manuscript map by C. A. Woodruff, Fort Cudahy, Canada.

Pennock Island: village, pop. 50, on $\mathrm{W}$ coast of Pennock I. on Whiskey Cove, $0.5 \mathrm{mi}$. S of Ketchikan, Alex. Arch.; 55 $19^{\prime} 40^{\prime \prime}$ N, $131^{\circ}$ $37^{\prime} 45^{\prime \prime} \mathrm{W}$; (map 3).

This is a part of the Ketchikan settlement area.

Pennock Island: island, $3.3 \mathrm{mi}$. long, between Gravina and Revillagigedo Is., divides Tongass Narrows into its East and West Channels,
Alex Arch.; $55^{\circ} 19^{\prime} 15^{\prime \prime} \mathrm{N}, 1^{\circ} 31^{\circ} 30^{\prime \prime} \mathrm{W}$; (map 3).

Named about 1895 by Capt. W. E. George, a local pilot, for Homer Pennock, a prospector who took a group of prospectors to the Cook Inlet area about 1900-1903. See Homer.

Pennock Island Reef: reef, see Pennock Reef.

Pennock Reef: reef, extends $0.7 \mathrm{mi}$. in Tongass Narrows, $0.7 \mathrm{mi}$. SW of Ketchikan, Alex

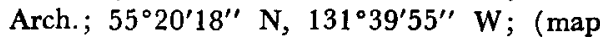
3). Var. Pennock Island Reef.

Named in 1883 by W. H. Dall, USC\&GS

Pennsylvania Creek: stream, flows NW $6 \mathrm{mi}$. to Fish Creek, $56 \mathrm{mi}$. SW of Eagle, YukonTanana High.; $64^{\circ} 22^{\prime} 45^{\prime \prime} \mathrm{N}, 142^{\circ} 46^{\prime} 10^{\prime \prime} \mathrm{W}$ (map 102).

Prospectors' name shown on 1898 manuscript map by G. A. Woodruff, Fort Cudahy, Canada.

Pennsylvania Creek: stream, flows NE $0.8 \mathrm{mi}$. to Slate Creek which flows to Pilgrim River, 25 mi. NW of Solomon, Seward Penin, High. $64^{\circ} 52^{\prime} 45^{\prime \prime} \mathrm{N}, 164^{\circ} 49^{\prime} 45^{\prime \prime} \mathrm{W}$; (map 95).

Prospectors' name reported in 1908 on a field sheet by P. S. Smith, USGS.

Pennsylvania Rock: rock, in Prince William Sound, between Seal and Smith Is., $26 \mathrm{mi}$. NE of Chenega, Chugach Mts.; $60^{\circ} 26^{\prime} 35^{\prime \prime} \mathrm{N}$ $147^{\circ} 24^{\prime} 05^{\prime \prime} \mathrm{W}$; (map 63 ).

Name published in 1943 by USC\&GS.

Penny Creek: stream, flows SE $2.9 \mathrm{mi}$. to Solomon River, $6 \mathrm{mi}$. NE of Solomon, Seward Penin. High.; $64^{\circ} 41^{\prime} \mathrm{N}, 164^{\circ} 22^{\prime} \mathrm{W}$; (map 95). Var. Penney Creek.

Prospectors' name reported in 1900 by E C. Barnard (in Brooks, 1901, pl. 17), USGS.

Penny Creek: stream, flows SW $0.8 \mathrm{mi}$. to Telegram Creek, between Adventuress and Shoal Creeks, in Pilgrim River basin, $22 \mathrm{mi}$. NW of Solomon, Seward Penin. High.; 64 $52^{\prime} 10^{\prime \prime}$ N, 164. $35^{\prime} 20^{\prime \prime} \mathrm{W}$; (map 95).

Prospectors' name reported in 1908 by $P$. S. Smith (in Brooks and others, 1909, pl. 10), USGS.

Penny River: stream, flows SW $13 \mathrm{mi}$. to Norton Sound, $10 \mathrm{mi}$. W of Nome, Seward Penin. High.; 64 $32^{\circ} \mathrm{N}, 165^{\circ} 45^{\prime} \mathrm{W}$; (map 94). Var. No Name River, Quartz Creek.

Local name reported in 1899 by D. C. Witherspoon (in Schrader and Brooks, 1900, map 2) USGS. Witherspoon designated the upper reach "Quartz Creek." Schrader (1900c, p. 16) labeled the stream "No Name R."

Pensive Pup: ravine, in Nutzotin Mts., extends SW $0.8 \mathrm{mi}$. to Little Eldorado Creek $1.2 \mathrm{mi}$ $\mathrm{N}$ of its junc. with Bonanza Creek, $5.5 \mathrm{mi}$. N of Beaver Lake, Alaska Ra.; $62^{\circ} 07^{\prime} \mathrm{N}, 141^{\circ}$ $51^{\prime} \mathrm{W}$; (map 84).

Name used by prospectors and published by S. R. Capps (in Brooks and others, 1915, p. 222), USGS.

Pentecost: point of land, see Izhut, Cape

Pepper Lake: lake, $1.5 \mathrm{mi}$. long, largest of the Swanson Lake., $15 \mathrm{mi}$. S of Point Possession and $35 \mathrm{mi}$. NE of Kenai, Cook Inlet Low.; $60^{\circ} 51^{\prime} \mathrm{N}, 150^{\circ} 26^{\prime} \mathrm{W}$; (map 62 ).

Local name reported in 1958 by USGS.

Pepper Point: point of land, on NE coast of Baker I., W point of entrance to Port Asun-

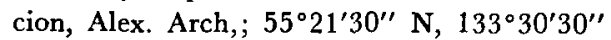
W; (map 4). Var. Mys de la Pimiyenta, Punta de la Pimienta.

Translation of the name "Punta de la Pimienta" given in 1775-79 by Don Juan de la Bodega y Quadra and Francisco Antonio Maurelle.

Peratovich Island: island, see Peratrovich Island. Peratovitch Island: island, see Peratrovich Island.

Peratrovich Island: island, $2.3 \mathrm{mi}$. long, in Klawak Inlet, $0.6 \mathrm{mi}$. $\mathrm{N}$ of Klawock, on $\mathrm{W}$ coast of Prince of Wales I., Alex Arch.; 55 ${ }^{\circ} 35^{\prime}$ N, $133^{\circ} 06^{\prime} \mathrm{W}$; BGN 1952; (map 4). Var. Graveyard Island, Peratovich Island, Peratovitch Island.

Named in 1929 by USC\&GS for "John Peratrovich, merchant and influential citizen of Klawock." This island was reported in 1929 by Capt. Patton, USC\&GS, to be known locally as "Graveyard Island."

Percabes, Punta: point of land, see Persebes, Punta.

Perch Rock: rock, in Kuliliak Bay, on $\mathrm{S}$ coast of Unalaska I., Aleutian Is.; 53 $27^{\prime} 05^{\prime \prime} \mathrm{N}$, $167^{\circ} 02^{\prime} 50^{\prime \prime} \mathrm{W} ;$ B BGN 1939; (map 23).

Descriptive name given by USC\&GS in 1937 "because birds always perch on this rock."

Percy Islands: islands, group $3.5 \mathrm{mi}$. long, in Clarence Strait, W of Duke I., Alex. Arch.; $54^{\circ} 57^{\prime} \mathrm{N}, 131^{\circ} 35^{\prime} \mathrm{W}$; (map 2).

Named by W. H. Dall, USC\&GS, and published in the 1883 Coast Pilot (p. 83).

Percy Point: point of land, W tip of Percy Is., extends into Clarence Strait, Alex. Arch.; $54^{\circ}$ $56^{\prime} 50^{\prime \prime} \mathrm{N}, 131^{\circ} 37^{\prime} 00^{\prime \prime} \mathrm{W}$; (map 2). Var. Pyerci Cape.

Named by Capt. G. Vancouver, RN, August 14, 1793, "after the Percy family, the Dukes of Northumberland" (Wagner, 1937, p. 402).

Perdidos, Rio de los: stream, see Copper River.

Perebluk: locality, on Port Clarence, Seward Penin. High.; $65^{\circ} 10^{\prime} \mathrm{N}, 166^{\circ} 30^{\prime} \mathrm{W}$; (map 111).

Former Eskimo village or camp recorded in the 1890 Census (1893, p. 162).

Peregrebni: islands, see Barren Islands.

Peregrebni Point: point of land, between Settler Cove and Kizhuyak Bay, on $\mathrm{N}$ coast of Kodiak I.; 57 $52^{\prime} \mathrm{N}, 152^{\circ} 51^{\prime} \mathrm{W}$; (map 34). Var. Mys Peregrebnyy.

Transliteration of the name "M[ys] Peregrebnyy," meaning "passable cape," given to this point by Murashev in 1839 or 1840 and published in 1849 on Russian Hydrog. Dept. Chart 1425 .

Peregrebnoy, Ostrov: island, see Wosnesenski Island.

Peregrebny Island: island, see Wosnesenski Island. 
Peregrebnyy, Mys : point of land, see Peregrebni Point.

Peregrine Creek: stream, flows N $9 \mathrm{mi}$. to Cobblestone Creek, $19 \mathrm{mi}$. SE of Table Top and $43 \mathrm{mi}$. NE of Anaktuvuk Pass. Arctic Slope; $68^{\circ} 27^{\prime} 30^{\prime \prime} \mathrm{N}, 150^{\circ} 23^{\prime} 00^{\prime \prime} \mathrm{W}$; (map 134).

Named by USGS geologists during the exploration of Naval Petroleum Reserve No. 4; name given in 1944. Named for the American peregrine falcon, Falco peregrinus anatum, which nests in this area.

Pereleshin: mountain, see Pereleshin Mountain. Pereleshin Mountain: mountain "on the mainland, east of the Stikine River and near the international boundary. Native name, from the Coast Survey. Has been written Peerleshin and Pereleshin, i.e., Pereles River" (Baker, 1906, p. 494). Var. Peerleshin, Pereleshin.

Perenosa, Mys : point of land, see Perenosa Point.

Perenosa Bay: bay, $5 \mathrm{mi}$. across, on $\mathrm{N}$ coast of Afognak I., N of Kodiak I. ; $58^{\circ} 25^{\prime} \mathrm{N}, 152^{\circ} 25^{\prime}$ W; BGN 1934; Var. Perenosnaia, Portage Bay.

Transliteration by USC\&GS in 1911 of the name "Pyeryenosnaya Bukhta" from "Pyeryenos" meaning "transport (transfer)" published by the Russian American Company in 1849. Baker (1906, p. 506) translated this name as "Portage."

Perenosa Point: point of land, on $\mathrm{W}$ shore of Dry Spruce Bay, on $\mathrm{N}$ coast of Kodiak I.; $57^{\circ} 56^{\prime} 10^{\prime \prime} \mathrm{N}, 1^{\circ} 03^{\circ} 30^{\prime \prime} \mathrm{W}$; BGN 1939; (map 34). Var. Drying Point, Mys Perenosa, Portage Point.

Transliteration in 1939 by USC\&GS of "M[ys] Perenosa," meaning "Transport Cape," given by $M$. Murashev in 1839 or 1840 and published in 1849 on Russian Hydrog. Dept. Chart 1425. Baker (1906, p. 227) misapplied the name "Drying Point" [2 miles northeastward] to this location. See Drying Point.

Perenosnaia Bay: bay, see Balboa Bay.

Perenosnaia Bay: bay, see Portage Bay.

Perenosnaya, Bukhta: bay, see Balboa Bay.

Perenosnaya Bukhta: bay, see Portage Bay.

Perenosnaya Creek: bay, see Portage Bay.

Perenosnaya Islands: islands, see Portage Islands.

Perenosnoi, Bukhta: bay, see Balboa Bay.

Perenosnoy, Zaliv: bay, see Portage Bay.

Peresheechnoi: bay, see Isthmus Bay.

Peresheek Point: point of land, $1.2 \mathrm{mi} . \mathrm{N}$ of Goddard, on W coast of Baranof I., Alex. Arch.; 56 $51^{\prime} 05^{\prime \prime} \mathrm{N}, 1^{\circ} 25^{\circ} 22^{\prime} 50^{\prime \prime} \mathrm{W}$; (map 5).

Russian name "peresheyek," meaning "isthmus" published in 1943 by USC\&GS.

Peresheyechnoy, Ostrov: island, see Isthmus Island.

Peresheynoy, Zaliv: bay, see Isthmus Bay.

Perevainoy: bay, see Carry Inlet.

Perevainoy Island: islands, see Perevalnie Islands.

Perevalnie Islands: islands, $1.5 \mathrm{mi}$. long, off NE coast of Shuyak I., $50 \mathrm{mi}$. N of Kodiak I., $58^{\circ} 38^{\prime}$ N, $152^{\circ} 22^{\prime}$ W; (map 43). Var. Carry Inlet, Carry Island, Perevainoy Island, Perevalnie Islet, Perewamno Island, Portage Island.
Transliteration by Baker (1906, p. 494), USGS, of the name "O[strov] Perevalnyy," meaning "draw across," published by the Russian American Company in $\mathbf{1 8 4 9}$ for the largest island of this group. Baker used the generic "islet." See Carry Inlet.

Perevalnie Islet: islands, see Perevalnie Islands. Perevalnie Passage: water passage, between Prevalnie Is. and NE coast of Shuyak I., 50 mi. N of Kodiak I.; $58^{\circ} 38^{\prime} \mathrm{N}, 152^{\circ} 21^{\prime} \mathrm{W}$; $B G N$ 1933; (map 43).

Name derived from the Perevalnie Islands and given by USC\&GS in 1931 .

Perewamno: bay, see Carry Inlet.

Perewamno Island: islands, see Perevalnie Islands.

Perez, Entrada de: water passage, see Dixon Entrance.

Perginik: locality, see Bernirk

Pergniak: locality, see Bernirk.

Perhaps Creek: stream, flows SE $1 \mathrm{mi}$. to Chatanika River, $9 \mathrm{mi}$. NE of Twin Buttes and 39 mi. NE of Fairbanks, Yukon-Tanana High.; $65^{\circ} 15^{\prime} 30^{\prime \prime} \mathrm{N}, 146^{\circ} 46^{\prime} 00^{\prime \prime} \mathrm{W}$; (map 104).

Prospectors' name reported in 1954 or 1955 by USGS topographers.

Perhaps Creek: stream, flows to Native Creek, about $3 \mathrm{mi}$. N of Council and $33 \mathrm{mi}$. NE of Solomon, Seward Penin. High,; (map 95).

Prospectors' name reported on the 1900 "Map of Nome Peninsula" by J. M. Davidson and B. D. Blakeslee. This stream cannot be precisely located on current maps.

Perignak: locality, see Bernirk.

Perignak: locality, on Seahorse Is., on Chukchi Sea coast near Point Franklin, Arctic Plain; $70^{\circ} 53^{\prime} \mathrm{N}, 158^{\circ} 42^{\prime} \mathrm{W}$; (map 147). Var. Pernyu.

Former Eskimo village or camp reported in the 1890 Census (1893, p. 162).

Perignax: locality, see Bernirk.

Perigniak: locality, see Bernirk

Peril Cape: point of land, at mouth of Izhut Bay, $20 \mathrm{mi}$. NE of Afognak, on SE coast of Afognak I., $\mathrm{N}$ of Kodiak I.; $58^{\circ} 07^{\prime} 30^{\prime \prime} \mathrm{N}$, $152^{\circ} 16^{\prime} 20^{\prime \prime} \mathrm{W}$; BGN 1910; (map 43).

Named by USC\&GS in 1910

Peril Peak: peak, 7,040 ft., between Eklutna Glacier and its West Fork, $30 \mathrm{mi}$. E of Anchorage, Chugach Mts.; $61^{\circ} 13^{\prime} \mathrm{N}, 148^{\circ} 59^{\prime}$ W; BGN 1964; (map 69). Var. Jane Russell Peaks, Marilyns Twins.

So named in 1963 by the members of the Mountaineering Club of Alaska, because "of the danger and difficulty involved in climbing it."

Peril Point: point of land, see Pogibshi Point

Peril Strait: water passage, extends $45 \mathrm{mi}$. from Salisburg Sound to Chatham Strait, between Chicagof and Baranof Is., Alex. Arch.; 57 $30^{\prime}$ N, $135^{\circ} 13^{\prime}$ W; (map 9). Var. Peril Straits, Pernicious Strait, Pogibshi Channel, Pogibshi Straits, Pogoobnoy Strait, Proliv Pogibshiy.

Translation in 1882 by USC\&GS of "Proliv Pogibshiy;" published in 1848 on Russian Hydrog. Dept. Chart 1397. The name is derived from "the circumstances that on its shores, in 1799, a large number of Aleuts (said to be 150) perished from eating poisonous mussels." This account was reported by Capt. V. F. Lisianski who called this feature "pernicious strait."

Peril Straits: island, see Elovoi Island.

Peril Straits: water passage, see Peril Strait.

Perkins Creek: stream, flows NW $3 \mathrm{mi}$. to South Arm Moira Sound, on SE coast of Prince of Wales I., Alex. Arch.; 54 $56^{\circ} 45^{\prime \prime}$ N, $132^{\circ} 11^{\prime}$ $00^{\prime \prime} \mathrm{W}$; (map 1).

Local name reported in 1948 by USGS.

Perkinsville: locality, on left bank of Anvil Creek, $3.8 \mathrm{mi}$. N of Nome, Seward Penin. High.; $64^{\circ} 33^{\prime} \mathrm{N}, 165^{\circ} 25^{\prime} \mathrm{W}$; (map 94).

Site of mining camp and RR. station reported in 1904 by T. G. Gerdine, USGS. The exact date of the camp is unknown; however, gold was discovered on Anvil Creek in 1898 and the RR. was built in 1900 .

Perlas Point: point of land, on $\mathrm{W}$ coast of Prince of Wales I. in Trocadero Bay, $3 \mathrm{mi}$. SE of Point Iphigenia, Alex. Arch.; 55 $22^{\prime}$ $05^{\prime \prime} \mathrm{N}, 133^{\circ} 04^{\prime} 30^{\prime \prime} \mathrm{W}$; (map 4). Var. Mys Perlas, Pearl Point, Punta de Perlas.

Spanish name given in 1779 by Don Juan de la Bodega y Quadra and Francisco Antonio Maurelle as "Punta de Perlas," meaning "point of pearls."

Perl Island: island, $3 \mathrm{mi}$. long, in Chugach Is., $22 \mathrm{mi}$. S of Seldovia, Chugach Mts.; $59^{\circ} 07^{\prime}$ $\mathrm{N}, 151^{\circ} 40^{\prime} \mathrm{W}$; BGN 1941; (map 50.) Var. Isla de Arriaga, Pearl Island, Middle Chugach Island.

Called "Islands of Pearl" by the Harriman Alaska Expedition (1902, p. 360). The spelling was changed when it was realized that the island derived its name from Perl $D$. Blodgett who came to Alaska about 1883, and was active in various enterprises at Kodiak and on Cook Inlet. Blodgett established a fox farm on this island prior to his death about 1920. This island was named "Isla de Arriaga" about August 1, 1779, by Don Ignacio Arteaga "probably after his second pilot, Juan Pantoja y Arriaga" (Wagner, 1937, p. 428).

Perl Rock: rock, $500 \mathrm{ft}$. across, in Gulf of Alaska, $2.5 \mathrm{mi}$. S of Perl I. and $25 \mathrm{mi}$. S of Seldovia, Chugach Mts.; $59^{\circ} 05^{\prime} 30^{\prime \prime} \mathrm{N}, 151^{\circ}$ $41^{\prime} 30^{\prime \prime}$ W ; BGN 1941; (map 50). Var. La Monja, Pearl Rock.

Named by USGS in 1941. See Perl Island. This is probably the small island called "La Monja" in August 1779 by Don Ignacio Arteaga.

Pernicious Strait: water passage, see Peril Strait.

Pern Lakes: lakes, two, each $0.5 \mathrm{mi}$. across, $\mathrm{N}$ of Howling Dog Canyon area of Porcupine River, $29 \mathrm{mi}$. E of Coleen Mtn., Brooks Ra.; $67^{\circ} 10^{\prime} \mathrm{N}, 141^{\circ} 44^{\prime} \mathrm{W}$; (map 121).

Local name reported in 1956 by T. E. Taylor, USGS.

Pernyu: locality, see Bernirk.

Pernyu: locality, see Perignak.

Peronosnaya, Bukhta: bay, see Balboa Bay.

Perouse Glacier, La: glacier, in Glacier Bay National Monument, heads on S slope of Mount Grillon, trends S $15 \mathrm{mi}$. to Gulf of Alaska, 8 
mi. NW of Icy Point, $71 \mathrm{mi}$. NW of Hoonah, St. Elias Mts.; $58^{\circ} 27^{\prime} \mathrm{N}, 137^{\circ} 17^{\prime} \mathrm{W}$; (map 10).

Named by W. H. Dall, USC\&GS, in 1874 for Jean François de Galaup de la Pérouse, 1741-88, French navigator who explored the coast in this area in 1786 . The name was published in the 1883 Alaska Coast Pilot (p. 201). La Perouse was a member of the French Navy, and in 1782 was sent to Canada to attack the British forts on Hudson Bay. In 1785 he was given command of an expedition of exploration by Louis XVI. With two ships, the La Boussole and the L'Astrolabe, he sailed in 1786 from the Sandwich Is. to the Alaskan coast in the neighborhood of Mount St. Elias, where he mapped the coast and studied the Indians. On the way home from his explorations his two ships and crew were lost. Parts of his ships were found in 1827 on Santa Cruz I. in the New Hebrides in the South Pacific.

Perpendiculaire, Cape: point of land, see Upright, Gape.

Perret Ridge: ridge, elev. 2,916 ft., $\mathrm{N}$ of Fenner Lake, Semisopochnoi I., Aleutian Is.; 51 ${ }^{\circ} 58^{\prime}$ $30^{\prime \prime} \mathrm{N}, 179^{\circ} 39^{\prime} 00^{\prime \prime} \mathrm{E}$; BGN 1952; (map 15).

Named in 1950 by R. R. Coats, USGS, for Frank Perret, volcanologist, who died in 1950. Perrier Inlet: estuary, see Taiya Inlet.

Perrier Pass: pass, see Chilkoot Pass.

Perry: village, see Perryville.

Perry, Point: point of land, northernmost point on Perry I., on S side of Wells Passage, $25 \mathrm{mi}$. $\mathrm{SE}$ of Whittier, Chugach Mts.; $60^{\circ} 45^{\prime} 05^{\prime \prime} \mathrm{N}$, $147^{\circ} 57^{\prime} 30^{\prime \prime} \mathrm{W}$; BGN 1914; (map 63).

Name reported in 1914 by USC\&GS.

Perry Creek: stream, flows to Hetta Inlet, 1.9 mi. W of Gould I., near center of Prince of Wales I., Alex. Arch.; $55^{\circ} 16^{\prime} 35^{\prime \prime}$ N, $132^{\circ}$ 40'05" W; (map 4).

Local name reported in 1908 by C. W. Wright (in Brooks and others, 1909, pl. 3), USGS.

Perry Creek: stream, flows NE $6 \mathrm{mi}$. to Pinnell River, $16 \mathrm{mi}$. N of Imuruk Lake, Seward Penin. High.; $65^{\circ} 49^{\prime}$ N, $163^{\circ} 04^{\prime}$ W; BGN 1952; (map 110).

Prospectors' name reported in 1903 by D. C. Witherspoon (in Moffitt, 1905, pl. 2), USGS.

Perry Island: island, $6.5 \mathrm{mi}$. long, in Prince William Sound, between Perry Passage and Lone Passage, $24 \mathrm{mi}$. SE of Whittier, Chugach Mts. ; $60^{\circ} 43^{\prime} \mathrm{N}, 147^{\circ} 55^{\prime} \mathrm{W}$; (map 63).

Name published on D. H. Sleem's map of Central Alaska, dated 1910. This is probably the same as the island called "Perry" by USC\&GS in 1900, and "Stamie" by F. C. Schrader, USGS, in 1900. Schrader reported that it had been "used as a blue fox farm by Kendall and Steamy [Stamie] since 1897."

Perry Passage: water passage, $10 \mathrm{~min}$. long, in Prince Willian Sound, between Perry and Culross Is., $22 \mathrm{mi}$. SE of Whittier, Chugach Mts.; $60^{\circ} 43^{\prime} \mathrm{N}, 148^{\circ} 03^{\prime}$ W. BGN 1914; (map 63). Name reported in 1914 by USC\&GS.
Perryville: village, pop. 111, on S coast of Alaska Penin. $19 \mathrm{mi}$. E of Stepovak Bay, Aleutian Ra; $55^{\circ} 54^{\prime} 40^{\prime \prime}$ N, $159^{\circ} 09^{\prime} 00^{\prime \prime} \mathrm{W}$; (map 27). Var. Perry.

This "native" village was established to provide for people who were driven away from the vicinity of Mount Katmai by the eruption of 1912. It consists of a number of wooden houses, including a store and school (Coast Pilot, 1947, p. 297). It was originally called Perry, but later was referred to as Perryville, probably to conform with the post office that was established there in 1930 (Ricks, 1965, p. 50 ).

Persebes, Punta: point of land, on the $\mathrm{E}$ side of San Juan Bautista I., Bucareli Bay, Alex. Arch.; (map 4). Var. Punta Percabes.

Spanish name given by members of the 1779 Don Ignacio Arteaga expedition.

Perseverance: locality, on SE side of Silverbow Basin, $3 \mathrm{mi}$. E of Juneau, Coast Mts. ; $58^{\circ} 18^{\prime}$ $45^{\prime \prime} \mathrm{N}, 134^{\circ} 20^{\prime} 45^{\prime \prime} \mathrm{W}$; (map 11).

Former mining camp named about 1885 by miners for the Perseverence claim and mine. A mill and other buildings of the camp were destroyed by a snowslide in 1895 . The mining camp remained in existence until 1921 when the mine was closed (DeArmond, 1957, p. 34-35).

Perseverance, Lake: lake, $1.3 \mathrm{mi}$. long, on Revillagigedo I., $3.4 \mathrm{mi}$. N of Ketchikan, Alex. Arch.; 55 $24^{\prime} \mathrm{N}, 131^{\circ} 40^{\prime} \mathrm{W}$; (map 3).

Local name reported in 1954 by USGS.

Perseverance Creek: stream, $0.5 \mathrm{mi}$. long, drains Lake Perseverance into Connell Lake, $1.8 \mathrm{mi}$. $\mathrm{E}$ of Ward Cove, on Revillagigedo I., Alex. Arch.; $55^{\circ} 25^{\prime} 05^{\prime \prime} \mathrm{N}, 131^{\circ} 40^{\prime} 05^{\prime \prime} \mathrm{W}$; (map 3 ).

Local name reported in 1954 by USGS.

Persian Ridge: ridge, trending $\mathrm{N} 1 \mathrm{mi}$ from Larry Hill, 3 mi. NW of Gertrude Cove, westcentral Kiska I., Aleutian Is.; 51 ${ }^{\circ} 58^{\prime} 15^{\prime \prime} \mathrm{N}$, $177^{\circ} 23^{\prime} 30^{\prime \prime} \mathrm{E}$; (map 14).

One of many arbitrary names applied to features on Kiska I. by USAAF for tactical purposes during World War II.

Peschanaia Bay: bay, see Sandy Bay.

Peschanaya: stream, see Sandy River.

Peschani: bay, see Martin Harbor.

Peschani Island: island, see Pyramid Island.

Peschani Point: point of land, $3 \mathrm{mi}$. $\mathrm{N}$ of Rodman Bay, on Duffield Penin., on $N$ coast of Baranof I., Alex. Arch.; 57 $32^{\prime} 15^{\prime}$ N, $135^{\circ}$. 19'15' W; (map 9). Var. Mys Peschanyy, Peschan Point, Sandy Point, Stony Point.

Russian name meaning "sandy," given in 1833 by the navigator Ens. Vasiliev; published in 1848 on Russian Hydrog. Dept. chart 1397 as "M[ys] Peschanyy."

Peschani Point: point of land, see Halibut Point.

Peschanoi: bight, see Shahakfka Cove.

Peschanoy, Zaliv: bight, see Shahafka Cove.

Peschan Point: point of land, see Peschani Point.

Peschanyy, Mys: point of land, see Halibut Point.

Peschanyy, Mys: point of land, see Peschani Point.
Peschanyy, Mys: point of land, see Pestchani Point.

Peschanyy, Ostrov: island, see Galankin Island. Peshchannaya Bukhta: bay, see Sandy Bay.

Peshchanoye, Mys: point of land, see Icehouse Point.

Peshchanoye, Ozero: lake, see Icehouse Lake. Peshchanyy, Zaliv: cove, see Sandy Cove.

Peschanyy Island: island, see Pyramid Island. Pesiak: island, see Martin Island.

Pesquera Island: island, $0.3 \mathrm{mi}$. across, N Maurelle Is., Alex. Arch.; $55^{\circ} 40^{\prime} 40^{\prime \prime} \mathrm{N}, 133^{\circ}$ $39^{\prime} 30^{\prime \prime}$ W; BGN 1925; (map 4).

Spanish name meaning "a place for catching fish," given in 1924 by Capt. Maher, USC\&GS, because "surrounding waters . . . thronged with fishing craft, which report an enormous catch."

Pestchanaia: bay, see Martin Harbor.

Pestchania: cove, see Sandy Cove.

Pestchani Point: point of land, on $\mathrm{E}$ shore of Kizhuyak Bay, on $\mathbf{N}$ coast of Kodiak I.; $57^{\circ}$ $47^{\prime}$ N, $152^{\circ} 51^{\prime}$ W; (map 34). Var. Mys Peschanyy.

Transliteration of the descriptive name "M[ys] Peschanyy," meaning "sandy cape," given to this point by Murashev in 1839 or 1840 and published in 1849 on Russian Hydrog. Dept. Chart 1425.

Pestchanoe Lake: lake, see Icehouse Lake.

Pestchanoe Point: point of land, see Icehouse Point.

Pestriak: locality, site of village on SE coast of Spruce I., 7 mi. N of Kodiak, Kodiak I.; $57^{\circ}$ $53^{\prime} 30^{\prime \prime} \mathrm{N}, 152^{\circ} 23^{\prime} 00^{\prime \prime} \mathrm{W}$; (map 34). Var. Pestriakof, Seleniye Pestryakova.

The Russian American Company published the name "Sel[eniye] Pestryakova" meaning "Eider duck Settlement," for this locality in 1849.

Pestriakof: locality, see Pestriak.

Pestriakof: point of land, see Pestriak Point.

Pestriakovo: point of land, see Eider Point.

Pestriak Point: point of land, on SE coast of Spruce I., $7 \mathrm{mi}$. N of Kodiak, NE of Kodiak I.; $57^{\circ} 53^{\prime} 30^{\prime \prime} \mathrm{N}, 152^{\circ} 23^{\prime} 00^{\prime \prime} \mathrm{W}$; (map 34). Var. Pestriakof.

See Pestriak, locality.

Pestsovaia baie: bay, see Bluefox Bay.

Pete Andrews Creek: stream, flows S $10 \mathrm{mi}$. to Iliamna Lake, $9 \mathrm{mi}$. SW of Iliamna, Bristol Bay Low. ; $59^{\circ} 39^{\prime} 35^{\prime \prime}$ N, $155^{\circ} 04^{\prime} 30^{\prime \prime}$ W ; (map 51).

Local name published by USGS in 1954 .

Pete Dahl Slough: stream, $11 \mathrm{mi}$. long, distributary of Copper River, $15 \mathrm{mi}$. SE of Cordova, Malaspina Coastal Plain; 60 $23^{\prime} \mathrm{N}$, $145^{\circ} 27^{\prime} \mathrm{W}$; (map 64).

Local name reported by Lt. Cmdr. Moser (1898, p. 132), USN.

Pete Larssen: bay, see Larsen Bay.

Peterboro Creek: stream, flows SW $2 \mathrm{mi}$. to Bay Creek which flows to Grantley Harbor, $5 \mathrm{mi}$. NE of Teller, Seward Penin. High.; $65^{\circ} 20^{\prime} \mathrm{N}$, $166^{\circ} 20^{\prime} \mathrm{W}$; (map 111$)$.

Prospectors' name reported on the 1908 "Map of Seward Peninsula" by Arthur Gibson. 
Peter Cleaver Lake: lake, $6 \mathrm{mi} . \mathrm{N}$ of junc. of Louie Creek and Koyukuk River and $5 \mathrm{mi}$. NW of Roundabout Mtn., Koyukuk Low.; $65^{\circ} 34^{\prime} \mathrm{N}, 156^{\circ} 48^{\prime} \mathrm{W}$; (map 108).

Local name obtained at Huslia by USGS in 1954 or 1955.

Peter Creek: stream, flows E $1 \mathrm{mi}$. to Bryan Creek which flows to Serpentine River, $8 \mathrm{mi}$. NE of Kougarok Mtn. and $33 \mathrm{mi}$. SE of Ear Mtn., Seward Penin. High.; $65^{\circ} 47^{\prime}$ N, $165^{\circ} 08^{\prime}$ W; (map 111).

Prospectors' name reported on the 1908 "Map of Seward Peninsula" by Arthur Gibson. Peter Creek: stream, see Peters Creek.

Peter Creek: stream, see Petes Creek.

Peter Island: island, $0.6 \mathrm{mi}$. across, in Anderson Bay, $\mathrm{S}$ side of Makushin Bay, on Unalaska I., Aleutian Is. ; $53^{\circ} 41^{\prime} 40^{\prime \prime} \mathrm{N}, 166^{\circ} 50^{\prime} 25^{\prime \prime} \mathrm{W}$; (map 23).

Local name published in 1951 on a USGS map.

Peter John Mountain: mountain, 3,611 ft., $5 \mathrm{mi}$. $E$ of Old John Lake and $17 \mathrm{mi}$. SE of Arctic Village, Brooks Ra.; $68^{\circ} 05^{\prime} \mathrm{N}, 144^{\circ} 51^{\prime} \mathrm{W}$; (map 136).

Local name reported in 1956 by $R$. C. Foley, USGS.

Peters, Lake: lake, $4.5 \mathrm{mi}$. long, $\mathrm{S}$ lake of Neruokpuk Lakes, in Franklin Mts., 19 mi. W of Mount Michelson, Brooks Ra.; $69^{\circ} 19^{\prime}$ N, 14503' W; BGN 1961; (map 139). Var. Lakes Peters and Schrader, Lake Schrader, Neruokpuk Lakes, Schrader Lake.

Named for William John Peters, 18631942, USGS, topographer. This lake was originally named Lake Schrader by Leffingwell $(1919$, p. 57$)$ who wrote, "The upper lake, Lake Schrader, which is about 4 miles long and a mile wide, fills the whole valley floor so that the water washes the steep rock walls in each side. The mountains here are about 3,000 feet high, ** * However, Leffingwell's map (pl. 1) shows the names transposed, and it is this application that influenced subsequent map and local use.

Peters, Point: point of land, extends S from Deer I., between Ernest Sound and Seward Passage, Alex. Arch.; 55 $58^{\prime} 30^{\prime \prime} \mathrm{N}, 132^{\circ} 01^{\prime} 45^{\prime \prime} \mathrm{W}$; (map 4).

Named by local fishermen and reported in 1904 by H. C. Fassett, USBF.

Peters Basin: basin, covered by Peters Glacier, extends NE $5 \mathrm{mi}$. from Kahiltna Dome to Tluna Icefall, between Peters Dome and Mount Capps, Alaska Ra.; $63^{\circ} 07^{\prime} \mathrm{N}, 151^{\circ} 10^{\prime}$ W; (map 88).

Mountain climbers' name published in 1954 by USGS.

Petersburg: town, pop. 1,592, on N end of Mitkof I., at $\mathrm{N}$ entrance to Wrangell Narrows, $32 \mathrm{mi}$. NW of Wrangell, Alex. Arch.; $56^{\circ} 48^{\prime}$ $10^{\prime \prime} \mathrm{N}, 132^{\circ} 58^{\prime} 00^{\prime \prime} \mathrm{W}$; (map 6).

Known as the "Little Norway" of Alaska. Petersburg is inhabited largely by Scandinavians whose chief occupation are fishing, canning, lumbering and fur farming. The town grew up around a salmon cannery and a sawmill built in 1897-99 by Peter Busch- mann, after whom it was named. A post office was obtained in 1900 (Ricks, 1965, p. 51). Two old storage plants, five canneries, and a sawmill are maintained here as well as an experimental fur farm under the direction of the University of Alaska. Petersburg's population was 1,252 in $1945 ; 1,323$ in 1950. It is an outfitting point for game hunters and is well known for its "Petersburg" shrimp taken from nearby waters (Colby, 1945 , p. 146)

Petersburg Greek: stream, on Lindenberg Penin., Kupreanof I., heads on N slope of Portage Mtn., flows SE $14 \mathrm{mi}$. through Petersburg Lake to Wrangell Narrows at West Petersburg; Alex. Arch.; $56^{\circ} 48^{\prime} 45^{\prime \prime} \mathrm{N}, 132^{\circ} 59^{\prime} 30^{\prime \prime}$ $\mathrm{W} ;(\operatorname{map} 6)$.

Local name published by USC\&GS in 1932 Coast Pilot (p. 273).

Petersburg Lake: lake, $1 \mathrm{mi}$. long, $9 \mathrm{mi}$. NW of Petersburg, on Lindenberg Penin., Kupreanof I., Alex. Arch.; $56^{\circ} 52^{\prime} 30^{\prime \prime} \mathrm{N}, 133^{\circ} 10^{\prime} 30^{\prime \prime} \mathrm{W}$; (map 6).

Local name recorded in 1951 by USGS.

Peters Creek: locality, on Glenn Highway, E of Birchwood, $20 \mathrm{mi}$. NE of Anchorage, Gook Inlet Low.; $61^{\circ} 24^{\prime} 45^{\prime \prime} \mathrm{N}, 149^{\circ} 26^{\prime} 15^{\prime \prime} \mathrm{W}$; (map 69).

Local name reported in 1960 by USGS. Recent USGS maps indicate a site with five or six buildings.

Peters Creek: locality, on Peters Creek S of the junc. of Martin Greek, $20 \mathrm{mi}$. NW of Talkeetna, Alaska Ra.; $62^{\circ} 22^{\prime} 30^{\prime \prime} \mathrm{N}, 150^{\circ} 44^{\prime} 00^{\prime \prime}$ W; (map 81).

This place, shown with four buildings on recent maps, may be a road or supply camp for the mines off Cache Creek; reported in 1936 by USGS

Peters Creek: stream, heads at glacier, flows NW $20 \mathrm{mi}$. to Knik Arm, N of Birchwood, $20 \mathrm{mi}$. NE of Anchorage, Cook Inlet Low.; 61 ${ }^{\circ} 25^{\prime}$ $35^{\prime \prime} \mathrm{N}, 149^{\circ} 30^{\prime} 00^{\prime \prime} \mathrm{W}$; (map 69). Var. Peter Greek.

Local name reported in 1906 by T. G. Gerdine and R. H. Sargent, USGS.

Peters Creek: stream, flows SW $18 \mathrm{mi}$. to Willow Creek, $24 \mathrm{mi}$. NW of Palmer, Talkeetna Mts. ; $61^{\circ} 47^{\prime} 10^{\prime \prime} \mathrm{N}, 1^{\circ} 49^{\circ} 43^{\prime} 15^{\prime \prime} \mathrm{W}$; (map 69). Var. Peterson Creek.

Local name reported in 1917 by S. R. Capps and J. B. Mertie (in Martin and others, 1919, pl. 1), USGS.

Peters Creek: stream, heads in Dutch Hills, flows S $45 \mathrm{mi}$. to Kahiltna River, $26 \mathrm{mi}$. SW of Talkeetna, Alaska Ra.; $62^{\circ} 10^{\prime} 40^{\prime \prime} \mathrm{N}, 150^{\circ}$. 52'45" W; (map 81).

Prospectors' name reported in 1906 by R. W. Porter, USGS.

Peters Creek: stream, see Petes Creek.

Peters Dome: mountain, 10,600 ft., $\mathrm{N}$ of Peters Basin and $W$ of Peters Glacier, $7.7 \mathrm{mi}$. NW of summit of Mount McKinley, Alaska Ra.; $63^{\circ} 08^{\prime} 15^{\prime \prime} \mathrm{N}, 151^{\circ} 12^{\prime} 00^{\prime \prime} \mathrm{W}$; (map 88)

Local name reported in 1954 by USGS. Petersen Creek: stream, see Peterson Creek. Petersen Islands: islands, $0.3 \mathrm{mi}$. across, in Ernest Sound, $4.5 \mathrm{mi}$. NE of Onslow Point,
Alex. Arch.; $55^{\circ} 53^{\prime} 05^{\prime \prime} \mathrm{N}, 132^{\circ} 13^{\prime} 30^{\prime \prime} \mathrm{W}$ (map 4).

Local name published in 1924 by USC\&GS.

Peters Glacier: glacier, heads at Peters Basin, trends NE and $\mathrm{N} 12 \mathrm{mi}$. to its terminus at the head of Muddy River, Alaska Ra.; $63^{\circ} 16^{\prime} 30^{\prime \prime}$ $\mathrm{N}, 150^{\circ} 59^{\prime} 30^{\prime \prime} \mathrm{W}$; $B G N$ 1947; (map 88). Var. Hanna Glacier.

Named by A. H. Brooks in 1902 for William John Peters, 1864-1942, USGS, topographer and explorer, who was in charge of USGS explorations in Alaska from 1898 to 1901 . It was also called "Hanna Glacier" for Marcus Alonzo Hanna, U.S. Senator from Ohio, "friend and political warwick of President McKinley, for whom Mount McKinley was named."

Peters Glacier: glacier, in Franklin Mts., on W slope of Mount Chamberlain, 2 mi. SE of Lake Peters and $17 \mathrm{mi}$. W of Mount Michelson, Brooks Ra.; $69^{\circ} 16^{\prime} 30^{\prime \prime} \mathrm{N}, 144^{\circ} 57^{\prime} 00^{\prime \prime} \mathrm{W}$; (map 139).

Named in 1959 by members of the Air Force Cambridge Research Center for Lake Peters.

Peters Hills: mountains, $3,800 \mathrm{ft}$., extend SW 18 mi. from Tokositna River, $24 \mathrm{mi}$. NW of Talkeetna, Alaska Ra.; $62^{\circ} 31^{\prime} 15^{\prime \prime} \mathrm{N}, 150^{\circ} 48^{\prime} 30^{\prime \prime}$ W; (map 81).

Local name reported in 1906 by $R$. W. Porter, USGS.

Peterson Bay: bay, $0.5 \mathrm{mi}$. wide and $2.5 \mathrm{mi}$. long, on S coast of Sanak I., Aleutian Ra.; $54^{\circ} 22^{\prime} 45^{\prime \prime} \mathrm{N}, 162^{\circ} 37^{\prime} 00^{\prime \prime} \mathrm{W}$; (map 25). Var. King Cove.

Named by USBF in 1888 . This bay or Salmon Bay may be identical to the King Cove of W. H. Dall, USC\&GS. See Salmon Bay.

Peterson Bay: bay, $1.7 \mathrm{mi}$. wide, on $\mathrm{E}$ shore of Kachemak Bay, on Kenai Penin., 9 mi. SE of Homer, Chugach Mts.; $59^{\circ} 35^{\prime} \mathrm{N}, 151^{\circ} 18^{\prime}$ W; (map 50).

Local name reported by USGS or USC\&GS in the 1940's.

Peterson Creek: stream, heads on Auke Mtn. and flows $7 \mathrm{mi}$. NW to Salt Lake, $0.3 \mathrm{mi}$. NW of Dotsons Landing and $19 \mathrm{mi}$. NW of Juneau, $58^{\circ} 29^{\prime} 45^{\prime \prime} \mathrm{N}, 134^{\circ} 46^{\prime} 45^{\prime \prime} \mathrm{W}$; (map 11). Var. Cheechako Creek.

Named for John G. Peterson, 1861-1916, a Juneau businessman and miner. In 1899 he staked a claim on the creek which he called Cheechako Creek. Later it become known as Peterson Creek (DeArmond, 1957, p. 35).

Peterson Creek: stream, heads on NW side of Blueberry Hill, flows SW $2.5 \mathrm{mi}$, to Turnagain Arm, $13 \mathrm{mi}$. E of Sunrise, Chugach Mts.; $60^{\circ} 53^{\prime \prime} 10^{\prime \prime} \mathrm{N}, 1^{\circ} 09^{\circ} 40^{\prime \prime} \mathrm{W}$; $B G N$ 1966; (map 63). Var. Petersen Creek.

Local name reported in 1899 by Lt. Herron (1901, map facing p. 11), USA.

Peterson Creek: stream, see Paterson Creek. Peterson Creek: stream, see Peters Creek.

Peterson Creek: stream, see Quiktalik Creek.

Peterson Island: island, $0.3 \mathrm{mi}$. across, one of Sanak Is., Aleutian Ra.; $54^{\circ} 20^{\prime} 25^{\prime \prime} \mathrm{N}, 162^{\circ}$. $36^{\prime} 45^{\prime \prime} \mathrm{W}$; (map 25).

Name reported by Ferdinand Westdahl, 
USC\&GS, commander of the Coast Survey steamer McArthur, who made surveys in this area in 1901.

Peterson Lagoon: lagoon, $1.8 \mathrm{mi}$. across, on $\mathrm{N}$ coast of Unimak I., Aleutian Is. ; $54^{\circ} 56^{\prime} 00^{\prime \prime}$ N, $164^{\circ} 10^{\prime} 30^{\prime \prime} \mathrm{W}$; (map 24).

Local name published in 1951 by USGS.

Peterson Lake: lake, $0.9 \mathrm{mi}$. long, on Peterson Creek, $3.8 \mathrm{mi}$. SE of Salt Lake and $17 \mathrm{mi}$. NW of Juneau, Coast Mts.; $58^{\circ} 26^{\prime} 45^{\prime \prime} \mathrm{N}, 134^{\circ} 44^{\prime}$ $00^{\prime \prime}$ W; BGN 1929; (map 11). Var. Reservoir Lake.

Named for John G. Peterson, 1861-1916, Juneau businessman and miner who staked a claim on Peterson Creek in 1899. At that time the lake was recorded in mining records as Reservoir Lake, but by 1905 it became known as Peterson Lake (DeArmond, 1957, p. 35).

Peterson Lake: lake, $0.4 \mathrm{mi}$. across, one of the Seven Lakes, on Kenai Penin., at head of East Fork Moose River, $3 \mathrm{mi}$. NW of Hidden Lake and $29 \mathrm{mi}$. SE of Kenai, Cook Inlet Low.; $60^{\circ} 31^{\prime} 30^{\prime \prime} \mathrm{N}, 150^{\circ} 23^{\prime} 45^{\prime \prime} \mathrm{W}$; (map 62).

Named about 1963 by officials of Kenai National Moose Range, for administrative purposes.

Peterson Point: point of land, on Kenai Penin., on $E$ shore of Kachemak Bay, $10 \mathrm{mi}$. ESE of Homer, Chugach Mts.; $59^{\circ} 36^{\prime} \mathrm{N}, 151^{\circ} 16^{\prime} \mathrm{W}$; (map 50).

Local name reported and published by USGS since 1950.

Peters Pass: Pass, 8,050 ft., between Peters Basin and Straitghtaway Glacier, at southern base of Peters Dome, Alaska Ra.; $63^{\circ} 06^{\prime} 30^{\prime \prime}$ $\mathrm{N}, 151^{\circ} 13^{\prime} 30^{\prime \prime} \mathrm{W}$; (map 88).

Mountain climbers' name published in 1954 by USGS.

Peters Point: point of land, NE point of Pearl I., in the Yukon River $22 \mathrm{mi}$. NE of Russian Mission, Yukon-Kuskokwim Delta; 61 ${ }^{\circ} 57^{\prime} \mathrm{N}$, $160^{\circ} 43^{\prime}$. W; (map 73).

Riverboat pilots' name shown on a 1916 field sheet by R. H. Sargent, USGS.

Petersville: locality, on Peters Creek, $24 \mathrm{mi}$. NW of Talkeetna, Alaska Ra.; $62^{\circ} 29^{\prime} 45^{\prime \prime} \mathrm{N}, 150^{\circ}$ $46^{\prime} 00^{\prime \prime} \mathrm{W}$; (map 81).

Mining camp reported in 1934 by USGS. The Petersville post office was located here from 1936 to 1939 (Ricks, 1965, p. 51).

Petes Creek: stream, on Kenai Penin., flows NW $1 \mathrm{mi}$. to Granite Creek $1.5 \mathrm{mi}$. upstream from its junc. with East Fork Sixmile Creek, $12 \mathrm{mi}$. SE of Sunrise, Chugach Mts.; 6043'55" N, 149 16'25" W; BGN 1966; (map 63). Var. Peter Creek, Peters Creek.

Local name reported in 1915 by USGS.

Petes Pass: water passage, E of Harbor I., 34 mi. SW of Seward, Chugach Mts.; $59^{\circ} 39^{\prime} \mathrm{N}$, $149^{\circ} 39^{\prime} \mathrm{W}$; (map 49).

Local name reported in the early 1950's by USC\&GS.

Petitski : island, see Bird Island.

Petkas Point: point of land, see Pitkas Point.

Pet Lake: lake, $0.5 \mathrm{mi}$. long, at head of tributary to Mashooshaluk Creek, in a passage between John and Allen Rivers, $50 \mathrm{mi}$. NW of Wise-

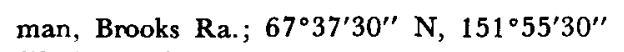
W; (map 124).

Local name obtained in 1956 by USGS topographers.

Pet-meg-é a: stream, see Pitmegea River.

Peterel Bank: submarine ridge, 16-20 mi. wide, $28 \mathrm{mi}$ long, in Bering Sea, off NE coast of Semisopochnoi I., Aleutian Is.; $52^{\circ} 08^{\prime} \mathrm{N}$. $179^{\circ} 48^{\prime} \mathrm{E}$; BGN 1937; (map 15).

Discovered by Lt. Comdr. F. H. Sherman, USN, in 1904, and named for his vessel, the USBF steamer Petrel. Name published on a 1906 USC\&GS chart.

Petrel Island: island, $0.7 \mathrm{mi}$. long, in Pacific Ocean, $0.4 \mathrm{mi}$. S of Forrester I., Alex. Arch.; $54^{\circ} 45^{\prime} 15^{\prime \prime} \mathrm{N}, 133^{\circ} 30^{\prime} 40^{\prime \prime} \mathrm{W}$; (map 1).

Name published by USC\&GS in 1917.

Petrel Island: island, $0.2 \mathrm{mi}$. across, one of Chiachi Is., $22 \mathrm{mi}$. E of Stepovak Bay, Aleutian Ra.; 55 $52^{\prime} 15^{\prime \prime} \mathrm{N}, 1^{\circ} 09^{\circ} 07^{\prime} 05^{\prime \prime} \mathrm{W}$; (map 27).

So named by W. H. Dall, USC\&GS, in 1875 for the Northern Fork-Tailed Petrel, Oceanodroma furcata furcata.

Petrel Point: point of land, $\mathrm{N}$ tip of Semisopochnoi I., Aleutian Is.; $52^{\circ} 01^{\prime} 45^{\prime \prime} \mathrm{N}, 179^{\circ}$ $36^{\prime} 00^{\prime \prime} \mathrm{E}$; BGN 1937; (map 15).

Named for Petnel Bank; reported by personnel of the U.S.S. Oglala in 1935.

Petrel Point: point of land, on W bank of Portland Canal $1.5 \mathrm{mi}$. S of Halibut Bay; Coast Mts.; 55 $11^{\prime} 40^{\prime \prime} \mathrm{N}, 130^{\circ} 07^{\prime} 00^{\prime \prime} \mathrm{W}$; (map 3).

Named in 1895 by USC\&GS.

Petries Strait: water passage, see Shelik of Strait. Petnof: village, see Nikolski.

Petrof, Point: point of land, on NW tip of Sanak I., Aleutian Ra.; $54^{\circ} 29^{\prime} 40^{\prime \prime} \mathrm{N}, 162^{\circ} 49^{\prime} 45^{\prime \prime}$ W; (map 25). Var. McLoughlins Point, Mys Petrova.

Russian name published by Capt. Tebenkov (1852, map 24), IRN, as "M[ys] Petrova" or "Petrof's Cape." According to USC\&GS, "The residents of Sanak call Point Petrof, McLoughlins Point * * Many years ago a man by that name lived at Point Petrof."

Petrof Bay: bay, $2.5 \mathrm{mi}$. across, on Kuiu I., at $\mathrm{S}$ end of Tebenkof Bay, Alex. Arch.; 56 $25^{\prime} \mathrm{N}$, 1340ㅗ' W; BGN 1929; (map 5).

Named in 1928 by USC\&GS for Ivan Petroff, special census agent for Alaska in 1880, "who contributed largely to the written history of Alaska."

Petrof Falls: waterfall, N of Iliamna Lake on Newhalen River, 4 mi NW of Iliamna, Alaska Ra.; $59^{\circ} 48^{\prime} \mathrm{N}, 154^{\circ} 57^{\prime} \mathrm{W}$; (map 51). Var. Petroff Falls.

Name published as "Petroff Falls" by Osgood (1904, p. 11-12), USDA.

Petroff Falls: waterfall, see Petrof Falls.

Petrof Glacier: glacier, heads at $59^{\circ} 31^{\prime} \mathrm{N}$, $150^{\circ} 49^{\prime}$ W, in Kenai Mts., trends S 9 mi. to its terminus at lake, $1 \mathrm{mi}$. N of Nuka Passage and $32 \mathrm{mi}$. ESE of Seldovia, Chugach Mts.; $59^{\circ} 23^{\prime} 15^{\prime \prime} \mathrm{N}, 150^{\circ} 48^{\prime} 00^{\prime \prime} \mathrm{W}$; (map 50).

Probably named for Ivan Petroff, who did extensive research in the area for the 10th U.S. Census of 1880 . Reported by U. S.
Grant and D. F. Higgins, USGS (Martin and others, 1915, pl. 2).

Petrof Point: point of land, on Kenai Penin., on $\mathrm{W}$ shore of Nuka Passage, $33 \mathrm{mi}$. ESE of Seldovia, Chugach Mts.; $59^{\circ} 17^{\prime} 30^{\prime \prime}$ N, $150^{\circ}$ $45^{\prime} 30^{\prime \prime} \mathrm{W}$; BGN 1931; (map 50).

So named for nearby Petrof Glacier by USC\&GS, in 1931.

Petrokoy Lake: lake, $0.6 \mathrm{mi}$. long, $2 \mathrm{mi}$. NE of junc. of Maclaren River and its West Fork and $30 \mathrm{mi}$. S of Mount Hayes, Alaska Ra.; $63^{\circ} 11^{\prime} 30^{\prime \prime} \mathrm{N}, 146^{\circ} 30^{\prime} 30^{\prime \prime} \mathrm{W}$; (map 86).

Name published on relatively recent maps. Petrova, Mys: point of land, see Petrof, Point. Peulik, Mount: mountain, 4,835 ft., on S shore of Becharof Lake, on Alaska Penin., $43 \mathrm{mi}$. NE of Ugashik, Aleutian Ra.; 57 $45^{\prime} \mathrm{N}, 156^{\circ}$ 22' W; (map 36). Var. Smoky Mountain.

Aleut name reported in 1902 by W. H. Osgood, USDA, as "Smoky Mountain" or "Mount Peulik." According to G. C. Martin, USGS, "Peulik" means "smoking" or "smoking mountain."

Peysar, Ostrov: island, see Peisar Island.

Pfaff Peak: peak, 3,100 ft., $2.7 \mathrm{mi}$. SW of Battle Lake and $50 \mathrm{mi}$. S of Iliamna, Aleutian Ra.; 59 $01^{\prime} \mathrm{N}, 154^{\circ} 57^{\prime} \mathrm{W}$; (map 51 ).

Local name pubiished by USGS in 1951.

Phalarope Lake: lake, 2 mi. long, on Kenai Penin., 1.1 mi. W of the Bedlam Lakes and $27 \mathrm{mi}$. SW of Anchorage, Cook Inlet Low.; $60^{\circ} 55^{\prime} \mathrm{N}, 150^{\circ} 24^{\prime} \mathrm{W}$; (map 62).

Named about 1963 by officials of Kenai National Moose Range, probably for the Northern Phalarope (Lobipes lobatus), the little swimming Sandpiper, which breeds from northern Alaska to the Aleutian Islands and is of great economic value, destroying immense numbers of mosquitoes and mosquito larvae. (Pearson, 1944, pt. 1, p. 217).

Phalarope Lake: lake, $0.7 \mathrm{mi}$. long, $\mathrm{N}$ of Denali Highway, in course of Rock Creek, $27 \mathrm{mi}$. NW of Paxson, Alaska Ra.; $63^{\circ} 06^{\prime} 20^{\prime \prime} \mathrm{N}$, $146^{\circ} 20^{\prime} 30^{\prime \prime} \mathrm{W}$; (map 86).

So named in 1955 by T. L. Péwé, USGS, because the lake "is the habitat of a multitude of phalarope [a small shore bird] during the summer season."

Phelan Creek: stream, heads $2.2 \mathrm{mi}$. SW of Gulkana Glacier terminus, flows NW $16 \mathrm{mi}$. to Delta River, 22 mi. NW of Paxson, Alaska Ra.; $63^{\circ} 20^{\prime} 08^{\prime \prime} \mathrm{N}, 145^{\circ} 44^{\prime} 30^{\prime \prime} \mathrm{W}$; (map 86).

Named in 1898 by Capt. E. F. Glenn, USA.

Phil, Lake: lake, $0.2 \mathrm{mi}$. long, $9.4 \mathrm{mi}$. SW of Kodiak, Kodiak I.; $57^{\circ} 42^{\prime} 30^{\prime \prime}$ N, $152^{\circ} 36^{\prime} 45^{\prime \prime}$ W; (map 34).

Local name reported in 1949 by USGS.

Philacte Bay: bay, $2 \mathrm{mi}$. across, at $\mathrm{W}$ end of Baird Inlet, $95 \mathrm{mi}$. W of Bethel, YukonKuskokwim Delta; $60^{\circ} 50^{\prime} \mathrm{N}, 164^{\circ} 26^{\prime} \mathrm{W}$; (map 58).

Name used by personnel of Clarence Rhode National Wildlife Range; reported in 1965. The name is derived from the scientific name, Philacte canagica, for the emperor goose.

Philadelphia Creek: stream, in York Mts., flows SW $1 \mathrm{mi}$. to Kanauguk River which flows to Bering Sea, $36 \mathrm{mi}$. NW of Teller, Seward 
Penin. High.; $65^{\circ} 29^{\prime}$ N, $167^{\circ} 28^{\prime}$ W ; (map 111).

Prospectors' name reported on the 1908 "Map of Seward Peninsula" by Arthur Gibson.

Philip Smith Mountains: mountains, extend 130 mi. from Sagavanirktok River and North Fork Chandalar River on SW to Canning River and East Fork Chandalar River on NE, Brooks Ra.; $68^{\circ} 55^{\prime} \mathrm{N}, 145^{\circ} 00^{\prime} \mathrm{W}$ [NE end], $68^{\circ} 10^{\prime} \mathrm{N}, 149^{\circ} 00^{\prime} \mathrm{W}$ [SW end]; (map 135).

Named in 1950 by USGS after Philip Sidney Smith, 1877-1949, chief Alaska geologist of the Geological Survey from 1925 to 1946 , and at one time the acting director of the Survey.

Phillips: locality, on Yukon-Kuskokwim Portage trail, SE of Johnson River and $23 \mathrm{mi}$. SE of Russian Mission, Yukon-Kuskokwim Delta; $61^{\circ} 27^{\prime} 50^{\prime \prime} \mathrm{N}, 161^{\circ} 06^{\prime} 00^{\prime \prime} \mathrm{W}$; (map 73).

This place probably represents a cabin or two on the trail, owned by the Phillips brothers (cnna).

Phillips Gulch: ravine, trends NE $1 \mathrm{mi}$. to Extra Dry Cieek, $6 \mathrm{mi}$. NE of Nome, Seward Penin. High.; $64^{\circ} 34^{\prime} \mathrm{N}, 165^{\circ} 16^{\prime} \mathrm{W}$; (map 94). Var. Little Gulch.

Prospectors' name published in 1956 by USGS. Reported as "Little Gulch" on Arthur Gibson's "Map of Cape Nome Precinct" dated 1904.

Phillips Rock: rock, in Gulf of Esquibel, W of St. Philip I., Alex. Arch.; $55^{\circ} 38^{\prime} 20^{\prime \prime}$ N, $133^{\circ}$ $25^{\prime} 55^{\prime \prime} \mathrm{W}$; (map 4).

Local name recorded in 1951 by USGS.

Phipps, Cape: peninsula, see Phipps Peninsula. Phipps, Cape: point of land, see Ocean Cape. Phipps Cape: point of land, on $\mathrm{N}$ end of Phipps Penin., $\mathrm{N}$ of Ankau Creek, $2.8 \mathrm{mi}$. W of Yakutat, Malaspina Coastal Plain; $59^{\circ} 33^{\prime} \mathrm{N}$, $139^{\circ} 50^{\prime} \mathrm{W}$; (map 46).

Local name reported in 1964 (Laguna and others, map 4)

Phipps Peninsula: peninsula, $3.5 \mathrm{mi}$. long, in Gulf of Alaska, S of Monti Bay, $1 \mathrm{mi}$. SW of Yakutat, Malaspina Coastal Plain; 59 $32^{\prime}$ N, $139^{\circ} 48^{\prime}$ W.; $(\operatorname{map} 46)$. Var. Cape Morskoi, Cape Phipps, Cape Phips, Ocean Cape.

Named "Cape Phipps" by Capt. George Dixon in 1787 for the Hon. Constantine John Phipps, Baron Mulgrave, English explorer, famous for his voyage to Spitzbergen and the Arctic Ocean in 1773 (U.S. Coast \& Geodetic Survey, 1883, p. 208). There has been some confusion in the application of the name. The name Cape Phipps was applied to Ocean Cape by some of the early hydrographers, and in 1823 it was applied by Capt. C. V. Kromchenko to Point Carew. It was called "Phipps Peninsula" by Baker (1906, p. 496), USGS, and "Phipps Bay Peninsula" by IBC in 1928. See Mulgrave, Port.

Phipps Point: point of land, on Hinchinbrook I., at entrance to Constantine Harbor, $33 \mathrm{mi}$. SW of Cordova, Chugach Mts.; $60^{\circ} 21^{\prime} \mathrm{N}$, $146^{\circ} 37^{\prime} \mathrm{W}$; (map 64)

Local name reported in 1902 by USC\&GS. Phips, Cape: peninsula, see Phipps Peninsula.
Phocena Rocks: rocks, extends $0.3 \mathrm{mi}$. off SW coast of Gravina I., $4.2 \mathrm{mi}$. NW of Dall Head, Alex. Arch.; $55^{\circ} 10^{\prime} 00^{\prime \prime} \mathrm{N}, 131^{\circ} 48^{\prime} 20^{\prime \prime} \mathrm{W}$; $B G N$ 1966; (map 3). Var. Chick Rocks, Porpoise Rocks, Skole Rocks.

Named in 1921 by USC\&GS ; derived from "Phocaena," the Latin term for "porpoise."

Phoebe Creek: stream, flows NW 5 mi. from more northerly of Twin Lakes, joins Robert Creek to form Bettles River, $21 \mathrm{mi}$. WNW of Chandalar, Brooks Ra.; $67^{\circ} 35^{\prime} 40^{\prime \prime} \mathrm{N}, 1^{\circ} 9^{\circ}$ $14^{\prime} 00^{\prime \prime} \mathrm{W}$; (map 123).

Prospectors' name; reported in 1899 by Schrader (1900b, pl. 60), USGS.

Phoenix: locality, on NW coast of Latouche I., $22 \mathrm{mi}$. SE of Chenega, Chugach Mts.; $60^{\circ} 02^{\prime}$ $33^{\prime \prime} \mathrm{N}, 147^{\circ} 54^{\prime} 40^{\prime \prime} \mathrm{W}$; (map 63). Var. The Madhouse.

Name of a mining camp and wharf reported in 1909 by Grant and Higgins (1910, pl. 12), USGS. The camp is now abandoned.

Phoenix Bay: bay, $0.6 \mathrm{mi}$. across, on $\mathrm{E}$ shore of Perenosa Bay, on $\mathrm{N}$ coast of Afognak I., $\mathrm{N}$ of Kodiak I.; $58^{\circ} 25^{\prime} 30^{\prime \prime} \mathrm{N}, 1^{\circ} 2^{\circ} 20^{\prime} 30^{\prime \prime} \mathrm{W}$; $B G N$ 1934; (map 43).

Named by USC\&GS in 1932 for the vessel Phoenix. This ship was the first one built in northwestern America, by James Shields, an Englishman in the Russian Navy, under the direction of Alexander Baranov, of the Shelikov Company, in 1794 (Bancroft, 1886, p. 329-331).

Phoenix Creek: stream, flows NE $4 \mathrm{mi}$. to Seventymile River, $8 \mathrm{mi}$. NW of Eagle, Yukon-Tanana High.; $64^{\circ} 53^{\prime} \mathrm{N}, 141^{\circ} 24^{\prime} \mathrm{W}$; (map 102).

Prospectors' name shown on a 1902 manuscript map by E. J. Chamberlain, U.S. Deputy Surveyor.

Phoenix Creek: stream, flows SE $1.5 \mathrm{mi}$. to Canyon Creek $1 \mathrm{mi}$. downstream from Dexter Greek, $23 \mathrm{mi}$. NW of Solomon, Seward Penin. High.; $64^{\circ} 53^{\prime} \mathrm{N}, 164^{\circ} 44^{\prime} \mathrm{W}$; (map 95).

Prospectors' name reported on a map of Cape Nome gold fields by David Fox, Jr., dated 1901.

Phoenix Peak: peak, 5,155 ft., 2 mi. SW of Iron Mtn. and $3.5 \mathrm{mi}$. W of Seward, Chugach Mts.; $60^{\circ} 07^{\prime} 23^{\prime \prime} \mathrm{N}, 149^{\circ} 32^{\prime} 10^{\prime \prime} \mathrm{W}$; $B G N$ 1966; (map 63).

Named in 1965 by the Mountaineering Club of Alaska "for the first ship ever built in Alaska, which was constructed in nearby Resurrection Bay in 1794."

Phonograph Creek: stream, flows SW $6.5 \mathrm{mi}$. to Lisianski Inlet on NW part of Chichagof I., $16 \mathrm{mi}$. N of Chichagof, Alex. Arch.; $57^{\circ} 54^{\prime} 30^{\prime \prime}$ $\mathrm{N}, 136^{\circ} 08^{\prime} 30^{\prime \prime} \mathrm{W}$; (map 9).

Local name reported in 1951 by USGS.

Phosphorite Creek: stream, flows NW $5.5 \mathrm{mi}$. to Saligvik Creek, S of its junc. with Kukpuk River, $13 \mathrm{mi}$. NE of Cape Thompson, Arctic Slope; $68^{\circ} 15^{\prime} 55^{\prime} \mathrm{N}, 165^{\circ} 36^{\prime} 20^{\prime \prime} \mathrm{W}$; $B G N$ 1963; (map 129).

Named by geologists about 1962 in connection with Project Chariot studies.

Piasuk River: stream, part of Ikpikpuk River distributary system, flows NE $25 \mathrm{mi}$. to Smith
Bay, 8 mi. S of Cape Simpson, A ctic Plain; $70^{\circ} 52^{\prime} \mathrm{N}, 154^{\circ} 42^{\prime} \mathrm{W}$; (map 148).

Eskimo name reported by USC\&GS in 1951. Orth was told in 1965, that it is "an old Barrow name" of unknown meaning.

Piatidesiatnitzi: point of land, see Izhut, Cape. Piatimilni Island: island, see Fivemile Island. Pichouligagamut: locality, on left bank of $\mathrm{Ka}$ nektok River, $3 \mathrm{mi}$. NE of Kwinhagak, $48 \mathrm{mi}$. N of Goodnews, Yukon-Kuskokwim Delta; $59^{\circ} 46^{\prime} \mathrm{N}, 161^{\circ} 48^{\prime} \mathrm{W}$; (map 53).

Eskimo name meaning "Pichouligak people"; shown on an 1898 fieldsheet by W. S. Post, USGS, with a note: "deserted houses."

Pickarts Creek: stream, see Bergman Creek.

Pickerel Lake: lake, $3 \mathrm{mi}$. long, at NW end of Nutzotin Mts., Alaska Ra.; $62^{\circ} 37^{\prime} \mathrm{N}, 142^{\circ}$ 24' W; (map 84). Var. Pickerel Lakes.

Local name reported in 1955.

Pickerel Lakes: lakes, extend NE-SW 7 mi., 4 $\mathrm{mi}$. E of Nondalton and $16 \mathrm{mi}$. NE of Iliamna, Aleutian Ra.; $59^{\circ} 59^{\prime} \mathrm{N}, 154^{\circ} 42^{\prime} \mathrm{W}$; (map 51).

Named by prospectors prior to 1909 ; published by Martin and Katz (1912, pl. 1), USGS.

Pickerel Lakes: lake, see Pickerel Lake.

Pickerel Slough: lake, oxbow, $1.2 \mathrm{mi}$. long, $\mathrm{E}$ of Yukon River and $10 \mathrm{mi}$. N of Eagle, Porcupine Plat.; $64^{\circ} 56^{\prime} \mathrm{N}, 141^{\circ} 10^{\prime} \mathrm{W}$; (map 102).

Local name published in 1956 by USGS.

Picket Gate Crags: ridge, extending S $1 \mathrm{mi}$. from Mount Moore, $6.5 \mathrm{mi}$. SE of Mount Ogilvie and $36 \mathrm{mi}$. N of Juneau, Coast Mts.; $58^{\circ} 47^{\prime} 40^{\prime \prime} \mathrm{N}, 1^{\circ} 4^{\circ} 07^{\prime} 30^{\prime \prime} \mathrm{W}$; BGN 1965; (map 11).

Named in 1964 by members of the Juneau Icefield Research Project.

Pickle Creek: stream, flows S $7.5 \mathrm{mi}$. to Kahiltna River, $28 \mathrm{mi}$. W of Talkeetna, Alaska Ra.; $62^{\circ} 17^{\prime} 15^{\prime \prime} \mathrm{N}, 150^{\circ} 58^{\prime} 45^{\prime \prime} \mathrm{W}$; (map 81).

Local name reported in 1958 by USGS.

Pick River: stream, heads at $66^{\circ} 32^{\prime} \mathrm{N}, 156^{\circ} 30^{\prime}$ W, flows NW $28 \mathrm{mi}$. to Kobuk River $2 \mathrm{mi}$. S of Shungnak, Kotzebue-Kobuk Low.; 66 ${ }^{\circ} 52^{\prime}$ $\mathrm{N}, 157^{\circ} 09^{\prime} \mathrm{W}$. Var. She-kluck-she-uck.

Named in 1886 by Lt. Stoney (1900, map), USN, who also gave its Eskimo name as "She-kluck-she-uck."

Picnic Creek: stream, in DeLong Mts., flows SSE $18 \mathrm{mi}$. to Anisak River, Brooks Ra.; $68^{\circ}$ $24^{\prime} \mathrm{N}, 159^{\circ} 24^{\prime} \mathrm{W}$; BGN 1960; (map 131). Named "Piknik" in 1953 by E. G. Sable and I. L. Tailleur, USGS, "for pleasant traverse of creek." The spelling was modified by BGN.

Picnic Harbor: cove, $0.6 \mathrm{mi}$. wide, at head of Rocky Bay, on Kenai Penin., $17 \mathrm{mi}$. SE of Seldovia, Chugach Mts.; $59^{\circ} 15^{\prime} 30^{\prime \prime} \mathrm{N}, 151^{\circ}$ $25^{\prime} 00^{\prime \prime} \mathrm{W}$; (map 50).

Local name published by USGS in 1951. Picnic Lake: lake, $0.3 \mathrm{mi}$ long, on Kenai Penin. $\mathrm{SE}$ of Campsite Lake, $3.5 \mathrm{mi}$. $\mathrm{N}$ of Hidden Lake and $34 \mathrm{mi}$. E of Kenai, Cook Inlet Low.; $60^{\circ} 33^{\prime} 10^{\prime \prime} \mathrm{N}, 150^{\circ} 16^{\prime} 30^{\prime \prime} \mathrm{W}$; (map 62).

Named about 1963 by officials of Kenai National Moose Range, for administrative purposes. 
Picnic Point: point of land, on left bank of Nushagak River, opposite mouth of Wood River, 4 mi. E of Dillingham, Bristol Bay Low.; $59^{\circ} 02^{\prime} \mathrm{N}, 158^{\circ} 22^{\prime} \mathrm{W} ; B G N$ 1932; (map 52).

Local name reported in 1904 by H. C. Fassett, USBF.

Piebles Passage: water passage, see Piehle Passage.

Piedras Island: island, $200 \mathrm{ft}$. long, between San Christoval Channel and San Alberto Bay, E of Cruz Is., Alex. Arch.; 55 $33^{\prime} 35^{\prime \prime} \mathrm{N}$, $133^{\circ} 17^{\prime} 50^{\prime \prime} \mathrm{W}$; BGN 1908; (map 4). Var. Rocky Island, Ysla de Piedras.

Spanish name recorded in 1907 by E. F. Dickins, USC\&GS; the name was taken from Ysla de Piedras, meaning "Island of Stones," given in 1775 by Don Juan de la Bodega y Quadra and Francisco Antonio Maurelle. Baker (1906, p. 531) published the translation "Rocky Island."

Piehle Passage: water passage, $1.5 \mathrm{mi}$. long, at $\mathrm{N}$ end of Khaz Penin., $9.5 \mathrm{mi}$. SSE of Chichagof, on W coast of Chichagof I., Alex. Arch.; $57^{\circ} 31^{\prime} 30^{\prime \prime} \mathrm{N}, 136^{\circ} 02^{\prime} 00^{\prime \prime} \mathrm{W}$; (map 9). Var. Hole in the Wall, Piebles Passage, Piehles Passage.

Local name published by USC\&GS in the 1927 Coast Pilot Suppl. (p. 18) as "Piebles Passage". The passage was reported in 1919 as "Hole in the Wall" by USGS.

Piehles Passage: water passage, see Piehle Passage.

Pie Lake: lake, $0.4 \mathrm{mi}$. long, $\mathrm{W}$ of Nabesna River, $30 \mathrm{mi}$. SW of Northway, Alaska Ra.; $62^{\circ} 36^{\prime} \mathrm{N}, 142^{\circ} 25^{\prime} \mathrm{W}$; (map 84).

Local name reported by USGS in 1960 .

Pieneluk Island: island, $1 \mathrm{mi}$. long, in Apoon Pass of Yukon Delta, E of Pieneluk Slough, $29 \mathrm{mi}$. NE of Kwiguk, Yukon-Kuskokwim Delta; $63^{\circ} 01^{\prime} \mathrm{N}, 163^{\circ} 47^{\prime} \mathrm{W}$; (map 92). Var. PEEIN-E-LUK Island.

Eskimo name obtained in 1952 by USC\&GS.

Pieneluk Slough: stream, in Yukon Delta, flows NE 2 mi. to Apoon Pass, W of Pieneluk I., $29 \mathrm{mi}$. NE of Kwiguk, Yukon-Kuskokwim Delta; $63^{\circ} 01^{\prime} \mathrm{N}, 163^{\circ} 46^{\prime} \mathrm{W}$; (map 92).

Eskimo name obtained in 1952 by USC\&GS

Pie Point: point of land, see Pio Point.

Pierce Creek: stream, heads on Mount Susitna, flows SE $5.8 \mathrm{mi}$. to Alexander Creek, 30 mi. NW of Anchorage, Cook Inlet Low.; $61^{\circ}$ $29^{\prime} 45^{\prime \prime} \mathrm{N}, 150^{\circ} 35^{\prime} 35^{\prime \prime} \mathrm{W}$; (map 70).

Local name reported in 1958 by USGS.

Pierce Peak: peak, 3,404 ft., $4 \mathrm{mi}$. W of head of Thomas Bay and $95 \mathrm{mi}$. E of Sitka, Coast Mts.; $57^{\circ} 06^{\prime} 50^{\prime \prime} \mathrm{N}, 132^{\circ} 56^{\prime} 15^{\prime \prime} \mathrm{W}$; (map 8).

Local name reported in 1961 by USGS.

Pierucci Ridge: ridge, $2.5 \mathrm{mi}$. long, extending from Vanderlann Peak to North Ridge, on $\mathrm{E}$ end of Attu I., Aleutian Is.; 52 $53^{\prime} 40^{\prime \prime} \mathrm{N}$, $173^{\circ} 16^{\prime} 30^{\prime \prime} \mathrm{E}$; (map 13).

Named by the U.S. Army during its occupation of the island during World War II ; shown on an AMS map published in 1948. Pies Islands: islands, see Pye Islands.

Pietmiektaligmiut: settlement, see Pikmiktalik. Pietmiektalik River: stream, see Pikmiktalik River.
Pigeon Island: island, $0.5 \mathrm{mi}$. long, near $\mathrm{W}$ end of Port Real Marina, between Baker and Lulu Is., Alex. Arch.; 55 $26^{\prime} \mathrm{N}, 133^{\circ} 34^{\prime} \mathrm{W}$; (map 4). Var. Isla Palomas, Ostrov de Palomas, Ysla de Palomas.

Translation of the name "Ysla de Palomas" given in 1775-79 by Don Juan de la Bodega y Quadra and Francisco Antonio Maurelle.

Pigoo Bluff : bluff, see Píngu Bluff.

Pigot, Point: point of land, between Pigot Bay and Passage Canal, $12 \mathrm{mi}$. NE of Whittier, Chugach Mts.; $60^{\circ} 48^{\prime} 15^{\prime \prime} \mathrm{N}, 148^{\circ} 20^{\prime} 45^{\prime \prime} \mathrm{W}$; (map 63). Var. Pigot Point.

Named by Capt. George Vancouver, RN, in 1794 "probably in honor of Robert Pigot, one of the midshipmen on the [English vessel] Chatham" (Wagner, 1937, p. 402).

Pigot Bay: estuary, extends SE $3 \mathrm{mi}$. to Port Wells, $12 \mathrm{mi}$. NE of Whittier, Chugach Mts.; $60^{\circ} 49^{\prime} 40^{\prime \prime} \mathrm{N}, 148^{\circ} 19^{\prime} 30^{\prime \prime} \mathrm{W} ; B G N$ 1910; (map 63). Var. Gannett Bay.

Local name reported in 1908 by Grant and Higgins (1910, pls. 1, 2), USGS. Name derived from nearby Point Pigot.

Pigot Glacier: glacier, trends SE $4 \mathrm{mi}$. to its terminus $3 \mathrm{mi}$. NW of head of Pigot Bay, 10 mi. NE of Whittier, Chugach Mts.; $60^{\circ} 53^{\prime} 00^{\prime \prime}$ N, 148 $27^{\prime} 15^{\prime \prime} \mathrm{W} ; B G N$ 1910; (map 63).

Local name reported in 1908 by Grant and Higgins (1910, pls. 1, 2), USGS. Name derived from nearby Point Pigot.

Pi Islands: islands, see Pye Islands.

Piinigsaam Kuuna: stream, see Shorty River.

Pik, Mys: point of land, see Peak Point.

Pik, Mys: point of land, see Upright, Cape.

Pikchowik River: stream, flows SE $12 \mathrm{mi}$. to Nuyakuk River, $66 \mathrm{mi}$. NE of Dillingham, Bristol Bay Low. ; $59^{\circ} 56^{\prime} \mathrm{N}, 157^{\circ} 40^{\prime} \mathrm{W}$; (map 52).

Eskimo name reported in 1935 by BIA.

Pik Dunes: dunes, surrounding several small lakes, $17 \mathrm{mi}$. S of Teshekpuk Lake, Arctic Plain; $70^{\circ} 14^{\prime} \mathrm{N}, 153^{\circ} 09^{\prime} \mathrm{W}$; (map 148).

Named by Orth in 1956. It is an Eskimo word (piq) meaning "dish (or pot)," descriptive of the lakes among the dunes.

Pike Creek: stream, flows NE $2 \mathrm{mi}$. to Lake Nerka, $40 \mathrm{mi}$. NW of Dillingham, KilbuckKuskokwim Mts.; $59^{\circ} 33^{\prime} \mathrm{N}, 159^{\circ} 02^{\prime} \mathrm{W}$; (map 53).

Local name reported in 1954 by USGS.

Pike Creek: stream, flows $\mathrm{N} 1 \mathrm{mi}$. to Kuzitrin River at Brockways Bar $4 \mathrm{mi}$. SSW of junc. of Kougarok River, $17 \mathrm{mi}$. W of Mount Bendeleben, Seward Penin. High.; $65^{\circ} 12^{\prime} 35^{\prime \prime} \mathrm{N}$, $164^{\circ} 39^{\prime} 00^{\prime \prime} \mathrm{W}$; (map 110).

Prospectors' name shown on a map of Cape Nome gold fields by David Fox, Jr., dated 1901.

Pike Lake: lake, $0.4 \mathrm{mi}$. long, $0.5 \mathrm{mi}$. S of Beaver Lake, between Dome and Wolf Creeks, $28 \mathrm{mi}$. NNW of Birches, Kokrines-Hodzana High.; $65^{\circ} 28^{\prime} 15^{\prime \prime} \mathrm{N}, 154^{\circ} 04^{\prime} 00^{\prime \prime} \mathrm{W}$; (map 107).

Local name obtained in 1952 by USGS topographers.
Pike Lakes: lakes, in a group $2 \mathrm{mi}$ long, $2.5 \mathrm{mi}$. $E$ of Snug Harbor and $22 \mathrm{mi}$. SE of Iliamna, Aleutian Ra.; $59^{\circ} 30^{\prime} 30^{\prime \prime} \mathrm{N}, 154^{\circ} 31^{\prime} 30^{\prime \prime} \mathrm{W}$; (map 51).

Local name published in 1954 by USGS. Pike Slough: stream, anabranch of Yukon River, flows $4.5 \mathrm{mi}$. along S side of Youngs I., $4 \mathrm{mi}$. SW of Birches, Nowitna Low.; $65^{\circ} 04^{\prime} 30^{\prime \prime} \mathrm{N}$, $153^{\circ} 42^{\prime} 00^{\prime \prime} \mathrm{W}$; (map 107).

Riverboat pilots' name shown on a 1940 "Navigation Chart of the Tanana-Yukon Rivers" published by the Department of the Interior.

Pike Trap Creek: stream, flows SE $8 \mathrm{mi}$. to Kaiyuh Slough, $1 \mathrm{mi}$. W of The Forks, $20 \mathrm{mi}$. $\mathrm{SE}$ of Nulato, Koyukuk Low.; $64^{\circ} 26^{\prime} \mathrm{N}, 157^{\circ}$ $59^{\prime}$ W; (map 97). Var. Gutqklaqatna.

Appears to be a translation of an Indian name; reported in 1935 by Frederica de Laguna, BAE.

Pikhmikhtalik: settlement, see Pikmiktalik.

Pikhmikhtalik, Reka: stream, see Pikmiktalik River.

Pikhta: locality, see Pikta.

Pikmikralik River: stream, see Pikmiktalik River.

Pikmiktalik: settlement, pop. 14 (1940), on S bank of Pikmiktalik River, 8 mi. E of Point Romanof and $23 \mathrm{mi}$. SW of St. Michael, Yukon-Kuskokwim Delta ; $63^{\circ} 14^{\prime} 15^{\prime \prime} \mathrm{N}, 162^{\circ}-$ $35^{\prime} 15^{\prime \prime} \mathrm{W}$; (map 92). Var. Pietmiektaligmiut, Pikhmikhtalik, Pikniktalik.

Small Eskimo village mentioned in 1842-44 by Lt. L. A. Zagoskin, IRN, who spelled the name "Pikhmikhtalik." The Russian Hydrog. Dept. spelled it "Piemiektaligmiut" in 1852 on Chart 1455. Lt. Zagoskin recorded a population here of 45 Eskimos in 4 houses. The 1880 Census listed a population of 10 .

Pikmiktalik River: stream, heads $6 \mathrm{mi}$. S of Kukaklik Lake at $61^{\circ} 32^{\prime} \mathrm{N}, 160^{\circ} 31^{\prime} \mathrm{W}$, flows SW $180 \mathrm{mi}$. to Johnson River, $16 \mathrm{mi}$. SW of Bethel, Yukon-Kuskokwim Delta; $60^{\circ} 45^{\prime} 45^{\prime \prime}$ $\mathrm{N}, 162^{\circ} 14^{\prime} 30^{\prime \prime} \mathrm{W}$; BGN 1965; (map 58). Var. Pikmikralik River, Tundra River, Ptrmichtalu River.

Eskimo name reported in 1949 by USC\&GS.

Pikmiktalik River: stream, flows N $45 \mathrm{mi}$. to Norton Sound, $22 \mathrm{mi}$. SW of St. Michael, Yukon-Kuskokwim Delta; $63^{\circ} 16^{\prime} 30^{\prime \prime} \mathrm{N}, 162^{\circ}$. $36^{\prime} 00^{\prime \prime} \mathrm{W}$; (map 92). Var. Pietmiektalik River, Reka Pikhmikhtalik, Reka Pytmykhtalik.

Eskimo name recorded as " $R[$ eka] Pikhmikhtalik" in '1842-44 by Lt. L. A. Zagoskin, IRN.

Pikniktalik: settlement, see Pikmiktalik.

Pikonik Mound: pingo, elev. $25 \mathrm{ft}$., between Colville and Miluveach Rivers, $9 \mathrm{mi}$. $\mathrm{S}$ of Harrison Bay, Arctic Plain; $70^{\circ} 21^{\prime} 35^{\prime \prime} \mathrm{N}$, $150^{\circ} 35^{\prime} 10^{\prime \prime} \mathrm{W}$; (map 149).

Eskimo name reported in 1951 by USC\&GS to mean "lookout place." It may be from the word "pingoqneq" meaning "high[?] hill."

Pikroka Creek: stream, flows NE $30 \mathrm{mi}$. to the Meade River, $11 \mathrm{mi}$. SE of village of Meade River, Arctic Plain; $70^{\circ} 19^{\prime} 30^{\prime \prime} \mathrm{N}, 157^{\circ} 10^{\prime} 30^{\prime \prime}$ W; (map 147). 
Eskimo name obtained in 1956 at Wainwright by T. E. Taylor, USGS.

Piksiksak Creek: stream, flows N $13 \mathrm{mi}$. to Meade River, $27 \mathrm{mi}$. SE of village of Meade River, Arctic Plain; $70^{\circ} 06^{\prime} \mathrm{N}, 157^{\circ} 03^{\prime} \mathrm{W}$; (map 147). Var. Pisiksagiakvik River, Pisiksak River.

Eskimo name shown on 1923 fieldsheet by E. C. Guerin, USGS, as "Pisiksagiakvik River."

Pikta: locality, on Seward Penin., at or near Tin City, SE of Cape Prince of Wales, Kotzebue-Kobuk Low.; $65^{\circ} 34^{\prime}$ N, $167^{\circ} 57^{\prime} \mathrm{W}$; (map 111). Var. Pikhta.

Former Eskimo village or camp published as "Pikhta" in 1850 on Lt. L. A. Zagoskin's map.

Pilcher Mountain: mountain, 1,948 ft., $4 \mathrm{mi}$. NE of Marshall, Nulato Hills; $61^{\circ} 55^{\prime} 45^{\prime \prime} \mathrm{N}$, $161^{\circ} 59^{\prime} 30^{\prime \prime} \mathrm{W}$; (map 73).

Local name reported by Harrington (1918, p. 11), USGS, in 1916; named for G. M. Pilcher, a miner who was elected local claim recorder October 25, 1913.

Pilcher Mountain Creek: stream, flows W 2.8 mi. to Poltes Slough, $1.5 \mathrm{mi}$. N of Marshall, Yukon-Kuskokwim Delta; $61^{\circ} 54^{\prime} 10^{\prime \prime} \mathrm{N}, 162^{\circ}$ $06^{\prime} 10^{\prime \prime} \mathrm{W}$; (map 74).

Miners' name shown on a fieldsheet by $\mathbf{R}$. $H$. Sargent, USGS, in 1916.

Pile Bay: estuary, $16 \mathrm{mi}$. long, on the $\mathrm{E}$ end of Iliamna Lake, $36 \mathrm{mi}$. NW of Augustine I., Aleutian Ra.; $59^{\circ} 41^{\prime} \mathrm{N}, 154^{\circ} 12^{\prime} \mathrm{W}$; $B G N$ 1910; (map 51). Var. Spile Bay.

Name shown as Spile Bay in 1906 by J. W. Walker on a manuscript map but shortened by local usage to Pile Bay. Name published by Martin and Katz (1912, pl. 1), USGS.

Pile Bay Village: village, pop. 48, on E shore of Iliamna Lake at head of Pile Bay, $36 \mathrm{mi}$. ESE of Nondalton, Aleutian Ra.; $59^{\circ} 46^{\prime} 50^{\prime \prime} \mathrm{N}$, $143^{\circ} 53^{\prime} 00^{\prime \prime} \mathrm{W}$; (map 51 ).

Local name derived from Pile Bay; published in 1952 by USGS.

Piledriver Cove: bay, $0.5 \mathrm{mi}$. across, on Kuiu I., on $\mathbf{N}$ shore of Tebenkof Bay, Alex. Arch.; $56^{\circ} 32^{\prime} 30^{\prime \prime} \mathrm{N}, 134^{\circ} 11^{\prime} 30^{\prime \prime} \mathrm{W}$; BGN 1954; (map 5).

Named in 1929 by USC\&GS for "a number of dolphins [buoys] placed in this cove as moorings for pile drivers."

Piledriver Cove: cove, $0.3 \mathrm{mi}$. across, on $\mathrm{W}$ coast of Admiralty I., $20 \mathrm{mi}$. S of Juneau, Alex. Arch.; $58^{\circ} 05^{\prime} 00^{\prime \prime} \mathrm{N}, 134^{\circ} 45^{\prime} 15^{\prime \prime} \mathrm{W}$; (map 11).

Local name published in 1950 by USGS.

Piledriver Roadhouse: locality, at the $S$ end of Piledriver Slough at the crossing of the Fairbanks-Valdez Trail, $30 \mathrm{mi}$. SE of Fairbanks, Tanana Low.; $64^{\circ} 36^{\prime} \mathrm{N}, 147^{\circ} 05^{\prime} \mathrm{W}$; (map 100). Var. Thirtymile Roadhouse.

Former roadhouse originally referred to as "Thirtymile Roadhouse", but after 1912 it was generally called "Piledriver" (Capps, 1912, pl. 1).

Piledriver Rock: rock, on $\mathrm{N}$ coast of Hawkins I., at entrance to Whiskey Cove, $13 \mathrm{mi}$. W of
Cordova, Chugach Mts.; $60^{\circ} 32^{\prime} 30^{\prime \prime} \mathrm{N}, 146^{\circ}$ $06^{\prime} 45^{\prime \prime}$ W ; (map 64).

Name published in 1950 by USGS.

Piledriver Slough: stream, anabranch, flows NW $16 \mathrm{mi}$. to Tanana River, $15 \mathrm{mi}$. SE of Fairbanks, Tanana Low.; 64 $43^{\prime} 15^{\prime \prime} \mathrm{N}, 147^{\circ} 19^{\prime}$ 20" W; (map 100). Var. Chena Slough, Fairbanks Slough.

This stream was originally considered part of Chena Slough, but called "Piledriver" about 1916 by USC\&GS.

Pile River: stream, heads at a glacier at $60^{\circ} 05^{\prime}$ $\mathrm{N}, 153^{\circ} 25^{\prime} \mathrm{W}$, and flows SW $30 \mathrm{mi}$. to Pile Bay, 35 mi. NW of Augustine I., Aleutian Ra.; $59^{\circ} 47^{\prime} 30^{\prime \prime} \mathrm{N}, 153^{\circ} 54^{\prime} 35^{\prime \prime} \mathrm{W} ; B G N$ 1910; (map 51). Var. Spile River, Syooknook River.

Name reported as Syooknook River by W. E. Smith, Chief Engineer, Alaska Short Line Railway in 1907, but local usage favored Pile River because the stream flows to Pile Bay. The name published by Martin and Katz (1912, pl. 1), USGS.

Pilgrim River: stream, heads in Salmon Lake, SE of Kigluaik Mts., flows NE then W $55 \mathrm{mi}$. to Kuzitrin River, $34 \mathrm{mi}$. SE of Teller, Seward Penin. High.; $65^{\circ} 09^{\prime} 25^{\prime \prime} \mathrm{N}, 165^{\circ} 13^{\prime} 10^{\prime \prime} \mathrm{W}$; $B G N$ 1965; (map 111). Var. Kruzgamapa River, Kruzgamapah River, Kruzgamepa River.

Prospectors' name shown on a precinct map of Seward Peninsula gold fields by Monroe and Hutchins, corrected up to June 1903 by Arthur Gibson. The Eskimo name "Kruzgamepa" was reported in 1900 by E. C. Barnard (in Brooks, 1901, pl. 17), USGS.

Pilgrim Springs: locality, on left bank of Pilgrim River, $13 \mathrm{mi}$. NE of Salmon Lake and $25 \mathrm{mi}$. SW of Mount Bendeleben, Seward Penin. High.; $65^{\circ} 06^{\prime} \mathrm{N}, 164^{\circ} 55^{\prime} \mathrm{W}$; (map 110). Var. Kruzgamepa Hot Springs.

Mineral springs and site of a resort. In the early days of gold mining on Seward Peninsula, about 1900 , the property was known as "Kruzgamepa Hot Springs" and "was kept up as a resort, and was often visited by parties from Nome and other mining centers of the region; but the roadhouse and saloon building was burned in $1908 * * *$ (Waring, 1917, p. 72). A mining town called "Pilgrim Springs" grew up here and "was active from 1923 to 1941 . In 1939 there were 60 Eskimos there who have since moved to the Nome vicinity to work on defense projects and mining operations" (Balcom, 1965, p. 27). The Pilgrim Springs Post Office was established in 1924 and discontinued in 1941 (Ricks, 1965, p. 51).

Piling Point: point of land, on Stephens Passage, on NE coast of Mansfield Penin., $1.6 \mathrm{mi}$. NE of Lone Mtn., and $14 \mathrm{mi}$. W of Juneau, Alex. Arch.; 58 $19^{\prime} 15^{\prime \prime} \mathrm{N}, 134^{\circ} 48^{\prime} 10^{\prime \prime} \mathrm{W}$; (map 11).

Local name published in 1962 by USGS.

Pillar: rock, see Stripe Rock.

Pillar Cape: point of land, $27 \mathrm{mi}$. NE of Afognak, on SE coast of Afognak I., $N$ of Kodiak I.; $58^{\circ} 09^{\circ} 00^{\prime \prime} \mathrm{N}, 152^{\circ} 06^{\prime} 40^{\prime \prime} \mathrm{W}$; (map 43). Var. Cape Kekur, Cape Whitsunday, Pillar Point.

Translation by USC\&GS of the name "M[ys] Kyekur," published by the Russian American Company in 1849. On Sunday, June 7, 1778 Capt. Cook (1785, p. 404), RN, reported "*** This promontory *** was named, after the day, Cape Whitsunday. A large bay [Izhut Bay], which lies to the West of it, obtained the name of Whitsunday Bay * * *." See Kekur Island.

Pillar Cape: point of land, see Bold Cape.

Pillar Cape: point of land, see Kekur Point.

Pillar Greek: stream, flows NE $3 \mathrm{mi}$. to Monashka Bay, 2 mi. NW of Kodiak, Kodiak I.; $57^{\circ} 25^{\prime} 30^{\prime \prime} \mathrm{N}, 152^{\circ} 48^{\prime} 55^{\prime \prime} \mathrm{W}$; (map 34).

Name derived from Pillar Mountain and published in 1949 by USGS.

Pillar Mountain: mountain, $1,270 \mathrm{ft}$., $1 \mathrm{mi}$. W of Kodiak, Kodiak I.; $57^{\circ} 47^{\prime} 20^{\prime \prime} \mathrm{N}, 152^{\circ} 26^{\prime} 10^{\prime \prime}$ W; (map 34).

Descriptive name given in 1869 by USC\&GS, because of a note on map 16 published by G. A. Sarichev in 1826; "Na Gory stolb vozvyshen ot poverkhnosti morya na 150 Sazhen," meaning "on this mountain a pillar rises 150 fathoms above sea level."

Pillar Point: point of land, at mouth of Shearwater Bay, in Kiliuda Bay, on SE coast of Kodiak I.; $57^{\circ} 19^{\prime} 15^{\prime \prime} \mathrm{N}, 152^{\circ} 54^{\prime} 30^{\prime \prime} \mathrm{W}$; (map 34).

Descriptive name published in 1912 by USC\&GS.

Pillar Point: point of land, see Pillar Cape.

Pillar Rock: rock, elev. $119 \mathrm{ft}$., in Bering Sea, $8.3 \mathrm{mi}$. W of Wolf Point, on NW coast of Kiska I., Aleutian Is.; $52^{\circ} 07^{\prime} 20^{\prime \prime} \mathrm{N}, 177^{\circ}$. 22'00' E; BGN 1937; (map 14.) Var. Rocher en form de Colonne, Stolb, Viesokie Kamen.

This is a translation of a descriptive name first reported in 1827 as "Rocher-en-form-de Colonne," meaning "Rock in the form of a Column," by Adm. A. J. von Krusenstern, commander of the Russian American Company ship Nadezhda. The Russians called it "Vysokiy kamen" meaning "High Rock" on the 1848 Russian Hydrog. Dept. Chart 1400, and "Stolb" meaning "Pillar" (Tebenkov, 1852, map 29).

Pillars, Bay of: $b a y, 1.5 \mathrm{mi}$. across, on $\mathrm{W}$ coast of Kuiu I., Alex. Arch.; 56 $35^{\prime}$ N, $134^{\circ} 15^{\prime}$ W; $B G N$ 1933; (map 5). Var. South Arm Bay of Pillars.

Local descriptive name published by $\mathbf{W}$. $\mathrm{H}$. Dall, USC\&GS, in 1883 Coast Pilot (p. 120); given because of "the abundance of rocky islands and pillars within it."

Pillars, The: rocks, in Pacific Ocean, $3.5 \mathrm{mi}$. E of Thumb Point on $\mathbf{E}$ coast of Umnak I., Aleutian Is.; $53^{\circ} 11^{\prime} 30^{\prime \prime} \mathrm{N}, 168^{\circ} 14^{\prime} 00^{\prime \prime} \mathrm{W}$; (map 22). Var. Stolby.

Translation of Russian name published by Capt. Tebenkov (1852, map 25), IRN, as "Stolby," meaning "Pillars."

Pillbox Rock: rock, W side of Gusty Bay, on NE coast of Tanaga I., Aleutian Is.; $51^{\circ} 51^{\prime}$. $20^{\prime \prime} \mathrm{N}, 177^{\circ} 52^{\prime} 15^{\prime \prime} \mathrm{W}$; (map 17). 
Name published by USC\&GS in 1956 on Chart 9145.

Pillsbury, Mount: peak, 5,790 ft., SE of McGinnis Glacier terminus, $21 \mathrm{mi}$. SE of Mount Hayes, Alaska Ra.; $63^{\circ} 34^{\prime} 40^{\prime \prime} \mathrm{N}, 146^{\circ} 02^{\prime} 40^{\prime \prime}$ W; BGN 1957; (map 86).

Named in 1955 by the U.S. Army for Gen. George B. Pillsbury, 1878-1951, of the U.S. Army Corps of Engineers, who surveyed the original trail which later became the Richardson Highway.

Pillsbury Point: point of land, on $\mathrm{N}$ shore of Kootznahoo Inlet, $1.8 \mathrm{mi}$. NE of Angoon, on W central Admiralty I., Alex. Arch.; 57 $31^{\prime}$ $10^{\prime \prime} \mathrm{N}, 134^{\circ} 32^{\prime} 30^{\prime \prime} \mathrm{W}$; (map 9).

Named in 1869 by Comdr. R. W. Meade, USN, for Lt. Comdr. John Elliott Pillsbury, 1846-1919, USN, a member of his party. Pillsbury served one year in the Hydrographic Office and ten years in the Coast Survey Service. He was made rear admiral in 1908.

Pilly Fork: stream, flows N, E, and NE 15 mi. to Nuka River, $50 \mathrm{mi}$. NE of Misheguk Mtn., Arctic Slope; $68^{\circ} 49^{\prime} \mathrm{N}, 159^{\circ} 36^{\prime} \mathrm{W}$; (map 131).

Name published by USGS in 1962.

Pilot Bluff: bluff, overlooks junc. of Captain and Pilot Creeks in Chatanika River valley, 22 mi. NE of Fairbanks, Yukon-Tanana High.; $65^{\circ} 08^{\prime} \mathrm{N}, 147^{\circ} 25^{\prime} \mathrm{W}$; (map 105).

Local name published by USGS in the 1950's.

Pilot Cabin: settlement, see Pilot Village.

Pilot Creek: stream, flows SE $9.5 \mathrm{mi}$. to Nowitna River, 57 mi. N of Medfra, KilbuckKuskokwim Mts.; $63^{\circ} 56^{\prime}$ N, $154^{\circ} 43^{\prime} \mathrm{W}$; (map 89).

Local name reported in 1915 by Mertie and Harrington (1924, pl. 3), USGS.

Pilot Creek: stream, flows NW $5 \mathrm{mi}$. to Chatanika River, $22 \mathrm{mi}$. NE of Fairbanks, YukonTanana High.; $65^{\circ} 08^{\prime} 40^{\prime \prime} \mathrm{N}, 147^{\circ} 25^{\prime} 30^{\prime \prime} \mathrm{W}$; (map 105).

Named by prospectors; reported in 1903 by T. G. Gerdine (Prindle, 1905, pl. 13), USGS.

Pilot Harbor: cove, $0.7 \mathrm{mi}$. wide, on shore of North Arm Nuka Bay, on SE coast of Kenai Penin., $36 \mathrm{mi}$. ESE of Homer, Chugach Mts.; $59^{\circ} 35^{\prime} \mathrm{N}, 150^{\circ} 30^{\prime} \mathrm{W}$; BGN 1908; (map 50). Named by USC\&GS in 1908.

Pilot Knob: mountain, 1,845 ft., $6.5 \mathrm{mi}$. SE of Spectacle Lake and $46 \mathrm{mi}$. SW of Augustine I., Aleutian Ra.; $59^{\circ} 10^{\prime} 15^{\prime \prime} \mathrm{N}, 154^{\circ} 37^{\prime} 30^{\prime \prime}$ W; (map 51).

Name published by K. F. Mather (in Brooks and others, 1925, pl. 3), USGS. It was probably reported by R. H. Sargent, USGS, in 1923.

Pilot Mountain: mountain, 1,029 ft., $23 \mathrm{mi}$. E of Nulato and $5 \mathrm{mi}$. S of Yukon River, Koyukuk Low.; 64 $4^{\circ} 45^{\prime} \mathrm{N}, 157^{\circ} 19^{\prime} \mathrm{W}$; (map 97). Var. Little Mountain.

Riverboat pilots' name shown on a 1940 "Navigation Chart of the Tanana-Yukon Rivers" published by U.S. Dept. of Interior. Lt. H. T. Allen, USA, in 1885 called it "Little Mountain."
Pilot Mountain Slough: stream, anabranch, flows NW $13 \mathrm{mi}$. to Yukon River, $21 \mathrm{mi}$. NE of Nulato, Koyukuk Low.; $64^{\circ} 48^{\prime}$ N, $157^{\circ} 25^{\prime}$ W; (map 97).

Local name reported in 1954 by USGS.

Pilotos, Islas de los: islands, name shown on a map by Don Juan de la Bodega y Quadra probably representing islands he saw July 7 and 8,1788 , which may have been some of the Shumagin Islands (Wagner, 1937, p. 484).

Pilot Peak: mountain, 8,670 ft., $6 \mathrm{mi}$. SE of Mount Haley and $27 \mathrm{mi}$. NW of Valdez, Chugach Mts.; $61^{\circ} 20^{\prime} 50^{\prime \prime} \mathrm{N}, 146^{\circ} 54^{\prime} 05^{\prime \prime} \mathrm{W}$; $B G N$ 1965; (map 68).

Named in 1955 by Nielsen (1963, p. 135) "because it is a very distinctive landmark that helped guide us back to camp ***."

Pilot Point: village, on E shore of Ugashik Bay, on $\mathrm{N}$ coast of Alaska Penin., $7 \mathrm{mi}$. NW of Ugashik, Bristol Bay Low.; 57 $33^{\prime} 50^{\prime \prime} \mathrm{N}$, $157^{\circ} 34^{\prime} 45^{\prime \prime} \mathrm{W}$; (map 36). Var. Pilot Station.

Aleut and Eskimo village, with a cannery; reported in 1900 by Lt. Comdr. J. F. Moser, USN, as "Pilot Station," named for the Ugashik River pilots stationed there. The name was changed in 1933 when the Pilot Point Post Office was established. Of 120 Aleuts, one family survived the flu epidemic of 1918 ; the village was repopulated by Eskimo in 1923. Population was 114 in $1939 ; 76$ in 1963.

Pilot Point: point of land, SE tip of Hemlock I., off $\mathrm{W}$ coast of Annette I., Alex. Arch.; $5^{\circ} 09^{\prime} 30^{\prime \prime} \mathrm{N}, 131^{\circ} 33^{\prime} 20^{\prime \prime} \mathrm{W}$; (map 3 ).

Named in 1896 by USC\&GS.

Pilot Rock: rock, in Blying Sound, $3.2 \mathrm{mi}$. NE of Aialik Cape, $28 \mathrm{mi}$. S of Seward, Chugach

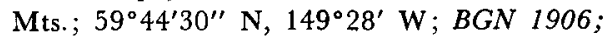
(map 49). Var. Light House Rock.

Named in June 1906 by BGN.

Pilot Station: village, pop. 219, on right bank of Yukon River, $2 \mathrm{mi}$. NE' of Hills I. and $26 \mathrm{mi}$. W of Marshall, Yukon-Kuskokwim Delta; $61^{\circ} 56^{\prime} 20^{\prime \prime} \mathrm{N}, 162^{\circ} 52^{\prime} 30^{\prime \prime} \mathrm{W}$; (map 74). Var. Potiliuk.

Local name, probably given by riverboat pilots, shown on a fieldsheet by R. H. Sargent, USGS, dated 1916. The present location of the site name has been moved about $0.3 \mathrm{mi}$. to where Sargent shows a village called Potiliuk.

Pilot Station: village, see Pilot Point.

Pilot Village: settlement, on right bank of Yukon River, $18 \mathrm{mi}$. NW of Marshall, Yukon-Kuskokwim Delta; $62^{\circ} 00^{\prime} 45^{\prime \prime} \mathrm{N}, 162^{\circ} 35^{\prime} 15^{\prime \prime} \mathrm{W}$; (map 77). Var. Pilot Cabin.

Indian village or camp reported by USGS in 1929 .

Pilzburg: city, see Juneau.

Pimenta Mountain: mountain, 1,900 ft., on E coast of Baker I., Alex. Arch.; 55 $21^{\prime} 30^{\prime \prime} \mathrm{N}$, $133^{\circ} 32^{\prime} 00^{\prime \prime} \mathrm{W}$; BGN 1923; (map 4). Var. Pimento Mountain, Pimienta Mountain.

Spanish word meaning "pepper" given in 1923 by USC\&GS; derived from Pepper Point.
Pimento Mountain: mountain, see Pimenta Mountain.

Pimienta, Punta de la: point of land, see Pepper Point.

Pimienta Mountain: mountain, see Pimenta Mountain.

Pimiyenta, Mys de la: point of land, see Pepper Point.

Pimute: settlement, see Paimiut.

Pinacle: island, see Pinnacle Island.

Pinaghat Cliff: cliff, E of Savoonga, N coast of St. Lawrence I. ; $63^{\circ} 42^{\prime} \mathrm{N}, 170^{\circ} 28^{\prime} \mathrm{W}$; (map 93).

Eskimo name reported in 1932 by $\mathrm{O}$. W. Geist, Univ. of Alaska.

Pina-ghiack, Ile: island, see Ninagiak Island.

Pinal, Punta del: point of land, near south point of San Fernando Island, Bucareli Bay, Alex. Arch.

Spanish name meaning "point of the pine grove" given by the 1779 Don Ignacio Arteaga expedition.

Pinauk River: stream, see Pinguk River.

Pincer Point: point of land, $2 \mathrm{mi}$. NE of Round Point, on W central Kanaga I., Aleutian Is.; $51^{\circ} 44^{\prime} 25^{\prime \prime} \mathrm{N}, 177^{\circ} 30^{\prime} 30^{\prime \prime} \mathrm{W}$; (map 17).

Descriptive name published by USC\&GS in 1956 on Chart 9145. This name was probably given because of the point's claw-like appearance.

Pincher Creek: stream, on Kenai Penin., flows N $5 \mathrm{mi}$. to Chickaloon Bay, $10 \mathrm{mi}$. SSE of Point Possession and $22 \mathrm{mi}$. SSW of Anchorage, Cook Inlet Low.; $60^{\circ} 55^{\prime} 30^{\prime \prime} \mathrm{N}, 150^{\circ}$ $11^{\prime} 30^{\prime \prime}$ W; (map 62).

Local name published by D. H. Sleem on his map of Central Alaska dated 1910.

Pine Creek: stream, flows E to W shore of Red Bay, between Goose and Duck Creeks, on $\mathrm{N}$ coast of Prince of Wales I., Alex. Arch.; 56 $18^{\prime} 15^{\prime \prime} \mathrm{N}, 133^{\circ} 20^{\prime} 45^{\prime \prime} \mathrm{W}$; (map 6).

Named in 1886 by Lt. J. M. Helm, USN, for charting purposes; name published in 1887 by USC\&GS on Chart 706.

Pine Creek: stream, flows N $4.5 \mathrm{mi}$. to Sumner Strait, on N coast of Prince of Wales I., Alex. Arch.; $56^{\circ} 19^{\prime} 30^{\prime \prime} \mathrm{N}, 133^{\circ} 16^{\prime} 35^{\prime \prime} \mathrm{W}$; (map 6).

Local name published in 1943 by USC\&GS.

Pine Creek: stream, flows SE $3.4 \mathrm{mi}$. to lagoon on Norton Sound, $4 \mathrm{mi}$. E of Solomon, Seward Penin. High.; $64^{\circ} 34^{\prime} \mathrm{N}, 164^{\circ} 18^{\prime} \mathrm{W}$; (map 95).

Prospectors' name reported in 1900 by E. C. Barnard (in Brooks, 1901, pl. 17), USGS.

Pine Creek: stream, flows N $4 \mathrm{mi}$. to Beaver Creek $4 \mathrm{mi}$. $\mathrm{E}$ of that stream's mouth, $46 \mathrm{mi}$. NW of Big Delta, Yukon-Tanana High.; $64^{\circ} 45^{\prime} 55^{\prime \prime} \mathrm{N}, 146^{\circ} 19^{\prime} 50^{\prime \prime} \mathrm{W}$; (map 101).

Local name reported in 1958 by USGS.

Pine Creek: stream, see Camp Creek.

Pine Creek: stream, see Foster Creek.

Pineda, Punta dc: point of land, "on east side of Yakutat Bay in about $59^{\circ} 44^{\prime}$ N."

Named by Capt. Alessandro Malaspina about 1791 "probably in honor of Arcadio Pineda" (Wagner, 1937, p. 484).

Pine Island: island, 1,250 ft. long, near E end of Port Real Marina, on SE coast of Lulu I., 
Alex. Arch.; $55^{\circ} 26^{\prime} 15^{\prime \prime} \mathrm{N}, 133^{\circ} 27^{\prime} 10^{\prime \prime} \mathrm{W}$; (map 4). Var. Isla del Pino, Ostrov de Pino, Ysla del Pino.

Translation of the name "Ysla del Pino" given in 1779 by Don Juan de la Bodega y Quadra and Francisco Antonio Maurelle.

Pine Island : island, see Spruce Island.

Pinekl: island, see Pinnacle Island.

Pinelak: $b a y$, see Punelok Bay.

Pine Lake: lake, $0.5 \mathrm{mi}$. long, on $\mathrm{NW}$ coast of Revillagigedo I., $1 \mathrm{mi}$. SE of Curlew Point, Alex. Arch.; 55 $54^{\prime} \mathrm{N}, 131^{\circ} 34^{\prime} \mathrm{W}$; (map 3 ).

Local name reported in 1955 by USGS.

Pine Lake: lake, $0.3 \mathrm{mi}$. across, $1.5 \mathrm{mi}$. E of $\mathbf{S}$ tip of Hasselborg Lake, on $\mathbf{E}$ central Admiralty I., Alex. Arch.; $57^{\circ} 39^{\prime} 20^{\prime \prime} \mathrm{N}, 134^{\circ}$ $10^{\prime} 15^{\prime \prime} \mathrm{W}$; (map 9).

Local name reported in 1951 by USGS.

Pine Point: point of land, $\mathrm{E}$ point of entrance to Red Bay, on $\mathbf{N}$ coast of Prince of Wales $\mathrm{I}$., Alex. Arch.; $56^{\circ} 20^{\prime} 05^{\prime \prime} \mathrm{N}, 133^{\circ} 16^{\prime} 15^{\prime \prime} \mathrm{W}$; (map 6).

Named in 1886 by Lt. J. M. Helm, USN, for charting purposes; name published in 1887 on USC\&GS Chart 706.

Pingaloorak: bluff, see Pingalurak Bluff.

Pingaluk River: stream, flows SW $22 \mathrm{mi}$. to Alatna River, $28 \mathrm{mi}$. SE of Survey Pass, Brooks Ra.; $67^{\circ} 28^{\prime} \mathrm{N}, 153^{\circ} 47^{\prime} \mathrm{W}$; $B G N$ 1912; (map 125). Var. Ping-ing-a-look River, Pingingaluk River, Ringingalook River.

Eskimo name reported by Lt. Stoney (1900, map), USN, in 1886 as "Ping-ing-a-look" but submitted by P. S. Smith, USGS, as "Pingaluk" in 1913. The name may mean "bad hill."

Pingaluligit Mountain: mountain, 3,120 ft., 24 mi. SW of junc. of Colville and Killik Rivers, Brooks Ra.; $68^{\circ} 40^{\prime} \mathrm{N}, 154^{\circ} 08^{\prime} \mathrm{W}$; (map 133).

Eskimo name meaning "humpy," reported in 1956 by Orth.

Pingalurak Bluff: bluff, on right bank of Omikviorok River, $1 \mathrm{mi}$. NE of Ipiavik Lagoon and $11 \mathrm{mi}$. SE of Kivalina, Kotzebue-Kobuk Low.; 6739' N, $164^{\circ} 09^{\prime}$ W; (map 128). Var. Pingaloorak, Pingaluuzaq.

Eskimo name reported in 1966 by E. S. Burch.

Pingaluuzaq: bluff, see Pingalurak Bluff.

Pingarorok Hill: pingo, see Pingororok Hill.

Pingasagrook: locality, see Pingasagruk.

Pingasagruk: locality, site of an Eskimo village, on barrier bar between the Chukchi Sea and $\mathrm{W}$ end of Peard Bay, $27 \mathrm{mi}$. NE of Wainwright, Arctic Plain, $70^{\circ} 53^{\prime} \mathrm{N}, 1^{\circ} 9^{\circ} 06^{\prime} \mathrm{W}$; (map 146). Var. Pingasagrook, Pingashuyaruk.

Pingasagruk was "a very large old settlement that has long been abandoned ***. According to the natives, this place was called 'Pingashugaruk,' and * * * several hundred people had lived there ***." (Smith and Mertie, 1930, p. 105).

Pingashuyaruk: locality, see Pingasagruk.

Pingau Hill: pingo, $43 \mathrm{ft}$., at NW end of Kivalina Lagoon, $10 \mathrm{mi}$. NW of Kivalina, Kotze-
bue-Kobuk Low.; $67^{\circ} 50^{\prime} \mathrm{N}, 164^{\circ} 47^{\prime} \mathrm{W}$; (map 128). Var. Pingo, Pingow.

Eskimo name meaning "mound" reported in 1966 by E. S. Burch.

Pingeyiksak River: stream, see Shorty River.

Ping-ing-a-look: stream, see Pingaluk River.

Pingingaluk River: stream, see Pingaluk River.

Pingishugumute: locality, see Pingoshugarun.

Pingneyiksak: stream, see Sapumik Creek.

Pingo: bluff, see Pingu Bluff.

Pingo: pingo, see Pingau Hill.

Pingoaceok: lake, see Pingoakeok.

Pingoakeok Lake: lake, $2 \mathrm{mi}$. long, $7 \mathrm{mi}$. SSE of Barrow, Arctic Plain; $71^{\circ} 12^{\prime} \mathrm{N}, 156^{\circ} 40^{\prime}$ W; (map 153). Var. Pingoaceok.

Eskimo name that refers in meaning to a "pingo" or "mound," published by R. F. Spencer (1959, map 2).

Pingok Island: barrier island, $6 \mathrm{mi}$. long, largest of Jones Is., on Beaufort Sea coast, $7 \mathrm{mi}$. NW of Beechey Point, Arctic Plain; 70 $31^{\prime} 10^{\prime \prime} \mathrm{N}$, $149^{\circ} 31^{\prime} 30^{\prime \prime}$ W; (map 150). Var. Leavitt Island.

Eskimo name reported to mean "mound" by Leffingwell (1919, p. 97) who originally named this "Leavitt Island, *** the largest of the Jones Islands, $* * *$ after Capt. George Leavitt of the whaling fleet." The name, Leavitt Island, is now relegated to a small island just W of Pingok Island.

Pingokraluk Lagoon: lagoon, $4 \mathrm{mi}$. long, SE of Siku Lagoon and $3.5 \mathrm{mi}$. W of Demarcation Point, Arctic Plain; $69^{\circ} 42^{\prime} \mathrm{N}, 141^{\circ} 28^{\prime} \mathrm{W}$; (map 138).

Eskimo name recorded by USC\&GS in 1952. It takes its name from the nearby point of land.

Pingokraluk Point: point of land, on $\mathrm{W}$ shore of Pingokraluk Lagoon, $4.5 \mathrm{mi}$. W of Demarcation Point, Arctic Plain; 69 $42^{\prime} 30^{\prime \prime} \mathrm{N}, 141^{\circ}$ 28'30" W; (map 138).

Eskimo name recorded on Barter I. in 1952 by USC\&GS and reported to refer in meaning to a "pingo" located at this point.

Pingo Lake: lake, $1.5 \mathrm{mi}$. long, $2 \mathrm{mi}$. $\mathrm{N}$ of Philacte Bay and $95 \mathrm{mi}$. W of Bethel, YukonKuskokwim Delta; $60^{\circ} 53^{\prime} \mathrm{N}, 164^{\circ} 33^{\prime} \mathrm{W}$; (map 58).

Name used by personnel of Clarence Rhode National Wildlife Range; reported in 1965. The name means "hill" or "mound" in Eskimo. The word has become a landform term referring to mounds formed by frost or freezing action above the permafrost.

Pingolee Island: barrier island, in Plover Is., Arctic Plain; (map 153).

Eskimo name, probably more correctly rendered "Pingolik" and meaning "having mound." The name first appears on Brit. Adm. Chart 593, 1827-55, but the island has not been identified on present-day maps.

Pingoo: bluff, see Pingu Bluff.

Pingookoosik: locality, $2 \mathrm{mi}$. W of Taphook Point, on Pungokosit Spit, St. Lawrence I. $63^{\circ} 37^{\prime} \mathrm{N}, 171^{\circ} 17^{\prime} \mathrm{W}$; (map 93).

This is the site of an Eskimo camp or village. The name means "always a mound" [pungokosik].
Pingootikook Bay: bay, $4.5 \mathrm{mi}$. wide, between Southeast Cape and Kialegik Point, St. Lawrence I.; $62^{\circ} 58^{\prime} \mathrm{N}, 169^{\circ} 36^{\prime} \mathrm{W}$; BGN 1951.

Eskimo name recommended by the Savoonga village council and reported in 1949 by Maj. H. B. Allen, USAF.

Pingorarok Hill: pingo, $107 \mathrm{ft}$., E of Kasegaluk Lagoon, $24 \mathrm{mi}$. SW of Wainwright, Arctic Plain; $70^{\circ} 22^{\prime} \mathrm{N}, 160^{\circ} 43^{\prime} \mathrm{W}$; (map 146). Var. Pingororok Hill.

Eskimo name reported by USGS in 1923. Pingo means "hill" or "mound" and thus the name may mean "many mounds."

Pingorarok Pass: water passage, in barrier bar between Chukchi Sea and Kasegaluk Lagoon, $25 \mathrm{mi}$. SW of Wainwright, Arctic Plain; $70^{\circ}$ $22^{\prime} \mathrm{N}, 160^{\circ} 49^{\prime} \mathrm{W}$; (map 146).

Name reported by USC\&GS in 1949; probably derived from nearby Pingorarok Hill.

Pingoshugarun: locality, on Chukchi Sea coast, on one of Seahorse Is., E of Point Franklin, Arctic Plain; $70^{\circ} 53^{\prime} \mathrm{N}, 158^{\circ} 42^{\prime} \mathrm{W}$; (map 147). Var. Pingishugumute, Pingosugrumiut, Pingosugtuk, Pinguishugamiut, Pinguishuk, Pinoshuragin, Tingo Shugarun.

Former Eskimo village or camp name meaning "big mound [pingosugtuk]" or "pingosugrumiut," meaning "people of the big mound," shown on Brit. Adm. Chart 593, 1827-53. Ivan Petroff's 10th Census of 1880 lists the name as "Pinoshuragin," population 29.

Pingosugrumiut: locality, see Pingoshugarun. Pingosugtuk: locality, see Pingoshugarun.

Pingow: pingo, see Pingau Hill.

Pingpong Mountain: mountain, 4,374 ft., on $\mathbf{N}$ bank of White River, $5 \mathrm{mi}$. S of Rock Lake and $56 \mathrm{mi}$. NE of McCarthy, Alaska Ra.; $61^{\circ} 44^{\prime} \mathrm{N}, 141^{\circ} 20^{\prime} \mathrm{W}$; (map 67).

Local name recorded in 1908 on a fieldsheet by S. R. Capps, USGS.

Pingston Creek: stream, heads at glacier, flows NW $40 \mathrm{mi}$. to Tonzona River $20 \mathrm{mi}$. SE of its junc. with East Fork Kuskokwim River, $47 \mathrm{mi}$. SE of Medfra, Kuskokwim Low.; $63^{\circ} 01^{\prime} \mathrm{N}, 153^{\circ} 14^{\prime} \mathrm{W}$; BGN 1964; (map 89).

Local name reported in 1958 by USGS.

Pingu Bluff: bluff, $40 \mathrm{ft}$., on barrier bar between Chukchi Sea and Marryat Inlet, $6 \mathrm{mi}$. NE of village of Point Hope, Arctic Slope; $68^{\circ} 23^{\prime} 35^{\prime \prime} \mathrm{N}, 166^{\circ} 33^{\prime} 30^{\prime \prime} \mathrm{W}$; (map 129). Var. Pigoo Bluff, Pingo, Pingoo.

Eskimo name meaning "hill" reported in 1950 by USC\&GS as "Pingoo."

Pingucheak: barrier bar, $40 \mathrm{ft}$., between Chukchi Sea and Aiautak Lagoon, $15 \mathrm{mi}$. SE of village of Point Hope, Arctic Slope ; $68^{\circ} 17^{\prime}$ N, $166^{\circ} 12^{\prime} \mathrm{W}$; (map 129). Var. Pinguchek.

Eskimo name meaning "little hill" reported in 1956 by Orth.

Pinguchek: barrier bar, see Pingucheak.

Pinguishugamiut: locality, see Pingoshugarun.

Pinguishuk: locality, see Pingoshugarun.

Pinguk River: stream, on Seward Penin., flows NW $34 \mathrm{mi}$. to Arctic Lagoon, $47 \mathrm{mi}$. NW of Teller, Kotzebue-Kobuk Low.; 65 $51^{\prime} \mathrm{N}$, $167^{\circ} 10^{\prime} \mathrm{W}$; (map 111). Var. Pinauk River. 
Eskimo name meaning "hill" obtained in 1901 by T. G. Gerdine, USGS.

Pingurbek Island: island, $8 \mathrm{mi}$. long, in Etolin Strait, $5 \mathrm{mi}$. W of Cape Avinof, $10 \mathrm{mi}$. SW of Kipnuk, Yukon-Kuskokwim Delta ; $59^{\circ} 50^{\prime}$ $\mathrm{N}, 164^{\circ} 12^{\prime} \mathrm{W}$; (map 54).

Eskimo name reported in 1950 by USC\&GS.

Pinik Islands: islands, see Punuk Islands.

Pink Bluff: bluff, 1,000 ft., extends $2 \mathrm{mi}$. along $S$ bank of Salmon Fork Black River, $30 \mathrm{mi}$. NW of Midnight Hill, Porcupine Plat.; $66^{\circ} 27^{\prime}$ N, 141 $33^{\prime} \mathrm{W}$; (map 120).

Local descriptive name; reported in 1956 by R. C. Foley, USGS

Pinkidulia Cove: cove, $0.5 \mathrm{mi}$. wide, on $\mathrm{W}$ shore of Akumwarvik Bay, $35 \mathrm{mi}$. SW of Augustine I., Aleutian Ra.; $59^{\circ} 04^{\prime} 30^{\prime \prime} \mathrm{N}, 154^{\circ} 11^{\prime} 00^{\prime \prime}$ W; (map 51).

Native name reported by $R$. H. Sargent, USGS, in 1923 and published by K. F. Mather (in Brooks and others, 1925, pl. 3), USGS.

Pinnacle: promontory, elev. $355 \mathrm{ft}$, , on $\mathrm{E}$ coast of Ikatan Penin., on SE coast of Unimak I., Aleutian Is.; $54^{\circ} 41^{\prime} 20^{\prime \prime} \mathrm{N}, 163^{\circ} 03^{\prime} 00^{\prime \prime} \mathrm{W}$; (map 25).

Descriptive name published in 1949 on a USGS map.

Pinnacle, The: pinnacle, 5,500 ft., $2 \mathrm{mi}$. $\mathrm{W}$ of junc. of Archangel and Reed Creeks, $15 \mathrm{mi}$. NW of Palmer, Talkeetna Mts.; $61^{\circ} 48^{\prime} 30^{\prime \prime} \mathrm{N}$, $149^{\circ} 15^{\prime} 35^{\prime \prime} \mathrm{W}$; (map 69)

Descriptive name reported in 1910 by F. J. Katz (in Brooks and others, 1911, p. 140), USGS.

Pinnacle, The: rock, off SW coast of Wosnesenski I., $10 \mathrm{mi}$. NE of Dolgoi I., Aleutian Ra.; $55^{\circ} 10^{\prime} \mathrm{N}, 161^{\circ} 25^{\prime} \mathrm{W}$; (map 28).

Noted as "a remarkable pear-shaped pinnacle rock" by USC\&GS in 1947 Coast Pilot (p. 331). Capt. Tebenkov (1852, map 24), IRN, showed some rocks in this area called "Kekuri," meaning "pillars"; these appear on an 1882 USC\&GS chart as "Pinnacles," and again on a 1953 USGS map as "The Pinnacles."

Pinnacle Cape: point of land, see Kekurnoi, Cape.

Pinnacle Creek: stream, heads in Pinnacle Gulch, on Ear Mtn.; flows SE 3 mi. to Crosby Creek, Seward Penin. High.; 65 ${ }^{\circ} 3^{\prime} 25^{\prime \prime} \mathrm{N}$, $166^{\circ} 10^{\prime} 00^{\prime \prime} \mathrm{W}$; BGN 1954; (map 111).

Named in 1954 relative to Pinnacle Gulch.

Pinnacle Glacier: glacier, heads at Pinnacle Pass, at $\mathbf{N}$ end of Hitcheock Hills, trends $3 \mathrm{mi}$. $\mathrm{W}$ to Seward Glacier, $48 \mathrm{mi}$. NW of Yakutat, St. Elias Mts.; $60^{\circ} 09^{\prime} \mathrm{N}, 140^{\circ} 23^{\prime} \mathrm{W}$; (map 66).

Name derived from Pinnacle Pass at which the glacier heads.

Pinnacle Gulch: ravine, heads between Ears Peak and East Peak, on Ear Mtn.; trends SSE $1 \mathrm{mi}$. along Pinnacle Creek, Seward Penin. High.; $65^{\circ} 55^{\prime} \mathrm{N}, 166^{\circ} 12^{\prime} \mathrm{W}$; BGN 1954; (map 111).

So named by a USGS field party "because of pinnacle rock outcrops."

Pinnacle Island: island, $1.5 \mathrm{mi}$. long, in Bering Sea, $10 \mathrm{mi}$. S of St. Matthew I.; $60^{\circ} 12^{\prime} \mathrm{N}$, $172^{\circ} 46^{\prime} \mathrm{W}$; (map 56). Var. Ile de Tours, Iles des Flêches, Ostrov Pyenikl, Ostrov Pinyekl, Penikl, Pinacle, Pinekl.

Named by Capt. Cook (1785, p. 491), RN on September 23, 1778, who wrote "a smal island, whose elevated summit terminates in several pinnacle rocks." Capt. Lutke (1836 p. 342), IRN, translated this to "Ile de Tours [towers]" or "Île des Flêches [spires]." The Russians transliterated the name to $O[$ strov] Pyenikl (Sarichev, 1826, map 3) and O[strov] Pinekl (Tebenkov, 1852, map 20).

Pinnacle Mountain: mountain, 2,600 ft., on Alaska Penin., 2 mi. $\mathbf{N}$ of Meshik Lake and $27 \mathrm{mi}$. W of Cape Kunmik, Aleutian Ra.; $56^{\circ}$. $49^{\prime} \mathrm{N}, 157^{\circ} 55^{\prime} \mathrm{W}$; (map 31). Var. Sugar Loaf.

Local descriptive name reported in 1923 by R. H. Sargent, USGS; the peak has been used as a reference point in locating oil claims.

Pinnacle Mountain: mountain, 2,268 ft., $16 \mathrm{mi}$ NW of Chichagof, on $W$ coast of Chichagof I., Alex. Arch.; 57 $51^{\prime} \mathrm{N}, 136^{\circ} 20^{\prime} \mathrm{W}$; (map 9).

Descriptive name published in 1928 by USC\&GS on Chart 8258. "So named because of its spire-like shape."

Pinnacle Mountain: mountain, 5,350 ft., on Kenai Penin., $4 \mathrm{mi}$. S of Sargent Icefield, 28 mi. W of Seward, Chugach Mts.; $60^{\circ} 06^{\prime} 30^{\prime \prime}$ $\mathrm{N}, 148^{\circ} 38^{\prime} 15^{\prime \prime} \mathrm{W}$; (map 63$)$

Local name reported in 1951 by USGS.

Pinnacle Mountain: mountain, 4,541 ft., $7 \mathrm{mi}$. $E$ of Sutton and $16 \mathrm{mi}$. NE of Palmer, Chugach Mts.; $61^{\circ} 42^{\prime} 30^{\prime \prime} \mathrm{N}, 148^{\circ} 40^{\prime} 05^{\prime \prime} \mathrm{W}$; (map 69)

Local name reported in 1905 by G. C. Martin (1906, pl. 1), USGS.

Pinnacle Pass: pass, 4,225 ft., between Hitchcock Hills and Pinnacle Pass Hills, $26 \mathrm{mi}$. NW of Yakutat, St. Elias Mts.; $60^{\circ} 08^{\prime} 45^{\prime \prime} \mathrm{N}$, $140^{\circ} 17^{\prime} 00^{\prime \prime} \mathrm{W}$; (map 66).

I. C. Russell (1891, p. 130), USGS, wrote: “The pass we named 'Pinnacle Pass,' on account of the many towering pinnacles overshadowing it."

Pinnacle Pass Cliffs: ridge, see Pinnacle Pass Hills.

Pinnacle Pass Hills: ridge, 5,520 ft., extends 9 mi. E-W between Seward and Pinnacle Glaciers, $5 \mathrm{mi}$. S of Mount Owen and $47 \mathrm{mi}$. $\mathrm{NW}$ of Yakutat, St. Elias Mts.; $60^{\circ} 09^{\prime} 30^{\prime \prime} \mathrm{N}$, $140^{\circ} 20^{\prime} 00^{\prime \prime} \mathrm{W}$; (map 66). Var. Pinnacle Pass Cliffs.

Originally named "Pinnacle Pass Cliffs" on a sketch map by M. B. Kerr (in Russell, 1891, pl. 8). The name "Pinnacle Pass Hills" was published on IBC Sheet 13 in 1928.

Pinnacle Peak: mountain, 2,600 ft., on $\mathrm{S}$ side of Herendeen Bay, near SW end of Alaska Penin., Aleutian Ra.; 55 $43^{\prime} 30^{\prime \prime}$ N, $160^{\circ} 45^{\prime}$ $00^{\prime \prime} \mathrm{W}$; (map 28).

Descriptive name given in 1900 by USC\&GS.

Pinnacle Peak: mountain, $3,215 \mathrm{ft}$., on $\mathrm{W}$ coast of Chichagof I., $6 \mathrm{mi}$. E of Chichagof, Alex. Arch.; $57^{\circ} 38^{\prime} 45^{\prime \prime} \mathrm{N}, 1^{\circ} 55^{\circ} 56^{\prime} 15^{\prime \prime} \mathrm{W}$; (map 9).
Local descriptive name reported in 1951 by USGS.

Pinnacle Point: point of land, SE entrance point to Amlia Pass, W coast of Amlia I., Aleutian Is.; $52^{\circ} 06^{\prime} 45^{\prime \prime} \mathrm{N}, 174^{\circ} 02^{\prime} 00^{\prime \prime} \mathrm{W}$; (map 18).

Descriptive name applied "because of a prominent $95-\mathrm{ft}$. pinnacle on the shore and an $80-\mathrm{ft}$. off-lying pinnacle"; published by the USC\&GS in the 1944 Aleutian Coast Pilot (p. 90).

Pinnacle Point: point of land, an $\mathrm{W}$ coast of Unga I., in Shumagin Is., Aleutian Ra.; $55^{\circ}$ $16^{\prime} 30^{\prime \prime} \mathrm{N}, 160^{\circ} 51^{\prime} 00^{\prime \prime} \mathrm{W}$; (map 28).

Descriptive name published in 1917 by USC\&GS. So named because "there is a prominent pinnacle on the shore."

Pinnacle Rock: point of land, at NE end of Security Cove, $2 \mathrm{mi}$. W of Chagvan Mtn. and 12 mi. NE of Cape Newenham, KilbuckKuskokwim Mts.; $58^{\circ} 43^{\prime}$ N, $161^{\circ} 52^{\prime}$ W ; (map 39).

Descriptive name given in 1914 by USG\&GS.

Pinnacle Rock: rock, $50 \mathrm{ft}$. high, off Cape Ida. lug, on $\mathrm{N}$ coast of Amlia I., Aleutian Is.; $52^{\circ} 09^{\prime} 30^{\prime \prime} \mathrm{N}, 173^{\circ} 31^{\prime} 45^{\prime \prime} \mathrm{W}$; (map 19).

Descriptive name published on a 1951 USGS map.

Pinnacle Rock: rock, $145 \mathrm{ft}$, off S coast of Akun I., Aleutian Is.; 54 $06^{\prime} 25^{\prime \prime} \mathrm{N}, 165^{\circ} 34^{\prime}$ 25 " W ; (map 24).

Named in 1901 by J. J. Gilbert, USC\&GS.

Pinnacle Rock: rock, $172 \mathrm{ft}$., at Scotch Cap, on SW coast of Unimak I., Aleutian Is.; $54^{\circ} 24^{\prime}$ $10^{\prime \prime} \mathrm{N}, 164^{\circ} 47^{\prime} 30^{\prime \prime} \mathrm{W}$; (map 24). Var. Hibahibgik, Ounga.

Descriptive name published in 1900 by USC\&GS. The Aleut name transcribed by Father Veniaminov, 1840, was Hibahibgik, and that transcribed by Capt. F. P. Lutke, 1830, was Ounga.

Pinnacle Rock: rock, at E limit of Sandman Reefs, $22 \mathrm{mi}$. SE of Deer I., Aleutian Ra.; $54^{\circ} 46^{\prime} 15^{\prime \prime}$ N, $161^{\circ} 45^{\prime} 45^{\prime \prime}$ W; (map 25) Var. Kekur.

Translation by USBF in 1888 of the Russian word "kekur," meaning "an isolated pillar-like rock," published by Capt. Tebenkov (1852, map 24), IRN. See Kekur Island. Pinnacle Rock: rock, E of Pinusuk I., in Chiachi Is., 24 mi. E of Stepovak Bay, Aleutian Ra.; $55^{\circ} 51^{\prime} 52^{\prime \prime} \mathrm{N}, 159^{\circ} 03^{\prime} 10^{\prime \prime} \mathrm{W}$; (map 27).

Named by W. H. Dall, USC\&GS, in 1875 .

Pinnacle Rock: rock, at W entrance to Jute Bay, on $\mathrm{E}$ coast of Alaska Penin., $49 \mathrm{mi}$. W of

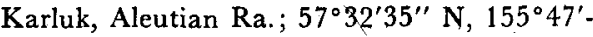
$15^{\prime \prime} \mathrm{W}$; (map 35 ).

Descriptive name given by USC\&GS in 1924

Pinnacle Rock: rock, in mouth of Kalsın Bay, $10 \mathrm{mi}$. S of Kodiak, Kodiak I.; $57^{\circ} 39^{\prime} 15^{\prime \prime} \mathrm{N}$ $152^{\circ} 20^{\prime} 30^{\prime \prime} \mathrm{W}$; (map 34).

Descriptive local name published in 1943 by USG\&GS.

Pinnacle Rock: rock, in Pavlof Harbor, on SW shore of Freshwater Bay, on Chichagof I., 8 mi. NE of Tenakee Springs, Alex. Arch.; $57^{\circ} 50^{\prime} 45^{\prime \prime} \mathrm{N}, 135^{\circ} 01^{\prime} 45^{\prime \prime} \mathrm{W}$; (map 9). 
Named by Comdr. R. W. Meade, USN; published in 1869 on Hydrog. Chart 225. Name not shown on recent maps.

Pinnacle Rock: rock, in mouth of Bluefox Bay, on $\mathrm{N}$ coast of Afognak I., Kodiak I., 58 $28^{\prime}$ $10^{\prime \prime} \mathrm{N}, 152^{\circ} 41^{\prime} 30^{\prime \prime} \mathrm{W}$; (map 43).

Local descriptive name reported in 1952 by USGS.

Pinnacle Rock: rock, in Gulf of Alaska, $0.3 \mathrm{mi}$. off SE coast of Nuku I., $38 \mathrm{mi}$. SE of Seldovia, Chugach Mts.; $59^{\circ} 19^{\prime} 20^{\prime \prime} \mathrm{N}, 150^{\circ} 39^{\prime} 00^{\prime \prime} \mathrm{W}$; (map 50).

Descriptive name published by USGS in 1953.

Pinnacle Rock: rock, in Gulf of Alaska, $0.4 \mathrm{mi}$. SW of Cape St. Elias, Kayak I., Malaspina Coastal Plain; $59^{\circ} 47^{\prime} 30^{\prime \prime} \mathrm{N}, 144^{\circ} 36^{\prime} 15^{\prime \prime} \mathrm{W}$; (map 48).

Descriptive name reported in 1903 by J. F. Pratt, USC\&GS; published in 1904 on Chart 8513.

Pinnacle Rock: rock, at W end of Johnstone Bay, off Kenai Penin., 26 mi. SE of Seward, Chugach Mts.; $59^{\circ} 55^{\prime} 30^{\prime \prime} \mathrm{N}, 148^{\circ} 50^{\prime} 00^{\prime \prime} \mathrm{W}$; (map 49).

Local name reported in the 1940's by USC\&GS.

Pinnacle Rock: rock, $1 \mathrm{mi}$. S of Mummy I., 12 mi. SW of Cordova, Chugach Mts. ; $60^{\circ} 27^{\prime} \mathrm{N}$, $146^{\circ} 02^{\prime} \mathrm{W}$; (map 64).

Descriptive name published in 1943 by USC\&GS.

Pinnacle Rock: rock, see Second Priest Rock.

Pinnaichwakamiut: locality, see Binajoaksmiut.

Pinnell Mountain: mountain, 4,721 ft., $4.5 \mathrm{mi}$. SW of Porcupine Dome and $55 \mathrm{mi}$. SW of Circle, Yukon-Tanana High.; 65 $29^{\circ} 45^{\prime \prime} \mathrm{N}$, $145^{\circ} 40^{\prime} 05^{\prime \prime} \mathrm{W} ; B G N$ 1960; (map 104). Var. Porcupine Dome.

Named by Lt. Comdr. R. Darling, USC\&GS, for Robert E. Pinnell, who was accidentally killed on July 17, 1952, while climbing nearby Porcupine Dome. The mountain was considered a part of Porcupine Dome by Spurr (1898, p. 50), USGS

Pinnell River: stream, flows N $17.7 \mathrm{mi}$. to Inmachuk River, $20 \mathrm{mi}$. N of Imuruk Lake, Seward Penin. High.; 65 $53^{\prime} \mathrm{N}, 163^{\circ} 04^{\prime} \mathrm{W}$; BGN 1952; (map 110). Var. Pannell River.

Prospectors' name reported in 1901 by USGS (Collier, 1902, pl. 12). Published as "Pannell" by D. L. Reaburn (in Mendenhall, 1902, pl. 4a), USGS. Named after Jesse Pinnell, a miner from Nome.

Pinnyanaktuk: stream, see Binnyanaktuk Creek. Pino, Isla del: island, see Pine Island.

Pino, Ostrov del: island, see Pine Island.

Pinochle Creek: stream, flows SW $5.5 \mathrm{mi}$, to Hicks Creek, $42 \mathrm{mi}$. NE of Palmer, Talkeetna Mts.; $61^{\circ} 47^{\prime} 40^{\prime \prime} \mathrm{N}, 147^{\circ} 56^{\prime} 00^{\prime \prime} \mathrm{W}$; (map 69).

Local name reported in 1952 by USGS.

Pinoshuragin: locality, see Pingoshugarun.

Pin Peak: mountain, 3,806 ft., near center of Prince of Wales I., $9.5 \mathrm{mi}$. E of Klawock, Alex. Arch.; 55 $32^{\prime} 15^{\prime \prime} \mathrm{N}, 132^{\circ} 50^{\prime} 30^{\prime \prime} \mathrm{W}$; (map 4).

Local name recorded in 1949 by USGS.
Pin Peak: mountain, 1,370 ft., NW Coronation I., Alex. Arch.; $55^{\circ} 54^{\prime} 50^{\prime \prime}$ N, $133^{\circ} 19^{\prime} 50^{\prime \prime} \mathrm{W}$; (map 4).

Descriptive name given in 1886 by $L t$. Comdr. A. S. Snow, USN.

Pin Peaks: peaks, 5,730 ft., $2 \mathrm{mi}$. SE of Church Peak, $18 \mathrm{mi}$. NE of Petersburg, Coast Mts.; $56^{\circ} 55^{\prime} 25^{\prime \prime} \mathrm{N}, 132^{\circ} 33^{\prime} 30^{\prime \prime} \mathrm{W}$; (map 6).

Descriptive name given by Lt. Comdr. C. M. Thomas, USN, in 1887.

Pin Point: point of land, on Liesnoi I., at mouth of Eliza Harbor, on Admiralty I., $26 \mathrm{mi}$. SE of Angoon, Alex. Arch.; 57 $09^{\circ} 30^{\prime \prime} \mathrm{N}, 134^{\circ}$. 15'45" W; (map 9).

Descriptive name given in 1889 by Lt. Comdr. H. B. Mansfield, USN, and published by USC\&GS in the 1891 Coast Pilot (p. 142). Off the point is "a projecting ledge about 100 yards in length" from which the name is derived.

Pin Rock: rock, on N coast of Rat I., Aleutian Is.; $51^{\circ} 49^{\prime} 20^{\prime \prime} \mathrm{N}, 178^{\circ} 18^{\prime} 50^{\prime \prime} \mathrm{E}$; (map 15). Name shown on the 1951 USGS map.

Pinta, Mount: mountain, 1,352 ft., on W coast of Chichagof I., 9 mi. NW of Chichagof, Alex. Arch.; $57^{\circ} 46^{\prime} \mathrm{N}, 136^{\circ} 14^{\prime} \mathrm{W}$; (map 9).

Name published in 1928 by USC\&GS on Chart 8258; probably derived from Pinta Bay at the foot of the mountain to the east.

Pinta, Mount: mountain, 5,530 ft., $3 \mathrm{mi}$. SE of Mount Ruhamah and $21 \mathrm{mi}$. NE of Yakutat, St. Elias Mts.; $59^{\circ} 40^{\prime} 55^{\prime \prime} \mathrm{N}, 139^{\circ} 09^{\prime} 35^{\prime \prime} \mathrm{W}$; $B G N$ 1962; (map 46).

Named in 1891 by Russell (1892, p. 88) for the U.S.S. Pinta, a "fourth rate man-ofwar with small armament." It was used in 1885 by Lt. H. T. Allen, USA, and later by other Alaska survey parties.

Pinta Bay: bay, $0.6 \mathrm{mi}$. across, $7.5 \mathrm{mi}$. NW of Chichagof, on W coast of Chichagof I., Alex. Arch.; $57^{\circ} 45^{\prime} 10^{\prime \prime} \mathrm{N}, 136^{\circ} 13^{\prime} 00^{\prime \prime} \mathrm{W}$; BGN 1926; (map 9). Var. Deep Bay.

Named by the USC\&GS and published in 1910 on Chart 8250. It was named for the U.S.S. Pinta which navigated these waters during the late 19th century. The name at one time applied to Goulding Harbor and Pinta Bay was called "Deep Bay."

Pinta Bay: bay, see Goulding Harbor.

Pinta Cove: cove, $0.7 \mathrm{mi}$. across, at $\mathrm{N}$ end of Chichagof I., in Icy Strait, $1.6 \mathrm{mi}$. SE of Point Adolphus and $49 \mathrm{mi}$. W of Juneau, St. Elias Mts.; $58^{\circ} 16^{\prime} 10^{\prime \prime} \mathrm{N}, 135^{\circ} 44^{\prime} 45^{\prime \prime} \mathrm{W}$; (map 11).

Named in 1901 by E. F. Dickins, USC\&GS, and published in the 1901 Coast Pilot (p. 204). The cove is named for the U.S.S. Pinta, a navy steamship used in Alaskan waters for several years.

Pinta Head: point of land, on Baranof I., at W end of Peril Strait, in Canoe Pass, $26 \mathrm{mi}$. NW of Sitka, Alex. Arch.; 57 $24^{\prime} 00^{\prime \prime}$ N, 135 $37^{\prime}$ $40^{\prime \prime} \mathrm{W}$; (map 9).

Named in 1884 by Comdr. J. B. Coghlan for the U.S.S. Pinta, USC\&GS vessel, which navigated these waters. The name was published by USC\&GS in the 1891 Coast Pilot (p. 181).
Pintail Lake: lake, $0.7 \mathrm{mi}$. long, on Kenai Penin SW of Quill Lake, 22 mi. NE of Kenai, Cook Inlet Low.; $60^{\circ} 45^{\prime} 15^{\prime \prime} \mathrm{N}, 150^{\circ} 45^{\prime} 45^{\prime \prime} \mathrm{W}$; (map 62)

Named about 1963 by officials of Kenai National Moose Range, for the Pintail, or Seapheasant (Anas acuta), an important game duck that breeds on the Arctic coast.

Pinta Lake: lake, $0.2 \mathrm{mi}$. across, on Baranof I., $1 \mathrm{mi}$. NW of Lucky Chance Mountain and 12 mi. SE of Sitka, Alex. Arch.; 56 57'30' N, $135^{\circ} 04^{\prime} 00^{\prime \prime} \mathrm{W}$; (map 5).

Local name recorded in 1951 by USGS

Pinta Point: point of land, on $\mathrm{N}$ end of Kupreanof I, $3.5 \mathrm{mi}$. SE of Turnabout I. and $55 \mathrm{mi}$. E of Sitka, Alex. Arch.; 57 07'12' N $133^{\circ} 53^{\prime} 20^{\prime \prime} \mathrm{W}$; BGN 1937; (map 8).

Named in 1937 by USFS, probably for the Pinta Rocks 3 miles to the west.

Pinta Rock: rock, in Icy Strait, at mouth of Port Frederick, on Chichagof I., $1.5 \mathrm{mi}$. W of Crist Point and $8.8 \mathrm{mi}$. N of Hoonah, Alex. Arch.; $58^{\circ} 10^{\prime} 00^{\prime \prime} \mathrm{N}, 135^{\circ} 27^{\prime} 25^{\prime \prime} \mathrm{W}$; (map 11).

Named in 1901 by E. F. Dickins, USC\&GS, and published in the 1901 Coast Pilot (p. 207-208). Named for the U.S.S. Pinta. See Pinta Cove.

Pinta Rocks: rocks, in Frederick Sound, off NW tip of Kupreanof I., $36 \mathrm{mi}$. SE of Angoon, Alex. Arch.; $56^{\circ} 05^{\prime} 10^{\prime \prime} \mathrm{N}, 134^{\circ} 00^{\prime} 30^{\prime \prime} \mathrm{W}$; (map 9).

Named by USC\&GS and published in the 1891 Coast Pilot (p. 141). Named for the U.S.S. Pinta, USC\&GS steamer, "which plied these waters."

Pinta Rocks: rocks, in Frederick Sound, off N coast of Kupreanof I., $2.5 \mathrm{mi}$. S of Turnabout I. and $58 \mathrm{mi}$. E of Sitka, Alex. Arch.; $57^{\circ} 05^{\prime}$. $20^{\prime \prime} \mathrm{N}, 133^{\circ} 58^{\prime} 10^{\prime \prime} \mathrm{W}$; (map 8).

Named by USC\&GS; published in 1891 Coast Pilot (p. 141). The name was derived from the U.S.S. Pinta, which navigated these waters.

Pinto Creek: stream, flows N $4 \mathrm{mi}$. to Savage River, 14 mi. W of Healy, Alaska Ra.; $63^{\circ}$. $48^{\prime} 45^{\prime \prime} \mathrm{N}, 149^{\circ} 22^{\prime} 20^{\prime \prime} \mathrm{W}$; BGN 1948; (map 87).

Name reported by Woodbury Abbey, U.S. Army Corps of Engineers, on the blueprint of his 1921 Mount McKinley National Park survey.

Pinusuk Island: island, $1 \mathrm{mi}$. across, in Chiachi Is., $24 \mathrm{mi}$. E of Stepovak Bay, Aleutian Ra.; $55^{\circ} 51^{\prime} 50^{\prime \prime} \mathrm{N}, 159^{\circ} 04^{\prime} 00^{\prime \prime} \mathrm{W}$; (map 27).

Aleut name reported in 1875 by W. H Dall, USC\&GS

Pioneer Creek: stream, formed by junc. of its North Fork and Deadwood Creek, flows SW $3.8 \mathrm{mi}$. to Eureka Creek at village of Eureka, $23 \mathrm{mi}$. S of Rampart, Yukon-Tanana High.; $65^{\circ} 10^{\prime} 30^{\prime \prime} \mathrm{N}, 150^{\circ} 13^{\prime} 00^{\prime \prime} \mathrm{W}$; ( $\left.\operatorname{map} 106\right)$.

Prospectors' name reported in 1904 by Prindle and Hess (1906, p. 85), USGS Gold was discovered here on What Cheer Bar in 1902.

Pioneer Creek: stream, see Berry Creek. 
Pioneer Gulch: ravine, in Peters Hills, trends $\mathrm{N}$ and E $1.4 \mathrm{mi}$. to Peters Creek, $32 \mathrm{mi}$. NW of Talkeetna, Alaska Ra.; 62 $31^{\prime} 55^{\prime \prime} \mathrm{N}, 150^{\circ}$ $48^{\prime} 50^{\prime \prime} \mathrm{W}$; (map 81$)$.

Prospectors' name reported in the 1930's by USGS.

Pioneer Gulch: ravine, trends NE $0.6 \mathrm{mi}$. to Snake River, $0.4 \mathrm{mi}$. downstream from Goldbottom Creek and $13 \mathrm{mi}$. NW of Nome, Seward Penin. High.; 64 $42^{\prime}$ N, $1^{\circ} 5^{\circ} 24^{\prime} \mathrm{W}$; (map 94)

Prospectors' name reported in 1904 by T. G. Gerdine, USGS.

Pioneer Peak: mountain, 6,398 ft., on S bank of Knik River, $9 \mathrm{mi}$. SE of Palmer, Chugach Mts.; $61^{\circ} 28^{\prime} 30^{\prime \prime}$ N, $149^{\circ} 01^{\prime} 45^{\prime \prime}$ W; (map 69).

Local name reported in 1939 by USGS; named for the pioneers of the Matanuska Valley.

Pioneer Ridge: ridge, elev. 6,500-19,470 ft., in Mount McKinley National Park, W of Muldrow Glacier, extends NNE $9 \mathrm{mi}$. from $\mathrm{N}$ summit of Mount McKinley to Gunsight Pass, Alaska Ra.; $63^{\circ} 09^{\prime} \mathrm{N}, 150^{\circ} 57^{\prime} \mathrm{W}$; BGN 1947; (map 88).

Named by Bradford Washburn about 1945 for "the sourdough party of Taylor, Anderson, McGonagall [McGonogal], and Lloyd, who made the first ascent of McKinley's North Peak, which was completed along the upper part of this ridge." See McKinley, Mount.

Pio Point: point of land, on $\mathrm{N}$ shore of North Passage, in Woewodski Harbor on $\mathrm{S}$ shore of Admiralty I., $25 \mathrm{mi}$. SSE of Angoon, Alex. Arch.; $57^{\circ} 10^{\prime} 40^{\prime \prime} \mathrm{N}, 134^{\circ} 16^{\prime} 15^{\prime \prime} \mathrm{W}$; $B G N$ 1966; (map 9). Var. Pie Point.

Named in 1889 by Lt. Comdr. H. B. Mansfield, USN.

Pipe Creek: stream, on Kenai Penin., in Kenai Mts., flows N $4 \mathrm{mi}$. to Skilak Lake, $38 \mathrm{mi}$. ESE of Kenai, Chugach Mts. ; $60^{\circ} 23^{\prime} 45^{\prime \prime} \mathrm{N}$, $150^{\circ} 13^{\prime} 00^{\prime \prime} \mathrm{W}$; (map 62).

Local name reported in 1959 by USGS.

Pipeline Lake: lake, $600 \mathrm{ft}$. across, $18 \mathrm{mi}$. SE of Cordova, Malaspina Coastal Plain; $60^{\circ} 27^{\prime}$ $\mathrm{N}, 145^{\circ} 14^{\prime} \mathrm{W}$; (map 64).

Local name published in 1951 by USGS.

Piper Cove: cove, $0.7 \mathrm{mi}$. across, on $\mathrm{S}$ coast of Little Tanaga I., Aleutian Is.; $51^{\circ} 48^{\prime} 00^{\prime \prime} \mathrm{N}$, $176^{\circ} 10^{\prime} 30^{\prime \prime} \mathrm{W} ; B G N$ 1936; (map 17).

Named by members of the U.S. Navy Aleutian Island Survey Expedition in 1934, for the U.S.S. Sandpiper.

Piper Island: island, in Schulze Cove, on $\mathbf{N}$ shore of Fish Bay, on Baranof I., $25 \mathrm{mi}$. NE of Sitka, Alex. Arch.; $57^{\circ} 23^{\prime} 30^{\prime \prime} \mathrm{N}, 135^{\circ} 35^{\prime}$ $30^{\prime \prime} \mathrm{W}$; (map 9).

Named in 1880 by the U.S. Navy and published by USC\&GS in the 1883 Coast Pilot (p. 161).

Pipe Spit: spit, on Baldwin Penin., extends 0.3 mi. into Hotham Inlet, $8 \mathrm{mi}$. NE of Kotzebue, Kotzebue-Kobuk Low. ; $66^{\circ} 57^{\prime} \mathrm{N}, 162^{\circ} 20^{\prime} \mathrm{W}$; (map 113).

Named in 1885 by Lt. Stoney (1900, map), USN.
Pippin Lake: lake, $1 \mathrm{mi}$. long, $3.2 \mathrm{mi}$. $\mathrm{N}$ of Tonsina and $54 \mathrm{mi}$. NE of Valdez, Chugach Mts.; $61^{\circ} 42^{\prime} 30^{\prime \prime} \mathrm{N}, 145^{\circ} 10^{\prime} 00^{\prime \prime} \mathrm{W} ; B G N$ 1932; (map 68). Var. Taktahni Lake.

Local name reported in 1932 by C. F. Feuchsel, USGS, "for a local teamster named Joe Pippin who fell in to the lake about 1924." The Ahtena Indian name was reported as Taktahni [presumably the name of a stream] meaning "high up" or "on top."

Pipsuk Bight: cove, $0.5 \mathrm{mi}$. across, $\mathrm{N}$ of Pipsuk Point, on Barter I., Arctic Plain; $70^{\circ} 08^{\prime} \mathrm{N}$, $143^{\circ} 36^{\prime} \mathrm{W}$; (map 152).

Eskimo name reported by USC\&GS in 1952.

Pipsuk Point: point of land, tip of Barter I., 0.5 mi. SE of Kaktovik, Arctic Plain; $70^{\circ} 07^{\prime} 45^{\prime \prime}$ N, $143^{\circ} 35^{\prime} 45^{\prime \prime} \mathrm{W}$; (map 152).

Local Eskimo name reported by USC\&GS in 1952.

Pirate Cove: locality, on Pirate Cove, on NE coast of Popof I., in Shumagin Is., Aleutian Ra.; $55^{\circ} 21^{\prime} 40^{\prime \prime} \mathrm{N}, 1^{\circ} 20^{\circ} 21^{\prime} 50^{\prime \prime} \mathrm{W}$; (map 28).

A post office was maintained here from 1909 to 1918, according to Ricks (1965, p. 51a). This once important cod-fishing station was abandoned before 1954.

Pirate Cove: bay, $0.1 \mathrm{mi}$. across, $5 \mathrm{mi}$. SW of Sitka, on W coast of Baranof I., Alex. Arch.; $56^{\circ} 59^{\prime} 15^{\prime \prime} \mathrm{N}, 135^{\circ} 22^{\prime} 00^{\prime \prime} \mathrm{W}$; (map 5).

Named for charting purposes; name published in 1943 by USC\&GS.

Pirate Cove: cove, $0.3 \mathrm{mi}$. across, on NE coast of Popof I., in Shumagin Is., Aleutian Ra.; $55^{\circ} 21^{\prime} 40^{\prime \prime} \mathrm{N}, 160^{\circ} 21^{\prime} 25^{\prime \prime} \mathrm{W}$; (map 28). Var. Pirates Cove.

Local name used in 1880 and "based on the reputation of the place"; shown on a USBF chart in 1890.

Pirate Cove: cove, $0.5 \mathrm{mi}$. wide, on $\mathrm{W}$ shore of Port Wells, $14 \mathrm{mi}$. NE of Whittier, Chugach Mts.; $60^{\circ} 52^{\prime} 15^{\prime \prime} \mathrm{N}, 148^{\circ} 17^{\prime} 30^{\prime \prime} \mathrm{W}$; (map 63).

Local name reported in 1916 by $\mathrm{J}$. W. Bagley, USGS.

Pirate Creek: stream, in Mount McKinley National Park, heads $W$ of Muldrow Glacier and flows $\mathrm{N}$ and $\mathrm{W} 5 \mathrm{mi}$. to East Fork Clearwater Creek, $13 \mathrm{mi}$. SE of Wonder Lake,

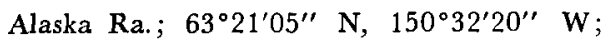
(map 88). Var. Whistler Creek, Windfall Creek.

So named in 1923 by USGS, because "the drainage of this creek is a good illustration of stream piracy."

Pirate Creek: stream, flows SW $2.4 \mathrm{mi}$. to Eldorado Creek in American River basin, $4 \mathrm{mi}$. SW of Kougarok Mtn. and $40 \mathrm{mi}$. NE of Teller, Seward Penin. High.: $65^{\circ} 38^{\prime} \mathrm{N}$, $165^{\circ} 18^{\prime} \mathrm{W}$; (map 111 ).

Prospectors' name reported on the 1908 "Map of Seward Peninsula" by Arthur Gibson.

Pirate Creek: stream, in Zane Hills, flows SE $3 \mathrm{mi}$. to Caribou Creek, $45 \mathrm{mi}$. W of Hughes,
Hogatza High.; $66^{\circ} 08^{\prime} \mathrm{N}, 155^{\circ} 49^{\prime} \mathrm{W}$; (map 116).

Named by mining engineers about 1940 .

Pirate Lake: lake, $3 \mathrm{mi}$. long, $13 \mathrm{mi}$. S of Spectacle Lake and $54 \mathrm{mi}$. SW of Augustine I., Aleutian Ra.; $59^{\circ} 00^{\prime} \mathrm{N}, 154^{\circ} 42^{\prime} \mathrm{W}$; (map 51).

Named by R. H. Sargent, USGS, in 1923 because stream piracy was evident in the vicinity. Published by K. F. Mather (in Brooks and others, 1925, pl. 3), USGS.

Pirate Peak: peak, 3,315 ft., $1.5 \mathrm{mi}$. S of Ruth Lake and $14 \mathrm{mi}$. NE of Petersburg, Coast Mts. ; $56^{\circ} 58^{\prime} 20^{\prime \prime} \mathrm{N}, 132^{\circ} 43^{\prime} 45^{\prime \prime} \mathrm{W}$; (map 6).

Named in 1887 by Lt. Comdr. C. M. Thomas, USN, for his steam launch Pirate.

Pirates Cove: cove, see Pirate Cove.

Pirate Shake: locality, at $\mathrm{N}$ end of Nagai I., in Shumagin Is., Aleutian Ra.; 55 $13^{\prime} 30^{\prime \prime} \mathrm{N}$, $159^{\circ} 54^{\prime} 25^{\prime \prime} \mathrm{W}$; (map 27).

Local name published in USC\&GS 1916 Coast Pilot (p. 171).

Pisa Point: point of land, $0.9 \mathrm{mi}$. E of Chichagof Harbor, on NE coast of Attu I., Aleutian Is.; $52^{\circ} 56^{\prime} 03^{\prime \prime} \mathrm{N}, 173^{\circ} 16^{\prime} 20^{\prime \prime} \mathrm{E}$; (map 13). Var. Pisa Tower, Point Pisa.

The descriptive name "Pisa Tower" was given by Lt. William Gibson, commander of the schooner U.S.S. Fenimore Cooper during the North Pacific Exploring Expedition in 1855 (Baker, 1906, p. 500). The name "Pisa Tower" was published in the 1944 Aleutian Coast Pilot (p. 130) and is mentioned in the 1946 Supplement to the above Coast Pilot (p. 16): "Pisa Point * * * a low point ending in reef. Pisa Tower is a prominent leaning pinnacle * * * on this point."

Pisa Tower: point of land, see Pisa Point.

Pishak Island: island, $0.1 \mathrm{mi}$. across, $2.9 \mathrm{mi}$. SW of Goddard, in Necker Is., on W coast of Baranof I., Alex. Arch.; $56^{\circ} 48^{\prime} 40^{\prime \prime}$ N, $135^{\circ}$. 26'00" W; (map 5).

Name published in 1929 by USC\&GS.

Pish River: stream, on Seward Penin., flows NE $31 \mathrm{mi}$. to Goodhope Bay, $35 \mathrm{mi}$. NW of Deering, Kotzebue-Kobuk Low.; $66^{\circ} 10^{\prime} \mathrm{N}$, $163^{\circ} 57^{\prime} \mathrm{W}$; (map 113). Var. Kutuk River.

Local name reported in 1903 by $D$. C. Witherspoon, USGS.

Pisiksagiakvik River: stream, see Piksiksak Creek. Pisiksak River: stream, see Piksiksak Creek.

Piskuk Peak: peak, see Pistuk Peak.

Piskut Mountain: peak, see Pistuk Peak.

Piskut Peak: peak, see Pistuk Peak.

Pistuk Peak: peak, $5 \mathrm{mi}$. W of Togiak Lake and $80 \mathrm{mi}$. NE of Goodnews, Kilbuck-Kuskokwim Mts. ; $59^{\circ} 43^{\prime} 30^{\prime \prime} \mathrm{N}, 159^{\circ} 42^{\prime} 45^{\prime \prime} \mathrm{W}$; (map 53 ). Var. Paviak Peak, Piskuk Peak, Piskut Mountain, Piskut Peak.

Eskimo name shown as "Piskut Peak" or "Paviak Peak" on one 1898 fieldsheet by W. S. Post, USGS, and as "Piskut Mountain" on another. It was published as "Piskuk Peak" by Spurr (1900, map 10), USGS.

Pitchfork Falls: falls, on stream flowing from Goat Lake to Skagway River, $1 \mathrm{mi}$. NE of 
Clifton and $6 \mathrm{mi}$. NW of Skagway, Coast Mts. ; $59^{\circ} 32^{\prime} \mathrm{N}, 135^{\circ} 12^{\prime} \mathrm{W}$; (map 45).

Local name published in 1951 by USGS.

Pitchie: point of land, see Bird Cape.

Pitchuk Lake: lake, $0.5 \mathrm{mi}$. long, $3 \mathrm{mi}$. NW of Bettles, Brooks Ra.; $66^{\circ} 56^{\prime} \mathrm{N}, 151^{\circ} 48^{\prime} \mathrm{W}$; (map 117).

Local name reported in 1956 by T. E. Taylor, USGS.

Pitka Fork: stream, heads at $62^{\circ} 24^{\prime} \mathrm{N}, 154^{\circ} 02^{\prime}$ W, flows NW 75 mi. to Middle Fork Kuskokwim River $7.5 \mathrm{mi}$. SE of its junc. with Kuskokwim River, 28 mi. E of McGrath, Kuskokwim Low.; $62^{\circ} 56^{\prime} \mathrm{N}, 154^{\circ} 45^{\prime} \mathrm{W}$; (map 80 ).

Local name reported in 1940 by USGS.

Pitka Fork: stream, heads at junc. of Slate and Trout Creeks, flows S $20 \mathrm{mi}$. to Hodzana River, $38 \mathrm{mi}$. NW of Beaver, Kokrines-Hodzana High.; $66^{\circ} 41^{\prime} \mathrm{N}, 148^{\circ} 28^{\prime} \mathrm{W}$; (map 118). Var. Pitka Fork Hodzana River.

Local name reported in 1909 by A. G. Maddren (in Brooks and others, 1910, pl. 7), USGS.

Pitka Fork Hodzana River: stream, see Pitka Fork.

Pitka Lake: lake, $1 \mathrm{mi}$. long, $2.5 \mathrm{mi}$. NW of Beaver, Yukon Flats; $66^{\circ} 22^{\prime} 40^{\prime \prime} \mathrm{N}, 147^{\circ} 30^{\prime}$ $00^{\prime \prime} \mathrm{W}$; (map 118).

Local name obtained in 1956 by USGS.

Pitka River: stream, flows NE $25 \mathrm{mi}$. to Kateel River, $35 \mathrm{mi}$. SW of Roundabout Mtn., Nulato Hills; $65^{\circ} 29^{\prime} \mathrm{N}, 157^{\circ} 46^{\prime} \mathrm{W}$; (map 108).

Local name obtained at Huslia by USGS in 1954 or 1955.

Pitkas Bar: bar, in Birch Creek, at mouth of Harrison Creek, $40 \mathrm{mi}$. SW of Circle, YukonTanana High.; $65^{\circ} 20^{\prime} \mathrm{N}, 144^{\circ} 45^{\prime} \mathrm{W}$; (map 104).

Named by prospectors for the two "halfbreeds named Pitka and Sorresco" (Mertie, 1937 , p. 5), who made the first discovery of gold on Birch Creek. The name was reported in 1908 by USGS (Covert and Ellsworth, 1909, pl. 4).

Pitkas Point: village, pop. 28, near junc. of Andreafsky and Yukon Rivers, $40 \mathrm{mi}$. NW of Marshall, Yukon-Kuskokwim Delta; $62^{\circ} 02^{\prime}$ N, $163^{\circ} 17^{\prime} \mathrm{W}$; (map 77).

Eskimo village reported by USC\&GS in 1898. Named for the trader "named Pitka whose store was a branch of the Northern Commercial Company's station at Andreafski." Its population was 50 in 1939 and 84 in 1950.

Pitkas Point: point of land, between Andreafsky and Yukon Rivers, $39 \mathrm{mi}$. NW of Marshall, Yukon-Kuskokwim Delta; $62^{\circ} 02^{\prime} \mathrm{N}, 163^{\circ} 17^{\prime}$ W; (map 77). Var. Petkas Point.

Local name reported as "Petkas Point" by USC\&GS in 1898.

Pitkik Creek: stream, flows S $5 \mathrm{mi}$. to Kobuk River $13 \mathrm{mi}$. NW of Shungnak, KotzebueKobuk Low.; $66^{\circ} 58^{\prime} 30^{\prime \prime} \mathrm{N}, 157^{\circ} 34^{\prime} 00^{\prime \prime} \mathrm{W}$; (map 115).

Eskimo name shown on a 1927 manuscript map by the "trader at Selawik."
Pitkik Lake: lake, $2.5 \mathrm{mi}$. long, an oxbow of Kobuk River, 14 mi. NW of Shungnak, Brooks Ra.; $67^{\circ} 01^{\prime} \mathrm{N}, 157^{\circ} 33^{\prime} \mathrm{W}$; (map 126).

Eskimo name reported by the U.S. Army Corps of Engineers in 1955.

Pitmagillik: stream, see Pitmegea River.

Pitmegea River: stream, heads in De Long Mts., flows NW $42 \mathrm{mi}$. to Chukchi Sea at Cape Sabine, $40 \mathrm{mi}$. NW of Mount Kelly, Arctic Slope; $68^{\circ} 54^{\prime} 40^{\prime \prime} \mathrm{N}, 164^{\circ} 37^{\prime} 00^{\prime \prime} \mathrm{W}$; (map 130). Var. Pet-meg-éa, Pitmigéa, Pitmagillik.

Eskimo name [Pitmegeak] obtained by John W. Kelly (or Kelley), prospector, who explored the stream in 1888 , and published by Stockton (1890, p. 178).

Pitmigéa: stream, see Pitmegea River.

Pitmik: village, see Inakpuk.

Pit-mik-ha-mut: village, see Inakpuk.

Pitmik River: stream, heads in lake at $61^{\circ} 33^{\prime} 10^{\prime \prime}$ $\mathrm{N}, 162^{\circ} 42^{\prime} 50^{\prime \prime} \mathrm{W}$, flows NW $60 \mathrm{mi}$. to Kashunuk River, $15 \mathrm{mi}$. N of Kgun Lake and 52 mi. W of Marshall, Yukon-Kuskokwim Delta; $61^{\circ} 47^{\prime} 15^{\prime \prime} \mathrm{N}, 163^{\circ} 38^{\prime} 00^{\prime \prime} \mathrm{W}$; (map 74).

Eskimo name obtained from a manuscript map of the Kashunuk River by "Father Delon," and reported by USC\&GS in 1951.

Pit Rock: rock, on S shore of Kuluk Bay, on NE coast of Adak I., Aleutian Is.; $51^{\circ} 51^{\prime} 38^{\prime \prime} \mathrm{N}$, $176^{\circ} 34^{\prime} 45^{\prime \prime}$ W; BGN 1936; (map 17).

Named by members of the U.S. Navy Aleutian Island Survey Expedition in 1934, "for the survey signal $P i t$ which was used by the Survey parties for two seasons."

Pitt, Cape:- point of land, see Muzon, Cape.

Pittalukruak Lake: lake, $4 \mathrm{mi}$. across, $\mathrm{SE}$ of Admiralty Bay, $44 \mathrm{mi}$. SE of Barrow, at mouth of Alaktak River, Arctic Plain; 70 $50^{\prime}$ $\mathrm{N}, 155^{\circ} 23^{\prime} \mathrm{W}$; (map 148).

Eskimo name reported by USG\&GS in 1951, meaning "the old coming through place" referring to the need to go through this lake to get to the Alaktak River.

Pitt Island: island, $0.2 \mathrm{mi}$. across, on $\mathrm{W}$ shore of Port Frederick, on Chichagof I., $0.2 \mathrm{mi}$. SW of Hoonah, Alex. Arch.; 58 $06^{\prime} 30^{\prime \prime} \mathrm{N}$, $135^{\circ} 27^{\prime} 10^{\prime \prime}$ W; (map 11). Var. Harbor Island.

Named in 1880 by the U.S. Navy and published by USC\&GS in the 1883 Coast Pilot (p. 191). It is called Harbor I. in an 1880 Hydrog. Office notice.

Pitt Island: island, see Kruzof Island.

Pittman: railroad station, on The Alaska RR., 17 mi. W of Palmer, Cook Inlet Low.; 61 $35^{\prime}$ 05" N, 149 38'30" W; (map 69).

Named in 1918 by the builders of The Alaska Railroad.

Pittock Pass: pass, 7,250 ft., $12 \mathrm{mi}$. SE of Denali Pass in Mt. McKinley National Park, Alaska Ra.; $62^{\circ} 56^{\prime} 55^{\prime \prime} \mathrm{N}, 150^{\circ} 45^{\prime} 15^{\prime \prime} \mathrm{W}$; (map 81). Mountain climbers' name published in the late 1940's.

Pittock Peaks: peak, see Barrille, Mount.

Pitt Point: point of land, northernmost point on coast of Beaufort Sea between Harrison and Smith Bays, Arctic Plain; $70^{\circ} 55^{\prime} \mathrm{N}, 153^{\circ} 10^{\prime}$ W; (map 148). Var. Point Pitt.
Named July 26, 1837, by P. W. Dease and Thomas Simpson (Simpson, 1843, p. 143).

Pittsberg Creek: stream, see Pittsburg Creek.

Pittsburg Creek: stream, flows SE $10 \mathrm{mi}$ to Middle Fork Fortymile River, $52 \mathrm{mi}$. SW of Eagle, Yukon-Tanana High.; 64 $26^{\prime} 40^{\prime \prime} \mathrm{N}, 142^{\circ} 43^{\prime}$ $30^{\prime \prime} \mathrm{W}$; (map 102). Var. Pittsberg Creek.

Named by prospectors and shown on a 1902 manuscript map by E. J. Chamberlain, U.S. Deputy Surveyor, as "Pittsberg Creek."

Pivot Point: point of land, on S shore of Kiliuda Bay, on SE coast of Kodiak I.; $57^{\circ} 18^{\prime} \mathrm{N}$, $153^{\circ} 01^{\prime} \mathrm{W}$; BGN 1933; (map 34).

Descriptive name given in 1931 by USC\&GS, "because it marks a turn [in the channel] in the western part of Kiliuda Bay." Piyukenok River: stream, see Piyukenuk River. Piyukenuk River: stream, heads in lake, flows W $8.5 \mathrm{mi}$. to Kokechik River, $34 \mathrm{mi}$. $\mathbf{E}$ of village of Hooper Bay, Yukon-Kuskokwim Delta; $61^{\circ} 38^{\prime} \mathrm{N}, 165^{\circ} 05^{\prime} \mathrm{W}$; (map 75). Var. Piyukenok River.

Eskimo name reported by USC\&GS in 1951 .

Place Creek: stream, flows W $1 \mathrm{mi}$. to Bonanza River near mouth of Cold Creek, about 14 mi. NW of Solomon, Seward Penin. High.; (map 95).

Prospectors' name reported on a map of Cape Nome gold fields by David Fox, Jr., dated 1901. This stream cannot be precisely located on current maps.

Placer Creek: stream, on Kenai Penin., heads at terminus of Lowell Glacier, flows NE $3 \mathrm{mi}$. to Resurrection River, $13 \mathrm{mi}$. NW of Seward, Chugach Mts. ; $60^{\circ} 16^{\prime} 10^{\prime \prime} \mathrm{N}, 149^{\circ} 40^{\prime} 30^{\prime \prime} \mathrm{W}$; $B G N$ 1966; (map 63). Var. Placer River.

Local name reported in 1915 by USC\&GS.

Placer Creek: stream, flows SW $4 \mathrm{mi}$. to Portage Lake, $5 \mathrm{mi}$. NW of Whittier, Chugach Mts.; $60^{\circ} 47^{\prime} 15^{\prime \prime} \mathrm{N}, 148^{\circ} 49^{\prime} 20^{\prime \prime} \mathrm{W}$; (map 63).

Local name reported in 1913 by C. E. Giffin and J. W. Bagley (in Brooks and others, 1914, manuscript pl. 2), USGS.

Placer Creek: stream, heads in Horn Mts., flows $\mathrm{N} 4 \mathrm{mi}$. to Flat Creek, $3 \mathrm{mi}$. SW of its junc. with Little Nelchina River and $13 \mathrm{mi}$. N of Tahneta Pass, Talkeetna Mts.; $62^{\circ} 04^{\prime} 20^{\prime \prime} \mathrm{N}$,

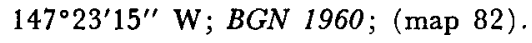

Local name reported in 1917 by USGS. This creek has been prospected for placer gold.

Placer Creek: stream, heads at $64^{\circ} 59^{\prime} \mathrm{N}$, $142^{\circ} 06^{\prime} \mathrm{W}$, flows $\mathrm{SE} 3 \mathrm{mi}$. to Seventymile River, $27 \mathrm{mi}$. NW of Eagle, Yukon-Tanana High.; 64 $58^{\prime} 30^{\prime \prime} \mathrm{N}, 142^{\circ} 00^{\prime} 00^{\prime \prime} \mathrm{W}$; (map 102). Var. Pleasant Creek.

Local name published in 1956 by USGS.

Placer Creek: stream, flows N $9.2 \mathrm{mi}$. to Goodhope River, $26 \mathrm{mi}$. NW of Imuruk Lake, Seward Penin. High.; $65^{\circ} 50^{\prime} \mathrm{N}, 164^{\circ} 01^{\prime} \mathrm{W}$; (map 110).

Prospectors' name reported in 1901 by USGS (Collier, 1902, pl. 12).

Placer Creek: stream, heads near head of Alta Creek, Hows SW $1 \mathrm{mi}$. to Bonanza River, about $11 \mathrm{mi}$. NW of Solomon, Seward Penin. High.; (map 95).

Prospectors' name reported on the 1900 "Map of Nome Peninsula" by J. M. Davidson 
and B. D. Blakeslee. This stream cannot be precisely located on current maps.

Placer Creek: stream, see Mead Creek.

Placer Lakes: lakes, $1 \mathrm{mi}$. across, between Chuck River and Endicott Arm, $5 \mathrm{mi}$. SE of Chuck Mining Camp and $70 \mathrm{mi}$. SE of Juneau, Coast Mts.; $57^{\circ} 31^{\prime} 50^{\prime \prime} \mathrm{N}, 133^{\circ} 14^{\prime} 00^{\prime \prime} \mathrm{W}$ (map 8).

Local name reported in 1960 by USGS.

Placer River: stream, on Kenai Penin., flows N $16 \mathrm{mi}$. to head of Turnagain Arm, $12 \mathrm{mi}$. NW of Whittier, Chugach Mts. ; $60^{\circ} 50^{\prime} \mathrm{N}, 149^{\circ} 00^{\prime}$ W; BGN 1912; (map 63). Var. Glacier River.

Local name reported in 1906 by F. H. Moffit, USGS.

Placer River: stream, see Glacier River.

Placer River: stream, see Placer Creek.

Placer River Glacier: glacier, see Lowell Glacier.

Placer River Glacier: glacier, see Spencer Glacier.

Placer River Valley: valley, on N end of Kenai Penin., trends N 9 mi. to head of Turnagain Arm along Placer River $12 \mathrm{mi}$. W of Whittier, Chugach Mts.; $60^{\circ} 49^{\prime} \mathrm{N}, 149^{\circ} 00^{\prime} \mathrm{W}$; (map 63).

Local name reported on recent USGS publications; derived from the Placer River that runs through the valley.

Placerville: locality, $0.8 \mathrm{mi}$. $\mathrm{N}$ of Poorman Creek and $8 \mathrm{mi}$. SW of Poorman, Kilbuck-Kuskokwim Mts. ; $64^{\circ} 02^{\prime} \mathrm{N}, 155^{\circ} 45^{\prime} \mathrm{W}$; BGN 1937; (map 98).

Placer mining camp reported in 1933 by $\mathrm{J}$. B. Mertie, USGS. It is reported to be abandoned.

Plain Mountain: mountain, 1,998 ft., on E coast of Gravina I., $2.8 \mathrm{mi}$. NW of Blank Point, Alex. Arch.; $55^{\circ} 16^{\prime} 50^{\prime \prime} \mathrm{N}, 131^{\circ} 43^{\prime} 10^{\prime \prime} \mathrm{W}$; (map 3).

Descriptive name given in 1883 by Lt. Comdr. H. E. Nichols, USN.

Planaria Lake: lake, $0.4 \mathrm{mi}$. long, on Slide Mtn., $42 \mathrm{mi}$. WSW of Glennallen, Copper River Basin; $62^{\circ} 01^{\prime} \mathrm{N}, 146^{\circ} 51^{\prime} \mathrm{W}$; (map 83).

Named in 1949 for the family of soft bodied aquatic worms (Planariidae); reported by USGS.

Plateau Glacier: glacier, in Glacier Bay National Monument, heads in Cushing Plateau, trends $\mathrm{SE}$ to Wachusett Inlet on Glacier Bay, $63 \mathrm{mi}$. $\mathrm{NW}$ of Hoonah, St. Elias Mts.; $58^{\circ} 55^{\prime} \mathrm{N}$, 136 $15^{\prime} \mathrm{W} ; B G N$ 1948; (map 10)

Name published by American Geographical Society (Cooper, 1937, pl. 1); named for Cushing Plateau.

Plateau Lake: lake, $0.6 \mathrm{mi}$. long, drains $\mathrm{S}$ to Berry Creek, $4 \mathrm{mi}$. S of Alaska Highway, 49

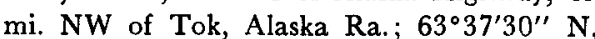
$144^{\circ} 25^{\prime} 45^{\prime \prime} \mathrm{W}$; (map 86).

Name published on relatively recent maps.

Plateau Mountain: mountain, 5,330 ft., in Endicott Mts., 16 mi. E of Survey Pass, Brooks Ra.; $67^{\circ} 49^{\prime} \mathrm{N}, 153^{\circ} 30^{\prime} \mathrm{W}$; BGN 1932; (map 125).

Named by Robert Marshall in 1931 because "the top was a great plateau ***."

Platinum: village, pop. 43 , near mouth of Smalls River on Goodnews Bay, $11 \mathrm{mi}$. SW of Good- news, Kilbuck-Kuskokwim Mts.; $59^{\circ} 00^{\prime} 45^{\prime \prime} \mathrm{N}$, $161^{\circ} 49^{\prime} 00^{\prime \prime} \mathrm{W}$; BGN 1938; (map 53). Var. Agvik.

Mining village so named because of platinum deposits in the vicinity. In 1937 Platinum was Alaska's newest boomtown with a population of 50 , two trading posts, a roadhouse and a post office which was established in 1935 (Ricks, 1965, p. 51). Adjoining it was an Eskimo village, now abandoned, named "Agvik," reported to mean "small stone to sharpen knives." This name was obtained about 1951 at Goodnews by J. M. Hoare, USGS. In 1950 the population of Platinum was 72 , and the town was the center of most of the commercial activity in the area (U.S. Coast and Geodetic Survey, 1954, p. 516). In 1960 the population had decreased to 43 .

Platinum Creek: stream, flows SE $3 \mathrm{mi}$. to Salmon River, $25 \mathrm{mi}$. NE of Cape Newenham, Kilbuck-Kuskokwim Mts.; 58 ${ }^{\circ} 3^{\prime} 35^{\prime \prime} \mathrm{N}$, $161^{\circ} 43^{\prime} 30^{\prime \prime}$ W; BGN 1938; (map 39).

Prospectors' name reported in 1933 by USGS and published by Mertie (1940, pl. 1 and p. 59). Much mining activity has occurred along this creek since platinum was discovered on Fox Gulch, one of its tributaries, in 1926.

Platinum Creek: stream, in Mentasta Mts., flows SE $17 \mathrm{mi}$. to Nebesna River, $7.5 \mathrm{mi}$. NE of Devils Mtn., Alaska Ra.; $62^{\circ} 26^{\prime} \mathrm{N}, 142^{\circ} 45^{\prime}$ W; (map 84).

Named by prospectors who found what they thought to be platinum in the creek gravels; reported in 1903 by F. C. Schrader, USGS.

Platt Creek: stream, see Platte Creek.

Platte Creek: stream, flows N, joins Fox Creek to form Homestake Creek, $16 \mathrm{mi}$. NE of Healy, Alaska Ra.; $63^{\circ} 59^{\prime} 00^{\prime \prime}$ N, $148^{\circ} 33^{\prime} 25^{\prime \prime} \mathrm{W}$; (map 87). Var. Platt Creek.

Local name reported in 1910 by D. C. Witherspoon (in Capps, 1912, pl. 2), USGS.

Plavezhnoi: lake, see Tazlina Lake.

Pleasant Bay: bay, on Admiralty I., on W shore of Seymour Canal, $2 \mathrm{mi}$. SE of Mole Harbor and $48 \mathrm{mi}$. S of Juneau, Alex. Arch.; $57^{\circ} 38^{\prime}$ $40^{\prime \prime} \mathrm{N}, 133^{\circ} 59^{\prime} 15^{\prime \prime} \mathrm{W}$; (map 8).

Named by local navigators and reported in 1904 by H. C. Fassett, USBF.

Pleasant Bay Lake: lake, $0.7 \mathrm{mi}$. long, $4 \mathrm{mi}$. S of Mole Harbor, on $\mathrm{E}$ coast of Admiralty I., $22 \mathrm{mi}$. E of Angoon, Alex. Arch. ; 57 $36^{\prime} 30^{\prime \prime}$ $\mathrm{N}, 134^{\circ} 01^{\prime} 30^{\prime \prime} \mathrm{W}$; (map 9).

Named in 1904 by H. C. Fassett, USBF.

Pleasant Camp: locality, on $\mathrm{N}$ bank of Klehini River, on Alaska-Canada boundary, at mouth of Jarvis Creek, $37 \mathrm{mi}$. W of Skagway, St. Elias Mts.; $59^{\circ} 27^{\prime} 00^{\prime \prime} \mathrm{N}, 136^{\circ} 21^{\prime} 30^{\prime \prime} \mathrm{W}$; $(\operatorname{map} 45)$.

Local name of an International Boundary Station reported by Brooks (1900b, pl. 47 and p. 338), USGS. In 1900 a Northwest Mounted Police post and a customhouse were there.

Pleasant Creek: stream, heads in Yukon, Canada, at $65^{\circ} 09^{\prime} \mathrm{N}, 140^{\circ} 59^{\prime} \mathrm{W}$, flows SW 5 mi. to join Harrington Creek to form Hard
Luck Creek, $23 \mathrm{mi}$. N of Eagle, Porcupine Plat.; $65^{\circ} 06^{\prime} 40^{\prime \prime} \mathrm{N}, 141^{\circ} 04^{\prime} 00^{\prime \prime} \mathrm{W}$; $B G N$ 1965; (map 103).

Named in 1930 by J. B. Mertie, Jr., USGS. Pleasant Creek: stream, sce Placer Creek.

Pleasant Island: island, $7.5 \mathrm{mi}$. across, in Icy Strait, $0.3 \mathrm{mi}$. SE of Gustavus and $44 \mathrm{mi}$. W of Juneau, St. Elias Mts.; $58^{\circ} 21^{\prime} \mathrm{N}, 135^{\circ} 38^{\prime}$ W; (map 11).

Named in 1879 by W. H. Dall, USC\&GS because of its "pleasant shore." The name was published in the 1883 Coast Pilot (p. 203).

Pleasant Island Reef: reef, $2.3 \mathrm{mi}$. long, $0.6 \mathrm{mi}$. off S coast of Pleasant I., in Icy Strait, $45 \mathrm{mi}$. W of Juneau, St. Elias Mts.; $58^{\circ} 18^{\prime} 45^{\prime \prime} \mathrm{N}$, $135^{\circ} 38^{\prime} 30^{\prime \prime} \mathrm{W}$; (map 11).

Named in 1901 by E. F. Dickins, USC\&GS, for Pleasant I. The name was published in the 1901 Coast Pilot (p. 203).

Pleiades Islands: islands, trend $\mathrm{N}-\mathrm{S} 1 \mathrm{mi}$. in Knight Island Passage, $4 \mathrm{mi}$. SE of Chenega, Chugach Mts.; $60^{\circ} 14^{\prime} 00^{\prime \prime} \mathrm{N}, 148^{\circ} 00^{\prime} 40^{\prime \prime} \mathrm{W}$; $B G N$ 1908; (map 63). Var. Seven Sisters, Sisters Islands.

Named in 1908 by USC\&GS for "the seven daughters of Atlas transformed according to Greek mythology into a group of stars."

Plenty Bear Greek: stream, flows SW $14 \mathrm{mi}$. to Meshik River, $16 \mathrm{mi}$. SW of Vent Mtn., in Aniakchak Crater, Bristol Bay Low.; 56 ${ }^{\circ} 42^{\prime}$ $\mathrm{N}, 158^{\circ} 25^{\prime} \mathrm{W}$; (map 30$)$.

So named in 1923 by R. H. Sargent, USGS, because of "the numerous bear encountered ***" here.

Pleveznie: lake, see Tazlina Lake

Plies, Islas des: island, see Sanak Island.

Plishnie Ostrova: islands, see Near Islands.

Plooma Island: island, see Pluma Island.

Plotnikof Lake: lake, $4 \mathrm{mi}$. long, $4 \mathrm{mi}$. E of Whale Bay, on $\mathrm{S}$ central Baranof I., Alex. Arch.; $56^{\circ} 34^{\prime} 00^{\prime \prime} \mathrm{N}, 134^{\circ} 53^{\prime} 30^{\prime \prime} \mathrm{W}$; $B G N$ 1935; (map 5). Var. Lake Plotnikof.

Named in 1935 by USFS "for Abrossin Plotnikof, one of the survivors of the Sitka massacre of 1802."

Plover Islands: barrier Islands, on Beaufort Sea coast, extend SE $35 \mathrm{mi}$. from Plover Point to Mackay Inlet, Arctic Plain; $71^{\circ} 15^{\prime} \mathrm{N}, 155^{\circ} 30^{\prime}$ W; (map 153). Var. Plovers Group.

Named "Plovers Group" in 1850 by Comdr. Thomas E. L. Moore, RN, after his ship the H.M.S. Plover, and originally applied to the islands NW of Ekilukruak Entrance (Leffingwell, 1919, p. 77).

Plover Lake: lake, $0.8 \mathrm{mi}$. long, on Kenai Penin., NW of Killdeer Lake, $13 \mathrm{mi}$. NNE of Kenai, Cook Inlet Low.; $60^{\circ} 43^{\prime} 30^{\prime \prime} \mathrm{N}, 151^{\circ} 02^{\prime} 30^{\prime \prime}$ W; (map 62).

Named about 1963 by officials of Kenai National Moose Range, for administrative purposes.

Plover Point: point of land, at end of spit extending SE from Point Barrow, forming W side of Eluitkak Entrance, between Elson Lagoon and Beaufort Sea, Arctic Plain; $71^{\circ} 21^{\prime}$ $40^{\prime \prime} \mathrm{N}, 156^{\circ} 21^{\prime} 28^{\prime \prime} \mathrm{W}$; (map 153).

Named by British Admiralty for the H.M.S. Plover which wintered near the point of land 
in 1852-54, and published on master Thomas Hull's 1853 map.

Plover Rock: rock, between Middle and South Arms Kelp Bay, on NE coast of Baranof I., 11 mi. SE of Todd, Alex. Arch.; $57^{\circ} 19^{\prime} \mathrm{N}, 134^{\circ}$. $56^{\prime} \mathrm{W}$; (map 9).

Named by Lt. Comdr. Moore, USN, and published by USC\&GS in the 1901 Coast Pilot (p. 160).

Plovers Group: barrier islands, see Plover Islands.

Pluma Island: island, $0.2 \mathrm{mi}$. across, $12.5 \mathrm{mi}$. NW of Chichagof, on $W$ coast of Chichagof I., Alex. Arch.; $57^{\circ} 47^{\prime} 35^{\prime \prime}$ N, $136^{\circ} 19^{\prime} 40^{\prime \prime}$ W ; (map 9). Var. Plooma Island.

Published as "Plooma" by the USC\&GS in the 1925 Coast Pilot (p. 322) and as "Pluma" in 1928 on Chart 8258. It may be the Spanish word meaning "feather."

Plumb Bob Lake: lake, $0.6 \mathrm{mi}$. long, $\mathrm{S}$ of Glenn Highway, $13 \mathrm{mi}$. W of Glennallen, Copper River Basin; 62 ${ }^{\circ} 06^{\prime} \mathrm{N}, 145^{\circ} 57^{\prime} \mathrm{W}$; (map 83). Var. Plum Bob Lake.

Local name reported in 1951 by USGS. So named because its outline resembles a plumb bob, a metal weight for a plumb line used to determine verticality.

Plum Bob Lake: lake, see Plumb Bob Lake.

Plume Creek, stream, see Flume Creek.

Plum Island: island, 40 yds. across, $W^{\prime}$ of Ringgold I., Bay of Is., Adak I., Aleutian Is.; $51^{\circ} 48^{\prime} 34^{\prime \prime} \mathrm{N}, 176^{\circ} 50^{\prime} 35^{\prime \prime} \mathrm{W}$; BGN 1936; (map 17).

Named by members of the U.S. Navy Aleutian Island Survey Expedition in 1934, "for Plum Island in Long Island Sound, N.Y."

Plummer, Mount: mountain, 3,768 ft., $70 \mathrm{mi}$. NE of Bethel, in Kilbuck Mts., Kilbuck-Kuskokwim Mts. ; $60^{\circ} 58^{\prime} \mathrm{N}, 159^{\circ} 40^{\prime} \mathrm{W}$; (map 59).

Local name reported in 1914 by A. G. Maddren (in Brooks, 1915, pl. 11), USGS.

Plunge Creek: stream, flows NE $10 \mathrm{mi}$. to Tupikchak Creek, $46 \mathrm{mi}$. NNW of Misheguk Mtn., Arctic Slope; $68^{\circ} 44^{\prime} \mathrm{N}, 161^{\circ} 23^{\prime} \mathrm{W}$; (map 131).

Named by USGS geologists "in 1950 because of its location near the west end of the plunging anticline" (Chapman and Sable, 1960 , p. 54).

Pluvezna, Lake: lake, see Tazlina Lake.

Poa Island: island, $0.7 \mathrm{mi}$. long, $1 \mathrm{mi}$. SE of Akun I., Krenitzen Is., Aleutian Is.; $54^{\circ} 07^{\prime} 45^{\prime \prime}$ $\mathrm{N}, 165^{\circ} 29^{\prime} 50^{\prime \prime} \mathrm{W}$; (map 24). Var. Foggy Island, Tumannoi Island.

Named in 1888 by USBF for a genus of grasses. Capt. Tebenkov (1852, map 26), IRN, called it "O[strov] Tumannoi," meaning "foggy island."

Pocahontas Creek: stream, flows SW $17 \mathrm{mi}$. to Mathews Slough, $30 \mathrm{mi}$. NE of Hochandochtla Mtn., Kokrines-Hodzana High.; $65^{\circ} 5^{\prime}$ '$50^{\prime \prime} \mathrm{N}, 154^{\circ} 21^{\prime} 30^{\prime \prime} \mathrm{W}$; (map 107).

Prospectors' name reported in 1913 by Eakin (1916, pl. 2), USGS.

Pochnoi Point: point of land, $\mathrm{E}$ tip of Semisopochnoi I., Aleutian Is.; $51^{\circ} 58^{\prime} 30^{\prime \prime}$ N, $179^{\circ}$ 45'30' E; BGN 1937; (map 15).
"Pochonoi" is part of the island name "Semisopachnoi," and was published on a 1935 chart of the U.S. Navy Hydrog. Office.

Pocket Island: island, $1.5 \mathrm{mi}$. long, at $\mathrm{S}$ end of Frederick Sound, $17 \mathrm{mi}$. SE of Petersburg, Coast Mts.; $56^{\circ} 40^{\prime} \mathrm{N}, 132^{\circ} 35^{\prime} \mathrm{W}$; (map 6).

Named in 1887 by Lt. Comdr. G. M. Thomas, USN, for charting purposes; name published in 1888 on USC\&GS Chart 705.

Poder Island: island, $0.3 \mathrm{mi}$. long, on $\mathrm{E}$ shore of Seldovia Bay, $1 \mathrm{mi}$. SSW of Seldovia, Chugach Mts.; $59^{\circ} 25^{\prime} 30^{\prime \prime} \mathrm{N}, 151^{\circ} 42^{\prime} 30^{\prime \prime} \mathrm{W}$; (map 50).

Name reported by USC\&GS in 1908.

Podsopochni Bay: bay, $1.5 \mathrm{mi}$. across, on $\mathrm{N}$ coast of Atka I., Aleutian Is.; $52^{\circ} 04^{\prime} 30^{\prime \prime} \mathrm{N}, 174^{\circ}$ $59^{\prime} 00^{\prime \prime} \mathrm{W}$; (map 18)

Named for Podsopchni Point; published by the USC\&GS in the 1944 Aleutian Coast Pilot (p. 97)

Podsopochni Cape: point of land, see Podsopochni Point.

Podsopochni Point: point of land, on NE coast of Atka I., Aleutian Is.; 52 $05^{\prime} \mathrm{N}, 174^{\circ} 57^{\prime} \mathrm{W}$; (map 18). Var. Podsopochni Cape.

Russian name, meaning "under the peak [Mount Sergief]," published as "Podsopotchnoi Cap," or "Cape Podsopotchnoi" by Capt. Lutke (1836, p. 315), IRN. Published as "Podsopochni Point" by the USC\&GS in 1944 Aleutian Coast Pilot (p. 97).

Poe Bay: estuary, $0.5 \mathrm{mi}$. wide, extends S 0.8 mi. to Passage Canal, $7 \mathrm{mi}$. NE of Whittier, Chugach Mts.; $60^{\circ} 49^{\prime} 40^{\prime \prime} \mathrm{N}, 148^{\circ} 30^{\prime} 20^{\prime \prime} \mathrm{W}$; BGN 1915; (map 63).

Named in 1914 by USC\&GS "in honor of the poet, Edgar. Allen Poe, 1809-49."

Poe Glacier: glacier, see Seth Glacier.

Poe Island: island, $200 \mathrm{ft}$. across, northernmost island of Barrier Is., in Cordova Bay, Alex. Arch.; $54^{\circ} 49^{\prime} 50^{\prime \prime} \mathrm{N}, 132^{\circ} 26^{\prime} 20^{\prime \prime} \mathrm{W}$; (map 1).

Local name reported in 1951 by USGS.

Pogakhluk Lake: lake, see Amanka Lake.

Pogibshi, Point: point of land, on SW end of Kenai Penin. $6 \mathrm{mi}$. WSW of Seldovia, Chugach Mts.; $59^{\circ} 25^{\prime} 30^{\prime \prime}$ N, $151^{\circ} 53^{\prime} 00^{\prime \prime} \mathrm{W}$; (map 50).

Russian name meaning "perilous" and published by USC\&GS in 1943 (Chart 8554).

Pogibshi Channel: water passage, see Peril Strait.

Pogibshi Island: island, see Near Island

Pogibshi Point: point of land, at SW end of Deadman Reach, on $W$ coast of Duffield Penin., on N coast of Baranof I., Alex. Arch.; $57^{\circ} 30^{\prime} 30^{\prime \prime} \mathrm{N}, 135^{\circ} 33^{\prime} 00^{\prime \prime} \mathrm{W} ; B G N$ 1897; (map 9). Var. Danger Point, Mys Pogibshiy, Peril Point.

Russian name meaning "perilous," given in 1833 by the navigator Ens. Vasiliev; published in 1848 on Russian Hydrog. Dept. Chart 1397 as "M[ys] Pogibshiy."

Pogibshi Straits: water passage, see Peril Strait. Pogibshiy, Mys: point of land, see Pogibshi Point. Pogibshiy, Proliv: water passage, see Peril Strait. Pogik Bay: bay, $3.5 \mathrm{mi}$. across, on coast of Beaufort Sea, $6 \mathrm{mi}$. E of Pitt Point, Arctic Plain; $70^{\circ} 53^{\prime} \mathrm{N}, 152^{\circ} 51^{\prime} \mathrm{W}$; (map 149).
Eskimo name reported in 1950 by USC\&GS referring to the "white belly fur of the caribou."

Pogik Point: point of land, on coast of Beaufort Sea, W tip of an island at mouth of Pogik Bay, $6 \mathrm{mi}$. E of Pitt Point, Arctic Plain; $70^{\circ} 54^{\prime} 35^{\prime \prime}$ N, $152^{\circ} 53^{\prime} 30^{\prime \prime}$ W; (map 149). Var. Ellice Point, Pogit Point.

Eskimo name reported in 1950 by USC\&GS, referring to the "white belly fur of the caribou." This feature appears to be the "Ellice Point" shown on the map of P. W. Dease and Thomas Simpson (Simpson, 1843, p. 134), named for "The Right Honourable Edward Ellice * * *"

Pogit Point: point of land, see Pogik Point.

Pogoobnoy Strait: water pássage, see Peril Strait.

Pogopuk Creek: stream, heads SW of Mount Salisbury, flows N $24 \mathrm{mi}$. to Kavik River, 55 mi. W of Mount Michelson, Arctic Slope; $69^{\circ} 23^{\prime} \mathrm{N}, 146^{\circ} 30^{\prime} \mathrm{W}$; (map 139).

Named in the 1950's by USGS geologists. Pogoreshapka: locality, on right bank of Yukon River about $20 \mathrm{mi}$. below Holy Cross, Innoko Low.; $62^{\circ} 00^{\prime} \mathrm{N}, 160^{\circ} 03^{\prime} \mathrm{W}$; (map 73). Var. Dagorashapka, Gagara-Shapka.

Eskimo village or camp reported with a population of 121 by Petroff in the 1880 Census (1884, p. 12). W. H. Dall gave "Gagara-Shapka" as the Russian name, meaning "loon cap" for the village where the natives made birdskin caps "(for which Pogoreshapka [burnt hat] is a mistake)" (Hodge, 1910 , p. 272). "Dagorashapka" was the name applied in 1869 to a nearby mountain by Capt. C. W. Raymond, U.S. Engineers.

Pogoseluk Hill: hill, $1.5 \mathrm{mi}$. SE of Tusikpok Lagoon and $19 \mathrm{mi}$. NW of Kivalina, Kotzebue-Kobuk Low.; $67^{\circ} 55^{\prime} \mathrm{N}$, $165^{\circ} 01^{\prime} \mathrm{W}$; (map 128). Var. Paugausailuk Hill, Powgowsayluk.

Eskimo name meaning "old bag"; so called because the hill resembles an old poke, "no longer watertight, but useful to carry things." Name reported in 1966 by E. S. Burch.

Pogromnaya, Mys: point of land, see Cave Point.

Pogromni: locality, on $\mathrm{N}$ shore of Unimak $\mathbf{I}$. near Pogromni Volcano, Aleutian Is.; $54^{\circ} 40^{\prime}$ N, 164 $45^{\prime} \mathrm{W}$; (map 24). Var. Pogramnoi.

Russian name, meaning "desolation," of a former Aleut village or camp reported in 1828 by Capt. F. P. Lutke, IRN.

Pogromnia: volcano, see Pogromni Volcano.

Pogromni River: stream, flows N $12 \mathrm{mi}$. to Bering Sea, $3.5 \mathrm{mi}$. SW of Cave Point, NW coast of Unimak I., Aleutian Is.; $54^{\circ} 44^{\prime} 30^{\prime \prime} \mathrm{N}$,

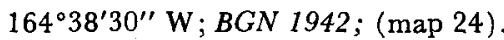

Russian name meaning "desolation" given by USC\&GS in 1940, "because it drains an area south of Pogromni Volcano and because the former village called Pogromni was at its mouth."

Pogromni Volcano: volcano, $6,568 \mathrm{ft}$., on SW end of Unimak I., Aleutian Is.; 54 $34^{\prime} 15^{\prime \prime} \mathrm{N}$, $164^{\circ} 41^{\prime} 25^{\prime \prime} \mathrm{W}$; BGN 1899; (map 24). Var. Devastation Volcano, Isanotskoi, Kugidach 
Jagutscha, Pogromnia, Pogromnoi Volcan, Pogromskaia, Pogrumnoj.

According to the 1883 Coast Pilot (p. 323) the name was published in 1836 by Capt. F. P. Lutke, IRN, as "Pogromnoi Volcan". Shown on Russian Hydrog. Dept. Chart 1379, dated 1847 , as "Sopka Pogromnaya," meaning "desolation peak." Its Aleut name, according to Grewingk (1850, p. 177) is "Kugidach Jagutscha."

Pogromnoi: locality, see Pogromni.

Pogromnoi: point of land, see Cave Point.

Pogromnoi First: point of land, see Sarichef Cape.

Pogromnoi Second: point of land, see Cave Point.

Pogromnoi Volcan: volcano, see Pogromni Volcano.

Pogromskaia: volcano, see Pogromni Volcano. Pogrumnoj: volcano, see Pogromni Volcano.

Point Agassiz Peninsula: peninsula, extends NW SE $7 \mathrm{mi}$. into Frederick Sound, $12 \mathrm{mi}$. NE of Petersburg, Coast Mts.; 56 $58^{\circ}$ N, $132^{\circ} 53^{\prime} \mathrm{W}$; (map 6).

Named by USC\&GS for charting purposes; name published in 1925 Coast Pilot (p. 211).

Point Baker: village, pop. 38, on offshore island off NW tip of Prince of Wales I., on Sumner Strait, Alex. Arch.; 56 $21^{\prime} 15^{\prime \prime} \mathrm{N}, 133^{\circ} 37^{\prime} 15^{\prime \prime}$ W; (map 6).

Fishing and logging village. The Point Baker post office was established in 1942 (Ricks, 1965, p. 52).

Point Creek: stream, flows NW $4.5 \mathrm{mi}$. to Norton Sound, $6.4 \mathrm{mi}$. NE of Tolstoi Point and $13 \mathrm{mi}$. SW of Unalakleet, Nulato Hills; $63^{\circ}$ $41^{\prime} 25^{\prime \prime} \mathrm{N}, 160^{\circ} 52^{\prime} 05^{\prime \prime} \mathrm{W}$; (map 91).

Local name reported in 1952 by USC\&GS.

Pointed Rock: rock, at S end of Patton Bay, off Montague I., $75 \mathrm{mi}$. SE of Seward, Chugach Mts.; $59^{\circ} 54^{\prime} 10^{\prime \prime} \mathrm{N}, 147^{\circ} 26^{\prime} 30^{\prime \prime} \mathrm{W}$; (map 49).

Local name reported in the early 1950's by USC\&GS.

Point Ellis Creek: stream, see Kutlaku Creek.

Point Ellis Lake: lake, see Kutlaku Lake.

Point Highfield, Anchorage off : anchorage, see Highfield Anchorage.

Point Highfield Harbor: anchorage, see Highfield Anchorage.

Point Hope: village, pop. 324, on foreland terminating at Point Hope on Chukchi Sea coast, Arctic Slope; $68^{\circ} 21^{\prime} \mathrm{N}, 166^{\circ} 47^{\prime} \mathrm{W} ; B G N$ 1947; (map 129). Var. Figarok, Hope, Teekee-voga-meuts, Tiekagamiut, Tigara, Tigarak, Tigera, Tikarakh, Tikeh, Tikek, Tikera, Tikeramiut, Tikerana, Tikeranmeun, Tikiqaq, Tikira, Tikirah, Tikirahmun, Tikirak, Tikirat, Tikkerak, Tkok, Ttiekigakg, Ttikigakg.

Eskimo village locally referred to as "Tikiqaq" or "Tikarakh," but because of the post office name, the place is more commonly referred to as "Point Hope". The Eskimo name, recorded in 1861 as "Tiekagagmiut" by P. Tikhmeniev, which on Russian Hydrog. Dept. Chart 1495, becomes "Tiekaga", is derived from the Eskimo name for the point of land, which means "forefinger". This ancient vil- lage site was advantageous, because the protrusion of Point Hope into the sea brought the whale close to shore. The 1880 Census gave the population as 276. See Hope, Point and Ipiutak.

Point Lake: lake, $0.5 \mathrm{mi}$. across, on Kenai Penin., on E shore of Tustumena Lake, $30 \mathrm{mi}$. $\mathrm{SE}$ of Kenai, Cook Inlet Low.; $60^{\circ} 11^{\prime} \mathrm{N}$, $150^{\circ} 45^{\prime} \mathrm{W}$; (map 62).

Named about 1963 by officials of Kenai National Moose Range, for administrative purposes.

Point Lay: village, pop. 20, on barrier bar, along Chukchi Sea coast, at Point Lay, $43 \mathrm{mi}$. SW of Icy Cape, Arctic Plain; $69^{\circ} 45^{\prime} 45^{\prime \prime} \mathrm{N}, 163^{\circ}$ 03'00' W; (map 145). Var. Kalee, Kali, Point Lay Village.

The Eskimo name (Kali) for this village means "mound," which refers to the elevated area the village is located on. This is probably the remaining village of the so-called Kukpowruk people. See Kukpowruk.

Point Lay Village: village, see Point Lay.

Point Lockwood Rock: rock, in Wrangell Narrows, $18 \mathrm{mi}$. S of Petersburg, between Woewodski and Sumner Is., Alex. Arch.; 56 $34^{\prime}$ $\mathrm{N}, 132^{\circ} 58^{\prime} \mathrm{W}$.

Local name used by fishermen; name published in 1901.

Point No Point: point of land, on $\mathrm{S}$ shore of Yukon River, $\mathrm{N}$ of Chicago Lakes, $12 \mathrm{mi}$. NNE of Rampart, Yukon-Tanana High.; 65 $40^{\prime} 30^{\prime \prime}$ $\mathrm{N}, 150^{\circ} 02^{\prime} 00^{\prime \prime} \mathrm{W}$; (map 130).

Riverboat pilots' descriptive name for this long round inside shore of the river bend. Name shown on a manuscript track chart of the Yukon River dated 1900

Point of Rocks: rocks, group of, in Knight Island Passage, off $\mathrm{W}$ coast of Squire I., $6 \mathrm{mi}$. SE of Chenega, Chugach Mts.; $60^{\circ} 14^{\prime} 59^{\prime \prime} \mathrm{N}, 147^{\circ}$. 57'45" W; BGN 1908; (map 63).

Descriptive name reported in 1908 by USC\&GS.

Point of Shoals: point of land, see Shoals Point. Point Pybus: point of land, see False Point Pybus.

Point Salisbury: point of land, see Bishop Point.

Point Shallow-Water: point of land, see Romanof Point.

Point Whitshed: locality, on Point Whitshed, 8 mi. SW of Cordova, Chugach Mts.; 60 $0^{\circ} 12^{\prime} \mathrm{N}$, $145^{\circ} 54^{\prime} \mathrm{W}$; (map 64).

Name of a settlement listed in U.S. Census.

Poison Cove: cove, $0.6 \mathrm{mi}$. across, $7 \mathrm{mi}$. S of Hoonah Sound, on S coast of Chichagof I., $22 \mathrm{mi}$. SE of Chichagof, Alex. Arch.; 57 $31^{\prime}$ $15^{\prime \prime} \mathrm{N}, 135^{\circ} 35^{\prime} 00^{\prime \prime} \mathrm{W}$; (map 9).

Named in 1869 by Comdr. R. W. Meade, USN, and published by USC\&GS in the 1883 Coast Pilot (p. 163). This name was given because "near here 150 Aleuts were killed in 1799 from eating poisonous mussels."

Poison Creek: stream, flows SW 16 mi. to Stink Creek $0.6 \mathrm{mi}$. NW of its junc. with Yukon River, $24 \mathrm{mi}$. SW of Kaltag and $56 \mathrm{mi}$. $\mathrm{E}$ of Unalakleet, Nulato Hills; $63^{\circ} 59^{\prime} 20^{\prime \prime} \mathrm{N}, 158^{\circ}$ $57^{\prime} 10^{\prime \prime}$ W ; (map 90).

Local name reported in 1954 by USGS.
Poison Creek: stream, see Thayer Creek. Pokang Bay: bay, see Pokok Bay.

Pokang Creek: stream, see Pokok Creek.

Pokatago Utesu, Mys: point of land, see Pokati Point.

Pokati Point: point of land, on S shore of Whale Passage, $18 \mathrm{mi}$. NW of Kodiak, on $\mathrm{N}$ coast of Kodiak 1.; $57^{\circ} 55^{\prime} 50^{\prime \prime} \mathrm{N}, 152^{\circ} 50^{\prime} 50^{\prime \prime} \mathrm{W}$; (map 34). Var. Mys Pokatago Utesu.

Named "M[ys] Pokatago Utesu," meaning "cape of rolling rocks," by Sub-Lt. Mikhail Murashev in 1839 or 1840 and published in 1849 on Russian Hydrog. Dept. Chart 1425. The name was changed to its present form in 1909 by USC\&GS

Poker, Point: point of land, $\mathrm{N}$ of Sarana Bay, Attu I., Aleutian Is.; 52 $53^{\prime} 47^{\prime \prime} \mathrm{N}, 173^{\circ} 18^{\prime}$ $10^{\prime \prime} \mathrm{E}$; (map 13 ).

Named by the U.S. Army during its occupation of the island during World War II; shown on an AMS map published in 1948.

Poker Creek: locality, at junc. of Davis and Poker Creeks, $52 \mathrm{mi}$. S of Eagle, Yukon-Tanana High.; $64^{\circ} 03^{\prime} 30^{\prime \prime} \mathrm{N}, 1^{\circ} 141^{\circ} 02^{\prime} 50^{\prime \prime} \mathrm{W}$; (map 102).

Mining camp reported in 1925 by ARC.

Poker Greek: stream, heads on W slope of Explorer Mtn., flows $5 \mathrm{mi}$. SW to Sphinx Creek, $5 \mathrm{mi}$. NW of Goodnews, Kilbuck-Kuskokwim Mts.; $59^{\circ} 11^{\prime} \mathrm{N}, 161^{\circ} 38^{\prime} \mathrm{W}$; (map 53).

Name reported in 1919 on a manuscript map by J. E. Spurr and W. S. Post, USGS.

Poker Creek: stream, flows N $9 \mathrm{mi}$. to Norton Sound, $2.7 \mathrm{mi}$. NE of Tolstoi Point and $17 \mathrm{mi}$. SW of Unalakleet, Nulato Hills; $63^{\circ} 38^{\prime} 45^{\prime \prime}$ $\mathrm{N}, 160^{\circ} 56^{\prime} 00^{\prime \prime} \mathrm{W}$; (map 91).

Local name reported in 1906 by USGS.

Poker Creek: stream, flows NW $2 \mathrm{mi}$. to Nenana River, $2.5 \mathrm{mi}$. NW of Healy, Alaska Ra.; $63^{\circ}$ $53^{\prime} 30^{\prime \prime} \mathrm{N}, 148^{\circ} 59^{\prime} 00^{\prime \prime} \mathrm{W}$; (map 87).

Local name reported in 1950 by USGS.

Poker Creek: stream, heads in Canada, flows W 3 mi. to join Davis Creek to form Walker Fork, $52 \mathrm{mi}$. S of Eagle, Yukon-Tanana High.; $64^{\circ}$ $03^{\prime} 30^{\prime \prime} \mathrm{N}, 141^{\circ} 02^{\prime} 50^{\prime \prime} \mathrm{W}$; (map 102). Var. Parker Creek.

Named by prospectors and reported in 1896 by Spurr (1898, pl. 46), USGS. "In 1899 Poker Creek and the headwaters of Walker Fork were staked out in claims" (p. 116).

Poker Creek: stream, flows SE $10 \mathrm{mi}$. to Chatanika River, $20 \mathrm{mi}$. NE of Fairbanks, YukonTanana High.; $65^{\circ} 08^{\prime} 15^{\prime \prime} \mathrm{N}, 147^{\circ} 28^{\prime} 40^{\prime \prime} \mathrm{W}$; (map 105).

Named by prospectors; published in 1906 by USGS.

Pokoinaia Bay: estuary, see Quiet Harbor.

Pokoinay Bay: estuary, see Quiet Harbor.

Pokok: locality, site of Eskimo camp on coast of Beaufort Sea, believed to have been located on Pokok Lagoon, Arctic Plain; (map 152).

The Eskimo name "Pokang" is shown in this area on John Simpson's native map, 1853, as the farthest point seen by the Point Barrow natives. Leffingwell (1919, p. 98), places the name "Pokok" between Points Humphreys and Griffin. The present-day Eskimo at Barter 
I. say the village was once located at the $E$ end of Pokok Lagoon.

Pokok Bay: bay, 2 mi. across, on Beaufort Sea coast, $\mathrm{W}$ of Point Humphrey and $35 \mathrm{mi}$. NW of Demarcation Point, Arctic Plain; 69 $59^{\prime}$ N, 142 $32^{\prime}$ W; (map 138). Var. Humphrey Bay, Pokang Bay, Pokok Lagoon.

Leffingwell (1919, p. 98) named and described this bay as being between Points Humphreys and Griffin; named for Pokok, a village once located on nearby Pokok Lagoon.

Pokok Bay: lagoon, see Pokok Lagoon

Pokok Creek: stream, flows $2 \mathrm{mi}$. N to Pokok Lagoon, $20 \mathrm{mi}$. SE of Barter I., Arctic Plain; $70^{\circ} 02^{\prime} 30^{\prime \prime} \mathrm{N}, 142^{\circ} 45^{\prime} 30^{\prime \prime} \mathrm{W}$; (map 152). Var. Pokang Creek.

Local Eskimo name reported by USC\&GS in 1952.

Pokok Lagoon: lagoon, $1.5 \mathrm{mi}$. long, on coast of Beaufort Sea, at mouth of Pokok Creek, NW of Pokok Bay, $20 \mathrm{mi}$. SE of Barter I., Arctic Plain; $70^{\circ} 02^{\prime} 45^{\prime \prime} \mathrm{N}, 142^{\circ} 46^{\prime} 00^{\prime \prime} \mathrm{W}$; (map 152). Var. Pokang Bay, Pokok Bay.

Local name reported by USC\&GS in 1948. Present-day tradition among the Eskimo at Barter I. is that the village of Pokok was once located at the east end of this lagoon.

Pokok Lagoon: bay, see Pokok Bay.

Poko Mountain: mountain, 3,243 ft., in De Long Mts., $12.5 \mathrm{mi}$. ENE of Igloo Mtn., W of junc. of Tingmerkpuk and Kokolik Rivers, $39 \mathrm{mi}$. NE of Mount Kelly, Brooks Ra.; $68^{\circ}-$ $48^{\prime} 30^{\prime \prime} \mathrm{N}, 162^{\circ} 23^{\prime} 00^{\prime \prime} \mathrm{W}$; (map 130).

Named by USGS, shown on 1926 fieldsheet by Gerald FitzGerald, USGS. According to P. S. Smith's, USGS, notes it means "seal poke" (Chapman and Sable, 1960, p. 54).

Pokoynaya, Gavan: estuary, see Quiet Harbor.

Poktovik Creek: stream, heads in Poktovik Mts., flows $S 8 \mathrm{mi}$. to Noatak River, $17 \mathrm{mi}$. SSW of Misheguk Mtn., Brooks Ra.; $68^{\circ} 00^{\prime} \mathrm{N}$, $161^{\circ} 14^{\prime} \mathrm{W}$; (map 131).

Eskimo name reported by USGS in 1956.

Poktovik Mountains: mountains, 3,526 ft., in De Long Mts., extend E-W $14 \mathrm{mi}$., $10 \mathrm{mi}$. S of Misheguk Mtn., Brooks Ra.; $68^{\circ} 05^{\prime} \mathrm{N}, 161^{\circ}$ 15' W; (map 131).

Eskimo name obtained at Noatak by Orth in 1956.

Polaraskh-mute: locality, in vicinity of Cape York, on Bering Sea coast, about $35 \mathrm{mi}$. NW of Teller, Seward Penin. High.; (map 111). Var. Pelazuk.

Site of an Eskimo village or camp reported to have been visited in 1886 by Capt. D. B. Libby and M. W. Harrington, of the Western Union Telegraph Exploration. This may have been the village later known as "Pelazuk."

Polar Bear Creek: stream, $2 \mathrm{mi}$. long, flows NW to Fork Creek, $13.5 \mathrm{mi}$. NW of Heart Lake and $72 \mathrm{mi}$. SE of Bethel, Kilbuck-Kuskokwim Mts.; $60^{\circ} 12^{\prime} 10^{\prime \prime} \mathrm{N}, 160^{\circ} 01^{\prime} 00^{\prime \prime} \mathrm{W}$; (map $59)$.

Local name reported in 1955 by J. M. Hoare, USGS.

Polar Bear Creek: stream, flows NE $6 \mathrm{mi}$. to Cripple River, $26 \mathrm{mi}$. NW of Imuruk Lake,
Seward Penin. High.; $65^{\circ} 56^{\prime} \mathrm{N}, 163^{\circ} 41^{\prime} \mathrm{W}$; (map 110).

Prospectors' name reported in 1901 by USGS (Collier, 1902, pl. 12).

Polar Bear Mountain: mountain, see Polar Bear Peak.

Polar Bear Peak: mountain, 6,955 ft., at head of South Fork Eagle River, $21 \mathrm{mi}$. E of Anchorage, Chugach Mts.; $61^{\circ} 09^{\prime} 10^{\prime \prime} \mathrm{N}, 149^{\circ}$. $11^{\prime} 45^{\prime \prime}$ W; BGN 1966; (map 69). Var. Polar Bear Mountain.

So named in 1963 by members of the Mountaineering Club of Alaska because "the peak has a snow patch on its North face that resembles a polar bear skin."

Polar Bear Peak: peak, see Eagle Peak.

Polar Creek: stream, flows SW $1 \mathrm{mi}$. to Sourdough Creek, 9.5 mi. NW of Mount Ryan and $76 \mathrm{mi}$. SW of Circle, Yukon-Tanana High.; $65^{\circ} 20^{\prime} 45^{\prime \prime} \mathrm{N}, 146^{\circ} 27^{\prime} 50^{\prime \prime} \mathrm{W}$; (map 104).

Prospectors' name reported in 1954 or 1955 by USGS topographers.

Polar Creek: stream, flows NE $1.4 \mathrm{mi}$. to Bear Creek, $25 \mathrm{mi}$. N of Haycock, Seward Penin. High.; $65^{\circ} 34^{\prime} \mathrm{N}, 161^{\circ} 06^{\prime} \mathrm{W}$; (map 109). Var. Poplar Creek.

Local name shown on a 1903 fieldsheet by D. C. Witherspoon, USGS.

Polar Creek: stream, flows NW to Kuzitrin River, downstream from mouth of Noxapaga River, about $15 \mathrm{mi}$. NW of Mount Bendeleben, Seward Penin. High.; (map 110)

Prospectors' name shown on a map of Cape Nome gold fields by David Fox, Jr., dated 1901. This stream cannot be precisely located on current maps.

Polar Creek: stream, flows W to Kougarok River between Galvin and Louise Creeks, about $17 \mathrm{mi}$. S of Midnight Mtn. and $45 \mathrm{mi}$. SW of Imuruk Lake, Seward Penin. High.; (map 110)

Prospectors' name shown on a map of Cape Nome gold fields by David Fox, Jr., dated 1901. This stream cannot be precisely located on current maps.

Polavina: rookery, see Polovina Rookery.

Polavina Hill: hill, see Polovina Hill.

Polavina Lake: lake, see Polovina Lake.

Polavina Point: point of land, see Halfway Point.

Polavina Sopka: hill, see Polovina Hill.

Pole, Cape: point of land, on SW coast of

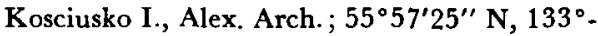
$49^{\prime} 00^{\prime \prime} \mathrm{W}$; (map 4).

Named on September 22, 1793, by Capt. George Vancouver, RN, for Capt. Charles Morice Pole, RN (Wagner, 1937, p. 402)

Poleakoon, Point: point of land, on coast of Beaufort Sea, on SE shore of Smith Bay, Arctic Plain; $70^{\circ} 49^{\prime} \mathrm{N}, 154^{\circ} 01^{\prime} \mathrm{W}$; (map 148). Var. Point Poleakun.

Eskimo name shown on Maguire's chart (Great Britain, 1854, facing p. 186). Leffingwell (1919, p. 98) spells it Poleakun.

Poleakun, Point: point of land, see Poleakoon, Point.
Pole Anchorage: bay, $0.6 \mathrm{mi}$. long, $W$ of Fishermans Harbor, SW coast of Kosciusko I., Alex. Arch.; 55 58' N, $133^{\circ} 49^{\prime} \mathrm{W}$; (map 4).

Local name published in 1901 by USC\&GS ; derived from Cape Pole.

Pole Island: barrier island, $2.5 \mathrm{mi}$. long, on Beaufort Sea coast, westernmost island of Stockton Is., $19.5 \mathrm{mi}$. NW of Flaxman I., Arctic Plain; $70^{\circ} 18^{\prime} 15^{\prime \prime} \mathrm{N}, 147^{\circ} 02^{\prime} 10^{\prime \prime} \mathrm{W}$; (map 150).

In 1910 Leffingwell (1919, p. 98) wrote, "This may not have been the original location, for there is no settled usage among the whalers." This island was named by whalers probably because a pole once was erected on its shore to identify the island.

Pole Point: point of land, on SW coast of Herbert Graves I., $5 \mathrm{mi}$. W of Chichagof, off W coast of Chichagof I., Alex. Arch.; 57 $39^{\prime} 40^{\prime \prime}$ N, 136 $13^{\prime} 45^{\prime \prime}$ W; (map 9).

Local name published by USC\&GS in the 1925 Coast Pilot (p. 319).

Poletica, Mount: pea.k, 7,620 ft., on AlaskaBritish Columbia boundary, $11 \mathrm{mi}$. SE of Mount Canning, $37 \mathrm{mi}$. SE of Skagway, Coast Mts. ; 59 $07^{\prime} 55^{\prime \prime} \mathrm{N}, 134^{\circ} 29^{\prime} 00^{\prime \prime} \mathrm{W}$; BGN 1923; (map 44). Var. Boundary Peak 102. Named in 1923 by Lawrence Martin for M. Pierre de Poletrica, Russian minister to the U.S. and a plenipotentiary in the Alaska boundary negotiations with Great Britain in 1824.

Politofski Lake: lake, $1.4 \mathrm{mi}$. long, $8 \mathrm{mi}$. NE of Whale Bay, on $\mathrm{S}$ central Baranof I., Alex. Arch.; $56^{\circ} 44^{\prime} 30^{\prime \prime} \mathrm{N}, 134^{\circ} 56^{\prime} 30^{\prime \prime} \mathrm{W}$; $B G N$ 1935; (map 5).

Named in 1935 by USFS "for one of the last ships built by the Russians at Sitka in 1863."

Polivnoi Rock: rock, between Umnak and Unalaska Is., Aleutian Is.; $53^{\circ} 16^{\prime} 00^{\prime \prime} \mathrm{N}, 167^{\circ} 57^{\prime}$ $48^{\prime \prime}$ W; (map 23). Var. Kamen Polivnoy.

Capt. Tebenkov (1852, map 26), IRN, published the Russian name as " $K$ [amen] Polivnoy" meaning "rock awash".

Polivnoi Rock: rock, see Midway Rock.

Polivnoi Rocks: rocks, three rocks in Woewodski Harbor, on SE coast of Admiralty Is., $26 \mathrm{mi}$. SE of Angoon, Alex. Arch.; $57^{\circ} 10^{\prime} 30^{\prime \prime} \mathrm{N}$, $134^{\circ} 15^{\prime} 00^{\prime \prime} \mathrm{W}$; (map 9). Var. Polivnoy Kamen, Polivnoy Rock.

Russian word meaning "washed over (awash)" given in 1838 by Capt. Lt. D. F. Zarembo. Name applied to the larger of the three rocks in 1848 on Russian Hydrog. Dept. Chart 1396; USC\&GS applied the name to all three rocks in 1891 Coast Pilot (p. 142).

Polivnoi Rocks: rock, see Surf Rock.

Polivnoy: rock, see Midway Rock.

Polivnoy Kamen: rocks, see Polivnoi Rocks.

Polivnoy Rock: rocks, see Polivnoi Rocks.

Polka Peninsula: peninsula, $0.4 \mathrm{mi}$. long, in Glacier Bay National Monument, $1.4 \mathrm{mi}$. NW of Point Villaluenga, on $\mathrm{N}$ shore of Grass Sound, $47 \mathrm{mi}$. NW of Hoonah, St. Elias Mts.; $58^{\circ} 13^{\prime} 50^{\prime \prime} \mathrm{N}, 136^{\circ} 42^{\prime} 30^{\prime \prime} \mathrm{W}$; BGN 1930; (map 10) 
Named by USC\&GS in 1929. The point of the peninsula is marked by triangulation station Shelf. The Russian word for shelf is "polka," the name given to the peninsula.

Polka Rock: rock, in Gulf of Alaska, $0.4 \mathrm{mi}$. W of Polka Penin. and $47 \mathrm{mi}$. NW of Hoonah, Glacier Bay National Monument, St. Elias Mts.; $58^{\circ} 13^{\prime} 45^{\prime \prime} \mathrm{N}, 136^{\circ} 43^{\prime} 10^{\prime \prime} \mathrm{W}$; $B G N$ 1930; (map 10). Var. Lone Rock.

Probably named in 1929 by USC\&GS. The name is derived from Polka Peninsula.

Polk Creek: stream, flows NW $2.5 \mathrm{mi}$. to head of Polk Inlet, on SE end of Prince of Wales I., Alex. Arch.; $55^{\circ} 19^{\prime} 00^{\prime \prime} \mathrm{N}, 132^{\circ} 27^{\prime} 35^{\prime \prime} \mathrm{W}$; (map 4).

Local name published in 1943 by USC\&GS. Polk Harbour: bay, see Wolk Harbor.

Polk Inlet: estuary, extends S 9 mi. from Skowl Arm Kasaan Bay, near center of Prince of Wales I., Alex. Arch.; $55^{\circ} 25^{\prime} \mathrm{N}, 132^{\circ} 28^{\prime} \mathrm{W}$; (map 4).

Named by local fishermen and reported in 1904 by H. C. Fassett, USBF.

Polk Island: island, $0.8 \mathrm{mi}$. long, in Clarence Strait, off SE coast of Prince of Wales I., Alex. Arch.; $55^{\circ} 00^{\prime} 30^{\prime \prime} \mathrm{N}, 131^{\circ} 58^{\prime} 45^{\prime \prime} \mathrm{W}$; (map 3).

Local navigators' name obtained in 1904 by H. C. Fassett, USBF.

Polk Point: point of land, in Highfield Anchorage, on $\mathrm{N}$ coast of Wrangell I., Alex. Arch.; $56^{\circ} 29^{\prime} 00^{\prime \prime} \mathrm{N}, 132^{\circ} 21^{\prime} 30^{\prime \prime} \mathrm{W}$; (map 6). Var. Rock Point.

Local name published in 1909 by USC\&GS ; "Rock Point" was reported to be in local use in 1904 by H. C. Fassett, USBF.

Pollard Gulch: ravine, trends $1.4 \mathrm{mi}$. NW to Copper Creek 3.5 mi. SE of its junc. with Dan Creek and $19 \mathrm{mi}$. SE of McCarthy, St. Elias Mts. ; $61^{\circ} 20^{\prime} 05^{\prime \prime} \mathrm{N}, 142^{\circ} 24^{\prime} 00^{\prime \prime} \mathrm{W}$; (map 67).

Local name obtained by USGS and published on maps since 1954.

Polly Creek: stream, flows SE $8.5 \mathrm{mi}$. to Cook Inlet, $1.9 \mathrm{mi}$. W of Redoubt Point and $45 \mathrm{mi}$. SW of Kenai, Aleutian Ra.; $60^{\circ} 17^{\prime} \mathrm{N}, 152^{\circ} 27^{\prime}$ $\mathrm{W}$; (map 62).

Name used by local prospectors; reported in 1920 by USGS.

Polly Creek: stream, flows NE $9 \mathrm{mi}$. to Fortymile River, $35 \mathrm{mi}$. SW of Eagle, YukonTanana High.; $64^{\circ} 18^{\prime} 25^{\prime \prime} \mathrm{N}, 141^{\circ} 26^{\prime} 20^{\prime \prime} \mathrm{W}$; (map 102). Var. Montana Creek.

Named by prospectors and reported in 1909 by L. M. Prindle, USGS; called Montana Creek in 1898 by E. C. Barnard, USGS.

Polly Island: island, $3.5 \mathrm{mi}$. long, in Yukon River $5 \mathrm{mi}$. NNE of Fox Point Island, Innoko Low.; $63^{\circ} 07^{\prime} \mathrm{N}, 159^{\circ} 45^{\prime} \mathrm{W}$; (map 91 ).

Riverboat pilots' name shown on a 1940 "Navigation Chart of the Tanana-Yukon Rivers" published by the U.S. Dept. of Interior.

Polnoi Island: island, see Brady Island.

Polocano, Point: point of land, on NE coast of San Fernando I., Alex. Arch.; 55 $32^{\prime} 25^{\prime \prime}$ N, $133^{\circ} 17^{\prime} 15^{\prime \prime} \mathrm{W}$; (map 4).

Local name published in 1943 by USC\&GS.
Polovina Cliffs Rookery: rookery, see Little Polovina Rookery.

Polovina Cliffs Rookery: rookery, see Polovina Rookery.

Polovina Hill: hill, $470 \mathrm{ft}$., on $\mathrm{E}$ coast of St. Paul I., in Pribilof Is.; $57^{\circ} 11^{\prime} 00^{\prime \prime}$ N, $170^{\circ} 11^{\prime}$ $30^{\prime \prime} \cdot \mathrm{W}$; (map 38). Var. Polavina Hill, Polavina Sopka, Poluvina Hill.

Russian name meaning "halfway" and taken from Halfway Point. It was published by USC\&GS in 1875 as "Poluvina Mountain" (Chart 886) and reported by H. W. Elliott, USGS, in 1881 as "Polavina Sopka". (sopochka), which means "halfway volcano."

Polovina Lake: lake, $0.4 \mathrm{mi}$. across, on $\mathrm{E}$ coast of St. Paul I., Pribilof Is.; $57^{\circ} 09^{\prime} 30^{\prime \prime} \mathrm{N}$, $170^{\circ} 11^{\prime} 30^{\prime \prime} \mathrm{W}$; (map 38). Var. Polavina Lake.

Name reported by Elliott (1881, p. 55). See Polovina Hill.

Polovina Point: point of land, see Halfway Point.

Polovina Rookery: rookery, at Halfway Point, on $\mathrm{E}$ coast of St. Paul I., in Pribilof Is.; $57^{\circ}$ $09^{\prime} 45^{\prime \prime} \mathrm{N}, 170^{\circ} 10^{\prime} 30^{\prime \prime} \mathrm{W}$; (map 38). Var. Polavina, Polovina Cliffs Rookery.

Elliott (1881, p. 164) writes "'Polavina,' meaning 'halfway,' so named because the point $* * *$ is nearly half-way between Novastoshnah and the village [St. Paul]." See Polovina Hill.

Polovina Sands: beach, $1 \mathrm{mi}$. long, between Tonki and Halfway Point, on SE coast of St. Paul I., Pribilof Is. ; $57^{\circ} 09^{\prime} 30^{\prime \prime}$ N, $170^{\circ} 11^{\prime} 30^{\prime \prime}$ W.; (map 38).

Local name reported in 1965 by USBF. See Polovina Hill.

Polovinnoi Point: point of land, see Halfway Point.

Polovinnoy, Mys: point of land, see Halfway Point.

Poltava Island: island, $1.3 \mathrm{mi}$. long, in Pacific Ocean, near entrance to Port Wrangell, on $\mathrm{S}$ coast of Alaska Penin., $37 \mathrm{mi}$. NE of Sutwil I., Aleutian Ra.; $57^{\circ} 00^{\prime} 30^{\prime \prime} \mathrm{N}, 156^{\circ} 28^{\prime} 30^{\prime \prime} \mathrm{W}$; (map 36). Var. Ostrov Poltava, Pultava Island, Pultawa Island.

Russian name given in 1832 by Ens. Vasiliev; published in 1836 by Capt. F. P. Lutke, IRN, as "O[strov] Poltava," meaning "Poltava Island."

Poltes Island: island, see Arbor Island.

Poltes Slough: stream, channel of Yukon River, extends $19 \mathrm{mi}$. N and $\mathrm{W}$ of Moonlight Point and Arbor I., NW of Marshall, Yukon-Kuskokwim Delta; $61^{\circ} 58^{\prime} \mathrm{N} 162^{\circ} 14^{\prime} \mathrm{W}$; (map 74).

Riverboat pilots' name. So named for "Capt. Otto Polte, a steamboat captain who died in Seattle about 1940," and reported on a fieldsheet by R. H. Sargent, USGS, dated 1916.

Poludennie, Mys: point of land, see Noon Point. Poluostrov, Mys: point of land, see Sabak, Cape. Poluvina Hill: hill, see Polovina Hill.

Polychrome Glacier: glacier, $2 \mathrm{mi}$. long, $6 \mathrm{mi}$. SE of Polychrome Mtn. and $40 \mathrm{mi}$. SW of Healy, Alaska Ra.; $63^{\circ} 27^{\prime} 30^{\prime \prime}$ N, 149 $50^{\prime} 25^{\prime \prime}$ W; (map 87)
Name taken from the name of the pass into which it flows; published in 1954 by USGS.

Polychrome Mountain: mountain, NE peak $5,150 \mathrm{ft}$., SW peak 5,790 ft., $38 \mathrm{mi}$. SW of Healy, Alaska Ra.; $63^{\circ} 32^{\prime} \mathrm{N}, 1^{\circ} 9^{\circ} 55^{\prime} \mathrm{W}$; (map 87).

Name taken from name of the adjoining pass; published in 1954 by USGS.

Polychrome Pass: pass, 3,500 ft., between Toklat River and East Fork Toklat River, S of Polychrome Mtn., $38 \mathrm{mi}$. SW of Healy, Alaska Ra.; $63^{\circ} 31^{\prime} \mathrm{N}, 149^{\circ} 56^{\prime} \mathrm{W}$; (map 87).

Descriptive name reported in 1916 by C. E. Giffin, USGS.

Pomeroy, Mount: mountain, 2,385 ft., on Iniskin Peninsula, $21 \mathrm{mi}$. N of Augustine I., Aleutian Ra.; $59^{\circ} 39^{\prime} 30^{\prime \prime} \mathrm{N}, 153^{\circ} 21^{\prime} 30^{\prime \prime} \mathrm{W}$; (map 51).

Named for a local prospector Pomeroy, who joined another prospector, named Griffen, and formed the Alaska Petroleum Co. in 1897. Name published by G. C. Martin (1905, pl. 4), USGS.

Pomeroy Creek: stream, flows NW $1.1 \mathrm{mi}$. to Iniskin Bay, $22 \mathrm{mi}$. $\mathrm{N}$ of Augustine I., Aleutian Ra. ; $59^{\circ} 40^{\prime} 00^{\prime \prime} \mathrm{N}, 153^{\circ} 23^{\prime} 20^{\prime \prime} \mathrm{W}$; BGN 1962; (map 51).

Local name derived from Mount Pomeroy on which the stream heads and published by USGS in 1958.

Pomeroy Island: island, $0.5 \mathrm{mi}$. long, in Cook Inlet, $3 \mathrm{mi}$. S of Mount Pomeroy and $18 \mathrm{mi}$. $\mathrm{N}$ of Augustine I., Aleutian Ra.; 59 $37^{\prime} \mathrm{N}$, $153^{\circ} 22^{\prime} \mathrm{W} ; B G N$ 1916; (map 51).

Name derived from nearby Mount Pomeroy and published in 1915 on USC\&GS Chart 8554.

Pond Bay: estuary, extends W 2 mi. off Kaigani Strait, on SE coast of Dall I., Alex. Arch.; $54^{\circ} 48^{\prime} 30^{\prime \prime} \mathrm{N}, 132^{\circ} 44^{\prime} 45^{\prime \prime} \mathrm{W}$; BGN 1929; (map 1). Var. Seal Bay.

Named in 1881 by L.t. Comdr. Nichols, USN, for Ens. Charles Fremont Pond, USN, a member of his party.

Pond Bay: bay, $3 \mathrm{mi}$. long, $\mathrm{N}$ coast of Duke I., Alex. Arch.; 54 $58^{\prime} 30^{\prime \prime} \mathrm{N}, 131^{\circ} 20^{\prime} 00^{\prime \prime} \mathrm{W}$; (map 2).

Named in 1883 by Lt. Comdr. Nichols, USN, for Ens. C. F. Pond, USN, a member of his party.

Pond Creek: stream, flows NE $9 \mathrm{mi}$. to Windy Cove in Imuruk Basin, $23 \mathrm{mi}$. SE of Teller, Seward Penin. High.; $65^{\circ} 04^{\prime}$ N, $165^{\circ} 44^{\prime}$ W; (map 111).

Local name reported in 1900 by E. C. Barnard (in Brooks, 1901, pl. 17), USGS.

Pond Creek: stream, flows SW $1 \mathrm{mi}$. to Kilignak Creek $1.7 \mathrm{mi}$. $\mathrm{N}$ of its junc. with Ogotoruk Creek, $8 \mathrm{mi}$. NE of Cape Thompson, Arctic Slope; $68^{\circ} 10^{\prime} 35^{\prime \prime} \mathrm{N}, 165^{\circ} 41^{\prime} 20^{\prime \prime} \mathrm{W}$; $B G N$ 1963; (map 129).

Named about 1962 by personnel of Project Chariot.

Pond Island: island, see Axel Lind Island.

Pond Island: island, $1.2 \mathrm{mi}$. across, in Kelp Bay, on NE coast of Baranof I., $23 \mathrm{mi}$. NE of Sitka, Alex. Arch.; $57^{\circ} 17^{\prime} \mathrm{N}, 134^{\circ} 53^{\prime} \mathrm{W}$; (map 9). 
Descriptive name given in 1895 by Lt. Comdr. Moore, USN, "because of two small ponds at the south end of the island." The name was published by USC\&GS in the 1901 Coast Pilot (p. 160).

Pond Lake: lake, $0.3 \mathrm{mi}$. long, on Kenai Penin., $\mathrm{SE}$ of Lonely Lake, $31 \mathrm{mi}$. NE of Kenai, Cook Inlet Low.; $60^{\circ} 47^{\prime} 10^{\prime \prime} \mathrm{N}, 150^{\circ} 32^{\prime} 15^{\prime \prime}$ $\mathrm{W}$; (map 62).

Named about 1963 by officials of Kenai National Moose Range for administrative purposes.

Pond Reef: reef, extends $0.2 \mathrm{mi}$. off SW coast of Revillagigedo I., in Tongass Narrows, 1.5 mi. SE of Point Higgins, Alex. Arch.; $55^{\circ} 26^{\prime}$ $15^{\prime \prime} \mathrm{N}, 131^{\circ} 48^{\prime} 45^{\prime \prime} \mathrm{W}$; (map 3).

Local name published by USC\&GS in the 1883 Coast Pilot (p. 81).

Pond Rock: rock, in Kaigani Strait, $0.5 \mathrm{mi}$. NW of Channel Is., $E$ of Dall I., Alex. Arch.; $54^{\circ} 53^{\prime} 15^{\prime \prime} \mathrm{N}, 132^{\circ} 50^{\prime} 00^{\prime \prime} \mathrm{W}$; (map 1 ).

Named by Lt. Comdr. Nichols, USN in 1881. See Pond Bay.

Ponglevik River: stream, heads in lake $\mathrm{S}$ of Ungulungwak Hill, flows W $20 \mathrm{mi}$. to Anakshek Pass, 33 mi. S of Kwiguk, YukonKuskokwim Delta ; $62^{\circ} 16^{\prime} 10^{\prime \prime} \mathrm{N}, 164^{\circ} 35^{\prime} 50^{\prime \prime}$ W; (map 77).

Eskimo name obtained in 1948 by USC\&GS.

Ponlouktoule Creek: stream, see Ponluktule Creek.

Ponluktule Creek: stream, flows NW $2 \mathrm{mi}$. to Norton Sound, $1.8 \mathrm{mi}$. $\mathrm{S}$ of Tolstoi Point and $19 \mathrm{mi}$. SW of Unalakleet, Nulato Hills; $63^{\circ} 36^{\prime} 45^{\prime \prime} \mathrm{N}, 161^{\circ} 01^{\prime} 00^{\prime \prime} \mathrm{W}$; (map 91). Var. Ponlouktoule Creek.

Eskimo word for "blackberry" reported in 1952 by USC\&GS.

Ponrakvirak Hill: hill, 602 ft., $2 \mathrm{mi}$. S of Iyikrok Mtn. and $28 \mathrm{mi}$. NE of Kivalina, Brooks Ra.; 67 $55^{\prime} \mathrm{N}, 163^{\circ} 40^{\prime} \mathrm{W}$; (map 128). Var. Paunraqviizak, Pownrakveerak. Eskimo name meaning "little blackberry place" reported in 1966 by E. S. Burch.

Pontag Creek: stream, flows W $11 \mathrm{mi}$. to North Fork Kuskokwim River, $42 \mathrm{mi}$. NE of Medfra, Kuskokwim Low.; $63^{\circ} 28^{\prime} \mathrm{N}, 153^{\circ} 39^{\prime} \mathrm{W}$; (map 89).

Local name reported in 1958 by USGS.

Ponte Point: point of land, on W bank of Davis Creek, $0.5 \mathrm{mi}$. S of Mitchell Bay on Admiralty I., $5.5 \mathrm{mi}$. NE of Angoon, Alex. Arch.; 57 $31^{\prime} 30^{\prime \prime} \mathrm{N}, 134^{\circ} 26^{\prime} 25^{\prime \prime} \mathrm{W}$; (map 9). Var. Ponte's Point.

Named by Comdr. R. W. Meade, USN, in 1869, for a Mr. Ponte [cnna], "an expert on coal" employed on board the USS Saginaw, which Meade commanded in 1868-1869 while maping this area. The name does not apear on recent maps.

Ponte's Point: point of land, see Ponte Point.

Pony Cove: cove, $1 \mathrm{mi}$. wide, on $\mathrm{E}$ coast of Aialik Penin., $26 \mathrm{mi}$. S of Seward, Chugach Mts.; 59 $45^{\prime} \mathrm{N}, 149^{\circ} 33^{\prime} \mathrm{W}$; BGN 1930; (map 49).

This was called "Pony Bay" by the 1928 USC\&GS field party. The generic was changed by BGN "because of smallness of feature."

Pony Point: point of land, on S shore of Chiniak Bay $0.8 \mathrm{mi}$. SE of Midway Point and $14 \mathrm{mi}$. SE of Kodiak, Kodiak I. ; $57^{\circ} 37^{\prime}$ N, $152^{\circ} 15^{\prime}$ $\mathrm{W}$; (map 34).

Local name reported in 1949 by USGS.

Poogooviliak: locality, see Powooiliak Camp.

Poogovellyak: locality, see Powooiliak Camp.

Poohseegrux Lagoon: lagoon, see Pusigrak Lagoon.

Pool Creek: stream, flows SW $6.5 \mathrm{mi}$. to Smith Creek, $76 \mathrm{mi}$. SW of Circle, Yukon-Tanana High.; $65^{\circ} 17^{\prime} \mathrm{N}, 146^{\circ} 20^{\prime} \mathrm{W}$; (map 104).

Named by prospectors; reported in 1903 by T. G. Gerdine (Prindle, 1905, pl. 13), USGS. Poongook Islands: islands, see Punuk Islands. Poonook: locality, see Punuk.

Poo-oosalook Lagoon: lagoon, see Pusaluk Lagoon.

Poo-oosalook Mountain: hill, see Pusaluk Mountain.

Poorman: settlement, pop. 20, on left bank of Poorman Creek, 7 mi. SW of Sulatna Crossing and $44 \mathrm{mi}$. S of Ruby, Kilbuck-Kuskokwim Mts.; 6406' N, $155^{\circ} 33^{\prime} \mathrm{W}$; BGN 1944; (map 98).

This mining camp came into being with the discovery of gold on Poorman Creek in 1913 and was named for the stream. A post office was maintained there from 1915 to 1952 .

Poor Man Bay: cove, $0.8 \mathrm{mi}$. across, in Kasaan Bay, on E coast of Prince of Wales I., Alex. Arch.; $55^{\circ} 32^{\prime} 45^{\prime \prime} \mathrm{N}, 132^{\circ} 25^{\prime} 45^{\prime \prime} \mathrm{W}$; (map 4).

Local name recorded in 1949 by USGS.

Poor Man Creek: stream, heads in a lake near head of Kasaan Penin., Prince of Wales I., Hlows S 2 mi. to Poor Man Bay, Alex. Arch; $55^{\circ} 33^{\prime} \mathrm{N}, 132^{\circ} 26^{\prime} \mathrm{W}$; (map 4).

Local name recorded in 1949 by USGS.

Poorman Creek: stream, flows N $0.9 \mathrm{mi}$. to Crooked Creek, $8.5 \mathrm{mi}$. NE of Tahneta Pass and $65 \mathrm{mi}$. SW of Gulkana, Talkeetna Mts.; $62^{\circ} 00^{\prime} 30^{\prime \prime} \mathrm{N}, 147^{\circ} 17^{\prime} 00^{\prime \prime} \mathrm{W}$; BGN 1960; (map 82).

Local name published by Theodore Chapin (in Brooks and others, 1915, fig. 3), USGS.

Poorman Creek: stream, in Nutzotin Mts., heads on Gold Hill, flows $\mathrm{N} 1 \mathrm{mi}$. to Gold Run Greek, 6 mi. NW of Beaver Lake, Alaska Ra.; $62^{\circ} 07^{\prime} 15^{\prime \prime} \mathrm{N}, 141^{\circ} 53^{\prime} 20^{\prime \prime} \mathrm{W}$; BGN 1936; (map 84).

Local name published by USGS (in Brooks and others, 1915, pl. 9).

Poorman Creek: stream, heads in Dutch Hills, flows SE $2.3 \mathrm{mi}$, to Cottonwood Creek, $27 \mathrm{mi}$. NW of Talkeetna, Alaska Ra.; $62^{\circ} 33^{\prime} 45^{\prime \prime} \mathrm{N}$, $150^{\circ} 47^{\prime} 25^{\prime \prime} \mathrm{W}$; (map 81).

Prospectors' name reported in 1906 by E. A. Porter, USGS.

Poorman Creek: stream, heads at $64^{\circ} 04^{\prime} 45^{\prime \prime} \mathrm{N}$, $155^{\circ} 23^{\prime} 45^{\prime \prime} \mathrm{W}$, flows SW $15 \mathrm{mi}$. to North Fork Innoko River, $55 \mathrm{mi}$. SW of Ruby, Kilbuck-Kuskokwim Mts.; $63^{\circ} 58^{\prime} \mathrm{N}, 155^{\circ} 59^{\prime} \mathrm{W}$; $B G N$ 1936; (map 89).

Local name reported in 1913 by Eakin (1914, pl. 2), USGS.
Pooseegruk Lagoon: lagoon, see Pusigrak Lagoon.

Poovkpuk Mountain: mountain, see Poovookpuk Mountain.

Poovookpak Mountain: mountain, see Poovookpuk Mountain.

Poovookpuk Mountain: mountain, 1,517 ft., in Poovoot Range, $10 \mathrm{mi}$. NW of Southwest Cape, St. Lawrence I.; $63^{\circ} 27^{\prime} \mathrm{N}, 171^{\circ} 34^{\prime} \mathrm{W}$; BGN 1951; (map 93). Var. Mount Poovukpuk, Mount Poowookpuk, Poovookpak Mountain, Poovkpuk Mountain, Poovukpuk, Puvutpak.

Eskimo name, meaning "big Puvut" [Puvutpak], reported in 1932 by $O$. W. Geist, Univ. of Alaska.

Poovoot Mountains: mountain range, See Poovoot Range.

Poovoot Range: mountain range, $1,517 \mathrm{ft}$., extends SW $20 \mathrm{mi}$. from Taphook Point, $20 \mathrm{mi}$. SE of Gambell, St. Lawrence I.; $63^{\circ} 30^{\prime} \mathrm{N}$, $171^{\circ} 28^{\prime}$ W ; BGN 1951; (map 93). Var. Poovoot Mountains, Puvut Mountains.

Eskimo name recommended by the Gambell village council and reported in 1949 by Maj. H. B. Allen, USAF.

Poovukpuk: mountain, see Poovookpuk Mountain.

Poovukpuk, Mount: mountain, see Poovookpuk Mountain.

Poowooiliak Camp: locality, see Powooiliak Camp.

Poowookpuk, Mount: mountain, see Poovookpuk Mountain.

Pōō wō'wā lŭk: locality, see Powooiliak Camp.

Pope Creek: stream, flows $\mathrm{N} 6 \mathrm{mi}$. to Harriet Creek $0.5 \mathrm{mi}$. $\mathrm{S}$ of its junc. with Koyukuk River, $39 \mathrm{mi}$. SW of Wiseman, Brooks Ra.; $67^{\circ} 01^{\prime} 15^{\prime \prime} \mathrm{N}, 151^{\circ} 08^{\prime} 00^{\prime \prime} \mathrm{W}$; BGN 1932; (map 124). Var. Popes Creek.

Local name reported by Robert Marshall to have been in use since 1898 and shown as "Popes Creek" on a map of the Koyukuk River, published in 1899 , compiled by G. H. Wonson, master of the steamer Dorothy.

Pope Creek Dome: mountain, 2,850 ft., in Jack White Ra., $20 \mathrm{mi}$. E of Bettles, Brooks Ra.; $66^{\circ} 57^{\prime} \mathrm{N}, 150^{\circ} 58^{\prime} \mathrm{W}$; (map 117).

Local name reported in 1956 by T. E. Taylor, USGS.

Poperechni Island: island, see Broad Island.

Poperechnoi Island: island, $4 \mathrm{mi}$. long, $3 \mathrm{mi}$. E of Dolgoi I., one of Pavlof Is., Aleutian Ra.; $55^{\circ} 05^{\prime} \mathrm{N}, 161^{\circ} 34^{\prime} \mathrm{W}$; (map 28). Var. Kuiagdak, Popereshnoi, Poperetchny.

Named Poperechnoi, meaning "crosswise," on Russian Hydrog. Dept. Chart 1379 (1847); the island is also shown on an 1890 USBF chart. The Aleut name is "Kuiagdak."

Poperechnoi Islet: islands, see Crosswise Islands. Poperechnoy, Ostrov: islands, see Crosswise Islands.

Poperechnyy, Ostrov: island, see Broad Island. Popereshnoi: island, see Poperechnoi Island. Poperetch Islands: island, see Broad Island. Poperetchny: island, see Poperechnoi Island. Popes Creek: stream, see Pope Creek. 
Popes River: stream, or slough, flows $\mathrm{W}$ to Bering Sea, in Yukon Delta area, $\mathbf{N}$ of Scammon Bay; $62^{\circ} 10^{\prime} \mathrm{N}, 165^{\circ} 30^{\prime} \mathrm{W}$; (map 76).

The identity of the stream called "Popes" by Dall $(1870$, p. 275), is not certain. He lists it as the second stream, going north, between Scammon Bay and the Yukon delta. It may have been named by Dall for Frank L. Pope, assistant engineer of the Western Union Telegraph Expedition of 1865 . The present application of the name was given by USC\&GS in 1925.

Poplar Creek: stream, flows NE $3.3 \mathrm{mi}$. to Bear Creek, $26 \mathrm{mi}$. N of Haycock, Seward Penin. High.; 653' N, $161^{\circ} 07^{\prime} \mathrm{W}$; (map 109).

Local name shown on a 1903 fieldsheet by D. C. Witherspoon, USGS.

Poplar Creek: stream, see Polar Creek.

Pop Mountain: mountain, 2,204 ft., on Annette I., $\mathbf{N}$ of Trout Lake, between Janesville and Tired Mts., Alex. Arch.; $55^{\circ} 10^{\prime} \mathrm{N}, 131^{\circ} 29^{\prime}$ W; BGN 1900; (map 3). Var. Top Mountain.

Named in 1883 by Lt. Comdr. H. E. Nichols, USN.

Popocamiut: locality, see Popokamiut.

Popof Bay: bay, see Mill Bay.

Popof Cape: point of land, see Miller Point.

Popoff: island, see Popof Island.

Popoff Island: island, see Kutkan Island.

Popof Glacier: glacier, trends SE $5 \mathrm{mi}$. to its 1953 terminus, $0.5 \mathrm{mi}$. SE of Mount Basargin, $19 \mathrm{mi}$. NE of Wrangell, Coast Mts. ; $56^{\circ} 43^{\prime} 50^{\prime \prime}$ N, $132^{\circ} 12^{\prime} 10^{\prime \prime}$ W; (map 6). Var. First Glacier, Little Glacier.

Russian name given in 1863 by the surveying party of the Rynda. Feature was called "First [or Little] Glacier" in 1877 by Joseph Hunter, Canadian engineer and surveyor. See Rynda Island.

Popof Head: point of land, SE tip of Popof I., in Shumagin Is., Aleutian Ra.; $55^{\circ} 15^{\prime} \mathrm{N}$, $160^{\circ} 20^{\prime} \mathrm{W}$; (map 28).

Local name published in 1872, and perhaps named for Vasili and Ivan Popof, traders and fur hunters here in $1762-63$.

Popof Island: island, $9 \mathrm{mi}$. long, E of Unga I. in Shumagin Is., Aleutian Ra.; $55^{\circ} 19^{\prime} \mathrm{N}$, $160^{\circ} 24^{\prime}$ W; BGN 1954; (map 28). Var. Bopof Island, Popoff, Popovskoi.

Popof is a Russian proper name, often written Popoff. Named Popovskoi by Capt. Tebenkov (1852, map 24), IRN, and on Russian Hydrog. Dept. Chart 1379 (1847); shown as Popof Island on 1890 USBF chart.

Popof Island: island, $0.8 \mathrm{mi}$. long, in Chiniak Bay, $\mathrm{S}$ of Near I., $1.5 \mathrm{mi}$. S of Kodiak, Kodiak I.; $57^{\circ} 46^{\prime} 00^{\prime \prime} \mathrm{N}, 152^{\circ} 24^{\prime} 10^{\prime \prime} \mathrm{W}$; (map 34). Var. Ostrov Popov.

Name published as "Os[trov] Popov," or "Popov Island," by Sarichev (1826, map 16). Popoff Reefs: reef, see Popof Reef.

Popof Reef: reef, in Popof Strait, in Shumagin Is., Aleutian Ra.; 55 $20^{\prime} 25^{\prime \prime} \mathrm{N}, 160^{\circ} 30^{\prime} 30^{\prime \prime}$ W; (map 28). Var. Popoff Reefs.

Named Popoff Reefs by W. H. Dall, USC\&GS, and shown on 1872 USC\&GS chart.
Popofskaia : bay, see Mill Bay.

Popofskie: point of land, see Miller Point.

Popof Strait: water passage, extends $16 \mathrm{mi} \mathrm{SE}$ From Unga Strait to Pacific Ocean, between Unga and Popof Is., in Shumagin Is., Aleutian Ra.; $55^{\circ} 16^{\prime} \mathrm{N}, 160^{\circ} 30^{\prime} \mathrm{W}$; (map 28).

Surveyed and named in 1872 by W. H. Dall, USC\&GS.

Popogg Bay: bay, see Mill Bay.

Popokamiut: locality, on right bank of Kuskokwim River at head of Kuskokwim Bay, 2 mi. $\mathrm{N}$ of Papka and $56 \mathrm{mi}$. SW of Bethel, YukonKuskokwim Delta; $60^{\circ} 04^{\prime} \mathrm{N}, 162^{\circ} 28^{\prime} \mathrm{W}$; (map 58). Var. Popocamiut, Popokamute.

Eskimo camp or village reported in 1914 by USC\&GS. See Papka.

Popokamute: locality, see Popokamiut.

Popov, Ostrov: island, see Popof Island.

Popovich Creek: stream, see Popovitch Creek.

Popovitch Creek: stream, flows S $4 \mathrm{mi}$. to Lignite Creek, $6 \mathrm{mi}$. NE of Healy, Alaska Ra.; $63^{\circ} 55^{\prime}$ $\mathrm{N}, 148^{\circ} 50^{\prime} \mathrm{W}$; (map 87). Var. Popovich Creek.

Local name reported in 1916 as "Popovich Creek" by A. G. Maddren, USGS.

Popovskaya, Bukhta: bay, see Mill Bay.

Popovskoi: island, see Popof Island.

Pop Point: point of land, on $\mathrm{N}$ shore of Thorne Arm, on S coast of Revillagigedo I., Alex. Arch.; 55 $23^{\prime} 35^{\prime \prime} \mathrm{N}, 131^{\circ} 12^{\prime} 00^{\prime \prime \prime} \mathrm{W}$; (map $3)$.

Arbitrary name given in 1891 by USC\&GS.

Porcupine: locality, $0.6 \mathrm{mi}$. SW of mouth of Porcupine Creek, on Klehini River, $32 \mathrm{mi}$. W of Skagway, St. Elias Mts.; $59^{\circ} 25^{\prime} 15^{\prime \prime} \mathrm{N}$, $136^{\circ} 14^{\prime} 15^{\prime \prime} \mathrm{W}$; (map 45).

A mining camp named by prospectors for Porcupine Creek. The town was established in 1898 as a result of the discovery of gold along the creek. The following year it had a population of 200, and in 1901 a post office of this name was established. In 1903 the town consisted of a dozen or more houses and log cabins, a trading store, a hotel, and about 80 people during the summer, but during the winter it was practically deserted (Wright, 1904, p. 11).

Porcupine Bay: bay, $0.4 \mathrm{mi}$. across, at head of Islas Bay, $15 \mathrm{mi}$. NW of Chichagof, on W coast of Chichagof I., Alex. Arch.; 57 $49^{\prime} 50^{\prime \prime}$ N, 136 $22^{\prime} 00^{\prime \prime} \mathrm{W} ; B G N 1908$; (map 9). Var. Ahues Bay, Porcupine Harbor.

Named in 1908 by USC\&GS and published in the 1908 Coast Pilot (p. 168). It was also locally called "Ahues Bay," for Capt. C. E. Ahues, master of a local fishing vessel.

Porcupine Butte: mountain, 2,093 ft., in Tordrillo Mts., between Hayes and Skwentna Rivers, 66 mi. NW of Tyonek, Alaska Ra.; $61^{\circ} 56^{\prime} \mathrm{N}, 151^{\circ} 59^{\prime} \mathrm{W}$; (map 70).

Local name reported in 1958 by USGS.

Porcupine Cove: cove, $0.7 \mathrm{mi}$. wide, on $\mathrm{E}$ coast of Aialik Penin., $18 \mathrm{mi}$. SW of Seward, Chugach Mts.; $59^{\circ} 51^{\prime} \mathrm{N}, 149^{\circ} 35^{\prime} \mathrm{W}$; (map 49).

Local name reported in the early 1950 's by USC\&GS.
Porcupine Creek: stream, flows NW $1.5 \mathrm{mi}$. to Steamer Bay, on $W$ coast of Etolin I., Alex. Arch.; $56^{\circ} 07^{\prime} 40^{\prime \prime} \mathrm{N}, 132^{\circ} 39^{\prime} 00^{\prime \prime} \mathrm{W}$; (map 6).

Named in 1886 by Lt. Comdr. A. S. Snow, USN; name published in 1887 on USC\&GS Chart 706.

Porcupine Creek: stream, on Alaska Penin., flows $5.6 \mathrm{mi}$. NW to Becharof Creek $5.5 \mathrm{mi}$. $\mathrm{SE}$ of its mouth at $\mathrm{E}$ end of Becharof Lake, $54 \mathrm{mi}$. NW of Karluk, Aleutian Ra.; $57^{\circ}$. $43^{\prime} 20^{\prime \prime} \mathrm{N}, 155^{\circ} 53^{\prime} 30^{\prime \prime} \mathrm{W}$; (map 35). Var. Arvesta Creek.

Local name reported by S. R. Capps, USGS, in 1921. The name "Arvesta" was published for this stream by G. C. Martin (1921, pl. 10), USGS.

Porcupine Creek: stream, heads in a glacier 3.4 mi. SW of Porcupine Peak, flows NE $8 \mathrm{mi}$. to Klehini River, $0.7 \mathrm{mi}$. NE of Porcupine, and $32 \mathrm{mi}$. W of Skagway, St. Elias Mts.; $59^{\circ} 25^{\prime} 35^{\prime \prime} \mathrm{N}, 136^{\circ} 13^{\prime} 10^{\prime \prime} \mathrm{W}$; (map 45). Var. Tlachkahíniku.

Prospectors' name reported in 1898 by J. A. Flemer, USC\&GS. Aurel and Arthur Krause (1883, map) reported the Tlingit Indian name as "Tlachkahíniku."

Porcupine Creek: stream, heads in Robinson Mts. and flows $3 \mathrm{mi}$. SE and SW to North Channel Yakataga River, $5 \mathrm{mi}$. NE of Cape Yakataga and $100 \mathrm{mi}$. NW of Yakutat, Chugach Mts.; $60^{\circ} 07^{\prime} 30^{\prime \prime} \mathrm{N}, 142^{\circ} 22^{\prime} 10^{\prime \prime} \mathrm{W}$; $B G N 1945$; (map 65).

Local name reported by USGS in 1945.

Porcupine Creek: stream, on Kenai Penin., flows NE $2 \mathrm{mi}$. to Kenai Lake, $1 \mathrm{mi}$. W of Porcupine I., $20 \mathrm{mi}$. NW of Seward, Chugach Mts.; $60^{\circ} 23^{\prime} 00^{\prime \prime} \mathrm{N}, 149^{\circ} 40^{\prime} 30^{\prime \prime} \mathrm{W}$; (map 63).

So named by USFS in 1960 "because it flows into Kenai Lake $1 \mathrm{mi}$, west of Porcupine Island."

Porcupine Creek: stream, flows NE $5 \mathrm{mi}$. to Cripple Creek, $75 \mathrm{mi}$. SE of Bethel, KilbuckKuskokwim Mts. ; $60^{\circ} 45^{\prime}$ N, $159^{\circ} 35^{\prime} \mathrm{W}$; (map 59).

Prospectors' name reported in 1914 by A. G. Maddren (in Brooks, 1915, pl. 11), USGS.

Porcupine Creek: stream, on $\mathrm{N}$ end of Kenai Penin., flows E $2.5 \mathrm{mi}$. to Turnagain Arm, $0.5 \mathrm{mi}$. NW of Hope, Chugach Mts.; $60^{\circ} 55^{\prime}$ $45^{\prime \prime} \mathrm{N}, 149^{\circ} 39^{\prime} 25^{\prime \prime} \mathrm{W}$; (map 63).

Local prospectors' name reported in 1904 by Moffit (1906, pl. 2), USGS.

Porcupine Creek: stream, heads in glacier, flows E $3.5 \mathrm{mi}$. to Little Bremner River, $1.6 \mathrm{mi}$. NW of mouth of East Fork and $63 \mathrm{mi}$. E of Valdez, Chugach Mts.; $61^{\circ} 06^{\prime} 35^{\prime \prime} \mathrm{N}, 144^{\circ} 21^{\prime} 50^{\prime \prime} \mathrm{W}$; (map 68).

Name published by USGS (Moffit, 1914, pl. 1).

Porcupine Creek: stream, flows SE and SW, 4.8 mi. to Kuskulana River, $29 \mathrm{mi}$. NW of McCarthy, Wrangell Mts.; $61^{\circ} 35^{\prime} \mathrm{N}, 143^{\circ} 48^{\prime}$ W; (map 67).

Local name reported on a manuscript map of Copper River and Northwestern Railway, Chitina Branch Line, dated 1909.

Porcupine Creek: stream, heads at junc. of Deadwood and Guggenheim Creeks, flows NW 
7 mi. to Dishna River, $22 \mathrm{mi}$. NE of Flat, Kilbuck-Kuskokwim Mts. ; $62^{\circ} 40^{\circ} 45^{\prime \prime} \mathrm{N}, 157^{\circ}$ $29^{\prime} 30^{\prime \prime}$ W; (map 79).

Local name obtained in 1952 by USGS topographers.

Porcupine Creek: stream, heads $\mathbf{N}$ of Indian Pass, flows SE $11 \mathrm{mi}$. to Slana River $3.4 \mathrm{mi}$. NE of its junc. with Copper River, Alaska Ra.; $62^{\circ} 43^{\prime}$ N, $143^{\circ} 53^{\prime}$ W; BGN 1963; (map 84).

Local name reported by USGS in 1936 .

Porcupine Creek: stream, flows $\mathrm{W} 7 \mathrm{mi}$. to Tanana River, $10 \mathrm{mi}$. E. of Tok, YukonTanana High.; $63^{\circ} 23^{\prime} \mathrm{N}, 142^{\circ} 41^{\prime} \mathrm{W}$; (map 85).

Local name reported by USGS in 1949.

Porcupine Creek: stream, flows NW $20 \mathrm{mi}$. to Salcha River, $49 \mathrm{mi}$. NE of Big Delta, YukonTanana High.; $64^{\circ} 42^{\prime} \mathrm{N}, 144^{\circ} 21^{\prime} \mathrm{W}$; (map 101 ).

Local name reported in 1958 by USGS.

Porcupine Creek: stream, flows E $13 \mathrm{mi}$., joins Mammoth Creek to form Crooked Creek, 37 mi. SW of Circle, Yukon-Tanana High.; $65^{\circ}$ $33^{\prime} 20^{\prime \prime} \mathrm{N}, 145^{\circ} 09^{\prime} 00^{\prime \prime} \mathrm{W}$; (map 104).

Named by prospectors; reported in 1896 by USGS (Spurr, 1898, pl. 50).

Porcupine Creek: stream, flows $S 4.5 \mathrm{mi}$, to Middle Fork Koyukuk River, $2.5 \mathrm{mi}$. N of mouth of Rosie Creek and $13 \mathrm{mi}$. S of Wiseman, Brooks Ra.; $67^{\circ} 13^{\prime} 45^{\prime \prime} \mathrm{N}, 150^{\circ} 16^{\prime} 00^{\prime \prime}$ W; (map 124).

Local name shown on an 1899 fieldsheet by T. G. Gerdine, USGS.

Porcupine Creek: stream, see Primrose Creek.

Porcupine Creek: stream, see Sulphur Creek.

Porcupine Dome: mountain, 4,915 ft., $48 \mathrm{mi}$. SW of Circle, Yukon-Tanana High.; $65^{\circ} 31^{\prime}$ N, $145^{\circ} 31^{\prime} \mathrm{W}$; (map 104).

Named by prospectors; reported in 1896 by USGS (Spurr, 1898, pl. 39).

Porcupine Dome: mountain, see Pinnell Mountain.

Porcupine Glacier: glacier, $1.5 \mathrm{mi}$. lang, $1 \mathrm{mi}$. SE of Thumb Cove, $10 \mathrm{mi}$. SE of Seward, Chugach Mts.; $60^{\circ} 00^{\prime} \mathrm{N}, 149^{\circ} 17^{\prime} \mathrm{W}$; $B G N$ 1911; (map 49). Var. Thumb Cove Glacier. Named in 1909 by U.S. Grant, USGS, "after local name of bay."

Porcupine Grass Lake: lake, $0.8 \mathrm{mi}$. long, 2.3 mi. NE of Tetlin, $19 \mathrm{mi}$. SE of Tok, Alaska Ra.; $63^{\circ} 10^{\prime}$ N., $142^{\circ} 28^{\prime} \mathrm{W}$; (map 85).

Local name published by USGS in 1965.

Porcupine Harbor, bay, see Porcupine Bay.

Porcupine Hill: peak, 4,000 ft., $2 \mathrm{mi}$. E of summit of Mount Carmack and $7 \mathrm{mi}$. N of Skagway, Coast Mts.; $59^{\circ} 33^{\prime} \mathrm{N}, 135^{\circ} 12^{\prime \prime} \mathrm{W}$; (map 45). GS.

Name given in 1898 by John Nelson, USC\&-

\section{GS.}

Porcupine House: locality, at junc. of Mammoth and Porcupine Creeks, $37 \mathrm{mi}$. SW of Circle, Yukon-Tanana High.; $65^{\circ} 33^{\prime} 20^{\prime \prime} \mathrm{N}$, $145^{\circ} 09^{\prime} 00^{\prime \prime} \mathrm{W}$; (map 104).

Local name of a former roadhouse, derived from Porcupine Creek; reported in 1896 by USGS (Spurr, 1898, pl. 50).
Porcupine Island: island, $6 \mathrm{mi}$. across, in Iliamna Lake between Pedro and Pile Bays, $36 \mathrm{mi}$. NW of Augustine I., Aleutian Ra.; 59 $45^{\prime} \mathrm{N}$, $154^{\circ} 08^{\prime} \mathrm{W}$; (map 51).

Name published by Martin and Katz (1912a, pl. 1), USGS.

Porcupine Island: island, on Kenai Penin., 0.7 mi. across, in Kenai Lake, $22 \mathrm{mi}$. NW of Seward, Chugach Mts.; $60^{\circ} 24^{\prime} 15^{\prime \prime} \mathrm{N}, 149^{\circ}$ 38'00" W; (map 63).

Named in 1898 by Mendenhall (1900, map 16), USGS

Porcupine Islands: islands, $1 \mathrm{mi}$. across, includes Winifred and Beric Is., $15 \mathrm{mi}$. NW of Chichagof, off W coast of Chichagof I., Alex. Arch.; $57^{\circ} 48^{\prime} \mathrm{N}, 136^{\circ} 23^{\prime} \mathrm{W}$; BGN 1908; (map 9). Var. Groundhog Islands.

So named in 1908 by USC\&GS "because of the porcupine shape of the wooded outer or Beric Island." The name was published in the 1908 Coast Pilot (p. 168).

Porcupine Lake: lake, $1.2 \mathrm{mi}$. long, on Kenai Penin. NW of Gavia Lake, $25 \mathrm{mi}$. NE of Kenai, Cook Inlet Low.; 60 $42^{\prime} 15^{\prime \prime} \mathrm{N}, 150^{\circ} 37^{\prime} 00^{\prime \prime}$ W; (map 62).

Named about 1963 by officials of Kenai National Moose Range, for administrative purposes.

Porcupine Lake: lake, $1.5 \mathrm{mi}$. long, in Philip Smith Mts. 14 mi. NW of Carter Pass; $68^{\circ}$ $47^{\prime} \mathrm{N}, 146^{\circ} 28^{\prime} \mathrm{W}$; BGN 1960; (map 136).

So named by USGS geologists in 1948 "because so many porcupines were seen in the area."

Porcupine Peak: mountain peak, 5,330 ft., 4.6 mi. S of Porcupine, $33 \mathrm{mi}$. W of Skagway, St. Elias Mts.; $59^{\circ} 21^{\prime} 15^{\prime \prime} \mathrm{N}, 136^{\circ} 13^{\prime} 30^{\prime \prime} \mathrm{W}$; (map 45).

Local name derived from the locality of Porcupine; reported by E. C. Robertson, geologist, and published in 1952 by USGS.

Porcupine Point: point of land, at $\mathrm{S}$ entrance to Port Fidalgo, $35 \mathrm{mi}$. NW of Cordova, Chugach Mts. ; $60^{\circ} 44^{\prime} 30^{\prime \prime} \mathrm{N}, 146^{\circ} 42^{\prime} 00^{\prime \prime} \mathrm{W}$; (map 64).

Named in 1898 by Capt. Abercrombie (1900, map), USA, during his exploration of the Copper River region.

Porcupine Ridge: ridge, $800 \mathrm{ft}$., extends E-W $8.5 \mathrm{mi}$. between Takotna and Tatalina Rivers, $4 \mathrm{mi}$. NW of McGrath, Kilbuck-Kuskokwim Mts. ; $63^{\circ} 00^{\prime} \mathrm{N}, 155^{\circ} 45^{\prime} \mathrm{W}$; (map 80 ).

Local name published in 1921 by USGS.

Porcupine River: stream, heads in Lake Elfendahl, flows SW $1 \mathrm{mi}$. through Lake Helen to Porcupine Bay, $15 \mathrm{mi}$. NW of Chichagof, on W coast of Chichagof I., Alex. Arch.; 57 ${ }^{\circ}$ $49^{\prime} 55^{\prime \prime} \mathrm{N}, 136^{\circ} 21^{\prime} 10^{\prime \prime} \mathrm{W}$; (map 9).

Named in 1928 by USC\&GS for Porcupine Bay. The name was published in 1928 on Chart 8258.

Porcupine River: stream, heads in Canada at $65^{\circ} 28^{\prime} \mathrm{N}, 139^{\circ} 32^{\prime} \mathrm{W}$, flows $\mathrm{W} 460 \mathrm{mi}$. to Yukon River $2 \mathrm{mi}$. NW of Fort Yukon, Yukon Flats; $66^{\circ} 34^{\prime} 30^{\prime \prime} \mathrm{N}, 145^{\circ} 19^{\prime} 00^{\prime \prime} \mathrm{W}$; (map 119) $B G N 1944$.

Name probably given before 1865 by agents of the Hudson's Bay Company.
Porcupine River: stream, right-hand tributary to Skagway River, about $5 \mathrm{mi}$. NE of Skagway (map 45).

This river, crossed by a horse bridge on the "Skagway Trail" to White Pass, was well known during the Klondike gold rush. It is shown on a sketch map in "En Route to the Klondike," a series of photographic views by F. LaRoche, published in 1898 by W. B Conkey Co., Chicago. The river is not identified on modern maps.

Porcupine Rock: rock, $1.5 \mathrm{mi}$. W of Porcupine Is., $16 \mathrm{mi}$. NW of Chichagof, on $\mathrm{W}$ coast of Chichagof I., Alex. Arch. ; $57^{\circ} 48^{\prime} 00^{\prime \prime} \mathrm{N}, 136^{\circ}$. $25^{\prime} 10^{\prime \prime} \mathrm{W}$; (map 9 ).

Named in 1908 by USC\&GS probably for the Porcupine Islands. The name was published in the 1908 Coast Pilot (p. 168).

Porfia, Cabo de: point of land, "near entrance to Port Santa Cruz in Bucareli Bay."

Spanish name frequently given when there was difficulty in rounding a cape. Named by the 1779 Don Ignacio Arteaga expedition (Wagner, 1937, p. 485).

Porgo Creek: stream, in Baird Mts., flows NE $8.5 \mathrm{mi}$. to Noatak River, $5.5 \mathrm{mi}$. NW of its junc. with Kaluktavik River, $55 \mathrm{mi}$. NE of Noatak, Brooks Ra.; $67^{\circ} 58^{\prime} 30^{\prime \prime} \mathrm{N}, 161^{\circ} 09^{\prime} 00^{\prime \prime}$ W; (map 127).

'Eskimo name obtained in 1955 by U.S. Army Corps of Engineers.

Poroga, Ostrov: island, see Rapids Island.

Poroshki, Bukhta: $b a y$, see No Thorofare Bay.

Poroshki Bay: bay, see No Thorofare Bay.

Porphyry Creek: stream, flows SE $4 \mathrm{mi}$. to Willow Creek, 56 mi. SW of Eagle, Yukon-Tanana High.; $64^{\circ} 12^{\prime} 40^{\prime \prime} \mathrm{N}, 142^{\circ} 26^{\prime} 50^{\prime \prime} \mathrm{W}$; (map 102).

Local name reported in 1956 by USGS.

Porphyry Gulch: ravine, extends $\mathrm{N}$ from Albert Creek, $8 \mathrm{mi}$. N of Tahneta Pass, $62^{\circ} 00^{\prime} \mathrm{N}$, $147^{\circ} 20^{\prime} \mathrm{W}$; (map 82).

Local name published by G. C. Martin and J. B. Mertie (in Brooks and others, 1914, pl. 11), USGS.

Porphyry GuIch: ravine, on E slope of White Mtn., S of Nabesna, Wrangell Mts.; $62^{\circ} 23^{\prime} \mathrm{N}$, $143^{\circ} 02^{\prime} \mathrm{W}$; BGN 1939; (map 84).

Local name reported in 1939 by P. S. Smith, USGS.

Porphyry Hill: hill, about $1,200 \mathrm{ft}, 17 \mathrm{mi}$. SE of Flat, Kilbuck-Kuskokwim Mts.; $62^{\circ} 13^{\prime} \mathrm{N}$, $157^{\circ} 56^{\prime} \mathrm{W}$; (map 79$)$.

Name reported in 1945 by USGS; but it appears the name has never become established or used.

Porphyry Mountain: mountain, 5,600 ft., E of Kennicott Glacier, $4 \mathrm{mi}$. NE of McCarthy, Wrangell Mts.; $61^{\circ} 28^{\prime} 15^{\prime \prime} \mathrm{N}, 142^{\circ} 49^{\prime} 30^{\prime \prime} \mathrm{W}$; (map 67).

Local name reported in 1908 by D. C. Witherspoon (Moffit and Capps, 1911, pl. 3), USGS. So named because the mountain is largely composed of porphyry, a type of igneous rock.

Porpoise Harbor: bay, $1.8 \mathrm{mi}$. across, on NW coast of Nagai I., in Shumagin Is., Aleutian Ra.; $55^{\circ} 12^{\prime} \mathrm{N}, 159^{\circ} 59^{\prime} \mathrm{W}$; (map 27). 
Named by USC\&GS in 1871 for the small schooner Porpoise which wintered here before that date.

Porpoise Islands: islands, group at junc. of Icy Passage and Icy Strait, $5 \mathrm{mi}$. S of village of Excursion Inlet and $38 \mathrm{mi}$. W of Juneau, St. Elias Mts.; $58^{\circ} 20^{\prime} \mathrm{N}, 135^{\circ} 28^{\prime} \mathrm{W}$; (map 11).

Named in 1880 by the U.S. Navy and published by USC\&GS in the 1883 Coast Pilot (p. 190).

Porpoise Point: point of land, on $\mathrm{N}$ shore of Boca de Quadra, $1.9 \mathrm{mi}$. W of entrance to

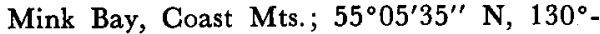
$46^{\prime} 20^{\prime \prime}$ W; (map 3).

One of many arbitrary names applied to features in this area in 1891 by USC\&GS.

Porpoise Rocks: rocks, off NW coast of Nagai I., in Shumagin Is., Aleutian Ra.; 55 $14^{\prime} 30^{\prime \prime}$ N, $159^{\circ} 57^{\prime} 30^{\prime \prime} \mathrm{W}$; (map 27).

Name published on USC\&GS Chart 8700 (1943).

Porpoise Rocks: rocks, near Hinchinbrook I., at W entrance to Port Etches, $35 \mathrm{mi}$. SW of Cordova, Chugach Mts.; $60^{\circ} 19^{\prime} \mathrm{N}, 146^{\circ} 41^{\prime}$ W; (map 64). Var. Bird Rocks, Los Negritos, Ostrova Ptichi.

Name published in 1869 Coast Pilot (p. 156). They were called "Ostrova Ptichi," meaning "bird islands," in 1830 by the Russian pilot Ivan Chernovo. The rocks were called "Los Negritos," i.e. "the little black ones," on an anonymous 1779 Spanish "plano."

Porpoise Rocks: rocks, see Phocena Rocks.

Portage: locality, near head of Tenakee Inlet, on central Chichagof I., $15 \mathrm{mi}$. E of Pelican, Alex. Arch.; $57^{\circ} 59^{\prime} 25^{\prime \prime} \mathrm{N}, 135^{\circ} 50^{\prime} 00^{\prime \prime} \mathrm{W}$; (map 9).

Name published in 1942 by USGS. On present-day maps a cabin is shown here.

Portage: village, pop. 71, on Seward Highway, mi. 64.2 on The Alaska RR., near head of Turnagain Arm, $16 \mathrm{mi}$. SE of Sunrise, Chugach Mts.; $60^{\circ} 50^{\prime} 15^{\prime \prime} \mathrm{N}, 148^{\circ} 58^{\prime} 45^{\prime \prime} \mathrm{W}$; (map 63).

The RR. guide of 1919 list the village as a flag stop. Recent USGS maps show it as a settlement of about 20 buildings. The 1966 RR. guide lists Portage as a major stop on The Alaska RR.

Portage Arm: bay, $5 \mathrm{mi}$. long, NW extension of Nuyakuk Lake, $105 \mathrm{mi}$. NE of Goodnews, Kilbuck-Kuskokwim Mts.; $59^{\circ} 54^{\prime} \mathrm{N}, 159^{\circ} 05^{\prime}$ W; BGN 1932; (map 53).

So named in 1932 by Gerald FitzGerald, USGS, "because at the head of the arm is a low pass to Lake Chauekuktuli."

Portage Arm: water passage, $0.7 \mathrm{mi}$. across, between Catherine I. and NE coast of Baranof I., 26 mi. NE of Sitka, Alex. Arch.; 57 $20^{\prime}$ $\mathrm{N}, 134^{\circ} 54^{\prime} \mathrm{W}$; (map 9).

Named in 1895 by Lt. Comdr. Moore, USN, and published by USC\&GS on Chart 8050 .

Portage Bay: bay, $0.8 \mathrm{mi}$. across, E arm of Makushin Bay, on Unalaska I., Aleutian Is.; $53^{\circ} 43^{\prime} 40^{\prime \prime} \mathrm{N}, 166^{\circ} 55^{\prime} 30^{\prime \prime} \mathrm{W}$; (map 23).

This name was published in the 1944 Aleutian Coast Pilot (p. 45).
Portage Bay: bay, trends SE $3 \mathrm{mi}$. to $\mathrm{N}$ end of Kuiukta Bay, $10 \mathrm{mi}$. SW of Chignik, Aleutian Ra.; 56 $11^{\prime}$ N, $158^{\circ} 33^{\prime} \mathrm{W}$; (map 30).

Local descriptive name reported by a 1951 USGS field party.

Portage Bay: bay, $3 \mathrm{mi}$. across, at head of Alitak Bay, at $S$ end of Kodiak I.; $56^{\circ} 56^{\prime}$ N, $153^{\circ} 56^{\prime}$ W; (map 33).

Name reported in 1943 by USC\&GS.

Portage Bay: bay, extends NW 6 mi. to Frederick Sound, on $\mathbf{N}$ coast of Kupreanof I., Alex. Arch.; $57^{\circ} 00^{\prime} \mathrm{N}, 133^{\circ} 20^{\prime} \mathrm{W}$; (map 6, 7) Var. Perenosnaia Bay, Perenosnaya Bukhta, Perenosnaya Creek, Portage Harbor.

Translation about 1882 by USC\&GS of "Perenosnaya Bukhta;" Published in 1848 on Russian Hydrog. Dept. Chart 1396. It was called "Perenosnaya Creek" in 1869 by Comdr. R. W. Meade, USN.

Portage Bay: bight, $0.5 \mathrm{mi}$. across, $3 \mathrm{mi}$. SE of Kake, on NW coast of Kupreanof I., Alex. Arch.; $56^{\circ} 56^{\prime} 40^{\prime \prime} \mathrm{N}, 133^{\circ} 53^{\prime} 30^{\prime \prime} \mathrm{W}$; (map 6).

Local descriptive name obtained in 1951 by USGS.

Portage Bay: bight, $2 \mathrm{mi}$. across, on $\mathrm{N}$ shore of Ugak Bay, on E coast of Kodiak I.; $57^{\circ} 28^{\prime}$ N, $152^{\circ} 37^{\prime} \mathbf{W}$; (map 34). Var. Kanatak, Zaliv Perenosnoy.

Translation in 1865 by USC\&GS of " $Z$ [aliv] Perenosnoy" published by Capt. Tebenkov (1852, map 22). The Russian Hydrog. Dept. published the native name "Kanatak" on Chart 1379 in 1847.

Portage Bay: cove, $6 \mathrm{mi}$. long, on SW shore of Lake Clark, $8 \mathrm{mi}$. NE of Nondalton, Alaska Ra.; $60^{\circ} 05^{\prime} 30^{\prime \prime} \mathrm{N}, 1^{\circ} 4^{\circ} 42^{\prime} 00^{\prime \prime} \mathrm{W}$; (map 61).

Local name reported by F. J. Katz and G. C. Martin (1912a, pl, 1), USGS. So named because the bay is a short-cut to the mouth of the Chulitna River from the SW.

Portage Bay: estuary, extends E $2 \mathrm{mi}$. from Gould I., at head of Hetta Inlet, on Prince of Wales I., Alex. Arch.; 55 $16^{\prime} 50^{\prime \prime}$ N, $132^{\circ}$ $34^{\prime} 00^{\prime \prime}$ W; $(\operatorname{map} 4)$.

Local name reported in 1905 by E. F. Dickins, USC\&GS; so called because "There is a portage from here to Cholmondeley Sound." Portage Bay: bay, see Balboa Bay.

Portage Bay: bay, see Chagvan Bay.

Portage Bay: bay, see Etienne Bay.

Portage Bay: bay, see Perenosa Bay.

Portage Bay: cove, see Portage Cove.

Portage Bay: estuary, see Passage Canal.

Portage Bight: cove, $2.2 \mathrm{mi}$. across, on NE coast of Tanaga I., Aleutian Is.; $51^{\circ} 50^{\prime} \mathrm{N}, 177^{\circ} 44^{\prime}$ W; (map 17).

Name published by USC\&GS in 1956 on Chart 9145

Portage Cove: estuary, extends $1 \mathrm{mi}$. W off Behm Canal, on NE coast of Revillagigedo I., Alex. Arch.; $55^{\circ} 46^{\prime} 25^{\prime \prime} \mathrm{N}, 131^{\circ} 02^{\prime} 30^{\prime \prime} \mathrm{W}$; (map $3)$.

Local navigators' name obtained in 1904 by H. C. Fassett, USBF

Portage Cove: cove, $1.4 \mathrm{mi}$. across, on $\mathrm{W}$ shore of Chilkoot Inlet, just S of Nukdik Point, 16 mi. S of Skagway, Coast Mts.; $59^{\circ} 14^{\prime} \mathrm{N}$ $135^{\circ} 25^{\prime} \mathrm{W}$; (map 45). Var. Portage Bay.

Named "Portage Bay" by local traders, but the name was changed to Portage Cove by the U.S. Navy in 1881, and this form was published by USG\&GS in the 1883 Coast Pilot (p. 199).

Portage Cove: cove, see Double Cove.

Portage Creek: stream, flows W $1.5 \mathrm{mi}$. to Porttage Bay, on Prince of Wales I., 2 mi. E of Gould I., Alex. Arch.; 55 $16^{\prime} 40^{\prime \prime}$ N, 132 $32^{\prime}$ $30^{\prime \prime} \mathrm{W}$; (map 4).

Local name published in 1943 by USC\&GS.

Portage Creek: stream, flows NW $4 \mathrm{mi}$. through Portage Valley to SE arm of Herendeen Bay, near SW end of Alaska Penin., Aleutian Ra.; $55^{\circ} 41^{\prime} 45^{\prime \prime} \mathrm{N}, 160^{\circ} 40^{\prime} 40^{\prime \prime} \mathrm{W}$; (map 28).

Named for Portage Valley; reported in 1929 by USGS.

Portage Creek: stream, on E coast of Alaska Penin., flows SW $5 \mathrm{mi}$. to Puale Bay, $43 \mathrm{mi}$. NW of Karluk, Aleutian Ra.; $57^{\circ} 47^{\prime} 05^{\prime \prime} \mathrm{N}$, $155^{\circ} 32^{\prime} 15^{\prime \prime} \mathrm{W}$; (map 35$)$.

Local name obtained in 1902 by USGS from J. L. McPherson of Iliamna.

Portage Creek: stream, in Glacier Bay National Monument, flows W $4.5 \mathrm{mi}$. to join Eagle Creek 2 mi. N of its mouth, on Gulf of Alaska, $90 \mathrm{mi}$. NW of Hoonah, Malaspina Coastal Plain ; $58^{\circ} 40^{\prime} 15^{\prime \prime} \mathrm{N}, 137^{\circ} 40^{\prime} 25^{\prime \prime} \mathrm{W}$; (map 10)

Name shown on an 1894 boundary survey map. (P. S. Smith, and others, 1933, p. 118).

Portage Creek: stream, flows NW $11 \mathrm{mi}$. to Keefer Cutoff $0.5 \mathrm{mi}$. E of its junc. with Nushagak River, $28 \mathrm{mi}$. NW of Naknek, Bristol Bay Low.; $58^{\circ} 54^{\prime} 25^{\prime \prime} \mathrm{N}, 157^{\circ} 43^{\prime} 20^{\prime \prime} \mathrm{W}$; (map 41).

Local name reported by $H$. C. Fassett, USBF, in 1910.

Portage Creek: stream, flows SW 4 mi. to Right Arm Iniskin Bay, $26 \mathrm{mi}$. N of Augustine I., Aleutian Ra.; $59^{\circ} 44^{\prime} \mathrm{N}, 153^{\circ} 21^{\prime} \mathrm{W}$; (map 51).

Name published by Moffit (1927, pl. 1), USGS.

Portage Creek: stream, flows S $5.5 \mathrm{mi}$. to Lake Clark, $37 \mathrm{mi}$. NE of Nondalton, Aleutian Ra.; $60^{\circ} 21^{\prime} \mathrm{N}, 154^{\circ} 01^{\prime} \mathrm{W}$; BGN 1910; (map 61). Var. Achteedeedung, Akhtididung, Akhtidung.

Local name reported in $i 902$ by W. H. Osgood, USDA, who gives its Tanaina Indian name as "Achteedeedung."

Portage Creek: stream, on Kenai Penin., flows NW $7 \mathrm{mi}$. to Placer River at head of Turnagain Arm, $16 \mathrm{mi}$. SE of Sunrise, Chugach Mts. ; $60^{\circ} 49^{\prime} 30^{\prime \prime} \mathrm{N}, 148^{\circ} 59^{\prime} 15^{\prime \prime} \mathrm{W}$; (map 63).

Local prospectors' name reported in 1904 by Moffit (1906, pl. 2), USGS

Portage Creek: stream, heads in lake, in Kiokluk Mts., flows SE $25 \mathrm{mi}$. to Holitna River $6 \mathrm{mi}$. SW of its junc. with Chuilnuk River, $45 \mathrm{mi}$. SW of Sleetmute, Kilbuck-Kuskokwim Mts. $61^{\circ} 05^{\prime} \mathrm{N}, 157^{\circ} 35^{\prime} \mathrm{W}$; BGN 1948; (map 72).

Locally named because the stream heads in a pass which is a portage between Kusko- 
kwim and upper Holitna Rivers; reported in 1945 by USGS

Portage Creek: stream, heads at Stoney Glacier, flows E $13 \mathrm{mi}$. to Skwentna River, $78 \mathrm{mi}$. NW of Tyonek, Alaska Ra.; 61 ${ }^{\circ} 58^{\prime} 00^{\prime \prime} \mathrm{N}, 152^{\circ}$ 33'45" W; (map 70).

Named by Spurr $(1900$, p. 50$)$, USGS, because it was along this stream he began his portage across the divide to the Kuskokwim River.

Portage Creek: stream, flows SW $1.5 \mathrm{mi}$. to Susitna River, $2.5 \mathrm{mi}$, SW of Curry and 18 mi. NE of Talkeetna, Talkeetna Mts.; $62^{\circ} 34^{\prime}$ $50^{\prime \prime} \mathrm{N}, 150^{\circ} 02^{\prime} 20^{\prime \prime} \mathrm{W}$; (map 81).

Local name reported in 1958 by USGS.

Portage Creek: stream, flows SW $30 \mathrm{mi}$. to Susitna River, $41 \mathrm{mi}$. SW of Cantwell, Talkeetna Mts.; $62^{\circ} 49^{\prime} 50^{\prime \prime} \mathrm{N}, 149^{\circ} 22^{\prime} 40^{\prime \prime} \mathrm{W}$; (map 82).

Named by Robert Muldrow, USGS, in 1898 .

Portage Creek: stream, flows SW $8 \mathrm{mi}$, to Middle Fork Fortymile River, $50 \mathrm{mi}$. SW of Eagle, Yukon-Tanana High.; $64^{\circ} 27^{\prime} 30^{\prime \prime} \mathrm{N}, 142^{\circ} 40^{\prime}$ $40^{\prime \prime} \mathrm{W}$; (map 102).

Named by prospectors and shown on 1902 manuscript map by E. J. Chamberlain, U.S. Deputy Surveyor.

Portage Creek: stream, flows SW $4 \mathrm{mi}$. to Golovnin Bay, $48 \mathrm{mi}$. SE of Solomon, Seward Penin. High.; $64^{\circ} 30^{\prime} \mathrm{N}, 162^{\circ} 51^{\prime} \mathrm{W}$; (map 95). Var. West Portage Creek.

Prospectors' name shown as "West Portage" on a precinct map of Seward Peninsula by Monroe and Hutchins corrected up to June 1903 by Arthur Gibson.

Portage Creek: stream, flows SE $7 \mathrm{mi}$. to West Fork Little Delta River, $60 \mathrm{mi}$. E of Healy, Alaska Ra.; $64^{\circ} 55^{\prime} \mathrm{N}, 147^{\circ} 00^{\prime} \mathrm{W}$; (map 87).

Local name reported in 1910 by J. W. Bagley (in Capps, 1912, pl. 2), USGS.

Portage Creek: stream, flows SW $4 \mathrm{mi}$. to Birch Creek, $37 \mathrm{mi}$. SW of Circle, Yukon-Tanana High.; $65^{\circ} 21^{\prime} 20^{\prime \prime} \mathrm{N}, 144^{\circ} 40^{\prime} 35^{\prime \prime} \mathrm{W}$; (map 104)

Named by prospectors; reported in 1904 by D. C. Witherspoon, USGS.

Portage Creek: stream, flows NE $8 \mathrm{mi}$. to Medicine Lake, $26 \mathrm{mi}$. SW of Circle, Yukon-Tanana High.; $65^{\circ} 30^{\prime} \mathrm{N}, 144^{\circ} 33^{\prime} \mathrm{W}$; (map 104).

Named by prospectors and reported in 1905 by D. C. Witherspoon (in Prindle, 1906, pl 1), USGS.

Portage Creek: stream, flows NE $1.7 \mathrm{mi}$. to North Fork Kougarok River, SE of Harris Dome and $39 \mathrm{mi}$. W of Imuruk Lake, Seward Penin. High.; $65^{\circ} 37^{\prime} \mathrm{N}, 164^{\circ} 32^{\prime} \mathrm{W}$; (map 110).

Prospectors' name reported in 1901 by T. G. Gerdine (in Collier, 1902, pl. 12), USGS.

Portage Creek: stream, flows SW $19 \mathrm{mi}$. to American River, $12 \mathrm{mi}$. W of Kougarok Mtn. and $36 \mathrm{mi}$. NE of Teller, Seward Penin. High.; $65^{\circ} 42^{\prime} \mathrm{N}, 165^{\circ} 39^{\prime} \mathrm{W}$; (map 111).

Prospectors' name reported in 1900 by Messrs. Kemp and David Fox (in Brooks, 1901, pl. 11).

Portage Creek: stream, flows SE $5 \mathrm{mi}$. to Kugruk River, $30 \mathrm{mi}$. NE of Imuruk Lake, Seward
Penin. High.; $65^{\circ} 54^{\prime} \mathrm{N}, 162^{\circ} 29^{\prime} \mathrm{W}$; (map 110).

Prospectors' name reported in 1908 by F. F. Henshaw (in Brooks and others, 1909, fig. 21), USGS.

Portage Creek: stream, flows N $7 \mathrm{mi}$. to Kobuk River, $25 \mathrm{mi}$. NW of Selawik, Hogatza High.; $66^{\circ} 56^{\prime} \mathrm{N}, 160^{\circ} 19^{\prime} \mathrm{W}$; (map 114).

Local name reported by the U.S. Army Corps of Engineers in 1955.

Portage Creek: stream, heads at $67^{\circ} 43^{\prime} \mathrm{N}$, $155^{\circ} 04^{\prime} \mathrm{W}$, flows SW $9 \mathrm{mi}$. to Noatak River, $35 \mathrm{mi}$. SW of Survey Pass, Brooks Ra.; 67 ${ }^{\circ} 08^{\prime}$ $\mathrm{N}, 155^{\circ} 18^{\prime} \mathrm{W}$; (map 125).

Name used by prospectors and reported by P. S. Smith (1913), USGS. So named because it heads at the best available pass between the headwaters of the Noatak and Alatna Rivers.

Portage Creek : stream, see Traverse Creek.

Portage Creek: watercourse, see Talbiksok River.

Portage Fork: stream, flows SE $8 \mathrm{mi}$. to Mosquito Creek, $100 \mathrm{mi}$. SE of Sleetmute, Kilbuck-Kuskokwim Mts. ; $60^{\circ} 20^{\prime} \mathrm{N}, 156^{\circ} 13^{\prime} \mathrm{W}$; (map 60).

Local name reported in 1952 by USG\&GS.

Portage Glacier: glacier, on Kenai Penin., trends $\mathrm{N} 6 \mathrm{mi}$. to Portage Lake, $4 \mathrm{mi}$. W of Whittier, Chugach Mts.; $60^{\circ} 46^{\prime} \mathrm{N}, 148^{\circ} 48^{\prime} \mathrm{W}$; (map 63).

Local name reported in 1898 Mendenhall (1900, p. 273), USGS. So called because it was on a portage route between Prince William Sound and Turnagain Arm.

Portage Glacier: glacier, see Whittier Glacier. Portage Harbor: bay, see Portage Bay.

Portage Island: island, see Perevalnie Islands.

Portage Islands: islands, $0.5 \mathrm{mi}$. $\mathrm{N}$ of West Point on Kupreanof I. and $76 \mathrm{mi}$. E of Sitka, Alex. Arch.; $57^{\circ} 01^{\prime} 10^{\prime \prime} \mathrm{N}, 133^{\circ} 20^{\prime} 50^{\prime \prime} \mathrm{W}$; (map 8). Var. Perenosnaya Islands, Portage Islets.

Named "Perenosnaya Islands" in 1869 by Comdr. R. W. Meade, USN. The name was suggested by "Perenosnaya Bay," now called "Portage Bay," one mile to the south. "Perenosnaya" is the Russian word meaning "portage." The name, "Portage Islets" was published by USC\&GS in 1883 Alaska Coast Pilot (p. 125)

Portage Islets: islands, see Portage Islands.

Portage Lagoon: lagoon, $1.6 \mathrm{mi}$. long, on $\mathrm{N}$ coast of Atka I., Aleutian Is.; 52 $03^{\prime} 10^{\prime \prime} \mathrm{N}$, $175^{\circ} 02^{\prime} 30^{\prime \prime} \mathrm{W}$; (map 18)

Descriptive name applied to the lagoon because "when seen from the northwest, it appears to be a low passage through the island"; published by the USG\&GS in the 1944 Aleutian Coast Pilot (p. 97).

Portage Lake: lake, $1.5 \mathrm{mi}$. long, on Afognak I. S of Discoverer Bay, $22 \mathrm{mi}$. NE of Afognak, Kodiak I.; $58^{\circ} 16^{\prime} 30^{\prime \prime} \mathrm{N}, 152^{\circ} 25^{\prime} 30^{\prime \prime} \mathrm{W}$; (map 43).

Local name reported in 1952 by USGS.

Portage Lake: lake, $1.5 \mathrm{mi}$. long, $2 \mathrm{mi}$. E of Lachbuna Lake, $50 \mathrm{mi}$. NE of Nondalton,
Aleutian Ra.; $60^{\circ} 30^{\prime} 15^{\prime \prime} \mathrm{N}, 153^{\circ} 51^{\prime} 30^{\prime \prime} \mathrm{W}$; (map 61).

Local name reported in 1954 by USGS.

Portage Lake: lake, on Kenai Penin., $1.7 \mathrm{mi}$. long, at terminus of Portage Glacier, $4.5 \mathrm{mi}$. W of Whittier, Chugach Mts.; $60^{\circ} 47^{\prime} \mathrm{N}$, $148^{\circ} 49^{\prime} \mathrm{W}$; (map 63).

Local name published on recent USGS maps; derived from nearby Portage Glacier.

Portage Lake: lake, $1 \mathrm{mi}$. long, $3 \mathrm{mi}$. S of Timber Lake and $28 \mathrm{mi}$. NW of Arctic Village, Brooks Ra.; $68^{\circ} 20^{\prime}$ N, $146^{\circ} 27^{\prime}$ W; (map 136).

Local name reported in 1956 by $R$. C. Foley, USGS.

Portage Lake: lake, see Long Lake.

Portage Lakes: lakes, two, on Kenai Penin., extend $0.5 \mathrm{mi}$. NW of Birch Lake, $28 \mathrm{mi}$. NE of Kenai, Cook Inlet Low.; $60^{\circ} 44^{\prime} 00^{\prime \prime} \mathrm{N}$, $150^{\circ} 32^{\prime} 30^{\prime \prime} \mathrm{W}$; (map 62).

Named about 1963 by officials of Kenai National Moose Range, for administrative purposes.

Portage Lakes: lakes, along Yukon-Kuskokwim Portage, largest are Kulik, Arhymot, and Kukaklik Lakes, Yukon-Kuskokwim Delta; $61^{\circ} 37^{\prime} \mathrm{N}, 160^{\circ} 30^{\prime} \mathrm{W}$; (map 73).

This is a general name used to refer to the largest lakes between the two rivers on or near the portage.

Portage Mountain: mountain, 3,650 ft., on W coast of Lindenberg Penin., Kupreanof I., 12 mi. NW of Petersburg, Alex. Arch.; 56 $51^{\prime} 40^{\prime \prime}$ N $133^{\circ} 13^{\prime} 45^{\prime \prime}$ W; (map 6). Var. Portage Mountains.

Named in 1887 by Lt. Comdr. C. M. Thomas, USN, for charting purposes; name published in 1888 on USC\&GS Chart 705.

Portage Mountains: mountains, 1,500 ft., N of Kuskokwim River, extends NE $25 \mathrm{mi}$. from Kalskag and Arhymot Lake, Kilbuck-Kuskokwim Mts.; $61^{\circ} 41^{\prime} \mathrm{N}, 160^{\circ} 06^{\prime} \mathrm{W}$; (map 73).

Name shown on a manuscript map of unknown origin dated 1902; so called because the mountains lie close to the Yukon-Kuskokwim portage.

Portage Mountains: mountain, see Portage Mountain.

Portage Pass: pass, between Portage Creek and Wrong Branch Trail Creek, on Iniskin Penin., Aleutian Ra.; $59^{\circ} 47^{\prime} \mathrm{N}, 153^{\circ} 18^{\prime} \mathrm{W}$; (map 51).

Local name derived from Portage Creek and published by USGS in 1958 .

Portage Pass: pass, $600 \mathrm{ft}$., between Portage Lake and Passage Canal, $2.5 \mathrm{mi}$. SW of Whittier, Chugach $\mathrm{M}$ ts. ; $60^{\circ} 45^{\prime} 50^{\prime \prime} \mathrm{N}, 148^{\circ} 45^{\prime} 30^{\prime \prime}$ W; (map 63)

Local name published on recent USGS maps; derived from nearby Portage Glacier.

Portage Pass: pass, 3,900 ft., $\mathbf{N}$ of Cathedral Mtn., 86 mi. NW of Tyonek, Alaska Ra.; $61^{\circ}$ $58^{\prime} 15^{\prime \prime} \mathrm{N}, 152^{\circ} 57^{\prime} 45^{\prime \prime} \mathrm{W}$; (map 70).

Name derived from nearby Portage Creek. Portage Point: point of land, between Portage Arm and Middle Arm Kelp Bay, on NE coast of Baranof I., Alex. Arch.; $57^{\circ} 20^{\prime} \mathrm{N}, 134^{\circ} 55^{\prime}$ W; (map 9). 
Named in 1895 by Lt. Comdr. Moore, USN, and published by USC\&GS in the 1901 Coast Pilot (p. 160).

Portage Point: point of land, see Drying Point. Portage Point: point of land, see Kaskulu Point. Portage Point: point of land, see Mikhail Point. Portage Point: point of land, see Perenosa Point. Portage Roadhouse: locality, at mouth of Carson Creek on NW shore of Norton Bay, $15 \mathrm{mi}$. SW of Elim, Seward Penin. High.; 64 $29^{\prime}$ N, $162^{\circ} 36^{\prime} \mathrm{W}$; (map 95$)$.

Site of a roadhouse reported in 1909 by P. S. Smith and H. M. Eakin (in Brooks and others, 1910, pl. 8), USGS.

Portage Slough: watercourse, channel of Yukon River, flows $7.2 \mathrm{mi}$. E of unamed island to Grand Junction Point 6 mi. S of Russian Mission, Yukon-Kuskokwim Delta; $61^{\circ} 41^{\prime} \mathrm{N}$, $161^{\circ} 20^{\prime} \mathrm{W}$; (map 73).

Local name shown on a 1916 field sheet by R. H. Sargent, USGS; so called because it leads to the Yukon-Kuskokwim Portage.

Portage Valley: valley, extends NW 5 mi. along course of Portage Creek to S shore of Herendeen Bay, on Alaska Penin., Aleutian Ra.; $55^{\circ} 41^{\prime} \mathrm{N}, 160^{\circ} 41^{\prime} \mathrm{W}$; (map 28).

Descriptive name applied in 1890 by Lt. Comdr. Z. L. Tanner, USN, because "it forms part of a portage between Herendeen Bay and Albatross Anchorage."

Portage Village: locality, see Parents Trading Post.

Portage Village: village, see Crooked Creek.

Portal Camp: locality, $1.4 \mathrm{mi}$. NW of Thane, on Gastineau Channel, $4 \mathrm{mi}$. SE of Juneau, Coast Mts.; 58 $16^{\prime} 40^{\prime \prime} \mathrm{N}, 134^{\circ} 18^{\prime} 15^{\prime \prime} \mathrm{W}$; (map 11).

Local name reported in 1917 by $D$. C. Witherspoon, USGS. This was the site of a temporary mining camp.

Port Alexander: village, pop. 18, on SE coast of Baranof I., on W side of Chatham Strait, Alex. Arch.; $56^{\circ} 15^{\prime} 00^{\prime \prime} \mathrm{N}, 133^{\circ} 38^{\prime} 40^{\prime \prime} \mathrm{W}$; (map 5).

Fishing village, once the center of the largest trolling fleet in Alaska (Balcom, 1965, p. 67). Named for the estuary it is located on. Its population was 107 in 1930; 87 in 1939; and 22 in 1950. The Port Alexander post office was established in 1926.

Port Alsworth: village, pop. 34, on SE shore of Lake Clark at Hardenburg Bay, $22 \mathrm{mi}$. NE of Nondalton, Aleutian Ra.; $60^{\circ} 12^{\prime} \mathrm{N}, 154^{\circ} 19^{\prime}$ W; BGN 1959; (map 61). Var. Tanalian, Tanalian Point.

Village and airfield. The Port Alsworth post office was established in 1950 (Ricks, 1965, p. 52).

Port Althorp: locality, on $\mathrm{N}$ coast of Chichagof I., on Port Althorp, 1.9 mi. SE of Point Lucan, and $32 \mathrm{mi}$. W of Hoonah, Alex. Arch.; 58 $8^{\circ} 07^{\prime}$ $55^{\prime \prime} \mathrm{N}, 136^{\circ} 19^{\prime} 50^{\prime \prime} \mathrm{W}$; (map 10).

Name derived from the bay of Port Althorp. A cannery was located here in 1941.

Portalus Valley: ravine, on Granite Mtn., extends $\mathrm{N} 1.5 \mathrm{mi}$., near head of Hajdukovich Creek, $21 \mathrm{mi}$. SE of Delta Junction, Alaska, Ra., $63^{\circ} 46^{\prime} 40^{\prime \prime} \mathrm{N}, 145^{\circ} 21^{\prime} 00^{\prime \prime} \mathrm{W}$; (map 86). Name published on relatively recent maps.
Port Armstrong: locality, on $\mathrm{N}$ shore of Port Armstrong, $3.3 \mathrm{mi}$. N of village of Port Alexander, on $\mathrm{S}$ coast of Baranof I., Alex. Arch.; $56^{\circ} 17^{\prime} 50^{\prime \prime} \mathrm{N}, 134^{\circ} 39^{\prime} 45^{\prime \prime} \mathrm{W}$; (map 5).

Former cannery, now a herring reduction plant. In 1933 its population was estimated to be 100. The Port Armstrong post office was approved in 1913 but was never in operation (Ricks, 1965, p. 52).

Port Ashton: village, on $\mathrm{E}$ coast of Evans I., NW shore of Sawmill Bay, $17 \mathrm{mi}$. S of Chenega, Chugach Mts.; $60^{\circ} 03^{\prime} 30^{\prime \prime} \mathrm{N}, 148^{\circ} 03^{\prime}$ $00^{\prime \prime} \mathrm{W}$; (map 63).

Fishing village reported in 1943 by USC\& GS. A post office was established here in 1952 (Ricks, 1965, p. 53).

Port Benney: locality, on $\mathbf{E}$ coast of Evans I., $\mathrm{N}$ side of Sawmill Bay, $16 \mathrm{mi}$. SSE of Chenega, Chugach Mts. ; $60^{\circ} 03^{\prime} 43^{\prime \prime} \mathrm{N}, 148^{\circ} 01^{\prime} 02^{\prime \prime} \mathrm{W}$; (map 63).

Fishing village reported in 1943 by USC\& GS, now abandoned.

Port Chester: town, see Metlakatla.

Port Chilkoot: village, pop. 120, $0.4 \mathrm{mi}$. S of Haines, on Portage Cove, Chilkoot Inlet, 17 mi. SSW of Skagway, Coast Mts.; $59^{\circ} 13^{\prime} 45^{\prime \prime}$ N, $135^{\circ} 26^{\prime} 10^{\prime \prime} \mathrm{W}$; (map 45). Var. Chilkoot Barracks, Fort William H. Seward.

The War Department made a permanent military post here in 1904, called Fort William $\mathbf{H}$. Seward in honor of the purchaser of Alaska. In 1922 the name was changed to Chilkoot Barracks after the Chilkoot tribe of Tlingit Indians living in this area. The post was abandoned in 1943 and the land and buildings were bought by private citizens who called the "new" town "Port Chilkoot." The fort had a population of 255 in $1910 ; 186$ in 1920 ; 234 in 1930; and 337 in 1939. Port Chilkoot's population was 125 in 1950.

Port Chilkoot: village, see Glennallen.

Port Clarence: area, around bay of Port Clarence and Grantley Harbor, Seward Penin. High.; $65^{\circ} 15^{\prime} \mathrm{N}, 166^{\circ} 30^{\prime} \mathrm{W}$; (map 111).

The 11th Census (U.S. Bureau of the Census, 1893, p. 8) listed a collective village of "Port Clarence" with a population of 485 , of which 236 were native, and 249 were foreign.

Port Clarence River: stream, see Kuzitrin River. Port Crawford: locality, on NW coast of Latouche I., $17 \mathrm{mi}$. SE of Chenega, Chugach

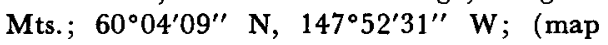
63).

Former mining camp reported in 1943 by USC\&GS. Recent USGS maps indicate a site with one building.

Port Dick Creek: stream, flows E $4.5 \mathrm{mi}$. to West Arm Port Dick, $17 \mathrm{mi}$. SE of Seldovia, Chugach Mts.; $59^{\circ} 18^{\prime} 30^{\prime \prime} \mathrm{N}, 151^{\circ} 20^{\prime} 00^{\prime \prime} \mathrm{W}$; (map 50).

Local name reported by Grant and Higgins (1913, pl. 2), USGS.

Porter Cove: cove, $0.5 \mathrm{mi}$. across, on $\mathrm{W}$ shore of Thomas Bay, $4 \mathrm{mi}$. $\mathrm{N}$ of Spurt Point and $100 \mathrm{mi}$. E of Sitka, Coast Mts.; $57^{\circ} 04^{\prime} 30^{\prime \prime} \mathrm{N}$, $132^{\circ} 52^{\prime} 00^{\prime \prime} \mathrm{W}$; (map 8).

Local name reported in 1961 by USGS.
Porterfield Creek: stream, flows SW $7 \mathrm{mi}$. to Virginia Lake, $9 \mathrm{mi}$. E of Wrangell, Coast Mts.; 56 $28^{\prime} 35^{\prime \prime} \mathrm{N}, 132^{\circ} 08^{\prime} 35^{\prime \prime} \mathrm{W}$; (map 6). Named in 1914 by E. Lester Jones, USBF, for Lt. L. B. Porterfield, USN, commander of the USBF steamer Albatross in 1914.

Porter Peak: mountain, 4,836 ft., $2 \mathrm{mi}$. E of Thomas Bay, $1 \mathrm{mi}$. NE of Waterfall Peak and $100 \mathrm{mi}$. E of Sitka, Coast Mts.; $57^{\circ} 02^{\prime} 55^{\prime \prime} \mathrm{N}$, $132^{\circ} 46^{\prime} 00^{\prime \prime}$ W; (map 8). Var. Waterfall Peak.

Name reported in 1964 by USC\&GS.

Port Graham: village, pop. 139, on S shore of Port Graham, Kenai Penin., $7.5 \mathrm{mi}$. SW of Seldovia, Chugach Mts.; $59^{\circ} 21^{\prime} 10^{\prime \prime} \mathrm{N}, 151^{\circ}$ $49^{\prime} 30^{\prime \prime}$ W ; BGN 1941; (map 50). Var. Port Grahame.

This place originally a cannery and wharf; reported by U. S. Grant and D. F. Higgins, USGS, in 1909. A post office was established in 1938, and discontinued in 1961.

Port Grahame: village, see Port Graham.

Port Heiden: village, pop. 74, on $\mathrm{N}$ shore of Alaska Penin., on $\mathrm{N}$ shore of Port Heiden, 20 mi. W of Aniakchak Crater, Bristol Bay Low; $56^{\circ} 55^{\prime}$ N, $158^{\circ} 41^{\prime}$ W; (map 30). Var. Mashik, Meshik, Mishik.

This settlement was formerly an Eskimo village spelled "Mishik" by USC\&GS in 1902. The Port Heiden Airfield is located a few miles north. The Port Heiden post office operated from 1912 to 1915 . The population of Port Heiden was 30 in 1920 and 51 in 1930.

Port Herbert: locality, at head of Port Herbert, $14 \mathrm{mi}$. NW of Port Alexander, on E coast of Baranof I., Alex. Arch.; $56^{\circ} 26^{\prime} 35^{\prime \prime} \mathrm{N}, 134^{\circ}$ $44^{\prime} 30^{\prime \prime} \mathrm{W}$; (map 5 ).

Local name published by USC\&GS in 1901 Coast Pilot (p. 149).

Port Higgins: settlement, pop. 66, on SW coast of Revillagigedo I. SE of Point Higgins, $8 \mathrm{mi}$. NW of Ketchikan, Alex. Arch.; 55 $27^{\prime} \mathrm{N}$, $131^{\circ} 49^{\prime} \mathrm{W}$; (map 3$)$.

This is an extention of the settlement area northwest of Ketchikan along the highway.

Port Hobron: locality, on $\mathrm{E}$ shore of Port Hobron, N coast of Sitkalidak I., SE of Kodiak I. ; $57^{\circ} 09^{\prime} 40^{\prime \prime} \mathrm{N}, 153^{\circ} 09^{\prime} 00^{\prime \prime} \mathrm{W}$; (map 34 ). Var. Fugitive.

Name derived from Port Hobron and published in 1952 by USGS. This name was probably given for an abandoned whaling station at this site. Baker (1906, p. 268) wrote, "Lisianski, 1805 (1814, p. 178), mentions a 'thriving village' of this name [Fugitive] on Sitkalidak island ***. It appears to have been on or near the Port Hobron of recent maps."

Portillo, Canal de: water passage, see Portillo Channel.

Portillo Channel: water passage, $8 \mathrm{mi}$. long, connecting Gulf of Esquibel and Ursua Channel, between Lulu and San Fernando Is., Alex. Arch.; $55^{\circ} 30^{\prime} \mathrm{N}, 133^{\circ} 26^{\prime} \mathrm{W}$; (map 4). Var. Canal de Portillo.

Named "Canal de Portillo" by Francisco Antonio Maurelle "about May 22, 1779, when he sailed through it, probably after José de 
Portillo who a little later became a minister of the Council of the Indies in Spain" (Wagner, 1937, p. 403).

Port Island: island, $250 \mathrm{ft}$. across, in Surveyor Passage, $2.5 \mathrm{mi}$. NW of Chichagof, on $\mathrm{W}$ coast of Chichagof I., Alex. Arch.; 57 $41^{\prime} 40^{\prime \prime} \mathrm{N}$, $136^{\circ} 07^{\prime} 50^{\prime \prime} \mathrm{W}$; BGN 1908; (map 9).

Named in 1908 by the USC\&GS and published in the 1908 Coast Pilot (p. 174). "The first syllable of the name 'Portlock [Capt. Nathaniel]' suggested this name." See Portlock Harbor.

Portland: village, see Hyder.

Portland Canal: water passage, forms part of boundary between Alaska and British Columbia, Canada, extends NE $70 \mathrm{mi}$. from NE end of Pearse I., Coast Mts.; $55^{\circ} 02^{\prime} \mathrm{N}, 130^{\circ} 12^{\prime}$ W; BGN 1953; (map 3). Var. Brown Canal, Pearse Canal, Pearse Channel, Portland Inlet, Portlands Canal, Portlands Channel.

Named by Capt. George Vancouver, RN, "August 15, 1793, no doubt after the Duke of Portland" (Wagner, 1937, p. 403). See Font, Streights du.

Portland City: village, see Hyder.

Portland Creek: stream, flows SE $2.3 \mathrm{mi}$. to Niukluk River 2 mi. above its junc. with Fish River, $34 \mathrm{mi}$. NE of Solomon, Seward Penin. High.; $64^{\circ} 50^{\prime} \mathrm{N}, 163^{\circ} 30^{\prime} \mathrm{W}$; (map 95).

Prospectors' name published on the 1908 "Map of Seward Peninsula" by Arthur Gibson.

Portland Creek: stream, flows WNW $1 \mathrm{mi}$. to Discovery Creek, $22 \mathrm{mi}$. NW of Solomon, Seward Penin. High.; $64^{\circ} 52^{\prime} \mathrm{N}, 164^{\circ} 43^{\prime} \mathrm{W}$; (map 95).

Prospectors' name reported on a map of Cape Nome gold fields by David Fox, Jr., dated 1901.

Portland Greek: stream, flows SE $2.4 \mathrm{mi}$. to Oxide Creek which flows to Ophir Creek, 12 mi. NW of Council and $40 \mathrm{mi}$. SW of Imuruk Lake, Seward Penin. High.; $65^{\circ} 03^{\prime} \mathrm{N}, 163^{\circ} 44^{\prime}$ W; (map 110).

Prospectors' name published on the 1908 "Map of Seward Peninsula" by Arthur Gibson.

Portland Creek: stream, flows SE $4.5 \mathrm{mi}$. to South Fork Koyukuk River, in South Fork Flats, $7 \mathrm{mi}$. SW of O'Keefe Hills and $29 \mathrm{mi}$. SW of Chandalar, Brooks Ra.; $67^{\circ} 18^{\prime} \mathrm{N}$, $149^{\circ} 27^{\prime} \mathrm{W}$; (map 123).

Local name reported in 1956 by T. E. Taylor, USGS.

Portland Inlet: water passage, see Portland Canal.

Portland Island: island, $1.1 \mathrm{mi}$. long, trends NW, in Stephens Passage, $2 \mathrm{mi}$. S of Point Louisa and $12 \mathrm{mi}$. NW of Juneau, Coast Mts.; $58^{\circ} 20^{\prime} 15^{\prime \prime} \mathrm{N}, 134^{\circ} 44^{\prime} 15^{\prime \prime} \mathrm{W}$; (map 11).

Named in 1880 by Capt. L. A. Beardslee, USN and published by USC\&GS in the 1883 Coast Pilot (p. 174).

Portlands Canal: water passage, see Portland Canal.

Portlands Channel: water passage, see Portland Canal.

Port Lions: village, pop. 190, on Settler Cove, near mouth of Kizhuyak Bay, $18 \mathrm{mi}$. NW of
Kodiak, N coast of Kodiak I.; $57^{\circ} 52^{\prime} \mathrm{N}, 152^{\circ}$ 53' W; BGN 1966; (map 34).

The village was built in 1964 by the Lions International for the displaced inhabitants of Afognak. A tidal wave, resulting from an earthquake on March 27, 1964, destroyed most of their village. See Afognak.

Portlock: locality, on S coast of Kenai Penin., on $S$ shore of Port Chatham, $16 \mathrm{mi}$. S of Seldovia, Chugach Mts.; $59^{\circ} 13^{\prime} \mathrm{N}, 151^{\circ} 45^{\prime}$ W; BGN 1944; (map 50).

This locality was primarily established as a cannery. A post office was established there in 1921; discontinued in 1950 (Ricks, 1965, p. 53). It was probably named for Capt. Nathaniel Portlock, who explored the area in 1786-87.

Portlock Glacier: glacier, on Kenai Penin., trends NW $6 \mathrm{mi}$. to an unnamed stream, $3 \mathrm{mi}$. $\mathrm{E}$ of Kachemak Bay and $18 \mathrm{mi}$. $\mathrm{E}$ of Homer, Chugach Mts.; $59^{\circ} 40^{\prime} \mathrm{N}, 151^{\circ} 02^{\prime} \mathrm{W}$; BGN 1913; (map 50).

Named by A. H. Brooks, USGS, in 1913, for Capt. Nathaniel Portlock, commander of the English vessel King George, who with Capt. George Dixon, RN, commander of the English vessel Queen Charlotte, did extensive exploration along the south coast of Alaska in 1786 and 1787.

Portlock Harbor: bay, $5 \mathrm{mi}$. across, $6 \mathrm{mi}$. NW of Chichagof, on W coast of Chichagof I., Alex. Arch.; $57^{\circ} 44^{\prime} \mathrm{N}, 136^{\circ} 14^{\prime} \mathrm{W}$; (map 9). Var. Kuk-kan Harbor.

Named in 1789 by Capt. Nathaniel Portlock. His ship was anchored in this harbor August 6-23 in 1787 (Wagner, 1937, p. 403). He published a sketch of the harbor in 1789. Lt. Comdr. H. E. Nichols, USN, regards the harbor the same as Kuk-kan of the Tlingit Indians (U.S. Coast and Geodetic Survey, 1891, p. 189).

Port Moller: village, pop. 33, on Entrance Point, Alaska Penin., Bristol Bay Low.; 55 $59^{\prime} 30^{\prime \prime}$ N, $160^{\circ} 34^{\prime} 30^{\prime \prime}$ W; (map 28). Var. Mashik, Mashikh.

Named for the bay; site of a cannery since about 1916. A post office was maintained here from 1952 to 1955 . The native village at Port Moller was called Mashikh by I. Petroff in the 10th census in 1880.

Port Nellie Juan: locality, on E coast of Kenai Penin., NE shore of McClure Bay, $20 \mathrm{mi}$. NW of Chenega, Chugach Mts.; $60^{\circ} 33^{\prime} 00^{\prime \prime} \mathrm{N}$, $148^{\circ} 09^{\prime} 45^{\prime \prime}$ W; (map 63). Var. West Gable Cannery.

Name of a cannery published on a 1952 USGS map.

Port O'Brien: locality, on $\mathrm{E}$ shore of Northeast Arm Uganik Bay, $\mathrm{N}$ coast of Kodiak I.; $57^{\circ} 44^{\prime} \mathrm{N}, 153^{\circ} 19^{\prime} \mathrm{W}$; (map 34 ).

Local name published in 1943 by USC\&GS.

Port Protection: locality, on S shore of Wooden Wheel Cove, $2.2 \mathrm{mi}$. S of village of Point Baker, on NW coast of Prince of Wales Island, Alex. Arch.; $56^{\circ} 19^{\prime} 20^{\prime \prime} \mathrm{N}, 133^{\circ} 36^{\prime} 35^{\prime \prime} \mathrm{W}$; (map 6).

This is a trading post and fish-buying station. A general store is also maintained here
(U.S. Coast and Geodetic Survey, 1962, p. 106).

Port Safety: locality, on spit between Safety and Norton Sounds, $6 \mathrm{mi}$. E of Cape Nome and 14 mi. SW of Solomon, Seward Penin. High.; $64^{\circ} 27^{\prime} \mathrm{N}, 164^{\circ} 49^{\prime}$ W; (map 95). Var. Safety.

Site of a mining camp established in the summer of 1900 at the height of the Nome gold rush (Brooks, 1901, p. 66). Safety Post Office established here in 1900 and discontinued in 1902 (Ricks, 1965, p. 55). Name was taken from the lagoon.

Port Snetisham: estuary, see Speel Arm.

Port Vita: locality, on $\mathrm{E}$ coast of Raspberry I., $12 \mathrm{mi}$. NW of Afognak, Kodiak I., 58 $03^{\prime} 50^{\prime \prime}$ $\mathrm{N}, 153^{\circ} 04^{\prime} 20^{\prime \prime} \mathrm{W}$; (map 43).

$A$ reduction and saltery plant by this name was reported in 1952 by USGS.

Port Wakefield: locality, on E coast of Raspberry I., $11 \mathrm{mi}$. NW of Afognak, Kodiak I.; $58^{\circ} 03^{\prime} 00^{\prime \prime} \mathrm{N}, 153^{\circ} 03^{\prime} 10^{\prime \prime} \mathrm{W}$; (map 43).

$A$ reduction and saltery plant by this name was reported in 1952 by USGS. See Port Wakefield: settlement.

Port Wakefield: settlement, on $\mathrm{W}$ side of Kizhuyak Bay at $\mathrm{N}$ end of Kodiak I., $1 \mathrm{mi}$. E of Port Lions, $57^{\circ} 52^{\prime} 00^{\prime \prime} \mathrm{N}, 152^{\circ} 51^{\prime} 30^{\prime \prime} \mathrm{W}$; (map 43).

This settlement was originally located on Raspsberry Island, but was partially destroyed by the March 1964 earthquake. In the summer of 1966 all salvageable buildings were to be moved to the new location and the original site abandoned.

Port Walter: locality, see Big Port Walter.

Port Walter: locality, see New Port Walter.

Port Whiteshed: village, see Whitshed.

Port Whitshed: village, see Whitshed.

Port William: locality, on S coast of Shuyak I., $40 \mathrm{mi}$. N of Kodiak I.; $58^{\circ} 29^{\prime} 30^{\prime \prime} \mathrm{N}, 152^{\circ}-$ $35^{\prime} 00^{\prime \prime} \mathrm{W}$; (map 43). Var. Port Williams.

Local name published by USC\&GS in 1926. Port Williams: locality, see Port William.

Posesion, Punta de: point of land, in Port Etches, Hinchinbrook Island. Var. Punta de la Primera Posesion, Punta de Sa Posesion.

Name shown on the 1779 Don Ignacio Arteaga map as "Sa Posesion" but on a chart of the port it is given as "Punta de la Primera Posesion" (Wagner, 1937, p. 486).

Posliednaho Liesu : point of land, see Last Timber Point.

Posliedni Gape: point of land, see Posliedni Point.

Posliedni Point: point of land, on NE shore of Afognak Bay, $2.5 \mathrm{mi}$. N of Afognak, on $\mathrm{S}$ coast of Afognak I., N of Kodiak I.; $58^{\circ} 03^{\prime}$ $30^{\prime \prime} \mathrm{N}, 154^{\circ} 45^{\prime 2} 5^{\prime \prime} \mathrm{W}$; (map 43).

Russian name "M[ys] Poslyedniy" meaning "last cape" given by Sub-Lt. Mikhail Murashev, IRN, in 1839 or 1840 and published by the Russian Hydrog. Dept. in 1849 on Chart 1425.

Posliedni Point: point of land, at mouth of Perenosa Bay, $34 \mathrm{mi}$. NE of Afognak, on $\mathrm{N}$ coast of Afognak I., $\mathrm{N}$ of Kodiak I.; $58^{\circ} 26^{\prime} 00^{\prime \prime} \mathrm{N}$, 
$152^{\circ} 19^{\prime} 30^{\prime \prime} \mathrm{W}$; (map 43). Var. Posliedni Cape.

Russian name, "M[ys] Poslyedniy," meaning "last cape"; published by USC\&GS in 1910.

Poslydnyago Lysu, Mys: point of land, see Last Timber Point.

Possession: locality, on Kenai Penin., SW of Point Possession, $22 \mathrm{mi}$. SW of Anchorage, Cook Inlet Low.; $61^{\circ} 02^{\prime} 00^{\prime \prime} \mathrm{N}, 150^{\circ} 24^{\prime} 10^{\prime \prime}$ W; BGN 1916; (map 70).

This is the site of a small Tanaina Indian village "occupied only during the summer" (U.S. Coast \& Geodetic Survey, 1964, p. 79). Capt. Tebenkov (1852, map 5), IRN, called the nearby point "Mys Naseleniya," meaning "Populated Cape," indicating a settlement here.

Possession, Point: point of land, on Kenai Penin., between Cook Inlet and Turnagain Arm, 20 mi. SW of Anchorage, Cook Inlet Low.; $61^{\circ} 02^{\prime} 22^{\prime \prime} \mathrm{N}, 150^{\circ} 22^{\prime} 30^{\prime \prime} \mathrm{W}$; (map 70). Var. Mys Naseleniya.

Named by Capt. Cook (1785, v. 2, p. 397), RN, on June 1, 1778, who "displayed the flag and took possession of the river and country in His Majesty's name." Capt. Tebenkov (1852, map 5), IRN, published the name "M[ys] Naseleniya," or "Populated Cape," for this point. See Possession.

Poss Mountain: mountain, elev. 6,100 ft., between South and Middle Forks of Koyukuk River, $33 \mathrm{mi}$. W of Chandalar, Brooks Ra., $67^{\circ} 26^{\prime} 30^{\prime \prime} \mathrm{N}, 149^{\circ} 45^{\prime} 00^{\prime \prime} \mathrm{W}$; (map 123).

Named about 1930 by Robert Marshall for Poss Postlethwaite, one of the oldest prospectors in the region.

Possum Creek: stream, heads in lake, flows $S$ $1.3 \mathrm{mi}$. to North Fork Montana Creek, $10 \mathrm{mi}$. SE of Talkeetna, Talkeetna Mts.; $62^{\circ} 13^{\prime} 30^{\prime \prime}$ N, 149 $53^{\prime} 00^{\prime \prime} \mathrm{W}$; (map 82).

Local name recorded in 1950 by USGS.

Post Creek: stream, flows SW $2.2 \mathrm{mi}$. to Niukluk River $1.2 \mathrm{mi}$. E of its junc. with Casadepaga River, $31 \mathrm{mi}$. NE of Solomon, Seward Penin.

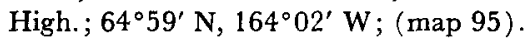

Prospectors' name reported in 1900 by E. C. Barnard (in Brooks, 1901, pl. 17), USGS.

Post Island: island, $0.6 \mathrm{mi}$. across, $13 \mathrm{mi}$. NW of Chichag of, on $\mathrm{W}$ coast of Chichagof I., Alex. Arch.; 57 $47^{\prime} 30^{\prime \prime} \mathrm{N}, 136^{\circ} 20^{\prime} 10^{\prime \prime} \mathrm{W}$; (map 9).

Name published in 1928 by UTC\&GS on Chart 8258.

Post Lake: lake, $0.6 \mathrm{mi}$. across, $17 \mathrm{mi}$. S of junc. of South Fork Kuskokwim and Post Rivers, $88 \mathrm{mi}$. SE of McGrath, Alaska Ra.; $62^{\circ} 08^{\prime} 45^{\prime \prime}$ $\mathrm{N}, 153^{\circ} 31^{\prime} 20^{\prime \prime} \mathrm{W}$; (map 80$)$.

Local name obtained in 1958 by USGS.

Post River: stream, heads at a glacier, $3.6 \mathrm{mi}$. W of Strand Pass, flows N $45 \mathrm{mi}$. to South Fork Kuskokwim River, $79 \mathrm{mi}$. SE of McGrath, Alaska Ra.; $62^{\circ} 24^{\prime} \mathrm{N}, 153^{\circ} 28^{\prime} \mathrm{W}$; (map 90).

Named in 1902 by A. H. Brooks, USGS, for W. S. Post, USGS, who descended the Kuskokwim River with J. E. Spurr in 1898.

Potainikof, Cape: point of land, $6.5 \mathrm{mi}$. NE of Cape Korovin, on NW coast of Atka I., Aleu- tian Is.; $52^{\circ} 22^{\prime} 30^{\prime \prime} \mathrm{N}, 174^{\circ} 20^{\prime} 00^{\prime \prime} \mathrm{W} ; B G N$ 1965; (map 18). Var. Cap Potainikoff, Mys Potaynikov.

Russian name meaning "hidden place" or "secret place" referring to rocks off the point which are revealed only by breakers in rough weather.

Potainikoff, Cap: point of land, see Potainikof, Cape.

Potato Creek: stream, on Seward Penin., heads SW of Potato Mtn., flows NW 6 mi. to Lopp Lagoon, $14 \mathrm{mi}$. NE of Cape Prince of Wales and $49 \mathrm{mi}$. NW of Teller, Kotzebue-Kobuk Low.; 654' $\mathrm{N}, 167^{\circ} 42^{\prime} \mathrm{W}$; BGN 1948; (map 111).

Prospectors' name reported in 1901 by T. G. Gerdine (in Collier, 1902, pl. 12), USGS.

Potato Creek: stream, flows E $4 \mathrm{mi}$ to Candle Creek, $10.4 \mathrm{mi}$. SW of Candle and $33 \mathrm{mi}$. NE of Imuruk Lake, Seward Penin. High.; $65^{\circ}$ $47^{\prime} \mathrm{N}, 162^{\circ} 06^{\prime} \mathrm{W}$; (map 110$)$.

Prospectors' name reported in 1903 by D. C. Witherspoon (in Moffit, 1905, pl. 2), USGS.

Potato Creek: stream, $40 \mathrm{mi}$. long, heads in Alaska, flows NE into Canada to Surprise Creek $8 \mathrm{mi}$. from its junc. with Old Grow River, Porcupine Plat.; $68^{\circ} 09^{\prime} \mathrm{N}, 140^{\circ} 24^{\prime} \mathrm{W}$; $B G N$ 1953; (map 137). Var. Schaefer Creek, Shaefer Creek, Shafer Creek.

Local name reported in 1949 by Cpl. E. A. Kirk, Royal Canadian Mounted Police. The name "Schaefer Creek" had been mistakenly applied to this stream during the IBC survey in 1911 and was so shown until 1950.

Potato Creek: stream, see Lynx Creek.

Potato Mountain: mountain, 1,400 ft., SE of Lopp Lagoon, $15 \mathrm{mi}$. E of Cape Prince of Wales and $44 \mathrm{mi}$. NW of Teller, Seward

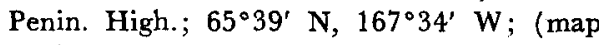
111). Var. Cone Hill, Conical Hill, Konicheskaya Sopka.

Local name published in 1900 on USC\&GS Chart 9380; reported in 1927 as "Conical Hill" by Capt. Beechey (1831, map facing p. 328 ), RN. In 1852 it was called "Konicheskaya Sopka," meaning "Conical Volcano," by the Russian Hydrog. Dept.

Potatopatch Lake: lake, $0.3 \mathrm{mi}$. long, W of Shahafka Cove, $1.2 \mathrm{mi}$. NE of Kodiak, Kodiak I. $57^{\circ} 47^{\prime} 55^{\prime \prime} \mathrm{N} ; 152^{\circ} 22^{\prime} 30^{\prime \prime} \mathrm{W}$; (map 34).

Local name published in 1943 by USC\&GS

Potato Point: point of land, in Valdez Arm at W entrance to Valdez Narrows, $15 \mathrm{mi}$. SW of Valdez, Chugach Mts.; $61^{\circ} 03^{\prime} 25^{\prime \prime} \mathrm{N}, 146^{\circ}$ 41'35" W; (map 68).

Named in 1898 by Capt. W. R. Abercrombie, USA.

Potaynikov, Mys: point of land, see Potainikof, Cape.

Pot Creek: stream, on Seward Penin., flows NE $6.8 \mathrm{mi}$. to Cripple River, $29 \mathrm{mi}$. SW of Deering, Kotzebue-Kobuk Low.; $66^{\circ} 00^{\prime}$ N., $163^{\circ}$ 44' W; (map 113).

Prospectors name reported in 1901 by Moffit (1905, pl. 2), USGS.

Pothole Glacier: glacier, in Tordrillo Mts., trends SW $9 \mathrm{mi}$. to its terminus at Nagishlamina River, $49 \mathrm{mi}$. NW of Tyonek, Alaska
Ra.; $61^{\circ} 17^{\prime} 45^{\prime \prime} \mathrm{N}, 152^{\circ} 33^{\prime} 30^{\prime \prime} \mathrm{W} ; B G N$ 1930; $(\operatorname{map} 70)$.

Descriptive name given in 1927 by S. R. Capps (in Smith and others, 1930, p. 148), USGS.

Pothole Lake: lake, $1 \mathrm{mi}$. long, in Kenai Mts. on Kenai Penin., $3.5 \mathrm{mi}$. ESE of Skilak Lake, and $44 \mathrm{mi}$. SE of Kenai, Chugach Mts.; $60^{\circ} 22^{\prime}$ $\mathrm{N}, 150^{\circ} 02^{\prime} \mathrm{W}$; (map 62$)$.

Local name reported in 1959 by USGS.

Potiliuk: village, see Pilot Station.

Potlatch Creek: stream, flows SW $11 \mathrm{mi}$. to Chena River, $14 \mathrm{mi}$. E of Fairbanks, Tanana Low.; $64^{\circ} 49^{\prime} \mathrm{N}, 147^{\circ} 16^{\prime} \mathrm{W}$; (map 100).

Local name reported in 1916 by USGS (Waring, 1917, fig. 8).

Potoniek Lake: lake, $3 \mathrm{mi}$. long, $48 \mathrm{mi}$. NW of Selawik, Kotzebue-Kobuk Low.; $66^{\circ} 55^{\prime} \mathrm{N}$, $161^{\circ} 33^{\prime} \mathrm{W}$; (map 114).

Eskimo name obtained in 1955 by U.S. Army Corps of Engineers.

Potter: settlement, pop. 14 , mi. 100.6 on The Alaska RR., near mouth of Potter Creek, 11 mi. S of Anchorage, Cook Inlet Low.; 61 $03^{\circ}$ $10^{\prime \prime} \mathrm{N}, 149^{\circ} 47^{\prime} 30^{\prime \prime} \mathrm{W}$; (map 69).

Local name reported in the 1919 Railway Guide Index; name derived from nearby Potter Creek.

Potter Creek: stream, heads on McHugh Peak, in Chugach Mts., flows $3.5 \mathrm{mi}$. to Turnagain Arm Cook Inlet, $12 \mathrm{mi}$. S of Anchorage, Cook Inlet Low.; $61^{\circ} 03^{\prime} 00^{\prime \prime} \mathrm{N}, 149^{\circ} 47^{\prime} 30^{\prime \prime} \mathrm{W}$; (map 69).

Local name reported in 1912 by USC\&GS.

Potter Hill: suburb, on Seward-Anchorage Highway, at Rabbit Creek, $9 \mathrm{mi}$. S of Anchorage, Cook Inlet Low.; $61^{\circ} 05^{\prime} \mathrm{N}, 149^{\circ} 49^{\prime} \mathrm{W}$; (map 69).

Local name reported in 1964 by USGS; name derived from nearby Potter Creek.

Potter Point: point of land, $\mathrm{E}$ point of entrance to Knudson Cove, in Clover Passage, on W coast of Revillagigedo I., Alex. Arch.; 55 $28^{\prime}$ $40^{\prime \prime} \mathrm{N}, 131^{\circ} 47^{\prime} 20^{\prime \prime} \mathrm{W}$; (map 3 ).

Local name reported in 1954 by USGS.

Potter Pup: stream, see Potter Pup Creek.

Potter Pup Creek: stream, flows W $1 \mathrm{mi}$. to Gold Run which flows to Bluestone River, 13 mi. SE of Teller, Seward Penin. High.; $65^{\circ} 05^{\prime}$ N, $166^{\circ} 12^{\prime}$ W; (map 111). Var. Potter Pup.

Prospectors' name reported on the 1908 "Map of Seward Peninsula" by Arthur Gibson.

Potter Rock: rock, at SE end of Tongass Narrows (East Channel), 0.7 mi. ESE of Pennock I., Alex. Arch.; $55^{\circ} 18^{\prime} 10^{\prime \prime} \mathrm{N}, 131^{\circ} 34^{\prime} 30^{\prime \prime} \mathrm{W}$; (map 3).

Local name published by USC\&GS in the 1917 Coast Pilot (p. 52).

Pouch Creek: stream, flows SW $1 \mathrm{mi}$. to Elliott Creek, $1.9 \mathrm{mi}$. SE of Alice Peak and $81 \mathrm{mi}$. NE of Valdez, Wrangell Mts.; $61^{\circ} 38^{\prime} 30^{\prime \prime} \mathrm{N}$, $144^{\circ} 05^{\prime} 00^{\prime \prime} \mathrm{W}$; (map 68).

Prospectors' name reported in 1903 by Mendenhall (1905, fig. 10), USGS.

Poul Creek: stream, heads $1.2 \mathrm{mi}$. SW of Munday Peak, flows S 3 mi. to Gulf of Alaska, 1.7 $\mathrm{mi}$. E of Umbrella Reef and $86 \mathrm{mi}$. NW of 
Yakutat, St. Elias Mts.; $60^{\circ} 01^{\prime} 20^{\prime \prime}$ N, $141^{\circ}-$ $59^{\prime} 45^{\prime \prime}$ W; (map 65).

Named for Angel Poul who located oil lands near Cape Yakataga in 1897. Name reported in 1903 by G. C. Martin, USGS.

Poul Point: point of land, on NE coast of Bering Lake, $11 \mathrm{mi}$. NE of Katalla, Chugach Mts.; $60^{\circ} 18^{\prime} \mathrm{N}, 144^{\circ} 17^{\prime} \mathrm{W}$; (map 64).

Local name used by prospectors, reported in 1905 by G. C. Martin, USGS.

Pounder, Mount: mountain, 6,502 ft., on AlaskaCanada boundary, $28 \mathrm{mi}$. $\mathrm{N}$ of Unuk River at Burroughs Bay, Coast Mts.; $56^{\circ} 27^{\prime} \mathrm{N}$, $131^{\circ} 10^{\prime} \mathrm{W}$; $B G N 1923$; (map 7 ).

Named in 1923 for John Pounder, a Canadian IBC surveyor.

Poundstone Rock: rock, in Favorite Channel, 1.3 mi. S of Sentinel I. and $24 \mathrm{mi}$. NW of Juneau, Coast Mts.; $58^{\circ} 31^{\prime} 45^{\prime \prime}$ N, $135^{\circ} 55^{\prime} 45^{\prime \prime} \mathrm{W}$; (map 11).

Named in 1890 by Lt. Comdr. H. B. Mansfield, USN for Ens. Homer Clark Poundstone, a member of his party. The name was published by USC\&GS in the 1891 Coast Pilot (p. 151).

Povero Island: island, see Povorotni Island.

Poverotni Island: island, see Povorotni Island.

Poverotni Point: point of land, see Lockwood, Point.

Poverotnoi Point: point of land, see Povorotni Point.

Poverotnyy, Mys: point of land, see Lockwood, Point.

Poverty Creek: stream, flows NW $1.5 \mathrm{mi}$. to Charley River $28 \mathrm{mi}$. SW of that stream's junc. with Yukan River, Yukon-Tanana High.; $65^{\circ} 03^{\prime} \mathrm{N}, 143^{\circ} 16^{\prime} \mathrm{W}$; (map 103).

Prospectors' name; from an unpublished map by E. J. Chamberlain, dated 1902. In 1956 USGS applied this name to a stream northeast of Essie Creek, instead of one to the south as the Chamberlain map shows it.

Poverty Island: island, see Refuge Island.

Poverty Rock: island, see Refuge Island.

Povorota, Mys: point of land, see Course Point. Povorotni, Ostrov: island, see Turning Island. Povorotni: point of land, see Vanderbilt Point. Povorotni Island: island, $0.1 \mathrm{mi}$. across, in Peril Strait, at SW end of Deadman Reach, off $\mathbf{N}$ coast of Baranof I., Alex. Arch.; 57 $30^{\prime} 50^{\prime \prime}$ $\mathrm{N}, 135^{\circ} 33^{\prime} 20^{\prime \prime} \mathrm{W}$; BGN 1897; (map 9). Var. Canoe Island, Ostrov Povorotnyy, Povero Island, Poverotni Island, Return Island, Turnabout Island.

Russian name meaning "turnabout," given in 1833 by the navigator Ens. Vasiliev; published in 1848 on Russian Hydrog. Dept. Chart 1397 as "Os[trov] Povorotnyy."

Povorotni Point: point of land, N point of entrance to Redoubt Bay, $7.5 \mathrm{mi}$. SW of Sitka, on $\mathrm{W}$ coast of Baranof I., Alex. Arch.; $56^{\circ}$ $57^{\prime}$ N, $135^{\circ} 24^{\prime}$ W; (map 5). Var. Mys Povorotnoy, Poverotnoi Point, Povorot Point, Turnabout Point.

Named in 1809 by the Russian navigator Ivan Vasiliev the first; published by Lt. Sarichev (1826, map 19), IRN, as "M[ys] Poyorotnoy," meaning "turnabout island."
Povorotnoi, Mys: point of land, see Protection Point.

Povorotnoy, Mys: point of land, see Povorotni Point.

Povorotny Island: island, see Turnabout Island. Povorotnyy, Mys: point of land, see Protection Point.

Povorotnyy, Mys: point of land, see Turner, Point.

Povorotnyy, Ostrov: island, see Povorotni Island.

Povorotnyy, Ostrov: island, see Turnabout Island.

Povorot Point: point of land, see Povorotni Point.

Powder Creek: stream, flows NE to Burnt River which flows to Kugruk River, about 15 mi. NE of Imuruk Lake, Seward Penin. High.; (map 110 ).

Local name published on precinct map of Seward Peninsula by Monroe and Hutchins; corrected to June 1903 by Arthur Gibson. This stream cannot be precisely identified on current maps.

Powder Point: point of iand, on NW coast of Latouche I., $18 \mathrm{mi}$. SE of Chenega, Chugach Mts.; $60^{\circ} 03^{\prime} 05^{\prime \prime} \mathrm{N}, 147^{\circ} 54^{\prime} 20^{\prime \prime} \mathrm{W}$; $B G N$ 1919; (map 63).

Local name published in 1917 by USC\&GS ; so called "because blasting powder for mining purposes was once stored here."

Powder Top, Mount: mountain peak, 9,140 ft., $1.3 \mathrm{mi}$. E of Flat Top Peak, $30 \mathrm{mi}$. NW of Valdez, Chugach Mts.; $61^{\circ} 25^{\prime} 55^{\prime \prime} \mathrm{N}, 106^{\circ}$. 53'17' W; BGN 1965; (map 68).

Named about 1955 by Nielsen (1963, p. 135 ) because of the powder snow on its summit.

Powee Creek: stream, flows S $2 \mathrm{mi}$. to Dome Creek, $28 \mathrm{mi}$. S of Eagle, Yukon-Tanana High.; $64^{\circ} 23^{\prime} \mathrm{N}, 141^{\circ} 11^{\prime} \mathrm{W}$; (map 102).

Prospectors' name shown on an 1898 manuscript map by C. A. Woodruff, Fort Cudahy, Canada.

Powell Creek: stream, flows E $2 \mathrm{mi}$. to Casadepaga River, $19 \mathrm{mi}$. NE of Solomon, Seward Penin. High.; $64^{\circ} 50^{\prime} \mathrm{N}, 164^{\circ} 20^{\prime} \mathrm{W}$; (map 95).

Prospectors' name reported in 1905 by $\mathrm{T}$. G. Gerdine, USGS.

Powell Gulch: ravine, extends SE $2.9 \mathrm{mi}$. to Chisna River, $\mathrm{S}$ of Chisna Pass, $23 \mathrm{mi}$. NE of Paxson. Alaska Ra.; $63^{\circ} 07^{\prime} 45^{\prime \prime} \mathrm{N}, 144^{\circ} 48^{\prime} 05^{\prime \prime}$ W; (map 86).

"Named by prospectors for A. W. Powell, engineer and pioneer in the Copper River country." The name was reported in 1900 by T. G. Gerdine, USGS.

Powell Knob: peak, see Powell Peak.

Powell Peak: peak, 2,662 ft., $1 \mathrm{mi}$. W of head of Thomas Bay and $98 \mathrm{mi}$. E of Sitka, Coast Mts.; $57^{\circ} 05^{\prime} 30^{\prime \prime} \mathrm{N}, 132^{\circ} 51^{\prime} 30^{\prime \prime} \mathrm{W}$; (map 8). Var. Powell Knob.

Named in 1887 by Lt. Comdr. C. M. Thomas, USN, for John Wesley Powell, 18341902, geologist and ethnologist; name published in 1888 by USC\&GS. Powell served as a major in the Union Army and professor of geology at Wesleyan College. He made the first geological and geographical survey of the Colorado River for the Smithsonian Institution in 1869. Later he was engaged in geological and ethnological studies in geological and ethnological studies in Arizonia and Utah. He helped establish the U.S. Geological Survey in 1879 and was its director, 1881-94.

Powell Peak: peak, 4,475 ft., $3.2 \mathrm{mi}$. NE of Dyke $\mathrm{Mtn}$. and $42 \mathrm{mi}$. N of Valdez, Chugach Mts.; $61^{\circ} 43^{\prime} 35^{\prime \prime} \mathrm{N}, 146^{\circ} 02^{\prime} 55^{\prime \prime} \mathrm{W}$; (map 68).

Named in 1898 by Capt. W. R. Abercrombie, USA, probably for Addison $\mathbf{M}$. Powell, a guide.

Power Creek: stream, flows SW $9 \mathrm{mi}$. to Eyak Lake, $5 \mathrm{mi}$. NE of Cordova, Chugach Mts.; $60^{\circ} 35^{\prime} \mathrm{N}, 145^{\circ} 39^{\prime} \mathrm{W}$; (map 64).

Local name published in 1951 by USGS.

Power Creek: stream, flows SW to Turner Creek which flows to Noxapaga River, about $33 \mathrm{mi}$. SW of Imuruk Lake, Seward Penin. High.; (map 110).

Prospectors' name shown on a map of Cape Nome gold fields by David Fox, Jr., dated 1901. This stream cannot be precisely located on current maps.

Power Lake: lake, $0.5 \mathrm{mi}$. long, on Prince of Wales I., near head of Kasaan Bay, $\mathrm{N}$ of village of Salt Chuck, Alex. Arch.; 55 $37^{\prime} 50^{\prime \prime}$ $\mathrm{N}, 132^{\circ} 32^{\prime} 30^{\prime \prime} \mathrm{W}$; (map 4).

Local name recorded in 1949 by USGS.

Powerline Pass: pass, 3,550 ft., $2 \mathrm{mi}$. NNE of Suicide Peak and $15 \mathrm{mi}$. SE of Anchorage, Chugach Mts.; $61^{\circ} 03^{\prime} 15^{\prime \prime} \mathrm{N}, 149^{\circ} 32^{\prime} 40^{\prime \prime} \mathrm{W}$; $B G N$ 1966; (map 69).

Local name reported in 1966 by the Mountaineering Club of Alaska. So named because a "major powerline crosses the pass and many people follow it."

Powerline Ridge: ridge. $1.5 \mathrm{mi}$. long, extends NE from Sheep Creek, $7 \mathrm{mi}$. E of Juneau, Coast Mts.; 58 $17^{\prime} 15^{\prime \prime}$ N, 134 $15^{\prime} 00^{\prime \prime}$ W; (map 11).

Local descriptive name reported in 1965 by D. A. Brew and A. B. Ford, USGS.

Powers Creek: stream, heads in Sumdum Glacier, flows SW $2 \mathrm{mi}$. to Endicott Arm, $3 \mathrm{mi}$. $\mathrm{E}$ of Round Islet and $48 \mathrm{mi}$. SE of Juneau, Coast Mts.; $57^{\circ} 45^{\prime} 40^{\prime \prime} \mathrm{N}, 133^{\circ} 31^{\prime} 00^{\prime \prime} \mathrm{W}$; (map 8).

Prospectors' name reported by Spencer and Wright (1906, fig. 3), USGS. A small amount of placer gold was found along this creek about 1880 .

Powers Creek: stream, flows W $1 \mathrm{mi}$. to Dick Creek, 13 mi. NE of Katalla, Chugach Mts.; $60^{\circ} 20^{\prime} \mathrm{N}, 144^{\circ} 19^{\prime} \mathrm{W}$; (map 64$)$.

Local name published in 1907 by USGS.

Powers Creek: stream, flows SW $7 \mathrm{mi}$. to Norton Sound, $4.3 \mathrm{mi}$. N of Unalakleet, Nulato Hills; $63^{\circ} 56^{\prime} \mathrm{N}, 160^{\circ} 50^{\prime} \mathrm{W}$; (map 91 ).

Local name reported in 1952 by USC\&GS. Powgowsayluk: hill, see Pogoseluk Hill.

Pow Island: island, $0.3 \mathrm{mi}$. across, in Hassler Harbor, off Revillagigedo Channel, on NE coast of Annette I., Alex. Arch.; 55 $13^{\prime} 00^{\prime \prime} \mathrm{N}$, $131^{\circ} 25^{\prime} 45^{\prime \prime} \mathrm{W}$; (map 8). 
Named in 1883 by Lt. Comdr. H. E. Nichols, USN.

Pownrakveerak : hill, see Ponrakvirak Hill.

Powoeluk: locality, see Powooiliak Camp.

Powoilak: bay, see Powooiliak Bay.

Powooiliak: locality, see Powooiliak Camp.

Powooiliak Bay: bay, S of $\mathrm{W}$ end of Koozata Lagoon, on S coast of St. Lawrence I., $35 \mathrm{mi}$. $\mathrm{SE}$ of Gambell; 63.25' N, $171^{\circ} 00^{\prime} \mathrm{W}$; (map 93). Var. Powoilak.

Eskimo name reported in 1949 by Maj. H. B. Allen, USAF; in 1965 Orth recorded the name as "Powoilak."

Powooiliak Camp: locality, on S coast of St. Lawrence I., $6 \mathrm{mi}$. NE of Southwest Cape, at Powooiliak Point; $63^{\circ} 22^{\prime} \mathrm{N}, 171^{\circ} 17^{\prime} \mathrm{W} ; B G N$ 1951; (map 93). Var. Poogooviliak, Poogovellyak, Poowooiliak Camp, Pōō wō'wā lŭk, Powoeluk, Powooiliak, Pugupiliak, Puguiviliak.

Eskimo camp reported in 1932 by O. W. Geist, Univ. of Alaska. In 1849 Capt. M. D. Tebenkov, IRN, recorded "Puguviliak" at or near this point; in 1900 the Bureau of Education published "Powoeluk" and in 1904 "Pōō wō'wā lŭk" (Baker, 1906, p. 510 and 514).

Powooiliak Point: point of land, $6 \mathrm{mi}$. NE of Southwest Cape, S coast of St. Lawrence I.; $63^{\circ} 22^{\prime} \mathrm{N}, 171^{\circ} 17^{\prime} \mathrm{W}$; BGN 1951; (map 93). Var. Cape Powooiliak, Cape Pugupiliak, Cape Puguviliak, Powooliak Cape, Powooiliak Cape, Puguviliak Cape, Southwest Cape.

Eskimo name reported in 1932 by O. W. Geist, Univ. of Alaska.

Powooliak Cape: point of land, see Powooiliak Point.

Practolus Creek: stream, flows SE $1 \mathrm{mi}$. to Cripple River, $16 \mathrm{mi}$. NW of Nome, Seward Penin. High.; $64^{\circ} 41^{\prime} 30^{\prime \prime} \mathrm{N}, 165^{\circ} 44^{\prime} 00^{\prime \prime} \mathrm{W}$; (map 94)

Prospectors' name shown on the 1904 "Map of Cape Nome Precinct" by Arthur Gibson.

Prairie Basin: valley, on Peterson Creek, $15 \mathrm{mi}$. NW of Juneau, Coast Mts. ; $58^{\circ} 28^{\prime} \mathrm{N}, 134^{\circ} 44^{\prime}$ W; (map 11).

Named in 1899 by J. G. Peterson (DeArmond, 1957, p. 35).

Prairie Creek: stream, heads in Stephan Lake, flows SW $8 \mathrm{mi}$. to Talkeetna River, $39 \mathrm{mi}$. NE of Talkeetna, Talkeetna Mts.; $62^{\circ} 36^{\prime} 00^{\prime \prime} \mathrm{N}$, $149^{\circ} 03^{\prime} 30^{\prime \prime} \mathrm{W}$; (map 82).

Local name recorded in 1952 by USGS

Pratt, Mount: mountain, 7,950 ft., $1.5 \mathrm{mi}$. W ol United States-Canada boundary, $32 \mathrm{mi}$. ENE of Petersburg, Coast Mts. ; $56^{\circ} 57^{\prime} 15^{\prime \prime} \mathrm{N}, 132^{\circ}$ $07^{\prime} 30^{\prime \prime} \mathrm{W}$; (map 6).

Named in 1895 by USC\&GS for John F. Pratt, USC\&GS.

Pratt Cove: bight, $1.5 \mathrm{mi}$. wide, on $\mathrm{W}$ coast of Ulak I., Delarof Is., Aleutian Is.; $51^{\circ} 22^{\prime} 00^{\prime \prime}$ $\mathrm{N}, 178^{\circ} 58^{\prime} 45^{\prime \prime} \mathrm{W}$; (map 16).

Name published in the 1946 supplement to the 1944 Aleutian Coast Pilot (U.S. Coast and Geodetic Survey, 1946, p. 120).

Pratt Point: point of land, E tip of Little Sitkin I., Aleutian Is.; $51^{\circ} 56^{\prime} 45^{\prime \prime} \mathrm{N}, 178^{\circ} 35^{\prime} 15^{\prime \prime} \mathrm{E}$; BGN 1937; (map 15).
Reported by personnel of the U.S.S. Oglala in 1935. Named for Capt. J. F. Pratt, 18481929, of the USC\&GS ship Patterson which was in these waters in 1904.

Pravoi, Mys: point of land, see Right Hand Point.

Pravoi Cape: point of land, see Outer Right Cape.

Pravoy, Mys: point of land, see Outer Right Cape.

Prazdnichnoi: island, see Holiday Island.

Prazdnichnoy, Ostrov: island, see Holiday Island.

Prazdnic Island: island, see Holiday Island

Praznic Island: island, see Holiday Island.

Preacher Creek: stream, heads at $65^{\circ} 33^{\prime} \mathrm{N}$, $146^{\circ} 24^{\prime} \mathrm{W}$, and flows NE $68 \mathrm{mi}$. to Birch Creek, $33 \mathrm{mi}$. SE of Fort Yukon, Yukon Flats; $66^{\circ} 08^{\prime} 20^{\prime \prime} \mathrm{N}, 144^{\circ} 50^{\prime} 00^{\prime \prime} \mathrm{W}$; (map 119).

Named for Robert McDonald, Church of England missionary at Fort Yukon, reported to have made the first discovery of gold on an unidentified stream in this area. Later, prospectors believing that they had reached the scene of this discovery, named this stream "Preacher Creek" in honor of the clergyman (Brooks, 1953, p. 311); name published in 1895 by USC\&GS.

Preacher Creek : stream, see Loper Creek.

Preble Peak: peak, 5,195 ft., $3 \mathrm{mi}$. E of head of Thomas Bay and $105 \mathrm{mi}$. E of Sitka, Coast Mts.; $57^{\circ} 06^{\prime} 25^{\prime \prime} \mathrm{N}, 132^{\circ} 43^{\prime} 30^{\prime \prime} \mathrm{W}$; (map 8). Named in 1887 by Lt. Comdr. C. M. Thomas, USN, for Rear Adm. George Henry Preble, 1761-1807, USN. The name was published in 1888 by USC\&GS on Chart 705 .

Precipices, Valley of: canyon, $5 \mathrm{mi}$. long, along Ernie Creek, W of Blackface Mtn., $24 \mathrm{mi}$. E of Anaktuvuk Pass, Brooks Ra.; 68 $02^{\prime} 30^{\prime \prime}$ N, $150^{\circ} 49^{\prime} 00^{\prime \prime}$ W ; (map 134).

So named by Marshall (1956, p. 16), about 1930 , who wrote "the valley was bounded by high, dark and dangerous looking precipices, surpassing, in my estimation, the grandeur of Yosemite. We called it the "Valley of Precipices.".

Premier Creek: stream, heads on Arkose Ridge, in Talkeetna Mts., flows SW $3 \mathrm{mi}$. to Moose Creek, 7.5 mi. N of Palmer, Cook Inlet Low.; $61^{\circ} 42^{\prime} 40^{\prime \prime} \mathrm{N}, 149^{\circ} 05^{\prime} 10^{\prime \prime} \mathrm{W}$; (map 69).

Local name reported in 1951 by USGS; derived from nearby Premier mine.

Premier Creek: stream, flows SE $1 \mathrm{mi}$. to Canyon Creek, upstream from Dexter Creek, $23 \mathrm{mi}$. NW of Solomon, Seward Penin. High.; 64 ${ }^{\circ} 52^{\prime}$ N, 164 $47^{\prime} \mathrm{W}$; (map 95). Var. Anita Creek.

Prospectors' name reported on a map of Cape Nome gold fields by David Fox, Jr., dated 1901.

Prendergast Ridge: ridge, see Prendergat Ridge.

Prendergat Ridge: ridge, $2.8 \mathrm{mi}$. long, $\mathrm{S}$ of East Arm Holtz Bay, on E end of Attu I., Aleutian Is.; $52^{\circ} 54^{\prime} \mathrm{N}, 173^{\circ} 10^{\prime} \mathrm{E}$; (map 13). Var. Prendergast Ridge.

Named by the U.S. Army during its occupation of the island during World War II; shown as Prendergast Ridge on an AMS map published in 1948.
President Bay: bay, $0.2 \mathrm{mi}$. across, on Windy Passage, $4.5 \mathrm{mi}$. SE of Goddard, on $W$ coast of Baranof I., Alex. Arch.; 56 $46^{\circ}$ N, $135^{\circ} 18^{\prime}$ W; $(\operatorname{map} 5)$.

Named by USC\&GS for charting purposes; name published in the 1932 Coast Pilot (p. 369).

Presidents Chair: peak, 10,372 ft., $6 \mathrm{mi}$. SW of Chisana Pass and $30 \mathrm{mi}$. N of McCarthy, Wrangell Mts.; $61^{\circ} 51^{\prime} 30^{\prime \prime} \mathrm{N}, 142^{\circ} 45^{\prime} 00^{\prime \prime} \mathrm{W}$; (map 67).

Local name obtained by USGS and published on maps since 1954.

Presno Creek: ravine, see Ina Gulch.

Preston Creek: stream, flows S $2 \mathrm{mi}$. to Macklin Creek which flows to Kougarok River, $8 \mathrm{mi}$. SW of Midnight Mtn. and $49 \mathrm{mi}$. NW of Imuruk Lake, Seward Penin. High.; $65^{\circ} 44^{\prime}$ N, $164^{\circ} 50^{\prime} \mathrm{W}$; (map 110).

Prospectors' name reported on the 1908 "Map of Seward Peninsula" by Arthur Gibson.

Pretty Creek: stream, flows SE $7 \mathrm{mi}$. to Beluga River, $14 \mathrm{mi}$. NE of Tyonek, Cook Inlet Low.; $61^{\circ} 15^{\prime} 10^{\prime \prime} \mathrm{N}, 150^{\circ} 58^{\prime} 30^{\prime \prime} \mathrm{W}$; (map 70).

Local descriptive name reported in 1958 by USGS.

Pribieli Islets: islands, see Sound Islands.

Pribilie Islands: islands, see Sound Islands.

Pribilof Islands: islands, in Bering Sea, consisting of St. Paul, St. George, Walrus, and Otter Is., $57^{\circ} \mathrm{N}, 170^{\circ} \mathrm{W}$; BGN 1890; (map 38). Var. Fur Seal Islands, Kotovy, Lebedevski, Novy, Ostrovski, Prybiloff Islands, Pribilov Islands, Pribulow, Pribyloff Islands, Privilof Islands, Sieverny, Seal Islands, Zouboff, Zoubov.

Named by Lt. G. A. Sarichev about 1792 for Gerassim Gavrilovich Pribilov (died 1796), who, while an employee of the Lebedev-Lastochkin Company, discovered St. George Island, one of the Pribilof Islands, in June 1786. The islands were first referred to as "Novy," meaning "new," and "Lebedevski," the name of the owner of Pribilov's vessel. G. I. Shelikov called the islands "Zoubov" for the then Russian Minister of the Interior. They were also referred to as "Kotovy," meaning "fur seal," and "Sieverny," meaning "north" (relative to Unalaska Island).

Pribilov Islands: islands, see Pribilof Islands.

Pribulow: islands, see Pribilof Islands.

Pribyloff Islands: islands, see Pribilof Islands.

Price Creek: stream, heads in York Mts., flows SE $2 \mathrm{mi}$. to Bering Sea, $30 \mathrm{mi}$. NW of Teller, Seward Penin. High.; $65^{\circ} 24^{\prime}$ N, $167^{\circ} 20^{\prime}$ W; (map 111).

Prospectors' name reported on the 1908 "Map of Seward Peninsula" by Arthur Gibson.

Price Island: island, $0.4 \mathrm{mi}$. across, off $\mathrm{E}$ coast of Admiralty I., $1.8 \mathrm{mi}$. SW of Gambier I. and $62 \mathrm{mi}$. NE of Sitka, Alex. Arch.; $57^{\circ}$ $25^{\prime} 50^{\prime \prime} \mathrm{N}, 133^{\circ} 53^{\prime} 10^{\prime \prime \prime} \mathrm{W}$; (map 8).

Named in 1889 by Lt. Comdr. H. B. Mansfield, USN; name published by USC\&GS in 1891 Coast Pilot (p. 114) 
Price River: stream, formed by Key and Wolf Creeks, flows W 45 mi. to Ikpikpuk River 36 mi. $N$ of its head, Arctic Plain; 69 $53^{\circ} \mathrm{N}$, $154^{\circ} 42^{\prime} \mathrm{W}$; $B G N$ 1925; (map 142).

Named in 1924 by USGS for C. M. Price, USN, an enlisted man who accompanied Ens. W. L. Howard on his expedition from Fort Cosmos, on the Kobuk River, to Point Barrow in the spring of 1886 .

Price River: stream, see Key Creek.

Priest Bay: $b a y$, see Mill Bay.

Priest Point: point of land, see Kalekta, Cape.

Priest River: stream, heads at terminus of Guyot Glacier and flows $7 \mathrm{mi}$. SW to Guyot Bay, 0.5 mi. N of Icy Cape and $74 \mathrm{mi}$. NW of Yakutat, Malaspina Coastal Plain; 60 $57^{\prime} 15^{\prime \prime} \mathrm{N}, 141^{\circ}$ $41^{\prime} 00^{\prime \prime} \mathrm{W}$; $(\operatorname{map} 47)$.

Local name published by USGS in 1948.

Priest Rock: rock, in Makushin Bay, on W coast of Unalaska I., S of Makushin, Aleutian Is. ; $53^{\circ} 45^{\prime} 52^{\prime \prime} \mathrm{N}, 166^{\circ} 59^{\prime} 15^{\prime \prime} \mathrm{W}$; (map 23).

Name published in 1951 on a USGS map.

Priest Rock: rock, off Cape Kalekta, on NE coast of Unalaska I., Aleutian Is. ; 54 $00^{\prime} 32^{\prime \prime}$ $\mathrm{N}, 166^{\circ} 22^{\prime} 30^{\prime \prime} \mathrm{W}$; (map 23)

Descriptive name used locally because of the resemblance of the rock to a Russian priest. Capt. Lutke (1836, p. 281), IRN, says: "The broken-down cliffs and isolated rocks sometimes take the most fantastic forms; as, for example, the one just in front of Cape Kalekta exactly resembles an old man having his head inclined and his arms crossed on his breast."

Priest Rock: rock, off Cape Darby in Norton Sound, $53 \mathrm{mi}$. SE of Solomon, Seward Penin. High.; $64^{\circ} 19^{\prime} \mathrm{N}, 162^{\circ} 47^{\prime} \mathrm{W}$; (map 95).

Local name reported about 1940 by USC\&GS and published on Chart 9382.

Prikhoda Island: island, see Prokoda Island.

Primera, Punta de la: point of land, see Posesion, Punta de.

Primrose: locality, on Kenai Penin., mi. 18.4 on The Alaska RR. and Seward Highway, 15 mi. N of Seward, Chugach Mts.; 60 $20^{\prime} 35^{\prime \prime}$ N, $149^{\circ} 20^{\prime} 30^{\prime \prime}$ W; (map 63). Var. Lake Kenai.

Listed as a flag stop on The Alaska RR. in the RR. guide of 1919. Recent USGS maps indicate a site with just one building.

Primrose Creek: stream, on Kenai Penin., heads $1 \mathrm{mi}$. N of Lost Lake, flows NE 6 mi. to Kenai Lake, $16 \mathrm{mi}$. $\mathrm{N}$ of Seward, Chugach Mts.; $60^{\circ} 20^{\prime} 30^{\prime \prime} \mathrm{N}, 149^{\circ} 22^{\prime} 00^{\prime \prime} \mathrm{W}$; BGN 1961; (map 63). Var. Porcupine Creek.

Named in 1960 by USFS; derived from nearby Primrose mine.

Primrose Ridge: ridge, extends $5 \mathrm{mi}$. from Sanctuary River to Savage River, $14 \mathrm{mi}$. W of village of McKinley Park, Alaska Ra.; 63 ${ }^{\circ} 45^{\prime}$ N, $149^{\circ} 24^{\prime} \mathrm{W}$; BGN 1963; (map 87).

So named in 1962 by NPS because "this ridge is the only place in the park where the primrose Primula Tschuktschorum, has been observed."

Primus Creek: stream, heads in De Long Mts., flows SW $12 \mathrm{mi}$. to Buccaneer Creek, $51 \mathrm{mi}$. WNW of Howard Pass, Brooks Ra.; $68^{\circ} 22^{\prime} \mathrm{N}$, $158^{\circ} 52^{\prime} \mathrm{W}$; BGN 1960; (map 132).
Named in 1951 by I. L. Tailleur, USGS, "for a stove used for camp cooking.",

Prince Creek: stream, flows SE $3.5 \mathrm{mi}$. to Bonanza Creek, between Butte and First Chance Creeks, $9 \mathrm{mi}$. SE of Flat and $50 \mathrm{mi}$. NW of Sleetmute, Kilbuck-Kuskokwim Mts.; $62^{\circ} 20^{\prime} \mathrm{N}, 157^{\circ} 54^{\prime} \mathrm{W}$; (map 79).

Name showis on a 1910 manuscript map of "Iditarod Placer Fields."

Prince Creek: stream, heads in a lake, flows $\mathbf{E}$ $45 \mathrm{mi}$. to Colville River, $7.5 \mathrm{mi}$. SW of Umiat, Arctic Slope; $69^{\circ} 19^{\prime} \mathrm{N}, 152^{\circ} 25^{\prime} \mathrm{W}$; BGN 1925; (map 141).

Named by personnel of 1924 USGS Expedition for a lead dog named "Prince," killed by mosquitoes and buried on the bank of this stream.

Prince Ernest Sound: water passage, see Ernest Sound.

Prince Frederick Sound: water passage, see Frederick Sound.

Prince Fredericks Sound: water passage, see Frederick Sound.

Prince Guillermo, Entrada del: gulf, see Prince William Sound.

Prince Island: island, $0.2 \mathrm{mi}$. across, in mouth of Appleton Cove at $\mathbf{N}$ end of Baranof I., 21 mi. S of Tanakee Springs, Alex. Arch.; $57^{\circ} 28^{\prime}$ $45^{\prime \prime} \mathrm{N}, 135^{\circ} 16^{\prime} 30^{\prime \prime} \mathrm{W}$; (map 9).

Local name reported in 1951 by USGS.

Prince Menshikoff, Cap du: bluff, see Menshikof, Cape.

Prince of Wales, Cape: point of land, westernmost point of Seward Penin., $55 \mathrm{mi}$. NW of Teller, Seward Penin. High.; $65^{\circ} 36^{\prime}$ N, $168^{\circ}-$ $05^{\prime}$ W; BGN 1944; (map 111). Var. Cape Kigmil, Mys Gvozdeva, Mys Nykhta, Mys Printsa Valliyskago ili Nykhta.

Named on Sunday, May 9, 1778, by Capt. Cook (1785, v. 2, p. 443), RN, who said, "This point of land, which I named Cape Prince of Wales, is the more remarkable, by being the Western extremity of all America hitherto known." The Eskimo name, published by Sarichev (1826, map 4), was "M[ys] Nykhta," that is, "Nykhta Cape." It is reported that in 1728 Bering named it "Mys Gvozdeva," or "Gvozdev Cape," probably for Michael Gvozdev, a Russian surveyor who made explorations in this area.

Prince of Wales Archipelago: islands, extend $135 \mathrm{mi}$., $65 \mathrm{mi}$. across, Alex. Arch.; $55^{\circ} 30^{\prime} \mathrm{N}$,

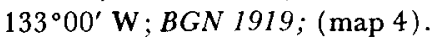

Name given on September 20,1793, by Capt. Vancouver, RN, "to the archipelago which he only suspected to be one [island] at the time" (Wagner, 1937, p. 403).

Prince of Wales Creek: stream, on Seward Penin., flows NW $8 \mathrm{mi}$. to Lopp Lagoon, $8 \mathrm{mi}$. NE of Cape Prince of Wales and $52 \mathrm{mi}$. NW of Teller, Kotzebue-Kobuk Low.; $65^{\circ} 40^{\prime} \mathrm{N}$, $167^{\circ} 50^{\prime} \mathrm{W}$; (map 111).

Prospectors' name reported on the 1908 "Map of Seward Peninsula" by Arthur Gibon.

Prince of Wales Island: island, $132 \mathrm{mi}$. long, 45 mi. across, largest island of Alex. Arch.; $55^{\circ} 21^{\prime} 30^{\prime \prime} \mathrm{N}, 133^{\circ} 36^{\prime} 15^{\prime \prime} \mathrm{W}$, to $54^{\circ} 41^{\prime} 30^{\prime \prime} \mathrm{N}$, $132^{\circ} 00^{\prime} 50^{\prime \prime} \mathrm{W}$; BGN 1944; (map 4).
According to Baker (1906, p. 511), "The earliest use of this name appears to be in the treaty between Great Britain and Russia of February 16-28, 1825"; obviously named for the Prince of Wales of England.

Prince of Wales Passage: water passage, trends SW $18 \mathrm{mi}$. from Knight Island Passage to Port Bainbridge, between Bainbridge and Evans Is., Chugach Mts.; $60^{\circ} 05^{\prime} \mathrm{N}, 148^{\circ} 05^{\prime} \mathrm{W}$; $B G N$ 1910; (map 63). Var. Flemming Passage.

Named in 1787 by Samuel Hayward of Capt. Portlock's vessel (Portlock, 1789, p. 245).

Prince of Wales Passage: water passage, see Elrington Passage.

Prince of Wales Peninsula: peninsula, see Seward Peninsula.

Prince of Wales Shoal: shoal, in Chukchi Sea, extends NE $20 \mathrm{mi}$. from Cape Prince of Wales, at $W$ end of Seward Penin. ; $65^{\circ} 55^{\prime} \mathrm{N}, 168^{\circ} 00^{\prime}$ W; (map 111).

Named and identified in 1890 on USC\&GS Chart 900 .

Princesa de Asturias: bay, "on northwest side of Unalaska Island."

Named by Martínez about July 28, 1788 (Wagner, 1937, p. 486).

Princesa Island: island, $1 \mathrm{mi}$. long, $\mathrm{E}$ island of Twin Is., Maurelle Is., Alex. Arch.; 55 $39^{\prime} 30^{\prime \prime}$ $\mathrm{N}, 133^{\circ} 40^{\prime} 00^{\prime \prime} \mathrm{W}$; (map 4).

Spanish name meaning "princess"; published in the 1925 Alaska Coast Pilot (p. 185).

Prince Shoal: shoal, $0.3 \mathrm{mi}$. across, at mouth of Purik Harbor, on Khantaak I., $2.2 \mathrm{mi}$. NW of Yakutat, Malaspina Coastal Plain; 59 $34^{\prime} 20^{\prime \prime} \mathrm{N}, 139^{\circ} 46^{\prime} 20^{\prime \prime} \mathrm{W}$; (map 46).

Named by Lt. Giles B. Harber, USN, in 1892; published in 1901 by USC\&GS on Chart 8455.

Princess Bay: bay, extends N $7 \mathrm{mi}$, off Behm Canal, on SE coast of Revillagigedo Channel, $\mathrm{W}$ of Smeaton I., Alex. Arch.; $55^{\circ} 19^{\prime} \mathrm{N}$, $131^{\circ} 00^{\prime} \mathrm{W}$; (map 3 ).

Local navigators' name obtained in 1904 by H. C. Fassett, USBF.

Princess Head: point of land, on $\mathrm{E}$ shore of Unalaska Bay, on NE coast of Unalaska I., Aleutian Is.; $53^{\circ} 59^{\prime} 03^{\prime \prime} \mathrm{N}, 166^{\circ} 24^{\prime} 25^{\prime \prime} \mathrm{W}$; (map 23). Var. Princes Head.

Name reported in 1871 by W. $\mathrm{H}$. Dall and published in 1900 by USC\&GS. It was shown on the 1875 USC\&GS Chart 821 as Princes Head.

Princess Peak: peak, 6,585 ft., in Taku Ra., 1 mi. S of The Dukes and $18 \mathrm{mi}$. N of Juneau, Coast Mts.; $58^{\circ} 33^{\prime} 38^{\prime \prime} \mathrm{N}, 134^{\circ} 22^{\prime} 30^{\prime \prime} \mathrm{W}$; $B G N$ 1965; (map 11). Var. Empress Peak.

Named in 1964 by members of the Juneau Icefield Research Project.

Princess Peak: peak, see Snowy Mountain.

Princess Rock: rock, between Sanak and Caton Is., Sanak Is., Aleutian Ra.; $54^{\circ} 24^{\prime} 00^{\prime \prime} \mathrm{N}$, $162^{\circ} 30^{\prime} 30^{\prime \prime} \mathrm{W}$; (map 25).

Name reported by Ferdinand Westdahl, USG\&GS, commander of the Coast Survey steamer McArthur, who made surveys in this area in 1901. 
Princeton Glacier: glacier, on E side of Kenai Penin., heads in Sargent Icefield, trends SE $5 \mathrm{mi}$. to its terminus, $1 \mathrm{mi}$. NW of head of Nassau Fiord, $18 \mathrm{mi}$. W of Chenega, Chugach Mts.; $60^{\circ} 18^{\prime} \mathrm{N}, 148^{\circ} 22^{\prime} \mathrm{W} ; B G N$ 1910; (map 63).

Named in 1909 by George W. Perkins, USC\&GS ; presumably for Princeton University, Princeton, New Jersey.

Prince William Sound: gulf, $70 \mathrm{mi}$. wide, extends $30 \mathrm{mi}$. $\mathrm{N}$ off Gulf of Alaska, E of Kenai Penin., bounded on $\mathrm{S}$ by Montague $\mathrm{I}$. and Hinchinbrook I.; $60^{\circ} 45^{\prime} \mathrm{N}, 147^{\circ} 00^{\prime} \mathrm{W} ; B G N$ Sixth Report; (map 63). Var. Chugach Sound, Chugatch Sound, Chugatskay Zaliv, Entrada del Prince Guillermo, Guba Chugatskaya ili Printsa Villiama, Sandwich Sound, Tchougatskoi Golfe.

Named by Capt. Cook (1785, v. 2, p. 366), RN, about May 20, 1778. It was called "Entrada del Prince Guillermo" by LaPerouse in 1786. The Eskimo name, published by Lt. Sarichev (1826, map 5), IRN, was "Guba Chugatskaya," or "Chugach Gulf."

Principe, Ensenada de: water passage, see Chatham Strait.

Principe, Enseñada del; water passage, see Chatham Strait.

Principe Carlos, Entrada de: water passage, "the entrance to Prince William Sound west of Montague Island."

Named by Martínez in 1788 . See Wagner (1937, p. 487).

Prindle, Mount: mountain, 5,286 ft., $31 \mathrm{mi}$. - NW of Chena Hot Springs and $72 \mathrm{mi}$. SW of Circle, Yukon-Tanana High.; $65^{\circ} 27^{\prime} 40^{\prime \prime} \mathrm{N}$, $146^{\circ} 28^{\prime 2} 25^{\prime \prime} \mathrm{W}$; (map 104).

Named in 1960 by USGS for Louis Marcus Prindle, 1865-1956, USGS geologist, who worked in central Alaska from 1902 through 1911.

Prindle Volcano: volcano, $4,580 \mathrm{ft}$., E of Dennison Fork, $50 \mathrm{mi}$. NE of Tok, Yukon-Tanana High.; $63^{\circ} 43^{\prime} \mathrm{N}, 141^{\circ} 38^{\prime} \mathrm{W}$; BGN 1962; (map 85).

Named by Waldo Smith, USGS, for Louis Marcus Prindle, 1865-1956, USGS geologist who published a photograph of this cinder cone (Mertie, 1931, pl. 8 B).

Prinsep, Mount: mountain, 6,342 ft., on AlaskaCanada boundary, $2.6 \mathrm{mi}$. NW of Chilkat Peak and $33 \mathrm{mi}$. W of Skagway, St. Elias Mts.; $59^{\circ} 31^{\prime} 30^{\prime \prime} \mathrm{N}, 136^{\circ} 14^{\prime} 15^{\prime \prime} \mathrm{W}$; BGN 1954; (map 45).

Named "Prinsep Peak" in 1926 by United States and Canada for G. T. Prinseps, Ottawa, surveyor with the Canadian section of the IBC.

Printsa Valliyskago ili Nykhta, Mys: point of land, see Cape Prince of Wales.

Printsa Villiama, Guba: gulf, see Prince William Sound.

Pritchard Rock: rock, NW of Whale I., in Galankin Is., 1.5 mi. S of Sitka, Alex. Arch.; $57^{\circ} 01^{\prime} 44^{\prime \prime} \mathrm{N}, 135^{\circ} 20^{\prime} 52^{\prime \prime} \mathrm{W}$; (map 9). Var. Pritchard Shoals.

Named in 1880 by the U.S. Navy and published by USC\&GS on Chart 725 .
Pritchard Shoals: rock, see Pritchard Rock.

Privilof Islands: islands, see Pribilof Islands.

Problem Creek: stream, flows NE $0.5 \mathrm{mi}$. to Mystery Creek which flows to Shovel Creek, 6 mi. $\mathrm{N}$ of Solomon, Seward Penin. High.; $64^{\circ}$ $39^{\prime} \mathrm{N}, 164^{\circ} 28^{\prime} \mathrm{W}$; (map 95).

Prospectors' name shown as "Problem Gh." on Arthur Gibson's "Map of Cape Nome Precinct" dated 1904.

Procession Rocks: group of rocks, in Port Bainbridge, off $\mathrm{S}$ coast of Bainbridge I., $22 \mathrm{mi}$. SW of Chenega, Chugach Mts.; $60^{\circ} 25^{\prime} \mathrm{N}$, $148^{\circ} 17^{\prime} \mathrm{W}$; ( $\left.\operatorname{map} 63\right)$.

Local name reported in 1905 by USC\&GS. Procrastination Creek: stream, flows NE $5 \mathrm{mi}$. to Coleen River, $7 \mathrm{mi}$. E of Lois Dome and 44 mi. N of Coleen Mtn., Brooks Ra.; $67^{\circ} 43^{\prime} \mathrm{N}$, $142^{\circ} 32^{\prime} \mathrm{W}$; (map 121).

Local name reported in 1956 by T. E. Taylor, USGS.

Profile Point: promontory, $184 \mathrm{ft}$., on $\mathrm{S}$ shore of Nazan Bay, on E coast of Atka I., Aleutian Is. ; $52^{\circ} 10^{\prime} 40^{\prime \prime} \mathrm{N}, 174^{\circ} 09^{\prime} 00^{\prime \prime} \mathrm{W}$; (map 18).

Name published in 1943 on a USC\&GS chart.

Profit Island: island, see Gui Kangulas.

Progressive Creek: stream, flows SW $5 \mathrm{mi}$. to Tanana River, $5.5 \mathrm{mi}$. ENE of Big Delta, Yukon-Tanana High.; $64^{\circ} 10^{\prime} 30^{\prime \prime} \mathrm{N}, 145^{\circ}$. $41^{\prime} 15^{\prime \prime} \mathrm{W}$; (map 101).

Local name reported in 1950 by USGS.

Project Peak: peak, see Emperor Peak.

Prokhoda, Ostrov: islands, see Passage Islands. Prokhoda, Ostrov: island, see Prokoda Island.

Prokhoda Islands: islands, see Passage Islands.

Prokhoda Point: point of land, S tip of Little Sitkin I., Rat Is., Aleutian Is.; $51^{\circ} 54^{\prime} 05^{\prime \prime} \mathrm{N}$, $178^{\circ} 30^{\prime 1} 5^{\prime \prime}$ E ; BGN 1937; (map 15).

Name published by U.S. Navy Hydrog. Office on a 1935 chart; derived from the Russian word "prokhoda," meaning "passage."

Prokoda Island: island, $0.3 \mathrm{mi}$. long, in Narrow Strait, 9.3 mi. NW of Kodiak, between Spruce and Kodiak Is.; $57^{\circ} 54^{\prime} 40^{\prime \prime} \mathrm{N}, 152^{\circ} 30^{\prime} 20^{\prime \prime} \mathrm{W}$; $B G N$ 1909; (map 34). Var. Ostrov Prokhoda, Prikhoda Island.

Transliteration in 1909 by USC\&GS of the name "Os[trov] Prokhoda" meaning "passage island" given by Capt. Tebenkov (1852, map 23 ).

Prolewy Point: point of land, on $\mathrm{E}$ coast of Lindenberg Penin., Kupreanof I., W shore of Frederick Sound, 2 mi. N of Petersburg, Alex. Arch.; $56^{\circ} 50^{\prime} 10^{\prime \prime} \mathrm{N}, 132^{\circ} 56^{\prime} 20^{\prime \prime} \mathrm{W}$; (map 6). Var. Mys Proliv, Proliva Point.

Name published by USC\&GS in 1883 Coast Pilot (p. 115); derived from the Russian name "Mys Proliv" given in 1838 by G. Lindenberg.

Prolewy Rock: rock, in Sergius Narrows of Peril Strait, off NW coast of Baranof I., Alex. Arch.; $57^{\circ} 24^{\prime} 20^{\prime \prime} \mathrm{N}, 135^{\circ} 37^{\prime} 40^{\prime \prime} \mathrm{W}$; (map 9).

Russian word from "proliv," meaning "strait"; probably given in 1884 by Comdr. J. B. Coghlan, USN

Prolewy Rocks: island, $1 \mathrm{mi}$. long, in $\mathbf{N}$ end of Wrangell Narrows, $1 \mathrm{mi}$. $\mathbf{N}$ of Petersburg,
Alex. Arch.; 56 $59^{\prime} 30^{\prime \prime} \mathrm{N}, 132^{\circ} 57^{\prime} \mathrm{W}$; (map 6). Var. Middle Rock.

Russian name from "proliv" meaning "strait" given in 1884 by Comdr. J. B. Coghlan, USN; called "Middle Rock" in 1868 by Comdr. R. W. Meade, USN.

Proliv, Mys: point of land, see Prolewy Point. Proliva Point: point of land, see Prolewy Point.

Prominence, Cape: point of land, between Usof and Open Bays, S coast of Unalaska I., Aleutian Is.; 53 $26^{\prime} 45^{\prime \prime} \mathrm{N}, 166^{\circ} 45^{\prime} 15^{\prime \prime} \mathrm{W}$; (map 23). Var. Cape Idaliuk, Idalyukh Cape, Eedalook.

Named by USBF in 1888. This cape was called "M[ys] Idalyukh," or "Cape Idalyukh," by Capt. Tebenkov (1852, map 26), IRN.

Prominent Rock: rock, at Cape Aksit, on SE coast of Unimak I., Aleutian Is. ; $54^{\circ} 39^{\prime} 18^{\prime \prime}$ N, $163^{\circ} 25^{\prime} 20^{\prime \prime} \mathrm{W}$; (map 25).

Descriptive name published in 1949 on a USGS map.

Promisla Bay: bay, $0.7 \mathrm{mi}$. across, on $\mathrm{S}$ coast of Krestof I., $9.5 \mathrm{mi}$. NW of Sitka, Alex. Arch.; $57^{\circ} 09^{\prime} \mathrm{N}, 135^{\circ} 30^{\prime} \mathrm{W}$; (map 9). Var. Providence Bay, Zaliv Promysla.

Russian name meaning "providence," given in 1833 by the navigator Ens. Vasiliev; published in 1848 on Russian Hydrog. Dept. Chart 1397 as "Zal[iv] Promysla" (from "Bozhiy Promysl").

Promontory, Cape: point of land, see Lutke, Cape.

Promontory, The: point of land, see Rocky Point.

Promontory Cove: cove, $1 \mathrm{mi}$. across, on SW shore of Unimak Bight on $\mathbf{S}$ coast of Unimak I., Aleutian Is.; $54^{\circ} 32^{\prime} \mathrm{N}, 164^{\circ} 20^{\prime} \mathrm{W}$; (map 24).

Named in 1888 by USBF; derived from nearby "Promontory Cape" which was later changed to Cape Lutke.

Promontory Hill: hill, $1,000 \mathrm{ft}$., on $\mathrm{S}$ coast of Unimak I., Aleutian Is.; $54^{\circ} 25^{\prime} 45^{\prime \prime} \mathrm{N}, 164^{\circ}$ $31^{\prime} 00^{\prime \prime}$ W ; (map 24).

Descriptive name published in 1902 by USC\&GS.

Promysla, Zaliv: bay, see Promisla Bay.

Propagation Island: island, see Tanginak Island.

Propas'tchy-koverushka: hill, see South Sealion Hill.

Propas'tcky: point of land, see Sea Lion Point. Prospect Bay: bay, see Warner Bay.

Prospect Creek: stream, flows SE $5 \mathrm{mi}$. to Mallard Cove, in Port Snettisham, $29 \mathrm{mi}$. SE of Juneau, Coast Mts. ; $58^{\circ} 02^{\prime} 50^{\prime \prime} \mathrm{N}, 133^{\circ} 48^{\prime} 15^{\prime \prime}$ W; BGN 1937; (map 12).

Name published in 1921 by USFS.

Prospect Creek: stream, heads in Dutch Hill, flows W, between Blank and First Creeks, $1.5 \mathrm{mi}$. to Dutch Creek, $35 \mathrm{mi}$. NW of Talkeetna, Alaska Ra.; $62^{\circ} 35^{\prime} 25^{\prime \prime} \mathrm{N}, 151^{\circ} 02^{\prime} 40^{\prime \prime}$ W; (map 81).

Prospectors' name reported in the 1930's by USGS.

Prospect Creek: stream, heads at glacier, flows W $6.3 \mathrm{mi}$. to Johnson River, $40 \mathrm{mi}$. NE of Paxson, Alaska Ra.; $63^{\circ} 31^{\prime} 55^{\prime \prime} \mathrm{N}, 144^{\circ} 49^{\prime} 20^{\prime \prime}$ W; BGN 1937; (map 86). 
Local name shown on a 1927 manuscript map of the "Endicott and Haley Hunting Expedition."

Prospect Creek: stream, flows NE $0.7 \mathrm{mi}$. to Discovery Creek, $12 \mathrm{mi}$. NE of Nome, Seward Penin. High.; $64^{\circ} 37^{\prime} \mathrm{N}, 165^{\circ} 04^{\prime} \mathrm{W}$; (map 94).

Prospectors' name shown on map dated September 1901 of Cape Nome goldfields by David Fox, Jr.

Prospect Creek: stream, flows W $0.6 \mathrm{mi}$. to Snake River, $8 \mathrm{mi}$. NW of Nome, Seward Penin. High.; $64^{\circ} 38^{\prime} \mathrm{N}, 165^{\circ} 28^{\prime} \mathrm{W}$; (map 94).

Prospectors' name reported in 1899 by D. C. Witherspoon (in Schrader and Brooks, 1900, map 2), USGS.

Prospect Creek: stream, flows W $14 \mathrm{mi}$. to Jim River 12 mi. E of its junc. with South Fork Koyukuk River, $27 \mathrm{mi}$. SE of Bettles, KokrinesHodzana High.; $66^{\circ} 47^{\prime} 30^{\prime \prime}$ N, $150^{\circ} 44^{\prime} 00^{\prime \prime} \mathrm{W}$; (map 117).

Local name reported in 1956 by T. E. Taylor, USGS.

Prospect Glacier: glacier, on Resurrection Penin., trends $\mathrm{E} 1 \mathrm{mi}$. to its terminus, $8 \mathrm{mi}$. SE of Seward, Chugach Mts.; $60^{\circ} 01^{\prime} 35^{\prime \prime} \mathrm{N}$,

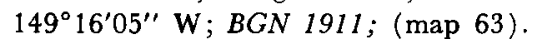

So named in 1908 by Grant and Higgins (1913, p. 55), USGS, "because of a copper prospect situated at the edge of the glacier."

Prospect Gulch: ravine, tributary to Gold Creek, about $2 \mathrm{mi}$. W of Juneau, Coast Mts.; $58^{\circ} 18^{\prime}$ $\mathrm{N}, 134^{\circ} 20^{\prime} \mathrm{W}$; (map 11$)$.

Miners' name for a gulch subsequently destroyed by mining operations (DeArmond, 1957, p. 22).

Prospect Head: mountain, see Ship Mountain.

Prospectors Peak: mountain peak, 5,516 ft., 9.5 mi. NE of Valdez, Chugach Mts.; $61^{\circ} 11^{\prime} 45^{\prime \prime}$ N, 146 $03^{\prime} 10^{\prime \prime} \mathrm{W}$; BGN 1960; (map 68).

Named in 1959 by L. E. Nielsen "in memory of all the prospectors of 1898 who crossed over the Valdez Glacier."

Prospect Point: point of land, in Port Snettisham, on N shore of Mallard Cove, $2.5 \mathrm{mi}$. N of Sharp Point and $29 \mathrm{mi}$. SE of Juneau, Coast Mts. ; 58 $02^{\prime} 55^{\prime \prime} \mathrm{N}, 133^{\circ} 47^{\prime} 35^{\prime \prime} \mathrm{W}$; (map 12 ).

Name derived from Prospect Creek; published in 1940 by USC\&GS.

Prospect Point: point, on right bank of Yukon River, $26 \mathrm{mi}$. NE of Nulato, Koyukuk Low; $64^{\circ} 48^{\prime} \mathrm{N}, 157^{\circ} 16^{\prime} \mathrm{W}$; (map 97).

Riverboat pilots' name shown on a 1940 "Navigation Chart of the Tanana-Yukon Rivers" published by U.S. Dept. of Interior. Protassof: village, see Morzhovoi.

Protassof Bay: bay, S tip of Bechevin Bay, between Nichols Point and Morzhovoi, at SW tip of Aleutian Ra.; $54^{\circ} 53^{\prime} \mathrm{N}, 163^{\circ} 22^{\prime} \mathrm{W}$; (map 25).

Russian name reported in 1926 by USC\& GS, but not shown on any maps.

Protection, Port: bay, extends NW $3.5 \mathrm{mi}$. to Sumner Strait, $1 \mathrm{mi}$. S of village of Point Baker, on $\mathrm{N}$ coast of Prince of Wales I., Alex. Arch.; $56^{\circ} 20^{\prime} \mathrm{N}, 133^{\circ} 38^{\prime} \mathrm{W}$; (map 6).
Named by Capt. George Vancouver, RN, who on September 8, 1793, rode out a storm here.

Protection Bay: bay, $1.7 \mathrm{mi}$. across, on S coast of Unalaska I., Aleutian Is. ; $53^{\circ} 35^{\prime} \mathrm{N}, 166^{\circ} 32^{\prime}$ W; (map 23).

Name given in 1888 by the USBF.

Protection Head: point of land, on $\mathrm{N}$ coast of Prince of Wales I., 3 mi. SW of village of Point Baker, Alex. Arch.; 56 $18^{\prime} 45^{\prime \prime} \mathrm{N}, 133^{\circ} 39^{\prime} 30^{\prime \prime}$ W; (map 6).

Named in 1901 by USC\&GS.

Protection Point: point of land, on $\mathrm{E}$ coast of Nushagak Penin., between Bristol and Nushagak Bays, $39 \mathrm{mi}$. SW of Dillingham, Bristol Bay Low. ; $58^{\circ} 29^{\prime} 30^{\prime \prime}$ N, $158^{\circ} 41^{\prime} 45^{\prime \prime}$ W; (map 40). Var. Mys Povorotnoi, Mys Povorotnyy.

Name given as "M[ys] Povorotnoi," meaning "Turn Point" by Capt. Tebenkov (1852, map 4), IRN, because the coast line turns at this point. Renamed "Protection Point" in 1890 by USBF.

Protestant Episcopal Mission of Our Savior: locality, see Tanana.

Providence, Cape: point of land, trends SE 7 mi. between Port Wrangell and Chiginagak Bay on the S shore of the Alaska Penin., Aleutian Ra.; $56^{\circ} 59^{\prime} \mathrm{N}, 156^{\circ} 33^{\prime} \mathrm{W}$; (map 31). Var. Cap der Vorsehung, Cape Prowitschenia, Mys Provideniya, Mys Prividinya, Naluktchvak.

Named "Mys Provideniya," i.e. "Cape Providence," by Ens. Vasiliev, IRN, in 1831; his skin-boat-bidarka was wrecked here and Vasiliev narrowly escaped drowning. The Aleut called the point of land "Naluktchvak," according to Lutke (1836, p. 277).

Providence, Cape : point of land, on $\mathrm{E}$ coast of Unalaska I., Aleutian Is.; (map 23).

Baker (1906, p. 513) reports that the cape is "not identified," and that the name was given in 1778 by Capt. Cook (1785, v. 2, p. 527), RN. The name was published by Galiano (atlas, map 3), in 1802 .

Providence, Point: point of land, on $\mathrm{W}$ coast of Prince of Wales I., between Bucareli Bay and Port Estrella, at entrance to Ulloa Channel, Alex. Arch.; $55^{\circ} 21^{\prime} 30^{\prime \prime} \mathrm{N}, 133^{\circ} 16^{\prime} 00^{\prime \prime} \mathrm{W}$; (map 4). Var. Ostrov Providens, Punta de la Providencia.

Translation of the name "Punta de la Providencia" given in 1775-79 by Don Juan de la Bodega y Quadra and Francisco Antonio Maurelle.

Providence Bay: bay, see Promisla Bay.

Providencia, Punta de la: point of land, see Providence, Point.

Provideniya, Mys: point of land, see Providence, Cape.

Providens, Ostrov: point of land, see Providence, Point.

Providiniya, Mys: point of land, see Providence, Cape.

Provodnik: island, see Leader Island.

Prowitschenia, Cape: point of land, see Providence, Cape.

Prudhoe Bay: bay, $9.6 \mathrm{mi}$. across, between Heald Point and Point McIntyre, on Beaufort
Sea coast, $15 \mathrm{mi}$. SE of Beechey Point, Arctic Plain, $70^{\circ} 22^{\prime} \mathrm{N}, 148^{\circ} 22^{\prime} \mathrm{W}$; (map 150). Var. Prudoe Bay.

So named by Franklin, RN (1828, p. 159) August 16, 1826. Leffingwell (1919, p. 98) writes, "Probably this bay includes 'Yarborough Inlet'," but Franklin's map does not indicate this.

Prudhoe Mound: pingo, elev. $30 \mathrm{ft} ., 3 \mathrm{mi}$. inland from $\mathrm{S}$ shore of Prudhoe Bay, on Beaufort Sea coast, Arctic Plain; $70^{\circ} 17^{\prime} \mathrm{N}, 148^{\circ}$. $29^{\prime} \mathrm{W}$; (map 150).

Named and used as a triangulation station by Leffingwell $(1919$, p. 41) in 1911.

Prudoe Bay: bay, see Prudhoe Bay.

Prybiloff Islands: islands, see Pribilof Islands.

Psalm Lake: lake, $0.4 \mathrm{mi}$. long, SW of Birchwood and $16 \mathrm{mi}$. NE of Anchorage, Cook Inlet Low.; 61 $22^{\prime} 50^{\prime \prime} \mathrm{N}, 149^{\circ} 33^{\prime} 35^{\prime \prime} \mathrm{W}$; BGN 1962; (map 69). Var. Cleo Lake.

Biblical name given in 1962 by the Western Area Alaska Camp Committee of the Methodist Church. The area is used as a church retreat.

Ptarmigan: locality, along Richardson Highway at junc. of Ptarmigan Creek and Tsina River, $1 \mathrm{mi}$. E of Ptarmigan Drop and $22 \mathrm{mi}$. NE of Valdez, Chugach Mts.; $61^{\circ} 11^{\prime} 20^{\prime \prime}$ N, $145^{\circ}$. $37^{\prime} 20^{\prime \prime} \mathrm{W}$; (map 68). Var. Ptarmigan Drop Roadhouse.

This place originated as a roadhouse or station on the Valdez winter trail.

Ptarmigan Creek: stream, in Glacier Bay National Monument, flows N $2.2 \mathrm{mi}$. to Glacier Bay, $2.5 \mathrm{mi}$. NW of Reid Inlet and $74 \mathrm{mi}$. NW of Hoonah, St. Elias Mts.; $58^{\circ} 53^{\prime} 15^{\prime \prime} \mathrm{N}, 136^{\circ}$ $53^{\prime} 00^{\prime \prime} \mathrm{W}$; BGN 1962; (map 10).

Local name reported in 1961 by NPS.

Ptarmigan Creek: stream, on Alaska Penin., flows W 6 mi. to Meadow Lake, $28 \mathrm{mi}$. NW of Augustine I., Aleutian Ra.; $59^{\circ} 38^{\prime} 40^{\prime \prime} \mathrm{N}$, $153^{\circ} 59^{\prime} 00^{\prime \prime} \mathrm{W}$; (map 51). Var. Ptarmigan Flat.

Name originally reported as Ptarmigan Flat by W. E. Smith, Chief Engineer, Short Line Railway, but name was transferred by local usage to the stream and published by Martin and Katz (1912a, pl. 1), USGS.

Ptarmigan Creek: stream, on Kenai Penin., heads at Ptarmigan Lake, flows W $3 \mathrm{mi}$. to Kenai Lake, $20 \mathrm{mi}$. $\mathrm{N}$ of Seward, Chugach Mts.; 60 $24^{\prime} 15^{\prime \prime} \mathrm{N}, 149^{\circ} 22^{\prime} 03^{\prime \prime} \mathrm{W}$; (map 63).

Local name reported in 1904 by Moffit (1906, pl. 2), USGS.

Ptarmigan Creek: stream, flows SW $25 \mathrm{mi}$. to the Chilikadrotna River, $40 \mathrm{mi}$. N of Nondalton, Alaska Ra.; $60^{\circ} 35^{\prime} 15^{\prime \prime} \mathrm{N}, 154^{\circ} 52^{\prime} 00^{\prime \prime} \mathrm{W}$; (map 61).

Local name reported in 1954 by USGS.

Ptarmigan Creek: stream, heads in small glacier, flows $6 \mathrm{mi}$. SW to North Fork Bremner River, $2.5 \mathrm{mi}$. NW of 1950 terminus of Bremner Glacier and $81 \mathrm{mi}$. NE of Cordova, Chugach

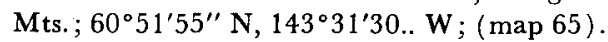

Local name published by Moffit (1914, pl. 1), USGS,

Ptarmigan Creek: stream, heads in Thompson Pass, flows NE $6 \mathrm{mi}$. to Tsina River at Ptar- 
migan, $22 \mathrm{mi}$. NE of Valdez, Chugach Mts.; $61^{\circ} 11^{\prime} 20^{\prime \prime} \mathrm{N}, 145^{\circ} 38^{\prime} 00^{\prime \prime} \mathrm{W}$; (map 68).

Name reported in 1900 by F. C. Schrader, USGS.

Ptarmigan Creek: stream, heads at Rock Lake, flows NE, through Ptarmigan Lake, $15 \mathrm{mi}$. to Beaver Creek, $72 \mathrm{mi}$. NE of McCarthy, Alaska Ra.; $61^{\circ} 52^{\prime}$ N, $141^{\circ} 09^{\prime}$ W; BGN 1922; (map 67).

Local name reported in 1908-09 by IBC surveyors; published in 1914 on IBC Sheet 32 (1918 atlas).

Ptarmigan Creek: stream, in Ptarmigan Valley, heads in lake at Houston Pass, flows $\mathrm{S} 9.5 \mathrm{mi}$ to Styx River $1 \mathrm{mi}$. E of its junc. with South Fork Kuskokwim River, $89 \mathrm{mi}$. NW of Tyonek, Alaska Ra.; $61^{\circ} 55^{\prime} \mathrm{N}, 153^{\circ} 09^{\prime} \mathrm{W}$; (map 71).

Local name reported in 1958 by USGS.

Ptarmigan Greek: stream, flows E $3.2 \mathrm{mi}$. to Limestone Creek $2 \mathrm{mi}$. $\mathrm{N}$ of its junc. with Middle Fork Chistochina River and $28 \mathrm{mi}$. $\mathrm{NE}$ of Paxson, Alaska Ra.; $63^{\circ} 07^{\prime} 00^{\prime \prime} \mathrm{N}$, $144^{\circ} 38^{\prime} 18^{\prime \prime} \mathrm{W}$; (map 86)

Name reported in 1952 by USGS.

Ptarmigan Creek: stream, heads on Molybdenum Ridge, flows NE $7.5 \mathrm{mi}$. to Delta Creek N of its junc. with Hayes Creek, $15 \mathrm{mi}$. NE of Mount Hayes, Alaska Ra.; $63^{\circ} 48^{\prime} 25^{\prime \prime} \mathrm{N}$, $146^{\circ} 28^{\prime} 40^{\prime \prime} \mathrm{W}$; (map 86).

Name reported in 1952 by USGS.

Ptarmigan Creek: stream, flows E $1.2 \mathrm{mi}$. to Homestake Creek, 15 mi. NE of Healy, Alaska Ra.; 63⒌ $59^{\prime} 20^{\prime \prime} \mathrm{N}, 148^{\circ} 33^{\prime} 50^{\prime \prime} \mathrm{W}$; (map 87).

Prospectors' name shown on a 1910 fieldsheet bx J. W. Bagley, USGS; published by Capps (1912, pl. 1), USGS.

Ptarmigan Creek: stream, flows SE $8 \mathrm{mi}$. to Basin Creek, $6 \mathrm{mi}$. SW of Long and $28 \mathrm{mi}$. SW of Ruby, Kilbuck-Kuskokwim Mts. ; $64^{\circ} 20^{\prime} 48^{\prime \prime}$ N, 155 39'48' W; (map 98).

Prospectors' name reported in 1913 by Eakin (1914, pl. 3), USGS.

Ptarmigan Creek: stream, flows SW $0.8 \mathrm{mi}$, joins Derby Creek at Norton Sound, $8.5 \mathrm{mi}$. ESE of Nome, Seward Penin. High.; $64^{\circ} 28^{\prime} \mathrm{N}, 165^{\circ}$ $09^{\prime} \mathrm{W}$; (map 94).

Prospectors' name reported in 1904 by T. G. Gerdine, USGS.

Ptarmigan Creek: stream, flows NW $1 \mathrm{mi}$. to Fox River, $25 \mathrm{mi}$. NE of Solomon, Seward Penin. High.; $64^{\circ} 46^{\prime} 48^{\prime \prime} \mathrm{N}, 163^{\circ} 47^{\prime} 45^{\prime \prime} \mathrm{W}$; (map 95).

Prospectors' name reported on a map of Cape Nome goldfields by David Fox, Jr., dated 1901.

Ptarmigan Creek: stream, flows $\mathrm{N} 1.4 \mathrm{mi}$. to Lower Willow Creek which flows to Casadepaga River, $18 \mathrm{mi}$. $\mathrm{N}$ of Solomon, Seward Penin. High.; $64^{\circ} 49^{\prime}$ N, $164^{\circ} 28^{\prime} \mathrm{W}$; (map 95).

Prospectors' name reported on a map of Cape Nome goldfields by David Fox, Jr., dated 1901.

Ptarmigan Creek: stream, 9 mi. long, on Seward Penin., heads at $65^{\circ} 16^{\prime} 25^{\prime \prime} \mathrm{N}, 164^{\circ} 58^{\prime} 05^{\prime \prime} \mathrm{W}$, flows $S$ to Kuzitrin River, $26 \mathrm{mi}$. W of Mount Bendeleben and $38 \mathrm{mi}$. S of Taylor, Seward Penin. High.; $65^{\circ} 11^{\prime} 20^{\prime \prime} \mathrm{N}, 164^{\circ} 55^{\prime} 40^{\prime \prime} \mathrm{W}$;
BGN 1966; (map 110). Var. Big Ptarmigan Creek.

Prospectors' name reported in 1901 by T. G. Gerdine, USGS.

Ptarmigan Creek: stream, flows SW $4 \mathrm{mi}$. to Chatanika River, $7 \mathrm{mi}$. NE of Twin Buttes and $41 \mathrm{mi}$. NE of Fairbanks, Yukon-Tanana High.; $65^{\circ} 14^{\prime} 15^{\prime \prime} \mathrm{N}, 146^{\circ} 49^{\prime} 15^{\prime \prime} \mathrm{W}$; (map 104).

Prospectors' name reported in 1954 or 1955 by USGS topographers.

Ptarmigan Creek: stream, flows SE $7.5 \mathrm{mi}$, joins Eagle Creek to form Birch Creek, $50 \mathrm{mi}$. SW of Circle, Yukon-Tanana High.; $65^{\circ} 26^{\prime} 20^{\prime \prime} \mathrm{N}$, $145^{\circ} 31^{\prime} 45^{\prime \prime} \mathrm{W}$; (map 104). Var. Birch Creek.

Named by prospectors; reported in 1903 by USGS (Prindle, 1905, pl. 13).

Ptarmigan Creek: stream, heads in Rampart Mts., flows NE and NW $20 \mathrm{mi}$. to Tozitna River, $24 \mathrm{mi}$. N of Tanana, Kokrines-Hodzana High.; $65^{\circ} 31^{\prime} 40^{\prime \prime} \mathrm{N}, 152^{\circ} 08^{\prime} 30^{\prime \prime} \mathrm{W}$; $B G N$ 1959; (map 106). Var. South Fork Tozitna River.

Local name reported in 1956 by Orth.

Ptarmigan Creek: stream, flows SE $2.2 \mathrm{mi}$. to Candle Creek, $12.5 \mathrm{mi}$. SW of Candle and 32 mi. NE of Imuruk Lake, Seward Penin. High.; $65^{\circ} 45^{\prime} \mathrm{N}, 162^{\circ} 08^{\prime} \mathrm{W}$; (map 110).

Prospectors' name reported in 1903 by D. C. Witherspoon (in Moffit, 1905, pl. 2), USGS.

Ptarmigan Creek: stream, see Big Ptarmigan Creek.

Ptarmigan Creek: stream, see Little Ptarmigan Creek.

Ptarmigan Dome: mountain, 3,267 ft., $1.4 \mathrm{mi}$. NNE of North Dome, $75 \mathrm{mi}$. NW of Hoonah, St. Elias Mts.; $58^{\circ} 34^{\prime} 45^{\prime \prime} \mathrm{N}, 137^{\circ} 19^{\prime} 15^{\prime \prime} \mathrm{W}$; (map 10).

Name reported by members of the HarvardDartmouth Expedition, 1933-34 (Washburn and Goldthwait, 1935, map)

Ptarmigan Drop: locality, along Richardson Highway, $1 \mathrm{mi}$. SW of Ptarmigan and $21 \mathrm{mi}$. $\mathrm{NE}$ of Valdez, Chugach Mts.; $61^{\circ} 11^{\prime} \mathrm{N}$, $145^{\circ} 39^{\prime} \mathrm{W}$; (map 68)

Name published by USGS (Moffit and Maddren, 1909, pl. 1) because of the abrupt drop of the highway to a roadhouse once popular with travelers. The name may also apply to the abrupt drop of Ptarmigan Creek forming a canyon across a ridge.

Ptarmigan Drop Roadhouse: locality, see Ptarmigan.

Ptarmigan Flat: stream, see Ptarmigan Creek.

Ptarmigan Glacier: glacier, heads on $\mathrm{N}$ slope of Cairn Peak, trends $\mathrm{N} 2 \mathrm{mi}$. to stream flowing to 1962 terminus of Lemon Creek Glacier, $5 \mathrm{mi}$. N of Juneau, Coast Mts.; 58 $23^{\prime} 10^{\prime \prime}$ $\mathrm{N}, 134^{\circ} 22^{\prime} 30^{\prime \prime} \mathrm{W}$; (map 11).

Name published in 1962 by USGS.

Ptarmigan Gulch: ravine, $1.2 \mathrm{mi}$. long, in Russian Mts., on left bank of Mission Creek 11 mi. NE of Aniak, Kilbuck-Kuskokwim Mts.; $61^{\circ} 37^{\prime} 45^{\prime \prime} \mathrm{N}, 159^{\circ} 12^{\prime} 50^{\prime \prime} \mathrm{W} ; B G N$ 1948; (map 73).

Local name reported in 1945 by USGS; given "for the abundance of ptarmigan that flock there during certain seasons of the year."
Ptarmigan Gulch: ravine, trends SE $2.5 \mathrm{mi}$. to Harrisan Creek, $42 \mathrm{mi}$. SW of Circle, YukonTanana High.; $65^{\circ} 21^{\prime} 25^{\prime \prime} \mathrm{N}, 144^{\circ} 59^{\prime} 20^{\prime \prime}$ W; (map 104).

Named by prospectors; reported in 1896 by USGS (Spurr, 1898, pl. 50).

Ptarmigan Head: hill, 2,850 ft., on Kenai Penin., in Caribou Hills, $5 \mathrm{mi}$. $\mathrm{N}$ of Caribou Lake and $28 \mathrm{mi}$. N of Homer, Cook Inlet Low.; $59^{\circ} 59^{\prime} \mathrm{N}, 151^{\circ} 04^{\prime} \mathrm{W}$; (map 50).

Local name reported and published by USGS in the 1950's.

Ptarmigan Island: island, $0.7 \mathrm{mi}$. long, in Baird Inlet, $4 \mathrm{mi}$. NE of Kalarvik Point and $82 \mathrm{mi}$. $W$ of Bethel, Yukon-Kuskokwim Delta; $60^{\circ} 44^{\prime} \mathrm{N}, 164^{\circ} 08^{\prime} \mathrm{W}$; (map 58).

Name used by personnel of Clarence Rhode National Wildlife Range; reported in 1965.

Ptarmigan Lake: lake, on Kenai Penin., extends SE $4 \mathrm{mi}$. from head of Ptarmigan Creek, 21 mi. NE of Seward, Chugach Mts. $60^{\circ} 23^{\prime} 45^{\prime \prime}$ N, $149^{\circ} 15^{\prime} 00^{\prime \prime} \mathrm{W}$; (map 63).

Local name reported in 1898 by Mendenhall (1900, map 16), USGS.

Ptarmigan Lake: lake, $2.5 \mathrm{mi}$. long, in course of Ptarmigan Creek, 2 mi. NE of Rock Lake and $64 \mathrm{mi}$. NE of McCarthy, Alaska Ra.; $61^{\circ} 51^{\prime} 30^{\prime \prime} \mathrm{N}, 141^{\circ} 10^{\prime} 00^{\prime \prime} \mathrm{W}$; (map 67).

Local name reported in 1908 by $S$. $R$. Capps, USGS (Moffit and Knopf, 1910, pl. 1); applied to lake now called Rock Lake. Present application proposed in 1963 by USGS.

Ptarmigan Lake: lake, $0.25 \mathrm{mi}$. across, $3.2 \mathrm{mi}$. NE of Jumbo Dome and $14 \mathrm{mi}$. NE of Healy, Alaska Ra.; $63^{\circ} 59^{\prime} 15^{\prime \prime} \mathrm{N}, 148^{\circ} 35^{\prime} 30^{\prime \prime} \mathrm{W}$; (map 87).

Local name obtained in 1910 by J. W. Bagley, USGS.

Ptarmigan Lake: lake, see Rock Lake.

Ptarmigan Peak: mountain, 2,972 ft., on Baranof I., $9.4 \mathrm{mi}$. NW of Port Alexander, Alex. Arch.; $56^{\circ} 22^{\prime} \mathrm{N}, 134^{\circ} 46^{\prime} \mathrm{W}$; (map 5).

Local name recorded in 1951 by USGS.

Ptarmigan Point: point of land, $\mathrm{S}$ point of entrance to Alpine Cove, near head of Deadman Bay, on $S$ coast of Kodiak I.; $57^{\circ} 07^{\prime} 45^{\prime \prime}$ $N, 153^{\circ} 47^{\prime} 00^{\prime \prime} \mathrm{W}$; (map 34).

Local name reported in 1954 by USGS.

Ptarmigan Ridge: ridge, $1.5 \mathrm{mi}$. long, along $\mathrm{W}$ edge of Ptarmigan Glacier, $5 \mathrm{mi}$. $\mathbf{N}$ of Juneau, Coast Mts.; $58^{\circ} 22^{\prime} 30^{\prime \prime} \mathrm{N}, 1.34^{\circ} 23^{\prime} 00^{\prime \prime} \mathrm{W}$; (map 11).

Local name reported in 1965 by $D$. A. Brew and A. B. Ford, USGS.

Ptarmigan Rock: promontory, NE of Slate Creek, $3 \mathrm{mi}$. NE of Mount Brynteson and 12 mi. N of Nome, Seward Penin. High.; $64^{\circ} 40^{\prime}$ N, $165^{\circ} 20^{\prime} \mathrm{W}$; (map 94).

Prospectors' name shown on the 1902 "Map of the Nome and Snake River Country" by J. M. Davidson.

Ptarmigan Valley: valley, extends NE $20 \mathrm{mi}$. from junc. of Ptarmigan Creek and Styx River, $100 \mathrm{mi}$. SE of McGrath, Alaska Ra.; $62^{\circ} 05^{\prime}$ $\mathrm{N}, 153^{\circ} 05^{\prime} \mathrm{W}$; ( $\operatorname{map} 80$ ).

Local name reported in 1931 by USGS. Ptichey, Ostrov: island, see Bird Island. 
Ptichi, Cape: point of land, see Bird Cape. Ptichi, Ostrova: rocks, see Porpoise Rocks. Ptichie Island: island, see Bird Island. Ptichi Island: island, see Bird Island. Ptichiy, Mys: point of land, see Bird Point. Ptichiy, Ostrov: island, see Bird Island. Ptichnie: island, see Bird Island. Ptichnoi: island, see Bird Island. Ptitchny: island, see Bird Island. Ptitsa: point of land, see Bird Cape.

Ptmichtalu River: stream, see Pikmiktalik River. Ptumichtalu River: stream, see Pikmiktalik River.

Puale Bay: bay, $9 \mathrm{mi}$. across, on $E$ coast of Alaska Penin., $37 \mathrm{mi}$. NW of Karluk, Aleutian Ra.; $57^{\circ} 41^{\prime} \mathrm{N}, 155^{\circ} 29^{\prime} \mathrm{W}$; BGN 1943; (map 35). Var. Cold Bay.

Name published by Capt. Lutke (1836, p. 276), IRN, as "Pouale" and spelled without the "o" by USC\&GS in 1943. This feature was called "Bukh[t] Studenaya" meaning "Cold Bay" by the Russian Hydrog. Dept. in 1847 "on account of the strong cold winds drawing through a deep ravine from Becharof Lake."

Publituk Creek: stream, flows W $15 \mathrm{mi}$. to John River, $5 \mathrm{mi}$. NE of Cairn Mtn. and $66 \mathrm{mi}$. NW of Wiseman, Brooks Ra.; $67^{\circ} 53^{\prime} \mathrm{N}, 152^{\circ}$. 17' W; BGN 1932; (map 124).

Named by Robert Marshall about 1930; it is an Eskimo word "denoting the hollow, drumlike sound one hears while walking on shell ice."

Puckmummie Creek: stream, flows NW $3 \mathrm{mi}$. to Casadepaga River $0.3 \mathrm{mi}$. S of its junc. with Niukluk River, $30 \mathrm{mi}$. NE of Solomon, Seward Penin. High.; $64^{\circ} 58^{\prime} \mathrm{N}, 164^{\circ} 05^{\prime} \mathrm{W}$; (map 95). Var. Pukmonie Creek.

Eskimo name spelled "Pukmonie" on the 1900 "Map of Nome Peninsula" by J. M. Davidson and B. D. Blakeslee. "Puckmummie" reported in 1907 by USGS geologists (Smith, P. S., 1910, pl. 3).

Puddingstone Hill: promontory, 4,200 ft., SW end of a ridge between Chickaloon River and Boulder Creek, $31 \mathrm{mi}$. NE of Palmer, Talkeetna Mts.; $61^{\circ} 51^{\prime} 30^{\prime \prime} \mathrm{N}, 148^{\circ} 10^{\prime} 30^{\prime \prime} \mathrm{W}$; (map 69).

Local name reported in 1913 by USGS.

Puddin Lake: lake, $1 \mathrm{mi}$. across near head of Prince Creek, $24 \mathrm{mi}$. N of junc. of Killik and Colville Rivers, Arctic Slope; $69^{\circ} 18^{\prime} 30^{\prime \prime} \mathrm{N}$, $153^{\circ} 27^{\prime} 00^{\prime \prime} \mathrm{W}$; BGN 1959; (map 142).

Descriptive name given in 1959 by William P. Brosgé, USGS, because it was a "good description of the [pudding-like] bog surrounding this lake."

Puente, Punta de: point of land, see Zaikof Point.

Puercas, Las: islands, "south of Point San Roque, Bucareli Bay," Alex. Arch.; (map 4).

Spanish name meaning "the sows" given by the 1779 Arteaga expedition (Wagner, 1937, p. 487 )

Puertezuelo, El: cove, "in Port San Antonio in Bucareli Bay," Alex. Arch.; (map 4).
Spanish name here meaning "little port" given by the 1779 Arteaga expedition. (Wagner, 1937, p. 487).

Puerto: estuary, see Fidalgo, Port.

Puff Creek: stream, flows SE $2 \mathrm{mi}$. to Fish River, $11 \mathrm{mi}$. SE of Council and $30 \mathrm{mi}$. NE of Solomon, Seward Penin. High.; 64. $45^{\prime} \mathrm{N}$, $163^{\circ} 32^{\prime} \mathrm{W}$; (map 95).

Prospectors' name reported on a map of Cape Nome gold fields by David Fox, Jr., dated 1901

Puffin Bay: bay, 1 mi. across, $8 \mathrm{mi}$. NW of Cape Ommaney, on $\mathrm{S}$ coast of Baranof I., Alex. Arch.; $56^{\circ} 15^{\prime} 30^{\prime \prime} \mathrm{N}, 134^{\circ} 48^{\prime} 00^{\prime \prime} \mathrm{W}$; (map 5$)$. Var. Toporkof Bay, Toporkoff Bay, Toporkov Bay, Toporkova Bukhta.

Name published by USC\&GS in 1883 Coast Pilot (p. 132); derived from "Toporkova Bukhta"; published in 1850 by the Russian American Company.

Puffin Island: island, $0.2 \mathrm{mi}$. long, $0.5 \mathrm{mi}$. SW of Sitkalidak I., SE of Kodiak I.; $57^{\circ} 00^{\prime} 20^{\prime \prime}$ N, 153 $21^{\prime} 15^{\prime \prime}$ W; (map 34). Var. Ostrov Toporkov, Toporkof.

Translation of "O[strov] Toporkov" published by Capt. Tebenkov (1852, map 23). This probably refers to the tufted puffin, Lunda cirrhata, one of the more abundant sea birds in this area. It is sometimes referred to as the sea-plant.

Puffin Island: island, $0.2 \mathrm{mi}$. long, between Saint Paul Harbor and Chiniak Bay, $2 \mathrm{mi}$. S of Kodiak, Kodiak I. ; $57^{\circ} 45^{\prime} 20^{\prime \prime}$ N, $152^{\circ} 26^{\prime} 00^{\prime \prime}$ W; (map 34). Var. Ostrov Toporkov, Toporkof.

Transliteration of the name "Os[trov] Toporkov" published by Sarichev (1826, map 16).

Puffin Island: island, $0.5 \mathrm{mi}$. long, on $\mathrm{E}$ side of Glacier Bay, $14 \mathrm{mi}$. N of Strawberry I., St. Elias Mts.; $58^{\circ} 43^{\prime} 45^{\prime \prime} \mathrm{N}$, $136^{\circ} 00^{\prime} 00^{\prime \prime} \mathrm{W}$; BGN 1954; (maps 10,11). Var. Cliff Island.

So named in 1948 by BGN "because it is a nesting place for puffins"; USC\&GS in 1940 proposed the name "Cliff Island" because of the bold cliff on the north shore.

Puffin Island: island, $2 \mathrm{mi}$. NW of Chamisso I., $58 \mathrm{mi}$. SW of Selawik, Kotzebue-Kobuk Low.; $66^{\circ} 14^{\prime} \mathrm{N}, 161^{\circ} 51^{\prime} \mathrm{W}$; (map 114).

Named in 1826 by Capt. Beechey (1831, p. 255), RN. He wrote, "Detached from Chamisso there is a steep rock which by way of distinction we named Puffin Island." The horned puffin is one of the most abundant Alaskan sea birds.

Puffin Peak: peak, 1,539 ft., on $\mathrm{E}$ end of $\mathrm{E}$ Amatuli I., in Barren Is., $72 \mathrm{mi}$. NE of

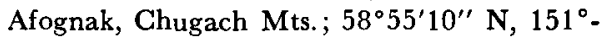
58' $25^{\prime \prime} \mathrm{W}$; (map 43).

Name published by USC\&GS in 1911 on Chart 8555.

Puffin Point: point of land, $7.5 \mathrm{mi}$. NW of Cape Ommaney, on $\mathrm{S}$ coast of Baranof $\mathrm{I}$., Alex. Arch.; $56^{\circ} 14^{\prime} 10^{\prime \prime} \mathrm{N}, 134^{\circ} 48^{\prime} 10^{\prime \prime} \mathrm{W}$; (map 5). Var. Mys Toporkovy, Toporkof Point, Toporkov Point.

Name published by USC\&GS in 1883 Coast Pilot (p. 132); derived from "Mys Topor- kovy"; published in 1850 by the Russian American Company.

Puffy Creek: stream, flows $2 \mathrm{mi}$. S to Puffy Slough, $6 \mathrm{mi}$. E of Katalla, Malaspina Coastal Plain; $60^{\circ} 12^{\prime} \mathrm{N}, 144^{\circ} 20^{\prime} \mathrm{W}$; (map 64).

Local name reported in 1904 by G. C. Martin as being named for McIver Forbes Morrison McIver Campbell, head of Clan McIver of Scotland, who was nicknamed "Puffy." He was probably associated with early oil exploration in the region.

Puffy River: stream, see Edwardes River.

Puffy Slough: stream, flows W $2.5 \mathrm{mi}$. to Redwood Bay, $5 \mathrm{mi}$. E of Katalla, Malaspina Coastal Plain; $60^{\circ} 11^{\prime} \mathrm{N}, 144^{\circ} 22^{\prime} \mathrm{W}$; (map 64).

Local name reported in 1904 by G. C. Martin. Name is derived from nearby creek.

Puget, Cape: point of land, on SE coast of Kenai Penin., at junction of Port Bainbridge and Puget Bay, $38 \mathrm{mi}$. SE of Seward, Chugach Mts.; $59^{\circ} 56^{\prime} 35^{\prime \prime} \mathrm{N}, 148^{\circ} 26^{\prime} 30^{\prime \prime} \mathrm{W}$; (map 49).

Named about June 1, 1974, by Lt. Joseph Whidbey, RN, for Lt. Peter Puget, RN, also of Capt. George Vancouver's party (Vancouver, 1798 , v. 3 , p. 176).

Puget Bay: bay, $6.5 \mathrm{mi}$. across, on $\mathrm{SE}$ coast of Kenai Penin., $35 \mathrm{mi}$. SE of Seward, Chugach Mts. ; $59^{\circ} 56^{\prime} \mathrm{N}, 148^{\circ} 31^{\prime} \mathrm{W}$; BGN 1910; (map 49).

Name reported in 1910 by USGS.

Puget Cove: cove, $0.6 \mathrm{mi}$. long, $0.7 \mathrm{mi}$. E of Shipyard Cove on Yakutat Roads, $1 \mathrm{mi}$. N of Yakutat, Malaspina Coastal Plain; 59 33'55" N, $139^{\circ} 43^{\prime} 00^{\prime \prime}$ W ; (map 46).

Named by W.H. Dall, USC\&GS, in 1879 for Lt. Peter Puget, RN, companion of Capt. George Vancouver, RN, who explored this area in 1794. The name was published in the 1883 Coast Pilot (p. 209).

Puget Glacier: glacier, heads on Pinnacle Mtn., Kenai Penin., trends SE $6 \mathrm{mi}$. to its terminus, $1.5 \mathrm{mi}$. N of Puget Bay, $34 \mathrm{mi}$. SE of Seward, Chugach Mts.; $60^{\circ} 06^{\prime} 45^{\prime \prime} \mathrm{N}, 148^{\circ} 37^{\prime} 45^{\prime \prime} \mathrm{W}$; $B G N$ 1910; (map 63).

Named in 1908 by Grant and Higgins (1910, pls. 1, 2), USGS. Name derived from nearby Cape Puget.

Puget Peninsula: peninsula, $21 \mathrm{mi}$. long, between Yakutat Bay and Russell Fiord, $15 \mathrm{mi}$. NE of Yakutat, St. Elias Mts.; $59^{\circ} 45^{\prime} \mathrm{N}$, $139^{\circ} 30^{\prime} \mathrm{W}$; ( $\left.\operatorname{map} 46\right)$.

Named by Tarr and Martin (1906, p. 146), USGS, for L.t. Peter Puget, RN, a member of Cápt. George Vancouver's party.

Puguiviliak: locality, see Powooiliak Camp.

Pugupiliak: locality, see Powooiliak Camp.

Pugupiliak Cape: point of land, see Powooiliak Point.

Pugutak Lake: lake, $3.5 \mathrm{mi}$. long, between Mumik and Tunusiktok Lakes, $22 \mathrm{mi}$. SE of Point Lay, Arctic Plain; $69^{\circ} 36^{\prime} \mathrm{N}, 162^{\circ} 12^{\prime}$ W; (map 145).

Eskimo name obtained at Point Lay by Orth in 1956, meaning "bag" (poq).

Puguviliak: locality, see Powooiliak Camp. 
Puguviliak Cape: point of land, see Powooiliak Point.

Puivlik Bluff: bluff, on right bank of Colville River $\mathbf{N}$ of junc. of Killik River, Arctic Slope; $69^{\circ} 02^{\prime} \mathrm{N}, 153^{\circ} 51^{\prime} \mathrm{W}$; (map 142).

Eskimo name obtained in 1956 at Anaktuvuk Pass by T. E. Taylor, USGS.

Pukmonie Creek: stream, see Puckmummie Creek.

Puknikruk: locality, on Kuk River, $25 \mathrm{mi}$. S of Wainwright, Arctic Plain; $70^{\circ} 17^{\prime} 05^{\prime \prime} \mathrm{N}, 159^{\circ}$. 52'50" W; (map 146).

Eskimo name reported in 1955 by AMS

Puk Palik Lake: lake, $7 \mathrm{mi}$. long, $W$ of Takslesluk Lake, $15 \mathrm{mi}$. NE of Baird Inlet, Yukon-Kuskokwim Delta ; $61^{\circ} 02^{\prime} \mathrm{N}, 163^{\circ} 14^{\prime}$ W; (map 74).

Eskimo name obtained at Bethel by USC\&GS in 1949

Pulizzi Island: island, $0.2 \mathrm{mi}$. across, in Icy Bay, off $\mathrm{N}$ coast of Chichagof $\mathrm{I} ., 1 \mathrm{mi}$. E of Spasski Bay and $35 \mathrm{mi}$. SW of Juneau, Alex. Arch.; $58^{\circ} 06^{\prime} 10^{\prime \prime} \mathrm{N}, 135^{\circ} 17^{\prime} 25^{\prime \prime} \mathrm{W}$; (map 11).

Named in 1901 by E. F. Dickins, USC\&GS, and published in the 1901 Coast Pilot ( $p$. 204).

Pullin Lake: lake, $0.6 \mathrm{mi}$. long, $1.5 \mathrm{mi}$. SE of Northway, Alaska Ra.; 62 ${ }^{\circ} 57^{\prime} \mathrm{N}, 141^{\circ} 53^{\prime} \mathrm{W}$; (map 84).

Local name reported by USGS in 1954.

Pulpit Rocks: rocks, in Chapel Cove, on SW coast of Adak I., Aleutian Is.; $51^{\circ} 38^{\prime} 45^{\prime \prime} \mathrm{N}$, $176^{\circ} 48^{\prime 25}$ " W; (map 17)

Descriptive name published by USG\&GS in the 1944 Aleutian Coast Pilot (p. 113).

Pultava Island: island, see Poltava Island.

Pultawa Island: island, see Poltava Island.

Pumahknuk Pond: lake, see Pumaknak Pond.

Pumaknak Pond: lake, $0.3 \mathrm{mi}$. across, $\mathrm{N}$ of Pond Creek, $8.6 \mathrm{mi}$. NE of Cape Thompson, Arctic Slope; $68^{\circ} 11^{\prime} 20^{\prime \prime} \mathrm{N}, 1^{\circ} 5^{\circ} 40^{\prime} 00^{\prime \prime} \mathrm{W}$; $B G N$ 1963; (map 129). Var. Pumahknuk Pond.

Eskimo name reported in 1962 by personnel of Project Chariot.

Pumice Creek: stream, flows NW $33 \mathrm{mi}$. to King Salmon River, on Alaska Penin., $19 \mathrm{mi}$. SW of Ugashik, Bristol Bay Low.; $57^{\circ} 19^{\prime} 00^{\prime \prime} \mathrm{N}$, $157^{\circ} 42^{\prime} 30^{\prime \prime} \mathrm{W}$; (map 36).

Descriptive name given in 1923 by R. H. Sargent, USGS; suggested by "the pumice particles from Aniakchak Volcano which cover its valley."

Pumicestone Bay: bay, 2 mi. across, SW coast of Unalaska I., Aleutian Is. ; $53^{\circ} 32^{\prime} \mathrm{N}, 167^{\circ} 08^{\prime}$ W; (map 23). Var. Aliuksuk, Alyukhsyuk, Mokrovskoi, Moorovskoy, Morkovskoi.

Named by USBF in 1888 . This name was published as "Zaliv Mokrovskoy," meaning "Wet Bay," by Lt. Sarichev (1826, map 14, dated 1792), IRN. It was also supposed to have been called "Alyukso" in 1802 by Sarichev. The Aleut name reported by Father Veniaminov $(1840$, v. 1, p. 165) is "Alyukhsyuk," possibly from the word "aluik," meaning "river otter."

Punak Lagoon: lagoon, see Punuk Lagoon.
Punchbowl Cove: estuary, on mainland, extends S 2.2 mi., off Rudyerd Bay, Coast Mts. ; 55 ${ }^{\circ} 33^{\prime}$ N, $130^{\circ} 48^{\prime} \mathrm{W}$; (map 3 ).

Descriptive name given in 1891 by USC\&GS.

Punchbowl Lake: lake, $4 \mathrm{mi}$. long, on mainland S of Rudyerd Bay, Coast Mts., $55^{\circ} 31^{\prime} \mathrm{N}, 130^{\circ}$. 44' W; BGN 1923; (map 3).

Named in 1923 by USFS.

Punch Hill: mountain, 1,935 ft., at SE end of Dall Ridge, on Gravina I., Alex. Arch.; $55^{\circ}$ $11^{\prime} 10^{\prime \prime} \mathrm{N}, 131^{\circ} 45^{\prime} 05^{\prime \prime} \mathrm{W}$; (map 3)

Named in 1883 by Lt. Comdr. H. E. Nich ols, USN. See Puppets, The

Punelok Bay: bay, $1.5 \mathrm{mi}$. wide, $4 \mathrm{mi}$. E of Savoonga, N coast of St. Lawrence I.; $63^{\circ} 41^{\prime}$ N, $170^{\circ} 21^{\prime} \mathrm{W} ; B C N 1951$ (map 93). Var Pinelak.

Reported in 1949 by Maj. H. B. Allen USAF. According to Orth, 1965, this is pronounced locally "pinelak."

Pungohat Spit: spit, see Panowat Spit.

Pungokepuk Creek: stream, heads at Pungokepuk Lake, flows SW 12 mi, to Togiak River, $50 \mathrm{mi}$. NE of Goodnews, Kilbuck-Kuskokwim Mts.; $59^{\circ} 16^{\prime} \mathrm{N}, 160^{\circ} 12^{\prime} \mathrm{W}$; (map 53). Var. Pangokepuk River, Pangokeput River.

Eskimo name reported in 1948 or 1949 by Frank Waskey, local trader and prospector as "Pangokeput River."

Pungokepuk Lake: lake, $5 \mathrm{mi}$. long, trends SW to head of Pungokepuk Creek, $18 \mathrm{mi}$. SW of Togiak Lake and $64 \mathrm{mi}$. NE of Goodnews, Kilbuck-Kuskokwim Mts.; $59^{\circ} 18^{\prime} \mathrm{N}, 159^{\circ} 54^{\prime}$ W; (map 53). Var. Pangokeput.

Eskimo name reported in 1948 or 1949 by Frank Waskey, local trader and prospector, as "Pangokeput Lake."

Pungokosit Spit: spit, $4 \mathrm{mi}$. long, part of barrier bar forming Niyrakpak Lagoon, $16 \mathrm{mi}$. SE of Gambell, $\mathbf{N}$ coast of St. Lawrence I.; $63^{\circ} 37^{\prime} \mathrm{N}, 171^{\circ} 19^{\prime} \mathrm{W} ;$ B BN 1951; (map 93).

Eskimo name reported in 1932 by $O$. W. Geist, Univ. of Alaska. Orth reported its meaning, obtained at Gambell in 1965, as "always a mound."

Punishment Point: point of land, on NE coast of Baker I., in Port Mayoral, Alex. Arch.; $55^{\circ} 23^{\prime} 25^{\prime \prime} \mathrm{N}, 133^{\circ} 27^{\prime} 30^{\prime \prime} \mathrm{W}$; (map 4). Var. Mys de Kastigo, Punta de Castigo.

Translation of the name "Punta de Castigo" given in 1775-1779 by Don Juan de la Bodega y Quadra and Francisco Antonio Maurelle.

Punk Lake: lake, $0.5 \mathrm{mi}$. long, in Mentasta Mts. between Platinum and Totschunda Creeks, 5 mi. E of Devils Mtn., Alaska Ra.; 62 ${ }^{\circ} 27^{\prime} 00^{\prime \prime}$ $\mathrm{N}, 142^{\circ} 45^{\prime} 40^{\prime \prime} \mathrm{W}$; (map 84)

Local name reported by USGS in 1960

Punnick Creek: stream, see Punuk Creek.

Punoarat Point: point of land, $\mathrm{N}$ point of Angyoyaravak Bay, $18 \mathrm{mi}$. S of village of Hooper Bay, Yukon-Kuskokwim Delta; $61^{\circ}$ $18^{\prime} \mathrm{N}, 165^{\circ} 50^{\prime} \mathrm{W}$; (map 75).

Eskimo name obtained in 1951 at Hooper Bay by USC\&GS.

Punok: locality, on Punok Creek, near Azun River, Yukon-Kuskokwim Delta; $61^{\circ} 08^{\prime} \mathrm{N}$, $164^{\circ} 35^{\prime} \mathrm{W}$; (map 74).
Eskimo name for a village reported by USC\&GS in 1951. This place is unverified and may merely refer to a fishing camp.

Punok Creek: stream, heads in lake at $61^{\circ} 07^{\prime} \mathrm{N}$, $164^{\circ} 18^{\prime} \mathrm{W}$, flows NW $20 \mathrm{mi}$. to Azun River, Yukon-Kuskokwim Delta; $61^{\circ} 11^{\prime} \mathrm{N}, 164^{\circ} 37^{\prime}$ W; (map 74).

Named in 1965 by Orth for an Eskimo village of the same name located on this stream and reported by USC\&GS in 1951. The existence of this village has not been verified and thus the name may merely refer to a fishing camp.

Puntade: point of land, see Steele Point.

Puntilla Creek: stream, flows N $9.5 \mathrm{mi}$. to Happy River, Ptarmigan Valley, $100 \mathrm{mi}$. SE of McGrath, Alaska Ra.; $62^{\circ} 08^{\prime} 45^{\prime \prime} \mathrm{N}, 153^{\circ} 00^{\prime}$ $40^{\prime \prime} \mathrm{W}$; (map 80).

Local name reported in 1931 by USGS.

Puntilla Lake: lake, $0.9 \mathrm{mi}$. long, in course of Squaw Greek, $\mathrm{S}$ of Rainy Pass Lodge and 86 mi SW of Talkeetna, Alaska Ra.; 62 $05^{\prime} 20^{\prime \prime}$ $\mathrm{N}, 152^{\circ} 43^{\prime} 45^{\prime \prime} \mathrm{W}$; (map 81).

Local name reported in 1945 by USGS.

Puntilla Mountain: mountain, 4,800 ft., $2 \mathrm{mi}$. SW of Rainy Pass Lodge, $87 \mathrm{mi}$. SW of Talkeetna, Alaska Ra.; $62^{\circ} 04^{\prime} 15^{\prime \prime} \mathrm{N}, 152^{\circ} 46^{\prime} 05^{\prime \prime}$ W; (map 81)

Local name reported in 1958 by USGS.

Punuck Creek: stream, see Punuk Creek.

Punuck Lagoon: lagoon, see Punuk Lagoon.

Punuck Mountain: hills, see Punuk Hills

Punuk: locality, on one of Punuk Is., in Bering Sea SE of St. Lawrence I.; $63^{\circ} 05^{\prime} \mathrm{N}, 168^{\circ}$ $49^{\prime} \mathrm{W}$; (map 93). Var. Poonook.

Former Eskimo village or camp listed as "Poonook" by H. W. Elliott (1886, p. 443).

Punuk Creek: stream, flows NE $3 \mathrm{mi}$. to lagoon on Chukchi Sea coast, between Mutaktuk and Ikikileruk Creeks, $11 \mathrm{mi}$. E of Cape Sabine, Arctic Slope ; $68^{\circ} 56^{\prime} 20^{\prime \prime} \mathrm{N}, 164^{\circ} 09^{\prime} 30^{\prime \prime} \mathrm{W}$; (map 130). Var. Punuck Creek, Punnick Creek.

Eskimo name said to mean "skinny" referring to a time when "two families starved near here" (Chapman and Sable, 1960, p. 54). Reported in 1950 by USC\&GS.

Punuk Creek: stream, see Mutaktuk Creek.

Punuk Hills: hills, $800 \mathrm{ft}$., extend N-S $3 \mathrm{mi}$ between Mutaktuk and Ikikileruk Creeks, 31 mi. NNW of Mount Kelly, Arctic Slope; $68^{\circ}$. $52^{\prime} \mathrm{N}, 164^{\circ} 09^{\prime} \mathrm{W}$; (map 130). Var. Punuck Mountain

Eskimo name reported in 1950 as "Punuck Mountain" by USC\&GS. See Punuk Creek.

Punuk Islands: islands, three, extend $2 \mathrm{mi}$. in Bering Sea, SE of Saint Lawrence I.; $63^{\circ} 05^{\prime}$ N, 168 $49^{\prime}$ W ; BGN 1951; (map 93). Var. Pinik Islands, Poongook Islands.

Eskimo name obtained in 1849 by Capt. M. D. Tebenkov, IRN.

Punuk Lagoon: lagoon, 2 mi. long, on Chukchi Sea coast, $11 \mathrm{mi}$. E of Cape Sabine; Arctic Slope; $68^{\circ} 57^{\prime} \mathrm{N}, 164^{\circ} 10^{\prime} \mathrm{W}$; (map 130). Var. Punuck Lagoon, Punak Lagoon.

Eskimo name reported in 1950 by USC\&GS as Punuck Lagoon. See Punuk Creek. The 
name is reported to mean "skinny" (Chapman and Sable, 1960, p. 54).

Pup, The: hill, $585 \mathrm{ft} ., 0.5 \mathrm{mi}$. S of $W$ end of Lake Fenner on Semisopochnoi Island, Aleutian Islands; about $51^{\circ} 57^{\prime} 45^{\prime \prime} \mathrm{N}, 179^{\circ} 37^{\prime} 20^{\prime \prime} \mathrm{E}$.

Descriptive name probably given in 1943 by U.S. Army Corps of Engineers. "A small extinct volcanic mountain."

Pupik Hills: hills, 2,560 ft., extend E-W $16 \mathrm{mi}$. between Aniuk River and Fauna Creek, $10 \mathrm{mi}$. SW of Howard Pass, Brooks Ra.; 68 ${ }^{\circ} 06^{\prime} \mathrm{N}$, $157^{\circ} 20^{\prime} \mathrm{W}$; ( $\operatorname{map} 132$ ).

Eskimo name obtained at Noatak in 1956 by Orth and reported to mean "tail". The hills were probably so named because they form a tail-like appendage from the main mountain range.

Pup Island: island, $0.6 \mathrm{mi}$. long, at $\mathbf{S}$ entrance to Clover Passage, between Betton and Revillagigedo Is., Alex. Arch.; 55 $29^{\prime} \mathrm{N}, 131^{\circ} 49^{\prime}$ W; BGN 1966; (map 3). Var. The Pup Island.

Local name reported in 1904 by H. C. Fassett, USBF.

Pup Island: island, $0.3 \mathrm{mi}$. long, in Keku Strait, on NE coast of Kuiu I., Alex. Arch.; $56^{\circ} 49^{\prime} 20^{\prime \prime}$ $\mathrm{N}, 133^{\circ} 53^{\prime} 15^{\prime \prime} \mathrm{W}$; $(\operatorname{map} 6)$.

Named in 1892 by Lt. W. I. Moore, USN.

Pup Island: island, see Hump Island.

Pup Island, The: island, see Pup Island.

Pup Lake: lake, $1,000 \mathrm{ft}$. long, easternmost of the Beaver Lakes, $25 \mathrm{mi}$. $\mathrm{N}$ of Anchorage, Cook Inlet Low.; $61^{\circ} 34^{\prime} 50^{\prime \prime} \mathrm{N}, 149^{\circ} 48^{\prime} 45^{\prime \prime}$ W; (map 69)

Local name reported in 1950 by USGS.

Puppets, The: mountains, two, 1,900 ft., at SW end of Dall Ridge, on Gravina I., Alex. Arch.; $55^{\circ} 10^{\prime} 45^{\prime \prime} \mathrm{N}, 131^{\circ} 46^{\prime} 30^{\prime \prime} \mathrm{W}$; (map 3 ).

Named in 1883 by Lt. Comdr. H. E. Nichols, USN. Punch and Judy Hills are nearby; "Punch" and "Judy" are the traditional names of the principal characters in the puppet show in which the husband quarrels with his wife and does outrageous and tragic things in a ludicrous way.

Purcell Mountain: mountain, 3,831 ft., $42 \mathrm{mi}$. SW of Shungnak, Hogatza High.; $66^{\circ} 20^{\prime} \mathrm{N}$, $157^{\circ} 39^{\prime} \mathrm{W}$; (map 115)

Named in 1886 by Lt. Stoney (1900, map), USN, for Ens. J. L. Purcell, USN, a member of his 1884 and 1885 expeditions.

Purcell Mountains: mountains, 3,831 ft., trend W $45 \mathrm{mi}$. from Wheeler Creek to Ingruksukruk Creek, between Selawik and Huslia Rivers, Hogatza High.; $66^{\circ} 09^{\prime} \mathrm{N}, 156^{\circ} 22^{\prime} \mathrm{W}$ [E end], $66^{\circ} 21^{\prime} \mathrm{N}, 157^{\circ} 54^{\prime} \mathrm{W}$ [W end] : $B G N$ 1966; (map 115).

Local name reported by USGS in 1965 to have been in use for 60 ycars; derived from Purcell Mountain, the highest point in the mountains.

Purches Creek: stream, flows W $17 \mathrm{mi}$. to Peters Creek, 23 mi. NW of Palmer, Talkeetna Mts.; $61^{\circ} 49^{\prime} 15^{\prime \prime} \mathrm{N}, 149^{\circ} 38^{\prime} 15^{\prime \prime} \mathrm{W}$; (map 69).

Local name reported in 1910 by F. J. Katz (in Brooks and others, 1911, fig. 18), USGS.
Purgatory: locality, on $\mathrm{N}$ bank of Yukon River, $20 \mathrm{mi}$. SW of Beaver, Yukon Flats; $66^{\circ} 16^{\prime}$ $\mathrm{N}, 148^{\circ} 03^{\prime} \mathrm{W}$; (map 118).

Former riverboat landing and cabin of the Yanert brothers, William and Herman; named by William Yanert in 1903 ("Jessen's Weekly" newspaper, Oct. 9, 1958); name shown in 1916 on a manuscript map by Yanert (in Stuck, 1917, map facing p. 122).

Purinton Creek: stream, heads on Anthracite Ridge, flows SW 6 mi. to Matanuska River, 35 mi. NE of Palmer, Talkeetna Mts.; 61 ${ }^{\circ} 47^{\prime} 15^{\prime \prime}$ $\mathrm{N}, 148^{\circ} 08^{\prime} 05^{\prime \prime} \mathrm{W}$; (map 69).

Local name reported in 1905 by G. C. Martin (1906, p. 18), USGS.

Purple Bluff: bluff, trends NE-SW $4 \mathrm{mi}$., on E coast of Montague I., $4.5 \mathrm{mi}$. SW of Montague Peak, Chugach Mts.; $60^{\circ} 03^{\prime} 30^{\prime \prime} \mathrm{N}, 147^{\circ} 21^{\prime}$ $00^{\prime \prime} \mathrm{W}$; (map 63).

Local name reported in 1951 by USGS.

Purple Lake: lake, $3.5 \mathrm{mi}$. long, on Annette I. near head of Tamgas Harbor, Alex. Arch.; $55^{\circ} 06^{\prime} \mathrm{N}, 131^{\circ} 29^{\prime} \mathrm{W}$; BGN 1917; (map 3).

Named in 1917 by USC\&GS ; derived from Purple Mountain.

Purple Mountain: mountain, 2,344 ft., on Annette I., between Port Chester and Purple Lake, Alex. Arch.; $55^{\circ} 06^{\prime} 35^{\prime \prime} \mathrm{N}, 131^{\circ} 31^{\prime} 30^{\prime \prime}$ W; (map 3$)$.

Descriptive name given in 1883 by Lt. Comdr. H. E. Nichols, USN.

Purvis Cove: bight, see Hodikof Bay.

Pusaluk Hill: hill, see Pusaluk Mountain.

Pusaluk Lagoon: lagoon, at shore of Chukchi Sea, $19 \mathrm{mi}$. NW of Kivalina, Kotzebue-Kobuk Low; $67^{\circ} 55^{\prime} \mathrm{N}, 165^{\circ} 02^{\prime} \mathrm{W}$; BGN 1963; (map 128). Var. Paugausailum Tasia, Pawgowsaylum Tessaya, Paugausailuk Lagoon.

Eskimo name meaning "old bag" reported in 1950 by L'SC\&GS.

Pusaluk Mountain: hill, $600 \mathrm{ft}$., on Chukchi Sea coast, $E$ of Pusaluk Lagoon, $16 \mathrm{mi}$. NW of Kivalina, Arctic Slope; $67^{\circ} 55^{\prime} \mathrm{N}, 164^{\circ} 57^{\prime}$ W; (map 128). Poo-oosalook Mountain, Pusaluk Hill.

Eskimo name meaning "old bag," according to USC\&GS in 1950.

Pushki, Ostrov: island, see Cannon Island.

Pusigrak Lagoon: lagoon, $1.3 \mathrm{mi}$. long, on Chukchi Sea coast, $19 \mathrm{mi}$. SE of Cape Thompson, Arctic Slope; $68^{\circ} 01^{\prime} \mathrm{N}, 165^{\circ} 17^{\prime} \mathrm{W} ; B G N$ 1963; (map 129). Var. Poohseegrux Lagoon, Pooseegruk Lagoon.

Eskimo name "Poohseegrux" reported in 1960 by D. C. Foote in connection with Project Chariot studies.

Pustoi Island: island, $0.3 \mathrm{mi}$. across, in Umnak Pass, 2 mi. N of Ship Rock, off NE coast of Umnak I., Aleutian Is.: $53^{\circ} 23^{\prime} 55^{\prime \prime} \mathrm{N}, 167^{\circ}$. 49'35" W; (map 23). Var. Breed Island, Tanghinakh Islet, Tanginak, Ostrov Pustoy.

Russian name given by the navigator Kuritzien as "O[strov] Pustoy" meaning "desert island"; published by Capt. Tebenkov (1852, map 25, inset dated 1849), IRN. The island was called "Tanghinakh" by Capt. Lutke (1836, p. 299), IRN, possibly from the
Aleut word "tangidak," which, according to R. H. Geoghegan, means "islet or small island." Baker (1906, p. 515) says "the name 'Tanginak' applies to Ship Island." See Ship Rock.

Pustoi Point: point of land, $0.5 \mathrm{mi}$. W of Pustoi I., at Fort Glenn, NE coast of Umnak I., Aleutian Is.; $53^{\circ} 23^{\prime} 48^{\prime \prime} \mathrm{N}, 167^{\circ} 50^{\prime} 15^{\prime \prime} \mathrm{W}$; (map 23).

Name derived from Pustoi I. and reported in 1942 by U.S. Army Corps of Engineers.

Pustoy, Ostrov: island, see Pustoi Island.

Putgut Plateau: flat, $15 \mathrm{mi}$. across, E of Poovoot Ra., $12 \mathrm{mi}$. NE of Southwest Cape and 28 mi. SE of Gambell, St. Lawrence I.; $63^{\circ} 27^{\prime} \mathrm{N}$, 171 '12' W; BGN 1951; (map 93).

Eskimo name reported in 1949 by Maj. H. B. Allen, USAF. Orth was informed at Gambell and Savoonga in 1965 that the name "Putgut" applies only to the $200 \mathrm{ft}$. cliff, or ridge, that extends about $50 \mathrm{mi}$. from Powooiliak Point to Cape Kitnik.

Putkuruk Creek: stream, see Nuka River.

Putmik Slough: watercourse, in Yukon Delta, extends E-W $7.2 \mathrm{mi}$. between Anuzukanuk Pass and Elukuzuk Slough, $10 \mathrm{mi}$. W of Kwiguk, Yukon-Kuskokwim Delta; 62 $43^{\prime}$ -

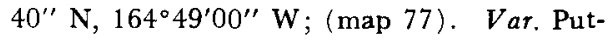
mikwa, Putmikwak.

Eskimo name obtained in 1948 by USC\&GS Putmikwa: water course, see Putmik Slough.

Putmikwak: water course, see Putmik Slough.

Putnam: stream, see Kobuk River.

Putnam, Lake: lake, $0.3 \mathrm{mi}$. long, on $\mathrm{N}$ end of Latouche I., $19 \mathrm{mi}$. SE of Chenega, Chugach Mts.; $60^{\circ} 02^{\prime} 15^{\prime \prime} \mathrm{N}, 147^{\circ} 54^{\prime} 00^{\prime \prime} \mathrm{W}$; (map 63).

Local name reported in 1909 by Grant and Higgins (1910, pl. 12), USGS.

Putnam Peak: mountain, 3,500 ft., in Missionary Ra., 14 mi. NW of Petersburg, on Lindenburg Penin., Kupreanof I., Alex. Arch.; 56 57'50" $\mathrm{N}, 133^{\circ} 11^{\prime} 00^{\prime \prime} \mathrm{W}$; (map 6).

Named in 1887 by Lt. Comdr. C. M. Thomas, USN, for Master Charles Flint Putnam, USN, "a member of Lt. R. M. Berry's party in the Bering Strait in 1880, who was driven to sea on an ice floe and perished.

Putnam Point: point of land, on $\mathrm{E}$ coast of Green I., at $\mathrm{S}$ end of Gibbon Anchorage in Prince William Sound, $22 \mathrm{mi}$. E of Chenega, Chugach Mts. ; $60^{\circ} 16^{\prime} 25^{\prime \prime} \mathrm{N}, 147^{\circ} 26^{\prime} 25^{\prime \prime} \mathrm{W}$; (map 63).

Name published by USC\&GS in 1943; named for George Rockwell Putnam, USC\&GS.

Putu Creek: stream, heads in lake at $61^{\circ} 27^{\prime} \mathrm{N}$, $162^{\circ} 29^{\prime} \mathrm{W}$, flows SE $30 \mathrm{mi}$. to Johnson River, Yukon-Kuskokwim Delta; $61^{\circ} 15^{\prime} 30^{\prime \prime} \mathrm{N}, 162^{\circ}$. 03'40" W; (map 74).

Eskimo name meaning "hole" published by USGS in 1966.

Putu Creek: stream, flows SE $1 \mathrm{mi}$. to Fish River, between Glacier and Slate Creeks, 12 mi. E. of Council and $41 \mathrm{mi}$. NE of Solomon, Seward Penin. High.; $64^{\circ} 53^{\prime} \mathrm{N}, 163^{\circ} 17^{\prime} \mathrm{W}$; (map 95) 
Prospectors' name published on the 1908 "Map of Seward Peninsula" by Arthur Gibson.

Putugook Creek: stream, flows $\mathrm{N} 7 \mathrm{mi}$. to Demarcation Bay, $4 \mathrm{mi}$. S of Demarcation Point; Arctic Plain; 69 $38^{\prime} \mathrm{N}, 141^{\circ} 16^{\prime} \mathrm{W}$; (map 138). 1948.

Eskimo name obtained by USC\&GS in

Putuligayuk River: stream, heads in lake at $69^{\circ} 58^{\prime} \mathrm{N}, 148^{\circ} 52^{\prime} \mathrm{W}$, flows NE $40 \mathrm{mi}$. to Prudhoe Bay, $20 \mathrm{mi}$. SE of Beechey Point, Arctic Plain; $70^{\circ} 19^{\prime} \mathrm{N}, 148^{\circ} 58^{\prime} \mathrm{W}$; (map 150).

This is the name of an Eskimo that once lived near the mouth of this stream; reported by USC\&GS in 1949 .

Puutik Mountain: mountain, 3,235 ft., in Poktovik Mts., $8 \mathrm{mi}$. SSW of Misheguk Mtn., Brooks Ra.; 68 $07^{\prime} \mathrm{N}, 161^{\circ} 21^{\prime} \mathrm{W}$; (map 131).

Eskimo name reported in 1956 by USGS.

Puvakrat Mountain: hill, 2,400 ft., S of Lisburne Ridge, $26 \mathrm{mi}$. N of Howard Pass, Arctic Slope; $68^{\circ} 33^{\prime} \mathrm{N}, 156^{\circ} 30^{\prime} \mathrm{W}$.

Eskimo name referring to a "swollen part" or "inflater," reported in 1956 by USGS.

Puvut Mountains: mountain range, see Poovoot Range.

Puvutpak: mountain, see Poovookpuk Mountain.

Puyulik Greek: stream, flows NW $10 \mathrm{mi}$. to the Goodnews River, $2.5 \mathrm{mi}$. SE of Goodnews, Kilbuck-Kuskokwim Mts. ; $59^{\circ} 06^{\prime} \mathrm{N}, 161^{\circ} 32^{\prime}$ W; (map 53).

Local name obtained about 1951 at Goodnews by J. M. Hoare, USGS. It is named for Puyulik Mountain.

Puyulik Mountain: hill, $825 \mathrm{ft}$., $3 \mathrm{mi}$. SW of Flat Mtn. and $4 \mathrm{mi}$. SE of Goodnews, Kilbuck-Kuskokwim Mts. ; $59^{\circ} 04^{\prime} \mathrm{N}, 161^{\circ} 32^{\prime} \mathrm{W}$; (map 53).

Eskimo name reported to mean "always smoking," the reason for which is unknown. The name was obtained at Goodnews about 1951 by J. M. Hoare, USGS.

Puzzle Creek: stream, flows NW $1.5 \mathrm{mi}$. to Mystery Creek, $10 \mathrm{mi}$. N of Medfra, KilbuckKuskokwim Mts.; $63^{\circ} 15^{\prime} \mathrm{N}, 1^{\circ} 4^{\circ} 46^{\prime} \mathrm{W}$; (map 89).

Local name reported in 1920 by G. C. Martin (in Brooks and others, 1922, fig. 5), USGS.

Puzzle Creek: stream, flows S $0.7 \mathrm{mi}$. to Mystery Creek which flows to Shovel Creek, $6 \mathrm{mi}$. N of Solomon, Seward Penin. High.; 64 ${ }^{\circ} 39^{\prime}$ N, $164^{\circ} 27^{\prime} \mathrm{W}$; (map 95)

Prospectors' name shown as "Puzzle Gh." on Arthur Gibson's "Map of Cape Nome Precinct" dated 1904.

Puzzle Gulch: ravine, trends NE $4.5 \mathrm{mi}$. to mouth of Caribou Creek, coursed by South Fork Birch Creek, $45 \mathrm{mi}$. SW of Circle, Yukon-Tanana High.; $65^{\circ} 10^{\prime} 40^{\prime \prime} \mathrm{N}, 144^{\circ} 19^{\prime} 30^{\prime \prime}$ W; (map 104).

Prospectors' name reported in 1954 or 1955 by USGS topographers.

Pyati Milnyy, Ostrov: island, see Fivemile Island.
Pybus, Point: point of land, on E coast of Admiralty I., at $\mathrm{N}$ entrance to Pybus Bay, $4 \mathrm{mi}$. $\mathrm{W}$ of The Brothers and $56 \mathrm{mi}$. $\mathrm{E}$ of Sitka, Alex. Arch.; $57^{\circ} 18^{\prime} 25^{\prime \prime} \mathrm{N}, 133^{\circ} 57^{\prime} 30^{\prime \prime} \mathrm{W}$; (map 8).

Named by Capt. George Vancouver, RN, when the point was discovered August 4, 1794, by Lt. Joseph Whidbey, RN, (Wagner, 1937, p. 403).

Pybus Bay: bay, $4 \mathrm{mi}$. across, on $\mathrm{E}$ coast of Admiralty I., $5 \mathrm{mi}$. W of The Brothers and $53 \mathrm{mi}$. E of Sitka, Alex. Arch.; $57^{\circ} 16^{\prime} \mathrm{N}$, $134^{\circ} 05^{\prime} \mathrm{W}$; (map 8).

Named in 1889 by Lt. Comdr. H. B. Mansfield, USN; published by USC\&GS in 1891 Coast Pilot (p. 143). The name was derived from Point Pybus, which marks the northeast entrance to the bay.

Pybus Lake: lake, $0.7 \mathrm{mi}$. long, on Admiralty I., $9 \mathrm{mi} . \mathrm{N}$ of Pybus Bay and $15 \mathrm{mi}$. E of Angoon, Alex. Arch.; $57^{\circ} 26^{\prime}$ N, $134^{\circ} 12^{\prime}$ W; (map 9). Local name reported in 1951 by USGS.

Pye Island Reef: reef, see Pye Reef.

Pye Islands: islands, group of islands on $\mathbf{E}$ side of Nuka Bay, $50 \mathrm{mi}$. E of Seldovia, Chugach Mts.; $59^{\circ} 23^{\prime} \mathrm{N}, 150^{\circ} 25^{\prime} \mathrm{W}$; (map 50). Var. Pi Islands, Pies Islands, Pye's Islands.

Shown on Capt. Nathaniel Portlock's 1786 track chart as "Pye's Islands." These islands were called "O[strova] Piy," or "Piy Islands," by Capt. Tebenkov (1852, map 5), IRN, and "Pye Islands" by USBF in 1888.

Pyerci Cape: point of land, see Percy Point.

Pye Reef: reef, at $\mathbf{S}$ tip of Pye Is., $2 \mathrm{mi}$. $\mathbf{S}$ of Outer I. and $47 \mathrm{mi}$. ESE of Seldovia, Chugach Mts.; $59^{\circ} 18^{\prime} \mathrm{N}, 150^{\circ} 25^{\prime} \mathrm{W}$; BGN 1931; (map 50). Var. Pye Island Reef.

Named "Pye Island Reef" by USC\&GS in 1908 , but was shortened to "Pye Reef" in 1931.

Pye's Islands: islands, see Pye Islands.

Pyke, Point: point of land, on SW tip of Bainbridge Island $37 \mathrm{mi}$. ESE of Seward; 60 02 N, $148^{\circ} 19^{\prime}$ W; Var. Harmon Point.

Named by Joseph Whidbey, RN, about May 27, 1794 (Wagner, 1937, p. 403). This may be the "Harman Point" reported by Capt. Nathaniel Portlock in 1787 (p. 461).

Pyramid Cove: cove, $0.7 \mathrm{mi}$. across, on $\mathrm{W}$ shore of Massacre Bay, on SE coast of Attu I., Aleutian Is.; $52^{\circ} 50^{\prime} 00^{\prime \prime} \mathrm{N}, 173^{\circ} 11^{\prime} 30^{\prime \prime} \mathrm{E}$; (map 13).

This name is listed in the 1944 Aleutian Coast Pilot.

Pyramid Creek: stream, flows NW $4.5 \mathrm{mi}$. from Holmes Pass $4 \mathrm{mi}$. NW of Boreal Mtn., to North Fork Koyukuk River, $39 \mathrm{mi}$. NW of Wiseman, Brooks Ra.; 67 $52^{\prime} 30^{\prime \prime}$ N, $150^{\circ}$ 52'30" W; BGN 1932; (map 124).

Named in 1929 by Robert Marshall (1956, p. 14) who wrote "it [the creek] cut into a deep gulch surrounded by a whole series of pyramid-shaped mountains. Consequently we called the stream 'Pyramid Creek'."

Pyramid Harbor: cove, $0.7 \mathrm{mi}$. across, on W shore of Chilkat Inlet, $4 \mathrm{mi}$. SW of Haines and $20 \mathrm{mi}$. SW of Skagway, St. Elias Mts., $59^{\circ} 10^{\prime} 50^{\prime \prime} \mathrm{N}, 135^{\circ} 28^{\prime} 30^{\prime \prime} \mathrm{W}$; (map 45).
Var. Labouchere Harbor, L'chtinigé, Tichtinigé, Pyramid Island Harbor.

The descriptive name "Pyramid Island Harbor" was given in 1868 by Comdr. R. W. Meade, USN, and published in 1881 on Hydrog. Chart 883 . It was called Pyramid Harbor by USC\&GS in the 1891 Coast Pilot (p. 201). The Tlingit Indian name was reported by Aurel and Arthur Krause (1883, map) as L'chtinigé. It was also called Labouchere Bay by the employees of the Hudson Bay Co. for the company steamer Labouchere.

Pyramid Island: island, $0.4 \mathrm{mi}$. long, part of rim of caldera enclosing Crater Bay, one of the Rat Is., between Khvostof I. and Davidof I., Aleutian Is.; $51^{\circ} 58^{\prime} 10^{\prime \prime} \mathrm{N}, 178^{\circ} 18^{\prime} 50^{\prime \prime} \mathrm{E}$; $B G N$ 1937; (map 15). Var. Pyramid Islet.

So named by personnel of the U.S.S. Oglala in 1935 "because of its shape."

Pyramid Island: island, $0.4 \mathrm{mi}$. long, in Chilkat Inlet, $1 \mathrm{mi}$. SW of Chilkat and $19 \mathrm{mi}$. SW of Skagway, Coast Mts.; $59^{\circ} 11^{\prime} 45^{\prime \prime} \mathrm{N}, 135^{\circ} 27^{\prime}$ 15" W; BGN 1900; (map 45). Var. Chlachótsch Island, Farewell Island, Indian Island, Kláhuch Island, Observatory Island, Peschanyy, Peschani Island, Shla-hatch Island, Stony Island.

Descriptive name, given in 1869 by Comdr. R. W. Meade, USN. It was called "Os[trov] Peschanyy," meaning "sandy (or gritty) island," by Capt. Lindenberg (cnna) in 1838. In 1868, it was called Indian Island by Comdr. Meade, USN, and Farewell Island, through a mistranslation of "Peschanyy," by G. D. Davidson, USC\&GS, in 1869. It has also been called Stony Island and Observatory Island (1883 Coast Pilot, p. 197). According to Aurel and Arthur Krause( 1883 , map), the Tlinget Indian name is Chlachatsch; according to W. H. Dall, USC\&GS, it is Shla-hatch (1883 Coast Pilot, p. 197).

Pyramid Island Harbor: cove, see Pyramid Harbor.

Pyramid Mountain: mountain, 2,800 ft., between Herendeen and Balboa Bays, near SW end of Alaska Penin., Aleutian Ra.; 55 $38^{\prime}$ $30^{\prime \prime} \mathrm{N}, 160^{\circ} 40^{\prime} 30^{\prime \prime} \mathrm{W}$; (map 28).

Name reported by Atwood (1911, pl. 2), USGS.

Pyramid Mountain: mountain, 2,420 ft., $7.5 \mathrm{mi}$. W of Kodiak, Kodiak I.; $57^{\circ} 47^{\prime} 10^{\prime \prime}$ N, $152^{\circ}$ $34^{\prime} 30^{\prime \prime} \mathrm{W}$; (map 34).

Descriptive local name published in 1943 by USC\&GS.

Pyramid Mountain: mountain, 2,001 ft., $2 \mathrm{mi}$. NE of Crater Hill and $7.5 \mathrm{mi}$. SE of Goodnews, Kilbuck-Kuskokwim Mts. ; $59^{\circ} 01^{\prime} 30^{\prime \prime} \mathbf{N}$, $161^{\circ} 29^{\prime} 00^{\prime \prime}$ W; (map 53). Var. Pyramid Peak.

Descriptive name published in 1915 by USC\&GS on Chart 9103.

Pyramid Mountain: mountain, 5,640 ft., $8.5 \mathrm{mi}$. SE of Mount Fellows, $21 \mathrm{mi}$. SE of Healy, Alaska Ra.; $63^{\circ} 38^{\prime} 30^{\prime \prime}$ N, $148^{\circ} 31^{\prime} 30^{\prime \prime}$ W; (map 87).

Local descriptive name reported in 1950 by USGS. 
Pyramid Mountain: mountain, see Pyramid Peak.

Pyramid Mountain Peak: mountain, see Pyramid Peak.

Pyramid Peak: mountain, 2,136 ft., $2 \mathrm{mi}$. S of Unalaska, NE part of Unalaska I., Aleutian Is.; $53^{\circ} 50^{\prime} 44^{\prime \prime} \mathrm{N}, 166^{\circ} 32^{\prime} 08^{\prime \prime} \mathrm{W}$; (map 23). Var. Pyramid Mountain, Pyramid Mountain Peak.

Descriptive name published in 1875 by USC\&GS on Chart 821 as "Pyramid Mountain Peak."

Pyramid Peak: mountain, 2,434 ft., NE of Tokeen Bay, on $\mathrm{SE}$ coast of Kosciusko I., Alex. Arch.; $56^{\circ} 03^{\prime} 00^{\prime \prime} \mathrm{N}, 133^{\circ} 21^{\prime} 30^{\prime \prime} \mathrm{W}$ (map 6).

Descriptive name given in 1904 by $E$. F. Dickins, USC\&GS, "on account of its shape."

Pyramid Peak: peak, 3,148 ft., on N part of Chichag of I. $2.5 \mathrm{mi}$. SE of head of Idaho Inlet and $21 \mathrm{mi}$. W of Hoonah, Alex. Arch.; 58 $02^{\prime}$ $15^{\prime \prime} \mathrm{N}, 136^{\circ} 04^{\prime} 00^{\prime \prime} \mathrm{W} ;$ B B $\mathrm{N}$ 1960; (map 10)

Descriptive name given by USGS in 1955, "because the peak is in the form of a pyramid."

Pyramid Peak: peak, 4,106 ft., $1 \mathrm{mi}$. N of head of Tidal Inlet, Glacier Bay National Monument, $59 \mathrm{mi}$. NW of Hoonah, St. Elias Mts. $58^{\circ} 50^{\prime} 45^{\prime \prime} \mathrm{N}, 136^{\circ} 17^{\prime} 25^{\prime \prime} \mathrm{W}$; (map 10).

Descriptive name given by Reid (1892, p. 22 and map).

Pyramid Peak: mountain, 1,110 ft., on Kayak I., $62 \mathrm{mi}$. SE of Cordova, Malaspina Coastal Plain ; $59^{\circ} 56^{\prime} \mathrm{N}, 144^{\circ} 24^{\prime} \mathrm{W}$; (map 48).

Descriptive name published in 1943 by USC\&GS on Chart 8513.

Pyramid Peak: mountain, 8,875 ft., $3.5 \mathrm{mi}$. NE of Andrus Peak and $22 \mathrm{mi}$. SE of McCarthy, St. Elias Mts.; $61^{\circ} 18^{\prime} \mathrm{N}, 142^{\circ} 20^{\prime} \mathrm{W}$; (map 67).

Local descriptive name reported in 1908 by D. C. Witherspoon, USGS.

Pyramid Peak: peak, 5,207 ft., $35 \mathrm{mi}$. SE of Healy and $20 \mathrm{mi}$. NE of Cantwell, Alaska Ra. $63^{\circ} 26^{\prime} 45^{\prime \prime} \mathrm{N}, 148^{\circ} 21^{\prime} 00^{\prime \prime} \mathrm{W}$; ( $\operatorname{map} 87$ ).

Local descriptive name obtained in 1951 by USGS.

Pyramid Peak: mountain, see Kinkaid, Mount. Pyramid Peak: mountain, see Pyramid Mountain.

Pyramid Point: point of land, on $\mathrm{S}$ end of Khantaak I., in Yakutat Roads, $0.7 \mathrm{mi}$. N of Point Turner and $2.3 \mathrm{mi}$. NW of Yakutat, Malaspina Coastal Plain; 59 $34^{\prime} 15^{\prime \prime}$ N, $139^{\circ}$ 46'40" W; (map 46).

Descriptive name published in 1959 by USGS.

Pyramid Point: point of land, see Green Point. Pyramids, The: mountain range, $2.5 \mathrm{mi}$. long, $7 \mathrm{mi}$. S of Sitka, on $W$ coast of Baranof $I$., Alex. Arch.; 56 $56^{\prime} \mathrm{N}, 135^{\circ} 16^{\prime} \mathrm{W}$; (map 5).

Descriptive name given in 1943 for charting purposes by USC\&GS

Pyre Peak: mountain, $3,458 \mathrm{ft}$., on central Seguam I., Aleutian Is.; $52^{\circ} 19^{\prime} 00^{\prime \prime} \mathrm{N}, 172^{\circ}$. $30^{\prime} 45^{\prime \prime} \mathrm{W}$; (map 19). Var. Seguam Volcano.
Probably a descriptive name; published by USC\&GS in 1954 Alaska Coast Pilot (p. 419).

Pyrim Creek: stream, see Enatalik Creek.

Pyrite Point: point of land, extends SE $1 \mathrm{mi}$. from mainland in Bristol Bay, $18 \mathrm{mi}$. W of Hagemeister I. and $4 \mathrm{mi}$. SE of Slug Mtn., Kilbuck-Kuskokwim Mts. ; 58 $36^{\circ} 30^{\prime \prime}$ N, $161^{\circ}$ $33^{\prime} 30^{\prime \prime} \mathrm{W}$; (map 39).

Local name published in 1952 by USGS. Pyrite, also called "fools gold" is a common iron mineral.

Pytmykhtalik, Reka: stream, see Pikmiktalik River.

\section{Q}

Qaagaqaglik: bluff, see Kagakaglik Bank.

Qaagusuk: cave, see Kagusuk Cave.

Qaalgiqsuq: stream, see Kalgiksuk Creek.

Qaaliiq: locality, on coast between Sinaru and Saatkunak, $19 \mathrm{mi}$. SW of Barrow, Arctic Plain $71^{\circ} 04^{\prime} \mathrm{N}, 157^{\circ} 14^{\prime} \mathrm{W}$; (map 153)

Eskimo locality or camp name published by R. F. Spencer (1959, map 2).

Qakulu Xagku: point of land, see Kaskulu Point.

Qangiligauzaq: stream, see Kangiligaurak Creek. Qatq!wāáltū': locality, see Katkwaahltu.

Qawiqsam Kuugauzanga: stream, see Kawiksak Creek

Qawiqsaqq: bluff, see Kawiksak Bluff.

Qayaqturiaq : stream, see Kayakturiak Creek.

Qilangnaq: bluff, see Kilangnak Bluff.

Qilaugauzaq: spit, see Kilogorak Spit.

Qilaun: spit, see Kilogorak Spit.

Qiligmiak: water passage, see Kiligmak Inlet.

Qimiqpak: ridge, see Kimikpak Ridge.

Qimiqpaum Kuugauzanga: stream, see Kimikpak Creek.

Qimiqpayaat Kuugauzanga: stream, see Kimikpeyat Creek.

Qimiqpayaat Kuugauzanga: stream, see Kumikpeyat Creek.

Qiqiqtauzalik: lake, see Kikiktauralik Lake.

Qoonukh Creek: stream, see Kunuk Creek.

Quadra, Boca de: estuary, extends SW $34 \mathrm{mi}$. from Keta River to Revillagigedo Channel, Coast Mts.; $55^{\circ} 04^{\prime} \mathrm{N}, 131^{\circ} 01^{\prime} \mathrm{W}$; (map 3 ). Var. Bokay Inlet, Quadra Bay, Quadra Channel.

Spanish name meaning "estuary of Quadra" given in 1792 by Jacinto Caamano for Don Juan de la Bodega y Quadra, who took part in expeditions and made surveys in southeast Alaska in 1775-79; this name was adopted by Capt. George Vancouver, RN, who explored this estuary on August 6, 1793 (Wagner, 1937, p. 404)

Quadra Bay: estuary, see Quadra, Boca de.

Quadra Channel: estuary, see Quadra, Boca de. Quadra Creek: stream, flows E to Mink Bay, S of Boca de Quadra, Coast Mts.; 55 $04^{\prime} \mathrm{N}$, $130^{\circ} 43^{\prime} \mathrm{W}$; (map 3).

Local name reported in 1897 by Lt. Comdr. J. F. Moser, USN

Quadra Creek: stream, see Sockeye Creek.

Quadra Island: island, see Dall Island.
Quadra Lake: lake, on $\mathrm{W}$ side of Mink Bay, $\mathrm{S}$ of Boca de Quadra, Coast Mts.; $55^{\circ} 04^{\prime} \mathrm{N}$. $130^{\circ} 44^{\prime} \mathrm{W}$; (map 3 ).

Local name reported in 1897 by Lt. Comdr. J. F. Moser, USN.

Quadra Lake: lake, see Hugh Smith Lake.

Quadra Lakes: lakes, two, $0.5 \mathrm{mi}$. long, $1 \mathrm{mi}$. NW of Boca de Quadra and $5 \mathrm{mi}$. N of Bactrian Point, Coast Mts.; 55 $11^{\prime} 45^{\prime \prime} \mathrm{N}$ $130^{\circ} 40^{\prime} 00^{\prime \prime} \mathrm{W}$; (map 3 ).

Local name recorded in 1955 by USGS.

Quadra Point: point of land, $\mathrm{N}$ point of entrance to Boca de Quadra, off Revillagigedo Channel, Coast Mts.; $55^{\circ} 05^{\prime} 10^{\prime \prime} \mathrm{N}, 130^{\circ} 58^{\prime}$. $50^{\prime \prime} \mathrm{W}$; (map 3 ).

Local name reported in 1904 by H. C. Fassett, USBF.

Quail Bay: bay, $0.6 \mathrm{mi}$. across, on SE coast of Kagalaska I., Aleutian Is.; $51^{\circ} 44^{\prime} 40^{\prime \prime} \mathrm{N}$, $176^{\circ} 18^{\prime} 20^{\prime \prime} \mathrm{W}$; BGN 1936; (map 17).

Named by members of the U.S. Navy Aleutian Island Survey Expedition in 1934, for the U.S.S. Quail.

Quail Creek: stream, flows SE $5.6 \mathrm{mi}$. to Troublesome Creek, $16 \mathrm{mi}$. SE of Rampart, Yukon-Tanana High.; $65^{\circ} 22^{\prime} \mathrm{N}, 149^{\circ} 45^{\prime} \mathrm{W}$; (map 105).

Named by prospectors in 1898; reported in 1904 by L. M. Prindle and F. L. Hess, USGS. "it is said that it was desired to call the stream 'Ptarmigan Creek,' but as no one in the party could spell ptarmigan it was named 'Quail,' the spelling of which was easier." (Prindle and Hess, 1908, p. 96).

Quail Island: island, $5 \mathrm{mi}$. long, in Yukon River, $50 \mathrm{mi}$. E of Unalakleet, Innoko Low.; $63^{\circ} 55$ $\mathrm{N}, 159^{\circ} 02^{\prime} \mathrm{W}$; (map 91). Var. Leah Island.

Local name reported in 1952 by the U.S. Army Corps of Engineers. Its earlier name "Leah Island" was given by steamboat pilots after the steamboat Leah built at Saint Michael about 1895 and named for Leah Shingleberger, mother-in-law of Capt. Gustav Niebaum of the Alaska Commercial Company.

Quake Lake: lake, 0.5 mi. long, on Kenai Penin., SSE of Finger Lakes, $13 \mathrm{mi}$. NE of Kenai, Cook Inlet Low.; $60^{\circ} 37^{\prime} 45^{\prime \prime} \mathrm{N}, 150^{\circ} 52^{\prime} 45^{\prime \prime}$ W; (map 62).

Named about 1963 by officials of Kenai National Moose Range, for administrative purposes.

Quandary Creek: stream, flows NE $15 \mathrm{mi}$. to Killik River $6 \mathrm{mi}$. SE of its junc. with Colville River, Brooks Ra.; $68^{\circ} 58^{\prime} \mathrm{N}, 153^{\circ} 43^{\prime} \mathrm{W}$; $B G N$ 1960; (map 133).

So named about 1950 by USGS geologists during exploration of Naval Petroleum Reserve No. 4, because of the "confusing way in which the stream meanders."

Quartz Bay: cove, $0.7 \mathrm{mi}$. wide, on $\mathrm{E}$ shore of West Arm Nuka Bay, on SE coast of Kenai Penin., $36 \mathrm{mi}$. ESE of Homer, Chugach Mts., $59^{\circ} 31^{\prime} \mathrm{N}, 150^{\circ} 33^{\prime} \mathrm{W}$; BGN 1929; (map 50). Var. Rock Bay.

Local name reported by USC\&GS in 1927 "as the name used by miners and prospectors in filing descriptions of claims." Quartz Creek: locality, see Dahl. 
Quartz Creek: stream, flows SE 2 mi. to Salmon River, $23 \mathrm{mi}$. NE of Cape Newenham, Kilbuck-Kuskokwim Mts.; $58^{\circ} 52^{\prime} 35^{\prime \prime}$ N, $161^{\circ}$ $44^{\prime 2} 5^{\prime \prime} \mathrm{W}$; BGN 1938; (map 39).

Local name reported in 1938 by J. B. Mertie and Gerald FitzGerald, USGS.

Quartz Creek: stream, on Kenai Penin., flows NW $6 \mathrm{mi}$. then SW $10 \mathrm{mi}$. to Kenai Lake, $28 \mathrm{mi}$. NW of Seward, Chugach Mts.; $B G N$ $1950 ; 60^{\circ} 32^{\prime} 05^{\prime \prime} \mathrm{N}, 149^{\circ} 28^{\prime} 30^{\prime \prime} \mathrm{W}$; (map 63).

Name used by local prospectors; reported in 1898 by Mendenhall (1900, p. 331), USGS.

Quartz Creek: stream, flows SW $24 \mathrm{mi}$. to Kisaralik River, $53 \mathrm{mi}$. SE of Bethel, KilbuckKuskokwim Mts.; $60^{\circ} 33^{\prime}$ N, 160¹9' W ; (map $59)$.

Local name reported in 1955 by J. M. Hoare, USGS.

Quartz Creek: stream, flows NE 2 mi. to Chitina River, $47 \mathrm{mi}$. SE of McCarthy, St. Elias Mts.; $61^{\circ} 02^{\prime} \mathrm{N}, 141^{\circ} 48^{\prime} \mathrm{W}$; (map 67).

Prospectors' name reported in 1900 by $\mathrm{T}$. G. Gerdine, USGS.

Quartz Creek: stream, flows NW $11 \mathrm{mi}$. to outlet of Tonsina Lake, $37 \mathrm{mi}$. NE of Valdez, Chugach Mts.; $61^{\circ} 31^{\prime} 20^{\prime \prime} \mathrm{N}, 145^{\circ} 29^{\prime} 30^{\prime \prime} \mathrm{W}$; (map 68).

Prospectors' name reported in 1899 by several members of Capt. W. R. Abercrombie's expedition.

Quartz Creek: stream, heads in lake, flows NE $7 \mathrm{mi}$. to anabranch of Skwentna River, $55 \mathrm{mi}$. NW of Tyonek, Alaska Ra.; 61 $51^{\prime} 15^{\prime \prime} \mathrm{N}$, $151^{\circ} 27^{\prime} 30^{\prime \prime} \mathrm{W}$; (map 70).

Local name reported in 1954 by USGS.

Quartz Creek: stream, flows W $1.2 \mathrm{mi}$. to Ahtell Creek, $7 \mathrm{mi}$. NW of Slana, Alaska Ra.; $62^{\circ}$ $48^{\prime} \mathrm{N}, 144^{\circ} 04^{\prime} \mathrm{W}$; (map 83 ).

Name used by prospectors and reported by USGS (in Moffit, 1937, p. 106).

Quartz Creek: stream, flows SW $1.3 \mathrm{mi}$. to Chisna River, $1.2 \mathrm{mi}$. SE of Chisna Pass and $25 \mathrm{mi}$. NE of Paxson, Alaska Ra.; 63 $09^{\prime} 00^{\prime \prime}$ $\mathrm{N}, 144^{\circ} 45^{\prime} 05^{\prime \prime} \mathrm{W}$; (map 86).

Prospectors' name reported in 1900 by T. G. Gerdine (in Mendenhall and Schrader, 1903, pl. 9), USGS.

Quartz Creek: stream, flows SW $3.5 \mathrm{mi}$., joins Shorty Creek to form Butte Creek, 30 rni. NE of Ophir and $41 \mathrm{mi}$. NW of McGrath, Kilbuck-Kuskokwim Mts.; $63^{\circ} 31^{\prime} \mathrm{N}, 156^{\circ} 08^{\prime} \mathrm{W}$; (map 90).

Prospectors' name reported in 1933 by USGS.

Quartz Creek: stream, flows SE $11 \mathrm{mi}$. to Sulatna River, 14 mi. SW of Monzonite Hills, Kilbuck-

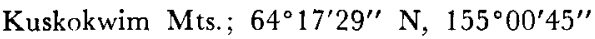
W; (map 98). Var. Rabbit Creek.

Prospectors' name reported in 1911 by A. G. Maddren (in Brooks and other, 1912, p. 294296), USGS.

Quartz Creek: stream, flows S $4 \mathrm{mi}$. to Norton Sound, $19 \mathrm{mi}$. NW of Nome, Seward Penin. High.; 64 $34^{\prime} \mathrm{N}, 166^{\circ} 00^{\prime} \mathrm{W}$; (map 94).

Prospectors' name reported in 1900 by E. C. Barnard (in Brooks, 1901, pl. 17), USGS.
Quartz Creek: stream, flows NW $1.7 \mathrm{mi}$. to Solomon River, $7 \mathrm{mi}$. NE of Solomon, Seward Penin. High.; $64^{\circ} 39^{\prime} \mathrm{N}, 164^{\circ} 20^{\prime} \mathrm{W}$; (map 95).

Prospectors' name reported in 1900 by E. C. Barnard (in Brooks, 1901, pl. 17), USGS

Quartz Creek: stream, flows NE $4 \mathrm{mi}$. to Boundary Creek, $9 \mathrm{mi}$. SE of Eagle, Yukon-Tanana High.; 64 $40^{\prime} 30^{\prime \prime}$ N, $141^{\circ} 07^{\prime} 00^{\prime \prime} \mathrm{W}$; (map 102).

Prospectors' name shown on a 1902 manuscript map by E. J. Chamberlain, U.S. Deputy Surveyor.

Quartz Creek: stream, flows E $1.7 \mathrm{mi}$. to Bonanza River, $15 \mathrm{mi}$. NW of Solomon, Seward Penin. High.; 64 $44^{\prime} \mathrm{N}, 164^{\circ} 45^{\prime} \mathrm{W}$; (map 95).

Prospectors' name reported on the 1900 "Map of Nome Peninsula" by J. M. Davidson and B. D. Blakeslee.

Quartz Greek: stream, flows N $4 \mathrm{mi}$. to Gold Creek, $48 \mathrm{mi}$. N of Big Delta, Yukon-Tanana High.; $64^{\circ} 49^{\prime} 30^{\prime \prime} \mathrm{N}, 145^{\circ} 33^{\prime} 00^{\prime \prime} \mathrm{W}$; (map 101).

Named by prospectors and reported in 1905 by D. C. Witherspoon (Prindle, 1913a, pl. 1), USGS

Quartz Creek: stream, flows SW $1.3 \mathrm{mi}$., joins Thompson Creek to form Stewart River, 23 mi. NE of Nome, Seward Penin. High.; 64 $4^{\circ} 50^{\prime}$ N, $165^{\circ} 19^{\prime} \mathrm{W}$; (map 94).

Prospectors' name reported in 1904 by T. G. Gerdine, USGS.

Quartz Creek: stream, flows SE $3.5 \mathrm{mi}$. to Goose Creek which flows to Casadepaga River, 23 mi. NE of Solomon, Seward Penin. High.; $64^{\circ} 53^{\prime} \mathrm{N}, 164^{\circ} 18^{\prime} \mathrm{W}$; (map 95).

Prospectors' name reported in 1900 by E. C. Barnard (in Brooks, 1901, pl. 17), USGS.

Quartz Greek: stream, flows SW $12 \mathrm{mi}$. to Kwik River, $45 \mathrm{mi}$. NW of Christmas Mtn., Seward Penin. High.; $64^{\circ} 55^{\prime} \mathrm{N}, 161^{\circ} 48^{\prime} \mathrm{W}$; (map 96).

Local name reported in 1943 by USC\&GS.

Quartz Creek: stream, flows NE $1 \mathrm{mi}$. to Gold Run which flows to Bluestone River, $16 \mathrm{mi}$. SE of Teller, Seward Penin. High.; $65^{\circ} 02^{\prime}$ N, $166^{\circ} 15^{\prime} \mathrm{W}$; (map 111).

Prospectors' name reported on a map of Cape Nome goldfields by David Fox, Jr., dated 1901

Quartz Creek: stream, heads on Serpentine Ridge, flows SW $4.6 \mathrm{mi}$. to Sullivan Creek, $1.2 \mathrm{mi}$. NW of Tofty and $34 \mathrm{mi}$. ESE of Tanana, Yukon-Tanana High.; 65 $06^{\circ} 30^{\prime \prime} \mathrm{N}$, $150^{\circ} 54^{\prime} 10^{\prime \prime} \mathrm{W}$; (map 106).

Prospectors' name reported by C. E. Ellsworth and G. L. Parker (in Brooks and others, 1911, p. 166), USGS.

Quartz Creek: stream, flows NW $1.8 \mathrm{mi}$. to Dese Creek which flows to Grantley Harbor, 7 mi. SE of Teller, Seward Penin. High.; $65^{\circ} 13^{\prime} \mathrm{N}, 166^{\circ} 08^{\prime} \mathrm{W}$; (map 111).

Prospectors' name reported on the 1908 "Map of Seward Peninsula" by Arthur Gibson.
Quartz Creek: stream, in Rampart Mts., flows SE $3.3 \mathrm{mi}$. to Yukon River, $22 \mathrm{mi}$. ENE of Tanana, Kokrines-Hodzana High.; $65^{\circ} 15^{\prime} 30^{\prime \prime}$ N, $151^{\circ} 22^{\prime} 00^{\prime \prime} \mathrm{W}$; (map 106).

Prospectors' name from Edwards Track Chart of the Yukon, dated 1899; published by Cantwell (1902, p. 277), USRCS.

Quartz Creek: stream, flows SE $11 \mathrm{mi}$. to Kougarok River $3 \mathrm{mi}$. NW of its junc. with Kuzitrin River, 46 mi. SW of Imuruk Lake, Seward Penin. High.; $65^{\circ} 18^{\prime} \mathrm{N}, 164^{\circ} 36^{\prime} \mathrm{W}$; (map 110).

Prospectors' name reported in 1900 by Brooks (1901, pl. 11), USGS.

Quartz Creek: stream, flows SW $5.4 \mathrm{mi}$. to Independence Creek, in Kugruk River basin, 24 mi. E of Imuruk Lake, Seward Penin. High.; $65^{\circ} 32^{\prime} \mathrm{N}, 162^{\circ} 22^{\prime} \mathrm{W}$; (map 110).

Prospectors' name reported in 1903 by D. C. Witherspoon (in Moffit, 1905, pl. 2), USGS. Quartz Creek: stream, flows NW $8 \mathrm{mi}$. to Bear Creek, $80 \mathrm{mi}$. SW of Circle, Yukon-Tanana High.; $65^{\circ} 32^{\prime} 20^{\prime \prime} \mathrm{N}, 146^{\circ} 42^{\prime} 50^{\prime \prime} \mathrm{W}$; (map 104).

Named by prospectors; reported in 1909 by L. M. Prindle, USGS.

Quartz Creek: stream, flows NW $21 \mathrm{mi}$. to Kiwalik River, $32 \mathrm{mi}$. NW of Haycock, Seward Penin. High.; $65^{\circ} 35^{\prime} \mathrm{N}, 161^{\circ} 48^{\prime} \mathrm{W}$; (map 109).

Local name shown on a 1903 fieldsheet by D. C. Witherspoon, USGS.

Quartz Creek: stream, flows SE $10 \mathrm{mi}$. to Crooked Creek, $18 \mathrm{mi}$. SW of Circle, YukonTanana High.; $65^{\circ} 36^{\prime} 45^{\prime \prime} \mathrm{N}, 144^{\circ} 27^{\prime} 45^{\prime \prime} \mathrm{W}$; (map 104). Var. Jump Off Creek.

Named by prospectors; reported in 1903 by USGS (Prindle, 1905, pl. 13). "Jump Off Creek," appearing on an unpublished map of 1898 , is either the same stream or one near it.

Quartz Creek: stream, flows NW $0.6 \mathrm{mi}$. to Candle Creek, $12 \mathrm{mi}$. SW of Candle and 32 mi. NE of Imuruk Lake, Seward Penin. High.; $65^{\circ} 45^{\prime} 45^{\prime \prime} \mathrm{N}, 162^{\circ} 07^{\prime} 00^{\prime \prime} \mathrm{W}$; (map 110).

Prospectors' name reported on the 1908 "Map of Seward Peninsula" by Arthur Gibson.

Quartz Creek: stream, flows NE $6 \mathrm{mi}$. to South Fork Serpentine River, $8 \mathrm{mi}$. N of Kougarok Mtn. and $29 \mathrm{mi}$. SE of Ear Mtn., Seward Penin. High.; $65^{\circ} 49^{\prime} \mathrm{N}, 165^{\circ} 15^{\prime} \mathrm{W}$; (map 111).

Prospectors' name reported in 1901 by T. G. Gerdine (in Collier, 1902, pl. 12), USGS.

Quartz Creek: stream, heads on Ear Mtn., flows SW $5 \mathrm{mi}$. to Tuttle Creek, in Kugrupaga River basin, $45 \mathrm{mi}$. N of Teller, Seward Penin. High.; $65^{\circ} 54^{\prime} \mathrm{N}, 166^{\circ} 25^{\prime} \mathrm{W}$; (map 111).

Prospectors' name reported in 1907 by Knopf (1908, p. 27), USGS.

Quartz Creek: stream, flows SE $3 \mathrm{mi}$. to Porcupine Creek, $1.5 \mathrm{mi}$. $\mathrm{N}$ of that stream's mouth and $12 \mathrm{mi}$. S of Wiseman, Brooks Ra.; $67^{\circ} 15^{\prime} \mathrm{N}, 150^{\circ} 18^{\prime} \mathrm{W}$; (map 124).

Local descriptive name obtained in 1956 by USGS topographers. 
Quartz Greek: stream, flows NE $9 \mathrm{mi}$. to North Fork Ghandalar River, $30 \mathrm{mi}$. NNW of Chandalar, Brooks Ra.; $67^{\circ} 51^{\prime} 30^{\prime \prime} \mathrm{N}, 149^{\circ} 02^{\prime} 00^{\prime \prime}$ W; (map 123).

Prospectors' name reported in 1899 by Schrader (1900b, pl. 60), USGS.

Quartz Creek: ravine, see Quartz Gulch.

Quartz Creek: stream, see Borg Creek.

Quartz Creek: stream, see Ingram Creek.

Quartz Creek: stream, see Penny River.

Quartz Creek: stream, see South Fork Serpentine River.

Quartz Creek: stream, see Star Creek.

Quartz Glacier: locality, in Glory Hole, $1.2 \mathrm{mi}$. $\mathrm{N}$ of Gastineau Peak and $2 \mathrm{mi}$. E of Juneau, Coast Mts.; $58^{\circ} 18^{\prime} 30^{\prime \prime} \mathrm{N}, 134^{\circ} 21^{\prime} 15^{\prime \prime} \mathrm{W}$; (map 11).

Name published in 1962 by USGS.

Quartz Gulch: ravine, $0.3 \mathrm{mi}$. long, extending $\mathrm{W}$ from Silverbow Basin, $2.5 \mathrm{mi}$. E of Juneau, Coast Mts.; $58^{\circ} 10^{\prime} 24^{\prime \prime} \mathrm{N}, 134^{\circ} 20^{\prime} 36^{\prime \prime} \mathrm{W}$; (map 11).

Named by Richard Harris in 1880 because "it contained the most gold-bearing quartz I had ever seen in one gulch." (DeArmond, 1957, p. 35).

Quartz Gulch: ravine, extends SE $2 \mathrm{mi}$. from Donlin Creek, $0.7 \mathrm{mi}$. W of Dome Creek and $43 \mathrm{mi}$. NW of Sleetmute, Kilbuck-Kuskokwim Mts.; $62^{\circ} 05^{\prime} \mathrm{N}, 158^{\circ} 11^{\prime} \mathrm{W}$; BGN 1945; (map 79). Var. Quartz Creek.

Prospectors' name obtained in 1913 by Eakin (1914, pl. 1), USGS.

Quartz Gulch: ravine, trends S $0.4 \mathrm{mi}$. to Anvil Creek NW of Anvil Peak and $5.5 \mathrm{mi}$. N of Nome, Seward Penin. High.; 64 $34^{\circ} 45^{\prime \prime}$ N, $165^{\circ} 23^{\prime 2} 25^{\prime \prime} \mathrm{W}$; (map 94).

Prospectors' name reported on the 1903 Campion Mining and Trading Co. map by George M. Ashford.

Quartzite Creek: stream, heads $14 \mathrm{mi}$. NW of Birthday Pass, flows S $20 \mathrm{mi}$. to Awuna River, $125 \mathrm{mi}$. SE of Wainwright, Arctic Slope; $69^{\circ} 08^{\prime \prime} \mathrm{N}, 157^{\circ} 03^{\prime} \mathrm{W}$; (map 143).

Named by USGS geologists in the 1950's.

Quartz Lake: lake, $2 \mathrm{mi}$. across, $4 \mathrm{mi}$. N of Big Delta, Tanana Low.; $64^{\circ} 13^{\prime} \mathrm{N}, 145^{\circ} 49^{\prime}$ W; (map 101).

Named by prospectors and reported in 1908 by J. W. Bagley, USGS.

Quartz Point: point of land, $\mathrm{S}$ point of entrance to Coal Harbor in Zachary Bay, Unga I., in Shumagin Is., Aleutian Ra.; 55 $19^{\prime} 45^{\prime \prime} \mathrm{N}$, $160^{\circ} 36^{\prime} 45^{\prime \prime} \mathrm{W}$; (map 28).

Named in 1872 by W. H. Dall, USC\&GS.

Quartz Point: point of land, on NE end of Goose I., in South Passage, $1.5 \mathrm{mi}$. NW of Mud Bay and $23 \mathrm{mi}$. NW of Hoonah, Alex., Arch.; $58^{\circ} 13^{\prime} \mathrm{N}, 136^{\circ} 02^{\prime} \mathrm{W}$; (map 10 ).

So named in 1882 by W. H. Dall, USC\&GS, "because the place is marked by large masses of white quartz, which look like ice."

Quartz Rock: rock, $0.1 \mathrm{mi}$. across, in Iphigenia Bay, $2.3 \mathrm{mi}$. E of Warren I., Alex. Arch.; $55^{\circ} 53^{\prime} 50^{\prime \prime} \mathrm{N}, 133^{\circ} 47^{\prime} 25^{\prime \prime} \mathrm{W}$; (map 4).

Local name published in 1965 by USC\&GS.
Quartz Rock: island, $0.1 \mathrm{mi}$. long, in Clarence Strait, SW coast of Etolin I., Alex. Arch.; $55^{\circ} 59^{\prime} 00^{\prime \prime} \mathrm{N}, 132^{\circ} 28^{\prime} 10^{\prime \prime} \mathrm{W}$; (map 4).

Descriptive name given in 1886 by $L t$. Comdr. A. S. Snow, USN.

Quat-a-hein: stream, see Kwatahein Creek.

Quay Peak: mountain, see Sugarloaf Mountain. Queakhpaghamiut: locality, see Kweakpak.

Queeguilmiut: locality, see Kyagamiut.

Queekagamut: locality, see Kwigalok.

Queekmute: locality, see Kwik.

Queen Creek: stream, flows SW $0.2 \mathrm{mi}$. to Carbon Creek, $19 \mathrm{mi}$. NE of Katalla, Chugach Mts.; $60^{\circ} 23^{\prime} \mathrm{N}, 144^{\circ} 11^{\prime} \mathrm{W}$; (map 64).

Local name used by prospectors, reported USGS by G. C. Martin (1905, p. 20).

Queen Creek: stream, flows SW $0.5 \mathrm{mi}$. to Dewey Creek, $10 \mathrm{mi}$. NE of Nome, Seward Penin. High.; $64^{\circ} 38^{\prime} \mathrm{N}, 165^{\circ} 16^{\prime} \mathrm{W}$; (map 94).

Prospectors' name shown on the 1902 "Map of the Nome and Snake River Country" by J. M. Davidson.

Queen Creek: stream, flows NW $4 \mathrm{mi}$. to North Fork Kougarok River, $3 \mathrm{mi}$. SW of Harris Dome and $42 \mathrm{mi}$. W of Imuruk Lake, Seward Penin. High.; $65^{\circ} 36^{\prime} \mathrm{N}, 164^{\circ} 40^{\prime} \mathrm{W}$; (map 110).

Prospectors' name reported in 1901 by T. G. Gerdine (in Collier, 1902, pl. 12), USGS.

Queen Creek: ravine, see Queen Gulch.

Queen Gulch: ravine, extends SE $1.6 \mathrm{mi}$. from Crooked Creek $1.6 \mathrm{mi}$. NE of junc. of American Creek, $43 \mathrm{mi}$. NW of Sleetmute, KilbuckKuskokwim Mts.; $62^{\circ} 03^{\prime} 40^{\prime \prime} \mathrm{N}, 158^{\circ} 13^{\prime} 30^{\prime \prime}$ W; BGN 1945; (map 79). Var. Queen Creek.

Prospectors' name obtained in 1913 by Eakin (1914, pl. 1), USGS.

Queen Inlet: bay, $4 \mathrm{mi}$. long, an Glacier Bay, Glacier Bay National Monument, $1 \mathrm{mi}$. N of Composite I. and $68 \mathrm{mi}$. NW of Hoonah, St. Elias Mts.; $58^{\circ} 54^{\prime} 30^{\prime \prime} \mathrm{N}, 136^{\circ} 33^{\prime} 00^{\prime \prime} \mathrm{W}$; (map 10).

Named in 1892 by Reid (1896, p. 422) for the SS Queen, which was the first ship to sail to the upper part of Glacier Bay.

Queen of Sheba Creek: stream, flows E $3 \mathrm{mi}$. to King Solomon Creek, $17 \mathrm{mi}$. S. of Eagle, Yukon-Tanana High.; $64^{\circ} 32^{\prime} 45^{\prime \prime} \mathrm{N}, 141^{\circ} 17^{\prime}$ 45" W; (map 102).

Prospectors' name published in 1925 by ARC.

Queen of Sheba Mountain: mountain, see Sheba Mountain.

Queens Creek: stream, flows SW $0.5 \mathrm{mi}$. to Elliott Creek, $1 \mathrm{mi}$. NW of Iron Mtn. and 32 mi. NE of Valdez, Wrangell Mts.; 61 ${ }^{\circ} 38^{\prime} 15^{\prime \prime}$ $\mathrm{N}, 144^{\circ} 02^{\prime} 30^{\prime \prime} \mathrm{W}$; (map 68).

Prospectors' name reported in 1903 by W. C. Mendenhall, USGS.

Queen Twin Creek: stream, flows S $2 \mathrm{mi}$. to Little Boulder Creek $\mathrm{N}$ of Boulder Ridge, 33 mi. E of Tanana, Yukon-Tanana High.; $65^{\circ}$ 10'32' N, 150'57'58' W; BGN 1965; (map 106).

Prospectors' name reported in 1963 by Bond Taher, USGS, as having "Long local usage."
Queer Creek: stream, heads in Rockys Lakes, flows NE 4 mi. to Rabideux Creek, $9.5 \mathrm{mi}$. SW of Talkeetna, Cook Inlet Low.; $62^{\circ} 11^{\prime} 25^{\prime \prime} \mathrm{N}$, $150^{\circ} 11^{\prime} 15^{\prime \prime} \mathrm{W}$; (map 81).

Local descriptive name reported in 1958 by USGS.

Queer Island: island, $0.6 \mathrm{mi}$. long, $8 \mathrm{mi} . \mathrm{S}$ of Kodiak, on E coast of Kodiak I.; $57^{\circ} 40^{\prime} 40^{\prime \prime}$ N, 152 22'45" W; (map 34). Var. Chudnoi, Ostrov Chudnoy.

This is a translation of the Russian name "Ost[rov] Chudnoy," published by Sarichev (1826, map 16).

Queer Ponds: lakes, extend E $6 \mathrm{mi}$. along course of Owl Creek, $21 \mathrm{mi}$. NW of Beaver, KokrinesHodzana High.; $66^{\circ} 28^{\prime} \mathrm{N}, 148^{\circ} 10^{\prime} \mathrm{W}$; (map 118).

Local descriptive name obtained in 1956 by USGS.

Quek: anchorage, on SE coast of Nushagak Penin., $4.5 \mathrm{mi}$. NE of Cape Constantine and $44 \mathrm{mi}$. SW of Dillingham, Bristol Bay Low.; $58^{\circ} 25^{\prime} 20^{\prime \prime} \mathrm{N}, 158^{\circ} 47^{\prime} 00^{\prime \prime} \mathrm{W}$; (map 40).

Eskimo name meaning "small boat anchorage," reported in 1947 by Lt. Comdr. A. N. Stewart, USC\&GS.

Quekilok Creek: stream, flows $\mathrm{N} 7 \mathrm{mi}$. to Norton Sound, $16 \mathrm{mi}$. E of Saint Michael, YukonKuskokwim Delta; $63^{\circ} 27^{\prime} \mathrm{N}, 161^{\circ} 31^{\prime} \mathrm{W}$; (map 91). Var. Quekilouk Creek.

Eskimo name reported in 1952 by USC\&GS. Quekilouk Creek: stream, see Quekilok Creek.

Quelochamiut: locality, see Kweleluk.

Quemabo, Cabo: point of land, see Quemada, Point.

Quemada, Point: point of land, on NW coast of Suemez I., $1 \mathrm{mi}$. S of Point Arboleda, Alex. Arch.; 55 $18^{\prime} 15^{\prime \prime} \mathrm{N}, 133^{\circ} 27^{\prime} 40^{\prime \prime} \mathrm{W}$; (map 4). Var. Cabo Quemabo, Mys Kuyemabo.

Spanish name given in 1775-79 by Don Juan de la Bodega y Quadra and Francisco Antonio Maurelle as "Cabo Quemabo," or "Cape Quemabo"; probably from "quemado," meaning "burnt."

Query Creek: stream, heads $\mathbf{N}$ of The Cockscomb, flows NNW to Kiligwa River $11 \mathrm{mi}$. S of Liberator Lake, Brooks Ra.; $68^{\circ} 43^{\prime} \mathrm{N}$, $158^{\circ} 26^{\prime} \mathrm{W}$; (map 132). Var. Why Creek.

So named in 1951 by I. J. Tailleur, USGS, because of the "complex geology" around the stream.

Question Creek: stream, heads in Little Question Lake, fows SW $4.5 \mathrm{mi}$. to Sunshine Creek, $10 \mathrm{mi}$. S of Talkeetna, Cook Inlet Low.; $62^{\circ} 10^{\prime} 45^{\prime \prime} \mathrm{N}, 150^{\circ} 05^{\prime} 45^{\prime \prime} \mathrm{W}$; (map 81).

Name shown on a RR. location blueprint map compiled in 1915.

Question Lake: lake, 2,800 ft. across, in course of Question Creek, $6 \mathrm{mi}$. S of Talkeetna, Cook Inlet Low.; 62 $13^{\prime} 30^{\prime \prime} \mathrm{N}, 150^{\circ} 04^{\prime} 30^{\prime \prime}$ W; BGN 1961; (map 81). Var. Tollison Lake.

Local name reported in 1961 by USGS; the variant "Tollison" was for Hugo Tollefson [sic], a resident near the lake.

Question Lake: lake, see Benka Lake.

Quethluk: stream, see Kwethluk River.

Quetoth River: stream, see Duktoth River. 
Quick: locality, see Kwik.

Quick River: stream, see Kwik River.

Quicksand Cove: bay, $1.3 \mathrm{mi}$. wide, on $\mathrm{E}$ coast of Harris Penin., $27 \mathrm{mi}$. SW of Seward, Chugach Mts.; $59^{\circ} 47^{\prime} \mathrm{N}, 149^{\circ} 46^{\prime} \mathrm{W}$; BGN 1930; (map 49).

Named by the 1912 USC\&GS field party; "name suggested by the description of the cove [?]."

Quicksilver Creek: stream, $22 \mathrm{mi}$. long, flows SW to Kisaralik River, $76 \mathrm{mi}$. SE of Bethel, Kilbuck-Kuskokwim Mts.; $60^{\circ} 23^{\prime}$ N, $159^{\circ} 59^{\prime}$ W; BGN 1960; (map 59).

Named by prospectors who entered the area 1911-1914; so called because "traces of quicksilver ore were found in the vicinity;" reported in 1954 by J. M. Hoare and W. L. Coonrad, USGS.

Quicksilver Creek: stream, see North Fork Kisaralik River.

Quicksilver River: stream, see Quicksilver Creek.

Quickumguila Creek: stream, flows W $5 \mathrm{mi}$. to Kanektok River, $49 \mathrm{mi}$. NE of Goodnews, KilbuckKuskokwim Mts. ; 59 $45^{\prime} \mathrm{N}, 161^{\circ} 03^{\prime} \mathrm{W}$; (map 53).

Eskimo name shown on an 1898 fieldsheet by W. S. Post, USGS, whose party camped at its mouth on August 29, 1898.

Quiechochlogamiut: locality, see Kwigalok.

Quiet Bay: estuary, see Quiet Harbor.

Quiet Creek: stream, on Kenai Penin., flows NW $1 \mathrm{mi}$. to a lagoon on $\mathrm{S}$ end of Neptune Bay, $9 \mathrm{mi}$. SE of Homer, Chugach Mts.; 59 $32^{\prime} 30^{\prime \prime}$ $\mathrm{N}, 151^{\circ} 22^{\prime} 00^{\prime \prime} \mathrm{W}$; (map 50).

Local name reported and published by USGS in the 1950's.

Quiet Harbor: estuary, $0.7 \mathrm{mi}$. long, on NW coast of Etolin I., Alex. Arch.; 56 $04^{\prime} 10^{\prime \prime} \mathrm{N}$, $132^{\circ} 39^{\prime} 40^{\prime \prime} \mathrm{W}$; (map 6). Var. Gavan Pokoynaya, Pokoinaia Bay, Pokoinay Bay, Quiet Bay.

An 1882 translation by USC\&GS of name published in 1853 on Russian Hydrog. Dept. Chart 1493 as "Gav[an] Pokoynaya."

Quigillingok: village, see Kwigillingok

Quigley Ridge: ridge, elev. 3,100 ft., extends SW $2 \mathrm{mi}$. from Wickersham Dome to Moose Greek, $3.3 \mathrm{mi}$. NNW of Wonder Lake, Alaska

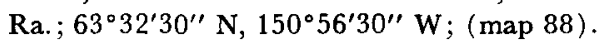

Local name reported in 1931 by F. G. Wells and S. C. Kain, USGS. Named for Joseph Quigley, who with his partner Jack Horn, first found gold on Glacier Creek in 1905.

Quigleys Camp: locality, on right bank of Solomon River, $7 \mathrm{mi}$. NE of Solomon, Seward Penin. High.; $64^{\circ} 39^{\prime} \mathrm{N}, 164^{\circ} 20^{\prime} \mathrm{W}$; (map 95).

Site of a mining camp; published in 1956 by USGS.

Quigmy River: stream, flows S $28 \mathrm{mi}$. to Togiak Bay, $12 \mathrm{mi}$. SW of Togiak, Kilbuck-Kuskokwim Mts. ; $58^{\circ} 57^{\prime} \mathrm{N}, 160^{\circ} 40^{\prime} \mathrm{W}$; (map 39). Var. Kwegamy River.

Eskimo name "Kwegamy," meaning "river" or "in the river [kuikime]" obtained about 1948 by USGS from Frank Waskey, local trader and prospector.
Quiktalik Creek: stream, flows SE $4 \mathrm{mi}$. to Norton Bay, $2 \mathrm{mi}$. SW of Elim and $64 \mathrm{mi}$. E of Solomon, Seward Penin. High.; 64 $36^{\prime} \mathrm{N}$, $162^{\circ} 18^{\prime} \mathrm{W}$; (map 95). Var. Kuiuktulik Creek, Peterson Creek.

Eskimo name reported in 1909 as "Kuiuktulik Creek" by Smith and Eakin (1911, pl. 1), USGS.

Quiktalik Mountain: mountain, see Kwiktalik Mountain.

Quillian Bay: estuary, on S coast of Esther I., extends SW $2 \mathrm{mi}$. to Wells Passage, $23 \mathrm{mi}$. E of Whittier, Chugach Mts.; $60^{\circ} 47^{\prime} 15^{\prime \prime} \mathrm{N}$, $148^{\circ} 02^{\prime} 55^{\prime \prime} \mathrm{W}$; (map 63).

Local name reported in 1952 by USGS.

Quillingok: village, see Kwigillingok.

Quill Lake: lake, $1 \mathrm{mi}$. long, on Kenai Penin., $2 \mathrm{mi}$. SW of Grus Lake and $23 \mathrm{mi}$. NE of Kenai, Cook Inlet Low.; $60^{\circ} 46^{\prime}$ N, $150^{\circ} 45^{\prime}$ W; (map 62).

Named about 1963 by officials of Kenai National Moose Range, for administrative purposes.

Quilochugamiut: locality, see Kwilokuk.

Quinahak: village, see Quinhagak.

Quinahak River: stream, see Kanektok River.

Quina River: stream, see Kanektok River.

Quinchaha: village, see Quinhagak.

Quincy Adams, Mount: mountain, 3,560 ft., in Glacier National Monument, on Alaska-Canada boundary, $2.6 \mathrm{mi}$. E of Mount Fairweather and $91 \mathrm{mi}$. NW of Hoonah, St. Elias Mts.; $58^{\circ} 54^{\prime} 30^{\prime \prime} \mathrm{N}, 137^{\circ} 27^{\prime} 00^{\prime \prime} \mathrm{W}:$ BGN 1954; (map 10). Var. Boundary Peak 163.

Named by Lawrence Martin, U.S. Dept. of State, in 1923 for John Quincy Adams, 17671848 , Secretary of State under President Monroe and sixth President of the United States, 1825-29. As Secretary of State, in 1825, he negotiated the first treaty between the United States and Russia, establishing a part of what would later become the boundary between the United States and Canada.

Quincy Gulch: ravine, trends NW $0.3 \mathrm{mi}$. to Osborn Creek, $8 \mathrm{mi}$. NE of Nome, Seward Penin. High.; $64^{\circ} 32^{\prime} 40^{\prime \prime}$ N., $165^{\circ} 09^{\prime} 25^{\prime \prime} \mathrm{W}$; (map 94).

Prospectors' name reported in 1904 by T. G. Gerdine, USGS.

Quinehaha: village, see Quinhagak.

Quinehahamute: village, see Quinhagak.

Quinhagak: village, pop. 228, on $\mathrm{E}$ side of Kuskokwim Bay, at mouth of Kanektok River, $46 \mathrm{mi}$. NW of Goodnews, Yukon-Kuskokwim Delta, 5945' N, 161 ${ }^{\circ} 54^{\prime} \mathrm{W}$; BGN 1957; (map 53). Var. Koingak, Kvingak, Kwinak, Kwinhagak, Kwinhagamut, Kwygyschpainagmjut, Quinahak, Quinchaha, Quinehaha, Quinehahamute, Quinhagamut, Quinhaghamiut, Quinhak Selo Koingak.

The name of this Eskimo village was reported as "S[elo] Koingak," meaning "Koingak Village," by Lt. Sarichev (1826, map 3), IRN. Ivan Petroff in the 1880 Census reports it as "Quinehahamute," and in the 1890 Census it is "Quinhaghamiut." The name is shown by W. S. Post, USGS, on an 1898 fieldsheet as "Quinhagamut." In 1919
G. L. Harrington, USGS, suggested that the name probably means "new formed river," which refers to the constantly changing channel of the stream on which the village is located. The population of the village in 1880 was 83 ; in 1890,109 ; in 1910,111 ; in 1920 193 ; and in 1930, 230. A post office was established here in 1905 (Ricks, 1965, p. 54). In 1954 the town had a Moravian mission, a store, and a government school.

Quinhagak River: stream, see Kanektok River. Quinhagamut: village, see Quinhagak.

Quinhaghamiut: village, see Quinhagak.

Quinhak: village, see Quinhagak.

Quinhak River: stream, see Kanektok River.

Quinlatah Slough: stream, see Kwinlatah Slough.

Quinn Creek: stream, flows NW $11 \mathrm{mi}$. to Iditarod River, $34 \mathrm{mi}$. NE of Aniak, KilbuckKuskokwim Mts. ; $61^{\circ} 59^{\prime} \mathrm{N}, 158^{\circ} 53^{\prime} \mathrm{W}$; BGN 1945; (map 72).

Local name reported in 1910 by C. G. Anderson (in Eakin, 1914, pl. 1), USGS.

Quinnehuk Mountains: mountains, see Kwiniuk, Mount.

Quinnehuk River: stream, see Kwiniuk River. Quinnelhock River: stream, see Kwiniuk River. Quintino Sella Glacier: glacier, heads at $60^{\circ} 38^{\prime}$ $\mathrm{N}, 141^{\circ} 07^{\prime} \mathrm{W}$, trends $\mathrm{S} 13 \mathrm{mi}$. to Columbus Glacier, $1 \mathrm{mi}$. NW of Table Mtn. and $81 \mathrm{mi}$. NW of Yakutat, St. Elias Mts.; $60^{\circ} 29^{\prime} \mathrm{N}$, $141^{\circ} 08^{\prime} \mathrm{W}$; BGN 1954; (map 65). Var. Sella Glacier

Named by His Royal Highness, Prince Luigi Amedeo di Savoia, Duke of the Abruzzi, in 1897 , while on the summit of Mount St. Elias, for Quintino Sella, pioneer of Italian Alpinism (Filippi, 1900, p. 159).

Quiros, Isla de: island, see Montague Island. Quisling Cove: cove, $0.5 \mathrm{mi}$. across, $4 \mathrm{mi} \mathrm{NE}$ of Lief Cove on W coast of Kiska I., Aleutian Is. ; $51^{\circ} 58^{\prime} 45^{\prime \prime} \mathrm{N}, 177^{\circ} 23^{\prime} 00^{\prime \prime} \mathrm{E}$; (map 14). Var. Eric Cove.

This is one of many arbitrary names applied by U.S. military forces to features on Kiska Island during World War II for tactical purposes.

Quitasueno Rock: rock, $0.1 \mathrm{mi}$. across, in N Portillo Channel, Alex Arch.; 55 $32^{\prime} \mathrm{N}, 133^{\circ}$. 28' W; (may 4). Var. Isla Quitasueño, Quita Sueño Rock, Quita Sueños.

Spanish name given in $1775-79$ by Don Juan de la Bodega y Quadra and Francisco Antonio Maurelle as "Isla Quitasueño" or "keep awake island" (Wagner, 1937, p. 404). Quithlook: village, see Kwethluk.

Quitoway Island: island, see Whale Island.

Quit Point: point of land, S tip of an island, $5 \mathrm{mi}$. S of Chichagof, off $W$ coast of Chichagof I., Alex. Arch.; 57 $35^{\prime} 25^{\prime \prime} \mathrm{N}, 136^{\circ} 06^{\prime} 30^{\prime \prime} \mathrm{W}$; $B G N 1908$; (map 9).

Named in 1908 by USC\&GS and published in the 1908 Coast Pilot (p. 171).

Quiukachamut: locality, on bank of Kanektok River, $60 \mathrm{mi}$. NE of Goodnews, KilbuckKuskokwim Mts.; $59^{\circ} 50^{\prime} \mathrm{N}, 160^{\circ} 42^{\prime} \mathrm{W}$; (map 53). 
This Eskimo name meaning "Quiukach people" was shown on an 1898 fieldsheet by W. S. Post, USGS, with the note "somewhere here."

Rabbit Creek: stream, heads in lake $\mathbf{N}$ of Suicide Peak, in Chugach Mts., flows NW and W 12 mi. to Turnagain Arm, $10 \mathrm{mi}$. S of Anchorage, Cook Inlet Low.; $61^{\circ} 04^{\prime} 25^{\prime \prime} \mathrm{N}, 149^{\circ} 50^{\prime} 15^{\prime \prime}$ W; (map 69).

Local name reported in 1906 by T. G. Gerdine and R. H. Sargent, USGS.

Rabbitt Creek: stream, flows SW $2.5 \mathrm{mi}$. to Kuslina Creek, $5.2 \mathrm{mi}$. NE of Liberty Falls and $70 \mathrm{mi}$. NE of Valdez, Wrangell Mts. ; $61^{\circ}$ $38^{\prime} 45^{\prime \prime} \mathrm{N}, 144^{\circ} 23^{\prime} 40^{\prime \prime} \mathrm{W}$; (map 68).

Name published in 1916 in Polk's Gazetteer.

Rabbit Creek: stream, flows $\mathrm{N} 8 \mathrm{mi}$. to Unalakleet River, $8.8 \mathrm{mi}$. E of Unalakleet, Nulato Hills; $63^{\circ} 52^{\prime} 15^{\prime \prime} \mathrm{N}, 160^{\circ} 29^{\prime} 50^{\prime \prime} \mathrm{W}$; (map 91).

Local name reported in 1952 by USC\&GS.

Rabbit Creek: stream, flows SE $2.2 \mathrm{mi}$. to Monument Creek, $5.5 \mathrm{mi}$. N of Sulatna Crossing and $25 \mathrm{mi}$. SW of Monzonite Hills, KilbuckKuskokwim Mts.; $64^{\circ} 16^{\prime} 20^{\prime \prime} \mathrm{N}, 155^{\circ} 25^{\prime} 25^{\prime \prime}$ W; BGN 1936; (map 98). Var. Jack Rabbit Greek.

Prospectors' name reported in 1913 by Eakin (1914, p. 367), USGS.

Rabbit Creek: stream, flows NE $1.8 \mathrm{mi}$., joins Teddy Creek to form Quartz Creek, $9 \mathrm{mi}$. SE of Long and $30 \mathrm{mi}$. SSE of Ruby, Kilbuck-

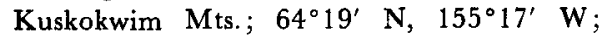
(map 98).

Prospectors' name reported in 1913 by Eakin (1914, pl. 3), USGS. The stream's identity is in doubt.

Rabbit Creek: stream, flows SE $1.3 \mathrm{mi}$. to Uncle Sam Creek, $5 \mathrm{mi}$. NE of Solomon, Seward Penin. High.; 64 ${ }^{\circ} 37^{\prime} \mathrm{N}, 164^{\circ} 19^{\prime} \mathrm{W}$; (map 95).

Prospectors' name shown on Arthur Gibson's "Map of Cape Nome Precinct" dated 1904.

Rabbit Creek: stream, flows W $1.7 \mathrm{mi}$. to Penny River, $10 \mathrm{mi}$. NW of Nome, Seward Penin. High.; $64^{\circ} 38^{\prime} \mathrm{N}, 165^{\circ} 38^{\prime} \mathrm{W}$; (map 94).

Prospectors' name published on the 1900 "Map of Nome Peninsula" by J. M. Davidson and B. D. Blakeslee.

Rabbit Creek: stream, flows NE $1.1 \mathrm{mi}$. to Iron Creek, $0.2 \mathrm{mi}$. $\mathrm{N}$ of junc. of Canyon and Dome Creeks and $25 \mathrm{mi}$. NW of Solomon, Seward Penin. High.; $64^{\circ} 54^{\prime} \mathrm{N}, 164^{\circ} 43^{\prime} \mathrm{W}$; (map 95). Var. Pajara Creek.

Prospectors' name reported on a map of Cape Nome gold fields by David Fox, Jr., dated 1901. Fox applied this name to a tributary north of this stream and called the stream described above "Pajara."

Rabbit Creek: stream, flows NW $1 \mathrm{mi}$. to Alder Creek, in Bluestone River basin $15 \mathrm{mi}$. SE of Teller, Seward Penin. High.; $65^{\circ} 04^{\prime} \mathrm{N}$, $166^{\circ} 09^{\prime} \mathrm{W}$; (map 111$)$.

Prospectors' name reported on the 1908 "Map of Seward Peninsula" by Arthur Gibson.
Rabbit Creek: stream, flows SW 6 mi. to Kobuk River $18 \mathrm{mi}$. NW of Shungnak, Brooks Ra.; $67^{\circ} 01^{\prime} \mathrm{N}, 157^{\circ} 42^{\prime} \mathrm{W}$; (map 126).

Local name reported by the U.S. Army Corps of Engineers in 1955.

Rabbit Creek: stream, heads in Mulgrave Hills, flows SW $23 \mathrm{mi}$. to Chukchi Sea, $24 \mathrm{mi}$. N of Cape Krusenstern, Kotzebue-Kobuk Low.; $67^{\circ} 28^{\prime}$ N, $163^{\circ} 58^{\prime}$ W; (map 128). Var. Ohkaleeksout, Ohkalicksuk.

Local name reported in 1950 by USC\&GS. This name evidently is a translation of the Eskimo name.

Rabbit Creek: stream, see Quartz Creek.

Rabbit Ears: peaks, 2,326 ft., E of Nimiuktuk River, $33 \mathrm{mi}$. ENE of Misheguk Mtn., Brooks Ra.; $68^{\circ} 20^{\prime} \mathrm{N}, 159^{\circ} 49^{\prime} \mathrm{W}$; (map 131).

Descriptive name probably given by USGS about 1925.

Rabbit Foot Lake: lake, $1.1 \mathrm{mi}$. long, on Kenai Penin. SW of Moose Lake, $34 \mathrm{mi}$. NE of Kenai, Cook Inlet Low.; $60^{\circ} 44^{\prime} 30^{\prime \prime} \mathrm{N}, 150^{\circ}$ $21^{\prime} 25^{\prime \prime} \mathrm{W}$; (map 62).

Named about 1963 by officials of the Kenai National Moose Range, for administrative purposes

Rabbit Island: island, $0.3 \mathrm{mi}$. across, $1 \mathrm{mi}$. W of Sanak, one of Sanak Is., Aleutian Ra.; $54^{\circ}$ $28^{\prime} 50^{\prime \prime} \mathrm{N}, 162^{\circ} 49^{\prime} 55^{\prime \prime} \mathrm{W}$; (map 25).

Descriptive name published in 1949 on a USGS map.

Rabbit Island: island, $0.3 \mathrm{mi}$. long, off S shore of Port Houghton, at mouth of Sanborn Canal, $81 \mathrm{mi}$. E of Sitka, Coast Mts. ; $57^{\circ} 17^{\prime} 40^{\prime \prime} \mathrm{N}$, $133^{\circ} 15^{\prime} 55^{\prime \prime} \mathrm{W}$; (map 8).

Local name reported in 1955 by USGS.

Rabbit Island: island, $2.5 \mathrm{mi}$. long, in Pye Is., E side of Nuka Bay, $46 \mathrm{mi}$ ESE of Seldovia, Chugach Mts.; $59^{\circ} 22^{\prime} 30^{\prime \prime} \mathrm{N}, 150^{\circ} 25^{\prime} 00^{\prime \prime} \mathrm{W}$; $B G N$ 1929; (map 50).

So named by USC\&GS in 1927, "because the outline of the island resembles a running rabbit."

Rabbit Islands: islands, extend $2.3 \mathrm{mi}$, in Iliamna Lake, $6 \mathrm{mi}$. ESE of Iliamna, Aleutian Ra.; $59^{\circ} 44^{\prime} \mathrm{N}, 154^{\circ} 43^{\prime} \mathrm{W}$; (map 51).

Local name published in 1954 by USGS.

Rabbit Lake: lake, 3,000 ft. long, SW of Alexander Lake, $44 \mathrm{mi}$. N of Tyonek, Cook Inlet Low.; $61^{\circ} 42^{\prime} 25^{\prime \prime} \mathrm{N}, 150^{\circ} 55^{\prime} 20^{\prime \prime} \mathrm{W}$; (map $70)$.

Local name reported in 1954 by USGS.

Rabbit Mountain: mountain, 3,081 ft., in Coleen Hills, 29 mi. NNE of Coleen Mtn., Brooks Ra.; $67^{\circ} 29^{\prime} \mathrm{N}, 142^{\circ} 18^{\prime} \mathrm{W}$; (map 121).

Local name reported in 1939 by FitzGerald (1944, p. 234), USGS.

Rabbit River: stream, heads at $66^{\circ} 44^{\prime} \mathrm{N}$, $157^{\circ} 30^{\prime} \mathrm{W}$, flows SW $25 \mathrm{mi}$. to Kugarak River, $33 \mathrm{mi}$. SW of Shungnak, Kotzebue-Kobuk Low.; $66^{\circ} 44^{\prime} \mathrm{N}, 158^{\circ} 15^{\prime} \mathrm{W}$; (map 115).

Local name shown on a 1927 manuscript map by the "trader at Selawik."

Rabbit Slough: stream, a distributary of Matanuska River, flows W 4 mi. to join Spring Creek to form Palmer Slough $7 \mathrm{mi}$. SW of
Palmer, Cook Inlet Low.; $61^{\circ} 32^{\prime} \mathrm{N}, 149^{\circ} 16^{\prime}$ W; (map 69).

Local name reported about 1951 by USGS. Rabenfluss: stream, see Kelsall River.

Rabideux Creek: stream, heads in a lake and flows SE $11 \mathrm{mi}$. to Susitna River, $11 \mathrm{mi}$. SW of Talkeetna, Cook Inlet Low.; $62^{\circ} 10^{\prime} 15^{\prime \prime} \mathrm{N}$, $150^{\circ} 11^{\prime} 15^{\prime \prime} \mathrm{W}$; (map 81).

Mountain climbers' name published in the late 1940's

Rabonisky: locality, see Razboinski.

Race, Mount: mountain, 3,170 ft., on $E$ coast of Baranof I., 24 mi. SE of Sitka, Alex. Arch.; $56^{\circ} 53^{\prime} 20^{\prime \prime} \mathrm{N}, 134^{\circ} 47^{\prime} 00^{\prime \prime} \mathrm{W}$; (map 5).

Local name recorded in 1951 by USGS.

Race, The: water passage, between Ringgold I. and Sachem Head, in W part of Bay of Is. Aleutian Is.; $51^{\circ} 48^{\prime} 30^{\prime \prime} \mathrm{N}, 176^{\circ} 50^{\prime} 40^{\prime \prime} \mathrm{W}$; BGN 1536; (map 17).

Named by members of the U.S. Navy Aleutian Island Survey Expedition in 1934, "for the passage of similar name between Fishers Island and Long Island, New York."

Race Point: point of land, $\mathrm{N}$ tip of Annette I., between Annette Bay and Revillagigedo Channel, Alex. Arch.; 55 $17^{\prime} 10^{\prime \prime} \mathrm{N}, 1^{\circ} 1^{\circ} 34^{\prime} 15^{\prime \prime}$ W; (map 3).

Named by local pilots about $1875-80$; published in 1885 by USC\&GS.

Race Point: point of land, elev. 3,000 ft., at $E$ end of $\mathrm{SE}$ ridge of Marathon Mtn., $1 \mathrm{mi}$. W of Seward, Chugach Mts.; $60^{\circ} 06^{\prime} 40^{\prime \prime} \mathrm{N}$, $149^{\circ} 28^{\prime} 25^{\prime \prime}$ W; BGN 1966; (map 63).

So named in 1965 by the Mountaineering Club of Alaska because "this is the turning point of the Marathon Mountain race held each year on July 4." See Marathon Mountain.

Race Point: point of land, NW point of Fire I., in Cook Inlet, $11 \mathrm{mi}$. SW of Anchorage, Cook Inlet Low.; $61^{\circ} 10^{\prime} 15^{\prime \prime} \mathrm{N}, 150^{\circ} 13^{\prime} 50^{\prime \prime} \mathrm{W}$; $(\operatorname{map} 70)$.

Local name published in 1912 by USC\&GS. Race Reef: rocks, see Walden Rocks.

Race Rocks: rocks, between Akutan and Akun Is., Krenitzin Is., Aleutian Is.; $54^{\circ} 07^{\prime} 57^{\prime \prime} \mathrm{N}$, $165^{\circ} 39^{\prime} 25^{\prime \prime} \mathrm{W}$; (map 24).

Name published in 1943 by USC\&GS.

Racetrack Basin: basin, $5 \mathrm{mi}$. long, $\mathrm{N}$ of Rooftop Ridge, $58 \mathrm{mi}$. NNE of Anaktuvuk Pass, Arctic Slope; $68^{\circ} 56^{\prime} \mathrm{N}, 151^{\circ} 00^{\prime} \mathrm{W} ; B G N$ 1960; (map 134).

So named by USGS geologists about 1950 because "exposed bedrock traces around the oval basin give it the appearance of a race track."

Racetrack Slough: stream, anabranch of Koyukuk River, $10 \mathrm{mi}$. long, $13 \mathrm{mi}$. NE of Roundabout Mtn., Koyukuk Low.; $65^{\circ} 44^{\prime}$ N, $156^{\circ}$ $31^{\prime} \mathrm{W}$; (map 108)

Local name obtained at Huslia by USGS in 1954 or 1955.

Rachek Island: island, $1 \mathrm{mi}$. long, in Necker Is., W of Baranof I., 7 mi. S of Goddard, Alex. Arch.; $56^{\circ} 44^{\prime} 30^{\prime \prime} \mathrm{N}, 135^{\circ} 23^{\prime} 00^{\prime \prime} \mathrm{W}$; (map 5).

Local name published in 1943 by USC\&GS. 
Racine Greek: stream, heads on Gold Hill, flows SW $4 \mathrm{mi}$. to Yukon River, $19 \mathrm{mi}$. W of Tanana, Kokrines-Hodzana High.; $65^{\circ} 12^{\prime} \mathrm{N}$, $152^{\circ} 46^{\prime} \mathrm{W}$; (map 106).

Local name reported in 1911 by $\mathrm{H}$. $M$. Eakin, USGS.

Racquet Creek: stream, heads in Canada, flows N 8 mi. to Drifting Snow Creek, $25 \mathrm{mi}$. N of Midnight Hill, Porcupine Plat.; $66^{\circ} 24^{\prime} 33^{\prime \prime} \mathrm{N}$, $141^{\circ} 04^{\prime} 50^{\prime \prime} \mathrm{W} ; B G N$ 1954; (map 120).

Named in 1908 by IBC surveyors; published in 1914 on IBC Sheet 14 (1918 Atlas).

Radamaker, Mount: mountain, 4,320 ft., on E coast of Baranof I., $13 \mathrm{mi}$. S of Baranof. Alex. Arch.; $56^{\circ} 53^{\prime} 40^{\prime \prime} \mathrm{N}, 134^{\circ} 49^{\prime} 00^{\prime \prime} \mathrm{W}$; (map 5).

Local name recorded in 1951 by USGS.

Radar Hill: hill, $360 \mathrm{ft}$., $\mathrm{S}$ of Willow, $36 \mathrm{mi}$. N of Anchorage, Cook Inlet Low.; 61 ${ }^{\circ} 44^{\prime} \mathrm{N}$, $150^{\circ} 02^{\prime} \mathrm{W}$; (map 70).

Local descriptive name reported in 1958 by USGS.

Radcliffe Glacier: glacier, heads on Mount Marcus Baker, trends SE $9.5 \mathrm{mi}$. to Harvard Glacier, $48 \mathrm{mi}$. NE of Valdez, Chugach Mts.; $61^{\circ} 18^{\prime} 30^{\prime \prime} \mathrm{N}, 147^{\circ} 41^{\prime} 30^{\prime \prime} \mathrm{W}$; (map 69).

Named by members of the Harriman Alaska Expedition in 1899 for Radcliffe College, Cambridge, Mass.

Radenbough Cove: cove, $800 \mathrm{ft}$. across, on $\mathrm{N}$ coast of Pennock I., $0.4 \mathrm{mi}$. S of Ketchikan, Alex. Arch.; $55^{\circ} 20^{\prime} 00^{\prime \prime} \mathrm{N}, 131^{\circ} 38^{\prime} 30^{\prime \prime} \mathrm{W}$; (map 3). Var. Rodenbough Cove.

Local name published by USC\&GS in 1923.

Rader Gulch: ravine, extends $1.3 \mathrm{mi}$. NE of Copper Creek, $0.7 \mathrm{mi}$. SE of junc. of Texas Creek and Copper Creek and $17 \mathrm{mi}$. SE of McCarthy, St. Elias Mts.; $61^{\circ} 21^{\prime} \mathrm{N}, 142^{\circ} 25^{\prime}$ W; (map 67)

Local name reported in 1908 by D. C. Witherspoon, USGS.

Radio Creek: stream, flows S $9 \mathrm{mi}$. along $\mathbf{E}$ side of Dulbatne Mtn. to Dulbi River, $48 \mathrm{mi}$. WNW of Birches, Kokrines-Hodzana High.; $65^{\circ} 17^{\prime} 50^{\prime \prime} \mathrm{N}, 155^{\circ} 09^{\prime} 10^{\prime \prime} \mathrm{W}$; (map 107).

Local name obtained in 1952 by USGS topographhers.

Radio Creek: stream, flows E $3 \mathrm{mi}$. to Kogoluktuk River, $13 \mathrm{mi}$. NE of Shungnak, Brooks Ra.; 66 $59^{\circ}$ N, $156^{\circ} 43^{\prime} \mathrm{W}$; (map 115).

Prospectors' name reported by USGS after 1940.

Radiolotden: locality, see Khadilotden.

Radovan Gulch: ravine, extends $22 \mathrm{mi}$. N from glacier to Glacier Creek $2.4 \mathrm{mi}$. SE of its junc. with Chitistone River and $18 \mathrm{mi}$. E of McCarthy, Wrangell Mts.; $60^{\circ} 26^{\prime} 15^{\prime \prime} \mathrm{N}$, 14221'15" W; BGN 1946; (map 67).

Local name reported by USGS in 1945 ; named for Martin F. Radovan, "a prospector who staked a number of copper lode claims in the gulch in 1929."

Raft Creek: stream, flows N $0.8 \mathrm{mi}$. to channel between East and West Kiska Lakes, Kiska I., Aleutian Is.; $52^{\circ} 03^{\prime} 30^{\prime \prime} \mathrm{N}, 177^{\circ} 34^{\prime} 15^{\prime \prime} \mathrm{E}$; (map 14).

An arbitrary name beginning with " $R$ " to correspond to " $R$ " grid used by the U.S. Army for tactical purposes during World War II ; published on a 1953 AMS map.

Raft Creek: stream, heads in Clearwater Mts., flows $\mathrm{S} 8.5 \mathrm{mi}$. to Susitna River $25 \mathrm{mi}$. N of junc. of Oshetna River, Alaska Ra.; $62^{\circ} 59^{\prime} 30^{\prime \prime} \mathrm{N}, 147^{\circ} 18^{\prime} 00^{\prime \prime} \mathrm{W}$; BGN 1959 ; (map 82).

Named in 1954 by USGS because a "Geological Survey party utilized the stream to ' $\mathrm{raft}$ ' supplies and boats to the Susitna River for a river traverse."

Ragged Cove: cove, extends S $0.7 \mathrm{mi}$. to Kashevarof Passage, $2 \mathrm{mi}$. N of Thorne I., on NE coast of Prince of Wales I., Alex. Arch.; $56^{\circ} 09^{\prime} \mathrm{N}, 133^{\circ} 03^{\prime} \mathrm{W}$; (map 6).

Named in 1886 by Lt. Comdr. A. S. Snow, USN; name published in 1887 on USC\&GS Chart 706.

Ragged Island: island, $7 \mathrm{mi}$. long, in Pye Is., $6 \mathrm{mi}$. E of Kenai Penin., $46 \mathrm{mi}$. E of Seldovia, Chugach Mts.; $59^{\circ} 30^{\prime} \mathrm{N}, 150^{\circ} 24^{\prime} \mathrm{W}$; BGN 1929; (map 50).

Named by USC\&GS in 1929, "because of the ragged and broken character of this island."

Ragged Mountain: mountain, 3,315 ft., extends $15 \mathrm{mi}$. N of Katalla, Chugach Mts. ; $60^{\circ} 17^{\prime} \mathrm{N}$, $144^{\circ} 35^{\prime} \mathrm{W}$; (map 64).

So named in 1903 by Martin (1905, p. 22), USGS.

Ragged Peak: peak, 9,160 ft., in Mount McKinley National Park, E of Brooks Glacier, 17 mi. NE of Mount McKinley, Alaska Ra.; $63^{\circ} 12^{\prime} 05^{\prime \prime} \mathrm{N}, 150^{\circ} 32^{\prime} 45^{\prime \prime} \mathrm{W} ;$ BGN 1948; (map 88).

So named in 1948 by Bradford Washburn because "It is extremely rugged being made of a slaty jagged rock that has been highly decomposed by frost action."

Ragged Point: point of land, on SE coast of Kagalaska I., Aleutian Is.; $51^{\circ} 44^{\prime} 40^{\prime \prime} \mathrm{N}$, $176^{\circ} 17^{\prime} 30^{\prime \prime}$ W; BGN 1936; (map 17).

Descriptive name given by members of the U.S. Navy Aleutian Island Survey Expedition in 1934

Ragged Point: point of land, on $\mathrm{S}$ coast of Alaska, at NE end of Wells Passage, $32 \mathrm{mi}$. E of Whittier, Chugach Mts.; $60^{\circ} 48^{\prime} 35^{\prime \prime} \mathrm{N}$, $147^{\circ} 46^{\prime} 30^{\prime \prime}$ W ; (map 63).

Local name reported in 1952 by USGS.

Ragged Point: point of land, see Oksenof Point. Ragged Top: volcano, 3,030 ft., $3.4 \mathrm{mi}$. E of Mount Cerberus, on SE part of Semisopochnoi I., Aleutian Is.; $51^{\circ} 55^{\prime} 50^{\prime \prime} \mathrm{N}, 179^{\circ} 40^{\prime} 20^{\prime \prime} \mathrm{E}$ BGN 1952; (map 15).

This descriptive name given by USGS in 1948 because of the "deeply dissected nature of the extinct volcano."

Raggedtop Mountain: mountain, 5,215 ft., 5 mi. N of Girdwood and $28 \mathrm{mi}$. SE of Anchorage, Chugach Mts.; $61^{\circ} 01^{\prime} 00^{\prime \prime} \mathrm{N}, 149^{\circ} 08^{\prime} 30^{\prime \prime}$ W; $B G N$ 1932; (map 69). Var. Ragged Top Mountain.

Named by USGS in 1932 "because of the very rugged topography on the mountain top."

Raging Creek: stream, flows SW $6 \mathrm{mi}$. to Simpson Bay, $8 \mathrm{mi}$. NW of Cordova, Chugach Mts. : $60^{\circ} 40^{\prime} \mathrm{N}, 145^{\circ} 49^{\prime} \mathrm{W}$; (map 64).
Local descriptive name published in 1951 by USGS

Rag Lake: lake, $0.2 \mathrm{mi}$. long, $\mathbf{S}$ of East Kiska Lake, Kiska I., Aleutian Is.; $52^{\circ} 03^{\prime} 05^{\prime \prime} \mathrm{N}$, $177^{\circ} 35^{\prime} 20^{\prime \prime} \mathrm{E}$; (map 14):

An arbitrary name beginning with " $R$ " to correspond to "R" grid used by the U.S. Army for tactical purposes during World War II published on a 1953 AMS map.

Raicheshnoe: locality, see Riechesni.

Railroad City: locality, on $\mathrm{S}$ bank of Innoko River, $4 \mathrm{mi}$. E of Holy Cross, Innoko Low.; $62^{\circ} 11^{\prime} 15^{\prime \prime} \mathrm{N}, 159^{\circ} 39^{\prime} 00^{\prime \prime} \mathrm{W}$; (map 78).

This name was applied about 1913 when the site was planned as the northern terminus of the Alaska Short Line Railroad, which was to extend from Iliamna Bay to the Yukon River. Recent USGS maps indicate a site with five or six buildings.

Railroad Lake: lake, see Rainbow Lake.

Rainbow: area, in S Anchorage, $1.3 \mathrm{mi}$. SSW of City Hall, Cook Inlet Low.; 61 ${ }^{\circ} 12^{\prime} 05^{\prime \prime} \mathrm{N}$, $149^{\circ} 54^{\prime} 00^{\prime \prime} \mathrm{W}$; (map 69)

Residential district in city of Anchorage reported in 1954 by office of city engineer of Anchorage.

Rainbow: village, pop. 20 , mi. 93.5 on The Alaska RR. on $\mathbf{N}$ coast of Turnagain Arm Cook Inlet, $17 \mathrm{mi}$. SE of Anchorage, Chugach Mts. ; $61^{\circ} 00^{\prime} 15^{\prime \prime} \mathrm{N}, 149^{\circ} 38^{\prime} 30^{\prime \prime} \mathrm{W}$; (map 69).

Name of a flag stop listed in the 1919 Railway Guide Index; name derived from Rainbow Creek.

Rainbow Basin: valley, trends NE $6 \mathrm{mi}$. to Golden Horn, $50 \mathrm{mi}$. NW of Dillingham, Kilbuck-Kuskokwim Mts.; $59^{\circ} 44^{\prime} \mathrm{N}, 159^{\circ} 01^{\prime} \mathrm{W}$; $B G N$ 1932; (map 53).

Local name reported in 1932 by Gerald FitzGerald, USGS.

Rainbow Bluff : bluff, see Nigu Bluff.

Rainbow Creek: stream, flows NW $2.5 \mathrm{mi}$. to Bering Sea, $0.5 \mathrm{mi}$ NE of Witchcraft Point, Kiska I., Aleutian Is.; $52^{\circ} 03^{\prime} 25^{\prime \prime} \mathrm{N}, 177^{\circ} 31^{\prime}$ $00^{\prime \prime} \mathrm{E}$; (map 14).

An arbitrary name beginning with " $R$ " to correspond to " $R$ " grid used by the U.S Army for tactical purposes during World War II; published on a 1953 AMS map.

Rainbow Creek: stream, flows S $6 \mathrm{mi}$. to Meshik River, $11 \mathrm{mi}$. S of Vent Mtn., Aleutian Ra.; $56^{\circ} 44^{\prime} \mathrm{N}, 158^{\circ} 04^{\prime} \mathrm{W}$; (map 30 ).

So named in 1923 by R. H. Sargent, USGS, because of " $a$ beautiful rainbow seen here after a long storm."

Rainbow Creek: stream, flows SW $3 \mathrm{mi}$. from Suicide Peak to $\mathrm{N}$ shore of Turnagain Arm, $15 \mathrm{mi}$. SE of Anchorage, Chugach Mts.; $61^{\circ}$ $00^{\prime} 02^{\prime \prime} \mathrm{N}, 149^{\circ} 38^{\prime} 30^{\prime \prime} \mathrm{W}$; (map 69).

Name used by local prospectors; reported in 1895 by Becker (1898, p. 82), USGS.

Rainbow Creek: stream, flows NW $4 \mathrm{mi}$. to Tonsina River, $2.8 \mathrm{mi}$. NE of Tonsina Lake and $40 \mathrm{mi}$. NE of Valdez, Chugach Mts.; $61^{\circ}$ $33^{\prime} 05^{\prime \prime} \mathrm{N}, 145^{\circ} 26^{\prime} 25^{\prime \prime} \mathrm{W}$; $B G N$ 1932; (map 68)

This stream was so named in 1932; the name was erroneously applied in 1912 to a stream in the Chitina quadrangle which 
was thought to be a tributary of Quartz Creek, but which was later found to be the main head of Slate Creek.

Rainbow Creek: stream, flows SW $1.5 \mathrm{mi}$. to Elliott Creek, $1.5 \mathrm{mi}$. SE of Alice Peak and 80 mi. NE of Valdez, Wrangell Mts. ; $61^{\circ} 38^{\prime} 45^{\prime \prime}$ $\mathrm{N}, 144^{\circ} 06^{\prime} 30^{\prime \prime} \mathrm{W}$; (map 68).

Prospectors' name reported in 1903 by W. C. Mendenhall, USGS.

Rainbow Creek: stream, flows S $2.5 \mathrm{mi}$. to Grand Central River, $29 \mathrm{mi}$. NE of Nome, Seward Penin. High.; $64^{\circ} 54^{\prime} \mathrm{N}, 165^{\circ} 06^{\prime} \mathrm{W}$; (map 94).

Prospectors' name reported in 1901 by E. C. Barnard (in Brooks, 1901, pl. 17), USGS.

Rainbow Creek: stream, see Slate Creek.

Rainbow Glacier: glacier, heads on E slope of Chilkat Ra., trends E $1.5 \mathrm{mi}$. to its terminus, $1.2 \mathrm{mi}$. NW of mouth of Ludaseska Creek and $24 \mathrm{mi}$. SW of Skagway, St. Elias Mts.; $59^{\circ}$ $07^{\prime} 10^{\prime \prime} \mathrm{N}, 135^{\circ} 28^{\prime} 40^{\prime \prime} \mathrm{W}$; (map 45).

Named by USC\&GS and published in 1893 on Chart 8300.

Rainbow Gulch: ravine, extends NW $1.7 \mathrm{mi}$. to Middle Fork Koyukuk River, $7 \mathrm{mi}$. NW of Poss Mtn. and $39 \mathrm{mi}$. W of Chandalar, Brooks Ra.; $67^{\circ} 28^{\prime} 30^{\prime \prime}$ N, $149^{\circ} 57^{\prime} 30^{\prime \prime}$ W; (map 123).

Local name reported in 1956 by T. E. Taylor, USGS.

Rainbow Lake: lake, $0.8 \mathrm{mi}$. long, on Kenai Penin. NW of Dolly Varden Lake, $18 \mathrm{mi}$. NW of Kenai, Cook Inlet Low.; $60^{\circ} 43^{\prime} 00^{\prime \prime} \mathrm{N}$, $150^{\circ} 48^{\prime} 30^{\prime \prime} \mathrm{W}$; ( $\operatorname{map} 62$ )

Named about 1963 by officials of Kenai National Moose Range, for administrative purposes.

Rainbow Lake: lake, $0.4 \mathrm{mi}$. long, in Matamuska Valley, $17 \mathrm{mi}$. W of Palmer, Cook Inlet Low.; $61^{\circ} 35^{\prime} 45^{\prime \prime} \mathrm{N}, 149^{\circ} 37^{\prime} 15^{\prime \prime} \mathrm{W}$; (map 69). Var. Railroad Lake.

Local name reported in 1965 by USGS

Rainbow Lake: lake, $1.4 \mathrm{mi}$. long, $3 \mathrm{mi}$. SW of Willow and $34 \mathrm{mi}$. N of Anchorage, Cook Inlet Low.; $61^{\circ} 41^{\prime} 45^{\prime \prime} \mathrm{N}, 150^{\circ} 05^{\prime} 15^{\prime \prime} \mathrm{W}$; $B G N$ 1960; (map 70).

So named in 1960 by James Nelson of Anchorage who has a homestead on the lake "because rainbows frequently appear above the lake."

Rainbow Lake: lake, $1 \mathrm{mi}$. long, between Sheep River and Iron Creek, $26 \mathrm{mi}$. E of Talkeetna, Talkeetna Mts.; $62^{\circ} 20^{\prime} \mathrm{N}, 149^{\circ} 19^{\prime} \mathrm{W}$; (map 82).

Local name recorded in 1950 by USGS.

Rainbow Mountain: peak, 6,700 ft., highest point of Rainbow Ridge, $20 \mathrm{mi}$. NW of Paxson, Alaska Ra. ; $63^{\circ} 18^{\prime} 35^{\prime \prime} \mathrm{N}, 145^{\circ} 37^{\prime} 40^{\prime \prime} \mathrm{W}$; (map 86).

So named locally because of the "vari-colored talus which slides down its face."

Rainbow Ridge: ridge, elev. 6,000 ft., extends NW $8 \mathrm{mi}$. from McCallum Creek, $E$ of Richardson Highway, $15 \mathrm{mi}$. NW of Paxson, near

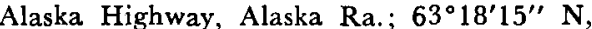
$145^{\circ} 37^{\prime} 30^{\prime \prime} \mathrm{W}$; (map 86)

Name published on relatively recent maps.

Rainbow River: stream, heads at central terminus of Serpent Tongue Glacier, flows NW
12 mi. to Savonoski River, on Alaska Penin., in Katmai National Monument, $21 \mathrm{mi}$. NE of Mount Katmai, Aleutian Ra.; $58^{\circ} 34^{\prime} 10^{\prime \prime} \mathrm{N}$, $154^{\circ} 49^{\prime} 00^{\prime \prime} \mathrm{W} ; B G N$ 1925; (map 42).

So named in 1923 by R. H. Sargent's USGS party "because six rainbows were seen there." Rainey Creek: stream, see Rainy Creek. Raineys Landing: locality, see Rennies Landing. Rain Gulch: ravine, trends NW $1 \mathrm{mi}$. to Candle Creek, $5.4 \mathrm{mi}$. SW of Candle and $38 \mathrm{mi}$. NE of Imuruk Lake, Seward Penin. High.; $65^{\circ} 51^{\prime}$ $\mathrm{N}, 162^{\circ} 01^{\prime} \mathrm{W}$; (map 110$)$.

Prospectors' name reported on the 1908 "Map of Seward Peninsula" by Arthur Gibson.

Rainy Creek: stream, flows NW $4 \mathrm{mi}$. to Eek River, $75 \mathrm{mi}$. SE of Bethel, Kilbuck-Kuskokwim Mts.; $60^{\circ} 02^{\prime} \mathrm{N}, 160^{\circ} 12^{\prime} \mathrm{W}$; (map 59).

Local name reported in 1955 by J. M. Hoare, USGS

Rainy Creek: stream, flows NW 6 mi. to Iditarod River, $4.7 \mathrm{mi}$. SE of Mosquito Mtn. and 33 mi. SE of Holy Cross, Kilbuck-Kuskokwim Mts.; $62^{\circ} 01^{\prime} 45^{\prime \prime} \mathrm{N}, 158^{\circ} 49^{\prime} 10^{\prime \prime} \mathrm{W}$; $B G N$ 1944; (map 79).

Prospectors' name obtained in 1913 by Eakin (1914, pl. 1), USGS.

Rainy Creek: stream, formed by its North and West Forks, flows E $3.6 \mathrm{mi}$. to Delta River $20 \mathrm{mi}$. NW of Paxson, Alaska Ra.; 63 ${ }^{\circ} 17^{\prime} 10^{\prime \prime}$ $\mathrm{N}, 145^{\circ} 47^{\prime} 20^{\prime \prime} \mathrm{W}$; (map 86). Var. Rainey Creek, Wilder Creek.

Local name reported on 1910 fieldsheet by C. E. Giffin, USGS. The stream was called "Wilder Creek" in 1898 by Capt. E. F. Glenn, USA.

Rainy Creek: stream, in Kantishna Hills, flows $S 3 \mathrm{mi}$. to Moose Creek, $3 \mathrm{mi}$. ENE of Wonder Lake, Alaska Ra.; $63^{\circ} 31^{\prime} 00^{\prime \prime} \mathrm{N}, 150^{\circ} 48^{\prime}$ 10" W; (map 88).

Prospectors' name reported in 1905 by L. M. Prindle, USGS.

Rainy Creek: stream, flows SE $17 \mathrm{mi}$. to Colville River, $4 \mathrm{mi}$. W of Umiat, Arctic Slope; $69^{\circ} 20^{\prime} \mathrm{N}, 152^{\circ} 17^{\prime} \mathrm{W}$; BGN 1959; (map 141).

Named in 1945 by U.S. Navy geological field party.

Rainy Glacier: glacier, heads $1.5 \mathrm{mi}$. SE of head of Tebenkof Glacier, trends NE $3 \mathrm{mi}$, to its terminus, $10 \mathrm{mi}$. SE of Whittier, Chugach Mts.; $60^{\circ} 39^{\prime} 45^{\prime \prime} \mathrm{N}, 148^{\circ} 30^{\prime} 30^{\prime \prime} \mathrm{W}$; $B G N$ 1911; (map 63).

Named in 1911 by U. S. Grant, USGS.

Rainy Pass: pass, 1,060 ft., at head of Moose Creek, central Kiska I., Aleutian Is. ; $51^{\circ} 57^{\prime}$ $05^{\prime \prime} \mathrm{N}, 177^{\circ} 31^{\prime} 00^{\prime \prime} \mathrm{E}$; (map 14).

One of many arbitrary names applied to features on Kiska I. by USAAF for tactical purposes during World War II.

Rainy Pass: pass, 3,400 ft., in Teocalli Mts., at head of Pass Fork Dalzell Creek, $96 \mathrm{mi}$. SE of McGrath, Alaska Ra. ; $62^{\circ} 13^{\prime} \mathrm{N}, 153^{\circ} 05^{\prime}$ W; (map 80).

Discovered and named in 1902 by A. H Brooks, USGS.

Rainy Pass Lake: lake, $0.25 \mathrm{mi}$. long, in Teocalli Mts., S of Rainy Pass, in course of Pass Creek,
97 mi. SE of McGrath, Alaska Ra.; 62 $12^{\prime}$ $10^{\prime \prime} \mathrm{N}, 153^{\circ} 04^{\prime} 30^{\prime \prime} \mathrm{W}$; (map 80).

Local name obtained in 1958 by USGS.

Rainy Pass Lodge: roadhouse, at Puntilla Lake, $86 \mathrm{mi}$. SW of Talkeetna, Alaska Ra.; 62 ${ }^{\circ} 05^{\prime}$ $30^{\prime \prime} \mathrm{N}, 152^{\circ} 43^{\prime} 50^{\prime \prime} \mathrm{W}$; (map 81).

Local name reported in 1945 by USGS.

Rake Lake: lake, $200 \mathrm{yd}$. across, on northeastern Kiska I., Aleutian Is. ; $52^{\circ} 02^{\prime} 12^{\prime \prime} \mathrm{N}, 177^{\circ} 36^{\prime}$ $35^{\prime \prime} \mathrm{E}$; (map 14).

An arbitrary name beginning with " $R$ " to correspond to "R" grid used by the U.S. Army for tactical purposes during World War II; published on a 1953 AMS map.

Rakof Bay: estuary, see Crawfish Inlet.

Rakof Islands: islands, $4.5 \mathrm{mi}$. across, $8 \mathrm{mi}$. SE of Goddard, on SW coast of Baranof I., Alex. Arch.; 56 $43^{\circ} \mathrm{N}, 135^{\circ} 17^{\prime} \mathrm{W}$; (map 5).

Russian name from "rakovyy," meaning "crawfish," published in 1926 by USC\&GS.

Rakov, Zaliv: estuary, see Crawfish Inlet.

Rakovoi Bay: bay, $0.4 \mathrm{mi}$. across, SE part of Whale Bay, on SW coast of Baranof I., Alex. Arch.; 56 $36^{\prime} \mathrm{N}, 134^{\circ} 58^{\prime} \mathrm{W}$; (map 5). Var. Shell Bay, Zaliv Rakovyy.

Russian name meaning "crawfish" given by Russian Hydrog. Dept.; published about 1850 on Chart 1434.

Rakovoi Bay: estuary, see Crawfish Inlet.

Rakovoy Bay: estuary, see Crawfish Inlet.

Rakovyy, Zaliv: bay, see Rakovoi Bay.

Ralston Island: island, $1 \mathrm{mi}$. long, in Lynn Canal, $0.2 \mathrm{mi}$. $\mathrm{N}$ of Lincoln $\mathrm{I}$. and $27 \mathrm{mi}$. NW of Juneau, Alex. Arch.; 58 $31^{\prime} 45^{\prime \prime} \mathrm{N}, 135^{\circ} 02^{\prime}$ 15" W; (map 11).

Named by Comdr. R. W. Meade, USN, in 1868 for W. C. Ralston; published by USC\& GS in the 1883 Coast Pilot (p. 194).

Rambler Camp: locality, $2.2 \mathrm{mi}$. E of Mount Cameron and $13 \mathrm{mi}$. WNW of Valdez, Chugach Mts. ; 61 ${ }^{\circ} 13^{\prime} \mathrm{N}, 146^{\circ} 36^{\prime} \mathrm{W}$; (map 68).

This mining camp name was reported in 1912 by USGS.

Rambler Creek: stream, flows SW $1.8 \mathrm{mi}$., between Lucky and Thunder Creeks, to Cache Creek, $30 \mathrm{mi}$. NW of Talkeetna, Alaska Ra.; $62^{\circ} 29^{\prime} 28^{\prime \prime} \mathrm{N}, 150^{\circ} 59^{\prime} 00^{\prime \prime} \mathrm{W}$; (map 81).

Prospectors' name reported in 1911 by Capps (1913, fig. 5), USGS.

Ram Creek: stream, flows $S 7 \mathrm{mi}$. to Alatna River, $16 \mathrm{mi}$. SW of Survey Pass, Brooks Ra.; $67^{\circ} 52^{\prime} \mathrm{N}, 154^{\circ} 31^{\prime} \mathrm{W}$; (map 125).

Local name reported by Robert Marshall in 1932.

Rampart: village, pop. 49, on S bank of Yukon River, $61 \mathrm{mi}$. ENE of Tanana,Yukon-Tanana High.; $65^{\circ} 30^{\prime} \mathrm{N}, 150^{\circ} 10^{\prime} \mathrm{W}$; (map 106). Var. Rampart City.

With the discovery of gold in the Minook Creek drainage in 1896 , a supply point on the Yukon River was established, called "Rampart City" by the miners for the "Ramparts of the the Yukon." A post office called "Rampart" was established in 1898 (Ricks, 1965, p. 54). One of the town's early prospectors, Rex Beach, proved more capable at making money by writing than by prospecting. Rampart is said to have had a population of about 1,500 
during its best days in 1898 and 1899 (Prindle, 1908, p. 60).

Rampart Canyon: canyon, see Rampart Gorge.

Rampart City: village, see Rampart.

Rampart Creek: stream, flows NW $2 \mathrm{mi}$. to Yukon River just $\mathbf{S}$ of Rampart, Yukon-Tanana High.; 65 $30^{\prime} 12^{\prime \prime} \mathrm{N}, 150^{\circ} 10^{\prime} 50^{\prime \prime} \mathrm{W}$; (map 106).

Named for the village; reported in 1956 by Orth.

Rampart Creek: stream, heads in De Long Mts., flows $\mathrm{N} 11 \mathrm{mi}$. to Jubilee Creek, $18 \mathrm{mi}$. SW of Liberator Lake, Brooks Ra.; $68^{\circ} 42^{\prime} \mathrm{N}$, $158^{\circ} 54^{\prime} \mathrm{W}$; BGN 1960; (map 132).

Named by I. L. Tailleur, USGS, in 1953, "for the rampart-like mountain front [of the De Long Mts.] drained by stream."

Rampart Gorge: canyon, of Yukon River, extends SW $20 \mathrm{mi}$. from Garnet I., $27 \mathrm{mi}$. NW of Tanana, Kokrines-Hodzana High.: $65^{\circ} 21^{\prime}$ N, $151^{\circ} 00^{\prime}$ W ; (map 106). Var. Lower Ramparts, Rampart Canyon, The Ramparts.

Descriptive name used in the late 1800's. "This canyon is one of the most beautiful and spectacular of the Yukon River."

Rampart Mountains: mountain range, elev. 1,800 to 3,400 ft., extends ENE $63 \mathrm{mi}$. from Tozitna River to Squaw Creek, between Tozitna and Yukon Rivers, Kokrines-Hodzana High.; $65^{\circ} 24^{\prime}$ N, $151^{\circ} 24^{\prime}$ W; (map 106). Var. Rampart Range, The Ramparts.

Descriptive name "Rampart Range" published in 1869 by Raymond (1871, p. 22), U.S. Army Corps of Engineers.

Rampart Range: mountain range, see Rampart Mountains.

Rampart Rapids: rapids, see Rapids, The.

Ramparts, The: canyon, see Rampart Gorge.

Ramparts, The: mountain range, see Rampart Mountains.

Ramp Island: island, $0.1 \mathrm{mi}$. across, in Khaz Bay, $7 \mathrm{mi}$. S of Chichagof, on W coast of Chichagof I., Alex. Arch.; 57 $33^{\prime} 40^{\prime \prime} \mathrm{N}, 136^{\circ}-$ 05'10" W ; BGN 1908; (map 9).

Named in 1908 by USC\&GS. This was an arbitrary name derived from the name assigned in 1897 by Lt. Comdr. E. K. Moore, USN, to a triangulation station on the island. The name was published in the 1908 Coast Pilot (p. 171).

Ram Point: point of land, on SW coast of Unalaska I., Aleutian Is.; $53^{\circ} 25^{\prime} 00^{\prime \prime} \mathrm{N}, 1^{\circ} 7^{\circ} 31^{\prime}$ 20" W; BGN 1940; (map 23). Var. Wedge Point.

Descriptive name given by USC\&GS in 1939 "because the sole inhabitants of the locality are sheep ranchers."

Ramsay: bay, see Ramsey Bay.

Ramsdyke Creek: stream, heads in Dutch Hills, flows NE $5 \mathrm{mi}$. to Tokositna River, $30 \mathrm{mi}$. NW of Talkeetna, Alaska Ra.; $62^{\circ} 38^{\prime} 05^{\prime \prime} \mathrm{N}, 150^{\circ}$ 45'20" W; (map 81).

Prospectors' name reported in 1906 by R. W. Porter, USGS

Ramsey Bay: bay, $1 \mathrm{mi}$. across, on $\mathbf{S}$ coast of Alaska Penin., NW part of Stepovak Bay,

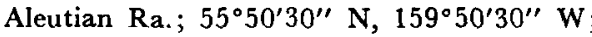
(map 27). Var. Ramsay.
Local name published by USC\&GS in 1916 Coast Pilot.

Ramshole Creek: stream, flows NE $4.3 \mathrm{mi}$. to Cross Creek, $7.2 \mathrm{mi}$. SW of its junc. with Chisana River, Wrangell Mts.; $62^{\circ} 08^{\prime} \mathrm{N}, 142^{\circ} 18^{\prime}$ W; (map 84).

Local name reported in 1960 by USGS.

Rana Reef: reef, extends $0.7 \mathrm{mi}$., at $\mathrm{E}$ entrance to Port Real Marina, between Lulu and St. Ignace Is., Alex. Arch.; $55^{\circ} 26^{\prime} \mathrm{N}, 133^{\circ} 26^{\prime} \mathrm{W}$; (map 4).

Spanish name meaning "frog"; published in the 1925 Alaska Coast Pilot (p. 176).

Ranchera Island: island, see Rancheria Island.

Rancheria Island: island, $0.3 \mathrm{mi}$. long, between Port Saint Nicholas and Trocadero Bay, on W coast of Prince of Wales I., Alex. Arch.; 55 $25^{\prime} 40^{\prime \prime} \mathrm{N}, 1^{\circ} 3^{\circ} 05^{\prime} 20^{\prime \prime} \mathrm{W}$; BGN 1923; (map 4). Var. La Rancheria, La Ransheria, Ranchera Island.

Named "La Rancheria," meaning "the settlement," by Francisco Antonio Maurelle on "May 31, 1779, * * because there was a stockade on it." He found it uninhabited but with a number of good houses (Wagner, 1937, p. 404). In 1923 the name was formally applied to this island by USC\&GS; its location was previously not clearly defined, and the name was in limited use.

Ranchers Point: point of land, at SW end of Unalaska I., Aleutian Is., $53^{\circ} 23^{\prime} 25^{\prime \prime} \mathrm{N}, 167^{\circ}$ 38'30" W; BGN 1939; (map 23).

Descriptive name given in 1939 by USC\&GS "because the locality is used for grazing by the sheep ranchers from Chernofski Harbor."

Randolph Peak: mountain, 4,165 ft., on Glass Penin., $33 \mathrm{mi}$. NE of Angoon, on E coast of Admiralty I., Alex. Arch.; $57^{\circ} 52^{\prime} 30^{\prime \prime} \mathrm{N}, 134^{\circ}$ 02'30" W; BGN 1934; (map 9).

Named in 1887 by Lt. C. M. Thomas, USN, for Peyton Randolph, first President of the Continental Congress in $\mathbf{1 7 7 5 .}$

Random Creek: stream, flows W'1.5 mi. to Bering Sea between Witchcraft and Conquer Points, Kiska I., Aleutian Is.; $52^{\circ} 01^{\prime} 50^{\prime \prime} \mathrm{N}$, $177^{\circ} 30^{\prime} 22^{\prime \prime} \mathrm{E}$; (map 14).

An arbitrary name beginning with " $R$ " to correspond to "R" grid used by the U.S. Army for tactical purposes during World War II; published on a 1953 AMS map.

Randsburg Creek: stream, flows SE $0.5 \mathrm{mi}$. to Hastings Creek, $10 \mathrm{mi}$. E of Nome, Seward Penin. High.; $64^{\circ} 29^{\prime} 35^{\prime \prime} \mathrm{N}, 165^{\circ} 03^{\prime} 12^{\prime \prime} \mathrm{W}$; (map 94).

Prospectors' name reported in 1904 by T. G. Gerdine, USGS.

Range Creek: stream, flows NW $5 \mathrm{mi}$. to Peril Strait, opposite Rapids Point, on Baranof I., $28 \mathrm{mi}$. N of Sitka, Alex. Arch.; 57 $26^{\prime} 45^{\prime \prime} \mathrm{N}$, $135^{\circ} 32^{\prime} 15^{\prime \prime} \mathrm{W}$; (map 9).

Named in 1884 by Comdr. J. B. Coghlan, USN, and published by USC\&GS in the 1891 Coast Pilot (p. 183).

Range Island: island, $0.3 \mathrm{mi}$. long, at $\mathrm{N}$ entrance of Popof Strait between Unga and Popof Is., in Shumagin Is., Aleutian Ra.; $55^{\circ} 21^{\prime} 15^{\prime \prime} \mathrm{N}$, $160^{\circ} 30^{\prime} 05^{\prime \prime} \mathrm{W}$; map 28).

Named in 1872 by W. H. Dall, USC\&GS.
Range Island: island, $0.1 \mathrm{mi}$. long, at mouth of McHenry Inlet, on SW coast of Etolin I., Alex. Arch.; $56^{\circ} 00^{\prime} 20^{\prime \prime} \mathrm{N}, 132^{\circ} 27^{\prime} 40^{\prime \prime} \mathrm{W}$; (map 6 ).

Descriptive name given for charting purposes in 1932 Coast Pilot (p. 151).

Range Island: island, in Prince William Sound, off $W$ coast of Knight $I$., on $N$ side of Drier Bay, $8.5 \mathrm{mi}$. NE of Chenega, Chugach Mts. $60^{\circ} 18^{\prime} 45^{\prime \prime} \mathrm{N}, 147^{\circ} 50^{\prime} 35^{\prime \prime} \mathrm{W}$; (map 63). Var. Range Isle.

Reported in 1910 as Range Isle by USC\&GS. Range Island: island, see Range Islet.

Range Isle: island, see Range Island.

Range Islet: island, 1,300 ft. across, in Coal Harbor on Zachary Bay, Unga I., in Shumagin Is., Aleutian Ra.; $55^{\circ} 20^{\prime} \mathrm{N}, 160^{\circ} 38^{\prime} \mathrm{W}$; (map 28). Var. Range Island.

Named Range Island in 1872 by $\mathrm{W}$. $\mathrm{H}$. Dall, USC\&GS; published as Range Islet in 1916 Coast Pilot (p. 181).

Range Peak: mountain, $3,000 \mathrm{ft}$, $32 \mathrm{mi}$. NE of Mount Veniaminof and $32 \mathrm{mi}$. S of Port Heiden Airfield, Aleutian Ra.; $56^{\circ} 30^{\prime} \mathrm{N}, 158^{\circ}$ $45^{\prime} \mathrm{W}$; (map 30$)$.

Local descriptive name reported by a 1951 USGS field party.

Range Peak: mountain, 1,900 ft., on E shore of Iniskin Bay, $27 \mathrm{mi}$. $\mathbf{N}$ of Augustine I., Aleutian Ra.; $59^{\circ} 45^{\prime} \mathrm{N}, 153^{\circ} 22^{\prime} \mathrm{W}$; BGN 1916; (map 51).

Named for the 60-61 W Seward base meridian range line that traverses the area. Name published in 1913 on USC\&GS Chart 3567.

Range Point: point of land, on SW shore of Kanaga Bay, SE coast of Kanaga I.; Aleutian Is.; $51^{\circ} 42^{\prime} 23^{\prime \prime} \mathrm{N}, 177^{\circ} 12^{\prime} 00^{\prime \prime} \mathrm{W}$; (map 17).

Name published in 1957 on an AMS map.

Range Point: point of land, on S coast of Staten I., Bay of Is., Adak I., Aleutian Is.; $51^{\circ} 47^{\prime} 45^{\prime \prime}$ N, $176^{\circ} 47^{\prime} 00^{\prime \prime} \mathrm{W}$; BGN 1936; (map 17).

Named by members of the U.S. Navy Aleutian Island Survey Expedition in 1933.

Range Point: point of land, on $\mathrm{E}$ shore of Chicagof Harbor, on NE coast of Attu I., Aleutian Is.; $52^{\circ} 55^{\prime} 53^{\prime \prime} \mathrm{N}, 1^{\circ} 3^{\circ} 15^{\prime} 20^{\prime \prime} \mathrm{E}$; (map 13).

This name was given by Lt. William Gibson who commanded the schooner U.S.S. Fenimore Cooper during the North Pacific Exploring Expedition of 1854-55. The name is listed in the 1944 Aleutian Coast Pilot and is shown on an AMS map published in 1943

Range Point: point of land, between Fish Bay and Louise Cove, in Kakul Narrows, on NW coast of Baranof I.; Alex. Arch.; 57 $22^{\prime} 25^{\prime \prime}$ $\mathrm{N}, 135^{\circ} 39^{\prime} 25^{\prime \prime} \mathrm{W}$; (map 9)

Named in 1884 by Comdr. J. B. Coghlan, USN, and published by USC\&GS in the 1891 Coast Pilot (p. 181).

Ranger Hill: hill, $1,265 \mathrm{ft}$., on northern Kiska I., Aleutian Is.; $52^{\circ} 02^{\prime} 05^{\prime \prime} \mathrm{N}, 177^{\circ} 34^{\prime} 05^{\prime \prime} \mathrm{E}$ (map 14).

An arbitrary name beginning with " $R$ " to correspond to " $R$ " grid used by the U.S. Army for tactical purposes during World War II; published on a 1953 AMS map.

Ranier Creek: stream, flows SE to American River, about $20 \mathrm{mi}$. SE of Ear Mtn. and 40 
mi. NE of Teller, Seward Penin. High.; (map 111).

Prospectors' name shown on a map of Cape Nome gold fields by David Fox, Jr., dated 1901. This feature cannot be precisely identified on current maps.

Rankin and Young Islands: islands, see Corlies Islands.

Ranney Creek: stream, heads at Ranney Glacier, flows SE $1.5 \mathrm{mi}$. to Unakwik Inlet, $42 \mathrm{mi}$. W of Valdez, Chugach Mts.; $61^{\circ} 09^{\prime} 10^{\prime \prime} \mathrm{N}, 147^{\circ}$ 31'30"' W B BGN 1910; (map 69).

Named in 1908 by U.S. Grant and D. F. Higgins, USGS.

Ranney Glacier: glacier, heads $\mathrm{E}$ of Mount Castner, trends SE $1.8 \mathrm{mi}$. to its terminus at head of Ranney Creek, $43 \mathrm{mi}$. W of Valdez, Chugach Mts.; $61^{\circ} 10^{\prime} \mathrm{N}, 147^{\circ} 33^{\prime} \mathrm{W}$; (map 69).

Named in 1908 by U. S. Grant and D. F. Higgins, USGS.

Ranney Hollow: ravine, trends N $1.5 \mathrm{mi}$. to Tolovana River, 4 mi. S of Livengood, YukonTanana High.; $65^{\circ} 28^{\prime} 20^{\prime \prime} \mathrm{N}, 148^{\circ} 31^{\prime} 25^{\prime \prime} \mathrm{W}$; (map 105).

Local name published by USGS in the 1950 's.

Ransheria, La: island, see Rancheria Island.

Rapid City: locality, on left bank of Alatna River, $26 \mathrm{mi}$. E of Walker Lake, Brooks Ra.; $67^{\circ} 05^{\prime} \mathrm{N}, 153^{\circ} 19^{\prime} \mathrm{W}$; (map 125).

This is the site of some cabins reported by Mendenhall (1902, pl. 4), USGS. Robert Marshall (1956, p. 97) visited the place in 1931 and related that it consisted of four crumbling cabins built in the autumn of 1898 when a group of pospectors were caught by an early freeze-up of the river. The place was probably occupied for one winter and was named for the adjacent rapids.

Rapid Creek: stream, flows E $0.8 \mathrm{mi}$. to Sredni Bight on northern Kiska I., Aleutian Is.; $52^{\circ}$ $04^{\prime} 00^{\prime \prime} \mathrm{N}, 177^{\circ} 37^{\prime} 55^{\prime \prime} \mathrm{E}$; (map 14).

An arbitrary name beginning with " $R$ " to correspond to " $R$ " grid used by the U.S. Army for tactical purposes during World War II ; published on a 1953 AMS map.

Rapid Creek: stream, heads at Crab Glacier on Mount Veniaminof, flows NE $12 \mathrm{mi}$. to West Fork Chignik River, $26.5 \mathrm{mi}$. W of Chignik, Aleutian Ra.; $56^{\circ} 22^{\prime} \mathrm{N}, 159^{\circ} 05^{\prime} \mathrm{W}$; (map $30)$.

Descriptive name reported in 1923 by $R$. H. Sargent, USGS.

Rapid Creek: stream, flows $\mathrm{N} 9 \mathrm{mi}$, to Shaw Creek, 13 mi. NE of Big Delta, Yukon-Tanana High.; $64^{\circ} 19^{\prime} \mathrm{N}, 145^{\circ} 37^{\prime} \mathrm{W}$; (map 101).

Descriptive name reported in 1908 by $\mathrm{J}$. W. Bagley, USGS.

Rapid Lake: lake, $100 \mathrm{yd}$. across, at head of Rapid Creek, on northern Kiska I., Aleutian Is. ; $52^{\circ} 03^{\prime} 52^{\prime \prime} \mathrm{N}, 177^{\circ} 37^{\prime} 10^{\prime \prime} \mathrm{E}$; (map 14).

An arbitrary name beginning with " $R$ " to correspond to " $R$ " grid used by the U.S. Army for tactical purposes during World War II; published on a 1953 AMS map.

Rapid River: stream, in York Mts., flows SE 8 mi. to Lost River which flows to Bering Sea,
25 mi. NW of Teller, Seward Penin. High.; $65^{\circ} 25^{\prime} \mathrm{N}, 167^{\circ} 09^{\prime} \mathrm{W}$; BGN 1957; (map 111).

Prospectors' name shown on the 1900 "Map of Nome Peninsula" by J. M. Davidson and B. D. Blakeslee.

Rapid River: stream, heads in Canada, flows SW $40 \mathrm{mi}$. to Porcupine River, $8 \mathrm{mi}$. N of Old Rampart and $33 \mathrm{mi}$. ENE of Coleen Mtn., Porcupine Plat.; $67^{\circ} 17^{\prime} \mathrm{N}, 141^{\circ} 38^{\prime} \mathrm{W}$; (map 121). Var. Sucker River.

This appears to be the same stream published as Sucker River by USC\&GS in 1890 . The present name was mentioned by $R$. G. McConnell, Canadian Geological Survey, in 1888 (FitzGerald, 1944, p. 226). So called because of the "boulder stream rapids that extend three quarters of a mile up stream from its mouth ***."

Rapid River: stream, see Don River.

Rapids, The: rapids, in Yukon River $\mathrm{E}$ of Senatis Mtn., $32 \mathrm{mi}$. ENE of Tanana, Kokrines-Hodzana High.; $65^{\circ} 20^{\prime} 30^{\prime \prime} \mathrm{N}, 151^{\circ}$ $04^{\prime} 00^{\prime \prime}$ W; (map 106). Var. Rampart Rapids.

Descriptive name "Rampart Rapids" reported in 1869 by Raymond (1871, p. 22), U.S. Army Corps of Engineers.

Rapids, The: rapids, see Black Rapids.

Rapids Glacier: glacier, see Black Rapids Glacier.

Rapids Island: island, $0.2 \mathrm{mi}$, across, $1 \mathrm{mi}$. N of Fish Bay, in Peril Strait, off NW coast of Baranof I., 26 mi. NW of Sitka, Alex. Arch.;

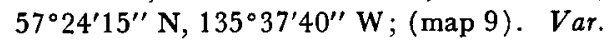
Ostrov Poroga.

This is a translation by USC\&GS about 1882 of the name given by the Russian pilot Ens. Vasiliev; published in 1848 on Russian Hydrog. Dept. Chart 1397 as "Os[trov] Poroga."

Rapids Point: point of land, $5 \mathrm{mi}$. N of Fish Bay, in Peril Strait, on Chichagof I., $29 \mathrm{mi}$. NW of Sitka, Alex. Arch.; $57^{\circ} 27^{\prime} 15^{\prime \prime} \mathrm{N}$, $135^{\circ} 33^{\prime} 10^{\prime \prime} \mathrm{W}$; (map 9).

Named by W. H. Dall, USC\&GS, and published in the 1883 Coast Pilot (p. 163). "Named for North Rapid in Rose Channel which is caused by the change in tides and which is located abreast of this point."

Rasa, Isla : rock, see Wolf Rock.

Rasa Island: island, see Middleton Island.

Rasbinik: locality, see Razboinski.

Rasboinsky: locality, see Razboinski.

Rasbonisky: locality, see Razboinski.

Rasmussen Glacier: glacier, see Rasmusson Glacier.

Rasmussen Mountain: mountain, see Rasmusson Mountain.

Rasmusson Glacier: glacier, heads on E slope of Rasmusson Mtn., trends E $1.5 \mathrm{mi}$. to its 1959 terminus, $1 \mathrm{mi}$. W of Russell Fiord and $21 \mathrm{mi}$. NE of Yakutat, St. Elias Mts.; $59^{\circ} 44^{\prime} 30^{\prime \prime} \mathrm{N}$, $139^{\circ} 23^{\prime} 45^{\prime \prime} \mathrm{W}$; (map 46). Var. Rasmussen Glacier.

Named in 1905 by Tarr and Martin (1906, map), USGS, for E. A. Rasmusson, teacher at a government school at Yakutat and missionary of the Swedish Evangelical Mission
Covenant of America. It was called Rasmussen Glacier by R. S. Tarr and Lawrence Martin $(1914$, p. 165).

Rasmusson Mountain: mountain, $3,800 \mathrm{ft} ., 2.7$ mi. SE of Mount Hendrickson and $20 \mathrm{mi}$. NE of Yakutat, St. Elias Mts.; $59^{\circ} 47^{\prime} 10^{\prime \prime} \mathrm{N}$, $139^{\circ} 26^{\prime} 10^{\prime \prime} \mathrm{W}$; (map 46). Var. Rasmussen Mountain.

Named by Tarr and Martin (1906, map), USGS, for E. A. Rasmusson, teacher at a government school at Yakutat and missionary of the Swedish Evangelical Mission Covenant of America.

Raso Rock: rock, $0.1 \mathrm{mi}$. long, in Iphigenia Bay, $1.2 \mathrm{mi}$. W of Heceta I., Alex. Arch.; $55^{\circ} 44^{\prime} 40^{\prime \prime}$ $\mathrm{N}, 133^{\circ} 40^{\prime} 50^{\prime \prime} \mathrm{W}$; (map 4).

Spanish name meaning "flat (clear of obstruction)"; recorded in 1951 by USGS.

Raspberry Cape: point of land, $24 \mathrm{mi}$. W of Afognak, on $\mathrm{W}$ coast of Raspberry $\mathrm{I}$., $\mathbf{N}$ of Kodiak I.; $58^{\circ} 03^{\prime} 35^{\prime \prime} \mathrm{N}, 153^{\circ} 25^{\prime} 00^{\prime \prime} \mathrm{W}$; (map 43). Var. Cape Malinoff, Malinovoi, Strawberry Point.

Translation of the name "M[ys] Malinovoy" given by Sub-Lt. Mikhail Murashev, IRN, in 1839 or 1840 and published by the Russian Hydog. Dept. in 1849 on Chart 1425. Murashev applied this name to the present location of Malina Point, 2 miles to the southeast. The Russian American Company reapplied the name to its present location in 1849 . This feature was called "Strawberry Point" by USC\&GS in 1900.

Raspberry Cape: point of land, see Malina Point.

Raspberry Island: island, $13 \mathrm{mi}$. long, between Afognak and Kodiak Is.; $58^{\circ} 02^{\prime} \mathrm{N}, 153^{\circ} 05^{\prime}$ W; (map 43). Var. Bolshoi Malinof, Iukuk, Malinoff Island, Malinof Island, North Island, Sievernoi.

USC\&GS in 1868 derived Raspberry by translation of part of the name "Os[trov] Malinovoy ili Syvernoy," meaning "raspberry or north island." This name was given by SubLt. Mikhail Murashev, IRN, in 1839 or 1840 , and published by the Russian Hydrog. Dept. in 1849 on Chart 1425. This island was shown as "North Island" by Capt. Lisianski 1814 , p. 169), IRN, and "O[strov] Bolshoy Malinovoy," meaning "big raspberry island," in Tebenkov (1852, map 22). The Russian American Company in 1849 published the name "Os[trov] Bol[shoy] Malinovsoky (Yukuk)" meaning "big raspberry (Yukuk) island."

Raspberry Lake: lake, $1.2 \mathrm{mi}$. long, $4 \mathrm{mi}$. E of Kings Slough Village, $25 \mathrm{mi}$. SW of Beaver, Yukon Flats; $66^{\circ} 11^{\prime} \mathrm{N}, 148^{\circ} 10^{\prime} \mathrm{W}$; (map 118).

Local name obtained in 1956 by USGS.

Raspberry Strait: water passage, between Raspberry and Afognak Is., $\mathrm{N}$ of Kodiak I.; $58^{\circ}$ $02^{\prime} \mathrm{N}, 153^{\circ} 00^{\prime} \mathrm{W}$; (map 43). Var. Malinovoi Strait.

Translation of the name "Pr[oliv] Malinovoy" given by Sub-Lt. Mikhail Murashev, IRN, in 1839 or 1840 , and published by the 
Russian Hydrog. Dept. in 1849 on Chart 1425.

Rasp Ledge: rock, at $\mathrm{N}$ entrance to Mole Harbor, on $E$ coast of Admiralty I., $24 \mathrm{mi}$. NE of Angoon, Alex. Arch.; $57^{\circ} 40^{\prime} 40^{\prime \prime} \mathrm{N}, 134^{\circ}$ 02'15" W; (map 9).

Named in 1889 by Lt. Comdr. H. B. Mansfield, USN, and published by USC\&GS in the 1891 Coast Pilot (p. 144).

Rat, The: mountain, see Knob G.

Rat Creek: stream, heads at $67^{\circ} 03^{\prime} \mathrm{N}, 141^{\circ} 59^{\prime}$ W, flows W $28 \mathrm{mi}$. to Porcupine River, $35 \mathrm{mi}$. NE of Chalkyitsik, Porcupine Plat.; $66^{\circ} 58^{\prime}$ N, $142^{\circ} 44^{\prime} \mathrm{W}$; (map 120).

Local name obtained in 1956 by T. E. Taylor and R. C. Foley, USGS.

Rat Creek: stream, see Fort Creek.

Rathlatulik River: stream, flows NW $33 \mathrm{mi}$. to Fish River, $50 \mathrm{mi}$. NE of Solomon, Seward Penin. High.; $64^{\circ} 59^{\prime} \mathrm{N}, 163^{\circ} 06^{\prime} \mathrm{W}$; BGN 1910; (map 95). Var. Arathlatuluk Creek.

Eskimo name "Arathlatuluk" reported in 1908 by USGS.

Rat Island: island, $9 \mathrm{mi}$. long, $13 \mathrm{mi}$. NW of Amchitka I., in Rat Is., Aleutian Is.; $51^{\circ} 48^{\prime}$ N, $178^{\circ} 19^{\prime}$ E; BGN 1937; (map 15). Var. Ajugadach Island, Ayougadakh Island, Ayugadak Island, Agadak Island, Krissey Island, Kryci Island, Krysi Island, Rats Island.

This name is a translation from the Russian "Krysi" and probably from the Aleut name "Ayugadak," meaning "rat." Commodore Billings (1802, p. 220-221), IRN, listed Krissey Island; A. Arrowsmith (in Sauer, 1802) called it "Rats Island." "Os[trov] Ayugadak (Krysi)" was published in 1848 on Russian Hydrog. Dept. Chart 1400. Capt. Lutke (1836, p. 326-327), IRN, published "Kryci" and "Ayougadakh."

Rat Island: island, $0.1 \mathrm{mi}$. across, off NW coast of Mansfield Penin., at mouth of Funter Bay, $0.6 \mathrm{mi}$. S of Clear Point and $19 \mathrm{mi}$. SW of Juneau, Alex. Arch.; 58 $14^{\prime} 00^{\prime \prime} \mathrm{N}, 1^{\circ} 4^{\circ}$ $54^{\prime} 55^{\prime \prime} \mathrm{W}$; (map 11).

Named by Lt. Comdr. H. B. Mansfield, USN, in 1890, and published by USC\&GS in the 1891 Coast Pilot (p. 161).

Rat Island Pass: water passage, $9 \mathrm{mi}$. wide, trends NW between Rat, Segula, and Little Sitkin Is., Aleutian Is.; $51^{\circ} 53^{\prime} \mathrm{N}, 178^{\circ} 18^{\prime}$ E ; BGN 1937; (map 15).

Named for Rat I., and reported by personnel of the U.S.S. Oglala in 1935.

Rat Islands: islands, in Aleutian Is., between Near Is. to W, and Andreanof Is. to E; extend from Amchitka Pass, $180 \mathrm{mi}$. W to Buldir I. ; they include Semisopochnoi, Amchitka, Rat, Little Sitkin, Segula, Kiska, and Buldir Is., and several other small islands; $51^{\circ} 58^{\prime}$ $\mathrm{N}, 179^{\circ} 47^{\prime} \mathrm{E}$ [E end], $52^{\circ} 23^{\prime} \mathrm{N}, 175^{\circ} 52^{\prime} \mathrm{E}$ [W end]; BGN 1963; (maps 14, 15). Var. Ayugadak Islands, Kryci Islands, Kryci Isles, Krysi Islands, Ostrova Krysiy.

Named "Ostrova Krysiy" meaning "Rat Is. lands" in 1827 by Capt. F. P. Lutke, IRN. The name was published (Lutke, 1836, p. $324)$ as "Kryci Iles" [French transliteration of the Russian]. Baker (1906, p. 521),
USGS, reported they were "usually called Krysi or Rat Islands."

Rat Islands: islands, see Near Islands.

Ratita, La: island, see Larzatita Island.

Ratkovsky: locality, see Afognak.

Rat Lake: lake, $0.2 \mathrm{mi}$. across, $0.7 \mathrm{mi}$. SE of Witchcraft Point, on northwestern Kiska I., Aleutian Is.; $52^{\circ} 02^{\prime} 30^{\prime \prime} \mathrm{N}, 177^{\circ} 30^{\prime} 40^{\prime \prime} \mathrm{E}$; (map 14).

An arbitrary name beginning with " $R$ " to correspond to "R" grid used by the U.S. Army for tactical purposes during World War II; published on a 1953 AMS map.

Rat Lake: lake, $0.3 \mathrm{mi}$. across, $\mathrm{S}$ of Frenchman Lake $0.2 \mathrm{mi}$. W of T Lake and $21 \mathrm{mi}$. NW of Glennallen, Copper River Basin; $62^{\circ} 10^{\prime} 30^{\prime \prime}$ N, $146^{\circ} 09^{\prime} 00^{\prime \prime} \mathrm{W}$; (map 83).

Local name reported by USGS in 1949.

Rat Lake: lake, $1 \mathrm{mi}$. across, $13 \mathrm{mi}$. SE of Beaver, Yukon Flats; $66^{\circ} 11^{\prime} 40^{\prime \prime} \mathrm{N}$, $147^{\circ} 06^{\prime} 40^{\prime \prime} \mathrm{W}$; (map 118).

Local name obtained in 1956 by USGS.

Rat Lake: lake, $1 \mathrm{mi}$. long, $23 \mathrm{mi}$. $\mathrm{N}$ of Chalkyitsik, Yukon Flats; $66^{\circ} 58^{\prime} \mathrm{N}, 143^{\circ} 45^{\prime}$ W; (map 120).

Local name published in 1890 by USC\&GS. Rat River: stream, see Little Black River.

Rats, Gavan: lagoon, see Ratz Harbor.

Rats Harbor: lagoon, see Ratz Harbor.

Rats Island: island, see Rat Island.

Rattlesnake Lake: lake, $100 \mathrm{Yd}$. across, $1 \mathrm{mi}$. S of West Kiska Lake, Kiska I., Aleutian Is.; $52^{\circ} 03^{\prime} 15^{\prime \prime}$ N, 177 32'28'; (map 14). Var. O'Brien Lake.

An arbitrary name beginning with " $R$ " to correspond to "R" grid used by the U.S. Army for tactical purposes during World War II; published on a 1953 AMS map.

Rattlesnake Ridge: ridge, $1 \mathrm{mi}$. long, $1 \mathrm{mi}$. $\mathrm{S}$ of West Kiska Lake, Kiska I., Aleutian Is.; $52^{\circ} 03^{\prime} \mathrm{N}, 177^{\circ} 32^{\prime} \mathrm{E}$; (map 14).

An arbitrary name beginning with " $R$ " to correspond to " $R$ " grid used by the U.S. Army for tactical purposes during World War II; published on a 1953 AMS map. The name "O'Brien Lake" was applied to this feature and annoted on an AMS map in the 1940's probably to commemorate one of the American soldiers killed on the island.

Ratz Creek: stream, $6 \mathrm{mi}$. long, flows $\mathrm{E}$ through Big Lake and $\mathrm{N}$ through Trumpeter Lake to Ratz Harbor, NE coast of Prince of Wales I., Alex. Arch.; 55 $53^{\prime} 25^{\prime} \mathrm{N}, 1^{\circ} 32^{\circ} 37^{\prime} 15^{\prime \prime} \mathrm{W}$; $B G N 1962$; (map 4).

"This stream is the principal drainage into Ratz Harbor and the name is used locally"; reported in 1961 by USFS.

Ratz Harbor: lagoon, 2 mi. long, off Clarence Strait, $7.5 \mathrm{mi}$. W of Onslow I., NE coast of Prince of Wales I., Alex. Arch.; 55 $53^{\prime} 15^{\prime} \mathrm{N}$, $132^{\circ} 35^{\prime} 45^{\prime \prime}$ W; BGN 1962; (map 4). Var. Gavan Rats, Rats Harbor.

Named "Gav[an] Rats," or "Rats Harbor," by Capt. Tebenkov (1849, map 9), IRN.

Ratz Point: point of land, $8.5 \mathrm{mi}$. W of Onslow I., NE coast of Prince of Wales I., Alex. Arch.; $55^{\circ} 54^{\prime} 30^{\prime \prime} \mathrm{N}, 132^{\circ} 36^{\prime} 50^{\prime \prime} \mathrm{W}$; (map 4).
Named in 1886 by Lt. Comdr. A. S. Snow, USN; derived from Ratz Harbor.

Ravalga Island: island, see Kavalga island.

Raven Basin: basin, extends $7 \mathrm{mi}$. from $\mathrm{N}$ to $\mathrm{S}$, along W side of Igloo Mtn., $25 \mathrm{mi}$. NNE of Mount Kelly, Arctic Slope; $68^{\circ} 47^{\prime} \mathrm{N}, 163^{\circ} 02^{\prime}$ W: (map 130).

Name published in 1964 by USGS.

Raven Bay: bay, $2.5 \mathrm{mi}$. across, S coast of Unalaska I., Aleutian Is.; $53^{\circ} 27^{\prime} \mathrm{N}, 166^{\circ} 51^{\prime}$ W; (map 23).

Name given by the USBF in 1888 .

Raven Bay: bight, see Sredni Bight.

Raven Creek: stream, heads at Raven Glacier, trends $\mathrm{N} 6 \mathrm{mi}$. to its junc. with Eagle River, $26 \mathrm{mi}$. E of Anchorage, Chugach Mts.; $61^{\circ}$ $09^{\prime} 20^{\prime \prime} \mathrm{N}, 149^{\circ} 07^{\prime} 20^{\prime \prime} \mathrm{W}$; ( $\left.\operatorname{map} 69\right)$.

Local name reported in 1898 by W. C. Mendenhall, USGS.

Raven Creek: stream, flows N $10 \mathrm{mi}$. to Lynx Creek, $20 \mathrm{mi}$. NE of Rampart, Yukon-Tanana High.; $65^{\circ} 38^{\prime} 30^{\prime \prime} \mathrm{N}, 149^{\circ} 34^{\prime} 15^{\prime \prime} \mathrm{W}$; (map 105).

Named by prospectors, according to report in 1902 by Lt. Hjalmar Erickson, USA; published by USGS (Prindle, 1905, pl. 16).

Raven Creek: stream, heads in Indian Mts., flows WNW $8 \mathrm{mi}$. to Atla Creek, $7 \mathrm{mi}$. NNE of Hughes, Kokrines-Hodzana High.; $66^{\circ} 08^{\prime}$ N, $154^{\circ} 08^{\prime} \mathrm{W}$; (map 116$)$.

Reported to be the name of an Indian clan; recorded at Hughes in 1956 by Orth.

Raven Glacier: glacier, trends NW $2.7 \mathrm{mi}$. to its terminus at the head of Raven Creek, 27 mi. SE of Anchorage, Chugach Mts.; 61 ${ }^{\circ} 04^{\prime}$ $15^{\prime \prime} \mathrm{N}, 149^{\circ} 07^{\prime} 00^{\prime \prime} \mathrm{W}$; (map 69).

Local name reported in 1931 by USGS.

Raven Hills: hills, $1.5 \mathrm{mi}$. E of Nabesna, Wrangell Mts.; 62 $22^{\prime} \mathrm{N}, 142^{\circ} 56^{\prime} \mathrm{W}$; (map 84).

Local name reported by USGS in 1960.

Raven Island: island, $250 \mathrm{ft}$. long, in Vixen Bay, $1.8 \mathrm{mi}$. S of Boca de Quadra, Coast Mts., $55^{\circ} 03^{\prime} \mathrm{N}, 130^{\circ} 47^{\prime} \mathrm{W}$; (map 3 ).

Name published in 1917 by USC\&GS.

Raven Lake: lake, $0.6 \mathrm{mi}$. across, on Kenai Penin., $0.7 \mathrm{mi}$. N of Star Lake and $18 \mathrm{mi}$. S of Kenai, Cook Inlet Low.; $60^{\circ} 18^{\prime} \mathrm{N}, 151^{\circ} 09^{\prime}$ W; (map 62).

Named about 1963 by officials of Kenai National Moose Range, probably for the Northern Raven (Corvus corax principalis).

Raven Lake: lake, $0.3 \mathrm{mi}$. long, on Kenai Penin., $0.5 \mathrm{mi}$. N of Swan Lake and $27 \mathrm{mi}$. NE of Kenai, Cook Inlet Low.; $60^{\circ} 41^{\prime} 30^{\prime \prime} \mathrm{N}, 150^{\circ}$ $32^{\prime} 00^{\prime \prime} \mathrm{W}$; (map 62).

Named about 1963 by officials of Kenai National Moose Range, for administrative purposes.

Raven Point: point of land, on $\mathrm{W}$ coast of Unimak I., 3 mi. NE of Cape Sarichef, Aleutian Is. ; $54^{\circ} 37^{\prime} 40^{\prime \prime} \mathrm{N}, 164^{\circ} 51^{\prime} 00^{\prime \prime} \mathrm{W}$; BGN 1942; (map 24).

Named in 1942 by USC\&GS for the triangulation station Raven on this point.

Raven Ridge: ridge, elev. 1,200-2,800 ft., in Rampart Mts., extends $\mathrm{S} 5 \mathrm{mi}$. to Yukon River, $38 \mathrm{mi}$. ENE of Tanana, Kokrines- 
Hodzana High.; $65^{\circ} 24^{\prime} \mathrm{N}, 150^{\circ} 56^{\prime} \mathrm{W}$; (map 106).

Riverboat pilots' name shown on a Yukon River track chart manuscript dated 1906.

Ray Anchorage: bay, $1.3 \mathrm{mi}$. across, E coast of Duke I., Alex. Arch.; $54^{\circ} 56^{\prime} \mathrm{N}, 131^{\circ} 14^{\prime} \mathrm{W}$; (map 2). Var. Bay.

Named as early as 1844 by USC\&GS.

Ravine Lake: lake, 2,100 ft. long, between Bonnie Lake and Matanuska River, $0.4 \mathrm{mi}$ $\mathrm{N}$ of Glenn Highway, $30 \mathrm{mi}$. NE of Palmer Talkeetna Mts.; $61^{\circ} 48^{\prime} 15^{\prime \prime} \mathrm{N}, 148^{\circ} 17^{\prime} 20^{\prime \prime} \mathrm{W}$; $B G N$ 1966; (map 69).

Local named reported about 1948 by USGS.

Raychevsnoi: locality, see Riechesni.

Ray Creek: stream, flows W $9 \mathrm{mi}$. to Ginder River, on Alaska Penin., $38 \mathrm{mi}$. NW. of Sutwik I., Aleutian Ra.; $57^{\circ} 02^{\prime} 00^{\prime \prime} \mathrm{N}, 157^{\circ} 49^{\prime} 45^{\prime \prime}$ W; (map 36).

Named in 1923 by R. H. Sargent, USGS, for "Ray Russell," recorder for his party and previous USGS expeditions.

Ray Creek: stream, flows W $1.8 \mathrm{mi}$. to Canyon Creek which flows to Imuruk Basin, $34 \mathrm{mi}$. NW of Nome, Seward Penin. High.; 64 $4^{\circ} 56^{\prime}$ N, $165^{\circ} 55^{\prime} \mathrm{W}$; (map 94).

Prospectors' name published on the 1908 "Map of Seward Peninsula" by Arthur Gibson.

Raymond, Mount: mountain, $6,620 \mathrm{ft}$, on Alaska-Canada boundary, $3 \mathrm{mi}$. $\mathrm{N}$ of junc. of Takini River with Chilkat River and 26 mi. NW of Skagway, Coast Mts.; $59^{\circ} 39^{\prime} 50^{\prime \prime} \mathrm{N}$, $135^{\circ} 57^{\prime} 00^{\prime \prime} \mathrm{W}$; BGN 19.54; (map 45).

Named "Raymond Peak" by the United States and Canada in 1927 for Raymond L. Ross of the U.S. section of the IBC.

Raymond Cove: estuary, extends N $1.5 \mathrm{mi}$. off Behm Canal, on E coast of Cleveland Penin., Alex. Arch.; $55^{\circ} 37^{\prime} 20^{\prime \prime} \mathrm{N}, 131^{\circ} 52^{\prime} 15^{\prime \prime} \mathrm{W}$; (map 3).

Local navigators' name obtained in 1904 by H. C. Fassett, USBF.

Raymond Peak: mountain, 2,290 ft., W of head of Middle Bay, $11 \mathrm{mi}$. SW of Kodiak, Kodiak I.; $57^{\circ} 39^{\prime} 40^{\prime \prime} \mathrm{N}, 152^{\circ} 32^{\prime} 50^{\prime \prime} \mathrm{W}$; (map 34). Local name reported in 1949 by USGS.

Ray Mountains: mountain range, elev. 2,500 to 5,500 ft., extends W $75 \mathrm{mi}$. from Yukon River N of Tozitna River, Kokrines-Hodzana High.; $65^{\circ} 43^{\prime} \mathrm{N}, 151^{\circ} 15^{\prime} \mathrm{W}$; (map 106).

Name reported by Eakin (1916, pl. 1), USGS; named for the Ray River.

Ray River: stream, heads at $65^{\circ} 51^{\prime} \mathrm{N}, 151^{\circ} 06^{\prime}$ $\mathrm{W}$, and flows E $50 \mathrm{mi}$. to Yukon River, $28 \mathrm{mi}$. NE of Rampart, Kokrines-Hodzana High.; $65^{\circ} 53^{\prime} \mathrm{N}, 149^{\circ} 48^{\prime} \mathrm{W}$; BGN 1959; (map 105). Var. Chetaht, Che-taut, Chetaut, Seet-oht, Shetchaut, Tseétoht.

Named by Lt. H. T. Allen, USA, in 1885 for Capt. Patrick Henry Ray, USA, who established a station at Barrow in 1881 for meteorologic and magnetic observations. The Indian name, according to Dall (1870, p. 281) of the Western Union Telegraph Expedition in 1867 , was "Tseétoht." It was spelled "Shetchaut," by Whymper (1869, map). Recent maps have confused the Ray and Big Salt Rivers.

Ray River Hot Spring: spring, in headwaters of Ray River, 38 mi. NNW of Rampart and 65 mi. NE of Tanana, Kokrines-Hodzana High.; $65^{\circ} 58^{\prime} \mathrm{N}, 150^{\circ} 55^{\prime} \mathrm{W}$; (map 106).

Prospectors' name reported by Waring (1917, p. 64), USGS.

Razbitie, Point: point of land, on $\mathrm{W}$ shore of Porcupine Bay, at head of Islas Bay, $16 \mathrm{mi}$. NW of Chichagof, on W coast of Chichagof I., Alex. Arch.; $57^{\circ} 50^{\prime} 00^{\prime \prime} \mathrm{N}, 136^{\circ} 22^{\prime} 15^{\prime \prime} \mathrm{W}$; (map 9).

Russian word meaning "wreck" given in 1928 by USC\&GS.

Razboiniksky: locality, see Razboinski.

Razboinski: locality, on right bank of Yukon River, Yukon-Kuskokwim Delta; $62^{\circ} 01^{\prime} \mathrm{N}$, $162^{\circ} 28^{\prime} \mathrm{W}$; BGN 1897; (map 77). Var. Kinegnagak, Kinegnagamiut, Rabonisky, Rasbinik, Rasboinsky, Rasbonisky, Razboiniksky, Razboinsky.

Russian name meaning "robber" given by the Russians for this former Eskimo village. The Eskimo name "Kinegnagamiut" was listed with a population of 92 in the 1890 Census.

Razboinsky: locality, see Razboinski.

Razrishénia, Mys: point of land, see Decision, Cape.

Razrysheniya, Mys: point of land, see Decision, Cape.

Reaburn, Mount: mountain, 5,700 ft., in Brabazon Ra., $5 \mathrm{mi}$. NW of head of Chamberlain Glacier and $39 \mathrm{mi}$. E of Yakutat, St. Elias Mts.; $59^{\circ} 26^{\prime} 00^{\prime \prime} \mathrm{N}, 138^{\circ} 38^{\prime} 15^{\prime \prime} \mathrm{W}$; (map 46).

So named by Blackwelder (1907, p. 416), USGS, for W. B. Reaburn, United States member of the IBC survey party of 1906. Reaburn was thought to be the first white man to cross the Yakutat Glacier from the surface of which Mount Reaburn is seen as a prominent feature.

Reach Point: point of land, on $\mathrm{E}$ coast of Umak I., Aleutian Is.; $51^{\circ} 52^{\prime} 10^{\prime \prime} \mathrm{N}, 175^{\circ} 57^{\prime} 10^{\prime \prime} \mathrm{W}$; $B G N$ 1936; (map 18).

Named by personnel of the U.S. Navy Aleutian Island Survey Expedition of 1934, and shown on a 1952 USGS map.

Read Island: island, $2 \mathrm{mi}$. long in Farragut Bay, $1.5 \mathrm{mi}$. $\mathrm{N}$ of Grand Point and $82 \mathrm{mi} . \mathrm{E}$ of Sitka, Coast Mts. ; $57^{\circ} 07^{\prime} 30^{\prime \prime} \mathrm{N}, 133^{\circ} 11^{\prime} 30^{\prime \prime}$ W; (map 8)

Named in 1887 by Comdr. C. M. Thomas, USN, for Ens. Maurice L. Read, a member of his surveying party; published in 1888 by USC\&GS.

Ready Bullion Beach: beach, on NE coast of Douglas I., on Gastineau Channel, $1.7 \mathrm{mi}$. SE of Treadwell and $5 \mathrm{mi}$. SE of Juneau, Coast Mts.; $58^{\circ} 14^{\prime} 48^{\prime \prime} \mathrm{N}, 134^{\circ} 20^{\prime} 12^{\prime \prime} \mathrm{W}$; (map 11).

Named by Frank Berry, Antone Marks, William Meehan, John Prior, and James Rosewall, prospectors, in 1880 . In their search for gold, they camped at the mouth of Ready Bullion Creek where William Mee- han, finding gold, is reported to have shouted "Look at this! Why it is almost ready bullion." (DeArmond, 1957, p. 36).

Ready Bullion Creek: stream, on Douglas I., flows NE $3 \mathrm{mi}$. to Gastineau Channel, $4 \mathrm{mi}$. $\mathrm{SE}$ of Juneau, Coast Mts. ; $58^{\circ} 15^{\prime} 15^{\prime \prime} \mathrm{N}$, $134^{\circ} 20^{\prime} 45^{\prime \prime}$ W; (map 11). Var. Bullion Creek.

Named by Frank Berry, Antone Marks, William Meehan, John Prior, and James Rosewall, prospectors, in 1880, when gold was discovered by William Meehan at the mouth of the stream (DeArmond, 1957, p. 36).

Ready Bullion Creek: stream, flows SE $2.5 \mathrm{mi}$. to Ester Creek, $8.5 \mathrm{mi}$. W of Fairbanks, YukonTanana High.; $64^{\circ} 50^{\prime} 40^{\prime \prime} \mathrm{N}, 148^{\circ} 01^{\prime} 05^{\prime \prime} \mathrm{W}$; (map 100).

Named by prospectors; shown on manuscript map in 1905 by C. W. Joint.

Ready Bullion Creek: stream, flows NW $0.7 \mathrm{mi}$. to Telegram Creek which joins Eldorado Creek to form Dome Creek, $22 \mathrm{mi}$. NW of Solomon, Seward Penin. High.; 64 $52^{\prime} \mathrm{N}$, $164^{\circ} 36^{\prime} \mathrm{W}$; (map 95).

Prospectors' name published on the 1908 "Map of Seward Peninsula" by Arthur Gibson.

Ready Bullion Creek: stream, flows NW 4 mi. to Bullion Creek in Pargon River basin, $10 \mathrm{mi}$. $\mathrm{NE}$ of Council and $40 \mathrm{mi}$. SW of Imuruk Lake, Seward Penin. High.; $65^{\circ} 01^{\prime} \mathrm{N}, 163^{\circ} 29^{\prime} \mathrm{W}$; (map 110).

Prospectors' name reported on a map of Cape Nome gold fields by David Fox, Jr., dated 1901.

Ready Bullion Creek: stream, flows SE $5 \mathrm{mi}$. to Tolovana River, 5 mi. S of Livengood, YukonTanana High.; $65^{\circ} 28^{\prime} \mathrm{N}, 148^{\circ} 33^{\prime} \mathrm{W}$; (map 105).

Name of stream flowing to Livengood Creek reported in 1915 by USGS (in Brooks and others, 1916, pl. 9); subsequently, the stream has been found to flow to the Tolovana River, as shown on recent maps. It was prospected, and probably named, by Ked Anderson.

Ready Bullion Creek: stream, flows $\mathrm{N} 4 \mathrm{mi}$. to Bettles River, $S$ of Wiehl Mtn. and $E$ of Emery Creek, $29 \mathrm{mi}$. WNW of Chandalar, Brooks Ra.; $67^{\circ} 34^{\prime} \mathrm{N}, 149^{\circ} 35^{\prime} \mathrm{W}$; (map 123).

Local name reported in 1956 by T. E. Taylor, USGS.

Ready Bullion Creek: stream, see Bullion Creek. Ready Money Creek: stream, heads on Serpentine Ridge, flows S $2.6 \mathrm{mi}$. to Sullivan Creek $6 \mathrm{mi}$. SW of Roughtop Mtn. and $34 \mathrm{mi}$. ESE of Tanana, Yukon-Tanana High.; $6^{\circ} 06^{\prime} 35^{\prime \prime}$ $\mathrm{N}, 150^{\circ} 54^{\prime} 25^{\prime \prime} \mathrm{W}$; (map 106).

Local name reported in 1952 by USGS.

Real Marina, Port: water passage, $7 \mathrm{mi}$. long, between Baker and Lulu Is., Alex. Arch.; $55^{\circ} 25^{\prime} 30^{\prime \prime} \mathrm{N}, 133^{\circ} 30^{\prime} \mathrm{W}$; (map 4). Var. Port de la Marina, Puerto de la Real Marina, Real Marine Port, Sea Otter Bay.

Named "Puerto de la Real Marina," or "Port of the Royal Navy," on May 22, 1779 , by Francisco Antonio Maurelle. The name probably arose because of its size; it was large 
enough to hold the entire Spanish Royal Navy (Wagner, 1937, p. 404).

Real Marina, Port: water passage, see Siketi Sound.

Real Marine Port: water passage, see Real Marina, Port.

Recheshnaia: village, see Nikolski.

Recheshnoe: village, see Nikolski.

Recheshnoi, Mount: mountain, 6,510 ft., in S central Umnak I., Aleutian Is.; $53^{\circ} 09^{\prime} 15^{\prime \prime} \mathrm{N}$ $168^{\circ} 32^{\prime} 00^{\prime \prime} \mathrm{W}$; BGN 1947; (map 22). Var. Mount Recheshnoy, Mount Retscheschnoj, Mount Vsevidof.

Russian name published by Coats (1950, p. 38), USGS.

Recheshnoi Mount: mountain, see Vsevidof, Mount.

Recheshnoy, Mount: mountain, see Recheshnoi, Mount.

Recheshnoy, Zaliv: $b a y$, see Akun Bay.

Rechnoy, Mys: point of land, see Rothsay, Point.

Recon Creek: stream, flows N $8 \mathrm{mi}$. to Jubilee Creek, $13 \mathrm{mi}$. SW of Liberator Lake, Brooks Ra.; $68^{\circ} 45^{\prime} \mathrm{N}, 158^{\circ} 49^{\prime} \mathrm{W}$; (map 132).

So named in 1952 by B. H. Kent and I. L. Tailleur, USGS, "for spike [reconnaissance] trip on this creek."

Record City: locality, at junc. of Pinnel and Inmachuk Rivers, $18 \mathrm{mi}$. N of Imuruk Lake, Seward Penin. High.; $65^{\circ} 53^{\prime} \mathrm{N}, 163^{\circ} 04^{\prime} \mathrm{W}$; (map 110).

Site of a mining camp; reported in 1903 by F. H. Moffit (in Emmons and Hayes, 1904, p. 76), USGS.

Redan Point: point of land, on $\mathrm{N}$ coast of Bobrof I., Aleutian Is.; $51^{\circ} 55^{\prime} 30^{\prime \prime} \mathrm{N}, 177^{\circ}$ $26^{\prime} 45^{\prime \prime} \mathrm{W}$; (map 17).

Name published in 1956 by USC\&GS.

Redaute Saint Nikolaus: village, see Kenai.

Red Bay: bay, extends NE $6 \mathrm{mi}$. to Sumner Strait, on N coast of Prince of Wales I., Alex. Arch.; $56^{\circ} 20^{\prime} \mathrm{N}, 133^{\circ} 18^{\prime} \mathrm{W}$; (map 6). Var. Bukhta Krasnaya, Krasnaia Bay.

An 1882 translation by USC\&GS of the name published in 1853 on Russian Hydrog. Dept. Chart 1493 as "Bukhta Krasnaya."

Red Bay Mountain: mountain, 3,042 ft., on Prince of Wales I., $5 \mathrm{mi}$. NE of Shakan Bay, Alex. Arch.; $56^{\circ} 13^{\prime} 00^{\prime \prime} \mathrm{N}, 133^{\circ} 22^{\prime} 30^{\prime \prime} \mathrm{W}$; $B G N$ 1900; (map 6). Var. False Mount Calder.

Named in 1891 by Lt. Comdr. H. E. Nichols, USN, who in 1881 called it "False Mount Calder."

Red Beach: beach, $0.2 \mathrm{mi}$. long, on Bering Sea, $\mathrm{N}$ of Holte Bay, Attu I., Aleutian Is.; $52^{\circ}$. $57^{\prime} 50^{\prime \prime} \mathrm{N}, 173^{\circ} 10^{\prime} 02^{\prime \prime} \mathrm{E}$; (map 13).

Named by the U.S. Army during its occupation of the island during World War II shown on an AMS map published in 1948.

Red Bed Peak: mountain, 3,500 ft., in Glacier Bay National Monument, $1.7 \mathrm{mi}$. SE of 1950 terminus of Charpentier Glacier and $55 \mathrm{mi}$. $\mathrm{NW}$ of Hoonah, St. Elias Mts.; $58^{\circ} 40^{\prime} 10^{\prime \prime} \mathrm{N}$, $146^{\circ} 30^{\prime} 35^{\prime \prime} \mathrm{W}$; (map 10).

Local name reported in 1951 by USGS.
Red Bluff: bluff, W of Haycock Rock, on N coast of Kiska I., Aleutian Is.; $52^{\circ} 05^{\prime} 00^{\prime \prime} \mathrm{N}$, $177^{\circ} 40^{\prime} 00^{\prime \prime} \mathrm{E}$; (map 14).

Named for triangulation station Red on top of bluff.

Red Bluff: bluff, elev. $89 \mathrm{ft}$,, on $\mathrm{N}$ shore of Egegik Bay, on $\mathrm{N}$ coast of Alaska Penin., $4 \mathrm{mi}$. NW of Egegik and $38 \mathrm{mi}$. SW of Naknek, Bristol Bay Low.; 58 $04^{\prime} \mathrm{N}, 157^{\circ} 29^{\prime} \mathrm{W}$; (map 41).

Local name reported in 1952 by USGS.

Red Bluff: bluff, $200 \mathrm{ft}$. high, extends $2 \mathrm{mi}$. along left bank of Black River, $6 \mathrm{mi}$. NE of Chalkyitsik, Yukon Flats; $66^{\circ} 41^{\prime} \mathrm{N}, 143^{\circ} 29^{\prime} \mathrm{W}$ (map 120).

Local descriptive name; reported in 1956 by R. C. Foley, USGS.

Red Bluff: hill, near Adak Air Base, $2.5 \mathrm{mi}$. S of Andrew Lagoon, on Adak I., Aleutian Is.; $51^{\circ} 53^{\prime} 05^{\prime \prime} \mathrm{N}, 176^{\circ} 38^{\prime} 45^{\prime \prime} \mathrm{W}$; (map 17).

Local name published by USGS (Coats, $1956 a$, p. 58), but since this report was written the hill has been removed.

Red Bluff: point of land, on $\mathrm{E}$ shore of Seldovia Bay, $0.3 \mathrm{mi}$. N of Seldovia, Chugach Mts. $59^{\circ} 27^{\prime} \mathrm{N}, 151^{\circ} 43^{\prime} \mathrm{W}$; (map 50).

Descriptive name reported by USG\&GS in 1909.

Red Bluff Bay: bay, $0.5 \mathrm{mi}$. across, $4 \mathrm{mi}$. long, 16 mi. S of Baranof, on $\mathbf{E}$ coast of Baronof $\mathbf{I}$. Alex. Arch.; 56 $50^{\prime} 30^{\prime \prime} \mathrm{N}, 134^{\circ} 42^{\prime} 00^{\prime \prime} \mathrm{W}$; (map 5).

Named in 1895 by Lt. Comdr. E. K. Moore, USN.

Red Bluff Creek: stream, flows N 14 mi. to Yellow Bluff Creek, $18 \mathrm{mi}$. S of Port Heiden Airfield, Bristol Bay Low.; $56^{\circ} 43^{\prime}$ N, $158^{\circ} 44^{\prime}$ W; (map 30).

Descriptive name reported in 1923 by $R$. H. Sargent, USGS.

Red Bluff Mountain: mountain; 2,200 ft., on S coast of Alaska Penin., $25 \mathrm{mi}$. E of Stepovak Bay, Aleutian Ra.; $55^{\circ} 56^{\prime} \mathrm{N}, 1^{\circ} 9^{\circ} 03^{\prime} \mathrm{W}$; (map 27)

Local descriptive name published by USC\&GS in 1947 Coast Pilot (v. 2, p. 297).

Red Bluffs: bluffs, elev. $393 \mathrm{ft}$., on $\mathrm{S}$ coast of St. George I., in Pribilof Is.; 56 $32^{\prime} 20^{\prime \prime} \mathrm{N}, 169^{\circ}$ $38^{\prime} 00^{\prime \prime}$ W; (map 38). Var. Kimilögchìl'ogh.

Descriptive name reported in 1891 by Joseph Stanley-Brown, naturalist. Putnam (1903, p. 1015), USC\&GS, gives the Aleut name as "Kìmílogchĭl'ogh" meaning "living place in autumn," "so called because there was formerly a barabara or native house here, where some natives lived during the season for fox trapping."

Red Cape: point of land, see Krasni Point.

Red Cinder Dome: mountain, $1,874 \mathrm{ft}$., on $N$ coast of Unalaska $\mathrm{I}$, Aleutian Is. ; $53^{\circ} 58^{\prime} 20^{\prime \prime}$

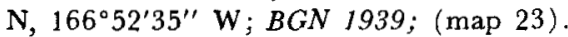

So named in 1937 by USC\&GS because it "is a large reddish cinder dune [sic], a sort of half crater ***."

Redcliff Islands: islands, $1.2 \mathrm{mi}$. long, in Freshwater Bay, $9 \mathrm{mi}$. NE of Tenakee Springs, on $E$ coast of Chichag of 1., Alex. Arch.; 57 53'$30^{\prime \prime} \mathrm{N}, 135^{\circ} 07^{\prime} 00^{\prime \prime} \mathrm{W}$; BGN 1933; (map 9).
So named in 1933 by USFS "because of a prominent red cliff on one of the islands."

Red Cloud River: stream, flows NE $4 \mathrm{mi}$. to Anton Larsen Bay, $8 \mathrm{mi}$. NW of Kodiak, Kodiak I.; $57^{\circ} 50^{\prime} 30^{\prime \prime} \mathrm{N}, 152^{\circ} 37^{\prime} 30^{\prime \prime} \mathrm{W}$; BGN 1966; (map 34).

Local name reported in 1952 by USGS.

Red Cove: bay, extends $\mathrm{N} 0.2 \mathrm{mi}$. inland from Popof Strait, on S coast of Popof I, in Shumagin Is., Aleutian Ra.; $55^{\circ} 17^{\prime} 30^{\prime \prime} \mathrm{N}, 160^{\circ}$ $26^{\prime} 30^{\prime \prime} \mathrm{W}$; ( $\operatorname{map} 28$ ).

This local name was reported in 1872 by W. H. Dall, USG\&GS; a colonial settlement was located on or near this cove, according to P. Tikhmeniev.

Red Greek: stream, flows N $4.8 \mathrm{mi}$. to Keta River $5.3 \mathrm{mi}$. NE of its junc. with Boca de Quadra, Coast Mts.; $55^{\circ} 23^{\prime} 18^{\prime \prime}$ N, $130^{\circ} 22^{\prime}$ $28^{\prime \prime} \mathrm{W}$; (map 3$)$.

Local name reported in 1955 by USGS.

Red Creek: stream, heads on $\mathrm{N}$ side of Red Glacier, flows NE $4.5 \mathrm{mi}$. to Johnson River, $63 \mathrm{mi}$. SW of Kenai, Aleutian Ra.; $60^{\circ} 04^{\prime} \mathrm{N}$, $152^{\circ} 48^{\prime} \mathrm{W}$; ( $\operatorname{map} 62$ ).

Name derived from Red Glacier; reported in 1921 by F. H. Moffit, USGS.

Red Creek: stream, heads $\mathrm{W}$ of and flows NE thru Red Lake $30 \mathrm{mi}$. to Johnson Creek, 51 mi. SW of Talkeetna, Alaska Ra.; $62^{\circ} 03^{\prime} 55^{\prime \prime}$ $\mathrm{N}, 151^{\circ} 36^{\prime} 15^{\prime \prime} \mathrm{W}$; (map 81).

Local name reported in 1945 by USGS

Red Creek: stream, flows N $5 \mathrm{mi}$. to Yacko Creek, $23 \mathrm{mi}$. S of junc. of Oshetna and Susitna Rivers and $66 \mathrm{mi}$. W of Gulkana, Talkeetna Mts.; $62^{\circ} 18^{\prime} 20^{\prime \prime} \mathrm{N}, 147^{\circ} 23^{\prime} 10^{\prime \prime} \mathrm{W}$; (map 82).

Local name reported by $\mathrm{F}$. H. Moffit (in Brooks and others, 1905, pl. 3), USGS.

Red Creek: stream, flows S $1.5 \mathrm{mi}$. to Niukluk River, $4.5 \mathrm{mi}$. NW of Council and $32 \mathrm{mi}$. NE of Solomon, Seward Penin. High.; 64 ${ }^{\circ} 56^{\prime} \mathrm{N}$, $163^{\circ} 48^{\prime} \mathrm{W}$; (map 95).

Prospectors' name reported on a 1901 map of the Cape Nome gold fields by David Fox, Jr.

Red Devil: village, pop. 152, on left bank of Kuskokwim River at mouth of Red Devil Greek, $6 \mathrm{mi}$. NW of Sleetmute, KilbuckKuskokwim Mts.; $61^{\circ} 45^{\prime} 45^{\prime \prime}$ N, $157^{\circ} 18^{\prime} 30^{\prime \prime}$ W; (map 72)

Mining town named for the mercury mine near which it is built; published in 1950 by USGS. A post office was established here in 1957.

Red Devil Creek: stream, flows N $1.3 \mathrm{mi}$. to Kuskokwim River at village of Red Devil, 6 mi. NW of Sleetmute, Kilbuck-Kuskokwim Mts.; $61^{\circ} 45^{\prime} 45^{\prime \prime} \mathrm{N}, 157^{\circ} 18^{\prime} 30^{\prime \prime} \mathrm{W}$; (map 72).

Local name obtained in 1952 by USGS.

Red Dog Lake: lake, $0.5 \mathrm{mi}$. across, $24 \mathrm{mi}$. N of Chalkyitsik, Yukon Flats; $67^{\circ} 00^{\prime} \mathrm{N}, 143^{\circ} 45^{\prime}$ W; (map 120).

Local name obtained in 1956 by T. E. Taylor and R. C. Foley, USGS.

Redfield, Lake: lake, $2 \mathrm{mi}$. across, $1 \mathrm{mi}$. E of Humpback Cove, $10 \mathrm{mi}$. NE of Yakutat, St. Elias Mts.; $59^{\circ} 38^{\prime} \mathrm{N}, 139^{\circ} 32^{\prime} \mathrm{W}$; (map 46). 
Named in 1914 by E. L. Jones, USBF, for William C. Redfield, then Secretary of Commerce; published in 1915 by USC\&GS on Chart 8002.

Redfield Cove: cove, $1.2 \mathrm{mi}$. across, $1.4 \mathrm{mi}$. W of Fitzgerald I. and $6 \mathrm{mi}$. NE of Yakutat, Malaspina Coastal Plain; 59 $36^{\prime} 30^{\prime \prime} \mathrm{N}, 139^{\circ}$ $36^{\prime} 15^{\prime \prime} \mathrm{W}$; (map 46).

Local name published in 1950 by USC\&GS.

Redfish Bay: bay, $0.5 \mathrm{mi}$. across, $9.7 \mathrm{mi}$. NW of village of Port Alexander, on $\mathrm{S}$ coast of $\mathrm{Ba}$ ranof I., Alex. Arch.; $56^{\circ} 19^{\prime} \mathrm{N}, 134^{\circ} 52^{\prime} \mathrm{W}$; (map 5). Var. Bukhta Krasnoy Ryby, Krasnoi Bay, Krasnoi Ribi.

Name published by USC\&GS in 1883 Coast Pilot (p. 132); derived from "Bukhta Krasnoy Ryby [from rybiy]"; published in 1850 by the Russian American Company.

Redfish Breaker: rock, S of Redfish Point, at W point of entrance to Redfish Bay, $9.7 \mathrm{mi}$. NW of village of Port Alexander, on $\mathbf{S}$ coast of Baranof I., Alex. Arch.; $56^{\circ} 18^{\prime} 00^{\prime \prime} \mathrm{N}$, $134^{\circ} 52^{\prime} 30^{\prime \prime} \mathrm{W}$; (map 5 ).

Named in 1897 by Lt. Comdr. J. F. Moser, USN, commander of USBF steamer Albatross.

Redfish Cape: point of land, on $\mathrm{W}$ coast of Baranof I., $10 \mathrm{mi}$. NW of Port Alexander, Alex. Arch.; $56^{\circ} 18^{\prime} 40^{\prime \prime} \mathrm{N}, 134^{\circ} 52^{\prime} 20^{\prime \prime} \mathrm{W}$; (map 5). Var. Krasnoi Ribi, Krasnyy Rybiy. Name published by USC\&GS in 1883 Coast Pilot (p. 132); translated from "Krasnyy Rybiy," meaning "Redfish," a species of salmon.

Redfish Islets: islands, at entrance to Redfish Bay, $10 \mathrm{mi}$. NW of Port Alexander, Alex. Arch.; 56 $18^{\prime} 15^{\prime \prime}$ N, 134 $52^{\prime} 20^{\prime \prime}$ W; (map 5). Var. Krasnoi Ribi, Krasnyy Rybiy.

Name published by USC\&GS in 1883 Coast Pilot (p. 132). See Redfish Cape.

Redfish Lake: lake, 1,500 ft. long, $3 \mathrm{mi}$. S of Swan Mtn. and $8 \mathrm{mi}$. NE of Arctic Village, Brooks Ra.; $68^{\circ} 10^{\prime} 30^{\prime \prime} \mathrm{N}, 145^{\circ} 14^{\prime} 00^{\prime \prime} \mathrm{W}$; (map 136).

Local name reported in 1956 by $R$. C. Foley, USGS.

Redfish Point: point of land, $\mathrm{S}$ tip of Redfish Islets, $W$ point of entrance to Redfish Bay, $9.5 \mathrm{mi}$. NW of village of Port Alexander, on $\mathrm{S}$ coast of Baranof I., Alex. Arch.; 56 $6^{\circ} 18^{\prime} 10^{\prime \prime}$ N, 134'52'25' W; (map 5). Var. Mys Krasnoy Ryby.

This is a translation by USC\&GS about 1882 of the name "M[ys] Krasnoy Ryby," given in 1850 by the Russian American Company.

Redfox Bay: bay, $1 \mathrm{mi}$. across, on $\mathrm{N}$ coast of Afognak I, Kodiak I.; $58^{\circ} 28^{\prime} \mathrm{N}, 152^{\circ} 36^{\prime} \mathrm{W}$; (map 43).

Local name published in 1926 by USC\&GS.

Red Fox Creek: stream, flows NE $6.8 \mathrm{mi}$. to Tyone Creek, $21 \mathrm{mi}$. N of Tahneta Pass, Talkeetna Mts. ; $62^{\circ} 11^{\prime} 05^{\prime \prime} \mathrm{N}, 147^{\circ} 22^{\prime} 30^{\prime \prime} \mathrm{W}$; $B G N$ 1960; (map 82).

Named in 1956 by USGS "because of the red fox which abound in the area."

Red Gate: bluffs, Porcupine River passes between two bluffs $5 \mathrm{mi}$. ESE of Fishhook Bend,
$24 \mathrm{mi}$. NE of Goleen Mtn., Porcupine Plat.; $67^{\circ} 11^{\prime} \mathrm{N}, 141^{\circ} 58^{\prime} \mathrm{W}$; (map 121).

Name published by Kindle (1908, fig. 1), USGS; "so named because of the coloration in the canyon walls * **" (FitzGerald, 1944, p. 227).

Red Glacier: glacier, in Lincoln Mts., trends N $2.3 \mathrm{mi}$. to its 1955 terminus $6.5 \mathrm{mi}$. NW of Hyder, Coast Mts. ; 55 $58^{\prime} 30^{\prime \prime} \mathrm{N}, 130^{\circ} 10^{\prime} 15^{\prime \prime}$ W; BGN 1927; (map 3 ).

Descriptive name given in 1926 by A. F. Buddington, USGS, because the "moraine of this glacier is almost wholly of red quartz monzonite boulders."

Red Glacier: glacier, heads at Iliamna Volcano, trends SE 12 mi. to terminus at Red River, $48 \mathrm{mi}$. NW of Homer, Aleutian Ra.; 59 $58^{\prime}$ $\mathrm{N}, 152^{\circ} 48^{\prime} \mathrm{W}$; (map 50).

Name reported in 1912 by USC\&GS

Red Head: promontory, at $\mathrm{W}$ end of Steller Cove, on $\mathrm{N}$ coast of Attu I., Aleutian Is.; $52^{\circ} 59^{\prime} 40^{\prime \prime} \mathrm{N}, 172^{\circ} 54^{\prime} 30^{\prime \prime} \mathrm{E}$; BGN 1938; (map 13).

Descriptive name given by the North Pacific Expedition in 1855. This feature is reported as being "readily identified even in fog because of its distinctive reddish color" (USC\&GS, 1944, p. 134)

Red Head: point of land, at W entrance to Port Gravina, $28 \mathrm{mi}$. NW of Cordova, Chugach Mts.; $60^{\circ} 40^{\prime} 15^{\prime \prime} \mathrm{N}, 146^{\circ} 30^{\prime} 00^{\prime \prime} \mathrm{W}$; (map 64).

Local name reported in 1898 by Capt. Abercrombie (1899, map), USA.

Red Hill: hill, $750 \mathrm{ft}$, , on $\mathrm{W}$ end of Unimak I., Aleutian Is.; $54^{\circ} 35^{\prime} 33^{\prime \prime} \mathrm{N}, 164^{\circ} 52^{\prime} 35^{\prime \prime} \mathrm{W}$; (map 24).

Descriptive name published on a 1943 AMS map.

Red Hill: mountain, 2,356 ft., on $S$ coast of Alaska Penin., W of Grub Gulch, NW shore of Stepovak Bay, Aleutian Ra.; $55^{\circ} 48^{\prime} 00^{\prime \prime} \mathrm{N}$, $159^{\circ} 58^{\prime} 30^{\prime \prime} \mathrm{W}$; (map 27).

Local descriptive name published by USC\&GS in 1947 Coast Pilot (p. 306).

Red Hill: mountain, $1,870 \mathrm{ft}$, at $\mathrm{W}$ end of Sadlerochit Mts., at head of Tamayariak River, $50 \mathrm{mi}$. NW of Mount Michelson, Brooks Ra.; $69^{\circ} 37^{\prime} 30^{\prime \prime} \mathrm{N}, 1^{\prime} 6^{\prime} 05^{\prime} 30^{\prime \prime} \mathrm{W}$; (map 139).

Leffingwell (1919, p. 116) wrote "On the top of Red Hill at the west end of the Sadlerochit Mts. * * *"

Red Hill Creek: stream, in Nutzotin Mts., flows W $5 \mathrm{mi}$. to Chisana River, $4.5 \mathrm{mi}$. NE of Euchre Mtn., Alaska Ra.; $62^{\circ} 05^{\prime} 30^{\prime \prime} \mathrm{N}$, $142^{\circ} 04^{\prime} 30^{\prime \prime} \mathrm{W}$; (map 84).

Local name reported in 1960 by USGS.

Red Hills: mountains, 3,000 ft., extend NW 10 mi. just $\mathrm{N}$ of Portage Arm, $10 \mathrm{mi}$. NW of Eagle Mtn. and $68 \mathrm{mi}$. NW of Dillingham, Kilbuck-Kuskokwim Mts.; 59 $57^{\prime}$ N, $159^{\circ} 04^{\prime}$ W; BGN 1932; (map 53).

Descriptive name given in 1931 by members of USGS field survey party because "the top of the ridges appeared to be red in the sunlight."
Red Lake: lake, 2 mi. long, at head of Red Bay, on $\mathrm{N}$ coast of Prince of Wales I., Alex. Arch.; $56^{\circ} 15^{\prime} \mathrm{N}, 133^{\circ} 19^{\prime} \mathrm{W}$; BGN 1923; (map 6). Named in 1923 by USFS.

Red Lake: lake, $3.7 \mathrm{mi}$. long, $22 \mathrm{mi}$. S of Karluk, near SW coast of Kodiak I.; $57^{\circ} 15^{\prime} \mathrm{N}, 154^{\circ}$ $17^{\prime} \mathrm{W}$; (map 35 ).

Local name reported in 1952 by USGS.

Red Lake: lake, $1.4 \mathrm{mi}$. long, in course of Red Creek, N of Skwentna River, $70 \mathrm{mi}$. NW of Tyonek, Alaska Ra.; $61^{\circ} 59 \mathrm{~N}, 152^{\circ} 06^{\prime} \mathrm{W}$; (map 70).

Local name reported in 1958 by USGS.

Redlands Creek: stream, see Chitanana River.

Redlands Lake: lake, $1.2 \mathrm{mi}$. long, drains to Chitanana River, $18 \mathrm{mi}$. NW of Bitzshtini Mts., Kilbuck-Kuskokwim Mts.; 64 $41^{\prime} \mathrm{N}$, $152^{\circ} 18^{\prime} \mathrm{W}$; (map 99).

Local name reported in 1952 by USGS; "Redlands" is an early name for the Chitanana River.

Redlands River: stream, see Chitanana River.

Red Lodge Creek: stream, flows NE $4 \mathrm{mi}$. to Faro Creek, $28 \mathrm{mi}$. N of Goodnews, KilbuckKuskokwim Mts. ; 59 $31^{\prime}$ N, 161 $30^{\prime}$ W ; (map 53).

Local name reported in 1919 by G. L. Harrington (in Brooks, 1921, pl. 7), USGS.

Redman Creek: stream, see Redmond Creek.

Redmond Creek: stream, flows $\mathrm{N} 10 \mathrm{mi}$. to Salcha River, $30 \mathrm{mi}$. NW of Big Delta, Yukon-

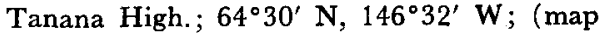
101). Var. Redman Creek.

Local name originally reported in 1907 as Redman Creek by Prindle (1908, pl. 4), USGS; present spelling published in 1911 (Brooks and others, p. 193).

Red Mountain: hill, $853 \mathrm{ft}$., on right bank of Yukon River, $2 \mathrm{mi}$. W of Paimiut and $37 \mathrm{mi}$. ENE of Russian Mission, Yukon-Kuskokwim Delta; $61^{\circ} 58^{\prime} \mathrm{N}, 160^{\circ} 18^{\prime} \mathrm{W}$; (map 73).

Riverboat pilots' name shown on a 1922 manuscript chart of the Yukon River.

Red Mountain: mountain, 1,235 ft., on S part of Unga I., in Shumagin Is., Aleutian Ra.; 55 $13^{\prime} 10^{\prime \prime} \mathrm{N}, 160^{\circ} 35^{\prime} 45^{\prime \prime} \mathrm{W}$; (map 28).

Descriptive name shown on 1907 USC\&GS chart.

Red Mountain: mountain, 2,068 ft., on Annettc I., $1.8 \mathrm{mi}$. SE of Walden Point, Alex. Arch.; $55^{\circ} 15^{\prime} 02^{\prime \prime} \mathrm{N}, 131^{\circ} 34^{\prime} 05^{\prime \prime} \mathrm{W}$; (map 3 ).

Descriptive name given in 1883 by Lt. Comdr. H. E. Nichols, USN.

Red Mountain: mountain, 3,920 ft., on Etolin I., Alex. Arch.; 56 $15^{\prime} 30^{\prime \prime} \mathrm{N}, 132^{\circ} 33^{\prime} 30^{\prime \prime} \mathrm{W}$; (map 6).

Local descriptive name published by $\mathrm{W}$. $\mathrm{H}$. Dall (in USC\&GS, 1883, p. 94), USC\&GS.

Red Mountain: mountain, 1,887 ft., $21 \mathrm{mi}$. N of Chagvan Mtn. and $33 \mathrm{mi}$. NE of Cape Newenham, Kilbuck-Kuskokwim Mts.; $58^{\circ}$ $57^{\prime} 15^{\prime \prime}$ N., $161^{\circ} 44^{\prime} 30^{\prime \prime}$ W.; (map 39).

Descriptive name published in a 1933 U.S. Dept. of Interior mining report.

Red Mountain: mountain, 3,580 ft., Glacier Bay National Monument, $3 \mathrm{mi}$. NE of The Nunatak and $67 \mathrm{mi}$ : NW of Hoonah, St. Elias 
Mts.; $58^{\circ} 59^{\prime} 55^{\prime \prime} \mathrm{N}, 136^{\circ} 00^{\prime} 50^{\prime \prime} \mathrm{W}$; (map 10).

Descriptive name given in 1890 by $H$. F. Reid. Name was published by Cushing (1891, map).

Red Mountain: mountain, 4,596 ft., in Glacier Bay National Monument, $2.4 \mathrm{mi}$. SW of Coleman Peak and $38 \mathrm{mi}$. SW of Skagway, St. Elias Mts.; $59^{\circ} 02^{\prime} 20^{\prime \prime} \mathrm{N}, 135^{\circ} 59^{\prime} 45^{\prime \prime} \mathrm{W}$; (map 45).

Named in 1890 by H. F. Reid (in Cushing, 1891, map, p. 228).

Red Mountain: mountain, 3,524 ft., in Kenai Mts, $10 \mathrm{mi}$. SE of Seldovia, Chugach Mts.; $59^{\circ} 21^{\prime} 30^{\prime \prime} \mathrm{N}, 151^{\circ} 29^{\prime} 00^{\prime \prime} \mathrm{W}$; BGN 1911; (map 50).

Descriptive local name reported in 1909 by U. S. Grant and D. F. Higgins (in Brooks and others, 1910 , p. 168), USGS.

Red Mountain: mountain, 1,461 ft., in Kuskokwin Mts. E of Vreeland Creek, $9 \mathrm{mi}$. SW of Sleetmute, Kilbuck-Kuskokwin Mts.; 61 $35^{\circ}$ N, $157^{\circ} 16^{\prime} \mathrm{W}$; (map 72 ).

Descriptive name reported in 1954 by W. M. Cady, R. E. Wallace, J. M. Hoare, and E. J. Webber, USGS.

Red Mountain: mountain, 4,410 ft., on W bank of Young Creek, $19 \mathrm{mi}$. NE of Palmer, Talkeetna Mts. ; $61^{\circ} 48^{\prime} \mathrm{N}, 148^{\circ} 42^{\prime} \mathrm{W}$; (map 69).

Local descriptive name reported in 1913 by USGS.

Red Mountain: peak, 7,165 ft., between Sunset and Muldrow Glaciers, at head of Crystal Creek, $10 \mathrm{mi}$. SE of head of McKinley River, Alaska Ra.; $63^{\circ} 19^{\prime} 40^{\prime \prime} \mathrm{N}, 150^{\circ} 17^{\prime} 00^{\prime \prime} \mathrm{W}$; (map 88).

Local name reported in 1954 by USGS.

Red Mountain Creek: stream, flows NW $2.5 \mathrm{mi}$. to Chisna River $2.5 \mathrm{mi}$. NE of its junc. with Chistochina River, $22 \mathrm{mi}$. NE of Paxson, Alaska Ra.; $63^{\circ} 04^{\prime} 36^{\prime \prime} \mathrm{N}, 144^{\circ} 48^{\prime} 10^{\prime \prime} \mathrm{W}$; (map 86).

Name reported in 1902 by W. C. Mendenhall, USGS.

Red Mountain Creek: stream, flows $N 3 \mathrm{mi}$. to Dry Creek, $53 \mathrm{mi}$. NE of Healy, Alaska Ra.; $63^{\circ} 56^{\prime} 45^{\prime \prime} \mathrm{N}, 147^{\circ} 21^{\prime} 10^{\prime \prime} \mathrm{W}$; (map 87).

Local descriptive name reported in 1910 by J. W. Bagley (in Capps, 1912, pl. 2), USGS.

Red Mountain Creek: stream, heads on Red Mtn., flows S $6 \mathrm{mi}$. to Koyukuk River, $20 \mathrm{mi}$. NE of Hughes, Hogatza High.; $66^{\circ} 17^{\prime} \mathrm{N}$, $153^{\circ} 53^{\prime} \mathrm{W}$; (map 116).

Local name recorded at Hughes in 1956 by Orth; named for the mountain on which it heads.

Red Mountain Creek : stream, see Willow Creek.

Red Mountains: mountains, 1,300 ft., trends E-W $4 \mathrm{mi}$., $2 \mathrm{mi}$. NE of Teller Mission and 6 mi. NW of Teller, Seward Penin. High; $65^{\circ} 22^{\prime} \mathrm{N}, 166^{\circ} 27^{\prime} \mathrm{W}$; (map 111).

Local name reported in 1950 by USC\&GS; "named for the red appearance of the soil and rock."

Redoubt Bay: bay, 2 mi. across, 9 mi. S of Sitka, on $W$ coast of Baranof I., Alex. Arch.; $56^{\circ} 55^{\prime} 30^{\prime \prime} \mathrm{N}, 135^{\circ} 22^{\prime} 00^{\prime \prime} \mathrm{W}$; (map 5). Var. Bukhta Redut, Oserski Bay, Toyons Bay, Tyons Bay.
Named "Bukhta Redut," i.e., "Redoubt Bay," by Capt. Tebenkov (1852, map 38), IRN. In 1804 it was called "Tyons Bay" by Capt. U. T. Lisianski, IRN.

Redoubt Bay: bight, extends SW $29 \mathrm{mi}$. on W shore of Cook Inlet, from West Foreland to Harriet Point, $28 \mathrm{mi}$. W of Kenai, Cook Inlet Low.; $60^{\circ} 35^{\prime} \mathrm{N}, 152^{\circ} 05^{\prime} \mathrm{W}$; (map 62).

Name published in 1869 by USC\&GS.

Redoubt Creek: stream, heads at glacier terminus, flows SE $15 \mathrm{mi}$. to Cook Inlet, $3 \mathrm{mi}$. SW of Harriet Point and $39 \mathrm{mi}$. WSW of Kenai, Aleutian Ra.; $60^{\circ} 22^{\prime} \mathrm{N}, 152^{\circ} 19^{\prime} \mathrm{W}$; (map 62).

Name published in 1959 by USGS; derived from Redoubt Volcano.

Redoubt Lake: lake, $9.5 \mathrm{mi}$. long, at head of Redoubt Bay, on W coast of Baranof I., Alex. Arch.; 56 56 $6^{\prime}$, $135^{\circ} 16$ W; BGN 1915; (map 5). Var. Deep Lake, Dertiefee See, Gloubokoi Lake, Glubokoe Lake, Kluchev Bay, Ozero Glubokoyee, Ozero Redutskoye, Redout.

Named "Ozero Glubokoye," meaning "deep lake," in 1809 by the Russian navigator, Ivan Vasilev the first; published as such by Lt. Sarichev (1826, map 19), IRN; called "Ozero Redutskoye," meaning "redoubt lake," possibly after a fishing station at the lake's outlet called "the Redoubt" in 1849 by Capt. Tebenkov (1852, map 38), IRN.

Redoubt Mountain: mountain, see Dranishnikof, Mount.

Redoubt Point: promontory, on W shore of Cook Inlet, $\mathbf{N}$ point of entrance to Tuxedni Bay, $44 \mathrm{mi}$. SW of Kenai, Aleutian Ra.; $60^{\circ}$ $17^{\prime} 15^{\prime} \mathrm{N}, 152^{\circ} 25^{\prime} 00^{\prime} \mathrm{W}$; (map 62).

Local name reported in 1920 by USGS; derived from Redoubt Bay.

Redoubt Saint Dionysius: town, see Wrangell.

Redoubt Saint Gabriel: locality, see Fort Saint Michael.

Redoubt Saint Michael: village, see Saint Michael.

Redoubt Volcano: volcano, 10,197 ft., $9 \mathrm{mi}$. NE of Crescent Lake and $52 \mathrm{mi}$. W of Kenai, Aleutian Ra.; $60^{\circ} 29^{\prime} 15^{\prime \prime} \mathrm{N}, 152^{\circ} 44^{\prime} 30^{\prime} \mathrm{W}$; $B G N$ 1891; (map 62). Var. Burnt Mountain, Goreloi, Goryalaya, Redoute Mountain, Ujakushatsch, Viesokaia, Volcan de Miranda.

Translation of the Russian name "Sopka Redutskaya" (Tebenkov, 1852, map 5). According to Constantin Grewingk in 1850 the native name "Ujakushatsch" also means "fortified place" but it is difficult to determine if one name is derived from the other. This may be the volcano called "Volcan de Miranda" by the Spanish in 1779 , but more likely it was Mliamna Volcano.

Capt. Tebenkov reports that the volcano erupted in 1778 . Grewingk also includes the mountain in his list of Alaska Volcanos and states that "in 1819 the Redoubt volcano of Cook's Inlet smoked" (in Dall, 1870, p. 499).

Redout: lake, see Redoubt I.ake.

Redoute Mountain: volcano, see Redoubt Volcano.

Red Paint Creek: stream, flows NW $17 \mathrm{mi}$. to Tonzona River, $27 \mathrm{mi}$. NW of Mount Rus- sell, Alaska Ra.; 62 $53^{\prime} 25^{\prime \prime}$ N, $152^{\circ} 42^{\prime} 50^{\prime}$ W; (map 81).

Local name reported in 1958 by USGS.

Red Peak: mountain, 2,425 ft., $27 \mathrm{mi}$. N of Afognak, on $\mathrm{N}$ central Afognak I., Kodiak I.; $58^{\circ} 24^{\prime} \mathrm{N}, 152^{\circ} 39^{\prime} \mathrm{W}$; (map 43).

Name published by USC\&GS in Chart 8555 in 1927.

Red Peak: peak, 3,130 ft., on Alaska Penin., $4.5 \mathrm{mi}$. W of Weasel Mtn., Aleutian Ra.; $56^{\circ} 29^{\prime} \mathrm{N}, 158^{\circ} 14^{\prime} \mathrm{W}$; (map 30).

Local descriptive name published in 1952 by USC\&GS; another "red peak" is shown $2.5 \mathrm{mi}$. to east.

Redpoll Lake: lake, $0.3 \mathrm{mi}$. long, on Kenai Penin., NE of Leaf Lake, $31 \mathrm{mi}$. NE of Kenai, Cook Inlet Low.; $60^{\circ} 48^{\prime} 10^{\prime \prime} \mathrm{N}, 150^{\circ} 33^{\prime} 00^{\prime \prime}$ W; (map 62).

Named about 1963 by officials of Kenai National Moose Range, probably for the Hoary Redpoll (Acanthis hornemanni) of the sparrow family, which breeds in the tundra bordering the Arctic Ocean (Pough, 1946, p. 230).

Red River: stream, heads in Peabody Mts., flows NW 11 mi. to Marten Arm, Coast Mts.; $55^{\circ} 08^{\prime} 40^{\prime \prime} \mathrm{N}, 130^{\circ} 32^{\prime} 05^{\prime \prime} \mathrm{W}$; (map 3).

Local name reported in 1955 by USGS.

Red River: stream, $4.5 \mathrm{mi}$. long, flows $S$ to Pacific Ocean, on W coast of Kodiak I., 2 mi. $\mathrm{E}$ of Bumble Bay and $22 \mathrm{mi}$. SSW of Karluk; $57^{\circ} 16^{\prime} 00^{\prime \prime} \mathrm{N}, 154^{\circ} 37^{\prime} 30^{\prime \prime} \mathrm{W}$; BGN 1939; (map 35).

Translation by USC\&GS in 1868 of the descriptive name published by Capt. Tebenkov (1852, map 22), IRN, as "R[eka] Krasnaya."

Red River: stream, flows SE $5 \mathrm{mi}$. from Red Glacier to Cook Inlet, $46 \mathrm{mi}$. NW of Homer, Aleutian Ra.; $59^{\circ} 54^{\prime} 30^{\prime \prime} \mathrm{N}, 152^{\circ} 43^{\prime} 50^{\prime \prime} \mathrm{W}$; (map 50).

Local name reported and published by USGS in the 1950's.

Red River: stream, see Ayakulik River.

Red River: stream, see Beartrack Creek.

Red Rock: rock, on N shore of Chapel Bay, in Bay of Waterfalls, Adak I., Aleutian Is.; $51^{\circ} 38^{\prime} 52^{\prime \prime} \mathrm{N}, 176^{\circ} 48^{\prime} 26^{\prime \prime} \mathrm{W}$; (map 17).

Descriptive name given in 1893 by U.S. Navy officers and published in 1895 by the U.S. Navy Hydrog. Office.

Red Rock: rock, in Niblack Anchorage, on SE coast of Prince of Wales I., Alex. Arch.; $55^{\circ} 03^{\prime} 50^{\prime \prime} \mathrm{N}, 132^{\circ} 07^{\prime} 45^{\prime \prime} \mathrm{W}$; (map 4).

Named in 1891 by Lt. Comdr. H. E. Nichols, USN.

Red Salmon Creek: stream, see Olga Creek.

Red SaImon Lake: lake, $0.8 \mathrm{mi}$. long, between Hayes and Skwentna Rivers, $66 \mathrm{mi}$. NW of Tyonek, Alaska Ra, ; $61^{\circ} 56^{\prime} 20^{\prime \prime} \mathrm{N}, 152^{\circ} 00^{\prime} 15^{\prime \prime}$ W; (map 70).

Local name reported in 1958 by USGS.

Red Sheep Creek: stream, flows SE $18 \mathrm{mi}$. to East Fork Chandalar River, $45 \mathrm{mi}$. NE of Arctic Village, Brooks Ra.; $68^{\circ} 42^{\prime}$ N, $144^{\circ} 48^{\prime}$ W; (map 136).

Local name reported in 1956 by $R$. C. Foley, USGS. 
Red Shirt Lake: lake, $3.4 \mathrm{mi}$. long, $8 \mathrm{mi}$. SW of Willow and $28 \mathrm{mi}$. NW of Anchorage, Cook Inlet Low.; 61 ${ }^{\circ} 37^{\prime} 30^{\prime \prime} \mathrm{N}, 150^{\circ} 10^{\prime} 16^{\prime \prime} \mathrm{W}$; BGN 1961; (map 70). Var. Rolejo Lake. Local name published in 1947 by AMS.

Reds Lake: lake, $1 \mathrm{mi}$. long, $\mathrm{N}$ of North Fork Chandalar River, $7 \mathrm{mi}$. WNW of Bend Mtn. and $24 \mathrm{mi}$. $\mathrm{N}$ of Chandalar, Brooks Ra.; $67^{\circ} 50^{\prime} 20^{\prime \prime} \mathrm{N}, 148^{\circ} 35^{\prime} 00^{\prime \prime} \mathrm{W}$; (map 123).

Local name reported in 1956 by T. E. Taylor, USGS.

Red Slough: stream, flows W from Canada near boundary monument $62 \mathrm{~A}$ to Kikahe River 2.5 mi. upstream from its junc. with Stikine River, Coast Mts.; $56^{\circ} 38^{\prime} 15^{\prime \prime} \mathrm{N}, 131^{\circ} 51^{\prime} 15^{\prime \prime} \mathrm{W}$; $(\operatorname{map} 7)$.

Local descriptive name reported in 1955 by USGS.

Red Slough: stream, an anabranch, flows NW 19 mi. to Swift Fork Kuskokwin River, $53 \mathrm{mi}$. $\mathrm{NE}$ of Medfra, Kuskokwin Low.; 63 $34^{\prime} \mathrm{N}$, $153^{\circ} 22^{\prime} \mathrm{W}$; ( $\operatorname{map} 89$ ).

Local name reported in 1958 by USGS.

Redstar Creek: stream, flows SW $7 \mathrm{mi}$. to North Fork Koyukuk River, $29 \mathrm{mi}$. NW of Wiseman, Brooks Ra.; $67^{\circ} 39^{\prime} 30^{\prime \prime} \mathrm{N} ; 1^{\circ} 01^{\circ} 00^{\prime} 30^{\prime \prime} \mathrm{W}$; $B G N 1932$; (map 124).

Named in 1932 by Robert Marshall for the mountain where it heads.

Redstar Mountain: mountain, 4,000 ft., $5 \mathrm{mi}$. $\mathrm{N}$ of Moving Mtn. and $30 \mathrm{mi}$. NW of Wiseman, Brooks Ra.; $67^{\circ} 44^{\prime} \mathrm{N}, 150^{\circ} 57^{\prime} \mathrm{W}$; $B G N$ 1932; (map 124).

In reporting this name, about 1930 Marshall (1956, p. 52) wrote, "it was capped by a red, star-shaped blotch, probably 2,000 ft. across."

Redstone River: stream, heads at $67^{\circ} 32^{\prime} \mathrm{N}$, $157^{\circ} 15^{\prime} \mathrm{W}$, flows SW $35 \mathrm{mi}$. to Ambler River, $22 \mathrm{mi}$. NW of Shungnak, Brooks Ra.; $67^{\circ} 09^{\prime}$ N, $157^{\circ} 39^{\prime}$ W; (map 126). Var. E-vel-she-ark, Evesheark, Ivishak River.

Named by Lt. Stoney (1900, map), USN, in 1885, apparently a translation of the Eskimo name he records as "E-vel-she-ark" and "Evesheark." This name was spelled "Ivishak" by Orth in 1956 and refers to an iron oxide used for making red paint.

Redut, Bukhta: bay, see Redoubt Bay.

Redutskoye, Ozero: lake, see Redoubt Lake.

Redut Svataya Dioniciya: town, see Wrangell.

Redut Svataya Nikolaya: village, see Kenai.

Red Wing Slough: stream, distributary of Innoko River, flows $4.8 \mathrm{mi}$. SW to Yukon River, $\mathrm{E}$ of Salmon I., $4.2 \mathrm{mi}$. S of Holy Cross, Innoko Low.; $62^{\circ} 08^{\prime} \mathrm{N}, 159^{\circ} 45^{\prime} \mathrm{W}$; (map 78). Var. South Slough.

Name shown on recent maps. It was called "South Slough" by riverboat pilots and was so reported in 1916 by R. H. Sargent, USGS.

Redwood: locality, on right bank of Mitcher Creek, $3.5 \mathrm{mi}$. E of Katalla, Chugach Mts.; $50^{\circ} 12^{\prime} \mathrm{N}, 144^{\circ} 25^{\prime} \mathrm{W}$; (map 64).

Name of a mining community reported in 1905 by G. C. Martin, USGS. The village is now abandoned.

Redwood Bay: cove, $1 \mathrm{mi}$. wide, at NW end of Controller Bay, $5 \mathrm{mi}$. SE of Katalla, Malas- pina Coastal Plain; $60^{\circ} 11^{\prime} \mathrm{N}, 144^{\circ} 23^{\prime} \mathrm{W}$; (map 64).

Named by J. L. McPherson, Deputy Mineral Surveyor, for Boverton Redwood, English geologist; reported in 1903 by G. C. Martin (1905, pl. 3), USGS.

Redwood Creek: stream, flows S $4 \mathrm{mi}$. to Redwood Bay, $4.5 \mathrm{mi}$. E of Katalla, Malaspina Coastal Plain; $60^{\circ} 11^{\prime} \mathrm{N}, 144^{\circ} 23^{\prime} \mathrm{W}$; (map 64).

Name derived from nearby Redwood Bay and reported in 1904 by G. C. Martin (1905, pl. 3), USGS.

Reechnoi: point, see Rothsay, Point.

Reed, Mount: mountain, 1,995 ft., on NW Adak I., Aleutian Is. ; $51^{\circ} 49^{\prime} \mathrm{N}, 176^{\circ} 43^{\prime} \mathrm{W}$; $B G N$ 1936; (map 17).

Named by members of the U.S. Navy Aleutian Island Survey Expedition in 1934 "after a local resident who was buried on or near the mountain."

Reed Creek: stream, heads in a lake, flows SW $4 \mathrm{mi}$. to Archangel Creek $14 \mathrm{mi}$. NW of Palmer, Talkeetna Mts.; $61^{\circ} 48^{\prime} 10^{\prime \prime} \mathrm{N}, 149^{\circ}$ $11^{\prime} 40^{\prime \prime} \mathrm{W}$; (map 69).

Local name reported in 1910 by F. J. Katz (in Brooks and others, 1911, p. 140), USGS.

Reed Creek: stream, see Kallarichuk River.

Reed Grass Point: point of land, see San Roque Point.

Reed River: stream, heads at Angiaak Pass, flows S $52 \mathrm{mi}$. to Kobuk River, $58 \mathrm{mi}$. NNW of Hughes, Brooks Ra.; $66^{\circ} 49^{\prime} \mathrm{N}, 154^{\circ} 57^{\prime} \mathrm{W}$; (map 116). Var. Anelagaggerack, Ungeeletargeeak, Ungeeleganjiak.

Named by Lt. Stoney (1900, p. 47 , map), USN, for Ens. M. L. Reed of his party, who discovered the "Reed River Hot Springs" at the stream's head in March 1886. Stoney gave the Eskimo name for this stream as "An-ne-lag-ag-ge-rack" and "An-e-la-gag-erack." In 1885 Lt. J. C. Cantwell recorded the Eskimo name as "Ung-ee-let-ar-geeak" and "Ung-ee-le-ganjiak" (Healy, 1887, p. $34)$.

Reed River: stream, see Kallarichuk River.

Reed River Hot Spring: spring, near head of Reed River, Brooks Ra.; $67^{\circ} 23^{\prime}$ N, $155^{\circ} 05^{\prime}$ W; (map 125). Var. Ah-lue-ga-wik, Al-luega-wick.

Ens. M. L. Reed of Stoney's expedition visited this spring, as reported by local Eskimos, in March 1886. His manuscript map shows the spring on the left bank of the river near its headwaters. Reed (in Stoney, 1900, p. 47) reported that "There was but one hot spring there, a pool twenty feet in circumference and two feet deep, full of water, of blood-warm temperature * * *." Stoney's maps show the Eskimo name "Al-lue-ga-wick" and "Ah-lue-ga-wik" for the spring. Presentday maps do not show the spring's exact location.

Reedy Lake: lake, 2,700 ft. across, in Matanuska Valley, $10 \mathrm{mi}$. SW of Palmer, Cook Inlet Low.; $61^{\circ} 32^{\prime} 30^{\prime \prime} \mathrm{N}, 149^{\circ} 24^{\prime} 00^{\prime \prime} \mathrm{W}$; (map 69).

Local name reported in 1942 by AMS.
Reef, The: rapids, in Black River $47 \mathrm{mi}$. NW of Midnight Hill, Porcupine Plat.; 66 ${ }^{\circ} 24^{\prime} \mathrm{N}$, $142^{\circ} 30^{\prime} \mathrm{W}$; (map 120).

Local name obtained in 1956 by T. E. Taylor and R. C. Foley, USGS.

Reef Bight: cove, $0.5 \mathrm{mi}$. across, $\mathrm{W}$ coast of Akutan I., Aleutian Is.; 54 $07^{\prime} 45^{\prime \prime} \mathrm{N}, 166^{\circ}$ $06^{\prime} 00^{\prime \prime}$ W; (map 23).

Descriptive name given by John J. Gilbert, USC\&GS, commander of the Coast Survey steamer Pathfinder during 1900-01.

Reef Cape: point of land, see Reef Point.

Reef Harbor: water passage, $1 \mathrm{mi}$. long, between NE coast of Duke I. and Duck Is., Alex. Arch.; $54^{\circ} 59^{\prime} 30^{\prime \prime} \mathrm{N}, 131^{\circ} 15^{\prime} 00^{\prime \prime} \mathrm{W}$; (map 2).

Named by Lt. Comdr. H. E. Nichols, USN, in 1882.

Reef Island: island, $0.3 \mathrm{mi}$. long, in Portland Canal, 3 mi. S of Harrison Point, Coast Mts.; $55^{\circ} 04^{\prime} 50^{\prime \prime} \mathrm{N}, 130^{\circ} 12^{\prime} 10^{\prime \prime} \mathrm{W}$; (map 3 ).

Name published by Lt. Comdr. H. E. Nichols (in U.S. Coast and Geodetic Survey, 1891, p. 76), USN.

Reef Islond: island, $1.3 \mathrm{mi}$. long, at SE entrance to Valdez Arm, $43 \mathrm{mi}$. NW of Cordova, Chugach Mts.; $60^{\circ} 51^{\prime} \mathrm{N}, 146^{\circ} 50^{\prime} \mathrm{W}, B G N$ 1908; (map 64). Var. Seal Island.

Local name reported in 1908 by USGS.

Reef Islands: islands, off-shore chain, extend $0.9 \mathrm{mi}$. in Baldy Bay, on $\mathrm{E}$ coast of Dall $\mathrm{I}$., Alex. Arch.; $55^{\circ} 02^{\prime} 10^{\prime \prime} \mathrm{N}, 132^{\circ} 58^{\prime} 30^{\prime \prime} \mathrm{W}$; (map 4).

Descriptive name given in 1881 by Lt. Comdr. H. E. Nichols, USN.

Reef Lake: lake, 2 mi. long, in Peabody Mts., 1.9 mi. W of Harrison Point on Portland Canal, Coast Mts.; $55^{\circ} 06^{\prime} 50^{\prime \prime} \mathrm{N}, 130^{\circ} 14^{\prime} 30^{\prime \prime} \mathrm{W}$; $B G N$ 1963; (map 3).

Local name reported in 1961 by USFS; derived from Reef Island.

Reef Point: point of land, between Open and Raven Bays, $S$ coast of Unalaska I., Aleutian Is.; $53^{\circ} 26^{\prime} 20^{\prime \prime} \mathrm{N}, 166^{\circ} 48^{\prime} 45^{\prime \prime} \mathrm{W}$; (map 23). Var. Cape Coongilak, Cape Kungitak, Cape Kungitakh, Reef Cape.

Named by USBF in 1888 . This feature was published by Capt. Tebenkov (1852, map 26, dated 1849), IRN, as "M[ys] Kungitakh," or "Cape Kungitakh," probably derived from its Aleut name.

Reef Point: point of land, W coast of Akutan I., Aleutian Is. ; $54^{\circ} 07^{\prime} 15^{\prime \prime} \mathrm{N}, 166^{\circ} 06^{\prime} 15^{\prime \prime} \mathrm{W}$; (map 23).

This name was published in the 1944 Aleutian Coast Pilot (p. 23).

Reef Point: point of land, between Tlevak Strait and View Cove, on E coast of Dall I., Alex. Arch.; $55^{\circ} 03^{\prime} 35^{\prime \prime} \mathrm{N}, 132^{\circ} 58^{\prime} 15^{\prime \prime} \mathrm{W}$; (map 4).

Descriptive name given in 1881 by Lt. Comdr. Nichols, USN.

Reef Point: point of land, on NE coast of Annette I., Alex. Arch.; 55 ${ }^{\circ} 15^{\prime} 00^{\prime \prime} \mathrm{N}, 131^{\circ} 28^{\prime}$ $30^{\prime \prime} \mathrm{W}$; (map 3$)$.

Descriptive name given in 1883 by Lt. Comdr. H. E. Nichols, USN. 
Reef Point: point of land, $0.7 \mathrm{mi}$. N of Arrecife Point, on SE coast of Lulu I., Alex. Arch.; $55^{\circ} 27^{\prime} 45^{\prime \prime} \mathrm{N}, 133^{\circ} 25^{\prime} 30^{\prime \prime} \mathrm{W}$; (map 4). Var. Arrecite Point, Mys del Arresife, Punta del Arecite, Punta del Arrecife.

Translation in 1923 by USC\&GS of the name "Punta del Arrecife"; given in 1775-79 by Don Juan de la Bodega y Quadra and Francisco Antonio Maurelle.

Reef Point: point of land, on E side of Albatross Anchorage, $14 \mathrm{mi}$. N of Unga I., Alaska Penin., Aleutian Ra.; 55 $34^{\prime} 30^{\prime \prime} \mathrm{N}, 160^{\circ} 35^{\prime}$ $30^{\prime \prime} \mathrm{W}$; (map 28).

This name was published in 1893 by U.S. Navy Hydrog. Office.

Reef Point: point of land, on SW coast of Woronkofski I., Alex. Arch.; $56^{\circ} 21^{\prime} 30^{\prime \prime} \mathrm{N}$, $132^{\circ} 32^{\prime} 30^{\prime \prime} \mathrm{W}$; (map 6).

Named in 1886 by Lt. Comdr. A. S. Snow, USN; name published in 1887. on USC\&GS Chart 706.

Reef Point: point of land, on S tip of St. Paul I., Pribilof Is.; $57^{\circ} 06^{\prime} 30^{\prime \prime} \mathrm{N}, 170^{\circ} 17^{\prime} 30^{\prime \prime} \mathrm{W}$; (map 38).

Local name published in 1875 by USC\&GS. Reef Point: point of land, see Mosman Point.

Reef Point: point of land, see Sakic Point.

Reef Point Lake: lake, $5 \mathrm{mi}$. long, near $\mathrm{W}$ bank of Portland Canal, $1.5 \mathrm{mi}$. W of Reef I., Coast Mts.; $5^{\circ} 05^{\prime} 00^{\prime \prime} \mathrm{N}, 130^{\circ} 15^{\prime} 30^{\prime \prime} \mathrm{W}$; (map 3).

Local name recorded in 1955 by USGS.

Reef Rock: rock, $200 \mathrm{ft}$. across, in central Redfish Bay, $9.8 \mathrm{mi}$. NW of village of Port Alexander, on S coast of Baranof I., Alex. Arch.; $56^{\circ} 19^{\prime} 05^{\prime \prime} \mathrm{N}, 134^{\circ} 52^{\prime} 00^{\prime \prime} \mathrm{W}$; (map 5).

Named in 1897 by Lt. Comdr. J. F. Moser, USN Commander of USBF steamer Albatross.

Reef Rookery: rookery, on Reef Point, on $\mathbf{S}$ coast of St. Paul I., in Pribilof Is.; 5 $7^{\circ} 06^{\prime} 30^{\prime \prime}$ $\mathrm{N}, 170^{\circ} 17^{\prime} 30^{\prime \prime} \mathrm{W}$; (map 38 ).

Local name for a seal rookery with 4,016 $\mathrm{ft}$. of sea-margin (Elliott, 1881, p. 50-51). See Ardiguen Rookery.

Reef Shoal: shoal, $0.1 \mathrm{mi}$. long, in central Redfish Bay, $9.8 \mathrm{mi}$. NW of village of Port Alexander, on $\mathrm{S}$ coast of Baranof I., Alex. Arch.; $56^{\circ} 19^{\prime} \mathrm{N}, 134^{\circ} 52^{\prime} \mathrm{W}$; (map 5).

Named in 1897 by Lt. Comdr. J. F. Moser, USN, commander of USBF steamer Albatross.

Rees: area, in S part of Anchorage, between East Chester and Lindale, Cook Inlet Low.; $61^{\circ} 12^{\prime} 18^{\prime \prime} \mathrm{N}, 149^{\circ} 51^{\prime} 30^{\prime \prime} \mathrm{W}$; (map 69).

Local name reported in 1954 by the city engineer of Anchorage.

Reese Bay: bay, $1.3 \mathrm{mi}$. across, $\mathrm{N}$ coast of Unalaska I., Aleutian Is.; $54^{\circ} 00^{\prime} 15^{\prime \prime} \mathrm{N}, 164^{\circ} 43^{\prime}$ 00" W; BGN 1937; (map 23). Var. Sakhtusik Bay.

Named by USC\&GS in 1937 in honor of Lt. Marshall Reese, USC\&GS, who drowned in this bay in 1936 while making a survey of the coast. Lt. G. A. Sarichev, IRN, is supposed to have published the name "Sakhtusik" for this feature in 1802.

Reflection Lake: lake, $4.5 \mathrm{mi}$. long, $5 \mathrm{mi}$. W of Eagle Lake, $10 \mathrm{mi}$. S of Bradfield Canal,
Alex. Arch.; $56^{\circ} 02^{\prime} 00^{\prime \prime} \mathrm{N}, 131^{\circ} 35^{\prime} 30^{\prime \prime} \mathrm{W}$; BGN 1923; (map 7).

Descriptive name given in 1923 by USFS. Refuge, Port : bay, see Refugio, Port.

Refuge Cove: village, pop. 146, on Refuge Cove, $0.4 \mathrm{mi}$. W of Wacker, on the SW coast of

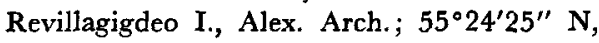
$131^{\circ} 44^{\prime} 30^{\prime \prime} \mathrm{W}$; (map 3).

Relatively recent village presently without a post office.

Refuge Cove: cove, $0.5 \mathrm{mi}$. across, on $\mathrm{SW}$ coast of Revillagigedo I., off Tongass Narrows, W of Ward Cove, Alex. Arch.; $55^{\circ} 24^{\prime} \mathrm{N}, 131^{\circ} 45^{\prime}$ W; (map 3 ).

Local name published in 1886 by USC\&GS. Refuge Inlet: estuary, see Walakpa Bay.

Refuge Island: island, $150 \mathrm{ft}$. across, in Chiniak Bay S of Long I., NE of Kodiak I.; 57 $44^{\prime} 50^{\prime \prime}$ $\mathrm{N}, 152^{\circ} 17^{\prime} 50^{\prime \prime} \mathrm{W} ; B G N$ 1935; (map 34). Var. Ostrov Ubezhisheha, Poverty Island, Poverty Rock, Ubezhitsha.

Translation of the name "Os[trov] Ubezhishcha," published by Sarichev (1826, map 16). Baker (1906, p. 509) translated the name as "Poverty Island," and USC\&GS corrected this erroneous translation in 1935, with "named by the Russians because the islet was used as a place of refuge for the women and children by the natives while the warriors were doing battle with invading tribes."

Refuge Valley: valley, $5 \mathrm{mi}$. long, at head of Sanctuary River, $26 \mathrm{mi}$. SSW of Healy, Alaska Ra.; $63^{\circ} 31^{\prime} \mathrm{N}, 149^{\circ} 20^{\prime} \mathrm{W}$; (map 87). Local name reported in 1949 by USGS.

Refugio, Port: bay, extends SW $2.5 \mathrm{mi}$. off Ulloa Channel on NE coast of Suemez I., Alex. Arch.; $55^{\circ} 18^{\prime} \mathrm{N}, 133^{\circ} 18^{\prime} \mathrm{W}$; (map 4). Var. Gavan Refugio, Port Refuge, Puerto del Refugio.

Named "Puerto del Refugio," meaning "port of refuge," on June 3, 1779, by Fran"cisco Antonio Maurelle (Wagner, 1937, p. 405).

Regal Glacier: glacier, trends SE $9 \mathrm{mi}$. from Mount Regal to Nizina Glacier, $23 \mathrm{mi}$. NE of McCarthy, Wrangell Mts.; $61^{\circ} 40^{\prime} \mathrm{N}, 142^{\circ} 29^{\prime}$ W; (map 67).

Named in 1900 by F. C. Schrader, USGS.

Regal Mountain: mountain, 13,845 ft., at head of Regal Glacier, $23 \mathrm{mi}$. N of McCarthy, Wrangell Mts.; $61^{\circ} 45^{\prime} \mathrm{N}, 1^{\circ} 142^{\circ} 52^{\prime} \mathrm{W}$; (map 67).

Name reported in 1899 by Rohn (1900, p. 411), USGS.

Regina Cove: bay, $0.5 \mathrm{mi}$. across, on $\mathrm{SE}$ coast of Fillmore I., Coast Mts.; 54 $48^{\prime} 15^{\prime \prime} \mathrm{N}$, $130^{\circ} 33^{\prime} 30^{\prime \prime}$ W; BGN 1937; (map 2).

Local name published in 1943 by USC\&GS. Rehin Creek: stream, see Rhine Creek.

Reid, Mount: mountain, 4,592 ft., $5.8 \mathrm{mi}$. NE of head of Carroll Inlet, on Revillagigedo I., Alex. Arch.; 55 $42^{\prime} 28^{\prime \prime}$ N, $131^{\circ} 14^{\prime} 45^{\prime \prime}$. W; $B G N$ 1931; (map 3)

Named in 1931 by USGS for "Thomas George Reid, USN, Chief Aviation Pilot of the First Naval Aerial Survey Expedition to Alaska in 1926."
Reid Bay: bay, 2 mi. across, $10 \mathrm{mi}$. W of Point Baker, on the E coast of Kuiu I., Alex. Arch.; $56^{\circ} 22^{\prime} 30^{\prime \prime} \mathrm{N}, 133^{\circ} 52^{\prime} 30^{\prime \prime} \mathrm{W}$; (map 6). Var. Reids Bay.

Named in 1886 by Lt. J. M. Helm, USN, probably for Ensign Maurice Lance Reid, USN, a member of his party.

Reid Falls: falls, $1.9 \mathrm{mi}$. W of Twin Dewey Peaks and $1.5 \mathrm{mi}$. NE of Skagway, Coast Mts.; $59^{\circ} 28^{\prime} 25^{\prime \prime} \mathrm{N}, 1^{\circ} 5^{\circ} 17^{\prime} 00^{\prime \prime} \mathrm{W}$; (map 45).

Local name obtained by USGS field personnel and published on Federal maps since 1950.

Reid Glacier: glacier, heads $2 \mathrm{mi}$. SW of Contact Nunatak, trends $\mathrm{N} 11 \mathrm{mi}$. to Reid Inlet, 2 mi. S of Glacier Bay, in Glacier Bay National Monument, $72 \mathrm{mi}$. NW of Hoonah, St. Elias Mts.; $58^{\circ} 50^{\prime} 40^{\prime \prime} \mathrm{N}, 136^{\circ} 48^{\prime} 30^{\prime \prime} \mathrm{W}$; (map 10).

Named by members of the Harriman Expedition in 1899 (Gilbert, 1910, v. 3, p. 25) for Harry Fielding Reid, 1859-1943, geologist and professor at the Case School of Applied Sciences and Johns Hopkins University, who visited Glacier Bay in 1890 and 1892, and made a study of the glaciers in the area.

Reid Inlet: $b a y$, heads at terminus (1961) of Reid Glacier, and trends $2.4 \mathrm{mi}$. $\mathrm{N}$ to Glacier Bay, S of Russell I., Glacier Bay National Monument, $73 \mathrm{mi}$. NW of Hoonah, St. Elias Mts.; $58^{\circ} 52^{\prime} 30^{\prime \prime} \mathrm{N}, 136^{\circ} 48^{\prime} 30^{\prime \prime} \mathrm{W}$; $B G N$ 1954; (map 10).

Named in 1893 for Harry Fielding Reid, 1859-1943, by the American Association for the Advancement of Science. Reid, geologist and professor at the Case School of Applied Sciences and Johns Hopkins University, visited Glacier Bay in 1890 and 1892. At that time the name, "Reid Inlet", was applied to the upper end of Glacier Bay east of Russell I., which was the terminus of the Grand Pacific and Johns Hopkins Glaciers. Subsequently, these glaciers have retreated, uncovering Tarr and Johns Hopkins Inlets. Reid Glacier has also retreated from the valley it formerly occupied to form another inlet. The name "Reid Inlet" is now restricted to this feature.

Reid Inlet: estuary, see Johns Hopkins Inlet. Reids Bay: bay, see Reid Bay.

Reihn Creek: stream, see Rhine Creek .

Reilly, Mount: mountain, see Seltat, Mount.

Reindeer Bay: bight, $1.5 \mathrm{mi}$. across, on $\mathrm{S}$ shore of Iliamna Lake, $30 \mathrm{mi}$. SW of Iliamna, Bristol Bay Low.; $59^{\circ} 23^{\prime} \mathrm{N}, 155^{\circ} 20^{\prime} \mathrm{W}$; (map 51 ).

Local name published in 1951 by USGS.

Reindeer Cove: cove, on Norton Bay, $17 \mathrm{mi}$. SW

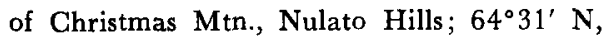
$161^{\circ} 10^{\prime} \mathrm{W}$; (map 96).

Local name published in 1943 by USC\&GS

Reindeer Creek: stream, $12 \mathrm{mi}$. long, on N side of Alaska Penin., flows W to Bristol Bay, 170 mi. SE of Cape Newenham, Bristol Bay Low.; $57^{\circ} 01^{\prime} \mathrm{N}, 158^{\circ} 41^{\prime} \mathrm{W}$; (map 37 ).

Name reported in 1923 by R. H. Sargent, USGS. 
Reindeer Creek: stream, flows E 2 mi. to Marsh Creek, at Otter Bight, NE coast of Umnak Island N of Fort Glenn, Aleutian Is. ; $57^{\circ} 25^{\prime}$ $40^{\prime \prime}$ N, $167^{\circ} 51^{\prime} 50^{\prime \prime}$ W; (map 23). Var. Falls Creek.

Name reported in 1942 as Falls Creek by U.S. Army Corps of Engineers and published as Reindeer Creek by USGS (Byers, 1959, pl. 41).

Reindeer Creek: stream, in Kokrines Hills, flows NW $6.8 \mathrm{mi}$. to Hot Springs Creek, $27 \mathrm{mi}$. WNW of Birches, Kokrines-Hodzana High.; $65^{\circ} 13^{\prime} 25^{\prime \prime} \mathrm{N}, 154^{\circ} 27^{\prime} 40^{\prime \prime} \mathrm{W}$; (map 107).

Local name obtained in 1954 by USGS topographers.

Reindeer Creek: stream, flows SW $2 \mathrm{mi}$. to lake on coast of Port Clarence, $1 \mathrm{mi}$. NW of Teller Mission and $7 \mathrm{mi}$. NW of Teller, Seward Penin. High.; $65^{\circ} 21^{\prime} \mathrm{N}, 166^{\circ} 29^{\prime} \mathrm{W}$; (map 111).

Prospectors' name reported on the 1908 "Map of Seward Peninsula" by Arthur Gibson.

Reindeer Creek: stream, heads in Rampart Mts., flows NW $13 \mathrm{mi}$. to Tozitna River, $19 \mathrm{mi}$. NW of Tanana, Kokrines-Hodzana High.; $65^{\circ} 26^{\prime}$ $\mathrm{N}, 152^{\circ} 18^{\prime} \mathrm{W}$; (map 106).

Local name reported in 1956 by Orth; so named because a reindeer corral was located here about 50 years ago.

Reindeer Creek: stream, flows NW $9 \mathrm{mi}$. to Schlitz Greek which flows to Serpentine River, $7 \mathrm{mi}$. NW of Midnight Mtn. and $50 \mathrm{mi}$. NW of Imuruk Lake, Seward Penin. High.; $65^{\circ} 50^{\prime}$ $\mathrm{N}, 164^{\circ} 50^{\prime} \mathrm{W}$; (map 110).

Prospectors' name reported in 1901 by T. G. Gerdine (in Collier, 1902, pl. 12), USGS.

Reindeer Creek: stream, flows SW $4.8 \mathrm{mi}$. to Kugruk River, $27 \mathrm{mi}$. NE of Imuruk Lake, Seward Penin. High.; $65^{\circ} 51^{\prime}$ N, $162^{\circ} 26^{\prime}$ W; (map 110).

Prospectors' name reported in 1901 by D. L. Reaburn (in Mendenhall, 1902, pl. 4a), USGS.

Reindeer Creek: stream, on Seward Penin., flows NW $5 \mathrm{mi}$. to Clifford Creek, $22 \mathrm{mi}$. SW of Deering, Kotzebue-Kobuk Low.; $66^{\circ} 03^{\prime} \mathrm{N}$, $163^{\circ} 29^{\prime} \mathrm{W}$; (map 113).

Name used by local prospectors; reported in 1901 by W. C. Mendenhall, USGS.

Reindeer Hill: hill, 2,485 ft., near SW end of Kantishna Hills, $5.5 \mathrm{mi}$. NW of Wonder Lake, Alaska Ra.; $63^{\circ} 32^{\prime} 45^{\prime \prime} \mathrm{N}, 151^{\circ} 01^{\prime} 45^{\prime \prime} \mathrm{W}$; $B G N$ 1932; (map 88).

Local name reported in 1932 by F. G. Wells and S. C. Kain, USGS.

Reindeer Hill: hill, $490 \mathrm{ft}$., at Cape Nome, 13 mi. SE of Nome and $18 \mathrm{mi}$. SW of Solomon, Seward Penin. High.; $64^{\circ} 28^{\prime}$ N, $165^{\circ} 00^{\prime} \mathrm{W}$; (map 95).

Local name published in 1900 by USC\&GS.

Reindeer Hills: mountains, 4,534 ft., trend SW 8 mi. from junc. of Bruskana Creek and Nenana River, $32 \mathrm{mi}$. SE of Healy, Talkeetna Mts.; $63^{\circ} 25^{\prime} \mathrm{N}, 148^{\circ} 46^{\prime} \mathrm{W}$; (map 87).

Local name obtained in 1951 by USGS.
Reindeer Hills: hills, $967 \mathrm{ft}$, trend NNE-SSW $11 \mathrm{mi}$. between Norton Bay and Norton Sound, Nulato Hills; $64^{\circ} 30^{\prime} \mathrm{N}, 161^{\circ} 24^{\prime} \mathrm{W}$; (map 96).

Local name reported in 1900 by W. J. Peters, USGS.

Reindeer Island: island, $1.7 \mathrm{mi}$. long, in Kakhonak Bay, $24 \mathrm{mi}$. SE of Iliamna, Aleutian Ra.; $59^{\circ} 27^{\prime}$ N, $154^{\circ} 36^{\prime} \mathrm{W}$; (map 51 ).

Local name published in 1951 by USGS.

Reindeer Island: barrier island, $2 \mathrm{mi}$. long, westernmost island of Midway Is., on Beaufort Sea coast, $18.5 \mathrm{mi}$. E of Beechey Point, Arctic Plain; $70^{\circ} 29^{\prime} \mathrm{N}, 148^{\circ} 20^{\prime} \mathrm{W}$; (map 150).

So named in 1910 by Leffingwell (1919, p. 98), "after the whale ship Reindeer, which was wrecked in the vicinity."

Reindeer Lake: lake, $1.5 \mathrm{mi}$. long, $6 \mathrm{mi}$. W of Kukaklek Lake and $49 \mathrm{mi}$. SW of Iliamna, Aleutian Ra.; $59^{\circ} 10^{\prime} \mathrm{N}, 155^{\circ} 42^{\prime}$. W; (map 51).

Local name published by USGS in 1951 .

Reindeer Lake: lake, $5 \mathrm{mi}$. long, in course of Reindeer River $1.5 \mathrm{mi}$. E of its junc. with Paimiut Slough and $11 \mathrm{mi}$. E of Holy Cross, Innoko Low.; $62^{\circ} 08^{\prime} \mathrm{N}, 159^{\circ} 23^{\prime} \mathrm{W}$; (map 78).

Local name obtained in 1952 by USGS.

Reindeer Lake: lake, $5 \mathrm{mi}$. long, $3 \mathrm{mi}$. W of Dease Inlet and $25 \mathrm{mi}$. SE of Barrow, Arctic Plain; $71^{\circ} 07^{\prime} \mathrm{N}, 155^{\circ} 42^{\prime} \mathrm{W}$; (map 153). Var. Rein Deer Lake.

Named Rein Deer Lake by Simpson (1843, map) in 1837.

Reindeer Point: point of land, on $\mathbf{N}$ coast of Umnak I., Aleutian Is.; 53 $32^{\prime} 45^{\prime \prime} \mathrm{N}$, 168 $09^{\prime} 15^{\prime \prime} \mathrm{W}$; BGN 1940; (map 22).

Named in 1938 by USC\&GS, "because of the herds of reindeer frequently seen in this locality."

Reindeer Point: village, see Elephant Point.

Reindeer River: stream, probable anabranch of Yukon River, heads $4.5 \mathrm{mi}$. S of Blade $\mathrm{I}$. at $61^{\circ} 31^{\prime} \mathrm{N}, 161^{\circ} 54^{\prime} \mathrm{W}$, flows NW $60 \mathrm{mi}$. to Yukon River at Dogtooth Bend, $19 \mathrm{mi}$. W of Marshall, Yukon-Kuskokwim Delta ; 61 ${ }^{\circ} 54^{\prime} \mathrm{N}$, $162^{\circ} 40^{\prime} \mathrm{W}$; (map 74). Var. Nookak River.

Local name reported by USGS in 1916. USC\&GS gives the Eskimo name "Nookak" for this stream. So called because reindeer were corralled near its mouth about 1900 .

Reindeer River: stream, heads at $62^{\circ} 15^{\prime} \mathrm{N}$, $158^{\circ} 28^{\prime} \mathrm{W}$, flows SW $65 \mathrm{mi}$. through Reindeer Lake to Paimiut Slough, $11 \mathrm{mi}$. SE of Holy Cross, Innoko Low.; $62^{\circ} 08^{\prime} \mathrm{N}, 159^{\circ} 27^{\prime} \mathrm{W}$; (map 78).

Local name reported in 1910 by A. G. Maddren (in Brooks, 1911, pl. 11), USGS.

Reindeer Slough: stream, anabranch, trends $\mathbf{S}$ $7 \mathrm{mi}$. from Kuskokwim River to Kisaralik River, $21 \mathrm{mi}$. NE of Bethel, Yukon-Kuskokwim Delta ; 6052' N, $161^{\circ} 09^{\prime} \mathrm{W}$; (map 59).

Local name reported in 1949 by USGS.

Reindeer Slough: watercourse, see Twelvemile Slough.

Reinhart Creek: stream, in Kantishna Hills, flows E $1.1 \mathrm{mi}$. from Brooker Mtn. to Eldorado Creek, $4 \mathrm{mi}$. W of Wonder Lake, Alaska
Ra.; $63^{\circ} 30^{\prime} 15^{\prime \prime}$ N, $151^{\circ} 01^{\prime} 00^{\prime \prime}$ W; (map 88).

Named in 1932 by UCGS.

Reliance Creek: stream, flows SW to Arctic Creek which flows to Cripple River, about 29 mi. NW of Nome, Seward Penin. High.; (map 94).

Prospectors' name reported on the 1900 "Map of Nome Peninsula" by J. M. Davidson and B. D. Blakeslee; this feature has not been positively identified.

Reliance Point: point of land, SE tip of Tigvariak I., at W point of entrance to Mikkelsen Bay, on Beaufort Sea coast, Arctic Plain; $70^{\circ} 12^{\prime} 32^{\prime \prime} \mathrm{N}, 147^{\circ} 10^{\prime} 15^{\prime \prime} \mathrm{W}$; (map 150).Var. Lion and Reliance Reef, Lion Reef, Point Reliance.

On Aug. 7, 1826, Franklin, RN (1828, p. 152) named the island "Lion and Reliance Reef," after his two boats. The Lion had been driven aground at this place. E. de $\mathbf{K}$. Leffingwill (1919, p. 89) adopted the Eskimo name Tigvariak for the island, and, in his text, applied Franklin's names to the NE [Point Reliance] and NW [Point Lion] points of the island. His maps, however, show these points as Reliance Point and Lion Point. A sandspit has extended the island in recent years, and the application of the name "Reliance Point" now extends one mile S of Leffingwell's location.

Remedios, Point: point of land, on NW coast of Suemez I., W point of entrance to Port Dolores, Alex. Arch.; $55^{\circ} 19^{\prime} 45^{\prime \prime} \mathrm{N}, 133^{\circ} 26^{\prime} 00^{\prime \prime}$ W; (map 4). Var. Mys de los Remedios, Punta de los Remedios.

Named, "Punta de los Remedios," meaning "point of the remedies," given in 177579 by Don Juan de la Bodega y Quadra and Francisco Antonio Maurelle. "Bodega [y Quadra] carried a bronze image of Nuestra Señora de los Remedios on this voyage and perhaps the name was given in her honor, or perhaps after his ship the Favorita, of which the real name was Nuestra Señora de los Remedios" (Wagner, 1937, p. 405).

Remedios, Puerto de los: cove, see Sealion Cove. Remedios, Puerto de los: water passage, see Salisbury Sound.

Remington Creek: stream, flows SE $1 \mathrm{mi}$ to Casadepaga River, $0.5 \mathrm{mi}$. SE of Casadepaga and $17 \mathrm{mi}$. $\mathrm{N}$ of Solomon, Seward Penin. High.; $64^{\circ} 47^{\prime} 30^{\prime \prime} \mathrm{N}, 164^{\circ} 22^{\prime} 05^{\prime \prime} \mathrm{W}$; (map 95)

Prospectors' name reported in 1907 by USGS geologists (Smith, P. S., 1910, pl. 4).

Renard Island: island, $3.4 \mathrm{mi}$. long, between Resurrection Bay and Eldorado Narrows, 14 mi. SE of Seward, Chugach Mts.; $59^{\circ} 55^{\prime} \mathrm{N}$, $149^{\circ} 20^{\prime}$ W; BGN 1906; (map 49). Var. Fox Island, Lowell Island.

USGS reported the local name in 1904 as "Lowell Island," and USC\&GS gave the local name as "Fox Island" in 1905. Because both these names "are much duplicated" the BGN officially bestowed the present name in 1906; it means "fox" in French.

Renards, Iles aux: island, see Fox Islands. 
Rendezvous Peak: peak, 4,000 ft., $3.5 \mathrm{mi}$. SW of junc. of Eagle River and its South Fork, $13 \mathrm{mi}$. NE of Anchorage, Chugach Mts.; $61^{\circ} 15^{\prime} 00^{\prime} \mathrm{N}, 149^{\circ} 30^{\prime} 15^{\prime} \mathrm{W}$; $B G N$ 1964; (map 69).

Local name reported in 1963 by members of the Mountaineering Club of Alaska; derived from nearby Rendezvous Bowl.

Rendu Glacier: glacier, heads in British Columbia at $59^{\circ} 13^{\prime} \mathrm{N}, 137^{\circ} 00^{\prime} \mathrm{W}$, trends SE $14 \mathrm{mi}$. to its terminus at head of Rendu Inlet, in Glacier Bay National Monument, $58 \mathrm{mi}$. SW of Skagway, St. Elias Mts.; $59^{\circ} 01^{\prime} 00^{\prime} \mathrm{N}$, $136^{\circ} 42^{\prime} 45^{\prime \prime}$ W; BGN 1901; (map 45). Var. Charpentier Glacier.

Named by H. F. Reid (1896, pl. 90 and p. 431), USGS, for a French glaciologist. It was called "Charpentier Glacier" by the Canadian Boundary Commission.

Rendu Inlet: estuary, in Glacier Bay National Monument, trends SE $10 \mathrm{mi}$. from Rendu Glacier to Glacier Bay, $1 \mathrm{mi}$. NW of Composite I. and $69 \mathrm{mi}$. NW of Hoonah, St. Elias Mts.; $58^{\circ} 54^{\prime} 30^{\prime \prime} \mathrm{N}, 136^{\circ} 36^{\prime} 30^{\prime \prime} \mathrm{W}$; (map 10).

Named in 1892 by Reid (1896, pl. 86 and p. 430), USGS.

Rennies Landing: locality, on S bank of Innoko River 6.4 mi. E of its junc. with Dishna River and $37 \mathrm{mi}$. NW of Ophir, Innoko Low.; $63^{\circ} 36^{\prime} 45^{\prime} \mathrm{N}, 157^{\circ} 04^{\prime} 30^{\prime \prime} \mathrm{W}$; BGN 1965; (map 90). Var. Raineys Landing.

Boat landing with a couple of cabins reported in 1950 by USGS; it is now abandoned.

Renshaw Point: point of land, marks $S$ entrance of Dorenoi Bay, on W shore of Stepovak Bay, near SW end of Alaska Penin., Aleutian Ra. $55^{\circ} 36^{\prime} 30^{\prime \prime} \mathrm{N}, 160^{\circ} 22^{\prime} 00^{\prime \prime} \mathrm{W}$; (map 28).

Named in 1880 by W. H. Dall, USC\&GS.

Repetition Point: point of land, in Kuliliak Bay, on $\mathrm{S}$ coast of Unalaska I., Aleutian Is.; $53^{\circ}$ $27^{\prime} 05^{\prime \prime} \mathrm{N}, 167^{\circ} 02^{\prime} 00^{\prime \prime} \mathrm{W}$; BGN 1939; (map 23).

Named by USC\&GS in 1937 "because the position of the point, dividing the bay into two parts, repeats a feature that is present in almost all the bays of Unalaska Island."

Rescue Harbor: cove, on E coast of Sullivan I., in Lynn Canal, $35 \mathrm{mi}$. $\mathrm{S}$ of Skagway, Coast Mts. ; $58^{\circ} 56^{\prime} \mathrm{N}, 135^{\circ} 18^{\prime} \mathrm{W}$; (map 11). Var. Rescue Roadstead.

So named in 1868 by Comdr. R. W. Meade, USN, because it was here that the American schooner Louisa Downs was wrecked in 1867 and six persons were rescued by the U.S.S. Saginaw, which Meade commanded (IJ.S. Coast and Geodetic Survey, 1891, p. 196)

Rescue Roadstead: cove, see Rescue Harbor.

Research Creek: stream, flows NW $3 \mathrm{mi}$. to Fisher Creek, $20 \mathrm{mi}$. SE of junc. of Charley and Yukon Rivers, Yukon-Tanana High.; $65^{\circ} 02^{\prime} 45^{\prime \prime} \mathrm{N}, 142^{\circ} 32^{\prime} 00^{\prime \prime} \mathrm{W}$; (map 103).

Prospectors' name from an unpublished map by E. J. Chamberlain, dated 1902.

Research Mountain: peak, see Camp 4 Peak. Reservoir Lake: lake, see Peterson Lake.

Reshimosti Island: island, $100 \mathrm{ft}$. across, in Whiting Harbor, in Sitka Sound, $1.2 \mathrm{mi}$. SW of Sitka, Alex. Arch.; 57 $02^{\prime} 44^{\prime \prime}$ N, $135^{\circ} 21^{\prime}-$ 52" W; (map 9). Var. Ostrov Reshitosti.

Russian name meaning "determination," given in 1809 by the navigator Ivan Vasiliev the first; published by Lt. Sarichev (1826, map 19), IRN, as "O[strov] Reshitosti." USC\&GS, in transliterating the name, erroneously kept the Russian " $t$ " which apepars as an English "m."

Reshitosti, Ostrov: island, see Reshimosti Island.

Restless Lake: lake, $0.2 \mathrm{mi}$. across, on northern Kiska I., Aleutian Is.; $52^{\circ} 05^{\prime} 13^{\prime \prime} \mathrm{N}, 177^{\circ}-$ $34^{\prime} 00^{\prime \prime} \mathrm{E}$; (map 14).

An arbitrary name beginning with " $R$ " to correspond to "R" grid used by the U.S. Army for tactical purposes during World War II; published on a 1953 AMS map.

Resurrection, Cape; point of land, on S tip of Resurrection Penin., $19 \mathrm{mi}$. SE of Seward, Chugach Mts.; $59^{\circ} 52^{\prime} \mathrm{N}, 149^{\circ} 17^{\prime} \mathrm{W}$ : (map 49). Var. Point Barwell.

Name published by USG\&GS in 1869 on Chart 20. This is the "Point Barwell" named by Capt. Nathaniel Portlock in December 1787.

Resurrection Bay: estuary, on SE coast Kenai Penin., trends S $24 \mathrm{mi}$. from mouth of Resurrection River at Seward to Harding Gateway and Blying Sound, Chugach Mts.; 59 ${ }^{\circ} 48^{\prime} \mathrm{N}$, $149^{\circ} 30^{\prime}$ W; (map 63). Var. Port Andrews, Voskresenskaia Bay, Voskresenskaya Gavan, Voskresenskaya Guba.

Named "Voskresenskaya Gavan" meaning "Resurrection (Sunday) Harbor" by Alexander Baranov in 1792. It was called "Port Andrews" by Capt. Nathaniel Portlock, in 1787. The first ship to be built in Alaska, the Phoenix, was built here in 1794.

Resurrection Bay: estuary, see Turnagain Arm.

Resurrection Creek: stream, on N end of Kenai Penin., flows N $18 \mathrm{mi}$. to Turnagain Arm at Hope, Chugach Mts.; 60 $55^{\prime} 30^{\prime \prime}$ N, 149 $38^{\prime}$ $45^{\prime \prime}$ W; BGN Sixth Report; (map 63).

Local name reported in 1895 by Becker (1898, map 26), USGS.

Resurrection Peninsula: peninsula, extends S 15 mi. between Resurrection Bay and Day Harbor, on SE coast of Kenai Penin., SE of Seward, Chugach Mts.; 59 52' $25^{\prime \prime}$ N, $149^{\circ}$. $17^{\prime} 30^{\prime \prime} \mathrm{W}$; (map 49).

Named in 1930 by USC\&GS for adjoining Resurrection Bay.

Resurrection River: stream, heads at Upper Russian Lake, flows SE to Resurrection Bay, $1.5 \mathrm{mi}$. NE of Seward, Chugach Mts.; $60^{\circ}$ $07^{\prime} 30^{\prime \prime} \mathrm{N}, 149^{\circ} 23^{\prime} 30^{\prime \prime} \mathrm{W}$; (map 63).

Local name reported in 1904 by Moffit (1906, pl. 2), USGS.

Retaliation Point: point of land, on E shore of Security Bay, on $\mathrm{N}$ coast of Kuiu I., Alex. Arch.; $56^{\circ} 51^{\prime} 30^{\prime \prime} \mathrm{N}, 1^{\circ} 4^{\circ} 20^{\prime} 20^{\prime \prime} \mathrm{W}$; (map 5).

Named in 1869 for charting purposes by Comdr. R. W. Meade, USN, "who in February, 1869, destroyed two Indian villages here because of the murder by the Indians of two white men under circumstances of great brutality."
Retchechnoi: village, see Nikolski.

Retreat, Point: point of land, on $\mathrm{N}$ tip of Mansfield Penin., in Lynn Canal, $2.9 \mathrm{mi}$. N of False Point Retreat and $20 \mathrm{mi}$. NW of Juneau, Alex. Arch.; $58^{\circ} 24^{\prime} 45^{\prime \prime} \mathrm{N}, 134^{\circ} 57^{\prime} 15^{\prime \prime} \mathrm{W}$; (map 11). Var. Mys Ostupleniya, Otstuplenie.

Named in 1794 by Joseph Whidbey, RN, because he was forced to seek safety here from hostile Indians (Wagner, 1937, p. 405).

Retscheschnoj, Mount: mountain, see Recheshnoi, Mount.

Return Creek: stream, flows W $6.8 \mathrm{mi}$. to Montana Creek $5.5 \mathrm{mi}$. S of its junc. with Iditarod River and $40 \mathrm{mi}$. SE of Holy Cross, KilbuckKuskokwim Mts.; 62 $02^{\prime} \mathrm{N}, 1^{158^{\circ}} 33^{\prime} \mathrm{W}$; BGN 1945; (map 79).

"Named by Matt De Courcy, prospector in 1911 and refers to the fact that he intended to return someday to a quicksilver prospect near the head of this creek."

Return Island: island, see Povorotni Island.

Return Islands: barrier islands, extend $13 \mathrm{mi}$. on Beaufort Sea coast, NE of Gwydyr Bay, Arctic Plain; $70^{\circ} 27^{\prime} \mathrm{N}, 148^{\circ} 47^{\prime} \mathrm{W} ; B G N$ 1916; (map 150). Var. Ooliktome Islands, Return Reef, Return Reefs.

The original name "Return Reef" was applied to a single sand island NE of Gwydyr Bay, by Franklin (1828, p. 166), RN, on August 18, 1826, "we quitted Return Reef *** and began to retrace our way toward the Mackenzie." Leffingwell (1919, p. 89) wrote, "The local usage, starting with the later explorers, has been to apply the term Return Reef to the chain of sand islands ***. The term Return Islands has been adopted for this chain on the writer's map." John Kelly's Eskimo vocabulary, 1885-89, lists the Eskimo name "Oo-lik-to-me," meaning "at Oliktok." See Oliktok Point.

Return Mound: pingo, elev. $60 \mathrm{ft}$., on $E$ bank of Kuparuk River, $8 \mathrm{mi}$. SSW of Gwydyr Bay, Arctic Plain; (map 150)

Named and used as a triangulation station by Leffingwell $(1919$, p. 41$)$ in 1911 .

Return Reef: barrier island, see Egg Island.

Return Reef: barrier islands, see Return Islands.

Return Reefs: barrier islands, see Return Islands.

Reveille Hill: hill, $220 \mathrm{ft}$., SW of East Kiska Lake, on northern Kiska I., Aleutian Is.; $52^{\circ} 03^{\prime} 45^{\prime \prime} \mathrm{N}, 177^{\circ} 34^{\prime} 45^{\prime \prime} \mathrm{E}$; (map 14).

An arbitrary name beginning with " $R$ " to correspond to " $R$ " grid used by the U.S. Army for tactical purposes during World War II; published on a 1953 AMS map.

Reverdy Johnson Mountains: mountains, see Reverdy Mountains.

Reverdy Mountains: mountains, 4,500 ft., extend NE $9 \mathrm{mi}$. from Hyder, between Bear and Salmon Rivers, Coast Mts.; $56^{\circ} 00^{\prime} \mathrm{N}, 130^{\circ}$. 00' W; (map 3). Var. Bear River Ridge, Reverdy Johnson Mountains.

Named in 1868 by David Pender, RN. Lt. Comdr. H. E. Nichols, USN, called this feature "Reverdy Johnson Mountains" (U.S. Coast and Geodetic Survey, 1891, p. 78). 
Reversed Glacier: glacier, see Thiel Glacier.

Revillagigedo Channel: water passage, trends NNW $40 \mathrm{mi}$. from Dixon Entrance to Tongass Narrows at Dairy, on $S$ coast of Revillagigedo I., Alex. Arch.; $54^{\circ} 48^{\prime} \mathrm{N}, 131^{\circ} 06^{\prime} \mathrm{W}$ [SE end], $55^{\circ} 17^{\prime} \mathrm{N}, 131^{\circ} 34^{\prime} \mathrm{W}$ [NW end]; $B G N$ 1927; (map 3). Var. Revilla Gigedo Channel.

Named in 1792 by Jacinto Caamaño (Wagner, 1937, p. 405). See Revillagigedo Island; Font, Streights du.

Revillagigedo Island: island, $55 \mathrm{mi}$. long and $35 \mathrm{mi}$. wide, between Prince of Wales Island and mainland, Alex. Arch.; $55^{\circ} 35^{\prime} \mathrm{N}, 131^{\circ}$ $20^{\prime \prime}$ W; BGN 1927; (map 3).

Named August 13, 1793, by Capt. Vancouver, RN, for Don Juan Vicente de Guemes Pacheco de Pedilla, Count of Revilla Gigedo and Viceroy of Mexico, 1789-94. "He [Vancouver] was no doubt influenced by the fact that Caamaño the year before had given the name to an adjoining channel" (Wagner, 1937, p. 405).

Revine Creek: stream, flows NW $13 \mathrm{mi}$. to Yanert Fork, $16 \mathrm{mi}$. SE of Healy, Alaska Ra.; $63^{\circ} 40^{\prime} \mathrm{N}, 148^{\circ} 40^{\prime} \mathrm{W}$; (map 87).

Named in 1902 by A. H. Brooks, USGS, for George Revine, cook of his survey party that year.

Revolt Hill: hill, $140 \mathrm{ft}$., between East Kiska and Christina Lakes, Kiska I., Aleutian Is.; $52^{\circ} 04^{\prime} 35^{\prime \prime} \mathrm{N}, 177^{\circ} 34^{\prime} 16^{\prime \prime} \mathrm{E}$; (map 14).

An arbitrary name beginning with " $R$ " to correspond to "R" grid used by the U.S. Army for tactical purposes during World War II; published on a 1953 AMS map.

Rex: railroad station, on The Alaska RR. 48 mi. SW of Nenana, Tanana Low.; $64^{\circ} 14^{\prime} \mathrm{N}$, $149^{\circ} 15^{\prime}$ W; BGN 1944; (map 100). Var. Kobe, Kobi.

Name derived from Rex Dome 10 miles southeast of the station. The place was called "Kobi" on a 1925 Alaska Road Commission map.

Rex Creek: stream, formed by its North and South Forks, flows SE $2.7 \mathrm{mi}$. to Dry Bay, on E coast of Masha Penin., $49 \mathrm{mi}$. W of Karluk, Aleutian Ra.; $57^{\circ} 38^{\prime} 30^{\prime \prime} \mathrm{N}, 155^{\circ} 46^{\prime} 20^{\prime \prime} \mathrm{W}$; (map 35).

Local name obtained from J. L. McPherson of Iliamna, reported in 1903, and published by Martin (1905, p. 53), USGS.

Rex Creek: stream, flows $6 \mathrm{mi}$. SW from Rex Glacier joining White Creek to form Chititu Creek, 15 mi. SE of McCarthy, St. Elias Mts.; $61^{\circ} 17^{\prime} 35^{\prime \prime} \mathrm{N}, 142^{\circ} 34^{\prime} 40^{\prime \prime} \mathrm{W}$; (map 67).

Local name reported in 1908 by D. C. Witherspoon, USGS (Moffit and Capps, 1911, pl. 2). Reported as "Rex Gulch" by G. M. Esterly, of Valdez, in 1902 (Mendenhall, 1905, fig. 11).

Rex Creek: stream, heads in Candle Hills, flows N $2.6 \mathrm{mi}$. to Tatalina River, $10 \mathrm{mi}$. SW of McGrath, Kilbuck-Kuskokwim Mts.; 62 ${ }^{\circ} 54^{\prime}$ N, $155^{\circ} 54^{\prime} \mathrm{W}$; (map 80 )

Local name reported in 1910 by C. G. Anderson (in Eakin, 1914, pl. 1), USGS.
Rex Creek: stream, flows NE $6 \mathrm{mi}$. to California Creek, $5 \mathrm{mi}$. E of Rex Dome and $50 \mathrm{mi}$. SE of Nenana, Alaska Ra. ; $64^{\circ} 07^{\prime} \mathrm{N}, 148^{\circ} 45^{\prime} \mathrm{W}$; (map 100).

Named by prospectors; reported in 1906 by L. M. Prindle (in Brooks and others, 1907, pl. 4), USGS.

Rex Creek: stream, flows SE $3 \mathrm{mi}$. to Smallwood Creek, $10 \mathrm{mi}$. NE of Fairbanks, Yukon-Tanana High.; $64^{\circ} 55^{\prime} 30^{\prime \prime} \mathrm{N}, 147^{\circ} 21^{\prime} 00^{\prime \prime} \mathrm{W}$; (map 100).

Local name published in 1908 by USGS.

Rex Creek: stream, on Seward Penin., flows NE $4.9 \mathrm{mi}$. to Kotzebue Sound, $16 \mathrm{mi}$. W of Deering, Kotzebue-Kobuk Low.; $66^{\circ} 05^{\prime} \mathrm{N}, 163^{\circ}$ $19^{\prime} \mathrm{W}$; (map 113).

Prospectors' name reported in 1901 by W. C. Mendenhall and D. L. Reaburn, USGS.

Rex Dome: mountain, 4,155 ft., between Nenana and Totatlanika Rivers, $30 \mathrm{mi}$. S of Nenana, Alaska Ra.; $64^{\circ} 07^{\prime} 50^{\prime \prime} \mathrm{N}, 148^{\circ} 54^{\prime} 00^{\prime \prime} \mathrm{W}$; BGN 1944; (map 100).

Name derived from Rex Creek; reported in 1910 by USGS (Capps, 1912, pl. 1).

Rex Glacier: glacier, trends $1.2 \mathrm{mi}$. NW from Andrus Peak to its terminus at head of Rex Creek, $18 \mathrm{mi}$. SE of McCarthy, St. Elias Mts.; $61^{\circ} 19^{\prime} 00^{\prime \prime} \mathrm{N}, 142^{\circ} 27^{\prime} 40^{\prime \prime} \mathrm{W}$; (map 67).

Local name obtained by USGS and published on maps since 1954 .

Rex Hill: hill, 1,000 ft., $1.3 \mathrm{mi}$. N of Salmon Lagoon, Kiska I., Aleutian Is.; $52^{\circ} 01^{\prime} 15^{\prime \prime} \mathrm{N}$, $177^{\circ} 32^{\prime} 20^{\prime \prime} \mathrm{E}$; (map 14).

An arbitrary name beginning with ' $R$ ' to correspond to "R" grid used by the U.S. Army for tactical purposes during World War II; published on a 1953 AMS map.

Rex Point: point of land, on Seward Penin., extends into Kotzebue Sound, $17 \mathrm{mi}$. W of Deering, Kotzebuk-Kobuk Low.; $66^{\circ} 05^{\prime} \mathrm{N}$, $163^{\circ} 20^{\prime} \mathrm{W}$; (map 113).

Local name reported in 1950 by USGS; derived from nearby Rex Creek.

Reynard Cove: cove, $0.4 \mathrm{mi}$. across, on $\mathrm{E}$ coast of Kiska I., Aleutian Is.; $52^{\circ} 01^{\prime} 25^{\prime \prime} \mathrm{N}, 177^{\circ}$ $36^{\prime} 00^{\prime \prime} \mathrm{E} ; B G N$ 1937; (map 14).

Local name found on a plotting sheet by USC\&GS

Reynard Creek: stream, flows N $11 \mathrm{mi}$. to Colville River, $7 \mathrm{mi}$. S of Lookout Ridge and 112 mi. S of Wainwright, Arctic Slope ; 69 $01^{\prime} 15^{\prime \prime}$ $\mathrm{N}, 1^{\circ} 9^{\circ} 28^{\prime} 00^{\prime \prime} \mathrm{W}$; BGN 1925; (map 144).

So named by W. T. Foran, USGS, in 1924, "because of the number of foxes seen in its basin."

Reynolds Creek: stream, heads in Summit Lake, flows SW $3 \mathrm{mi}$. through Lake Mellen to Copper Harbor, near head of Hetta Inlet, on SW coast of Prince of Wales I., Alex. Arch.; 55 $12^{\prime} 50^{\prime \prime} \mathrm{N}, 132^{\circ} 36^{\prime} 15^{\prime \prime} \mathrm{W}$; (map 4).

Local name reported in 1908 by C. W. Wright (in Brooks and others, 1909, pl. 3), USGS.

Reynolds Creek: stream, flows SE $1 \mathrm{mi}$. to Landlocked Bay, $35 \mathrm{mi}$. NW of Cordova, Chugach Mts.; $60^{\circ} 51^{\prime} 30^{\prime \prime} \mathrm{N}, 146^{\circ} 31^{\prime} 30^{\prime \prime} \mathrm{W}$; (map 64).

Local name published in 1952 by USGS.
Reynolds Creek: stream, in Nutzotin Mts., flows $\mathrm{N} 2 \mathrm{mi}$. to East Fork Snag Creek $3.3 \mathrm{mi}$. SE of its junc. with Snag Creek, $9 \mathrm{mi}$. SW of Garden Hills, Alaska Ra.; $62^{\circ} 12^{\prime} 00^{\prime \prime} \mathrm{N}, 141^{\circ}$ 24'35" W; (map 84).

Local name reported in 1959 by USGS.

Reynolds Head: point of land, on $\mathrm{E}$ shore of Morzhovoi Bay, $16 \mathrm{mi}$. SW of village of Cold Bay, at SW end of Alaska Penin., Aleutian Ra.; $55^{\circ} 00^{\prime} 30^{\prime \prime} \mathrm{N}, 162^{\circ} 57^{\prime} 00^{\prime \prime} \mathrm{W}$; (map 29).

Name reported by USC\&GS in 1925.

Reynolds Peak: peak, 1,950 ft., on $\mathbf{E}$ side of Latouche I., at SE end of Broon Buttes, $22 \mathrm{mi}$. $\mathrm{SE}$ of Chenega, Chugach Mts. ; $60^{\circ} 00^{\prime} 35^{\prime \prime} \mathrm{N}$, $147^{\circ} 53^{\prime} 02^{\prime \prime} \mathrm{W}$; (map 63).

Local name reported in 1909 by Grant and Higgins (1910, pl. 12), USGS; name derived from the Reynolds-Alaska Development Company that operated mines in that region.

Reynolds Point: point of land, see Alexander Point.

Rezanof Lake: lake, $3 \mathrm{mi}$. long, $7 \mathrm{mi}$. SE of Whale Bay, on $\mathbf{S}$ central Baranof I., Alex. Arch.; $56^{\circ} 32^{\prime} 30^{\prime \prime} \mathrm{N}, 134^{\circ} 50^{\prime} 00^{\prime \prime} \mathrm{W} ; B G N$ 1933; (map 5).

Named in 1933 by USFS "for Nikolai Petrovich Rezanof, who was instrumental in organizing the Russian American Company in 1799, and who saved the settlement at Sitka from starvation in 1806."

Rhea Rocks: rocks, extend $500 \mathrm{ft}$. between Cordova and Tah Bays, on SW coast of Prince of Wales I., Alex. Arch.; 54 $51^{\prime} \mathrm{N}, 132^{\circ} 21^{\prime} \mathrm{W}$; (map 1).

Named in 1923 by USC\&GS because of the nearby triangulation station "Rhea."

Rhein Creek: stream, see Rhine Creek.

Rhine Creek: stream, flowing SE $4.7 \mathrm{mi}$. to Stephens Passage, $0.7 \mathrm{mi}$. W of Bishop Point and $11 \mathrm{mi}$. SE of Juneau, Coast Mts.; $58^{\circ} 12^{\prime} 30^{\prime \prime}$ N, $134^{\circ} 09^{\prime} 55^{\prime \prime}$ W ; (map 11). Var. Rehin Creek, Reihn Greek, Rhein Creek, Rhinestone Creek.

In 1890 John G. Peterson and "Chris" Fuhr located a claim on this stream which they called Reihn Creek. Since both miners were born in Germany, it is probable that they would have spelled the name "Rhine" if they had meant to name the stream after the Rhine River. It has been thought they may have intended to name the stream after John J. Ryan, a prospector, who had claims near the creek (DeArmond, 1957, p. 36). The names Rhine Creek and Rhein Creek were published by USGS (1916, Brooks and others, pl. 2, and p. 76).

Rhinestone Creek: stream, see Rhine Creek.

Rhino Horn: peak, see Rhino Peak.

Rhino Peak: peak, 6,400 ft., at head of Mendenhall Glacier, $2 \mathrm{mi}$. NE of Mendenhall Towers and $18 \mathrm{mi}$. $\mathrm{N}$ of Juneau, Coast Mts.; $58^{\circ} 33^{\prime} 30^{\prime \prime} \mathrm{N}, 134^{\circ} 26^{\prime} 15^{\prime \prime} \mathrm{W}$; (map 11). Var. Rhino Horn.

Descriptive name published in 1960 by USGS. Members of the Juneau Icefield Research Project have proposed to change the name to Rhino Horn. 
Rhoads Creek: stream, heads near Shovel Point Horn of Granite Mtn., flows NE $18 \mathrm{mi}$. to Granite Creek, $9 \mathrm{mi}$. ESE of Delta Junction, Tanana Low.; $63^{\circ} 59^{\prime} 30^{\prime \prime} \mathrm{N}, 1^{\circ} 5^{\circ} 17^{\prime} 40^{\prime \prime} \mathrm{W}$; (map 86).

Named between 1948 and 1955 by T. L. Péwé, USGS.

Rhode Island Creek: stream, flows SW $7 \mathrm{mi}$. to Omega Creek, $50 \mathrm{mi}$. E of Tanana, YukonTanana High.; $65^{\circ} 07^{\prime} 30^{\prime \prime} \mathrm{N}, 150^{\circ} 20^{\prime} 00^{\prime \prime} \mathrm{W}$; (map 106).

Prospectors' name reported in 1904 by Prindle and Hess (1906, pl. 3), USGS.

Rhode Lake: lake, $1.3 \mathrm{mi}$. long, on Kenai Penin. $W$ of the Finger Lakes, $12 \mathrm{mi}$. NE of Kenai, Cook Inlet Low.; $60^{\circ} 38^{\prime} 10^{\prime \prime} \mathrm{N}, 150^{\circ} 55^{\prime} 40^{\prime \prime}$ W; (map 62).

Named about 1963 by officials of Kenai National Moose Range, for administrative purposes.

Rhododendron Cone: hill, 1,235 ft., $1.5 \mathrm{mi} . \mathrm{S}$ of Imuruk Lake, Seward Penin. High.; 65 $32^{\prime}$ N, $163^{\circ} 09^{\prime} \mathrm{W}$; BGN 1952; (map 110).

Reported in 1950 by D. M. Hopkins, USGS; one of "Four conspicuous volcanic cones*** named for wildflowers which are common on the slopes of all four cones."

Rhumba Creek: stream, in De Long Mts., flows $\mathrm{N} 7 \mathrm{mi}$. to Sorepaw Creek, $62 \mathrm{mi}$. NE of Misheguk Mtn., Brooks Ra.; 68 $46^{\prime} \mathrm{N}$, $159^{\circ} 07^{\prime} \mathrm{W}$; (map 131).

Named by E. G. Sable, USGS, in 1953, "for crooked course of stream."

Rhyolite Creek: stream, in Nutzotin Mts., flows W $2.7 \mathrm{mi}$. to Chathenda Creek $5 \mathrm{mi}$. E of its junc. with Chisana River, Alaska Ra.; $62^{\circ} 03^{\prime} 40^{\prime \prime} \mathrm{N}, 141^{\circ} 57^{\prime} 10^{\prime \prime} \mathrm{W}$; (map 84).

Name reported by S. R. Capps (in Brooks and others, 1916, p. 202), USGS.

Ribdon River: stream, in Philip Smith Mts., flows W $46 \mathrm{mi}$. to Sagavanirktok River, S of Kakuktukruich Bluff, Brooks Ra.; 68 ${ }^{\circ} 49^{\prime}$ N, $148^{\circ} 48^{\prime} \mathrm{W}$; BGN 1960; (map 135). Var. Sagavanirktok River, Shulukpaukat River.

So named by USGS geologists in 1951, "because one of the geologists named Don had a rib injury." The Eskimo name for this stream is "Shukukpaukat" which refers to the "high, steep, sharp mountains" that bound it.

Ribnaia: locality, on right bank of Yukon River, SW of Russian Mission, Yukon-Kuskokwim Delta; 61 ${ }^{\circ} 39^{\prime} \mathrm{N}, 161^{\circ} 30^{\prime} \mathrm{W}$; (map 73). Var. Ruibnaia, Rybniä.

Russian name meaning "fish," for a former Eskimo village reported as "Ruibnai," population 40 , in the 1880 census by Ivan Petroff $(1881$, p. 57) and as "Rybnia" (ibid., 1884, p. 12).

Ribnaia Bay: bay, see Fish Bay.

Ribni, Point: point of land, see Fish Point.

Rice, Mount: mountain, 6,500 ft., in Glacier Bay National Monument, $8 \mathrm{mi}$. NW of Snow Dome and $33 \mathrm{mi}$. SW of Skagway, St. Elias Mts. ; 59 $01^{\prime} 10^{\prime \prime} \mathrm{N}, 135^{\circ} 42^{\prime} 15^{\prime \prime} \mathrm{W}$; (map 45).

Named by the American Geographical Society (Field, 1947, pl. 1) for W. H. Rice, geologist, who visited Muir Inlet in 1913.
Rice Gulch Creek: stream, flows SE $12 \mathrm{mi}$. to Salmon Fork Black River, $32 \mathrm{mi}$. N of Midnight Hill, Porcupine Plat.; $66^{\circ} 31^{\prime} \mathrm{N}, 141^{\circ} 10^{\prime}$ W; (map 120).

Local name obtained in 1956 by T. $E$. Taylor and R. C. Foley, USGS.

Rice Mountain: mountain, $6,600 \mathrm{ft}$., $4.6 \mathrm{mi}$. SW of Tiekel Cache and $34 \mathrm{mi}$. NE of Valdez, Chugach Mts.; $61^{\circ} 21^{\prime} 45^{\prime \prime} \mathrm{N}, 145^{\circ} 21^{\prime} 40^{\prime \prime} \mathrm{W}$; (map 68).

Local name reported in 1900 by F. C. Schrader (in Baker, 1906), USGS. This mountain may be named for quartermaster's clerk John F. Rice, USA, who led a small expedition from Valdez to Eagle City in 1899.

Rice Peak: mountain peak, see Townsend Peak.

Rich, Mount: mountain, $6,180 \mathrm{ft}$., $1.6 \mathrm{mi}$. W of junc. of South Fork Kuskokwim and Styx Rivers, $90 \mathrm{mi}$. NW of Tyonek, Alaska Ra.; $61^{\circ} 54^{\prime} 15^{\prime \prime} \mathrm{N}, 153^{\circ} 14^{\prime} 00^{\prime \prime} \mathrm{W}$; (map 71).

Named in 1898 by J. E. Spurr and W. S. Post, USGS.

Richards Camp: locality, on right bank of Koyukuk River, $8 \mathrm{mi}$. NE of Roundabout Mtn., Koyukuk Low.; $65^{\circ} 40^{\prime} \mathrm{N}, 156^{\circ} 28^{\prime} \mathrm{W}$; (map 108).

Local name obtained at Huslia by USGS in 1954 or 1955.

Richardson: locality, on right bank of Tanana River, $18 \mathrm{mi}$. NW of Big Delta, Tanana Low.; $64^{\circ} 17^{\prime} \mathrm{N}, 146^{\circ} 20^{\prime} \mathrm{W}$; (map 101). Var. Richardson Roadhouse, Richardson Telegraph Station.

Former village and post office established in 1906 and named for Major Wilds P. Richardson, USA, first President of the Board of the ARC, who "established a sled road between Valdez on the coast, and Fairbanks, the largest settlement in the interior, a distance of 370 miles." (Brooks, 1953, p. 425-436). Eventually, the Tanana River changed its course and the erosive effects forced the people to move. The post office was discontinued in 1943 (Ricks, 1965, p. 54).

Richardson, Fort: military reservation, $7 \mathrm{mi}$. NE of Anchorage, Cook Inlet Low.; 61 ${ }^{\circ} 15^{\prime} 30^{\prime \prime}$ $\mathrm{N}, 149^{\circ} 41^{\prime} 00^{\prime \prime} \mathrm{W}$; (map 69).

Name of a military installation that was established in 1940; presumably named for General Wilds Preston Richardson, 18611921, first president of the Alaska Road Commission.

Richardson Creek: stream, flows NW $14 \mathrm{mi}$. to Hess Creek, $32 \mathrm{mi}$. NE of Rampart, YukonTanana High.; $65^{\circ} 40^{\prime} \mathrm{N}, 149^{\circ} 04^{\prime} \mathrm{W}$; (map 105).

Named by prospectors, according to a report in 1902 by Lt. Erickson, USA; published by USGS (Prindle, 1905, pl. 16).

Richardson Roadhouse: locality, see Richardson.

Richardson Telegraph Station: locality, see Richardson.

Richards Slough: stream, flows SE $8.6 \mathrm{mi}$. to Koyukuk River, $8 \mathrm{mi}$. NE of Roundabout Mtn., Koyukuk Low.; $60^{\circ} 40^{\prime} \mathrm{N}, 156^{\circ} 28^{\prime} \mathrm{W}$; (map 108).
Local name obtained at Huslia in 1954 or 1955 by USGS.

Rich Creek: stream, flows N $1.3 \mathrm{mi}$. to East Kiska Lake, Kiska I., Aleutian Is.; 52 $03^{\prime} 32^{\prime \prime}$. N, $177^{\circ} 35^{\prime} 25^{\prime \prime} \mathrm{E}$; (map 14).

An arbitrary name beginning with " $R$ " to correspond to "R" grid used by the U.S. Army for tactical purposes during World War II ; published on a 1953 AMS map.

Rich Creek: stream, flows W 2 mi. to Brown Creek, $2 \mathrm{mi}$. N of Dry Bay and $27 \mathrm{mi}$. NE of Augustine I., Aleutian Ra.; 59 $43^{\prime}$ N., $153^{\circ} 09^{\prime} \mathrm{W}$; BGN 1962; (map 51).

Local name published in 1958 by USGS.

Rich Creek: stream, flows SW $7 \mathrm{mi}$. to East Fork Yentna River, $54 \mathrm{mi}$. W of Talkeetna, Alaska Ra.; $62^{\circ} 17^{\prime} 35^{\prime \prime}$ N. $151^{\circ} 45^{\prime} 30^{\prime \prime}$ W; (map 81).

Prospectors' name reported in 1911 by $S . R$. Capps (in Brooks, 1912, pl. 9), USGS.

Rich Gulch: stream, $3 \mathrm{mi}$. long, flows NE to Fork Creek, $11.5 \mathrm{mi}$ NW of Heart Lake, $74 \mathrm{mi}$. SE of Bethel, Kilbuck-Kuskokwim Mts. ; $60^{\circ} 10^{\prime} \mathrm{N}, 159^{\circ} 59^{\prime} \mathrm{W}$; (map 59$)$.

Local name reported in 1955 by $\mathrm{J}$. M. Hoare, USGS.

Rich Hill: hill, $800 \mathrm{ft}, 1.7 \mathrm{mi}$. SE of Witchcraft Point, Kiska I., Aleutian Is.; $52^{\circ} 02^{\prime} 02^{\prime \prime} \mathrm{N}$, $177^{\circ} 31^{\prime} 55^{\prime \prime} \mathrm{E}$; (map 14).

An arbitrary name beginning with " $R$ " to correspond to " $R$ " grid used by the U.S. Army for tactical purposes during World War II; published on a 1953 AMS map.

Richmond Creek: stream, flows NE $8.1 \mathrm{mi}$. to Minnehaha Creek, $59 \mathrm{mi}$. NW of Haycock, Seward Penin. High.; $65^{\circ} 59^{\prime}$ N, $161^{\circ} 59^{\prime}$ W; (map 109).

Local name reported in 1908 by USGS (Brooks and others, 1909, fig. 21).

Richmond Creek: stream, flows SW $4 \mathrm{mi}$. from a lake to North Fork Koyukuk River, $10 \mathrm{mi}$. $\mathrm{NE}$ of Ipnek Mtn. and $19 \mathrm{mi}$. W. of Wiseman, Brooks Ra.; $67^{\circ} 27^{\prime} 00^{\prime \prime} \mathrm{N}, 150^{\circ} 49^{\prime} 30^{\prime \prime} \mathrm{W}$; $B G N 1932$; (map 124)

Local name "in use since 1900, for Volney Richmond, then manager of the N.C. [Northern Commercial] store in Bettles ***"; reported by Robert Marshall in 1932 .

Richmond Gulch: ravine, on E slope of Mount Brynteson, trends NE $0.2 \mathrm{mi}$. to Glacier Creek, $9 \mathrm{mi}$. NE of Nome, Seward Penin. High.; $64^{\circ} 37^{\prime} 52^{\prime \prime} \mathrm{N}, 165^{\circ} 20^{\prime} 50^{\prime \prime} \mathrm{W}$; (map 94).

Prospectors' name shown on the 1902 "Map of the Nome and Snake River Country" by J. M. Davidson.

Richter Creek: stream, flows NE $10 \mathrm{mi}$. to Niukluk River, $32 \mathrm{mi}$. NE of Solomon, Seward Penin. High.; $64^{\circ} 55^{\prime} \mathrm{N}, 163^{\circ} 47^{\prime} \mathrm{W}$; (map 95). Var. Slate Creek.

This appears to be the stream reported in 1899 as "Slate Creek" by Schrader and Brooks (1900, map 3), USGS.

Ricks Creek: stream, flows NW $10 \mathrm{mi}$. to North Fork Salcha River, $50 \mathrm{mi}$. NE of Big Delta, Yukon-Tanana High.; $64^{\circ} 49^{\prime} \mathrm{N}, 145^{\circ} 12^{\prime} \mathrm{W}$; (map 101).

Local name reported in 1958 by USGS. Ricord, Cape: promontory, see Thompson, Cape. 
Riddle Gulch: ravine, trends SE $0.6 \mathrm{mi}$. to Hidden Creek, $7 \mathrm{mi}$. NW of Medfra, KilbuckKuskokwim Mts.; $63^{\circ} 12^{\prime} \mathrm{N}, 154^{\circ} 48^{\prime} \mathrm{W}$; $B G N$ 1936; (map 89).

Local name reported in 1913 by J. B. Mertie, Jr., USGS.

Riddle Hills: hills, $500 \mathrm{ft}$., $1.2 \mathrm{mi}$. SE of Witchcraft Point, Kiska I., Aleutian Is.; 52 ${ }^{\circ} 2^{\prime}{ }^{\prime 2} 0^{\prime \prime}$ N, $177^{\circ} 31^{\prime} 45^{\prime \prime}$ E; (map 14).

An arbitrary name beginning with " $R$ " to correspond to "R" grid used by the U.S. Army for tactical purposes during World War II; published on a 1953 AMS map.

Riddle Lake: lake, $0.2 \mathrm{mi}$. across, one of group of five, $1 \mathrm{mi}$. SE of Witcheraft Point, Kiska I., Aleutian Is.; $52^{\circ} 02^{\prime} 25^{\prime \prime} \mathrm{N}, 1^{\prime} 77^{\circ} 31^{\prime} 20^{\prime \prime} \mathrm{E}$; (map 14).

An arbitrary name beginning with " $R$ " to correspond to " $R$ " grid used by the U.S. Army for tactical purposes during World War II; published on a 1953 AMS map.

Ridge Hill: hill, 493 ft., between Rush and Cone Hills, on west-central St. Paul I., in Pribilof Is. ; $57^{\circ} 11^{\prime} 00^{\prime \prime} \mathrm{N}, 170^{\circ} 22^{\prime} 15^{\prime \prime} \mathrm{W}$; (map 38). Var. Dot Hill.

Name published in 1875 by USC\&GS; called "Dot Hill" in 1891 by Joseph StanleyBrown, naturalist.

Ridge Hill: hill, see Bear Hill.

Ridge Island: island, $0.5 \mathrm{mi}$. long, on $\mathrm{E}$ coast of Suemez I., between Meares Passage and Ulloa Channel, Alex. Arch.; $55^{\circ} 16^{\prime} 30^{\prime \prime} \mathrm{N}$, $133^{\circ} 12^{\prime} 30^{\prime \prime} \mathrm{W}$; (map 4).

Descriptive name published in 1914 by USC\&GS.

Ridge Lake: lake, see Setgun Lake.

Ridge Point: point of land, on NE coast of Akutan I., Krenitzin Is., Aleutian Is.; 54 $11^{\prime}$ $30^{\prime \prime} \mathrm{N}, 165^{\circ} 47^{\prime} 45^{\prime \prime} \mathrm{W}$; (map 24).

Named in 1901 by J. J. Gilbert, USC\&GS, because it is "formed by a narrow mountain ridge."

Ridgetop: locality, $1 \mathrm{mi}$. W of Dome Camp and $15 \mathrm{mi}$. N of Fairbanks, Yukon-Tanana High.; $65^{\circ} 02^{\prime} \mathrm{N}, 147^{\circ} 40^{\prime} \mathrm{W}$; (map 105).

Descriptive name of a former railroad station on the Tanana Valley Railroad; published in 1907 by USGS.

Ridge Wall: hill, $325 \mathrm{ft}$., $0.4 \mathrm{mi}$. long, on SW coast of St. Paul I., in Pribilof Is.; 57 $09^{\prime} 50^{\prime \prime}$ $\mathrm{N}, 170^{\circ} 22^{\prime} 20^{\prime \prime} \mathrm{W}$; (map 38). Var. Ridgewall.

Local name reported by Elliott (1881, St. Paul map).

Ridgeway Creek: stream, flows NE $1.4 \mathrm{mi}$. to Lower Willow Creek which flows to Casadepaga River, $18 \mathrm{mi}$. N of Solomon, Seward Penin. High.; $64^{\circ} 49^{\prime} \mathrm{N}, 164^{\circ} 25^{\prime} \mathrm{W}$; (map 95). Var. Myers Creek, Ridgewood Creek.

Prospectors' name reported as "Myers or Ridgeway" on a 1902 prospectors' manuscript map. Reported as "Ridgewood" on a 1901 map of Cape Nome gold fields by David Fox, Jr.

Ridgewood Creek: stream, see Ridgeway Creek.

Riding Cove: cove, $0.7 \mathrm{mi}$. across, on $\mathrm{SW}$ coast of Unalaska I., Aleutian Is.; $53^{\circ} 22^{\prime} 00^{\prime \prime} \mathrm{N}$, $167^{\circ} 17^{\prime} 20^{\prime \prime} \mathrm{W}$; BGN 1939; (map 23).
Named by USC\&GS in 1938, "as the cove is the only shelter for small craft in this vicinity from northwesterly weather. Small boats may ride out such weather and also receive limited protection from southerly swells."

Rieba Bay: bay, see Fish Bay.

Riecheshni Bay: bay, see Little Bay.

Riecheshnoe: village, see Nikolski.

Riecheshnoi: bay, see Akun Bay.

Riechesni : locality, on Little Bay, on $\mathrm{N}$ coast of Akun I., Aleutian Is.; $54^{\circ} 16^{\prime} \mathrm{N}, 165^{\circ} 35^{\prime} \mathrm{W}$; (map 24). Var. Raicheshnoe, Raychevsnoi.

Russian name for a former Aleut village or camp recorded in 1830 as "Raicheshnoe," population 37, by Father Veniaminov (1840, v. 2, p. 202).

Rifle Butte: hill, $400 \mathrm{ft}$., $17 \mathrm{mi}$. NE of Mount Veniaminof, Bristol Bay Low; $56^{\circ} 25^{\prime} \mathrm{N}$, $159^{\circ} 14^{\prime} \mathrm{W}$; (map 30$)$.

Name reported in 1923 by R. H. Sargent, USGS; published in 1927 by USGS.

Rifle Creek: stream, heads on King Mtn., flows E $1 \mathrm{mi}$. to Nome River, $8 \mathrm{mi}$. NNE of Nome, Seward Penin. High.; $64^{\circ} 37^{\prime} \mathrm{N}, 165^{\circ} 17^{\prime} \mathrm{W}$ (map 94).

Prospectors' name published on the 1900 "Map of Nome Peninsula" by J. M. Davidson and B. D. Blakeslee.

Rifle Lake: lake, $0.4 \mathrm{mi}$. long, on Kenai Penin. W of Ursus Lake, $31 \mathrm{mi}$. NE of Kenai, Cook Inlet Low; $60^{\circ} 46^{\prime} \mathrm{N}, 150^{\circ} 28^{\prime} \mathrm{W}$; (map 62)

Named about 1963 by officials of Kenai National Moose Range, for administrative purposes.

Riggs, Mount: mountain, 11,783 ft., between Mount Natazhat and Alaska-Canada boundary, $\mathrm{N}$ of Klutlan Glacier, $60 \mathrm{mi}$. NE of McCarthy, St. Elias Mts.; BGN 1917; $61^{\circ} 30^{\prime}$ N, $141^{\circ} 06^{\prime} \mathrm{W}$; (map 67).

Named by the Alaska-Canada boundary surveyors, 1909-13, for Thomas Riggs, Jr., surveyor in charge for the United States.

Riggs Glacier: glacier, in Glacier Bay National Monument, heads on S slope of Takhinsha Mts., $4 \mathrm{mi}$. SE of Mount Harris, trends $17 \mathrm{mi}$. SSE to head of Muir Inlet, $43 \mathrm{mi}$. SW of Skagway, St. Elias Mts.; $59^{\circ} 04^{\prime} 00^{\prime \prime} \mathrm{N}, 136^{\circ}$. $11^{\prime} 00^{\prime \prime} \mathrm{W}$; (map 45).

Named by the American Geographical Society in 1947 for Thomas Riggs, Jr., 18731945; Engineer of the Alaskan Boundary Survey, 1906-13; Governor of Alaska, 1918-21; and United States Commissioner of the IBC about 1936-45. He was born in Maryland and educated at Princeton Univ. He was in the lumber business in Alaska 1897-1901 and was with the Boundary Survey from 1903-05 before becoming engineer in 1906 . He was in charge of the Fairbanks Division of location and construction of government railroads in Alaska before becoming Governor of Alaska in 1918.

Right Arm Creek: stream, on Iniskin Penin., flows W $1.4 \mathrm{mi}$. to Right Arm Iniskin Bay, Aleutian Ra.; $59^{\circ} 43^{\prime} 45^{\prime \prime} \mathrm{N}, 153^{\circ} 20^{\prime} 30^{\prime \prime} \mathrm{W}$; BGN 1962; (map 51). Var. Steep Creek.

Local name derived from Right Arm Iniskin Bay; published by USGS in 1958.
Right Arm Iniskin Bay: estuary, on W coast of Iniskin Penin., extends E $2 \mathrm{mi}$. off Iniskin Bay, Aleutian Ra.; $59^{\circ} 43^{\prime} 30^{\prime \prime} \mathrm{N}, 153^{\circ} 22^{\prime} 30^{\prime \prime}$ W; BGN 1916; (map 51).

Name published in 1914 on USC\&GS Chart 3421.

Right Branch Big Hurrah Creek: stream, see Trilby Creek.

Right Branch Solomon River: stream, see East Fork Solomon River.

Right Branch Trail Creek: stream, in Chigmit Mts., at head of Iniskin Penin., flows NE $1 \mathrm{mi}$., joins Wrong Branch to form Trail Creek, $0.7 \mathrm{mi}$. S of Chinitna Bay, Aleutian Ra.; $59^{\circ}$ $47^{\prime} 45^{\prime \prime} \mathrm{N}, 153^{\circ} 16^{\prime} 40^{\prime \prime} \mathrm{W}$; BGN 1962; (map 51). Var. Tonnie Greek.

Named in 1951 by USGS.

Right Cape: point of land, see Outer Right Cape.

Right Fork Banner Creek: stream, see Slate Creek.

Right Fork Bluestone River: stream, flows SE $8 \mathrm{mi}$. to join Gold Run, forms Bluestone River, $13 \mathrm{mi}$. SE of Teller, Seward Penin. High.; $65^{\circ} 05^{\prime} \mathrm{N}, 166^{\circ} 13^{\prime} \mathrm{W}$; (map 111).

Local name reported in 1900 by E. C. Barnard (in Brooks, 1901, pl. 17), USGS.

Right Fork Canning River: stream, see Marsh Fork Canning River.

Right Fork Canyon Creek: stream, flows NW 2.5 mi. to Canyon Creek which flows to Imuruk Basin, $31 \mathrm{mi}$. NW of Nome, Seward Penin. High.; 64 $4^{\circ} 54^{\prime} \mathrm{N}, 165^{\circ} 51^{\prime} \mathrm{W}$; (map 94).

Prospectors' name published on the 1908 "Map of Seward Peninsula" by Arthur Gibson. Right Fork Goodhope River: stream, see Goodhope River.

Right Fork Kooguru River: stream, see Marsh Fork Canning River.

Right Fork Kugruk River: stream, see Kugruk River.

Right Fork Macklin Creek: stream, flows N 1.4 mi. to Macklin Greek which flows to Kougarok River, $4 \mathrm{mi}$. SW of Midnight Mtn. and $45 \mathrm{mi}$. NW of Imuruk Lake, Seward Penin. High.; $65^{\circ} 45^{\prime} \mathrm{N}, 164^{\circ} 43^{\prime} \mathrm{W}$; (map 110).

Prospectors' name reported on the 1908 "Map of Seward Peninsula" by Arthur Gibson. Right Fork Ono-ko-vuk River: stream, see Monday Creek.

Right Fork Quartz Creek: stream, see North Fork Quartz Creek.

Right Fork Slate Creek: stream, flows NE 0.5 mi., joins Left Fork to form Slate Creek which flows $\mathrm{E}$ to Nome River, $13 \mathrm{mi}$. $\mathrm{N}$ of Nome, Seward Penin. High.; $64^{\circ} 42^{\prime} \mathrm{N}, 165^{\circ}$ $20^{\prime} \mathrm{W}$; (map 94).

Prospectors' name shown on the 1902 "Map of the Nome and Snake River Country" by J. M. Davidson.

Right Fork Solomon River: stream, see East Fork Solomon River.

Right Fork Stewart River: stream, sec Silver Creek.

Right Fork Vermont Creek: stream, flows NE 1 mi. from Vermont Pass to Vermont Creek, $2.5 \mathrm{mi}$. ESE of Vermont Dome and $7 \mathrm{mi}$. N of Wiseman, Brooks Ra.; $67^{\circ} 31^{\prime} \mathrm{N}, 150^{\circ} 08^{\prime}$ W; (map 124). 
Local name reported in 1956 by T. E. Taylor, USGS.

Right Fork West Glacier Creek: stream, in Chigmit Mts., heads at Umbrella Glacier terminus, flows SW $4 \mathrm{mi}$., joins Left Fork to form West Glacier Creek, $5 \mathrm{mi}$. N of Chin-. itna Bay, Aleutian Ra.; $59^{\circ} 55^{\prime} 40^{\prime \prime} \mathrm{N}, 153^{\circ}$ $17^{\prime} 20^{\prime \prime} \mathrm{W}$; (map 51).

Local name reported in 1957 by USGS.

Right Hand Point: point of land, W point of entrance to Kulukak Bay, on $\mathbf{N}$ shore of Bristol Bay, $54 \mathrm{mi}$. SW of Dillingham, Kilbuck-Kuskokwim Mts.; $58^{\circ} 46^{\prime} 10^{\prime \prime} \mathrm{N}, 159^{\circ}$ 54'00" W; (map 40). Var. Mys Pravoi.

Translation of Russian "M[ys] Pravoi" reported by Capt. Tebenkov (1852, map 4), IRN.

Right Head: bay, SE arm of Port Moller, extends $6 \mathrm{mi}$. inland, Alaska Penin., Aleutian Ra. ; $55^{\circ} 48^{\prime} \mathrm{N}, 160^{\circ} 20^{\prime} \mathrm{W}$; (map 28).

Reported by Atwood (1911, pl. 2), USGS. Rikord, Mys: promontory, see Thomspon, Cape. Rikorda, Mys: promontory, see Thompson, Cape.

Riley: settlement, see McKinley Park.

Riley, Cape: point of land, on W shore of Port Clarence, $4 \mathrm{mi}$. SW of Teller, Seward Penin. High.; $65^{\circ} 13^{\prime} \mathrm{N}, 166^{\circ} 28^{\prime} \mathrm{W}$; (map 111).

"Apparently so named by Beechey, 1827, or possibly by Trollope, 1854" (Baker, 1906, p. 528). For some years the name was misapplied to the south point of the entrance to Grantley Harbor, at Teller.

Riley Channel: stream, a distributary of Kobuk River, flows SW $33 \mathrm{mi}$. to Hotham Inlet, 53 mi. WNW of Selawik, Kotzebue-Kobuk Low.; $66^{\circ} 47^{\prime} \mathrm{N}, 161^{\circ} 52^{\prime} \mathrm{W}$; (map 114).

The name "Riley Channel" is written in pencil on a manuscript map by Lt. G. M. Stoney, USN; probably named by him in 1885 for an Eskimo interpreter in his party, Ounalook, whom they nicknamed "Riley."

Riley Creek: stream, flows N $3.7 \mathrm{mi}$. to Matanuska River $29 \mathrm{mi}$. NE of Palmer, Chugach Mts. ; $61^{\circ} 47^{\prime} 15^{\prime \prime} \mathrm{N}, 148^{\circ} 20^{\prime} 15^{\prime \prime} \mathrm{W}$; (map 69).

Local name reported in 1948 by USGS.

Riley Creek: stream, heads at Riley Creek Glacier terminus, flows NW $7 \mathrm{mi}$. to Jarvis Creek, $28 \mathrm{mi}$. S of Delta Junction, Alaska Ra.; $63^{\circ} 38^{\prime} 40^{\prime \prime} \mathrm{N}, 145^{\circ} 37^{\prime} 20^{\prime \prime} \mathrm{W} ; B G N$ 19.37; (map 86).

Local name reported in 1937 by USFS.

Riley Creek: stream, flows NE $22 \mathrm{mi}$. to Nenana River, $10 \mathrm{mi}$. S of Healy, Alaska Ra.; $63^{\circ} 43^{\prime}$ $30^{\prime \prime} \mathrm{N}, 148^{\circ} 53^{\prime} 00^{\prime \prime} \mathrm{W}$; (map 87).

Local name reported by Woodbury Abbey, U.S. Army Corps of Engineers, on the blueprint of his 1921 Mount McKinley National Park survey.

Riley Creek: stream, flows E $8 \mathrm{mi}$. to Kogoluktuk River, $16 \mathrm{mi}$. NE of Shungnak, Brooks Ra.; $67^{\circ} 02^{\prime}$ N, $156^{\circ} 40^{\prime} \mathrm{W}$; (map 126).

Prospectors' name given about 1908 and reported by $\mathrm{P}$. S. Smith and H. M. Eakin, USGS, in 1910 (in Brooks and others, 1911, p. 294). Lt. G. M. Stoney's Eskimo interpreter was called "Riley" (Stoney, 1900, p.
17). However, it was more likely named for the small steamboat John Riley which plied the Kobuk River about the time the stream was named.

Riley Creek: settlement, see McKinley Park.

Riley Creek Glacier: glacier, trends N $2 \mathrm{mi}$. to its 1950 terminus at head of Riley Creek, 34 mi. SE of Delta Junction, Alaska Ra.; $63^{\circ} 34^{\prime}$ $00^{\prime \prime} \mathrm{N}, 145^{\circ} 34^{\prime} 20^{\prime \prime} \mathrm{W}$; (map 86).

Name published on relatively recent maps.

Riley Lake: lake, $0.8 \mathrm{mi}$. long, $6.5 \mathrm{mi}$. NE of Beaver, Yukon Flats; $66^{\circ} 26^{\prime} \mathrm{N}, 147^{\circ} 13^{\prime} \mathrm{W}$; (map 118)

Local name obtained in 1956 by USGS.

Rim Butte: mountain, 3,570 ft., in Brooks Ra., $27 \mathrm{mi}$. NNW of Howard Pass; 68 $34^{\prime} \mathrm{N}$, $157^{\circ} 21^{\prime} \mathrm{W}$; (map 132).

Named in 1950 by I. L. Tailleur, USGS, geologist with the Naval Petroleum Reserve No. 4 explorations because of the "prominent butt of rim rock." Name was published by USGS in 1951.

Rime Peak: peak, 12,741 ft., $4.5 \mathrm{mi}$. NE of Mount Blackburn and $26 \mathrm{mi}$. NW of McCarthy, Wrangell Mts. ; BGN 1966; 61 ${ }^{\circ} 44^{\prime} 52^{\prime \prime}$

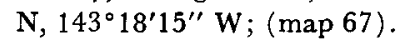

Named in 1965 by the Mountaineering Club of Alaska, "because of the unusual accumulations of rime crystals found on the peak."

Rimrock Creek: stream, on Kenai Penin., flows SE $3 \mathrm{mi}$. to Resurrection Creek, $5.5 \mathrm{mi}$. S of

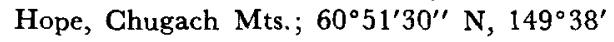
$00^{\prime \prime} \mathrm{W}$; (map 63).

Local prospectors' name; reported in 1904 by Moffit (1906, pl. 2), USGS.

Ring Creek: stream, flows SW $3.5 \mathrm{mi}$. to Right Fork Bluestone River, $11 \mathrm{mi}$. S of Teller, Seward Penin. High.; $65^{\circ} 07^{\prime} \mathrm{N}, 166^{\circ} 23^{\prime} \mathrm{W}$; (map 111).

Local name reported in 1900 by E. C. Barnard (in Brooks, 1901, pl. 17), USGS.

Ringgold, Lake: lake, $0.1 \mathrm{mi}$. long, on Ringgold I., Bay of Is., Adak I., Aleutian Is.; $51^{\circ}$ $48^{\prime} 11^{\prime \prime}$ N, $176^{\circ} 48^{\prime} 55^{\prime \prime} \mathrm{W}$; BGN 1936; (map 17). Var. Agatha Lake.

Name derived from Ringgold Island and given by the U.S. Navy Hydrog. Office in 1936. See Ringgold Island.

Ringgold Island: island, $1.5 \mathrm{mi}$. long, on W coast of Adak I. in Bay of Islands, Aleutian Is.; $51^{\circ} 48^{\prime} 10^{\prime \prime} \mathrm{N}, 176^{\circ} 49^{\prime} 00^{\prime \prime} \mathrm{W}$; BGN 1936; (map 17). Var. Agatha Island.

Named in 1936 by the U.S. Navy Hydrog. Office, for Capt. Cadwalader Ringgold, USN, Commander of the North Pacific Exploring Expedition in 1855.

Ringgold Sound: water passage, on $\mathrm{W}$ coast of Adak I., $\mathbf{S}$ of Ringgold I. in Bay of Islands, Aleutian Is.; $51^{\circ} 48^{\prime} 10^{\prime \prime} \mathrm{N}, 176^{\circ} 50^{\prime} 00^{\prime \prime} \mathrm{W}$; BGN 1936; (map 17). Var. Agatha Sound. See Ringgold Island.

Ringingalook River: stream, see Pingaluk River.

Ring Island: island, $0.2 \mathrm{mi}$. across, in Jamestown Bay, $2 \mathrm{mi}$. SE of Sitka, on $\mathrm{W}$ coast of Baranof I., Alex. Arch.; $57^{\circ} 02^{\prime} 20^{\prime \prime}$ N, $135^{\circ}$ 17'20' W; (map 9). Var. Ring Islet.

Named by U.S. Navy in 1880 for paymaster James Andrew Ring, USN. The name was published by USC\&GS in the 1883 Coast Pilot (p. 144).

Ring Islet: island, see Ring Island.

Ring Lake: lake, $0.2 \mathrm{mi}$. across, on northeastern Kiska I., Aleutian Is.; $52^{\circ} 02^{\prime} 48^{\prime \prime}$ N, $177^{\circ} 36^{\prime}$ $40^{\prime \prime} \mathrm{E}$; (map 14).

An arbitrary name beginning with " $R$ " to correspond to "R" grid used by the U.S. Army for tactical purposes during World War II; published on a 1953 AMS map.

Rio: point of land, see Riou, Point.

Rio Shore Creek: stream, flows $\mathrm{S}$ to Bering Sea, about $25 \mathrm{mi}$. NE of Nome, Seward Penin. High.; (map 94).

Prospectors' name reported on the 1900 "Map of Nome Peninsula" by J. M. Davidson and B. D. Blakeslee; this feature has not been positively identified.

Riot Hill: mountain, $1,100 \mathrm{ft}$., $1.5 \mathrm{mi}$. $\mathrm{N}$ of Salmon Lagoon, Kiska I., Aleutian Is.; $52^{\circ}$ $01^{\prime} 28^{\prime \prime}$ N, $177^{\circ} 32^{\prime} 52^{\prime \prime}$ E; (map 14). Var. Tundra Hill.

An arbitrary name beginning with " $R$ " to correspond to "R" grid used by U.S. Army for tactical purposes during World War II ; published on a 1953 AMS map. Variant published on a 1943 USAAF map.

Riou, Point: point of land, extends SW into Gulf of Alaska, near S entrance of Icy Bay, $64 \mathrm{mi}$. NW of Yakutat, Malaspina Coastal Plain; $59^{\circ} 52^{\prime} 30^{\prime \prime} \mathrm{N}, 1^{\circ} 21^{\circ} 30^{\prime \prime} \mathrm{W}$; (map 47). Var. Pionte de Boussole, Nizmennoi, Rio, Cape Riou.

Named by Vancouver $(1798$, v. 3, p. 204) June 28, 1794, probably in honor of Edward Riou, midshipman on the Third Cook Expedition. Tebenkov (1852, map 7) calls it "Nizmennoi," meaning "low" although he also includes, beneath the name, the Russian transliteration of "Riou," which is shown on later Russian Hydrog. Dept. charts as "Rio." This may also be the point of land the La Perouse map shows as "Pointe de Boussole" although some authorities feel the name applies to what is now called "Cape Manby." La Perouse appears not to have mentioned "Pointe de Boussole" in his text which would indicate that the name was added when the map was drawn later in Paris (Wagner, 1937, p. 434). The Boussole was one of $\mathrm{La} \mathrm{Pe}$ rouse's ships,

Riou Bay: bay, $3 \mathrm{mi}$. long, on S side of Icy Bay, $64 \mathrm{mi}$. NW of Yakutat, Malaspina Coastal Plain; 59 $54^{\prime} \mathrm{N}, 141^{\circ} 27^{\prime} \mathrm{W}$; (map 47).

Name published on a 1945 USC\&GS chart. Its name was taken from nearby Point Riou. Riph Point: point of land, see Shakmanof Point. Ripinski, Mount: mountain, 3,600 ft., at $E$ end of Takshanuk Mts., $2.6 \mathrm{mi}$. W of Tanani and $15 \mathrm{mi}$. SW of Skagway, Coast Mts.; $59^{\circ} 15^{\prime} 55^{\prime \prime}$ N, $135^{\circ} 31^{\prime} 15^{\prime \prime} \mathrm{W}$; (map 45).

Named locally for "Mr. Ripinski" of the Hainos Mission and published in 1897 by USC\&GS.

Ripon Glacier: glacier, on E side of Kenai Penin., trends NW $1.5 \mathrm{mi}$. to its terminus, $6 \mathrm{mi}$. SE of Whittier, Chugach Mts.; $60^{\circ} 41^{\prime}$ $30^{\prime \prime} \mathrm{N}, 148^{\circ} 36^{\prime} 00^{\prime \prime} \mathrm{W}$; BGN 1930; (map 63). 
Named in 1910 by Lawrence Martin, USGS, for Ripon College, Ripon, Wis.

Ripple Cove: cove, $1 \mathrm{mi}$. across, in Glacier Bay National Monument, on W shore of Glacier Bay, $0.6 \mathrm{mi}$. S of Rush Point and $33 \mathrm{mi}$. NW of Hoonah, St. Elias Mts.; $58^{\circ} 27^{\prime} \mathrm{N}, 136^{\circ} 04^{\prime}$ W; BGN 1942; (map 10).

So named by USC\&GS in 1938 "because of the high velocity of the currents in this locality."

Ripple Cove: cove, $1 \mathrm{mi}$. long, $2 \mathrm{mi}$. SE of Crater Bay, on SW coast of Harris Penin., 33 mi. SW of Seward, Chugach Mts.; 59 $40^{\prime} 15^{\prime \prime}$ N, $149^{\circ} 47^{\prime} 45^{\prime \prime} \mathrm{W} ; B G N 1930$; (map 49).

So named by the 1928 USC\&GS field party because of the "comparative smoothness of water."

Ripple Narrows: water passage, see Sitakaday Narrows.

Rip Point: point of land, on SE coast of Great Sitkin I., Aleutian Is.; $51^{\circ} 59^{\prime} 02^{\prime \prime} \mathrm{N}, 176^{\circ} 01^{\prime}$ 30" W; BGN 1936; (map 17).

So named by members of the U.S. Navy Aleutian Island Survey Expedition in 1934, because of "the strong tide rips in the locality."

Rip Point: point of land, on SE coast of Prince of Wales I., $1.3 \mathrm{mi}$. SE of Whiterock I., Alex. Arch.; 55 $02^{\prime} 15^{\prime \prime} \mathrm{N}, 131^{\circ} 58^{\prime} 45^{\prime \prime} \mathrm{W}$; (map 3).

Local name published in the 1925 Coast Pilot (p. 74).

Rip Rock: rock, on NW coast of Gape Chisak, Little Tanaga I., Aleutian Is.; $51^{\circ} 46^{\prime} 45^{\prime \prime} \mathrm{N}$, $176^{\circ} 10^{\prime} 40^{\prime \prime} \mathrm{W}$; BGN 1936; (map. 17).

So named by members of the U.S. Navy Aleutian Island Survey Expedition in 1934, because it is "marked by strong tide rips and overfalls."

Rip Rock: rock, in Hawkins Island Cutoff, between Hinchinbrook I., and Hawkins I. and 20 mi. SW of Cordova, Chugach Mts.; $60^{\circ} 27^{\prime} 30^{\prime \prime} \mathrm{N}, 146^{\circ} 20^{\prime} 10^{\prime \prime} \mathrm{W}$; (map 64).

Named in 1900 by H. P. Ritter, USC\&GS.

Ripsnorter Creek: stream, heads at glacier, flows SW $10 \mathrm{mi}$. to Tonzona River, $15 \mathrm{mi}$. W of Mount Russell, Alaska Ra.; 62 ${ }^{\circ} 47^{\prime} 05^{\prime \prime} \mathrm{N}$, $152^{\circ} 20^{\prime} 35^{\prime \prime} \mathrm{W}$; (map 81).

Prospectors' name reported in 1925 by S. R. Capps (in Moffit, 1927, pl. 3), USGS.

Rishénia, Mys: point of land, see Decision, Cape.

Risk Hill: hill, $300 \mathrm{ft}$., $1.3 \mathrm{mi}$. S of Witchcraft Point, Kiska .I., Aleutian Is.; $52^{\circ} 02^{\prime} 05^{\prime \prime} \mathrm{N}$, $177^{\circ} 30^{\prime} 30^{\prime \prime} \mathrm{E}$; (map 14).

An arbitrary name beginning with " $R$ " to correspond to the "R" grid used by the U.S. Army for tactical purposes during World War II ; published on a 1953 AMS map.

Risky Creek: stream, flows NE $2 \mathrm{mi}$. to Chukchi Sea, $\mathrm{E}$ of Sapumik Ridge, $23 \mathrm{mi}$. E of Cape Lisburne, Arctic Slope; $68^{\circ} 51^{\prime} 38^{\prime \prime} \mathrm{N}, 165^{\circ} 18^{\prime}$. $45^{\prime \prime}$ W; (map 129).

Named in 1953 by USGS geologists "because it is the last available beaching point in several miles for small boats traveling from Corwin to Ahyougatuk [Ayugatak] Lagoon" (Chapman and Sable, 1960, p. 54).

Ritter Point: point of land, on W coast of Dall I., $2.5 \mathrm{mi}$. N of Port Bazan, Alex. Arch.; $54^{\circ} 51^{\prime} 30^{\prime \prime} \mathrm{N}, 133^{\circ} 02^{\prime} 00^{\prime \prime} \mathrm{W}$; BGN 1929; (map 1).

Named by USC\&GS in 1928 for "the late Homer P. Ritter," USC\&GS, who made early surveys in Alaska.

River: locality, along Seward Penin. RR. and Nome River, about $13 \mathrm{mi}$. NE of Nome, Seward Penin. High.; (map 94).

Site of a railroad station built in 1905 or 1906 (Cole, 1953, p. 14). Its precise location is not known.

River Bay: bay, $5 \mathrm{mi}$. long, in Lake Nerka, drained by the Agulowak River, $30 \mathrm{mi}$. NW of Dillingham, Kilbuck-Kuskokwim Mts.; $59^{\circ} 25^{\prime}$ N, $158^{\circ} 50^{\prime} \mathrm{W}$; BGN 1931; (map 52).

So called because the head of this arm of Lake Nerka leads into the lake's outlet. Local name reported by Gerald FitzGerald, USGS, in 1930.

River Cove: cove, $0.3 \mathrm{mi}$. across, in $\mathrm{E}$ part of Nikolski Bay, on SW coast of Umnak I., Aleutian Is.; $52^{\circ} 57^{\prime} 15^{\prime \prime} \mathrm{N}, 168^{\circ} 51^{\prime} 15^{\prime \prime} \mathrm{W}$; (map 21).

Name published by USC\&GS in 1944 Aleutian Coast Pilot (p. 67).

Rivermouth Point: point of land, at mouth of Afognak River, $4.4 \mathrm{mi}$. $\mathrm{N}$ of Afognak, on $\mathrm{S}$ coast of Afognak I., N of Kodiak I.; $58^{\circ} 04^{\prime}$ $\mathrm{N}, 152^{\circ} 47^{\prime} \mathrm{W}$; (map 43). Var. Ustia rieki, Ustya Ryki.

Translation of the name "M[ys] Ustya Ryki" given by Sub-Lt. Mikhail Murashev, IRN, in 1839 or 1840 and published by the Russian Hydrog. Dept. in 1849 on Chart 1425.

River Point: point of land, on $\mathrm{W}$ bank of Portland Canal, $10 \mathrm{mi}$. N of Turn Point, Coast Mts.; $55^{\circ} 34^{\prime} \mathrm{N}, 130^{\circ} 08^{\prime} \mathrm{W}$; (map 3).

Local descriptive name published in 1891 by USC\&GS; this point is just north of the mouth of a river.

River Point: point of land, on $\mathrm{E}$ shore of Gilbert Bay at mouth of Whiting River, 2 mi. $\mathbf{E}$ of Sentinel Point and $33 \mathrm{mi}$. SE of Juneau, Coast Mts.; 57 $59^{\prime} 45^{\prime \prime} \mathrm{N}, 133^{\circ} 42^{\prime} 30^{\prime \prime} \mathrm{W}$; (map 8).

Descriptive name given in 1888 by Lt. Comdr. C. M. Thomas, USN.

Rjätscheschnoje: village, see Nikolski.

Roadhouse Bay: cove, $0.6 \mathrm{mi}$. across, on N shore of Iliamna Lake, $3 \mathrm{mi}$. SE of Iliamna, Aleutian Ra.; $59^{\circ} 45^{\prime} \mathrm{N}, 154^{\circ} 49^{\prime} \mathrm{W}$; (map 51).

Local name derived from Roadhouse Mountain; published in 1954 by USGS.

Roadhouse Creek: stream, flows SW $9 \mathrm{mi}$. to Roadhouse Bay, Iliamna Lake, $3 \mathrm{mi}$. E of Iliamna, Aleutian Ra.; $59^{\circ} 45^{\prime} \mathrm{N}, 154^{\circ} 50^{\prime} \mathrm{W}$; (map 51).

Local name derived from Roadhouse Mountain; published in 1954 by USGS.

Roadhouse Creek: stream, in Rampart Mts., flows S $4.5 \mathrm{mi}$. to Yukon River, $11 \mathrm{mi}$. W of Rampart and $50 \mathrm{mi}$. ENE of Tanana, Kokrines-Hodzana High.; $65^{\circ} 29^{\prime} \mathrm{N}, 150^{\circ} 34^{\prime} \mathrm{W}$, (map 106).

Local name reported in 1956 by Orth; so named because McCormick Roadhouse was located at the stream's mouth.

Roadhouse Hills: mountain, see Roadhouse Mountain.
Roadhouse Moses: village, see Moses Point.

Roadhouse Mountain: mountain, $\mathrm{N}$ of Iliamna Lake, $10 \mathrm{mi}$. SE of Nondalton, Aleutian Ra.; $59^{\circ} .51^{\prime} 30^{\prime \prime} \mathrm{N}, 154^{\circ} 40^{\prime} 00^{\prime \prime} \mathrm{W}$; (map 51). Var. Roadhouse Hills.

Local name published by G. C. Martin and F. J. Katz (1912, pl. 1), USGS.

Road Island: island, $1 \mathrm{mi}$. long, in Ivanof Bay, $6 \mathrm{mi}$. NE of Stepovak Bay, Aleutian Ra.; $55^{\circ} 51^{\prime} 00^{\prime \prime} \mathrm{N}, 159^{\circ} 29^{\prime} 40^{\prime \prime} \mathrm{W}$; (map 27). Var. John Island.

Named "John Island" in 1880 by W. $H$. Dall, USC\&GS. In 1947, USC\&GS reported that "Road Island" had been in use for some years.

Road Island: island, $150 \mathrm{ft}$. across, in Redoubt Bay, 9 mi. S of Sitka, Alex. Arch.; 56 $55^{\prime} 30^{\prime \prime}$ N, $135^{\circ} 21^{\prime} 05^{\prime \prime}$ W; (map 5). Var. Dorozhoi Island, Ostrov Dorozhnoy.

This is a translation by USC\&GS of the name given in 1809 by the navigator Ivan Vasiliev the first, IRN. Lt. Sarichev (1826, map 19), IRN, published it as "O[strov] Dorozhnoy."

Roadstead Island: island, $0.2 \mathrm{mi}$. across, in Security Bay, on $\mathrm{N}$ coast of Kuiu I., Alex. Arch. $56^{\circ} 52^{\prime} 20^{\prime \prime} \mathrm{N}, 134^{\circ} 22^{\prime} 10^{\prime \prime} \mathrm{W}$; (map 5).

Named in 1869 by Comdr. R. W. Meade, USN.

Roaring Bear Lake: lake, $1 \mathrm{mi}$. across, at head of Meadow Creek, $18 \mathrm{mi}$. W of Beaver, Yukon Flats; $66^{\circ} 21^{\prime} 30^{\prime \prime} \mathrm{N}, 148^{\circ} 04^{\prime} 00^{\prime \prime} \mathrm{W}$; (map 118). Var. First Lake.

Local name reported in 1956 by USGS; the lake was shown as "First Lake" on a 1916 manuscript map by William Yanert because it was first in a series of lakes (Stuck, 1917, map facing p. 122).

Roaring Cove: cove, $600 \mathrm{ft}$. wide, on $\mathrm{W}$ coast of Ragged I., in Pye Is., $46 \mathrm{mi}$. E of Seldovia, Chugach Mts.; $59^{\circ} 25^{\prime} \mathrm{N}, 150^{\circ} 25^{\prime} \mathrm{W}$; $B G N$ 1929; (map 50).

So named by USC\&GS in 1927, "because of the roar and echo of the waves."

Roaring Creek: stream, on Kenai Penin., flows NW 2 mi. to Canyon Creek, $10 \mathrm{mi}$. S of Sunrise, Chugach Mts.; $60^{\circ} 43^{\prime} 25^{\prime \prime} \mathrm{N}, 149^{\circ} 27^{\prime} 00^{\prime \prime}$ W; (map 63).

Local prospectors' name; reported about 1914 by B. L. Johnson (in Martin and others, 1915, pl. 2), USGS.

Roaring Creek: stream, flows NW $3.3 \mathrm{mi}$. to Kotsina River, $37 \mathrm{mi}$. NW of McCarthy, Wrangell Mts. ; $61^{\circ} 47^{\prime} \mathrm{N}, 143^{\circ} 51^{\prime} \mathrm{W}$; (map 67).

Local name reported in 1900 by T. G. Gerdine, USGS.

Roaring Creek: stream, flows SE $4.7 \mathrm{mi}$. to Oshetna River, $31 \mathrm{mi}$. NW of Tahneta Pass and $82 \mathrm{mi}$. W of Gulkana, Talkeetna Mts.; $62^{\circ} 15^{\prime} \mathrm{N}, 147^{\circ} 53^{\prime} \mathrm{W}$; (map 82).

Local descriptive name reported in 1931 by USGS.

Roaring Glacier: glacier, E of Surprise Glacier, trends NE $3.5 \mathrm{mi}$. to its terminus at head of a stream $1 \mathrm{mi}$. long which drains into Harriman Fiord, 52 mi. SE of Anchorage, Chugach 
Mts.; $61^{\circ} 00^{\prime} 45^{\prime \prime} \mathrm{N}, 148^{\circ} 24^{\prime} 30^{\prime \prime} \mathrm{W} ; B G N$ 1964; (map 69).

Descriptive name given in 1899 by members of the Harriman Alaska Expedition; name suggested by the noise of tumbling ice masses on the steep slope at the glacier terminus.

Roaring Glacier: glacier, see Surprise Glacier.

Robber Hill: hill, $320 \mathrm{ft}$., $0.7 \mathrm{mi}$. E of Witchcraft Point, on northern Kiska I., Aleutian Is.; $52^{\circ} 03^{\prime} 00^{\prime \prime} \mathrm{N}, 177^{\circ} 31^{\prime} 15^{\prime \prime} \mathrm{E}$; (map 14).

An arbitrary name beginning with " $R$ " to correspond to "R" grid used by the U.S. Army for tactical purposes during World War II ; published on a 1953 AMS map.

Robber Island: island, see Toti Island.

Robber Islands: islands, see Ladrones Islands.

Robber Lake: lake, one of group of five, $0.2 \mathrm{mi}$. across, $0.8 \mathrm{mi}$. SE of Witchcraft Point, on northern Kiska I., Aleutian Is.; $52^{\circ} 02^{\prime} 40^{\prime \prime} \mathrm{N}$, $177^{\circ} 31^{\prime} 00^{\prime \prime} \mathrm{E}$; (map 14).

An arbitrary name beginning with " $R$ " to correspond to "R" grid used by the U.S. Army for tactical purposes during World War II; published on a 1953 AMS map.

Robe Lake: lake, $2.2 \mathrm{mi}$. long, $1.5 \mathrm{mi}$. $\mathrm{N}$ of Washbowl Basin and $3 \mathrm{mi}$. SE of Valdez, Chugach Mts.; $61^{\circ} 05^{\prime} 20^{\prime \prime} \mathrm{N}, 146^{\circ} 10^{\prime} 30^{\prime \prime} \mathrm{W}$; (map 68).

Named in 1898 by Capt. W. R. Abercrombie, USA, for a local prospector, Harvey Robe, who joined Abercrombie's party. for a short time.

Robe River: stream, heads in Robe Lake, flows W $3 \mathrm{mi}$. to Lowe River at its mouth on Port Valdez, $1.8 \mathrm{mi}$. SE of Valdez, Chugach Mts.; $61^{\circ} 05^{\prime} 45^{\prime \prime} \mathrm{N}, 146^{\circ} 14^{\prime} 20^{\prime \prime} \mathrm{W}$; (map 68).

Named in 1898 by Capt. W. R. Abercrombie, USA, for a local prospector, Harvey Robe, who joined Abercrombie's party for a short time.

Robert Barron, Mount: mountain, 3,475 ft., on Mansfield Penin., 2 mi. SE of Funter Bay and $16 \mathrm{mi}$. SW of Juneau, Alex. Arch.; 58 $13^{\prime} 35^{\prime \prime}$ N, 134 $50^{\prime} 20^{\prime \prime} \mathrm{W}$; BGN 1919; (map 11). Var. Robert Barron Peak.

Named by USC\&GS in 1919 for Robert Barron, son of James T. Barron, both of whom were instrumental in developing the Funter Bay region. The name was published in 1919 by USC\&GS.

Robert Barron Peak: mountain, see Robert Barron, Mount.

Robert Creek: stream, flows SW $17 \mathrm{mi}$. around E side of Horace Mtn., joins Phoebe Creek to form Bettles River, $21 \mathrm{mi}$. WNW of Chandalar, Brooks Ra.; $67^{\circ} 35^{\prime} 40^{\prime \prime} \mathrm{N}, 149^{\circ} 14^{\prime} 00^{\prime \prime}$ W; (map 123).

Prospectors' name reported in 1899 by Schrader (1900b, pl. 60), USGS.

Robert Island: island, $1 \mathrm{mi}$. long, largest of Robert Is. in Port Houghton, $2 \mathrm{mi}$. NE of Fort Point and $73 \mathrm{mi}$. E of Sitka, Coast Mts. $57^{\circ} 18^{\prime} 15^{\prime \prime} \mathrm{N}, 133^{\circ} 28^{\prime} 50^{\prime \prime} \mathrm{W}$; ( $\operatorname{map} 8$ ).

Name published by USC\&GS in 1883 Coast Pilot (p. 128).

Robert Islands: islands, off $\mathrm{S}$ shore of Port Houghton at its junc. with Stephens Passage, $2.5 \mathrm{mi}$. NE of Fort Point and $73 \mathrm{mi}$. $\mathrm{E}$ of
Sitka, Coast Mts.; $57^{\circ} 18^{\prime} 15^{\prime \prime} \mathrm{N}, 133^{\circ} 28^{\prime} 00^{\prime \prime}$ W; (map 8). Var. Roberts Islands.

Named in 1882 by Lt. Comdr. H. E. Nichols, USN; published by USC\&GS in 1891 Coast Pilot (p. 128).

Robert Lincoln, Mount: mountain, see Roberts Mountain.

Robert Ridge: ridge, $1 \mathrm{mi}$. long, $1.3 \mathrm{mi}$. NE of Conquer Point, Kiska I., Aleutian Is.; $52^{\circ} 01^{\prime}$ $15^{\prime \prime} \mathrm{N}, 177^{\circ} 30^{\prime} 35^{\prime \prime} \mathrm{E}$; (map 14).

An arbitrary name beginning with " $R$ " to correspond to "R" grid used by the U.S. Army for tactical purposes during World War II; published on a 1953 AMS map.

Roberts, Mount: peak, 3,819 ft., $1.6 \mathrm{mi}$. N of Thane, on Gastineau Channel, $3 \mathrm{mi}$. SE of Juneau, Coast Mts.; 58 $17^{\prime} 10^{\prime \prime}$ N, 134 $4^{\circ} 19^{\prime}$ $30^{\prime \prime}$ W; (map 11). Var. Gold Mountain, Little Mount Juneau, Roberts Peak, Swede Hill.

Source of name uncertain. In 1881 there were numerous references to the mountain as Gold Mtn. However, in 1883, Henry Roberts located a number of mining claims along Roberts Gulch below this mountain and thus may be the source of the name. Between 1902 and 1913 the mountain was frequently called "Swede Hill," but since that time the name "Mount Roberts" has been generally adopted (DeArmond, 1957, p. 36, 37).

Roberts, Mount: mountain, see Roberts Mountain.

Roberts Bay: bay, see Sawmill Bay.

Roberts Creek: stream, flows NE $18 \mathrm{mi}$, to Bonasila River, $2 \mathrm{mi}$. W of Anvik and $46 \mathrm{mi}$. NW of Holy Cross, Nulato Hills: $62^{\circ} 37^{\prime} 50^{\prime \prime} \mathrm{N}$, $160^{\circ} 53^{\prime} 00^{\prime \prime} \mathrm{W}$; (map 78).

Local name reported in 1949 by USC\&GS.

Roberts Creek: stream, heads on NW slope of Cloudy Mtn., flows SW $12 \mathrm{mi}$. to Innoko River, $13 \mathrm{mi}$. SE of Ophir and $19 \mathrm{mi}$. NW of McGrath, Kilbuck-Kuskokwim Mts.; $63^{\circ}$. $06^{\prime} \mathrm{N}, 156^{\circ} 08^{\prime} \mathrm{W}$; (map 90).

Prospectors' name published in 1921 by USGS.

Roberts Gulch: ravine, probably on SE slope of Mount Roberts, about $3.5 \mathrm{mi}$. SE of Juneau; Coast Mts.; $58^{\circ} 17^{\prime} \mathrm{N}, 134^{\circ} 17^{\prime} \mathrm{W}$; (map 11).

Locally named for Henry Roberts, who located a number of claims on this gulch in 1883 (DeArmond, 1957, p. 37).

Roberts Islands: islands, see Robert Islands.

Roberts Mountain: mountain, 1,675 ft., $19 \mathrm{mi}$. W of Twin Mtn. and $16 \mathrm{mi}$. NW of Cape Mendenhall, on Nunivak I.; $60^{\circ} 01^{\prime} 45^{\prime \prime} \mathrm{N}$, $166^{\circ} 15^{\prime} 50^{\prime \prime}$ W ; (map 57). Var. Mount Robert Lincoln, Mount Roberts.

Name reported about 1908 by USC\&GS. Ivan Petroff in the 1880 Census applied the name "Mt. Robe[r]t Lincoln" to this feature. Baker (1906, p. 529), USGS, notes that it was apparently so named in 1778 by $\mathrm{E}$. W. Nelson, U.S. Engineers, after the Honorable Robert Lincoln, Secretary of War, 1881-85, and eldest son of President Abraham Lincoln.

Robertson Creek: stream, see Robinson Creek.
Robertson Glacier: glacier, heads on Mount Kimball, trends NE $10 \mathrm{mi}$. to its 1955 terminus at head of Robertson River, $39 \mathrm{mi}$. NE of Paxson, Alaska Ra.; $63^{\circ} 17^{\prime} 30^{\prime \prime} \mathrm{N}, 144^{\circ} 22^{\prime} 40^{\prime \prime}$ W; $B G N 1936$; (map 86).

Local name reported in 1936 by USGS.

Robertson River: stream, heads at terminus of Robertson Glacier, flows NE $33 \mathrm{mi}$. to Tanana River, $16 \mathrm{mi}$. NW of Tanacross, Alaska Ra.; $63^{\circ} 30^{\prime} \mathrm{N}, 143^{\circ} 47^{\prime} \mathrm{W}$; (map 85).

Named in 1885 by Lt. Allen (1887, p. 81), USA, in honor of Sgt. Cady Robertson, USA, a member of his party.

Roberts Peak: peak, see Roberts, Mount.

Robin Creek: stream, flows NW $1.4 \mathrm{mi}$. to West Kiska Lake, Kiska I., Aleutian Is. ; $52^{\circ} 03^{\prime} 12^{\prime \prime}$ $\mathrm{N}, 177^{\circ} 33^{\prime} 10^{\prime \prime} \mathrm{E}$; (map 14).

An arbitrary name beginning with " $R$ " to correspond to " $R$ " grid used by the U.S. Army for tactical purposes during World War II; published on a 1953 AMS map.

Robin Creek: stream, flows NE $2 \mathrm{mi}$. to Dominion Creek, 76 mi. NE of Bethel, KilbuckKuskokwin Mts. ; $61^{\circ} 00^{\prime} \mathrm{N}, 159^{\circ} 33^{\prime} \mathrm{W}$; (map 59).

Prospectors' name reported in 1914 by A. G. Maddren (in Brooks, 1915, pl. 11), USGS.

Robin Island: islands, see Saint Lazaria Islands.

Robinson Creek: stream, flows SW $5.5 \mathrm{mi}$. through a lake, to Behm Canal, $9 \mathrm{mi}$. SE of Point Fitzgibbon, Coast Mts.; 55 $52^{\prime} \mathrm{N}$, $131^{\circ} 06^{\prime} \mathrm{W}$; BGN 1942; (map 3).

Local name reported in 1942 by USFS.

Robinson Creek: stream, flows NW $3 \mathrm{mi}$. to Wade Creek, $45 \mathrm{mi}$. SW of Eagle, Yukon-

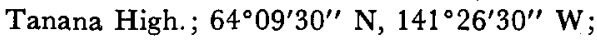
(map 102). Var. Robertson Creek.

Named by prospectors and shown as "Robertson Creek" on an 1898 manuscript map by C. A. Woodruff.

Robinson Falls Creek: stream, flows S $2.5 \mathrm{mi}$. to end of Orca Inlet, $9 \mathrm{mi}$. NE of Cordova, Chugach Mts.; $60^{\circ} 40^{\prime} \mathrm{N}, 145^{\circ} 39^{\prime} \mathrm{W}$; (map 64).

Local name reported in 1913 by B. L. John. son (in Brooks and others, 1914, pl. 7), USGS.

Robinson Hills: mountain range, see Robinson Mountains.

Robinson Lake: lake, see Nikabuna Lake.

Robinson Mountains: mountain range, trends $\mathbf{5 0}$ mi. along Gulf of Alaska from Bering Glacier on $\mathrm{W}$ to Guyot Glacier on E, $100 \mathrm{mi}$. NW of Yakutat, St. Elias Mts. ; $60^{\circ} 18^{\prime}$ N. $142^{\circ} 20^{\prime}$ W; $B G N$ 1960; (map 65). Var. Robinson Hills.

Named by I. G. Russell in 1891 to commemorate Lt. L. I. Robinson, USRCS, who was drowned while landing at Icy Bay that year.

Robinson Ridge: ridge, 1 mi. long, between West Massacre Valley and Prendergast Ridge, on eastern Attu I., Aleutian Is.; 52 $53^{\prime} 25^{\prime \prime} \mathrm{N}$, $173^{\circ} 09^{\prime} 25^{\prime \prime} \mathrm{E}$; (map 13).

Name given by the U.S. Army during World War II and shown on an AMS map published in 1948; name is not used today.

Rob Point: point of land, on SW coast of Krestof I., $11 \mathrm{mi}$. NW of Sitka, Alex. Arch.; $57^{\circ} 09^{\prime} \mathrm{N}, 135^{\circ} 33^{\prime} \mathrm{W}$; (map 9). 
Probably a local name reported in 1897 by Lt. Comdr. E. K. Moore, USN, and published in 1900 by USC\&GS on Chart 8281 .

Rochanoff Lake: lake, see Becharof Lake.

Rocher en forme de Colonne: rock, see Pillar Rock.

Rocheshnoe: village, see Nikolski.

Rock Bay: cove, see Quartz Bay.

Rock Butte: mountain, 3,165 ft., on Prince of Wales I, near head of West Arm Cholmondeley Sound, Alex. Arch.; 55 ${ }^{\circ} 17^{\prime} 00^{\prime \prime} \mathrm{N}, 132^{\circ} 28^{\prime} 30^{\prime \prime}$ W; (map 4).

Local name published in 1943 by USC\&GS

Rock Candy Creek: stream, heads at glacier terminus, flows NW $2.8 \mathrm{mi}$. to larger glacier, $2 \mathrm{mi}$. SW of that glacier's terminus at head of West Fork Robertson River, $32 \mathrm{mi}$. NE of Paxson, Alaska Ra., $63^{\circ} 19^{\prime} 15^{\prime \prime}$ N, $144^{\circ} 41^{\prime} 30^{\prime \prime}$ W; (map 86).

Name published on relatively recent maps. Rock Cliff: cliff, $1.5 \mathrm{mi}$. NE of Arch Point, 4 mi. NW of Dolgoi I., near SW end of Alaska Penin., Aleutian Ra,; 55 $04^{\prime} 10^{\prime \prime} \mathrm{N}, 161^{\circ} 53^{\prime}$ $00^{\prime \prime} \mathrm{W}$; (map 28).

Named in 1943 by USC\&GS

Rock Creek: stream, flows N $3 \mathrm{mi}$. to head of Polk Inlet, near center of Prince of Wales I., Alex. Arch.; $55^{\circ} 18^{\prime} 55^{\prime \prime} \mathrm{N}, 132^{\circ} 27^{\prime} 55^{\prime \prime} \mathrm{W}$; (map 4).

Local name published in 1943 by USC\&GS.

Rock Creek: stream, flows NE $10 \mathrm{mi}$. to Chulitna River, $10 \mathrm{mi}$. NW of Nondalton, Alaska Ra.; $60^{\circ} 07^{\prime} 30^{\prime \prime}$ N, $155^{\circ} 03^{\prime} 30^{\prime \prime}$ W; (map 61).

Local name reported in 1954 by USGS.

Rock Creek: stream, flows SW $24 \mathrm{mi}$. to Stony River $13 \mathrm{mi}$. NW of its junc. with Telaquana River, $65 \mathrm{mi}$. NW of Lake Clark, Lime Hills; $61^{\circ} 12^{\prime} \mathrm{N}, 154^{\circ} 41^{\prime} \mathrm{W}$; (map 71).

Prospectors' name published in 1951 by USGS.

Rock Creek: stream, heads at glacier terminus and flows $6.1 \mathrm{mi}$. NW to Kotsina River $2 \mathrm{mi}$. SE of its junc. with Kluvesna River and 40 mi. NW of McCarthy, Wrangell Mts.; $61^{\circ} 43^{\prime}$ N, $143^{\circ} 58^{\prime} \mathrm{W}$; (map 67).

Name obtained from prospectors, reported by T. G. Gerdine (Mendenhall and Schrader, 1903, pl. 3).

Rock Creek: stream, flows $6 \mathrm{mi}$. E to Willow Creek, $5 \mathrm{mi}$. NW of Kenney Lake and $58 \mathrm{mi}$. NE of Valdez, Chugach Mts. ; $61^{\circ} 45^{\prime} 45^{\prime \prime} \mathrm{N}$, $145^{\circ} 05^{\prime} 00^{\prime \prime} \mathrm{W}$; BGN 1932; (map 68). Var. Mosquito Creek.

Local name reported in 1930 by USGS.

Rock Creek: stream, heads in Mentasta Mts., flows SW $5 \mathrm{mi}$. to Caribou Creek $10 \mathrm{mi}$. SE of its junc. with Copper River, Alaska Ra.; $62^{\circ} 34^{\prime} \mathrm{N}, 143^{\circ} 28^{\prime} \mathrm{W} ; B G N$ 1939; (map 84).

Local name reported by USGS in 1939.

Rock Creek: stream, heads in lake at $W$ end of High Valley, flows SE, through Phalarope and other lakes, $19 \mathrm{mi}$. to one of Tangle Lakes, near head of Delta River, $18 \mathrm{mi}$. W of Paxson, Alaska Ra.; $63^{\circ} 02^{\prime} 25^{\prime \prime} \mathrm{N}, 1^{\circ} 46^{\circ} 03^{\prime} 10^{\prime \prime} \mathrm{W}$; (map 86). Var. Boulder Creek.

Named by ARC; reported in 1955 by Reuben Kachadoorian, USGS
Rock Creek: stream, flows SW $2.2 \mathrm{mi}$. to Chisna River $3 \mathrm{mi}$. NE of its junc. with Chistochina River, $23 \mathrm{mi}$. NE of Parsons, Alaska Ra. ; $63^{\circ}$ $05^{\prime} 00^{\prime \prime} \mathrm{N}, 144^{\circ} 47^{\prime} 08^{\prime \prime} \mathrm{W}$; (map 86). Var. Willow Creek.

Prospectors' name reported in 1902 by W. C. Mendenhall, USGS.

Rock Creek: stream, in Kantishna Hills, flows NW $12 \mathrm{mi}$. to Bearpaw River, $15 \mathrm{mi}$. N of Wonder Lake, Alaska Ra.; $63^{\circ} 42^{\prime} 45^{\prime \prime} \mathrm{N}$, $150^{\circ} 55^{\prime} 20^{\prime \prime} \mathrm{W}$; (map 88).

Local name shown on a 1916 fieldsheet by C. E. Giffin, USGS

Rock Creek: stream, flows E $3.5 \mathrm{mi}$. to Wood River, $36 \mathrm{mi}$. NE of Healy, Alaska Ra.; $63^{\circ}$. $54^{\prime} 10^{\prime \prime} \mathrm{N}, 147^{\circ} 50^{\prime} 10^{\prime \prime} \mathrm{W}$; (map 87).

Local descriptive name reported in 1951 by USGS.

Rock Creek: stream, flows S $5 \mathrm{mi}$. to Goodpaster River, $48 \mathrm{mi}$. NE of Big Delta, YukonTanana High.; $64^{\circ} 30^{\prime} \mathrm{N}, 144^{\circ} 30^{\prime} \mathrm{W}$; (map 101).

Named by prospectors and reported in 1903 by T. G. Gerdine (Prindle, 1913a, pl. 16), USGS.

Rock Creek stream, flows SE $5.5 \mathrm{mi}$. to Topkok River near its mouth, $15 \mathrm{mi}$. E of Solomon, Seward Penin. High.; 64 $34^{\circ} 00^{\prime \prime} \mathrm{N}, 163^{\circ}$ $56^{\prime} 30^{\prime \prime}$ W; (map 95).

Prospectors' name reported on the 1904 "Map of Cape Nome Precinct" by Arthur Gibson.

Rock Creek: stream, flows SW $2.6 \mathrm{mi}$. to Snake River, $7 \mathrm{mi}$. NW of Nome, Seward Penin. High.; $64^{\circ} 36^{\prime} N, 165^{\circ} 28^{\prime} W$; (map 94).

Prospectors' name reported in 1899 by $D$. C. Witherspoon (in Schrader and Brooks, 1900, map 2), USGS.

Rock Creek: stream, flows SW $1.2 \mathrm{mi}$. to Solomon River, $0.3 \mathrm{mi}$. N of Chambers Creek and $3.5 \mathrm{mi}$. NE of Solomon, Seward Penin. High.; $64^{\circ} 36^{\prime} 30^{\prime \prime} \mathrm{N}, 164^{\circ} 23^{\prime} 00^{\prime \prime} \mathrm{W}$; (map 95).

Prospectors' name reported on a 1902 prospectors' manuscript map.

Rock Creek: stream, flows N $1.5 \mathrm{mi}$. to Coal Creek which flows to Solomon River, $14 \mathrm{mi}$. NE of Solomon, Seward Penin. High.; $64^{\circ}$. $44^{\prime} 40^{\prime \prime} \mathrm{N}, 164^{\circ} 14^{\prime} 45^{\prime \prime} \mathrm{W}$; (map 95).

Prospectors' name reported on a map of Cape Nome gold fields by David Fox, Jr., dated 1901

Rock Creek: stream, flows NW $8 \mathrm{mi}$. to Tanana River, $66 \mathrm{mi}$. W of Fairbanks, Tanana Low.; $64^{\circ} 45^{\prime} 30^{\prime \prime} \mathrm{N}, 149^{\circ} 56^{\prime} 50^{\prime \prime} \mathrm{W}$; (map 100).

Local name reported in 1921 by USGS.

Rock Creek: stream, flows S $2.2 \mathrm{mi}$. to Fox Creek which flows to Eldorado River, $20 \mathrm{mi}$. NE of Nome, Seward Penin. High.; 64 $4^{\circ} 5^{\prime}$ $58^{\prime \prime} \mathrm{N}, 165^{\circ} 06^{\prime} 59^{\prime \prime} \mathrm{W}$; (map 94).

Prospectors' name reported in 1904 by $\mathrm{T}$. G. Gerdine, USGS.

Rock Creek: stream, flows W 2 mi. to Big Four Creek which flows to Casadepaga River, 22 mi. NE of Solomon, Seward Penin. High.; $64^{\circ} 50^{\prime} \mathrm{N}, 164^{\circ} 05^{\prime} \mathrm{W}$; (map 95).

Prospectors' name reported on a map of Cape Nome gold fields by David Fox, Jr., dated 1901
Rock Creek: stream, flows $\mathrm{N} 4 \mathrm{mi}$. to Seventymile River, $11 \mathrm{mi}$. NW of Eagle, YukonTanana High.; 64 $53^{\prime} 45^{\prime \prime} \mathrm{N}, 141^{\circ} 29^{\prime} 30^{\prime \prime} \mathrm{W}$; $B G N$ 1913; (map 102). Var. Little Blanche Creek.

Local name reported in 1912 by $R$. W. Davenport (in Brooks and others, 1913, p. 249), USGS. This stream was reported in 1898 by E. C. Barnard, USGS as "Little Blanche Creek."

Rock Greek: stream, flows NE $2.5 \mathrm{mi}$. to Slate Creek which flows to Pilgrim River, $27 \mathrm{mi}$. NW of Solomon, Seward Penin. High.; 64 ${ }^{\circ} 54^{\prime} \mathrm{N}$, $164^{\circ} 51^{\prime} \mathrm{W}$; (map 95).

Prospectors' name reported in 1900 by $E$. C. Barnard (in Brooks, 1901, pl. 17), USGS.

Rock Creek: stream, flows NW 5 mi. to Chena River 3 mi. SW of junc. with its East Fork and $39 \mathrm{mi}$. E of Fairbanks, Yukon-Tanana High.; $64^{\circ} 54^{\prime} 25^{\prime \prime} \mathrm{N}, 146^{\circ} 20^{\prime} 30^{\prime \prime} \mathrm{W}$; (map 101).

Local descriptive name; published in 1956 by USGS.

Rock Creek: stream, flows NW $7.5 \mathrm{mi}$. to Patterson Creek, $44 \mathrm{mi}$. NE of Bitzshtini Mts., Yukon-Tanana High.; $65^{\circ} 00^{\prime} \mathrm{N}, 151^{\circ} 08^{\prime} \mathrm{W}$; (map 99).

Local descriptive name reported in 1952 by USGS.

Rock Creek: stream, heads in Darby Mts., flows NE $11 \mathrm{mi}$. to Tubutulik River, $29 \mathrm{mi}$. $\mathbf{N}$ of Elim and $50 \mathrm{mi}$. SE of Imuruk Lake, Seward Penin. High.; $65^{\circ} 02^{\prime} \mathrm{N}, 162^{\circ} 10^{\prime} \mathrm{W}$; (map 110).

Prospectors' name reported in 1909 by Smith and Eakin (1911, p1.1), USGS.

Rock Creek: stream, flows SW $1 \mathrm{mi}$. to Baker Creek which flows to Boston Creek, in Pargon River basin, $18 \mathrm{mi}$. $\mathrm{E}$ of Mount Bendeleben, Seward Penin. High.; $65^{\circ} 12^{\prime}$ N, $163^{\circ} 29^{\prime}$ W; (map 110).

Prospectors' name reported on a map of Cape Nome gold fields by David Fox, Jr., dated 1901.

Rock Creek: stream, flows N $7 \mathrm{mi}$. to Garnet Creek, $13 \mathrm{mi}$. SW of Rampart, Yukon-Tanana High.; $65^{\circ} 21^{\prime} \mathrm{N}, 150^{\circ} 26^{\prime} \mathrm{W}$; (map 106).

Prospectors' name reported in 1902 by Lt. Hjalmer Erickson, USA.

Rock Creek: stream, flows SE $5 \mathrm{mi}$. to Peace River, 14 mi. $N$ of Haycock, Seward Penin. High.; $65^{\circ} 24^{\prime} \mathrm{N}, 161^{\circ} 01^{\prime} \mathrm{W}$; (map 109).

Local name reported in 1917 by G. L. Harrington, USGS.

Rock Creek: stream, flows NW $3.4 \mathrm{mi}$. to Taylor Creek which flows to Kougarok River, $7 \mathrm{mi}$. SW of Midnight Mtn. and $45 \mathrm{mi}$. NW of Imuruk Lake, Seward Penin. High.; 65 ${ }^{\circ} 41^{\prime}$ N, 164'45' W; (map 110).

Prospectors' name reported in 1901 by T. G. Gerdine (in Collier, 1902, pl. 12), USGS.

Rock Creek: stream, flows SW 5 mi. to Burke Creek which flows to American River, $10 \mathrm{mi}$. W of Kougarok Mtn. and $37 \mathrm{mi}$. NE of Teller, Seward Penin. High.; $65^{\circ} 41^{\prime} \mathrm{N}, 165^{\circ} 35^{\prime} \mathrm{W}$; (map 111). 
Prospectors' name reported on the 1908 "Map of Seward Peninsula" by Arthur Gibson.

Rock Creek: stream, flows NW $13 \mathrm{mi}$, to Preacher Greek, $8 \mathrm{mi}$. SW of mouth of Mule Creek and $38 \mathrm{mi}$. W of Circle, Yukon-Tanana High.; $65^{\circ} 49^{\prime} \mathrm{N}, 145^{\circ} 23^{\prime} \mathrm{W}$; (map 104).

Named by prospectors and reported in 1904 by D. C. Witherspoon, USGS.

Rock Creek: stream, flows NE $3.3 \mathrm{mi}$. to Waldron Creek, $40 \mathrm{mi}$. NE of Rampart, YukonTanana High.; $65^{\circ} 50^{\prime}$ N, $149^{\circ} 17^{\prime}$ W; (map 105).

Local name published by USGS in the 1950 's.

Rock Creek: stream, on Seward Penin., flows NE $17.6 \mathrm{mi}$. to North Fork Serpentine River, $59 \mathrm{mi}$. NW of Deering, Kotzebue-Kobuk Low.; $66^{\circ} 06^{\prime} \mathrm{N}, 164^{\circ} 50^{\prime} \mathrm{W}$; (map 113).

Local name published in 1908 on the "Map of Seward Peninsula" by Arthur Gibson.

Rock Creek: stream, flows SW $8.5 \mathrm{mi}$. to North Fork Koyukuk River, $11 \mathrm{mi}$. SW of Emma Dome and $18 \mathrm{mi}$. SW of Wiseman, Brooks Ra. ; $67^{\circ} 16^{\prime} 30^{\prime \prime} \mathrm{N}, 150^{\circ} 41^{\prime} 00^{\prime \prime} \mathrm{W}$; BGN 1932; (map 124).

Local name reported by Robert Marshall in 1932.

Rock Creek: stream, flows NE $8 \mathrm{mi}$. to Middle Fork Chandalar River, $18 \mathrm{mi}$. E of Chandalar, Brooks Ra.; $67^{\circ} 31^{\prime} 10^{\prime \prime} \mathrm{N}, 147^{\circ} 49^{\prime} 00^{\prime \prime} \mathrm{W}$; (map 123).

Prospectors' name obtained in 1909 by A. G. Maddren (in Brooks and others, 1910, pl. 7), USGS.

Rock Creek: stream, see Boil Creek.

Rock Crossing: crossing, on Tanana River, 3 mi. downstream from mouth of Kantishna River, Tanana Low.; $64^{\circ} 47^{\prime} 20^{\prime \prime}$ N., $150^{\circ}$. $03^{\prime} 00^{\prime \prime} \mathrm{W}$; (map 99).

Riverboat crossing (a shift from one side of the stream to the other) published on a 1940 "Navigation Chart of the Tanana-Yukon Rivers" by U.S. Dept. of Interior.

Rocker Creek: stream, flows $6.6 \mathrm{mi}$. NW to Ptarmigan Creek, 2 mi. W of Alaska-Canada boundary and $70 \mathrm{mi}$. NE of McCarthy, Alaska Ra.; $61^{\circ} 55^{\prime} \mathrm{N}, 141^{\circ} 04^{\prime} \mathrm{W} ; B G N$ 1912; (map 67).

Local name reported in 1908-09 by IBC surveyors; published in 1914 on IBC Sheet 32 (1918 atlas). Named for a sluice rocker.

Rocker Gulch: ravine, trends S $0.5 \mathrm{mi}$. to Norton Sound, $1 \mathrm{mi}$. E of Nome, Seward Penin. High.; 64 $29^{\prime} 35^{\prime \prime} \mathrm{N}, 165^{\circ} 21^{\prime} 30^{\prime \prime} \mathrm{W}$; (map 94).

Prospectors' name reported in 1904 by $\mathrm{T}$. G. Gerdine, USGS.

Rocket Lake: lake, $200 \mathrm{yd}$. across, $0.5 \mathrm{mi}$. W of Sredni Bight, Kiska I., Aleutian Is.; 52 ${ }^{\circ}$. $03^{\prime} 25^{\prime \prime} \mathrm{N}, 177^{\circ} 37^{\prime} 20^{\prime \prime} \mathrm{E}$; (map 14).

An arbitrary name beginning with " $R$ " to correspond to "R" grid used by the U.S. Army for tactical purposes during World War II; published on a 1953 AMS map.

Rockfish Cove: bight, $1.8 \mathrm{mi}$. wide, on NW coast of Revillagigedo I.; indents S shore of Neets
Bay, Alex. Arch.; 55 $46^{\prime} \mathrm{N}, 131^{\circ} 37^{\prime} \mathrm{W}$; (map 3).

One of many arbitrary names applied to features in this area in 1891 by USC\&GS.

Rockford Creek: stream, flows E to Solomon River, about $8 \mathrm{mi}$. NE of Solomon, Seward Penin. High.; (map 95).

Prospectors' name reported on a prospector's manuscript map dated 1902 . This stream cannot be precisely located on current maps.

Rock Glacier Creek: stream, flows NW $6.2 \mathrm{mi}$. to Matanuska River, $\mathrm{E}$ of Lion Head and 50 mi. NE of Palmer, Chugach Mts.; $61^{\circ} 47^{\prime} \mathrm{N}$, $147^{\circ} 39^{\prime} \mathrm{W}$; BGN 1960; (map 69).

Named in 1956 by USGS for the rock glaciers located at the headwaters of the stream. A rock glacier is a tongue-like body of angular boulders, similar to a small ice glacier, and generally occurs at high altitudes in rugged terrain.

Rock Head West: mountain, 2,800 ft., $7 \mathrm{mi}$. SW of Arctic Village, Brooks Ra.; $68^{\circ} 06^{\prime} \mathrm{N}, 145^{\circ}$ $48^{\prime} \mathrm{W}$; (map 136).

Local name reported in 1956 by R. C. Foley, USGS.

Rock Island: rock, $2 \mathrm{mi}$. W of Cape Lazaref, on SE coast of Unimak I., Aleutian Is.; 54 $37^{\prime}$ $00^{\prime \prime} \mathrm{N}, 163^{\circ} 37^{\prime} 20^{\prime \prime} \mathrm{W}$; (map 25).

Descriptive name reported by Ferdinand Westdahl, USC\&GS, commander of the Coast Survey steamer McArthur, who made surveys in this area in 1901.

Rock Island Point: locality, on left bank of Koyukuk River, $1.5 \mathrm{mi}$. N of Huggins Is., 33 mi. NE of Hochandochtla Mtn., KokrinesHodzana High.; $65^{\circ} 56^{\prime} 45^{\prime \prime} \mathrm{N}, 154^{\circ} 19^{\prime} 45^{\prime \prime}$ W; (map 107).

Name published in a 1905 folder of the Northern Commercial Company.

Rock Islets: islands, see Triplets, The.

Rock Lake: lake, $0.8 \mathrm{mi}$. long, on Prince of Wales I. near head of Polk Inlet, $\mathbf{N}$ of Rock Butte, Alex. Arch.; $55^{\circ} 17^{\prime} 45^{\prime \prime} \mathrm{N}, 132^{\circ} 29^{\prime} 30^{\prime \prime}$ W; BGN 1963; (map 4).

Local name reported in 1961 by USFS.

Rock Lake: lake, $0.2 \mathrm{mi}$. long, on Kenai Penin. between Hidden and Skilak Lakes, $37 \mathrm{mi}$. E of Kenai, Chugach Mts. ; $60^{\circ} 27^{\prime} 15^{\prime \prime} \mathrm{N}, 150^{\circ} 15^{\prime}$ $00^{\prime \prime} \mathrm{W}$; (map 62).

Named about 1963 by officials of Kenai National Moose Range, for administrative purposes.

Rock Lake: lake, $1.3 \mathrm{mi}$. long, on Kenai Penin., $9 \mathrm{mi}$. NE of Sterling and $23 \mathrm{mi}$. ENE of Kenai, Cook Inlet Low.; $60^{\circ} 39^{\prime} \mathrm{N}, 150^{\circ} 38^{\prime} \mathrm{W}$; (map 62).

Local name reported in 1958 by USGS.

Rock Lake: lake, $1 \mathrm{mi}$. long, $2.5 \mathrm{mi}$. $\mathrm{SE}$ of Girahina Butte and $6 \mathrm{mi}$. NNE of Nelson Mtn., Wrangell Mts.; $61^{\circ} 24^{\prime} 40^{\prime \prime} \mathrm{N}, 143^{\circ} 44^{\prime}$ 50" W; BGN 1966; (map 67).

So named in 1966 by Dave Dann of Chitina because of a "large rock rising above waterline 50 feet from NW shore."

Rock Lake: lake, $5 \mathrm{mi}$. long, at head of Ptarmigan Creek, $60 \mathrm{mi}$. NE of McCarthy, Al iska Ra. ; $61^{\circ} 48^{\prime} \mathrm{N}, 141^{\circ} 15^{\prime} \mathrm{W}$; (map 67). Var. Ptarmigan Lake.
Local name reported in 1963 by USGS.

Rock Lake: lake, $0.9 \mathrm{mi}$. long, $2 \mathrm{mi}$. E of Crosswind Lake and $21 \mathrm{mi}$. NW of Glennallen, Copper River Basin, 62 $21^{\prime} 45^{\prime \prime} \mathrm{N}, 145^{\circ} 54^{\prime}$ 30" W; (map 83).

Local name reported in 1951 by USGS.

Rock Lake: lake, $0.6 \mathrm{mi}$. long, E of Upper Fish Lake, $4.5 \mathrm{mi}$. NE of Paxson, Alaska Ra.; $63^{\circ} 04^{\prime} 30^{\prime \prime} \mathrm{N}, 145^{\circ} 22^{\prime} 40^{\prime \prime} \mathrm{W}$; (map 86).

Name published on relatively recent maps.

Rock Lake: lake, $0.6 \mathrm{mi}$. long, $20 \mathrm{mi}$. $\mathrm{N}$ of Chalkyitsik, Yukon Flats; $66^{\circ} 56^{\prime} \mathrm{N}, 143^{\circ} 46^{\prime}$ W; (map 120).

Local descriptive name; reported in 1956 by R. C. Foley, USGS.

Rock Mountain: mountain, 2,300 ft., in Kenai Mts., at NW end of Chugach Bay, $16 \mathrm{mi}$. S of Seldovia, Chugach Mts.; $59^{\circ} 13^{\prime} \mathrm{N}, 151^{\circ} 38^{\prime}$ W; BGN 1911; (map 50).

Named by U. S. Grant, USGS, in 1909, for Thomas Rock, a local prospector.

Rock of Ages: reef, projects into Yukon River, below mouth of Fourth of July Creek and 34 mi. NW of Eagle, Yukon-Tanana High.; $65^{\circ} 12^{\prime} \mathrm{N}, 141^{\circ} 50^{\prime} \mathrm{W}$; (map 103).

Local name reported in 1937 by J. B. Mertie, Jr., USGS. This name may refer to the same feature shown on recent maps as "Nation Reef." Although the latter name seems to be applied to an island, the generic "Reef" implies that the application should be narrower.

Rockpile Pass: pass, $1,800 \mathrm{ft}$., in Kilbuck Mts., $\mathrm{W}$ of Mount Hamilton and $28 \mathrm{mi}$. SW of Aniak, Kilbuck-Kuskokwim Mts.; $61^{\circ} 10^{\prime} \mathrm{N}$, 159 $47^{\prime} \mathrm{W}$; (map 73).

Prospectors' name shown on a 1914 field sheet by A. G. Maddren, USGS.

Rock Point: point of land, on $\mathrm{W}$ bank of Portland Canal, $2.1 \mathrm{mi}$. NW of Hattie I., Canada, Coast Mts., $55^{\circ} 13^{\prime} 30^{\prime \prime} \mathrm{N}, 130^{\circ} 00^{\prime} 35^{\prime \prime} \mathrm{W}$; map 3).

Local name published in 1891 by USC\&GS. Rock Point: point of land, on Revillagigedo I., on W shore of Carroll Inlet, $4 \mathrm{mi}$. NE of California Head, Alex. Arch.; $55^{\circ} 21^{\prime} 25^{\prime \prime} \mathrm{N}$, $131^{\circ} 23^{\prime} 45^{\prime \prime}$ W; (map 3)

Descriptive name given in 1891 by USC\&GS

Rock Point: point of land, on NE coast of Gravina I., $8 \mathrm{mi}$. NW of Ketchikan, Alex. Arch.; $55^{\circ} 24^{\prime} 48^{\prime \prime} \mathrm{N}, 131^{\circ} 48^{\prime} 22^{\prime \prime} \mathrm{W}$; (map 3).

Named by W. H. Dall, USC\&GS ; published in 1883 Coast Pilot (p. 81).

Rock Point: point of land, on $W$ coast of Mitkof I., $9.5 \mathrm{mi}$. S of Petersburg, Alex. Arch.; $56^{\circ} 40^{\prime} 20^{\prime \prime} \mathrm{N}, 132^{\circ} 55^{\prime} 50^{\prime \prime} \mathrm{W}$; (map 6). Var. Mielkie Point, Mys Mylkiy.

Named in 1869 by Comdr. R. W. Meade, USN; named "Mys Mylkiy," meaning "shallow cape" in 1838 by the Russian surveyor, G. Lindenberg.

Rock Point: point of land, in Deadman Reach, on NW side of Duffield Penin., on N coast of Baranof I., 34 mi. N of Sitka, Alex. Arch.; $57^{\circ} 31^{\prime} 45^{\prime \prime}$ N, $135^{\circ} 29^{\prime} 30^{\prime \prime} \mathrm{W}$; (map 9). Var. Mys Kamenistyy.

This is a translation by USC\&GS about 1882 of the name given by the Russian pilot Ens. 
Vasiliev; published in 1848 on Russian $\mathrm{Hy}-$ drog. Dept. Chart 1397 as "M[ys] Kamenistyy" (Rocky Cape).

Rock Point: point of land, on S shore of Endicott Arm, $2 \mathrm{mi}$. S of Sumdum I. and $55 \mathrm{mi}$. $\mathrm{SE}$ of Juneau, Coast Mts.; $57^{\circ} 40^{\prime} 50^{\prime \prime} \mathrm{N}$, $133^{\circ} 28^{\prime} 15^{\prime \prime} \mathrm{W}$; (map 8).

Descriptive name given in 1889 by $\mathrm{Lt}$. Comdr. H. B. Mansfield, USN.

Rock Point: point of land, at mouth of Northeast Arm Uganik Bay, on $\mathbf{N}$ coast of Kodiak I. ; $57^{\circ} 46^{\prime} 25^{\prime \prime} \mathrm{N}, 153^{\circ} 29^{\prime} 10^{\prime \prime} \mathrm{W}$; (map 34).

Descriptive name given in 1897 by Lt. Comdr. J. F. Moser, USN, of the USBF steamer Albatross.

Rock Point: point of land, on Chichagof I., in Chichagof Strait, $0.5 \mathrm{mi}$. SW of Miner I. and $34 \mathrm{mi}$. SW of Hoonah, Alex. Arch.; $58^{\circ} 00^{\prime} \mathrm{N}$, $136^{\circ} 21^{\prime} \mathrm{W}$; (map 10).

Local navigators' name reported by $\mathrm{H}$. C. Fassett, USBF, in 1904.

Rock Point: bluff, elev. 1,800 ft., NE of Close Lake, $20 \mathrm{mi}$. SE of Tok, Alaska Ra.; $63^{\circ} 09^{\prime}$ $30^{\prime \prime} \mathrm{N}, 142^{\circ} 28^{\prime} 30^{\prime \prime} \mathrm{W}$; (map 85).

Local name published by USGS in 1965.

Rock Point: point of land, on $\mathrm{N}$ coast of St. Michael I., $2.5 \mathrm{mi}$. N of St. Michael, YukonKuskokwim Delta; $63^{\circ} 31^{\prime} \mathrm{N}, 1^{\circ} 62^{\circ} 04^{\prime} \mathrm{W}$; (map 92).

Descriptive name given in 1898 by USC\&GS. "The point is very rocky * * *"

Rock Point: point of land, see Kamenoi Point.

Rock Point: point of land, see Polk Point.

Rock Point Hill: hill, $109 \mathrm{ft}$., on $\mathrm{N}$ coast of St. Michael I., W of Rock Point, 3 mi. NW of St. Michael, Yukon-Kuskokwim Delta; $63^{\circ}$ $30^{\prime} 35^{\prime \prime} \mathrm{N}, 162^{\circ} 06^{\prime} 30^{\prime \prime} \mathrm{W}$; (map 92).

Local name obtained in 1952 by USC\&GS.

Rock Slough: stream, $5.5 \mathrm{mi}$. long, anabranch of Porcupine River $22 \mathrm{mi}$. NE of Ghalkyitsik, Yukon Flats; $66^{\circ} 57^{\prime} \mathrm{N}, 143^{\circ} 33^{\prime} \mathrm{W}$; (map 120).

Local name published in 1951 by USGS.

Rocks Point: point of land, between Sannak I. and Shumagin Is., on S coast of Alaska Penin., Aleutian Ra.

Shown on J. Billings' track chart as published by $M$. Sauer in 1802 , but not identified on other sources. It cannot be identified at this time.

Rockwell : city, see Juneau.

Rockwell Island: island, $0.1 \mathrm{mi}$. across, in Galankin Is., $0.8 \mathrm{mi}$. $\mathrm{S}$ of Sitka, Alex. Arch.; $57^{\circ} 02^{\prime} 15^{\prime \prime} \mathrm{N}, 135^{\circ} 20^{\prime} 13^{\prime \prime} \mathrm{W}$; (map 9).

Named in 1880 by the U.S. Navy for Comdr. Charles W. Rockwell, USN. The name was published by USC\&GS in the 1883 Coast Pilot (p. 143)

Rockwell Point: point of land, $\mathrm{S}$ point of entrance to Waterfall Bay, $\mathrm{cn}$ W coast of Dall I., Alex. Arch.; $54^{\circ} 56^{\prime} \mathrm{N}, 133^{\circ} 08^{\prime} \mathrm{W} ; B G N$ 1929; (map 1).

Named in 1928 by USC\&GS, "in honor of Kiffin Rockwell, aviator in the Lafayette Escadrille, World War I, who lost his life in action."

Rocky Bay: bay, $1.5 \mathrm{mi}$. across, in Whale Passage, $1 \mathrm{mi}$. SW of Thorne I., on $\mathrm{N}$ coast of
Prince of Wales I., Alex. Arch.; 56 $03^{\prime} \mathrm{N}$, $133^{\circ} 05^{\prime} \mathrm{W}$; ( $\left.\operatorname{map} 6\right)$.

Local descriptive name reported in 1949 by USGS.

Rocky Bay: bay extends S $4.5 \mathrm{mi}$. to Clarence Strait, on SW coast of Etolin I., Alex. Arch.; $56^{\circ} 03^{\prime} 30^{\prime \prime} \mathrm{N}, 132^{\circ} 35^{\prime} 00^{\prime \prime} \mathrm{W}$; (map 6).

Named in 1886 by Lt. Comdr. A. S. Snow, USN; name published in 1887 on USC\&GS Chart 706

Rocky Bay: cove, $0.3 \mathrm{mi}$. across, on SE coast of Takeena Penin., $8 \mathrm{mi}$. SE of Chichagof, on W coast of Chichagof I., Alex. Arch.; 57 $34^{\prime} 00^{\prime \prime} \mathrm{N}, 135^{\circ} 58^{\prime} 30^{\prime} \mathrm{W}$; (map 9).

Descriptive name given by USC\&GS and published in 1928 on Chart 8280.

Rocky Bay: bay, $2.3 \mathrm{mi}$. wide, on $\mathrm{S}$ coast of Kenai Penin., $17 \mathrm{mi}$. SE of Seldovia, Chugach Mts. ; $59^{\circ} 14^{\prime} 15^{\prime \prime} \mathrm{N}, 151^{\circ} 25^{\prime} 00^{\prime \prime} \mathrm{W}$; (map 50).

Local descriptive name reported by U. S. Grant and D. F. Higgins, USGS, in 1909 (in Brooks and others, 1910, pl. 3).

Rocky Bay: bay, on Kenai Penin., at $\mathbf{N}$ end of Montague I., extends NE $3.5 \mathrm{mi}$. to Prince William Sound, $38 \mathrm{mi}$. NE of Chenega, Chugach Mts.; $60^{\circ} 21^{\prime} 30^{\prime \prime} \mathrm{N}, 147^{\circ} 03^{\prime} 00^{\prime \prime} \mathrm{W}$; (map 63).

Descriptive name reported in 1902 by Ferdinand Westdahl, USC\&GS. "Named because of the rocks that are present along the shore line of the bay."

Rocky Bay: estuary, see Necker Bay.

Rockybottom Creek: stream, flows SE, SW, and NW $18 \mathrm{mi}$. to Alatna River, $35 \mathrm{mi}$. NW of Allakaket, Brooks Ra.; $66^{\circ} 58^{\prime} \mathrm{N}, 153^{\circ} 25^{\prime} \mathrm{W}$; $B G N 1932$; (map 116).

Local name reported in 1932 by Robert Marshall.

Rocky Cove: bay, $0.2 \mathrm{mi}$. long, off El Capitan Passage, $\mathrm{W}$ coast of Prince of Wales I., Alex. Arch.; $55^{\circ} 59^{\prime} 28^{\prime \prime} \mathrm{N}, 133^{\circ} 15^{\prime} 50^{\prime \prime} \mathrm{W}$; (map 4).

Descriptive name published in 1925 Coast Pilot (p. 156).

Rocky Cove: bay, $0.3 \mathrm{mi}$. across, on SW coast of Biorka I., on $W$ coast of Baranof I.. Alex. Arch.; $56^{\circ} 50^{\prime} 30^{\prime \prime} \mathrm{N}, 135^{\circ} 33^{\prime} 00^{\prime \prime} \mathrm{W}$; (map 5).

Descriptive name given in 1879 by Lt. F. M. Symonds, USN

Rocky Cove: cove, $1 \mathrm{mi}$. across, on $\mathrm{SW}$ shore of Cook Inlet, $\mathbf{N}$ of Kamishak Bay, Aleutian Ra.; $59^{\circ} 26^{\prime} 45^{\prime \prime} \mathrm{N}, 153^{\circ} 43^{\prime} 30^{\prime \prime} \mathrm{W}$; BGN 1916; (map 51).

Named in 1903 by G. C. Martin, USGS; published in 1912 on USC\&GS Chart 8554.

Rocky Creek: stream, on Kenai Penin., flows W $2 \mathrm{mi}$. to Kenai Lake, $20 \mathrm{mi}$. NE of Seward, Chugach Mts. ; $60^{\circ} 22^{\prime} 40^{\prime \prime} \mathrm{N}, 149^{\circ} 21^{\prime} 10^{\prime \prime} \mathrm{W}$; (map 63)

Descriptive name reported in 1951 by USGS.

Rocky Creek: stream, flows NW 7 mi. to Quicksilver Creek, $7 \mathrm{mi}$. S of Mount Romig and 73 mi. SE of Bethel, Kilbuck-Kuskokwim Mts.; $60^{\circ} 30^{\prime} 30^{\prime \prime} \mathrm{N}, 159^{\circ} 41^{\prime} 00^{\prime \prime} \mathrm{W}$; (map 59).
Local descriptive name; reported in 1955 by J. M. Hoare, USGS.

Rocky Creek: stream, flows SE $1.5 \mathrm{mi}$. to Lower Willow Creek which flows to Casadepaga River, $18 \mathrm{mi}$. NE of Solomon, Seward Penin. High.; $64^{\circ} 49^{\prime} \mathrm{N}, 164^{\circ} 24^{\prime} \mathrm{W}$; (map 95).

Prospectors' name reported in 1905 by $\mathrm{T}$. G. Gerdine, USGS.

Rocky Creek: stream, in Kallarichuk Hills of Baird Mts., flows WSW $3.5 \mathrm{mi}$. to Klery Creek, $17 \mathrm{mi}$. $\mathbf{N}$ of Kiana, Brooks Ra.; $67^{\circ} 13^{\prime} 15^{\prime \prime} \mathrm{N}$, $160^{\circ} 24^{\prime} 00^{\prime \prime} \mathrm{W}$; (map 127).

Name used by prospectors; reported in 1910 by P. S. Smith (in Brooks and others, 1911, pl. 13), USGS.

Rocky Creek: stream, see Rocky Mountain Creek.

Rocky Island: island, $0.1 \mathrm{mi}$. across, in Icy Strait, at mouth of Lynn Canal, $25 \mathrm{mi}$. SW of Juneau, St. Elias Mts.; $58^{\circ} 10^{\prime} 40^{\prime \prime}$ N, $135^{\circ} 03^{\prime}$ $00^{\prime \prime}$ W; (map 11). Var. Rocky Islet.

Named by Lt. F. M. Symonds, USN, in 1880 , or possibly by Comdr. R. W. Meade, USN, in 1869. Name was published on Hydrog. Chart 225 in 1880 . The island was called "Rocky Islet" by Baker (1906, p. 531).

Rocky Island: island, $34 \mathrm{mi}$. N of Afognak, 3.5 mi. off $\mathrm{N}$ coast of Afognak I.; $58^{\circ} 29^{\prime} 45^{\prime \prime} \mathrm{N}$, $152^{\circ} 46^{\prime} 50^{\prime \prime} \mathrm{W}$; (map 43).

Descriptive name reported in 1901 by Lt. Comdr. J. F. Moser, USN, commander of the USBF steamer Albatross.

Rocky Island: island, in Prince William Sound, off $\mathbf{W}$ coast of Knight $\mathbf{I}$., on $\mathbf{N}$ side of Drier Bay, $8 \mathrm{mi}$. NE of Chenega, Chugach Mts.; $60^{\circ} 18^{\prime} 55^{\prime \prime} \mathrm{N}, 147^{\circ} 51^{\prime} 55^{\prime \prime} \mathrm{W}$; (map 63).

Descriptive name published in 1908 by USC\&GS.

Rocky Island: island, see Holiday Island.

Rocky Island: island, see Kak Island.

Rocky Island: island, see Piedras Island

Rocky Island: shoal, see Utesistoi Island

Rocky Islands: islands, see Triplets, The.

Rocky Islet: island, $600 \mathrm{ft}$. long, in Saint Paul Harbor, between Near and Gull Is., $1 \mathrm{mi}$. SW oc Kodiak, Kodiak I.; $57^{\circ} 46^{\prime} 40^{\prime \prime}$ N, $152^{\circ} 25^{\prime}$ 00" W; (map 34). Var. Ostrov Utichey.

Translation by Baker $(1906$, p. 532$)$ of the name "Os[trov] Utichey," published on undated [probably early 1800's] Russian map. This feature is not named on current maps.

Rocky Islet: island, see Rocky Island.

Rocky Islets: islands, see Triplets, The.

Rocky Lake: lake, $0.3 \mathrm{mi}$. long, at Tonki Point, on SE coast of St. Paul I., in Pribilof Is.; $57^{\circ} 09^{\prime} 10^{\prime \prime} \mathrm{N}, 170^{\circ} 12^{\prime} 45^{\prime \prime} \mathrm{W}$; (map 38).

Descriptive name reported in 1965 by USBF. It is a shallow lake with many volcanic boulders rising above the surface.

Rocky Lake: lake, $0.6 \mathrm{mi}$. long, on Kenai Penin., $2 \mathrm{mi}$. $\mathbf{N}$ of Rocky Bay and $15 \mathrm{mi}$. SE of Seldovia, Chugach Mts. : $59^{\circ} 17^{\prime} 30^{\prime \prime} \mathrm{N}, 151^{\circ} 26^{\prime}$ $30^{\prime \prime} \mathrm{W}$; (map 50).

Name published by USGS in 1953 ; probably named for nearby Rocky Bay.

Rocky Lake: lake, $0.3 \mathrm{mi}$. across, on Phipps Penin., $2.5 \mathrm{mi}$. SW of Yakutat, Malaspina 
Coastal Plain; 59 $31^{\prime} 10^{\prime \prime}$ N, $139^{\circ} 47^{\prime} 20^{\prime \prime} \mathrm{W}$; (map 46).

Local name reported in 1964 (de Laguna and others, map 4); this feature is not shown on recent USGS maps.

Rocky Lake: lake, see Sucker Lake.

Rocky Mountain: mountain, 1,760 ft., $13 \mathrm{mi}$. W of Midnight Hill, Porcupine Plat.; $66^{\circ} 02^{\prime} 30^{\prime \prime}$ N, $141^{\circ} 34^{\prime} 00^{\prime \prime} \mathrm{W}$; (map 120).

Local descriptive name; reported in 1956 by R. C. Foley, USGS.

Rocky Mountain Creek: stream, flows SW $2 \mathrm{mi}$. to Nome River, $19 \mathrm{mi}$. NE of Nome, Seward Penin. High.; $64^{\circ} 46^{\prime} 12^{\prime \prime} \mathrm{N}, 165^{\circ} 13^{\prime} 10^{\prime \prime} \mathrm{W}$; (map 94). Var. Rocky Creek.

Reported as "Rocky" on a map by S. E. King dated 1900. Published as "Rocky Mt." on the 1900 "Map of Nome Peninsula" by J. M. Davidson and B. D. Blakeslee.

Rocky Mountains: mountain range, see Brooks Range.

Rocky Pass: water passage, $2.5 \mathrm{mi}$. long, in Barrier Is., E of Middle I., Alex. Arch.; $54^{\circ} 48^{\prime}$ $\mathrm{N}, 132^{\circ} 25^{\prime} \mathrm{W}$; (map 1 ).

Local descriptive name reported in 1951 by USGS.

Rocky Pass: water passage, $15 \mathrm{mi}$. long, in Keku Strait, between Kupreanof and Kuiu Is., 20 mi. N of Point Baker, Alex. Arch.; $56^{\circ} 40^{\prime} \mathrm{N}$, $133^{\circ} 44^{\prime} \mathrm{W}$; (map 6).

Local named published by USC\&GS in 1932 Coast Pilot (p. 257).

Rocky Patch: rocks, $0.4 \mathrm{mi}$. across, in Eastern Channel, 2 mi. SE of Sitka, on $W$ coast of Baranof I., Alex. Arch.; 57 $01^{\prime} 45^{\prime \prime}$ N, $135^{\circ}$ $18^{\prime} 00^{\prime \prime}$ W; (map 9)

Descriptive name published by USC\&GS in the 1943 Coast Pilot (p. 358).

Rocky Point: bluff, elev. 31 ft., on $\mathrm{N}$ bank of Naknek River, on Alaska Penin., $7.8 \mathrm{mi}$. SE of Naknek, Bristol Bay Low.; 58 $42^{\prime} 45^{\prime \prime} \mathrm{N}$, 156 49'35" W; (map 41).

Local name reported in 1952 by USGS.

Rocky Point: point of land, on Amaknak I., at $S$ end of Dutch Harbor, in Unalaska Bay, Unalaska I., Aleutian Is.; $53^{\circ} 53^{\prime} 20^{\prime \prime} \mathrm{N}, 166^{\circ}$ 31'35" W; (map 23).

Descriptive name, given by W. H. Dall, USC\&GS, and published in 1875 on USC\&GS Chart 821.

Rocky Point: point of land, on NE coast of Unimak I., Aleutian Is. ; $54^{\circ} 56^{\prime} 30^{\prime \prime} \mathrm{N}, 163^{\circ} 26^{\prime}$ $30^{\prime \prime} \mathrm{W}$; (map 25).

Descriptive name published by USC\&GS in 1912.

Rocky Point: point of land, on SE shore of Chignik Lagoon, $6.5 \mathrm{mi}$. W of Chignik, Aleutian Ra.; $56^{\circ} 17^{\prime} \mathrm{N}, 158^{\circ} 34^{\prime} \mathrm{W}$; (map 30).

Local descriptive name reported by a 1951 USGS field party.

Rocky Point: point of land, on S shore of Whitewater Bay, on SW coast of Admiralty I., Alex. Arch,; 57 $13^{\prime} 25^{\prime \prime} \mathrm{N}, 134^{\circ} 35^{\prime} 10^{\prime \prime} \mathrm{W}$; (map 9).

Descriptive name given in 1881 by Comdr. Glass, USN, and published in the 1883 Coast Pilot (p. 175).
Rocky Point: point of land, on S shore of Chaik Bay, $13.5 \mathrm{mi}$. S. of Angoon, on W coast of Admiralty I., Alex. Arch.; 57 $18^{\prime} 15^{\prime \prime} \mathrm{N}$, $134^{\circ} 34^{\prime} 00^{\prime \prime} \mathrm{W}$; ( $\operatorname{map} 9$ ).

Descriptive name given in 1869 by Comdr. Meade, USN, and published in the 1883 Coast Pilot (p. 175).

Rocky Point: point of land, on E shore of Stephens Passage, $3 \mathrm{mi}$. SE of Sunset I. and $75 \mathrm{mi}$. NE of Sitka, Coast Mts.; 57 $28^{\prime} 05^{\prime \prime}$ $N, 133^{\circ} 31^{\prime} 10^{\prime \prime} \mathrm{W}$; (map 8).

Local name reported in 1955 by USGS.

Rocky Point: point of land, SW tip of Long I., in Kootznahoo Inlet, $3.5 \mathrm{mi}$. NE of Angoon, on W central Admiralty I., Alex. Arch.; $57^{\circ}$ $32^{\prime} 05^{\prime \prime} \mathrm{N}, 134^{\circ} 30^{\prime} 10^{\prime \prime} \mathrm{W}$; (map 9).

Descriptive name given by Comdr. R. W. Meade, USN, and published in 1869 on Chart 225.

Rocky Point: point of land, on W coast of Kodiak I., $10 \mathrm{mi}$. NE of Karluk, 57 $39^{\prime} 45^{\prime \prime}$ N, $154^{\circ} 13^{\prime} 50^{\prime \prime}$ W; (map 35). Var. Mys Makhnashka, Kekurnyy.

Descriptive name reported in 1897 by Lt. Comdr. J. F. Moser, USN, commander of the USBF steamer Albatross. Named "Makhnashka" by Capt. Tebenkov (1852, map 23), IRN; called "Kekurnyy," meaning "pillar," by the Russian Hydrog. Dept. in 1849.

Rocky Point: point of land, $N$ tip of Hagemeister I., $19 \mathrm{mi}$. SW of Togiak, Kilbuck-Kuskokwim Mts. ; $58^{\circ} 49^{\prime} \mathrm{N}, 160^{\circ} 41^{\prime} \mathrm{W}$; (map 39).

Local descriptive name published in 1948 by USGS.

Rocky Point: point of land, on E shore of Togiak Bay, $13 \mathrm{mi}$. SE of Togiak, KilbuckKuskokwin Mts. ; $58^{\circ} 53^{\prime} \mathrm{N}, 160^{\circ} 14^{\prime} \mathrm{W}$; (map 39).

Local descriptive name reported in 1912 by USC\&GS.

Rocky Point: point of land, in Prince William Sound, on $W$ cosst of Knight I., at $N$ entrance to Drier Bay, $7.5 \mathrm{mi}$. NE of Chenega, Chugach Mts.; $60^{\circ} 19^{\prime} 08^{\prime \prime} \mathrm{N}, 147^{\circ} 52^{\prime} 30^{\prime \prime} \mathrm{W}$; (map 63).

Descriptive name published in 1908 by USC\&GS.

Rocky Point: point of land, on SE shore of Valdez Arm, $45 \mathrm{mi}$. NW of Cordova, Chugach Mts.; $60^{\circ} 57^{\prime} 15^{\prime \prime}$ N, $146^{\circ} 45^{\prime} 30^{\prime \prime}$ 'W.; (map 64).

Named by Capt. W. R. Abercrombie, USA, while exploring the Prince William Sound region in 1898.

Rocky Point: point of land, tip of peninsula W of Golovin Bay, $40 \mathrm{mi}$. SE of Solomon, Seward Penin. High.; 64 $24^{\circ}$ N, $163^{\circ} 08^{\prime} \mathrm{W}$; (map 95). Var. Cap Kamennoi (Rocheux), Mys Kamennoy, Mys Kamennyy, Point Fergusson, Stony Cape, The Promontory.

Named "Kamennoy" meaning "rocky" in 1821 by Kromchenko (cnna), IRN. It was called "Point Fergusson" on the 1900 "Map of Nome Peninsula" by J. M. Davidson and B. D. Blakeslee.

Rocky Point: point of land, see Inner Point.

Rocky Point: point of land, see Kamenoi Point. Rocky Point: point of land, see Tonki Point.
Rocky Point Creek: stream, flows $1.2 \mathrm{mi}$. SW to Temnac Bay, Attu I., Aleutian Is. ; $52^{\circ} 49^{\prime}$ $27^{\prime \prime} \mathrm{N}, 173^{\circ} 04^{\prime} 45^{\prime \prime} \mathrm{E}$; (map 13).

Named by the U.S. Army during its occupation of the island during World War II; shown on an AMS map published in 1948.

Rocky Reef Point: rocks, see Laida Rocks.

Rocky River: stream, on Kenai Penin., flows S $12 \mathrm{mi}$. to cove at $\mathrm{N}$ end of Rocky Bay, $17 \mathrm{mi}$. SE of Seldovia, Chugach Mts.; $59^{\circ} 17^{\prime} 00^{\prime \prime} \mathrm{N}$, $151^{\circ} 24^{\prime} 30^{\prime \prime} \mathrm{W}$; (map 50). Var. Windy River.

Name published by USGS in 1951; probably named for nearby Rocky Bay.

Rocky River: stream, see Kogoluk River.

Rocky River Point: point of land, $5 \mathrm{mi}$. W of Otter Point, 23 mi. NW of False Pass, on NE Coast of Unimak I., Aleutian Is.; $55^{\circ} 02^{\prime} \mathrm{N}$ $163^{\circ} 53^{\prime} \mathrm{W}$; (map 29).

Name published in 1902 by USC\&GS.

Rockys Lakes: lakes, extend N-S $2.3 \mathrm{mi}$., $12 \mathrm{mi}$. SW of Talkeetna, Cook Inlet Low.; $62^{\circ} 09^{\prime} 00^{\prime \prime}$ $\mathrm{N}, 150^{\circ} 14^{\prime} 45^{\prime \prime} \mathrm{W}$; (map 81).

Local name reported in 1958 by USGS.

Rodenbough Cove: cove, see Radenbough Cove.

Rodgers Peak: mountain, 4,780 ft., $15 \mathrm{mi}$. ENE of Petersburg, Coast Mts; 56 $53^{\prime} \mathrm{N}, 132^{\circ} 35^{\prime}$ W; BGN 1934; (map 6).

Named in 1887 by Lt. Comdr. C. M. Thomas, USN, for Commodore John Rodgers, 1812 82 who was the first commander of the North Pacific Exploring Expedition of 1855.

Rodgers Point: point of land, SW point of entrance to Hoonah Sound, $1.5 \mathrm{mi}$. NE of Ushk Bay, on $\mathrm{S}$ coast of Chichagof I., Alex. Arch.; $57^{\circ} 35^{\prime} 00^{\prime \prime} \mathrm{N}, 135^{\circ} 33^{\prime} 30^{\prime \prime} \mathrm{W}$; BGN 1898; (map 9). Var. Rogers Point.

Named in 1895 by USC\&GS for Augustus Ferdinand Rogers, USC\&GS.

Rodgnof: peninsula, see Rozhnof, Cape.

Rodgnoff: peninsula, see Rozhnof, Cape.

Rodiac: island, see Kodiak Island.

Rodman Bay: estuary, $1 \mathrm{mi}$. across, $6 \mathrm{mi}$. long, on $\mathrm{N}$ coast of Baranof I., $30 \mathrm{mi}$. N of Sitka, Alex. Arch.; $57^{\circ} 29^{\prime} \mathrm{N}, 135^{\circ} 19^{\prime} \mathrm{W}$; (map 9).

Named in 1895 by Lt. Comdr. E. K. Moore, USN, for Lt. Hugh Rodman, USN, a member of his party. The name was published by USC\&GS on Chart 8283.

Rodman Cove: cove, see Louise Cove

Rodman Creek: stream, flows NW $10 \mathrm{mi}$. to Rodman Bay, on $\mathrm{N}$ coast of Baranof I., Alex. Arch.; $57^{\circ} 26^{\prime} 00^{\prime \prime} \mathrm{N}, 135^{\circ} 23^{\prime} 45^{\prime \prime} \mathrm{W} ; B G N$ 1930; (map 9).

Named in 1895 by Lt. Comdr. E. K. Moore, USN, for Lt. Hugh Rodman, USN, a member of his party.

Rodman Glacier: glacier, on SW slope of Brabazon Ra., trends S 4.4 mi. to its 1961 terminus on Ustay Lake, $40 \mathrm{mi}$. SE of Yakutat, St. Elias Mts.; $59^{\circ} 18^{\prime} 10^{\prime \prime} \mathrm{N}, 138^{\circ} 43^{\prime} 10^{\prime \prime} \mathrm{W}$; (map 46).

Named by Lt. Comdr. Moser (1901, p. 387), USN, for Lt. Hugh Rodman, USN, a member of his organization. Lt. Rodman had charge of a traverse party from Yakutat to Dry Bay. 
Rodman Island: island, $2.5 \mathrm{mi}$. long, in Porcupine River, $5 \mathrm{mi}$. NE of Fort Yukon, Yukon Flats; $66^{\circ} 38^{\prime} 30^{\prime \prime} \mathrm{N}, 145^{\circ} 08^{\prime} 00^{\prime \prime} \mathrm{W}$; (map 119).

Local name obtained in 1956 by USGS.

Rodman Peak: mountain, 3,100 ft., 2 mi. NE of Hancock Peak and $96 \mathrm{mi}$. E of Sitka, Coast

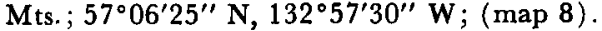

Named in 1887 by Lt. Comdr. C. M. Thomas, USN, for Lt. Hugh Rodman, USN, member of several surveying parties in this area, $1887-1900$; published in 1888 by USC\&GS.

Rodman Reach: water passage, between Tanner Head and Kodiak I., at S end of Kodiak I.; $56^{\circ} 52^{\prime} 30^{\prime \prime} \mathrm{N}, 154^{\circ} 15^{\prime} 30^{\prime \prime} \mathrm{W}$; (map 32 ).

Named in 1900 by Lt. Comdr. J. F. Moser, USN, commander of the Albatross, for Lt. Hugh Rodman, USN, one of his party.

Rodman Rock: rock, off Baranof I. at mouth of Rodman Bay, 30 mi. N of Sitka, Alex. Arch.; $57^{\circ} 29^{\prime} 40^{\prime \prime} \mathrm{N}, 135^{\circ} 14^{\prime} 45^{\prime \prime} \mathrm{W}$; (map 9).

Local name reported in 1951 by USGS

Rodney, Cape: point of land, on Bering Sea, 30 mi. NW of Nome, Seward Penin. High.; $64^{\circ} 39^{\prime} \mathrm{N}, 165^{\circ} 24^{\prime} \mathrm{W}$; (map 94). Var. Point Rodney, Rodney Point.

On August 5, 1778, Capt. Cook (1785, v. 2, p. 441), RN, wrote, "The coast of the continent seemed to take a turn Northward at a low point named Point Rodney, * * *"

Rodney Creek: stream, flows S $3.3 \mathrm{mi}$. to Norton Sound, $13 \mathrm{mi}$. NW of Nome, Seward Penin. High.; $64^{\circ} 32^{\prime} 30^{\prime \prime} \mathrm{N}, 165^{\circ} 50^{\prime} 20^{\prime \prime} \mathrm{W}$; (map 94).

Prospectors' name reported in 1900 by $\mathrm{E}$. C. Barnard (in Brooks, 1901, pl. 17), USGS.

Rodney Mountain: mountain, 1,110 ft., on Bering Sea coast, $15 \mathrm{mi}$. WNW of Nome, Seward Penin. High.; $64^{\circ} 33^{\prime}$ N, $165^{\circ} 54^{\prime}$ W ; (map 94).

Local name reported on Arthur Gibson's "Map of Cape Nome Precinct" dated 1904.

Rodokakat: locality, on right bank of Yukon River, $36 \mathrm{mi}$. SW of Nulato, Nulato Hills.; $64^{\circ} 17^{\prime} \mathrm{N}, 158^{\circ} 42^{\prime} \mathrm{W}$; (map 97).

Indian fish camp reported in 1916 by USGS ; name derived from nearby Rodo River.

Rodokakat: stream, see Rodo River.

Rodo River: stream, flows NE $32 \mathrm{mi}$. to Yukon River, $36 \mathrm{mi}$. SW of Nulato, Nulato Hills; $64^{\circ} 17^{\prime}$ N, $158^{\circ} 43^{\prime}$ ' W; (map 97). Var. Khodolkakat, Rodokakat.

Indian name reported about 1901 as "Rodokakat" by Father Julius Jetté of Nulato. Father Jetté used the letter " $R$ " for the " $K h$ " sound. The name obviously is the same as that of the Khotol River. "Khodokakat" means "mouth of the Khodo (or Khotol)."

Roe Point: point of land, on mainland, on $\mathrm{E}$ shore of Behm Canal, $5 \mathrm{mi}$. NE of Point Sykes, Coast Mts.; $55^{\circ} 59^{\prime} 35^{\prime \prime} \mathrm{N}, 1^{\circ} 1^{\circ} 00^{\prime} 15^{\prime \prime} \mathrm{W}$; (map 3).

One of many arbitrary names applied to features in this area in 1891 by USC\&GS.

Roger Creek: stream, flows NW 0.7 mi. to Benson Creek which flows to Iron Creek, $25 \mathrm{mi}$.
NW of Solomon, Seward Penin. High.; $64^{\circ}$ $54^{\prime} 50^{\prime \prime} \mathrm{N}, 164^{\circ} 40^{\prime} 30^{\prime \prime} \mathrm{W}$; (map 95).

Prospectors' name reported in 1908 by P. S. Smith (in Brooks and others, 1909, pl. $10)$, USGS.

Roger Creek: stream, flows S $5 \mathrm{mi}$. to Rainy Creek, $7 \mathrm{mi}$. W of Umiat, Arctic Slope ; 69 $19^{\circ}$ ' $30^{\prime \prime} \mathrm{N}, 152^{\circ} 25^{\prime} 00^{\prime \prime} \mathrm{W}$; BGN 1960; (map 141). Var. Rogers Creek.

Name used by personnel of Naval Petroleum Reserve No. 4 explorations in 1944, derived from the radio communications term "Roger."

Rogers Creek: locality, on left bank of Susitna River, where The Alaska Railroad crosses Rogers Creek, $40 \mathrm{mi}$. N of Anchorage, Cook Inlet Low.; $61^{\circ} 48^{\prime} \mathrm{N}, 150^{\circ} 04^{\prime} \mathrm{W}$; (map 70).

Local name reported on 1917 railroad location manuscript map.

Rogers Creek: stream, flows SW $8.6 \mathrm{mi}$. to Little Willow Creek, $2 \mathrm{mi} \mathrm{E}$ of Susitna River and $41 \mathrm{mi}$. N of Anchorage, Cook Inlet Low.; $61^{\circ} 48^{\prime} \mathrm{N}, 150^{\circ} 05^{\prime} \mathrm{W}$; (map 70$)$.

Local name reported on 1917 railroad location manuscript map.

Rogers Creek: stream, flows NW $6 \mathrm{mi}$. to Sheep Creek, $40 \mathrm{mi}$. NE of Healy, Alaska Ra.; $63^{\circ} 57^{\prime} 30^{\prime \prime} \mathrm{N}, 147^{\circ} 40^{\prime} 10^{\prime \prime} \mathrm{W}$; (map 87).

Prospectors' name shown on a 1910 fieldsheet by J. W. Bagley, USGS; published by Capps (1912, pl. 1), USGS.

Rogers Creek: stream, flows E $1 \mathrm{mi}$. to Allene Creek, in Agiapuk River basin, $10 \mathrm{mi}$ NE of Teller, Seward Penin. High.; $65^{\circ} 19^{\prime} \mathrm{N}, 166^{\circ}$ 03' W; (map 111).

Prospectors' name reported on the 1908 "Map of Seward Peninsula" by Arthur Gibson. Rogers Creek: stream, flows NE $35 \mathrm{mi}$. to Yukon River, $60 \mathrm{mi}$. NE of Rampart, Yukon Flats; $66^{\circ} 06^{\prime} \mathrm{N}, 148^{\circ} 40^{\prime} \mathrm{W}$; (map 118).

Local name reported in 1902 by Lt. Hjalmar Erickson, USA, as Roger Creek.

Rogers Creek: stream, see Roger Creek.

Rogers Island: island, $0.4 \mathrm{mi}$. across, in Necker Is., on $\mathrm{W}$ coast of Baranof I., $5 \mathrm{mi}$. SW of Goddard, Alex. Arch.; 56 $46^{\prime} 50^{\prime \prime} \mathrm{N}, 1^{\circ} 5^{\circ}$. 27'45" W; BGN 1929; (map 5).

Named in 1925 by USC\&GS for John Jacob Rogers, assistant, USC\&GS. See John Rock and Jacob Rock.

Rogers Park: area, in SE part of Anchorage, Cook Inlet Low.; 61 $11^{\prime} 54^{\prime \prime} \mathrm{N}, 149^{\circ} 51^{\prime} 15^{\prime \prime}$ W; (map 69).

Local name reported in 1952 by USGS.

Rogers Point: point of land, see Rodgers Point. Rogova, Ostrov: island, see Morne Island.

Rogue Creek: stream, flows SW $4 \mathrm{mi}$. to Simpson Bay, $6 \mathrm{mi}$. NW of Cordova, Chugach Mts.; $60^{\circ} 39^{\prime} \mathrm{N}, 145^{\circ} 49^{\prime} \mathrm{W}$; (map 64).

Local name published in 1951 by USGS.

Rohn Glacier: glacier, trends $10 \mathrm{mi}$. SE to head of Nizina Glacier, $23 \mathrm{mi}$. NE of McCarthy, Wrangell Mts.; $61^{\circ} 42^{\prime} \mathrm{N}, 142^{\circ} 28^{\prime} \mathrm{W}$; (map 67).

Named in 1901 by USGS for Oscar Rohn, who crossed this glacier in 1899.

Rohn River : stream, see Tatina River.
Rojnoff : peninsula, see Rozhnof, Cape.

Rojnoff, Cap: point of land, see Lagoon Point. Roketaloi Creek: stream, heads in Kaiyuh Mts., flows NE and SE $10 \mathrm{mi}$. to Magitchlie Creek, $58 \mathrm{mi}$. S of Nulato and $75 \mathrm{mi}$. E of Unalakleet, Innoko Low.; $63^{\circ} 53^{\prime} 15^{\prime \prime} \mathrm{N}, 158^{\circ} 20^{\prime} 20^{\prime \prime} \mathrm{W}$; map (90).

Local name reported in 1954 by USGS.

Rokhova Island: island, see Morne Island.

Rolejo Lake: lake, see Red Shirt Lake.

Roller Bay: bay, $2.5 \mathrm{mi}$. wide, $\mathrm{W}$ coast of Noyes I., Alex. Arch.; $55^{\circ} 31^{\prime} \mathrm{N}, 133^{\circ} 46^{\prime} \mathrm{W}$; (map 4).

Descriptive name given in 1923 by USC\& GS because "Bay exposed to squalls and rolling waves from Ocean * * *."

Rolling Bay: bight, $2 \mathrm{mi}$. across, on SW coast of Sitkalidak I., SE of Kodiak I.; 57 $02^{\prime} \mathrm{N}$, $153^{\circ} 20^{\prime} \mathrm{W}$; (map 34).

Local name published in 1943 by USG\&GS.

Rolling Hills: hills, 1,252 ft., SW of Wolf Creek Mtn., $32 \mathrm{mi}$. N of Russian Mission, YukonKuskokwim Delta; $62^{\circ} 15^{\prime} 30^{\prime \prime} \mathrm{N}, 161^{\circ} 28^{\prime} 00^{\prime \prime}$ W; (map 78).

Local descriptive name obtained in 1952 by USGS.

Rolling Pin Creek: stream, heads in De Long Mts., flows NE $11 \mathrm{mi}$. to Kiligwa River, $12 \mathrm{mi}$. $\mathrm{S}$ of Liberator Lake, Brooks Ra.; 68 $41^{\prime} \mathrm{N}$, $158^{\circ} 29^{\prime} \mathrm{W} ; B G N 1960$; (map 132).

Named in 1951 by I. L. Tailleur, USGS, "for a rolling pin left behind on this creek."

Rolling Point: point of land, on W shore near head of Viekoda Bay, on $\mathrm{N}$ coast of Kodiak I.; $57^{\circ} 51^{\prime} 20^{\prime \prime} \mathrm{N}, 153^{\circ} 07^{\prime} 00^{\prime \prime} \mathrm{W}$; (map. 34).

Local name published in 1943 by USC\&GS.

Rolph Slough: stream, distributary of Nushagak River, flows SW 6 mi. to Nushagak Bay, S of Grassy I., $5 \mathrm{mi}$. S of Dillingham, Bristol Bay Low.; $58^{\circ} 58^{\prime} 25^{\prime \prime} \mathrm{N}, 158^{\circ} 26^{\prime} 15^{\prime \prime} \mathrm{W}$; (map 40).

Local name reported in 1952 by USGS.

Romanoff, Point: point of land, see Romanof, Point.

Romanof, Point: point of land, $\mathrm{E}$ point of entrance to Pastol Bay, on Norton Sound, 30 mi. SW of St. Michael, Yukon-Kuskokwim Delta ; $63^{\circ} 12^{\prime} \mathrm{N}, 162^{\circ} 50^{\prime} \mathrm{W}$; (map 92). Var. Asiatchak Point, Cape Onman, Cap Nord du haut-fond, Mys Azachagvyak, Mys Aziachak, Mys Azyachagyak, Point Romanoff, Point Shallow-Water.

On September 19, 1778, Capt. Cook (1785, v. 2, p. 489), RN, named this "Point Shallow Water." Published in French in 1836 as "Cap Nord du haut-fond," meaning "Northern Cape Shallow Waters" by Capt. F. P. Lutke, IRN. The Eskimo name was recorded as "Asiatchak" by Capt. Lutke and as "Aziachak" by Capt. Tebenkov (1852, map 2), IRN.

Romantic Hill: hill, $240 \mathrm{ft}$., E of East Kiska Lake, Kiska I., Aleutian Is.; $52^{\circ} 03^{\prime} 45^{\prime \prime} \mathrm{N}$, $177^{\circ} 36^{\prime} 50^{\prime \prime} \mathrm{E}$; (map 14).

An arbitrary name beginning with " $R$ " to correspond to "R" grid used by the U.S. Army for tactical purposes during World War II; published on a 1953 AMS map. 
Romantzof, Cape: point of land, see Romanzof, Cape.

Romantzoff Mountains: mountain range, see Romanzof Mountains.

Romanzof, Cape: point of land, at $\mathrm{W}$ end of Asiknuk Mts., between Kokechik and Scammon Bays, Yukon-Kuskokwim Delta; $61^{\circ} 49^{\prime}$ N, 166 $06^{\prime}$ W ; BGN 1900; (map 75). Var. Cape Count, Cape Rumiantsof, Cape Roumiantsoff, Cape Romantzof.

Named "Mys Grafa Rumyantsova," "Cape of Count Rumyantsov," by Capt. Lt. G. S. Shishmarev, IRN, in 1821. In the same year it was named by A. K. Etolin. The name commemorates Count Rumyantsov who built and outfitted a vessel of one hundred and eighty tons, named the Rurik, "for the purpose of exploring the supposed northwest passage by way of Davis Strait or Hudson Bay ***" (Bancroft, 1886, p. 494). The present spelling of the name was established by BGN.

Romanzoff Chain: mountain range, see Romanzof Mountains.

Romanzoff Range: mountain range, see Romanzof Mountains.

Romanzof Mountains: mountains, extend $65 \mathrm{mi}$. between Hulahula and Kongakut Rivers, Brooks Ra.; $69^{\circ} 11^{\prime}$ N, $143^{\circ} 07^{\prime}$ W; BGN Sixth Report; (map 138). Var. Pelly Mountains, Romantzoff Mountains, Romanzoff Chain, Romanzoff Range, Romiantzoff Mountains, Roumiantzoff Mountains, Rumiantzof Mountains.

On August 3, 1826, Sir John Franklin wrote: "We * * had now arrived opposite the commencement of another range, which I named after the late Count Nicholas Romanzoff, Chancellor of the Russian Empire, as a tribute of respect to the memory of that distinguished patron and promoter of discovery and science." This range was believed by Franklin to extend west to the Canning River. Leffingwell (1919, p. 99) confined the term Romanzof Mountains "to a roughly circular area about 15 miles in diameter, between the headwaters of Jago and Hulahula Rivers." Baker (1906, p. 534), USGS, thought these are the mountains which P. W. Dease and Thomas Simpson in 1837 named "Pelly Mountains."

Romer Glacier: glacier, in Glacier Bay National Monument, trends E $1.9 \mathrm{mi}$. to its 1961 terminus, $0.4 \mathrm{mi}$. W of Rendu Inlet and $76 \mathrm{mi}$. NW of Hoonah, St. Elias Mts.; 58 $59^{\prime} 20^{\prime \prime} \mathrm{N}$, $136^{\circ} 42^{\prime} 45^{\prime \prime} \mathrm{W}$; BGN 1923; (map 10).

Named in 1923 by Lawrence Martin, U.S. Dept. of State, for Eugeniusz Romer, 18711954, professor of geography at the Univ. of Lemberg, in Austria, who visited Glacier Bay in 1913.

Romiantzoff Mountains: mountain range, see Romanzof Mountains.

Romig: area, in S Anchorage $1.2 \mathrm{mi}$. SSW of City Hall, Cook Inlet Low.; 61 $1^{\circ} 12^{\prime} 05^{\prime \prime} \mathrm{N}$, $149^{\circ} 54^{\prime} 30^{\prime \prime} \mathrm{W}$; (map 69).
Residential district in city of Anchorage reported in 1954 by office of city engineer of Anchorage.

Romig, Mount: mountain, $4,000 \mathrm{ft}$., in Kilbuck Mountains, W of Cripple Mts., $70 \mathrm{mi}$. SE of Bethel, Kilbuck-Kuskokwim Mts.; $60^{\circ} 37^{\prime}$ N, $159^{\circ} 43^{\prime} \mathrm{W}$; ( $\operatorname{map} 59$ ).

Named in 1898 by W. S. Post and J. E. Spurr, USGS ; named for Dr. Joseph Herman Romig, Moravian missionary in the area from 1896 to 1905.

Romp Island: island, $0.8 \mathrm{mi}$. across, on $\mathrm{E}$ coast of Admiralty I., $1 \mathrm{mi}$. NW of Gambier I. and $63 \mathrm{mi}$. E of Sitka, Alex. Arch.; $57^{\circ} 26^{\prime} 30^{\prime \prime} \mathrm{N}$, $133^{\circ} 50^{\prime} 45^{\prime \prime} \mathrm{W}$; (map 8).

Named in 1889 by Lt. Comdr. H. B. Mansfield; published by USC\&GS in 1891 Coast Pilot (p. 144).

Rona Island: island, $0.5 \mathrm{mi}$. across, $7 \mathrm{mi}$. SW of Dolgoi I., at SW end of Aleutian Ra.; 54 ${ }^{\circ} 59^{\prime}$ N, $161^{\circ} 50^{\prime} \mathrm{W}$; (map 25).

Name published in 1949 on a USGS map. Rooftop Ridge: ridge, elev. 2,448 ft., $9 \mathrm{mi}$. long, $E$ of Anaktuvuk River, $9 \mathrm{mi}$. NW of Kayak Mtn. and $56 \mathrm{mi}$. NE of Anaktuvuk Pass, Arctic Slope; $68^{\circ} 54^{\prime} \mathrm{N}, 150^{\circ} 58^{\prime} \mathrm{W} ; B G N$ 1949; (map 134). Var. Willow Creek Ridge.

Descriptive name given by USGS geologists during the exploration of Naval Petroleum Reserve No. 4 ; name given in 1944.

Rookery Island: island, $300 \mathrm{ft}$. long, in Duncan Canal, $12 \mathrm{mi}$. SW of Petersburg, on S coast of Kupreanof I., Alex. Arch.; 56 $41^{\prime} 30^{\prime \prime} \mathrm{N}$, 13312'00" W; BGN 1933; (map 6).

So named in 1933 by R. H. Sargent, USGS, because the "island is the resting place of thousands of sea birds, known locally as sea pigeons."

Rookery Islands: islands, extend $0.6 \mathrm{mi}$. in Clarence Strait, between Zarembo and Prince of Wales Is., Alex. Arch.; $56^{\circ} 03^{\prime} 45^{\prime \prime} \mathrm{N}$, $133^{\circ} 06^{\prime} 30^{\prime \prime} \mathrm{W}$; (map 6).

Named in 1886 by Lt. Comdr. A. S. Snow, USN; name published in 1887 on USC\&GS Chart 706.

Rookie Lake: lake, $0.1 \mathrm{mi}$. across, $1.4 \mathrm{mi}$. WNW of Sredni Point, on northeastern Kiska I., Aleutian Is.; $52^{\circ} 03^{\prime} 05^{\prime \prime} \mathrm{N}, 177^{\circ} 36^{\prime} 45^{\prime \prime} \mathrm{E}$; (map 14).

An arbitrary name beginning with " $R$ " to correspond to "R" grid used by the U.S. Army for tactical purposes during World War II; published on a 1953 AMS map.

Rook Lake: lake, $0.5 \mathrm{mi}$. long, $13 \mathrm{mi}$. $\mathrm{N}$ of Chalkyitsik, Yukon Flats; $66^{\circ} 50^{\prime} \mathrm{N}, 143^{\circ} 41^{\prime}$ W; (map 120).

Local descriptive name: reported in 1956 by R. C. Foley, USGS.

Roc-evelt: locality, see Lawing.

Rosevelt, Mount: peak, see Hunter, Mount.

Roosevelt Creek: stream, heads at Roosevelt Lake, flows NW $3.5 \mathrm{mi}$. to Valdez Creek, 70 mi. SE of Hezly, Alaska Ra.; $63^{\circ} 12^{\prime} 30^{\prime \prime} \mathrm{N}$, $147^{\circ} 16^{\prime} 20^{\prime \prime} \mathrm{W}$; (map 87).

Prospectors' name shown on a 1910 fieldsheet by D. C. Witherspoon, USGS; published by Moffit (1912, pl. 1).
Roosevelt Creek: stream, flows W 6 mi. to Tatlanika Creek, $45 \mathrm{mi}$. SE of Nenana, Alaska Ra.; $64^{\circ} 04^{\prime} 30^{\prime \prime} \mathrm{N}, 148^{\circ} 12^{\prime} 45^{\prime \prime} \mathrm{W}$; (map 100).

Named by prospectors in 1905 for Theodore Roosevelt, 1858-1919, 26th President of the United States. The name was reported in 1906 by L. M. Prindle (in Brooks and others, 1907, pl. 4), USGS.

Roosevelt Creek: stream, flows $\mathbf{7} \mathrm{mi}$. to Malamute Fork Alatna River, $9 \mathrm{mi}$. WNW of Deadman Mtn. and $78 \mathrm{mi}$. SW of Wiseman, Brooks Ra.; 67 $06^{\prime} 45^{\prime \prime} \mathrm{N}, 152^{\circ} 55^{\prime} 45^{\prime \prime} \mathrm{W}$; $B G N 1932$; (map 124).

Name used by prospectors and reported by Robert Marshall in 1932.

Roosevelt Harbor: cove, extends NE $0.7 \mathrm{mi}$. to Stikine Strait, on NE coast of Zarembo I., Alex. Arch.; $56^{\circ} 24^{\prime} 00^{\prime \prime} \mathrm{N}, 132^{\circ} 37^{\prime} 40^{\prime \prime} \mathrm{W}$; (map 6).

Named by USC\&GS for charting purposes; name published in 1921; probably named for Theodore Roosevelt, 1858-1919, the 26th President of the United States.

Roosevelt Island: island, $4 \mathrm{mi}$. long, between Yukon River and Ickes Slough, $12 \mathrm{mi}$. SSW of Russian Mission, Yukon-Kuskokwim Delta; $61^{\circ} 37^{\prime} \mathrm{N}, 161^{\circ} 29^{\prime} \mathrm{W}$; (map 73).

Name shown on 1940 navigation chart of the Yukon River. Because this chart was compiled by the Riverboat Service, The Alaska Railroad, and U.S. Dept. of the Interior, one can assume the island was named for Franklin Delano Roosevelt, 1882-1945, 32nd President of the United States.

Roosevelt Lagoon: lagoon, on Revillagigedo I., E. of Naha Bay, near mouth of Naha River, Alex. Arch.; $55^{\circ} 35^{\prime} 30^{\prime \prime} \mathrm{N}, 131^{\circ} 36^{\prime} 00^{\prime \prime} \mathrm{W}$; (map 3).

Local navigators' name obtained in 1904 by H. C. Fassett, USBF; named for Theodore Roosevelt, 1858-1919, 26th President of the United States.

Roosevelt Lake: lake, $0.7 \mathrm{mi}$. long, $2.5 \mathrm{mi}$. E of Lucky Hill and $72 \mathrm{mi}$. SE of Healy, Alaska Ra.; 6311' N, $147^{\circ} 09^{\prime} \mathrm{W}$; (map 87).

Local name obtained in 1951 by USGS.

Rooster Comb: mountain, see Denson, Mount.

Rooster Comb, The: mountain, 10,180 ft., SW Ruth Amphitheater, $10 \mathrm{mi}$. SE of Mount McKinley, Alaska Ra.; $62^{\circ} 58^{\prime} 25^{\prime \prime} \mathrm{N}, 150^{\circ} 50^{\prime} 05^{\prime \prime}$ W; (map 81).

Name submitted by Bradford Washburn in 1957: mountain originally described in 1910 by Claude Rusk in the story of the Mazama Expedition, as "a remarkable mountain * * * its tip a succession of corniced spires like a great rooster comb."

Rooster Hills: hills, $640 \mathrm{ft}$., $1.8 \mathrm{mi}$. NE of Conquer Point, Kiska I., Aleutian Is.; $52^{\circ} 01^{\prime} 25^{\prime \prime}$ N, $17^{\circ} 31^{\prime} 10^{\prime \prime} \mathrm{E}$; (map 14).

An arbitrary name beginning with " $R$ " to correspond to "R" grid used by the U.S. Army for tactical purposes during World War II; published on a 1953 AMS map.

Root, Mount: mountain, 12,860 ft., on AlaskaCanada boundary, $5.5 \mathrm{mi}$. NE of Mount Fairweather and $96 \mathrm{mi}$. NW of Hoonah, St. Elias 
Mts.; $58^{\circ} 59^{\prime} 10^{\prime \prime} \mathrm{N}, 137^{\circ} 30^{\prime} 00^{\prime \prime} \mathrm{W} ; B G N$ 1954; (map 10). Var. Boundary Peak 165 Named by USC\&GS and published in 1908 on Chart 8000 . The feature was named for Elihu Root, 1845-1937. Root was a member of the Alaska Boundary Tribunal and U.S. Secretary of War, 1899-1904, under Presidents McKinley and Roosevelt; Secretary of State, 1905-09, under President Roosevelt; and U.S. Senator from New York 1909-15. He was also a member of the Hague Tribunal. Rootak Island: island, see Rootok Island.

Root Creek : stream, flows E 1 mi. to Flint Creek, $4.5 \mathrm{mi}$. SE of Long and $26 \mathrm{mi}$. S of Ruby, Kilbuck-Kuskokwim Mts. ; $64^{\circ} 21^{\prime} 45^{\prime \prime} \mathrm{N}, 155^{\circ} 23^{\prime}$ 30 " W ; (map 98).

Prospectors' name reported in 1913 by Eakin $(1914$, pl. 3), USGS. The stream's identity is in doubt.

Root Glacier: glacier, trends $15 \mathrm{mi}$. S from Regal Mtn. to Kennicott Glacier, $5 \mathrm{mi}$. N of McGarthy, Wrangell Mts.; $61^{\circ} 32^{\prime} \mathrm{N}, 142^{\circ} 56^{\prime} \mathrm{W}$; (map 67).

Named in 1899 by Oscar Rohn for U.S. Secretary of War, Elihu Root, 1845-1937.

Rootok Island: island, $3.5 \mathrm{mi}$. long, in Krenitzin Is., Aleutian Is.; $54^{\circ} 02^{\prime} 30^{\prime \prime} \mathrm{N}, 165^{\circ} 31^{\prime} 30^{\prime \prime} \mathrm{W}$ BGN 1904; (map 24). Var. Aiaiepta, Aiaktak, Aikhak, Goloi, Ostrov Aektok, Ostrov Goly, Ouektock, Rootak Island.

Aleut name recorded by Father Veniaminov (1846) as Aikhak meaning "travel" or "traveling." R. H. Geoghegan spells the word "aixag" and says it means "travel." Capt. Tebenkov (1852, map 26) and Capt. Lutke (1836, p. 290), IRN, published it as Ostrov Aektok. Adm. von Krusenstern spells the name Ouektock, an intermediate form in the name's evolution to its present spelling, used first by USBF in 1888. The Russians also called the island by a descriptive name: "Ostrov Goly" meaning "bare."

Rootok Island: island, see Aiktak Island.

Rootok Strait: water passage, between Rootok and Avatanak Is., $11 \mathrm{mi}$. SE of Akutan, in Krenitzin Is., Aleutian Is. ; $54^{\circ} 03^{\prime} 35^{\prime \prime} \mathrm{N}, 165^{\circ}$ $30^{\prime} 00^{\prime \prime}$ W; BGN 1904; (map 24). Var Aektok.

Name published prior to 1900 by USC\&GS. So named because of its association with Rootok Island.

Rope Creek: stream, flows $\mathrm{N} 2 \mathrm{mi}$. to Bering Lake, $9 \mathrm{mi}$. NE of Katalla, Chugach Mts.; $60^{\circ} 15^{\prime} 30^{\prime \prime} \mathrm{N}, 144^{\circ} 16^{\prime} 30^{\prime \prime} \mathrm{W}$; (map 64).

So named by prospectors "because a rope has been hung to aid travelers over a falls in the creek." Reported in 1905 by G. C. Martin, USGS.

Rosa Creek: stream, flows SE $8 \mathrm{mi}$. to Shaw Creek, $10 \mathrm{mi}$. NW of Big Delta, Yukon-Tanana High.; $64^{\circ} 16^{\prime} 30^{\prime \prime} \mathrm{N}, 146^{\circ} 04^{\prime} 45^{\prime \prime} \mathrm{W}$; (map 101). Var. Rosy Creek.

Name reported in 1907 as Rosy Creek by Prindle (1908, pl. 4), USGS; present spelling published in 1912 by USGS.

Rosa Creek: stream, in Rampart Mts., flows S $6 \mathrm{mi}$. to Morelock Creek $2.5 \mathrm{mi}$. N of that stream's junc. with Yukon River, 25 mi. NNE of Tanana, Kokrines-Hodzana High.; $65^{\circ} 18^{\prime}$ $00^{\prime \prime} \mathrm{N}, 151^{\circ} 17^{\prime} 30^{\prime \prime} \mathrm{W}$; (map 106).

Prospectors' name reported in 1911 by H. M. Eakin (in Brooks and others, 1912, pl. 13), USGS

Rosalia Point: point of land, see Santa Rosalia, Point.

Rosalie Creek: stream, flows NW $2.5 \mathrm{mi}$. to Chandalar Lake, at Chandalar, Brooks Ra.; $67^{\circ} 29^{\prime} 30^{\prime \prime} \mathrm{N}, 148^{\circ} 30^{\prime} 00^{\prime \prime} \mathrm{W}$; (map 123).

Local name reported in 1956 by T. E. Taylor, USGS.

Rosa Reef: reef, extends $0.2 \mathrm{mi}$., in Tongass Narrows, off Rock Point, on NE coast of Gravina I., Alex. Arch.; 55 $24^{\prime} 45^{\prime \prime} \mathrm{N}, 131^{\circ}$ 48'05" W; (map 3)

Local name published in 1899 by USC\&GS. Rosario, Isla del : island, see Rosary Island.

Rosario, Mys de: point of land, see Rosary. Point.

Rosary, Point: point of land, $\mathrm{S}$ point of entrance to Port Santa Cruz, on W coast of Suemez I. Alex. Arch; $55^{\circ} 16^{\prime} 25^{\prime \prime} \mathrm{N}, 133^{\circ} 28^{\prime} 00^{\prime \prime} \mathrm{W}$; (map 4). Var. Mys de Rosario, Point Rosario, Punta del Rosario.

Translation of the name "Punta del Rosario" given in 1775-79 by Don Juan de la Bodega y Quadra and Francisco Antonio Maurelle.

Rosary Island: island, $0.7 \mathrm{mi}$. long, in San Christoval Channel, between Prince of Wales and San Fernando Is., Alex. Arch.; 55 $35^{\prime} \mathrm{N}$, $133^{\circ} 18^{\prime}$ W; (map 4). Var. Isla del Rosario, Ostrov del Rozario, Ysla del Rosario.

Translation of the name "Isla del Rosario" given in 1779 by Don Juan de la Bodega y Quadra and Francisco Antonio Maurelle "after Lt. Arteaga's vessel, the Princesa, of which the real name was Nuestra Señora del Rosario * * " (Wagner, 1937, p. 492).

Rosaunt Creek: stream, heads in Canada, flows E $4 \mathrm{mi}$. to Nataga Creek, $3 \mathrm{mi}$. NE of Mount Prinsep and $30 \mathrm{mi}$. NW of Skagway, St. Elias Mts.; $59^{\circ} 32^{\prime} 35^{\prime \prime} \mathrm{N}, 136^{\circ} 09^{\prime} 20^{\prime \prime} \mathrm{W}$; $B G N$ 1922: (map 45). Var. Clear Creek, Katschadelch, L'Kudinaku, Rose Creek.

Local name reported in 1905. It is said to be named for "a man commonly called Rosy." The stream was called Clear Creek in 1903 by C. W. Wright, USGS, and Rose Greek in 1905 by J. A. Flemer, USC\&GS. The Tlingit Indian name is reported to be "L'Kudinaku."

Roscoe Creek: stream, in Chigmit Mts., flows NE $6 \mathrm{mi}$. to Clearwater Creek $1.8 \mathrm{mi}$. W of head of Chinitna Bay, Aleutian Ra.; $59^{\circ} 48^{\prime}$ $40^{\prime \prime} \mathrm{N}, 153^{\circ} 20^{\prime} 00^{\prime \prime} \mathrm{W}$; BGN 1962; (map 51)

Name derived from Roscoe Peak; published in 1958 by USGS.

Roscoe Glacier: glacier, in Chigmit Mts., trends N 1 mi. on Roscoe Peak, at head of Iniskin Bay, Aleutian Ra.; $59^{\circ} 48^{\prime} 30^{\prime \prime} \mathrm{N}, 153^{\circ} 25^{\prime} 00^{\prime \prime}$ W; (map 51).

Name derived from Roscoe Peak; published in 1958 by USGS.

Roscoe Peak: mountain, 3,850 ft., in Chigmit Mts. at head of Iniskin Bay, Aleutian Ra.; $59^{\circ} 47^{\prime} 40^{\prime \prime} \mathrm{N}, 153^{\circ} 24^{\prime} 50^{\prime \prime}$ W; BGN 1916 (map 51).

Named about 1914 by USC\&GS.

Rose, Port: bay, see Etches, Port.

Rosebud Creek: stream, flows $\mathrm{N} 4 \mathrm{mi}$. to Crooked Creek, $64 \mathrm{mi}$. SW of Eagle, Yukon-Tanana High.; $65^{\circ} 16^{\prime} 45^{\prime \prime} \mathrm{N}, 145^{\circ} 49^{\prime} 15^{\prime \prime} \mathrm{W}$; (map 104).

Named by prospectors; reported in 1911 by USGS (Prindle, 1913, pl. 1).

Rosebud Creek: stream, flows SE $2.5 \mathrm{mi}$. to Tolovana River, $5 \mathrm{mi}$. S of Livengood, YukonTanana High.; $65^{\circ} 28^{\prime} \mathrm{N}, 148^{\circ} 37^{\prime} \mathrm{W}$; (map 105).

Named by prospectors; reported in 1915 by USGS (Brooks and others, 1916, pl. 9).

Rose Channel: water passage, in Peril Strait, E of Rapids Point, between Little Rose I. and S. coast of Chichagof I., Alex. Arch.; 57 ${ }^{\circ} 27^{\prime}$. $30^{\prime \prime} \mathrm{N}, 135^{\circ} 33^{\prime} 00^{\prime \prime} \mathrm{W}$; (map 9).

Named in 1884 by Comdr. J. B. Goghlan, USN, "for the little steamer Rose which navigated these waters." The name was published by USC\&GS in the 1891 Coast Pilot (p. 183)

Rose Creek: stream, flows NW $1.5 \mathrm{mi}$. to Gilmore Creek, $11 \mathrm{mi}$. NE of Fairbanks; YukonTanana High.; $64^{\circ} 58^{\prime} 30^{\prime \prime} \mathrm{N}, 147^{\circ} 31^{\prime} 30^{\prime \prime} \mathrm{W}$; (map 100).

Local name published in 1908 by USGS.

Rose Creek: stream, tributary to Coal Creek about $5 \mathrm{mi}$. SW of that stream's junc. with Yukon River, Porcupine Plat.; $65^{\circ} 17^{\prime} \mathrm{N}$, $143^{\circ} 10^{\prime} \mathrm{W}$; (map 103).

Mentioned by C. E. Ellsworth and R. W. Davenport (in Brooks and others, 1913, p. 213), USGS; this feature has not been positively identified.

Rose Creek: stream, see Rosaunt Creek.

Rose Creek: stream, see Rosie Creek.

Rose Hill: hill, $1,010 \mathrm{ft}$., $0.7 \mathrm{mi}$. N of Reynard Cove, on northeastern Kiska I., Aleutian Is.; $52^{\circ} 02^{\prime} 00^{\prime \prime} \mathrm{N}, 177^{\circ} 35^{\prime} 15^{\prime \prime} \mathrm{E}$; (map 14). Var. Sunrise Hill.

An arbitrary name beginning with " $R$ " to correspond to "R" grid used by U.S. Army for tactical purposes during World War II ; published on a 1953 AMS map. Variant published on a 1943 USAAF map.

Rose Inlet: estuary, extends SW $2.5 \mathrm{mi}$. off Kaigani Strait, on $\mathrm{E}$ coast of Dall I., Alex. Arch.; 54 $57^{\circ} 30^{\prime \prime} \mathrm{N}, 132^{\circ} 56^{\prime} 00^{\prime \prime} \mathrm{W}$; (map 1).

Named in 1882 by W. H. Dall, and published by USC\&GS in the 1883 Alaska Coast Pilot (p. 68).

Rose Island: island, $0.1 \mathrm{mi}$. across, $16 \mathrm{mi}$. $E$ of Deer I., at SW end of Aleutian Ra., Aleutian Ra.; $54^{\circ} 53^{\prime} 15^{\prime \prime} \mathrm{N}, 161^{\circ} 51^{\prime} 35^{\prime \prime} \mathrm{W}$; (map 25 ).

Name published in 1949 on a USGS map.

Rose Island: island, $0.2 \mathrm{mi}$. long, at SE end of Kashevarof Passage, on NE coast of Prince of Wales I., Alex. Arch.; 56 $04^{\prime} 50^{\prime \prime}$ N, $132^{\circ}$ $51^{\prime} 15^{\prime \prime} \mathrm{W}$; (map 6).

Local name used by fishermen and published in 1907 by USC\&GS.

Rose Island: island, $1 \mathrm{mi}$. long, at $\mathbf{N}$ end of Nevensky I., in Yukon River, $3 \mathrm{mi}$. NW of 
Marshall, Yukon-Kuskokwim Delta ; 61 ${ }^{\circ} 55^{\prime}$ $\mathrm{N}, 162^{\circ} 08^{\prime} \mathrm{W}$; (map 74$)$.

Riverboat pilots' name shown on a 1940 navigation chart of the Yukon River.

Rose Island: island, see Hinchinbrook Island. Rose Island: rocks, see Seal Rocks.

Rosenberg, Mount: mountain, 3,050 ft., $15.5 \mathrm{mi}$ $\mathbf{N}$ of Sitka, on $\mathbf{N}$ central Baranof I., Alex. Arch.; $57^{\circ} 17^{\prime} 00^{\prime \prime} \mathrm{N}, 135^{\circ} 19^{\prime} 15^{\prime \prime} \mathrm{W}$; BGN 1935; (map 9).

Named in 1935 by USFS for Lt. Nikolai Yakovlevich Rosenberg, chief manager of the Russian American Co. and Governor of Russian America, 1850-53.

Rose Point: point of land, $\mathrm{N}$ point of entrance to Rose Inlet, on $E$ coast of Dall I., Alex, Arch.; $54^{\circ} 58^{\prime} 10^{\prime \prime} \mathrm{N}, 132^{\circ} 56^{\prime} 30^{\prime \prime} \mathrm{W}$; BGN 1928; (map 1).

So named in 1927 by Capt. R. S. Patton, USC\&GS, "because of its proximity to Rose Inlet and also because the triangulation station Rose is on this point."

Rose Point: point of land, NE tip of Klag I., 2.5 mi. S of Chichagof, on W coast of Chicagof $I$., Alex. Arch.; $57^{\circ} 37^{\prime} 35^{\prime \prime} \mathrm{N}, 136^{\circ} 05^{\prime} 20^{\prime \prime} \mathrm{W}$; (map 9).

Name published in 1928 by USC\&GS on Chart 8280.

Rose Point: point of land, see Ross Point.

Rose Rock: rock, at SE end of Kashevarof Passage in Kashevarof Is., on NE coast of Prince of Wales I., Alex. Arch.; 56 $05^{\prime} 10^{\prime \prime} \mathrm{N}, 132^{\circ}$ $52^{\prime} 45^{\prime \prime} \mathrm{W}$; ( $\left.\operatorname{map} 6\right)$

Local name published by USC\&GS in 1925 Coast Pilot (p. 91)

Rose Rock: rock, in Galankin Is., Sitka Sound, 1 mi. S of Sitka, Alex. Arch.; 57 $02^{\prime} 15^{\prime \prime} \mathrm{N}$, $135^{\circ} 20^{\prime} 35^{\prime \prime}$ W ; (map 9').

Named in 1880 by U.S. Navy "for the little steamer Rose." The name was published by USC\&GS in the 1883 Coast Pilot (p. 143).

Rose Rock: rock, at W end of Kootznahoo Inlet, 0.4 mi. $\mathbf{E}$ of Angoon, on $\mathrm{W}$ coast of Admiralty I., Alex. Arch.; 57 $30^{\prime} 10^{\prime \prime}$ N, $134^{\circ} 34^{\prime} 20^{\prime \prime} \mathrm{W}$; (map 9).

Named in 1895 by Lt. Comdr. E. K. Moore, USN, "for the little steamer Rose."

Rose Tead, Lake: lake, $1.3 \mathrm{mi}$. long, $0.7 \mathrm{mi}$. N of head of Pasagshak Bay, $6 \mathrm{mi}$. NW of Narrow Cape, on $\mathbf{E}$ coast of Kodiak I.; $57^{\circ} 29^{\prime} \mathrm{N}$, $152^{\circ} 27^{\circ} \mathrm{W}$; (map 34$)$.

Local name reported in 1951 by USGS.

Rosie Creek: stream, flows SW $4.5 \mathrm{mi}$. to Tanana River, $12 \mathrm{mi}$. SW of Fairbanks, Tanana Low.; $64^{\circ} 44^{\prime} 35^{\prime \prime} \mathrm{N}, 148^{\circ} 05^{\prime} 00^{\prime \prime} \mathrm{W}$; (map 100 ).

Local name reported in 1916 by USGS.

Rosie Creek: stream, flows from Rosie Creek Pass $\mathrm{N}$ and W $5 \mathrm{mi}$. around Cathedral Mtn. to Middle Fork Koyukuk River, $16 \mathrm{mi}$. $\mathrm{S}$ of

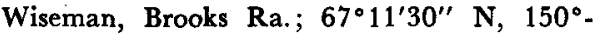
$18^{\prime} 00^{\prime \prime} \mathrm{W}$; BGN 1932; (map 124). Var. Rose Greek, Rosy Creek.

Local name reported in 1932 by Robert Marshall, correcting the earlier-used "Rose" or "Rosy."

Rosie Creek Pass: pass, 1,600 ft., between heads of Rosie and Wilson Creeks, $E$ of Cathedral
Mtn., 18 mi. S of Wiseman, Brooks Ra.; $67^{\circ}$ $09^{\prime} 30^{\prime \prime} \mathrm{N}, 150^{\circ} 11^{\prime} 00^{\prime \prime} \mathrm{W}$; (map 124).

Named for the creek which heads in the pass; reported by Robert Marshall about 1932.

Roslyn Creek: stream, heads on $\mathbf{N}$ side of Marin Ra., flows NNE $5 \mathrm{mi}$. to Isthmus Bay, $12 \mathrm{mi}$. $\mathrm{SE}$ of Kodiak, Kodiak I.; 57 $37^{\prime} 05^{\prime \prime}$ N, $152^{\circ}$. $18^{\prime} 30^{\prime \prime} \mathrm{W}$; BGN 1966; (map 34).

Local name reported in 1966 by the Alaska State Geographic Board.

Rosie Mountain: mountain, see Cathedral Mountain.

Rosoff Mount: mountain, see Myghapowit Mountain.

Ross Bay: lagoon, $1.2 \mathrm{mi}$. long, on Beaufort Sea coast, $2 \mathrm{mi}$. S of Ross Point and $21 \mathrm{mi}$. SE of Barrow, Arctic Plain ; $71^{\circ} 11^{\prime} \mathrm{N}, 155^{\circ} 53^{\prime} \mathrm{W}$; (map 153).

Named August 3, 1837, by Thomas Simpson $(1843$, p. 151), for a personal friend, a partner of Charles and Rowand in the fur trade at Fort Garry. The name was originally applied to the larger area, north of the lagoon, extending east of Ross Point.

Ross Cove: cove, $0.5 \mathrm{mi}$. wide, on $\mathrm{SE}$ coast of Alaska Penin., trends SE $2 \mathrm{mi}$. to Pacific Ocean, 12 mi. $\mathbf{S}$ of Chignil, Aleutian Ra.; $56^{\circ} 07^{\prime} \mathrm{N}, 158^{\circ} 25^{\prime} \mathrm{W}$; (map 30 ).

Local name published by USC\&GS in 1916 Coast Pilot (p. 161).

Ross Creek: stream, flows NW $14 \mathrm{mi}$. to Yukon River, $5 \mathrm{mi}$. E of Stevens Village, Yukon Flats; $65^{\circ} 59^{\prime} 40^{\prime \prime} \mathrm{N}, 148^{\circ} 57^{\prime} 00^{\prime \prime} \mathrm{W}$; (map 105)

Named by prospectors and reported in 1902 by Lt. Hjalmar Erickson, USA; published by USGS (Prindle, 1905 pl. 15).

Ross Green Lake: lake, $1.5 \mathrm{mi}$. long, $1 \mathrm{mi}$. $\mathrm{E}$ of Barkely Lake and $45 \mathrm{mi}$. N of Cape Yakataga, Chugach Mts.; $60^{\circ} 43^{\prime} 30^{\prime \prime} \mathrm{N}, 142^{\circ} 31^{\prime} 00^{\prime \prime} \mathrm{W}$; $B G N$ 1960; (map 65).

Named by D. J. Miller, USGS, in 1960 for Ross V. Green, 1886-1959, who on many occasions helped USGS field parties based in Cordova. Born in Missouri, and after living many years in Idaho, Green came to Cordova in 1942. He was much interested in outdoor activities and was the founder of the local Izaac Walton Chapter. The first known landing on this lake by airplane was made by Miller on the day of Mr. Green's funeral.

Ross Point: point of land, on S tip of Cape Rozhnof, $10 \mathrm{mi}$. WSW of village of Port Moller, Bristol Bay Low.; 55 $56^{\prime} 00^{\prime \prime}$ N, 160 $51^{\prime}$ $30^{\prime \prime} \mathrm{W}$; (map 28).

Shown on a 1963 USC\&GS chart.

Ross Point: point of land, E point of entrance to Iko Bay, $20 \mathrm{mi}$. SE of Point Barrow, Arctic Plain; $71^{\circ} 14^{\prime} \mathrm{N}, 1^{\circ} 5^{\circ} 58^{\prime} \mathrm{W}$; (map 153). Var. Rose Point.

Named August 4, 1837, by Thomas Simpson for Capt. James Ross.

Rostilaf Lakes: lakes, see Rostilaf Lakes.

Rostislaf Lakes: lakes, $2 \mathrm{mi}$. across, $16 \mathrm{mi}$. N of village of Port Alexander, on $\mathrm{S}$ coast of Baranof I., Alex. Arch.; 56 $28^{\prime} 30^{\prime \prime} \mathrm{N}, 134^{\circ} 41^{\prime} 30^{\prime \prime}$ W; BGN 1935; (map 5). Var. Rostilaf Lakes.
Named in 1935 by USFS "for a ship built in Yakutat in 1804 as a part of the Sitka fleet."

Rosy Creek : stream, see Rosa Creek.

Rosy Creek: stream, see Rosie Creek.

Rothsay, Point: point of land, at mouth of Stikine River, $7 \mathrm{mi}$. N of Wrangell, Coast Mts.; $56^{\circ} 35^{\prime} 35^{\prime \prime} \mathrm{N}, 132^{\circ} 21^{\prime} 50^{\prime \prime} \mathrm{W}$; (map 6). Var. Mys Rechnoy, Reechnoi Point.

Named on August 27, 1793, by Capt. George Vancouver, RN (Wagner, 1937, p 407). Name "Mys Rechnoy," meaning "river point" was applied to this point in 1863 by the Russian surveyors from the corvette Rynda. See Rynda Island.

Rotokakat: stream, see Kaltag River.

Rotol River: stream, see Khotol River

Rotten Fish Slough: lake, an oxbow $1.5 \mathrm{mi}$. long, $22 \mathrm{mi}$. E of Chalkyitsik, Porcupine Plat.; $66^{\circ}$. $37^{\prime} \mathrm{N}, 142^{\circ} 55^{\prime} \mathrm{W}$; (map 120).

Local name reported in 1956 by T. E. Taylor, USGS. It may be a form of translation of an Indian name.

Rouge Point: point of land, see Krasni Point.

Rough Bay: bay, $1.5 \mathrm{mi}$. across; $\mathrm{E}$ of Gusty Bay, on NE coast of Tanaga I., Aleutian Is.; $51^{\circ}$. $50^{\prime} \mathrm{N}, 177^{\circ} 51^{\prime} \mathrm{W}$; (map 17 ).

Name published by USC\&GS in 1956

Rough Beach : bight, see Lumber Bay.

Rough Channel: water passage, between Ogden Passige and Khaz Bay, $4 \mathrm{mi}$. SSW of Chichagof, on W coast of Chichagof I., Alex. Arch.; $57^{\circ} 36^{\prime} 30^{\prime \prime} \mathrm{N}, 136^{\circ} 08^{\prime} 00^{\prime \prime} \mathrm{W}$; 'BGN 1908; (map 9).

Descriptive name given by USC\&GS and published in the 1908 Coast Pilot (p. 174). So named because "there is generally a heavy swell in the channel ***."

Rough Mountain Creek: stream, heads near Nukatpiak Mtn., flows W $38 \mathrm{mi}$. to Aniuk River, $10 \mathrm{mi}$. SW of Howard Pass, Brooks Ra.; $68^{\circ} 07^{\prime}$ N, $157^{\circ} 09^{\prime}$ W; (map 132).

Named by Orth in 1956; this name is a rough translation of an Eskimo name.

Roughtop Mountain: mountain, 3,150 ft., at NE end of Boulder Ridge, $37 \mathrm{mi}$. E of Tanana, Yukon-Tanana High.; $65^{\circ} 11^{\prime} 15^{\prime \prime} \mathrm{N}, 150^{\circ} 48^{\prime}$ 30" W; (map 106).

Prospectors' descriptive name reported in 1906 by Prindle (1908, pl. 5), USGS.

Roumiantsoff Cape: point of land, see Romanzof, Cape.

Roumiantzoff Mountains: mountain range, see Romanzof Mountains.

Roundabout Mountain: hill, $500 \mathrm{ft}$., on $\mathrm{N}$ bank of Yukon River $21 \mathrm{mi}$. SE of Marshall, YukonKuskokwim Delta ; $61^{\circ} 34^{\prime} 30^{\prime \prime} \mathrm{N}, 161^{\circ} 51^{\prime} 10^{\prime \prime}$ W; (map 73).

Riverboat pilots' name shown on a manuscript chart dated 1922; so called because the Yukon River goes around three sides of the steep hill.

Roundabout Mountain: mountain, $1,088 \mathrm{ft}$., 28 mi. SE of The Nogahabara Sand Dunes, Koyukuk Low., $65^{\circ} 33^{\prime} \mathrm{N}, 156^{\circ} 33^{\prime} \mathrm{W}$; (map 108). Var. Suskita Range.

So called by riverboat pilots as early as 1900 , because the circuitous Koyukuk River 
"approaches the mountain numerous times and eventually goes around it." The Koyukuk Indian name is "Suskita," according to Lt. B. H. Camden (Cantwell, 1904, p. 244), USRCS.

Roundabout Mountain: ridge, extends SW 15 mi. along $W$ bank of Kuskokwim River, 3 mi. $\mathrm{S}$ of McGrath, Kilbuck-Mts.; $62^{\circ} 53^{\prime} \mathrm{N}, 155^{\circ}$ $46^{\prime} \mathrm{W}$; (map 80).

Named in 1898 by W. S. Post, USGS.

Round Cove: cove, $1 \mathrm{mi}$. across, on $\mathrm{E}$ coast of Little Tanaga I., Aleutian Is.; $51^{\circ} 49^{\prime} \mathrm{N}$, $176^{\circ} 02^{\prime} \mathrm{W}$; BGN 1936; (map 17).

Descriptive name given in 1934 by members of the U.S. Navy Aleutian Island Survey Expedition.

Round Head: point of land, on NE coast of Kanaga I., Aleutian Is. ; $51^{\circ} 54^{\prime} \mathrm{N}, 177^{\circ} 03^{\prime} \mathrm{W}$; BGN 1936, (map 17).

So named in 1934 by members of the U.S. Navy Aleutian Island Survey Expedition, "because of its shape."

Round Head: point of land, on E coast of Akun I., Krenitzin Is., Aleutian Is.; $54^{\circ} 10^{\prime} 35^{\prime \prime} \mathrm{N}$, $165^{\circ} 24^{\prime} 00^{\prime \prime} \mathrm{W}$; (map 24).

Descriptive name given in 1901 by J. J. Gilbert, USC\&GS.

Round Hill: hill, 193 ft., on Akhiok I., in Alitak Bay, at $S$ end of Kodiak I.; $56^{\circ} 55^{\prime} 30^{\prime \prime} \mathrm{N}$, $154^{\circ} 09^{\prime} 40^{\prime \prime} \mathrm{W}$; (map 32).

Descriptive name reported in 1900 by Lt. Comdr. J. F. Moser, USN, commander of the USBF steamer Albatross.

Round Hill: mountain, 1,600 ft., at $S$ end of Peninsula Ridge, between Harry Bay and Nakat Inlet, Coast Mts.; $54^{\circ} 50^{\prime} 30^{\prime \prime} \mathrm{N}$, $130^{\circ} 46^{\prime} 20^{\prime \prime} \mathrm{W}$; (map 2).

Descriptive name given in 1883 by L.t. Comdr. H. E. Nichols, USN.

Round Island: island, $0.1 \mathrm{mi}$, across, in Beaver Inlet, eastern Unalaska I., Aleutian Is.; $53^{\circ} 46^{\prime} 11^{\prime \prime} \mathrm{N}, 166^{\circ} 23^{\prime} 00^{\prime \prime} \mathrm{W}$; (map 23).

Descriptive name given by J. J. Gilbert, USC\&GS, commander of the Coast Survey steamer Pathfinder during 1900-01.

Round Island: island, $0.14 \mathrm{mi}$. across, $0.5 \mathrm{mi}$. S of SE coast of Ugamak I., Krenitzin Is., Aleutian Is. ; $54^{\circ} 12^{\prime} 25^{\prime \prime} \mathrm{N}, 164^{\circ} 46^{\prime} 30^{\prime \prime} \mathrm{W}$; (map 24).

Descriptive name given in 1901 by $J$. J. Gilbert, USC\&GS.

Round Island: island, $400 \mathrm{ft}$., near mouth of Klakas Inlet, on SW coast of Prince of Wales I., Alex. Arch.; 54 $52^{\prime} 20^{\prime \prime}$ N, $132^{\circ} 23^{\prime} 50^{\prime \prime} \mathrm{W}$; (map 1).

Descriptive name given in 1897 by Lt. Comdr. J. F. Moser, USN.

Round Island: island, $150 \mathrm{ft}$. across, in Tlevak Strait, near mouth of Soda Bay, on W coast of Prince of Wales I., Alex. Arch.; 55 $14^{\prime} 35^{\prime \prime} \mathrm{N}$, $133^{\circ} 04^{\prime} 15^{\prime \prime} \mathrm{W}$; (map 4).

Local descriptive name published in the 1925 Coast Pilot (p. 138).

Round Island: island, $0.3 \mathrm{mi}$. long, near mouth of Thorne Arm, $0.5 \mathrm{mi}$. E of Bold I., Alex. Arch.; $55^{\circ} 15^{\prime} \mathrm{N}, 131^{\circ} 23^{\prime} \mathrm{W}$; (map 3 ).

Descriptive name given in 1883 by Lt. Comdr. H. E. Nichols, USN.
Round Island: island, $0.2 \mathrm{mi}$. across, in entrance to Coal Harbor in Zachary Bay, Unga 1 ., in Shumagin Is., Aleutian Ra.; $55^{\circ} 20^{\prime} 35^{\prime \prime} \mathrm{N}$, $160^{\circ} 37^{\prime} 15^{\prime \prime} \mathrm{W}$; (map 28).

Descriptive name probably given in 1865 by Western Union Telegraph Expedition and shown on USC\&GS chart published in 1872.

Round Island: island, 1,400 ft. long, in Kasaan Bay, NW of Kasaan Island, off $\mathrm{E}$ coast of Prince of Wales I., Alex. Arch.; $55^{\circ} 31^{\prime} \mathrm{N}$, $132^{\circ} 23^{\prime} \mathrm{W}$; (map 4).

Descriptive name given in 1886 by Lt. Comdr. R. C. Glover, USN.

Round Island: island, $0.1 \mathrm{mi}$. across, in Pavlof Bay, near SW end of Alaska Penin., Aleutian Ra.; $55^{\circ} 32^{\prime} 50^{\prime \prime} \mathrm{N}, 161^{\circ} 36^{\prime} 00^{\prime \prime} \mathrm{W}$; ( $\operatorname{map} 28$ ).

Descriptive name given in 1925 by USC\&GS.

Round Island: island, $0.3 \mathrm{mi}$. long, in Davidson Inlet, Alex. Arch.; $55^{\circ} 53^{\prime} 30^{\prime \prime} \mathrm{N}, 133^{\circ} 39^{\prime} 35^{\prime \prime}$ W; (map 4).

Local descriptive name published in 1964 by USC\&GS

Round Island: island, $0.1 \mathrm{mi}$. long, one of Rookery Is. in Clarence Strait, between Zarembo and Prince of Wales Is., Alex. Arch.; $56^{\circ} 18^{\prime} 50^{\prime \prime} \mathrm{N}, 133^{\circ} 05^{\prime} 15^{\prime \prime} \mathrm{W}$; (map 6).

Local descriptive name reported in 1949 by USGS.

Round Island: island, $0.1 \mathrm{mi}$. across, in Security Bay, on $\mathrm{N}$ coast of Kuiu I., Alex. Arch.; $56^{\circ}$. $52^{\prime} 50^{\prime \prime} \mathrm{N}, 134^{\circ} 21^{\prime} 20^{\prime \prime} \mathrm{W}$; (map 5).

Named in 1869 by Comdr. R. W. Meade, USN.

Round Island: island, $500 \mathrm{ft}$. across, in Redoubt Bay, $10 \mathrm{mi}$. S of Sitka, Alex. Arch.; 56 $54^{\prime} 50^{\prime \prime}$ N, $135^{\circ} 22^{\prime} 40^{\prime \prime}$ W ; (map 5). Var. Krugloi Island, Ostrov Krugloy.

This is a translation by USC\&GS of the name given in 1809 by the navigator Ivan Vasiliev the first, IRN. Lt. Sarichev (1826, map 19), IRN, published it as "O[strov] Krugloy."

Round Island: island, $0.1 \mathrm{mi}$. across, in Kasnyku Bay, off NE coast of Baranof I., Alex. Arch.; $57^{\circ} 12^{\prime} 35^{\prime \prime} \mathrm{N}, 134^{\circ} 50^{\prime} 20^{\prime \prime} \mathrm{W}$; (map 9). Var Ostrov Krugloy.

This is a translation by USC\&GS about 1882 of the name given by the Russian pilot Ens. Vasiliev; published in 1848 on Russian Hydrog. Dept. Chart 1397 as "Os[trov] Krugloy."

Round Island: island, $0.1 \mathrm{mi}$. across, in Salisbury Sound, off S coast of Chichagof I., $26 \mathrm{mi}$. NW of Sitka, Alex. Arch.; 57 $22^{\prime} 00^{\prime \prime} \mathrm{N}$, $135^{\circ} 42^{\prime} 40^{\prime \prime} \mathrm{W}$; (map 9).

Descriptive name reported in 1896 by Lt. Comdr. E. K. Moore, USN, and published by USC\&GS in the 1901 Coast Pilot (p. 191). It is "wooded, 200 feet high, dome-shaped top."

Round Island: island, $100 \mathrm{ft}$. across, in Inner Anchorage, NE of Gull I., $0.7 \mathrm{mi}$. SW of Kodiak, Kodiak I.; $57^{\circ} 46^{\prime} 50^{\prime \prime}$ N, $152^{\circ} 25^{\prime} 00^{\prime \prime}$ W; (map 34). Var. Krugloi Island, Ostrov Krugloy.

Translation of the name "Os[trov] Krugloy," published by Sarichev (1826, map 16).
Round Island: island, $1.5 \mathrm{mi}$. across, $15 \mathrm{mi}$. SE of Crooked I. and $35 \mathrm{mi}$. E of Hagemeister I., easternmost of Walrus Is., between-Kulukak and Togiak Bays; in Bristol Bay; 58 $36^{\prime} \mathrm{N}$, $159^{\circ} 58^{\prime} \mathrm{W}$; (map 39). Var. Kayashek, Kayashik, Krugloi Island, Walrus Island.

This island is thought to be the one named by Capt. Cook (1785, v. 2, p. 431), RN, on July 12, 1778, on account of its shape. Capt. Tebenkov (1852, map 4), IRN, called it "Os[trov] Krugloi," meaning "round island." Lt. Sarichev (1826, map 3), IRN, called it "Os[trov] Morzh," meaning "walrus island." Tebenkov and Sarichev gave the native name as "Kayashek" and "Kayashik," respectively. Round Island: island, $0.6 \mathrm{mi}$. long, in Copper River, $25 \mathrm{mi}$. NW of Katalla, Malaspina Coastal Plain; $60^{\circ} 27^{\prime} \mathrm{N}, 1^{\circ} 05^{\circ} 04^{\prime} \mathrm{W}$; (map $64)$.

Local descriptive name published in 1952 by USGS.

Round Island: island, see Akhiok Island.

Round Island: island, see Hound Island.

Round Islands: islands, SW group of the Barrier Is., extend $1 \mathrm{mi}$. in Cordova Bay, Alex. Arch.; $54^{\circ} 47^{\prime} \mathrm{N}, 132^{\circ} 30^{\prime} \mathrm{W}$; (map 1).

Descriptive name reported in 1905 by E. F. Dickins, USC\&GS.

Round Islet: island, $0.5 \mathrm{mi}$. long, largest of Round Islets, in Holkham Bay, $0.5 \mathrm{mi}$. SE of Harbor I. and $48 \mathrm{mi}$. SE of Juneau, Coast Mts. $57^{\circ} 45^{\prime} 10^{\prime \prime} \mathrm{N}, 133^{\circ} 36^{\prime} 00^{\prime \prime} \mathrm{W}$; (map 8). Var. Round Islets.

Named by Comdr. R. W. Meade, USN; published in 1869 on Hydrog. Chart 225 as "Round Islet (or islets)." Meade may have thought the group to be one island. The name was restricted to the southernmost and largest of the islands by the USC\&GS in 1891 Coast Pilot (p. 147).

Round Islet: islands, see Round Islets.

Round Islets: islands, in Holkham Bay, $0.5 \mathrm{mi}$. $\mathrm{SE}$ of Harbor I. and $48 \mathrm{mi}$. SE of Juneau, Coast Mts.; $57^{\circ} 45^{\prime} 10^{\prime \prime} \mathrm{N}, 133^{\circ} 36^{\prime} 00^{\prime \prime} \mathrm{W}$; (map 8). Var. Round Islet.

Named in 1869 by Comdr. R. W. Meade, USN; published in 1891 by USC\&GS. See Round Islet.

Round Islets: island, see Round Islet.

Round Lake: lake, $0.1 \mathrm{mi}$. across, on northern Kiska I., Aleutian Is.; $52^{\circ} 04^{\prime} 42^{\prime \prime} \mathrm{N}, 177^{\circ} 36^{\prime}$ 45" E; (map 14).

An arbitrary name beginning with " $R$ " to correspond to "R" grid used by the U.S. Army for tactical purposes during World War II; published on a 1953 AMS map.

Round Lake: lake, $0.2 \mathrm{mi}$. across, $8.5 \mathrm{mi}$. $\mathrm{N}$ of Port Alexander, on $\mathbf{E}$ coast of Baranof $\mathbf{I}$., Alex. Arch.; $56^{\circ} 22^{\prime} 10^{\prime \prime} \mathrm{N}, 134^{\circ} 42^{\prime} 00^{\prime \prime} \mathrm{W}$; (map 5).

Local descriptive name obtained in 1951 by USGS.

Round Lake: lake, on Kenai Penin. N of Harvey Lake, $0.4 \mathrm{mi}$. across, $6.5 \mathrm{mi}$. SW of Skilak Lake and $30 \mathrm{mi}$. SE of Kenai, Chugach Mts.; $60^{\circ}$ $19^{\prime} 15^{\prime \prime} \mathrm{N}, 150^{\circ} 32^{\prime} 30^{\prime \prime} \mathrm{W}$; (map 62). 
Named about 1963 by officials of Kenai National Moose Range, for administrative purposes.

Round Lake: lake, $0.2 \mathrm{mi}$. long, drains $\mathrm{S}$ to Tolsona Creek, $15 \mathrm{mi}$. WNW of Glennallen, Copper River Basin; 62 $12^{\prime} \mathrm{N}, 145^{\circ} 57^{\prime} \mathrm{W}$; (map 83).

Local descriptive name; reported in 1951 by USGS.

Round Lake: lake, $0.6 \mathrm{mi}$. long, $2 \mathrm{mi}$. E of Crosswind Lake and $22 \mathrm{mi}$. NW of Glennallen, Copper River Basin; 62 $22^{\prime}$ N, $145^{\circ} 5^{\prime}$ W ; (map 83).

Local name reported in 1951 by USGS.

Round Lake: lake, $0.4 \mathrm{mi}$. across, between Finland Creek and bend in Innoko River, $35 \mathrm{mi}$. NW of Ophir and $61 \mathrm{mi}$. NW of McGrath, Innoko Low.; $63^{\circ} 35^{\prime} 30^{\prime \prime} \mathrm{N}, 157^{\circ} 15^{\prime} 00^{\prime \prime} \mathrm{W}$; (map 90).

Local name obtained in 1954 by $R$. E. Isto, USGS.

Round Lake: lake, $0.6 \mathrm{mi}$. across, $\mathrm{E}$ of Tanana River, $21 \mathrm{mi}$. NW of Tanacross, YukonTanana High, ; $63^{\circ} 37^{\prime} \mathrm{N}, 143^{\circ} 48^{\prime} \mathrm{W}$; (map 85).

Descriptive name published by USGS in 1954.

Round Lake: lake, $0.5 \mathrm{mi}$. across, between Sundown and Tincan Lakes, $19 \mathrm{mi}$. SW of Beaver, Yukon Flats; $66^{\circ} 10^{\prime} 20^{\prime \prime} \mathrm{N}, 147^{\circ} 56^{\prime} 30^{\prime \prime} \mathrm{W}$; (map 118).

Local descriptive name obtained in 1956 by USGS.

Round Mountain: mountain, 2,300 ft, on Annette I., $4.6 \mathrm{mi}$. N of Metlakatla, Alex. Arch.; $55^{\circ} 11^{\prime} 50^{\prime \prime} \mathrm{N}, 131^{\circ} 33^{\prime} 28^{\prime \prime} \mathrm{W}$; (map 3)

Descriptive name given in 1883 by $L$ t. Comdr. H. E. Nichols, USN.

Round Mountain: mountain, 3,850 ft., in Kenai Mts., on Kenai Penin., $5 \mathrm{mi}$. NW of Cooper Landing and $42 \mathrm{mi}$. ESE of Kenai, Chugach Mts. ; $60^{\circ} 30^{\prime} 30^{\prime \prime} \mathrm{N}, 150^{\circ} 00^{\prime} 00^{\prime \prime} \mathrm{W}$; (map 62).

Local descriptive name; reported in 1944 by USGS.

Round Mountain: mountain, $1,026 \mathrm{ft}$., at E side of entrance to Columbia Bay, $1.5 \mathrm{mi}$. SE of $\mathrm{S}$ tip of Heather I., $60 \mathrm{mi}$. E of Whittier, Chugach Mts.; $60^{\circ} 56^{\prime} 45^{\prime \prime} \mathrm{N}, 147^{\circ} 02^{\prime} 00^{\prime \prime} \mathrm{W}$; BGN 1911; (map 63).

Descriptive name given in 1908 by U. S. Grant, USGS.

Round Mountain: mountain, 2,800 ft., $2.5 \mathrm{mi}$. SE of Rainy Pass Lodge, $85 \mathrm{mi}$. SW of Talkeetna, Alaska Ra.; $62^{\circ} 03^{\prime} 50^{\prime \prime} \mathrm{N}, 152^{\circ} 41^{\prime} 10^{\prime \prime}$ W; (map 81).

Local descriptive name reported in 1958 by USGS.

Round Mountain: mountain, $1,872 \mathrm{ft} ., 24 \mathrm{mi}$. W of Hughes, Hogatza High.; $66^{\circ} 04^{\prime} \mathrm{N}, 155^{\circ} 06^{\prime}$ W; (map 116)

Local name reported in 1956 by Orth.

Round Point: point of land, on SW coast of Kanaga I., Aleutian Is.; $51^{\circ} 42^{\prime} 10^{\prime \prime} \mathrm{N}, 177^{\circ}$ $31^{\prime} 15^{\prime \prime} \mathrm{W}$; (map 17).

Descriptive name published in 1951 on a USGS map.

Round Point: point of land, point of entrance to Sukkwan Strait, on E coast of Blanket I.,
Alex. Arch.; $55^{\circ} 07^{\prime} 30^{\prime \prime} \mathrm{N}, 132^{\circ} 41^{\prime} 15^{\prime \prime} \mathrm{W}$; (map 4).

Descriptive name given in 1924 by USC\& GS.

Round Point point of land, on SE coast of Zarembo I., in Stikine Strait, Alex. Arch.; $56^{\circ} 16^{\prime} 40^{\prime \prime} \mathrm{N}, 132^{\circ} 39^{\prime} 30^{\prime \prime} \mathrm{W}$; (map 6).

Descriptive name given in 1886 by $L t$. Comdr. A. S. Snow, USN, because of its shape.

Round Point: point of land, on SE tip of Takeena Penin., $8 \mathrm{mi}$. SE of Chichagof, on W coast of Chichagof I., Alex. Arch.; 57 $33^{\prime} 25^{\prime \prime}$ $\mathrm{N}, 135^{\circ} 59^{\prime} 40^{\prime \prime} \mathrm{W}$; (map 9).

Descriptive name published in 1928 by USC\&GS on Chart 8280

Round Point: point of land, on W bank of Yukon River $14 \mathrm{mi}$. SE of Marshall, Yukon-Kuskokwim Delta; $61^{\circ} 41^{\prime} \mathrm{N}, 161^{\circ} 57^{\prime} \mathrm{W}$; (map 73).

Riverboat pilots' name descriptive of the long round curve of the point; shown on a 1916 field sheet by R. H. Sargent, USGS.

Round Point: point of land, on $\mathrm{S}$ bank of Yukon River $1 \mathrm{mi}$. F of junc. of Tozitna River, $9 \mathrm{mi}$. WSW of Tanana, Nowitna Low.; $65^{\circ} 08^{\prime} \mathrm{N}$, $152^{\circ} 22^{\prime} \mathrm{W}$; (map 106).

Descriptive name shown on a riverboat manuscript chart, dated in 1906.

Round Point: point of land, see Cape Glazenap.

Round Point: point of land, see Krugloi Point.

Round Rock: rock, 2 mi. W of Chirikof I., 100 mi. SW of Kodiak J.; $55^{\circ} 49^{\prime} \mathrm{N}, 155^{\circ} 46^{\prime} \mathrm{W}$; (map 32).

Descriptive name reported in 1874 by W.H. Dall, USC\&GS.

Round Rock: rock, $40 \mathrm{ft}$. high, in Frederick Sound, $3.4 \mathrm{mi}$. SW of West Brother I. and 55 mi. E of Sitka, Alex. Arch.; 57 15'35" N, $133^{\circ} 56^{\prime} 00^{\prime \prime} \mathrm{W}$; (map 8).

Descriptive name published by USC\&GS in 1891 Coast Pilot (p. 143).

Round Tangle Lake: lake, $1 \mathrm{mi}$. across, one of Tangle Lakes, near head of Delta River, 15 mi. W of Paxson, Alaska Ra.; 63 $3^{\circ} 03^{\prime} 30^{\prime \prime} \mathrm{N}$. $145^{\circ} 09^{\prime} 20^{\prime \prime} \mathrm{W}$; (map 86).

Name published on relatively recent maps.

Round Top Mountain: mountain, 3,900 ft., 8.5 mi. SE of Paxson Lake, $49 \mathrm{mi}$. NE of Glennallen, Copper River Basin; $62^{\circ} 48^{\prime} \mathrm{N}, 145^{\circ} 19^{\prime}$ W; (map 83).

Local descriptive name reported by USGS in 1951.

Roundtop Mountain: mountain, 6,140 ft., on Unimak I., Aleutian Is. ; $54^{\circ} 48^{\circ} 00^{\prime \prime} \mathrm{N}, 163^{\circ}$ $35^{\prime} 30^{\prime \prime}$ W; (map 25). Var. Dome, Round Top.

Name reported as "Round Top" by USC\&GS in 1902. This feature was called "Dome" by J. F. Moser, USN, in 1897.

Rousseau Range: mountain range, elev. 4,600 ft., extends W $13 \mathrm{mi}$. from Portland Canal, $\mathrm{N}$ of Peabody Mts., Coast Mts.; $55^{\circ} 26^{\prime} \mathrm{N}$, $130^{\circ} 12^{\prime} \mathrm{W}$; (map 3 ).

Named in 1868 by Staff Comdr. David Pender, RN, possibly for Gen. Lovell H. Rousseau, who accepted the territory of Alaska for the United States in 1867 , in a ceremony with Russian representatives at Sitka.
Rover Creek: stream, flows NE $1 \mathrm{mi}$. to Casadepaga River, $16 \mathrm{mi}$. $\mathrm{N}$ of Solomon, Seward Penin. High.; $64^{\circ} 47^{\prime}$ N, $164^{\circ} 22^{\prime}$ W; (map 95). Var. Slate Creek.

Shown as "Slate" on a 1901 map of Cape Nome gold fields by David Fox., Jr. Prospectors' name reported on a 1902 prospectors' manuscript map.

Rowan Bay: bay, $1 \mathrm{mi}$ across, $7 \mathrm{mi}$. $\mathrm{N}$ of Tebenkof Bay, on W coast of Kuiu I., Alex. Arch.; $56^{\circ} 39^{\prime} 00^{\prime \prime} \mathrm{N}, 134^{\circ} 17^{\prime} 30^{\prime \prime} \mathrm{W}$; BGN 1933; (map 5). Var. North Arm Bay of Pillars.

Named in 1933 by USFS "for Capt. Rowan of the brig Eliza, who traded with the Indians of Southeast Alaska in the late 18th and early 19th centuries." The name "North Arm Bay of Pillars" was published in 1899 by USG\&GS and was used locally until 1933.

Rowe Island: island, $250 \mathrm{ft}$. across, in Klag Bay, $1.7 \mathrm{mi}$. S of Chichagof, on $\mathrm{W}$ coast of Chichagof I., Alex. Arch.; $57^{\circ} 38^{\prime} 20^{\prime \prime} \mathrm{N}, 136^{\circ} 05^{\prime}$ $50^{\prime \prime} \mathrm{W} ; B G N 1908$; (map 9).

Named in 1908 by USC\&GS and published in 1909 on Chart 8280.

Rowena, Lake: lake, $1.2 \mathrm{mi}$. long, on mainland $2 \mathrm{mi}$. NW of Baily Bay, Alex. Arch.; $56^{\circ} 00^{\prime}$ $\mathrm{N}, 131^{\circ} 40^{\prime} \mathrm{W}$; (map 7 ).

Local name reported in 1955 by USGS.

Rowlee Point: point of land, in Muir Inlet, in Glacier Bay National Monument, at mouth of Wachusett Inlet, $1.4 \mathrm{mi}$. NW of Point McLeod and $62 \mathrm{mi}$. NW of Hoonah, St. Elias Mts.; $58^{\circ} 56^{\prime} 05^{\prime \prime} \mathrm{N}, 136^{\circ} 07^{\prime} 20^{\prime \prime} \mathrm{W}$; BGN 1948; (map 10.) Var. Cushing Point, Wachusett Point.

Named for Willard Winfield Rowlee, 18611923, professor of botany, Cornell Univ. He was botanist for the Cushing Expedition to Glacier Bay in 1890 . The name "Point Wachusett" was published by the American Geographical Society (Field, 1947, map).

Roxas, Puerto de : bay, see Ugak Bay.

Roy Creek: stream, flows SW $9 \mathrm{mi}$. to Beaver Greek, $42 \mathrm{mi}$. NE of Fairbanks, Yukon-Tanana

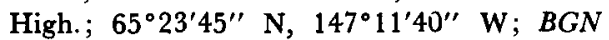
1910; (map 105). Var. Bear Creek.

Originally published in 1908 by USGS as Bear Creek, but prospectors called the stream "Roy," and the name was published in 1912 by USGS.

Roy Creek: stream, flows SW $11 \mathrm{mi}$. joining Chimney Fork to form Glacier River, $4 \mathrm{mi}$. $\mathrm{NE}$ of Foggytop Mtn. and $22 \mathrm{mi}$. N of Wiseman, Brooks Ra.; $67^{\circ} 42^{\prime} 30^{\prime \prime} \mathrm{N}, 150^{\circ} 25^{\prime} 30^{\prime \prime}$ W; BGN 1932; (map 124).

Named about 1930 by Robert Marshall "for Roy King, the prospector wi:o first explored the creek and built a cabin on it."

Roy Island: island, $200 \mathrm{ft}$. across, off $\mathrm{N}$ coast of Duke Island, Alex. Arch.; $54^{\circ} 57^{\prime} 45^{\prime \prime} \mathrm{N}, 131^{\circ}$ $25^{\prime} 00^{\prime \prime} \mathrm{W}$; (map 2).

Local name published in 1943 by USC\&GS. Rozario, Ostrov del: island, see Rosary Island. Rozhnof: point of land, see Lagoon Point.

Rozhnof, Cape: peninsula, between Nelson Lagoon and Herendeen Bay, $11 \mathrm{mi}$. W of village of Port Moller, Alaska Penin., Bristol Bay Low.; $55^{\circ} 58^{\prime} \mathrm{N}, 160^{\circ} 57^{\prime} \mathrm{W}$; (map 28 ). 
Var. Cape Rozhnot, Rodgnof, Rodgnoff, Rojnoff.

Named Cape Rojnoff by Capt. Lutke (1836, p. 261), IRN. The name was applied at first to what is now called Lagoon Point. Cape Rodgnoff is shown in its present location on an 1882 USC\&GS chart; the spelling "Rozhnof" is derived from "Rozhnova," shown in 1847 on Russian Hydrog. Dept. Chart 1379. Rozhnot, Cape: peninsula, see Rozhnof, Cape. Rua Cove: cove, in Prince William Sound, on E coast of Knight I., $0.5 \mathrm{mi}$. across, $16 \mathrm{mi}$. $\mathrm{NE}$ of Chenega, Chugach Mts.; $60^{\circ} 21^{\prime} 00^{\prime \prime} \mathrm{N}$, $147^{\circ} 38^{\prime} 15^{\prime \prime} \mathrm{W}$; BCN 1917; (map 63).

Name used by local miners and reported in 1908 by U. S. Grant and D. F. Higgins (in Brooks and others, 1910, pl. 4), USGS. It was probably named for Charles Rua who operated 2 mines near here in 1908.

Rubber Boot Lake: lake, $0.2 \mathrm{mi}$. long, on $\mathrm{E}$ side of Kenai Penin., $13 \mathrm{mi}$. NE of Chenega, Chugach Mts.; 60 $27^{\prime} 25^{\prime \prime} \mathrm{N}, 147^{\circ} 55^{\prime} 30^{\prime \prime} \mathrm{W}$; (map 63).

Name reported in 1897 by Lt. Comdr. J. F. Moser, USN. A "rubber boot" is the local name of a small edible mussel.

Rube Creek: stream, flows SE $4.2 \mathrm{mi}$. to Peace River, 12 mi. N of Haycock, Seward Penin. High.; $65^{\circ} 22^{\prime} \mathrm{N}, 161^{\circ} 02^{\prime} \mathrm{W}$; (map 109).

Local name reported in 1917 by G. L. Harrington, USGS.

Rubertz: locality, see Afognak.

Rubia Bay: bay, see Fish Bay.

Rubin Glacier: glacier, trends SW $2 \mathrm{mi}$. to its 1952 terminus at head of Goat Creek, $6 \mathrm{mi}$. E of Valdez, Chugach Mts.; $61^{\circ} 07^{\prime} 10^{\prime \prime} \mathrm{N}$, $146^{\circ} 04^{\prime} 30^{\prime \prime} \mathrm{W}$; (map 68).

Local name published in the 1950 's by USGS.

Rubtsovskaya : locality, see Afognak.

Rubtzovskaia: locality, see Afognak.

Ruby: locality, at mouth of Ruby Creek, $1 \mathrm{mi}$. $\mathrm{N}$ of Casadepaga and $18 \mathrm{mi}$. N of Solomon, Seward Penin. High.; $64^{\circ} 49^{\prime} \mathrm{N}, 164^{\circ} 20^{\prime} \mathrm{W}$; (map 95). Var. Ruby Roadhouse.

Site of a roadhouse shown on the 1908 "Map of Seward Peninsula" by Arthur Gibson; probably named for its location at the mouth of Ruby Creek.

Ruby: village, pop. 179, on left bank of Yukon River, $\mathbf{S}$ of junc. of Melozitna River, KilbuckKuskokwim Mts. ; $64^{\circ} 45^{\prime} \mathrm{N}, 155^{\circ} 30^{\prime} \mathrm{W}$; $B G N$ 1944; (map 98). Var. Lozi-koket.

Gold was discovered on Ruby Creek, near the site of this village in 1907; however, a town did not develop until 1911, when gold was discovered on Long Creek, and a "stampede" followed. A substantial town grew in 1 year, and for the next several years the population was over 1,000 . Ruby post office was established in 1912. By 1920 the population was reduced to 128 , and has remained under 200 since. Baker (1906 p. 415) recorded "Lozi-koket: Indian village, on left bank of the Yukon, opposite the mouth of Melozi [Melozitna] river, * * Name taken from Edwards' Track Chart of the Yukon, 1899."
Ruby Creek: stream, flows NW $5.5 \mathrm{mi}$. to Bonanza Creek, $11.5 \mathrm{mi}$. E of Flat and $53 \mathrm{mi}$. NW of Sleetmute, Kilbuck-Kuskokwim Mts. $62^{\circ} 25^{\prime} 40^{\prime \prime} \mathrm{N}, 157^{\circ} 38^{\prime} 40^{\prime \prime} \mathrm{W}$; (map 79).

Prospectors' name reported in 1933 by J. B. Mertie, USGS.

Ruby Creek: stream, flows NW $6 \mathrm{mi}$. to Nixon Fork Takotna River, $13 \mathrm{mi}$. NW of Medfra, Kilbuck-Kuskokwim Mts.; $63^{\circ} 16^{\prime} \mathrm{N}, 154^{\circ} 54^{\prime}$ W; (map 89).

Prospectors' name obtained in 1921 by G. C. Martin (in Brooks, 1922, fig. 5), USGS

Ruby Creek: stream, flows S $3.5 \mathrm{mi}$. to West Fork Chulitna River, $48 \mathrm{mi}$. SW of Healy, Alaska Ra.; $63^{\circ} 16^{\prime} 15^{\prime \prime} \mathrm{N}, 149^{\circ} 44^{\prime} 35^{\prime \prime} \mathrm{W}$; (map 87).

Prospectors' name obtained in 1913 by J. W. Bagley, USGS; published by S. R. Capps (in Martin, 1919, pl. 5), USGS.

Ruby Creek: stream, in Kantishna Hills, flows W $0.8 \mathrm{mi}$. to Yellow Creek, $4.8 \mathrm{mi}$. NNE of Wonder Lake, Alaska Ra.; $63^{\circ} 33^{\prime} 30^{\prime \prime} \mathrm{N}, 150^{\circ}$. 49'40" W; BGN 1932; (map 88).

Local name reported in 1932 by F. G. Wells and S. C. Kain, USGS.

Ruby Creek: stream, flows NW $7.4 \mathrm{mi}$. to Delta River, crosses Richardson Highway, $29 \mathrm{mi}$. S of Delta Junction, Alaska Ra.; $63^{\circ} 39^{\prime} 08^{\prime \prime} \mathrm{N}$, $145^{\circ} 54^{\prime} 30^{\prime \prime} \mathrm{W}$; (map 86).

So named, about 1902 , because of the rubycolored pebbles found along the stream by prospectors (Davies, 1965, p. 23).

Ruby Creek: stream, flows SE $10 \mathrm{mi}$. to Slate Creek, $50 \mathrm{mi}$. SW of Eagle, Yukon-Tanana High.; 64 $38^{\prime} \mathrm{N}, 142^{\circ} 45^{\prime} \mathrm{W}$; (map 102).

Prospectors' name shown on a 1902 manuscript map by E. J. Chamberlain, U.S. Deputy Surveyor.

Ruby Creek: stream, flows N $1.4 \mathrm{mi}$. to Yukon River at Ruby, Kilbuck-Kuskokwim Mts.; $64^{\circ} 44^{\prime} 20^{\prime \prime} \mathrm{N}, 155^{\circ} 29^{\prime} 50^{\prime \prime} \mathrm{W}$; (map 98).

Prospectors' name reported in 1907 by Brooks (1908, p. 46), USGS. Gold was discovered on this stream, near the present town, called Ruby, in 1907.

Ruby Creek: stream, flows NW $4 \mathrm{mi}$. to Casadepaga River, $17 \mathrm{mi}$. NE of Solomon, Seward Penin. High.; $64^{\circ} 49^{\prime} \mathrm{N}, 164^{\circ} 20^{\prime} \mathrm{W}$; (map 95).

Prospectors' name reported in 1900 by E. C. Barnard (in Brooks, 1901, pl. 17), USGS

Ruby Creek: stream, flows SW $1.6 \mathrm{mi}$. to Steele Creek, $9 \mathrm{mi}$. NE of Fairbanks, Yukon-Tanana High.; $B G N$ 1933; $64^{\circ} 55^{\prime} 20^{\prime \prime} \mathrm{N}, 147^{\circ} 29^{\prime} 30^{\prime \prime}$ W; (map 100).

Local name reported in 1933 by J. M. Hill, USGS.

Ruby Greek: stream, flows SW $3 \mathrm{mi}$. to Little Washington Creek, $21 \mathrm{mi}$. NW of Eagle, Yukon-Tanana High.; 64 $56^{\circ} 45^{\prime \prime} \mathrm{N}, 141^{\circ} 48^{\prime} 45^{\prime \prime}$ W: (map 102)

Local name published in 1956 by USGS.

Ruby Creek: stream, flows NW $3 \mathrm{mi}$. to Chatanika River, $18 \mathrm{mi}$. NE of Fairbanks, YukonTanana High.; $65^{\circ} 06^{\prime} 30^{\prime \prime} \mathrm{N}, 147^{\circ} 32^{\prime} 50^{\prime \prime} \mathrm{W}$; (map 105).

Named by prospectors, shown on a manuscript map by C. W. Joynt dated 1905 .
Ruby Creek: stream, flows SE $3 \mathrm{mi}$. to Bluestone River, $11 \mathrm{mi}$. SE of Teller, Seward Penin. High.; 65 ${ }^{\circ} 07^{\prime} \mathrm{N}, 166^{\circ} 11^{\prime} \mathrm{W}$; (map 111).

Local name reported in 1900 by E. C. Barnard (in Brooks, 1901, pl. 17); USGS.

Ruby Creek: stream, flows NE $1.5 \mathrm{mi}$. to Fourth of July Creek, $8 \mathrm{mi}$. SW of that stream's junc. with Yukon River and $34 \mathrm{mi}$. NW of Eagle, Yukon-Tanana High.; $65^{\circ} 07^{\prime} 15^{\prime \prime} \mathrm{N}$, $142^{\circ} 03^{\prime} 00^{\prime \prime} \mathrm{W}$; (map 103).

Prospectors' name reported by L. M. Prindle and J. B. Mertie, Jr. (in Brooks and others, 1912, p. 208), USGS.

Ruby Creek: stream, flows SW 2 mi. to Sourdough Creek, $8 \mathrm{mi}$. NW of Mount Ryan and $76 \mathrm{mi}$. SW of Circle, Yukon-Tanana High.; $65^{\circ} 18^{\prime} 30^{\prime \prime} \mathrm{N}, 146^{\circ} 28^{\prime} 00^{\prime \prime} \mathrm{W}$; (map 104).

Prospectors' name reported in 1954 or 1955 by USGS topographers.

Ruby Creek: stream, flows NE $7 \mathrm{mi}$. to Minook Creek, $7 \mathrm{mi}$. S of Rampart, Yukon-Tanana High.; $65^{\circ} 24^{\prime} 30^{\prime \prime} \mathrm{N}, 150^{\circ} 08^{\prime} 00^{\prime \prime} \mathrm{W}$; (map 106).

Prospectors' name published in 1898 by USC\&GS on Chart 3098. So named because of the garnets, sometimes referred to as "rubies," found in the stream's gravels.

Ruby Creek: stream, flows NW $2.5 \mathrm{mi}$. to Igloo Greek which flows to American River, $30 \mathrm{mi}$. NE of Teller, Seward Penin. High.; $65^{\circ} 27^{\prime}$ $\mathrm{N}, 165^{\circ} 25^{\prime} \mathrm{W}$; (map 111).

Prospectors' name reported in 1901 by T. G. Gerdine (in Collier, 1902, pl. 12), USGS.

Ruby Creek: stream, flows N $8 \mathrm{mi}$. to Shungnak River, 17 mi. NE of Shungnak, Brooks Ra.; $67^{\circ} 07^{\prime} \mathrm{N}, 156^{\circ} 55^{\prime} \mathrm{W}$; (map 126).

Prospectors' name "derived from the ruby garnet," reported by $P$. S. Smith and H. M. Eakin, USGS (in Brooks and others, 1911, p. 300).

Ruby Creek: stream, flows E $5 \mathrm{mi}$. from E of Ipnek Mtn. to North Fork Koyukuk River, $17 \mathrm{mi}$. W of Wiseman, Brooks Ra.; $67^{\circ} 21^{\prime} \mathrm{N}$, $150^{\circ} 45^{\prime} \mathrm{W}$; (map 124).

Local name reported in 1909 by A. G. Maddren (in Brooks and others, 1910, pl. 7), USGS.

Ruby Creek: stream, flows SE $2.5 \mathrm{mi}$. to Woodland Echo Creek, $4 \mathrm{mi}$. E of Woodland Echo Pass and $10 \mathrm{mi}$. SW of Chandalar, Brooks Ra.; $67^{\circ} 26^{\prime} 20^{\prime \prime} \mathrm{N}, 148^{\circ} 51^{\prime} 00^{\prime \prime} \mathrm{W}$; (map 123).

Local name reported in 1956 by T. E. Taylor, USGS:

Ruby Creek: stream, flows $\mathrm{N}$ to Paystreak Creek which flows to Pilgrim River, $12 \mathrm{mi}$. NE of Salmon Lake and $24 \mathrm{mi}$. W of Mount Bendeleben, Seward Penin. High.; (map 110).

Prospectors' name reported on a 1901 map of Cape Nome gold fields by David Fox, Jr. This stream cannot be precisely located on current maps.

Ruby Creek: ravine, see Ruby Gulch.

Ruby Creek: stream, see Emerald Creek.

Rubyets: locality, see Afognak.

Ruby Gulch: ravine, trends W 1 mi. to Crooked Creek, N of Queen Gulch, $43 \mathrm{mi}$. NW of Sleetmute, Kilbuck-Kuskokwim Mts. ; 62 ${ }^{\circ} 03^{\prime}$ $45^{\prime \prime} \mathrm{N}, 158^{\circ} 13^{\prime} 20^{\prime \prime} \mathrm{W}$; BGN 1945; (map 79). 
Local name reported in 1914 by USGS in reference to "the large quantity of red garnets found in rich gold placers at the mouth of the gulch."

Ruby Gulch: ravine, trends SSE $0.8 \mathrm{mi}$. to Falls Creek $0.8 \mathrm{mi}$. NW of its junc. with Cache Greek, $32 \mathrm{mi}$. NW of Talkeetna, Alaska Ra.; $62^{\circ} 29^{\prime} 00^{\prime \prime} \mathrm{N}, 151^{\circ} 01^{\prime} 15^{\prime \prime} \mathrm{W}$; (map 81).

Prospectors' name reported in the 1930's by USGS.

Ruby Gulch: ravine, in Dutch Hills, extends NE $1 \mathrm{mi}$. from Willow Creek, $29 \mathrm{mi}$. NW of Talkeetna, Alaska Ra.; $62^{\circ} 34^{\prime} 50^{\prime \prime} \mathrm{N}, 150^{\circ} 50^{\prime} 45^{\prime \prime}$ W; (map 81). Var. Ruby Creek.

Name published as "Ruby Creek" by Cook (1908, map).

Ruby Gulch: ravine, extends SW $1.1 \mathrm{mi}$. to tributary of Chisna River, $0.5 \mathrm{mi}$. E Chisna Pass and $25 \mathrm{mi}$. NE of Paxson, Alaska Ra.; $63^{\circ} 09^{\prime} 15^{\prime \prime} \mathrm{N}, 144^{\circ} 46^{\prime} 20^{\prime \prime} \mathrm{W}$; (map 86).

Prospectors' name reported in 1900 by T. G. Gerdine (in Mendenhall and Schrader, 1903 pl. 9), USGS.

Ruby Gulch: ravine, trends NW $1.7 \mathrm{mi}$. to Hazel Creek, $7 \mathrm{mi}$. NE of Nome, Seward Penin.

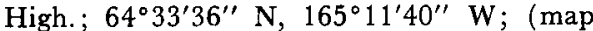
94).

Prospectors' name reported on the 1903 Campion Mining and Trading Co. map by George M. Ashford.

Ruby Gulch: stream, see Rulby Creek.

Ruby Roadhouse: locality, see Ruby.

Ruby Slough: stream, anabranch, heads at Yukon River and flows SW $27 \mathrm{mi}$. to Yuki River, $59 \mathrm{mi}$. E of Nulato, Kilbuck-Kuskokwim Mts. ; $64^{\circ} 42^{\prime} \mathrm{N}, 156^{\circ} 06^{\prime} \mathrm{W}$; (map 97).

Local name reported in 1954 by USGS.

Rucksock Creek: stream, flows $1.2 \mathrm{mi}$. N to Peaceful River, on SE coast of Attu I., Aleutian Is.; $52^{\circ} 50^{\prime} 24^{\prime \prime} \mathrm{N}, 173^{\circ} 07^{\prime} 45^{\prime \prime} \mathrm{E}$; (map 13).

Named by the U.S. Army during its occupation of the island during World War II; shown on an AMS map published in 1948.

Rudakof, Mount: mountain, 3,540 ft., $16 \mathrm{mi}$. NW of Port Alexander on S coast of Baranof I., Alex. Arch.; $56^{\circ} 27^{\prime} 30^{\prime \prime} \mathrm{N}, 1^{\circ} 34^{\circ} 49^{\prime} 15^{\prime \prime} \mathrm{W}$; $B G N$ 1933; (map 5). Var. Rudakof Mountain.

Named in 1933 by USFS "for Alexander Rudakof, eleventh Russian Governor of Alaska, 1853-54."

Rudakof Mountain: mountain, see Rudakof, Mount.

Rude Lake: lake, $1 \mathrm{mi}$. long, at terminus of Cordova Glacier, $22 \mathrm{mi}$. NE of Cordova, Chugach Mts.; $60^{\circ} 49^{\prime} 30^{\prime \prime} \mathrm{N}, 1^{\circ} 35^{\circ} 31^{\prime} 00^{\prime \prime} \mathrm{W}$; (map 64).

Name published by USGS in 1959; derived from nearby Rude River.

Rude River: stream, flows SW 16 mi. to Nelson Bay, at NE end of Orca Inlet, $10 \mathrm{mi}$. NNE of Cordova, Chugach Mts.; $60^{\circ} 40^{\prime} \mathrm{N}$, $145^{\circ} 37^{\prime}$ W; BGN 1966; (map 64). Var. Cordova Creek.
Locally named for Gilbert Rude, USC\&GS ; name published by the Norris Peters Company on their 1911 map of Orca Bay.

Rudisell Reef: reef, $0.2 \mathrm{mi}$. long, at mouth of Mueller Cove, in SE part of Nikolski Bay, on SW coast of Umnak I., Aleutian Is.; 52 ${ }^{\circ} 56^{\prime}$ 45" N, 168 $52^{\prime} 05^{\prime \prime} \mathrm{W}$; BGN 1940; (map 21).

Named in 1939 by USC\&GS for Maurice G. Rudisell, USC\&GS, a fireman on a survey party who was drowned on May 28, 1938, when a survey boat struck this reef. See Mueller Cove.

Rudolph Creek: stream, flows NW $0.9 \mathrm{mi}$. to Snake River, $12 \mathrm{mi}$. N of Nome, Seward Penin. High.; $64^{\circ} 41^{\prime} \mathrm{N}, 165^{\circ} 24^{\prime} \mathrm{W}$; (map 94).

Prospectors' name reported on a map by S. E. King dated 1900 .

Rudyerd Bay: estuary, on the mainland, extends SW $14 \mathrm{mi}$. to Behm Canal, Coast Mts.; $55^{\circ}$ $33^{\prime} \mathrm{N}, 130^{\circ} 52^{\prime} \mathrm{W}$; (map 3 ).

Named in 1879 by W. H. Dall, USC\&GS, for the English engineer, John Rudyerd, who rebuilt the Eddystone lighthouse after its destruction in 1703.

Rudyerd Island: island, $1.5 \mathrm{mi}$. long, in Behm Canal, at the mouth of Princess Bay, on the SE coast of Revillagigedo I., Alex. Arch.; $55^{\circ} 16^{\prime} 40^{\prime \prime} \mathrm{N}, 131^{\circ} 02^{\prime} 05^{\prime \prime} \mathrm{W}$; (map 3).

Named in 1879 by W. H. Dall, USC\&GS, for the English engineer John Rudyerd.

Rue Ledge: rocks, $3 \mathrm{mi}$. W of Turf Point, off SW coast of Seguam I., Aleutian Is.; $52^{\circ} 15^{\prime}$ $00^{\prime \prime} \mathrm{N}, 172^{\circ} 36^{\prime} 30^{\prime \prime} \mathrm{W}$; (map 19)

Named by a special U.S. Navy survey party and published by USC\&GS in 1944 Aleutian Coast Pilot (p. 86)

Rufus Creek: stream, flows NW $5.5 \mathrm{mi}$. to Slana River $1.6 \mathrm{mi}$. NE of its junc. with Copper River, Alaska Ra.; $62^{\circ} 43^{\prime} \mathrm{N}, 143^{\circ} 56^{\prime} \mathrm{W}$; (map 84). Var. Natat Creek.

Local name reported by USGS in 1960 .

Rufus Creek: stream, see Sufus Creek.

Rugged Island: island, $2.5 \mathrm{mi}$. long, at junc. of Resurrection Bay and Harding Gateway, 19 mi. S of Seward, Chugach Mts.; $59^{\circ} 51^{\prime} 30^{\prime \prime}$

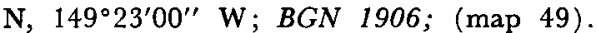
Var. Baker Island.

Named by BGN after a proposal to name it "Baker Island" in honor of Marcus Baker was rejected.

Ruhama, Mount: mountain, see Ruhamah, Mount.

Ruhamah, Mount: mountain, 5,620 ft., $3.2 \mathrm{mi}$. $\mathrm{E}$ of Shelter Cove on Russell Fiord and 22 mi. NE of Yakutat, St. Elias Mts. ; 59 $43^{\prime} 00^{\prime \prime}$ N, $139^{\circ} 12^{\prime} 30^{\prime \prime} \mathrm{W}$; (map 46). Var. Mount Ruhama.

Named "Mount Ruhama" by Russell (1892, p. 88), USGS, for Miss Ruhama Scidmore, author of a book on journeys in Alaska.

Ruibnaia: locality, see Ingregamiut.

Ruibnaia: locality, see Ribnaia.

Ruin, Cape: point of land, on E coast of Umak I., Aleutian Is.; $51^{\circ} 54^{\prime} 40^{\prime \prime} \mathrm{N}, 175^{\circ} 59^{\prime} 15^{\prime \prime} \mathrm{W}$; $B G N$ 1936; ( $\operatorname{map} 18$ ).

Descriptive name applied by personnel of the 1934 U.S. Navy Aleutian Island Survey
Expedition because of the Cape's "ruined" appearance; published by the USC\&GS in the 1944 Aleutian Coast Pilot (p. 104).

Ruins Point: point of land, on NW coast of Kosciusko I., $1.5 \mathrm{mi}$. S of Shipley Bay, Alex. Arch.; 56 $04^{\prime} \mathrm{N}, 133^{\circ} 42^{\prime} \mathrm{W}$; (map 6).

Named in 1879 by W. H. Dall, USC\&GS, "on account of a ruined Indian village there."

Rukavitsie, Cape: point of land, on $\mathrm{S}$ coast of Unimak I., Aleutian Is.; $54^{\circ} 37^{\prime} 50^{\prime \prime} \mathrm{N}, 164^{\circ}$ 03'00" W; (map 24).

Russian name published by Veniaminov (1840, v. 1, p. 211) meaning "gloves" or "mittens."

Rukav Ledyanoy: estuary, see Taku Inlet.

Rulby Creek: stream, flows W $1.9 \mathrm{mi}$. to Sinuk River, $22 \mathrm{mi}$. NW of Nome, Seward Penin. High.; $64^{\circ} 47^{\prime} \mathrm{N}, 165^{\circ} 48^{\prime} \mathrm{W}$; (map 94). Var. Ruby Gulch.

Prospectors' name reported in 1900 by $E$. C. Barnard (in Brooks, 1901, pl. 17), USGS.

Rumble Creek: stream, heads at glacier terminus NW of Tok Glacier, flows NE $11 \mathrm{mi}$. to Robertson River, $3 \mathrm{mi}$. E of Robertson Glacier terminus and $36 \mathrm{mi}$. W of Tok, Alaska Ra. $63^{\circ} 18^{\prime} 20^{\prime \prime} \mathrm{N}, 144^{\circ} 07^{\prime} 00^{\prime \prime} \mathrm{W}$; $B G N$ 1936; (map 86).

Named in 1936 by USGS "because of the curious rumbling sound caused by large rolling boulders in the swift stream."

Rumbling Mountain: mountain, 6,520 ft., at head of Kenunga Creek, 17.5 mi. SE of Anaktuvuk Pass, Brooks Ra.; 68 $00^{\prime} 45^{\prime \prime} \mathrm{N}$, $151^{\circ} 09^{\prime} 15^{\prime \prime} \mathrm{W}$; (map 134).

Named in 1930 by Marshall, (1956, p. 45) who wrote, "Chunks of rock were continually breaking off and rumbling down into the valley, so I called that peak the Rumbling Mountain."

Rum Brook: stream, see Moss Creek.

Rumiantsof, Cape: point of land, see Romanzof, Cape.

Rumiantzof Mountains: mountain range, see Romanzof Mountains.

Rungun Creek: stream, flows SE $11.6 \mathrm{mi}$. to North Fork Kuskokwim River, $44 \mathrm{mi}$. NE of Medfra, Kilbuck-Kuskokwim Mts.; 63․ $30^{\prime} \mathrm{N}, 153^{\circ} 37^{\prime} \mathrm{W}$; (map 89).

Local name reported in 1958 by USGS

Runkels Creek: stream, flows NE and SE $10 \mathrm{mi}$. to Anvik River, $60 \mathrm{mi}$. S of Unalakleet, Nulato Hills; $63^{\circ} 00^{\prime} 20^{\prime \prime} \mathrm{N}, 160^{\circ} 43^{\prime} 30^{\prime \prime} \mathrm{W}$ (map 91).

Local name reported in 1949 by USC\&GS.

Runstettler: area, in NE part of Anchorage, Cook Inlet Low.; $61^{\circ} 13^{\prime} 00^{\prime \prime} \mathrm{N}, 149^{\circ} 47^{\prime} 10^{\prime \prime}$ W; (map 69).

Local name reported in 1954 by the city engineer of Anchorage.

Runt Creek: stream, heads in Canada, flows NW $26 \mathrm{mi}$. to Salmon Fork, $30 \mathrm{mi}$. NW of Midnight Hill, Porcupine Plat.; $66^{\circ} 26^{\prime} 20^{\prime \prime} \mathrm{N}$, $141^{\circ} 30^{\prime} 20^{\prime \prime} \mathrm{W}$; BGN 1954; (map 120).

Named in 1908 by IBC surveyors; published in 1914 on IBC Sheet 14 (1918 Atlas).

Rurik Harbor: bay, $0.8 \mathrm{mi}$. long, on $\mathrm{S}$ end of Khantaak I., 1 mi. N of Point Turner and $2.2 \mathrm{mi}$. NW of Yakutat, Malaspina Coastal 
Plain; $59^{\circ} 34^{\prime} 15^{\prime \prime} \mathrm{N}, 139^{\circ} 46^{\prime} 30^{\prime \prime} \mathrm{W}$; (map 46).

Named by Khromchenko, who surveyed the area in 1823, after a ship (brig) belonging to the Russian-American Co. The name was originally applied to the combined water area of what is now Rurik Harbor and Port Mulgrave. The name is now restricted to the northernmost of the two bays.

Rurik Harbor: cove, see Mulgrave, Port.

Rush Hill: hill, $665 \mathrm{ft}$., highest of Einahnuhto Hills, on W coast of St. Paul I., in Pribilof Is. ; $57^{\circ} 11^{\prime} 20^{\prime \prime} \mathrm{N}, 170^{\circ} 23^{\prime} 50^{\prime \prime} \mathrm{W}$; (map 38 ).

Probably named in 1891 by Joseph StanleyBrown, naturalist, for the U.S. Revenue Cutter, Richard Rush, during fur-seal investigations of the islands in 1891 by the U.S. Treassury Department.

Rush Hills: hills, see Einahnuhto Hills.

Rush Lake: lake, $1.5 \mathrm{mi}$. long, between Boulder Creek and Glenn Highway, $31 \mathrm{mi}$. NE of Palmer, Talkeetna Mts.; $61^{\circ} 49^{\prime} 45^{\prime \prime} \mathrm{N}, 148^{\circ}$ $15^{\prime} 45^{\prime \prime} \mathrm{W}$; (map 69).

Local name reported in 1913 by USGS.

Rush Peak: mountain, 2,734 ft., near center of Prince of Wales I., N of Salmon Lake, 17 mi. NE of Klawock, Alex. Arch.; 55 $37^{\prime} 25^{\prime \prime}$ $\mathrm{N}, 132^{\circ} 40^{\prime} 15^{\prime \prime} \mathrm{W}$; (map 4).

Local name recorded in 1949 by USGS.

Rush Point: point of land, on SW coast of St. George I., in Pribilof Is.; $56^{\circ} 35^{\prime} 20^{\prime \prime} \mathrm{N}, 169^{\circ}$ $44^{\prime} 30^{\prime \prime} \mathrm{W}$; ( $\left.\operatorname{map} 38\right)$.

Name published in 1898 by USC\&GS presumably for the U.S. Revenue Cutter, Richard Rush.

Rush Point: point of land, on W shore of Glacier Bay, in Glacier Bay National Monument, 0.6 mi. $\mathbf{N}$ of Ripple Cove, $34 \mathrm{mi}$. NW of Hoonah, St. Elias Mts.; $58^{\circ} 28^{\prime} 05^{\prime \prime} \mathrm{N}, 136^{\circ} 04^{\prime} 10^{\prime \prime} \mathrm{W}$; (map 10).

So named in 1892 by Reid (1896, p. 424), "because there is a ceaseless rush of tidal water flowing past the point."

Rush Rock: rock, between Sanak I. and Alaska Penin., $11.5 \mathrm{mi}$. SW of Deer I., Aleutian Ra.; $54^{\circ} 48^{\prime} 45^{\prime \prime} \mathrm{N}, 162^{\circ} 40^{\prime} 55^{\prime \prime} \mathrm{W}$; (map 25).

Name reported by W. H. Dall, USC\&GS, and published in 1882 on USC\&GS Chart 806.

Russel Creek: stream, flows SE $1.7 \mathrm{mi}$. to Snake River, $5 \mathrm{mi}$. NW of Nome, Seward Penin, High.; 643' N,' $165^{\circ} 30^{\prime} \mathrm{W}$; (map 94).

Prospectors' name reported in 1900 by $\mathrm{E}$. C. Barnard (in Brooks, 1901, pl. 17), USGS.

Russel Creek: stream, flows SE $2.3 \mathrm{mi}$. to join Virginia Creek to form Goldbottom Creek which flows to Niukluk River, $10 \mathrm{mi}$. NW of Council and $43 \mathrm{mi}$. SW of Imuruk Lake, Seward Penin. High.; $65^{\circ} 01^{\prime} \mathrm{N}, 163^{\circ} 50^{\prime} \mathrm{W}$; (map 110).

Prospectors' name published on the 1908 "Map of Seward Peninsula" by Arthur Gibson.

Russel Creek: stream, see Delta Creek.

Russell, Mount: peak, 11,670 ft., marks SW corner of Mount McKinley National Park, 34 mi. SW of Denali Pass and $66 \mathrm{mi}$. NW of
Talkeetna, Alaska Ra.; $62^{\circ} 48^{\prime} \mathrm{N}, 151^{\circ} 53^{\prime}$ W; (map 81).

Named in 1902 by A. H. Brooks, USGS, for Israel Cook Russell, 1852-1906, geologist, explorer, and author.

Russell Cove: cove, see Shelter Cove.

Russell Fiord: estuary, extends N $25 \mathrm{mi}$. to Disenchantment Bay, at head of Yakutat Bay, St. Elias Mts.; $60^{\circ} 00^{\prime} \mathrm{N}, 139^{\circ} 27^{\prime} \mathrm{W}$; (map 46).

Named in 1906 by Marcus Baker, USGS, for Israel Cook Russell, 1852-1906, explorer of the Yakutat region in 1890 and 1891 and discoverer of this estuary in 1891. Russell was born in New York and received B.S. and C.E. degrees in 1872 from the Univ. of the City of New York. In 1880 he became a member of the USGS. He was a USGS representative in 1889 in an expedition sent to Alaska by the USC\&GS to establish a portion of Alaska's eastern boundary. During the next two years he explored, under the joint auspices of the USGS and the National Geographic Society, the slopes of Mount St. Elias and the Yakutat Bay area. In 1892 he became professor of geology at the Univ. of Michigan. At the time of his death he was President of the Geological Society of America.

Russell Glacier: glacier, heads at $61^{\circ} 22^{\prime} \mathrm{N}$, $141^{\circ} 53^{\prime} \mathrm{W}$ and trends $26 \mathrm{mi}$. $\mathrm{N}$ through Skolai Pass to its terminus at head of White River, $40 \mathrm{mi}$. NE of McCarthy, Wrangell Mts.; $61^{\circ} 41^{\prime} \mathrm{N}, 141^{\circ} 48^{\prime} \mathrm{W}$; (map 67)

Named in 1891 by Hayes (1892, p. 152), USGS, for Israel Cook Russell, 1852-1906. See Russell Fiord.

Russell Island: island, $3.7 \mathrm{mi}$. long, in Glacier Bay, Glacier Bay National Monument, 2 mi. $\mathrm{N}$ of Ibach Point and $75 \mathrm{mi}$. NW of Hoonah, St. Elias Mts.; $58^{\circ} 55^{\prime} 45^{\prime \prime} \mathrm{N}, 136^{\circ} 49^{\prime} 30^{\prime \prime} \mathrm{W}$; (map 10).

Named by Field and Cooper (1937, pl. 1) for Israel Cook Russell, 1852-1906. See Russell Fiord.

Russian America: state, see Alaska.

Russian Anchorage: bight, $1 \mathrm{mi}$. across, near mouth of Kinak Bay, on E coast of Alaska Penin. in Katmai National Monument, $23 \mathrm{mi}$ $\mathrm{SE}$ of Mount Katmai, Aleutian Ra. ; $58^{\circ} 06^{\prime} 30^{\prime \prime}$ N, $154^{\circ} 22^{\prime} 30^{\prime \prime}$ W; (map 42). Var. Russian Harbor.

Named "Russian Harbor in 1910 by USC\&GS; "Russian Anchorage" was reported in 1919 by R. F. Griggs, National Geographic Society.

Russian Bay: bay, $1.3 \mathrm{mi}$. across, on $\mathrm{SE}$ coast of Umnak I., Aleutian Is. ; $53^{\circ} 09^{\prime} 00^{\prime \prime} \mathrm{N}, 168^{\circ}$ 21'15" W; (map 22).

Name published by USC\&GS in 1944 Aleutian Coast Pilot (p. 71).

Russian Cove: cove, at $\mathrm{S}$ junc. of Stephens Passage and Port Houghton, $0.4 \mathrm{mi}$. SE of Crow I. and $63 \mathrm{mi}$. W of Sitka, Coast Mts.; $57^{\circ} 17^{\prime} 45^{\prime \prime}$ $\mathrm{N}, 133^{\circ} 28^{\prime} 30^{\prime \prime} \mathrm{W}$; (map 8$)$.

Local name reported in 1955 by USGS.

Russian Creek: stream, flows NE $9 \mathrm{mi}$. to Womens Bay, $8.5 \mathrm{mi}$. SW of Kodiak, Kodiak I. ; 57 $42^{\prime} 25^{\prime \prime} \mathrm{N}, 152^{\circ} 34^{\prime} 00^{\prime \prime} \mathrm{W}$; BGN 1964; Var. Russian River.
Local name published in 1949 by USC\&GS. Russian Creek: stream, flows $\mathrm{N} 8.5 \mathrm{mi}$. to Yukon River, $3 \mathrm{mi}$. SW of Rampart, YukonTanana High.; $65^{\circ} 29^{\prime} \mathrm{N}, 150^{\circ} 17^{\prime} \mathrm{W}$; (map 106).

Local name reported in 1899 by Cantwell (1902, p. 277), USRCS; also shown on Edwards Track Chart of the Yukon, dated 1899.

Russian Gardens: locality, on E coast of St. Michael I., $1.3 \mathrm{mi}$. N of St. Michael, YukonKuskokwim Delta ; $63^{\circ} 29^{\prime} 45^{\prime \prime}$ N, $162^{\circ} 03^{\prime} 30^{\prime \prime}$ W; (map 92).

Local name reported in a 1950 USC\&GS field report that stated, "In the days of Russian occupation the hilltop was used as a garden plot; signs of cultivation still exist."

Russian Harbor: water passage, $2.5 \mathrm{mi}$. across, between Aiaktalik and Kodiak I.; $56^{\circ} 44^{\prime} \mathrm{N}$, $154^{\circ} 05^{\prime} \mathrm{W}$; (map 32$)$.

Named by USBF in 1888; derived from the name "Russian Lodge," shown on a map by Capt. Tebenkov (1852, map 22).

Russian Harbor: bight, see Russian Anchorage. Russian Island: island, see Bamdoroshni Island.

Russian Jack Springs: springs, in Anchorage, at head of Middle Fork Chester Creek, Cook Inlet Low.; $61^{\circ} 12^{\prime} 24^{\prime \prime} \mathrm{N}, 149^{\circ} 46^{\prime} 47^{\prime \prime} \mathrm{W}$; (map 69).

Local name reported in 1954 by the city engineer of Anchorage.

Russian John Creek: stream, flows E $2 \mathrm{mi}$. to Limestone Creek, $1.2 \mathrm{mi}$. $\mathrm{N}$ of that stream's junc. with Middle Fork Chistochina River, $27 \mathrm{mi}$. NE of Paxson, Alaska Ra.; 63 ${ }^{\circ} 06^{\prime} 25^{\prime \prime}$ N, $144^{\circ} 38^{\prime} 40^{\prime \prime} \mathrm{W}$; (map 86).

Name published on relatively recent maps. Russian Lake: lake, see Upper Russian Lake.

Russian Mission: settlement, on $\mathrm{N}$ bank of Kuskokwim River $9.5 \mathrm{mi}$. E of Aniak, Kilbuck-Kuskokwim Mts. ; $61^{\circ} 34^{\prime} 20^{\prime \prime}$ N, $159^{\circ} 34^{\prime}$ 30" W; BGN 1948; (map 73). Var. Little Russian Mission

The establishment of Moravian missionaries on the river in 1885 motivated the Orthodox Church to reactivate its Kuskokwim Mission. This led to the founding of the Russian Mission (sometimes referred to as Little Russian Mission to distinguish it from Russian Mission on the Yukon River), in 1891, with Father J. Orlof as resident priest. The major centers of the Russian (Greek) Orthodox Church along the Kuskokwim River are Sleetmute, Russian Mission, Lower Kalskag, Kwethluk, and Napaiskak (Oswalt, 1963, p. 7).

Russian Mission: village, pop. 102, on right bank of Yukon River $25 \mathrm{mi}$. SE of Marshall, Yukon-Kuskokwim Delta; $61^{\circ} 47^{\prime} \mathrm{N}, 161^{\circ} 19^{\prime}$ W; (map 73). Var. Ekogmute, Ikagmiut, Ikogmut, Ikogmute, The Mission.

The Eskimo name for this village appears to have been reported by Lt. L. A. Zagoskin, IRN, in 1842-44 and published in Russian by $\mathbf{P}$. Tikhmeniev, in 1861, as "S[elo] Ikogmyut," possibly meaning "people of the point." It is listed by I. Pctroff in the 1880 Census as "Ikogmute," with 143 inhabitants; the 1890 Census lists 140. Baker (1906, p. 32), gives 
a population of 350 Eskimo in 1902 . This village was the location of a Russian Orthodox Mission (sometimes called "Pokrovskaya Mission)," established in 1851, the first in the interior of Alaska (Oswalt, 1963, p. 6). The designation "Russian Mission" supplanted the Eskimo name about 1900.

Russian Mountain: mountain, 6,300 ft., in Kenai Mts., on Kenai Penin., $2 \mathrm{mi}$. E of Skilak Lake and $43 \mathrm{mi}$. ESE of Kenai, Chugach Mts.; $60^{\circ}$ $27^{\prime} \mathrm{N}, 150^{\circ} 02^{\prime} \mathrm{W}$; (map 62).

Local name reported in 1950 by USGS.

Russian Mountains: mountain, 3,200 ft., extends N $13 \mathrm{mi}$. from Kuskokwim River, E of Owhat River and $9 \mathrm{mi}$. NE of Aniak, Kilbuck-Kuskokwim Mts.; $61^{\circ} 40^{\prime} \mathrm{N}, 159^{\circ} 10^{\prime} \mathrm{W} ; B G N$ 1948; (map 73).

Named during the "Yellow River stampede" of the winter of 1900-01 because the Russian Orthodox Mission was located on the south edge of the mountain (see Brooks and others, 1915 , p. 300).

Russian Point: point of land, at SW entrance to Port Graham, on SW end of Kenai Penin., $10 \mathrm{mi}$. SW of Seldovia, Chugach Mts.; 59 $21^{\prime}$ $30^{\prime \prime} \mathrm{N}, 151^{\circ} 55^{\prime} 00^{\prime \prime} \mathrm{W}$; (map 50).

Name published by Capt. Portlock (1789, map facing p. 102). A Russian trading post was located on Port Graham.

Russian Reef: reef, in Chatham Strait, $15 \mathrm{mi}$. S of Angoon, off W coast of Admiralty I., Alex. Arch.; 57 $17^{\prime} 15^{\prime \prime} \mathrm{N}, 134^{\circ} 37^{\prime} 15^{\prime \prime} \mathrm{W}$; (map 9).

Named by Comdr. R. W. Meade, USN, and published on Chart 225 in 1869. This name was given because "a Russian vessel is said to have struck upon it."

Russian Ridge: ridge, elev. $1500-1600 \mathrm{ft} ., 0.5$ mi. long, $2.5 \mathrm{mi}$. NE of Lief Cove, west-central Kiska I., Aleutian Is. ; $51^{\circ} 58^{\prime} 30^{\prime \prime} \mathrm{N}, 177^{\circ} 22^{\prime}$ 15" E; (map 14).

One of many arbitrary names applied to features on Kiska I. by USAF for tactical purposes during World War II.

Russian Ridge: hill, see Lame Hill.

Russian River: stream, heads at Upper Russian Lake, flows NW $13 \mathrm{mi}$. to Kenai River, $34 \mathrm{mi}$. SW of Hope, Chugach Mts. ; $60^{\circ} 29^{\prime} 15^{\prime \prime} \mathrm{N}$, $150^{\circ} 00^{\prime} 00^{\prime \prime} \mathrm{W}$; (map 63).

Local name reported in 1904 by Moffit (1906, pl. 2), USGS.

Russian River: stream, see.Russian Creek.

Russian River Rendezvous: locality, on Kenai Penin., $0.5 \mathrm{mi}$. N of Lower Russian Lake and $36 \mathrm{mi}$. SW of Hope, Chugach Mts. ; $60^{\circ} 27^{\prime} 15^{\prime \prime}$ N, $149^{\circ} 49^{\prime} 00^{\prime \prime}$ W; (map 63).

Roadhouse along Russian River Trail. Recent USGS maps indicate a site with one building.

Rustabach Lake: lake, $0.2 \mathrm{mi}$. across, near SE coast of Chilkat Penin. $1 \mathrm{mi}$. S of Mud Bay and $22 \mathrm{mi}$. S of Skagway, Coast Mts.; $59^{\circ} 07^{\prime}$ $50^{\prime \prime} \mathrm{N}, 135^{\circ} 20^{\prime} 10^{\prime \prime} \mathrm{W}$; (map 45).

Local name obtained by USGS field personnel and published on Federal maps since 1950.

Rust Creek: stream, flows SW $4.5 \mathrm{mi}$. through Rust Lake to Sister Lake, $4 \mathrm{mi}$. SE of Chichagof, on W coast of Chichagof I., Alex. Arch.; $57^{\circ} 38^{\prime} 00^{\prime \prime} \mathrm{N}, 135^{\circ} 59^{\prime} 45^{\prime \prime}$ W; BGN 1939; (map 9).

Name given to creek in 1935 by local inhabitants; named for W. R. Rust who died in 1928, "who was one of the pioneers of the Chichagof Mine."

Rust Lake: lake, $1 \mathrm{mi}$. long, $4.5 \mathrm{mi}$. E of Chichagof, on $W$ coast of Chichagof I., Alex. Arch.; $57^{\circ} 39^{\prime} \mathrm{N}, 135^{\circ} 58^{\prime} \mathrm{W}$; (map 9).

Name reported by G. H. Canfield (in Brooks and others, 1918, p. 154), USGS.

Rust Mountain: mountain, 2,360 ft., $6 \mathrm{mi}$. NE of Chichagof, on $\mathrm{W}$ coast of Chichag of $\mathrm{I}$., Alex. Arch.; $57^{\circ} 41^{\prime} 30^{\prime \prime} \mathrm{N}, 1^{\circ} 55^{\circ} 30^{\prime \prime} \mathrm{W}$; $B G N 1939$; (map 9).

Named by local inhabitants in 1939 for W. R. Rust. See Rust Creek.

Rust Slough: stream, distributary of Drift River, flows SE $6 \mathrm{mi}$. to Redoubt Bay, $30 \mathrm{mi}$. W of Kenai, Cook Inlet Low.; $60^{\circ} 35^{\prime} \mathrm{N}, 152^{\circ} 10^{\prime}$ $\mathrm{W}$; (map 62).

Local name reported in 1958 by USGS.

Rusty Creek: stream, flows N $2.5 \mathrm{mi}$. to White Creek, $68 \mathrm{mi}$. SE of Healy, Alaska Ra.; $63^{\circ}$ $11^{\prime} 45^{\prime \prime} \mathrm{N}, 147^{\circ} 19^{\prime} 10^{\prime \prime} \mathrm{W}$; (map 87).

Local name reported in 1910 by D. C. Witherspoon, USGS.

Rusty Gold Creek: stream, flows N $3 \mathrm{mi}$. to Kokomo Creek, 26 mi. NE of Fairbanks, Yu-

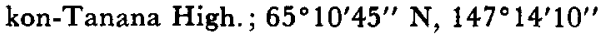
W; (map 105). Var. Alder Creek.

Named by prospectors; reported in 1903 by T. G. Gerdine, USGS, to be Alder Creek; the present name was published in 1908 by USGS.

Rusty Hill: hill, $460 \mathrm{ft} ., 1.3 \mathrm{mi}$. SE of Witchcraft Point, Kiska I., Aleutian Is.; 52 $02^{\prime} 12^{\prime \prime}$ N, 177 $31^{\prime} 10^{\prime \prime} \mathrm{E}$; (map 14).

An arbitrary name beginning with " $R$ " to correspond to " $R$ " grid used by the U.S. Army for tactical purposes during World War II; published on a 1953 AMS map.

Rusty Hill: mountain, 4,300 ft., $2.3 \mathrm{mi}$. NE of Denali and $67 \mathrm{mi}$. SE of Healy, Alaska Ra.; $63^{\circ} 12^{\prime} 30^{\prime \prime} \mathrm{N}, 147^{\circ} 25^{\prime} 50^{\prime \prime} \mathrm{W}$; (map 87).

Descriptive name published in 1952 by USGS.

Rusty Mountain: mountain, 1,916 ft., on $\mathrm{N}$ shore of Tuxedni Bay, $58 \mathrm{mi}$. SW of Kenai, Aleutian Ra.; $60^{\circ} 14^{\prime} \mathrm{N}, 152^{\circ} 48^{\prime} \mathrm{W}$; (map 62).

Local name reported in 1962 by USGS.

Ruth Amphitheater: basin, at head of Ruth Glacier, extends $7 \mathrm{mi}$, between Explorers Peak and West Fork Ruth Glacier, $10 \mathrm{mi}$. SE of Mount McKinley, Alaska Ra.; $63^{\circ} 00^{\prime} \mathrm{N}$, $150^{\circ} 42^{\prime} \mathrm{W}$; (maps 81, 88).

Mountain climbers' name reported in 1954 by USGS.

Ruth Amphitheatre: basin, see Ruth Amphitheater.

Ruth Bay: bay, extends $\mathbf{N} 2 \mathrm{mi}$. off Cordova Bay, on SW coast of Prince of Wales I., W of Klakas Inlet, Alex. Arch.; 54 $53^{\prime} 40^{\prime \prime} \mathrm{N}$, $132^{\circ} 25^{\prime} 30^{\prime \prime} \mathrm{W}$; (map 1 ).

Local name published by USC\&GS in 1911.

Ruth Creek: stream, flows NW $1 \mathrm{mi}$. to Livengood Greek at Livengood, Yukon-Tanana
High; $65^{\circ} 31^{\prime} 30^{\prime \prime} \mathrm{N}, 148^{\circ} 32^{\prime} 45^{\prime \prime} \mathrm{W}$; (map 105).

Prospected and named by Jay Livengood; reported in 1915 by USGS (Brooks and others, 1916, pl. 9).

Ruth Cutoff: water passage, between SW coast of Prince of Wales and Klakas Is., near W entrance to Klakas Inlet, Alex. Arch.; $54^{\circ} 54^{\prime} 20^{\prime \prime} \mathrm{N}, 132^{\circ} 24^{\prime} 45^{\prime \prime} \mathrm{W}$; (map 1).

Local name reported in 1951 by USGS; derived from Ruth Bay.

Ruth Gap: $g a p$, in ridge between heads of Southeast Fork Kahiltna Glacier and West Fork Ruth Glacier, $7 \mathrm{mi}$. S of Denali Pass in Mount McKinley National Park, Alaska Ra.; 62 ${ }^{\circ} 59^{\prime}$ $15^{\prime \prime} \mathrm{N}, 151^{\circ} 02^{\prime} 40^{\prime \prime} \mathrm{W}$; (map 81).

Name shown by Bradford Washburn on his Mount McKinley map published about 1960. Ruth Glacier: glacier, heads at Ruth Amphitheater, trends SE through The Great Corge $31 \mathrm{mi}$. to its terminus, $25 \mathrm{mi}$. NW of Talkeetna, Alaska Ra.; $62^{\circ} 39^{\prime} \mathrm{N}, 150^{\circ} 25^{\prime} \mathrm{W}$; (map 81). Var. Big Glacier, Chulitna Glacier.

Named in 1903 by F. A. Cook for his daughter. The Browne-Parker Expedition of 1910 referred to it as "Big Glacier."

Ruth Island: island, $400 \mathrm{ft}$. long, near mouth of Ruth Bay, on SW coast of Prince of Wales I., Alex. Arch.; $54^{\circ} 53^{\prime} 45^{\prime \prime} \mathrm{N}, 132^{\circ} 25^{\prime} 30^{\prime \prime} \mathrm{W}$; (map 1).

Local name reported in 1951 by USGS.

Ruth Island: island, $500 \mathrm{ft}$. across, in Ryus Bay, N coast of Duke I., Alex. Arch.; 54 $57^{\prime} 45^{\prime \prime} \mathrm{N}$, $131^{\circ} 24^{\prime} 30^{\prime \prime} \cdot \mathrm{W}$; (map 2).

Local name published in 1920 by USC\&GS.

Ruth Island: island, $3.7 \mathrm{mi}$. long, in Thomas Bay, $14 \mathrm{mi}$. NE of Petersburg, Coast Mts.; $56^{\circ} 59^{\prime} 45^{\prime \prime} \mathrm{N}, 132^{\circ} 50^{\prime} 00^{\prime \prime} \mathrm{W}$; (map 6).

Named in 1887 by Lt. Comdr. C. M. Thomas, USN, for charting purposes; name published in 1888 on USC\&GS Chart 705.

Ruth Lake: lake, $0.5 \mathrm{mi}$. long, at head of Delta Creek, 16 mi. NE of Petersburg, Coast Mts.; $56^{\circ} 59^{\prime} 25^{\prime \prime} \mathrm{N}, 132^{\circ} 44^{\prime} 00^{\prime \prime} \mathrm{W}$; (map 6).

Local name recorded in 1961 by USGS.

Ruth Lake: lake, $3.7 \mathrm{mi}$. long, drains $\mathrm{N}$ into Becharof Lake, $W$ of Kanatak Pass, on Alaska Penin., $47 \mathrm{mi}$. E of Ugashik, Aleutian Ra.; $57^{\circ} 35^{\prime} \mathrm{N}, 156^{\circ} 07^{\prime} \mathrm{W}$; (map 36).

Local name reported in 1902 by J. L. McPherson of Iliamna; published by G. C. Martin (1921, pl. 10), USGS.

Ruth Lake: lake, $1,600 \mathrm{ft}$. long, $5 \mathrm{mi}$. NE of junc. of Chitina and Lakina Rivers and 18 mi. W of McCarthy, Wrangell Mts.; $B G N$ 1966 ; $61^{\circ} 22^{\prime} 03^{\prime \prime} \mathrm{N}, 143^{\circ} 26^{\prime} 35^{\prime \prime} \mathrm{W}$; (map 67).

Local name reported by USGS in 1966.

Ruth Lake: lake, 2,100 ft. long, E of The Alaska Railroad, SE of Willow, $36 \mathrm{mi}$. $\mathrm{N}$ of Anchorage, Cook Inlet Low.; $61^{\circ} 44^{\prime} 20^{\prime \prime} \mathrm{N}, 150^{\circ}$ 01'30" W; (map 70).

Local name reported in 1958 by USGS.

Ruth River: stream, heads in a lake in Tokosha Mts. and flows SE around terminus of Ruth Glacier, 13 mi. to Tokositna River, $22 \mathrm{mi}$. NW of Talkeetna, Cook Inlet Low.; $62^{\circ} 37^{\prime} 30^{\prime \prime} \mathrm{N}$, 
$150^{\circ} 22^{\prime} 10^{\prime \prime} \mathrm{W}$; (map 81).

Mountain climbers' name published in the late 1940's.

Rutkovsky: locality, see Afognak.

Rutland Island: barrier island, on Beaufort Sea coast in Plover Is., Arctic Plain; (map 153).

Name first appears on Brit. Adm. Chart 593 and may have been named by Ccmdr. $R$. Maguire, RN, in 1853. The island cannot now be identified.

Ryan, Mount: mountain, 3,555 ft., $75 \mathrm{mi}$. SW of Circle, Yukon-Tanana High.; $65^{\circ} 14^{\prime} 30^{\prime \prime} \mathrm{N}$, $146^{\circ} 15^{\prime} 00^{\prime \prime} \mathrm{W}$; (map 104).

Named by prospectors; reported in 1903 by USGS (Prindle, 1905, pl. 13).

Ryan Creek: stream, flows S $1.1 \mathrm{mi}$. to Norton Sound, $19 \mathrm{mi}$. E of Solomon, Seward Penin. High.; $64^{\circ} 35^{\prime} \mathrm{N}, 163^{\circ} 48^{\prime} \mathrm{W}$; (map 95).

Prospectors' name reported in 1900 by E. C. Barnard (in Brooks, 1901, pl. 17), USGS.

Ryan Creek: stream, flows NE $3 \mathrm{mi}$. to Riley Creek, 15 mi. NE of Shungnak, Brooks Ra.; $67^{\circ} 03^{\prime} \mathrm{N}, 156^{\circ} 45^{\prime} \mathrm{W}$; (map 126).

Local name given by prospectcrs; reported by USGS in 1956.

Ryan Creek: stream, flows SW to Cripple River, about $21 \mathrm{mi}$. NW of Nome, Seward Penin. High.; (map 94).

Prospectors' name reported on the 1900 "Map of Nome Peninsula" by J. M. Davidson and B. D. Blakeslee; this feature has not been positively identified.

Ryan Creek: stream, see Bryan Creek.

Ryan Creek: stream, see Colorado Creek.

Ryan Creek: stream, see Eldorado Creek.

Ryan Gulch: ravine, trends SE $3 \mathrm{mi}$. to Kougarok River $10 \mathrm{mi}$. N of its junc. with Kuzitrin River, $44 \mathrm{mi}$. SW of Imuruk Lake, Seward Penin. High.; 65 $24^{\prime} \mathrm{N}, 164^{\circ} 38^{\prime} \mathrm{W}$; (map 110).

Prospectors' name reported on the 1907 "Map of Seward Peninsula" by Arthur Gibson.

Ryan Lake: lake, $0.3 \mathrm{mi}$. across, $2.7 \mathrm{mi}$. SE of Unalakleet, Nulato Hills; $63^{\circ} 50^{\prime} 15^{\prime \prime} \mathrm{N}, 160^{\circ}$ $43^{\prime} 30^{\prime \prime} \mathrm{W}$; (map 91).

Local name reported in 1952 by USC\&GS. Rybnia: locality, see Ribnaia.

Rybnyy, Mys: point of land, see Fish Point.

Rybya, Guba: bay, see Fish Bay.

Rychesnoi: village, see Nikolski.

Rye Creek: stream, flows W 6 mi. to Flat Creek $4 \mathrm{mi}$. SE of Mathews Dome and $35 \mathrm{mi}$. W of Wiseman, Brooks Ra.; $67^{\circ} 24^{\prime} 50^{\prime \prime} \mathrm{N}, 151^{\circ} 25^{\prime}$ 00" W; BGN 1932; (map 124).

Local name reported by Robert Marshall in 1932.

Ryka Toukatl ili Tstsytseka-toyna:' stream, see Ulukuk River.

Rynda, Mount: mountain, 2,408 ft., on left bank of Stikine River, $12 \mathrm{mi}$. NE of Wrangell, Coast Mts. $56^{\circ} 39^{\prime} 00^{\prime \prime} \mathrm{N}, 132^{\circ} 15^{\prime} 30^{\prime \prime} \mathrm{W}$; (map 6).

Named in 1877 by Joseph Hunter, Canadian engineer and surveyor, for Russian corvette $R y n d a$ which was used for surveying in this vicinity in 1863 . See Rynda Island.

Rynda Island: island, $3 \mathrm{mi}$. long, in mouth of Stikine River, $7 \mathrm{mi}$. NW of Wrangell, Alex. Arch.; $56^{\circ} 32^{\prime} \mathrm{N}, 132^{\circ} 33^{\prime} \mathrm{W}$; (map 6).
Named in 1863 by surveyors from the Russian corvette Rynda for their ship in which they made surveys of Stikine River and vicinity under the command of Lt. Vladimir Basargin, IRN. The Russian Hydrog. Dept. published in 1867 a chart of the Stikine River as a result of this survey.

Ryus Bay: cove, $0.7 \mathrm{mi}$. wide, $\mathrm{S}$ shore of Felice Strait, on $\mathrm{N}$ coast of Duke I., Alex. Arch.; $54^{\circ} 58^{\prime} \mathrm{N}, 131^{\circ} 25^{\prime} \mathrm{W}$; BGN 1917; (map 2). Local name published in 1917 by USC\&GS.

\section{$\mathrm{S}$}

SA, Point: point of land, on SW coast of Kanaga I., Aleutian Is.; $51^{\circ} 40^{\prime} 42^{\prime \prime} \mathrm{N}, 177^{\circ} 38^{\prime} 10^{\prime \prime} \mathrm{W}$; (map 17).

Name published in 1943 on an AMS map. Saatkunak: locality, on coast between Qaaliiq and Nulavik, $20 \mathrm{mi}$. SW of Barrow, Arctic Plain; $71^{\circ} 03^{\prime} \mathrm{N}, 157^{\circ} 15^{\prime} \mathrm{W}$; (map 153).

Eskimo locality or camp name published by R. F. Spencer (1959, map 2).

Sabachey, Mys: point of land, see Dog Point.

Sabak, Cape: point of land, SE tip of Agattu I., Aleutian Is.; $52^{\circ} 21^{\prime} 40^{\prime \prime} \mathrm{N}, 173^{\circ} 43^{\prime} 30^{\prime \prime} \mathrm{E}$; $B G N$ 1938; (map 13). Var. Mys Sabakh, Dog Cape, Poluostrov Mys.

This point was shown by Capt. Tebenkov (1852, map 30), IRN, as "Po[loustrov] Mys (M[ys] Sabakh)" meaning "Peninsula Cape (Dog Cape)."

Sabaka, Lake: lake, $0.6 \mathrm{mi}$. long, on Kenai Penin. NE of Dolly Varden Lake, $20 \mathrm{mi}$. NE of Kenai, Cook Inlet Low.; $60^{\circ} 43^{\prime} 15^{\prime \prime} \mathrm{N}, 150^{\circ}$. 45'30' W ; (map 62).

Named about 1963 by officials of Kenai National Moose Range, for administrative purposes.

Sabakh, Mys: point of land, see Sabak, Cape.

Sabine, Cape: point of land, at mouth of Pitmegea River extends into Chukchi Sea, 39 mi. NW of Mount Kelly, Arctic Slope ; $68^{\circ} 55^{\prime}$ $00^{\prime \prime} \mathrm{N}, 164^{\circ} 36^{\prime} 15^{\prime \prime} \mathrm{W}$; (map 130).

Named in 1826 by Capt. Beechey (1831, chart facing p. 328), RN, for "his old messmate, the astronomer of the Ross and Parry expeditions * *" (Stuck, 1920, p. 167)

Sable Mountain: mountain, 5,923 ft., $3.5 \mathrm{mi}$. W of Cathedral Mtn. and $30 \mathrm{mi}$. SW of Healy, Alaska Ra.; $63^{\circ} 34^{\prime} 30^{\prime \prime} \mathrm{N}, 1^{\circ} 49^{\circ} 42^{\prime} 30^{\prime \prime} \mathrm{W}$; (map 87).

Local name shown on a 1916 fieldsheet by C. E. Giffin, USGS

Sable Pass: pass, 3,880 ft., $1 \mathrm{mi}$. W of Cathedral Mtn., 2 mi. SE of Sable Mtn., and $30 \mathrm{mi}$. SW of Healy, Alaska Ra.; $63^{\circ} 33^{\prime} 30^{\prime \prime}$ N, $149^{\circ} 40^{\prime}$ $00^{\prime \prime} \mathrm{W}$; (map 87).

Named for the mountain northwest of it; reported in 1954 by USGS.

Sabonoski River: stream, see Savonoski River. Saboomaygruck: mountain, see Sapumegrak Mountain.

Saboomick: mountain, see Sapumik, Mount. Saboomim Koonga: stream, see Sapumik Creek. Saboomim Nayacaw: mountain, see Sapumim Neakau Mountain.

Sabotnisky: locality, see Uglovaia.

Sacharowskaja: bay, see Zachary Bay.
Sachem Head: point of land, on W shore of Bay of Is., 1 mi. SE of Careful Point, Adak I., Aleutian I.; $51^{\circ} 48^{\prime} 45^{\prime \prime} \mathrm{N}, 176^{\circ} 51^{\prime} 10^{\prime \prime} \mathrm{W}$; $B G N$ 1936; (map 17). Var. Sachem's Head.

Named by members of the U.S. Navy Aleutian Island Survey Expendition in 1934.

Sachem Island: island, $0.1 \mathrm{mi}$. across, in Saginaw Bay, on N coast of Kuiu I., Alex. Arch.; $56^{\circ}$ $53^{\prime} 40^{\prime \prime} \mathrm{N}, 134^{\circ} 13^{\prime} 50^{\prime \prime} \mathrm{W}$; (map 5).

Named in 1892 by Lt. W. I. Moore, USN. Sachem's Head: point of land, see Sachem Head.

Sachertelontin: locality, see Louden.

Sachlidok Island: island, see Sitkalidak Island. Sachsaiya Glacier: glacier, see Saksaia Glacier. Sackdoor Creek: stream, flows SW to Bering Sea at York, about $15 \mathrm{mi}$. SE of Cape Prince of Wales, Seward Penin. High.; (map 111).

Prospectors' name shown on the 1900 "Map of Nome Peninsula" by J. M. Davidson and B. D. Blakeslee. This feature cannot be precisely identified on current maps.

Sacramento River: stream, flows SE $6 \mathrm{mi}$ to Gulf of Alaska, 19 mi. SE of Kodiak, Kodiak I.; $57^{\circ} 31^{\prime} 00^{\prime \prime} \mathrm{N}, 152^{\circ} 17^{\prime} 40^{\prime \prime} \mathrm{W}$; (map 34).

Local name reported in 1949 by USGS.

Sacrocruk Creek : stream, see Sakrorak Creek.

Sacroeruk Mountain: hill, see Sakrorak Mountain.

Sadatanak Island: island, $1.5 \mathrm{mi}$. long, off S coast of Atka I., Aleutian Is.; $52^{\circ} 02^{\prime} 00^{\prime \prime} \mathrm{N}$, $174^{\circ} 25^{\prime} 30^{\prime \prime} \mathrm{W}$; (map 18).

Aleut name published by Capt. Tebenkov (1852, map 27), IRN, as "O[strov] Sadatanak," or "Sadatanak Island."

Saddlebag Glacier: glacier, trends S $5 \mathrm{mi}$. to a lake, $1.5 \mathrm{mi}$. E of Copper River, $28 \mathrm{mi}$. NW of Katalla, Chugach Mts.; $60^{\circ} 29^{\prime} \mathrm{N}, 145^{\circ} 05^{\prime}$ W; (map 64).

Local name reported in 1912 by U. S. Grant and D. F. Higgins, USGS.

Saddle Creek: stream, heads SE of East Peak on Ear Mtn., flows SE $1.5 \mathrm{mi}$. to Crosby Creek near its head, Seward Penin. High.; 65 ${ }^{\circ} 54^{\prime}$ $30^{\prime \prime} \mathrm{N}, 166^{\circ} 09^{\prime} 30^{\prime \prime} \mathrm{W}$; BGN 1954; (map 111).

So named in 1945 by a USGS field party "because it rises in saddle south of East Peak." Saddle Mountain: mountain, 2,094 ft., $2.5 \mathrm{mi}$. SE of Cape Kuliuk, on NW coast of Kodiak I. ; $57^{\circ} 47^{\prime} 10^{\prime \prime} \mathrm{N}, 153^{\circ} 52^{\prime} 00^{\prime \prime} \mathrm{W}$; (map 34).

Descriptive name published in 1911 by USC\&GS.

Saddle Mountain: mountain, 3,068 ft., on $\mathrm{N}$ part of Douglas I., $0.4 \mathrm{mi}$. NW of Table Top Mtn. and $3.5 \mathrm{mi}$. W of Juneau, Coast Mts.; $58^{\circ} 17^{\prime} 50^{\prime \prime} \mathrm{N}, 134^{\circ} 30^{\prime} 30^{\prime \prime} \mathrm{W}$; (map 11).

Local name published in 1962 by USGS.

Saddle Mountain: mountain, 3,253 ft., on $\mathrm{S}$ coast of Alaska Penin., $10 \mathrm{mi}$. NE of entrance to Chinitna Bay and $47 \mathrm{mi}$. NW of Homer, Aleutian Ra.; 59 $59^{\prime} 45^{\prime \prime} \mathrm{N}, 152^{\circ} 45^{\prime} 00^{\prime \prime} \mathrm{W}$; (map 50)

Name taken from a USC\&GS fieldsheet and reported by F. H. Moffit, USGS (in Brooks and others, 1920, pl. 2).

Saddle Mountain: mountain, 1,000 ft., $8 \mathrm{mi}$. SE of Reindeer Lake and $22 \mathrm{mi}$. SE of Holy 
Cross, Kilbuck-Kuskokwim Mts.; $62^{\circ} 06^{\prime} \mathrm{N}$, $159^{\circ} 06^{\prime} \mathrm{W}$; (map 78).

Local descriptive name obtained in 1952 by USGS.

Saddle Peak: peak, 3,005 ft., on E coast of Kenai Penin., between Eshamy and Ewan Lakes, 12 mi. NW of Chenega, Chugach Mts.; $60^{\circ} 26^{\prime} \mathrm{N}, 148^{\circ} 10^{\prime} \mathrm{W}$; (map 63).

Name published in 1943 by USC\&GS.

Saddle Point: point of land, on NW coast of Great Sitkin I., Aleutian Is., $52^{\circ} 06^{\prime} 00^{\prime \prime} \mathrm{N}$, $176^{\circ} 10^{\prime} 30^{\prime \prime} \mathrm{W}$; BGN 1936; (map 17).

Named by members of the U.S. Navy Aleutian Island Survey Expedition in 1934 "for its shape."

Saddle Point: point of land, on S shore of Orca Inlet, $1.5 \mathrm{mi}$. SW of Cordova, Chugach Mts.; $60^{\circ} 32^{\prime} \mathrm{N}, 145^{\circ} 47^{\prime} \mathrm{W}$; (map 64).

Local name published in 1943 by USC\&GS.

Saddleridge Point: point of land, on NW coast of Seguam I., Aleutian Is.; $52^{\circ} 21^{\prime} \mathrm{N}, 172^{\circ} 34^{\prime}$ W; (map 19).

Descriptive name given by a special U.S. Navy survey party because of a "saddle in the ridge" leading to this point; published by USC\&GS in 1944 Aleutian Coast Pilot (p. $86)$.

Saddle Rock: hill, see Bonanza Hill.

Saddlers Mistake: ridge, $1.5 \mathrm{mi}$. long, connects two hilly sections of southern Nagai I., in Shumagin Is., Aleutian Ra.; $54^{\circ} 56^{\prime} 30^{\prime \prime} \mathrm{N}$, $160^{\circ} 10^{\prime} 45^{\prime \prime} \mathrm{W}$; (map 26).

So named because a vessel attempted at night to pass between the adjacent hilly sections of the island; published in 1916 Coast Pilot (p. 172) by USC\&GS.

Sadie Cove: cove, $0.7 \mathrm{mi}$. wide, on SE shore of Kachemak Bay, on Kenai Penin. $10 \mathrm{mi}$. NE of Seldovia, Chugach Mts.; 59 $30^{\prime} 30^{\prime \prime} \mathrm{N}$, $151^{\circ} 28^{\prime} 00^{\prime \prime} \mathrm{W}$; (map 50).

Named by W. H. Dall, USC\&GS, in 1880 , for Sarah [Sadie] Eldred, wife of Marcus Baker.

Sadie Lake: lake, $1 \mathrm{mi}$. long, $1 \mathrm{mi}$. N of Baranof on $\mathbf{E}$ coast of Baranof I., Alex. Arch.; $57^{\circ} 06^{\prime} 00^{\prime \prime} \mathrm{N}, 134^{\circ} 50^{\prime} 30^{\prime \prime} \mathrm{W}$; (map 9). Var. McBlaine Lake.

Local name reported in 1948 by USGS.

Sadlerochit Mountains: mountain range, 4,000 ft., $45 \mathrm{mi}$. long and $4 \mathrm{mi}$. wide, trends E-W between Canning and Sadlerochit Rivers, 26 mi. NW of Mount Michelson, Brooks Ra.; $69^{\circ} 37^{\prime} \mathrm{N}, 145^{\circ} 12^{\prime} \mathrm{W}$; BGN 1961; (map 139). Var. Sagligochit Mountains.

Leffingwell $(1919$, p. 50, 51) wrote: "The outer two of the three outlying ranges south of Camden Bay have been given separate names ***. The Sadlerochit Mountains are the northernmost."

Sadlerochit River: stream, heads in Franklin Mts. at $69^{\circ} 15^{\prime} \mathrm{N}, 145^{\circ} 21^{\prime} \mathrm{W}$, and flows NE and $\mathrm{N} 75 \mathrm{mi}$. to Camden Bay, Arctic Plain; $70^{\circ} 03^{\prime} 30^{\prime \prime} \mathrm{N}, 144^{\circ} 26^{\prime} 00^{\prime \prime} \mathrm{W} ; B G N$ 1961; (map 151). Var. Barter River, Saligochit River, Shudtaroshik River.

Eskimo name reported in 1912 by Leffingwell $(1919$, p. 99) to mean "area outside of the mountains." Probably the same as
Marsh's Barter River. It appears on Surg. John' Simpson's native map, 1855, as "Shudta-ro-shik."

Sadlerochit Spring: spring, on W bank of Sadlerochit River, $12 \mathrm{mi}$. E of Mount Weller and $25 \mathrm{mi}$. $\mathrm{N}$ of Mount Michelson, Brooks Ra.; 69 $40^{\prime}$ N, $144^{\circ} 24^{\prime}$ W; BGN 1961; (map 139).

Leffingwell surveyed and reported the Eskimo name "Sadlerochit River," and it is probable that he also named this spring, which was first reported by the Canadian Arctic Expedition, 1913-14.

Sadlerochit Valley: valley, extends $25 \mathrm{mi} \mathrm{NE}$ of Lake Peters, at E end of Third Ra., in Shublik Mts. and Sadlerochit Mts., Brooks Ra. $69^{\circ} 30^{\prime} \mathrm{N}, 144^{\circ} 51^{\prime} \mathrm{W}$; (map 139).

Leffingwell does not list this as a geographic name but wrote $(1919$, p. 135) "the most favorable path for the granite to have followed to the Sadlerochit Valley is through the pass mentioned."

Sadliok Island: island, see Sitkalidak Island.

Safari Creek: stream, flows NNW $18 \mathrm{mi}$. to Kuna River, $23 \mathrm{mi}$. NNE of Feniak Lake, Brooks Ra.; 68 $34^{\prime}$ N, $157^{\circ} 54^{\prime}$ W; (map 132).

Named in 1951 by B. H. Kent and I. L Tailleur, USGS, "for a spike [reconnaissance] trip to stream."

Safety: locality, see Port Safety.

Safety, Port: lagoon, see Safety Sound.

Safety Cove: cove, $0.7 \mathrm{mi}$. across, on $\mathrm{E}$ coast of Resurrection Penin., $13 \mathrm{mi}$. SE of Seward, Chugach Mts.; $59^{\circ} 59^{\prime} \mathrm{N}, 148^{\circ} 13^{\prime} \mathrm{W}$; (map 49).

Local name reported in 1909 by U. S. Grant and D. F. Higgins, USGS.

Safety Rock: rock, $400 \mathrm{ft}$. long, between Moira Sound and Niblack Anchorage, on SE coast of Prince of Wales I., Alex. Arch.; 55 $03^{\prime} 35^{\prime \prime}$ N, $132^{\circ} 05^{\prime} 05^{\prime \prime} \mathrm{W}$; (map 4).

Named in 1885 by Lt. Comdr R. Glover, USN.

Safety Sound: lagoon, extends NE-SW $9 \mathrm{mi}$. along Norton Sound, $10 \mathrm{mi}$. SW of Solomon, Seward Penin. High.; $64^{\circ} 29^{\prime}$ N, $164^{\circ} 45^{\prime}$ W; (map 95). Var. Port Safety.

Surveyed and named "Port Safety" in 1899 by USC\&GS.

Safftan, Mount: mountain, 2,009 ft., between Chapin and Herring Bays, on $S$ coast of Admiralty I., $26 \mathrm{mi}$. SE of Angoon, Alex.

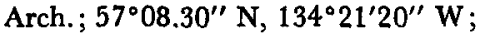

Local name reported in 1948 by USGS.

Sagak, Cape: point of land, SW tip of Umnak I., Aleutian Is.; $52^{\circ} 49^{\prime} 25^{\prime \prime} \mathrm{N}, 169^{\circ} 07^{\prime} 00^{\prime \prime} \mathrm{W}$; (map 21). Var. Sigak, Mys Sagakh.

Aleut name reported by Capt. Lutke (1836, p. 298), IRN, as "Sigak," probably from the Aleut "sagaq," which, according to R. H. Geoghegan, means "sleep." This point was published by Capt. Tebenkov (1852, map 25), IRN, as "M[ys] Sagakh," or "Cape Sagakh."

Sagakh, Mys: point of land, see Sagak, Cape. Sagavanirktok Lake: lake, see Elusive Lake. Sagavanirktok Lake: lake, see Galbraith Lake.
Sagavanirktok River: stream, heads between Endicott and Philip Smith Mts. at $68^{\circ} 10^{\prime} \mathrm{N}$, $149^{\circ} 04^{\prime} \mathrm{W}$, flows N $180 \mathrm{mi}$. to Beaufort Sea, Arctic Plain; $70^{\circ} 18^{\prime} 30^{\prime \prime} \mathrm{N}, 147^{\circ} 52^{\prime} 30^{\prime \prime} \mathrm{W}$ (Main Channel mouth); BGN 1959; (map 150). Var. Ivishak River, Sagvaniktuuk River, Sakovanuktok River, Sawanukto River, Shagavanuktok River, Sharavanaktok River, Suwanukto River.

Eskimo name "Sawanukto" reported in 1901 by S. J. Marsh, prospector, to mean "strong current" (Brooks, 1906, p. 289). Leffingwell $(1919$, p. 99) referring to variant spellings, states, "The writer prefers Shagavanuktok."

Sagavanirktok River: stream, see Ivishak River. Sagavanirktok River: stream, see Ribdon River. Sagavanirktok River Delta: delta, $13 \mathrm{mi}$. across, cut by several distributaries, on Beaufort Sea coast, between Foggy Island and Prudhoe Bays, Arctic Plain; $70^{\circ} 17^{\prime} \mathrm{N}, 148^{\circ} 10^{\prime} \mathrm{W}$; (map 150).

Name published by AMS in 1962.

Sagchudak Island: island, $1.3 \mathrm{mi}$. across, off Kobakof Bay, on S coast of Atka I., Aleutian Is.; $52^{\circ} 01^{\prime} \mathrm{N}, 174^{\circ} 29^{\prime} \mathrm{W}$; (map 18). Var. Sagtchudakh.

Aleut name published by Capt. Tebenkov (1852, map 27), IRN, as "O[strov] Sagchudak," or "Sagchudak Island."

Saghadellautin: locality, see Louden.

Sagigik Island: island, $0.2 \mathrm{mi}$. across, in Pacific Ocean, $5 \mathrm{mi}$. S of Amlia I., Andreanof Is., Aleutian Is.; $52^{\circ} 00^{\prime} \mathrm{N}, 173^{\circ} 09^{\prime} \mathrm{W}$; (map 19).

Aleut name published by Capt. Tebenkov (1852, map 27), IRN, possibly from the Aleut "sāgik" which, according to $R$. H. Geoghegan, means "anything having a sharp edge." The name Sagik was published by Father Veniaminov (1846, dictionary) meaning "point, sharp edge."

Saginaw Bay: bay, $1.8 \mathrm{mi}$. across, on $\mathrm{N}$ coast of Kuiu I., Alex. Arch.; 56 $55^{\prime} \mathrm{N}, 134^{\circ} 16^{\prime} \mathrm{W}$; (map 5).

Named in 1869 by Comdr. R. W. Meade, USN, for charting purposes, for his ship, the U.S.S. Saginaw.

Saginaw Channel: water passage, $9.5 \mathrm{mi}$. long, trends NW frorn Stephens Passage to Lynn Canal, W of Shelter I., $18 \mathrm{mi}$. NW of Juneau, Alex. Arch.; 58 $24^{\prime} \mathrm{N}, 134^{\circ} 53^{\prime} \mathrm{W}$; (map 11).

Named in 1869 by Comdr. R. W. Meade, USN, for the U.S.S. Saginaw, the first known warship to pass through the channel.

Saginaw Creek: stream, flows NE $4.5 \mathrm{mi}$. to Saginaw Bay on N coast of Kuiu I., Alex. Arch.; $56^{\circ} 50^{\prime} 30^{\prime \prime} \mathrm{N}, 134^{\circ} 09^{\prime} 10^{\prime \prime} \mathrm{W}$; (map 5).

Local name recorded in 1948 by USGS.

Saginaw Point: point of land, on $\mathrm{E}$ shore of Kootznahoo Roads, in Chatham Strait, $2 \mathrm{mi}$. $\mathrm{S}$ of Angoon, on Admiralty I., Alex. Arch.; $57^{\circ} 28^{\prime} 40^{\prime \prime} \mathrm{N}, 134^{\circ} 34^{\prime} 30^{\prime \prime} \mathrm{W}$; (map 9).

Named in 1869 by Comdr. R. W. Meade, USN, for the U.S.S. Saginaw which he commanded in 1868-69 while mapping this area. 
The name was published in 1869 on Hydrog. Chart 225. The name is not shown on recent maps.

Sagligochit Mountains: mountain range, see Sadlerochit Mountains.

Sagtchudakh : island, see Sagchudak Island.

Sagvailak River: stream, see Sakvailak River.

Sagvailuk River: stream, see Awuna River.

Sagvaniktuuk River: stream, see Sagavanirktok River.

Sa-heen Cove: bay, see Sarheen Cove.

Sahligvik Creek: stream, see Saligvik Creek.

Sahligvik Ridge: ridge, see Saligvik Ridge.

Sahligvik Valley: valley, see Saligvik Valley.

Sahlin Creek: stream, flows SE 1 mi. to Sheep Bay, $13 \mathrm{mi}$. NW of Cordova, Chugach Mts.; $60^{\circ} 41^{\prime} 40^{\prime \prime} \mathrm{N}, 145^{\circ} 57^{\prime} 50^{\prime \prime} \mathrm{W} ; B G N$ 1933; (map 64).

Local name reported in 1933 by USFS as being named for Julius Sahlin who erected a sawmill at the mouth of this creek about 1918.

Sahlin Falls: waterfall, in Sahlin Creek, $600 \mathrm{ft}$. from its mouth at Sheep Bay, $13 \mathrm{mi}$. NW of Cordova, Chugach Mts.; $60^{\circ} 41^{\prime} 40^{\prime \prime} \mathrm{N}$, $145^{\circ} 56^{\prime} 00^{\prime \prime} \mathrm{W}$; BGN 1933; (map 64).

Local name reported in 1933 by USFS and derived from Sahlin Creek, on which the falls are located.

Sahlin Lagoon: lagoon, $0.7 \mathrm{mi}$. wide, at $\mathrm{N}$ end of Sheep Bay $13 \mathrm{mi}$. NW of Cordova Chugach Mts.; $60^{\circ} 40^{\prime} 30^{\prime \prime} \mathrm{N}, 145^{\circ} 54^{\prime} 30^{\prime \prime} \mathrm{W}$; (map 64).

Local name reported in 1933 by USFS. See Sahlin Creek.

Sahlin Lake: lake, $0.5 \mathrm{mi}$. long, $1 \mathrm{mi}$. NW of Sheep Bay, $14 \mathrm{mi}$. NW of Cordova, Chugach Mts.; $60^{\circ} 42^{\prime} 30^{\prime \prime} \mathrm{N}, 145^{\circ} 58^{\prime} 30^{\prime \prime} \mathrm{W}$; $B G N$ 1933; (map 64).

Local name reported in 1933 by USFS and derived from nearby Sahlin Creek.

Sahot Lake: lake, 0.5 mi. long, on Kenai Penin., $0.4 \mathrm{mi}$. W of Fire Lake and $25 \mathrm{mi}$. SE of Kenai, Cook Inlet Low.; $60^{\circ} 26^{\prime} 15^{\prime \prime} \mathrm{N}, 150^{\circ}$ $34^{\prime} 15^{\prime \prime} \mathrm{W}$; (map 62).

Named about 1963 by officials of Kenai National Moose Range, for administrative purposes.

Saik-took: stream, see Saitut Creek.

Sail Island: island, $0.6 \mathrm{mi}$. across, in Stephens Passage, $5 \mathrm{mi}$. NE of The Brothers and $66 \mathrm{mi}$. $\mathrm{E}$ of Sitka, Alex. Arch.; $57^{\circ} 20^{\prime} 50^{\prime \prime} \mathrm{N}, 133^{\circ}$ 43'10" W; BGN 1900; (map 8). Var. Ship Island.

Named "Ship Island" by Lt. Comdr. R. W. Meade, USN, and published in 1869 on $\mathrm{Hy}-$ drog. Chart 225. The name, "Sail Island," was published by USC\&GS in 1891 Coast Pilot (p. 143).

Sailor Gulch: ravine, extends $1 \mathrm{mi}$. E of Crooked Creek, $7 \mathrm{mi}$. NNE of Tahneta Pass and 65 mi. NE of Palmer, Talkeetna Mts.; 61 $59^{\prime} 10^{\prime \prime}$

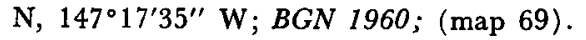

Local name reported in 1956 by USGS; used in placer notices prior to this date. Saina: locality, see Tsina Station.

Saint Abraham: island, see Shemya Island.
Saint Abraham Island: island, see Agattu Island.

Saint Abraham Island: island, see Attu Island. Saint Abram: island, see Shemya Island.

Saint Agnes, Mount: mountain, see Marcus Baker, Mount.

Saint Albans, Point: point of land, $8 \mathrm{mi}$. NE of Cape Decision, on S coast of Kuiu I., Alex. Arch.; 56 $05^{\prime} 00^{\prime \prime} \mathrm{N}, 133^{\circ} 59^{\prime} 30^{\prime \prime} \mathrm{W}$; (map 6).

Named in September, 1793, by Capt. George Vancouver, RN (Wagner, 1937, p. 406).

Saint Amand Creek: stream, flows $1.5 \mathrm{mi}$. SE to Kuyukutuk River, $12.5 \mathrm{mi}$. NW of Russian Mission, Nulato Hills; $61^{\circ} 48^{\prime} 40^{\prime \prime} \mathrm{N}, 161^{\circ}$ $40^{\prime} 10^{\prime \prime} \mathrm{W}$; (map 73).

Prospectors' name reported by Harrington (1918, map), USGS, in 1916; "possibly named for Cyrias Saint Amand, or his brother."

Saint Andrean, Islands of : islands, see Andreanof Islands.

Saint Anne Creek: stream, heads in St. Anne Lake, flows SSE $8 \mathrm{mi}$. to Klutina Lake, 2.6 mi. ENE of Powell Peak and $44 \mathrm{mi}$. N of Valdez, Chugach Mts.; $61^{\circ} 44^{\prime} 15^{\prime \prime} \mathrm{N}, 145^{\circ}$ 57'45" W; (map 68).

Local name published in 1932 by USGS.

Saint Anne Lake: lake, $5.8 \mathrm{mi}$. long, extends $\mathrm{N}-\mathrm{S}$ at head of St. Anne Creek, $50 \mathrm{mi}$. N of Valdez, Chugach Mts. ; $61^{\circ} 49^{\prime} 45^{\prime \prime} \mathrm{N}, 146^{\circ}$ 03'10" W; (map 68).

Local name published in 1932 by USGS.

Saint Anthony Pass: pass, 5,130 ft, near head of McCumber Creek, $29 \mathrm{mi}$. SE of Delta Junction; Alaska Ra.; $63^{\circ} 39^{\prime} \mathrm{N}, 145^{\circ} 22^{\prime} \mathrm{W}$; BGN 1937; (map 86).

Local name reported in 1937 by USGS.

Saint Augustin, Mount: island, see Augustine Island.

Saint Augustin, Mount: mountain, see Augustine Volcano.

Saint Augustine, Cape: point of land, see Augustine, Cape.

Saint Augustine, Mount: mountain, see Augustine Volcano.

Saint Augustine Bay: estuary, see Augustine Bay.

Saint Augustine Island: island, see Augustine Island.

Saint Barnabas, Cape: point of land, see Barnabas Cape.

Saint Bartolom, Cape: point of land, see Bartolome, Cape.

Saint Boniface, Point: point of land, on E coast of Baker I., in Port San Antonio, Alex. Arch.; $55^{\circ} 20^{\prime} 25^{\prime \prime} \mathrm{N}, 133^{\circ} 34^{\prime} 30^{\prime \prime} \mathrm{W}$; (map 4). Var. Mys San Bonifacio, Punta de San Bonifacio.

Translation of the name "Punta de San Bonifacio" given by Bodega y Quadra and Francisco Antonio Maurelle, "probably on May 18 [1779] in honor of the saint whose day is May $14^{*} * *$ *" (Wagner, 1937, p. 406). Saint Catherine Cove: cove, $2.5 \mathrm{mi}$. across, NE part of Bechovin Bay, $12 \mathrm{mi}$. NW of False Pass, on NE coast of Unimak I., Aleutian Is.; $55^{\circ} 01^{\prime} \mathrm{N}, 163^{\circ} 30^{\prime} \mathrm{W}$; (map 29).

Named by W. H. Dall, USC\&GS, in 1882 for Capt. Lt. P. K. Krenitzin's vessel, the galiot St. Catherine, in which Dall spent the winter of 1768-69 in Isanotski Strait (Coxe, 1787 , p. 208).

Saint Charles Creek: stream, flows NW $3 \mathrm{mi}$. to Totatlanika River, $40 \mathrm{mi}$. SE of Nenana, Alaska Ra.; $64^{\circ} 02^{\prime} 30^{\prime \prime} \mathrm{N}, 148^{\circ} 30^{\prime} 45^{\prime \prime} \mathrm{W}$; (map 100).

Local name reported in 1910 by USGS (Capps, 1912, pl. 1).

Saint Demetrius Islands: islands, see Diomede Islands.

Saint Demoid Islands: islands, see Diomede Islands.

Saint Dimitre Islands: islands, see Diomede Islands.

Saint Diomede Islands: islands, see Diomede Islands.

Saint Diomed Islands: islands, see Diomede Islands.

Saint Dolmat : mountain, see Fourpeaked Mountain.

Saint Elias, Cape: point of land, on SW end of Kayak I., $65 \mathrm{mi}$ SE of Cordova., Malaspina Coastal Plain; 59 $54^{\prime} \mathrm{N}, 144^{\circ} 36^{\prime} \mathrm{W}$; $B C N$ 1944; (map 48). Var. Cabo Español, Hamond Point, Mys Gamon, Punta de Cañas, Punta de Navia, Punta Español, Punta Santa Rosa.

Named by Vitus Bering on July 20, 1741 (O.S.), for the saint whose day it was. This feature was also called "Santa Rosa" in 1779 by Don Ignacio Arteaga; "Españo" in 1791 by Capt. Alessandro Malaspina; "Punta de Cañas," meaning "point of reeds," in 1796, by T. M. Lopez. Capt. George Vancouver, RN, named it "Hamond Point" in 1794 for Sir Andrew Snape Hamond (Wagner, 1937, p. 406). See also Español, Cabo.

Saint Elias, Cape: point of land, see Manby Point.

Saint Elias, Cape: point of land, see Sitkagi, Cape.

Saint Elias, Mount: mountain, $18,008 \mathrm{ft}$., on the Alaska-Canada boundary $67 \mathrm{mi}$. NW of Yakutat, St. Elias Mts.; $60^{\circ} 17^{\prime} 40^{\prime \prime} \mathrm{N}, 140^{\circ} 55^{\prime} 30^{\prime \prime}$ W; BGN 1917; (map 66). Var. Boundary Peak 186, Mont Saint Elie, Yahtse-tah-shah.

The sighting of Mount Saint Elias on July 16, 1741 (O.S.), by Vitus Bering on the Saint Peter represents the "official" discovery of northwestern America by the Russians. Although many authorities give Bering credit for naming the mountain, it appears more likely that the name was borrowed from Cape Saint Elias by eighteenth century mapmakers and applied to the "high volcano" left unnamed by its discoverer. The first ascent of the mountain was made July 31,1897 , by His Royal Highness, Prince Luigi Amedeo di Savoia, Duke of the Abruzzi and his party. See Farquhar (1959, p. 229, 230). According to H. W. Topham, in 1888, its Tlingit Indian name was "Yahtse-tah-shah."

Saint Elias Alps: mountain range, see Saint Elias Mountains.

Saint Elias Island: island, see Kayak Island.

Saint Elias Mountains: mountain range, $300 \mathrm{mi}$. long and $90 \mathrm{mi}$. wide, extends NW along Alaska-Canada boundary from. Cross Sound, 
Icy Strait, and Lynn Canal on SE to Bering Glacier, Tana Glacier, Tana River, Chitistone River, and White River on NW; $58^{\circ} 15^{\prime} \mathrm{N}$, $135^{\circ} 00^{\prime} \mathrm{W}$ [SE end], $61^{\circ} 00^{\prime} \mathrm{N}, 142^{\circ} 30^{\prime} \mathrm{W}$ [NW end]; BGN 1944. Var. Saint Elias Alps, Saint Elias Range.

In 1870, Dall (p. 286) wrote: "The Coast or St. Elias Range contains the highest peaks and most of the volcanoes. It extends along the whole northwest coast from California to the peninsula of Aliáska." On an 1880 Census map, Ivan Petroff applied the name "St. Elias Alps" to the mountains between the Copper River and Mount Fairweather. Subsequent maps have restricted the application of the name to the above described mountains.

Saint Elias Range: mountain range, see Saint Elias Mountains.

Saint Elizabeth, Cape: point of land, see Elizabeth, Cape.

Saint Etienne Island: island, see Agattu Island. Saint Etienne Island: island, see Attu Island.

Saint Felix Point: point of land, see Felix, Cape. Saint George: village, pop. 264, on $\mathrm{N}$ coast of St. George I., Pribilof Is. ; $56^{\circ} 36^{\prime} 00^{\prime \prime}$ N, $169^{\circ}$. $32^{\prime} 30^{\prime \prime} \mathrm{W}$; ( $\left.\operatorname{map} 38\right)$.

Local name for the present village on the island. According to Elliott (1881, p. 19) the first settlement on St. George I. was in 1786, located on the north coast, at Staraya Artil, about 5 miles west of the present location. A short time later a village was established at Zapadni Bay on the southwest coast of the island. In the 1880 Census Petroff (1884, p. 23) listed "Saint George," population 88; population 92 in 1890 .

Saint George Creek: stream, flows N $22 \mathrm{mi}$. to Wood River, $36 \mathrm{mi}$. SW of Fairbanks, Tanana Low.; $64^{\circ} 21^{\prime} 40^{\prime \prime} \mathrm{N}, 148^{\circ} 05^{\prime} 45^{\prime \prime} \mathrm{W}$; (map 100). Var. Saint Gorge Creek.

Local name shown as Saint Gorge Creek, which flows into Fish Creek, on an ARC manuscript map by Arnt Greve in 1909.

Saint George Rock: rock, $0.7 \mathrm{mi}$. NE of Spruce Cape, 5 mi. NE of Kodiak, Kodiak I.; $57^{\circ} 50^{\prime}$ $15^{\prime \prime} \mathrm{N}, 152^{\circ} 18^{\prime} 35^{\prime \prime} \mathrm{W}$; (map 34).

Name published in 1881 by USC\&GS on Chart 776.

Saint Gertruda, Point: point of land, see Santa Gertrudis, Point.

Saint Gertrude Point: point of land, see Santa Gertrudis, Point.

Saint George Island: island, $12 \mathrm{mi}$. long, one of Pribilof Is., Aleutian Is.; $56^{\circ} 35^{\prime} \mathrm{N}, 169^{\circ} 35^{\prime}$ W; (map 38). Var. George Island Ostrov Georgiya.

Discovered and named by G. G. Pribilov in June, 1786, after his vessel the Sveti Georgiy. See Pribilof Islands and St. Paul Island.

Saint Gorge Creek: stream, see Saint Geonge Creek.

Saint Hermogenes, Cape: point of land, on NE coast of Marmot I., N of Kodiak I.; $58^{\circ} 15^{\prime} 00^{\prime \prime}$ $\mathrm{N}, 151^{\circ} 47^{\prime} 30^{\prime \prime} \mathrm{W}$; (map 43). Var. Cape Germogena.

Named by Capt. Cook (1785, v. 2, p. 383 ), $R N$, on May 24, 1778, because he thought this was the same feature previously named by
Vitus Bering. Cook says "and by what I can gather from the account of Beering's [sic] voyage, and the chart that accompanies it in the English edition, I conclude, that it must be what he called Cape St. Hermogenes * * *" Wagner $(1937$, p. 406) says "a name given by *** Bering July 26,1741 , to a place concerning the location of which there has been much discussion $* * *$. This was undoubtedly the north point of Marmot Island [Cook's location] *** although it is now, I believe, erroneously applied to the eastern point of the island * * *." The name was published by Capt. Tebenkov (1852, map 22), RN, as "M[ys] Germogena," or "Cape Germogena."

Saint Hermogenes Island: island, see Marmot Island.

Saint Hyacinth: island, see Kruzof Island.

Saint Hyacinthe, Mount: volcano, see Edgecumbe, Mount.

Saint Ignace Island: island, $3.2 \mathrm{mi}$. long, between Port Mayoral and Ursua Channel, off NE coast of Baker I., Alex. Arch.; 55 $24^{\prime}$ N, $133^{\circ} 26^{\prime} \mathrm{W}$; (map 4). Var. Ignatio Island, Isla San Ignacio, Ostrov San Ignatsa, Ysla de San Ygnacio.

Translation of the name "Isla San Ignacio" given "about May 22, 1779," by Francisco Antonio Maurelle (Wagner, 1937, p. 501).

Saint Isidor, Point: point of land, W tip of Lulu I., Alex. Arch.; 55 $27^{\prime}$ N, $133^{\circ} 37^{\prime}$ W; (map 4). Var. Mys San Izidor, Punta de San Isodoro, Punta de San Ysidoro.

Translation of the name "Punta de San Isodoro" given by Francisco Antonio Maurelle "about May 23, 1779, perhaps after San Isidro Labrador whose day is May 15" (Wagner, 1937, p. 501).

Saint Jacinto: island, see Kruzof Island.

Saint Jacob: island, see Jacob Island.

Saint James Bay: bay, 2 mi. across, extends NW from Lynn Canal, at Point Whidbey, $34 \mathrm{mi}$. NW of Juneau, St. Elias Mts. ; 58 $34^{\prime} 30^{\prime \prime} \mathrm{N}$, $135^{\circ} 09^{\prime} 30^{\prime \prime} \mathrm{W}$; (map 11 ).

Named by USC\&GS and published in 1889 on Chart 701.

Saint James Episcopal Mission: locality, see Tanana.

Saint James Mission: locality, see Tanana.

Saint James Point: point of land, on $\mathrm{W}$ shore of Lynn Canal, at entrance to St. James Bay, $1.4 \mathrm{mi}$. SW of Point Whidbey and $32 \mathrm{mi}$. NW of Juneau, St. Elias Mts.; $58^{\circ} 33^{\prime} 45^{\prime \prime} \mathrm{N}, 135^{\circ}$ $09^{\prime} 45^{\prime \prime} \mathrm{W}$; (map 11).

Name published in 1948 by USGS.

Saint Joe Creek: stream, flows SW $18 \mathrm{mi}$. to Yukon River, $11 \mathrm{mi}$. SW of Blackburn I. and $55 \mathrm{mi}$. SE of Unalakleet, Innoko Low.; $63^{\circ} 14^{\prime} \mathrm{N}, 159^{\circ} 42^{\prime} \mathrm{W}$; (map 91 ).

Local name reported in 1949 by USC\&GS. Saint John, Cape : point of land, see Kupreanof Point.

Saint John, Mount: mountain; "on one of the Aleutian Islands, discovered and named [in 1841] by Vitus Bering" (Wagner, 1937, p. 493).
Saint John, Point: point of land, on NW coast of Zarembo I., Alex. Arch.; 56 $25^{\prime} 30^{\prime \prime} \mathrm{N}$, $133^{\circ} 00^{\prime} 30^{\prime \prime} \mathrm{W}$; (map 6).

Named in August, 1793, by Capt. George Vancouver, RN (Wagner, 1937, p. 407).

Saint John Baptist Bay: bay, $0.5 \mathrm{mi}$. across, empties into Neva Strait, on NW coast of

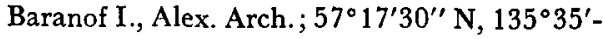
30" W; (map 9). Var. Baptist Bay, Saint Johns Bay, Zaliv Svataya Ioanna Predtechi.

This is a translation by USC\&GS about 1882 of the name given by the Russian pilot Ens. Vasiliev; published in 1848 on Russian Hydrog. Dept. Chart 1397 as "Zaliv Svataya Ioanna Predtechi."

Saint John Harbor: bay, extends $\mathrm{N} 2 \mathrm{mi}$. to Sumner Strait, on NW coast of Zarembo I., Alex. Arch.; $56^{\circ} 27^{\prime} 00^{\prime \prime} \mathrm{N}, 132^{\circ} 57^{\prime} 30^{\prime \prime} \mathrm{W}$; (map 6).

Named by W. H. Dall, USC\&GS; published in 1883 Coast Pilot.

Saint Johns Bay: bay, see Saint John Baptist Bay.

Saint Johns Hill: mountain, 2,180 ft., W of Sheep Creek, $1.5 \mathrm{mi}$. S. of Farewell Airport and $64 \mathrm{mi}$. SE of McGrath, Alaska Ra.; $62^{\circ}$ $28^{\prime} 45^{\prime \prime} \mathrm{N}, 153^{\circ} 52^{\prime} 40^{\prime \prime} \mathrm{W}$; (map 80).

Local name obtained in 1958 by USGS.

Saint Johns Hill: hill, see Cross Hill.

Saint Joseph Island: island, $2 \mathrm{mi}$. long, in Iphigenia Bay, $1.7 \mathrm{mi}$. N of Noyes I., Alex. Arch.; $55^{\circ} 36^{\prime} \mathrm{N}, 133^{\circ} 43^{\prime} \mathrm{W}$; (map 4). Var. Isla de San Josep, Isla San Joseph, Ostrov San Goze, Ysla de San Josep.

Translation of the name "Isla de San Josep" given "about May 23, 1779," by Francisco Antonio Maurelle (Wagner, 1937, p. 409).

Saint Laurence Island: island, see Saint Lawrence Island.

Saint Lawrence Island: island, $95 \mathrm{mi}$. long and $25 \mathrm{mi}$. wide in the Bering Sea, $130 \mathrm{mi}$. SW of Nome; $63^{\circ} 30^{\prime} \mathrm{N}, 170^{\circ} 30^{\prime} \mathrm{W} ; B G N$ 1951; (map 93). Var. Anderson Island, Chebukak Island, Clerkes Island, Eivoogiena Island, Eivugen Island, E-oo-vogen Island, Ostrova Sind, Ostrov Sinde, Saint Laurence Island, Tschibocki Island.

Discovered by Vitus Bering on Saint Lawrence day, August 10,1728 (O.S.), and named by him, "Saint Lawrence." Baker (1906, p. 542) noted: "G. F. Muller (Voyages, 1761) says: 'They heard of an island which was said to lie somewhat farther, at no great distance from the continent; to this they gave the name of Saint Lawrence, on account of its being the 10th of August, that saint's day, when they passed by it, without observing anything upon it besides cottages of fishermen'." It was also called "Sind" on early Russian charts, for Lt. Sind [cnna], who passed somewhere near it in $\mathbf{1 7 6 6 .}$

Capt. James Cook, RN, passed east of this island in 1778 and west of it in 1779 . Its eastern end he named "Anderson Island" for Dr. William Anderson, surgeon on H.M.S. Discovery, believing it to be a separate island. Later, according to Capt. F. W. Beechey, Cook found that it was part of what the Russians 
called Saint Lawrence Island, but died before the correction was made in his published account. Cook named the main body of the island, "Clerkes Island" for Capt. Charles Clerke of the Discovery, and its western end, which he shows as another separate island, he calls "Saint Laurence" and "Saint Lawrence," taking the name from Bering.

According to Commodore Joseph Billings, the Chukchi natives of Siberia call this island "E-oo-vogen" which he spells on his chart "Eivoogiena." $\mathrm{He}$ also gives the variant names "Clerke" and "Sinde." G. A. Sarichev, who accompanied Billings in 1791-92 shows "Saint Lawrence" or "Eivugen." Lt. Otto von Kotzebue gave the island's Eskimo name as "Tschibocki," a name now preserved as "Chibukak Point."

Saint Lazaria, Cape: point of lead, see Edgecumbe, Cape.

Saint Lazaria, Mount: volcano, see Edgecumbe, Mount.

Saint Lazaria Islands: islands, in Sitka Sound, $1.5 \mathrm{mi}$. S. of Kruzof I. and $15 \mathrm{mi}$. SW of Sitka, Alex. Arch.; $56^{\circ} 59^{\prime} 15^{\prime \prime} \mathrm{N}, 135^{\circ} 42^{\prime} 00^{\prime \prime} \mathrm{W}$; (map 5). Var. Cape Island, Muisofski Island, Ostrov Mysovskoy, Ostrov Svataya Lazarya, Robin Island.

Named in 1809 by the Russian navigator Ivan Vasiliev the first, IRN. It was published by Lt. Sarichev (1826, map 19), IRN, as "Os[trov] Sv[ataya] Lazarya," or "Saint Lazarus Island", he also called it "Os[trov] Mysovskoy," meaning "Cape Island." In 1787, Capt. George Dixon, called it "Robin Island."

Saint Lazarius, Cape: point of land, see Edgecumbe, Cape.

Saint Lazaro, Mount: mountain, see Lazaro, Mount.

Saint Leonard Point: point of land, see San Leonardo, Point.

Saint Louis Creek: stream, flows SE $6 \mathrm{mi}$. to Allen River, $5 \mathrm{mi}$. NW of Sirr Mtn. and $46 \mathrm{mi}$. NW of Wiseman, Brooks Ra.; $67^{\circ} 37^{\prime} 00^{\prime \prime} \mathrm{N}$, $151^{\circ} 36^{\prime} 45^{\prime \prime} \mathrm{W}$; BGN 1932; (map 124).

A local name reported by Robert Marshall in 1932.

Saint Louis Creek: stream, flows E to Antikovik River, about $15 \mathrm{mi}$. E of Cape Prince of Wales, Seward Penin. High.; (map 111).

Prospectors' name shown in the 1900 "Map of Nome Peninsula" by J. M. Davidson and B. D. Blakeslee. This feature cannot be precisely identified on current maps.

Saint Makarius: island, see Amchitka Island.

Saint Makarius: island, see Kiska Island.

Saint Makarius Bay: bay, see Makarius Bay.

Saint Makarius Point: point of land, on SE coast of Amchitka I., Aleutian Is.; $51^{\circ} 22^{\prime} 00^{\prime \prime} \mathrm{N}$, 179'12'30' E; BGN 1937; (map 15).

Named by personnel of the U.S.S. Oglala in 1935, based on the belief that Amchitka was the island seen October 25, 1741 (O.S.) by Vitus Bering and named by him St. Makarius (St. Markiana). See Amchitka Island.

Saint Markiana: island, see Amchitka Island.

Saint Markiana: island, see Kiska Island.

Saint Marks Indian Mission: village, see Nenana.
Saint Mary, Point: point of land, on E shore of Lynn Canal, at $\mathrm{N}$ entrance to Berners Bay, 1 $\mathrm{mi}$. N of Point Bridget and $37 \mathrm{mi}$. NW of Juneau, Coast Mts. ; $58^{\circ} 44^{\prime} 00^{\prime \prime} \mathrm{N}, 135^{\circ} 01^{\prime} 15^{\prime \prime}$ W; (map 11).

Discovered about July 17, 1794, by Joseph Whidbey, RN, and named by Capt. George Vancouver, probably for Saint Mary Wiggenhall, birthplace of his mother (Wagner, 1937, p. 407).

Saint Marys : village, see Andreafsky.

Saint Matthew Bay: bay, see Saint Matthews Bay.

Saint Matthew Island: island, $35 \mathrm{mi}$. long, 4 mi. wide, high elevation of about $1,500 \mathrm{ft}$., in Bering Sea, $162 \mathrm{mi}$. SW of Nome; $60^{\circ} 24^{\prime}$ $\mathrm{N}, 172^{\circ} 42^{\prime} \mathrm{W}$; (map 56). Var. Choris Island, Gores Island, Ile Saint Matthieu, Island Apostle Matthei, Matwi Island, Ostrov Svyataya Matvyya, Saint Matwey Island.

According to the Rev. Coxe (1787, map facing p. 223) this island was discovered and named by L.t. Sind (Synd) in August 1766. Coxe's map showed it as "I. Apost. Matthei" which is probably a translation from the Russian meaning "Island [of the] Apostle Matthew" probably implying the island was sighted on or near St. Matthew's day. Capt. Cook (1785, p. 491), RN, found the island September 23, 1778 and erroneously thought "it was wholly unknown to the Russians; and therefore, considering it as a discovery of our own, I named it Gore's Island," for Lt. John Gore, RN, of his party. The later Russian maps, however, continued calling it $\mathrm{O}$ [strov] Sv[yataya] Matvyya (Sarichev, 1826, map 3, Tebenkov, 1852, map 3 ) which has been translated into English in its present form.

Saint Matthews Bay: bay, $1.5 \mathrm{mi}$. wide, on N shore of Port Gravina, $25 \mathrm{mi}$. NW of Cordova, Chugach Mts.; $60^{\circ} 44^{\prime} \mathrm{N}, 146^{\circ} 20^{\prime} \mathrm{W}$; $B G N$ 1933; (map 64). Var. St. Matthew Bay.

A 1914 USGS reconnaissance map shows the bay as St. Matthew Bay.

Saint Matthieu, Ile: island, see Saint Matthew Island.

Saint Matwey Island: island, see Saint Matthew Island.

Saint Michael: village, pop. 205, on E coast of St. Michael I. in Norton Sound, $43 \mathrm{mi}$. SW of Unalakleet, Yukon-Kuskokwim Delta; $63^{\circ} 29^{\prime} \mathrm{N}, 162^{\circ} 02^{\prime} \mathrm{W}$; (map 92). Var. Fort Saint Michael, Michaelovski, Redoubt Saint Michael, Saint Michaels.

About 1833 the Russians established a stockaded post, which, "according to (Lt. L. A.) Zagoskin, (IRN), was named after Capt. Michael Dmitrievich Tebenkov, afterwards governor of the Russian-American colony." (Baker, 1906, p. 543). At an early date the name was changed to "Michaelovski," or "Redoubt Saint Michael." The population, 109 in 1880, was predominantly Eskimo, and included the village of Techek. In 1890 the population was 101 (in 14 houses); in 1910, 450 ; in 1920,371 ; in 1930,147 ; in 1940,142 ; and in 1950, 157. The Saint Michael post office and an American military post, called
"Fort Saint Michael," were established in 1897, following the Klondike gold strike and the subsequent increased Yukon River traffic most of which originated at Saint Michael. The fort was abandoned in 1922. See Techek.

Saint Michael Bay: bay, 2 mi. across, on $E$ side of St. Michael I., in Norton Sound, YukonKuskokwim Delta; $63^{\circ} 27^{\prime}$ N, $162^{\circ} 00^{\prime} \mathrm{W}$; (map 92). Var. Tebenkof Bay, Zaliv Tebenkova.

This feature was originally named in $\mathbf{1 8 3 6}$ by Capt. F. P. Lutke, IRN, for Capt. Michael Dmitrievich Tebenkov, IRN, who discovered it in 1831. The name was later changed to "Saint Michael," probably in the 1880's by USC\&GS.

Saint Michael Canal: watercourse, extends W $17 \mathrm{mi}$. from St. Michael Bay to Norton Sound, $4.2 \mathrm{mi}$. SW of St. Michael, YukonKuskokwim Delta; 63 $26^{\prime} \mathrm{N}, 162^{\circ} 08^{\prime} \mathrm{W}$; (map 92). Var. Big Saint Michael Canal, South Branch Big Saint Michal Canal.

Local name reported in 1898 by USC\&GS.

Saint Michael Creek: stream, see North Fork Snake River.

Saint Michael Island: island, $10 \mathrm{mi}$. long, on Norton Sound, separated from mainland by North Branch Big St. Michael Canal, $40 \mathrm{mi}$. SW of Unalakleet, Yukon-Kuskokwim Delta; $63^{\circ} 28^{\prime} \mathrm{N}, 162^{\circ} 10^{\prime} \mathrm{W} ; B G N$ Sixth Report; (map 92). Var. Michaelovski Island, Ostrov Mikhaila, Saint Michaels Island.

Name reported in $1842-44$ by Lt. L. A. Zagoskin, IRN, as "Ostrov Mikhaila," or "Mikhail Island." See Saint Michael, village. Saint Michael Mountain: hill, $450 \mathrm{ft}$,, on St. Michael I., 4 mi. W of St. Michael, YukonKuskokwim Delta; $63^{\circ} 28^{\prime} \mathrm{N}, 162^{\circ} 10^{\prime} \mathrm{W}$; (map 92).

Local name reported in 1898 by USC\&GS. Saint Michaels: village, see Saint Michael.

Saint Michaels Creek: stream, flows NW $4.7 \mathrm{mi}$. to Osborn Creek, $7 \mathrm{mi}$. NE of Nome, Seward Penin. High.; $64^{\circ} 32^{\prime} 40^{\prime \prime}$ N., $165^{\circ} 09^{\prime} 55^{\prime \prime}$ W; (map 94). Var. Jessie Creek.

Prospectors' name published on the 1900 "Map of Nome Peninsula" by J. M. Davidson and B. D. Blakeslee.

Saint Michaels Island: island, see Saint Michael Island.

Saint Mitrofania Island: island, see Mitrofania Island.

Saint Mitrophan: island, see Mitrofania Island.

Saint Nicholas, Lake: lake, $1.5 \mathrm{mi}$. long, on Prince of Wales I., $9 \mathrm{mi}$. SE of Craig, Alex. Arch.; $55^{\circ} 25^{\prime} 30^{\prime \prime} \mathrm{N}, 132^{\circ} 54^{\prime} 30^{\prime \prime} \mathrm{W}$; BGN 1935; (map 4).

Named in 1935 by USGS; derived from other features in the vicinity called Saint Nicholas.

Saint Nicholas, Port: estuary, extends E $5 \mathrm{mi}$. off Bucareli Bay, on $W$ coast of Prince of Wales I., Alex. Arch.; 55 $26^{\prime}$ N, $133^{\circ} 07^{\prime}$ W; (map 4). Var. Mys de San Nikolay, Puerto de San Nicolao, Puerto de San Nicolas.

Translation of the name "Puerto de San Nicolas" given "about June 1, 1779," by 
Francisco Antonio Maurelle (Wagner, 1937, p. 412).

Saint Nicholas Channel: water passage, extends $9 \mathrm{mi}$. S, off Gulf of Esquibel, between Lulu and Noyes Is., Alex. Arch.; $55^{\circ} 26^{\prime} \mathrm{N}, 133^{\circ}$ $40^{\prime}$ W; (map 4). Var. Canal de San Nicolas, Kanal de San Nikola, San Nicholas Canal, San Nicholas Channel, San Nicolas Channel, San Nicolo Channel.

Translation of the name "Canal de San Nicolas" given "about May 22, 1779," by Francisco Antonio Maurelle (Wagner, 1937, p. 412).

Saint Nicholas Fort De Pawlofsk: village, see Kenai.

Saint Nicholas Point: point of land, SE tip of Noyes I., Alex. Arch.; 55 $26^{\prime} 20^{\prime \prime}$ N, $133^{\circ} 40^{\prime}$ $00^{\prime \prime}$ W; BGN 1923; (map 4). Var. Nicolo Point, Punta de Santa Theresa, San Nicolao Point, San Nicolo Point.

Named "Punta de Santa Theresa" by Francisco Antonio Maurelle "probably on that saint's day May 19, 1779" (Wagner, 1937, p. 513). Renamed in 1923 by USC\&GS; derived from Saint Nicholas Channel.

Saint Orloff : locality, see Eagle Harbor.

Saint Orlovsk: locality, see Eagle Harbor.

Saint Patrick Creek: stream, flows NW 6 mi. to Deadwood Creek $1.5 \mathrm{mi}$. NE of its junc. with Guggenheim Creek, $27 \mathrm{mi}$. NE of Flat, Kilbuck-Kuskokwim Mts.; $62^{\circ} 40^{\prime} 20^{\prime \prime} \mathrm{N}, 157^{\circ} 18^{\prime}$ $50^{\prime \prime} \mathrm{W}$; (map 79).

Prospectors' name obtained in 1952 by USGS topographers.

Saint Patrick Creek: stream, flows E $3 \mathrm{mi}$. to Ace Creek, $6 \mathrm{mi}$. NW of Fairbanks, YukonTanana High.; $64^{\circ} 52^{\prime} 15^{\prime \prime} \mathrm{N}, 147^{\circ} 54^{\prime} 30^{\prime \prime} \mathrm{W}$; (map 100).

This name first appears on a location map of the Tanana Mines RR. dated 1904.

Saint Patricks Creek: stream, flows S $5.5 \mathrm{mi}$. from Wien Mtn. to Clear River, $5 \mathrm{mi}$. WSW of Harvey Mtn. and $33 \mathrm{mi}$. NW of Wiseman, Brooks, Ra.; $67^{\circ} 50^{\prime} 30^{\prime \prime} \mathrm{N}, 150^{\circ} 28^{\prime} 00^{\prime \prime} \mathrm{W}$; BGN 1932; (map 124).

Robert Marshall (1956, p. 75) reports naming this creek: "I explored the deep, Yosemite-like valley, and its creek-later named by us 'St Patricks Creek' * * *."

Saint Paul: town, see Kodiak.

Saint Paul: village, pop. 378 , on S coast of St. Paul I., Pribilof Is.; $57^{\circ} 07^{\prime} 20^{\prime \prime}$ N, $170^{\circ} 16^{\prime} 30^{\prime \prime}$ W; (map 38).

Locally named for the island. First occupied about 1788 by Aleuts, who were employed by the Russians in the fur seal industry. Listed in the 1880 Census, with a population of 298 , by Petroff (1884 p. 23) ; population 244 in 1890.

Saint Paul Harbor: bight, $3.5 \mathrm{mi}$. across, SW of Kodiak, on Kodiak I.; $57^{\circ} 46^{\prime}$ N, $152^{\circ} 27^{\prime} \mathrm{W}$; (map 34). Var. Kodiak Harbor, Pauls Harbor, Pavlovsk Gaven.

Reported by USC\&GS in 1867. Name derived from Saint Paul, an early name for the village of Kodiak given in 1805 by Lisianski (1814, p. 168).

Saint Paul Harbor: bay, see Captains Bay.
Saint Paul Harbor: $b a y$, see Levashef, Port.

Saint Paul Island: island, $10 \mathrm{mi}$. across, one of Pribilof Is.; $57^{\circ} 10^{\prime} \mathrm{N}, 170^{\circ} 15^{\prime} \mathrm{W}$; (map 38). Var. Saint Peter and Saint Paul Island.

Early in June, 1786, G. G. Pribilov left some hunters on St. George Island with provisions for the winter. A year later, on June 29,1787 (O.S.), an unusually clear atmosphere permitted the promyshlenniki to see another large island 30 miles northward which they named "Saint Peter and Saint Paul," because it was the dedicated day of those two Holy Apostles.

The first half of the name was soon lost in popular usage (Bancroft, 1886, p. 192 and 193).

Saint Peter and Saint Paul Island: island, see Saint Paul Island.

Saint Philip Island: island, $1.5 \mathrm{mi}$. long, in Gulf of Esquibel, $W$ of Prince of Wales I., Alex. Arch.; 55 $39^{\prime} \mathrm{N}, 133^{\circ} 25^{\prime} \mathrm{W}$; (map 4). Var. Isla San Felipe, Ostrov de San Filip, Ysla de San Felipe.

Translation of the name "Isla San Felipe" given "about May 23, 1779, by Francisco Antonio Maurelle after San Felipe Neri, who died May 25" (Wagner, 1937, p. 499).

Saint Sebastian, Point: point of land, on W coast of Prince of Wales I., on Trocadero Bay, Alex. Arch.; 55 $21^{\prime} 55^{\prime \prime} \mathrm{N}, 132^{\circ} 59^{\prime} 15^{\prime \prime} \mathrm{W}$; (map 4). Var. Mys San Sebastian, Punta de San Sebastian, Punta San Sebastian.

Translation of the name "Punta de San Sebastian" given in 1775-79 by Don Juan de la Bodega y Quadra and Francisco Antonio Maurelle.

Saints Hill: hill, $800 \mathrm{ft}$., on northern Kiska I., Aleutian Is.; $52^{\circ} 04^{\prime} 50^{\prime \prime} \mathrm{N}, 177^{\circ} 38^{\prime} 45^{\prime \prime} \mathrm{E}$; (map 14).

An arbitrary name beginning with " $\mathrm{S}$ " to correspond to "S" grid used by the U.S. Army for tactical purposes during World War II; published on a 1953 AMS map.

Saint Stephen, Cape: point of land, SW tip of Kiska I., Aleutian Is.; $51^{\circ} 51^{\prime} \mathrm{N}, 177^{\circ} 12^{\prime} \mathrm{E}$; $B G N$ 1937; (map 14).

Named by personnel of the U.S.S. Oglala in 1935, based on the belief that Kiska was the island seen by Vitus Bering on October 28, 1741 (O.S.), and named by him "St. Stephen." See Kiska Island.

Saint Stephen Island: island, see Buldir Island. Saint Stephen Island: island, see Kiska Island. Saint Terese: locality, on island, on $\mathbf{S}$ side of Pearl Harbor, on Favorite Channel, $1.2 \mathrm{mi}$. $\mathrm{S}$ of Dotsons Landing and $18 \mathrm{mi}$. NW of Juneau, Coast Mts. ; $58^{\circ} 28^{\prime} 20^{\prime \prime} \mathrm{N}, 134^{\circ} 47^{\prime} 10^{\prime \prime}$ W; (map 11).

Shrine named for the French Carmelite nun, Thérès de Lisieux, 1873-97. The site was selected in 1931 and the shrine was completed in 1933.

Saint Theodore Island: island, see Attu Island. Saint Thomas, Point: point of land, on $\mathrm{E}$ coast of Lulu I., Alex. Arch.; 55 $29^{\prime} 30^{\prime \prime}$ N, $133^{\circ}$. 26'15' W; (map 4). Var. Mys San Tomas, Punta de San Tomas, Punta San Tomas.
Translation of the name "Punta de San Tomas" given in $1775-79$ by Don Juna de la Bodega y Quadra and Francisco Antonio Maurelle.

Saint Timothys: village, see Tanacross.

Saioogham Island: island, see Seguam Island.

Saitchuck, The: estuary, $1 \mathrm{mi}$. long, at head of Biscuit Lagoon, on SW coast of Prince of Wales I., Alex. Arch.; $54^{\circ} 54^{\prime} 30^{\prime \prime} \mathrm{N}, 132^{\circ}$ $18^{\prime} 30^{\prime \prime} \mathrm{W}$; (map 1).

Name reported in 1948 by USGS. This may be a typographical error of the Chinook word "saltchuck," referring to "salt water."

Saitut Creek: stream, flows SW $6 \mathrm{mi}$. to Okpiksurok Creek, E of Kevroruk Springs, $14 \mathrm{mi}$. NW of Kivalina, Kotzebue-Kobuk Low.; $67^{\circ} 52^{\prime} \mathrm{N}, 164^{\circ} 52^{\prime} \mathrm{W}$; (map 128). Var. Siaktak Creek, Saik-took, Saitut Kuuganzanga, Saytut Koogowranga.

Eskimo name reported in 1966 by E. S. Burch; named after the hills. See Siaktak Hills.

Saitut Kuuganzanga: stream, see Saitut Creek. Sai-uk-stchu-schluk: $b a y$, see Silver Horn.

Sajaga, Cape: point of land, see Sajaka, Cape. Sajaka, Cape: point of land, on NW coast of Tanaga I., Aleutian Is.; $51^{\circ} 52^{\prime} 30^{\prime \prime}$ N., $178^{\circ}$ $13^{\prime} 30^{\prime \prime} \mathrm{W}$; (map 16). Var. Cape Sajaca, Cape Sajaga, Cape Sasaka, Northwest Cape.

This feature was named "Cape Sajaga" by the North Pacific Exploring Expedition of 1855. Capt. Tebenkov (1852, map 28), IRN, called it "M[ys] N.W.," or "Northwest Cape."

The adopted form was published by USC\& GS in the 1944 Aleutian Coast Pilot (p. 117).

Sa-Kaa Cove: estuary, see Sarkar Cove.

Sakadelontin: locality, see Louden.

Sakamna: locality, "inland from Point Barrow." (Hodge 1910, p. 413); (map 153).

Former Eskimo summer village or camp reported by Sgt. Murdoch (1892, p. 83), USA.

Sakatalan: locality, see Louden.

Sakataloden: locality, see Louden.

Sakedelontin: locality, see Louden.

Sakha Golovy, Mys: promontory, see Sugarloaf Mountain.

Sákhalis: locality, see Alaganik.

Sakhtusik Bay: bay, see Reese Bay.

Sakie Bay: estuary, extends SE $2.5 \mathrm{mi}$. to Pacific Ocean, on W coast of Dall I., Alex. Arch.; $55^{\circ} 04^{\prime} \mathrm{N}, 133^{\circ} 14 \mathrm{~W}$; (map 4).

Local name published in 1914 by USC\&GS; derived from the Japanese word "saki," which is a wine made from rice.

Sakie Point: point of land, point of entrance to Sakie Bay, on W coast of Dall I., Alex. Arch.; $55^{\circ} 03^{\prime} 25^{\prime \prime} \mathrm{N}, 133^{\circ} 13^{\prime} 10^{\prime \prime} \mathrm{W}$; BGN 1928; (map 4). Var. Reef Point.

Named in 1927 by Capt. R. S. Patton, USC\&GS "because of its proximity to Sakie Bay. This feature was called Reef Point by USC\&GS in 1919; changed because of duplication.

Sakisalnak Point: point of land, on right bank of Noatak River, $18 \mathrm{mi}$. NE of Kotzebue, Kotzebue-Kobuk Low.; $67^{\circ} 09$ N, $162^{\circ} 22^{\prime}$ W ; (map 128). Var. Sukisalnuk Point. 
Eskimo name meaning "point of sharp rocks" according to USC\&GS in 1950.

Saklekageta: stream, see Baker Creek.

Saklidok Island: island, see Sitkalidak Island. Saklidov Island: island, see Sitkalidak Island. Saklolik Mountain: hill, $701 \mathrm{ft}$., on E shore of Kukpuk River, 19 mi. NE of Cape Thompson, Arctic Slope, $68^{\circ} 14^{\prime} 20^{\prime \prime} \mathrm{N}, 165^{\circ} 16^{\prime} 45^{\prime \prime} \mathrm{W}$; $B G N$ 1963; (map 129). Var. Suklowik Mountain.

Eskimo name reported in 1960 by D. C. Foote in connection with Project Chariot studies.

Sakǒä-n: locality, see Sukkwan.

Sakonowyak River: stream, flows NE $35 \mathrm{mi}$. to Gwydyr Bay, $4 \mathrm{mi}$. SE of Beechey Point, Arctic Plain; $70^{\circ} 27^{\prime} \mathrm{N}, 149^{\circ} 01^{\prime} \mathrm{W}$; (map 150).

Eskimo name meaning "twisting waters" ["it twists" taken from Sanguroq] reported by USC\&GS in 1951.

Sakoonang Channel: stream, distributary of Colville River, $15 \mathrm{mi}$. long between Nechelik and Tamayayak Channels, in Colville River Delta, Arctic Plain; $70^{\circ} 25^{\prime} \mathrm{N}, 150^{\circ} 58^{\prime} \mathrm{W}$; (map 149). Var. Sa-koo-nowg River.

Eskimo name reported in 1951 by USC\&GS as Sakoonawg meaning "big curves" [?]. The variant spelling on a USGS map probably represents a typographical error.

Sa-koo-nowg River: stream, see Sakoonang Channel.

Sakovanuktck River: stream, see Sagavanirktok River.

Sakpik Mountain: mountain, 1,510 ft., extends $\mathrm{S} 5 \mathrm{mi}$. from Ipewik River, $16 \mathrm{mi}$. NE of Cape Thompson, Arctic Slope; $68^{\circ} 21^{\prime} 15^{\prime \prime} \mathrm{N}, 165^{\circ}$ 34'15' W; BGN 1963; (map 129). Var. Saukpeek Mountain.

Eskimo name meaning "whale's tail" reported in 1960 by D. C. Foote, Project Chariot; he spelled it "Saukpeek."

Sakrorak Creek: stream, heads on Utkusikrak Hill, flows W $4.8 \mathrm{mi}$. to Tasikpak Lagoon, 22 mi. NW of Kivalina, Kotzebue-Kobuk Low.; $67^{\circ} 57^{\prime} \mathrm{N}, 165^{\circ} 07^{\prime} \mathrm{W}$; BGN 1963; (map 128). Var. Sacrocruk Greek.

Eskimo name meaning "stretched out," according to USC\&GS in 1950.

Sakrorak Mountain: hill, $165 \mathrm{ft}$., on Chukchi Sea coast, $\mathrm{N}$ of Tasikpak Lagoon, $22 \mathrm{mi}$. NW of Kivalina, Kotzebue-Kobuk Low.; 67 ${ }^{\circ} 57^{\prime}$

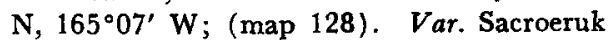
Mountain, Sayagrowrak, Togrorurak.

Eskimo meaning "stretched out," according to USC\&GS in 1950. D. C. Foote called the hill "Togrorurak" in 1960.

Saksaia Glacier: glacier, heads on Flower Mtn., trends N $3 \mathrm{mi}$. to head of Glacier Creek, 3.6 mi. NE of Mount Henry Clay and $38 \mathrm{mi}$. SW of Skagway, St. Elias Mts.; $59^{\circ} 23^{\prime} 15^{\prime \prime} \mathrm{N}$, $136^{\circ} 22^{\prime} 20^{\prime \prime} \mathrm{W}$; (map 45). Var. Sachsaiya Glacier, Sayaéja.

Tlingit Indian name reported by Aurel and Arthur Krause (1883, map) as "Saxaéja (Gletscher)." J. A. Flemer, USC\&GS reported the name in 1898 as Sachsaiya.

Saks Cove: estuary, on mainland, extends $\mathrm{N}$ $1.5 \mathrm{mi}$. off Behm Canal, $4.5 \mathrm{mi}$. SE of Point
Fitzgibbon, Coast Mts. ; $55^{\circ} 55^{\prime} 45^{\prime \prime} \mathrm{N}, 131^{\circ} 08^{\prime}$ 40 " W; (map 3 ).

Named in 1891 by USC\&GS.

Saks Creek: stream, on mainland, flows WNW $9.5 \mathrm{mi}$. from Saks Lake to Saks Cove, Coast Mts.; $55^{\circ} 57^{\prime} \mathrm{N}, 131^{\circ} 07^{\prime} \mathrm{W}$; BGN 1962; (map $3)$.

Local name reported in 1961 by USFS.

Saks Lake: lake, $1.5 \mathrm{mi}$. long, on mainland, in course of Saks Creek, $7.5 \mathrm{mi}$. E of Point Fitzgibbon, Coast Mts.; $55^{\circ} 57^{\prime} 45^{\prime \prime} \mathrm{N}, 131^{\circ} 30^{\prime} 00^{\prime \prime}$ W; BGN 1962; (map 3$)$.

Local name reported in 1961 by USFS.

Sakthidak Island: island, see Sitkalidak Island.

Saktuina Island: point of land, see Saktuina Point.

Saktuina Islands: islands, see Eskimo Islands.

Saktuina Point: point of land, between Harrison Bay and Kogru River, Arctic Plain; $70^{\circ} 35^{\prime}$ N, $152^{\circ} 03^{\prime} \mathrm{W} ; B G N 1961$; (map 149). Var. Saktuina Island.

This name was originally applied to an island [Eskimo Islands] on Maguire's map (Great Britain, 1854, facing p. 186). The application was changed by the BGN on recommendation of USC\&GS. The name freely translated means "waiting place."

Sakvailak River: stream, flows SE $18 \mathrm{mi}$. to Awuna River, $28 \mathrm{mi}$. W of Birthday Pass, Arctic Slope ; $69^{\circ} 12^{\prime} \mathrm{N}, 157^{\circ} 43^{\prime} \mathrm{W}$; (map 143). Var. North Fork Sakvailak River, Sagvailak River.

Present-day Eskimo name for the Awuna River which, on some publications, has been relegated to this headwater stream.

Sakvailak River: stream, see Awuna River.

Sakvailuk River: stream, see Awuna River.

Sakvelak Creck: stream, heads on Kitkonak Hill, flows SE $14 \mathrm{mi}$. to Nilik River, $29 \mathrm{mi}$. E of Cape Dyer, Arctic Slope; $68^{\circ} 40^{\prime} 30^{\prime \prime} \mathrm{N}, 165^{\circ}$ 05'50" W; (map 129). Var. Olikvik Creek, Sukwayluk Creek.

Eskimo descriptive name meaning "no current" reported in 1956 by Orth.

Salamander Lake: lake, $0.6 \mathrm{mi}$. long, on $\mathrm{E}$ coast of Prince of Wales I., $3.2 \mathrm{mi}$. NW of Thorne Head, Alex. Arch.; $55^{\circ} 43^{\prime} 40^{\prime \prime} \mathrm{N}, 132^{\circ} 29^{\prime} 45^{\prime \prime}$ W; BGN 1960; (map 4).

So named by C. L. Sainsbury, USGS, in 1956 "because of the large population of salamanders in it."

Salamatof: locality, on $\mathbf{E}$ shore of Cook Inlet at mouth of Salamatof Creek, $5.5 \mathrm{mi}$. NW of Kenai, Cook Inlet Low.; $60^{\circ} 37^{\prime} 15^{\prime \prime} \mathrm{N}, 151^{\circ}$ $20^{\prime} 30^{\prime \prime} \mathrm{W}$; (map 62).

Tanaina Indian village reported about 1911 by USGS (Martin and others, 1915, pl. 2). Recent USGS maps indicate an abandoned site.

Salamatof Creek: stream, heads in Salamatof Lake, flows SW $3 \mathrm{mi}$. to Cook Inlet at Salamatof Beach, $5.5 \mathrm{mi}$. NW of Kenai, Cook Inlet Low.; $60^{\circ} 37^{\prime} 15^{\prime \prime} \mathrm{N}, 151^{\circ} 20^{\prime} 30^{\prime \prime} \mathrm{W}$; (map 62)

Local name reported in 1951 by USGS; derived from the village.
Salamatof Lake: lake, on Kenai Penin., $1.2 \mathrm{mi}$. long, $7 \mathrm{mi}$. N of Kenai, on Kenai Penin. Cook Inlet Low. ; 60³9' N, $151^{\circ} 18^{\prime} \mathrm{W}$; (map 62).

Russian name reported in 1840 as "Salamatowa" by Ilia G. Wosnesenski. The present spelling was used by Constantin Grewingk in 1850. "Salamatov" is a Russian surname.

Salawik Lake: lake, see Selawik Lake.

Salawik River: stream, see Selawik River.

Salcha: settlement, see Aurora Lodge.

Salcha Bluff: bluff, 2,600 ft., extends E $8 \mathrm{mi}$. from Aurora Lodge, on $\mathbf{N}$ bank of Salcha River, Yukon-Tanana High.; 64 $28^{\circ} 45^{\prime \prime} \mathrm{N}$, $146^{\circ} 51^{\prime} 00^{\prime \prime} \mathrm{W}$; (map 101).

Local name derived from Salcha River; published in 1951 by USGS.

Salchacket River: stream, see Salcha River.

Salchakaket: settlement, see Aurora Lodge.

Salchakaket River: stream, see Salcha River.

Salchaket: settlement, see Aurora Lodge.

Salchaket Lake: lake, see Harding Lake.

Salchaket River: stream, see Salcha River.

Salchaket Slough: stream, anabranch of Tanana River, flows NW $29 \mathrm{mi}$. along $S$ side of Tanana River to $10 \mathrm{mi}$. SW of Fairbanks, Tanana Low.; $64^{\circ} 44^{\prime} 40^{\prime \prime} \mathrm{N}, 148^{\circ} 02^{\prime} 30^{\prime \prime} \mathrm{W}$; (map 100).

So named because this stream heads near mouth of Salcha River. The name is shown on an ARC wagonroad manuscript map dated 1909.

Salcha River: stream, heads at $65^{\circ} 05^{\prime} \mathrm{N}$, $143^{\circ} 55^{\prime} \mathrm{W}$, flows SW $125 \mathrm{mi}$. to Tanana River, $33 \mathrm{mi}$. SE of Fairbanks, Tanana Low.; $64^{\circ} 28^{\prime} \mathrm{N}, 146^{\circ} 59^{\prime} \mathrm{W}$; BGN 1965; (map 101) Var. East Fork Salcha River, Middle Fork Salcha River, Salchacket River, Salchakaket River, Salchaket River, Salt Jacket River, Saltshatsheg River.

Indian name reported in 1898 as "Salchaket," i.e. "mouth of the Salcha," by Brooks (1900, map 23), USGS. R. H. Geoghegan in 1904 recorded the Indian name as "Saltshatsheg."

Salcha Slough: stream, distributary of Salcha River, flows NW $6 \mathrm{mi}$. to Tanana River, 45 mi. NW of Big Delta, Tanana Low.; 64 $4^{\circ} 33^{\prime}$ $\mathrm{N}, 147^{\circ} 03^{\prime} \mathrm{W}$; (map 100$)$.

Local name reported in 1905 by $L$. M. Prindle (in Brooks and others, 1906, p. 124), USGS.

Sal Creek: stream, flows E $5 \mathrm{mi}$. to Clarence Strait, $2 \mathrm{mi}$. $\mathbf{N}$ of Narrow Point, $\mathbf{E}$ coast of Prince of Wales I., Alex. Arch.; 55 $49^{\prime} \mathrm{N}$, $132^{\circ} 30^{\prime} \mathrm{W} ; B G N 1962$; (map 4).

Local name reported in 1961 by USFS. "This small stream flows into Clarence Strait near triangulation station Sal * * *"

Saldovia: village, see Seldovia.

Saldovoi Bay: estuary, see Seldovia Bay.

Saleekvik Creek: stream, see Saligvik Creek.

Saleekvik Ridge: ridge, see Saligvik Ridge.

Saleekvik Valley: valley, see Saligvik Valley.

Saleexvik Creek: stream, see Saligvik Creek.

Saleexvik Mountain: ridge, see Saligvik Ridge.

Sale Gulch: ravine, trends W $1.3 \mathrm{mi}$. to Fish Creek, $56 \mathrm{mi}$. SW of Eagle, Yukon-Tanana 
High.; $64^{\circ} 21^{\prime} 15^{\prime \prime} \mathrm{N}, 142^{\circ} 45^{\prime} 00^{\prime \prime} \mathrm{W}$; (map 102).

Prospectors' name shown on an 1898 manuscript map by C. A. Woodruff, Fort Cudahy, Canada.

Salennoj: island, see Salt Island.

Salghat Beach: beach, barrier beach forming Seepanpak Lagoon, $47 \mathrm{mi}$. SE of Savoonga St. Lawrence I.; $63^{\circ} 20^{\prime} \mathrm{N}, 169^{\circ} 12^{\prime} \mathrm{W} ; B G N$ 1951; (map 93).

Eskimo name recommended by the Savoonga village council and reported in 1949 by Maj. H. B. Allen, USAF.

Saligochit River: stream, see Sadlerochit River.

Saligvik Creek: stream, flows NE $7.5 \mathrm{mi}$. to Kukpuk River, E of Saligvik Ridge, $13 \mathrm{mi}$. NE of Cape Thompson, Arctic Slope; 68 $16^{\prime} 25^{\prime \prime}$ N, $165^{\circ} 35^{\prime} 45^{\prime \prime} \mathrm{W}$; BGN 1963; (map 129). Var. Sahligvik Creek, Saleekvik Creek, Saleexvik Creek.

Eskimo name reported in 1962 by personnel of Project Chariot as "Saleekvik." It was reported to mean "dodge an arrow" by W. $O$. Pruitt, Univ. of Alaska.

Saligvik Ridge: ridge, $800 \mathrm{ft}$., extends NE $13 \mathrm{mi}$. between Chukchi Sea and Kukpuk River, 9 mi. NE of Cape Thompson, Arctic Slope; $68^{\circ} 12^{\prime} \mathrm{N}, 165^{\circ} 45^{\prime} \mathrm{W}$; BGN 1963; (map 129). Var. Sahligvik Ridge, Saleekvik Ridge, Saleexvik Mountain.

Eskimo name reported in 1962 by personnel of Project Chariot. See Saligvik Creek.

Saligvik Valley: valley, extends SW $6.5 \mathrm{mi}$. from Kukpuk River, E of Saligvik Ridge, 9 mi. NE of Cape Thompson, Arctic Slope; $68^{\circ} 14^{\prime} \mathrm{N}$, $165^{\circ} 37^{\prime}$ W; BGN 1963; (map 129). Var. Sahligvik Valley, Saleekvik Valley.

Eskimo name reported in 1962 by personnel of Project Chariot. See Saligvik Creek.

Salisbury, Mount: mountain, $12,170 \mathrm{ft}$., in Glacier National Monument, $7 \mathrm{mi}$. SE of Mount Fairweather and $87 \mathrm{mi}$. NW of Hoonah, St. Elias Mts.; 58 $51^{\prime} 05^{\prime \prime}$ N. $137^{\circ} 22^{\prime} 10^{\prime \prime} \mathrm{W}$; BGN 1937; (map 10).

Named by W. O. Field, Jr., and W. S. Cooper in 1936 for Rollin D. Salisbury, 18581922, professor of geology at the Univ. of Chicago from 1892 until his death, and an eminent student of Pleistocene and Recent glaciers.

Salisbury, Mount: mountain, 7,060 ft., W of Canning River, at head of Kavik River, $51 \mathrm{mi}$. SW of Mount Michelson, Brooks Ra.; $69^{\circ} 09^{\prime}$ N, $146^{\circ} 17^{\prime} \mathrm{W}$; BGN 1944; (map 139).

Named by Leffingwell $(1919$, p. 99) for Rollin D. Salisbury, 1858-1922.

Salisbury, Point: point of land, on Stephens Passage, at $\mathrm{S}$ end of Gastineau Channel, 2.5 mi. W of Bishop Point and $10 \mathrm{mi}$. SW of Juneau, Coast Mts.; $58^{\circ} 12^{\prime} 15^{\prime \prime} \mathrm{N}, 134^{\circ} 13^{\prime}$ $00^{\prime \prime} \mathrm{W}$; (map 11).

Discovered August 11, 1794, by Joseph Whidbey, RN, and named by Capt. George Vancouver for the Bishop of Salisbury (Wagner, 1937, p. 407).

Salisbury Sound: water passage, between Kruzof and Chichagof Is., $26 \mathrm{mi}$. NW of Sitka, Alex. Arch.; $57^{\circ} 22^{\prime} \mathrm{N}, 135^{\circ} 50^{\prime} \mathrm{W}$; BGN Sixth Re- port; (map 9). Var. Bay of Islands, Chastyye Ostrova, Klokacheff Sound, Olga Sound, Olga Strait, Proliv Olgi, Puerto de los Remedios, Bahia de las Islas.

Named in 1787 by Capt. Nathaniel Portlock, "in honor of Bishop Salisbury" (Wagner, 1937, p. 407). This feature was also called "Puerto de los Remedios" meaning "Port of the Remedies," in 1775 by Francisco Antonio Maurelle; "Bay of Islands" on May 2, 1778, by Capt. James Cook, RN (Wagner, p. 464); "Zund Klokacheva," or "Klokachev Sound," in 1809 by the Russian navigator Ivan Vasiliev the first; and "Proliv Olgi," or "Olgi Strait," by Capt. Tebenkov (1852, map 8), IRN.

Saliuliuktusikh: island, see Saüluktoucikh.

Salix Bay: bay, $2 \mathrm{mi}$. across, at $\mathrm{N}$ end of Imuruk Lake, Seward Penin. High.; $65^{\circ} 39^{\prime} \mathrm{N}, 163^{\circ}$ 12' W; BGN 1952; (map 110).

Reported in 1950 by D. M. Hopkins, USGS; so named because "the shores are partly lined by Salix Alaxensis (felt-leaf willow)."

Sally Island: island, $2.3 \mathrm{mi}$. long, in Northeast Arm Uganik Bay, on $\mathrm{N}$ coast of Kodiak I.; $57^{\circ} 44^{\prime} \mathrm{N}, 153^{\circ} 21^{\prime} \mathrm{W}$; (map 34 ).

Local name published in 1943 by USC\&GS. Salmon: settlement, see Salmon Village.

Salmon Bay: bay, $0.4 \mathrm{mi}$. across, on $\mathrm{S}$ coast of Sanak I., Aleutian Ra.; $54^{\circ} 23^{\prime} 25^{\prime \prime} \mathrm{N}, 162^{\circ}$ $36^{\prime} 00^{\prime \prime}$ W; (map 25). Var. King Cove.

Named by USBF in 1888 . This bay or Peterson Bay may be the King Cove of W. H. Dall, USC\&GS. See Peterson Bay.

Salmon Bay: bay, see Herring Cove.

Salmon Bay: cove, $0.8 \mathrm{mi}$. long, at $\mathrm{NW}$ end of Clarence Strait, on $\mathbf{N}$ coast of Prince of Wales I., Alex. Arch.; 56 $18^{\prime} 15^{\prime \prime} \mathrm{N}, 133^{\circ} 09^{\prime} 00^{\prime \prime} \mathrm{W}$; (map 6).

Named in 1886 by Lt. Comdr. A. S. Snow, USN; published in 1887 on USC\&GS Chart 706.

Salmon Bay Lake: lake, $3 \mathrm{mi}$. long, on $\mathrm{N}$ coast of Prince of Wales I., Alex. Arch.; 56 $14^{\prime} \mathrm{N}$, $133^{\circ} 11^{\prime} \mathrm{W}$; (map 6).

Local name recorded in 1949 by USGS.

Salmonberry Cove: cove, $0.1 \mathrm{mi}$. across, in Kakul Narrows, on $S$ coast of Chichagof I., $21 \mathrm{mi}$ NW of Sitka, Alex. Arch.; $57^{\circ} 22^{\prime} 25^{\prime \prime}$ N., $135^{\circ}$ $42^{\prime} 00^{\prime \prime} \mathrm{W}$; (map 9).

Named in 1884 by Comdr. J. B. Coghlan, USN, and published by USC\&GS on Chart 727.

Salmon Berry Lake: lake, $0.2 \mathrm{mi}$. across, $1 \mathrm{mi}$. S of Stony River, $18 \mathrm{mi}$. E of Tundra Lake, $75 \mathrm{mi}$. SE of Sleetmute, Lime Hills ; $61^{\circ} 14^{\prime} 45^{\prime \prime}$ N, $155^{\circ} 07^{\prime} 30^{\prime \prime} \mathrm{W}$; (map 71).

Local name reported in 1958 by USGS.

Salmon Berry Lake: lake, $1.9 \mathrm{mi}$. long, NW of Game Trail Lake, $21 \mathrm{mi}$. NW of Glennallen, Copper River Basin; $62^{\circ} 17^{\prime} \mathrm{N}, 140^{\circ} 09^{\prime} \mathrm{W}$; (map 83).

Local name reported in 1951 by USGS.

Salmon Cove: bay, see Herring Cove.

Salmon Cove : cove, see Sweeper Cove.

Salmon Creek: stream, flows N $0.5 \mathrm{mi}$. to Red Bay, on $\mathrm{N}$ coast of Prince of Wales I., Alex. Arch.; $56^{\circ} 16^{\prime} 30^{\prime \prime} \mathrm{N}, 133^{\circ} 17^{\prime} 50^{\prime \prime} \mathrm{W}$; (map 6).
Named in 1886 by Lt. J. M, Helm, USN, for charting purposes; published in 1887 on USC\&GS Chart 706

Salmon Creek: stream, flows NE $6 \mathrm{mi}$. to Salmon Bay, on NE coast of Prince of Wales I., Alex. Arch.; $56^{\circ} 16^{\prime} 50^{\prime \prime} \mathrm{N}, 133^{\circ} 10^{\prime} 00^{\prime \prime} \mathrm{W}$; (map 6).

Named in 1886 by Lt. J. M. Helm, USN, for charting purposes; published in 1887 on USC\&GS Chart 706.

Salmon Creek: stream, heads at Lucky Chance Lakes, flows $W$ and N 6.5 mi. to Silver Bay, $8.5 \mathrm{mi}$. SE of Sitka, on central Baranof I., Alex. Arch.; $56^{\circ} 58^{\prime} 50^{\prime \prime} \mathrm{N}, 1^{\circ} 5^{\circ} 08^{\prime} 30^{\prime \prime} \mathrm{W}$; (map 5).

Local name published by Knopf (1912, fig. 5), USGS.

Salmon Creek: stream, flows NW $3.8 \mathrm{mi}$. to Thumb River, E of Karluk Lake, Kodiak I.; $57^{\circ} 21^{\prime} 15^{\prime \prime} \mathrm{N}, 153^{\circ} 59^{\prime} 30^{\prime \prime} \mathrm{W}$; (map 34).

Local name reported in 1954 by USGS. Salmon Creek: stream, heads $\mathrm{N}$ of Tule Bay, flows NW $11 \mathrm{mi}$. to Becharof Lake, between Bear and Otter Creeks, on Alaska Penin., 51 mi. NE of Ugashik, Aleutian Ra.; $57^{\circ} 40^{\prime} 25^{\prime \prime}$ $\mathrm{N}, 156^{\circ} 05^{\prime} 25^{\prime \prime} \mathrm{W}$; (map 36 ).

Local name reported in 1903 by G. G. Martin, USGS.

Salmon Creek: stream, heads in Salmon Creek Reservoir, flows SW $3 \mathrm{mi}$. to Gastineau Channel, $3 \mathrm{mi}$. NW of Juneau, Coast Mts.; $58^{\circ} 19^{\prime}$ $50^{\prime \prime} \mathrm{N}, 134^{\circ} 28^{\prime} 20^{\prime \prime} \mathrm{W}$; (map 11). Var. Tilhini Creek.

Named by Richard Harris and Joe Juneau in 1880. The name probably derived from the Indian name "Tilhini," meaning "dog salmon," which appears on some early maps (DeArmond, 1957, p. 37).

Salmon Creek: stream, heads at terminus of Bear Lake Glacier, flows WSW $7 \mathrm{mi}$. to Resurrection River, $2 \mathrm{mi}$. NE of Seward, Chugach Mts.; $60^{\circ} 08^{\prime} \mathrm{N}, 149^{\circ} 24^{\prime} \mathrm{W}$; (map 63).

Local name reported in 1898 by Mendenhall $(1900$, p. 302$)$, USGS.

Salmon Creek: stream, flows S $6 \mathrm{mi}$. to McKinley Lake, $20 \mathrm{mi}$. SE of Cordova, Chugach Mts.; $60^{\circ} 27^{\prime} \mathrm{N}, 145^{\circ} 10^{\prime} \mathrm{W}$; (map 64).

Local name reported in 1912 by U. $S$. Grant and D. F. Higgins, USGS.

Salmon Creek: stream, flows SW $5 \mathrm{mi}$. to Bremner River, $1.6 \mathrm{mi}$. NE of mouth of Eagle Creek and $64 \mathrm{mi}$. E of Valdez, Chugach Mts.; $61^{\circ} 01^{\prime} 40^{\prime \prime} \mathrm{N}, 1^{\circ} 4^{\circ} 18^{\prime} 30^{\prime \prime} \mathrm{W}$; (map 68)

Name published by USGS (Moffit, 1914, pl. 1).

Salmon Creek: stream, heads in glacier, flows $\mathrm{N}$ $3 \mathrm{mi}$. to Port Valdez at Sawmill Spit, $6.2 \mathrm{mi}$. SW of Valdez, Chugach Mts.; $61^{\circ} 04^{\prime} 55^{\prime \prime} \mathrm{N}$, $146^{\circ} 26^{\prime} 15^{\prime \prime} \mathrm{W}$; (map 68).

Local name reported in 1905 by U. S. Grant, USGS.

Salmon Creek: stream, heads in swamp at Chulitna Pass, flows S $2 \mathrm{mi}$. to Indian River $6 \mathrm{mi}$. NE of its junc. with Susitna River and $41 \mathrm{mi}$. SW of Cantwell, Talkeetna Mts.; $62^{\circ} 52^{\prime} 15^{\prime \prime} \mathrm{N}, 149^{\circ} 35^{\prime} 50^{\prime \prime} \mathrm{W}$; (map 82).

Local name reported in 1951 by USGS.

Salmon Creek: stream, flows NE $18 \mathrm{mi}$. to the Koyuk River, 15 mi. SW of Haycock, Seward 
Penin. High.; $65^{\circ} 10^{\prime} \mathrm{N}, 161^{\circ} 39^{\prime} \mathrm{W}$; (map 109).

Local name reported in 1921 by USGS.

Salmon Creek: stream, flows S $3.8 \mathrm{mi}$. to Taylor Creek which flows to Kougarok River, $5 \mathrm{mi}$. $\mathrm{S}$ of Midnight Mtn. and $41 \mathrm{mi}$. NE of Imuruk Lake, Seward Penin. High.; $65^{\circ} 42^{\prime}$ N, $164^{\circ}$ $35^{\prime} \mathrm{W}$; (map 110). Var. Solomon Creek.

Prospectors' name reported as "Solomon Creek" in 1901 by T. G. Gerdine (in Collier, 1902, pl. 12), USGS.

Salmon Creek: stream, see Currant Creek.

Salmon Creek: stream, see Sweeper Creek.

Salmon Creek Divide: ridge, extends $3 \mathrm{mi}$. NE from Mount Juneau, $2 \mathrm{mi}$. NE of Juneau, Coast Mts.; $58^{\circ} 20^{\prime}$ N, $134^{\circ} 22^{\prime} \mathrm{W}$; (map 11).

Name used by miners; published by Spencer and Wright (1906, pl. 15), USGS.

Salmon Creek Reservoir: reservoir, $1 \mathrm{mi}$. long, fed by Salmon Creek, 1 mi. S of Blackerby Ridge and $2.7 \mathrm{mi}$. N of Juneau, Coast Mts.; $58^{\circ} 20^{\prime} 30^{\prime \prime} \mathrm{N}, 134^{\circ} 24^{\prime} 20^{\prime \prime} \mathrm{W}$; (map 11).

The name was derived from Salmon Creek and was published by USGS in 1962 . Power from this reservoir, built in 1915, supplies electricity to Juneau (DeArmond, 1957, p. 37).

Salmon Falls: waterfalls, see Brooks Falls.

Salmon Flats: tidal fats, $5 \mathrm{mi}$. across, near head of Kvichak Bay, 6 mi. NW of Naknek, Bristol Bay Low.; $58^{\circ} 50^{\prime} \mathrm{N}, 157^{\circ} 04^{\prime} \mathrm{W}$; (map 41).

Local name reported in 1952 by USGS.

Salmonfoot Creek: stream, flows $\mathrm{N} 5 \mathrm{mi}$. to East Fork Chena River, $64 \mathrm{mi}$. SW of Circle, Yukon-Tanana High.; $65^{\circ} 02^{\prime} 45^{\prime \prime} \mathrm{N}, 145^{\circ} 12^{\prime}$ 45" W; (map 104).

Named by prospectors and reported in 1911 by USGS (Prindle, 1913, pl. 1).

Salmon Fork: stream, flows $5 \mathrm{mi}$. NE and SE, joins Cold Creek to form Carlson Creek, on Taku Inlet, $4 \mathrm{mi}$. NW of Sunny Cove and $9 \mathrm{mi}$. E of Juneau, Coast Mts. ; $58^{\circ} 20^{\prime} 15^{\prime \prime} \mathrm{N}$, $134^{\circ} 14^{\prime} 00^{\prime \prime} \mathrm{W}$; (map 11$)$.

Local name published in 1951 by USGS.

Salmon Fork: stream, see Black River.

Salmon Fork Black River: stream, heads at $66^{\circ} 53^{\prime} \mathrm{N}, 140^{\circ} 00^{\prime} \mathrm{W}$ in Canada, flows SW $90 \mathrm{mi}$. to Black River, $2 \mathrm{mi}$. SW of Salmon Village and $32 \mathrm{mi}$. SE of Chalkyitsik, Porcupine Plat.; $66^{\circ} 33^{\prime} \mathrm{N}, 142^{\circ} 32^{\prime} \mathrm{W}$; BGN 1959; (map 120). Var. Black River, Salmon River. Local name reported in 1956 by $R$. C. Foley, USGS. The name "Black River" was applied in 1910 by the IBC survey.

Salmon Island: island, $4.5 \mathrm{mi}$. long, at mouth of Innoko River, between Red Wing Slough and Yukon River, $1.5 \mathrm{mi}$. SE of Holy Cross, Innoko Low.; $62^{\circ} 10^{\prime} \mathrm{N}, 159^{\circ} 42^{\prime} \mathrm{W}$; (map 78).

Local name reported in 1916 by G. L. Harrington and R. H. Sargent (in Harrington, 1918, pl. 1), USGS.

Salmon Lagoon: lagoon, $1 \mathrm{mi}$. across, $1.5 \mathrm{mi}$. NW of North Head, on E coast of Kiska I., Aleutian Is.; $51^{\circ} 59^{\prime} 50^{\prime \prime} \mathrm{N}, 177^{\circ} 33^{\prime} 30^{\prime \prime} \mathrm{E}$; $B G N$ 1937; (map 14).

Name published on a 1905 USC\&GS chart.
Salmon Lake: lake, near center of Prince of Wales I., 15 mi. E of Klawock, Alex. Arch.; $55^{\circ} 34^{\prime} 30^{\prime \prime} \mathrm{N}, 132^{\circ} 40^{\prime} 30^{\prime \prime} \mathrm{W}$; (map 4).

Local name reported in 1905 by Wright and Wright (1908, fig. 15), USGS.

Salmon Lake: lake, $0.8 \mathrm{mi}$. long, on Salmon Creek, $9 \mathrm{mi}$. SE of Sitka, on central Baranof 1 ., Alexander Arch.; $55^{\circ} 57^{\prime} 45^{\prime \prime} \mathrm{N}, 134^{\circ} 08^{\prime} 45^{\prime \prime}$ W; (map 6).

Local name recorded in 1951 by USGS.

Salmon Lake: lake, $1 \mathrm{mi}$. long, in course of Salmon Creek, on Baranof I., $9 \mathrm{mi}$. SE of Sitka, Alex. Arch.; 56 $58^{\prime}$ N, $135^{\circ} 09^{\prime}$ W; (map 5).

Local name published by Knopf (1912, fig. 5), USGS.

Salmon Lake: lake, $4 \mathrm{mi}$. long, at head of Pilgrim River, $29 \mathrm{mi}$. NW of Solomon, Seward Penin. High.; $64^{\circ} 55^{\prime} \mathrm{N}, 165^{\circ} 00^{\prime} \mathrm{W}$; (map 95). Var. Nahwazúk.

Local name reported in 1900 by $E$. C. Barnard (in Brooks, 1901, pl. 17), USGS. Barnard also noted the Eskimo name is "Nahwazúk" meaning "salmon."

Salmon Lake: lake, see Bear Lake.

Salmon Mountain: mountain, 4,540 ft., $12 \mathrm{mi}$. $S$ of Tetsyeh Mtn. and $23 \mathrm{mi}$. NE of Arctic Village, Brooks $\mathrm{Ra}$; $68^{\circ} 19^{\prime} \mathrm{N}, 144^{\circ} 47^{\prime} \mathrm{W}$; (map 136).

Local name reported in 1956 by R. C. Foley, USGS.

Salmon Pass: pass, $360 \mathrm{ft}$., $2.5 \mathrm{mi}$. NW of Kiska Harbor, central Kiska I., Aleutian Is.; $52^{\circ} 00^{\prime}$ $10^{\prime \prime} \mathrm{N}, 177^{\circ} 30^{\prime} 50^{\prime \prime} \mathrm{E}$; (map 14).

One of many arbitrary names applied to features on Kiska I. by USAAF for tactical purposes during World War II.

Salmon Point: point of land, on $\mathrm{W}$ bank of Portland Canal, $1.5 \mathrm{mi} \mathrm{S}$ of Hyder, Coast

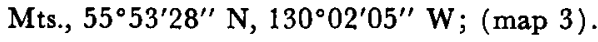
Name published in 1891 by USC\&GS.

Salmon Ridge: ridge, $2 \mathrm{mi}$. long, extends $\mathrm{S}$ from Observation Peak to Juneau Ridge, 4 mi. NE of Juneau, Coast Mts.; $58^{\circ} 20^{\prime} 30^{\prime \prime} \mathrm{N}$, $134^{\circ} 20^{\prime} 45^{\prime \prime} \mathrm{W}$; (map 11).

Local name reported in 1965 by D. A. Brew and A. B. Ford, USGS.

Salmon River: stream, heads at Salmon Glacier in British Columbia, Canada, flows S $14 \mathrm{mi}$., across the Alaska-Canada boundary to Portland Canal, Coast Mts. ; $55^{\circ} 54^{\prime} \mathrm{N}, 130^{\circ} 01^{\prime} \mathrm{W}$; (map 3).

Named in 1868 by Staff Comdr. David Pender, RN.

Salmon River: stream, $0.3 \mathrm{mi}$. long, between Pavlof Harbor and Pavlof Lake, on SW shore of Freshwater Bay, Chichagof I., Alex. Arch.; $57^{\circ} 50^{\prime} 25^{\prime \prime} \mathrm{N}, 135^{\circ} 01^{\prime} 40^{\prime \prime} \mathrm{W}$; (map 9).

Named by Comdr. R. W. Meade, USN; published in 1869 on Hydrog. Chart 225. Name not shown on recent maps.

Salmon River: stream, heads in Glacier Bay National Monument, flows $13 \mathrm{mi}$. S to Icy Passage at Gustavus, $48 \mathrm{mi}$. NW of Jùneau, St. Elias Mts.; $58^{\circ} 24^{\prime} \mathrm{N}, 135^{\circ} 44^{\prime} \mathrm{W}$; (map 11).

Named in 1902 by E. F. Dickins, USC\&GS.
Salmon River: stream, flows SW 9 mi. to Kuskokwim Bay, $21 \mathrm{mi}$. NE of Cape Newenham, Kilbuck-Kuskokwim Mts.; $58^{\circ} 52^{\prime} \mathrm{N}, 161^{\circ} 46^{\prime} \mathrm{W}$; $B G N$ 1938; (map 39).

Local name published in 1933 by USGS. The valley of this river and its tributaries has been the site of much mining activity since platinum was discovered on Fox Gulch in 1926.

Salmon River: stream, heads in Kilbuck Mts. and flows NE $40 \mathrm{mi}$. to Aniak River $37 \mathrm{mi}$. SE of Aniak, Kilbuck-Kuskokwim Mts.; $61^{\circ}$ $04^{\prime} \mathrm{N}, 159^{\circ} 11^{\prime} \mathrm{W}$; (map 73).

Prospectors' name shown on a 1914 field sheet by A. G. Maddren, USGS.

Salmon River: stream, in Baird Mts., flows S $60 \mathrm{mi}$. to Kobuk River $2 \mathrm{mi}$. SW of its junc. with Tutksuk River, $24 \mathrm{mi}$. NE of Kiana, Brooks Ra.; $67^{\circ} 09^{\prime}$ N, $159^{\circ} 27^{\prime} \mathrm{W}$; (map 127). Var. Kal-la-gu-nick.

In 1885, Lt. Stoney (1900, map), USN, reported the name for this stream as "Salmon or Kal-la-gu-nick River" (Eskimo, probably meaning "Salmon").

Salmon River: stream, see Black River.

Salmon River: stream, see Getmuna Creek.

Salmon River: stream, see Salmon Fork Black River.

Salmon River: stream, see Sheenjek River.

Salmon River: stream, see Tsirku River.

Salmon River: watercourse, in distributary system of South Fork Kuskokwim River, flows N and W $30 \mathrm{mi}$. to Pitka Fork $6 \mathrm{mi}$. SE of its junc. with Middle Fork Kuskokwim River, 33 mi. SE of McGrath, Kuskokwim Low.; $62^{\circ}$ $53^{\prime} 30^{\prime \prime} \mathrm{N}, 154^{\circ} 34^{\prime} 20^{\prime \prime} \mathrm{W}$; (map 80).

Local name reported in 1940 by USGS.

Salmon River Village: fish camp, see Salmon Village.

Salmon Run: estuary, arm of Sanborn Harbor, Nagai I., in Shumagin Is., Aleutian Ra.; (map 28).

Named in 1872 by W. H. Dall, USC\&GS, but not identified on available sources.

Salmon Slough: stream, flows E $1 \mathrm{mi}$. to Salmon Fork Black River, $36 \mathrm{mi}$. SE of Chalkyitsik, Porcupine Plat.; $66^{\circ} 29^{\prime} \mathrm{N}, 142^{\circ} 30^{\prime} \mathrm{W}$; (map 120).

Local name obtained in 1956 by T. E. Taylor and R. C. Foley, USGS.

Salmon Trout River: stream, flows NE then NW $50 \mathrm{mi}$. to Porcupine River at Old Camp, 31 mi. NE of Coleen Mtn., Porcupine Plat.; $67^{\circ}$ $10^{\prime} \mathrm{N}, 141^{\circ} 40^{\prime} \mathrm{W}$; (map 121). Var. Salmontrout River.

Name reported in 1895 by USC\&GS. "During the days of the Hudson's Bay post at Old Rampart, this river was said to be one of the best fishing streams in the district" (FitzGerald, 1944, p. 232).

Salmon Village: fish camp, $2 \mathrm{mi}$. $\mathrm{N}$ of junc. of Black River with its Salmon Fork, $35 \mathrm{mi}$. SE of Chalkyitsik, Porcupine Plat.; $66^{\circ} 34^{\prime} \mathrm{N}$, $142^{\circ} 33^{\prime} \mathrm{W}$; (map 120). Var. Salmon, Salmon River Village.

Local name reported in 1940 by FitzGerald (1944, pl. 18), USGS. 
Salmon Village: settlement, $1 \mathrm{mi}$. $\mathrm{S}$ of Vacahanyande Mtn. and $33 \mathrm{mi}$. SE of Chalkyitsik, Porcupine Plat.; $66^{\circ} 34^{\prime} \mathrm{N}, 142^{\circ} 33^{\prime} \mathrm{W}$; (map 120). Var. Salmon.

Indian settlement listed in the 1930 Census with a population of $30 ; 5$ in 1939 .

Salmo Point: point of land, at $\mathbf{N}$ tip of Hawkins I., $5 \mathrm{mi}$. $\mathrm{N}$ of Cordova, Chugach Mts.; $60^{\circ} 37^{\prime}$ $\mathrm{N}, 1^{\circ} 45^{\circ}$ ' W; (map 64). Var. Hawkins Point.

Named in 1898 by Capt. Abercrombie (1900, p. 15), USA, for his little steam vessel Salmo.

Salmo Rock: rock, in Cook Inlet, $3.5 \mathrm{mi}$. SW of Kenai, Cook Inlet Low.; $60^{\circ} 31^{\prime} 20^{\prime \prime} \mathrm{N}$, 151 '21'10" W; BGN 1906; (map 62).

Name reported in 1905 by USC\&GS.

Salonie Creek: stream, flows NE $9 \mathrm{mi}$. to head of Womens Bay, 8.5 mi. SW of Kodiak, Kodiak I.; $57^{\circ} 41^{\prime} 55^{\prime \prime} \mathrm{N}, 152^{\circ} 33^{\prime} 25^{\prime \prime} \mathrm{W}$; (map 34).

Russian name meaning "salon" published in 1949 by USGS.

Saloon Island: island, in Yukon River, $1.3 \mathrm{mi}$. long, $26 \mathrm{mi}$. SE of Fort Yukon, Yukon Flats; $66^{\circ} 14^{\prime} 30^{\prime \prime} \mathrm{N}, 144^{\circ} 43^{\prime} 00^{\prime \prime} \mathrm{W}$; (map 119).

Local name obtained in 1956 by USGS.

Salt Chuck: village, pop. 10, on $\mathbf{E}$ coast of Prince of Wales I., at head of Kasaan Bay, Alex. Arch.; $55^{\circ} 37^{\prime} 40^{\prime \prime} \mathrm{N}, 132^{\circ} 33^{\prime} 10^{\prime \prime} \mathrm{W}$; (map 4).

Local name published in 1943 by USC\&GS ; "chuck" is a Chinook jargon word meaning "water." According to E. L. Keithahn of the Alaska Historical Library and Museum, this word is usually applied to "a salt lake that fills at high tide, sometimes with a bore, and empties or partly empties at low tide with a reverse bore or sometimes 'falls.' A strong or dangerous chuck is sometimes called skookum chuck; 'skookum' meaning 'strong.' "

Salt Chuck: lagoon, $2.5 \mathrm{mi}$. long, at head of North Arm Duncan Canal, on Kupreanof I., Alex. Arch.; $56^{\circ} 53^{\prime} \mathrm{N}, 133^{\circ} 20^{\prime} \mathrm{W}$; (map 6).

Local name recorded in 1951 by USGS. See Salt Chuck, village.

Salt Chuck, The: lagoon, $1.5 \mathrm{mi}$. long, at head of Hobart Bay, $1.5 \mathrm{mi}$. NW of Entrance I. and $82 \mathrm{mi}$. E of Sitka, Coast Mts.; $57^{\circ} 27^{\prime}$ $\mathrm{N}, 133^{\circ} 20^{\prime} \mathrm{W}$; (map 8).

Local name reported in 1955 by USGS. See Salt Chuck, village.

Salt Creek: stream, flows $2.5 \mathrm{mi}$. E to Bering Sea, on $\mathrm{N}$ coast of Kiska I., Aleutian Is.; $52^{\circ} 05^{\prime} 35^{\prime \prime} \mathrm{N}, 177^{\circ} 40^{\prime} 20^{\prime \prime} \mathrm{E}$; (map 14).

An arbitrary name beginning with " $S$ " to correspond to " $\mathrm{S}$ " grid used by the U.S. Army for tactical purposes during World War II; published on a 1953 AMS map.

Salt Creek: stream, heads at $57^{\circ} 39^{\prime} 20^{\prime \prime} \mathrm{N}$, $152^{\circ} 34^{\prime} 03^{\prime \prime} \mathrm{W}$, flows E $3 \mathrm{mi}$. to $\mathrm{SW}$ end of Middle Bay, $11 \mathrm{mi}$. SW of Kodiak, Kodiak I.; $57^{\circ} 39^{\prime} 12^{\prime \prime} . \mathrm{N}, 152^{\circ} 31^{\prime} 02^{\prime \prime} \mathrm{W}$; BGN 1966; (map 34).

Local name reported in 1966 by the Alaska State Geographic Board.

Salt Creek: stream, in Nutzotin Mts., flows S 1 mi. to Chathenda Creek $5 \mathrm{mi}, \mathrm{E}$ of its junc. with Chisana River, Alaska Ra.; 62 $04^{\prime} 25^{\prime \prime}$ $\mathrm{N}, 141^{\circ} 56^{\prime} 00^{\prime \prime} \mathrm{W}$; (map 84).

Local name reported by USGS in 1960 . Salt Creek: stream, partially ditched, flows SE $2.4 \mathrm{mi}$. to Trail Creek $0.5 \mathrm{mi}$. NE of that stream's junc. with Boulder Creek and $27 \mathrm{mi}$. $\mathrm{E}$ of Tanana, Yukon-Tanana High.; $65^{\circ} 08^{\prime}$ $30^{\prime \prime} \mathrm{N}, 151^{\circ} 09^{\prime} 30^{\prime \prime} \mathrm{W}$; (map 106).

Local name reported in 1952 by USGS.

Salt Creek: stream, on coast of Beaufort Sea, between Drew and Pitt Points, Arctic Plain; (map 148).

This name appears on P. W. Dease and Thomas Simpson's 1843 map. See McLeod, Point.

Salt Creek: stream, flows $\mathbf{N}$ to Arctic River, about $5 \mathrm{mi}$. E of Ear Mtn. and $45 \mathrm{mi}$. NE of Teller, Seward Penin. High.; (map 111).

Prospectors' name reported on a precinct map of Seward Peninsula gold fields by Monroe and Hutchins, corrected up to June 1903 by Arthur Gibson. This feature cannot be precisely identified on current maps.

Saltery Bay: estuary, $3 \mathrm{mi}$. long, on S shore of Tenakee Inlet, on Chichagof I., $7 \mathrm{mi}$. W of Tenakee Springs, Alex. Arch.; $57^{\circ} 46^{\prime} \mathrm{N}$, $135^{\circ} 25^{\prime} \mathrm{W}$; BGN 1929; (map 9).

Named in 1929 by USFS because "a saltery is located there."

Saltery Cove: bight, $3 \mathrm{mi}$. across, on $\mathrm{N}$ shore of Ugak Bay, on E coast of Kodiak I. ; $57^{\circ} 30^{\prime} \mathrm{N}$, $152^{\circ} 45^{\prime} \mathrm{W}$; (map 34).

Name derived from Saltery Creek; published in 1943 by USC\&GS.

Saltery Cove: cove, extends SE $1.5 \mathrm{mi}$. off Skowl Arm Kasaan Bay, on $E$ coast of Prince of Wales I. E of McKenzie Inlet, Alex. Arch.; $55^{\circ} 25^{\prime} \mathrm{N}, 132^{\circ} 20^{\prime} \mathrm{W}$; (map 4).

Navigators' name reported in 1904 by $\mathrm{H}$. C. Fassett, USBF; so called because "a small saltery is located in the cove."

Saltery Creek: stream, flows S $3 \mathrm{mi}$. to Saltery Cove in Ugak Bay, on $\mathbf{E}$ coast of Kodiak I.; $57^{\circ} 30^{\prime} 25^{\prime \prime} \mathrm{N}, 152^{\circ} 44^{\prime} 35^{\prime \prime} \mathrm{W}$; BGN 1933; (map 34).

Local name reported in 1933 by Gerald FitzGerald, USGS, "because for many years a salmon saltery was situated at the mouth of the creek."

Saltery Point: point of land, on $\mathrm{W}$ coast of Prince of Wales I., in Sukkwan Strait, $1.6 \mathrm{mi}$. $\mathrm{SE}$ of Hydaburg, Alex. Arch.; 55 $5^{\circ} 11^{\prime} \mathrm{N}, 132^{\circ}$ 48' W; (map 4).

Named in 1924 by USC\&GS because of "a nearby salmon saltery ***."

Saltery River: stream, on Chichagof I., heads $3 \mathrm{mi}$. N of Big Chief Mtn., flows NW $5 \mathrm{mi}$. to Stag Bay, $18 \mathrm{mi}$. NW of Chichagof, Alex. Arch.; $57^{\circ} 54^{\prime} 07^{\prime \prime} \mathrm{N}, 136^{\circ} 16^{\prime} 10^{\prime \prime} \mathrm{W}$; $B G N$ 1960; (map 9).

So named by USGS in 1955 because "a saltery for preserving fish once existed near the mouth of the river."

Salthidak, Ostrov: island, see Sitkalidak Island. Salt Island: island, $1.3 \mathrm{mi}$. long, off Banner B ay, on $\mathrm{N}$ coast of Atka I., Aleutian Is.; $52^{\circ} 10^{\prime} 30^{\prime \prime}$ N, $174^{\circ} 38^{\prime} 00^{\prime \prime} \mathrm{W}$; (map 18). Var. Salennoj, Soleni, Solenoi, Solney.
Translated from the Russian-French names "Soleni ile" and "Soleny ile," or "Salt Island," published by Capt. Lutke (1836, p. 310), IRN.

Salt Jacket River: stream, see Salcha River.

Salt Lagoon: estuary, $1.2 \mathrm{mi}$. long, at head of George Inlet, on Revillagigedo I., Alex. Arch.; $55^{\circ} 31^{\prime} 30^{\prime \prime} \mathrm{N}, 131^{\circ} 26^{\prime} 45^{\prime \prime} \mathrm{W}$; (map 3).

Local navigators' name obtained in 1904 by H. C. Fassett, USBF.

Salt Lagoon: lagoon, $1.5 \mathrm{mi}$. long, at head of Seclusion Harbor, on E coast of Kuiu I., 18 mi. NW of Point Baker, Alex. Arch.; 56 $33^{\prime}$ $40^{\prime \prime} \mathrm{N}, 133^{\circ} 55^{\prime} 00^{\prime \prime} \mathrm{W}$; (map 6).

Local name recorded in 1948 by USGS.

Salt Lagoon: lagoon, $0.2 \mathrm{mi}$. across, on $\mathrm{E}$ coast of Baranof I., at head of Warm Spring Bay, $\mathrm{S}$ of Baranof, Alex. Arch.; $57^{\circ} 05^{\prime} 00^{\prime \prime} \mathrm{N}, 134^{\circ}$. $49^{\prime} 50^{\prime \prime} \mathrm{W}$; (map 9).

Local descriptive name reported in 1951 by USGS.

Salt Lagoon: lagoon, $0.6 \mathrm{mi}$. across, on $\mathrm{S}$ penin. of St. Paul I., Pribilof Is.; $57^{\circ} 08^{\prime} 10^{\prime \prime} \mathrm{N}$, $170^{\circ} 16^{\prime} 20^{\prime \prime} \mathrm{W}$; (map 38). Var. Lagoon Lake.

This feature was called "Lagoon Lake" by Elliott (1881, Saint Paul map).

Salt Lake: lagoon, $0.2 \mathrm{mi}$. across, at mouth of Peterson Creek, at Eagle Harbor, on Favorite Ghannel, $0.3 \mathrm{mi}$. $\mathrm{N}$ of Dotsons Landing and $19 \mathrm{mi}$. NW of Juneau, Coast Mts. ; $58^{\circ} 29^{\prime} 40^{\prime \prime}$ $N, 134^{\circ} 47^{\prime} 10^{\prime \prime} \mathrm{W}$; (map 11).

Name first appeared in records in 1902, when W. N. Lazier claimed a trade and manufacturing site on the lake (DeArmond, 1957, p. 37,38 ). Name was published in 1925 by USC\&GS.

Salt Lake: lake, 2 mi. across, on $\mathrm{W}$ central Admiralty I. $9.5 \mathrm{mi}$. NE of Angoon, Alex. Arch.; $57^{\circ} 34^{\prime} 20^{\prime \prime} \mathrm{N}, 134^{\circ} 22^{\prime} 00^{\prime \prime} \mathrm{W}$; (map 9).

Local descriptive name reported in 1951 by USGS.

Salt Lake: lake, $0.2 \mathrm{mi}$. long, on NW coast of Woody I., $2.3 \mathrm{mi}$. E of Kodiak, Kodiak I.; $57^{\circ} 47^{\prime} 30^{\prime \prime} \mathrm{N}, 152^{\circ} 20^{\prime} 30^{\prime \prime} \mathrm{W}$; (map 34).

Descriptive local name published in 1943 by USC\&GS.

Salt Lake: lake, see Imuruk Basin.

Salt Lake Bay: bay, $2 \mathrm{mi}$. long, W coast of Prince of Wales I., Alex. Arch.; 55 $41^{\prime}$ N, $133^{\circ} 22^{\prime} \mathrm{W}$; (map 4).

Descriptive name given in 1914 by USC\&GS.

Salt Lake Bay: bay, $0.6 \mathrm{mi}$. across, on $\mathrm{S}$ shore of Port Frederick, $13 \mathrm{mi}$. SW of Hoonah, on $\mathrm{N}$ central Chichagof I., Alex. Arch.; $57^{\circ} 58^{\prime}$. $30^{\prime \prime} \mathrm{N}, 135^{\circ} 39^{\prime} 30^{\prime \prime} \mathrm{W}$; (map 9).

Local name published by USC\&GS in 1943 Coast Pilot (p. 418).

Salt Lake Bay: bay, 2 mi. across, on Chichagof I., at SW end of Port Frederick, $4 \mathrm{mi}$. SW of Neka Bay and $13 \mathrm{mi}$. SW of Hoonah, Alex. Arch.; $58^{\circ} 00^{\prime} \mathrm{N}, 135^{\circ} 44^{\prime} \mathrm{W}$; (map 11).

Local name published in 1951 by USGS.

Salt Point: point of land, S entrance to Dakaneek Bay, $9.5 \mathrm{mi}$. SE of Kake, on $W$ coast of Kupreanof I., Alex. Arch.; 56 $50^{\prime} 40^{\prime \prime} \mathrm{N}$, $133^{\circ} 51^{\prime} 50^{\prime \prime} \mathrm{W}$; (map 6). 
Local name published in 1943 by USC\&GS. Saltshatsheg River: stream, see Salcha River.

Salt Water Lagoon: lagoon, $1 \mathrm{mi}$. long, E end of Tunga Inlet, W coast of Prince of Wales I., Alex. Arch.; $55^{\circ} 58^{\prime} 10^{\prime \prime} \mathrm{N}, 133^{\circ} 14^{\prime} 20^{\prime \prime} \mathrm{W}$; (map 4).

Local name recorded in 1949 by USGS.

Salt Water Lagoon: water passage, see Tunga Inlet.

Salty Cape: point of land, see Aspid Cape.

Saluluktussich: island, see Saüluktoucikh.

Samalga Island: island, $4.2 \mathrm{mi}$. long, $W$ end of Fox Is., Aleutian Is.; $52^{\circ} 47^{\prime} \mathrm{N}, 169^{\circ} 12^{\prime} \mathrm{W}$; (map 21).

Aleut name published by Lt. Sarichev (1826, map 3), IRN, as "O[strov] Samalga," or "Samalga Island." Father Veniaminov (1840, v. 1, p. 157) reported that in 1764 there was a settlement on this island containing not less than 400 people.

Samalga Pass: water passage, between Samalga and Chuginadak Is., Aleutian Is.; $52^{\circ} 47^{\prime} \mathrm{N}$, $169^{\circ} 28^{\prime} \mathrm{W}$; (map 21$)$.

Name derived from Samalga Island; published by USC\&GS in 1947 Coast Pilot (p. 423).

Samaloch-kiya: ridge, see Samalogh Ridge.

Samalogh-kiya: ridge, see Samalogh Ridge.

Samalogh Ridge: ridge, $658 \mathrm{ft}$., $0.7 \mathrm{mi}$. long, on $W$ end of St. George I., in Pribilof Is.; 56 $36^{\prime}$ $\mathrm{N}, 169^{\circ} 44^{\prime} \mathrm{W}$; (map 38). Var. Samalochkiya, Samalogh-kiya.

Aleut name given by Putnam (1903, p. 1015), USC\&GS, as "Samaloch-kiya," meaning "ridge where eggs are gathered * * * the bluffs at each end of this ridge are covered with myriads of birds ** *."

Samatra Creek: stream, see Sumatra Creek.

Sam Charley Island: island, $1.3 \mathrm{mi}$. across, in Tanana River, $16 \mathrm{mi}$. SW of Fairbanks, Tanana Low.; $64^{\circ} 43^{\prime} \mathrm{N}, 148^{\circ} 10^{\prime} \mathrm{W}$; (map 100).

Local name reported in 1950 by USGS topographers.

Sam Creek: locality, site of landing and winter trail cabin, on $\mathbf{S}$ bank of Yukon River, at mouth of Sam Creek, $49 \mathrm{mi}$. SE of Circle, Yukon-Tanana High.; $65^{\circ} 19^{\prime} \mathrm{N}, 142^{\circ} 52^{\prime} \mathrm{W}$; (map 103).

Published in 1951 by USGS.

Sam Creek: stream, flows S $6 \mathrm{mi}$. to Kanektok River, $55 \mathrm{mi}$. NE of Goodnews, KilbuckKuskokwim Mts. ; $59^{\circ} 48^{\prime} \mathrm{N}, 160^{\circ} 45^{\prime} \mathrm{W}$; (map 53).

Local name published in 1951 by USGS.

Sam Creek: stream, flows NW $5 \mathrm{mi}$. to Tanana River, $48 \mathrm{mi}$. NW of Tok, Alaska Ra.; $63^{\circ}$ $42^{\prime} 10^{\prime \prime} \mathrm{N}, 144^{\circ} 18^{\prime} 30^{\prime \prime} \mathrm{W}$; BGN 1961; (map 86).

Local name reported in 1958 by R. E. Isto, USGS.

Sam Creek: stream, flows NE $18 \mathrm{mi}$. to Yukon River $3 \mathrm{mi}$. W of junc. of Charley River, Yukon-Tanana High.; $65^{\circ} 19^{\prime} \mathrm{N}, 142^{\circ} 52^{\prime} \mathrm{W}$; (map 103).

Prospectors' name from a fieldsheet prepared in 1902 by A. J. Collier, USGS ; also re- corded the same year by Lt. Hjalmar Erickson, USA, and William Yanert.

Sam Creek: stream, in Ray Mts., flows S $9 \mathrm{mi}$. to Tozitna River, $9 \mathrm{mi}$. SSW of Mount Tozi and $40 \mathrm{mi}$. NE of Tanana, Kokrines-Hodzana High.; $65^{\circ} 34^{\prime} 00^{\prime \prime} \mathrm{N}, 151^{\circ} 04^{\prime} 30^{\prime \prime} \mathrm{W}$; (map 106).

Named in 1956 by Don Orth, for Sam Stulberg, USGS, who made field surveys in the area that season.

Samdan: locality, see Sumdum.

Samganooda Bay: bay, see English Bay.

Samganoodha Bay: bay, see English Bay.

Samganuda Bay: bay, see English Bay.

Samla'logh-chuka': depression, on bluff line $1.2 \mathrm{mi}$. W of High Bluffs, on NW coast of Saint George I., in Pribilof Is.; 56 $6^{\circ} 36^{\prime} 35^{\prime \prime}$ $\mathrm{N}, 169^{\circ} 42^{\prime} 30^{\prime \prime} \mathrm{W}$; (map 38).

Aleut name reported by Putnam (1903, p. 1015), USGS, as "Samla'logh-chuka" meaning "hollow where eggs are gathered *** remarkable depression *** natives let themselves down with ropes over the edge of this bluff to gather birds' eggs."

Sammy Creek: stream, flows SW $3.5 \mathrm{mi}$. to Squaw Lake, $11 \mathrm{mi}$. NE of Chandalar, Brooks Ra.; $67^{\circ} 36^{\prime} 30^{\prime \prime} \mathrm{N}, 148^{\circ} 10^{\prime} 00^{\prime \prime} \mathrm{W}$; (map 123). Local name reported in 1956 by T. E. Taylor, USGS.

Samoi Islands: islands, see Scraggy Islands.

Samoilof Islands : islands, see Scraggy Islands.

Samovar Hills: mountain range, 6,000 ft., extends $12 \mathrm{mi}$. E-W between Agassiz, Seward, and Malaspina Glacers, $55 \mathrm{mi}$. NW of Yakutak, St. Elias Mts.; $60^{\circ} 10^{\prime} \mathrm{N}, 140^{\circ} 41^{\prime} \mathrm{W}$; (map 66).

Named by I. C. Russell in 1890. A samovar is a Russian urn used for heating water to make tea.

Samoylov, Ostrov: islands, see Scraggy Islands. Sam Patch Creek: stream, flows SE $5 \mathrm{mi}$. to Fortymile River, $35 \mathrm{mi}$. S of Eagle, YukonTanana High.; $64^{\circ} 19^{\prime} \mathrm{N}, 141^{\circ} 01^{\prime} \mathrm{W} ; B G N$ 1912; (map 192). Var. Patch Creek, Uncle Sam Creek.

Named in 1907 by IBC surveyors for Samuel Patch, 1807-29, a diving champion of his era. Called "Uncle Sam Creek" by prospectors; reported in 1898 by E. C. Barnard, USGS. See Liberty Fork.

Sam Peak: mountain, 2,416 ft., on E coast of Mitkof I., $11 \mathrm{mi}$. NW of Wrangell, Alex. Arch.; $56^{\circ} 34^{\prime} 50^{\prime \prime} \mathrm{N}, 132^{\circ} 37^{\prime} 00^{\prime \prime} \mathrm{W}$; (map 6).

Named in 1887 by Lt. Comdr. C. M. Thomas, USN, for charting purposes; published in 1888 on USC\&GS Chart 705.

Sampson Creek: stream, flows NW $2.4 \mathrm{mi}$. to Nome River, $16 \mathrm{mi}$. NE of Nome, Seward Penin. High.; $64^{\circ} 44^{\prime} \mathrm{N}, 165^{\circ} 18^{\prime} \mathrm{W}$; (map 94).

Local name published in 1900 by USC\&GS on Chart 9380. Name commemorates Rear Adm. William Thomas Sampson, 1840-1902, USN, who during the Spanish-American War, had active command of various functions including the investigation of the sinking of the U.S.S. Maine.
Sampson Creek: stream, flows SE to Snowshoe Creek which flows to Cripple River, about 33 mi. NW of Nome, Seward Penin. High.; (map 94).

Prospectors' name reported on the 1900 "Map of Nome Peninsula" by J. M. Davidson and B. D. Blakeslee; this feature has not been positively identified.

Sams Big Lake: lake, $0.7 \mathrm{mi}$. across, $19 \mathrm{mi}$. NW of Chalkyitsik, Yukon Flats; $66^{\circ} 55^{\prime} \mathrm{N}, 143^{\circ}$ 52' W; (map 120).

Local name obtained in 1956 by T. E. Taylor and R. C. Foley, USGS.

Samsing Cove: $b a y, 0.6 \mathrm{mi}$. across, $5 \mathrm{mi} . \mathrm{S}$ of Sitka, on W coast of Baranof I., Alex. Arch.; $56^{\circ} 59^{\prime} \mathrm{N}, 135^{\circ} 21^{\prime} \mathrm{W}$; (map 6).

Local fishermen's name reported in 1947 by USC\&GS.

Samuel, Point: point of land, on $\mathrm{W}$ coast of Killisnoo I., $2.5 \mathrm{mi}$. SW of Angoon, off W coast of Admiralty I., Alex. Arch.; 57 $28^{\prime} 15^{\prime \prime}$ N, $134^{\circ} 36^{\prime} 30^{\prime \prime}$ W; (map 9). Var. Samuels Point.

Named in 1794 by Capt. George Vancouver, RN, for Samuel Hood, 1724-1816, First Viscount and an English admiral. The point was discovered by Lt. Joseph Whilbey, RN, of Capt. Vancouver's party about July 21, 1794 (Wagner, 1937, p. 407).

Samuels Point: point of land, see Samuel, Point. Sam White Lake: lake, oxbow lake, $28 \mathrm{mi}$. SW of Roundabout Mtn., Koyukuk Low.; $65^{\circ} 27^{\prime}$ N, $157^{\circ} 30^{\prime} \mathrm{W}$; (map 108).

Local name "for Sam White, Alaska bush pilot." Name reported in 1954 by USGS.

Sanachno, Cape: point of land, see Tatik Point. San Adrian Island: island, $800 \mathrm{ft}$. long, in Ulloa Channel, on NE coast of Suemez I., Alex. Arch.; $55^{\circ} 19^{\prime} 10^{\prime \prime} \mathrm{N}, 133^{\circ} 17^{\prime} 45^{\prime \prime} \mathrm{W}$; (map 4). Var. Islas de San Adrian, Ostrov San Adriyan.

Named "Ysla de San Adriano" by Francisco Antonio Maurelle and Don Juan de la Bodega y Quadra in 1779. This was published in Russian as "Os[trov] San Adriyan" by Lt. Sarichev (1826, map 21), IRN

San Adriyan, Ostrov: island, see San Adrian Island.

San Ageda Point: point of land, see Agueda Point.

Sanaguich River: stream, flows N $24 \mathrm{mi}$. to Shishmaref Inlet, $16 \mathrm{mi}$. SE of Shishmaref, Kotzebue-Kobuk Low.; $66^{\circ} 07^{\prime} \mathrm{N}, 165^{\circ} 07^{\prime} \mathrm{W}$; (map 112).

Eskimo name reported in 1901 by T. G. Gerdine, USGS.

San Agustin, Cabo: point of land, "in the Gulf of Esquibel at the south entrance to Bocas de Finas," Alex. Arch.; (map 4).

Name found on maps of the 1779 Arteaga expedition.

Sanak: village, pop. 39 (1940), on E shore of Sanak Harbor, on NW coast of Sanak I., Aleutian Ra.; $54^{\circ} 29^{\prime} 54^{\prime \prime} \mathrm{N}, 162^{\circ} 48^{\prime} 40^{\prime \prime} \mathrm{W}$; $B G N$ 1919; (map 25). Var. Sannak.

Aleut village reported in the 1890 Census as "Sannak," population 132 (1893, p. 163). The Sannak post office was established in 
1909; discontinued in 1953 (Ricks, 1965, p. $56)$.

Sanak Bank: shoal, $15 \mathrm{mi}$. long, $30 \mathrm{mi}$. SE of Sanak Is., Aleutian Ra.; $54^{\circ} 07^{\prime} \mathrm{N}, 161^{\circ} 20^{\prime}$ W; (map 25). Var. Sannak Bank, Sannakh Bank.

Name given in 1888 by USBF as "Sannakh Bank."

Sanak Harbor: harbor, $0.3 \mathrm{mi}$. across, on NW coast of Sanak I., Aleutian Ra.; $54^{\circ} 29^{\prime} 10^{\prime \prime} \mathrm{N}$, $162^{\circ} 49^{\prime} 10^{\prime \prime} \mathrm{W}$; BGN 1919; (map 25). Var. Acherk Harbor.

Name derived from Sanak Island and reported by USC\&GS in 1919. This harbor is shown on a sketch published by Capt. Tebenkov (1852, map 24), IRN, entitled "Ochyerk Gavanina NW Stor O[stro]va Sannakh" meaning "Sketch of the harbor in the northwest part of the island of Sannakh." The USC\&GS misinterpreted this title and published the name Acherk [sketch] Harbor on Charts 817 and 8901 in 1875.

Sanak Island: island, $13 \mathrm{mi}$. long, largest of Sanak Is., $37 \mathrm{mi}$. SE of False Pass, Aleutian Ra.; 542 $5^{\prime} \mathrm{N}, 162^{\circ} 40^{\prime} \mathrm{W}$; BGN 1919; (map 25). Var. Halibut Island, Issanak Island, Islas des Plies, Sannach Island, Sannak Island, Sannakh Island.

Aleut name published by G. A. Sarichev (1826, map 3) as "Os[trov] Sannakh," or "Sannakh Island." The name "Halibut" was given to this island by Capt. James Cook, RN (1785, v. 2, p. $416-417$ ), because his crew caught more than 100 halibut weighing from 20 to 100 pounds each, off the coast in 1778 . The island was called "Islas des Plies [pez]" meaning "islands of fish" by Don Dionisoi A. Galiano (1802, Atlas Chart 3). The name was shortened to Sanak by the U.S. Post Office Department in 1919 when it established a post office at Sanak village.

Sanak Islands: islands, in a group $21 \mathrm{mi}$. long and $8 \mathrm{mi}$. wide, $25 \mathrm{mi}$. SE of Unimak I., Aleutian Ra.; $54^{\circ} 23^{\prime} \mathrm{N}, 162^{\circ} 35^{\prime} \mathrm{W}$; (map 25). Var. Isannak Is., Sannak Is., Sannakh Is.

This group consists of two large islands (Sanak and Caton), Sanak Island being the larger of the two, and numerous small islands and rocks. These islands were reported by Capt. Cook (1785, v. 2, p. 416), RN. The name was published as "Sannakh" by 'USBF in 1888.

Sanakno, Cape: point of land, see Tatik Point. Sanak Peak: mountain, 1,740 ft., on Sanak I., Aleutian Ra.; $54^{\circ} 27^{\prime} 40^{\prime \prime} \mathrm{N}, 162^{\circ} 45^{\prime} 00^{\prime \prime} \mathrm{W}$; (map 25). Var. Halibut Head.

Name derived from Sanak Island and published by Baker (1906, p. 550). This feature was named Halibut Head by Capt. Cook (1785, v. 2, p. 415), RN.

Sanak Reef : reefs, see Sanak Reefs.

Sanak Reefs: reefs, $10 \mathrm{mi}$. long, off S coast of Sanak I., Aleutian Ra.; $54^{\circ} 20^{\prime} \mathrm{N}, 162^{\circ} 42^{\prime} \mathrm{W}$; (map 25). Var. Sanak Reef.

Name derived from Sanak Island and published by USC\&GS in 1943 as Sanak Reef. San Alberti Bay: bay, see San Alberto Bay.
San Alberto, Punta de: point of land, "the southeast point of Montague Island" opposite the Wooded Islands; (map 49).

Named about July 29, or August 1, 1779, by Don Ignacio Arteaga.

San Alberto Bay: bay, $7.5 \mathrm{mi}$. long, between Prince of Wales and San Fernando Is., Alex. Arch.; $5^{\circ} 28^{\prime}$ N, $133^{\circ} 14^{\prime}$ W; BGN 1899; (map 4). Var. Guba San Alverto, San Alberti Bay, Seno de San Alberto.

Named "Seno de San Alberto," or "Saint Albert Bay," by Francisco Antonio Maurelle "about May 24, 1779, the day he entered it" (Wagner, 1937, p. 407).

San Alverto, Guba: bay, see San Alberto Bay.

San Angel, Isla de: island, see East Chugach Island.

San Aniceto, Isla : island, see Elizabeth Island.

San Antonio, Isla: island, see Latouche Island.

San Antonio, Islas: islands, Latouche and Elrington Is. off the E coast of Kenai Penin.; (map 49).

Named by Juan y Zayas Martínez in $\mathbf{1 7 8 8 .}$ See Wagner (1937, p. 496).

San Antonio, Point: point of land, on W coast of Prince of Wales I., near $\mathbf{S}$ entrance to Ulloa Channel, Alex. Arch.; 55 $17^{\prime} 10^{\prime \prime} \mathrm{N}, 133^{\circ}$ $14^{\prime} 00^{\prime \prime}$ W; (map 4). Var. Punta de San Antonio.

Spanish name given in 1779 by Don Juan de la Bodega y Quadra and Francisco Antonio Maurelle as "Punta de San Antonio," meaning "Point of Saint Anthony."

San Antonio, Port: bay, extends NW 3 mi., off Bucareli Bay, on E coast of Baker I., Alex. Arch.; $55^{\circ} 20^{\prime} \mathrm{N}, 133^{\circ} 33^{\prime} \mathrm{W}$; (map 4). Var. Puerto de San Antonio, San Antonio Bay.

Named "Puerto de San Antonio," or "Port of Saint Anthony," on May 18, 1779, by Francisco Antonio Maurelle (Wagner, 1937, p. 407).

San Antonio, Punta de: point of land, see Maria Antonia, Punta de.

San Antonio Bay: bay, see San Antonio, Port.

San Antonio Maurelle, Cabo de: point of land, see Felix, Cape.

San Agustin, Cabo de: point of land, see Augustine, Cape.

San Agustin, Monte: mountain, see Augustine Volcano.

San Augustine, Mount: mountain, see Augustine Volcano.

San Bernabe, Cabo: point of land, see Barnabas Cape.

San Bartolome, Cabo de: point of land, see Bartolome, Cape.

San Blas Island: island, see Forrester Island.

San Bonifacio, Punta de: point of land, see Saint Boniface, Point.

San Bonifacio, Mys: point of land, see Saint Boniface, Point.

Sanborn Canal: estuary, see Sandborn Canal.

Sanborn Harbor: bay, extends SE $8 \mathrm{mi}$. inland from Pacific Ocean, on W coast of Nagai I., in Shumagin Is., Aleutian Ra.; $55^{\circ} 10^{\prime} \mathrm{N}$, $160^{\circ} 04^{\prime} \mathrm{W}$; (map 28).

Named for the schooner J. D. Sanborn commanded by Capt. William Morse, who dis- covered the harbor in 1866; published in 1872 by USC\&GS.

San Carlos, Punta de: point of land, "the south point to the entrance of Port Etches, on Hinchinbrook Island"; (map 64).

Named in July, 1779, by Don Ignacio Arteaga during his stay in Port Etches.

San Carlos Island: island, see Forrester Island. Sancho Creek: stream, see Schieffelin Creck.

San Christoval, Canal de: water passage, see San Christoval Channel.

San Christoval Channel: water passage, extends SE 6 mi., from Gulf of Esquibel to San Alberto Bay, Alex. Arch.; 55 $33^{\prime} \mathrm{N}, 133^{\circ} 20^{\prime} \mathrm{W}$; (map 4). Var. Canal de San Christoval, Canal de San Cristoval.

Named "Canal de San Cristoval," or "Saint Christopher Channel," by Francisco Antonio Maurelle on May 24, 1779, the day he passed through it (Wagner, 1937, p. 408).

San Christoval Rock: rock, between San Christoval Channel and San Alberto Bay, E of Cruz I., Alex. Arch.; 55 $33^{\prime} 50^{\prime \prime}$ N, $133^{\circ} 17^{\prime} 40^{\prime \prime}$ W; (map 4).

Taken from the Spanish name meaning "St. Christopher," published in 1917 by USC\&GS.

San Clemente Island: island, 1,600 ft. long, in Portillo Channel, between Lulu and San Fernando Is., Alex. Arch.; $55^{\circ} 28^{\prime} 25^{\prime \prime} \mathrm{N}, 1^{\circ} 3^{\circ}$. 24'30' W; BGN 1923; (map 4). Var. Clam Island, Clement Island, Clem Island, Isla San Clemente, Ostrov San Klementa, Ysla de San Clemente.

Spanish name given in 1779 by Don Juan de la Bodega y Quadra and Francisco Antonio Maurelle as "Isla San Clemente," i.e., "Saint Clement Island."

San Cosme, Punta: point of land, "in east part of Bucareli Bay, at the entrance to Trocadero Bay, on Prince of Wales Island," Alex. Arch.; (map 4).

Name found on the maps of the 1779 Arteaga expedition (Wagner, 1937, p. 498).

San Cristoval, Canal de: water passage, see San Christoval Channel.

Sanctuary River: stream, flows N $26 \mathrm{mi}$. to Teklanika River, $18 \mathrm{mi}$. SW of Healy, Alaska Ra.; $63^{\circ} 49^{\prime} \mathrm{N}, 149^{\circ} 31^{\prime} \mathrm{W}$; (map 87).

Local name shown on a 1916 fieldsheet by C. E. Giffin, USGS.

Sand Bar Creek: stream, see Duck Greek.

Sand Bay: bay, $2.5 \mathrm{mi}$. across, on $\mathrm{S}$ coast of Great Sitkin I., Aleutian Is.: $51^{\circ} 59^{\prime} \mathrm{N}, 176^{\circ}$ 08' W; BGN 1936; (map 17).

Descriptive name given by members of the U.S. Navy Aleutian Island Survey Expedition in 1933.

Sand Bay: bay, see Martin Harbor.

Sand Bay: cove, $0.5 \mathrm{mi}$. across, on $\mathrm{E}$ shore of Stephens Passage, $3 \mathrm{mi}$. S of Point Astley and $51 \mathrm{mi}$. SE of Juneau, Coast Mts.; $57^{\circ} 40^{\prime} 40^{\prime \prime}$ N, $133^{\circ} 39^{\prime} 30^{\prime \prime} \mathrm{W}$; (map 8).

Local descriptive name reported by Spencer and Wright (1906, fig. 4), USGS.

Sand Beach, The: beach, on Barlow Cove on W part of Mansfield Penin., $1.6 \mathrm{mi}$. SE of Point Retreat and $20 \mathrm{mi}$. NW of Juneau, Alex. 
Arch.; $58^{\circ} 23^{\prime} 30^{\prime \prime}$ N, $134^{\circ} 56^{\prime} 00^{\prime \prime}$ W; (map 11).

Descriptive name published in 1962 by USGS.

Sand Bluff: bluff, on left bank of Koyukuk River, $23 \mathrm{mi}$. SW of Roundabout Mtn., Koyukuk Low.; $65^{\circ} 27^{\prime} \mathrm{N}, 157^{\circ} 18^{\prime} \mathrm{W}$; (map 108).

Local name obtained at Huslia by USGS in 1954 or 1955.

Sandborn Canal: estuary, trends NW $4 \mathrm{mi}$. to Port Houghton on Stephens Passage, $80 \mathrm{mi}$. NE of Sitka, Coast Mts.; $57^{\circ} 17^{\prime} 30^{\prime \prime} \mathrm{N}, 133^{\circ}$ 15'30" W; BGN 1966; (map 8). Var. Sanborn Canal, Walter Island Arm.

Local name reported in 1961. It was called Walter Island Arm in 1954 by USGS.

Sand Creek: stream, flows E $6.5 \mathrm{mi}$. to Martin Creek, 23 mi. NW of Talkeetna, Alaska Ra.; $62^{\circ} 23^{\prime} 50^{\prime \prime} \mathrm{N}, 150^{\circ} 47^{\prime} 40^{\prime \prime} \mathrm{W}$; (map 81).

Local descriptive name reported in 1958 by USGS.

Sand Creek: stream, flows SW through Sand Lake and other lakes, $34 \mathrm{mi}$. to Tanana River, $49 \mathrm{mi}$. NW of Tok, Tanana Low.; $63^{\circ} 43^{\prime} 35^{\prime \prime}$

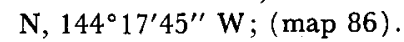

Descriptive name reported on 1907 fieldsheet by D. C. Witherspoon, USGS.

Sand Creek: stream, flows SE $9 \mathrm{mi}$. to Goodpaster River, $22 \mathrm{mi}$. NE of Big Delta, YukonTanana High.; $64^{\circ} 15^{\prime} \mathrm{N}, 145^{\circ} 09^{\prime} \mathrm{W}$; (map 101).

Named by prospectors and reported in 1908 by J. W. Bagley, USGS.

Sand Creek: stream, flows E $4 \mathrm{mi}$. to Beaver Creek, $5.5 \mathrm{mi}$. E of Victoria Mtn. and 77 mi. W of Circle, Yukon-Tanana High.; $65^{\circ}$ $47^{\prime} 30^{\prime \prime} \mathrm{N}, 146^{\circ} 42^{\prime} 30^{\prime \prime} \mathrm{W}$; (map 104).

Prospectors' name reported in 1954 or 1955 by USGS topographers.

Sanders Cape: point of land, on $\mathrm{W}$ shore of Temnac Bay, Attu I., Aleutian Is., $52^{\circ} 48^{\prime} 00^{\prime \prime}$ N, $173^{\circ} 00^{\prime} 05^{\prime \prime}$ E; (map 13). Var. Sanders Point.

Named by the U.S. Army during its occupation of the island during World War II; shown on an AMS map published in 1948.

Sanders Creek: stream, see Saunders Creek.

Sanderson Creek: stream, flows NW $5 \mathrm{mi}$. to Lignite Creek, $9 \mathrm{mi}$. NE of Healy, Alaska Ra.; $63^{\circ} 55^{\prime} 15^{\prime \prime} \mathrm{N}, 148^{\circ} 42^{\prime} 15^{\prime \prime} \mathrm{W}$; (map 87). Prospectors' name reported in 1910 by S. R. Capps (in Brooks and others, 1918, pl. 17), USGS.

Sanders Point: point of land, see Sanders Cape. Sandfly Bay: estuary, extends N $0.7 \mathrm{mi}$. off Portland Canal, $4.2 \mathrm{mi}$. SW of Halibut Bay, Coast Mts.; $55^{\circ} 09^{\prime} 30^{\prime \prime} \mathrm{N}, 130^{\circ} 09^{\prime} 00^{\prime \prime} \mathrm{W}$; (map 3).

Descriptive name given in 1868 by Staff Comdr. David Pender, RN, "for obvious reasons."

Sandford Cove: cove, see Sanford Cove.

Sand Harbor: bay, see Martin Harbor.

Sand Hill Gap: water gap, of Meadow Creek, 25 mi. W of Beaver, Yukon Flats; $66^{\circ} 19^{\prime} \mathrm{N}$, $148^{\circ} 17^{\prime} \mathrm{W}$; (map 118).

Local descriptive name obtained in 1956 by USGS.
Sand Hills: hills, $380 \mathrm{ft}$, extend NE $11 \mathrm{mi}$. from Sand Hill Gap, $18 \mathrm{mi}$. W of Beaver, Yukon Flats; $66^{\circ} 20^{\prime} \mathrm{N}, 148^{\circ} 06^{\prime} \mathrm{W}$; (map 118).

Probably named by William Yanert who showed it on a 1916 manuscript map of the Yukon Flats (Stuck, 1917, map facing p. 122).

San Diego Bay: bight, $1 \mathrm{mi}$. across, on $\mathrm{W}$ shore of Stepovak Bay, near SW end of Alaska Penin., Aleutian Ra.; $55^{\circ} 33^{\prime} 30^{\prime \prime} \mathrm{N}, 160^{\circ}$ $26^{\prime} 30^{\prime \prime} \mathrm{W}$; (map 28).

This local name was reported by Atwood (1911, pl. 2), USGS.

San Diego Island: island, see Guillemot Island.

San Dionisio, Punta: point of land, on Rita Island in Bucareli Bay," Alex. Arch.; (map 4).

Spanish name found on the maps of the 1779 Arteaga expedition (Wagner, 1937, p. 498).

Sand Island: island, $0.1 \mathrm{mi}$. across, at mouth of Hood Bay, on W coast of Admiralty I., $4 \mathrm{mi}$. $\mathrm{S}$ of Angoon, Alex. Arch.; $57^{\circ} 26^{\prime} 45^{\prime \prime} \mathrm{N}, 134^{\circ}$ $33^{\prime} 10^{\prime \prime} \mathrm{W}$; (map 9).

Descriptive name published by USC\&GS in the 1891 Coast Pilot (p. 157). "The island is low and sandy, therefore the name."

Sand Island: island, see Sumdum Island.

Sand Islands: barrier islands, consist of Krekatok and Neragon Is., extend N-S $15 \mathrm{mi}$. between Bering Sea and Scammon Bay, Yukon-Kuskokwim Delta; $61^{\circ} 59^{\prime} \mathrm{N}, 165^{\circ} 58^{\prime} \mathrm{W}$; (map 75). Var. Sandy Islands.

Named by Dall (1870, p. 263) who wrote "Seven miles off the coast are two long islands, or dry sand-bars, known as the Sandy Islands."

Sand Islands: islands, see Beardslee Islands.

Sand Lake: lake, $0.7 \mathrm{mi}$. long, $5 \mathrm{mi}$. SW of Anchorage, Cook Inlet Low. ; $61^{\circ} 09^{\prime} 06^{\prime \prime} \mathrm{N}, 149^{\circ}$ $57^{\prime} 45^{\prime \prime} \mathrm{W}$; (map 69).

Local name reported in 1942 by AMS.

Sand Lake: lake, $0.8 \mathrm{mi}$. long, $\mathrm{N}$ of Dathlalmund Lake, $19 \mathrm{mi}$. SE of Tok, Alaska Ra.; $63^{\circ} 06^{\prime}$ N, $142^{\circ} 37^{\prime} \mathrm{W}$; (map 85 ).

Local name published by USGS in 1964 .

Sand Lake: lake, $2.3 \mathrm{mi}$. long, in course of Sand Creek, $48 \mathrm{mi}$. NW of Tok, Yukon-Tanana High.; $63^{\circ} 45^{\prime} 30^{\prime \prime} \mathrm{N}, 144^{\circ} 15^{\prime} 30^{\prime \prime} \mathrm{W}$; (map 86).

Name published on relatively recent maps.

Sandless Lake: lake, $0.6 \mathrm{mi}$. long, $4.2 \mathrm{mi}$. SE of junc. of Flume Creek and Bearpaw River and $33 \mathrm{mi}$. NNE of Wonder Lake, Tanana Low.; $63^{\circ} 57^{\prime} 45^{\prime \prime} \mathrm{N}, 150^{\circ} 40^{\prime} 45^{\prime \prime} \mathrm{W}$; (map 88).

Local name reported in 1954 by USGS.

Sandman Reefs: reefs, $28 \mathrm{mi}$. long, $10 \mathrm{mi}$. S of Deer I., Aleutian Ra.; $54^{\circ} 42^{\prime} \mathrm{N}, 162^{\circ} 15^{\prime} \mathrm{W}$; (map 25).

Named for Capt. Sandman of the Alaska Commercial Company, given by W. H. Dall, USC\&GS, and published in 1882 by USC\&GS on Chart 806.

Sandpiper Lake: lake, $0.6 \mathrm{mi}$. long, on Kenai Penin., $23 \mathrm{mi}$. SW of Anchorage, Cook Inlet Low.; $61^{\circ} 00^{\prime} 15^{\prime \prime} \mathrm{N}, 150^{\circ} 24^{\prime} 25^{\prime \prime} \mathrm{W}$; (map 70).
Named about 1963 for administrative purposes by officials of the Kenai National Moose Range.

Sand Point: village, pop. 254, on Humboldt Harbor, on NW coast of Popof I., in Shumagin Is., Aleutian Ra.; $55^{\circ} 20^{\prime} 15^{\prime \prime} \mathrm{N}, 160^{\circ}$ $30^{\prime} 00^{\prime \prime} \mathrm{W}$; (map 28). Var. Sandpoint.

Fishing village which obtained a post office in 1891. Its population was 60 in 1920; 69 in 1930; 99 in 1939; and 107 in 1950.

Sand Point: point of land, on N shore of Whitewater Bay, on Admiralty I., $18 \mathrm{mi}$. S of Angoon, Alex. Arch.; 57 $14^{\prime} 35^{\prime \prime} \mathrm{N}, 134^{\circ} 34^{\prime} 40^{\prime \prime}$ W; (map 9).

Descriptive name published by USC\&GS in the 1943 Coast Pilot (p. 337). So named because "it is composed of sand."

Sand Point: point of land, see Williwaw Point. Sand Point: spit, $0.5 \mathrm{mi}$. long, on $\mathrm{W}$ coast of Popof I., in Shumagin Is., Aleutian Ra.; $55^{\circ} 19^{\prime} 10^{\prime \prime} \mathrm{N}, 160^{\circ} 31^{\prime} 30^{\prime \prime} \mathrm{W}$; (map 28).

This flat sandy spit was named in 1872 by W. H. Dall, USC\&GS.

Sandspit Point: point of land, on $\mathrm{E}$ coast of Renard I., $14 \mathrm{mi}$. SE of Seward, Chugach Mts.; $59^{\circ} 56^{\prime} 25^{\prime \prime} \mathrm{N}, 149^{\circ} 18^{\prime} 20^{\prime \prime} \mathrm{W}$; (map 49).

Local name reported in the early 1950 's by USC\&GS.

Sandstone Bluff: bluff, on right bank of Yukon River, $58 \mathrm{mi}$. E of Nulato, Kokrines-Hodzana High.; $64^{\circ} 44^{\prime} \mathrm{N}, 156^{\circ} 05^{\prime} \mathrm{W}$; (map 97).

Local descriptive name reported in 1954 by USGS.

Sandusky Creek: stream, flows NW $3.7 \mathrm{mi}$. to Stevens Creek, $3.4 \mathrm{mi}$. N of Roughtop Mtn. and $37 \mathrm{mi}$. ENE of Tanana, Yukon-Tanana High.; $65^{\circ} 14^{\prime} \mathrm{N}, 150^{\circ} 50^{\prime} \mathrm{W}$; BGN 1965; (map 106).

Prospectors' name reported in 1963 by Bond Taber, USGS, as having "long local usage."

Sandwich Sound: gulf, see Prince William Sound.

Sandy Bay: bay, $1.2 \mathrm{mi}$. across, on $\mathrm{S}$ central coast of Sanak I., Aleutian Ra.; $54^{\circ} 23^{\prime} 20^{\prime \prime} \mathrm{N}$, $162^{\circ} 41^{\prime} 00^{\prime \prime} \mathrm{W}$; (map 25$)$.

Descriptive name reported by Ferdinand Westdahl, USC\&GS, commander of the Coast Survey steamer McArthur, who made surveys in this area in 1901.

Sandy Bay: bay, $0.4 \mathrm{mi}$. across, $20 \mathrm{mi}$. NW of village of Port Armstrong, on $\mathrm{S}$ coast of Baranof I., Alex. Arch.; 56 $28^{\prime} \mathrm{N}, 134^{\circ} 59^{\prime} \mathrm{W}$; (map 5). Var. Peschanaia Bay, Peshchannaya Bukhta.

This is a translation by USC\&GS about 1882 of the name "Peshchannaya B[ukhta]" given in 1850 by the Russian American Company.

Sandy Bay: bay, $1.8 \mathrm{mi}$. wide, on SE coast of Kenai Penin., SW of Harris Point, $39 \mathrm{mi}$. SW of Seward, Chugach Mts.; $59^{\circ} 39^{\prime} \mathrm{N}, 149^{\circ} 58^{\prime}$ W; (map 49).

Local name reported in the early 1950's by USC\&GS.

Sandy Bight: bight, $0.1 \mathrm{mi}$. across, at mouth of Red Bay, on N coast of Prince of Wales I., 
Alex. Arch.; $56^{\circ} 19^{\prime} 20^{\prime \prime}$ N, $133^{\circ} 17^{\prime} 10^{\prime \prime} \mathrm{W}$; (map 6).

Named in 1886 by Lt. J. M. Helm, USN, for charting purposes; published in 1887 on USC\&GS Chart 706.

Sandy Cove: bay, $1.5 \mathrm{mi}$. across, between Morzhovoi Bay and Deer I., SW end of Alaska Penin., Aleutian Ra.; $54^{\circ} 56^{\prime} \mathrm{N}, 162^{\circ} 48^{\prime} \mathrm{W}$; (map 25).

Descriptive name published in the 1926 Coast Pilot (p. 214).

Sandy Cove: cove, $0.5 \mathrm{mi}$. across, on NE coast of Akutan I., $S$ of Ridge Point, in Krenitzin Is., Aleutian Is.; $54^{\circ} 10^{\prime} 25^{\prime \prime} \mathrm{N}, 165^{\circ} 48^{\prime} 00^{\prime \prime} \mathrm{W}$; (map 24).

Named in 1901 by J. J. Gilbert, USC\&GS

Sandy Cove: cove, $1.2 \mathrm{mi}$. across, on $\mathrm{E}$ coast of Little Koniuji I., in Shumagin Is., Aleutian Ra.; $55^{\circ} 02^{\prime} \mathrm{N}, 159^{\circ} 21^{\prime} \mathrm{W}$; (map 27).

Named by W. H. Dall, USC\&GS, in 1874 and published in 1888.

Sandy Cove: cove, $0.7 \mathrm{mi}$. long, $W$ of Deep Inlet, $4.5 \mathrm{mi}$. S of Sitka, Alex. Arch.; 56 ${ }^{\circ} 59^{\prime}$ N, $135^{\circ} 19^{\prime}$ W; (map 5). Var. Pestchania, Zaliv Peshchanyy.

This is a translation by USC\&GS of the name given in 1809 by the navigator Ivan Vasiliev the first, IRN. Lt. Sarichev (1826, map 19), IRN, published it as "Z[aliv] Peschanyy."

Sandy Cove: cove, $1.2 \mathrm{mi}$. across, on $\mathrm{E}$ shore of Glacier Bay, in Glacier Bay National Monument, $2 \mathrm{mi}$. N of Leland I. and $53 \mathrm{mi}$. NW of Juneau, St. Elias Mts.; $58^{\circ} 42^{\prime} 15^{\prime \prime} \mathrm{N}, 135^{\circ} 59^{\prime}$ 45" W; BGN 1948; (map 11 ).

Descriptive name given in 1892 by $H$. F. Reid (1896, p. 426).

Sandy Cove: cove, see Arena Cove.

Sandy Creek: stream, see Camp Creek.

Sandy Hook: bar, on left bank of Yukon River, $39 \mathrm{mi}$. E of Nulato, Koyukuk Low.; $64^{\circ} 43^{\prime}$ N, $156^{\circ} 16^{\prime} \mathrm{W}$; (map 97).

Riverboat pilots' name shown on a 1940 "Navigation Chart of the Tanana-Yukon Rivers" published by U.S. Dept. of Interior. Sandy Island: island, see Galankin Island.

Sandy Islands: barrier islands, see Sand Islands.

Sandy Lake: lake, $0.8 \mathrm{mi}$. across, $10 \mathrm{mi}$. S of Imuruk Lake, Seward Penin. High.; $6^{\circ}{ }^{\circ} 8^{\prime}$ N, $163^{\circ} 13^{\prime} \mathrm{W}$; (map 110$)$.

Local descriptive name reported in 1951 by USGS.

Sandy Point: point of land, $\mathrm{N}$ point of entrance to Twelvemile Arm Kasaan Bay, on E coast of Prince of Wales Island, Alex. Arch.; 55 $33^{\prime} 20^{\prime \prime} \mathrm{N}, 132^{\circ} 31^{\prime} 15^{\prime \prime} \mathrm{W}$; (map 4).

Descriptive name given in 1886 by $L t$. Comdr. R. C. Clover, USN.

Sandy Point: point of land, see Anchorage Point. Sandy Point: point of land, see Peschani Point. Sandy River: stream, on $\mathrm{W}$ end of Unimak $\mathrm{I}$., Aleutian Is.; $54^{\circ} 30^{\prime} \mathrm{N}, 164^{\circ} 50^{\prime} \mathrm{W}$; (map 24). Var. Peschanaya.

Translation of the descriptive name Peschanaya published by Father Veniaminov (1840, v. 1, p. 214-215).

San Elias, Cabo de: point of land, see Suckling, Cape.
San Eugenio, Punta: point of land, see Eugenia, Point.

San Eusebio, Punta: point of land, "on southwest side of St. Ignace Island in Bucareli Bay," Alex. Arch.; (map 4).

Spanish name found on the maps of the 1779 Arteaga expedition (Wagner, 1937, p. 499).

San Faustino, Punta: point of land, "on the east side of San Juan Bautista Island in Bucareli Bay," Alex. Arch.; (map 4).

Named about June 2, 1779, by Francisco Antonio Maurelle, "although the day of the Saint is May 22" (Wagner, 1937, p. 499).

San Federico, Punta de: point of land, "at the south entrance to Port Gravina," Alex. Arch.; (map 64).

Named by "Fidalgo June 10, 1790, no doubt after Federico Gravina, whose name was given to the bay [Port Gravina]" (Wagner, 1937, p. 499).

San Felipe, Isla: island, see Saint Philip Island. San Feliz, Gabo de: point of land, see Felix, Cape.

San Fernando Island: island, $8 \mathrm{mi}$. long, $5.6 \mathrm{mi}$. W of Graig, W of Prince of Wales I., Alex. Arch.; $55^{\circ} 30^{\prime} \mathrm{N}, 133^{\circ} 20^{\prime} \mathrm{W}$; (map 4). Var. Isla San Fernando, Ostrov San Fernando.

Named "Isla San Fernando," i.e., "Saint Ferdinand Island," by Francisco Antonio Maurelle who "reached the southern point of this island on the night of May 21, 1779. He again anchored at this point May 30 and probably named the island at that time in honor of San Fernando, King of Spain, whose day it was" (Wagner, 1937, p. 409).

San Filip, Ostrov de: island, see Saint Philip Island.

Sanford, Mount: mountain, 16,237 ft., $40 \mathrm{mi}$. E of Gulkana, Wrangell Mts.; $62^{\circ} 13^{\prime} \mathrm{N}, 144^{\circ}$ $08^{\prime} \mathrm{W}$; (map 83).

Named in 1885 by Lt. Allen (1887, p. 59), USA, for the Sanford family; his great-grandfather was Reuben Sanford. It was first climbed July 21, 1938, by Terris Moore and Bradford Washburn (Farquhar, 1959, p. 230).

Sanford Cove: cove, $1 \mathrm{mi}$. across, on $\mathrm{S}$ shore of Endicott Arm, 2 mi. SW of Sumdum I. and $55 \mathrm{mi}$. SE of Juneau, Coast Mts.; $57^{\circ} 41^{\prime} \mathrm{N}$, $133^{\circ} 29^{\prime}$ W; BGN 1900; (map 8). Var. Sandford Cove.

Named in 1889 by Comdr. R. W. Meade, USN, for Lawson Sanford, a member of his survey party. The name was published by USC\&GS in 1891 Coast Pilot (p. 148).

Sanford Glacier: glacier, trends SW $12 \mathrm{mi}$. from Mount Sanford to its terminus at head of Sanford River, Wrangell Mts. ; $62^{\circ} 08^{\prime} 30^{\prime \prime} \mathrm{N}$, $144^{\circ} 27^{\prime} 30^{\prime \prime} \mathrm{W}$; (map 83).

Name taken from mountain and river of the same name. See Sanford, Mount.

Sanford River: stream, flows NW $24 \mathrm{mi}$. from Sanford Glacier terminus to Copper River, 8.5 mi. NE of Gulkana, Copper River Basin; $62^{\circ} 20^{\prime} 30^{\prime \prime} \mathrm{N}, 145^{\circ} 10^{\prime} 00^{\prime \prime} \mathrm{W}$; (map 83).

Named in 1885 by Lt. H. T. Allen, USA. See Sanford, Mount.
San Francisco, Isla: island, see San Francisco Island.

San Francisco, Point: point of land, on $\mathrm{E}$ coast of Noyes I., Alex. Arch.; 55 $30^{\prime} 20^{\prime \prime}$. N, $133^{\circ}$ $35^{\prime} 00^{\prime \prime} \mathrm{W}$; (map 4).

Named by the 1779 Arteaga expedition (Wagner, 1937, p. 409).

San Francisco, Ysla de: island, see San Francisco Island.

San Francisco Creek: stream, flows E $4 \mathrm{mi}$. to Eldorado River near its head, $25 \mathrm{mi}$. NW of Solomon, Seward Penin. High.; 64 $51^{\prime} \mathrm{N}$, $164^{\circ} 58^{\prime} \mathrm{W}$; (map 95)

Prospectors' name reported in 1900 by $E$. C. Barnard (in Brooks, 1901, pl. 17), USGS.

San Francisco Creek: stream, flows NE $3.4 \mathrm{mi}$ : to Pargon River, $17 \mathrm{mi}$. NE of Council and 40 mi. E of Imuruk Lake, Seward Penin. High.; $65^{\circ} 00^{\prime} \mathrm{N}, 163^{\circ} 09^{\prime} \mathrm{W}$; (map 110 ).

Prospectors' name reported on a map of Cape Nome gold fields by David Fox, Jr., dated 1901.

San Francisco Island: island, $500 \mathrm{ft}$. long, in St. Nicholas Channel, on W coast of Lulu I., Alex.

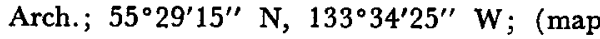
4). Var. Isla San Francisco, Ysla de San Francisco.

Named "Ysla de San Francisco," i.e. "Island of Saint Francis," probably by Don Ignacio Arteaga in 1779 , as the name is found only on the maps of this expedition.

Sangaina Creek: stream, heads at lake and flows $10 \mathrm{mi}$. N to Hanagita River, $37 \mathrm{mi}$. NW of McCarthy, Chugach Mts.; $61^{\circ} 15^{\prime} \mathrm{N}, 143^{\circ} 58^{\prime}$ W; (map 67).

Local name reported in 1911 by D. C. Witherspoon, USGS

Sanganoac, Paso de: water passage, see Akutan Pass.

Sanganooda, Port: bay, see English Bay.

Sangao Island: island, $0.5 \mathrm{mi}$. long, between El Capitan and Prince of Wales Is., Alex. Arch.; $55^{\circ} 00^{\prime} 15^{\prime \prime} \mathrm{N}, 133^{\circ} 17^{\prime} 45^{\prime \prime} \mathrm{W}$; (map 4).

Local name published in 1964 by USC\&GS. Sango Creek: stream, flows $\mathrm{N} 5 \mathrm{mi}$. to Arctic River, $12 \mathrm{mi}$. NE of Ear Mtn. and $52 \mathrm{mi}$. NE of Teller, Seward Penin. High.; $65^{\circ} 58^{\prime} \mathrm{N}$, $165^{\circ} 49^{\prime} \mathrm{W}$; (map 111).

Prospectors' name reported in 1901 by T. G. Gerdine (in Collier, 1902, pl. 12), USGS.

San Gonzalo, Isla: island, see Unimak Island. San Goze, Ostrov: island, Saint Joseph Island.

Sanigaroak: stream, see Shaningarok Greek.

Sanigaruak Island: barrier island, $0.5 \mathrm{mi}$. long, in Plover Is., $31 \mathrm{mi}$. SE of Barrow, Arctic Plain; $71^{\circ} 11^{\prime} \mathrm{N}, 155^{\circ} 24^{\prime} \mathrm{W}$; (map 153).

Eskimo name referring to the "crazy" or crosswise manner in which the island lies. It trends SW-NE rather than the normal NWSE direction.

Sanigaruak Pass: water passage, between Martin and Sanigaruak Is., in Plover Is., $31 \mathrm{mi} . \mathrm{E}$ of Barrow, Arctic Plain; $71^{\circ} 12^{\prime} \mathrm{N}, 155^{\circ} 24^{\prime} \mathrm{W}$ : (map 153).

Probably named for the adjacent island with the same name.

San Ignacio, Isla: island, see Saint Ignace Island. 
San Ignatsa, Ostrov: island, see Saint Ignace Island.

San Ildefonso, Punta: point of land, see Ildefonso, Point.

Saninak Creek: stream, flows S $4 \mathrm{mi}$. to Noatak River, $17 \mathrm{mi}$. NE of Kotzebue, KotzebueKobuk Low.; $67^{\circ} 08^{\prime} 30^{\prime \prime}$ N, $162^{\circ} 30^{\prime} 00^{\prime \prime}$ W; (map 128). Var. Suninuk Creek.

Eskimo name meaning "bare spot" according to USC\&GS in 1950.

San Island: island, $0.8 \mathrm{mi}$. wide, SW El Capitan Passage, Alex. Arch.; 55 $56^{\prime} 15^{\prime \prime} \mathrm{N}, 133^{\circ} 21^{\prime}$ 15" W; BGN 1932; (map 4). Var. Middle Island Sankhat, Sankat Island.

Tlingit Indian name meaning "middle"; given in 1932 by USC\&GS. The translated name was published for this island in 1925 Coast Pilot (p. 154). "San-Kat means 'middle island." "

San Isodoro, Punta de: point of land, see Saint Isodoro, Point.

Sanitarium: locality, see Goddard.

San Izidor, Mys: point of land, see Saint Isidor, Point.

San Jacinto, Montaña de: mountains, on Kruzof Island, Alex. Arch.; (map 9).

Don Juan de la Bodega y Quadra's 1775 map shows three mountains with the notation that they terminate at the Cabo de Engaño (Engano Point). One of these must have been Mount Edgecumbe (Wagner, 1937, p. 501 ).

San Jacinto, Mount: volcano, see Edgecumbe, Mount.

San Jean Bautista Island: island, see San Juan Bautista Island.

San Jose, Point: point of land, $\mathrm{N}$ point of entrance to Port Santa Cruz, on W coast of Suemez I., Alex. Arch.; $55^{\circ} 17^{\prime} 25^{\prime \prime}$ N, $133^{\circ}$. 27'15" W; (map 4). Var. Mys San Khosy, Punta de San Jose, Punta San Josef.

Spanish name given in 1775-79 by Don Juan de la Bodega y Quadra and Francisco Antonio Maurelle as "Punta de San Jose," or "Point of Saint Joseph."

San Jose Creek: stream, flows W 4 mi. to Eldorado River, $20 \mathrm{mi}$. NW of Solomon, Seward Penin. High.; $64^{\circ} 44^{\prime} \mathrm{N}, 164^{\circ} 59^{\prime} \mathrm{W}$; (map 95).

Prospectors' name reported in 1900 by E. C. Barnard (in Brooks, 1901, pl. 17), USGS.

San Josef, Punta: point of land, see San Jose, Point.

San Josep, Isla de: island, see Saint Joseph Island.

San Joseph, Isla: island, see Saint Joseph Island.

San Juan: locality, see San Juan Cannery.

San Juan Bautista Island: island, $4.5 \mathrm{mi}$. long, between Bucareli Bay and Ursua Channel, W of Prince of Wales I., Alex. Arch.; 55 $26^{\prime}$ $\mathrm{N}, 133^{\circ} 16^{\prime} \mathrm{W} ; B G N$ 1899; (map 4). Var. Isla San Juan Bautista, Ostrov de San Khuan Batista, San Jean Bautista Island.

The name "Isla San Juan Bautista," i.e. "St. John the Baptist Island," was given to this feature by Francisco Antonio Maurelle who "in his exploration of the bay [Bucareli] ex- amined the northern part of this island on May 30,1779, but no doubt he had discovered it before" (Wagner, 1937, p. 410).

San Juan Bay: bay, $2.8 \mathrm{mi}$. across, on SW end of Montague I., $58 \mathrm{mi}$. SE of Seward, Chugach Mts. ; $59^{\circ} 49^{\prime} \mathrm{N}, 147^{\circ} 55^{\prime} \mathrm{W}$; (map 49).

Local name reported in the early 1950's by USC\&GS.

San Juan Cannery: locality, on E coast of Evans I., at SW end of Sawmill Bay, $17 \mathrm{mi}$. S of Chenega, Chugach Mts.; $60^{\circ} 03^{\prime} \mathrm{N}, 148^{\circ} 04^{\prime}$ W; (map 63). Var. San Juan.

Name published in 1943 by USC\&GS.

San Juan Islands: islands, in Pybus Bay, $\mathrm{E}$ of Admiralty I., $6 \mathrm{mi}$. W of The Brothers and $53 \mathrm{mi}$. E of Sitka, Alex. Arch.; 57 $17^{\circ} 30^{\prime \prime} \mathrm{N}$, $134^{\circ} 00^{\prime} 00^{\prime \prime} \mathrm{W}$; (map 8).

Name reported in $1924 ;$ published in 1928 by USC\&GS.

San Juanito, Isla: island, see San Juanito Island.

San Juanito Island: island, $200 \mathrm{ft}$. long, in Bucareli Bay, $0.3 \mathrm{mi}$. E of Point Miliflores, the SE tip of San Juan Bautista I., Alex. Arch.; 55 $24^{\prime} 30^{\prime \prime} \mathrm{N}, 133^{\circ} 14^{\prime} 40^{\prime \prime} \mathrm{W}$; (map 4). Var. Isla San Juanito, San Khuyenito.

Named "Isla San Juanito" or "Saint John Island," by Francisco Antonio Maurelle "about June 2, 1779, perhaps after San Juan de la Cruz, whose day is May 21" (Wagner, 1937, p. 410).

Sankat Island: island, see San Island.

San Khosy, Mys: point of land, see San Jose, Point.

San Khuan Batista, Ostrov de: island, see San Juan Bautista Island.

San Khuyenito: island, see San Juanito Island. Sankik: island, see Sankin Island.

Sankin Bay: bay, $1.5 \mathrm{mi}$. across, part of Ikatan Bay, SW end of Aleutian Ra.; 54 $49^{\prime} 30^{\prime \prime} \mathrm{N}$, $163^{\circ} 17^{\prime} 00^{\prime \prime} \mathrm{W}$; (map 25).

Name derived from Sankin Island, given by W. H. Dall, USC\&GS, and published in 1882 on USC\&GS Chart 806.

Sankin Island: island, $0.2 \mathrm{mi}$. long, in Ikatan Bay, SW end of Aleutian Ra.; 54 $58^{\prime} 30^{\prime \prime} \mathrm{N}$, $163^{\circ} 16^{\prime} 20^{\prime \prime} \mathrm{W}$; (map 25). Var. Sankik.

Aleut name published by the Russian Hydrog. Dept. in 1847 on Chart 1379 as "O[strov] Sankik," or "Sankik Island." The name was published as Sankin by USC\&GS in 1882 on Chart 806.

San Klementa, Ostrov: island, see San Clemente Island.

San Leonardo, Point: point of land, on $\mathrm{W}$ coast of Saint Ignace I., Alex. Arch.; $55^{\circ} 24^{\prime} 15^{\prime \prime} \mathrm{N}$, $133^{\circ} 26^{\prime} 35^{\prime \prime}$ W ; (map 4). Var. Punta de San Leonardo, Saint Leonard Point.

Spanish name given in 1779 by Don Juan de la Bodega y Quadra and Francisco Antonio Maurelle as "Punta de San Leonardo," i.e. "Point of Saint Leonard."

San Lorenzo Island: islands, see San Lorenzo Islands.

San Lorenzo Islands: islands, extend $1.6 \mathrm{mi}$., form S point of Maurelle Is., $W$ of Gulf of Esquibel, Alex. Arch.; $55^{\circ} 35^{\prime} 45^{\prime \prime} \mathrm{N}, 133^{\circ}$ $37^{\prime} 00^{\prime \prime}$ W; BGN 1917; (map 4). Var. Isla
San Lorenzo, San Lorenzo Island, Ysla de San Lorenzo.

Spanish name given about May 23, 1779, by Don Juan de la Bodega y Quadra and Francisco Antonio Maurelle as "Isla San Lorenzo," or "Saint Lawrence Island:"

San Luis, Punta de: point of land, see Hinchinbrook, Cape.

Sannach Island: island, see Sanak Island.

Sannak: village, see Sanak.

Sannak Bank: shoal, see Sanak Bank.

Sannakh Bank: shoal, see Sanak Bank.

Sannakh Island: island, see Sanak Island.

Sannakh Islands: islands, see Sanak Islands.

Sannak Island: island, see Sanak Island.

Sannak Islands: islands, see Sanak Islands.

San Nicholas Canal: water passage, see Saint Nicholas Channel.

San Nicholas Channel: water passage, see Saint Nicholas Channel.

San Nicolao, Puerto de: estuary, see Saint Nicholas, Port.

San Nicolao Point: point of land, see Saint Nicholas Point.

San Nicolas, Canal de: water passage, see Saint Nicholas Channel.

San Nicolas, Puerto de : estuary, see Saint Nicholas, Port.

San Nicolas Channel: water passage, see Saint Nicholas Channel.

San Nicolo Channel: water passage, see Saint Nicholas Channel.

San Nicolo Point: point of land, see Saint Nicholas Point.

San Nikola, Kanal de: water passage, see Saint Nicholas Channel.

San Nikolay, Mys de: estuary, see Saint Nicholas, Port.

Sanona Creek: stream, formed by Joe and Yako Greeks, flows NE $25 \mathrm{mi}$. to Tyone Creek, 9.5 $\mathrm{mi}$. SE of junc. of Oshetna and Susitna Rivers, Talkeetna Mts. ; $62^{\circ} 33^{\prime} 20^{\prime \prime} \mathrm{N}, 147^{\circ} 08^{\prime} 00^{\prime \prime} \mathrm{W}$; (map 82)

Local name reported by F. H. Moffit (in Brooks and others, 1915, fig. 3), USGS.

San Pablo, Punta: point of land, "on east end of San Juan Bautista Island in Bucareli Bay," Alex. Arch.; (map 4).

Named about May 30, 1779, by Francisco Antonio Maurelle (Wagner, 1937, p. 506).

San Pascual Point: point of land, see San Pasqual, Point.

San Paskala, Mys : point of land, see San Pasqual, Point.

San Pasqual, Point: point of land, on $\mathbf{N}$ coast of San Fernando I., Alex. Arch.; 55 $34^{\prime} 10^{\prime \prime} \mathrm{N}$, $133^{\circ} 23^{\prime} 10^{\prime \prime}$ W; BGN 1923; (map 4). Var. Mys San Paskala, Punta de San Pasqual, Punta San Pasqual, San Pascual Point.

Named "Punta San Pasqual," i.e. "Saint Pasqual Point," about May 27, 1779, by Francisco Antonio Maurelle, perhaps after San Pasqual Bailon whose day is May 17 (Wagner, 1937 , p. 412). In 1923 the location of this feature was formally defined by USC\&GS; previously, it was confused with Point Santa Rosalia, 1 mile to the west. 
San Pedro y San Pablo: mountain, see Fourpeaks Mountain.

San Rafael, Point: point of land, on SE coast of Saint Ignace I., in Bucareli Bay, Alex. Arch.; $55^{\circ} 23^{\prime} 10^{\prime \prime} \mathrm{N}, 133^{\circ} 25^{\prime} 00^{\prime \prime} \mathrm{W}$; (map 4). Var. Mys San Rafayel, Punta de San Rafael.

Named "Punta de San Rafael," i.e. "Point of Saint Raphael," by Francisco Antonio Maurelle "about May 21, 1779, perhaps after San Rafael whose apparition is celebrated May 7" (Wagner, 1937, p. 412-413).

San Rafayel, Mys: point of land, see San Rafael, Point.

San Ramon, Punta de: point of land, the $\mathrm{N}$ tip of Kayak I., $1 \mathrm{mi}$. NW of Lemesurier Point; $60^{\circ} 01^{\prime} \mathrm{N}, 144^{\circ} 14^{\prime} \mathrm{W}$; (map 64).

Named about July 17,1779 , by Don Ignacio Arteaga.

San Roch, Point: point of land, see San Roque, Point.

San Rok, Mys: point of land, see San Roque, Point.

San Roque, Point: point of land, N point of entrance to Port San Antonio, on E coast of Baker I., Alex. Arch.; $55^{\circ} 20^{\prime} 10^{\prime \prime} \mathrm{N}, 133^{\circ} 32^{\prime}-$ 35" W; (map 4). Var. Mys San Rok, Point San Roch, Punta de Carrizales, Punta de San Roque, Reed Grass Point.

Named "Punta de San Roque," or "Point of Saint Roque," on "May 18 or 19, 1779," by Francisco Antonio Maurelle (Wagner, 1937, p. 413). This may also be the point called "Punta de Carrizales," another time by the same expedition.

San Salvador, Punta: point of land, "on Santa Rita Island northeast of Baker Island, Bucareli Bay," Alex. Arch.; (map 4).

Named about May 21, 1779, by Francisco Antonio Maurelle. Perhaps the reference in the name is to the Renovacion del Señor which is celebrated May 19, "as there is no San Salvador, strictly speaking" (Wagner, 1937, p. 507),

San Sebastian, Mys: point of land, see Saint Sebastian, Point.

San Sebastion, Punta: point of land, see Saint Sebastian, Point.

San Silbestre, Mys de: point of land, see Silvester Point.

San Silvestre, Punta: point of land, see Silvester Point.

Sanson, Punta de: point of land, "between Ports Estrella and Caldera on Prince of Wales Island in Bucareli Bay," Alex. Arch.; (map 4).

Spanish name found on maps of the 1779 Arteaga expedition (Wagner, 1937, p. 509). Santa Agueda, Punta de: point of land, see Agueda Point.

Santa Ana, Playas de: beach, on Port Etches on Hinchinbrook I.; (map 64).

Probably named in July 1779 by Don Ignacio Arteaga for the saint whose day is July 26.

Santa Anna: locality, on W coast of Cleveland Penin., at head of Santa Anna Inlet, Alex. Arch.; $55^{\circ} 58^{\prime} 40^{\prime \prime} \mathrm{N}, 131^{\circ} 55^{\prime} 40^{\prime \prime} \mathrm{W}$; (map 3).
Local name published in 1901 by USC\&GS. This is the site of a cannery which was abandoned in the late 1920's.

Santa Anna, Point: point of land, between Santa Anna Inlet and Seward Passage, on NW coast of Cleveland Penin., Alex. Arch.; 55 59'45" $\mathrm{N}, 131^{\circ} 57^{\prime} 55^{\prime \prime} \mathrm{W}$; (map 3).

Local name published in 1901 by USC\&GS. Santa Anna Inlet: estuary, extends SE $2 \mathrm{mi}$., off Seward Passage, on NW coast of Cleveland Penin., Alex. Arch.; 55 59'50' N, 131 $57^{\prime} 30^{\prime \prime}$ W; (map 3).

Local name published in 1901 by USC\&GS. See Santa Anna.

Santa Buenaventura, Punta: point of land, "on the east side of San Fernando Island in Bucareli Bay," Alex. Arch.; (map 4).

Spanish name found on the maps of the 1779 Arteaga expedition (Wagner, 1937, p. 509).

Santa Catalina Island: island, see Forrester Island.

Santa Christina Island: island, see Forrester Island.

Santa Clara, Rio de: stream, "the western mouth of the Copper River"; (map 64).

Named about July 17,1779 , by Don Ignacio Arteaga (Wagner, 1937, p. 510).

Santa Cristina Island: island, see Forrester Island.

Santa Cruz, Port: bay, extends E $2.5 \mathrm{mi}$. off Bucareli Bay, on $W$ coast of Suemez I., Alex. Arch.; 55 $5^{\circ} 17^{\prime} \mathrm{N}, 133^{\circ} 27^{\prime} \mathrm{W}$; (map 4). Var. Puerto de la Santa Cruz, Puerto de la Santissima Cruz, Zaliv de la Santa Krus.

Named "Puerto de la Santissima Cruz," or "Port of the Most Holy Cross" by Lt. Arteaga, on "May 13,1779, in remembrance of 'the finding of the Cross,' celebrated May 3, the day he reached the Port" (Wagner, 1937, p. 414).

Santa Cruz Creek: stream, flows W $1.5 \mathrm{mi}$. to Gache Greek which flows to Norton Sound, $9 \mathrm{mi}$. NE of Solomon, Seward Penin. High.; $64^{\circ} 36^{\prime} \mathrm{N}, 164^{\circ} 09^{\prime} \mathrm{W}$; (map 95).

Prospectors' name shown on Arthur Gibson's "Map of Cape Nome Precinct" dated 1904.

Santa Efigenia, Punta de: point of land, see Iphigenia, Point.

Santa Flavia Bay: bay, extends NE $2.2 \mathrm{mi}$. off Kiliuda Bay, W of Boulder Bay, on SE coast of Kodiak I.; $57^{\circ} 17^{\prime} \mathrm{N}, 152^{\circ} 52^{\prime} \mathrm{W}$; (map 34).

Spanish name published in 1943 by USC\&GS. Saint Flavian lived in the fifth century.

Santa Gertrudis, Point: point of land, $\mathrm{N}$ tip of

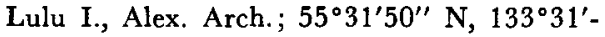
$15^{\prime \prime} \mathrm{W}$; (map 4). Var. Point Saint Gertruda, Punta Santa Gertrudis, Saint Gertrude Point.

Named "Punta.Santa Gertrudis," or "Point Saint Gertrude," by the Spaniards in the 1770 's, reportedly for the Spanish man-of-war Santa Gertrudis (Wagner, 1937, p. 414; Baker, 1906, p. 551)
Santa Ines, Punta de: point of land, "in Bucareli Bay, on east side of St. Ignace Island," Alex. Arch.; (map 4).

Spanish name found on the maps of the 1779 Arteaga expedition (Wagner, 1937, p. 511).

Santa Inez, Isla de: island, "at entrance to Prince William Sound [as] shown on Camacho's map of 1779 south of Hawkins Island with two others to the northwest of it. In reality there are no such islands * * *." See Wagner (1937, p. 511).

Santa Krus, Zaliv de la: bay, see Santa Cruz, Port.

Santa Lucia, Point: point of land, on $\mathbf{N}$ coast of San Fernando I., Alex. Arch.; 55 $34^{\prime} 15^{\prime \prime} \mathrm{N}$, $133^{\circ} 20^{\prime} 30^{\prime \prime}$ W; (map 4). Var. Mys Santa Lutsia; Punta de Santa Lucia.

Spanish name given in $1775-79$ by Don Juan de la Bodega y Quadra and Francisco Antonio Maurelle as "Punta de Santa Lucia," or "Point of Saint Lucy."

Santa Lucia, Yslas de: island, see Santa Lucia Island.

Santa Lucia Island: island, in San Christoval Channel, off $\mathbf{N}$ coast of San Fernando I., SW of Prince of Wales I., Alex. Arch.; 55 $34^{\prime} \mathrm{N}$, $133^{\circ} 20^{\prime} \mathrm{W}$; (map 4). Var. Isla de Santa Lucia, Ostrov Santa Lutsia, Yslas de Santa Lucia.

Spanish name given in $1775-79$ by Don Juan de la Bodega y Quadra and Francisco Antonio Maurelle as "Isla de Santa Lucia," or "Saint Lucy Island"; not shown on current sources.

Santa Lutsia, Mys: point of land, see Santa Lucia, Point.

Santa Lutsia, Ostrov: island, see Santa Lucia Island.

Santa Maria, Punta: point of land, "on Santa Rita Island in Bucareli Bay," Alex. Arch.; (map 4).

Named about May 11, 1779, by Francisco Antonio Maurelle for the Virgin whose day was celebrated May 8 and 9 (Wagner, 1937, p. 512).

Santa Maria Magdalena: island, see Hinchinbrook Island.

Santa Maria Magdalena, Cabo de: point of land, see Magdalena, Cape.

Santa Maria Magdalena, Punta: point of land, "probably Cape Muzon on the south tip of Dall Island," Alex. Arch.; (map 1).

This point of land was discovered by Juan Pérez July 19 or 20,1774, and named in honor of the saint. It was known to the Russians as "Kaigani." The name "Magdalena" is still retained on maps applied to a point on the west side of Dall Island. See Capes Muzon and Magdalena. See also Wagner $(1937$, p. 512).

Santa Rita Island: island, $0.9 \mathrm{mi}$. long, between Baker and Saint Ignace Is. in Port Mayoral, Alex. Arch.; 55 $25^{\prime} 00^{\prime \prime} \mathrm{N}, 133^{\circ} 27^{\prime} 30^{\prime \prime} \mathrm{W}$; (map 4). Var. Isla de Santa Rita, Ysla de Santa Rita.

Named "Isla de Santa Rita," i.e., "Saint Rita Island," by Francisco Antonio Maurelle 
on "May 22, 1779, in honor of Santa Rita de Casia whose day it was" (Wagner, 1937, p. 415).

Santa Rosa, Point: point of land, $\mathrm{S}$ tip of Santa Rita I., between Baker and Saint Ignace Is., Alex. Arch.; $55^{\circ} 24^{\prime} 35^{\prime \prime} \mathrm{N}, 133^{\circ} 27^{\prime} 30^{\prime \prime} \mathrm{W}$; (map 4). Var. Punta de Santa Rosa.

Spanish name given in 1779 by Don Juan de la Bodega y Quadra and Francisco Antonio Maurelle as "Punta de Santa Rosa," or "Point of Saint Rose."

Santa Rosa, Punta: point of land, see Saint Elias, Cape.

Santa Rosalia, Point: point of land, on $\mathrm{N}$ coast of San Fernando I., Alex. Arch.; 55 $34^{\prime} 15^{\prime \prime}$ N, $133^{\circ} 24^{\prime} 45^{\prime \prime}$ W; (map 4). Var. Mys Santa Rosalia, Punta de Santa Rosalia, Punta Santa Rosalia, Rosalia Point.

Spanish name given in $1775-79$ by Don Juan de la Bodega y Quadra and Francisco Antonio Maurelle as "Punta de Santa Rosalia" or "Saint Rosalie Point."

Santa Teresa: point of land, see Santa Theresa, Point.

Santa Tereza, Mys: point of land, see Santa Theresa, Point.

Santa Theresa, Point: point of land, $0.9 \mathrm{mi}$. N of Cone I., on SE coast of Noyes I., Alex. Arch.; $55^{\circ} 27^{\prime} 05^{\prime \prime} \mathrm{N}, 133^{\circ} 38^{\prime} 30^{\prime \prime} \mathrm{W}$; (map 4). Var. Mys Santa Tereza, Punta de Santa Theresa, Santa Teresa.

The name "Punta de Santa Theresa," or "Saint Theresa Point," was applied by Francisco Antonio Maurelle to the south point of Noyes Island [Saint Nicholas Point] "*** probably on that saint's day May 19, 1779" (Wagner, 1937, p. 513). The name was reapplied to its present location in 1923 by USC\&GS.

Santa Theresa, Punta de: point of land, see Saint Nicholas Point.

Santa Yefigeniya, Mys: point of land, see Iphigenia, Point.

Santiago, Puerto de: bay, see Etches, Port

Santissima Cruz, Puerto de la: bay, see Santa Cruz, Port.

San Tomas, Mys: point of land, see Saint Thomas, Point.

Sanya: locality, near Cape Fox, on NE shore of Dixon Entrance, Coast Mts.; $54^{\circ} 46^{\prime} \mathrm{N}, 130^{\circ}$. $50^{\prime} \mathrm{W}$; (map 2). Var. Sanyakoan.

Former Tlingit Indian village or camp listed by Hodge (1910, p. 53)

Sanyakoan: locality, see Sanya.

San Ygnacio, Ysla de: island, see Saint Ignace Island.

San Yldefonso, Punta de: point of land, see Ildefonso, Point.

San Ysidoro, Punta de: point of land, Saint Isidor, Point.

S!aodā'n: locality, see Sumdum.

Saook Bay: bay, $1 \mathrm{mi}$. across, on $\mathrm{N}$ coast of Baranof I., 28 mi. NE of Sitka, Alex. Arch.; $57^{\circ} 27^{\prime} \mathrm{N}, 135^{\circ} 10^{\prime} \mathrm{W}$; BGN 1898; (map 9).

Tlingit Indian name [sa-uk] given in 1895 by USC\&GS and published on Chart 8283.

Saook Point: point of land, $N$ point of entrance to Saook Bay, on $N$ coast of Baranof I., 28 mi. NE of Sitka, Alex. Arch.; 57 $27^{\prime} 30^{\prime \prime} \mathrm{N}$, $135^{\circ} 10^{\prime} 00^{\prime \prime} \mathrm{W}$; $B G N$ 1898; (map 9).

Tlingit Indian name [sa-uk] given in 1895 by USC\&GS and published in 1897 on Chart 8000.

Saposa Bay: $b a y$, extends N $2 \mathrm{mi}$. at head of Izhut Bay, on SE coast of Afognak I., $26 \mathrm{mi}$. NE of Afognak, Kodiak I.; $58^{\circ} 14^{\prime} 40^{\prime \prime} \mathrm{N}$, $152^{\circ} 15^{\prime} 00^{\prime \prime} \mathrm{W}$; (map 43).

Local name published in 1943 by USC\&GS. Sa Posesion, Punta de: point of land, see Posesion, Punta de.

Sapozhkova: stream, see Buskin River.

Sapozhkovo, Reka: stream, see Buskin River.

Sapphire Creek: stream, flows SE $0.8 \mathrm{mi}$. to Minnesota Creek which flows to Penny Creek, $0.1 \mathrm{mi}$. SW of Meddler Creek and $8 \mathrm{mi}$. N of Solomon, Seward Penin. High.; 64 $40^{\prime} 30^{\prime \prime}$ $\mathrm{N}, 164^{\circ} 21^{\prime} 30^{\prime \prime} \mathrm{W}$; (map 95).

Prospectors' name reported in 1907 by USGS geologists (Smith, P. S., 1910, pl. 3).

Sapsuk Lake: lake, $4 \mathrm{mi}$. long, at head of Sapsuk River, on Alaska Penin., $28 \mathrm{mi}$. SW of village of Port Moller, Aleutian Ra.; 55 $41^{\prime} \mathrm{N}$, $161^{\circ} 03^{\prime} \mathrm{W}$; (map 28). Var. Hoodoo Lake.

This feature is shown as Hoodoo Lake on a 1953 USGS map; USGS reported the above name in 1966.

Sapsuk River: stream, heads in Hoodoo Lake, flows NW $25 \mathrm{mi}$. to Caribou River, $33 \mathrm{mi}$. W of village of Port Moller, on Alaska Penin., Bristol Bay Low.; 55 $54^{\prime} 20^{\prime \prime} \mathrm{N}, 161^{\circ} 23^{\prime} 54^{\prime \prime}$ W; (map 28). Var. Lake Creek.

Named Lake Creek in 1929 by USGS: error reported January 20, 1966.

Sapumegrak Mountain: mountain, $1,071 \mathrm{ft}$., 5 mi. SW of Mount Sapumik and $30 \mathrm{mi}$. NE of Kivalina, Brooks Ra.; $68^{\circ} 07^{\prime} \mathrm{N}, 164^{\circ} 06^{\prime} \mathrm{W}$; (map 130). Var. Saboomaygruck.

Eskimo name reported in 1966 by E. S. Burch.

Sapumik, Mount: mountain, 1,773 ft., $32 \mathrm{mi}$. NE of Kivalina, Brooks Ra.; $68^{\circ} 10^{\prime} \mathrm{N}, 163^{\circ}$ $58^{\prime} \mathrm{W}$; (map 130). Var. Saboomick, Sapuumiq.

Eskimo name reported in 1966 by E. S. Burch.

Sapumik Creek: stream, heads at $68^{\circ} 18^{\prime} \mathrm{N}$ $163^{\circ} 22^{\prime} \mathrm{W}$; and flows SW $35 \mathrm{mi}$. to Kivalina River, $22 \mathrm{mi}$. NE of Kivalina, Arctic Slope; $68^{\circ} 01^{\prime} \mathrm{N}, 164^{\circ} 14^{\prime} \mathrm{W}$; (map 130). Var. Saboomim Koonga, Sapumik Kunga, Pingneyiksak.

Eskimo name reported in 1966 by E. S. Burch.

Sapumik Kunga: stream, see Sapumik Creels.

Sapumik Ridge: ridge, $600 \mathrm{ft}$., $5.5 \mathrm{mi}$. long, on Chukchi Sea coast, $17 \mathrm{mi}$. E of Cape Lisburne, Arctic Slope; $68^{\circ} 51^{\prime} 10^{\prime \prime} \mathrm{N}, 165^{\circ} 26^{\prime} 30^{\prime \prime} \mathrm{W}$; (map 129).

Eskimo name reported in 1955 by U.S. Army Corps of Engineers.

Sapumim Neakau Mountain: mountain, 1,201 ft., $5 \mathrm{mi}$. NE of Mount Sapumik and $36 \mathrm{mi}$. NE of Kivalina, Brooks Ra.; 68 $12^{\prime} \mathrm{N}, 163^{\circ}$ $53^{\prime}$ W. Var. Saboomim Nayacaw.

Eskimo name reported by E. S. Burch, in 1966, to mean "Sapumik's head."
Sapun Creek: stream, in Baird Mts., flows NW $16 \mathrm{mi}$. to Noatak River $11 \mathrm{mi}$. E of its junc. with Nakolik River, $64 \mathrm{mi}$. $\mathrm{N}$ of Kiana, Brooks Ra.; $67^{\circ} 54^{\prime} \mathrm{N}, 160^{\circ} 21^{\prime} \mathrm{W}$; (map 127).

Eskimo name referring to some kind of a fence; obtained in 1956 at Noatak by Orth. Sapuumiq: mountain, see Sapumik, Mount. Sarah Creek: stream, heads in Ray Mts., flows SE $6 \mathrm{mi}$. to Yukon River, $7 \mathrm{mi}$. N of Rampart and $63 \mathrm{mi}$. ENE of Tanana, Kokrines-Hodzana High.; $65^{\circ} 36^{\prime} 15^{\prime \prime} \mathrm{N}, 150^{\circ} 10^{\prime} 30^{\prime \prime} \mathrm{W}$; (map 106).

Named in 1956 by Orth, for the Sarah, one of the three largest and handsomest steamboats on the Yukon during the gold rush days. The Sarah was named for Mrs. Sarah Sloss, wife of Louis Sloss, of the Alaska Commercial Company. See Hannah Creek.

Sarah Gulch: ravine, trends N $1.5 \mathrm{mi}$. to Confederate Creek, $50 \mathrm{mi}$. SW of Eagle, YukonTanana High; 64 $17^{\prime} \mathrm{N}, 142^{\circ} 21^{\prime} \mathrm{W}$; (map 102).

Prospectors' name shown on an 1898 manuscript map by C. A. Woodruff, Fort Cudahy, Canada.

Saraina Brook: stream, see Sarana Brook.

Sarana Bay: bay, $2.3 \mathrm{mi}$. across, E coast of Attu I., Aleutian Is. ; $52^{\circ} 52^{\prime} 30^{\prime \prime} \mathrm{N}, 173^{\circ} 17^{\prime} 30^{\prime \prime} \mathrm{E}$; (map 13). Var. Saranna Bay, Sarannaia Bay.

Russian name "Sarana" meaning "lily," referring to a kind of fern which grew extensively on Kamchatka and from which liquor was made for Vitus Bering's expedition (Bancroft, 1886, p. 57). The name was reported as "Sarannaia" by Capt. Lutke (1836, p. 329), IRN

Sarana Bay: bay, $3 \mathrm{mi}$. across, on $\mathbf{S}$ coast of Akutan I., Krenitzin Is., Aleutian Is.; 54 $04^{\circ}$ $30^{\prime \prime} \mathrm{N}, 165^{\circ} 50^{\prime} 00^{\prime \prime} \mathrm{W}$; BGN 1936; (map 24.) Var. Saranna Bay, Vulcan Cove.

Name reported in 1830 by Father Ioann Veniaminov as "Saranna Bukhta," i.e., "Saranna Bay." It was named "Vulcan Cove" in 1888 by USBF "because the fire of Vulcan is much in evidence on this island." USC\&GS reported "Sarana Bay" as the local usage in 1935. "Sarana is the Russian name for the Kamchatkan lily." Early USC\&GS charts applied the name to the large bay west of Battery Point. However, Father Veniaminov (1840, v. 1, p. 192-194) described it as the largest bay on Akutan Island with Cape Kayanak (Battery Point) on its right bank.

Sarana Bay: cove, see Sarana Cove

Sarana Beach: beach, $1.1 \mathrm{mi}$. long, at head of Sarana Bay, on E end of Attu I., Aleutian Is.; $52^{\circ} 52^{\prime} 30^{\prime \prime} \mathrm{N}, 173^{\circ} 15^{\prime} 50^{\prime \prime} \mathrm{E}$; (map 13).

Named by the U.S. Army during its occupation of the island during World War II; shown on an AMS map published in 1948.

Sarana Brook: stream, flows from lake, probably into Sarana Bay, on E coast of Attu I., Aleutian Is.; $52^{\circ} 52^{\prime} 30^{\prime \prime} \mathrm{N}, 173^{\circ} 15^{\prime} 50^{\prime \prime} \mathrm{E}$; (map 13). Var. Saraina Brook.

This name was reported by Constantin Grewingk as "Saraina Brook" (1850, p. 235). It is not shown on modern maps and its exact application is not known. 
Sarana Cove: cove, $0.4 \mathrm{mi}$. across, on $\mathrm{S}$ side of Korovin Bay, $\mathbf{N}$ coast of Atka I., Aleutian Is.; $52^{\circ} 12^{\prime} 00^{\prime \prime} \mathrm{N}, 174^{\circ} 20^{\prime} 30^{\prime \prime} \mathrm{W}$; (map 18). Var. Sarana Bay, Saranna, Sarannaia.

Russian name for the Kamchatkan lily, the roots of which are eaten by the Aleuts and made into a liquor. The name was published in Russian-French by Capt. Lutke (1836, p. $316,328)$, IRN, as "Sarannaia baie," or "Sarannaia Bay."

Saranac Peak: peak, 2,600 ft., W of North Arm Farragut Bay, 2 mi. $\mathbf{N}$ of Bay Point Knoll and $79 \mathrm{mi}$. E of Sitka, Coast Mts.; $57^{\circ} 09^{\prime} 20^{\prime \prime}$ $\mathrm{N}, 133^{\circ} 16^{\prime} 55^{\prime \prime} \mathrm{W}$; (map 8).

Named in 1887 by Lt. Comdr. C. M. Thomas, USN, for the U.S.S. Saranac lost in Seymour Channel, British Columbia, in June 1875 ; published in 1889 by USC\&GS.

Sarana Island: island, $0.5 \mathrm{mi}$. across, $10 \mathrm{mi}$. SW of Dolgoi I., at SW end of Aleutian Ra.; $54^{\circ}$ $58^{\prime} \mathrm{N}, 161^{\circ} 54^{\prime} \mathrm{W}$; (map 25). Var. Ostrov Sarannoy, Saranna Island, Saranoy Island.

Russian name published by Capt. Tebenkov (1852, map 24), IRN, as "O[strov] Sarannoy" meaning "Martagon Island." The martagon is a kind of lily grown on the Kamchatka Peninsula and was used to make liquor for the Bering expedition in 1738 (Bancroft, 1886, p. 57). "Saranoy", the transliteration of the Russian name, was published in 1888 by USBF.

Saranna: cove, see Sarana Cove.

Saranna Bay: bay, see Sarana Bay.

Sarannaia: cove, see Sarana Cove.

Sarannaia Bay: bay, see Sarana Bay.

Saranna Island: island, see Sarana Island.

Sarannoy, Ostrov: island, see Sarana Island.

Sarcar Cove: estuary, see Sarkar Cove.

Sardine Can Lake: lake, $1 \mathrm{mi}$. long, $2 \mathrm{mi}$. W of Gache Lake and $42 \mathrm{mi}$. NW of Fort Yukon, Yukon Flats; $66^{\circ} 47^{\prime} \mathrm{N}, 146^{\circ} 41^{\prime} \mathrm{W}$; (map 119).

Local descriptive name obtained in 1956 by USGS.

Sardine Creek: stream, flows SW $6.8 \mathrm{mi}$. to Anakeksik Creek, $11 \mathrm{mi}$. SE of Christmas Mtn., Nulato Hills; $64^{\circ} 25^{\prime} \mathrm{N}, 160^{\circ} 29^{\prime} \mathrm{W}$; (map 96).

Local name reported about 1954 by U.S. Army Corps of Engineers.

Sardine Creek: stream, flows SW $1.3 \mathrm{mi}$. to Ophir Creek, $9 \mathrm{mi}$. $\mathrm{N}$ of Council and $40 \mathrm{mi}$ SW of Imuruk Lake, Seward Penin. High.; $65^{\circ} 02^{\prime} \mathrm{N}, 163^{\circ} 09^{\prime} \mathrm{W}$; (map 110 ).

Prospectors' name published on the 1908 "Map of Seward Peninsula" by Arthur Gibson.

Sar-du-Loten: locality, see Louden.

Sargeant Cove: cove, $0.8 \mathrm{mi}$. across, trends SE 1 mi. between Hammer and Hatchet Points, on SE coast of Kiska I., Aleutian Is.; $51^{\circ}$ $55^{\prime} 30^{\prime \prime} \mathrm{N}, 177^{\circ} 34^{\prime} 00^{\prime \prime} \mathrm{E}$; (map 14). Var. Sargent Gove.

Name shown on a 1943 AMS map; variant shown on a 1943 USAAF map. This is one of many arbitrary names applied to features during World War II for tactical purposes.

Sargent Bay: estuary, extends N $2.5 \mathrm{mi}$. off Behm Canal, between Cactus and Tramp
Points, on $\mathbf{E}$ coast of Revillagigedo I., Alex. Arch.; $55^{\circ} 33^{\prime} \mathrm{N}, 130^{\circ} 58^{\prime} \mathrm{W}$; (map 3 ).

Local navigators' name obtained in 1904 by H. C. Fassett, USBF.

Sargent Cove: cove, see Sargeant Cove.

Sargent Creek: stream, flows E $6 \mathrm{mi}$. to head of Womens Bay, $8 \mathrm{mi}$. SW of Kodiak, Kodiak I.; $57^{\circ} 42^{\prime} 25^{\prime \prime} \mathrm{N}, 152^{\circ} 34^{\prime} 00^{\prime \prime} \mathrm{W} ; B G N$ 1941; (map 34).

Named by USC\&GS in 1940, "after Fred Sargent who settled in Kodiak in 1868 and died there in 1911, aged 83."

Sargent Creek: stream, in Nutzotin Mts., flows W $1.3 \mathrm{mi}$. to Glacier Greek $0.9 \mathrm{mi}$. SE of its junc. with Chavolda Creek, $6.5 \mathrm{mi}$. NW of Beaver Lake, Alaska Ra.; $62^{\circ} 07^{\prime} 45^{\prime \prime} \mathrm{N}, 141^{\circ}$ 53'50" W; (map 84).

Local name reported by S. R. Capps (in Brooks and others, 1915, p. 223), USGS.

Sargent Creek: stream, heads in lake, flows E $2 \mathrm{mi}$. to Jarvis Creek, $25 \mathrm{mi}$. S of Delta Junction, $63^{\circ} 41^{\prime} 20^{\prime \prime} \mathrm{N}, 145^{\circ} 42^{\prime} 50^{\prime \prime} \mathrm{W}$; (map 86).

Name published on relatively recent maps.

Sargent Creek: stream, flows NW $3.5 \mathrm{mi}$. to Chatanika River, $14 \mathrm{mi}$. NW of Fairbanks, Yukon-Tanana High.; $65^{\circ} 03^{\prime} 15^{\prime \prime} \mathrm{N}, 147^{\circ}$ $50^{\prime} 10^{\prime \prime} \mathrm{W}$; (map 105).

Named by prospectors; published in 1908 by USGS.

Sargent Creek: stream, flows NW $1 \mathrm{mi}$. to the Bluestone River, $12 \mathrm{mi}$. SE of Teller, Seward Penin. High.; $65^{\circ} 06^{\prime} \mathrm{N}, 166^{\circ} 12^{\prime} \mathrm{W}$; (map 111).

Prospectors' name reported on the 1908 "Map of Seward Peninsula" by Arthur Gibson. Sargent Icefield: icefield, on Kenai Penin., trends NE-SW 24 mi., 24 mi. NE of Seward, Chugach Mts.; $60^{\circ} 15^{\prime} \mathrm{N}, 148^{\circ} 33^{\prime} \mathrm{W}$; BGN 1953; (map 63).

Named in 1952 by USGS for Rufus Harvey Sargent, 1875-1951, USGS topographer who did extensive exploration and mapping on Kenai Peninsula.

Sarheen Cove: bay, $0.2 \mathrm{mi}$. across, on $\mathrm{E}$ shore of El Capitan Passage, $3 \mathrm{mi}$. SE of Devilfish Bay, on NE coast of Prince of Wales I., Alex. Arch.; $56^{\circ} 03^{\prime} \mathrm{N}, 133^{\circ} 16^{\prime} \mathrm{W}$; BGN 1908; (map 6). Var. Sa-heen Gove, Sar-Hene Cove, Sarhini Cove.

Tlingit Indian name meaning "Sar River"; reported as "Sar-Hene Cove" in 1902 by USBF.

Sar-Hene Cove: $b a y$, see Sarheen Cove.

Sar-hini: stream, see Karheen Creek.

Sarhini Cove: bay, see Sarheen Cove.

Sarichef Cape: point of land, on $\mathrm{W}$ coast of Unimak I., Aleutian Is.; $54^{\circ} 35^{\prime} 50^{\prime \prime} \mathrm{N}, 164^{\circ}$ 55'30" W; (map 24). Var. Kakatkusik, Northwest Cape, Pogromnoi First, Saritchey Cape, Sarytcheff Cape, West-Southwest Cape.

Named by Capt. Lutke $(1836$, p. 293$)$ for Vice Admiral and Hydrographer Gavrila Andreivich Sarichev who explored the Arctic in 1787 and who later served under Commodore Joseph Billings during explorations of the Bering Sea and Alaska in 1790-92. An atlas was published in 1826, which was compiled under the direction of Sarichev entitled "Atlas of the Northern Part of the Pacific Ocean" and which was used in the preparation of this dictionary. The Aleut name for this point was published by Father Veniaminov (1840, v. 1, p. 212) as Kakatkhusik, which may possibly come from the word "qakatikuqing" which, according to R. H. Geoghegan, means "to grow dry." Northwest Cape was the name applied to this feature by Capt. Tebenkov (1852, map 24) and USBF in 1888.

Sarichef Island: barrier island, $4.5 \mathrm{mi}$. long, at mouth of Shishmaref Inlet, Kotzebue-Kobuk Low.; $66^{\circ} 14^{\prime} \mathrm{N}, 166^{\circ} 05^{\prime} \mathrm{W}$; (map 112).

Named in 1916 by Lt. Otto von Kotzebue, IRN, who wrote "I named the narrow island after our worthy vice-admiral, Saritscheff [sic.]." Vice-Admiral Gavrila Andreevich Sarichev compiled the first Alaska atlas in 1826; this atlas was used extensively in the compilation of the present work.

Sarichef Strait: water passage, $4 \mathrm{mi}$. wide, between Hall I. and Glory of Russia Cape, St. Matthew I. ; $60^{\circ} 37^{\prime} \mathrm{N}, 173^{\circ} 00^{\prime} \mathrm{W}$; (map 56). Var. Proliv Sarycheva.

Lt. G. A. Sarichev, IRN, on the Slava Rossii (Glory of Russia), anchored here July 14, 1791 (O.S.). The water passage was afterward named for him by the Russians; "Pro[liv] Sarycheva," or "Sarychev's Strait" (Tebenkov, 1852, map 20).

Sarichef Volcano: mountain, 2,000 ft., NE part of Atta I., Aleutian Is.; $52^{\circ} 19^{\prime} \mathrm{N}, 174^{\circ} 03^{\prime} \mathrm{W}$; (map 18).

Name published by Coats, USGS (1950, p. 38).

Sarihkahuk Cape: point of land, see Shlokovik Point.

Saritchey Cape: point of land, see Sarichef Cape. Sarkar Cove: estuary, $1 \mathrm{mi}$. long, off El Capitan Passage, $W$ coast of Prince of Wales $I$., Alex. Arch.; 55 $57^{\prime} 45^{\prime \prime} \mathrm{N}, 133^{\circ} 16^{\prime} 00^{\prime \prime} \mathrm{W}$; BGN 1908; (map 4). Var. Sa-Kaa Cove, Sarcar Cove, Sar-Kar Cove.

Named in 1908 by USC\&GS.

Sarkar Creek: stream, $1.2 \mathrm{mi}$.long, drains Sarkar Lake into Sarkar Cove, $W$ of Prince of Wales I., Alex. Arch.; 55 $57^{\prime} 20^{\prime \prime} \mathrm{N}, 1^{\circ} 3^{\circ} 14^{\prime} 45^{\prime \prime} \mathrm{W}$; (map 4). Var. Sar-Kar.

Indian name applied by the fisheries; reported in 1897 as "Sar-Kar" by Lt. Comdr. J. F. Moser, USN.

Sarkar Lake: lake, $2.8 \mathrm{mi}$. long, W coast of Prince of Wales I., Alex. Arch.; 55 $57^{\prime} \mathrm{N}$, $133^{\circ} 13^{\prime} \mathrm{W}$; (map 4). Var. Sar-Kar.

Indian name. See Sarkar Creek.

Sarkar Point: point of land, in El Capitan Passage, near mouth of Sarkar Cove, W coast of Prince of Wales I., Alex. Arch.; 55 $57^{\prime} 25^{\prime \prime}$ $\mathrm{N}, 133^{\circ} 17^{\prime} 00^{\prime \prime} \mathrm{W}$; (map 4).

Local name published by USC\&GS in 1925 Coast Pilot (p. 155).

Sarutschew, Vulcan: volcano, see Sergief, Mount. Sarycheva, Proliv: water passage, see Sarichef Strait.

Sarytcheff Cape: point of land, see Sarichef Cape.

Sasaka, Cape: point of land, see Sajaka, Cape. Sasedney, Ostrov: island, see Sasedni Island. 
Sasedni Group: island, see Sasedni Island.

Sasedni Island: island, $0.2 \mathrm{mi}$. across, connected to Japonski I., in Sitka Sound, $1.7 \mathrm{mi}$. W of Sitka, Alex. Arch.; $57^{\circ} 03^{\prime} \mathrm{N}, 135^{\circ} 23^{\prime} \mathrm{W}$; (map 9). Var. Ostrov Sasedney, Sasedni Group.

Named in 1809 by the Russian navigator Ivan Vasiliev the first; published by Lt. Sarichev (1826, map 19), IRN, as "O[strov] Sasedney," meaning "neighbor island."

Sashin Greek: stream, on Baranof I., flows NE 4 mi., through Sashin Lake, to Little Port Walter on Chatham Strait, $8 \mathrm{mi}$. N of Port

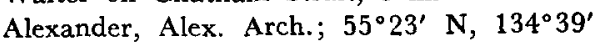
W; (map 6).

Name reported in 1965 by USGS.

Sashin Lake: lake, $1.3 \mathrm{mi}$. long, $7.6 \mathrm{mi}$. N of village of Port Alexander, on S coast of Baranof I., Alex. Arch.; $56^{\circ} 21^{\prime} 30^{\prime \prime} \mathrm{N}, 134^{\circ} 41^{\prime} 30^{\prime \prime}$ W; BGN 1933; (map 5). Var. Lake Sashin.

Named in 1930 by USFS "for one of the Russians killed in the massacre at the original site of Sitka" in 1802.

Sasmik, Cape: point of land, on S coast of Tanaga I., Aleutian Is.; $51^{\circ} 36^{\prime} 30^{\prime \prime} \mathrm{N}, 177^{\circ} 55^{\prime} 00^{\prime \prime}$ W; (map 17). Var. Cape Sasmikh.

Aleut name published by Capt. Tebenkov (1852, map 28), IRN, as "M[ys] Sasmikh," or "Cape Sasmikh."

Sasmikh, Cape: point of land, see Sasmik, Cape. Sasseen: spit, see Asigyukpak Spit.

Sasseen Creek: stream, flows W $3 \mathrm{mi}$. to Slug River, 24 mi. E of Cape Newenham, KilbuckKuskokwim Mts.; 58 $42^{\prime}$ N, 161 $32^{\prime}$ W; (map 39).

Local name shown on a 1937 fieldsheet by J. B. Mertie, USGS.

Satailak Creek: stream, flows N $4 \mathrm{mi}$. to Easter Creek $8.7 \mathrm{mi}$. SE of its junc. with Killik River, Brooks Ra.; $68^{\circ} 04^{\prime} \mathrm{N}, 153^{\circ} 55^{\prime} \mathrm{W}$; (map 133).

Eskimo name reported in 1956 by Orth.

Satanna: point of land, see Bird Cape.

Satchrun, Point: point of land, E point of entrance to Takanis Bay on Yakobi I., off W coast of Chichagof I., $24 \mathrm{mi}$. NW of Chichagof, Alex. Arch.; 57 $54^{\prime} 10^{\prime \prime} \mathrm{N}, 136^{\circ} 31^{\prime} 00^{\prime \prime}$ W; BGN 1908; (map 9).

Tlingit Indian name said to have the same meaning as Takanis [Bay]; named in 1908 by USC\&GS and published in the 1908 Coast Pilot (p. 169).

Satklidak Island: island, see Sitkalidak Island. Satsiksuk Mountain: mountain, 2,800 ft., $1 \mathrm{mi}$. $\mathrm{N}$ of Sapumik Creek and $52 \mathrm{mi}$. SE of Cape Sabine, Brooks Ra.; 68 $17^{\circ} \mathrm{N}, 1^{\circ} 3^{\circ} 30^{\prime} \mathrm{W}$; (map 130). Var. Satsiksuq, Sechiksuk.

Eskimo name meaning "it is further out (than the others)" reported in 1966 by E. S. Burch.

Satsiksuq: mountain, see Satsiksuk Mountain.

Saturday Creek: stream, flows SE $13 \mathrm{mi}$. to Friday Creek, $44 \mathrm{mi}$. NW of Tyonek, Alaska Ra.; $61^{\circ} 41^{\prime} 30^{\prime \prime} \mathrm{N}, 151^{\circ} 29^{\prime} 15^{\prime \prime} \mathrm{W}$; (map 70).

Local name reported in 1954 by USGS.

Saturday Creek: stream, flows SW $0.5 \mathrm{mi}$. to Wonder Creek which flows to Center Creek,
$3 \mathrm{mi}$. N of Nome, Seward Penin. High.; $64^{\circ}$ $32^{\prime} 30^{\prime \prime} \mathrm{N}, 165^{\circ} 22^{\prime} 55^{\prime \prime} \mathrm{W}$; (map 94).

Prospectors' name shown on the 1902 "Map of the Nome and Snake River Country" by J. M. Davidson.

Saturday Creek: stream, flows SE $2 \mathrm{mi}$. to North Creek which flows to Agiapuk River, $14 \mathrm{mi}$. NE of Teller, Seward Penin. High.; $65^{\circ} 23^{\prime} \mathrm{N}$, $165^{\circ} 58^{\prime} \mathrm{W}$; (map 111).

Prospectors' name reported in 1901 by T. G. Gerdine (in Collier, 1902, pl. 12), USGS.

Saukpeek Mountain: mountain, see Sakpik Mountain.

Saulich: railroad station, mile 450.8 on The Alaska RR., $16.5 \mathrm{mi}$. W of Fairbanks, YukonTanana High.; $64^{\circ} 52^{\prime} 45^{\prime \prime} \mathrm{N}, 148^{\circ} 14^{\prime} 30^{\prime \prime} \mathrm{W}$; (map 100).

Railroad station originally located a short distance away. See Old Saulich.

Saüluktoucikh: island, in Shumagin Is., Aleutian Ra.; $55^{\circ} \mathrm{N}, 160^{\circ} \mathrm{W}$; (map 27). Var. Saliuliuktusikh, Saluluktussich.

Aleut name reported by G. A. Sarichev as "Saliuliuktusikh" and "Saluluktussich." Lutke (1836, p. 267) called the island "Saüluktoucikh." Its exact location is not known.

Saunders Creek: stream, flows S $4 \mathrm{mi}$. to Hastings Creek, $10 \mathrm{mi}$. E of Nome, Seward Penin. High.; $64^{\circ} 28^{\prime} \mathrm{N}, 165^{\circ} 07^{\prime} \mathrm{W}$; (map 94). Var. Sanders Creek.

Prospectors' name reported in 1900 by E. C. Barnard (in Brooks, 1901, pl. 17), USGS.

Savage Island: island, $0.3 \mathrm{mi}$. long, in Temnac Bay, Attu I., Aleutian Is. ; $52^{\circ} 48^{\prime} 05^{\prime \prime} \mathrm{N}, 173^{\circ}$ 04'35" E; (map 13).

Named by the U.S. Army during its occupation of the island during World War II; shown on an AMS map published in 1948.

Savage River: stream, flows NW $27 \mathrm{mi}$. to Teklanika River, $17 \mathrm{mi}$. NW of Healy, Alaska Ra.; $63^{\circ} 55^{\prime} \mathrm{N}, 149^{\circ} 30^{\prime} \mathrm{W}$; (map 87).

Local name shown on a 1916 fieldsheet by C. E. Giffin, USGS.

Savailok River: stream, see Nilik River.

Savakvik Point: point of land, see Bullen Point.

Savannah Creek: stream, flows SW $1 \mathrm{mi}$. to head of Discovery Creek, $21 \mathrm{mi}$. NW of Solomon, Seward Penin. High.; $64^{\circ} 50^{\prime} \mathrm{N}, 164^{\circ} 43^{\prime} \mathrm{W}$; (map 95).

Prospectors' name reported on a map of Cape Nome gold fields by David Fox, Jr., dated 1901.

Savaovik River: stream, see Shaviovik River.

Savayeit Lake: lake, $1 \mathrm{mi}$. long, $18 \mathrm{mi}$. N of Stevens Village, Yukon Flats; $66^{\circ} 16^{\prime} \mathrm{N}, 149^{\circ}$. 11' W; (map 118).

Kutchin Indian name obtained in 1956 by T. E. Taylor, USGS.

Saviovic River: stream, see Shaviovik River.

Saviovik River: stream, see Shaviovik River.

Savioyok Creek: stream, flows SE $13 \mathrm{mi}$. to Tinayguk River, W of Gray Mtn. and $51 \mathrm{mi}$. NW of Wiseman, Brooks Ra.; $67^{\circ} 52^{\prime} \mathrm{N}, 151^{\circ}$ $34^{\prime} \mathrm{W}$; (map 124).

Eskimo name obtained in 1956 by T. E. Taylor, USGS.

Savitovik River: stream, see Shaviovik River.
Saviukviayak River: stream, heads in Brooks Ra., flows NW $35 \mathrm{mi}$. to Ivishak River $30 \mathrm{mi}$. $\mathrm{S}$ of its junc. with Sagavanirktok River, Arctic Slope; 69 $06^{\prime} \mathrm{N}, 148^{\circ} 00^{\prime} \mathrm{W}$; (map 140).

Eskimo name reported in 1956 by T. E. Taylor, USGS.

Savka Lake: lake, $0.3 \mathrm{mi}$. across, on Kenai Penin., $5 \mathrm{mi}$. NNE of Sterling and $15 \mathrm{mi}$. ENE of Kenai, Cook Inlet Low.; 60 $35^{\prime} 45^{\prime \prime} \mathrm{N}$, $150^{\circ} 48^{\prime} 50^{\prime \prime} \mathrm{W}$; (map 62).

Named about 1963 by officials of Kenai National Moose Range, for administrative purposes.

Savonga: village, see Savoonga.

Savonoski: locality, site of Eskimo village, on Alaska Penin., near mouth of Savonoski River, at head of Iliuk Arm Naknek Lake, $21 \mathrm{mi}$. NW of Mount Katmai, Aleutian Ra.; 58 $32^{\prime} \mathrm{N}$, $155^{\circ} 19^{\prime} \mathrm{W}$; (map 42). Var. Ikak, Ikkhagamut, Ikkhagmute, Severnosky, Ukak.

Name reported in 1898 by J. E. Spurr and W. S. Post, USGS, who obtained it from Rev. A. Petelin. Spurr also reported it as "Ikkhagamut." Savonoski was abandoned after the Katmai area eruptions on June 2-6, 1912.

Savonoski: village, pop. 20, on S bank of Naknek River, on Alaska Penin., 5 mi. ESE of Naknek, Bristol Bay Low.; 58 $43^{\prime}$ N, 156 52' W; (map 41 ).

Name published in 1962 by USGS. There is another Savonoski near the east end of Iliuk Arm Naknek Lake.

Savonoski Lakes: lake, see Coville, Lake.

Savonoski Lakes: lake, see Grosvenor, Lake.

Savonoski River: stream, heads at central terminus of Hook Glacier, flows W $35 \mathrm{mi}$. to Iliuk Arm Naknek Lake, on Alaska Penin., in Katmai National Monument, $22 \mathrm{mi}$. NW of Mount Katmai, Aleutian Ra.; $58^{\circ} 32^{\prime} \mathrm{N}, 155^{\circ}$ 20' W; BGN 1924; (map 42). Var. Sabonoski River.

Named in 1919 as "Savonoski" or "Sabonoski" by R. F. Griggs, National Geographic Society, "after the abandoned Eskimo village at its mouth."

Savoonga: village, pop. 299 , on $\mathrm{N}$ coast of Saint Lawrence I:, $39 \mathrm{mi}$. SE of Gambell; $63^{\circ} 42^{\prime} \mathrm{N}$, $170^{\circ} 29^{\prime}$ W; BGN 1951; (map 93). Var. Savonga, Savunga, Sevoonga.

This is a relatively new Eskimo village with a population of 139 in 1930; 209 in 1939; and 249 in 1950 . A 1965 report listed a population of 397. The Savoonga post office was established in 1934.

Savoonga Cape: point of land, see Savoonga Point.

Savoonga Point: point of land, $\mathrm{W}$ of Savoonga, $\mathrm{N}$ coast of St. Lawrence I., $39 \mathrm{mi}$. SE of Gambell; $63^{\circ} 42^{\prime} \mathrm{N}, 170^{\circ} 30^{\prime} \mathrm{W}$; BGN 1951; (map 93). Var. Cape Savoonga, Cape Sevoonga, North Cape, Savoonga Cape, Sevoonga Cape.

Named for the nearby village.

Savoonga Reef: reef, $0.2 \mathrm{mi}$. N of Savoonga Point, $40 \mathrm{mi}$. SE of Gambell, $\mathrm{N}$ coast of St. Lawrence I.; $62^{\circ} 42^{\prime} \mathrm{N}, 170^{\circ} 30^{\prime} \mathrm{W}$; $B G N$ 1951; (map 93).

Named for the nearby village. 
Savukahuk Point: point of land, $14 \mathrm{mi}$. S of Gambell, W coast of St. Lawrence I.; $63^{\circ} 35^{\prime}$ N, $171^{\circ} 49^{\prime} \mathrm{W}$; BGN 1951; (map 93). Var. Savukhahak.

Eskimo name reported in 1949 by Maj. H. B. Allen, USAF. Orth recorded the name as "Savukhahak" at Gambell, in 1965, and reports it refers to "material for a harpoon head" which may in turn refer to artifacts from an old village site reported to be located near here.

Savukhahak: point of land, see Savukahuk Point. Savunga: village, see Savoonga.

Sawanukto River: stream, see Sagavanirktok River.

Sawlog Creek: stream, flows NW $1.5 \mathrm{mi}$. to South Fork Koyukuk River, $19 \mathrm{mi}$. WSW of Chandalar, Brooks Ra.; $67^{\circ} 25^{\prime} 00^{\prime \prime}$ N, $149^{\circ} 10^{\prime} 30^{\prime \prime}$ W; (map 123).

Local name reported in 1956 by T. E. Taylor, USGS.

Sawmill Bay: bay, $3 \mathrm{mi}$. long, in Glacier Bay National Monument, on Excursion Inlet, 2.5 mi. NW of village of Excursion Inlet and 41 mi. NW of Juneau, St. Elias Mts.; $58^{\circ} 25^{\prime} \mathrm{N}$, $135^{\circ} 27^{\prime} \mathrm{W}$; BGN 1962; (map 11).

Local name reported by NPS in 1961 . The name was derived from the presence of a sawmill, built about 1914, near the head of the bay. The remains of various sawmills and docks were still visible in 1960 .

Sawmill Bay: bay, $3 \mathrm{mi}$. across, at $\mathrm{N}$ end of Elrington Passage, on $\mathbf{E}$ coast of Evans I., $18 \mathrm{mi}$. SE of Chenega, Chugach Mts.; $60^{\circ}$ 03'30" N, 148 00'30' W; BGN 1919; (map 63). Var. Evans Bay, Roberts Bay.

Local name reported in 1918 by USC\&GS.

Sawmill Bay: bay, $2 \mathrm{mi}$. long, on $\mathrm{N}$ shore of Valdez Arm, $11 \mathrm{mi}$. W of Valdez, Chugach Mts. ; $61^{\circ} 02^{\prime} 30^{\prime \prime} \mathrm{N}, 146^{\circ} 46^{\prime} 30^{\prime \prime} \mathrm{W}$; (map 68).

Local name reported in 1902 by H. P. Ritter, USC\&GS.

Sawmill Cove: cove, $0.3 \mathrm{mi}$. across, at mouth of Sawmill Creek, $4 \mathrm{mi}$. E of Sitka, on W coast of Baranof I., Alex. Arch.; $57^{\circ} 02^{\prime} 45^{\prime \prime} \mathrm{N}$, $135^{\circ} 13^{\prime} 30^{\prime \prime} \mathrm{W}$; (map 9). Var. Ham Cove.

Named by Lt. Comdr. H. E. Nichols, USN, and published by USC\&GS in the 1883 Coast Pilot. So named because "in this vicinity a saw-mill was erected by missionaries to supply material for building purposes." It was also called "Ham Cove" by Sheldon Jackson for J. M. Ham who contributed funds for the erection of the sawmill in 1882 .

Sawmill Cove: cove, $0.2 \mathrm{mi}$. across, on $\mathrm{SE}$ shore of Yakutat Bay, $1.7 \mathrm{mi}$. S of Dolgoi I. and $2.6 \mathrm{mi}$. NE of Yakutat, Malaspina Coastal Plain; 59 $34^{\prime} 10^{\prime \prime} \mathrm{N}, 1^{\circ} 39^{\circ} 39^{\prime} 45^{\prime \prime} \mathrm{W}$; (map 46).

Local name published in 1959 by USGS.

Sawmill Cove : estuary, see Ham Cove.

Sawmill Creek: stream, heads in Blue Lake, flows SW $1.8 \mathrm{mi}$. to mouth of Silver Bay, 4 mi. E of Sitka, on W coast of Baranof I., Alex. Arch.; $57^{\circ} 02^{\prime} 50^{\prime \prime} \mathrm{N}, 135^{\circ} 13^{\prime} 35^{\prime \prime} \mathrm{W}$; (map 9). Var. Kirinskaia Bay, Kirinskaya Bukhta, Medvetcha River, Reka Medvyzhya.
Named in the 1890's by USC\&GS for a sawmill reported in 1850 by Capt. Tebenkov (1852, map 38), IRN, to be located at its mouth. This stream was called "Reka Medvyzhya," meaning "bear river," in 1809 by the Russian navigator Ivan Vasiliev the first; published as such by Lt. Sarichev (1826, map 19), IRN.

Sawmill Creek: stream, flows $4.5 \mathrm{mi}$. SW to Berners Bay, on Lynn Canal, $2 \mathrm{mi}$. $\mathrm{N}$ of Echo Cove and $35 \mathrm{mi}$. NW of Juneau, Coast Mts.; $58^{\circ} 43^{\prime} 00^{\prime \prime} \mathrm{N}, 134^{\circ} 56^{\prime} 10^{\prime \prime} \mathrm{W}$; (map 11).

Local name reported by A. C. Spencer and C. W. Wright (1906, fig. 36), USGS.

Sawmill Creek: stream, on $\mathbf{N}$ end of Kenai Penin., flows NE $2 \mathrm{mi}$. to Turnagain Arm, 6 mi. E of Sunrise, Chugach Mts.; $60^{\circ} 53^{\prime} 40^{\prime \prime}$ $\mathrm{N}, 149^{\circ} 14^{\prime} 45^{\prime \prime} \mathrm{W}$; (map 63 ).

Local name reported in 1899 by Lt. Herron (1901, sketch facing p. 11), USA.

Sawmill Creek: stream, heads in glacier, flows NW 4 mi. to Port Valdez at Sawmill Spit, 6 mi. WSW of Valdez, Chugach Mts.; 61 ${ }^{\circ} 05^{\prime}$ $15^{\prime \prime} \mathrm{N}, 146^{\circ} 23^{\prime} 10^{\prime \prime} \mathrm{W}$; (map 68).

Local name reported in 1911 by USGS.

Sawmill Creek: stream, flows NW $1.3 \mathrm{mi}$. to Willow Creek, $18 \mathrm{mi}$. NW of Palmer, Talkeetna Mts. ; $61^{\circ} 45^{\prime} 50^{\prime \prime} \mathrm{N}, 149^{\circ} 32^{\prime} 00^{\prime \prime} \mathrm{W}$; (map 69).

Local name reported in 1951 by USGS.

Sawmill Creek: stream, flows SW through Bonnie Lake $9.6 \mathrm{mi}$. to Chickaloon River, $\mathrm{E}$ of Chickaloon, $26 \mathrm{mi}$. NE of Palmer, Talkeetna Mts.; $61^{\circ} 48^{\prime} 00^{\prime \prime} \mathrm{N}, 148^{\circ} 26^{\prime} 15^{\prime \prime} \mathrm{W}$; $B G N$ 1933; (map 69).

Local name reported about 1932 by USGS. So named locally "because some years ago a sawmill was located on this creek."

Sawmill Creek: stream, heads on Syncline Mtn., flows N $1.7 \mathrm{mi}$. to Alfred Creek, $57 \mathrm{mi}$. NE of Palmer, Talkeetna Mts.; $61^{\circ} 57^{\prime} 00^{\prime \prime} \mathrm{N}, 147^{\circ}$ $31^{\prime} 30^{\prime \prime} \mathrm{W}$; BGN 1960; (map 69).

Local name reported in 1952 by USGS but probably has been used prior to this date. So named because there was an abandoned sawmill along the stream near Alfred Creek.

Sawmill Creek: stream, heads in Sawmill Lake, flows SE $6.3 \mathrm{mi}$. to Rabideux Creek, $6 \mathrm{mi}$. SW of Talkeetna, Cook Inlet Low.; 62 ${ }^{\circ} 14^{\prime} 45^{\prime \prime}$ N, 150 $14^{\prime} 20^{\prime \prime} \mathrm{W}$; (map 81 ).

Local name reported in 1958 by USGS.

Sawmill Creek: stream, flows NW $30 \mathrm{mi}$. to Clearwater Creek, $16 \mathrm{mi}$. ESE of Big Delta, Alaska Ra.; $64^{\circ} 03^{\prime} \mathrm{N}, 145^{\circ} 21^{\prime} \mathrm{W}$; (map 101). Local name reported in 1955 by USGS.

Sawmill Gulch: ravine, extends $3.5 \mathrm{mi}$. $\mathrm{S}$ from Sourdough Peak to Nizina River, $7 \mathrm{mi}$. SE of McCarthy Wrangell Mts.; $61^{\circ} 22^{\prime} 20^{\prime \prime} \mathrm{N}$, $142^{\circ} 43^{\prime} 35^{\prime \prime} \mathrm{W}$; (map 67).

Local name obtained by USGS and published on maps since 1954 .

Sawmill Island: island, $1.7 \mathrm{mi}$. long, in Tanana River, $11 \mathrm{mi}$. $\mathrm{N}$ of Nenana, Tanana Low.; $64^{\circ} 43^{\prime} 30^{\prime \prime} \mathrm{N}, 1^{\circ} 9^{\circ} 08^{\prime} 15^{\prime \prime} \mathrm{W}$; (map 100).

Local name reported in 1950 by USGS topographers.

Sawmill Lake: lake, $0.6 \mathrm{mi}$. long at head of Sawmill Creek, $6.7 \mathrm{mi}$. SW of Talkeetna, Cook
Inlet Low.; $62^{\circ} 17^{\prime} 35^{\prime \prime} \mathrm{N}, 150^{\circ} 19^{\prime} 15^{\prime \prime} \mathrm{W}$; (map 81).

Local name reported in 1958 by USGS.

Sawmill Point: point of land, on $\mathrm{E}$ coast of Woody I., $3.5 \mathrm{mi}$. E of Kodiak, Kodiak I.; $57^{\circ} 47^{\prime} 05^{\prime \prime} \mathrm{N}, 152^{\circ} 18^{\prime} 40^{\prime \prime} \mathrm{W}$; (map 34).

Local name reported in 1949 by USGS.

Sawmill Slough: stream, an anabranch of Unuk River, flows SW $2 \mathrm{mi}$. to a point $12 \mathrm{mi}$. upstream of mouth of Unuk River at Burroughs Bay, Coast Mts.; $56^{\circ} 13^{\prime} 20^{\prime \prime}$ N, $130^{\circ} 53^{\prime} 40^{\prime \prime}$ W; $(\operatorname{map} 7)$.

Local name reported in 1955 by USGS.

Sawmill Slough: stream, $7 \mathrm{mi}$. long, anabranch of Tanana River, $3 \mathrm{mi}$. W of Minto and 46 mi. W of Fairbanks, Tanana Low.; 64 ${ }^{\circ} 53^{\prime}$ $\mathrm{N}, 149^{\circ} 15^{\prime} \mathrm{W}$; (map 100).

Local name published on a 1940 "Navigation Chart of the Tanana-Yukon Rivers" published by U.S. Dept. of Interior.

Sawmill Spit: shoals, $0.5 \mathrm{mi}$. across, on $\mathrm{S}$ shore of Port Valdez, $6 \mathrm{mi}$. SW of Valdez, Chugach Mts.; $61^{\circ} 05^{\prime} 05^{\prime \prime} \mathrm{N}, 146^{\circ} 26^{\prime} 15^{\prime \prime} \mathrm{W}$; (map 68).

Local name reported in 1901 by H. P. Ritter, USC\&GS.

Sawoonhak Creek: stream, flows $\mathrm{N}$ to Bering Sea, $1 \mathrm{mi}$. E of Savoonga, $\mathrm{N}$ coast of St. Lawrence I.; $63^{\circ} 41^{\prime} \mathrm{N}, 170^{\circ} 29^{\circ} \mathrm{W}$; BGN 1951; (map 93). Var. Sawoonhak River.

Eskimo name recommended by the Savoonga village council and reported in 1949 by Maj. H. B. Allen, USAF.

Sawoonhak River: stream Sawoonhak Creek.

Saw Peaks: peaks, 5,256 ft., $3 \mathrm{mi}$. S of Patterson Glacier, $16 \mathrm{mi}$. NE of Petersburg, Coast Mts. ; $56^{\circ} 55^{\prime} 15^{\prime \prime} \mathrm{N}, 132^{\circ} 36^{\prime} 00^{\prime \prime} \mathrm{W}$; (map 6).

Local descriptive name reported in 1961 by USGS.

Sawpit Creek: stream, heads in Kilbuck Mts. and flows NE $16 \mathrm{mi}$. to Swift Creek $29 \mathrm{mi}$. S. of Aniak, Kilbuck-Kuskokwim Mts., $61^{\circ} 10^{\prime} \mathrm{N}$, 159²1' W; (map 73). Var. Amotoloriasak River.

Prospectors' name shown on a 1914 field sheet by A. G. Maddren, USGS. This probably is meant to be the same stream shown on a manuscript map of the "Kuskokwim Gold Belt," by H. W. Reeth, as "Amotoloriasak River," obviously an Eskimo name.

Sawpit Creek: stream, flows N $3 \mathrm{mi}$. to Crooked Creek, $7 \mathrm{mi}$. W of Central and $33 \mathrm{mi}$. SW of Circle, Yukon-Tanana High.; 65 $34^{\prime} 30^{\prime \prime} \mathrm{N}$, $145^{\circ} 01^{\prime} 30^{\prime \prime} \mathrm{W}$; BGN 1937; (map 104).

Named by prospectors and reported in 1937 by USGS.

Saw Point: point of land, in South Passage, at mouth of Eliza Harbor, on Admiralty I., 27 mi. SE of Angoon, Alex. Arch.; 5 $7^{\circ} 09^{\prime} 30^{\prime \prime} \mathrm{N}$, $134^{\circ} 17^{\prime} 00^{\prime \prime} \mathrm{W}$; (map 9).

Named in 1889 by Lt. Comdr. H. B. Mansfield, USN, and published by USC\&GS in 1891 Coast Pilot (p. 142). "So named because of the sunken rocks and ledges along it [the point of land]."

Saw Ridge: ridge, $3 \mathrm{mi}$. long, on SE penin. of Revillagigedo I., $3.3 \mathrm{mi}$. N of Point Alava, Alex. Arch.; $55^{\circ} 00^{\prime} 15^{\prime \prime} \mathrm{N}, 131^{\circ} 12^{\prime 25^{\prime \prime}} \mathrm{W}$; (map 3). 
Descriptive name given in 1883 by $\mathrm{Lt}$. Comdr. H. E. Nichols, USN.

Sawtooth Mountain: mountain, 3,670 ft., in Eek Mts., $10 \mathrm{mi}$. S of Eek Lake and $70 \mathrm{mi}$. SE of Bethel, Kilbuck-Kuskokwim Mts. ; $60^{\circ} 04^{\prime}$ N, $160^{\circ} 23^{\prime} \mathrm{W}$; (map 59).

Local name reported in 1951 by USC\&GS.

Sawtooth Mountain: mountain, 4,494 ft., $20 \mathrm{mi}$. SE of Rampart, Yukon-Tanana High.; $65^{\circ} 23$ N, 149 $31^{\prime}$ W; (map 105). Var. Saw Tooth Mountains, Sawtooth Mountains, Lynx Mountains.

Descriptive name published in 1906 by USGS as "Saw Tooth Mountains." Subsequently, the peaks have been determined to be part of one mountain with a jagged crest.

Sawtooth Mountains: mountain, see Sawtooth Mountain.

Sawtboth Range: mountain range, see Kigluaik Mountains.

Sawyer Creek: stream, flows SE $3 \mathrm{mi}$., between Moose and Emma Creeks, from Emma Dome to Middle Koyukuk River, $5.5 \mathrm{mi}$. S. of Wiseman, Brooks Ra.; $67^{\circ} 20^{\prime} 30^{\prime \prime} \mathrm{N}$, $150^{\circ} 09^{\prime} 00^{\prime \prime}$ W; (map 124).

Local name obtained in 1956 by USGS topographers.

Sawyer Creek: stream, tributary of Sam Creek, about $4 \mathrm{mi}$. SW of that stream's junc. with Yukon River, Porcupine Plat.; $65^{\circ} 16^{\prime} \mathrm{N}$, $142^{\circ} 57^{\prime} \mathrm{W}$; (map 103).

Mentioned by Mertie (1942, p. 250), USGS; this feature has not been positively identified.

Sawyer Glacier: glacier, heads in British Columbia at about $57^{\circ} 55^{\prime} \mathrm{N}, 132^{\circ} 40^{\prime} \mathrm{W}$, and trends W $22 \mathrm{mi}$. to Tracy Arm, $54 \mathrm{mi}$. SE of Juneau, Coast Mts.; $57^{\circ} 53^{\prime} 45^{\prime \prime} \mathrm{N}, 133^{\circ} 10^{\prime} 45^{\prime \prime} \mathrm{W}$; $B G N 1922$; (map 8).

Named in 1889 by Comdr. H. B. Mansfield, USN; name published by USC\&GS in 1891 Goast Pilot (p. 147).

Saxman: village, pop. 153, on S coast of Revillagigedo I. $2.5 \mathrm{mi}$. SE of Ketchikan, Alex. Arch.; $55^{\circ} 19^{\prime} 05^{\prime \prime} \mathrm{N}, 131^{\circ} 35^{\prime} 45^{\prime \prime} \mathrm{W}$; (map 3).

Tlingit Indian village founded in 1894; named for Samuel Saxman, school teacher. The population was 154 in $1910 ; 103$ in 1920 ; 112 in 1930; 111 in 1939; and 167 in 1950. The Saxman post office operated from 1897 to 1900 (Ricks, 1965, p. 56).

Saxton: locality, on Kenai Penin., along Seward Highway, 12 mi. S of Sunrise, Chugach Mts.; $60^{\circ} 42^{\prime} 05^{\prime \prime} \mathrm{N}, 149^{\circ} 27^{\prime} 59^{\prime \prime} \mathrm{W}$; (map 63).

Former mining camp located along Canyon Creek. Recent USGS maps indicate a site with three buildings.

Sayaéja: glacier, see Saksaia Glacier.

Sayagrowrak: hill, see Sakrorak Mountain.

Sayagrowrak: locality, see Siagrorak.

Sayalik Creek: stream, flows W $8 \mathrm{mi}$. to Kuskokwim Bay, $36 \mathrm{mi}$. NW of Goodnews, YukonKuskokwim Delta; $59^{\circ} 37^{\prime} \mathrm{N}, 161^{\circ} 51^{\prime} \mathrm{W}$; map 53).

Eskimo name pubfished in 1951 by USGS. Sayraidneuskoi: locality, see Seredka.

Saytut Koogowranga: stream, see Saitut Creek.
Sbichsak: bay, see Swikshak Bay.

Sbichsak Bay: bay, see Kaguyak Bay.

Sbjeznikof: cove, see Sviechnikof Harbor.

SC, Bay: bight, $1.5 \mathrm{mi}$. across, on SW coast of Kanaga I., Aleutian Is.; $51^{\circ} 42^{\prime} \mathrm{N}, 177^{\circ} 35^{\prime}$ W; (map 17).

Name published in 1943 on an AMS map.

Scabbard Bay: $b a y, 0.5 \mathrm{mi}$. across, on $\mathrm{S}$ shore of Kuluk Bay, on NE coast of Adak I., Aleutian Is.; $51^{\circ} 50^{\prime} \mathrm{N}, 176^{\circ} 31^{\prime} \mathrm{W}$; $B G N$ 1936; (map 17).

So named by members of the U.S. Navy Aleutian Island Survey Expedition in 1934 "because it is shaped like a scabbard."

Scachlitak Island: island, see Sitkalidak Island.

Scald Point: point of land, on Admiralty I., on W shore of Snug Cove, $58 \mathrm{mi}$. NE of Sitka, Alex. Arch.; $57^{\circ} 26^{\prime} 00^{\prime \prime} \mathrm{N}, 133^{\circ} 58^{\prime} 25^{\prime \prime} \mathrm{W}$; (map 8).

Named in 1889 by Comdr. R. W. Mansfield, USN; name published in 1892 by USC\&GS.

Scammon Bay: village, pop. 115, at $\mathrm{N}$ foot of Askinuk Mts., on left bank of Kun River $1 \mathrm{mi}$. from its mouth, Yukon-Kuskokwim Delta; $61^{\circ} 50^{\prime} 45^{\prime \prime} \mathrm{N}, 165^{\circ} 35^{\prime} 00^{\prime \prime} \mathrm{W}$; (map 75). Var. Kutmiut, Mariagamiut, Mariakamut, Mariuk.

The post office, established in 1951, is primarily responsible for standardizing this name on maps as Scammon Bay; named for the nearby bay. The village is known in Eskimo as "Mariak" and the people are referred to as Mariagamiut.

Scammon Bay: bay, $13 \mathrm{mi}$. across, on coast of Bering Sea, $N$ of Cape Romanzof, YukonKuskokwim Delta; 61 ${ }^{\circ} 55^{\prime} \mathrm{N}, 165^{\circ} 50^{\prime} \mathrm{W}$; (map 75).

Named by Dall (1870, p. 264) who wrote "The bay north and east of Cape Dyer, and southeast of the southern sand island, it is proposed to call Scammon Bay, in honor of Captain C[harles] M. Scammon, USRCS, Chief of Marine of the Western Union Telegraph Expedition."

Scandinavian Creek: stream, flows $N$ and $W 40$ $\mathrm{mi}$ to Innoko River, $39 \mathrm{mi}$. NW of Ophir and $62 \mathrm{mi}$. NW of McGrath, Innoko Low.; $63^{\circ} 40^{\prime} 30^{\prime \prime} \mathrm{N}, 156^{\circ} 52^{\prime} 00^{\prime \prime} \mathrm{W}$; (map 90). Var. Parka Creek.

Prospectors' name obtained in 1908 by Maddren (1910, pl. 1), USGS.

Scandinavian Slough: stream, anabranch of $\mathrm{Nu}$ shagak River, flows W $8.5 \mathrm{mi}$., $29 \mathrm{mi}$. NW of Naknek, Bristol Bay Low.; 58 55'50' $\mathrm{N}$, $157^{\circ} 55^{\prime} 30^{\prime \prime}$ W; BGN 1931; (map 41).

Local name published in 1925 by USBF.

Scarab Rock: rock, $1.2 \mathrm{mi}$. off SW coast of Tanaga I., Aleutian Is.; $51^{\circ} 38^{\prime} 00^{\prime \prime} \mathrm{N}, 1^{\prime 7} 8^{\circ} 01^{\prime}$ $20^{\prime \prime} \mathrm{W}$; (map 16).

Local name published on a 1954 USGS map.

Scarp Creek: stream, heads in lake, flows N 10 mi. to Bishop Greek, $18 \mathrm{mi}$. NW of Tyonek, Cook Inlet Low.; $61^{\circ} 19^{\prime} 02^{\prime \prime} \mathrm{N}, 151^{\circ} 19^{\prime} 42^{\prime \prime}$ W; BGN 1964; (map 70).

So named by USGS in 1962 "because of the steep cliff along its lower course."
Scatter Peaks, The: ridge, series of peaks, forms crescent $3 \mathrm{mi}$. long, $7 \mathrm{mi}$. SW of Devils Paw and $29 \mathrm{mi}$. $\mathrm{N}$ of Juneau, Coast Mts.; $58^{\circ} 40^{\prime}$ $30^{\prime \prime} \mathrm{N}, 134^{\circ} 02^{\prime} 30^{\prime \prime} \mathrm{W}$; BGN 1965; (map 11).

Descriptive name given by members of the Juneau Icefield Research Project. in 1964.

Scaup Lake: lake, $0.5 \mathrm{mi}$. long, near $\mathrm{W}$ coast of Kenai Penin., $4 \mathrm{mi}$. E. of Gray Cliff and 25 mi. NE of Kenai, Cook Inlet Low.; $60^{\circ} 51^{\prime} \mathrm{N}$, $150^{\circ} 49^{\prime} \mathrm{W}$, (map 62).

Named about 1963 by officials of Kenai National Moose Range, probably for the Greater Scaup, or Blue-billed Widgeon, (Aythya marila nearctica), a duck which breeds and winters in Alaska.

Scaup Lake: lake, $2.5 \mathrm{mi}$. long, $4 \mathrm{mi}$. SE of Canvasback Lake, $30 \mathrm{mi}$. SW of Fort Yukon, Yukon Flats; $66^{\circ} 21^{\prime} 20^{\prime \prime} \mathrm{N}, 146^{\circ} 12^{\prime} 00^{\prime \prime} \mathrm{W}$; (map 119).

Local name obtained in 1956 by USGS.

Scenery Cove: cove, $1 \mathrm{mi}$. long, on $\mathrm{E}$ shore of Thomas Bay, $100 \mathrm{mi}$. E. of Sitka, Coast Mts.; $57^{\circ} 04^{\prime} 30^{\prime \prime} \mathrm{N}, 132^{\circ} 49^{\prime} 00^{\prime \prime} \mathrm{W}$; (map 8).

Descriptive name given in 1887 by Lt. Comdr. G. M. Thomas, USN; published in 1888 by USC\&GS.

Scenery Creek: stream, flows W $11 \mathrm{mi}$. to Scenery Cove, on Thomas Bay, $100 \mathrm{mi}$. E. of Sitka, Coast Mts.; $57^{\circ} 04^{\prime} 50^{\prime \prime} \mathrm{N}, 132^{\circ} 47^{\prime} 15^{\prime \prime} \mathrm{W}$; BGN 1930; (map 8).

Named in 1930 by USGS for Scenery Cove. Scenery Lake: lake, extends $2.5 \mathrm{mi}$. along Scenery Creek, $3 \mathrm{mi}$. E of Scenery Cove and $105 \mathrm{mi}$. E of Sitka, Coast Mts.; $57^{\circ} 04^{\prime} 55^{\prime \prime} \mathrm{N}, 132^{\circ}$ $42^{\prime} 40^{\prime \prime} \mathrm{W}$; (map 8).

Named for Scenery Cove and published in 1949 by USGS.

Scenic Lake: lake, $0.5 \mathrm{mi}$. across, on Kenai Penin., $3 \mathrm{mi}$. W of Trapper Joe Lake and 40 mi. NE of Kenai, Cook Inlet Low.; 60 $45^{\prime} 45^{\prime \prime}$ N, $150^{\circ} 09^{\prime} 40^{\prime \prime} \mathrm{W}$; (map 62).

Named about 1963 by officials of Kenai National Moose Range for administrative purposes.

Schachun Rocks: rock, see Shakun Rock.

Schaefer Creek: stream, see Potato Creek.

Schakaliakh: point of land, see Thatcher, Point. Schaws Insel: island, see Shaw Island.

Schelikoff Harbor: cove, see Three Saints Harbor.

Schellman River: stream, see Shelman Creek.

Schieffelin Creek: stream, in Rampart Mts., flows SE $12 \mathrm{mi}$. to Yukon River, $19 \mathrm{mi}$. ENE of Tanana, Kokrines-Hodzana High.; $65^{\circ} 13^{\prime} 45^{\prime \prime}$ N, $151^{\circ} 26^{\prime} 00^{\prime \prime} \mathrm{W}$; (map 106). Var. Sancho Creek, Shefflin Creek, Sheflin Creek, Shevlin Creek.

Named for Edward and "Eff" Schiefferlin (the former discovered gold at Tombstone, Ariz., in 1877) who organized a large party and prospected along the Yukon in this area in 1882 and 1883. The name appears first as "Sheflin" on Edward's Track Chart of the Yukon, dated 1899 (Cantwell, 1902, p. 277). The name "Shevlin Creek," applied in 1898 to a stream on the left bank of the Yukon near here by USC\&GS, was also intended to commemorate the Schieffelin brothers' expedition. 
The exact identity of this stream is doubtful, but it probably is the same as "Sancho Creek" listed by Cantwell (p. 277), which may be the "Stevens Creek" of today.

Schikossean: island, see Anyaka Island.

Schikuk: island, see Sullivan Island.

Schilling Creek: stream, flows NE $7 \mathrm{mi}$., from W of Sixty-one Mtn. to Chandalar River, $33 \mathrm{mi}$. SSE of Chandalar, Brooks Ra., $67^{\circ} 07^{\prime} 00^{\prime \prime} \mathrm{N}$, $147^{\circ} 46^{\prime} 30^{\prime \prime} \mathrm{W}$; ( $\operatorname{map} 123$ ).

Local name reported in 1956 by T. E. Taylor, USGS.

Schilter Creek: stream, heads on S side of Madson Mtn., flows S $2.5 \mathrm{mi}$. to Kenai Lake, $22 \mathrm{mi}$. N of Seward, Chugach Mts. ; $60^{\circ} 24^{\prime} 40^{\prime \prime}$ $\mathrm{N}, 149^{\circ} 26^{\prime} 10^{\prime \prime} \mathrm{W}$; (map 63).

Local name reported in 1951 by USGS.

Schischaldenskoje: locality, see Sisaguk.

Schischmareff Bay: bay, see Shishmaref Inlet.

Schist Creek: stream, flows SW $8 \mathrm{mi}$. to Nenana River, $30 \mathrm{mi}$. SE of Healy, Alaska Ra.; $63^{\circ} 27^{\prime}$ N, $148^{\circ} 46^{\prime} \mathrm{W}$; (map 87).

Local name obtained in 1913 by $\mathrm{J}$. W. Bagley, USGS; published by Moffit (1915, pl. 1), USGS.

Schist Creek: stream, flows NE $1.4 \mathrm{mi}$. to Spruce Creek, $3.5 \mathrm{mi}$. NE of Poorman, KilbuckKuskokwim Mts.; $64^{\circ} 08^{\prime} 24^{\prime \prime}$ N, $155^{\circ} 28^{\prime} 12^{\prime \prime}$ W; (map 98).

Prospectors' name reported by Mertie and Harrington (1924, p. 95), USGS.

Schitcha: town, see Sitka.

Schitka: town, see Sitka.

Schitkha: town, see Sitka.

Schkagué : village, see Skagway.

Schkagué River: stream, see Skagway River.

Schley Creek: stream, flows NE 5 mi. to Yukon River, $35 \mathrm{mi}$. NW of Eagle, Yukon-Tanana High.; $65^{\circ} 13^{\prime} \mathrm{N}, 141^{\circ} 53^{\prime} \mathrm{W}$; (map 103).

Prospectors' name from an unpublished map by E. F. Ball, dated 1898 .

Schley Creek: stream, flows NW to Nome River, about $17 \mathrm{mi}$. NNE of Nome, Seward Penin. High.; (map 94).

Prospectors' name published on the 1900 "Map of Nome Peninsula" by J. M. Davidson and B. D. Blakeslee. This stream cannot be precisely identified on recent maps.

Schlitz Creek: stream, flows NW $15 \mathrm{mi}$. to join Bryan Creek, forms Serpentine River, $13 \mathrm{mi}$. NW of Midnight Mtn. and $54 \mathrm{mi}$. NW of Imuruk Lake, on Seward Penin., KotzebueKobuk Low.; $65^{\circ} 55^{\prime} \mathrm{N}, 164^{\circ} 55^{\prime} \mathrm{W}$; (map 110). Var. Hoggom Creek.

Prospectors' name reported in 1901 by T. G. Gerdine (in Collier, 1902, pl. 12), USGS.

Schneider Lake: lake, see Schnieder Lake.

Schnieder Lake: lake, $0.6 \mathrm{mi}$. long, $5 \mathrm{mi}$. W of Amber Lake and $21 \mathrm{mi}$. SW of Talkeetna, Cook Inlet Low.; $62^{\circ} 10^{\prime} 15^{\prime \prime} \mathrm{N}, 150^{\circ} 41^{\prime} 05^{\prime \prime}$ $W$; (map 81). Var. Schneider Lake.

Local name reported in 1958 by USGS.

Schnuna River: stream, see Sinona Creek.

Schonthda Hill: hill, 2,523 ft., in Black Hills, S of Mundthag Lake, $13 \mathrm{mi}$. S of Northway, Alaska Ra.; 62 $46^{\prime} \mathrm{N}, 141^{\circ} 59^{\prime} \mathrm{W}$; (map 84).
Indian name reported by USGS in 1955.

Schönwetterberg: mountain, see Fairweather, Mount.

Schoolhouse Lake: lake, $1 \mathrm{mi}$. across, on $\mathrm{N}$ shore of Iliamna Lake, $2.5 \mathrm{mi}$. SE of Iliamna, Bristol Bay Low ; 59 $44^{\prime} 30^{\prime \prime} \mathrm{N}, 154^{\circ} 51^{\prime} 15^{\prime \prime} \mathrm{W}$; (map 51).

Name published in 1954 by USGS.

Schooner Bend: locality, on Kenai Penin., along S bank of Kenai River, $34 \mathrm{mi}$. SW of Hope, Chugach Mts. ; $60^{\circ} 28^{\prime} 50^{\prime \prime} \mathrm{N}, 149^{\circ} 56^{\prime} 45^{\prime \prime} \mathrm{W}$; (map 63).

Recent USGS maps indicate a site with four or five buildings.

Schooner Channel Nushagak Bay: channel, in Nushagak Bay, extends SE $14 \mathrm{mi}$. S of Ekuk, $W$ of Flounder Flat, $18 \mathrm{mi}$. $S$ of Dillingham, Bristol Bay Low. ; $58^{\circ} 36^{\prime} \mathrm{N}, 158^{\circ} 24^{\prime} \mathrm{W}$; (map $40)$.

Local name reported in 1950 by USC\&GS. Nushagak Bay channels are constantly changing in location and navigability.

Schooner Rock: rock, in Hinchinbrook Entrance, off NE tip of Montague I., $45 \mathrm{mi}$. SW of Cordova, Chugach Mts.; $60^{\circ} 18^{\prime} 20^{\prime \prime} \mathrm{N}, 146^{\circ} 54^{\prime}$ $15^{\prime \prime} \mathrm{W}$; (map 64).

So named "because of the rocks resemblance to a schooner," reported by $F$. Westdahl, USC\&GS, while doing survey work aboard the steamer McArthur in the Hinchinbrook Island region 1902.

Schoonhoven Creek: stream, see Boulder Creek.

Schoppe Bay: estuary, extends SW 2 mi. to Eaglek Bay, $36 \mathrm{mi} \mathrm{NE}$ of Whittier, Chugach Mts.; $60^{\circ} 52^{\prime} 30^{\prime \prime} \mathrm{N}, 147^{\circ} 41^{\prime} 30^{\prime \prime} \mathrm{W}$; (map 63).

Local name reported in 1951 by USGS.

Schrader, Lake: lake, $4.5 \mathrm{mi}$. long, northernmost lake of Neruokpuk Lakes, in Franklin Mts., $17 \mathrm{mi}$. NW of Mount Michelson, Brooks Ra.; $69^{\circ} 22^{\prime} 30^{\prime \prime} \mathrm{N}, 145^{\circ} 00^{\prime} 00^{\prime \prime} \mathrm{W} ; B G N$ 1961; (map 139). Var. Lake Peters, Lakes Peters and Schrader, Neruokpuk Lakes, Peters Lake.

Named for Frank Charles Schrader, 18601944, USGS, geologist. This lake was originally named Lake Peters by Leffingwell (1919, p. 57) who wrote, "a narrow channel which heads a few hundred yards to Lake Peters. Here the high mountains cease, and the lake lies in an open basin whose slopes rise only a few hundred feet above the water." Leffingwell's map (pl. 1), however, shows the names transposed, and it is this application that influenced subsequent map and local usage.

Schrader, Mount: mountain, 7,300 ft., $3 \mathrm{mi}$. SE of Townsend Peak and $14 \mathrm{mi}$. NE of Valdez, Chugach Mts. ; $61^{\circ} 19^{\prime} 05^{\prime \prime} \mathrm{N}, 146^{\circ} 10^{\prime} 15^{\prime \prime} \mathrm{W}$; BGN 1960; (map 68).

Named in 1959 by L. E. Nielsen for Frank Charles Schrader, 1860-1944, geologist for the USGS who as "a member of Capt. W. R. Abercrombie's 1898 expedition was the first geologist to investigate the Valdez Glacier area and in so doing spent several days at the base of this mountain."

Schrader Bluff: bluff, elev. $700 \mathrm{ft}$., on $\mathrm{E}$ bank of Anaktuvuk River, 5 mi. E of Outpost Mtn., and $30 \mathrm{mi}$. SE of Umiat, Arctic Slope; $69^{\circ}$ $09^{\prime} \mathrm{N}, 151^{\circ} 01^{\prime} \mathrm{W}$; BGN 1949; (map 141).

Named by USGS geologists about 1950 for Frank Charles Schrader, 1860-1944, USGS geologist, who with $W$. J. Peters made a reconnaisance expedition down the Anaktuvuk River in 1901.

Schrader Creek: stream, flows SE $6.5 \mathrm{mi}$. to North Fork Chandalar River, $1 \mathrm{mi}$. SW of southern end of Chandalar Lake and $6.5 \mathrm{mi}$. SW of Chandalar Lake, Brooks Ra.; 67 $27^{\prime}$. $30^{\prime \prime} \mathrm{N}, 148^{\circ} 44^{\prime} 00^{\prime \prime} \mathrm{W}$; (map 123).

This name reported in 1956 . The stream was probably named for F. C. Schrader, USGS, who made geological investigations in this area in 1900 and 1901.

Schrader Island: island, $0.7 \mathrm{mi}$. across, in Long Bay, $52 \mathrm{mi}$. NE of Whittier, Chugach Mts.; $60^{\circ} 57^{\prime} 45^{\prime \prime} \mathrm{N}, 147^{\circ} 15^{\prime} 00^{\prime \prime} \mathrm{W}$; (map 63).

Local name reported in 1951 by USGS.

Schrader Lake: lake, $2.2 \mathrm{mi}$. long, $12 \mathrm{mi}$. $\mathrm{N}$ of Chalkyitsik, Yukon Flats; $66^{\circ} 49^{\prime} \mathrm{N}, 143^{\circ} 44^{\prime}$ W; (map 120).

Local name obtained in 1956 by T. E. Taylor and R. C. Foley, USGS.'

Schrader Lake: lake, see Peters, Lake.

Schroeder Point: point of land, see Spruce Point. Schubee Glacier: glacier, trends $1.5 \mathrm{mi}$. W to its terminus, $6 \mathrm{mi}$. $\mathrm{N}$ of Mount Villard and 8 mi. S of Skagway, Coast Mts.; $59^{\circ} 21^{\prime} 30^{\prime \prime} \mathrm{N}$, $135^{\circ} 19^{\prime} 30^{\prime \prime} \mathrm{W}$; (map 45).

Name published by USC\&GS in the 1883 Coast Pilot (pl, 1819).

Schujek Island: island, see Shuyak Island.

Schuler Beach: beach, $0.3 \mathrm{mi}$. long, $2 \mathrm{mi}$. W of Buchanan Point, E end of Attu I., Aleutian Is.; $52^{\circ} 51^{\prime} 20^{\prime \prime} \mathrm{N}, 173^{\circ} 23^{\prime} 00^{\prime \prime} \mathrm{E}$; (map 13).

Name shown on an AMS map published in 1948, and given by the U.S. Army during World War II. The name is not used today.

Schulze Cove: bay, $0.4 \mathrm{mi}$. across, in Fish Bay, on NW coast of Baranof I., $24 \mathrm{mi}$. NW of Sitka, Alex. Arch.; 57 $23^{\prime} 30^{\prime \prime} \mathrm{N}, 135^{\circ} 35^{\prime} 45^{\prime \prime}$ W; (map 9). Var. Shulze Cove.

Named in 1880 by the U.S. Navy for Paul Schulze, president of Northwest Trading Co. of Portland, Oregon, who did business in this region (U.S. Coast and Geodetic Survey, 1883, p. 161).

Schulze Glacier: glacier, see Taku Glacier.

Schulze Head: point of land, between Schulze Cove and Fish Bay, on Baranof I., $24 \mathrm{mi}$. N of Sitka, Alex. Arch.; $57^{\circ} 23^{\prime} 15^{\prime \prime} \mathrm{N}, 135^{\circ} 36^{\prime}$ $30^{\prime \prime} \mathrm{W}$; (map 9).

Named in 1884 by Comdr. J. B. Coghlan, USN, and published by USC\&GS in 1891 Coast Pilot (p. 181). The name was derived from Schulze Cove.

Schumachinskaia: island, in Shumagin Is., Aleutian Ra.; $55^{\circ} \mathrm{N}, 160^{\circ} \mathrm{W}$; (map 27).

Name reported by von Langsdorff (1814, v. 2, p. 54); however, the exact location of this island is not known.

Schunachtuli Island: island, see Shaw Island. Schwanda Glacier: glacier, heads on Mt. Hubley in Romanzof Mts., trends SE $2.5 \mathrm{mi}$. to its 
terminus, $12 \mathrm{mi}$. SE of Mt. Michelson, Brooks Ra. ; $69^{\circ} 15^{\prime} \mathrm{N}, 143^{\circ} 42^{\prime} \mathrm{W}$; (map 138).

Named about 1957 by personnel participating in the International Geophysical Year glaciological work in the Romanzof Mountains.

Schwan Glacier: glacier, heads $6 \mathrm{mi}$. NE of Cordova Peak, trends NE $10 \mathrm{mi}$. to its terminus, $2 \mathrm{mi}$. S of Tasnuna River and $40 \mathrm{mi}$. SE of Valdez, Chugach Mts.; $61^{\circ} 00^{\prime} 45^{\prime \prime} \mathrm{N}, 145^{\circ}$ $04^{\prime} 15^{\prime \prime} \mathrm{W}$; (map 68).

Named in 1898 by Capt. W. R. Abercrombie, USA, for Col. Theodore Schwan, USA.

Schwatka, Mount: mountain, 4,177 ft., $45 \mathrm{mi}$ NE of Livengood, Yukon-Tanana High.; $65^{\circ}$ $53^{\prime} \mathrm{N}, 147^{\circ} 15^{\prime} \mathrm{W}$; (map 105). Var. Mkleetokumenah.

Named in 1902 by Lt. Hjalmar Erickson, USA, for Lt. Frederick Schwatka, USA, who explored the Yukon in 1883. Erickson also reported that the Indians called it "Mkleetokumenah," "which means 'mountain with lake on top.' "'

Schwatka Mountains: mountains, in Brooks Ra. between Baird and Endicott Mts., extend 75 mi. from Amakomanak Creek and Redstone River on $W$ to Noatak River, Kaluluktok Creek, and Walker Lake on $\mathrm{E} ; 67^{\circ} 20^{\prime} \mathrm{N}$, $154^{\circ} 45^{\prime} \mathrm{W}$ [E end], $67^{\circ} 30^{\prime} \mathrm{N}, 157^{\circ} 10^{\prime} \mathrm{W}$ [W end] ; (map 126).

Named in 1884 by Lt. G. M. Stoney, USN, presumably for Lt. Frederick Schwatka, USA, who the previous year had made a military reconnaissance along the Yukon River.

Scidmore Glacier: glacier, in Glacier Bay National Monument, trends NW and E $2.5 \mathrm{mi}$. to its 1961 terminus $4.5 \mathrm{mi}$. SE of head of Reid Inlet and $66 \mathrm{mi}$. NW of Hoonah, St. Elias Mts.; $58^{\circ} 48^{\prime} 20^{\prime \prime} \mathrm{N}, 136^{\circ} 42^{\prime} 08^{\prime \prime} \mathrm{W}$; BGN 1937; (map 10).

Named by Field and Cooper (1937, pl. 1 and p. 62) for Eliza R. Scidmore, 1856-1928 author of "Alaska, its Southern Coast and the Sitkan Archipelago," (1885), and "Guide to Alaska and the Northwest Coast," (1890). After visiting Glacier Bay she wrote about its discovery in the National Geographic Magazine in 1896 .

Scofield Creek: stream, flows SW $4 \mathrm{mi}$. to Wild River E of Twoday Mtn. and $35 \mathrm{mi}$. W of Wiseman, Brooks Ra.; $67^{\circ} 17^{\prime} 45^{\prime \prime} \mathrm{N}, 151^{\circ}$ 24'00" W; BGN 1932; (map 124).

Locally named "for Slim Scofield who prospected the stream in 1905"; reported by Robert Marshall in 1932.

Scolai Pass: pass, see Skolai Pass.

Scoloi Pass: pass, see Skolai Pass.

Scookuk: locality, see Chiukak.

Scorpion Peak: peak, 4,450 ft., $1.5 \mathrm{mi}$. NE of Vesper Peak and $6 \mathrm{mi}$. NE of Juneau, Coast Mts. ; $58^{\circ} 22^{\prime} 45^{\prime \prime} \mathrm{N}, 134^{\circ} 19^{\prime} 20^{\prime \prime} \mathrm{W}$; (map 11).

Local name reported in 1965 by D. A. Brew and A. B. Ford, USGS.

Scotch Cap: promontory, $420 \mathrm{ft}$., on SW coast of Unimak I., Aleutian Is.; $54^{\circ} 24^{\prime} 15^{\prime \prime} \mathrm{N}$, $164^{\circ} 47^{\prime} 30^{\prime \prime}$ W; (map 24). Var. Cape Hibahibgik, Cape Khitkhouk, Gape Khitkouk, Cape Khituk, Cape Kitkhuk, Cape Kitkuk, Scotch Cape.

This name was originally applied about 1890 to what is now called "Scotch Cap Pinnacle," because of the latters' resemblance to a "Scotch cap." However, because the precipitous cliff behind the rock was a better landmark from the sea, the name was transferred to it.

Scotch Cape: promontory, see Scotch Cap.

Scotch Creek: stream, flows NE $1.5 \mathrm{mi}$. to Fairhaven Creek, $34 \mathrm{mi}$. N of Haycock, Seward Penin. High.; $65^{\circ} 42^{\prime} \mathrm{N}, 161^{\circ} 09^{\prime} \mathrm{W}$; (map 109).

Local name published on maps after 1950. Scotch Gulch: ravine, trends $\mathrm{S} 1 \mathrm{mi}$. to $\mathrm{St}$. Michaels Creek, $8 \mathrm{mi}$. NE of Nome, Seward Penin. High.; $64^{\circ} 31^{\prime} 55^{\prime \prime} \mathrm{N}, 165^{\circ} 06^{\prime} 50^{\prime \prime} \mathrm{W}$; (map 94).

Prospectors' name reported in 1904 by T. G. Gerdine, USGS.

Scotch Gulch: ravine, trends NW $1 \mathrm{mi}$. to Snake River, $12 \mathrm{mi}$. N of Nome, Seward Penin. High.; $64^{\circ} 41^{\prime} \mathrm{N}, 165^{\circ} 24^{\prime} \mathrm{W}$; (map 94). Var. Scotch-Irish Greek.

Reported as "Scotch-Irish Greek" on a map by S. E. King dated 1900 .

Scotch-Irish Greek:ravine, see Irish Gulch.

Scotch-Irish Creek: ravine, see Scotch Gulch. Scotchmans Crossing: crossing, on Tanana River, $11 \mathrm{mi}$. downstream from mouth of Kantishma River, Tanana Low.; $64^{\circ} 50^{\prime} 45^{\prime \prime} \mathrm{N}, 150^{\circ} 15^{\prime}$ $00^{\prime \prime} \mathrm{W}$; (map 99). Var. Scotsmans Crossing.

Riverboat crossing (a shift from one side of the stream to the other) published on a 1940 "Navigation Chart of Tanana-Yukon Rivers" by U.S. Dept. of Interior.

Scotland Point: point of land, NE tip of Korovin I., in Shumagin Is., Aleutian Ra.; 55 ${ }^{\circ}$ $26^{\prime} 50^{\prime \prime} \mathrm{N}, 160^{\circ} 08^{\prime} 30^{\prime \prime} \mathrm{W}$; (map 28).

Named for Scotland Rock to the northeast, and published by USC\&GS in 1916 Coast Pilot (p. 175).

Scotland Rock: rock, between Korovin and Karpa Is., in Shumagin Is., Aleutian Ra.; $55^{\circ} 28^{\prime} \mathrm{N}, 160^{\circ} 05^{\prime} \mathrm{W}$; (map 28).

Named in 1875 by W. H. Dall, USC\&GS, for the fishing schooner Scotland which reported the rock in 1871. No evidence of this rock was found by sounding and wire drag, according to 1954 Coast Pilot 9 (p. 308), thus its location is uncertain.

Scotsmans Crossing: crossing, see Scotchmans Crossing.

Scott Glacier: glacier, trends SW $15 \mathrm{mi}$. to its terminus $6 \mathrm{mi}$. NE of Cordova, Chugach Mts.; $60^{\circ} 37^{\prime} \mathrm{N}, 145^{\circ} 24^{\prime} \mathrm{W}$; (map 64).

Local name "of a miner" reported in 1908 by U. S. Grant and D. F. Higgins (in Brooks and others, 1909, pl. 4), USGS.

Scottie Creek: stream, heads in Yukon, Canada, flows SW across Alaska-Canada boundary 50 mi. to Chisana River, $28 \mathrm{mi}$. SE of Northway Junction, Alaska Ra.; $62^{\circ} 41^{\prime} \mathrm{N}, 141^{\circ} 16^{\prime} \mathrm{W}$; $B G N$ 1960; (map 84).. Var. Big Scotty Creek, Scotty Creek.
Named by W. J. Peters and A. H. Brooks, USGS, for a member of their 1898 survey party.

Scott Island: island, $1.1 \mathrm{mi}$. long, in Tokeen Bay, between Marble and Orr Is., Alex. Arch.; $55^{\circ} 59^{\prime} 20^{\prime \prime} \mathrm{N}, 133^{\circ} 23^{\prime} 00^{\prime \prime} \mathrm{W}$; (map 4).

Local descriptive name published in 1964 by USC\&GS.

Scott Island: island, $0.3 \mathrm{mi}$. across, at mouth of Inishkin Bay, $19 \mathrm{mi}$. $\mathrm{N}$ of Augustine I., Aleutian Ra.; $59^{\circ} 38^{\prime} 20^{\prime \prime} \mathrm{N}, 153^{\circ} 26^{\prime} 00^{\prime \prime} \mathrm{W}$; $B G N$ 1916; (map 51).

Named by USC\&GS, in 1914, for Capt. Robert Falcon Scott, 1868-1912, Royal Navy and English Antarctic explorer.

Scott Lagoon: estuary, $1 \mathrm{mi}$. long, $\mathrm{W}$ coast of Tuxekan I., Alex. Arch.; 55 51' $20^{\prime \prime}$ N, $133^{\circ}$. $19^{\prime} 45^{\prime \prime}$ W; BGN 1963; (map 4). Var. Scotts Lagoon.

Local name reported in 1961 by USFS.

Scott Lake: lake, $0.7 \mathrm{mi}$. long, $2.5 \mathrm{mi}$. SW of terminus of Scott Glacier, $10 \mathrm{mi}$. NE of Cordova, Chugach Mts.; $60^{\circ} 35^{\prime} \mathrm{N}, 145^{\circ} 25^{\prime} \mathrm{W}$; (map 64).

Local name reported in 1908 by U. S. Grant and D. F. Higgins (in Brooks and others, 1909, pl. 4), USGS. Name derived from Scott Glacier.

Scott Peak: mountain, 3,248 ft., $8 \mathrm{mi}$. NW of Petersburg, on W coast of Lindenberg Penin., Kupreanof I., Alex. Arch.; $56^{\circ} 52^{\prime} 20^{\prime \prime}$ N, $133^{\circ} 10^{\prime} 30^{\prime \prime} \mathrm{W}$; (map 6).

Named in 1887 by Lt. Comdr. C. $M$. Thomas, USN, for Gen. Winfield Scott, USA. Scott Peak: peak, 8,828 ft., at head of Sunset Glacier, $14 \mathrm{mi}$. E of mouth of McKinley River, Alaska Ra.; $63^{\circ} 20^{\prime} 45^{\prime \prime} \mathrm{N}, 150^{\circ} 07^{\prime} 30^{\prime \prime} \mathrm{W}$; $B G N$ 1954; ( $\operatorname{map} 88$ ).

Named in 1953 by R. E. Isto, USGS, and Bradford Washburn for Lt. Gordon Scott, USC\&GS, who was killed in the course of mapping operations that summer.

Scott Point: point of land, $0.4 \mathrm{mi}$. S of Ingraham Bay, SE coast of Prince of Wales I., Alex. Arch.; $54^{\circ} 57^{\prime} 26^{\prime \prime} \mathrm{N}, 131^{\circ} 58^{\prime} 00^{\prime \prime} \mathrm{W}$; (map 2).

Local navigators' name recorded in 1904, by H. C. Fassett, USBF.

Scott Point: point of land, on $\mathbf{S}$ shore of Elson Lagoon, $W$ point of entrance to Iko Bay, 16 mi. E of Barrow, Arctic Plain; $71^{\circ} 14^{\prime} 30^{\prime \prime} \mathrm{N}$, $156^{\circ} 04^{\prime} 30^{\prime \prime} \mathrm{W}$; (map 153). Var. Avachiak Point, Point Scott.

Named Point Scott by Simpson (1843, p. 152 ) in 1837

Scotts Lagoon: estaury, see Scott Lagoon.

Scotty Creek: stream, see Scottie Creek.

Scotty Gulch: ravine, extends NE $2.8 \mathrm{mi}$. to Beaver Creek, in Nutzotin Mts., $8 \mathrm{mi}$. SE of Carden Lake, Alaska Ra.; $62^{\circ} 10^{\prime} 30^{\prime \prime} \mathrm{N}, 141^{\circ}$ $02^{\prime} 25^{\prime \prime} \mathrm{W}$; (map 84)

Local name reported in 1959 by USGS.

Scotty Lake: lake, $1 \mathrm{mi}$. long, at head of Ninemile Creek, $6 \mathrm{mi}$. W of Talkeetna, Cook Inlet Low.; $62^{\circ} 19^{\prime} 30^{\prime \prime} \mathrm{N}, 150^{\circ} 19^{\prime} 00^{\prime \prime} \mathrm{W}$; (map 81).

Local name reported in 1958 by USGS. 
Scotty Lake: lake, $0.7 \mathrm{mi}$. long, $5 \mathrm{mi}$. NE of Amos Lakes, $21 \mathrm{mi}$. NW of Mount Russell Alaska Ra.; $62^{\circ} 55^{\prime} 25^{\prime \prime}$ N, $152^{\circ} 30^{\prime} 05^{\prime \prime} \mathrm{W}$; (map 81).

Local name reported in 1958 by USGS.

Scotty Lake: lake, $1 \mathrm{mi}$. across, $15 \mathrm{mi}$. NE of Chalkyitsik, Yukon Flats; $66^{\circ} 49^{\prime}$ N, $143^{\circ} 29^{\prime}$ W; (map 120).

Local name obtained in 1956 by T. E. Taylor and R. G. Foley, USGS

Scotty Lake: lake, see Imiaknikpak Lake.

Scotty Peak: mountain, 7,416 ft., $4 \mathrm{mi}$. NE of junc. of Kluvesna and Kotsina Rivers, $19 \mathrm{mi}$. $\mathrm{W}$ of Mount Blackburn, Wrangell Mts.; $61^{\circ}$ $46^{\prime} 35^{\prime \prime} \mathrm{N}, 143^{\circ} 58^{\prime} 00^{\prime \prime} \mathrm{W}$; (map 67).

Name reported by F. H. Moffit (in Brooks and others, 1915, pl. 5), USGS.

Scout Canyon: canyon, trends $2.5 \mathrm{mi}$. ESE to head of West Arm Holtz Bay on NE coast of Attu I., Aleutian Is. ; $53^{\circ} 55^{\prime} 50^{\prime \prime} \mathrm{N}, 173^{\circ} 07^{\prime} 40^{\prime \prime}$ E; (map 13)

Named by the U.S. Army during its occupation of the island during World War II shown on an AMS map published in 1948.

Scout Creek: stream, flows $2.5 \mathrm{mi}$. ESE to West Arm Holtz Bay, on NE coast of Attu I., Aleutian Is.; $53^{\circ} 55^{\prime} 50^{\prime \prime} \mathrm{N}, 173^{\circ} 07^{\prime} 40^{\prime \prime} \mathrm{E}$; (map 13).

Name used by the U.S. Army during its occupation of the island during World War II, but, as far as can be determined, name was never published.

Scout Lake: lake, $0.1 \mathrm{mi}$. across, on Revillagigedo I., $0.4 \mathrm{mi}$. NE of Ketchikan, Alex. Arch. ; 55 $5^{\circ}$ $20^{\circ} 45^{\prime \prime} \mathrm{N}, 131^{\circ} 37^{\prime} 05^{\prime \prime} \mathrm{W}$; (map 3 ).

Local name reported in 1954 by USGS.

Scout Lake: lake, $500 \mathrm{ft}$. long, in Heney Ra. $2.5 \mathrm{mi}$. SE of Cordova, Chugach Mts.; $60^{\circ}$. $32^{\prime} \mathrm{N}, 145^{\circ} 41^{\prime} \mathrm{W}$; (map 64).

Local name published in 1951 by USGS.

Scout Lake: lake, $0.8 \mathrm{mi}$. long, on Kenai Penin., $2.5 \mathrm{mi}$. W of Sterling and $15 \mathrm{mi}$. E of Kenai Cook Inlet Low.; $60^{\circ} 32^{\prime} \mathrm{N}, 150^{\circ} 50^{\prime} \mathrm{W}$; (map. 62).

Local name reported in 1965 by USGS.

Scow Bay: area, pop. 74, on NW side of Mitkof I. along $\mathbf{E}$ shore of Wrangell Narrows, $3 \mathrm{mi}$. S of Petersburg, Alex. Arch.; $56^{\circ} 46^{\prime} 20^{\prime \prime} \mathrm{N}$, $132^{\circ} 57^{\prime} 30^{\prime \prime} \mathrm{W}$; (map 6). Var. Doyhof.

This is a residential suburb of Petersburg, published in the "Alaska Sportsman" (1962, no. 12, p. 31). The suburb was formerly a part of Doyhof (Balcom, 1965, p. 42).

Scow Bay: bay, $0.3 \mathrm{mi}$. across, on $\mathrm{W}$ coast of Beauchamp I., $9 \mathrm{mi}$. SE of Goddard, on SW coast of Baranof I., Alex. Arch.; 56 $42^{\prime} 45^{\prime \prime}$ N., $135^{\circ} 16^{\prime} 30^{\prime \prime} \mathrm{W}$; (map 5).

Named by USC\&GS for charting purposes; name published in the 1925 Coast Pilot (p. 285)

Scow Bay: bight, along E shore of Wrangell Narrows, $3 \mathrm{mi}$. S of Petersburg, Alex. Arch.; $56^{\circ} 46^{\prime} 20^{\prime \prime} \mathrm{N}, 132^{\circ} 57^{\prime} 50^{\prime \prime} \mathrm{W}$; (map 6)

Local name used by fishermen, published in 1912 by USC\&GS.

Scow Cove: cove, $0.3 \mathrm{mi}$. across, on $\mathrm{W}$ shore of Taku Inlet, 1.6 mi. $\mathrm{N}$ of Flat Point and $14 \mathrm{mi}$.
NE of Juneau, Coast Mts.; 58 $21^{\prime} 15^{\prime \prime}$ N, $134^{\circ} 03^{\prime} 30^{\prime \prime}$ W; (map 11).

Local name published in 1952 by USGS.

Scow Harry Creek: stream, flows SW $22 \mathrm{mi}$. to Kuskokwim River, 0.5 mi. NE of Medfra, Kilbuck-Kuskokwim Mts. ; $63^{\circ} 07^{\prime} \mathrm{N}, 154^{\circ} 42^{\prime} \mathrm{W}$; (map 89).

Local name obtained in 1924 by J. S. Brown (in Smith, P. S., and others, 1926, pl. 5), USGS.

Scow Island: island, $0.2 \mathrm{mi}$. long, in El Capitan Passage, Alex. Arch.; 55 57'35' N, $133^{\circ} 20^{\prime}$. 25" W; (map 4).

Local name published in 1925 Coast Pilot (p. 155).

Scow Island: island, $0.5 \mathrm{mi}$. long, $10 \mathrm{mi}$. SE of Goddard, on SW coast of Baranof I., Alex. Arch.; $56^{\circ} 42^{\prime} 10^{\prime \prime} \mathrm{N}, 135^{\circ} 17^{\prime} 15^{\prime \prime} \mathrm{W}$; (map 5).

Named by USC\&GS for charting purposes; name published in the 1925 Coast Pilot (p. 285).

Scow Mountain: mountain, 1,740 ft., $15 \mathrm{mi}$. S of Ruby, Kilbuck-Kuskokwim Mts.; 64ำ $31^{\prime} \mathrm{N}$. $155^{\circ} 28^{\prime} \mathrm{W}$; (map 98).

Prospectors' name reported by Eakin (1916, pl. 1), USGS.

Scrafford: locality, along Tanana Mines RR., 10 mi. N of Fairbanks, Yukon-Tanana High.; $64^{\circ} 59^{\prime} \mathrm{N}, 149^{\circ} 38^{\prime} \mathrm{W}$; (map 100)

This is the site of a former railroad station named for Eugene L. Scrafford, a well-known prospector and miner in the Fairbanks region. The name was published in the 1915-16 Polk's Gazetteer.

Scraggy Island: island, $0.1 \mathrm{mi}$. across, in Icy Strait, at mouth of Port Frederick, $0.8 \mathrm{mi}$. NE of Crist Point and $4.6 \mathrm{mi}$. NW of Hoonah, Alex. Arch.; $58^{\circ} 10^{\prime} 30^{\prime \prime} \mathrm{N}, 135^{\circ} 28^{\prime} 10^{\prime \prime} \mathrm{W}$; (map 11).

Descriptive name given in 1901 by J. F. Pratt, USC\&GS, and published in the 1901 Coast Pilot (p. 202).

Scraggy Island: island, see Fivemile Island.

Scraggy Islands: islands, extend $0.2 \mathrm{mi}$. in head of Salisbury Sound, between Baranof and Kruzof Is., 24 mi. NW of Sitka, Alex. Arch.; $57^{\circ} 20^{\prime} 20^{\prime \prime} \mathrm{N}, 135^{\circ} 42^{\prime} 15^{\prime \prime} \mathrm{W}$; BGN 1901; (map 9). Var. Ostrov Samoylov, Samoi Islands, Samoilof Islands.

Local descriptive name published in 1901 Coast Pilot (p. 196). Originally named in 1833 by the Russian navigator Ens. Vasiliev for an early Russian explorer Gerasim Izmailov; published in 1848 as "Os[trov] Samoylov," or "Samoylov Island" on Russian Hydrog. Dept. Chart 1397.

Scraggy Islands: islands, see Scrag Islands.

Scraggy Point: point of land, on SE coast of Prince of Wales I., in Port Johnson, Alex. Arch.; $55^{\circ} 07^{\prime} 35^{\prime \prime} \mathrm{N}, 132^{\circ} 02^{\prime} 00^{\prime \prime} \mathrm{W}$; (map 4).

Local descriptive name obtained in 1905 by E. F. Dickins, USC\&GS.

Scraggy Point: point of land, at $\mathrm{E}$ entrance to Sinitsin Cove, Salisbury Sound, on Kruzof I., $24 \mathrm{mi}$. NW of Sitka, Alex. Arch.; $57^{\circ} 20^{\prime} 20^{\prime \prime}$ $N, 135^{\circ} 43^{\prime} 40^{\prime \prime} \mathrm{W}$; (map 9)
Named in 1896 by Lt. Comdr. E. K. Moore, USN, and published in 1900 by USC\&GS on Chart 8282. The name was derived from the nearby Scraggy Islands.

Scrag Islands: islands, two, each $300 \mathrm{ft}$. long, in South Pass Sukkwan Strait, on NW coast of Sukkwan I., Alex. Arch.; $55^{\circ} 11^{\prime} 20^{\prime \prime} \mathrm{N}$, $132^{\circ} 51^{\prime} 10^{\prime \prime}$ W; (map 4). Var. Scraggy Islands.

Descriptive name given in 1916 by USC\&GS. In 1912 the name Scraggy Islands was published by USC\&GS.

Screen Islands: islands, $1.5 \mathrm{mi}$. long, on $\mathrm{W}$ coast of Etolin I., Alex. Arch.; 56 $05^{\prime} \mathrm{N}, 132^{\circ} 41^{\prime}$ W; (map 6)

Named in 1879 by W. H. Dall, USC\&GS.

Scripps Bay: bay, $0.7 \mathrm{mi}$. across, on $\mathrm{N}$ coast of Little Tanaga I., Aleutian Is.; 51 $51^{\prime} 00^{\prime \prime} \mathrm{N}$, $176^{\circ} 07^{\prime} 10^{\prime \prime} \mathrm{W}$; BGN 1936; (map 17).

Named by members of the U.S. Navy Aleutian Island Survey Expedition in 1934 "after Scripps Institute which cooperated with the expedition."

Scrub Island: island, $250 \mathrm{ft}$. long, in Port Chester, on $\mathrm{W}$ coast of Annette I., Alex. Arch.; 55 ${ }^{\circ}$ $08^{\prime} 30^{\prime \prime} \mathrm{N}, 131^{\circ} 34^{\prime} 01^{\prime \prime} \mathrm{W}$; (map 3 ).

Descriptive name given in 1883 by Lt. Comdr. H. E. Nichols, USN.

Scull Island: island, $0.1 \mathrm{mi}$. across, in Stephen Passage, $3.3 \mathrm{mi}$. NW of Point Young on Admiralty I. and $11 \mathrm{mi}$. SW of Juneau, Alex. Arch.; $58^{\circ} 12^{\prime} 15^{\prime \prime} \mathrm{N}, 134^{\circ} 38^{\prime} 45^{\prime \prime} \mathrm{W} ; B G N$ 1900; (map 11). Var. Scull Islet, Skull Island.

Named in 1869 by Comdr. R. W. Meade USN, and published by USC\&GS in the 1883 Coast Pilot (p. 172). Called "Scull Islet" by Baker (1906, p. 556).

Scull Islet: island, see Scull Island.

Scutshon: locality, see Neltushkin.

Seabee Creek: stream, flows SE $10 \mathrm{mi}$. to Colville River $\mathrm{N}$ of Umiat, Arctic Slope; $69^{\circ} 22^{\prime}$ $25^{\prime \prime} \mathrm{N}, 152^{\circ} 06^{\prime} 30^{\prime \prime} \mathrm{W}$; BGN 1949; (map 141). Var. Sea Bee Creek.

Named by Naval Petroleum Reserve No. 4 geologists about 1945 for the Seabees (an alternation of "cee" and "bee," the initial letters for construction battalion), a construction battalion organized as a volunteer branch of the Civil Engineer Corps of the U.S. Navy; a group that participated in establishing camps during the early period of exploration of Naval Petroleum Reserve No. 4.

Seaborg Bay: bay, $0.6 \mathrm{mi}$. across, on $\mathrm{E}$ shore of Alitak Bay, at $S$ end of Kodiak I.; 56 $53^{\prime} 15^{\prime \prime}$ N, $153^{\circ} 59^{\prime} 00^{\prime \prime}$ W; (map 33). Var. Seaborg Cove.

Name reported in 1943 by USC\&GS as Seaborg Cove.

Seaborg Cove: bay, see Seaborg Bay.

Seaflower Cove: bay, $0.3 \mathrm{mi}$. across, on NW coast of Tanner Head, on $W$ shore of Alitak Bay, $\mathrm{S}$ end of Kodiak I.; $56^{\circ} 53^{\prime} 10^{\prime \prime} \mathrm{N}, 154^{\circ} 14^{\prime} 30^{\prime \prime}$ W; (map 32).

Name published in 1943 by USC\&GS.

Seaforth: locality, site of prospectors' camp at junc. of Fish Creek and South Fork Koyukuk 
River, $20 \mathrm{mi} . \mathrm{S}$ of Bettles, Kanuti Flats; $66^{\circ}$. $37^{\prime} 30^{\prime \prime}$ N, 151 $30^{\prime} 00^{\prime \prime} \mathrm{W}$; (map 117).

Name reported in 1899 by G. H. Wonson, Master of the steamer Dorothy, on his manuscript map of the Koyukuk River. One of several temporary camps established, by prospectors caught on the river during the winter of 1898-99.

Seagher Bluff: hill, see Bishop Rock.

Seagull Cove: cove, $0.3 \mathrm{mi}$. across, facing $\mathrm{SE}$ to McArthur Pass, on NE coast of Kiska I., 0.5 mi. N of Reynard Cove, Aleutian Is.; $52^{\circ} 01^{\prime}$ $50^{\prime \prime} \mathrm{N}, 177^{\circ} 36^{\prime} 30^{\prime \prime} \mathrm{E}$; (map 14).

One of the "bird names" arbitrarily applied to features on Kiska I. in 1943 by USAAF for tactical purposes during World War II.

Seagull Creek: stream, flows $6 \mathrm{mi}$. S to Port Frederick, on Chichagof I., 2 mi. S of Burnt Point and $7.8 \mathrm{mi}$. SW of Hoonah, Alex. Arch.; $58^{\circ} 00^{\prime} 55^{\prime \prime} \mathrm{N}, 135^{\circ} 33^{\prime} 40^{\prime \prime} \mathrm{W}$; (map 11) Var. Sea Gull Creek.

Name published in 1923 by USC\&GS on Chart 8304

Seagull Creek: stream, in De Long Mts., flows SE $23 \mathrm{mi}$. to Nimiutuk River, $30 \mathrm{mi}$. E of Misheguk Mtn., Brooks Ra.; $68^{\circ} 18^{\prime} \mathrm{N}, 159^{\circ} 54^{\prime} \mathrm{W}$; $B G N$ 1925; (map 131).

Named by the 1924 USGS exploring expedition, "because the only food the [field] party had was a sea gull killed near this stream."

Sea Gull Flat: island, $0.9 \mathrm{mi}$. long, between Coffee Creek Channel and main channel of Kvichak River, $15 \mathrm{mi}$. N of Naknek, Bristol Bay Low.; 58 $57^{\prime} 00^{\prime \prime} \mathrm{N}, 156^{\circ} 59^{\prime} 30^{\prime \prime} \mathrm{W}$; (map 41).

Local name reported in 1952 by USGS.

Seagull Island: island, $500 \mathrm{ft}$. across, at $\mathrm{S}$ entrance to Buschmann Pass, off SW coast of Prince of Wales I., Alex. Arch.; 54 $44^{\prime} 45^{\prime \prime} \mathrm{N}$, $132^{\circ} 19^{\prime} 20^{\prime \prime} \mathrm{W}$; (map 1 ).

Local name reported in 1948 by USGS.

Sea Gull Island : island, see Ham Island.

Sea Gull Islands: islands, see Baby Islands.

Seagull Islets: islands, see Baby Islands.

Seagull Lake: lake, $0.9 \mathrm{mi}$. long, at head of Tritt Creek, $12 \mathrm{mi}$. NE of Arctic Village, Brooks Ra.; $68^{\circ} 15^{\prime} \mathrm{N}, 145^{\circ} 11^{\prime} \mathrm{W}$; (map 136).

Local name reported in 1956 by R. C. Foley, USGS.

Sea Gull Point: point of land, in Yukon Delta, on island between Kawanak and Kwikpak Passes, $19 \mathrm{mi}$. N of Kwiguk, Yukon-Kuskokwim Delta; $63^{\circ} 02^{\prime} \mathrm{N}, 164^{\circ} 21^{\prime} \mathrm{W}$; (map 92).

Local name obtained in 1952 by USC\&GS.

Seahorse Islands: barrier islands, extend $3.5 \mathrm{mi}$., between Peard Bay and Chukchi Sea, 1 mi. E of Point Franklin, Arctic Plain; $70^{\circ} 53^{\prime} \mathrm{N}$, $158^{\circ} 42^{\prime} \mathrm{W}$; (map 147).

Capt. Beechey (1831, p. 306), RN, wrote on August 21, 1826, "a chain of sandy islands which I have distinguished by the name of the Sea Horse Islands." The forms of the islands have changed over the years.

Seakgluka: locality, see Sixtukak.

Seakoovook Bay: bay, extends $\mathrm{E} 2 \mathrm{mi}$. from Siknik Cape, $36 \mathrm{mi}$. SE of Savoonga, $\mathrm{S}$ coast of
St. Lawrence I.; $63^{\circ} 11^{\prime} \mathrm{N}, 170^{\circ} 15^{\prime} ; B G N$ 1951; (map 93).

Eskimo name recommended by the Savoonga village council and reported in 1949 by Maj. H. B. Allen, USAF.

Seal Bay: bay, $0.5 \mathrm{mi}$. across, $3.5 \mathrm{mi}$. long, on W shore of Tenakee Inlet, on central Chichagof I., $11 \mathrm{mi}$. NW of Tenakee Springs, Alex. Arch.; $57^{\circ} 50^{\prime} 30^{\prime \prime} \mathrm{N}, 135^{\circ} 31^{\prime} 00^{\prime \prime} \mathrm{W}$; BGN 1929; (map 9).

Local name reported in 1928 by USFS.

Seal Bay: bay, $2 \mathrm{mi}$. across, $33 \mathrm{mi}$. NE of Afognak, on NE coast of Afognak I., N of Kodiak I.; $58^{\circ} 22^{\prime} \mathrm{N}, 152^{\circ} 12^{\prime} \mathrm{W}$; (map 43). Var. Nerpichie Bay.

Translation of the name "Za[iv] Nyerpichiy," published in 1849 by the Russian American Company.

Seal Bay: bay, $1 \mathrm{mi}$. across, on $\mathrm{E}$ shore of Russell Fiord, $2.3 \mathrm{mi}$. NW of Mount Unana and $23 \mathrm{mi}$. NE of Yakutat, St. Elias Mts.; 59 $47^{\prime}$ $\mathrm{N}, 139^{\circ} 17^{\prime} \mathrm{W}$; (map 46).

Name reported by Lt. Comdr. Moser, (1901, pl. 43), USN.

Seal Bay: estuary, see Pond Bay.

Seal Cape: point of land, on $\mathrm{S}$ coast of Unimak I., Aleutian Is. ; $54^{\circ} 23^{\prime} 30^{\prime \prime}$ N, $164^{\circ} 38^{\prime}$ $30^{\prime \prime}$ W ; (map 24). Var. Cape Khituk, Mys Kishnak, Seal Point.

Named in 1888 by USBF. Capt. Tebenkov (1852, map 26), IRN, published the Aleut name as "Mys Kishnak." Early charts showed the name "Cape Khituk (Scotch Cap)" but this was an error in the application of that name.

Seal Cape: point of land, $\mathrm{E}$ entrance point to Coal Bay, $7 \mathrm{mi}$. E of Pavlof Bay, on Alaska Penin., Aleutian Ra.; $55^{\circ} 21^{\prime} 45^{\prime \prime} \mathrm{N}, 161^{\circ} 18^{\prime}$ $30^{\prime \prime} \mathrm{W}$; (map 28). Var. Hair Seal Cape, Nerpichie.

Translation of "Nerpichi", shown on Russian Hydrog. Dept. Chart 1379 (1847); the feature is shown as Seal Cape on an 1882 USC\&GS chart, although 1916 Coast Pilot (p. 182) describes it as Hair Seal Cape

Seal Cape: point of land, on $\mathrm{S}$ coast of Alaska Penin., $20 \mathrm{mi}$. S of Chignik, Aleutian Ra.; $56^{\circ} 00^{\prime} 00^{\prime \prime} \mathrm{N}, 158^{\circ} 25^{\prime} 30^{\prime \prime}$ W; BGN 1939; (map 27).

Local name published by USC\&GS in 1916 . Seal Cape : point of land, see Ikolik, Cape.

Seal Cove: bay, extends $0.8 \mathrm{mi}$., off Nichols Passage, on SE coast of Gravina I., Alex. Arch.; $55^{\circ} 11^{\prime} \mathrm{N}, 131^{\circ} 43^{\prime} \mathrm{W}$; (map 3).

Local name reported in 1901 by $A . H$. Brooks (1902b, pl. 2), USGS.

Seal Creek: stream, flows SSE $5 \mathrm{mi}$. to Freshwater Bay, on $\mathrm{E}$ coast of Chichag of I., 10.7 mi. N of Tenakee Springs, Alex. Arch.; $57^{\circ} 56^{\prime}$ N, $135^{\circ} 09^{\prime} \mathrm{W}$; BGN 1960; (map 9).

So named by USGS in 1958 "because its delta is the breeding grounds for seals."

Seal Creek: stream, flows S $12 \mathrm{mi}$. on Yakutat Foreland to Ahrnklin River, $5.5 \mathrm{mi}$. SE of Situk and $15 \mathrm{mi}$. SE of Yakutat, Malaspina Coastal Plain; $59^{\circ} 24^{\prime} 00^{\prime \prime} \mathrm{N}, 139^{\circ} 27^{\prime} 30^{\prime \prime} \mathrm{W}$; (map 46)

Name published by IBC in 1928 .
Sealed Passage: water passage, $4 \mathrm{mi}$. long, from Clarence Strait to Felice Strait, between Duke I. and Hotspur I. and Percy Is., Alex. Arch.; $54^{\circ} 56^{\prime} \mathrm{N}, 131^{\circ} 31^{\prime} \mathrm{W}$; (map 2).

Local descriptive name published in 1885 by USC\&GS.

Sealer Creek: stream, flows E 1 mi. to Cripple River $1 \mathrm{mi}$. above its mouth on Norton Sound and $12 \mathrm{mi}$. W of Nome, Seward Penin. High.; $64^{\circ} 33^{\prime} \mathrm{N}, 165^{\circ} 46^{\prime} \mathrm{W}$; (map 94).

Prospectors' name reported in 1899 by. $D$. C. Witherspoon (in Schrader and Brooks, 1900, map 2), USGS.

Sealers Island: island, $0.3 \mathrm{mi}$. long, in the Muir Inlet, in Glacier Bay National Monument, 1 mi. S of Nunatak Cove, $64 \mathrm{mi}$. NW of Hoonah, St. Elias, Mts.; $58^{\circ} 57^{\prime} 35^{\prime \prime} \mathrm{N}, 136^{\circ} 06^{\prime} 15^{\prime \prime} \mathrm{W}$; $B G N$ 1948; (map 10). Var. Muir Island.

Named by members of the American Geographical Society Glacier Bay Expedition of 1941 (Field, 1947, pl. 1), because in 1926 B. S. Wood and W. O. Field found a seal blind built by the Indians on the island. The name of this island was published as Muir Island by USC\&GS on Chart 8306 in 1942.

Sea Level Slough: estuary, $1 \mathrm{mi}$. long, $12 \mathrm{mi}$. NW of Chichagof, on W coast of Chicagof I., Alex. Arch.; $57^{\circ} 48^{\prime} \mathrm{N}, 136^{\circ} 18^{\prime} \mathrm{W} ; B G N$ 1937; (map 9)

Local descriptive name reported in 1936 by USFS. It is "a narrow shallow tidal slough ***."

Sealing Reef: reef, $0.6 \mathrm{mi}$. long, $\mathrm{S}$ of Percy Is., in Clarence Straight, Alex. Arch.; 54 ${ }^{\circ} 5^{\prime} 45^{\prime \prime}$ N, 131 $35^{\prime} 00^{\prime \prime}$ W; BGN 1917; (map 2).

Local name published in 1943 by USC\&GS.

Sea Lion Bay: cove, see Sealion Cove.

Sealion Cape: point of land, see Lutke, Cape.

Sealion Cove: cove, $1 \mathrm{mi}$. across, on NW coast of Kruzof I., 25 mi. NW of Sitka, Alex. Arch.; $57^{\circ} 18^{\prime} \mathrm{N}, 135^{\circ} 50^{\prime} \mathrm{W}$; (map 9). Var. Puerto de los Remedios, Sea Lion Bay, Siouchi Bay, Sioutchi Creek, Siuchiya Guba.

This is a translation by USC\&GS about 1882 of the name "Siuchiya Guba," given in 1833 by the Russian navigator Ens. Vasiliev. This feature was called "Puerto de los Remedios," meaning "Port of the Remedy," by Francisco Antonio Maurelle and Don Juan de la Bodega y Quadra, who named it for Nuestra Señora de los Remedios (Wagner, 1937, p. 490).

Sealion Hill: hill, see Hutchinson Hill.

Sealion Island: island, see Kaligagan Island.

Sealion Island: islands, $1 \mathrm{mi}$. across, $5 \mathrm{mi}$. S of Salisbury Sound, off NW coast of Kruzof I., $25 \mathrm{mi}$. NW of Sitka, Alex. Arch.; $57^{\circ} 17^{\prime} \mathrm{N}$, $135^{\circ} 53^{\prime} \mathrm{W}$; (map 9). Var. Islas de Lobos, Ostrov Sinchiy, Sealion Rocks.

This is a translation by USC\&GS about 1882 of the name given by the Russian pilot Ens. Vasiliev; published in 1848 on Russian $\mathrm{Hy}$ drog. Dept. Chart 1397 as "Os[trov] Siuchiy." This feature was called "Islas de Lobos," meaning "sealion islands" in 1775 by Francisco Antonio Maurelle and Don Juan de la Bodega y Quadra. Wagner (1937, p. 468) 
thinks this latter name may be identified with "Eagle Rock or Sea Rock farther north."

Sealion Neck: point of land, see Sea Lion Point.

Sea Lion Pass: water passage, has $2 \mathrm{mi}$. navigable width, between Tanadok I. and Sea Lion Rock, $15 \mathrm{mi}$. E of Kiska Is.; $51^{\circ} 53^{\prime} 30^{\prime \prime} \mathrm{N}$, $177^{\circ} 54^{\prime} 00^{\prime \prime} \mathrm{E}$; (map 14).

Shown on recent maps and charts of Kiska Island; listed in 1954 Coast Pilot (p. 466).

Sea Lion Point: point of land, on SE coast of St. George I., in Pribilof Is.; $56^{\circ} 34^{\prime} 40^{\prime \prime} \mathrm{N}$, $169^{\circ} 28^{\prime} 50^{\prime \prime} \mathrm{W}$; (map 38). Var. Propas'tcky, Sealion Point, Tug'una'raro'logh.

Name reported by H. W. Elliott in 1874 . Putnam (1903, p. 1015), USC\&GS, lists the Russian name as "Propas'tcky," meaning "perished *** so called because here dead sea-lions have been found on shore." The Aleut name is similar in meaning; "Tug'una'raro'logh," meaning "dead sea-lion place" (ibid., p. 1016).

Sea Lion Point: point of land, $\mathbf{S}$ of Northeast Point, on E coast of St. Paul I., in Pribilof Is.; $57^{\circ} 14^{\prime} 20^{\prime} \mathrm{N}, 170^{\circ} 06^{\prime} 00^{\prime \prime} \mathrm{W}$; (map 38). Var. Sealion Neck, Sealion Point.

Name reported by USC\&GS in 1875; probably obtained from Elliott (1881, p. 56) who referred to the point as "a little tongue of low basaltic jutting, is the principal corner where the natives take these animals [sea-lions] when they capture them in the fall for their hides and sinews."

Sea Lion Point: point of land, see Georgiana, Cape.

Sea Lion Point: point of land, see Harpoon Point.

Sealion Rock: rock, a few mi. W of Atka I., Aleutian Is.; $52^{\circ} 00^{\prime} \mathrm{N}, 175^{\circ} 30^{\prime} \mathrm{W}$; (map 18). Var. Sivoutchy.

This is an unidentified rock reported as "Sivoutchy roche," or "Sea Lion Rock" (Lutke, 1836, p. 290).

Sea Lion Rock: rock, elev. $10 \mathrm{ft}$., $10 \mathrm{mi}$. SE of Tanadak I., $17 \mathrm{mi}$. ESE of South Head on Kiska I., on E side of Sea Lion Pass, Aleutian Is.; $51^{\circ} 53^{\prime} \mathrm{N}, 177^{\circ} 59^{\prime} \mathrm{E}$; $B G N$ 193\%; (map 14). Var. Sealion Rock, Sivoutchi, Sivoutchy.

Local name published in 1836 by Capt. Lutke (1836, p. 327), IRN, as "Sivoutchy Roche (du lion marin)," or "Sea Lion Rock."

Sea Lion Rock: rock, $900 \mathrm{ft}$. long, in Pacific Ocean $0.4 \mathrm{mi}$. $\mathrm{N}$ of Forrester I., Alex. Arch.; $54^{\circ} 50^{\prime} 40^{\prime \prime}$ N, $133^{\circ} 32^{\prime} 15^{\prime \prime}$ W; (map 1). Var. Sealion Rock.

Name published by USC \& GS in 1912.

Sea Lion Rock: rock, off Reef Point, $\mathrm{S}$ tip of St. Paul I., in Pribilof Is.; $57^{\circ} 06^{\prime} 15^{\prime \prime} \mathrm{N}, 170^{\circ}$ $17^{\prime} 30^{\prime \prime} \mathrm{W}$; (map 38). Var. Kamen Sivuchiy, Sealion Rock, Seevitchie Kammin, Sivoutchi Rock, Sivutch Rock.

Russian name "sivuchiy," meaning "sealion," translated and published by USC\&GS in 1875 . Elliott $(1881$, p. 51$)$ calls it "Seevitchie Kammin [sea-lion rock]." It was published by Capt. Tebenkov. (1852, map 21), IRN, as "K[amen] Sivuchiy," or "Sea-lion Rock."
Sealion Rocks: islands, see Sealion Islands.

Sealion Rocks: rocks, $4 \mathrm{mi}$. S of Unga Cape, Unga I. in Shumagin Is., Aleutian Ra.; $55^{\circ}$ $04^{\prime} 40^{\prime \prime} \mathrm{N}, 160^{\circ} 30^{\prime} 30^{\prime \prime} \mathrm{W}$; (map 28). Var. Sea Lion Rocks.

Local name shown on a 1963 USGS map and USC\&GS chart.

Sealion Rocks: rocks, $1 \mathrm{mi}$. $\mathrm{N}$ of Amak I., in Bering Sea, $\mathbf{N}$ of $\mathrm{SW}$ end of Alaska Penin., Bristol Bay Low.; $55^{\circ} 28^{\prime} \mathrm{N}, 163^{\circ} 10^{\prime} \mathrm{W}$; (map 29). Var. Siouchi, Sioutchi, Siuchi, Suichi.

Translation of the Russian name "Siuchi" from the word "Sivuch" meaning "sealion;" given by Capt. Lutke (1836, atlas map 14), IRN.

Sealion Rocks: rocks, 5 mi. E of Tonki Cape, off $\mathrm{E}$ coast of Afognak I., $\mathrm{N}$ of Kodiak I.; $58^{\circ}$. $20^{\prime} 30^{\prime \prime} \mathrm{N}, 151^{\circ} 48^{\prime} 40^{\prime \prime} \mathrm{W}$; (map 43). Var. Siuchi.

Translation by USC\&GS of the name "Siuchiy Kamen," published in 1849 by the Russian American Company.

Seal Island: island, $0.5 \mathrm{mi}$. long, in Prince William Sound, $7 \mathrm{mi}$. E of Knight I., $25 \mathrm{mi}$. NE of Chenega, Chugach Mts.; 60 $25^{\prime} 40^{\prime \prime} \mathrm{N}$, $147^{\circ} 24^{\prime} 30^{\prime \prime} \mathrm{W}$; (map 63).

Name published in 1899 by USC\&GS.

Seal Island : island, see Ikignak Island.

Seal Island: island, see Reef Island.

Seal Islands: barrier islands, dozen or more, trend NE $7 \mathrm{mi}$. along Bristol Bay coast, 33 mi. SW of Port Heiden Airfield, Bristol Bay Low.; $56^{\circ} 42^{\prime} \mathrm{N}, 159^{\circ} 21^{\prime} \mathrm{W}$; (map 30).

Shown as "O[stro]va Nerpichoi," meaning "Seal Islands," by Capt. Tebenkov (1852, map 24), IRN, and as "Seal Islands" on an 1888 USBF chart.

Seal Islands: islands, $1 \mathrm{mi}$. across, $35 \mathrm{mi}$. NE of Afognak, on $\mathrm{N}$ coast of Afognak $\mathrm{I}$., $\mathrm{N}$ of Kodiak I.; $58^{\circ} 26^{\prime} 30^{\prime \prime} \mathrm{N}, 152^{\circ} 17^{\prime} 00^{\prime \prime} \mathrm{W}$; (map 43). Var. Nerpichie Islets.

Translation of the name "Os[tro]va Nerpichi" published in 1849 by the Russian American Company.

Seal Islands: islands, group, extend $1.6 \mathrm{mi}$, in Iliamna Lake, $1 \mathrm{mi}$. W of Flat I. and $22 \mathrm{mi}$. E of Iliamna, Aleutian Ra.; $59^{\circ} 43^{\prime} \mathrm{N}, 154^{\circ}$ 22' W: (map 51)

Local name published in 1957 by USGS.

Seal Islands: islands, see Pribilof Islands.

Seal Lake: lake, $0.1 \mathrm{mi}$. across, SE of St. George, on NE coast of St. George I., in Pribilof Is. $56^{\circ} 36^{\prime} 00^{\prime \prime} \mathrm{N}, 169^{\circ} 31^{\prime} 15^{\prime \prime} \mathrm{W}$; (map 38). Var. An'im-al'gera.

This is a translation of an Aleut name reported by Putnam (1903, p. 1014), USC\&GS, as An'im-al'gera[e], and so named because, according to native lore, "the seals extended as far back as this lake * * *."

Seal Oil Creek: stream, flows NW $8.5 \mathrm{mi}$. to Norton Sound, $2.5 \mathrm{mi}$. S of Tolstoi Point and $21 \mathrm{mi}$. SW of Unalakleet, Nulato Hills; $63^{\circ}$. $35^{\prime} 20^{\prime \prime} \mathrm{N}, 161^{\circ} 01^{\prime} 45^{\prime \prime} \mathrm{W}$; (map 91).

Local name reported in 1952 by USC\&GS. Seal Point: point of land, on $\mathrm{E}$ shore of Becharof Lake, $\mathrm{N}$ of Bellim Bay, on Alaska Penin., 54 mi. NE of Ugashik, Aleutian Ra.; $57^{\circ} 43^{\prime} 40^{\prime \prime}$ $\mathrm{N}, 156^{\circ} 00^{\prime} 30^{\prime \prime} \mathrm{W}$; (map 36$)$.

Local name reported in 1902 by J. L. McPherson of Iliamna.

Seal Point: point of land, see Seal Cape.

Seal River: stream, heads in lake at 1950 terminus of Bering Glacier, flows SW $3 \mathrm{mi}$. to Gulf of Alaska, $13 \mathrm{mi}$. NE of Cape Suckling, Malaspina Coastal Plain; $60^{\circ} 02^{\prime} 40^{\prime \prime} \mathrm{N}, 143^{\circ} 32^{\prime} 00^{\prime \prime}$ W; (map 65).

Local name published in 1951 by USGS.

Seal River: stream, distributary of South Fork Big River, flows SE $11 \mathrm{mi}$. to Redoubt Bay, $28 \mathrm{mi}$. W of Kenai, Cook Inlet Low.; $60^{\circ}$. $38^{\prime} 35^{\prime \prime} \mathrm{N}, 152^{\circ} 03^{\prime} 30^{\prime \prime} \mathrm{W}$; (map 62).

Local name reported in 1958 by USGS.

Seal Rock : island, see Bird Rock.

Seal Rock: rock, 8 mi. S of Sanak I., Aleutian Ra., 54 ${ }^{\circ} 17^{\prime} 48^{\prime \prime} \mathrm{N}, 162^{\circ} 35^{\prime} 20^{\prime \prime} \mathrm{W}$; (map 25).

Name reported by Ferdinand Westdahl, USC\&GS, commander of the Coast Survey steamer McArthur, who made surveys in this area in 1901.

Seal Rock: rock, at SE end of Kashevarof Passage, on NE coast of Prince of Wales I., Alex. Arch.; 56 $04^{\prime} 20^{\prime \prime} \mathrm{N}, 132^{\circ} 50^{\prime} 00^{\prime \prime} \mathrm{W}$; (map 6 ).

Local name used by fishermen, published in 1907 by USC\&GS.

Seal Rocks: rocks, extend $400 \mathrm{ft}$., in Portland Canal, $1 \mathrm{mi}$. NE of Glacier Point, Coast Mts.; $5^{\circ} 49^{\prime} 35^{\prime \prime}$ N, $130^{\circ} 05^{\prime} 30^{\prime \prime}$ W; (map 3). Var. Seal Rock.

Descriptive name given in 1868 by Staff Comdr. David Pender, RN.

Seal Rocks: rocks, off Cape Ikolik, on W coast of Kodiak I., $24 \mathrm{mi}$. SW of Karluk; $57^{\circ} 17^{\prime} 50^{\prime \prime}$ N, $154^{\circ} 49^{\prime} 00^{\prime \prime}$ W; (map 35). Var. Kamen Sivuchiy.

Translation by USC\&GS in 1868 of the Russian name "K[amen] Sivuchiy," published by Capt. Tebenkov (1852, map 22), IRN. See Inner and Outer Seal Rocks.

Seal Rocks: rocks, $6 \mathrm{mi}$. S of Matushka I. in Gulf of Alaska, $44 \mathrm{mi}$. SW of Seward, Chugach

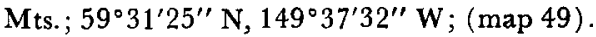

Named "K[amen] Sivuchi," meaning "sealion rocks," by Capt. Tebenkov (1852, map 5 ), IRN; erroneously translated in 1888 by USC\&GS.

Seal Rocks: rocks, at $\mathbf{S}$ end of Hinchinbrook Entrance, $8 \mathrm{mi}$. SW of Hinchinbrook I. and 45 mi. SW of Cordova, Chugach Mts.; $60^{\circ} 10^{\prime} \mathrm{N}$, $146^{\circ} 50^{\prime} \mathrm{W}$; (map 64). Var. Isla Triste, Kamen Siuchiy, Rock Surprise, Rose Island, Sivuchi Kamen.

Name published in 1869 Coast Pilot (p. 155). This feature was shown in 1788 as part of the "Rose Island" of Capt. John Meares, RN. "Isla Triste," meaning "dismal islands," was published in 1788 by Bodega y Quadra and Francisco Antonio Maurelle. It was published as "Kamen Siuchiy," meaning "Sealion Rocks," in 1847 on Russian Hydrog. Dept. Chart 1378.

Seal Rocks: rocks, see Kitleekot Rocks.

Seal Slough: stream, flows SW $1.5 \mathrm{mi}$. to Redoubt Bay in Cook Inlet, $1.5 \mathrm{mi}$. SW of Kustatan 
River and $25 \mathrm{mi}$. NW of Kenai, Cook Inlet Low.; $60^{\circ} 43^{\prime} 30^{\prime \prime} \mathrm{N}, 151^{\circ} 53^{\prime} 10^{\prime \prime} \mathrm{W}$; (map 62).

Local name reported in 1958 by USGS.

Seal Slough: stream, distributary of Chakachatna River, flows SE $3 \mathrm{mi}$. to Trading Bay in Cook Inlet, $30 \mathrm{mi}$. NNW of Kenai, Cook Inlet Low.; $60^{\circ} 56^{\prime} \mathrm{N}, 151^{\circ} 40^{\prime} \mathrm{W}$; (map 62).

Local name reported in 1958 by USGS.

Seal Spit: spit, on $\mathrm{N}$ coast of Iniskin Penin., in Chinitna Bay, W of Camp Point, Aleutian Ra.; $59^{\circ} 49^{\prime} 59^{\prime \prime} \mathrm{N}, 153^{\circ} 05^{\prime} 29^{\prime \prime} \mathrm{W}$; BGN 1962; (map 51).

Local name reported in 1951 by USGS.

Sealy Lake: lake, see Seeley Lake.

Sea Otter Bay: bay, see Beaver Bay.

Sea Otter Bay: cove, see Deep Bay.

Sea Otter Bay: water passage, see Meares Passage.

Sea Otter Bay: water passage, see Real Marina, Port.

Sea Otter Greek: stream, heads at 1961 terminus of Sea Otter Glacier, flows SW $4.5 \mathrm{mi}$. to Gulf of Alaska, $5 \mathrm{mi}$. N of Cape Fairweather and $105 \mathrm{mi}$. NW of Hoonah, Malaspina Coastal Plain; 58 $52^{\prime} 40^{\prime \prime}$ N, 137 $56^{\prime}$ $30^{\prime \prime} \mathrm{W}$; (map 10).

Local name published by USGS in the 1950 's.

Sea Otter Glacier: glacier, in Glacier Bay National Monument, heads $4 \mathrm{mi}$. SW of Mount Root, trends W $11 \mathrm{mi}$. to its 1961 terminus on Sea Otter Creek, $3 \mathrm{mi}$. E of Gulf of Alaska and $104 \mathrm{mi}$. NW of Hoonah, St. Elias Mts. $58^{\circ} 53^{\prime} 45^{\prime \prime} \mathrm{N}, 137^{\circ} 51^{\prime} 00^{\prime \prime} \mathrm{W}$; (map 10 ).

Local name published by USGS in the 1950's.

Sea Otter Harbor: bay, extends $\mathrm{E} 2 \mathrm{mi}$., off $\mathrm{Pa}$ cific Ocean, on $W$ coast of Dall I. between Cape Lookout and Juel Point, Alex. Arch.; $55^{\circ} 07^{\prime} \mathrm{N}, 133^{\circ} 12^{\prime} \mathrm{W}$; (map 4).

Name published in the 1925 Coast Pilot (p. 169)

Sea Otter Harbor: bay, see Sea Otter Sound. Sea Otter Harbor: water passage, see Siketi Sound.

Sea Otter Island: island, $0.4 \mathrm{mi}$. across, $6 \mathrm{mi}$. E of Shuyak I., and $43 \mathrm{mi}$. N of Kodiak I.; $58^{\circ} 31^{\prime} 20^{\prime \prime} \mathrm{N}, 152^{\circ} 13^{\prime} 00^{\prime \prime} \mathrm{W}$; (map 43). Var. Beaver Island, Bobroff Island, Bobrovie Island, Bobrovy Island, Bobrovoy, Ostrov, Bobrovoy (valga), Ostrov, Bobrovyy, Ostrov, Bobrow Island, Bohrow Island.

Translation of the name "Os[trov] Bobrovyy," published in 1849 by the Russian American Company.

Sea Otter Island: island, see Bobrof Island.

Sea Otter Island: island, see Otter Island.

Sea Otter Islet: island, see Bobrof Island.

Sea Otter Islets: rocks, see Latax Rocks.

Sea Otter Pass: water passage, SW of Ogliuga Pass, NE of Kavalga I., Delarof Is., Aleutian Is.; $51^{\circ} 33^{\prime} \mathrm{N}, 178^{\circ} 43^{\prime} \mathrm{W}$; (map 16).

Name published in the 1946 supplement to the 1944 Aleutian Coast Pilot (U.S. Coast and Geodetic Survey, 1946, p. 120).
Sea Otter Point: promontory, on NE coast of Iniskin Penin., Aleutian Ra.; 59 $50^{\prime} \mathrm{N}, 1^{153^{\circ} \text {. }}$ $01^{\prime} \mathrm{W}$; (map 51 ).

Local name reported in 1957 by USGS.

Sea Otter Reef: reef, see Douglas Reef.

Sea Otter Rock: rock, in Amchitka Pass, $1 \mathrm{mi}$. E of East Cape, Amchitka I., Aleutian Is.; $51^{\circ} 22^{\prime} 10^{\prime \prime} \mathrm{N}, 179^{\circ} 29^{\prime} 20^{\prime \prime} \mathrm{E}$; (map 15).

Local name published by AMS in 1955.

Sea Otter Rocks: reef, see Douglas Reef.

Sea-Otter Rocks : rocks, see Latax Rocks.

Sea Otter Rocks: rocks, see Augustine Rocks.

Sea Otters Bay: bay, see Beaver Inlet.

Sea Otter Sound: bay, $8 \mathrm{mi}$. across, opens into

Davidson Inlet, surrounded by Marble, Orr,

Tuxekan and Heceta Is., Alex. Arch.; 55 52'

N, $133^{\circ} 33^{\prime}$ W; (map 4). Var. Otter Sound, Sea Otter Harbor.

Name published by Dall (U.S. Coast and Geodetic Survey, 1883, p. 99) who said "To this bight *** the name of Otter Sound or Sea Otter Sound has been applied, under the supposition that it was the Otter Sound of [J.] Meares * * *."

Sea Parrot Island: island, $0.2 \mathrm{mi}$. across, $\mathrm{W}$ of Dora I., Bay of Is., Adak I., Aleutian Is.; $51^{\circ}$ $48^{\prime} 55^{\prime \prime} \mathrm{N}, 176^{\circ} 48^{\prime} 25^{\prime \prime} \mathrm{W}$; BGN 1936; (map 17).

Named by members of the U.S. Navy Aleutian Island Survey Expedition in 1933.

Sea Ranger Reef: reef, in Gulf of Alaska, $4 \mathrm{mi}$. $\mathbf{N}$ of Cape St. Elias, Kayak I., Malaspina Coastal Plain; $59^{\circ} 51^{\prime} 20^{\prime \prime} \mathrm{N}, 144^{\circ} 36^{\prime} 45^{\prime \prime} \mathrm{W}$; $B G N 1910$; (map 48).

Name published in 1943 by USC\&GS on Chart 8513.

Sea Rock: rock, 1 mi. off NW end of Kruzof I., $28 \mathrm{mi}$. NW of Sitka, Alex. Arch.; $57^{\circ} 20^{\prime} 15^{\prime \prime} \mathrm{N}$, $135^{\circ} 52^{\prime} 30^{\prime \prime} \mathrm{W}$; (map 9).

Local navigators' name published by USC\&GS in the 1943 Coast Pilot (p. 370).

Sea Rock: rock, see Morskoi Rock.

Sears Creek: stream, flows NW $5 \mathrm{mi}$. to Johnson Slough, $5 \mathrm{mi}$. SE of junc. of Johnson and Tanana Rivers and $46 \mathrm{mi}$. SE of Delta Junction, Tanana Low.; $63^{\circ} 41^{\prime} 35^{\prime \prime} \mathrm{N}, 144^{\circ} 28^{\prime} 00^{\prime \prime}$ W; (map 86).

Name published on relatively recent maps. Seat Island: island, see East Clump.

Seattle, Mount: mountain, 10,070 ft., on AlaskaCanada boundary, $17 \mathrm{mi}$. SSW of Mount Hubbard and $42 \mathrm{mi}$. NE of Yakutat, St. Elias Mts.; $60^{\circ} 05^{\prime} 20^{\prime \prime} \mathrm{N}, 139^{\circ} 11^{\prime} 40^{\prime \prime} \mathrm{W}$; (map 66). Var. Boundary Peak 178, Mount Bozman.

Named by I. C. Russell, USGS, in 1890 after the city of Seattle, Wash

Seattle Creek: stream, flows W $2.5 \mathrm{mi}$. to Kuskokwim Bay, $27 \mathrm{mi}$. NE of Cape Newenham, Kilbuck-Kuskokwim Mts.; $58^{\circ} 58^{\prime} 20^{\prime \prime} \mathrm{N}, 161^{\circ}$ 47'10" W; BGN 1938; (map 39).

Name used by prospectors; reported in 1938 by J. B. Mertie and Gerald FitzGerald, USGS.

Seattle Creek: stream, on N end of Kenai Penin., flows NE $6 \mathrm{mi}$. to Turnagain Arm, $9 \mathrm{mi}$. E of Sunrise, Chugach Mts.; $60^{\circ} 52^{\prime} 50^{\prime \prime} \mathrm{N}, 149^{\circ}$ $09^{\prime} 30^{\prime \prime} \mathrm{W}$; (map 63).
Local name reported in 1895 by Becker (1898, map 2), USGS.

Seattle Creek: stream, flows NE $11 \mathrm{mi}$. to Nenana River, $43 \mathrm{mi}$. SE of Healy, Talkeetna Mts.; $63^{\circ} 20^{\prime} 40^{\prime \prime} \mathrm{N}, 148^{\circ} 14^{\prime} 10^{\prime \prime} \mathrm{W}$; (map 87).

Local name reported in 1913 by J. M. Bagley, USGS.

Seattle Creek: stream, flows SE $3.5 \mathrm{mi}$. to Flambeau River, $12 \mathrm{mi}$. ENE of Nome, Seward Penin. High.; $64^{\circ} 32^{\prime} 20^{\prime \prime} \mathrm{N}, 165^{\circ} 00^{\prime} 00^{\prime \prime} \mathrm{W}$; (map 94).

Prospectors' name reported in 1900 by E. C. Barnard (in Brooks, 1901, pl. 17), USGS.

Seattle Creek: stream, flows SW $1 \mathrm{mi}$. to Snake River, 13 mi. NW of Nome, Seward Penin. High.; $64^{\circ} 41^{\prime} \mathrm{N}, 165^{\circ} 24^{\prime} \mathrm{W}$; (map 94). Var. Wesley Creek.

Prospectors' name reported on a map by S. E. King dated 1900.

Seattle Creek: stream, flows N $0.8 \mathrm{mi}$. to Dome Greek, $13 \mathrm{mi}$. $\mathbf{N}$ of Fairbanks, Yukon-Tanana High.; 650.' $50^{\prime \prime} \mathrm{N}, 147^{\circ} 34^{\prime} 40^{\prime \prime} \mathrm{W}$; (map 105). Var. Seattle Gulch.

Named by prospectors and published in 1913 by USGS (Prindle, 1913a, pl. 2).

Seattle Creek: stream, flows SSE $1.5 \mathrm{mi}$. to Rhode Island Creek, $3 \mathrm{mi}$. SSW of Eureka Dome and $22 \mathrm{mi}$. S of Rampart, YukonTanana High.; 65 $11^{\prime} 10^{\prime \prime} \mathrm{N}, 150^{\circ} 16^{\prime} 40^{\prime \prime} \mathrm{W}$; (map 106).

Prospectors' name reported in 1904 by Prindle and Hess (1906, pl. 3), USGS.

Seattle Gulch: ravine, trends $1 \mathrm{mi}$. NE to Copper Creek SE of its junc. with Eagle Creek, 19 mi. SE of McCarthy, St. Elias Mts.; $61^{\circ} 20^{\prime} \mathrm{N}$, $142^{\circ} 24^{\prime} \mathrm{W}$; (map 67).

Name reported in 1908 by D. C. Witherspoon, USGS.

Seattle Gulch: stream, see Seattle Creek.

Seattle Junior Creek: stream, flows S $1 \mathrm{mi}$, to Pioneer Creek $2 \mathrm{mi}$. NE of that stream's junc. with Eureka Creek, $21 \mathrm{mi}$. S of Rampart, Yukon-Tanana High.; $65^{\circ} 11^{\prime} 40^{\prime \prime}$ N, $150^{\circ} 09^{\prime}$ $30^{\prime \prime} \mathrm{W}$; (map 106).

Prospectors' name reported in 1904 by Prindle and Hess (1906, pl. 3), USGS.

Seattle River: stream, see Glacier River.

Seaweed Pass: water passage, between Umnak and Ananiuliak Is., Aleutian Is.; $53^{\circ} 00^{\prime} 10^{\prime \prime}$ $\mathrm{N}, 168^{\circ} 53^{\prime} 00^{\prime \prime} \mathrm{W}$; BGN 1940; (map 22).

Named in 1938 by USC\&GS.

Sebree Cove: water passage, $0.3 \mathrm{mi}$. across, just W of Sebree I., at mouth of Muir Inlet, in Glacier Bay National Monument, $52 \mathrm{mi}$. NW of Hoonah, St. Elias Mts.; $58^{\circ} 45^{\prime} 15^{\prime \prime} \mathrm{N}$, $136^{\circ} 10^{\prime} 00^{\prime \prime} \mathrm{W} ; B G N$ 1948; (map 10 ).

Name suggested by USC\&GS in 1948.

Sebree Island: island, 2 mi. long, in Glacier Bay National Monument, at mouth of Muir Inlet, $0.5 \mathrm{mi}$. SW of Caroline Point and $52 \mathrm{mi}$. NW of Hoonah, St. Elias Mts.; $58^{\circ} 45^{\prime} 10^{\prime \prime} \mathrm{N}$, $136^{\circ} 09^{\prime} 30^{\prime \prime} \mathrm{W}$; (map 10). Var. Headland Island.

Named about 1890 for Comdr. Uriel Sebree, 1848-1922, USN. He was on the Arctic Relief Expedition in 1873 and the Greely Relief Expedition in 1884. The feature was 
called "Headland Island" by Cushing (1891, p. 228).

Sechiksuk: mountain, see Satsiksuk Mountain

Secluded Bay: bay, $2.5 \mathrm{mi}$. long, at head of Necker Bay, on W coast of Baranof I., Alex. Arch.; $56^{\circ} 45^{\prime} \mathrm{N}, 135^{\circ} 01^{\prime} \mathrm{W}$; $B G N$ 1926; (map 5).

Descriptive name given in 1924 by charting purposes by USC\&GS; so named because of its location.

Seclusion, Lake: lake, $0.7 \mathrm{mi}$. long, on $\mathrm{W}$ coast of Long I., Alex. Arch.; 54 $50^{\prime} 00^{\prime \prime} \mathrm{N}, 132^{\circ}$ $43^{\prime} 20^{\prime \prime}$ W; (map 1).

Local name published in 1924 by USC\&GS.

Seclusion Harbor: bay, extends E $1.2 \mathrm{mi}$. from Salt Lagoon to Keku Strait, on E coast of Kuiu I., $16 \mathrm{mi}$. NW of Point Baker, Alex. Arch.; $56^{\circ} 33^{\prime} 20^{\prime \prime} \mathrm{N}, 133^{\circ} 52^{\prime} 00^{\prime \prime} \mathrm{W}$; (map 6 ).

Named in 1892 by Lt. W. I. Moore, USN.

Seclusion Lake: lake, about $8 \mathrm{mi}$. long, in Glacier Bay National Monument, $1.5 \mathrm{mi}$. W of Mount Wood and $48 \mathrm{mi}$. NW of Hoonah, St. Elias Mts.; $58^{\circ} 32^{\prime} 20^{\prime \prime} \mathrm{N}, 1^{\prime} 36^{\circ} 21^{\prime} 50^{\prime \prime} \mathrm{W}$; $B G N$ 1962; (map 10).

So named by NPS in 1962 "because the lake is relatively inaccessible and isolated."

Second Berg Lake: lake, $0.5 \mathrm{mi}$. long at 1905 terminus of Bering Glacier, $3 \mathrm{mi}$. E of Doughton Peak and $66 \mathrm{mi}$. E of Cordova, Chugach Mts.; $60^{\circ} 25^{\prime} \mathrm{N}, 143^{\circ} 49^{\prime} \mathrm{W}$; (map 65) Var. Second Lake.

Local name reported in 1905 by G. C. Martin (1908, pl. 2), USGS. This lake originally was the smallest of five Berg Lakes. As a result of the retreat of Steller and Bering Glaciers in recent times, Second Berg and Third Berg Lakes have joined with First Berg Lake to form Berg Lake.

Second Berg Lake: lake, see Berg Lake.

Second Creek: stream, flows NW $9.6 \mathrm{mi}$. to Reindeer Cove, $15 \mathrm{mi}$. SW of Christmas Mtn. Nulato Hills ; $64^{\circ} 30^{\prime} \mathrm{N}, 161^{\circ} 02^{\prime} \mathrm{W}$; (map 96).

Local name reported about 1954 by U.S. Army Corps of Engineers.

Second Hill Lake: lake, $2 \mathrm{mi}$. long, $3.8 \mathrm{mi}$. W of Crosswind Lake and $26 \mathrm{mi}$. NW of Glennallen, Copper River Basin; $62^{\circ} 21^{\prime} \mathrm{N}, 146^{\circ} 13^{\prime} \mathrm{W}$; (map 83).

Local name reported in 1951 by USGS.

Second Kekoor: rock, see Second Kekur.

Second Kekour: rock, see Second Kekur.

Second Kekur: rock, 0.2 mi. across, W of Kekur Penin., $15 \mathrm{mi}$. NW of village of Port Alexander, on S coast of Baranof I., Alex. Arch.; $56^{\circ} 23^{\prime} 18^{\prime \prime} \mathrm{N}, 134^{\circ} 57^{\prime} 00^{\prime \prime} \mathrm{W}$; (map 5). Var. Second Kekoor, Second Kekour.

Descriptive name meaning "pinnacle rock" given in 1849 by the Russian American Company. See Kekur Island.

Second Lake: lake, 2,200 ft. across, at head of Indian Creek, $1 \mathrm{mi}$. NW of Tyonek, Cook Inlet Low.; $61^{\circ} 05^{\prime} 00^{\prime \prime} \mathrm{N}, 151^{\circ} 09^{\prime} 45^{\prime \prime} \mathrm{W}$; (map 70).

Local name published in 1898 by USC\&GS.

Second Lake: lake, $0.3 \mathrm{mi}$. long, $2.6 \mathrm{mi}$. $\mathrm{N}$ of Chitina and $67 \mathrm{mi}$. NE of Valdez, Copper River Basin; $61^{\circ} 33^{\prime} 50^{\prime \prime} \mathrm{N}, 144^{\circ} 26^{\prime} 35^{\prime \prime} \mathrm{W}$; (map 68).
Local name published in the 1950's by USGS.

Second Lake: lake, see Berg Lake.

Second Lake: lake, see Doctor Cook Lake.

Second Lake: lake, see Kenai Lake.

Second Narrows: water passage, in $\mathrm{N}$ part of Redfish Bay, $10.5 \mathrm{mi}$. NW of village of Port Alexander, on $\mathbf{S}$ coast of Baranof I., Alex. Arch.; $56^{\circ} 20^{\prime} 20^{\prime \prime} \mathrm{N}, 134^{\circ} 51^{\prime} 40^{\prime \prime} \mathrm{W}$, (map 5).

Named in 1897 by Lt. Comdr. J. F. Moser, USN, commander of USBF steamer Albatross.

Second Narrows: water passage, extends W 0.5 mi. from Middle Channel between Lodge I. and Rak of Is., off $W$ coast of Baranof 1., Alex. Arch., 56 $44^{\prime} 05^{\prime \prime} \mathrm{N}, 135^{\circ} 15^{\prime} 45^{\prime \prime} \mathrm{W}$; (map 5).

Local fishermen's name reported in 1947 by USC\&GS.

Second North Tributary: glacier, see McBride Glacier.

Second Nuyakuk Lake: lake, see Nuyakuk Lake. Second Point: point of land, see Inner Point.

Second Priest Rock: rock, between Summer and Iliuluk Bays, SE shore of Unalaska Bay, NE coast of Unalaska I., Aleutian Is.; $53^{\circ} 54^{\prime} 14^{\prime \prime}$ N, $166^{\circ} 27^{\prime} 58^{\prime \prime}$ W; (map 23). Var. Pinnacle Rock.

Local name published by USC\&GS on Chart 821 as "Pinnacle" in 1872. See Priest Rock. Second Pup: stream, flows NW 2 mi. to Flat Creek, $40 \mathrm{mi}$. NW of Fairbanks, YukonTanana High.; $65^{\circ} 13^{\prime} 25^{\prime \prime}$ N, $146^{\circ} 47^{\prime} 10^{\prime \prime}$ W; (map 104).

Named "Second Pup" by prospectors; published by USGS (Prindle, 1908, pl. 4). See First Pup and Third Pup.

Second Rapids: rapids, see Southern Rapids.

Second Timber Creek: stream, flows SE $3 \mathrm{mi}$. to Nushagak River, $80 \mathrm{mi}$. SE of Sleetmute, Kilbuck-Kuskokwim Mts., $60^{\circ} 37^{\prime}$ N, $156^{\circ} 32^{\prime}$ W; (map 60).

Local descriptive name reported in 1952 by USC\&GS.

Second Waterfall Creek: stream, heads in a lake, flows NW $4 \mathrm{mi}$. to Clover Passage, $1.8 \mathrm{mi}$. NE of Potter Point, on W coast of Revillagigedo I., Alex. Arch.; $55^{\circ} 29^{\prime} 40^{\prime \prime} \mathrm{N}, 131^{\circ} 45^{\prime} 20^{\prime \prime} \mathrm{W}$; (map 3).

Local name recorded in 1954 by USGS.

Secret Bay: bay, 1 mi. across, in S part of Beardslee I., in Glacier Bay, Glacier Bay National Monument, $\mathrm{N}$ of Lester I., $56 \mathrm{mi}$. NW of Juneau, St. Elias Mts.; $58^{\circ} 29^{\prime} \mathrm{N}, 1^{3} 5^{\circ} 56^{\prime} \mathrm{W}$; BGN 1948; (map 11).

Descriptive name given in 1939 by USC\&\&S because the bay is so well concealed.

Secret Creek: stream, heads E of Uncle Sam Mtn., flows S $4 \mathrm{mi}$. to lagoon on Norton Sound, $6 \mathrm{mi}$. E. of Solomon, Seward Penin. High.; $64^{\circ} 34^{\prime} \mathrm{N}, 164^{\circ} 15^{\prime}$ W; (map 95). Var. Basin Creek, Secret Ravine Creek.

Prospectors' name reported in 1905 by $\mathrm{T}$. G. Gerdine, USGS. Shown as "Secret Ravine Cr." on Arthur Gibson's "Map of Cape Nome Precinct" dated 1902. USGS geologists reported the upper course of the stream in 1907 as "Basin Creek" (Smith, P. S., 1910, pl. 3).
Secret Ravine Creek: stream, see Secret Creek. Section Creek: stream, heads $13 \mathrm{mi}$. E of Birthday Pass, flows S $15 \mathrm{mi}$. to Awuna River, 145 mi. SE of Wainwright, Arctic Slope ; $69^{\circ} 04^{\prime} \mathrm{N}$, $156^{\circ} 01^{\prime} \mathrm{W}$; (map 143).

Named by USGS geologists in the 1950's. Section House Lake: lake, $0.2 \mathrm{mi}$. long, $\mathrm{E}$ of The Alaska RR., $11 \mathrm{mi}$. S of Talkeetna, Cook Inlet Low.; $62^{\circ} 09^{\prime} 45^{\prime \prime} \mathrm{N}, 150^{\circ} 04^{\prime} 15^{\prime \prime} \mathrm{W}$; (map 81).

Local name reported in 1958 by USGS.

Security Bay: bay, $1.5 \mathrm{mi}$. across, on $\mathrm{N}$ coast of Kuiu I., Alex. Arch.; $56^{\circ} 53^{\prime} \mathrm{N}, 134^{\circ} 21^{\prime} \mathrm{W}$; (map 5)

Named in 1869 for charting purposes by Comdr. R. W. Meade, USN, who made a reconnaissance of the bay in that year.

Security Cove: bay, $5 \mathrm{mi}$. across, extends from Castle Rock to Pinnacle Rock, $10 \mathrm{mi}$. E. of Cape Newenham, Kilbuck-Kuskokwim Mts.; $58^{\circ} 41^{\prime} 30^{\prime \prime} \mathrm{N}, 161^{\circ} 54^{\prime} 00^{\prime \prime} \mathrm{W}$; (map 39).

Named in 1914 by USC\&GS because "the cove offered security during a storm." The name was published in 1916 Coast Pilot (p. 246).

Security Cove: estuary, extends E $2 \mathrm{mi}$, on SW coast of Dall I., Alex. Arch.; $54^{\circ} 45^{\prime} 00^{\prime \prime} \mathrm{N}$, $132^{\circ} 52^{\prime} 30^{\prime \prime} \mathrm{W}$; (map 1 ).

Name published by USC\&GS in 1917 .

Security Point: point of land, $\mathbf{S}$ point of entrance to Security Cove, on SW coast of Dall I., Alex. Arch:; 54 ${ }^{\circ} 44^{\prime} 29^{\prime \prime}$ N, $132^{\circ} 53^{\prime} 05^{\prime \prime}$ W; BGN 1929; (map 1).

Name derived from Security Cove; given in 1928 by Capt. R. S. Patton, USC\&GS.

Sedaghuv Island: island, see Sedanka Island.

Sedanka: locality, on Sedanka Point, at mouth of Kismaliuk Bay, on SW coast of Unalaska I., Aleutian Is.; $53^{\circ} 28^{\prime} 45^{\prime \prime} \mathrm{N}, 167^{\circ} 17^{\prime} 30^{\prime \prime} \mathrm{W}$; (map 23).

Former Aleut village reported by $\mathbf{L t}$. Sarichev (1826, map 14, dated 1792) as "S[eleniye] Sedanka," i.e., "Sedanka Village." Sedanka: village, see Biorka.

Sedanka, Cape: point of land, on NE tip of Sedanka I., Aleutian Is.; $53^{\circ} 50^{\prime} 30^{\prime \prime} \mathrm{N}, 166^{\circ}$ 05'20" W; BGN 1921; (map 23). Var. Biorka Cape, Burka Cape.

Named by USC\&GS in 1921 after Sedanka Island. The USBF called this point "Burka Cape" in 1888.

Sedanka Cape: point of land; see Sedanka Point.

Sedanka Island: island, $11 \mathrm{mi}$. long, in Fox Is., off NE coast of Unalaska I., Aleutian Is.; $53^{\circ}$ $47^{\prime} \mathrm{N}, 166^{\circ} 12^{\prime} \mathrm{W}$; BGN 1921; (map 23). Var. Beaver Island, Biorka Island, Borka, Burka, Ostrov Spirkin, Sedaghuv Island, Siginak, Siginaq, Sithanak, Spirkine.

In $1792 \mathrm{Lt}$. Sarichev (1826, map 14), IRN, recorded "O[strov] Spirkin." In the same year Martin Sauer gave the Aleut name "Sithanak," which Marcus Baker recorded "Siginak," and R. H. Geoghegan spelled "Siginaq," meaning "braided" or "curled." Between 1824 and 1834 Father Veniaminov and Capt. Lutke, IRN, used the names "Borka" and "Spirkin" or "Spirkine." Baker (1906, p 133) published "Biorka," which he reported 
as being from the "Norwegian Bjerk ö, or Swedish Björk OO, meaning Birch Island." Named "Sedanka Island" in 1921 by USC\&GS.

Sedanka Pass: water passage, between Sedanka and Egg Is., Aleutian Is.; $53^{\circ} 51^{\prime} \mathrm{N}, 166^{\circ} 04^{\prime}$ W; BGN 1922; (map 23). Var. Egg Island Passage.

Named for Sedanka Island by USG\&GS in 1921. John J. Gilbert, USC\&GS, commander of the Coast Survey steamer Pathfinder between 1900-01, called this feature "Egg Island Passage" for the island located on its east side.

Sedanka Point: point of land, E point of entrance to Kismaliuk Bay, on W coast of Unalaska I., Aleutian I. ; $53^{\circ} 28^{\prime} 45^{\prime \prime} \mathrm{N}, 167^{\circ} 17^{\prime} 30^{\prime \prime}$ W; BGN 1965; (map 23). Var. Cape Hague, Point Sedanka, Sedanka Cape, Umshaliuk Cape.

This name was first reported by Capt. Tebenkov (1852, map 26, dated 1849), IRN, as "M[ys] Sedanka," or "Cape Sedanka." It was called "M[ys] Umshalyuk," or "Cape Umshalyuk" by Lt. Sarichev (1826, map 14, dated 1792), IRN, and "Cape Hague" by USBF in 1888 .

Sedanki: village, see Biorka.

Seduction Point: point of land, on S tip of Chilkat Penin., $2.6 \mathrm{mi}$. SE of Kalhagu Cove, on Chilkat Inlet, $26 \mathrm{mi}$. S of Skagway, Coast Mts.; 59 $04^{\prime} 55^{\prime \prime} \mathrm{N}, 135^{\circ} 18^{\prime} 25^{\prime \prime} \mathrm{W}$; (map 45). Var. Mys Seduktion, Seduction Tongue, Mys Soblazna.

So named by Capt. Vancouver (1798, v. 3 , p. 248), RN, because of the designing nature of the Indians whom Joseph Whidbey encountered here, July 16, 1794. It was called "M[ys] Seduktion," Russian transliteration of the name "Seduction," on Chart 1396 of the Russian Hydrog. Dept. in 1848. Capt. M. D. Tebenkov, IRN, recorded it as "M[ys] Soblazna," meaning "Cape Seduction," in 1852. In 1867, George Davidson, USC\&GS, called the point "Seduction Tongue."

Seduction Tongue: point of land, see Seduction Point.

Seduktion, Mys: point of land, see Seduction Point.

Seegikroorak Point: point of land, see Siksrikpak Point.

Seegreepaugrauk Ridge: ridge, see Sigrikpak Ridge.

Seekoosooweelak: springs, see Kavrorak Springs. Seelawik Mutes : village, see Selawik.

Seeley Lake: lake, $0.8 \mathrm{mi}$. long, one of Chedatna Lakes, on $\mathbf{N}$ shore of Cook Inlet, $33 \mathrm{mi}$. W of Anchorage, Cook Inlet Low.; 61 ${ }^{\circ} 13^{\prime} 10^{\prime \prime}$ $N, 150^{\circ} 54^{\prime} 00^{\prime \prime} \mathrm{W}$; (map 70). Var. Sealv Lake.

Local name reported in 1958 by USGS.

Seemalik Butte: hill, $866 \mathrm{ft}$., $5 \mathrm{mi}$. NW of Kimiksthek Hill, $42 \mathrm{mi}$. NW of Cape Mendenhall, Nunivak I.; $60^{\circ} 09^{\prime} 15^{\prime \prime} \mathrm{N}, 167^{\circ} 08^{\prime} 05^{\prime \prime}$ W; (map 57). Var. Simalik Hill.

Eskimo name obtained in 1949 by USC\&GS. Seemick: hill, see Simik Hill.

Seenrakroorak: water passage, see Sinrakrurak Inlet.
Seepanpak: locality, $\mathbf{N}$ coast of St. Lawrence I. at entrance to Seepanpak Lagoon, $47 \mathrm{mi}$. SE of Savoonga; $63^{\circ} 21^{\prime} \mathrm{N}, 169^{\circ} 18^{\prime} \mathrm{W}$; (map 93).

Eskimo name "Seepenpak" reported in 1932 by O. W. Geist, Univ. of Alaska.

Seepanpak Inlet: estuary, flows NW $2 \mathrm{mi}$. from Seepanpak Lagoon to Bering Sea, $18 \mathrm{mi}$. W of Northeast Cape, St. Lawrence I.; $63^{\circ} 21^{\prime} \mathrm{N}$, $169^{\circ} 18^{\prime} \mathrm{W} ; B G N 1951$; (map 93). Var. Seepenpak Lagoon, Seepinpuk River.

Eskimo name reported in 1932 by O. W. Geist, Univ. of Alaska, as "Seepenpak."

Seepanpak Lagoon: lake, $5 \mathrm{mi}$. long, $3 \mathrm{mi}$. W of Kangukhsam Mtn., N coast of St. Lawrence I., $63^{\circ} 19^{\prime} \mathrm{N}, 169^{\circ} 08^{\prime} \mathrm{W}$; BGN 1951; (map 93). Var. Seepinpugum Lagoon, Sepinpak Lagoon.

Eskimo name recommended by the Savoonga village council and reported in 1949 by $\mathbf{M a j}$. H. B. Allen, USAF.

Seepenpak: locality, see Seepanpak.

Seepenpak Lagoon: estuary, see Seepanpak Inlet.

Seepinpuk River: estuary, see Seepanpak Inlet.

Seethah: locality, S of Fox Hill, near SW coast of St. Paul I., in Pribilof Is.; 57 $10^{\circ} \mathrm{N}, 170^{\circ}$ $23^{\prime} \mathrm{W}$; (map 38).

Name published by Elliott (1881, St. Paul map).

Seetien Island: island, see Great Sitkin Island.

Seet-oht: stream, see Ray River.

See-tuck : stream, see Situk River

Seevitchie Kammin: rock, see Sea Lion Rock. Seevolookruk Creek: stream, see Asikpak River. Seevoo: bluff, see Sivu Bluff.

Seevoochaek: stream, see Tutak Creek.

Seevoochyak: hill, see Sivutsiak Hill

Seevoochyam Igaylungee: hills, see Kisaymaruktuk Mountain.

Seevoogak: hill, see Sivugak Hill.

Seevooka, Cape: point of land, see Northeast Cape.

Seevooka Camp: locality, see Camp Kulowiye. Seevookat Mountain: mountain, see Sivukat Mountain.

Seevookhan Mountain: mountain, 1,448 ft., in Kinighulghat Mts., $3 \mathrm{mi}$. SW of Northeast Cape, St. Lawrence I., $63^{\circ} 17^{\prime} \mathrm{N}, 168^{\circ} 48^{\prime} \mathrm{W}$; $B G N 1951$; (map 93). Var. Sivukhan Mountain.

Eskimo name reported in 1949 by Maj. H. B. Allen, USAF.

Seevookuk: village, see Gambell.

Seevookuk: point of land, see Chibukak Point. Seevoonah Mountain: hill, $700 \mathrm{ft}$., in Kialegak Mts., $2 \mathrm{mi}$. N of Southeast Cape, St. Lawrence I. ; $62^{\circ} 57^{\prime} 30^{\prime \prime} \mathrm{N}, 169^{\circ} 39^{\prime} 30^{\prime \prime} \mathrm{W}$; BGN 1951; (map 93).

Eskimo name reported in 1949 by Maj. H. B. Allen, USAF.

Seevoo Point: point of land, $\mathrm{N}$ coast of $\mathrm{St}$. Lawrence I., $56 \mathrm{mi}$. SE of Savoonga ; $63^{\circ} 20^{\prime}$ N, 168 52' W.; BGN 1951; (map 93). Var. Cape Seevoo, Seevoo, Seevoo Cape, Sevuo Cape.

Eskimo name reported in 1932 by O. W. Geist, Univ. of Alaska.
Seevoorak: bluff, see Sivurak Bluff.

Seevooram Koonga: stream, see Tutak Creek. Seeyicksinick: locality, see Siyiksinik.

Seeyicktagnaylick: locality, see Siniktagnelik.

Sefagnuk: locality, see Sfaganuk.

Segouam: water passage, see Seguam Pass.

Segouam Island: island, see Seguam Island.

Seguam Island: island, $15 \mathrm{mi}$. long, easternmost of Andreanof Is., Aleutian Is.; 52 $19^{\prime} \mathrm{N}$, $172^{\circ} 30^{\prime} \mathrm{W} ; B G N$ 1890; (map 19). Var. Genunam Island, Goreli Island, Gorely Island, Saioogham Island, Segouam Island, Signam Island, Siguam Island, Tenounam Island.

Reported in 1778 by Cook (1785, v. 2, track chart), RN. Lt. Sarichev in his atlas (1826, map 3) indicated "Ostrov Seguam" from an Aleut name. Called "Segouam ile" and "Gorely Ile" by Lutke (1836, p. 306). Goreli is Russian for "burnt."

Seguam Pass: water passage, between Seguam and Amlia Is., Aleutian Is.; $52^{\circ} 10^{\prime} \mathrm{N}, 172^{\circ}$ 45' W; (map 19). Var. Segouam, Sigouam, Siguam Pass.

Named "Sigouam detroit," i.e., "Siguam Strait," by Lutke (1836, p. 308).

Seguam Volcano: mountain, see Pyre Peak.

Segula: island, see Chugal Island.

Segula Island: island, $4 \mathrm{mi}$. across, $11 \mathrm{mi}$. WNW of Little Sitkin I. in Rat Is., Aleutian Is.; $52^{\circ} 01^{\prime} \mathrm{N}, 178^{\circ} 07^{\prime} \mathrm{E}$; $B G N$ 1931; (map 15). Var. Chugal Island, Chugul Island, Dawydoff Island, Iron Island, Sigoola Island, Tchougoule Island, Tschechovla Island, Tschechovle Island.

Aleut name used by early Russian explorers along with the name "'Chugul." The U.S. Navy North Pacific Exploring Expedition of 1855, reported its Aleut name as "Tchougoule (or Tschechovla)" and also called it "Iron Island." This may be the island Admiral A. J. von Krusenstern, IRN, called "Dawydoff" in 1827. See Davidof Island.

Segula Pass: water passage, wide, deep, and clear, between McArthur Reef and Segula I., Rat Is., Aleutian Is.; $52^{\circ} 03^{\prime} \mathrm{N}, 177^{\circ} 58^{\prime} \mathrm{E}$; (map 14).

Shown on recent maps and charts of the area; listed in 1954 Coast Pilot (p. 465).

Segula Peak: volcano, 3,817 ft., comprises most of Segula I., Rat Is., Aleutian Is. ; 52 $01^{\prime} 15^{\prime \prime}$ N, 178 $08^{\prime} 12^{\prime \prime}$ E; (map 15). Var. Segula Volcano.

Name published on a 1951 USGS map. It is shown as Segula Volcano by W. H. Nelson (1959, pl. 37), USGS.

Segula Volcano: volcano, see Segula Peak.

Seiba Point: point of land, on NE shore of Viekoda Bay, on N coast of Kodiak I. ; $57^{\circ} 57^{\prime} 20^{\prime \prime}$ $\mathrm{N}, 153^{\circ} 15^{\prime} 45^{\prime \prime} \mathrm{W}$; (map 34).

Local name published in 1943 by USC\&GS. Seismo Creek: stream, heads on Meat Mountain, flows S, W, and NNW 15 mi. to Utukok River, Arctic Slope; $69^{\circ} 00^{\prime} \mathrm{N}, 161^{\circ} 00^{\prime} \mathrm{W}$; (map 131).

So named by USGS geologists in 1950 "for the seismic operations of that year in this vicinity" (Chapman and Sable, 1960, p. 54). 
Sekinak Lagoon: lagoon, $11 \mathrm{mi}$. long, $8 \mathrm{mi} . \mathrm{NW}$ of Southeast Cape, St. Lawrence I.; $63^{\circ} 05^{\prime} \mathrm{N}$, $169^{\circ} 48^{\prime} \mathrm{W}$; BGN 1951; (map 93).

Eskimo name recommended by the Gambell village council and reported in 1949 by Maj. H. B. Allen, USAF.

Seknak River: stream, heads at Myghapowit Mtn., flows S $16 \mathrm{mi}$. to Sekinak Lagoon, St. Lawrence I ; $63^{\circ} 05^{\prime} \mathrm{N}, 169^{\circ} 47^{\prime} \mathrm{W} ; B G N$ 1951; (map 93).

Eskimo name recommended by the Gambell village council and reported in 1949 by Maj. H. B. Allen, USAF. The difference in spelling of the specific between this name and Sekinak Lagoon is reported to be correct.

Sekuiak Bluff: bluff, elev. $960 \mathrm{ft}$., on $\mathrm{N}$ bank of Noatak River at Noatak Canyon, $50 \mathrm{mi}$. NE of Noatak, Brooks Ra.; 67 $57^{\prime} \mathrm{N}, 161^{\circ} 39^{\prime} \mathrm{W}$; (map 127).

Eskimo name meaning "clay-like," obtained in 1956 at Noatak by Orth.

Selatna Mountain: mountain, $1,183 \mathrm{ft}$., on $\mathrm{E}$ bank of Kuskokwim River between Selatna and Little Selatna Rivers, $30 \mathrm{mi}$. S of McGrath, Kilbuck-Kuskokwim Mts.; 62 $32^{\prime} \mathrm{N}$, $155^{\circ} 43^{\prime} \mathrm{W}$; (map 80).

Local name obtained in 1954 by USGS.

Selatna River: stream, heads at $62^{\circ} 19^{\prime} \mathrm{N}, 155^{\circ}$ $08^{\prime}$ W, flows NW $50 \mathrm{mi}$. to Kuskokwim River E of Nunivak Bar, $31 \mathrm{mi}$. S of McGrath, Kilbuck-Kuskokwim Mts.; $62^{\circ} 31^{\prime} \mathrm{N}, 155^{\circ} 48^{\prime} \mathrm{W}$; (map 80). Var. Reka Challono, Reka Chalono, Tschallono.

Ingalik Indian name obtained in June 1844 by Lt. L. A. Zagoskin, IRN; he spelled it "R[eka] Chalono" and "R[eka] Challono." The present spelling was reported in 1915 by USC\&GS.

Selawigamute: village, see Selawik.

Selāwiğ mūt: village, see Selawik.

Selawik: village, pop. 348 , on left bank of Selawik River, $44 \mathrm{mi}$. NE of Elephant Point, Kotzebue-Kobuk Low.; $66^{\circ} 36^{\prime} \mathrm{N}, 160^{\circ} 00^{\prime} \mathrm{W}$; BGN 1944; (map 114). Var. Chilivik, Seelawik Mutes, Selawigamute, Selāwiğ mūt, Silawĭ ñmium, Sulawig-meuts.

Eskimo village or tribe reported in 1842-44 by Lt. L. A. Zagoskin, IRN, who spelled it "Chilivik." Ivan Petroff in the 1880 U.S. Census lists the Selawik people, i.e., "Selawigamute," as numbering 100. In 1920 the population of the above-described village was 274; 227 in 1930; 239 in 1939; and 273 in 1950. The Selawik post office was established in 1930 (Ricks, 1965, p. 56). The people and the village probably took their name from the nearby lake or river.

Selawik Hills: hills, trends W $55 \mathrm{mi}$. from Tagagawik River to Buckland River, just $\mathbf{S}$ of Kauk River, $10 \mathrm{mi}$. S of Selawik Lake, Nulato Hills; $66^{\circ} 00^{\prime} \mathrm{N}, 159^{\circ} 17^{\prime} \mathrm{W}$ [E end], $66^{\circ} 04^{\prime}$ $\mathrm{N}, 161^{\circ} 17^{\prime} \mathrm{W}$ [W end]; $B G N$ 1966; (map 114).

Named in 1965 by W. W. Patton, Jr., USGS.

Selawik Lake: lake, $31 \mathrm{mi}$. across, $7 \mathrm{mi}$. SW of Selawik, Kotzebue-Kobuk Low.; $66^{\circ} 30^{\prime} \mathrm{N}$, $160^{\circ} 45^{\prime} \mathrm{W}$; BGN 1895; (map 114). Var. Chilivik, Salawik Lake, Silawik Lake.

Eskimo name first reported in 1842-44 by Lt. L. A. Zagoskin, IRN, who spelled it "Chilivik," and probably meant to apply to an Eskimo tribe or village. See Selawik. The documented naming of the lake appears to have been by one of the Sir John Franklin search expeditions about 1850 .

Selawik River: stream, heads in Zane Hills, flows W $140 \mathrm{mi}$. to Selawik Lake, $8 \mathrm{mi}$. NW of Selawik, Kotzebue-Kobuk Low.; $66^{\circ} 37^{\prime}$ N, $160^{\circ} 18^{\prime}$ W; (map 114). Var. Salawik River, Sal-a-wik River, Selawick River.

Eskimo name published on a Brit. Adm. chart dated 1854.

Selby, Lake: lake, $4 \mathrm{mi}$. long, WSW of Angayucham Mts., 70 mi. NW of Hughes, Brooks Ra.; $66^{\circ} 52^{\prime} \mathrm{N}, 155^{\circ} 40^{\prime} \mathrm{W}$; (map 116). Var. Nudrewok Lake.

Named in 1884 by Lt. Stoney (1900, p. 53 ), USN. Eskimo name "Nud-re-wok" was recorded in 1885 by Lt. J. C. Cantwell (in Healy, 1887, p. 32), USRCS.

Selby River: stream, heads in Lake Selby, flows SSW $8 \mathrm{mi}$. to Kobuk River, $70 \mathrm{mi}$. NW of Hughes, Kotzebue-Kobuk Low.; $66^{\circ} 46^{\prime} \mathrm{N}$, $155^{\circ} 47^{\prime} \mathrm{W}$; (map 116).

Local name published by Smith (1913, p. 24), USGS; derived from Lake Selby.

Seldevoe Lagoon: lagoon, $0.3 \mathrm{mi}$. across, on $\mathrm{N}$ tip of Spruce I., $12 \mathrm{mi}$. N of Kodiak, NW of Kodiak I.; $57^{\circ} 57^{\prime} 35^{\prime \prime}$ N, $152^{\circ} 26^{\prime} 00^{\prime \prime}$ W; (map 34).

Transliteration derived from the Russian word "selyodochka" meaning "herring," published in 1943 by USC\&GS.

Seldevoi Bay: estuary, see Seldovia Bay.

Seldevoy, Zaliv: estuary, see Seldovia Bay.

Seldovaia Bay: bay, see Herring Bay.

Seldovaya Bay: bay, see Herring Cove.

Seldovia: village, pop. 460 , on $W$ coast of Kenai Penin. on E shore of Seldovia Bay, $16 \mathrm{mi}$. SW of Homer, Chugach Mts.; $59^{\circ} 26^{\prime} 15^{\prime \prime} \mathrm{N}, 151^{\circ}$ $42^{\prime} 30^{\prime \prime} \mathrm{W}$; (map 50). Var. Chesloknu, Saldovia

This village, named for the nearby bay, is recorded in the 1880 Census as consisting of "68 Kodiak natives and 3 Creoles. They are sea-otter hunters and live here in loghouses, and have a small chapel." The 1890 Census (p. 163) gives the population as 99; 19 families in 17 houses with a small chapel. Seldovia post office was established in 1898 (Ricks, 1965, p. 57).

Seldovia Bay: estuary, $5 \mathrm{mi}$. long and $0.7 \mathrm{mi}$. wide, on SW shore of Kachemak Bay, Kenai Penin., 16 mi. SW of Homer, Chugach Mts.; $59^{\circ} 27^{\prime} 45^{\prime \prime}$ N, $151^{\circ} 43^{\prime} 30^{\prime \prime}$ W; (map 50). Var. Saldovoi Bay, Herring Bay, Seldevoi Bay, Chesloknu Bay, Zaliv Seldevoy, Chestoknu Bay.

Local name reported in 1910 Coast Pilot notes (p. 39). Named "Z[aliv] Seldevoy," meaning "herring bay," by Capt. Tebenkov (1852, map 5), IRN. The Kenai Indian name for the bay, "Chesloknu," was published by USC\&GS in 1883.
Seldovia Lagoon: lake, $0.4 \mathrm{mi}$. long, on Kenai Penin., $0.4 \mathrm{mi}$. E of Seldovia Bay and $0.5 \mathrm{mi}$. $\mathrm{N}$ of Seldovia, Chugach Mts.; $59^{\circ} 27^{\prime} \mathrm{N}$, $151^{\circ} 42^{\prime} \mathrm{W}$; (map 50).

Name derived from nearby bay.

Seldovia Lake: lake, $1 \mathrm{mi}$. long, at head of Seldovia River, $30 \mathrm{mi}$. SE of Seldovia, Chugach Mts.; $59^{\circ} 20^{\prime} 30^{\prime \prime} \mathrm{N}, 151^{\circ} 35^{\prime} 30^{\prime \prime} \mathrm{W}$; (map 50).

Name derived from nearby bay.

Seldovia Point: point of land, on Kenai Penin., at NE entrance to Seldovia Bay, $2.2 \mathrm{mi}$. $\mathrm{N}$ of Seldovia, Chugach Mts.; $59^{\circ} 28^{\prime} 15^{\prime \prime} \mathrm{N}, 151^{\circ}$ 42'00" W ; (map 50).

Name derived from nearby bay.

Seldovia River: stream, flows NW $5 \mathrm{mi}$. to Seldovia Bay, $14 \mathrm{mi}$. SSE of Seldovia, Chugach Mts.; $59^{\circ} 23^{\prime} 30^{\prime \prime} \mathrm{N}, 151^{\circ} 41^{\prime} 00^{\prime \prime} \mathrm{W}$; $B G N$ 1911; (map 50).

Local name reported by U. S. Grant and D. F. Higgins, USGS, in 1909 (in Brooks and others, 1910, pl. 3). Named derived from Seldovia Bay.

Seldovia Slough: stream, flows SW $1 \mathrm{mi}$. through village of Seldovia to Seldovia Bay, on Kenai Penin., Chugach Mts. ; 59 27' N, $151^{\circ} 43^{\prime} \mathrm{W}$; (map 50).

Name derived from nearby bay.

Selenia Point: point of land, see Settlement Point.

Selenie: locality, see Pavlof.

Selenie Aleksandrovskaia: locality, see Nushagak.

Selenie Kviguglyugmyut: locality, see Kwigalok. Selenie Lagoon: lagoon; $0.3 \mathrm{mi}$. wide, on $\mathrm{N}$ shore of Port Graham, on Kenai Penin., $7 \mathrm{mi}$. SW of Seldovia, Chugach Mts. ; $59^{\circ} 22^{\prime} 30^{\prime \prime} \mathrm{N}, 151^{\circ}$ $52^{\prime} 00^{\prime \prime}$ W; (map 50). Var. Celenie Lake.

Name shown as "Celenie Lake" by USC\&GS in 1869. "Apparently this is a mistaken rendering of the Russian word Seleniye (settlement.)"

Selenie Point: point of land, see Settlement Point.

Seleni Point: point of land, see Settlement Point. Seleniya, Mys: point of land, see Settlement Point.

Seleniye Chasintsev: locality, see Chasintsev. Seleniye Chiukak-myut: locality, see Chiukak. Seleniye Danishnikova: locality, see The Redoubt.

Seleniye Ikalikhvig-myut: village, see Golovin. Seleniye Imyak: locality, see Imiak.

Seleniye Katmayskoe: locality, see Katmai.

Seleniye Pavlovskoy Gavani: town, see Kodiak. Seleniye Pestryakova: locality, see Pestriak.

Seleniye Rossiysko-Amyerikanskoy Kampaniy: locality, see Three Saints Harbor.

Seleniye Ruskiy i Kreolovy: village, see Uzinki. Seleniye Sapozhkovo: locality, see Buskin. Seleniye Skvortsova: village, see Uzinki. Selezneva: locality, see Duck Village.

Selezneva: bay, see Duck Bay.

Selezneva: point of land, see Duck Cape.

Selief Bay: cove, extends SW $1.1 \mathrm{mi}$. off Raspberry Strait on E coast of Raspberry I., $10 \mathrm{mi}$. 
NW of Afognak, Kodiak I.; $58^{\circ} 02^{\prime} \mathrm{N}, 153^{\circ} 02^{\prime}$ W; (map 43)

Local name reported in 1952 by USGS.

Selin Creek: stream, flows N $2.5 \mathrm{mi}$. to Chukchi Sea, $3.3 \mathrm{mi}$. E of Cape Lisburne, Arctic Slope; $68^{\circ} 52^{\prime} 30^{\prime \prime} \mathrm{N}, 166^{\circ} 05^{\prime} 00^{\prime \prime} \mathrm{W}$; (map 129). Var. Si-lin Creek.

Eskimo name reported in 1950 by USC\&GS to mean "canyon" and spelled "Si-lin."

Selin Creek: stream, see Silvia Creek.

Sella Glacier: glacier, see Quintino Sella Glacier. Sellen Lake: lake, $500 \mathrm{ft}$. long, $2.5 \mathrm{mi}$. W of terminus of Sheridan Glacier and $10 \mathrm{mi}$. E of Cordova, Chugach Mts.; $60^{\circ} 32^{\prime} \mathrm{N}, 145^{\circ} 27^{\prime}$ W; (map 64).

Name published in 1950 by USGS.

Sellick Creek: stream, flows W $4.5 \mathrm{mi}$. to Fourth of July Creek $1 \mathrm{mi}$. S of its junc. with Sanona Creek and $23 \mathrm{mi}$. S of junc. of Oshetna and Susitna Rivers, Talkeetna Mts. ; $62^{\circ} 18^{\prime} 35^{\prime \prime} \mathrm{N}$, $147^{\circ} 16^{\prime} 20^{\prime \prime} \mathrm{W}$; (map 82)

Local name reported by $F$. $H$. Moffit (in Brooks and others, 1915, fig. 3), USGS. Selo Akmagan: village, see Starichkof. Selo Bobrova: locality, see Beaver. Selo Bobrovo: locality, see Beaver. Selo Chalyuknakh: locality, see Chaliuknak. Selo Ikogmiut: locality, see Akahamut. Selo Ikuagmyut: locality, see Akahamut. Selo Kalekhta: locality, see Kalekta. Selo Katmay: locality, see Katmai. Selo Morzhovoi: village, see Morzhovoi. Selo Pestrekovo: village, see Eider. Selo Tugiak: village, see Togiak.

Seltat, Mount: mountain, 6,630 ft., on AlaskaCanada boundary $6.4 \mathrm{mi}$. NW of Mount Ashmun and $38 \mathrm{mi}$. NW of Skagway, St. Elias Mts.; $59^{\circ} 36^{\prime} 00^{\prime \prime} \mathrm{N}, 136^{\circ} 21^{\prime} 10^{\prime \prime} \mathrm{W}$; $B G N$ 1953; (map 45). Var. Mount Reilly, Seltat Peak.

Tlingit Indian name reported by Aurel and Arthur Krause (1883, map) as "Seltathinschokschage," of which "Seltat" is a contraction.

Seltat Peak: mountain, see Seltat, Mount. Selton: locality, see Shelton.

Semenoffsky: island, see Simeonof Island. Semenovskie: island, see Simeonof Island. Semenovsky: island, see Simeonof Island.

Semiahmoo: locality, on Unalaska I., Aleutian Is.; (map 23).

This locality is not found on modern maps but was listed in "Polk's Gazetteer of 1916." Semichi Islands: islands, in chain $13 \mathrm{mi}$. long, includes Alaid, Nizki, Hammerhead, Lotus, and Shemya Is., $20 \mathrm{mi}$. ESE of Attu 1.; part of the Near Is., Aleutian Is.; $52^{\circ} 44^{\prime} \mathrm{N}$, $174^{\circ} 00^{\prime}$ E; BGN 1890; (map 13). Var. Semitchi Islands, Semitkhi Islands, Semitsch Islands, Shemya Islands, Simitkhi Islands.

Probably discovered on October 29, 1741 (O.S.), by Vitus Bering who applied the name "St. Abraham" to one of them. See Shemya Island. According to Baker (1906, p. 561), USGS, who cites W. H. Dall, the name "Semichi" was applied to these islands by the early Russians, the name being derived from the Russian "Semik," which is "the feast on the seventh Thursday after Easter, on which day they were discovered." Rev. Coxe (1787, p. 50) called them "Shemya."

Semichi Pass: water passage, between Semichi and Attu Is., Aleutian Is.; $52^{\circ} 48^{\prime} \mathrm{N}, 173^{\circ} 40^{\prime}$ E; (map 13).

Name derived from the Semichi Islands and published on a USGS map in 1953.

Semidi Islands: islands, in Pacific Ocean, $23 \mathrm{mi}$. SE of Sutwik I. and $80 \mathrm{mi}$. SW of Trinity Is., Aleutian Ra.; $56^{\circ} 10^{\prime} \mathrm{N}, 156^{\circ} 47^{\prime} \mathrm{W}$; BGN Sixth Report; (map 31). Var. Eudocia Islands, Eudokievskie Islands, Eudoxia Islands, Evdokeevskie Islands, Ewodokijefftian Islands, Foggy Islands, Islas Fogoi, Seven Islands, Ostrova Semidy, Ostrova Yevdokevskiye, Simedan Islands, Simedun Islands, Tumannoi Islands, Zumik Islands.

Although thought by some to have been discovered in 1741 by Capt. Commander I. I. (Vitus) Bering, IRN, and named "Tumannoi," meaning "foggy," the present name is derived from "O[stro]va Semidy ili Yevdokevskiye," meaning "Seven or Yevdokevskiye Islands," which was published by Lt. Sarichev, (1826, map 3), IRN. The nine islands were identified on June 16, 1778, by Capt. Cook (1785, v. 2, p. 410$), \mathrm{RN}$, who wrote "We found it to be an island *** lying in the latitude of $56^{\circ} 10^{\prime} * * *$ and it is distinguished in our chart by the name of Foggy Island; having reason to believe from its situation, that it is the same which had that name given to it by Beering." Commodore Joseph Billings, (in Sauer, 1802, p. 200), IRN, called the islands "Simedan (or Simedun)" while von Langsdorff (1813-14, v. 2, p. 54), of the Russian embassy to Japan, published the name "Ewdokijeff tian Islands" for this group. In 1868, USC\&GS called them "Seven Islands." Semidin: island, see Aghiyuk Island.

Semidin : island, see Chowiet Island.

Semisopochnoi Island: island, $13 \mathrm{mi}$. across, northeasternmost of Rat Is., Aleutian Is. $51^{\circ} 55^{\prime} \mathrm{N}, 179^{\circ} 36^{\prime}$ E; BGN 1937; (map 15). Var. Island of the Seven Mountains, Ostrov Semisopochnyy, Semisopokh, Semisopotchny, Semi Soposhna.

Descriptive name derived from the Russian words "sem" meaning "seven," and "sopochka," meaning "extinct volcano"seven volcanoes or seven peaks. Published by Lt. G. A. Sarichev (1826, map 3), IRN, as "O[strov] Semisoposhnoy," or "Semisoposhnoy Island." It was published as "O[strov] Semisopochnyy" or "Semisopchnyy Island" by Capt. Tebenkov (1852, map 29), IRN. The island may have been named in 1790 by Lt. Sarichev.

Semisopochnyy, Ostrov: island, see Semisopochnoi Island.

Semisopokh: island, see Semisopochnoi Island. Semi Soposhna: island, see Semisopochnoi Island.

Semisopotchny: island, see Semisopochnoi Island.

Semitchi Islands: islands, see Semichi Islands. Semitkhi Islands: islands, see Semichi Islands.
Semitsch Islands: islands, see Semichi Islands.

Semiutak Bend: bend, of Ikpikpuk River, at junc. of Titaluk River, Arctic Plain; $69^{\circ} 58^{\prime} \mathrm{N}$, 154'43' W; (map 142).

Eskimo name; obtained in 1956 at Anaktuvuk Pass by T. E. Taylor, USGS. It means "it blocks or closes" [simiaqtoq], referring to the shifting shallows at the confluence of the two streams.

Senati: locality, on right bank of Yukon River "below Rampart Rapids," Kokrines-Hodzana High.; $65^{\circ} 16^{\prime} \mathrm{N}, 151^{\circ} 11^{\prime} \mathrm{W}$; (map 106). Var. Senati's Village.

Former Indian village or camp named for the old Indian chief, Senati; reported as "Senati's Village" in 1869 by Capt. C. W. Raymond, U.S. Engineers.

Senatis Mountain: mountain, 2,772 ft., in Rampart Mts., on $\mathrm{N}$ bank of Yukon River, $29 \mathrm{mi}$. NNE of Tanana, Kokrines-Hodzana High.; $65^{\circ} 20^{\prime} \mathrm{N}, 151^{\circ} 10^{\prime} \mathrm{W}$; (map 106).

Name shown on a Yukon River chart manuscript dated 1906. Named for Senati, chief of a group of Indians who had a village near the foot of this mountain. See Senati.

Senatis Village: locality, see Senati.

Senezatt: locality, see Sinrazat.

Seniavin, Cape: point of land, elev. $175 \mathrm{ft}$., on Bristol Bay coast of Alaska Penin., $33 \mathrm{mi}$. NE of Port Moller, Bristol Bay Low.; 56 ${ }^{\circ} 24^{\prime} \mathrm{N}$, $160^{\circ} 09^{\prime} \mathrm{W}$; (map 30). Var. Cap Seniavine, Mys Seniavina.

Named by Capt. Lutke (1836, p. 261), IRN, as "Cap Seniavine" for the corvette in which he explored this area in 1828; shown as Cape Seniavin on an 1888 USBF chart.

Seniavina, Mys: point of land, see Seniavin, Cape.

Seniavine, Cap: point of land, see Seniavin, Cape.

Seniavine, Cap: promontory, see Kutuzof, Cape. Senikave: locality, on NW shore of Norton Sound, at or near West Point, $20 \mathrm{mi}$. W of Nome, Seward Penin. High.; $64^{\circ} 34^{\prime} \mathrm{N}, 166^{\circ}$ 03' W; (map 94).

Former Eskimo village or camp reported in the 1890 Census (1893, p. 162).

Sennett Point: point of land, on SW coast of Unimak I., Aleutian Is.; $54^{\circ} 29^{\prime} 00^{\prime \prime}$ N., $164^{\circ}$ 54'30" W; BGN 1938; (map 24). Var. Middle Point.

Named "Middle Point" in 1901 by J. J. Gilbert, USC\&GS, and listed as such by Baker (1906). USC\&GS changed the name to "Sennett Point" to eliminate repetition of a common name. The James Sennett was a vessel wrecked just south of this point in 1901 . Sentinal Island: rock, see Sentinel Rock.

Sentinal Peak: mountain, see Sentinel Peak.

Sentinel Hill: hill, $168 \mathrm{ft}$., between Colville and Kogosukruk Rivers, $35 \mathrm{mi}$. NE of Umiat, Arctic Plain; $69^{\circ} 50^{\prime} \mathrm{N}, 151^{\circ} 35^{\prime} \mathrm{W}$; BGN 1964; (map 141). Var. Umiukrak Hill, Umiurak Hill, Umivrak Hill.

Named in 1901 by W. J. Peters and F. C. Schrader, USGS, "An isolated hill, so named on account of being a prominent landmark." T. E. Taylor, USGS, reported in 1956 the 
Eskimo name "Umiukrak," which is supposed to mean "smallest canoe [umiagrak]."

Sentinel Island: island, $0.2 \mathrm{mi}$. long, in center of Favorite Channel, $0.6 \mathrm{mi}$. SW of Benjamin I. and $25 \mathrm{mi}$. NW of Juneau, Coast Mts.; $58^{\circ}$ $32^{\prime} 45^{\prime \prime} \mathrm{N}, 134^{\circ} 55^{\prime} 15^{\prime \prime} \mathrm{W}$; (map 11).

Probably named by Comdr. R. W. Meade, USN, in 1869. The name was published in 1881 on Hydrog. Chart 883.

Sentinel Islands: islands, see Nichols Islands.

Sentinel Islands: rocks, see Sentinels, The.

Sentinel Peak: mountain, 5,355 ft., in Glacier Bay National Monument, $1.6 \mathrm{mi}$. NW of terminus of Carroll Glacier, $74 \mathrm{mi}$. NW of Hoonah, St. Elias Mts.; $58^{\circ} 59^{\prime} 40^{\prime \prime} \mathrm{N}, 136^{\circ}$ $33^{\prime} 30^{\prime \prime} \mathrm{W}$; (map 10$)$.

Named in 1892 by Reid (1896, p. 430) because Carroll Glacier is "guarded by Sentinel Peak * * *

Sentinel Peak: mountain, 2,020 ft., at SW tip of Alaska Penin., on $\mathbf{N}$ shore of Ikatan Bay, Aleutian Ra.; $54^{\circ} 49^{\prime} 30^{\prime \prime} \mathrm{N}, 163^{\circ} 19^{\prime} 50^{\prime \prime} \mathrm{W}$; (map 25). Var. Sentinal Peak.

Name reported by Ferdinand Westdahl, USC\&GS, commander of the Coast Survey steamer McArthur, who made surveys in this area in 1901

Sentinel Point: point of land, $\mathrm{N}$ end of Snettisham Penin., at entrance to Gilbert Bay, 31 mi. SE of Juneau, Coast Mts.; 57 $59^{\prime} 45^{\prime \prime} \mathrm{N}$, $133^{\circ} 45^{\prime} 30^{\prime \prime} \mathrm{W}$; (map 8).

Named in 1888 by Lt. Comdr. C. M. Thomas, USN; name published in 1892 by USC\&GS.

Sentinel Rock: rock, in Western Channel, Sitka Sound, $2.5 \mathrm{mi}$. W of Sitka, Alex. Arch.; $57^{\circ}$ $02^{\prime} 50^{\prime \prime} \mathrm{N}, 135^{\circ} 24^{\prime} 30^{\prime \prime} \mathrm{W}$; (map 9).

Name given by the U.S. Navy in 1879 and published by USC\&GS in 1883 Coast Pilot (p. 140). This rock "is the southernmost islet on the west side of Western Channel," therefore the name.

Sentinel Rock: rock, $1 \mathrm{mi}$. N of Point Banks, off the NE coast of Shuyak I., $51 \mathrm{mi}$. N of Kodiak I., $58^{\circ} 38^{\prime} 45^{\prime \prime} \mathrm{N}, 152^{\circ} 19^{\prime} 30^{\prime \prime} \mathrm{W}$; $B G N 1933$; (map 43). Var. Sentinal Island.

Named by USC\&GS in 1933, "because it is conspicuous from all directions."

Sentinels, The: rocks, a group, extend $1.2 \mathrm{mi}$, in Tlevak Strait, between Dall and Goat Is., $\mathrm{N}$ of Nichols Is., Alex. Arch.; $55^{\circ} 10^{\prime} 45^{\prime \prime} \mathrm{N}$, $133^{\circ} 00^{\prime} 40^{\prime \prime}$ W; (map 4). Var. Sentinel Islands.

Named "Sentinel Islands" in 1881 by Lt. Comdr. H. E. Nichols, USN.

Sentry Rock: rock, $1.7 \mathrm{mi}$. SE of Round Point, on SW coast of Kanaga I., Aleutian Is.; $51^{\circ}$ $41^{\prime} 00^{\prime \prime} \mathrm{N}, 177^{\circ} 29^{\prime} 40^{\prime \prime} \mathrm{W}$; (map 17).

Name published by USC\&GS in 1956 on Chart 9145

Sepilla Camp: locality, see Unguriak Camp.

Sepinpak Lagoon: lake, see Seepanpak Lagoon.

Sepping, Cape: point of land, see Seppings, Cape.

Seppings, Cape: point of land, on Chukchi Sea coast between Singoalik and Tasikpak Lagoons, $23 \mathrm{mi}$. NW of Kivalina, KotzebueKobuk Low.; $68^{\circ} 58^{\prime} \mathrm{N}, 165^{\circ} 11^{\prime} \mathrm{W}$; (map
128). Var. Cape Lepping's, Cape Sepping, Nuvwa.

Named in 1827 by Capt. Beechey (1831, track chart), RN. The cape is not very conspicuous unless one considers that when seen from the sea the highland area between Singoalik River and Asikpak Creek stands out like a cape.

Seppings Lagoon: lagoon, $0.8 \mathrm{mi}$. long, on shore of Chukchi Sea, $22 \mathrm{mi}$. NW of Kivalina, Kotzebue-Kobuk Low.; $67^{\circ} 57^{\prime} 30^{\prime \prime} \mathrm{N}, 164^{\circ}$ $59^{\prime} 30^{\prime \prime}$ W; (map 128).

Named for the nearby point of land; shown about 1923 on a USC\&GS field map.

September, Lake: lake, $0.5 \mathrm{mi}$. across, at head of September Creek, $18 \mathrm{mi}$. NW of Tutna Lake and $50 \mathrm{mi}$. NW of Nondalton, Lime Hills; $60^{\circ} 35^{\prime} 35^{\prime \prime} \mathrm{N}, 1^{\circ} 37^{\prime} 30^{\prime \prime} \mathrm{W}$; (map 61).

Local name reported in 1950 by USC\&GS. September Creek: stream, flows SW $3.5 \mathrm{mi}$. to Weasel Creek, 22 mi. NW of Tutna Lake and $52 \mathrm{mi}$. NW of Nondalton, Lime Hills; $60^{\circ} 34^{\prime}$ $30^{\prime \prime} \mathrm{N}, 155^{\circ} 43^{\prime} 30^{\prime \prime} \mathrm{W}$; (map 61).

Local name reported in 1950 by USC\&GS. September Creek: stream, flows N $15 \mathrm{mi}$. to Maybe Creek, $5 \mathrm{mi}$. SE of head of Ikpikpuk River, Arctic Slope; $69^{\circ} 17^{\prime} 30^{\prime \prime}$ N, $154^{\circ} 30^{\prime}$ $45^{\prime \prime} \mathrm{W}$; (map 142).

Probably named in the 1940's by geologists on the Naval Petroleum Reserve No. 4 exploration.

Sequel Point: point of land, on W shore of Gulf of Alaska, $4.5 \mathrm{mi}$. SW of Cape Chiniak, Kodiak I.; $57^{\circ} 33^{\prime} 40^{\prime \prime} \mathrm{N}, 152^{\circ} 12^{\prime} 30^{\prime \prime} \mathrm{W}$; (map 34).

Local name reported in 1949 by USGS.

Seraak Camp: fish camp, see Sevak Camp.

Serebrennikof Arm: $b a y$, see Silver Bay.

Serebrinikov Cove: $b a y$, see Silver Bay.

Serebryanikova, Bukhta: bay, see Silver Bay.

Seredka: locality, on SE coast of Akun I., on Seredka Bay, Aleutian Is.; $54^{\circ} 10^{\prime} \mathrm{N}, 165^{\circ} 29^{\prime}$ W; (map 24). Var. Sayraidneuskoi, Seredkinskoje, Seredninskoe.

Former Aleut village or camp reported in 1834 as "Seredninskoye," with a population of 16, living in 2 huts, by Father Veniaminov (1840, v. 2, p. 202)

Seredka Bay: bay, $2 \mathrm{mi}$. across, on SE coast of Akun I., Krenitzin Is., Aleutian Is.; $54^{\circ} 10^{\prime} \mathrm{N}$, $165^{\circ} 28^{\prime} \mathrm{W}$; (map 24). Var. Seredkinskoy.

Published by Father Veniaminov (1840, v. 1, p. 195) as "Seredkinskoy," meaning "middle."

Seredkinskoy: bay, see Seredka Bay.

Seredkinskoje: locality, see Seredka.

Serednie Point: point of land, see Seredni Point. Seredninskoe: locality, see Seredka.

Seredni Point: point of land, on $\mathbf{S}$ shore of Low I. Anchorage, $10 \mathrm{mi}$. NW of Kodiak, Kodiak I.; $57^{\circ} 54^{\prime} 20^{\prime \prime} \mathrm{N}, 152^{\circ} 34^{\prime} 20^{\prime \prime} \mathrm{W}$; BGN 1909 ; (map 34). Var. Middle Cape, Mys Sredniy, Serednie Point.

Transliteration of "M[ys] Sredniy," the name given by Sub-Lt. Mikhail Murashev in 1839 or 1840 and published in 1849 cn Russian Hydrog. Dept. Chart 1425. Baker (1906, p. 434) published "Middle Cape," the translation of Murashev's name. Because of duplication the name was changed to its present form by USC\&GS in 1909.

Serene, Cabo: point of land, see Cleare, Cape. Sergeant Robinson, Mount: mountain, 10,415 ft., $10 \mathrm{mi}$. NW of Mount Marcus Baker and 41 mi. E of Palmer, Chugach Mts.; $61^{\circ} 34^{\prime} 35^{\prime \prime} \mathrm{N}$, $147^{\circ} 51^{\prime} 00^{\prime \prime} \mathrm{W} ; B G N$ 1965; (map 69).

Named in 1965 by Senator E. L. Bartlett for Sergeant George F. Robinson, USA, who, in 1865, thwarted the assassination attempt on Secretary of State William H. Seward. This assassination attempt took place the same evening that Abraham Lincoln was assassinated.

Sergejewsky: peninsula, see Sergief Peninsula.

Sergheieff Bay: bay, see Sergief Bay.

Sergief, Mount: volcano, $1,638 \mathrm{ft}$., on $\mathrm{W}$ central Atka I., Aleutian Is.; $52^{\circ} 03^{\prime} 10^{\prime \prime} \mathrm{N}, 174^{\circ}$ 57'00' W; (map 18). Var. Vulcan, Sarutschew Sergief Volcano, Sergheiff.

This volcano was called "Sergheieff" by Lutke (1836, p. 311-312). The name Mount Sergief was published by Coats (1950, p. 38), USGS, applied to a feature located at $52^{\circ} 19^{\prime}$ $\mathrm{N}, 174^{\circ} 23^{\prime} \mathrm{W}$, on the Cape Korovin peninsula. Mount Sergief is shown on a 1952 USGS map on western Atka I. near Sergief Bay.

Sergief Bay: bay, $1.2 \mathrm{mi}$. across, on $\mathrm{S}$ coast of Atka I., Aleutian Is.; $52^{\circ} 01^{\prime} \mathrm{N}, 175^{\circ} 00^{\prime} \mathrm{W}$; (map 18). Var. Sergheieff Bay, Sergieff Bay, Bukhta Sergievskaia.

Russian family name, published as "Sergheieff' by Capt. Lutke (1836, p. 311-12), IRN, and as "Buk[hta] Sergievskaia," or "Sergievskaia Bay," on Russian Hydrog. Dept. Chart 1400, 1848.

Sergieff Bay: bay, see Sergief Bay.

Sergief Island: island, $3 \mathrm{mi}$. long, at mouth of Stikine River, $7 \mathrm{mi}$. N of Wrangell, Coast Mts.; $56^{\circ} 35^{\prime} \mathrm{N}, 132^{\circ} 26^{\prime} \mathrm{W}$; (map 6). Var. Sergiev Island.

Named in 1863 by surveyors of the Russian corvette Rynda for a member of the party (Sergief) who drowned at Sergief Rapid in Stikine River. See Rynda Island.

Sergief Peninsula: peninsula, on $\mathrm{S}$ coast of Atka I., $S$ of Mount Sergief, Aleutian Is. ; $52^{\circ} 03^{\prime} \mathrm{N}$, $174^{\circ} 57^{\prime} \mathrm{W}$; (map 18). Var. Sergejewsky.

Named for Mount Sergief to north, and published as "Sergheieff' by Capt. Lutke (1836, p. 311-12), IRN.

Sergief Volcano: volcano, see Sergief, Mount. Sergiev Island: island, see Sergief Island. Sergievskaia Bukhta: $b a y$, see Sergief Bay.

Sergius Channel: channel, between Sergius Point and Pinta Head, $W$ end of Peril Strait, off coast of Baranof I., $25 \mathrm{mi}$. NW of Sitka, Alex. Arch.; $57^{\circ} 24^{\prime} 25^{\prime \prime} \mathrm{N}, 135^{\circ} 37^{\prime} 45^{\prime \prime} \mathrm{W}$; (map 9).

Probably named in 1884 by Comdr. J. B. Coghlan, USN; published in 1891 Coast Pilot (p. 181).

Sergius Narrows: water passage, at $\mathrm{W}$ end of Peril Strait, between Rapids I. and Sergius 
Point, $26 \mathrm{mi}$. NW of Sitka, Alex. Arch.; 57 ${ }^{\circ}$ $24^{\prime} 20^{\prime \prime} \mathrm{N}, 135^{\circ} 38^{\prime} 00^{\prime \prime} \mathrm{W}$; (map 9).

Apparently named in 1895 by Lt. Comdr. E. K. Moore, USN.

Sergius Point: point of land, in Sergius Narrows, at W end of Peril Strait, on SW coast of Chichagof I., $24 \mathrm{mi}$. SE of Chichagof, Alex. Arch.; $57^{\circ} 24^{\prime} 30^{\prime \prime} \mathrm{N}, 135^{\circ} 38^{\prime} 00^{\prime \prime} \mathrm{W}$; (map 9).

Probably named by Comdr. J. B. Coghlan, USN, in 1884; published by USC\&GS in 1891 Coast Pilot (p. 181).

Serpentine Bluff: bluff, $400 \mathrm{ft}$,, on right bank of Yukon River, $20 \mathrm{mi}$. SW of Russian Mission, Yukon-Kuskokwim Delta; 61 $36^{\prime} \mathrm{N}$, 161 ${ }^{\circ} 49^{\prime} \mathrm{W}$; (map 73).

Riverboat pilots' name shown on a 1916 field sheet by R. H. Sargent, USGS.

Serpentine Creek: stream, flows SW $5 \mathrm{mi}$. to South Fork Goodpaster River, $9 \mathrm{mi}$. NNE of Black Mtn. and $45 \mathrm{mi}$. E of Big Delta, YukonTanana High.; $64^{\circ} 12^{\prime} 15^{\prime \prime} \mathrm{N}, 144^{\circ} 19^{\prime} 30^{\prime \prime} \mathrm{W}$; (map 101).

Local name reported in 1955 by USGS.

Serpentine Creek: stream, flows SW $15 \mathrm{mi}$. to Lost Greek $0.3 \mathrm{mi}$. NNE of that stream's junc. with Salcha River and $62 \mathrm{mi}$. NE of Big Delta, Yukon-Tanana High.; $64^{\circ} 50^{\prime} \mathrm{N}, 144^{\circ} 29^{\prime} \mathrm{W}$; (map 101). Var. Lost Creek.

Local descriptive name; reported in 1958 by USGS.

Serpentine Glacier: glacier, trends SW $6 \mathrm{mi}$. to Harriman Fiord, $4.5 \mathrm{mi}$. W of Point Doran and $54 \mathrm{mi}$. $\mathrm{E}$ of Anchorage, Chugach Mts.; $61^{\circ} 05^{\prime} \mathrm{N}, 148^{\circ} 18^{\prime} \mathrm{W}$; (map 69).

Descriptive name given in 1899 by members of the Harriman Alaska Expedition.

Serpentine Hot Springs: locality, on right bank of Hot Springs Creek which flows to Serpentine River, $47 \mathrm{mi}$. NW of Imuruk Lake, Kotzebue-Kobuk Low.; $65^{\circ} 51^{\prime} \mathrm{N}, 164^{\circ} 43^{\prime} \mathrm{W}$; $B G N$ 1954; (map 110). Var. Arctic Hot Springs, Serpentine Springs.

Mineral springs and site of a settlement. Collier (1902, p. 55), USGS, notes "Charles McLennan, who with a dog team and Eskimo assistants *** in May $1900 * * *$ was the first white man to reach the hot springs." Collier further noted that in September 1901 he found a small settlement at the hot springs. Waring $(1917$, p. 76), USGS, referred to this as "Arctic Hot Springs" and noted "A few years ago prospectors built a cabin near the upper spring and a bathhouse over a bathing pool * **." The name "Serpentine Hot Springs" came into local use and was published in 1951 by USGS.

Serpentine Island: island, in Yukon River, $33 \mathrm{mi}$. $\mathrm{NE}$ of Nulato, Koyukuk Low.; $64^{\circ} 46^{\prime} \mathrm{N}, 156^{\circ}$ $59^{\prime} \mathrm{W}$; (map 97)

Riverboat pilots' name shown on a 1940 "Navigation Chart of the Tanana-Yukon Rivers" published by U.S. Dept. of Interior. Serpentine Ridge: ridge, elev. 2,000 to $6,000 \mathrm{ft}$., extends W $14 \mathrm{mi}$. on S bank of Boulder Creek, $26 \mathrm{mi}$. ESE of Tanana, Yukon-Tanana High.; $65^{\circ} 07^{\prime} 30 \mathrm{~N}, 1^{\circ} 01^{\circ} 00^{\prime} 00^{\prime \prime} \mathrm{W}$; (map 106).

Local name reported in 1952 by USGS.
Serpentine River: stream, flows NW $37 \mathrm{mi}$. to Shismaref Inlet, $17 \mathrm{mi}$. SE of Shishmaref, Kotzebue-Kobuk Low.; $66^{\circ} 09^{\prime} \mathrm{N}, 165^{\circ} 32^{\prime} \mathrm{W}$; (map 112).

This stream was explored and so named, in May 1900 , by Charles McLennan, prospector, because of its "very sinuous course, * * *" (Collier, 1902, p. 55).

Serpentine Springs: locality, see Serpentine Hot Springs.

Serpent Point: point of land, on SW coast of Unalaska I., Aleutian Is.; $53^{\circ} 15^{\prime} \mathrm{N}, 167^{\circ} 37^{\prime}$ W; BGN 1937; (map 23).

Named by USC\&GS in 1937.

Serpent Tongue Glacier: glacier, on Alaska Penin., in Katmai National Monument, heads on ridge, between Mount Denison and Snowy Mtn., trends NW $9 \mathrm{mi}$. to its 1951 terminus at head of Rainbow River, $18 \mathrm{mi}$. NE of Mount Katmai, Aleutian Ra.; $58^{\circ} 26^{\prime} \mathrm{N}, 1^{\circ} 4^{\circ} 37 \mathrm{~W}$; BGN 1925; (map 42).

Descriptive name given in 1923 by R. H. Sargent, USGS, "because of its forked outline."

Serrated Peak: peak, 3,757 ft., in Glacier Bay Naticnal Monument, $2.5 \mathrm{mi}$. S of Wood Lake and $47 \mathrm{mi}$. NW of Hoonah, St. Elias Mts.; $58^{\circ} 30^{\prime} 20^{\prime \prime} \mathrm{N}, 136^{\circ} 28^{\prime} 30^{\prime \prime} \mathrm{W}$; (map 10).

Descriptive name published in 1929 by USFS.

Sesūalik: locality, see Sheshalik.

Setgun Lake: lake, $1 \mathrm{mi}$. long, in course of Meadow Creek, 2 mi. W of Beaver, Yukon Flats; $66^{\circ} 21^{\prime} 20^{\prime \prime} \mathrm{N}, 148^{\circ} 08^{\prime} 30^{\prime \prime} \mathrm{W}$; (map 118). Var. Ridge Lake.

Local name obtained in 1956 by USGS; the lake was shown as "Ridge Lake" on William Yanert's 1916 manuscript map (Stuck, 1917, map facing p. 122).

Seth Glacier: glacier, trends SW $1.5 \mathrm{mi}$. to its terminus, $2.5 \mathrm{mi}$. NW of Poe Bay and 7.5 mi. NE of Whittier, Chugach Mts.; 60 $51^{\prime} 50^{\prime \prime} \mathrm{N}$,

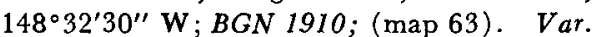
Poe Glacier.

Local name reported in 1908 by U. S. Grant and D. F. Higgins (1910, pls. 1, 2), USGS.

Sethkokna River: stream, flows NE $52 \mathrm{mi}$. to Titna River, $32 \mathrm{mi}$. SW of The Bitzshtini Mts., Kilbuck-Kuskokwim Mts.; $64^{\circ} 20^{\prime} \mathrm{N}, 152^{\circ} 59^{\prime}$ W; (map 99).

Tanana Indian name reported in 1909 by C. E. Giffin and R. B. Oliver (in Eakin, 1918. pl. 1), USGS.

Setter Lake: lake, 1 mi. long, on $\mathrm{E}$ coast of Prince of Wales I., SW of Thorne Bay, Alex. Arch.; $55^{\circ} 39^{\prime} \mathrm{N}, 132^{\circ} 31^{\prime} \mathrm{W}$; (map 4).

Local descriptive name reported in 1956 by C. L. Sainsbury, USGS, who stated, "This name is in local usage by the loggers at a nearby logging camp, and the name is suggested by the shape of the lake [?]."

Setting Sun Creek: stream, in De Long Mts., flows S $18 \mathrm{mi}$. to Anisak River, Brooks Ra.; $68^{\circ} 22^{\prime} \mathrm{N}, 159^{\circ} 12^{\prime} \mathrm{W}$; BGN 1960; (map 131).

Named in 1951 by H. N. Reiser, USGS, for stone ring markings "for ceremonial to setting sun."
Settlement Point: point of land, on $\mathrm{E}$ shore of Pavlof Bay, near SW end of Alaska Penin., Aleutian Ra.; 55 $29^{\prime} 20^{\prime \prime} \mathrm{N}, 161^{\circ} 28^{\prime} 40^{\prime \prime} \mathrm{W}$; $B G N$ 1926; (map 28). Var. Mys Seleniya, Seleniye Point, Seleni Point.

This is a translation of the Russian word "selenie" meaning "village (or settlement)," shown by Capt. Tebenkov (1852, map 24), and applied to a settlement about one mile $\mathrm{NE}$ of the point. This "village" reference suggested to Dall, USC\&GS, the name for the point of land in 1880. Settlement Point is a local name used by the fishermen.

Settlement Point: point of land, at mouth of Afognak Bay, on S coast of Afognak I., $N$ of Kodiak I.; 58 $03^{\prime} 05^{\prime \prime}$ N, $152^{\circ} 43^{\prime} 35^{\prime \prime}$ W (map 43). Var. Selenia Point.

Translation of the name "M[ys] Seleniya" given by Sub-Lt. Mikhail Murashev, IRN, in 1839 or 1840 and published by the Russian Hydrog. Dept. in 1849 in Chart 1425.

Settler Cove: cove, extends SW 3 mi., on W shore of Kizhuyak Bay, on $\mathrm{N}$ coast of Kodiak I.; $57^{\circ} 52^{\prime} 40^{\prime \prime} \mathrm{N}$; $152^{\circ} 51^{\prime} 00^{\prime \prime} \mathrm{W}$; BGN 1936; (map 34)

Descriptive name given in 1935 by USC\&GS "because of a small settlement adjacent to the cove."

Setuck: locality, see Situk Village.

Setuk River: stream, see Situk River.

Sevalk Camp: fish camp, on Saighat Beach, N coast of St. Lawrence I., $45 \mathrm{mi}$. SE of Savoonga; $63^{\circ} 20^{\prime} \mathrm{N}, 169^{\circ} 12^{\prime} \mathrm{W}$; (map 93). Var. Camp Sevok, Seraak Camp.

Eskimo name reported in 1932 by $O$. W Geist, Univ. of Alaska.

Seven Dikes Mountain: mountain, 2,840 ft., extends NE-SW $9 \mathrm{mi} .53 \mathrm{mi}$. NW of Coleen Mtn., Brooks Ra.; $67^{\circ} 51^{\prime}$ N, $143^{\circ} 06^{\prime} \mathrm{W}$; (map 121).

Local name reported in 1956 by T. E Taylor, USGS

Seven Egg Creek: stream, on Kenai Penin., heads in lake $\mathrm{S}$ of Kakoon Lake and flows NW and SW $12 \mathrm{mi}$. to Cook Inlet $1.5 \mathrm{mi}$. SW of Moose Point and $34 \mathrm{mi}$. NE of Kenai, Cook Inlet Low.; 60 $56^{\prime} 25^{\prime \prime}$ N, $150^{\circ} 42^{\prime} 30^{\prime \prime}$ W ; (map 62).

Named about 1963 by officials of Kenai National Moose Range, for administrative purposes.

Seven Fathon Anchorage: bay, see Seven Fathom Bay.

Seven Fathom Bay: bay, $0.1 \mathrm{mi}$. across, on Windy Bay, 3.6 mi. SE of Goddard Bay, on W coast of Baranof Is., Alex. Arch.; 56 $47^{\prime} 30^{\prime \prime}$ N, $135^{\circ}$ $18^{\prime} 45^{\prime \prime}$ W; (map 5). Var. Seven Fathom Anchorage.

Descriptive name given because of its depth; published in 1925 by USC\&GS as "Seven Fathom Anchorage" and in 1927 as "Seven Fathom Bay."

Seven Gulch: ravine, trends SW $1.3 \mathrm{mi}$. to Fourth of July Creek, $5.4 \mathrm{mi}$. SW of that stream's junc. with Yukon River and $33 \mathrm{mi}$. NW of Eagle, Yukon-Tanana High.; $65^{\circ} 08^{\prime 2} 5^{\prime \prime} \mathrm{N}$. $141^{\circ} 57^{\prime} 00^{\prime \prime} \mathrm{W}$; (map 103).

Local name published in 1956 by USGS. 
Seven Islands: islands, see Semidi Islands.

Seven Lakes: lakes, on Kenai Penin., chain of 7, extend $7 \mathrm{mi}$., in valley of East Fork Moose River, 26 mi. E of Kenai, Cook Inlet Low.; $60^{\circ} 32^{\prime} \mathrm{N}, 150^{\circ} 28^{\prime} \mathrm{W}$; (map 62)

Local name reported in 1958 by USGS.

Sevenmile Beach: beach, $5 \mathrm{mi}$. long, $14 \mathrm{mi}$. NE of Karluk, on W coast of Kodiak I.; $57^{\circ} 39^{\prime}$. $10^{\prime \prime} \mathrm{N}, 154^{\circ} 08^{\prime} 30^{\prime \prime} \mathrm{W}$; (map 35).

Descriptive local name published in 1943 by USC\&GS.

Sevenmile Creek: stream, flows SW $3.8 \mathrm{mi}$. to Peters Creek, $23 \mathrm{mi}$. NW of Palmer, Talkeetna Mts.; 61 $51^{\prime} 05^{\prime \prime} \mathrm{N}, 149^{\circ} 34^{\prime} 05^{\prime \prime} \mathrm{W}$; (map 69). Local name reported in 1951 by USGS.

Sevenmile Creek: stream, flows SE 7 mi. to Goodpaster River, $28 \mathrm{mi}$. NE of Big Delta, YukonTanana High.; $64^{\circ} 19^{\prime} 45^{\prime \prime} \mathrm{N}, 145^{\circ} 06^{\prime} 00^{\prime \prime} \mathrm{W}$ (map 101)

Descriptive name given by prospectors; reported in 1910 by USGS (Prindle, 1913b, pl. 1).

Sevenmile Creek: stream, flows SE 4 mi. to Kandik River, $14 \mathrm{mi}$. NE of junc of Charley and Yukon Rivers, Porcupine Plat.; $65^{\circ} 24^{\prime} 45^{\prime \prime} \mathrm{N}$, $142^{\circ} 22^{\prime} 30^{\prime \prime} \mathrm{W}$; (map 103).

Local name published on a 1956 USGS map. This stream is located about 7 miles upstream from the mouth of the Kandik River.

Sevenmile Creek: stream, flows SE $5.5 \mathrm{mi}$. to Mardow Creek, $9 \mathrm{mi}$. NE of junc. of Kandik and Yukon Rivers, Porcupine Plat.; 65 $30^{\circ}$ $15^{\prime \prime} \mathrm{N}, 142^{\circ} 25^{\prime} 50^{\prime \prime} \mathrm{W}$; (map 103).

So named locally, because it was considered to be 7 miles upstream from the mouth of Mardow Creek; published in 1956 by USGS.

Sevenmile Hill: hill, $820 \mathrm{ft}$, , between Muddy River and Birch Creek, $4 \mathrm{mi}$. E of Lake Minch-

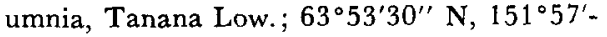
$30^{\prime \prime} \mathrm{W}$; (map 88).

Local name reported in 1954 by USGS.

Sevenmile Island: island, in Yukon River, $25 \mathrm{mi}$. SW of Nulato, Koyukuk Low.; $64^{\circ} 26^{\prime} \mathrm{N}$, $158^{\circ} 30^{\prime} \mathrm{W}$; (map 97).

Local descriptive name reported in 1954 by USGS.

Sevenmile Lake: lake, $0.8 \mathrm{mi}$. long, $\mathrm{S}$ of Stephen Lake, $16 \mathrm{mi}$. N. of Anchorage, Cook Inlet Low.; $61^{\circ} 27^{\prime} 45^{\prime \prime} \mathrm{N}, 1^{\circ} 49^{\circ} 56^{\prime} 15^{\prime \prime} \mathrm{W}$; (map 69).

Local name reported in 1942 by AMS.

Sevenmile Lake: lake, $1 \mathrm{mi}$. long, drains into Eightmile Creek, $51 \mathrm{mi}$. N of Tyonek, Cook Inlet Low.; $61^{\circ} 49^{\prime} 30^{\prime \prime} \mathrm{N}, 151^{\circ} 13^{\prime} 10^{\prime \prime} \mathrm{W}$; (map 70).

Local name reported in 1954 by USGS.

Sevenmile Lake: lake, $0.8 \mathrm{mi}$. long, $\mathrm{N}$ of Denali Highway, $6 \mathrm{mi}$. NW of Paxson, Alaska Ra.; $63^{\circ} 06^{\prime} \mathrm{N}, 145^{\circ} 37^{\prime} \mathrm{W}$; (map 86). Var. Seven Mile Lake.

Local name reported in 1949 by T. L. Péwé, USGS.

Sevenmile Lake: lake, $6 \mathrm{mi}$. long, $\mathrm{N}$ of Amphitheater Mts., $24 \mathrm{mi}$. NW of Paxon, Alaska Ra.; $63^{\circ} 11^{\prime} \mathrm{N}, 146^{\circ} 16^{\prime} \mathrm{W}$; (map 86).

Local name reported in 1955 by $T$. $L$. Péwé, USGS.
Sevenmile Point: point of land, see Uyak, Cape.

Sevenmile Slough: stream, $7 \mathrm{mi}$. long, anabranch of Tanana River, 22 mi. SW of Fairbanks, Tanana Low.; $64^{\circ} 40^{\prime} \mathrm{N}, 148^{\circ} 19^{\prime} \mathrm{W}$; (map 100).

Descriptive name published on recent USGS maps.

Seven Mountains, Island of the: island, see Semisopochnoi Island.

Seven Sisters: mountain, 2,808 ft., $9 \mathrm{mi}$. E of Kahonak Bay and $29 \mathrm{mi}$. W. of Augustine I., Aleutian Ra.; $59^{\circ} 25^{\prime} 30^{\prime \prime} \mathrm{N}, 154^{\circ} 14^{\prime} 10^{\prime \prime} \mathrm{W}$; (map 51).

Name descriptive of the many spires on the summit and published in 1926 by USGS.

Seven Sisters: islands, see Pleiades Islands.

Seven Sisters, The: rocks, in Prince William Sound, off NW coast of Hinchinbrook I., Chugach Mts.; $60^{\circ} 28^{\prime} \mathrm{N}, 146^{\circ} 39^{\prime} \mathrm{W}$; (map 64).

Name reported in 1898 by Capt. W. R. Abercrombie, USA; apparently so named because there are seven rocks in the group.

Seventeen Gulch: ravine, trends $\mathrm{N} 1 \mathrm{mi}$. to Fourth of July Creek, $7.7 \mathrm{mi}$. SW of that stream's junc. with Yukon River and $33 \mathrm{mi}$. NW of Eagle, Yukon-Tanana High.; 65 ${ }^{\circ} 07^{\prime}$ $30^{\prime \prime} \mathrm{N}, 142^{\circ} 01^{\prime} 00^{\prime \prime} \mathrm{W}$; (map 103).

Local name published in 1956 by USGS.

Seventeenmile: locality, at junc. of Porcupine River and Seventeenmile Slough, $10 \mathrm{mi}$. NE of Fort Yukon, Yukon Flats; $66^{\circ} 38^{\prime} 10^{\prime \prime} \mathrm{N}$, $144^{\circ} 56^{\prime} 30^{\prime \prime} \mathrm{W}$; (map 119).

Local name derived from Seventeenmile Slough; obtained in 1956 by USGS.

Seventeenmile Creek: stream, flows SW $9 \mathrm{mi}$, to Kroto Greek, $16 \mathrm{mi}$. W. of Talkeetna, Cook Inlet Low.; $62^{\circ} 17^{\prime} 30^{\prime \prime} \mathrm{N}, 150^{\circ} 36^{\prime} 45^{\prime \prime} \mathrm{W}$; (map 81).

Local descriptive name reported in 1958 by USGS.

Seventeenmile Island: island, see Twelvemile Island.

Seventeenmile Lake: lake, $0.7 \mathrm{mi}$. across, $2.3 \mathrm{mi}$. $\mathrm{W}$ of Sutton and $9 \mathrm{mi}$. NE of Palmer, Cook Inlet Low.; $61^{\circ} 43^{\prime} 00^{\prime \prime} \mathrm{N}, 148^{\circ} 58^{\prime} 15^{\prime \prime} \mathrm{W}$; (map 69).

Local name reported by AMS in 1942.

Seventeenmile Slough: stream, anabranch, flows N $17 \mathrm{mi}$. to Nenana River, $3 \mathrm{mi}$. SW of Nenana, Tanana Low.; $64^{\circ} 32^{\prime} \mathrm{N}, 1^{\circ} 9^{\circ} 08^{\prime}$ W; (map 100).

So named because the stream is $17 \mathrm{mi}$. long; published in 1916 on a GLO [BLM] survey plat.

Seventeenmile Slough: stream, anabranch of Yukon River, flows NW $10 \mathrm{mi}$., $9 \mathrm{mi}$. SE of Fort Yukon, Yukon Flats; $66^{\circ} 27^{\prime} 30^{\prime \prime} \mathrm{N}$, $145^{\circ} 05^{\prime} 30^{\prime \prime} \mathrm{W}_{\text {; ( }}$ (map 119).

Local name obtained in 1956 by USGS; so called because the upper end of the anabranch is 17 miles up the Yukon River from Fort Yukon.

Seventeenmile Slough: stream, anabranch of Porcupine River, flows NW $7 \mathrm{mi}$., $10 \mathrm{mi}$. NE of Fort Yukon, Yukon Flats; $66^{\circ} 38^{\prime} 20^{\prime \prime} \mathrm{N}$, $144^{\circ} 56^{\prime} 30^{\prime \prime} \mathrm{W}$; (map 119)
Local name obtained in 1956 by USGS; so called because the anabranch flows into the Porcupine River 17 miles from Fort Yukon. Seventymile: locality, on left bank of Yukon River at its junc. with Seventymile River, 1 mi. W of Star City, 11 mi. N of Eagle, YukonTanana High.; $64^{\circ} 56^{\prime} \mathrm{N}, 141^{\circ} 18^{\prime} \mathrm{W}$; (map 102).

This mining camp was named by prospectors for the stream on which it was located and reported in 1898 by E. C. Barnard, USGS. It was deserted a few years later by the prospectors at news of other gold strikes.

Seventymile Creek: stream, see Seventymile River.

Seventymile River: stream, flows E $58 \mathrm{mi}$. to Yukon River, $10 \mathrm{mi}$. N of Eagle, YukonTanana High.; $64^{\circ} 55^{\prime} \mathrm{N}, 141^{\circ} 18^{\prime} \mathrm{W}$; (map 102). Var. Seventymile Creek, Seventy Mile River.

So named by prospectors because the mouth is 70 miles down the Yukon River from Fort Reliance, Canada; reported in 1897 by Capt. P. H. Ray, USA.

Seventymile River at the falls: falls, see Falls, The.

Seventy-Second Pass: water passage, see Amukta Pass.

Seventy-two Pass: water passage, see Amukta Pass.

Severnosky: locality, see Savonoski.

Severnoye Point: point of land, see North Point. Severn's Roadhouse: locality, see Seversens.

Seversens: locality, on Roadhouse Bay, on $\mathbf{N}$ shore of Iliamna Lake, $1 \mathrm{mi}$. E of Iliamna, Aleutian $\mathrm{Ra}$; $59^{\circ} 45^{\prime} \mathrm{N}, 154^{\circ} 49^{\prime} \mathrm{W}$; (map 51). Var. Severn's Roadhouse.

Local name published in 1923 by ARC, as "Severn's Roadhouse," and in 1933 by USGS, as "Seversens."

Severson Peninsula: peninsula, extends W 4.5 mi. in Becharof Lake, on Alaska Penin., 53 mi. NE of Ugashik, Aleutian Ra.; $57^{\circ} 49^{\prime} 15^{\prime \prime} \mathrm{N}$, $156^{\circ} 08^{\prime} 30^{\prime \prime} \mathrm{W}$; (map 36 ).

Name reported in 1902 by J. L. McPherson of Iliamna.

Sevidovskaia, Ostrovki: island, see Vsevidof Island.

Sevidovskie Ostrovki: island, see Vsevidof Island. Sevidow Isiand: island, see Vsevidof Island.

Sevisok Slough: stream, anabranch of Noatak River, heads at $67^{\circ} 23^{\prime} \mathrm{N}, 163^{\circ} 03^{\prime} \mathrm{W}$, flows SE $23 \mathrm{mi}$., $22 \mathrm{mi}$. SE of Noatak, Arctic Slope; $67^{\circ} 01^{\prime} \mathrm{N}, 162^{\circ} 45^{\prime} \mathrm{W}$; (map 128). Var. Sevisook Slough, Sevisuk Slough, Shivishak River, Shivishuk River.

Eskimo name meaning "long way to go by," according to USC\&GS in 1950.

Sevisook Slough: stream, see Sevisok Slough.

Sevisuk Slough: stream, see Sevisok Slough.

Sevognak: point of land, see Southeast Cape.

Sevooghak, Mount: hill, $0.5 \mathrm{mi}$. S of Chibukak Point, 2 mi. E of Gambell, Saint Lawrence I.; $63^{\circ} 47^{\prime} \mathrm{N}, 171^{\circ} 42^{\prime} \mathrm{W}$; BGN 1951; (map 93). Var. Mount Sevoognak, Mount Sevooghat, Sevoukuk Mountain.

Eskimo name reported in 1932 by Otto $W$. Geist, Univ. of Alaska. 
Seevooghat, Mount: hill, see Sevooghak, Mount. Sevooghnak: locality, on Southeast Cape, Saint Lawrence I.; $62^{\circ} 56^{\prime} 10^{\prime \prime} \mathrm{N}, 169^{\circ} 39^{\prime} 00^{\prime \prime} \mathrm{W}$; (map 93). Var. Sevukhnak.

This is the Eskimo name for Southeast Cape.

Sevooghnak Cape: point of land, see Southeast Cape.

Sevoognak, Mount: hill, see Sevooghak Mount.

Sevooka Cape: point of land, see Northeast Cape.

Sevookak, Cape: point of land, see Northwest Cape.

Sevoonak Point: point of land, see Southeast Cape.

Sevoonga: village, see Savoonga.

Sevoonga Cape: point of land, see Savoonga Point.

Sevukhnak: locality, see Sevooghnak.

Sevuo Cape: point of land, see Seevoo Point.

Sevuokaa Cape: point of land, see Northeast Cape.

Sevuokok: village, see Gambell.

Sevuokok, Cape: point of land, see Northwest Cape.

Sevuokok Cape: point of land, see Northeast Cape.

Sevuokuk Mountain: hill, $614 \mathrm{ft} ., 1.5 \mathrm{mi}$. SE of Gambell, on NW part of Saint Lawrence I.; $63^{\circ} 46^{\prime} \mathrm{N}, 171^{\circ} 42^{\prime} \mathrm{W}$; BGN 1951; (map 93).

This is the Eskimo name for the village of Gambell.

Sevuokuk Point: point of land, see Northeast Cape.

Sevuokuk Point: point of land, see Northwest Cape.

Seward: town, pop. 1,891, on Kenai Penin., at NW end of Resurrection Bay, Chugach Mts.; $60^{\circ} 06^{\prime} 30^{\prime \prime} \mathrm{N}, 149^{\circ} 26^{\prime} 30^{\prime \prime} \mathrm{W} ; B G N$ 1906; (map 63).

Named for William Henry Seward, 180172, U.S. Secretary of State, 1861-69, who negotiated the purchase of Alaska. "The town was founded in 1902 by surveyors for The Alaska RR. (built 1915-23) as the ocean terminus of the RR. with an airfield and an ice-free harbor, it is an important supply center for the Alaska interior" (Bridgewater and Sherwood, 1950, p. 1799). A post office was established here in 1895, discontinued in 1896, but reestablished in 1903 (Ricks, 1965, p. 57). Its population was 534 in $1910 ; 652$ in $1920 ; 835$ in $1930 ; 949$ in 1939 ; and 2,114 in 1950 .

Seward City: locality, see Comet.

Seward Creek: stream, flows E $8 \mathrm{mi}$. to Mission Creek, $10 \mathrm{mi}$. SW of Eagle, Yukon-Tanana High.; 64 $45^{\circ} 25^{\prime \prime} \mathrm{N}, 141^{\circ} 31^{\prime} 40^{\prime \prime} \mathrm{W}$; (map 102).

Prospectors' named obtained in 1898 by E. C. Barnard, USGS.

Seward Creek: stream, flows E $4 \mathrm{mi}$. to Wild Lake, S of Sirr Mtn., $39 \mathrm{mi}$. W of Wiseman, Brooks Ra.; $67^{\circ} 30^{\prime} 00^{\prime \prime} \mathrm{N}, 151^{\circ} 35^{\prime} 00^{\prime \prime} \mathrm{W}$; (map 124).

Local name obtained in 1956 by USGS topographers.
Seward Glacier: glacier, heads in Canada in icefield, near head of Columbus Glacier, at about $60^{\circ} 24^{\prime} \mathrm{N}, 140^{\circ} 55^{\prime} \mathrm{W}$, trends $\mathrm{E}$ and SW $52 \mathrm{mi}$. to Malaspina Glacier, $55 \mathrm{mi}$. NW of Yakutat, St. Elias Mts.; $60^{\circ} 06^{\prime} \mathrm{N}, 140^{\circ} 27^{\prime} \mathrm{W}$; (map 66).

Named by Russell (1891, p. 129), for William Henry Seward, 1801-72. See Seward: town.

Seward Mountains: mountain range, extends NW-SE $14 \mathrm{mi}$., NE of Davis River and SW of Soule Glacier, Coast Mts. ; $55^{\circ} 50^{\prime} \mathrm{N}, 130^{\circ}$ 15' W; (map 3 ).

Named in 1868 by Staff Comdr. David Pender, RN.

Seward Passage: water passage, $11 \mathrm{mi}$. long, between Deer I. and mainland, in E Ernest Sound, Alex. Arch.; 56 $03^{\circ} \mathrm{N}, 131^{\circ} 59^{\prime} \mathrm{W}$; (map 7).

Name derived from the Seward Mountains; given in 1886 by Lt. Comdr. A. S. Snow, USN.

Seward Peninsula: peninsula, extends W $200 \mathrm{mi}$ from line between heads of Eschscholtz Bay and Norton Bay; bounded on $\mathrm{S}$ by Norton Sound, on $\mathbf{N}$ by Chukchi Sea, and $\mathrm{W}$ by Bering Strait; $65^{\circ} \mathrm{N}, 164^{\circ} \mathrm{W}$; BGN 1944; Var. Kaviak Peninsula, Nome Peninsula, Prince of Wales Peninsula, Sumner Peninsula.

About 1898 Governor John Green Brady suggested the peninsula be named in compliment to William Henry Seward, 1801-72. See Seward: town. Dall (1870, p. 268) wrote of this peninsula: "it is proposed to call the [it] Kaviak Peninsula from the native name of Kavi-iak and the Kaviak Inniut who inhabit it." The names "Sumner Peninsula" and "Nome Peninsula" were published in 1900, but were not used subsequently.

Sewards Folly: state, see Alaska.

Sewidowsky, Mount: mountain, see Vsevidof, Mount.

Sextant Point: point of land, on S coast of Annette I., $0.8 \mathrm{mi}$. NE of Point Davison, Alex. Arch.; $55^{\circ} 00^{\prime} 52^{\prime \prime} \mathrm{N}, 131^{\circ} 35^{\prime} 29^{\prime \prime} \mathrm{W}$; (map $3)$.

Named in 1883 by Lt. Comdr. H. E. Nichols, USN.

Seykes, Mys: point of land, see Sykes, Point.

Seymour Canal: estuary, on E coast of Admiralty I., trends SE $40 \mathrm{mi}$. to Stephens Passage from neck of Glass Penin., $56 \mathrm{mi}$. SE of Juneau, Alex. Arch.; 57 $32^{\prime} \mathrm{N}, 133^{\circ} 50^{\prime} \mathrm{W}$; (map 8). Var. Seymour's Channel.

Examined by Joseph Whidbey, RN, and named in 1794 by Capt. George Vancouver as "Seymour's Channel" for Lord Hugh Seymour (Wagner, 1937, p. 416).

Seymour's Channel: estuary, see Seymour Canal. Sfaganugamute: locality, see Sfaganuk.

Sfaganuk: locality, $13 \mathrm{mi}$. $\mathrm{N}$ of Chefornak and $88 \mathrm{mi}$. SW of Bethel, Yukon-Kuskokwim Delta; $60^{\circ} 24^{\prime} \mathrm{N}, 164^{\circ} 15^{\prime} \mathrm{W}$; (map 58). Var. Sefagnuk, Sfaganugamute, Sfoganugamiut, Sfugunugumut, Staganuk.

Former Eskimo village visited in December 1878 by E. W. Nelson, U.S. Signal Service, who wrote the name "Sfoganugamiut."
Sfoganugamiut: locality, see Sfaganuk.

Sfugunugumut: locality, see Sfaganuk.

Shack Creek: stream, flows $0.9 \mathrm{mi}$. SW along N shore of Alsek River to sand bar, $2.8 \mathrm{mi}$. W of First Rapids and $50 \mathrm{mi}$. SE of Yakutat, Malaspina Coastal Plain; $59^{\circ} 11^{\prime} 45^{\prime \prime} \mathrm{N}, 138^{\circ} 30^{\prime} 00^{\prime \prime}$ W; (map 46).

Local name published by USGS in 1959.

Shack Lake: lake, $1.5 \mathrm{mi}$. long, between Cow and Long Lakes, $20 \mathrm{mi}$. SW of Beaver, Yukon Flats; $66^{\circ} 17^{\prime} 30^{\prime \prime} \mathrm{N}, 148^{\circ} 06^{\prime} 30^{\prime \prime} \mathrm{W}$; (map 118).

Probably named by William Yanert who showed it on a 1916 manuscript map of the Yukon Flats (Stuck, 1917, map facing p. 122).

Shackleford Creek: stream, heads between Coope: and Kenai Lakes, flows N $2.5 \mathrm{mi}$. to Kenai Lake, $30 \mathrm{mi}$. NW of Seward, Chugach Mts. ; $60^{\circ} 29^{\prime} 15^{\prime \prime} \mathrm{N}, 149^{\circ} 46^{\prime} 45^{\prime \prime} \mathrm{W}$; (map 63).

Local name reported in 1952 by USGS.

Shade Creek: stream, heads in Canada, flows W $5 \mathrm{mi}$. to Yukon River, Porcupine Plat.; $64^{\circ}$. $53^{\prime} 30^{\prime \prime} \mathrm{N}, 141^{\circ} 06^{\prime} 10^{\prime \prime} \mathrm{W}$; (map 102).

Local name reported in $1909-10$ by IBC surveycrs; published in 1914 on IBS Sheet 20.

Shadeetic Mountain: mountain, see Distik, Mount.

Shadistik: mountain, see Distik, Mount.

Shadow Bay: lake, $2.5 \mathrm{mi}$. long, at $\mathrm{W}$ tip of Lake Chauekuktuli, $100 \mathrm{mi}$. SE of Bethel, Kilbuck-Kuskokwim Mts.; $60^{\circ} 01^{\prime} \mathrm{N}, 159^{\circ} 10^{\prime}$ W; (map 59).

Descriptive name suggested by Gerald FitzGerald, USGS, in 1932 because "due to the high and steep slopes of the surrounding mountains this bay is almost always dark and in shadow."

Shadura Lake: lake, $0.8 \mathrm{mi}$. across, on Kenai Penin. E of Lake Ootka, $12 \mathrm{mi}$. NE of Kenai, Cook Inlet Low.; $60^{\circ} 42^{\prime} \mathrm{N}, 151^{\circ} 01^{\prime} \mathrm{W}$; (map 62).

Named about 1963 by officials of Kenai National Moose Range, for administrative purposes.

Shady Creek: stream, flows N $3 \mathrm{mi}$. to Bettles River $0.7 \mathrm{mi}$. W of junc. of Phoebe and Robert Creeks and $21 \mathrm{mi}$. NW of Chandalar, Brooks Ra.; $67^{\circ} 35^{\prime} 30^{\prime \prime} \mathrm{N}, 149^{\circ} 16^{\prime} 00^{\prime \prime} \mathrm{W}$; (map 123).

Local name reported in 1956 by T. E. Taylor, USGS.

Shaefer Creek: stream, see Potato Creek.

Shafer Creek: stream, see Potato Creek.

Shaft Creek: stream, on Kenai Penin., flows NW $5.5 \mathrm{mi}$. to Juneau Creek, $1.5 \mathrm{mi}$. S of Juneau Lake and $27 \mathrm{mi}$. SW of Hope, Chugach Mts.; $60^{\circ} 32^{\prime} 55^{\prime \prime} \mathrm{N}, 149^{\circ} 53^{\prime} 00^{\prime \prime} \mathrm{W}$; (map 63).

Local name reported in 1951 by USGS.

Shaft Gully: ravine, heads on $\mathrm{E}$ side of North Hill, trends SE $0.5 \mathrm{mi}$. to Eldorado Creek, 1.8 mi. NE of The Ears on Ear Mtn., Seward Penin. High.; $65^{\circ} 56^{\prime} 20^{\prime \prime} \mathrm{N}, 166^{\circ} 10^{\prime} 30^{\prime \prime} \mathrm{W}$; (map 111). Var. Vatney Gulch.

So named in 1945 by a USGS field party because there is a mine shaft nearby. This appears to be the ravine referred to as "Vat- 
ney Gulch" by Steidmann and Cathcart (1922, p. 107), USGS.

Shaft Peak: mountain, 2,138 ft., $5 \mathrm{mi}$. NW of Narrow Cape, $\mathbf{N}$ of Ugak Bay, Kodiak I.; $57^{\circ} 29^{\prime} \mathrm{N}, 152^{\circ} 25^{\prime} \mathrm{W}$; (map 34$)$.

Local name reported in 1951 by USGS.

Shaft Rock: rock, $200 \mathrm{ft}$. long, in Pacific Ocean, off SW penin. of Noyes I., $1.2 \mathrm{mi}$. $\mathrm{N}$ of Cape Addington, Alex. Arch.; 55 $27^{\prime} 15^{\prime \prime} \mathrm{N}, 133^{\circ}$ $19^{\prime} 10^{\prime \prime} \mathrm{W}$; (map 4).

Descriptive name given in 1923 by USC\&GS.

Shagak Bay: bay, $1 \mathrm{mi}$. across, on NW coast of Adak I., Aleutian Is.; $51^{\circ} 52^{\prime} \mathrm{N}, 176^{\circ} 45^{\prime} \mathrm{W}$; $B G N$ 1936; (map 17). Var. Chagak Bay, Chagakh Bay, Zaliv Shagakh.

Aleutian name published by Capt. Tebenkov (1852, map 28), IRN, as "Z[aliv] Shagakh," meaning "Shagakh Bay."

Shagakh, Zaliv: bay, see Shagak Bay.

Shagauka, Zaliv: bight, see Shahafka Cove.

Shagavanuktok River: stream, see Sagavanirktok River.

Shag Bluff: cliff, at mouth of Portage Bay, in Alitak Bay, at $\mathrm{S}$ end of Kodiak 1.; 56 $55^{\circ} 30^{\prime \prime}$ $\mathrm{N}, 153^{\circ} 53^{\prime} 30^{\prime \prime} \mathrm{W}$; (map 33).

Name reported in 1943 by USC\&GS.

Shag Cove: cove, in Glacier Bay National Monument, $2 \mathrm{mi}$. long, $1 \mathrm{mi}$. $\mathrm{S}$ of mouth of Geikie Inlet, $0.7 \mathrm{mi}$. SW of Marble Mtn., $50 \mathrm{mi}$. NW of Hoonah, St. Elias Mts.; $58^{\circ} 38^{\prime} 45^{\prime \prime} \mathrm{N}$, $136^{\circ} 20^{\prime} 00^{\prime \prime} \mathrm{W}$; (map 10).

Local name reported by USGS in 1951.

Shagelook: stream, see Shageluk Slough.

Shageluk: village, pop. 155, on $\mathrm{E}$ bank of Innoko River, $20 \mathrm{mi}$. E of Anvik and $34 \mathrm{mi}$. NE of Holy Cross, Innoko Low.; $62^{\circ} 41^{\prime} \mathrm{N}, 159^{\circ}$ $34^{\prime} \mathrm{W}$; (map 78). Var. Chageluk, Chagvagchat, Inselnostleide, Intenleiden, Khuingshtetakhten, Khulishganat, Khushgichagat, Kuingshtetakten, Tizhgelede, Tlégogitno, Tlégoshitno, Tlegozhitno.

Ingalik Indian village recorded as "Tlégoshitno" on Lt. L. A. Zagoskin's 1850 map. P. Tikhmeniev showed several villages or camps in this area on his 1861 map. They were named "Inselnostleide," "Inteleiden," "Khuingshtetakhten," "Khushgichagat," "Tizhgelede," "Tlegozhitno." Ivan Petroff in the 1880 U.S. Census calls them, collectively, the "Chageluk settlements." "Shageluk," as applied above, became one of the permanent villages in this wet lowland. Its population in 1920 was 130 ; in 1930 , 88. A post office was established in 1924 (Ricks, 1965, p. 57).

Shageluk Lake: lake, $2.3 \mathrm{mi}$. long, E of Innoko River at Shageluk, $33 \mathrm{mi}$. NE of Holy Cross, Innoko Low.; $62^{\circ} 41^{\prime} \mathrm{N}, 159^{\circ} 33^{\prime} \mathrm{W}$; (map 78).

Local name obtained in 1952 by USGS

Shageluk Slough: stream, anabranch of Yukon River, extends N-S $40 \mathrm{mi}$, between Yukon and Innoko Rivers, $42 \mathrm{mi}$. N of Holy Cross, Innoko Low.; $62^{\circ} 48^{\prime} \mathrm{N}, 159^{\circ} 34^{\prime} \mathrm{W}$; (map 78). Var. Chagalook, Chageluk, Chagelyuk, Ittëge, Shagelook.
Ingalik Indian name appears to have been applied to the Innoko River by the Russian colonial administration on the Yukon, although it is difficult to ascertain exact name application now. Lt. L. A. Zagoskin, IRN, applied the names "Chagelyuk" or "Ittëge" to the lower Innoko River in 1842-44. The name has been standardized to "Shageluk" and is now applied to part of the Yukon anabranch. See Innoko River.

Shag Island: island, $0.1 \mathrm{mi}$. across, in Wonder Bay, on NW coast of Shuyak Island, $50 \mathrm{mi}$. $\mathrm{N}$ of Kodiak I.; $58^{\circ} 37^{\prime} 12^{\prime \prime} \mathrm{N}, 152^{\circ} 36^{\prime} 00^{\prime \prime} \mathrm{W}$. (map 43). Var. Urili Island.

Translation of the name "Os[trov] Urili," or "shag" or "cormorant"; given by the Russian American Company in 1849.

Shagitak Island: island, see Sitkalidak Island.

Shag Rock: rock, at head of Sanborn Harbor, NW coast of Magai I., in Shumagin Is., Aleutian Ra.; $55^{\circ} 07^{\prime} 20^{\prime \prime} \mathrm{N}, 159^{\circ} 58^{\prime} 30^{\prime \prime} \mathrm{W}$; (map 27).

Named by W. H. Dall, USC\&GS, in 1872 and published on Chart 813.

Shag Rock: rock, on NW shore of Moser Bay, $40 \mathrm{mi}$. SE of Karluk, in SW part of Kodiak I. ; $57^{\circ} 02^{\prime} \mathrm{N}, 154^{\circ} 07^{\prime} \mathrm{W}$; (map 35).

Local name published in 1943 by USC\&GS. Shag Rock: rock, in Sitkalidak Strait, near mouth of Amee Bay, between Sitkalidak and Kodiak Is. ; $57^{\circ} 12^{\prime} 50^{\prime \prime} \mathrm{N}, 153^{\circ} 12^{\prime} 10^{\prime \prime} \mathrm{W}$; (map 34).

Local name published in 1943 by USC\&GS.

Shag Rock: rock, in Davison Bay, $11 \mathrm{mi}$. NW of Chichagof, on W coast of Chichagof I., Alex. Arch.; 57 $46^{\prime} 50^{\prime \prime} \mathrm{N}, 136^{\circ} 18^{\prime} 40^{\prime \prime} \mathrm{W}$; (map 9).

Named in 1928 by USC\&GS; published on Chart 8258.

Shag Rock: rock, $0.7 \mathrm{mi}$. E of Mummy I., $10 \mathrm{mi}$. SW of Cordova, Chugach Mts.; $60^{\circ} 28^{\prime} \mathrm{N}$, $145^{\circ} 58^{\prime} \mathrm{W}$; (map 64).

Local name published in 1943 by USC\&GS. Shag Rocks: rocks, in SE entrance to Whale Passage, between Whale and Kodiak Is. ; $57^{\circ}$ $54^{\prime} 30^{\prime \prime} \mathrm{N}, 152^{\circ} 47^{\prime} 25^{\prime \prime} \mathrm{W}$; (map 34). Var. Kamen Urili, Oreel Rocks, Oreelie Rocks, Urili Rocks, Urilie Rocks.

Translation of "K[amen] Urili," published in 1849 on Russian Hydrog. Dept. Chart 1425.

Shahafka Cove: bight, $0.2 \mathrm{mi}$. across, on $\mathrm{W}$ shore of Woody I. Channel, $1.5 \mathrm{mi}$. NE of Kodiak, Kodiak I.; $57^{\circ} 47^{\prime} 55^{\prime \prime}$ N, $152^{\circ} 22^{\prime} 00^{\prime \prime}$ W; (map 34). Var. Chagafka Cove, Peschanoi, Zaliv Peschanoy, Zaliv Shagauka.

Transliteration of the name "Z[aliv] Shagauka" published by Capt. Tebenkov (1852, map 23). Named "Za[liv] Peschanoy," meaning "Sandy Bay" by Sarichev (1826, map 16).

Shaheen Creek: stream, on Prince of Wales I., heads on Kogish Mtn., flows NW $7 \mathrm{mi}$. to Kaguk Cove, $20 \mathrm{mi}$. NW of Craig, Alex. Arch.; $55^{\circ} 45^{\prime} \mathrm{N}, 133^{\circ} 15^{\prime} \mathrm{W}$; (map 4).

Indian name recorded in 1949 by USGS.

Shaiak Island: island, $0.5 \mathrm{mi}$. long, $0.4 \mathrm{mi}$. E of mainland, in Bristol Bay, $4.6 \mathrm{mi}$. S of Slug Mtn., and $22 \mathrm{mi}$. W of Hagemeister I.; 58*$33^{\prime} 30^{\prime \prime} \mathrm{N}, 161^{\circ} 40^{\prime} 00^{\prime \prime} \mathrm{W}$; (map 39).
Native name published by Lt. Sarichev (1826, map 3), IRN, as "O[strov] Morzhevoi [Russian for 'Walrus Island'] Shayak." Capt. Tebenkov (1852, map 4), IRN, showed "O[strov] Shayak." The Shaiak spelling is due to the transliteration table used by BGN in the 1890's.

Shainin Lake: lake, $2.7 \mathrm{mi}$. long, in course of Alapah Creek, W of Mount Wachsmuth, 22 mi. NE of Anaktuvuk Pass, Arctic Slope; $68^{\circ}$ $20^{\prime} \mathrm{N}, 151^{\circ} 03^{\prime} \mathrm{W}$; BGN 1960; (map 134). Var. Kanayut Lake:

Named by USGS geologists in 1951 for Vincent E. Shainin, USGS geologist, who drowned in this lake in 1950. The Eskimo name for this lake is Kanayut (Rausch, 1951, p. 150).

Shaishnikof River: stream, flows NE $9 \mathrm{mi}$. to Nateekin Bay, in Unalaska Bay, Unalaska I., Aleutian Is.; $53^{\circ} 49^{\prime} 40^{\prime \prime} \mathrm{N}, 166^{\circ} 36^{\prime} 25^{\prime \prime} \mathrm{W}$; (map 23).

Local name published in 1951 on a USGS map.

Shakaan Bay: bay, see Shakan Bay.

Shakaan Strait: water passage, see Shakan Strait. Shakan: locality, at head of Shakan Bay E of Hamilton I., on NW coast of Kosciusko I., Alex. Arch.; $56^{\circ} 08^{\prime} 15^{\prime \prime} \mathrm{N}, 133^{\circ} 27^{\prime} 35^{\prime \prime} \mathrm{W}$; (map 6). Var. Caxan, Chican, Hamiltons Mills, Olivers Place, Tsī'choān.

Former Indian village that "grew up in 1879 around a sawmill established by Oliver Fontain and was known at the time as 'Oliver's Place'" (Colby, 1945, p. 145). The summer village of the Henya tribe of Tlingit Indians, who came here for fish eggs (Hodge, 1910, p. 520), BAE. Shakan post office was established in 1886; discontinued in 1936 (Ricks, 1965 , p. 57). In 1890 , with a population of 38 , the village included the sawmill and about 12 houses (U.S. Bureau of the Census, 1893, p. 34). The population was 19 in 1930 , but only one person was reported to have been living there in 1938 (Colby, 1945, p. 145). The name "Shakan" is probably derived from the name of the Tlingit chief, Cēks, or Shakes, with the ending "an," meaning "village." See Kah Shakes, village.

Shakan: locality, see Sukkwan.

Shakan Bay: bay, $3 \mathrm{mi}$. across, between $\mathbf{N}$ coast of Kosciusko I. and NW coast of Prince of Wales I., Alex. Arch.; 56 $10^{\prime} \mathrm{N}, 133^{\circ} 37^{\prime} \mathrm{W}$; (map 6). Var. Shakaan Bay, Shukan Bay.

Local name published by USC\&GS in 1883 Coast Pilot (p. 101). See Shakan, village.

Shakan Creek: stream, flows N $3.5 \mathrm{mi}$. to Shakan Bay, on $\mathrm{N}$ coast of Kosciusko I., Alex. Arch.; $56^{\circ} 08^{\prime} 20^{\prime \prime} \mathrm{N}, 133^{\circ} 27^{\prime} 40^{\prime \prime} \mathrm{W}$; (map 6).

Local name recorded in 1949 by USGS.

Shakan Island: island, $0.1 \mathrm{mi}$. long, at $\mathrm{S}$ point of entrance to Shakan Bay, on $\mathbf{N}$ coast of Kosciusko I., Alex. Arch.; $56^{\circ} 08^{\prime} 55^{\prime \prime}$ N, $133^{\circ} 37^{\prime}$ $55^{\prime \prime} \mathrm{W}$; (map 6).

Local name published by USC\&GS in 1883 Coast Pilot (p. 101). See Shakan, village. Shakan Nipples: mountain, see Nipples, The

Shakan Strait: water passage, in Shakan Bay, between Hamilton and Kosciusko Is., Alex. 
Arch.; $56^{\circ} 07^{\prime} 30^{\prime \prime} \mathrm{N}, 133^{\circ} 30^{\prime} 00^{\prime \prime} \mathrm{W}$; (map 6). Var. Shakaan Strait.

Local name published by USC\&GS in 1883 Coast Pilot (p. 101). See Shakan: locality.

Shake Cabin: locality, a shelter cabin on the left bank of Texas Creek, $9 \mathrm{mi}$. $\mathbf{N}$ of Hyder, Coast Mts.; 56 $02^{\prime} 50^{\prime \prime} \mathrm{N}, 130^{\circ} 04^{\prime} 30^{\prime \prime} \mathrm{W}$; (map 7).

Local name reported in 1928 by USGS.

Shakes, Mount: mountain, 3,305 ft., on E coast of Etolin I., Alex. Arch.; 56 $00^{\prime} \mathrm{N}, 132^{\circ} 15^{\prime}$ W; (map 4).

Named in 1886 , by Lt. Comdr. A. S. Snow, USN, "after Shakes, an Indian chief."

Shakes Glacier: glacier, trends $\mathbf{S} 7 \mathrm{mi}$. to Shakes Lake, $22 \mathrm{mi} \mathrm{NE}$ of Wrangell, Cost Mts.; $56^{\circ}$ $47^{\prime} 30^{\prime \prime} \mathrm{N}, 132^{\circ} 08^{\prime} 00^{\prime \prime} \mathrm{W}$; (map 6).

Local name recorded in 1961 by USGS. See Kah Shakes, village.

Shakes Lake: lake, $3 \mathrm{mi}$. long, at mouth of Shakes Glacier, $16 \mathrm{mi}$. NE of Wrangell, Coast Mts.; $56^{\circ} 45^{\prime} \mathrm{N}, 132^{\circ} 08^{\prime} \mathrm{W}$; (map 6). Var. Soinai Lake.

Local name recorded in 1953 by USGS.

Shakespeare Glacier: glacier, on NE end of Kenai Penin., trends NW 2 mi. to its terminus, $2 \mathrm{mi}$. SW of Whittier, Chugach Mts.; $60^{\circ} 45^{\prime} 40^{\prime \prime}$ N, $148^{\circ} 44^{\prime} 30^{\prime \prime}$ W ; (map 63).

Named in 1915 by USC\&GS "for William Shakespeare, 1564-1616, English dramatist and poet."

Shakes Slough: stream, heads in Shakes Lake, flows SE $2.5 \mathrm{mi}$ to Stikine River, $19 \mathrm{mi}$. NE of Wrangell, Coast Mts.; $56^{\circ} 42^{\prime} 45^{\prime \prime} \mathrm{N}, 1^{132^{\circ}}$ $06^{\prime} 30^{\prime \prime} \mathrm{W}$; (map 6)

Local name recorded in 1953 by USGS

Shakes Village: locality, on E coast of Etolin I., Alex. Arch.; 55 $58^{\prime} \mathrm{N}, 132^{\circ} 13^{\prime} \mathrm{W}$; (map 4).

Former Tlingit Indian summer camp of the head Stikine chief, Cēks; reported in the 1880 Census as "Shakes' Village," population 38. $(1884$, p. 32). See Kah Shakes.

Shakhmanova, Mys: point of land, see Shakmanof Point.

Shakhmanova, Zaliv: bay, see Kizhuyak Bay

Shakhtoli, Zaliv: bay, see Shaktoolik Bay.

Shakhtolik, Reka: stream, see Shaktoolik River.

Shakhtolik, Zaliv: bay, see Shaktoolik Bay.

Shakhun, Kamen: rock, see Shakun Rock.

Shakhun Rock: rock, Shakun Rock.

Shaklolik: village, see Shaktoolik.

Shakmanof: $b a y$, see Kizhuyak Bay.

Shakmanof Cove: bay, extends $\mathbf{S} 1 \mathrm{mi}$. between Kizhuyak and Shakmanof Points, $12 \mathrm{mi}$. NW of Kodiak, Kodiak I.; $57^{\circ} 55^{\prime} \mathrm{N}, 152^{\circ} 36^{\prime} \mathrm{W}$; $B G N$ 1939; (map 34). Var. Nutty Cove, Womens Bay.

Name derived from Shakmanof Point and given in 1939 by USC\&GS. This feature was called "Nutty Cove" in 1933 by USC\&GS and "Womens Bay" by Capps (1937, p. 129), USGS.

Shakmanof Point: point of land, E point of entrance to Shakmanof Cove, $12 \mathrm{mi}$. NW of Kodiak, Kodiak I.; $57^{\circ} 55^{\prime} 30^{\prime \prime} \mathrm{N}, 152^{\circ}$ 35'15" W; (map 34). Var. Mys Chiniak, Mys Shakhmanova, Riph Point.

Named "M[ys] Shakhmanova," or "Cape Shakmanov," by Sub-Lt. Mikhail Murashev in
1839 or 1840 and published in 1849 on Russian Hydrog. Dept. Chart 1425. Called "M[ys] Chiniak" or "Cape Chiniak," by Capt. Tebenkov (1852, map 23). "Riph Point" was Baker's (1906, p. 565) transliteration of Capt. Tebenkov's word for "reef."

Shakon, Cape: point of land, see Chacon, Cape. Shaktol, Guba: bay, see Shaktoolik Bay.

Shaktolik: village, see Shaktoolik.

Shaktolik Hills: hills, near the Shaktoolik River,

E of Norton Sound, Nulato Hills; (map 96).

So called by Dall $(1870$, p. 24$)$.

Shaktolik River: stream, see Shaktoolik River. Shaktolit: village, see Shaktoolik.

Shaktoolik: village, pop. 187, on E shore of Norton Sound, $12 \mathrm{mi}$. ESE of Cape Dembigh, Nulato Hills; $64^{\circ} 20^{\prime} \mathrm{N}, 161^{\circ} 09^{\prime} \mathrm{W} ; B G N$ 1966; (map 96). Var. Shaklolik, Shaktolik, Shaktolit, Tshakhtog-myut, Ttakhtog-myut.

Eskimo village reported in $1842-44$ by $\mathrm{Lt}$.

L. A. Zagoskin, IRN, who recorded it as

"Tshakhtog-myut." The population was 60 in 1880 ; 38 in $1890 ; 73$ in $1920 ; 104$ in 1930 ; 128 in 1940; and 127 in 1950. The Shaktoolik post office was located here from 1930 to 1933 and from 1944 to 1949 (Ricks, 1965, p. 58).

Shaktoolik Bay: bay, on Norton Sound, $23 \mathrm{mi}$. SW of Christmas Mtn., Nulato Hills; 64 $22^{\prime}$ N, $161^{\circ} 11^{\prime}$ W; (map 96). Var. Baie Chaktolimont, Chacktoole Bay, Guba Shaktol, Guba Tshakhtol, Zaliv Shakhtoli, Zaliv Shakhtolik.

Eskimo name reported on September 16, 1778 , by Capt. Cook (1785, v. 2, p. 485), RN, as "Chacktoole Bay." It was called "Shaktol" and "Shakhtolik" by the Russians.

Shaktoolik River: stream, flows SW $92 \mathrm{mi}$. to Shaktoolik Bay $22 \mathrm{mi}$. SW of Christmas Mtn., Nulato Hills; $64^{\circ} 22^{\prime} \mathrm{N}, 161^{\circ} 11^{\prime} \mathrm{W}$; $B G N$ 1966; (map 96). Var. Reka Shakhtolik, Shaktolik River.

Eskimo name published by Capt. Tebenkov (1852, map 2), IRN, as "R[eka] Shakhtolik." Shakun Islands: islands, see Shakun Islets.

Shakun Islets: islands, group extends $1.8 \mathrm{mi}$., in Shelikof Strait, on NE coast of Alaska Penin., in Katmai National Monument, $7 \mathrm{mi}$. NE of Cape Chiniak and $49 \mathrm{mi}$. NE of Mount Katmai, Aleutian Ra.; $58^{\circ} 34^{\prime} \mathrm{N}$, $153^{\circ} 43^{\prime} \mathrm{W}$; (map 43). Var. Shakun Islands.

Name derived from Shakun Rock; published by USC\&GS as Shakun Islands in 1943.

Shakun Rock: rock, $400 \mathrm{ft}$. long, in Shelikof Strait, $1.7 \mathrm{mi}$. SE of Shakun Islets, Aleutian $\mathrm{Ra}$; $58^{\circ} 32^{\prime} 55^{\prime \prime} \mathrm{N}, 153^{\circ} 41^{\prime} 10^{\prime \prime} \mathrm{W}$; BGN 1897; (map 43). Var. Schachun Rocks, Shakhun Rock, Kamen Shakhun.

Name transliterated by USC\&GS from "K[amen] Shakhun," published by Capt. Tebenkov (1852, map 22), IRN.

Shakuseya Creek: stream, see Shakuseyi Creek. Shakuseyi Creek: stream, heads on E slope of Tukgahgo Mtn., flows NE $2 \mathrm{mi}$. to head of Lutak Inlet, $1.4 \mathrm{mi}$. SE of Chilkoot and $13 \mathrm{mi}$. SW of Skagway, Coast Mts.; $59^{\circ} 18^{\prime} 50^{\prime \prime} \mathrm{N}$, $135^{\circ} 32^{\prime} 30^{\prime \prime} \mathrm{W}$; (map 45). Var. Shakuseya Creek.
Tlingit Indian name reported to mean "mountain-foot"; published in 1923 on IBC Sheet 9 (1951 atlas).

Shākwan: locality, see Sukkwan.

Shale Island: island, $600 \mathrm{ft}$. long, $4 \mathrm{mi}$. SSW of Chichagof, off $W$ coast of Chichagof I., Alex. Arch.; $57^{\circ} 36^{\prime} 48^{\prime \prime} \mathrm{N}, 136^{\circ} 07^{\prime} 45^{\prime \prime} \mathrm{W}$; (map 9).

Descriptive name given in 1908 by USC\&GS; published in 1909 on Chart 8280. Shaler Mountains: mountains, $15 \mathrm{mi}$. long, central Unalaska I., Aleutian Is.; $53^{\circ} 35^{\prime} \mathrm{N}, 166^{\circ}$. 48' W; (map 23).

Name published by USGS (Drewes and others, 1961, pl. 75).

Shaleruckik Mountain: hill, $718 \mathrm{ft}, 17 \mathrm{mi}$. SW of Shungnak, Kotzebue-Kobuk Low; $66^{\circ} 51^{\prime}$ $\mathrm{N}, 157^{\circ} 45^{\prime} \mathrm{W}$; (map 115)

Eskimo name shown on a 1901 field sheet by USGS.

Shale Wall Bluff: bluff, elev. $900 \mathrm{ft}$, , on W bank of Nanushuk River, $10 \mathrm{mi}$. SE of Outpost Mtn. and $36 \mathrm{mi}$. SE of Umiat; Arctic Slope; $69^{\circ} 04^{\prime} \mathrm{N}, 150^{\circ} 51^{\prime} \mathrm{W}$; BGN 1960; (map 141).

So named by USGS geologists during the exploration of Naval Petroleum Reserve No. 4, between 1944 and 1953, "because a name was needed for a type locality for the Shale Wall member of the Seabee formation."

Shallow Bay: delta, see Dry Bay.

Shallow Lake: lake, $2.3 \mathrm{mi}$. long, $12 \mathrm{mi}$. SE of Beaver, Yukon Flats; $66^{\circ} 14^{\prime} 15^{\prime \prime} \mathrm{N}, 147^{\circ} 04^{\prime}-$ $00^{\prime \prime} \mathrm{W}$; (map 118).

Local descriptive name obtained in 1956 by USGS.

Shallow Lake: lake, see Kenibuna Lake.

Shallow-water, Point: point of land, see Romanof, Point.

Shallyanys Village: locality, on Stikine River, $\mathrm{N}$ of Wrangell, Alex. Arch.; $56^{\circ} 31^{\prime} \mathrm{N}, 132^{\circ} 23^{\prime}$ W; (map 6).

Former Tlingit Indian summer camp reported in the 1880 Census, with a population of 24 , by Petroff $(1884$, p. 32$)$.

Shaman: village, see Stevens Village.

Shaman Island: island, $0.1 \mathrm{mi}$. long, in Stephens Passage, $0.3 \mathrm{mi}$. NW of Outer Point on W coast of Douglas I. and $9.5 \mathrm{mi}$. W of Juneau, Coast Mts.; $58^{\circ} 18^{\prime} 20^{\prime \prime} \mathrm{N}, 134^{\circ} 41^{\prime} 00^{\prime \prime} \mathrm{W}$; (map 11).

Named in 1890 by Lt. Comdr. H. B. Mansfield, USN. "Shaman" is an Indian name for medicine-man or doctor. Reason for this name is unknown. The name was published in 1893 by USC\&GS on Chart 8300 .

Shamansville: village, see Stevens Village.

Shamrock Bay: bay, $1.5 \mathrm{mi}$. long, at head of West Shamrock Inlet, on central Baranof I., Alex. Arch.; $56^{\circ} 49^{\prime} 45^{\prime \prime} \mathrm{N}, 135^{\circ} 08^{\prime} 00^{\prime \prime} \mathrm{W}$; (map 5)

Descriptive name given in 1929 by USC\&GS "because its charted outline resembles a shamrock."

Shamrock Creek: stream, flows S $3.7 \mathrm{mi}$. to Bear Creek $3 \mathrm{mi}$. NE of Nyac and $39 \mathrm{mi}$. SW of Aniak, Kilbuck-Kuskokwim Mts.; $61^{\circ} 01^{\prime}$ N, $159^{\circ} 51^{\prime} \mathrm{W}$; (map 73). 
Prospectors' name shown on a 1914 field sheet by A. G. Maddren, USGS.

Shamrock Creek: stream, flows NW $4 \mathrm{mi}$. to Redmond Creek, $28 \mathrm{mi}$. NW of Big Delta, Yukon-Tanana High.; $64^{\circ} 24^{\prime} \mathrm{N}, 146^{\circ} 32^{\prime} \mathrm{W}$; (map 101).

Named by prospectors; reported in 1910 by USGS (Capps, 1912, pl. 1)

Shamrock Creek: stream, flows $\mathrm{N}$ then $\mathrm{E} 5 \mathrm{mi}$. to Golovnin Lagoon, $10 \mathrm{mi}$. NW of Golovin and $32 \mathrm{mi}$. E of Solomon, Seward Penin. High.; $64^{\circ} 35^{\prime} \mathrm{N}, 163^{\circ} 22^{\prime} \mathrm{W}$; (map 95).

Prospectors' name published on the 1908 "Map of Seward Peninsula" by Arthur Gibson. Shamrock Creek: stream, flows NW $6 \mathrm{mi}$. to East Fork Chena River, $68 \mathrm{mi}$. SW of Circle, Yukon-Tanana High.; $65^{\circ} 02^{\prime} \mathrm{N}, 145^{\circ} 28^{\prime} \mathrm{W}$; (map 104).

Named by prospectors; reported in 1811 by E. A. Porter (in Brooks and others, 1912, p. 244), USGS.

Shamrock Creek: stream, flows NE $2 \mathrm{mi}$. to Big Lake, $1.4 \mathrm{mi}$. SE of mouth of Holy Moses Creek and $23 \mathrm{mi}$. W of Chandalar, Brooks Ra.; $67^{\circ} 29^{\prime} 15^{\prime \prime}$ N, $149^{\circ} 22^{\prime} 00^{\prime \prime} \mathrm{W}$; (map 123). Local name reported in 1956 by T. E. Taylor, USGS.

Shamrock Glacier: glacier, in Chigmit Mts., trends $\mathrm{N} 13 \mathrm{mi}$. to its terminus between Chakachamna and Kenebuna Lakes, $55 \mathrm{mi}$. W of Tyonek, Aleutian Ra.; $61^{\circ} 11^{\prime} \mathrm{N}, 152^{\circ} 49^{\prime}$ W; BGN 1930; (map 70).

Local name reported in 1927 by S. R. Capps (in Smith and others, 1930, p. 147), USGS. Shamrock Isle: island, see Emerald Island.

Shamrock Lake: lake, $1.7 \mathrm{mi}$. long, at terminus of Shamrock Glacier, $55 \mathrm{mi}$. W of Tyonek, Aleutian Ra.; $61^{\circ} 11^{\prime} 15^{\prime \prime} \mathrm{N}, 152^{\circ} 47^{\prime} 30^{\prime \prime} \mathrm{W}$; (map 70).

Local name reported in 1958 by USGS.

Shand, Mount: peak, 12,660 ft., at head of Trident Glacier, $10 \mathrm{mi}$. SE of Mount Hayes, Alaska Ra.; $63^{\circ} 32^{\prime} 40^{\prime \prime} \mathrm{N}, 146^{\circ} 26^{\prime} 55^{\prime \prime} \mathrm{W}$; $B G N$ 1962; (map 86).

Named for William Shand, Jr., 1918-46, reported to be one of a party of two that made the first ascent of nearby Mount Moffit, August 13, 1941. Bradford Washburn proposed this name in 1949 to be applied to what is now called Mount Moffit. The present application of the name was suggested in 1961 by USGS to resolve the conflict of two names applied to the same feature.

Shangavinapok: stream, see Swift Fork.

Shangin Bay: bay, $4 \mathrm{mi}$. long, $0.2 \mathrm{mi}$. wide, on $\mathrm{N}$ coast of Shuyak I., $50 \mathrm{mi}$. N of Kodiak I.; $58^{\circ} 36^{\prime} 30^{\prime \prime} \mathrm{N}, 152^{\circ} 25^{\prime} 10^{\prime \prime} \mathrm{W}$; BGN 1933; (map 43).

Name published by USC\&GS in 1927 on Chart 8555.

Shangin Rock: rock, off $\mathrm{N}$ coast of Shuyak I., $52 \mathrm{mi}$. $\mathrm{N}$ of Kodiak I.; $58^{\circ} 38^{\prime} 35^{\prime \prime} \mathrm{N}, 152^{\circ}$ $26^{\prime} 00^{\prime \prime}$ W ; BGN 1933; (map 43).

So named by USC\&GS in 1931 because it marks the entrance to Shangin Bay.

Shanigarok: stream, see Shaningarok Creek.

Shaningarok Creek: stream, heads at $69^{\circ} 21^{\prime} \mathrm{N}$, $159^{\circ} 01^{\prime} \mathrm{W}$, flows $\mathrm{N}$ and E $80 \mathrm{mi}$. to Meade
River, $95 \mathrm{mi}$. SE of Wainwright, Arctic Slope; 69³7' N, 157'26' W; BGN 1949; (map 143). Var. Kaksu River, Sanigaroak, Shanigarok.

Eskimo name reported by T. E. Taylor, USGS, in 1956.

Shaningarok Ridge: ridge, extends $40 \mathrm{mi}$. W from Meade River, $\mathrm{N}$ of Shaningarok Creek, $85 \mathrm{mi}$. SE of Wainwright, Arctic Slope; $69^{\circ} 41^{\prime}$ $\mathrm{N}, 158^{\circ} 11^{\prime} \mathrm{W}$; (map 143 ).

Named by USGS in 1956, and derived from the stream name.

Shannon, Mount: mountain, 2,055 ft., on $\mathrm{N}$ shore of Wide Bay, on $\mathbf{S}$ coast of Alaska Penin., 39 mi. ESE of Ugashik, Aleutian Ra.; $57^{\circ} 25^{\prime} 30^{\prime \prime}$ $\mathrm{N}, 156^{\circ} 23^{\prime} 45^{\prime \prime} \mathrm{W}$; (map 36 ).

Named by prospectors for "Mr. Shannon (cnna) who died in the vicinity in 1922"; published by W. R. Smith and A. A. Baker (in Brooks and others, 1924, pl. 11), USGS.

Shannon Hill: mountain, 1,900 ft., in Indian Mts., 25 mi. NE of Hughes, Kokrines-Hodzana High.; 66 $19^{\prime} \mathrm{N}, 153^{\circ} 37^{\prime} \mathrm{W}$; (map 116).

Local name published in 1956 by USGS.

Shannon Point: point of land, $W$ of Nyman Penin., on NW shore of Womens Bay, $6 \mathrm{mi}$. SW of Kodiak, Kodiak I.; $57^{\circ} 43^{\prime} 45^{\prime \prime} \mathrm{N}, 152^{\circ}$ $31^{\prime} 40^{\prime \prime} \mathrm{W}$; (map 34).

Local name reported in 1949 by USGS.

Shantatalik Creek: stream, flows SW $5 \mathrm{mi}$. to Tustumena, $21 \mathrm{mi}$. SE of Kenai, Cook Inlet Low.; $60^{\circ} 17^{\prime} 30^{\prime \prime} \mathrm{N}, 150^{\circ} 59^{\prime} 30^{\prime \prime} \mathrm{W}$; (map 62). Var. Tschantotalich.

Tanaina Indian name reported in 1840 by the Russian scientist I. G. Wosnesenski. It was published by Grewingk (1850, map 3) as "Tschantatalich."

Shapka Island: island. $0.6 \mathrm{mi}$. across, one of Chiachi Is., $22 \mathrm{mi}$. E of Stepovak Bay, Aleutian

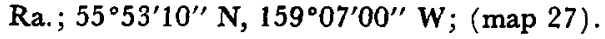

Descriptive name derived from the Russian word for "hat;" given because of the island's rounded shape; published by USC\&GS on Chart 8881 (1891).

Sharatin Bay: bay, extends S $3.5 \mathrm{mi}$, off Kizhuyak Bay, $13 \mathrm{mi}$. NW of Kodiak, Kodiak I.; $57^{\circ} 51^{\prime} \mathrm{N}, 152^{\circ} 44^{\prime} \mathrm{W}$; BGN 1933; (map 34).

Local name reported in 1933 by Gerald FitzGerald, USGS, who wrote, "probably was given for an early Russian settler."

Sharatin Mountain: mountain, 2,869 ft., at head of Sharatin Bay, $10 \mathrm{mi}$. W of Kodiak, Kodiak I.; $57^{\circ} 48^{\prime} 45^{\prime \prime} \mathrm{N}, 152^{\circ} 41^{\prime} 15^{\prime} \mathrm{W}$; $B G N$ 1933; (map 34).

Name derived from Sharatin Bay and given in 1933 by Gerald FitzGerald, USGS.

Shariepof, Cape: point of land, see Izhut, Cape.

Shark Edge Mountain: peak, 3,734 ft., $4 \mathrm{mi}$. NW of Old John Lake and $7 \mathrm{mi}$. SE of Arctic Village, Brooks Ra.; 68 $06^{\prime} \mathrm{N}, 1^{\circ} 5^{\circ} 16^{\prime} \mathrm{W}$; (map 136).

Local name reported in 1956 by R. C. Foley, USGS.

Shark Point: point of land, on NE shore of Ugak Bay, on E coast of Kodiak I. ; $57^{\circ} 27^{\prime} \mathrm{N}, 152^{\circ}$ $35^{\prime} \mathrm{W}$; (map 34$)$.

Local name reported in 1951 by USGS.

Sharkstooth Mountain: mountain, 9,660 ft., near head of Columbia Glacier, $30 \mathrm{mi}$. NW of Valdez, Chugach Mts.; $61^{\circ} 22^{\prime} 20^{\prime} \mathrm{N}, 147^{\circ}-$ 01'33" W; BGN 1965; (map 69).

Named about 1957 by members of the Chugach Mountains Expedition sponsored by the Arctic Institute of North America (Nielsen, 1963, p. 135).

Shark Tooth Hill: mountain, 2,740 ft., $1.5 \mathrm{mi}$. $E$ of Oil Bay and $23 \mathrm{mi}$. NE of Augustine I., Aleutian Ra.; $59^{\circ} 40^{\prime} 15^{\prime \prime} \mathrm{N}, 153^{\circ} 14^{\prime} 00^{\prime \prime} \mathrm{W}$; $B G N$ 1916; (map 51).

Named by USC\&GS in 1913 because of the mountain's resemblance to a shark's tooth.

Sharp, Mount: mountain, 2,569 ft., $4.5 \mathrm{mi}$. SE of Goddard, on W coast of Baranof I., Alex. Arch.; $56^{\circ} 48^{\prime} 45^{\prime \prime} \mathrm{N}, 135^{\circ} 15^{\prime} 00^{\prime \prime} \mathrm{W}$; (map 5).

Descriptive name given in 1943 for charting purposes by USC\&GS.

Sharp Cape: point of land, on S coast Kagalaska I., Aleutian Is.; $51^{\circ} 43^{\prime} 50^{\prime \prime} \mathrm{N}, 176^{\circ} 20^{\prime} 50^{\prime \prime} \mathrm{W}$; $B G N 1936$; (map 17).

So named by members of the U.S. Navy Aleutian Island Survey Expedition in 1934 "because it is a sharp, rocky headland."

Sharp Ledge: cliff, on S end of Couverden I., W of Point Couverden, at mouth of Lynn Canal, $25 \mathrm{mi}$. SW of Juneau, St. Elias Mts.; $58^{\circ}$ $11^{\prime} 30^{\prime \prime} \mathrm{N}, 135^{\circ} 03^{\prime} 45^{\prime \prime} \mathrm{W}$; (map 11).

Descriptive name given in 1890 by USC\&GS and published in the 1891 Coast Pilot (p. 195).

Sharp Mountain: mountain, 2,200 ft., $\mathbf{N}$ of Iliamna Lake, $20 \mathrm{mi}$. W of Iliamna, Alaska Ra.; $59^{\circ} 46^{\prime} \mathrm{N}, 155^{\circ} 29^{\prime} \mathrm{W}$; (map 51 ).

Descriptive name published in 1957 by USGS.

Sharp Peak: mountain, 6,030 ft., $3.2 \mathrm{mi}$. NE of terminus of Klutina Glacier, $21 \mathrm{mi}$. NE of Valdez, Chugach Mts.; $61^{\circ} 25^{\prime} 15^{\prime \prime} \mathrm{N}, 146^{\circ}$ 02'10" W; (map 68).

Named in 1898 by Capt. W. R. Abercrombie, USA.

Sharp Point: point of land, on W shore of Princess Bay, on SE coast of Revillagigedo I., Alex. Arch.; $55^{\circ} 20^{\prime} 35^{\prime \prime} \mathrm{N}, 131^{\circ} 01^{\prime} 30^{\prime \prime} \mathrm{W}$; (map 3 ).

Descriptive name given in 1891 by USC \&GS.

Sharp Point: point of land, at mouth of Eliza Harbor, in South Passage, on Admiralty I., 27 mi. SE of Angoon, Alex. Arch.; $57^{\circ} 09^{\prime} 30^{\prime \prime} \mathrm{N}$, $134^{\circ} 16^{\prime} 40^{\prime \prime} \mathrm{W}$; (map 9).

Descriptive name given in 1889 by $L t$. Comdr. H. B. Mansfield, USN; published by USC\&GS in the 1891 Coast Pilot (p. 142).

Sharp Point: point of land, on W shore of Port Snettisham, $2.4 \mathrm{mi}$. S of Mallard Cove and $31 \mathrm{mi}$. SE of Juneau, Coast Mts.; $58^{\circ} 08^{\prime} \mathrm{N}$, $133^{\circ} 44^{\prime} \mathrm{W}$; (map 12).

Descriptive name given in 1888 by $L t$. Comdr. C. M. Thomas, USN.

Shaseki Pass: pass, see Chilkoot Pass.

Shashamund Lake: lake, $1.3 \mathrm{mi}$. long, $0.5 \mathrm{mi} . \mathrm{S}$ of confluence of Chisana and Nabesna Rivers, $41 \mathrm{mi}$. SE of Tok, Yukon-Tanana High.; $63^{\circ}$. $02^{\prime} \mathrm{N}, 141^{\circ} 52^{\prime} \mathrm{W}$; BGN 1961; (map 85).

Indian name said to mean "duck lake"; reported by USGS in 1960.

Shasheki: pass, see White Pass. 
Shashgat Bay: bay, on SE coast of Kodiak I.; (map 34).

Native name recorded in 1805 by Lisianski (1814, p. 184-185). "Apparently an arm of Igak [Ugak] bay * * *" (Baker, 1906, p. 566). Location unknown.

Shasta, Mount: mountain, 4,100 ft., $1.7 \mathrm{mi}$. NE of head of Shoup Bay and $11 \mathrm{mi}$. NW of Valdez, Chugach Mts.; $61^{\circ} 10^{\prime} 05^{\prime \prime} \mathrm{N}, 146^{\circ}$ 33'55" W ; (map 68).

Prospectors' name derived from Mount Shasta, in California; reported in 1911 by C. E. Giffin, USGS.

Shasta, Mount: mountain, see Jackknife Mountain.

Shasta Creek: stream, flows SW $1.4 \mathrm{mi}$. to join Lucky Creek to form Harris Creek which flows to North Fork Kougarok River, $5 \mathrm{mi}$ NE of Harris Dome and $37 \mathrm{mi}$. NW of Imuruk Lake, Seward Penin. High.; $65^{\circ} 41^{\prime} \mathrm{N}, 164^{\circ}$ $27^{\prime} \mathrm{W}$; (map 110).

Prospectors' name reported in 1901 by T. G. Gerdine (in Collier, 1902, pl. 12), USGS.

Shatavanaktok River: stream, see Sagavanirktok River.

Shaviovia River: stream, see Shaviovik River.

Shaviovik Mound: pingo, elev. $80 \mathrm{ft}$., on Beaufort Sea coast, $5 \mathrm{mi}$. inland, $\mathrm{SW}$ of Tigvarvak I. and $\mathrm{W}$ of Shaviovik River, Arctic Plain; $70^{\circ} 08^{\prime} \mathrm{N}, 147^{\circ} 29^{\prime} \mathrm{W}$; (map 150).

Named and used as a triangulation station by Leffingwell (1919, p. 41) in 1911.

Shaviovik River: stream, heads at $69^{\circ} 14^{\prime} \mathrm{N}$, $147^{\circ} 00^{\prime} \mathrm{W}$, flows NE $75 \mathrm{mi}$. to Beaufort Sea between Foggy I. and Mikkelsen Bay, Arctic Plain; $70^{\circ} 12^{\prime} 20^{\prime \prime} \mathrm{N}, 147^{\circ} 16^{\prime} 30^{\prime \prime} \mathrm{W}$; BGN 1959; (map 150). Var. Savaovik River, Saviovic River, Saviovik River, Savitovik River, Shavioia River, West Fork Shaviovik River.

Eskimo name meaning "place where there is iron"; reported in 1901 as "Saviovic" by S. J. Marsh, prospector.

Shaviovik River: stream, see Juniper Creek.

Shavugavik Point: point of land, see Bullen Point.

Shaw, Cape: point of land, E tip of Atka I., Aleutian Is.; $52^{\circ} 18^{\prime} \mathrm{N}, 174^{\circ} 00^{\prime} \mathrm{W}$; (map 19).

Listed in the 1944 USC\&GS Aleutian Coast Pilot (p. 91).

Shaw-a-gan: locality, see Sukkwan.

Shaw Bay: bay, see Urilia Bay.

Shaw Creek: locality, on left bank of Shaw Creek at its junction with Tanana River, $11 \mathrm{mi}$. NW of Big Delta, Tanana Low.; $64^{\circ} 15^{\prime} 40^{\prime \prime} \mathrm{N}$, $146^{\circ} 06^{\prime} 30^{\prime \prime} \mathrm{W}$; (map 101).

Roadhouse reported by the Alaska Road Commission in 1932.

Shaw Creek: stream, flows SE $5 \mathrm{mi}$. to Kinegnak River, $5 \mathrm{mi}$. SE of Kemuk Mtn. and $26 \mathrm{mi}$. NE of Cape Newenham, Kilbuck-Kuskokwim Mts.; 58 $51^{\prime} 15^{\prime \prime} \mathrm{N}, 161^{\circ} 34^{\prime} 45^{\prime \prime} \mathrm{W}$; BCN 1938; (map 39).

Local name reported in 1938 by J. B. Mertie and Gerald FitzGerald, USGS.
Shaw Creek: stream, heads at $64^{\circ} 29^{\prime} \mathrm{N}, 145^{\circ} 05^{\prime}$ W, flows SW $40 \mathrm{mi}$. to Tanana River, $11 \mathrm{mi}$. NW of Big Delta, Tanana Low.; 64' $15^{\prime} 40^{\prime \prime}$ N, $146^{\circ} 06^{\prime} 30^{\prime \prime}$ W; (map 101). Var. Debetendig, Thompson Creek.

In 1902 Lt. G. S. Gibbs, USA called this stream Thompson Creek, but in 1904 L. M. Prindle, USGS, reported that the miners called it Shaw Creek. Its Indian name was "Debetendig" according to J. T. Geoghegan in 1904.

Shaw Creek Flats: flats, extend WSW $18 \mathrm{mi}$., along Shaw Creek from Gilles Creek to Tanana River, $5 \mathrm{mi}$. $\mathrm{N}$ of Big Delta, Tanana Low.; $64^{\circ} 15^{\prime} \mathrm{N}, 146^{\circ} 00^{\prime} \mathrm{W}$; (map 101).

Local name published in 1951 by USGS.

Shaw Island: island, $0.6 \mathrm{mi}$. long, in Cook Inlet, at head of Alaska Penin., in Katmai National Monument, Aleutian Ra.; 59 $00^{\prime} 15^{\prime \prime} \mathrm{N}, 153^{\circ}$ 23'00" W; BCN 1906; (map 51). Var. Ostrov Kamyshak, Ostrov Shunakhtuli, Schaws Insel, Shaws Island, Schunachtuli Island, Shunaktuli Island.

Named in 1794 "Shaw's Island" by Capt. George Vancouver. "Shown on Vancouver's Chart [of 1798] but not mentioned in the text" (Wagner, 1937, p. 416). Native name was published in 1847 as "Ostrov Shunakhtuli" on Russian Hydrog. Dept. Chart 1378; named "O[strov] Kamyshak" in 1849 by Capt. Tebenkov (1852, map 5), IRN.

Shaw Islands: islands, $0.6 \mathrm{mi}$. across, at mouth of Idaho Inlet, on $\mathbf{N}$ coast of Chichagof I., 2.4 mi. SE of Lacy Cove, Alex. Arch. ; 58 $12^{\prime} 10^{\prime \prime}$ N, $136^{\circ} 14^{\prime} 20^{\prime \prime} \mathrm{W}$; (map 10).

Named by E. F. Dickins, USC\&GS, probably for E. V. Shaw, a member of his party in 1902. The name was published on Chart 8304 in 1904.

Shaws Island: island, see Shaw Island.

Shayak Island: island, see Hog Island.

Shea Creek: stream, flows NW $0.7 \mathrm{mi}$. to Birch Creek which flows to Big Four Creek, $21 \mathrm{mi}$. $\mathrm{NE}$ of Solomon, Seward Penin. High.; 64 ${ }^{\circ} 50^{\prime}$ $\mathrm{N}, 164^{\circ} 08^{\prime} \mathrm{W}$; (map 95).

Prospectors' name reported on a 1902 prospectors' manuscript map.

Shea Roadhouse: locality, on Bering Sea coast, at mouth of Feather River, $37 \mathrm{mi}$. NW of Nome, Seward Penin. High.; $64^{\circ} 51^{\prime} \mathrm{N}, 166^{\circ} 24^{\prime} \mathrm{W}$; (map 94).

Site of a roadhouse reported in 1900 by $\mathrm{E}$. C. Barnard (in Brooks, 1901, pl. 17), USGS.

Shearwater Bay: $b a y$, extends NE $3 \mathrm{mi}$., off Kiliuda Bay, on SE coast of Kodiak I.; $57^{\circ} 20^{\prime} \mathrm{N}$, $152^{\circ} 55^{\prime} \mathrm{W}$; (map 34).

Descriptive name given by USC\&GS in 1904, "probably owing to the abundance of one or more of the many species of waterfowl to which the name is applied." The name probably refers to the slendor-billed Shearwater, Puffinus tenuirostris.

Shearwater Point: point of land, on $\mathrm{N}$ shore of Kiliuda Bay, at mouth of Shearwater Bay, on SE coast of Kodiak I.; $57^{\circ} 20^{\prime} \mathrm{N}, 152^{\circ} 58^{\prime} \mathrm{W}$; BGN 1933; ( $\operatorname{map} 34$ ). Bay.

Named by USC\&GS in 1933 for Shearwater
Sheba Mountain: mountain, 4,615 ft., $64 \mathrm{mi}$. SW of Eagle, Yukon-Tanana High.; $64^{\circ} 15^{\prime}$ N, $142^{\circ} 53^{\prime} \mathrm{W}$; (map 102). Var. Queen of Sheba Mountain.

Local name shown on an 1899 fieldsheet by W. J. Peters, USGS.

She Beaver: stream, see Beaver Slough.

Shedden, Point: point of land, on Chukchi Sea coast, entrance to Walakpa Bay, Arctic Plain; $71^{\circ} 09^{\prime} \mathrm{N}, 157^{\circ} 04^{\prime} \mathrm{W}$; (map 153).

Probably named by British naval officers engaged in the Franklin search expeditions, 1849-53, and first published on Brit. Adm. Chart 593. The name is not now used. (Baker, 1906).

Shed Mountain: mountain, 2,585 ft., on mainland between Nakat and Willard Inlets, Coast Mts.; $54^{\circ} 54^{\prime} 45^{\prime \prime} \mathrm{N}, 130^{\circ} 42^{\prime} 00^{\prime \prime} \mathrm{W}$; (map 2).

Named in 1883 by Lt. Comdr. H. E. Nichols, USN.

Shee-gar-rik-puk: stream, see Squirrel River.

Sheeleelictok: stream, see Squirrel River.

Shee-lee-lie-tok: stream, see Squirrel River.

Sheenjek Lake: lake, $1.4 \mathrm{mi}$. long, drains NE to Sheenjek River, $9.4 \mathrm{mi}$. SW of Table Mtn. and $45 \mathrm{mi}$. NE of Arctic Village, Brooks Ra.; $68^{\circ} 13^{\prime} \mathrm{N}, 143^{\circ} 48^{\prime} \mathrm{W}$; (map 137).

Local name reported in 1956 by USGS.

Sheenjek River: stream, heads at $69^{\circ} 00^{\prime} \mathrm{N}, 144^{\circ}$. $00^{\prime} \mathrm{W}$, flows S $200 \mathrm{mi}$. to Porcupine River, 23 mi. NE of Fort Yukon, Yukon Flats; $66^{\circ} 44^{\prime}$ $30^{\prime \prime} \mathrm{N}, 144^{\circ} 34^{\prime} 30^{\prime \prime} \mathrm{W}$; (map 119). Var. Salmon River.

Indian name published in 1895 by USC\&GS. J. H. Turner, USC\&GS, in 1889 called it "Salmon," presumably a translation of the Indian name.

Sheep Bay: bay, $4.5 \mathrm{mi}$. wide at $\mathrm{N}$ end of Orca Bay, 12 mi. NW of Cordova, Chugach Mts.; $60^{\circ} 38^{\prime} \mathrm{N}, 146^{\circ} 04^{\prime} \mathrm{W}$; (map 64). Var. Ensenada de Menendez, Jackson Bay.

Named in 1897 by Lt. Comdr. J. F. Moser, USN. This is probably the same bay called "Ensenada de Menendez" by Don Salvador Fidalgo on June 8, 1790, when he took possession; named for Salvador Menéndez Valdés, one of his officers.

Sheep Bay: bay, see Midway Bay.

Sheep Creek : village, see Thane.

Sheep Creek: stream, flows SW $4 \mathrm{mi}$. to River Cove in Nikolski Bay, on $\mathrm{S}$ coast of Umnak I., Aleutian Is.; $52^{\circ} 57^{\prime} 22^{\prime \prime} \mathrm{N}, 168^{\circ} 51^{\prime} 05^{\prime \prime} \mathrm{W}$; (map 21).

Name published by USC\&GS in 1944 Aleutian Coast Pilot (p. 67).

Sheep Creek: stream, heads in glacier, flows mostly W $3 \mathrm{mi}$. to Gastineau Channel at Thane, $4.5 \mathrm{mi}$. SE of Juneau, Coast Mts.; $58^{\circ} 15^{\prime} 40^{\prime \prime} \mathrm{N}, 134^{\circ} 19^{\prime} 30^{\prime \prime} \mathrm{W}$; (map 11).

Named in 1880 by Joe Juneau and Richard Harris. "We went about four miles further south to another nice looking creek we named Sheep Creek as we killed several mountain sheep, hence the name." DeArmond, 1957, p. 39).

Sheep Creek: stream, on Kenai Penin., flows W $18 \mathrm{mi}$. to NE end of Kachemak Bay, $24 \mathrm{mi}$. 
NE of Homer, Chugach Mts.; 59 $47^{\prime} 40^{\prime \prime} \mathrm{N}$, $150^{\circ} 56^{\prime} 30^{\prime \prime} \mathrm{W}$; (map 50).

Name reported by R. W. Stone (in Moffit, 1906, pl. 3), USGS.

Sheep Creek: stream, heads on NE slope of Carbon Mtn., flows $3 \mathrm{mi}$. to 1950 terminus of Bering Glacier, $4 \mathrm{mi}$. E of Doughton Peak and $68 \mathrm{mi}$. $\mathrm{E}$ of Cordova, Chugach Mts.; $60^{\circ}$ $26^{\prime} 20^{\prime \prime} \mathrm{N}, 143^{\circ} 46^{\prime} 30^{\prime \prime} \mathrm{W}$; (map 65).

Local name reported in 1905 by G. C. Martin, USGS.

Sheep Creek: stream, flows SW $14 \mathrm{mi}$. to Copper River, $20 \mathrm{mi}$. NW of Cordova, Chugach Mts.; $60^{\circ} 27^{\prime} \mathrm{N}, 144^{\circ} 50^{\prime} \mathrm{W}$; (map 64).

Local name reported in 1905 by G. C. Martin (in Brooks and others, 1906, pl. 16), USGS.

Sheep Creek: stream, heads in a glacier, trends SE $5 \mathrm{mi}$. to Lowe River, $0.5 \mathrm{mi}$. SE of Wortmanns and $15 \mathrm{mi}$. E of Valdez, Chugach Mts.; $61^{\circ} 06^{\prime} 15^{\prime \prime} \mathrm{N}, 145^{\circ} 48^{\prime} 30^{\prime \prime} \mathrm{W}$; (map 68).

Local name published in the 1950's by USGS.

Sheep Creek: stream, flows $3.6 \mathrm{mi}$. SW to Young Creek, $4 \mathrm{mi}$. W of Big Bend Lakes and $23 \mathrm{mi}$. SE of McCarthy, St. Elias Mts.; 61 ${ }^{\circ} 13^{\prime} 05^{\prime \prime}$ $\mathrm{N}, 142^{\circ} 24^{\prime} 45^{\prime \prime} \mathrm{W}$; (map 67$)$.

Local name obtained by USGS and published on maps since 1954 .

Sheep Creek: stream, flows $3.3 \mathrm{mi}$. S to Kuskulana River W of Clear Creek, $32 \mathrm{mi}$. NW of McCarthy, Wrangell Mts.; $61^{\circ} 34^{\prime} \mathrm{N}, 143^{\circ} 50^{\prime}$ W ; (map 67).

Local name reported in 1921 by F. $H$. Moffit, USGS.

Sheep Creek: stream, heads $\mathrm{N}$ of Alice Peak, flows N $2.5 \mathrm{mi}$. to Kotsina River, $3.2 \mathrm{mi}$. ESE of terminus of Long Glacier and $82 \mathrm{mi}$. ENE of Valdez, Wrangell Mts. ; $61^{\circ} 42^{\prime} 40^{\prime \prime} \mathrm{N}, 144^{\circ}$ $06^{\prime} 15^{\prime \prime} \mathrm{W}$; (map 68).

Prospectors' name reported in 1900 by T. G. Gerdine, USGS, (Baker, 1906). Local name published in the 1950's by USGS.

Sheep Creek: stream, flows N $5 \mathrm{mi}$. to White River, 46 mi. NE of McCarthy, St. Elias Mts.; $61^{\circ} 43^{\prime} \mathrm{N}, 141^{\circ} 40^{\prime} \mathrm{W}$; (map 67).

Local name reported by Capps (1916, pl. 1), USGS.

Sheep Creek: stream, flows S $4.8 \mathrm{mi}$. to Caribou Creek 53 mi. NE of Palmer, Talkeetna Mts.; $61^{\circ} 56^{\prime} 15^{\prime \prime} \mathrm{N}, 147^{\circ} 40^{\prime} 30^{\prime \prime} \mathrm{W}$; (map 69).

Name used by local prospectors; reported in 1906 by T. G. Gerdine and R. H. Sargent, USGS.

Sheep Creek: stream, heads in glacier, in Talkeetna Mts., flows SW $40 \mathrm{mi}$. to Sheep Creek Slough $1.8 \mathrm{mi}$. N of its junc. with Susitna River, Cook Inlet Low.; 61 $59^{\prime} 35^{\prime \prime} \mathrm{N}, 150^{\circ}$ $04^{\prime} 00^{\prime \prime}$ W; BGN 1954; (map 70). Var. Montana Creek.

Name shown on 1916 railroad location manuscript map.

Sheep Creek: stream, heads in Teocalli Mts., flows SE $8.5 \mathrm{mi}$. to Happy River, Ptarmigan Valley, $100 \mathrm{mi}$. SE of McGrath, Alaska Ra.; $60^{\circ} 08^{\prime} 30^{\prime \prime} \mathrm{N}, 153^{\circ} 02^{\prime} 00^{\prime \prime} \mathrm{W}$; (map 80).

Local name reported in 1931 by USGS.
Sheep Creek: stream, heads at glacier terminus in Nutzotin Mts., flows N $13 \mathrm{mi}$. to Chisana River, Alaska Ra.; 62 $17^{\prime} 00^{\prime \prime} \mathrm{N}, 141^{\circ} 48^{\prime} 45^{\prime \prime}$ W; (map 84).

Local name reported by USGS in 1960.

Sheep Creek: stream, heads at Sheep Glacier terminus, flows NE $4 \mathrm{mi}$. to Boulder Creek, $18 \mathrm{mi}$. SE of Chistochina, Wrangell Mts.; $62^{\circ} 24^{\prime} 00^{\prime \prime} \mathrm{N}, 144^{\circ} 14^{\prime} 30^{\prime \prime} \mathrm{W}$; (map 83).

Local name reported in 1959 by USGS. See Sheep Glacier.

Sheep Creek: stream, heads $14 \mathrm{mi}$. S of Farewell Airport, flows NW 50 mi. to Pitka Fork Middle Fork Kuskokwim River $15 \mathrm{mi}$. SE of its junc. with Middle Fork, $39 \mathrm{mi}$. SE of McGrath, Kuskokwim Low.; $62^{\circ} 46^{\prime} 30^{\prime \prime} \mathrm{N}, 154^{\circ} 29^{\prime} 20^{\prime \prime}$ W; (map 80).

Local name reported in 1940 by USGS.

Sheep Creek: stream, flows NE $7 \mathrm{mi}$. to Tanana River, $14 \mathrm{mi}$. W of Tanacross, Alaska Ra.; $63^{\circ} 25^{\prime} 30^{\prime \prime} \mathrm{N}, 143^{\circ} 48^{\prime} 00^{\prime \prime} \mathrm{W}$; (map 85).

Local name reported by USGS in 1964.

Sheep Creek: stream, heads at glacier, flows NE $8 \mathrm{mi}$. to Little Gerstle River, $35 \mathrm{mi}$. SE of Delta Junction, Alaska Ra.; $63^{\circ} 40^{\prime} 25^{\prime \prime} \mathrm{N}$, 144 '38'30" W; BGN 1937; (map 86).

Local name reported on a 1927 manuscript map of the Endicott and Haley hunting expedition.

Sheep Creek: stream, flows NE 1.5 to Nenana River, $18 \mathrm{mi}$. S of Healy, Alaska Ra.; $63^{\circ}$ $47^{\prime} 40^{\prime \prime} \mathrm{N}, 148^{\circ} 55^{\prime} 20^{\prime \prime} \mathrm{W}$; (map 87).

Local name reported in 1950 by USGS.

Sheep Creek: stream, flows NW $8 \mathrm{mi}$. to Wood River, $40 \mathrm{mi}$. NE of Healy, Alaska Ra.; $63^{\circ}$ $59^{\prime} 40^{\prime \prime} \mathrm{N}, 147^{\circ} 43^{\prime} 10^{\prime \prime} \mathrm{W}$; (map 87).

Prospectors' name shown on a 1910 fieldsheet by J. W. Bagley, USGS; published by Capps (1912, pl. 1), USGS.

Sheep Creek: stream, flows $\mathrm{N} 7 \mathrm{mi}$. to join Moose Creek, $46 \mathrm{mi}$. SE of Nenana, Alaska Ra.; 64 $01^{\prime} \mathrm{N}, 148^{\circ} 12^{\prime} \mathrm{W}$; (map 100).

Named by prospectors; reported in 1906 by L. M. Prindle (in Brooks and others, 1907, pl. 4), USGS.

Sheep Creek: stream, flows NE $3.6 \mathrm{mi}$. to Gold Stream Creek, $3.8 \mathrm{mi}$. NE of Ester Dome and $9 \mathrm{mi}$. NW of Fairbanks, Yukon-Tanana High.; $64^{\circ} 55^{\prime} \mathrm{N}, 17^{\circ} 58^{\prime} \mathrm{W}$; (map 100$)$.

Named by prospectors and shown on a manuscript map in 1905 by C. W. Joint.

Sheep Creek: stream, flows NE $13 \mathrm{mi}$. to Birch Creek, $37 \mathrm{mi}$. SW of Circle, Yukon-Tanana High.; $65^{\circ} 19^{\prime} 30^{\prime \prime} \mathrm{N}, 144^{\circ} 31^{\prime} 45^{\prime \prime} \mathrm{W}$; (map 104).

Named by prospectors; reported in 1904 by D. C. Witherspoon, USGS.

Sheep Creek: stream, flows NW $10 \mathrm{mi}$. to Beaver Creek, $45 \mathrm{mi}$. NE of Livengood, Yukon-Tanana High.; $65^{\circ} 44^{\prime} 15^{\prime \prime} \mathrm{N}, 147^{\circ} 06^{\prime} 00^{\prime \prime} \mathrm{W}$; (map 105).

Named by prospectors; published in 1906 by USGS.

Sheep Creek: stream, flows NW $4 \mathrm{mi}$. to Middle Fork Koyukuk River, $1 \mathrm{mi}$. $\mathrm{S}$ of mouth of Gold Creek and $37 \mathrm{mi}$. W of Chandalar, Brooks Ra.; $67^{\circ} 30^{\prime} 10^{\prime \prime} \mathrm{N}, 149^{\circ} 52^{\prime} 00^{\prime \prime} \mathrm{W}$; (map 123).
Prospectors' name obtained in 1909 by A. G. Maddren (in Brooks and others, 1910, pl. 7), USGS.

Sheep Creek: stream, flows SW $6.5 \mathrm{mi}$., $\mathrm{N}$ of Gunsight Mtn., to John River, $9 \mathrm{mi}$. S of mouth of Wolverine Creek and $54 \mathrm{mi}$. W of Wiseman, Brooks Ra.; $67^{\circ} 30^{\prime} \mathrm{N}, 152^{\circ} 08^{\prime} \mathrm{W}$; (map 124).

Local name obtained in 1956 by USGS topographers.

Sheep Creek: stream, flows S $7.3 \mathrm{mi}$., W of Horace Mtn., to Robert Creek, $21 \mathrm{mi}$. WNW of Chandalar, Brooks Ra.; $67^{\circ} 38^{\prime} \mathrm{N}, 149^{\circ} 11^{\prime}$ W; (map 123). Var. Spruce Creek.

Name reported in 1931 by Marshall (1934, pl. 6).

Sheep Creek: stream, in Baird Mts., flows SW $10 \mathrm{mi}$. to Salmon River, $14 \mathrm{mi}$. S of Kanatok Mtn., 49 mi. NE of Kiana, Brooks Ra.; $67^{\circ} 38^{\prime}$ N, $159^{\circ} 48^{\prime} \mathrm{W}$; (map 127$)$.

Local name reported in 1955 by the U.S. Army Corps of Engineers.

Sheep Creek: stream, see Sheep River.

Sheep Creek: stream, see Tatonduk River.

Sheep Creek: stream, see Trembley Creek.

Sheep Creek: stream, see Willow Creek.

Sheep Creek Basin: valley, $1 \mathrm{mi}$--long, on Sheep Creek, $0.7 \mathrm{mi}$. $\mathrm{N}$ of Thane and $4 \mathrm{mi}$. SE of Juneau, Coast Mts. ; $58^{\circ} 16^{\prime} 15^{\prime \prime} \mathrm{N}, 134^{\circ} 19^{\prime} 15^{\prime \prime}$ W; (map 11).

Miners' name derived from Sheep Creek (DeArmond, 1957, p. 39).

Sheep Creek Divide: ridge, $3 \mathrm{mi}$. long, extends $\mathrm{NE}$ from Mount Roberts, $5 \mathrm{mi}$. $\mathbf{E}$ of Juneau, Coast Mts.; $58^{\circ} 17^{\prime} 30^{\prime \prime}$ N, $138^{\circ} 18^{\prime} 00^{\prime \prime}$ W; (map 11).

Name used by miners; published by Spencer and Wright (1906, pl. 15), USGS.

Sheep . Fork: stream, flows $\mathrm{N} 3 \mathrm{mi}$. to Carlson Creek, $2.6 \mathrm{mi}$. W of Sunny Cove and $8 \mathrm{mi}$ E of Juneau, Coast Mts.; $58^{\circ} 19^{\prime} 15^{\prime \prime} \mathrm{N}$, $134^{\circ} 12^{\prime} 30^{\prime \prime} \mathrm{W}$; ( $\operatorname{map} 11$ ).

Local name published in 1952 by USGS.

Sheep Glacier: glacier, heads at glacier on Mount Sanford and trends NW $5 \mathrm{mi}$. to its 1959 terminus at head of Sheep Creek $19 \mathrm{mi}$. SE of Chistochina, Wrangell Mts.; $62^{\circ} 21^{\prime} \mathrm{N}$, $144^{\circ} 16^{\prime} \mathrm{W}$; (map 83).

Local name reported in 1959 by USGS. Probably named for the number of mountain sheep (Ovis dalli) in the area.

Sheep Gulch: ravine, extends $0.9 \mathrm{mi}$. S to Rex Creek $3 \mathrm{mi}$. NE of head of Chititu Creek and $16 \mathrm{mi}$. SE of McCarthy, St. Elias Mts. $61^{\circ} 19^{\prime} 27^{\prime \prime} \mathrm{N}, 142^{\circ} 30^{\prime} 30^{\prime \prime} \mathrm{W}$; (map 67).

Local name recorded in 1902 by G. W. Easterly of Valdez.

Sheep Gulch: ravine, extends $\mathrm{N}-\mathrm{S} 2.5 \mathrm{mi}$. on stream $0.4 \mathrm{mi}$. N of its junc. with Chichokna River, $84 \mathrm{mi}$. NE of Valdez, Wrangell Mts. $61^{\circ} 57^{\prime} 30^{\prime \prime} \mathrm{N}, 144^{\circ} 27^{\prime} 00^{\prime \prime} \mathrm{W}$; (map 68).

Local name published in the 1950's by USGS.

Sheep Island: island, $250 \mathrm{ft}$. across, in Galankin Is., $1.5 \mathrm{mi}$. S of Sitka, off $W$ coast of Baranof

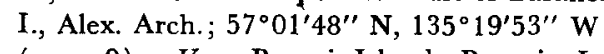
(map 9). Var. Barani Island, Baranie Is land, Ostrov Baraney. 
This is an 1882 translation by USC\&GS of the name given in 1809 by the Russian navigator Ivan Vasiliev the first; reported by Lt. Sarichev (1826, map 19), IRN, as "O[strov] Baraney."

Sheep Island: island, $0.4 \mathrm{mi}$. long. in Sitkalidak Strait, at mouth of Midway Bay, between Sitkalidak I. and SE coast of Kodiak I.; $57^{\circ}$. $13^{\prime} 00^{\prime \prime} \mathrm{N}, 153^{\circ} 14^{\prime} 20^{\prime \prime} \mathrm{W}$; (map 34 ).

Local name published in 1943 by USC\&GS.

Sheep Island: island, $0.7 \mathrm{mi}$. long, at head of Northeast Arm Uganik Bay, on $\mathbf{N}$ coast of Kodiak I. ; $57^{\circ} 43^{\prime} 00^{\prime \prime} \mathrm{N}, 153^{\circ} 19^{\prime} 30^{\prime \prime} \mathrm{W}$; (map $34)$.

Local name published in 1943 by USC\&GS.

Sheep Island: island, $1.3 \mathrm{mi}$. long, near mouth of Wood River, $3 \mathrm{mi}$. N of Dillingham, Bristol Bay Low.; $59^{\circ} 05^{\prime} \mathrm{N}, 158^{\circ} 27^{\prime} \mathrm{W}$; BGN 1932 ; (map 52).

Local name written "Ke-ik-dok," or "Sheep Id." by H. C. Fassett, USBF, in 1910.

Sheep Lake: lake, $0.4 \mathrm{mi}$. across, $\mathrm{W}$ of Big Lake, on NE end of St. Paul I., in Pribilof Is.; $57^{\circ}$. $12^{\prime} 20^{\prime \prime} \mathrm{N}, 170^{\circ} 12^{\prime} 20^{\prime \prime} \mathrm{W}$; (map 38).

Local name reported by Joseph StanleyBrown, USGS, in 1891.

Sheep Lake: lake, $0.6 \mathrm{mi}$. long, on Kenai Penin., in Kenai Mts. $2.3 \mathrm{mi}$. E of Arctic Lake and $48 \mathrm{mi}$. SE of Kenai, Chugach Mts. ; $60^{\circ} 02^{\prime} 10^{\prime \prime}$ $\mathrm{N}, 150^{\circ} 22^{\prime} 15^{\prime \prime} \mathrm{W}$; (map 62).

Named about 1963 by officials of Kenai National Moose Range, for administrative purposes.

Sheep Lake: lake, $0.5 \mathrm{mi}$. long, in Ptarmigan Valley, $0.4 \mathrm{mi}$, $\mathrm{N}$ of junc. of Sheep Creek and Happy River, $100 \mathrm{mi}$. SE of McGrath, Alaska Ra.; $62^{\circ} 09^{\prime} \mathrm{N}, 153^{\circ} 02^{\prime} \mathrm{W}$; (map 80).

Local name obtained in 1958 by USGS.

Sheep Lake: lake, $1.2 \mathrm{mi}$. long, at head of Goat Creek, $8 \mathrm{mi}$. S of Tanada Lake, Wrangell Mts.; $62^{\circ} 16^{\prime} 00^{\prime \prime} \mathrm{N}$; $143^{\circ} 22^{\prime} 30^{\prime \prime} \mathrm{W}$; (map 84).

Local name reported by USGS in 1960.

Sheep Mountain: mountain, 4,238 ft., $3 \mathrm{mi}$. S of Olds Mtn. and $1 \mathrm{mi}$. E of Juneau, Coast Mts.; $58^{\circ} 17^{\prime} 30^{\prime \prime} \mathrm{N}, 134^{\circ} 18^{\prime} 00^{\prime \prime} \mathrm{W}$; (map 11).

Local name reported by W. J. Peters, USGS, and published in 1902. In the 1800's mountain goats, sometimes called sheep by the miners, frequented this area, hence the name (DeArmond, 1957, p. 39).

Sheep Mountain: mountain, 6,250 ft., on Kenai Penin. along Seward Highway, between Victor Creek and Paradise Valley Trail, $16 \mathrm{mi}$. NE of Seward, Chugach Mts.; $60^{\circ} 20^{\prime} 20^{\prime \prime} \mathrm{N}, 149^{\circ}$. $16^{\prime} 00^{\prime \prime} \mathrm{W}$; BGN 1960; (map 63). Var. Wolcot Mountain, Wolcott Mountain.

Local name reported by Grant and Higgins (1910, pl. 2), USGS. "It received its name due to the fact that in the early days sheep could be seen on the side of the mountain at almost any time."

Sheep Mountain: mountain, 6,100 ft., $1.2 \mathrm{mi}$. NNW of Alice Peak and $80 \mathrm{mi}$. ENE of Valdez, Wrangell Mts. ; $61^{\circ} 40^{\prime} 55^{\prime \prime} \mathrm{N}, 144^{\circ} 07^{\prime} 50^{\prime \prime}$ $\mathrm{W}$; (map 68).

Local name reported by F. H. Moffit (in Brooks and others, 1915, pl. 5), USGS.
Sheep Mountain: mountain, 6,300 ft., extends NE 11 mi., along Glenn Highway, between Caribou Greek and Tahneta Pass, $50 \mathrm{mi}$. NE of Palmer, Talkeetna Mts. ; $61^{\circ} 50^{\prime} \mathrm{N}, 147^{\circ} 31^{\prime}$ W; (map 69).

Local name reported in 1906 by Sidney Paige and Adolph Knopf (in Brooks and others, 1907, p. 116), USGS.

Sheep Mountain: peak, 3,325 ft., $21 \mathrm{mi}$. SE of Mount Kelly, $51 \mathrm{mi}$. N of Noatak, Brooks Ra. ; $68^{\circ} 18^{\prime} 40^{\prime \prime} \mathrm{N}, 162^{\circ} 55^{\prime} 40^{\prime \prime} \mathrm{W}$; BGN 1965; (map 130)

Name proposed in 1965 by geologists of the B. P. Exploration Co. Inc., presumably referring to the Dall Sheep (Ovis dalli dalli).

Sheep Point: point of land, on N shore of Orca Bay, $10 \mathrm{mi}$. NW of Cordova, Chugach Mts.; $60^{\circ} 37^{\prime} \mathrm{N}, 146^{\circ} 00^{\prime} \mathrm{W}$; (map 64).

Named in 1897 by Lt. Comdr. J. F. Moser, USN.

Sheep Point: point of land, see Otter Point.

Sheep River: stream, flows SW $4 \mathrm{mi}$. to Sahlin Lagoon, $13 \mathrm{mi}$. NW of Cordova, Chugach Mts.; $60^{\prime} 43^{\prime} \mathrm{N}, 145^{\circ} 54^{\prime} \mathrm{W}$; (map 64).

Name published in 1950 by USGS; derived from Sheep Bay to which the stream flows.

Sheep River: stream, heads at glacier, flows NW $41 \mathrm{mi}$. to Talkeetna River, $11 \mathrm{mi}$. NE of Talkeetna, Talkeetna Mts.; $62^{\circ} 22^{\prime} 25^{\prime \prime} \mathrm{N}$, $149^{\circ} 47^{\prime} 00^{\prime \prime}$ W; (map 82). Var. Sheep Creek.

Local name recorded in 1906 by T. G. Gerdine and R. H. Sargent, USGS, as "Sheep Creek."

Sheep Valley: ravine, extends $1.4 \mathrm{mi}$, at head of Young Creek, $19 \mathrm{mi}$. NE of Palmer, Talkeetna Mts., $61^{\circ} 49^{\prime} 30^{\prime \prime} \mathrm{N}, 148^{\circ} 43^{\prime} 30^{\prime \prime} \mathrm{W}$; (map 69).

Local name reported in 1952 by USGS.

Sheer-off-there Rock: islands, see Alargate Rocks.

Sheeshaldenskoi: locality, see Sisaguk.

Shefflin Creek: stream, see Schieffelin Creek.

Sheflin Creek: stream, see Schieffelin Creek.

Shekak Sound: water passage, see Hoonah Sound.

Shekesti, Mys: point of land, see Shekesti, Point.

Shekesti, Point: point of land, on $\mathrm{W}$ shore of Wrangell Harbor at Wrangell, $N$ coast of Wrangell I., Alex. Arch.; $56^{\circ} 27^{\prime} 55^{\prime \prime} \mathrm{N}, 132^{\circ}$ $23^{\prime} 00^{\prime}$ W; (map 6). Var. Mys Shekesti, Point Zhekiski.

Named in 1834 by Capt. Lt. D. F. Zarembo, published in 1848 as "Mys Shekesti," or "Shekesti Cape," on Russian Hydrog. Dept. Chart 1396.

She-kluck-she-uck: stream, see Pick River.

Sheklukshuk Range: mountain range, $1,500 \mathrm{ft}$., trends SE $44 \mathrm{mi}$. from junc. of Kugarak and Rabbit Rivers, $16 \mathrm{mi}$. SW of Shungnak, Hogatza High.; $66^{\circ} 40^{\prime} \mathrm{N}, 157^{\circ} 30^{\prime} \mathrm{W}$; (map 115).

Eskimo name reported in 1901 by W. G. Mendenhall, USGS

Sheldon, Mount: mountain, 5,670 ft., in Mount McKinley National Park, on W bank of Toklat River, $13 \mathrm{mi}$. NNE of Eielson Visitor
Center, Alaska Ra.; $63^{\circ} 35^{\prime} 30^{\prime \prime} \mathrm{N}, 150^{\circ} 07^{\prime} 00^{\prime \prime}$ W; (map 88)

Name shown on a 1916 fieldsheet by C. E. Giffin, USGS. Named for Charles Sheldon, 1867-1928, noted author and hunter-naturalist, who studied Dall sheep and other wildlife in the Mount McKinley area in 1906, 1907 , and 1908. He was the prime figure in Mount Kinley's establishment as a National Park. See Mount McKinley National Park.

Sheldon Cove: cove, $0.2 \mathrm{mi}$. across, in Donkey Bay, in NW part of Pybus Bay, on SE coast of Admiralty I., Alex. Arch.; $57^{\circ} 20^{\prime} \mathrm{N}, 134^{\circ}$. 09' W; (map 9).

Local name reported in 1951 by USGS.

Sheldon Creek: stream, in Mount McKinley National Park, flows S and E $2.5 \mathrm{mi}$. from Mount Sheldon to Toklat River, $13 \mathrm{mi}$. NE of Eielson Visitor Center, Alaska Ra.; $63^{\circ} 34^{\prime} 45^{\prime \prime} \mathrm{N}$, $150^{\circ} 02^{\prime} 30^{\prime \prime} \mathrm{W}$; (map 88).

Local name reported in 1954 by USGS.

Sheldon Point: village. pop. 110, on Sheldon Point, $18 \mathrm{mi}$. SW of Kwiguk, Yukon-Kuskokwin Delta, 62 $32^{\prime} \mathrm{N}, 164^{\circ} 52^{\prime} \mathrm{W}$; (map 77). Var. Sheldons Point.

Eskimo village named for the nearby point of land. Its population in 1950 was 43 ; not listed in prior censuses.

Sheldon Point: point of land, on left bank of Kwemeluk Pass, $18 \mathrm{mi}$. SW of Kwiguk, Yukon-Kuskokwim Delta; $62^{\circ} 32^{\prime} \mathrm{N}, 164^{\circ} 52^{\prime} \mathrm{W}$; (map 77). Var. Noona-mekrot, Nunamekrot.

Locally named for "a man named Sheldon [cnna], who had a saltry on the point." Its Eskimo name is "Nunamekrot," meaning "long land," according to USC\&GS in 1952. Sheldons Point: village, see Sheldon Point. Shelekhovo, Lake: lake, see Iliamna Lake.

Shelekof, Lake: lake, see Iliamna Lake.

Shelf Creek: stream, on Granite Mtn., flows $N 1$ mi. to Rhoads Creek, $18 \mathrm{mi}$. SE of Delta Junction, Alaska Ra.; $63^{\circ} 48^{\prime} 12^{\prime \prime} \mathrm{N}, 145^{\circ} 25^{\prime}$ $55^{\prime \prime} \mathrm{W}$; (map 86).

Named between 1948 and 1955 by T. L. Péwé, USGS.

Shelikhoff Strait: water passage, see Shelikof Strait.

Shelikhova, Zaliv: bay, see Shelikof Bay.

Shelikof Bay: bay, $4.5 \mathrm{mi}$. across, on $\mathrm{W}$ coast of Kruzof I., Alex. Arch.; $57^{\circ} 08^{\prime} \mathrm{N}, 135^{\circ} 49^{\prime} \mathrm{W}$; $B G N$ 1897; (map 9). Var. Ensenada de Guadalupe, Port Mariy, Port Mary, Port Meri, Puerto de Guadalupe, Shelikoff Bay, Shelikova Gulf, Silk Bay, Zaliv Shelikhova.

This feature was probably named in the 1850's by the Russian American Company for Grigori Ivanovich Shelikov, founder of the Russian American Company. The name is shown on a Russian American Company map of 1850 as "Port Meri ili Zal[iv] Shelikhova," meaning "Port Mary or Shelikov Bay." The name "Port Mary" was given in 1794 by Capt. George Vancouver, RN; "Ensenada de Guadalupe," i.e. "Guadalupe Entrance," on August 17, 1775, by Don Juan de la Bodega y Quadra (Wagner, 1937, p. 460). See Shelikof Strait.

Shelikoff Bay: bay, see Shelikof Bay. 
Shelikoff Strait: water passage, see Shelikof Strait.

Shelikof Island: island, $2 \mathrm{mi}$. across, in Soda Bay, off $W$ coast of Prince of Wales I., Alex. Arch.; $55^{\circ} 15^{\prime} 20^{\prime \prime} \mathrm{N}, 133^{\circ} 01^{\prime} 15^{\prime \prime} \mathrm{W}$; (map 4).

Named in 1928 by USFS for Grigori Ivanovich Shelikov, who established the first permanent Russian settlement in Alaska in 1784. See Shelikof Strait.

Shelikof Strait: water passage, $20 \mathrm{mi}$. wide, extends SW $150 \mathrm{mi}$. from Barren Is. between Alaska Penin. and Kodiak I., $57^{\circ} 30^{\prime} \mathrm{N}, 155^{\circ}$ $00^{\prime}$ W; (map 35). Var. Aliaskinskoi, Proliv Alyaskinskoy ili Shelikova, Canal de Flores, Chélékhoff Strait, Helikoff Strait, Ismaeloff Strait, Kenai Strait, Prolov Kenayskoy, Petrie's Strait, Prolov Shelekova, Shelikhoff Strait, Shelikoff Strait, Smokey Bay, Whitsuntide Bay.

Named "P[roliv] Shelekova," or "Shelikov's Strait," by Ens. Vasiliev in 1831 or 1832 (Lutke, 1836, p. 274) for Grigori Ivanovich Shelikov, a Siberian shipbuilder and merchant. This feature was called. Smokey Bay in 1778 by Capt. Cook $(1785$, v. 2, p. 385) RN. Capt. Meares (1790, pl. 11), named it "Petrie's Strait" in 1786 for William Petrie. The strait was called "Canal de Flores," or "strait of flowers," by D. A. Galiano (1802, map 3) -nd "Prol[iv] Kenayskoy," or "Kenai Strait," by Lt. Sarichev (1826, map 3), IRN. The Russian American Company called it "Proliv Alyaskinskoy ili Shelikova," "Alaska or Shelikov's Strait," in 1849 Shelikov (Bancroft, 1886, p. 182) "has justly been called the founder of the Russian colonies on this continent." He formed several partnerships in the fur trading business. They led to his expedition across the Pacific in 1783 to establish a permanent settlement in order to protect and further the interests of the fur hunters and traders. His expedition led to the first permanent Russian settlement of Alaska in 1784. He named the settlement after his ship, the Three Saints (Chevigny, 1965, p. 52-55).

Shelikova Gulf: $b a y$, see Shelikof Bay.

Shellabarger Pass: pass, 3,300 ft., at head of Dillinger River, $86 \mathrm{mi}$. NW of Talkeetna, Alaska Ra.; $62^{\circ} 31^{\prime} 30^{\prime \prime} \mathrm{N}, 152^{\circ} 47^{\prime} 00^{\prime \prime} \mathrm{W}$ (map 81).

Mountain climbers' name published in the late 1940 's.

Shell Bay: bay, see Rakovoi Bay.

Shell Creek: stream, flows SE through Shell Lake, $12 \mathrm{mi}$. to Skwentna River, $56 \mathrm{mi}$. NW of Tyonek, Alaska Ra.; 61 ${ }^{\circ} 52^{\prime} 30^{\prime \prime} \mathrm{N}, 151^{\circ} 25^{\prime}$ $00^{\prime \prime} \mathrm{W}$; (map 70).

Named in 1898 by Spurr (1900, map 6) USGS, for P. G. Shell who prospected in the region in 1887.

Shell Hills: hills, extend $10 \mathrm{mi}$. along $\mathrm{E}$ bank of Shell Creek and Shell Lake, $57 \mathrm{mi}$. NW of Tyonek, Alaska Ra.; 61 ${ }^{\circ} 57^{\prime} 30^{\prime \prime}$ N, $151^{\circ} 27^{\prime}$ $00^{\prime} \mathrm{W} ;(\operatorname{map} 70)$
Named in 1898 by Spurr (1900, map 6), USGS, for P. G. Shell who prospected in the region in 1887 .

Shell Island: island, see Mogilnoi Island.

Shellman Creek: stream, flows SW $12 \mathrm{mi}$. to North Fork Kuskokwim River, $57 \mathrm{mi}$. NE of Medfra, Kilbuck-Kuskokwim Mts. ; $63^{\circ} 41^{\prime}$ N, $153^{\circ} 26^{\prime} \mathrm{W}$; (map 89)

Local name reported in 1958 by USGS.

Shellman River: stream, see Shelman Creek.

Shell Mountain: mountain, 1,608 ft., on central Kruzof I., 14 mi. NW of Sitka, Alex. Arch.; $57^{\circ} 07^{\prime} 30^{\prime \prime} \mathrm{N}, 135^{\circ} 41^{\prime} 00^{\prime \prime} \mathrm{W}$; (map 9).

Local name reported in 1951 by USGS.

Shelman Creek: stream, flows SW 3 mi. to Port Clarence at Teller Mission, $6 \mathrm{mi}$. NW of Teller, Seward Penin. High.; $65^{\circ} 20^{\prime}$ N, $166^{\circ}$ 29' W; (map 111). Var. Mission Creek, Schellman River, Shellman River.

A "Schellman River" is shown in this area on the 1900 "Map of Nome Peninsula" by J. M. Davidson and B. D. Blakeslee. Reported as "Mission Creek" in 1900 by T. G. Gerdine (in Brooks, 1901, pl. 17), USGS.

Shelockham, Lake: lake, see Shelokum, Lake.

Shelockum, Lake; lake, see Shelokum, Lake.

Shelokum, Lake: lake, on Gleveland Penin., NW of Bailey Bay, Alex. Arch.; 55 $59^{\prime}$ N, $131^{\circ} 39^{\prime}$ W; BGN 1923; (map 3). Var. Lake Shelockham, Lake Shelockum

This is a Chinook word, meaning "lookingglass" or "mirror"; spelled "Shelockham" by G. H. Canfield (in Brooks and others, 1916, pl. 4), USGS

Shelter Bay: bight, $3.4 \mathrm{mi}$. wide, off Cook Inlet, on W shore of Fire I., $12 \mathrm{mi}$. SW of Anchorage, Cook Inlet Low.; $61^{\circ} 08^{\prime} 45^{\prime \prime} \mathrm{N}, 150^{\circ} 15^{\prime} 30^{\prime \prime}$ W; BGN 1916; (map 70).

Local name published in 1916 by USC\&GS.

Shelter Bay: estuary, at $\mathrm{N}$ end of Evans I., extends N $2.5 \mathrm{mi}$. to Knight Island Passage, 12 mi. SE of Chenega, Chugach Mts.; $60^{\circ} 08^{\prime} \mathrm{N}$, $147^{\circ} 57^{\prime} \mathrm{W}$; ( $\operatorname{map} 63$ ).

Local name reported in 1908 by U. S. Grant and D. F. Higgins (in Brooks and others, 1909, pl. 4), USGS.

Shelter Bay: lagoon, $0.7 \mathrm{mi}$. across, on $\mathrm{W}$ coast of Hinchinbrook I., $32 \mathrm{mi}$. SW of Cordova, Chugach Mts.; $60^{\circ} 26^{\prime} \mathrm{N}, 146^{\circ} 39^{\prime} \mathrm{W}$; (map 64).

Name published by USC\&GS in 1900 . Probably so named for the shelter the lagoon would provide for vessels during stormy weather.

Shelter Cove: cove, $0.6 \mathrm{mi}$. across, on $\mathrm{SE}$ coast of Igitkin I., Aleutian Is.; $51^{\circ} 58^{\prime} 45^{\prime \prime} \mathrm{N}, 175^{\circ}$ 52'30" W; BGN 1936; (map 18).

Named by a member of U.S. Navy Aleutian Island Survey Expedition of 1934, and published by the USC\&GS in the 1944 Aleutian Coast Pilot (p. 103).

Shelter Cove: cove, $0.4 \mathrm{mi}$. wide, on $\mathrm{W}$ shore of Carroll Inlet, on Revillagigedo I., Alex. Arch.; $55^{\circ} 32^{\prime} 20^{\prime \prime} \mathrm{N}, 131^{\circ} 20^{\prime} 45^{\prime \prime} \mathrm{W}$; (map 3 ).

Local name published in 1943 by USC\&GS. Shelter Cove: cove, $1 \mathrm{mi}$. across, on NW coast of Shelter I., in Saginaw Channel, $1 \mathrm{mi}$. S of
North Pass and $20 \mathrm{mi}$. NW of Juneau, Alex. Arch.; 58 $27^{\prime} \mathrm{N}, 134^{\circ} 54^{\prime} \mathrm{W}$; (map 11).

Local name derived from Shelter Island and published in 1962 by USGS.

Shelter Cove: cove, $0.4 \mathrm{mi}$. wide, on Kenai Penin. on S shore of Beauty Bay, $33 \mathrm{mi}$. SE of Homer, Chugach Mts.; $59^{\circ} 31^{\prime} 45^{\prime \prime} \mathrm{N}, 150^{\circ}$ $38^{\prime} 00^{\prime \prime}$ W; BGN 1908; (map 50).

Descriptive name given by USC\&GS in 1908.

Shelter Cove: cove, $0.6 \mathrm{mi}$. across, on $\mathrm{E}$ shore of Russell Fiord, $3.2 \mathrm{mi}$. W of Mount Ruhamah and $19 \mathrm{mi}$. NE of Yakutat, St. Elias Mts.; $59^{\circ} 43^{\prime} 15^{\prime \prime} \mathrm{N}, 139^{\circ} 18^{\prime} 05^{\prime \prime} \mathrm{W}$; (map 46). Var. Russell Cove.

Descriptive name given by Tarr (1909, p. 18, pl. 37), USGS. He had previously named it Russell Cove in 1905 for I. C. Russell.

Shelter Cove: cove, $0.1 \mathrm{mi}$. wide, on $\mathrm{W}$ shore of Cook Inlet, $48 \mathrm{mi}$. NW of Homer, Aleutian Ra.; $59^{\circ} 53^{\prime} 15^{\prime \prime} \mathrm{N}, 152^{\circ} 48^{\prime} 15^{\prime \prime} \mathrm{W}$; (map 50).

Local name reported by USGS or USC\&GS in the 1940's.

Shelter Creek: stream, flows SE $5 \mathrm{mi}$. to Shelter Cove, on W shore of Cook Inlet, $49 \mathrm{mi}$. NW of Homer, Aleutian Ra.; $59^{\circ} 53^{\prime} 45^{\prime \prime} \mathrm{N}, 152^{\circ}$ $48^{\prime} 45^{\prime \prime} \mathrm{W}$; (map 50).

Local name reported and published by USGS in the 1950's.

Shelter Island: island, 9 mi. long., trends NW between Favorite and Saginaw Channels, $0.6 \mathrm{mi}$. SE of Lincoln I. and $15 \mathrm{mi}$. NW of Juneau, Alex. Arch.; $58^{\circ} 26^{\prime} \mathrm{N}, 134^{\circ} 52^{\prime} \mathrm{W}$; (map 11).

Named in 1869 by Comdr. R. W. Meade, USN, and published in the 1883 Coast Pilot (p. 173)

Shelter Lake: lake, $0.7 \mathrm{mi}$. long, on Shelter I., $2 \mathrm{mi}$. SW of Shelter Cove and $18 \mathrm{mi}$. NW of Juneau, Alex. Arch.; $58^{\circ} 25^{\prime} 20^{\prime \prime} \mathrm{N}, 134^{\circ}$. $52^{\prime} 30^{\prime \prime} \mathrm{W}$; (map 11).

Local name derived from Shelter Island and published in 1962 by USGS.

Shelter Point: point of land, $\mathrm{E}$ tip of Killisnoo I., off $W$ coast of Admiralty I., $S$ of Killisnoo, $2.5 \mathrm{mi}$. S of Angoon, Alex. Arch.; $57^{\circ} 28^{\prime} 00^{\prime \prime}$ N, $134^{\circ} 33^{\prime} 50^{\prime \prime} \mathrm{W}$; (map 9).

Descriptive name given by Comdr. R. W. Meade, USN; published in 1869 on Hydrog. Chart 225. This name does not appear on recent maps.

Shelter Valley Glacier: glacier, trends $3 \mathrm{mi}$. SW to Rohn Glacier, $4 \mathrm{mi}$. N of Chimney Mtn. and $28 \mathrm{mi}$. NE of McCarthy, Wrangell Mts.; $61^{\circ}$. $47^{\prime} \mathrm{N}, 142^{\circ} 30^{\prime} \mathrm{W}$; (map 67)

Local name obtained by USGS and published on maps since 1954.

Shelton: locality, along right bank of Kuzitrin River, $45 \mathrm{mi}$. E of Teller and $53 \mathrm{mi}$. NE of Nome, Seward Penin. High.; $65^{\circ} 14^{\prime}$ N, $164^{\circ}$ $49^{\prime} \mathrm{W}$; (map 110). Var. Lanes Landing, Selton.

The settlement of Lanes Landing was established about 1901 at the ford where the trail from Nome to the Kougarok gold mining region crossed the Kuzitrin River. The settlement was probably named for Charles $D$. Lane who started building the Seward Peninsula 
Railroad at Nome in 1900 and completed it to here in 1906 (Cole, 1953, p. 13). In 1907 the Shelton Post Office was established here and the village picked up the name. Balcom (1965, p. 30) states that Shelton "was active from 1907 to 1918," the same year the post office was discontinued.

Shemya: locality, pop. 124, Shemya I., (map 13). This name often appears in publications as a populated place on Shemya I. but, as far as can be determined, it is a name arbitrarily used to refer to the collective population of the island.

Shemya Island: island, $4 \mathrm{mi}$. long, easternmost of Semichi Is., Aleutian Is.; 52 ${ }^{\circ} 43^{\prime} 20^{\prime \prime} \mathrm{N}$, $174^{\circ} 07^{\prime} 00^{\prime \prime} \mathrm{E}$; BGN 1938; (map 13). Var. Saint Abraham, Saint Abram.

Rev. Coxe $(1787$, p. 50$)$ applied this name to the entire group of islands called "Semichi" by the Russians. The name has subsequently been reapplied to this particular island. According to Golder $(1922$, p. 202, 275) this may have been the island named "St. Abraham" on October 29, 1741 (O.S.), by Vitus Bering on the St. Peter. See Semichi Island. Shemya Islands: islands, see Semichi Islands.

Shemya Pass: water passage, between Nizki and Shemya Is., Semichi Is., Aleutian Is. ; 52 ${ }^{\circ} 3^{\prime}$ $30^{\prime \prime} \mathrm{N}, 173^{\circ} 57^{\prime} 30^{\prime \prime} \mathrm{E}$; (map 13).

This name is derived from Shemya Island. Shepard Creek: stream, flows E $0.7 \mathrm{mi}$. to Nome River, 0.1 mi. upstream from Basin Creek and $13 \mathrm{mi}$. N of Nome, Seward Penin. High.; $64^{\circ}-$ $41^{\prime} \mathrm{N}, 165^{\circ} 19^{\prime} \mathrm{W}$; (map 94). Var. Upland Creek.

Prospectors' name published on the 1900 "Map of Nome Peninsula" by J. M. Davidson and B. D. Blakeslee. This appears to be the "Upland Creek" shown in 1900 on USC\&GS Chart 9380.

Shepard Creek: stream, see Sunset Creek.

Shepard Point: point of land, on NE shore of Orca Inlet, $3 \mathrm{mi}$. SW of Rude River delta, $7 \mathrm{mi}$. NE of Cordova, Chugach Mts. ; $60^{\circ} 38^{\prime}$ N, $145^{\circ} 40^{\prime} \mathrm{W}$; BGN 1933; (map 64)

Local name "for the salmon cannery there" reported by USC\&GS in 1931.

Shephard Glacier: glacier, trends S $2.5 \mathrm{mi}$. to its terminus $5 \mathrm{mi}$. N of the terminus of Scott Glacier and $17 \mathrm{mi}$. NE of Cordova, Chugach Mts.; $60^{\circ} 41^{\prime} \mathrm{N}, 145^{\circ} 21^{\prime} \mathrm{W}$; (map 64).

Local name reported in 1908 by U. S. Grant and D. F. Higgins (1910, pl. 2), USGS.

Shepherd Creek: stream, flows $\mathrm{S} 9 \mathrm{mi}$. to Bering Lake, $11 \mathrm{mi}$. NE of Katalla, Chugach Mts.; $60^{\circ} 17^{\prime} \mathrm{N}, 144^{\circ} 16^{\prime} \mathrm{W}$; (map 64).

Local name published by the Norris Peters Company on their 1911 map of southeastern part of Prince William Sound and the Bering River coal field.

Shepherd Creek: stream, flows NE $14 \mathrm{mi}$. to White Mtn. Creek, $44 \mathrm{mi}$. NE of Medfra, Kilbuck-Kuskokwim Mts.; $63^{\circ} 41^{\prime} \mathrm{N}, 154^{\circ} 11^{\prime} \mathrm{W}$; (map 89).

Local name reported in 1954 by USGS.

Sherang Island: island, on Beaufort Sea coast, Arctic Plain; (map 151).
Recorded on Surg. John Simpson's native map, 1855, as located at or near Flaxman I. The present location is not known.

Sheridan Creek: stream, flows SW $2.4 \mathrm{mi}$. to Bear Creek, $25 \mathrm{mi}$. N of Haycock, Seward Penin. High.; $65^{\circ} 35^{\prime} \mathrm{N}, 161^{\circ} 07^{\prime} \mathrm{W}$; (map 109).

Local name shown on a 1903 fieldsheet by D. C. Witherspoon, USGS.

Sheridan Glacier: glacier, trends SW $15 \mathrm{mi}$. to its terminus at Glacier River, $13 \mathrm{mi}$. E of Cordova, Chugach Mts.; $60^{\circ} 31^{\prime} \mathrm{N}, 145^{\circ} 20^{\prime} \mathrm{W}$ (map 64).

Named in 1884 by Capt. Abercrombie (1900, map), USA, for Gen. Philip H. Sheridan, 1831-88, USA, of Civil War fame.

Sheridan Peak: mountain, 3,650 ft., on $\mathbf{E}$ coast of Lindenberg Penin., Kupreanof I., $7 \mathrm{mi}$. $\mathrm{N}$ of Petersburg, Alex. Arch.; $56^{\circ} 54^{\prime} 40^{\prime \prime} \mathrm{N}$, $133^{\circ} 01^{\prime} 10^{\prime \prime} \mathrm{W}$; (map 6).

Named in 1887 by Lt. Comdr. C. M. Thomas, USN, for Gen. Philip Henry Sheridan, USA.

Sherman: $R R$. station, mile 258.3 on The Alaska Railroad, $29 \mathrm{mi}$. NE of Talkeetna, Talkeetna Mts. ; $62^{\circ} 42^{\prime} 50^{\prime \prime} \mathrm{N}, 149^{\circ} 48^{\prime} 30^{\prime \prime} \mathrm{W}$; (map 82).

Named about 1916; the station has been in use since the opening of the line.

Sherman, Point: point of land, on $\mathrm{E}$ shore of Lynn Canal, $0.6 \mathrm{mi}$. SW of mouth of Sweeny Creek and 46 mi. NW of Juneau, Coast Mts. ; $58^{\circ} 51^{\prime} 20^{\prime \prime} \mathrm{N}, 135^{\circ} 09^{\prime} 00^{\prime \prime} \mathrm{W}$; (map 11).

Named in 1869 by Comdr. R. W. Meade, USN, for Gen. William Tecumseh Sherman, 1820-91, Civil War general. The name was published by USC\&GS in the 1883 Coast Pilot (p. 195).

Sherman Creek: stream, flows $3 \mathrm{mi}$. NW to Comet, on $\mathrm{E}$ shore of Lynn Canal, $1 \mathrm{mi}$. NE of Point Sherman and $47 \mathrm{mi}$. NW of Juneau, Coast Mts.; 58 $52^{\prime} 05^{\prime \prime}$ N, $135^{\circ} 08^{\prime} 25^{\prime \prime}$ W; (map 11).

Local name derived from Point Sherman and reported in 1903 by A. C. Spencer (in Emmons and Hayes, 1904, p. 38), USGS.

Sherman Glacier: glacier, trends SW $6 \mathrm{mi}$. to its terminus $1.5 \mathrm{mi}$. E of Sheridan Glacier, $15 \mathrm{mi}$. E of Cordova, Chugach Mts.; $60^{\circ} 33^{\prime} \mathrm{N}, 145^{\circ}$. $13^{\prime} \mathrm{W}$; BGN 1930; (map 64).

Named in 1910 by Lawrence Martin, USGS, for Gen. William Tecumseh Sherman, 1820-91, USA, Civil War general of the Union Army. He fought in many battles but is best known for his famous march from Atlanta to the sea. He was promoted to Commander of the USA in 1869. Martin's notes read 'he (Sherman) said 'war is hell;' so I put him on ice, near the Sheridan Glacier."

Sherman Peak: mountain, 3,900 ft., $7 \mathrm{mi}$. NW of Petersburg, on $\mathrm{E}$ coast of Lindenberg Penin., Kupreanof I., Alex. Arch.; $56^{\circ} 53^{\prime} 50^{\prime \prime}$ N, $133^{\circ} 02^{\prime} 40^{\prime \prime} \mathrm{W}$; (map 6).

Named in 1887 by Lt. Comdr. C. M. Thomas, USN, for Gen. William Tecumseh Sherman, USA.

Sherman Rock: rock, off E shore of Lynn Canal, $0.6 \mathrm{mi}$. SW of Point Sherman and $46 \mathrm{mi}$. NW of Juneau, Coast Mts.; $58^{\circ} 50^{\prime} 55^{\prime \prime}$ N, $135^{\circ}$ 09'35" W; (map 11).

Named in 1890 by Lt. Comdr. H. B. Mansfield, USN, for Sherman Point and published by USC\&GS in the 1891 Coast Pilot (p. 200). Sherret Creek: stream, see Sherrette Creek.

Sherrett Creek: stream, see West Branch Sherrette Creek.

Sherrette Creek: stream, flows NW $9.4 \mathrm{mi}$. to Pilgrim River, $57 \mathrm{mi}$. SW of Imuruk Lake, Seward Penin. High.; $65^{\circ} 02^{\prime} \mathrm{N}, 164^{\circ} 37^{\prime} \mathrm{W}$; (map 110). Var. Cupel Creek, Killkuhn Creek, Sherret Creek.

Prospectors' name reported in 1901 by $T$. G. Gerdine (in Collier, 1902, pl. 12), USGS.

Reported in 1900 as "Killkuhn Creek" by E. C. Barnard (in Brooks, 1901, pl. 17), USGS.

Sheshalegamute: locality, see Sheshalik.

Sheshalek: locality, see Sheshalik.

Sheshalik: locality, on Sheshalik Spit, $9 \mathrm{mi}$. NW of Kotzebue, Kotzebue-Kobuk Low.; $66^{\circ} 59^{\prime}$ $30^{\prime \prime} \mathrm{N}, 162^{\circ} 49^{\prime} 45^{\prime \prime} \mathrm{W}$; (map 113). Var. Sesūalik, Sheshalegamute, Sheshalek, Sheshoalik, Sheshore-lik, Shesualek, She-surare-lick, Shishaluk.

Former Eskimo village and summer camp, famous as a trading area for Eskimo and Indian, recorded as "Sesūalik," in Capt. F. W. Beechey's chart, dated 1831. In the 1880 Census, Petroff (1884, p. 4) listed "Sheshalegamute," population 100. Capt. Hooper (1881, p. 44) published "She-shore-lik," and Lt. G. M. Stoney's manuscript map, dated 1883, shows "She-sur-are-lick."

Sheshalik Spit: spit, on N shore of Kotzebue Sound, $9 \mathrm{mi}$. NW of Kotzebue, KotzebueKobuk Low.; $67^{\circ} 00^{\prime} \mathrm{N}, 162^{\circ} 51^{\prime} \mathrm{W}$; (map 128). Var. Shesualek Spit.

Named for the Eskimo camp located on the spit; reported in 1925 by USC\&GS.

Sheshoalik: locality, see Sheshalik.

Sheshok Creek: stream, flows S 5 mi. to Kobuk River, $8 \mathrm{mi}$. NW of Shungnak, KotzebueKobuk Low.; $66^{\circ} 55^{\prime}$ N, $157^{\circ} 20^{\prime}$ W ; (map 115).

Eskimo name reported in 1954 by the U.S. Army Corps of Engineers.

Sheshore-lik: locality, see Sheshalik.

Shesrghoyemená: lake, see Thirtyeight Mile Lake.

Shesualek: locality, see Sheshalik.

Shesualek Spit: spit, see Sheshalik Spit.

She-sur-are-lick: locality, see Sheshalik.

Shetchaut: stream, see Ray River.

Shetnak: locality, see Chitnak.

Shevenagamute: locality, see Shevenak.

Shevenak: locality, on left bank of Kuskokwim River, at or near Eek Point, Yukon-Kuskokwim Delta; $60^{\circ} 12^{\prime} \mathrm{N}, 162^{\circ} 15^{\prime} \mathrm{W}$; (map 58). Var. Shevenagamute, Shovenagamiut, Shovenagamute.

Former Eskimo village or camp reported in 1878-79 as "Shevenagamute" by E. W. Nelson, U.S. Signal Service. This spelling was shown on the 1880 Census map, but published "Shovenagamute," population 58, in Petroff's 
text (1884, p. 17). The 1890 Census lists "Shovenagamiut," population 62.

Shevlin Creek: stream, see Schieffelin Creek. Shi: island, see Baranof Island.

Shiekuk Creek: stream, flows W $3 \mathrm{mi}$. to Bering Sea, $10 \mathrm{mi}$. SW of Savoonga, $\mathbf{N}$ coast of St. Lawrence I.; $63^{\circ} 38^{\prime} \mathrm{N}$, $170^{\circ} 45^{\prime} \mathrm{W} ; B G N$ 1951; (map 93).

Eskimo name recommended by the Savoonga village council and reported in 1949 by Maj. H. B. Allen, USAF.

Shield: locality, on Kenai Penin., $1 \mathrm{mi}$. $\mathrm{N}$ of Lower Summit Lake and $15 \mathrm{mi}$. S of Sunrise, Chugach Mts.; $60^{\circ} 40^{\prime} 45^{\prime \prime} \mathrm{N}, 149^{\circ} 28^{\prime} 35^{\prime \prime} \mathrm{W}$; (map 63).

Former mining community along Canyon Creek. Recent USGS maps indicate a site with three buildings.

Shields Point: point of land, on $\mathbf{E}$ shore of Perenosa Bay, on $\mathrm{N}$ coast of Afognak I., $\mathrm{N}$ of Kodiak I.; $58^{\circ} 25^{\prime} 20^{\prime \prime} \mathrm{N}, 152^{\circ} 21^{\prime} 20^{\prime \prime} \mathrm{W}$; BGN 1934; (map 43).

Named by USC\&GS in 1932 for the Englishman, James Shields, builder and first master of the vessel Phoenix. See Phoenix Bay.

Shiels Glacier: glacier, trends NE $2 \mathrm{mi}$. to its terminus $2.5 \mathrm{mi}$. W of Copper River, $50 \mathrm{mi}$. $\mathrm{N}$ of Katalla, Chugach Mts.; $60^{\circ} 53^{\prime} \mathrm{N}, 144^{\circ}$ $44^{\prime}$ W; BGN 1930; (map 64).

Named in 1914 by Lawrence Martin for Archie Shields [sic] of the Copper River and Northwestern RR.

Shiganik, Ostrov: island, see Wingham Island. Shikat Point: point of land, N tip of Tuxekan I., $31 \mathrm{mi}$. N of Craig, Alex. Arch.; 55 54'50" N, $133^{\circ} 17^{\prime} 20^{\prime \prime} \mathrm{W}$; (map 4).

Indian name published in 1964 by USC\&GS. Shikene River: stream, see Stikine River.

Shikosi Island: island, $0.8 \mathrm{mi}$. across, in Chilkat Is., in Lynn Canal, $0.6 \mathrm{mi}$. S of Anyaka I. and $29 \mathrm{mi}$. S of Skagway, Coast Mts.; $59^{\circ} 01^{\prime} 45^{\prime \prime}$ $\mathrm{N}, 135^{\circ} 16^{\prime} 00^{\prime \prime} \mathrm{W}$; (map 45).

Tlingit Indian name published in 1923 on IBC Sheet 9 (1951 atlas).

Shiliak Creek: stream, flows SW $15 \mathrm{mi}$. to Little Noatak Slough, $15 \mathrm{mi}$. NE of Kotzebue, Kotzebue-Kobuk Low.; $67^{\circ} 03^{\prime} \mathrm{N}, 162^{\circ} 14^{\prime} \mathrm{W}$; (map 128).

Eskimo name meaning "store room" obtained at Kotzebue in 1956 by Orth. So called because a cabin used for storage was located here.

Shiltonotno, Reka: stream, see Innoko River.

Shinacoo Inlet: water passage, see Shinaku Inlet.

Shinagrua: locality, on Beaufort Sea coast, W of Flaxman I., Arctic Plain; (map 151). Var. Shiningrua.

Recorded as "Shiningrua" on Surg. John Simpson's native map, 1855. Published in 1862 as "Shinagrua" on USC\&GS Chart 20.

Shinaku Creek: stream, flows SW $7 \mathrm{mi}$. to Shinaku Inlet on $W$ coast of Prince of Wales I., $10 \mathrm{mi}$. N of Craig, Alex. Arch.; 55 $36^{\prime} 30^{\prime \prime}$ N, $133^{\circ} 09^{\prime} 00^{\prime \prime} \mathrm{W}$; BGN 1963; (map 4).

Indian name reported in 1961 by USFS.

Shinaku Inlet: water passage, extends NE $4 \mathrm{mi}$. off San Alberto Bay, between Prince of Wales and Wadleigh Is., Alex. Arch.; BGN 1928; (map 4). Var. Shinacoo Inlet.

Indian name given in 1925 by USGS.

Shindata Creek: stream, flows W $10 \mathrm{mi}$. to Tok River $16 \mathrm{mi}$. NW of junc. of Little Tok River and $26 \mathrm{mi}$. SW of Tok, Alaska Ra.; $63^{\circ} 12^{\prime} \mathrm{N}$, $143^{\circ} 47^{\prime}$ W; BGN 1936; (map 85). Var. Shindata River.

Indian name reported by USGS in 1936. Shindata River: stream, see Shindata Creek.

Shine Creek: stream, flows NE $1.4 \mathrm{mi}$. to Buster Bay, on $\mathbf{N}$ coast of Prince of Wales I., Alex. Arch.; 56 $19^{\prime} 35^{\prime \prime} \mathrm{N}, 133^{\circ} 26^{\prime} 30^{\prime \prime} \mathrm{W}$; (map 6).

Local name recorded in 1949 by USGS.

Shineyagamut: locality, see Shiniak.

Shineyagamut: locality, see Shinyagamute.

Shineyagamute: locality, see Shiniak.

Shineyagamute: locality, see Shinyagamute.

Shingle Island: island, $0.1 \mathrm{mi}$. long, at mouth of Totem Bay, on S coast of Kupreanof I., Alex. Arch.; 56 $26^{\prime} 20^{\prime \prime} \mathrm{N}, 133^{\circ} 23^{\prime} 30^{\prime \prime} \mathrm{W}$; (map 6).

Named in 1886 by Lt. J. M. Helm, USN, for charting purposes; published in 1887 on USC\&GS Chart 706.

Shingle Point: point of land, on E shore of Herendeen Bay $16 \mathrm{mi}$. SW of village of Port Moller, on Alaska Penin., Bristol Bay Low.; $55^{\circ} 47^{\prime} \mathrm{N}, 160^{\circ} 45^{\prime} \mathrm{W}$; (map 28 ).

Named in 1890 by Lt. Comdr. Z. L. Tanner, USN.

Shingnek River: stream, see Shungnak River.

Shin-i-a-ga-mut: locality, see Shiniak.

Shiniagmiut: locality, see Shiniak.

Shiniagmiut: locality, see Shinyagamute.

Shin-i-a-ga-mut: locality, see Shinyagamute.

Shiniak: locality, on E shore of Kuskokwim Bay, $\mathrm{N}$ of Kanektok River, $50 \mathrm{mi}$. NW of Goodnews, Yukon-Kuskokwim Delta; $59^{\circ} 48^{\prime} \mathrm{N}$, $161^{\circ} 57^{\prime} \mathrm{W}$; (map 53). Var. Mission Warehouse, Shineyagamute, Shineyagamut, Shiniagmiut, Shin-i-a-ga-mut, Shinyagamiut, Shinyagamute.

Former Eskimo village reported as "Shiniagmiut," meaning "Shiniak people," by Lt. Sarichev (1826, map), IRN. Recorded as "Shineyagamute" by Ivan Petroff in the 1880 U.S. Census. Its population in 1880 was 40 ; in 1890,7 . The Moravian missionaries had a warehouse here in 1910, which appeared on some maps as "Mission Warehouse."

Shiniliaok Creek: stream, flows NE $16 \mathrm{mi}$. to Selawik River, $29 \mathrm{mi}$. S of Shungnak, Hogatza High.; $66^{\circ} 29^{\prime} \mathrm{N}, 156^{\circ} 53^{\prime} \mathrm{W}$; (map 115).

Eskimo name shown on a 1927 manuscript map by the "trader at Selawik."

Shinilikrok Creek: stream, flows NE $10 \mathrm{mi}$. to Selawik River, $29 \mathrm{mi}$. SW of Shungnak, Hogatza High.; $66^{\circ} 29^{\prime} \mathrm{N}, 157^{\circ} 25^{\prime} \mathrm{W}$; (map 115).

Eskimo name shown on a 1927 manuscript map by the "trader at Selawik."

Shiningarok: barrier island, see Martin Island.

Shining Creek: stream, flows NE to Big Four Creek which flows to Casadepaga River, about 2 miles NW of Birch Creek and $17 \mathrm{mi}$. NE of Solomon, Seward Penin. High.; (map 95).

Prospectors' name reported on a prospector's manuscript map dated 1902. This stream cannot be precisely located on current maps.

Shining Dome: hill, $500 \mathrm{ft}$., W of Spein Mtn., 43 mi. SE of Bethel, Kilbuck-Kuskokwim Mts.; $60^{\circ} 34^{\prime} \mathrm{N}, 160^{\circ} 35^{\prime} \mathrm{W}$; (map 59).

Local descriptive name, reported in 1955 by J. M. Hoare, USGS.

Shiningrua: locality, see Shinagrua.

Shinnapago: locality, at Port Clarence, Seward Penin. High.; $65^{\circ} 10^{\prime} \mathrm{N}, 166^{\circ} 07^{\prime} \mathrm{W}$; (map 111).

Former Eskimo village or camp reported in the 1890 Census (1893, p. 162). This may have been at or near the old village of Bering. Shinningnellichshunga Creek: stream, see Sleepy Creek.

Shinyagamiut: locality, see Shiniak.

Shinyagamiut: locality, see Shinyagamute.

Shinyagamute: locality, see Shiniak.

Ship Channel: channel, $17 \mathrm{mi}$. long, in Nushagak Bay, $E$ of Long Sands shoal, $16 \mathrm{mi}$. S of Diilingham, Bristol Bay Low. ; 58 $33^{\prime} \mathrm{N}, 158^{\circ}$ 25' W; (map 40).

Local name reported in 1950 by USC\&GS. These channels are constantly changing in location, width, and depth.

Ship Cove: $b a y, 0.3 \mathrm{mi}$. long, on $\mathrm{S}$ shore of Port Conclusion, Baranof I., $0.7 \mathrm{mi}$. NW of village of Port Alexander, Alex. Arch.; 56 $15^{\prime} 20^{\prime \prime} \mathrm{N}$, $134^{\circ} 39^{\prime} 45^{\prime \prime} \mathrm{W}$; (map 5).

Named by Capt. George Vancouver, RN, "during his stay in Port Conclusion between August 1 and 22, 1794" (Wagner, 1937, p. 416).

Ship Creek: stream, heads in Kenai Mts., flows NE $4 \mathrm{mi}$. to Kenai Lake, $20 \mathrm{mi}$. N of Seward, Chugach Mts. ; $60^{\circ} 23^{\prime} 30^{\prime \prime} \mathrm{N}, 149^{\circ} 30^{\prime} 40^{\prime \prime} \mathrm{W}$; (map 63).

Local name reported in 1951 by USGS.

Ship Creek: stream, heads in a lake in Chugach Mts., flows NW $11 \mathrm{mi}$. to Knik Arm at Anchorage, Cook Inlet Low.; 61 ${ }^{\circ} 13^{\prime} 36^{\prime \prime} \mathrm{N}$, $149^{\circ} 53^{\prime} 45^{\prime \prime} \mathrm{W}$; BGN 1959; (map 69). Var. Woodrow Creek.

Local name reported in 1906 by Paige and Knopf (1907, pl. 1), USGS.

Ship Creek : city, see Anchorage.

Shipinskaia River: stream, see Sturgeon River. Ship Island: island, $0.5 \mathrm{mi}$. long, in Cordova Bay, $1.2 \mathrm{mi}$. S of Kassa Point, on SW coast of Prince of Wales I., Alex. Arch.; 54 54'10" $\mathrm{N}, 132^{\circ} 31^{\prime} 30^{\prime \prime} \mathrm{W}$; (map 1 ).

Local name reported in 1951 by USGS.

Ship Island: island, $200 \mathrm{ft}$. long, in Clarence Strait, on SW coast of Cleveland Penin., Alex. Arch.; $55^{\circ} 35^{\prime} 58^{\prime \prime} \mathrm{N}, 132^{\circ} 12^{\prime} 05^{\prime \prime} \mathrm{W}$; (map 4).

Named in 1880 by Baker (1906, p. 570), USGS, "on account of its appearance from the south ***."

Ship Island: island, at $\mathbf{N}$ of end Prince of Wales Passage, off $E$ coast of Flemming $1 ., 9 \mathrm{mi}$. SE of Chenega, Chugach Mts.; 60 $09^{\prime} 45^{\prime \prime} \mathrm{N}$, $148^{\circ} 00^{\prime} 20^{\prime \prime} \mathrm{W}$; (map 63$)$.

Local name reported in 1951 by USGS. Ship Island : island, see Error Island.

Ship Island: island, see Labouchere Island. Ship Island: island, see Sail Island. 
Ship Island Passage: water passage, extends SE 2 mi. from Kassa Point, between $S W$ coast of Prince of Wales I. and Ship I., Alex Arch.; $54^{\circ} 54^{\prime} 30^{\prime \prime} \mathrm{N}, 132^{\circ} 31^{\prime} 15^{\prime \prime} \mathrm{W}$; (map 1).

Local name reported in 1951 by USGS.

Shipley Bay: bay, extends W $5 \mathrm{mi}$. to Sumner Strait, on NW coast of Kosciusko I., Alex. Arch.; $56^{\circ} 06^{\prime} \mathrm{N}, 133^{\circ} 38^{\prime} \mathrm{W}$; (map 6).

Named in 1886 by Lt. Comdr. A. S. Snow, USN, for Ens. John Harry Shipley, USN, a member of his party.

Shipley Lake: lake, $2 \mathrm{mi}$. long, at head of Shipley Bay, on $\mathrm{N}$ coast of Kosciusko I., Alex. Arch.; $56^{\circ} 05^{\prime} 30^{\prime \prime} \mathrm{N}, 133^{\circ} 27^{\prime} 00^{\prime \prime} \mathrm{W}$; (map 6).

Local name recorded in 1949 by USGS.

Ship Mountain: mountain, 2,525 ft., on Alaska Penin., at SW end of Castle Cape, $11 \mathrm{mi}$. S of Chignik, Aleutian Ra.; $56^{\circ} 08^{\prime} \mathrm{N}, 158^{\circ} 21^{\prime}$ W; (map 30). Var. Prospect Head.

This feature was originally called "Prospect Head" in 1916 by USC\&GS Coast Pilot ( p. 161 ) ; "Ship Mountain" was the name given in 1923 by R. H. Sargent, USGS, "because it looks like the prow of a ship."

Ship Rock: island, 500 yds. long, off NE coast of Umnak I. in Umnak Pass, $2 \mathrm{mi}$. S of Pustoi I. and $15 \mathrm{mi}$. SE of Fort Glenn, Aleutian Is.; $53^{\circ} 22^{\prime} 30^{\prime \prime}$ N, $167^{\circ} 49^{\prime} 50^{\prime \prime}$ W; (map 23). Var. Karablin, Tanghinakh, Tanginak.

Translation from the Russian "K[amen] Korabl" (Tebenkov, 1852, map 25, dated 1849). Capt. Lutke (1836, p. 302) calls it "Tanghinakh," possibly from the Aleut word "tangidak," which according to R. H. Geoghegan, means "islet or small island," a name which also applies to Pustoi Island. Although Ship Rock is surrounded by treacherous riptides and currents that make boat landings almost impossible, Hrdlička (1945, p. 182, 323-329), Smithsonian Institution, excavated here in 1937. He found mummified remains of the "pre-Aleut * * *" which had not been disturbed and showed "no trace of White man's influence ***."

Ship Rock: rock, on $\mathbf{N}$ central Kanaga I., Aleutian Is.; $51^{\circ} 46^{\prime} 15^{\prime \prime} \mathrm{N}, 177^{\circ} 22^{\prime} 20^{\prime \prime} \mathrm{W}$; (map 17).

Descriptive name published by USC\&GS in the 1944 Aleutian Coast Pilot (p. 116).

Ship Rock: rock, off SW coast of Sitkalidak I., $18 \mathrm{mi}$. NE of Kaguyak, on SE coast of Kodiak I.; $57^{\circ} \mathrm{L} \mathrm{\gamma}^{\prime} 00^{\prime \prime} \mathrm{N}, 153^{\circ} 02^{\prime} 30^{\prime \prime} \mathrm{W}$; BGN 1932; (map 33).

Named in 1931 by USC\&GS "because the rock appears as a vessel from a distance when seen against the horizon."

Shipwreck Point: point of land, $2 \mathrm{mi}$. SE of Kassa Point, on SW coast of Prince of Wales I., Aled Arch.; $54^{\circ} 53^{\prime} 45^{\prime \prime} \mathrm{N}, 132^{\circ} 29^{\prime} 30^{\prime \prime} \mathrm{W}$; (map 1).

Local name published by USC\&SS in 1911. Shipyard Bay: bight, on Hawkins I., on $\forall$ bore of Orca Inlet, $2 \mathrm{mi}$. NW of Cordova, Chugack. Mts. ; $60^{\circ} 34^{\prime} 20^{\prime \prime} \mathrm{N}, 145^{\circ} 48^{\prime} 00^{\prime \prime} \mathrm{W}$; $B G N$ 1961; (map 64)

Local name reported in 1960 by USFS

Shipyard Cove: cove, on $\mathrm{E}$ shore of Yakutat Roads, $0.7 \mathrm{mi}$. W of Puget Cove and $1 \mathrm{mi}$. N of Yakutat, Malaspina Coastal Plain; $59^{\circ}$ $33^{\prime} 50^{\prime \prime} \mathrm{N}, 139^{\circ} 44^{\prime} 20^{\prime \prime} \mathrm{W}$; (map 46).

Local name published in 1959 by USGS.

Shiripof: point of land, see Izhut, Cape.

Shirley Lake: lake, $0.8 \mathrm{mi}$. long, $2 \mathrm{mi}$. NW of junc. of Happy and Skwentna Rivers, $76 \mathrm{mi}$ NW of Tyonek, Alaska Ra.; 61 ${ }^{\circ} 59^{\prime} 40^{\prime \prime} \mathrm{N}$, $152^{\circ} 24^{\prime} 20^{\prime} \mathrm{W}$; (map 70$)$.

Local name reported in 1958 by USGS

Shirokaia: bight, see Broad Bay.

Shirttail Point: point of land, on NE tip of Hinchinbrook I., $15 \mathrm{mi}$. SW of Cordova, Chugach Mts. ; $60^{\circ} 26^{\prime} \mathrm{N}, 146^{\circ} 07^{\prime} \mathrm{W}$; (map 64).

Local name published in 1959 by USGS.

Shirukak Lake: lake, $1.5 \mathrm{mi}$. across, between Colville and Itkillik Rivers, $33 \mathrm{mi}$. NE of Umiat, Arctic Plain, $69^{\circ} 43^{\prime} \mathrm{N}, 151^{\circ} 07^{\prime} \mathrm{W}$; (map 141).

Eskimo name reported in 1956 by T. E. Taylor, USGS. It may mean "ice house [sirukak]."

Shishakshinovik Pass: pass, 3,050 ft., in Schwatka Mts., 4 mi. S of Blind Pass Mtn., Brooks Ra. ; $67^{\circ} 27^{\prime} \mathrm{N}, 156^{\circ} 20^{\prime} \mathrm{W}$; (map 126).

Eskimo name generally meaning "place where some were caught in a snow slide," obtained at Kobuk by Orth in 1956.

Shishaldin: locality, see Sisaguk.

Shishaldinskaya, Sopka: mountain, see Shishaldin Volcano.

Shishaldinski: locality, see Sisaguk.

Shisaldinskoe: locality, see Sisaguk.

Shishaldin Volcano: volcano, 9,372 ft., on Unimak I., Aleutian Is.; $54^{\circ} 45^{\prime} 20^{\prime \prime} \mathrm{N}, 163^{\circ} 58^{\prime} 15^{\prime \prime}$ W; (map 25). Var. Agajedan, Chichaldinskoi, Shushaldinskaia, Sisaguk, Sopka Shishaldinskaya, Volcan de Fernandez.

'Transliteration by USBF in 1888 of "So[pka] Shishaldinskaya," published by Capt. Tebenkov (1852, map 24), IRN. Active volcano seen and reported in 1790 by Capt. G. A. Sarichev "who gives, according to Grewingk, Agajedan as its native name" (Baker, 1906, p. 571). Wagner $(1937$, p. 453$)$ wrote that it was named Volcan de Fernandez, by Martínez for, as he said, his second surname. Shishaluk: locality, see Sheshalik.

Shishkin, Cape: point of land, on NW shore of Lake Clark, $18 \mathrm{mi}$. NE of Nondalton, Alaska Ra.; $60^{\circ} 11^{\prime} \mathrm{N}, 154^{\circ} 27^{\prime} \mathrm{W}$; (map 61).

Named in 1891 by A. B. Schantz for Innokente Shishkin, a Russian, who assisted Schantz in gathering census information for the 11 th Census in 1890 (U.S. Bureau of the Census, 1893, p. 94).

Shishkof Pond: lagoon, $1.5 \mathrm{mi}$. across, NE of Cave Point, on NW coast of Unimak I., Aleutian Is.; $54^{\circ} 48^{\prime} \mathrm{N}, 164^{\circ} 35^{\prime} \mathrm{W}$; BGN 1943; (map 24). Var. Big Pond.

Named by USC\&GS in 1940, for the former "Russian name for Gave Point-Shishkof Point."

Shishkova Mys: point of land, see Cave Point Shishmaref: village, pop. 217, on Sarichef I., between Chukchi Sea and Shishmaref Inlet, Kotzebue-Kobuk Low.; $66^{\circ} 15^{\prime}$ N, $166^{\circ} 04^{\prime}$ W $B G N$ 1944; (map 112).
Eskimo village named for the inlet. Shishmaref post office was established here in 1901. The village was probably founded about 1900 because of a fairly good harbor that served as a supply center for mining activity to the south.

Shishmaref, Cape: point of land, see Northeast Cape.

Shishmaref Inlet: bay, extends SW $17 \mathrm{mi}$. from Sarichef I., at mouth of Serpentine River, Kotzebue-Kobuk Low. ; $66^{\circ} 15^{\prime} \mathrm{N}, 166^{\circ} 05^{\prime} \mathrm{W}$; (map 112). Var. Chichmareff Inlet, Schischmareff Bay, Shishmarej Sound, Shishmaret Inlet.

Named in August 1816, by Lt. Otto von Kotzebue, IRN, for Capt. Lt. Glieb Semenovich Shishmarev, IRN, who accompanied him on his exploration.

Shishmarej Sound: bay, see Shishmaref Inlet. Shishmaret Inlet: $b a y$, see Shishmaref Inlet.

Shishmarev, Cape: point of land, see Northeast Cape.

Shisloiso Hills: ridge, elev. $990 \mathrm{ft}$, extends NE $2 \mathrm{mi}$. from Lake Snohomish, $6.5 \mathrm{mi}$. SW of village of Lake Minchumina, Tanana Low. $63^{\circ} 46^{\prime} 30^{\prime \prime} \mathrm{N}, 152^{\circ} 28^{\prime} 00^{\prime \prime} \mathrm{W}$; (map 88). Var. Shiss-loy-so.

Tanana Indian name obtained in 1899 by Lt. J. S. Herron, USA, and written "Shissloy-so." The name probably refers to "bear" in meaning.

Shisnona Creek: stream, see Shisnona River.

Shisnona Lake: lake, $1 \mathrm{mi}$. long, $8.5 \mathrm{mi}$. WNW of Carey Lake and $36 \mathrm{mi}$. SSW of village of Lake Minchumina, Kuskokwim Low.; $63^{\circ} 26^{\prime}$ $\mathrm{N}, 152^{\circ} 54^{\prime} \mathrm{W}$; (map 88).

Local name reported about 1952 by Fabian Carey.

Shisnona River: stream, flows NW $15 \mathrm{mi}$. to Chedotlothna River, Kuskokwim Low.; $63^{\circ}$ $19^{\prime} \mathrm{N}, 152^{\circ} 39^{\prime} \mathrm{W}$; (map 88). Var. Shisnona Creek, Shissnona River.

Indian name reported as Shissnona in 1899 by Lt. J. S. Herron, USA.

Shiss-loy-so: hills, see Shisloiso Hills.

Shissnona River: stream, see Shisnona River. Shitando River: stream, see Fortymile River. Shitka Bay: water passage, see Sitka Sound. Shitna Creek: stream, see Chitna Creek.

Shitnak: locality, see Chitnak.

Shitnak: point of land, see Siknik Cape.

Shittok: locality, see Skittok.

Shivering Mountain: mountain, 5,425 ft., in Endicott Mts., $11 \mathrm{mi}$. E of Survey Pass, Brooks Ra.; $67^{\circ} 53^{\prime}$ N, $153^{\circ} 42^{\prime} \mathrm{W}$; (map 125).

Named by Robert Marshall in 1931 because of the cold wind encountered while climbing it.

Shivishak River: stream, see Sevisok Slough. Shivishuk River: stream, see Sevisok Slough.

Shivugak Bluff: bluff, elev. $700 \mathrm{ft}$., on $\mathrm{N}$ bank of Colville River $3 \mathrm{mi}$. W of its junc. with Chandler River, Arctic Slope; $69^{\circ} 26^{\prime} \mathrm{N}$, $151^{\circ} 42^{\prime} \mathrm{W}$; (map 141)

Eskimo name [sivugak] that refers to the bluff as being "first"; reported in 1956 by $\mathrm{T}$. E. Taylor, USGS. 
Shiyi Bay: cove, $0.5 \mathrm{mi}$. across, $\mathrm{S}$ of Portage Cove, 17 mi. S of Skagway, Coast Mts.; $59^{\circ}$ $13^{\prime} 30^{\prime \prime} \mathrm{N}, 135^{\circ} 25^{\prime} 45^{\prime \prime} \mathrm{W}$; (map 45).

Indian name published by the IBC (1923, sheet 9). According to E. C. Robertson, USGS, "the name is now rarely used."

Shkagway: village, see Skagway.

Shkagway River: stream, see Skagway River.

Shkaliakh: point of land, see Thatcher, Point.

Shkin, Ostrov: island, see Skin Island.

Shla-hatch Island: island, see Pyramid Island.

Shlokovik Cape: point of land, see Shlokovik Point.

Shlokovik Point: point of land, $19 \mathrm{mi}$. S of Gambell, W coast of St. Lawrence I.; $63^{\circ}$ $34^{\prime} \mathrm{N}, 171^{\circ} 50^{\prime} \mathrm{W}$; BGN 1951; (map 93). Var. Cape Lhookoovik, Lhookoovik Cape, Sarihkahuk Cape, Shlokovik Cape.

Eskimo name reported in 1932 by O. W. Geist, Univ. of Alaska, as "Lhookoovik." Orth was told at Gambell in 1965 that the name "Shlokovik" means "place where sling is used [for getting birds]."

Shnu Creek: stream, see Sinona Creek.

Shoal Bay: bay, $1 \mathrm{mi}$. across, on NW coast of Little Koniuji I., in Shumagin Is., Aleutian Ra.; $55^{\circ} 03^{\prime} 20^{\prime \prime} \mathrm{N}, 159^{\circ} 27^{\prime} 00^{\prime \prime} \mathrm{W}$; (map 27). Named by W. H. Dall, USG\&GS, in 1874 and published on Coast Chart 810 .

Shoal Bay: cove, near entrance to Sanborn Harbor, on NW coast of Nagai I., Shumagin Is., Aleutian Ra.; $55^{\circ} 10^{\prime} 20^{\prime \prime} \mathrm{N}, 160^{\circ} 02^{\prime} 10^{\prime \prime} \mathrm{W}$; (map 28).

Named by W. H. Dall, USC\&GS, in 1872 , and published on USC\&GS Chart 813.

Shoal Bay: lagoon, off W coast of Cape Etolin, E of Mekoryuk and $27 \mathrm{mi}$. SW of Cape Vancouver, on Nunivak I.; $60^{\circ} 23^{\prime} 20^{\prime \prime} \mathrm{N}, 166^{\circ}$ $10^{\prime} 46^{\prime \prime} \mathrm{W}$; (map 57).

Name reported about 1908 by USC\&GS.

Shoal Cape: point of land, see Otmeloi Point.

Shoal Cape: point of land, see Shoal Point.

Shoal Cove: estuary, on Revillagigedo I., extends N $1.1 \mathrm{mi}$., off Carroll Inlet, NE of Osten I., Alex. Arch.; $55^{\circ} 25^{\prime} 50^{\prime \prime} \mathrm{N}, 131^{\circ} 17^{\prime} 15^{\prime \prime} \mathrm{W}$; (map 3).

Local navigators' descriptive name reported in 1904 by H. C. Fassett, USBF.

Shoal Cove: cove, see Flat Cove.

Shoal Creek: stream, on Revillagigedo I., flows NW $0.8 \mathrm{mi}$. to Shoal Cove on E side of Carroll Inlet, Alex. Arch.; 55 $26^{\prime} 18^{\prime \prime} \mathrm{N}, 131^{\circ}$ $16^{\prime} 30^{\prime \prime} \mathrm{W}$; BGN 1923; (map 3 ).

Named in 1923 by USFS.

Shoal Creek: stream, flows SW $1 \mathrm{mi}$. to Telegram Creek, in Pilgrim River basin, $22 \mathrm{mi}$. NW of Solomon, Seward Penin. High.; 64ㅇ$52^{\prime} 15^{\prime \prime} \mathrm{N}, 164^{\circ} 36^{\prime} 30^{\prime \prime} \mathrm{W}$; (map 95).

Prospectors' name reported in 1908 by $P$. S. Smith (in Brooks and others, 1909, pl. 10), USGS.

Shoal Point: point of land, on NE coast of Kanaga I., Aleutian Is.; $51^{\circ} 51^{\prime} 45^{\prime \prime} \mathrm{N}, 177^{\circ}$ $04^{\prime} 00^{\prime \prime} \mathrm{W}$; BGN 1936; (map 17). Var. Sharp Point.

Name given by members of the U.S. Navy Aleutian Island Survey Expedition in 1934 "due to the shoal and rock awash off the point."

Shoal Point: point of land, in Sergius Narrows, at $W$ end of Peril Strait, $24 \mathrm{mi}$. SE of Chichagof, Chichagof I., Alex. Arch.; 57 $24^{\prime} 45^{\prime \prime} \mathrm{N}, 135^{\circ} 37^{\prime} 15^{\prime \prime} \mathrm{W}$; (map 9).

Named in 1884 by Comdr. J. B. Coghlan, USN; published by USC\&GS in 1891 Coast Pilot (p. 182).

Shoal Point: point of land, on S coast of Afognak I., $3 \mathrm{mi}$. SW of Afognak, $\mathrm{N}$ of Kodiak I. ; $57^{\circ}$ $59^{\prime} 30^{\prime \prime} \mathrm{N}, 152^{\circ} 50^{\prime} 30^{\prime \prime} \mathrm{W}$; (map 34). Var. Mys Otmyloy, Otmieloi Cape, Shoal Cape.

This is a translation of the descriptive name "M[ys] Otmyloy" given by Sub-Lt. Mikhail Murashev in 1839 or 1840 and published in 1849 on Russian Hydrog. Dept. Chart 1425. Shoals Island: island, see Otmeloi Island.

Shoals Point: point of land, on SE tip of Kruzof I., $11 \mathrm{mi}$. W of Sitka, Alex. Arch.; 57. $00^{\prime} 40^{\prime \prime}$ N, $135^{\circ} 38^{\prime} 00^{\prime \prime}$ W; BGN 1901; (map 9). Var. First Point, Mys Nizmennyya, Mys Otmeloy Vnyshniy, Mys Otmyloy Vnyshchey, Outer Point of Shoals, Point of Shoals, Whites Point.

USC\&GS about 1882 derived "Shoals Point" by a translation of part of the name "Mys Otmyloy Vnyshchney," meaning "outer shoals cape." This name was given in 1809 by the Russian navigator Ivan Vasiliev the first. Capt. George Dixon in June 1787, called it "White's Point" for the mate of the Queen Charlotte (Wagner, 1937, p. 523). The name "Mys Nizmennyya," meaning "low cape," was published for this feature by Capt. Tebenkov (1852, map 38), IRN.

Shoalwater Pass: water passage, in Behm Canal, extends $5 \mathrm{mi}$., between Winstanley I. and mainland, Coast Mts.; $55^{\circ} 26^{\prime} 00^{\prime \prime}$ N, $130^{\circ}$ 54'30" W; (map 3).

Named in 1879 by W. H. Dall, USC\&GS; published in the 1883 Coast Pilot (p. 72).

Shoalwater Slough: stream, flows $15 \mathrm{mi}$. from Deadmans Slough to a point where the Bonasila River joins the Yukon River, $28 \mathrm{mi}$. NW of Holy Cross, Nulato Hills. ; $62^{\circ} 32^{\prime} \mathrm{N}, 160^{\circ}$. $13^{\prime} \mathrm{W}$; (map 78).

Riverboat pilots' name shown on a 1940 "Navigation Chart of the Tanana-Yukon Rivers" published by U.S. Dept. of Interior.

Shoaty Creek: stream, flows SW $5.5 \mathrm{mi}$. to Moore Creek, $5 \mathrm{mi} \mathrm{NW}$ of Sugarloaf Mtn. and $32 \mathrm{mi}$. NE of Flat, Kilbuck-Kuskokwim Mts. ; $62^{\circ} 33^{\prime} 30^{\prime \prime} \mathrm{N}, 157^{\circ} 02^{\prime} 30^{\prime \prime} \mathrm{W}$; (map 79).

Prospectors' name obtained in 1952 by USGS topographers.

Shoaty Mountain: mountain, $1,510 \mathrm{ft}$, in Kuskokwim Mts., between Moore and Shoaty Creeks, $33 \mathrm{mi}$. NE of Flat, Kilbuck-Kuskokwim Mts.; $62^{\circ} 35^{\prime} 45^{\prime \prime} \mathrm{N}, 157^{\circ} 02^{\prime} 00^{\prime \prime} \mathrm{W}$; (map 79).

Prospectors' name obtained in 1952 by USGS topographers.

Shockum Mountains: mountains, 1,453 ft., along right bank of Bering River, $18 \mathrm{mi}$. NE of Katalla, Chugach Mts.; $60^{\circ} 21^{\prime} \mathrm{N}, 144^{\circ} 05^{\prime}$ W; (map 64).
Named "after a local Indian who so wrote his name," reported in 1905 by G. C. Martin, USGS.

Shoe Creek: stream, flows NW $4.5 \mathrm{mi}$. to Meshik River, $11 \mathrm{mi}$. S of Vent Mtn., in Aniakchak Crater, Bristol Bay Low.; $56^{\circ} 43^{\prime} \mathrm{N}, 158^{\circ} 06^{\prime}$ W; (map 30).

Name reported in 1923 by R. H. Sargent, USGS; published in 1927 by USGS.

Shoeheel Lake: lake, $0.5 \mathrm{mi}$. long, $1.5 \mathrm{mi}$. W of Mud Canyon, $22 \mathrm{mi}$. SE of Beaver, YukonTanana High.; $66^{\circ} 07^{\prime} 30^{\prime \prime} \mathrm{N}, 146^{\circ} 51^{\prime} 30^{\prime \prime} \mathrm{W}$; (map 119).

Local name obtained in 1956 by USGS.

Shoehorn Mountain: mountain, 5,310 ft., NW of Cambridge Basin, on Taku Glacier, $1.6 \mathrm{mi}$. $\mathrm{W}$ of Juncture Peak and $21 \mathrm{mi}$. NE of Juneau, Coast Mts.; $58^{\circ} 36^{\prime} 10^{\prime \prime} \mathrm{N}, 134^{\circ} 18^{\prime} 00^{\prime \prime} \mathrm{W}$; (map 11). Var. Shoehorn Peak.

Local name published in 1960 by USGS. "Shoehorn Peak" was the name proposed by members of the Juneau Icefield Research Project in 1964.

Shoehorn Peak: mountain, see Shoehorn Mountain.

Shoe Inlet: estuary, extends $\mathbf{S} 2 \mathrm{mi}$., on $\mathrm{N}$ coast of Long I., Alex. Arch.; 54 $55^{\prime} 45^{\prime \prime} \mathrm{N}$, $132^{\circ} 48^{\prime} 30^{\prime \prime}$ W; BGN 1928; (map 1).

Local name derived from Shoe Island; published on a 1918 USFS map.

Shoe Island: island, 1,400 ft. long, in Tlevak Strait, $1 \mathrm{mi}$. N of Long I., Alex. Arch.; $54^{\circ} 57^{\prime} 00^{\prime \prime} \mathrm{N}, 132^{\circ} 44^{\prime} 45^{\prime \prime} \mathrm{W}$; BGN 1966; (map 1).

Named in 1881 by Lt. Comdr. H. E. Nichols, USN.

Shoeleather Creek: stream, flows SW and NW $24 \mathrm{mi}$. to Cheeneetnuk River $25 \mathrm{mi}$. NE of its junc. with Swift River, $63 \mathrm{mi}$. NE of Sleetmute, Lime Hills; $61^{\circ} 57^{\prime} 15^{\prime \prime} \mathrm{N}, 155^{\circ} 18^{\prime} 40^{\prime \prime}$ W; (map 71).

Name shown on a prospectors' manuscript map dated 1907.

Shoemaker Bay: bight, $2 \mathrm{mi}$. across, $5 \mathrm{mi}$. S of Wrangell, on NW coast of Wrangell I., Alex. Arch.; $56^{\circ} 24^{\prime} 00^{\prime \prime} \mathrm{N}, 132^{\circ} 20^{\prime} 30^{\prime \prime} \mathrm{W}$; (map 6).

Local name recorded in 1953 by USGS.

Shoepac Lake: lake, $1 \mathrm{mi}$. long, one of the Swanson Lakes, on Kenai Penin. NE of Birch Tree Lake, $37 \mathrm{mi}$. NE of Kenai, Cook Inlet Low.; $60^{\circ} 51^{\prime} 50^{\prime \prime}$ N. $150^{\circ} 22^{\prime} 15^{\prime \prime}$ W ; (map 62).

Named about 1963 by officials of Kenai National Moose Range, for administrative purposes.

Shoe Rock: rock, in Tlevak Strait, on $\mathbf{N}$ coast of Long I., Alex. Arch.; 54 ${ }^{\circ} 56^{\prime} 55^{\prime \prime}$ N, $132^{\circ} 44^{\prime}$ $02^{\prime \prime} \mathrm{W}$; (map 1).

Descriptive name given in 1905 by $\mathbf{E}$. F. Dickins, USC\&GS.

Shoestring, Cove: estuary, on E coast of Esther I., extends SE $1.5 \mathrm{mi}$. to Esther Passage, $26 \mathrm{mi}$. NE of Whittier, Chugach Mts. ; 60 $50^{\prime} 10^{\prime \prime} \mathrm{N}$, $147^{\circ} 56^{\prime} 40^{\prime \prime} \mathrm{W}$; (map 63).

Local name reported in 1952 by USGS. Shoestring Creek: stream, see Niukluk River. Shoestring Dune: sand dune, extends NE-SW $12 \mathrm{mi}$., in lower Koyukuk River valley, $25 \mathrm{mi}$. 
$\mathrm{SW}$ of Huslia; $65^{\circ} 20^{\prime} \mathrm{N}, 156^{\circ} 55^{\prime} \mathrm{W}$; (map 108).

So called by F. R. Weber, USGS, in 1959 , because of the dunes' long linear shape.

Shoestring Dune Lake: lake, $1.5 \mathrm{mi}$. long, in lower Koyukuk River valley, $2.5 \mathrm{mi}$. N of Coffee Can Lake and $30 \mathrm{mi}$. SW of Huslia; $65^{\circ} 19^{\prime} \mathrm{N}, 156^{\circ} 58^{\prime} \mathrm{W}$; (map 108).

So named in 1959 , by F. R. Weber, USGS, because this long, narrow lake parallels Shoestring Dune.

Shogvik Lake: lake, $2 \mathrm{mi}$. across, $4 \mathrm{mi}$. NW of 's, Kotzebue-Kobuk Low.; $66^{\circ} 39^{\prime}$ N, $160^{\circ} 05^{\prime} \mathrm{W}$; (map 114).

Eskimo name obtained by U.S. Army Corps of Engineers in 1955.

Shok-ah-bok-shegiak: stream, see Pah River.

Shokfak: village, see Chakwaktolik.

Shokfak tolik: village, see Chakwaktolik.

Shoko Creek: stream, flows SE to Sicmouth Creek which flows to Pargon River, about 16 mi. NE of Council, Seward Penin. Highlands (map 110).

Prospectors' name reported on the 1900 "Map of Nome Peninsula" by J. M. Davidson and B. D. Blakeslee. This stream cannot be precisely located on current maps.

Shokum Creek: stream, flows SW $1.5 \mathrm{mi}$. to Gulf of Alaska, $12 \mathrm{mi}$. ESE of Cape Yakataga, St. Elias Mts.; $60^{\circ} 01^{\prime} 40^{\prime \prime} \mathrm{N}, 142^{\circ} 05^{\prime} 50^{\prime \prime} \mathrm{W}$; (map 65).

Indian name reported in 1904 by G. C. Martin, USGS.

Sholes, Mount: peak, 5,230 ft., $4 \mathrm{mi}$. NE of Glacier Point, E of Ruth Glacier, Alaska Ra.; $62^{\circ} 55^{\prime} 40^{\prime \prime} \mathrm{N}, 150^{\circ} 30^{\prime} 30^{\prime \prime} \mathrm{W}$; (map 81).

Mountain climbers' name probably given by members of the 1945 Mazama expedition to the area.

Sholin Island: island, $0.4 \mathrm{mi}$. long, in Portlock Harbor, $7 \mathrm{mi}$. NW of Chichagof, on $\mathrm{W}$ coast of Chichagof I., Alex. Arch.; 57 $44^{\prime} 35^{\prime \prime} \mathrm{N}$, $136^{\circ} 15^{\prime} 00^{\prime \prime} \mathrm{W}$; (map 9).

Named published in 1928 by USC\&GS on Chart 8258.

Shoniktok Point: point of land, extends into Selawik Lake, 9 mi. NW of Selawik, KotzebueKobuk Low.; $66^{\circ} 36^{\prime} \mathrm{N}, 160^{\circ} 20^{\prime} \mathrm{W}$; (map 114).

Eskimo name obtained by U.S. Army Corps of Engineers in 1955.

Shoo Fly Rock: rock, see Eye Opener, the.

Shooiack Island: island, see Shuyak Island.

Shore Creek : stream, see Short Creek.

Shoreline Drive: settlement, pop. 56 , on $\mathrm{W}$ coast of Revillagigedo I., $3 \mathrm{mi}$. NW of Ketchikan, Alex. Arch.; 55 $22^{\prime} 30^{\prime \prime} \mathrm{N}, 131^{\circ} 43^{\prime} 30^{\prime \prime} \mathrm{W}$; (map 3).

This is an extension of the Ketchikan settlement area northwest along the highway.

Short Arm: cove, on $\mathrm{E}$ coast of Knight I., trends $\mathrm{N} 1 \mathrm{mi}$. to Bay of Isles, $16 \mathrm{mi}$. NE of Chenega, Chugach Mts.; $60^{\circ} 23^{\prime} 15^{\prime \prime} \mathrm{N}, 147^{\circ} 40^{\prime} 00^{\prime \prime} \mathrm{W}$; (map 63).

Name published in 1943 by USC\&GS.

Short Arm Kendrick Bay: estuary, extends SW $2 \mathrm{mi}$. off Kendrick Bay, on SE coast of Prince of Wales I., Alex. Arch.; 54 $52^{\prime} 30^{\prime \prime}$ N, $132^{\circ}$ $02^{\prime} 15^{\prime \prime} \mathrm{W}$; (map 1$)$.

Local name reported by H. C. Fassett, USBF, in 1904.

Short Bay: estuary, on Cleveland Penin., extends N 2 mi., off Bell Arm, Alex. Arch.; 55 58'30" $\mathrm{N}, 131^{\circ} 30^{\prime} 50^{\prime \prime} \mathrm{W}$; (map 3). Var. Short Inlet.

Named in 1879 by W. H. Dall, USC\&GS; published in 1883 Coast Pilot (p. 73) as Short Inlet.

Short Creek: stream, flows SE $9 \mathrm{mi}$. through Reflection Lake to Short Bay, $7 \mathrm{mi}$. N of Revillagigedo I. and $50 \mathrm{mi}$. SE of Wrangell, Alex. Arch.; $56^{\circ} 00^{\prime} 15^{\prime \prime} \mathrm{N}, 131^{\circ} 31^{\prime} 30^{\prime \prime} \mathrm{W}$; $B G N$ 1923; (map 7)

Descriptive name given in 1923 by USFS.

Short Creek: stream, flows N $0.4 \mathrm{mi}$. to Red Bay, on $\mathbf{N}$ coast of Prince of Wales I., Alex. Arch. ; $56^{\circ} 16^{\prime} 05^{\prime \prime} \mathrm{N}, 133^{\circ} 19^{\prime} 35^{\prime \prime} \mathrm{W}$; (map 6).

Named in 1886 by Lt. J. M. Helm, USN, for charting purposes; published in 1887 on USC\&GS Chart 706.

Short Creek: stream, heads near Sids Pass, flows SE $5.7 \mathrm{mi}$. to Wide Bay, on E coast of Alaska Penin., $39 \mathrm{mi}$. SE of Ugashik, Aleutian Ra.; $57^{\circ} 22^{\prime} 15^{\prime \prime} \mathrm{N}, 156^{\circ} 24^{\prime} 30^{\prime \prime} \mathrm{W}$; (map 36). Var. Shore Creek.

Descriptive name reported in 1923 by R. H. Sargent, USGS.

Short Creek: stream, heads in lake, flows SE 1.2 mi. to Cache Creek, $32 \mathrm{mi}$. NW of Talkeetna, Alaska Ra.; $62^{\circ} 28^{\prime} 05^{\prime \prime} \mathrm{N}, 151^{\circ} 01^{\prime} 25^{\prime \prime} \mathrm{W}$; (map 81).

Prospectors' name reported in 1911 by USGS.

Short Creek: stream, flows SE $4.4 \mathrm{mi}$. to Beaver Creek $8.5 \mathrm{mi}$. W of its junc. with Anvik River, $28 \mathrm{mi}$. NW of Anvik, Nulato Hills; $62^{\circ} 53^{\prime} \mathrm{N}$, $160^{\circ} 58^{\prime} \mathrm{W}$; (map 78).

Local descriptive name obtained in 1952 by USGS.

Short Creek: stream, flows NW $1.9 \mathrm{mi}$. to Long Creek, $3 \mathrm{mi}$. SW of Long and $26 \mathrm{mi}$. SW of

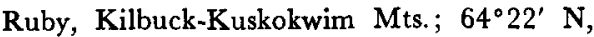
$155^{\circ} 34^{\prime} \mathrm{W}$; ( $\left.\operatorname{map} 98\right)$.

Prospectors' name reported in 1921 by USGS.

Short Creek: stream, flows N $1.3 \mathrm{mi}$. to Yukon River, $0.8 \mathrm{mi}$. W of Ruby, Kilbuck-Kuskokwim Mts.; $64^{\circ} 44^{\prime} 15^{\prime \prime} \mathrm{N}, 155^{\circ} 31^{\prime} 00^{\prime \prime} \mathrm{W}$; (map 98). Prospectors' name reported in 1908 by A. G. Maddren, USGS.

Short Creek: stream, flows E I mi. to Dorothy Creek, $21 \mathrm{mi}$. NE of Nome, Seward Penin. High.; 64. $49^{\prime} 15^{\prime \prime} \mathrm{N}, 165^{\circ} 14^{\prime} 35^{\prime \prime} \mathrm{W}$; (map 94).

Prospectors' name reported in 1904 by T. G. Gerdine, USGS.

Short Creek: stream, flows SE $1.5 \mathrm{mi}$. to Stewart River, $21 \mathrm{mi}$. NE of Nome, Seward Penin. High.; $64^{\circ} 49^{\prime} 12^{\prime \prime} \mathrm{N}, 165^{\circ} 22^{\prime} 20^{\prime \prime} \mathrm{W}$; (map 94).

Prospectors' name reported in 1904 by T. G. Gerdine, USGS.

Short Creek: stream, flows SW $5 \mathrm{mi}$. to Agiapuk River, $12 \mathrm{mi}$. NE of Teller, Seward Penin. High.; $65^{\circ} 26^{\prime} \mathrm{N}, 166^{\circ} 18^{\prime} \mathrm{W}$; (map 111).
Prospectors' name reported on the 1908 "Map of Seward Peninsula" by Arthur Gibson.

Short Creek: stream, flows SW $1.7 \mathrm{mi}$. to Kugruk River, $28 \mathrm{mi}$. NE of Imuruk Lake, Seward Penin. High.; $65^{\circ} 52^{\prime} \mathrm{N}, 162^{\circ} 26^{\prime} \mathrm{W}$; (map $110)$.

Prospectors' name published on the 1908 "Map of Seward Peninsula" by Arthur Gibson.

Short Creek: stream, flows ENE $1 \mathrm{mi}$. to Kreuger Creek which flows to Arctic River, 3.8. mi. E of The Ears on Ear Mtn., Seward Penin. High.; $65^{\circ} 55^{\prime} 45^{\prime \prime} \mathrm{N}, 166^{\circ} 05^{\prime} 40^{\prime \prime} \mathrm{W}$; BGN 1954; (map 111).

Descriptive name given in 1945 by a USGS field party.

Shortcut Slough: channel, of Tanana River, crosses Harper Bend W of mouth of Patterson Creek, $18 \mathrm{mi}$. SE of Tanana, Nowitna Low.; $65^{\circ} 01^{\prime} \mathrm{N}, 151^{\circ} 34^{\prime} \mathrm{W}$; (map 106).

Riverboat pilots' name shown on a 1940 Navigation Chart, Tanana-Yukon Rivers.

Short Gulch: ravine, trends NW $1.2 \mathrm{mi}$. to Oregon Creek which flows to Cripple River, $14 \mathrm{mi}$. NW of Nome, Seward Penin. High.; $64^{\circ} 42^{\prime} \mathrm{N}, 165^{\circ} 39^{\prime} \mathrm{W}$; (map 94$)$.

Prospectors' name reported on Arthur Gibson's "Map of Cape Nome Precinct" dated 1904.

Short Inlet: estuary, see Short Bay.

Short Island: island, in Yukon River, $26 \mathrm{mi}$. SW of Nulato, Koyukuk Low.; $64^{\circ} 24^{\prime} \mathrm{N}, 158^{\circ} 36^{\prime}$ W; (map 97).

Riverboat pilots' name shown on a 1940 "Navigation Chart of the Tanana-Yukon Rivers" published by U.S. Dept. of Interior. Short Pass: water passage, 1.3 mi. long, connects Behm Canal to Princess Bay, $N$ of Smeaton I., Coast Mts.; $55^{\circ} 22^{\prime} 45^{\prime \prime} \mathrm{N}$, $130^{\circ} 58^{\prime} 30^{\prime \prime} \mathrm{W}$; (map 3).

Descriptive name given in 1891 by USC\&GS.

Short Point: point of land, on S shore of Smeaton Bay, $2.2 \mathrm{mi}$. E of Point Nelson, Coast Mts.; $55^{\circ} 17^{\prime} 45^{\prime \prime} \mathrm{N}, 130^{\circ} 52^{\prime} 08^{\prime \prime} \mathrm{W}$; (map 3).

Descriptive name given in 1891 by USC\&GS

Shorty Cove: $b a y, 1$ mi. across, off Norton Sound, $8.5 \mathrm{mi}$. SW of Tolstoi Point and $27 \mathrm{mi}$. SW of Unalakleet, Nulato Hills; $63^{\circ} 30^{\prime} 30^{\prime \prime} \mathrm{N}$, $161^{\circ} 09^{\prime} 00^{\prime \prime} \mathrm{W}$; (map 91 ).

"Named for a prospector;" reported in 1952 by USC\&GS.

Shorty Creek: stream, flows E $0.3 \mathrm{mi}$. to Cook Inlet, $4.5 \mathrm{mi}$. NE of Tyonek, Cook Inlet Low.; $61^{\circ} 07^{\prime} 50^{\prime \prime} \mathrm{N}, 151^{\circ} 04^{\prime} 50^{\prime \prime} \mathrm{W}$; BGN 1916; (map 70). Var. Shortys Creek, Shorty's Creek.

Local name published in 1916 by USC\&GS. "Shorty was the nickname of a local resident, A. R. McConahay, who lived in the area at the time."

Shorty Creek: stream, heads in lake, flows SW $3 \mathrm{mi}$. to Willow Creek, W of Craigie Creek, $17 \mathrm{mi}$. NW of Palmer, Talkeetna Mts.; $61^{\circ}$ $45^{\prime} 45^{\prime \prime}$ N, $149^{\circ} 29^{\prime} 15^{\prime \prime} \mathrm{W}$; (map 69). 
Local name reported in 1913 by USGS (Brooks and others, 1914, fig. 2).

Shorty Creek: stream, flows $\mathrm{N} 4.5 \mathrm{mi}$. to Shorty Cove, $9 \mathrm{mi}$. SW of Tolstoi Point and $27 \mathrm{mi}$. $\mathrm{SW}$ of Unalakleet, Nulato Hills; $63^{\circ} 30^{\prime} 30^{\prime \prime} \mathrm{N}$, $161^{\circ} 08^{\prime} 00^{\prime \prime} \mathrm{W}$; (map 91$)$.

Local name reported in 1952 by USC\&GS. See Shorty Cove.

Shorty Creek: stream, flows W $4 \mathrm{mi}$, joins Quartz Creek to form Butte Creek, $30 \mathrm{mi}$. NE of Ophir and $41 \mathrm{mi}$. NW of McGrath, Kilbuck-Kuskokwim Mts.; $63^{\circ} 31^{\prime} \mathrm{N}, 156^{\circ} 08^{\prime} \mathrm{W}$; (map 90).

Prospectors' name reported in 1933 by USGS.

Shorty Creek: stream, flows NW $4 \mathrm{mi}$. to Tolovana River, $6 \mathrm{mi}$. S of Livengood, Yukon. Tanana High.; $65^{\circ} 26^{\prime} 30^{\prime \prime} \mathrm{N}, 148^{\circ} 38^{\prime} 00^{\prime \prime} \mathrm{W}$; (map 105).

Local name published by USGS in the 1950's.

Shorty Creek: stream, see Indian Creek.

Shorty River: stream, flows SW $12 \mathrm{mi}$. and joins Manikam Creek to form Kangnirvik Creek, $25 \mathrm{mi}$. NE of Kivalina, Arctic Slope; $68^{\circ} 02^{\prime}$ $\mathrm{N}, 163^{\circ} 56^{\prime} \mathrm{W}$; (map 130). Var. Peenyiksahm Koonga, Piinigsaam Kuuna, Pingeyiksak River.

Named for "Shorty" Knox, an Eskimo trapper, whose Eskimo name was "Piiniqsaaq."

Shortys Creek: stream, see Indian Creek.

Shortys Creek: stream, see Shorty Creek.

Shosky Creek: stream, flows W $25 \mathrm{mi}$. to Egegik River on Alaska Penin., $15 \mathrm{mi}$. SE of Egegik and $42 \mathrm{mi}$. S of Naknek, Bristol Bay Low.; $58^{\circ} 07^{\prime} 40^{\prime \prime} \mathrm{N}, 157^{\circ} 01^{\prime} 45^{\prime \prime} \mathrm{W}$; (map 41).

Local name reported in 1923 by R. H. Sargent, USGS.

Shotgold Creek: stream, flows $4.3 \mathrm{mi}$. NW to North Fork White River $4.8 \mathrm{mi}$. N of Solo Lake, and $53 \mathrm{mi}$. NE of McCarthy, Alaska Ra.; 61 ${ }^{\circ} 52^{\prime} 15^{\prime \prime} \mathrm{N}, 141^{\circ} 39^{\prime} 45^{\prime \prime} \mathrm{W}$; (map 67).

Local name obtained by USGS and published on maps since 1954.

Shotgun Cove: cove, on NE coast of Kenai Penin., extends NE 2 mi. to Passage Canal, 5 mi. NE of Whittier, Chugach Mts. ; $60^{\circ} 48^{\prime} 05^{\prime \prime}$ $\mathrm{N}, 148^{\circ} 32^{\prime} 30^{\prime \prime} \mathrm{W}$; BGN 1911; (map 63). Var. Passage Bay.

Named in 1911 by U. S. Grant and D. F. Higgins, USGS.

Shotgun Creek: stream, flows NW 32 mi., joins Kogrukluk River to form Holitna River, 65 mi. SW of Sleetmute, Kilbuck-Kuskokwim Mts.; $60^{\circ} 49^{\prime} \mathrm{N}, 157^{\circ} 51^{\prime} \mathrm{W} ; B G N$ 1948; (map 60). Var. I-am-tuk, I-im-tuck, Lishtak.

This appears to be a local translation of the Eskimo name often spelled "I-am-tuk" [Aiamtak?]. The Eskimo name was first reported about 1900 and spelled "I-im-tuck". The stream is thought to be so called because "a bend on the creek has the comparable appearance of a breech-loading shotgun when broken for loading[?]." P. Tikhmeniev putlished another Eskimo name, "Lishtak," for this stream in 1861 .
Shotgun Creek: stream, flows SE $6 \mathrm{mi}$. to Ohio Creek, $61 \mathrm{mi}$. SW of Healy, Alaska Ra.; $63^{\circ}$ $03^{\prime} 20^{\prime \prime} \mathrm{N}, 149^{\circ} 44^{\prime} 40^{\prime \prime} \mathrm{W}$; (map 87).

Prospectors' name obtained in 1913 by $\mathrm{J}$. W. Bagley, USGS; published by S. R. Capps (in Martin, 1919, pl. 5), USGS

Shotuih Hill: hill, $600 \mathrm{ft}$., $0.2 \mathrm{mi}$. N of Shovun Lake and $15 \mathrm{mi}$. NW of Fort Yukon, Yukon Flats; $66^{\circ} 48^{\prime} \mathrm{N}, 145^{\circ} 24^{\prime} \mathrm{W}$; (map 119).

Kutchin Indian name obtained in 1956 by T. E. Taylor, USGS.

Shou-a-gan: locality, see Sukkwan.

Shoulderblade Island: island, $0.4 \mathrm{mi}$. long, in Iliamna Lake, $9 \mathrm{mi}$. SW of Big I. and $37 \mathrm{mi}$. SW of Iliamna, Bristol Bay Low.; 59 $21^{\prime} \mathrm{N}$, $155^{\circ} 35^{\prime} \mathrm{W}$; (map 51).

Named locally because of its similarity in appearance to a shoulderblade. Published in 1951 by USGS.

Shoulder Mountain: mountain, 3,430 ft., extending NE-SW $13 \mathrm{mi}$. along Sheenjek River, $60 \mathrm{mi}$. NW of Coleen Mtn., Brooks Ra.; $67^{\circ}$ $56^{\prime} \mathrm{N}, 143^{\circ} 38^{\prime} \mathrm{W}$; (map 121).

Local descriptive name reported by USGS in 1932.

Shoumagin Islands: islands, see Shumagin Islands.

Shoup Bay: bay, $1 \mathrm{mi}$. across, on $\mathrm{N}$ shore of Port Valdez, $2.9 \mathrm{mi}$. W of Camp Bowie and $11 \mathrm{mi}$. W of Valdez, Chugach Mts.; $61^{\circ} 07^{\prime}$ $15^{\prime \prime} \mathrm{N}, 146^{\circ} 35^{\prime} 30^{\prime \prime} \mathrm{W}$; (map 68).

Local name reported in 1905 by $U$. $S$. Grant, USGS.

Shoup Glacier: glacier, trends SW $17 \mathrm{mi}$. to its terminus, $0.4 \mathrm{mi}$. NW of head of Shoup Bay and $12 \mathrm{mi}$. W of Valdez, Chugach Mts.; $61^{\circ} 08^{\prime} 50^{\prime \prime} \mathrm{N}, 146^{\circ} 36^{\prime} 00^{\prime \prime} \mathrm{W}$; (map 68). $V a r$. Canyon Creek Glacier.

Named Canyon Creek Glacier in 1898 by Capt. W. R. Abercrombie, USA; the local name Shoup Glacier was reported by him in 1899.

Shouplina, Mount: mountain, 8,510 ft., $2 \mathrm{mi}$. SW of Mount Cashman and $18 \mathrm{mi}$. NNW of Valdez; $61^{\circ} 20^{\prime} 21^{\prime \prime} \mathrm{N}, 146^{\circ} 29^{\prime} 10^{\prime \prime} \mathrm{W}$; $B G N$ 1965; (map 68).

Probably named about 1959 by Nielsen (1963, p. 135), USGS

Shovel Creek: stream, flows NW to Agiapuk River, N of Flat Creek, about $25 \mathrm{mi}$. NE of Teller, Seward Penin. High.; (map 111).

Prospectors' name reported on a precinct map of Seward Peninsula gold fields by Monroe and Hutchins, corrected up to June 1903 by Arthur Gibson. This feature cannot be precisely identified on current maps.

Shovel Creek: stream, flows N $2.3 \mathrm{mi}$. to Flat Creek, $12 \mathrm{mi}$. NW of Tahneta Pass and 68 mi. SW of Gulkana, Talkeetna Mts.; 62 ${ }^{\circ} 03^{\prime}$ $37^{\prime \prime} \mathrm{N}, 147^{\circ} 25^{\prime} 08^{\prime \prime} \mathrm{W}$; (map 82).

Local name reported in 1917 by USGS.

Shovel Creek: stream, heads in Shovel Lake, flows NE $6 \mathrm{mi}$. to Treasure Creek, $27 \mathrm{mi}$. SW of Talkeetna, Alaska Ra.; $62^{\circ} 13^{\prime} 20^{\prime \prime} \mathrm{N}, 150^{\circ}$ $56^{\prime} 30^{\prime \prime} \mathrm{W}$; (map 81).

Local name reported in 1958 by USGS. Shovel Creek: stream, flows NW $30 \mathrm{mi}$. to Papa Willie Creek, $3 \mathrm{mi}$. E of Blackburn I. and
$57 \mathrm{mi}$. SE of Unalakleet, Innoko Low.; $63^{\circ}$ $22^{\prime} 40^{\prime \prime} \mathrm{N}, 159^{\circ} 18^{\prime} 30^{\prime \prime} \mathrm{W}$; (map 91).

Local name reported in 1949 by USC\&GS. Shovel Creek: stream, flows NW $6 \mathrm{mi}$. to Totalanika River, $20 \mathrm{mi}$. NE of Healy, Alaska Ra.; $63^{\circ} 58^{\prime} 50^{\prime \prime} \mathrm{N}, 148^{\circ} 29^{\prime} 40^{\prime \prime} \mathrm{W}$; (map 87).

Prospectors' name shown on a 1910 fieldsheet by J. W. Bagley, USGS; published by Capps (1912, pl. 1), USGS.

Shovel Creek: stream, flows SW $4.6 \mathrm{mi}$. to Anakeksik Creek, 12 mi. SE of Christmas Mtn., Nulato Hills; $64^{\circ} 24^{\prime} \mathrm{N}, 160^{\circ} 28^{\prime} \mathrm{W}$; (map 96).

Local name reported about 1954 by U.S. Army Corps of Engineers.

Shovel Creek: stream, flows SE $8.5 \mathrm{mi}$. to Solomon River, $4 \mathrm{mi}$. NE of Solomon, Seward Penin. High.; $64^{\circ} 37^{\prime} \mathrm{N}, 164^{\circ} 23^{\prime} \mathrm{W}$; (map 95).

Prospectors' name reported in 1899 by Schrader and Brooks (1900, map 3), USGS. Shovel Creek: stream, flows SW $6.3 \mathrm{mi}$. to Yukon River, $15 \mathrm{mi}$. NE of Ruby, Kokrines-Hodzana High.; $64^{\circ} 52^{\prime} 30^{\prime \prime} \mathrm{N}, 155^{\circ} 04^{\prime} 55^{\prime \prime} \mathrm{W}$; (map 98).

Prospectors' name reported in 1911 by A. G. Maddren (in Brooks and others, 1912, p. 294-296), USGS.

Shovel Creek: stream, heads at $64^{\circ} 57^{\prime} \mathrm{N}$, $148^{\circ} 24^{\prime} \mathrm{W}$, flows N 6 mi. to Chatanika River, $25 \mathrm{mi}$. NW of, Fairbanks, Yukon-Tanana High.; $65^{\circ} 01^{\prime} 40^{\prime \prime} \mathrm{N}, 148^{\circ} 24^{\prime} 20^{\prime \prime} \mathrm{W}$; (map 105).

Named by prospectors; published in 1906 by USGS.

Shovel Horn Point: pinnacle, see Shovel Point Horn.

Shovel Lake: lake, $1.3 \mathrm{mi}$. long, at head of Shovel Creek, $31 \mathrm{mi}$. SW of Talkeetna, Alaska Ra.; $62^{\circ} 13^{\prime} \mathrm{N}, 151^{\circ} 30^{\prime} \mathrm{W}$; (map 81).

Local name reported in 1958 by USGS.

Shovel Point: ridge and promontory, 4,800 ft., extends $\mathbf{N} 2 \mathrm{mi}$. on Granite $\mathbf{M t n}$. $\mathbf{E}$ of Till Valley, $18 \mathrm{mi}$. SE of Delta Junction, Alaska Ra.; $63^{\circ} 48^{\prime} 00^{\prime \prime} \mathrm{N}, 145^{\circ} 27^{\prime} 15^{\prime \prime} \mathrm{W}$; (map 86). Name reported in 1952 by USGS.

Shovel Point Horn: pinnacle, 5,100 ft., on Granite Mtn., near head of Rhoads Creek, $20 \mathrm{mi}$. SE of Delta Junction, Alaska Ra.; $63^{\circ}$ $47^{\prime} 05^{\prime \prime} \mathrm{N}, 145^{\circ} 26^{\prime} 05^{\prime \prime} \mathrm{W}$; (map 86). Var. Shovel Horn Point.

Named between 1948 and 1955 by T. L. Péwé, USGS.

Shovenagamiut: locality, see Shevenak.

Shovenagamute: locality, see Shevenak.

Shovun Lake: lake, $1.5 \mathrm{mi}$. long, $1 \mathrm{mi}$. E of Alexanders Village and $15 \mathrm{mi}$. NW of Fort Yukon, Yukon Flats; $66^{\circ} 47^{\prime} 20^{\prime \prime} \mathrm{N}, 145^{\circ} 24^{\prime}$ $00^{\prime \prime} \mathrm{W}$; (map 119).

Kutchin Indian name obtained in 1956 by T. E. Taylor, USGS.

Show-a-gan; locality, see Sukkwan.

Shower Gulch: ravine, extends $1.2 \mathrm{mi}$. NW from glacier, $3.3 \mathrm{mi}$. NE of Skyscraper Peak and $35 \mathrm{mi}$. NW of McCarthy, Wrangell Mts.; $61^{\circ} 43^{\prime} 50^{\prime \prime} \mathrm{N}, 143^{\circ} 43^{\prime} 30^{\prime \prime} \mathrm{W}$; (map 67).

Local name obtained by USGS and published on maps since 1954, 
Show Gulch: ravine, see Snow Gulch.

Show Me Creek: stream, flows S $1.5 \mathrm{mi}$. to Valdez Creek, $67 \mathrm{mi}$. SE of Healy, Alaska Ra.; $63^{\circ} 12^{\prime} \mathrm{N}, 147^{\circ} 24^{\prime} \mathrm{W}$; (map 87).

Local name obtained in 1951 by USGS.

Shrew Lake: lake, $0.3 \mathrm{mi}$. long, on Kenai Penin.

SW of Lonely Lake, $30 \mathrm{mi}$. NE of Kenai, Cook Inlet Low.; $60^{\circ} 47^{\prime} 00^{\prime \prime} \mathrm{N}, 150^{\circ} 33^{\prime} 30^{\prime \prime} \mathrm{W}$; (map 62).

Named about 1963 by officials of Kenai National Moose Range, for administrative purposes.

Shrimp Bay: estuary, extends E $2.3 \mathrm{mi}$. off Gedney Pass, on NW coast of Revillagigedo I., Alex. Arch.; $55^{\circ} 50^{\prime} 25^{\prime \prime} \mathrm{N}, 131^{\circ} 31^{\prime} 00^{\prime \prime} \mathrm{W}$; (map 3).

One of many arbitrary names applied to features in this area in 1891 by USC\&GS.

Shrine Creek: stream, flows $2 \mathrm{mi}$. NW to St. Terese, on Favorite Channel, $0.1 \mathrm{mi}$. $\mathrm{S}$ of Pearl Harbor and $18 \mathrm{mi}$. NW of Juneau, Coast Mts.; $58^{\circ} 28^{\prime} 15^{\prime \prime} \mathrm{N}, 134^{\circ} 47^{\prime} 00^{\prime \prime} \mathrm{W}$; $B G N$ 1937; (map 11).

Name reported in 1937 by USFS and derived from the Shrine of Saint Teresa near the creek's mouth.

Shrode, Lake: lake, on E side of Kenai Penin., 0.5 mi. across, between Lake Jack and Cochrane Bay, $15 \mathrm{mi}$. SE of Whittier, Chugach Mts. ; $60^{\circ} 39^{\prime} 15^{\prime \prime} \mathrm{N}, 148^{\circ} 19^{\prime} 00^{\prime \prime} \mathrm{W}$; (map 63). Local name reported in 1952 by USGS.

Shrubby Island: island, $3 \mathrm{mi}$. long, one of Kashevarof Is between Clarence Strait and Kashevarof Passage, off $\mathrm{N}$ coast of Prince of Wales I., Alex. Arch.; 56 ${ }^{\circ} 13^{\prime} \mathrm{N}, 132^{\circ} 58^{\prime} \mathrm{W}$; (map 6).

Named by W. H. Dall, USC\&GS ; published in 1883 Coast Pilot.

Shrub Islet: island, $0.1 \mathrm{mi}$. long, NE coast of Coronation I., Alex. Arch.; $55^{\circ} 55^{\prime} 20^{\prime \prime} \mathrm{N}$, $134^{\circ} 07^{\prime} 25^{\prime \prime} \mathrm{W}$; (map 4).

Local name recorded in 1948 by USGS.

Shubelik Mountains: mountain range, see Shublik Mountains.

Shubelik Range: mountain range, see Shublik Mountains.

Shubelik Spring: springs, see Shublik Spring.

Shubelik Springs: springs, see Shublik Spring.

Shublick Mountains: mountain range, see Shublik Mountains.

Shublik Island: island, $1 \mathrm{mi}$. long, in Canning River, at mouth of Cache Creek, $46 \mathrm{mi}$. W of Mount Michelson, Arctic Slope; 69 $24^{\prime} \mathrm{N}$, $146^{\circ} 08^{\prime} \mathrm{W}$; (map 139).

Leffingwell (1919, p. 116), does not list this in his geographic names, but writes in his text, "The type locality is at Shublik I. on Canning River, at the southwest corner of the Shublik Mountains, ***" The name is derived from Shublik Spring.

Shublik Mountains: mountain range, $4,500 \mathrm{ft}$., $30 \mathrm{mi}$. long, $5 \mathrm{mi}$. S of Sadlerochit Mts., trends E-W between Canning and Sadlerochit Rivers, $26 \mathrm{mi}$. NW of Mount Michelson, Brooks Ra.; $69^{\circ} 31^{\prime} \mathrm{N}, 145^{\circ} 40^{\prime} \mathrm{W}$; $B G N$ 1959; (map 139). Var. Shubelik Mountains, Shubelik Range, Shublick Mountains, Sublik Mountains.
Leffingwell (1919, p. 51) wrote: "The outer two of the three outlying ranges south of Camden Bay have been given separate names ***. The middle range, called the Shublik Mountains, is shorter, wider and in general higher * * *."

Shublik Spring: springs, on E bank of Canning River $3 \mathrm{mi}$. N its junc. with Cache Creek, 45 mi. NW of Mount Michelson, Arctic Slope; $69^{\circ} 27^{\prime} \mathrm{N}, 146^{\circ} 03^{\prime} \mathrm{W}$; BGN 1959; (map 139). Var. Shubelik Spring, Shubelik Springs, Shublik Springs, Sublik Springs.

Eskimo name which was reported by Leffingwell $(1919$, p. 99) to mean "a spring." Leffingwell wrote, "There are two springs which deserve mention. The larger one by report is the Shublik Spring, at the west end of Shublik Mountains, ***" (p. 58).

Shokokluk Creek: stream, flows SE $17 \mathrm{mi}$. from Sillyasheen Mtn. to Wolverine Creek, $2 \mathrm{mi}$. SW of Crag Peak and $65 \mathrm{mi}$. W of Wiseman, Brooks Ra.; $67^{\circ} 37^{\prime} \mathrm{N}, 152^{\circ} 29^{\prime} \mathrm{W}$; BGN 1932 ; (map 124).

This is an "Eskimo name for a certain black rock found on the creek," as reported by Robert Marshall in 1932.

Shublik Springs: springs, see Shublik Spring.

Shuck River: stream, see Chuck River.

Shudtaroshik River: stream, see Sadlerochit River.

Shuiak Island: island, see Shuyak Island.

Shuitna River: stream, see Chuitna River.

Shukan Bay: bay, see Shakan Bay.

Shukok Creek: stream, flows NE $11 \mathrm{mi}$. from a lake to Wolverine Creek, $6 \mathrm{mi}$. SW of Crag Peak and $68 \mathrm{mi}$. W of Wiseman, Brooks Ra.; $67^{\circ} 35^{\prime} 40^{\prime \prime} \mathrm{N}, 152^{\circ} 37^{\prime} 00^{\prime \prime} \mathrm{W} ;$ BGN 1932 (map 124).

Eskimo name "referring to the kind of rock found on the creek," as reported by Robert Marshall in 1932

Shuktusa Branch: stream, flows NE $3.5 \mathrm{mi}$. to Stikine River, $19 \mathrm{mi}$. NE of Wrangell, Coast Mts. ; $56^{\circ} 42^{\prime} 10^{\prime \prime} \mathrm{N}, 132^{\circ} 04^{\prime} 30^{\prime \prime} \mathrm{W}$; (map 6). Var. Shuktusa Creek.

Local name recorded in 1953 by USGS.

Shulakpachak Peak: peak, 6,500 ft., in Schwatka Mts., $26 \mathrm{mi}$. W of Mount Igikpak, Brooks Ra.; $67^{\circ} 26^{\prime} \mathrm{N}, 155^{\circ} 56^{\prime} \mathrm{W}$; (map 125).

Eskimo name recorded in Kobuk by Orth, USGS, in 1956 and reported to mean "like a big feather."

Shulin Lake: lake, $2 \mathrm{mi}$. long, $3 \mathrm{mi}$. $\mathrm{E}$ of Willow Mtn. and $26 \mathrm{mi}$. SW of Talkeetna, Cook Inlet Low.; $62^{\circ} 08^{\prime} 25^{\prime \prime} \mathrm{N}, 150^{\circ} 51^{\prime} 30^{\prime \prime} \mathrm{W}$; (map 81).

Local name reported in 1958 by USGS.

Shultna River: stream, see Chuitna River.

Shultz, Point: point of land, S tip of Fleming I, $12 \mathrm{mi}$. NW of Chichagof, on $W$ coast of Chichagof I., Alex. Arch.; 57 $47^{\circ} 15^{\prime \prime} \mathrm{N}, 136^{\circ}$. $19^{\prime} 25^{\prime \prime} \mathrm{W}$; (map 9).

Local name published by USC\&GS in 1925 Coast Pilot (p. 322).

Shulukpaukat River: stream, see Ribdon River. Shulunarurak Creek: stream, heads on Tupikchak Mountain, flows NW $4 \mathrm{mi}$. to Kokolik
River, Arctic Slope; $68^{\circ} 53^{\prime} \mathrm{N}, 161^{\circ} 58^{\prime} \mathrm{W}$; (map 131).

Eskimo name reported by T. E. Taylor, USGS, in 1956.

Shulze Cove: bay, see Schulze Cove

Shumagin Bank: shoal, in Pacific Ocean, SE of Shumagin Is., Aleutian Ra.; $54^{\circ} 40^{\prime} \mathrm{N}, 159^{\circ}$ $26^{\prime} \mathrm{W}$; (map 26).

Named in 1888 by USBF.

Shumagin Islands: islands, $60 \mathrm{mi}$. across, $\mathrm{S}$ of Alaska Penin., including Unga, Popof, Korovin, Nagai, Simeonof, and Big and Little Koniuji Is., plus other smaller islands; $55^{\circ} 10^{\prime}$ $\mathrm{N}, 160^{\circ} 00^{\prime \prime} \mathrm{W} ; B G N 1890$; (map 28). Var. Choumagin Islands, Choumaghin Islands, Kagigun Islands, Shoumagin Islands, Unga Islands.

Named by Capt. Comdr. Vitus Bering, IRN, for one of his sailors, who died of scurvy and was buried here August 30, 1741. Father Veniaminov (1840, v. 1, p. 255) reported the Aleut name as "Kagigun" and Golovin said the Aleuts called the islands "Unga," from the name of the largest of the group (1862, voyage $1, \mathrm{p} .174$ ). The name was published in French as "I[les] Choumagin," or "Shumagin Islands," by Adm. Krusenstern (1827, map 20), IRN.

Shuman, Mount: mountain, 3,185 ft., on E shore of Karluk Lake, Kodiak I.; $57^{\circ} 19^{\prime} 15^{\prime \prime}$ N, $153^{\circ} 59^{\prime} 15^{\prime \prime} \mathrm{W}$; $B G N$ 1957; (map 34).

Named in 1954 by USF\&WS for Richard Frederick Shuman, 1906-54, Fishery Management Supervisor of USF\&WS, "who was killed in line of official duty in an airplane crash."

Shuman House: locality, pop. 19 (1940), on right bank of Porcupine River, $17 \mathrm{mi}$. N of Chalkyitsik, Yukon Flats; $66^{\circ} 54^{\prime} \mathrm{N}, 143^{\circ} 46^{\prime}$ W; (map 120).

Local name published in 1951 by USGS.

Shuman Lake: lake, an oxbow $1.5 \mathrm{mi}$. long, $\mathrm{S}$ of Sheenjek River, $36 \mathrm{mi}$. NE of Fort Yukon, Yukon Flats; $66^{\circ} 54^{\prime} 20^{\prime \prime} \mathrm{N}, 144^{\circ} 17^{\prime} 00^{\prime \prime} \mathrm{W}$; (map 119)

Local name obtained in 1956 by USGS.

Shuna Creek: stream, see Sinona Creek. Shunakhtuli, Ostrov: island, see Shaw Island Shunaktuli Island: island, see Shaw Island. Shung-nack River: stream, see Shungnak River. Shungnak: village, pop. 135 , on right bank of Kobuk River $85 \mathrm{mi}$. NE of Selawik, KotzebueKobuk Low.; $66^{\circ} 52^{\prime} \mathrm{N}, 157^{\circ} 09^{\prime} \mathrm{W}$; (map 115).

Eskimo village relocated from a site about 10 miles upstream. See Kobuk. A post office was established for a few months in 1934 and then again in 1946 (Ricks, 1965 p. 58). The village population was 193 in 1939 and 141 in 1950

Shungnak: village, see Kobuk.

Shungnak Mountain: mountain, 2,250 ft., W of Cosmos Mtn., $9 \mathrm{mi}$. N of Shungnak, Brooks Ra.; $67^{\circ} 01^{\prime} \mathrm{N}, 157^{\circ} 10^{\prime} \mathrm{W}$; (map 126).

Local name given by prospectors reported by USGS in 1956.

Shungnak River: stream, heads in Schwatka Mts. at $67^{\circ} 16^{\prime} \mathrm{N}, 156^{\circ} 25^{\prime} \mathrm{W}$, flows SW 47 
mi. to Kobuk River, $8 \mathrm{mi}$. NW of Shungnak, Kotzebue-Kobuk Low.; $66^{\circ} 55^{\prime}$ N, $157^{\circ} 25^{\prime}$ W; (map 115). Var. Shingnek River, Shung-nack River.

Eskimo name, meaning "jade," written "Shung-nack" by Lt. G. M. Stoney, USN, in 1885 , and "Shingnek" by W. C. Mendenhall, USGS, in 1901. Jade is found near its headwaters. See Jade Mountain.

Shusana Glacier: glacier, see Chisana Glacier. Shushaldinskaia: mountain, see Shishaldin Volcano.

Shushalluk Creek: stream, flows E $6 \mathrm{mi}$. to Ernie Creek, $4 \mathrm{mi}$. SE of Slatepile Mtn. and $39 \mathrm{mi}$. NW of Wiseman, Brooks Ra.; 67 ${ }^{\circ} 55^{\prime}$ N, 150 $51^{\prime}$ W; BGN 1932; (map 124).

Named about 1930 by Robert Marshall "after an Eskimo who built a cabin at the mouth of this creek and wintered there."

Shushana: village, see Chisana.

Shushana River: stream, see Chisana River.

Shushana River: stream, see Sushana River.

Shushanna Junction: settlement, see McCarthy. Shu-shuk-to-ark: stream, see Squirrel River.

Shuyak Harbor: bay, $3 \mathrm{mi}$. across, on SW coast of Shuyak I., $41 \mathrm{mi}$. $\mathbf{N}$ of Kodiak I.; $58^{\circ} 30^{\prime}$ $00^{\prime \prime} \mathrm{N}, 152^{\circ} 37^{\prime} 35^{\prime \prime} \mathrm{W}$; (map 43). Var. Svendson and Shaw.

Local name derived from Shuyak Island and published by USC\&GS in 1926. “* * * Sometimes called Svendson and Shaw after a firm engaged in the herring fishery there."

Shuyak Island: island, $11 \mathrm{mi}$. across, $\mathrm{N}$ of Afognak I., $40 \mathrm{mi}$. N of Kodiak I.; $58^{\circ} 31^{\prime}$ N, 152 $30^{\prime} \mathrm{W}$; BGN 1890; (map 43). Var. Chouyak Island, Chugak Island, Chuyak Island, Huiak Island, Iluiak Island, Isla de Bonilla, Nebel Island, Schujek Island, Shooiack Island, Shuiak Island, Shuyuch Island.

Native name reported by G. I. Shelikov in 1785 (in Bancroft, 1886, p. 228). This may be the same island called "Isla de Bonilla" on Don Juan de la Bodega y Quadra's 1791 map.

Shuyak, Strait: water passage, between Shuyak and Afognak Is., $\mathrm{N}$ of Kodiak I.; 58 ${ }^{\circ} 29^{\prime} \mathrm{N}$, $152^{\circ} 36^{\prime} \mathrm{W}$; (map 43). Var. Chuyak Strait.

Name derived from Shuyak Island and published by the Russian American Company in 1849 as "Pr[oliv] Shuyak."

Shuyuch Island: island, see Shuyak Island.

Siagraurak: locality, see Siagrorak.

Siagrorak: locality, outcrop of rocks $\mathrm{N}$ of Kivalina Lagoon, $10 \mathrm{mi}$. NW of Kivalina, Kotzebue-Kobuk Low.; $67^{\circ} 50^{\prime} \mathrm{N}, 164^{\circ} 44^{\prime} \mathrm{W}$; (map 128). Var. Sayagrowrak, Siagraurak, Siagzauzaq.

Eskimo name reported in 1966 by E. S. Burch.

Siagzauzaq : locality, see Siagrorak.

Siaklidok Island: island, see Sitkalidak Island. Siaktak Creek: stream, see Saitut Creek.

Siaktklidak Island: island, see Sitkalidak Island. Siamese Lakes: lakes, $3 \mathrm{mi}$. NW of terminus of Sheridan Glacier, $10 \mathrm{mi}$. E of Cordova, Chu- gach Mts.; $60^{\circ} 34^{\prime} \mathrm{N}, 145^{\circ} 26^{\prime} \mathrm{W}$; (map 64).

So named "because the lakes are about the same size and close together." Name published in 1950 by USGS.

Siavlat Mountain: mountain, 5,200 ft., $35 \mathrm{mi}$. SE of Howard Pass, Brooks Ra.; 68 ${ }^{\circ} 03^{\prime} \mathrm{N}$, $155^{\circ} 34^{\prime} \mathrm{W}$; (map 133).

Eskimo name reported in 1956 by Orth.

Siberia Hill: mountain, see Knob Hill.

Sichtunak: island, see Sitkinak Island.

Sic-sic-puk River: stream, see Siksikpuk River. Sidankin: village, see Biorka.

Sidaru: locality, on Chukchi Seacoast SW of Point Belcher, Arctic Plain; $70^{\circ} 45^{\prime} \mathrm{N}, 1^{\circ} 9^{\circ}$ 45' W; (map 146). Var. Nunaria, Sedard, Sedaroo, Sedars, Sedaru, Sezaro.

Former Eskimo village settled by people from Nunaria, reported in 1883 by Lt. P. H. Ray, USA, who gave its population as 50 . It was once a large village but abandoned by 1905 .

Siddens Valley: valley, $1.5 \mathrm{mi}$. long, formed by Bassett Creek, on E coast of Attu I., W of Lake Nicholas, Aleutian Is.; $52^{\circ} 53^{\prime} 00^{\prime \prime} \mathrm{N}$, $173^{\circ} 13^{\prime} 10^{\prime \prime} \mathrm{E}$; (map 13).

Named by the U.S. Army during its occupation of the island during World War II; shown on an AMS map published in 1948.

Sidecar Creek: stream, see Mike Creek.

Side Creek: stream, in Ray Mts., flows E 3.5 mi. to Twentymile Creek, $14 \mathrm{mi}$. N of Rampart and $67 \mathrm{mi}$. NE of Tanana, KokrinesHodzana High.; $65^{\circ} 42^{\prime} 30^{\prime \prime} \mathrm{N}, 150^{\circ} 08^{\prime} 45^{\prime \prime}$ W; (map 106).

Local descriptive name reported by Orth in 1956; so named because it flows to the side of and parallel to Twentymile Creek.

Side Island: island, see Lewis Island.

Sidik Lake: lake, $1 \mathrm{mi}$. across, in Anisak River valley, $17 \mathrm{mi}$. SW of Feniak Lake, Brooks Ra.; $68^{\circ} 09^{\prime} \mathrm{N}, 158^{\circ} 58^{\prime} \mathrm{W}$; (map 132 ).

Eskimo name obtained by Orth at Noatak in 1956.

Sid Larson Bay: inlet, $2.5 \mathrm{mi}$. long, in Kakhonak Bay at SE end of Iliamna Lake, $26 \mathrm{mi}$. SE of Iliamna, Aleutian Ra.; $59^{\circ} 26^{\prime} \mathrm{N}, 154^{\circ} 33^{\prime}$ W; (map 51).

Local name published in 1951 by USGS.

Sidney Creek: stream, flows NE $1.7 \mathrm{mi}$. to Archangel Creek, $15 \mathrm{mi}$. NW of Palmer, Talkeetna Mts.; $61^{\circ} 48^{\prime} 35^{\prime \prime} \mathrm{N}, 149^{\circ} 12^{\prime} 55^{\prime \prime}$ W; (map 69).

Local name reported in 1913 by USGS (Brooks and others, 1914, fig. 2).

Sidney Creek: stream, flows NE $4.5 \mathrm{mi}$. to Cripple River, $15 \mathrm{mi}$. NW of Nome, Seward Penin. High.; $64^{\circ} 37^{\prime} \mathrm{N}, 165^{\circ} 52^{\prime} \mathrm{W}$; (map 94).

Prospectors' name reported in 1900 by E. C. Barnard (in Brooks, 1901, pl. 17), USGS.

Sidney Creek: stream, flows NW $1 \mathrm{mi}$. to Iron Creek which flows to Pilgrim River, between Dome and Hillard Creeks, $25 \mathrm{mi}$. NW of Solomon, Seward Penin. High.; 64 $54^{\circ} 25^{\prime \prime}$ N, $164^{\circ} 41^{\prime} 40^{\prime \prime} \mathrm{W}$; ( $\left.\operatorname{map} 95\right)$.

Prospectors' name reported in 1908 by P.S. Smith (in Brooks and others, 1909, pl, 10), USGS.
Sidney Creek: stream, flows E to Cripple River, about $31 \mathrm{mi}$. NW of Nome, Seward Penin. High.; (map 94).

Prospectors' name reported on the 1900 "Map of Nome Peninsula" by J. M. Davidson and B. D. Blakeslee; this feature has not been positively identified.

Sidrak Island: barrier island, see Flaxman Island.

Sids Pass: pass, elev. $600 \mathrm{ft}$., at head of Black and Short Creeks, on Alaska Penin., $36 \mathrm{mi}$. SE of Ugashik, Aleutian Ra.; $57^{\circ} 23^{\prime} 45^{\prime \prime} \mathrm{N}$, $156^{\circ} 24^{\prime} 40^{\prime \prime} \mathrm{W}$; (map 36$)$.

Named in 1923 by R. H. Sargent, USGS, for "Seward (Sid) Old," one of his packers, who examined the pass.

Siegfried, Mount: mountain, 9,205 ft., near head of Tarr Glacier, $36 \mathrm{mi}$. NW of Valdez, Chugach Mts. ; $61^{\circ} 30^{\prime} 40^{\prime \prime} \mathrm{N}, 147^{\circ} 00^{\prime} 35^{\prime \prime} \mathrm{W}$; $B G N$ 1965; (map 69).

Named in 1957 for "Siegfried, a figure from the heroic literature of the ancient Teutons" by members of the Chugach Mountains Expedition sponsored by the Arctic Institute of North America (Nielsen, 1963, p. 135).

Sievernie: point of land, see North Cape.

Sievernoi: island, see Raspberry Island.

Sievernoi: point of land, see North Cape.

Sievernoi: promontory, see Akun Head.

Sievernoi: water passage, see Whale Passage.

Sievernoi Strait: water passage, see Kupreanof Strait.

Sieverny: islands, see Pribilof Islands.

Sigak: point of land, see Sagak, Cape.

Sigak Cape: point of land, see North Head.

Sigakh, Mys: point of land, see North Head.

Siganaka, Ostrova: islands, see Siginaka Islands.

Sigard Creek: stream, flows SW $2.5 \mathrm{mi}$. to join Linton Creek to form Bonanza River, $18 \mathrm{mi}$. NW of Solomon, Seward Penin. High.; $64^{\circ} 46^{\prime} 55^{\prime \prime} \mathrm{N}, 164^{\circ} 47^{\prime} 30^{\prime \prime} \mathrm{W}$; (map 95). Var. Sigurd Creek.

Shown as "Sigurd" on the 1900 "Map of Nome Peninsula" by J. M. Davidson and B. D. Blakeslee.

Sigdak Island: island, see Great Sitkin Island.

Sigeakruk Point: point of land, extends $\mathrm{N}$ into Wainwright Inlet, $4 \mathrm{mi}$. S of Wainwright, Arctic Plain; $70^{\circ} 34^{\prime} 58 \mathrm{~N}, 160^{\circ} 01^{\prime} 15^{\prime \prime} \mathrm{W}$; (map 146).

Eskimo name reported in 1955 by AMS.

Sigh Islands: islands, $0.5 \mathrm{mi}$. wide, in Jinhi Bay, NE coast of Tuxekan I., Alex. Arch.; $55^{\circ} 52^{\prime} 45^{\prime \prime} \mathrm{N}, 133^{\circ} 16^{\prime} 10^{\prime \prime} \mathrm{W}$; (map 4).

Local name published in 1964 by USC\&GS.

Sightas Island: island, $0.6 \mathrm{mi}$. long, in Yukon River, $28 \mathrm{mi}$. NE of Rampart, Yukon-Tanana High.; $65^{\circ} 52^{\prime} \mathrm{N}, 149^{\circ} 46^{\prime} \mathrm{W}$; (map 105).

Local name published on recent USGS maps. The island is apparently separated from the left bank of the Yukon River during the flood stage of that river in the spring; however, the island is connected to the land during low water periods in the summer.

Sight Peak: peak, 8,610 ft., at head of Johnson Glacier, $25 \mathrm{mi}$. NE of Paxson, Alaska Ra.; $63^{\circ} 23^{\prime} 20^{\prime \prime} \mathrm{N}, 145^{\circ} 23^{\prime} 30^{\prime \prime} \mathrm{W}$; (map 86).

Name published on relatively recent maps. 
Sigikrurak Point: point of land, see Siksrikpak Point.

Siginak: island, see Sedanka Island.

Siginaka Islands: islands, $1 \mathrm{mi}$. across, in Sitka Sound, $8 \mathrm{mi}$. NW of Sitka, Alex. Arch.; $57^{\circ} 09^{\prime} \mathrm{N}, 135^{\circ} 27^{\prime} \mathrm{W}$; BGN 1897; (map 9). Var. Ostrov Siginaki, Ostrova Siganaka, Ostrova Siginaka, Siginak Islands.

Named in 1809 by the Russian navigator Ivan Vasiliev the first, published by Lt. Sarichev (1826, map 19), IRN, as "O[strov] Siginaki," or "Siginaki Island." Vasiliev applied this name to the largest of the group; it was applied to the group in 1848 by the Russian Hydrog. Dept.

Siginaka, Ostrova: islands, see Siginaka Islands. Siginaki, Ostrov: islands, see Siginaka Islands. Siginak Islands: islands, see Siginaka Islands. Siginaq: island, see Sedanka Island.

Signal Creek: stream, flows N $1.3 \mathrm{mi}$. to Ward Lake, $0.8 \mathrm{mi}$. E of Ward Cove, on SW coast of Revillagigedo I., Alex. Arch.; $55^{\circ} 24^{\prime} 35^{\prime \prime} \mathrm{N}$, $131^{\circ} 41^{\prime} 55^{\prime \prime} \mathrm{W}$; BGN 1962; (map 3).

Local name reported in 1961 by USFS.

Signal Island: island, $0.5 \mathrm{mi}$. long, in South Pass, $1.5 \mathrm{mi}$. W of Hydaburg, Alex. Arch.; 55 $12^{\prime}$ $15^{\prime \prime} \mathrm{N}, 132^{\circ} 52^{\prime} 00^{\prime \prime} \mathrm{W}$; (map 4).

Local name published in 1965 by USC\&GS

Signal Island: island, $0.1 \mathrm{mi}$. across, in Western Channel, Sitka Sound, 2 mi. W of Sitka, Alex. Arch.; 57 $02^{\prime} 45^{\prime \prime} \mathrm{N}, 1^{\circ} 5^{\circ} 23^{\prime} 30^{\prime \prime} \mathrm{W}$; (map 9). Var. Maiachnoi Island, Mayastetchnoi Island, Ostrov Mayachnoy, Signal-light Island Signal Light Island.

This is an 1882 translation by USC\&GS of the name given in 1809 by the Russian navigator Ivan Vasiliev the first; reported by Lt. Sarichev (1826, map 19), IRN, as "O[strov] Mayachnoy."

Signal Light Island: island, see Signal Island. Signal Mountain: mountain, 1,631 ft., E of Peninsula Point, on SW coast of Revillagigedo I., Alex. Arch.; $55^{\circ} 23^{\prime} 15^{\prime \prime} \mathrm{N}, 131^{\circ} 42^{\prime} 25^{\prime \prime} \mathrm{W}$; (map 3)

Named in 1883 by Lt. Comdr. H. E. Nichols, USN.

Signal Mountain: mountain, 1,545 ft., on SW end of Hinchinbrook I., $35 \mathrm{mi}$. SW of Cordova, Chugach Mts.; $60^{\circ} 17^{\prime} \mathrm{N}, 146^{\circ} 38^{\prime \prime} \mathrm{W}$; (map 64).

Local name reported by USC\&GS in 1902.

Signal Mountain: mountain, 4,200 ft., $4 \mathrm{mi}$. W of Titus Mtn, and $14 \mathrm{mi}$. NE of Arctic Village, Brooks Ra.; $68^{\circ} 13^{\prime} \mathrm{N}, 145^{\circ} 03^{\prime} \mathrm{W}$; (map 136).

So named by Gerald FitzGerald, USGS, "because of the survey control station placed on it"; reported in 1926 by J. B. Mertie, Jr. (in Smith and others, 1929, pl. 1), USGS.

Signal Point: point of land, see Yellow Point.

Signals, The: island, $0.2 \mathrm{mi}$. long, off Northwest Point on NW coast of Kanaga I., Aleutian Is. ; $51^{\circ} 44^{\prime} 45^{\prime \prime} \mathrm{N}, 177^{\circ} 38^{\prime} 25^{\prime \prime} \mathrm{W}$; (map 17).

Name published by USC\&GS in 1956 (Chart 9145).

Signals, The: rocks, off NE coast of Sedanka I., Aleutian Is.; $53^{\circ} 47^{\prime} 30^{\prime \prime} \mathrm{N}, 166^{\circ} 04^{\prime} 00^{\prime \prime}$ W; (map 23). Var. Kekur Kuka.
Named in 1888 by USBF. Capt. Tebenkov (1852, map 26), IRN, referred to them as "Kekur Kuka," possibly meaning "Cook's Pillars."

Signam Island: island, see Seguam Island. Signik, Cape: point of land, see Siknik Cape. Sigoola: Island, see Chugul Island.

Sigoola Island: island, see Segula Island.

Sigouam: water passage, see Seguam Pass.

Sigrikpak Creek: stream, flows W $1.2 \mathrm{mi}$. to Chukchi Sea, $5 \mathrm{mi}$. S of Cape Dyer, Arctic Slope; $68^{\circ} 34^{\prime} 45^{\prime \prime} \mathrm{N}, 166^{\circ} 13^{\prime} 30^{\prime \prime} \mathrm{W}$; (map 129). Var. Sikrikpuk Creek.

Eskimo name for the hoary marmot reported in 1955 by the U.S. Army Corps of Engineers.

Sigrikpak Ridge: ridge, $1,000 \mathrm{ft}$., extends SW 9 mi. between Kukpuk River and Chukchi Sea, $14 \mathrm{mi}$. E of Cape Thompson, Arctic Slope; $68^{\circ} 10^{\prime} \mathrm{N}, 165^{\circ} 27^{\prime} \mathrm{W}$; BGN 1963; (map 129). Var. Seegreepaugrauk Ridge.

Eskimo name for the "hoary marmot," Marmota caligata broweri; reported in 1960 as "Seegreepaugrauk" by D.C. Foote in connection with Project Chariot studies.

Siguam Island: island, see Seguam Island. Siguam Pass: water passage, see Seguam Pass. Sigurd Creek: stream, see Sigard Creek.

Sigvow: water passage, see Sigvu Inlet.

Sigvu Inlet: water passage, between Siguv Lagoon and Chuckchi Sea, $12 \mathrm{mi}$. NW of Kivalina, Kotzebue-Kobuk Low.; 67 $51^{\prime} \mathrm{N}$, $164^{\circ} 50^{\prime} \mathrm{W}$; (map 128). Var. Sigvow, Sigwu, Sigwuluuzak.

Eskimo name reported in 1966 by $\mathrm{E}$. S Burch.

Signu Lagoon: lagoon, $3 \mathrm{mi}$. long, on shore of Chukchi Sea, $12 \mathrm{mi}$. NW of Kivalina, Kotzebue-Kobuk Low.; $67^{\circ} 51^{\prime} \mathrm{N}, 164^{\circ} 50^{\prime} \mathrm{W}$; (map 128). Var. Sigvum Tessaya, Sigwum Tasia. Eskimo name reported in 1966 by E. S. Burch.

Sigvum Tessaya: lagoon, see Sigvu Lagoop. Sigwu: water passage, see Sigvu Inlet. Sigwuluuzak: water passage, see Sigvu Inlet. Sigwum Tasia: lagoon, see Sigvu Lagoon. Siimik: hill, see Simik Hill.

Siinaat Kivalik: locality, see Nulavik

Siinaat Waalaa: stream, see Singat Creek.

Siingak: water passage, see Singauk Entrance.

Siiqsinniq: locality, see Siyiksinik.

Sikady Lake: lake, $0.9 \mathrm{mi}$. long, on $\mathrm{W}$ central Admiralty I., $18 \mathrm{mi}$. NE of Angoon, Alex. Arch.; 57 $43^{\prime} 30^{\prime \prime} \mathrm{N}, 134^{\circ} 20^{\prime} 30^{\prime \prime} \mathrm{W}$; (map 9).

Local name reported in 1951 by USGS.

S'ikanakhse'ni: village, see Kake.

Sikanasankian: locality, at mouth of Grindstone Creek, $10 \mathrm{mi}$. SE of Juneau, Coast Mts.; $58^{\circ}$ $13^{\prime} \mathrm{N}, 134^{\circ} 11^{\prime} \mathrm{W}$; (map 11). Var. Tseknuk-sank-y.

Former Tlingit Indian village name meaning "small-black-bear town," published in 1908 by J. R. Swanton (Hodge; 1910, p. 675), BAE.

S'îkanaxsā'nî: village, see Kake.

Sikarnoi Golovie: promontory, see Sugarloaf Mountain.
Sikete Point: point of land, see Siketi Point.

Siketi Point: point of land, SW tip of Cone I., between Baker and Noyes I., Alex. Arch.; 55 .

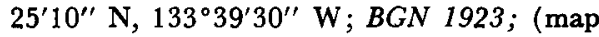
4). Var. Sikete Point.

Tlingit Indian name meaning "sea otter," given in 1923 by USC\&GS

Siketi Sound: water passage, $4.5 \mathrm{mi}$. long, between Baker and Cone Is., Alex. Arch.; 55 ${ }^{\circ}$ $24^{\prime} \mathrm{N}, 133^{\circ} 40^{\prime}$ W; $B G N$ 1925; (map 4). Var. Port Real Marina, Sea Otter Harbor.

Tlingit Indian name meaning "sea otter" given in 1924 by USC\&GS; taken from Siketi Point. Baker (1906, p. 558) published the name "Sea Otter Harbor" for this feature. "This place may be the one so named by $\mathrm{J}$. Meares, 1788. The identity is doubtful."

Sikharnoy Golovy, Mys: promontory, see Sugarloaf Mountain.

Sikhinak: island, see Sitkinak Island.

Sikhta: town, see Sitka.

Sikik Lake: lake, $1 \mathrm{mi}$. across, in Noatak River valley, $13 \mathrm{mi}$. SE of Feniak Lake, Bnooks Ra.; $68^{\circ} 03^{\prime} \mathrm{N}, 158^{\circ} 07^{\prime} \mathrm{W}$; (map 132).

Eskimo name obtained by Orth at Noatak in 1956, and reported to mean "deep water."

Sikisikpak Hill: ridge, see Siksikpak Ridge.

Sikmiut: village, see Sleetmute.

Siknik Cape: point of land, at $\mathrm{W}$ end of Sea Koovook Bay, $62 \mathrm{mi}$. SE of Gambell, on S coast of Saint Lawrence I.; $63^{\circ} 11^{\prime} \mathrm{N}, 170^{\circ} 18^{\prime}$ W; BGN 1951; (map 93). Var. Cape Chitnak, Cape Signik, Cape Tchitnak, Chiknik Cape, Chitnak Cape, Shitnak.

Eskimo name reported in 1932 by Otto W. Geist, Univ. of Alaska.

Siko Island: barrier bar, near Icy Reef, Arctic Plain; (map 138)

Surgeon John Simpson's 1855 native map shows this near Icy Reef.

Sikolik Lake: lake, $4 \mathrm{mi}$. across, $8 \mathrm{mi}$. SE of Icy Cape, Arctic Plain; $70^{\circ} 10^{\prime} \mathrm{N}, 161^{\circ} 29^{\prime} \mathrm{W}$; (map 146).

Eskimo name, meaning "has ice," recorded at Wainwright in 1956 by Orth; so named because ice remains on this lake longer than others.

Sikonsina Pass: pass, $30 \mathrm{mi}$. SW of Tok, Alaska Ra.; $63^{\circ} 03^{\prime} \mathrm{N}, 143^{\circ} 44^{\prime} \mathrm{W}$; (map 85).

Indian name, applied by prospectors and reported by F. C. Schrader (in Mendenhall and Schrader, 1903, pl. 20), USGS.

Sikovuk Cape: promontory, see Southwest Cape.

Sikrelurak River: stream, flows $18 \mathrm{mi}$. NE to Angun Lagoon, $W$ of Angun Point and $32 \mathrm{mi}$. NW of Demarcation Point, Arctic Plain; $69^{\circ} 56^{\prime}$ $\mathrm{N}, 142^{\circ} 26^{\prime} \mathrm{W}$; (map 138). Var. Sikutaktukvik River.

Eskimo name recorded in 1956 by T. E. Taylor, USGS. The variant name Sikutaktukvik was recorded at Barter I, in 1952, by USC\&GS and is reported to mean "place where ice is found."

Sikrikpuk Creek: stream, see Sigrikpak Creek.

Siksatok: locality, on Agattu I., Aleutian Is.; $52^{\circ} 26^{\prime} \mathrm{N}, 173^{\circ} 36^{\prime} \mathrm{E}$; (map 13).

Former Aleut village or camp listed by Hodge (1910, p. 570), BAE. 
Siksik Creek: stream, see Siksik River.

Siksik Lake: lake, $0.7 \mathrm{mi}$. long, $24 \mathrm{mi}$. SW of Mount Deborah and $45 \mathrm{mi}$. SE of Healy, Alaska Ra.; $63^{\circ} 26^{\prime} 15^{\prime \prime} \mathrm{N}, 1^{\circ} 7^{\circ} 53^{\prime} 25^{\prime \prime} \mathrm{W}$; $B G N$ 1965; (map 87). Var. Hall Lake.

Named in 1964 by the Alaska Geographic Names Board after the "ground squirrel whose Eskimo name is Siksik."

Siksikpak Ridge: ridge, $900 \mathrm{ft}$., extends NE-SW $6 \mathrm{mi}$. between Colville River and Ninuluk Creek, $31 \mathrm{mi}$. SW of Umiat, Arctic Slope; $69^{\circ} 05^{\prime} \mathrm{N}, 153^{\circ} 20^{\prime} \mathrm{W}$; (map 142). Var. Sikisikpak Hill.

Eskimo name; obtained in 1956 at Anaktuvuk Pass by T. E. Taylor, USGS. It is the Eskimo word for the hoary marmot [Sikrikpak].

Siksikpalak River: stream, flows $20 \mathrm{mi}$. NE to Matsutnak River $3 \mathrm{mi}$. $\mathrm{S}$ of its junc. with Ekaluakat River and $18 \mathrm{mi}$. W of Demarcation Point, Arctic Plain; $69^{\circ} 41^{\prime} \mathrm{N}, 142^{\circ} 03^{\prime}$ W; (map 138).

Eskimo name recorded on Barter I. in 1952 by USC\&GS. The Eskimo name for the hoary marmot is Sikrikpak or Sikrikpaluk.

Siksikpuk River: stream, flows NNE $49 \mathrm{mi}$. to Chandler River, $4 \mathrm{mi}$. $\mathrm{E}$ of Ayiyak Mesa and 51 mi. N of Anaktuvuk Pass, Brooks Ra.; 6852' N, $151^{\circ} 55^{\prime} \mathrm{W}$; BGN 1949; (map 134). Var. Sic-sic-puk River.

Eskimo name for the hoary marmot (Marmota caligata broweri); sometimes spelled sikrikpak. The name was reported in 1944 by USGS geologists during exploration of Naval Petroleum Reserve No. 4.

Siksik River: stream, flows 6.5 ui. NE to Anguk Lagoon, $\mathrm{S}$ of Humphrey Point and $34 \mathrm{mi}$. NW of Demarcation Point, Arctic Plain; $69^{\circ} 57^{\prime} \mathrm{N}$, $142^{\circ} 30^{\prime} \mathrm{W}$; (map 138). Var. Siksik Creek.

Eskimo name recorded on Barter I. in 1952 by USC\&GS. The name Sikrik generally refers to the Parry groundsquirrel (Rausch, 1951, p. 179).

Siksrikpak Point: point of land, extends $\mathrm{N}$ into Kasegaluk Lagoon $4.5 \mathrm{mi}$. S of Point Lay, Arctic Plain; $69^{\circ} 41^{\prime} 30^{\prime \prime} \mathrm{N}, 163^{\circ} 02^{\prime} 15^{\prime \prime} \mathrm{W}$; (map 145). Var. Seegikroorak Point, Sigikrurak Point.

Eskimo name [Sikrikpak] for the hoary marmot, Marmota caligata broweri (Rausch, 1951 , p. 178), published by USGS in 1955. Orth obtained the name "Sigikrurak" at Point Lay in 1956.

Siktunak Island: islands, see Trinity Islands.

Siku Entrance: water passage, connecting Beaufort Lagoon and Beaufort Sea at $W$ end of Icy Reef, $17 \mathrm{mi}$. NW of Demarcation Point, Arctic Plain; $69^{\circ} 49^{\prime} \mathrm{N}, 141^{\circ} 55^{\prime} \mathrm{W}$; (map 138).

Eskimo name meannig "ice" recorded on Barter I. in 1952 by USC\&GS. The full name of this feature is "Siku Ikik" meaning "ice strait."

Sikukik Lake: lake, see Tusikvoak, Lake.

Sikuk Point: point of land, see Siku Point.

Siku Lagoon: lagoon, extends $15 \mathrm{mi} \mathrm{SE}$ from Siku Point behind Icy Reef, $6 \mathrm{mi}$. NW of
Demarcation Point, Arctic Plain; $69^{\circ} 47^{\prime} \mathrm{N}$, $141^{\circ} 41^{\prime} \mathrm{W}$; (map 138).

Eskimo name meaning "ice" recorded on Barter I. in 1952 by USC\&GS.

Sikulik Lake: lake, partially drained, $1.5 \mathrm{mi}$. long, $10 \mathrm{mi}$. SE of Barrow, Arctic Plain; $71^{\circ}$ $11^{\prime} 20^{\prime \prime} \mathrm{N}, 156^{\circ} 24^{\prime} 40^{\prime \prime} \mathrm{W}$; (map 153).

Eskimo name recorded by USGS in 1956, which means "having ice."

Siku Point: point of land, on island in Kongakut River delta, between Beaufort and Siku Lagoons, $16.5 \mathrm{mi}$. NW of Demarcation Point, Arctic Plain; $69^{\circ} 49^{\prime} \mathrm{N}, 141^{\circ} 54^{\prime} \mathrm{W}$; BGN 1962; (map 138). Var. Sikuk Point.

Eskimo name recorded on Barter I. in 1952 by USC\&GS and meaning "ice." It is descriptive of the semipermanent ice, or aufeis, that is found on the delta of the Kongakut River.

Sikutaktukvik River: stream, see Sikrelurak River.

Silakh, Ostrov: island, see Silak Island.

Silak Island: island, $0.2 \mathrm{mi}$. across, between Little Tanaga and Kagalaska Is.; Aleutian Is.; $51^{\circ}$ $48^{\prime} 55^{\prime \prime} \mathrm{N}, 176^{\circ} 14^{\prime} 30^{\prime \prime} \mathrm{W}$; BGN 1936; (map 17). Var. Ostrov Silakh.

Aleut name published by Capt. Tebenkov (1852, map 28), IRN, as "O[strov] Silakh," or "Silakh Island."

Silalinigun Creek: stream, flows W $4.5 \mathrm{mi}$. to Killik River, NW of Kaikshak Hill, Brooks Ra.; 68 $24^{\prime}$ N, $154^{\circ} 03^{\prime}$ W; (map 133).

Eskimo name that refers to exposed rock bedding or "mountain lines," reported in 1956 by Orth.

Silas Pup: stream, flows SW $1 \mathrm{mi}$. to My Creek, $80 \mathrm{mi}$. SW of Eagle, Yukon-Tanana High.; $64^{\circ} 07^{\prime} \mathrm{N}, 143^{\circ} 12^{\prime} \mathrm{W}$; (map 102).

Local name published in 1956 by USGS.

Silawĩ'ñmium: village, see Selawik.

Si-lin Creek: stream, see Selin Creek.

Silk Bay: bay, see Mary, Port.

Silk Bay: bay, see Shelikof Bay.

Sillyasheen Mountain: mountain, 6,188 ft., 9 mi. SW of Cairn Mtn. and $73 \mathrm{mi}$. NW of Wiseman, Brooks Ra.; $67^{\circ} 46^{\prime} \mathrm{N}, 152^{\circ} 42^{\prime} \mathrm{W}$; BGN 1932; (map 124).

Robert Marshall reported this Eskimo name in 1932.

Silok Creek: stream, see Delta Creek.

Silok Creek: stream, see Dry Creek.

Silok Creek: stream, see Little Delta River. Silokh Creek: stream, see Little Delta River.

Silook Camp: locality, left bank of Koozata River, at Koozata Lagoon, $43 \mathrm{mi}$. SE of Gambell, on St. Lawrence I.; $63^{\circ} 24^{\prime} \mathrm{N}, 170^{\circ}$ $40^{\prime}$ W; BGN 1951; (map 93). Var. Tapphaghuk Camp.

Eskimo family name reported in 1949 by Maj. H. B. Allen, USAF.

Silver Bay: locality, at Silver Bay, on $\mathrm{W}$ coast of Baranof I., Alex. Arch.; $56^{\circ} 59^{\prime}$ N, $135^{\circ} 07^{\prime}$ W; $(\operatorname{map} 5)$.

Former summer camp of the Sitka Indians reported in the 1880 Census by Petroff (1884, p. 32).

Silver Bay: bay, $0.5 \mathrm{mi}$. across, $5 \mathrm{mi}$. long, $5 \mathrm{mi}$. $E$ of Sitka, on W coast of Baranof I., Alex.
Arch.; 57 02' N, $135^{\circ} 12^{\prime}$ W; (map 9). Var. Bukhta Serebryanikova, Serebrennikof Arm, Serebrinikov Cove.

This is an 1882 translation by USC\&GS of the name "Bukhta Serebryanikova," published by Capt. Tebenkov (1852, map 38), IRN.

Silverbow Basin: valley, on Gold Creek, N of Icy Gulch, $1.5 \mathrm{mi}$. N of the Gastineau Peak and $2.4 \mathrm{mi}$. NE of Juneau, Coast Mts. ; $58^{\circ} 18^{\prime} 45^{\prime \prime}$ $\mathrm{N}, 134^{\circ} 20^{\prime} 45^{\prime \prime} \mathrm{W}$; (map 11).

Named by Richard Harris in 1880 for the Silver Bow Mine in Montana. This basin was the site of the earliest gold discoveries in the Juneau area (DeArmond, 1957, p. 39-40).

Silver Bow Creek: stream, flows NE 5 mi. to join Enterprise Creek to form McKinley Creek, $64 \mathrm{mi}$. SW of Eagle, Yukon-Tanana High.; $64^{\circ} 17^{\prime} \mathrm{N}, 142^{\circ} 58^{\prime} \mathrm{W}$; (map 102).

Prospectors' name shown on an 1898 manuscript map by C. A. Woodruff, Fort Cudahy, Canada.

Silverbow Creek: stream, flows SW $2.7 \mathrm{mi}$. to Norton Sound, $17 \mathrm{mi}$. E of Solomon, Seward Penin. High.; $64^{\circ} 35^{\prime}$ N, $163^{\circ} 51^{\prime}$ W; (map 95). Var. Little Anvil Creek.

Prospectors' name shown on Arthur Gibson's "Map of Cape Nome Precinct" dated 1904. Reported in 1900 as "Little Anvil Creek" by E. C. Barnard (in Brooks, 1901, pl. 17), USGS.

Silverbow Creek: stream, flows W $4.3 \mathrm{mi}$. to Hutlinana Creek, $2.8 \mathrm{mi}$. ESE of Eureka and 19 mi. S of Rampart, Yukon-Tanana High.; $65^{\circ} 10^{\prime} \mathrm{N}, 150^{\circ} 08^{\prime} \mathrm{W}$; (map 106).

Prospectors' name reported in 1906 by USGS (Prindle, 1908, pl. 5).

Silver Creek: stream, on Revillagigedo I., flows SW $0.4 \mathrm{mi}$. to Fish Creek, $1 \mathrm{mi}$. N of Thorne Arm, Alex. Arch.; $55^{\circ} 24^{\prime} 30^{\prime \prime} \mathrm{N}, 131^{\circ} 11^{\prime} 32^{\prime \prime}$ W; $(\operatorname{map} 3)$.

Local name published by F. E. Wright and C. W. Wright (1908, fig. 12), USGS.

Silver Creek: stream, on Kenai Penin., flows N $1 \mathrm{mi}$. to China Poot Bay, on $\mathrm{E}$ shore of Kachemak Bay, $10 \mathrm{mi}$. SE of Homer, Chugach Mts.; $59^{\circ} 33^{\prime} 15^{\prime \prime} \mathrm{N}, 151^{\circ} 18^{\prime} 00^{\prime \prime} \mathrm{W}$; (map 50).

Local name reported and published by USGS in the 1950's.

Silver Creek: stream, flows SW $4 \mathrm{mi}$. to Ptarmigan Creek, $27 \mathrm{mi}$. NW of Augustine I., Aleutian Ra.; $59^{\circ} 38^{\prime} 41^{\prime \prime} \mathrm{N}, 153^{\circ} 58^{\prime} 20^{\prime \prime} \mathrm{W}$; (map 51).

Local name published by Martin and Katz (1912, pl. 1), USGS.

Silver Creek: stream, flows $\mathrm{S} 5.3 \mathrm{mi}$. to Eliza Lake, $4.8 \mathrm{mi}$. SE of Northway Junction, Alaska Ra.; $62^{\circ} 58^{\prime} 40^{\prime \prime}$ N, $141^{\circ} 40^{\prime} 20^{\prime \prime} \mathrm{W}$; (map 84).

Local name reported by USGS in 1954.

Silver Creek: stream, flows W $15 \mathrm{mi}$. to Poorman Creek, 70 mi. NW of Medfra, KilbuckKuskokwim Mts.; $63^{\circ} 58^{\prime} \mathrm{N}, 155^{\circ} 56^{\prime} \mathrm{W}$; $B G N$ 1936; (map 89).

Local name reported by Eakin (1914, pl. 1), USGS.

Silver Creek: stream, flows SE $1.6 \mathrm{mi}$. to Goldbottom Creek, $16 \mathrm{mi}$. N of Nome, Seward 
Penin. High,; $64^{\circ} 44^{\prime} 36^{\prime \prime}$ N, $165^{\circ} 23^{\prime} 40^{\prime \prime}$ W; (map 94).

Prospectors' name reported in 1904 by $T$. G. Gerdine, USGS.

Silver Creek: stream, flows S $3.4 \mathrm{mi}$. to Stewart River, $21 \mathrm{mi}$. N of Nome, Seward Penin. High.; $64^{\circ} 48^{\prime} 40^{\prime \prime} \mathrm{N}, 165^{\circ} 25^{\prime} 10^{\prime \prime} \mathrm{W}$; (map 94). Var. Right Fork Stewart River.

Prospectors' name reported in 1904 by $T$. G. Gerdine, USGS. This appears to be the stream shown as "Right Fork [Stewart River]" on a map dated 1901 of Cape Nome gold fields by David Fox, Jr.

Silver Creek: stream, flows S $2.5 \mathrm{mi}$. to Goldstream Creek, $6.5 \mathrm{mi}$. N of Fairbanks, YukonTanana High.; $64^{\circ} 56^{\prime} 40^{\prime \prime} \mathrm{N}, 14^{\circ} 42^{\prime} 15^{\prime \prime} \mathrm{W}$; (map 100).

Local name shown 1905 on a manuscript map by C. W. Joint.

Silver Creek: stream, flows SE $0.7 \mathrm{mi}$. to Sourdough Creek, $10 \mathrm{mi}$. NW of Mount Ryan and $76 \mathrm{mi}$. SW of Circle, Yukon-Tanana High.; $65^{\circ} 21^{\prime} 45^{\prime \prime} \mathrm{N}, 146^{\circ} 28^{\prime} 30^{\prime \prime} \mathrm{W}$; (map 104).

Prospectors' name reported in 1954 or 1955 by USGS topographers.

Silver Creek: stream, flows W $2 \mathrm{mi}$. to head of Dry Creek, $4 \mathrm{mi}$. NE of Nome, Seward Penin. High.; (map 94).

Prospectors' name published in 1900 by Schrader (1900c, p. 16), USGS. Subsequent maps show a different drainage pattern at the head of Dry Creek.

Silver Creek: stream, flows $\mathrm{NE}$ to Hannum Creek which flows to Inmachuk River, about 20 mi. N of Imuruk Lake, Seward Penin. High.; (map 110).

Prospectors' name reported in 1901 by USGS (Collier, 1902, pl. 12). This stream cannot be identified on current maps.

Silver Creek: stream, see Fourmile Creek.

Silver Creek: stream, see Snowslide Creek.

Silver Creek: stream, see Stibnite Creek.

Silver Falls: falls, in course of Fish Creek, $4 \mathrm{mi}$. $\mathrm{N}$ of Hyder, Coast Mts.; $55^{\circ} 58^{\prime} 40^{\prime \prime} \mathrm{N}$, $130^{\circ} 03^{\prime} 05^{\prime \prime} \mathrm{W}$; (map 3 ).

Local name reported in 1955 by USGS.

Silver Farm Lodge: locality, see Fox Farm Lodge.

Silver Fox Lodge: locality, see Fox Farm Lodge.

Silver Fox Roadhouse: locality, see Fox Farm Lodge.

Silver Glacier: glacier, trends N $3 \mathrm{mi}$. to its terminus, $2 \mathrm{mi}$. SE of Silver Lake, $35 \mathrm{mi}$. NW of Cordova, Chugach Mts. ; $60^{\circ} 55^{\prime} \mathrm{N}, 146^{\circ} 23^{\prime}$ W; (map 64).

Local descriptive name published in 1952 by USGS.

Silver Gulch: ravine, trends S $1 \mathrm{mi}$. to Fox Creek, $7 \mathrm{mi}$. NE of Fairbanks, Yukon-Tanana High.; $64^{\circ} 57^{\prime} \mathrm{N}, 147^{\circ} 39^{\prime} \mathrm{W}$; (map 100).

Local name shown on a location map of the Tanana Mines RR. 1905.

Silver Horn: $b a y$, extends $W 4 \mathrm{mi}$. from $W$ end of Lake Beverly, $46 \mathrm{mi}$. NW of Dillingham, Kilbuck-Kuskokwim Mts.; $59^{\circ} 41^{\prime} \mathrm{N}, 158^{\circ} 50^{\prime}$ W; BGN 1931; (map 52). Var. Sai-ukstchu-schluk.
Named in 1929 by the U.S. Commissioner of Fisheries. The Eskimo name "Sai-ukstchu-schluk" was shown on a 1910 manuscript map by H. G. Fassett, USBF.

Silver Lake: lake, $1.2 \mathrm{mi}$. long, on Kenai Penin. in course of West Fork Moose River, $16 \mathrm{mi}$. $E$ of Kenai, Cook Inlet Low.; $60^{\circ} 38^{\prime} 45^{\prime \prime} \mathrm{N}$, $150^{\circ} 48^{\prime} 00^{\prime \prime} \mathrm{W}$; (map 62).

Named about 1963 by officials of Kenai National Moose Range, for administrative purposes.

Silver Lake: lake, $3 \mathrm{mi}$. long, $3 \mathrm{mi}$. NW of Mount Denson, 35 mi. NW of Cordova, Chugach Mts.; $60^{\circ} 57^{\prime} \mathrm{N}, 146^{\circ} 29^{\prime} \mathrm{W}$; (map 64).

Local descriptive name published in 1952 by USGS.

Silver Point: point of land, on small island, in Eastern Channel, $3 \mathrm{mi}$. SE of Sitka, off W coast of Baranof I., Alex. Arch.; 57 $00^{\prime} 50^{\prime \prime}$ $\mathrm{N}, 135^{\circ} 18^{\prime} 00^{\prime \prime} \mathrm{W}$; (map 9).

Named by the U.S. Navy in 1880 ; published by USC\&GS in 1883 Coast Pilot (p. 144).

Silver Salmon Creek: stream, flows E $6 \mathrm{mi}$. to Wood River, $13 \mathrm{mi}$. N of Dillingham, Bristol Bay Low.; $59^{\circ} 13^{\prime} 45^{\prime \prime}$ N, $158^{\circ} 33^{\prime} 00^{\prime \prime}$ W; (map 52).

Local name reported in 1952 by USGS.

Silver Salmon Creek: stream, in Chigmit Mts., distributary of West Glacier Creek, Hows SE $4 \mathrm{mi}$. to Chinitna Bay, Aleutian Ra.; $59^{\circ} 51^{\prime}$ $50^{\prime \prime} \mathrm{N}, 153^{\circ} 12^{\prime} 50^{\prime \prime} \mathrm{W}$; (map 51$)$.

Local name reported in 1957 by USGS.

Silver Salmon Falls: waterfall, on Lester River $4.5 \mathrm{mi}$. from its mouth, $W$ coast of Prince of Wales I., Alex. Arch.; $55^{\circ} 47^{\prime} 30^{\prime \prime}$ N, $133^{\circ} 00^{\prime}$ $45^{\prime \prime} \mathrm{W}$; $(\operatorname{map} 4)$.

Local name recorded in 1949 by USGS.

Silver Salmon Lakes: lakes, group of lakes, $5 \mathrm{mi}$. E of Red Glacier and $47 \mathrm{mi}$. NW of Homer, Aleutian Ra.; $59^{\circ} 59^{\prime} 50^{\prime \prime} \mathrm{N}, 152^{\circ} 40^{\prime} 30^{\prime \prime} \mathrm{W}$; (map 50).

Local name reported and published by USGS in the 1950's.

Silver Salmon Rapids: rapids, in Kasilof River, on Kenai Penin., W of Tustumena Lake, 20 $\mathrm{mi}$. S of Kenai, Cook Inlet Low.; $60^{\circ} 16^{\prime} 40^{\prime \prime}$ $\mathrm{N}, 151^{\circ} 12^{\prime} 50^{\prime \prime} \mathrm{W}$; (map 62 ).

Local name reported in 1959 by USGS.

Silverthrone Col: pass, 10,500 ft., between Brooks and Traleika Glaciers, with West Pyramid Peak to $\mathrm{N}$ and Mount Silverthrone to $\mathrm{S}$, $10.7 \mathrm{mi}$. NE of summit of Mount McKinley, Alaska Ra.; $63^{\circ} 08^{\prime} 15^{\prime \prime} \mathrm{N}, 150^{\circ} 42^{\prime} 00^{\prime \prime} \mathrm{W}$; $B G N$ 1948; ( $\operatorname{map} 88$ ).

Named in 1945 by a USAAF Cold Weather test party; reported in 1946 by Bradford Washburn.

Silverthrone, Mount: peak, 13,220 ft., in Mount McKinley National Park at head of Brooks Glacier, $11 \mathrm{mi}$. ENE of Mount McKinley, Alaska Ra.; $63^{\circ} 07^{\prime} 00^{\prime \prime} \mathrm{N}, 150^{\circ} 40^{\prime} 30^{\prime \prime} \mathrm{W}$; $B G N$ 1948; (map 88).

Climbed and named by the U.S. Army Forces Cold Weather test party about March 1945. "So named because of its stately appearance at the head of Brooks Glacier."
Silvertip: locality, on Kenai Penin., between Seward Highway and East Fork Sixmile Creek, $24 \mathrm{mi}$. SW of Whittier and $9 \mathrm{mi}$. SE of Sunrise, Chugach Mts.; $60^{\circ} 45^{\prime} \mathrm{N}, 149^{\circ} 22^{\prime} \mathrm{W}$; (map 63).

Former mining camp in Sixmile Creek mining area. Recent USGS maps indicate a site with four buildings. Name derived from nearby Silvertip Creek.

Silvertip Creek: stream, on Kenai Penin., flows N. $4 \mathrm{mi}$. to East Fork Sixmile Creek, $12 \mathrm{mi}$. SE of Sunrise, Chugach Mts. ; $60^{\circ} 44^{\prime} 59^{\prime \prime} \mathrm{N}$, $149^{\circ} 21^{\prime} 45^{\prime \prime} \mathrm{W}$; (map 63).

Local prospectors' name; reported in 1904 by Moffit (1906, pl. 2), USGS.

Silvester Point: point of land, on NE coast of Saint Ignace I., Alex. Arch.; $55^{\circ} 25^{\prime} 15^{\prime \prime} \mathrm{N}$, $133^{\circ} 24^{\prime} 40^{\prime \prime}$ W; (map 4). Var. Mys de San Silbestre, Punta de San Silbestre, Punta San Silvestre.

Translation of the name "Punta de San Silbestre" given in 1775-79 by Don Juan de la Bodega y Quadra and Francisco Antonio Maurelle.

Silvia Creek: stream, flows SE $4 \mathrm{mi}$. to Charley River, $14 \mathrm{mi}$. SW of that stream's junc. with Yukon River, Yukon-Tanana High. ; $65^{\circ} 09^{\prime} \mathrm{N}$, $142^{\circ} 57^{\prime} \mathrm{W}$; (map 103). Var. Selin Creek.

Local name; published in 1956 by USGS. "Selin" was recorded on an unpublished map by E. J. Chamberlain, dated 1902.

Silvis Lake: lake, see Lower Silvis Lake.

Silvis Lakes: lake, see Upper Silvis Lake.

Simanoff Island: island, see Simonof Island.

Simanof Island: island, see Simonof Island.

Simedan Islands: islands, see Semidi Islands.

Simedun Islands: islands, see Semidi Island.

Simel Mountain: mountain, see Bonasila Dome.

Simels: locality, on S bank of Innoko River, 2.6 mi. SE of its junc. with Dishna River and 38

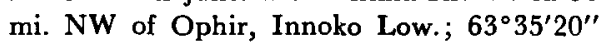
$\mathrm{N}, 157^{\circ} 12^{\prime} 30^{\prime \prime} \mathrm{W}$; (map 90).

Landing with a couple of cabins; now abandoned.

Simel Slough: stream, see Bonasila Slough.

Simeon, Mount: mountain, 1,000 ft., $2 \mathrm{mi}$. W of village of Cold Bay, at SW end of Alaska Penin., Bristol Bay Low.; 55 $11^{\prime} 30^{\prime \prime} \mathrm{N}, 162^{\circ}$ $47^{\prime} 30^{\prime \prime} \mathrm{W}$; (map 29).

Name published by USGS (Waldron, 1961, pl. 79).

Simeon, Mount: peak, 1,500 ft., near S arm of Becharof Lake, $\mathbf{E}$ of Simeon Pass, on Alaska Penin., $48 \mathrm{mi}$. NE of Ugashik, Aleutian Ra.; $57^{\circ} 42^{\prime} \mathrm{N}, 156^{\circ} 11^{\prime} \mathrm{W}$; (map 36 ).

Name reported in 1902 by J. L. McPherson of Iliamna; published by G. C. Martin (1921, pl. 10), USGS.

Simeon Creek: stream, heads $W$ of Simeon Pass, flows N $5.2 \mathrm{mi}$. to Featherly Creek $4 \mathrm{mi}$. SW of its mouth at Becharof Lake, on Alaska Penin., 48 mi. NE of Ugashik, Aleutian Ra.; $57^{\circ} 44^{\prime} 40^{\prime} \mathrm{N}, 156^{\circ} 13^{\prime} 25^{\prime \prime} \mathrm{W}$; (map 36 ).

Name reported in 1902 by J. L. McPherson of Iliamna.

Simeonoff Harbor: anchorage, see Simeonof Harbor.

Simeonoff: island, see Simeonof Island. 
Simeonoffsky Harbor: anchorage, see Simeonof Harbor.

Simeonof Harbor: anchorage, $0.5 \mathrm{mi}$. across, on NW coast of Simeonof I., in Shumagin Is.,

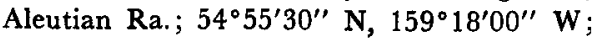
(map 26). Var. Simeonoff Harbor, Simeonoffsky Harbor.

Surveyed and named in 1872 by W. H. Dall, USC\&GS.

Simeonof Island: island, $6 \mathrm{mi}$. across, easternmost of Shumagin Is., Aleutian Ra.; 54 $54^{\prime} \mathrm{N}$, 159 16' W; BGN 1890; (map 26). Var. Semenoffsky, Semenovskie, Semenovsky, Simeonoff, Simeonovski, Tachkinach, Taghinak, Takhinak, Tankh-kin-iakh, Tiakinak, Tikhiniak.

Called "Simeonoff" in 1872 by W. H. Dall, USC\&GS; other Russian forms of "Simon" include "Semenovsky," by Capt. F. P. Lutke, IRN, and "Semenovskie" by Capt. M. D. Tebenkov, IRN, and the Russian Hydrog. Dept. Aleut names applied to this island include "Tachkinach," by Lt. G. A. Sarichev, IRN, and "Taghinak," "Tikhiniak," and "Takh-kiniakh" by Capt. Lutke, IRN.

Simeonovski: island, see Simeonof Island.

Simeon Pass: pass, elev. $800 \mathrm{ft}$., between Simeon Creek and W tributary to Burl Creek, on Alaska Penin., $47 \mathrm{mi}$. NE of Ugashik, Aleutian Ra.; $57^{\circ} 41^{\prime} 40^{\prime \prime} \mathrm{N}, 156^{\circ} 11^{\prime} 45^{\prime \prime} \mathrm{W}$; (map $36)$.

Local name reported in 1902 by J. L. McPherson of Iliamna; the name was published by G. G. Martin (1921, pl. 10), USGS.

Simidin: island, see Aghiyuk Island.

Simik Hill: hill, $556 \mathrm{ft}$., 10 i. SW of Jarvis Mtn. and $9 \mathrm{mi}$. NE of Kivalina, Arctic Slope; $67^{\circ} 50^{\prime} \mathrm{N}, 164^{\circ} 21^{\prime} \mathrm{W}$; (map 128). Var. Seemick, Siimik.

Eskimo name meaning "stopper" or "plug"; so called because from upriver the hill seems to block the Kivalina River; reported in 1966 by E. S. Burch.

Simik Mountain: hill, $600 \mathrm{ft}$., in Igichuk Hills, on W bank of Milokrawlok Creek, $10 \mathrm{mi}$. NE of Cape Krusenstern, Arctic Plain; 67\%. $10^{\prime} 30^{\prime \prime} \mathrm{N}, 163^{\circ} 22^{\prime} 30^{\prime \prime} \mathrm{W}$; (map 128).

Eskimo name meaning "stopper" (or plug)" obtained in 1950 by USC\&GS.

Simitkhi Islands: islands, see Semichi Islands.

Simmons, Lake: lake, see Summit Lake.

Simmons Point: point of land, on SW coast of Prince of Wales I., between Copper Harbor and Hetta Inlet, Alex. Arch.; $55^{\circ} 12^{\prime} 15^{\prime \prime} \mathrm{N}$, $132^{\circ} 37^{\prime} 35^{\prime \prime} \mathrm{W}$; (map 4).

Local name reported in 1905 by E. F. Dickins, USC\&GS.

Simon Creek: stream, flows SE $18 \mathrm{mi}$. to Yukon River, $39 \mathrm{mi}$. N of Anvik and $57 \mathrm{mi}$. SE of Unalakleet, Nulato Hills; $63^{\circ} 11^{\prime} 20^{\prime \prime} \mathrm{N}, 159^{\circ}$. $44^{\prime} 00^{\prime \prime}$ W; (map 91).

Local name reported in 1949 by USC\&GS.

Simonds, Point: point of land, S tip of Post I., along W coast of Chichag of I. $13 \mathrm{mi}$. NW of Chichagof, Alex. Arch.; 57 $47^{\prime} 18^{\prime \prime} \mathrm{N}, 136^{\circ}$. 20'10" W; (map 9).

Name published in 1928 by USC\&GS on Chart 8258.
Simonoff Island: island, see Simonof Island. Simonof Island: island, $0.1 \mathrm{mi}$. long, in Highfield Anchorage, off $\mathrm{N}$ tip of Wrangell I., Alex. Arch.; $56^{\circ} 29^{\prime} 40^{\prime \prime} \mathrm{N}, 132^{\circ} 22^{\prime} 00^{\prime \prime} \mathrm{W}$; (map 6). Var. Observation Islet, Simanoff Island, Simanof Island, Simonoff Island.

Named in 1865 by the British Admiralty.

Simon Point: point of land, on $\mathrm{W}$ bank of Yukon River, $9.5 \mathrm{mi}$. $\mathrm{N}$ of Fox Point $\mathrm{I}$. and $58 \mathrm{mi}$. SE of Unalakleet, Nulato Hills; $63^{\circ} 10^{\prime} 25^{\prime \prime} \mathrm{N}$, $159^{\circ} 43^{\prime} 10^{\prime \prime} \mathrm{W}$; ( $\operatorname{map} 91$ ).

Local name reported in 1949 by USC\&GS

Simonton Point: point of land, $\mathrm{N}$ end of Nakat Harbor entrance, in Nakat Inlet, $2 \mathrm{mi}$ NE of Nakat Bay, Coast Mts.; $54^{\circ} 49^{\prime} 45^{\prime \prime} \mathrm{N}, 130^{\circ}$ 42'45" W; (map 2).

Named in 1883 by Lt. Comdr. H. E. Nichols, USN

Simplex Greek: stream, flows NW $4 \mathrm{mi}$. to Middle Fork Chandalar River, $15 \mathrm{mi}$. ESE of Chandalar, Brooks Ra.; $67^{\circ} 26^{\prime}$ N, $148^{\circ} 57^{\prime} \mathrm{W}$; (map 123).

Prospectors' name obtained in 1909 by A. G. Maddren (in Brooks and others, 1910, pl. 7), USGS.

Simpson, Cape: point of land, on coast of Beaufort Sea, $W$ point of entrance to Smith Bay, Arctic Plain; $70^{\circ} 59^{\prime} \mathrm{N}, 154^{\circ} 34^{\prime} \mathrm{W}$; (map 148). Var. Cape George Simpson, Cape Governor Simpson, We-wa-le-ah.

On July 28, 1837, Thomas Simpson (1843, p. 138) wrote: "We encamped on the extremity of this well-defined point, which, as a testimony of sincere respect and regard for the able and indefatigable Governor of all the Company's [Hudson's Bay] territories, we named Cape George Simpson." The Eskimo name We-wa-le-ah appears on Maguire's chart (Great Britain, 1854, facing p. 186).

Simpson, Mount: mountain, 4,345 ft., $5 \mathrm{mi}$. SE of outlet of Klutina Lake, $44 \mathrm{mi}$. NNE of Valdez, Chugach Mts.; $61^{\circ} 41^{\prime} 15^{\prime \prime} \mathrm{N}, 145^{\circ}$ $37^{\prime} 55^{\prime \prime} \mathrm{W}$; (map 68).

Named in 1898 by Capt..W. R. Abercrombie, USA.

Simpson Bay: bay, U-shaped, $8 \mathrm{mi}$. long, on NE shore of Orca Bay, $8 \mathrm{mi}$. NW of Cordova, Chugach Mts.; $60^{\circ} 37^{\prime} 30^{\prime \prime} \mathrm{N}, 145^{\circ} 55^{\prime} 00^{\prime \prime} \mathrm{W}$; (map 64).

Local name reported by Lt. Comdr. J. F. Moser, USN, in 1397.

Simpson Cove: cove, $4 \mathrm{mi}$. across, off Camden Bay, S of Collinson Point, $28 \mathrm{mi}$. SW of Barter I., Arctic Plain; $69^{\circ} 57^{\prime} \mathrm{N}, 144^{\circ} 54^{\prime} \mathrm{W}$; (map 139).

Named by Lt. Comdr. C. H. Stockton, USN, for Thomas Simpson, factor of the Hudson's Bay Company, who with Peter Warren Dease in 1837, made an exploring journey along the Arctic coast from the mouth of the Mackenzie River to Point Barrow.

Simpson Creek: stream, flows SW $9 \mathrm{mi}$. to Simpson Bay, $10 \mathrm{mi}$. NW of Cordova, Chugach Mts. ; $60^{\circ} 42^{\prime} \mathrm{N}, 145^{\circ} 50^{\prime} \mathrm{W}$; (map 64).

Local name published in 1951 by USGS; derived from Simpson Bay to which the stream flows.
Simpson Lagoon: lagoon, extends NW $40 \mathrm{mi}$. from Point McIntyre, between Jones and Return Is. and mainland, on Beaufort Sea coast ; Arctic Plain; $70^{\circ} 30^{\prime} \mathrm{N}, 149^{\circ} 12^{\prime} \mathrm{W}, B G N$ 1916; (map 150).

Named by Leffingwell (1919, p. 91) "After Thomas Simpson of the Hudson's Bay Company. * * His name has been placed at Simpson Lagoon, behind Return Islands and Jones Islands, as he was the first white man to traverse this body of water."

Simpson Pass: pass, 3,900 ft., at head of Earl River, S of Kichatna Mts., $88 \mathrm{mi}$. W of Talkeetna, Alaska Ra.; $62^{\circ} 20^{\prime} \mathrm{N}, 152^{\circ} 51^{\prime} \mathrm{W}$; (map 81).

Discovered and named in 1889 by Lt. J. S. Herron, USA.

Simpson Peak: mountain, 5,599 ft., $18 \mathrm{mi}$. ENE of Petersburg, Coast Mts.; $56^{\circ} 52^{\prime} 30^{\prime \prime} \mathrm{N}, 132^{\circ}$ $29^{\prime} 00^{\prime \prime} \mathrm{W}$; (map 6).

Local name published in 1943 by USC\&GS. Simpson Rock: rock, in Galankin Is., Sitka Sound, 2 mi. S of Sitka, Alex. Arch.; 57 $01^{\prime}$ $10^{\prime \prime} \mathrm{N}, 135^{\circ} 20^{\prime} 40^{\prime \prime} \mathrm{W}$; (map 9).

Discovered and named in 1862 by officers of H.M.S. Devastation (U.S. Coast and Geodetic Survey, 1883, p. 143).

Simson Peak: mountain, $1,470 \mathrm{ft} ., 0.5 \mathrm{mi}$. E of Lake Cories, eastern Attu I., Aleutian Is.; $52^{\circ} 54^{\prime} 20^{\prime \prime} \mathrm{N}, 173^{\circ} 15^{\prime} 15^{\prime \prime} \mathrm{E}$; (map 13).

Name shown on an AMS map published in 1948 , and given by the U.S. Army during World War II. The name is not used today.

Sin: locality, on Khlehnikof Point, on $\mathrm{E}$ coast of Attu I., Aleutian Is. ; $52^{\circ} 55^{\prime} 30^{\prime \prime} \mathrm{N}, 173^{\circ} 18^{\prime}$ $00^{\prime \prime} \mathbf{E}$; (map 13).

This archaeological site was reported to be an old village and one of three sites excavated on Attu Island in 1909-10 (Jochelson, 1925, p. 24).

Sinaaruaq : locality, see Sinaru.

Sinagnia: locality, see Imagnee.

Sinagnya: locality, see Imagnee.

Sinar: locality, on $\mathrm{W}$ coast of Seward Penin., near Port Clarence, Seward Penin. High.; $65^{\circ} 09^{\prime} \mathrm{N}, 166^{\circ} 30^{\prime} \mathrm{W}$; (map 111). Var. Sinarmete.

Former Eskimo village or camp recorded on Sheldon Jackson's 1896 map.

Sinara: locality, see Sinaru.

Sinarmete: locality, see Sinar.

Sinaru: locality, on Chukchi Sea coast, near mouth of Singaruak Creek, $18 \mathrm{mi}$. SW of Barrow, Arctic Plain; $71^{\circ} 04^{\prime} 30^{\prime \prime} \mathrm{N}, 157^{\circ} 11^{\prime}$. 40" W; (map 153). Var. Sinaaruaq, Sinara, Singaroo, Singorauk, Sinra, Sinragahroo, Sinrarua.

This is an old and well-established coastal camp named for the estuary-like mouth of Singaruak Creek. Lt. D. H. Jarvis, USRCS, established a reindeer camp here in 1898 and spells the name "Sinra."

Sinaru Creek: stream, see Singaruak Creek.

Sinaru Inlet: stream, see Singaruak Creek.

Sinaruruk: locality, on Chukchi Sea coast $\mathbf{S}$ of Sinaruruk River, Arctic Plain; $70^{\circ} 41^{\prime} 30^{\prime \prime} \mathrm{N}$, $159^{\circ} 54^{\prime} 30^{\prime \prime}$ W; (map 146). Var. Kululin. 
Former Eskimo village or camp shown on P. Tikhmeniev's map of 1861 as "Kululin," which is also recorded on USC\&GS sailing Chart T, 1890.

Sinaruruk River: stream, flows $W 7 \mathrm{mi}$. to Chukchi Sea, $4.5 \mathrm{mi}$. NE of Wainwright, Arctic Plain; $70^{\circ} 41^{\prime} 45^{\prime \prime} \mathrm{N}, 159^{\circ} 54^{\prime} 15^{\prime \prime} \mathrm{W}$; (map 146).

Eskimo name reported in 1923 by USGS.

Sinbad, Point: point of land, $\mathrm{N}$ entrance to Suloia Bay, on $S$ coast of Chichagof I., at W end of Peril Strait, Alex. Arch.; 57 $24^{\prime} 20^{\prime \prime}$ N, $135^{\circ} 39^{\prime} 00^{\prime \prime} \mathrm{W}$; (map 9).

Name published in 1900 by USC\&GS on Chart 8282.

Sinbad Cove: bight, $0.5 \mathrm{mi}$. across, facing $\mathrm{E}$ to Vega Bay, at mouth of Fork Creek, on S coast of Kiska I., Aleutian Is.; $51^{\circ} 52^{\prime} 30^{\prime \prime} \mathrm{N}$, $177^{\circ} 19^{\prime} 40^{\prime \prime} \mathrm{E}$; (map 14).

One of many arbitrary names applied to features on Kiska I. by USAAF for tactical purposes during World War II.

Sinchiy, Ostrov: islands, see Sealion Islands.

Sinclair Lake: lake, $5 \mathrm{mi}$. long, $9 \mathrm{mi}$. E of Dease Inlet, and $46 \mathrm{mi}$. SE of Barrow, Arctic Plain; $71^{\circ} 00^{\prime} \mathrm{N}, 154^{\circ} 47^{\prime} \mathrm{W}$; BGN 1961; (map 153).

Named by Thomas Simpson (1843, p. 144), August 1, 1837, for George Sinclair, an Eskimo guide who served Sir George Back in 1834. Known locally as "Lake Minga."

Sinclair Mountain: mountain, 6,300 ft., $3.5 \mathrm{mi}$. $\mathrm{E}$ of Chilkoot Inlet and $26 \mathrm{mi}$. SSE of Skagway, Coast Mts.; $59^{\circ} 05^{\prime} 45^{\prime \prime} \mathrm{N}, 135^{\circ} 09^{\prime} 20^{\prime \prime}$ W; BGN 1920; (map 45).

Named in 1920 by USC\&GS for C. H. Sinclair who died in 1920 and who had 47 years of field service with the bureau. The name was published in 1924 on Chart 8303.

Sinclair River: stream, heads in Sinclair Lake, flows $\mathrm{N} 3 \mathrm{mi}$. to Mackey Inlet, $43 \mathrm{mi}$. SE of Point Barrow, Arctic Plain; $71^{\circ} 04^{\prime} 45^{\prime \prime} \mathrm{N}$, $154^{\circ} 50^{\prime} 30^{\prime \prime} \mathrm{W}$; BGN 1961; (map 153).

Named by Thomas Simpson $(1843$, p. 144), August 1, 1837, for George Sinclair, an Eskimo guide who served Sir George Back in 1834.

Sind, Ostrova: island, see Saint Lawrence Island.

Sinde, Ostrov: island, see Saint Lawrence Island.

Sindsha, Ostrov: island, see Hall Island.

Sineak River: stream, flows S $9 \mathrm{mi}$. to Norton Sound, $27 \mathrm{mi}$. SW of Christmas Mtn., Nulato Hills; $64^{\circ} 25^{\prime} \mathrm{N}, 161^{\circ} 24^{\prime} \mathrm{W}$; (map 96).

Eskimo name reported about 1954 by U.S. Army Corps of Engineers.

Sinegpuk Cape: point of land, see Singikpak Point.

Sinerazat: locality, see Sinrazat.

Singa Island: island, $0.6 \mathrm{mi}$. long, in SW El Capitan Passage, Alex. Arch.; 55 56 $45^{\prime \prime} \mathrm{N}$, $133^{\circ} 21^{\prime} 15^{\prime \prime}$ W; BGN 1932; (map 4). Var. North Island.

Haida Indian name from the word "shingia," meaning "night," and "used as a synonym for north, oold, dark or gloom." The translated name "North Island" was published in 1925 Coast Pilot (p. 154).
Singak Inlet: water passage, see Kukpowruk Pass.

Singaroo: locality, see Sinaru.

Singaroo Creek: stream, see Singaruak Creek.

Singaruak Creek: stream, flows N $10 \mathrm{mi}$. to Chukchi Sea, $18 \mathrm{mi}$. SW of Barrow, Arctic Plain; $71^{\circ} 04^{\prime} 40^{\prime \prime} \mathrm{N}, 157^{\circ} 11^{\prime} 45^{\prime \prime} \mathrm{W}$; (map 153). Var. Singorauk Creek, Sinrarua Creek, Sinaru Creek, Singaroo Creek, Sinaru Inlet.

Eskimo name which refers in meaning to the stream's estuary-like mouth. The stream has been important because of a well established campsite near its mouth. The name seems to have been first recorded as "Sinrarua" by British naval officers, 1849-53, and published on Brit. Adm. Chart 593 (Baker, 1906). Lt. P. H. Ray (1885, map) crossed the stream in 1883 with an Eskimo guide, and spelled the name "Singaroo."

Singat Creek: stream, flows N $8 \mathrm{mi}$. to Chukchi Sea, $23 \mathrm{mi}$. SW of Barrow, Arctic Plain; $71^{\circ}$ $00^{\prime} 45^{\prime \prime} \mathrm{N}, 157^{\circ} 19^{\prime} 30^{\prime \prime} \mathrm{W}$; (map 153). Var. Siinaat Waalaa.

Eskimo name recorded by USC\&GS about 1950 and may refer in meaning to the stream's estuary-like mouth.

Singatook Range: mountain range, see Kigluaik Mountains.

Singaugalik Inlet: water passage, see Singogalik Inlet.

Singauk Entrance: water passage, in barrier reef between Chukchi Sea and Kivalina Lagoon, SE of Kivalina, Kotzebue-Kobuk Low.; $67^{\circ} 58^{\prime} 30^{\prime \prime} \mathrm{N}, 164^{\circ} 31^{\prime} 45^{\prime \prime} \mathrm{W}$; (map 128). Var. Ohlick, Siingak.

Eskimo name meaning "separating entrance" according to USC\&GS in 1950.

Singaugalik Lagoon: lagoon, see Singagalik Lagoon.

Singaugalium Tasia: lagoon, see Singogalik Lagoon.

Singauruk Point: point of land, extends into Selawik Lake, $14 \mathrm{mi}$. W of Selawik, KotzebueKobuk Low.; $66^{\circ} 35^{\prime} \mathrm{N}, 160^{\circ} 30^{\prime} \mathrm{W}$; (map 114).

Eskimo name obtained by U.S. Army Corps of Engineers in 1955.

Singauruk River: stream, flows SW $25 \mathrm{mi}$. to Selawik Lake, $14 \mathrm{mi}$. W of Selawik, KotzebueKobuk Low.; $66^{\circ} 35^{\prime} \mathrm{N}, 160^{\circ} 30^{\prime} \mathrm{W}$; (map 114).

Eskimo name obtained by U.S. Army Corps of Engineers in 1955.

Singayoak Creek: stream, heads in De Long Mts., flows N $32 \mathrm{mi}$. to Nuka River, $67 \mathrm{mi}$. NE of Misheguk Mtn., Brooks Ra.; 6855' N, $159^{\circ} 12^{\prime} \mathrm{W}$; BGN 1960; (map 131).

Eskimo name reported to mean "loaded" given in 1953 by I. L. Tailleur, USGS, and so called "for the [large] amount of geologic information."

Singdolik Creek: stream, see Mapsorak Creek. Singeak: locality, on Seward Penin., at E end of Shishmaref Inlet, $64 \mathrm{mi}$. NW of Deering, Kotzebue-Kobuk Low.; $66^{\circ} 32^{\prime} \mathrm{N}, 164^{\circ} 41^{\prime}$ W; (map 113).

Eskimo camp reported in 1940 by USGS.
Singeakpuk River: stream, on Seward Penin., flows $\mathrm{N} 10 \mathrm{mi}$. to Shishmaref Inlet, $65 \mathrm{mi}$. NW of Deering, Kotzebue-Kobuk Low.; 663'. N, $164^{\circ} 48^{\prime} \mathrm{W}$; (map 113).

Eskimo name reported in 1931 by USGS. Singeegrock: spit, see Singigrak Spit.

Singick: locality, see Siniogamute.

Singick: village, see Teller Mission.

Singick: village, see Siniogamute.

Singigrak Spit: spit, in Imigrook Lagoon, $7.2 \mathrm{mi}$. SE of Kivalina, Kotzebue-Kobuk Low.; $67^{\circ} 40^{\prime} \mathrm{N}, 164^{\circ} 17^{\prime} \mathrm{W}$; (map 128). Var. Singeegrock, Singigzaaq.

Eskimo name meaning "old mukluk tiestrap" reported in 1966 by E. S. Burch.

Singigyak: locality, $0.5 \mathrm{mi}$. NE of Cape Woolley, on Bering Sea, $37 \mathrm{mi}$. NW of Nome, Seward Penin. High.; $64^{\circ} 48^{\prime}$ N, $166^{\circ} 27^{\prime}$ W ; (map 94).

Site of an Eskimo village or mining camp reported about 1940 by USC\&GS and published on Chart 9380.

Singigzaaq: spit, see Singigrak Spit.

Singik Cape: point of land, see Singik Point. Singikga, Cape: point of land, see Singikpo Cape.

Singikpa: point of land, see Singikpak Point.

Singikpa Cape: promontory, see Southwest Cape.

Singikpak Cape: point of land, see Singikpak Point.

Singikpak Point: point of land, $4 \mathrm{mi}$. NE of Southwest Cape and $33 \mathrm{mi}$. SE of Gambell, $S$ coast of St. Lawrence I.; $63^{\circ} 20^{\prime} \mathrm{N}, 171^{\circ} 19^{\prime}$ W; BGN 1951; (map 93). Var. Sinegpuk Cape, Singikpa, Singikpak Cape, Southwest Cape.

Eskimo name, meaning "big point," reported in 1949 by Maj. H. B. Allen, USAF.

Singikpo Cape: point of land, NE coast of St. Lawrence I., $13 \mathrm{mi}$. SE of Savoonga and 50 mi. SE of Gambell; $63^{\circ} 37^{\prime} \mathrm{N}, 170^{\circ} 06^{\prime} \mathrm{W}$; $B G N$ 1951; (map 93). Var. Cape Singikga, Cape Singikpo, Singikpo Point.

Eskimo name, meaning "sharp" [singikhpa], reported in 1932 by $\mathrm{O}$. W. Geist, Univ. of Alaska.

Singik Point: point of land, $10 \mathrm{mi}$. S of Gambell, W coast of St. Lawrence I.; $63^{\circ} 39^{\prime} \mathrm{N}, 171^{\circ} 46^{\prime}$ W; BGN 1951; (map 93). Var. Kavalghak Cape, Kavalrok, Singik Cape.

Eskimo name, meaning "pointed," reported in 1949 by Maj. H. B. Allen, USAF.

Singikpo Point: point of land, see Singikpo Cape.

Sing-i-too-rok: locality, see Kukpowruk.

Singogalik Inlet: water passage, between Singaugalik Lagoon and Chukchi Sea, $26 \mathrm{mi}$. NW of Kivalina, Kotzebue-Kobuk Low.; 67 $59^{\prime}$ N, $165^{\circ} 13^{\prime} \mathrm{W}$; (map 128). Var. Singaugalik Inlet, Singowgalick.

Eskimo name reported in 1966 by E. S. Burch.

Singogalik Lagoon: lagoon, on shore of Chukchi Sea, $26 \mathrm{mi}$. NW of Kivalina, Kotzebue-Kobuk Low.; $67^{\circ} 59^{\prime} \mathrm{N}, 165^{\circ} 13^{\prime} \mathrm{W}$; (map 128). Var. Singaugalik Lagoon, Singaugalium Tasia, Singowgaleeyoom Tessaya. 
Eskimo name reported in 1966 by E. S. Burch.

Singoolik Creek: stream, see Mapsorak Creek. Singorauk: locality, see Sinaru.

Singorauk Creek: stream, see Singaruak Creek.

Singowgaleeyoom Tessaya: lagoon, see Singogalik Lagoon.

Singowgalick: water passage, see Singogalik Inlet.

Siniagamute: locality, see Siniogamute.

Sinicktuknayluk Creek: stream, see Siniktaneyak Creek.

Sinigrok Point: point of land, extends SW into Aiautak Lagoon, $14 \mathrm{mi}$. SE of Point Hope, Arctic Slope; $68^{\circ} 18^{\prime} 22^{\prime \prime} \mathrm{N}, 166^{\circ} 18^{\prime} 50^{\prime \prime} \mathrm{W}$; (map 129).

Eskimo name meaning "shoe lace [thong]" reported in 1956 by Orth; descriptive of the spit's narrowness.

Siniktagnailik: locality, see Siniktagnelik.

Siniktagnelik: locality, on right bank of Wulik River, $19 \mathrm{mi}$. NE of Kivalina, KotzebueKobuk Low.; $67^{\circ} 48^{\prime} \mathrm{N}, 164^{\circ} 04^{\prime} \mathrm{W}$; (map 128). Var. Seeyicktagnaylick, Siniktagnailik.

Eskimo name referring to "no camping place because one cannot sleep because many years ago some people mysteriously died here." Name reported in 1966 by E. S. Burch. There is another Siniktagnelik 10 miles north of here.

Siniktagnelik: locality, on right bank of Kivalina River, $17 \mathrm{mi}$. NE of Kivalina, Arctic Slope; $67^{\circ} 56^{\prime} \mathrm{N}, 164^{\circ} 13^{\prime} \mathrm{W}$; (map 128). Var. Seeyicktagnaylick, Siniktagnailik, Siniqtagnailik.

Eskimo name referring to "no camping place" because "one cannot sleep" due to it being haunted; reported in 1966 by E. S. Burch. There is another Siniktagnelik 10 miles south of here.

Siniktaneyak Creek: stream, flows NW $1.6 \mathrm{mi}$. to Chukchi Sea, $6.6 \mathrm{mi}$. S of Cape Dyer, Arctic Slope; $68^{\circ} 33^{\prime} 25^{\prime \prime} \mathrm{N}, 166^{\circ} 14^{\prime} 30^{\prime \prime} \mathrm{W}$; (map 129). Var. Sinicktuknayluk Creek.

Eskimo name that refers in meaning to "some way or reason for not sleeping"; reported by USC\&GS in 1950 and spelled "Sinick-tuk-nay-luk."

Siniktanneyak Mountain: mountain, 4,600 ft., 9 mi. long, in De Long Mts., Brooks Ra., $40 \mathrm{mi}$. WNW of Howard Pass; $68^{\circ} 20^{\prime} \mathrm{N}, 158^{\circ} 30^{\prime}$ W; (map 132).

An Eskimo name obtained at Noatak by Orth in 1956, and reported to mean "place where one cannot sleep."

Siningmon: locality, on S coast of Seward Penin. at Golovnin Bay, Seward Penin. High.; $64^{\circ}$ $25^{\prime} \mathrm{N}, 163^{\circ} 00^{\prime} \mathrm{W}$; (map 95).

Former Eskimo village or camp reported in the 1890 Census (1893, p. 162).

Siniogarnut: locality, see Siniogamute.

Siniogamut: village, see Teller Mission.

Siniogamute: village, see Teller Mission.

Siniogamute: locality, on $\mathrm{N}$ shore of Port Clarence, $8 \mathrm{mi}$. NW of Teller, Seward Penin. High.; $65^{\circ} 21^{\prime} \mathrm{N}, 166^{\circ} 33^{\prime} \mathrm{W}$; (map 111).
Var. Singick, Siniagamute, Siniogamut, Sinuk, Zingaramute.

Former Eskimo village reported as "Zingaramute" by members of the Western Union Telegraph Expedition quartered at Teller, 1866-67. In the 1880 Census Petroff (1884, p. 11) listed the village of "Siniogamute" population 36 ; in 1890 the population was recorded with the villages of Port Clarence. Hodge (1910, p. 577), BAE, lists "Sinuk" located on $\mathbf{N}$ shore of Port Clarence.

Siniqtagnailik: locality, see Siniktagnelik.

Sin-i-Rock: locality, on spit on Chukchi Sea coast, $14 \mathrm{mi}$. NE of Cape Prince of Wales, at $W$ end of Seward Penin., Kotzebue-Kobuk Low.; $65^{\circ} 46^{\prime} \mathrm{N}, 167^{\circ} 49^{\prime} \mathrm{W}$; (map 111).

Site of an Eskimo campground; the name was recorded on the 1908 "Map of Seward Peninsula" by Arthur Gibson.

Sinitsin Cove: bay, $0.6 \mathrm{mi}$. across, on $\mathrm{N}$ coast of Kruzof I., 25 mi. NW of Sitka, Alex. Arch.; $57^{\circ} 20^{\prime} 00^{\prime \prime} \mathrm{N}, 135^{\circ} 44^{\prime} 30^{\prime \prime} \mathrm{W}$; (map 9).

Name reported in 1896 by Lt. Comdr. E. K. Moore, USN, and published by USC\&GS in 1901 Coast Pilot (p. 196).

Sinitsin Island: island, $0.3 \mathrm{mi}$. across, in Salisbury Sound, off $\mathrm{N}$ coast of Kruzof I., Alex. Arch.; 57 $20^{\prime} 45^{\prime \prime} \mathrm{N}, 135^{\circ} 45^{\prime} 40^{\prime \prime} \mathrm{W}$; (map 9). Var. Ostrov Sinitsyna, Sinits Island.

Named in 1833 by the Russian navigator Ens. Vasiliev for Lt. Nikolai Sinitzin, IRN, who accompanied Hagemeister in $1828-30$ on the Krotkoi on his third voyage to the Russian American colonies.

Sinits Island: island, see Sinitsin Island.

Sinitsyna, Ostrov: island, see Sinitsin Island.

Sink Hole Lake: lake, $0.2 \mathrm{mi}$. long, $4.5 \mathrm{mi}$. N of Neck Lake, on Prince of Wales I., Alex. Arch.; $56^{\circ} 10^{\prime} 10^{\prime \prime} \mathrm{N}, 133^{\circ} 10^{\prime} 20^{\prime \prime} \mathrm{W} ; B G N$ 1963; (map 6).

Local descriptive name reported in 1961 by USFS. "The lake drains into a nearby sink hole and there is no other outlet. This sink hole and several others in the area are quite impressive."

Sinking Creek: stream, on Iniskin Penin., flows NW 2 mi. to Chinitna Bay, E of Camp Point, Aleutian Ra.; $59^{\circ} 50^{\prime} \mathrm{N}, 153^{\circ} 04^{\prime} \mathrm{W}$; $B G N$ 1962; (map 51).

Local name reported in 1951 by USGS.

Sinnott Creek: stream, flows NW $4 \mathrm{mi}$. to Seventymile River, $8 \mathrm{mi}$. NW of Eagle, YukonTanana High.; $64^{\circ} 53^{\prime} \mathrm{N}, 141^{\circ} 21^{\prime} \mathrm{W}$; (map 102).

Prospectors' name shown on a 1902 manuscript map by E. J. Chamberlain, U.S. Deputy Surveyor.

Sinnyu: locality, see Sinyu.

Sinnyu: lagoon, see Middle Salt Lágoon.

Sinnyuli: locality, see Sinyu.

Sinnyuli: lagoon, see Middle Salt Lagoon.

Sinona Creek: stream, flows S $40 \mathrm{mi}$. to Chistochina River $1.5 \mathrm{mi}$. $\mathrm{N}$ of its junc. with Copper River, Copper River Basin ; $62^{\circ} 34^{\prime}$ N, $144^{\circ} 38^{\prime}$ W; BGN 1936; (map 83). Var. Schnuna River, Shnu Creek, Shuna Creek.

Indian name, said to mean "Brush Creek." Recorded as "Schnuna River" in 1885 by Lt.
Allen (1887, p. 65), USA. Local use of the name "Sinona Creek" reported by USGS in 1936.

Sinona Lake: lake, $1.3 \mathrm{mi}$. long, drains $\mathrm{SW}$ to Sinona Creek, $28 \mathrm{mi}$. NW of Chistochina, Alaska Ra. ; $62^{\circ} 57^{\prime}$ N, $144^{\circ} 53^{\prime}$ W ; (map 83).

Local name reported by USGS in 1954. Named for Sinona Creek.

Sinona Lodge: roadhouse, on Glenn Highway at Sinona Creek, $44 \mathrm{mi}$. NE of Glennallen, Copper River Basin ; 62 $35^{\prime} 30^{\prime \prime} \mathrm{N}, 144^{\circ} 39^{\prime} 00^{\prime \prime} \mathrm{W}$; (map 83).

Sinook River: stream, see Sinuk River.

Sinra: locality, see Sinaru.

Sinragahroo: locality, see Sinaru.

Sinrakrurak Inlet: water passage, between Imigrook Lagoon and Chukchi Sea, $5 \mathrm{mi}$. SE of Kivalina, Kotzebue-Kobuk Low.; 67 $41^{\prime}$ N, $164^{\circ} 22^{\prime} \mathrm{W}$; (map 128). Var. Seenrakroorak, Sinraqzuuzaq.

Eskimo name meaning "little outlet" reported in 1966 by E. S. Burch.

Sinraqzuuzaq: water passage, see Sinrakrurak Inlet.

Sinrarua: locality, see Sinaru.

Sinrarua Creek: stream, see Singaruak Creek.

Sinrazat: locality, on barrier island, between Arctic Lagoon and Chukchi Sea, $20 \mathrm{mi}$. SW of Shishmarev, Kotzebue-Kobuk Low.; $66^{\circ} 06^{\prime}$ N, $166^{\circ} 40^{\prime} \mathrm{W}$; (map 112). Var. Senezatt, Senerazat.

Eskimo name for a village visited in 1898 by Lt. D. H. Jarvis, USRCS. The 1880 and 1890 censuses do not list this place. Presentday maps show a "Sinrazat Shelter Cabin." Sinrock Greek: stream, see Sinuk River.

Sinuk: village, see Siniogamute.

Sinuk: locality, see Siniogamute.

Sinuk: village, see Teller Mission.

Sinuk: locality, at mouth of Sinuk River, on Bering Sea coast, $26 \mathrm{mi}$. NW of Nome, Seward Penin. High.; $64^{\circ} 36^{\prime} \mathrm{N}, 166^{\circ} 15^{\prime} \mathrm{W}$; (map 94). Var. Sinuk Missionary Station.

Site of an Eskimo village reported in 1900 by E. C. Barnard (in Brooks, 1901, pl. 17), USGS. See Siniogamute.

Sinuk: water passage, from Chukchi Sea to mouth of Kukpuk River, $12 \mathrm{mi}$. NE of village of Point Hope, Arctic Slope; $68^{\circ} 25^{\prime} 10^{\prime \prime} \mathrm{N}$, $166^{\circ} 23^{\prime} 30^{\prime \prime} \mathrm{W}$; (map 129).

Eskimo name reported in 1950 by USGS to mean "stream mouth."

Sinuk Creek: stream, flows N $6 \mathrm{mi}$. to Killik River $4.5 \mathrm{mi}$. SW of its junc. with Easter Creek, Brooks Ra.; $68^{\circ} 06^{\prime} \mathrm{N}, 154^{\circ} 17^{\prime} \mathrm{W}$; (map 133).

Eskimo name meaning "stream mouth," reported in 1956 by Orth.

Sinuk Missionary Station: locality, see Sinuk.

Sinuk River: stream, heads $\mathbf{N}$ of Tigaraha Mtn., flows SW $48 \mathrm{mi}$. to Norton Sound, $25 \mathrm{mi}$. NW of Nome, Seward Penin. High.; 64 ${ }^{\circ} 35^{\prime} \mathrm{N}$, $166^{\circ} 15^{\prime}$ W; (map 94). Var. Sinook River, Sinrock Creek, Synrock River.

Eskimo name reported in 1900 by E. C. Barnard (in Brooks, 1901, pl. 17), USGS. 
Sinyalak Creek: stream, flows $\mathrm{S} 15 \mathrm{mi}$. to Alatna River, 57 mi. NE of Hughes, Hogatza High.; $66^{\circ} 40^{\prime} \mathrm{N}, 153^{\circ} 03^{\prime} \mathrm{W}$; (map 116).

Eskimo name recorded in 1956 at Kobuk by Orth and reported to mean "all split up."

Sinyu: locality, on Chukchi Sea coast, at Middle Salt Lagoon, $2 \mathrm{mi}$. NE of Barrow, Arctic Plain; $71^{\circ} 19^{\prime} \mathrm{N}, 156^{\circ} 41^{\prime} \mathrm{W}$; (map 153). Var. Sinnyu, Sinnyuli.

Former Eskimo summer village reported as "Sinnyu" by Sgt. John Murdoch, USA (Hodge, 1910, p. 577).

Siomouth Creek: stream, flows NE to Pargon River, about $15 \mathrm{mi}$. NE of Council, Seward Penin. High.; (map 110).

Prospectors' name reported on the 1900 "Map of Nome Peninsula" by J. M. Davidson and B. D. Blakeslee. This stream cannot be precisely located on current maps.

Siotukuyuk Bluff: bluff, elev. $300 \mathrm{ft}$., on E bank of Itkillik River, $32 \mathrm{mi}$. NE of Umiat, Arctic Plain, $69^{\circ} 34^{\prime} \mathrm{N}, 150^{\circ} 57^{\prime} \mathrm{W}$; (map 141).

Eskimo name reported in 1956 by T. E. Taylor, USGS.

Siouchi: rocks, see Sealion Rocks.

Siouchi Bay: cove, see Sealion Cove.

Siouchi Point: point of land, see Georgiana, Cape.

Sioutchi: rocks, see Sealion Rocks.

Sioutchi Creek: cove, see Sealion Cove.

Sirius Point: point of land, northernmost point on Kiska I., Rat Is., Aleutian Is., $52^{\circ} 08^{\prime} \mathrm{N}, 177^{\circ}$ $36^{\prime}$ E; BGN 1937; (map 14).

Named in 1936 by the U.S. Navy Hydrog. Office for the U.S.S. Sirius, supply ship of the Navy Aleutian Island Survey Expedition of 1935.

Sipewtaq Lagoon: lagoon, see Ipiutak Lagoon. Sir Henry Martin, Point: point of land, see Martin Point.

Siroi, Point: point of land, $2.5 \mathrm{mi}$. N of Fish Bay, near $W$ end of Peril Strait, on NW coast of Baranof I., Alex. Arch.; $57^{\circ} 25^{\prime} \mathrm{N}, 135^{\circ} 35^{\prime}$ W; (map 9). Var. Mys Syroy.

Russian name meaning "wet," given in 1833 by the navigator Ens. Vasiliev; published in 1848 on Russian Hydrog. Dept. Chart 1397 as "M[ys] Syroy."

Sir Pulteney Malcolm River: stream, see Malcolm River.

Sirr Creek: stream, flows S $4 \mathrm{mi}$. from Sirr Mtn. to Seward Creek, $1 \mathrm{mi}$. W of Wild Lake and $41 \mathrm{mi}$. W of Wiseman, Brooks Ra.; 67 $30^{\prime} 30^{\prime \prime}$ N, $151^{\circ} 38^{\prime} 00^{\prime \prime} \mathrm{W}$; BGN 19.32; (map 124). Var. Surr Creek.

Named in 1932 by Robert Marshall, "for Ben Sirr, one of the veteran prospectors of the Koyukuk."

Sirr Mountain: mountain, $5,705 \mathrm{ft}$., $4 \mathrm{mi}$. NW of Wild Lake and $42 \mathrm{mi}$. NW of Wiseman, Brooks Ra.; 67 $34^{\prime} 20^{\prime \prime} \mathrm{N}, 151^{\circ} 39^{\prime} 00^{\prime \prime} \mathrm{W}$; (map 124). Var. Surr Mountain.

Named about 1930 by Robert Marshall, "because it lies at the head of the creek named for the prospector, Ben Sirr."

Sir T. Staines River: stream, see Staines River.

Siruk Creek: stream, heads in lake, flows SE and NE $50 \mathrm{mi}$. to Alatna River, $52 \mathrm{mi}$. NE of Hughes, Hogatza High.; $66^{\circ} 42^{\prime} \mathrm{N}, 153^{\circ} 18^{\prime}$ W; (map 116). Var. Chalatna Creek, Sirurk Creek.

Eskimo name obtained in 1901 by Mendenhall (1902, pl. 5), USGS. The Indian name is "Chalatna," reported in 1956 by Orth.

Sirurk Creek: stream, see Siruk Creek.

Sisaguk: locality, on $N$ coast of Unimak I., near Cape Lapin, Aleutian Is.; $54^{\circ} 39^{\prime} \mathrm{N}, 163^{\circ} 18^{\prime}$ W; (map 25). Var. Schischaldenskoje, Sheeshaldenskoi, Shishaldin, Shishaldinski, Shishaldinskoe.

Former Aleut village name recorded in 1833 as "Shishaldinskoe," population 91, by Father Veniaminov (1840, v. 2, p. 203), which name was derived from the Russian name for the nearby volcano.

Sisaguk: mountain, see Shishaldin Volcano,

Sischu Creek: stream, flows W $9 \mathrm{mi}$. to Sethkokna River, $4.5 \mathrm{mi}$. E of Novi Mtn. and $42 \mathrm{mi}$. N. of Telida, Kilbuck-Kuskokwim Mts.; $63^{\circ}$ $58^{\prime} \mathrm{N}, 153^{\circ} 18^{\prime} \mathrm{W}$; (map 89).

Local name reported in 1958 by USGS.

Sischu Mountain: mountain, 3,510 ft., at head of 'Titna River, 39 mi. SW of Bitzshtini Mts. Kilbuck-Kuskokwim Mts. ; $64^{\circ} 06^{\prime} \mathrm{N}, 152^{\circ} 55^{\prime}$ W; (map 99).

Indian name obtained in 1899 by Lt. J. S. Herron, USA.

Sischu Mountain: mountains, see Sischu Mountains.

Sischu Mountains: mountains, 2,422 ft., trends NE-SW $25 \mathrm{mi}$. along SE side of Kuskokwim Mts., $37 \mathrm{mi}$. $\mathrm{N}$ of Telida, Kilbuck-Kuskokwim Mts.; $63^{\circ} 56^{\prime} \mathrm{N}, 153^{\circ} 10^{\prime} \mathrm{W}$; (map 89). Var. Sischu Mountain.

Indian name obtained in 1899 by Lt. J. S. Herron, USA, who applied it to a single mountain.

Sisdlartna River: stream, see Papa Willie Creek. Sisek Bay: bay, see Sisek Cove.

Sisek Cove: bay, $0.3 \mathrm{mi}$. across, $\mathrm{N}$ coast of Sedanka I., Aleutian Is.; $53^{\circ} 50^{\prime} 00^{\prime \prime} \mathrm{N}, 166^{\circ}$. 10'30" W; (map 23). Var. Sisek Bay.

Aleut name, called "Zal[iv] Sisek," or "Sisek Bay," by Lt. Sarichev (1826, map 14, dated 1792), IRN. This name was possibly taken from the Aleut word "sisak," which, according to R. H. Geoghegan, means "a hundred."

Sisgravik Lake: lake, $4 \mathrm{mi}$. long, near mouth of Inaru River, $26 \mathrm{mi}$. SE of Barrow, Arctic Plain; $70^{\circ} 57^{\prime} \mathrm{N}, 156^{\circ} 10^{\prime} \mathrm{W}$; (map 147).

Eskimo name obtained in 1956 at Wainwright by T. E. Taylor, USGS.

Sishimkak: island, see Sitymkan.

Sishulathna River: stream, see Herron River.

Sisiak Creek: stream, flows $S 11 \mathrm{mi}$. to Noatak River, $E$ of Isacheluich Mts., $64 \mathrm{mi}$. $\mathrm{N}$ of Kiana, Brooks Ra.; $67^{\circ} 54^{\prime} \mathrm{N}, 160^{\circ} 35^{\prime} \mathrm{W}$; (map 127).

Eskimo name meaning "many [fox] dens"; obtained in 1956 at Noatak by Orth.

Sisiak Creek: stream, heads in lake, flows S 4 mi. to Noatak River, $17 \mathrm{mi}$. SSW of Misheguk Mtn., Brooks Ra.; 68 $01^{\prime} \mathrm{N}, 161^{\circ} 25^{\prime} \mathrm{W}$; (map 131).

Eskimo name meaning "fox den" obtained at Noatak by Orth in 1956.
Sisikikaret Hill: pingo, on right bank of Noatak River, between Anorat and Otkurak Creeks, Brooks Ra.; $67^{\circ} 40^{\prime} \mathrm{N}, 155^{\circ} 22^{\prime} \mathrm{W}$; (map 125).

Eskimo name reported by USGS in 1956 to literally mean "ground squirrel's dancehill."

Siskokhtanten: stream, see North Fork Dagislakhna Creek.

Sistdlila: mountain range, see Magitchlie Range. Sister Islands: islands, extend $0.4 \mathrm{mi}$. along S coast of Duke I., S of Kelp I., Alex. Arch.; $54^{\circ} 52^{\prime} 15^{\prime \prime} \mathrm{N}, 131^{\circ} 17^{\prime} 15^{\prime \prime} \mathrm{W}$; (map 2). Var. Twin Islands.

Descriptive name published in 1885 by USC\&GS ; named Twin Islands by pilot W. E. George (USC\&GS, 1883, p. 77).

Sister Islands: islands, in Yukon River, about 62 mi. E of Nulato, Koyukuk Low.; $64^{\circ} 43^{\prime} \mathrm{N}$, $156^{\circ} 00^{\prime} \mathrm{W}$; (map 97).

Riverboat pilots' name shown on a 1940 "Navigation Chart of the Tanana-Yukon Rivers" published by U.S. Dept. of Interior.

Sister Lake: lake, $3 \mathrm{mi}$. across, $4 \mathrm{mi}$. SE of Chichagof, on W coast of Chichagof I., Alex. Arch.; $57^{\circ} 37^{\prime} \mathrm{N}, 136^{\circ} 01^{\prime} \mathrm{W}$; BGN 1908; (map 9).

Named by USC\&GS in 1908; published in 1908 Coast Pilot (p. 173).

Sister Rock: rock, in Knight Island Passage, $\mathbf{N}$ of Pleiades Is., $4 \mathrm{mi}$. SE of Chenega, Chugach Mts.; $60^{\circ} 14^{\prime} 30^{\prime \prime} \mathrm{N}, 148^{\circ} 00^{\prime} 35^{\prime \prime} \mathrm{W}$; (map 63).

Local name reported in 1951 by USGS.

Sisters, The: islands, two islands, $1 \mathrm{mi}$. and 0.5 mi. long, in Icy Strait, 4 mi. NE of Neck Point on Chichagof I. and $32 \mathrm{mi}$. WSW of Juneau, St. Elias Mts. ; $58^{\circ} 10^{\prime} 30^{\prime \prime} \mathrm{N}, 135^{\circ} 15^{\prime} 30^{\prime \prime} \mathrm{W}$; (map 11).

Named in 1880 by USN and published by USC\&GS in the 1883 Coast Pilot (p. 197).

Sisters, The: islands, see Hazy Islands.

Sisters, The: islands, see Lynn Sisters.

Sisters, The: islands, see Twin Islands.

Sisters, The: mountain, 1,020 ft., on W end of Unimak I., $4 \mathrm{mi}$. E of Cape Sarichev, Aleutian Is. ; $54^{\circ} 34^{\prime} 45^{\prime \prime} \mathrm{N}, 164^{\circ} 50^{\prime} 10^{\prime \prime} \mathrm{W}$; (map 24).

Named by the U.S. military during World War II and published in 1943 on an AMS map.

Sisters, The: mountains, 1,669 ft., W of Klikitarik River, $15 \mathrm{mi}$. SE of St. Michael, YukonKuskokwim Delta; $63^{\circ} 19^{\prime} \mathrm{N}, 161^{\circ} 42^{\prime} \mathrm{W}$; (map 91).

Two cinder cones named in 1898 by USC\&GS and published on Chart 9370.

Sisters, The: mountains, $3,880 \mathrm{ft}$., $5 \mathrm{mi}$. NE of Sitka, on W coast of Baranof I., Alex. Arch.; $57^{\circ} 05^{\prime} 30^{\prime \prime} \mathrm{N}, 135^{\circ} 14^{\prime} 00^{\prime \prime} \mathrm{W}$; (map 9). Var. Patterson Mountains.

Local name published in 1916 by USC\&GS. Sisters, The: mountain, see Cecil, Mount. Sisters, The: mountain, see Elizabeth, Mount. Sisters, The: rocks, group of three, elev. $5 \mathrm{ft}$., in Cook Inlet, $19 \mathrm{mi}$. SSW of Kenai, Cook Inlet Low.; $60^{\circ} 18^{\prime} \mathrm{N}, 151^{\circ} 27^{\prime} \mathrm{W}$; (map 62). Local name reported in 1897 by Lt. Comdr. J. F. Moser, USN. 
Sisters Island: island, $0.6 \mathrm{mi}$. long, $4.5 \mathrm{mi} . \mathrm{S}$ of Sanak I., one of Sanak Is., Aleutian Ra.; $54^{\circ}$ $20^{\prime} 00^{\prime \prime} \mathrm{N}, 162^{\circ} 41^{\prime} 35^{\prime \prime} \mathrm{W}$; (map 25).

Name reported by Ferdinand Westdahl, USC\&GS, commander of the Coast Survey steamer McArthur, who made surveys in this area in 1901.

Sisters Islands: islands, see Pleiades Islands.

Sisters Reef: reef, in Icy Strait, $1.1 \mathrm{mi}$. W of The Sisters and $33 \mathrm{mi}$. SW of Juneau, St. Elias Mts. ; $58^{\circ} 10^{\prime} 45^{\prime \prime} \mathrm{N}, 135^{\circ} 17^{\prime} 25^{\prime \prime} \mathrm{W}$; (map 11).

Named by E. F. Dickins, USCi\&GS, and published in the 1901 Coast Pilot (p. 203).

Sitadaka: peak, see Sitth-gha-ee Peak.

Sit-a-da-kay: peak, see Sitth-gha-ee Peak.

Sitakaday Narrows: water passage, $1 \mathrm{mi}$. long, at $\mathrm{S}$ end of Glacier Bay, in Glacier Bay $\mathrm{Na}$ tional Monument, just $W$ of the Beardslee Is., $34 \mathrm{mi}$. NW of Hoonah, St. Elias Mts.; $58^{\circ} 30^{\prime}$ N, $136^{\circ} 02^{\prime} \mathrm{W} ; B G N$ 1942; (map 10). Var. Ripple Narrows.

Named by USC\&GS in 1942 . The name Sit-a-ka-day means "icy bay," and is said to be the Tlingit Indian name for Glacier Bay. The passage is the narrowest part of the entrance to Glacier Bay and was called Ripple Narrows on USC\&GS Chart 8304 in 1940.

Sitakane River: stream, see Sittakanay River.

Sitak River: stream, see Situk River.

Sitcha: town, see Sitka.

Sitchiak Lake: lake, $1 \mathrm{mi}$. across, $\mathbf{N}$ of Kayak Mtn., $6.5 \mathrm{mi}$. NW of junc. of May Greek and Nanushuk River, $52 \mathrm{mi}$. NE of Anaktuvuk Pass, Arctic Slope; $68^{\circ} 48^{\prime} 15^{\prime \prime} \mathrm{N}, 150^{\circ} 47^{\prime} 30^{\prime \prime}$ W; (map 134).

Eskimo name obtained at Anaktuvuk Pass and reported in 1956 by T. E. Taylor, USGS; it may mean "new ice."

Sitchinak: island, see Sitkinak Island.

Sitchini Island: island, see Great Sitkin Island. Sitchin Island: island, see Great Sitkin Island. Sitchunack Island: island, see Sitkinak Island. Sitcknak: island, see Sitkinak Island.

Sitdown Creek: stream, see Big Sitdown Creek. Siteeluk Bay: $b a y, 0.5 \mathrm{mi}$. wide, $8 \mathrm{mi}$. NW of Southwest Cape, SW coast of St. Lawrence I.; $63^{\circ} 21^{\prime} \mathrm{N}, 171^{\circ} 41^{\prime} \mathrm{W}$; BGN 1951; (map 93). Var. Sitilak Bay.

Eskimo name reported in 1949 by Maj. H. B. Allen, USAF.

Sithanak: island, see Sedanka Island.

Sithdondit Creek: stream, flows NE and E 16 mi. to Melozitna River, W of Slokhenjikh Hills, 57 mi. NW of Tanana, Kokrines-Hodzana High.; $65^{\circ} 55^{\prime} \mathrm{N}, 152^{\circ} 55^{\prime} \mathrm{W}$; (map 106).

Koyukuk Indian name obtained in 1956 at Hughes by Orth.

Sithoh Bay: lake, see Sitkoh Lake.

Sithoonack: island, see Sitkinak Island.

Sithylemenkat Lake: lake, $2 \mathrm{mi}$. across, $46 \mathrm{mi}$. $\mathrm{SE}$ of Allakaket, Kokrines-Hodzana High.; $66^{\circ} 07^{\prime} \mathrm{N}, 151^{\circ} 12^{\prime} \mathrm{W}$; (map 117).

Koyukan Indian name obtained in 1956 at Allakaket by Orth.

Sitilak Bay: bay, see Siteeluk Bay.

Sitka: town, pop. 3,237 , on $W$ coast of Baranof I., $95 \mathrm{mi}$. SW of Juneau, Alex. Arch.; $57^{\circ} 03^{\prime}$ N, $135^{\circ} 20^{\prime} \mathrm{W}$; BGN 1897; (map 9). Var.
Fort New Archangel, New Archangel, Novo Arkhangelsk, Novoarkhangelsk, Schitcha, Schitka, Schitkha, Sitcha, Sikhta, Sitki.

After the destruction in 1802 of Mikhailovsk, named for Saint Michael Archangel (see Old Sitka), a new Russian settlement was established in 1804 , several miles from the old fort, under the direction of A. A. Baranov. This new settlement, built around a fortification on Castle Hill, was consequently named "Novoarkhangelsk," i.e. "New Archangel." This became the headquarters of the Russian American Company and capital of Russian America. When Russian America was purchased by the United States the town was named Sitka, a Tlingit Indian name, said to mean "by the sea" or "on Shi," the native name for Baranof Island. Sitka was the capital of Alaska until 1900 when territorial administration was transferred to Juneau. The population of the town was 968 in $1867 ; 1,039$ in $1910 ; 1,175$ in $1920 ; 1,056$ in $1930 ; 1,987$ in 1939; and 1,985 in 1950 . The Sitka post office was established in 1867 .

Sitka Bay: water passage, see Sitka Sound.

Sitkagi, Cape: point of land, on shore of Gulf of Alaska, $1.5 \mathrm{mi}$. S of 1961 terminus of the Malaspina Glacier and $4 \mathrm{mi}$. W of Sitkagi Bluffs, $42 \mathrm{mi}$. NW of Yakutat, Malaspina Coastal Plain; $59^{\circ} 44^{\prime} 15^{\prime \prime} \mathrm{N}, 140^{\circ} 53^{\prime} 00^{\prime \prime} \mathrm{W}$; (map 46). Var. Cape Saint Elias, Punta Novales.

Apparently a Tlingit Indian name recorded by Capt. Tebenkov (1852, map 7), IRN. He calls it "M[ys] Sitkagi," or "Cape Sitkagi." This point is probably the same as "M[ys] Svat Iliy" or "Cape St. Elias," a name published in 1847 on Russian Hydrog. Dept. Chart 1378. See Novales, Punta.

Sitkagi Bluffs: bluffs, at 1961 terminus of Malaspina Glacier, extend W $6 \mathrm{mi}$. along shore of Gulf of Alaska, $35 \mathrm{mi}$. NW of Yakutat, Malaspina Coastal Plain; $59^{\circ} 43^{\prime} \mathrm{N}, 140^{\circ} 42^{\prime} \mathrm{W}$; (map 46).

Named in 1891 by Russell (1892, pl. 4 and pl. 56); name was derived from Sitkagi Point. Sitka Harbor: water passage, between Japonski I. and Sitka, on $W$ coast of Baranof I., Alex. Arch.; $57^{\circ} 03^{\prime} 15^{\prime \prime} \mathrm{N}, 135^{\circ} 21^{\prime} 00^{\prime \prime} \mathrm{W}$; (map 9).

Name derived from the town of Sitka; published by USC\&GS in 1891 Coast Pilot (p. 175).

Sitka Hot Springs: locality, see Goddard.

Sitka Island: island, see Baranof Island.

Sitka Island: island, see Kruzof Island.

Sitkalidak Island: island, $23 \mathrm{mi}$. long, SE of Kodiak I.; $57^{\circ} 07^{\prime} \mathrm{N}, 153^{\circ} 14^{\prime} \mathrm{W}$; (map 34). Var. Isla de Soto, Kukan Island, Kunakan Island, Ostrov Salthidak, Ostrov Syakhlidok, Ostrov Syatkhlidak, Sachlidok Island, Sadlidok Island, Saklidok Island, Saklidov Island, Sakthidak Island, Satklidak Island, Scachlitak Island, Shagitak Island, Siaklidok Island, Siaktklidak Island, Zatchlitschak Island.

Transliteration by USC\&GS from various Russian forms of what Baker (1906, p. 579) calls "a corruption of some native word or phrase * * *." In 1794, Billings (in Sauer, 1802 , p. 170) named it "Kukan" or "Kunakan Island." Called "O[strov] Salthidack" in 1805 by Lisianski (1814, p. 181) and published as "Os[trov] Syakhlidok," or "Syakhlidok Island," by Sarichev (1826, map 3) and "O[strov] Syatkhlidak," or "Syatkhlidak Island," by Capt. Tebenkov (1852, map 23), etc. Also named "Isla de Soto," or "forest island," by Galiano (1802, map 3).

Sitkalidak Lagoon: lagoon, $2 \mathrm{mi}$. long, at head of Natalia Bay, on SW coast of Sitkalidak I., SE of Kodiak I.; $57^{\circ} 06^{\prime} \mathrm{N}, 153^{\circ} 17^{\prime} \mathrm{W}$; (map 34).

Name derived from Sitkalidak Island and published in 1943 by USC\&GS.

Sitkalidak Narrows: water passage, see Sitkalidak Passage.

Sitkalidak Passage: water passage, $1 \mathrm{mi}$. long, part of Sitkalidak Strait, W of Midway Bay, between Sitkalidak I., and SE coast of Kodiak I.; $57^{\circ} 12^{\prime} 40^{\prime \prime} \mathrm{N}, 153^{\circ} 16^{\prime} 00^{\prime \prime} \mathrm{W}$; BGN 1930; (map 34). Var. Sitkalidak Narrows, The Narrows.

Name derived from Sitkalidak Island and given by USC\&GS in 1930 .

Sitkalidak Strait: water passage, between Sitkalidak I. and SE coast of Kodiak I.; $57^{\circ} 10^{\prime} \mathrm{N}$, $153^{\circ} 20^{\prime} \mathrm{W}$; (map 34). Var. Proliv Syatkhlidak.

This is a transliteration by USC\&GS of the Russian name "Provliv Syatkhlidak," or "Syatkhlidak Strait," published by Capt. Tebenkov (1852, map 23). Baker erroneously (1906, p. 579) wrote "Corruption of some native name."

Sitka National Monument, 54 acres, at mouth of Indian' River, on Baranof I., SE of Sitka, Alex.

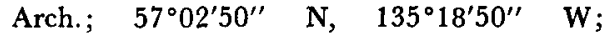
(map 9).

This national monument was established March 23, 1910, on the site of the Indian stockade, where the Tlingit Indians made their last stand against the Russian settlers at Sitka. The Indian fortress, consisting of thick logs, was occupied by the Indians in 1804 , after retreating from their village on Castle Hill, during the occupation of Sitka by the Russians. The fort was attacked by the Russians under the command of Gov. A. A. Baranov and Capt. U. T. Lisianski, IRN, supported by several hundred Aleuts. After a week's siege the fort was abandoned by the Indians and was destroyed by the attackers; however, they left a collection of totem poles, now within the monument. (Bancroft, 1886, p. 428-432).

Sitka Point: point of land, on S tip of Kruzof I., $20 \mathrm{mi}$. SW of Sitka, Alex. Arch.; 56 59'$30^{\prime \prime} \mathrm{N}, 135^{\circ} 49^{\prime} 30^{\prime \prime} \mathrm{W}$; (map 5). Var. Cape Edgecumbe, Mys Sitkha.

Probably named in 1809 by Russian navigator Ivan Vasiliev the first, IRN. Lt. Sarichev (1826, map 19), IRN, published the name as "Mys Sitkha," or "Cape Sitkha," and also called it "Cape Edgecumbe."

Sitka Point: point of land, see Edgecumbe, Cape. 
Sitka Sound: water passage, $15 \mathrm{mi}$. across, between Baranof and Kruzof Is., Alexander Arch.; $57^{\circ} 00^{\prime} \mathrm{N}, 135^{\circ} 30^{\prime} \mathrm{W}$; (map 9). Var. Ensenada del Susto, Norfolk Sound, Shitka Bay, Sitka Bay, Tchinkitanay Bay.

Named "Ensenada del Susto" meaning "bay of terrors" by Don Juan de la Bodega y Quadra and Francisco Antonio Maurelle who first visited the sound in 1775. Capt. George Dixon, who entered the sound in 1787 and sketched it, called it "Norfolk" for the Duke of Norfolk, which name was later adopted by Capt. George Vancouver. Etienne Marchant, a French fur trader, who visited the sound in 1791 and 1792, reported the Tlingit Indian name as "Tchinkitanay Bay." The Russians, who began a settlement on the sound in 1799 gave it the name "Sitka Bay," derived from the Tlingit Indian name, "Shitka" or "Sitka," the meaning of which is unknown. Sitk Creek: Stream, see Eagle River.

Sitkha, Mys: point of land, see Sitka Point.

Sitkha (Baranov), Ostrov: island, see Baranof Island.

Sitkhin, Ostrov: island, see Great Sitkin Island.

Sitkhinak, Ostrov: island, see Sitkinak Island. Sitkhunak, Ostrov: island, see Sitkinak Island. Sitki: town, see Sitka.

Sitkinak, Cape: point of land, on E tip of Sitkinak I., in Trinity Is.; $13 \mathrm{mi}$. S of Kodiak I., $56^{\circ} 33^{\prime} 45^{\prime \prime} \mathrm{N}, 153^{\circ} 52^{\prime} 00^{\prime \prime} \mathrm{W}$; BGN 1934; (map 33).

Named in 1934 by USC\&GS.

Sitkinak Dome: mountain, 1,470 ft., on Sitkinak I., in Trinity Is., Kodiak I.; $56^{\circ} 33^{\prime} 35^{\prime \prime} \mathrm{N}$, $154^{\circ} 10^{\prime} 50^{\prime \prime} \mathrm{W}$; BGN 1934; (map 32). Var. Sitkinak Mountain.

Name derived from Sitkinak Island and given in 1906 by W. C. Hodgkins, USC\&GS. The triangulation station Dome is located on this mountain and may account for a generic form unusual in this area.

Sitkinak Island: island, in Trinity Is., Kodiak I., $56^{\circ} 33^{\prime} \mathrm{N}, 154^{\circ} 10^{\prime} \mathrm{W}$; BGN 1890; (map 3233). Var. Ostrov Sitkhinak, Ostrov Sitkhunak, Sichtunak, Sikhinak, Sitchinak, Sitchunack Island, Sitcknak, Sithoonack, Sitkunak.

Eskimo name published by Sarichev (1826, map 3) as "Os[trov] Sitkhunak," or "Sitkhunak Island"; by von Krusenstern (1827, map 17) also as "Sitchunack Island." Capt. Tebenkov (1852, map 22) called it "O[strov] Sitkhinak," or "Sitkhinak Island."

Sitkinak Lagoon: lagoon, $3 \mathrm{mi}$. long, on NE coast of Sitkinak I., in Trinity Is., Kodiak I.; $56^{\circ} 33^{\prime} 30^{\prime \prime} \mathrm{N}, 1^{\prime} 54^{\circ} 03^{\prime} 30^{\prime \prime} \mathrm{W}$; (map 32).

Name derived from Sitkinak Island; published in 1943 by USC\&GS.

Sitkinak Mountain: mountain, see Sitkinak Dome.

Sitkinak Strait: water passage, between Sitkinak and Aiaktalik Is., Kodiak I.; $56^{\circ} 39^{\prime}$ N, $154^{\circ}$. 06' W; BGN 1916; (map 32).

Name derived from Sitkinok Island and given by USC\&GS in 1916.
Sitkin Creek: stream, flows NE $5 \mathrm{mi}$. to Bering Sea, $W$ of Sulphur Point, on NE coast of Great Sitkin I., Aleutian Is.; $52^{\circ} 04^{\prime} 35^{\prime \prime} \mathrm{N}$, $176^{\circ} 01^{\prime} 48^{\prime \prime} \mathrm{W}$; (map 17).

Name derived from Great Sitkin I. and published in 1951 on a USGS map.

Sitkin Island: island, see Great Sitkin Island.

Sitkin Point: point of land, $\mathrm{W}$ tip of Little Sitkin I., Aleutian Is.; $51^{\circ} 56^{\prime} 45^{\prime \prime} \mathrm{N}, 178^{\circ} 26^{\prime} 45^{\prime \prime} \mathrm{E}$; $B G N 1937$; (map 15).

Name derived from Little Sitkin I. and given by the U.S. Navy Hydrog. Office in 1935.

Sitklan Island: island, $3.5 \mathrm{mi}$. long, W of Tongass Passage, Coast Mts. ; $54^{\circ} 45^{\prime} \mathrm{N}, 130^{\circ} 40^{\prime}$ W; (map 2)

Indian name reported in 1869 by G. Davidson, USC\&GS; published on USC\&GS Chart 711

Sitklan Passage: water passage, extends $3 \mathrm{mi}$. W from Tongass Passage to Nakat Bay, between Sitklan I. and mainland, Coast Mts.; $54^{\circ} 46^{\prime}$ N, $130^{\circ} 41^{\prime} \mathrm{W}$; BGN 1937; (map 2). Var. Tongass Passage.

Name derived from Sitklan Island; given in 1936 by USC\&GS.

Sitkoh: site, former Indian village on Chichagof I., on Point Craven at mouth of Sitkoh Bay, $6 \mathrm{mi}$. E of Todd, Alex. Arch.; 59 $28^{\prime} 00^{\prime \prime} \mathrm{N}$, $134^{\circ} 52^{\prime} 10^{\prime \prime} \mathrm{W}$; (map 9).

Tlingit Indian name of a village once located here. "It was to a stockade behind a steep detached rock in this vicinity, according to Lisianski, that the natives retreated after their defeat at Sitka by the Russians in 1804." There were some Indian houses here in 1883 (U.S. Coast and Geodetic Survey, 1883 , p. 178.)

Sitkoh Bay: bay, $1 \mathrm{mi}$. across, $7 \mathrm{mi}$. long, on SE tip of Chichagof I., $6 \mathrm{mi}$. E of Todd, Alex. Arch.; $57^{\circ} 28^{\prime} \mathrm{N}, 134^{\circ} 51^{\prime} \mathrm{W}$; (map 9).

A Tlingit Indian name published by USC\&GS in 1883 Coast Pilot (p. 166).

Sitkoh Lake: lake, $2.5 \mathrm{mi}$. long, $4.5 \mathrm{mi}$. NW of Todd, near SE tip of Chichagof I., Alex. Arch. $57^{\circ} 30^{\prime} 30^{\prime \prime} \mathrm{N}, 1^{\circ} 05^{\circ} 00^{\prime \prime} \mathrm{W}$; BGN 1933; (map 9). Var. Sithoh Bay.

Local name used by fishermen who frequent this lake; reported in 1933 by USFS.

Sitkok Point: point of land, extends NW into Kasegaluk Lagoon, $11 \mathrm{mi}$. S of Point Lay, Arctic Plain; $69^{\circ} 36^{\prime} \mathrm{N}, 163^{\circ} 07^{\prime} \mathrm{W}$; (map 145).

Eskimo name (sitqoq), meaning "knee," obtained at Point Lay by Orth in 1956.

Sitkum Bay: bay, see Kujulik Bay.

Sitkum Creek: stream, flows SE $7 \mathrm{mi}$. to Hamilton Bay, $4 \mathrm{mi}$. SE of Kake, on NW coast of Kupreanof I., Alex. Arch.; 56 $55^{\prime} 50^{\prime \prime} \mathrm{N}$, $133^{\circ} 52^{\prime} 15^{\prime \prime} \mathrm{W}$; (map 6).

Local name recorded in 1951 by USGS.

Sitkum Pass: pass, 1,800 ft., $7 \mathrm{mi}$. E of Cathedral Mtn. and 16 mi. S of Wiseman, Brooks Ra.; $67^{\circ} 10^{\prime} 30^{\prime \prime} \mathrm{N}, 150^{\circ} 02^{\prime} 00^{\prime \prime} \mathrm{W}$; BGN 1932 (map 124). Var. Sitkun Pass.

Local name reported by W. J. Peters and F. C. Schrader, USGS, in 1901 as "Sitkun." A. G. Maddren, USGS, gives "Sitkum" on his name sheet, and Robert Marshall concurs in this spelling.

Sitkunak: island, see Sitkinak Island.

Sitkun Pass: pass, see Sitkum Pass.

Sitnazoak: locality, see Sitnazuak.

Sitnazuak: locality, on $\mathrm{N}$ coast of Norton Sound, near mouth of Penny River, $9 \mathrm{mi}$. NW of Nome, Seward Penin. High.; 64 $33^{\prime} \mathbf{N}$, $165^{\circ} 42^{\prime}$ W; (map 94). Var. Chitashuak, Chitnashuak, Sitnazoak.

Former Eskimo village reported by Ivan Petroff as "Chitnashuak," population 20, in the 1880 Census.

Sitta: locality, on Pungokosit Spit, $1 \mathrm{mi}$. W of Taphook Point and $18 \mathrm{mi}$. SE of Gambell, St. Lawrence I.; $63^{\circ} 37^{\prime} \mathrm{N}, 171^{\circ} 16^{\prime} \mathrm{W}$; (map 93).

O. W. Geist, Univ. of Alaska, gave this name in 1932 for an "old camp."

Sittakanay River: stream, heads in British Columbia, flows NW $18 \mathrm{mi}$. to Taku River at Canyon I., $24 \mathrm{mi}$. NE of Juneau, Coast Mts. $58^{\circ} 33^{\prime} 50^{\prime \prime} \mathrm{N}, 133^{\circ} 40^{\prime} 20^{\prime \prime} \mathrm{W}$; BGN 1922; (map 12). Var. Sitakane River, Sittakane River, Sittikanay River.

Tlingit Indian name published in 1895 by USC\&GS.

Sittakane River: stream, see Sittakanay River. Sitth-gha-ee Peak: peak, 5,870 ft., in Glacier Bay National Monument, $2.7 \mathrm{mi}$. NW of Coleman Peak and $33 \mathrm{mi}$. SW of Skagway, St. Elias Mts.; $59^{\circ} 06^{\prime} 15^{\prime \prime} \mathrm{N}, 135^{\circ} 56^{\prime} 00^{\prime \prime} \mathrm{W}$; (map 45). Var. Sitadaka, Sit-a-da-kay.

Tlingit Indian name reported to mean "great cold lake," which refers to Glacier Bay at the time of John Muir's visit in 1879. "They told us that the big bay was called by them Sit-a-da-kay, or Ice Bay; that there were many large ice mountains in it * * *." (Muir, 1915, p. 143.) The name was published by the American Geographical Society in 1947.

Sitth Kadischle: glacier, see Norris Glacier. Sittikanay River: stream, see Sittakanay River. Sittookooyook River: stream, see Situkuyok River.

Situk Lake: lake, $1.8 \mathrm{mi}$. across, at head of Situk River, $2.7 \mathrm{mi}$. E of Lake Redfield and $13 \mathrm{mi}$. NE of Yakutat, Malaspina Coastal Plain; $59^{\circ} 37^{\prime} 55^{\prime \prime} \mathrm{N}, 139^{\circ} 24^{\prime} 30^{\prime \prime} \mathrm{W}$; BGN 1962; (map 46). Var. Miller Lake.

Local name reported by USGS in 1961. The lake was originally named Miller Lake by Tarr (1906, p. 145), USGS, for Ens. Cyrus R. Miller, USN, who accompanied Lt. Comdr. J. F. Moser in 1901, and who first discovered and explored the lake.

Situk River: stream, heads at Situk Lake, flows SW $18 \mathrm{mi}$. to Situk, $11 \mathrm{mi}$. SE of Yakutat, Malaspina Coastal Plain; 59 $26^{\prime} 30^{\prime \prime} \mathrm{N}$, $139^{\circ} 33^{\prime} 00^{\prime \prime}$ W; (map 46). Var. See-tuck, Setuk River, Sitak River.

Tlingit Indian name reported as " $\mathrm{R}$ [eka] Sitak," or "Sitak River," by Capt. Tebenkov (1852, map 7), IRN. It was spelled "Situk" by E. J. Glave in 1890, and "See-tuck" by Lt. Comdr J. F. Moser, USN, in 1901.

Situkuyok River: stream, heads between Milokrawlok and Tiyaktalik Mts. in Igichuk Hills, 
flows NE and SW $22 \mathrm{mi}$. to Tukrok River, 10 mi. SE of Cape Krusenstern, Kotzebue-Kobuk Low.; $67^{\circ} 04^{\prime} 30^{\prime \prime} \mathrm{N}, 163^{\circ} 23^{\prime} 00^{\prime \prime} \mathrm{W}$; (map 128). Var. Sittookooyook River, Situkuyuk River.

Eskimo name meaning "conch[?] shell" according to USC\&GS in 1950.

Situkuyuk River: stream, see Situkuyok River.

Situk Village: locality, $1 \mathrm{mi}$. N of Situk, on $\mathrm{E}$ bank of Situk River, $9 \mathrm{mi}$. SE of Yakutat, Malaspina Coastal Plain; $59^{\circ} 26^{\prime} 45^{\prime \prime}$ N, $139^{\circ}$ $34^{\prime} 05^{\prime \prime}$ W; (map 46). Var. Setuck.

Former Tlingit Indian village reported as "Setuck" in 1891 by I. C. Russell. The village was reported to have been founded about 1875 and abandoned in 1916.

Sitymkan: island, in Shumagin Is., Aleutian Ra.; $55^{\circ} \mathrm{N}, 160^{\circ} \mathrm{W}$; (map 27). Var. Sishimkak.

Named "Sitymkan" by Lutke (1836, p. 267) ; published as "Sishimikak" by Father Veniaminov (1840, v. 1, p. 255). The exact location of this island is not known.

Siuchi: point of land, see Lutke, Cape.

Siuchi: rocks, see Sealion Rocks.

Siuchiy, Kamen: rocks, see Seal Rocks.

Siuchiy, Mys: point of land, see Georgiana, Cape. Siuchiya Guba: cove, see Sealion Cove.

Sivneghak Lagoon: lagoon, $1 \mathrm{mi}$. long, $1.3 \mathrm{mi}$. S of Northeast Cape, E coast of St. Lawrence I.; $63^{\circ} 16^{\prime} \mathrm{N}, 168^{\circ} 44^{\prime} \mathrm{W}$; BGN 1951; (map 93).

Eskimo name recommended by the Savoonga village council and reported in 1949 by Maj. H. B. Allen, USAF.

Sivogakruak Bluff: bluff, $200 \mathrm{ft}$., on W bank of Okpikruak River $3 \mathrm{mi}$. SW of its junc. with Okokmilaga River, Brooks Ra.; 68 $41^{\prime} \mathrm{N}$, $153^{\circ} 23^{\prime} \mathrm{W}$; (map 133).

Eskimo name reported in 1956 by T. E. Taylor, USGS.

Sivouchek Mountain: hill, see Sivuchek Mountain.

Sivoutchi Rock: rock, see Sea Lion Rock.

Sivoutchy: rock, see Sea Lion Rock.

Sivoutchy: rock, see Sealion Rock.

Sivu Bluff: bluff, on right bank of Wulik River, $15 \mathrm{mi}$. NE of Kivalina, Arctic Slope; $67^{\circ} 48^{\prime} \mathrm{N}$, $164^{\circ} 02^{\prime} \mathrm{W}$; (map 128). Var. Seevoo, Siwu.

Eskimo name meaning "bow of a boat" reported in 1950 by USC\&GS.

Sivuchek Mountain: hill, $215 \mathrm{ft}$., on N bank of Kivalina River, $6 \mathrm{mi}$. N of Kivalina, Kotzebue-Kobuk Low. ; $67^{\circ} 49^{\prime} \mathrm{N}, 164^{\circ} 32^{\prime} \mathrm{W}$; (map 128). Var. Sivouchek Mountain.

Eskimo name meaning "pointed," according to USC\&GS in 1950.

Sivuchi Kamen: rocks, see Seal Rocks.

Sivuchiy, Kamen: rock, see Sea Lion Rock.

Sivuchiy, Kamen: rocks, see Seal Rocks.

Sivuchiy, Mys: point of land, see Lutke, Cape.

Sivugak Bluff: bluff, on E side of Chandler River, $10 \mathrm{mi}$. S of Tuktu Bluff and $36 \mathrm{mi}$. NW of Anaktuvuk Pass, Arctic Slope; 68 $36^{\prime} \mathrm{N}$, $152^{\circ} 22^{\prime} \mathrm{W}$; (map 134).

Eskimo name used by USGS geologists during the exploration of Naval Petroleum Reserve No. 4; name given in 1944.
Sivugak Hill: hill, $356 \mathrm{ft}$., $2.5 \mathrm{mi}$. S of Iyikrok Mtn. and $30 \mathrm{mi}$. NE of Kivalina, Brooks Ra.; $67^{\circ} 55^{\prime} \mathrm{N}, 163^{\circ} 37^{\prime} \mathrm{W}$; (map 128). Var. Seevoogak, Siwugaq.

Eskimo name meaning "ordinary bow of a boat" reported in 1966 by E. S. Burch.

Sivukat Mountain: mountain, 1,915 ft., $13 \mathrm{mi}$. W of junc. of Kelly and Noatak Rivers, 27 mi. N of Noatak, Brooks Ra.; $67^{\circ} 58^{\prime} \mathrm{N}, 162^{\circ}$ $51^{\prime}$ W ; BGN 1963; (map 128). Var. Seevookat Mountain.

Eskimo name reported in 1952 by the Corps of Engineers, USA.

Sivukhan Mountain: mountain, see Seevookhan Mountain.

Sivukuk: village, see Gambell.

Sivukuk: point of land, see Chibukak Point.

Sivurak Bluff: bluff, on right bank of Tutak Creek, $33 \mathrm{mi}$. NE of Kivalina, Brooks Ra.; $67^{\circ} 52^{\prime} \mathrm{N}, 163^{\circ} 22^{\prime} \mathrm{W}$; (map 128). Var. Seevoorak.

Eskimo name meaning "little bow of a boat" reported in 1966 by E. S. Burch.

Sivutch Rock: rock, see Sea Lion Rock.

Sivutsiak Hill: hill, $250 \mathrm{ft}$., $7 \mathrm{mi}$. N of Kivalina, Kotzebue-Kobuk Low.; $67^{\circ} 49^{\prime} \mathrm{N}, 164^{\circ} 31^{\prime} \mathrm{W}$; (map 128). Var. Seevoochyak, Siwutsiaq.

Eskimo name meaning "new bow of a boat" reported in 1966 by E. S. Burch.

Siwash Bay: estuary, extends E $2 \mathrm{mi}$. to Unakwik Inlet, $40 \mathrm{mi}$. NE of Whittier, Chugach Mts.; $60^{\circ} 57^{\prime} 40^{\prime \prime} \mathrm{N}, 147^{\circ} 37^{\prime} 00^{\prime \prime} \mathrm{W}$; $B G N$ 1910; (map 63).

Named in 1908 by U. S. Grant and D. F. Higgins, USGS.

Siwash Channel: estuary, see Tenakee Inlet.

Siwash Creek: stream, heads in Dutch Hills, flows NW $1.8 \mathrm{mi}$. to Dutch Creek, $35 \mathrm{mi}$ NW of Talkeetna, Alaska Ra.; $62^{\circ} 34^{\prime} 15^{\prime \prime} \mathrm{N}$, $151^{\circ} 04^{\prime} 10^{\prime \prime} \mathrm{W}$; (map 81).

Prospectors' name reported in the 1930's by USGS.

Siwash Creek: stream, flows W $12 \mathrm{mi}$. to Mosquito Fork, $38 \mathrm{mi}$. SW of Chandalar, Brooks Ra.; $67^{\circ} 07^{\prime} 30^{\prime \prime} \mathrm{N}, 1^{\circ} 39^{\circ} 33^{\prime} 00^{\prime \prime} \mathrm{W}$; (map 123).

Prospectors' name obtained in 1909 by A. G. Maddren (in Brooks and others, 1910, pl. 7), USGS.

Siwash Creek: stream, see Bull Creek.

Siwash Island: island, $0.2 \mathrm{mi}$. across, at mouth of Siwash Bay, in Unakwik Inlet, $40 \mathrm{mi}$. NE of Whittier, Chugach Mts.; $60^{\circ} 57^{\prime} 40^{\prime \prime} \mathrm{N}$, $147^{\circ} 36^{\prime} 45^{\prime \prime} \mathrm{W}$; (map 63 ).

Local name reported in 1951 by USGS.

Siwash Pass: pass, between Big Creek and Middle Fork Chandalar River, $13 \mathrm{mi}$. SSE of Chandalar, Brooks Ra.; $67^{\circ} 19^{\prime} 00^{\prime \prime}$ N, $148^{\circ}$ $23^{\prime} 30^{\prime \prime} \mathrm{W}$; (map 123).

Local name reported in 1956 by T. E. Taylor, USGS.

Siwu: bluff, see Sivu Bluff.

Siwugaq: hill, see Sivugak Hill.

Siwutsiam Irialuni: hills, see Kisaymaruktuk Mountain.

Siwutsiaq : hill, see Sivutsiak Hill.
Six, Lake: lake, 1,500 ft. long, SE of Question Lake, 7 mi. S of Talkeetna, Cook Inlet Low.; $62^{\circ} 13^{\prime} 20^{\prime \prime} \mathrm{N}, 150^{\circ} 03^{\prime} 15^{\prime \prime} \mathrm{W}$; (map 81$)$.

Local descriptive name reported in 1958 by USGS.

Six Gulch: ravine, trends NW $2 \mathrm{mi}$. to Ganes Creek $1.3 \mathrm{mi}$. NE of its junc. with Spalding Creek, $28 \mathrm{mi}$. W of McGrath, Kilbuck-Kuskokwim Mts. ; 62 $58^{\prime} \mathrm{N}, 156^{\circ} 31^{\prime} \mathrm{W}$; (map 79).

Prospectors' name obtained in 1952 by USGS topographers.

Sixmile Creek: stream, heads at junc. of Canyon and East Fork Sixmile Creeks, flows $\mathrm{N} 9 \mathrm{mi}$. to Turnagain Arm at Sunrise, Chugach Mts.; $60^{\circ} 54^{\prime} 20^{\prime \prime}$ N, $149^{\circ} 25^{\prime} 30^{\prime \prime}$ W; (map 63). Var. Canyon Creek.

Local name reported in 1895 by Becker (1898, p. 82), USGS.

Sixmile Creek: stream, heads in Sixmile Lake, flows NW $1.3 \mathrm{mi}$. to Knik Arm Cook Inlet, $5.6 \mathrm{mi}$. NE of Anchorage, Cook Inlet Low.; $61^{\circ} 17^{\prime} 38^{\prime \prime} \mathrm{N}, 149^{\circ} 49^{\prime} 50^{\prime \prime} \mathrm{W}$; (map 69).

Local name reported in 1942 by AMS.

Sixmile Creek: stream, flows N $9 \mathrm{mi}$. to Yukon River, $6 \mathrm{mi}$. W of Rampart, Yukon-Tanana High.; $65^{\circ} 29^{\prime} \mathrm{N}, 150^{\circ} 23^{\prime} \mathrm{W}$; (map 106).

Local name reported in 1956 by Orth; so named because it was 6 miles downstream from Rampart.

Sixmile Creek: stream, flows NE $6 \mathrm{mi}$. to an oxbow of Yukon River, $3 \mathrm{mi}$. S of Circle, YukonTanana High.; $65^{\circ} 47^{\prime} \mathrm{N}, 144^{\circ} 02^{\prime} \mathrm{W}$; (map 104).

Named by prospectors and reported in 1915 by Waring (1917, fig. 6), USGS.

Sixmile Island: island, $0.5 \mathrm{mi}$. long, in Tanana River $1.5 \mathrm{mi}$. SE of its junc. with Yukon River, $5 \mathrm{mi}$. SE of Tanana, Nowitna Low.; $65^{\circ} 09^{\prime}$ $30^{\prime \prime} \mathrm{N}, 151^{\circ} 55^{\prime} 00^{\prime \prime} \mathrm{W}$; (map 106).

Riverboat pilots' name shown on a Yukon River track chart manuscript dated 1906.

Sixmile Island: island, $1.5 \mathrm{mi}$. long, in Yukon River $3 \mathrm{mi}$. NE of junc. with Tanana River, Kokrines-Hodzana High.; $65^{\circ} 11^{\prime} 30^{\prime \prime} \mathrm{N}$, $151^{\circ} 53^{\prime} 00^{\prime \prime} \mathrm{W}$; (map 106).

Riverboat pilots' name shown on a Yukon River track chart manuscript dated 1906.

Sixmile Island: island, $1.4 \mathrm{mi}$. long, in Yukon River, $5.5 \mathrm{mi}$. W of Rampart, Yukon-Tanana High.; $65^{\circ} 29^{\prime} 15^{\prime \prime} \mathrm{N}, 150^{\circ} 21^{\prime} 00^{\prime \prime} \mathrm{W}$; (map 106).

Local name reported in 1956 by Orth; so named because it was considered to be 6 miles downstream from Rampart.

Sixmile Lake: lake, $6 \mathrm{mi}$. long, between SW end of Lake Clark and Newhalen River, $16 \mathrm{mi}$. N of Iliamna, Aleutian Ra.; $59^{\circ} 59^{\prime} \mathrm{N}, 154^{\circ} 47^{\prime}$ W; BGN 1910; (map 51). Var. Nondalton Lake, Nondalty Lake, Noondalty Lake, Nundalti Lake.

Local descriptive name reported in 1902 by A. G. Maddren, USGS. The native name for this feature was shown as "Nondalton" on a manuscript map by J. W. Walker and as "Noondalty" [Nundalti] on an Alaska Short Line Railway manuscript map by W. E. Smith. 
Sirmile Lake: lake, $1.5 \mathrm{mi}$. long, $5.6 \mathrm{mi}$. NE of Anchorage, Cook Inlet Low.; $61^{\circ} 17^{\prime} 20^{\prime \prime} \mathrm{N}$, $149^{\circ} 47^{\prime} 40^{\prime \prime} \mathrm{W}$; (map 69).

Local name reported in 1952 by USGS; derived from Sixmile Creek that flows into the lake.

Sixmile Lake: lake, $2.8 \mathrm{mi}$. across, between Iditarod and Yetna Rivers, $44 \mathrm{mi}$. E of Holikachuck and $48 \mathrm{mi}$. W of Ophir, Innoko Low.; $63^{\circ} 03^{\prime}$ $\mathrm{N}, 158^{\circ} 05^{\prime} \mathrm{W}$; (map 90).

Local name reported in 1964 by Arthur Gervais, USGS.

Sixmile Lake: lake, $0.5 \mathrm{mi}$. long, $2 \mathrm{mi}$. SE of junc. of Tozitna and Yukon Rivers, $9 \mathrm{mi}$. SW of Tanana, Nowitna Low.; $65^{\circ} 07^{\prime} \mathrm{N}, 152^{\circ} 22^{\prime}$ W; (map 106).

Local name reported in 1952 by USGS.

Sixmile Lake: lake, $1.5 \mathrm{mi}$. long, drains $\mathrm{S}$ to Hay Slough, $6.5 \mathrm{mi}$. E of Tanana, YukonTanana High.; $65^{\circ} 11^{\prime} \mathrm{N}, 151^{\circ} 52^{\prime} \mathrm{W}$; (map 106).

Name reported in 1954 by R. E. Isto, USGS.

Sixmile Lake: lake, $0.7 \mathrm{mi}$. long, $4.7 \mathrm{mi}$. SE of Fort Yukon, Yukon Flats; $66^{\circ} 31^{\prime} 30^{\prime \prime} \mathrm{N}$, $145^{\circ} 08^{\prime} 00^{\prime \prime} \mathrm{W}$; (map 119).

Local name obtained in 1956 by USGS; so called because the lake is about 6 miles up the Yukon River from Fort Yukon.

Sixmile Pass: pass, on road to Hogatza, $6 \mathrm{mi}$. NW of Hog Landing and $35 \mathrm{mi}$. W of Hughes, Hogatza High.; $66^{\circ} 04^{\prime} \mathrm{N}, 155^{\circ} 28^{\prime} \mathrm{W}$; (map 116).

Named by placer mine road builders about 1955 ; reported in 1956 by Orth.

Sixmile Slough: stream, $3 \mathrm{mi}$. long, anabranch of Porcupine River 15 mi. NW of Chalkyitsik, Yukon Flats; $66^{\circ} 51^{\prime} \mathrm{N}, 143^{\circ} 52^{\prime}$ W ; (map 120).

Local name published in 1952 by USGS

Sixteenmile Island: island, $1 \mathrm{mi}$. long, in Yukon River $13 \mathrm{mi}$. E of Tanana, Kokrines-Hodzana High.; $65^{\circ} 11^{\prime} 00^{\prime \prime} \mathrm{N}, 151^{\circ} 39^{\prime} 30^{\prime \prime} \mathrm{W}$; (map 106).

Riverboat pilots' name shown on a Yukon River track chart manuscript dated 1906.

Sixteenmile Lake: lake, $0.5 \mathrm{mi}$. across, on $\mathrm{N}$ bank of Yukon River, 17 mi. ENE of Tanana, Kokrines-Hodzana High.; $65^{\circ} 12^{\prime} 00^{\prime \prime} \mathrm{N}, 151^{\circ}$ $33^{\prime} 30^{\prime \prime} \mathrm{W}$; (map 106).

Name reported in 1954 by $R$. E. Isto, USGS.

Sixteen Gulch: stream, see Deadwood Creek.

Sixteen Pup: stream, flows NW 1.7 mi. to Deadwood Creek, $36 \mathrm{mi}$. SW of Circle, YukonTanana High.; $65^{\circ} 26^{\prime} 45^{\prime \prime} \mathrm{N}, 144^{\circ} 58^{\prime} 00^{\prime \prime} \mathrm{W}$; (map 104).

Named by prospectors; reported in 1909 by B. L. Johnson (in Brooks and others, 1910, fig. 5), USGS.

Sixteen-to-one Creek: stream, flows E $1.5 \mathrm{mi}$. to Fairbanks Greek, $21 \mathrm{mi}$. NE of Fairbanks, Yukon-Tanana High.; $65^{\circ} 03^{\prime} 20^{\prime \prime} \mathrm{N}, 147^{\circ} 08^{\prime}$ $40^{\prime \prime} \mathrm{W}$; (map 105). Var. Sixteen to One Creek.

Named by prospectors; published in 1908 by USGS.

Sixtukak: locality, area on Chukchi Sea coast SW of Nunavak Bay, $5 \mathrm{mi}$. SW of Barrow,
Arctic Plain; $71^{\circ} 13^{\prime} \mathrm{N}, 156^{\circ} 56^{\prime} \mathrm{W}$; (map 153). Var. Seakgluka.

Eskimo camp name published by $R$. F Spencer (1959, map 2) and may be the same name Lt. P. H. Ray (1885, p. 55), USA, spells "Seakgluka."

Sixty-foot Rock: rock, at N entrance to Eldred Passage, on $\mathrm{E}$ shore of Kachemak Bay, on Kenai Penin., $8 \mathrm{mi}$. SE of Homer, Chugach Mts.; 59 33' N, $151^{\circ} 28^{\prime} \mathrm{W}$; (map 50).

Local name reported by USGS or USC\&GS in the 1940's.

Sixtyfour Creek: stream, flows S $4 \mathrm{mi}$. to Springway Creek, $50 \mathrm{mi}$. NW of Nondalton, Lime Hills; $60^{\circ} 30^{\prime} 30^{\prime \prime} \mathrm{N}, 155^{\circ} 46^{\prime} 45^{\prime \prime} \mathrm{W}$; (map 61 ).

Local name reported in 1950 by USC\&GS. Sixtymile Butte: butte, $4,138 \mathrm{ft}$., $15 \mathrm{mi}$. NNE of Tanacross, Yukon-Tanana High.; $63^{\circ} 33^{\prime} \mathrm{N}$, $143^{\circ} 06^{\prime} \mathrm{W}$; (map 85).

Name used by prospectors; reported in 1896 by J. E. Spurr (1898, p. 332), USGS. Sixtymile Creek: stream, flows SE $23 \mathrm{mi}$. to John River, opposite mouth of Allen River, $51 \mathrm{mi}$. W of Wiseman, Brooks Ra.; $67^{\circ} 22^{\prime} 00^{\prime \prime}$ N, $152^{\circ} 02^{\prime} 30^{\prime \prime} \mathrm{W}$; $B G N$ 1932; (map 124). Var. Fool Creek.

Local name "in general use since 1905," reported about 1930 by Robert Marshall and "used because it lies about sixty mi. from Bettles."

Sixtymile Creek: stream, see Sixtymile River.

Sixtymile River: stream, heads on Divide Mtn., flows $\mathrm{E}$ across Alaska-Canada boundary 85 mi. to Yukon River in Yukon, Canada, YukonTanana High.; $63^{\circ} 35^{\prime} \mathrm{N}, 139^{\circ} 40^{\prime} \mathrm{W}$; (map 85). Var. Sixty Mile Creek, Sixtymile Creek.

Local name reported as "Sixtymile Creek" (Baker, 1906, p. 580).

Sixty-one Mile Cabin: locality, a roadhouse on Sixty-one Mtn., E of Schilling Creek, $36 \mathrm{mi}$. SSE of Chandalar, Brooks Ra.; $67^{\circ} 03^{\prime} \mathrm{N}$, $147^{\circ} 49^{\prime} \mathrm{W}$; (map 123).

Local name reported in 1956 by T. E. Taylor, USGS.

Sixty-one Mountain: mountain, 2,890 ft., 10 mi. long, on S side of Chandalar River opposite mouth of Funchion Creek and $35 \mathrm{mi}$. SSE of Chandalar, Brooks Ra.; $67^{\circ} 02^{\prime} 30^{\prime \prime} \mathrm{N}, 147^{\circ}$ $45^{\prime} 00^{\prime \prime} \mathrm{W}$; (map 123).

Local name reported in 1956 by T. E. Taylor, USGS.

Sixty-six Mile Camp: locality, see Canyon Creek Camp.

Siyiksinik: area, of aufeis, near mouth of Owbesookruk River, $12 \mathrm{mi}$. SE of Kivalina, Kotzebue-Kobuk Low. ; $67^{\circ} 41^{\prime} \mathrm{N}, 164^{\circ} 04^{\prime} \mathrm{W}$; (map 128). Var. Seeyicksinick.

Eskimo name meaning "place where there is an overflow of ice" reported in 1966 by $\mathbf{E}$. S. Burch.

Siyiksinik: area, of aufeis, along Okpiksurok Creek, $16 \mathrm{mi}$. NW of Kivalina, KotzebueKobuk Low.; $67^{\circ} 56^{\prime} \mathrm{N}, 164^{\circ} 51^{\prime} \mathrm{W}$; (map 128). Var. Seeyicksinick, Siiqsinniq.

Eskimo name meaning "place where there is an overflow of ice" reported by E. S. Burch in 1966.
Skaguay: village, see Skagway.

Skaguay River: stream, see Skagway River.

Skagul Island: island, $1.8 \mathrm{mi}$. across, Delarof Is., Aleutian Is. ; $51^{\circ} 36^{\prime} \mathrm{N}, 178^{\circ} 35^{\prime} \mathrm{W}$; (map 16). Var. Skakhoul Island.

Aleut name published as "Skakhoul Ile" which, with Ogliuga Island, constituted the Delarof Islands, according to Capt. Lutke (1836, p. 323), IRN. The adopted form was used by Capt. Tebenkov (1852, map 28), IR.N, as "O[strov] Skagul," or "Skagul Island."

Skagul Pass: water passage, between Skagul and Ogliuga Is., Delarof Is., Aleutian Is.; $51^{\circ} 36^{\prime}$ $00^{\prime \prime} \mathrm{N}, 178^{\circ} 36^{\prime} 30^{\prime \prime} \mathrm{W}$; (map 16).

Local name published on a 1954 USGS map.

Skagwa: village, see Skagway.

Skagwa River: stream, see Skagway River.

Skagway: village, pop. 659, at mouth of Skagway River, near head of Taiya Inlet, $90 \mathrm{mi}$.

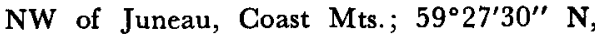
$135^{\circ} 18^{\prime} 45^{\prime \prime} \mathrm{W}$; BGN Sixth Report; (map 45). Var. Gqagué, Schkagué, Shkagway, Skaguay, Skagwa.

Name derived from Skagway River. The town, called "The Gateway to the Golden Interior," was founded in 1897 by Capt. William Moore, who had a cabin here, when gold was first discovered in 1896 near Dawson, on the Yukon River. The town served as a base of operations for thousands of prospectors during the Klondike gold rush of 1897-98, and became the largest town in Alaska at that time. Both Canada and the United States claimed possession, but Canada yielded to the United States until the boundary dispute was settled. Skagway post office was established in 1897 , and the population grew to 3,117 in 1900. The town is the terminus of the White Pass and Yukon RR., which was built to Whitehorse in Yukon, Canada, during the gold rush period. A military post at Skagway was called "Skaguay" by the U.S. Army.

Skagway Pass: pass, see White Pass.

Skagway River: stream, heads at glacier terminus in British Columbia, Canada, flows SW across Alaska Canada boundary, $18 \mathrm{mi}$. to Taiya Inlet, $0.4 \mathrm{mi}$. SW of Skagway; $59^{\circ} 27^{\prime}$ -

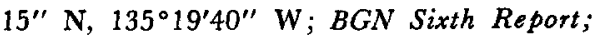
(map 45). Var. Schkagué River, Shkagway River, Skaguay River, Skagwa River.

A Tlingit Indian name said to mean "home of the north wind." Aurel and Arthur Krause (1883, map) recorded "Schkagué." In 1891 Lt. Comdr. H. E. Nichols, USN, wrote "Shkagway."

Skakhoul Island: island, see Skagul Island.

Skan Bay: bay, $2 \mathrm{mi}$. across, W coast of Unalaska I., Aleutian Is.; $53^{\circ} 38^{\prime} 30^{\prime \prime} \mathrm{N}, 167^{\circ} 03^{\prime}$ $30^{\prime \prime}$ W; (map 23). Var. Skhan Bay, Starichkof Bay, Twin Bay.

The Russian name was published by Lt. Sarichev (1826, map 14, dated 1792), IRN, as "Zal[iv] Skhan," or "Skhan Bay." This bay was descriptively called "Twin Bay" by USBF in 1888 . 
Skan Point: point of land, in Skan Bay, on $\mathrm{W}$ coast of Unalaska I., Aleutian Is.; $53^{\circ} 38^{\prime} 00^{\prime \prime}$ N, 167 $02^{\prime} 30^{\prime \prime} \mathrm{W}$; (map 23).

Name derived from Skan Bay and published in 1951 on a USGS map.

Skarland, Mount: peak, 10,315 ft., $5.5 \mathrm{mi}$. NW of Mount Hayes and $43 \mathrm{mi}$. SW of Delta Junction, Alaska Ra.; $63^{\circ} 40^{\prime} 18^{\prime \prime} \mathrm{N}, 146^{\circ} 50^{\prime}$ 25" W; BGN 1965; (map 86).

Named for T. L. Péwé for Ivar Skarland, 1899-1965, head of the Department of Anthropology of the Univ. of Alaska at the time of his death. A graduate of the University, he pioneered in Alaskan anthropology and archeology.

Skarn, Mount: mountain, 2,500 ft., $0.9 \mathrm{mi}$. W of the head of Tyndall Cove, on Geikie Inlet, Glacier Bay National Monument, $47 \mathrm{mi}$. NW of Hoonah, St. Elias Mts.; $58^{\circ} 35^{\prime} 10^{\prime \prime} \mathrm{N}$, $136^{\circ} 22^{\prime} 45^{\prime \prime} \mathrm{W}$; (map 10).

Local name reported by USGS in 1951 .

Skatalis: locality, see Alaganik.

Skate Lake: lake, $0.7 \mathrm{mi}$. long, SE of Northway Indian Village, $1 \mathrm{mi}$. $\mathrm{N}$ of Northway, Alaska Ra.; 62 ${ }^{\circ} 58^{\prime} 45^{\prime \prime}$ N, $141^{\circ} 56^{\prime} 45^{\prime \prime}$ W; (map 84). Local name reported by USGS in 1954.

Skate Lake: lake, $0.5 \mathrm{mi}$. long, $0.4 \mathrm{mi}$. SW of Tetlin and $18 \mathrm{mi}$. SE of Tok, Alaska Ra.; $63^{\circ} 07^{\prime} 45^{\prime \prime} \mathrm{N}, 142^{\circ} 32^{\prime} 00^{\prime \prime} \mathrm{W}$; (map 85).

Local name published by USGS in 1965 . Named because the outline of the lake resembles the silhouette of a skate, a fish of the ray family.

Skaters Lake: lake, 1,100 ft. long, on Annette I., $0.3 \mathrm{mi}$. $\mathrm{S}$ of Metlakatla, Alex. Arch.; $55^{\circ}$ $07^{\prime} 20^{\prime \prime} \mathrm{N}, 131^{\circ} 34^{\prime} 15^{\prime \prime} \mathrm{W}$; (map 3 ).

Local name reported in 1955 by USGS.

Skecter Bay: bay, see Lituya Bay.

Skee Glacier: glacier, $2 \mathrm{mi}$. long, $1 \mathrm{mi}$. W of Bear Glacier, 16 mi. SW of Seward, Ghugach Mts.; $59^{\circ} 59^{\prime} \mathrm{N}, 149^{\circ} 42^{\prime} \mathrm{W}$; BGN 1911; (map 49).

Named in 1909 by U. S. Grant, USGS, for F. P. Skee, prospector. See Lechner Glacier. Skeleton Butte: hill, 1,837 ft., $1 \mathrm{mi}$. W of Cloud Lake and $5 \mathrm{mi}$. $\mathrm{N}$ of Imuruk Lake, Seward Penin. Higk.; $65^{\circ} 43^{\prime} \mathrm{N}, 163^{\circ} 17^{\prime} \mathrm{W}$; $B G N$ 19.52; (map 110).

Reported in 1950 by D. M. Hopkins, USGS; so named because a USGS field party in 1948 "found a skeleton within a cairn at a prehistoric Eskimo village site on the summit of the butte."

Skhan Bay: bay, see Skan Bay.

Ski Creek: stream, flows SW $4 \mathrm{mi}$. to Holokuk River $8.6 \mathrm{mi}$. SE of its junc. with Kuskokwim River, $37 \mathrm{mi}$. SE of Añiak and $46 \mathrm{mi}$. SW of Sleetmute, Kilbuck-Kuskokwim Mts.; $61^{\circ}$. $26^{\prime} 30^{\prime \prime} \mathrm{N}, 158^{\circ} 27^{\prime} 00^{\prime \prime} \mathrm{W} ;$ BGN 1948; (map 72).

Prospectors' name reported in 1945 by USGS.

Skiff Island: island, $0.5 \mathrm{mi}$. long, in Keku Strait, $12 \mathrm{mi}$. N of Point Baker, off SW coast of Kupreanof I., Alex. Arch.; $56^{\circ} 31^{\prime} \mathrm{N}, 133^{\circ} 41^{\prime} \mathrm{W}$; (map 6).

Named by USC\&GS for charting purposes; name published in 1932 Coast Pilot (p. 257).
Skiff Passage: water passage, in NW portion of Shuyak I., $47 \mathrm{mi}$. N of Kodiak I.; $58^{\circ} 36^{\prime} 20^{\prime \prime}$ $N, 152^{\circ} 33^{\prime} 00^{\prime \prime} \mathrm{W}$; BGN 1933; (map 43).

Descriptive name published by USC\&GS in 1931 "because it is navigable by a skiff only at high water."

Skihi Creek: stream, flows NE $4.2 \mathrm{mi}$. to Hidden River, 41 mi. $\mathbf{N}$ of Talkeetna, Alaska Ra.; $62^{\circ} 54^{\prime} 55^{\prime \prime} \mathrm{N}, 150^{\circ} 08^{\prime} 00^{\prime \prime} \mathrm{W}$; (map 81).

Local name published in 1940 by USGS. Skilak: locality, on Kenai Penin. $\mathrm{S}$ of Tustumena Lake, Chugach Mts.; $60^{\circ} 02^{\prime} \mathrm{N}, 150^{\circ} 12^{\prime} \mathrm{W}$; (map 62). Var. Skilakh.

Former Indian village or camp recorded in the 1880 Census as "Skilakh," population 44, by Petroff $(1884$, p. 29$)$.

Skilak Glacier: glacier, in Kenai Mts., on Kenai Penin., trends $\mathrm{N} 9 \mathrm{mi}$. from Harding Icefield to its 1950 terminus at head of Skilak River, 46 mi. ESE of Kenai, Chugach Mts.; $60^{\circ} 19^{\prime}$ $\mathrm{N}, 150^{\circ} 02^{\prime} \mathrm{W}$; (map 62).

Local name reported about 1911 by USGS (Martin, G. C., and others, 1915, pl. 2).

Skilakh: locality, see Skilak.

Skilakh Lake: lake, see Skilak Lake.

Skilakh Lake: lake, see Tustumena Lake.

Skilak Lake: lake, 12 mi. long, on Kenai Penin., $27 \mathrm{mi}$. SE of Kenai, Cook Inlet Low.; $60^{\circ} 25^{\prime}$ $\mathrm{N}, 150^{\circ} 20^{\prime} \mathrm{W}$; (map 62). Var. Kaknu Lake, Kenai Lake, Ozero Skilyakh, Skilakh Lake, Skilloch See, Skillokh Lake.

Tanaina Indian name reported in 1840 by the Russian scientist I. G. Wosnesenski. Published in 1847 as "Oz[ero] Skilyakh," meaning "Skilyakh Lake," on Russian Hydrog. Dept. Chart 1378. Skilak and Tustumena Lakes were shown on Ivan Petroff's 1880 map as one lake, to which he applied the name "Skilakh Lake."

Skilak River: stream, in Kenai Mts., on Kenai Penin., heads at Skilak Glacier terminus, flows NW $8 \mathrm{mi}$. to Skilak Lake, $41 \mathrm{mi}$. ESE of Kenai, Chugach Mts.; $60^{\circ} 24^{\prime} \mathrm{N}, 150^{\circ} 09^{\prime} \mathrm{W}$; (map 62).

Tanaina Indian name; reported in 1958 by USGS.

Skilloch See: lake, see Skilak Lake.

Skillokh Lake: lake, see Skilak Lake.

Skilyakh, Ozero: lake, see Skilak Lake.

Skimo Creek: stream, flows $5.5 \mathrm{mi}$. to Tiglukpuk Creek, $14 \mathrm{mi}$. N of Anaktuvuk Pass, Brooks Ra.; $68^{\circ} 20^{\prime} \mathrm{N}, 151^{\circ} 52^{\prime} \mathrm{W}$; (map 134).

So named in 1950 by W. W. Patton and A. S. Keller, USGS, because "A small band of Eskimos [sic] were camped on this creek when the field party was in the area. Skimo is derived from the word Eskimo."

Skin Island: island, $0.7 \mathrm{mi}$. long, in Clarence Strait near entrance to Cholmondeley Sound, on $\mathbf{E}$ coast of Prince of Wales I., Alex. Arch.; $55^{\circ} 17^{\prime} 50^{\prime \prime} \mathrm{N}, 132^{\circ} 04^{\prime} 45^{\prime \prime} \mathrm{W}$; (map 4). Var. Shkin Island, Ostrov Shkin.

Name published in the 1869 Coast Pilot (p. 79). Published in 1853 as "O[strov] Shkin" on Russian Hydrog. Dept. Chart 1493; probably named by early traders (Baker, 1906, p. 580 ).
Skinner Island: island, $0.3 \mathrm{mi}$. long, on S shore of Bertha Bay, $13 \mathrm{mi}$. NW of Chichagof, on W coast of Chichagof I., Alex. Arch.; 57 $47^{\prime}$ $30^{\prime \prime} \mathrm{N}, 136^{\circ} 20^{\prime} 40^{\prime \prime} \mathrm{W}$; (map 9).

Name published by USC\&GS in 1925 Coast Pilot (p. 322).

Skinny Fish Lake: lake, $3 \mathrm{mi}$. SE of junc. of Kaiyuh Slough and Wounded Cub Creek, 16 mi. SE of Nulato, Koyukuk Low.; $64^{\circ} 30^{\prime} \mathrm{N}$, $158^{\circ} 05^{\prime} \mathrm{W}$; (map 97). Var. Tlukatsukot.

Appears to be a translation of an Indian name; reported by Frederica de Laguna, BAE.

Skipwith Reefs: reefs, $2.5 \mathrm{mi}$. long, at mouth of Afognak Bay, $3.5 \mathrm{mi}$. NE of Afognak, on $\mathrm{S}$ coast of Afognak I.; $58^{\circ} 02^{\prime} 30^{\prime \prime} \mathrm{N}, 152^{\circ} 40^{\prime} 30^{\prime \prime}$ W; (map 43).

Local name reported in 1900 by Lt. Comdr. J. F. Moser. USN, commander of the USBF steamer Albatross.

Skirt Point: point of land, N of Manzanita Bay on $\mathrm{E}$ coast of Revillagigedo I., Alex. Arch.; $55^{\circ} 37^{\prime} 05^{\prime \prime} \mathrm{N}, 130^{\circ} 56^{\prime} 20^{\prime \prime} \mathrm{W}$; (map 3 ).

Local name published in 1891 by USC\&GS. Skittok: locality, on Kenai River, at or near Kenai, Cook Inlet Low.; $60^{\circ} 33^{\prime} \mathrm{N}, 151^{\circ} 16^{\prime}$ W; (map 62). Var. Chkituk, Shittok.

Former Indian village, the population of which was probably absorbed by the expansion of Kenai; reported in the 1890 Census as "Chkituk" (1893, p. 70).

Skolai: locality, on Nizina River, near junc. of Chitistone River, $12 \mathrm{mi}$. E of McCarthy, Wrangell Mts.; $61^{\circ} 25^{\prime} \mathrm{N}, 142^{\circ} 36^{\prime} \mathrm{W}$; (map $67)$. Var. Nicolai's Village, Nikolai.

Former Indian village or camp reported in 1885 as "Nicolai's village" by Lt. Allen (1887, p. 128), USA.

Skolai Creek: stream, heads in Upper Skolai Lake at Russell Glacier, flows W $16 \mathrm{mi}$. to Nizina Glacier, $23 \mathrm{mi}$. NE of McCarthy, Wrangell Mts.; $61^{\circ} 40^{\prime} \mathrm{N}, 142^{\circ} 25^{\prime} \mathrm{W}$; (map 67)

Named for the pass.

Skolai Mountains: mountain range, see Skolai Range.

Skolai Pass: pass, on Russell Glacier, 2 mi. E of Castle Mtn. and $35 \mathrm{mi}$. NE of McCarthy, Wrangell Mts.; $61^{\circ} 39^{\prime} \mathrm{N}, 141^{\circ} 55^{\prime} \mathrm{W}$; (map 67). Var. Scolai Pass, Scoloi Pass.

Named in 1891 by Lt. Frederick Schwatka, USA. "Scolai" or "Skolai" is the name by which the Copper River Chief, "Nicolai," was known to the upper Tanana River Indians (Hayes, 1892, p. 135).

Skolai Range: mountain range, in Wrangell Mts.; NE of Skolai Pass; $61^{\circ} 45^{\prime} \mathrm{N}, 142^{\circ} 30^{\prime}$ W; (map 67). Var. Skolai Mountains.

Rohn (1900, pl. 52), USGS, used both Skolai Range and Skolai Mountains in reference to this very high portion of the Wrangell Mountains. The name has had little subsequent use.

Skole Rocks: rocks, see Phocena Rocks.

Skoogy Creek: stream, flows S $1 \mathrm{mi}$. to Twin Creek, $15 \mathrm{mi}$. NE of Fairbanks, Yukon-Tanana High.; 65 $01^{\circ} 45^{\prime \prime} \mathrm{N}, 147^{\circ} 28^{\prime} 00^{\prime \prime} \mathrm{W}$; (map 105). Var. Skoogy Gulch. 
Named by prospectors; published in 1908 by USGS.

Skoogy Gulch: stream, see Skoogy Creek.

Skookumchuck: water passage, $1 \mathrm{mi}$. long, between El Capitan I. and Tuxekan I., Alex. Arch.; 55 $54^{\prime} 45^{\prime \prime} \mathrm{N}, 133^{\circ} 18^{\prime} 45^{\prime \prime} \mathrm{W}$; (map 4).

Published in 1923 by USC\&GS. See Salt Chuck, village.

Skookum Chuck, The: water passage, see Tlevak Narrows.

Skookum Creek: stream, in Reverdy Mts., flows S $2.3 \mathrm{mi}$. to Fish Creek, $4.5 \mathrm{mi}$. N of Hyder, Coast Mts.; $55^{\circ} 59^{\prime} \mathrm{N}, 130^{\circ} 03^{\prime} \mathrm{W}$; (map 3). Var. Skookum Creek Fork.

Named by prospectors and recorded in 1915 by Theodore Chapin (in Brooks and others, 1916, p. 98), USGS. See Salt Chuck, village.

Skookum Creek: stream, on Kenai Penin., flows NW $4 \mathrm{mi}$. to Placer River, $11 \mathrm{mi}$. W of Whittier, Chugach Mts.; $60^{\circ} 47^{\prime} 10^{\prime \prime} \mathrm{N}, 148^{\circ} 59^{\prime} 40^{\prime \prime}$ W; (map 63).

Local prospectors' name; reported about 1914 by B. L. Johnson (in Martin and others, 1915, pl. 2), USGS. See Salt Chuck, village.

Skookum Creek: stream, heads at Caribou Pass, in Nutzotin Mts., flows SE $0.5 \mathrm{mi}$. to Little Eldorado Creek $0.4 \mathrm{mi}$. N of its junc. with Bonanza Creek, $4.6 \mathrm{mi}$. N of Beaver Lake, Alaska Ra.; $62^{\circ} 06^{\prime} 30^{\prime \prime} \mathrm{N}, 141^{\circ} 50^{\prime} 00^{\prime \prime} \mathrm{W}$; (map 84).

Local name reported by S. R. Capps (in Brooks and others, 1915, p. 219), USGS. See Salt Chuck, village.

Skookum Creek: stream, flows E 5 mi. to Jack Creek, $\mathbf{N}$ of White $\mathbf{M t n}$., Wrangell Mts.; $62^{\circ} 24^{\prime} 00^{\prime \prime} \mathrm{N}, 142^{\circ} 58^{\prime} 20^{\prime \prime} \mathrm{W}$; BGN 1939; (map 84).

Local name reported by USGS in 1939. See Salt Chuck, village.

Skookum Creek: stream, flows SW $3 \mathrm{mi}$. to Crooked Creek, $7 \mathrm{mi}$. W of Medfra, KilbuckKuskokwim Mts.; $63^{\circ} 06^{\prime} \mathrm{N}, 154^{\circ} 55^{\prime} \mathrm{W}$; (map 89).

Local name reported in 1958 by USGS. See Salt Chuck, village.

Skookum Creek: stream, flows SE 2 mi. to Gold Run which flows to Bonita Creek, $11 \mathrm{mi}$. NE of Nome, Seward Penin. High.; 64 $39^{\prime} \mathbf{N}$, $165^{\circ} 13^{\prime} \mathrm{W}$; (map 94).

Prospectors' name reported on a 1901 map of Cape Nome gold fields by David Fox, Jr. See Salt Chuck, village.

Skookum Creek: stream, flows SE $1 \mathrm{mi}$. to Lower Willow Creek which flows to Casadepaga River, $20 \mathrm{mi}$. NW of Solomon, Seward Penin. High.; $64^{\circ} 51^{\prime} \mathrm{N}, 164^{\circ} 33^{\prime} \mathrm{W}$; (map 95).

Prospectors' name reported on a map of Cape Nome gold fields by David Fox, Jr., dated 1901. See Salt Chuck, village.

Skookum Creek: stream, flows NE 3 mi. to Gold Run which flows to Bluestone River, $17 \mathrm{mi}$. $S$ of Teller, Seward Penin. High.; $65^{\circ} 02^{\prime} \mathrm{N}$, $166^{\circ} 12^{\prime} \mathrm{W}$; (map 111).
Local name reported in 1900 by E. C. Barnard (in Brooks, 1901, pl. 17), USGS. See Salt Chuck, village.

Skookum Creek: stream, flows NE 2 mi. to Right Fork Bluestone River, $12 \mathrm{mi}$. SE of Teller, Seward Penin. High.; $65^{\circ} 06^{\prime} \mathrm{N}, 166^{\circ} 15^{\prime} \mathrm{W}$; (map 111).

Prospectors' name reported on a map of Cape Nome goldfields by David Fox, Jr., dated 1901. See Salt Chuck, village.

Skookum Creek: stream, flows S $1.3 \mathrm{mi}$. to Pioneer Creek, $2.4 \mathrm{mi}$. NE of Eureka and 21 mi. S of Rampart, Yukon-Tanana High.; $65^{\circ}$ $12^{\prime} 00^{\prime \prime} \mathrm{N}, 150^{\circ} 08^{\prime} 45^{\prime \prime} \mathrm{W}$; (map 106).

Prospectors' name reported in 1904 by Prindle and Hess (1906, pl. 3), USGS. See Salt Chuck, village.

Skookum Creek: stream, flows SW $4 \mathrm{mi}$. to Turner Creek which flows to Noxapaga River, $32 \mathrm{mi}$. SW of Imuruk Lake, Seward Penin. High.; $65^{\circ} 31^{\prime} \mathrm{N}, 164^{\circ} 17^{\prime} \mathrm{W}$; BGN 1952; (map 110).

Prospectors' name reported in 1901 by T. G. Gerdine (in Collier, 1902, pl. 12), USGS. See Salt Chuck, village.

Skookum Creek: stream, heads in York Mts., flows NW $8 \mathrm{mi}$. to Grouse Creek which flows to Mint River, $40 \mathrm{mi}$. NW of Teller, Seward Penin. High.; $65^{\circ} 38^{\prime} \mathrm{N}, 167^{\circ} 26^{\prime} \mathrm{W}$; (map 111).

Prospectors' name reported on the 1908 "Map of Seward Peninsula" by Arthur Gibson. See Salt Chuck, village.

Skookum Creek: stream, flows SW $2.7 \mathrm{mi}$. to Alder Creek which flows to North Fork Kougarok River, $4 \mathrm{mi}$. NE of Harris Dome and 36 mi. W of Imuruk Lake, Seward Penin. High.; $65^{\circ} 39^{\prime} \mathrm{N}, 164^{\circ} 25^{\prime} \mathrm{W}$; (map 110).

Prospectors' name reported in 1901 by T. G. Gerdine (in Collier, 1902, pl. 12), USGS. See Salt Chuck, village.

Skookum Greek Fork: stream, see Skookum Creek.

Skookum River: stream, flows SE $9 \mathrm{mi}$. to Klokerblok River, $20 \mathrm{mi}$. NE of Solomon, Seward Penin. High.; 64 $44^{\circ} \mathrm{N}, 163^{\circ} 48^{\prime} \mathrm{W}$; (map 95).

Prospectors' name reported in 1900 by E. C. Barnard (in Brooks, 1901, pl. 17), USGS. See Salt Chuck, village.

Skoot Cove: cove, $0.13 \mathrm{mi}$. across, on $\mathrm{SW}$ coast of Shemya I., Semichi Is., Aleutian Is.; $52^{\circ} 53^{\prime} 00^{\prime \prime} \mathrm{N}, 174^{\circ} 04^{\prime} 20^{\prime \prime} \mathrm{E}$; (map 13 ).

Name published in 1953 on a USGS map. Skotnik: mountain, see Barometer Mountain.

Skowl: locality, see Old Kasaan.

Skowl Arm: estuary, $6.5 \mathrm{mi}$. long, off Kasaan Bay on $\mathrm{E}$ coast of Prince of Wales Island; Polk and McKenzie Inlets are arms of this estuary, Alex. Arch.; 55 $26^{\prime} \mathrm{N}, 132^{\circ} 16^{\prime} \mathrm{W}$; (map 4). Var. Skowl Bay.

Named Skowl Bay by traders around 1880, after the "well-known Chief Skowl [Sqa'oal], whose wealth, and enormous stature and obesity made him a notable man on the coast * * *"' (U.S. Coast and Geodetic Survey, 1891, p. 89). Skowl was the chief of the original Kasaan village, located on the north side of this feature. See Kasaan, Old Kasaan National Monument.

Skowl Bay: estuary, see Skowl Arm.

Skowl Island: island, $0.4 \mathrm{mi}$. across, between Kasaan Bay and its Skowl Arm, on E coast of Prince of Wales I., Alex. Arch.; $55^{\circ} 25^{\prime} 20^{\prime \prime}$ $\mathrm{N}, 132^{\circ} 16^{\prime} 00^{\prime \prime} \mathrm{W}$; (map 4).

Name published in 1883 Coast Pilot (p. 86) ; derived from nearby Skowl village. Because of the vague charting of this vicinity, this island was shown (pl. 1571, map facing p. 72) about 3 miles west of its true position.

Skowl Point: point of land, E tip of Skowl I., between Kasaan Bay and its Skowl Arm, on E coast of Prince of Wales I., Alex. Arch.; $55^{\circ} 25^{\prime} 25^{\prime \prime} \mathrm{N}, 132^{\circ} 15^{\prime} 40^{\prime \prime} \mathrm{W}$; (map 4).

Named in 1880 by W. H. Dall, USC\&GS,

Skukum Creek: stream, flows NE 2 mi. to Walker Fork, 50 mi. S of Eagle, Yukon-Tanana High.; $64^{\circ} 04^{\prime} 30^{\prime \prime} \mathrm{N}, 141^{\circ} 13^{\prime} 00^{\prime \prime} \mathrm{W}$; (map 102).

Local name published in 1956 by USGS.

Skull Cliff: cliff, elev. 50-75 ft., extends 6.5 mi. along coast of Chukchi Sea, $30 \mathrm{mi}$. SW of Barrow, Arctic Plain; $70^{\circ} 54^{\prime} \mathrm{N}, 156^{\circ} 48^{\prime} \mathrm{W}$; $B G N$ 1949; (map 147).

Named about 1850 by English naval officers connected with the Sir John Franklin search expeditions. It is believed to be a translation of an Eskimo name.

Skull Creek: stream, flows $6 \mathrm{mi}$. $\mathrm{N}$ to Smeaton Bay, $3 \mathrm{mi}$. E of Point Nelson, Coast Mts. $55^{\circ} 17^{\prime} 38^{\prime \prime} \mathrm{N}, 130^{\circ} 51^{\prime} 00^{\prime \prime} \mathrm{W}$; BGN 1962; (map 3).

Local name reported in 1961 by USFS.

Skull Creek: stream, flows $13 \mathrm{mi}$. NW to Chitina River, 26 mi. SW of McCarthy, Copper River Basin; $61^{\circ} 19^{\prime} 35^{\prime \prime} \mathrm{N}, 143^{\circ} 39^{\prime} 40^{\prime \prime} \mathrm{W}$; (map 67).

Local name obtained by USGS and published on maps since 1954.

Skull Creek: stream, flows SW $7 \mathrm{mi}$. to Don River which flows to Breving Lagoon, $17 \mathrm{mi}$. NW of Teller, Seward Penin. High.; 65 $24^{\prime}$ N, $166^{\circ} 49^{\prime} \mathrm{W}$; (map 111).

Prospectors' name reported in 1918 by Steidtmann and Cathcart (1922, pl. 12), USGS.

Skull Island: island, see Scull Island.

Skull Lake: lake, $0.9 \mathrm{mi}$. long, $\mathrm{N}$ of Chitina River, $25 \mathrm{mi}$. SW of McCarthy, Copper River Basin; 61 $22^{\prime} \mathrm{N}, 143^{\circ} 40^{\prime} \mathrm{W}$; (map 67).

Local name obtained by USGS and published on maps since 1954 .

Skull Peak: peak, $6,740 \mathrm{ft}$., $0.8 \mathrm{mi}$. SW of Cony Mtn., 18 mi. NNE of Paxson, Alaska Ra.; $63^{\circ}$. $17^{\prime} 00^{\prime \prime} \mathrm{N}, 145^{\circ} 26^{\prime} 40^{\prime \prime} \mathrm{W}$; (map 86).

Named between 1948 and 1955 by T. L. Péwé, USGS.

Shwentna: village, pop. 16 , on $\mathrm{S}$ bank of Skwentna River at its junc. with Eightmile Creek, $62 \mathrm{mi}$. N of Tyonek, Cook Inlet Low. $61^{\circ} 57^{\prime} 30^{\prime \prime} \mathrm{N}, 151^{\circ} 10^{\prime} 55^{\prime \prime} \mathrm{W}$; (map 70).

Local name published in 1954 by USGS; derived from nearby river. A post office was maintained there from 1937 to 1939 (Ricks, 1965 , p. 59).

Skwentna River: stream, heads at South Twin Glacier at $61^{\circ} 26^{\prime} \mathrm{N}, 152^{\circ} 41^{\prime} \mathrm{W}$, flows $\mathrm{N}$ and 
E $100 \mathrm{mi}$. to Yentna River, $63 \mathrm{mi}$. N of Tyonek, Cook Inlet Low.; $61^{\circ} 59^{\prime} 10^{\prime \prime} \mathrm{N}, 151^{\circ}$ $08^{\prime} 30^{\prime \prime} \mathrm{W}$; (map 70). Var. Squent River, Squentna River, Skwent River.

Tanaina Indian name reported in 1898 by Spurr (1900, p. 48), USGS, as "Skwent River."

Skwent River: stream, see Skwentna River.

Skyscraper Mountain: mountain, 4,775 ft., E of Bullion Mtn., between Fishhook and Upper Willow Creeks, $14 \mathrm{mi}$. NW of Palmer, Talkeetna Mts.; $61^{\circ} 46^{\prime} 45^{\prime \prime} \mathrm{N}, 149^{\circ} 18^{\prime} 00^{\prime \prime} \mathrm{W}$; (map 69).

Descriptive name reported in 1942 by USGS.

Skyscraper Peak: mountain, 5,800 ft., between Kuskulana and Kotsina Rivers, $31 \mathrm{mi}$. NW of McCarthy, Wrangell Mts. ; $61^{\circ} 42^{\prime} \mathrm{N}, 143^{\circ}$ 48' W; (map 67).

Local name reported in 1900 by T. G. Gerdine, USGS.

Slab Point: point of land, on $\mathrm{W}$ bank of Portland Canal, $19 \mathrm{mi}$. S of Hyder, Coast Mts.; $55^{\circ} 38^{\prime} 30^{\prime \prime} \mathrm{N}, 130^{\circ} 07^{\prime} 25^{\prime \prime} \mathrm{W}$; (map 3 ).

Descriptive name given in 1868 by Staff Comdr. David Pender, RN.

Sladen Creek: stream, tributary to Bubb Creek from the SW, $62^{\circ} 03^{\prime} \mathrm{N}, 147^{\circ} 35^{\prime} \mathrm{W}$; (map 82). USA.

Sladen Creek: stream, see Bubb Creek.

Slag Point: point of land, on the mainland, NE point of entrance to Shoalwater Pass, 0.2 mi. NE of Winstanley I., Coast Mts.; $55^{\circ} 28^{\prime}$ $N, 130^{\circ} 54^{\prime}$ W ; (map 3).

Descriptive name given in 1891 by USC\&GS.

Slahna: stream, see Slana River.

S Lake: lake, $1 \mathrm{mi}$. long, $13 \mathrm{mi}$. SW of Lake Louise and $28 \mathrm{mi}$. NE of Tahneta Pass, Copper River Basin; 62 ${ }^{\circ} 15^{\prime} 35^{\prime \prime}$ N, $147^{\circ} 00^{\prime} 00^{\prime \prime}$ W; BGN 1959; (map 82).

Local descriptive name reported in 1958 by USGS.

Slakna: stream, see Slana River.

Slana: village, pop. 12, $\mathrm{S}$ of Glenn Highway, on $\mathbf{N}$ bank of Slana River near its junc. with Copper River, $53 \mathrm{mi}$. SW of Tok, Alaska Ra.; $62^{\circ} 42^{\prime} 30^{\prime \prime} \mathrm{N}, 143^{\circ} 57^{\prime} 45^{\prime \prime} \mathrm{W}$; BGN 1936; (map 84).

Indian village name derived from name of river on which it is located; published in 1936 by USGS.

Slana River: stream, heads at glacier terminus, flows S 55 mi. to Copper River, Alaska Ra.; $62^{\circ} 42^{\prime} \mathrm{N}, 144^{\circ} 00^{\prime} \mathrm{W}$; BGN 1936; (map 84). Var. Slahna, Slakna, Sla River.

Indian name reported in 1885 by Lt. Allen (1887, p. 71), USA.

Slanting Peak: peak, 5,200 ft., at head of North Branch Norris Glacier, 2.4 mi. NE of Guardian Mtn. and $18 \mathrm{mi}$. NE of Juneau, Coast Mts.; $53^{\circ} 32^{\prime} 15^{\prime \prime} \mathrm{N}, 134^{\circ} 12^{\prime} 50^{\prime \prime} \mathrm{W}$; (map 11).

Descriptive name published in $196 \overline{0}$ by USGS.

Sla River: stream, see Slana River.
Slate Creek: locality, on $\mathbf{N}$ bank of Slate Creek, $0.3 \mathrm{mi}$. E of Chistochina River and $22 \mathrm{mi}$. NE of Paxson, Alaska Ra.; $63^{\circ} 10^{\prime} 20^{\prime \prime} \mathrm{N}, 144^{\circ}$. $51^{\prime} 30^{\prime \prime} \mathrm{W}$; (map 86).

Local name reported in 1950 by USGS.

Slate Creek: stream, flows NE $1.5 \mathrm{mi}$. to Chuck River, $4 \mathrm{mi}$. S of Windham Bay, and $67 \mathrm{mi}$. SE of Juneau, Coast Mts. ; $57^{\circ} 34^{\prime} 00^{\prime \prime} \mathrm{N}, 133^{\circ}$ 20'50" W; (map 8).

Prospectors' name reported in 1903 by Spencer and Wright (1906, fig. 3), USGS; so called because "the bed rock in this vicinity is mostly black slate." Gold mining was started along this stream about 1903 including the Lost Rocker mines named for "The Lost Rocker," a drama popular at Juneau in the 1890's.

Slate Creek: stream, flows N $4.5 \mathrm{mi}$. to Windfall Creek, $2.3 \mathrm{mi}$. E of Dotsons Landing on Favorite Channel and $17 \mathrm{mi}$. NW of Juneau, Coast Mts.; $58^{\circ} 29^{\prime} 30^{\prime \prime} \mathrm{N}, 134^{\circ} 43^{\prime} 00^{\prime \prime} \mathrm{W}$; (map 11).

Name reported by Knopf (1912a, pl. 1), USGS.

Slate Creek: stream, flows SE $3 \mathrm{mi}$. to Berners Bay, on Lynn Canal, $2.5 \mathrm{mi}$. NW of Cove Point and $40 \mathrm{mi}$. NW of Juneau, Coast Mts.; $58^{\circ} 47^{\prime} 30^{\prime \prime} \mathrm{N}, 135^{\circ} 02^{\prime} 00^{\prime \prime} \mathrm{W}$; (map 11).

Local name reported in 1906 by $R$. B. Oliver, USGS, and published in 1908.

Slate Creek: stream, flows SW $9 \mathrm{mi}$. to Goodnews River, $18 \mathrm{mi}$. NE of Goodnews, KilbuckKuskokwim Mts.; $59^{\circ} 18^{\prime} \mathrm{N}, 161^{\circ} 15^{\prime} \mathrm{W}$; (map 53).

Probably a prospector's name reported in 1919 by G. L. Harrington (in Brooks, 1921, pl. 7), USGS. So named because it flows over slate-like rocks in the upper part of its course.

Slate Creek: stream, flows NE $3.5 \mathrm{mi}$. to Fork Creek, $14 \mathrm{mi}$. NW of Heart Lake and $71 \mathrm{mi}$. SE of Bethel, Kilbuck-Kuskokwim Mts.; $60^{\circ}$ $13^{\prime} \mathrm{N}, 160^{\circ} 00^{\prime} \mathrm{W}$; (map 59).

Local name reported in 1955 by J. M. Hoare, USGS.

Slate Creek: stream, heads on $\mathbf{E}$ side of Gilpatrick Mtn., Pows E $2.5 \mathrm{mi}$. to Summit Creek at Gilpatricks, $20 \mathrm{mi}$. S of Sunrise, Chugach Mts.; $60^{\circ} 36^{\prime} 00^{\prime \prime} \mathrm{N}, 1^{\circ} 49^{\circ} 32^{\prime} 25^{\prime \prime} \mathrm{W}$; $B G N$ 1910; (map 63).

Local name reported in 1908 by U. S. Grant and D. F. Higgins (1910, pl. 4), USGS.

Slate Creek: stream, on $\mathbf{N}$ end of Kenai Penin., flows N $1.5 \mathrm{mi}$. to Turnagain Arm. $6 \mathrm{mi}$. E of Sunrise, Chugach Mts.; $60^{\circ} 53^{\prime} 30^{\prime \prime}$ N, $149^{\circ} 14^{\prime}$ 20 " W; (map 63).

Local prospectors' name; reported in 1904 by Moffit (1906, pl. 2), USGS.

Slate Creek: stream, flows NW $12 \mathrm{mi}$. to Tuluksak River, $60 \mathrm{mi}$. NE of Bethel, KilbuckKuskokwim Mts.; $60^{\circ} 59^{\prime} \mathrm{N}, 160^{\circ} 01^{\prime} \mathrm{W}$; (map 59).

Prospectors' name reported in 1914 by $\mathrm{A}$. G. Maddren (in Brooks, 1915, pl. 11), USGS. Slate Creek: stream, flows NNE $9 \mathrm{mi}$. to Little Tonsina River, $5 \mathrm{mi}$. NW of Ernestine and 43 mi. NE of Valdez, Chugach Mts.; 61 ${ }^{\circ} 30^{\prime} 00^{\prime \prime}$
$\mathrm{N}, 145^{\circ} 12^{\prime} 30^{\prime \prime} \mathrm{W} ; B G N$ 1932; (map 68). Var. Rainbow Creek.

Local name reported in 1930 by USGS. F. C. Schrader, USGS, reported the name in 1900 as Rainbow Creek.

Slate Creek: stream, flows NW $2.9 \mathrm{mi}$. to Iditarod River, $5 \mathrm{mi}$. SE of Mosquito $\mathrm{Mtn}$. and 33 mi. SE of Holy Cross, Kilbuck-Kuskokwim Mts.; $62^{\circ} 02^{\prime} 15^{\prime \prime} \mathrm{N}, 158^{\circ} 47^{\prime} 30^{\prime \prime} \mathrm{W}$; (map 79).

Prospectors' name published in 1921 by USGS.

Slate Creek: stream, heads between Chisna Pass and Chistochina Glacier, flows SW $3.6 \mathrm{mi}$. to Chistochina River, $22 \mathrm{mi}$. NE of Paxson, Alaska Ra.; $62^{\circ} 10^{\prime} 22^{\prime \prime} \mathrm{N}, 144^{\circ} 52^{\prime} 15^{\prime \prime} \mathrm{W}$; (map 86).

Prospector's name reported in 1900 by T. G. Gerdine (in Mendenhall and Schrader, 1903, pl. 9), USGS.

Slate Creek: stream, flows SE $3.6 \mathrm{mi}$. to Camp Greek, $48 \mathrm{mi}$. W of Talkeetna, Alaska Ra.; $62^{\circ} 25^{\prime} 35^{\prime \prime} \mathrm{N}, 151^{\circ} 35^{\prime} 55^{\prime \prime} \mathrm{W}$; (map 81).

Prospectors' name reported in 1906 by $R$. W. Porter, USGS.

Slate Creek: stream, heads on Chicken Mtn., flows N $4.8 \mathrm{mi}$. to Otter Creek $11 \mathrm{mi}$. E of its junc. with Iditarod River, $3.2 \mathrm{mi}$. $\mathrm{E}$ of Flat and $57 \mathrm{mi}$. NW of Sleetmute, KilbuckKuskokwim Mts.; $62^{\circ} 27^{\prime} 10^{\prime \prime} \mathrm{N}, 157^{\circ} 54^{\prime} 10^{\prime \prime}$ W; (map 79).

Name shown on a 1910 manuscript map of "Iditarod Placer Fields."

Slate Creek: stream, heads in Peters Hills, flows NW $1.3 \mathrm{mi}$. to Cache Creek, $29 \mathrm{mi}$. NW of Talkeetna, Alaska Ra.; $62^{\circ} 30^{\prime} 45^{\prime \prime} \mathrm{N}$, $150^{\circ} 55^{\prime} 00^{\prime \prime} \mathrm{W}$; (map 81).

Prospectors' name reported in 1911 by $S$. R. Capps, USGS.

Slate Creek: stream, in Kantishna Hills, flows NE $2 \mathrm{mi}$. to Eldorado Creek, $4 \mathrm{mi}$. W of Wonder Lake, Alaska Ra.; $63^{\circ} 29^{\prime} 45^{\prime \prime} \mathrm{N}, 151^{\circ} 01^{\prime}$ $10^{\prime \prime} \mathrm{W}$; (map 88).

Local name shown on a 1916 fieldsheet by C. E. Giffin, USGS.

Slate Creek: stream, flows NE $7 \mathrm{mi}$. to Nenana River, $17 \mathrm{mi}$. NW of Healy, Alaska Ra.; $63^{\circ} 59^{\prime} 45^{\prime \prime} \mathrm{N}, 1^{\circ} 9^{\circ} 06^{\prime} 30^{\prime \prime} \mathrm{W}$; (map 87).

Local name reported in 1951 by USGS.

Slate Creek: stream, flows SW $13 \mathrm{mi}$. to Goodpaster River, $50 \mathrm{mi}$. ENE of Big Delta, YukonTanana High.; $64^{\circ} 30^{\prime} \mathrm{N}, 144^{\circ} 21^{\prime} \mathrm{W}$; (map 101 ).

Local name reported in 1958 by USGS.

Slate Creek: stream, flows SE $24 \mathrm{mi}$., joins Independence Creek to form North Fork Fortymile River, $37 \mathrm{mi}$. SW of Eagle, YukonTanana High.; $64^{\circ} 38^{\prime} \mathrm{N}, 142^{\circ} 24^{\prime} \mathrm{W}$; (map 102).

Named by prospectors and shown on an 1898 manuscript map by C. A. Woodruff, Fort Cudahy, Canada.

Slate Creek: stream, flows SE $1.1 \mathrm{mi}$. to Banner Creek, $9 \mathrm{mi}$. NE of Nome, Seward Penin. High.; $64^{\circ} 39^{\prime} \mathrm{N}, 165^{\circ} 20^{\prime} \mathrm{W}$; (map 94). Var. Right Fork Banner Creek.

Prospectors' name reported on a 1901 map of Cape Nome gold fields by David Fox, Jr. 
Slate Creek: stream, flows E $1 \mathrm{mi}$. to Nome River, 14 mi. N of Nome, Seward Penin. High.; $64^{\circ} 42^{\prime} \mathrm{N}, 165^{\circ} 19^{\prime} \mathrm{W}$; (map 94$)$.

Prospectors' name reported on a map by S. E. King dated 1900

Slate Creek: stream, flows NW $2 \mathrm{mi}$. to Cripple River, $18 \mathrm{mi}$. NW of Nome, Seward Penin. High.; $64^{\circ} 45^{\prime} \mathrm{N}, 165^{\circ} 38^{\prime} \mathrm{W}$; (map 94).

Prospectors' name reported on a 1901 map of Cape Nome gold fields by David Fox, Jr.

Slate Creek: stream, flows NW $3 \mathrm{mi}$. to Fox River, 24 mi. NE of Solomon, Seward Penin. High.; $64^{\circ} 46^{\prime} \mathrm{N}, 163^{\circ} 49^{\prime} \mathrm{W}$; (map 95).

Prospectors' name reported in 1900 by E. C. Barnard (in Brooks, 1901, pl. 17), USGS.

Slate Creek: stream, flows SW $2.5 \mathrm{mi}$. to Stewart River, $22 \mathrm{mi}$. N of Nome, Seward Penin. High.; $64^{\circ} 49^{\prime} 36^{\prime \prime} \mathrm{N}, 16^{\circ} 21^{\prime} 15^{\prime \prime} \mathrm{W}$; (map 94).

Prospectors' name reported in 1904 by T. G. Gerdine, USGS.

Slate Creek: stream, flows SE $4 \mathrm{mi}$. to Fish River, $43 \mathrm{mi}$. NE of Solomon, Seward Penin. High.; $64^{\circ} 54^{\prime} \mathrm{N}, 163^{\circ} 15^{\prime} \mathrm{W}$; (map 95 ).

Prospectors' name reported in 1900 by E. C. Barnard (in Brooks, 1901, pl. 17), USGS.

Slate Creek: stream, flows $\mathrm{N} 4 \mathrm{mi}$. to Pilgrim River, $27 \mathrm{mi}$. NW of Solomon, Seward Penin. High.; $64^{\circ} 55^{\prime} \mathrm{N}, 164^{\circ} 51^{\prime} \mathrm{W}$; (map 95).

Prospectors' name reported in 1900 by E. C. Barnard (in Brooks, 1901, pl. 17), USGS.

Slate Creek: stream, flows N $2 \mathrm{mi}$. to Sunset Creek, in Bluestone River basin, $17 \mathrm{mi}$. S of Teller, Seward Penin. High.; $65^{\circ} 01^{\prime} \mathrm{N}, 166^{\circ}$ $17^{\prime} \mathrm{W}$; (map 111). Var. Upper Quartz Greek.

Local name reported in 1900 by $E$. C. Barnard (in Brooks, 1901, pl. 17), USGS.

Slate Creek: stream, flows S $1 \mathrm{mi}$. to Right Fork Bluestone River, $12 \mathrm{mi}$. SE of Teller, Seward Penin. High.; $65^{\circ} 06^{\prime} \mathrm{N}, 166^{\circ} 18^{\prime} \mathrm{W}$; (map 111).

Prospectors' name reported on the 1908 "Map of Seward Peninsula" by Arthur Gibson.

Slate Creek: stream, flows SW $1 \mathrm{mi}$. to Lucky Strike Creek which flows to Bluestone River, $10 \mathrm{mi}$. SE of Teller, Seward Penin. High.; $65^{\circ} 09^{\prime} \mathrm{N}, 166^{\circ} 09^{\prime} \mathrm{W}$; (map 111).

Prospectors' name reported on the 1908 "Map of Seward Peninsula" by Arthur Gibson.

Slate Creek: stream, flows SW $17 \mathrm{mi}$. to Tatalina River, $19 \mathrm{mi}$. SE of Livengood, Yukon-Tanana High.; $65^{\circ} 16^{\prime} \mathrm{N}, 148^{\circ} 24^{\prime} \mathrm{W}$; (map 105).

Local name published by USGS in the 1950's.

Slate Creek: stream, flows SW 2 mi. to Grantley Harbor, $4 \mathrm{mi}$. NE of Teller, Seward Penin. High.; $65^{\circ} 18^{\prime} \mathrm{N}, 166^{\circ} 15^{\prime} \mathrm{W}$; (map 111).

Prospectors' name reported on the 1908 "Map of Seward Peninsula" by Arthur Gibson.

Slate Creek: stream, flows E $1 \mathrm{mi}$. to Woodchopper Creek, $3.3 \mathrm{mi}$. SSW of that stream's junc. with Yukon River and $40 \mathrm{mi}$. SE of Circle, Yukon-Tanana High.; $65^{\circ} 18^{\prime} 45^{\prime \prime} \mathrm{N}$, $143^{\circ} 21^{\prime} 30^{\prime \prime} \mathrm{W}$; (map 103).

Local name published in 1956 by USGS.
Slate Creek: stream, heads on Baldry Mtn., flows NE $7 \mathrm{mi}$. to Minook Creek, $10 \mathrm{mi}$. S of Rampart, Yukon-Tanana High.; $65^{\circ} 22^{\prime} \mathrm{N}, 150^{\circ}$ $08^{\prime} \mathrm{W}$; (map 106)

Prospectors' name reported in 1904 by Prindle and Hess (1906, pl. 3), USGS.

Slate Creek: stream, flows NE $5 \mathrm{mi}$. to Tozimoran Creek, $2 \mathrm{mi}$. W of mouth of Wells Creek, $23 \mathrm{mi}$. WNW of Tanana, KokrinesHodzana High.; $65^{\circ} 23^{\prime} \mathrm{N}, 152^{\circ} 43^{\prime} \mathrm{W}$; (map 106).

Prospectors' name reported in 1943 by $R$. M. Chapman, USGS.

Slate Creek: stream, flows N $1.6 \mathrm{mi}$. to Boulder Creek, $40 \mathrm{mi}$. SW of Circle, Yukon-Tanana High.; $65^{\circ} 28^{\prime} \mathrm{N}, 145^{\circ} 06^{\prime} \mathrm{W}$; (map 104).

Named by prospectors; reported by USGS (Prindle, 1906, p. 17).

Slate Creek: stream, flows $\mathrm{S} 9 \mathrm{mi}$., joins Trout Creek to form Pitka Fork Hodzana River, 53 mi. NW of Beaver, Kokrines-Hodzana High.; $66^{\circ} 58^{\prime} 20^{\prime \prime} \mathrm{N}, 148^{\circ} 33^{\prime} 30^{\prime \prime} \mathrm{W}$; (map 118).

Local descriptive name obtained in 1956 by USGS.

Slate Creek: stream, flows W 19 mi., N of Sitkum Pass, to Middle Fork Koyukuk River, $11 \mathrm{mi}$. S of Wiseman, Brooks Ra. ; 67 $7^{\circ} 15^{\prime} 30^{\prime \prime} \mathrm{N}, 150^{\circ}$ $11^{\prime} 30^{\prime \prime} \mathrm{W}$; (map 124).

Local name shown on an 1899 fieldsheet by T. G. Gerdine, USGS.

Slate Creek: stream, flows S $6 \mathrm{mi}$. from a lake, joins McLellan Creek to form Grave Creek 15 mi. ENE of Chandalar, Brooks Ra.; $67^{\circ}$. $34^{\prime} 30^{\prime \prime} \mathrm{N}, 147^{\circ} 58^{\prime} 00^{\prime \prime} \mathrm{W}$; (map 123 ).

Local name reported in 1956 by T. E. Taylor, USGS.

Slate Creek: locality, see Coldfoot.

Slate Creek: stream, see Richter Creek.

Slate Creek: stream, see Rover Creek.

Slate Creek: stream, see Stella Creek.

Slate Gulch: ravine, trends $W 1 \mathrm{mi}$. to Slate Creek which flows to Banner Creek, $11 \mathrm{mi}$. N of Nome, Seward Penin. High.; 64 $39^{\prime} \mathrm{N}$, $165^{\circ} 20^{\prime} \mathrm{W}$; (map 94)

Prospectors' name shown on the 1902 "Map of the Nome and Snake River Country" by J. M. Davidson.

Slate Island: island, $1.2 \mathrm{mi}$. long, in Aialik Bay, $17 \mathrm{mi}$. SW of Seward, Chugach Mts.; $59^{\circ} 55^{\prime}$ N, 149 43' W; BGN 1911; (map 49).

Named in 1909 by U. S. Grant, USGS.

Slate Island: islands, see Slate Islands.

Slate Islands: islands, group of 4, largest is 800 $\mathrm{ft}$. long, extend $0.8 \mathrm{mi}$., near $\mathrm{E}$ shore of Revillagigedo Channel, $\mathbf{N}$ of Boca de Quadra, Coast Mts.; $55^{\circ} 05^{\prime} 45^{\prime \prime} \mathrm{N}, 131^{\circ} 03^{\prime} 00^{\prime \prime} \mathrm{W}$; (map 3). Var. Slate Island, Slate Islet.

Named "Slate Islet" in 1793 by Capt. George Vancouver, RN, because it is "entirely composed of that rock"; published in 1883 Coast Pilot (p. 71).

Slate Islet: islands, see Slate Islands.

Slate Islets: islands, on W coast of Baranof I., $27 \mathrm{mi}$. S of Sitka, Alex. Arch.; $56^{\circ} 40^{\prime} 20^{\prime \prime} \mathrm{N}$, $135^{\circ} 13^{\prime} 00^{\prime \prime} \mathrm{W}$; (map 5). Var. Aspid Islets, Ostrov Aspid.

This is an 1880 translation by USC\&GS of the Russian name "Ostrov Aspid."
Slate Lake: lake, $3.5 \mathrm{mi}$. long, among Tikchik Lakes, $1.5 \mathrm{mi}$. $\mathrm{N}$ of Upnuk Lake and $112 \mathrm{mi}$. SW of Sleetmute, Kilbuck-Kuskokwim Mts.; $60^{\circ} 24^{\prime} \mathrm{N}, 158^{\circ} 54^{\prime} \mathrm{W}$; (map 60$)$.

Local name reported in 1950 by USGS.

Slate Peak: peak, 3,380 ft., $2.5 \mathrm{mi}$. SW of terminus of Moser Glacier and $21 \mathrm{mi}$. E of Yakutat, St. Elias Mts.; 59³3'35" N, $139^{\circ}$ 07'15" W; (map 46).

Descriptive name given in 1960 by Thomas Riggs, Jr., and published by Blackwelder (1907, p. 421), USGS.

Slatepile Mountain: mountain, 5,000 ft., $10 \mathrm{mi}$. NW of Mt. Doonerak and $43 \mathrm{mi}$. NW of Wiseman, Brooks Ra.; 67 $57^{\prime}$ N, $150^{\circ} 59^{\prime}$ W; (map 124).

In describing this mountain, Marshall (1956, p. 15) wrote, "It was just one great pile of loose slate heaped up in spots ***."

Slater Creek: stream, flows W $4 \mathrm{mi}$. to outwash plain of Valdez Glacier, $3 \mathrm{mi}$. NE of Valdez, Chugach Mts.; $61^{\circ} 07^{\prime} 40^{\prime \prime}$ N, $146^{\circ} 11^{\prime} 30^{\prime \prime} \mathrm{W}$; (map 68).

Local name published in the 1950's by USGS.

Slaterville: village, pop. 611 (1950), residential suburb on Garden I., N of Fairbanks, Tanana

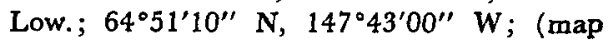
$100)$.

Local name reported in 1950 by USGS topographers.

Slathtouka Creek: stream, heads in Indian Mts., flows $\mathrm{E} 23 \mathrm{mi}$. to Mentanontli River, $35 \mathrm{mi}$. NE of Hughes, Kokrines-Hodzana High.; $66^{\circ}{ }^{\prime} 5^{\prime}$ $\mathrm{N}, 153^{\circ} 07^{\prime} \mathrm{W}$; (map 116$)$.

Indian name reported to mean "trapping," recorded at Hughes in 1956 by Orth.

Slatka Creek: stream, flows W 3.5 mi. to Kuskulana River, $30 \mathrm{mi}$. NW of McCarthy, Wrangell Mts.; $61^{\circ} 35^{\prime} \mathrm{N}, 143^{\circ} 44^{\prime} \mathrm{W}$; (map 67).

Indian name reported in 1900 by T. G. Gerdine, USGS.

Slaughter Creek: stream, on Kenai Penin., flows NW $3 \mathrm{mi}$. to Juneau Creek, $2 \mathrm{mi}$. S of Juneau Lake and $32 \mathrm{mi}$. NW of Seward, Chugach

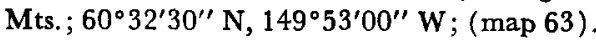

Local name reported in 1951 by USGS.

Slaughter Island: island, $0.2 \mathrm{mi}$. across, at $\mathrm{N}$ entrance to Shelikof Bay, on W coast of Kruzof I., $20 \mathrm{mi}$. NW of Sitka, Alex. Arch.; $57^{\circ} 10^{\prime} 00^{\prime \prime} \mathrm{N}, 135^{\circ} 49^{\prime} 45^{\prime \prime} \mathrm{W}$; (map 9).

Named in 1897 by Lt. Comdr. E. K. Moore, USN; published by USC\&GS in 1901 Coast Pilot (p. 198).

Slavarassi : locality, see Glory of Russia.

Slava Rossie, Mys: promontory, see Glory of Russia Cape.

Slava Rossii Bay: bay, see Tanaga Bay.

Slavna Point: point of land, on $\mathrm{W}$ shore of Belkofski Bay, $23 \mathrm{mi} \mathrm{SE}$ of village of Cold Bay, at SW end of Alaska Penin., Aleutian Ra.; $55^{\circ} 04^{\prime} \mathrm{N}, 162^{\circ} 12^{\prime} \mathrm{W}$; (map 29).

Russian name from the word "slava" meaning "glory" published by USC\&GS in the 1926 Alaska Coast Pilot (pt. 2, p. 209).

Slavy Rossii, Mys: promontory, see Glory of Russia Cape.

Slawa Rossiji: locality, see Glory of Russia. 
Sledge Creek: stream, flows E $3.3 \mathrm{mi}$. to Snake River, $8 \mathrm{mi}$. NW of Nome, Seward Penin. High.; $64^{\circ} 37^{\prime} \mathrm{N}, 165^{\circ} 28^{\prime} \mathrm{W}$; (map 94).

Prospectors' name reported in 1900 by E. C. Barnard (in Brooks, 1901, pl. 17), USGS.

Sledge Island: island, $1.5 \mathrm{mi}$. across, in Bering Sea, $5 \mathrm{mi}$. off $\mathrm{S}$ coast of Seward Penin., $25 \mathrm{mi}$. W of Nome ; $64^{\circ} 29^{\prime} \mathrm{N}, 166^{\circ} 13^{\prime} \mathrm{W}$; (map 94) Var. Ajak Island, Asiak Island, Asshiak Island, Ayak Island, Aziak Island, Azjiak Island, Ostrov Azvyak, Ostrov Azzhiak.

Named August 5, 1778, by Capt. Cook (1785, v. 2, p. 441$)$, RN: "We found, a little way from the shore where we landed, a sledge, which occassioned this name being given to the island." According to Martin Sauer the Eskimo name is "Ayak." Capt. Beechey (1831, p. 291-292), RN, noted: "It is singular that this island, which was named Sledge Island by Captain Cook, from the circum. stances of one of these implements being found upon it, should be called by a word signifying the same thing in the Esquimaux language."

Sled Pass: pass, 3,300 ft., near head of Pass Fork Hartman River, $95 \mathrm{mi}$. NW of Tyonek, Alaska Ra.; 61 $38^{\prime} 30^{\prime \prime} \mathrm{N}, 153^{\circ} 43^{\prime} 30^{\prime \prime}$ W; $B G N$ 1930; (map 71).

Local name reported in 1929 by S. R. Capps and Gerald FitzGerald, USGS; so called "because dog sleds are used by natives over this pass during winter."

Sleem Creek: stream, flows SE $3 \mathrm{mi}$. to Hutchinson Creek, $48 \mathrm{mi}$. SW of Eagle, Yukon-Tanana High.; $64^{\circ} 22^{\prime} \mathrm{N}, 142^{\circ} 15^{\prime} \mathrm{W}$; (map 102).

Prospectors' name shown on an 1898 manuscript map by C. A. Woodruff, Fort Cudahy, Canada.

Sleeping Sister Mountain: mountain, 4,150 ft., in Kenai Mts., between Ship Creek and Meadow Creek, on $\mathrm{S}$ side of Kenai Lake, $18 \mathrm{mi}$. NW of Seward, Chugach Mts.; $60^{\circ} 22^{\prime} 45^{\prime \prime}$ $\mathrm{N}, 149^{\circ} 28^{\prime} 45^{\prime \prime} \mathrm{W}$; (map 63).

Local name reported in 1951 by USGS.

Sleepy Bay: bight, $1 \mathrm{mi}$. across, at $\mathbf{N}$ tip of Latouche I., at SE end of Knight Island Passage, $54 \mathrm{mi}$. E of Seward, Chugach Mts.; $60^{\circ} 04^{\prime} 30^{\prime \prime} \mathrm{N}, 147^{\circ} 50^{\prime} 00^{\prime \prime} \mathrm{W}$; BGN 1910; (map 63).

Local name reported in 1909 by U. S. Grant and D. F. Higgins (1910, p. 29), USGS.

Sleepy Creek: stream, flows $\mathrm{N} 4 \mathrm{mi}$. to Blue Violet Creek, $24 \mathrm{mi}$. NE of Chignik, Aleutian Ra.; $56^{\circ} 37^{\prime} \mathrm{N}, 158^{\circ} 17^{\prime} \mathrm{W}$; (map 30).

Name reported in 1923 by $R$. H. Sargent, USGS; published in 1927 by USGS.

Sleepy Creek: stream, flows SW $7 \mathrm{mi}$. to Glacier River, 6 mi. SE of Foggytop Mtn. and 16 mi. NW of Wiseman, Brooks Ra.; 67'37'30' N, $150^{\circ} 22^{\prime} 45^{\prime \prime} \mathrm{W}$; BGN 1932; (map 124). Var. Shinningnellichshunga Creek.

Robert Marshall (1956, p. 162) wrote "we forded Hammond River and followed up Shinningnellichshunga (I am Sleepy) Greek which I had named eight years before ***. Jesse *** refused to say anything lengthier than Sleepy Creek."

Sleepy Sea: sea, see Bering Sea.
Sleetmute: village, pop. 122, on E bank of Kuskokwim River $1.5 \mathrm{mi}$. $\mathrm{N}$ of its junc. with Holitna River, $78 \mathrm{mi}$. E of Aniak, Stony River Low.; $61^{\circ} 42^{\prime \prime} \mathrm{N}, 157^{\circ} 10^{\prime} \mathrm{W}$; BGN 1948; (map 72). Var. Sikmiut, Sleitmut, Steelmut, Steitmute.

Eskimo village mentioned in 1907 by Gordon (1917, p. 109-119), who spelled' it "Sikmiut." The present form of the name (and "Sleitmut") was published by USGS in 1913 and reported to mean "stones people" or "whetstone people." The population of the village was 133 in $1930 ; 86$ in 1939; and 120 in 1950.

Sleigh Creek: stream, flows NW 3 mi. to Grooked Creek, $9 \mathrm{mi}$. $\mathrm{N}$ of Tahneta Pass, Talkeetna Mts.; $62^{\circ} 00^{\prime} 50^{\prime \prime} \mathrm{N}, 147^{\circ} 17^{\prime} 00^{\prime \prime} \mathrm{W}$; $B G N$ 1960; (map 82). Var. Cottonwood Creek. Local name reported in 1956 by USGS.

Sleitat Mountain: mountain, 1,800 ft., $85 \mathrm{mi}$. $\mathrm{W}$ of Lake Clark and $115 \mathrm{mi}$. S of Sleetmute, Kilbuck-Kuskokwim Mts.; $60^{\circ} 03^{\prime}$ N, $157^{\circ} 06^{\prime}$ W; BGN 1932; (map 60).

Eskimo name meaning "whetstone"; reported in 1931 by Gerald FitzGerald, USGS. Sleitmut: village, see Sleetmute.

Slender Lake: lake, $1 \mathrm{mi}$. long, at head of Martin Creek, $12 \mathrm{mi}$. NE of 1950 terminus of Tana Glacier and $114 \mathrm{mi}$. NE of Cordova; Chugach Mts.; $60^{\circ} 53^{\prime} \mathrm{N}, 142^{\circ} 26^{\prime} \mathrm{W}$; (map 65).

Descriptive name reported by Moffit (1918, pl. 6), USGS.

Slide Creek: stream, $7 \mathrm{mi}$. long, heads $5 \mathrm{mi}$. $W$ of Narrow Point and flows SE then NE to Clarence Strait, E coast of Prince of Wales I., Alex. Arch.; 55 $45^{\prime} 20^{\prime \prime} \mathrm{N}, 1^{\prime 3} 2^{\circ} 29^{\prime} 30^{\prime \prime} \mathrm{W}$; BGN 1962; (map 4).

Local name reported in 1961 by USFS; given "because of a large slide near its mouth * * *."

Slide Creek: stream, on Mount Dolly, in Reverdy Mts., flows W $1.5 \mathrm{mi}$. to Fish Greek, $4 \mathrm{mi}$. N of Hyder, Coast Mts.; 55 58'35" N, $130^{\circ} 03^{\prime}$ $12^{\prime \prime} \mathrm{W}$; (map 3 ).

Local name reported in 1955 by USGS.

Slide Greek: stream, heads at glacier, flows SE $5 \mathrm{mi}$. to Alder Creek $8 \mathrm{mi}$. NW of its junc. with Tokositna River, $25 \mathrm{mi}$. NW of Talkeetna, Alaska Ra.; $62^{\circ} 46^{\prime} 50^{\prime \prime} \mathrm{N}, 150^{\circ} 25^{\prime} 45^{\prime \prime}$ W; (map 81).

Prospectors' descriptive name published in 1940 by USGS.

Slide Creek: stream, flows E 6 mi. to Dry Creek, $25 \mathrm{mi}$. S of Blair Lakes and $60 \mathrm{mi}$. S of Fairbanks, Alaska Ra.; $64^{\circ} 00^{\prime} 30^{\prime \prime} \mathrm{N}, 147^{\circ} 12^{\prime} 30^{\prime \prime}$ W; (map 100).

Local name reported in 1910 by USGS (Capps, 1912, pl. 1).

Slide Lake: lake, $1 \mathrm{mi}$. long, on Admiralty I., 3 mi. SW of head of King Salmon Bay and 21 mi. S of Juneau, Alex. Arch.; $58^{\circ} 00^{\prime} 05^{\prime \prime} \mathrm{N}$, $134^{\circ} 22^{\prime} 45^{\prime \prime} \mathrm{W}$; (map 11).

Descriptive name published in 1951 by USGS.

Slide Mountain: mountain, 4,000 ft., N of Glenn Highway, $42 \mathrm{mi}$. WSW of Glennallen, Copper River Basin; $62^{\circ} 01^{\prime} \mathrm{N}, 146^{\circ} 50^{\prime} \mathrm{W}$; (map 83).
Local descriptive name reported in 1949 by USGS. So called because the south face of the mountain is the site of many landslides.

Slide Point: point of land, see Eva, Point.

Slide Reef: rocks, offshore between Cape Lynch and Dead Tree Point, W coast of Heceta I., Alex. Arch.; $55^{\circ} 45^{\prime} 40^{\prime \prime} \mathrm{N}, 133^{\circ} 40^{\prime} 45^{\prime \prime} \mathrm{W}$; $B G N$ 1908; (map 4).

Local descriptive name "suggested by a landslide near it on Heceta Island"; reported in 1907 by E. F. Dickins, USC\&GS.

Slide Ridge: ridge, extends SW $3.5 \mathrm{mi}$. from Thornton Mtn. to Tongass Narrows, $N$ of Ward Cove, on Revillagigedo I., Alex. Arch.; $55^{\circ} 26^{\prime} \mathrm{N}, 131^{\circ} 43^{\prime} \mathrm{W}$; (map 3).

Descriptive name given in 1883 by Lt. Comdr. H. E. Nichols, USN.

Slikok Creek: stream, on Kenai Penin., flows N $10 \mathrm{mi}$. to Kenai River, $2 \mathrm{mi}$. W of Soldatna and $7 \mathrm{mi}$. SE of Kenai, Cook Inlet Low.; $60^{\circ} 28^{\circ} 45^{\prime \prime} \mathrm{N}, 151^{\circ} 07^{\prime} 28^{\prime \prime} \mathrm{W}$; (map 63).

Tanaina Indian name, reported in 1944 by USGS.

Slikok Lake: lake, $0.6 \mathrm{mi}$. long, drains $\mathrm{W}$ to Slikok Creek, on Kenai Penin., $11 \mathrm{mi}$. SE of Kenai, Cook Inlet Low.; $60^{\circ} 25^{\prime} 30^{\prime \prime} \mathrm{N}, 151^{\circ}$ $03^{\prime} 00^{\prime \prime} \mathrm{W}$; ( $\operatorname{map} 62$ ).

Tanaina Indian name; reported in 1958 by USGS.

Slime Bank: shoal, along $\mathbf{N}$ coast of Unimak I., seaward of Urilia Bay, Aleutian Is.; 54 $57^{\circ}$ $\mathrm{N}, 164^{\circ} 16^{\prime} \mathrm{W}$; (map 24).

Name reported in 1890 by Lt. Comdr. Z. L. Tanner, USN; so called by fishermen because of the abundant jellyfish found there.

Slime Creek: stream, flows NW $4 \mathrm{mi}$. to Nenana River, $25 \mathrm{mi}$. SE of Healy, Alaska Ra.; $63^{\circ} 30^{\prime} 45^{\prime \prime} \mathrm{N}, 148^{\circ} 49^{\prime} 30^{\prime \prime} \mathrm{W}$; (map 87).

Descriptive name reported by The Alaska $R R$. on a 1923 manuscript map.

Slim Glacier: glacier, on E slope of Mount Veniaminof, trends SE $5 \mathrm{mi}$. to its terminus $7 \mathrm{mi}$. SW of Knife Peak, Aleutian Ra.; $56^{\circ} 11^{\prime} \mathrm{N}, 159^{\circ} 11^{\prime} \mathrm{W}$; (map 30 ).

Descriptive name reported in 1923 by $R$. H. Sargent, USGS.

Slim Island: island, $0.5 \mathrm{mi}$. long, of $\mathrm{W}$ shore of Harry Bay, at entrance to Nakat Bay, NE of Dixon Entrance, Coast Mts.; 54 $48^{\prime} 00^{\prime \prime} \mathrm{N}$, $130^{\circ} 46^{\prime} 45^{\prime \prime} \mathrm{W}$; (map 2).

Descriptive name given in 1883 by Lt. Comdr. H. E. Nichols, USN.

Slim Island: island, $1.8 \mathrm{mi}$. long, in Yukon River, $2 \mathrm{mi}$. S of Anvik and $31 \mathrm{mi}$. N of Holy Cross, Nulato Hills; $62^{\circ} 37^{\prime} 00^{\prime \prime} \mathrm{N}, 160^{\circ} 11^{\prime} 30^{\prime \prime}$ W; (map 78).

Riverboat pilots' name reported in 1916 by Harrington (1918, pl. 1), USGS.

Slim Lake: lake, $0.6 \mathrm{mi}$ long, in course of Donchelok Creek, $3 \mathrm{mi}$. S of village of Minchumina, Tanana Low.; $63^{\circ} 50^{\prime} \mathrm{N}, 152^{\circ} 20^{\prime} \mathrm{W}$; (map 88). Var. Dontsólakhmena.

Local descriptive name reported in 1952 by Fabian Carey. The Tanana Indian name is given as "Dontsólakhmena," meaning "suckerfish lake."

Slim Point: point of land, see Thin Point. 
Slipper Lake: lake, 1,400 ft. long, between Eska and Jonesville, $11 \mathrm{mi}$. NE of Palmer, Cook Inlet Low.; 61 ${ }^{\circ} 44^{\prime} \mathrm{N}, 148^{\circ} 55^{\prime} \mathrm{W}$; (map 69). Local name reported in 1951 by USGS.

Slipper Point: point of land, on $\mathrm{S}$ coast of Alaska, between Long Bay and Buyers Cove, $1.5 \mathrm{mi}$. $\mathrm{N}$ of Glacier I. and $51 \mathrm{mi}$. NE of Whittier, Chugach Mts.; $60^{\circ} 55^{\prime} 05^{\prime \prime} \mathrm{N}$, $147^{\circ} 15^{\prime} 30^{\prime \prime} \mathrm{W}$; (map 63).

Local name reported in 1951 by USGS.

Slippery Creek: stream, flows SW $3 \mathrm{mi}$. to Portage Creek just $\mathbf{N}$ of Right Arm Iniskin Bay and $26 \mathrm{mi}$. $\mathrm{N}$ of Augustine I., Aleutian Ra.; $59^{\circ} 44^{\prime} 25^{\prime \prime} \mathrm{N}, 153^{\circ} 20^{\prime} 32^{\prime \prime} \mathrm{W}$; BGN 1962; (map 51).

Name published by USGS in 1958.

Slippery Creek: stream, heads on Peters Dome, in Mount McKinley National Park, flows NW $50 \mathrm{mi}$. to McKinley River, $22 \mathrm{mi}$. ESE of village of Lake Minchumina, Tanana Low.; $63^{\circ} 45^{\prime} \mathrm{N}, 151^{\circ} 40^{\prime} \mathrm{W}$; (map 88).

Local name reported in 1925 by $S$. R. Capps, USGS.

Slippery Creek: flows $\mathrm{N}$ to Fish Creek about 1 mile S of Fairbanks Creek, $24 \mathrm{mi}$. NE of Fairbanks, Yukon-Tanana High.; $65^{\circ} 02^{\prime} 25^{\prime \prime}$ $\mathrm{N}, 147^{\circ} 05^{\prime} 40^{\prime \prime} \mathrm{W}$; BGN 1939; (map 105).

Local name reported in 1939 by USGS; this stream cannot be precisely located on present maps.

Sliscovitchs Roadhouse: locality, SE of junc. of Slate Creek and Pilgrim River, $27 \mathrm{mi}$. NW of Solomon, Seward Penin. High.; 64 $4^{\circ} 55^{\prime} \mathrm{N}$, $164^{\circ} 50^{\prime} \mathrm{W}$; (map 95).

Site of roadhouse shown on map of Cape Nome gold fields by David Fox, Jr., dated 1901.

Slocum, Point: point of land, on Khaz Penin., $14 \mathrm{mi}$. SE of Chichagof, Alex. Arch.; 57 $28^{\prime}$ N, $135^{\circ} 58^{\prime} \mathrm{W}$; (map 9).

Named in 1897 by Lt. Comdr. E. K. Moore, USN ; published by USG\&GS in 1901 Coast Pilot (p. 198).

Slocum Arm: estuary, on SW coast of Chichagof I., extends NW $13 \mathrm{mi}$. to Khaz Bay, $4 \mathrm{mi}$. S of Chichagof, Alex. Arch.; $57^{\circ} 34^{\prime} \mathrm{N}, 136^{\circ} 03^{\prime}$ W; BGN 1908; (map 9).

Named in 1897 by Lt. Comdr. E. K. Moore, USN; and published by USC\&GS in 1901 Coast Pilot (p. 108).

Slocum Inlet: $b a y, 0.5 \mathrm{mi}$. across, on $\mathrm{E}$ shore of Stephens Passage, $5 \mathrm{mi}$. $\mathrm{N}$ of Taku Harbor and $17 \mathrm{mi}$. SE of Juneau, Coast Mts.; $58^{\circ} 07^{\prime}$ $50^{\prime \prime} \mathrm{N}, 134^{\circ} 04^{\prime} 30^{\prime \prime} \mathrm{W}$; (map 11$)$.

Named in 1888 by Lt. Comdr. C. M. Thomas, USN, for Ens. George Ralph Slocum, USN, a member of his party. The name was published by USC\&GS in the 1891 Coast Pilot (p. 149).

Slo Duc Creek: stream, flows W $3.5 \mathrm{mi}$. to Hamilton Bay, $5.3 \mathrm{mi}$. SE of Kake, on NW coast of Kupreanof I., Alex. Arch.; 56 $55^{\prime} 15^{\prime \prime} \mathrm{N}$, $133^{\circ} 51^{\prime} 00^{\prime \prime} \mathrm{W}$; (map 6).

Local name recorded in 1951 by USGS.

Sloistie: point of land, see Lay, Point.

Slokhenjikh Creek: stream, flows SW $18 \mathrm{mi}$. to Melozitna River, $49 \mathrm{mi}$. NW of Tanana,
Kokrines-Hodzana High.; $65^{\circ} 47^{\prime}$ N, $152^{\circ} 55^{\prime}$ W; (map 106).

Koyukan Indian name obtained in 1956 at Hughes by Orth.

Slokhenjikh Hills: hills, 1,600 ft., extend $15 \mathrm{mi}$. NE from junc. of Slokhenjikh Creek and Melozitna River, 52 mi. WNW of Tanana, Kokrines-Hodzana High.; $65^{\circ} 52^{\prime} 30^{\prime \prime} \mathrm{N}, 152^{\circ}$ 42'30" W; (map 106).

Koyukan Indian name obtained in 1956 at Hughes by Orth.

Slope Creek: stream, flows SE $2.6 \mathrm{mi}$. to Willow Creek, $7.8 \mathrm{mi}$. SE of Marshall, Nulato Hills; $61^{\circ} .47^{\prime} 50^{\prime \prime} N, 161^{\circ} 54^{\prime} 50^{\prime \prime} \mathrm{W}$; (map 73).

Prospectors' name reported by Harrington (1918, map), USGS, in 1916, as flowing into Spruce Greek. Recent maps apply the name as above.

Slope Creek: stream, flows NE $3 \mathrm{mi}$. to Moose Creek, $13 \mathrm{mi}$. NE of Livengood, YukonTanana High.; $65^{\circ} 39^{\prime} 15^{\prime \prime}$ N, $148^{\circ} 14^{\prime} 45^{\prime \prime} \mathrm{W}$; (map 105).

Local name reported in 1916 by J. B. Mertie (in Brooks and others, 1918, pl. 13), USGS.

Slope Glacier: glacier, on NW slope of Carbon Mtn., trends NE $2 \mathrm{mi}$. to its 1950 terminus, $3 \mathrm{mi}$. N of Doughton Peak and $64 \mathrm{mi}$. $\mathrm{E}$ of Cordova, Chugach Mts. ; $60^{\circ} 28^{\prime} 40^{\prime \prime} \mathrm{N}, 143^{\circ}$ 52'30" W; (map 65).

Descriptive name given by prospectors and reported in 1905 by G. C. Martin, USGS.

Slope Hill: hill, $475 \mathrm{ft}$., W of Bogoslof Hill, on central St. Paul I., in Pribilof Is.; $57^{\circ} 10^{\prime} 45^{\prime \prime}$ $\mathrm{N}, 170^{\circ} 18^{\prime} 30^{\prime \prime} \mathrm{W}$; (map 38).

Named by Joseph Stanley-Brown, USGS, in 1891.

Slope Mountain: mountain, 3,800 ft., on W shore of Cook Inlet, S of Chisik I., $58 \mathrm{mi}$. SW of Kenai, Aleutian Ra. ; $60^{\circ} 04^{\prime} 00^{\prime \prime} \mathrm{N}, 152^{\circ} 38^{\prime} 45^{\prime \prime}$ W; (map 62)

Local descriptive name; reported about 1910 by G. C. Martin (1921, pl. 8), USGS.

Slope Peak: mountain, 1,612 ft., $7 \mathrm{mi}$. SW of Cape Chiniak, on E coast of Kodiak I.; $57^{\circ}$ $32^{\prime} 30^{\prime \prime} \mathrm{N}, 152^{\circ} 16^{\prime} 30^{\prime \prime} \mathrm{W}$; (map 34).

Local name reported in 1949 by USGS.

Slope Point: point of land, $\mathrm{W}$ entrance point to Crescent Bay, on $\mathrm{N}$ coast of Atka I., Aleutian Is.; 52 $03^{\circ} 00^{\prime \prime} \mathrm{N}, 175^{\circ} 15^{\prime} 30^{\prime \prime} \mathrm{W}$; (map 18).

Descriptive name applied "because of the ridge rising gradually to a hill to the south." Published by USC\&GS in the 1944 Aleutian Coast Pilot (p. 99).

Slope Point: point of land, off $\mathrm{W}$ coast of Chichagof I., on S tip of island in Rough Channel, $45 \mathrm{mi}$. SW of Chichagof, Alex. Arch.; $57^{\circ} 36^{\prime} \mathrm{N}, 136^{\circ} 08^{\prime} \mathrm{W}$; (map 9$)$.

Named in 1908 by USC\&GS; published in 1909 on Chart 8280.

Slope Point: point of land, on $\mathrm{N}$ side of Passage Canal, 10 mi. NE of Whittier, Chugach Mts.; $60^{\circ} 48^{\prime} 15^{\prime \prime} \mathrm{N}, 148^{\circ} 23^{\prime} 10^{\prime \prime} \mathrm{W}$; (map 63).

Descriptive name given in 1914 by USC\&GS.

Sloss Bay: lagoon, see Moffet Lagoon.

Slough, The: water passage, $2 \mathrm{mi}$. long, between Raspberry and Little Raspberry Is., N of Ko- diak I.; $57^{\circ} 59^{\prime} 30^{\prime \prime} \mathrm{N}, 152^{\circ} 55^{\prime} 00^{\prime \prime} \mathrm{W}$; (map $34,43)$.

Local name reported in 1950 by USGS.

Slow Creek: stream, heads on SW slope of Hunch Mtn., flows NW 35 mi. to North Fork Innoko River $0.7 \mathrm{mi}$. $\mathrm{E}$ of its junc. with $\mathrm{In}$ noko River, $49 \mathrm{mi}$. N of Ophir and $63 \mathrm{mi}$. $\mathrm{S}$ of Galena, Innoko Low.; 63 $49^{\prime} 30^{\prime \prime} \mathrm{N}$, $156^{\circ} 36^{\prime} 00^{\prime \prime} \mathrm{W}$; (map 90). Var. Elk Creek, Slow Fork.

Local name obtained from Joseph Ferris in 1954 by R. E. Isto, USGS.

Slow Fork: stream, heads at $63^{\circ} 02^{\prime} \mathrm{N}, 152^{\circ} 56^{\prime}$ W, flows NW 63 mi. to East Fork Kuskokwim River $4 \mathrm{mi}$. NW of Lake Hoyle and $32 \mathrm{mi}$. NE of Medfra, Kuskokwim Low.; 63 ${ }^{\circ} 11^{\prime} \mathrm{N}$, $153^{\circ} 45^{\prime}$ W; BGN 1964; (map 89). Var. East Fork Kuskokwim River, Slow Fork Kuskokwim River.

Local name reported in 1950 by USGS.

Slow Fork: stream, see Highpower Creek.

Slow Fork: stream, see Slow Creek.

Slow Fork Hills: ridge, elev. 900-2,000 ft., extends NW-SE $20 \mathrm{mi}$. between Slow Fork Kuskokwim and Tonzona Rivers, $40 \mathrm{mi}$. E of Medfra, Kuskokwim Low.; $63^{\circ} 00^{\prime} \mathrm{N}$, $152^{\circ} 45^{\prime} \mathrm{W}$; [E end]; $63^{\circ} 08^{\prime} \mathrm{N}, 153^{\circ} 27^{\prime} \mathrm{W}$; [W end]; (map 88).

Local name reported in 1954 by USGS.

Slow Fork Kuskokwim River: stream, see Highpower Creek.

Slow Fork of Swift Fork Kuskokwim River: stream, see Highpower Creek.

Slug Mountain: mountain, 1,565 ft., $6.5 \mathrm{mi}$. NE of Cape Peirce and $22 \mathrm{mi}$. W of Hagemeister I., Kilbuck-Kuskokwim Mts.; 58 $37^{\prime} 45^{\prime \prime} \mathrm{N}$, $161^{\circ} 39^{\prime} 10^{\prime \prime} \mathrm{W}$; (map 39).

Local name published in 1949 by USGS; name probably derived from the river at its foot.

Slug River: stream, flows SW $15 \mathrm{mi}$. to Nanvak Bay, $3 \mathrm{mi}$. NW of Slug Mtn. and $24 \mathrm{mi}$. W of Hagemeister Is., Kilbuck-Kuskokwim Mts.; $58^{\circ} 38^{\prime} 15^{\prime \prime} \mathrm{N}, 161^{\circ} 44^{\prime} 00^{\prime \prime} \mathrm{W}$; (map 39).

Local name published in 1938 by USGS. Sluicebox Creek: stream, flows NE $5 \mathrm{mi}$. to Troublesome Creek, $15 \mathrm{mi}$. SE of Rampart, Yukon-Tanana High.; $65^{\circ} 25^{\prime} \mathrm{N}, 149^{\circ} 42^{\prime} \mathrm{W}$; (map 105).

So named by prospectors; reported in 1908 by USGS (Covert and Ellsworth, 1909, pl. 5).

Small Arm Whale Bay: bay, $0.5 \mathrm{mi}$. across, N part of Whale Bay, on SW coast of Baranof I., Alex. Arch.; 56 $33^{\prime} \mathrm{N}, 135^{\circ} 01^{\prime} \mathrm{W}$; (map 5). Var. Little Whale Bay, Maley Roukav, Maloy Rukav, Maloi Rukov, Lesser Arm, Small Sleeve.

Name published by USC\&GS in 1883 Coast Pilot (p. 133) ; derived from "Maloi Rukov," meaning "small sleeve"; published in 1850 by the Russian American Company.

Small Bay: $b a y, 0.2 \mathrm{mi}$. across, $\mathrm{W}$ side of Beaver Inlet, $\mathrm{E}$ coast of Unalaska I., Aleutian Is.; $53^{\circ} 46^{\prime} 45^{\prime \prime} \mathrm{N}, 166^{\circ} 27^{\prime} 00^{\prime \prime} \mathrm{W}$; (map 23).

Descriptive name given by J. J. Gilbert, USC\&GS, commander of the Coast Survey steamer Pathfinder during 1900-01. 
Small Creek: stream, on Chichagof I., flows 0.3 mi. $\mathbf{N}$ to Pavlof Harbor, on Freshwater Bay, $8 \mathrm{mi}$. NE of Tenakee Springs, Alex. Arch.; $57^{\circ} 50^{\prime} 25^{\prime \prime} \mathrm{N}, 135^{\circ} 01^{\prime} 30^{\prime \prime} \mathrm{W}$; (map 9).

Descriptive name given by Comdr. R. W. Meade, USN; published in 1869 on Hydrog. Chart 225. Name not shown on recent maps.

Small Creek: stream, flows NE $1 \mathrm{mi}$. to Anton Larsen Bay, $11 \mathrm{mi}$. NW of Kodiak, Kodiak I.; $57^{\circ} 51^{\prime} 50^{\prime \prime} \mathrm{N}, 152^{\circ} 39^{\prime} 08^{\prime \prime} \mathrm{W}$; BGN 1966; (map 34).

Local name reported in 1966 by the Alaska State Geographic Board.

Small Creek: stream, flows NW $1.8 \mathrm{mi}$. to Tsina River, $3 \mathrm{mi}$. E of Ptarmigan and $25 \mathrm{mi}$. NE of Valdez, Chugach Mts.; $61^{\circ} 12^{\prime} 15^{\prime \prime} \mathrm{N}, 145^{\circ}$ $32^{\prime} 15^{\prime \prime} \mathrm{W}$; (map 68).

Local name published in the 1950's by USGS.

Small Creek: stream, flows N $6.3 \mathrm{mi}$. to Iditarod River, $4.7 \mathrm{mi}$. SE of Mosquito Mtn. and 33 mi. E of Holy Cross, Kilbuck-Kuskokwim Mts.; $62^{\circ} 04^{\prime} 00^{\prime \prime} \mathrm{N}, 158^{\circ} 45^{\prime} 30^{\prime \prime} \mathrm{W}$; BGN 1948; (map 79).

Local name obtained in 1945 by USGS.

Small Pass: water passage, see South Pass.

Smalls River: stream, flows W $11 \mathrm{mi}$. to Goodnews Bay, $11 \mathrm{mi}$. SW of Goodnews, KilbuckKuskokwim Mts.; $59^{\circ} 01^{\prime} \mathrm{N}, 161^{\circ} 49^{\prime} \mathrm{W}$; BGN 1938; (map 53).

Local name reported in 1933 by USGS.

Small Sleeve: bay, see Small Arm Whale Bay.

Small Timber Lake: lake, $1.5 \mathrm{mi}$. long, $3 \mathrm{mi}$. E of Chalkyitsik, Yukon Flats; $66^{\circ} 40^{\prime} \mathrm{N}, 143^{\circ}$ 50' W; (map 120).

Local descriptive name; reported in 1956 by R. C. Foley, USGS.

Smallwood Creek: locality, on Smallwood Creek, $15 \mathrm{mi}$. NE of Fairbanks, Tanana Low.; $64^{\circ}$ $54^{\prime} 00^{\prime \prime} \mathrm{N}, 147^{\circ} 14^{\prime} 00^{\prime \prime} \mathrm{W}$; (map 100).

This is the site of a mining camp shown in Polk's Gazetteer of 1916.

Smallwood Creek: stream, heads at junc. of Johnson and Victoria Creeks, flows SE $7 \mathrm{mi}$ to Little Chena River, $15 \mathrm{mi}$. NE of Fairbanks, Tanana Low.; $64^{\circ} 00^{\prime} 54^{\prime \prime} \mathrm{N}, 147^{\circ} 15^{\prime}$ $00^{\prime \prime} \mathrm{W}$; (map 100).

Local name reported in 1903 by T. G. Gerdine (in Prindle, 1905, pl. 16), USGS. The stream was shown flowing to Nugget Creek but, in 1907, C. C. Covert, USGS, reported the stream flowing to the Little Chena River (Henshaw and Covert, 1908, pl. 9).

Smally Greek: stream, flows W $1.5 \mathrm{mi}$. to John River Creek, $29.5 \mathrm{mi}$. SW of Wiseman, Brooks Ra.; 67 $01^{\prime} 15^{\prime \prime} \mathrm{N}, 150^{\circ} 35^{\prime} 30^{\prime \prime} \mathrm{W}$; (map 124).

Local name obtained in 1956 by. USGS topographers.

Smeaton Bay: estuary, heads at junc. of its Wilson and Bakewell Arms, trends W $7 \mathrm{mi}$. to Behm Canal, Coast Mts.; $55^{\circ} 19^{\prime}$ N, $130^{\circ} 54^{\prime}$ W; (map 3).

Named in 1879 by W. H. Dall, USC\&GS, for the English engineer who rebuilt the Eddystone Lighthouse near Plymouth, England, in 1759, after its destruction by fire in 1755; published in the 1883 Coast Pilot (p. 72).
Smeaton Island: island, $4.6 \mathrm{mi}$. long, in Behm Canal, between Revillagigedo $I$. and the mainland, Coast Mts.; $55^{\circ} 21^{\prime} \mathrm{N}, 130^{\circ} 57^{\prime} \mathrm{W}$; (map 3).

Named in 1879 by W. H. Dall, USC\&GS; derived from Smeaton Bay.

Smeaton's Trading Post: locality, see Mellicks Trading Post.

Smelt Creek: stream, heads in lake, flows $\mathrm{E}$ and N 40 mi. to Naknek River, on Alaska Penin., $10 \mathrm{mi}$. SW of Naknek, Bristol Bay Low.; $58^{\circ} 41^{\prime} 15^{\prime \prime} \mathrm{N}, 156^{\circ} 44^{\prime} 30^{\prime \prime} \mathrm{W}$; (map 41).

Local name reported in 1952 by USGS.

Smelt Island: island, $0.4 \mathrm{mi}$. across, in Naknek River at mouth of Smelt Creek, on Alaska Penin., $10 \mathrm{mi}$. SW of Naknek, Bristol Bay Low.; $58^{\circ} 41^{\prime} \mathrm{N}, 156^{\circ} 44^{\prime} \mathrm{W}$; (map 41).

Local name reported in 1952 by USGS.

Smith, Point: point of land, on S shore of Scammon Bay, 6 mi. E of Cape Romanzof, YukonKuskokwim Delta; $61^{\circ} 49^{\prime} 50^{\prime \prime} \mathrm{N}, 165^{\circ} 55^{\prime} 00^{\prime \prime}$ W; (map 75).

Named by W. H. Dall (1870, p. 263) who wrote "The next, Cape Smith (named for Captain E[lijah] E[verett] Smith, to whom we owe the first chart of the Yukon Delta), is a long, low point * * *."

Smith Bay: bay, $10 \mathrm{mi}$. across, on coast of Beaufort Sea, first sizable bay $E$ of Point Barrow, Arctic Plain; $70^{\circ} 54^{\prime} \mathrm{N}, 154^{\circ} 19^{\prime} \mathrm{W}$; (map 148). Var. E. Smith's Bay, Smith's Bay, Smyth Bay.

On July 27, 1837, Thomas Simpson (1843, p. 137) wrote: "We now found ourselves in a large and very shallow bay, which we had much pleasure in naming after our worthy friend Chief Factor Smith, * * " of the Hudson's Bay Company. It is E. Smith's Bay on Simpson's map.

Smith Beach: beach, $0.8 \mathrm{mi}$. long, at mouth of Steller River, in Auburn Cove, on $\mathbf{N}$ coast of Attu I., Aleutian Is. ; $52^{\circ} 58^{\prime} 40^{\prime \prime} \mathrm{N}, 172^{\circ} 54^{\prime} 50^{\prime \prime}$ E; (map 13).

Name shown on an AMS map published in 1948, and given by the U.S. Army during World War II. The name is not used today. Smith Cape, point of land, see Smyth, Cape.

Smith Cove: cove, extends N 1 mi., off Skowl Arm Kasaan Bay, on $E$ coast of Prince of Wales I., Alex. Arch.; 55 $26^{\prime} 15^{\prime \prime} \mathrm{N}, 132^{\circ} 20^{\prime}$ 30 " W; (map 4).

Local name published in 1962 by USC\&GS. Smith Creek: stream, flows NW $14 \mathrm{mi}$. to Iditarod River, $24 \mathrm{mi}$. SW of Flat and $40 \mathrm{mi}$. E of Holy Cross, Kilbuck-Kuskokwim Mts.; 62 ${ }^{\circ} 11^{\prime}$ $30^{\prime \prime} \mathrm{N}, 158^{\circ} 31^{\prime} 20^{\prime \prime} \mathrm{W}$; BGN 1945; (map 79).

Local name obtained in 1944 by USGS.

Smith Creek: stream, flows N $10 \mathrm{mi}$. to Fortymile River, $37 \mathrm{mi}$. S of Eagle, Yukon-Tanana High.; $64^{\circ} 16^{\prime} \mathrm{N}, 141^{\circ} 05^{\prime} \mathrm{W}$; (map 102). Var. Davis Creek.

Named by prospectors and reported in 1896 by Spurr (1898, pl. 46), USGS; the stream was erroneously called "Davis Creek" in 1898 by E. C. Barnard, USGS.

Smith Creek: stream, heads in Kigluaik Mts., flows NW $9 \mathrm{mi}$. to Pilgrim River, $36 \mathrm{mi}$. SE of
Teller, Seward Penin. High.; $65^{\circ} 06^{\prime} \mathrm{N}, 165^{\circ}$ 09' W; (map 111).

Prospectors' name reported on the 1908 "Map of Seward Peninsula" by Arthur Gibson. Smith Creek: stream, flows NE $12 \mathrm{mi}$., joins McManus Creek to form Chatanika River, 76 mi. SW of Circle, Yukon-Tanana High.; $65^{\circ} 17^{\prime} 30^{\prime \prime} \mathrm{N}, 146^{\circ} 20^{\prime} 50^{\prime \prime} \mathrm{W}$; (map 104).

Named by prospectors; reported in 1903 by T. G. Gerdine (in Prindle, 1905, pl. 13), USGS.

Smith Creek: stream, on Seward Penin., flows NE $10 \mathrm{mi}$. to Inmachuk River, $57 \mathrm{mi}$. SW of Kotzebue, Kotzebue-Kobuk Low.; $66^{\circ} 05^{\prime}$ N, $162^{\circ} 43^{\prime} \mathrm{W}$; (map 113).

Name used by local prospectors and reported in 1901 by W. C. Mendenhall, USGS. Smith Creek: stream, flows W $2 \mathrm{mi}$. to Nolan Creek at Nolan, 6 mi. NW of Wiseman, Brooks Ra.; $67^{\circ} 28^{\prime} 30^{\prime \prime} \mathrm{N}, 150^{\circ} 14^{\prime} 00^{\prime \prime} \mathrm{W}$; BGN 1932; (map 124).

Local name "used since the turn of the century"; reported by Robert Marshall in 1932.

Smith Creek: stream, see Sooner River.

Smith Creek Dome: mountain, 3,870 ft., $1 \mathrm{mi}$. N of Midnight Dome and $3.5 \mathrm{mi} . \mathrm{N}$ of Wiseman, Brooks Ra.; 67 $28^{\prime} 45^{\prime \prime} \mathrm{N}, 150^{\circ} 10^{\prime} 00^{\prime \prime} \mathrm{W}$ (map 124).

Local name reported about 1930 by Marshall $(1956$, p. 7$)$.

Smith Glacier: glacier, trends SE $5.5 \mathrm{mi}$. to Harvard Arm College Fiord, $2.8 \mathrm{mi}$. N of College Point and $51 \mathrm{mi}$. NW of Valdez, Chugach Mts.; 61 $14^{\prime} 45^{\prime \prime} \mathrm{N}, 147^{\circ} 01^{\prime} 10^{\prime \prime} \mathrm{W}$; (map 69).

Named in 1899 by members of the Harriman Alaska Expedition for Smith College, Northampton, Mass.

Smith Island: island, $0.1 \mathrm{mi}$. across, in Sitka Sound, $1.3 \mathrm{mi}$. SW of Sitka, Alex. Arch.; 57 ${ }^{\circ}$. $02^{\prime} 35^{\prime \prime} \mathrm{N}, 135^{\circ} 22^{\prime} 05^{\prime \prime} \mathrm{W}$; (map 9).

Named in 1880 by USN; published by USC\&GS is 1883 Coast Pilot (p. 142).

Smith Island: island, in Prince William Sound, $3.5 \mathrm{mi}$. long, $7 \mathrm{mi}$. S of Naked I., and $30 \mathrm{mi}$. NE of Chenega, Chugach Mts.; 60 $31^{\prime} 30^{\prime \prime}$ N, $147^{\circ} 22^{\prime} 00^{\prime \prime}$ W; (map 63). Var. Smith Islands.

Local name reported in 1900 by F. C. Schrader, USGS.

Smith Islands: island, see Little Smith Island. Smith Islands: island, see Smith Island.

Smith Lagoon: lagoon, $0.7 \mathrm{mi}$. long, $\mathrm{N}$ of Smith Gove, on $\mathrm{E}$ coast of Prince of Wales I., $\mathrm{N}$ of Skowl Arm Kasaan Bay, Alex. Arch.; 55 ${ }^{\circ} 27^{\prime}$ $\mathrm{N}, 132^{\circ} 21^{\prime} \mathrm{W}$; (map 4).

Local name recorded in 1949 by USGS.

Smith Lake: lake, $0.5 \mathrm{mi}$. across, $0.5 \mathrm{mi}$. $\mathrm{S}$ of Alaska-Canada boundary, $32 \mathrm{mi}$. NW of Hyder, Coast Mts.; $56^{\circ} 15^{\prime} \mathrm{N}, 130^{\circ} 36^{\prime} \mathrm{W}$; (map 7).

Name published in 1927 on IBC sheet 3. This lake was probably named for IBC surveyor W. F. Smith who worked in this area in 1908 or for N. Smith who worked in the area in 1920. 
Smith Lake: lake, $0.8 \mathrm{mi}$. long, $10 \mathrm{mi}$. SW of junc. of South Fork Kuskokwim and Post Rivers, $73 \mathrm{mi}$. SE of McGrath, Alaska Ra.; $62^{\circ} 19^{\prime} 45^{\prime \prime} \mathrm{N}, 153^{\circ} 43^{\prime} 40^{\prime \prime} \mathrm{W}$; ( $\operatorname{map} 80$ ).

Local name obtained in 1958 by USGS.

Smith Lake: lake, $0.3 \mathrm{mi}$. across, $4.5 \mathrm{mi}$. NW of Fairbanks, Yukon-Tanana High.; 64.52' N, 14752' W; (map 100). Var. Smiths Lake.

Local name shown on the manuscript location map of the Tanana Mines RR. in 1904.

Smith Lake: lake, extends NNW-SSE $1.7 \mathrm{mi}$., $3.5 \mathrm{mi}$. NE of junc. of Salmon Trout and Porcupine Rivers, $35 \mathrm{mi}$. NE of Coleen Mtn., Porcupine Plat.; $67^{\circ} 12^{\prime} \mathrm{N}, 141^{\circ} 35^{\prime} \mathrm{W}$; (map 121).

Local name reported in 1939 by FitzGerald (1944, pl. 18), USGS.

Smith Lake: lake, see Hugh Smith Lake.

Smith Mill: locality, on Mineral Creek, at mouth of Glacier Creek, $7.2 \mathrm{mi}$. NW of Valdez, Chugach Mts.; $61^{\circ} 13^{\prime} 05^{\prime \prime} \mathrm{N}, 146^{\circ} 19^{\prime} 10^{\prime \prime} \mathrm{W}$; (map 68).

Local name published in the 1950's by USGS.

Smith Mountain: mountain, 2,972 ft., forms two separate parts, the easternmost named Kingak Mountain, $37 \mathrm{mi}$. NNE of Howard Pass, Arctic Slope; $68^{\circ} 42^{\prime} \mathrm{N}, 156^{\circ} 30^{\prime} \mathrm{W}$; (map 132).

Named in 1949 by Mangus, USGS, geologist connected with Naval Petroleum Reserve No. 4 explorations; name published by USGS in 1951.

Smith Mountain Lakes: lakes, extend E-W 3 mi., $\mathbf{N}$ of Smith Mtn., $39 \mathrm{mi}$. NNE of Howard Pass, Arctic Slope; $68^{\circ} 45^{\prime} \mathrm{N}, 156^{\circ} 24^{\prime} \mathrm{W}$; (map 132). Var. Araga Lakes.

Named in 1950 by I. L. Tailleur, USGS, geologist connected with the Naval Petroleum Reserve No. 4 explorations for adjacent Smith Mountain. Name published by USGS in 1951.

Smith River: stream, heads in lake on $\mathrm{N}$ shore of Teshekpuk Lake, flows N $20 \mathrm{mi}$. to Beaufort Sea, near Pitt Point, Arctic Plain; 70 $55^{\prime} 30^{\prime \prime}$ $\mathrm{N}, 153^{\circ} 09^{\prime} 00^{\prime \prime} \mathrm{W}$; (map 148). Var. W. Smith's River, William Smith River.

On July 26, 1839, Thomas Simpson (1843, p. 134) wrote: "a considerable river, named after William Smith, Esquire, Secretary to the Hudson's Bay Company." Recorded as "W. Smith's River" on Simpson's map.

Smith's Bay: bay, see Smith Bay.

Smiths Lake: lake, see Smith Lake.

Smiths Slough: lake, $1 \mathrm{mi}$. long in swamp, 2.5 $\mathrm{mi}$. W of Nowitna River and $22 \mathrm{mi}$. NE of Monzonite Hills, Nowitna Low.; $64^{\circ} 44^{\prime} 30^{\prime \prime}$ $\mathrm{N}, 154^{\circ} 31^{\prime} 30^{\prime \prime} \mathrm{W}$; (map 98).

Local name obtained in 1956 by Orth.

Smoke Creek: stream, heads at $68^{\circ} 25^{\prime} \mathrm{N}$, $146^{\circ} 51^{\prime} \mathrm{W}$, flows SE $52 \mathrm{mi}$. to East Fork Chandalar River $42 \mathrm{mi}$. NW of Christian, Brooks Ra.; 67 $53^{\prime} \mathrm{N}, 146^{\circ} 04^{\prime} \mathrm{W}$; (map 122).

Local name reported in 1927 by J. B. Mertie, USGS.

Smoke Mountain: peak, 5,631 ft., $19 \mathrm{mi}$. SW of Arctic Village, Brooks Ra.; $68^{\circ} 02^{\prime} \mathrm{N}, 146^{\circ} 15^{\prime}$ W; (map 136).
Local name reported in 1926 by J. B. Mertie, Jr. (in Smith and others, 1929, pl. 1), USGS.

Smokey Bay: water passage, see Shelikof Strait. Smokey Lake: lake, $0.5 \mathrm{mi}$. long, at Tazlina, $\mathrm{S}$ of Glenn Highway, $30 \mathrm{mi}$. W of Glennallen, Copper River Basin; $62^{\circ} 04^{\prime}$ N, $146^{\circ} 27^{\prime} \mathrm{W}$; (map 83).

Local name reported in 1949 by USGS.

Smoky Hollow: valley, at head of Ivanof Bay, $6 \mathrm{mi}$. NE of Stepovak Bay, on S coast of the Alaska Penin., Aleutian Ra.; $55^{\circ} 52^{\prime} \mathrm{N}, 159^{\circ}$ $34^{\prime}$ W ; (map 27).

Published by USC\&GS on Chart 8859 (1964).

Smoky Mountain: mountain, see Peulik, Mount. Smoky Point: bluff, elev. $46 \mathrm{ft}$., N point of entrance to Ugashik Bay, on $\mathbf{N}$ coast of Alaska Penin., $12 \mathrm{mi}$. NW of Ugashik, Bristol Bay Low.; $57^{\circ} 36^{\prime} 45^{\prime \prime} N$, $157^{\circ} 41^{\prime} 15^{\prime \prime} \mathrm{W}$; (map 36)

Local name reported in 1900 by Lt. Comdr. J. F. Moser, USN, of the USBF steamer Albatross.

Smooth Channel: water passage, extends SE 2 $\mathrm{mi}$. along $\mathrm{W}$ coast of Chichagof $I$. from Ogden Passage to Khaz Bay, 4 mi. $\mathbf{S}$ of Chichagof, Alex. Arch.; $57^{\circ} 36^{\prime} \mathrm{N}, 136^{\circ} 06^{\prime} \mathrm{W}$; BGN 1908; (map 9).

Descriptive name given in 1908 by USC\&GS; published in 1908 Coast Pilot (p. 172). "Smooth Channel, the best entrance to Ogden Passage, is protected from the ocean swell by a chain of wooded islands and legdes."

Smoothface Mountain: hill, $820 \mathrm{ft}$., extends E 5 mi. from Woodcamp Creek along $\mathrm{N}$ bank of Yukon River, $32 \mathrm{mi}$. NE of Rampart, KokrinesHodzana High.; 65 $53^{\prime} 30^{\prime \prime}$ N, 149 $35^{\circ} 45^{\prime \prime}$ W ; (map 105).

Local name published by USGS in the 1950 's.

Smooth Mountain: mountain, 1,905 ft., on W coast of Gravina I., Alex. Arch.; $55^{\circ} 17^{\prime} 00^{\prime \prime} \mathrm{N}$, $131^{\circ} 49^{\prime} 30^{\prime \prime} \mathrm{W}$; (map 3).

Descriptive name given in 1883 by $L t$ Comdr. H. E. Nichols, USN.

Smuggler Cove: cove, $1.2 \mathrm{mi}$. across, on SW coast of Annette I., Alex. Arch.; 55 $05^{\prime} 30^{\prime \prime} \mathrm{N}$, $131^{\circ} 36^{\prime} 15^{\prime \prime} \mathrm{W}_{\text {; }}$ (map 3). Yar. Smugglers Cove.

Named in 1883 by Lt. Comdr. H. E. Nichols, USN

Smugglers Cove: cove, $0.2 \mathrm{mi}$ across, in Auke Bay, on SW coast of Mendenhall Penin., 9 mi. NW of Juneau, Coast Mts.; $58^{\circ} 20^{\prime} 50^{\prime \prime} \mathrm{N}$, $134^{\circ} 38^{\prime} 45^{\prime \prime} \mathrm{W}$; (map 11).

Name first appears in a lode claim on the cove filed by Louis Levy and William Murphy. The derivation of the name is unknown (DeArmond, 1957, p. 40).

Smugglers Cove: estuary, extends NW 2 mi., off Behm Canal, on E coast of Cleveland Penin., Alex. Arch.; 55 $34^{\circ} 30^{\prime \prime} \mathrm{N}, 1^{\circ} 56^{\circ} 00^{\prime \prime} \mathrm{W}$; (map 3).

Local name reported in 1901 by A. H. Brooks (1902b, pl. 2), USGS.

Smugglers Cove: cove, see Smuggler Cove.
Smugglers Creek: stream, on Cleveland Penin., heads in a lake and flows SE through Smugglers Lake $5 \mathrm{mi}$. to Smugglers Cove, Alex. Arch.; $55^{\circ} 35^{\prime} 40^{\prime \prime} \mathrm{N}, 131^{\circ} 58^{\prime} 10^{\prime \prime} \mathrm{W}$; (map 3 ).

Local name recorded in 1949 by USGS.

Smugglers Lake: lake, $1.2 \mathrm{mi}$. long, on Cleveland Penin., W of Helm Bay, in course of Smugglers Creek, Alex. Arch.; 55 $35^{\prime} 30^{\prime \prime} \mathrm{N}, 132^{\circ} 00^{\prime} 00^{\prime \prime}$ W; (map 3).

Local name recorded in 1949 by USGS.

Smyth Bay: bay, see Smith Bay.

Smyth, Cape: point of land, on Chukchi Sea coast, at Barrow, $10 \mathrm{mi}$. SW of Point Barrow, Arctic Plain; $71^{\circ} 17^{\prime} 35^{\prime \prime} \mathrm{N}, 156^{\circ} 47^{\prime}$ 15" W; (map 153). Var. Ikpiling, Smith Cape, Smythe Cape.

The Eskimo name for this place is "Utkiakvik" and refers in meaning to a "high place for viewing." It was the same name as that of the village which was located on this high (30 $\mathrm{ft}$.) ground. The present name of the cape was given in September 1826, by Capt. Beechey (1831, p. 302-303), RN, to honor William Smyth, RN, mate of H.M.S. Blossom, who, with Thomas Elson and party, in an open boat explored the coast NE of Icy Cape and discovered Point Barrow. In bestowing the name Beechey wrote "To the nearest conspicuous object to the southward of Point Barrow, I attach the name of Smyth ***." See also Barrow.

Smythe Cape: point of land, see Smyth, Cape.

Snag Creek: stream, flows E $2.4 \mathrm{mi}$. to Lower Sucker Creek, $39 \mathrm{mi}$. NE of Tyonek, Cook Inlet Low.; $61^{\circ} 37^{\prime} \mathrm{N}, 150^{\circ} 47^{\prime} \mathrm{W}$; (map 70).

Local descriptive name reported in 1954 by USGS.

Snag Creek: stream, flows NE $75 \mathrm{mi}$. from glacier terminus in Nutzotin Mts. across Alaska-Canada boundary to White River in Yukon, Canada, Alaska Ra.; $62^{\circ} 24^{\prime} 45^{\prime \prime} \mathrm{N}, 140^{\circ} 21^{\prime} 00^{\prime \prime} \mathrm{W}$; $B G N$ 1954; (map 84). Var. Snag River.

Descriptive name given in 1898 by Brooks (1900a, p. 434), USGS.

Snag Flats: flats, about $5 \mathrm{mi}$. long, in lower course of Skwentna River, $8 \mathrm{mi}$. upstream from Yentna River and $55 \mathrm{mi}$. N of Tyonek, Alaska Ra.; $61^{\circ} 56^{\prime} \mathrm{N}, 151^{\circ} 20^{\prime} \mathrm{W}$; (map $70)$.

Named in 1898 by Spurr (1900, p. 48), USGS, who said "nearly every channel was choked with dead trees, so that we gave the place the name of Snag Flats."

Snag Island: island, $0.5 \mathrm{mi}$. long, in North Pass, NE of Horseshoe I., Alex. Arch.; 55 $13^{\prime} 20^{\prime \prime}$ $\mathrm{N}, 132^{\circ} 55^{\prime} 40^{\prime \prime} \mathrm{W}$; (map 4).

Local name published in 1965 by USC\&GS. Snag Island: island, $150 \mathrm{ft}$. across, off $\mathrm{W}$ coast of Chichagof I., in Davison Bay, 11 mi. NW of Chichagof, Alex. Arch.; $57^{\circ} 47^{\prime} 00^{\prime \prime} \mathrm{N}$, $136^{\circ} 19^{\prime} 30^{\prime \prime} \mathrm{W}$; (map 9).

Name published by USC\&GS in 1925 Coast Pilot (p. 322).

Snag Lake: lake, $1.5 \mathrm{mi}$. long, on Kenai Penin., $9 \mathrm{mi}$. S of Moose Point and $28 \mathrm{mi}$. NE of Kenai, Cook Inlet Low.; $60^{\circ} 49^{\prime} 30^{\prime \prime}$ N, $150^{\circ}$ 41'30' W; (map 62). 
Named about 1963 by officials of Kenai National Moose Range, for administrative purposes.

Snag Point: point of land, formed by Nushagak and Wood Rivers, $1 \mathrm{mi}$. NE of Dillingham, Bristol Bay Low.; $59^{\circ} 03^{\prime} \mathrm{N}, 158^{\circ} 26^{\prime} \mathrm{W}$; (map 52).

Local descriptive name reported by J. F. Moser, USN, in 1901 (Baker, 1906).

Snag Point: village, see Dillingham.

Snag River: stream, see Snag Creek.

Snail Cape: point of land, see Ulitka, Cape.

Snail Point: point of land, W tip of Caracol I., in Portillo Channel, Alex. Arch.; 55 $31^{\prime} 15^{\prime \prime}$ N, 133 $26^{\prime} 55^{\prime \prime}$ W; (map 4). Var. Mys de la Karakol, Punta del Caracol.

Translation of the name "Punta del Caracol" given in 1775-79 by Don Juan de la Bodega y Quadra and Francisco Antonio Maurelle.

Snail Point: point of land, $\mathrm{S}$ point of entrance to Spacious Bay, on NE coast of Cleveland Penin., Alex. Arch. ; 55 $49^{\prime} 30^{\prime \prime}$ N, $131^{\circ} 46^{\prime} 10^{\prime \prime}$ W; (map 3). Var. Punta del Caracol.

This feature was named "Punta del Caracol," meaning "Snail Point," in 1775-79 by Don Juan de la Bodega y Quadra and Francisco Antonio Maurelle.

Snail Rock: rock, $700 \mathrm{ft}$. long, near E shore of Revillagigedo Channel, $3 \mathrm{mi}$. SW of Boca de Quadra, Coast Mts.; $55^{\circ} 02^{\prime} \mathrm{N}, 131^{\circ} 03^{\prime} \mathrm{W}$; (map 3).

Named in 1883 by Lt. Gomdr. H. E. Nichols, USN.

Snake Creek: stream, flows NE $5 \mathrm{mi}$. to Boswell Bay, on $\mathrm{N}$ end of Hinchinbrook $1 ., 20 \mathrm{mi}$. SW of Cordova, Chugach Mts.; $60^{\circ} 24^{\prime} \mathrm{N}$, $146^{\circ} 11^{\prime} \mathrm{W}$; (map 64).

Name published in 1959 by USGS.

Snake Creek: stream, see Whistler Creek.

Snake Island: islands, see Culebra Islands.

Snake River: stream, heads at Lake Nunavaugaluk, flows SE $45 \mathrm{mi}$. to Nushagak Bay, 15 mi. SW of Dillingham, Bristol Bay Low.; $58^{\circ} 52^{\prime} \mathrm{N}, 158^{\circ} 45^{\prime} \mathrm{W}$; (map 40). Var. Igushik River.

Local descriptive name given in 1898 by J. E. Spurr and W. S. Post, USGS, apparently because of the "tortuous course of the stream." The Eskimo name is "Igushik."

Snake River: stream, formed by junc. of Goldbottom Creek and North Fork Snake River, flows SW $15 \mathrm{mi}$., then SE $5 \mathrm{mi}$. to Norton Sound at Nome, Seward Penin. High.; 64․ $30^{\prime} \mathrm{N}, 165^{\circ} 25^{\prime} \mathrm{W}$; (map 94).

Local name reported in 1899 by $D$. C. Witherspoon, USGS; published in 1900 on USC\&GS Chart 9380 and by Schrader and Brooks (1900, map 2). So named in 1898 because of its serpentine-like course by the three men who found gold in the area; John Brynteson, E. O. Lindblom, and Jafet Lindeberg (Rickard, 1909, p. 332).

Snake River: stream, see Igushik River.

Snake River: stream, see Winding Creek.

Snare Creek: stream, flows SE $1 \mathrm{mi}$. to Coal Creek, $4 \mathrm{mi}$. SSW of that stream's junc. with Yukon River and $44 \mathrm{mi}$. SE of Circle, Yukon-
Tanana High.; $65^{\circ} 18^{\prime} \mathrm{N}, 143^{\circ} 15^{\prime} \mathrm{W}$; (map 103).

Local name reported in 1936 by Mertie (1938a, p. 250), USGS.

Snee-dee Mountain: mountain, see Beluga Mountain.

Snettisham: locality, on $\mathrm{N}$ coast of Snettisham Penin., $1 \mathrm{mi}$. SW of Sentinel Point and 31 mi. SE of Juneau, Coast Mts.; $57^{\circ} 59^{\prime} 05^{\prime \prime} \mathrm{N}$, $133^{\circ} 47^{\prime} 15^{\prime \prime} \mathrm{W}$; (map 8).

Site of a gold-mining camp named after Port Snettisham when established about 1895. Snettisham remained as a harbor village until 1926; a post office was maintained from 1900 to 1912 (Ricks, 1965, p. 59).

Snettisham, Port: estuary, trends SW $9 \mathrm{mi}$. from Speel Arm to Stephens Passage at $\mathrm{N}$ end of Snettisham Penin., $30 \mathrm{mi}$. SE of Juneau; Coast Mts.; $57^{\circ} 57^{\prime} 30^{\prime \prime}$ N, $133^{\circ} 52^{\prime} 00^{\prime \prime} \mathrm{W}$; (map 8).

Named by Capt. George Vancouver, RN, "for a town in Norfolk, England" after its discovery by Lt. Joseph Whidbey, RN, on August 12, 1794 (Wagner, 1937, p. 417). Snettisham Peninsula: peninsula, $15 \mathrm{mi}$. long, from Holkham Bay NW to Port Snettisham, $31 \mathrm{mi}$. SE of Juneau, Coast Mts.; 57 $53^{\circ}$ $\mathrm{N}, 133^{\circ} 45^{\prime} \mathrm{W}$; (map 8 ).

Local name reported in 1951 by USGS.

Snider Creek: stream, in Baird Mts., flows SE 2 mi. to Klery Greek $12 \mathrm{mi}$. NE of its junc. with Squirrel River, $20 \mathrm{mi}$. $\mathbf{N}$ of Kiana, Brooks Ra.; 67 ${ }^{\circ} 15^{\prime} \mathrm{N}, 160^{\circ} 25^{\prime} \mathrm{W}$; (map 127).

Name used by prospectors; reported in 1910 by P. S. Smith (in Brooks and others, 1911, pl. 13), USGS.

Snider Peak: mountain, 8,250 ft., S of Mount Drum, $30 \mathrm{mi}$. E of Glennallen, Wrangell Mts.; $62^{\circ} 04^{\prime} \mathrm{N}, 144^{\circ} 38^{\prime} \mathrm{W}$; (map 83).

Local name reported in 1903 by T. G. Gerdine, USGS. It may have been the name of a prospector.

Snidi Mountain: mountain, see Beluga Mountain.

Snipe Bay: bay, $0.4 \mathrm{mi}$. across, $17 \mathrm{mi}$. NW of village of Port Alexander, on S coast of Baranof I., Alex. Arch.; 56 $25^{\prime}$ N, $134^{\circ} 57^{\prime}$ W; (map 5). Var. Koulitchkow Bay, Kulichkof Bay, Kulichkova Bukhta, Kulitch Bay, Kulitchok.

This is a translation by USC\&GS about 1882 of the name "Kulichkova B[ukhta]" given in 1850 by the Russian American Company.

Snipe Head: point of land, W point of entrance to Snipe Bay, $16.8 \mathrm{mi}$. NW of village of Port Alexander, on $\mathrm{S}$ coast of Baranof I., Alex. Arch.; $56^{\circ} 25^{\prime} 10^{\prime \prime} \mathrm{N}, 134^{\circ} 57^{\prime} 30^{\prime \prime} \mathrm{W}$; (map 5).

Named by USC\&GS for charting purposes; name published in the 1925 Coast Pilot (p. 281).

Snipe Island: island, $400 \mathrm{ft}$. long, off S coast of Annette I., $0.5 \mathrm{mi}$. S of Annette Point, in Felice Strait, Alex. Arch.; $55^{\circ} 00^{\prime} 15^{\prime \prime} \mathrm{N}, 131^{\circ}$ $23^{\prime} 15^{\prime \prime} \mathrm{W}$; (map 3).

Named in 1883 by Lt. Comdr. H. E. Nichols, USN.
Snipe Island: island, $0.3 \mathrm{mi}$. across, in Thorne Arm on $\mathrm{S}$ coast of Revillagigedo I., Alex. Arch.; $55^{\circ} 21^{\prime} 40^{\prime \prime} \mathrm{N}, 131^{\circ} 15^{\prime} 30^{\prime \prime} \mathrm{W}$; (map 3). Arbitrary name given in 1891 by USC\&GS Snipe Island: island, $0.1 \mathrm{mi}$. across, in Portlock Harbor, 6.5 mi. NW of Chichagof, Alex. Arch.; 57 $43^{\prime} 45^{\prime \prime} \mathrm{N}, 136^{\circ} 14^{\prime} 00^{\prime \prime} \mathrm{W}$; (map 9). Local name reported in 1917 by USGS; published by R. M. Overbeck (in Martin and others, 1919, pl. 2), USGS.

Snipe Lake: lake, $2 \mathrm{mi}$. long, $13 \mathrm{mi}$. NW of Lachbuna Lake and $45 \mathrm{mi}$. NE of Nondalton, Alaska Ra.; $60^{\circ} 37^{\prime} 30^{\prime \prime} \mathrm{N}, 154^{\circ} 17^{\prime} 30^{\prime \prime} \mathrm{W}$; (map 61).

Local name reported in 1954 by USGS.

Snipe Lake: lake, $0.7 \mathrm{mi}$. long, on Kenai Penin., $3 \mathrm{mi}$. SE of mouth of Swanson River and 17 mi. NE of Kenai, Cook Inlet Low.; $60^{\circ} 45^{\prime}$ $30^{\prime \prime} \mathrm{N}, 150^{\circ} 58^{\prime} 25^{\prime \prime} \mathrm{W}$; (map 62).

Named about 1963 by officials of Kenai National Moose Range for Wilson's Snipe, or Jack Snipe (Capella gallinago delicata), a shore bird which breeds from northwestern Alaska south to northern California.

Snipe Point: point of land, in Eagle Bay, on $\mathbf{S}$ coast of Unalaska I., Aleutian Is.; $53^{\circ} 27^{\prime} 45^{\prime \prime}$ N, 166 $56^{\prime} 20^{\prime \prime} \mathrm{W}$; BGN 1939; (map 23).

So named by USC\&GS in 1937 "because of the large number of Russian snipe noted along the shoreline of the point."

Snipe Point: point of land, W tip of Bell I., in Behm Canal, Alex. Arch.; 55 $55^{\prime} 35^{\prime \prime} \mathrm{N}$, $131^{\circ} 36^{\prime} 45^{\prime \prime} \mathrm{W}$; (map 3).

One of many arbitrary names applied to features in this area in 1891 by USC\&GS.

Sniper Hill: hill, $620 \mathrm{ft}$, on northern Kiska I., Aleutian Is.; $52^{\circ} 05^{\prime} 10^{\prime \prime} \mathrm{N}, 177^{\circ} 39^{\prime} 45^{\prime \prime} \mathrm{E}$; (map 14).

An arbitrary name beginning with " $\mathrm{S}$ " to correspond to "S" grid used by the U.S. Army for tactical purposes during World War II; published on a 1953 AMS map.

Snipe Rock: rock, in Ogden Passage, off W coast of Chichagof I., $2.5 \mathrm{mi}$. SW of Chichagof, Alex. Arch.; $57^{\circ} 38^{\prime} 15^{\prime \prime} \mathrm{N}, 136^{\circ} 10^{\prime} 35^{\prime \prime} \mathrm{W}$; $B G N$ 1908; (map 9).

Named in 1908 by USC\&GS ; and published in 1908 Coast Pilot (p. 174).

Snipe Rock: rock, see Kulichkof Rock.

Sniper Point: point of land, see Snipers Point. Snipers Point: point of land, on N end of Kenai Penin. at mouth of Sixmile Creek, on $\mathrm{S}$ shore of Turnagain Arm, $1 \mathrm{mi}$. NE of Sunrise, Chugach Mts.; $60^{\circ} 54^{\prime} 30^{\prime \prime} \mathrm{N}, 1^{\circ} 9^{\circ} 24^{\prime} 30^{\prime \prime} \mathrm{W}$; BGN 1966; (map 63). Var. Sniper Point.

Local name reported in 1899 by Lt. Herron (1901, map facing p. 11), USA.

Snip Islands: islands, extend $0.6 \mathrm{mi}$., in Behm Canal, off $\mathrm{E}$ coast of Revillagigedo I., Alex. Arch. ; 55 $41^{\prime} 30^{\prime \prime} \mathrm{N}, 130^{\circ} 57^{\prime} 30^{\prime \prime} \mathrm{W}$; (map 3).

Arbitrary name given in 1891 by USC\&GS. Snohomish, Lake: lake, $2 \mathrm{mi}$. long, drains $\mathrm{E}$ to Deep Creek, $10 \mathrm{mi}$. SW of village of Lake Minchumina, Tanana Low.; $63^{\circ} 45^{\prime} \mathrm{N}, 152^{\circ}$ $30^{\prime} \mathrm{W}$; (map 88). Var. Lake Tukomina, Trekhamena, Tu-ca-omina. 
Local name reported in 1952 by USGS. Its Tanana Indian name is said to be "Trekhamena," or "Trek Lake."

Snohomish Hills: ridge, elev. 1,400-1,786 ft., extends NE-SW $10 \mathrm{mi}$. on $\mathrm{E}$ bank of Fish Creek, $11 \mathrm{mi}$. WSW of village of Lake Minchumina, Tanana Low.; $63^{\circ} 47^{\prime} \mathrm{N}, 152^{\circ} 45^{\prime}$ W; (map 88).

Local name obtained in 1958 from Fabian Carey and "Val" Blackburn by USGS.

Snoring Inn: locality, on The Alaska RR., on Kenai Penin., between Henry and Trail Creeks, $24 \mathrm{mi}$. SE of Sunrise, Chugach Mts.; $60^{\circ} 36^{\prime} 45^{\prime \prime} \mathrm{N}, 149^{\circ} 05^{\prime} 45^{\prime \prime} \mathrm{W}$; (map 63).

Name of a station stop on The Alaska RR., published on a 1951 USGS map.

Snowball Creek: stream, flows SW $5 \mathrm{mi}$. to Ophir Creek, $5.5 \mathrm{mi}$. N of Council and $37 \mathrm{mi}$. NE of Solomon, Seward Penin. High.; 64 ${ }^{\circ} 58^{\prime}$ N, $163^{\circ} 39^{\prime} \mathrm{W}$; (map 95).

Prospectors' name reported in 1899 by Schrader and Brooks (1900, map 3), USGS.

Snowbank Creek: stream, flows SE $1.5 \mathrm{mi}$. to Ogotoruk Creek, S of Tobit Creek, $6.4 \mathrm{mi}$. SE of Cape Thompson, Arctic Slope; 68 $8^{\circ} 06^{\prime} 25^{\prime \prime}$ N, $165^{\circ} 45^{\prime} 20^{\prime \prime} \mathrm{W}$; BGN 1963; (map 129). Var. Ahpuiak Creek.

Named about 1962 by personnel of Project Chariot.

Snowcap Mountain: mountain, $8,350 \mathrm{ft}$., $8 \mathrm{mi}$. SE of Tired Pup Glacier and $70 \mathrm{mi}$. NE of Lake Clark, Alaska Ra.; 61 ${ }^{\circ} 27^{\prime} 15^{\prime \prime}$ N, $153^{\circ}$ $37^{\prime} 40^{\prime \prime} \mathrm{W}$; BGN 1930; (map 71).

Named by S. R. Capps and Gerald FitzGerald, USGS, who discovered it in 1928; so called because it "is snowcapped the year round."

Snow Creek: stream, flows SW to Bering Sea, about $2 \mathrm{mi}$. E of York and $17 \mathrm{mi}$. SE of Cape Prince of Wales, Seward Penin. High.; (map 111).

Local name published in 1900 by USC\&GS on Chart 9380.

Snow Creek: stream, heads at $64^{\circ} 19^{\prime} \mathrm{N}$, $141^{\circ} 08^{\prime} \mathrm{W}$, flows E $3 \mathrm{mi}$. to Fortymile River, $35 \mathrm{mi}$. S of Eagle, Yukon-Tanana High.; $64^{\circ}$ $18^{\prime} 25^{\prime \prime} \mathrm{N}, 141^{\circ} 02^{\prime} 00^{\prime \prime} \mathrm{W}$; (map 102).

Local name reported in 1914 by IBC surveyors.

Snow Creek: stream, flows SW $1.5 \mathrm{mi}$. to Skookum River which flows to Klokerblok River, $19 \mathrm{mi}$. NE of Solomon, Seward Penin. High.; $64^{\circ} 40^{\prime} \mathrm{N}, 163^{\circ} 51^{\prime} \mathrm{W}$; (map 95).

Prospectors' náme reported in 1900 by E. C. Barnard (in Brooks, 1901, pl. 17), USGS.

Snow Creek: stream, flows SW $1.5 \mathrm{mi}$. to Canyon Creek which flows to Imuruk Basin, $31 \mathrm{mi}$. NW of Nome, Seward Penin. High.; $64^{\circ} 55^{\prime} \mathrm{N}$, $165^{\circ} 52^{\prime} \mathrm{W}$; (map 94).

Prospectors' name published on the 1908 "Map of Seward Peninsula" by Arthur Gibson.

Snow Creek: stream, flows NW $2.5 \mathrm{mi}$. to Eagle Creek which flows to Goodhope River near its mouth, $29 \mathrm{mi}$. NW of Imuruk Lake, Seward Penin. High.; $65^{\circ} 56^{\prime}$ N, $163^{\circ} 56^{\prime}$ W; (map 110).
Local name published on a precinct map of Seward Peninsula by Monroe and Hutchins; corrected to June 1903 by Arthur Gibson.

Snow Creek: stream, heads, in Third Ra., flows NE $5 \mathrm{mi}$. to Sadlerochit River, $25 \mathrm{mi}$. NW of Mount Michelson, Brooks Ra.; 69 28'30' N, $145^{\circ} 10^{\prime} 00^{\prime \prime} \mathrm{W}$; BGN 1961; (map 139).

So named by USGS geologists in 1948, because snow drifts persist in the valley of the stream until late summer. Reported by G. L. Whittington, USGS, in 1960.

Snow Creek: stream, flows NW to Pinnell River which flows to Inmachuk River, between Doll and Logan Creeks, about $16 \mathrm{mi}$. N of Imuruk Lake, Seward Penin. High.; (map 110).

Local name published on a precinct map of Seward Peninsula by Monroe and Hutchins; corrected to June 1903 by Arthur Gibson. This stream cannot be precisely identified on current maps.

Snowden Creek: stream, flows SW $5.5 \mathrm{mi}$. from Snowden Mtn. to Dietrich River, $6.5 \mathrm{mi}$. N of the junc. of Bettles and Dietrich Rivers and $37.5 \mathrm{mi}$. WNW of Chandalar, Brooks Ra.; $67^{\circ} 44^{\prime} 20^{\prime \prime} \mathrm{N}, 149^{\circ} 46^{\prime} 20^{\prime \prime} \mathrm{W}$; BGN 1939; (map 123).

Named in 1939 by Robert Marshall for his Eskimo friend and hunting companion, Nutirwik, or Harry Snowden.

Snowden Mountain: mountain, elev. 6,400 ft., $E$ of Dietrich River, $13 \mathrm{mi}$. N of Sukakpak Mtn. and $37 \mathrm{mi}$. NW of Chandalar, Brooks Ra.; $67^{\circ} 48^{\prime} \mathrm{N}, 149^{\circ} 40^{\prime} \mathrm{W}$; (map 123).

Named for the creek heading on its slope which was named in 1939 by Robert Marshall for his Eskimo hunting partner, Harry Snowden.

Snow Dome: mountain, 3,900 ft., in Glacier Bay National Monument, $2.2 \mathrm{mi}$. SW of Mount Elder and $71 \mathrm{mi}$. NW of Juneau, St. Elias Mts.; $58^{\circ} 58^{\prime} 10^{\prime \prime} \mathrm{N}, 135^{\circ} 54^{\prime} 15^{\prime \prime} \mathrm{W}$; (map 11).

Descriptive name given in 1888 by John Muir and published by H. F. Reid (1892, pl. 14).

Snow Dome: mountain, see Elder, Mount.

Snowdrift Crag: peak, see Snowdrift Peak.

Snowdrift Peak: peak, 6,360 ft., on S edge of

Taku Glacier, $3.4 \mathrm{mi}$. NE of Mendenhall Towers and $19 \mathrm{mi}$. N of Juneau, Coast Mts. $58^{\circ} 34^{\prime} 45^{\prime \prime} \mathrm{N}, 134^{\circ} 27^{\prime} 00^{\prime \prime} \mathrm{W}$; (map 11). Var. Snowdrift Crag.

Descriptive name published in 1960 by USGS. The name Snowdrift Crag was proposed by members of the Juneau Icefield Research Project in 1964.

Snowflake Lake: lake, $0.5 \mathrm{mi}$. long, on Kenai Penin. W of McLain Lake, $32 \mathrm{mi}$. NE of Kenai, Cook Inlet Low.; 60 $51^{\prime} 30^{\prime \prime} \mathrm{N}, 150^{\circ} 36^{\prime} 25^{\prime \prime}$ W; (map 62).

So named about 1963 by officials of Kenai National Moose Range, because the outline of the lake vaguely resembles a snowflake.

Snow Gulch: ravine, trends W $1.5 \mathrm{mi}$. to Salmon River, $25 \mathrm{mi}$. NE of Cape Newenham, Kilbuck-Kuskokwim Mts.; 58 $54^{\prime} 59^{\prime \prime} \mathrm{N}, 161^{\circ}$ $42^{\prime} 40^{\prime \prime}$ W; BGN 1938; (map 39).

Local name reported in 1938 by J. B. Mertie and Gerald FitzGerald, USGS.
Snow Gulch: ravine, trends $\mathrm{S} 2 \mathrm{mi}$. to Arolik River, $31 \mathrm{mi}$. N of Goodnews, Kilbuck-Kuskokwim Mts.; 59 $33^{\prime} \mathrm{N}, 161^{\circ} 25^{\prime} \mathrm{W}$; (map 53). Local name reported in 1919 by G. L. Harrington (in Brooks, 1921, pl. 7), USGS.

Snow Gulch: ravine, extends SE $3.7 \mathrm{mi}$. from Donlin Creek $0.6 \mathrm{mi}$. E of its junc. with Flat Creek, $15 \mathrm{mi}$. $\mathrm{N}$ of village of Crooked Creek and $43 \mathrm{mi}$. NW of Sleetmute, KilbuckKuskokwim Mts. ; $62^{\circ} 05^{\prime} \mathrm{N}, 158^{\circ} 12^{\prime} \mathrm{W}$; (map 79).

Prospectors' name obtained in 1913 by Eakin (1914, pl. 1), USGS.

Snow Gulch: ravine, in Nutzotin Mts., extends 1 mi. SW to Little Eldorado Creek $0.2 \mathrm{mi}$. N of its junc. with Bonanza Creek, $4.5 \mathrm{mi}$. $\mathrm{N}$ of Beaver Lake, Alaska Ra.; 62 ${ }^{\circ} 06^{\prime} 30^{\prime \prime} \mathrm{N}, 141^{\circ}$ $50^{\prime} 00^{\prime \prime} \mathrm{W}$; (map 84).

Name used by prospectors and reported by S. R. Capps (in Brooks and others, 1915, p. 222), USGS

Snow Gulch: ravine, trends NW $1 \mathrm{mi}$. to Long Creek, $1.4 \mathrm{mi}$. SW of Long and $24 \mathrm{mi}$. S of Ruby, Kilbuck-Kuskokwim Mts.; 64 $23^{\circ} \mathrm{N}$, 155³1' W; BGN 1936; (map 98).

Prospectors' name reported in 1913 by Eakin (1914, pl. 2), USGS.

Snow Gulch: ravine, trends NW $0.7 \mathrm{mi}$. to Hastings Creek, $10 \mathrm{mi}$. E of Nome, Seward Penin. High.; $64^{\circ} 28^{\prime} 15^{\prime \prime} \mathrm{N}, 165^{\circ} 05^{\prime} 45^{\prime \prime} \mathrm{W}$; (map 94).

Prospectors' name reported in 1904 by $T$. G. Gerdine, USGS.

Snow Gulch: ravine, trends NW $0.7 \mathrm{mi}$. to Glacier Creek, $6 \mathrm{mi}$. N of Nome, Seward Penin. High,; $64^{\circ} 36^{\prime} \mathrm{N}, 165^{\circ} 24^{\prime} \mathrm{W}$; (map 94). Var. Show Gulch.

Prospectors' name reported in 1899 by $D$. C. Witherspoon (in Schrader and Brooks, 1900, map 2), USGS.

Snow Gulch: ravine, on SW slope of Fourth of July Hill, trends SW to Fairbanks Creek, 22 mi. NE of Fairbanks, Yukon-Tanana High.; $65^{\circ} 03^{\prime} \mathrm{N}, 147^{\circ} 07^{\prime} \mathrm{W}$; BGN 1939; (map 105).

Local name reported in 1939 by $P$. $S$. Smith, USGS.

Snow Gulch: ravine, heads in Kigluaik Mts., trends NW $5 \mathrm{mi}$. to Windy Cove, in Imuruk Basin, $24 \mathrm{mi}$. SE of Teller, Seward Penin. High.; $65^{\circ} 03^{\prime} \mathrm{N}, 165^{\circ} 43^{\prime} \mathrm{W}$; (map 111).

Local name reported about 1905 by USGS (Collier and others, 1908, pl. 8).

Snow Gulch: ravine, trends NW to Louise Creek which flows to Kougarok River, $18 \mathrm{mi}$. S of Midnight Mtn. and $44 \mathrm{mi}$. SW of Imuruk Lake, Seward Penin. High.; $65^{\circ} 31^{\prime}$ N, $164^{\circ}$. 40' W; (map 110).

Prospectors' name reported on the 1908 "Map of Seward Peninsula" by Arthur Gibson. Snow Gulch: ravine, trends SE $1.5 \mathrm{mi}$. to Goldstream Creek, $6 \mathrm{mi}$. NE of Livengood, YukonTanana High.; $65^{\circ} 34^{\prime} 45^{\prime \prime} \mathrm{N}, 148^{\circ} 23^{\prime} 30^{\prime \prime} \mathrm{W}$; (map 105).

Local name published by USGS in the 1950's.

Snowheel Mountain: mountain, 7,000 ft., at head of Oolah Valley, $34 \mathrm{mi}$. E of Anaktuvuk 
Pass, Brooks Ra.; 6803' N, $150^{\circ} 25^{\prime}$ W; (map 134).

Local name reported by Marshall (1956, map) in 1932.

Snow Lake: lake, $0.9 \mathrm{mi}$. long, on Revillagigedo I., near head of Naha River, $7 \mathrm{mi}$. NE of Loring, Alex. Arch.; 55 $39^{\prime} \mathrm{N}, 1^{\circ} 1^{\circ} 27^{\prime} \mathrm{W}$; (map 3).

Local name reported in 1948 by USGS.

Snow Lake: lake, see Nellie Juan Lake.

Snow Mountain Gulch: ravine, trends NW $4 \mathrm{mi}$. to Wood River, $10 \mathrm{mi}$. SE of Japan Hills and

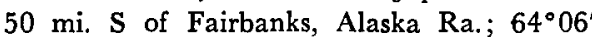
N, $147^{\circ} 31^{\prime} \mathrm{W}$; (map 100).

Local name derived from a descriptive variant name for the Alaska Ra., published on recent maps.

Snow Passage: water passage, in Clarence Strait, between Bushy and Zarembo Is.; Alex. Arch.; $56^{\circ} 17^{\prime} \mathrm{N}, 132^{\circ} 57^{\prime} \mathrm{W}$; (map 6).

Named in 1886 by USC\&GS for "Lt. Comdr. Albert Sidney Snow, USN, who in that year made surveys in this region."

Snowpatch Crag: peak, 6,345 ft., $1.3 \mathrm{mi}$. S of Tricouni Peak and $25 \mathrm{mi}$. N of Juneau, Coast Mts.; $58^{\circ} 39^{\prime} 08^{\prime \prime}$ N, $134^{\circ} 29^{\prime} 25^{\prime \prime}$ W; $B G N$ 1965; (map 11). Var. Snowpatch Peak.

Named by members of the Juneau Icefield Research Project in 1964.

Snowpatch Peak: peak, see Snowpatch Crag.

Snow River: stream, on Kenai Penin., flows SW $28 \mathrm{mi}$. to Kenai Lake, $12 \mathrm{mi}$. NE of Seward, Chugach Mts.; $60^{\circ} 20^{\prime} 15^{\prime \prime} \mathrm{N}, 149^{\circ} 21^{\prime} 15^{\prime \prime} \mathrm{W}$; (map 63).

Local name reported in 1898 by Mendenhall (1900, map 6), USGS.

Snow River Pass: pass, 1,800 ft., $1.5 \mathrm{mi}$. W of Lower Paradise Lake and $20 \mathrm{mi}$. NE of Seward, Chugach Mts.; $60^{\circ} 20^{\prime} 15^{\prime \prime}$ N, $149^{\circ} 07^{\prime}$ $20^{\prime \prime} \mathrm{W}$; (map 63).

Local name reported in 1951 by USGS.

Snowshoe Creek: stream, in Mentasta Mts., flows $\mathrm{S} 4.8 \mathrm{mi}$. to Station Creek, $32 \mathrm{mi}$. SW of Tok, Alaska Ra.; $62^{\circ} 55^{\prime} \mathrm{N}, 143^{\circ} 29^{\prime} \mathrm{W}$; (map 84).

Local name reported in 1960 by USGS.

Snowshoe Creek: stream, in Kantishna Hills, flows N $2.3 \mathrm{mi}$. to Caribou Creek, $13 \mathrm{mi}$. N of Wonder Lake, Alaska Ra.; 63 $36^{\circ} 30^{\prime \prime} \mathrm{N}$, $150^{\circ} 49^{\prime} 30^{\prime \prime} \mathrm{W}$; (map 88).

Local name shown on a 1916 fieldsheet by C. E. Giffin, USGS.

Snowshoe Creek: stream, heads on Cone Mtn., flows SE $3 \mathrm{mi}$. to Penny River, $2 \mathrm{mi}$. NW of Nome, Seward Penin. High.; $64^{\circ} 44^{\prime} \mathrm{N}, 165^{\circ}$. 40' W; (map 94).

Prospectors' name reported in 1899 by $D$. C. Witherspoon (in Schrader and Brooks, 1900, map 2), USGS. The 1900 "Map of Nome Peninsula" by J. M. Davidson and B. D. Blakeslee applied this name to a southcast-flowing tributary of Penny River, $5 \mathrm{mi}$. to the north.

Snowshoe Creek: stream, flows SE $6 \mathrm{mi}$. to Washington Creek, $20 \mathrm{mi}$. NW of Fairbanks, YukonTanana High.; $65^{\circ} 08^{\prime} \mathrm{N}, 147^{\circ} 55^{\prime} \mathrm{W}$; (map 105).
Local name published by USGS in the 1950's.

Snowshoe Creek: stream, flows NE $11 \mathrm{mi}$. to South Fork Serpentine River, $18 \mathrm{mi}$. N of Kougarok Mtn. and $27 \mathrm{mi}$. E of Ear Mtn., Seward Penin. High.; 65 $56^{\prime} \mathrm{N}, 165^{\circ} 17^{\prime} \mathrm{W}$; (map 111)

Prospectors' name reported in 1901 by T. G. Gerdine (in Collier, 1902, pl. 12), USGS. Snowshoe Gulch: ravine, trends SW $1.7 \mathrm{mi}$. to Cripple River, $16 \mathrm{mi}$. NW of Nome, Seward Penin. High.; $64^{\circ} 42^{\prime} \mathrm{N}, 165^{\circ} 43^{\prime} \mathrm{W}$; (map 94).

Prospectors' name reported on Arthur Gibson's "Map of Cape Nome Precinct" dated 1904.

Snowshoe Lake: lake, $0.1 \mathrm{mi}$. long, on Kenai Penin., $1 \mathrm{mi}$. S of Eagle Lake and $18 \mathrm{mi}$. NE of Homer, Cook Inlet Low.; $59^{\circ} 48^{\prime} 30^{\prime \prime} \mathrm{N}$, $151^{\circ} 08^{\prime} 10^{\prime \prime} \mathrm{W}$; (map 50$)$.

Local name reported and published by USGS in the 1950's.

Snowshoe Lake: lake, $1 \mathrm{mi}$. long, on Kenai Penin., $2 \mathrm{mi}$. SW of King Lake and $34 \mathrm{mi}$. NE of Kenai, Cook Inlet Low.; $60^{\circ} 46^{\prime} 30^{\prime \prime} \mathrm{N}, 150^{\circ}$ 23'00" W; (map 62).

Named about 1963 by officials of Kenai National Moose Range, for administrative purposes.

Snowshoe Lake: lake, $1.1 \mathrm{mi}$. long, $\mathrm{N}$ of Glenn Highway, in course of Cache Creek, $38 \mathrm{mi}$. W of Glennallen, Copper River Basin; 62 $02^{\prime} \mathrm{N}$, $146^{\circ} 41^{\prime} \mathrm{W}$; (map 83).

Local name reported by USGS in 1949.

Snowshoe Pass: pass, between valleys of Wiseman Greek and Glacier River, $8 \mathrm{mi}$. NW of Wiseman, Brooks Ra.; 67 $29^{\prime} 00^{\prime \prime} \mathrm{N}, 150^{\circ} 20^{\prime}$ $30^{\prime \prime} \mathrm{W}$; (map 124).

Local name reported by Robert Marshall in 1939.

Snowshoe Roadhouse: locality, at head of Snowshoe Creek on Livengood-Fairbanks Trail (now Elliott Highway), $25 \mathrm{mi}$. NW of Fairbanks, Yukon-Tanana High.; $65^{\circ} 11^{\prime}$ N, $147^{\circ}$ 59' W; (map 105).

This former roadhouse was named for Snowshoe Creek; its name was reported in 1915 by USGS (Brooks and others, 1916, pl. 9).

Snowslide Creek: stream, on W side of Gastineau Peak, flows $1 \mathrm{mi}$. SW to Gastineau Channel, $2 \mathrm{mi}$. SE of Juneau, Coast Mts. ; $58^{\circ} 16^{\prime} 55^{\prime \prime} \mathrm{N}$, $134^{\circ} 22^{\prime} 15^{\prime \prime}$ W ; (map 11). Var. Silver Creek.

Named in 1894 by Anton Liljestrand when he claimed mining water from the creek. The name was derived from frequent snowslides along the creek in the spring and winter. It was called Silver Creek in 1885 in a mining claim location by Andrew T. Lewis (DeArmond, 1957, p. 40). The name Snowslide Creek was reported for use on Federal maps in 1917 by D. C. Witherspoon, USGS.

Snowslide Creek: stream, heads at glacier, flows SW $4.5 \mathrm{mi}$. to Cripple Creek, $2.2 \mathrm{mi}$. $\mathrm{N}$ of Chelatna Lake and $49 \mathrm{mi}$. NW of Talkeetna, Alaska Ra.; 62 $33^{\prime} 25^{\prime \prime}$ N, $151^{\circ} 32^{\prime} 10^{\prime \prime} \mathrm{W}$; (map 81).

Prospectors' name reported in 1906 by R. W. Porter, USGS.
Snowslide Creek: stream, heads at glacier terminus, flows NW $1.5 \mathrm{mi}$. to head of West Fork Robertson River, 34 mi. NE of Paxson, Alaska Ra.; $63^{\circ} 20^{\prime} 15^{\prime \prime} \mathrm{N}, 144^{\circ} 38^{\prime} 40^{\prime \prime} \mathrm{W}$; (map 86).

Name published on relatively recent maps. Snowslide Gulch: ravine, $0.4 \mathrm{mi}$. long, on upper tributary of Johnson Creek, $3.5 \mathrm{mi}$. SE of Point Sherman on Lynn Canal and $44 \mathrm{mi}$. NW of Juneau, Coast Mts. ; $58^{\circ} 50^{\prime} 30^{\prime \prime}$ N, $135^{\circ} 03^{\prime}$ $30^{\prime \prime} \mathrm{W}$; (map 11).

The name first appeared in mining records in 1881, when Richard Dailey, Charles B. Sherry, and James E. Woods claimed water in the gulch for mining purposes. The name is derived from the heavy snowslides down this gulch each spring (DeArmond, 1957, p. 40). This name was reported in local use in 1906 by USGS.

Snow Top: peak, 6,576 ft., on Alaska-British Columbia boundary, $9 \mathrm{mi}$. WNW of Mount Canning, $17 \mathrm{mi}$. SE of Skagway, Coast Mts.; $59^{\circ} 16^{\prime} 55^{\prime \prime} \mathrm{N}, 134^{\circ} 57^{\prime} 30^{\prime \prime} \mathrm{W}$; (map 44). Var. Boundary Peak 106.

Descriptive name published by USGS in 1951.

Snow Tower: mountain, 6,572 ft., $3 \mathrm{mi}$. S of Crescent Lake, $39 \mathrm{mi}$. ESE of Juneau, Coast Mts.; $58^{\circ} 10^{\prime} 20^{\prime \prime} \mathrm{N}, 133^{\circ} 24^{\prime} 00^{\prime \prime} \mathrm{W}$; (map 12).

Local descriptive name reported in.1951 by USGS.

Snow Towers, The: peaks, 7,000 ft., two peaks $0.1 \mathrm{mi}$. apart, $1.7 \mathrm{mi}$. SW of Snowpatch Crag and $23 \mathrm{mi}$. N of Juneau, Coast Mts.; 58 $37^{\prime}$ $45^{\prime \prime} \mathrm{N}, 134^{\circ} 30^{\prime} 40^{\prime \prime} \mathrm{W}$; BGN 1965; (map 11). Var. Empress Mountain.

Named by members of the Juneau Icefield Research Project in 1964.

Snow White: mountain, $9,000 \mathrm{ft}$., at head of Fels Glacier, $23 \mathrm{mi}$. NE of Paxson, Alaska Ra.; $62^{\circ} 21^{\prime} 25^{\prime \prime} \mathrm{N}, 145^{\circ} 22^{\prime} 05^{\prime \prime} \mathrm{W}$; (map 86).

Name published on relatively recent maps. Snowy Lake: lake, at head of Wilson River, on Latouche I., $20 \mathrm{mi}$. SE of Chenega, Chugach Mts.; $60^{\circ} 51^{\prime} 35^{\prime \prime} \mathrm{N}, 147^{\circ} 53^{\prime} 20^{\prime \prime} \mathrm{W}$; $B G N$ 1910; (map 63).

Local name reported in 1909 by Grant and Higgins (1910, pl. 12), USGS.

Snowy Mountain: peak, 3,185 ft., on Mansfield Penin., Admiralty I., 4 mi. SE of Funter Bay and $17 \mathrm{mi}$. SW of Juneau, Alex. Arch.; 58 ${ }^{\circ}$ $11^{\prime} 45^{\prime \prime} \mathrm{N}, 134^{\circ} 49^{\circ} 15^{\prime \prime} \mathrm{W}$; (map 11).

Descriptive name given by W. H. Dall, USC\&GS, and published in the 1883 Coast Pilot (map, p. 182).

Snowy Mountain: peak, 7,090 ft., on Alaska Penin., in Katmai National Monument, $11 \mathrm{mi}$. NE of Mount Katmai, Aleutian Ra.; $58^{\circ} 20^{\prime}$ N, 154.41' W; BGN 1924; (map 42). Var. Princess Peak.

Identified by R. F. Griggs, National Geographic Society, as "Princess Peak" in 1916 and as "Snowy Mountain" in 1919 "because of the extensive glaciers nearby."

Snowy Peak: peak, 4,273 ft., $19 \mathrm{mi}$. NW of junc. of Charley and Yukon Rivers and $33 \mathrm{mi}$. ESE of Circle, Porcupine Plat.; $65^{\circ} 35^{\prime} 00^{\prime} \mathrm{N}, 142^{\circ}$. 51'10' W; BGN 1965; (map 103). Var. White Mountain. 
So named in 1965 by Earl Brabb, USGS, because "the peak retains snow longer than the surrounding area."

Snug Anchorage: anchorage, extends NW 1.7 mi. off Clarence Strait, on $\mathbf{E}$ coast of Prince of Wales I., $\mathrm{N}$ of Thorne Head, Alex. Arch.; $55^{\circ} 42^{\prime} \mathrm{N}, 132^{\circ} 27^{\prime} \mathrm{W}$; (map 4).

Descriptive name given in 1886 by $L t$. Comdr. R. G. Clover, USN.

Snug Corner Bay: bay, see Snug Corner Cove. Snug Corner Cove: bay, 2 mi. wide, on S shore of Port Fidalgo, $35 \mathrm{mi}$. NW of Cordova, Chugach Mts.; $60^{\circ} 45^{\prime} \mathrm{N}, 146^{\circ} 39^{\prime} \mathrm{W}$; (map 64). Var. Snug Corner Bay.

Local name published by the Norris Peters Company on their 1911 map of southeastern part of Prince William Sound and the Bering River coal field.

Snug Cove: $b a y$, off Admiralty I., extends NE $3 \mathrm{mi}$. to Gambier Bay, 59 mi. NE of Sitka, Alex. Arch.; $57^{\circ} 26^{\prime} 30^{\prime \prime} \mathrm{N}, 1^{\circ} 33^{\circ} 57^{\prime} 00^{\prime \prime} \mathrm{W}$; (map 8).

Named in 1889 by Lt. Comdr. H. B. Mansfield, USN; name published by USC\&GS in the 1891 Coast Pilot (p. 144).

Snug Cove: cove, $0.6 \mathrm{mi}$. across, in Moser Bay, at $\mathrm{S}$ end of Kodiak I.; 56 $59^{\prime} 30^{\prime \prime} \mathrm{N}, 154^{\circ} 10^{\prime}$ 00" W; (map 32). Var. Snug Harbor.

Name reported in 1900 by Lt. Comdr. J. F. Moser, USN.

Snug Cove: cove, see Cozy Cove.

Snug Harbor: locality, on NW shore of Kenai Lake, Kenai Penin., at mouth of Shackleford Creek, $32 \mathrm{mi}$. SSW of Hope, Chugach Mts.; $60^{\circ} 29^{\prime} 15^{\prime \prime} \mathrm{N}, 149^{\circ} 46^{\prime} 40^{\prime \prime} \mathrm{W}$; (map 63).

Name published on 1952 USGS map.

Snug Harbor: bay, $1.5 \mathrm{mi}$. across, on SE coast of Knight I., in Montague Strait, $8 \mathrm{mi}$. W of Green I. and $59 \mathrm{mi}$. E of Steward, Chugach Mts.; $60^{\circ} 15^{\prime} \mathrm{N}, 147^{\circ} 43^{\prime} \mathrm{W}$; BGN 1908; (map 63). Var. Discovery Bay.

Local name published in 1908 by USC\&GS

Snug Harbor: bight, on W coast of Chisik I., at $\mathrm{S}$ end of Tuxedni Channel, $56 \mathrm{mi}$. SW of Kenai, Aleutian Ra.; $60^{\circ} 06^{\prime} 15^{\prime \prime} \mathrm{N}, 152^{\circ} 34^{\prime}$ $30^{\prime \prime} \mathrm{W}$; (map 62).

Local name reported in 1958 by USGS.

Snug Harbor: lagoon, $1 \mathrm{mi}$. long, on SE shore of Iliamna Lake, $6.5 \mathrm{mi}$. NE of Kakhonak, Aleutian Ra.; $59^{\circ} 30^{\prime} \mathrm{N}, 154^{\circ} 36^{\prime} \mathrm{W}$; (map 51 ).

"So named because the cove has a narrow entrance and therefore provides a safe place to anchor a vessel"; reported in 1954 by USGS.

Snug Harbor: cove, see Snug Cove.

Snug Harbor: estuary, see Tuxedni Bay.

Snyder Falls Creek: stream, flows NW 2 mi. to delta of Rude River, $10 \mathrm{mi}$. NE of Cordova, Chugach Mts.; $60^{\circ} 40^{\prime} \mathrm{N}, 145^{\circ} 36^{\prime} \mathrm{W}$; (map 64).

Local name reported in 1913 by B. L. Johnson (in Brooks and others, 1914, pl. 7), USGS. Name derived from nearby Snyder Mountain.

Snyder Mountain: mountain, 3,432 ft., $1.3 \mathrm{mi}$. SE of Rude River delta, $10 \mathrm{mi}$. NE of Cordova,
Chugach Mts. ; $60^{\circ} 39^{\prime} 30^{\prime \prime} \mathrm{N}, 145^{\circ} 34^{\prime} 00^{\prime \prime} \mathrm{W}$; $B G N$ 1910; (map 64).

Local name reported by Grant and Higgins (1910, pl. 1 and 2).

Soakpak Mountain: mountain, 5,883 ft., at head of John River, $5 \mathrm{mi}$. NW of Anaktuvuk Pass, Brooks Ra.; $68^{\circ} 11^{\prime} 00^{\prime \prime} \mathrm{N}, 151^{\circ} 51^{\prime} 30^{\prime \prime} \mathrm{W}$; (map 134).

Eskimo name published by Rausch (1951, p. 150) ; reported to be named for an "old Tulugakmiut hunter."

Soapberry Mountain: mountain, 3,225 ft., on Admiralty I., $2.5 \mathrm{mi}$. N of Bear Pass Mtn., and $46 \mathrm{mi}$. NE of Sitka, Alex. Arch.; $57^{\circ} 21^{\prime}$ $\mathrm{N}, 134^{\circ} 15^{\prime} \mathrm{W} ; B G N 1962$; (map 9).

Local name reported in 1962 by USFS. "It was named by the Tlingit Indians because they picked soapberries nearby."

Soapstone Cove: estuary, $1.2 \mathrm{mi}$. long, on N coast of Yakobi I., trends NE to Cross Sound $0.4 \mathrm{mi}$. E of Soapstone Point, $39 \mathrm{mi}$. W of Hoonah, Alex. Arch.; $58^{\circ} 06^{\prime} 15^{\prime \prime} \mathrm{N}, 136^{\circ} 28^{\prime}$ 15" W; BGN 1928; (map 10). Var. Indian Cove, Miliak Cove.

Name suggested by USC\&GS in 1928, derived from Soapstone Point. Its original wellestablished local name was Indian Cove because of a Tlingit Indian village located there. The change in the name was because of possible confusion with Indian Cove located to the NE. The variant name Miliak is a transliteration of a Russian word meaning "soapstone." Soapstone Point: point of land, on $\mathbf{N}$ tip of Yakobi I., on Cross Sound, $2 \mathrm{mi}$. NE of Bingham Cove, $39 \mathrm{mi}$. W of Hoonah, Alex. Arch.; 58 $06^{\prime} 10^{\prime \prime} \mathrm{N}, 136^{\circ} 29^{\prime} 50^{\prime \prime} \mathrm{W}$; (map 10).

Named by W. H. Dall, USC\&GS, in 1880 because of the greenish appearance of the rocks, resembling soapstone. The name was published in the 1883 Alaska Coast Pilot (p. 187).

Sobaka Rock: island, $0.1 \mathrm{mi}$ across, $1.6 \mathrm{mi}$. SSE of Vega Point on S coast of Kiska I., Aleutian Is.; $51^{\circ} 48^{\prime} 40^{\prime \prime} \mathrm{N}, 177^{\circ} 20^{\prime} 15^{\prime \prime} \mathrm{E}$; BGN 1937; (map 14).

Russian word "sobaka" meaning "dog" given by the U.S. Navy Hydrog. Office in 1937 after the USC\&GS signal Dog located here.

Soblazna, Mys: point of land, see Seduction Point.

Sobrero: island, see Sombrero Island.

Sockeye Creek: stream, $0.5 \mathrm{mi}$. long, drains Hugh Smith Lake into Boca de Quadra, Coast Mts.; $55^{\circ} 05^{\prime} 45^{\prime \prime} \mathrm{N}, 130^{\circ} 43^{\prime} 00^{\prime \prime} \mathrm{W}$; BGN 1915; (map 3). Var. Hugh Smith Creek, Quadra Creek.

Local name reported in 1914 by $E$. Lester Jones, USBF; named for the Sockeye salmon. Called "Quadra Creek" in 1897 by Lt. Comdr. J. F. Moser, USN.

Sockeye Creek: stream, heads in a branch of Taku Glacier, flows SE $5 \mathrm{mi}$. to Taku River, 21 mi. NE of Juneau, Coast Mts.; $58^{\circ} 29^{\prime} 45^{\prime \prime} \mathrm{N}$, $133^{\circ} 58^{\prime} 45^{\prime \prime} \mathrm{W}$; BGN 1932; (map 12).

Local descriptive name reported in 1932 by B. D. Stewart, USGS; the name had been "given for the sockeye salmon which spawn in great numbers in this creek."

Sockeye Falls: falls, $4 \mathrm{mi}$. above mouth of Lyman Creek (?), NE part of Prince of Wales I.; Alex. Arch.; BGN 1915; (map 4).

Reported in 1915 by E. L. Jones, USC\&GS. Neither the falls nor Lyman Creek are known locally or are shown on maps.

Soda Bay: bay, $2 \mathrm{mi}$. across, on Tlevak Strait, on $\mathrm{W}$ coast of Prince of Wales I., $16 \mathrm{mi}$. S of Craig, Alex. Arch.; $55^{\circ} 15^{\prime} \mathrm{N}, 133^{\circ} 02^{\prime} \mathrm{W}$; (map 4).

Named in 1906 by USC\&GS for "the carbonated springs at its head ***."

Soda Creek: stream, flows S $3 \mathrm{mi}$. to Soda Bay, on $W$ coast of Prince of Wales I., $16 \mathrm{mi}$. SE of Craig, Alex. Arch.; $55^{\circ} 17^{\prime} \mathrm{N}, 132^{\circ} 55^{\prime} \mathrm{W}$; (map 4).

Descriptive name given in 1916 by $R$. B. Dole and A. A. Chambers (in Waring, 1917, fig. 15), USGS; "because of carbonated springs located along its banks."

Soda Creek: stream, in Mentasta Mts., flows SW through glacial lake $4.5 \mathrm{mi}$. to Platinum Creek, $6.5 \mathrm{mi}$. N of Devils Mtn., Alaska Ra.; 62 ${ }^{\circ} 31^{\prime}$ N, $142^{\circ} 57^{\prime} \mathrm{W}$; BGN 1939; (map 84).

Local name reported by USGS in 1939.

Soda Creek: stream, flows SE $28 \mathrm{mi}$. to North Fork Kuskokwim River, 25 mi. NE of Medfra, Kilbuck-Kuskokwim Mts. ; $63^{\circ} 15^{\prime} \mathrm{N}, 154^{\circ} 01^{\prime}$ W; (map 89).

Local name reported in 1955 by USGS.

Soda Creek: stream, flows NE $0.7 \mathrm{mi}$. to South Fork Fortymile River, $55 \mathrm{mi}$. SW of Eagle, Yukon-Tanana High.; $64^{\circ} 07^{\prime} \mathrm{N}, 141^{\circ} 46^{\prime} \mathrm{W}$; (map 102).

Prospectors' name obtained in 1898 by $\mathbf{E}$. C. Barnard, USGS. Named for the soda springs at the mouth of the stream.

Soda Creek: stream, flows E $1 \mathrm{mi}$. to Dese Greek which flows to Grantley Harbor, $6 \mathrm{mi}$. $\mathrm{SE}$ of Teller, Seward Penin. High.; 65 $12^{\prime}$ $\mathrm{N}, 166^{\circ} 13^{\prime} \mathrm{W}$; (map 111).

Prospectors' name reported on the 1908 "Map of Seward Peninsula" by Arthur Gibson.

Sodomniia Islands: islands, see Noisy Islands.

Sodomnyya, Ostrova: islands, see Noisy Islands.

Sofia Gulch: ravine, trends W $0.5 \mathrm{mi}$. to Rock Greek which flows to Snake River, $7 \mathrm{mi}$. N of Nome, Seward Penin. High.; 64 $4^{\circ} 36^{\prime} 50^{\prime \prime} \mathrm{N}$, $165^{\circ} 25^{\prime} 20^{\prime \prime}$ W ; (map 94). Var. Sophia Gulch.

Prospectors' name reported in 1904 by $\mathbf{T}$. G. Gerdine, USGS.

Softuk Bar: spit, $3 \mathrm{mi}$. long, at SE tip of Copper River Delta, $4 \mathrm{mi}$. W of Katalla, Malaspina Coastal Plain; $60^{\circ} 13^{\prime} \mathrm{N}, 144^{\circ} 40^{\prime} \mathrm{W}$; (map 64).

This is probably an Eskimo name, reported in 1903 by G. C. Martin (1905, pl. 3), USGS, and by J. F. Pratt, USC\&GS, the same year.

Softuk Lagoon: lagoon, extends SE $3 \mathrm{mi}$., at SE tip of Copper River Delta, N of Softuk Bar, $6 \mathrm{mi}$. NW of Katalla, Malaspina Coastal Plain; $60^{\circ} 13^{\prime} \mathrm{N}, 144^{\circ} 40^{\prime} \mathrm{W}$; (map 64). 
Name published by USGS in 1950; derived from Softuck Bar.

Sohy Bay: lake, see Nanvaranak Lake.

Sohy Bay Slough: stream, see Nungatak River.

Soinai Lake: lake, see Shakes Lake.

Sokoloff Island: island, see Sokolof Island.

Sokolof Island: island, $2 \mathrm{mi}$. long, in Sumner

Strait, $8 \mathrm{mi}$. W of Wrangell, Alex. Arch.;

$56^{\circ} 30^{\prime} \mathrm{N}, 132^{\circ} 35^{\prime} \mathrm{W}$; (map 6). Var. Soko-

loff Island, Sokolov Island.

Named in the middle of the 1800's by the Russians; probably for Alexander Sokolof who wrote extensively about Alaska.

Sokolov Island: island, sec Sokolof Island.

Sola, La: rock, see Sola Rock.

Solano, Puerto de: bay, see Izhut Bay.

Sola Rock: rock, in Port Real Marina, between Bake and Lulu Is., Alex. Arch.; 55 $25^{\prime} 35^{\prime \prime} \mathrm{N}$, $133^{\circ} 28^{\prime} 45^{\prime \prime}$ W; (map 4). Var. La Sola.

Spanish name given in 1775-79 by Don

Juan de la Bodega y Quadra and Francisco Antonio Maurelle as "La Sola," meaning "The Single [one]."

Solars Sawmill: locality, on Kenai Penin., at SW tip of Grant Lake, $24 \mathrm{mi}$. NE of Seward, Chugach Mts.; $60^{\circ} 27^{\prime} 45^{\prime \prime} \mathrm{N}, 149^{\circ} 20^{\prime} 00^{\prime \prime} \mathrm{W}$; (map 63).

Local name of a former sawmill.

Solatna: stream, see Sulatna River.

Soldatna: village, see Soldotna.

Soldatna Creek: stream, see Soldotna Creek.

Soldier Bay: bight, see Sredni Bight.

Soldier Creek: stream, heads in Caves Lake, flows SE $0.3 \mathrm{mi}$. to Knik Arm, $1.5 \mathrm{mi}$. SW of Knik and $16 \mathrm{mi}$. NE of Anchorage, Cook Inlet Low.; $61^{\circ} 26^{\prime} 30^{\prime \prime} \mathrm{N}, 149^{\circ} 45^{\prime} 25^{\prime \prime} \mathrm{W}$; (map $69)$.

Local name reported in 1952 by USGS.

Soldier Slough: stream, a 2 mi. section of main channel of Tanana River, S of Sawmill I., 10 mi. N of Nenana, Tanana Low.; $64^{\circ} 42^{\prime} 40^{\prime \prime} \mathrm{N}$, 14908'30" W; (map 100).

Local name probably derived from the existence of soldiers at the U.S. Army Signal Corps telegraph station at North Nenana. Name reported in 1950 by USGS.

Soldotna: village, pop. 32, along Sterling Highway $\mathbf{N}$ of Kenai River, $8 \mathrm{mi}$. SE of Kenai, Cook Inlet Low.; $60^{\circ} 29^{\prime} \mathrm{N}, 151^{\circ} 03^{\prime} \mathrm{W} ; B G N$ 1966; (map 62). Var. Kenai Junction, Soldatna.

Village, named for the stream, reported to have been established in the late 1930's or early 1940's at the Sterling-Kenai Road junction. A post office was established here in 1949 (Ricks, 1965, p. 60).

Soldotna Creek: stream, flows SW $7 \mathrm{mi}$. to Kenai River at Soldotna, $8 \mathrm{mi}$. SE of Kenai, Cook Inlet Low.; $60^{\circ} 29^{\prime} \mathrm{N}, 151^{\circ} 03^{\prime} \mathrm{W}$; BCN 1966; (map 62). Var. Soldatna Creek, Suldahtnah, Tscldatna, Tycldatnu.

Name shown as "Suldahtnah" on a 1918 manuscript shect probably by B. I. Johnson, USGS. The name is considered by many to be derived from the Russian word meaning "soldier," i.e. "soldat," with a name ending determined by its use. Others consider it of Indian origin meaning "stream fork" or from
"Tseldatna," meaning "a kind of herb." The second vowel in the present name is pronounced the same as the final vowel, i.e. the same as "a" in "father."

Soleni: island, see Salt Island.

Solenoi : island, see Salt Island.

Soleny: island, see Salt Island.

Solianka: point of land, see Solyanka Point.

Solivik Island: barrier island, extends SW $16 \mathrm{mi}$. from Icy Cape between Chukchi Sea and Kasegaluk Lagoon, Arctic Plain; $70^{\circ} 11^{\prime} \mathrm{N}$, $162^{\circ} 20^{\prime} \mathrm{W}$; (map 146).

Eskimo name reported in 1956 to mean "sewing place" by T. E. Taylor, USGS.

Solmon City: locality, see Solomon.

Solo Creek: stream, flows SE $10.5 \mathrm{mi}$. to White River, $46 \mathrm{mi}$. NE of McCarthy, Alaska Ra.; $61^{\circ} 45^{\prime} \mathrm{N}, 141^{\circ} 40^{\prime} \mathrm{W}$; (map 67).

Local name reported in 1907 by $\mathbf{S}$. R. Capps, USGS.

Solo Creek: stream, flows SE $5 \mathrm{mi}$. to Fish Creek, $16 \mathrm{mi}$. NE of Fairbanks, Yukon-Tanana High.; $65^{\circ} 00^{\prime} 35^{\prime \prime} \mathrm{N}, 147^{\circ} 11^{\prime} 55^{\prime \prime} \mathrm{W}$; (map 105).

Named by prospectors; reported in 1903 by T. G. Gerdine (Prindle, 1905, pl. 13), USGS.

Solo Flats: valley, extends $7 \mathrm{mi}$. NE from Solo Mtn. to North Fork White River, $46 \mathrm{mi}$. NE of McCarthy, Wrangell Mts.; $61^{\circ} 51^{\prime} \mathrm{N}, 141^{\circ}$ $45^{\prime \prime} \mathrm{W}$; (map 67).

Name taken from the name of the creek and adjoining mountain, reported by USGS in 1959.

Solo Lake: lake, $1.2 \mathrm{mi}$. across, between North Fork White River and Solo Creek, $49 \mathrm{mi}$. NE of McCarthy, Alaska Ra.; $61^{\circ} 47^{\prime} 30^{\prime \prime}$ N, $141^{\circ}$ $39^{\prime} 00^{\prime \prime} \mathrm{W}$.

Name shown on 1908 field sheet by S. R. Capps, USGS.

Soloma Flat: tidal flat, at Soloma Point, near head of Lisianski Inlet, on W Chichagof I., Alex. Arch.; 57 $51^{\prime} 40^{\prime \prime} \mathrm{N}, 1^{\circ} 36^{\circ} 03^{\prime} 30^{\prime \prime} \mathrm{W}$; BGN 1928; (map 9).

Russian word meaning "straw" given in 1928 by USC\&GS; derived from triangulation station Straw located here.

Soloma Point: point of land, near head of Lisianski Inlet, $13 \mathrm{mi}$. N of Chichagof, in NW part of Chichagof I., Alex. Arch.; 57 $51^{\prime} 30^{\prime \prime} \mathrm{N}$, $136^{\circ} 03^{\prime} 30^{\prime \prime} \mathrm{W}$; BGN 1928; (map 9).

Russian word meaning "straw" given in 1928 by USC\&GS; derived from triangulation station Straw located here.

Solomon: locality, village, pop. 12 (1958), on W bank of Solomon River, 1 mi. N of Norton Sound and $30 \mathrm{mi}$. E of Nome, Seward Penin. High.; 64ㅇ․ $\mathrm{N}, 164^{\circ} 26^{\prime} \mathrm{W}$; (map 95). Var. Erok, Solmon City.

Established as a mining camp in the summer of 1900 at the height of the Nome gold rush (Brooks, 1901, p. 66). The name "Erok" was shown here on the 1900 "Map of Nome Peninsula" by J. M. Davidson and B. D. Blakeslee. A post office was established here in 1900 , discontinued in 1925 , reestablished in 1928, and finally discontinued in 1956 (Ricks, 1965, p. 60). In 1965 Balcom (p. 30) noted: "there was one Alaska Native Service school here. There are still a few white families mining in the area but most of the Eskimos have moved to more prosperous towns to find employment."

Solomon Creek: stream, flows N $4.5 \mathrm{mi}$. to Kisaralik River, $64 \mathrm{mi}$. SE of Bethel, KilbuckKuskokwim Mts.; $60^{\circ} 26^{\prime} \mathrm{N}, 160^{\circ} 03^{\prime} \mathrm{W}$; (map 59).

Local name reported in 1949 by USGS. Solomon Creek: stream, flows W $2.5 \mathrm{mi}$. to Poorman Creek, $3.4 \mathrm{mi}$. SW of Poorman and 46 mi. SW of Ruby, Kilbuck-Kuskokwim Mts.; $64^{\circ} 04^{\prime} 36^{\prime \prime} \mathrm{N}, 155^{\circ} 39^{\prime} 00^{\prime \prime} \mathrm{W}$; (map 98).

Prospectors' name reported in 1921 by USGS.

Solomon Creck: stream, see Salmon Creek.

Solomon Gulch: ravine, extends N-S $3 \mathrm{mi} ., 1 \mathrm{mi}$. $\mathrm{N}$ of Solomon Lake and $4.5 \mathrm{mi}$. S of Valdez, Chugach Mts.; $61^{\circ} 02^{\prime} 30^{\prime \prime} \mathrm{N}, 146^{\circ} 17^{\prime} 00^{\prime \prime} \mathrm{W}$; (map 68).

Name reported in 1900 by F. C. Schrader. and T. G. Gerdine, USGS.

Solomon Gulch: stream, see Little Whiteman Creek.

Solomon Lake: lake, $1 \mathrm{mi}$. long, $3.4 \mathrm{mi}$. SW of Valdez, Chugach Mts.; $61^{\circ} 04^{\prime} 25^{\prime \prime} \mathrm{N}, 146^{\circ}$ $18^{\prime} 10^{\prime \prime} \mathrm{W}$; (map 68).

Local name published in the 1950's by USGS.

Solomon Lake: lake, $1 \mathrm{mi}$. long, $1 \mathrm{mi}$. N of Old John Lake, $11 \mathrm{mi}$. SE of Arctic Village, Brooks Ra.; $68^{\circ} 07^{\prime} 00^{\prime \prime} \mathrm{N}, 145^{\circ} 05^{\prime} 30^{\prime \prime} \mathrm{W}$; (map 136).

Local name reported in 1956 by $\mathrm{R}$. C. Foley, USGS

Solomon Railroad: ridge, in Glacier Bay $\mathrm{Na}-$ tional Monument, $4 \mathrm{mi}$. long, $1 \mathrm{mi}$. NW of Lituya Bay and $88 \mathrm{mi}$. NW of Hoonah, St. Elias Mts.; $58^{\circ} 40^{\prime} \mathrm{N}, 137^{\circ} 37^{\prime} \mathrm{W}$; (map 84).

So named in 1929 by USC\&GS because of a "fancied resemblance to a railroad embankment."

Solomon River: stream, flows WSW $22 \mathrm{mi}$. to Norton Sound, $0.8 \mathrm{mi}$. SE of Solomon, Seward Penin. High.; $64^{\circ} 33^{\prime} \mathrm{N}, 164^{\circ} 25^{\prime} \mathrm{W}$; (map 95).

Prospectors' name reported in 1899 by Schrader and Brooks (1900, map 3), USGS. Solo Mountain: mountain, 5,870 ft., on S bank of North Fork White River, $47 \mathrm{mi}$. NE of McCarthy, Alaska Ra.; 61 $51^{\prime} \mathrm{N}, 141^{\circ} 49^{\prime} \mathrm{W}$; (map 67).

Name shown on 1908 field sheet by S. R. Capps, USGS.

Solsmunket Lake: lake, $3 \mathrm{mi}$. long, $65 \mathrm{mi}$. SE of Shungnak, Koyukuk Low.; $66^{\circ} 03^{\prime}$ N, $156^{\circ} 07^{\prime}$ W; (map 115)

Koyukan Indian name reported by USGS in 1952 .

Sol Thumb: ridge, $1.5 \mathrm{mi}$. long, $3 \mathrm{mi}$. SW of junc. of Dead Branch Norris Glacier with Norris Glacier and $9 \mathrm{mi}$. NE of Juneau, Coast Mts.; $58^{\circ} 23^{\prime} 30^{\prime \prime} \mathrm{N}, 134^{\circ} 15^{\prime} 30^{\prime \prime} \mathrm{W}$; (map 11).

Name published in 1962 by USGS.

Soluka Creek: stream, heads at glacier terminus, on Alaska Penin., in Katmai National Monu- 
ment, flows SW 20 mi. to Katmai Bay; $58^{\circ} 01^{\prime}$ $\mathrm{N}, 154^{\circ} 53^{\prime} \mathrm{W}$; (map 42).

Native name obtained from Rev. A. Petelin and reported in 1898 by J. E. Spurr and W. S. Post, USGS.

Solyanka Point: point of land, 2 mi. SE of Sakie Point, on $\mathrm{W}$ coast of Dall I., Alex. Arch.; $55^{\circ} 03^{\prime} 20^{\prime \prime} \mathrm{N}, 133^{\circ} 13^{\prime} 10^{\prime \prime} \mathrm{W}$; BGN 1923; (map 4). Var. Solianka.

Russian word meaning "kelp," given in 1923 by USC\&GS; triangulation station Kelp is located on this point.

Somber Creek: stream, heads at glacier terminus, in Mount McKinley National Park, flows WNW $12 \mathrm{mi}$., joins Barren Creek to form Highpower Creek, $30 \mathrm{mi}$. W of Mount McKinley, Alaska Ra.; $63^{\circ} 05^{\prime} 10^{\prime \prime}$ N, $151^{\circ}$ 57'10' W; (map 88).

Local name reported in 1925 by S. R. Capps, USGS.

Sombrero, El: island, see Sombrero Island.

Sombrero Island: island, $750 \mathrm{ft}$. across, in San Alberto Bay, 2 mi. NW of Abbess I., Alex. Arch.; 55 $34^{\prime} 05^{\prime \prime}$ N, $133^{\circ} 14^{\prime} 05^{\prime \prime}$ W; BGN 1923; (map 4). Var. El Sombrero, Sobrero, Sombrero Islet.

Spanish name given in 1779 by Bodega $y$ Quadra and Francisco Antonio Maurelle as "E1 Sombrero," meaning "the hat." This name was formally applied to its present location in 1923 by USC\&GS; previously its application was not clearly defined and in limited use.

Sombrero Islet: island, see Sombrero Island.

Sombrero Point: point of land, on $\mathrm{W}$ coast of Unga I., in Shumagin Is., Aleutian Ra.; 55 ${ }^{\circ}$ $12^{\prime} 30^{\prime \prime} \mathrm{N}, 160^{\circ} 50^{\prime} 45^{\prime \prime} \mathrm{W}$; (map 28).

Local name shown on a 1963 USC\&GS chart.

Someone Creek: stream, flows NE $1.1 \mathrm{mi}$. to Alpha Creek $0.1 \mathrm{mi}$. W of its junc. with Snake River, $8 \mathrm{mi}$. NW of Nome, Seward Penin. High, ; 64 $37^{\circ} 20^{\prime \prime} \mathrm{N}, 165^{\circ} 28^{\prime} 45^{\prime \prime} \mathrm{W}$; (map 94).

Prospectors' name reported on the 1903 Campion Mining and Trading Co. map by George M. Ashford.

Songlghak River: stream, see Soonglaghak Creek.

Sonickson Creek: stream, flows NE $7 \mathrm{mi}$. to Seventymile River, $42 \mathrm{mi}$. NW of Eagle,

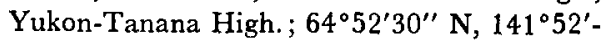
$00^{\prime \prime} \mathrm{W}$; (map 102).

Prospectors' name obtained in 1898 by $\mathrm{E}$. C. Barnard, USGS.

Sonoma Beach: beach, see Sonom Beach.

Sonom Beach: beach, $0.3 \mathrm{mi}$. long, at mouth of Aboud Creek, on $\mathrm{E}$ shore of Temnac Bay, Attu I., Aleutian Is. ; $52^{\circ} 48^{\prime} 00^{\prime \prime} \mathrm{N}, 173^{\circ} 06^{\prime} 22^{\prime \prime}$ E.; BGN 1965; (map 13). Var. Sonoma Beach.

Name shown as "Sonoma Beach" on an AMS map published in 1948 and as Sonom Beach on a USGS map published in 1953.

Sonora Creek: stream, flows SW $5 \mathrm{mi}$. to Central Creek $3.5 \mathrm{mi}$. E of that stream's junc. with Goodpaster River and $35 \mathrm{mi}$. NE of Big Delta, Yukon-Tanana High.; $64^{\circ} 22^{\prime} \mathrm{N}, 144^{\circ} 50^{\prime} \mathrm{W}$; (map 101).
Local name reported in 1958 by USGS. Sonora Creek: stream, flows S $2 \mathrm{mi}$. to Norton Sound, $15 \mathrm{mi}$. NW of Nome, Seward Penin.

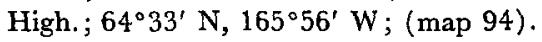

Prospectors' name reported in 1900 by E. C. Barnard (in Brooks, 1901, pl. 17), USGS.

Sonora Island: island, $1.2 \mathrm{mi}$. long, in Maurelle Is., Alex. Arch.; $55^{\circ} 36^{\prime} 30^{\prime \prime} \mathrm{N}, 133^{\circ} 38^{\prime} 30^{\prime \prime}$ W; (map 4).

Named in 1925 by USC\&GS; derived from Sonora Passage.

Sonora Passage: water passage, extends $3 \mathrm{mi}$. N from Arriaga Passage, between Saint Joseph I. and Maurelle Is., SE Iphigenia Bay, Alex. Arch.; 55 $36^{\prime} \mathrm{N}, 133^{\circ} 40^{\prime} \mathrm{W}$; (map 4). Var. Arriaga Passage.

Named in 1923 by USC\&GS "for the Spanish galiot Sonora, commanded by Don Juan de la Bodega y Quadra, who explored this vicinity in 1775."

Sonya Creek: stream, flows $5.3 \mathrm{mi}$. NW to Beaver Creek SE of Lower Mtn., $65 \mathrm{mi}$. NE of McCarthy, Alaska Ra.; $61^{\circ} 59^{\prime} \mathrm{N}, 141^{\circ} 20^{\prime}$ W; (map 67).

Local name obtained by USGS and published on maps since 1954.

Sonyakay Ridge: ridge, $6 \mathrm{mi}$. long, on $\mathrm{E}$ coast of Chichagof I., $15 \mathrm{mi}$. NE of Tenakee Springs, Alex. Arch.; $57^{\circ} 58^{\prime} \mathrm{N}, 135^{\circ} 00^{\prime} \mathrm{W}$; $B G N$ 1960; (map 9).

Local name published in 1951 by USGS.

Soo City: locality, site of prospectors' camp on $\mathrm{W}$ bank of South Fork Koyukuk River, $15 \mathrm{mi}$. SE of Bettles, Kanuti Flats ; $66^{\circ} 43^{\prime}$ N, $151^{\circ} 29^{\prime}$ W; (map 117).

Name reported in 1899 by G. H. Wonson, Master of the steamer Dorothy, on his manuscript map of the Koyukuk River. One of several temporary camps established by prospectors caught on the river during the winter of 1898-99.

Sooghmeghat: locality, $\mathrm{N}$ coast of St. Lawrence I., $22 \mathrm{mi}$. W of Northeast Cape; $63^{\circ} 21^{\prime} \mathrm{N}$, $169^{\circ} 24^{\prime} \mathrm{W}$; (map 93). Var. Alowas Camp, Nelsons Camp, Soomaghat, Tamnik Camp.

Eskimo name published by USGS in 1948.

Sooghmeghat, Mount: hill, see Soomaghat Mountain.

Sooghmeghat, Mount: hill, see Tomname Mountain.

Sooghmeghat Mountain: hill, see Tomname Mountain.

Sooloktingirack: mountain, see Suloktingirak.

Soo-loo-poa-gak-took: stream, see Sulupoagaktak Channel.

Sooloopoagaktuk Channel: stream, see Sulupoagaktak Channel.

Soomaghat: locality, sce Sooghmeghat.

Soomagat: hill, see Soomaghat Mountain.

Soomaghat Mountain: hill, $847 \mathrm{ft}$., $22 \mathrm{mi}$. W of Northeast Cape, St. Lawrence I.; $63^{\circ} 16^{\prime} \mathrm{N}$, $169^{\circ} 23^{\prime}$ W; BGN 1951; (map 93). Var. Mary Mountain, Mount Sooghmeghat, Soomagat, Soomakhat.

Eskimo name reported in 1949 by Maj. H. B. Allen, USAF.

Soomakhat: hill, see Soomaghat Mountain.
Sooner River: stream, heads at $68^{\circ} 19^{\prime} \mathrm{N}$, $163^{\circ} 20^{\prime} \mathrm{W}$, flows N $19 \mathrm{mi}$. to Kukpowruk River, $9 \mathrm{mi}$. NE of Mount Kelly, and $41 \mathrm{mi}$. SE of Cape Sabine, Arctic Slope; $68^{\circ} 33^{\prime} \mathrm{N}$, $163^{\circ} 20^{\prime}$ W; BGN 1965; (map 130). Var. Smith Creek.

Name proposed in 1965 by geologists of the B.P. Exploration Co., Inc., "a nickname for Oklahoma."

Soonglaghak Creek: stream, flows SE $1 \mathrm{mi}$. to Kiloknak Lagoon, $9 \mathrm{mi}$. SW of Northeast Cape, E coast of St. Lawrence I.; 631 $13^{\prime} 00^{\prime \prime}$ N, 168 $44^{\prime} 30^{\prime \prime} \mathrm{W}$; BGN 1951; (map 93) Var. Songlghak River, Soonglaghak River.

Eskimo name reported in 1932 by $\mathrm{O}$. W. Geist, Univ. of Alaska.

Soonglaghak River: stream, see Soonglaghak Creek.

Soonkakat: locality, on left bank of Yukon River $\mathrm{S}$ of Kokrines, $27 \mathrm{mi}$. NE of Ruby, Nowitna Low.; $64^{\circ} 55^{\prime} \mathrm{N}, 154^{\circ} 40^{\prime} \mathrm{W}$; (map 98). Var. Sūnkā'kāt.

Former Indian village reported as "Sūnkā'kāt" by Dall (1877, p. 28).

Soonkakat River: stream, flows NE $31 \mathrm{mi}$. to Yukon River, 2 mi. E of Nulato, Koyukuk Low.; 64 $43^{\prime} \mathrm{N}, 158^{\circ} 03^{\prime} \mathrm{W}$; (map 97). Var. Soonkaket, Yukokakat.

Koyukan Indian name, probably the same as "Junekaket" (Jhunkakat), published in 1898 by USC\&GS. On an 1885 map Lt. H. T. Allen, USA, recorded a stream identical with this one, which he named "Yukokakat." Soonkaket: stream, see Soonkakat River.

Sootin Rocks: rocks, off SE coast of Attu I., Aleutian Is. ; $52^{\circ} 47^{\prime} \mathrm{N}, 173^{\circ} 15^{\prime} \mathrm{E}$; (map 13).

This name is shown on a manuscript map drawn by Lucien M. Turner in the 1880's; but does not appear on modern maps.

Sophia, Point: point of land, on $\mathbf{N}$ coast of Chichagof I., at mouth of Port Frederick, 2.5 mi. NW of Hoonah, Alex. Arch.; $58^{\circ} 08^{\prime} 35^{\prime \prime} \mathrm{N}$, $135^{\circ} 24^{\prime} 30^{\prime \prime} \mathrm{W}$; (map 11).

Named in 1794 by Capt. George Vancouver, RN, for Augusta Sophia, daughter of King George III of England (Wagner, 1937, p. 417).

Sophia Gulch: ravine, see Sofia Gulch.

Sopka Chornaia: mountain, see Black Peak.

Sopka Vinisali: mountain, see Vinasale Mountain.

Sore Finger Cove: cove, on $\mathrm{W}$ coast of Glass Peninsula, $4 \mathrm{mi}$. SE of Dorn I. and $43 \mathrm{mi}$. S of Juneau, Alex. Arch.; $57^{\circ} 43^{\prime} 45^{\prime \prime}$ N, $133^{\circ}$ $55^{\prime} 00^{\prime \prime} \mathrm{W}$; (map 8).

Local name reported in 1955 by USGS.

Sorensen, Mount: mountain, see Sorenson, Mount.

Sorenson, Mount: mountain, 5,620 ft., $25 \mathrm{mi}$ SW of junc. of Kandik and Yukon Rivers, 55 mi. NW of Eagle, Yukon-Tanana High.; $64^{\circ}$ $59^{\prime} \mathrm{N}, 142^{\circ} 58^{\prime} \mathrm{W}$; (map 102). Var. Mount Sorensen.

Prospectors' name shown on a 1902 manuscript map by E. J. Chamberlain, U.S. Deputy Surveyor.

Sorepaw Creek: stream, in De Long Mts., flows N $16 \mathrm{mi}$. to Singayoak Creek, $64 \mathrm{mi}$. NE of 
Misheguk Mtn., Brooks Ra.; 6850' N, $159^{\circ}$ 09' W; BGN 1960; (map 131).

Named in 1953 by E. G. Sable, USGS, "for sore feet of camp dog."

Sorghum Hill: mountain, see Lore Hill.

Sorrels Creek: stream, flows SW $11 \mathrm{mi}$. to Little Chena River, $30 \mathrm{mi}$. NE of Fairbanks, YukonTanana High.; 65 $04^{\prime} 45^{\prime \prime}$ N, $146^{\circ} 52^{\prime} 45^{\prime \prime}$ W; (map 104).

Named by prospectors; reported in 1903 by T. G. Gerdine (in Prindle, 1905, pl. 13), USGS.

Sosiego, Punta: point of land, see Tranquil Point.

Sosiyego, Mys del: point of land, see Tranquil Point.

Sosnovoi Island: island, $0.2 \mathrm{mi}$. long, $4.7 \mathrm{mi}$. N of Goddard, on W coast of Baranof I., Alex. Arch.; 56 $54^{\prime} 10^{\prime \prime} \mathrm{N}, 135^{\circ} 21^{\prime} 50^{\prime \prime} \mathrm{W}$; (map 5). Var. Fir Island, Ostrov Sosnovoy.

Named in 1809 by the Russian navigator, Ivan Vasiliev the first; published by Lt. Sarichev (1826, map 19), IRN, as "Ostrov Sosnovoy," meaning "fir island."

Sosnovoy, Ostrov: island, see Sosnovoi Island. Soto, Isla de: island, see Sitkalidak Island. Souchikova: cove, see Sviechnikof Harbor.

Soundun: locality, see Sumdum.

Souhoi Strait: water passage, see Sukoi Inlet.

Soukhoi Strait: water passage, see Dry Strait.

Soukhoi Strait: water passage, see Hayward Strait.

Soukhoi Strait: water passage, see Sukoi Inlet. Soukoi Inlet: water passage, sce Hayward Strait. Soule Creek: stream, flows NW $10 \mathrm{mi}$. to Jack River, $28 \mathrm{mi}$. S of Healy, Talkeetra Mts.; $63^{\circ} 09^{\prime} 20^{\prime \prime} \mathrm{N}, 148^{\circ} 41^{\prime} 45^{\prime \prime} \mathrm{W}$; (map 87).

Local name obtained in 1913 by J. W. Bagley, USGS; published by Moffit (1915, pl. 1).

Soule Glacier: glacier, heads at Through Glacier, trends SE $11 \mathrm{mi}$. to its 1955 terminus at head of Soule River, $4.5 \mathrm{mi}$. W of Glacier Point on Portland Canal, Coast Mts.; 55 $50^{\prime} 25^{\prime \prime} \mathrm{N}$, $130^{\circ} 13^{\prime} 30^{\prime \prime} \mathrm{W}$; (map 3).

Named in 1897 by USC\&GS for Pierre Soule, 1801-70, American political leader and diplomat.

Soule River: stream, heads at Soule Glacier, flows SE $4.5 \mathrm{mi}$. to Portland Canal, $1 \mathrm{mi}$. W of Glacier Point, Coast Mts.; 55 $48^{\prime} 45^{\prime \prime} \mathrm{N}$, $130^{\circ} 08^{\prime} 30^{\prime \prime} \mathrm{W}$; (map 3 ).

Local name recorded in 1955 by USGS.

Soulima, Riviere: stream, see Ugashik River.

Sound Islands: islands, $0.3 \mathrm{mi}$. long, between Nakwasina Passage and Krestof Sound, $14 \mathrm{mi}$. NW of Sitka, Alex. Arch.; $57^{\circ} 13^{\prime} 30^{\prime \prime} \mathrm{N}, 135^{\circ}$ $33^{\prime} 00^{\prime \prime}$ W; (map 9). Var. Pribieli Islets, Pribilie Islands.

Named in 1897 by Lt. Comdr. E. K. Moore, USN; published by USC\&GS in 1900 Coast Pilot (p. 193). Ens. Vasiliev called the largest island of the group "Pribilie," meaning "profitable," in 1833. W. H. Dall, USG\&GS, reported the name of the group as "Pribieli" and the island name as "Pribilie" in 1883 Coast Pilot (p. 155).

Soundon Glacier: glacier, see Sumdum Glacier. Soundon Island: island, see Sumdum Island.
Soup Lake: lake, $0.5 \mathrm{mi}$. long, $\mathrm{N}$ of Glenn Highway, $19 \mathrm{mi}$. W of Glennallen, Copper River Basin; 62 ${ }^{\circ} 06^{\prime} \mathrm{N}, 146^{\circ} 07^{\prime} \mathrm{W}$; (map 83).

Local name reported in 1949 by USGS

Sourdough: locality, site of camp on $\mathrm{S}$ bank of Nizina River, at mouth of Young Creek, $8 \mathrm{mi}$. SE of McCarthy, Wrangell Mts.; $61^{\circ} 22^{\prime} 00^{\prime \prime}$ N, 142 $53^{\prime} 45^{\prime \prime}$ W; (map 67).

Name used by prospectors; reported in 1908 by D. C. Witherspoon (Moffit and Capps, 1911, pl. 2), USGS.

Sourdough: locality, on Richardson Highway, $29 \mathrm{mi}$. N of Glennallen, Copper River Basin; $62^{\circ} 32^{\prime} \mathrm{N}, 145^{\circ} 31^{\prime} \mathrm{W}$; (map 83).

Local name reported by USGS (in Moffit, 1911, fig. 14).

Sourdough Camp: locality, W of Sourdough Creek, $11 \mathrm{mi}$. S of Mount Prindle and $79 \mathrm{mi}$. SW of Circle, Yukon-Tanana High.; $65^{\circ} 17^{\prime}$ $30^{\prime \prime} \mathrm{N}, 146^{\circ} 29^{\prime} 00^{\prime \prime} \mathrm{W}$; (map 104).

Name of a road camp, along the Steese Highway, published in 1954 by USGS.

Sourdough Creek: stream, heads in lakes, flows SW $16 \mathrm{mi}$. to Gulkana River at Sourdough, 29 mi. N of Glennallen, Copper River Basin; $62^{\circ} 31^{\prime} \mathrm{N}, 145^{\circ} 31^{\prime} \mathrm{W}$; (map 83).

Local name reported by USGS in 1950; probably named for the locality at stream's mouth.

Sourdough Creek: stream, flows SW $2 \mathrm{mi}$. to Skookum River which flows to Klokerblok River, $18 \mathrm{mi}$. NE of Solomon, Seward Penin. High.; $64^{\circ} 41^{\prime} \mathrm{N}, 163^{\circ} 55^{\prime} \mathrm{W}$; (map 95).

Prospectors' name reported in 1900 by $\mathrm{E}$. C. Barnard (in Brooks, 1901, pl. 17), USGS. Sourdough Creek: stream, flows SE $10 \mathrm{mi}$. to a lagoon on Bering Sea, $5 \mathrm{mi}$. SE of Cape Douglas and $45 \mathrm{mi}$. NW of Nome, Seward Penin. High.; $64^{\circ} 57^{\prime} \mathrm{N}, 166^{\circ} 33^{\prime} \mathrm{W}$; (map 94).

Prospectors' name reported on a 1901 map of Cape Nome gold fields by David Fox, Jr.

Sourdough Creek: stream, flows S $7 \mathrm{mi}$. to Chatanika River, $79 \mathrm{mi}$. SW of Circle, Yukon-Tanana High.; $65^{\circ} 17^{\prime} \mathrm{N}, 146^{\circ} 29^{\prime} \mathrm{W}$; (map 104).

Named by prospectors; reported in 1903 by T. G. Gerdine (in Prindle, 1905, pl. 13), USGS.

Sourdough Gulch: ravine, trends W $0.5 \mathrm{mi}$. to Cache Creek, $\mathrm{S}$ of Cheechako Gulch, $31 \mathrm{mi}$. NW of Talkeetna, Alaska Ra.; $62^{\circ} 27^{\prime} 55^{\prime \prime} \mathrm{N}$, $151^{\circ} 01^{\prime} 25^{\prime \prime} \mathrm{W}$; (map 81).

Prospectors' name reported in the 1930's by USGS.

Sourdough Hill: ridge, elev. 2,000 to 5,700 ft., extends SW $5 \mathrm{mi}$. from Sourdough Peak, $4 \mathrm{mi}$. SE of McCarthy, Wrangell Mts.; $61^{\circ} 24^{\prime} \mathrm{N}$, $142^{\circ} 46^{\prime} \mathrm{W}$; ( $\operatorname{map} 67$ ).

Name used by prospectors; reported in 1908 by D. C. Witherspoon (Moffit and Capps, 1911, pl. 2), USGS.

Sourdough Peak: mountain, 6,201 ft., on N bank of Nizina River, $6 \mathrm{mi}$. SE of McCarthy, Wrangell Mts.; $61^{\circ} 25^{\prime} \mathrm{N}, 142^{\circ} 45^{\prime} \mathrm{W}$; (map 67).

Name used by prospectors; reported in 1908 by $\mathrm{D}$. C. Witherspoon, USGS.
Sourdough Peak: mountain, see Logan, Mount. South, Cape: point of land, see Trinity, Cape. South Aluk Hill: mountain, 1,092 ft., between Oligavik and Sakvelak Creeks, $25 \mathrm{mi}$. SE of Cape Lisburne, Arctic Slope; $68^{\circ} 44^{\prime} \mathrm{N}, 165^{\circ}$ $17^{\prime} \mathrm{W}$; (map 129). Var. Allook.

Eskimo name meaning "sole of foot [aloq]" or "coal [aloaq]"; spelled "Allook" by D. C. Foote, of Project Chariot, in 1960.

South Amaknak Rocks: rocks, off $\mathbf{S}$ tip of Amaknak I., in Unalaska Bay, Unalaska I., Aleutian Is.; $53^{\circ} 51^{\prime} 57^{\prime \prime} \mathrm{N}, 166^{\circ} 33^{\prime} 23^{\prime \prime} \mathrm{W}$; (map 23).

Named in 1873 by W. H. Dall, USC\&GS.

South American Island: island, $0.8 \mathrm{mi}$. across, near head of Mitchell Bay in W central Admiralty I., $8 \mathrm{mi}$. NE of Angoon, Alex. Arch.; $57^{\circ} 33^{\prime} 20^{\prime \prime} \mathrm{N}, 134^{\circ} 23^{\prime} 00^{\prime \prime} \mathrm{W}$; (map 9).

Local name reported in 1951 by USGS.

South Anchorage: bay, $2 \mathrm{mi}$. across on $\mathrm{S}$ coast of Yunaska I., Aleutian Is.; $52^{\circ} 35^{\prime} 50^{\prime \prime} \mathrm{N}$, $170^{\circ} 41^{\prime} 00^{\prime \prime} \mathrm{W}$; (map 20 ).

Descriptive name published by USC\&GS in the 1944 Aleutian Coast Pilot (p. 79).

South Arm: bay, $3 \mathrm{mi}$. across, NE extension of Farragut Bay, $\mathbf{N}$ of Read I., 83 mi. E of Sitka, Coast Mts. ; $57^{\circ} 08^{\prime} \mathrm{N}, 133^{\circ} 11^{\prime} \mathrm{W}$; (map 8). Local name reported in 1951 by USGS.

South Arm Bay of Isles: estuary, on E coast of Knight I., trends N $1.7 \mathrm{mi}$. to head of Bay of Isles, $15 \mathrm{mi}$. NE of Chenega, Chugach Mts.; $60^{\circ} 22^{\prime} 45^{\prime \prime} \mathrm{N}, 147^{\circ} 42^{\prime} 00^{\prime \prime} \mathrm{W}$; (map 63).

Name published in 1943 by USC\&GS.

South Arm Bay of Pillars: bay, see Pillars, Bay of.

South Arm Cabin Cove: cove, see Lower Arm Cabin Cove.

South Arm Cholmondeley Sound: estuary, extends SW $8.5 \mathrm{mi}$., at head of Cholmondeley Sound, on SE coast of Prince of Wales I, Alex. Arch.; $55^{\circ} 14^{\prime} 45^{\prime \prime} \mathrm{N}, 132^{\circ} 16^{\prime} 45^{\prime \prime} \mathrm{W}$; $B G N$ 1961; (map 4).

Local name reported in 1901 by A. H. Brooks, USGS.

South Arm Hood Bay: estuary, on S central Admiralty I., extends NW $4 \mathrm{mi}$. to Hood Bay, $11 \mathrm{mi}$. SE of Angoon, Alex. Arch.; 57 $22^{\prime} \mathrm{N}$, $134^{\circ} 24^{\prime} \mathrm{W}$; (map 9).

Name published in 1910 by USC\&GS on Chart 8247.

South Arm Hoonah Sound: water passage, extends SE $8 \mathrm{mi}$. to Hoonah Sound on S central Chichagof I., $18 \mathrm{mi}$. E of Chichagof, Alex. Arch.; $57^{\circ} 38^{\prime} \mathrm{N}, 135^{\circ} 38^{\prime} \mathrm{W}$; (map 9).

Named by USC\&GS; published in 1899 on Chart 8050.

South Arm Kelp Bay: estuary, extends NE 4.5 mi. to Kelp Bay, on E coast of Baranof I., $20 \mathrm{mi}$. SW of Angoon, Alex. Arch.; $57^{\circ} 18^{\prime} 30^{\prime \prime}$ N, $134^{\circ} 58^{\prime} 30^{\prime \prime} \mathrm{W}$; (map 9).

Named in 1895 by Lt. Comdr. E. K. Moore, USN; published in 1899 by USC\&GS.

South Arm Kendrick Bay: estuary, extends S $2.8 \mathrm{mi}$. off Kendrick Bay, on SE coast of Prince of Wales I., Alex. Arch.; 54 ${ }^{\circ} 2^{\prime} 20^{\prime \prime}$ N, 132 $01^{\prime} 55^{\prime \prime} \mathrm{W}$; (map 1).

Local name reported by H. C. Fassett, USBF, in 1904. 
South Arm Moira Sound: estuary, extends S 6 mi., off Moira Sound, on SE coast of Prince of Wales I., Alex. Arch.; 54 ${ }^{\circ} 59^{\prime} 45^{\prime \prime} \mathrm{N}, 132^{\circ}$ $08^{\prime} 45^{\prime \prime} \mathrm{W}$; (map 1).

Descriptive local name; recorded by $H$. C. Fassett, USBF, in 1904.

South Arm Three Arm Bay: bay, $0.5 \mathrm{mi}$. across, part of Three Arm Bay, on W coast of Adak I., Aleutian Is. ; $51^{\circ} 44^{\prime} 15^{\prime \prime} \mathrm{N}, 176^{\circ} 50^{\prime} 40^{\prime \prime} \mathrm{W}$; BGN 1936; (map 17).

Descriptive name given by Lt. William Gibson, USN, commander of the schooner Fenimore Cooper, during the North Pacific Exploring Expedition in 1855.

South Arm Uganik Bay: estuary, extends S 7 mi. from Mink Point, at head of Uganik Bay, on $\mathrm{N}$ coast of Kodiak I. ; $57^{\circ} 43^{\prime} 00^{\prime \prime} \mathrm{N}, 153^{\circ}$ $31^{\prime} 30^{\prime \prime} \mathrm{W}$; (map 34).

Descriptive name derived from Uganik Bay and named in 1887 by Lt. Comdr. J. F. Moser, USN, of the USBF steamer Albatross.

South Bay: bay, $2 \mathrm{mi}$. across, on $\mathrm{S}$ coast of Tanaga I., Aleutian Is.; $51^{\circ} 38^{\prime} 15^{\prime \prime} \mathrm{N}, 177^{\circ}$ 58'30' W; (map 17).

Name published by USC\&GS in the 1947 Coast Pilot (pt. 2, p. 472).

South Bay: bay, 2 mi. across, on $\mathbf{S}$ side of Perry I., between Lone Passage and Perry Passage, $28 \mathrm{mi}$. NE of Chenega, Chugach Mts.; 60$39^{\prime} 45^{\prime \prime} \mathrm{N}, 147^{\circ} 43^{\prime} 45^{\prime \prime} \mathrm{W}$; (map 63).

Local name reported in 1952 by USGS.

South Bay: bay, see Farallon Bay.

South Beaver Greek: stream, on Kenai Penin, flows NW $3.5 \mathrm{mi}$. to Anchor River, $6 \mathrm{mi}$. NNW of Homer, Cook Inlet Low.; 59 $43^{\prime} 50^{\prime \prime}$ $\mathrm{N}, 151^{\circ} 35^{\prime} 30^{\prime \prime} \mathrm{W}$; (map 50).

Local name reported and published by USGS in the 1950's.

South Bight: bay, $0.7 \mathrm{mi}$. across, faces SW to the Pacific Ocean, $4 \mathrm{mi}$. W of East Cape, Amchitka I., Aleutian Is.; $51^{\circ} 22^{\prime} 45^{\prime \prime} \mathrm{N}$, $179^{\circ} 22^{\prime} 00^{\prime \prime}$ E; (map 15). Var. Southwest Bight.

Listed in the 1946 Supplement (p. 120) to the Aleutian Coast Pilot as "South Bight" instead of the variant name as given in the 1944 Aleutian Coast Pilot.

South Bight: bay, $2 \mathrm{mi}$. long, on $\mathrm{W}$ shore of Port Frederick, on Chichagof I., $10 \mathrm{mi}$. SW of Hoonah, Alex. Arch.; 58 $01^{\prime} 30^{\prime \prime} \mathrm{N}, 135^{\circ}$ $39^{\prime} 00^{\prime \prime} \mathrm{W}$; (map 11).

Local descriptive name published in 1942 by USGS.

South Billy Goat Mountain: mountain, 3,265 ft., $2 \mathrm{mi}$. W of Gilbert Inlet, $97 \mathrm{mi}$. NW of Hoonah, St. Elias Mts.; $58^{\circ} 40^{\prime} 50^{\prime \prime} \mathrm{N}, 137^{\circ}$ $33^{\prime} 00^{\prime \prime} \mathrm{W}$; (map 10).

Name published by members of the Harvard-Dartmouth Expedition, 1933-34 (Washburn and Goldthwait, 1936, map).

South Bjerremark: village, see Broadmoor.

South Branch Big Saint Michael Canal: water course, see Saint Michael Canal.

South Branch South Fork Chester Creek: stream, heads in Chugach Mts., flows NW, then SW $9.5 \mathrm{mi}$. to join the Middle Branch to form South Fork Chester Creek in Anchorage, Cook
Inlet Low.; $61^{\circ} 11^{\prime} 23^{\prime \prime} \mathrm{N}, 149^{\circ} 47^{\prime} 05^{\prime \prime} \mathrm{W}$; (map 69).

Local name reported in 1962 by USGS.

South Branch Trimble Glacier: glacier, in Tordrillo Mts., heads on Mount Gerdine, trends NE 15 mi., joins North Branch Trimble Glacier to form Trimble Glacier, $55 \mathrm{mi}$. NW of Tyonek, Alaska Ra.; $61^{\circ} 42^{\prime} 30^{\prime \prime} \mathrm{N}, 152^{\circ} 06^{\prime} 30^{\prime \prime}$ W; BGN 1963; (map 70). Var. Hayes Glacier.

Named in 1961 by USGS. See Trimble Glacier.

South Burnett Island: island, $0.3 \mathrm{mi}$. long, at mouth of Burnett Inlet, on SW coast of Etolin I., Alex. Arch.; $56^{\circ} 04^{\prime} 00^{\prime \prime}$ N, $132^{\circ} 27^{\prime} 30^{\prime \prime} \mathrm{W}$; $B G N 1917$; (map 6).

Named by USC\&GS for charting purposes; name published in 1916 .

South Buttress: mountain, 8,100 ft., near headwaters of North Fork Swift River, $12 \mathrm{mi}$. NW of Stony Glacier and $102 \mathrm{mi}$. SE of McGrath, Alaska Ra.; 61 $38^{\circ} 45^{\prime \prime} \mathrm{N}, 154^{\circ} 11^{\prime} 20^{\prime \prime} \mathrm{W}$; (map 71).

Local name reported in 1958 by USGS.

South Buttress: ridge, 14,000 ft., on Mount McKinley, extends NE $5 \mathrm{mi}$. from East Fork Kahiltna Glacier to Thayer Basin, Alaska Ra.; $63^{\circ} 01^{\prime} \mathrm{N}, 151^{\circ} 00^{\prime} \mathrm{W}$; (map 88).

Mountain climbers' name published in 1954 by USGS.

South Cape: point of land, on $\mathrm{S}$ coast of Chirikof I., $100 \mathrm{mi}$. SW of Kodiak I.; $55^{\circ} 45^{\prime}$ $30^{\prime \prime} \mathrm{N}, 155^{\circ} 36^{\prime} 00^{\prime \prime} \mathrm{W}$; (map 32).

Descriptive name reported in 1874 by $W$. H. Dall, USC\&GS.

South Cape: point of land, see Fawn Point.

South Cape: point of land, see Yug Point.

South Channel: water passage, between Captains Bay and Iliuliuk Harbor in Unalaska Bay, on NE coast of Unalaska I., Aleutian Is.; $53^{\circ}$ $52^{\prime} 25^{\prime \prime} \mathrm{N}, 166^{\circ} 32^{\prime} 40^{\prime \prime} \mathrm{W}$; (map 23).

Name published by USC\&GS in 1965 on Chart 9008.

South Channel Yakataga River: stream, heads at Yakataga Glacier, flows $W$ and SW $10 \mathrm{mi}$. to Gulf of Alaska, $2 \mathrm{mi}$. NW of Cape Yakataga and $103 \mathrm{mi}$. NW of Yakutat, St. Elias Mts.; $60^{\circ} 04^{\prime} 45^{\prime \prime} \mathrm{N}, 142^{\circ} 29^{\prime} 10^{\prime \prime} \mathrm{W}$; (map 65). Var. Yakataga River.

Local name published in 1951 by USGS.

South Chinitna Mountain: mountain, 3,040 ft., in Tilted Hills, on NE coast of Iniskin Penin., Aleutian Ra.; $59^{\circ} 45^{\prime} 50^{\prime \prime} \mathrm{N}, 153^{\circ} 03^{\prime} 00^{\prime \prime} \mathrm{W}$; (map 51).

Local name derived from Chinitna Mountain; published by Moffit (1927, pl. 1), USGS.

South Cove: bay, $1.5 \mathrm{mi}$. across, on south-central Chuginadak I., Aleutian Is.; $52^{\circ} 49^{\prime} 30^{\prime \prime} \mathrm{N}$, $169^{\circ} 51^{\prime} 00^{\prime \prime} \mathrm{W}$; (map 21$)$.

Descriptive name published by USC\&GS in the 1944 Aleutian Coast Pilot (p. 76).

South Craig Island: point of land, see South Craig Point.

South Craig Point: point of land, on NE coast of Zarembo I., Alex. Arch.; $56^{\circ} 23^{\prime} 20^{\prime \prime} \mathrm{N}$, $132^{\circ} 37^{\prime} 30^{\prime \prime} \mathrm{W}$; (map 6). Var. South Craig Island.
Named by USC\&GS for charting purposes; name published in the 1883 Coast Pilot (p. $94)$ as "South Craig Island."

South Creek: stream, flows NE $2.5 \mathrm{mi}$. through South Lake, to Crooked Creek, $65 \mathrm{mi}$. NE of Palmer, Talkeetna Mts.; $61^{\circ} 59^{\prime} 20^{\prime \prime} \mathrm{N}$, $147^{\circ} 17^{\prime} 45^{\prime \prime} \mathrm{W}$; (map 69).

Local name reported in 1951 by USGS.

South Crillon Glacier: glacier, in Glacier Bay National Monument, heads in Fairweather Ra., trends WSW $8 \mathrm{mi}$. to Crillon Lake, 79 mi. WNW of Hoonah, St. Elias Mts.; $58^{\circ} 35^{\prime}$. $50^{\prime \prime}$ N, $137^{\circ} 23^{\prime} 15^{\prime \prime} \mathrm{W}$; BGN 1945; (map 10). Var. Eastern Glacier.

Name published by members of the Harvard-Dartmouth Expedition, 1933-34 (Washburn and Goldthwait, 1936, map).

South Currant Creek: stream, flows W $14 \mathrm{mi}$. to Currant Creek, $36 \mathrm{mi}$. NE of Nondalton, Aleutian Ra.; $60^{\circ} 15^{\prime} \mathrm{N}, 153^{\circ} 52^{\prime} \mathrm{W}$; (map 61).

Local name reported in 1954 by USGS.

South Deception Lake: lake, $1.4 \mathrm{mi}$. long, in Glacier Bay National Monument, $2 \mathrm{mi}$. N of Torch Bay and $52 \mathrm{mi}$. NW of Hoonah, St. Elias Mts.; $58^{\circ} 22^{\prime} 00^{\prime \prime} \mathrm{N}, 136^{\circ} 46^{\prime} 45^{\prime \prime} \mathrm{W}$; $B G N 1962$; (map 10).

So named by NPS in 1962 because "although near sea level, its mountainous location makes it appear higher." North Deception Lake, into which it drains, is directly to the north.

South Dome: mountain, 2,442 ft., in Glacier Bay National Monument, between La Perouse and Finger Glaciers, $2.6 \mathrm{mi}$. N of Gulf of Alaska and $69 \mathrm{mi}$. NW of Hoonah, St. Elias Mts.; $58^{\circ} 29^{\prime} 30^{\prime \prime} \mathrm{N}, 137^{\circ} 12^{\prime} 30^{\prime \prime} \mathrm{W}$; (map $10)$.

Local name published by USGS in the 1950's.

Southeast Bight: bight, $2 \mathrm{mi}$. across, in Tanaga Bay, on W coast of Tanaga I., Aleutian Is.; $51^{\circ} 43^{\prime} 30^{\prime \prime} \mathrm{N}, 177^{\circ} 59^{\prime} 00^{\prime \prime} \mathrm{W}$; (map 17).

Descriptive name published in 1951 on a USGS map.

Southeast Cape: point of land, on $\mathrm{S}$ coast of Saint Lawrence Island; $62^{\circ} 56^{\prime} 10^{\prime \prime} \mathrm{N}, 169^{\circ} 39^{\prime}$ 00" W; BGN 1951; (map 93). Var. Sevognak, Sevooghnak Cape, Sevoonak Point.

Descriptive name given in 1849 by Capt. M. D. Tebenkov.

Southeast Cape: point of land, see Emeghee Point.

Southeast Cape: point of land, see Kialegak Point.

Southeast Cove: bay, extends SE 2 mi. to Ernest Sound, on S tip of Wrangell I., Alex. Arch.; $56^{\circ} 08^{\prime} \mathrm{N}, 132^{\circ} 03^{\prime} \mathrm{W}$; (map 6$)$.

Descriptive name given in 1886 by Lt. Comdr. A. S. Snow, USN; probably because it is cast of the southeastern end of Zimovia Strait. See Southwest Cove.

Southeast End: point of land, SE end of Douglas I., on Stephens Passage, $2.5 \mathrm{mi}$. S of Dupont and $9.5 \mathrm{mi}$. SE of Juneau, Coast Mts.; $58^{\circ}$. $11^{\prime} 30^{\prime \prime} \mathrm{N}, 134^{\circ} 15^{\prime} 50^{\prime \prime} \mathrm{W}$; (map 11).

Local descriptive name published in 1951 by USGS. 
Southeastern Cove: cove, $0.4 \mathrm{mi}$. across, faces NE toward Rat Island Pass, $2.3 \mathrm{mi}$. NW of Ayugadak Point, SE tip of Rat I., Aleutian Is.; $51^{\circ} 47^{\prime} 30^{\prime \prime} \mathrm{N}, 178^{\circ} 21^{\prime} 10^{\prime \prime} \mathrm{E}$; (map 15).

Name published on a 1943 U.S. Army Corps of Engineers map.

Southeast Fork Kahiltna Glacier: glacier, trends SW $5 \mathrm{mi}$. to Kahiltna Glacier, $9 \mathrm{mi}$. SW of Denali Pass, Alaska Ra.; 62 $58^{\prime} 25^{\prime \prime} \mathrm{N}, 151^{\circ}$ $11^{\prime} 30^{\prime \prime} \mathrm{W}$; (map 81).

Mountain climbers' name reported about 1954 by USGS.

Southeast Pass: water passage, between Elma and Caton Is., Sanak Is., Aleutian Ra.; $54^{\circ}$. $22^{\prime} 50^{\prime \prime} \mathrm{N}, 162^{\circ} 28^{\prime} 30^{\prime \prime} \mathrm{W}$; (map 25).

Descriptive name published in 1949 on a USGS map.

Southeast Point: point of land, part of Eastsou theast Head, on SE coast of Semisopochnoi I., Aleutian Is.; $51^{\circ} 55^{\prime} 20^{\prime \prime} \mathrm{N}, 179^{\circ} 43^{\prime} 40^{\prime \prime} \mathrm{E}$; (map 15).

Name published on a 1943 U.S. Army Corps of Engineers map.

Southeast Point: point of land, on Buldir I., Aleutian Is.; $52^{\circ} 20^{\prime} 30^{\prime \prime} \mathrm{N}, 175^{\circ} 57^{\prime} 00^{\prime \prime} \mathrm{E}$ (map 14).

Name shown on a 1950 AMS map.

Southeast Point: point of land, see Cascade Point.

Southeast Rock: rock, in Gulf of Alaska, $2.5 \mathrm{mi}$. S of Cape St. Elias, Kayak I., Malaspina Coastal Plain; $59^{\circ} 45^{\prime} 45^{\prime \prime} \mathrm{N}, 144^{\circ} 35^{\prime} 20^{\prime \prime} \mathrm{W}$ (map 48).

Name published in 1913 by USC\&GS on Chart 8513.

Southeast Shoal: shoal, see Tzuse Shoal.

Southeast Spur: ridge, 13,000 ft., extends E 3.5 mi. along $S$ side of Northwest Fork Ruth Glacier from South Buttress, on Mount McKinley, Alaska Ra.; $63^{\circ} 02^{\prime} \mathrm{N}, 150^{\circ} 55^{\prime} \mathrm{W}$; (map 88).

Mountain climbers' name published in 1954 by USGS.

Southeast Tributary Muir Glacier: glacier, see Adams Glacier.

South Entrance: water passage, on $\mathrm{W}$ coast of Prince of Wales I., connects Big Salt Lake and Klawak Inlet, $2.5 \mathrm{mi}$. NE of Klawock, Alex. Arch.; 55 $35^{\prime} 30^{\prime \prime} \mathrm{N}, 133^{\circ} 05^{\prime} 00^{\prime} \mathrm{W}$; (map 4).

Local name recorded in 1949 by USGS.

Southerly Island: island, $0.3 \mathrm{mi}$. long, in St. John Harbor, on NW coast of Zarembo I., Alex. Arch.; $56^{\circ} 26^{\prime} 40^{\prime \prime} \mathrm{N}, 132^{\circ} 58^{\prime} 00^{\prime \prime} \mathrm{W}$; (map 6).

Descriptive name given in 1884 by officers of U.S.S. Adams.

Southern Glacier: glacier, heads at $59^{\circ} 23^{\prime} \mathrm{N}$, $151^{\circ} 06^{\prime} \mathrm{W}$, in Kenai Mts., Kenai Penin., trends W 2 mi. to its terminus at a stream, 21 mi. ESE of Seldovia, Chugach Mts.; $59^{\circ} 24^{\prime}$ $\mathrm{N}, 151^{\circ} 09^{\prime} \mathrm{W} ;(\operatorname{map} 50)$.

Name reported in 1904 on a USGS fieldshect by E. G. Hamilton, who placed the glacier approximately $5 \mathrm{mi}$. SW of the location shown on recent maps.

Southern Rapid: rapids, sec Southern Rapids. Southern Rapids: rapids, in Sergius Narrows of Peril Strait, off Rapids I., 25 mi. NW of Sitka,
Alex. Arch.; $57^{\circ} 24^{\prime} 25^{\prime \prime}$ N, $135^{\circ} 37^{\prime} 45^{\prime \prime}$ W; (map 9). Var. Second Rapids, Southern Rapid, Vtoryee Porogi.

Published in 1882 on Brit. Adm. Chart 2337; called "Vtoryye Porogi," meaning "second rapids," in 1848 on Russian Hydrog. Dept. Chart 1397.

South Fairbanks: suburb, in S section of Fairbanks, Tanana Low.; $64^{\circ} 50^{\prime} \mathrm{N}, 147^{\circ} 43^{\prime} \mathrm{W}$; (map 100).

South Finger Lake: lake, $1 \mathrm{mi}$. long, one of the Finger Lakes, on Kenai Penin., $13 \mathrm{mi}$. NE of Kenai, Cook Inlet Low.; $60^{\circ} 38^{\prime} 30^{\prime \prime} \mathrm{N}, 150^{\circ}$ $53^{\prime} 30^{\prime \prime} \mathrm{W}$; (map 62).

Named about 1963 by officials of Kenai National Moose Range, for administrative purposes.

South Flat: tidal fat, $1 \mathrm{mi}$. long, in Wrangell Narrows, on E coast of Lindenberg Penin., Kupreanof I., $8 \mathrm{mi}$. S of Petersburg, Alex. Arch.; $56^{\circ} 41^{\prime} 30^{\prime \prime} \mathrm{N}, 132^{\circ} 57^{\prime} 15^{\prime \prime} \mathrm{W}$; (map 6). Var. Wrangell South Flat.

Feature was originally called "Wrangell South Flat" in 1869 by Comdr. R. W. Meade, USN. Local usage shortened the name.

South Foreland: point of land, see. East Foreland.

South Fork: stream, see Sulatna River.

South Fork Andrew Creek: stream, flows NW $8.5 \mathrm{mi}$. to Andrew Creek, $14 \mathrm{mi}$. NE of Wrangell, Coast Mts. ; $56^{\circ} 39^{\prime} 00^{\prime \prime} \mathrm{N}, 132^{\circ} 12^{\prime}$ $10^{\prime \prime} \mathrm{W}$; (map 6).

Local name recorded in 1953 by USGS.

South Fork Anvil Creek: stream, flows SW 2 mi. to join Discovery Fork to form Anvil Creek, $4 \mathrm{mi}$. NE of Nome, Seward Penin. High.

Prospectors' name published in 1900 by Schrader (1900c, p. 16), USGS. Subsequent maps show a different drainage pattern at the head of Anvil Creek.

South Fork Arolic Creek: stream, see South Fork Arolik River.

South Fork Arolic River: stream, see South Fork Arolik River.

South Fork Arolik River: stream, flows N $12 \mathrm{mi}$, joins East Fork Arolik River to form Arolik River, $30 \mathrm{mi}$. NE of Goodnews, KilbuckKuskokwim Mts.; 59 $31^{\prime} \mathrm{N}, 1^{\circ} 1^{\circ} 21^{\prime} \mathrm{W}$; (map 53). Var. South Fork Arolic Creek, South Fork Arolic River.

Narne published by G. L. Harrington (in Brooks, 1921, pl. 7), USGS.

South Fork Big River: stream, heads at terminus of Big River Lobe Double Glacier, flows $\mathrm{NE} 11 \mathrm{mi}$. to Big River, $38 \mathrm{mi}$. NW of Kenai, Cook Inlet Low.; $60^{\circ} 46^{\prime} \mathrm{N}, 152^{\circ} 12^{\prime} \mathrm{W}$; (map 62).

Local name reported in 1962 by USGS.

South Fork Birch Creek: stream, flows N $18 \mathrm{mi}$. to Birch Creek, $38 \mathrm{mi}$. SW of Circle, YukonTanana High.; $65^{\circ} 18^{\prime} \mathrm{N}, 144^{\circ} 26^{\prime} \mathrm{W}$; (map 104).

Named by prospectors; reported in 1896 by USGS (Spurr, 1898, pl. 39).

South Fork Bremner River: stream, flows NW 15 $\mathrm{mi}$. to Bremner River, $55 \mathrm{mi}$. NE of Katalla, Chugach Mts.; $60^{\circ} 59^{\prime} 45^{\prime \prime} \mathrm{N}, 144^{\circ} 15^{\prime} 00^{\prime \prime} \mathrm{W}$; (map 64).
Name published in 1959 by USGS.

South Fork Buckland River: stream, flows NW $26 \mathrm{mi}$. to the Buckland River, $50 \mathrm{mi}$. NE of Haycock, Nulato Hills; $65^{\circ} 44^{\prime} \mathrm{N}, 160^{\circ} 00^{\prime} \mathrm{W}$; (map 109).

Local name published in 1951 by USGS.

South Fork Burls Creek: stream, flows NE 6.4 mi. to Burls Creek 2 mi. W of its mouth at Becharof Lake, on Alaska Penin., $49 \mathrm{mi}$. NE of Ugashik, Aleutian Ra.; $57^{\circ} 41^{\prime} 10^{\prime \prime} \mathrm{N}$, $156^{\circ} 09^{\prime} 00^{\prime \prime} \mathrm{W}$; (map 36).

Name reported in 1902 by J. L. McPherson of Iliamna; published by G. C. Martin (1921, pl. 10), USGS.

South Fork Butte Creek: stream, flows NE 1.2 mi. to Butte Creek which flows to Solomon River, $11 \mathrm{mi}$. NE of Solomon, Seward Penin. High.; $64^{\circ} 43^{\prime} \mathrm{N}, 164^{\circ} 20^{\prime} \mathrm{W}$; (map 95).

Prospectors' name reported in 1903 or 1904 on a location map of Council City \& Solomon River Railroad.

South Fork Campbell Creek: stream, heads in lake, in Chugach Mts., flows NW 13 mi., joins North Fork to form Campbell Creek, $3.8 \mathrm{mi}$. SE of Anchorage, Cook Inlet Low.; 61 ${ }^{\circ} 10^{\prime} 39^{\prime \prime}$ $\mathrm{N}, 149^{\circ} 49^{\prime} 20^{\prime \prime} \mathrm{W}$; (map 69)

Local name reported in 1916 by GLO [BLM].

South Fork Chena River: stream, heads at $64^{\circ} 46^{\prime} \mathrm{N}, 145^{\circ} 54^{\prime} \mathrm{W}$, flows NW $41 \mathrm{mi}$. to Chena River, $33 \mathrm{mi}$. NE of Fairbanks, YukonTanana High.; 64 $53^{\circ} 05^{\prime \prime}$ N, $146^{\circ} 40^{\prime} 15^{\prime \prime} \mathrm{W}$; $B G N 1965$; (map 101).

Named by prospectors and reported in 1907 by Prindle (1913a, pl. 4), USGS.

South Fork Chester Creek: stream, formed by its Middle and South Branches, flows NW $2.7 \mathrm{mi}$. to join the Middle Fork to form Chester Creek in Anchorage, Cook Inlet Low.; $61^{\circ} 11^{\prime} 58^{\prime \prime} \mathrm{N}, 149^{\circ} 49^{\prime} 55^{\prime \prime} \mathrm{W}$; (map 69).

Local name reported in 1962 by USGS.

South Fork Chickamin River: stream, heads at glacier SW of Through Glacier, flows W 18 mi. to Chickamin River, $2.5 \mathrm{mi}$. SE of mouth

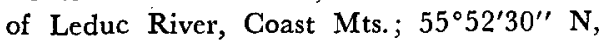
$130^{\circ} 44^{\prime} 25^{\prime \prime} \mathrm{W}$; BGN 1962; (map 3).

Local name reported in 1961 by USFS.

South Fork Cowee Creek: stream, flows NW 4 mi. to Cowee Creek, $2.5 \mathrm{mi}$. E of Bridget Cove and $27 \mathrm{mi}$. NW of Juneau, Coast Mts.; $58^{\circ} 37^{\prime} 30^{\prime \prime} \mathrm{N}, 134^{\circ} 52^{\prime} 00^{\prime \prime} \mathrm{W}$; (map 11).

Name published in 1951 by USGS. See Cowee Creek.

South Fork Deep Creek: stream, on Kenai Penin., flows NW $11 \mathrm{mi}$. to Deep Creek, 15 mi. NW of Caribou Lake and $22 \mathrm{mi}$. $\mathrm{N}$ of Homer, Cook Inlet Low.; 59 $58^{\prime} \mathrm{N}, 151^{\circ} 29^{\prime}$ W; (map 50).

Local name published on maps after 1950.

South Fork Doame River: stream, heads in lake, in Deception Hills, flows W $9 \mathrm{mi}$. to join Doame River $2 \mathrm{mi}$. E of its mouth on Gulf of Alaska and $60 \mathrm{mi}$. SE of Yakutat, St. Elias Mts.; $59^{\circ} 04^{\prime} 45^{\prime \prime} \mathrm{N}, 138^{\circ} 17^{\prime} 30^{\prime \prime} \mathrm{W}$; (map 46). Local name published in 1959 by USGS.

South Fork Eagle River: stream, heads at a glacier, flows NW $12 \mathrm{mi}$., through Eagle Lake to Eagle River $15 \mathrm{mi}$. NE of Anchorage, Chu- 
gach Mts.; $61^{\circ} 17^{\prime} 50^{\prime \prime} \mathrm{N}, 1^{\circ} 49^{\circ} 28^{\prime} 15^{\prime \prime} \mathrm{W}$; (map 69).

Local name reported in 1942 by AMS.

South Fork East Fork George River: stream, flows NW 30 mi. to East Fork George River 4.3 mi. E of its junc. with George River, $22 \mathrm{mi}$. NW of Sleetmute, Kilbuck-Kuskokwim Mts.; $61^{\circ} 59^{\prime} 30^{\prime \prime} \mathrm{N}, 157^{\circ} 28^{\prime} 45^{\prime \prime} \mathrm{W}$; (map 72).

Local name reported in 1914 by $R$. $H$. Sargent, USGS.

South Fork Eldorado Creek: stream, heads on Ear Mtn., flows NE $1 \mathrm{mi}$. to Eldorado Creek, in Arctic River basin, $3 \mathrm{mi}$. $\mathbf{E}$ of The Ears, Seward Penin. High.; 65 $56^{\prime} 00^{\prime \prime}$ N, $166^{\circ} 07^{\prime}$ $10^{\prime \prime} \mathrm{W}$; BGN 1954; (map 111).

Named in 1945 by a USGS field party.

South Fork Flats: fiats, along course of South Fork Koyukuk River, extends SW $25 \mathrm{mi}$. from Twin Lakes, $25 \mathrm{mi}$. WSW from Chandalar, Brooks Ra.; $67^{\circ} 15^{\prime}$ N, $149^{\circ} 30^{\prime}$ W; (map 123).

Local name reported in 1956 by T. E. Taylor, USGS.

South Fork Folger Greek: stream, heads in Kuskokwim Mts., flows N 24 mi., joins Canyon Creek to form Folger Creek, $23 \mathrm{mi}$. NE of Ophir and $36 \mathrm{mi}$. NW of McGrath, Kilbuck-Kuskokwim Mts. ; $63^{\circ} 26^{\prime} 30^{\prime \prime} \mathrm{N}, 156^{\circ} 09^{\prime}$ $30^{\prime \prime} \mathrm{W}$; (map 90).

Local name obtained in 1954 by R. E. Isto, USGS.

South Fork Fortymile River: stream, heads at junc. of Mosquito and Dennison Forks, flows NE $33 \mathrm{mi}$. to join North Fork to form Fortymile River, $42 \mathrm{mi}$. SW of Eagle, YukonTanana High.; $64^{\circ} 14^{\prime} \mathrm{N}, 141^{\circ} 45^{\prime} \mathrm{W}$; (map 102).

Named by prospectors and reported in 1896 by Spurr $(1898$, pl. 38$)$, USGS. This name was probably in use as early as 1886 .

South Fork Goodnews River: stream, heads at $59^{\circ} 12^{\prime} \mathrm{N}, 160^{\circ} 54^{\prime} \mathrm{W}$, flows SW $24 \mathrm{mi}$. to Goodnews River, $4 \mathrm{mi}$. E of Goodnews, Kilbuck-Kuskokwim Mts.; $59^{\circ} 07^{\prime} 30^{\prime \prime}$ N, $161^{\circ}$ 29'30" W; (map 53). Var. Mumtrak Creek.

Originally called "Mumtrak Creek" in 1909 by USC\&GS on Chart 8802 for Mumtrak, the Eskimo village at its mouth. It was called "South Fork Goodnews River" in 1919 by G. L. Harrington (in Brooks, 1921, pl. 7), USGS.

South Fork Goodpaster River: stream, heads at $64^{\circ} 14^{\prime} \mathrm{N}, 143^{\circ} 59^{\prime} \mathrm{W}$, flows W 40 mi. to Goodpaster River, $22 \mathrm{mi}$. E of Big Delta, YukonTanana High.; $64^{\circ} 12^{\prime} 30^{\prime \prime} \mathrm{N}, 145^{\circ} 10^{\prime} 10^{\prime \prime} \mathrm{W}$; (map 101).

Local name reported in 1907 by D. C. Witherspoon, USGS.

South Fork Goodpaster River: stream, see Eisenmenger Fork.

South Fork Grouse Creek: stream, flows NE 5 mi. to join East Fork Grouse Creek to form Grouse Creek which flows to Mink River, 41 mi. NW of Teller, Seward Penin. High.; $65^{\circ}$ $38^{\prime} \mathrm{N}, 167^{\circ} 29^{\prime} \mathrm{W}$; (map 111).

Prospectors' name reported on the 1908 "Map of Seward Peninsula" by Arthur Gibson
South Fork Harrison Creek: stream, flows SE 8 mi., joins North Fork Harrison Creek to form Harrison Creek, 44 mi. SW of Circle, YukonTanana High.; $65^{\circ} 21^{\prime} 45^{\prime \prime} \mathrm{N}, 145^{\circ} 07^{\prime} 30^{\prime \prime} \mathrm{W}$; (map 104). Var. Harrison Creek.

Local name reported in 1896 by USGS (Spurr, 1898, pl. 50).

South Fork Hess Creek: stream, heads at junc. of Goldstream and Alabam Creeks, flows N 11 mi. to join North Fork Hess Creek to form Hess Creek, $14 \mathrm{mi}$. NE of Livengood, YukonTanana High.; $65^{\circ} 42^{\prime} 30^{\prime \prime} \mathrm{N}, 148^{\circ} 21^{\prime} 30^{\prime \prime} \mathrm{W}$; (map 105). Var, Goldstream Creek.

Prospectors' name reported in 1902 by Lt. Hjalmar Erickson, USA.

South Fork Hoholitna River: stream, flows NW $26 \mathrm{mi}$. to Hoholitna River, $65 \mathrm{mi}$. SE of Sleetmute, Kilbuck-Kuskokwim Mts.; $60^{\circ} 54^{\prime} \mathrm{N}$, $156^{\circ} 15^{\prime} \mathrm{W}$; (map 60).

Local name reported in 1952 by USC\&GS.

South Fork Huslia River: stream, flows NE 50 mi. to join North Fork Huslia River to form Huslia River, 38 mi. NW of Roundabout Mtn.,

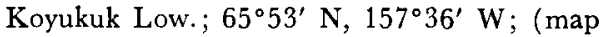
108).

Local name obtained at Huslia by USGS in 1954 or 1955.

South Fork Iliamna River: stream, see Iliamna River.

South Fork Indian River: stream, flows NW 8 mi., joins North Fork Indian River to form Indian River, $16 \mathrm{mi}$. NW of Goodnews, Kilbuck-Kuskokwim Mts.; 59 $18^{\prime} \mathrm{N}, 161^{\circ} 51^{\prime} \mathrm{W}$; (map 53).

Name published by G. L. Harrington (in Brooks, 1921, pl. 7), USGS.

South Fork Jones Creek: stream, flows NW 18 mi. to Jones Creek, $27 \mathrm{mi}$. SE of Medfra, Kuskokwim Low.; $63^{\circ} 00^{\prime} 20^{\prime \prime} \mathrm{N}, 153^{\circ} 51^{\prime} 50^{\prime \prime}$ W; BGN 1964; ( map 89).

Local name reported in 1958 by USGS.

South Fork Kamishak River: stream, heads at glacier terminus, in Katmai National Monument, flows NW 19 mi. to Kamishak River, 10 mi. S of Akumwarvik Bay, at head of Alaska Penin., Aleutian Ra.; 58 $53^{\prime} 05^{\prime \prime} \mathrm{N}, 154^{\circ} 11^{\prime}$ $40^{\prime \prime} \mathrm{W}$; (map 42).

Local name reported in 1923 by R. H Sargent, USGS.

South Fork Koyukuk River: stream, heads $8 \mathrm{mi}$ W of Chandalar Lake, flows SW $140 \mathrm{mi}$. to Koyukuk River, $20 \mathrm{mi}$. E of Allakaket, Kanuti Flats; $66^{\circ} 35^{\prime} \mathrm{N}, 151^{\circ} 57^{\prime} \mathrm{W}$; (map 117). Var. Nohoolchintna, Nokhulchitna.

Local name published by USC\&GS in 1899 This stream appears to be the "Nohoolchintna" which Lt. Allen (1887, p. 100), USA, reported in 1885

South Fork Kuskokwim River: stream, heads at a glacier on NE slope of Snowcap Mtn. at $61^{\circ} 33^{\prime} 40^{\prime \prime} \mathrm{N}, 153^{\circ} 32^{\prime} 40^{\prime \prime} \mathrm{W}$, flows NW 150 mi. to Kuskokwim River, $2.4 \mathrm{mi}$. SE of Med-

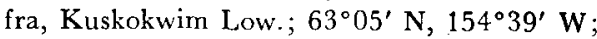
$B C N$ 1964; (map 89). Var. Echeatnu River, Istna River, Kuskokwim River, Nando River

The name was used in 1907 by Gordon (1917, p. 104) who also reported its Indian name as "Istna." In 1899 Lt. J. S. Herron,
USA, had reported the Indian name as "Echeat-nu." J. E. Spurr and W. S. Post, USGS, considered this stream the main Kuskokwim River.

South Fork Kuyukutuk River: stream, flows NW $10 \mathrm{mi}$. to its junc. with West Fork to form Kuyukutuk River, $13 \mathrm{mi}$. NW of Russian Mission, Nulato Hills; $61^{\circ} 52^{\prime} \mathrm{N}, 161^{\circ} 41^{\prime} \mathrm{W}$; (map 73).

Local name reported by Harrington (1918, map), USGS, in 1916.

South Fork Kuzitrin River: stream, see Minnie Creek.

South Fork Ladue River: stream, flows N $22 \mathrm{mi}$ to Ladue River, $44 \mathrm{mi}$. E of Tok, Yukon-Tanana High.; $63^{\circ} 24^{\prime} \mathrm{N}, 141^{\circ} 35^{\prime} \mathrm{W}$; (map 85). Local name reported by USGS in 1955 .

South Fork Lake: lake, $1.5 \mathrm{mi}$. across, on W side of South Fork Flats, $3.5 \mathrm{mi}$. SE of Big Lake and $20 \mathrm{mi}$. WSW of Chandalar, Brooks Ra.; $67^{\circ} 26^{\prime} \mathrm{N}, 149^{\circ} 15^{\prime} \mathrm{W}$; (map 123).

Local name reported in 1956 by T. E. Taylor, USGS.

South Fork Lodge: roadhouse, on $\mathrm{N}$ bank of South Fork Fortymile River, $0.3 \mathrm{mi}$. E of Atwater Creek, $54 \mathrm{mi}$. SW of Eagle, YukonTanana High.; $64^{\circ} 03^{\prime} \mathrm{N}, 141^{\circ} 47^{\prime} \mathrm{W}$; (map 102).

Local name reported in 1956 by USGS.

South Fork Martin Creek: stream, heads in Peters Hills, flows SE $6.4 \mathrm{mi}$. to Martin Creek, $23 \mathrm{mi}$. NW of Talkeetna, Alaska Ra.; $62^{\circ} 24^{\prime}$ $20^{\prime \prime} \mathrm{N}, 150^{\circ} 48^{\prime} 18^{\prime \prime} \mathrm{W}$; (map 81).

Local name reported in 1958 by USGS.

South Fork Matanuska River: stream, flows NW $12 \mathrm{mi}$. to join East Fork to form the Matanuska River, $55 \mathrm{mi}$. NE of Palmer, Copper River Basin; $61^{\circ} 47^{\prime} 30^{\prime \prime} \mathrm{N}, 147^{\circ} 30^{\prime} 15^{\prime \prime} \mathrm{W}$; (map 69).

Local name reported about 1964 by USGS. South Fork Montana Creek: stream, heads in lake, flows W $20 \mathrm{mi}$. to Montana Creek, 11 mi. SE of Talkeetna, Cook Inlet Low.; $62^{\circ}$. $11^{\prime} \mathrm{N}, 149^{\circ} 57^{\prime} \mathrm{W}$; (map 82).

Local name recorded in 1950 by USGS.

South Fork Mosquito Creek: stream, heads in Darby Mts., flows SW $5.3 \mathrm{mi}$. to Mosquito Creek, in Fish River basin, $39 \mathrm{mi}$. SE of Imuruk Lake, Seward Penin. High.; 65 $02^{\prime} \mathrm{N}$, $162^{\circ} 43^{\prime} \mathrm{W}$; (map 110).

Prospectors' name published on the 1908 "Map of Seward Peninsula" by Arthur Gibson. South Fork Mulchatna River: stream, see Chilchitna River.

South Fork Ninuluk Creek: stream, flows NW 20 mi. to Ninuluk Creek, $31 \mathrm{mi}$. SW of Umiat, Arctic Slope; $69^{\circ} 03^{\prime} \mathrm{N}, 153^{\circ} 05^{\prime} \mathrm{W}$; $B G N$ 1960; (map 142).

Name published in 1956 by USGS.

South Fork Nulato River: stream, flows NE 54 mi. to Nulato River, $3 \mathrm{mi}$. W of Nulato, Nulato Hills; $64^{\circ} 43^{\prime} N, 158^{\circ} 12^{\prime} \mathrm{W}$; (map 97).

Local name reported in 1954 by USGS.

South Fork Nuluk River: stream, flows NE $8 \mathrm{mi}$. to join North Fork Nuluk River to form Nuluk River, $26 \mathrm{mi}$. N of Teller, Seward Penin. High.; $65^{\circ} 38^{\prime} \mathrm{N}, 166^{\circ} 15^{\prime} \mathrm{W}$; (map 111). 
Prospectors' name reported on the 1908 "Map of Seward Peninsula" by Arthur Gibson.

South Fork of Birch Creek: stream, see Yukon Fork.

South Fork Otter Creek: stream, flows W $8 \mathrm{mi}$. to join North Fork to form Otter. Creek, 10 mi. NE of Flat, Kilbuck-Kuskokwim Mts.; $62^{\circ} 31^{\prime} \mathrm{N}, 157^{\circ} 43^{\prime} \mathrm{W}$; (map 79).

Local name obtained in 1952 by USGS topographers.

South Fork Paint River: stream, flows NW 1.5 mi., joins Middle Fork Paint River to form Paint River, $8 \mathrm{mi}$. SE of Spectacle Lake, 47 mi. SW of Augustine I., Aleutian Ra.; $59^{\circ} 07^{\prime} 15^{\prime \prime} \mathrm{N}, 154^{\circ} 38^{\prime} 10^{\prime \prime} \mathrm{W}$; (map 51).

Local name reported by $K$. F. Mather, in 1923 (in Brooks and others, 1925, pl. 3).

South Fork Pass Creek: stream, flows NE $6 \mathrm{mi}$. to Pass Creek, $76 \mathrm{mi}$. SE of Healy, Alaska Ra.; $63^{\circ} 10^{\prime} 20^{\prime \prime} \mathrm{N}, 147^{\circ} 01^{\prime} 00^{\prime \prime} \mathrm{W}$; (map 87).

Local name obtained in 1951 by USGS.

South Fork Quail Creek: stream, flows NE $4 \mathrm{mi}$. to Quail Creek, $16 \mathrm{mi}$. SE of Rampart, YukonTanana High.; $65^{\circ} 21^{\prime} 30^{\prime \prime} \mathrm{N}, 1^{\circ} 49^{\circ} 45^{\prime} 50^{\prime \prime} \mathrm{W}$; (map 105).

Local name given relative to Quail Creek; reported in 1904 by L. M. Prindle and F. L. Hess (in Brooks and others, 1905, fig. 6), USGS.

South Fork Rex Creek: stream, flows NE 2.4 mi. and joins the North Fork to form Rex Creek, on E coast of Alaska Penin., 2 mi. NW of Dry Bay and $51 \mathrm{mi}$. W of Karluk, Aleutian Ra.; $57^{\circ} 39^{\prime} 35^{\prime \prime} \mathrm{N}, 155^{\circ} 49^{\prime} 00^{\prime \prime} \mathrm{W}$; (map 35).

Descriptive local name obtained from J. L. McPherson of Iliamna and published by $G$. C. Martin (1921, pl. 10), USGS.

South Fork Salcha River: stream, flows N 20 mi. to Salcha River, $37 \mathrm{mi}$. NE of Big Delta Yukon-Tanana High.; $64^{\circ} 40^{\prime} \mathrm{N}, 145^{\circ} 26^{\prime} \mathrm{W}$ (map 101).

Local name reported in 1958 by USGS.

South Fork Serpentine River: stream, flows N $35 \mathrm{mi}$. to Serpentine River, $25 \mathrm{mi}$. SE of Shishmaref, Kotzebue-Kobuk Low.; $66^{\circ} 07^{\prime} \mathrm{N}$, $165^{\circ} 16^{\prime}$ W; (map 112). Var. Quartz Creek.

Prospectors' name published by Collier (1902, pl. 12), USGS.

South Fork Snow River: stream, heads at Nellie Juan Lake, flows NW 12 mi. to Snow River, $4 \mathrm{mi}$. S of Kenai Lake and $12 \mathrm{mi}$. NE of Seward, on Kenai Penin., Chugach Mts.; $60^{\circ}$. $17^{\prime} 00^{\prime \prime} \mathrm{N}, 149^{\circ} 20^{\prime} 20^{\prime \prime} \mathrm{W}$; (map 63).

Name published on a 1951 USGS map.

South Fork Sulatna River: stream, flows NE 37 mi. to Sulatna River, $12 \mathrm{mi}$. NE of Sulatna Crossing and $19 \mathrm{mi}$. SW of Monzonite Hills, Kilbuck-Kuskokwim Mts.; $64^{\circ} 14^{\prime} \mathrm{N}, 155^{\circ} 04^{\prime}$ W; (map 98).

Prospectors' name reported in 1912 by Eakin (in Brooks and others, 1913, pl. 10), USGS.

South Fork Tozitna River: stream, see Ptarmigan Creek.

South Fork Twelvemile Creek: stream, flows NE $3 \mathrm{mi}$. to Twelvemile Creek, $58 \mathrm{mi}$. SW of
Circle, Yukon-Tanana High.; $65^{\circ} 24^{\prime} \mathrm{N}, 145^{\circ}-$ 48' W; (map 104).

Local name reported in 1911 by USGS (Prindle, 1913b, pl. 1).

South Fork Upper Carmen River: stream, flows NW $5 \mathrm{mi}$. to Upper Carmen River, $8 \mathrm{mi}$. NW of Whittier, Chugach Mts.; 60 $50^{\circ} 15^{\prime \prime} \mathrm{N}$, $148^{\circ} 45^{\prime} 40^{\prime \prime} \mathrm{W}$; (map 63 )

Local name reported in 1951 by USGS.

South Glacier: glacier, heads on Alaska-Canada boundary $0.8 \mathrm{mi}$. SW of Boundary Peak 111 and trends W $2 \mathrm{mi}$. to its 1949 terminus 1.8 $\mathrm{mi}$. NW of Hefty Mtn. and $8 \mathrm{mi}$. E of Skagway, Coast Mts.; $59^{\circ} 28^{\prime} 30^{\prime \prime} \mathrm{N}, 135^{\circ} 05^{\prime} 45^{\prime \prime}$ W; (map 45)

Local name obtained by USGS field personnel and published on Federal maps since 1950.

South Gland Lake: lake, $0.5 \mathrm{mi}$. $\mathrm{N}$ of Bukhti Point, Kiska I., Aleutian Is.; $51^{\circ} 55^{\prime} 28^{\prime \prime} \mathrm{N}$, $177^{\circ} 28^{\prime} 10^{\prime \prime} \mathrm{E}$; (map 14)

An arbitrary name beginning with " $S$ " to correspond to " $S$ " grid used by the U.S. Army for tactical purposes during World War II; published on a 1953 AMS map.

South Head: point of land, SE point of entrance to Kiska Harbor, on E coast of Kiska $\mathrm{I}$. Aleutian Is.; $51^{\circ} 57^{\prime} 15^{\prime \prime} \mathrm{N}, 177^{\circ} 36^{\prime} 25^{\prime \prime} \mathrm{E}$ BGN 1937; (map 14).

Local name recorded by USC\&GS in 1905. South Head: promontory, on the $\mathrm{S}$ side of entrance to Iliamma Bay, $18 \mathrm{mi}$. $\mathrm{N}$ of Augustine I., Aleutian Ra.; $59^{\circ} 36^{\prime} 25^{\prime \prime}$ N, $153^{\circ}$. 33'30" W; BGN 1916; (map 51).

Descriptive name published in 1913 on USC\&GS Chart 3420.

South Head: point of land, see Battery Point. South Hill: hill, $668 \mathrm{ft}$., SW of Ulakaia Hill, on St. George I., Pribilof Is.; $56^{\circ} 33^{\prime} 40^{\prime \prime} \mathrm{N}$, $169^{\circ} 35^{\prime} 55^{\prime \prime} \mathrm{W}$; (map 38 ). Var. Ikoum-ungaKoverushka.

Descriptive name reported by $W$. W. Duffield, USC\&GS, in 1897. The Aleut-Russian name for this hill, according to Putnam, (1903, p. 1014), USC\&GS, is 'Ikoum'-unga'-koberushka" " or "hill near Ikoum-unga."

South Inian Pass: water passage, $3 \mathrm{mi}$. long, on $\mathrm{N}$ end of Chichagof I., from Cross Sound $\mathbf{E}$ to Icy Strait, $34 \mathrm{mi}$. NW of Hoonah, Alex. Arch.; 58 $13^{\prime} 30^{\prime \prime} \mathrm{N}, 136^{\circ} 10^{\prime} 00^{\prime \prime} \mathrm{W}$; (map 10).

Named by J. F. Pratt, USC\&GS, in 1891. South Island: island, $0.3 \mathrm{mi}$. long, Bay of Is., Adak I., Aleutian Is.; $51^{\circ} 49^{\prime} 20^{\prime \prime} \mathrm{N}, 176^{\circ} 48^{\prime}$ 00" W; BGN 1936; (map 17).

Descriptive name given by members of the U.S. Navy Aleutian Island Survey Expedition in 1934.

South Island: island, $0.2 \mathrm{mi}$. across, at mouth of Port McArthur, in Affleck Canal, on $S$ coast of Kuiu I., Alex. Arch.; $56^{\circ} 03^{\prime} 30^{\prime \prime} \mathrm{N}$, $134^{\circ} 06^{\prime} 30^{\prime \prime} \mathrm{W}$; (map 5 )

Named in 1886 by Lt. J. M. Helm, USN, for charting purposes; published in 1887 by USC\&GS on Chart 706.

South Island: island, $0.4 \mathrm{mi}$. long, in Stephens Passage, off E coast of Glass Penin., Admiralty
I., $25 \mathrm{mi}$. SE of Juneau, Alex. Arch.; 57 58'$15^{\prime \prime} \mathrm{N}, 134^{\circ} 02^{\prime} 45^{\prime \prime} \mathrm{W}$; (map 9).

Named in 1889 by Lt. Comdr. H. B. Mansfield, USN; published by USC\&GS in 1891 Coast Pilot (p. 148).

South Island: island, near SW coast of Unalaska I., Aleutian Is.; (map 23).

This name was published by USBF in 1888 , and by Baker (1906, p. 590). It does not appear on modern maps.

South Island: island, see Biorka Island.

South Island: island, see Teal Island.

South Island: rock, elev. $260 \mathrm{ft}$., in Semidi Is., $2 \mathrm{mi}$. SW of S tip of Chowiet I., Aleutian Ra.; $55^{\circ} 59^{\prime} \mathrm{N}, 156^{\circ} 43^{\prime} \mathrm{W}$; (map 31). Var. Ile du Sud, Kutloot Island, Kytlek Island, Ostrov Yuzhniy.

Name translated from the Russian "O[strov] Yuzhniy," published by the Russian Hydrog. Dept. in 1847. Also shown in French "I[le] du Sud" by Adm. von Krusenstern (1827, map 20), IRN.

South Island: rocks, see Huddle Rocks.

South Kaigahnee Harbor: $b a y$, see South Kaigani Harbor.

South Kaigani Harbor: bay, extends NW $1.2 \mathrm{mi}$. off Kaigani Strait, on SE coast of Dall I., Alex. Arch.; $54^{\circ} 45^{\prime} 10^{\prime \prime} \mathrm{N}, 132^{\circ} 43^{\prime} 00^{\prime \prime} \mathrm{W}$; (map 1). Var. Middle Harbor Kai-gah-nee Harbors, Middle Kaigani Harbor, South Kaigahnee Harbor.

Haida Indian name published by USC\&GS in the 1883 Coast Pilot (p. 66) as "Middle Harbor Kai-gah-nee Harbors." See Kaigani Harbors.

South Kaigani Harbor: bay, see Datzkoo Harbor.

South Lake: lake, $0.7 \mathrm{mi}$. long, in course of South Creek, SW of Table Mtn., $64 \mathrm{mi}$. NE of Palmer, Talkeetna Mts.; 61 ${ }^{\circ} 58^{\prime} 55^{\prime \prime} \mathrm{N}$, $147^{\circ} 20^{\prime} 30^{\prime \prime} \mathrm{W}$; (map 69).

Local name reported in 1951 by USGS.

South Ledge: rocks, in Wrangell Narrows, on W coast of Mitkof I., $13 \mathrm{mi}$. S of Petersburg, Alex. Arch.; $56^{\circ} 37^{\prime} 20^{\prime \prime} \mathrm{N}, 132^{\circ} 57^{\prime} 20^{\prime \prime} \mathrm{W}$; (map 6).

Named in 1869 by Comdr. R. W. Meade, USN.

South Maktak Hills: hills, $900 \mathrm{ft}$, extend $8 \mathrm{mi}$. $\mathrm{E}$ of Angmakrok Mtn., $\mathbf{N}$ of Kakpeyak River, $17 \mathrm{mi}$. NE of Cape Thompson, Arctic Slope; $68^{\circ} 19^{\prime} \mathrm{N}, 165^{\circ} 19^{\prime} \mathrm{W}$; BGN 1963; (map 129). Var. South Muktuk Hills.

Name reported in 1960 by D. C. Foote, Project Chariot. See Maktak Mountain.

South Marble Island: island, $0.3 \mathrm{mi}$. across, most southerly of Marble Is., in Glacier Bay National Monument, in Glacier Bay, $1.6 \mathrm{mi}$. SE of North Marble I. and $43 \mathrm{mi}$. NW of Hoonah, St. Elias Mts. ; $58^{\circ} 38^{\prime} 40^{\prime \prime} \mathrm{N}, 136^{\circ} 02^{\prime} 30^{\prime \prime} \mathrm{W}$; (map 10). Var. South Marble Islet.

Name published by the IBC (1923, sheet 10).

South Marble Islet: island, see South Marble Island.

South Meadow Lake: lake, $0.25 \mathrm{mi}$. across, 2.8 mi. NE of Barrow, Arctic Plain; $71^{\circ} 18^{\prime} 10^{\prime \prime}$ $\mathrm{N}, 156^{\circ} 38^{\prime} 40^{\prime \prime} \mathrm{W}$; (map 153). 
Named about 1955 for scientific purposes. South Mountain: peak, 3,050 ft., $1.2 \mathrm{mi}$. NW of Mount Unana, $24 \mathrm{mi}$. NE of Yakutat, St. Elias Mts.; $59^{\circ} 46^{\prime} 30^{\prime \prime} \mathrm{N}, 139^{\circ} 14^{\prime} 10^{\prime \prime} \mathrm{W}$; (map 46).

Name appears on USGS fieldsheet dated 1909

South Mouth Arolic River: stream, see South Mouth Arolik River.

South Mouth Arolik River: stream, S distributary of Arolik River, heads at $59^{\circ} 38^{\prime} \mathrm{N}$, $161^{\circ} 36^{\prime} \mathrm{W}$, flows NW $12 \mathrm{mi}$. to Kuskokwim Bay, $40 \mathrm{mi}$. N. of Goodnews, Yukon-Kuskokwim Delta; $59^{\circ} 41^{\prime} \mathrm{N}, 161^{\circ} 53^{\prime} \mathrm{W}$; (map 53). Var. South Mouth Arolic River.

Named in 1914 by USC\&GS; published in 1915 on Chart 9103.

South Muktuk Hills: hills, see South Maktak Hills.

South Naknek: village, pop. 142, on S bank of Naknek River, on Alaska Penin., $1 \mathrm{mi}$. SE of Naknek, Bristol Bay Low.; $58^{\circ} 41^{\prime} \mathrm{N}, 157^{\circ} 00^{\prime}$ W; BGN 1948; (map 41). Var. Naknek, Suwarof, Suworof, Paugwik.

Eskimo and Aleut village listed in the 1880 Census with a population (including Kingiak) of $192 ; 93$ in 1890 . See Naknek. The South Naknek post office was established in 1937.

South Olga Stream: stream, see Olga Creek.

South Pass: water passage, SE approach to Kiska Harbor, between Kiska and Little Kiska Is., Aleutian Is.; $51^{\circ} 57^{\prime} 20^{\prime \prime} \mathrm{N}, 177^{\circ} 36^{\prime} 50^{\prime \prime} \mathrm{E}$; $B G N$ 1937; (map 14). Var. Kiska Pass, Small Pass.

Recorded as "Small Pass" in 1875 and as "South Pass" in 1906 by USC\&GS.

South Pass: pass, between Bottle Cork and Lookout Hills, on southeastern Attu I., Aleutian Is. ; $52^{\circ} 49^{\prime} 55^{\prime \prime} \mathrm{N}, 173^{\circ} 06^{\prime} 15^{\prime \prime} \mathrm{E}$; ( $\operatorname{map} 13$ ).

Named by the U.S. Army during its occupation of the island during World War II; shown on an AMS map published in 1948.

South Pass: water passage, see South Passage.

South Passage: water passage, in Eliza Harbor, between Liesnoi I. and SE coast of Admiralty I., $27 \mathrm{mi}$. SE of Angoon, Alex. Arch.; $57^{\circ} 09^{\prime}$ $35^{\prime \prime} \mathrm{N}, 134^{\circ} 16^{\prime} 40^{\prime \prime} \mathrm{W}$; (map 9)

Named in 1889 by Lt. Comdr. H. B. Mansfield, USN; published in 1891 Coast Pilot ( $p$ 142).

South Passage: water passage, $\mathrm{E}$ of Whitney $\mathrm{I}$., extends S $1 \mathrm{mi}$. from Cleveland Passage to Fanshaw Bay, $71 \mathrm{mi}$. E of Sitka, Coast Mts.; $57^{\circ} 13^{\prime} 00^{\prime \prime} \mathrm{N}, 133^{\circ} 30^{\prime} 15^{\prime \prime} \mathrm{W}$; (map 8).

Descriptive name probably given by $L t$. Comdr. H. E. Nichols, USN; published by USC\&GS in the 1891 Coast Pilot (p. 145).

South Passage: water passage, $2 \mathrm{mi}$. long, between Hogan and Herbert Graves Is., $5.5 \mathrm{mi}$. NW of Chichagof, Alex. Arch.; 57 $41^{\prime} 30^{\prime \prime} \mathrm{N}$, $136^{\circ} 14^{\prime} 30^{\prime \prime} \mathrm{W}$; (map 9). Var. South Pass.

Name published by USC\&GS in 1910 as "South Pass," and in 1917 Coast Pilot (pt. 1, p. 216) as "South Passage."

South Passage: water passage, $5 \mathrm{mi}$. long, on $\mathrm{N}$ coast of Chichagof I., S of Lemesurier I., 23 $\mathrm{mi}$. NW of Hoonah, Alex. Arch.; $58^{\circ} 13^{\prime} \mathrm{N}$, $136^{\circ} 05^{\prime} \mathrm{W}$; (map 10).
Name published by USC\&GS in 1904 on Chart 8304

South Passage Point: point of land, on Chichagof I., S point of entrance to Tenakee Inlet, 10 mi. E of Tenakee Springs, Alex. Arch.; 57 $45^{\prime}$ $30^{\prime \prime} \mathrm{N}, 134^{\circ} 56^{\prime} 00^{\prime \prime} \mathrm{W}$; (map 9).

Descriptive name given in 1869 by Comdr. R. W. Meade, USN; published in 1883 Coast Pilot (p. 179).

South Pass Sukkwan Strait: water passage, $4 \mathrm{mi}$ long, connects Sukkwan and Tlevak Straits, between Goat and Sukkwan Is., $23 \mathrm{mi}$. SE of Craig, Alex. Arch.; $55^{\circ} 11^{\prime} \mathrm{N}, 132^{\circ} 52^{\prime} \mathrm{W}$ $B G N$ 1916; (map 4).

Named in 1916 by USC\&GS.

South Peak: peak, 4,251 ft., at S end of Mount Susitna, $33 \mathrm{mi}$. NW of Anchorage, Alaska Ra. $61^{\circ} 27^{\prime} 10^{\prime \prime} \mathrm{N}, 150^{\circ} 44^{\prime} 55^{\prime \prime} \mathrm{W} ; B G N$ 1962; (map 70).

Local name reported in 1949 by USGS.

South Peak Mount McKinley: mountain, 20,320 $\mathrm{ft}$., summit of Mount McKinley, one of the Churchill Peaks, 2 mi. S of North Peak, in Mount McKinley National Park, Alaska Ra. $63^{\circ} 04^{\prime} 20^{\prime \prime} \mathrm{N}, 151^{\circ} 00^{\prime} 15^{\prime \prime} \mathrm{W}$; (map 88).

This descriptive name was used as early as 1910. See Mount McKinley.

South Pinnacle Rock: rock, at Cape Lazaref, on SE coast of Unimak I., Aleutian Is.; $54^{\circ} 36$ $\mathrm{N}, 163^{\circ} 35^{\prime} \mathrm{W}$; (map 25 ).

Descriptive name reported in 1926 by USC\&GS.

South Point: point of land, $\mathrm{S}$ tip of Semisopochnoi I., Aleutian Is.; $51^{\circ} 52^{\prime} 45^{\prime \prime} \mathrm{N}, 179^{\circ}$ $36^{\prime} 30^{\prime \prime} \mathrm{E}$; (map 15).

Name published on a 1943 U.S. Army Corps of Engineers map.

South Point: point of land, on $\mathbf{E}$ coast of Baranof I., at entrance to Kelp Bay, $20 \mathrm{mi}$. SW of Angoon, Alex. Arch.; 57 $16^{\prime} 15^{\prime \prime} \mathrm{N}, 134^{\circ} 51^{\prime}$ $40^{\prime \prime} \mathrm{W}$; (map 9).

Descriptive name given in 1895 by Lt. Comdr E. K. Moore, USN.

South Point: point of land, NE tip of an island between Mitchell Bay and Kootznahoo Inlet, off Admiralty I., $5 \mathrm{mi}$. NE of Angoon, Alex. Arch.; 57 $32^{\prime} 30^{\prime \prime} \mathrm{N}, 134^{\circ} 28^{\prime} 05^{\prime \prime} \mathrm{W}$; (map 9).

Named in 1869 by Comdr. R. W. Meade, USN; published by USC\&GS in 1883 Coas Pilot (p. 177).

South Point: point of land, $\mathbf{N}$ tip of Mindalina I., off Yakobi I., $20 \mathrm{mi}$. NW of Chichagof, Alex. Arch.; $57^{\circ} 52^{\prime} 25^{\prime \prime} \mathrm{N}, 136^{\circ} 29^{\prime} 30^{\prime \prime} \mathrm{W}$ (map 9)

Local name reported in 1951 by USGS.

South Point: point of land, S tip of Spruce I., NE of Kodiak I. ; $57^{\circ} 53^{\prime} 10^{\prime \prime} \mathrm{N}, 152^{\circ} 22^{\prime} 00^{\prime \prime}$ W; (map 34). Var. Mys Vkhoda il Yuzhnyy

Partial translation of "M[ys] Vkhoda :li Yuzhnyy" meaning "entrance or south cape," the name given to this point by Sub-Lt. Mikhail Murashev in 1839 or 1840 and published in 1849 on Russian Hydrog. Dept. Chart 1425.

South Point: point of land, see Harbor Point South Point: point of land, see Lauder, Point. South Point: point of land, see Meares Point.
South Point: point of land, see Nuka Point. South Point: point of land, see Ommaney, Cape. South Point: point of land, see Paralysis Point. South Point: point of land, see Zapadni Point. South Punuk Island: island, in Punuk Is. group, $16 \mathrm{mi}$. S of Northeast Cape, St. Lawrence I.; $63^{\circ} 05^{\prime} \mathrm{N}, 168^{\circ} 49^{\prime} \mathrm{W}$; (map 93).

Probably named by USC\&GS about 1925 .

South Pustoi Bay: cove, $0.2 \mathrm{mi}$. across, at $\mathrm{E}$ end of Umnak I., at Fort Glenn, $0.6 \mathrm{mi}$. SW of Pustoi I., Aleutian Is.; $53^{\circ} 23^{\prime} 35^{\prime \prime}$ N, $167^{\circ} 50^{\prime}$ $20^{\prime \prime} \mathrm{W}$; (map 23).

Name derived from Pustoi I. and reported in 1942 by U.S. Army Corps of Engineers.

South Quadra Mountain: mountain, 1,968 ft., on $\mathbf{S}$ shore of Boca de Quadra, $3 \mathrm{mi}$. $\mathbf{E}$ of Kah Shakes Point, Coast Mts.; $55^{\circ} 04^{\prime} 15^{\prime \prime} \mathrm{N}$, $130^{\circ} 54^{\prime} 45^{\prime \prime} \mathrm{W}$; (map 3).

Named in 1883 by Lt. Comdr. H. E. Nichols, USN.

South Rhine Peak: peak, 3,400 ft., $2.8 \mathrm{mi}$. SE of Hawthorn Peak and $8 \mathrm{mi}$. SE of Juneau, Coast Mts. ; $58^{\circ} 15^{\prime} \mathrm{N}$; $134^{\circ} 10^{\prime} \mathrm{W}$; (map 11).

Local mountaineering name reported in 1965 by D. A. Brew and A. B. Ford, USGS.

South River: stream, flows N $40 \mathrm{mi}$. to Unalakleet River, $3.5 \mathrm{mi}$. E of Unalakleet, Nulato Hills; $63^{\circ} 52^{\prime} 15^{\prime \prime} \mathrm{N}, 160^{\circ} 40^{\prime} 00^{\prime \prime} \mathrm{W}$; (map 91).

Local descriptive name reported in 1903 by Carl O. Lind of Unalakleet.

South Rock: rock, 2 mi. S of Cape Izigan, at $S$ end of Unalaska I., Aleutian Is. ; 53 ${ }^{\circ} 13^{\prime} 20^{\prime \prime}$ $\mathrm{N}, 167^{\circ} 39^{\prime} 35^{\prime \prime} \mathrm{W}$; (map 23).

Name reported in 1942 by U.S. Army Corps of Engineers and published in the 1944 Aleutian Coast Pilot (p. 57)

South Rock: rock, $8 \mathrm{mi}$. S of Sanak I., Aleutian Ra.; $54^{\circ} 17^{\prime} 43^{\prime \prime} \mathrm{N}, 162^{\circ} 42^{\prime} 20^{\prime \prime} \mathrm{W}$; (map 25).

Descriptive name reported by Ferdinand Westdahl, USC\&GS, commander of the Coast Survey steamer McArthur, who made surveys in this area in 1901.

South Rock: rock, $1,000 \mathrm{ft}$. long, in Pacific Ocean, off S coast of Petrel I., $1 \mathrm{mi}$. S of Forrester I., Alex. Arch.; 54 $45^{\circ} 00^{\prime \prime} \mathrm{N}, 133^{\circ} 30^{\prime}$ $30^{\prime \prime} \mathrm{W}$; (map 1).

Local descriptive name reported in 1948 by USGS.

South Rock: rock, $0.3 \mathrm{mi}$. off $\mathrm{N}$ coast of Chichagof 1. , in Lacy Cove, $1 \mathrm{mi}$. SW of Point Lavina, $33 \mathrm{mi}$. NW of Hoonah, Alex. Arch.; $58^{\circ} 13^{\prime} 05^{\prime \prime} \mathrm{N}, 136^{\circ} 19^{\prime} 25^{\prime \prime} \mathrm{W}$; (map 10).

Named by J. F. Pratt, USC\&GS, in 1901; published on Chart 8304 in 1904.

South Rock: rock, N of Observation I., $4 \mathrm{mi}$. N of Cordova, Chugach Mts.; 60 $36^{\prime} 30^{\prime \prime} \mathrm{N}$, $145^{\circ} 44^{\prime \prime} 00^{\prime \prime} \mathrm{W}$; (map 64)

Named by Lt. Comdr. J. F. Moser, USN, in 1897

South Rock: rock, see Nuka Rock.

South Rocks: rocks, off S shore of Chapel Cove, on SW coast of Adak I., Aleutian Is.; $51^{\circ}$ $38^{\prime} 46^{\prime \prime}$ N, $176^{\circ} 48^{\prime} 32^{\prime \prime}$ W; (map 17).

Descriptive name given by USC\&GS in 1929.

South Rocks: rocks, extend $900 \mathrm{ft}$. in Cordova Bay, off SE point of Long I., Alex. Arch.; 
$54^{\circ} 46^{\prime} \mathrm{N}, 132^{\circ} 36^{\prime} \mathrm{W}$; (map 1$)$.

Local descriptive name published by USC\&GS in 1943.

South Rocks: rocks, in Pacific Ocean, $10 \mathrm{mi}$. SE of Dolgoi I., Aleutian Ra.; $55^{\prime} 00^{\prime} 30^{\prime} \mathrm{N}$, $161^{\circ} 29^{\prime} 40^{\prime \prime} \mathrm{W}$; (map 28).

Local name shown on a 1953 USGS map.

South Rocks: rocks, $9.5 \mathrm{mi}$. S of Goddard, off SW coast of Baranof I., Alex. Arch.; 56 $42^{\prime}$ $00^{\prime \prime} \mathrm{N}, 135^{\circ} 19^{\prime} 40^{\prime \prime} \mathrm{W}$; (map 5).

Local name used by fishermen; published in 1929 by USC\&GS.

South Saddle Lake: lake, 1,200 ft. across, on Revillagigedo I. W of Carroll Inlet, $2.4 \mathrm{mi}$. SW of Nigelius Point, Alex. Arch.; 55 $31^{\prime} 30^{\prime \prime}$ N, 131 $22^{\prime} 20^{\prime \prime} \mathrm{W}$; BGN 1923; (map 3).

Named in 1923 by USFS.

South Salt Lagoon: lake, $0.7 \mathrm{mi}$. long, on Chukchi Sea coast, $1.4 \mathrm{mi}$. NE of Barrow, Arctic Plain: $71^{\circ} 18^{\prime} 40^{\prime \prime} \mathrm{N}, 156^{\circ} 43^{\prime} 10^{\prime \prime} \mathrm{W}$.; (map 153). Var. Ikpilin, Ikpiling.

Named for scientific purposes (Carson and Hussey, 1962). This feature may be the same lake Sgt. John Murdoch (1892, p. 28) recorded as "Ikpilin[g]" [Ikpiklik] meaning "having high banks."

South Sandy Cove: cove, $1.5 \mathrm{mi}$. across, in Glacier Bay National Monument, on E shore of Glacier Bay, $2 \mathrm{mi}$. SE of Sturgess I. and $44 \mathrm{mi}$. NW of Hoonah, St. Elias Mts.; $58^{\circ} 42^{\prime} 30^{\prime \prime} \mathrm{N}$, $136^{\circ} 00^{\prime} 30^{\prime \prime} \mathrm{W}$; (map 10).

Name published in 1959 by NPS.

South Sawyer Glacier: glacier, heads near Alaska-Canada boundary, at $57^{\circ} 40^{\prime} \mathrm{N}, 132^{\circ}$ $45^{\prime} \mathrm{W}$, trends NW $25 \mathrm{mi}$. to Tracy Arm, 60 mi. SE of Juneau, Coast Mts.; 57 $53^{\prime} \mathrm{N}$, $133^{\circ} 07^{\prime} \mathrm{W}$; (map 8).

Name in 1946 published by USFS.

South Sealion Hill: hill, $679 \mathrm{ft}$., on $\mathrm{E}$ coast of St. George I., in Pribilof Is.; $56^{\circ} 35^{\prime} 00^{\prime \prime}$ N, $169^{\circ} 30^{\prime} 10^{\prime \prime} \mathrm{W}$; (map. 38). Var. Propas'tchykoverushka, Tug'una'raro'logh-koverushka.

Name reported by Joseph Stanley-Brown, USGS, in 1891. This appears to be a partial translation of the Aleut-Russian name “' 'Tug'una'raro'logh-koverushka' * * * hill near Tugunararologh [i.e. dead sea-lion place] *** the southern of two Sealion Hills" listed by Putnam (1903, p. 1016), USC\&GS. Putnam (p. 1015) also gives the Russian name as 'Propas'tchy-koverushka' * * * hill near Propastchy * * *."

South Semidi Island: island, see Chowiet Island. South Slough: stream, see Red Wing Slough.

South-southeast Bay: bight, $1.2 \mathrm{mi}$. across, at mouth of Fenner Creek, on SE coast of Semisopochnoi I., Aleutian Is.; $51^{\circ} 54^{\prime} \mathrm{N}, 179^{\circ} 40^{\prime}$ E; (map 15).

Name published on a 1943 U.S. Army Corps of Engineers map.

South-southeast Point: point of land, on $\mathrm{S}$ coast of Little Sitkin I., Aleutian Is.; $51^{\circ} 54^{\prime} 15^{\prime \prime} \mathrm{N}$, $178^{\circ} 32^{\prime} 15^{\prime \prime} \mathrm{E}$; (map 15).

Name published on a 1943 U.S. Army Corps of Engineers map.

South-southeast Point: point of land, on SE coast of Semisopochnoi I., Aleutian Is.; $51^{\circ}$ $54^{\prime} 15^{\prime \prime} \mathrm{N}, 179^{\circ} 40^{\prime} 25^{\prime \prime} \mathrm{E}$; (map 15).
Name published on a 1943 U.S. Army Corps of Engineers map.

South-southwest Indent: bight, on SW coast of Semisopochnoi I., Aleutian Is.; $51^{\circ} 53^{\prime} 30^{\prime \prime} \mathrm{N}$, $179^{\circ} 34^{\prime} 00^{\prime \prime} \mathrm{E}$; (map 15).

Name published on a 1943 U.S. Army Corps of Engineers map.

South-southwest Point: point of land, $2.9 \mathrm{mi}$. NW of South Point, on SW coast of Semisopochnoi I., Aleutian Is.; 51 ${ }^{\circ} 53^{\prime} 40^{\prime \prime} \mathrm{N}, 179^{\circ}$ $32^{\prime} 40^{\prime \prime} \mathbf{E}$; (map 15).

Name published on a 1943 U.S. Army Corps of Engineers map.

South-southwest Point: point of land, $0.8 \mathrm{mi}$. NW of Prokhoda Point, Little Sitkin I., Aleutian Is.; $51^{\circ} 54^{\prime} 35^{\prime \prime} \mathrm{N}, 178^{\circ} 29^{\prime} 15^{\prime \prime} \mathrm{E}$; (map 15).

Name published on a 1943 U.S. Army Corps of Engineers map.

South Spit: island, $0.8 \mathrm{mi}$. long, between Golovnin Bay and Golovnin Lagoon, $1 \mathrm{mi}$. S. of Golovin and $42 \mathrm{mi}$. E of Solomon, Seward Penin. High.; 64 $31^{\prime} \mathrm{N}, 163^{\circ} 02^{\prime} \mathrm{W}$; (map 95).

Local named published in the 1938 USC\&GS Light List.

South Spit: point of land, extends N $2.5 \mathrm{mi}$, at entrance to Goodnews Bay, $10 \mathrm{mi}$. SW of Goodnews, Kilbuck-Kuskokwim Mts.; 59 03' N, $161^{\circ} 50^{\prime} \mathrm{W}$; (map 53).

Descriptive name published by G. L. Harrington (in Brooks, 1921, pl. 7), USGS.

South Spit: spit, on S shore of Shagak Bay, on NW coast of Adak I., Aleutian Is.; $51^{\circ} 51^{\prime} 50^{\prime \prime}$ N, $176^{\circ} 45^{\prime} 40^{\prime \prime} \mathrm{W}$; $B G N$ 1936; (map 17).

Descriptive name given by members of the U.S. Navy Aleutian Island Survey Expedition in 1934.

South Spit: spit, 3 mi. long, between Bristol and Egegik Bays on $\mathrm{N}$ coast of Alaska Penin., 41 mi. SW of Naknek, Bristol Bay Low.; 58 ${ }^{\circ}$ $11^{\prime} \mathrm{N}, 157^{\circ} 32^{\prime} \mathrm{W}$; (map 41).

Local name reported in 1952 by USGS.

South Summit Ear Mountain: peak, see West Peak.

South Trick Lake: lake, $0.8 \mathrm{mi}$. across, near terminus of Brady Glacier, in Glacier Bay National Monument, $3.5 \mathrm{mi}$. N of Murk Bay and $59 \mathrm{mi}$. SW of Hoonah, St. Elias Mts.; $58^{\circ}$ $21^{\prime} 20^{\prime \prime} \mathrm{N}, 136^{\circ} 42^{\prime} 45^{\prime \prime} \mathrm{W}$; BGN 1962; (map 10).

So named by the NPS in 1962 "because the lake empties itself periodically, apparently annually." It is about a mile south of North Trick Lake.

South Tuman Point: point of land, part of Tuman Head, on $W$ coast of Semisophochnoi I., Aleutian Is.; $51^{\circ} 58^{\prime} 00^{\prime \prime} \mathrm{N}, 179^{\circ} 28^{\prime} 05^{\prime \prime} \mathrm{E}$; (map 15).

Name published on a 1943 U.S. Army Corps of Engineers map.

South Twin: mountain, 7,444 ft., in Chigmit Mts., 3 mi. S of Iliamna Volcano, Aleutian Ra.; $59^{\circ} 59^{\prime} 10^{\prime \prime} \mathrm{N}, 153^{\circ} 04^{\prime} 00^{\prime \prime} \mathrm{W}$; (map 51 ).

Local descriptive name published in 1912 by USC\&GS.

South Twin Bay: $b a y, 1.5 \mathrm{mi}$. across, at SW end of Elrington I., $\mathrm{N}$ of Point Elrington, $45 \mathrm{mi}$.
SE of Seward, Chugach Mts., $59^{\circ} 57^{\prime} \mathrm{N}, 148^{\circ}$ 14' W; BGN 1929; (map 49).

Descriptive name given in 1927 by USC\&GS. See North Twin Bay.

South Twin Creek: stream, flows SE $5 \mathrm{mi}$. to North Fork Chandalar River $1.5 \mathrm{mi}$. S of mouth of North Twin Creek and $9 \mathrm{mi}$. N of Chandalar, Brooks Ra.; $67^{\circ} 37^{\prime} 30^{\prime \prime} \mathrm{N}, 148^{\circ}$ $26^{\prime} 00^{\prime \prime} \mathrm{W}$; (map 123).

Local name reported in 1956 by T. E. Taylor, USGS.

South Twin Glacier: glacier, in Tordrillo Mts., trends SW $9 \mathrm{mi}$. to its terminus at head of Skwentna River, $58 \mathrm{mi}$. NW of Tyonek, Alaska Ra.; $61^{\circ} 26^{\prime} 00^{\prime \prime} \mathrm{N}, 152^{\circ} 43^{\prime} 30^{\prime \prime} \mathrm{W}$; (map 70).

Local name reported in 1927 by S. R. Capps and R. H. Sargent (in Smith and others, 1929, pls. 1, 2), USGS.

South Twin Peak: mountain, 1,407 ft., one of Twin Peaks, on $\mathrm{W}$ shore of Alitak Bay, at $\mathrm{S}$ end of Kodiak I.; $56^{\circ} 54^{\prime} 10^{\prime \prime}$ N, 154 $13^{\prime} 30^{\prime \prime}$ W; (map 32).

Descriptive name published in 1943 by USC\&GS.

South Vallenar Point: point of land, on NE coast of Gravina I., $3.4 \mathrm{mi}$. S of Vallenar Point, Alex. Arch.; 55 $22^{\prime} 50^{\prime \prime}$ N, $131^{\circ} 52^{\prime} 40^{\prime \prime}$ W; (map 3).

Named in 1886 by USC\&GS.

Sout-hvick, Ile: island, see Sutwik Island.

Southwall: cliff, see Stonewall.

South Walrus Peak: peak, 2,927 ft., between Morzhovoi Bay and Thinpoint Cove, at SW end of Alaska Penin., 24 mi. NE of False Pass, Aleutian Ra.; 54 $58^{\prime} 40^{\prime \prime} \mathrm{N}, 162^{\circ} 50^{\prime} 40^{\prime \prime} \mathrm{W}$; BGN 1966; (map 25). Var. Walrus Peak, Walrus Peak South.

Descriptive name published by USC\&GS in the 1947 Alaska Coast Pilot (p. 339).

Southwest Anchorage: bay, $1.5 \mathrm{mi}$. across, on SW coast of Chirikof I., $100 \mathrm{mi}$. SW of Kodiak I.; $55^{\circ} 48^{\prime} \mathrm{N}, 155^{\circ} 44^{\prime} \mathrm{W}$; (map 32).

Descriptive name published in 1943 by USC\&GS.

Southwest Anchorage: cove, see Cemetery Cove. Southwest Bay: bay, $0.1 \mathrm{mi}$. across, part of English Bay, on SW coast of St. Paul I., in Pribilof Is.; $57^{\circ} 09^{\prime} 05^{\prime \prime} \mathrm{N}, 170^{\circ} 19^{\prime} 45^{\prime \prime} \mathrm{W}$; (map 38).

So called by Joseph Stanley-Brown, USGS, in 1891.

Southwest Bay: bay, see Zapadni Bay.

Southwest Bight: bay, see South Bight.

Southwest Branch Taku Glacier: glacier, heads $1 \mathrm{mi}$. E of Amherst Peak, trends NE $8 \mathrm{mi}$. to Taku Glacier, $21 \mathrm{mi}$. N of Juneau, Coast Mts.; $58^{\circ} 35^{\prime} 30^{\prime \prime} \mathrm{N}, 134^{\circ} 14^{\prime} 00^{\prime \prime} \mathrm{W}$; BGN 1965; (map 11).

Named by members of the Juneau Icefield Research Project in 1964.

Southwest Cape: promontory, $34 \mathrm{mi}$. SE of Gambell, on $S$ coast of Saint Lawrence Island; $63^{\circ} 19^{\prime} \mathrm{N}, 171^{\circ} 27^{\prime} \mathrm{W}$; BGN 1951; (map 93). Var. Cape Singikpa, Pekalok Cape, Pekaluk Cape, Pekaluk Point, Sikovuk Cape, Singikpa Cape. 
Descriptive name given in 1849 by Capt. M. D. Tebenkov.

Southwest Cape: point of land, see Powooiliak Point.

Southwest Cape: point of land, see Singikpak Point.

Southwest Cove: cove, extends $\mathrm{S} 1.5 \mathrm{mi}$. to Ernest Sound, 2 mi. E of Menefee Inlet, on $\mathbf{E}$ coast of Etolin I., $30 \mathrm{mi}$. SE of Wrangell, Alex. Arch.; $56^{\circ} 04^{\prime} 30^{\prime \prime} \mathrm{N}, 132^{\circ} 08^{\prime} 30^{\prime \prime} \mathrm{W}$; (map 6).

Descriptive name given in 1886 by Lt. Comdr. A. S. Snow, USN, probably because it is southwest of the southern end of Zimovia Strait. See Southeast Cove.

Southwest End: point of land, see Konets Head. Southwest End: point of land, see Tiderip Point. Southwest Fork of Gold Creek: stream, see Ice Creek.

Southwest Indent: bight, $1 \mathrm{mi}$. across, on SW coast of Semisopochnoi I., Aleutian Is.; $51^{\circ}$ $54^{\prime} 45^{\prime \prime} \mathrm{N}, 179^{\circ} 30^{\prime} 00^{\prime \prime} \mathrm{E}$; (map 15).

Name published on a 1943 U.S. Army Corps of Engineers map.

Southwest Islands: islands, off SE coast of Admiralty I., in Pybus Bay, $26 \mathrm{mi}$. SE of Angoon, Alex. Arch.; $57^{\circ} 17^{\prime} \mathrm{N}, 134^{\circ} 04^{\prime} \mathrm{W}$; (map 9).

Local name published by USC\&GS in 1943 Coast Pilot (p. 283).

Southwest Knob: promontory, elev. $160 \mathrm{ft}$., on SW coast of Semisopochnoi I., Aleutian Is.; $51^{\circ} 54^{\prime} 00^{\prime \prime} \mathrm{N}, 179^{\circ} 30^{\prime} 50^{\prime \prime} \mathrm{E}$; (map 15$)$.

Name published on a 1943 U.S. Army Corps of Engineers map.

Southwest Konets: point of land, see Konets Head.

Southwest Peak: peak, 1,960 ft., $2.2 \mathrm{mi}$. SW of Attu and $1 \mathrm{mi}$. S of West Peak, Attu I., Aleution Is.; $52^{\circ} 54^{\prime} 45^{\prime \prime} \mathrm{N}, 173^{\circ} 12^{\prime} 43^{\prime \prime} \mathrm{E}$; (map 13). Var. Brewer Peak.

Descriptive name reported by Lt. William Gibson, USN, a member of the North Pacific Exploring Expedition in 1855. The USC\&GS Chart 9198 (1947) shows the above name, but was also published in 1948 as "Brewer Peak" on an AMS map.

Southwest Point: point of land, on Buldir I., Aleutian Is.; $52^{\circ} 21^{\prime} \mathrm{N}, 175^{\circ} 54^{\prime}$ E. ; (map 14). Name shown on a 1950 AMS map.

Southwest Point: point of land, on SW coast of Wosnesenski I., $11 \mathrm{mi}$. NE of Dolgoi I., Ale'ıtian Ra.; 55 $11^{\prime} 00^{\prime \prime} \mathrm{N}, 161^{\circ} 24^{\prime} 30^{\prime \prime} \mathrm{W}$; (map 28).

Local name shown on a 1964 USC\&GS chart.

Southwest Point: point of land, on SW tip of St. Paul I., in Pribilof Is.; 57 $09^{\prime} 40^{\prime \prime} \mathrm{N}$, $170^{\circ} 24^{\prime} 50^{\prime \prime} \mathrm{W}$; (map 38). Var. South West Point, Mys Zapadnyy, Zapadnie Point.

Descriptive name published by Elliott (1881, St. Paul map) as "South West Point." It was called "M[ys] Zapadnyy," meaning "West Cape" by the Russians (Tebenkov, 1852, map 21).

Southwest Point: point of land, see Ikolik, Cape. Southwest Point: point of land, see Munoz, Point.
Southwest Twin: peak, 2,195 ft., on Twin Mtn., $9 \mathrm{mi}$. N of Tooth Mtn. and $20 \mathrm{mi}$. N of Goodnews, Kilbuck-Kuskokwim Mts.; 59 $23^{\prime} \mathrm{N}$, $161^{\circ} 42^{\prime} \mathrm{W}$; (map 53). Var. S. W. Twin.

Descriptive name given in 1914 by USC\&GS.

South Yoke Creek: stream, flows S $1.2 \mathrm{mi}$. to Yoke Bay, on E coast of Great Sitkin I., Aleutian Is. ; $52^{\circ} 00^{\prime} 10^{\prime \prime} \mathrm{N}, 176^{\circ} 03^{\prime} 40^{\prime \prime} \mathrm{W}$; (map 17).

Name published by USGS (in Simons and Mathewson, 1955, pl. 5).

South Yoke Mountain: peak, 2,448 ft., one of two peaks on Yoke Mountain, $4 \mathrm{mi}$. E of Jacksmith Bay and $28 \mathrm{mi}$. N of Goodnews, Kilbuck-Kuskokwim Mts.; $59^{\circ} 30^{\prime} \mathrm{N}, 161^{\circ} 38^{\prime}$ W; (map 53).

Named in 1914 by USC\&GS; published in 1915 on Chart 9103.

Soutkhvik: island, see Sutwik Island.

Soutvik Island: island, see Sutwik Island.

Souvoroff, Cape: bluff, see Suworof, Cape.

Sovwalk Creek: stream, flows N $3.5 \mathrm{mi}$. to Bering Sea, 2 mi. E of Savoonga, $\mathrm{N}$ coast of St. Lawrence I.; $63^{\circ} 41^{\prime} \mathrm{N}, 170^{\circ} 26^{\prime} \mathrm{W}$; $B G N$ 1951 ; (map 93). Var. Sovwalk River.

Eskimo name recommended by the Savoonga village council and reported in 1949 by Maj. H. B. Allen, USAF.

Sovwalk River: stream, see Sovwalk Creek.

Sowik: locality, see Iron Creek.

Soyhekla Creek: stream, see Henshaw Creek.

Sozavarika Island: island, $0.4 \mathrm{mi}$. across, $6 \mathrm{mi}$. $W$ of Deer I., Aleutian Ra.; $54^{\circ} 51^{\prime} 20^{\prime \prime} \mathrm{N}$, $162^{\circ} 31^{\prime} 35^{\prime \prime} \mathrm{W}$; (map 25). Var. Grassy Island, Low Island No. 1.

Aleut name given by USC\&GS in 1916 . This island was called "Low Island Number 1 " by USBF in 1888 .

Sozhekla River: stream, see Henshaw Creek.

Spacious Bay: estuary, extends W 6 mi. off Behm Canal, on NE coast of Cleveland Penin., Alex. Arch.; $55^{\circ} 51^{\prime} \mathrm{N}, 131^{\circ} 46^{\prime} \mathrm{W}$; (map 3).

Named in 1879 by W. H. Dall, USC\&GS, from Capt. Vancouver's description of its size (U.S. Coast and Geodetic Survey, 1883, p. $73)$.

Spafarief Bay: bay, $15 \mathrm{mi}$. across, on Kotzebue Sound, $10 \mathrm{mi}$. N of Candle, Kotzebue-Kobuk Low.; $66^{\circ} 08^{\prime} \mathrm{N}, 161^{\circ} 51^{\prime} \mathrm{W}$; (map 114). Var. Spafariefs Bay.

Named "Spafariefs Bay" by Lt. Otto von Kotzebue, IRN, in August, 1816.

Spafariefs Bay: bay, see Spafarief Bay.

Spalding Creek: stream, flows NE $5 \mathrm{mi}$. to Ganes Creek $5.5 \mathrm{mi}$. NE of its junc. with Last Chance Creek and $29 \mathrm{mi}$. W of McGrath, Kilbuck-Kuskokwim Mts.; $62^{\circ} 57^{\prime}$ N, $156^{\circ} 33^{\prime}$ W; (map 79).

Prospectors' name obtained in 1952 by USGS topographers.

Spalding Creek: stream, see Last Chance Creek. Spanberg, Cape: point of land, see Espenberg, Cape.

Spanberg Island: island, $2 \mathrm{mi}$. long, in $\mathrm{El}$ Capitan Passage, $\mathrm{N}$ of Orr I., Alex. Arch.; $55^{\circ} 59^{\prime} 30^{\prime \prime} \mathrm{N}, 133^{\circ} 19^{\prime} 30^{\prime \prime} \mathrm{W}$; (map 4). Var. Spangenberg Island.
Named in 1928 by USFS for Lt. Martin Spanberg, who was second in command on Vitus Bering's voyage in 1725.

Spangenberg Island: island, see Spanberg Island. Spangle Creek: stream, flows NE $3.9 \mathrm{mi}$. to Sulatna River, $0.5 \mathrm{mi}$. SE of Sulatna Crossing and $39 \mathrm{mi}$. $\mathrm{S}$ of Ruby, Kilbuck-Kuskokwim Mts. ; $64^{\circ} 11^{\prime} 10^{\prime} \mathrm{N}, 155^{\circ} 27^{\prime} 00^{\prime \prime} \mathrm{W}$; (map 98).

Prospectors' name published in 1921 by USGS.

Spangle Creek: stream, see Banner Creek.

Spangle Island: island, $10 \mathrm{mi}$. long, in Yukon River, $5 \mathrm{mi}$. W of Marshall, Yukon-Kuskokwim Delta ; $61^{\circ} 55^{\prime} \mathrm{N}, 162^{\circ} 25^{\prime} \mathrm{W}$; (map 74).

Riverboat pilots' name shown on a 1940 navigation chart of the Yukon River.

Spanish Islands: islands, extend $4 \mathrm{mi}$. $\mathrm{N}$ off NE tip of Coronation I., $49 \mathrm{mi}$. NW of Craig, Alex. Arch.; 55 $57^{\prime} \mathrm{N}, 134^{\circ} 07^{\prime} \mathrm{W}$; (map 4). Var. Iles des Espagnols.

The name "Iles des Espagnols," or "Spanish Islands," was given on August 8, 1786, by La Perouse who "applied [the name] to Warren Island" (Wagner, 1937, p. 451). W. H. Dall applied this name to "Warren and Coronation Islands and adjacent islets and rocks * * * (U.S. Coast and Geodetic Survey, 1883, p. 99). The name as presently applied was published by Baker (1906, p. 592), USGS.

Sparkle Creek: stream, flows W $1 \mathrm{mi}$. to Nome River, $10 \mathrm{mi}$. NE of Nome, Seward Penin. High.; $64^{\circ} 39^{\prime} \mathrm{N}, 165^{\circ} 17^{\prime} \mathrm{W}$; (map 94).

Prospectors' name reported on a map by S. E. King dated 1900 .

Sparks: locality, on left bank of Igushik River, $4 \mathrm{mi}$. SE of Amanka Lake and $25 \mathrm{mi}$. W of Dillingham, Kilbuck-Kuskokwim Mts. ; $59^{\circ} 02^{\prime}$ N, $159^{\circ} 09^{\prime} \mathrm{W}$; (map 53 ).

This village, named for an early settler, was reported in 1948 or 1949 by Frank Waskey, trader and prospector. It is no longer permanently occupied.

Sparrow Creek: stream, flows NE $0.4 \mathrm{mi}$. to head of Prospect Creek, in Flambeau River basin, $12 \mathrm{mi}$. NE of Nome, Seward Penin. High.; $64^{\circ} 37^{\prime} \mathrm{N}, 165^{\circ} 05^{\prime} \mathrm{W}$; (map 94).

Prospectors' name reported in 1904 by $\mathrm{T}$. G. Gerdine, USGS.

Sparrow Rocks: rocks, in Bering Sea, 2 mi. SW of Conquer Point, west-central coast of Kiska I., Aleutian Is.; $51^{\circ} 59^{\prime} 20^{\prime \prime} \mathrm{N}, 177^{\circ} 26^{\prime} 45^{\prime \prime} \mathrm{E}$; (map 14).

One of the "bird names" arbitrarily applied to features on Kiska I. in 1943 by USAAF for tactical purposes during World War II.

Spaska: cove, see Spasski Bay.

Spaskai, Port: cove, see Spasski Bay.

Spaskaia Bay; cove, see Spasski Bay.

Spaskaia Harbor: cove, see Spasski Bay. Spaskaia Island: island, see Spasski Island. Spaskai Island: island, see Spasski Island. Spaskaya Gavan: cove, see Spasski Bzy. Spasskaia Bay: cove, see Spasski Bay.

Spasskaia Creek: stream, see Spasski Creek. Spasskaia Island: island, see Spasski Island.

Spasski Bay: cove, $0.6 \mathrm{mi}$. across, on $\mathrm{N}$ coast of Chichagof I., $4 \mathrm{mi}$. E of Hoonah and $35 \mathrm{mi}$. 
SW of Juneau, Alex. Arch.; 58 $06^{\prime} 35^{\prime \prime} \mathrm{N}$, $135^{\circ} 19^{\prime} 00^{\prime \prime} \mathrm{W}$; BGN 1930; (map 11). Var. Port Spaskai, Spaska, Spaskaia Bay, Spaskaia Harbor, Spaskaya Gavan, Spasskaia Bay.

Russian name published by Lt. Sarichev (1826, map 5), IRN, as "Spaskaya Gavan" or literally "harbor of the church of our Savior," although the name in this case may commemorate Gregori Spasskaya, Russian hydrographer.

Spasski Creek: stream, on $\mathrm{N}$ end of Chichagof I., flows NW $8 \mathrm{mi}$. to Icy Strait, $1 \mathrm{mi}$. S of Pulizzi I. and $35 \mathrm{mi}$. SW of Juneau, Alex. Arch.; 58 $05^{\prime} 15^{\prime \prime} \mathrm{N}, 135^{\circ} 17^{\prime} 15^{\prime \prime} \mathrm{W}$; $B G N$ 1929; (map 11). Var. Spasskaia Creek.

Local name derived from Spasski Bay and reported in 1928 by USFS.

Spasski Island: island, $0.1 \mathrm{mi}$. across, in Icy Strait, $2 \mathrm{mi}$. NE of Neck Point on Chichagof I. and $33 \mathrm{mi}$. SW of Juneau, Alex. Arch.; $58^{\circ} 06^{\prime} 15^{\prime \prime} \mathrm{N}, 135^{\circ} 17^{\prime} 20^{\prime \prime} \mathrm{W}$; BGN 1930; (map 11). Var. Spaskaia Island, Spaskai Island, Spasskaia Island.

Named 'Spasskaia Island" in 1869 by Comdr. R. W. Meade, USN, on Hydrog. Chart 225 for the bay of this name (U.S. Coast and Geodetic Survey, 1883, p. 193). The spelling was modified by BGN to conform with the anglicized pronunciation. See Spasski Bay.

Spaulding Point: point of land, at $\mathrm{N}$ end of Auke Bay, E of village of Auke Bay, $10 \mathrm{mi}$. NW of Juneau, Coast Mts.; $58^{\circ} 23^{\circ} 00^{\prime \prime} \mathrm{N}$, $134^{\circ} 39^{\prime} 15^{\prime \prime} \mathrm{W}$; (map 11).

Named for Victor C. Spaulding, 1867-1937, who lived for many years near the point. Born in Massachusetts, he came to Alaska in 1897. He lived at Dawson and Atlin before going to Juneau to mine in 1906 (DeArmond, 1957 , p. 40).

Spawning Creek: stream, flows NE 4 mi. to Lake Schrader, $20 \mathrm{mi}$. NW of Mount Michelson, Brooks Ra. ; $69^{\circ} 22^{\prime} \mathrm{N}, 145^{\circ} 04^{\prime} \mathrm{W}$; (map 139).

Named in July 1952 by Bee and Hall (1956, p. 295).

Specimen Creek: ravine, former tributary of Gold Creek, about $2 \mathrm{mi}$. W of Juneau, Coast Mts.; 58 $18^{\prime} \mathrm{N}, 134^{\circ} 20^{\prime} \mathrm{W}$; (map 11).

Miners' name for a stream subsequently destroyed by mining operations (DeArmond, 1957, p. 22).

Specimen Gulch: ravine, trends W $1 \mathrm{mi}$. to Anvil Creek, $5 \mathrm{mi}$. $\mathrm{N}$ of Nome, Seward Penin. High.; $64^{\circ} 35^{\prime} \mathrm{N}, 165^{\circ} 23^{\prime} \mathrm{W}$; (map 94).

Prospectors' name shown on a 1900 "Map of Nome Peninsula" by J. M. Davidson and B. D. Blakeslee.

Spectacle Island: island, $3 \mathrm{mi}$. long, between Big Koniuji and Nagai Is., in Shumagin Is., Aleutian Ra. ; 55 $06^{\prime} 30^{\prime \prime}$ N, $159^{\circ} 43^{\prime} 30^{\prime \prime}$ W; (map 27). Var. Kangaiulouk Island, Kunaiugiuk Island.

Local name reported in 1872 by W. H. Dall, USC\&GS. It may be the "Kunaiugiuk Island" of Father Veniaminov (1840, v. 1, p. 255), which is described as "long with two hills;" or "Kangaiulouk," as published by Capt. Lutke (1836, p. 267).
Spectacle Lake: lake, $2.7 \mathrm{mi}$. long, $20 \mathrm{mi}$. SE of Big Mtn. and $38 \mathrm{mi}$. S of Iliamna, Aleutian Ra.; 58 $12^{\prime} 30^{\prime \prime} \mathrm{N}, 154^{\circ} 50^{\prime} 00^{\prime \prime} \mathrm{W}$; (map 51).

So named by R. H. Sargent, USGS, in 1923 because of its resemblance in outline to a pair of spectacles. Published by K. F. Mather (in Brooks and others, 1925, pl. 3), USGS.

Spectacle Lake: lake, $2.5 \mathrm{mi}$. long, $1 \mathrm{mi}$. W of Old Cache Lake and $8 \mathrm{mi}$. SW of junc. of Herron and Foraker Rivers, Tanana Low.; $63^{\circ} 35^{\prime} 00^{\prime \prime} \mathrm{N}, 152^{\circ} 23^{\prime} 00^{\prime \prime} \mathrm{W}$; (map 88).

Name reported in 1954 by USGS; so named because the lake's outline resembles a pair of spectacles.

Speedway Creek: stream, flows N $4 \mathrm{mi}$. to Castle Creek, $3 \mathrm{mi}$. SW of Castle Mtn. and $36 \mathrm{mi}$. NW of Anaktuvuk Pass, Arctic Slope ; $68^{\circ} 32^{\prime}$ $\mathrm{N}, 152^{\circ} 40^{\prime} \mathrm{W}$; (map 134).

So named in 1949 by W. W. Patton, USGS, "because the creek is bordered by smooth fiat upland surfaces that can be traversed by vehicles on wheels at top speed."

Speel Arm: estuary, trends S $5 \mathrm{mi}$. from mouth of Speel River to Bogert Point, at head of Port Snettisham, $29 \mathrm{mi}$. SE of Juneau, Coast Mts.; $58^{\circ} 04^{\prime} \mathrm{N}, 133^{\circ} 47^{\prime} \mathrm{W}$; (map 12). Var. Port Snettisham.

Name derived from Speel River; published in 1951 on a USGS map.

Speel Glacier: glacier, heads in British Columbia at $58^{\circ} 22^{\prime} \mathrm{N}, 133^{\circ} 22^{\prime} \mathrm{W}$, trends SW $12 \mathrm{mi}$. to Speel River, 34 mi. E of Juneau, Coast Mts.; $58^{\circ} 18^{\prime} 15^{\prime \prime} \mathrm{N}, 133^{\circ} 29^{\prime} 15^{\prime \prime} \mathrm{W}$; (map 12).

Name derived from Speel River, published in 1951 on a USGS map.

Speel Lake: lake, see Indian Lake.

Speel Point: point of land, on E bank of Speel River, $28 \mathrm{mi}$. SE of Juneau, Coast Mts.; $58^{\circ}$. $08^{\prime} 05^{\prime \prime} \mathrm{N}, 133^{\circ} 42^{\prime} 55^{\prime \prime} \mathrm{W}$; (map 12).

Named in 1888 by Lt. Comdr. C. M. Thomas, USN.

Speel River: locality, $2 \mathrm{mi}$. SE of Speel Point, and $30 \mathrm{mi}$. SE of Juneau, Coast Mts. ; $58^{\circ} 06^{\prime}$ $45^{\prime \prime} \mathrm{N}, 133^{\circ} 41^{\prime} 00^{\prime \prime} \mathrm{W}$; (map 12).

Name derived from Speel Point; published in 1943 by USC\&GS. The Speel River post office was established here in 1920 but was discontinued in 1931 (Ricks, 1965, p. 60).

Speel River: stream, heads in Speel Glacier, flows SW $16 \mathrm{mi}$. to Speel Arm $28 \mathrm{mi}$. SE of Juneau, Coast Mts. ; $58^{\circ} 07^{\prime} 40^{\prime \prime}$ N, $133^{\circ} 43^{\prime} 15^{\prime \prime}$ W; (map 12).

Named in 1888 by Lt. Comdr. C. M. Thomas, USN.

Spein Mountain: mountain, 2,381 ft., $46 \mathrm{mi}$. $\mathrm{SE}$ of Bethel, Kilbuck-Kuskokwim Mts.; $60^{\circ}$ $36^{\prime} \mathrm{N}, 160^{\circ} 27^{\prime} \mathrm{W}$; (map 59).

Local name reported in 1955 by J. M. Hoare, USGS.

Spellman River: stream, see Kavik River.

Spenard: city, pop. 9,074, between Anchorage and Anchorage International Airport, $3 \mathrm{mi}$. SE of Point Woronzof, Cook Inlet Low.; $61^{\circ}$ $11^{\prime} 18^{\prime \prime} \mathrm{N}, 149^{\circ} 55^{\prime} 00^{\prime \prime} \mathrm{W}$; (map 69).

Named for Joseph A. Spenard, 1879-1934, an early Anchorage settler and businessman who had a homestead on the shore of Lake Spenard. A post office, established here in
1949 but was discontinued in 1953 (Ricks, 1965 , p. 60 ).

Spenard, Lake: lake, $0.5 \mathrm{mi}$. across, at head of Hood Canal, $3.1 \mathrm{mi}$. SW of Anchorage, Cook Inlet Low.; $61^{\circ} 10^{\prime} 42^{\prime \prime} \mathrm{N}, 149^{\circ} 56^{\prime} 50^{\prime \prime} \mathrm{W}$; (map 69). Var. Jeter Lake.

Named for Joseph A. Spenard, 1879-1934, an early Anchorage settler and businessman who had a homestead on the shore of the lake. The Anchorage Times reported the name on August 24, 1916.

Spence Creek: stream, heads in lake, flows NW $5.5 \mathrm{mi}$. to Muddy River, $2 \mathrm{mi}$. NE of Lake Minchumina, Tanana Low.; $63^{\circ} 54^{\prime} 30^{\prime \prime} \mathrm{N}$, $152^{\circ} 03^{\prime} 40^{\prime \prime} \mathrm{W}$; (map 88).

Local name reported in 1954 by USGS.

Spencer: locality, $58.8 \mathrm{mi}$. on The Alaska RR., in S end of Placer River Valley, $19 \mathrm{mi}$. SE of Sunrise and $42 \mathrm{mi}$. NE of Seward, Chugach Mts.; $60^{\circ} 43^{\prime} 40^{\prime \prime} \mathrm{N}, 1^{\circ} 49^{\circ} 01^{\prime} 55^{\prime \prime} \mathrm{W}$; (map 63).

Listed as a flag stop in the 1913 Alaska RR. guide. Recent USGS maps indicate only one building at this site.

Spencer, Cape: point of land, at mouth of Dicks Arms, on N shore of Cross Sound, $45 \mathrm{mi}$. NW of Hoonah, St. Elias Mts. ; $58^{\circ} 12^{\prime} 45^{\prime \prime} \mathrm{N}, 136^{\circ}$.$39^{\prime} 30^{\prime \prime}$ W; BGN 1944; (map 10). Var. Punta de Villaluenga.

Named in 1794 by Capt. Vancouver, RN (1798, v. 3, p. 211), for Earl George John Spencer, 1758-1834, a member of the English House of Commons and First Lord of the Admiralty, 1794-1801. It was called "M[ys] Spenser" on Russian Hydrog. Dept. Chart 1378 in 1847. It is shown as "Punta de Villaluenga" on a general map in de Mofras' atlas published in 1845 (USC\&GS, 1883, p. 185).

Spencer, Point: point of land, at $\mathrm{N}$ end of spit between Bearing Sea and Point Clarence, 14 mi. W of Teller, Seward Penin. High.; $65^{\circ} 17^{\prime}$ N, $166^{\circ} 50^{\prime} \mathrm{W}$; (map 3). Var. Mys Spenser.

Named in 1827 by Capt. Beechey (1831, p. 543), RN, for Capt. Robert Spencer, RN.

Spencer Creek: stream, flows SE to Klokerblok River, about $25 \mathrm{mi}$. NE of Solomon, Seward Penin. High.; (map 95).

Prospectors' name reported on the 1900 "Map of Nome Peninsula" by J. M. Davidson and B. D. Blakeslee. This stream cannot be precisely located on current maps.

Spencer Glacier: glacier, heads in Kenai Mts., $6 \mathrm{mi}$. S of Carpathian Peak, and trends NW $11 \mathrm{mi}$. to $\mathrm{S}$ end of Placer River Valley, $20 \mathrm{mi}$. SE of Sunrise, Chugach Mts.; $60^{\circ} 42^{\prime} \mathrm{N}, 149^{\circ}$ 02' W; (map 63). Var. Placer River Glacier, Tebenkof Glacier.

Named in 1909 by U. S. Grant and D. F. Higgins, USGS, for a Mr. Spencer, paymaster of the Alaska Central RR., who fell in a crevasse in the glacier in 1906 and whose body was never recovered.

Spencer Glacier: glacier, see Tebenkof Glacier. Spenser, Mys: point of land, see Spencer, Point. Sphinx Creek: stream, flows SE $8 \mathrm{mi}$. to Tunulik River, $2.5 \mathrm{mi}$. N of Goodnews, Kilbuck- 
Kuskokwim Mts.; 5909'20" N, $161^{\circ} 36^{\prime} 00^{\prime \prime}$ W; (map 53).

Local name reported in 1954 by USGS.

Sphinx Island: island, in Prince William Sound, $1 \mathrm{mi}$. off SE coast of Ingot I., $68 \mathrm{mi}$. NE of Seward, Chugach Mts. ; $63^{\circ} 30^{\prime} 00^{\prime \prime} \mathrm{N}, 147^{\circ}$ $34^{\prime} 30^{\prime \prime}$ W; (map 63).

Name published in 1910 by USC\&GS

Sphinx Mountain: mountain, 3,571 ft., in DeLong Mts., 24 mi. NNE of Misheguk Mtn., Brooks Ra.; 68 $34^{\prime} 45^{\prime \prime}$ N, $160^{\circ} 51^{\prime} 00^{\prime \prime} \mathrm{W}$; $B G N 1966$; (map 131)

So named by the B. P. Exploration Co. in 1965 , because the mountain "when seen from the west looking east, bears a fanciful sphinxlike appearance."

Spicer Creek: stream, in Rampart Mts., flows S $11 \mathrm{mi}$. to Yukon River, $11 \mathrm{mi}$. ENE of Tanana, Kokrines-Hodzana High.; $65^{\circ} 12^{\prime} \mathrm{N}, 151^{\circ} 43^{\prime}$ W; (map 106).

Name reported in 1899 by Cantwell (1902, p. 277), USRCS.

Spider Island: island, $0.3 \mathrm{mi}$. long, in Glacier Bay National Monument, in Beardslee Is., 3.6 $\mathrm{mi}$. E of Strawberry I. and $55 \mathrm{mi}$. W of Juneau, St. Elias Mts., $58^{\circ} 31^{\prime} 20^{\prime \prime} \mathrm{N}, 1^{\circ} 5^{\circ} 53^{\prime} 00^{\prime \prime} \mathrm{W}$ $B G N$ 1948; (map 11).

Named in 1939 by USC\&GS.

Spier Creek: stream, flows NW $2 \mathrm{mi}$. to Goldstream Creek, $15 \mathrm{mi}$. NW of Fairbanks, Yukon-Tanana High.; $64^{\circ} 53^{\prime} 20^{\prime \prime} \mathrm{N}, 148^{\circ} 11^{\prime} 20^{\prime \prime}$ W; (map 100).

Named by prospectors; published in 1906 by USGS.

Spike Creek: stream, in De Long Mts., flows NNE $13 \mathrm{mi}$., to Iligluruk Creek, $36 \mathrm{mi}$. NW of Misheguk Mtn., Brooks Ra.; 68 $42^{\prime} \mathrm{N}$, $161^{\circ} 44^{\prime}$ W; BGN 1961; (map 131). Var. West Fork Iligluruk Greek

So named by USGS geologists in 1950 "because of several spike [temporary] camps located on its banks."

Spike Island: island, $0.2 \mathrm{mi}$. long, in Orca Inlet, $0.3 \mathrm{mi}$. W of Cordova, Chugach Mts.; $60^{\circ}$ $33^{\prime} \mathrm{N}, 145^{\circ} 46^{\prime} \mathrm{W}$; (map 64).

Local name reported by Moffit (1914, pl. 1), USGS.

Spike Mountain: mountain, 3,737 ft., $19 \mathrm{mi}$. NE of Rabbit Mtn., and $46 \mathrm{mi}$. NE of Coleen Mtn., Brooks Ra.; 67 $36^{\prime} \mathrm{N}, 141^{\circ} 39^{\prime} \mathrm{W}$; (map 121).

Local name for a prominent landmark reported in 1939 by FitzGerald (1944, p. 236), USGS.

Spike Rock: rock, in Wrangell Narrows at junc. with Beecher Pass, 15 mi. S of Petersburg, W coast of Mitkof Is., Alex. Arch.; $56^{\circ} 35^{\prime} 55^{\prime \prime} \mathrm{N}$, $132^{\circ} 58^{\prime} 30^{\prime \prime} \mathrm{W}$; (map 6).

Named in 1881 by USC\&GS

Spile Bay: estuary, see Pile Bay.

Spile River: stream, see Pile River.

Spinach Greek: RR. station, see Martin.

Spinach Creek: stream, flows SE $5 \mathrm{mi}$, to Goldstream Creek, $15 \mathrm{mi}$. NW of Fairbanks, YukonTanana High.; $64^{\circ} 54^{\prime} 05^{\prime \prime} \mathrm{N}, 148^{\circ} 10^{\prime} 20^{\prime \prime} \mathrm{W}$; (map 100)
Named by prospectors; reported in 1908 by L. M. Prindle and F. J. Katz (in Brooks and others, 1909, pl. 8), USGS.

Spine Mountain: mountain, 2,400 ft., on Annette I. between Cove and Narrows Mts. ; Alex. Arch.; $55^{\circ} 11^{\prime} 30^{\prime \prime} \mathrm{N}, 1^{\circ} 1^{\circ} 28^{\prime} 20^{\prime \prime} \mathrm{W}$; (map 3).

Descriptive name given in 1883 by Lt. Comdr. H. E. Nichols, USN.

Spink Creek: stream, flows $S$ through Spink Lake $10 \mathrm{mi}$. to Ghulitna River, $28 \mathrm{mi}$. NW of Talkeetna, Cook Inlet Low.; 62 $43^{\prime} 50^{\prime \prime} \mathrm{N}$, $150^{\circ} 15^{\prime} 00^{\prime \prime} \mathrm{W}$; (map 81)

Prospectors' name published in 1940 by USGS.

Spink Lake: lake, $1.3 \mathrm{mi}$. long, in course of Spink Creek $3 \mathrm{mi}$. $\mathrm{N}$ of its junc. with Chulitna River, $31 \mathrm{mi}$. $\mathrm{N}$ of Talkeetna, Alaska Ra.; $62^{\circ} 46^{\prime} 45^{\prime \prime} \mathrm{N}, 150^{\circ} 14^{\prime} 05^{\prime \prime} \mathrm{W}$; (map 81).

Prospectors' name published in 1940 by USGS.

Spiny Ridge: ridge, trends NE-SW $4 \mathrm{mi}$., in De Long Mts., $9 \mathrm{mi}$. NW of Wulik Peaks, 17 mi. SW of Mount Kelly, Brooks Ra.; $68^{\circ}$ $16^{\prime} 30^{\prime \prime} \mathrm{N}, 163^{\circ} 55^{\prime} 00^{\prime \prime} \mathrm{W}$ [NE end], $68^{\circ} 15^{\prime} \mathrm{N}$, $164^{\circ} 04^{\prime}$ W [SW end]; BGN 1965; (map 130).

Descriptive name proposed in 1965 by geologists of the B. P. Exploration Co., Inc.

Spiral Cove: cove, extends W $0.7 \mathrm{mi}$. off Kasaan Bay, on E coast of Prince Wales I., W of Patterson I., Alex. Arch.; 55 $22^{\prime} 17^{\prime \prime}$ N, $132^{\circ} 13^{\prime}$ 48" W; BGN 1966; (map 4).

Local name reported in 1961 by USFS.

Spiral Creek: stream, flows NE $1 \mathrm{mi}$. to Kasaan Bay, on $\mathbf{E}$ coast of Prince of Wales I., $35 \mathrm{mi}$. E of Craig, Alex. Arch.; 55 $22^{\prime} 20^{\prime \prime} \mathrm{N}, 132^{\circ}$ 14'15" W; (map 4).

Local descriptive name published in 1920 by USC\&GS

Spire Island: island, $0.4 \mathrm{mi}$. long, off $\mathbf{N}$ coast of Annette I., in Revillagigedo Channel, Alex. Arch.; $55^{\circ} 15^{\prime} 55^{\prime \prime}$ N, $131^{\circ} 30^{\prime} 15^{\prime \prime} \quad$ W (map 3).

Named in 1882 by USC\&GS.

Spire Island Reef: reef, extends $0.7 \mathrm{mi}$. in Revillagigedo Channel, $\mathrm{N}$ of Spire I., Alex. Arch.; $55^{\circ} 16^{\prime} 10^{\prime \prime} \mathrm{N}, 131^{\circ} 30^{\prime} 00^{\prime \prime} \mathrm{W}$; (map 3).

Named published in 1901 by USC\&GS.

Spire Rock: rock, on $\mathbf{E}$ shore of Eagle Bay, on $S$ coast of Unalaska I., Aleutian Is. ; $53^{\circ} 26^{\prime} 35^{\prime \prime}$ $\mathrm{N}, 166^{\circ} 55^{\prime} 30^{\prime \prime} \mathrm{W} ; B G N$ 1939; (map 23).

So named in 1937 by USC\&GS because of "the shape of the rock."

Spiridon Bay: bay, extends SE $16 \mathrm{mi}$., off Uyak Bay, on NW coast of Kodiak I.; $57^{\circ} 40^{\prime} \mathrm{N}$, $153^{\circ} 52^{\prime} \mathrm{W}$; BGN 1931; (map 34).

Local name reported in 1931 by USC\&GS to be "Named after the Russian saint, St. Spiridon."

Spiridon Lake: lake, $6 \mathrm{mi}$. long, $\mathrm{N}$ of Spiridon Bay, on NW coast of Kodiak I.; $57^{\circ} 43^{\prime} \mathrm{N}$, $153^{\circ} 41^{\prime} \mathrm{W}$; (map 34$)$.

Name derived from Spiridon Bay; published in 1952 by USGS

Spirit Lake: lake, $0.8 \mathrm{mi}$. long, in course of Fish Creek, E of Munsatli Ridge, $23 \mathrm{mi}$. WSW of village of Lake Minchumina, Kuskokwim Low.; 63 ${ }^{\circ} 41^{\prime} 15^{\prime \prime} \mathrm{N}, 152^{\circ} 55^{\prime} 00^{\prime \prime} \mathrm{W}$; (map 88).
Local name obtained in 1958 from Fabian Carey and "Val" Blackburn by USGS.

Spirit Mountain: mountain, $7,287 \mathrm{ft}$., $3.4 \mathrm{mi}$. SE of junc. of Uranalina River with Copper River, and $56 \mathrm{mi}$. NE of Valdez, Chugach Mts.; $61^{\circ} 19^{\prime} 35^{\prime \prime} \mathrm{N}, 144^{\circ} 37^{\prime} 30^{\prime \prime} \mathrm{W}$; (map 68).

Named in 1885 by Lt. Allen (1887, p. 46), USA, because "Kawkus, the oldest of the coast natives, informed us that formerly much fire and smoke were emitted from the mountain, and that now terrific rumblings were at times heard, all the workings of a Mighty Spirit."

Spirit Range: ridge, 6,600 ft., trends $\mathrm{N} 2 \mathrm{mi}$. $2 \mathrm{mi}$. E of Stronghold Peak and $33 \mathrm{mi}$. N of Juneau, Coast Mts.; $58^{\circ} 46^{\prime} 30^{\prime \prime} \mathrm{N}, 134^{\circ}$. 14'00" W; BGN 1965; (map 11).

Named by members of the Juneau Icefield Research Project in 1964.

Spirkin, Ostrov: island, sce Sedanka Island.

Spirkine: island, see Sedanka Island.

Spirkin Strait: water passage, see Udagak Strait. Spithead: point of land, E coast of Amaknak I., in Unalaska Bay, Unalaska I., Aleutian Is.; $53^{\circ} 53^{\prime} 54^{\prime \prime} \mathrm{N}, 166^{\circ} 30^{\prime} 49^{\prime \prime} \mathrm{W}$; (map 23).

Named in 1871 by W. H. Dall, USG\&GS.

Spitover, The: channel, of Hodzana River, 15 mi. NW of Beaver, Yukon Flats; $66^{\circ} 28^{\prime} 30^{\prime \prime} \mathrm{N}$, $147^{\circ} 52^{\prime} 00^{\prime \prime} \mathrm{W}$; (map 118).

Descriptive name of a meander cutoff obtained in 1956 by USGS.

Spit Point: point of land, on Revillagigedo I., on $\mathrm{S}$ shore of Carroll Inlet, $5.8 \mathrm{mi}$. NE of California Head, Alex. Arch.; 55 $22^{\prime} 35^{\prime} \mathrm{N}, 131^{\circ}$ $21^{\prime} 45^{\prime \prime} \mathrm{W}$; (map 3 ).

Descriptive name given in 1891 by USC\&GS.

Spit Point: point of land, see Split Point.

Spitz Island: island, $0.5 \mathrm{mi}$. across, $1 \mathrm{mi}$. S of Mitrofania- I., $32 \mathrm{mi}$. E of Stepovak Bay, Aleutian Ra.; $55^{\circ} 48^{\prime} 30^{\prime \prime} \mathrm{N}, 158^{\circ} 53^{\prime} 00^{\prime \prime} \mathrm{W}$; (map 27).

Named by Capt. Tebenkov (1852, map 24) in 1849 from the Russian word "spitsa," which is derived from the German "spitze," meaning "a pointed stick."

Split Creek: stream, heads at Canyon Glacier, flows $\mathrm{S} 4.5 \mathrm{mi}$. to Alsek River, $4.6 \mathrm{mi}$. NE of Dry Bay and $50 \mathrm{mi}$. SE of Yakutat, St. Elias Mts.; $59^{\circ} 12^{\prime} 00^{\prime \prime} \mathrm{N}, 138^{\circ} 28^{\prime} 15^{\prime \prime} \mathrm{W}$; (map 46).

Descriptive name published in 1959 by USGS. So called because of its braided condition.

Split Creek: stream, flow! N $3.5 \mathrm{mi}$. to Bering Lake, $8 \mathrm{mi}$. NE of Katalla, Chugach Mts.; $60^{\circ} 17^{\prime} \mathrm{N}, 144^{\circ} 20^{\prime} \mathrm{W}$; (map 64).

Name used by local prospectors "because the stream divides, one part fowing to Bering Lake and the other to the Katalla River," reported in 1905 by G. C. Martin, USGS.

Split Creek: stream, flows NE $2.3 \mathrm{mi}$. to Bear Creek, $24 \mathrm{mi}$. N of Haycock, Seward Penin. High.; $65^{\circ} 33^{\prime} \mathrm{N}, 161^{\circ} 05^{\prime} \mathrm{W}$; (map 109).

Local name shown on a 1903 fieldsheet by D. C. Witherspoon, USGS

Split Creek: stream, flows E $3 \mathrm{mi}$. from Split Glacier to Okpilak River in Romanzof Mts., 
Brooks Ra.; $69^{\circ} 16^{\prime} \mathrm{N}, 144^{\circ} 00^{\prime} \mathrm{W}$; (map 139).

Name published on a map by E. G. Sable, in USGS Open File report 810, 1965 . Named for Split Glacier.

Split Glacier: glacier, trends S $1.5 \mathrm{mi}$. from unnamed ice field in Kenai Mts. to an unnamed stream $3 \mathrm{mi}$. $\mathrm{N}$ of North Arm Nuka Bay, $38 \mathrm{mi}$. E of Homer, Chugach Mts.; $59^{\circ}$ $38^{\prime} 30^{\prime \prime} \mathrm{N}, 150^{\circ} 28^{\prime} 00^{\prime \prime} \mathrm{W}$; BGN 1929; (map $50)$.

Descriptive name given by Grant and Higgins (1913, pl. 2), USGS, and so named "because a huge rock splits or divides this glacier."

Split Glacier: glacier, trends NE $3 \mathrm{mi}$, to head of Split Creek, in Romanzof Mts., $5 \mathrm{mi}$. S of Mount Michelson, Brooks Ra.; $69^{\circ} 15^{\prime} \mathrm{N}$, $144^{\circ} 07^{\prime} \mathrm{W}$; (map 139).

Name published on a map by E. G. Sable, in USGS Open File Report 810, 1965. So named because the foot of the glacier is split or bifurcated.

Split Island: island, $0.1 \mathrm{mi}$. long, in Clarence Strait, $0.8 \mathrm{mi}$. S of Kelp Point, $\mathrm{W}$ coast of Etolin I., Alex. Arch.; $55^{\circ} 57^{\prime} \mathrm{N}, 132^{\circ} 27^{\prime} \mathrm{W}$; (map 4).

Descriptive name given in 1886 by Lt. Comdr. A. S. Snow, USN.

Split Point: point of land, between Middle and South Arms of Three Arm Bay, on $W$ coast Adak I., Aleutian Is.; 51 ${ }^{\circ} 44^{\prime} 28^{\prime \prime} \mathrm{N}$, $176^{\circ} 51^{\prime} 00^{\prime \prime}$ W ; BGN 1936; (map 17). Var. Spit Point.

Named by members of the U.S. Navy Aleutian Island Survey Expedition in 1934, "because it separates the South Arm from the Middle Arm of Three Arm Bay."

Split Rock: rock, in Bering Sea, $1 \mathrm{mi}$. SW of St. Matthew I. and $6.5 \mathrm{mi}$. NW of Sugarloaf Mtn.; $60^{\circ} 22^{\prime} \mathrm{N}, 172^{\circ} 46^{\prime} \mathrm{W}$; (map 56).

Descriptive name published in 1874 by USC\&GS on Chart 891 .

Splitrock Point: point of land, on SE shore of Olga Bay, 35 mi. SE of Karluk, on SW part of Kodiak I.; $57^{\circ} 06^{\prime} 18^{\prime \prime} \mathrm{N}, 154^{\circ} 05^{\prime} 30^{\prime \prime} \mathrm{W}$; (map 35).

Descriptive local name published in 1943 by USC\&GS

Splits, The: reach, $3 \mathrm{mi}$. long, in Salcha River, between North and South Forks Salcha River, 36 mi. NE of Big Delta, Yukon-Tanana High.; $64^{\circ} 39^{\prime} \mathrm{N}, 145^{\circ} 24^{\prime} \mathrm{W}$; (map 101).

A reach having a braided pattern; reported in 1904 by D. C. Witherspoon (in Prindle, 1913a, pl. 1), USGS.

Split Thumb: peak, 5,523 ft., $2 \mathrm{mi}$. SE of Nugget Mtn. and $9 \mathrm{mi}$. NE of Juneau, Coast Mts.; $58^{\circ} 24^{\prime} 25^{\prime \prime} \mathrm{N}, 134^{\circ} 18^{\prime} 35^{\prime \prime} \mathrm{W}$; (map 11).

Local name published in 1951 by USGS.

Split Thumb Icefall: icefall, at head of Middle Branch Morris Glacier, $1.5 \mathrm{mi}$. E of Split Thumb and $10 \mathrm{mi}$. NE of Juneau, Coast Mts.; $58^{\circ} 24^{\prime} 30^{\prime \prime} \mathrm{N}, 134^{\circ} 16^{\prime} 30^{\prime \prime} \mathrm{W}$; (map 11).

Local : ountaineering name reported in 1965 by D. A. Brew and A. B. Ford, USGS. Split Tip Island: island, see Megotsol Island.
Split Top: mountain, 2,010 ft., on SW coast of Adak I., Aleutian Is., $51^{\circ} 42^{\prime} 30^{\prime \prime} \mathrm{N}, 176^{\circ} 45^{\prime}$ $00^{\prime \prime} \mathrm{W}$; (map 17).

Descriptive name given by Lt. William Gibson, USN, commander of the schooner Fenimore Cooper, during the North Pacific Exploring Expedition in 1855.

Split Top Mountain: mountain, $1,851 \mathrm{ft}$., $E$ shore of Unalaska Bay, NE coast of Unallaska I., Aleutian Is.; 53 ${ }^{\circ} 5^{\prime} 59^{\prime \prime} \mathrm{N} 166^{\circ} 25^{\prime}$ 44" W; (map 23).

Descriptive name given in 1871 by W. $\mathrm{H}$. Dall, USC\&GS.

Spokane Cove: bay, $1 \mathrm{mi}$. across, in Glacier Bay National Monument, on E side of Glacier Bay, $20 \mathrm{mi}$. NW of Gustzvus, St. Elias Mts.; $58^{\circ} 41^{\prime} 45^{\prime \prime} \mathrm{N}, 135^{\circ} 58^{\prime} 00^{\prime \prime} \mathrm{W}$; BGN 1963; (map 11).

Named in 1942 by USC\&GS for the excursion steamer SS Spokane. After the great Yakutat Earthquake of 1899, excursion steamers had not been able to get to the vicinity of the Muir Glacier. In 1907, however, the SS Spokane succeeded for the first time in approaching to within one mile of the face of the glacier.

Spokane Creek: stream, on Kenai Penin., flows NW $1.5 \mathrm{mi}$. to Granite Creek, $2 \mathrm{mi}$. SW of Whittier, Chugach Mts.; $60^{\circ} 44^{\prime} 30^{\prime}$ W, $149^{\circ} 15^{\prime} 30^{\prime \prime} \mathrm{W}$; (map 63).

Local name reported in 1909 by Grant and Higgins (1913, pl. 1), USGS.

Spook Island: island, $0.6 \mathrm{mi}$. long, in South Pass, $0.5 \mathrm{mi}$. W of Hydaburg, on W coast of Prince of Wales I., Alex. Arch.; 55 $12^{\prime} 15^{\prime \prime} \mathrm{N}$, $132^{\circ} 50^{\prime} 35^{\prime \prime} \mathrm{W}$; (map 4).

Local name published in 1965 by USC:\&GS.

Spooky Valley: valley, in Ray Mts., extends 4.5 mi. across headwaters of Kobuk Creek, $9 \mathrm{mi}$. WNW of Mount Tozi and $45 \mathrm{mi}$. NNE of Tanana, Kokrines-Hodzana High.; $65^{\circ} 43^{\prime} \mathrm{N}$, $151^{\circ} 16^{\prime} \mathrm{W}$; (map 106).

Local name reported in 1956 by Orth: so named because of the weird rock formations there.

Spooner: locality, at junc. of Noxapaga and Kuzitrin Rivers, $32 \mathrm{mi}$. SW of Imuruk Lake, Seward Penin. High.; $65^{\circ} 23^{\prime} \mathrm{N}, 164^{\circ} 13^{\prime} \mathrm{W}$; (map 110).

Site of a mining camp established about 1901 at the beginning of gold mining in the region: reported that year by T. G. Gerdine (in Collier, 1902, pl. 12), USGS. The Spooner Post Office was established in 1902 and discontinued in 1903 (Ricks, 1965, p. 60). By 1906, the name was left off maps.

Spoon Fish Lake: lake, $1 \mathrm{mi}$. long, $4 \mathrm{mi}$. N of Titus Mtn. and $19 \mathrm{mi}$. NE of Arctic Village, Brooks Ra.; $68^{\circ} 17^{\prime} \mathrm{N}, 144^{\circ} 55^{\prime} \mathrm{W}$; (map 136).

Local name reported in 1956 by R. C. Foley, USGS.

Spoon Glacier: glacier, on Resurrection Penin., trends $\mathrm{E} 1 \mathrm{mi}$. to its terminus, $8 \mathrm{mi}$. SE of Seward, Chugach Mts.; 6001'15" N, $149^{\circ}-$ $16^{\prime} 05^{\prime \prime} \mathrm{W} ; B G N 1911$; (map 63)

Named in 1908 by Grant and Higgins (1913, p. 55), USGS. So named "on ac- count of its smooth, glassy, round front, which reminds one approaching from below of the inverted end of a huge spoon."

Sportfish Lake: lake, $1 \mathrm{mi}$. long, on Kenai Penin. NW of Barabara Lake, $27 \mathrm{mi}$. SSW of Anchorage, Cook Inlet Low.; $60^{\circ} 51^{\prime} 30^{\prime \prime} \mathrm{N}, 150^{\circ} 17^{\prime}$ 00" W; BGN 1965; (map 62). Var. Fish Lake, Hinchey Lake, One Island Lake.

Named about 1963 by officials of Kenai National Moose Range, because it "has a good population of sport fish *** and the name *** is more compatible [than Hinchey Lake] with a recreational area."

Spot Mountain: mountain, 1,755 ft., on E coast of Gravina I., $1.6 \mathrm{mi}$. W of Blank Point, Alex. Arch.; 55 $5^{\circ} 15^{\prime} 35^{\prime \prime} \mathrm{N}, 131^{\circ} 42^{\prime} 35^{\prime \prime} \mathrm{W}$; (map $3)$.

Named in 1883 by Lt. Comdr. H. E. Nichols, USN.

Spotted Glacier: glacier, heads on Mount Douglas, in Katmai National Monument, trends $\mathbf{N}$ $8 \mathrm{mi}$. to its terminus, $24 \mathrm{mi}$. $\mathrm{S}$ of Augustine I., Aleutian Ra.; $58^{\circ} 58^{\prime} \mathrm{N}, 153^{\circ} 28^{\prime} \mathrm{W}$; (map 43).

Descriptive name published in 1926 on a USGS map.

Spray Cape: point of land, $\mathrm{W}$ coast of Unalaska I., Aleutian Is.; $53^{\circ} 36^{\prime} 50^{\prime \prime} \mathrm{N}, 1^{\circ} 7^{\circ} 09^{\prime}$ 20" W; (map 23). Var. Cape Mokrovskoi, Cape Morkovskoi. Mys Mokrovskoy.

Named by USBF in 1888 . This cape was called "Mys Mokrovskoy" meaning "wet cape" by Capt. Sarichev (1826, map 14, dated 1792), IRN.

Spray Creek: stream, flows SW $3 \mathrm{mi}$. to Maclaren River, $0.8 \mathrm{mi}$. S of Maclaren Glacier terminus and $25 \mathrm{mi}$. SE of Mount Hayes, Alaska Ra.; $63^{\circ} 16^{\prime} 30^{\prime \prime} \mathrm{N}, 146^{\circ} 31^{\prime} 00^{\prime \prime} \mathrm{W}$; (map 86).

Name published on relatively recent maps. Spray Island: island, $5 \mathrm{mi}$. long, in Thomas Bay, $1 \mathrm{mi}$. E of Ruth I., and $15 \mathrm{mi}$. NE of Petersburg, Coast Mts. ; $57^{\circ} 00^{\prime} 00^{\prime \prime} \mathrm{N}, 132^{\circ} 47^{\prime} 35^{\prime \prime}$ W; (map 6).

Named in 1887 by Lt. Comdr. C. M. Thomas, USN, for charting purposes; published in 1888 on USC\&GS Chart 705.

Spring Camp Lake: lake, $3 \mathrm{mi}$. long, drains $\mathrm{N}$ to Fish Creek, $1.5 \mathrm{mi}$. WSW of Fish Lake and $22 \mathrm{mi}$. SE of Tanana, Nowitna Low.; $65^{\circ} 01^{\prime}$ $30^{\prime \prime} \mathrm{N}, 151^{\circ} 23^{\prime} 00^{\prime \prime} \mathrm{W}$ : (map 106).

Local name reported in 1952 by USGS.

Spring Cove: cove, $0.3 \mathrm{mi}$. across, $2.3 \mathrm{mi}$. SE of Dark Cove, on SW coast of Kiska I., Aleutian Is. ; $51^{\circ} 51^{\prime} 40^{\prime \prime} \mathrm{N}, 177^{\circ} 16^{\prime} 15^{\prime \prime} \mathrm{E}$; (map 14).

One of many arbitrary names applied to features on Kiska I. by USAAF for tactical purposes during World War II.

Spring Creek: stream, flows E $5 \mathrm{mi}$. to Marsh Creek at Otter Bight, $N$ of Fort Glenn, NE coast of Umnak I., Aleutian Is.; $53^{\circ} 25^{\prime} 40^{\prime \prime}$ $\mathrm{N}, 167^{\circ} 51^{\prime} 30^{\prime \prime} \mathrm{W}$; (map 23).

Name reported in 1942 as Reindeer Creek by U.S. Army Corps of Engineers and published as Spring Creek by USGS (Byers, 1959, pl. 41).

Spring Creek: stream, on Cleveland Penin., flows NE $2.5 \mathrm{mi}$. to Lake Shelokum, Alex. Arch.; 
$55^{\circ} 59^{\prime} 15^{\prime \prime} \mathrm{N}, 131^{\circ} 39^{\prime} 28^{\prime \prime} \mathrm{W}$; (map 3 ).

Local name recorded in 1916 by Waring (1917, fig. 1), USGS ; derived from Bailey Bay Hot Springs.

Spring Creek: stream, flows S $0.2 \mathrm{mi}$. to $\mathrm{N}$ tip of Karluk Lake, in E part of Kodiak I., $16 \mathrm{mi}$. $\mathrm{SE}$ of Karluk; $57^{\circ} 26^{\prime} 35^{\prime \prime} \mathrm{N}, 154^{\circ} 05^{\prime} 50^{\prime \prime} \mathrm{W}$; (map 35).

Name published in 1957 on an AMS map.

Spring Creek: stream, anabranch of Rabbit Slough, flows W $4.3 \mathrm{mi}$. to join Rabbit Slough to form Palmer Slough, $7 \mathrm{mi}$. SW of Palmer, Cook Inlet Low.; $61^{\circ} 32^{\prime} \mathrm{N}, 149^{\circ} 16^{\prime} \mathrm{W}$; (map 69).

Local name reported in 1951 by USGS.

Spring Creek: stream, heads at glacier in Tordrillo Mts., flows NE $17 \mathrm{mi}$. to Hayes River, $64 \mathrm{mi}$. NW of Tyonek, Alaska Ra.; $61^{\circ} 53^{\prime} 45^{\prime \prime}$ $\mathrm{N}, 152^{\circ} 03^{\prime} 50^{\prime \prime} \mathrm{W}$; (map 70).

Local descriptive name reported in 1958 by USGS

Spring Creek: stream, flows S $18 \mathrm{mi}$. to Gakona River, $19 \mathrm{mi}$. NW of Chistochina, Copper River Basin; $62^{\circ} 37^{\prime} \mathrm{N}, 145^{\circ} 15^{\prime} \mathrm{W}$; (map 83).

Local name reported by USGS in 1950.

Spring Creek: stream, flows SW $8 \mathrm{mi}$. to Sweepstakes Creek, $9 \mathrm{mi}$. NW of Haycock, Seward Penin. High.; $65^{\circ} 20^{\prime} \mathrm{N}, 161^{\circ} 16^{\prime} \mathrm{W}$; (map 109).

Local name reported in 1917 by G. L. Harrington, USGS.

Spring Creek: stream, flows W $3 \mathrm{mi}$. to Wild Lake, $9 \mathrm{mi}$. N of junc. of Flat Creek and Wild River, Brooks Ra.; $67^{\circ} 31^{\prime} 10^{\prime \prime} \mathrm{N}, 151^{\circ} 32^{\prime} 15^{\prime \prime}$ W; (map 124).

Local descriptive name obtained in 1909 by A. G. Maddren, USGS.

Spring Creek: stream, flows SE $18 \mathrm{mi}$. to Junjik River, $4.5 \mathrm{mi}$. SE of Little Njoo Mtn. and 22 mi. NW of Arctic Village, Brooks Ra.; 68 ${ }^{\circ} 25^{\prime}$ $N, 145^{\circ} 57^{\prime} \mathrm{W}$; (map 136).

Local name reported in 1956 by R. C. Foley, USGS.

Spring Creek: stream, see Bull Creek.

Spring Gulch: ravine, tributary to Gold Creek, about $2 \mathrm{mi}$. W of Juneau, Coast Mts.; $58^{\circ} 18^{\prime}$ N, $134^{\circ} 20^{\prime \prime} \mathrm{W}$; (map 11).

Miners' name for a gulch subsequently destroyed by mining operations (DeArmond, 1957, p. 22).

Spring Lake: lake, 1,000 ft. long, 1,300 ft. SW of Sixmile Lake and $5 \mathrm{mi}$. NE of Anchorage, Cook Inlet Low.; $61^{\circ} 17^{\prime} \mathrm{N}, 149^{\circ} 49^{\prime} \mathrm{W}$; (map 69).

Local name reported in 1942 by AMS.

Spring Lakes: lakes, group of lakes, at NE entrance to Chinitna Bay, $48 \mathrm{mi}$. NW of Homer, Aleutian Ra.; $59^{\circ} 53^{\prime} 30^{\prime \prime} \mathrm{N}, 152^{\circ} 51^{\prime} 00^{\prime \prime} \mathrm{W}$; (map 50)

Local name reported and published by USGS in the 1950's.

Spring Point: point of land, on $\mathrm{W}$ shore of Cook Inlet, $48 \mathrm{mi}$. NW of Homer, Aleutian Ra.; $59^{\circ} 52^{\prime} 45^{\prime \prime} \mathrm{N}, 152^{\circ} 48^{\prime} 15^{\prime \prime} \mathrm{W}$; (map 50$)$.

Local name reported and published by USGS in the 1950's.

Springs Mountain: hill, see Kliuchef, Mount.
Spring Water Lakes: lakes, four, largest $800 \mathrm{ft}$. across, $0.3 \mathrm{mi} \mathrm{N}$ of Tyonek, Cook Inlet Low.; $61^{\circ} 04^{\prime} 20^{\prime \prime} \mathrm{N}, 151^{\circ} 08^{\prime} 25^{\prime \prime} \mathrm{W}$; (map 70).

This group of lakes was reported by USGS on a map published in 1958 .

Springway Creek: stream, flows $\mathrm{S} 7 \mathrm{mi}$. to $\mathrm{Mul}$ chatna River, $14 \mathrm{mi}$. NW of Tutná Lake and $45 \mathrm{mi}$. NW of Nondalton, Lime Hills; $60^{\circ} 28^{\prime}$ $30^{\prime \prime} \mathrm{N}, 155^{\circ} 44^{\prime} 00^{\prime \prime} \mathrm{W}$; (map 61).

Local name reported in 1950 by USC\&GS.

Spruce Cape: point of land, between Mill Bay and Woody I. Channel, $3.5 \mathrm{mi}$. NE of Kodiak, Kodiak I.; 5 $7^{\circ} 49^{\prime} 15^{\prime \prime} \mathrm{N}, 152^{\circ} 20^{\prime} 00^{\prime \prime} \mathrm{W}$; (map 34). Var. Elovoi Cape, Elovoi Vneshnie Cape, Mys Yelovoy Vneshney.

Name derived from Spruce Island and published as "M[ys] Yelovoy Vneshney," meaning "outer spruce cape," by Sarichev (1826, map 16).

Spruce Cape: point of land, see Uzinki Point.

Spruce Creek: stream, heads on $\mathrm{W}$ side of Bear Mtn., flows S $2 \mathrm{mi}$., then NE $3 \mathrm{mi}$., to Resurrection Bay, $1.5 \mathrm{mi}$. S of Seward, Chugach Mts.; $60^{\circ} 04^{\prime} 30^{\prime \prime} \mathrm{N}, 149^{\circ} 26^{\prime} 30^{\prime \prime} \mathrm{W}$; (map 63).

Local name reported in 1951 by USGS.

Spruce Creek: stream, on Hawkins I., flows NW $1.5 \mathrm{mi}$. to Cedar Bay, $9 \mathrm{mi}$. W of Cordova, Chugach Mts.; $60^{\circ} 33^{\prime} 20^{\prime \prime} \mathrm{N}, 146^{\circ} 00^{\prime} 00^{\prime \prime} \mathrm{W}$; (map 64).

Name published in 1950 by USGS.

Spruce Creek: stream, flows S $1.9 \mathrm{mi}$. to Bear Creek, $5.4 \mathrm{mi}$. NE of Nyac and $38 \mathrm{mi}$. SW of Aniak, Kilbuck-Kuskokwim Mts.; $61^{\circ} 02$ $35^{\prime \prime} \mathrm{N}, 159^{\circ} 48^{\prime} 00^{\prime \prime} \mathrm{W}$; (map 73).

Prospectors' name shown on a 1914 fieldsheet by A. G. Maddren, USGS.

Spruce Creek: stream, flows W $12.5 \mathrm{mi}$. to Wilson Creek Slough, $5 \mathrm{mi}$. S of Marshall, YukonKuskokwim Delta ; $61^{\circ} 48^{\prime} 20^{\prime \prime} \mathrm{N}, 162^{\circ} 02^{\prime} 10^{\prime \prime}$ W; (map 74).

Miners' name published by Harrington (1918, p. 63), USGS.

Spruce Creek: stream, heads in Peters Hills, flows SW $3.1 \mathrm{mi}$. to Cache Creek, S of Fox Gulch, $30 \mathrm{mi}$. NW of Talkeetna, Alaska Ra.; $62^{\circ} 25^{\prime}$ $25^{\prime \prime} \mathrm{N}, 151^{\circ} 01^{\prime} 40^{\prime \prime} \mathrm{W}$; (map 81).

Prospectors' name obtained in 1906 by $R$. W. Porter, USGS,

Spruce Creek: stream, flows NE $6.4 \mathrm{mi}$. to Innoko River, $1.7 \mathrm{mi} \mathrm{SE}$ of Ophir, $30 \mathrm{mi}$. NW of McGrath, Kilbuck-Kuskokwim Mts.; 63․ $07^{\prime} 40^{\prime \prime} \mathrm{N}, 156^{\circ} 28^{\prime} 20^{\prime \prime} \mathrm{W}$; (map 90).

Prospectors' name obtaincd in 1908 by Maddren (1910, pl. 1), USGS.

Spruce Creek: stream, at $\mathrm{S}$ end of Kantishna Hills, flows SSE $4 \mathrm{mi}$. to North Fork Moose Creek, $7.5 \mathrm{mi}$. ENE of Wonder Lake, Alaska

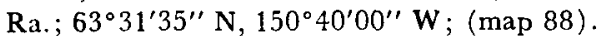

Local name shown on a 1916 fieldsheet by C. E. Giffin, USGS.

Spruce Creek: stream, flows NW $7 \mathrm{mi}$. to Norton Sound, $4.9 \mathrm{mi}$. NE of Tolstoi Point and $14 \mathrm{mi}$. SW of Unalaklect, Nulato Hills; $63^{\circ} 40^{\prime} 15^{\prime \prime} \mathrm{N}, 160^{\circ} 53^{\prime} 20^{\prime \prime} \mathrm{W}$; (map 91).

Local name reported in 1952 by USC\&GS; so named because of "the growth of scrub spruce pine in the ravine through which the stream runs."

Spruce Creek: stream, flows NE $3.5 \mathrm{mi}$. to Rex Creek, $50 \mathrm{mi}$. SE of Nenana, Alaska Ra.; $64^{\circ} 06^{\prime} 25^{\prime \prime} \mathrm{N}, 148^{\circ} 49^{\prime} 30^{\prime \prime} \mathrm{W}$; (map 100).

Local name reported in 1950 by USGS topographers.

Spruce Creek: stream, flows NE $4 \mathrm{mi}$. to Sulatna River, $2.8 \mathrm{mi}$. SE of Sulatna Crossing and 2.5 mi. W of Tamarack Bluff, Kilbuck-Kuskokwim Mts.; $64^{\circ} 10^{\prime} 12^{\prime \prime} \mathrm{N}, 155^{\circ} 24^{\prime} 45^{\prime \prime} \mathrm{W}$; (map 98).

Prospectors' name reported in 1913 by Eakin (1914, pl. 3), USGS.

Spruce Creek: stream, flows SW $1 \mathrm{mi}$. to Eldorado Creek which flows to Norton Sound, N of Basin Creek, $22 \mathrm{mi}$. E of Solomon, Seward Penin. High.; 64 $36^{\circ}$ N, $163^{\circ} 44^{\prime}$ W; (map 95).

Prospectors' name shown on Arthur Gibson's "Map of Cape Nome Precinct" dated 1904. This feature cannot be precisely located on current maps.

Spruce Creek: stream, flows SE $2 \mathrm{mi}$. to Klokerblok River, 22 mi. NE of Solomon, Seward Penin. High.; $64^{\circ} 40^{\prime} 30^{\prime \prime} \mathrm{N}, 163^{\circ} 44^{\prime} 45^{\prime \prime} \mathrm{W}$; (map 95).

Prospectors' name published on the 1908 "Map of Seward Peninsula" by Arthur Gibson.

Spruce Creek: stream, flows NW $3 \mathrm{mi}$. to Casadepaga River, $23 \mathrm{mi}$. NE of Solomon, Seward Penin. High.; $64^{\circ} 53^{\prime} \mathrm{N}, 164^{\circ} 13^{\prime} \mathrm{W}$; (map 95).

Prospectors' name reported in 1900 by E. C. Barnard (in Brooks, 1901, pl. 17), USGS.

Spruce Creek: stream, flows SW $8 \mathrm{mi}$. to Peluk Creek, 46 mi. NW of Nome, Seward Penin. High.; 64ํ․ $58^{\prime} \mathrm{N}, 166^{\circ} 32^{\prime} \mathrm{W}$; (map 94).

Prospectors' name reported in 1900 by E. C. Barnard (in Brooks, 1901, pl. 17), USGS.

Spruce Creek: stream, flows $\mathrm{N} 2 \mathrm{mi}$. to Little Eldorado Creek, 16 mi. NE of Fairbanks, Yukon-Tanana High.; $65^{\circ} 04^{\prime} 50^{\prime \prime} \mathrm{N}, 147^{\circ} 35^{\prime}$ $00^{\prime \prime} \mathrm{W}$; (map 105).

Named by prospectors, published in 1908 by USGS.

Spruce Creek: stream, flows SW $1.5 \mathrm{mi}$. to Minook Creek, $9 \mathrm{mi}$. S of Rampart, YukonTanana High.; $65^{\circ} 22^{\prime} 30^{\prime \prime} \mathrm{N}, 150^{\circ} 07^{\prime} 30^{\prime \prime} \mathrm{W}$; (map 106).

Prospectors' name reported in 1931 by J. B. Mertie, USGS

Spruce Creek: stream, flows S $4.5 \mathrm{mi}$. to Tozimoran Creek, $22 \mathrm{mi}$. NW of Tanana, KokrinesHodzana High.; $65^{\circ} 24^{\prime} \mathrm{N}, 152^{\circ} 38^{\prime} \mathrm{W}$; (map 106).

Prospectors' name reported in 1956 by R. M. Chapman, USGS.

Spruce Creek: stream, flows NE $7.8 \mathrm{mi}$. to join Circle Creek to form Holtz Creek in Kugruk River Basin, 19 mi. E of Imuruk Lake, Seward Penin. High.; $65^{\circ} 33^{\prime}$ N, $162^{\circ} 32^{\prime} \mathrm{W}$; (map 110).

Prospectors' name reported in 1903 by D. C Witherspoon (in Moffit, 1905, pl. 2), USGS. Spruce Creek: stream, flows NE $2 \mathrm{mi}$. to Hunter Creek, $35 \mathrm{mi}$. NW of Haycock, Seward Penin. 
High.; $65^{\circ} 42^{\prime} \mathrm{N}, 161^{\circ} 25^{\prime} \mathrm{W}$; (map 109).

Local name reported in 1908 by USGS (Brooks and others, 1909, fig. 21).

Spruce Creek: stream, in Baird Mts., flows SW $11 \mathrm{mi}$. to Timber Creek $11 \mathrm{mi}$. $\mathrm{N}$ of its junc. with Squirrel River, $22 \mathrm{mi}$. NW of Kiana, Brooks Ra.; $67^{\circ} 16^{\prime} 15^{\prime \prime} \mathrm{N}, 160^{\circ} 42^{\prime} 30^{\prime \prime} \mathrm{W}$; (map 127).

Prospectors' name; reported in 1910 by P. S. Smith, USGS.

Spruce Creek: stream, see Cache Greek.

Spruce Creek: stream, see Sheep Creek.

Sprucefish Lake: lake, $1.5 \mathrm{mi}$. long, in course of Lonestar Creek, $24 \mathrm{mi}$. SSW of village of Lake Minchumina, Kuskokwim Low.; $63^{\circ} 34^{\prime}$ 15" N, $152^{\circ} 42^{\prime} 30^{\prime \prime}$ W; (map 88). Var. Texas Star Lake, Tsemalukmená.

This name is a translation of the Tanana Indian name "Tsemalukmená" reported in 1962 by USGS.

Spruce Island: island, $0.3 \mathrm{mi}$. long, in Frederick Sound, 2 mi. off SE coast of Admiralty I., Alex. Arch.; 57 $12^{\prime} 45^{\prime \prime} \mathrm{N}, 134^{\circ} 05^{\prime} 00^{\prime \prime} \mathrm{W}$; BGN 1910; (map 9). Var. Ostrov Yelovyy, Yelowy Island, Yellowy Island.

An 1882 translation by USC\&GS of the name given in 1838 by Capt. Lt. D. F. Zarembo; published in 1848 on Russian Hydrog. Dept. Chart 1396 as "Os[trov] Yelovyy."

Spruce Island: island, 7 mi. long, NNE of Kodiak I., $8 \mathrm{mi}$. N of Kodiak; $57^{\circ} 55^{\prime} \mathrm{N}, 152^{\circ} 25^{\prime} \mathrm{W}$; (map 34). Var. Elow Island, Elovoi Island, Jellowa Island, Ostrov Yelovoi, Pine Island, Yelovoi Island.

The name "Ostrov Yelovoi," or "Pine Island," was recorded in 1805 by Lisianski (1814, map facing p. 169).

Spruce Island: island, see Elovoi Island.

Spruce Knob: peak, 2,300 ft., spur of Zane Hills, $47 \mathrm{mi}$. WNW of Hughes, Hogatza High.; $66^{\circ}$ $14^{\prime} \mathrm{N}, 155^{\circ} 52 \mathrm{~W}$; (map 116).

Named by mining engineers about 1940 .

Spruce Lake: lake, $1 \mathrm{mi}$. long, on Kenai Penin., $1 \mathrm{mi}$. N of Rock Lake and $23 \mathrm{mi}$. NE of Kenai, Cook Inlet Low.; $60^{\circ} 41^{\prime} 15^{\prime \prime}$ N, $150^{\circ}$ $38^{\prime} 30^{\prime \prime} \mathrm{W}$; ( $\left.\operatorname{map} 62\right)$.

Named about 1963 by officials of Kenai National Moose Range, for administrative purposes.

Spruce Lake: lake, $0.5 \mathrm{mi}$. long, between Halfway Lake and Lake Long, $8 \mathrm{mi}$. SE of Talkeetna, Cook Inlet Low.; $62^{\circ} 12^{\prime} 35^{\prime \prime}$ N., $150^{\circ} 01^{\prime}$ $30^{\prime \prime} \mathrm{W}$; (map 81).

Local descriptive name reported in 1958 by USGS.

Spruce Lake: lake, $1 \mathrm{mi}$. across, $51 \mathrm{mi}$. NE of Medfra, Kuskokwim Low.; $63^{\circ} 33^{\prime} \mathrm{N}, 153^{\circ} 24^{\prime}$ W; (map 89).

Local name reported in 1958 by USGS.

Spruce Peak: peak, 4,753 ft., in Kantishna Hills, $8 \mathrm{mi}$. NE of Wonder Lake, Alaska Ra.; $63^{\circ}-$ $35^{\prime} \mathrm{N}, 150^{\circ} 42^{\prime} \mathrm{W}$; (map 88$)$.

Name shown on a 1916 fieldsheet by C. E. Giffin, USGS.

Spruce Point: point of land, on $\mathrm{W}$ coast of Mitkof I., in Wrangell Narrows, $13 \mathrm{mi}$. S of Petersburg, Alex. Arch.; 56 $37^{\prime} 50^{\prime \prime}$ N, $132^{\circ}$ -
56'30' W; (map 6). Var. Point Schroeder, Schroeder Point, Yelovyy.

Name published by USG\&GS in the 1883 Coast Pilot (p. 114) ; translated from the Russian "Yelovyy" given in 1838 by G. Lindenberg. Feature was named "Point Schroeder" in 1869 by Comdr. R. W. Meade, USN, for Lt. Seaton Schroeder, USN.

Spruce Point: point of land, at junc. of Nizina and Chitistone Rivers, $12 \mathrm{mi}$. E of McCarthy, Wrangell Mts.; $61^{\circ} 25^{\prime} \mathrm{N}, 142^{\circ} 36^{\prime} \mathrm{W}$; (map 67).

Local name obtained by USGS and published on maps since 1954.

Spruce Point: point of land, see Uzinki Point.

Spruce Strait: water passage, see Narrow Strait. Spruce Tree Point: point of land, on $\mathrm{S}$ tip of Big Eightmile I., in Yukon River, $47 \mathrm{mi}$. SW of Nulato, Nulato Hills; $64^{\circ} 05^{\prime} 30^{\prime \prime} \mathrm{N}$, $158^{\circ} 48^{\prime} 00^{\prime \prime} \mathrm{W}$; (map 97).

Riverboat pilots' name shown on a 1940 "Navigation Chart of the Tanana-Yukon Rivers" published by the U.S. Dept. of Interior. Spuhn Island: island, $1.2 \mathrm{mi}$. long, off $\mathrm{SW}$ coast of Mendenhall Penin., in Fritz Cove, $2 \mathrm{mi}$. W of Entrance Point and $9 \mathrm{mi}$. NW of Juneau, Coast Mts.; 58 $20^{\prime} 15^{\prime \prime} \mathrm{N}, 134^{\circ} 39^{\prime} 30^{\prime \prime}$ W; (map 11). Var. Mineral Island.

Named in 1880 by Capt. L. A. Beardslee, USN, for Carl Sphun, 1855-1927, of the Northwest Trading Company. He was born in Germany and came to Juneau soon after the town was founded in 1881 and operated the company's store, and engaged in mining. Later he moved to Killisnoo where he managed the herring fishery and reduction plant, and served as postmaster and commissioner (DeArmond, 1957, p. 40). The name was published by USC\&GS in the 1883 Coast Pilot (p. 173).

Spuhn Point: point of land, on SW end of Spuhn I., at $\mathrm{N}$ end of Gastineau Channel, $9 \mathrm{mi}$. NW of Juneau, Coast Mts.; $58^{\circ} 20^{\prime} \mathrm{N}, 134^{\circ} 40^{\prime} \mathrm{W}$; (map 11).

Name published by USC\&GS in the 1883 Coast Pilot (p. 173).

Spuhn Point: point of land, see Zimovia Point. Spur Mountain: mountain, 4,930 ft., $8.5 \mathrm{mi}$. long, extends from East Bradfield River to Unuk River, $\mathrm{N}$ of Burroughs Bay, Coast Mts.; $56^{\circ} 09^{\prime} 25^{\prime \prime} \mathrm{N}, 131^{\circ} 05^{\prime} 35^{\prime \prime} \mathrm{W}$; (map 7).

Local name reported in 1955 by USGS.

Spur Mountain Lake: lake, $1.5 \mathrm{mi}$. long, $1 \mathrm{mi}$. E of Spur Mtn., Coast Mts.; 56 $09^{\prime} 20^{\prime \prime} \mathrm{N}$, 131 $04^{\prime} 15^{\prime \prime} \mathrm{W}$; BGN 1966; (map 7).

Named in 1966 by USGS.

Spurr, Mount: mountain, 11,100 ft., in Tordrillo Mts., $40 \mathrm{mi}$. NW of Tyonek, Alaska Ra.; $61^{\circ} 18^{\prime} \mathrm{N}, 152^{\circ} 15^{\prime} \mathrm{W}$; (map 70). Var. Hatay Mountain.

Named in 1900 by A. H. Brooks, for Josiah Edward Spurr, 1870-1950, USGS, who led an expedition in the area in 1898.

Spurt Point: point of land, on $\mathrm{W}$ shore of Thomas Bay, $2 \mathrm{mi}$. NW of Ruth I. and $98 \mathrm{mi}$. $\mathrm{E}$ of Sitka, Coast Mts.; 57 $01^{\prime} 30^{\prime \prime} \mathrm{N}, 132^{\circ}$ $53^{\prime} 30^{\prime \prime} \mathrm{W}$; (map 8).
Named in 1887 by Lt. Comdr. C. M. Thomas, USN; name published in 1888 by USC\&GS.

Spurt Point Lake: lake, $2 \mathrm{mi}$. long, trends N-S $2 \mathrm{mi}$. $\mathrm{N}$ of Spurt Point, on Thomas Bay, 90 mi. E of Sitka, Coast Mts.; $57^{\circ} 04^{\prime} 40^{\prime \prime} \mathrm{N}, 132^{\circ}$ $54^{\prime} 15^{\prime \prime} \mathrm{W}$; (map. 8).

Local name reported in 1961 by USGS.

Spy Islands: barrier islands, $3.5 \mathrm{mi}$. long, one of Jones Is., on Beaufort Sea coast, $3.5 \mathrm{mi}$. N of Oliktok Point, $15 \mathrm{mi}$. NW of Beechey Point; Arctic Plain; $70^{\circ} 34^{\prime} \mathrm{N}, 149^{\circ} 50^{\prime} \mathrm{W}$; (map 150).

There were "two or three closely connected sand islands," when Leffingwell (1919, p. 99) named them, "after the schooner $S p y$, which went inside them about 1881."

Squab Island: island, $0.2 \mathrm{mi}$. long, at $\mathrm{N}$ end of Aialik Bay, $16 \mathrm{mi}$. SW of Seward, Chugach Mts. ; 59 $56^{\prime} \mathrm{N}, 149^{\circ} 43^{\prime} \mathrm{W}$; BGN 1911; (map 49).

Named in 1909 by U. S. Grant, USGS.

Square Bluff: promontory, $1 \mathrm{mi}$. SE of Bird Cape, on Bering Sea coast of Amchitka I., Aleutian Is.; $51^{\circ} 39^{\prime} 15^{\prime \prime} \mathrm{N}, 178^{\circ} 40^{\prime} 50^{\prime \prime} \mathrm{E}$; BGN 1937; (map 15).

Named by the U.S. Navy North Pacific Exploring Expedition in 1855.

Square Cove: cove, $0.2 \mathrm{mi}$. across, on $\mathrm{W}$ coast of Admiralty $\mathbf{I}, 33 \mathrm{mi}$. $\mathrm{N}$ of Angoon, Alex. Arch, ; $57^{\circ} 58^{\prime} 40^{\prime \prime} \mathrm{N}, 134^{\circ} 45^{\prime} 45^{\prime \prime} \mathrm{W}$; (map 9).

Descriptive name given in 1880 by $M$. Baker, USC\&GS; published in 1883 Coast Pilot (p. 179). So named because the head of the cove is square in shape.

Squarehead Cove: cove, $1.5 \mathrm{mi}$. across, on $\mathrm{N}$ shore of Tuxedni Bay, $53 \mathrm{mi}$. SW of Kenai, Aleutian Ra.; $60^{\circ} 14^{\prime} \mathrm{N}, 152^{\circ} 40^{\prime} \mathrm{W}$; (map 62).

Local name reported in 1958 by USGS.

Square Island: island, $600 \mathrm{ft}$. long, between Kaigani and Tlevak Straits, $2 \mathrm{mi}$. E of Rose Point, on $\mathrm{E}$ coast of Dall I., Alex. Arch.; $54^{\circ} 58^{\prime} 15^{\prime} \mathrm{N}, 132^{\circ} 53^{\prime} 30^{\prime \prime} \mathrm{W}$; (map 1).

Descriptive name given in 1881 by $\mathbf{L t}$. Comdr. H. E. Nichols, USN.

Square Island: island, $1 \mathrm{mi}$. across, in Spacious Bay on NE coast of Cleveland Penin., Alex. Arch.; 55 $51^{\prime} \mathrm{N}, 131^{\circ} 50^{\prime} \mathrm{W}$; (map 3).

Descriptive name given in $1891 \mathrm{~b}$; USG\&GS.

Square Lake: lake, $0.8 \mathrm{mi}$. long, $4 \mathrm{mi}$. S of Ustay Lake, and $42 \mathrm{mi}$. SE of Yakutat, Malaspina Coastal Plain; $59^{\circ} 14^{\prime} 10^{\prime \prime} \mathrm{N}, 138^{\circ} 43^{\prime} 15^{\prime \prime}$ W; BGN 1966; (map 46).

Local descriptive name reported in 1966 by USFS.

Square Lake: lake, $0.6 \mathrm{mi}$. long, $2 \mathrm{mi}$. NE of junc. of Little Oshetna and Oshneta Rivers, $17 \mathrm{mi}$. S of Susitna River, Talkeetna Mts.; $62^{\circ} 24^{\prime} \mathrm{N}, 147^{\circ} 28^{\prime} \mathrm{W}$; BGN 1960; (map 82).

Local descriptive name reported in 1956 by USGS.

Square Lake: lake, $0.8 \mathrm{mi}$. across, $30 \mathrm{mi}$. SE of Bitzshtini Mts., Tanana Low.; $64^{\circ} 11^{\prime} \mathrm{N}, 151^{\circ}$. 13' W; (map 99).

Local descriptive name reported in 1952 by USGS. 
Square Lake: lake, $0.5 \mathrm{mi}$. across, $5 \mathrm{mi}$. $\mathrm{E}$ of Christian, Brooks Ra. ; $67^{\circ} 22^{\prime} \mathrm{N}, 145^{\circ} 01^{\prime} \mathrm{W}$; (map 122).

Local name reported in 1956 by T. E. Taylor, USGS.

Square Lake: lake, $1 \mathrm{mi}$. across, E of Key Creek, $30 \mathrm{mi}$. NW of Umiat, Arctic Plain; $69^{\circ} 35^{\prime} \mathrm{N}$, $153^{\circ} 15^{\prime} \mathrm{W}$; BGN 1960; (map 142).

Descriptive name given in the 1940's by geologists on the Naval Petroleum Reserve No. 4 exploration.

Square Point: point of land, $0.8 \mathrm{mi}$. NW of Matthews Mtn., on E coast of Attu I., Aleutian Is.; $52^{\circ} 51^{\prime} 45^{\prime \prime} \mathrm{N}, 173^{\circ} 20^{\prime} 20^{\prime \prime} \mathrm{E}$; $B G N$ 1945; (map 13).

Descriptive name listed in the 1944 Aleutian Coast Pilot.

Square Rock: rock, in Norton Sound, $4 \mathrm{mi}$. E of village of Bluff and $25 \mathrm{mi}$. E of Solomon,

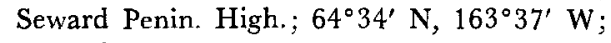
(map 95).

Local name reported about 1940 by USC\&GS and published on Chart 9380.

Squashinski Bay: sound, see Nakwasina Sound.

Squaw Bay: estuary, trends SW $2.5 \mathrm{mi}$. to $\mathrm{SE}$ end of Esther Passage, $29 \mathrm{mi}$. NE of Whittier, Chugach Mts. ; $60^{\circ} 49^{\prime} 15^{\prime \prime} \mathrm{N}, 147^{\circ} 50^{\prime} 30^{\prime \prime} \mathrm{W}$; (map 63).

Name published in 1943 by USC\&GS

Squaw Creek: stream, flows $\mathrm{S} 1.8 \mathrm{mi}$. to Whale Passage, 2 mi. NW of Thorne I., Alex. Arch.; $56^{\circ} 07^{\prime} 50^{\prime \prime} \mathrm{N}, 133^{\circ} 05^{\prime} 15^{\prime \prime} \mathrm{W}$; (map 6).

Local name recorded in 1949 by USC\&GS.

Squaw Creek: stream, heads in lake, flows E 5 mi. to Kvichak River at Nakeen, 14 mi. $N$ of Naknek, Bristol Bay Low.; $58^{\circ} 56^{\prime} 10^{\prime \prime} \mathrm{N}$, $157^{\circ} 02^{\prime} 15^{\prime \prime} \mathrm{W}$; (map 41).

Local name reported in 1952 by USGS.

Squaw Creek: stream, heads in lake and flows SE $5 \mathrm{mi}$. to Nushagak River, $1.5 \mathrm{mi}$. W of Dillingham, Bristol Bay Low.; $59^{\circ} 02^{\prime} \mathrm{N}, 158^{\circ} 31^{\prime} \mathrm{W}$; (map 52).

Local name recorded in 1948 by USGS.

Squaw Creek: stream, flows SE $4 \mathrm{mi}$. to Tiekel River, $1.7 \mathrm{mi}$. SW of Tiekel Cache and $37 \mathrm{mi}$. $\mathrm{NE}$ of Valdez, Chugach Mts.; $61^{\circ} 22^{\prime} 00^{\prime \prime} \mathrm{N}$, $145^{\circ} 16^{\prime} 15^{\prime \prime} \mathrm{W}$; (map 68).

Local name published in the 1950's by USGS.

Squaw Creek: stream, flows SE $2.1 \mathrm{mi}$. to Kuskulana River, $33 \mathrm{mi}$. NW of McCarthy, Wrangell Mts.; $61^{\circ} 33^{\prime} \mathrm{N}, 143^{\circ} 52^{\prime} \mathrm{W}$; (map 67).

Local name reported in 1901 by T. G. Gerdine (in Brooks and others, 1915, pl. 5), USGS.

Squaw Creek: stream, flows SW $11 \mathrm{mi}$. to Caribou Creek, 54 mi. NE of Palmer, Talkeetna Mts.; $61^{\circ} 52^{\prime} 20^{\prime \prime} \mathrm{N}, 147^{\circ} 35^{\prime} 35^{\prime \prime} \mathrm{W}$; (map 69).

Name used by local prospectors; reported in 1906 by T. G. Gerdine and R. H. Sargent, USGS.

Squaw Creek: stream, heads at glacier, flows $\mathrm{E}$ through Puntilla Lake $9 \mathrm{mi}$. to Happy River, $84 \mathrm{mi}$. SW of Talkeetna, Alaska Ra.; $62^{\circ} 04^{\prime}$ $10^{\prime \prime} \mathrm{N}, 152^{\circ} 40^{\prime} 00^{\prime \prime} \mathrm{W}$; (map 81).

Local name reported in 1945 by USGS.
Squaw Creek: stream, flows S $5 \mathrm{mi}$. to Middle Fork Chulitna River, $45 \mathrm{mi}$. SW of Healy, Alaska Ra.; 6314' N, 149 $18^{\prime} \mathrm{W}$; (map 87). Local name obtained in 1951 by USGS.

Squaw Creek: stream, flows S $2.6 \mathrm{mi}$. to Harrison Creek, $39 \mathrm{mi}$. SW of Circle, Yukon-Tanana High.; $65^{\circ} 22^{\prime} 30^{\prime \prime} \mathrm{N}, 144^{\circ} 54^{\prime} 00^{\prime \prime} \mathrm{W}$; $B G N$ 1938; (map 104). Var. Squaw Gulch.

Originally named Squaw Gulch by prospec. tors; reported in 1896 by USGS (Spurr, 1898, pl. 50). However, the present name was reported in 1904 by D. C. Witherspoon, USGS. Squaw Creek: stream, between Ray and Ram. part Mts., flows SE $23 \mathrm{mi}$. to Yukon River, 1 mi. N of Rampart and $61 \mathrm{mi}$. ENE of Tanana, Kokrines-Hodzana High.; $65^{\circ} 31^{\prime} 00^{\prime \prime}$ N, $150^{\circ}$. 09'30' W; (map 106).

Local name shown on Edwards Track Chart of the Yukon River, dated 1899.

Squaw Creek: stream, flows NE $3.5 \mathrm{mi}$. to Victoria Creek, $78 \mathrm{mi}$. W of Circle, YukonTanana High.; $65^{\circ} 50^{\prime} \mathrm{N}, 146^{\circ} 45^{\prime} \mathrm{W}$; (map 104).

Named by prospectors; published in 1906 by USGS.

Squaw Creek: stream, flows W $5.5 \mathrm{mi}$. to South Fork Koyukuk River, $21 \mathrm{mi}$. E of Bettles, Kokrines-Hodzana High.; $66^{\circ} 55^{\prime} \mathrm{N}, 150^{\circ} 56^{\prime}$ W; (map 117).

Named used by prospectors; reported in 1899 by F. C. Schrader and T. G. Gerdine, USGS.

Squaw Creek: stream, flows NE then NW 4 mi. from Little Squaw Peak to Squaw Lake, 11 mi. NE of Chandalar, Brooks Ra.; 67 $36^{\prime} \mathrm{N}$, $148^{\circ} 12^{\prime} \mathrm{W}$; (map 123). Var. Big Squaw Creek.

Name reported in 1909 as "Big Squaw Creek" by A. G. Maddren, USGS.

Squaw Creek: stream, see Kal Creek.

Squaw Crossing: stream, channel of Tanana River, flows $W$ from Squaw Point toward Aeolian Hills, $10 \mathrm{mi}$. SE of Tanana, Nowitna Low.; $65^{\circ} 05^{\prime} 30^{\prime \prime} \mathrm{N}, 151^{\circ} 47^{\prime} 00^{\prime \prime} \mathrm{W}$; (map 106).

Riverboat pilots' name shown on a 1940 Navigation Chart, Tanana-Yukon Rivers.

Squaw Crossing Slough: stream, flows N $3 \mathrm{mi}$. from Tanana River at Squaw Point to Hay Slough, 9 mi. SE of Tanana; Nowitna Low.; $65^{\circ} 08^{\prime} 50^{\prime \prime} \mathrm{N}, 151^{\circ} 45^{\prime} 30^{\prime \prime}$; (map 106).

Riverboat pilots' name shown on a 1940 Navigation Chart, Tanana-Yukon Rivers.

Squawgirl Creek: stream, see Chinitna River.

Squaw Gulch: ravine, trends NE $4 \mathrm{mi}$. to Canyon Creek, $45 \mathrm{mi}$. S of Eagle, Yukon-Tanana High.; $64^{\circ} 10^{\prime} \mathrm{N}, 141^{\circ} 08^{\prime} \mathrm{W}$; (map 102).

Named by prospectors and reported in 1896 by Spurr (1898, pl. 46), USGS.

Squaw Gulch: stream, see Bottom Dollar Creek. Squaw Gulch: stream, sce Squaw Creek.

Squaw Harbor: village, pop. 45 (1950), on E coast of Unga I., on N shore of Baralof Bay, in Shumagin Is., Aleutian Ra.; $55^{\circ} 14^{\prime} 30^{\prime \prime} \mathrm{N}$, 160'32'55" W; BGN 1966; (map 28). Var. Baralof Bay.

Name published as "Baralof or Squaw Harbor" by Atwood (1911, p. 21), USGS.
Squaw Harbor is shown on a 1953 USGS map as being located on the south coast of Unga Island, but USGS in 1966 reported the location given above.

Squaw Harbor: $b a y$, see Baralof Bay.

Squaw Island: island, 1,300 ft. long, in Nizina River $11 \mathrm{mi}$. NE of MeCarthy, Wrangell Mts.; $61^{\circ} 27^{\prime} 00^{\prime \prime} \mathrm{N}, 142^{\circ} 36^{\prime} 30^{\prime \prime} \mathrm{W}$; (map 67).

Local name obtained by USGS and published on maps since 1954.

Squaw Lake: lake, $2.7 \mathrm{mi}$. long, at mouth of Squaw Creek and head of Lake Creek, $11 \mathrm{mi}$. NE of Chandalar, Brooks Ra.; 67 $37^{\prime} \mathrm{N}$, $148^{\circ} 11^{\prime} \mathrm{W}$; (map 123).

Local named published in 1951 by USGS. Squaw Mountain: mountain, 2,575 ft., NE of Sakie Bay, on W coast of Dall I., Alex. Arch.; $55^{\circ} 04^{\prime} \mathrm{N}, 133^{\circ} 09^{\prime} \mathrm{W}$; (map 4).

Name published in 1924 by USC\&GS.

Squaw Mountain: mountain, $4,715 \mathrm{ft}$, on Alaska-Canada boundary, $20 \mathrm{mi}$. NNE of Eagle, Porcupine Plat.; $65^{\circ} 03^{\prime} 30^{\prime \prime} \mathrm{N}, 141^{\circ}$ $00^{\prime} 30^{\prime \prime} \mathrm{W}$; (map 103).

Named for IBC triangulation station Squaw placed on its summit in 1910; published by Mertie (1930, pl. 12), USGS.

Squaw Point: point of land, on $\mathrm{E}$ bank of Tanana River, $11 \mathrm{mi}$. SE of Tanana, Nowitna Low. ; $65^{\circ} 06^{\prime} 30^{\prime \prime} \mathrm{N}, 151^{\circ} 45^{\prime} 00^{\prime \prime} \mathrm{W}$; (map $106)$.

Riverboat pilots' name shown on a 1940 Navigation Chart, Tanana-Yukon Rivers.

Squaw Rapids: rapids, in North Fork Koyukuk River, at mouth of Glacier River, $17 \mathrm{mi}$. W of Wiseman, Brooks Ra.; $67^{\circ} 19^{\prime} 45^{\prime \prime} \mathrm{N}, 150^{\circ} 42^{\prime}$ $00^{\prime \prime} \mathrm{W}$; (map 124).

In reporting this name, Marshall (1956, p. 116) wrote, "Just below the mouth of Glacier River we battled Squaw Rapids, named after an Indian woman who drowned in its fury more than fifty years ago."

Squentna River: stream, see Skwentna River.

Squent River: stream, see Skwentna River.

Squid Bay: bay, $0.5 \mathrm{mi}$. across, on SW coast of Yakobi I., $21 \mathrm{mi}$. NW of Chichagof, Alex. Arch.; $57^{\circ} 53^{\prime} \mathrm{N}, 136^{\circ} 29^{\prime} \mathrm{W}$; BGN 1928; (map 9).

Named in 1926 by USC\&GS and published in 1928 on Chart 8250 .

Squire Island: island, $4 \mathrm{mi}$. long, in Knight Island Passage, off SW end of Knight I., 6 mi. SE of Chenega, Chugach Mts.; $60^{\circ} 14^{\prime} 30^{\prime \prime}$ $\mathrm{N}, 147^{\circ} 55^{\prime} 30^{\prime \prime} \mathrm{W}$; BGN 1908; (map 63). Var. Long Island.

Name published in 1908 by USC\&GS.

Squire Point: point of land, $\mathrm{S}$ end of Squire I., Chugach Mts.; $60^{\circ} 13^{\prime} 25^{\prime \prime} \mathrm{N}, 147^{\circ} 56^{\prime} 20^{\prime \prime} \mathrm{W}$; BGN 1929; (map 63).

Name reported in 1929 by USC\&GS.

Squirrel Bay: $b a y$, trends $\mathrm{W} 1 \mathrm{mi}$. to Prince of Wales Passage, at SW end of Evans I., $20 \mathrm{mi}$. $\mathrm{S}$ of Chenega, Chugach Mts.; $60^{\circ} 00^{\prime} 20^{\prime \prime} \mathrm{N}$, 14809'30" W; BGN 1930; (map 63). Var. Gopher Bay.

So named in 1927 by a USC\&GS party "because feature on topographic map bears likenesss to head and paws of a squirrel." 
Squirrel Cove: cove, $0.5 \mathrm{mi}$. across, on NE coast of Kenai Penin., at SE end of Passage Canal, $7 \mathrm{mi}$. NE of Whittier, Chugach Mts.; $60^{\circ} 48^{\prime}$ $20^{\prime \prime} \mathrm{N}, 148^{\circ} 28^{\prime} 00^{\prime \prime} \mathrm{W}$; BGN 1915; (map 63). Name reported in 1914 by USC\&GS.

Squirrel Creek: stream, flows $\mathrm{S} 1.5 \mathrm{mi}$. to Platinum Creek, $25 \mathrm{mi}$. NE of Cape Newenham, Kilbuck-Kuskokwim Mts.; 58 55'25" N, 161 43'30" W; BGN 1938; (map 39).

Local name published in a 1933 U.S. Dept. of Interior mining report.

Squirrel Creek: stream, flows E $1.5 \mathrm{mi}$. to lake on S edge of Red Glacier, $7.5 \mathrm{mi}$. $\mathrm{N}$ of Chinitna Bay and $55 \mathrm{mi}$. NW of Homer, Aleutian Ra.; $59^{\circ} 59^{\prime} 30^{\prime \prime} \mathrm{N}, 152^{\circ} 56^{\prime} 30^{\prime \prime} \mathrm{W}$; (map 50).

Local name reported and published by USGS in the 1950 's.

Squirrel Creek: stream, flows NE $16 \mathrm{mi}$. to Tonsina River, $1 \mathrm{mi}$. $\mathrm{N}$ of Tonsina and $53 \mathrm{mi}$. $\mathrm{NE}$ of Valdez, Chugach Mts.; 61 ${ }^{\circ} 40^{\prime} 05^{\prime \prime} \mathrm{N}$, $145^{\circ} 10^{\prime} 00^{\prime \prime} \mathrm{W}$; BGN 1932; (map 68).

Local name reported in 1930 by USGS.

Squirrel Creek: stream, flows NE $0.5 \mathrm{mi}$., joins Wagner Gulch to form Mills Creek, $46 \mathrm{mi}$. W of Talkeetna, Alaska Ra.; $62^{\circ} 21^{\prime} 25^{\prime \prime} \mathrm{N}$, $151^{\circ} 32^{\prime} 00^{\prime \prime} \mathrm{W}$; (map 81).

Prospectors' name reported in 1911 by Capps (1913, fig. 7), USGS.

Squirrel Greek: stream, flows SW $20 \mathrm{mi}$. to Patsy Slough, $6 \mathrm{mi}$. NE of Nulato, Koyukuk Low.; $64^{\circ} 46^{\prime} \mathrm{N}, 157^{\circ} 56^{\prime} \mathrm{W}$; (map 97).

Local name reported in 1954 by USGS.

Squirrel Creek: stream, flows NW $1 \mathrm{mi}$. to Casadepaga River, $14 \mathrm{mi}$. N of Solomon, Seward Penin. High.; $64^{\circ} 46^{\prime} \mathrm{N}, 164^{\circ} 28^{\prime} \mathrm{W}$; (map 95). Var. Dewey Creek.

Prospectors' name reported on a 1902 prospectors' manuscript map. Reported as "Dewey" on a 1901 map of Cape Nome gold fields by David Fox, Jr.

Squirrel Creek: stream, flows NW $18 \mathrm{mi}$. to Sucker River, $5 \mathrm{mi}$. E of Fort Yukon, Yukon Flats; $66^{\circ} 34^{\prime} 30^{\prime \prime} \mathrm{N}, 145^{\circ} 05^{\prime} 00^{\prime \prime} \mathrm{W}$; (map 119). Var. Black River.

Local name reported in 1909 by A. G. Maddren (in Brooks and others, 1910, pl. 7), USGS.

Squirrel Creek: stream, see Black River.

Squirrel Island: island, $1 \mathrm{mi}$. long, in Prince William Sound, off $W$ coast of Knight I., in Knight Island Passage, $7 \mathrm{mi}$. NE of Chenega, Chugach Mts. ; $60^{\circ} 20^{\prime} 00^{\prime \prime} \mathrm{N}, 147^{\circ} 53^{\prime} 45^{\prime \prime} \mathrm{W}$; (map 63). GS.

Local name published in 1910 by USC\&-

Squirrel Point: point of land, near $\mathrm{E}$ end and on $S$ shore of Iliamna Lake at the mouth of Pile Bay, 24 mi. SE of Iliamna, Aleutian Ra.; $59^{\circ} 40^{\prime} 30^{\prime \prime} \mathrm{N}, 154^{\circ} 15^{\prime} 00^{\prime \prime} \mathrm{W}$; (map 51 ).

Name published by USGS in 1954 .

Squirrel Point: point of land, on NE coast of Kenai Penin., $6.5 \mathrm{mi}$. NE of Whittier, Chugach Mts.; $60^{\circ} 48^{\prime} 20^{\prime \prime} \mathrm{N}, 1^{\circ} 48^{\circ} 28^{\prime} 30^{\prime \prime} \mathrm{W} ; B G N$ 1915; (map 63).

Name reported in 1914 by USC\&GS.

Squirrel River: stream, flows SE $72 \mathrm{mi}$, to Kobuk River, 28 mi. NW of Selawik, Hogatza High.; $66^{\circ} 59^{\prime} \mathrm{N}, 160^{\circ} 24^{\prime}$ W; (map 114). Var. Shee-gar-rik-puk, Sheeleelictok, Shee-lee-li-tok, Shu-shuk-to-ark.

This is a translation of the Eskimo name "sikrikpak," for the hoary marmot, Marmota caligata broweri, or "sikrik," for the Parry ground squirel, Citellus parryii barrowensis (Rausch, 1951, p. 178, 179). In 1884 Lt. Cantwell (in Healy, 1889, p. 55), USRCS, called it "Sheeleelicktok or squirrel," and a year later he spelled the Eskimo name "Sheegar-rik-puk" and "Shee-lee-lie-tok" (Healy, 1887 , p. 47 and map). Lt. Stoney (1900, map), USN, called it "Squirrel or Shu-shukto-ark."

Squirrel River: stream, see Black River.

Srednaia: bay, see Middle Bay.

Srednaia Bay: bay, see Alimuda Bay.

Srednaya Bay: bay, see Alimuda Bay.

Sredney, Kamen: rock, see Middle Rock.

Sredney, Ostrov: island, see Middle Island.

Sredni Bight: bight, $1.9 \mathrm{mi}$. across, $7 \mathrm{mi}$. NE of Kiska Harbor, on NE coast of Kiska I., Aleutian Is.; $52^{\circ} 03^{\prime} 40^{\prime \prime} \mathrm{N}, 177^{\circ} 38^{\prime} 40^{\prime \prime} \mathrm{E}$; (map 14). Var. Raven Bay, Soldier Bay.

Russian name "Sredniy," meaning "middle," given in 1935 by the U.S. Navy Hydrog. Office relative to nearby Sredni Point. "Soldier" and "Raven" are names applied by U.S. forces during World War II for tactical purposes.

Srednie Island: island, see Middle Island.

Srednie Point: point of land, see Middle Point. Srednie Rock: rock, see Middle Rock.

Sredni Island: island, see Apple Islands.

Sredni Point: point of land, S of Sredni Bight, on NE coast of Kiska I., Aleutian Is. ; $52^{\circ} 02^{\prime}$ $48^{\prime \prime} \mathrm{N}, 177^{\circ} 38^{\prime} 35^{\prime \prime} \mathrm{E}$; BGN 1937; (map 14).

Russian name "Sredniy," meaning "middle," given in 1935 by the U.S. Navy Hydrog. Office.

Sredniy, Farvater: water passage, see Middle Channel.

Sredniy, Kamen: rock, see Midway Rock. Sredniy, Mys: point of land, see Middle Point. Sredniy, Mys: point of land, see Nome Cape. Sredniy, Mys: point of land, see Seredni Point. Srednyaya, Guba: bay, see Middle Bay.

Sshitnak: locality, see Chitnak.

Ssitkajē: glacier, see Davidson Glacier.

Sskǒãn: locality, see Sukkwan.

Stab Creek: stream, in Bendeleben Mts., flows NE $3 \mathrm{mi}$. to Pargon River, $32 \mathrm{mi}$. SW of Imuruk Lake, Seward Penin. High.; $65^{\circ} 11^{\prime} \mathrm{N}$, $163^{\circ} 41^{\prime} \mathrm{W}$; (map 110).

Prospectors' name published on the 1908 "Map of Seward Peninsula" by Arthur Gibson. Stachine River: stream, see Stikine River. Stachin River: stream, see Stikine River.

Stachinski Strait: Water passage, see Stakine Strait.

Stachtan Nitada: area, "discovered by the Russians in 1730" applied to the region east of Bering Strait, that is Alaska; it means "great continent." See Wagner (1937, p. 517) and Thomas Jefferys 1775 chart of "North and
South America including the Atlantic and Pacific oceans, etc."

Stack Island: island, $0.3 \mathrm{mi}$. long, between Behm Canal and Moser Bay, off $W$ coast of Revillagigedo I., $16 \mathrm{mi}$. $\mathrm{N}$ of Ketchikan, Alex. Arch.; 55 $33^{\prime} 40^{\prime \prime} \mathrm{N}, 131^{\circ} 41^{\prime} 55^{\prime \prime} \mathrm{W}$; (map 3).

Local navigators' name obtained in 1904 by H. C. Fassett, USBF; probably named for Capt. R. Stack [cnna], a local seaman.

Stack Pup: stream, flows N $2 \mathrm{mi}$. to Crooked Creek, $10 \mathrm{mi}$. W of Central and $36 \mathrm{mi}$. SW of Circle, Yukon-Tanana High.; $65^{\circ} 33^{\prime} 20^{\prime \prime} \mathrm{N}$, $145^{\circ} 09^{\prime} 10^{\prime \prime} \mathrm{W}$; (map 104).

Prospectors' name reported in 1954 or 1955 by USGS topographers.

Stadia Rock: rock, in Rocky Pass of Keku Strait, $16 \mathrm{mi}$. SE of Kake, on NE coast of Kuiu I., Alex. Arch.; $56^{\circ} 46^{\prime} 40^{\prime \prime} \mathrm{N}, 133^{\circ} 43^{\prime} 35^{\prime \prime} \mathrm{W}$; BGN 1929; (map 6).

Named in 1927 by USC\&GS.

Staganuk: locality, see Sfaganuk.

Stagarok: village, see Clarks Point.

Stag Bay: estuary, on Chichagof I., extends NW $4 \mathrm{mi}$. to Lisianski Strait, $22 \mathrm{mi}$. N of Chichagof, Alex. Arch.; $57^{\circ} 35^{\prime} 45^{\prime \prime} \mathrm{N}, 136^{\circ} 21^{\prime} 30^{\prime \prime} \mathrm{W}$; $B G N$ 1908; (map 9). Var. Deer Bay.

Named in 1908 by USC\&GS; published in 1908 Coast Pilot (p. 169). It was locally known as "Deer Bay."

Stag Island: island, $750 \mathrm{ft}$. long, in Behm Canal off S Coast of Smeaton I., Coast Mts.; $55^{\circ}$ $19^{\prime} 10^{\prime \prime} \mathrm{N}, 130^{\circ} 56^{\prime} 50^{\prime \prime} \mathrm{W}$; (map 3).

Local name published in 1911 by USC\&GS.

Stag Point: point of land, on N coast of Deer I., at SW end of Aleutian Ra.; $54^{\circ} 59^{\prime} \mathrm{N}, 162^{\circ} 18^{\prime}$ W; (map 25). Var. North Cape.

Named by H. Dall, USC\&GS, and published on USC\&GS Chart 806 in 1882 . The USBF called this point North Cape in 1888.

Stag River: stream, on Chichagof I., flows NW $4 \mathrm{mi}$. to Stag Bay, $5 \mathrm{mi}$. SW of Pelican and $18 \mathrm{mi}$. N of Chichagof, Alex. Arch.; 57 53'$50^{\prime \prime} \mathrm{N}, 136^{\circ} 16^{\prime} 30^{\prime \prime} \mathrm{W}$; BGN 1960; (map 9).

Named in 1955 by D. L. Rossman, USGS, "for Stag Bay."

Stah-Keena River: stream, see Stikine River. Stahkin River: stream, see Stikine River.

Staines River: stream, distributary of Canning River, heads at $69^{\circ} 52^{\prime} 45^{\prime \prime} \mathrm{N}, 146^{\circ} 23^{\prime} 45^{\prime \prime} \mathrm{W}$, and flows NE $20 \mathrm{mi}$. to Lion Bay, Arctic Plain; $70^{\circ} 08^{\prime} 20^{\prime \prime} \mathrm{N}, 145^{\circ} 59^{\prime} 45^{\prime \prime} \mathrm{W}$; (map 151). Var. Sir T. Staines River.

Named by Franklin (1828, map) in 1826; the name appeared on his map as "Sir $T$. Staines R." and was applied to either this stream or the West Canning River.

Staines River: stream, see Canning River.

Stair Mountain: mountain, 1,732 ft., $4.3 \mathrm{mi}$. $\mathrm{N}$ of Cape Cleare, on Montague I., $59 \mathrm{mi}$. SE of Seward, Chugach Mts.; $59^{\circ} 50^{\prime} \mathrm{N}, 147^{\circ} 53^{\prime}$ W; BGN 1931; (map 49).

Named by the 1927 USC\&GS field party; suggested by the name of the triangulation station "Stair" on its summit.

Stairway, The: glacier, see Surprise Glacier.

Stairway Glacier: glacier, trends S $4 \mathrm{mi}$. to Surprise Glacier, $49 \mathrm{mi}$. SE of Anchorage, 
Chugach Mts.; $61^{\circ} 03^{\prime} 15^{\prime \prime} \mathrm{N}, 148^{\circ} 28^{\prime} 05^{\prime \prime} \mathrm{W}$; (map 69).

So named by members of the Harriman Alaska Expedition in 1899 because the glacier resembles a stairway.

Stairway Icefall: icefall, extends $4 \mathrm{mi}$. S at head of Rost Glacier, $15 \mathrm{mi}$. N of McCarthy, Wrangell Mts.; BGN 1966; 61 $38^{\prime} 00^{\prime \prime} \mathrm{N}$, $142^{\circ} 53^{\prime} 15^{\prime \prime} \mathrm{W}$; (map 67). Var. Stairway to Heaven Icefall.

The name "Stairway to Heaven Icefall" was proposed in 1965 by USGS, but it was shortened by BGN.

Stairway to Heaven Icefall: icefall, see Stairway Icefall.

Stakeen River: stream, see Stikine River.

Stake Island: island, in Yukon River, $3.5 \mathrm{mi}$. SW of Nulato, Nulato Hills; $64^{\circ} 41^{\prime} \mathrm{N}$, $158^{\circ} 13^{\prime} \mathrm{W}$; (map 97).

Riverboat pilots' name shown on a 1940 "Navigation Chart of the Tanana-Yukon Rivers" published by U.S. Dept. of Interior.

Stakhin, Ryka: stream, see Stikine River.

Stakhinski Strait: water passage, see Stikine Strait.

Stakhinskiy, Proliv: water passage, see Stikine Strait.

Stalemate Bank: reef, extends $\mathrm{W}$ about $100 \mathrm{mi}$. from Attu I., Aleutian Is.; $53^{\circ} 00^{\prime} \mathrm{N}, 171^{\circ} 00^{\prime}$ E; (map 13). Var. Juan de Gama Bank.

This bank was discovered by Comdr. L. V. Kielhorn, of the USGS cutter Chelan, while on patrol in the Bering Sea in 1936. The name was proposed by USGS in 1936 as "Juan de Gama Bank" in honor of the early Spanish navigator who was probably the first to sight the Aleutian Is. This name was not approved by the BGN pending further investigations as to the extent and definition of the feature. It was appropriately published as "Stalemate Bank" in 1954 Coast Pilot (p. 481).

Stampede Creek: stream, in Kantishna Hills, flows NE $2.5 \mathrm{mi}$. to Clearwater Fork $4 \mathrm{mi}$. S of that stream's junc. with Toklat River, Alaska Ra.; $63^{\circ} 45^{\prime} 35^{\prime \prime} \mathrm{N}, 150^{\circ} 19^{\prime} 30^{\prime \prime} \mathrm{W}$; (map 88).

Local name shown on a 1916 fieldsheet by C. E. Giffin, USGS.

Stamy, Mount: mountain, 4,685 ft., $8.4 \mathrm{mi}$. SW of Mount Jette and $31 \mathrm{mi}$. NE of Yakutat, St. Elias Mts.; $59^{\circ} 56^{\prime} 00^{\prime \prime} \mathrm{N}, 1^{\prime} 9^{\circ} 14^{\prime} 30^{\prime \prime} \mathrm{W}$; (map 46).

Named in 1905 by Tarr (1906, p. 145), USGS, for P. Stamy, one of the camp hands of I. C. Russell's party in 1891 .

Standard: $R R$. station, mi. 439.5 on The Alaska RR., $25 \mathrm{mi}$. SW of Fairbanks, Yukon-Tanana High.; $64^{\circ} 47^{\prime} \mathrm{N}, 148^{\circ} 32^{\prime} \mathrm{W}$; (map 100). Var. Standard Creek.

Local name derived from Standard Creek, listed in a timetable in 1922.

Standard Creek: RR. station, see Standard.

Standard Creek: stream, flows $2.3 \mathrm{mi}$. W to Golconda Creek $5 \mathrm{mi}$. NE of its junc. with North Fork Bremner River and $34 \mathrm{mi}$. SW of McCarthy, Chugach Mts.; $61^{\circ} 00^{\prime} \mathrm{N}, 143^{\circ} 28^{\prime}$ W; (map 67).
Local name reported in 1911 by D. C. Witherspoon (Moffit, 1914, pl. 1), USGS.

Standard Creek: stream, flows SE $7.5 \mathrm{mi}$. to Goldstream Creek, $25 \mathrm{mi}$. SW of Fairbanks, Yukon-Tanana High.; $64^{\circ} 47^{\prime} \mathrm{N}, 148^{\circ} 32^{\prime} \mathrm{W}$; (map 100).

Local name shown on a manuscript map of The Alaska RR. in 1916.

Standing Rock Lake: lake, $0.8 \mathrm{mi}$. across, $2 \mathrm{mi}$. $\mathrm{E}$ of Seward Passage and $42 \mathrm{mi}$. SE of Wrangell, Alex. Arch.; 56 $00^{\prime} 15^{\prime \prime} \mathrm{N}, 131^{\circ} 54^{\prime} 30^{\prime \prime}$ $\mathrm{W} ; B G N 1923$; $(\operatorname{map} 7)$.

Local name reported in 1923 by USFS.

Staney Cone: mountain, $2,765 \mathrm{ft}$., on $\mathrm{W}$ coast of Prince of Wales I., $12 \mathrm{mi}$. N of Klawock, Alex. Arch.; $55^{\circ} 43^{\prime} 45^{\prime \prime} \mathrm{N}, 133^{\circ} 09^{\prime} 10^{\prime \prime} \mathrm{W}$; (map 4).

Named in 1904 by E. F. Dickins, USC\&GS. See Stanley Island.

Staney Creek: stream, flows W 5 mi. to Lester River, on W coast of Prince of Wales I., $\mathrm{N}$ of Twin Mtn., Alex. Arch.; 55 $48^{\prime} 55^{\prime \prime} \mathrm{N}, 133^{\circ}$. 07'55" W; (map 4).

Local name recorded in 1949 by USGS

Staney Creek: stream, see Lester River.

Stanhope, Point: point of land, S tip of Stanhope I., on SW coast of Etolin I., Alex. Arch.; $56^{\circ}$ $00^{\prime} 50^{\prime \prime} \mathrm{N}, 132^{\circ} 36^{\prime} 10^{\prime \prime} \mathrm{W}$; (map 6).

Named on September 6, 1793, by Capt. George Vancouver, RN (Wagner, 1937, p. 417).

Stanhope Island: island, $1 \mathrm{mi}$. long, in Clarence Strait, on SW coast of Etolin I., Alex. Arch.; $56^{\circ} 01^{\prime} 30^{\prime \prime} \mathrm{N}, 132^{\circ} 36^{\prime} 00^{\prime \prime} \mathrm{W}$; (map 6).

Named in 1879 by W. H. Dall, USC\&GS.

Staniukovich Mountain: mountain, 2,500 ft., between Port Moller and Herendeen Bay, on Alaska Penin., Aleutian Ra.; $55^{\circ} 49^{\prime} \mathrm{N}, 160^{\circ}$. $37^{\prime} \mathrm{W}$; ( $\operatorname{map} 28$ ).

Named by Atwood (1911, pl. 2), USGS

Stanley Island: island, $0.4 \mathrm{mi}$. long, in Tuxekan Passage, Alex Arch.; 55 $49^{\prime} 10^{\prime \prime}$ N, 133 ${ }^{\circ} 11^{\prime}$ $25^{\prime \prime} \mathrm{W}$; (map 4)

Named in 1904 by E. F. Dickins, USC\&GS, for "an Indian chief who once resided in Tuxekan Village."

Stanovoi Islet: island, see Kutkan Island.

Stanovoy, Ostrov: island, see Kutkan Island

Stanstrom Creek: stream, see Paradise Creek.

Stanton Narrows: ieater passage, see Valdez Narrows.

Stanton Peak: peak, 4,265 ft., $5 \mathrm{mi}$. NE of Farragut Bay and $88 \mathrm{mi}$. E of Sitka, Coast Mts.; $57^{\circ} 12^{\prime} 38^{\prime \prime} \mathrm{N}, 133^{\circ} 03^{\prime} 15^{\prime \prime} \mathrm{W}$; BGN 1934; (map 8).

Named in 1887 by Lt. Comdr. C. M Thomas, USN; probably for Edwin McMasters Stanton, 1814-69, statesman and Justice of the Supreme Court.

Star: locality, site of mining camp, on left bank of Yukon River, $11 \mathrm{mi}$. N of Eagle, YukonTanana High.; $64^{\circ} 56^{\prime} \mathrm{N}, 141^{\circ} 17^{\prime} \mathrm{W}$; (map 102). Var. Star City, Starr.

Named by prospectors and reported as "Star City" in 1897 by Lt. W. P. Richardson, USA. A post office was maintained here from 1898 to 1902 (Ricks, 1965 , p. 60 ).

Staraia Gavan: $b a y$, see Driftwood Bay.
Staraia Selenie: locality, on right bank of Yukon River between Russian Mission and Devils Elbows; $61^{\circ} 37^{\prime} \mathrm{N}, 161^{\circ} 45^{\prime} \mathrm{W}$; (map 73).

This unidentified place is listed in the 1880 Census as having 55 inhabitants. It may be the old village referred to on Thirty-two Kazyga Slough (q.v.). It is a Russian name meaning "old village."

Staraya Artel: locality, see Staraya Artil.

Staraya Artel: rookery, see Staraya Artil Rookery.

Staraya Artil: locality, between High Bluffs and First Bluff, on $\mathrm{N}$ coast of St. George I., in Pribilof Is.; $56^{\circ} 36^{\prime} 15^{\prime \prime} \mathrm{N}, 169^{\circ} 38^{\prime} 30^{\prime \prime} \mathrm{W}$; (map 38). Var. Old Settlement, Staraya Artel, Starry Ateel.

Reported location of one of the first Russian settlements in the Pribilof Is., founded in 1786. The name is derived from "staryy artel'nyy" meaning "old company (workmen's association)," which was probably founded by the promyshlenniki (fur traders).

Staraya Artil Rookery: rookery, near First Bluff, on N coast of St. George I., in Pribilof Is.; $56^{\circ} 36^{\prime} 10^{\prime \prime} \mathrm{N}, 169^{\circ} 37^{\prime} 30^{\prime \prime} \mathrm{W}$; (map 38). Var. Staraya Artel, Starry Arteel, Tanogtuckan-Algaralogray.

This seal rookery, called "Starry Ateel," by Elliott (1881, p. 59), has $500 \mathrm{ft}$. of sea-margin. The Aleut name, according to Putnam (1903, p. 1015), USC\&GS, is Tanogtuck'an-algaral'ogray [Tanagtakan-algarel'ogre] meaning "old village rookery." See Staraya Artil, locality, and Tanogtukan Lake.

Staraya Bay: bay, $0.8 \mathrm{mi}$. across, S coast of Unalaska I., Aleutian I.; $53^{\circ} 37^{\prime} \mathrm{N}, 166^{\circ} 32^{\prime}$ W; (map 23). Var. Old Harbor.

Russian named published as "Star Gavan" meaning "Old Harbor" by Capt. Tebenkov (1852, map 26), IRN. Baker (1906, p. 479) says that this name was probably erroneously applied to this location by Tebenkov and should have been applied to a small harbor near the northern entrance of Makushin Bay.

Starboard Cape: point of land, see Outer Right Cape.

Star City: locality, see Star.

Star Creek: stream, heads at glacier terminus, in Nutzotin Mts., and flows S $4 \mathrm{mi}$. to Notch Creek $7 \mathrm{mi}$. NW of its junc. with Cross Creek, $5 \mathrm{mi}$. SE of Cooper Pass, Alaska Ra.; 62 ${ }^{\circ} 12^{\prime}$ $45^{\prime \prime} \mathrm{N}, 142^{\circ} 22^{\prime} 00^{\prime \prime} \mathrm{W}$; BGN 1941; (map 84).

Local name reported by USGS in 1940.

Star Creek: stream, flows SW $2.9 \mathrm{mi}$. to Sulatna River, $1.2 \mathrm{mi}$. SE of Sulatna Crossing and 39 mi. SE of Ruby, Kilbuck-Kuskokwim Mts.; $64^{\circ} 11^{\prime} 09^{\prime \prime} \mathrm{N}, 155^{\circ} 25^{\prime} 30^{\prime \prime} \mathrm{W}$; (map 98).

Prospectors' name reported in 1921 by USGS.

Star Creek: stream, flows W $2.5 \mathrm{mi}$. to Bonanza River, $16 \mathrm{mi}$. NW of Solomon, Seward Penin. High.; $64^{\circ} 45^{\prime} \mathrm{N}, 164^{\circ} 45^{\prime} \mathrm{W}$; (map 95). Var. Burley Creek.

Prospectors' name reported on the 1900 "Map of Nome Peninsula" by J. M. Davidson and B. D. Blakeslee.

Star Creek: stream, flows SE $3.6 \mathrm{mi}$. to Pilgrim River $0.4 \mathrm{mi}$. E of Salmon Lake and $29 \mathrm{mi}$. 
NW of Solomon, Seward Penin. High.; 64 $4^{\circ} 5^{\prime}$ $\mathrm{N}, 164^{\circ} 57^{\prime} \mathrm{W}$; (map 95).

Prospectors' name reported on a map of Cape Nome gold fields by David Fox, Jr., dated 1901.

Star Creek: stream, flows SW $16 \mathrm{mi}$. to Pargon River, $14 \mathrm{mi}$. NE of Council and $38 \mathrm{mi}$. S of Imuruk Lake, Seward Penin. High.; 65 $01^{\prime}$ N, $163^{\circ} 19^{\prime} \mathrm{W}$; (map 110).

Prospectors' name reported on a map of Cape Nome gold fields by David Fox, Jr, dated 1901.

Star Creek: stream, flows SE $2 \mathrm{mi}$. to Sunset Creek which flows to Grantley Harbor, $6 \mathrm{mi}$. NE of Teller, Seward Penin. High.; $65^{\circ} 20^{\prime} \mathrm{N}$, $166^{\circ} 15^{\prime} \mathrm{W}$; (map 111).

Prospectors' name reported on the 1908 "Map of Seward Peninsula" by Arthur Gibson.

Star Creek: stream, flows NE $6.5 \mathrm{mi}$. to South Fork Serpentine River, 6 mi. N of Kougarok Mtn. and $30 \mathrm{mi}$. SE of Ear Mtn., Seward Penin. High.; $65^{\circ} 47^{\prime} \mathrm{N}, 165^{\circ} 15^{\prime} \mathrm{W}$; (map 111). Var. Quartz Creek.

Prospectors' name published in 1956 by USGS.

Star Creek: stream, flows NW $2.3 \mathrm{mi}$. to Schlitz Greek which flows to Serpentine River, $7 \mathrm{mi}$. NW of Midnight Mtn. and $49 \mathrm{mi}$. NW of Imuruk Lake, Seward Penin. High.; 65 ${ }^{\circ} 49^{\prime}$ N, $164^{\circ} 49^{\prime}$ W ; (map 110).

Prospectors' name reported on the 1908 "Map of Seward Peninsula" by Arthur Gibson.

Star Creek: stream, see Little Champion Creek.

Starfish Bluff: bluff, $700 \mathrm{ft}$, , on right bank of Colville River $6 \mathrm{mi}$. $\mathrm{N}$ of junc. of Killik River, Arctic Slope; $69^{\circ} 04^{\prime} \mathrm{N}, 153^{\circ} 41^{\prime} \mathrm{W}$; $B G N$ 1949; (map 142).

So named by USGS geologists "because of fossil starfish found in the rocks of this bluff."

Star Gulch: ravine, trends NW $1.5 \mathrm{mi}$. to Discovery Fork, $9 \mathrm{mi}$. S of Eagle, Yukon-Tanana High.; $64^{\circ} 40^{\prime} \mathrm{N}, 141^{\circ} 18^{\prime} \mathrm{W}$; (map 102).

Prospectors' name obtained in 1898 by E. C. Barnard, USGS.

Star Hill: hill, $700 \mathrm{ft}$, in NE part of Juneau, $0.3 \mathrm{mi}$. E of Mount Maria, Coast Mts.; $58^{\circ}$ $18^{\prime} 20^{\prime \prime} \mathrm{N}, 134^{\circ} 24^{\prime} 00^{\prime \prime} \mathrm{W}$; (map 11).

Local name reported by R. N. DeArmond (1957, p. 32).

Starichkof: village, $\mathrm{N}$ end of Unalaska I., Aleutian Is.; (map 23). Var. Selo Akmagan.

Russian name reported by Father Veniaminov $(1840$, v. 1, p. 181) and published by Baker (1906, p. 597). It was called "S[elo] Akmagan" by Lt. Sarichev (1826, map 14), IRN. The name does not appear on modern maps.

Starichkof, Cape: point of land, S shore of Mukushin Bay, on W coast of Unalaska I., Aleutian Is.; $53^{\circ} 41^{\prime} 50^{\prime \prime} \mathrm{N}, 167^{\circ} 03^{\prime} 00^{\prime \prime} \mathrm{W}$; (map 23). Var. Cape Odd Fellows, Mys Starichkov.

Russian name published by Capt. Tebenkov (1852, map 26), IRN as "M[ys] Starichkov" meaning "Old Fellow Cape." It was called
"Cape Odd Fellows" by USBF in 1888, possibly due to a typographical error.

Starichkof, Cape: point of land, $300 \mathrm{ft}$. wide, on W coast of Kenai Penin., $7.5 \mathrm{mi}$. NNE of Anchor Point and $18 \mathrm{mi}$. NW of Homer, Cook Inlet Low.; $59^{\circ} 53^{\prime} \mathrm{N}, 151^{\circ} 48^{\prime} \mathrm{W}$; (map 50). Var. Staritschkow, Stuk Talj Chak, Stuk Talj Chin.

This Russian name, "Staritschkow" or "Starichische," meaning "stout old man," appears to have been given about 1840 by Ilia G. Wosenesenski and published by Constantin Grewingk (1850, map 3). Wosenesenski also gives the Kenai Indian name as "Stuk Talji Chin" or "Chak."

Starichkof Bay: bay, see Skan Bay.

Starichkof Reef: reef, at mouth of Egg Bay, off $\mathrm{N}$ coast of Atka I., Aleutian Is.; $52^{\circ} 12^{\prime} 30^{\prime \prime} \mathrm{N}$, $174^{\circ} 30^{\prime} 15^{\prime \prime}$ W ; (map 18). Var. Staritchkoff.

Russian name published as "Staritchkoff ile," meaning "old codger island," by Capt. Lutke (1836, p. 134), IRN.

Starichkov, Mys: point of land, see Starichkof, Cape.

Stariski Creek: stream, on Kenai Penin., flows W $23 \mathrm{mi}$. to Cook Inlet at Cape Starichkof, $19 \mathrm{mi}$. NW of Homer, Cook Inlet Low.; $49^{\circ} 53^{\prime} \mathrm{N}, 151^{\circ} 48^{\prime} \mathrm{W}$; (map 50).

Local name recorded in the 1950's by USGS; derived from the Russian word "staryy" meaning "old."

Staritchkoff: reef, see Starichkof Reef.

Staritschkow: point of land, see Starichkof, Cape. Star Lake: lake, 1,600 ft. long, on Revillagigedo I., near head of Thorne Arm, between Bevver and Granite Lakes, Alex. Arch.; 55 ${ }^{\circ} 22^{\prime} 58^{\prime \prime}$ N, $131^{\circ} 10^{\prime} 30^{\prime \prime} \mathrm{W}$; (map 3).

Local name reported in 1901 by A. H. Brooks (1920b, pl. 2), USGS.

Star Lake: lake, $1 \mathrm{mi}$. long, on Kenai Penin. near NW shore of Tustumena Lake, $20 \mathrm{mi}$. S Kenai, Cook Inlet Low.; $60^{\circ} 17^{\prime} \mathrm{N}, 151^{\circ} 09^{\prime}$ $\mathrm{W}$; (map 62).

Named about 1963 by officials of Kenai National Moose Range, for administrative purposes.

Star Lake: lake, $0.6 \mathrm{mi}$. across, $7.2 \mathrm{mi}$. $\mathrm{E}$ of junc. of Nizina and Chitina Rivers, $7 \mathrm{mi}$. S of McCarthy, Wrangell Mts.; $B G N$ 1966; $61^{\circ} 20^{\prime} 15^{\prime \prime} \mathrm{N}, 143^{\circ} 01^{\prime} 00^{\prime \prime} \mathrm{W}$; (map 67).

Local name descriptive of five-pointed outline of the shoreline, reported in 1965 by L. A. Yehle, USGS.

Starling: village, see Uzinki.

Starling Cape: point of land, see Leontovich, Cape.

Starling Point: point of land, see Leontovich, Cape.

Starr: locality, see Star.

Starr, Cape: point of land, SW of Nikolski Bay on SW coast of Umnak I., Aleutian Is.; $52^{\circ} 55^{\prime} 30^{\prime \prime} \mathrm{N}, 168^{\circ} 57^{\prime} 30^{\prime \prime} \mathrm{W}$; (map 21).

Name published by USC\&GS in the 1944 Aleutian Coast Pilot (p. 67).

Starr Creek: stream, flows S $5 \mathrm{mi}$. to Michigan Creek $1.6 \mathrm{mi}$. NW of its junc. with George River $39 \mathrm{mi}$. N of Sleetmute, Kilbuck-Kuskokwim Mts.; $62^{\circ} 14^{\prime} 45^{\prime \prime} \mathrm{N}, 157^{\circ} 20^{\prime} 40^{\prime \prime} \mathrm{W}$; (map 79).

Local name obtained in 1945 by USGS topographers.

Starr Hill: area, in NE section of Juneau, Coast Mts.; $58^{\circ} 18^{\prime} 15^{\prime \prime} \mathrm{N}, 134^{\circ} 24^{\prime} 25^{\prime \prime} \mathrm{W}$; (map 11).

Named for Frank Starr, 1849-98. Born in Maine, he came to Alaska in 1874. He lived first in Sitka and moved to Juneau where he built the first wharf and did some mining. In 1888 he operated a salmon saltery at Whitewater Bay and in 1896 he claimed a number of lots on Starr Hill (DeArmond, 1957, p. 41).

Starri-gavan: locality, see Nunamiut.

Starri-Gavan: locality, see Old Sitka.

Starrigavan: locality, see Three Saints Harbor. Starrigavan Bay: bay, $1.4 \mathrm{mi}$. across, on $\mathrm{W}$ coast of Baranof I., 5.5 mi. N of Sitka, Alex. Arch.; $57^{\circ} 08^{\prime} 00^{\prime \prime} \mathrm{N}, 135^{\circ} 22^{\prime} 30^{\prime \prime} \mathrm{W}$; BGN 1897; (map 9). Var. Bay of Starri-gavan, Great Bay, Large Bay, Old Harbor Bay, Old Sitka Harbor.

Russian name, "Starri-gavan," meaning "old harbor," reported in 1809 by Ivan Vasiliev the first. On the harbor in this bay the first Russian settlement in this area was founded in 1799. After the fort's destruction in 1802, and the construction of a new settlement at Sitka, this bay acquired its present name. See Old Sitka.

Starr Lake: lake, 2 mi. across, between Muddy River and Birch Creek, $5 \mathrm{mi}$. N of junc. of McKinley and Kantishna Rivers, Tanana Low.; $63^{\circ} 57^{\prime} \mathrm{N}, 151^{\circ} 40^{\prime} \mathrm{W}$; (map 88).

Local name reported in 1954 by USGS.

Star Rock: rock, at S end of Lisianski Strait, off $\mathrm{S}$ tip of Yakobi I., $18 \mathrm{mi}$. NW of Chichagof, Alex. Arch.; $57^{\circ} 49^{\prime} 50^{\prime \prime} \mathrm{N}, 136^{\circ} 28^{\prime} 00^{\prime \prime} \mathrm{W}$; (map 9).

Name published in 1925 by USC\&GS; published in 1925 Coast Pilot (p. 324).

Star Rock: rock, in Funter Bay, on Mansfield Penin., $0.3 \mathrm{mi}$. S of Funter and $18 \mathrm{mi}$. SW of Juneau, Alex. Arch.; 58 $15^{\prime} 05^{\prime \prime} \mathrm{N}, 134^{\circ} 53^{\prime} 35^{\prime \prime}$ W; (map 11).

Named in 1890 by Lt. Comdr. H. B. Mansfield, USN, and published by USC\&GS in the 1891 Coast Pilot (p. 162).

Star Rocks: rocks, see Starr Rocks.

Starr Point: point of land, on E shore of Northeast Arm Uganik Bay, on $N$ coast of Kodiak I. ; $57^{\circ} 45^{\prime} 30^{\prime \prime} \mathrm{N}, 153^{\circ} 22^{\prime} 00^{\prime \prime} \mathrm{W}$; (map 34).

Local name published in 1943 by USC\&GS.

Starr Rocks: rocks, in Dark Passage, $\mathbf{N}$ of Shuyak I., $51 \mathrm{mi}$. N of Kodiak I.; 58 $37^{\prime} 40^{\prime \prime}$ N, 152 $32^{\prime} 30^{\prime \prime}$ W; $B G N$ 1938; (map 43). Var. Star Rocks.

Named by USC\&GS in 1931, "ber.ause the steamer Starr is reported to have struck on these rocks and remained several hours until floated off by the tide."

Starry Arteel: rookery, see Staraya Artil Rookery. Starry Ateel: locality, see Staraya Artil.

Starry Ateel: rookery, see Staraya Artil Rookery. Starry Creek: stream, flows SE $0.5 \mathrm{mi}$. to Howard Creek which flows to California Creek, between Alta and Crush Creeks, $10 \mathrm{mi}$. NW of Solomon, Seward Penin. High.; (map 95). 
Prospectors' name reported on the 1900 "Map of Nome Peninsula" by J. M. Davidson and B. D. Blakeslee. This stream cannot be precisely located on current maps.

Startup Camp: locality, at head of Squaw Creek, $20 \mathrm{mi}$. WSW of Eureka Roadhouse and 65 mi. NE of Palmer, Chugach Mts.; (map 69).

Name of former camp used as supply point for gold placers on Albert Creek; reported in 1914 by Theodore Chapin (in Brooks and others, 1915, p. 128), USGS. Recent USGS maps do not indicate this locality.

Startup Creek: stream, heads in lake, flows SE $3.5 \mathrm{mi}$. to Tahneta Lake, $63 \mathrm{mi}$. NE of Palmer, Copper River Basin; $61^{\circ} 51^{\prime} 10^{\prime \prime} \mathrm{N}, 147^{\circ} 18^{\prime} 00^{\prime \prime}$ W; BGN 1960; (map 69).

Local name reported in 1956 to USGS by George Belanger; derived from "Startup," abandoned supply camp for Albert Creek placers.

Startup Lake: lake, see Tahneta Lake.

Startup Lakes: lakes, extend NE-SW $1.8 \mathrm{mi}$, between Syncline Mtn. and Glenn Highway, $64 \mathrm{mi}$. NE of Palmer, Talkeetna Mts.; $61^{\circ} 55^{\prime}$ $45^{\prime \prime} \mathrm{N}, 147^{\circ} 16^{\prime} 00^{\prime \prime} \mathrm{W}$; BGN 1960 (map 69). Var. Eureka Lake.

Local name reported in 1956 by USGS; derived from "Startup," abandoned supply camp for Albert Creek placers. See Startup Creek. Starui Gavan: locality, see Three Saints Harbor. Staruigavan: locality, see Nunamiut.

Staruigavan: village, see Old Harbor.

Starvation Creek: stream, flows NE 14 mi., joins Goose Greek to form West Fork Tolovana River, $30 \mathrm{mi}$. SE of Rampart, Yukon-Tanana High.; $65^{\circ} 21^{\prime} 20^{\prime \prime} \mathrm{N}, 149^{\circ} 15^{\prime} 00^{\prime \prime} \mathrm{W}$; (map 105).

Named by prospectors; published in 1906 by USGS.

Stary Gavan: cove, see Old Harbor.

Staryy Gavan: locality, see Three Saints Harbor. Staryy Gavan: cove, see Three Saints Harbor. Staten Island: island, $1 \mathrm{mi}$. long, on $\mathrm{W}$ coast of Adak I. in Bay of Islands, Aleutian Is. ; 51 ${ }^{\circ} 48^{\prime}$ N, $176^{\circ} 47^{\prime} \mathrm{W}$; BGN 1936; (may 17).

So named in 1934 by members of the U.S. Navy Aleutian Island Survey Expedition, "because of a fancied resemblance in outline to Staten Island, N.Y."

Station Bay: bay, $1.3 \mathrm{mi}$. across, SW coast of Unalaska I., Aleutian Is. ; $53^{\circ} 23^{\prime} 30^{\prime \prime} \mathrm{N}, 167^{\circ}$ $37^{\prime} 00^{\prime \prime} \mathrm{W}$; ( $\operatorname{map} 23$ ).

This name was published in the 1944 Aleutian Coast Pilot (p. 50)

Station Creek: stream, flows $1.3 \mathrm{mi}$. E to Frederika Creek, $0.5 \mathrm{mi}$. SE of Frederika Glacier terminus and $30 \mathrm{mi}$. NE of McCarthy, Wrangell Mts. ; $61^{\circ} 41^{\prime} 00^{\prime \prime} \mathrm{N}, 142^{\circ} 11^{\prime} 40^{\prime \prime} \mathrm{W}$; (map 67).

Local name obtained by USGS and published on maps since 1954.

Station Creek: stream, heads $6 \mathrm{mi}$. N of Mentasta Lake, flows SE, then E, $16 \mathrm{mi}$. through Mineral Lake to Little Tok River, $27 \mathrm{mi}$. SW of Tok, Alaska Ra.; $62^{\circ} 57^{\prime} 00^{\prime \prime} \mathrm{N}, 143^{\circ} 21^{\prime} 30^{\prime \prime}$ W; BGN 1952; (map 84). Var. Mentasta Creek, Tokio River.
So named locally because the old Mentasta Pass telegraph station was located on the west bank of this creek at Eagle Trail crossing. Recent maps show the above heading; previous maps headed the stream north of Mentasta Pass.

Station Island: island, $0.1 \mathrm{mi}$. long, at $\mathrm{S}$ point of entrance to Shakan Bay, on $\mathrm{N}$ coast of Kosciusko I., Alex. Arch.; 56 $08^{\prime} 55^{\prime \prime} \mathrm{N}, 1^{\circ} 33^{\circ} 37^{\prime}$ $25^{\prime \prime} \mathrm{W}$; (map 6).

Named in 1886 by Lt. J. M. Helm, USN, for charting purposes; published in 1887 on USC\&GS Chart 706.

Station Island: island, $0.3 \mathrm{mi}$. long, in Sumner Strait, off S coast of Mitkof I., Alex. Arch.; $56^{\circ} 29^{\prime} 35^{\prime \prime} \mathrm{N}, 132^{\circ} 46^{\prime} 00^{\prime \prime} \mathrm{W}$; (map 6). Var. Station Islet.

Feature was named "Station Islet" in 1881 by Lt. Comdr. H. E. Nichols, USN.

Station Island: island, $0.2 \mathrm{mi}$. across, in Lynn Canal, near mouth of Funter Bay, $0.8 \mathrm{mi}$. SW of Clear Point and $19 \mathrm{mi}$. SW of Juneau, Alex. Arch.; 58 $13^{\prime} 55^{\prime \prime}$ N, $134^{\circ} 55^{\prime} 15^{\prime \prime}$ W; (map 11).

Named in 1890 by Lt. Comdr. H. B. Mansfield, USN, and published by USC\&GS in the 1891 Coast Pilot (p. 161).

Station Island: island, $1 \mathrm{mi}$. long, in Yukon River, $\mathbf{N}$ of Basco I., $13 \mathrm{mi}$. WSW of Tanana, Nowitna Low.; $65^{\circ} 08^{\prime} 30^{\prime \prime} \mathrm{N}, 152^{\circ} 32^{\prime} 00^{\prime \prime} \mathrm{W}$; (map 106). Var. Old Station Island, Walker Station Island.

Riverboat pilots' name reported in the 1920 's; so named because "A telegraph relay station [Walker Station] was located near here."

Station Islet: island, see Station Island.

Station Number One: locality, $1.5 \mathrm{mi}$. SE of Valdez, Chugach Mts. ; $61^{\circ} 06^{\prime} \mathrm{N}, 146^{\circ} 13^{\prime} \mathrm{W}$; (map 68).

Site of a station on a former military telegraph line reported by USGS (Moffit and Maddren, 1909, pl. 1).

Station Point: point of land, on E coast of Glass Penin., on Admiralty I., $39 \mathrm{mi}$. NE of Angoon, Alex. Arch.; $58^{\circ} 00^{\prime} 00^{\prime \prime} \mathrm{N}, 134^{\circ} 05^{\prime} 30^{\prime \prime} \mathrm{W}$; (map 9).

Named in 1886 by Lt. Comdr. A. S. Snow, USN, who had an astronomical station here. The name was published in 1888 by USC\&GS on Chart 729.

Station Point: point of land, see Cemetery Point. Station Rock: rock, in W channel of Tanana River, S of Eightmile I., $7.5 \mathrm{mi}$. SE of Tanana, Nowitna Low.; $65^{\circ} 07^{\prime} \mathrm{N}, 151^{\circ} 51^{\prime} \mathrm{W}$; (map 106).

Riverboat pilots' name shown on a 1940 Navigation Chart, Tanana-Yukon Rivers.

Staunch Point: point of land, $\mathrm{S}$ point of entrance to Windfall Harbor, on $\mathrm{E}$ coast of Admiralty I., $28 \mathrm{mi}$. NE of Angoon, Alex. Arch.; 57 52'$20^{\prime \prime} \mathrm{N}, 134^{\circ} 14^{\prime} 40^{\prime \prime} \mathrm{W}$; (map 11 ).

Named in 1889 by Lt. Comdr. H. B. Mansfield; published by USC\&GS on Chart 8228 . Steamboat Bay: bay, $1 \mathrm{mi}$. across, on $\mathrm{E}$ shore of Stephens Passage, $0.5 \mathrm{mi}$. $\mathrm{N}$ of Cleveland Passage and $71 \mathrm{mi}$. E of Sitka, Coast Mts.; $57^{\circ} 16^{\prime} 15^{\prime \prime} \mathrm{N}, 133^{\circ} 32^{\prime} 00 \mathrm{~W}$; (map 8).
Named in 1887 by Lt. Comdr. C. M. Thomas, USN; name published in 1888 by USC\&GS.

Steamboat Bay: estuary, $1.3 \mathrm{mi}$. long, N coast of Noyes I., Alex. Arch.; $55^{\circ} 33^{\prime} \mathrm{N}, 133^{\circ} 38^{\prime}$ W; BGN 1923; (map 4).

Named in 1923 by USC\&GS; derived from Steamboat Point.

Steamboat Cabin Slough: lake, $1.5 \mathrm{mi}$. long, oxbow, $\mathrm{S}$ of Black River, $20 \mathrm{mi}$. NE of Fort Yukon, Yukon Flats; $66^{\circ} 40^{\prime} \mathrm{N}, 144^{\circ} 35^{\prime} \mathrm{W}$; (map 119).

Local name obtained in 1956 by USGS.

Steamboat Creek: stream, heads on Twin Buttes, flows SE $14 \mathrm{mi}$. to Kuskokwim River $1.8 \mathrm{mi}$. W of its junc. with George River, $24 \mathrm{mi}$. NW of Sleetmute, Kilbuck-Kuskokwim Mts.; 61 $53^{\prime} 45^{\prime \prime} \mathrm{N}, 157^{\circ} 45^{\prime} 50^{\prime \prime} \mathrm{W}$; (map 72).

Local name reported in 1914 by $\mathbf{R}$. $\mathbf{H}$. Sargent (in Smith, P. S., 1917, pl. 5), USGS. "So called because a steamboat woodyard was once located here."

Steamboat Creek: stream, flows SE $1.4 \mathrm{mi}$. to Pedro Creek, $13 \mathrm{mi}$. NE of Fairbanks, YukonTanana High.; $65^{\circ} 00^{\prime} 20^{\prime \prime}$ N, $147^{\circ} 30^{\prime} 50^{\prime \prime} \mathrm{W}$; (map 105).

Named by prospectors; reported in 1903 by T. G. Gerdine (Prindle, 1905, pl. 13), USGS.

Steamboat Creek: stream, see Steamboat Slough. Steamboat Lake: lake, $0.6 \mathrm{mi}$. across, on $\mathrm{S}$ bank of Bremner River, $2 \mathrm{mi}$. SW of mouth of Little Bremner River and $58 \mathrm{mi}$. E of Valdez, Chugach Mts. ; $61^{\circ} 01^{\prime} 10^{\prime \prime} \mathrm{N}, 144^{\circ} 30^{\prime} 50^{\prime \prime} \mathrm{W}$; (map 68).

Local name published in the 1950 's by USGS.

Steamboat Mountain: mountain, $1,775 \mathrm{ft} ., 11$ mi. NW of Midnight Hill, Porcupine Plat.; $66^{\circ} 06^{\prime} \mathrm{N}, 141^{\circ} 28^{\prime} \mathrm{W}$; (map 120$)$.

Local name obtained in 1956 by T. E. Taylor and R. C. Foley, USGS.

Steamboat Point: point of land, $\mathrm{W}$ point of entrance to Steamboat Bay, N coast of Noyes I., Alex. Arch.; $55^{\circ} 33^{\prime} \mathrm{N}, 133^{\circ} 39^{\prime} \mathrm{W}$; (map 4).

Local navigators' name; published in 1925 Coast Pilot (p. 147).

Steamboat Slough: stream, anabranch of Kuskokwim River, trends SW $1.5 \mathrm{mi}$., $2 \mathrm{mi}$. SE of Bethel, Yukon-Kuskokwim Delta.; $60^{\circ} 47^{\prime} \mathrm{N}$, $161^{\circ} 42^{\prime} \mathrm{W}$; (map 59).

Local name reported in 1949 by USCS.

Steamboat Slough: stream, flows W $14 \mathrm{mi}$. to Fish River, $33 \mathrm{mi}$. NE of Solomon, Seward Penin. High.; $64^{\circ} 46^{\prime}$ N, $163^{\circ} 27^{\prime}$ W; (map 95). Var. Kuearuk River, Steamboat Creek.

Reported as "Steamboat Creek" in 1900 by E. C. Barnard (in Brooks, 1901, pl. 17); shown as "Kuearuk River" by Schrader and Brooks (1900, map 3), USGS.

Steamboat Slough: stream, channel of Yukon River, $0.8 \mathrm{mi}$. long, at mouth of Tozitna River, $9 \mathrm{mi}$. WSW of Tanana, Nowitna Low.; $65^{\circ} 08^{\prime} 30^{\prime \prime} \mathrm{N}, 152^{\circ} 24^{\prime} 00^{\prime \prime} \mathrm{W}$; (map 106).

Named when the riverboats May West and Seattle No. 1 wintered here in 1897-98. Name shown on a navigation manuscript chart dated 1906 . 
Steamboat Slough: watercourse, $2.5 \mathrm{mi}$. long, anabranch of Andreafsky River, $37 \mathrm{mi}$. NW of Marshall, Yukon-Kuskokwim Delta; 62 $02^{\prime}$ $35^{\prime \prime} \mathrm{N}, 163^{\circ} 11^{\prime} 00^{\prime \prime} \mathrm{W}$; (map 77).

Riverboat pilots' name shown on a 1916 fieldsheet by R. H. Sargent, USGS. So named because it was used as a wintering place for steamboats from 1898 to 1905.

Steamboat Slough: watercourse, anabranch of the Yukon River, $11 \mathrm{mi}$. long, $48 \mathrm{mi}$. E of Unalakleet, Nulato Hills; $63^{\circ} 52^{\prime} \mathrm{N}, 159^{\circ} 13^{\prime}$ W; (map 91). Var. Three Mouth Creek.

River pilots' name shown on a 1901 manuscript chart of the Yukon River.

Steamer Bay: bay, extends NW $2.5 \mathrm{mi}$. to Stikine Strait, on W coast of Etolin I., Alex. Arch.; $56^{\circ} 11^{\prime} \mathrm{N}, 132^{\circ} 43^{\prime} \mathrm{W}$; (map 6). Var. Bukhta Parakhodnaya, Parakhotnia Bay.

This is an 1882 translation by USC\&GS of "Bukhta Parakhodnaya," which was published in 1853 on Russian Hydrog. Dept. Chart 1493.

Steamer Eclipse Slough: stream, see Eclipse Slough.

Steamer Knoll: mountain, 2,115 ft., S of Steamer Bay, on W coast of Etolin I., Alex. Arch.; $56^{\circ}$. $07^{\prime} 30^{\prime \prime} \mathrm{N}, 132^{\circ} 41^{\prime} 00^{\prime \prime} \mathrm{W}$; (map 6).

Named in 1886 by Lt. Comdr. A. S. Snow, USN; published in 1887 on USC\&GS Chart 706.

Steamer Point: point of land, N entrance to Kindergarten Bay, on NW coast of Etolin I., Alex. Arch.; $56^{\circ} 13^{\prime} 00^{\prime \prime} \mathrm{N}, 132^{\circ} 42^{\prime} 40^{\prime \prime} \mathrm{W}$ (map 6).

Local navigators' name reported in 1904 by H. C. Fassett, USBF.

Steamer Rocks: rocks, extend $0.5 \mathrm{mi}$. in Clarence Strait, off W coast of Etolin I., Alex. Arch.; $56^{\circ} 08^{\prime} 30^{\prime \prime} \mathrm{N}, 132^{\circ} 43^{\prime} 30^{\prime \prime} \mathrm{W}$; (map 6).

Local navigators' name reported in 1904 by H. C. Fassett, USBF.

Stebbins: village, pop. 158, on NW coast of St. Michael I., $8 \mathrm{mi}$. NW of St. Michael, YukonKuskokwim Delta; $63^{\circ} 31^{\prime} 20^{\prime \prime} \mathrm{N}, 162^{\circ} 17^{\prime}$ $20^{\prime \prime} \mathrm{W}$; (map 92). Var. Atroic, Atroik, Stephens.

Village which a 1950 USC\&GS field report gave as primarily Eskimo with about " 80 people whose main livelihood is hunting, fishing, and herding reindeer." The village was first mentioned in 1898 by USC\&GS; the name was published in 1900 on Chart 9370. Its Eskimo name is reported to be "Atroik."

Stedatna Creek: stream, flows SW $4.7 \mathrm{mi}$. to Nikolai Creek, $13 \mathrm{mi}$. W of Tyonek, Cook Inlet Low.; $61^{\circ} 02^{\prime} 45^{\prime \prime} \mathrm{N}, 151^{\circ} 32^{\prime} 00^{\prime \prime} \mathrm{W}$; (map 70).

Tanaina Indian name reported in 1958 by USGS.

Stedman Cove: cove, $1.2 \mathrm{mi}$. long, on Horseshoe I. between Big John Bay and Rocky Pass of Keku Strait, $14 \mathrm{mi}$. SE of Kake, on $\mathrm{W}$ coast of Kupreanof I., Alex. Arch.; $56^{\circ} 47^{\prime} 50^{\prime \prime} \mathrm{N}$, $133^{\circ} 45^{\prime} 00^{\prime \prime} \mathrm{W}$; (map 6).

Named by USC\&GS for charting purposes; published in the 1932 Coast Pilot (p. 259). Steel Creek: locality, see Steele Creek.
Steel Creek: stream, flows NE $4 \mathrm{mi}$. to Tolovana River, $6 \mathrm{mi}$. SE of Livengood, Yukon-Tanana High.; $65^{\circ} 28^{\prime} \mathrm{N}, 148^{\circ} 25^{\prime} \mathrm{W}$; (map 105).

Named by prospectors; reported in 1915 by USGS (Brooks and others, 1916, pl. 9).

Steel Creek: stream, see Steele Creek.

Steele, Point: point of land, on NE coast of Hinchinbrook I., $20 \mathrm{mi}$. SW of Cordova, Chugach Mts.; $60^{\circ} 21^{\prime} \mathrm{N}, 146^{\circ} 12^{\prime} \mathrm{W}$; $B G N$ 1901; (map 64). Var. Aguirre, Bentinck Point, Puntade, Steel Point.

Named in 1787 by Capt. Nathaniel Portlock (1789, map facing p. 1) while exploring the region. It was later called "Point Bentinck," for William Henry Cavendish Bentinck, third Duke of Portland from 1762 (Wagner, 1937, p. 376) by Capt. George Vancouver, RN, during one of his many visits to the northwest American coast at the end of the 18th Century. Don Ignacio Arteaga who, with Don Juan de la Bodega y Quadra on the Spanish vessels La Princesa and $L a$ Favorita explored the region in 1779, named the point "Punta De Aguirre" on July 17, 1779, probably after the pilot of the La Favorita, Juan Bautista de Aguirre (Wagner, 1937, p. 424).

Steele Creek: locality, on $\mathbf{S}$ bank of Fortymile River, at Stecle Creek, $38 \mathrm{mi}$. S of Eagle, Yukon-Tanana High.; $64^{\circ} 16^{\prime} 38^{\prime \prime}$ N, $141^{\circ} 17^{\prime}$ $00^{\prime \prime}$ W; BGN 1964; (map 102). Var. Steel Creek.

Mining camp and post office reported in 1903 by Prindle (1905, pl. 16), USGS. A post office was maintained here from 1907 to 1951 (Ricks, 1965, p. 61).

Steele Creek: stream, flows NE $7 \mathrm{mi}$. to Fortymile River, $37 \mathrm{mi}$. S of Eagle, Yukon-Tanana High.; $64^{\circ} 16^{\prime} 20^{\prime \prime} \mathrm{N}, 141^{\circ} 17^{\prime} 00^{\prime \prime} \mathrm{W}$; BGN 1964; (map 102). Var. Steel Creek.

Prospectors' name reported in 1897 as "Steel Creek" by Spurr (1898, pl. 46), USGS. Steele Creek: stream, flows S $8 \mathrm{mi}$. to Chena River, $7 \mathrm{mi}$. E of Fairbanks, Tanana Low.; $64^{\circ} 51^{\prime} \mathrm{N}, 147^{\circ} 28^{\prime} \mathrm{W}$; (map 100). Var. Steel Creek.

Local name published in 1908 by USGS.

Steele Creek Dome: mountain, 4,015 ft., $43 \mathrm{mi}$. $\mathrm{S}$ of Eagle, Yukon-Tanana High.; 64. $11^{\prime} \mathrm{N}$, $141^{\circ} 20^{\prime} \mathrm{W}$; (map 102). Var. Steele Dome.

Local name derived from Steele Creek; the stream was reported in 1903 by Prindle (1905, pl. 16), USGS.

Steele Dome: mountain, see Steele Creek Dome. Steele Lake: lake, $0.9 \mathrm{mi}$. long, $\mathrm{N}$ of Farewell Lake, $1.5 \mathrm{mi}$. SW of junc. of South Fork Kuskokwim and Dillinger Rivers and $68 \mathrm{mi}$. $\mathrm{SE}$ of McGrath, Kuskokwim Low.; 62 $34^{\prime} 20^{\prime \prime}$ N, 153⒊ $38^{\prime \prime}$ W; (map 80).

Local name obtained in 1958 by USGS.

Steelhead Creek: stream, rises on $N$ slope of Trader Mtn., flows N $15 \mathrm{mi}$. to Bering Sea, Bristol Bay Low. ; $55^{\circ} 49^{\prime} \mathrm{N}, 161^{\circ} 55^{\prime} \mathrm{W}$; (map 28).

Local name shown on a 1963 USGS map.

Steelhead Creek: stream, in Glacier Bay National Monument, flows SE and SW $5 \mathrm{mi}$. to Gulf of Alaska, $4.5 \mathrm{mi}$. SE of Harbor Point,
$83 \mathrm{mi}$. NW of Hoonah, Malaspina Coastal Plain; 58 $34^{\prime} 45^{\prime \prime} \mathrm{N}, 137^{\circ} 33^{\prime} 00^{\prime \prime} \mathrm{W}$; BGN 1959; (map 10). Var. Gaskal Creek.

Local name reported by J. B. Mertie (in Smith and others, 1933, p. 118 and fig. 4), USGS. It was called "Gaskal Creek" by members of the Harvard-Dartmouth Expedition, 1933-34 (Washburn and Goldthwait, 1936, map).

Steelhead Creek: stream, see Topsy Creek.

Steelhead River: stream, on Chichagof I., NW $6.5 \mathrm{mi}$. to Lisianski Inlet, $14 \mathrm{mi}$. N of Chichagof, Alex. Arch.; 57 $51^{\prime} 50^{\prime \prime} \mathrm{N}, 136^{\circ} 05^{\prime} 55^{\prime \prime}$ W; BGN 1960; (map 9).

Named in 1955 by D. L. Rossman, USGS, "for the Steelhead trout, which are reported to spawn in this stream. It is said to be the only stream on Chichagof Island in which these fish spawn."

Steelmut: village, see Sleetmute.

Steel Point: point of land, see Steele, Point.

Steep Cape: point of land, $21 \mathrm{mi}$. NW of Afognak, on $\mathrm{W}$ coast of Afognak I., $\mathrm{N}$ of Kodiak I.; 58 $12^{\prime} 00^{\prime \prime} \mathrm{N}, 153^{\circ} 12^{\prime} 30^{\prime \prime} \mathrm{W}$; (map 43). Var. Cape Kruto, Cape Krutoi, Cape Krutoy.

Translation by USC\&GS of the name "M[ys] Krutoy," published in 1849 by the Russian American Company.

Steep Creek: stream, flows $3 \mathrm{mi}$. NW to Mendenhall Lake, $0.6 \mathrm{mi}$. N of outlet to Mendenhall River and $10 \mathrm{mi}$. NW of Juneau, Coast Mts.; $58^{\circ} 25^{\prime} \mathrm{N}, 134^{\circ} 34^{\prime} \mathrm{W}$; (map 11).

Local descriptive name published by Adolf Knopf (1912a, pl. 1), USGS.

Steep Creek: stream, flows NW $4 \mathrm{mi}$. to Totatlanika River, $40 \mathrm{mi}$. SE of Nenana, Alaska Ra.; $64^{\circ} 03^{\prime} \mathrm{N}, 148^{\circ} 30^{\prime} \mathrm{W}$; (map 100).

Local name reported in 1910 by USGS (Capps, 1912, pl. 1).

Steep Creek: stream, flows SW $1.4 \mathrm{mi}$. to Silver Creek, $16 \mathrm{mi}$. N of Nome, Seward Penin. High.; 64 ${ }^{\circ} 45^{\prime} \mathrm{N}, 165^{\circ} 24^{\prime} \mathrm{W}$; (map 94).

Prospectors' name reported in 1899 by Schrader (1900c, p. 16), USGS.

Steep Creek: stream, see Right Arm Creek.

Steep Glacier: glacier, see Canyon Glacier.

Steep Island: island, $150 \mathrm{ft}$. across, in Ogden Passage, 2 mi. NW of Chicagof, Alex. Arch.; $57^{\circ} 40^{\prime} 27^{\prime \prime} \mathrm{N}, 136^{\circ} 09^{\prime} 15^{\prime \prime} \mathrm{W}$; BGN 1960; (map 9).

Descriptive name given in 1908 by USC\&GS; published in 1908 Coast Pilot ( $p$. 174).

Steep Island: island, see Krutoi Island.

Steeple Peak: mountain peak, 2,300 ft., $1.6 \mathrm{mi}$. NE of Taku Harbor on Stephens Passage and $22 \mathrm{mi}$. SE of Juneau, Coast Mts.; 58 $05^{\prime} 10^{\prime \prime}$ N, $133^{\circ} 59^{\prime} 30^{\prime \prime} \mathrm{W}$; (map 12).

Descriptive name given in 1888 by Lt. Comdr. C. M. Thomas, USN.

Steeple Point: point of land, in Inanudak Bay, on W central coast of Umnak I., Aleutian Is. ; $53^{\circ} 16^{\prime} 35^{\prime \prime} \mathrm{N}, 168^{\circ} 20^{\prime} 35^{\prime \prime} \mathrm{W}$; BGN 1940; (map 22).

Descriptive name given in 1938 by USC\&GS "because of the steeple or spire-like rock formation which characterizes the point." 
Steep Point: point of land, on $\mathrm{W}$ bank of Portland Canal, $6.5 \mathrm{mi}$. N of Turn Point, Coast

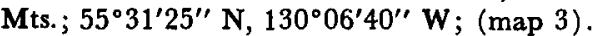

Descriptive name given in 1868 by Staff Comdr. David Pender, RN.

Steep Point: point of land, on SE coast of Kenai Penin., $2 \mathrm{mi}$. NE of Ragged I. and $52 \mathrm{mi}$. ENE of Seldovia, Chugach Mts.; $59^{\circ} 29^{\prime} \mathrm{N}, 150^{\circ} 15^{\prime}$ W; (map 50).

Descriptive name reported in 1951 by USGS.

Steer Creek: stream, flows S to Anikovik River, about $14 \mathrm{mi}$. SE of Cape Prince of Wales, Seward Penin. High.; (map 111).

Prospectors' name shown on a 1901 map of Cape Nome gold fields by David Fox, Jr. This feature cannot be precisely identified on current maps.

Steitmute: village, see Sleetmute.

Stella Creek: stream, flows SE $1.1 \mathrm{mi}$. to West Fork Kuyukutuk River $9.9 \mathrm{mi}$. E of Marshall, Nulato Hills; $61^{\circ} 52^{\prime} 15^{\prime \prime} \mathrm{N}, 161^{\circ} 46^{\prime} 50^{\prime \prime} \mathrm{W}$ (map 73).

Prospectors' name reported by Harrington (1918, map), USGS, in 1916.

Stella Creek: stream, flows NW $1.7 \mathrm{mi}$. to Cripple River, $16 \mathrm{mi}$. NW of Nome, Seward Penin. High.; $64^{\circ} 40^{\prime} \mathrm{N}, 165^{\circ} 50^{\prime} \mathrm{W}$; (map 94). Var. Slate Creek.

Prospectors' name reported in 1900 by $\mathbf{E}$. C. Barnard (in Brooks, 1901, pl. 17), USGS.

Stella Creek: stream, flows NW $1.5 \mathrm{mi}$. to Iron Creek $0.5 \mathrm{mi}$. S of its junc, with Pilgrim River, $28 \mathrm{mi}$. NW of Solomon, Seward Penin. High, $64^{\circ} 58^{\prime} \mathrm{N}, 164^{\circ} 38^{\prime} \mathrm{W}$; (map 95).

Prospectors' name reported in 1908 by P. S. Smith (in Brooks and others, 1909, pl. 10), USGS.

Stella Creek: stream, flows SW to California Creek which flows to Bonanza River, between Disappointment and Gold Greeks, $10 \mathrm{mi}$. NW of Solomon, Seward Penin. High.; (map 95).

Prospectors' name reported on the 1900 "Map of Nome Peninsula" by J. M. Davidson and B. D. Blakeslee. This stream cannot be precisely located on current maps.

Stellar, Mount: peak, see Steller, Mount.

Stellar Creek: stream, flows NW $3 \mathrm{mi}$. to Sawmill Bay, $0.3 \mathrm{mi}$. N of Devish Lake and $18 \mathrm{mi}$. SW of Valdez, Chugach Mts.; $61^{\circ} 03^{\prime} 10^{\prime \prime} \mathrm{N}$, $146^{\circ} 48^{\prime} 00^{\prime \prime}$ W; (map 68). Var. Steller Creek.

Prospectors' name published in 1915 as Steller Creek by USGS.

Steller, Mount: mountain, 10,267 ft., on Waxell Ridge, $20.5 \mathrm{mi}$. SE of Mount Tom White and $90 \mathrm{mi}$. E of Cordova, Chugach Mts.; $60^{\circ}$. $31^{\prime} 25^{\prime \prime} \mathrm{N}, 143^{\circ} 06^{\prime} 45^{\prime \prime} \mathrm{W}$; BGN 1966; (map $65)$.

Named in 1928 by USGS for George Wilhelm Steller, naturalist with Vitus Bering on his discovery voyage in 1741 . Steller went ashore and collected specimens on Kayak Island which is about 60 miles southwest of this peak.

Steller, Mount: peak, 7,300 ft., on ridge at head of Hook Glacier, on Alaska Penin. in Katmai National Monument, $24 \mathrm{mi}$. NE of Mount
Katmai, Aleutian Ra.; $58^{\circ} 25^{\prime} 50^{\prime \prime}$ N, $154^{\circ}$ 23'15" W; BGN 1966; (map 42). Var. Mount Stellar.

Named for George Wilhelm Steller; published in 1951 by USGS. See Steller, Mount. Steller Cove: cove, $2.8 \mathrm{mi}$. across, on $\mathrm{N}$ coast of Attu I., Aleutian Is.; $52^{\circ} 59^{\prime} 20^{\prime \prime} \mathrm{N}, 172^{\circ} 56^{\prime}$ 00" E; BGN 1938; (map 13). Var. Big Bay, Michael Bay, Three Arm Bay.

Named for George Wilhelm Steller. See Steller, Mount. This cove is shown as "Big Bay" on a manuscript map drawn by $L$. $M$. Turner in the 1880's. The name was published in 1943 on an AMS map as "Steller Cove."

Steller Creek: stream, see Stellar Creek.

Steller Glacier: glacier, heads in $W$ end of Bagley Icefield, trends SW $12 \mathrm{mi}$. to Bering Glacier, $3 \mathrm{mi}$. E of Fourth Lake and $73 \mathrm{mi}$. E of Cordova, Chugach Mts.; $60^{\circ} 24^{\prime} \mathrm{N}, 143^{\circ} 38^{\prime}$ W; (map 65).

Name derived from Mount Steller near the glacier's head and published in 1950 by USGS. Steller River: stream, heads at $52^{\circ} 56^{\prime} 07^{\prime \prime} \mathrm{N}$, $172^{\circ} 49^{\prime} 10^{\prime \prime} \mathrm{E}$, flows $5.5 \mathrm{mi}$. NE through West Steller Valley to Auburn Cove, in Steller Cove, on N coast of Attu I., Aleutian Is.; 52 $58^{\prime} 50^{\prime \prime}$ $\mathrm{N}, 172^{\circ} 54^{\prime} 25^{\prime \prime} \mathrm{E}$; (map 13).

Name derived from Steller Cove and shown on an AMS map published in 1948.

Steopender Creek: stream, flows SE to Solomon River, about $12 \mathrm{mi}$. N of Solomon, Seward Penin. High.; (map 95).

Prospectors' name reported on the 1900 "Map of Nome Peninsula" by J. M. Davidson and B. D. Blakeslee. This stream cannot be precisely located on current maps.

Stepanof Cove: cove, $1 \mathrm{mi}$. across, in Inanudak Bay on W coast of Umnak I., Aleutian Is.; $53^{\circ} 17^{\prime} 15^{\prime \prime} \mathrm{N}, 168^{\circ} 21^{\prime} 00^{\prime \prime} \mathrm{W}$; BGN 1940; (map 22). Var. Cinder Cove, Stepanofskaia Anse, Stepanow Bay.

Name reported by Capt. Lutke (1836, p. 301), IRN, as "Stepanovskaia"; also called "Cinder Cove" by a 1939 USC\&GS field party "because it is adjacent to Cinder Point."

Stepanof Flats: beach, at mouth of the Big River, on S coast of Alaska Penin., at head of Stepovak Bay, Aleutian Ra.; 55 $51^{\prime} 30^{\prime \prime} \mathrm{N}$, $159^{\circ} 45^{\prime} 00^{\prime \prime} \mathrm{W}$; (map 27).

Name published by USC\&GS in 1947 Coast Pilot (p. 305).

Stepanofskaia Anse: cove, see Stepanof Cove.

Stepanow Bay: bay, see Inanudak Bay.

Stepanow Bay: cove, see Stepanof Cove.

Stepanutcha Cliff: cliff, $\mathrm{S}$ of Tolstoi Point, on E coast of St. George I., in Pribilof Is.; 56 35'$30^{\prime \prime} \mathrm{N}, 169^{\circ} 28^{\prime} 00^{\prime \prime} \mathrm{W}$; (map 38).

Aleut name listed by Putnam (1903, p. 1015), USC\&GS, as "Ste'pan-utcha" meaning "Stepan's shelf *** so called because here Stepan, a native, gathered eggs, this ridge being reserved for him."'

Step Creek: stream, heads in Step Gulch, on Ear Mtn., flows SE $3 \mathrm{mi}$. to Crosby Creek, Seward Penin. High.; $66^{\circ} 53^{\prime} 00^{\prime \prime} \mathrm{N}, 166^{\circ} 10^{\prime}$ $30^{\prime \prime} \mathrm{W}$; (map 111). Var. Step Gulch Creek.

Named in 1954 relative to Step Gulch.
Step Gulch: ravine, heads between Ears Peak and West Peak on Ear Mtn., trends SE $1 \mathrm{mi}$. along Step Greek, Seward Penin. High.; $6^{\circ}$ $55^{\prime} \mathrm{N}, 166^{\circ} 13^{\prime} \mathrm{W}$; BGN 1954; (map 111).

So named in 1945 by a USGS field party "for the conspicuous step like flats on the fill of its bed in the headwater portion."

Step Gulch Creek: stream, see Step Creek.

Stephan Lake: lake, $1.8 \mathrm{mi}$. long, at head of Goose Creek, $18 \mathrm{mi}$. N of Anchorage, Cook Inlet Low.; $61^{\circ} 29^{\prime} \mathrm{N}, 149^{\circ} 56^{\prime} \mathrm{W}$; (map 69).

Local name reported in 1942 by AMS.

Stephan Lake: lake, $4.2 \mathrm{mi}$. long, at head of Prairie Greek, $45 \mathrm{mi}$. NE of Talkeetna, Talkeetna Mts.; $62^{\circ} 42^{\prime} 30^{\prime \prime} \mathrm{N}, 148^{\circ} 53^{\prime} 00^{\prime \prime} \mathrm{W}$.; (map 82).

Local name reported in 1951 by USGS.

Stephans Creek: stream, see Stevens Creek.

Stephens: village, see Stebbins.

Stephens: village, see Stevens Village.

Stephens, Cape: point of land, northernmost tip of St. Michael I., $9 \mathrm{mi}$. NW of St. Michael, Yukon-Kuskokwim Delta ; $63^{\circ} 32^{\prime} 30^{\prime \prime} \mathrm{N}$; $162^{\circ} 18^{\prime} 40^{\prime \prime} \mathrm{W}$; (map 92).

Named by Capt. James Cook, RN, in September 1778 .

Stephens, Point: point of land, in Favorite Channel, $0.2 \mathrm{mi}$. W of village of Tee Harbor and $15 \mathrm{mi}$. NW of Juneau, Coast Mts. ; 58 $25^{\prime} 15^{\prime \prime}$ $\mathrm{N}, 134^{\circ} 46^{\prime} 00^{\prime \prime} \mathrm{W}$; (map 11).

Named in 1880 by Capt. L. A. Beardslee, USN. The name was published in the 1883 Coast Pilot (p. 173), and probably was derived from Stephens Passage.

Stephens Cove: bay, see Tee Harbor.

Stephens Creek: stream, flows NE $8 \mathrm{mi}$. to Klutina River, $2.2 \mathrm{mi} \mathrm{SE}$ of Garrett Peak and 24 mi. NE of Valdez, Chugach Mts.; $61^{\circ} 28^{\prime} 45^{\prime \prime}$ $\mathrm{N}, 146^{\circ} 01^{\prime} 50^{\prime \prime} \mathrm{W}$; (map 68).

Named in 1898 by P. G. Lowe, USA, presumably for Sherman C. Stephens, a member of Capt. W. R. Abercrombie's party.

Stephens Creek: stream, see Stevens Creek.

Stephens Glacier: glacier, heads $1.5 \mathrm{mi}$. N of Mount Cashman, trends NE $8.5 \mathrm{mi}$. to its terminus at head of Stephens Creek, $22 \mathrm{mi}$. $\mathrm{N}$ of Valdez, Ghugach Mts.; 61 ${ }^{\circ} 26^{\prime} 15^{\prime \prime} \mathrm{N}$, $146^{\circ} 14^{\prime} 15^{\prime \prime} \mathrm{W}$; (map 68)

Local name published in the 1950's by USGS.

Stephens Gulch: ravine, see Stevens Gulch.

Stephensons Stream: stream, flows SW $5.9 \mathrm{mi}$. to Koyuk River, 6 mi. SW of Haycock, Seward Penin. High.; $65^{\circ} 08^{\prime} \mathrm{N}, 161^{\circ} 15^{\prime} \mathrm{W}$; (map 109).

Local name published on maps after 1950. Stephens Pass: water passage, $1 \mathrm{mi}$. long, between St. Michael and Stuart Is., $9.5 \mathrm{mi}$. NW of St. Michael, Yukon-Kuskokwim Delta; $63^{\circ}$ $32^{\prime} 30^{\prime \prime} \mathrm{N}, 162^{\circ} 20^{\prime} 00^{\prime \prime} \mathrm{W}$; (map 92).

Local name published in 1900 by USC\&GS. Stephens Passage: water passage, $80 \mathrm{mi}$. long, trends SE from Portland I. to Frederick Sound, $11 \mathrm{mi}$. W. of Juneau, Coast Mts.; $57^{\circ} 13^{\prime} \mathrm{N}$, $133^{\circ} 39^{\prime} \mathrm{W}$; (map 11).

Named in 1794 by Capt. George Vancouver, RN, probably for Sir Philip Stephens (Wagner, 1937, p. 417). 
Stephens Village: village, see Stevens Village. Step Mountain: mountain, 1,386 ft., $1 \mathrm{mi}$. NE of Fortification Bluff and $16 \mathrm{mi}$. NW of Augustine I., Aleutian Ra.; $59^{\circ} 26^{\prime} 10^{\prime \prime} \mathrm{N}, 153^{\circ} 45^{\prime}$ 50" W; BGN 1916; (map 11).

Descriptive name published in 1913 on USC\&GS Chart 3420.

Step Mountains: ridge, elev. 3,000-4,440 ft., extends NE-SW 5 mi. between Kandik and Nation Rivers, $48 \mathrm{mi}$. N of Eagle, Porcupine Plat.; $65^{\circ} 29^{\prime} \mathrm{N}, 141^{\circ} 28^{\prime} \mathrm{W} ; B G N$ 1965; (map 103).

So named in 1965 by Earl Brabb, USGS, because "the mountains are comprised of parallel ridges, either flat-topped or with flat benches near the top that look like steps at a distance."

Stepo, Mount: mountain, 3,895 ft., on $W$ shore of Stepovak Bay, near SW end of Alaska Penin., Aleutian Ra.; $55^{\circ} 43^{\prime} \mathrm{N}, 160^{\circ} 11^{\prime} \mathrm{W}$; (map 28).

Name shown on a 1953 USGS map.

Stepovak Bay: bay, $15 \mathrm{mi}$. across, on $\mathbf{S}$ coast of Alaska Penin., Aleutian Ra.; $55^{\circ} 40^{\prime} \mathrm{N}, 159^{\circ}$ $50^{\prime} \mathrm{W} ; B G N$ 1890; map 27). Var. Stepovakho Bay, Stepowoj Bai, Zaliv Zakharova.

Named "Stepovakho," or "Stepof's Bay," by USC\&GS in 1888, possibly for Stepanof, a Russian American Company captain who cruised in the Shumagin Is. prior to 1835 . Capt. Tebenkov (1852, map 24) called it "Zal[iv] Zakharova," or "Zachary Bay."

Stepovakho Bay: bay, see Stepovak Bay.

Stepowoj Bai: bay, see Stepovak Bay.

Sterling: village, pop. $115, \mathrm{~S}$ of Sterling Highway at junc. of Moose and Kenai Rivers, 18 mi. E of Kenai, Cook Inlet Low.; 60 $32^{\prime} 15^{\prime \prime}$ N, $150^{\circ} 45^{\prime} 30^{\prime \prime} \mathrm{W}$; BGN 1959; (map 62). Var. Naptowne.

Village that apparently had its name formalized in 1954 when a post office was established (Ricks, 1965, pl. 61).

Sterling Creek: stream, flows SE 3 mi. to Beverly Creek, $6 \mathrm{mi}$. W of Twin Mtn. and $52 \mathrm{mi}$. SSE of Circle, Yukon-Tanana High.; $65^{\circ} 05^{\prime} \mathrm{N}$, $143^{\circ} 44^{\prime}$ W ; (map 103).

Prospectors' name reported in 1905 by D. C. Witherspoon, USGS.

Sterling Creek: stream, flows NW $2.8 \mathrm{mi}$. to Grouse Creek which flows to Mint River, 41 mi. NW of Teller, Seward Penin. High.; $65^{\circ}$ $38^{\prime} \mathrm{N}, 167^{\circ} 26^{\prime} \mathrm{W}$; (map 111$)$.

Prospectors' name reported on the 1908 "Map of Seward Peninsula" by Arthur Gibson.

Sterling Landing: locality, on W bank of Kuskokwim River, $6.5 \mathrm{mi}$. SW of McGrath, Kilbuck-Kuskokwim Mts.; $62^{\circ} 52^{\prime} \mathrm{N}, 155^{\circ} 40^{\prime} \mathrm{W}$; $B G N$ 1966; (map 80). Var. Candle Landing. River landing reported in 1923 by the ARC.

Sterling Shoal: shoal, 7 mi. long, in Bristol Bay, $6 \mathrm{mi}$. S of Cape Constantine and $54 \mathrm{mi}$. SW of Dillingham, Bristol Bay Low.; $58^{\circ} 18^{\prime} \mathrm{N}$, $158^{\circ} 53^{\prime} \mathrm{W}$; $B G N$ 1932; (map 40).

Named in 1911 by USC\&GS for the cannery ship Sterling which was lost here.

Stern Gulch: ravine, extends $\mathrm{N}$ from junc. of Idaho Creck, $6 \mathrm{mi}$. along course of Sunshine
Creek, $51 \mathrm{mi}$. NW of Talkeetna, Alaska Ra.; $62^{\circ} 31^{\prime} 15^{\prime \prime} \mathrm{N}, 151^{\circ} 39^{\prime} 00^{\prime \prime} \mathrm{W}$; (map 81).

Prospectors' name reported in 1906 by $R$. w. Porter, USGS.

Stetson Creek: stream, on Kenai Penin., flows N $4.5 \mathrm{mi}$. to Gooper Creek, $28 \mathrm{mi}$. NW of Seward, Chugach Mts.; $60^{\circ} 26^{\prime} 45^{\prime \prime} \mathrm{N}$, $149^{\circ} 50^{\prime} 50^{\prime \prime} \mathrm{W}$; (map 63).

Local name reported in 1898 by Mendenhall $(1900$, p. 320), USGS

Steve Creek: stream, flows $\mathbf{N}$ to Arctic River, about $5 \mathrm{mi}$. E of Ear Mtn. and $45 \mathrm{mi}$. NE of Teller, Seward Penin. High.; (map 111).

Prospectors' name reported on a precinct map of Seward Peninsula gold fields by Monroe and Hutchins, corrected up to June 1903 by Arthur Gibson. This feature cannot be precisely identified on current maps.

Steve Lake: lake, $0.5 \mathrm{mi}$. long, between Alaska Highway and Chisana River, $1 \mathrm{mi}$. S of Northway Junction, Yukon-Tanana High.; $63^{\circ} 00^{\prime}$ N. $141^{\circ} 44^{\prime}$ W; BGN 1961; (map 85). Var. Totsahdmund Lake.

Local name reported in 1960 by T. E. Taylor, USGS.

Stevens: village, see Stevens Village.

Stevens Creek: stream, heads in Taylor Mts., flows NE $10 \mathrm{mi}$. to Taylor Creek $8 \mathrm{mi}$. S of its junc. with Holitna River, $46 \mathrm{mi}$. S of Sleetmute, Kilbuck-Kuskokwim Mts.; $61^{\circ} 02^{\prime} \mathrm{N}$, 157'13' W; BGN 1948; (map 72).

Named for a prospector and trapper who worked on the stream; reported in 1945 by USGS.

Stevens Creek: stream, heads on Roughtop Mtn., flows NW $20 \mathrm{mi}$. to Yukon River, $22 \mathrm{mi}$. WSW of Rampart, Yukon-Tanana High.; 65 ${ }^{\circ} 23^{\prime} 40^{\prime \prime}$ N, 150'53'08' W; BGN 1961; (map 106). Var. Stephans Creek, Stephens Creek.

Riverboat pilots' name shown on Edwards Track Chart of the Yukon, dated 1899. The same year Cantwell (1902, p. 277), USRCS, spelled the name "Stephens."

Stevens Creek: stream, see Norberg Creek.

Stevens Creek: stream, see Orum Creek.

Stevens Gulch: ravine, trends $\mathrm{SW} 0.8 \mathrm{mi}$, to Washington Creek $0.1 \mathrm{mi}$. $\mathrm{N}$ of its junc. with Nome River, $6 \mathrm{mi}$. NE of Nome, Seward Penin. High.; $64^{\circ} 31^{\prime} 12^{\prime \prime}$ N, $165^{\circ} 12^{\prime} 20^{\prime \prime}$ W; (map 94). Var. Stephens Gulch.

Prospectors' name published as "Stephens" on the 1900 "Map of Nome Peninsula" by J. M. Davidson and B. D. Blakeslee.

Stevens Lake: lake, $0.7 \mathrm{mi}$. long, $1 \mathrm{mi}$. SE of Willow and $30 \mathrm{mi}$. NW of Palmer, Cook Inlet Low.; $61^{\circ} 44^{\prime} 10^{\prime \prime} \mathrm{N}, 149^{\circ} 59^{\prime} 45^{\prime \prime} \mathrm{W}$; (map 69).

Local name reported in 1950 by USGS.

Stevens Lakes: lakes, two, each $0.7 \mathrm{mi}$. long, 1 mi. W of Wellesley Mtn. and $17 \mathrm{mi}$. SW of point where Alaska Highway crosses AlaskaCanada boundary, Alaska Ra.; $62^{\circ} 26^{\prime} \mathrm{N}$, $141^{\circ} 22^{\prime} \mathrm{W}$; (map 84)

Local name reported by USGS in 1960.

Stevenson Entrance: water passage, between Shuyuk I. and Barren Is., connecting Gulf of Alaska with Shelikof Strait; $58^{\circ} 47^{\prime}$ N, $152^{\circ} 24^{\prime}$ W; BGN 1966; (map 43).
Named in 1966 by Alaska State Geographic Board to commemorate Adlai E. Stevenson, 1900-1965, Governor of Illinois and United States Ambassador to the United Nations.

Stevenson Island: island, $3.5 \mathrm{mi}$. long, on NE coast of Prince of Wales I. ; Alex. Arch.; 56 $02^{\prime}$ $\mathrm{N}, 132^{\circ} 57^{\prime} \mathrm{W}$; (map 6$)$.

Named in 1886 by Lt. Comdr. A. S. Snow, USN; published in 1887 on USC\&GS Chart 706.

Stevens Village: village, pop. 102, on $\mathrm{N}$ bank of Yukon River, $5 \mathrm{mi}$. E of Dall River and 54 mi. SW of Beaver, Yukon Flats; $66^{\circ} 01^{\prime} \mathrm{N}$, 149 $06^{\prime}$ W; (map 118). BGN 1957; Var. Denyeet, Denyit, Shaman, Shamans Village, Shamansville, Stephens, Stephens Village, Stevens.

Indian village, which according to local tradition, was founded by three brothers from Kokrines, "Old Jacob," "Gochonayeeya," and "Old Steven." According to the story, the village was first called "Denyeet" meaning "canyon." In 1902 Old Steven was elected chief, and the village then took the name "Stevens Village" according to Leonard John (Alaska Sportsman, 1959, v. 25, no. 9, p. 32, 34).

This may be the same village called "Shamans" or "Shamansville" in 1898 by USC\&GS. In 1910 the village (Stephens Village) had a population of $100 ; 103$ in 1920 ; 48 in 1930 ; 54 in 1939 (Stevens); and 84 in 1950. The Stevens Village post office was established in 1936.

Steward Creek: stream, flows SE $0.8 \mathrm{mi}$. to Birch Creek which flows to Big Four Creek, $21 \mathrm{mi}$. NE of Solomon, Seward Penin. High.; 64 ${ }^{\circ} 50^{\prime}$ $\mathrm{N}, 164^{\circ} 08^{\prime} \mathrm{W}$; (map 95)

Prospectors' name reported on a 1902 prospectors' manuscript map.

Stewart, Port: estuary, extends NW $4 \mathrm{mi}$. off Behm Canal, on $\mathbf{E}$ coast of Cleveland Penin., Alex. Arch.; $55^{\circ} 42^{\prime} \mathrm{N}, 131^{\circ} 50^{\prime} \mathrm{W}$; (map 3).

Named by Capt. George Vancouver, RN, on September 2, 1793, after John Stewart, master's mate on the ship Discovery, "who made a good survey of it." Vancouver was anchored here from August 22 to September 5, 1793 (Wagner, 1937, p. 417).

Stewart Bend: bend, of Kuskokwim River, 1.5 mi. W of junc. of Grayling Creek, $9 \mathrm{mi}$. $E$ of McGrath, Kuskokwim Low.; $62^{\circ} 57^{\prime} \mathrm{N}, 155^{\circ}$ $18^{\prime} \mathrm{W}$; (map 80$)$.

Local name reported in 1931 by USGS.

Stewart Island: island, $100 \mathrm{ft}$. across, $\mathrm{SE}$ of Smith I., 1 mi. SW of Sitka, Alex. Arch.; $57^{\circ}$. $02^{\prime} 33^{\prime \prime} \mathrm{N}, 135^{\circ} 21^{\prime} 58^{\prime \prime} \mathrm{W}$; (map 9).

Named in 1880 by the U.S. Navy; published by the USC\&GS in 1883 Coast Pilot (p. 142). Stewart Peak: peak, 3,080 ft., on Elephants Head, $1 \mathrm{mi}$. E of head of Thomas Bay and 101 mi. E of Sitka, Coast Mts.; 57 $05^{\prime} 40^{\prime \prime}$ $\mathrm{N}, 132^{\circ} 47^{\prime} 35^{\prime \prime} \mathrm{W}$; (map 8).

Named in 1887 by Lt. Comdr. C. M. Thomas, USN; name published in 1888 by USC\&GS.

Stewart River: stream, formed by junc. of Quartz and Thompson Creeks, flows SW $12 \mathrm{mi}$. to 
Sinuk River, $22 \mathrm{mi}$. NW of Nome, Seward Penin. High. ; $64^{\circ} 48^{\prime} \mathrm{N}, 165^{\circ} 43^{\prime} \mathrm{W}$; (map 94).

Prospectors' name reported in 1900 by E. C. Barnard (in Brooks, 1901, pl. 17), USGS.

Stewart Rock: rock, in Security Bay, on $\mathrm{N}$ coast of Kuiu I., Alex. Arch.; $56^{\circ} 50^{\prime} 45^{\prime \prime} \mathrm{N}, 134^{\circ}$ $20^{\prime} 45^{\prime \prime} \mathrm{W}$; (map 5 ).

Local name used by fishermen; published in 1891 by USC\&GS.

Steylmen, Mys: point of land, see Styleman, Point.

Stibnite Creek: stream, flows SW $5 \mathrm{mi}$ to Tok River, $27 \mathrm{mi}$. W of Tok, Alaska Ra.; $63^{\circ} 14^{\prime} \mathrm{N}$, $143^{\circ} 50^{\prime} \mathrm{W}$; BGN 1950; (map 85). Var. Boulder Creek, Silver Creek.

Local name published by A. H. Brooks (1916, p. 62), USGS ; given in 1914 because of the discovery of stibnite (the primary ore of antimony) in the vicinity of this stream.

Stickeen River: stream, see Stikine River.

Stickienes River: stream, see Stikine River.

Stickleback Creek: stream, see Muddy Creek.

Stickwan Greek: stream, flows N $5 \mathrm{mi}$. to Nenana River, $44 \mathrm{mi}$. SE of Healy, Talkeetna Mts.; $63^{\circ} 19^{\prime} 40^{\prime \prime} \mathrm{N}, 148^{\circ} 10^{\prime} 45^{\prime \prime} \mathrm{W}$; (map 87).

Local name obtained in 1951 by USGS. Stiernfeld Island: island, see Turner Island. Stikeen River: stream, see Stikine River.

Stikine River: stream, heads in British Columbia, Canada, at $57^{\circ} 14^{\prime} 30^{\prime \prime} \mathrm{N}, 128^{\circ} 19^{\prime} 00^{\prime \prime} \mathrm{W}$, flows NW and $\mathrm{S}$ across Alaska Canada boundary, $330 \mathrm{mi}$. to Eastern Passage, $2 \mathrm{mi}$. N of Wrangell, Alex. Arch.; $56^{\circ} 31^{\prime} \mathrm{N}, 132^{\circ} 24^{\prime} \mathrm{W} ; B G N$ 1952; (map 6). Var. Francis River, Pelly River, Ryka Stakhin, Shikene River, Stachine River, Stachin River, Stah-Keena River, Stahkin River, Stakeen River, Stickeen River, Stickienes River, Stikeen River, Stikin River, Sucheen River.

Tlingit Indian name meaning "Great River," reported in 1799 as "Stikine River" by Capt. Rowan, of the whaling ship Eliza out of Boston, Mass. Published in 1848 on Russian Hydrog. Dept. Chart 1396 as "Ryka Stakhin," or "Stakhin River." The present spelling of the name was adopted in 1869 by USC\&GS.

Stikine Strait: water passage, separates Zarembo I. from Etolin and Woronkofski Is., near mouth of Stikine River; $56^{\circ} 20^{\prime} \mathrm{N}, 132^{\circ} 36^{\prime} \mathrm{W}$; BGN Sixth Report; (map 6). Var. Proliv Stakhinskiy, Stachinski Strait, Stakhinski Strait.

Tlingit Indian name; published in 1848 on Russian Hydrog. Dept. Chart 1396 as "Proliv Stakhinskiy," or "Stakhin Strait."

Stikin River: stream, see Stikine River.

Stiles Creek: stream, flows ESE $8 \mathrm{mi}$. to Chena River, $42 \mathrm{mi}$. ENE of Fairbanks, YukonTanana High.; $64^{\circ} 56^{\prime} 20^{\prime \prime}$ N, $146^{\circ} 16^{\prime} 45^{\prime \prime} \mathrm{W}$; (map 101)

Local name published in 1956 by USGS.

Still Harbor: bay, $0.5 \mathrm{mi}$. across, on $\mathrm{S}$ shore of Whalc Bay, on SW coast of Baranof 1., Alex. Arch.; 56 $33^{\prime} 30^{\prime \prime} \mathrm{N}, 135^{\circ} 02^{\prime} 30^{\prime \prime} \mathrm{W}$; (map 5). Var. Gavan Tikhaya, Tichai Bay, Tichaia Bay, Tikhaia Bay.
This is a translation of the name "Gavan Tikhaya" given in 1850 by the Russian American Company.

Still Island: island, $0.8 \mathrm{mi}$. long, $\mathrm{W}$ of Tanana I. in Corbusier Slough, $2.5 \mathrm{mi}$. S of Tanana, Nowitna Low.; $65^{\circ} 08^{\prime} 30^{\prime \prime} \mathrm{N}, 152^{\circ} 03^{\prime} 00^{\prime \prime} \mathrm{W}$; (map 106).

Local name reported in 1952 by USGS.

Stillwater Anchorage: water passage, in Kootznahoo Inlet on Admiralty 1., extends SW 1.2 mi. from Pillsbury Point to Turn Point, 0.5 mi. NE of Angoon, Alex. Arch.; 57 $30^{\prime} 30^{\prime \prime} \mathrm{N}$, $134^{\circ} 34^{\prime} 00^{\prime \prime} \mathrm{W}$; (map 9).

Descriptive name given in 1869 by Comdr. R. W. Meade, USN; published by USC\&GS in 1833 Coast Pilot (p. 177).

Stillwater Creek: stream, flows SE $4.5 \mathrm{mi}$. to Bering River, $21 \mathrm{mi}$. NE of Katalla, Chugach Mts.; $60^{\circ} 22^{\prime} \mathrm{N}, 144^{\circ} 00^{\prime} \mathrm{W}$; (map 64).

Local name reported in 1903 by G. C. Martin (in Emmons and Hayes, 1904, p. 366), USGS.

Stillwell: locality, on N shore of Kenai Lake, Kenai Penin., 1.5 mi. NW of Black Point and $22 \mathrm{mi}$. N of Seward, Chugach Mts. ; 60 $24^{\prime} 45^{\prime \prime}$ $\mathrm{N}, 149^{\circ} 23^{\prime} 45^{\prime \prime} \mathrm{W}$; (map 63).

A 1951 USGS map indicates that this is a site of a single dwelling.

Stinenia, Mount: mountain, 4,050 ft., on left bank of Stikine River, $16 \mathrm{mi}$. NE of Wrangell, Coast Mts.; $56^{\circ} 40^{\prime} 30^{\prime \prime} \mathrm{N}, 132^{\circ} 08^{\prime} 30^{\prime \prime} \mathrm{W}$; (map 6).

Named by USC\&GS for charting purposes; name published in 1943.

Stink Creek: stream, on $\mathrm{N}$ end of Admiralty I., flows N $3.7 \mathrm{mi}$. to Stephens Passage, 4.8 mi. SE of Point Young and $10 \mathrm{mi}$. S of Juneau, Alex. Arch.; $58^{\circ} 10^{\prime} 15^{\prime \prime} \mathrm{N}, 134^{\circ} 26^{\prime} 10^{\prime \prime} \mathrm{W}$; (map 11).

Local name published in 1951 by USGS.

Stink Creek: stream, flows S 3 mi. to Stink Lake, near Innoko River, $38 \mathrm{mi}$. NW of Ophir, Innoko Low.; $63^{\circ} 38^{\prime} \mathrm{N}, 157^{\circ} 03^{\prime} \mathrm{W}$; (map 90).

Local name reported in 1964 by Arthur Gervais, USGS.

Stink Creek: stream, flows NE $40 \mathrm{mi}$. to Yukon River, W of Morgan I., $57 \mathrm{mi}$. SW of Nulato and $57 \mathrm{mi}$. E of Unalakleet, Nulato Hills; $63^{\circ} 59^{\prime} \mathrm{N}, 158^{\circ} 56^{\prime} \mathrm{W}$; (map 90). Var. Aleek River.

Local name reported in 1954 by USGS.

Stinking Lake: lake, $0.6 \mathrm{mi}$. long, $1.7 \mathrm{mi}$. S of Beaver Creek, Yukon Flats; $66^{\circ} 12^{\prime} 00^{\prime \prime} \mathrm{N}$, $146^{\circ} 47^{\prime} 20^{\prime \prime} \mathrm{W}$; (map 119).

Local descriptive name obtained in 1956 by USGS.

Stink Lake: lake, $3 \mathrm{mi}$. long, on $\mathrm{N}$ bank of Innoko River, $\mathrm{N}$ of Rennies Landing, $38 \mathrm{mi}$. NW of Ophir and $64 \mathrm{mi}$. NW of McGrath, Innoko Low.; 63 $38^{\prime} \mathrm{N}, 157^{\circ} 04^{\prime} \mathrm{W}$; (map 90).

Local name obtained in 1954 by R. E. Isto, USGS.

Stink River: stream, heads in Tundra Lake, flows NW $35 \mathrm{mi}$. to Stony River $24 \mathrm{mi}$. SE of its junc. with Kuskokwim River, $37 \mathrm{mi}$. SE of Sleetmute, Stony River Low.; $61^{\circ} 30^{\prime} 30^{\prime \prime} \mathrm{N}$, $156^{\circ} 07^{\prime} 50^{\prime \prime} \mathrm{W}$; ( $\operatorname{map} 72$ ).
Local name reported in 1914 by $R$. $H$. Sargent (in Smith, P. S., 1917, pl. 5), USGS. Stintz Bluffs: bluffs, on S shore of Olga Bay, 32 mi. $\mathbf{S}$ of Karluk, in SW part of Kodiak I., $57^{\circ} 06^{\prime} 45^{\prime \prime} N$., $154^{\circ} 17^{\prime} 00^{\prime \prime} W$; (map 35).

Local name published in 1943 by USC\&GS. Stockade Point: point of land, on $\mathrm{E}$ shore of Stephens Passage, at mouth of Taku Harbor, $2 \mathrm{mi}$. NW of Limestone Inlet and $22 \mathrm{mi}$. SE of Juneau, Coast Mts.; $58^{\circ} 03^{\prime} 30^{\prime \prime} \mathrm{N}$, $134^{\circ} 01^{\prime} 45^{\prime \prime} \mathrm{W}$; (map 11).

So named in 1869 by Comdr. R. W. Meade, USN, because the ruins of a blockhouse and stockade built by the Hudson's Bay Co. in 1840-41 were on the point. The name was published by USC\&GS in the 1883 Coast Pilot (p. 169).

Stockdale Harbor: bight, in Prince William Sound, on NW coast of Montague I., at NE end of Montague Strait, $32 \mathrm{mi}$. $\mathrm{E}$ of Chenega, Chugach Mts.; $60^{\circ} 18^{\prime} 45^{\prime \prime} \mathrm{N}, 147^{\circ} 12^{\prime} 30^{\prime \prime} \mathrm{W}$; (map 63).

Named in 1787 by Capt. Portlock for his publisher John Stockdale.

Stockholm Bay: cove, $0.2 \mathrm{mi}$. across, on SE shore of Olga Bay, $34 \mathrm{mi}$. SE of Karluk, on SW part of Kodiak I.; $57^{\circ} 07^{\prime} 30^{\prime \prime} \mathrm{N}, 154^{\circ} 07^{\prime} 00^{\prime \prime} \mathrm{W}$; (map 35).

Local name reported in 1900 .

Stockholm Point: point of land, on SE shore of Olga Bay, 34 mi. SE of Karluk, on SW part of Kodiak I.; $57^{\circ} 07^{\prime} 30^{\prime \prime} \mathrm{N}, 154^{\circ} 06^{\prime} 30^{\prime \prime} \mathrm{W}$; (map 35).

Local name reported in 1900 .

Stockley Creek: stream, flows SW $0.8 \mathrm{mi}$. to Dahl Creek, $10 \mathrm{mi}$. NE of Shungnak, Brooks Ra.; $66^{\circ} 59^{\prime} \mathrm{N}, 156^{\circ} 52^{\prime} \mathrm{W}$; (map 115).

Local name reported in 1943 by $R$. $R$. Coats, USGS.

Stockton Islands: barrier islands, on Beaufort Sea coast W of Flaxman I., extending $9 \mathrm{mi}$. between Challenge and Newport Entrances, Arctic Plain; $70^{\circ} 18^{\prime} \mathrm{N}, 146^{\circ} 55^{\prime} \mathrm{W}$; (map 151).

Named by Leffingwell $(1919$, p. 99) in 1913 after Rear Adm. Charles Herbert Stockton, USN, 1845-1923.

Stoeckl, Mount: mountain, 6,014 ft., on AlaskaCanada Boundary, on right bank of Unuk River, Coast Mts.; $56^{\circ} 21^{\prime} 56^{\prime \prime}$ N, $130^{\circ} 47^{\prime} 10^{\prime \prime}$ W; BGN 1952; (map 7).

Named in 1924 by USGS for "Privy-Councilor Edward de Stoeckl, Russian Minister to the United States, who signed the convention ceding Alaska on March 30, 1867"; published in 1927 on IBC Sheet 3 (1951 atlas).

Stoggnang Creek: stream, flows W $5 \mathrm{mi}$. to Kuskokwim Bay, $50 \mathrm{mi}$. NW of Goodnews, Yukon-Kuskokwim Delta; 59 $48^{\prime} \mathrm{N}, 161^{\circ} 57^{\prime}$ W; (map 53).

Eskimo name published in 1951 by USGS.

Stolb: rock, see Pillar Rock.

Stolb, Mys: point of land, see Bold Cape.

Stolbi Rocks: rocks, composed of Noonaghak and Tappaghak Rocks in Bering Sea, 3 mi. SE of Cape Myaughee, Saint Lawrence I.; $63^{\circ} 38^{\prime}$ N, 170 06' W; BGN 1951; (map 93). Var. Noonaghak, Stolby Rocks. 
Descriptive Russian term meaning "pillar" (stolb) applied to these rocks "on an old Russian chart" and published in 1908 as a geographic name by USC\&GS.

Stolby: rocks, see Pillars, The.

Stolby Rocks: rocks, see Stolbi Rocks.

Stone Bay : estuary, see Necker Bay.

Stone Boy Creek: stream, flows NW $17 \mathrm{mi}$. to Salcha River $4.8 \mathrm{mi}$. SW of junc. with Lost Creek and $58 \mathrm{mi}$. NE of Big Delta, YukonTanana High.; $64^{\circ} 47^{\prime} \mathrm{N}, 144^{\circ} 36^{\prime} \mathrm{W}$; (map 101).

Local name reported in 1958 by USGS.

Stone Creek: stream, in Nutzotin Mts., heads at glacier terminus, flows NW $16 \mathrm{mi}$. to $\mathrm{Na}$ besna River $10 \mathrm{mi}$. E of Devils Mtn., Alaska Ra.; $62^{\circ} 28^{\prime} \mathrm{N}, 142^{\circ} 37^{\prime} \mathrm{W}$; (map 84).

Named in 1902 by F. C. Schrader, USGS, "from the conspicuity and size of its barren stoney delta."

Stone Greek: stream, flows SE $11 \mathrm{mi}$. to Eden Creek, $47 \mathrm{mi}$. NE of Medfra, Kilbuck-Kuskokwim Mts.; $63^{\circ} 36^{\prime} \mathrm{N}, 153^{\circ} 43^{\prime} \mathrm{W}$; (map 89). Local name reported in 1958 by USGS.

Stone Gulch: ravine, trends E $1.5 \mathrm{mi}$. to Myrtle Creek, $1 \mathrm{mi}$. NW of Livengood, Yukon-Tanana High.; $65^{\circ} 32^{\prime} \mathrm{N}, 148^{\circ} 34^{\prime} \mathrm{W}$; (map 105)

Named by prospectors; reported in 1916 by J. B. Mertie (in Brooks and others, 1918, pl. 13 ), USGS.

Stonehocker Creek: stream, on Kenai Penin., flows N $3 \mathrm{mi}$. to China Poot Bay, on E shore of Kachemak Bay, $10 \mathrm{mi}$. SE of Homer, Chugach Mts.; $59^{\circ} 33^{\prime} 15^{\prime \prime} \mathrm{N}, 151^{\circ} 18^{\prime} 30^{\prime \prime} \mathrm{W}$; (map 50).

Local name reported and published by USGS in the 1950's.

Stonehouse Creek: stream, flows SE $3 \mathrm{mi}$. to Chicken Creek, 52 mi. SW of Eagle, YukonTanana High.; $64^{\circ} 06^{\prime} 20^{\prime \prime} \mathrm{N}, 141^{\circ} 54^{\prime} 30^{\prime \prime} \mathrm{W}$; (map 102).

Prospectors' name obtained in 1898 by $\mathrm{E}$. C. Barnard, USGS

Stonehouse Lake: lake, $0.4 \mathrm{mi}$. long, on $\mathrm{N}$ shore of Iliamna Lake, $8.5 \mathrm{mi}$. E of Iliamna, Aleutian Ra.; $59^{\circ} 46^{\prime} 30^{\prime \prime} \mathrm{N}, 154^{\circ} 34^{\prime} 30^{\prime \prime} \mathrm{W}$; (map 51).

Local name reported in 1958 by USGS.

Stone Hut Peak: mountain, 2,505 ft., in De Long Mts.; 8 mi. N of Mount Kelly; Brooks Ra.; 68 $35^{\circ}$ N, $163^{\circ} 39^{\prime}$ W; (map 130).

So named in 1956 by Orth because a stone hut was discoveerd on the mountain's summit in 1889 by Stockton ( 1890 , p. 179).

Stone Islands: islands, an offshore group, extends $2.7 \mathrm{mi}$., in Ernest Sound, S of Etolin I., Alex. Arch.; 55 $54^{\prime} \mathrm{N}, 132^{\circ} 19^{\prime} \mathrm{W}$; (map 4).

Named in 1886 by Lt. Comdr. A. S. Snow, USN, for J. C. Stone, a member of his party. Stone Mountain: mountain, $2,747 \mathrm{ft}$., $8 \mathrm{mi}$. W of Paradise Pass and $51 \mathrm{mi}$. NE of Medfra, Kilbuck-Kuskokwim Mts.; $63^{\circ} 43^{\prime} \mathrm{N}, 153^{\circ} 51^{\prime}$ W: (map 89).

Local name reported in 1958 by USGS.

Stone Ring Creek: stream, in De Long Mts. flows SSW $15 \mathrm{mi}$, to Anisak River, Brooks Ra.; $68^{\circ} 22^{\prime} \mathrm{N}, 159^{\circ} 06^{\prime} \mathrm{W}$; BGN 1960; (map 131).
Named in 1951 by B. H. Kent, USGS, "for large stone ring nearby."

Stone Rock: rock, elev. $20 \mathrm{ft}$., SW end of Clarence Strait, $4 \mathrm{mi}$. NE of Cape Chacon, Alex. Arch.; $54^{\circ} 44^{\prime} 45^{\prime \prime} \mathrm{N}, 131^{\circ} 58^{\prime} 00^{\prime \prime} \mathrm{W}$; (map 2).

Named in 1885 by Lt. Comdr. R. C. Clover, USN.

Stone Rock Bay: bay, $1 \mathrm{mi}$. wide, SE coast of Prince of Wales I., $4.3 \mathrm{mi}$. N of Cape Chacon, Alex. Arch.; 54 $45^{\prime} 30^{\prime \prime} \mathrm{N}, 132^{\circ} 00^{\prime} 00^{\prime \prime} \mathrm{W}$; (map 2). Var. Mallard Bay.

Name derived from Stone Rock and published in 1913 on USG\&GS Chart 8074. According to P. S. Smith (in Brooks and others, 1914, p. 82), USGS, this feature was known locally as Mallard Bay. See Mallard Bay.

Stonewall: cliff, on SE shore of Isanotski Strait, Aleutian Ra.; $54^{\circ} 50^{\prime} 00^{\prime \prime} \mathrm{N}, 163^{\circ} 21^{\prime} 40^{\prime \prime} \mathrm{W}$; (map 25). Var. Southwall.

Probably a local name; published by USC\& GS in 1912.

Stoney, Mount: mountain, 6,915 ft., between Skwentna and Styx Rivers, $4 \mathrm{mi}$. $\mathrm{N}$ of Mount Estelle and $82 \mathrm{mi}$. NW of Tyonek, Alaska Ra.; 61 $54^{\prime} 20^{\prime \prime}$ N, $152^{\circ} 54^{\prime} 30^{\prime \prime} \mathrm{W}$; (map 70). Var. Allen, Mount.

Named by Spurr (1900, p. 115), USGS, for Comdr. George Morse Stoney, USN, who explored the Kobuk River region from 1883 to 1886.

Stoney Creek: stream, flows SE to Noxapaga River, N of Turner Creek, about $24 \mathrm{mi}$. W of Imuruk Lake, Seward Penin. High.; (map 110).

Prospectors' name shown on a map of Cape Nome gold fields by David Fox, Jr., dated 1901. This stream cannot be precisely located on current maps.

Stoney Creek : stream, see Stony Creek.

Stoney Glacier: glacier, on Mount Stoney, trends NE $2.5 \mathrm{mi}$. to its terminus at head of Portage Creek, $83 \mathrm{mi}$. NW of Tyonek, Alaska Ra.; $61^{\circ} 56^{\prime} 30^{\prime \prime} \mathrm{N}, 152^{\circ} 52^{\prime} 00^{\prime \prime} \mathrm{W}$; (map 70). Var. Allen Glacier.

Named by Spurr (1900, p. 115), USGS, for Comdr. George Morse Stoney, USN, who explored the Kobuk River region from 1883 to 1886 .

Stoney Ridge: hill, $200 \mathrm{ft}$, , between Conglomerate and Ogotoruk Creeks, $8.3 \mathrm{mi}$. E of Cape Thompson, Arctic Slope; $68^{\circ} 08^{\prime} 15^{\prime \prime} \mathrm{N}, 165^{\circ}$ $38^{\prime} 45^{\prime \prime}$ W; BGN 1963; (map 129). Var. Talavéeroqraw, Talaverokra Ridge.

Named about 1962 by personnel of Project Chariot. This name is a translation of the Eskimo name, spelled "Talavéeroqraw," by W. P. Pruitt, Univ. of Alaska, in 1962.

Stoney River: stream, see Stony River.

Stony Bay : estuary, see Necker Bay.

Stony Cape: point of land, see Rocky Point.

Stony Creek: stream, flows W $2 \mathrm{mi}$, to Dutch Crcek, $36 \mathrm{mi}$. NW of Talkeetna, Alaska Ra.; $62^{\circ} 33^{\prime} 00^{\prime \prime} \mathrm{N}, 151^{\circ} 07^{\prime} 30^{\prime \prime} \mathrm{W}$; (map 81).

Prospectors' name reported in the 1930's by USGS.
Stony Creek: stream, in Mount McKinley National Park, flows N $25 \mathrm{mi}$. from Gravel Mtn. to Clearwater Fork $5 \mathrm{mi}$. S of that stream's junc. with Toklat River, Alaska Ra.; 63 $44^{\circ}$ 15" N, 150 $19^{\prime} 30^{\prime \prime}$ W; (map 88).

Local name shown on a 1916 fieldsheet by C. E. Giffin, USGS.

Stony Creek: stream, flows S $1.6 \mathrm{mi}$. to Turner Creek which flows to Noxapaga Creek, $34 \mathrm{mi}$. SW of Imuruk Lake, Seward Penin. High.; $65^{\circ} 34^{\prime} \mathrm{N}, 164^{\circ} 27^{\prime} \mathrm{W}$; (map 110). Var. Stoney Creek.

Prospectors' name reported as "Stoney Creek" in 1901 by T. G. Gerdine (in Collier, 1902, pl. 12), USGS.

Stony Dome: peak, 4,700 ft., in Mount McKinley National Park, $\mathbf{S}$ of Denali Highway, $3.5 \mathrm{mi}$. NE of Eielson Visitor Center, Alaska Ra.; $63^{\circ} 27^{\prime} 15^{\prime \prime} \mathrm{N}, 150^{\circ} 12^{\prime} 30^{\prime \prime} \mathrm{W}$; $B G N$ 1932; (map 88).

Local name reported in 1932 by J. C. Reed, Sr., and S. N. Stoner, USGS.

Stony Glacier: glacier, extends NE $4.5 \mathrm{mi}$. from Mount Mausolus to the head of Stony River, $95 \mathrm{mi}$. NW of Tyonek, Alaska Ra.; 61 ${ }^{\circ} 36^{\prime} 15^{\prime \prime}$ $\mathrm{N}, 153^{\circ} 45^{\prime} 30^{\prime \prime} \mathrm{W}$; (map 71).

Local name reported in 1958 by USGS.

Stony Hill: mountain, 4,508 ft, in Mount McKinley National Park, $N$ of Denali Highway, $3.6 \mathrm{mi}$. NE of Eielson Visitor Center, Alaska Ra.; $63^{\circ} 28^{\prime} 00^{\prime \prime} \mathrm{N}, 150^{\circ} 13^{\prime} 40^{\prime \prime} \mathrm{W}$; (map 88).

Local name reported in 1932 by J. C. Reed, Sr., USGS.

Stony Island: island, see Pyramid Island.

Stony Point: point of land, at $\mathrm{S}$ end of Karluk Lake, $27 \mathrm{mi}$. SE of Karluk, Kodiak I.; $57^{\circ}$ $16^{\prime} 50^{\prime \prime} \mathrm{N}, 154^{\circ} 00^{\prime} 45^{\prime \prime} \mathrm{W}$; (map 35).

Local descriptive name reported in 1952 by USGS.

Stony Point: point of land, see Peschani Point. Stony Point: point of land, see Tonki Point. Stony River: village, pop. 75 , on $\mathrm{N}$ bank of Kuskokwim River $0.9 \mathrm{mi}$. N of its junc. with Stony River, $20 \mathrm{mi}$. NE of Sleetmute, Stony River Low.; $61^{\circ} 47^{\prime} \mathrm{N}, 156^{\circ} 35^{\prime} \mathrm{W}$; (map 72). Var. Moose Creek, Moose Village, Stony River Village.

Indian village that began with a trading post and riverboat landing to supply the mining area to the north. This settlement, originally called "Moose Village," was located near the mouth of Moose Creek, but subsequently has moved to this location about 1.5 miles upstream. The Stony River post office was established in 1935 (Ricks, 1965, p. 61). See Moose Village.

Stony River: stream, heads at Stony Glacier in Alaska Ra. at $61^{\circ} 36^{\prime} 15^{\prime \prime} \mathrm{N}, 153^{\circ} 45^{\prime} 30^{\prime \prime} \mathrm{W}$, flows SW and NW $190 \mathrm{mi}$. to Kuskokwim River, $20 \mathrm{mi}$. NE of Sleetmute, Stony River Low.; 61 ${ }^{\circ} 46^{\prime} 10^{\prime \prime} \mathrm{N}, 156^{\circ} 35^{\prime} 20^{\prime \prime} \mathrm{W}$; (map 72). Var. Mantaschlano, Mantashtano, Stoney River, Tchalchug, Tchalchuk, Tchaltshuck, Tkhalkhak, Tschaljchuk, Tschaltschuk.

Descriptive name probably given by prospectors and reported in 1908 by A. G. Maddren, USGS. Native names obtained in 184244 by Lt. L. A. Zagoskin, IRN, were written 
"R[eka] Tkhalkhuk ili [or] Mantashtano"; the first is Eskimo, the last Indian.

Stony River Cutoff: stream, distributary of Stony River, flows NW 5.7 mi. to Kuskokwim River $3 \mathrm{mi}$. W of its junc. with Stony River, $17 \mathrm{mi}$. NE of Sleetmute, Stony River Low.; $61^{\circ} 47^{\prime}$ $\mathrm{N}, 156^{\circ} 41^{\prime} \mathrm{W}$; (map 72).

Local descriptive name reported in 1952 by USGS.

Stony River Village: locality, see Moose Village. Stony River Village: village, see Stony River.

Stop Island: island, $0.3 \mathrm{mi}$. long, in Portage Bay, $16 \mathrm{mi}$. NW of Petersburg, on N coast of Kup-

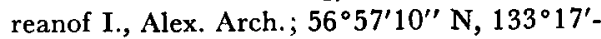
$15^{\prime \prime} \mathrm{W}$; (map 6$)$.

So named in 1882 by Lt. Comdr. H. E. Nichols, USN, "because there is an extensive mud flat and shoal water beyond this island."

Storey Island: island, $1.5 \mathrm{mi}$. long, at Copper River Delta, $22 \mathrm{mi}$. NW of Katalla, Chugach Mts. ; $60^{\circ} 19^{\prime} \mathrm{N}, 145^{\circ} 10^{\prime} \mathrm{W}$; (map 64).

Local name published by USGS in 1951; derived from nearby Storey Slough.

Storey Island: island, $4 \mathrm{mi}$. Iong, in Prince William Sound, $\mathrm{N}$ of Peak I., $38 \mathrm{mi}$. NE of Chenega, Chugach Mts.; $60^{\circ} 43^{\prime} 30^{\prime \prime} \mathrm{N}, 147^{\circ} 25^{\prime}$ $00^{\prime \prime} \mathrm{W}$; BGN 1906; (map 63).

Local name reported in 1898 as Story Island by Schrader (1900a, pl. 5), USGS. "The island is named for Walter Storey of San Francisco." The present spelling reported in 1909 by Grant and Higgins (1910, pl. 2), USGS.

Storey Slough: stream, $8 \mathrm{mi}$. long, distributary of Copper River, $27 \mathrm{mi}$. SE of Cordova, Malaspina Coastal Plain; $60^{\circ} 18^{\prime} \mathrm{N}, 145^{\circ} 12^{\prime} \mathrm{W}$; $B G N$ 1906; (map 64). Var. Story Slough.

Local name reported in 1898 by H. P. Ritter, USC\&GS

Storkersen Point: point of land, on Beaufort Sea coast, E point of entrance to Gwydyr Bay, 11 mi. SE of Beechey Point, Arctic Plain, $70^{\circ} 25^{\prime} 30^{\prime \prime} \mathrm{N}, 148^{\circ} 43^{\prime} 30^{\prime \prime} \mathrm{W}$; (map 150, Var. Point Storkersen.

Named Point Storkersen by Leffingwell (1919, p. 99), USGS, "after Storker Storkersen, who worked for Mikkelsen and Leffingwell and later for Stefánsson."

Storm Creek: stream, heads in De Long Mts., flows NE and W $23 \mathrm{mi}$. to join Thunder Creek to form Colville River, Brooks Ra.; 68 ${ }^{\circ} 49^{\prime} 20^{\prime \prime}$ N, $160^{\circ} 20^{\prime} 00^{\prime \prime} \mathrm{W}$; BGN 1961; (map 131).

Named by the 1925 USGS exploring expedition "because of severe storms experienced while near this stream."

Storm Islands: islands, in Stephens Passage, 2 mi. $\mathrm{N}$ of Cape Fanshaw and $68 \mathrm{mi}$. E of Sitka, Coast Mts.; $57^{\circ} 13^{\prime} \mathrm{N}, 133^{\circ} 34^{\prime} \mathrm{W}$; (map 8).

Named in 1887 by Lt. Comdr. C. M. Thomas, USN; name published in 1888 by USC\&GS

Storm Mountain: mountain, 3,793 ft., in Kenai Mts., on SE coast of Kenai Penin., 34 mi. ESE of Homer, Chugach Mts.; $59^{\circ} 36^{\prime} \mathrm{N}, 150^{\circ} 37^{\prime}$ W; BGN 1929; (map 50).

Named by USC\&GS in 1929 and so called "because of the stormy conditions in the locality."
Storm Range: ridge, $1.5 \mathrm{mi}$. long, $1.5 \mathrm{mi}$. SE of Mount Ogilvie and $38 \mathrm{mi}$. N of Juneau, Coast Mts.; $58^{\circ} 50^{\prime} 25^{\prime \prime} \mathrm{N}, 134^{\circ} 14^{\prime} 45^{\prime \prime} \mathrm{W}$; BGN 1965; (map 11).

Named by members of the Juneau Icefield Research Project in 1964.

Stormy Creek: stream, on Kenai Penin., flows NW $2.5 \mathrm{mi}$. to Mills Creek, $34 \mathrm{mi}$. N of Seward, Chugach Mts.; $60^{\circ} 36^{\prime} 25^{\prime \prime} \mathrm{N}, 149^{\circ} 24^{\prime} 30^{\prime \prime}$ W; (map 63).

Local name reported in 1912 by Grant and Higgins (1913, pl. 1), USGS.

Stormy Lake: lake, 2 mi. long, on NW coast of Kenai Penni., $\mathbf{S}$ of Number Three Bay, 16 mi. NE of Kenai, Cook Inlet Low.; $60^{\circ} 47^{\prime} \mathrm{N}$, $151^{\circ} 02^{\prime} \mathrm{W}$; BGN 1966; (map 62). Var. Three Bay Lake.

So named in 1966 by Division of Lands, Department of Natural Resources, Alaska, because the "prevailing winds produce whitecaps."

Stormy Point: point of land, on NW shore of Olga Bay, $31 \mathrm{mi}$. S of Karluk, on SW coast of Kodiak I.; $57^{\circ} 07^{\prime} 10^{\prime \prime}$ N, $154^{\circ} 24^{\prime} 30^{\prime \prime}$ W; (map 35).

Descriptive local name published in 1943 by USC\&GS.

Story Creek: stream, flows N $20 \mathrm{mi}$. to Kuna River, $23 \mathrm{mi}$. NNE of Feniak Lake, Brooks Ra.; 68 $34^{\prime}$ N, $157^{\circ} 54^{\prime}$ W ; (map 132).

Named in 1951 by B. H. Kent and I. L. Tailleur, USGS, "for an episode on traverse of creek."

Story Island: island, see Storey Island.

Story Slough: stream, see Storey Slough.

Stoss, Cape: point of land, near S end of Russell Fiord, $3.8 \mathrm{mi}$. SE of Situk Lake and 16 mi. NE of Yakutat, St. Elias Mts.; $59^{\circ} 37^{\prime} \mathrm{N}$, $139^{\circ} 17^{\prime} \mathrm{W}$; (map 46).

Named in 1891 by Russell (1892, p. 90 and pl. 4).

Stout Island: island, $3 \mathrm{mi}$. across, in Koyukuk River, $5.7 \mathrm{mi}$. E of Allakaket, Kanuti Flats; $66^{\circ} 32^{\prime} \mathrm{N}, 152^{\circ} 24^{\prime} \mathrm{W}$; (map 117).

Named in 1885 by Lt. Allen (1887, map 4), USA.

Stove Creek: stream, flows NW $5.4 \mathrm{mi}$. to Unalakleet River, $22 \mathrm{mi}$. E of Unalakleet, Nulato Hills; $63^{\circ} 56^{\prime} 35^{\prime \prime} \mathrm{N}, 160^{\circ} 05^{\prime} 05^{\prime \prime} \mathrm{W}$; (map 91).

Local name reported in 1952 by USC\&GS. Straightaway Glacier: glacier, in Mount McKinley National Park, trends NW $13 \mathrm{mi}$. from Mount Crosson to its 1954 terminus, $3.5 \mathrm{mi}$. NE of Foraker Glacier terminus and $17 \mathrm{mi}$. WNW of Mount McKinley, Alaska Ra.; $63^{\circ}$ $10^{\prime} \mathrm{N}, 151^{\circ} 30^{\prime} \mathrm{W}$; BGN 1954; (map 88). Var. Crosson Glacier.

Local name reported in 1925 by S. R. Capps, USGS.

Straight Creek: stream, on N coast of Kuiu I., flows NW 2.5 mi. to Saginaw Bay, Alex. Arch.; $56^{\circ} 50^{\prime} 30^{\prime \prime} \mathrm{N}, 134^{\circ} 06^{\prime} 30^{\prime \prime} \mathrm{W}$; (map 5).

Local name recorded in 1948 by USGS.

Straight Creek: stream, in Tordrillo Mts., heads at glacier E of Mount Spurr, flows SE $9 \mathrm{mi}$. to Chakachatna River, $24 \mathrm{mi}$. W of Tyonek,
Alaska Ra.; $61^{\circ} 09^{\prime} 15^{\prime \prime} \mathrm{N}, 151^{\circ} 50^{\prime} 30^{\prime \prime} \mathrm{W}$; $B G N$ 1930; (map 70).

Named in 1927 by S. R. Capps and R. H. Sargent (in Smith and others, 1929, pls. 1, 2), USGS, "because of the straight course of the river."

Straight Creek: stream, flows NW $5 \mathrm{mi}$. to Sulatna River, $14 \mathrm{mi}$. NE of Sulatna Crossing and $17 \mathrm{mi}$. SW of Monzonite Hills, KilbuckKuskokwim Mts. ; 64 ${ }^{\circ} 15^{\prime} \mathrm{N}, 155^{\circ} 01^{\prime} \mathrm{W}$; (map 98).

Local name reported about 1952 by USGS. Straight Creek: stream, flows E $2.7 \mathrm{mi}$. to Birch Creek, $5.5 \mathrm{mi}$. NE of Long and $20 \mathrm{mi}$. SE of Ruby, Kilbuck-Kuskokwim Mts. ; 64' $27^{\prime} 36^{\prime \prime}$ N, $155^{\circ} 22^{\prime} 10^{\prime \prime} \mathrm{W}$; BGN 1936; (map 98).

Prospectors' name reported in 1913 by Eakin (1914, pl. 3), USGS.

Straight Creek: stream, flows NW $3.5 \mathrm{mi}$. to Goldstream Creek, $16 \mathrm{mi}$. W of Fairbanks, Yukon-Tanana High.; $64^{\circ} 52^{\prime} \mathrm{N}, 148^{\circ} 15^{\prime} \mathrm{W}$; (map 100).

Named by prospectors; published in 1906 by USGS

Straight Island: island, extends NE-SW $3.1 \mathrm{mi}$. in Yukon River, 5 mi. NE of Ruby, Nowitna Low.; $64^{\circ} 48^{\prime} \mathrm{N}, 155^{\circ} 23^{\prime} \mathrm{W}$; (map 98).

Riverboat pilots' name shown on 1940 "Navigation Chart, Tanana-Yukon River" of the River Boat Service, U.S. Dept. of Interior.

Strait, Cape: point of land, $14 \mathrm{mi}$. NW of Petersburg, on NE coast of Lindenberg Penin., Kupreanof I., Alex. Arch.; 56 59'55' N, $133^{\circ} 05^{\prime} 30^{\prime \prime} \mathrm{W}$; (map 6). Var. Cape of the Strait, Cape of the Straits.

Published in 1865 on Brit. Adm. Chart 2431 as "Cape of the Straits."

Strait Bay: bay, $1 \mathrm{mi}$. across, on $\mathrm{S}$ side of Beaver Inlet, W coast of Sedanka I., $13 \mathrm{mi}$. SE of Dutch Harbor, Aleutian Is.; $53^{\circ} 47^{\prime} 45^{\prime \prime} \mathrm{N}$. $166^{\circ} 17^{\prime} 00^{\prime \prime} \mathrm{W}$; (map 23).

Name given by J. J. Gilbert, USG\&GS, Commander of the Coast Survey steamer Pathfinder during 1900-01.

Strait Creek: stream, flows NW $1.3 \mathrm{mi}$. to Buster Bay, on $\mathrm{N}$ coast of Prince of Wales $\mathrm{I}$., Alex. Arch.; $56^{\circ} 19^{\prime} 40^{\prime \prime} \mathrm{N}, 133^{\circ} 24^{\prime} 50^{\prime \prime} \mathrm{W}$; (map 6).

Local name recorded in 1949 by USGS.

Strait Island: island, $0.7 \mathrm{mi}$. long, in Sumner Strait, $4.5 \mathrm{mi}$. NW of Point Baker, Prince of Wales I., Alex. Arch.; 56 ${ }^{\circ} 23^{\prime} 10^{\prime \prime}$ N, $133^{\circ} 42^{\prime}$ $30^{\prime \prime} \mathrm{W}$; (map 6). Var. Barrie Island.

Named in 1886 by Lt. J. M. Helm, USN; called "Barrie Island" by W. H. Dall (U.S. Coast and Geodetic Survey, 1883, p. 104), USC\&GS.

Straits, Cape of the: point of land, see Strait, Cape.

Strandline Lake: lake, $4.6 \mathrm{mi}$. long, in Tordrillo Mts., N of Triumvirate Glacier, $37 \mathrm{mi}$. NW of Tyonek, Alaska Ra.; $61^{\circ} 30^{\prime} 30^{\prime \prime} \mathrm{N}, 151^{\circ} 55^{\prime}$ $00^{\prime \prime} \mathrm{W}$; (map 70).

Local descriptive name reported in 1958 by USGS.

Strand Pass: pass, 3,000 ft., $2.6 \mathrm{mi}$. N of Fish Creek, near SW end of Terra Cotta Mts., 98 
mi. NW of Tyonek, Alaska Ra.; $61^{\circ} 52^{\prime} 30^{\prime \prime} \mathrm{N}$, $153^{\circ} 35^{\prime} 00^{\prime \prime} \dot{W}$; (map 71).

Local name reported in 1958 by USGS.

Strand Peak: mountain, $1,610 \mathrm{ft}$., $12 \mathrm{mi}$. N of Medfra, Kilbuck-Kuskokwin Mts.; $63^{\circ} 17^{\prime} \mathrm{N}$, $154^{\circ} 43^{\prime} \mathrm{W}$; (map 89).

Local name reported in 1920 by G. C. Martin (in Brooks and others, 1922, fig. 5), USGS.

Stranger River: stream, flows SW $3 \mathrm{mi}$. to Ilin Bay, on $W$ coast of Chichagof I., $16 \mathrm{mi}$. NW of Chichagof, Alex. Arch.; 57 50'45" N, $136^{\circ} 22^{\prime} 20^{\prime \prime} \mathrm{W}$; (map 9).

Named by USBF and reported in 1897 by Lt. Comdr. Moser (1899a, p. 128), USN.

Strangle Woman Creek: stream, flows WNW 38 mi. to Coleen River, $17 \mathrm{mi}$. NE of Lois Dome and $54 \mathrm{mi}$. NE of Coleen Mtn., Brooks Ra.; $67^{\circ} 51^{\prime} \mathrm{N}, 142^{\circ} 15^{\prime} \mathrm{W}$; (map 121).

Local name reported in 1956 by T. E. Taylor, USGS.

Stranstrom Creek: stream, flows SE $25 \mathrm{mi}$. to Bonasila River, $33 \mathrm{mi}$. NW of Holy Cross, Nulato Hills; 62 $30^{\prime} \mathrm{N}, 160^{\circ} 34^{\prime} \mathrm{W}$; (map 78).

Local name reported in 1949 by USC\&GS

Strauss Rock: rock, in Stephens Passage, $0.6 \mathrm{mi}$. $\mathrm{S}$ of Shelters I. and $15 \mathrm{mi}$. NW of Juneau, Alex. Arch.; $58^{\circ} 21^{\prime} 45^{\prime \prime} \mathrm{N}, 1^{\circ} 44^{\circ} 48^{\prime} 40^{\prime \prime} \mathrm{W}$; (map 11).

Named by USC\&GS in or prior to 1891 and published in the 1891 Coast Pilot (p. 151).

Strawberry Channel: channel, $3 \mathrm{mi}$. long, $\mathrm{E}$ of NE tip of Hinchinbrook I., $15 \mathrm{mi}$. SW of Cordova, Chugach Mts.; $60^{\circ} 24^{\prime}$ N, $146^{\circ} 03^{\prime}$ W: (map 64).

Name published by USGS in 1959; derived from nearby Strawberry Hill.

Strawberry Harbor: cove, $1 \mathrm{mi}$. wide, at NW end of Controller Bay, $5 \mathrm{mi}$. SE of Katalla, Malaspina Coastal Plain; $60^{\circ} 10^{\prime} \mathrm{N}, 144^{\circ} 23^{\prime} \mathrm{W}$; (map 64).

Local name reported in 1903 by J. F. Pratt, USC\&GS

Strawberry Hill: hill, on NE tip of Hinchinbrook I., $17 \mathrm{mi}$. SW of Cordova, Chugach Mts.; $60^{\circ} 24^{\prime} \mathrm{N}, 146^{\circ} 08^{\prime} \mathrm{W}$; (map 64).

Local name reported in 1899 by H. P. Ritter, USC\&GS.

Strawberry Island: island, $1.6 \mathrm{mi}$. across, W of Beardslee Entrance, in Glacier Bay, Glacier Bay National Monument, $60 \mathrm{mi}$. NW of Juneau, St. Elias Mts.; $58^{\circ} 31^{\prime} \mathrm{N}, 136^{\circ} 00^{\prime} \mathrm{W}$; $B G N$ 1923; (map 11).

Named in 1923 by W. S. Cooper, Univ. of Minnesota.

Strawberry Island: island, $2 \mathrm{mi}$. across, in Grand Wash River, $1.2 \mathrm{mi}$. W of Blizhni Point and $20 \mathrm{mi}$. NW of Yakutat, Malaspina Coastal Plain; $59^{\circ} 50^{\prime} \mathrm{N}, 139^{\circ} 50^{\prime} \mathrm{W}$; (map 46).

Named by Tarr and Martin (1906, map facing p. 145), USGS.

Strawberry Passage: water passage, see Beardslee Entrance.

Strawberry Point: village, see Gustavus.

Strawberry Point: point of land, on $\mathbf{S}$ coast of Alaska, $2 \mathrm{mi}$. NW of Kanak I. and $4 \mathrm{mi}$. SE of Katalla, Malaspina Coastal Plain; $60^{\circ} 10^{\prime}$ N, $144^{\circ} 26^{\prime} \mathrm{W}$; (map 64).

Local name reported in 1903 by G. C. Martin, USGS.

Strawberry Point: point of land, see Blaine Point. Strawberry Point: point of land, see Raspberry Cape.

Straw Pass: water passage, $0.1 \mathrm{mi}$. wide, between an island and $\mathbf{S}$ tip of Kosciusko I., Alex. Arch.; $55^{\circ} 54^{\prime} 05^{\prime \prime} \mathrm{N}, 133^{\circ} 42^{\prime} 35^{\prime \prime} \mathrm{W}$; $B G N$ 1963; (map 4).

Local name "common to fishermen and loggers at Edna Bay;" reported in 1961 by USFS.

Stream Point: point of land, on N shore of Spiridon Bay, S of Spiridon Lake, on NW coast of Kodiak I.; $57^{\circ} 39^{\prime} 10^{\prime \prime} \mathrm{N}, 153^{\circ} 38^{\prime} 30^{\prime \prime} \mathrm{W}$; $B G N$ 1931; (map 34).

Descriptive name given by USC\&GS in 1929 "because of the large stream that flows into the cove to the east."

Street Lake: lake, see Streets Lake.

Streets Island: island, 1,000 ft. long, in Clarence Strait, $1.8 \mathrm{mi}$. N of Grindall I., on E coast of Prince of Wales I., Alex. Arch.; 55 $28^{\prime} 40^{\prime \prime} \mathrm{N}$, $132^{\circ} 08^{\prime} 15^{\prime \prime} \mathrm{W}$; (map 4).

Named in 1886 by Lt. Comdr. R. C. Clover, USN.

Streets Lake: lake, $1 \mathrm{mi}$. long, at head of Rocky Bay, on SW coast of Etolin I., Alex. Arch.; $56^{\circ} 06^{\prime} \mathrm{N}, 132^{\circ} 38^{\prime} \mathrm{W}$; BGN 1966; (map 6). Var. Lake Streets, Street Lake.

Named in 1886 by Lt. Comdr. A. S. Snow, USN, for surgeon Thomas Hale Streets, USN, a member of his party.

Strelna: locality, on Strelna Creek $1.7 \mathrm{mi}$. N of its junc. with Kuskulana River, $77 \mathrm{mi}$. NE of Valdez, Wrangell Mts. ; $61^{\circ} 30^{\prime} 40^{\prime \prime} \mathrm{N}, 144^{\circ} 04^{\prime}$ $00^{\prime \prime} \mathrm{W}$; (map 68).

Mining camp named for the stream, reported by USGS in 1910. The Strelna post office was in operation from 1912 to 1925.

Strelna Creek: stream, flows SW $14 \mathrm{mi}$. to Kuskulana River, $1.6 \mathrm{mi}$. S of Strelna and $77 \mathrm{mi}$. NE of Valdez, Wrangell Mts.; $61^{\circ} 29^{\prime} \mathrm{N}, 144^{\circ}$ $03^{\prime} \mathrm{W}$; (map 68).

Ahtena Indian name adopted about 1899 by prospectors.

Strelshla Mountain: peak, 5,400 ft., on Anthracite Ridge, $40 \mathrm{mi}$. NE of Palmer, Talkeetna Mts.; $61^{\circ} 49^{\prime} 45^{\prime \prime} \mathrm{N}, 147^{\circ} 58^{\prime} 30^{\prime \prime} \mathrm{W}$; $B G N$ 1933 ; (map 69).

Tanaina Indian name meaning "humped," reported in 1933 by USGS.

Strident Creek: stream, flows NE $10 \mathrm{mi}$. to Jubilce Creek, $7 \mathrm{mi}$. WSW of Liberator Lake, Arctic Slope; $65^{\circ} 51^{\prime} \mathrm{N}, 158^{\circ} 37^{\prime} \mathrm{W}$; (map 132).

Named in 1951 by B. H. Kent, USGS, "for a camping incident," which may have been a noisy argument.

Strike Creek: stream, flows NE $23 \mathrm{mi}$. to Little Kamishak River, $36 \mathrm{mi}$. SW of Augustine I., Aleutian Ra.; $59^{\circ} 01^{\prime} 15^{\prime \prime} \mathrm{N}, 154^{\circ} 13^{\prime} 30^{\prime \prime} \mathrm{W}$; (map 51).

So named by $R$. H. Sargent's USGS field party in 1923 because the stream follows the strike of the underlying rock. Published by
K. F. Mather (in Brooks and others, 1925, pl. 3).

String Creek: stream, flows SE $5.5 \mathrm{mi}$. to Martin Creek, 23 mi. NW of Talkeetna, Alaska Ra.; $62^{\circ} 25^{\prime} 35^{\prime \prime} \mathrm{N}, 150^{\circ} 48^{\prime} 00^{\prime \prime} \mathrm{W}$; (map 81).

Local descriptive name reported in 1958 by USGS.

Stringo Lakes: lakes, $\mathrm{W}$ of Middle Fork Chandalar River and $\mathrm{S}$ of its confluence with Your Creek, $25 \mathrm{mi}$. NE of Chandalar, Brooks Ra.; $67^{\circ} 45^{\prime} \mathrm{N}, 147^{\circ} 48^{\prime} \mathrm{W}$; (map 123).

Local name reported in 1956 by T. E. Taylor, USGS.

Stripe Mountain: mountain, 2,240 ft., on SW coast of Dall I.; Alex. Arch.; $54^{\circ} 43^{\prime} 05^{\prime \prime} \mathrm{N}$, $132^{\circ} 50^{\prime} 50^{\prime \prime} \mathrm{W}$; (map 1$)$.

Local descriptive name published by USC\&GS in 1924.

Stripe Mountain: mountain, 2,746 ft., in Peabody Mts., $2 \mathrm{mi}$. $\mathrm{N}$ of Hidden Inlet, Coast Mts.; $55^{\circ} 03^{\prime} 15^{\prime \prime} \mathrm{N}, 130^{\circ} 17^{\prime} 50^{\prime \prime} \mathrm{W}$; (map 3).

Descriptive name given in 1868 by Staff Comdr. David Pender, RN.

Stripe Point: point of land, $\mathrm{E}$ entrance point to Crescent Bay, on $\mathrm{N}$ coast of Atka I., Aleutian Is. ; $52^{\circ} 03^{\prime} 00^{\prime \prime} \mathrm{N}, 175^{\circ} 11^{\prime} 45^{\prime \prime} \mathrm{W}$; (map 18).

Descriptive name applied "because of conspicuous striped, gray rock slides." Published by USC\&GS in the 1944 Aleutian Coast Pilot (p. 99).

Stripe Rock: rock, in Marmot Bay, $7 \mathrm{mi}$. NE of Afognak, on SE coast of Afognak I.; $58^{\circ} 02^{\prime}$ $30^{\prime \prime} \mathrm{N}, 152^{\circ} 35^{\prime} 30^{\prime \prime} \mathrm{W} ;$ B BN 1910; (map 43). Var. Pillar.

Name published by USC\&GS in 1910 . The name "Pillar" was previously used for this feature by USC\&GS, but was later changed because of duplications.

Stroganoff, Pointe: point of land, see Strogonof Point.

Strogonoff, Cape: point of land, see Strogonof Point.

Strogonoff Point: point of land, see Strogonof Point.

Strogonof Point: point of land, on $\mathrm{N}$ shore of Alaska Penin., NE end of 8-mi.-long barrier beach that extends from SW side of Port Heiden, $10 \mathrm{mi}$. SW of Port Heiden Airfield, Bristol Bay Low.; $56^{\circ} 50^{\prime} \mathrm{N}, 158^{\circ} 52^{\prime} \mathrm{W}$; (map 30). Var. Mys Strogonova, Pointe Stroganoff, Strogonov Point, Strogonoff Point, Cape Strogonoff, Cap du Baron Stroganoff.

Shown as "Cap du Baron Stroganoff," meaning "Baron Stroganofs Cape," in A. J. von Krusenstern's Atlas of the Pacific Ocean (1827, map 20). The point was possibly named for the early Russian salt merchant, Anika Stroganof. Strogonof Point is shown on an 1890 USBF chart.

Strogonova, Mys: point of land, see Strogonof Point.

Strogonov Point: point of land, see Strogonof Point.

Stroller White: mountain, see Stroller White, Mount.

Stroller White, Mount: mountain, $5,150 \mathrm{ft}$., on $\mathrm{W}$ side of Mendenhall Glacier, $3 \mathrm{mi} \mathrm{NW}$ of 
Mendenhall Lake and $13 \mathrm{mi}$. NW of Juneau, Coast Mts.; $58^{\circ} 28^{\prime} 30^{\prime \prime} \mathrm{N}, 134^{\circ} 34^{\prime} 45^{\prime \prime} \mathrm{W}$; (map 11). Var. Stroller White, Stroller White Mountain.

Named in 1931 by USFS for EImer John ("Stroller") White, 1859-1930, a Douglas and Juneau newspaper publisher, who was born in Ohio. He went to Alaska in 1898 and worked for the Skagway News, published the Whitehorse Star, and purchased the Douglas Island News. In 1917 he moved to Juneau where he published the Strollers Weekly. In 1918 he was appointed Chief of the Territorial Bureau of Publicity and later served as Speaker of the Territorial House of Representatives (DeArmond, 1957, p. 41, 42).

Stroller White Mountain: mountain, see Stroller White, Mount.

Stronghold Peak: peak, 6,310 ft, $0.7 \mathrm{mi}$. SE of head of Avalanche Canyon and $32 \mathrm{mi}$. NE of Juneau, Coast Mts.; $58^{\circ} 45^{\prime} 15^{\prime \prime}$ N., $134^{\circ} 16^{\prime}$ $15^{\prime \prime} \mathrm{W}$; (map 11$)$

Local name published in 1960 by USGS.

Strong Point: point of land, on NE coast of Kenai Penin., at W entrance to Blackstone Bay, $7.5 \mathrm{mi}$. E of Whittier, Chugach Mts.; $60^{\circ} 47^{\prime} 30^{\prime \prime} \mathrm{N}, 148^{\circ} 26^{\prime} 55^{\prime \prime} \mathrm{W}$; BGN 1915; (map 63).

Local name reported in 1914 by USC\&GS.

Struya Point: point of land, on Chichagof I., on E shore of Bradshaw Cove, $3 \mathrm{mi}$. NE of Salisbury Sound and $25 \mathrm{mi}$. SE of Chichagof, Alex. Arch.; $57^{\circ} 23^{\prime} 00^{\prime \prime} \mathrm{N}, 135^{\circ} 39^{\prime} 45^{\prime \prime} \mathrm{W}$; BGN 1930; ( $\operatorname{map} 9$ ).

Named in 1930 by USC\&GS. "Struya" is the Russian word meaning "ripple" and refers to the ripples caused by tidal swirls off this point.

Stuart Canal: water course, see Stuart Island Canal.

Stuart Creek: stream, flows E $12 \mathrm{mi}$. to Tsina River $1 \mathrm{mi}$. SW of its junc. with Tiekel River and $34 \mathrm{mi}$. NE of Valdez, Chugach Mts.; $61^{\circ} 15^{\prime} 30^{\prime \prime} \mathrm{N}, 145^{\circ} 16^{\prime} 45^{\prime \prime} \mathrm{W}$; (map 68)

Local name reported in 1900 by F. C. Schrader, USGS.

Stuart Creek: stream, flows NE $11 \mathrm{mi}$. to South Fork Chena River $11 \mathrm{mi}$. SSE of that stream's mouth and $46 \mathrm{mi}$. NW of Big Delta, YukonTanana High.; $64^{\circ} 45^{\prime} 15^{\prime \prime} \mathrm{N}, 146^{\circ} 28^{\prime} 45^{\prime \prime} \mathrm{W}$; (map 101).

Local name reported in 1958 by USGS.

Stuart Creek: stream, flows N 5.3 mi. to Fairview Creek, $30 \mathrm{mi}$. NW of Nome, Seward Penin. High.; $64^{\circ} 47^{\prime} \mathrm{N}, 166^{\circ} 12^{\prime} \mathrm{W}$; (map 94).

Prospectors' name reported in 1900 by $E$. C. Barnard (in Brooks, 1901, pl. 17), USGS.

Stuart Island: island, $11 \mathrm{mi}$. long, in Norton Sound, $10 \mathrm{mi}$. NW of St. Michael, YukonKuskokwim Delta; $63^{\circ} 35^{\prime} \mathrm{N}, 162^{\circ} 30^{\prime} \mathrm{W}$ : (map 92). Var. Kikhtaknak, Ostrov Styard, Ostrov Styuart, Stuarts Island.

Named on September 18, 1778, by Capt. Cook (1785, v. 2, p. 488), RN. Eskimo name was published by Lt. Sarichev (1826, map 4), IRN, as "Kikhataknak."
Stuart Island Canal: watercourse, $6.3 \mathrm{mi}$. long, divides Stuart $I$. in half from its $S$ shore to North Bay, $16 \mathrm{mi}$. NW of St. Michael, YukonKuskokwim Delta; $63^{\circ} 32^{\prime} 30^{\prime \prime} \mathrm{N}, 162^{\circ} 33^{\prime} 00^{\prime \prime}$ W; (map 92). Var. Stuart Canal.

Named in 1898 by USC\&GS ; published on Chart 9380

Stuart Island Reef: reef, extends $8 \mathrm{mi}$. to Norton Sound, off SW coast of Stuart I., $17 \mathrm{mi}$. W of St. Michael, Yukon-Kuskokwim Delta; $63^{\circ} 32^{\prime} \mathrm{N}, 162^{\circ} 40^{\prime} \mathrm{W} ;(\operatorname{map} 92)$.

Local name obtained by USC\&GS in 1952.

Stuart Mountain: hill, $480 \mathrm{ft}$., on Stuart I., 15 mi. NW of St. Michael, Yukon-Kuskokwim Delta; $63^{\circ} 36^{\prime} \mathrm{N}, 162^{\circ} 26^{\prime} \mathrm{W}$; (map 92).

Named in 1898 by USC\&GS.

Stuarts Island: island, see Stuart Island.

Stubble Ridge: mountain, see Magic Mountain. Stuck: mountain, see Stuck Mountain.

Stuck Mountain: mountain, $3,800 \mathrm{ft}$., $4 \mathrm{mi}$. W of Willow Lake and $55 \mathrm{mi}$. NE of Valdez, Chugach Mts.; $61^{\circ} 46^{\prime} 40^{\prime \prime} \mathrm{N}, 145^{\circ} 18^{\prime} 10^{\prime \prime} \mathrm{W}$; (map 68).

Named Stuck Mountain in 1898 by Capt. W. R. Abercrombie, USA.

Stugarok: village, see Clarks Point.

Stuhinuk Creek: stream, see Cannery Creek.

Stuk Talj Chak: point of land, see Starichkof, Cape.

Stuk Talj Chin: point of land, see Starichkof, Cape.

Stump Cove: cove, $0.5 \mathrm{mi}$. across, on $\mathrm{W}$ shore of Muir Inlet, in Glacier Bay National Monument, $0.3 \mathrm{mi}$. SW of Westdahl Point, $65 \mathrm{mi}$. NW of Hoonah, St. Elias Mts.; 58 $58^{\prime} 30^{\prime \prime} \mathrm{N}$, $136^{\circ} 09^{\prime} 00^{\prime \prime} \mathrm{W}$; (map 10$)$.

Named by members of the American Geographical Society, Glacier Bay Expedition of 1941 (Field, 1947, pl. 1), because of the many stumps of an interglacial forest on the hillside at the head of the bay.

Stump Island: barrier island, $3 \mathrm{mi}$. long, $\mathrm{E}$ island of Return Is., on Beaufort Sea coast, $13 \mathrm{mi}$. SE of Beechey Point, Arctic Plain; 70 25' N, $148^{\circ} 36^{\prime} \mathrm{W}$; (map 150).

Named by Leffingwell (1919, p. 99), USGS, in 1911.

Stump Lake: lake, $2 \mathrm{mi}$. long, largest of Chedatna Lakes, in Susitna River delta, $20 \mathrm{mi}$. $\mathrm{NE}$ of Tyonek, Cook Inlet Low.; $61^{\circ} 17^{\prime} \mathrm{N}$, $150^{\circ} 42^{\prime} \mathrm{W}$; $(\operatorname{map} 70)$.

Local descriptive name reported in 1958 by USGS.

Sturdevant Rock: rock, in Bering Sea, $12 \mathrm{mi}$. W of Wolf Point, on $\mathrm{N}$ coast of Kiska I., Aleutian Is. ; $52^{\circ} 08^{\prime} 00^{\prime \prime} \mathrm{N}, 177^{\circ} 17^{\prime} 15^{\prime \prime} \mathrm{E}$; (map 14$)$.

Listed in 1954 Coast Pilot (p. 467) which reports the rock "covered by about 7 fathoms at low water."

Sturgeon Head: point of land, on $\mathrm{W}$ coast of Kodiak I., $7.5 \mathrm{mi}$. SW of Karluk; $57^{\circ} 30^{\prime} 40^{\prime \prime}$ $\mathrm{N}, 154^{\circ} 37^{\prime} 20^{\prime \prime} \mathrm{W}$; (map 35$)$.

Name derived from Sturgeon River; published by Capps (1937, pl. 2), USGS.

Sturgeon Ridge: hill, 2,061 ft., $1 \mathrm{mi}$. E of Kuzitrin Lake and $13 \mathrm{mi}$. S of Imuruk Lake, Seward Penin. High.; $65^{\circ} 23^{\prime} \mathrm{N}, 163^{\circ} 07^{\prime} \mathrm{W}$; $B G N 1952$; (map 110).
Reported in 1950 by D. M. Hopkins; so named by a USGS field party because "the hill bears a series of rock monuments along the crest-line so that its profile suggests the spiny back of a sturgeon."

Sturgeon River: stream, heads at $57^{\circ} 27^{\prime} \mathrm{N}$, $154^{\circ} 15^{\prime} \mathrm{W}$, flows SW and NW $23 \mathrm{mi}$. to Shelikof Strait, $3.5 \mathrm{mi}$. SW of Karluk, on W coast of Kodiak I.; $57^{\circ} 32^{\prime} 30^{\prime \prime} \mathrm{N}, 154^{\circ} 31^{\prime} 30^{\prime \prime} \mathrm{W}$; (map 35). Var. Shipinskaia River.

Translation by USBF in 1888 of the Russian name " $R$ [eka] Shipinskaya" published by Capt. Tebenkov (1852, map 22), IRN.

Sturgess Island: island, $0.6 \mathrm{mi}$. across, in Glacier Bay, in Glacier Bay National Monument, 1.6 mi. NW of Sandy Cove, $48 \mathrm{mi}$. NW of Hoonah, St. Elias Mts.; $58^{\circ} 43^{\prime} 20^{\prime \prime} \mathrm{N}, 136^{\circ} 03^{\prime} 00^{\prime \prime} \mathrm{W}$; (map 10).

Name published on Brit. Adm. Chart 2431 in 1890 .

Stuver, Mount: mountain, 6,220 ft., at head of Akvalutak Creek, E of Anaktuvuk River, 12 mi. NE of Anaktuvuk Pass, Brooks Ra.; 68 $12^{\prime} 30^{\prime \prime} \mathrm{N}, 151^{\circ} 20^{\prime} 00^{\prime \prime} \mathrm{W}$; (map 134).

Named Stuver Mountain in 1901 by F. G. Schrader or W. J. Peters, USGS, for Charles H. Stuver, a member of their field party (Schrader, 1904, map).

Stuver Creek: stream, flows NE from Nutzotin Mts. $53 \mathrm{mi}$. to Chisana River $12 \mathrm{mi}$. SE of Northway, Alaska Ra.; $62^{\circ} 50^{\prime} \mathrm{N}, 141^{\circ} 40^{\prime} \mathrm{W}$; (map 84).

Named in 1902 by D. C. Witherspoon, USGS, for Charles $\mathrm{H}$. Stuver, a member of the exploration party.

Stuyahak River: stream, see Stuyahok River.

Stuyahok: settlement, in Ilivit Mountains, near head of Stuyahok River, $22 \mathrm{mi}$. NE of Russian Mission, Nulato Hills; 62 $03^{\prime} 35^{\prime \prime} \mathrm{N}$, $160^{\circ} 57^{\prime} 00^{\prime \prime} \mathrm{W}$; (map 78).

Name of mining camp shown on recent USGS maps.

Stuyahok River: stream, heads at $59^{\circ} 48^{\prime} \mathrm{N}$, $155^{\circ} 51^{\prime} \mathrm{W}$, flows SW $30 \mathrm{mi}$. to Swan River, $58 \mathrm{mi}$. W of Iliamna, Bristol Bay Low.; $59^{\circ} 44^{\prime}$ $\mathrm{N}, 156^{\circ} 21^{\prime} \mathrm{W}$; (map 52). Var. Stuyahak River.

Eskimo name reported in 1954 by USGS.

Stuyahok River: stream, flows $\mathrm{N} 75 \mathrm{mi}$. to Bonasila River, $38 \mathrm{mi}$. NW of Holy Cross, Nulato Hills; 62 $28^{\prime} 15^{\prime \prime} \mathrm{N}, 160^{\circ} 49^{\prime} 20^{\prime \prime} \mathrm{W}$; (map $78)$.

Eskimo name meaning "the going down way" reported in 1916 by G. L. Harrington (in Brooks, 1918, pl. 16), USGS.

Stuyarok: locality, on Mulchatna River, $75 \mathrm{mi}$. NE of Dillingham, Bristol Bay Low.; 59 $50^{\prime}$ $\mathrm{N}, 156^{\circ} 42^{\prime} \mathrm{W}$; (map 52 ).

Eskimo village or camp reported in 1890 by A. B. Schanz, in Frank Leslie's Illustrated Newspaper.

Stuyarok River: stream, flows NW $16 \mathrm{mi}$. to Mulchatna River, $75 \mathrm{mi}$. NE of Dillingham, Bristol Bay Low.; $59^{\circ} 50^{\prime} \mathrm{N}, 156^{\circ} 42^{\prime} \mathrm{W}$; (map 52). Var. Estu-y-a-rok.

Eskimo name reported as "Estu-y-a-rok" on a 1910 manuscript map by H. C. Fassett, USBF. 
Styard, Ostrov: island, see Stuart Island.

Styleman, Point: point of land, at $\mathrm{N}$ entrance to Port Snettisham, on Stephens Passage, $2 \mathrm{mi}$. SW of Mist Creek and $29 \mathrm{mi}$. SE of Juneau, Coast Mts., $57^{\circ} 58^{\prime} 30^{\prime \prime} \mathrm{N}, 133^{\circ} 53^{\prime} 45^{\prime \prime} \mathrm{W}$; (map 8). Var. Mys Steylmen.

Named by Capt. George Vancouver, RN, after its discovery by Lt. Joseph Whidbey on Aug. 12, 1794, for Henry Styleman of Snettisham, England (Wagner, 1937, p. 17). This name was published in 1848 as "Mys Steylmen," by the Russian Hydrog. Dept. on Chart 1396.

Styuart, Ostrov: island, see Stuart Island.

Styx Lake: lake, $0.5 \mathrm{mi}$. long, in Ptarmigan Valley, $3.8 \mathrm{mi}$. NE of junc. of Styx River and Ptarmigan Creek, $90 \mathrm{mi}$. NW of Tyonek, Alaska Ra.; $61^{\circ} 58^{\prime} \mathrm{N}, 153^{\circ} 06^{\prime} \mathrm{W}$; (map 17).

Local name reported in 1958 by USGS.

Styx River: stream, heads at glacier, flows N 35 mi. to South Fork Kuskokwim River $5.4 \mathrm{mi}$. $\mathrm{SE}$ of its junc. with Hartman River, $90 \mathrm{mi}$. NW of Tyonek, Alaska Ra.; $61^{\circ} 54^{\prime} 45^{\prime \prime} \mathrm{N}$, $153^{\circ} 11^{\prime} 20^{\prime \prime} \mathrm{W}$; $(\operatorname{map} 71)$.

Named in 1898 by W. S. Post and J. E. Spurr, USGS, after the chief river of the lower world in Greek mythology.

Subienna Bay: bay, see Massacre Bay.

Sublik Mountains: mountain range, see Shublik Mountains.

Sublik Springs:springs, see Shublik Spring.

Submarine Creek: stream, flows NW $4.7 \mathrm{mi}$. to Mystery Creek, $13 \mathrm{mi}$. NW of Medfra, Kilbuck-Kuskokwim Mts. ; $63^{\circ} 17^{\prime} \mathrm{N}, 154^{\circ} 49^{\prime} \mathrm{W}$; (map 89).

Local name reported in 1924 by J. S. Brown (in Smith, P. S., and others, 1926, map), USGS.

Submarine Lake: lake, $1.3 \mathrm{mi}$. long, $0.5 \mathrm{mi}$. NW of Farewell Lake, $2.5 \mathrm{mi}$. W of junc. of South Fork Kuskokwim and Dillinger Rivers and 67 mi SE of McGrath, Kuskokwim Low.; 62 $34^{\circ}$ $30^{\prime \prime} \mathrm{N}, 153^{\circ} 41^{\prime} 00^{\prime \prime} \mathrm{W}$; ( $\left.\operatorname{map} 80\right)$.

Local name obtained in 1958 by USGS.

Sub Point: point of land, on $\mathrm{S}$ shore of Kiska Harbor, on E coast of Kiska I., Aleutian Is.; $51^{\circ} 57^{\prime} 25^{\prime \prime} \mathrm{N}, 177^{\circ} 34^{\prime} 00^{\prime \prime} \mathrm{E}$; (map 14).

Shown on recent maps of Kiska Island.

Sucheen River: stream, see Stikine River.

Suchitna Mountain: mountain, see Susitna, Mount.

Suchitna River: stream, see Susitna River.

Suchitna Station: village, see Susitna.

Suchitno River: stream, see Susitna River.

Sucho: bay, see Dry Spruce Bay.

Suchoi Channel: water passage, see Dry Strait.

Sucia Ledge: reef at $\mathbf{S}$ end of Portillo Channel, between Lulu and San Fernando Is., Alex. Arch.; $55^{\circ} 27^{\prime} \mathrm{N}, 133^{\circ} 25^{\prime} \mathrm{W}$; BGN 1923; (map 4).

Spanish nautical word meaning "foul," given in 1923 by USC\&GS. The triangulation station Foul is located on this feature.

Sucker Creek: stream, flows S $55 \mathrm{mi}$. to Holikachuk Slough, $3.4 \mathrm{mi}$. N of Holikachuk and $53 \mathrm{mi}$. N of Holy Cross, Innoko Low.; 62 $57^{\circ}$. $40^{\prime \prime} \mathrm{N}, 159^{\circ} 32^{\prime} 10^{\prime \prime} \mathrm{W}$; (map 78).

Local name obtained in 1952 by USGS.
Sucker Lake: lake, 0.4 mi. long, on Kenai Penin. WNW of Canoe Lake, $23 \mathrm{mi}$. NE of Kenai, Cook Inlet Low.; $60^{\circ} 43^{\prime} 15^{\prime \prime} \mathrm{N}, 150^{\circ} 40^{\prime} 45^{\prime \prime}$ W; (map 62).

Named about 1963 by officials of Kenai National Moose Range, for administrative purposes.

Sucker Lake: lake, $0.6 \mathrm{mi}$. long, NE of Big Lake, $24 \mathrm{mi}$. N of Anchorage, Cook Iulet Low.; $61^{\circ} 33^{\prime} 25^{\prime \prime} \mathrm{N}, 149^{\circ} 49^{\prime} 25^{\prime \prime} \mathrm{W}$; BGN 1954; (map 69). Var. Rocky Lake.

Local name reported in 1953 by USGS.

Sucker Lake: lake, $1.2 \mathrm{mi}$. long, between Upper and Lower Sucker Creeks, $41 \mathrm{mi}$. NE of Tyonek, Cook Inlet Low. ; $61^{\circ} 39^{\prime} 15^{\prime \prime}$ N, 150 $54^{\prime}$ $00^{\prime \prime} \mathrm{W}$; (map 70).

Local name reported in 1935 by USGS.

Sucker Lake: lake, $3 \mathrm{mi}$. long, $\mathrm{N}$ of Tazlina Lake, $27 \mathrm{mi}$. SW of Glennallen, Copper River Basin; 62 $01^{\prime} 30^{\prime \prime} \mathrm{N}, 146^{\circ} 20^{\prime} 00^{\prime \prime} \mathrm{W}$; (map 83).

Local name reported by USGS in 1949.

Sucker River: stream, S distributary of Little Black River, flows NW $50 \mathrm{mi}$. to Porcupine River, $4 \mathrm{mi}$. NE of Fort Yukon, Yukon Flats; $66^{\circ} 36^{\prime} 40^{\prime \prime} \mathrm{N}, 145^{\circ} 12^{\prime} 00^{\prime \prime} \mathrm{W} ; B G N$ 1959; (map 119).

This name, presumably a translation of an Indian name, was given in 1889 by J. H. Turner, USC\&GS, to what is now called the Coleen River. The application of the name "Sucker" was changed about 1900.

Sucker River: stream, see Rapid River.

Suckik Creek: stream, flows SW $6 \mathrm{mi}$. to Timber Creek, $\mathrm{N}$ of Button Mtn., $47 \mathrm{mi}$. SW of Wiseman, Brooks Ra.; $67^{\circ} 11^{\prime} 30^{\prime \prime} \mathrm{N}, 151^{\circ} 46^{\prime} 00^{\prime \prime}$ W; BGN 1932; ( $\operatorname{map} 124)$.

Local name "for an Eskimo prospector, Charlie Suckik ***"; reported by Robert Marshall in 1932.

Suckling, Cape: point of land, on Gulf of Alaska, $6 \mathrm{mi}$. SE of Controller Bay and $75 \mathrm{mi}$. SE of Cordova, Malaspina Coastal Plain ; 59 $59^{\prime} 30^{\prime \prime}$ $N, 143^{\circ} 53^{\prime} 00^{\prime \prime}$; (map 47). Var. Cabo Chupador, Cabo de San Elias, Punta de la Isia.

Named by Capt. Cook $(1785$, v. 2, p. 349 ), RN, May 10, 1778, for Maurice Suckling, Comptroller of the Royal Navy when Cook left England. Malaspina's manuscript chart of 1791 shows Cabo Chupador meaning "sucking" or "suckling." The name Cabo de San Elias appears on Camacho's chart showing results of the Don Ignacio Artega expedition in 1779 with Francisco Antonio Maurelle as pilot (Wagner, 1937, p. 498).

Suckling Hill: hills, extend NE-SW $10 \mathrm{mi} ., 2$ mi. N of Cape Suckling, near 1950 terminus of Bering Glacier, $74 \mathrm{mi}$. SE of Cordova, Malaspina Coastal Plain; $60^{\circ} 03^{\prime} \mathrm{N}, 143^{\circ} 47^{\prime} \mathrm{W}$; (map 65).

Name derived from nearby Cape Suckling and published in 1951 by USGS.

Suckqwan: locality, see Sukkwan.

Sud, Ile du: rock, see South Island.

Sudak, Gape: point of land, on E coast of Tanaga I., Aleutian Is.; $51^{\circ} 50^{\prime} 30^{\prime \prime} \mathrm{N}, 177^{\circ} 37^{\prime} 40^{\prime \prime} \mathrm{W}$; (map 17). Var. Mys Sudakh.
Russian name published by Capt. Tebenkov (1852, map 28), IRN, as "M[ys] Sudakh," or "Cape Sudak."

Sudakh, Mys: point of land, see Sudak, Cape.

Sudden Stream: stream, heads in lake at terminus of Malaspina Glacier, flows S $2 \mathrm{mi}$. to Yakutat Bay, $8 \mathrm{mi}$. SW of Blizhni Point and $18 \mathrm{mi}$. NW of Yakutat, Malaspina Coastal Plain; 59 $47^{\prime} 00^{\prime \prime} \mathrm{N}, 139^{\circ} 58^{\prime} 30^{\prime \prime} \mathrm{W}$; (map 46).

Local name published by USGS in 1951 .

Sud Island: island, $1 \mathrm{mi}$. long, in Gulf of Alaska, one of Barren Is., $5 \mathrm{mi}$. SW of Nord I., $67 \mathrm{mi}$. $\mathrm{NE}$ of Afognak, Chugach Mts.; 58 $54^{\prime} 00^{\prime \prime} \mathrm{N}$, $152^{\circ} 12^{\prime} 30^{\prime \prime} \mathrm{W}$; BGN 1908; (map 43).

Named by USC\&GS in 1908 . The name is a French word meaning "south."

Sudueste, Punta: point of land, "on the southwest point of San Fernando Island in Bucareli Bay," Alex. Arch.; (map 4).

Spanish name meaning "southwest point" found on the maps of the 1779 Arteaga expedition (Wagner, 1937, p. 517).

Sue Creek: stream, heads in Horn Mts., flows SE $16 \mathrm{mi}$. to Kuskokwim River, $36 \mathrm{mi}$. E of Aniak, Kilbuck-Kuskokwim Mts.; 61 ${ }^{\circ} 35^{\prime} 30^{\prime \prime}$ N, 158 $26^{\prime} 00^{\prime \prime} \mathrm{W}$; BGN 1948; (map 72).

Local name reported in 1945 by USGS.

Suedla Island: island, $0.3 \mathrm{mi}$. across, in Auke Bay off SW coast of Mendenhall Penin., 0.4 $\mathrm{mi}$. $\mathrm{N}$ of Spuhn I. and $9 \mathrm{mi}$. NW of Juneau, Coast Mts.; $58^{\circ} 21^{\prime} 00^{\prime \prime} \mathrm{N}, 134^{\circ} 39^{\prime} 30^{\prime \prime} \mathrm{W}$; (map 11).

Local name apparently formed by combining the initial letters of several names or words. Its origin is unknown (DeArmond, 1957, p. 42).

Suemez, Isla: island, see Suemez Island.

Suemez Island: island, $9.5 \mathrm{mi}$. across, $\mathrm{E}$ of Bucareli Bay, Alex. Arch.; 55 $16^{\prime} \mathrm{N}, 133^{\circ} 21^{\prime}$ W; (map 4). Var. Isla de Güemes, Isla Suemez, Ostrov Syumetsy.

Spanish name given in 1775-79 by Don Juan de la Bodega y Quadra and Francisco Antonio Maurelle as "Isla Suemez," i.e. "Suemez Island"; shown as "Guemes" by D. A. Galiano (1802, map 2). It may have been named "Güemes" for "the Viceroy" (Wagner, 1937 , p. 460 ).

Sufus Creek: stream, flows NE $0.3 \mathrm{mi}$. to Nome River, $0.4 \mathrm{mi}$. upstream from Extra Dry Creek and $7 \mathrm{mi}$. NE of Nome, ijeward Penin. High.; $64^{\circ} 34^{\prime} \mathrm{N}, 165^{\circ} 16^{\prime} \mathrm{W}$; (nap 94). Var. Rufus Creek.

Prospectors' name reported on the 1903 Campion Mining and Trading Co. map by George M. Ashford. Reported as "Rufus Cr." on a map by S. E. King dated 1900 .

Sugakuik Creek: stream, see Sugakvik Creek.

Sugakvik Creek: stream, flows SE 3 mi. to Killik River $\mathrm{W}$ of its junc. with Easter Creek, Brooks Ra. ; $68^{\circ} 08^{\prime} \mathrm{N}, 154^{\circ} 10^{\prime} \mathrm{W}$; (map 133). Var. Sugakuik Creek.

Eskimo name meaning "resting place," obtained in 1956 at Anaktuvuk Pass by Orth.

Sugar Creek: stream, flows $1 \mathrm{mi}$. E to Bering Sea, on $\mathbf{N}$ coast of Kiska I., Aleutian Is.; $52^{\circ} 05^{\prime} 45^{\prime \prime}$ N; $177^{\circ} 40^{\prime} 15^{\prime \prime}$ E; (map 14). 
An arbitrary name beginning with " $\mathrm{S}$ " to correspond to "S" grid used by the U.S. Army for tactical purposes during World War II; published on a 1953 AMS map.

Sugar Hill: hill, $400 \mathrm{ft}$., on $\mathrm{N}$ coast of Kiska I., Aleutian I.; $52^{\circ} 06^{\prime} 45^{\prime \prime} \mathrm{N}, 177^{\circ} 39^{\prime} 50^{\prime \prime} \mathrm{E}$; (map 14).

An arbitrary name beginning with " $\mathrm{S}$ " to correspond to "S" grid used by the U.S. Army for tactical purposes during World War II; published on a 1953 AMS map.

Sugar Loaf: mountain, see Pinnacle Mountain.

Sugar Loaf, Cape: promontory, see Sugarloaf Mountain.

Sugar Loaf Creek: stream, flows SE $2.8 \mathrm{mi}$. to Fairhaven Creek, $37 \mathrm{mi}$. N of Haycock, Seward Penin. High.; $65^{\circ} 44^{\prime} \mathrm{N}, 161^{\circ} 07^{\prime} \mathrm{W}$; (map 109).

Local name published on maps after 1950.

Sugarloaf Head: point of land, on $\mathrm{S}$ coast of Semisopochnoi I., Aleutian Is.; $51^{\circ} 52^{\prime} 45^{\prime \prime} \mathrm{N}$, $179^{\circ} 73^{\prime} 40^{\prime \prime} \mathrm{E}$; BGN 1937; (map 15).

Reported by personnel of the U.S.S. Oglala in 1935, and named for nearby Sugarloaf Peak.

Sugarloaf Island: island, $0.8 \mathrm{mi}$. across, in Gulf of Alaska, at mouth of Dixon Harbor, in Glacier Bay National Monument, $54 \mathrm{mi}$. NW of Hoonah, St. Elias Mts.; $58^{\circ} 19^{\prime}$ N, $136^{\circ} 52^{\prime}$ W; (map 10)

Descriptive name given by USC\&GS and published in 1889.

Sugarloaf Island: island, $0.7 \mathrm{mi}$. across, one of Barren Is., $1.3 \mathrm{mi}$. $\mathrm{S}$ of Amatuli Is., in Gulf of Alaska, $68 \mathrm{mi}$. NE of Afognak, Chugach Mts; $58^{\circ} 53^{\prime} 10^{\prime \prime} \mathrm{N}, 152^{\circ} 02^{\prime} 15^{\prime \prime} \mathrm{W}$; (map 43).

Probably named by Capt. Dixon (1789, p. 69), RN, of the vessel Queen Charlotte (178588).

Sugar Loaf Island: island, see Hive Island.

Sugarloaf Knob: point of land, $1 \mathrm{mi}$. NE of Sugarloaf Head, on SE coast of Semisopochnoi I., Aleutian Is.; $51^{\circ} 53^{\prime} 10^{\prime \prime} \mathrm{N}, 179^{\circ} 39^{\prime} 00^{\prime \prime} \mathrm{E}$; (map 15).

Name published on a 1943 U.S. Army Corps of Engineers map.

Sugarloaf Mountain: mountain, $1,725 \mathrm{ft}$., on $\mathrm{W}$ coast of Baranof I., $4.5 \mathrm{mi}$. SE of Sitka, Alex. Arch.; $57^{\circ} 01^{\prime} 40^{\prime \prime} \mathrm{N}, 135^{\circ} 13^{\prime} 20^{\prime \prime} \mathrm{W}$; (map 9). Var. Sugarloaf.

Local descriptive name published in 1900 by USC\&GS. The mountain has a conical shape like a loaf of refined sugar, now rarely made.

Sugarloaf Mountain: peak, 2,085 ft., $12 \mathrm{mi}$. N of Naknek Lake, on Alaska Penin. at NW corner of Katmai National Monument, $30 \mathrm{mi}$. $\mathrm{NE}$ of Naknek, Aleutian Ra.; 58 $53^{\prime} 30^{\prime \prime} \mathrm{N}$, $155^{\circ} 57^{\prime} 45^{\prime \prime}$ W; (map 42). Var. Sugarloaf Peak.

Named "Sugarloaf Peak" in 1890 by USBF

Sugarloaf Mountain: mountain, 3,050 ft., in Chigmit Mts., on NW shore of Iniskin Bay, Aleutian Ra.; $59^{\circ} 45^{\prime} 40^{\prime \prime} \mathrm{N}, 153^{\circ} 29^{\prime} 00^{\prime \prime} \mathrm{W}$; (map 51).

Descriptive name reported in 1904 by $\mathbf{G}$. C. Martin, USGS
Sugarloaf Mountain: promontory, 1,380 ft., on $\mathrm{S}$ coast of St. Matthew I., $13 \mathrm{mi}$. W of Cape Upright; $60^{\circ} 19^{\prime} \mathrm{N}, 172^{\circ} 37^{\prime} \mathrm{W}$; (map 56). Var. Cape Sugar Loaf, Mys Sakha Golovy, Mys Sikharnoy Golovy, Pain du Sucre, Sikarnoi Golovie.

Called by the Russians "My[s] Sikharnoy golovy" (Hydrog. Dept. Chart 1427, dated 1849) and "My[s] Sakha Golovy" (Tebenkov, 1852, map 20), both names meaning "Cape Sugar Loaf." Capt. Lutke (1836, p. 341), IRN, calls it "Pain de Sucre," "sugarloaf," so called from its appearance.

Sugarloaf Mountain: mountain, 3,484 ft., 0.6 mi. E of Solomon Lake and $3.7 \mathrm{mi}$. S of Valdez, Chugach Mts.; $61^{\circ} 03^{\prime} 50^{\prime \prime} \mathrm{N}, 146^{\circ}$ $16^{\prime} 00^{\prime \prime} \mathrm{W}$; (map 68). Var. Quay Peak.

Local name reported in 1911 by USGS. Originally named "Quay Peak" in 1898 by Capt. Abercrombie, USA, for the Hon. M. S. Quay, U.S. Senator from Pennsylvania.

Sugarloaf Mountain: mountain, 1,680 ft., in Kuskokwim Mts., on $\mathrm{N}$ bank of Moore Creek, $36 \mathrm{mi}$. E of Flat, Kilbuck-Kuskokwim Mts.; $62^{\circ} 32^{\prime} 30^{\prime \prime} \mathrm{N}, 156^{\circ} 54^{\prime} 00 \mathrm{~W}$; (map 79).

Local name obtained in 1952 by USGS topographers.

Sugarloaf Mountain: peak, 5,341 ft., in Amphitheater Mts., $E$ of Lower Tangle Lake, $16 \mathrm{mi}$.

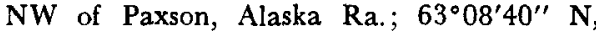
$145^{\circ} 55^{\prime} 05^{\prime \prime} \mathrm{W}$; (map 86). Var. Sugar Loaf Mountain.

Local name reported in 1949 by T. L. Péwé, USGS.

Sugar Loaf Mountain: mountain, 4,450 ft., $4 \mathrm{mi}$. SW of Dora Peak, and $6 \mathrm{mi}$. SE of Healy, Alaska Ra.; $63^{\circ} 47^{\prime} 30^{\prime \prime} \mathrm{N}, 148^{\circ} 49^{\prime} 00^{\prime \prime} \mathrm{W}$; (map 87). Var. Sugar Mountain.

Local desciptive name reported in 1950 by USGS.

Sugarloaf Peak: volcano, $2,870 \mathrm{ft}$., on $\mathbf{S}$ Semisopochnoi I., Aleutian Is.; $51^{\circ} 54^{\prime} 00^{\prime \prime} \mathrm{N}, 179^{\circ}$ 37'50" E; BGN 1952; (map 15). Var. Sugar Loaf Peak.

Named by the U.S. Navy North Pacific Exploring Expedition in 1855. According to $\mathbf{R}$. $R$. Coats, USGS, the name may have been originally applied to a 1620-foot cinder cone on its flank.

Sugarloaf Peak: peak, see Sugarloaf Mountain.

Sugarloaf Rock: rock, see Humpback Rock.

Sugar Mountain: mountain, see Sugar Loaf Mountain.

Sugar Top: mountain, $1,827 \mathrm{ft} ., 41 \mathrm{mi}$. NW of Haycock, Seward Penin. High.; 65 $48^{\prime} \mathrm{N}$, $161^{\circ} 18^{\prime} \mathrm{W}$; (map 109).

Local name published on maps after 1950 . Sugtutlig Mountain: mountain, 2,470 ft., 3 peaks, $10 \mathrm{mi}$. S of Island Mtn. and $17 \mathrm{mi}$. NE of Goodnews, Kilbuck-Kuskokwim Mts. $59^{\circ} 19^{\prime} \mathrm{N}, 161^{\circ} 20^{\prime} \mathrm{W}$; (map 53).

Eskimo name reported to mean "old high mountain"; obtained at Goodnews about 1951 by J. M. Hoare, USGS.

Suhti Island: island, $1,000 \mathrm{ft}$. across, in Tuxekan Passage, SE of Tuxekan I., $22 \mathrm{mi}$. N of Craig,
Alex. Arch.; $55^{\circ} 47^{\prime} 00^{\prime \prime} \mathrm{N}, 133^{\circ} 14^{\prime} 40^{\prime \prime} \mathrm{W}$; (map 4).

Indian name published in 1964 by USC\&GS. Suichi: rocks, see Sealion Rocks.

Suicide Cove: cove, $0.2 \mathrm{mi}$. across, on $\mathrm{E}$ shore of Stephens Inlet, $1 \mathrm{mi}$. S of Slocum Inlet and $18 \mathrm{mi}$. SE of Juneau, Coast Mts.; 58 $07^{\prime} 50^{\prime \prime}$ $\mathrm{N}, 134^{\circ} 04^{\prime} 15^{\prime \prime} \mathrm{W}$; (map (11).

Local name published in 1951 by USGS.

Suicide Creek: stream, see Chalk Creek.

Suicide Falls: talls, on Cross Bay Creek near its mouth on Gastineau Channel, $2.8 \mathrm{mi}$. SE of Juneau, Coast Mts. ; $58^{\circ} 16^{\prime} 05^{\prime \prime} \mathrm{N}, 134^{\circ} 31^{\prime} 20^{\prime \prime}$ W; (map 11).

Local name published in 1962 by USGS.

Suicide Peak: mountain, 5,005 ft., at heads of Rainbow and McHugh Creeks, $17 \mathrm{mi}$. SE of Anchorage, Chugach Mts.; $61^{\circ} 01^{\prime} 50^{\prime \prime} \mathrm{N}$, $149^{\circ} 34^{\prime} 25^{\prime \prime} \mathrm{W}$; (map 69).

Local name reported in 1951 by USGS.

Suikhchak: bay, see Swikshak Bay.

Sukakpak Mountain: mountain, $4,200 \mathrm{ft}$., $S$ of junc. of Dietrich, Bettles, and Middle Fork Koyukuk Rivers, $39 \mathrm{mi}$. WNW of Chandalar, Brooks Ra.; $67^{\circ} 36^{\prime} 30^{\prime \prime} \mathrm{N}, 149^{\circ} 45^{\prime} 00^{\prime \prime} \mathrm{W}$; $B G N 1932$; (map 123).

Eskimo word, said to mean "martin deadfall," reported about 1930 by Robert Marshall (1956, map).

Sukhago Yelnika, Poluostrov: island, see Dry Spruce Island.

Sukhlikh Island: island, see Suklik Island.

Sukhoi: bay, see Dry Spruce Bay.

Sukhoi Bay: bay, $1.5 \mathrm{mi}$. across, $7 \mathrm{mi}$. $W$ of Alitak Bay, at $S$ end of Kodiak I.; $56^{\circ} 57^{\prime} \mathrm{N}$, $154^{\circ} 21^{\prime}$ W; (map 32). Var. Dry Bay.

Transliteration by USC\&GS in 1910 of the Russian "Z[aliv] Sukhoi," meaning "Dry Bay"; published by Capt. Tebenkov (1852, map 22). Baker (1906, p. 226) published the translation "Dry Bay."

Sukhoi Lagoon: lagoon, $2.5 \mathrm{mi}$. long, $5 \mathrm{mi}$. W of Alitak Bay, at $\mathrm{S}$ end of Kodiak I.; $56^{\circ} 57^{\prime} \mathrm{N}$, $154^{\circ} 18^{\prime} \mathrm{W}$; (map 32).

Russian name meaning "dry," derived from Sukhoi Bay, and published in 1943 by USC\&GS. This lagoon is reported by USG\&GS to be dry at low tide.

Sukhoi Strait: water passage, see Dry Strait.

Sukhoy, Proliv: water passage, see Hayward Strait.

Sukhoy, Proliv: water passage, see Dry Strait. Sukhoy Bay: bay, see Sukoi Bay.

Sukhoy Proliv: estuary, see Blind Slough.

Sukhoy Proliv Blind Slough: stream, see Blind River.

Sukhoy Yelnik, Zaliv: bay, see Dry Spruce Bay. Sukisalnuk Point: point of land, see Sakisalnak Point.

Sukkwan: locality, on Sukkwan I., at head of Cordova Bay, Alex. Arch.; (map 4). Var. Sakoā-n, Shakan, Shākwan, Shaw-a-gan, Shou-a-gan, Show-a-gan, Ssokăōn, Suckqwan, Suqq-an.

Former Tlingit Indian village or camp name published in 1895 by USC\&GS. According to Hodge (1910, p. 648), the name "Sukkwan" was (said [by R. S. Swanton, BAE], to 
be from Tlingit suqq-an, 'grassy town'). A Haida town of the Koetas family, formerly on Cordova Bay, in the Kaigani country, Alaska. In 1836-41 John Work stated, "the number of houses here was 14 and the number of people 229." The population was absorbed by the village of Kaigani, which, in turn, was abandoned in 1911, when the village of Hydaburg was established, in order to centralize the school system. See Kaigani.

Sukkwan Island: island, $15 \mathrm{mi}$. long, between Dall and Prince of Wales Is., Alex. Arch.; $55^{\circ}$ $06^{\prime} \mathrm{N}, 132^{\circ} 46^{\prime} \mathrm{W}$; (map 4$)$.

Name recorded in 1897 by Lt. Comdr. J. F. Moser, USN; published in 1899 by USC\&GS.

Sukkwan Lake: lake, $1.3 \mathrm{mi}$. long, near $\mathrm{S}$ end of Sukkwan I., Alex. Arch.; $55^{\circ} 02^{\prime} 30^{\prime \prime} \mathrm{N}, 132^{\circ}$ $45^{\prime} 35^{\prime \prime} \mathrm{W}$; (map 4).

Local name published in 1960 by USFS.

Sukkwan Narrows: water passage, at $\mathrm{N}$ entrance to Sukkwan Strait, W of Hydaburg, on W coast of Prince of Wales I., Alex. Arch.; 55 $12^{\prime} \mathrm{N}, 132^{\circ} 49^{\prime} \mathrm{W}$; (map 4).

Local named published in 1905 by USC\&GS.

Sukkwan Strait: water passage, $9 \mathrm{mi}$. long, between Prince of Wales and Sukkwan Is., Alex. Arch.: $55^{\circ} 10^{\prime} \mathrm{N}, 132^{\circ} 46^{\prime} \mathrm{W} ; B G N 1916$, (map 4).

Local name recorded in 1897 by Lt. Comdr. J. F. Moser, USN: published in 1899 by USC\&GS.

Suklik Island: island, $0.6 \mathrm{mi}$. long, $1.5 \mathrm{mi}$. E of Chowict I., in Semidi Is., in Pacific Ocean, Aleutian Ra.; $56^{\circ} 03^{\prime} \mathrm{N}, 156^{\circ} 38^{\prime} \mathrm{W}$; (map 31). Var. Sukhlikh Island.

Native name reported in 1874 by $W$. $H$. Dall, USC\&GS, as "Sukhlikh Island."

Suklowik Mountain: mountain, see Saklolik Mountain.

Sukoi Bay: bay, extends W $3 \mathrm{mi}$. on NE coast of Alaska Penin. in Katmai National Monument, $\mathrm{N}$ of Cape Douglas, $31 \mathrm{mi}$. $\mathrm{S}$ of Augustine $\mathrm{I}$., Aleutian Ra.; $58^{\circ} 52^{\prime} \mathrm{N}, 153^{\circ} 16^{\prime} \mathrm{W}$; (map 43). Var. Dry Bay, Sukhoy Bay, Sukoi Cove.

This name is a transliteration of "Z[aliv] Sukhoy," or "Sukhoy Bay," published by Capt. Tebenkov (1852, map 22), IRN.

Sukoi Cove: bay, see Sukoi Bay.

Sukoi Inlet: zuater passage, extends S $6 \mathrm{mi}$. from Salisbury Sound to Krestof Sound between Partishkof and Kruzof Is., $17 \mathrm{mi}$. NW of Sitka, Alex. Arch.; $57^{\circ} 14^{\prime} \mathrm{N}, 135^{\circ} 36^{\prime} \mathrm{W}$; $B G N 1931$; (map 9). Var. Dry Strait, Hayward Strait, Souhoi Strait, Soukhoi Strait.

It was called "Sukoi," meaning "dry," by the Russians, because at low water the inlet becomes partly dry. It was originally named "Hayward's Straits" in 1787 by Capt. Nathaniel Portlock, for Samuel Hayward, the third mate of Portlock's ship (Wagner, 1937, p. 391). The name "Hayward Strait" is now applied to the passage connecting Krestof and Sitka Sounds.

Sukoi Islets: islands, group of three, extend E-W $1.6 \mathrm{mi}$., in Frederick Sound, off E coast of Lindenberg Penin., Kupreanof I., $6 \mathrm{mi} . \mathrm{N}$ of
Petersburg, Alex. Arch.; 56 $53^{\prime} 30^{\prime \prime}$ N, $132^{\circ}-$ $55^{\prime 25}$ " W; (map 6).

Indian name published by USC\&GS in 1925 Coast Pilot (p. 211).

Sukoi Point: point of land, on NE coast of Kruzof I., at $\mathrm{N}$ end of Sukoi Inlet, on Alex. Arch.; $57^{\circ} 19^{\prime} 20^{\prime \prime} \mathrm{N}, 135^{\circ} 42^{\prime} 00^{\prime \prime} \mathrm{W}$; $B G N$ $1960(\operatorname{map} 9)$.

Named in 1930 by USC\&GS for Sukoi Inlet; published on Chart 8248.

Sukok Lake: lake, $3 \mathrm{mi}$. across, $15 \mathrm{mi}$. S of Barrow, Arctic Plain; $71^{\circ} 03^{\prime} 15^{\prime \prime} \mathrm{N}, 156^{\circ} 48^{\prime}$ $15^{\prime \prime}$ W; (map 153).

Eskimo name recorded by USC\&GS about 1950. It seems to be a mistranscription of the name "Sikolik," meaning "having ice."

Suktu River: stream, see Usuktuk River.

Sukwayluk Creek: stream, see Sakvelak Creek. Sulakpoatokvik Creek: stream, heads on NW side of Nilunorat Hills, flows S $9 \mathrm{mi}$. to Kobuk River, $46 \mathrm{mi}$. ESE of Kobuk, Kotzebue-Kobuk Low.; $66^{\circ} 46^{\prime} \mathrm{N}, 15^{\circ} 14^{\prime} \mathrm{W}$; (map 116).

Eskimo name obtained at Kobuk by Orth in 1956 and reported to refer to a "place where grayling are caught."

Su-lan-na: locality, see Lulanna.

Sulatna Bluff: bluff, on right bank of Sulatna River, near Sulatna Crossing, $38 \mathrm{mi}$. SE of Ruby, Kilbuck-Kuskokwim Mts.; 64 $12^{\prime} \mathrm{N}$, $155^{\circ} 29^{\prime}$ W; (map 98). Var. Tamerack Bluff.

Local name published in 1921 by USGS.

Sulatna Bluff: bluff, see Tamarack Bluff.

Sulatna Crossing: locality, on left bank of Sulatna River, $0.5 \mathrm{mi}$. NW of junc. of Spangle Creek and Sulatna River and $39 \mathrm{mi}$. S of Ruby, Kilbuck-Kuskokwim Mts.; $64^{\circ} 11^{\prime} \mathrm{N}, 155^{\circ} 28^{\prime}$ W; (map 98). Var. Tamarack Landing.

Name reported in 1923 by ARG; so called because the trail from Ruby to Poorman crossed the Sulatna River at this point.

Sulatna River: stream, flows NE $100 \mathrm{mi}$. to Nowitna River, $6 \mathrm{mi}$. NE of Monzonite Hills and $32 \mathrm{mi}$. SE of Ruby, Nowitna Low.; $64^{\circ} 36^{\prime} \mathrm{N}, 154^{\circ} 28^{\prime} \mathrm{W}$; BGN 1916; (map 98). Var. Solatna, South Fork, Suletna.

Prospectors' name reported in 1908 by Maddren (in Brooks and others, 1909, p. 230), USGS.

Sulawig-meuts: village, see Selawik.

Suldahtnah: stream, see Soldotna Creek.

Suletna: stream, see Sulatna River.

Sulima, Reka: stream, see Ugashik River.

Sulima River: stream, see Ugashik River.

Sullivan: locality, in Bluestone River basin, at junc. of Alder Creek and Gold Run, $15 \mathrm{mi}$. SE of Teller, Seward Penin. High.; $65^{\circ} 04^{\prime}$ N, 166¹2' W; (map 111). Var. Sullivan Camp, Sullivan Gity.

Site of a mining camp which was the center of the Bluestone gold mining region. The Bluestone region was staked in the stampedes of 1899 , although gold was not found here until 1900 (Brooks, 1901, p. 131). A post office was established here in 1902 and was discontinued in 1909 (Ricks, 1965, p. 62). In 1907 USGS reported that Sullivan "has a summer population of about 50 , a post office, and several roadhouses, and is connected with Teller and a landing at the mouth of Tisuk Creek by a regular line of stages" (Collier and others, 1908, p. 59).

Sullivan, Point: point of land, on $\mathrm{W}$ coast of Kuiu I. $32 \mathrm{mi}$. NE of Port Alexander, Alex. Arch.; $56^{\circ} 40^{\prime} 45^{\prime \prime} \mathrm{N}, 134^{\circ} 22^{\prime} 00^{\prime \prime} \mathrm{W}$; (map 5)

Named by Capt. George Vancouver, RN, on August 8, 1794, "apparently after William Francis Sullivan, who served in the navy during the American war" (Wagner, 1937, p. 418).

Sullivan Bluffs: bluffs, on Seward Penin., extends $2.5 \mathrm{mi}$. along Kotzebue Sound, $15 \mathrm{mi}$. $\mathrm{W}$ of Deering, Kotzebue-Kobuk Low.; $66^{\circ} 04^{\prime}$ N, $163^{\circ} 12^{\prime} \mathrm{W}$; (map 113).

Local name reported in 1950 by USGS; derived from nearby Sullivan Creek.

Sullivan Camp: locality, see Sullivan.

Sullivan City: locality, see Sullivan.

Sullivan Creek: stream, flows NW $18 \mathrm{mi}$. between Bear and Sheep Creeks to Pitka Fork Kuskokwim River, $37 \mathrm{mi}$. SE of McGrath, Kuskokwim Low.; $62^{\circ} 48^{\prime} \mathrm{N}, 154^{\circ} 29^{\prime} \mathrm{W}$; (map 80).

Local name obtained in 1954 by USGS.

Sullivan Creek: stream, heads on Serpentine Ridge, flows S $7.5 \mathrm{mi}$, , joins Cache Creek to form Patterson Creek, $34 \mathrm{mi}$. ESE of Tanana, Yukon-Tanana High.; $65^{\circ} 02^{\prime} 30^{\prime \prime} \mathrm{N}, 150^{\circ} 55^{\prime}$ $55^{\prime \prime} \mathrm{W}$; (map 106).

Prospectors' name reported in 1911 by $H$. M. Eakin, USGS.

Sullivan Creek: stream, on Seward Penin., flows NE $7 \mathrm{mi}$. to Kotzebue Sound, $9 \mathrm{mi}$. W of Deering, Kotzebue-Kobuk Low.; 66 $04^{\prime} \mathrm{N}$, $163^{\circ} 04^{\prime} \mathrm{W}$; (map 113). Var. May Creek.

Name used by local prospectors and reported in 1901 by W. C. Mendenhall, USGS.

Sullivan Creek: stream, flows NE to Agiapuk River, about $18 \mathrm{mi}$. NE of Teller, Seward Penin. High.; (map 111).

Prospectors' name reported on a precinct map of Seward Peninsula gold fields by Monroe and Hutchins corrected up to June 1903 by Arthur Gibson. This feature cannot be precisely identified on current maps.

Sullivan Island: island, $7.4 \mathrm{mi}$. long, off $\mathrm{W}$ shore of Lynn Canal, 2.5 mi. SW of Chilkat Is. and $53 \mathrm{mi}$. NW of Juneau, St. Elias Mts.; $58^{\circ} 53^{\prime}$ N, $135^{\circ} 19^{\prime}$ W; (map 11). Var. Schikuk.

Named by Comdr. R. W. Meade, USN, in 1869 for the master of the American Schooner Louisa Downs, which was wrecked on the island in 1867. The name was published by USC\&GS in the 1883 Coast Pilot (p. 196). The Tlingit Indian name for this island is "Schikuk" (Krause, 1885, p. 253)

Sullivan Lake: lake, on Seward Penin., $0.8 \mathrm{mi}$. across, $12 \mathrm{mi}$. W of Deering, Kotzebue-Kobkuk Low.; $66^{\circ} 03^{\prime} \mathrm{N}, 163^{\circ} 09^{\prime} \mathrm{W}$; (map 113).

Local name reported in 1950 by USGS; derived from nearby Sullivan Creek.

Sullivan Mountain: mountain, 2,000 ft., on Gravina I, N of High Mtn., $3.7 \mathrm{mi}$. W of Ketchikan, Alex. Arch.; $55^{\circ} 22^{\prime} 00^{\prime \prime} \mathrm{N}$, $131^{\circ} 47^{\prime} 15^{\prime \prime} \mathrm{W}$; (map 3 ). 
Named in 1886 by USC\&GS

Sullivan Mountain: mountain, 3,900 ft., $3.3 \mathrm{mi}$. SW of mouth of Glacier River on Chilkat Inlet, $29 \mathrm{mi}$. SSW of Skagway, St. Elias Mts.; $59^{\circ} 02^{\prime} 45^{\prime \prime} \mathrm{N}, 135^{\circ} 27^{\prime} 15^{\prime \prime} \mathrm{W}$; (map 45).

Local name obtained by USGS field personnel and published on Federal maps since 1950.

Sullivan Point: point of land, on $\mathrm{W}$ coast of Admiralty I., $1 \mathrm{mi}$. $\mathrm{E}$ of Angoon, Alex. Arch.; $57^{\circ} 29^{\prime} 50^{\prime \prime} \mathrm{N}, 134^{\circ} 33^{\prime} 30^{\prime \prime} \mathrm{W}$; (map 9).

Named in 1895 by Lt. Comdr. E. K. Moore, USN.

Sullivan Rock: rock, off W shore of Lynn Canal, $0.2 \mathrm{mi}$. S of Sullivan I. and $52 \mathrm{mi}$. NW of Juneau, St. Elias Mts.; $58^{\circ} 53^{\prime} 50^{\prime \prime} \mathrm{N}, 1^{\circ} 5^{\circ}$ $18^{\prime} 00^{\prime \prime} \mathrm{W}$; (map 11).

Named in 1869 by the U.S. Navy Hydrog. Office and published by USC\&GS in the 1883 Coast Pilot (p. 196).

Sullivans Roadhouse: locality, right bank of Delta Creek, $15 \mathrm{mi}$. SW of Big Delta, Tanana Low.; 64 $03^{\prime} \mathrm{N}, 146^{\circ} 21^{\prime} \mathrm{W}$; (map 101).

Name of a former roadhouse; reported in 1910 by USGS (Capps, 1912, pl. 1).

Suloia, Lake: lake, $2 \mathrm{mi}$. long, on $\mathrm{S}$ coast of Chichagof I., $3 \mathrm{mi}$. NE of Salisbury Sound and $28 \mathrm{mi}$. NW of Sitka, Alex. Arch.; $57^{\circ} 25^{\prime} \mathrm{N}$, $135^{\circ} 42^{\prime}$ W; BGN 1923; (map 9).

Named in 1923 by USFS for nearby Suloia Bay.

Suloia Bay: bight, $1 \mathrm{mi}$. across, at $\mathrm{W}$ end of Peril Strait, on SW coast of Chichagof I., 25 mi. SE of Chichagof, Alex. Arch.; 57 $24^{\prime} \mathrm{N}$, $135^{\circ} 39^{\prime}$ W; (map 9). Var. Sulovoy Bay, Zaliv Suloya.

Published in 1848 on Russian Hydrog. Dept. Chart 1397 as "Zal[iv] Suloya," meaning "porridge bay." It was called "Sulovoy," meaning "ripple," by George Kostrometinoff, U.S. court interpreter at Sitka.

Suloia Island: island, see Suloia Islet.

Suloia Islet: island, $200 \mathrm{ft}$. across, in Suloia Bay, at $\mathrm{W}$ end of Peril Strait, $25 \mathrm{mi}$. SE of Chi-

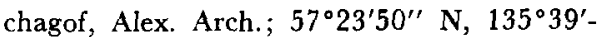
$25^{\prime \prime} \mathrm{W}$; (map 9). Var. Suloia Island.

Named in 1884 by Comdr. J. B. Coghlan, USN; published by USC\&GS on Chart 727. The name was derived from Suloia Bay.

Suloia Point: point of land, $\mathrm{S}$ point of entrance to Suloia Bay, at $W$ end of Peril Strait, on SW coast of Chichagof I., $25 \mathrm{mi}$. SE of Chichagof, Alex. Arch.; $57^{\circ} 24^{\prime} \mathrm{N}, 135^{\circ} 39^{\prime} \mathrm{W}$; (map 9). Var. Mys Suloya.

Published in 1848 on Russian Hydrog. Dept. Chart 1397 as "M[ys] Suloya".

Suloia Rock: rock, in Suloia Bay, at $\mathrm{W}$ end of Peril Strait, $25 \mathrm{mi}$. SE of Chichagof, Alex. Arch.; $57^{\circ} 24^{\prime} 00^{\prime \prime}$ N, $135^{\circ} 39^{\prime} 20^{\prime \prime}$ W ; (map 9).

Named in 1884 by Comdr. J. B. Coghlan, USN, and published by USC\&GS on Chart 727. The name was derived from Suloia Bay.

Suloktingirak: mountain, 1,150 ft., $2 \mathrm{mi}$. $\mathbf{S}$ of Sapumik Creek and $30 \mathrm{mi}$. NE of Kivalina, Brooks Ra.; $68^{\circ} 08^{\prime} \mathrm{N}, 163^{\circ} 58^{\prime} \mathrm{W}$; (map 130). Var. Sooloktingirack.

Eskimo name reported in 1966 by E. S. Burch.
Sulovoy Bay: bight, see Suloia Bay.

Suloya, Mys: point of land, see Suloia Point.

Suloya, Zaliv: bight, see Suloia Bay.

Sulphide Gulch: canyon, $2.5 \mathrm{mi}$. long, extends SW from Washbowl Basin, $5 \mathrm{mi}$. SE of Valdez, Chugach Mts. ; $61^{\circ} 02^{\prime} 30^{\prime \prime} \mathrm{N}, 146^{\circ} 10^{\prime} 00^{\prime \prime} \mathrm{W}$; (map 68).

Local name published in the 1950's by USGS.

Sulphur Creek: stream, on Alaska Penin., flows NW $3.3 \mathrm{mi}$. to Porcupine Creek $0.8 \mathrm{mi}$. SW of its junc. with Becharof Creek, $54 \mathrm{mi}$. NW of Karluk, Aleutian Ra.; $57^{\circ} 42^{\prime} 45^{\prime \prime} \mathrm{N}, 155^{\circ}$ 54'10" W; (map 35). Var. Porcupine Creek.

Local name obtained from J. L. McPherson of Iliamna; published by G. C. Martin (1921, pl. 10), USGS.

Sulphur Creek: stream, formed by junc. of Alfield and Monte Cristo Creeks, flows SW 1 $\mathrm{mi}$. to Nome River, $22 \mathrm{mi}$. NE of Nome, Seward Penin. High.; $64^{\circ} 48^{\prime} \mathrm{N}, 165^{\circ} 13^{\prime} \mathrm{W}$; (map 94).

Prospectors' name reported in 1900 by E. C. Barnard (in Brooks, 1901, pl. 17), USGS.

Sulphur Point: point of land, on $\mathrm{W}$ coast of Great Sitkin I., Aleutian Is.; $52^{\circ} 04^{\prime} 30^{\prime \prime} \mathrm{N}$, $176^{\circ} 00^{\prime} 30^{\prime \prime} \mathrm{W}$; BGN 1936; (map 17).

So named by members of the U.S. Navy Aleutian Island Survey Expedition in 1934, "because there is a sulphur spring not far from this point."

Sultana: peak, see Foraker, Mount.

Sulua Bay: bay, $1 \mathrm{mi}$. across, part of Portage Bay, at head of Alitak Bay, at $\mathbf{S}$ end of Kodiak I.; $57^{\circ} 00^{\prime} \mathrm{N}, 153^{\circ} 51^{\prime} \mathrm{W}$; BGN 1934; (map 33 ).

Named in 1934 by USC\&GS, "from the Eskimo word meaning 'cabin', there being several cabins on both shores of the bay."

Suluak Creek: stream, heads in lake, flows SW $17 \mathrm{mi}$. to Easter Creek $6.3 \mathrm{mi}$. SE of its junc. with Killik River, Brooks Ra.; 68 ${ }^{\circ} 05^{\prime} \mathrm{N}$, $153^{\circ} 59^{\prime} \mathrm{W}$; (map 133).

Eskimo name meaning "hawk feather," reported in 1956 by Orth.

Sulu Creek: stream, see Benson Creek.

Sulugiak Creek: stream, flows E $4.5 \mathrm{mi}$. from lake, joins Agiagiak Creek to form Okokmilaga River, Brooks Ra.; $68^{\circ} 07^{\prime} \mathrm{N}, 153^{\circ} 08^{\prime}$ W ; (map 133).

Eskimo name obtained in 1956 at Anaktuvuk Pass by T. E. Taylor, USGS.

Sulukna River: stream, heads in Sischu Mts., flows N $31 \mathrm{mi}$. to Nowitna River, $27 \mathrm{mi}$. SE of Monzonite Hills, Kilbuck-Kuskokwim Mts.; $64^{\circ} 07^{\prime} \mathrm{N}, 154^{\circ} 03^{\prime} \mathrm{W}$; (map 98).

Local name reported in 1915 by $H$. M. Eakin (in Brooks and others, 1916, pl. 10), USGS.

Sulukpuk Creek: stream, flows NE 5 mi. to Paint River, $2 \mathrm{mi}$. W of Akjemguiga Cove, $34 \mathrm{mi}$. SW of Augustine I., Aleutian Ra.; $59^{\circ} 09^{\prime} 30^{\prime \prime}$ $\mathrm{N}, 154^{\circ} 17^{\prime} 30^{\prime \prime} \mathrm{W}$; (map 51).

Local name published on a 1926 USGS map.

Sulungatak Ridge: ridge, $3,000 \mathrm{ft}$., extends $\mathbf{E}-\mathbf{W}$ $7 \mathrm{mi}$., on De Long Mts., $37 \mathrm{mi}$. NW of Misheguk Mtn., Brooks Ra.; $68^{\circ} 41^{\prime} \mathrm{N}, 161^{\circ} 54^{\prime} \mathrm{W}$; (map 131).
Eskimo name published by USGS in 1962. Sulupoagaklak Channel: stream, see Sulupoagaktak Channel.

Sulupoagaktak Channel: stream, distributary of Kukpuk River, flows NW 7.5 mi. to Marryat Inlet, $10 \mathrm{mi}$. NE of village of Point Hope, Arctic Slope; $68^{\circ} 24^{\prime} 15^{\prime \prime} \mathrm{N}, 166^{\circ} 25^{\prime} 20^{\prime \prime} \mathrm{W}$; (map 129). Var. Soo-loo-poa-gak-took, Sooloopoagaktuk Channel, Sulupoagaklak Channel.

Eskimo name reported in 1950 by USC\&GS to mean "it abounds with grayling"; ; spelled "Soo-loo-poa-gak-took."

Sulutak Creek: stream, flows E $4 \mathrm{mi}$. to Quigmy River, $37 \mathrm{mi}$. NE of Goodnews, KilbuckKuskokwim Mts.; $59^{\circ} 11^{\prime} \mathrm{N}, 160^{\circ} 36^{\prime} \mathrm{W}$; (map 53).

Eskimo name reported to mean "gold" because gold was once found here; obtained at Goodnews about 1951 by J. M. Hoare, USGS.

Sulven Creek: stream, flows NW $3 \mathrm{mi}$. to Willow Creek which flows to Port Clarence, $3 \mathrm{mi}$. S of Teller, Seward Penin. High.; $65^{\circ} 13^{\prime} \mathrm{N}$, $166^{\circ} 22^{\prime} \mathrm{W}$; (map 111).

Prospectors' name reported on the 1908 "Map of Seward Peninsula" by Arthur Gibson.

Sulzer: locality, on Prince of Wales I., near head of Hetta Inlet, on $\mathbf{N}$ shore of Sulzer Passage, Alex. Arch.; $55^{\circ} 17^{\prime} 20^{\prime \prime}$ N, 132 $37^{\prime} 15^{\prime \prime}$ W; $B G N$ 1966; (map 4).

Site of a mining camp settled about 1900 . The post office established in 1901 was discontinued in 1933 (Ricks, 1965, p. 3).

Sulzer, Mount: peak, $10,926 \mathrm{ft}$., $6.5 \mathrm{mi}$ SE of Russell Glacier terminus and $45 \mathrm{mi}$. NE of McCarthy, St. Elias Mts.; $61^{\circ} 37^{\prime} 30^{\prime \prime} \mathrm{N}$, $141^{\circ} 36^{\prime} 30^{\prime \prime} \mathrm{W}$; (map 67).

Local name obtained by USGS and published on maps since 1954.

Sulzer Passage: water passage, $1.5 \mathrm{mi}$. long, between Hetta Inlet and Portage Bay, on Prince of Wales I., $24 \mathrm{mi}$. SE of Craig, Alex. Arch.; $55^{\circ} 17^{\prime} 15^{\prime \prime} \mathrm{N}, 132^{\circ} 36^{\prime} 15^{\prime \prime} \mathrm{W}$; (map 4).

Named in 1908 by USC\&GS; derived from village of Sulzer.

Sumatra Greek: stream, flows NW 2 mi. to Portage Creek, in American River basin, $22 \mathrm{mi}$. SE of Ear Mtn. and $41 \mathrm{mi}$. NE of Teller, Seward Penin. High.; $6^{\circ} 45^{\prime} \mathrm{N}, 165^{\circ} 36^{\prime} \mathrm{W}$; (map 111). Var. Samatra Creek, Summit Creek.

Prospectors' name reported on the 1908 "Map of Seward Peninsula" by Arthur Gibson. Sumdum: locality, pop. 42 (1890), at head of Sanford Cove on $S$ shore of Endicott Arm, $8 \mathrm{mi}$. SE of Harbor I. and $55 \mathrm{mi}$. SE of Juneau, Coast Mts.; $57^{\circ} 40^{\prime} 30^{\prime \prime}$ N, $133^{\circ} 28^{\prime}$ 45" W; (map 8). Var. Samdan, Slaodāń, Soundun, Sundowns.

Former mining town named for Sumdum Glacier; Sumdum post office was intermittently maintained here from 1897 to 1942 (Ricks, 1965, p. 62). This may be the same Sumdum which Hodge (1910, p. 649), BAE, listed as a Tlingit Indian village located at Port Houghton. He noted the population in 1868 as 150 
Sumdum, Mount: mountain, 6,666 ft., $7 \mathrm{mi}$. SE Snettisham Penin., and $50 \mathrm{mi}$. SE of Juneau, Coast Mts.: $57^{\circ} 48^{\prime} 25^{\prime \prime} \mathrm{N}, 133^{\circ} 26^{\prime} 05^{\prime \prime} \mathrm{W}$; (map 8).

Named for Sumdum Glacier on its southcrn flank and published in 1895 by USC\&GS. Sum Dum: bay, see Holkham Bay.

Sum Dum Glacier: glacier, see Sumdum Glacier. Sumdum Glacier: glacier, heads on S slope of Mount Sumdum, trends SW $3 \mathrm{mi}$. to Powers Creek, $6 \mathrm{mi}$. E of Harbor I. and $50 \mathrm{mi}$. SE of Juneau, Coast Mts. ; $57^{\circ} 46^{\prime} 25^{\prime \prime} \mathrm{N}, 133^{\circ} 28^{\prime} 35^{\prime \prime}$ W; (map 8). Var. Soundon Glacier, Sum Dum Glacier.

Tlingit Indian name reportedly representing the booming sound of the icebergs as they break off from the glacier; published in 1892 by USC\&GS as "Soundon."

Sumdum Island: island, $1.5 \mathrm{mi}$. long, in Endicott Arm, $8 \mathrm{mi}$. SE of Harbor I. and $54 \mathrm{mi}$. SE of Juneau, Coast Mts.; $57^{\circ} 42^{\prime} 15^{\prime \prime} \mathrm{N}, 133^{\circ}$ $27^{\prime} 30^{\prime \prime}$ W; BGN 1900; (map 8). Var. Fox Island, Sand Island, Soundon Island.

Tlingit Indian name published as "Soundon" in 1869 by U.S. Navy Hydrog. Office; the island was called "Sumdum Island" by USC\&GS in the 1883 Coast Pilot (p. 168). Locally, it was known as "Fox Island" because of a fox ranch there.

Summer Bay: bay, $1.7 \mathrm{mi}$. across, E shore of Unalaska Bay, NE coast of Unalaska I., Aleutian Is.; $53^{\circ} 54^{\prime} 45^{\prime \prime} \mathrm{N}, 166^{\circ} 27^{\prime} 30^{\prime \prime} \mathrm{W}$; (map 23). Var. Imagninskoe, Indian Bay

Local name reported by W. H. Dall, USC\&GS, in 1871. Father Veniaminov (1840, v. 1, p. 184) called it "Imagninskoe." It was reported as "Indian Bay" by G. Davidson, USC\&GS, in 1869.

Summer Cove: bight, $0.5 \mathrm{mi}$. across, $\mathrm{W}$ of Vega Point, on S coast of Kiska I., Aleutian Is.; $51^{\circ} 49^{\prime} 50^{\prime \prime} \mathrm{N}, 177^{\circ} 19^{\prime} 00^{\prime \prime} \mathrm{E}$; (map 14).

One of many arbitrary names applied to features on Kiska I. by USAAF for tactical purposes during World War II.

Summer Creek: stream, flows NW $5 \mathrm{mi}$. to Norton Sound, $5.5 \mathrm{mi}$. S of Unalakleet, Nulato Hills; $63^{\circ} 47^{\prime} 30^{\prime \prime} \mathrm{N}, 160^{\circ} 45^{\prime} 30^{\prime \prime} \mathrm{W}$; (map 91).

Local name reported in 1952 by USC\&GS. Summer Slough: watercourse, $5 \mathrm{mi}$. long, channel of Yukon River $\mathrm{N}$ of Paimiut I. and 18 mi. SW of Holy Cross, Innoko Low.; 61 ${ }^{\circ} 58^{\prime}$ $15^{\prime \prime} \mathrm{N}, 160^{\circ} 06^{\prime} 30^{\prime \prime} \mathrm{W}$; (map 73). Var. Paimiut Slough.

Steamboat pilots' name shown on a 1922 manuscript chart of the Yukon River.

Summit: locality, on divide between headwaters of Joseph Creek and Goodpaster River, $75 \mathrm{mi}$. SW of Eagle, Yukon-Tanana High.; 64 $30^{\prime}$ $\mathrm{N}, 143^{\circ} 30^{\prime} \mathrm{W}$; (map 102).

Name of telegraph station cstablished in 1903 by U.S. Army Signal Corps.

Summit: locality, along Seward Penin. RR., at NE base of Anvil Mtn., $5 \mathrm{mi}$. NE of Nome, Seward Penin. High.; $64^{\circ} 35^{\prime} \mathrm{N}, 165^{\circ} 21^{\prime} \mathrm{W}$; (map 94). Var. Summit Station.

Site of a mining camp and RR. station shown as "Summit Station" on the 1903 Cam- pion Mining and Trading Co. map by George M. Ashford.

Summit: village, pop. 39 , mi. 312.5 on The Alaska RR., SW of Mirror Lake, $37 \mathrm{mi}$. S of Healy, Alaska Ra.; $63^{\circ} 19^{\prime} 45^{\prime \prime} \mathrm{N}, 149^{\circ} 07^{\prime} 10^{\prime \prime}$ W; (map 87). Var. Summit Broad Pass Station, Summit Lake.

This place began as a railroad camp, first called "Summit Lake" on a 1919 manuscript location map of the railroad.

Summit, The: point of land, in Rocky Pass in Keku Strait, on SW coast of Kupreanof I., 23 mi. N of Point Baker, Alex. Arch.; 56 $41^{\prime} 00^{\prime \prime}$ N, $133^{\circ} 43^{\prime} 30^{\prime \prime} \mathrm{W}$; (map 6).

Local name published in 1943 by USC\&GS. Summit Broad Pass Station: village and $R R$. station, see Summit.

Summit Creek: stream, flows $\mathrm{E} 4 \mathrm{mi}$. to Isirku River, $7.5 \mathrm{mi}$. SW of Klukwan and $28 \mathrm{mi}$. SW of Skagway, St. Elias Mts.; $59^{\circ} 20^{\prime} 15^{\prime \prime} \mathrm{N}$, $136^{\circ} 04^{\prime} 40^{\prime \prime} \mathrm{W}$; (map 45).

Prospectors' name reported by $\mathrm{C}$. W. Wright (1904, pl. 2), USGS.

Summit Creek: stream, on Kenai Penin., flows NE $4 \mathrm{mi}$. to Resurrection River, $20 \mathrm{mi}$. NW of Seward, Chugach Mts.; $60^{\circ} 19^{\prime} 05^{\prime \prime} \mathrm{N}$, $149^{\circ} 48^{\prime} 00^{\prime \prime} \mathrm{W}$; (map 63).

Local name reported in 1912 by Grant and Higgins (1913, pl. 1), USGS.

Summit Creek: stream, on Kenai Penin., flows SE $5 \mathrm{mi}$, to Quartz Creek, S of Gilpatricks, $32 \mathrm{mi}$. N of Seward, Chugach Mts. ; $60^{\circ} 35^{\prime} 45^{\prime \prime}$ N, $149^{\circ} 32^{\prime} 45^{\prime \prime} \mathrm{W}$; (map 63).

Local name reported in 1898 by USGS (1899, map 6).

Summit Creek: stream, flows $\mathrm{S} 8 \mathrm{mi}$. to Mulchatna River, $50 \mathrm{mi}$. NW of Nondalton, Lime Hills; $60^{\circ} 42^{\prime} 30^{\prime \prime} \mathrm{N}, 155^{\circ} 13^{\prime} 00^{\prime \prime} \mathrm{W}$; (map 61).

Local name reported in 1954 by USGS.

Summit Creek: stream, flows W $18 \mathrm{mi}$. to Mulchatna River, $60 \mathrm{mi}$. NE of Nondalton, Alaska Ra.; $60^{\circ} 49^{\prime} 15^{\prime \prime} \mathrm{N}, 154^{\circ} 24^{\prime} 30^{\prime \prime} \mathrm{W}$; (map 61).

Local name reported in 1914 by P. S. Smith and R. H. Sargent, USGS.

Summit Creek: stream, flows SE $4 \mathrm{mi}$. to Kahiltna River, $\mathbf{S}$ of junc. of Cache Creek, 34 mi. W of Talkeetna, Alaska Ra. ; 62 $20^{\prime} 25^{\prime \prime} \mathrm{N}$, $151^{\circ} 09^{\prime} 15^{\prime \prime} \mathrm{W}$; (map 81).

Local descriptive name reported in 1958 by USGS.

Summit Creek: stream, flows E $3 \mathrm{mi}$. to Boulder Creek $3.6 \mathrm{mi}$. S. of that stream's junc. with Eisenmenger Fork and $54 \mathrm{mi}$. ENE of Big Delta, Yukon-Tanana High.; 64 $23^{\circ} \mathrm{N}, 144^{\circ}$ 06' W; (map 101).

Local name published in 1956 by USGS.

Summit Creek: stream, flows NE $2.7 \mathrm{mi}$. to Eldorado River, $21 \mathrm{mi}$. NE of Nome, Seward Penin. High.; $64^{\circ} 45^{\prime} \mathrm{N}, 164^{\circ} 59^{\prime} \mathrm{W}$; (map 95).

Prospectors' name reported in 1900 by E. C. Barnard (in Brooks, 1901, pl. 17), USGS.

Summit Creek: stream, flows NW 1 mi. to French Creek which flows to North Fork Kougarok Creek, $4 \mathrm{mi}$. SE of Harris Dome and $33 \mathrm{mi}$. W of Imuruk Lake, Seward Penin. High.; $65^{\circ} 36^{\prime} \mathrm{N}, 164^{\circ} 25^{\prime} \mathrm{W}$; (map 110$)$.
Prospectors' name shown on a map of Cape Nome gold fields by David Fox, Jr., dated 1901.

Summit Creek: stream, see Sumatra Creek.

Summit Creek: stream, see Surprise Creek.

Summit Glacier: glacier, trends NE $6 \mathrm{mi}$. to Shakes Glacier, $25 \mathrm{mi}$. E of Petersburg, Coast Mts.; $56^{\circ} 50^{\prime} \mathrm{N}, 132^{\circ} 13^{\prime} \mathrm{W}$; (map 6).

So named in 1887 by Lt. Comdr. C. M. Thomas, USN, "because of its high elevation."

Summit Island: island, $0.2 \mathrm{mi}$. long, in Dry Strait at mouth of Stikine River, off $\mathrm{E}$ coast of Mitkof I., Alex. Arch.; 56 $36^{\prime} \mathrm{N}, 132^{\circ} 32^{\prime}$ W; (map 6).

Local name recorded in 1948 by USGS.

Summit Island: island, $0.6 \mathrm{mi}$. long, in Rocky Pass of Keku Strait between Kuiu and Kupreanof Is., $22 \mathrm{mi}$. N of Point Baker, Alex. Arch.; $56^{\circ} 40^{\prime} 30^{\prime \prime} \mathrm{N}, 133^{\circ} 43^{\prime} 30^{\prime \prime} \mathrm{W}$; (map 6).

Descriptive name given for charting purposes by USC\&GS in 1932 Coast Pilot (p. 258).

Summit Island: island, $2.5 \mathrm{mi}$. long, $3 \mathrm{mi}$. S of Rocky Point and $17 \mathrm{mi}$. NE of Hagemeister I., Kilbuck-Kuskokwim Mts. ; $58^{\circ} 50^{\prime} \mathrm{N}, 160^{\circ} 12^{\prime}$ W; (map 39).

Local descriptive name published in 1943 by USC\&GS on Chart 8802.

Summit Lake: lake, on Prince of Wales I., E of Hetta Inlet, at head of Reynolds Creek, Alex. Arch.; 55 $14^{\prime} \mathrm{N}, 132^{\circ} 32^{\prime} \mathrm{W}$; (map 4). Var. Lake Simmons.

Name reported in 1908 by C. W. Wright (in Brooks and others, 1909, pl. 3), USGS. "So called because it is located at an elevation of 1300 feet." This feature was called "Lake Simmons" by E. F. Dickins, USC\&GS, in 1905.

Summit Lake: lake, 1,500 ft. long, in Kanatak Pass, on E coast of Alaska Penin., $50 \mathrm{mi}$. E of Ugashik, Aleutian Ra.; 57 $35^{\prime} 15^{\prime \prime} \mathrm{N}, 156^{\circ}$ $03^{\prime} 45^{\prime \prime} \mathrm{W}$; (map 36).

Name reported in 1902 by J. L. McPherson of Iliamna; published by G. C. Martin (1921, pl. 10), USGS.

Summit Lake: lake, $0.8 \mathrm{mi}$. long, most easterly of Summit Lakes, on Phipps Penin., $2.8 \mathrm{mi}$. SW of Yakutat, Malaspina Coastal Plain; $59^{\circ}$ $30^{\prime} 30^{\prime \prime} \mathrm{N}, 139^{\circ} 45^{\prime} 30^{\prime \prime} \mathrm{W}$; (map 46).

Local name published in 1964 (de Laguna and others, map 4).

Summit Lake: lake, $5.5 \mathrm{mi}$. long, source of White Pass Fork, $\mathrm{S}$ of White Pass on Alaska-Canada boundary, $13 \mathrm{mi}$. NE of Skagway, Coast Mts.; $59^{\circ} 37^{\prime} 15^{\prime \prime} \mathrm{N}, 135^{\circ} 08^{\prime} 05^{\prime \prime} \mathrm{W}$; (map 45).

Local descriptive name reported in 1917 by the Canadian Permanent Committee on Geographical Names.

Summit Lake: lake, $1.5 \mathrm{mi}$. long, on Kenai Penin., along Canyon Creek, $34 \mathrm{mi}$. N of Seward, Chugach Mts.; $60^{\circ} 37^{\prime} 45^{\prime \prime} \mathrm{N}, 149^{\circ}$ $30^{\prime} 30^{\prime \prime} \mathrm{W}$; (map 63).

Local name reported in 1912 by Grant and Higgins (1913, pl. 1), USGS. Name derived from nearby Summit Creek.

Summit Lake: lake, $2 \mathrm{mi}$. long, at head of Tlikakila River, SW of Lake Clark Pass, 50 
mi. NW of Kenai, Aleutian Ra.; $60^{\circ} 47^{\prime} 30^{\prime \prime}$ $\mathrm{N}, 152^{\circ} 47^{\prime} 30^{\prime \prime} \mathrm{W}$; (map 62).

Local name reported in 1958 by USGS.

Summit Lake: lake, $2.4 \mathrm{mi}$. long, $2.3 \mathrm{mi}$. SE of Falls Creek, $69 \mathrm{mi}$. NE of Valdez, Chugach Mts. ; $61^{\circ} 18^{\prime} 25^{\prime \prime} \mathrm{N}, 144^{\circ} 09^{\prime} 25^{\prime \prime} \mathrm{W}$; (map 68).

Descriptive name given in 1900 by F. C. Schrader and A. C. Spencer, USGS.

Summit Lake: lake, 6,000 ft. across, $1.2 \mathrm{mi}$. NE of junc. of Upper Willow and Willow Creeks, $13 \mathrm{mi}$. NW of Palmer, Talkeetna Mts.; $61^{\circ}$ $46^{\prime} \mathrm{N}, 149^{\circ} 19^{\prime} \mathrm{W}$; (map 69).

Local name reported in 1942 by AMS.

Summit Lake: lake, $0.4 \mathrm{mi}$. long, in Chulitna Pass, at head of Pass Creek, $39 \mathrm{mi}$. SW of Cantwell, Talkeetna Mts.; 62 ${ }^{\circ} 54^{\prime} 15^{\prime \prime} \mathrm{N}$, $149^{\circ} 36^{\prime} 30^{\prime \prime} \mathrm{W}$; ( $\left.\operatorname{map} 82\right)$.

Local descriptive name reported in 1931 by USGS.

Summit Lake: lake, $7 \mathrm{mi}$. long, W of Richardson Highway, $3 \mathrm{mi}$. NW of Paxson, Alaska Ra.; $63^{\circ} 07^{\prime} 45^{\prime \prime} \mathrm{N}, 145^{\circ} 31^{\prime} 40^{\prime \prime} \mathrm{W}$; (map 86)

Local name reported in 1900 by T. G. Gerdine, USGS. So named because of its location near the pass between the Delta and Gulkana Rivers.

Summit Lake: village and $R R$. station, see Summit.

Summit Lake: lake, see Edes Lake.

Summit Lake: lake, see Tutna Lake.

Summit Lakes: lakes, two, largest $1 \mathrm{mi}$. long, on SW coast of Phipps Penin., $2.6 \mathrm{mi}$. SW of Yakutat, Malaspina Coastal Plain ; 59 $30^{\prime} 50^{\prime \prime}$ N, $139^{\circ} 46^{\prime} 20^{\prime \prime} \mathrm{W}$; (map 46).

Local name published by USGS in 1959; shown as Aka Lake and Summit Lake in 1964 (de Laguna and others, map 4).

Summit Lakes: lakes, on Chinkelves Creek, 2.5 mi. NW of Iliamna Bay and $26 \mathrm{mi}$. NW of Augustine I., Aleutian Ra.; 59 42'15' N, $153^{\circ} 40^{\prime} 30^{\prime \prime} \mathrm{W}$; (map 51).

Name published by USGS in 1958.

Summit Mountain: mountain, 5,300 ft., between Milk and Raven Glaciers, $29 \mathrm{mi}$. SE of Anchorage, Chugach Mts.; $61^{\circ} 03^{\prime} 25^{\prime \prime} \mathrm{N}, 149^{\circ} 04^{\prime}$ $30^{\prime \prime} \mathrm{W}$; BGN 1932 ; (map 69).

Local descriptive name reported in 1932 by USGS.

Summit Peak: mountain peak, see Townsend Peak.

Summit Roadhouse : locality, see Gleary Summit Lodge.

Summit Station: locality, sec Divide.

Summit Station: locality, see Summit.

Sumner Creek: stream, flows SW $2.5 \mathrm{mi}$. to Nome Creek, $10 \mathrm{mi}$. E of Table Top Mtn. and 50 mi. NE of Fairbanks, Yukon-Tanana High.; $65^{\circ} 21^{\prime} 10^{\prime \prime} \mathrm{N}, 146^{\circ} 37^{\prime} 50^{\prime \prime} \mathrm{W}$; (map 104).

Prospectors' name reported in 1954 or 1955 by USGS topographers.

Sumner Glacier: glacier, see Turner Glacier.

Sumner Island: island, $1.5 \mathrm{mi}$. long, in Sumner Strait, between Kuiu, Kupreanof, and Prince of Wales Is., Alex. Arch., $56^{\circ} 24^{\prime} 30^{\prime \prime}$ N, $133^{\circ}$ $48^{\prime} 30^{\prime \prime} \mathrm{W}$; (map 6).
Named in 1886 by Lt. J. M. Helm, USN, for charting purposes; name published in 1887 on USC\&GS Chart 706.

Sumner Mountains: mountains, 2,690 ft., $5 \mathrm{mi}$. long, on SW coast of Mitkof I., $18 \mathrm{mi}$. S. of Petersburg, Alex. Arch.; $56^{\circ} 33^{\prime}$ N, $132^{\circ} 53^{\prime}$ W; (map 6).

Named in 1887 by Lt. Comdr. C. M. Thomas, USN, for charting purposes; published in 1888 on USC\&GS Chart 705.

Sumner Peninsula: peninsula, see Seward Peninsula.

Sumner Strait: water passage, $10 \mathrm{mi}$. wide, extends $\mathrm{N}$ and $\mathrm{E} 80 \mathrm{mi}$. from Iphigenia Bay, around $\mathrm{N}$ end of Prince of Wales I., Alex. Arch.; $55^{\circ} 53^{\prime} \mathrm{N}, 133^{\circ} 59^{\prime} \mathrm{W}$ to $56^{\circ} 31^{\prime} \mathrm{N}$, $132^{\circ} 35^{\prime} \mathrm{W}$; (map 4$)$.

Named in 1875 by W. H. Dall, USC\&GS, for Charles Sumner, 1811-1874, Senator from Massachusetts from 1851 to 1874 .

Sumner Strait: water passage, heads at mouth of Stikine River at $\mathbf{S}$ end of Mitkof Is., extends $W$ and $S 80 \mathrm{mi}$. to Gulf of Alaska, between Kuiu and Kupreanof Is. on NW and Prince of Wales and Zarembo Is. on SE, Alex. Arch.; $56^{\circ} 32^{\prime} \mathrm{N}, 132^{\circ} 36^{\prime} \mathrm{W}$ [NE end], $55^{\circ} 50^{\prime} \mathrm{N}$, $134^{\circ} 05^{\prime} \mathrm{W}$ [SW end]; (map 6).

Named in 1875 by W. H. Dall, USC\&GS, for the Honorable Charles Sumner, 1811-74, U.S. Senator from Massachusetts from 1851 to 1874 . See Alaska, state of.

Sunaghun Creek: stream, heads in Canada, flows SE $13 \mathrm{mi}$. to Porcupine River, $3.5 \mathrm{mi}$. N of Canalaska Mtn. and $54 \mathrm{mi}$. ENE of Coleen Mtn., Brooks Ra.; $67^{\circ} 25^{\prime} \mathrm{N}, 141^{\circ} 00^{\prime} \mathrm{W}$; $B G N$ 1959; (map 121). Var. Old Woman Creek, Sunagun Creek.

Kutcha-kutchin Indian name reported by IBC in 1914 (sheet 9, 1918 atlas) and, according to $\mathrm{O}$. W. Geist, Univ. of Alaska, means "old woman." The creek was so called because "an old native woman at Rampart House couldn't climb the steep river banks for wood, so she used this creek as route to obtain firewood, hence, Old Woman Creek."

Sunagun Creek: stream, see Sunaghun Creek.

Sunbeam: area, in S Anchorage, $1.5 \mathrm{mi}$. SSW of City Hall, Cook Inlet Low.; 61 ${ }^{\circ} 11^{\prime} 50^{\prime \prime} \mathrm{N}$, $149^{\circ} 54^{\prime} 00^{\prime \prime} \mathrm{W}$; (map 69)

Residential district in city of Anchorage reported in 1954 by office of city engineer of Anchorage.

Sunbeam Creek: stream, flows $\mathrm{S}$ to Camp Creek which flows to Sinuk River, about $35 \mathrm{mi}$. NE of Nome, Seward Penin. High.; (map 94).

Prospectors' name reported on the 1900 "Map of Nome Peninsula" by J. M. Davidson and B. D. Blakeslee; this feature has not been positively identified

Sunby Creek: stream, heads on King Mtn., flows E $1.5 \mathrm{mi}$. to Nome River, $8 \mathrm{mi}$. NNE of Nome, Seward Penin. High.; $64^{\circ} 36^{\prime} \mathrm{N}, 165^{\circ} 17^{\prime} \mathrm{W}$; (map 94). Var. Sundby Creek.

Prospector's name published on the 1900 "Map of Nome Peninsula" by J. M. Davidson and B. D. Blakeslee.

Sunday Bay: cove, see Sunday Harbor.
Sunday Creek: stream, flows SE $7 \mathrm{mi}$. to Rocky Cove, $11 \mathrm{mi}$. NW of Augustine I., Aleutian Ra. ; $59^{\circ} 26^{\prime} 50^{\prime \prime} \mathrm{N}, 153^{\circ} 44^{\prime} 20^{\prime \prime} \mathrm{W}$; BGN 1916; (map 51).

Name published in 1913 on USC\&GS Chart 3420 .

Sunday Creek: stream, flows SW $4 \mathrm{mi}$. to Savage River, $20 \mathrm{mi}$. SW of Healy, Alaska Ra.; $63^{\circ}$ -

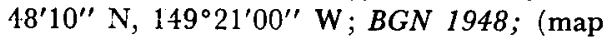
$87)$.

Local name reported in 1947 by USGS.

Sunday Creek: stream, flows W $6.4 \mathrm{mi}$. to Savage River, $15 \mathrm{mi}$. NW of Healy, Alaska Ra.; $63^{\circ} 54^{\prime} 30^{\prime \prime} \mathrm{N}, 149^{\circ} 26^{\prime} 20^{\prime \prime} \mathrm{W}$; (map 87). Var. Fish Creek.

Local name reported in 1951 by USGS.

Sunday Creek: stream, flows SE $6.5 \mathrm{mi}$. to Poorman Creek, $2 \mathrm{mi}$. W of Poorman and $45 \mathrm{mi}$. SW of Ruby, Kilbuck-Kuskokwim Mts.; $64^{\circ} 06^{\prime} 36^{\prime \prime} \mathrm{N}, 155^{\circ} 36^{\prime} 55^{\prime} \mathrm{W}$; (map 98).

Prospectors' name reported in 1913 by Eakin (1914, pl. 3), USGS.

Sunday Creek: stream, flows SW to Anikovik River, about $15 \mathrm{mi}$. SE of Cape Prince of Wales, Seward Penin. High.; (map 111).

Prospectors' name shown on the 1900 "Map of Nome Peninsula" by J. M. Davidson and B. D. Blakeslee. This feature cannot be precisely identified on current maps.

Sunday Creek: stream, flows NW to Belt Creek which flows to Kuzitrin River, about $6 \mathrm{mi}$. NW of Mount Bendeleben, Seward Penin. High.; (map 110).

Prospectors' name shown on a map of Cape Nome gold fields by David Fox, Jr., dated 1901. This stream cannot be precisely located on current maps.

Sunday Creek: stream, flows E to Flambeau River, about $20 \mathrm{mi}$. NE of Nome, Seward Penin. High.; (map 94).

Prospectors' name reported on the 1900 "Map of Nome Peninsula" by J. M. Davidson and B. D. Blakeslee; this feature has not been positively identified

Sunday Creek: stream, see Fish Creek.

Sunday Gulch: stream, flows SW $0.6 \mathrm{mi}$. to Chititu Creek, $14 \mathrm{mi}$. SE of McCarthy, St. Elias Mts.; $61^{\circ} 18^{\prime} \mathrm{N}, 142^{\circ} 36^{\prime} \mathrm{W}$; (map 67).

Local name used by prospectors; reported by George M. Easterly of Valdez on his 1902 map of the Nizina Mining District; and used by USGS (Mendenhall and Schrader, 1903, fig. 5).

Sunday Harbor: cove, $1.5 \mathrm{mi}$. long, on E side of Port Dick, Kenai Penin., $28 \mathrm{mi}$. SE of Seldovia, Chugach Mts.; $59^{\circ} 16^{\prime} \mathrm{N}, 151^{\circ} 00^{\prime} \mathrm{W}$ $B G N$ 1908; (map 50). Var. Sunday Bay.

Local name recorded by USGS in 1908.

Sunday Harbor: cove, see Takoma Cove.

Sunday Rapids: rapids, in Killik River, $8.5 \mathrm{mi}$. NE of Lake Udrivik, Brooks Ra.; $68^{\circ} 37^{\prime} \mathrm{N}$, 1534' W; BGN 1960; (map 133).

So named by USGS geologists during exploration of Naval Petroleum Reserve No. 4, because a "Field party swamped several boats in going through the rapids on Sunday, June 3, 1945."

Sundby Creek: stream, see Sunby Creek. 
Sunde Creek: stream, heads on Bean Ridge, flows NE $4.5 \mathrm{mi}$. to Baker Creek, $44 \mathrm{mi}$. ESE of Tanana, Yukon-Tanana High.; $65^{\circ} 05^{\prime} 20^{\prime \prime} \mathrm{N}$, $150^{\circ} 34^{\prime} 00^{\prime \prime} \mathrm{W}$; (map 106).

Local name reported in 1952 by USGS.

Sundi Lake: lake, 1,100 ft. long, $5.5 \mathrm{mi}$. SW of Anchorage, between Jewel and Sand Lakes, Cook Inlet Low.; $61^{\circ} 08^{\prime} 25^{\prime \prime} \mathrm{N}, 149^{\circ} 57^{\prime} 59^{\prime \prime}$ W; (map 69).

Local name reported in 1952 by USGS.

Sundown Lake: lake, $1.8 \mathrm{mi}$. long, between Big and Round Lakes $20 \mathrm{mi}$. SW of Beaver, Yukon Flats; $66^{\circ} 10^{\prime} 30^{\prime \prime} \mathrm{N}, 147^{\circ} 58^{\prime} 00^{\prime \prime} \mathrm{W}$; (map 118).

Local name obtained in 1956 by USGS.

Sundown Lake: lake, $1.4 \mathrm{mi}$. long, in course of Meadow Creek $21 \mathrm{mi}$. W of Beaver, Yukon Flats; $66^{\circ} 20^{\prime} 40^{\prime \prime} \mathrm{N}, 148^{\circ} 11^{\prime} 00^{\prime \prime} \mathrm{W}$; (map 118).

Local name obtained in 1956 by USGS.

Sundowns: locality, see Sumdum.

Sundstrom Island: island, $1.2 \mathrm{mi}$. long, off SW tip of Aiaktalik 1., $4 \mathrm{mi}$. S of Kodiak I.; $56^{\circ} 41^{\prime} 20^{\prime \prime} \mathrm{N}, 154^{\circ} 08^{\prime} 30^{\prime \prime} \mathrm{W}$; $B G N$ 1931; (map 32). Var. Little Aiktalik Island, Wart Island.

Named in 1906 by Capt. Hodgkins, USC\&GS, for Quartermaster Gustaf L. Sundstrom, USC\&GS, a crewmember of the USC\&GS steamer Patterson, "who lost his life on June 29, 1906, by drowning, in the performance of his official duties * * *."

Sunflower Basin: basin, $5 \mathrm{mi}$. long, near head of Sunflower Creek, $50 \mathrm{mi}$. NW of Talkeetna, Alaska Ra.; $62^{\circ} 29^{\prime} 25^{\prime \prime} \mathrm{N}, 151^{\circ} 37^{\prime} 40^{\prime \prime} \mathrm{W}$; (map 81).

Local name reported in 1958 by USGS.

Sunflower Creek: stream, heads in Stern Gulch, flows SE $25 \mathrm{mi}$. through Sunflower Basin, to Lake Creek, $38 \mathrm{mi}$. W of Talkeetna, Alaska Ra.; $62^{\circ} 22^{\prime} 00^{\prime \prime} \mathrm{N}, 151^{\circ} 17^{\prime} 40^{\prime \prime} \mathrm{W}$; (map 81).

Prospectors' name reported in 1906 by $R$. W. Porter, USGS.

Sungokruak Creek: stream, see Kolipsun Creek.

Sungooraq Lake: lake, see Sungovoak.

Sungovoak, Lake: lake, $9 \mathrm{mi}$. long, $11 \mathrm{mi}$. SE of Barrow, Arctic Plain; $71^{\circ} 05^{\prime} 40^{\prime \prime} \mathrm{N}, 156^{\circ}$ $30^{\prime} 00^{\prime \prime}$ W; (map 153). Var. Sungooraq Lake, Sunguruak Lake.

Eskimo name recorded by USC\&GS as "Sunguruak" about 1950. The name means "bridge of the nose" and refers to the $4 \mathrm{mi}$. long penin. extending into the lake.

Sunguruak Lake: lake, see Sungovoak.

Sunik: locality, on Aggatu I., Aleutian Is.; $52^{\circ} 26^{\prime} \mathrm{N}, 173^{\circ} 36^{\prime} \mathrm{E}$; (map 13 ).

Former Aleut village or camp listed by Hodge (1910, p. 652), BAE.

Sūnkā' kāt: locality, see Soonkakat.

Sunken Island Lake: lake, $1.1 \mathrm{mi}$. long, on Kenai Penin. E of Donkey Lake, $6 \mathrm{mi}$. NW of Sterling and $12 \mathrm{mi}$. NE of Kenai, Cook Inlet Low. ; $60^{\circ} 35^{\prime} 30^{\prime \prime} \mathrm{N}, 150^{\circ} 53^{\prime} 00^{\prime \prime} \mathrm{W}$; (map 62).

Named about 1963 by officials of Kenai National Moose Range, for administrative purposes.

Sunken Lake: lake, $0.6 \mathrm{mi}$. long, $2 \mathrm{mi}$. SE of Sweeny Lake and $17 \mathrm{mi}$. SW of Beaver, Yukon
Flats; $66^{\circ} 07^{\prime} 30^{\prime \prime} \mathrm{N}, 147^{\circ} 39^{\prime} 40^{\prime \prime} \mathrm{W}$; (map 118).

Probably named by William Yanert who showed it on a 1916 manuscript map of the Yukon Flats (Stuck, 1917, map facing p. 122).

Sun Lake: lake, $0.4 \mathrm{mi}$. across, NW of Tetlin, $19 \mathrm{mi}$. SE of Tok, Alaska Ra.; $63^{\circ} 08^{\prime} 40^{\prime \prime} \mathrm{N}$, $142^{\circ} 32^{\prime} 00^{\prime \prime} \mathrm{W}$; (map 85).

Local name published by USGS in 1965.

Sun Mountain: mountain, 2,193 ft., at southern end of Isahultila Mts., $\mathrm{N}$ of Koyukuk River and $24 \mathrm{mi}$. N of Hochandochtla Mtn., Kokrines-Hodzana High.; $65^{\circ} 52^{\prime} 30^{\prime \prime}$ N, $154^{\circ} 45^{\prime}$ $00^{\prime \prime} \mathrm{W}$; (map 107).

Local name obtained in 1954 by USGS topographers.

Sunny Bay: bay, $2 \mathrm{mi}$ across, off Seward Passage on NW coast of Cleveland Penin., Alex. Arch.; $55^{\circ} 59^{\prime} \mathrm{N}, 132^{\circ} 00^{\prime} \mathrm{W}$; (map 3 ).

Named in 1924 by USC\&GS.

Sunny Cove: estuary, extends NW $1.5 \mathrm{mi}$. off Cholmondeley Sound, on E coast of Prince of Wales I., Alex. Arch.; $55^{\circ} 15^{\prime} \mathrm{N}, 132^{\circ} 15^{\prime} \mathrm{W}$; (map 4).

Local name reported in 1901 by $\mathrm{A}$. $\mathrm{H}$. Brooks, USGS.

Sunny Cove: cove, extends N $0.2 \mathrm{mi}$., off Narrow Strait, on $S$ coast of Spruce I., NE of Kodiak I.; $57^{\circ} 54^{\prime} 10^{\prime \prime} \mathrm{N}, 152^{\circ} 25^{\prime} 35^{\prime \prime} \mathrm{W}$; (map $34)$.

Local name published in 1943 by USC\&GS.

Sunny Cove: cove, $0.6 \mathrm{mi}$. across, on $\mathrm{W}$ shore of Taku Inlet, $3.5 \mathrm{mi}$. SW of Flat Point and $10 \mathrm{mi}$. E of Juneau, Coast Mts. ; 58 $18^{\prime} 15^{\prime \prime}$ $\mathrm{N}, 134^{\circ} 08^{\prime} 00^{\prime \prime} \mathrm{W}$; (map 11).

Name used by local navigators and reported in 1900 by Lt. Comdr. J. F. Moser, USN.

Sunny Cove: cove, $1 \mathrm{mi}$. wide, on Renard I., 15 mi. SE of Seward, Chugach Mts.; 59 $54^{\prime} 45^{\prime \prime}$ N, $149^{\circ} 21^{\prime} 10^{\prime \prime}$ W; BGN 1908; (map 49).

Sunny Creek: stream, flows E $2.5 \mathrm{mi}$. to Sunny Cove, on $\mathrm{E}$ coast of Prince of Wales I., 37 mi. SE of Craig, Alex. Arch.; 55 ${ }^{\circ} 15^{\prime} 55^{\prime \prime} \mathrm{N}$, $132^{\circ} 16^{\prime} 55^{\prime \prime} \mathrm{W}$; (map 4).

Local name published in 1943 by USC\&GS.

Sunny Gulch: ravine, trends N $1.5 \mathrm{mi}$. to Timberline Creek, $67 \mathrm{mi}$. SE of Healy, Alaska Ra.; $63^{\circ} 11^{\prime} \mathrm{N}, 147^{\circ} 24^{\prime} \mathrm{W}$; (map 87).

Local descriptive name obtained in 1951 by USGS.

Sunny Hay Mountain: mountain, 2,920 ft., 2.5 mi. SE of Craig, on $W$ coast of Prince of Wales I., Alex. Arch.; $55^{\circ} 27^{\prime} 45^{\prime \prime} \mathrm{N}, 133^{\circ}$ $04^{\prime} 45^{\prime \prime}$ W; (map 4).

Local name recorded in 1951 by USGS.

Sunny Peak: mountain peak, 3,980 ft., $1.5 \mathrm{mi}$. $\mathrm{SE}$ of Mount Carter and $49 \mathrm{mi}$. NE of Valdez, Chugach Mts.; $61^{\circ} 46^{\prime} 45^{\prime \prime}$ N, $145^{\circ} 42^{\prime} 20^{\prime \prime}$ W; (map 68).

Named in 1898 by Capt. W. R. Abercrombie, USA.

Sunny Point: point of land, $\mathrm{N}$ point of entrance to West Arm Cholmondeley Sound, at mouth of Sunny Creek, on SE coast of Prince of Wales I., Alex. Arch.; $55^{\circ} 15^{\prime} \mathrm{N}, 132^{\circ} 16^{\prime} \mathrm{W}$; (map 4).
Local name reported in 1901 by A. H. Brooks, USGS.

Sunny Point: point of land, on $\mathbf{N}$ shore of Gastineau Ghannel, $1 \mathrm{mi}$. E of Juneau Airport and $5.5 \mathrm{mi}$. NE of Juneau, Coast Mts.; $58^{\circ} 21^{\prime} 15^{\prime \prime} \mathrm{N}, 134^{\circ} 31^{\prime} 30^{\prime \prime} \mathrm{W}$; (map 11).

Local name which came into use in the 1930's (DeArmond, 1957, p. 42).

Sunnyside: locality, on Chichagof I., $1.7 \mathrm{mi}$. NW of Pelican and $24 \mathrm{mi}$. N of Chichagof, Alex. Arch.; 57 $59^{\prime} \mathrm{N}, 136^{\circ} 15^{\prime} \mathrm{W}$; (map 9).

Name of a former mining camp reported in 1903 by A. C. Spencer and C. W. Wright, USGS.

Sunnyside Creek: stream, flows NE $0.8 \mathrm{mi}$. to Niukluk River, $6 \mathrm{mi}$. NW of Council and 30 mi. NE of Solomon, Seward Penin. High. ; $64^{\circ}$. $55^{\prime} \mathrm{N}, 163^{\circ} 52^{\prime} \mathrm{W}$; (map 95).

Prospectors' name reported on a 1902 prospectors' manuscript map.

Sunrise: village, on $\mathrm{N}$ end of Kenai Penin., at mouth of Sixmile Creek, $7 \mathrm{mi}$. SE of Hope and $52 \mathrm{mi}$. N of Seward, Chugach Mts. ; $60^{\circ}-$ $53^{\prime} 30^{\prime \prime} \mathrm{N}, 149^{\circ} 25^{\prime} 30^{\prime} \mathrm{W}$; (map 63). Var. Sunrise City, Sunrise Station.

Mining town founded about 1895 and called Sunrise City; reported in 1898 by USGS (1899, map 6). A post office was established here in 1899 but was discontinued in 1918 (Ricks, 1965, p. 62). Present-day maps indicate Sunrise as a site with three or four buildings.

Sunrise Basin: valley, see Middle Basin.

Sunrise City: village, see Sunrise.

Sunrise Creek: stream, on $\mathrm{N}$ end of Kenai Penin., flows NE $2.5 \mathrm{mi}$. to Turnagain Arm, $0.5 \mathrm{mi}$. NW of Sunrise and $52 \mathrm{mi}$. N of Seward, Chugach Mts.; $60^{\circ} 54^{\prime} 20^{\prime \prime} \mathrm{N}, 149^{\circ} 26^{\prime} 15^{\prime \prime}$ W; (map 63).

Local name reported about 1914 by B. L. Johnson (in Martin and others, pl. 2), USGS. Name derived from nearby mining town.

Sunrise Creek: stream, in Mount McKinley National Park, flows NW $2.9 \mathrm{mi}$. from Sunrise Glacier terminus to Thorofare River, $2.5 \mathrm{mi}$. SSE of Eielson Visitor Center, Alaska Ra.; $63^{\circ} 24^{\prime} 00^{\prime \prime} \mathrm{N}, 150^{\circ} 16^{\prime} 40^{\prime \prime} \mathrm{W}$; BGN 1932; (map 88).

Local name reported in 1932 by J. C. Reed, Sr., and S. N. Stoner, USGS.

Sunrise Creek: stream, flows SW $12.3 \mathrm{mi}$. to Susulatna River, $51 \mathrm{mi}$. NW of Medfra, Kilbuck-Kuskokwim Mts. ; $63^{\circ} 50^{\prime} \mathrm{N}, 155^{\circ} 02^{\prime}$ W; (map 89).

Local name obtained in 1924 by J. S. Brown (in Smith and others, 1926, pl. 5), USGS.

Sunrise Creek: stream, flows NW $1 \mathrm{mi}$. to Fox River between Slate and Windy Creeks, 22 mi. NE of Solomon, Seward Penin. High.; $64^{\circ} 45^{\prime} 10^{\prime \prime} \mathrm{N}, 163^{\circ} 50^{\prime} 30^{\prime \prime} \mathrm{W}$; (map 95). Var. Sunrise Creek.

Prospectors' name reported on a map of Cape Nome gold fields by David Fox, Jr., dated 1901.

Sunrise Creek: stream, flows NE $3.5 \mathrm{mi}$. to Bonanza River, $16 \mathrm{mi}$. NW of Solomon, Seward Penin. High.; $64^{\circ} 45^{\prime} \mathrm{N}, 164^{\circ} 45^{\prime} \mathrm{W}$; (map 95). 
Prospectors' name reported on the 1900 "Map of Nome Peninsula" by J. M. Davidson and B. D. Blakeslee.

Sunrise Creek: stream, flows NE $5 \mathrm{mi}$. to Agiapuk River, $16 \mathrm{mi}$. NE of Teller, Seward Penin. High,; $65^{\circ} 27^{\prime} \mathrm{N}, 166^{\circ} 04^{\prime} \mathrm{W}$; (map 111).

Prospectors' name reported in 1901 by T. G. Gerdine (in Collier, 1902, pl. 12), USGS.

Sunrise Glacier: glacier, in Mount McKinley National Park, trends NW $2 \mathrm{mi}$. to its 1954 terminus at head of Sunrise Creek, $5 \mathrm{mi}$. SE of Eielson Visitor Center, Alaska Ra.; $63^{\circ} 22^{\prime} 45^{\prime \prime} \mathrm{N}, 150^{\circ} 11^{\prime} 40^{\prime \prime}$ W; BGN 1932; (map 88).

Local name reported in 1932 by J. C. Reed, Sr., and S. N. Stoner, USGS.

Sunrise Gulch: ravine, extends $\mathrm{S} 2 \mathrm{mi}$. to Hammond River, $3 \mathrm{mi}$. E of Vermont Dome and $9 \mathrm{mi}$. N of Wiseman, Brooks Ra.; $67^{\circ} 32^{\prime} 20^{\prime \prime}$ N, $150^{\circ} 05^{\prime} 30^{\prime \prime} \mathrm{W}$; (map 124).

Local name obtained in 1956 by USGS topographers.

Sunrise Hill : hill, see Rose Hill

Sunrise Lake: lake, $0.4 \mathrm{mi}$. long, on Woronokofski I., Alex. Arch.; $56^{\circ} 24^{\prime} 40^{\prime \prime} \mathrm{N}, 132^{\circ} 29^{\prime} 10^{\prime \prime}$ W; BGN 1917; (map 6).

Named in 1916 by USC\&GS.

Sunrise Lake: lake, $0.6 \mathrm{mi}$. long, on Kenai Penin. NE of Grus Lake, $27 \mathrm{mi}$. NE of Kenai, Cook Inlet Low.; $60^{\circ} 47^{\prime} 15^{\prime \prime} \mathrm{N}, 150^{\circ} 38^{\prime} 45^{\prime \prime}$ W; (map 62).

Named about 1963 by officials of Kenai National Moose Range, for administrative purposes.

Sunrise Peak: mountain, 2,750 ft., on Woronkofski I., Alex. Arch.; $56^{\circ} 24^{\prime} 40^{\prime \prime} \mathrm{N}, 132^{\circ} 28^{\prime} 40^{\prime \prime}$ W; BGN 1917; (map 6). Var. Adams Peak.

Named in 1916 by USC\&GS; named "Adams Peak" in 1886 by Lt. Comdr. A. S. Snow, USN, for U.S.S. Adams.

Sunrise Station: locality, see Johnson.

Sunrise Station: village, see Sunrise.

Sun Rocks: rocks, off-shore group, extends 0.3 mi., in Clarence Strait, S of Rip Point, on SE coast of Prince of Wales I., Alex. Arch.; $55^{\circ} 02^{\prime} 05^{\prime \prime} \mathrm{N}, 131^{\circ} 58^{\prime} 30^{\prime \prime} \mathrm{W}$; (map 3 ).

Local name published in 1912 by USC\&GS.

Sunset: locality, on left bank of Sunset Creek, 7 mi. NW of Nome, Seward Penin. High.; $64^{\circ}$ $34^{\prime} \mathrm{N}, 165^{\circ} 34^{\prime} \mathrm{W}$; (map 94).

Site of a mining camp; published in 1956 by USGS.

Sunset Cove: cove, $0.5 \mathrm{mi}$. across, on $\mathrm{E}$ shore of Stephens Passage, $2 \mathrm{mi}$. SE of Sunset I. and 75 mi. NE of Sitka, Coast Mts. ; $57^{\circ} 29^{\prime} 00^{\prime \prime} \mathrm{N}$, $133^{\circ} 31^{\prime} 15^{\prime \prime} \mathrm{W}$; (map 8).

Named for Sunset Island and published in 1948 by USGS.

Sunset Creek: stream, $2 \mathrm{mi}$. long, flows NE to Mountain Creek, $9.5 \mathrm{mi}$. NW of Heart Lake and $76 \mathrm{mi}$. SE of Bethel, Kilbuck-Kuskokwim Mts. ; $60^{\circ} 11^{\prime} \mathrm{N}, 159^{\circ} 54^{\prime} \mathrm{W}$; (map 59)

Local name reported in 1955 by J. M. Hoare, USGS.

Sunset Creek: stream, on N end of Kenai Penin., flows $\mathrm{N} 2 \mathrm{mi}$. to Turnagain Arm, $2 \mathrm{mi}$. NW of Sunrise and $52 \mathrm{mi}$. N of Seward, Chugach Mts. ; $60^{\circ} 55^{\prime} 05^{\prime \prime} \mathrm{N}, 149^{\circ} 28^{\prime} 15^{\prime \prime} \mathrm{W}$; (map 63).
Local prospectors' name; reported in 1898 by W. C. Mendenhall, USGS.

Sunset Creek: stream, heads on Takotna Mtn., flows N $3.2 \mathrm{mi}$. to Takotna River, $1.2 \mathrm{mi}$. E of Takotna and $3 \mathrm{mi}$. W of McGrath, Kilbuck-Kuskokwim Mts.; $62^{\circ} 59^{\prime} 10^{\prime \prime} \mathrm{N}, 156^{\circ}-$ 01'30" W; (map 79).

Prospectors' name reported in 1923 by J. B. Mertie and G. L. Harrington, USGS.

Sunset Creek: stream, flows NW $9.4 \mathrm{mi}$. to South Fork Sulatna River, $11 \mathrm{mi}$. SE of Poorman and $33 \mathrm{mi}$. SW of Monzonite Hills, KilbuckKuskokwim Mts. ; $64^{\circ} 01^{\prime} \mathrm{N}, 155^{\circ} 13^{\prime} \mathrm{W}$; (map 98).

Prospectors' name published, but misapplied in 1921 , by USGS.

Sunset Creek: stream, flows SE $5.8 \mathrm{mi}$. to Snake River, $4 \mathrm{mi}$. NW of Nome, Seward Penin. High.; 64 $32^{\prime}$ N, $165^{\circ} 33^{\prime}$ W; (map 94). Var. Shepard Creek.

Prospectors' name reported in 1900 by E. C. Barnard (in Brooks, 1901, pl. 17), USGS Reported in 1899 as "Shepard Creek" by D. C. Witherspoon (in Schrader and Brooks, 1900, map 2), USGS.

Sunset Creek: stream, flows NE $3 \mathrm{mi}$. to Gold Run which flows to Bluestone River, $15 \mathrm{mi}$. S of Teller, Seward Penin. High.; 65 $5^{\circ} 02^{\prime} \mathrm{N}$, $166^{\circ} 17^{\prime} \mathrm{W}$; (map 111).

Local name reported in 1900 by E. C. Barnard (in Brooks, 1901, pl. 17), USGS.

Sunset Creek: stream, heads on Gold Mtn., flows S $8 \mathrm{mi}$. to Yukon River opposite Youngs I., $20 \mathrm{mi}$. WSW of Kallands, Kokrines-Hodzana High.; $65^{\circ} 04^{\prime} 20^{\prime \prime} \mathrm{N}, 153^{\circ} 44^{\prime} 00^{\prime \prime} \mathrm{W}$; (map 107).

Local name obtained in 1952 by USGS topographers.

Sunset Creek: stream, heads SW of Eva Mtn., flows SW 6 mi. to Grantley Harbor, $4 \mathrm{mi}$. NE of Teller, Seward Penin. High.; $65^{\circ} 18^{\prime} \mathrm{N}$, $166^{\circ} 17^{\prime} \mathrm{W}$; (map 111).

Local name reported in 1900 by E. C. Barnard (in Brooks, 1901, pl. 17), USGS.

Sunset Creek: stream, flows SE $2.3 \mathrm{mi}$. to Harris Creek which flows to North Fork Kougarok River, NW of Harris Dome and $40 \mathrm{mi}$. NW of Imuruk Lake, Seward Penin. High.; 65 $38^{\circ}$ N, $164^{\circ} 34^{\prime} \mathrm{W}$; (map 110).

Prospectors' name reported on the 1908 "Map of Seward Peninsula" by Arthur Gibson.

Sunset Creek: stream, flows E to Agiapuk River, about $15 \mathrm{mi}$. NW of Teller, Seward Penin. High.; (map 111).

Prospectors' name shown on a 1901 map of Cape Nome gold fields by David Fox, Jr. This feature cannot be precisely identified on current maps.

Sunset Glacier: glacier, in Mount McKinley National Park, trends NW 5 mi. from Scott Peak to its 1954 terminus at head of Thorofare River, Alaska Ra.; $63^{\circ} 22^{\prime} 00^{\prime \prime} \mathrm{N}, 150^{\circ} 14^{\prime} 30^{\prime \prime}$ W; BGN 1932; (map 88).

Named by USGS in 1932. "This name was suggested as being appropriate in view of the fact that sunrise is the name of the glacier on the west fork [east fork] of the Thorofare River" [Sunrise Creek].

Sunset Island: island, $0.7 \mathrm{mi}$. across, in Stephens Passage, $4 \mathrm{mi}$. S of Point Windham and 64 mi. SE of Juneau, Coast Mts.; $57^{\circ} 30^{\prime} 00^{\prime \prime} \mathrm{N}$, $133^{\circ} 34^{\prime} 45^{\prime \prime} \mathrm{W}$; (map 8).

Named by Comdr. R. W. Meade, USN; published in 1869 by U.S. Navy Hydrog. Office.

Sunset Pass: pass, 2,000 ft., in Sadlerochit Mts., at head of Itkilyariak Creek, $22 \mathrm{mi}$. NW of Mount Michelson, Brooks Ra.; 69 $35^{\prime} \mathrm{N}$, $144^{\circ} 45^{\prime} \mathrm{W}$; BGN 1961; (map 139).

Probably named by $\mathrm{S}$. J. Marsh, prospector, who in 1903 wrote, "At Sunset Pass, a low gap through the Franklin Mountains, leading from the head of Ooselik [Itkilyariak] Creek to the head of Barter [Sadlerochit] River * * " (Brooks, 1906, p. 261).

Sunset Peak: mountain, 3,040 ft., on Woronkofski I., $8 \mathrm{mi}$. SW of Wrangell, Alex. Arch.; $56^{\circ} 22^{\prime}$ N, $132^{\circ} 31^{\prime}$ W; BGN 1917; (map 6). Var. Idaho Peak.

Named in 1916 by USC\&GS; named "Idaho Peak" in 1886 by Lt. Comdr. A. S. Snow, USN, for the steamship Idaho.

Sunset Peak: peak, 7,865 ft., in Mount McKinley National Park, $8.5 \mathrm{mi}$. SSE of Eielson Visitor Center, Alaska Ra.; $63^{\circ} 10^{\prime} \mathrm{N}, 150^{\circ} 12^{\prime} \mathrm{W}$; BGN 1932; (map 88).

Named in 1932 by USGS "for the glacier." Sunshine: locality, pop. 4, mi. 215.3 on The Alaska RR., $10 \mathrm{mi}$. S of Talkeetna, Cook Inlet Low.; $62^{\circ} 10^{\prime} 00^{\prime \prime} \mathrm{N}, 150^{\circ} 04^{\prime} 20^{\prime \prime} \mathrm{W}$; (map 81).

Name listed as a flag stop on the railroad. Sunshine Bay: bay, $2.5 \mathrm{mi}$. across, on left side of Kwikluak Pass, $5 \mathrm{mi}$. SE of Kwiguik, YukonKuskokwim Delta ; $62^{\circ} 41^{\prime} 30^{\prime \prime} \mathrm{N}, 164^{\circ} 21^{\prime} 00^{\prime \prime}$ W; (map 77).

Local name obtained in 1948 by USC\&GS. The water here is very shallow, and the land may in time be above normal water level owing to deposition.

Sunshine Creek: stream, flows $1.1 \mathrm{mi}$. SW to Surprise Creek N of Skyscraper Peak, $18 \mathrm{mi}$. W of Mount Blackburn, Wrangell Mts.; $61^{\circ}$ $44^{\prime} 00^{\prime \prime} \mathrm{N}, 143^{\circ} 48^{\prime} 30^{\prime \prime} \mathrm{W}$; (map 67).

Local name obtained by USGS and published on maps since 1954.

Sunshine Creek: stream, heads in largest of Sunshine Lakes, flows W $2.6 \mathrm{mi}$. to Susitna River, $10 \mathrm{mi}$. S of Talkeetna, Cook Inlet Low.; $62^{\circ}$. $10^{\prime} 33^{\prime \prime} \mathrm{N}, 150^{\circ} 07^{\prime} 35^{\prime \prime} \mathrm{W}$; (map 81).

Prospectors' name reported in 1906 by T. G. Gerdine and R. H. Sargent, USGS.

Sunshine Creek: stream, flows S $1 \mathrm{mi}$. to Canyon Creek which flows to Casadepaga River, $21 \mathrm{mi}$. NE of Solomon, Seward Penin. High.; 64 $51^{\circ}$ N, $164^{\circ} 22^{\prime} \mathrm{W}$; (map 95).

Prospectors' name reported on a map of Cape Nome gold fields by David Fox, Jr., dated 1901.

Sunshine Creek: stream, flows SW $1.3 \mathrm{mi}$. to Quartz Creek in Casadepaga River basin, 24 mi. N of Solomon, Seward Penin. High.; $64^{\circ}$ $55^{\prime} \mathrm{N}, 164^{\circ} 20^{\prime} \mathrm{W}$; (map 95). 
Prospectors' name reported in 1907 by USGS geologists (Smith, P. S., 1910, pl. 4). Sunshine Creek: stream, see Montana Creek.

Sunshine Island: island, $0.2 \mathrm{mi}$. across, in Vixen Inlet, off $W$ coast of Cleveland Penin., $47 \mathrm{mi}$. NE of Craig, Alex. Arch.; 55 $49^{\prime} 05^{\prime \prime} \mathrm{N}, 132^{\circ}$ $05^{\prime} 05^{\prime \prime} \mathrm{W}$; (map 4).

Named in 1915 by E. Lester Jones, USC\&GS.

Sunshine Lakes: lakes, at head of Sunshine Creek, $9 \mathrm{mi}$. S of Talkeetna, Cook Inlet Low.; $62^{\circ} 11^{\prime} 10^{\prime \prime} \mathrm{N}, 150^{\circ} 02^{\prime} 45^{\prime \prime} \mathrm{W}$; (map 81).

Local name reported in 1958 by USGS.

Sunshine Mountains: mountains, 3,905 ft., trend NW $8 \mathrm{mi}$. from junc. of Nixon Fork and Boulder Creek, $28 \mathrm{mi}$. NE of Medfra, KilbuckKuskokwim Mts. ; $63^{\circ} 29^{\prime} \mathrm{N}, 154^{\circ} 57^{\prime} \mathrm{W}$; (map 89).

Local name reported in 1924 by USGS.

Sunshine Point: hill, on N side of Kaliakh River, 2 mi. below mouth of Kulthieth River and 100 mi. SE of Cordova, St. Elias Mts.; $60^{\circ} 10^{\prime} 30^{\prime \prime}$ $\mathrm{N}, 142^{\circ} 53^{\prime} 00^{\prime \prime} \mathrm{W}$; (map 65).

Local name published in 1951 by USGS.

Sunshine Valley: valley, extends NW $10 \mathrm{mi}$. from $W$ end of Lake Aleknagik, $38 \mathrm{mi}$. NW of Dillingham, Kilbuck-Kuskokwim Mts.; 59 $30^{\prime}$ N, 159 05' W; BGN 1931; (map 53).

Named by Frank Waskey, trader and pros. pector; reported in 1930 by USGS.

Suntaheen Creek: stream, on $\mathbf{N}$ end of Chichagof I., flows S $6 \mathrm{mi}$. to Whitestone Harbor, on Icy Inlet, $30 \mathrm{mi}$. SW of Juneau, Alex. Arch.; $58^{\circ} 03^{\prime} 25 \mathrm{~N}, 135^{\circ} 05^{\prime} 45^{\prime \prime} \mathrm{W}$; BGN 1959; (map 11). Var. Flounder Creek.

Local Tlingit Indian name reported by USGS in 1959 and thought to mean "middle creek." It is also locally known as Flounder Creek.

Suntrana: village, pop. 81 , on right bank of Healy River at Mouth of Suntrana Creek, $3.5 \mathrm{mi}$. E of Healy, Alaska Ra.; 63 $3^{\circ} 51^{\prime} 30^{\prime \prime}$ $\mathrm{N}, 148^{\circ} 50^{\prime} 45^{\prime \prime} \mathrm{W}$; (map 87).

Village and mining camp listed in the 1930 census with a population of 61,78 in 1939 , and 130 in 1950 .

Suntrana Creek: stream, flows S $1.3 \mathrm{mi}$. to Healy Creek, $3.5 \mathrm{mi}$. E of Healy, Alaska Ra.; 63․ $51^{\prime} 30^{\prime \prime} \mathrm{N}, 148^{\circ} 50^{\prime} 45^{\prime \prime} \mathrm{W}$; BGN 1945; (map 87). Var. Coal Creek.

Reported by USGS in 1927 to be an In. dian name meaning "burning hills;" so called because "When it rains, steam rises from the surrounding ground." It is difficult to determine whether this is an indigenous Indian name.

Sunvalluk: locality, on NW shore of Norton Sound, opposite Sledge I., at or near West Point, $20 \mathrm{mi}$. W of Nome, Seward Penin. High.; 64 $34^{\circ} \mathrm{N}, 166^{\prime} 03^{\prime} \mathrm{W}$; (map 94).

Former Eskimo village or camp reported in the 1890 Census (1893, p. 162).

Superior: locality, on Chichagof I., $4 \mathrm{mi}$. E of Tenakee Springs, Alex. Arch.; $57^{\circ} 47^{\prime} \mathrm{N}$, $135^{\circ} 05^{\prime} \mathrm{W}$; (map 9).

Cannery reported to have been in operation prior to 1950.
Supply Creek: stream, heads in Supply Lake, flows S $2.2 \mathrm{mi}$. to Kvichak Bay, $28 \mathrm{mi}$. W of Naknek, Bristol Bay Low. ; $58^{\circ} 42^{\prime} 00^{\prime \prime} \mathrm{N}, 157^{\circ}$ 47'35" W; (map 41).

Local name published in 1958 by USGS.

Supply Lake: lake, $1.5 \mathrm{mi}$. across, on $\mathrm{N}$ shore of Kvichak Bay at head of Supply Creek, 27 mi. W of Naknek, Bristol Bay Low.; $58^{\circ} 44^{\prime}$ N, $157^{\circ} 48^{\prime} \mathrm{W}$; (map 41).

Local name published in 1958 by USGS. Suqq-an: locality, see Sukkwan.

Suquonillá Range: mountains, see Kokrines Hills.

Sure Thing Gulch: ravine, see Surprise Gulch. Surf Bay: bay, $4 \mathrm{mi}$. across, on $\mathrm{SW}$ coast of Akun I., in Krenitzin Is., Aleutian Is.; $54^{\circ}$ $10^{\prime} \mathrm{N}, 165^{\circ} 37^{\prime} \mathrm{W}$; (map 24).

Named in 1901 by J. J. Gilbert, USC\&GS.

Surf Point: point of land, on $\mathrm{S}$ coast of Prince of Wales I., $6 \mathrm{mi}$. W of Cape Chacon, Alex. Arch.; 54 $41^{\prime} 30^{\prime \prime} \mathrm{N}, 132^{\circ} 09^{\prime} 50^{\prime} \mathrm{W}$; (map 1 ).

Local descriptive name published by USC\&GS in 1943.

Surf Point: point of land, NW tip of Heceta I., Alex. Arch.; 55 $50^{\prime} \mathrm{N}, 133^{\circ} 38^{\prime} \mathrm{W}$; (map 4).

Descriptive name given in 1903 or 1904 by E. F. Dickins, USC\&GS, who wrote "named by our party, has no local name."

Surf Rock: rock, in Sitka Sound, $2 \mathrm{mi}$. SW of Sitka, Alex. Arch.; $57^{\circ} 01^{\prime} 55^{\prime \prime} \mathrm{N}, 135^{\circ} 22^{\prime} 30^{\prime \prime}$ W; (map 9). Var. Burun Rocks, Kamen Burun, Polivnoi Rocks.

This is an 1882 translation by USC\&GS of the name given in 1809 by the Russian navigator Ivan Vasiliev the first; reported by Lt. Sarichev (1826, map 19), IRN, as "K[amen] Burun."

Surge Bay: bay, $2.5 \mathrm{mi}$. across, on NW coast of Yakobi I., $5 \mathrm{mi}$. $\mathrm{N}$ of Cape Cross and $41 \mathrm{mi}$. SW of Hoonah, Alex. Arch.; $58^{\circ} 20^{\prime} \mathrm{N}, 136^{\circ}$. $33^{\prime} \mathrm{W}$; (map 10).

Probably named by W. H. Dall, USC\&GS ; published in the 1883 Alaska Coast Pilot (p. 185 ).

Surge Lake: lake, $1.1 \mathrm{mi}$. across, on $\mathrm{W}$ coast of Yakobi I., $1 \mathrm{mi}$. S of Bingham Peak, $40 \mathrm{mi}$. WSW of Hoonah, Alex. Arch.; 58 $00^{\prime} 10^{\prime \prime} \mathrm{N}$, $136^{\circ} 31^{\prime} 30^{\prime \prime} \mathrm{W}$; (map 10).

Local name published by USGS in the 1950 's.

Surgeon Mountain: mountain, 4,397 ft., on Alaska-Canada boundary, $2 \mathrm{mi}$. NE of Pleasant Camp and $35 \mathrm{mi}$. W of Skagway, St. Elias Mts.; $59^{\circ} 27^{\prime} 55^{\prime \prime} \mathrm{N}, 136^{\circ} 18^{\prime} 00^{\prime \prime} \mathrm{W}$; $B G N$ 1952; (map 45). Var. Boundary Peak 144, Yealthanuk Mountain.

Named in 1952 for Samuel Martin Fraser, Surgeon of the Royal Mounted Police, when the international boundary was being surveyed in this area. This is apparently the same mountain reported by E. C. Robertson, USGS, in 1952 as being called "Yealthanuk" by the Tlingit Indians. The word "yealth" reportedly means "raven" and probably refers to the Raven Tribe living nearby.

Surise Creek: stream, Sunrise Creek.

Surku Cove: estuary, $0.7 \mathrm{mi}$. long, on $\mathrm{W}$ coast of Prince of Wales $\mathrm{I}$., $\mathrm{N}$ of Kussan Point, $26 \mathrm{mi}$.
N. of Craig, Alex. Arch.; $55^{\circ} 50^{\prime} 45^{\prime \prime} \mathrm{N}, 1^{\circ}{ }^{\circ}-$ $09^{\prime} 45^{\prime \prime} \mathrm{W}$; (map 4).

Indian name published in 1964 by USC\&GS. Surok Point: point of land, on SE coast of Kenai Penin. at $E$ entrance to Paguna Arm, $53 \mathrm{mi}$. $\mathrm{E}$ of Homer, Chugach Mts.; 59 $37^{\prime} 45^{\prime \prime} \mathrm{N}$, $150^{\circ} 04^{\prime} 00^{\prime \prime} \mathrm{W}$; BGN 1930; (map 50).

Named "Marmot Point" by USC\&GS in 1912 , probably referring to the hoary marmot, but later changed to the Russian equivalent to avoid confusion because of numerous other uses of the word.

Surprise, Lake: lake, $0.8 \mathrm{mi}$. Iong, on NW tip of Kruzof I., $26 \mathrm{mi}$. NW of Sitka, Alex. Arch.; $57^{\circ} 19^{\prime} 30^{\prime \prime} \mathrm{N}, 135^{\circ} 49^{\prime} 30^{\prime \prime} \mathrm{W}$; (map 9).

Probably named in 1929 by USC\&GS.

Surprise, Rock: rocks, see Seal Rocks.

Surprise Bay: bay, $1.5 \mathrm{mi}$. wide, on $\mathrm{E}$ edge of West Arm Nuka Bay, $46 \mathrm{mi}$. $\mathrm{E}$ of Seldovia, Chugach Mts.; $50^{\circ} 29^{\prime}$ N, $150^{\circ} 32^{\prime}$ W; BGN 1929; (map 50). Var. Palisade Bay.

Named by U. S. Grant, USGS, in 1911 (Grant and Higgins, 1913, pl. 2).

Surprise Cove: cove, $0.7 \mathrm{mi}$. across, on NE coast of Kenai Penin., $1 \mathrm{mi}$. S of entrance to Passage Canal and $10 \mathrm{mi}$. SE of Whittier, Chugach Mts.; $60^{\circ} 45^{\prime} 30^{\prime \prime} \mathrm{N}, 148^{\circ} 22^{\prime} 15^{\prime \prime} \mathrm{W}$; $B G N 1911$; (map 63).

Named by U. S. Grant in 1909 and published by Grant and Higgins (1910-11, p. 402), USGS.

Surprise Creek: stream, on Kenai Penin., flows NW $4 \mathrm{mi}$. to Kenai River, $40 \mathrm{mi}$. SE of Kenai, Chugach Mts. ; $60^{\circ} 28^{\prime} 20^{\prime \prime} \mathrm{N}, 150^{\circ} 07^{\prime} 30^{\prime \prime} \mathrm{W}$; (map 62).

Local name reported about 1911 by USGS (Martin, Johnson, and Grant, 1915, pl. 2). Surprise Creek: stream, flows N $2.7 \mathrm{mi}$. to Nevelna Creek, $1.8 \mathrm{mi}$. E of mouth of Willow Creek and $70 \mathrm{mi}$. NE of Valdez, Chugach Mts.; $61^{\circ} 25^{\prime} 10^{\prime \prime} \mathrm{N}, 144^{\circ} 14^{\prime} 15^{\prime \prime} \mathrm{W}$; (map 68).

Local name published by USGS (Moffit, 1914, pl. 1).

Surprise Creek: stream, heads at glacier, flows SE $2.3 \mathrm{mi}$. to Kotsina River, $13 \mathrm{mi}$. W of Mount Blackburn, Wrangell Mts.; $61^{\circ} 44^{\prime} \mathrm{N}$, $143^{\circ} 48^{\prime} \mathrm{W}$; (map 67).

Name used by prospectors; reported in 1900 by T. G. Gerdine (in Brooks and others, 1908, pl. 3), USGS.

Surprise Creek: stream, flows NW $2.4 \mathrm{mi}$. to Wilson Creek, between Davis and Disappoint. ment Creeks, $4.8 \mathrm{mi}$. $\mathrm{E}$ of Marshall, Nulato Hills; 61 $51^{\circ} 40^{\prime \prime} \mathrm{N}, 161^{\circ} 56^{\prime} 15^{\prime \prime} \mathrm{W}$; (map 73).

Prospectors' name reported by Harrington (1918, map), USGS, in 1916.

Surprise Greek: stream, flows SW $1 \mathrm{mi}$. to Roosevelt Lake, $2.5 \mathrm{mi}$. E of Lucky Hill and $72 \mathrm{mi}$. SE of Healy, Alaska Ra.; $63^{\circ} 11^{\prime} \mathrm{N}, 147^{\circ} 09^{\prime}$ W; (map 87).

Local name obtained in 1951 by USGS.

Surprise Greek: stream, flows NW $4 \mathrm{mi}$. to Totatlanika River, $20 \mathrm{mi}$. NE of Healy, Alaska Ra. ; 63 $58^{\circ} 30^{\prime \prime}$ N, $148^{\circ} 24^{\prime} 30^{\prime \prime}$ W; (map 87).

Prospectors' name shown on a 1910 fieldsheet by J. W. Bagley, USGS; published by Capps (1912, pl. 1), USGS. 
Surprise Creek: stream, flows SE $3.5 \mathrm{mi}$. to Topkok River, $1.8 \mathrm{mi}$. NE of Topkok on Norton Sound and $15 \mathrm{mi}$. NE of Solomon, Seward

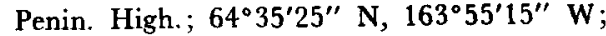
(map 95). Var. Allen Creek.

Prospectors' name reported in 1900 by E. C. Barnard (in Brooks, 1901, pl. 17), USGS.

Surprise Creek: stream, flows NE $2 \mathrm{mi}$. to Big Four Creek which flows to Casadepaga River, $20 \mathrm{mi}$. NE of Solomon, Seward Penin. High.; $64^{\circ} 48^{\prime} \mathrm{N}, 164^{\circ} 04^{\prime} \mathrm{W}$; (map 95). Var. California Creek.

Prospectors' name reported on a map of Cape Nome gold fields by David Fox, Jr., dated 1901.

Surprise Creek: stream, flows NW $5 \mathrm{mi}$. to Washington Creek, $10 \mathrm{mi}$. S of that stream's junc. with Yukon River and $41 \mathrm{mi}$. NE of Eagle, Yukon-Tanana High.; $65^{\circ} 11^{\prime} \mathrm{N}, \mathbf{1 4 2}^{\circ}$ 17' W; (map 103). Var. Butte Creek.

Prospectors' name reported by A. H. Brooks (in Brooks and others, 1907, p. 201), USGS.

Surprise Creek: stream, flows SW $2 \mathrm{mi}$. to Wild Lake, $9.2 \mathrm{mi}$. $\mathrm{N}$ of junc. of Flat Creek and Wild River, Brooks Ra.; 67 $31^{\prime} 15^{\prime \prime} \mathrm{N}, 151^{\circ}$ 32'15" W; (map 124). Var. Summit Creek.

Local name obtained in 1956 by USGS topographers.

Surprise Creek: stream, heads at $68^{\circ} 46^{\prime} \mathrm{N}$, $162^{\circ} 26^{\prime} \mathrm{W}$, flows NW $24 \mathrm{mi}$. to Tupikchak Creek, 46 mi. E of Cape Sabine, Arctic Slope; $68^{\circ} 58^{\prime} 25^{\prime \prime} \mathrm{N}, 162^{\circ} 48^{\prime} 15^{\prime \prime} \mathrm{W}$; BGN 1965; (map 130).

Name proposed in 1965 by geologists of the B. P. Exploration Co., Inc., because of their surprise at finding an unexpected rock sequence along the stream.

Surprise Creek: ravine, see Surprise Gulch.

Surprise Creek: stream, see Allen Creek.

Surprise Glacier: glacier, trends NE $8.5 \mathrm{mi}$. to Surprise Inlet, W of Harriman Fiord, $51 \mathrm{mi}$. $\mathrm{SE}$ of Anchorage, Chugach Mts.; $61^{\circ} 03^{\prime} \mathrm{N}$, $148^{\circ} 25^{\prime}$ W; BGN 1964; (map 69). Var. Roaring Glacier, The Stairway.

Named by members of the Harriman Alaska Expedition in 1899.

Surprise Glacier: glacier, heads at junc. of two branches, trends SW $5.5 \mathrm{mi}$. to its terminus near head of Tonzona River, $4 \mathrm{mi}$. NE of Mystic Pass, Alaska Ra.; $62^{\circ} 41^{\prime} \mathrm{N}, 152^{\circ} 24^{\prime}$ W; (map 81).

Local name reported in 1925 by $\mathbf{S}$. R. Capps (in Moffit, 1927, pl. 3), USGS.

Surprise Gulch: ravine, trends SW $0.8 \mathrm{mi}$. to Osborn Creek, $10 \mathrm{mi}$. NE of Nome, Seward Penin. High.; $64^{\circ} 35^{\prime} 36^{\prime \prime}$ N, $165^{\circ} 06^{\prime} 12^{\prime \prime}$ W; (map 94). Var. Sure Thing Gulch, Surprise Creek.

Reported as "Surprise Cr." on the 1902 "Map of the Nome and Snake River Country" by J. M. Davidson.

Surprise Harbor: bay, $1.4 \mathrm{mi}$. across, on S tip of Admiralty I., $33 \mathrm{mi}$. S of Angoon, Alex. Arch.; $57^{\circ} 01^{\prime} \mathrm{N}, 134^{\circ} 35^{\prime} \mathrm{W}$; (map 9).

Probably named in 1869 by Comdr. R. W. Meade, USN; published on Hydrographic Chart 225. "It owes its name to one of the two tragedies in the area, which resulted from attacks of Indians on whites."

Surprise Inlet: estuary, extends W $2.5 \mathrm{mi}$. off Harriman Inlet, at terminus of Surprise Glacier, $51 \mathrm{mi}$. SE of Anchorage, Chugach Mts.; $61^{\circ} 03^{\prime} \mathrm{N}, 148^{\circ} 21^{\prime} \mathrm{W}$; (map 69).

Local name reported in 1960 by USGS.

Surprise Lake: lake, 2 mi. long, on Alaska Penin., at head of Aniakchak River and in NE part of Aniakchak Crater, $3.5 \mathrm{mi}$. NE of Vent Mtn., Aleutian Ra.; $56^{\circ} 55^{\prime} \mathrm{N}, 158^{\circ} 05^{\prime} \mathrm{W}$; (map 30). Var. Devils Wash Basin.

Named in 1922 by R. H. Sargent, USGS, "to indicate my reaction upon discovering it."

Surprise Point: point of land, on $\mathrm{N}$ coast of island in Nakat Inlet, $1 \mathrm{mi}$. NE of Nakat Bay, Coast Mts.; $54^{\circ} 49^{\prime} 15^{\prime \prime} \mathrm{N}, 130^{\circ} 43^{\prime} 45^{\prime \prime} \mathrm{W}$; (map 2).

Named in 1888 by Lt. Comdr. H. E. Nichols, USN.

Surr Creek: stream, see Sirr Creek.

Surr Mountain: mountain, see Sirr Mountain Survey Cove: bay, $1.2 \mathrm{mi}$. wide, SW coast of Kosciusko I., Alex. Arch.; $55^{\circ} 54^{\prime}$ N, $133^{\circ} 44^{\prime}$ W; (map 4).

Local name recorded in 1951 by USGS.

Survey Creek: stream, flows S $6.5 \mathrm{mi}$. to Survey Cove, on S coast of Kosciusko I., Alex. Arch.; $55^{\circ} 55^{\prime} 40^{\prime \prime} \mathrm{N}, 133^{\circ} 43^{\prime} 30^{\prime \prime} \mathrm{W}$; (map 4).

Local name recorded in 1951 by USGS.

Survey Creek: stream, heads at Survey Pass, flows SE 9 mi. to Unakserak River, Brooks Ra.; $67^{\circ} 46^{\prime} \mathrm{N}, 153^{\circ} 59^{\prime} \mathrm{W}$; BGN 1925; (map 125).

Named by the USGS expedition of 1924 to commemorate the U.S. Geological Survey.

Surveyor Bay: bay, $4 \mathrm{mi}$. across, on SW coast of Unalaska I., Aleutian Is.; $53^{\circ} 16^{\prime} \mathrm{N}, 167^{\circ}$ 34' W ; BGN 1937; (map 23).

Named by USC\&GS in 1937 for the Coast Survey ship Surveyor, which was used for surveys in the vicinity in 1936 .

Surveyor Creek: stream, heads in Canada, flows NW across Alaska-Canada boundary $9 \mathrm{mi}$. to Bull Creek, $50 \mathrm{mi}$. NE of junc. of Charley and Yukon Rivers, Porcupine Plat.; 6558' N, $141^{\circ} 09^{\prime} \mathrm{W}$; (map 103).

Local name published in 1956 by USGS.

Surveyor Passage: water passage, $2 \mathrm{mi}$. long, along NE coast of Herbert Graves I., on W coast of Chichagof $1 ., 3 \mathrm{mi}$. NW of Chichagof, Alex. Arch.; $57^{\circ} 42^{\prime} 20^{\prime \prime} \mathrm{N}, 136^{\circ} 09^{\prime} 20^{\prime \prime} \mathrm{W}$; BGN 1926; ( $\operatorname{map} 9$ ).

Named in 1926 by USC\&GS for the USC\&GS steamer Surveyor, from which the passage was charted in 1925 . This vessel was the first of any large size to navigate this waterway. The name was published on Chart 8280 in 1928.

Survey Pass: pass, 3,300 ft., in Endicott Mts., at head of Survey Creek to the $S$ and April Greek to the N, Brooks Ra.; $67^{\circ} 51^{\prime} \mathrm{N}, 154^{\circ}$ $06^{\prime} \mathrm{W}$; BGN 1925; (map 125).

Named by the USGS expedition of 1924 to commemorate the U.S. Geological Survey. The expedition led by P. S. Smith crossed the Brooks Range at this point.

Survey Point: point of land, $2 \mathrm{mi}$. NE of Raven Point, on shore of Cataract Cove, on W coast of Unimak I., Aleutian Is.; $54^{\circ} 38^{\prime} 37^{\prime \prime} \mathrm{N}$, 16448'12" W; BGN 1942; (map 24). Var. Tundra Point.

Named in 1940 by USC\&GS, presumably for the "Coast Survey."

Survey Point: point of land, on S coast of Annette I., near $E$ entrance to Tamgas Harbor, Alex. Arch.; $55^{\circ} 00^{\prime} 45^{\prime \prime} \mathrm{N}, 1^{\circ} 21^{\circ} 25^{\prime} 15^{\prime \prime} \mathrm{W}$; (map 3).

Named in 1883 by Lt. Comdr. H. E. Nichols, USN, "for the U.S. Coast Survey [now U.S. Coast and Geodetic Survey]."

Survey Point: point of land, at $S$ entrance to Clover Passage, on $W$ coast of Revillagigedo I., Alex. Arch.; $55^{\circ} 28^{\prime} \mathrm{N}, 131^{\circ} 50^{\prime} \mathrm{W}$; (map 3).

Local navigators' name obtained in 1904 by H. C. Fassett, USBF.

Susetna: village, see Susitna.

Sushana River: stream, heads at $63^{\circ} 42^{\prime} \mathrm{N}$, $149^{\circ} 47^{\prime} \mathrm{W}$ and flows NW $40 \mathrm{mi}$. to Toklat River, $12 \mathrm{mi}$. NE of Chitsia Mtn. and $40 \mathrm{mi}$. SW of Nenana, Tanana Low.; 64. $09^{\prime} 30^{\prime \prime} \mathrm{N}$, $149^{\circ} 59^{\prime} 20^{\prime \prime}$ W; (map 100). Var. Knight Creek, Shushana River, Toklat River.

Tanana Indian name reported in 1910 by L. M. Prindle, USGS. The Indian name, "Toklat," was originally reported for it in 1905 by USGS. The stream was called "Knight Creek" from 1916 to 1925, by prospectors, possibly referring to a headwater branch.

Sushetna: village, see Susitna.

Sushetna River: stream, see Susitna River.

Sushetno: village, see Susitna.

Sushetno Mountain: mountain, see Susitna, Mount.

Sushgitit Hills: hills, 2,000 ft., extend E-W 10 mi., $22 \mathrm{mi}$. E of Hughes, Kokrines-Hodzana High.; $66^{\circ} 02^{\prime} \mathrm{N}, 153^{\circ} 15^{\prime} \mathrm{W}$; (map 116).

A broad rendering of an Indian name recorded as "Sushgititgla," meaning "cache hill"; reported in 1956 by Orth.

Sushilna Island: island, $0.3 \mathrm{mi}$. across, off Chichagof I., in Islas Bay, $16 \mathrm{mi}$. NW of Chichagof, Alex. Arch.; 57 $50^{\prime} 00^{\prime \prime} \mathrm{N}, 136^{\circ}$ 22'40" W; (map 9).

Local name derived from the Russian word "suchilna" meaning "drying place;" name reported in 1928 by USC\&GS.

Sushilnoi Island: island, $0.4 \mathrm{mi}$. across, $16 \mathrm{mi}$. E of Deer I., at SW end of Aleutian Ra.; $54^{\circ}$. $53^{\prime} 10^{\prime \prime} \mathrm{N}, 161^{\circ} 51^{\prime} 00^{\prime \prime} \mathrm{W}$; (map 25). Var. Chishelnoi, Ostrov Sushilnyy, Sushitnoi, Sushilnoy.

Name published in 1847 by the Russian Hydrog. Dept. on Chart 1379 as "O[strov] Sushilnyy" meaning "drying-ground island." Sushilnoy: island, see Sushilnoi Island.

Sushilnyy, Ostrov: island, see Sushilnoi Island. Sushitna: village, see Susitna.

Sushitna, Reka: stream, see Susitna River.

Sushitna Mountain: mountain, see Susitna, Mount.

Sushitna River: stream, see Susitna River. Sushitnoi: island, see Sushilnoi Island.

Sushit River: stream, see Susitna River. 
Susie Creek: stream, flows SW $1.5 \mathrm{mi}$. to Medicine Creek, $3 \mathrm{mi}$. SE of Red Mtn. and 28 mi NE of Cape Newenham, Kilbuck-Kuskokwim Mts.; $58^{\circ} 57^{\prime} \mathrm{N}, 161^{\circ} 39^{\prime} \mathrm{W}$; BGN 1938; (map 39).

Local name reported in 1938 by J. B. Mertie and Gerald FitzGerald, USGS. Named for Susie Mtn., on which it heads.

Susie Creek: stream, heads in Ray Mts., flows SE $8 \mathrm{mi}$. to Yukon River, $5 \mathrm{mi}$. $\mathrm{N}$ of Rampart and $63 \mathrm{mi}$. ENE of Tanana, Kokrines-Hodzana High.; $65^{\circ} 34^{\prime} 30^{\prime \prime} \mathrm{N}, 150^{\circ} 10^{\prime} 00^{\prime \prime} \mathrm{W}$; (map 106).

Named in 1956 by Orth, for the Susie, one of the three largest and handsomest steamboats on the Yukon during the gold rush days. The Susie was named for Mrs. Susie Niebaum, wife of Capt. Gustav Niebaum. See Hannah Greek.

Susie Cutoff : stream, see Clayhill Slough.

Susie Mountain: mountain, $1,085 \mathrm{ft}$., $4.5 \mathrm{mi}$. E of Red Mtn. and $30 \mathrm{mi}$. NE of Cape Newenham, Kilbuck-Kuskokwim Mts.; $58^{\circ} 57^{\prime} \mathrm{N}$, $161^{\circ} 37^{\prime}$ W; BGN 1938; (map 39).

Local name published in a 1933 U.S. Dept. of Interior mining report.

Susitna: village, pop. 42, on E bank of Susitna River, $30 \mathrm{mi}$. NW of Anchorage, Cook Inlet Low.; $61^{\circ} 32^{\prime} 40^{\prime \prime} \mathrm{N}, 150^{\circ} 30^{\prime} 45^{\prime \prime} \mathrm{W}$; BGN 1962; (map 70). Var. Susetna, Sushetna, Sushetno, Sushitna, Suchitna Station, Susitna Station.

Petroff (1881, p. 40) listed the name "Sushetno" referring to a collection of 146 Kenai Indians "on and up the Sushetno River." The 1890 Census listed "Sushitna," population 142 , and 27 houses. Swanton (1952, p. 538 and 539 ) referred to the village as Tanaina Indian. Susitna post office was established in 1906 and discontinued in 1943 (Ricks, 1965, p. 63)

Susitna, Mount: mountain, 4,396 ft., extends $\mathrm{N}-\mathrm{S} 13 \mathrm{mi}$., $6 \mathrm{mi}$. SW of Susitna and $31 \mathrm{mi}$. $\mathrm{NW}$ of Anchorage, Alaska Ra.; $61^{\circ} 28^{\prime} 30^{\prime \prime} \mathrm{N}$, 150 44'00" W; BGN 1962; (map 70). Var Suchitna Mountain, Sushetno Mountain, Sushitna Mountain.

Tanaina Indian name reported in 1900 by USGS; name derived from nearby Susitna River.

Susitna Flats: flats, extend $\mathrm{E}$ and $\mathrm{W} 15 \mathrm{mi}$. at mouth of Little Susitna River, $7 \mathrm{mi}$. NW of Anchorage, Cook Inlet Low. ; $61^{\circ} 16^{\prime} \mathrm{N}, 150^{\circ}$. $16^{\prime} \mathrm{W}$; (map 70).

Local name reported in recent USGS publications; name derived from the Little Susitna River which flows through the flats.

Susitna Glacier: glacier, heads at $63^{\circ} 29^{\prime} \mathrm{N}$, $146^{\circ} 35^{\prime} \mathrm{W}$, trends SW $22 \mathrm{mi}$. to its 1956 terminus, at junc. of East Fork Susitna and Susitna Rivers, $64 \mathrm{mi}$. SE of Healy, Alaska Ra.; $63^{\circ} 26^{\prime} \mathrm{N}, 147^{\circ} 12^{\prime} \mathrm{W}$; (map 87)

Reported in 1910 by D. C. Witherspoon (in Moffit, 1912, pl. 1), USGS; named for the river.

Susitna Lake: lake, $10 \mathrm{mi}$. long, NW of Lake Louise, $42 \mathrm{mi}$. NW of Glennallen, Copper River Basin; 62 ${ }^{\circ} 24^{\prime} \mathrm{N}, 146^{\circ} 39^{\prime} \mathrm{W}$; (map 83).
Ahtena Indian name published by the ARC in 1925. See Susitna River.

Susitna River: stream, heads at Susitna Glacier, in Alaska Ra.; flows SW $260 \mathrm{mi}$. to Cook Inlet, $24 \mathrm{mi}$. W of Anchorage, Cook Inlet Low.; $61^{\circ} 15^{\prime} \mathrm{N}, 150^{\circ} 36^{\prime} \mathrm{W}$; BGN 1906; (map 70). Var. Reka Sushitna, Suchitna River, Sushetna River, Sushit River, Sushitna River, Suchitno River, Sutschitna River, Sustchino River.

Tanaina Indian name meaning "sandy river" published by the Russian Hydrog. Dept. as " $R$ [eka] Sushitna," meaning "Sushitna River," on Chart 1378 dated 1847. The river appears to have been first explored in 1834, by a "creole named Málakov," and the name may have been obtained by the Russians at that time (Dall, 1870, p. 12, 273). The present spelling of the name has evolved due to euphemistic reasons.

Susitna River Station: locality, see Gold Creek. Susitna Station: village, see Susitna.

Suskaralogh Point: point of land, on NW coast of St. George I., in Pribilof Is.; 56 $36^{\prime} 45^{\prime \prime}$ $\mathrm{N}, 169^{\circ} 45^{\prime} 00^{\prime \prime} \mathrm{W}$; (map 38).

Aleut name reported by W. W. Duffield, USC\&GS, in 1897. Putnam (1903, p. 1015), USC\&GS, gives the meaning as "place where they get whales *** so called because whales are said to have been cut up by the natives on the shore below this bluff, and carried away in bidarkas." Putnam presents the name as "Suskara'logh [Saskare'loj]."

Suskita Range: mountain, see Roundabout Mountain.

Suslositna Creek: stream, in Mentasta Mts., heads in lake, flows NW through Suslota Pass $16 \mathrm{mi}$. to Slana River, $7 \mathrm{mi}$. S of Mentasta Pass, Alaska Ra. ; $62^{\circ} 49^{\prime} \mathrm{N}, 143^{\circ} 41^{\prime} \mathrm{W}$; (map 84).

Indian name reported in 1903 by F. C. Schrader, USGS.

Suslota Creek: stream, flows NW $20 \mathrm{mi}$. from Mentasta Mts. to Slana River, $14 \mathrm{mi}$. SW of Mentasta Pass, Alaska Ra.; $62^{\circ} 44^{\prime} \mathrm{N}, 143^{\circ} 49^{\prime}$ W; (map 84). Var. Sustota Creek.

Indian name reported in $\mathbf{1 8 8 5}$ by Lt. Allen (1887, p. 69), USA.

Suslota Lake: lake, $2.3 \mathrm{mi}$. long, in Mentasta Mts., drains E to Suslota Creek $14 \mathrm{mi}$. S of Mentasta Pass, Alaska Ra.; 62 ${ }^{\circ} 42^{\prime}$ N, $143^{\circ} 35^{\prime}$ W; (map 84).

Indian name reported in 1885 by Lt. Allen (1887, p. 69), USA.

Suslota Pass: pass, 3,000 ft., in Mentasta Mts., $12 \mathrm{mi}$. SE of Mentasta Pass, Alaska Ra.; $62^{\circ}$ $46^{\prime} \mathrm{N}, 143^{\circ} 27^{\prime} \mathrm{W}$; (map 84). Var. Miles Pass.

Named in 1899 by Schrader (1909a, p. 375 ), USGS, for Suslota Lake, which is $5 \mathrm{mi}$. $S$ of the pass.

Suspiro, Cape: point of land, on $\mathrm{W}$ coast of Prince of Wales I., $1 \mathrm{mi}$. S of Craig, Alex. Arch.; 55 $27^{\prime} 30^{\prime \prime}$ N, $133^{\circ} 08^{\prime} 30^{\prime \prime}$ W ; (map 4). Var. Cabo Suspiro, Mys Suspiro.

Spanish name given in $1775-79$ by Don Juan de la Bodega y Quadra and Francisco Antonio Maurelle as "Cabo Suspiro," meaning "cape sigh (hissing of the wind)."
Sussaymin Lakes: lakes, extend NE-SW $3 \mathrm{mi}$., $\mathrm{S}$ of Dall River and $17 \mathrm{mi}$. NW of Stevens Village, Yukon Flats; $66^{\circ} 10^{\prime} 30^{\prime \prime} \mathrm{N}, 149^{\circ} 35^{\prime}$ $00^{\prime \prime} \mathrm{W}$; (map 118).

Indian name reported in 1956 by T. E. Taylor, USGS.

Sustchino River: stream, see Susitna River.

Susto, Ensenada del: water passage, see Sitka Sound.

Sustota Creek: stream, see Suslota Creek.

Susulatna River: stream, heads on Fossil Mtn. at $63^{\circ} 31^{\prime} \mathrm{N}, 155^{\circ} 49^{\prime} \mathrm{W}$, flows NE $41 \mathrm{mi}$. to Nowitna River, $35 \mathrm{mi}$. SE of Ruby, KilbuckKuskokwim Mts. ; $63^{\circ} 54^{\prime} \mathrm{N}, 154^{\circ} 47^{\prime} \mathrm{W}$; (map 89). Var. Agate Fork.

Indian name reported in 1915 by J. B. Mertie and G. L. Harrington (in Brooks and others, 1916, pl. 11), USGS.

Susy $\mathbf{Q}$ Creek: stream, flows W $3 \mathrm{mi}$. to Delta River, crosses Richardson Highway, $28 \mathrm{mi} \mathrm{SE}$ of Mount Hayes, Alaska Ra.; $63^{\circ} 29^{\prime} 40^{\prime \prime} \mathrm{N}$, $145^{\circ} 51^{\prime} 55^{\prime \prime} \mathrm{W}$; (map 86).

Name published on relatively recent maps. Sutchum: island, see Sutwik Island.

Sutchwik: island, see Sutwik Island.

Suter Creek: stream, heads in Russian Mts., flows SE $15 \mathrm{mi}$. to Kolmakof River $1 \mathrm{mi}$. N of its junc. with Kuskokwim River, $21 \mathrm{mi}$. E of Aniak, Kilbuck-Kuskokwim Mts.; 61 $34^{\prime} 30^{\prime \prime}$ N, 158 $53^{\prime} 45^{\prime \prime} \mathrm{W}$; BGN 1948; (map 72).

Prospectors' name reported in 1914 by A. G. Maddren (in Brooks and others, 1915; p. 360), USGS.

Suter Creek: stream, see Sutter Creek.

Sutkhoon: locality, see Sutkum.

Sutkhum: locality, see Sutkum.

Sutkhum Island: island, see Sutwik Island.

Sutkhvik, Ostrov: island, see Sutwik Island.

Sutkum: locality, on Sutwik I., off SE coast of Alaska Penin., Aleutian Ra.; $56^{\circ} 34^{\prime}$ N, $157^{\circ}$ -

$12^{\prime}$ W; (map 31). Var. Sutkhoon, Sutkhum.

Former Eskimo village or camp reported in the 1880 Census as "Sutkhoon" by Petroff (1884, p. 28)

Sutkum, Ostrov: island, see Sutwik Island.

Sutkwik Island: island, see Sutwik Island.

Sutro Creek: stream, flows NE $3 \mathrm{mi}$. to Fox

River, $30 \mathrm{mi}$. NE of Solomon, Seward Penin.

High.; 64 $48^{\prime} \mathrm{N}, 163^{\circ} 35^{\prime} \mathrm{W}$; (map 95).

Prospectors' name reported in 1900 by E. C. Barnard (in Brooks, 1901, pl. 17), USGS.

Sutschitna River: stream, see Susitna River.

Sutter Creek: stream, flows NW $3 \mathrm{mi}$. to El Capitan Passage, on $\mathrm{N}$ coast of Kosciusko I., Alexander Arch.; $56^{\circ} 09^{\prime} 00^{\prime \prime} \mathrm{N}, 133^{\circ} 26^{\prime} 30^{\prime \prime}$ W; $(\operatorname{map} 6)$.

Local name recorded in 1949 by USGS.

Sutter Creek: stream, flows $\mathbf{N} 8 \mathrm{mi}$. to Seventymile River, $28 \mathrm{mi}$. NW of Eagle, YukonTanana High.; $64^{\circ} 58^{\prime} \mathrm{N}, 142^{\circ} 02^{\prime} \mathrm{W}$; (map 102). Var. Suter Creek

Local name shown on a 1902 manuscript map by E. J. Chamberlain, U.S. Deputy Surveyor.

Sutter Creek: stream, flows E $3 \mathrm{mi}$. to Buck Creek which flows to Grouse Creek, in Mint River basin, $42 \mathrm{mi}$. NW of Teller, Seward 
Penin. High.; $65^{\circ} 38^{\prime} \mathrm{N}, 167^{\circ} 30^{\prime} \mathrm{W}$; (map 111).

Prospectors' name reported in 1903 by Collier (1904, pl. 2), USGS.

Sutter Lake: lake, $0.2 \mathrm{mi}$. long, on Sutter Creek, E shore of Shakan Bay, on N coast of Kosciusko I., Alex. Arch.; $56^{\circ} \mathrm{J} 8^{\prime} 50^{\prime \prime} \mathrm{N}, 133^{\circ} 26^{\prime}-$ $20^{\prime \prime} \mathrm{W}$; (map 6).

Local name recorded in 1949 by USGS

Sutton: village, pop. 162, on Glenn Highway, 11 mi. NE of Palmer, Cook Inlet Low.; $61^{\circ} 42^{\prime}$ $40^{\prime \prime} \mathrm{N}, 148^{\circ} 53^{\prime} 30^{\prime \prime} \mathrm{W}$; (map 69). Var. Sutton Siding.

RR. station and siding on the Mattanuska Branch of The Alaska RR. founded about 1918. The Sutton post office was established in 1948 (Ricks, 1965, p. 63).

Sutton Siding: village, see Sutton.

Sutwik Island: island, $14 \mathrm{mi}$. long, SE of Alaska Penin, $14 \mathrm{mi}$. S of Cape Kunmik, Aleutian Ra.; $56^{\circ} 34^{\prime} \mathrm{N}, 157^{\circ} 12^{\prime} \mathrm{W}$; (map 31). Var. Ile Sout-hvick, Ostrov Sutkhvik, Ostrov Sutkum Soutkhvik, Soutvik Island, Sutchum, Sutchwik, Sutkhum Island, Sutkwik Island, Zutchwik Island.

Eskimo name, shown as "I[le] Sout-hvick" by Adm. von Krusenstern (1827, map 20), IRN ; published in 1847 as "Ostrov Sutkhvik" by the Russian Hydrog. Dept.

Suvaloyuk Creek: stream, in De Long Mts., flows NW $7 \mathrm{mi}$. to Singayoak Creek, $54 \mathrm{mi}$. NE of Misheguk Mtn., Brooks Ra.; 68 $43^{\prime} \mathrm{N}, 159^{\circ}$ $27^{\prime} \mathrm{W} ; B$ BN 1960; (map 131).

Eskimo name reported to mean "waster of food," given in 1953 by E. G. Sable and I. L. Trailleur, USGS.

Suvarov: village, see Naknek.

Suvoroff, Cape: bluff, see Suworof, Cape.

Suwanukto River: stream, see Sagavanirktok River.

Suwarof: village, see Naknek.

Suwarof: village, see South Naknek.

Suwarof, Cape: bluff, see Suworof, Cape.

Suworof: village, see Naknek.

Suworof: village, see South Naknek.

Suworof, Cape: bluff, elev. $100 \mathrm{ft}$, , on $\mathrm{N}$ coast of Alaska Penin., $\mathbf{N}$ point of entrance to Naknek River, W of Naknek, Bristol Bay Low.; $58^{\circ} 43^{\prime} 20^{\prime \prime} \mathrm{N}, 157^{\circ} 02^{\prime} 30^{\prime \prime} \mathrm{W}$; BGN 1932; (map 41). Var. Cape Souvoroff, Cape Suvoroff, Cape Suwarof.

Named in 1828 by Capt. M. N. Staniukovich of the corvette Moller, probably after nearby Russian Fort Suvorof. This "Russian family name was also spelled Souvoroff, Suvoroff, etc." The Moller, one of Capt. F. P. Lutke's ships, ended its exploration of the Alaska Peninsula at this point.

Suworof, Cape: bluff, sec Pederson Point.

Svataya Diomida, Ostrova: islands, see Diomede Islands.

Svataya Ioanna Predtechi, Zaliv: bay, see Saint John Baptist Bay.

Svataya Lazarya: volcano, see Edgecumbe, Mount.

Svataya Lazarya, Mys: point of land, see Edgecumbe, Cape.
Svataya Lazarya, Ostrov: island, see Saint Lazaria Islands.

Svendson and Shaw: bay, sec Shuyak Harbor.

Svensen Rock: rock, in $\mathbf{E}$ end of Peril Strait, $\mathrm{N}$ of Catherine I., off Chichagof I., $4 \mathrm{mi}$. SE of Todd, Alex. Arch.; 5 $7^{\circ} 26^{\prime} 05^{\prime \prime} \mathrm{N}, 134^{\circ} 56^{\prime}$ 55" W; (map 9). Var. Swenson Rock.

Named "Swenson Rock" in 1895 by Lt. Comdr. E. K. Moore, USN; published by USC\&GS on Chart 8283. Baker (1906, p. $609)$, USGS, changed the name to "Svensen," the usual spelling of this Swedish proper name.

Svetchnikoff Port: cove, see Sviechnikof Harbor.

Sviatoy Paula, Ostrov: island, see Paul Island. Svidania, Mys: point of land, see Swedania Point.

Sviechnikof Harbor: cove, $0.5 \mathrm{mi}$. across, on $\mathrm{S}$ coast of Atka I., Aleutian Is.; $52^{\circ} 02^{\prime} 30^{\prime \prime} \mathrm{N}$, $173^{\circ} 23^{\prime} 20^{\prime \prime} \mathrm{W}$; (map 19). Var. Sbjeznikof, Souchikova, Svetchnikoff.

Surveyed and probably named by pilot Ivan Chernof in 1832, and published as Svetchnikoff Port by Capt. Lutke (1836, p. 308), IRN It may be a family name, or from "sviechnik," Russian for "tallow chandler."

Svikhchak Golfe: bay, see Kaguyak Bay.

Svikhshak: bay, see Swikshak Bay.

Svinoy, Ostrov: island, see Hog Island.

Svitlak Island: island, $0.4 \mathrm{mi}$. long, in Kalsin Bay, $11 \mathrm{mi}$. S of Kodiak, Kodiak I.; $57^{\circ} 38^{\prime} 00^{\prime \prime}$ N, $152^{\circ} 21^{\prime} 20^{\prime \prime} \mathrm{W}$; (map 34).

Transliteration of the Russian word "svytlyak" meaning "firefly," published in 1910 by USC\&GS,

Svoger Slough: stream, anabranch of Kvichak River on its N bank, flows SW $2.8 \mathrm{mi} ., 17$ mi. N of Naknek, Bristol Bay Low.; 58 $59^{\prime} \mathrm{N}$, $156^{\circ} 58^{\prime} \mathrm{W}$; (map 41).

Local name reported in 1952 by USGS.

Svyataya Matvyya, Ostrov: island, see Saint Matthew Island.

Swaine Point: point of land, SW point of entrance to Explorer Basin, on W coast of Kuiu I., $\mathrm{S}$ of Tebenkof Bay, Alex. Arch.; $56^{\circ} 25^{\prime} 45^{\prime \prime}$ $\mathrm{N}, 134^{\circ} 14^{\prime} 00^{\prime \prime} \mathrm{W} ; B G N$ 1929; (map 5). Var. Blake Point.

Named in 1928 by USC\&GS for "Lt. Swaine [cnna], a member of the Vancouver expedition of 1792-1794."

Swallow Creek: stream, see Louse Creek.

Swallow Head: point of land, on $\mathrm{N}$ coast of Great Sitkin I., Aleutian Is.; $52^{\circ} 07^{\prime} \mathrm{N}$, $176^{\circ} 09^{\prime} \mathrm{W}$; BGN 1936; (map 17)

Named by members of the U.S. Navy Aleutian Island Survey Expedition in 1934.

Swallow Point: point of land, on SW shore of Kanaga Bay, SE coast of Kanaga I., Aleutian Is. ; $51^{\circ} 42^{\prime} 05^{\prime \prime} \mathrm{N}, 177^{\circ} 12^{\prime} 15^{\prime \prime} \mathrm{W}$; (map 17).

Name published in 1957 on an AMS map. Swallow Reef: reef, in Captains Bay, in Unalaska Bay, NE coast of Unalaska I., Aleutian Is.; $53^{\circ} 50^{\prime} 39^{\prime \prime} \mathrm{N}, 166^{\circ} 35^{\prime} 30^{\prime \prime} \mathrm{W}$; (map 23).

This name was published in the 1944 Aleutian Coast Pilot (p. 39).

Swallow Rocks: rocks, elev. $20 \mathrm{ft}$., between Bluff and Beach Coves, west-central coast of Kiska
I., Aleutian Is.; $51^{\circ} 59^{\prime} 35^{\prime \prime} \mathrm{N}, 177^{\circ} 29^{\prime} 00^{\prime \prime} \mathrm{E}$; (map 14).

One of the "bird names" arbitrarily applied to features on Kiska I. in 1943 by USAAF for tactical purposes during World War II.

Swampbuggy Lake: lake, $0.4 \mathrm{mi}$. long, $80 \mathrm{mi}$. $\mathrm{SE}$ of Healy, Alaska Ra.; $63^{\circ} 03^{\prime} 20^{\prime \prime} \mathrm{N}, 147^{\circ}$ $25^{\prime} 10^{\prime \prime} \mathrm{W}$; $(\operatorname{map} 87)$.

Named and reported in 1953 by personnel of ARC. "Beside the lake is an abandoned vehicle used in 1952 called a 'swampbuggy' [used for transportation across tundra and swampy country.]"

Swamp Creek: stream, on Kalgin I., flows NE $3 \mathrm{mi}$. to Cook Inlet, $28 \mathrm{mi}$. WSW of Kenai, Cook Inlet Low.; $60^{\circ} 23^{\prime} 45^{\prime \prime} \mathrm{N}, 1^{\circ} 51^{\circ} 58^{\prime} 50^{\prime \prime}$ W: (map 62).

Local name reported in 1958 by USGS.

Swamp Creek: stream, heads in Canada, flows W $0.3 \mathrm{mi}$. into Alaska, to Yellow Water Creek, $25 \mathrm{mi}$. E of Northway Junction, Alaska Ra.; $62^{\circ} 58^{\prime} 40^{\prime \prime} \mathrm{N}, 141^{\circ} 00^{\prime} 40^{\prime \prime} \mathrm{W}$; BGN 1954; (map 84). Var. Yellow Water Creek.

Local name published in 1914 on AlaskaCanada boundary sheet 28 .

Swamp Creek: stream, flows S $8 \mathrm{mi}$. to Allen River, $4 \mathrm{mi}$. W of Tobin Mtn. and $44 \mathrm{mi}$. NW of Wiseman, Brooks Ra.; 67 $39^{\prime} 30^{\prime \prime} \mathrm{N}, 151^{\circ}$ $40^{\prime} 00^{\prime \prime} \mathrm{W}$; BGN 1932; (map 124).

Named about 1930 by Robert Marshall, "because of the flat swampy country which this creek drains."

Swamp Lake: lake, see Memory Lake.

Swampy Lakes: lakes, group, extend $2.5 \mathrm{mi}$. W of Gakona River, $7 \mathrm{mi}$. NE of Paxson, Alaska Ra.; $63^{\circ} 06^{\prime} 15^{\prime \prime} \mathrm{N}, 145^{\circ} 17^{\prime} 15^{\prime \prime} \mathrm{W}$; (map $86)$.

Name published on relatively recent maps.

Swampy River: stream, heads in lake, winds $\mathrm{N}$ $16 \mathrm{mi}$. through several lakes to Egegik River on Alaska Penin., $4 \mathrm{mi}$. E of Egegik and 38 mi. SW of Naknek, Bristol Bay Low.; $58^{\circ} 11^{\prime}$ $30^{\prime \prime} \mathrm{N}, 17^{\circ} 15^{\prime} 50^{\prime \prime} \mathrm{W}$; (map 41).

Descriptive name given by $R$. H. Sargent, USGS, in 1923 "because of the swampy area bordering the river's lower course."

Swan Cove: cove, $2 \mathrm{mi}$. across, on $\mathrm{E}$ coast of Admiralty I., in Seymour Canal, NW of Swan I., 23 mi. S. of Juneau, Alex. Arch.; 57 $59^{\prime}$ $\mathrm{N}, 134^{\circ} 19^{\prime} \mathrm{W}$; (map 9).

Local name reported in 1951 by USGS.

Swan Creek: stream, heads in Little Merganser Lake and flows N and W $8 \mathrm{mi}$. to Swanson River $\mathbf{S}$ of Quill Lake, $22 \mathrm{mi}$. NE of Kenai, Cook Inlet Low.; $60^{\circ} 44^{\prime} 45^{\prime \prime} \mathrm{N}, 150^{\circ} 44^{\prime} 10^{\prime \prime}$ W; (map 62).

Named about 1963 by officials of Kenai National Moose Range, for administrative purposes.

Swan Creek: stream, see Kakhtul River.

Swan Creek: stream, see Swan River.

Swan Island: island, $3 \mathrm{mi}$. across, on $\mathbf{E}$ coast of Admiralty I., in Seymour Canal, $24 \mathrm{mi}$. S of Juneau, Alex. Arch.; 57 $56^{\prime} \mathrm{N}, 134^{\circ} 14^{\prime} \mathrm{W}$; (map 9).

Named in 1890 by Lt. Comdr. H. B. Mansfield, USN; published by USC\&GS in the 1891 Alaska Coast Pilot (p. 144). 
Swan Island: island, $700 \mathrm{ft}$. across, largest in Walker Lake, Brooks Ra.; $67^{\circ} 07^{\prime} \mathrm{N}, 154^{\circ} 22^{\prime}$ W; $(\operatorname{map} 125)$.

Local name reported by Orth, USGS, in 1956.

Swan Lake: lake, 3 mi. long, on Revillagigedo I. near head of Carroll Inlet, Alex. Arch.; $55^{\circ} 37^{\prime} \mathrm{N}, 131^{\circ} 17^{\prime} \mathrm{W}$; (map 3).

Local name recorded in 1916 by G. $H$. Canfield (in Brooks and others, 1918, p. 113), USGS.

Swan Lake: lake, 2 mi. long, on Cascade Creek $2 \mathrm{mi}$. $\mathrm{N}$ of Cosmos Peak and $105 \mathrm{mi}$. E of Sitka, Coast Mts.; 57 $01^{\prime} 45^{\prime \prime}$ N, $132^{\circ} 44^{\prime} 30^{\prime \prime}$ W; BGN 1923; (map 8).

Name reported in 1917 by G. H. Canfield (in Martin and others, 1919, p. 53), USGS.

Swan Lake: lake, $0.4 \mathrm{mi}$. across, in Sitka, on W coast of Baranof I., Alex. Arch.; 57 03'30' $\mathrm{N}, 135^{\circ} 20^{\prime} 10^{\prime \prime} \mathrm{W}$; (map 9). Var. Ozero Lebyazhye.

This is an 1882 translation by USC\&GS of the name given in 1809 by the Russian navigator Ivan Vasiliev the first; reported by Lt. Sarichev (1826, map 19), IRN, as "Oz[ero] Lebazhye."

Swan Lake: lake, $0.5 \mathrm{mi}$. across, on Kenai Penin., S of Skilak Lake, $40 \mathrm{mi}$. ESE of Kenai, Cook Inlet Low.; $60^{\circ} 23^{\prime} 30^{\prime \prime} \mathrm{N}, 150^{\circ} 24^{\prime} 30^{\prime \prime}$ W; (map 62).

Local name reported in 1951 by USGS.

Swan Lake: lake, on Kenai Penin., extends SW 2 mi., near head of Chickaloon River, $22 \mathrm{mi}$. SW of Hope, Chugach Mts.; $60^{\circ} 37^{\prime} 25^{\prime \prime} \mathrm{N}$, $149^{\circ} 52^{\prime} 00^{\prime \prime} \mathrm{W}$; (map 63).

Local name reported in 1951 by USGS.

Swan Lake: lake, 2 mi. long, on Kenai Penin., $2.5 \mathrm{mi}$. E of Rock Lake, $25 \mathrm{mi}$. ENE of Kenai, Cook Inlet Low.; $60^{\circ} 40^{\prime} \mathrm{N}, 150^{\circ} 33^{\prime} \mathrm{W}$; (map 62).

Local name reported in 1958 by USGS.

Swan Lake: lake, $1.3 \mathrm{mi}$. long, between Jim Creek and Knik River, $7 \mathrm{mi}$. SE of Palmer, Cook Inlet Low; 61 $31^{\prime} 40^{\prime \prime} \mathrm{N}, 148^{\prime} 54^{\prime} 00^{\prime \prime}$ W; (map 69).

Local name reported in 1942 by AMS.

Swan Lake: lake, $2 \mathrm{mi}$. long, $15 \mathrm{mi}$. NW of Talkeetna, Cook Inlet Low.; 62 $31^{\prime} 30^{\prime \prime} \mathrm{N}$, $150^{\circ} 23^{\prime} 20^{\prime \prime} \mathrm{W}$; (map 81$)$.

Local name reported in 1958 by USGS

Swan Lake: lake, $0.6 \mathrm{mi}$. long, on $\mathrm{N}$ bank of Tanana River, $1 \mathrm{mi}$. S of Midway Lake and $23 \mathrm{mi}$. SE of Tok, Yukon-Tanana High.; $63^{\circ} 12^{\prime} \mathrm{N}, 142^{\circ} 19^{\prime} \mathrm{W}$; (map 85).

Local name published by USGS in 1964.

Swan Lake: lake, $1.5 \mathrm{mi}$. long, $4 \mathrm{mi}$. NW of Swan Mtn. and $8 \mathrm{mi}$. NE of Arctic Village, Brooks Ra.; 68 $14^{\prime}$ N, $145^{\circ} 22^{\prime}$ W ; (map 136).

Local name reported in 1956 by $R$. C. Foley, USGS.

Swan Lake: lake, see High Lake.

Swan Mountain: mountain, 4,110 ft., $4 \mathrm{mi}$. W of Signal Mtn. and $10 \mathrm{mi}$. NE of Arctic Village, Brooks $\mathrm{Ra}$; $68^{\circ} 13^{\prime} \mathrm{N}, 145^{\circ} 13^{\prime} \mathrm{W}$; (map 136).

Local name reported in 1956 by $R$. C. Foley, USGS.
Swanneck Crossing: winter crossing, across Swanneck Slough, $4 \mathrm{mi}$. NW of Minto and $47 \mathrm{mi}$. W of Fairbanks, Tanana Low.; 64 $54^{\circ}{ }^{\prime}$ $36^{\prime \prime} \mathrm{N}, 149^{\circ} 17^{\prime} 00^{\prime \prime} \mathrm{W}$; (map 100).

Local name published in 1950 by USGS

Swanneck Slough: stream, an anabranch, flows NW $21 \mathrm{mi}$. from Tanana River to Tolovana River, 40 mi. SE of Rampart, Tanana Low.; $65^{\circ} 01^{\prime} \mathrm{N}, 149^{\circ} 33^{\prime} \mathrm{W}$; (map 105).

Descriptive name derived from "Swanneck Bend" in the Tanana River; reported by USGS in 1940.

Swanport: anchorage, on S shore of Port Valdez, $5.2 \mathrm{mi}$. SW of Valdez, Chugach Mts. ; 61 ${ }^{\circ} 05^{\prime}-$ $15^{\prime \prime} \mathrm{N}, 146^{\circ} 24^{\prime} 10^{\prime \prime} \mathrm{W}$; (map 68).

Local name reported in 1898 by Capt. E. F. Glenn, USA.

Swan River: stream, flows SW $16 \mathrm{mi}$. to Kakhtul River, 84 mi. NE of Dillingham, Alaska Ra.; $59^{\circ} 45^{\prime} \mathrm{N}, 156^{\circ} 32^{\prime} \mathrm{W}$; (map 52). Var. Estuy-a-rok, Kogiukhtuli, Swan Creek.

Local name obtained in 1898 by J. E. Spurr and W. S. Post, USGS, from A. Mittendorf, a local trader; published by Spurr (1900, p. 235), USGS. The stream was shown as "Swan Creek" or "Estu-y-a-rok" on a 1910 manuscript map by H. C. Fassett, USBF.

Swan River: stream, see Kakhtul River.

Swan River: stream, see Kugruk River.

Swanson Bay: estuary, on SW coast of Bainbridge $\mathrm{I}$,, trends $\mathrm{W} 4.5 \mathrm{mi}$. to Port Bainbridge, $40 \mathrm{mi}$. E of Seward, Chugach Mts.; $60^{\circ} 02^{\prime} 30^{\prime \prime} \mathrm{N}, 148^{\circ} 18^{\prime} 30^{\prime \prime} \mathrm{W}$; (map 63).

Local name reported in 1908 by U. S. Grant and D. F. Higgins (in Brooks and others, 1909, pl. 4), USGS.

Swanson Creek: stream, heads on Eva Mtn., flows SE $2 \mathrm{mi}$. to Allene Creek, $11 \mathrm{mi}$. NE of Teller, Seward Penin. High.; 65 $21^{\prime} \mathrm{N}, 166^{\circ}$. 03' W; (map 111).

Prospectors' name reported in 1901 by T. G. Gerdine (in Collier, 1902, pl. 12), USGS.

Swanson Harbor: zeater passage, $0.6 \mathrm{mi}$. long, at mouth of Lynn Canal, between Couverden, Ansley, and Entrance Is., $25 \mathrm{mi}$. SW of Juneau, St. Elias Mts.; $58^{\circ} 11^{\prime} 30^{\prime \prime} \mathrm{N}, 135^{\circ}$. $05^{\prime} 00^{\prime \prime} \mathrm{W}$; (map 11).

Named in 1869 by Comdr. R. W. Meade, USN, and published in the 1883 Coast Pilot (p. 193).

Swanson Island: island, $3 \mathrm{mi}$. long, in Yukon River, 19 mi. W of Tanana, Nowitna Low.; $65^{\circ} 11^{\prime} \mathrm{N}, 152^{\circ} 44^{\prime} \mathrm{W}$; (map 106).

Local name reported in 1952 by USGS.

Swanson Lagoon: lagoon, $4 \mathrm{mi}$. across, at $\mathrm{NE}$ end of Unimak I., Aleutian Is.; $55^{\circ} 02^{\prime} \mathrm{N}$, $163^{\circ} 36^{\prime} \mathrm{W}$; (map 29).

Name published by USC\&GS in 1943 on Chart 8701.

Swanson Lake: lake, $1.5 \mathrm{mi}$. long, one of the Swanson Lakes, on Kenai Penin. W of Gene Lake, 33 mi. NE of Kenai, Cook Inlet Low.; $60^{\circ} 49^{\prime} 30^{\prime \prime} \mathrm{N}, 150^{\circ} 31^{\prime} 30^{\prime \prime} \mathrm{W}$; (map 62.)

Named about 1963 by officials of Kenai National Moose Range, for administrative purposes.

Swanson Lakes: lakes, group extends $10 \mathrm{mi}$, on Kenai Penin., at head of Swanson River, 15 mi. S of Point Possession and $28 \mathrm{mi}$. NE of Kenai, Cook Inlet Low.; $60^{\circ} 50^{\prime} \mathrm{N}, 150^{\circ} 30^{\prime}$ W; (map 62).

Local name reported in 1960 by USGS; derived from Swanson River.

Swanson Point: point of land, on SW coast of Bainbridge I., at $\mathrm{N}$ entrance to Swanson Bay, $18 \mathrm{mi}$. SW of Chenega, Chugach Mts.; $60^{\circ}$. $03^{\prime} \mathrm{N}, 148^{\circ} 18^{\prime} \mathrm{W}$; BGN 1929; (map 63).

Named in 1929 by USC\&GS for nearby Swanson Bay.

Swanson River: stream, heads at Gene Lake, flows SW and N $40 \mathrm{mi}$. to Number Three Bay, on NW coast of Kenai Penin., $19 \mathrm{mi}$. NE of Kenai, Cook Inlet Low.; $60^{\circ} 48^{\prime} \mathrm{N}$, $151^{\circ} 02^{\prime} \mathrm{W}$; (map 62).

Local name published in 1939 by USGS.

Swanson Slough: channel, of Yukon River, flows NW $2.5 \mathrm{mi}$. S of Swanson I., $19 \mathrm{mi}$. W of Tanana, Nowitna Low.; $65^{\circ} 11^{\prime} \mathrm{N}, 152^{\circ} 45^{\prime}$ W; (map 106).

Local name reported in 1952 by USGS.

Swayback Creek: stream, flows NE $30 \mathrm{mi}$. to Kuna River, $15 \mathrm{mi}$. SE of Liberator Lake, Arctic Slope; $68^{\circ} 47^{\prime} \mathrm{N}, 157^{\circ} 46^{\prime} \mathrm{W} ; B G N$ 1960; (map 132).

Named in 1949 by I. L. Tailleur, USGS, for nearby Swayback Mtn.; a name originally applied to a hill on the left bank of this stream at $68^{\circ} 43^{\prime} \mathrm{N}, 157^{\circ} 56^{\prime}$ W. See Swayback Mountain.

Swayback Lakes: lakes, between Swayback Creek and Kuna River, $17 \mathrm{mi}$. SE of Liberator Lake, Arctic Slope; $68^{\circ} 42^{\prime} \mathrm{N}, 157^{\circ} 51^{\prime} \mathrm{W}$; $B G N$ 1960; (map 132).

Named in 1950 by B. H. Kent and I. L. Tailleur, USGS, for adjacent Swayback Mtn.

Swayback Mountain: hill, 2,780 ft., $11 \mathrm{mi}$. SSE of Liberator Lake, Arctic Slope; $68^{\circ} 42^{\prime} \mathrm{N}$, $158^{\circ} 14^{\prime} \mathrm{W}$; (map 132).

Named by USGS geologists in 1949. The name was originally applied to a hill on the left bank of Swayback Creek at $68^{\circ} 43^{\prime} \mathrm{N}$, $157^{\circ} 56^{\prime} \mathrm{W}$. This feature was so named because of its "swayback" appearance. When the 1951 USGS Howard Pass map was edited, the orginal feature did not show, and the name was inadvertently misapplied to this mountain.

Sweater Bay: bay, trends SW 4 mi. to Kuiukta Bay on Alaska Penin., 19 mi. SW of Chignik, Aleutian Ra.; $56^{\circ} 02^{\prime} \mathrm{N}, 158^{\circ} 34^{\prime} \mathrm{W}$; (map $30)$.

Local name reported by a 1951 USGS field party.

Swedania Point: point of land, SW entrance point to Stepovak Bay near SW end of Alaska Penin., Aleutian Ra.; 55 28 $45^{\prime \prime}$ N, $160^{\circ} 31^{\prime} 30^{\prime \prime}$ W; (map 28). Var. Cape Swedania, Mys Svidaniya, Point Swedania.

Name shown as "Point Swedania" on a USC\&GS chart published in 1882; "M[ys] Svidaniya" is shown on a Russian Hydrog. Dept. chart published in 1847 , possibly derived from the Russian expression "do svidaniy" meaning "till we meet again."

Swede Boys Camp: locality, on left bank of Beaver Creek, NW of Olaf Lake, $18 \mathrm{mi}$. SE 
of Beaver, Yukon Flats; $66^{\circ} 12^{\prime} 30^{\prime \prime} \mathrm{N}$, $146^{\circ} 52^{\prime} 25^{\prime \prime} \mathrm{W}$; (map 119).

Local name obtained in 1956 by USGS.

Swede Creek: stream, flows SE $8 \mathrm{mi}$. to Glacier River, $5 \mathrm{mi}$. NW of Vermont Dome and $12.5 \mathrm{mi}$. NW of Wiseman, Brooks Ra.; $67^{\circ} 33^{\prime} 15^{\prime \prime} \mathrm{N}, 150^{\circ} 25^{\prime} 30^{\prime \prime} \mathrm{W} ; B G N$ 1932; (map 124).

Local name reported by Robert Marshall in 1932.

Swede Creek: stream, flows NW to Snake River, about $32 \mathrm{mi}$. NE of Nome, Seward Penin. High.; (map 94).

Prospectors' name reported on the 1900 "Map of Nome Peninsula" by J. M. Davidson and B. D. Blakeslee; this feature has not been positively identified.

Swede Hill : peak, see Roberts, Mount.

Swede Lake: lake, $2.2 \mathrm{mi}$. long, drains $\mathrm{S}$ to Middle Fork Gulkana River, $13 \mathrm{mi}$. SW of Paxson, Alaska Ra.; $63^{\circ} 00^{\prime} \mathrm{N}, 145^{\circ} 53^{\prime} \mathrm{W}$; (map 83).

Local name reported in 1950 by USGS.

Swede Point: point of land, on N bank of Taku River, at its junc. with Taku Inlet, $1.6 \mathrm{mi}$. E of terminus of Taku Glacier and $18 \mathrm{mi}$. NE of Juneau, Coast Mts. ; $58^{\circ} 26^{\prime} 10^{\prime \prime} \mathrm{N}, 133^{\circ} 59^{\prime}$ $00^{\prime \prime} \mathrm{W}$; (map 12).

Name published in 1943 by USC\&GS.

Swedish Gulch: ravine, trends $\mathrm{S} 1 \mathrm{mi}$. to Norton Sound, $1.7 \mathrm{mi}$. E of village of Bluff and $22 \mathrm{mi}$. E of Solomon, Seward Penin. High.; $64^{\circ} 34^{\prime} \mathrm{N}, 163^{\circ} 42^{\prime} \mathrm{W}$; (map 95).

Prospectors' name shown on Arthur Gibson's "Map of Cape Nome Precinct" dated 1904.

Sweeney, Point: point of land, on Beaufort Sea coast, $2 \mathrm{mi}$. E of Point Hopson and $5 \mathrm{mi}$. W of Flaxman I., Arctic Plain; $70^{\circ} 11^{\prime} 15^{\prime \prime} \mathrm{N}$, $146^{\circ} 25^{\prime} 45^{\prime \prime} \mathrm{W}$; (map 151).

Named by Leffingwell $(1919$, p. 100) in 1913, "After Dan Sweeney, who worked for the writer."

Sweeney Lake: lake, $1.8 \mathrm{mi}$. long, $16 \mathrm{mi}$. SW of Beaver, Yukon Flats; $66^{\circ} 09^{\prime} \mathrm{N}, 147^{\circ} 43^{\prime} \mathrm{W}$; (map 118).

Local name obtained in 1956 by USGS

Sweeny Creek: stream, flows NW $4 \mathrm{mi}$. to E shore of Lynn Canal, $0.3 \mathrm{mi}$. NE of Point Sherman and $47 \mathrm{mi}$. NW of Juneau, Coast Mts.; $58^{\circ} 52^{\prime} 05^{\prime \prime} \mathrm{N}, 135^{\circ} 08^{\prime} 25^{\prime \prime} \mathrm{W}$; (map 11$)$.

Local name reported in 1906 by $R$. B. Oliver, USGS; published in 1908.

Sweeper Cove: cove, $1 \mathrm{mi}$. across, on $\mathrm{W}$ shore of Kuluk Bay, on NE coast of Adak I., Aleutian Is. : $51^{\circ} 51^{\prime} 40^{\prime \prime} \mathrm{N}, 176^{\circ} 37^{\prime} 30^{\prime \prime} \mathrm{W} ; B G N$ 1936; (map 17). Var. Salmon Cove.

So named by members of the U.S. Navy Aleutian Island Survey Expedition in 1934, "because it was used as a refuge for the smaller ships of the expedition (mine sweepers) during bad weather."

Sweeper Creek: stream, flows S $1.2 \mathrm{mi}$. to Sw'ceper Cove, Kuluk Bay, on NE coast of

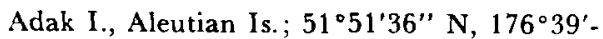
$10^{\prime \prime} \mathrm{W} ; B G N$ 1936; (map 17). Var. Salmon Creek.
Name derived from Sweeper Cove, given by members of the U.S. Navy Aleutian Island Survey Expedition in 1934.

Sweepstakes Creek: stream, flows SE $13 \mathrm{mi}$. to Peace River, $6 \mathrm{mi}$. N of Haycock, Seward Penin. High.; $65^{\circ} 17^{\prime} \mathrm{N}, 161^{\circ} 08^{\prime} \mathrm{W}$; (map 109).

Local name reported in 1917 by G. L. Harrington, USGS.

Sweet Briar Creek: stream, see Sweetbrier Creek. Sweetbrier Creek: stream, flows SE $0.8 \mathrm{mi}$. to Shovel Creek, opposite Kasson Creek, $9 \mathrm{mi}$. N of Solomon, Seward Penin. High.; 64 $41^{\circ} 30^{\prime \prime}$ N, $164^{\circ} 25^{\prime} 35^{\prime \prime}$ W ; (map 95). Var. Sweet Briar Creek.

Prospectors' name reported on a 1902 prospectors' manuscript map.

Sweetcake Creek: stream, flows S $4 \mathrm{mi}$. to Ophir Creek, $3 \mathrm{mi}$. NW of Council and $33 \mathrm{mi}$. NE of Solomon, Seward Penin. High.; 64 $56^{\prime}$ N, $163^{\circ} 44^{\prime} \mathrm{W}$; (map 95).

Prospectors' name published in January 1900 by Schrader (1900c, p. 16), USGS.

Sweetheart Creek: stream, flows W $11 \mathrm{mi}$. through Upper and Lower Sweetheart Lakes to Gilbert Bay, $37 \mathrm{mi}$. SE of Juneau, Coast Mts.; $57^{\circ} 56^{\prime} 40^{\prime \prime} \mathrm{N}, 133^{\circ} 41^{\prime} 00^{\prime \prime} \mathrm{W}$; $B G N$ 1931; (map 8).

Named in 1931 for Sweetheart Falls by USFS.

Sweetheart Falls: falls, on Sweetheart Creek, 0.3 mi. E of Gilbert Bay and $37 \mathrm{mi}$. SE of Juneau, Coast Mts.; $57^{\circ} 56^{\prime} 40^{\prime \prime} \mathrm{N}, 133^{\circ} 40^{\prime} 30^{\prime \prime} \mathrm{W}$; (map 8).

Named in 1888 by Lt. Comdr. C. M. Thomas, USN.

Sweetheart Lake: lake, see Lower Sweetheart Lake and Upper Sweetheart Lake.

Sweetwater Creek: stream, flows W $13 \mathrm{mi}$. to Chisana River, $16 \mathrm{mi}$. SE of Northway Junction, Alaska Ra.; $62^{\circ} 45^{\prime} 20^{\prime \prime} \mathrm{N}, 141^{\circ} 27^{\prime} 55^{\prime \prime}$ W; (map 84).

Local name reported by USGS in 1955.

Sweetwater Lake: lake, $4.5 \mathrm{mi}$. long, $\mathrm{N}$ central Prince of Wales I., Alex. Arch.; 55 $58^{\prime} \mathrm{N}$, $132^{\circ} 56^{\prime} \mathrm{W}$; (map 4).

Local name recorded in 1949 by USGS.

Swenson Rock: rock, see Svensen Rock.

Swen Waxell Ridge: ridge, see Waxell Ridge.

Swewidow: mountain, see Vsevidof, Mount.

Swift, Point: point of land, N point of entrance to Tonowek Narrows, on $W$ coast of Prince of Wales I., Alex. Arch.; $55^{\circ} 45^{\prime} 45^{\prime \prime} \mathrm{N}, 133^{\circ}$ $19^{\prime} 28^{\prime \prime}$ W; (map 4).

Local name published in 1917 by USC\&GS.

Swift Creek: stream, on Kenai Penin., flows SE $5.5 \mathrm{mi}$. to NE end of Kachemak Bay, $19 \mathrm{mi}$. NE of Homer, Cook Inlet Low.; 59 $47^{\prime} 15^{\prime \prime}$ $\mathrm{N}, 151^{\circ} 04^{\prime} 30^{\prime \prime} \mathrm{W}$; (map 50).

Local name reported by Grant and Higgins (1913, pl. 2), USGS. Probably so named because of the sharp stream gradient which would create a fast flowing stream.

Swift Creek: stream, flows NW $13 \mathrm{mi}$. to Crooked Creek, $65 \mathrm{mi}$. SE of Bethel, Kilbuck-Kuskokwim Mts.; $60^{\circ} 18^{\prime} \mathrm{N}, 159^{\circ} 56^{\prime} \mathrm{W}$; $B G N$ 1959; (map 59). Var. Crooked Creek.

Local descriptive name; reported in 1955 by J. M. Hoare, USGS.

Swift Creek: stream, flows SW $8 \mathrm{mi}$. to Kisaralik River, $58 \mathrm{mi}$. SE of Bethel, KilbuckKuskokwim Mts.; $60^{\circ} 29^{\prime}$ N, $160^{\circ} 10^{\prime}$ W; (map 59).

Local name reported in 1949 by USGS.

Swift Creek: stream, flows $4 \mathrm{mi}$. SE to Kennicott River, $3 \mathrm{mi}$. SW of McCarthy, Wrangell Mts.; BGN 1966; $61^{\circ} 24^{\prime} 23^{\prime \prime} \mathrm{N}, 142^{\circ} 59^{\prime} 53^{\prime \prime}$ W; (map 67).

Descriptive name used by local landowner and reported in 1965 by L. A. Yehle, USGS. Swift Creek: stream, heads in Kilbuck Mts. and flows N $40 \mathrm{mi}$. to Aniak Slough, $5 \mathrm{mi} \mathrm{SW}$ of Aniak, Yukon-Kuskokwim Delta; 61 $31^{\prime} 30^{\prime \prime}$ N, $159^{\circ} 37^{\prime} 10^{\prime \prime} \mathrm{W}$; Var. Amotoloriasak River.

A. G. Maddren, USGS, shows this name on a 1914 field sheet applied to what is now called "Discovery Creek." USGS reapplied the name to this stream in 1948 .

Swift Creek: stream, heads at glacier, flows S $4.3 \mathrm{mi}$. to Hidden River, $41 \mathrm{mi}$. N of Talkeetna, Alaska Ra.; $62^{\circ} 54^{\prime} 55^{\prime \prime} \mathrm{N}, 150^{\circ} 07^{\prime} 40^{\prime \prime}$ W; (map 81)

Descriptive name published in 1940 by USGS.

Swift Creek: stream, flows S $2.1 \mathrm{mi}$. to Basin Greek, $3.7 \mathrm{mi}$. W of Long and $23 \mathrm{mi}$. SW of Ruby, Kilbuck-Kuskokwim Mts.; 64ㅇ$24^{\prime} 32^{\prime \prime} \mathrm{N}, 155^{\circ} 37^{\prime} 10^{\prime \prime} \mathrm{W}$; BGN 1936; (map 98).

Prospectors' name reported by Mertie and Harrington (1924, p. 94), USGS.

Swift Creek: stream, see Crooked Creek.

Swift Fork: stream, $75 \mathrm{mi}$. long, flows NW from Chedotlothna Glacier, to North Fork Kuskokwim River, $2 \mathrm{mi}$. SE of Little Hog Butte and $50 \mathrm{mi}$. NE of Medfra, Kuskokwim Low.; $63^{\circ} 34^{\prime} \mathrm{N}, 153^{\circ} 30^{\prime} \mathrm{W}$; BGN 1956; (map 89). Var. McKinley Fork Kuskokwim River, Shangavinapok, Swift Fork Kuskokwim River, Swift River, Chedotlothna River.

Local name reported about 1912 by Jacob Johnson, trapper, as "Swift River" or "as the natives called it 'Shangavinapok'." Although local usage of "McKinley Fork" was reported in 1955 by USGS, "Swift Fork" was recommended in 1956.

Swift Fork: stream, see Tonzona River.

Swift Fork Kuskokwim River: stream, see Swift Fork.

Swift Islands: islands, see Twin Islands.

Swift Point: point of land, on $\mathrm{W}$ coast of Amlia I., Aleutian Is.; 52 $07^{\prime} 20^{\prime \prime} \mathrm{N}, 174^{\circ} 02^{\prime} 50^{\prime \prime} \mathrm{W}$; (map 18).

Descriptive name applied "because of the swift currents and tide rips in Amlia Pass." Published by USC\&GS in the 1944 Aleutian Coast Pilot (p. 90).

Swift River: stream, flows SE $8 \mathrm{mi}$. to Chikululnuk Creek, $3 \mathrm{mi}$. N of mouth of Gemuk River and $80 \mathrm{mi}$. SW of Sleetmute, KilbuckKuskokwim Mts. ; $60^{\circ} 50^{\prime} \mathrm{N}, 158^{\circ} 32^{\prime} \mathrm{W}$; (map $60)$.

Local name obtained in 1932 by BIA.

Swift River: stream, heads from several glaciers in Alaska Ra. at $61^{\circ} 36^{\prime} 30^{\prime \prime} \mathrm{N}, 153^{\circ} 58^{\prime} 50^{\prime \prime} \mathrm{W}$, flows $W$ and NW 100 mi. to Kuskokwim River, 
$13 \mathrm{mi}$. NE of Sleetmute, Stony River Low.; $61^{\circ} 53^{\prime} 20^{\prime \prime} \mathrm{N}, 156^{\circ} 18^{\prime} 30^{\prime \prime} \mathrm{W}$; (map 72). Var. Chagavenapuk, Chagvanakhtuli, Chakawunapuk River, Chotschnalitno, Khochalitno River, Tschagevanchtuli.

Local translation of Eskimo name recorded as "R[eka] Chagvanakhtuli" in $1842-44$ by Lt. L. A. Zagoskin, IRN. Given as "Chakawunapuk" on a 1898 fieldsheet by W. S. Post, USGS, but published as "Chagavenapuk" by J. E. Spurr, USGS. Zagoskin also gave the Indian name which he recorded as "Khockalitno." In 1908 A. G. Maddren, USGS, reported the translated name as "Swift River."

Swift River: stream, flows NE and SE $20 \mathrm{mi}$. to Anvik River, $55 \mathrm{mi}$. S of Unalakleet, Nulato Hills, $63^{\circ} 04^{\prime} 10^{\prime \prime} \mathrm{N}, 160^{\circ} 43^{\prime} 00^{\prime \prime} \mathrm{W}$; (map 91).

Local name reported in 1949 by USC\&GS. Swift River: stream, see Swift Fork.

Swift Rock, Point: rock, $0.3 \mathrm{mi}$. N of Point Swift, W coast of Prince of Wales I., $21 \mathrm{mi}$. NW of Craig, Alex. Arch.; $55^{\circ} 46^{\prime} \mathrm{N}, 133^{\circ} 19^{\prime} \mathrm{W}$; (map 4).

Local name published in 1925 Coast Pilot (p. 151).

Swikschak: bay, see Swikshak Bay.

Swikshak: locality, site of village, on NE coast of Alaska Penin. in Katmai National Monument, at mouth of Swikshak River, $50 \mathrm{mi}$. SW of Augustine I., Aleutian Ra.; $58^{\circ} 36^{\prime} 30^{\prime \prime} \mathrm{N}$, $153^{\circ} 46^{\prime} 25^{\prime \prime} \mathrm{W}$; (map 43).

Name derived from Swikshak Bay and published on a 1952 USGS map.

Swikshak Bay: bay, $8 \mathrm{mi}$. across, on $\mathrm{S}$ shore of Alaska Penin., in Katmai National Monument, $25 \mathrm{mi}$. SW of Cape Douglas, Aleutian Ra.; $58^{\circ} 36^{\prime} \mathrm{N}, 153^{\circ} 48^{\prime} \mathrm{W}$; (map 43). Var. Sbichsak, Suikhchak, Swikschak, Svikhshak.

Native name published by Capt. Lutke (1836, p. 275), IRN, as "Svikhchak golfe" and by Capt. Tebenkov (1852, map 22), IRN, as "Z[aliv] Svikhshak," or "Svikhshak Bay."

Swikshak Lagoon: lagoon, mouth of Swikshak River, extends NE $2.2 \mathrm{mi}$., on NE coast of Alaska Penin., in Katmai National Monument, $50 \mathrm{mi}$. SW of Augustine I., Aleutian Ra.; $58^{\circ} 36^{\prime} 30^{\prime \prime} \mathrm{N}, 153^{\circ} 46^{\prime} 30^{\prime \prime} \mathrm{W}$; (map 43).

Name derived from Swikshak Bay and published in 1952 on a USGS map.

Swikshak River: stream, heads at glacier terminus, on NE coast of Alaska Penin., in Katmai National Monument, flows $\mathbf{S}$ through Swikshak Lagoon, $6.5 \mathrm{mi}$. to Shelikof Strait, Aleutian Ra.; 58 $36^{\prime} 25^{\prime \prime} \mathrm{N}, 143^{\circ} 46^{\prime} 35^{\prime \prime} \mathrm{W}$; (map 43).

Name derived from Swikshak Bay and published on a 1952 USGS map.

Swineford, Mount: mountain, elev. 6,841 ft., $8.7 \mathrm{mi}$. SE of Taku Lodge on Taku River and $28 \mathrm{mi}$. NE of Juneau, Coast Mts.; $58^{\circ} 26^{\prime} 05^{\prime \prime}$ N, $133^{\circ} 43^{\prime} 15^{\prime \prime} \mathrm{W}$; (map 12).

Named in 1932 by B. D. Stewart, USGS, for Alfred P. Swineford, second governor of Alaska, who was appointed in 1885 , and because "the mountain lies in the vicinity of the city of Juneau, where members of family of ex-Governor Swineford now reside."
Swineford Lake: lakes, $2.6 \mathrm{mi}$. long, along Yehring Creek, $2 \mathrm{mi}$. NW of Mount Swineford and $26 \mathrm{mi}$. NE of Juneau, Coast Mts.; $58^{\circ} 27^{\prime} 30^{\prime \prime} \mathrm{N}, 133^{\circ} 46^{\prime} 30^{\prime \prime} \mathrm{W}$; BGN 1932; (map 12)

Named in 1952 by B. D. Stewart, USGS, because "the lakes received their principal water supply from hanging glaciers lying on the westerly slopes of Mount Swineford."

Swing Creek: stream, see Hammer Creek.

Swinging Dome: mountain, 2,264 ft., $\mathrm{W}$ of Iditarod River, $11.7 \mathrm{mi}$. SW of Flat and 49 mi. NE of Holy Cross, Kilbuck-Kuskokwim Mts.; $62^{\circ} 20^{\prime} \mathrm{N}, 158^{\circ} 17^{\prime} \mathrm{W}$; (map 79).

Prospectors' name published in 1921 by USGS

Swinoi Island: island, see Hog Island.

Swirl Islands: islands, see Yelnu Islets.

Swirl Reef: reef, see Fathometer Reef.

Swirl Rock: rock, in Akun Strait between Akun and Akutan Is., $4.5 \mathrm{mi}$. $\mathrm{E}$ of Akutan, Aleutian. Is. ; $54^{\circ} 08^{\prime} 05^{\prime \prime} \mathrm{N}, 165^{\circ} 39^{\prime} 25^{\prime \prime} \mathrm{W}$; (map 24)

Name published in 1943 by USC\&GS.

Switchback Mountain: mountain, 1,711 ft., W Illinois Creek, $14 \mathrm{mi}$. NE of Birches, KokrinesHodzana High.; $65^{\circ} 16^{\prime} 00^{\prime \prime} \mathrm{N}, 153^{\circ} 13^{\prime} 30^{\prime \prime}$ W; (map 107).

Local name reported in 1915 by Waring (1917, fig. 12), USGS.

Switch Creek: stream, flows W $2 \mathrm{mi}$. to Chicken Creek, $50 \mathrm{mi}$. SW of Eagle, Yukon-Tanana High.; 64ㅇ․ $06^{\prime} \mathrm{N}, 141^{\circ} 55^{\prime} \mathrm{W}$; (map 102).

Prospectors' name shown on an 1898 manuscript map by C. A. Woodruff, Fort Cudahy, Canada.

Switch Creek: stream, flows NW $2 \mathrm{mi}$. to Deadwood Creek, $35 \mathrm{mi}$. SW of Circle, YukonTanana High.; $65^{\circ} 28^{\prime} 30^{\prime \prime} \mathrm{N}, 144^{\circ} 54^{\prime} 00^{\prime \prime} \mathrm{W}$; (map 104).

Named by prospectors; reported in 1903 by USGS (Prindle, 1905, pl. 3).

Sword Point: point of land, SW tip of San Fernando I., $10 \mathrm{mi}$. W of Craig, Alex. Arch.; $55^{\circ} 28^{\prime} 15^{\prime \prime}$ N, $133^{\circ} 23^{\prime} 50^{\prime \prime}$ W; (map 4). Var. Punta de Espada.

Translation by USC\&GS of the name "Punta de Espada" given in 1775-1779 by Bodega y Quadra and Francisco Antonio Maurelle.

Sword Point: point of land, $W$ tip of Tozitna I., in Yukon River, $12 \mathrm{mi}$. WSW of Tanana, Nowitna Low. ; $65^{\circ} 07^{\prime} 30^{\prime \prime} \mathrm{N}, 152^{\circ} 28^{\prime} 00^{\prime \prime} \mathrm{W}$; (map 106).

Riverboat pilots' descriptive name shown on Navigation Chart of the Tanana-Yukon Rivers, dated 1940

Sword Point: point of land, see Espada, Point. S. W. Twin: peak, see Southwest Twin.

Syakhlidok, Ostrov: island, see Sitkalidak Island. Syatkhlidak, Ostrov: island, see Sitkalidak Island.

Syatkhlidak, Proliv: water passage, see Sitkalidak Strait.

Syble Point: point of land, on NE coast of Cleveland Penin., between Behm Canal and Yes Bay, Alex. Arch.; 55 $53^{\prime} 20^{\prime \prime} \mathrm{N}, 131^{\circ} 44^{\prime}$ $00^{\prime \prime} \mathrm{W}$; (map 3$)$.
Named in 1891 by USC\&GS.

Sycamore Bay: bay, see Monashka Bay. Syemidy, Ostrova: islands, see Semidi Islands. Sykes, Point: point of land, $\mathrm{E}$ point of entrance to Behm Canal, Coast Mts.; 55 $11^{\prime} 30^{\prime \prime} \mathrm{N}$, $131^{\circ} 05^{\prime} 30^{\prime \prime}$ W; (map 3). Var. Mys Seykes.

Named by Capt. Vancouver, RN, "August 7, 1793, after John Sykes, a master's mate on the Discovery" (Wagner, 1937, p. 418). Sykes Cove: estuary, extends S $0.5 \mathrm{mi}$. off Behm Canal, 2 mi. W of Behm Mts., Coast Mts.; $55^{\circ} 12^{\prime} 00^{\prime \prime} \mathrm{N}, 131^{\circ} 04^{\prime} 45^{\prime \prime} \mathrm{W}$; BGN 1929; (map 3).

Local name reported in 1929 by USFS.

Sykes Lake: lake, $1.4 \mathrm{mi}$. long, $4 \mathrm{mi}$. SE of Point Sykes on Behm Canal, Coast Mts.; $55^{\circ} 09^{\prime} \mathrm{N}$, $131^{\circ} 00^{\prime} \mathrm{W} ; B G N$ 1962; (map 3).

Local name recorded in 1955 by USGS.

Sylburn Harbor: $b a y, 2 \mathrm{mi}$. across, on W coast of Annette I., N of Port Chester, Alex. Arch.; $55^{\circ} 12^{\prime} \mathrm{N}, 131^{\circ} 36^{\prime} \mathrm{W}$; (map 3).

Named in 1883 by Lt. Comdr. H. E. Nichols, USN.

Sylva Creek: stream, heads about $57^{\circ} 32^{\prime} \mathrm{N}$, $133^{\circ} 13^{\prime} \mathrm{W}$, flows $\mathrm{W}$ about $4 \mathrm{mi}$. to Chuck River $1.5 \mathrm{mi}$. above river's mouth at head of Windham Bay and $65 \mathrm{mi}$. SE of Juneau, Coast Mts.; 57 $33^{\prime} 50^{\prime \prime} \mathrm{N}, 133^{\circ} 20^{\prime} 40^{\prime \prime} \mathrm{W}$; (map 8). Var. Sylvia Creek.

Named by prospectors and reported in 1903 by Spencer (1906, fig. 3). It was probably named for "Nix" Sylva, prospector, who in 1869 made gold discoveries on Windham and Holkham Bays and later in the Juneau area. The creek contains gold-bearing gravels.

Sylvanite Greek: stream, flows S $2.5 \cdot \mathrm{mi}$. to Aurora Creek which flows to Noxapaga River, $27 \mathrm{mi}$. W of Imuruk Lake, Seward Penin. High.; $65^{\circ} 38^{\prime} \mathrm{N}, 164^{\circ} 13^{\prime} \mathrm{W}$; (map 110).

Prospectors' name reported on the 1908 "Map of Seward Peninsula" by Arthur Gibson.

Sylvia Creek: stream, see Sylva Creek.

Symond Bay: bay, see Symonds Bay.

Symonds Bay: bay, $0.5 \mathrm{mi}$. across, on $\mathrm{N}$ coast of Biorka I., W of Baranof I., Alex. Arch. $56^{\circ} 51^{\prime} 40^{\prime \prime} \mathrm{N}, 135^{\circ} 31^{\prime} 00^{\prime \prime} \mathrm{W} ; B G N$ 1897; (map 5). Var. Symond Bay.

Named in 1879 by USC\&GS for Lt. Frederick Martin Symonds, USN, who surveyed the bay in 1879 with Master G. C. Hanus, USN.

Symonds Point: point of land, on $\mathrm{N}$ coast of Mansfield Penin., 3.3 mi. SE of Barlow Point and $15 \mathrm{mi}$. NW of Juneau, Alex. Arch.; $58^{\circ} 20^{\prime} 30^{\prime \prime} \mathrm{N}, 134^{\circ} 50^{\prime} 00^{\prime \prime} \mathrm{W}$; (map 11).

Named in 1884 by Comdr. J. B. Coghlan, USN, for Lt. Frederick M. Symonds, who served under Capt. L. A. Beardslee on the U.S.S. Jamestown and under Comdr. H. Glass, USN, on the U.S.S. Wachusett, while surveying this part of Alaska in 1879-81. The name was published by USC\&GS in the 1883 Coast Pilot (p. 173).

Syncline Mountain: mountain, 5,400 ft., extends SW $8 \mathrm{mi}$. from Belanger Pass, between Alfred and Squaw Creeks, $55 \mathrm{mi}$. NE of Palmer, 
Talkeetna Mts. ; $61^{\circ} 55^{\prime} 45^{\prime \prime} \mathrm{N}, 147^{\circ} 28^{\prime} 05^{\prime \prime} \mathrm{W}$; $B G N$ 1960; (map 69).

So named in 1956 by USGS because "it is composed entirely of bedded rocks folded into a large syncline.'

Synrock River: stream, see Sinuk River.

Syooknook River: stream, see Pile River.

Syroy, Mys: point of land, see Siroi Point.

Syumetsy, Ostrov: island, see Suemez Island.

Syvernoy, Mys: point of land, see Lighthouse Point.

Syvernoy, Mys: promontory, see Akun Head.

Syvernoy, Proliv: water passage, see Kupreanof Strait.

Syvernyy, Mys: point of land, see North Cape.

\section{$\mathbf{T}$}

T, Mount: mountain, 8,001 ft., Boundary Peak 72 on Alaska-Canada boundary, $3.5 \mathrm{mi}$. NE of Mount Burkett and $118 \mathrm{mi}$. E of Sitka, Coast Mts.; $57^{\circ} 12^{\prime} 45^{\prime \prime} \mathrm{N}, 132^{\circ} 14^{\prime} 45^{\prime \prime} \mathrm{W}$; BGN 1953; (map 8). Var. Boundary Peak 72, T Mountain, T Peak.

So designated in 1903 by the Alaskan Boundary Tribunal.

T, Peak: mountain, $1,000 \mathrm{ft}$., $1.5 \mathrm{mi}$. $\mathrm{N}$ of Beluga Hill, $6 \mathrm{mi}$. W of Goodnews, KilbuckKuskokwim Mts.; $59^{\circ} 08^{\prime} \mathrm{N}, 161^{\circ} 44^{\prime} \mathrm{W}$; (map 53).

Name reported in 1954 by USGS.

Taain Creek: stream, $1 \mathrm{mi}$. long, flows $\mathrm{SW}$ to Wrangell Narrows on NW coast of Mitkof I. $6 \mathrm{mi}$. S of Petersburg, Alex. Arch.; 56 ${ }^{\circ} 44^{\prime} 45^{\prime \prime}$ N, 132 $56^{\prime} 25^{\prime \prime} \mathrm{W}$; BGN 1933; (map 6).

Named in 1933 by USFS "for an Indian who is said to have settled in this vicinity early in the nineteenth century, and to have had a widespread influence for good among the natives."

Taain Creek: stream, see Falls Creek.

Taaltsug River: river, one of five rivers on delta of Alsek River, flows to Gulf of Alaska, 50 mi. SE of Yukutat, Malaspina Coastal Plain; $59^{\circ} 07^{\prime} \mathrm{N}, 138^{\circ} 30^{\prime} \mathrm{W}$; (map 46).

Tlingit Indian name published by Capt. Tebenkov (1852, map 7), IRN, on an 1849 map.

Taapkuk: locality, at Cape Espenberg on Kotzebue Sound, Kotzebue-Kobuk Low.; 66 $33^{\circ}$ N, 163 $36^{\prime}$ W; (map 113). Var. Tapkachmiut, Tapkhakgmut, Tup-kug-ameuts.

Former Eskimo village or camp reported in 1847 as "Tapkhakgmut" by Lt. L. A. Zagoskin, IRN, (Hodge, 1910, p. 691); listed as "Ta-apkuk," population 42 , in the 1880 Census by Petroff $(1884$, p. 4$)$.

Taaqtaluuzaq: locality, see Taktalurak Rocks.

Tabasco Creek: stream, flows SE $2.4 \mathrm{mi}$. to Sawpit Creek, $30 \mathrm{mi}$. S of Aniak, KilbuckKuskokwim Mts.; $61^{\circ} 08^{\prime} \mathrm{N}, 159^{\circ} 28^{\prime} \mathrm{W}$; (map 73)

Prospectors' name "from tabasco sauce" reported by USC\&GS in 1948 .

Tabeascot Lake: lake, $2 \mathrm{mi}$. long, on $\mathrm{N}$ bank of Koyukuk River, $27 \mathrm{mi}$. E of Allakaket, Kanuti Flats; $66^{\circ} 34^{\prime} 45^{\prime \prime} \mathrm{N}, 152^{\circ} 32^{\prime} 00^{\prime \prime} \mathrm{W}$; (map $117)$.
Koyukan Indian name obtained in 1956 at Allakaket by T. E. Taylor, USGS.

Tabernacle Mountain: mountain, 1,163 ft., in Paimiut Hills, on $\mathrm{W}$ bank of Yukon River, $16 \mathrm{mi}$. SW of Holy Cross, Nulato Hills, $62^{\circ} 00^{\prime} 25^{\prime \prime} \mathrm{N}, 160^{\circ} 04^{\prime} 20^{\prime \prime} \mathrm{W}$; (map 78).

Local name obtained in 1952 by USGS.

Tabert Lake: lake, $0.8 \mathrm{mi}$. long, $2.6 \mathrm{mi}$. WSW of Little Lake Louise and $40 \mathrm{mi}$. WNW of Glennallen, Copper River Basin; 62 ${ }^{\circ} 17^{\prime} 30^{\prime \prime}$ N, $146^{\circ} 45^{\prime} 00^{\prime \prime} \mathrm{W}$; (map 83).

Local name reported in 1959 by USGS.

Table Bay: bay, $1.5 \mathrm{mi}$. across, $11 \mathrm{mi}$. NW of Cape Decision, on S coast of Kuiu I., Alex. Arch.; $56^{\circ} 09^{\prime} \mathrm{N}, 134^{\circ} 15^{\prime} \mathrm{W}$; (map 5).

Local name used by fishermen; published in 1917 by USC\&GS.

Table Island: island, $800 \mathrm{ft}$. long, at NE entrance to Sitkalidak Strait, SE of Kodiak I.; $57^{\circ} 11^{\prime}$ $20^{\prime \prime} \mathrm{N}, 152^{\circ} 55^{\prime} 00^{\prime \prime} \mathrm{W}$; BGN 1930; (map 34). Var. Entrance Island.

Descriptive name given in 1928 by USC\&GS, "because of the table-like appearance of the island." Previously called "Entrance Island;" the name was changed because of duplications.

Table Island: island, $0.1 \mathrm{mi}$. across, southernmost of two islands in Killisnoo Harbor, off W coast of Admiralty I., $3 \mathrm{mi}$. $S$ of Angoon, Alex. Arch.; 57 $27^{\prime} 25^{\prime \prime} \mathrm{N}, 134^{\circ} 34^{\prime} 55^{\prime \prime} \mathrm{W}$; (map 9). Var. Table Islands.

Named in 1869 by Comdr. R. W. Meade, USN; published as "Table Islands" on Hydrographic Ghart 225

Table Islands: island, see Table Island.

Table Mountain: hill, between heads of Koyuk and Kuzitrin Rivers, about $10 \mathrm{mi}$. SW of Imuruk Lake, Seward Penin. High.; (map $110)$.

Prospectors' name shown on a map of Cape Nome gold fields by David Fox, Jr., dated 1901. This stream cannot be precisely located on current maps.

Table Mountain: mountain, 2,700 ft., on Cleveland Penin. near head of Santa Anna Inlet, Alex. Arch.; $55^{\circ} 58^{\prime} 30^{\prime \prime} \mathrm{N}, 131^{\circ} 54^{\prime} 15^{\prime \prime} \mathrm{W}$; (map 3$)$.

Name published in 1910 by USC\&GS.

Table Mountain: mountain, 2,701 ft., on $S$ end of Admiralty I., S of Whitewater Bay, $20 \mathrm{mi}$. S of Angoon, Alex. Arch.; 57 $12^{\prime} 15^{\prime \prime} \mathrm{N}, 134^{\circ}$ $34^{\prime} 45^{\prime \prime} \mathrm{W}$; (map 9).

Descriptive name published by USC\&GS in the 1901 Alaska Coast Pilot (p. 161). This mountain is a prominent landmark in the Whitewater Bay area.

Table Mountain: mountain, 1,350 ft., on NE end of Ushagat I., in Barren Is., $70 \mathrm{mi}$. NE of Afognak, Chugach Mts.; $58^{\circ} 56^{\prime} 35^{\prime \prime} \mathrm{N}$, $152^{\circ} 10^{\prime} 05^{\prime \prime} \mathrm{W}$; (map 43$)$.

Descriptive name given in 1908 and published in 1910 by USC\&GS.

Table Mountain: mountain, 9,360 ft., surrounded by Columbus and Quintino Sella Glaciers, $9 \mathrm{mi}$. NE of Mount Huxley and 79 mi. NW of Yakutat, St. Elias Mts.; $60^{\circ} 27^{\prime} 20^{\prime \prime}$ N, $141^{\circ} 05^{\prime} 00^{\prime \prime}$ W; BGN 1917; (map 65).
Descriptive name proposed by the IBC in 1916.

Table Mountain: mountain, $4,300 \mathrm{ft}$., on $\mathrm{W}$ bank of Crooked Creek, $66 \mathrm{mi}$. NE of Palmer, Talkeetna Mts.; 61 ${ }^{\circ} 59^{\prime} 35^{\prime \prime} \mathrm{N}, 147^{\circ} 18^{\prime} 30^{\prime \prime} \mathrm{W}$. (map 69).

Local descriptive name reported in 1951 by USGS.

Table Mountain: mountain, $.5,042 \mathrm{ft}$., $\mathrm{E}$ of Sheenjek River, $50 \mathrm{mi}$. NE of Arctic Village, Brooks Ra.; $68^{\circ} 20^{\prime} \mathrm{N}, 143^{\circ} 39^{\prime} \mathrm{W}$; (map 137).

Local descriptive name reported in 1926 by J. B. Mertie, Jr., USGS

Table Rock: rock, on $\mathrm{N}$ side of Deer Passage, off Bold Cape, $23 \mathrm{mi}$. SE of village of Cold Bay, at SW end of Alaska Penin., Aleutian Ra.; $55^{\circ} 01^{\prime} 30^{\prime \prime} \mathrm{N}, 162^{\circ} 13^{\prime} 50^{\prime \prime} \mathrm{W}$; (map 29).

Descriptive name given by USC\&GS in 1927 on Chart 8703.

Table Rock: rock, $375 \mathrm{ft}$. long, in Sakie Bay, on W coast of Dall I., Alex. Arch.; 55 $04^{\prime} 15^{\prime \prime}$ $\mathrm{N}, 133^{\circ} 12^{\prime} 45^{\prime \prime} \mathrm{W}$; (map 4).

Descriptive name published in 1924 by USC\&GS.

Table Top: mountain, $3,312 \mathrm{ft}$., $8.5 \mathrm{mi}$. S of the junc. of Kanayut and Anaktuvuk Rivers, 38 mi. NE of Anaktuvuk Pass, Arctic Slope; $68^{\circ} 37^{\prime} 00^{\prime \prime} \mathrm{N}, 151^{\circ} 02^{\prime} 30^{\prime \prime} \mathrm{W}$; (map 134).

Descriptive name given by USGS geologists during the exploration of Naval Petroleum Reserve No. 4 ; name given in 1944.

Table Top Mountain: mountain, 2,710 ft., N coast of Unalaska I., Aleutian Is.; $53^{\circ} 58^{\prime} 15^{\prime \prime}$ $\mathrm{N}, 166^{\circ} 40^{\prime} 50^{\prime \prime} \mathrm{W}$; (map 23 ).

This descriptive name was published in the 1944 Aleutian Coast Pilot (p. 41).

Table Top Mountain: mountain, 3,166 ft., on $N$ part of Douglas I., $3.5 \mathrm{mi}$. W of Juneau, Coast Mts. ; 58 $17^{\prime} 35^{\prime \prime} \mathrm{N}, 1^{\circ} 34^{\circ} 10^{\prime \prime} \mathrm{W}$; (map 11).

Descriptive name given in 1962 by the USGS.

Table Top Mountain: mountain, 3,130 ft., 34 $\mathrm{mi} \mathrm{NW}$ of Chena Hot Springs and $50 \mathrm{mi}$. NE of Fairbanks, Yukon-Tanana High.; 65 ${ }^{\circ} 22^{\prime}$ $\mathrm{N}, 146^{\circ} 57^{\prime} \mathrm{W}$; (map 104).

Prospectors' name reported in 1954 or 1955 by USGS topographers.

Tacghli, Ile: island, see Takli Island.

Tachaichagat River: stream, see Iditarod River. Tachanlowa Lake: lake, in Koyukuk River flats, $20 \mathrm{mi}$. SW of Roundabout Mtn., Koyukuk Low.; $65^{\circ} 29^{\prime} \mathrm{N}, 157^{\circ} 12^{\prime} \mathrm{W}$; (map 108).

Koyukan Indian name reported by USGS in 1955

Tachatna River: stream, see Takotna River.

Tachat River: stream, see Takotna River.

Tachik: locality, see Techek.

Tachik: bay, see Golovnin Bay.

Tachik: bay, see Pavlof Bay.

Tachikthluk Bay: bay, see Duchikthluk Bay.

Tachilni, Cape: point of land, on $\mathrm{E}$ shore of Morzhovoi Bay, Aleutian Ra.; 53 $56^{\prime} 00^{\prime \prime} \mathrm{N}$, $162^{\circ} 52^{\prime} 30^{\prime \prime}$ W; (map 25). Var. Animatchoutchkok, Tochilnoi

Descriptive Russian name published by Capt. Tebenkov (1852, map 24), IRN, as "M[ys] Tochilnoi" meaning "Cape Grind- 
stone." The Aleut name for this point was reported by Capt. Lutke (1836, p. 272), IRN, as "Animatchoutchkok."

Tachimesoa Lagoon: lagoon, $6 \mathrm{mi}$. long, on coast of Chukchi Sea, at S end of Kasegaluk Lagoon, $28 \mathrm{mi}$. S of Point Lay, Arctic Plain; $69^{\circ} 19^{\prime} \mathrm{N}, 163^{\circ} 12^{\prime} \mathrm{W}$; (map 145).

This is the Eskimo name meaning "end lagoon," for the S end of Kasegaluk Lagoon. Name obtained by Orth in 1956.

Tachinisok Inlet: lagoon, $1 \mathrm{mi}$. across, off Peard Bay, $12 \mathrm{mi}$. SE of Point Franklin, Arctic Plain; $70^{\circ} 49^{\prime} \mathrm{N}, 158^{\circ} 19^{\prime} \mathrm{W}$; (map 147). Var. Kuahru, Tatchinesua Inlet, Woody Inlet.

Eskimo name reported by USC\&GS in 1950 . It was called "Woody Inlet" by English naval officers about 1850 . Sgt. John Murdoch reported the Eskimo name as "Kuahru" (Ray, P. H., 1885, p. 95).

Tachkinach: island, see Simeonof Island.

Tachshilik River: stream, see Takshilik Greek.

Tachti Island: island, see Takli Island.

Tachyhuimiut: locality, fish camp, on $\mathrm{W}$ shore of Dahloongamiut Lagoon, $35 \mathrm{mi}$. NW of Cape Mendenhall, Nunivak I.; $60^{\circ} 00^{\prime} 07^{\prime \prime} \mathrm{N}, 167^{\circ}$ $04^{\prime} 55^{\prime \prime}$ W; (map 57). Var. Dahloongamiut, Daloongmute, Talungamiut.

Eskimo name reported in 1937 by USAAF.

Tachyhuimiut: locality, see Dahloongamiut.

Ta-clik: locality, see Tklik.

Taclodahten Lake: lake, $1.3 \mathrm{mi}$. long, at head of Kadakina Creek, $32 \mathrm{mi}$. SE of Allakaket, Kanuti Flats; $66^{\circ} 18^{\prime} 30^{\prime \prime} \mathrm{N}, 151^{\circ} 40^{\prime} 30^{\prime \prime} \mathrm{W}$; (map 117). Var. Taklodaten Lake.

Koyukan Indian name obtained in 1956 at Allakaket by T. E. Taylor, USGS.

Taco Gulf : estuary, see Taku Inlet.

Taco Harbor: cove, see Taku Harbor.

Taco Inlet: estuary, see Taku Inlet.

Tacoma: locality, "on Valdez-Fairbanks trail (Richardson Highway) $55 \mathrm{mi}$. N of Valdez," Chugach Mts.; $61^{\circ} 25^{\prime} \mathrm{N}, 1^{\circ} 5^{\circ} 15^{\prime} \mathrm{W}$; (map 68). Var. Kendall Gache.

Former roadhouse name published in 1908 by USGS; and in 1916 in Polk's Gazetteer Located at or near Kendall Cache roadhouse.

Tacotna: village, see Takotna.

Tacotna River: stream, see Takotna River.

Tacou Harbor: cove, see Taku Harbor.

Tacou Inlet: estuary, see Taku Inlet.

Taddiskey Harbor: bay, see Datzkoo Harbor.

Taddys Cove : bay, see Datzkoo Harbor.

Tadluk, Cape: point of land, on $\mathrm{S}$ coast of Atka I., Aleutian Is.; $52^{\circ} 01^{\prime} \mathrm{N}, 174^{\circ} 43^{\prime} \mathrm{W}$; (map 18).

Aleut name published as "M[ys] Tadluk," or "Cape Tadluk," by Capt. Tebenkov (1852, map 27), IRN.

Tadoosh: locality, see Charley Village.

Tadrandike: lake, see Chandalar Lake.

Tadrandike River: stream, see Chandalar River. Tadush: locality, see Charley Village.

Taffy Creek: stream, flows NW $5 \mathrm{mi}$. to Ipnavik River, Brooks Ra.; $68^{\circ} 36^{\prime} \mathrm{N}, 157^{\circ} 07^{\prime} \mathrm{W}$; (map 132).

Named in 1950 by I. L. Tailleur, USGS, connected with the Naval Petroleum Reserve No. 4 explorations, for a taffy colored bear.
Taft Creek: stream, flows NW 13 mi. to Big Lake $1.5 \mathrm{mi}$. S of Rennies Landing on Innoko River, $37 \mathrm{mi}$. NW of Ophir and $64 \mathrm{mi}$. NW of McGrath, Innoko Low.; $63^{\circ} 35^{\prime} 30^{\prime \prime} \mathrm{N}$, $157^{\circ} 04^{\prime} 50^{\prime \prime} \mathrm{W}$; (map 90).

Local name obtained from Joseph Ferris in 1954 by R. E. Isto, USGS.

Tagachalgise Island: islands, see Tag Islands. Tagachalugis Island: islands, see Tag Islands. Tagadakh Island: island, see Tagadak Island.

Tagadak Island: island, $1 \mathrm{mi}$. across, between Great Sitkin and Umak Is., one of Andreanof Is., Aleutian Is.; $51^{\circ} 57^{\prime} 30^{\prime \prime} \mathrm{N}, 176^{\circ} 00^{\prime} 00^{\prime \prime}$ W; BGN 1936; (maps 17, 18). Var. Tagadakh Island.

Aleut name published by Capt. Tebenkov (1852, map 28), IRN, as "O[strov] Tagadakh," or "Tagadakh Island." According to R. H. Geoghegan, this Aleut word means "fresh" or "new."

Tagadak Island: island, see Tagalak Island.

Tagagawik River: stream, flows N $85 \mathrm{mi}$. to Selawik River, $30 \mathrm{mi}$. SE of Selawik, Kotzebue-Kobuk Low.; $66^{\circ} 28^{\prime}$ N, $159^{\circ} 00^{\prime} \mathrm{W}$; (map 114). Var. Tag-gag-a-wik.

Eskimo name reported in 1886 as "Taggag-a-wik" by Lt. Stoney (1900, map), USN.

Tagakvik, Lake: lake, $2.4 \mathrm{mi}$. long, $7 \mathrm{mi}$. NE of junc. of Kelley and Noatak Rivers, $35 \mathrm{mi}$. NE of Noatak, Brooks Ra.; $67^{\circ} 59^{\prime} \mathrm{N}, 162^{\circ} 07^{\prime} \mathrm{W}$; (map 128).

Eskimo name meaning "shadowy place" obtained at Noatak in 1956 by Orth.

Tagalack Bay: bay, see Dakavak Bay.

Tagalack Lake: lake, see Dakavak Lake.

Tagalak Bay: bay, see Dakavak Bay.

Tagalakh Island: island, see Tagalak Island.

Tagalak Island: island, $4 \mathrm{mi}$. long, between Atka and Adak Is., Andreanof Is., Aleutian Is.; $51^{\circ} 57^{\prime} \mathrm{N}, 175^{\circ} 43^{\prime} \mathrm{W}$; BGN 1936; (map 18). Var. Tagadak Island, Tagalakh Island.

Aleut name published from Commodore Joseph Billings' track chart of 1790-92 by Lt. Sarichev, IRN, in 1802; also published as "Tagalak" by Capt. Lutke (1836, p. 320), IRN.

Tagalak Pass: water passage, between Tagalak and Chugul Is., Aleutian Is.; 51 ${ }^{\circ} 56^{\prime} \mathrm{N}$, $175^{\circ} 45^{\prime}$ W; BGN 1936; (map 18).

Named for Tagalak I. by the U.S. Navy Aleutian Island Survey Expedition of 1934, and published by the USC\&GS in the 1944 Aleutian Coast Pilot (p. 104)

Tagalaviksak Slough: watercourse, see Talbiksok River.

Tagamak: island, see Cherni Island.

Taganak: island, see Cherni Island.

Tagarayak: locality, see Tagayarak.

Tagarayak River: stream, see Tagayarak River. Tagatchalgise Island: islands, see Tag Islands.

Tagayarak: locality, on left bank of Tagayarak River, $25 \mathrm{mi} \mathrm{W}$ of Eek and $48 \mathrm{mi}$. SW of Bethel, Yukon-Kuskokwim Delta; $60^{\circ} 17^{\prime} \mathrm{N}$, $162^{\circ} 45^{\prime} \mathrm{W}$; (map 58). Var. Tagarayak.

Former Eskimo camp or village, named for the stream; reported to be abandoned in 1951 by USC\&GS.
Tagayarak River: stream, heads at $60^{\circ} 18^{\prime} \mathrm{N}$, $163^{\circ} 12^{\prime} \mathrm{W}$, flows SE $25 \mathrm{mi}$. to Kuskokwim River, $18 \mathrm{mi}$. W of Eek and $46 \mathrm{mi}$. SW of Bethel, Yukon-Kuskokwim Delta; $60^{\circ} 15^{\prime} \mathrm{N}$, $162^{\circ} 32^{\prime}$ W; (map 58). Var. Tagarayak River.

Eskimo name reported in 1949 by USC\&GS. Tagayooneechuk: lakes, see Tagiunituk Lakes. Tagayooneeichuk: stream, see Tagiunituk Creek. Tag-gag-a-wik: stream, see Tagagawik River.

Taghiaratzoriamute: locality, see Togiaratsorik. Taghinak: island, see Simeonof Island.

Tagiak: village, see Togiak.

Tag Island: islands, see Tag Islands.

Tag Islands: islands, $0.5 \mathrm{mi}$. across, $2.5 \mathrm{mi}$. S of Skagul Is., Delarof Is., Aleutian Is.; $51^{\circ} 33^{\prime} 30^{\prime \prime} \mathrm{N}, 178^{\circ} 34^{\prime} 15^{\prime \prime} \mathrm{W}$; (map 16). Var. Tag Island, Tagachalugis Island, Tagachalgise Island, Tagatchalgise Island.

Aleut name published as "O[strov] Tagachalugis," or "Tagachalugis Island," by Capt. Tebenkov (1852, map 28), which refers to the largest island. This and other long variants were shortened to "Tag Islands" by BGN recommendation.

Tagiunituk Creek: stream, flows SW $1 \mathrm{mi}$. to Tatigirok Creek, $2 \mathrm{mi}$. $\mathbf{N}$ of Kavroak Springs and $16 \mathrm{mi}$. NW of Kivalina, Kotzebue-Kobuk Low.; 67 $54^{\prime} \mathrm{N}, 164^{\circ} 55^{\prime} \mathrm{W}$; (map 128). Var. Tagayooneeichuk, Tagiunituq.

Eskimo name meaning "there is salt" reported in 1966 by E. S. Burch.

Tagiunituk Lakes: lakes, $5 \mathrm{mi}$. ESE of mouth of Omikviorok River and $19 \mathrm{mi}$. SE of Kivalina, Kotzebue-Kobuk Low ; $67^{\circ} 35^{\prime}$ N, $163^{\circ} 56^{\prime}$ W; (map 128). Var. Tagayooneechuk, Tagiunituq.

Eskimo name meaning "there is salt" reported in 1966 by E. S. Burch.

Tagiunituq: lakes, see Tagiunituk Lakes.

Tagiunituq: stream, see Tagiunituk Creek.

Tagoomenik River: stream, flows NW $23 \mathrm{mi}$. to Shaktoolik Bay, $24 \mathrm{mi}$. SW of Christmas Mtn., Nulato Hills; $64^{\circ} 21^{\prime} \mathrm{N}, 161^{\circ} 11^{\prime} \mathrm{W}$; BGN 1966; (map 96). Var. Tagumanik River, Tagumenik River.

Eskimo name reported in 1867 by members of the Western Union Telegraph Expedition as "Tagumanik."

Tagumanik River: stream, see Tagoomenik River.

Tagumenik River: stream, see Tagoomenik River.

Taguntna Creek: stream, see Alexander Creek. Taguta: locality, on $\mathrm{N}$ bank of Yukon River, about $15 \mathrm{mi}$. below junc. of Khotol River,

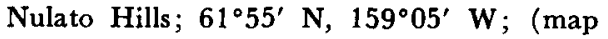
91). Var. Tagutakaka, Taguta-kakat.

Former Indian village or camp recorded in 1869 as "Tagutakaka," by Capt. Raymond (1871, p. 25), U.S. Engineers.

Tagutakaka: locality, see Taguta.

Taguta-kakat: locality, see Taguta.

Tahamund Lake: lake, 2 mi. long, $\mathrm{N}$ of Black Hills, $14 \mathrm{mi}$. S of Northway, Alaska Ra.; $62^{\circ}-$ 45' N, 141 $52^{\prime}$ W; (map 84). Var. Tahanund Lake.

Indian name reported by USGS in 1955 . 
Tahanund Lake: lake, see Tahamund Lake.

Tah Bay: bay, extends SE $3.3 \mathrm{mi}$. off Cordova Bay, on SW coast of Prince of Wales I., SE of Klakas Inlet, Alex. Arch.; 54 $51^{\prime} \mathrm{N}$, $132^{\circ} 21^{\prime} \mathrm{W}$; (map 1$)$.

Tlingit Indian name published in 1943 by USC\&GS.

Taheen River: stream, see Tahini River.

Tahinichok Mountains: mountains, 1,200 ft., extends $10 \mathrm{mi}$. W of Rabbit Creek at $\mathrm{SW}$ end of Mulgrave Hills, $15 \mathrm{mi}$. W of Noatak, Arctic Slope; $67^{\circ} 34^{\prime} \mathrm{N}, 163^{\circ} 42^{\prime} \mathrm{W}$; (map 128). Var. Agaerruich Hills, Agagrak Mountains, Ahgeyagrock, Tooinichook Mountains, Tueenichook Mountains, Tuinichuk Mountains.

Eskimo name meaning "tastes salty" according to USC\&GS in 1950.

Tahini River: stream, heads in Duff Lake in Canada, flows SE $11 \mathrm{mi}$. to Chilkat River, 26 mi. NW of Skagway, St. Elias Mts. ; 59 $36^{\prime} 45^{\prime \prime}$ N, $135^{\circ} 59^{\prime} 10^{\prime \prime} \mathrm{W}$; BGN 1954; (map 45). Var. Taheen River.

Tlingit Indian name meaning "Ta River" reported by Aurel and Arthur Krause (1883 map).

Tahini River: stream, see Takhin River.

Tah Island: island, $1.2 \mathrm{mi}$. long, in Tah Bay, on SW coast of Prince of Wales 1., Alex. Arch.; $54^{\circ} 50^{\prime} 45^{\prime \prime} \mathrm{N}, 132^{\circ} 19^{\prime} 30^{\prime \prime} \mathrm{W}$; (map 1 ).

Name published in 1951 by USGS

Tahkandik River: stream, see Nation River.

Tahkandit River: stream, see Nation River.

Tahka Point: point of land, on W coast of Prince of Wales I. at S end of Tuxekan Narrows, 28 mi. $\mathrm{N}$ of Craig, Alex. Arch.; 55 52' N, $133^{\circ}$. $13^{\prime} \mathrm{W}$; (map 4).

Indian name published in 1964 by USC\&GS.

Tahko Inlet: estuary, see Taku Inlet.

Tahkonah Creek: stream, see Takonak Creek.

Tahk-sahk-wee-vik: water course, see Taksakwivik Slough.

Tahneta Lake: lake, $0.9 \mathrm{mi}$. long, in course of Eureka Creek, NE of Tahneta Pass, on Glenn Highway, 62 mi. NE of Palmer, Copper River Basin; 61 ${ }^{\circ} 54^{\prime} 00^{\prime \prime} \mathrm{N}, 147^{\circ} 18^{\prime} 20^{\prime \prime} \mathrm{W}$; BGN 1960; (map 69). Var. Climax Lake, Eureka Lake, Startup Lake.

Named in 1956 by USGS; derived from. nearby Tahneta Pass.

Tahneta Pass: pass, 3,000 ft., on Glenn Highway, $60 \mathrm{mi}$. SW of Glennallen and $62 \mathrm{mi}$. NE of Palmer, Talkeetna Mts.; 61 $53^{\prime} 10^{\prime \prime} \mathrm{N}$, $147^{\circ} 20^{\prime} 00^{\prime} \mathrm{W}$; (map 69$)$.

Tanaina Indian name reported by Mendenhall (1900, p. 316), USGS.

Tahnohkalony: locality, see Tanakot.

Tahoma Reef: reef, $1.3 \mathrm{mi}$. long, in Pacific Ocean, $33 \mathrm{mi}$. S. of Buldir I. and $55 \mathrm{mi}$. W of Kiska I., Aleutian Is.; $51^{\circ} 48^{\prime} \mathrm{N}, 175^{\circ} 47^{\prime} \mathrm{E}$; (map 14).

Named for cutter Tahoma lost here in 1914 (U.S. Coast and Geodetic Survey, 1944, p 129).

Taiga Lake: lake, $0.6 \mathrm{mi}$. long, on Kenai Penin. NW of Norak Lake, $38 \mathrm{mi}$. NE of Kenai, Cook Inlet Low.; $60^{\circ} 54^{\prime} 30^{\prime \prime} \mathrm{N}, 150^{\circ} 27^{\prime} 00^{\prime} \mathrm{W}$; (map 62).
Named about 1963 by officials of Kenai National Moose Range. "Taiga" is a transliterated Russian word for a cold, swampy, forested region which begins where the tundra leaves off

Taigud Island: island, $0.5 \mathrm{mi}$. across, one of Taigud Is., in Redoubt Bay, on W coast of Baranof I., Alex. Arch.; 56 $55^{\prime} 30^{\prime \prime} \mathrm{N}, 135^{\circ}$ $24^{\prime} 00^{\prime \prime}$ W; (map 5). Var. Ostrov Taygud.

Named in 1809 by the Russian navigator, Ivan Vasiliev the first; published by Lt. Sarichev (1826, map 19), IRN, as "O[strov] Taygud," or "Taygud Island."

Taigud Islands: islands, 2 mi. across, at mouth of Redoubt Bay, $10 \mathrm{mi}$. S of Sitka, on W coast of Baranof I., Alex. Arch.; 56 $55^{\prime}$ N., 135 ${ }^{\circ} 5^{\prime}$ W; (map 5). Var. Ostrov Taygud.

Named "Ostrov Taygud," or "Taygud Island," in 1809 by the Russian navigator Ivan Vasiliev the first; published by Lt. Sarichev (1826, map 19), IRN.

Taiholman Lake: lake, $0.8 \mathrm{mi}$ across, $7 \mathrm{mi}$. S of Taclodahten Lake and $38 \mathrm{mi}$. SE of Allakaket, Kanuti Flats; $66^{\circ} 12^{\prime} 00^{\prime \prime} \mathrm{N}, 151^{\circ} 37^{\prime} 30^{\prime \prime}$ W; (map 117).

Koyukan Indian name obtained in 1956 at Allakaket by T. E. Taylor, USGS.

Taiklano: stream, see Little Nelchina River.

Taiklano Creek; stream, see Bubb Creek.

Taixtsalda Hill: hill, 2,335 ft., between Kalukna and Tetlin Rivers, $17 \mathrm{mi}$. SW of Northway, Alaska Ra.; $62^{\circ} 50^{\prime} \mathrm{N}, 142^{\circ} 23^{\prime} \mathrm{W}$; (map 84).

Tetlin Indian name reported to mean "sharp hill" by USGS in 1962 .

Taiya: locality, see Dyea.

Taiya Inlet: estuary, $13 \mathrm{mi}$. long, trends $\mathrm{S}$ from mouth of Taiya River to Chilkoot Inlet, 12 mi. S of Skagway, Coast Mts.; $59^{\circ} 17^{\prime} \mathrm{N}, 135^{\circ}$ 23' W; BGN Sixth Report; (map 45). Var. Dayay Inlet, Dehjäh Inlet, Dejah Inlet, Dyea Inlet, Perrier Inlet, Tayay Inlet, Tya Inlet, Tÿ̈a Inlet.

A Tlinglit Indian name reported in 1868 by Comdr. R. W. Meade, USN, as Tyÿa and Tya; published in 1870 by USC\&GS on Chart 701. Aurel and Arthur Krause (1883 map) reported the name as Dejäh Inlet, and in 1883 Lt. Schwatka, USA, called it Dayay Inlet.

Taiya Point: point of land, at head of Chilkoot Inlet, $1 \mathrm{mi}$. SE of Taiyasanka Harbor and 12 mi. SW of Skagway, Coast Mts.; $59^{\circ} 17^{\prime} 15^{\prime \prime}$ N, $135^{\circ} 24^{\prime} 00^{\prime \prime} \mathrm{W}$; (map 45).

Named for Taiya Inlet in 1923 on IBC Sheet 9 (1951 atlas).

Taiya River: stream, heads at Chilkoot Pass, on the Alaska-Canada boundary, flows S $17 \mathrm{mi}$. to head of Taiya Inlet, $1 \mathrm{mi}$. N of Dyea Point, and $2 \mathrm{mi}$. NW of Skagway, Coast Mts.; $59^{\circ}$ $28^{\prime} 50^{\prime \prime}$ N, $135^{\circ} 21^{\prime} 15^{\prime \prime}$ W ; BGN Sixth Report ; (map 45). Var. Dyea River.

Name derived from Taiya Inlet and published by USC\&GS in the 1891 Coast Pilot (p. 203). This stream was the first part of the "Dyea Trail" from Dyea through Chilkoot Pass to the Klondike. See Dyea, locality. Taiya Sahnka: bay, see Taiyasanka Harbor.

Taiyasanka Harbor: bay, $1.4 \mathrm{mi}$. long, at head of Chilkoot Inlet, $1 \mathrm{mi}$. NW of Taiya Point and
12 mi. SW of Skagway, Coast Mts.; $59^{\circ} 17^{\prime} 45^{\prime \prime}$ N, $135^{\circ} 25^{\prime} 45^{\prime \prime} \mathrm{W}$; (map 45). Var. Dejahssánke, Taiya Sahnka.

Tlingit Indian name reported by Aurel and Arthur Krause (1883, map), as Dejahssánke. It is published by USC\&GS in the 1891 Coast Pilot (p. 203) as Taiya Sahnka.

Tajittro Creek: stream, flows NW $11 \mathrm{mi}$. to Upper Mouth Birch Creek, $25 \mathrm{mi}$. SW of Fort Yukon, Yukon Flats; $66^{\circ} 29^{\prime} 00^{\prime \prime} \mathrm{N}$, $146^{\circ} 04^{\prime} 30^{\prime \prime} \mathrm{W}$; (map 119).

Kutchin Indian name obtained in 1956 by T. E. Taylor, USGS.

Ta-kahoela Lake: lake, see Takahula Lake.

Takahola Lake: lake, see Takahula Lake.

Takahula Lake: lake, $1 \mathrm{mi}$. across, in Alatna River valley, $25 \mathrm{mi}$. NE of Walker Lake, Brooks Ra.; $67^{\circ} 21^{\prime} \mathrm{N}, 153^{\circ} 40^{\prime} \mathrm{W}$; BGN 1912; (map 125), Var. Ta-kahoela Lake, Takahola Lake.

Eskimo name, variously spelled, reported in 1886 by Lt. Stoney (1900, map), USN. Stoney's manuscript map shows "Ta-kaho-la." His description "eight miles long, one to one and a half miles wide * * * "exaggerates the lake's size but this may be due to snow cover in a fairly flat valley. The present spelling was established by P.S. Smith, USGS, in 1913.

Takaiak: locality, in Kaiyuh Mts. near Totson Mtn., $23 \mathrm{mi}$. SW of Galena, KilbuckKuskokwim Mts. ; $64^{\circ} 28^{\prime} \mathrm{N}, 157^{\circ} 15^{\prime} \mathrm{W}$; (map 97). Var. Letnik-Takaiak, Takaiaksa, Tăkājăksen.

Former Indian village or camp shown as "Letniki-Takaïak" on Lt. L. A. Zagoskin's 1850 map (Hodge 1910, p. 673).

Takaïaka, Monte: mountain, see Totson Mountain.

Takaiaksa: locality, see Takaiak.

Takai River: stream, see Tok River.

Takaitsky: range, see Kaiyuh Mountains.

Tăkājăksen: locality, see Takaiak.

Takakchak: locality, see Johnnys Village.

Takali, Ostrov: island, see Takli Island.

Takamgia Point: point of land, NE point of North Rookery, on $\mathbf{N}$ coast of St. George I., in Pribilof Is. ; 56 $36^{\prime} 20^{\prime \prime} \mathrm{N}, 169^{\circ} 33^{\prime} 35^{\prime \prime} \mathrm{W}$; (map 38).

Aleut name reported by $W$. W. Duffield in 1897, and Putnam (1903, p. 1015), USC\&GS, as "Takam'gia."

Takamitka: locality, on Unalaska I., Aleutian Is.; $53^{\circ} 40^{\prime} \mathrm{N}, 166^{\circ} 45^{\prime} \mathrm{W}$; (map 23). Var. Tatamitka.

Former Eskimo village or camp reported by Rev. Coxe (1787, p. 164).

Takanis Bay: bay, extends SW 2 mi. to Pacific Ocean, on SW coast of Yakobi I., Alex. Arch.; $57^{\circ} 55^{\prime} \mathrm{N}, 136^{\circ} 31^{\prime} \mathrm{W}$; (map 9). Var. Takhanis Bay, Zaliv Takhanys.

Tlingit Indian name published by Capt. Tebenkov (1852, map 8) as "Z[aliv] Takhanys," meaning "Takhanys Bay."

Takanis Creek: stream, flows SW $4 \mathrm{mi}$. through Takanis Lake to Takanis Bay, on SW coast of Yakobi I., $23 \mathrm{mi}$. NW of Chichagof, Alex. Arch.; $57^{\circ} 55^{\prime} 40^{\prime \prime} \mathrm{N}, 136^{\circ} 29^{\prime} 30^{\prime \prime} \mathrm{W}$; (map 9). 
Name reported in 1942 by USGS (Kennedy and Walton, 1946, pl. 9).

Takanis Lake: lake, $1 \mathrm{mi}$. long, in Takanis Creek, on S central Yakobi I., $23 \mathrm{mi}$. NW of Chichagof, Alex. Arch.; 57 57'30' N, $136^{\circ}$ 27'15" W; (map 9).

Name reported in 1942 by USGS (Kennedy and Walton, 1946, pl. 9)

Takanis Peak: mountain, 2,233 ft., on central Yakobi I., off W coast of Chichagof I., 25 mi. NW of Chichagof, Alex. Arch.; 57 $57^{\prime} 35^{\prime \prime}$ $\mathrm{N}, 136^{\circ} 28^{\prime} 00^{\prime \prime} \mathrm{W}$; (map 9).

Named in 1928 by USC\&GS, and published in 1929 on Chart 8260. The name is derived from Takanis Bay.

Takanis Peninsula: peninsula, $2.5 \mathrm{mi}$. long, on W coast of Yakobi I., off Chichagof I., 24 mi. NW of Chichagof, Alex. Arch.; $57^{\circ} 56^{\prime} \mathrm{N}$, $136^{\circ} 32^{\prime}$ W; BGN 1928; (map 9).

Named in 1928 by USC\&GS for Takanis Bay.

Takapna River: stream, see Takotna River.

Takatz Bay: bay, $3 \mathrm{mi}$. long, on $\mathrm{E}$ coast of Baranof I., $4 \mathrm{mi} . \mathrm{N}$ of Baranof, Alex. Arch.; $57^{\circ} 09^{\prime} \mathrm{N}, 134^{\circ} 50^{\prime} \mathrm{W}$; (map 9).

Tlingit Indian name reported in 1895 by Lt. Comdr. E. K. Moore, USN, and published in 1899 by USC\&GS on Chart 8050.

Takatz Creek: stream, on Baranof I., heads in Takatz Lake, flows NE $1 \mathrm{mi}$. to Takatz Bay, $4 \mathrm{mi}$. N of Baranof, Alex. Arch.; $57^{\circ} 08^{\prime} 30^{\prime \prime}$ $\mathrm{N}, 134^{\circ} 51^{\prime} 50^{\prime \prime} \mathrm{W}$; (map 9).

Local name reported in 1951 by USGS.

Takatz Island: islands, $1.2 \mathrm{mi}$. across, $3.5 \mathrm{mi}$. NE of Baranof, on $\mathbf{E}$ coast of Baranof I., Alex. Arch. ; $57^{\circ} 08^{\prime} \mathrm{N}, 134^{\circ} 48^{\prime} \mathrm{W}$; (map 9).

Tlingit Indian name given in 1895 by Lt. Comdr. E. K. Moore, USN.

Takatz Lake: lake, $1.5 \mathrm{mi}$. across, draining into Takatz Bay, on E coast of Baranof I., 3 mi. NW of Baranof, Alex. Arch.; $57^{\circ} 07^{\prime} 30^{\prime \prime} \mathrm{N}$, $134^{\circ} 54^{\prime} 00^{\prime \prime} \mathrm{W} ; B G N 1923$; (map 9).

Named in 1921 or 1922 by USFS for nearby Takatz Bay.

Takawangha Island: island, see Tanaga Island.

Takayofo Creek: stream, heads near Kejulik Pass and flows NW $25 \mathrm{mi}$., joining Contact Creek to form King Salmon River, on Alaska Penin. in Katmai National Monument, 39 mi. SW of Mount Katmai, Aleutian Ra.; $58^{\circ} 09^{\prime} 45^{\prime \prime} \mathrm{N}, 156^{\circ} 00^{\prime} 25^{\prime \prime} \mathrm{W}$; BGN 1966; (map 41). Var. Takayoto Creek.

Native name said to mean "king salmon" reported in 1923 by R. H. Sargent, USGS.

Takayoto Creek: stream, see Takayofo Creek.

Takchag-miut: settlement, see Takshak.

Tak-chak: locality, see Takechak.

Takchak: locality, see Techek.

Takchak: settlement, see Takshak.

Takchuk: locality, see Tuksuk.

Takchuk Channel: water passage, see Tuksuk Channel.

Takechak: locality, on left side of mouth of Takechak Creek, on Nelson I., $96 \mathrm{mi}$. W of Bethel, Yukon-Kuskokwim Delta; $60^{\circ} 49^{\prime} \mathrm{N}$, $164^{\circ} 36^{\prime} \mathrm{W} ; \cdot(\operatorname{map} 58)$. Var. Tak-chak.

Former Eskimo village now used as a camp. According to USC\&GS in 1951, "A grave or two are the only signs of former habitation." This may be the same place referred to as "Tak-chak."

Takechak Creek: stream, flows N $8 \mathrm{mi}$. to Baird Inlet, on Nelson I., $96 \mathrm{mi}$. W of Bethel, Yukon-Kuskokwim Delta; $60^{\circ} 49^{\prime} \mathrm{N}, 164^{\circ} 35^{\prime}$ W; (map 58).

Eskimo name reported in 1964 by .Orth.

Takeena Peninsula: peninsula, $4 \mathrm{mi}$. across, 6 mi. S of Chichag of, on W coast of Chichagof I., Alex. Arch.; $57^{\circ} 34^{\prime} \mathrm{N}, 136^{\circ} 00^{\prime} \mathrm{W} ; B G N$ 1933; (map 9).

Named in 1933 by USFS "for Jacob Takeena, a Tlingit Indian who was friendly to both the Russian and American settlers, who hunted on this peninsula."

Taket Creek: stream, flows W $3 \mathrm{mi}$. to Norton Sound, $4.9 \mathrm{mi}$. S of Unalakleet, Nulato Hills; $63^{\circ} 48^{\prime} \mathrm{N}, 160^{\circ} 46^{\prime} \mathrm{W}$; (map 91).

Eskimo name reported in 1924 by USC\&GS. "This name comes from a native word meaning 'place to catch blackfish'."

Takhakhdona Hills: hills, between Nayuka River and Glacier Creek, extend SE $15 \mathrm{mi}$. from Bear Mtn. on NW to Hochandochutla Mtn. on S, Kokrines-Hodzana High.; $65^{\circ} 42^{\prime}$ $30^{\prime \prime} \mathrm{N}, 155^{\circ} 00^{\prime} 00^{\prime \prime} \mathrm{W}$; (map 107).

Koyukan Indian name obtained at Huslia in 1956 by Orth.

Takhakna: stream, see North Fork Innoko River.

Takhanis Bay: bay, see Takanis Bay.

Takhanys, Mys: point of land, see Bingham, Gape.

Takhanys, Zaliv: bay, see Takanis Bay.

Takheen River: stream, see Takhin River.

Takhinak: island, see Simeonof Island.

Takhin Glacier: glacier, heads in Takhinsha Mts., trends N $6 \mathrm{mi}$. to its 1954 terminus at head of Takin River, 2 mi. E of terminus of Le Blondeau Glacier and $31 \mathrm{mi}$. SW of Skagway, St. Elias Mts.; $59^{\circ} 16^{\prime} 30^{\prime \prime} \mathrm{N}, 136^{\circ} 09^{\prime} 40^{\prime \prime}$ W; (map 45)

Tlingit Indian name publishd in 1923 on IBC Sheet 9 (1951 atlas).

Takhin Ridge: ridge, $12 \mathrm{mi}$. long, extends $\mathrm{E}-\mathrm{W}$, $2 \mathrm{mi}$. N of Takhin River and $24 \mathrm{mi}$. SW of Skagway, St. Elias Mts.; $59^{\circ} 17^{\prime} \mathrm{N}, 135^{\circ} 58^{\prime}$ W; (map 45). Var. Takhinschá.

Tlingit Indian name reported as Takhinschá by Aurel and Arthur Krause (1883, map).

Takhin River: stream, heads in the Takhin Glacier, flows E $16 \mathrm{mi}$. to the Chilkat River, $6 \mathrm{mi}$. NW of McClellan Flats, and $19 \mathrm{mi}$. SW of Skagway, St. Elias Mts.; $59^{\circ} 16^{\prime} 30^{\prime \prime} \mathrm{N}$, $135^{\circ} 41^{\prime} 00^{\prime \prime} \mathrm{W}$; (map 45). Var. Tahini River, Takheen River, Taklin River.

Tlingit Indian name reported in 1880 by the U.S. Navy as Takheen River. Aurel and Arthur Krause (1883, map) show it as Takhin.

Takhinschá: ridge, see Takhin Ridge.

Takhinsha Mountains: mountain range, extends WNW $25 \mathrm{mi}$. from $\mathrm{N}$ end of Chilkat Ra. to head of Riggs Glacier, $29 \mathrm{mi}$. SW of Skagway, St. Elias Mts.; $59^{\circ} 11^{\prime} \mathrm{N}, 135^{\circ} 55^{\prime} \mathrm{W}$; (map 45).
Tlingit Indian name reported by E. C. Robertson, USGC; published in 1952. Takhli, Ostrov: island, see Takli Island. Takikatagamute: locality, see Takiketak. Takiketagamute: locality, see Takiketak. Takiketak: locality, on $\mathbf{E}$ shore of Kuskokwim Bay, near mouth of Cripple Creek, $21 \mathrm{mi}$. NW of Goodnews, Kilbuck-Kuskokwim Mts.; $59^{\circ} 25^{\prime}$ N, $161^{\circ} 55^{\prime}$ W; (map 53). Var. Takikatagamute, Takiketagamute.

Former Eskimo village or camp reported in $1878-79$ by E. W. Nelson, U.S. Signal Service, as "Takikatagamute," meaning "Takikatak people," population 21; published by Ivan Petroff in the 1880 Census (1884, p. 17).

Takiroq: lake, see Takrak Lake.

Takkala Bay: bay, see Dakavak Bay.

Takkala Lake: lake, see Dakavak Lake.

Taklek: point of land, see Aklek, Cape.

Takli Island: island, $2 \mathrm{mi}$. long, between Amalik Bay and Shelikof Strait, on S coast of Alaska Penin., in Katmai National Monument, $21 \mathrm{mi}$. SE of Mount Katmai, Aleutian Ra.; 58 $04^{\prime}$ N, $154^{\circ} 29^{\prime}$ W; (map 42). Var. Ile Tacghli, Ile Takhli, Ostrov Takali, Ostrov Takhli, Tachti Island, Takhli Island.

Native name published in 1847 as "Os[trov] Takali" on Russian Hydrog. Dept. Chart 1378. Taklin River: stream, see Takhin River.

Taklodaten Lake: lake, see Taclodahten Lake. Tako: locality, see Taku Harbor.

Takoka Creek: stream, flows NW $5.5 \mathrm{mi}$. to Kontrashibuna Lake, $25 \mathrm{mi}$. NE of Nondalton, Aleutian Ra.; $60^{\circ} 10^{\prime} 45^{\prime \prime} \mathrm{N}, 154^{\circ} 10^{\prime} 45^{\prime \prime} \mathrm{W}$; (map 61).

Local name reported in 1954 by USGS.

Takokakaan: locality, see Taku Harbor.

Takoma Bluff: bluf, extends N-S $2.5 \mathrm{mi}$. along left bank of Yukon River at mouth of Takoma Creek, $28 \mathrm{mi}$. SE of Circle, Yukon-Tanana High.; $65^{\circ} 28^{\prime} 30^{\prime \prime} \mathrm{N}, 143^{\circ} 41^{\prime} 00^{\prime \prime} \mathrm{W}$; (map 103).

The bluff evidently received its name from Takoma Creek.

Takoma Cove: cove, $0.7 \mathrm{mi}$. wide, at NE end of Port Dick, Kenai Penin., $28 \mathrm{mi}$. SE of Seldovia, Chugach Mts.; $59^{\circ} 15^{\prime} 45^{\prime \prime} \mathrm{N}, 151^{\circ}$. $00^{\prime} 00^{\prime \prime} \mathrm{W}$; (map 50). Var. Sunday Harbor.

Local name reported by USGS in 1951.

Takoma Creek: stream, flows E $4 \mathrm{mi}$. to Yukon River, $28 \mathrm{mi}$. SE of Circle, Yukon-Tanana High.; $65^{\circ} 27^{\prime} 30^{\prime \prime} \mathrm{N}, 143^{\circ} 41^{\prime} 00^{\prime \prime} \mathrm{W}$; (map 103).

Local name published in 1925 by ARC.

Takomahto Lake: lake, $2 \mathrm{mi}$. long, $\mathrm{E}$ of Jatahmund Lake, $23 \mathrm{mi}$. S of Northway, Alaska Ra.; $62^{\circ} 37^{\prime} \mathrm{N}, 141^{\circ} 57^{\prime} \mathrm{W}$; (map 84).

Indian name reported by USGS in 1955 .

Takonak Creek: stream, flows W $9 \mathrm{mi}$. to Kashunuk River, E of Mankakvik Creek, 36 mi. W of Marshall, Yukon-Kuskokwim Delta ; $61^{\circ} 49^{\prime} 45^{\prime \prime} \mathrm{N}, 163^{\circ} 10^{\prime} 30^{\prime \prime} \mathrm{W}$; (map 74). Var. Tahkonak Creek.

Eskimo name obtained from a manuscript map of the Kashunuk River by "Father Delon," reported as "Tahkonak" by USC\&GS in 1951 . 
Takondit River: stream, see Nation River.

Takoo: locality, see Taku Harbor.

Takoo River: stream, see Taku River.

Takotna: village, pop. 40 , on $\mathrm{N}$ bank of Takotna River, $14 \mathrm{mi}$. W of McGrath, Kilbuck-Kuskokwim Mts.; 62 $59^{\prime} 15^{\prime \prime} \mathrm{N}, 156^{\circ}$ $04^{\prime} 00^{\prime \prime}$ W; BGN 1922; (map 79). Var. Tacotna, Takotna Station, Tokotna.

Riverboat landing and supply point for the Innoko placer district, reported in 1910 as "Takotna Station" by Maddren (1911, p. 243), USGS. The "Tokotna" post office was maintained from 1914 to 1926 , then the name was changed to "Takotna" according to Ricks $(1965$, p. 63). The name is derived from the Takotna River. The population in 1930 was 65.

Takotna Mountain: mountain, 3,203 ft., in Kuskokwim Mts., E of Takotna River, 12 mi. SW of McGrath, Kilbuck-Kuskokwim Mts.; $62^{\circ} 56^{\prime} \mathrm{N}, 156^{\circ} 01^{\prime} \mathrm{W}$; (map 79 ).

Indian name published in 1921 by USGS.

Takotna River: stream, heads at confluence of Little Waldren Fork and Moore Creek, $62^{\circ}$ $32^{\prime} 30^{\prime \prime} \mathrm{N}, 156^{\circ} 47^{\prime} 30^{\prime \prime} \mathrm{W}$, flows NE $120 \mathrm{mi}$. to Kuskokwim River and N of McGrath, Kilbuck-Kuskokwim Mts.; $62^{\circ} 58^{\prime}$ N, $155^{\circ} 36^{\prime} \mathrm{W}$; $B G N$ 1936; (map 90). Var. Reka Tochatno, Reka Tochotno, Tachat River, Tachatna River, Tacotna River, Takapna River, Tokopna River, Totschotno.

Ingalik Indian name reported in 1838 by Alexander Kolmakov who was followed in 1842-44 by Lt. Zagoskin, IRN, who wrote it "Tochotno" and "Tochatno." W. S. Post, USGS, spelled the name "Tachatna" on an 1898 fieldsheet. The present spelling was established in 1908 by A. G. Maddren, USGS.

Takotna Station: village, see Takotna.

Takou Harbor: cove, see Taku Harbor.

Takou Village: locality, see Taku Harbor.

Takrak Lake: lake, $6 \mathrm{mi}$. long, at head of Mikigealiak River, $33 \mathrm{mi}$. SE of Wainwright, Arctic Plain; $70^{\circ} 14^{\prime} \mathrm{N}, 159^{\circ} 05^{\prime} \mathrm{W}$; (map 146). Var. Takiroq

Eskimo name reported in 1956 by Orth as "Takiroq," meaning "it is long."

Taksakwivik Slough: water course, in Yukon Delta, extends E-W $2.8 \mathrm{mi}$. between Gukyuk Slough and Kwikpak Pass, $18 \mathrm{mi}$. NE of Kwiguk, Yukon-Kuskokwim Delta; 62 $57^{\prime} 15^{\prime \prime} \mathrm{N}$, $164^{\circ} 09^{\prime} 00^{\prime \prime} \mathrm{W}$; (map 77). Var. Tahk-sakhwee-vik.

Eskimo name obtained in 1948 by USC\&GS. Takshagemut: settlement, see Takshak.

Takshak: settlement, on point of land between Five Day and Poltes Sloughs, $6 \mathrm{mi}$. NW of Marshall, Yukon-Kuskokwim Delta ; 61 $57^{\circ}$. $30^{\prime \prime} \mathrm{N}, 162^{\circ} 10^{\prime} 00^{\prime \prime} \mathrm{W}$; (map 74). Var. Takchag-miut, Takchak, Takshagemut, Taktchag-miout, Taktschagmjut, Tatschikmjut, Tlatekamute.

Eskimo village reported as "Takchag-miut" by Lt. L. A. Zagoskin, IRN, in 1842-44. In 1949 USC\&GS reported this village abandoned, however, the 1950 Census listed a population of 39 . It may be a summer village or camp.
Takshanuk Mountains: mountain range, $26 \mathrm{mi}$. long, extends NW-SE NE of Chilkat River, $17 \mathrm{mi}$. SW of Skagway, Coast Mts.; $59^{\circ} 26^{\prime} \mathrm{N}$, $135^{\circ} 50^{\prime} \mathrm{W}$; (map 45).

Tlingit Indian naine meaning "water falls" reported by E. C. Robertson, USGS; published in 1952.

Takshilik Creek: stream, flows N $12 \mathrm{mi}$. to Kanektok River, $50 \mathrm{mi}$. NE of Goodnews, Kilbuck-Kuskokwim Mts. ; $59^{\circ} 44^{\prime} \mathrm{N}, 161^{\circ} 00^{\prime} \mathrm{W}$; (map 53). Var. Tachshilik River.

Eskimo name reported as "Tachshilik" on an 1898 fieldsheet by W. S. Post, USGS; published as "Takshilik Creek" by Spurr (1900, map 10), USGS.

Takslesluk Lake: lake, $12 \mathrm{mi}$. long, $\mathrm{E}$ of Puk Palik Lake, $25 \mathrm{mi}$. NE of Baird Inlet, YukonKuskokwim Delta; $61^{\circ} 04^{\prime} \mathrm{N}, 1^{\circ} 2^{\circ} 52^{\prime} \mathrm{W}$; (map 74). Var. Long Lake.

Eskimo name obtained at Bethel by USC\&GS in 1948. Local airplane pilots call it Long Lake, according to Orth in 1965.

Takso: locality, see Tuksuk.

Taksomut: locality, see Tuksuk.

Taksomute: locality, see Tuksuk.

Taksumut: locality, see Tuksuk.

Taktahni Lake: lake, see Pippin Lake.

Taktalurak Rocks: locality, outcrops of rock, $\mathbf{S}$ of Umagatsiak Hill and $16 \mathrm{mi}$. N of Kivalina, Arctic Slope; $67^{\circ} 57^{\prime} \mathrm{N}, 164^{\circ} 33^{\prime} \mathrm{W}$; (map 128). Var. Taaqtaluuzaq, Talktaloorak.

Eskimo name meaning "little black things" reported in 1966 by E. S. Burch.

Tak-tchag-mïout: settlement, see Takshak.

Taktelak Creek: stream, flows SW $8 \mathrm{mi}$. to Kukpuk River, $19 \mathrm{mi}$. NE of Point Hope, Arctic Slope ; $68^{\circ} 25^{\prime} 45^{\prime \prime} \mathrm{N}, 166^{\circ} 07^{\prime} 00^{\prime \prime} \mathrm{W}$; (map 129). Var. Daktaeluk Creek.

Eskimo name recorded in 1960 as "Daktaeluk" by D. C. Foote in connection with Project Chariot studies.

Taktschagmjut: settlement, see Takshak.

Taktusak Hill: hill, $210 \mathrm{ft}$, on penin. near center of Kgun Lake, Yukon-Kuskokwim Delta; $61^{\circ} 33^{\prime} 30^{\prime \prime} \mathrm{N}, 163^{\circ} 46^{\prime} 15^{\prime \prime} \mathrm{W}$; (map 74).

Eskimo name, meaning "kidney-like," obtained at Hooper Bay by Orth in 1965.

Takuak Creek: stream, flows W $3 \mathrm{mi}$. to Okokmilaga River $9.5 \mathrm{mi}$. $\mathrm{N}$ of its head, Brooks Ra.; $68^{\circ} 16^{\prime} \mathrm{N}, 153^{\circ} 04^{\prime} \mathrm{W}$; (map 133).

Eskimo name reported in 1956 by T. E. Taylor, USGS.

Taku Channel: water passage, extends $1.5 \mathrm{mi}$., in off-shore mud flats, between Acharon Channel and Bering Sea, $14 \mathrm{mi}$. N of Black, Yukon-Kuskokwim Delta; $62^{\circ} 32^{\prime} \mathrm{N}, 165^{\circ} 12^{\prime}$ W; (map 76).

So named by G. R. Putnam, USC\&GS, in 1899, for the Coast Survey steamer Taku.

Taku Glacier: glacier, heads at $58^{\circ} 42^{\prime} \mathrm{N}$, $134^{\circ} 22^{\prime} \mathrm{W}$ and trends SE $27 \mathrm{mi}$. to Taku Inlet, $2 \mathrm{mi}$. NW of Taku Point and $15 \mathrm{mi}$ $\mathrm{NE}$ of Juneau, Coast Mts.; 58 25'30' $\mathrm{N}$, 134'03'00" W; BGN 1965; (map 11). Var. Foster Glacier, Klumma Gutto, Klumū Gutta, Schulze Glacier.
Local name used since 1890 . The feature was named Schulze Glacier in 1883 for Paul Schulze, president of the Northwest Trading Co. Later, in 1890, it was named Foster Glacier by USC\&GS for Hon. Charles Foster, 1828-1904, Governor of Ohio and Secretary of the Treasury under President Harrison. "Klumū Gutta" or "Klumma Klutt," meaning the "spirits home", is the Tlingit Indian name for the glacier.

Taku Harbor: locality, on $\mathrm{E}$ shore of Taku Harbor, $22 \mathrm{mi}$. SE of Juneau, Coast Mts.; $58^{\circ} 04^{\prime} 10^{\prime \prime} \mathrm{N}, 134^{\circ} 00^{\prime} 30^{\prime \prime} \mathrm{W}$; (map 11). Var. Tako, Takoo, Takokakaan, Takou Village, Taku-kon Villages, Taku Settlement.

Former Tlingit Indian village or camp, collectively listed as four Taku-kon villages, population 269, in the 1800 Census by Ivan Petroff. In 1908 J. R. Swanton, BAE, published the name as "Takokakaan" (Hodge, 1910, p. 675).

Taku Harbor: cove, $0.6 \mathrm{mi}$. across, on $\mathrm{E}$ shore of Stephens Passage, $2.4 \mathrm{mi}$. NW of Limestone Inlet and $22 \mathrm{mi}$. SE of Juneau, Coast Mts.; $58^{\circ} 03^{\prime} 30^{\prime \prime} \mathrm{N}, 134^{\circ} 02^{\prime} 00^{\prime \prime} \mathrm{W}$; (map 11).Var. Taco Harbor, Tacou Harbor, Takou Harbor.

Named after the Taku division of the Tlingit Indians living in the vicinity, and first applied to the cove in 1848 by Capt. Lt. M. N. Vasiliev, IRN. This harbor was, through a treaty with the Russians, the site of a former Hudson's Bay Company trading post, which was established in 1840 (1883 Coast Pilot, p. 169). It was called "Tacou" and "Takou" by Comdr. R. W. Meade, USN, in 1868 and "Taco" by Sir George Simpson in 1841 .

Taku Hill: hill, probably on $\mathbf{N}$ slope of Mount Roberts, $3 \mathrm{mi}$. SE of Juneau, Coast Mts.; $58^{\circ} 18^{\prime} \mathrm{N}, 134^{\circ} 20^{\prime} \mathrm{W}$; (map 11).

Named by miners about 1885 (DeArmond, 1957 , p. 37).

Taku Inlet: estuary, fiord $20 \mathrm{mi}$. long, extends $\mathrm{N}$ from Stephens Passage to mouth of Taku River, $13 \mathrm{mi}$. SE of Juneau, Coast Mts.; $58^{\circ} 12^{\prime} \mathrm{N}, 134^{\circ} 06^{\prime} \mathrm{W}$; (map 11). Var. Icy Arm, Rukav Ledyanoy, Taco Gulf, Taco Inlet, Tacou Inlet, Tahko Inlet.

Named for the Taku subdivision of the Tlingit Indians; probably first mentioned in 1841 by Sir George Simpson $(1847$, v. 1 , p. 214) as Taco Gulf. The Russians called it "Rukav Ledyanoy," or "Icy Arm" (Tebenkov, 1852, map 8).

Takukak Lake: lake, $0.7 \mathrm{mi}$. long, on Kenai Penin. E of Ursus Lake, 32 mi. NE of Kenai, Cook Inlet Low.; $60^{\circ} 45^{\prime} 45^{\prime \prime} \mathrm{N}, 150^{\circ} 26^{\prime} 00^{\prime \prime}$ W; (map 62)

Named about 1963 by officials of Kenai National Moose Range, for administrative purposes.

Taku-kon Villages: locality, see Taku Harbor. Taku Lake: lake, $0.4 \mathrm{mi}$. across, in course of stream, $1.5 \mathrm{mi}$. NW of Taku Harbor and 20 mi. SE of Juneau, Coast Mts. ; $58^{\circ} 05^{\prime} 20^{\prime \prime}$ $\mathrm{N}, 134^{\circ} 01^{\prime} 30^{\prime \prime} \mathrm{W}$; (map 11$)$. 
Named in 1888 by Lt. Comdr. C. M. Thomas, USN; published in 1889 by USC\&GS on Chart 8229.

Taku Lodge: locality, on left bank of Taku River, $20 \mathrm{mi}$. NE of Juneau, Coast Mts; $58^{\circ} 29^{\prime} 30^{\prime \prime} \mathrm{N}, 133^{\circ} 56^{\prime} 27^{\prime \prime} \mathrm{W} ;$ B BGN 1966; (map 12). Var. Twin Glacier Camp.

Name derived from the Taku River; published in 1951 on a USGS map. In 1932 the name "Twin Glacier Camp" was reported by B. D. Stewart, USGS, who wrote, "The name is in general use locally and has also been adopted by the U.S. Forest Service * **."

Taku Mountain: mountain, 2,139 ft., on E shore of Stephens Passage, $1 \mathrm{mi}$. NW of Taku Harbor and $21 \mathrm{mi}$. SE of Juneau, Coast Mts.; $58^{\circ} 04^{\prime} 30^{\prime \prime} \mathrm{N}, 134^{\circ} 02^{\prime} 30^{\prime \prime} \mathrm{W}$; (map 11).

Named in 1888 by Lt. Comdr. C. M. Thomas, USN; published in 1891 Coast Pilot (p. 149).

Taku Point: point of land, on E shore of Taku Inlet, $3 \mathrm{mi}$. SW of Swede Point and $16 \mathrm{mi} \mathrm{NE}$ of Juneau, Coast Mts. $58^{\circ} 24^{\prime} 10^{\prime \prime}$ N, $134^{\circ} 01^{\prime}$ $00^{\prime \prime} \mathrm{W}$; (map 11).

Local name published by USC\&GS in the 1891 Coast Pilot (p. 153).

Taku Range: mountain range, trends $7.5 \mathrm{mi}$. $\mathrm{S}$ from $58^{\circ} 38^{\prime} \mathrm{N}, 134^{\circ} 22^{\prime} \mathrm{W}, 20 \mathrm{mi}$. $\mathrm{N}$ of Juneau, Coast Mts.; $58^{\circ} 31^{\prime} \mathrm{N}, 134^{\circ} 22^{\prime} \mathrm{W}$; $B G N 1965$; (map 11).

Named by the Juneau Icefield Research Project in 1964.

Taku River: stream, heads in British Columbia at $58^{\circ} 59^{\prime} \mathrm{N}, 133^{\circ} 09^{\prime} \mathrm{W}$, flows SW $54 \mathrm{mi}$. to Taku Inlet, $18 \mathrm{mi}$. NE of Juneau, Coast Mts.; $58^{\circ} 25^{\prime} 30^{\prime \prime} \mathrm{N}, 133^{\circ} 59^{\prime} 00^{\prime \prime} \mathrm{W}$; (map 12). Var. Takoo River.

Name derived from Taku Inlet; published by Baker (1906, p. 614), USGS.

Taku Settlement: locality, see Taku Harbor.

Taku Towers: peaks, $6,000 \mathrm{ft}$., pair of peaks 0.2 mi. apart, in Taku Range, 1.1. mi. NE of Emperor Peak and $21 \mathrm{mi}$. $\mathrm{N}$ of Juneau, Coast Mts.; $58^{\circ} 35^{\prime} 50^{\prime \prime} \mathrm{N}, 134^{\circ} 22^{\prime} 15^{\prime \prime} \mathrm{W}$; (map 11).

Local name published by USGS in 1960 .

Takuzatolatlna: stream, see Lakso Slough.

Takwaklanuk Slough: watercourse, in Yukon Delta, extends NE-SW $4.6 \mathrm{mi}$. between Kwikluak Pass and Naringolapak Slough, 15 mi. E of Kwiguk, Yukon-Kuskokwim Delta ; $62^{\circ} 43^{\prime} 15^{\prime \prime} \mathrm{N}, 164^{\circ} 01^{\prime} 30^{\prime \prime} \mathrm{W}$; (map 77). Var. Naringolapak Slough.

Eskimo name obtained in 1899 by G. R. Putnam, USC\&GS.

Talaaq: locality, see Talak.

Talachulitna Creek: stream, flows E $28 \mathrm{mi}$. through Talachulitna and Judd Lakes to Talachulitna River, $37 \mathrm{mi}$. N of Tyonek, Cook Inlet Low.; $61^{\circ} 35^{\prime} 50^{\prime \prime} \mathrm{N}, 151^{\circ} 16^{\prime} 30^{\prime \prime} \mathrm{W}$; (map 70)

Tanaina Indian name reported in 1954 by USGS.

Talachulitna Lake: lake, 2,500 ft. long, in course of Talachulitna Creek, W of Judd Lake, 38 mi. NW of Tyonek, Cook Inlet Low.; 61 '34'$10^{\prime \prime} \mathrm{N}, 151^{\circ} 37^{\prime} 30^{\prime \prime} \mathrm{W}$; (map 70).
Tanaina Indian name reported in 1954 by USGS; derived from Talachulitna Creek.

Talachulitna River: stream, heads on Beluga Mtn., flows S and NW $45 \mathrm{mi}$. to Skwentna River, $56 \mathrm{mi}$. NW of Tyonek, Alaska Ra.; $61^{\circ} 52^{\prime} 00^{\prime \prime} \mathrm{N}, 151^{\circ} 24^{\prime} 45^{\prime \prime} \mathrm{W}$; (map 70). Talushalitna River, Talushulitna River, Tu-lu-shu-lit-na.

Tanaina Indian name spelled "Tu-lu-shulit-na" by Lt. J. S. Herron, USA, in 1899.

Talaghun River: stream, see Talarhun River. Talahk: locality, see Talak.

Talak: locality, on left bank of Wulik River, 5 mi. NE of Kivalina, Kotzebue-Kobuk Low.; $67^{\circ} 47^{\prime} \mathrm{N}, 164^{\circ} 24^{\prime} \mathrm{W}$; (map 128). Var. Talaaq, Talahk.

Named for an Eskimo who wintered here one year; reported in 1966 by E. S. Burch.

Talarhun River: stream, on Nelson I., flows SE $15 \mathrm{mi}$. to Kolavinarak River at Emperor I., $93 \mathrm{mi}$. W of Bethel, Yukon-Kuskokwim Delta; $60^{\circ} 34^{\prime} \mathrm{N}, 164^{\circ} 30^{\prime} \mathrm{W}$; (map 58). Var. Tallaghun River, Talaghun River.

Eskimo name, meaning "rot" or "die," so called "because of the smell"; reported in 1949 by USC\&GS.

Talarik Creek: stream, see Upper Talarik Creek.

Talavéeroqraw: hill, see Stoney Ridge.

Talaverat Hill: hill, $200 \mathrm{ft}$, , between Kisimilok Creek and Kisimilok Mtn., $19 \mathrm{mi}$. SE of Cape Thompson, Arctic Slope; 68 $04^{\prime} 25^{\prime \prime} \mathrm{N}$, $165^{\circ} 28^{\prime} 00^{\prime \prime}$ W; (map 129). Var. Tal-ave-rut.

Eskimo name obtained in 1950 by USC\&GS and spelled "Tal-a-ve-rut."

Talaverokra Ridge: hill, see Stoney Ridge.

Tal-a-ve-rut: hill, see Talaverat Hill.

Talawiizaq: hills, see Telavirak Hills.

Talawiizut: hills, see Telavirak Hills.

Talbigsak River: watercourse, see Talbiksok River.

Talbiksak River: watercourse, see Talbiksok River.

Talbiksokh River: watercourse, see Talbiksok River.

Talbiksok River: watercourse, in distributary system of Yukon River, heads in Twelvemile Slough at $61^{\circ} 53^{\prime} 30^{\prime \prime} \mathrm{N}, 160^{\circ} 11^{\prime} 30^{\prime \prime} \mathrm{W}$, and flows SW $80 \mathrm{mi}$. to Portage Slough, $6.5 \mathrm{mi}$. $S$ of Russian Mission, Yukon-Kuskokwim Delta; $61^{\circ} 41^{\prime} 30^{\prime \prime}$ N, $161^{\circ} 14^{\prime} 20^{\prime \prime} \mathrm{W}$; (map 73). Var. Johnson Creek, Portage Creek, Tagalaviksak Slough, Talbigsak River, Talbiksak River, Talbiksokh River, Talgaksyuak River, Talgiksyuak River, Tatlaweeksak River, Toloviksak River.

Eskimo name reported in Russian by Lt. L. A. Zagoskin, IRN, 1842-44, as "R[eka] Talgaksyuak" and "R[eka] Talgiksyuak." Capt. C. W. Raymond, USA, shows "Talbiksokh" on his 1869 map. This name was simplified by USC\&GS in 1895 to "Talbiksok." A 1951 USC\&GS field survey calls the feature "Tagalaviksak Slough."

Talbot, Mount: mountain, 4,461 ft., on AlaskaCanada boundary, $10 \mathrm{mi}$. $\mathrm{N}$ of Stikine River and $41 \mathrm{mi}$. E of Petersburg, Coast Mts.; $56^{\circ} 48^{\prime} 20^{\prime \prime} \mathrm{N}, 131^{\circ} 52^{\prime} 15^{\prime \prime} \mathrm{W} ; B G N \quad 1923$; (map 7).

Named in 1923 for A. C. Talbot, Canadian IBC surveyor.

Talbot Lake: lake, $0.7 \mathrm{mi}$. long, on Revillagigedo I., $6.7 \mathrm{mi}$. $\mathrm{N}$ of Ketchikan, Alex. Arch.; $55^{\circ} 26^{\prime} 45^{\prime \prime} \mathrm{N}, 131^{\circ} 38^{\prime} 30^{\prime \prime} \mathrm{W}$; BGN 1954; (map 3). Var. Imhoff Lake, Ingraham Lake, Ingram Lake, Third Lake.

Named in 1951 by USFS for John A. Talbot, 1893-1951, former mayor of Ketchikan.

Talgaksyuak River: watercourse, see Talbiksok River.

Talgiksiuak: stream, see Tatlawiksuk River.

Talgiksjuak: stream, see Tatlawiksuk River.

Talgiksyuak River: watercourse, see Talbiksok River.

Talgotno: stream, see Tatlawiksuk River.

Talhak, Lake: lake, $0.5 \mathrm{mi}$. long, in Ambler Low.; 19 mi. N of Shungnak, Brooks Ra.; $67^{\circ} 09^{\prime} \mathrm{N}, 157^{\circ} 17^{\prime} \mathrm{W}$; (map 126).

Eskimo name reported by the U.S. Army Corps of Engineers in 1955.

Talikoot: locality, on $\mathrm{E}$ shore of Krusenstern Lagoon, $6.5 \mathrm{mi}$. E of Cape Krusenstern, Kotzebue-Kobuk Low.; $67^{\circ} 09^{\prime} \mathrm{N}, 163^{\circ} 30^{\prime}$ W; (map 128).

Eskimo camp and shelter; name reported in 1925 by USGS; according to USC\&GS it means "seals forepaws."

Talik Ridge: ridge, trends NW-SE $18 \mathrm{mi}$., 26 mi NE of Haycock, Nulato Hills; $65^{\circ} 24^{\prime} \mathrm{N}$, $160^{\circ} 24^{\prime} \mathrm{W}$; (map 109).

Eskimo name reported in 1949 by the U.S. Army Corps of Engineers.

Talik River: stream, heads in lake at $61^{\circ} 19^{\prime} \mathrm{N}$, $163^{\circ} 54^{\prime} \mathrm{W}$, flows W $50 \mathrm{mi}$. to Azun River $7 \mathrm{mi}$. S of its junc. with Manokinak River, Yukon-Kuskokwim Delta ; $61^{\circ} 13^{\prime} 30^{\prime \prime} \mathrm{N}, 164^{\circ}$ $39^{\prime} 00^{\prime \prime} \mathrm{W}$; (map 74).

Eskimo name reported by Orth in 1965. Taliti: locality, see Dementi.

Talitui: locality, see Dementi.

Talit Village: locality, see Dementi.

Tality: locality, see Dementi.

Taljgotno: stream, see Tatlawiksuk River.

Taljiks-yu-ak: stream, see Tatlawiksuk River.

Talkeetna: village, pop. 76 , mi. 226.7 on the Alaska RR., at junc. of Talkeetna and Susitna Rivers, $80 \mathrm{mi}$. N of Anchorage, Cook Inlet Low.; $62^{\circ} 19^{\prime} 30^{\prime \prime} \mathrm{N}, 150^{\circ} 06^{\prime} 00^{\prime \prime} \mathrm{W}$; (map 81).

This is reported to be the site of a Tanaina Indian village. Its present name was derived from that of the river. It developed as a major camp when the railroad was built; the village obtained a post office in 1916. A railroad station was opened to trafic here in 1920. Its population was 70 in $1920 ; 89$ in $1930 ; 136$ in 1939; and 106 in 1950.

Talkeetna Glacier: glacier, trends NE $8 \mathrm{mi}$. to head of Talkeetna River, $43 \mathrm{mi}$. NW of Tahneta Pass, Talkeetna Mts. ; $62^{\circ} 11^{\prime} \mathrm{N}, 148^{\circ} 29^{\prime}$ W; (map 82).

Local name recorded in 1952 by USGS.

Talkeetna Lake: lake, see Larson Lake.

Talkeetna Lakes: lakes, extend N-S $3 \mathrm{mi}$., SE of Talkeetna, Cook Inlet Low.; $62^{\circ} 18^{\prime} 00^{\prime \prime} \mathrm{N}$, 
$150^{\circ} 03^{\prime} 30^{\prime \prime} \mathrm{W}$; BGN 1959; (map 81 ).

Local name reported in 1958 by $W$. H. Darch of Talkeetna.

Talkeetna Mountains: mountains, $6,000-8,800$ ft., extend N-S $100 \mathrm{mi}$., E-W $80 \mathrm{mi}$.; bounded on $\mathrm{N}$ by Broad Pass and Nenana River, on $\mathbf{E}$ by Susitna River and Tyone Creek; on $\mathrm{S}$ by Matanuska River; and on $\mathrm{W}$ by Chulitna and Susitna Rivers; $62^{\circ} 30^{\prime} \mathrm{N}, 149^{\circ} 00^{\prime} \mathrm{W}$; (map 82).

Eldridge (1900, p. 8), USGS, reported that in 1898 the name "Talkeetna" had been suggested for these mountains.

Talkeetna River: stream, heads at Talkeetna Glacier in Talkeetna Mts. at $62^{\circ} 11^{\prime} \mathrm{N}$, $148^{\circ} 29^{\prime} \mathrm{W}$, flows NW and SW $85 \mathrm{mi}$. to Susitna River at Talkeetna, Cook Inlet Low.; $62^{\circ} 19^{\prime} 30^{\prime \prime} \mathrm{N}, 150^{\circ} 07^{\prime} 15^{\prime \prime} \mathrm{W}$; (map 81). Var. Chunilna Creek, Talkeetno, Talkeet River, Talkitnu, Talkutna.

Tanaina Indian name reported in 1898 to mean "river of plenty" by G. H. Eldridge and Robert Muldrow, USGS.

Talkeetno: stream, see Talkeetna River.

Talkeet River: stream, see Talkeetna River.

Talkitnu: stream, see Talkeetna River.

Talktaloorak: locality, see Taktalurak Rocks.

Talkutna: stream, see Talkeetna River.

Tallaghun River: stream, see Talarhun River.

Tallapoosa Shoal: shoal, in Sitkalidak Strait, near S end of Sitkalidak I., SE of Kodiak I.; $57^{\circ} 02^{\prime} 25^{\prime \prime} \mathrm{N}, 153^{\circ} 27^{\prime} 00^{\prime \prime} \mathrm{W}$; (map 34).

Local name published in 1943 by USC\&GS.

Taller Pinnacle: rock, in Chiniak Bay, $0.2 \mathrm{mi}$. NE of Cliff Point, on $\mathrm{E}$ coast of Kodiak I.; $57^{\circ} 43^{\prime} 40^{\prime \prime} \mathrm{N}, 152^{\circ} 26^{\prime} 20^{\prime \prime}$ W; (map 34).

Local descriptive name reported in 1949 by USGS.

Talliti: locality, see Dementi.

Tallity: locality, see Dementi.

Tallowpot Creek: stream, flows SW $5 \mathrm{mi}$. to Goodhope River, $24 \mathrm{mi}$. NW of Imuruk Lake, Seward Penin, High.; 65 $50^{\prime} \mathrm{N}, 163^{\circ} 55^{\prime} \mathrm{W}$; (map 110)

Prospectors' name reported on a map of Cape Nome gold fields by David Fox, Jr., dated 1901.

Talneek Point: point of land, see Talnik Point. Talnika, Mys: point of land, see Talnik Point. Talnika Point: point of land, see Talnik Point. Talnik Point: point of land, $16.5 \mathrm{mi}$. NW of Kodiak, on N coast of Kodiak I. ; 57 $53^{\prime} 30^{\prime \prime}$ N, $152^{\circ} 49^{\prime} 00^{\prime \prime} \mathrm{W}$; BGN 1939; (map 34). Var. Mys Talnika, Talneek Point, Talnika Point, Willow Point.

Transliteration of "M[ys] Talnika," the name given by Sub-Lt. Mikhail Murashev in 1839 or 1840 and published in 1849 on Russion Hydrog. Dept. Chart 1425. Baker (1906, p. 676) published "Willow Point," the translation of Murashev's name. Because of duplication the name was changed to its present form by USC\&GS in 1937.

Talnik Zhilye: locality, see Akshadak.

Talsani Island: $i$ sland, $0.8 \mathrm{mi}$. long in the Chilkat Is. in Chilkoot Inlet, $1 \mathrm{mi}$. SE of $\mathrm{S}$ end of Chilkat Penin. and $26 \mathrm{mi}$. S of Skagway, Coast
Mts.; $59^{\circ} 04^{\prime} 40^{\prime \prime} \mathrm{N}, 135^{\circ} 16^{\prime} 20^{\prime \prime} \mathrm{W}$; (map 45). Var. Alzáne.

Tlingit Indian name reported as "Alzáne" by Aurel and Arthur Krause (1883, map). Published as "Talsani I." in 1923 on IBC Sheet 9 (1951 atlas).

Talsona Creek: stream, see Tulsona Creek.

Taltheadamund Lake: lake, $0.8 \mathrm{mi}$. long, $\mathrm{SW}$ of Old Albert Lake, $3.5 \mathrm{mi}$. E of Tetlin Lake and $23 \mathrm{mi}$. SE of Tok, Alaska Ra.; 63 $03^{\prime} \mathrm{N}$, $142^{\circ} 34^{\prime} \mathrm{W}$; (map 85).

Indian name published by USGS in 1964.

Taltlinkho Creek: stream, heads in lake, flows WNW $11 \mathrm{mi}$. to Hogatza River, $25 \mathrm{mi}$. NW of Hughes, Hogatza High.; $66^{\circ} 22^{\prime} \mathrm{N}, 154^{\circ} 40^{\prime}$ W ; (map 116).

Indian name "Talt-lin-khó," reported to mean "always flowing," recorded at Hughes in 1956 by Orth.

Taluidek Island: island, $0.4 \mathrm{mi}$. long, one of The Triplets, in Marmot Bay, between Afognak and Kodiak Is.; $57^{\circ} 59^{\prime} 30^{\prime \prime} \mathrm{N}, 152^{\circ} 28^{\prime} 30^{\prime \prime} \mathrm{W}$; (map 34).

Native name published in 1943 by USC\&GS.

Talungamiut: locality, see Tachyhuimiut.

Talurarevuk Cape: point of land, see Talurarevuk Point.

Talurarevuk Point: point of land, on NW coast of Nelson I., 2 mi. NE of Cape Vancouver, Yukon-Kuskokwim Delta ; 60³5' N, $165^{\circ} 23^{\prime}$ W; (map 57). Var. Talurarevuk Cape.

Eskimo name meaning "place where nets are placed" obtained at Tanunak in 1951 by USC\&GS.

Talus Bay: cove, $0.5 \mathrm{mi}$. across, on NE coast of Resurrection Penin., W side of Day Harbor, $12 \mathrm{mi}$. SE of Seward, Chugach Mts.; $60^{\circ} 00^{\prime}$ $\mathrm{N}, 149^{\circ} 12^{\prime} \mathrm{W}$; BGN 1929; (map 63).

So named in 1928 by a USC\&GS field party "because of the talus formation in the vicinity." Talus is an accumulation of rock fragments at the base of a mountain or tliff.

Talus Creek: stream, heads in Franklin Mts., flows NE $6.5 \mathrm{mi}$. to Sadlerochit River, NW of Okiotak Peak, $25 \mathrm{mi}$. NW of Mount Michelson, Brooks, Ra.; $69^{\circ} 27^{\prime}$ N, $145^{\circ} 12^{\prime}$ W; BGN 1961; (map 139).

So named by USGS geologists in 1948 because of the extensive amount of limestone talus in the area where the stream cuts through Third Ra. Name reported in 1960 by C. L. Whittington, USGS.

Talushalitna River: stream, see Talachulitna River.

Talushulitna River: stream, see Talachulitna River.

Talus Point: point of land, on SE coast of Akutan I., 5 mi. $S$ of Akutan, Krenitzin Is., Aleutian Is.; $54^{\circ} 04^{\prime} 15^{\prime \prime} \mathrm{N}, 165^{\circ} 50^{\prime} 00^{\prime \prime} \mathrm{W}$; (map 24).

Local name published in 1951 on a USGS map. "So called because of the talus [broken rock] accumulated on a slope at the point."

Taluyetlek Creek: stream, flows SW $5 \mathrm{mi}$. to Bessie Creek, $43 \mathrm{mi}$. N of Goodnews, YukonKuskokwim Delta; 59 $58^{\prime}$ N, $161^{\circ} 39^{\prime}$ W; (map 53).
Eskimo name published in 1951 by USGS. Tamantaloi Hill: mountain, 1,296 ft., $27 \mathrm{mi}$. SW of Nulato, Nulato Hills; $64^{\circ} 25^{\prime} \mathrm{N}, 158^{\circ} 39^{\prime}$ W; (map 97).

Koyukan Indian name reported in 1954 by USGS.

Tamarack Bluff: bluff, elev. $1,245 \mathrm{ft}$., on left bank of Sulatna River between Foley and Masters Creeks, $4 \mathrm{mi}$. E of Sulatna Crossing and $26 \mathrm{mi}$. SW of Monzonite Hills, KilbuckKuskokwim Mts.; $64^{\circ} 10^{\prime} \mathrm{N}, 155^{\circ} 20^{\prime} \mathrm{W}$; (map 98). Var. Sulatna Bluff.

Local name reported in 1933 by USGS.

Tamarack Creek: stream, flows NW $1 \mathrm{mi}$. to Spruce Creek, $3.2 \mathrm{mi}$. S of Ophir and $31 \mathrm{mi}$. NW of McGrath, Kilbuck-Kuskokwim Mts.; $63^{\circ} 05^{\prime} 45^{\prime \prime} \mathrm{N}, 156^{\circ} 31^{\prime} 20^{\prime \prime} \mathrm{W}$; (map 90).

Prospectors' name reported in 1912 by H. M. Eakin, USGS.

Tamarack Creek: stream, flows NE $5.6 \mathrm{mi}$. to Sulatna River, $3.2 \mathrm{mi}$. SE of Sulatna Crossing and $40 \mathrm{mi}$. SE of Ruby, Kilbuck-Kuskokwim Mts. ; 64. $09^{\prime} \mathrm{N}, 155^{\circ} 22^{\prime} \mathrm{W}$; (map 98).

Prospectors' name reported in 1913 by Eakin (1914, pl. 3), USGS.

Tamarack Creek: stream, flows $\mathrm{N} 0.7 \mathrm{mi}$. to Chatham Creek, $17 \mathrm{mi}$. NE of Fairbanks, Yukon-Tanana High.; $65^{\circ} 03^{\prime} 45^{\prime \prime} \mathrm{N}, 147^{\circ}$ 24'15" W; (map 105). Var. West Branch.

Named by prospectors; published in 1908 by USGS.

Tamarack Creek: stream, flows E $2 \mathrm{mi}$. to Sullivan Creek, $6 \mathrm{mi}$. SW of Roughtop Mtn., $33 \mathrm{mi}$. E of Tanana, Yukon-Tanana High.; $65^{\circ} 07^{\prime} 00^{\prime \prime} \mathrm{N}, 150^{\circ} 55^{\prime} 30^{\prime \prime} \mathrm{W}$; (map 106).

Local name reported in 1952 by USGS.

Tamarack Landing: locality, at Tamarack Bluff, on Sulatna River, 40 mi. S of Ruby, KilbuckKuskokwim Mts.; $64^{\circ} 10^{\prime} \mathrm{N}, 155^{\circ} 20^{\prime} \mathrm{W}$; (map 98).

Name derived from Tamarack Bluff; published in 1951 by USGS. So called because small boats unloaded supplies here for nearby mining operations. See Sulatna Crossing.

Tamarack Landing: locality, see Sulatna Crossing.

Tamayagiak Creek: stream, see Tamayariak River.

Tamayariak Greek: stream, see Tamayariak River.

Tamayariak River: stream, heads in lake, at W end of Sadlerochit Mts. and flows NE $40 \mathrm{mi}$. to Canning River $2 \mathrm{mi}$. SW of its mouth, Arctic Plain; $70^{\circ} 03^{\prime} \mathrm{N}, 145^{\circ} 34^{\prime} \mathrm{W} ; B G N$ 1964; (map 151). Var. Tamayagiak Creek, Tamayariak Creek.

Eskimo name reported in 1912 by Leffingwell $(1919$, p. 100), USGS, to mean, "route where some people were lost."

Tamayayak Channel: stream, distributary of Colville River, flows NW $16 \mathrm{mi}$. to Harrison Bay, Arctic Plain; $70^{\circ} 26^{\prime} 40^{\prime \prime} \mathrm{N}, 151^{\circ} 01^{\prime} 50^{\prime \prime}$ W; (map 149).

Eskimo name reported in 1951 by USC\&GS; probably from tamxqtoq, meaning "it is lost." Tamerack Bluff: bluff, see Sulatna Bluff.

Tamgas Harbor: bay, extends N $5.5 \mathrm{mi}$. off Felice Strait, on S coast of Annette I., Alex. 
Arch.; 55 $01^{\prime} \mathrm{N}, 131^{\circ} 31^{\prime} \mathrm{W}$; (map 3). Var. Gavan Tomgaz, Tomgass Harbor.

Tlingit Indian name recorded in 1883 by A. K. Etolin; derived from the Tongas or Tamgas tribe living in the area.

Tamgas Lake: lake, $2.3 \mathrm{mi}$. long, $\mathbf{E}$ of Tamgas Harbor, on Annette I., Alex. Arch.; 55 $04^{\prime} \mathrm{N}$, $131^{\circ} 29^{\prime} \mathrm{W}$; (map 3).

Name reported in 1901 by Lt. Comdr. J. F. Moser, USN; the Tongass (sometimes written Tamgas) are a subdivision of the Tlingit Indians.

Tamgas Mountain: mountain, 3,591 ft., on Annette I., E of Tamgas Lake, Alex. Arch.; $55^{\circ} 04^{\prime} \mathrm{N}, 131^{\circ} 24^{\prime} \mathrm{W}$; (map 3 ).

Named in 1883 by Lt. Comdr. H. E. Nichols, USN; derived from Tamgass Harbor.

Tamgas Reef: reef, $0.5 \mathrm{mi}$. long, in Felice Strait, 1 mi. N of Duke I., Alex. Arch.; 54 $59^{\prime} 05^{\prime \prime}$ $\mathrm{N}, 131^{\circ} 25^{\prime} 00^{\prime \prime} \mathrm{W}$; (map 2).

Named in 1883 by Lt. Comdr. H. E. Nichols, USN; derived from Tamgas Harbor.

Tam-nik, Cape: point of land, see Tomname Point.

Tamnik Camp: locality, see Sooghmeghat.

Tamnik Lagoon: lagoon, see Tomname Lagoon.

Tamnik Point: point of land, see Tomname Point.

Tamoschgon: locality, see Tashoshgon.

Tamoshgon: locality, see Tashoshgon.

Tanaak: point of land, see Paramanof, Cape.

Tanaak Cape: point of land, $21 \mathrm{mi}$. NW of Afognak, on $W$ coast of Afognak I., $N$ of Kodiak I. ; $58^{\circ} 15^{\prime} 30^{\prime \prime} \mathrm{N}, 153^{\circ} 05^{\prime} 50^{\prime \prime} \mathrm{W}$; BGN 1910; (map 43).

Aleut name reported by USC\&GS in 1910. Baker (1906, p. 489) says Tanaak is the native name for Cape Paramanof, 4 miles northeast of this point; however, the name probably comes from the word, "tanaq" meaning "land" or "place," according to R. H. Geoghegan.

Tana Bight: cove, $1 \mathrm{mi}$. across, on $\mathrm{W}$ coast of Little Tanaga I., Aleutian Is.; $51^{\circ} 51^{\prime} \mathrm{N}, 176^{\circ}$ 13' W; BGN 1936; (map 17).

A clipped name derived from Tanaga Island, given by members of the U.S. Navy Aleutian Island Survey Expedition in 1934.

Tanach-Angunach Island: island, see Carlisle Island.

Tanacross: village, pop. 102, on Tanana River, $12 \mathrm{mi}$. NW of Tok, Yukon-Tanana High. $63^{\circ} 23^{\prime} \mathrm{N}, 143^{\circ} 21^{\prime} \mathrm{W}$; BGN 1942; (map 85). Var. Tanana Crossing, Tanana Junction, Saint Timothys.

This village originated as a telegraph station, called "Tanana Crossing," where the telegraph lines crossed the river. After the telegraph was dismantled, it remained a village, and, upon the recommendation of the BIA, in 1932 the name was contracted to Tanacross. The post office was established in 1920 and called Saint Timothys. The post office name was changed to Tanacross in 1934 (Ricks, 1965, p. 55).

Tanada Creek: stream, heads in Tanada Lake, in Wrangell Mts., flows NW $17 \mathrm{mi}$. to Copper
River $8 \mathrm{mi}$ SE of junc. of Slana River, Copper River Basin; $62^{\circ} 18^{\prime} \mathrm{N}, 143^{\circ} 48^{\prime} \mathrm{W}$; (map 84). Indian name reported in 1899 by $\mathrm{W}$. J. Peters, USGS.

Tanadakh: island, see Tanadak Island.

Tanadak Island: island, $0.5 \mathrm{mi}$. long, $1.5 \mathrm{mi}$. W of Ulak I., Delarof Is., Aleutian Is.; $51^{\circ}$ $21^{\prime} 30^{\prime \prime} \mathrm{N}, 179^{\circ} 10^{\prime} 00^{\prime \prime} \mathrm{W}$; (map 16). Var. Tanadakh.

Aleut name published by Capt. Tebenkov (1852, map 28), IRN, as "O[strov] Tanadak," or "Tanadak Island." The Aleut name may mean "crab place" or according to R. H. Geoghegan, the name means "eternal ground" or "burial place," and comes from the Aleut "tanadakuq," which means "he goes to his eternal ground, he dies."

Tanadak Island: island, $0.25 \mathrm{mi}$. across, $3 \mathrm{mi}$ $\mathrm{E}$ of Little Kiska $I$. and $7.5 \mathrm{mi}$. E of South Head on Kiska I., Aleutian Is.; $51^{\circ} 56^{\prime} 48^{\prime \prime} \mathrm{N}$, $177^{\circ} 47^{\prime} 00^{\prime \prime}$ W; BGN 1937; (map 14). Var. Tanadakh.

Aleut name reported by Capt. Lutke (1836 p. 327), IRN, as "Tannadakh Ile" and published by Capt. Tebenkov (1852, map 29), as "O[strov] Tanadakh," or "Tanadakh Island." According to $\mathbf{R}$. $\mathbf{H}$. Geoghegan the name means "eternal ground or burial place" from Tanadakug; literal meaning is "he dies or he goes to his eternal ground."

Tanadak Island: island, $0.6 \mathrm{mi}$. long, $1.5 \mathrm{mi}$. $\mathrm{S}$ of $\mathrm{E}$ tip of Amlia I., Andreanof Is., Aleutian Is.; $52^{\circ} 04^{\prime} 15^{\prime \prime} \mathrm{N}, 172^{\circ} 57^{\prime} 00^{\prime \prime} \mathrm{W}$; (map 19).

Named by Capt. Tebenkov (1852, map 27), IRN, as "Ostrov Tanadak," from an Aleut name.

Tanadak Pass: water passage, navigable channel 225 yd. wide, between Tanadok and Little Kiska Is., $6 \mathrm{mi}$. E of South Head on Kiska I., Aleutian Is.; $51^{\circ} 57^{\prime} 20^{\prime \prime} \mathrm{N}, 177^{\circ} 45^{\prime} 30^{\prime \prime} \mathrm{E}$; $B G N$ 1937; (map 14).

Named for Tanadak Island.

Tanada Lake: lake, $5.7 \mathrm{mi}$. long, at head of Tanada Creek, $11 \mathrm{mi}$. W of Nabesna, Wrangell Mts.; $62^{\circ} 25^{\prime} \mathrm{N}, 143^{\circ} 22^{\prime} \mathrm{W}$; (map 84).

Indian name reported in 1899 by W. J. Peters, USGS.

Tanada Peak: mountain, 9,240 ft., $11 \mathrm{mi}$. NE of Copper Glacier terminus and $17 \mathrm{mi}$. SW of Nabesna, Wrangell Mts.; $62^{\circ} 17^{\prime} 30^{\prime \prime} \mathrm{N}, 143^{\circ}$. 31'00" W; (map 84).

Named in 1902 by D. C. Witherspoon, USGS, for nearby Tanada Lake.

Tanaga Bay: bay, $5 \mathrm{mi}$. across, on $W$ coast of Tanaga I., Aleutian Is.; $51^{\circ} 45^{\prime} \mathrm{N}, 178^{\circ} 03^{\prime}$ W; (map 16). Var. Glory of Russia Bay, Slava Rossii Bay.

Aleut name published by Lt. Sarichev (1826, map 13), IRN, as "Tanaga B[ukhta]," or "Tanaga Bay." The name "Zal[iv] Slav[a] Rossii" translated as "Glory of Russian Bay" was used by Capt. Tebenkov (1852, map 28), IRN, after the ship Glory of Russia under the command of Commodore Joseph Billings, IRN, 1790-92. Subsequent USC\&GS and U.S. Navy charts also shown "Glory of Russia Bay."
Tanaga Island: island, $25 \mathrm{mi}$. across, one of Andreanof Is., Aleutian Is.; $51^{\circ} 48^{\prime} \mathrm{N}, 177^{\circ}$. 53' W; BGN 1944; (map 17). Var. Takawangha I., Taniaga I., Tannaga I.

Aleut name published by Lt. Sarichev (1826, map 3), IRN, and Capt. Tebenkov (1852, map 28), IRN, as "O[strov] Tanaga," or "Tanaga Island." It was reported by Capt. Lutke (1836, p. 322), IRN, as "Taniaga" and by Grewingk (1850, p. 230) as "Takawangha."

Tanaga Island: island, see Little Tanaga Island. Tanaga Pass: water passage, between Tanaga I. and Delarof Is., Aleutian Is.; $51^{\circ} 38^{\prime} \mathrm{N}$, $178^{\circ} 20^{\prime} \mathrm{W}$; (map 16).

Named for Tanaga $I$, and published by Dall (1870, p. 248).

Tanaga Volcano: volcano, $5,925 \mathrm{ft}$., in NW part of Tanaga I., Aleutian Is.; $51^{\circ} 53^{\prime} 05^{\prime \prime} \mathrm{N}$, $178^{\circ} 08^{\prime} 25^{\prime \prime} \mathrm{W}$; (map 16).

Name published by USC\&GS in the 1944 Aleutian Coast Pilot (p. 117)

Tanager Point: point of land, $\mathrm{W}$ tip of Chugul I., Aleutian Is.; $51^{\circ} 56^{\prime} 45^{\prime \prime} \mathrm{N}, 175^{\circ} 52^{\prime} 25^{\prime \prime}$ W; BGN 1936; (map 18).

Named for one of the ships of the U.S. Navy Aleutian Island Survey Expedition of 1934; name published in 1952 on a USGS map.

Tana Glacier: glacier, heads in Bagley Icefield, trends NW $17 \mathrm{mi}$. to its 1950 terminus near head of Tana River, Chugach Mts.; $60^{\circ} 50^{\prime}$ $30^{\prime \prime} \mathrm{N}, 142^{\circ} 46^{\prime} 00^{\prime \prime} \mathrm{W}$; (map 65).

Native name from a manuscript map made by prospectors in 1900 .

Tanaguni Island: island, see Chuginadak Island.

Tanaina Peak: peak, 5,350 ft., $2 \mathrm{mi}$. N of Mount Williwaw and $14 \mathrm{mi}$. ESE of Anchorage, Chugach Mts.; $61^{\circ} 08^{\prime} 05^{\prime \prime} \mathrm{N}, 149^{\circ} 31^{\prime} 04^{\prime \prime} \mathrm{W}$; BGN 1966; (map 69).

So named in 1966 by the Mountaineering Club of Alaska for the Tanaina Indians. It was first ascended September 4, 1966, by Theodore Shohl, Brian Wilson, and Todman Wilson.

Tanak, Cape: point of land, on $\mathrm{N}$ coast of Umnak I., Aleutian Is.; $53^{\circ} 33^{\prime} 50^{\prime \prime} \mathrm{N}, 168^{\circ} 00^{\prime} 00^{\prime \prime} \mathrm{W}$; (map 22, 23). Var. Egorkovskoi, Mys Tanakh.

Name published by Capt. Tebenkov ( 1852 , map 25), IRN, as "M[ys] Tanakh," or "Cape Tanakh," from the Aleut word "tanaq," meaning "lace," according to R. H. Geoghegan. This point was called "Egorkovskoi" by Capt. Lutke (1836, p. 300), IRN. See Egorkovskoi.

Tanak-Agunak Island: island, see Chuginadak Island.

Tanak-aniunak Island: island, see Chuginadak Island.

Tanakh, Mys: point of land, see Tanak, Cape.

Tanakh-Angounakh Island: island, see Chuginadak Island.

Tanakh-Angunakh Island: island, see Carlisle Island.

Tanakhothaiak: locality, see Tanakot.

Tanakhotkhaiak: locality, see Tanakot

Tanakhotkhaik: locality, see Tanakot. 
Tanaklakh Island, islands see Tanaklak Island.

Tanaklak Island: island, $1.7 \mathrm{mi}$. long, between Great Sitkin and Umak Is., one of Andreanof Is., Aleutian Is.; $51^{\circ} 57^{\prime} 20^{\prime \prime} \mathrm{N}, 176^{\circ} 06^{\prime} 30^{\prime \prime} \mathrm{W}$; $B G N$ 1936; (map 17). Var. Tanaklakh Island.

Aleut name published by Capt. Tebenkov (1852, map 28), IRN, as "O[strov] Tanaklakh", or "Tanaklakh Island."

Tanakot: locality, on right bank of Yukon River $8 \mathrm{mi}$. N of Bullfrog I., Nulato Hills, 63 $52^{\prime} \mathrm{N}$, $159^{\circ} 12^{\prime} \mathrm{W}$; (map 91). Var. Tahnohkalony, Tanakhothaiak, Tanakhotkhaiak, Tanakhotkhaik.

Former Indian village or camp reported in 1880 as "Tanakhotkhaik," population 62 , by Petroff $(1881$, p. 62).

Tanaku: mountain, see Fairweather, Mount.

Tanalian: village, see Port Alsworth.

Tanalian Mountain: mountain, 3,960 ft., between Lake Clark and Kontrashibuna Lake, 25 mi. NE of Nondalton, Aleutian Ra.; $60^{\circ} 12^{\prime}$ $\mathrm{N}, 154^{\circ} 12^{\prime} \mathrm{W}$; $(\operatorname{map} 61)$.

Name reported in 1954 by USGS. See Tanalian River.

Tanalian Point: village, see Port Alsworth.

Tanalian Point: point of land, on SE shore of Lake Clark, $23 \mathrm{mi}$. NE of Nondalton, Aleutian

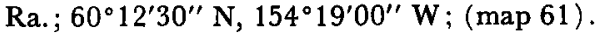

Name reported in 1909 by G. C. Martin, USGS. See Tanalian River.

Tanalian River: stream, flows W 4 mi. to Lake Clark, $22 \mathrm{mi}$. NE of Nondalton, Aleutian Ra.; $60^{\circ} 12^{\prime} \mathrm{N}, 154^{\circ} 21^{\prime} \mathrm{W}$; BGN 1911; (map 61). Var. Koonthrashiboona River, Kunthrashiboona River, Kunthrashibuna River, Kontrashibuna River.

Tanaina Indian name originally applied to a fall or rapid on the stream, which, according to Chief Zachar of the Lake Clark people, descriptively means "strong falls." Map usage by USGS in 19n9, however, applied the name to the stream which the Indians called "Kunthrashibuna."

Tanana: village, pop. 349 , near junc. of Tanana and Yukon Rivers, Kokrines-Hodzana High.; $65^{\circ} 10^{\prime} \mathrm{N}, 152^{\circ} 04^{\prime} \mathrm{W}$; (map 106). Var. Fort Adams (American Station), Fort Gibbon, Harpers Station, Protestant Episcopal Mission of Our Savior, Saint James Episcopal Mission, Saint James Mission, Tanana Station, Weare.

The junction of the Yukon and Tanana Rivers had been a long and well established Indian trading locality before the coming of the European. See Nuklukayet. Except for the Indian name, the first mention of a settlement in this area was made in 1869 by Capt. C. W. Raymond, U.S. Engineers, who on his map, applied the name "Fort Adams (American Station)," near the mouth of the Tozitna River. Near here, in 1880, Arthur Harper established his Alaska Commercial Company trading post, which he called "Nuklukyet," and which others often referred to as "Harpers Station." "St. James Episcopal Mission," or "Protestant Episcopal Mission of Our Savior," was founded in 1891 by Rev. J. L. Prevost, west of Mission Hill. About 1897, one mile downstream from the mission, the trading post of the Northern Commercial Company, "Tanana Station," was established and the Tanana post office was located here in 1898. A halfmile below "Tanana" was the post of the North American Trading and Transportation Company called "Weare," named for Portus B. or Ely E. Weare of that company. In 1899, immediately below Weare, the U.S. Army built "Fort Gibbon" which was abandoned in 1923. The population of the settlement was 27 in 1880 (Nuklukayet); 120 in $1890 ; 512$ in 1910 (Tanana); 312 in 1920; 281 in $1930 ; 170$ in 1939 ; and 228 in 1950. Tanana Crossing: village, see Tanacross.

Tanana Ferry: village, see Big Delta.

Tanana Glacier: glacier, see Chisana Glacier.

Tanana Hills: mountains, extend SE $225 \mathrm{mi}$. from Minto Flats to Alaska-Canada boundary, $\mathrm{N}$ of Tanana River; $65^{\circ} 00^{\prime} \mathrm{N}, 149^{\circ} 00^{\prime} \mathrm{W}$ [W end], $64^{\circ} 00^{\prime} \mathrm{N}, 141^{\circ} 00^{\prime} \mathrm{W}$ [E end]; Var. Tennanah Mountains, Yukon-Tanana Highlands, Yukon-Tanana Upland.

Ivan Petroff on an 1880 Census map showed the name "Tennanah Mts." paralleled to the middle course of the Tanana River. The name "Tanana Hills" was applied in 1948 by Erwin Raisz to the physiographic province referred to as the "Yukon-Tanana Highlands" in this rcport and as the "Yukon-Tanana Upland" in Wahrhaftig (1965, pl. 1), USGS.

Tanana Hills: mountain range; see Kuskokwim Mountins.

Tanana Island: island, $2.5 \mathrm{mi}$. long, SW of junc. of Tanana and Yukon Rivers, 2 mi. SE of Tanana, Nowitna Low.; $65^{\circ} 09^{\prime} 00^{\prime \prime} \mathrm{N}$, $152^{\circ} 01^{\prime} 00^{\prime \prime} \mathrm{W}$; (map 106).

Name shown on Navigation Chart of the Tanana-Yukon Rivers, dated 1940.

Tanana Junction: village, see Tanacross.

Tananak: village, see Tanunak.

Tanana River: stream, formed by confluence of Chisana and Nabesna Rivers at Northway Junction, flows NW $440 \mathrm{mi}$. to Yukon River, $3.5 \mathrm{mi}$. E of Tanana; $65^{\circ} 09^{\prime} 30^{\prime \prime} \mathrm{N}, 151^{\circ} 57^{\prime} 30^{\prime \prime}$ W; BGN 1960; (map 106). Var. Gens des Buttes, Nabesná, River of the Mountain Men, Tananah, Tannanah, Tenan, Tenan-ná, Tennanah.

Indian name reported by the Western Union Telegraph expedition in 1867 as " $\mathrm{Ta}$ nanáh" which, according to Dall (1870, p. 281), means "mountain river." The Hudson's Bay Company traders called it "Gens des Buttes" (French meaning "mountain people") which actually referred to the Indians living on its upper course and the Nabesna River. It was also known as "River of the Mountain Men." The present spelling of the name was recorded in 1885 by Lt. Allen (1887, p. 71 ), USA.

Tanana River: stream, see Ghisana River.

Tanana Station: locality, see Tanana.

Tananei: locality, see Chilkoot.

Tanani: locality, on Tanani Bay, at head of
Ghilkoot Inlet, just $S$ of Tanani Point, 14 mi. SW of Skagway, Coast Mts.; 59 $16^{\prime} 10^{\prime \prime}$ $\mathrm{N}, 135^{\circ} 26^{\prime} 30^{\prime \prime} \mathrm{W}$; (map 45).

This is the name of a Tlingit Indian village said to mean "leaping place," reported by Aurel and Arthur Krause (1883, map) and published by USC\&GS in the 1883 Coast Pilot (p. 200). In 1883 it consisted of three houses.

Tanani Bay: bay, $1 \mathrm{mi}$. across, at head of Chilkoot Inlet, just $\mathrm{S}$ of Tanani Point and $14 \mathrm{mi}$. SSW of Skagway, Coast Mts.; $59^{\circ} 16^{\prime} \mathrm{N}$, $135^{\circ} 26^{\prime}$ W; BGN 1923; (map 45).

Name derived from the village of Tanani on the bay shore.

Tanani Beach: beach, at mouth of Lutak Inlet just $\mathrm{N}$ of Tanani Bay, $13 \mathrm{mi}$. SW of Skagway, Coast Mts.; $59^{\circ} 16^{\prime} 20^{\prime \prime} \mathrm{N}, 1^{\prime} 5^{\circ} 26^{\prime} 20^{\prime \prime} \mathrm{W}$; (map 45).

Local name obtained by USGS field personnel and published on Federal maps since 1950.

Tanani Point: point of land, on $\mathrm{N}$ end of Tanani Bay, in Chilkoot Inlet, $\mathbf{N}$ of Tanani and 14 mi. SW of Skagway, Coast Mts.; $59^{\circ} 16^{\prime} 20^{\prime \prime}$ N, $135^{\circ} 26^{\prime} 20^{\prime \prime}$ W; BGN 1923; (map 45). Var. Entrance Point.

Name derived from the Indian village of Tanani near the point. The name was published in 1923 on IBC Sheet 9 (1951 atlas). USC\&GS reports that the local fishermen call this feature Entrance Point because of its location at the mouth of Lukat Inlet.

Tanani Village: locality, site of an Indian village, on Tanani Point, $3 \mathrm{mi}$. $\mathbf{N}$ of Haines and $14 \mathrm{mi}$. S of Skagway, Coast Mts.; $59^{\circ} 16^{\prime} 30^{\prime \prime}$ $\mathrm{N}, 135^{\circ} 26^{\prime} 30^{\prime \prime} \mathrm{W}$; (map 45).

Indian name published by USC\&GS in the 1883 Coast Pilot (p. 100). At that time the settlement consisted of three houses.

Tana Point: point of land, on $\mathrm{W}$ coast of Little Tanaga I., Aleutian Is.; $51^{\circ} 49^{\prime} 30^{\prime \prime} \mathrm{N}, 176^{\circ}$ 13'45" W; BGN 1936; (map 17).

A clipped name derived from Tanaga Island, and given by members of the U.S. Navy Aleutian Island Survey Expedition in 1934.

Tana River: stream, heads at Tana Glacier terminus and flows NW $31 \mathrm{mi}$. to Chitina River, $15 \mathrm{mi}$. S of McCarthy, St. Elias Mts.; $61^{\circ}$ $12^{\prime} 45^{\prime \prime} \mathrm{N}, 142^{\circ} 50^{\prime} 00^{\prime \prime} \mathrm{W}$; (map 67).

Indian name reported in 1907 by D. C. Witherspoon, USGS (Moffit and Maddren, 1909, pl. 1).

Tanaskan Bay: bay, $0.9 \mathrm{mi}$. across, part of Beaver Inlet, $\mathrm{E}$ coast of Unalaska I., Aleutian Is.; $53^{\circ} 43^{\prime} 30^{\prime \prime} \mathrm{N}, 166^{\circ} 28^{\prime} 45^{\prime \prime} \mathrm{W}$; BGN 1904; (map 23). Var. Macks Bay, Tanaskhan Bay, Taneska Bay.

Aleut name reported as "Zal[iv] Taneska," or "Taneska Bay," by Lt. Sarichev (1826, map 14), IRN. Father Veniaminov (1840, v. 1, p. 162) called this bay "Tanaskhan," from the word "tanaskha," meaning "garden with vegetables" (1846, p. 57). According to R. H. Geoghegan, who translated Veniaminov's dictionary in 1904, the name comes from the Aleut word "tanasxa" and means 
"field, meadow ; kitchen garden." The USBF called this feature "Macks Bay" in 1888.

Tanaskhan Bay: bay, see Tanaskan Bay.

Tana-Unok Island: island, see Carlisle Island.

Taneska Bay: bay, see Tanaskan Bay.

TAnga'sh: locality, see Tongass.

Tangent Peak: peak, 2,562 ft., $8 \mathrm{mi}$. SE of Cape Fanshaw and $77 \mathrm{mi}$. E of Sitka, Coast Mts.; $57^{\circ} 08^{\prime} 25^{\prime \prime} \mathrm{N}, 133^{\circ} 21^{\prime} 30^{\prime \prime} \mathrm{W}$; (map 8).

Named in 1887 by Lt. Comdr. C. M. Thomas, USN.

Tangent Point: point of land, $2.8 \mathrm{mi}$. NE of Cape Sajaka, on NW coast of Tanaga I., Aleutian Is.; $51^{\circ} 54^{\prime} 30^{\prime \prime} \mathrm{N}, 178^{\circ} 11^{\prime} 45^{\prime \prime} \mathrm{W}$; (map $16)$.

Local name published on a 1954 USGS map.

Tangent Point: point of land, $\mathrm{E}$ point of entrance to Dease Inlet, $39 \mathrm{mi}$. SE of Barrow, Arctic Plain; $71^{\circ} 08^{\prime} 50^{\prime \prime} \mathrm{N}, 155^{\circ} 05^{\prime} 30^{\prime \prime} \mathrm{W}$; (map 153). Var. Kulgurak Point, Maghi Point, Point Tangent, Tungent Point.

Thomas Simpson (1843, p. 145) wrote, August 2, 1837, "The land, soon turned sharply off to SSW, forming an acute angle, well termed Point Tangent." However, it appears on his chart as Tangent Point. Comdr. Maguire's map (Great Britain, 1854, facing p. 186) gives the Eskimo name "Maghi."

Tangerra Lake: lake, $1.5 \mathrm{mi}$. long, on Kenai Penin. E of Neckshortka Lake, $44 \mathrm{mi}$. NE of Kenai, Cook Inlet Low.; $60^{\circ} 58^{\prime} 15^{\prime \prime} \mathrm{N}, 150^{\circ}$ $21^{\prime} 45^{\prime \prime} \mathrm{W}$; (map 62$)$.

Named about 1963 by officials of Kenai National Moose Range, for administrative purposes.

Tanghinakh: island, see Ship Rock.

Tanghinakh Islet: island, see Pustoi Island.

Tangik Island: island, $0.5 \mathrm{mi}$. long, $1 \mathrm{mi}$. SE of Akun I.; one of Krenitzin Is., Aleutian Is.; $54^{\circ} 08^{\prime} 45^{\prime \prime} \mathrm{N}, 165^{\circ} 29^{\prime} 00^{\prime \prime} \mathrm{W}$; BGN 1904; (map 24). Var. Waverly Island.

Aleut name published by Capt. Tebenkov (1852, map 26), IRN, as "O[strov] Tangik," which, according to R. H. Geoghegan, means "island." USBF proposed the name Waverly."

Tangimak: island, see Karpa Island.

Tangimak Island: island, see Little Koniuji Island.

Tanginak: island, see Pustoi Island.

Tanginak: island, see Ship Rock.

Tanginak Anchorage: anchorage, $1.5 \mathrm{mi}$. across, on NE coast of Sitkalidak I., SE of Kodiak I. ; $57^{\circ} 10^{\prime} 30^{\prime \prime} \mathrm{N}, 153^{\circ} 01^{\prime} 30^{\prime \prime} \mathrm{W}$; BGN 1930; (map 34).

So named in 1928 by USC\&GS, "because the whaling vessel Tanginak made occasional use of this anchorage."

Tanginak Island: island, $0.2 \mathrm{mi}$. across, $2.2 \mathrm{mi}$. $\mathrm{E}$ of Akun I., one of Krenitzin Is., Aleutian Is.; $54^{\circ} 12^{\prime} 00^{\prime \prime} \mathrm{N}, 165^{\circ} 19^{\prime} 15^{\prime \prime} \mathrm{W}$; BGN 1902; (map 24). Var. Breed Island, Propagation Island.

Aleut name recorded by Capt. Tebenkov (1852, map 26), IRN, as "O[strov] Tanginakh." R. H. Geoghegan reports that the name is probably derivec from the Aleut word "Tangidak" meaning "islet" or "small island." Tangleblue Creek: stream, flows W $6.5 \mathrm{mi}$. to John River, 1 mi. S of mouth of Mashooshalluk Creek and $57 \mathrm{mi}$. W of Wiseman, Brooks Ra.; $67^{\circ} 34^{\prime} 15^{\prime \prime} \mathrm{N}, 152^{\circ} 12^{\prime} 00^{\prime \prime} \mathrm{W}$; (map 124).

Local name obtained in 1956 by USGS topographers.

Tanglefoot Bay: bay, $1 \mathrm{mi}$. across, on $\mathrm{W}$ coast of Kodiak I., $1 \mathrm{mi}$. W of Karluk; 5 $7^{\circ} 34^{\prime} 30^{\prime \prime}$ $\mathrm{N}, 154^{\circ} 29^{\prime} 30^{\prime \prime} \mathrm{W}$; (map 35$)$.

Local name published by Baker (1906, p. 616), USGS.

Tangle Lakes: lakes, group, extend SW $16 \mathrm{mi}$. at head of Delta River, $15 \mathrm{mi}$. W of Paxson, Alaska Ra.; $63^{\circ} 02^{\prime} 45^{\prime \prime} \mathrm{N}, 146^{\circ} 01^{\prime} 20^{\prime \prime} \mathrm{W}$; (map 86).

Descriptive name given in 1898 by W. C. Mendenhall, USGS

Tango Creek: stream, flows NW $12 \mathrm{mi}$. to Iditarod River, $12 \mathrm{mi}$. SW of Flat, Kilbuck-Kuskokwim, Mts.; $62^{\circ} 18^{\prime} 20^{\prime \prime} \mathrm{N}, 158^{\circ} 11^{\prime} 30^{\prime \prime} \mathrm{W}$; $B G N 1945$; ( $\operatorname{map} 79)$.

Local name obtained in 1944 by USGS.

Tango Creek: stream, $17 \mathrm{mi}$. long, heads at $63^{\circ} 42^{\prime} 08^{\prime \prime} \mathrm{N}, 155^{\circ} 59^{\prime} 00^{\prime \prime} \mathrm{W}$, flows NE to North Fork Innoko River, $17 \mathrm{mi}$. SSW of Poorman, Kilbuck-Kuskokwim Mts.; 635' $16^{\prime \prime} \mathrm{N}, 155^{\circ} 51^{\prime} 48^{\prime \prime} \mathrm{W}$; BGN 1963; (map 89).

Local name reported in 1925 by J. S. Brown, USGS.

Tango Creek: stream, see North Fork Innoko River.

Taniaga Island: island, see Tanaga Island.

Tanignak Lake: lake, $0.4 \mathrm{mi}$. long, on $\mathrm{W}$ coast of Woody I., 2 mi. E of Kodiak, Kodiak I.; $57^{\circ} 47^{\prime} 05^{\prime \prime} \mathrm{N}, 152^{\circ} 20^{\prime} 45^{\prime \prime} \mathrm{W}$; (map 34).

Aleut name published in 1943 by USC\&GS.

Tanis Lake: lake, $1 \mathrm{mi}$. across, at mouth of Fassett Glacier, $46 \mathrm{mi}$. SE of Yakutat and 9 mi. NW of Dry Bay, St. Elias Mts.; $59^{\circ} 16^{\prime} 30^{\prime \prime}$ N, $138^{\circ} 32^{\prime} 00^{\prime \prime} \mathrm{W}$; BGN 1926; (map 46).

Name derived from the Tanis River which heads at this lake. Name was published in 1928 by IBC.

Tanis River: stream, heads in Tanis Lake, flows SW $11 \mathrm{mi}$. to Ustay River, $4 \mathrm{mi}$. NW of Dry Bay and $43 \mathrm{mi}$. SE of Yukutat, Malaspina Coastal Plain; $59^{\circ} 12^{\prime} 40^{\prime \prime} \mathrm{N}, 138^{\circ} 42^{\prime} 30^{\prime \prime} \mathrm{W}$; $B G N$ 1926; (map 46). Var. Ustay, Us-tay.

Probably a Tlingit Indian name, first reported by Capt. Tebenkov (1852, map 7), IRN. There has been considerable confusion of the stream names in this area. Tebenkov shows the name "Tanis" on what seems to be the headstream of the Ustay, which he calls the "Akve." See Ustay River and Kakanhini River.

Tanis River: stream, see Ustay River.

Tanjoga Lake: lake, $9 \mathrm{mi}$. long, $20 \mathrm{mi}$. NE of Stevens Village, $66^{\circ} 16^{\prime} \mathrm{N}, 148^{\circ} 40^{\prime} \mathrm{W}$; (map 118).

Kutchin Indian name obtained in 1956 by T. E. Taylor, USGS.

Tanker Island: island, $0.2 \mathrm{mi}$. across, among the Wooded Islands, $75 \mathrm{mi}$. SE of Seward, Chu- gach Mts. ; $59^{\circ} 52^{\prime} 28^{\prime \prime} \mathrm{N}, 147^{\circ} 22^{\prime} 30^{\prime \prime} \mathrm{W}$; $B G N$ 1929; (map 49).

So named by the 1928 USC\&GS field party because of the island's "likeness to an oil tanker when viewed from the southwest."

Tankh-kin-iakh: island, see Simeonof Island.

Tankinak: island, see Little Koniuji Island.

Tannaga Island: island, see Tanaga Island.

Tannak Island: island, see Little Tanaga Island.

Tanner Head: island, $4.2 \mathrm{mi}$. long, on $\mathrm{W}$ shore of Alitak Bay, tied to Kodiak I. ; $56^{\circ} 52^{\prime} 20^{\prime \prime} \mathrm{N}$, $154^{\circ} 15^{\prime} 00^{\prime \prime} \mathrm{W}$; (map 32).

Named in 1900 by Comdr. J. F. Moser, USN, commander of the Albatross, for $\mathbf{L t}$. Comdr. Zera Luther Tanner, USN, commander of the Albatross from 1888-93.

Tanogtuckan-Algaralogray: rookery, see Staraya Artil Rookery.

Tanogtuck'an-an'yi: lagoon, see Tanogtukan Lake.

Tanogtukan Lake: lagoon, $0.1 \mathrm{mi}$. long, on $\mathrm{N}$ coast of St. George I., in Pribilof Is.; $56^{\circ}-$ $36^{\prime} 15^{\prime \prime}$ N, $169^{\circ} 36^{\prime} 15^{\prime \prime}$ W; (map 38). Var. Tanogtuck'an-an'yi.

Aleut name recorded in 1897 as "Tănŏgtŭck'an-än'yi," meaning "old lake village," referring to the nearby site of an old Russian village, by Putnam (1903, p. 1016), USC\&GS. Elliott (1881, p. 59) wrote that he was told by the Aleut that this site "marks the first spot selected by the Russians for their village after the discovery of St. George [I.], in 1786."

Tano Island: island, see Carlisle Island.

Tano Island: island, see Chuginadak Island.

Tantallon Point: point of land, at SE end of Douglas I., on Stephens Passage, at $\mathrm{S}$ end of Gastineau Channel, $2.4 \mathrm{mi}$. S of Dupont and $9.5 \mathrm{mi}$. SE of Juneau, Coast Mts.; $58^{\circ} 11^{\prime} 45^{\prime \prime}$ $\mathrm{N}, 134^{\circ} 15^{\prime} 30^{\prime \prime} \mathrm{W}$; (map 11).

Named in 1884 by W. H. Dall, USC\&GS; published in 1883 Coast Pilot (p. 171). DeArmond (1957, p. 42-43) believed that Dall, as a student of Sir Walter Scott's writings, took the name from Tantallon Castle, North Berwick, Scotland, one of the castles of the Douglas Clan.

Tanuna: village, see Tanunak.

Tanunah: village, see Tanunak.

Tanunak: village, pop. 183, on $\mathrm{NW}$ coast of Nelson I. at Tanunak Bay, $6 \mathrm{mi}$. NE of Cape Vancouver, Yukon-Kuskokwim Delta; 60 ${ }^{\circ} 37^{\prime}$ $\mathrm{N}, 165^{\circ} 15^{\prime} \mathrm{W}$; (map 57). Var. Dununak, Dununuk, Tananak, Tanuna, Tanunah, Tununa, Tununak, Tununuk.

Eskimo village which was visited in December 1878 by E. W. Nelson, U.S. Signal Service, and reported as "Tununuk," population 6; listed as "Dununak" in the 1890 Census, population 48; 65 in 1939; and 112 in 1950. A Roman Catholic mission was established here in 1891.

Tanunak Bay: bay, on NW coast of Nelson I., $6 \mathrm{mi}$. NE of Cape Vancouver, Yukon-Kuskokwim Delta; $60^{\circ} 36^{\prime} \mathrm{N}, 165^{\circ} 18^{\prime} \mathrm{W}$; (map 57).

Name reported in 1951 by USC\&GS. 
Tanunak River: stream, flows N 6 mi. to Tanunak Bay at Tanunak, $6 \mathrm{mi}$. NE of Cape Vancouver, Yukon-Kuskokwim Delta; 60 $37^{\prime}$ $\mathrm{N}, 165^{\circ} 15^{\prime} \mathrm{W}$; (map 57).

Eskimo name meaning "behind one's back." So called because "both forks of this river has its mouth at the village [?]"; reported in 1929 by USC\&GS.

Tapaghtalghee Bay: bight, $12 \mathrm{mi}$. NE of Southeast Cape, SE coast of St. Lawrence $1 . ; 63^{\circ} 06^{\prime}$ N, $169^{\circ} 29^{\prime} \mathrm{W} ; B G N$ 1951; (map 93). Var. Tappaghtalghee Bay.

Eskimo name recommended by the $\mathrm{Sa}$ voonga village council and reported in 1949 by Maj. H. B. Allen, USAF.

Taphaparak: locality, see Ataakas Camp.

Taphatikuk Bay: cove, $1.5 \mathrm{mi}$. wide, between Agnayaghit Point and Oomyousit Point, N coast of St. Lawrence I.; $63^{\circ} 28^{\prime} \mathrm{N}, 169^{\circ} 57^{\prime}$ W; BGN 1951; (map 93). Var. Tapphatickuk Bay.

Eskimo name recommended by the Savoonga village council and reported in 1949 by Maj. H. B. Allen, USAF.

Tap-hok: locality, see Topkok.

Taphok Camp: locality, see Apatiki Camp.

Taphok Mountain: mountain, see Taphook Mountain.

Taphook: locality, see Apatiki.

Taphook: point of land, see Taphook Point.

Taphook Mountain: mountain, 1,200 ft., in Poovoot Ra., $20 \mathrm{mi}$. SE of Gambell, St. Lawrence I. ; $63^{\circ} 35^{\prime} \mathrm{N}, 171^{\circ} 15^{\prime} \mathrm{W}$; BGN 1951; (map 93). Var. Mount Tapphook, Taphok Mountain, Tapphook, Tapphook Mountain.

Named for Taphook Point. Reported in 1949 by Maj. H. B. Allen, USAF.

Taphook Point: point of land, $\mathrm{N}$ coast of St. Lawrence I., $8 \mathrm{mi}$. SE of Naskok Camp and $19 \mathrm{mi}$. SE of Gambell; $63^{\circ} 37^{\prime} \mathrm{N}, 171^{\circ} 15^{\prime}$ W; BGN 1951; (map 93). Var. Cape Tapphook, Taphook, Tapphook Cape, Tapphook Point.

Eskimo name probably from taphak meaning "barrier bar"; reported in 1932 by O. W. Geist, Univ. of Alaska.

Tapioca Creek: stream, flows E $2 \mathrm{mi}$. to Grouse Creek which flows to Mint River, $41 \mathrm{mi}$. NW of Teller, Seward Penin. High.; 65 $38^{\prime} \mathrm{N}$, $167^{\circ} 26^{\prime} \mathrm{W}$; (map 111).

Prospectors' name published in 1956 by USGS.

Tapirag, Mount: mountain, see Fourpeaked Mountain.

Tapisaghak River: stream, heads in Kimpaghulghat Mts., flows $N 7 \mathrm{mi}$. to Bering Sea, 5 mi. NW of Northeast Cape, $\mathbf{N}$ coast of St. Lawrence I.; $63^{\circ} 19^{\prime} \mathrm{N}, 168^{\circ} 51^{\prime} \mathrm{W} ; B G N$ 1951; (map 93).

Eskimo name reported in 1949 by Maj. $\mathrm{H}$. B. Allen, USAF.

Tapkachmiut: locality, see Taapkuk.

Tapkaluk Island: barrier islands, see Tapkaluk Islands.

Tapkaluk Islands: barrier islands, extend $9 \mathrm{mi}$., in Plover Is., between Elson Lagoon and Beaufort Sea, $13 \mathrm{mi}$. NE of Barrow, Arctic Plain; $71^{\circ} 19^{\prime} \mathrm{N}, 156^{\circ} 01^{\prime} \mathrm{W}$; (map 153). Var. Deadmans Island, Tapkaluk Island.

Eskimo name recorded by Leffingwell (1919, p. 100) in 1914.

Tapkaurak Entrance: water passage, on coast of Beaufort Sea, 9 mi. E of Barter I., between Jago and Tapkaurak Spits, Arctic Plain; $70^{\circ} 08^{\prime} \mathrm{N}, 143^{\circ} 12^{\prime} \mathrm{W}$; (map 152).

Local Eskimo name reported by USC\&GS in 1952. The name is derived from that of the spit.

Tapkaurak Lagoon: lagoon, $6 \mathrm{mi}$. long, on coast of $B \approx a u f o r t ~ S e a$, between Martin and Tapkaurak Points, $8 \mathrm{mi} \mathrm{E}$ of Barter I., Arctic Plain; $70^{\circ} 06^{\prime} \mathrm{N}, 143^{\circ} 08^{\prime} \mathrm{W}$; (map 152).

Local Eskimo name derived from that of the spit, reported by USC\&GS in 1952.

Tapkaurak Point: point of land, on coast of Beaufort Sea, between Oruktalik and Tapkaurak Lagoons, Arctic Plain; $70^{\circ} 05^{\prime} \mathrm{N}, 143^{\circ} 01^{\prime}$ W; (map 152).

Local Eskimo name derived from that of the spit, reported by USC\& GS in 1952.

Tapkaurak Spit: barrier island, $7 \mathrm{mi}$. long, between Beaufort Sea and Tapkaurak Lagoon, 9 mi. E of Barker I., Arctic Plain; $70^{\circ} 06^{\prime} \mathrm{N}$, $143^{\circ} 05^{\prime} \mathrm{W}$; (map 152).

Eskimo name reported by USC\&GS in 1952 to mean "little narrow spit."

Tapkhakg-miut: locality, on Chukchi Sea coast, on Seward Penin., midway between Cape Prince of Wales and Shishmaref Inlet, Kotzebue-Kobuk Low.; (map 111). Var. Topok.

Site of an Eskimo village recorded by Lt. L. A. Zagoskin, IRN, in 1842-44.

Tapkhakgmut: locality, see Taapkuk.

Tapkhamikhuagmut: locality, see Topanika.

Tapkhamikkhuag-myut: locality, see Topanika.

Tapok Camp: locality, see Apatiki.

Tapor Point: point of land, see Hatchet Point.

Tappaghtalghee Bay: bight, see Tapaghtalghee Bay.

Tappghappaghak: rock, northernmost rock of Stolbi Rocks, in Bering Sea, $12 \mathrm{mi}$. ESE of Savoonga, St. Lawrence I.; $63^{\circ} 38^{\prime}$ N, $170^{\circ} 06^{\prime}$ W; (map 93).

Eskimo name reported in 1932 by O. W. Geist, Univ, of Alaska.

Tapphaghuk Camp: locality, see Silook Camp.

Tapphatickuk Bay: cove, see Taphatikuk Bay.

Tapphook: locality, see Apatiki Camp.

Tapphook, Cape: point of land, see Taphook Point.

Tapphook, Mount: mountain, see Taphook Mountain.

Tapphook Mountain: mountain, see Taphook Mountain.

Tapphook Point: point of land, see Taphook Point.

Taqdjikan: locality, see Tuxekan.

Taral: locality, on E bank of Copper River, $\mathrm{N}$ of Wood Canyon, $64 \mathrm{mi}$. NE of Valdez, Chugach Mts.; $61^{\circ} 28^{\prime} 20^{\prime \prime} \mathrm{N}, 144^{\circ} 27^{\prime} 00^{\prime \prime} \mathrm{W}$; (map 68). Var. Tarál, Toral, Tarel.

Former Ahtena Indian village or camp reported in 1885 by Lt. Allen (1887, p. 49), USA ; at that time it consisted of two houses.
Taral Creek: stream, flows NE $5.5 \mathrm{mi}$. to Copper River at Taral, $64 \mathrm{mi}$. ENE of Valdez, Chugach Mts.; 61 $28^{\prime} 15^{\prime \prime} \mathrm{N}, 144^{\circ} 27^{\prime} 00^{\prime \prime} \mathrm{W}$; (map 68). Var. Taralna.

According to T. G. Gerdine, USGS, in 1901, the local name for this stream was "Taralna," meaning "Taral River."

Taralna: stream, see Taral Creek.

Taranovokchovik Pass: watercourse, in Yukon Delta, E. of Kwiklokchum Channel, extends N-S 2.4 mi. between Kwemeluk and Kwikluak Passes, $16 \mathrm{mi}$. SW of Kwiguk, Yukon-Kuskokwim Delta; $62^{\circ} 34 \mathrm{~N}, 164^{\circ} 50 \mathrm{~W}$; (map 77).

Eskimo name obtained in 1899 by G. R. Putnam, USC\&GS.

Tarasof Bay: bay, see Humpback Bay.

Tarasof Point: point of land, between Anderson Bay and Makushin Bay, $W$ coast of Unalaska I., Aleutian Is. ; $53^{\circ} 42^{\prime} 55^{\prime \prime} \mathrm{N}, 166^{\circ} 53^{\prime} 40^{\prime \prime} \mathrm{W}$; $B G N$ 1939; (map 23).

Name derived from Tarasof Bay, which was the name for the present Humpback Bay.

Tarel: locality, see Taral.

Target Island: island, $0.1 \mathrm{mi}$. across, in Mitchell Bay, $6.5 \mathrm{mi}$. NE of Angoon, on central Admiralty I., Alex. Arch.; $57^{\circ} 32^{\prime} 27^{\prime \prime} \mathrm{N}, 134^{\circ} 25^{\prime}$ 30" W; (map 9). Var. Target Islet.

Named in 1869 by Comdr. R. W. Meade, USN, because "target practice was held here." The name was published by USC\&GS in the 1891 Coast Pilot (p. 159).

Tarheel Lagoon: lagoon, $0.2 \mathrm{mi}$. across, at NE end of Cataract Cove, on $W$ coast of Unimak I., Aleutian Is. ; $54^{\circ} 39^{\prime} 50^{\prime \prime} \mathrm{N}, 164^{\circ} 42^{\prime} 10^{\prime \prime} \mathrm{W}$; $B G N$ 1942; (map 24).

Name selected in 1940 at random by USC\&GS field party; presumably the nickname of North Carolina.

Tarn Mountain: mountain, 3,800 ft., on Chichagof I., $3.6 \mathrm{mi}$. NE of Pelican and $25 \mathrm{mi}$. W of Hoonah, Alex. Arch.; BGN 1960; (map $10)$.

So named in 1955 by USGS "because many small lakes in depressions carved in solid rock occur on its flanks." A tarn is a small mountain lake.

Tarn Valley: ravine, extends $1.3 \mathrm{mi}$. S of Sevenmile Lake, near $\mathrm{W}$ end of Amphitheater Mts., $27 \mathrm{mi}$. NW of Paxson, Alaska Ra.; 63 ${ }^{\circ} 10^{\prime} 45^{\prime \prime}$ $\mathrm{N}, 146^{\circ} 17^{\prime} 30^{\prime \prime} \mathrm{W}$; (map 86).

Named in 1955 by T. L. Péwé, USGS, for the small (tarn) lake at the head of the valley.

Taroka Arm: bay, 1 mi. wide, on SE coast of Kenai Penin., $50 \mathrm{mi}$. E of Homer, Chugach Mts.; $59^{\circ} 36^{\prime} \mathrm{N}, 150^{\circ} 07^{\prime} \mathrm{W}$; (map 50). Var. West Arm.

Native name "for the brown bear found in this locality"; given in 1930 by USC\&GS.

Tarpkwa: locality, on Seward Penin., on Chukchi Sea coast, $\mathrm{N}$ of Cape Prince of Wales, Kotzebue-Kobuk Low.; (map 111).

Site of an Eskimo village reported in 1897 by Lt. E. P. Bertholf, USRCS, but not found on any map.

Tarr Inlet: estuary, heads in Grand Pacific Glacier, trends SE $10 \mathrm{mi}$. to Glacier Bay, 1 mi. NW of Russell I., in Glacier Bay Na- 
tional Monument, $78 \mathrm{mi}$. NW of Hoonah, St. Elias Mts.; $58^{\circ} 57^{\prime} 30^{\prime \prime} \mathrm{N}, 136^{\circ} 54^{\prime} 00^{\prime \prime} \mathrm{W}$; $B G N$ 1954; (map 10).

Named by Lawrence Martin, USGS, about 1912 for Ralph Stockman Tarr, 1864-1912, professor of physical geography at Cornell Univ., who visited this fiord in 1911. Tarr was with USGS 1888-91, and taught geology and geography at Harvard and Cornell Universities 1890-1912. He was the author of many geological publications including several on Alaska.

Tasaitsaat: lagoons, sce Tasaitsat Lagoons.

Tasaitsaat Angayukaangaq: lagoon, see Tasaitsat Angayukangak Lagoon.

Tasaitsat Angayukangak Lagoon: lagoon, $17 \mathrm{mi}$. SE of Kivalina, Kotzebue-Kobuk Low.; $67^{\circ}$ $34^{\prime} \mathrm{N}, 164^{\circ} 03^{\prime} \mathrm{W}$; (map 128). Var. Tasaitsaat Angayukaangaq, Tessaychaht Angayookahngak.

Eskimo name meaning "parent of Tasaitsat [Lagoons]" reported in 1966 by E. S. Burch.

Tasaitsat Lagoons: lagoons, $15 \mathrm{mi}$. SE of Kivalina, Kotzebue-Kobuk Low.; $67^{\circ} 35^{\prime} \mathrm{N}, 164^{\circ}$ $04^{\prime} \mathrm{W}$; (map 128). Var. Tasaitsaat, Tessaychaht.

Eskimo name meaning "lagoons" reported in 1966 by $\mathbf{E}$. S. Burch.

Tasaychak Lagoon: lagoon, see Tasaychek Lagoon.

Tasaychek Lagoon: lagoon, $1 \mathrm{mi}$. long, on Chukchi Sea coast, $9.5 \mathrm{mi}$. N of Cape Krusenstern, Kotzebue-Kobuk Low.; $67^{\circ} 16^{\prime} 30^{\prime \prime} \mathrm{N}$, $163^{\circ} 45^{\prime} 30^{\prime \prime} \mathrm{W}$; (map 128). Var. Tasaychak Lagoon, Tasechek Lagoon.

Eskimo name meaning "small lagoon," according to USC\&GS in 1950.

Taschemna River: stream, see Tazimina River. Tasechek Lagoon: lagoon, see Tasaychek Lagoon.

Tasekpuk Lake: lake, see Teshekpuk Lake.

Tasezekot: lake, see White Fish Lake.

Tash-a leach: stream, see Tashalich River.

Tashalich River: stream, heads in lake at 1950 Bering Glacier terminus, flows SW $4 \mathrm{mi}$. to Gulf of Alaska, $8 \mathrm{mi}$. NE of Cape Suckling, Malaspina Coastal Plain; $60^{\circ} 01^{\prime} 30^{\prime \prime} \mathrm{N}, 143^{\circ}$ $39^{\prime} 30^{\prime \prime} \mathrm{W}$; (map 65). Var. Tash-a leach.

Indian name "Tash-a leach" reported in 1904 by G. C. Martin, USGS.

Tashicpuk Lake: lake, see Teshekpuk Lake.

Tashoshgon: locality, on left bank of Yukon River at mouth of Pilot Slough, $10 \mathrm{mi}$. SSW of junc. of Koyukuk River, Koyukuk Low. $64^{\circ} 48^{\prime} \mathrm{N}, 157^{\circ} 25^{\prime} \mathrm{W}$; (map 97). Var. Tamoschgon, Tamoshgon.

Former Indian village or camp reported in $1842-44$ by Lt. L. A. Zagoskin, IRN. Population 30 in 1880 .

Tashuk: locality, see Techek.

Tashuk: lagoon, see Elson Lagoon.

Tasighoovik Bay: cove, $2 \mathrm{mi}$. NW of Southeast Cape, S coast of St. Lawrence I., $62^{\circ} 57^{\prime} \mathrm{N}$, $169^{\circ} 42^{\prime}$ W; BGN 1951; (map 93). Var. Tasiguvik Gove.

Eskimo name recommended by the Savoonga village council and reported in 1949 by Maj. H. B. Allen, USAF.
Tasiguvik Cove: cove, see Tasighoovik Bay. Tasikpak: lagoon, see Kivalina Lagoon.

Tasikpak Creek: stream, flows SW $2.5 \mathrm{mi}$. to Tasikpak Lagoon, $19 \mathrm{mi}$. NW of Kivalina, Kotzebue-Kobuk Low. ; 67 $56^{\prime}$ N, 165 04' W; $B G N$ 1963; (map 128). Var. Toosigpahk Creek, Tusigpak Creek, Tusikpok Creek.

Local name reported in 1950 by USC\&GS.

Tasikpak Lagoon: lagoon, $3 \mathrm{mi}$. long, on Chukchi Sea coast, $19 \mathrm{mi}$. NW of Kivalina, Kotzebue-Kobuk Low.; $67^{\circ} 56^{\prime}$ N, $165^{\circ} 06^{\prime} \mathrm{W}$; $B G N$ 1963; (map 128). Var. Toosigpahk Lagoon, Tusikpak Lagoon, Tusikpok Lagoon. Eskimo name meaning "big lagoon," according to USC\&GS in 1950.

Tasirkpuk Lake: lake, see Teshekpuk Lake.

Tasiswane Lake: lake, $1 \mathrm{mi}$. across, on $\mathrm{E}$ bank of Koyukuk River, $5 \mathrm{mi}$. SW of Allakaket, Kokrines-Hodzana High.; $66^{\circ} 30^{\prime} 30^{\prime \prime} \mathrm{N}, 152^{\circ}$ 44'30' W; (map 117).

Koyukan Indian name obtained in 1956 at Allakaket by T. E. Taylor, USGS.

Tas-lin-tna: stream, see Tazlina River.

Tasnuna Glacier: glacier, heads $13 \mathrm{mi}$. NW of Cordova Peak, trends NE $8 \mathrm{mi}$. to its 1953 terminus, $3.4 \mathrm{mi}$. SE of Marshall Pass and $28 \mathrm{mi}$. SE of Valdez, Chugach Mts.; 61 ${ }^{\circ} 03^{\prime}$ $50^{\prime \prime} \mathrm{N}, 145^{\circ} 24^{\prime} 50^{\prime \prime} \mathrm{W}$; BGN 1964; (map 68).

Named in 1963 by A. S. Post, Univ. of Washington, "for the Tasnuna River."

Tasokpoh Lake: lake, see Teshekpuk Lake.

Tasuk: lagoon, see Elsor. Lagoon.

Tas'yuk: lagoon, see Elson Lagoon.

Tasyukpun Lake: lake, see Teshekpuk Lake.

Tatalena River: stream, see Tatalina River.

Tatalina River: stream, heads $8 \mathrm{mi}$. S of Mount Joaquin, flows NE $55 \mathrm{mi}$. to Takotna River and $1.8 \mathrm{mi}$. N of McGrath, Kilbuck-Kuskokwim Mts.; $62^{\circ} 58^{\prime} 45^{\prime \prime} \mathrm{N}, 155^{\circ} 37^{\prime} 40^{\prime \prime} \mathrm{W}$; (map 80). Var. Tatalena River.

Indian name "Tatalena" reported in 1910 by C. G. Anderson (in Eakin, 1914, pl. 1), USGS.

Tatalina River: stream, heads at $65^{\circ} 30^{\prime} \mathrm{N}$, $147^{\circ} 55^{\prime} \mathrm{W}$, flows SW $60 \mathrm{mi}$. to Chatanika River, $48 \mathrm{mi}$. NW of Fairbanks, Tanana Low.; $65^{\circ} 04^{\prime} 30^{\prime \prime} \mathrm{N}, 149^{\circ} 17^{\prime} 00^{\prime \prime} \mathrm{W}$; (map 105). Var. Benikakakat River, East Fork Tolovana River.

Indian name published in 1907 by USGS.

Tatalina Road House: locality, an left bank of Tatalina River, $1 \mathrm{mi}$. SW of O'Brien Creek, $15 \mathrm{mi}$. SE of Livengood, Yukon-Tanana High.; $65^{\circ} 19^{\prime} \mathrm{N}, 148^{\circ} 18^{\prime} \mathrm{W}$; (map 105). Var. Lankey Road House.

Former roadhouse reported as "Lankey" in 1915 by USGS and a year later it was called "Tatalina" by J. B. Mertie, USGS.

Tatamitka: locality, see Takamitka.

Tatasco: locality, at Cape Muzon on $\mathrm{S}$ tip of Dall I., Alex. Arch.; $54^{\circ} 40^{\prime} \mathrm{N}, 132^{\circ} 40^{\prime} \mathrm{W}$; (map 1).

Name shown on the 1795 Arrowsmith map and if an Indian village, it may be Kaigani. See Kaigani.

Tatatontly, Lake: lake, see Todatonten, Lake. Tatchek: locality, see Techek.

Tatchik: bay, see Golovnin Bay.
Tatchinesua Inlet: lagoon, see Tachinisok Inlet. Tateekeerak: hill, see Tatigirok Hill.

Tategnak Cape: point of land, see Tategnak Point.

Tategnak Point: point of land, $1.6 \mathrm{mi}$. SE of Chibukak Point, 3 mi. SE of Gambell, NW tip of St. Lawrence I.; $63^{\circ} 46^{\prime} \mathrm{N}, 171^{\circ} 39^{\prime} \mathrm{W}$; $B G N$ 1951; (map 93). Var. Tategnak Cape.

Eskimo name said to mean "like the bridge of the nose" [tateghnak]. The name was reported in 1949 by Maj. H. B. Allen, USAF.

Tatena River: stream, see Tatina River.

Tatcno River: stream, see Tatina River.

Tatigirok Hill: hill, $400 \mathrm{ft}$., $2 \mathrm{mi}$. N of Kevroruk Springs and $16 \mathrm{mi}$. NW of Kivalina, Arctic Slope; $67^{\circ} 54^{\prime} \mathrm{N}, 164^{\circ} 56^{\prime} \mathrm{W}$; (map 128). Var. Tateekeerak, Tatikiizaq, Tatikirak Hill.

Eskimo name meaning "to touch" reported in 1950 by USC\&GS.

Tatik Cape: point of land, see Tatik Point.

Tatikhlek: village, see Tatitlek.

Tatikiizaq: hill, see Tatigirok Hill.

Tatikirak Hill: hill, see Tatigirok Hill.

Tatik Point: point of land, $4 \mathrm{mi}$. NW of Bunnell Cape, 26 mi. S of Gambell, W coast of St. Lawrence I.; $63^{\circ} 24^{\prime} \mathrm{N}, 171^{\circ} 48^{\prime} \mathrm{W}$; $B G N$ 1951; (map 93). Var. Cape Sanachno, Cape Sanakno, Tatik Cape, West Cape.

Eskimo name meaning "bridge of the nose," reported in 1949 by Maj. H. B. Allen, USAF. Tatilack: village, see Tatitlek.

Tatina: stream, see Dadina River.

Tatina River: stream, heads at a glacier, in Cathedral Spires of Kichatna Mts., flows SW $24 \mathrm{mi}$. to South Fork Kuskokwim River, 85 mi. SE of McGrath, Alaska Ra.; 62 ${ }^{\circ} 18^{\prime} \mathrm{N}$, $153^{\circ} 23^{\prime}$ W; BGN 1963; (map 80). Var. Rohn River, Tatena River, Tateno River, Tatino River.

Indian name reported as "Tateno" and "Tat-no" by Lt. J. S. Herron, USA, who went down the stream in 1899 . It was called "Rohn River" in 1898 by J. E. Spurr, USGS, for Oscar Rohn, a member of his party.

Tatino River: stream, see Tatina River.

Tatitlack: village, see Tatitlek.

Tatitlak: village, see Tatitlek.

Tatitlek: village, pop. 96 , on NE shore of Tatitlek Narrows, $1 \mathrm{mi}$. NE of Bligh I. and $40 \mathrm{mi}$. NW of Cordova, Chugach Mts. $60^{\circ} 52^{\prime} 45^{\prime \prime} \mathrm{N}, 146^{\circ} 41^{\prime} 00^{\prime \prime} \mathrm{W}$; (map 64). Var. Tatikhlek, Tatilack, Tatitlack, Tatitlak, Taytét-lěk.

Indian village reported by Ivan Petroff in the 1880 Census as "Tatikhlek," population $73 ; 90$ in 1890 . The present spelling was published by Grant and Higgins (1910, pl. 2), USGS. T. E. Gerdine, USGS wrote, "formerly it stood at the head of Gladhaugh Bay, but some years ago it was moved to its present site near Copper Mountain." A post office was established here in 1946 (Ricks, 1965, p. 64).

Tatitlek Narrows: water passage, $5 \mathrm{mi}$. long, E of Bligh Island, $40 \mathrm{mi}$. NW of Cordova, Chugach Mts.; $60^{\circ} 53^{\prime} \mathrm{N}, 146^{\circ} 43^{\prime} \mathrm{W}$; (map 64). 
Named by H. P. Ritter in 1903, USC\&GS "Tatitlack." Named for the nearby village. Tatlalinguk Pass: water course, in Yukon Delta, extends N $2.7 \mathrm{mi}$. from Apoon Pass to Pastol Bay, $41 \mathrm{mi}$. NE of Kwiguk, Yukon-Kuskokwim Delta; $63^{\circ} 05^{\prime} \mathrm{N}, 163^{\circ} 25^{\prime} \mathrm{W}$; (map 92).

Eskimo name obtained in 1899 by R. L. Faris, USC\&GS ; published in 1901 on Chart 9372.

Tatlanika Creek: stream, heads at junc. of Sheep and Moose Creeks, flows N $50 \mathrm{mi}$. to Wood River, $14 \mathrm{mi}$. E of Nenana, Tanana Low.; $64^{\circ} 35^{\prime} 30^{\prime \prime} \mathrm{N}, 148^{\circ} 39^{\prime} 00^{\prime \prime} \mathrm{W}$; (map 100$)$.

Tanana Indian name meaning "Tatla Creek" adopted by miners and reported in 1906 by L. M. Prindle (in Brooks and others, 1907, pl. 4), USGS.

Tatlaweeksak River: watercourse, see Talbiksok River.

Tatlawiksuk River: stream, heads at $62^{\circ} 19^{\prime} 40^{\prime \prime}$ $\mathrm{N}, 155^{\circ} 14^{\prime} 00^{\prime \prime} \mathrm{W}$, flows SW $80 \mathrm{mi}$. to Kuskokwim River, $3 \mathrm{mi}$. NE of its junc. with Swift River, $34 \mathrm{mi}$. NE of Sleetmute, Stony River Low.; $61^{\circ} 55^{\prime} 10^{\prime \prime} \mathrm{N}, 156^{\circ} 14^{\prime} 30^{\prime \prime} \mathrm{W}$; (map 72). Var. Talgiksiuak, Talgiksjuak, Talgotno, Taljgotno, Taljiks-you-ak, Tuliviksak, Tusoluksuk.

Eskimo name known as "R[eka] Talgiksiuak" to Russian fur traders as early as 1832 , according to Lt. L. A. Zagoskin, IRN, in 1842-44. He gives the Indian name as "Talgotno." In 1908 A. G. Maddren, USGS, recorded the Eskimo name as "Tusoluksuk," and in 1914, R. H. Sargent, USGS, recorded the present form.

Tatlignagpeke Mountain: mountain, 2,498 ft., with 3 major peaks, $5 \mathrm{mi}$. NW of Sugtutlig $\mathrm{Mtn}$. and $20 \mathrm{mi}$. $\mathrm{N}$ of Goodnews, KilbuckKuskokwim Mts.; 59 $22^{\prime} \mathrm{N}, 161^{\circ} 25^{\prime} \mathrm{W}$; (map 53)

Eskimo name reported in 1954 by USGS.

Tatondan Lake: lake, $0.9 \mathrm{mi}$. long, at mouth of Lake Creek, between Gravel Creek and Matanusha River, $39 \mathrm{mi}$. NE of Palmer, Chugach Mts.; $61^{\circ} 56^{\prime} 35^{\prime \prime} \mathrm{N}, 147^{\circ} 59^{\prime} 00^{\prime \prime} \mathrm{W}$; (map 69).

Tanaina Indian name meaning "curved" or "bent"; reported in 1933 by USGS.

Tatonduc River: stream, see Tatonduk River.

Tatondue River: stream, see Tatonduk River.

Tatonduk River: stream, heads in Canada at $65^{\circ} 24^{\prime} \mathrm{N}, 140^{\circ} 10^{\prime} \mathrm{W}$, flows SW $60 \mathrm{mi}$. to Yukon River, $15 \mathrm{mi}$. N of Eagle, Porcupine Plat.; $65^{\circ} 00^{\prime} \mathrm{N}, 141^{\circ} 20^{\prime} \mathrm{W}$; BGN 1954; (map 102). Var. Sheep Creek, Tatondu River, Tatonduc River, Tatondue River, Totondu River.

Indian name reported in 1883 by $L t$. Schwatka (1885, sheet 7); USA, as "Tatondu River or Totondu River." In 1896 the name was reported as "Tatonduc" by Spurr (1898, p. 261), USGS.

Tatondu River: stream, see Tatonduk River.

Tatoosh Islands: islands, group extending 1.3 mi. in Behm Canal, off W coast of Betton I., Alex. Arch.; $55^{\circ} 31^{\prime} \mathrm{N}, 131^{\circ} 50^{\prime} \mathrm{W}$; (map 3 ). Named in 1886 by USC\&GS.
Tatoosh Point: point of land, on $\mathrm{W}$ coast of Belton I., near $W$ entrance to Behm Canal, Alex. Arch.; $55^{\circ} 31^{\prime} 50^{\prime \prime} \mathrm{N}, 131^{\circ} 49^{\prime} 30^{\prime \prime} \mathrm{W}$; (map 3).

Local navigators' name obtained in 1904 by H. C. Fassett, USBF; derived from Tatoosh Islands.

Tatoosh Rocks: rocks, $\mathbf{N}$ of Tatoosh Is., near $\mathbf{W}$ entrance to Behm Canal, Alex. Arch.; 55 $32^{\prime}$ $\mathrm{N}, 131^{\circ} 51^{\prime} \mathrm{W}$; (map 3$)$.

Named by local pilots in the late 1880 's.

Ta-tot-lee: bluff, see Eagle Bluff.

Tatotlinda: stream, see Mission Creek.

Tatschik: locality, see Techek

Tatschik: bay, see Pavlof Bay.

Tatschikmiut: locality, see Techek.

Tatschikmjut: settlement, see Takshak.

Tatsimisa: locality, on NW end of Kivalina Lagoon, $10 \mathrm{mi}$. NW of Kivalina, KotzebueKobuk Low.; 67 $7^{\circ} 0^{\prime} \mathrm{N}, 164^{\circ} 45^{\prime} \mathrm{W}$; (map 128). Var. Tatsimisaa, Techeemeesaw.

Eskimo name reported in 1966 by E. S. Burch.

Tatsimisaa: locality, see Tatsimisa.

Tattitgak Bluff: bluff, elev. $500 \mathrm{ft}$., on S bank of Colville River, 2 mi. S of Umiat, Arctic Slope; 69 $20^{\prime} \mathrm{N}, 152^{\circ} 11^{\prime} \mathrm{W}$; (map 141).

Eskimo name "tatidgak" for the lesser sandhill crane, Grus canadensis canadensis, reported in 1956 by T. E. Taylor, USGS.

Tatum, Mount: peak, 11,140 ft., in Mount McKinley National Park on Carpe Ridge, between Muldrow and Traleika Glaciers, $10 \mathrm{mi}$. NNE of Mount McKinley, Alaska Ra.; $63^{\circ}$ $10^{\prime} 50^{\prime \prime} \mathrm{N}, 150^{\circ} 48^{\prime} 30^{\prime \prime} \mathrm{W}$; BGN 1947; (map $88)$.

Named by Bradford Washburn about 1945 for Robert G. Tatum, postulant for holy orders, stationed at the mission at Nenana, who at the age of 21 accompanied Archdeacon Stuck, Henry Karstens, and Walter Harper on the first ascent of Mount McKinley (South Peak) on June 7, 1913.

Taupanica: locality, see Topanika.

Tava Island: island, $1 \mathrm{mi}$. long, $3 \mathrm{mi}$. W of Goddard, in Necker Is., on W coast of Baranof I., Alex. Arch.; $56^{\circ} 49^{\prime} 30^{\prime \prime} \mathrm{N}, 1^{\circ} 5^{\circ} 28^{\prime} 30^{\prime \prime} \mathrm{W}$; (map 5). Var. Ostrov Tava.

Named in 1809 by the Russian navigator, Ivan Vasiliev the first; published by Lt. Sarichev (1826, map 19), IRN, as "Os[trov] Tava," meaning "tent island."

Taveeluk Gape: point of land, see Taveeluk Point.

Taveeluk Point: point of land, $6 \mathrm{mi}$. NW of Southwest Cape, SW coast of St. Lawrence I.; $63^{\circ} 20^{\prime} \mathrm{N}, 171^{\circ} 39^{\prime} \mathrm{W}$; BGN 1951; (map 93). Var. Taveeluk Cape, Tavilak Point.

Eskimo name recommended by the Gambell village council and reported in 1949 by Maj. H. B. Allen, USAAF.

Tavilak Point: point of land, see Taveeluk Point. Tawah: estuary, see Ankau, The

Tawah Creek: stream, flows SE along the coast 7 mi. to Lost River, $0.8 \mathrm{mi}$. $\mathrm{N}$ of its mouth in the Gulf of Alaska and $6.5 \mathrm{mi}$. SE of Yakutat, Malaspina Coastal Plain; 59 $28^{\prime} 00^{\prime \prime} \mathrm{N}, 39^{\circ}$. $36^{\prime} 50^{\prime \prime}$ W; BGN 1962; (map 46). Var. An- kau Creek, Ankau River, Ankau Inlet, Ta-wah Creek.

Tlingit Indian name reported by Lt. Comdr. Moser, USN, in 1901. This stream was often called "Ankau Creek" on early charts.

Tawak Passage: water passage, $2 \mathrm{mi}$. long, on coast of Gulf of Alaska, E of Myriad Is., 4.5 mi. SW of Chichagof, Alex. Arch.; 57 $38^{\prime} 00^{\prime \prime}$ N, 136 $12^{\prime} 15^{\prime \prime} \mathrm{W}$; BGN 1926; (map 9).

Named in 1926 by USC\&GS. "Tawak" is the Tlingit Indian name for "goose." The name was published in 1928 on Chart 8280.

T'awat Creek: stream, $0.3 \mathrm{mi}$. long, connects Aka and Kardy Lakes, $2.7 \mathrm{mi}$. SW of Yakutat, Malaspina Coastal Plain; 59 $31^{\prime} 25^{\prime \prime} \mathrm{N}$, $139^{\circ} 47^{\prime} 45^{\prime \prime} \mathrm{W}$; (map 46).

Tlingit Indian name reported in 1964 (de Laguna and others, 1964, p. 23, map 4).

Tawawe Lake: lake, $0.5 \mathrm{mi}$. long, SE of Old Man Lake, $36 \mathrm{mi}$. W of Glennallen, Copper River Basin; 62 $06^{\prime} \mathrm{N}, 146^{\circ} 39^{\prime} \mathrm{W}$; (map 83).

Local name reported by USGS in 1949.

Taxlina Glacier: glacier, see Tazlina Glacier.

Taxlina River: stream, see Tazlina River.

Tayay Inlet: estuary, see Taiya Inlet.

Taygud, Ostrov: island, see Taigud Island.

Taygud, Ostrov: islands, see Taigud Islands.

Taylor: locality, pop. 29 (1940), on left bank of Kougarok River, $8 \mathrm{mi}$. SW of Midnight Mtn. and $48 \mathrm{mi}$. W of Imuruk Lake, Seward Penin.

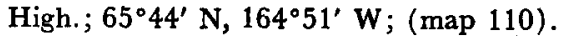

Mining camp founded about 1906 . A post office of this name was established in 1906 and discontinued in 1934 (Ricks, 1965, p. 64). Taylor served as a center for the upper Kougarok gold mining region.

Taylor: locality, see Camp Taylor.

Taylor Bay: bay, $3.4 \mathrm{mi}$. across, in Glacier Bay National Monument, extends NW from Cross Sound to Brady Glacier, $41 \mathrm{mi}$. NW of Hoonah, St. Elias Mts.; 58 $16^{\prime} 30^{\prime \prime}$ N, $136^{\circ}$ 30'30" W; (map 10).

Named by W. H. Dall, USC\&GS, "for Mr. C. H. Taylor of Chicago, who visited this locality." The name was published in the 1883 Alaska Coast Pilot (p. 186).

Taylor Bay: bay, 2 mi. wide, at $N$ end of Port Dick, on Kenai Penin., $26 \mathrm{mi}$. SE of Saldovia, Chugach Mts.; $59^{\circ} 16^{\prime} 30^{\prime \prime} \mathrm{N}, 151^{\circ} 06^{\prime} 00^{\prime \prime} \mathrm{W}$; $B C N$ 1910; (map 50).

Local name reported in 1909 by U. S. Grant (in Martin and others, 1915, pl. 2), USGS.

Taylor Creek: stream, flows W $4.5 \mathrm{mi}$. to head of Duncan Canal, on Lindenberg Penin., Kupreanof I., Alex. Arch.; 56 $46^{\prime} 50^{\prime \prime} \mathrm{N}, 133^{\circ}$ $20^{\prime} 00^{\prime \prime} \mathrm{W}$; (map 6).

Local name published by F. E. Wright and C. W. Wright (1908, fig. 11), USGS.

Taylor Creek: stream, heads in Taylor Lake, flows $0.5 \mathrm{mi}$. SW to Windham Bay, $61 \mathrm{mi}$. SE of Juneau, Coast Mts.; $57^{\circ} 35^{\prime} 30^{\prime \prime} \mathrm{N}, 133^{\circ}$ $24^{\prime} 45^{\prime \prime} \mathrm{W}$; (map 8).

Local name reported in 1951 by USGS.

Taylor Creek: stream, on Kenai Penin., flows NW 2 mi. to Granite Creek, $11 \mathrm{mi}$. SE of Sunrise, Chugach Mts.; $60^{\circ} 45^{\circ} 45^{\prime \prime}$ N, $149^{\circ}$ $14^{\prime} 00^{\prime \prime} \mathrm{W}$; (map 63). 
Local name reported in 1912 by Grant and Higgins (1913, pl. 1), USGS.

Taylor Creek: stream, on N end of Kenai Penin., flows $\mathrm{N} 7 \mathrm{mi}$. to SW side of Turnagain Arm, 8 mi. NW of Hope, Chugach Mts.; 60 $0^{\circ} 58^{\prime} 00^{\prime \prime}$ $\mathrm{N}, 149^{\circ} 49^{\prime} 30^{\prime \prime} \mathrm{W}$; (map 63).

Local name reported in 1952 by USGS.

Taylor Creek: stream, heads in Taylor Mts., flows $\mathrm{N} 30 \mathrm{mi}$. to Holitna River, $38 \mathrm{mi}$. S of Sleetmute, Kilbuck-Kuskokwim Mts. ; $61^{\circ} 09^{\prime}$ N, 157 $13^{\prime}$ W; BGN 1948; (map 72).

Named for a prospector who discovered gold near the headwaters of the stream; reported in 1945 by USGS.

Taylor Creek: stream, flows SE $1 \mathrm{mi}$. to Wade Creek, $46 \mathrm{mi}$. SW of Eagle, Yukon-Tanana High.; $64^{\circ} 08^{\prime} 30^{\prime \prime} \mathrm{N}, 141^{\circ} 29^{\prime} 30^{\prime \prime} \mathrm{W}$; (map 102).

Local name published in 1956 by USGS.

Taylor Creek: stream, flows NE 2 mi. to American Creek which flows to Niukluk River, 26 mi. N of Solomon, Seward Penin. High.; $64^{\circ} 56^{\prime} \mathrm{N}, 164^{\circ} 32^{\prime} \mathrm{W}$; (map 95).

Prospectors' name reported in 1908 by P. S. Smith (in Brooks and others, 1909, pl. 10), USGS.

Taylor Creek: stream, flows SW $24 \mathrm{mi}$. to Kougarok River, $9 \mathrm{mi}$. SW of Midnight Mts. and $46 \mathrm{mi}$. NW of Imuruk Lake, Seward Penin. High.; $65^{\circ} 41^{\prime} \mathrm{N}, 164^{\circ} 48^{\prime} \mathrm{W}$; (map 110).

Prospectors' name reported in 1900 by Brooks (1901, pl. 11), USGS.

Taylor Glacier: glacier, trends SE $5.5 \mathrm{mi}$. to its terminus, $0.5 \mathrm{mi}$. NW of Kings Bay and 16 mi. SE of Whittier, Chugach Mts. ; $60^{\circ} 33^{\prime} 10^{\prime \prime}$ N, 148 $34^{\prime} 00^{\prime \prime} \mathrm{W}$; BGN 1910; (map 63).

Named by U.S. Grant in 1910 and published by Grant and Higgins (1910, pl. 2), USGS.

Taylor Island: island, $2.2 \mathrm{mi}$. long, off E shore of Taylor Bay, in Glacier Bay National Monument, $4 \mathrm{mi}$. W of Point Wimbledon, $40 \mathrm{mi}$. $\mathrm{NW}$ of Hoonah, St. Elias Mts.; $58^{\circ} 18^{\prime} \mathrm{N}$, $136^{\circ} 30^{\prime} \mathrm{W}$; (map 10).

Named by J. F. Pratt, USC\&GS ; published in the 1901 Alaska Coast Pilot (p. 205). The name was derived from Taylor Bay.

Taylor Lagoon: lagoon, extends E-W $2.5 \mathrm{mi}$. along Norton Sound, $10 \mathrm{mi}$. E of Solomon, Seward Penin. High.; $64^{\circ} 34^{\prime} \mathrm{N}, 164^{\circ} 08^{\prime} \mathrm{W}$; (map 95).

Local name reported on Arthur Gibson's "Map of Cape Nome Precinct" dated 1904.

Taylor Lake: lake, $0.8 \mathrm{mi}$. long at head of Taylor Creek, $0.8 \mathrm{mi}$. from stream's mouth on Windham Bay, $60 \mathrm{mi}$. SE of Juneau, Coast Mts.; $57^{\circ} 35^{\prime} 55^{\prime \prime} \mathrm{N}, 133^{\circ} 23^{\prime} 50^{\prime \prime} \mathrm{W}$; (map 8).

Local name reported in 1951 by USGS.

Taylor Mountain: mountain, 5,059 ft., $55 \mathrm{mi}$. SW of Eagle, Yukon-Tanana High.; 64 ${ }^{\circ} 03^{\prime}$ $\mathrm{N}, 142^{\circ} 18^{\prime} \mathrm{W}$; (map 102).

Local name published in 1943 by USGS.

Taylor Mountains: mountains, 3,583 ft., in group $8 \mathrm{mi}$. across, $25 \mathrm{mi}$. NW of Finn Mtn. and $55 \mathrm{mi}$. S of Sleetmute, Kilbuck-Kuskokwim Mts.; $60^{\circ} 55^{\prime} \mathrm{N}, 157^{\circ} 26^{\prime} \mathrm{W}$; BGN 1948; (map 60).
Locally named for "a prospector who spent a number of years in the area [cnna]" and reported in 1945 by USGS.

Taylor Peak: mountain, 1,910 ft., $1.6 \mathrm{mi}$. SW of Point Hope, eastern Attu I.; Aleutian Is.; $52^{\circ} 54^{\prime} 30^{\prime \prime} \mathrm{N}, 173^{\circ} 16^{\prime} 23^{\prime \prime} \mathrm{E}$; (map 13).

Name shown on an AMS map published in 1948 , and given by the U.S. Army during World War II. The name is not used today. Taylor Spur: ridge, 15,000 ft., extends $\mathrm{E}$ from Pioneer Ridge to Muldrow Glacier, on NE side of Mount McKinley, Alaska Ra.; $63^{\circ} 07^{\prime}$ $30^{\prime \prime} \mathrm{N}, 150^{\circ} 56^{\prime} 00^{\prime \prime} \mathrm{W}$; (map 88).

Mountain climbers' name published in 1954 by USGS.

Tay-tét-lĕk: village, see Tatitlek.

Taz Basin: cove, $0.4 \mathrm{mi}$. across, on $\mathrm{W}$ coast of Granite I., $35 \mathrm{mi}$. SW of Seward, Chugach Mts.; $59^{\circ} 39^{\prime}$ N, $149^{\circ} 49^{\prime}$ W ; (map 49).

Local name reported in the early 1950 's by USC\&GS.

Tazcol Peak: mountain, 7,800 ft., $3.5 \mathrm{mi}$. NE of Pandora Peak and $21 \mathrm{mi}$. NW of Valdez, Chugach Mts.; $61^{\circ} 20^{\prime} 53^{\prime \prime} \mathrm{N}, 146^{\circ} 37^{\prime} 28^{\prime \prime} \mathrm{W}$; $B G N 1965$; (map 68).

Probably named about 1959 by Nielsen (1963, p. 153); a made-up name from the first three letters of the Tazlina and Columbia Glaciers.

Tazhemina Lake: lake, see Lower Tazimina Lake.

Tazimeena River: stream, see Tazimina River. Taziminah Lake: lake, see Lower Tazimina Lake.

Taziminah River: stream, see Tazimina River. Tazimina River: stream, heads at $60^{\circ} 03^{\prime} \mathrm{N}$, $153^{\circ} 43^{\prime} \mathrm{W}$, flows $\mathrm{SW} 48 \mathrm{mi}$., through Tazimina Lakes, to Sixmile Lake, $1 \mathrm{mi}$. S of Nondalton, Aleutian Ra.; $59^{\circ} 58^{\prime} \mathrm{N}, 154^{\circ} 50^{\prime} \mathrm{W}$; $B G N$ 1910; (map 51). Var. Nulhutno Greek, Nulhutno River, Taschemna River, Tazimeena River, Taziminah River, Tazimine River.

Tanaina Indian name meaning "trap lake" reported in 1902 as "Tazimeena" by W. H. Osgood, USDA.

Tazimine River: stream, see Tazimina River.

Tazlena River: stream, see Tazlina River.

Tazlina: roadhouse, on Glenn Highway, $30 \mathrm{mi}$. $\mathrm{W}$ of Glennallen, Copper River Basin, $62^{\circ}$ $04^{\prime} \mathrm{N}, 146^{\circ} 27^{\prime} \mathrm{W}$; (map 83 ). Var. Tazlina Glacier Lodge, Tazlina Lodge.

Local name of a roadhouse reported by USGS (in Brooks and others, 1914, pl. 11) as being on the Copper River at the mouth of the Tazlina River. The name has been transferred to this lodge on the Glenn Highway.

Tazlina Glacier: glacier, heads $1.6 \mathrm{mi}$. $\mathrm{N}$ of Mount Cashman, trends N $25 \mathrm{mi}$. to its 1960 terminus, $1 \mathrm{mi}$. S of Tazlina Lake and $43 \mathrm{mi}$. $\mathrm{N}$ of Valdez, Chugach Mts.; 61 $44^{\prime} 30^{\prime \prime} \mathrm{N}$, $146^{\circ} 25^{\prime} 30^{\prime \prime} \mathrm{W} ;$ BGN 1915; (map 68). Var. Taxlina Glacier.

Lt. Allen (1887, map), USA, obtained Ahtena Indian name "Tezliná" for the present-day Tazlina River (p. 62). W. C. Mendenhall, USGS, is responsible for applying the Indian stream name, which he spelled Tax- lina [Takhlina], to the glacier at the stream's head in 1898. Tazlina [Tas-lińtna] means "swift river."

Tazlina Glacier Lodge: roadhouse, see Tazlina. Tazlina Lake: lake, $21 \mathrm{mi}$. long, at head of Tazlina River, $1 \mathrm{mi}$. $\mathrm{N}$ of 1952 terminus of Tazlina Glacier and $62 \mathrm{mi}$. N of Valdez, Copper River Basin; $61^{\circ} 53^{\prime} \mathrm{N}, 146^{\circ} 27^{\prime} \mathrm{W}$; (map 68). Var. Lake Pluvezna, Plavezhnoi, Pleveznie.

Local name taken from the stream that drains the lake, reported in 1898 by F. C. Schrader, USGS. The Russian Serebrenikov (cnna) appears to have been the first "white man" to reach this lake; according to his notes he was here on May 30, 1848. He recorded the name as "Plavezhnoye Ozero," or "Plavezhni Lake." $\mathrm{He}$ reported two Indian families living on the lake (Allen, 1887, p. 21).

Tazlina Lodge: roadhouse, see Tazlina.

Tazlina River: stream, flows E $30 \mathrm{mi}$. from Tazlina Lake to Copper River, $7 \mathrm{mi}$. SE of Glennallen, Copper River Basin; $62^{\circ} 02^{\prime} \mathrm{N}, 145^{\circ}$ 23' W; BGN 1915; (map 83). Var. Tas-lintna, Taxlina River, Tazlena River, Tezliná River, Tlieshitna River.

Ahtena Indian name sometimes written "Tas-lin-tna," meaning "swift river," reported in 1848 by the Russian Serebrenikov (cnna) as "Tlieshitna." This name was spelled "Tezliná" in 1885 by Lt. Allen (1887, p. 62), USA.

Tazlina River: stream, see Nelchina River.

Tazlina Tower: peak, 8,300 ft., on divide between Tazlina and Columbia Glaciers, $0.8 \mathrm{mi}$. NW of Madean Peak and $26 \mathrm{mi}$. NW of Valdez, Chugach Mts.; $61^{\circ} 23^{\prime} 17^{\prime \prime} \mathrm{N}, 146^{\circ} 45^{\prime} 45^{\prime \prime}$ W; BGN.1965; $(\operatorname{map} 68)$.

Probably named about 1959 by Nielsen (1963, p. 135).

Tchagulak Island: island, see Herbert Island. Tchagvagtchatchachat: locality, see Chagvagchat.

Tchagvan Bay: bay, see Chagvan Bay.

Tchaimuth: locality, see Chaik.

Tchakhikh, point of land: see Chakik, Cape.

Tchakoch: stream, see Chakok River.

Tchalchuk: stream, see Stony River.

Tchaseni, Point: point of land, see Chasina Point.

Tchegoula Island: island, see Chagulak Island Tchegoulak Island: island, see Chugul Island. Tcheguulak Island: island, see Herbert Island. Tchernobour Island: island, see Cherni Island. Tchernofskaia: harbor, see Ghernofski Harbor. Tchiboukak: point of land, see Chibukak Point.

Tchiboukoukak: village, see Gambell.

Tchibukak: point of land, see Chibukak Point.

Tchigul: island, See Chugul Island.

Tchillkat Inlet: estuary, see Chilkat Inlet.

Tchillkat Islands: islands, see Chilkat Islands.

Tchillkat River: stream, see Chilkat River.

Tchineyak, Cape: point of land, see Chiniak, Cape.

Tchinik: locality, see Chinik.

Tchinimuth: village, see Golovin. 
Tchinkitanay Bay: water passage, see Sitka Sound.

Tchirikoff: island, see Chirikof Island.

Tchitchagoff, Cap: bluff, see Chichagof, Cape. Tchitchagow, Cape: bluff, see Chichagof, Cape.

Tchitchakoff Strait: water passage, see Chichagof Pass.

Tchitnak: locality, see Chitnak.

Tchitnak, Cape: point of land, see Siknik Cape.

Tchouchago: locality, see Tutago.

Tchougatskoi: mountain range, see Chugach Mountains.

Tchougatskoi Golfe: gulf, see Prince William Sound.

Tchougoulak: island, see Chugul Island.

Tchougoule Island: island, see Segula Island.

Tchougoul Ile: island, see Chugul Island.

Tchougoulok: island, see Chugul Island.

Tchougoulok Island: island, see Chagulak Island.

Tchougovlak: island, see Chugul Island.

Tchounnok: point of land, see Chunak Point.

Tchovgoul: island, see Chugul Island.

Tchuginadak: island, see Chuginadak Island.

Tchulkade Lake: lake, $0.5 \mathrm{mi}$. across, $24 \mathrm{mi}$. SE of Chalkyitsik, Porcupine Plat.; $66^{\circ} 22^{\prime} \mathrm{N}$, $143^{\circ} 20^{\prime} \mathrm{W}$; (map 120).

Tranjik-kutchin Indian name; obtained in 1956 by T. E. Taylor, USGS.

Tchuna, Cape: point of land, see Chunu, Cape. T'Click: locality, see Tklik.

Tdlogaiyakh: locality, off right bank of Khotol River, $2.5 \mathrm{mi}$. E of Yukon River and $39 \mathrm{mi}$. SW of Nulato, Koyukuk Low.; 64 ${ }^{\circ} 11^{\prime} \mathrm{N}$, $158^{\circ} 30^{\prime} \mathrm{W}$; (map 97).

Indian name reported in 1935 by Frederica de Laguna, BAE.

Tea Creek: stream, flows NW $7 \mathrm{mi}$. to Unalakleet River, $11 \mathrm{mi}$. E of Unalakleet, Nulato Hills; $63^{\circ} 53^{\prime} 30^{\prime \prime} \mathrm{N}, 160^{\circ} 25^{\prime} 50^{\prime \prime} \mathrm{W}$; (map 91).

Local name reported in 1952 by USC\&GS.

Tea Kettle Rock: rock, see Teapot Rock.

Tea Lake: lake, 1,200 ft. long, on Kenai Penin., $8 \mathrm{mi}$. SW of Sterling and $23 \mathrm{mi}$. SE of Kenai, Cook Inlet Low.; $60^{\circ} 25^{\prime} 45^{\prime \prime} \mathrm{N}, 150^{\circ} 38^{\prime} 40^{\prime \prime}$ W; (map 62).

Named about 1963 by officials of Kenai National Moose Range, for administrative purposes.

Teal Creek: stream, flows E $4 \mathrm{mi}$. to Thirtythree Creek, $\mathrm{N}$ of Fort Glenn, on NE coast of Umnak I., Aleutian Is.; $53^{\circ} 24^{\prime} 57^{\prime \prime} \mathrm{N}, 167^{\circ}$ $51^{\prime} 35^{\prime \prime} \mathrm{W}$; (map 23).

Name published in 1958 on an AMS map and later by USGS (Byers, 1959, pl. 41). This is one of the many names given by the U.S. military during World War II and probably refers to the Aleutian common teal Anas crecca nimia, which is one of the most common of the so-called river ducks (Gabrielson and Lincoln, 1959, p. 160-161).

Teal Island: island, $0.6 \mathrm{mi}$. long, in SW EI Capi$\tan$ Passage, Alex. Arch.; $55^{\circ} 55^{\prime} 40^{\prime \prime} \mathrm{N}, 133^{\circ}$ 21'15" W; (map 4). Var. South Island.

Named in 1932 by R. S. Patton, USC\& GS, for triangulation station Teal located on this island and "to replace the descriptive name by a distinctive one." The descriptive name
"South Island" was published in the 1925 Coast Pilot (p. 154).

Teal Lake: lake, $0.5 \mathrm{mi}$. long, on Kenai Penin. SE of Birch Lake, 2 mi. N of Swan Lake and $28 \mathrm{mi}$. ENE of Kenai, Cook Inlet Low.; $60^{\circ}$ $42^{\prime} 45^{\prime \prime} \mathrm{N}, 150^{\circ} 31^{\prime} 00^{\prime \prime} \mathrm{W}$; (map 62).

Named about 1963 by officials of Kenai National Moose Range, probably for the green-winged teal (Nettion carolinense), a duck which breeds in the Aleutian Islands.

Teapot Hill: hill, $250 \mathrm{ft}$., on SW coast of Umnak I., Aleutian Is.; $53^{\circ} 08^{\prime} 40^{\prime \prime} \mathrm{N}, 168^{\circ} 47^{\prime} 57^{\prime \prime} \mathrm{W}$; (map 22).

Name published in 1951 on a USGS map.

Teapot Rock: rock, off NE coast of Great Sitkin I., Aleutian Is.; $52^{\circ} 06^{\prime} 50^{\prime \prime} \mathrm{N}, 176^{\circ} 03^{\prime} 00^{\prime \prime} \mathrm{W}$; BGN 1936; (map 17). Var. Tea Kettle Rock.

So named by members of the U.S. Navy Aleutian Island Survey Expedition in 1934, "because of its shape."

Teasekpuk Lake: lake, see Teshekpuk Lake.

Tease Lake: lake, $0.5 \mathrm{mi}$. across, $3 \mathrm{mi}$. SE of Speel Point on the Speel River and $31 \mathrm{mi}$. SE of Juneau, Coast Mts.; 58 $06^{\prime} 30^{\prime \prime} \mathrm{N}, 133^{\circ} 40^{\prime}$ 00" W; BGN 1930; (map 12).

Local name published by Theodore Chapin (in Brooks and others, 1916, p. 107), USGS.

Tebay, Mount: mountain, see Tebay Mountain. Tebay Creek: stream, see Tebay River.

Tebay Lakes: lakes, in line $7 \mathrm{mi}$. long trend NE at head of Tebay River, $68 \mathrm{mi}$. E of Valdez, Chugach Mts.; $61^{\circ} 12^{\prime} \mathrm{N}, 144^{\circ} 15^{\prime} \mathrm{W}$; (map 68).

Local name published in 1912 by USGS.

Tebay Mountain: mountain, "in Mentasta Mountains, near Suslota Pass," Alaska Ra.; Var. Mount Tebay.

Named in 1885 by Lt. Allen (1887, p. 7), USA.

Tebay River: stream, heads in Tebay Lakes, flows NE $15 \mathrm{mi}$. to Chitina River, $36 \mathrm{mi}$. SW of McCarthy, Copper River Basin; $61^{\circ} 24^{\prime} \mathrm{N}$, $143^{\circ} 59^{\prime} \mathrm{W}$; (map 67). Var. Tebay Creek.

Indian name reported in 1885 by Lt. Allen (1887, p. 57), USA, to mean "a variety of sheep" (p. 54).

Tebenkof, Mount: mountain, 4,280 ft., $2.2 \mathrm{mi}$. NE of Chicago Harbor, 16 mi. NE of Yakutat, St. Elias Mts.; $59^{\circ} 23^{\prime} 20^{\prime \prime} \mathrm{N}, 139^{\circ} 25^{\prime} 30^{\prime \prime} \mathrm{W}$; (map 46). Var. Mount Tebienkof.

Named in 1890 by Russel (1892, pl. 4) for Capt. Mikhail Dmitrievich Tebenkov, governor of the Russian-American Colonies, 1845-50.

Tebenkof, Point: point of land, on $\mathrm{N}$ coast of Unalaska I., Aleutian Is.; $53^{\circ} 59^{\prime} 20^{\prime \prime} \mathrm{N}, 166^{\circ}$. 52'45" W; BGN 1938; (map 23).

Named by USC\&GS in 1938 for Capt. Mikhail Dmitrievich Tebenkov, director of the Russian American Company and Governor of Russian America between 1845 and 1850. $\mathrm{He}$ was responsible for the compilation of one of the early atlases of Alaska (1852) which has been used extensively in the preparation of this publication.

Tebenkof Bay: bay, $5 \mathrm{mi}$. across, on $\mathrm{W}$ central coast of Kuiu I., Alex. Arch.; $56^{\circ} 30^{\prime} \mathrm{N}, 134^{\circ}$. 12' W; BGN 1899; (map 5). Var. Kon Bay,
Tebenkoff Bay, Tebenkov Bay, Tebienkof Bay, Tebienkoff Bay.

Named in 1879 by W. H. Dall, USC\&GS, for Capt. Michael Dmitrievich Tebenkov, governor of the Russian American colonies in 1845-50," whose "Atlas of the Northwest Coast of America" was used extensively in the preparation of this dictionary.

Tebenkof Bay: bay, see Saint Michael Bay.

Tebenkoff Bay: bay, see Tebenkof Bay.

Tebenkof Glacier: glacier, on E side of Kenai Penin., heads at $60^{\circ} 38^{\prime} 30^{\prime \prime} \mathrm{N}, 148^{\circ} 35^{\prime} 30^{\prime \prime}$ $\mathrm{W}$, trends NE $8 \mathrm{mi}$. to its terminus, $2 \mathrm{mi}$. $\mathrm{S}$ of SE side of Blackstone Bay and $7 \mathrm{mi}$. SE of Whittier, Chugach Mts.; $60^{\circ} 44^{\prime} 30^{\prime \prime} \mathrm{N}, 148^{\circ}$ 28'30' W; BGN 1910; (map 63). Var. Spencer Glacier.

Named about 1909 by U. S. Grant, USGS, for Mikhail Dmitrievich Tebenkov. Published by Grant and Higgins (1910, pls. 1, 2), USGS.

Tebenkof Glacier: glacier, see Spencer Glacier. Tebenkov Bay: bay, see Tebenkof Bay.

Tebetnkova, Zaliv: bay, see Saint Michael Bay.

Tebienkof, Mount: mountain, see Tebenkof, Mount.

Tebienkof Bay: bay, see Tebenkof Bay.

Tebienkoff Bay: bay, see Tebenkof Bay.

Tebooktolic: locality, see Tubutulik.

Tebooktolic River: stream, see Tubutulik River.

Techeemeesaw: locality, see Tatsimisa.

Techek: locality, at or near Saint Michael, Yukon-Kuskokwim Delta; $63^{\circ} 29^{\prime} \mathrm{N}, 162^{\circ} 02^{\prime}$ W ; (map 92). Var. Agakhlyak, Tachik, Takchak, Tashuk, Tatchek, Tatschik, Tatschikmiut, T'satsúmi, Tutsógemut.

Eskimo village name reported to mean "the bay"; recorded in $1842-44$ by Lt. L. A. Zagoskin, IRN, as "Tachik ili Agakhlyak," i.e. "Tachik or Agakhlyak." In 1842 Lt. L. A. Zagoskin recorded a population of 19 Eskimos in 3 houses. The 1880 Census lists "Tachik," population included in that of Saint Michael.

Techik: bay, see Golovnin Bay.

Teck Island: island, $0.3 \mathrm{mi}$. across, at mouth of Bluefox Bay, on N coast of Afognak I.; $58^{\circ}$ $27^{\prime} 50^{\prime \prime} \mathrm{N}, 152^{\circ} 42^{\prime} 20^{\prime \prime} \mathrm{W}$; (map 43).

Local name published by USC\&GS on Chart 8573 in 1928.

Tecla Creek: stream, flows NE $0.7 \mathrm{mi}$. to Ruby Creek, $10 \mathrm{mi}$. NW of Medfra, Kilbuck-Kuskokwim Mts.; $63^{\circ} 14^{\prime} \mathrm{N}, 154^{\circ} 48^{\prime} \mathrm{W}$; (map 89).

Local name reported in 1920 by G. C. Martin (in Brooks and others, 1922, fig. 5), USGS.

Tecumseh Greek: stream, flows SE $1.5 \mathrm{mi}$. to Bear Creek, $19 \mathrm{mi}$. NE of Fairbanks, YukonTanana High.; $65^{\circ} 02^{\prime} 40^{\prime \prime} \mathrm{N}, 147^{\circ} 11^{\prime} 30^{\prime \prime} \mathrm{W}$; (map 105).

Named by prospectors; published in 1908 by USGS.

Teddy Bear Harbor: harbor, see Bernard Harbor.

Teddy Creek: stream, flows SE $2.5 \mathrm{mi}$, joins Rabbit Creek to form Quartz Creek, $9 \mathrm{mi}$. SE of Long and $30 \mathrm{mi}$. SSE of Ruby, Kilbuck- 
Kuskokwim Mts. ; $64^{\circ} 19^{\prime} \mathrm{N}, 155^{\circ} 17^{\prime} \mathrm{W}$; (map 98).

Propectors' name reported in 1913 by Eakin (1914, pl. 3), USGS. The stream's identity is in doubt.

Teddys Fork: stream, flows NE $8 \mathrm{mi}$. to join Discovery Fork to form American Creek, 10 mi. SW of Eagle, Yukon-Tanana High.; 64ㅇ$40^{\prime} 45^{\prime \prime} \mathrm{N}, 141^{\circ} 19^{\prime} 15^{\prime \prime} \mathrm{W}$; (map 102). Var. Alder Creek.

Prospectors' name shown on a 1902 manuscript map by E. J. Chamberlain, U.S. Deputy Surveyor.

Tée-atee-ógemut: locality, see Tiatiuk.

Teé-at-iókwik River: stream, flows to Bering Sea in Yukon Delta area S of Kwemeluk Pass; $62^{\circ} 30^{\prime} \mathrm{N}, 165^{\circ} 10^{\prime} \mathrm{W}$; (map 76$)$.

Eskimo name reported by Dall (1870, p. 275). Its identity, however, is uncertain and may apply to the channel shown on presentday maps as Kiangolevik Pass. Dall gives it as the fourth and last stream, going north, from Scammon Bay to the Yukon Delta.

Teecan Creek: stream, see Tikan Creek.

Tee Greek: stream, flows $1 \mathrm{mi}$. N and $\mathrm{W}$ to Tee Harbor, $0.5 \mathrm{mi}$. $\mathrm{N}$ of village of Tee Harbor and $15 \mathrm{mi}$. NW of Juneau, Coast Mts.; $58^{\circ}$ $23^{\prime} 45^{\prime \prime} \mathrm{N}, 134^{\circ} 44^{\prime} 45^{\prime \prime} \mathrm{W}$; (map 11).

Local name published by USGS in 1962. Name derived from Tee Harbor.

Teegaldenskoi : locality, see Tigalda.

Tee Harbor: village, pop, 32 (1950), at S end of Tee Harbor, on Favorite Channel, $3 \mathrm{mi}$. NW of Fairhaven and $14 \mathrm{mi}$. NW. of Juneau, Coast Mts.; $58^{\circ} 24^{\prime} 35^{\prime \prime} \mathrm{N}, 134^{\circ} 45^{\prime} 30^{\prime \prime} \mathrm{W}$; (map 11).

Local name derived from the harbor. Originally a saltery built by $W$. N. Lazier in 1901, followed by a salmon cannery on the same site in 1911. The cannery burned down in 1912 (DeArmond, 1957, p. 43). The name was published in Polk's Gazetteer in 1916.

Tee Harbor: bay, $1.5 \mathrm{mi}$. long, on $\mathrm{E}$ shore of Favorite Channel, $0.4 \mathrm{mi}$. N of Lena Cove and $15 \mathrm{mi}$. NW of Juneau, Coast Mts.; $58^{\circ}$ $25^{\prime} 30^{\prime \prime} \mathrm{N}, 1^{\circ} 44^{\prime} 00^{\prime \prime} \mathrm{W}$; BGN 1906; (map 11). Var. Stephens Cove.

Named by local navigators because of its resemblance to the letter "T." In 1887 USC\&GS called it "Stephens Cove," a name derived from Point Stevens. The name was changed to "Tee Harbor" by BGN.

Tee-kee-voga: point of land, see Hope, Point.

Tce-kee-voga-meuts: village, see Point Hope.

Teelaveeruk Mountain: hills, see Telavirak Hills.

Tee Pee Creek: stream, flows W 2 mi. to Flambeau River, $16 \mathrm{mi}$. NE of Nome, Seward Penin. High.; $64^{\circ} 41^{\prime} 30^{\prime \prime} \mathrm{N}, 165^{\circ} 04^{\prime} 30^{\prime \prime} \mathrm{W}$; (map 94).

Prospectors' name shown on the 1904 "Map of Cape Nome Precinct" by Arthur Gibson.

Teetaluk River: stream, see Titaluk River.

Teethcanoe Lake: lake, oxbow of Dulbi River, $10 \mathrm{mi}$. S of Roundabout Mtn., Koyukuk Low.; $65^{\circ} 24^{\prime} \mathrm{N}, 156^{\circ} 28^{\prime} \mathrm{W}$; (map 108).

Local name obtained at Huslia by USGS in 1954 or 1955.
Tefaknaghamiut: locality, see Tefaknak.

Tefaknak: locality, $\mathbf{S}$ of the Yukon River, Yukon-Kuskokwim Delta; (map 74). Var. Tefaknaghamiut.

Former Eskimo village reported as "Tefaknaghamiut," population 195, in the 1890 Census (1893, p. 110).

Tehighinagac, Baie: bay, see Chiginagak Bay.

Tehitchagoff Bay:bay, see Chichagof Bay.

Tehivilh-Kyd, Baie: bay, see Missak Bay.

Teikcll River: stream, see Uranatina River.

Teikhell: locality, see Tiekel and Tiekel Cache.

Téikhell River: stream, see Uranatina River.

Teiteluk River: stream, see Titaluk River.

Tekeaksakrak Lake: lake, $2 \mathrm{mi}$. long, $6 \mathrm{mi}$. SW of Shungnak, Kotzebue-Kobuk Low.; $66^{\circ} 50^{\prime}$ N, $157^{\circ} 15 \mathrm{~W}$; (map 115). Var. Tekeaksukrak Lake.

Eskimo name reported in 1954 by the U.S. Army Corps of Engineers.

Tekeaksukrak Lake: lake, see Tekeaksakrak Lake.

Tekegakrok Point: point of land, extends $\mathrm{N}$ into Elson Lagoon, 7 mi. E of Barrow, Arctic Plain; $71^{\circ} 17^{\prime} 32^{\prime \prime}$ N, $156^{\circ} 26^{\prime} 10^{\prime \prime} \mathrm{W}$; (map 153). Var. Eider Point, Tikigasukruk Point.

Eskimo name "Tikikasugruk" recorded by USC\&GS at Barrow in 1950, means "great big finger." Its spelling on recent maps appears to be a corruption of the Eskimo pronounciation.

Teklanika Channel Lake: lake, $0.7 \mathrm{mi}$. long, 15 mi. SW of INenana, Tanana Low.; $64^{\circ} 29^{\prime} \mathrm{N}$, $149^{\circ} 34^{\prime} \mathrm{W}$; (map 100).

Name derived from Teklanika River and published on recent maps.

Teklanika River: stream, heads at Cantwell Glacier, in Alaska Ra., flows N 90 mi. to Nenana River, $10 \mathrm{mi}$. SW of Nenana, Tanana Low.; $64^{\circ} 28^{\prime} 45^{\prime \prime} \mathrm{N}, 149^{\circ} 19^{\prime} 00^{\prime \prime} \mathrm{W}$; (map 100).

Indian name, meaning "Tekla Creek," reported in 1910 by L. M. Prindle, USGS.

Telaquana Lake: lake, $9 \mathrm{mi}$. long, on Telaquana River, $75 \mathrm{mi}$. NE of Nondalton, Alaska Ra.; $60^{\circ} 57^{\prime} \mathrm{N}, 153^{\circ} 52^{\prime} \mathrm{W}$; BCN 1930; (map 61).

Tanaina Indian name reported about 1928 by Capps (1935, pl. 2), USGS.

Telaquana Mountain: mountain, 8,070 ft., $3 \mathrm{mi}$. $\mathrm{E}$ of Turquoise Lake, $70 \mathrm{mi}$. NE of Nondalton, Alaska Ra.; 60 $48^{\prime} 30^{\prime \prime} \mathrm{N}, 153^{\circ} 45^{\prime} 30^{\prime \prime} \mathrm{W}$; (map 61).

Tanaina Indian name shown on 1928 fieldsheet by S. R. Capps and Gerald FitzGerald, USGS.

Telaquana Pass: pass, 3,100 ft., between headwaters of Neacola and Telaquana Rivers, 80 mi. NE of Nondalton, Alaska Ra.; $60^{\circ} 56^{\prime} \mathrm{N}$, $153^{\circ} 28^{\prime} \mathrm{W}$; (map 61).

Tanaina Indian name reported in 1958 by USGS; derived from nearby Telaquana River.

Telaquana River: stream, heads at glacier, 5.4 mi. SW of Telaquana Pass, flows NW $60 \mathrm{mi}$., through Telaquana Lake to Stony River, 60 mi. N of Tanalian Point on Lake Clark, Alas-

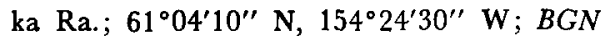
1931; (map 71).

Indian name reported in 1919 by USGS.
Telavirak Hills: hills, $800 \mathrm{ft}$., on Chukchi Sea coast, between Kuropak and Ogotoruk Creeks, $7.5 \mathrm{mi}$. SE of Cape Thompson, Arctic Slope; $68^{\circ} 06^{\prime} \mathrm{N}, 165^{\circ} 38^{\prime} \mathrm{W}$; BGN 1963; (map 129). $V a r$ Teelaveeruk Mountain, Tellaveeruk Hills.

Eskimo name reported as "Tellaveeruk" by personnel of Project Chariot about 1962.

Telegram Creek: stream, flows NW 2.2 mi., joins Eldorado Creek to form Dome Creek, $23 \mathrm{mi}$. NW of Solomon, Seward Penin. High.; 64 ${ }^{\circ} 53^{\prime}$ N, 1643' W; (map 95). Var. Telegraph Greek.

Prospectors' name reported on a map of Cape Nome gold fields by David Fox, Jr., dated 1901.

Telegraph Creek: stream, flows SE $8 \mathrm{mi}$, to Kechumstak Creek, $68 \mathrm{mi}$. SW of Eagle, Yukon-Tanana High.; 64 $04^{\circ} 15^{\prime \prime} \mathrm{N}, 142^{\circ} 50^{\prime} 30^{\prime \prime}$ W; (map 102).

Local name published in 1956 by USGS.

Telegraph Creek: stream, see Telegram Creek.

Telegraph Hill: hill, $375 \mathrm{ft}$., between Thinpoint Cove and Deer I., SW end of Alaska Penin., Aleutian Ra.; 54 $59^{\prime} \mathrm{N}, 162^{\circ} 36^{\prime} \mathrm{W}$; (map 25).

Name published by USC\&GS in 1925.

Telegraph Hill: hill, $248 \mathrm{ft}$, $2 \mathrm{mi}$. N of St. Paul, on S-central St. Paul I., in Pribilof Is.; $57^{\circ} 08^{\prime} 45^{\prime \prime} \mathrm{N}, 170^{\circ} 16^{\prime} 10^{\prime \prime} \mathrm{W}$; (map 38).

Name reported in 1875 by USC\&GS.

Telegraph Hill: hill, see Court House Hill.

Telemitz Island: island, $0.2 \mathrm{mi}$. across, $2 \mathrm{mi}$. S of Sanak I., one of Sanak Is., Aleutian Ra.; $54^{\circ} 20^{\prime} 40^{\prime \prime}$ N, $162^{\circ} 31^{\prime} 25^{\prime \prime} \mathrm{W}$; (map 25).

Name reported by Ferdinand Westdahl, USC\&GS, commander of the Coast Survey steamer McArthur, who made surveys in this area in 1901.

Telephone Creek: stream, heads in Bendeleben Mts., flows SW $17 \mathrm{mi}$. to Fish River, $35 \mathrm{mi}$. SE of Imuruk Creek, Seward Penin. High.; $65^{\circ} 04^{\prime} \mathrm{N}, 162^{\circ} 58^{\prime} \mathrm{W}$; BGN 1910; (map 110).

Prospectors' name published on the 1908 "Map of Seward Peninsula" by Arthur Gibson.

Telephone Point: bluff, elev. $105 \mathrm{ft}$, on $\mathrm{N}$ bank of Naknek River, on Alaska Penin., $3.5 \mathrm{mi}$. NE of Naknek, Bristol Bay Low.; 58 $44^{\prime} 15^{\prime \prime}$ N, 156 $54^{\prime} 40^{\prime \prime} \mathrm{W}$; (map 41).

Local name reported in 1952 by USGS.

Telephone Point: point of land, on $\mathrm{W}$ bank of Kvichak River, $13 \mathrm{mi}$. N of Naknek, Bristol Bay Low.; $58^{\circ} 54^{\prime} 50^{\prime \prime}$ N, $157^{\circ} 02^{\prime} 10^{\prime \prime}$ W; (map 41).

Local name reported in 1952 by USGS.

Telephone Slough: lake, $0.6 \mathrm{mi}$. long, on $\mathrm{E}$ bank of Fish River, $12 \mathrm{mi}$. NW of Golovnin Lagoon and $30 \mathrm{mi}$. NE of Solomon, Seward Penin. High.; 64 $44^{\prime} \mathrm{N}, 163^{\circ} 31^{\prime} \mathrm{W}$; (map 95).

Local name reported on the 1908 "Map of Seward Peninsula" by Arthur Gibson.

Teliamina Lake: lake, $0.7 \mathrm{mi}$. across, $58 \mathrm{mi}$. NE of Medfra, Kuskokwim Low.; $63^{\circ} 36^{\prime} \mathrm{N}, 153^{\circ}$ $14^{\prime} \mathrm{W}$; (map 89).

Indian name obtained in 1958 by T. E. Taylor, USGS. 
Telida: village, pop. 14, on left bank of Swift Fork Kuskokwim River, $50 \mathrm{mi}$. NE of Medfra, Kuskokwim Low.; $63^{\circ} 23^{\prime} \mathrm{N}, 153^{\circ} 16^{\prime} \mathrm{W}$; (map 89). Var. Old Telida.

In 1960, this Ingalik Indian village consisted of three families (Hosley, 1961, p. 95). The village was established at its present site about 1916. Lt. J. S. Herron, USA, visited Telida in 1899 and gave its population then as 17 persons. This "old" location is closer to Lake Minchumina and is now referred to as "Old Telida."

Telida, Lake: lake, see Fish Creek Lake.

Telida Mountains: mountain, 2,981 ft., between Swift Fork Kuskokwim River and Highpower Creek, $57 \mathrm{mi}$. NE of Medfra, Kuskokwim Low.; $63^{\circ} 32^{\prime} \mathrm{N}, 153^{\circ} 08^{\prime} \mathrm{W}$; (map 89).

Local name derived from the nearby village; reported in 1958 by USGS.

Telidaside Creek: stream, flows SW $40 \mathrm{mi}$. to Middle Creek, $43 \mathrm{mi}$. NE of Medfra, Kuskokwim Low.; $63^{\circ} 17^{\prime} \mathrm{N}, 153^{\circ} 25^{\prime} \mathrm{W}$; (map 89).

Local name derived from the village name; reported in 1958 by USGS.

Tellamishuk: locality, see Igiak.

Tellamishuk River: stream, see Kwecharak River.

Tellaveerak: hills, see Telavirak Hills.

Tellaveeruk Hills: hills, see Telavirak Hills.

Tellaveeruk Mountain: hills, see Telavirak Hills.

Teller: village, pop. 217 , on a spit between Port Clarence and Grantley Harbor, $55 \mathrm{mi}$. SE of Cape Prince of Wales, Seward Penin. High.; $65^{\circ} 16^{\prime} \mathrm{N}, 166^{\circ} 22^{\prime} \mathrm{W}$; BGN 1944; (map 1111). Var. Libby Station, Libbysville, Nook, Nooke, Nookmut, Nookmute, Nukmiute.

In 1827 Capt. Beechey (1831, p. 543), RN, reported that at this place "called Nooke by the natives, there were some Esquimaux fishermen ***. They appeared to have established themselves upon this point for the purpose of catching and drying fish." This location was used in the winter of 1866-67 as quarters by Capt. Daniel B. Libby's section of the Western Union Telegraph Expedition, and was known as "Libbysville" or "Libby Station." In 1867 "The Esquimaux," a monthly newspaper, which was published there, noted (July 2, p. 38), "Nook, the spot which divided Grantley Harbor from Port Clarence." In the 1880 Census, Petroff (1884, p. 11) listed a "Nook" at Cape Douglas with a population of 36 Eskimos. It is doubtful that any permanent settlement was established here before 1900 , when the village of Teller "was founded * * * after the Bluestone placers, 15 miles to the south, were discovered. A town named "Bering ***5 miles south of Teller, was the first settlement, but the newer town of Teller drew its people from it. The latter town [Teller], which, during the boom of 1900, had over 1,000 inhabitants, now has not over 100" (Collier and others, 1908, p. 270). The name was probably derived from the Teller Reindeer Station situated on the north shore of Port Clarence. The population in 1910 was 125 ; in 1920,80 ; in 1930,76 ; in 1939,118 ; in 1950, 160. Teller post office was established in 1900 (Ricks, 1965, p. 64). See Teller Mission.

Teller Creek: stream, flows NE $9 \mathrm{mi}$. to Snowshoe Creek which flows to South Fork Serpentine River, $16 \mathrm{mi}$. N of Kougarok Mtn. and 26 mi. E of Ear Mtn., Seward Penin. High.; $65^{\circ} 54^{\prime} \mathrm{N}, 165^{\circ} 20^{\prime} \mathrm{W}$; (map 111).

Prospectors' name reported in 1901 by T. G. Gerdine (in Collier, 902, pl. 12), USGS.

Teller Mission: village, pop. 77 , at mouth of Shelman Creek, on N shore of Port Clarence, $6 \mathrm{mi}$. NW of Teller, Seward Penin. High.; $65^{\circ} 20^{\prime} \mathrm{N}, 166^{\circ} 29^{\prime} \mathrm{W}$; (map 111). Var. Brevig Mission, Okaveenok, Singick, Siniogamut, Siniogamute Sinuk, Teller Reindeer Station.

Established in 1892 as "Teller Reindeer Station" by Sheldon Jackson, who named it for the Hon. Henry Moore Teller, 1830-1914, U.S. Senator, 1876-82 and 1885-1909, and Secretary of the Interior, 1882-85. The station was operated by the U.S. Government from 1892 to 1900. On September 1, 1900, a Norwegian Evangelical Lutheran mission was established here, and received 100 deer on a five-year loan from the Government (Jackson, 1906, p. 15). About 1906 the U.S. Government's role was diminished, and the mission became dominant. The population in 1950 was 109 ; prior to this time no population was given. In 1963 the Brevig Mission Post Office was established here. This may have been the site of an old Eskimo village. See Siniogamute.

Teller Reindeer Station: village, see Teller Mission.

Telrod Cove: cove, extends N $0.7 \mathrm{mi}$, on NE shore of Spiridon Bay, E of Stream Point, on NW coast of Kodiak I.; $57^{\circ} 39^{\prime}$ N, $153^{\circ} 38^{\prime}$ W; BGN 1931; (map 34).

Descriptive name given by USC\&GS in 1929 because a "field party found a lost telemeter rod in this cove."

Telsitna River: stream, heads in Sischu Mts., flows NE $37 \mathrm{mi}$. to Titna River $8 \mathrm{mi}$. SE of its junc. with Nowitna River, $39 \mathrm{mi}$. SE of Monzonite Hills, Kilbuck-Kuskokwim Mts.; $64^{\circ} 20^{\prime} \mathrm{N}, 153^{\circ} 22^{\prime} \mathrm{W}$; (map 98).

Local name reported in 1915 by $H$. M. Eakin (in Brooks and others, 1916, pl. 10), USGS.

Teltakatschkahin Creek: stream, see Little Boulder Creek.

Teltakhatskahin Creek: stream, see Little Boulder Creek.

Telukhti Creek: stream, flows NE $20 \mathrm{mi}$. to Nayuka River, $17 \mathrm{mi}$. NW of Hochandochtla Mtn., Kokrines-Hodzana High.; 65 ${ }^{\circ} 21^{\prime} 50^{\prime \prime}$ N, 155 $18^{\prime} 15^{\prime \prime} \mathrm{W}$; (map 107).

Koyukan Indian name obtained at Huslia in 1956 by Orth.

Temnac Bay: bay, $2 \mathrm{mi}$. across, on $\mathrm{S}$ coast of Attu I., Aleutian Is.; $52^{\circ} 48^{\prime} 30^{\prime \prime} \mathrm{N}, 173^{\circ} 02^{\prime}-$ $30^{\prime \prime} \mathrm{E} ; B G N$ 1965; (map 13). Var. Temnac Cove, Temnag Bay, Ubiennoi Bay, Uchtumuch Bay, Yubae Wan.
Named for a native of Attu Island who was taken from his home to Kamchatka by Michael Nevidiskov, the navigator of the merchant fur-hunting vessel Yevdokia, in 1746, to facilitate the Russians' knowledge of the native language. Temnac confirmed the suspicions of the Russian authorities by telling them about the cruel treatment given the natives by the hunters on the island. He was later baptized as Paul and adopted by Nevidiskov (Coxe, 1787, p. 30-31, and Bancroft, 1886 , p. 102-107). This name was first published in 1943 on an AMS map.

Temnac Beach: beach, $0.8 \mathrm{mi}$. long, at mouth of Temnac Bay, $52^{\circ} 50^{\prime} 02^{\prime \prime} \mathrm{N}, 173^{\circ} 03^{\prime} 45^{\prime \prime} \mathrm{E}$; (map 13).

Named by the U.S. Army during its occupation of the island during World War II; shown on an AMS map published in 1948.

Temnac Cove: bay, see Temnac Bay.

Temnac Point: point of land, see Krasni Point.

Temnac River: stream, heads at AbrahamTemnac Pass, flows ESE $8.4 \mathrm{mi}$. to Temnac Bay, Attu I., Aleutian Is. ; $52^{\circ} 50^{\prime} 02^{\prime \prime} \mathrm{N}, 173^{\circ}$ 03'30" E; (map 13).

Name derived from Temnac Bay and shown on an AMS map published in 1948.

Temnac Valley: valley, $7.5 \mathrm{mi}$. long, formed by Temnac River, Attu I., Aleutian Is.; 52 $50^{\prime}$ $02^{\prime \prime} \mathrm{N}, 173^{\circ} 03^{\prime} 30^{\prime \prime} \mathrm{E}$; (map 13).

Named by the U.S. Army during its occupation of the island during World War II shown on an AMS map published in 1948.

Temnag Bay: bay, see Temnac Bay.

Temnie Island: island, see Dark Island.

Temptation Peak: mountain, 5,300 ft., $2.5 \mathrm{mi}$. NW of junc. of Ship Creek with its North Fork and $12 \mathrm{mi}$. SE of Anchorage, Chugach Mts.; $61^{\circ} 10^{\prime} 00^{\prime \prime} \mathrm{N}, 149^{\circ} 31^{\prime} 15^{\prime \prime} \mathrm{W}$; $B G N$ 1964; (map 69).

So named in 1963 by members of the Mountaineering Club of Alaska because "many have been tempted to climb it."

Tenadziladlakatna: stream, see Manslaughter Creek.

Tenakee: locality, see Cannery.

Tenakee: village, see Tenakee Springs.

Tenakee Channel: estuary, see Tenakee Inlet.

Tenakee Hot Springs: village, see Tenakee Springs.

Tenakee Inlet: estuary, $35 \mathrm{mi}$. long, in E central Chicagof I., $44 \mathrm{mi}$. E of Chicagof, Alex Arch.; 57 $7^{\circ} 7^{\prime} \mathrm{N}, 134^{\circ} 57^{\prime} \mathrm{W}$; (map 9). Var. Berry Passage, Blind Passage, Siwash Canal, Siwash Channel, Tenakee Channel, Tenakee Passage.

Tlingit Indian name giver. in 1869 by USC\&GS and published in the 1883 Coast Pilot (p. 178).

Tenakee Passage: estuary, see Tenakee Inlet.

Tenakee Springs: village, pop. 109, on N shore of Tenakee Inlet, on Chicag of I., $50 \mathrm{mi}$. NE of Sitka, Alex. Arch.; 57 $46^{\prime} 50^{\prime \prime} \mathrm{N}, 135^{\circ} 13^{\prime}$ $00^{\prime \prime}$ W; BGN 1965; (map 9). Var. Hoonah Hot Springs, Hooniah, Tenakee, Tenakee Hot Springs.

Local name derived from "Tenakee," the former name of a cannery located 4 miles to 
the east. Tenakee Springs is a health resort because of the warm springs located here. It has a wharf, store, cafe, crab cannery (USC\&GS, 1962, p. 145) and a post office, established here in 1903, called "Tenakee," but the name was changed to Tenakee Springs in April 1928. It was called "Hoonah Hot Springs" by Lt. Comdr. H. E. Nichols, USN, in 1891 Coast Pilot (p. 163).

Tenany: locality, see Chilkoot.

Tenas Creek: stream, flows NW $3.5 \mathrm{mi}$. to Copper River at Wood Canyon, $63 \mathrm{mi}$. NE of Valdez, Chugach Mts.; $61^{\circ} 26^{\prime} 00^{\prime \prime} \mathrm{N}, 144^{\circ}$. 26'45' W; (map 68). Var. Tinnas Creek.

Named by prospectors about 1898 , reported in 1901 by T. Gerdine, USGS. "Tenas" is a Chinook name meaning "little."

Tenas Lake: lake, $0.4 \mathrm{mi}$. long, along Roosevelt Creek, $0.3 \mathrm{mi}$. W of Roosevelt Lake and 72 mi. SE of Healy, Alaska Ra.; 63 $11^{\prime} 15^{\prime \prime} \mathrm{N}$, $147^{\circ} 11^{\prime} 10^{\prime \prime} \mathrm{W}$; (map 87).

Indian name reported in 1951 by USGS.

Tenass Island: island, $0.9 \mathrm{mi}$. long, in El Capi$\tan$ Passage, $0.4 \mathrm{mi}$. E of Spanbery I., Alex. Arch.; 55 $59^{\prime} 45^{\prime \prime} \mathrm{N}, 133^{\circ} 17^{\prime} 40^{\prime \prime} \mathrm{W}$; (map 4).

Local "chinook name" meaning "small"; published in 1923 by USC\&GS.

Tenass Pass: water passage, $2.5 \mathrm{mi}$. long, between Kosciusko I. and Orr and Spanberg Is., Alex. Arch.; $56^{\circ} 00^{\prime} \mathrm{N}, 133^{\circ} 20^{\prime} \mathrm{W}$; (map 4). Var. Tenass Passage.

Local "chinook name" meaning "small"; published in 1923 by USC\&GS.

Tenass Passage: water passage, see Tenass Pass.

Tendashundu River: stream, see Washington Creek.

Tenderfoot: locality, near the mouth of Tenderfoot Creek, $15 \mathrm{mi}$. NW of Big Delta, TananaYukon High.; 64 $4^{\circ} 15^{\prime} 15^{\prime \prime} \mathrm{N}, 146^{\circ} 13^{\prime} 30^{\prime \prime} \mathrm{W}$; (map 101).

Site of a mining camp and roadhouse reported by USGS in 1918.

Tenderfoot Creek: stream, on Kenai Penin., flows NW $2.5 \mathrm{mi}$. to NE side of Summit Lake, $18 \mathrm{mi}$. S of Sunrise, Chugach Mts. ; $60^{\circ} 38^{\prime} 10^{\prime \prime}$ N, $149^{\circ} 29^{\prime} 58^{\prime \prime} \mathrm{W}$; (map 63).

Local prospectors' name reported about 1914 by B. L. Johnson (in Martin and others, 1915, pl. 2), USGS.

Tenderfoot Creek: stream, flows SW $2.2 \mathrm{mi}$. to Poorman Creek at Poorman, $45 \mathrm{mi}$. S of Ruby, Kilbuck-Kuskokwim Mts.; $64^{\circ} 06^{\prime} 10^{\prime \prime}$ N, $155^{\circ} 32^{\prime} 45^{\prime \prime} \mathrm{W} ; B G N 19366^{\prime}$ (map 98).

Prospectors' name reported in 1913 by Eakin (1914, p. 367), USGS.

Tenderfoot Creek: stream, flows SE $5 \mathrm{mi}$. to Tanana River, $13 \mathrm{mi}$. NW of Big Delta, Tanana Low. ; $64^{\circ} 15^{\prime} 15^{\prime \prime} \mathrm{N}, 146^{\circ} 11^{\prime} 15^{\prime \prime} \mathrm{W}$; (map 101).

Named by prospectors and reported in 1905 by L. M. Prindle (in Brooks and others, 1906, fig. 8), USGS.

Tenfathom Anchorage: bay, $0.2 \mathrm{mi}$. across, in Redfish Bay, $9.3 \mathrm{mi}$. NW of village of Port Alexander, on $\mathrm{S}$ coast of Baranof $\mathrm{I}$., Alex. Arch.; $56^{\circ} 18^{\prime} 45^{\prime \prime} \mathrm{N}, 134^{\circ} 51^{\prime} 30^{\prime \prime} \mathrm{W}$; (map 5). Var. Ten Fathom Anchorage.
Named in 1897 by Lt. Comdr. J. F. Moser, USN.

Ten Gulch: ravine, trends SE $1 \mathrm{mi}$. to Fourth of July Creek $6 \mathrm{mi}$. SW of that stream's junc. with Yukon River and $33 \mathrm{mi}$. NW of Eagle Yukon-Tanana High.; $65^{\circ} 08^{\prime} 30^{\prime \prime}$ N, $141^{\circ} 58^{\prime}$ $30^{\prime \prime} \mathrm{W}$; (map 103).

Local name published in 1956 by USGS.

Tenk Creek: stream, a short stream flowing into Salt Lake, E of Eagle Harbor and $20 \mathrm{mi}$. NW of Juneau, Coast Mts.; $58^{\circ} 29^{\prime} 45^{\prime \prime} \mathrm{N}$, $134^{\circ} 47^{\prime} 00^{\prime \prime} \mathrm{W}$; (map 11).

Local name found in early mining records and reported by DeArmond (1957, p. 38).

Tenmile Creek: stream, flows SW $5.5 \mathrm{mi}$. to Chisana River, $10 \mathrm{mi}$. SE of Northway Junction, Alaska Ra.; 62 $54^{\prime} 55^{\prime \prime} \mathrm{N}, 141^{\circ} 36^{\prime} 20^{\prime \prime}$ W; (map 84).

Local name reported by USGS in 1954. So named because the stream crosses the Alaska Highway 10 miles from Northway Junction.

Tenmile Creek: stream, flows NW $17 \mathrm{mi}$. to Unalakleet River, $44 \mathrm{mi}$. SE of Christmas Mtn., Nulato Hills; $64^{\circ} 05^{\prime} \mathrm{N}, 159^{\circ} 08^{\prime} \mathrm{W}$; map 96). Var. Tenmile River.

Local name reported about 1954 by U.S. Army Corps of Engineers.

Tenmile Creek: stream, flows SE $21 \mathrm{mi}$. to Goodpaster River, 25 mi. NE of Big Delta, YukonTanana High.; $64^{\circ} 17^{\prime} \mathrm{N}, 145^{\circ} 09^{\prime} \mathrm{W}$; (map 101).

Named by prospectors and reported in 1908 by J. W. Bagley, USGS.

Tenmile Creek: stream, flows SW $14 \mathrm{mi}$. to Tozitna River $3 \mathrm{mi}$. N of that stream's junc. with Yukon River, $10 \mathrm{mi}$. W of Tanana, Kokrines-Hodzana High.; $65^{\circ} 10^{\prime} 00^{\prime \prime} \mathrm{N}, 152^{\circ}$ $26^{\prime} 30^{\prime \prime} \mathrm{W}$; (map 106).

Local name reported in 1952 by USGS: so named because it is considered to be 10 miles from Tanana on the sled trail.

Tenmile Hill: hill, 2,310 ft., between Chisana River and Alaska Highway, $13 \mathrm{mi}$. SE of Northway Junction, Alaska Ra.; 62 $51^{\prime} \mathrm{N}$, $141^{\circ} 38^{\prime} \mathrm{W}$; (map 84).

Locally named for Tenmile Creek and reported by USGS in 1955.

Tenmile Island: island, $0.5 \mathrm{mi}$. long, in Iliamna Lake $8 \mathrm{mi}$. SW of Iliamna, Bristol Bay Low.; $59^{\circ} 39^{\prime} \mathrm{N}, 155^{\circ} 00^{\prime} \mathrm{W}$; (map 51 ).

Name published by USGS in 1954.

Tenmile Lake: lake, $2.1 \mathrm{mi}$. long, drains $\mathrm{N}$ to Tenmile Creek $\mathrm{N}$ of Tenmile Hill, $4.5 \mathrm{mi}$. SE of Northway Junction, Alaska Ra.; 62 $54^{\prime} \mathrm{N}$, $141^{\circ} 36^{\prime} \mathrm{W}$; (map 84).

Locally named for Tenmile Creek and reported by USGS in 1955.

Tenmile Post: locality, on left bank of Oksik Channel, Kobuk River, $28 \mathrm{mi}$. NW of Selawik, Kotzebue-Kobuk Low.; $66^{\circ} 53^{\prime} \mathrm{N}, 160^{\circ} 46^{\prime} \mathrm{W}$; (map 114). Var. Oksik.

Local name reported by the U.S. Army Corps of Engineers in 1955. Former Eskimo village reported as "Oksik" by P. S. Smith (1913, p. 46), USGS.

Tennaly: mountain, see McKinley, Mount.

Tennanah Mountains: mountains, see Tanana Hills.
Tenos Creek: stream, see Texas Creek.

Tenounam Island: island, see Seguam Island.

Ten Pup: stream, heads on Yukon Bar, flows SW $0.7 \mathrm{mi}$. to Hunter Creek, $0.4 \mathrm{mi}$. ESE of Rampart, Yukon-Tanana High.; $65^{\circ} 08^{\prime} 40^{\prime \prime} \mathrm{N}$, $150^{\circ} 02^{\prime} 30^{\prime \prime} \mathrm{W}$; (map 106).

Prospectors' name shown on a manuscript map dated 1906; reported in 1956 by Orth.

Tenra'rum-any'i; lake, see Bear Lake.

Ten Thousand Smokes, Valley of: valley, of River Lethe, extends NW $13 \mathrm{mi}$. from Mount Mageik, on Alaska Penin., in Katmai National Monument, $10 \mathrm{mi}$. W of Mount Katmai, Aleutian Ra.; $58^{\circ} 19^{\prime} \mathrm{N}, 155^{\circ} 15^{\prime} \mathrm{W}$; BGN 1924; (map 42).

Discovered and named July 31,1916 , by R. F. Griggs and L. G. Folsum, members of the National Geographic Society Katmai Expedition. Griggs wrote, "The whole valley as far as the eye could reach was full of hundreds, no thousands-literally, tens of thousands-of smokes curling up from its fissured floor." By 1950 , the number of smokes had dwindled to fewer than 100. Most of the original smokes are now extinct and the valley is becoming a "valley of evolution," as hardy pioneer plants struggle to re-establish a floral mantle over nearly sterile ground.

Tent Point: point of land, on W shore of Tamgas Harbor, on $\mathrm{S}$ coast of Annette I., Alex. Arch. ; 55 $03^{\circ} 40^{\prime \prime} \mathrm{N}, 131^{\circ} 02^{\prime} 00^{\prime \prime} \mathrm{W}$; (map 3$)$. Var. Observatory Point.

So named in 1883 by Lt. Comdr. H. E. Nichols, USN, because "his observation tent was erected at this point"; the name "Observatory Point" has been published by USC\& GS for this feature.

Tent Point: point of land, on NW shore of Karluk Lake, $18 \mathrm{mi}$. SE of Karluk, Kodiak I.; $57^{\circ} 24^{\prime} 05^{\prime \prime} \mathrm{N}, 154^{\circ} 04^{\prime} 35^{\prime \prime} \mathrm{W}$; (map 35).

Local name reported in 1952 by USGS.

Tentree Island: island, $100 \mathrm{ft}$. across in Islas Bay on W coast of Chichagof I., $16 \mathrm{mi}$. NW of Chichagof, Alex. Arch.; 57 $49^{\prime} 45^{\prime \prime} \mathrm{N}, 136^{\circ}$ $22^{\prime} 45^{\prime \prime}$ W; (map 9).

Named published in 1928 by USC\&GS on Chart 8258.

T'eocalli Mountains: range, 6,060 ft., $\mathrm{E}$ of South Fork Kuskokwim River, extends N $40 \mathrm{mi}$. from junc. of Styx River, $80 \mathrm{mi}$. SE of McGrath, Alaska Ra.; $62^{\circ} 14^{\prime} \mathrm{N}, 153^{\circ} 17^{\prime} \mathrm{W}$; (map 80).

So named in 1898 by J. E. Spurr, USGS, "because of the fancied resemblance to the Aztec temples."

Teplyya Tseplitel Yuchya Klyuchi: locality, see Goddard.

Terbilon Island: island, $0.5 \mathrm{mi}$. across, $\mathrm{S}$ of Biorka I., on W coast of Baranof I., Alex. Arch.; $56^{\circ} 49^{\prime} 45^{\prime \prime} \mathrm{N}, 135^{\circ} 32^{\prime} 00^{\prime \prime} \mathrm{W}$; (map 5). Var. Ostrov Terbilon.

Named in 1809 by the Russian navigator, Ivan Vasiliev the first; published by Lt. Sarichev (1826, map 19), IRN, as "O[strov] Terbilon," or "Terbilon Island."

Terentief: locality, on right bank of Yukon River below junc. of Koyukuk River, Koyukuk Low. ; 64 $51^{\prime} \mathrm{N}, 157^{\circ} 55^{\prime} \mathrm{W}$; (map 97). Var. 
Terentief's Barabara, Terentief's Station.

Former Indian village or camp recorded as "Terentief's Barabara" by Petroff (1881, p. 62); listed in the 1880 Census (1884, p. 12) as "Terentief's Station," population 15.

Terentief's Barabara: locality, see Terentief.

Terentief's Station: locality, see Terentief.

Teresa Creek: stream, on E coast of Alaska Penin., flows SE $4.3 \mathrm{mi}$. to Puale Bay, $44 \mathrm{mi}$. NW of Karluk, Aleutian Ra.; $57^{\circ} 44^{\prime} 20^{\prime \prime} \mathrm{N}$, $155^{\circ} 37^{\prime} 05^{\prime \prime}$ W; (map 35). Var. Terrace Creek.

Local name obtained from J. L. McPherson of Iliamna in 1903 by G. C. Martin, USGS. This stream was called "Terrace Creek" by R. H. Sargent, USGS, in 1923.

Terminal Island: island, see Anthony Island. Terminal Lake: lake, sec Harlequin Lake.

Termination Cape: point of land, see Termination Point.

Termination Point: point of land, NE tip of Long I., in Kootznahoo Inlet, 4 mi. NE of Angoon, on W central Admiralty I., Alex. Arch.; $57^{\circ} 32^{\prime} 20^{\prime \prime} \mathrm{N}, 134^{\circ} 29^{\prime} 40^{\prime \prime} \mathrm{W}$; (map 9).

Descriptive name given in 1869 by Comdr. R. W. Meade, USN; published by USC\&GS in the 1883 Coast Pilot (p. 177).

Termination Point: point of land, $4.5 \mathrm{mi}$. $\mathrm{N}$ of Kodiak, on NE coast of Kodiak I.; 57 $51^{\prime} 15^{\prime \prime}$ N, $152^{\circ} 24^{\prime} 00^{\prime \prime}$ W; (map 34). Var. Mys Okonchatelnyy, Okonchatelnie, Termination Cape.

Translation of "M[ys] Okonchatelnyy," the name given to this point by Sub-Lt. Mikhail Murashev in 1839 or 1840 and published in 1849 on Russian Hydrog. Dept. Chart 1425.

Tern Lake: lake, $0.6 \mathrm{mi}$. long, on Kenai Penin. $\mathrm{S}$ of Lake Ootka, $11 \mathrm{mi}$. NE of Kenai, Cook Inlet Low.; $60^{\circ} 41^{\prime} 30^{\prime \prime} \mathrm{N}, 151^{\circ} 03^{\prime} 00^{\prime \prime} \mathrm{W}$; (map 62).

Named about 1963 by officials of Kenai National Moose Range, probably for the Arctic Tern (Sterna paradisaea), called "The world's migration champion * **, [round trip of 22,000 mi.]" (Pearson, 1944, pt. 1, p. 64).

Terrace Creek: stream, heads in lake, flows NE $11 \mathrm{mi}$. to Kosina Creek, $22 \mathrm{mi}$. SW of junc. of Oshetna and Susitna Rivers, Talkeetna Mts. ; 62 $34^{\circ} 45^{\prime \prime} \mathrm{N}, 148^{\circ} 03^{\prime} 00^{\prime \prime} \mathrm{W}$; (map 82).

Local name recorded in 1917 by USGS.

Terrace Creek: stream, flows NE $25 \mathrm{mi}$. W of Banded Mtn. to Anaktuvuk River, $15 \mathrm{mi}$. N of Table Top and $51 \mathrm{mi}$. NE of Anaktuvuk Pass, Arctic Slope; $68^{\circ} 50^{\prime} \mathrm{N}, 151^{\circ} 10^{\prime} \mathrm{W}$; BGN 1949; (map 134).

Descriptive name given by USGS geologists during exploration of Naval Petroleum Reserve No. 4; name given in 1944.

Terrace Creek: stream, see Teresa Creek.

Terrace Island: island, $1.2 \mathrm{mi}$. across, in Wide Bay, between Hartman and West Channel Is., off S coast of Alaska Penin., $44 \mathrm{mi}$. SE of Ugashi, Aleutian Ra.; $57^{\circ} 23^{\prime} \mathrm{N}, 156^{\circ} 16^{\prime} \mathrm{W}$; (map 36).

Descriptive name given in 1923 by USC\&GS
Terrace Mountain: mountain, 5,535 ft., $5 \mathrm{mi}$. W of head of Klutina Lake and $34 \mathrm{mi}$. $\mathrm{N}$ of Valdez, Chugach Mts. ; $61^{\circ} 35^{\prime} 00^{\prime \prime} \mathrm{N}, 146^{\circ} 08^{\prime} 40^{\prime \prime}$ W; (map 68).

Named in 1898 by Capt. W. R. Abercrombie (Baker, 1906). Local name published in the 1950's by USGS.

Terrace Point: point of land, on edge of Atrevida Glacier, $2.2 \mathrm{mi}$. NW of Amphitheater Knob and $29 \mathrm{mi}$. NW of Yakutat, St. Elias Mts. ; $59^{\circ} 57^{\prime} 35^{\prime \prime} \mathrm{N}, 139^{\circ} 50^{\prime} 20^{\prime \prime} \mathrm{W}$; (map 46).

So named by Russell (1891, p. 105), " * * because this point of land consists of a series of glacial stream terraces."

Terra Cotta Mountains: range, 6,210 ft., extends N 40 mi. from Fish Crek, between South Fork Kuskokwim and Post Rivers, $80 \mathrm{mi}$. SE of McGrath, Alaska Ra.; $62^{\circ} 05^{\prime} \mathrm{N}, 153^{\circ} 26^{\prime}$ W; $(\operatorname{map} 80)$.

So named in 1898 by J. E. Spurr and W.S Post, USGS, because of "their superb and peculiar coloring."

Terrible Mountain: mountain, 2,200 ft., at SE end of Henderson Ridge on eastern Attu I., Aleutian Is.; $52^{\circ} 51^{\prime} 30^{\prime \prime} \mathrm{N}, 1^{\circ} 3^{\circ} 09^{\prime} 30^{\prime \prime} \mathrm{E}$; (map 13).

Named by the U.S. Army during its occupation of the island during World War II ; shown on an AMS map published in 1948.

Territory of Alexander: state, see Alaska.

Terror Bay: $b a y$, extends S $6.5 \mathrm{mi}$., off Uganik Passage, SE of Uganik I., on N coast of Kodiak I.; $57^{\circ} 46^{\prime} \mathrm{N}, 153^{\circ} 12^{\prime} \mathrm{W}$; BGN 1909; (map 34)

Named in 1909 by W. C. Hodgkins, USC\&GS.

Terror Lake: lake, $1.8 \mathrm{mi}$. long, $25 \mathrm{mi}$. SW of Kodiak, on N central Kodiak I.; 57 $38^{\prime} 30^{\prime \prime}$ $\mathrm{N}, 153^{\circ} 00^{\prime} 45^{\prime \prime} \mathrm{W}$; (map 34$)$.

Name derived from Terror Bay and published in 1952 by USGS.

Teschekpuk Lake: lake, see Teshekpak Lake. Teseeruq Lake: lake, see Tusikvoak, Lake.

Teshekpak Lake: lake, $1.8 \mathrm{mi}$. long, $10 \mathrm{mi}$. E of village of Point Hope, Arctic Slope; 68 ${ }^{\circ} 21^{\prime}$ N, $166^{\circ} 23^{\prime}$ W; (map 129). Var. Teschekpuk Lake, Teshepak Lake.

Eskimo name meaning "big lake" reported in 1956 by Orth.

Teshekpuk Lake: lake, $22 \mathrm{mi}$. across, $12 \mathrm{mi}$. E of Harrison Bay, S of Pitt Point, Arctic Plain, $70^{\circ} 35^{\prime} \mathrm{N}, 153^{\circ} 26^{\prime} \mathrm{W}$; BGN 1930; (map 148). Var. Tasekpuk Lake, Tashicpuk Lake, Tasirkpuk Lake, Tasokpoh Lake, Tasyukpun Lake, Teasekpuk Lake, Tesukpuk Lake.

Eskimo name recorded on Maguire's chart (Great Britain, 1954, facing p. 186) as Tasokpoh, and reported to mean "big enclosed coastal water" or "big coastal lake." Capt. P. H. Ray's (1885), p. 55) vocabulary lists Tasyukpun, meaning "great enclosed water." According to Leffingwell (1919, p. 100), USGS, Stefánsson spells it Tasirkpuk, while Leffingwell himself appears to have established the present-day spelling.

Teshepak Lake: lake, see Teshekpak Lake. Tessaychaht: lagoons, see Tasaitsat Lagoons.
Tessaychaht Angayookangak: lagoon, see Tasaitsat Angayukangak Lagoon.

Testigos, Los: islands, see Witnesses, The.

Testin, Mount: mountain, see Distin, Mount. Tesukpuk Lake: lake, see Teshekpuk Lake.

Tetahena River: stream, see Bremner River.

Tetelna: stream, see Indian Creek.

Tetena: stream, see Dadina River.

Tetilesook Creek: stream, flows NNW $7.5 \mathrm{mi}$. to Kobuk River $1 \mathrm{mi}$. SE of its junc. with Kallarichuk River, $21 \mathrm{mi}$. NE of Kiana, Brooks Ra.; $67^{\circ} 06^{\prime} \mathrm{N}, 159^{\circ} 43^{\prime} \mathrm{W}$; (map 127).

Eskimo name obtained in 1955 by U.S. Army Corps of Engineers.

Tetlin: village, pop. 122, on Tetlin River, 4.5 mi. E of Tetlin Lake and $20 \mathrm{mi}$. SE of Tok, Yukon-Tanana High.; $63^{\circ} 08^{\prime} \mathrm{N}, 142^{\circ} 31^{\prime} \mathrm{W}$; $B G N$ 1942; (map 85). Var. Tetling, Tetlings, Tetling's Village.

Lt. Allen (1887, p. 77) wrote "We reached 'Tetling's June 12, $1885 * * *$ six men * * * four women, and seven children, occupying two houses situated on a deep, clear stream, the outlet of a lake ***." Apparently named for the local tyone or chief "Tetling." Lt. P. G. Lowe (Glenn and Abercrombie, 1899, p. 370), USA, wrote "On August 29, 1898 we stopped at 'Tetling,' and were met by Chief David ***. 'Tetlings' consists of four log houses * * *." In 1942 at the recommendation of BIA, BGN officially changed the spelling to "Tetlin" to agree with that of the river.

Tetling: village, see Tetlin.

Tetling Center: village, see Tetlin Junction. Tetling Hills; ridge, see Tetlin Hills.

Tetling Junction: village, see Tetlin Junction. Tetling Lake: lake, see Tetlin Lake.

Tetling River: stream, see Tetlin River.

Tetlings: village, see Tetlin.

Tetling's Village: village, see Tetlin.

Tetlin Hills: ridge, elev. 3,000 ft., extends 11 mi., $\mathbf{E}$ of Tok River, $\mathbf{N}$ of Tetlin Lake, $10 \mathrm{mi}$. S. of Tok, Alaska Ra.; $63^{\circ} 11^{\prime} \mathrm{N}, 142^{\circ} 45^{\prime} \mathrm{W}$; BGN 1943; (map 85). Var. Tetling Hills.

Local name reported by USGS in 1936.

Tetlin Junction: village, at junc. of Alaska and Taylor Highways, $12 \mathrm{mi}$. E of Tok, YukonTanana High.; $63^{\circ} 19^{\prime} \mathrm{N}, 142^{\circ} 36^{\prime} \mathrm{W}$; $B G N$ 1952; (map 85). Var. Forty Mile, Tetling Center, Tetling Junction.

Local name published by USGS in 1951. Named because it marks the junction of two important highways in the Tetlin Indian Reservation.

Tetlin Lake: lake, $8 \mathrm{mi}$. long, in course of Tetlin River, $16 \mathrm{mi}$. S of Tok, Alaska Ra.; $63^{\circ} 05^{\prime} \mathrm{N}$, $142^{\circ} 45^{\prime} \mathrm{W}$; BGN 1942; (map 85). Var. Big Tetling Lake, Lake Wagner, Tetling Lake, Wagner Lake.

Local name reported in 1936 by USGS. In 1889 Lt. P. G. Lowe, USA, called it "Lake Wagner."

Tetlin River: stream, heads at glacier terminus, flows NE $75 \mathrm{mi}$. to Tanana River, $22 \mathrm{ml}$. SE of Tok, Alaska Ra.; $63^{\circ} 10^{\prime} \mathrm{N}, 142^{\circ} 24^{\prime} \mathrm{W}$; $B G N 1942$; (map 85). Var. Bear Creek, Tetling River. 
Indian name recorded in 1885 as "Tetling" by Lt. Allen (1887, p. 78 ), USA. It was called "Bear Creek" by F. C. Schrader, USGS, because some bears were seen on this stream during his trip in 1902.

Teton Creek: stream, flows S $1.7 \mathrm{mi}$. to Hutlinana Creek, $20 \mathrm{mi}$. SE of Rampart, YukonTanana High.; $65^{\circ} 15^{\prime} 30^{\prime \prime}$ N, $149^{\circ} 56^{\prime} 10^{\prime \prime} \mathrm{W}$; (map 105).

Named by prospectors; reported in 1906 by USGS.

Tetrakof Point: point of land, on SE coast of Shuyak I., Kodiak I.; $58^{\circ} 31^{\prime} 00^{\prime \prime}$ N, $152^{\circ} 23^{\prime}$. $40^{\prime \prime} \mathrm{W}$; (map 43).

Local name reported in 1952 by USGS.

Tetravun Lakes: lakes, $5 \mathrm{mi}$. E of Venetie and $41 \mathrm{mi}$. SW of Christian, Yukon Flats; $67^{\circ} 02^{\prime}$ N, $146^{\circ} 17^{\prime} \mathrm{W}$; (map 122$)$.

Kutcha-kutchin Indian name obtained in 1956 by T. E. Taylor, USGS.

Tetsyeh Lake: lake, $1 \mathrm{mi}$. long, $8 \mathrm{mi}$. SW of Tetsyeh Mtn. and $21 \mathrm{mi}$. NE of Arctic Village, Brooks Ra.; $68^{\circ} 24^{\prime}$ N, $145^{\circ} 08^{\prime} \mathrm{W}$; (map 136).

Kutchin Indian name obtained at Arctir Village in 1956 by T. E. Taylor, USGS.

Tetsyeh Mountain: peak, 6,528 ft., $29 \mathrm{mi}$. NE of Arctic Village, Brooks Ra.; $68^{\circ} 29^{\prime} \mathrm{N}, 144^{\circ}$ $54^{\prime} \mathrm{W}$; (map 136).

Kutchin Indian name obtained at Arctic Village in 1956 by T. E. Taylor, USGS.

Tetthajik Creek: stream, heads at $66^{\circ} 46^{\prime} \mathrm{N}$, $141^{\circ} 13^{\prime} \mathrm{W}$, flows SW $30 \mathrm{mi}$. to Salmon Fork Black River, $38 \mathrm{mi}$. NW of Midnight Hill, Porcupine Plat.; $66^{\circ} 31^{\prime} \mathrm{N}, 141^{\circ} 49^{\prime}$; (map 120).

Tranjik-kutchin Indian name; obtained in 1956 by T. E. Taylor, USGS.

Teucher Creek: stream, see Teuchet Creek.

Teuchet Creek: stream, flows NW $10 \mathrm{mi}$. to East Fork Chena River, $60 \mathrm{mi}$. N of Big Delta, Yukon-Tanana High.; $64^{\circ} 59^{\prime} 30^{\prime \prime} \mathrm{N}, 145^{\circ} 37^{\prime}$ 45" W; (map 101). Var. Teucher Creek.

Prospectors' name derived from the German words "Teichel," or later "Teuchel," meaning "water conduit" or "conduit-pipe"; reported in 1909 by USGS (Capps, 1912, pl. 1).

Teufelsberg: hill, see Devil Mountain.

Texas Creek: stream, flows $3 \mathrm{mi}$. S to Pacific Ocean, $2 \mathrm{mi}$. NE of Kettle Cape, on E coast of Umnak I., Aleutian Is.; $53^{\circ} 17^{\prime} 45^{\prime \prime} \mathrm{N}, 168^{\circ}$ $04^{\prime} 40^{\prime \prime} \mathrm{W}$; (map 22).

Name published by Byers (1959, pl. 41), USGS.

Texas Creek: stream, heads at confluence of its North and West Forks, flows S 2 mi. to Salmon River, $7.5 \mathrm{mi} . \mathrm{N}$ of Hyder, Coast Mts.: $56^{\circ} 01^{\prime} 30^{\prime \prime} \mathrm{N}, 130^{\circ} 04^{\prime} 30^{\prime \prime} \mathrm{W}$; (map 7).

Local name published by Theodore Chapin (in Brooks and others, 1916, p. 95), USGS.

Texas Creek: stream, flows $3 \mathrm{mi}$. W to Copper Creek NW of its junc. with Eagle Creek, 18 mi. SE of McCarthy, St. Elias Mts. $61^{\circ} 21^{\prime} \mathrm{N}$, $142^{\circ} 26^{\prime} \mathrm{W}$; (map 67).

Local name reported in 1908 by D. C. Witherspoon (Moffit and Capps, 1911, pl. 2), USGS.
Texas Creek: stream, heads on Beluga Mtn., flows E $8 \mathrm{mi}$. to Bear Creek, W of Alexander Lake, $45 \mathrm{mi}$. $\mathbf{N}$ of Tyonek, Cook Inlet Low.; $61^{\circ} 43^{\prime} 30^{\prime \prime} \mathrm{N}, 150^{\circ} 57^{\prime} 30^{\prime \prime} \mathrm{W}$; (map 70 ).

Local name reported in 1935 by USGS.

Texas Creek: stream, flows NE $3 \mathrm{mi}$. to Fish Creek, $55 \mathrm{mi}$. SW of Eagle, Yukon-Tanana High.; 64 $4^{\circ} 17^{\prime} \mathrm{N}, 142^{\circ} 40^{\prime} \mathrm{W}$; (map 102).

Prospectors' name shown on an 1898 manuscript map by C. A. Woodruff, Fort Cudahy, Canada.

Texas Creek: stream, flows NE $1.8 \mathrm{mi}$. to Canyon Creek which flows to Casadepaga River, $21 \mathrm{mi}$. NE of Solomon, Seward Penin. High.; $64^{\circ} 51^{\prime} \mathrm{N}, 164^{\circ} 25^{\prime} \mathrm{W}$; (map 95).

Prospectors' name reported in 1900 by E. C. Barnard (in Brooks, 1901, pl. 17), USGS.

Texas Creek: stream, flows N $11 \mathrm{mi}$. to Yukon River, $33 \mathrm{mi}$. ENE of Tanana, Yukon-Tanana High.; $65^{\circ} 18^{\prime} \mathrm{N}, 151^{\circ} 00^{\prime} \mathrm{W}$; (map 106). Var. Dickie Creek, Tenos Creek.

Local name reported in 1931 by USGS; called "Tenos Creek" by ARC surveyors in 1905.

Texas Creek: stream, flows NW $3 \mathrm{mi}$. to Troublesome Creek, $16 \mathrm{mi}$. SE of Rampart, YukonTanana High.; $65^{\circ} 25^{\prime} \mathrm{N}, 149^{\circ} 42^{\prime} \mathrm{W}$; (map 105).

Named by prospectors; reported in 1908 by USGS (Covert and Ellsworth, 1909, pl. 5).

Texas Glacier: glacier, trends E 5 mi. to its 1955 terminus at North Fork Texas Creek, 11.5 mi. $\mathrm{N}$ of Hyder, Coast Mts.; $56^{\circ} 04^{\prime} 45^{\prime \prime} \mathrm{N}$, $130^{\circ} 05^{\prime} 45^{\prime \prime} \mathrm{W}$; (map 7).

Local name published by Theodore Chapin (in Brooks and others, 1916, p. 95), USGS

Texas Lake: lake, $0.3 \mathrm{mi}$. across, at head of West Fork Texas Creek, 13 mi. NW of Hyder, Coast Mts.; $56^{\circ} 03^{\prime} 10^{\prime \prime} \mathrm{N}, 130^{\circ} 15^{\prime} 30^{\prime \prime} \mathrm{W}$; (map 7).

Local name reported in 1928 by USGS.

Texas Star Lake: lake, see Sprucefish Lake.

Thadlthamud Lake: lake, see Thadlthamund Lake.

Thadlthamund Lake: lake, $1.4 \mathrm{mi}$. long, $\mathrm{N}$ of Halthalda Hill, $13 \mathrm{mi}$. W of Northway, Alaska Ra.; $62^{\circ} 59^{\prime} \mathrm{N}, 142^{\circ} 22^{\prime} \mathrm{W}$; (map 84). Var. Thadlthamud Lake.

Indian name obtained in 1962 at Tetlin by USGS and reported to mean "lily pads on lake," or possibly "lily pad lake."

Thadlthamund Lake: lake, $0.8 \mathrm{mi}$. long, SE of Shashamund Lake, $1.2 \mathrm{mi}$. NW of Northway Junction, Yukon-Tanana High.; 63 $01^{\prime} 30^{\prime \prime}$ $\mathrm{N}, 141^{\circ} 50^{\prime} 45^{\prime \prime} \mathrm{W} ; B G N$ 1961; (map 85).

Indian name meaning "lily pad lake," reported in 1960 by T. E. Taylor, USGS.

Tha-ghe-an: stream, see Lost River.

Thaghian River: stream, see Lost River.

Thane: village, pop. $82,4 \mathrm{mi}$. SE of Juneau on Gastineau Channel and $6 \mathrm{mi}$. NW of Point Salisbury, Coast Mts. ; 58 $15^{\prime} 50^{\prime \prime}$ N, 134 $14^{\circ}$ '45" W; BGN 1929; (map 11). Var. Sheep Creek.

Named in 1914 for Bartlett L. Thane, 1878-1927, general manager of the Alaska Gastineau Mining Co. which had its mill here. Bartlett Thane was born in Califor- nia and went to Alaska in 1897. The name "Sheep Creek," which was the original miners' name for the town, was published by USC\&GS in the 1901 Coast Pilot but was later changed to "Thane" by BGN. The town was founded in 1881 as a result of mining operations in the vicinity.

Thane Mountain: mountain, 3,200 ft., $2 \mathrm{mi}$. W of 1951 terminus of Eagle Glacier and 30 mi. NW of Juneau, Coast Mts.; 58 $35^{\prime} 15^{\prime \prime}$ $\mathrm{N}, 134^{\circ} 47^{\prime} 00^{\prime \prime} \mathrm{W}$; (map 11).

Named about 1902 for Bartlett L. Thane, mine superintendent of the Eagle River mine, which is located on its southeast slope. The name is no longer in use (DeArmond, 1957. p. 5). See Thane.

Thanksgiving Creek: stream, flows SE $5.5 \mathrm{mi}$. to Omega Creek $1.2 \mathrm{mi}$. $\mathrm{N}$ of that stream's junc. with Baker Creek, 27 mi. SSW of Rampart, Yukon-Tanana High.; $65^{\circ} 07^{\prime} 00^{\prime \prime}$ N, $150^{\circ} 20^{\prime}$ 30 " W ; (map 106).

Prospectors' name reported in 1904 by USGS (Prindle and Hess, 1906, p. 45). Gold was discovered here in February 1903.

Thanksgiving Creek: stream, flows NE 16 mi. to Yukon River, $30 \mathrm{mi}$. SSE of Circle, YukonTanana High.; $65^{\circ} 25^{\prime} 40^{\prime \prime} \mathrm{N}, 143^{\circ} 37^{\prime} 50^{\prime \prime} \mathrm{W}$; (map 103).

Prospectors' name recorded in 1905 by $\mathrm{D}$. C. Witherspoon (in Prindle, 1906, pl. 1), USGS. Thanksgiving Ditch: water course, flows SE 11 mi., diverts head waters of California, Chicago, and New York Creeks, to Omega Creek, $6.8 \mathrm{mi}$. N of Baker Lake and $27 \mathrm{mi}$. S of Rampart, Yukon-Tanana High.; $65^{\circ} 07^{\prime} \mathrm{N}$, $150^{\circ} 20^{\prime} \mathrm{W}$; (map 106).

Local name reported in 1963 by USGS.

Thatcher, Point: point of land, on NE coast of Catherine I., off NE coast of Baranof I., Alex. Arch.; 57 $25^{\prime} \mathrm{N}, 134^{\circ} 50^{\prime} \mathrm{W}$; (map 9). Var. Coleman Point, Scahkaliakh, Shkaliakh.

Named in 1869 by Comdr. R. W. Meade, USN. It was called "Shkaliakh" or "Schkaliakh" by the Tlingit Indians. It is "Point Coleman" on the maps of Homfray, Cartographer of the Western Union Telegraph Expedition in 1867 (USC\&GS, 1883, p. 167).

Thatcher Channel: water passage, $1.5 \mathrm{mi}$. long, between Trader Is. and $\mathrm{N}$ coast of Catherine I., off NE coast of Baranof I., Alex. Arch.; $57^{\circ} 25^{\prime} 30^{\prime \prime} \mathrm{N}, 134^{\circ} 53^{\prime} 00^{\prime \prime} \mathrm{W}$; (map 9).

Name published by USC\&GS in the 1943 Coast Pilot (p. 379). It was probably named for Point Thatcher at the channel's mouth.

Thayer Basin: cirque, at head of Traleika Glacier, in Mount McKinley National Park, on E slope of Mount McKinley, Alaska Ra.; $62^{\circ} 04^{\prime} \mathrm{N}, 150^{\circ} 56^{\prime} \mathrm{W}$; BGN 1960; (map 88).

Named in 1955 by Bradford Washburn for Elton S. Thayer, NPS ranger, who was the first to cross this basin while climbing South Peak Mount McKinley in May 1954 and who lost his life in the descent.

Thayer Creek: stream, heads in Thayer Lake, fows SW 6 mi. to Chatham Strait, on W coast of Admiralty I., $5.5 \mathrm{mi}$. $\mathrm{N}$ of Angoon, Alex. Arch.; 57 $34^{\prime} 45^{\prime \prime} \mathrm{N}, 134^{\circ} 37^{\prime} 30^{\prime \prime} \mathrm{W}$; (map 9). Var. Poison Creek. 
Named in 1929 by USFS for John A. Thayer, 1896-1929, a junior forester in the USFS. See Thayer Lake.

Thayer Lake: lake, $7 \mathrm{mi}$. long, $10 \mathrm{mi}$. NE of Angoon, on W central Admiralty I., Alex. Arch.; $57^{\circ} 39^{\prime} \mathrm{N}, 134^{\circ} 29^{\prime} \mathrm{W}$; (map 9).

Named in 1929 by USFS for John A. Thayer, 1896-1929, a junior forester in the USFS, who was killed by a brown bear on Admiralty Island. John Thayer made a reconnaissance of the timber bordering this lake a few weeks before his death and was the first United States forester to visit the lake.

Thayer Mountain: mountain, 3,890 ft., $5 \mathrm{mi}$. long, on W central Admiralty I., E of Thayer Lake, $14 \mathrm{mi}$. NE of Angoon, Alex. Arch.; $57^{\circ} 41^{\prime} \mathrm{N}, 134^{\circ} 21^{\prime} \mathrm{W}$; (map 9).

Local name reported in 1951 by USGS.

Thayer Peak: mountain, 3,550 ft., on W central Admiralty I., $3 \mathrm{mi}$. $\mathrm{N}$ of Thayer Lake and $14.5 \mathrm{mi}$. NNE of Angoon, Alex. Arch.; $57^{\circ} 42^{\prime} 15^{\prime \prime} \mathrm{N}, 134^{\circ} 30^{\prime} 00^{\prime \prime} \mathrm{W}$; (map 9).

Local name reported in 1951 by USGS.

Thazzik Mountain: mountain, 5,600 ft., between Funchion Creek and East Fork Chandalar River, $33 \mathrm{mi}$. SE of Chandalar, Brooks Ra.; $67^{\circ} 17^{\prime} \mathrm{N}, 147^{\circ} 22^{\prime} \mathrm{W}$; (map 123).

Kutchin Indian name reported in 1956 by T. E. Taylor, USGS

The-con-da: stream, see Cooper Creek.

The Cache: locality, on Crow Creek, 6 mi. $\mathrm{N}$ of Girdwood and $29 \mathrm{mi}$. SE of Anchorage, Chugach Mts.; $61^{\circ} 01^{\prime} 45^{\prime \prime} \mathrm{N}, 1^{\circ} 09^{\circ} 07^{\prime} 10^{\prime \prime} \mathrm{W}$; $B C N 1932$; (map 69).

Local name reported in 1932 by W. G. Carson and C. F. Park, USGS, as a place "at the end of the wagon road where supplies are left [cached] for the mines, Girdwood district."

The Forks: locality, at confluence of Nixon and Takotna Rivers, $31 \mathrm{mi}$. SW of Medfra, Kilbuck-Kuskokwim Mts.; $63^{\circ} 02^{\prime} \mathrm{N}, 155^{\circ} 40^{\prime} \mathrm{W}$; (map 89).

Local name reported in 1955 by USGS

The Forks: locality, at junc. of Khotol River and Kaiyuh Slough, $20 \mathrm{mi}$. SE of Nulato, Koyukuk Low.; $64^{\circ} 26^{\prime} \mathrm{N}, 157^{\circ} 57^{\prime} \mathrm{W}$; (map 97). Var. Tlutlertaut.

Appears to be a translation of an Indian name; reported in 1935 by Frederica de Laguna, BAE.

Thekonda: stream, see Camp Creek.

Thekonda: stream, see Cooper Creek.

The Mission: village, see Russian Mission.

Theodore, Point: point of land, $\mathrm{S}$ tip of Yakobi I., off W coast of Chichagof I., $19 \mathrm{mi}$. NW of Chichagof, Alex. Arch.; 57 50'50" N, 136 27'. $30^{\prime \prime}$ W; (map 9). Var. Theodor Point.

Named in 1879 by W. H. Dall, USC\&GS, for Capt. Urey Theodorovich Lisianski, Russian navigator, who explored these waters and was the first to make detailed charts of this region, 1804-05.

Theodore Creek: stream, flows SE $20 \mathrm{mi}$. to Anvik River, $17 \mathrm{mi}$. NW of Anvik and $48 \mathrm{mi}$. NW of Holy Cross, Nulato Hills; $62^{\circ} 45^{\prime} \mathrm{N}$, $160^{\circ} 43^{\prime} \mathrm{W}$; (map 78).

Local name reported in 1949 by USC\&GS.
Theodore Island: island, $3 \mathrm{mi}$. long, in Yukon River, $48 \mathrm{mi}$. NE of Rampart, Yukon Flats; $65^{\circ} 59^{\prime} 15^{\prime \prime} \mathrm{N}, 149^{\circ} 01^{\prime} 00^{\prime \prime} \mathrm{W}$; (map 105).

Named for Theodore Hudson, who prospected in the Livengood area.

Theodore Point: point of land, S tip of Attu I., Aleutian Is.; $52^{\circ} 45^{\prime} 10^{\prime \prime} \mathrm{N}, 172^{\circ} 55^{\prime} 00^{\prime \prime} \mathrm{E}$ BGN 1938; (map 13). Var. Tubkooch Point.

Derived from "Saint Theodore, former name of Attu Island." The name was proposed in 1938 by U.S. Navy Hydrog. Office; published in 1943 by AMS. Shown as "Tubkooch Point" on a manuscript map by $\mathrm{L}$. $\mathrm{M}$. Turner in the 1880's.

Theodore Ridge: ridge, elev. $1,000-2,500 \mathrm{ft}$., on $S$ coast of Attu I., extends $\mathrm{N} 6 \mathrm{mi}$. from Theodore Point, Aleutian Is.; 52 $47^{\prime} 30^{\prime \prime} \mathrm{N}, 172^{\circ}$ $56^{\prime} 00^{\prime \prime} \mathrm{E}$; (map 13)

Name derived from Theodore Point; published in 1948 by AMS.

Theodore River: stream, flows SE $35 \mathrm{mi}$. to Cook Inlet, $32 \mathrm{mi}$. W of Anchorage, Cook Inlet Low.; $61^{\circ} 13^{\prime} 45^{\prime \prime} \mathrm{N}, 150^{\circ} 49^{\prime} 50^{\prime \prime} \mathrm{W}$; (map $70)$.

Local name reported in 1898 by USGS.

Theodor Point: point of land, see Theodore, Point.

The Redoubt: locality, on W side of Baranof I., $S$ of Mount Dranishnikov, between Redoub Bay and Redoubt Lake, $4 \mathrm{mi}$. NE of God-

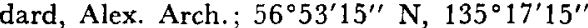
W; (map 5). Var. Dranishikoff Settlement, Ozerskoy Redut, Seleniye Danishnikova.

Previously called "Seleniye Dranishnikova," or "Dranishnikov Settlement," by Lt. Sarichev (1826, map 19), IRN, for Mount Drainishnikof. It was first reported by Capt. Tebenkov (1852, map 38), IRN, as "Ozerskoy Redut," meaning "redoubt lake." It is the site of an abandoned Russian fishery and flour mill (Colby, 1945, p. 175).

Theresa Creek: stream, flows SW $6.7 \mathrm{mi}$. to Independence Creek in Kugruk Riber basin, 22 mi. E of Imuruk Lake, Seward Penin. High.; $65^{\circ} 34^{\prime} \mathrm{N}, 162^{\circ} 25^{\prime} \mathrm{W}$; (map 110 )

Prospectors' name reported in 1903 by D. C. Witherspoon (in Moffit, 1905, pl. 2), USGS.

The Stone Wall: locality, on W coast of Glass Peninsula, $2 \mathrm{mi}$. SE of Sore Finger Cove, 45 mi. S of Juneau, Alex. Arch.; 57 $42^{\prime} 00^{\prime \prime} \mathrm{N}$, $133^{\circ} 58^{\prime} 20^{\prime \prime} \mathrm{W}$; (map 8).

Local name reported in 1955 by USGS.

Thetis Bay: $b a y, 1 \mathrm{mi}$. across, at $\mathrm{S}$ end of Tebenkof Bay, on $W$ coast of Kuiu I., Alex. Arch.; 56 $24^{\prime} 00^{\prime \prime} \mathrm{N}, 134^{\circ} 08^{\prime} 30^{\prime \prime} \mathrm{W}$; BGN 1929; (map 5).

Named in 1928 by USC\&GS for USRCS ship Thetis, in which Adm. Stockton, USN made explorations in Alaska in 1889.

Thetis Creek: stream, flows NW $19 \mathrm{mi}$. to Chukchi Sea $7 \mathrm{mi}$. W of Cape Sabine, $43 \mathrm{mi}$. NW of Mount Kelly, Arctic Slope, 68 ${ }^{\circ} 3^{\prime}$ $30^{\prime \prime} \mathrm{N}, 164^{\circ} 54^{\prime} 00^{\prime \prime} \mathrm{W}$; (map 130). Var. Eegik-kah-Lik Creek, Igikalik Creek.

So named in 1901 by Schrader (1904, p. 111 ) and W. J. Peters, USGS, "because the
Thetis Coal Mine is near its mouth." The Thetis Coal Mine was named about 1889 for the U.S.S. Thetis. The Eskimo name for this stream is "Igikalik" which is said, by USC\&GS, to refer to the "black cormorant."

Thetis Creek: stream, flows SE to Anikovik River, about $15 \mathrm{mi}$. SE of Cape Prince of Wales, Seward Penin. High.; (map 111).

Prospectors' name shown on the 1900 "Map of Nome Peninsula" by J. M. Davidson and B. D. Blakeslee. This feature cannot be precisely identified on current maps.

Thetis Island: barrier island, $1.5 \mathrm{mi}$. long, on coast of Beaufort Sea, the $\mathrm{W}$ island of the Jones Islands, Arctic Plain; $70^{\circ} 33^{\prime} 25^{\prime \prime} \mathrm{N}$, $150^{\circ} 10^{\prime} 00^{\prime \prime} \mathrm{W}$; (map 149). Var. Amandliktok Island, Amaudliktok Island, West Thetis Island.

In 1889 the revenue cutter U.S.S. Thet is under command of Capt. Charles H. Stockton, USN, "skirted along some long, low islands, which stretched between the mouth of the Colville and Return Reef. These islands, * * * [he] designated the Thetis Islands" (Leffingwell, 1919, p. 100). Because these islands had previously been discovered and named "Jones Islands" by Dease and Simpson in 1837, Leffingwell applied the name "Thetis" to the unnamed western island of this chain of barrier islands (p. 91). Leffing. well (p. 100) reports the Eskimo name "Amaudliktok," meaning perhaps "Pacific eider," but spells it "Amandliktok" on his map. He further reports the whalers call this "West Thetis Island."

Thetis Islands: barrier islands, see Jones Islands.

Thetis Mound: pingo, elev. $36 \mathrm{ft}$., $4 \mathrm{mi}$. SE of Oliktok Point and $13 \mathrm{mi}$. W of Beechey Point, Arctic Plain; $70^{\circ} 28^{\prime} 25^{\prime \prime} \mathrm{N}, 149^{\circ} 43^{\prime} 30^{\prime \prime} \mathrm{W}$; (map 150).

Named and used as a triangulation station by Leffingwell (1919, p. 41), USGS, in 1911.

Thetis Ridge: ridge, $1,462 \mathrm{ft}$., trends NE-SE $7 \mathrm{mi}$., $15 \mathrm{mi}$. S of Cape Sabine and $60 \mathrm{mi}$. NE of Point Hope, Arctic Slope; $68^{\circ} 42^{\prime} \mathrm{N}$, $164^{\circ} 43^{\prime} \mathrm{W}$. [NW end] $68^{\circ} 38^{\prime} \mathrm{N}, 16431^{\prime} \mathrm{W}$. [SE end]; BGN 1965; (map 130).

Named in 1965 by geologists of the B.P. Exploration Co. Inc., for the U.S.S. Thetis, which coaled on the coast near here in the 1880's.

Thicket Creek: stream, flows NW $5 \mathrm{mi}$. to Tatonduk River $4 \mathrm{mi}$. ENE of that stream's junc. with Yukon River and $16 \mathrm{mi}$. $\mathrm{N}$ of Eagle, Porcupine Plat.; 650.1'15" N, $141^{\circ}$. $12^{\prime} 30^{\prime \prime} \mathrm{W}$; (map 103).

So named in 1930 by J. B. Mertie, Jr., USGS, because "its valley was filled with underbrush from source to mouth."

Thief Creek: stream, flows W $3.5 \mathrm{mi}$. to Wells Creek, $40 \mathrm{mi}$. SE of Healy, Alaska Ra.; $63^{\circ}$. $27^{\prime} 15^{\prime \prime} \mathrm{N}, 148^{\circ} 05^{\prime} 00^{\prime \prime} \mathrm{W}$; (map 87).

Local name obtained in 1913 by J. W. Bagley, USGS ; published by Moffit (1915, pl. 1), USGS.

Thiel Glacier: glacier, heads at $58^{\circ} 41^{\prime} \mathrm{N}$, $134^{\circ} 45^{\prime} \mathrm{W}$ trends $7 \mathrm{mi}$. NE to Battle Glacier, 
$2.5 \mathrm{mi}$. NE of Horn Spire and $31 \mathrm{mi}$. N of Juneau, Coast Mts. ; 58 $44^{\prime} 30^{\prime \prime} \mathrm{N}, 134^{\circ} 34^{\prime} 30^{\prime \prime}$ W; BGN 1965; (map 11). Var. Reversed Glacier.

Named by members of the Juneau Icefield Research Project in 1964 for Edward Thiel, 1928-61, glaciologist and geophysicist. He received his Ph.D. from Univ. of Wisconsin in 1955. Thiel was chief seismologist with the Arctic Institute of North America and coleader of the Fletcher Ice Shelf Traverse in Antarctica. $\mathrm{He}$ was chief scientist for Antarctic airborne geophysical operations as well as assistant professor of geophysics at the Univ. of Minnesota.

Thiel Pass: pass, $\mathrm{W}$ of McNew Hill, on eastern Attu I., Aleutian Is.; $52^{\circ} 50^{\prime} 50^{\prime \prime} \mathrm{N}, 173^{\circ} 22^{\prime}$. $00^{\prime \prime} \mathrm{W}$; (map 13).

Name shown on an AMS map published in 1948 , and given by the U.S. Army during World War II.

Thimbleberry Bay: bay, $0.6 \mathrm{mi}$. across, $2.5 \mathrm{mi}$. SE of Sitka, on W coast of Baranof I., Alex. Arch.; $57^{\circ} 02^{\prime} \mathrm{N}, 135^{\circ} 16^{\prime} \mathrm{W}$; (map 9).

Local name reported in 1954 by $R$. N. DeArmond. Thimbleberry is the common name of plants belonging to the genus Rubus, which have thimble-shaped fruits, such as raspberries and blackberries.

Thimbleberry Lake: lake, $0.2 \mathrm{mi}$. across, $3 \mathrm{mi}$. E of Sitka, on W coast of Baranof I., Alex. Arch.; $57^{\circ} 02^{\prime} 30^{\prime \prime} \mathrm{N}, 135^{\circ} 15^{\prime} 00^{\prime \prime} \mathrm{W}$; (map 9).

Local name derived from Thimbleberry Bay and reported in 1954 by R. N. DeArmond.

Thimble Cove: cove, $1,200 \mathrm{ft}$. across, on $\mathrm{E}$ coast of Baker I., N of Amarilla Point, Alex. Arch.; $55^{\circ} 18^{\prime} 45^{\prime \prime} \mathrm{N}, 133^{\circ} 34^{\prime} 40^{\prime \prime}$ W; (map 4).

Descriptive name given in 1923 by USC\&GS because of "its shape, the outline being remarkably perfect."

Thin Point: locality, on Thin Point, at SW end of Alaska Penin., Aleutian Ra.; 54 ${ }^{\circ} 57^{\prime} \mathrm{N}$, $162^{\circ} 33^{\prime} \mathrm{W}$; (map 25).

Former cannery; reported in 1898 by Lt. Comdr. J. F. Moser (1899a, p. 171), USN.

Thin Point: point of land, $\mathrm{W}$ point of entrance to Cold Bay, on S coast of Alaska Penin., Aleutian Ra.; 54 $57^{\prime} 30^{\prime \prime} \mathrm{N}, 162^{\circ} 33^{\prime} 30^{\prime \prime} \mathrm{W}$; (map 25). Var. Cape Tonkoy, Mys Tonkoi, Slim Point, Tonki Point.

Translation of "M[ys] Tonkoi" published by Capt. Tebenkov (1852, map 24), IRN; called "Slim Point" and "Cape Tonkoy" by USBF in 1888.

Thinpoint Cove: $b a y, 4 \mathrm{mi}$. across, $30 \mathrm{mi}$. E of False Pass, between Morzhovoi and Cold Bays, on SW end of Aleutian Ra.; $54^{\circ} 58^{\prime} \mathrm{N}, 162^{\circ}$ $40^{\prime} \mathrm{W}$; (map 25). Var. Thin Point Cove.

Name derived from Thin Point and published in 1912 by USC\&GS.

Thinpoint Lagoon: lake, see Thinpoint Lake.

Thinpoint Lake: lake, $3 \mathrm{mi}$. long, $10 \mathrm{mi}$. S of village of Cold Boy, at SW end of Alaska Penin., Aleutian Ra.; 55 $02^{\prime} \mathrm{N}, 162^{\circ} 38^{\prime} \mathrm{W}$; (map 29). Var. Thinpoint Lagoon.

Name published by USC\&GS in 1943 on Chart 8860.

Third Berg Lake: lake, $3 \mathrm{mi}$. across, at 1905 ter- minus of Bering Glacier, $3 \mathrm{mi}$. $\mathbf{E}$ of Doughton Peak and $66 \mathrm{mi}$. E. of Cordova, Chugach Mts.; $60^{\circ} 25^{\prime} \mathrm{N}, 143^{\circ} 49^{\prime} \mathrm{W}$; (map 65). Var. Third Lake.

Local name reported in 1905 by G. C. Martin (1908, pl. 2), USGS. This lake was originally one of five Berg Lakes. As a result of the retreat of Steller and Bering Glaciers in recent times, Third Berg Lake and Second Berg Lake have joined with First Berg Lake to form Berg Lake.

Third Creek: stream, flows NW $14 \mathrm{mi}$. to Reindeer Cove, $16 \mathrm{mi}$. SW of Christmas Mtn., Nulato Hills; $64^{\circ} 30^{\prime} \mathrm{N}, 161^{\circ} 05^{\prime} \mathrm{W}$; (map 96).

Local name reported about 1954 by U.S. Army Corps of Engineers.

Third Kekoor: rock, see Third Kekur.

Third Kekour: rock, see Third Kekur.

Third Kekur: rock, $0.2 \mathrm{mi}$. across, $22 \mathrm{mi}$. NW of village of Port Alexander, on $\mathrm{S}$ coast of Baranof I., Alex. Arch.; $56^{\circ} 29^{\prime} 15^{\prime \prime} \mathrm{N}$, $135^{\circ} 01^{\prime} 15^{\prime \prime}$ W; (map 5). Var. Third Kekour.

Descriptive name meaning "pinnacle rock" given in 1849 by the Russian American Company. See Kekur Island.

Third Lake: lake, $1 \mathrm{mi}$. long, on Revillagigedo I., $\mathbf{N}$ of Throne Arm, in course of Fish Creek, Alex. Arch.; $55^{\circ} 26^{\prime} 30^{\prime \prime} \mathrm{N}, 131^{\circ} 16^{\prime} 45^{\prime \prime} \mathrm{W}$; (map 3).

Local name reported in 1955 by USGS.

Third Lake: lake, 1,700 ft. long, $2 \mathrm{mi}$. NW of Tyonek, Cook Inlet Low.; $61^{\circ} 05^{\prime} 30^{\prime \prime} \mathrm{N}$, $151^{\circ} 10^{\prime} 30^{\prime \prime} \mathrm{W}$; (map 70).

Local name reported in 1958 by USGS. So named because it is the third lake in a chain of lakes which extend NW from Tyonek.

Third Lake: lake, one of Chenan Lakes, $0.5 \mathrm{mi}$. long, $3 \mathrm{mi}$. N of Chitina and $67 \mathrm{mi}$. NNE of Valdez, Chugach Mts. ; $61^{\circ} 33^{\prime} 50^{\prime \prime} \mathrm{N}, 144^{\circ} 26^{\prime}$ $40^{\prime \prime} \mathrm{W}$; (map 68).

Local name published in the 1950's by USGS.

Third Lake: lake, see Berg Lake.

Third Lake: lake, see Luke Lake.

Third Lake: lake, see Talbot Lake.

Third Lake: lake, see Third Berg Lake.

Third Pup: stream, flows NW 2 mi. to Flat Creek, $41 \mathrm{mi}$. NE of Fairbanks, Yukon-Tanana High.; $65^{\circ} 12^{\prime} 30^{\prime \prime} \mathrm{N}, 146^{\circ} 41^{\prime} 00^{\prime \prime} \mathrm{W}$; (map 104).

Named "3rd Pup" by prospectors; reported in 1907 by Covert (Henshaw and Covert, 1908, pl. 9). See First Pup and Second Pup.

Third Range: mountain range, 4,500 ft., extends W $18 \mathrm{mi}$. from Sadlerochit River, between Ikiakpuk and Ikiakpaurak Valleys, $26 \mathrm{mi}$. NW of Mount Michelson, Brooks Ra.; 69 ${ }^{\circ} 26^{\prime}$ N, $145^{\circ} 30^{\prime} \mathrm{W}$; BGN 1961; (map 139).

Leffingwell $(1919$, p. 50$)$ wrote, "of the three outlying ranges south of Camden Bay * * the southern most range is simply called the Third Range."

Thirteen Gulch: ravine, trends SE $1.5 \mathrm{mi}$. to Fourth of July Creek $6.5 \mathrm{mi}$. SW of that stream's junc. with Yukon River and $33 \mathrm{mi}$.
NW of Eagle, Yukon-Tanana High.; 65 ${ }^{\circ} 07^{\prime}-$ $46^{\prime \prime} \mathrm{N}, 141^{\circ} 59^{\prime} 45^{\prime \prime} \mathrm{W}$; (map 103).

Local name published in 1956 by USGS.

Thirteen Pup: ravine, extends NE $2.5 \mathrm{mi}$. to Quail Creek, $13 \mathrm{mi}$. SE of Rampart, YukonTanana High.; $65^{\circ} 22^{\prime} \mathrm{N}, 149^{\circ} 53^{\prime} \mathrm{W}$; (map 105).

Local name published by USGS in the 1950's.

Thirteen Pup: stream, flows SE $1.5 \mathrm{mi}$. to Grant Creek, $3.2 \mathrm{mi}$. SSE of Grant Dome and $22 \mathrm{mi}$ WNW of Tanana, Kokrines-Hodzana High. $65^{\circ} 15^{\prime} 30^{\prime \prime} \mathrm{N}, 152^{\circ} 48^{\prime} 30^{\prime \prime} \mathrm{W}$; (map 106).

Prospectors' name reported in 1956 by R. M Chapman, USGS.

Thirtyeight Mile Lake: lake, $0.9 \mathrm{mi}$. long, drain $W$ to Fish Creek Lake, $17 \mathrm{mi}$. SSW of village of Lake Minchumina, Tanana Low.; $63^{\circ} 41^{\prime}$ $30^{\prime \prime} \mathrm{N}, 152^{\circ} 38^{\prime} 00^{\prime \prime} \mathrm{W}$; (map 88). Var. Shesrghoyemená.

Local name reported in 1958 by USGS "Sherghoyemená" is a Tanana Indian name meaning "lake where bear was killed."

Thirtymile Lake: lake, $0.5 \mathrm{mi}$. long, on Glenn Highway, $20 \mathrm{mi}$. NE of Palmer, Talkeetna Mts.; $61^{\circ} 45^{\prime} 45^{\prime \prime} \mathrm{N}, 148^{\circ} 34^{\prime} 40^{\prime \prime} \mathrm{W}$; (map 69) Local name reported in 1942 by AMS.

Thirtymile River: stream, see Eureka Creek.

Thirtymile Roadhouse: locality, see Piledriver Roadhouse.

Thirty-Seven Hill: hill, $650 \mathrm{ft}$., on Attu I., W of Navy Town, on $\mathbf{N}$ bank of Peaceful River, Aleutian Is. ; $52^{\circ} 50^{\prime} 43^{\prime \prime} \mathrm{N}, 173^{\circ} 09^{\prime} 10^{\prime \prime} \mathrm{E}$ (map 13).

Named by U.S. Army during World War II; published in 1948 by AMS.

Thirty-three Creek: stream, flows $\mathrm{E} 4 \mathrm{mi}$. to Marsh Creek, $\mathrm{N}$ of Fort Glenn, on NE coast of Umnak I., Aleutian Is.; $53^{\circ} 25^{\prime} 05^{\prime \prime} \mathrm{N}, 167^{\circ}$ 51'25" W; (map 23).

Name published in 1958 on AMS map and later by USGS (Byers, 1959, pl. 41).

Thirtytwo Kazim Slough: watercourse, see Thirtytwo Kazyga Slough.

Thirtytwo Kazyga Slough: watercourse, $7 \mathrm{mi}$. long, channel of Yukon River W of Grand I. and $12 \mathrm{mi}$. SW of Russian Mission, YukonKuskokwim Delta ; 61 ${ }^{\circ} 38^{\prime} 30^{\prime \prime}$ N, $161^{\circ} 32^{\prime} 00^{\prime \prime}$ W; (map 73). Var. Thirtytwo Kazim Slough.

This name is first mentioned in Hrdlička's (1943, p. 67) diary on July 7, 1926. A USC\&GS report of 1949 states "so called because an old village of 32 kazygas (native dwelling) was thought to have been located here. Repeated searches by anthropologists have failed to turn up any trace."

Thirtytwo Mile Cireek: stream, heads on Twentynine Mile Ridge, flows $\mathrm{NE}$ to Hadweenzic River, $29 \mathrm{mi}$. N of Beaver, Yukon Flats; $66^{\circ}$. $46^{\prime} 30^{\prime \prime} \mathrm{N}, 147^{\circ} 13^{\prime} 40^{\prime \prime} \mathrm{W}$; (map 118).

Local name obtained in 1956 by USGS: name derived from the distance to Beaver via a year-round trail.

Thistle Cove: cove, $1.2 \mathrm{mi}$. long, on NE side of Astrolabe Penin., at $\mathrm{N}$ end of Dixon Harbor, $55 \mathrm{mi}$. NW of Hoonah, St. Elias Mts. ; $58^{\circ} 22^{\prime}$ N, $136^{\circ} 52^{\prime} \mathrm{W}$; (map 10). 
Name published in 1923 on IBC Sheet 10 (1951 atlas).

Thistle Creek: stream, flows $\mathrm{N} 6 \mathrm{mi}$. to Totat. lanika River, $17 \mathrm{mi}$. NE of Healy, Alaska Ra.; $63^{\circ} 59^{\prime} 15^{\prime \prime} \mathrm{N}, 148^{\circ} 31^{\prime} 00^{\prime \prime} \mathrm{W}$; (map 87).

Local name reported in 1910 by J. W. Bagley (in Capps, 1912, pl. 2), USGS.

Thistle Creek: stream, flows W $3 \mathrm{mi}$. to Feather River, $34 \mathrm{mi}$. NW of Nome, Seward Penin. High.; $64^{\circ} 51^{\prime} \mathrm{N}, 166^{\circ} 14^{\prime} \mathrm{W}$; (map 94).

Prospectors' name reported in 1900 by E. C. Barnard (in Brooks, 1901, pl. 17), USGS.

Thistle Creek: stream, flows E $1.5 \mathrm{mi}$. to Star Creek in Pargon River basin, $12 \mathrm{mi}$. N of Council and $16 \mathrm{mi}$. SE of Mount Bendeleben, Seward Penin. High.; $65^{\circ} 04^{\prime} \mathrm{N}, 163^{\circ} 37^{\prime} \mathrm{W}$; (map 110).

Prospectors' name reported on a map of Cape Nome gold fields by David Fox, Jr., dated 1901.

Thistle Ledge: shoal, off E shore of Stephens Passage, 1.4 mi. N of Point Lookout and 50 mi. SE of Juneau, Coast Mts.; $57^{\circ} 40^{\prime} 20^{\prime \prime} \mathrm{N}$, $133^{\circ} 40^{\prime} 45^{\prime \prime} \mathrm{W}$; (map 8).

Discovered and named in 1893 by Otto $\mathrm{J}$. Klotz for his steamer the SS Thistle. The name was published in 1895 by USC\&GS.

Thistle Rock: island, $0.1 \mathrm{mi}$. across, in $\mathrm{N}$ end of Lord Is., at mouth of Nakat Bay, Coast Mts. ; $54^{\circ} 44^{\prime} 55^{\prime \prime} \mathrm{N}, 130^{\circ} 48^{\prime} 15^{\prime \prime} \mathrm{W}$; (map 2).

Named in 1883 by Lt. Comdr. H. E. Nichols, USN.

Thistle Rock: rock, in Spiridon Bay $3.6 \mathrm{mi}$. W of Anguk 1., on NW coast of Kodiak I.; $57^{\circ} 39^{\prime}$.

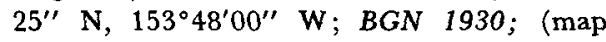
34).

Descriptive name given in 1929, by USC\&GS, because of "the barrenness of rock and puncturing possibilities to ships ***" Thlewhakh: village, see Klawock.

Thlikhahdaluk: lake, $0.7 \mathrm{mi}$. across, $13 \mathrm{mi}$. N of Okstukuk Lake and $48 \mathrm{mi}$. $\mathrm{N}$ of Dillingham, Bristol Bay Low.; 59 $43^{\prime} \mathrm{N}, 158^{\circ} 21^{\prime}$ W; (map 2).

Eskimo name shown as "Thlik-hah-da-luk" on a 1910 manuscript map by H. C. Fassett, USBF.

Thlingit Point: point of land, see Tlingit Point. Thluichohnjik Creek: stream, flows E $20 \mathrm{mi}$. to Sheenjek River $24 \mathrm{mi}$. NE of Christian, Yukon Flats; $67^{\circ} 26^{\prime} \mathrm{N}, 144^{\circ} 14^{\prime} \mathrm{W}$; (map 122).

Kutcha-kutchin Indian name obtained in 1956 by T. E. Taylor, USGS.

Thomas, Mount: mountain, 4,350 ft., $2 \mathrm{mi}$. NNW of Potato Point and $15 \mathrm{mi}$. WSW of Valdez, Chugach Mts.; $61^{\circ} 05^{\prime} 00^{\prime \prime} \mathrm{N}, 146^{\circ}$. $43^{\prime} 00^{\prime \prime} \mathrm{W}$; ( $\left.\operatorname{map} 68\right)$.

Named in 1898 by Capt. W. R. Abercrombie, USA, presumably for Gen. G. H. Thomas, USA.

Thomas Basin: harbor, SE of Ketchikan Harbor, on $\mathrm{S}$ coast of Revillagigedo I., Alex. Arch.; $55^{\circ} 20^{\prime} 20^{\prime \prime} \mathrm{N}, 131^{\circ} 38^{\prime} 30^{\prime \prime} \mathrm{W}$; (map 3).

Local name published in the 1932 Coast Pilot (p. 102).
Thomas Bay: bay, extends SW $10 \mathrm{mi}$. from Baird Glacier to Frederick Sound, $14 \mathrm{mi}$. N of Petersburg, Coast Mts.; 57 00'30" N, $132^{\circ} 59^{\prime} 00^{\prime \prime} \mathrm{W}$; (map 6).

Named by USC\&GS for charting purposes; published in 1925 Coast Pilot (p. 211).

Thomas Bay: estuary, see Clover Bay.

Thomas Bay: estuary, see Culross Bay.

Thomas Creek: stream, flows E $5.5 \mathrm{mi}$. to Birch Creek, $46 \mathrm{mi}$. SW of Circle, Yukon-Tanana High.; $65^{\circ} 18^{\prime} 40^{\prime \prime} \mathrm{N}, 145^{\circ} 01^{\prime} 40^{\prime \prime} \mathrm{W}$; (map 104).

Named by prospectors and reported in 1905 by D. C. Witherspoon (in Prindle, 1906, pl. 1), USGS.

Thomas Creek: stream, flows SE $2 \mathrm{mi}$. to Candle Creek, $9.5 \mathrm{mi}$. SW of Candle and $34 \mathrm{mi}$. NE of Imuruk Lake, Seward Penin. High.; $65^{\circ} 48^{\prime}$ $\mathrm{N}, 162^{\circ} 05^{\prime} \mathrm{W}$; (map 110).

Prospectors' name reported in 1903 by D.C. Witherspoon (in Moffit, 1905, pl. 2), USGS.

Thomas Creek: stream, flows SW to Goodhope River, about $24 \mathrm{mi}$. NW of Imuruk Lake, Seward Penin. High.; (map 110).

Prospectors' name reported in 1901 by USGS (Collier, 1902, pl. 12). This stream cannot be identified on current maps.

Thomas Island: island, 1,700 ft. long, in Helm Bay, on $\mathrm{E}$ coast of Cleveland Penin., Alex. Arch.; 55 $37^{\prime} 10^{\prime \prime} \mathrm{N}, 131^{\circ} 56^{\prime} 45^{\prime \prime} \mathrm{W}$; (map 3).

Local navigators' name obtained in 1904 by H. C. Fassett, USBF.

Thomas Rock: rock, between Afognak and Kupreanof Straits, N of Kodiak I.; $57^{\circ} 58^{\prime} 10^{\prime \prime}$ $N, 152^{\circ} 56^{\prime} 20^{\prime \prime} \mathrm{W}$; (map 34).

Local name reported in 1900 by Lt. Comdr. Moser, USN, of the USBF steamer Albatross.

Thompson: area, in S Anchorage $1 \mathrm{mi} \mathrm{SSW}$ of City Hall, Cook Inlet Low.; $61^{\circ} 12^{\prime} 15^{\prime \prime} \mathrm{N}$, $149^{\circ} 53^{\prime} 45^{\prime \prime} \mathrm{W}$; (map 69).

Residential district in city of Anchorage reported in 1954 by office of city engineer of Anchorage.

Thompson, Cape: point of land, $\mathrm{N}$ tip of Big Koniuji I., in Shumagin Is., Aleutian Ra.; $55^{\circ} 15^{\prime} \mathrm{N}, 159^{\circ} 31^{\prime} \mathrm{W}$; (map 27).

Named by W. H. Dall, USC\&GS, in 1880 and published in 1888 on USC\&GS Chart 806.

Thompson, Cape: promontory, on Chukchi Sea coast, $26 \mathrm{mi}$. SE of Point Hope, Arctic Slope; $68^{\circ} 08^{\prime} 40^{\prime \prime} \mathrm{N}, 165^{\circ} 58^{\prime} 40^{\prime \prime} \mathrm{W} ; B G N$ 1963; (map 129). Var. Eebruligorruk, Cape Ricord, Ipnot, Mys Rikord, Mys Rikorda, Uivaq Qanitoq, Unukpay, Unuqpay, Webuk Konikto.

Named by Capt. Beechey (1831, p. 262), $\mathrm{RN}$, who wrote on August 2, 1886, "we closed with a high cape, which I named after Mr. Deas Thomson, one of the commissioners of the navy." Beechey spelled the name "Thompson" on his chart, a form that has been copied by succeeding cartographers. An early Eskimo name for the cape was "Uivaq," generally spelled "Wevuk" or "Wevok." Cape Thompson was often referred to as "Uivaq Qanitoq," meaning "near cape," as opposed to "Uivaq Ungasiktoq" (Cape Lis- burne) meaning "distant cape." This cape was discovered by the Russians in the late eighteenth century and was called by them "M[ys] Rikord," i.e. "Cape Rikord," for Peter Ivanovich Rikord, 1776-1855, IRN, Governor of Kamchatka, 1817-22.

Thompson, Point: point of land, on Beaufort Sea Coast, at $W$ entrance to Lion Bay, 2.5 mi. SW of Flaxman I., Arctic Plain; 70 $11^{\prime}$ $15^{\prime \prime}$ N, 146 19'45" W; (map 151). Var. Point Thomson, Thomson Point.

Named "Point Thomson" by Franklin (1828, p. 152) August 7, 1826, but appears on his map as "Point Thompson."

Thompson Creek: stream, flows SE $6 \mathrm{mi}$ to Chignik Bay, $11 \mathrm{mi}$. N of Chignik, on Alaska Penin., Aleutian Ra.; $56^{\circ} 27^{\prime} \mathrm{N}, 158^{\circ} 25^{\prime} \mathrm{W}$; (map 30)

Local name reported in 1904 by $R$. W. Stone, USGS.

Thompson Creek: stream, flows SE $45 \mathrm{mi}$. to Yukon River, $29 \mathrm{mi}$. N of Anvik and $61 \mathrm{mi}$. $\mathrm{SE}$ of Unalakleet, Nulato Hills; $63^{\circ} 06^{\prime} \mathrm{N}$, $159^{\circ} 48^{\prime} \mathrm{W}$; (map 91).

Named about 1916 after Thompson Landing at the stream's mouth.

Thompson Creek: stream, flows SE $2 \mathrm{mi}$. to Walker Fork, $53 \mathrm{mi}$. SW of Eagle, YukonTanana High.; 64 $03^{\prime} 15^{\prime \prime} \mathrm{N}, 141^{\circ} 24^{\prime} 30^{\prime \prime} \mathrm{W}$; (map 102).

Named by prospectors and shown on an 1898 manuscript map by E. F. Ball, prospector.

Thompson Creek: stream, flows NE $1 \mathrm{mi}$. to Snake River, $8 \mathrm{mi}$. NW of Nome, Seward Penin. High.; $64^{\circ} 37^{\prime} \mathrm{N}, 165^{\circ} 29^{\prime} \mathrm{W}$; (map 94).

Prospectors' name shown on a 1900 "Map of Nome Peninsula" by J. M. Davidson and B. D. Blakeslee.

Thompson Creek: stream, flows SE $1 \mathrm{mi}$. to Klokerblok River, $0.5 \mathrm{mi}$. E of Spruce Creek and $22 \mathrm{mi}$. NE of Solomon, Seward Penin. High.; $64^{\circ} 40^{\prime} 50^{\prime \prime} \mathrm{N}, 163^{\circ} 44^{\prime} 45^{\prime \prime} \mathrm{W}$; (map 95).

Prospectors' name reported in 1900 by E. C Barnard (in Brooks, 1901, pl. 17), USGS.

Thompson Creek: stream, flows NW $1.5 \mathrm{mi}$., joins Quartz Creek to form Stewart River, 23 mi. NE of Nome, Seward Penin. High.; $64^{\circ} 50^{\prime} \mathrm{N}, 165^{\circ} 19^{\prime} \mathrm{W}$; Var. Thomson Creek. Prospectors' name reported in 1904 by T. G. Gerdine, USGS.

Thompson Creek: stream, flows NE $3 \mathrm{mi}$. to Grand Central River, $31 \mathrm{mi}$. NE of Nome, Seward Penin. High.; $64^{\circ} 57^{\prime} \mathrm{N}, 165^{\circ} 11^{\prime} \mathrm{W}$; (map 94).

Prospectors' name reported in 1906 by USGS.

Thompson Creek: stream, flows SW $6 \mathrm{mi}$. to Breving Lagoon, $14 \mathrm{mi}$. NW of Teller, Seward Penin. High.; $65^{\circ} 22^{\prime} \mathrm{N}, 166^{\circ} 45^{\prime} \mathrm{W}$; (map 111).

Prospectors' name reported on a map of Cape Nome gold fields by David Fox, Jr., dated 1901.

Thompson Creek: stream, flows $\mathrm{N}$ to Arctic River, about $5 \mathrm{mi}$. E of Ear Mtn. and $45 \mathrm{mi}$. 
NE of Teller, Seward Penin. High.; (map 111).

Prospectors' name reported on a precinct map of Seward Peninsula gold fields by Monroe and Hutchins, corrected up to June 1903 by Arthur Gibson. This feature cannot be precisely identified on current maps.

Thompson Creek: stream, see Shaw Creek.

Thompson Island: island, see Galankin Island.

Thompson lake: lake, $0.5 \mathrm{mi}$. long, drains $\mathrm{E}$ to Indian Greek $1 \mathrm{mi}$. $\mathbf{N}$ of that stream's junc. with Tanana River and $5.5 \mathrm{mi}$. NE of Big Delta, Yukon-Tanana High.; $64^{\circ} 12^{\prime} \mathrm{N}, 145^{\circ}$. 42' W; (map 101).

Local name published in 1951 by USGS.

Thompson Landing: locality, on right bank of Yukon River at mouth of Thompson Creek, Nulato Hills; $63^{\circ} 06^{\prime} \mathrm{N}, 159^{\circ} 48^{\prime} \mathrm{W}$; (map 91).

Riverboat landing and trading post name published in 1916 Polk's Gazetteer.

Thompson Pass: pass, 2,771 ft., $0.3 \mathrm{mi}$. long, on Richardson Highway, at head of Ptarmigan Creek, $3.2 \mathrm{mi}$. NE of Wortmanns and $18 \mathrm{mi}$. E of Valdez, Chugach Mts.; $61^{\circ} 07^{\prime} 45^{\prime \prime} \mathrm{N}$, $145^{\circ} 43^{\prime} 45^{\prime \prime}$ W; (map 68). Var. Thomson Pass.

Named in 1898 by Capt. Abercrombie (1899, p. 302), USA, "in compliment to Hon. Frank Thomson, of Pennsylvania." He spells the name "Thompson" on his map and it is this form that survived.

Thompson Passage: water passage, $4 \mathrm{mi}$. long, through a group of offshore islands, $\mathrm{E}$ of Eureka Channel, on SW coast of Prince of

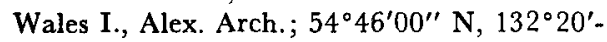
$30^{\prime \prime} \mathrm{W}$; (map 1 .

Local name reported in 1951 by USGS.

Thompson Ridge: ridge, extends E $17 \mathrm{mi}$. from Tana Glacier, $8 \mathrm{mi}$. S of Granite Ra. and 43 mi. N of Cape Yakataga, Chugach Mts.; $60^{\circ}$ $42^{\prime} \mathrm{N}, 142^{\circ} 25^{\prime} \mathrm{W}$; BGN 1960; (map 65).

Named in 1960 by USGS for J. B. Thompson, a prospector who, with J. B. Miller, went from Cape Yakataga across the glaciers to Granite Creek and returned the same way in 1906 or 1907.

Thompson Valley: valley, trends SE $6 \mathrm{mi}$. to Chignik Bay, $11 \mathrm{mi}$. N of Chignik, on Alaska Penin., Aleutian Ra.; $56^{\circ} 27^{\prime} \mathrm{N}, 158^{\circ} 25^{\prime} \mathrm{W}$; (map 30).

Local name reported in 1908 by W. W. Atwood, USGS.

Thoms (Aw-aw): lake, see Thoms Lake.

Thoms Creek: stream, heads in Thoms Lake, flows SE $4.5 \mathrm{mi}$. to Thoms Place, on $\mathrm{S}$ coast of Wrangell I., Alex. Arch.; $56^{\circ} 11^{\prime} 00^{\prime \prime} \mathrm{N}$, $132^{\circ} 08^{\prime} 45^{\prime \prime}$ W; (map 6). Var. Aw-aw Creek, Old Village Stream.

Local name reported in 1901 by Lt. Comdr. J. F. Moser, USN, who, in 1897 , called it "Old Village Stream:"

Thoms Lake: lake, $1.5 \mathrm{mi}$. long, on $\mathrm{SW}$ coast of Wrangell I., $18 \mathrm{mi}$. SSE of Wrangell, Alex. Arch.; 56 $14^{\prime} \mathrm{N}, 132^{\circ} 15^{\prime} \mathrm{W}$; (map 6). Var. Aw-aw Lake, Thoms (Aw-aw).

Local name reported in 1900 by Lt. Comdr. J. F. Moser, USN, as "Thoms (Aw-aw)."
This is probably derived from the Tlingit Indian word "ah" meaning "lake."

Thomson Creek: stream, see Thompson Creek.

Thomson Pass: pass, see Thompson Pass.

Thomson Point: point of land, see Thompson Point.

Thoms Place: bay, extends SE 2 mi. to Zimovia Strait, $24 \mathrm{mi}$. SE of Wrangell, on $\mathrm{S}$ coast of Wrangell I., Alex. Arch.; 56 $09^{\prime} 30^{\prime \prime} \mathrm{N}, 1^{132^{\circ}-}$ $07^{\prime} 00^{\prime \prime} \mathrm{W}$; (map 6).

Local name reported in 1900 by Lt. Comdr. J. F. Moser, USN.

Thoms Point: point of land, southernmost tip of Wrangell I., Alex. Arch.; $56^{\circ} 07^{\prime} 00^{\prime \prime} \mathrm{N}$, $132^{\circ} 04^{\prime} 15^{\prime \prime} \mathrm{W}$; (map 6). Var. Thorns Point.

Local name recorded in 1948 by USGS.

Thorne Arm: estuary, extends NE $14 \mathrm{mi}$. off Revillagigedo Channel, on $\mathrm{S}$ coast of Revillagigedo I., Alex. Arch.; $55^{\circ} 14^{\prime} \mathrm{N} ; 131^{\circ} 21^{\prime}$ W; (map 3).

Named in 1880 by USC\&GS for Capt. Charles Thorne, commander of the steamer California which explored this area (U.S. Coast and Geodetic Survey, 1883, p. 77).

Thorne Bay: locality, on Thorne Bay, $\mathrm{E}$ coast of Prince of Wales I., $12 \mathrm{mi}$. NNW of Kasaan, Alex. Arch.; $54^{\circ} 41^{\prime} \mathrm{N}, 132^{\circ} 31^{\prime} \mathrm{W}$; (map 3 ).

Logging camp reported in 1960.

Thorne Bay: estuary, extends NW $6.5 \mathrm{mi}$. off Clarence Strait, on E coast of Prince of Wales I., Alex. Arch.; $55^{\circ} 41^{\prime} \mathrm{N}, 132^{\circ} 27^{\prime} \mathrm{W}$; (map 4).

Named in 1891 after Frank Manley Thorn, Superintendent of USC\&GS from 1885 to 1889 ; misspelled when published.

Thorne Head: point of land, on $\mathbf{E}$ coast of Prince of Wales I., N point of entrance to entrance to Thorne Bay, Alex. Arch.; 55 $41^{\prime} 00^{\prime \prime}$ $\mathrm{N}, 132^{\circ} 27^{\prime} 30^{\prime \prime} \mathrm{W}$; (map 4).

Named by local fishermen and reported in 1904 by H. C. Fassett, USBF.

Thorne Island: island, $4 \mathrm{mi}$. long, between Kashevarof and Whale Passages, on NE coast of Prince of Wales I., Alex. Arch.; 56 $06^{\circ} \mathrm{N}$, $133^{\circ} 02^{\prime} \mathrm{W}$; (map 6).

Named in 1886 by Lt. Comdr. A. S. Snow, USN, for Frank Manley Thorn, Superintendent of USC\&GS 1885-89.

Thorne Lake: lake, $1.5 \mathrm{mi}$. long, on Thorne River, central Prince of Wales I., Alex. Arch.; $55^{\circ} 46^{\prime} \mathrm{N}, 132^{\circ} 46^{\prime} \mathrm{W}$; BGN 1935; (map 4).

Named in 1935 by USC\&GS for Frank Manley Thorn (erroneously spelled Thorne when published), superintendent of USC\&GS from 1885 to 1889.

Thorne River: stream, heads in lake, on Prinice of Wales I. and flows SE $15 \mathrm{mi}$. to Thorne Bay, Alex. Arch.; 55 $42^{\prime} \mathrm{N}, 132^{\circ} 35^{\prime} \mathrm{W}$; (map 4).

Local name reported in 1949 by USGS. See Thorne Bay.

Thorns Point: point of land, see Thoms Point. Thornton Mountain: mountain, 2,608 ft., 5.7 mi. E of Point Higgins, on Revillagigedo I., Alex. Arch.; $55^{\circ} 27^{\prime} \mathrm{N}, 131^{\circ} 41^{\prime} \mathrm{W}$; (map 3).

Named in 1883 by Lt. Comdr. H. E. Nichols, USN.
Thorofare Pass: pass, 3,800 ft., in Mount McKinley National Park, S of Denali Highway, $1.6 \mathrm{mi}$. ENE of Eielson Visitor Genter, Alaska Ra.; $63^{\circ} 26^{\prime} 20^{\prime \prime} \mathrm{N}, 150^{\circ} 15^{\prime} 30^{\prime \prime} \mathrm{W}$; (map 88).

Descriptive name shown on a 1916 fieldsheet by C. E. Giffin, USGS.

Thorofare River: stream, in Mount McKinley National Park, flows W $16 \mathrm{mi}$. from Sunset Glacier terminus to McKinley River, $6 \mathrm{mi}$. SW of Wonder Lake, Alaska Ra.; 63 $25^{\prime} \mathrm{N}$, $150^{\circ} 42^{\prime} \mathrm{W}$; BGN 1932; (map 88).

Shown on a 1921 field map of Mount MCKinley National Park. So named because the stream's "valley has been an important caribou thorofare."

Thoroughfare, The: ridge, $6.2 \mathrm{mi}$. long, extends NE from Martin Peak to Mount Thoroughfare, $10 \mathrm{mi}$. NE of Juneau, Coast Mts.; $58^{\circ} 22^{\prime} \mathrm{N}, 134^{\circ} 15^{\prime} \mathrm{W}$; (map 11).

Local name reported by D. A. Brew and A. B. Ford, USGS, in 1965.

Thoroughfare Creek: stream, flows $S 8 \mathrm{mi}$. to Portage Creek, $34 \mathrm{mi}$. SW of Cantwell, Talkeetna Mts.; $62^{\circ} 55^{\prime} 20^{\prime \prime} \mathrm{N}, 149^{\circ} 10^{\prime} 40^{\prime \prime} \mathrm{W}$; (map 82).

Local name recorded in 1950 by USGS.

Thoroughfare Mountain: mountain, 4,170 ft., $\mathrm{SE}$ of Dead Branch Norris Glacier, $5 \mathrm{mi}$. NW of Scow Cove on Taku Inlet and $8 \mathrm{mi}$. NE of Juneau, Coast Mts. ; $58^{\circ} 22^{\prime} 00^{\prime \prime} \mathrm{N}, 134^{\circ} 14^{\prime}$ $30^{\prime \prime} \mathrm{W}$; (map 11).

Local name published by USGS in 1962.

Thorpe Creek: stream, flows NW $1 \mathrm{mi}$. to Casadepaga River, $24 \mathrm{mi}$. NE of Solomon, Seward Penin. High.; 64 $53^{\prime} 20^{\prime \prime} \mathrm{N}, 164^{\circ} 12^{\prime} 30^{\prime \prime} \mathrm{W}$; (map 95)

Prospectors' name reported on a map of Cape Nome gold fields by David Fox, Jr., dated 1901.

Thorsen Mountain: mountain, 1,110 ft., $3 \mathrm{mi}$. S of Red Mtn. and $24 \mathrm{mi}$. NE of Cape Newenham, Kilbuck-Kuskokwim Mts.; $58^{\circ} 54^{\prime} 30^{\prime \prime}$ $\mathrm{N}, 161^{\circ} 45^{\prime} 10^{\prime \prime} \mathrm{W}$; BGN 1938; (map 39).

Named by local miners and prospectors for one of the discoverers of the platinum placers of this district. Name published in 1933 by the U.S. Dept. of the Interior.

Thors Pond: lake, $800 \mathrm{ft}$. long, $20 \mathrm{mi}$. SE of junc. of Copper and Slana Rivers, Wrangell Mts.; $62^{\circ} 34^{\prime} \mathrm{N}, 143^{\circ} 25^{\prime} \mathrm{W}$; (map 84).

Local name reported in 1965 by Arthur Gervais, USGS.

Thóthendig: stream, see Delta River.

Thousand Flowers Point: point of land, see Miliflores, Point.

Three Arm Bay: bay, $1 \mathrm{mi}$. across, includes North, Middle, and South Arms, on $W$ coast of Adak I., Aleutian Is.; $51^{\circ} 45^{\prime} 20^{\prime \prime} \mathrm{N}, 176^{\circ}$. $53^{\prime} 00^{\prime \prime}$ W; BGN 1936; (map 17). Var. West Bay.

Descriptive name given by Lt. William Gibson, USN, commander of the schooner Fenimore Cooper, during the North Pacific Exploring Expedition in 1855.

Three Arm Bay: cove, see Steller Cove.

Three Bay Lake: lake, see Stormy Lake.

Three Brothers: rocks, three, extend 1,200 ft., near NW entrance to Narrow Strait, $1.2 \mathrm{mi}$. 
E of Shakmanof Point, $\mathrm{N}$ of Kodiak I.; $57^{\circ}$ $55^{\prime} 30^{\prime \prime} \mathrm{N}, 152^{\circ} 33^{\prime} 00^{\prime \prime} \mathrm{W}$; (map 34). Var. Kamen Tri Brata, Tre Brata.

Partial translation of the name "K[amen] Tri Brata," meaning "three brothers rocks," given by Sub-Lt. Mikhail Murashev in 1839 or 1840 and published in 1849 on Russian Hydrog. Dept. Chart 1425.

Three Castle Mountain: mountain, $5 \mathrm{mi}$. W of Alaska-Canada boundary and $28 \mathrm{mi}$. $\mathrm{N}$ of Eagle, Porcupine Plat. ; $65^{\circ} 12^{\prime} \mathrm{N}, 141^{\circ} 11^{\prime} \mathrm{W}$; (map 103).

So named in 1930 by J. B. Mertie, Jr., USGS, because of "a group of pinnacles along the ridge ***."

Three Day Slough: stream, anabranch of Koyukuk River, $46 \mathrm{mi}$. long, $27 \mathrm{mi}$. SW of Roundabout Mtn., Koyukuk Low.; 65 $29^{\prime}$ N, $157^{\circ} 30^{\prime} \mathrm{W}$; (map 108).

Local name obtained at Huslia by USGS in 1954 or 1955.

Three Domes, The: hills, 1,000 ft., extends N-S 10. mi., $20 \mathrm{mi}$. NW of Anvik, Nulato Hills; $62^{\circ} 52^{\prime} \mathrm{N}, 160^{\circ} 36^{\prime} \mathrm{W}$; (map 78).

Local descriptive name reported in 1949 by USC\&GS.

Three Entrance Bay: cove, $0.5 \mathrm{mi}$. across, $5.5 \mathrm{mi}$. SW of Sitka, on W coast of Baranof I., Alex. Arch.; $56^{\circ} 58^{\prime} 40^{\prime \prime} \mathrm{N}, 135^{\circ} 22^{\prime} 40^{\prime \prime} \mathrm{W}$; (map $6)$.

Local fishermen's name reported in 1947 by USC\&GS.

Three Forks: locality, junc, of Knife and Windy Creeks with River Lethe, on Alaska Penin., Katmai National Monument, $16 \mathrm{mi}$. NW of Mount Katmai, Aleutian Ra.; $58^{\circ} 22^{\prime} 25^{\prime \prime} \mathrm{N}$, $155^{\circ} 22^{\prime} 00^{\prime \prime} \mathrm{W}$; (map 42).

Local name published in 1919 by $R$. F. Griggs, National Geographic Society.

Three Hill Island: island, $1.7 \mathrm{mi}$. long, in Cross Sound, off $\mathbf{N}$ coast of Chichagof I., $0.8 \mathrm{mi}$. NW of Point Lucan, $35 \mathrm{mi}$. W of Hoonah, Alex. Arch.; $58^{\circ} 10^{\prime} \mathrm{N}, 136^{\circ} 22^{\prime} \mathrm{W}$; (map 10).

Descriptive name given by $W, H$. Dall, USG\&GS, in 1880, "because the island consists of three high hills united by low isthmuses" (U.S. Coast and Geodetic Survey, 1883, p. 187).

Three Hole Bay: bay, 2 mi. wide, on $\mathrm{W}$ coast of Aialik Penin., $5 \mathrm{mi}$. NW of Aialik Cape, $26 \mathrm{mi}$. SW of Seward, Chugach Mts.; $59^{\circ} 45^{\prime} \mathrm{N}$, $149^{\circ} 38^{\prime} \mathrm{W}$; $B G N$ 1911; (map 49).

Named in 1909 by U. S. Grant, USGS, "for the three prominent natural arches there."

Three Hole Point: point of land, on $\mathrm{W}$ coast of Aialik Penin. at Three Hole Bay, $25 \mathrm{mi}$. SW of Seward, Chugach Mts.; 59 $45^{\prime} 50^{\prime \prime} \mathrm{N}$, $149^{\circ} 38^{\prime} 30^{\prime \prime}$ W; BGN 1911; (map 49).

Named in 1909 by U. S. Grant, USGS. See Three Hole Bay.

Three Island Bay: bay, $1.5 \mathrm{mi}$. across and $5 \mathrm{mi}$. deep, SE coast of Unalaska I., Aleutian Is.; $53^{\circ} 33^{\prime} \mathrm{N}, 166^{\circ} 38^{\prime} \mathrm{W}$; (map 23).

Descriptive name given in 1888 by USBF.

Three Islands: islands, each $200 \mathrm{ft}$. long, in Clarence Strait, on SW coast of Cleveland Penin., Alex. Arch.; 55 $42^{\prime} 10^{\prime \prime}$ N, $132^{\circ} 14^{\prime} 00^{\prime \prime}$ W; (map 4).
Local descriptive name recorded in 1951 by USGS.

Three Lakes: lakes, $4 \mathrm{mi}$. SW of Birch Creek (locality), $30 \mathrm{mi}$. SW of Fort Yukon, Yukon Flats; $66^{\circ} 13^{\prime} \mathrm{N}, 145^{\circ} 50^{\prime} \mathrm{W}$; (map 119).

Local name obtained in 1956 by USGS.

Threemile Arm: bay, extends SE 2 mi. to Keku Strait, $18 \mathrm{mi}$. NW of Point Baker, on E coast of Kuiu I., Alex. Arch.; 56 $35^{\prime} \mathrm{N}, 133^{\circ} 50^{\prime} \mathrm{W}$; $B G N$ 1966; (map 6). Var. Three Mile Arm.

Named in 1892 by Lt. W. I. Moore, USN.

Three Mile Bay: cove, $0.4 \mathrm{mi}$. wide, on $\mathrm{S}$ shore of Orca Inlet, $3 \mathrm{mi}$. SW of Cordova, Chugach Mts.; $60^{\circ} 31^{\prime} \mathrm{N}, 145^{\circ} 48^{\prime} \mathrm{W}$; $B G N$ 1961; (map 64).

Local name reported in 1960 by USFS. So called because it is three miles from Cordova.

Threemile Canyon: canyon, $3 \mathrm{mi}$. long, on Bremner River, $0.5 \mathrm{mi}$. E of junc. of Bremner River and South Fork Bremner River, 55 mi. NE of Katalla, Chugach Mts. ; $60^{\circ} 58^{\prime} 30^{\prime \prime}$ N. $144^{\circ} 12^{\prime} 00^{\prime \prime} \mathrm{W}$; (map 64). Var. Three Mile Canyon.

Local name reported in 1911 by F. H. Moffit (in Brooks and others, 1912, p. 99), USGS.

Threemile Creek: stream, heads in a lake, near center of Prince of Wales I., flows W $4.5 \mathrm{mi}$. to Klawak Lake, $4 \mathrm{mi}$. SW of Klawock, Alex. Arch.; $55^{\circ} 31^{\prime} 45^{\prime \prime} \mathrm{N}, 132^{\circ} 59^{\prime} 50^{\prime \prime} \mathrm{W}$; (map 4). Var. Three-mile Creek.

Local descriptive name; reported as "Threemile Creek" in 1897 by Lt. Comdr. J. F. Moser, USN.

Threemile Greek: stream, heads in lake, flows SE $8 \mathrm{mi}$. through Tukallah Lake to Cook Inlet, $5.5 \mathrm{mi}$. NE of Tyonek, Cook Inlet Low.; $61^{\circ} 08^{\prime} 35^{\prime \prime} \mathrm{N}, 151^{\circ} 04^{\prime} 00^{\prime \prime} \mathrm{W}$; (map 70).

Local name reported in 1933 by USGS.

Threemile Creek: stream, heads in Threemile Lake, flows SW $2.8 \mathrm{mi}$. to Fish Creek, $18 \mathrm{mi}$. $\mathrm{N}$ of Anchorage, Cook Inlet Low. ; $61^{\circ} 28^{\prime} 40^{\prime \prime}$ $\mathrm{N}, 149^{\circ} 48^{\prime} 55^{\prime \prime} \mathrm{W}$; (map 69).

Local name reported in 1942 by USGS.

Threemile Creek: stream, heads in a lake, flows SE $12 \mathrm{mi}$. to Happy River, $87 \mathrm{mi}$. SW of Talkeetna, Alaska Ra. ; $62^{\circ} 10^{\prime} \mathrm{N}, 152^{\circ} 48^{\prime} \mathrm{W}$; (map 81).

Local name reported in 1945 by USGS.

Threemile Creek: stream, flows NW $7 \mathrm{mi}$. to Wood River, $56 \mathrm{mi}$. S of Fairbanks, Alaska

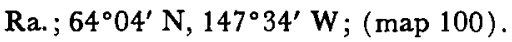

Local name reported in 1950 by USGS topographers.

Threemile Creek: stream, flows SE $20 \mathrm{mi}$. to Kandik River, $2.3 \mathrm{mi}$. NE of that stream's junc. with Yukon River, Porcupine Plat.; $65^{\circ}$ $23^{\prime} 30^{\prime \prime} \mathrm{N}, 142^{\circ} 27^{\prime} 00^{\prime \prime} \mathrm{W}$; (map 103).

So named locally because this stream is located about 3 miles upstream from the mouth of the Kandik River; published in 1956 by USGS.

Threemile Lake: lake, $2.5 \mathrm{mi}$. long, $8.4 \mathrm{mi}$. SE of junc. of Chitina and Nizina Rivers and 12 mi. SW of McCarthy, Copper River Basin; $61^{\circ} 19^{\prime} 15^{\prime \prime} \mathrm{N}, 142^{\circ} 57^{\prime} 30^{\prime \prime} \mathrm{W}$; (map 67).

Local name obtained by USGS and published on maps since 1954.
Threemile Lake: lake, $1 \mathrm{mi}$. long, at head of Threemile Creek, $2.7 \mathrm{mi}$. NW of Knik and $20 \mathrm{mi}$. NE of Anchorage, Cook Inlet Low.; $61^{\circ} 30^{\prime} 05^{\prime \prime} \mathrm{N}, 149^{\circ} 45^{\prime} 30^{\prime \prime} \mathrm{W}$; ( $\operatorname{map} 69$ ).

Local name reported in 1942 by AMS.

Three Mouth Creek: watercourse, see Steamboat Slough.

Threenob Rock: rock, $0.5 \mathrm{mi}$. S of Point Urey, $16 \mathrm{mi}$. NW of Chichagof, on W coast of Chichagof I., Alex. Arch.; 57 $48^{\prime} 55^{\prime \prime}$ N, $136^{\circ} 25^{\prime}$ 30 " W; (map 9).

Descriptive name published in 1928 by USC\&GS on Chart 8258. "A conspicuous triple-headed rock, the highest part having an elevation of 20 feet *** ."

Three Pillar Cape: point of land, see Three Pillar Point.

Three Pillar Point: point of land, on $\mathbf{E}$ shore of Sharatin Bay, $12 \mathrm{mi}$. NW of Kodiak, N coast of Kodiak I.; $57^{\circ} 51^{\prime} 10^{\prime \prime} \mathrm{N}, 152^{\circ} 42^{\prime} 50^{\prime \prime}$ W; BGN 1966; (map 34). Var. Mys Trekh Kekurnyy, Three Pillar Cape, Threepillar Point, Trekh Kekurnie.

Translation of the name " $M[y s]$ Trekh Kekurnyy" given by Sub-Lt. Mikhail Murashev in 1839 or 1840 and published in 1849 on Russian Hydrog. Dept. Chart 1425.

Threequarter Cone: peak, cinder cone, elev. $1,700 \mathrm{ft}$., on $\mathrm{W}$ wall of caldera in central Semisopochnoi I., 2 mi. NW of Mount Cerberus, Aleutian Is.; $51^{\circ} 57^{\prime} 00^{\prime} \mathrm{N}, 179^{\circ} 32^{\prime} 50^{\prime \prime}$ E; BGN 1951; (map 15).

So named in 1950 by R. R. Coats, USGS, because "part of the cone has been removed in the formation of the caldera."

Three River Mountain: mountain, 6,140 ft., 7 mi. across, at heads of John, Anaktuvuk, and North Fork Koyukuk Rivers, $6 \mathrm{mi}$. S of Anaktuvuk Pass, Brooks Ra.; 68 $04^{\prime} \mathrm{N}, 151^{\circ}$ 38' W; BGN 1933; (map 134).

Reported by Robert Marshall, after his 1930 trip, (1956, p. 46) who wrote, "to the southwest, about two miles along the divide on which I stood, was a very high mountain (later named Three River Mountain) which I imagined must be at the junction of the major rivers, the Anaktuvuk, North Fork, and John."

Three Saints, Harbor of: cove, see Three Saints Harbor.

Three Saints Bay: bay, extends N 9 mi., off Sitkalidak Strait, on SE coast of Kodiak I.; $57^{\circ} 06^{\prime} \mathrm{N}, 153^{\circ} 28^{\prime} \mathrm{W}$; (map 34). Var. Liakik Bay, Zaliv Lyakhik.

Name derived from Three Saints Harbor and reported by Petroff in the 10th Census in 1880 (1881, p. 32). Called "Z[aliv] Lyakhik," or "Lyakhik Bay," by Capt. Tebenkov (1852, map 23). Baker (1906, p. 625) transliterated the Russian spelling of this Aleut name as "Liakik," "perhaps from liak, the Aleut name for the black-footed goose." R. H. Geoghegan (notes) suggests "Liakik," "may be dual form of laq, blackfoot goose-pair of geese."

Three Saints Harbor: locality, on W shore of Three Saints Harbor, in Three Saints Bay, SE coast of Kodiak I. ; $57^{\circ} 09^{\prime} \mathrm{N}, 153^{\circ} 31^{\prime} \mathrm{W}$; (map 34). Var. Nunamiut, Old Harbor, 
Starri-gavan, Starrigavan, Starui Gavan, Staryy Gavan, Seleniye Rossiysko-Amyerikanskoy Kompaniy, Ziatitz.

Site of the first permanent Russian settlement in Alaska; established by Shelikov, founder of the Russian American Company. It was the headquarters of the company for only a short time before it was moved to Saint. Paul (Kodiak). Sarichev (1826, map 17) applied the name "Seleniye RossiyskoAmyerikanskoy Kompaniy," or "Settlement of the Russian American Company." Baker (1906, p. 625) wrote, "Three Saints has, by a curious transformation, became Ziatitz on some maps. The Russian verb sviatit, to sanctify, whence sviatoi, a saint, was written in English, 1849, by the Russian skipper Archimandritof Zfiatitz. The manuscript map on which this appeared *** was published by the United States [Navy] Hydrographic Office in 1869 . On that map we have ' $\mathrm{Hr}$ of 3 Saints and Zfiatitz'. One more changed and we have-on late chartsZiatitz as the name of the native village Nunamiut." See Nunamiut.

Three Saints Harbor: locality, see Nunamiut.

Three Saints Harbor: village, see Old Harbor.

Three Saints Harbor: cove, $0.5 \mathrm{mi}$. across, on W shore of Three Saints Bay, SE coast of Kodiak I.; $57^{\circ} 09^{\prime} \mathrm{N}, 153^{\circ} 30^{\prime} \mathrm{W}$; (map 34). Var. Gavan Trekh Svyatiteley, Harbor of 3 Saints, Old Harbor, Schelikoff Harbor, Starrigavan, Staryy Gavan, Zfiatitz, Ziatitz.

Named by Grigori Shelikov in 1784 for his ship the Three Saints. Von Langsdorff (1813-14, v. 2, p. 88) called the cove "Schelikoff Harbor." Sarichev (1826, map 17) used the name "Gavan Trekh Svyatiteley," meaning "Three Saints." See Three Saints Harbor, locality.

Three Sisters: peaks, 2,001-2,405 ft., $3.5 \mathrm{mi}$. NW of Kodiak, on NE end of Kodiak I.; $57^{\circ} 48^{\prime} 30^{\prime \prime} \mathrm{N}, 152^{\circ} 29^{\prime} 30^{\prime \prime} \mathrm{W}$; (map 34). Var. The Devils Prongs.

Local name recorded in 1949 by USGS.

Three Sisters: peaks, see Devils Prongs.

Three Sisters, The: islands, group of three, each $0.2 \mathrm{mi}$. long, in Three Arm Bay, on W coast of Adak I., Aleutian Is.; $51^{\circ} 45^{\prime} \mathrm{N}, 176^{\circ} 53^{\prime}$ W; BGN 1936; (map 17).

Named by members of the U.S. Navy Aleutian Island Survey Expedition in 1934. Three Sisters Mountain: ridge, elev. 2,000-4,810 ft., in Chigmit Mts., extends $8.5 \mathrm{mi}$. on $\mathbf{E}$ bank of Pile River, NE of Iliamna Lake, Aleutian Ra.; $59^{\circ} 55^{\prime} \mathrm{N}, 153^{\circ} 41^{\prime} \mathrm{W}$; (map 51).

"So named because the mountain is composed of three peaks over 4,500 ft."; reported in 1958 by USGS.

Three Sisters Rocks: rocks, in Sitkalidak Strait, $0.8 \mathrm{mi}$. NW of Cathedral I., between Sitkalidak I. and SE coast of Kodiak Is.; $57^{\circ} 12^{\prime} 45^{\prime \prime}$ N, $153^{\circ} 09^{\prime} 00^{\prime \prime} \mathrm{W}$; (map 34).

Local name published in 1943 by USC\&GS.

Three Sleep Point: point of land, on a hill, 1 mi. E of The Buttes Gap, $22 \mathrm{mi}$. SW of
Beaver, Yukon Flats; $66^{\circ} 06^{\prime} 30^{\prime \prime} \mathrm{N}, 147^{\circ} 54^{\prime}$ $00^{\prime \prime} \mathrm{W}$; (map 118).

Local name obtained in 1956 by USGS.

Threesome Mountain: mountain, 4,230 ft., in Glacier Bay National Monument, $1.3 \mathrm{mi}$. N of Abyss Lake and $52 \mathrm{mi}$. NW of Hoonah, St. Élias Mts.; $58^{\circ} 32^{\prime} 20^{\prime \prime} \mathrm{N}, 136^{\circ} 35^{\prime} 30^{\prime \prime} \mathrm{W}$; (map 10).

Local descriptive name reported in 1951 by USGS.

Three Star Point: point of land, $1 \mathrm{mi}$. SW of Perryville, on $\mathbf{S}$ coast of Alaska Penin., 19 mi. E of Stepovak Bay, Aleutian Ra.; 55 $53^{\prime}$ $20^{\prime \prime} \mathrm{N}, 159^{\circ} 10^{\prime} 30^{\prime \prime} \mathrm{W}$; (map 27).

Descriptive name published in 1916 by USC\&GS

Three Step Mountain: mountain, 1,500 ft., 9 mi. N of Elbow Mtn. and $37 \mathrm{mi}$. SE of Bethel, Kilbuck-Kuskokwim Mts.; $60^{\circ} 26^{\prime} \mathrm{N}, 160^{\circ} 58^{\prime}$ W; (map 59).

Descriptive name shown on a 1902 manuscript map by USRCS.

Threetime Mountain: mountain, 2,635 ft., between Timber Creek and John River, $49 \mathrm{mi}$. SW of Wiseman, Brooks Ra.; $67^{\circ} 14^{\prime} \mathrm{N}, 151^{\circ}$ 54' W; (map 124).

Local name obtained in 1956 by USGS topographers.

Three Tree Island: island, $200 \mathrm{ft}$. across, $5.5 \mathrm{mi}$. SW of Chichagof, W of Rough Channel, off W coast of Chichagof I., Alex. Arch.; 57 $35^{\prime}$ $30^{\prime \prime} \mathrm{N}, 136^{\circ} 08^{\prime} 50^{\prime \prime} \mathrm{W}$; BGN 1908; (map 9).

Descriptive name given in 1908 by $\mathbf{E}$. F. Dickens, USC\&GS; published in 1909 on Chart 8280 . So named because "of three lone trees which identify it."

Three Way Passage: water passage, between Stanhope and Etolin Is., Alex. Arch.; $56^{\circ} 02^{\prime}$ N, $132^{\circ} 37^{\prime} \mathrm{W} ; B G N$ 1917; (map 6).

Named in 1917 by USC\&GS.

Throat River: stream, flows NE $5 \mathrm{mi}$. to Selawik River, $3 \mathrm{mi}$. $\mathrm{S}$ of Selawik, KotzebueKobuk Low.; $66^{\circ} 33^{\prime}$ N, $159^{\circ} 58^{\prime} \mathrm{W}$; (map 114). Var. Eegyak.

Translation of an Eskimo name reported in 1884 as "Eegyak or Throat River," by Lt. J. C. Cantwell, USRCS.

Through Creek: stream, flows E 6 mi. to Chignik Bay, $8 \mathrm{mi}$. NNW of Chignik, on $\mathrm{S}$ shore of Alaska Penin., Aleutian Ra.; $56^{\circ} 24^{\prime}$ N, $158^{\circ}$ 28' W; (map 30).

Named in 1923 by R. H. Sargent, USGS, because of the low pass at its head leading across the Aleutian Ra. to Boulevard Creek and the Bristol Bay Low.

Through Glacier: glacier, heads at $55^{\circ} 59^{\prime} \mathrm{N}$, $130^{\circ} 22^{\prime} \mathrm{W}$, trends NE $5 \mathrm{mi}$. to Chickamin Glacier, $14 \mathrm{mi}$. NW of Hyder, Coast Mts.; $56^{\circ} 02^{\prime} 30^{\prime \prime} \mathrm{N}, 130^{\circ} 19^{\prime} 00^{\prime \prime} \mathrm{W}$; BGN 1927; $(\operatorname{map} 7)$.

Descriptive name given in 1926 by A. F. Buddington, USGS, because "this glacier extends over a high divide and for many miles toward Portland Canal."

Thru Creek: stream, flows NE $3 \mathrm{mi}$. then S 4 mi. to North Fork Chandalar River $W$ of Reds Lake and $24 \mathrm{mi}$. NNW of Chandalar,
Brooks Ra.; $67^{\circ} 50^{\prime} \mathrm{N}, 148^{\circ} 40^{\prime} \mathrm{W}$; (map 123).

Local name reported in 1956 by T. E. Taylor, USGS.

Thumb, The: bluff, see Devils Thumb.

Thumb Bay: estuary, trends W $1.5 \mathrm{mi}$. to Mummy Bay, at $\mathrm{S}$ end of Knight I., $7 \mathrm{mi}$. SE of Chenega, Chugach Mts.; $60^{\circ} 12^{\prime} 45^{\prime \prime} \mathrm{N}$, $147^{\circ} 49^{\prime} 00^{\prime \prime} \mathrm{W}$; (map 63$)$.

Local name published in 1911 by USC\&GS.

Thumb Cove: bay, on W coast of Resurrection Penin., extends SW $1.5 \mathrm{mi}$. to Resurrection Bay, $8 \mathrm{mi}$. SE of Seward, Chugach Mts.; $60^{\circ} 00^{\prime} 15^{\prime \prime} \mathrm{N}, 149^{\circ} 19^{\prime} 30^{\prime \prime} \mathrm{W}$; BGN 1906; (map 63). Var. Dickinson Cove.

Named in 1906 by Andrew Braid, USC\&GS.

Thumb Cove Glacier: glacier, see Porcupine Glacier.

Thumb Creek: stream, heads at Thumb Glacier, flows E $5 \mathrm{mi}$. to Salmon River, $5.5 \mathrm{mi}$. N of Hyder, Coast Mts.; $56^{\circ} 00^{\prime} \mathrm{N}, 130^{\circ} 05^{\prime} \mathrm{W}$; (map 3).

Local name recorded in 1923 by A. F. Buddington (in Brooks and others, 1925, p. 85), USGS.

Thumb Glacier: glacier, in Lincoln Mts., trends E $2 \mathrm{mi}$. to its (1955) terminus at head of Thumb Creek, $7.5 \mathrm{mi}$. NW of Hyder, Coast Mts.; $55^{\circ} 59^{\prime} 10^{\prime \prime} \mathrm{N}, 130^{\circ} 11^{\prime} 30^{\prime \prime} \mathrm{W}$; (map 3).

Local name recorded in 1955 by USGS.

Thumb Island: island, see Akusha Island.

Thumb Lake: lake, $0.7 \mathrm{mi}$. long, $\mathrm{E}$ of Karluk Lake, at head of Thumb River, Kodiak I.; $57^{\circ} 21^{\prime} 10^{\prime \prime} \mathrm{N}, 153^{\circ} 59^{\prime} 00^{\prime \prime} \mathrm{W}$; (map 34).

Local name reported in 1954 by USGS

Thumb Mountain: mountain, 2,969 ft., $20 \mathrm{mi}$. NE of Jack Smith Bay and $38 \mathrm{mi}$. N of Goodnews, Kilbuck-Kuskokwim Mts.; 59 $37^{\prime} \mathrm{N}$, $161^{\circ} 14^{\prime}$ W; (map 53). Var. Helmick Mountain.

Originally named "Helmick Mountain" by J. E. Spurr and W. S. Post (in Spurr, 1900, map 10), USGS, for Rev. Benjamin Helmick, Moravian missionary who worked in this area. The descriptive name "Thumb Mountain" was published in 1915 by USC\&GS on Chart 9103. It was so called because "from off Quinhagak it resembles a huge thumb placed on a high flat mountain plateau." (U.S. Coast and Geodetic Survey, 1916, p. 249).

Thumb Point: point of land, on $\mathrm{SE}$ coast of Umnak I., Aleutian Is.; $53^{\circ} 11^{\prime} 55^{\prime \prime} \mathrm{N}$, $168^{\circ} 19^{\prime} 00^{\prime \prime} \mathrm{W}$; BGN 1938; (map 22).

Descriptive name given in 1.938 by USC\&GS, "because of its remarkable resemblance to the outline of a thumb."

Thumb Point: point of land, on SW coast of Liesnoi I., at mouth of Eliza Harbor, on Admiralty I., $21 \mathrm{mi}$. E of Baranof, Alex. Arch. ; $57^{\circ} 09^{\prime} 50^{\prime \prime} \mathrm{N}, 134^{\circ} 17^{\prime} 20^{\prime \prime} \mathrm{W}$; (map 9).

Descriptive nome given in 1889 by Lt. Comdr. H. B. Mansfield, USN; published by USC\&GS in the 1891 Coast Pilot (p. 142).

Thumb River: stream, heads at Thumb Lake, flows NW 0.4 mi. to Karluk Lake, Kodiak I.; $57^{\circ} 21^{\prime} 25^{\prime \prime} \mathrm{N}, 153^{\circ} 59^{\prime} 45^{\prime \prime} \mathrm{W}$; (map 34). 
Local name reported in 1954 by USGS. Thumit Greek: stream, see Tumit Creek.

Thunder Bay: bay, $1.5 \mathrm{mi}$. wide, on SE coast of Kenai Penin., $48 \mathrm{mi}$. E of Homer, Chugach Mts.; $59^{\circ} 33^{\prime} \mathrm{N}, 150^{\circ} 10^{\prime} \mathrm{W}$; (map 50).

Local name reported by USGS or USC\&GS in the 1940's.

Thunder Bay: bay, see LeConte Bay.

Thunder Bird Creek: stream, flows NW $12 \mathrm{mi}$ to Eklutna River, $24 \mathrm{mi}$. NE of Anchorage, Cook Inlet Low.; $61^{\circ} 26^{\prime} 45^{\prime \prime} \mathrm{N}, 149^{\circ} 21^{\prime} 40^{\prime \prime}$ W; (map 69).

Local name reported in 1951 by USGS

Thunder Bird Falls: waterfalls, on Thunder Bird Creek, $0.4 \mathrm{mi}$. S of its junc. with Eklutna River, $4.7 \mathrm{mi}$. NE of Birchwood and $24 \mathrm{mi}$. NE of Anchorage, Cook Inlet Low.; 61 ${ }^{\circ} 26^{\prime}$ $30^{\prime \prime} \mathrm{N}, 149^{\circ} 21^{\prime} 15^{\prime \prime} \mathrm{W}$; (map 69).

Local name reported in 1942 by AMS.

Thunder Creek: stream, heads in a glacier, flows $2.5 \mathrm{mi}$. E to Copper River, $3 \mathrm{mi}$. above mouth of Cleave Creek and $70 \mathrm{mi}$. E of Valdez, Chugach Mts. ; $61^{\circ} 10^{\prime} 45^{\prime \prime} \mathrm{N}, 144^{\circ} 54^{\prime} 35^{\prime \prime} \mathrm{W}$; (map 68).

Local name published in the 1950 's by USGS.

Thunder Creek: stream, heads in Dutch Hills, flows SW $4.8 \mathrm{mi}$. to Cache Creek, $31 \mathrm{mi}$. NW of Talkeetna, Alaska Ra.; $62^{\circ} 29^{\prime} 05^{\prime \prime} \mathrm{N}$, $151^{\circ} 00^{\prime} 00^{\prime \prime} \mathrm{W}$; (map 81).

Prospectors' name reported in 1906 by $R$. W. Porter, USGS.

Thunder Creek: stream, heads on Thunder Mtn., in De Long Mts., flows $\mathrm{N} 12 \mathrm{mi}$. to join Storm Creek to form Colville River, Brooks Ra.; $68^{\circ} 49^{\prime} 20^{\prime \prime} \mathrm{N}, 160^{\circ} 20^{\prime} 00^{\prime \prime} \mathrm{W}$; BGN 1961; (map 131).

Named by the 1925 USGS exploring expedition after Thunder Mtn.

Thunder Glacier: glacier, see LeConte Glacier.

Thunder Mountain: mountain, 3,110 ft., $\mathrm{N}$ of Sakie Bay, on W coast of Dall I., Alex. Arch. $55^{\circ} 04^{\prime} 30^{\prime \prime} \mathrm{N}, 133^{\circ} 10^{\prime} 20^{\prime \prime} \mathrm{W}$; (map 4).

Name published in 1924 by USC\&GS.

Thunder Mountain: mountain, 3,425 ft., $13 \mathrm{mi}$. E of Petersburg, Coast Mts.; $56^{\circ} 49^{\prime} 30^{\prime \prime} \mathrm{N}$, $132^{\circ} 36^{\prime} 00^{\prime \prime} \mathrm{W}$; (map 6).

Named in 1887 by L.t. Comdr. C. M. Thomas, USN; name published in 1888 on USG\&GS Chart 705.

Thunder Mountain: mountain, 2,900 ft., 1.5 mi. NE of Juneau Airport and $6 \mathrm{mi}$. NW of Juneau, Coast Mts. ; $58^{\circ} 22^{\prime} 50^{\prime \prime} \mathrm{N}, 134^{\circ} 31^{\prime} 30^{\prime \prime}$ W; (map 11).

Local name reported by D. A. Brew and A. B. Ford, USGS, in 1965.

Thunder Mountain: mountain, 4,850 ft., in DeLong Mts., 35. mi. NE of Misheguk Mtn., Brooks Ra.; 68 $34^{\prime} \mathrm{N}, 160^{\circ} 18^{\prime} \mathrm{W} ; B G N$ 1961; (map 131).

Named by USGS exploring expedition in 1925 "because of numerous thunder-storms experienced in the area."

Thunder Point: point of land, on $\mathrm{E}$ coast of Adak I., Aleutian Is.; $51^{\circ} 51^{\prime} 10^{\prime \prime} \mathrm{N}, 176^{\circ} 28^{\prime}$ 00" W; BGN 1936; ( $\operatorname{map} 17$ ).

Named by members of the U.S. Navy Aleutian Island Survey Expedition in 1934.
Thunder Point: point of land, on N shore of LeConte Bay, 19 mi. E of Petersburg, Coast Mts. ; $56^{\circ} 47^{\prime} 10^{\prime \prime} \mathrm{N}, 132^{\circ} 27^{\prime} 40^{\prime \prime} \mathrm{W}$; (map 6).

Named in 1887 by Lt. Comdr. C. M. Thomas, USN; name published in 1888 on USC\&GS Chart 705.

Thurman Creek: stream, heads in lake, on Kenai Penin., in Kenai Mts., NW of Trout Lake, flows NW $10 \mathrm{mi}$. to Ghickaloon River, $26 \mathrm{mi}$. SW of Hope, Chugach Mts.; $60^{\circ} 39^{\prime} \mathrm{N}, 150^{\circ}$ 05' W: (map 62).

Local name reported in 1944 by USGS.

Thursday Creek: stream, flows E $12.4 \mathrm{mi}$. to Talachulitna River, $51 \mathrm{mi}$. NW of Tyonek, Alaska Ra.; $61^{\circ} 47^{\prime} 45^{\prime \prime}$ N, $151^{\circ} 24^{\prime} 45^{\prime \prime}$ W: (map 70).

Local name reported in 1954 by USGS.

Thurston Canyon: canyon, on Kenai Penin., 0.5 mi. long, $3 \mathrm{mi}$. E of Lookout Mtn. and $8 \mathrm{mi}$. NE of Homer, Cook Inlet Low.; 59 $42^{\prime} 30^{\prime \prime} \mathrm{N}$, $151^{\circ} 22^{\prime} 30^{\prime \prime} \mathrm{W}$; (map 50)

Local name reported and published by USGS in the 1950's.

Thurston Creek: stream, flows NW $6 \mathrm{mi}$. to Seventymile River, $9 \mathrm{mi}$. NW of Eagle, YukonTanana High.; $64^{\circ} 55^{\prime} \mathrm{N}, 141^{\circ} 18^{\prime} \mathrm{W}$; (map 102).

Prospectors' name shown on a 1902 manuscript map by E. J. Chamberlain, U.S. Deputy Surveyor.

Tiakinak: island, see Simeonof Island.

Tiatiuk: locality, on Yukon-Kuskokwim Delta $\mathrm{N}$ of Black River, $62^{\circ} 25^{\prime} \mathrm{N}, 165^{\circ} 15^{\prime} \mathrm{W}$; (map 76).Var. Tée-atee-ógemut.

Former Eskimo village or camp reported as "Tée-atee-ógemut" by Dall (1870, p. 264).

Tibbs Creek: stream, fows N $10 \mathrm{mi}$. to Goodpaster River, $52 \mathrm{mi}$. ENE of Big Delta, YukonTanana High.; $64^{\circ} 28^{\prime} \mathrm{N}, 144^{\circ} 15^{\prime} \mathrm{W}$; (map 101).

Local name published in 1943 by USGS.

Tibukligarra Creek: stream, flows $\mathrm{W}$ to Inglutalik River, Nulato Hills; near $65^{\circ} 00^{\prime} \mathrm{N}, 160^{\circ}$. 00' W; (map 109).

Eskimo name reported in 1907 by P. S. Smith, USGS. This feature cannot be identified on current maps.

Tichaia Bay: bay, see Still Harbor.

Tichai Bay: bay, see Still Harbor.

Tichaichachass: locality, see Paltchikatno.

Tichik River: stream, see Nuyakuk River.

Tichininik River: stream, see North Fork Kuskokwim River.

Tichnak Creek: stream, see Cheenik Creek.

Tichtinigé : cove, see Pyramid Harbor.

Tick Shoal: shoal, $0.5 \mathrm{mi}$. across, in Yakutat Roads, $0.3 \mathrm{mi}$. $\mathrm{N}$ of Puget Cove and $1.5 \mathrm{mi}$. $\mathrm{N}$ of Yakutat, Malaspina Coastal Plain; $59^{\circ}$ $34^{\prime} 15^{\prime \prime} \mathrm{N}, 139^{\circ} 43^{\prime} 30^{\prime \prime} \mathrm{W}$; (map 46).

Named by Lt. Giles B. Harber, USN, and published on Hydrog. Chart 2157 in 1892.

Tidal Basin: lagoon, $0.5 \mathrm{mi}$. long, on SW coast of Marmot I., Kodiak I.; $58^{\circ} 11^{\prime}$ N, $151^{\circ} 52^{\prime}$ W; (map 43)

Local descriptive name reported in 1952 by USGS.

Tidal Inlet: estuary, fiord in Glacier Bay National Monument, trends W $4.5 \mathrm{mi}$. to Gla- cier Bay, $4 \mathrm{mi}$. E of Gilbert I. and $61 \mathrm{mi}$. NW of Hoonah, St. Elias Mts.; $58^{\circ} 49^{\prime} 30^{\prime \prime} \mathrm{N}, 136^{\circ}$. 24'00" W; BGN 1948; (map 10). Var. Favorite Inlet.

Named in 1890 by H. F. Reid (1896, p. 427) who established a tidal observation station in the inlet. The inlet is not tidal in the true sense, however, but is protected by a natural breakwater.

Tide Island: island, $0.1 \mathrm{mi}$. long, at $\mathrm{N}$ end of Clarence Strait, between Zarembo and Prince of Wales Is., Alex. Arch.; $56^{\circ} 17^{\prime} 00^{\prime \prime}$ $\mathrm{N}, 133^{\circ} 03^{\prime} 35^{\prime \prime} \mathrm{W}$; (map 6).

Named in 1886 by Lt. Comdr. A. S. Snow, USN; name published in 1887 on USC\&GS Chart 706.

Tidertip Point: point of land, on SW coast of Unalaska I., Aleutian Is.; $53^{\circ} 16^{\prime} 45^{\prime \prime} \mathrm{N}$, $167^{\circ} 46^{\prime} 30^{\prime \prime}$ W; BGN 1939; (map 23). Var. Southwest End.

This descriptive name given by USC\&GS in 1939 "because of heavy tiderips encountered upon this point." The name "Southwest End" was applied by USC\&GS before the area had been surveyed.

Tidgatukh Island: island, see Tidgituk Island. Tidgitok, Ostrov: island, see Tidgituk Island.

Tidgituk Island: island; $0.5 \mathrm{mi}$. long, in entrance to South Bay, on $S$ coast of Tanaga $I$., Aleutian Is.; $51^{\circ} 38^{\prime} 00^{\prime \prime} \mathrm{N}, 178^{\circ} 00^{\prime} 30^{\prime \prime} \mathrm{W}$; (map 16). Var. Ostrov Tidgitok, Tidgatukh Island.

Aleut name published by Capt. Tebenkov (1852, map 28), IRN, as "O[strov] Tidgitok," i.e. "Tidgitok Island."

Tiedeman Island: island, $9 \mathrm{mi}$. long, in Seymour Canal, off E coast of Admiralty I., $27 \mathrm{mi}$. NE of Angoon, Alex. Arch.; $57^{\circ} 50^{\prime} \mathrm{N} ; 134^{\circ} 10^{\prime}$ W; (map 9).

Named by W. H. Dall, USC\&GS, and published in the 1883 Coast Pilot (p. 129).

Tiedeman Slough: stream, $5 \mathrm{mi}$. long, distributary of Glacier River, $12 \mathrm{mi}$. SE of Cordova, Malaspina Coastal Plain; $60^{\circ} 25^{\prime} \mathrm{N}, 145^{\circ} 28^{\prime}$ W; (map 64).

Local name published in 1951 by USGS.

Tieehovun Lake: lake, $3 \mathrm{mi}$. long, $18 \mathrm{mi}$. S of Chalkyitsik, Yukon Flats; $66^{\circ} 24^{\prime} \mathrm{N}, 143^{\circ} 40^{\prime}$ W; (map 120).

Tranjik-kutchin Indian name; obtained in 1956 by T. E. Taylor, USGS.

Tiekaga: point of land, see Hope, Point.

Tiekagagmiut: village, see Point Hope.

Tiekel: locality, between Tiekel River and Richardson Highway, $2.3 \mathrm{mi}$. NE of Mount Tiekel and $35 \mathrm{mi}$. NE of Valdez, Chugach Mts.; $61^{\circ} 19^{\prime} 35^{\prime \prime} \mathrm{N}, 145^{\circ} 18^{\prime} 30^{\prime \prime} \mathrm{W}$; (map 68). Var. Teikhell, Tiekell City, Tiekel Roadhouse.

In June, 1899, John F. Rice (in U.S. Congress, 1900, p. 780) wrote, "After several miles of travel we passed what was known as Tiekell City, it having been destroyed by fire some few years before our arrival." A roadhouse was established later, which was reported in 1908 by USGS (Moffit and Maddren, 1909, pl. 1). 
Tiekel, Mount: mountain, 6,300 ft., $3.5 \mathrm{mi}$. S of Rice Mtn. and $32 \mathrm{mi}$. NE of Valdez, Chugach Mts. ; $61^{\circ} 15^{\prime} 15^{\prime \prime} \mathrm{N}, 145^{\circ} 20^{\prime} 40^{\prime \prime} \mathrm{W}$; (map 68).

Local name published in the 1950 's by USCe.

Tiekel Cache: locality, on Tiekel River, $1.7 \mathrm{mi}$. $\mathrm{NE}$ of mouth of Squaw Creek and $40 \mathrm{mi}$. ENE of Valdez, Chugach Mts.; 61 ${ }^{\circ} 23^{\prime} \mathrm{N}$, $145^{\circ} 14^{\prime} \mathrm{W}$; BGN 1932; (map 68). Var. Teikhell, Tiekel City,

Former telegraph station named "Teikhell" in 1902 by U.S. Signal Corps; may be the same place referred to as "Tiekel City" (See Tiekel). In 1932 USGS reported that the old buildings are now maintained by the ARC and used as a "cache" for supplies and road equipment.

Tiekel City: locality, see Tiekel and Tiekel Cache.

Tiekell River: stream, see Uranatina River.

Tiekel River: stream, flows SW and E $34 \mathrm{mi}$. to Copper River, 3.5 mi. NE of junc. of Thunder Creek and $47 \mathrm{mi}$. ENE of Valdez, Chugach Mts. ; $61^{\circ} 13^{\prime} 15^{\prime \prime} \mathrm{N}, 144^{\circ} 50^{\prime} 40^{\prime \prime} \mathrm{W}$; (map 68).Var. Konsena, Konsina, Tiekhell, Tsaina, Zeikhell.

Indian names "Tiekel" and "Tiekhell" applied by Lt. H. T. Allen, USA, to a stream now known as Uranatina River. In about 1900 the name was reapplied to this stream by USGS. In 1885 Allen reported another Indian name, "Konsina," for this stream; in 1898 Capt. W. R. Abercrombie, USA, recorded the names "Tsina" and "Konsena." "Tsina," is now applied to the south fork of the Tiekel River.

Tiekel Roadhouse: locality, see Tiekel.

Tiekhell: stream, see Tiekel River.

Tienasheavun Slough: stream, 2 mi. long, anabranch of Black River $33 \mathrm{mi}$. E of Chalkyitsik, Porcupine Plat.; $66^{\circ} 34^{\prime} \mathrm{N}, 142^{\circ} 34^{\prime} \mathrm{W}$; (map 120).

Tranjik-kutchin Indian name; obtained in 1956 by T. E. Taylor, USGS.

Tiengak: locality, on Kvichavak River, YukonKuskokwim Delta ; $61^{\circ} 20^{\prime} \mathrm{N}, 161^{\circ} 00^{\prime} \mathrm{W}$; (map 73).

Former Eskimo village or camp reported as "Tiengaghamiut," population 60 , in the 1890 Census (1893, p. 111).

Tieschenni: stream, see Chistochina River.

Tifcha-ak: locality, see Difchahak.

Tiflighak Bay: bight, between Tetegnak Point and Meruwtu Point, along $\mathrm{N}$ coast of St. Lawrence I., $3 \mathrm{mi}$. SE of Gambell; $63^{\circ} 46^{\prime} \mathrm{N}$, 171'38' W; BGN 1951; (map 93). Var. Asowalak Cove, Tiplighak Bay.

Recorded in 1932 as "Tiplighak Bay" by USCG. Orth was told in 1955 at Gambell that this name is locally applied to what is shown on present-day maps as "Dovelawik Bay." This bight is locally known as "Asowalak," meaning "something white."

Tiflighak Bay: bight, see Dovelawik Bay.

Tigaida: island, see Tigalda Island.

Tigalda: locality, on Tigalda I., Aleutian Is.; $54^{\circ} 06^{\prime}$ N, $165^{\circ} 05^{\prime}$ W; (map 24). Var. Teegaldenskoi, Tigaldinskoe.

Former Aleut village reported in 1833 as "Tigaldinskoe," population 91, by Father Veniaminov (1840, v. 2. p. 203).

Tigalda Bay: bay, $2 \mathrm{mi}$. long, on $\mathrm{N}$ coast of Tigalda I., Krenitzin Is., Aleutian Is.; $54^{\circ} 07^{\prime}$ $45^{\prime \prime} \mathrm{N}, 165^{\circ} 00^{\prime} 00^{\prime \prime} \mathrm{W}$; (map 24).

Named in 1888 by USBF for Tigalda Island.

Tigalda Island: island, $12 \mathrm{mi}$. long, $23 \mathrm{mi}$. E of Akutan, in Krenitzin Is., Aleutian Is.; $54^{\circ} 06^{\prime} \mathrm{N}, 165^{\circ} 05^{\prime} \mathrm{W}$; (map 24). Var. Coagalga, Coogalga, Croyalgu, Kagalga, Kigalga, Kugalga, Tigaida, Tigalga.

Aleut name published by Capt. Lutke (1836, p. 291) ; called "Kagalga" by Capt. Lt. Krenitzin and Lt. Levashev in 1768 (Coxe, 1787, map p. 205).

Tigaldinskoe: locality, see Tigalda.

Tigalga: island, see Tigalda Island.

Tigara: point of land, and village, see Hope, Point and Point Hope.

Tigaraha Mountain: mountain, 3,200 ft., in Kigluaik Mts., $4.5 \mathrm{mi}$. S of Mount Osborn and $30 \mathrm{mi}$. NE of Nome, Seward Penin. High.; $64^{\circ} 56^{\prime} \mathrm{N}, 165^{\circ} 18^{\prime} \mathrm{W}$; (map 94).

Eskimo name meaning "index finger" reported in 1912 by R. H. Sargent, USGS.

Tigarak: point of land, and village, see Hope, Point and Point Hope.

Tigara River: stream, see Kukpuk River.

Tigcheldé: locality, see Tigshelde.

Tigera: point of land, and village, see Hope, Point and Point Hope.

Tiger Cape: point of land, on NE coast of Raspberry I., $8 \mathrm{mi}$. NW of Afognak, Kodiak I. ; $58^{\circ} 01^{\prime} 20^{\prime \prime} \mathrm{N}, 152^{\circ} 58^{\prime} 45^{\prime \prime} \mathrm{W}$; (map 43).

Local name reported in 1952 by USGS.

Tiger Cove: cove, see Navy Cove.

Tiger Glacier: glacier, heads at Sargent Icefield, on Kenai Penin., trends E $6 \mathrm{mi}$. to Icy Bay, $14 \mathrm{mi}$. SW of Chenega, Chugach Mts.; $60^{\circ} 11^{\prime} 00^{\prime \prime} \mathrm{N}, 148^{\circ} 26^{\prime} 40^{\prime \prime} \mathrm{W}$; BGN 1910; (map 63).

Named in 1910 by U. S. Grant and D. F. Higgins, USGS

Tigertail Glacier: glacier, heads on Sargent Icefield, on Kenai Penin., trends NE $4 \mathrm{mi}$. to Nassau Fiord, $10 \mathrm{mi}$. W of Chenega, Chugach Mts.; $60^{\circ} 15^{\prime} 45^{\prime \prime} \mathrm{N}, 148^{\circ} 23^{\prime} 35^{\prime \prime} \mathrm{W}$; (map 63).

Named in 1909 by George W. Perkins, USGS (Grant and Higgins, 1910-11, p. 415).

Tiglukpuk Creek: stream, heads on $\mathrm{N}$ slope of Soakpak Mtn., fows N $25 \mathrm{mi}$. to Siksikput River, $24 \mathrm{mi}$. NE of Chandler Lake, Arctic Slope; 68 $31^{\prime} \mathrm{N}, 152^{\circ} 03^{\prime} \mathrm{W}$; BGN 1960; (map 134).

Eskimo name meaning "moose" given in 1950 by a USGS field party.

Tignagvik Point: point of land, on SW shore of Cook Inlet, $\mathbf{N}$ point of entrance to Kamishak Bay, Aleutian Ra.; $59^{\circ} 26^{\prime} 15^{\prime \prime} \mathrm{N}, 153^{\circ} 43^{\prime} 30^{\prime \prime}$ W; (map 51).

Eskimo name published in 1915 on USC\&GS Chart 8554

Tigshelde: locality, on left bank of Innok River,
$7 \mathrm{mi}$. SE of Holikachuk, Innoko Low.; $62^{\circ} 51^{\prime}$ N, $159^{\circ} 21^{\prime} \mathrm{W}$; (map 78). Var. Tigcheldé, Tizhgelede, Tozhgelede.

Former Indian village or camp recorded as "Tigchelde" " on Lt. L. A. Zagoskin's 1850 map.

Tigugha Point: point of land, see Tikugha Point. Tigvariak Island: island, $2 \mathrm{mi}$. long, between Mikkelsen and Foggy I. Bays, on Beaufort Sea coast, $23 \mathrm{mi}$. W of Flaxman I., Arctic Plain; $70^{\circ} 13^{\prime} 15^{\prime \prime}$ N $147^{\circ} 12^{\prime} 55^{\prime \prime}$ W; (map 150). Var. Lion and Reliance Reef, Lion Island.

E. de K. Leffingwell (1919, p. 100), USGS, adopted this Eskimo name for the island, which Franklin, RN, (1828, p. 152) originally named "Lion and Reliance Reef," after his two boats, the Lion having been driven aground at this place. Leffingwell applied Franklin's names to "the NE and NW points of the islands ***." Lt. W. H. Hooper, RN, in 1853, calls this Lion Island. As the name "Lion" has been misapplied on the early charts, Hooper may have been referring to the chain of islands lying several miles to the north. The Eskimo name Tigvariak means "portage."

Tiinkdhul Lake: lake, $2.5 \mathrm{mi}$. across, $17 \mathrm{mi}$. SE of Chalkyitsik, Porcupine Plat.; 66 $34^{\prime} \mathrm{N}$, $143^{\circ} 10^{\prime} \mathrm{W}$; (map 120).

Tranjik-kutchin Indian name; obtained in 1956 by T. E. Taylor, USGS.

Tikaghapuk Cape: point of land, see Tikaghapuk Point.

Tikaghapuk Point: point of land, $10 \mathrm{mi}$. NW of Bunnell Cape, $21 \mathrm{mi}$. S of Gambell, W coast of St. Lawrence I.; $63^{\circ} 29^{\prime} \mathrm{N}, 171^{\circ} 51^{\prime} \mathrm{W}$; $B G N$ 1951; (map 93). Var. Cape Tikighapak, Tikaghapuk Cape, Tikerapak Point, Tikighapak Cape, Tikighpat Cape.

Eskimo name meaning "big point of land" [tikerapak], reported in 1949 by Maj. H. B. Allen, USAF.

Tikan Creek: stream, heads in Canada, flows W $10 \mathrm{mi}$. to Grayling Fork Black River, $9 \mathrm{mi}$. NW of Midnight Hill, Porcupine Plat.; $66^{\circ}$ $10^{\prime} 20^{\prime \prime} \mathrm{N}, 141^{\circ} 10^{\prime} 40^{\prime \prime} \mathrm{W}$; BGN 1914; (map 120). Var. Teecan Creek.

Indian name reported as "Teecan" in 1908 by IBC surveyors; published in 1914 on IBC Sheet 15 (1918 Atlas). The spelling was changed to "Tikan" in 1914 by the Canadian Geographic Board.

Tikarakh: point of land and village, see Hope, Point and Point Hope.

Tikchik: locality, on N shore of Tikchik Lake, $E$ of Tikchik River and $65 \mathrm{mi}$. N of Dillingham, Kilbuck-Kuskokwim Mts.; 59 59' N, $158^{\circ} 22^{\prime} \mathrm{W}$; (map 52). Var. Tuk-shik-hamut.

Eskimo village reported with a population of 38 by Ivan Petroff in the 10th Census in 1880 ; recorded as "Tuk-shik-ha-mut" on a 1910 manuscript map by H. C. Fassett, USBF.

Tikchik Falls: falls, on Nuyakuk River, $3 \mathrm{mi}$. $\mathrm{E}$ of Tikchik Lake and $63 \mathrm{mi}$. NE of Dillingham, Kilbuck-Kuskokwim Mts.; 59 54' N, $158^{\circ} 08^{\prime} \mathrm{W}$; (map 52 ). 
Local name obtained in 1919 from C. A. Fowler, local inhabitant, by G. L. Harrington, USGS.

Tikchik Lake: lake, extends E $10 \mathrm{mi}$. from Nuyakuk Lake to head of Nuyakuk River, 63 mi. NE of Dillingham, Kilbuck-Kuskokwim Mts. ; $59^{\circ} 56^{\prime} \mathrm{N}, 158^{\circ} 13^{\prime} \mathrm{W}$; $B G N$ 1932; (map 52). Var. Nushagak, Nu-ya-kok, Nu-ya-kok Nun-vuk, Nuyukuk, Tikshik, Tukshik.

Eskimo name reported in 1891 as "Tikshik," variously written "Tikchik" and "Tukshik," by A. B. Schanz in Frank Leslie's Illustrated Newspaper. Ivan Petroff in the 1880 Census recorded the name as "Lake Nushagak, but it may also apply to Lake Beverley." The Eskimo names, "Nu-ya-kok" and "Nuyukuk," appear on a 1910 manuscript map by $H$. C. Fassett, USBF. The name "Tikchik Lake" was adopted because of the long local usage.

Tikchik Lake: lake, see Nuyakuk Lake.

Tikchik Lakes: lakes, seven, $\mathrm{N}$ of Wood River Lakes, extend $45 \mathrm{mi}$. between Nishlik Lake on $\mathrm{N}$ and Nuyakuk Lake on S, $65 \mathrm{mi}$. NW of Dillingham, Kilbuck-Kuskokwim Mts.; $60^{\circ}$ $15^{\prime} \mathrm{N}, 158^{\circ} 59^{\prime} \mathrm{W}$; BGN 1931; (map 60).

Name derived from Tikchik Lake; a descriptive reference name used as early as 1891 .

Tikchik Mountain: mountain, 2,742 ft., $40 \mathrm{mi}$. $\mathrm{W}$ of Sleitat Mtn. and $115 \mathrm{mi}$. SW of Sleetmute, Kilbuck-Kuskokwim Mts., $60^{\circ} 03^{\prime} \mathrm{N}$, $158^{\circ} 16^{\prime} \mathrm{W}$; BGN 1932; (map 60).

Eskimo name reported in 1902 by W. H. Osgood, USDA; "A conspicuous landmark on the right bank of the Nushagak River, near the mouth of Tikchik River."

Tikchik Mountains: mountains, see Wood River Mountains.

Tikchik River: stream, heads in Nishlik Lake, flows SE $45 \mathrm{mi}$. to Tikchik Lake, $65 \mathrm{mi}$. $\mathrm{N}$ of Dillingham, Kilbuck-Kuskokwim Mts.; 59 $59^{\prime}$ N, $158^{\circ} 22^{\prime} \mathrm{W}$; BGN 1932; (map 52). Var. Tikshik River, Tukshik River.

Eskimo name shown on a 1910 manuscript map by H. C. Fassett, USBF, as "Tuk-shik." Originally reported as the name of what is now the Nuyakuk River by A. B. Schanz, a member of the Leslie Expedition in 1890.

Tikeerot: locality, see Tikizat.

Tikeh: point of land, and village, see Hope, Point and Point Hope.

Tikek: point of land, and village, see Hope, Point and Point Hope.

Tikekowac: locality, see Tikekowak.

Tikekowak: locality, on Norton Sound, probably in area of Shorty Cove; (map 91). Var. Tikekowac.

Eskimo village or camp reported in 1890 by E. H. Wells. This may be the same place called "Klikitarik" on present-day maps, although it appears doubtful.

Tikera: point of land, and village, see Hope, Point and Point Hope.

Tikerak: point of land, see Hope, Point.

Tikeramiut: village, see Point Hope.

Tikerana: point of land, and village, see Hope, Point and Point Hope.

Tikeranmeun: village, see Point Hope.
Tikerapak Point: point of land, see Tikaghapuk Point.

Tikhaia Bay: bay, see Still Harbor.

Tikhaia Islands: islands, $0.7 \mathrm{mi}$. across, at mouth of Still Harbor, on SW coast of Baranof I., Alex Arch.; 56 $33^{\prime} 30^{\prime \prime} \mathrm{N}, 135^{\circ} 03^{\prime} 00^{\prime \prime} \mathrm{W}$; BGN 1926; (map 5).

Russian name "tikhaya," meaning "still," given in 1925 by USC\&GS; taken from the original Russian name for "Still Harbor."

Tikhaya, Gavan: bay, see Still Harbor.

Tik Hill: cinder cone, $572 \mathrm{ft}$., in Ingakslugwat Hills, $8.5 \mathrm{mi}$. $\mathrm{N}$ of Aropuk Lake, YukonKuskokwim Delta; $61^{\circ} 21^{\prime}$ N, $163^{\circ} 50^{\prime} \mathrm{W}$; (map 74).

Eskimo name, meaning "rectum," published by USGS in 1966.

Tikhiniak: island, see Simeonof Island.

Tikigaruk Point: point of land, on $\mathrm{W}$ shore of Elson Lagoon, $S$ point of entrance to Central Marsh Slough, $5 \mathrm{mi}$. NE of Barrow, Arctic Plain; $71^{\circ} 18^{\prime} 40^{\prime \prime} \mathrm{N}, 156^{\circ} 32^{\prime} 50^{\prime \prime} \mathrm{W}$; (map 153).

Eskimo name recorded by USC\&GS in 1950 and reported to mean "big finger."

Tikigasukruk Point: point of land, see Tekegakrok Point.

Tikighapak Cape: point of land, see Tikaghapuk Point.

Tikighapak Cape: point of land, see Vngyat Point.

Tikighpat Cape: point of land, see Tikaghapuk Point.

Tikigiluk River: stream, see Tikikluk Creek.

Tikigiuk River: stream, see Tikikluk Creek.

Tikikluk: village, see Meade River.

Tikikluk Creek: stream, flows NW $20 \mathrm{mi}$. to Nigisaktuvik River, $7 \mathrm{mi}$. W of village of Meade River, Arctic Plain; $70^{\circ} 27^{\prime} 15^{\prime \prime} \mathrm{N}$, $157^{\circ} 42^{\prime} 00^{\prime \prime}$ W ; (map 147). Var. Tikigiluk River, Tikigiuk River.

Eskimo name meaning "bad finger"; shown on 1923 fieldsheet by E. C. Guerin, USGS, as "Tikigluk River."

Tikilook: village, see Meade River.

Tikiluk: village, see Meade River.

Tikiqaq: point of land, and village, see Hope, Point and Point Hope.

Tikira: point of land, and village, see Hope, Point and Point Hope.

Tikirah: point of land, and village, see Hope, Point and Point Hope.

Tikirahmun: village, see Point Hope.

Tikirak: point of land, and village, see Hope, Point and Point Hope.

Tikirat: point of land, and village, see Hope, Point and Point Hope.

Tikirat: locality, see Tikizat.

Tikizaat: locality, see Tikizat.

Tikizat: locality, on Chukchi Sea Coast at $N$ end of Krusenstern Lagoon, $5 \mathrm{mi}$. NE of Cape Krusenstern, Kotzebue-Kobuk Low.; 6712' $\mathrm{N}, 163^{\circ} 39^{\prime} \mathrm{W}$; (map 128). Var. Tee-keezaht-meuts, Tikeerot, Tikirat, Tikizaat.

Eskimo camp or shelter cabin; the name, according to E. S. Burch, means "other sides of the bend" referring to two vaguely defined areas near Cape Krusenstern. When one is traveling north "Tikizat" is any place just to the north of the cape that can be considered "the other side." When traveling south from Kivalina, the reverse is true. Ivan Petroff, in the 1880 Census, applied the name to a camp or settlement near the cape with a population of 75 .

Tikkerak: point of land and village, see Hope, Point and Point Hope.

Tikmiakpalik Creek: stream, flows NE $3 \mathrm{mi}$. to Okokmilaga River, $6.3 \mathrm{mi}$. $\mathrm{S}$ of mouth of Fire Creek, Brooks Ra.; $68^{\circ} 22^{\prime} \mathrm{N}, 153^{\circ} 06^{\prime} \mathrm{W}$; (map 133).

Eskimo name for "golden eagle's nest," obtained in 1956 at Anaktuvuk Pass by T. E. Taylor, USGS.

Tikshik: lake, see Tikchik Lake.

Tikshik River: stream, see Tikchik River.

Tikudasetzk: stream, see Ludaseska Creek.

Tikugha Cape: point of land, see Tikugha Point.

Tikugha Point: point of land, $15 \mathrm{mi}$. SW of Savoonga, N Coast of St. Lawrence I.; $63^{\circ} 35^{\prime}$ N, 170 53' W; BGN 1951; (map 93). Var. Cape Kagh-Kasalik, Cape Kagh-Kasslik, Kangea, Tigugha Point, Tikugha Cape.

Eskimo name meaning "pointer" [tikara], reported in 1949 by Maj. H. B. Allen, USAF. Tilhini Creek: stream, see Salmon Creek.

Till Creek: stream, flows W $9.5 \mathrm{mi}$. to John River, $20 \mathrm{mi}$. NE of Sillyasheen Mtn. and 67 mi. NW of Wiseman, Brooks Ra.; 67 $58^{\prime} 30^{\prime \prime}$ $\mathrm{N}, 152^{\circ} 09^{\prime} 00^{\prime \prime} \mathrm{W}$; (map 124).

Local name reported about 1930 by Marshall (1956, map).

Tillman Mountain: mountain, see Wrangell, Mount.

Till Valley: ravine, extends NW 2 mi., on Granite Mtn., W of Rhoades Creek, $18 \mathrm{mi}$. SE of Delta Junction, Alaska Ra.; $63^{\circ} 48^{\prime \prime} 00^{\prime \prime}$ $\mathrm{N}, 145^{\circ} 28^{\prime} 30^{\prime \prime} \mathrm{W}$; (map 86).

Named between 1948 and 1955 by T. L. Péwé, USGS.

Tilman, Point: bluff, elev. 1,000 ft., on S bank of Yukon River, $17 \mathrm{mi}$. E of Tanana, YukonTanana High.; $65^{\circ} 10^{\prime} 30^{\prime \prime} \mathrm{N}, 151^{\circ} 29^{\prime} 00^{\prime \prime} \mathrm{W}$; (map 106).

Riverboat pilots' name shown on a Yukon River track chart manuscript dated 1906.

Tilounan Naivak: lagoon, see Kiloknak Lagoon.

Tilted Hills: ridge, extends NE $22 \mathrm{mi}$. from Iniskin Bay to Chinitna Bay, on $\mathrm{W}$ shore of Cook Inlet, Aleutian Ra.; $59^{\circ} 50^{\prime} \mathrm{N}, 153^{\circ} 00^{\prime}$ $\mathrm{W}$; [NE end], $59^{\circ} 39^{\prime} \mathrm{N}, 153^{\circ} 25^{\prime} \mathrm{W}$ [SW end]; BGN 1963; (map 51).

So named in 1903 by G. C. Martin (1905, pl. 4), USGS, because the beds of resistant rock tilt to the SE. In the 1950's the name was applied to another ridge 6 miles to the west; the error was corrected in 1963 by R. L. Detterman, USGS.

Timber Cove: cove, see Anchor Cove.

Timber Creek: stream, flows NW $16 \mathrm{mi}$. to Aniak River, $34 \mathrm{mi}$. SE of Aniak, KilbuckKuskokwim Mts. ; $61^{\circ} 07^{\prime} \mathrm{N}, 159^{\circ} 08^{\prime} \mathrm{W} ; B G N$ 1948; (map 73).

Prospectors' name reported by USGS in 1919. 
Timber Creek: stream, flows NW $6.3 \mathrm{mi}$. to Styx River $3.2 \mathrm{mi}$. SE of that streams junc. with South Fork Kuskokwim River, $86 \mathrm{mi}$. NW of Tyonek, Alaska Ra.; 61 $53^{\prime} 20^{\prime \prime} \mathrm{N}, 153^{\circ} 06^{\prime}$ $30^{\prime \prime} \mathrm{W}$; (map 71).

This name reported in 1926 by S. R. Capps and $\mathrm{K}$. W. Trimble, USGS, "because it was the first timber met on the west side of the divide."

Timber Creek: stream, flows N $15 \mathrm{mi}$. to Iditarod River, $3.3 \mathrm{mi}$. SE of Swinging Dome and $13 \mathrm{mi}$. SW of Flat, Kilbuck-Kuskokwim Mts.; $62^{\circ} 17^{\prime} 30^{\prime \prime} \mathrm{N}, 158^{\circ} 13^{\prime} 30^{\prime \prime} \mathrm{W}$; BGN 1945; (map 79).

Local name obtained in 1944 by USGS.

Timber Creek: stream, heads NW of Sikonsina Pass, flows NE $8.5 \mathrm{mi}$. to Tok River $8.5 \mathrm{mi}$. W of junc. of Little Tok River, $24 \mathrm{mi}$. SW of Tok, Alaska Ra.; $63^{\circ} 07^{\prime} \mathrm{N}, 143^{\circ} 37^{\prime} \mathrm{W}$; (map 85).

Local name published by USGS in 1964 .

Timber Creek: stream, flows NW $11 \mathrm{mi}$. to Poorman Creek, $3.7 \mathrm{mi}$. SW of Poorman and $47 \mathrm{mi}$. SW of Ruby, Kilbuck-Kuskokwim

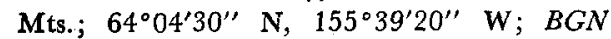
1936; (map 98).

Prospectors' name reported in 1913 by Eakin (1914, pl. 3), USGS.

Timber Creek: stream, flows N $6 \mathrm{mi}$. to Koyuk River, $10 \mathrm{mi}$. S of Kiwalik Mtn. and $32 \mathrm{mi}$. SE of Imuruk Lake, Seward Penin, High.; $65^{\circ} 21^{\prime} \mathrm{N}, 162^{\circ} 15^{\prime} \mathrm{W}$; (map 110 ).

Prospectors' name reported in 1903 by D. C. Witherspoon (in Moffit, 1905, pl. 2), USGS.

Timber Creek: stream, flows S $21 \mathrm{mi}$. to John River, 52 mi. SW of Wiseman, Brooks Ra.; $67^{\circ} 04^{\prime} \mathrm{N}, 151^{\circ} 50^{\prime} \mathrm{W}$; (map 124).

Local name reported in 1909 by Maddren (1910, pl. 7) USGS.

Timber Creek: stream, in Baird Mts., flows SW $28 \mathrm{mi}$. to Squirrel River, $13 \mathrm{mi}$. NW of Kiana, Brooks Ra.; $67^{\circ} 07^{\prime} 15^{\prime \prime}$ N, $160^{\circ} 44^{\prime} 15^{\prime \prime} \mathrm{W}$; (map 127).

Name used by prospectors; reported in 1910 by P. S. Smith (in Brooks and others, 1911, pl. 13), USGS.

Timber Creek: stream, flows E $10 \mathrm{mi}$. to Christian River $10 \mathrm{mi}$. NW of Christian, Brooks Ra.; $67^{\circ} 28^{\prime} \mathrm{N}, 145^{\circ} 22^{\prime} \mathrm{W}$; (map 122).

Local name reported in 1956 by T. E. Taylor, USGS.

Timbered Island: island, $0.3 \mathrm{mi}$. long, in Iphigenia Bay, $7 \mathrm{mi}$. NW of St. Joseph I., Alex. Arch.; $55^{\circ} 41^{\prime} 45^{\prime \prime} \mathrm{N}, 133^{\circ} 48^{\prime} 00^{\prime \prime} \mathrm{W}$; (map 4). Var. Timbered Islet.

Descriptive name published in 1906 by USG\&GS as "Timbered Islet."

Timbered Islet: island, see Timbered Island.

Timber Gulch: ravine, somewhere along Sheep Creek, about $5 \mathrm{mi}$. SE of Juneau, Coast Mts.; $58^{\circ} 16^{\prime} \mathrm{N}, 134^{\circ} 19^{\prime} \mathrm{W}$; (map 11).

Miners' name reported by R. N. DeArmond (1957, p. 39).

Timber Knob: mountain, 1,551 ft., SW Heceta I., Alex. Arch.; 55 $44^{\prime} 45^{\prime \prime} \mathrm{N}, 133^{\circ} 34^{\prime} 10^{\prime \prime} \mathrm{W}$; (map 4).

Descriptive name given in 1903 or 1904 by
E. F. Dickins, USC\&GS, who wrote "named by our party, has no local name."

Timber Lake: lake, between Happy Slough and Tom Cook Slough, $21 \mathrm{mi}$. NE of Roundabout Mtn., Koyukuk Low.; $65^{\circ} 50^{\prime} \mathrm{N}, 156^{\circ} 27^{\prime} \mathrm{W}$; (map 108).

Local name obtained at Huslia by USGS in 1954 or 1955.

Timber Lake: lake, $1.2 \mathrm{mi}$. long, $3 \mathrm{mi}$. $\mathrm{N}$ of Portage Lake and $29 \mathrm{mi}$. NW of Arctic Village, Brooks Ra.; $68^{\circ} 23^{\prime} \mathrm{N}, 146^{\circ} 27^{\prime} \mathrm{W}$; (map 136).

Local name reported in 1956 by $R$. C. Foley, USGS.

Timberline Creek: stream, on Kenai Penin., flows NW $4 \mathrm{mi}$. to Mills Creek, $18 \mathrm{mi}$. S of Sunrise, Chugach Mts.; $60^{\circ} 39^{\prime} 00^{\prime \prime} \mathrm{N}, 149^{\circ}$ $24^{\prime} 45^{\prime \prime} \mathrm{W}$; (map 63$)$.

Local name reported in 1952 by USGS.

Timberline Creek: stream, flows NW $3.5 \mathrm{mi}$. to Valdez Creek, $67 \mathrm{mi}$. SE of Healy, Alaska $\mathrm{Ra}$; $63^{\circ} 11^{\prime} \mathrm{N}, 147^{\circ} 35^{\prime} \mathrm{W}$; (map 87).

Local descriptive name reported in 1910 by Moffit (in Brooks, 1911, fig. 15), USGS.

Timberline Lake: lake, $0.4 \mathrm{mi}$. long, on Kenai Penin., in Kenai Mts., $7 \mathrm{mi}$. E of Tustumena Lake, $30 \mathrm{mi}$. SE of Kenai, Chugach Mts.; $60^{\circ} 14^{\prime} 30^{\prime \prime} \mathrm{N}, 150^{\circ} 34^{\prime} 30^{\prime \prime} \mathrm{W}$; (map 62).

Named about 1963 by officials of Kenai National Moose Range, for administrative purposes.

Timberlost Lake: lake, $1.1 \mathrm{mi}$. long, on Kenai Penin., 11 mi. NE of Kenai, Cook Inlet Low.; $60^{\circ} 42^{\prime} \mathrm{N}, 151^{\circ} 08^{\prime} \mathrm{W} ; B G N$ 1960; (map 62).

Named in 1959 by Stanley F. Thompson, a homesteader on the lake, "because the lake shore is caving in, allowing the trees to fall into the water."

Timber Point: point of land, between Hodzana Slough and Yukon River, $16 \mathrm{mi}$. SW of Beaver, Yukon Flats; $66^{\circ} 14^{\prime} \mathrm{N}, 147^{\circ} 55^{\prime} \mathrm{W}$; (map 118).

Local descriptive name obtained in 1956 by USGS.

Tina Creek: stream, see Mascot Creek.

Tina Lake: lake, 1,200 ft. long, $1.3 \mathrm{mi}$. NW of junc, of Campbell and Little Campbell Creeks, $3.5 \mathrm{mi}$. S of Anchorage, Cook Inlet Low.; $61^{\circ} 10^{\prime} 00^{\prime \prime} \mathrm{N}, 149^{\circ} 53^{\prime} 20^{\prime \prime} \mathrm{W}$; (map 69).

Local name reported in 1942 by USGS.

Tinast: stream, see Chisana River.

Tinayguk River: stream, flows $W$ and SE 44 mi. to North Fork Koyukuk River, $3 \mathrm{mi}$. S of Eroded Mtn. and $27 \mathrm{mi}$. NW of Wiseman, Brooks Ra.; 67 $34^{\prime} 15^{\prime \prime}$ N, $151^{\circ} 01^{\prime} 15^{\prime \prime} \mathrm{W}$; $B G N$ 1932; (map 124). Var. West Fork Koyukuk River.

In 1930 Robert Marshall recommended "tinayguk," the Eskimo word for moose, for the name of this stream because of the abundance of these animals in the area. In his recommendation he noted a limited local use of the name "West Fork," a term he felt was already too commonly used.

Tincan Creek: stream, on N end of Kenai Penin., flows NW $5 \mathrm{mi}$. to Granite Creek, $10 \mathrm{mi}$. SE of Sunrise, Chugach Mts.; $60^{\circ} 46^{\prime} 45^{\prime \prime} \mathrm{N}$, $149^{\circ} 13^{\prime} 50^{\prime \prime} \mathrm{W}$; (map 63).

Local name reported in 1912 by Grant and Higgins (1913, pl. 1), USGS.

Tincan Lake: lake, $1 \mathrm{mi}$. across, at mouth of Lost Creek, $19 \mathrm{mi}$. SW of Beaver, Yukon Flats; $66^{\circ} 10^{\prime} \mathrm{N}, 147^{\circ} 54^{\prime} \mathrm{W}$; (map 118). Var. Tin-Can Lake.

Probably named by William Yanert who recorded it on a 1916 manuscript map of the Yukon Flats (Stuck, 1917, map facing p. 122)

Tin Can Point: point of land, on Yukon Delta, between Caseys Channel and Kwikluak Pass, $13 \mathrm{mi}$. SW of Kwiguk, YukonKuskokwim Delta; $62^{\circ} 36^{\prime} 30^{\prime \prime} \mathrm{N}, 164^{\circ} 46^{\prime}$ 50" W; (map 77). Var. A-gahk-la-rok, Agaklarok.

Local name obtained in 1948 by USC\&GS. The Eskimo name for this point, or locality on the point, is "Agaklarok."

Tin City: village, pop. 10, at mouth of Cape Creek, on Bering Sea Coast, 5 mi. SE of Cape Prince of Wales, Seward Penin. High.; $65^{\circ} 33^{\prime}$ N, $167^{\circ} 51^{\prime} \mathrm{W}$; (map 111).

Former mining camp established at the base of Cape Mountain in 1903 (Collier, 1904, p. 59). Tin ore was discovered on Cape Mountain in July 1902, by Mr. W. C. J. Bartels. * * Extensive developments were planned for the season of 1903 , and a well-equipped prospecting plant was sent to Cape Mountain" (Collier, 1904, p. 25), By 1907 "a few widely scattered houses" formed Tin City (Knopf, 1908, p. 35), and two companies operated out of the village and a 10-stamp mill was located here (p. 40). Tin City post office was established in 1904 and was discontinued in 1909 (Ricks, 1965, p. 65$)$.

Tin Creek: stream, flows N $13 \mathrm{mi}$. to South Fork Kuskokwim River, $1 \mathrm{mi}$. E of Farewell Lake, 72 mi. SE of McGrath, Alaska Ra.; $62^{\circ} 32^{\prime} 40^{\prime \prime} \mathrm{N}, 153^{\circ} 35^{\prime} 10^{\prime \prime} \mathrm{W}$; (map 80).

Locally so called "because of tin ore [cassiterite?] found along this stream." Name reported in 1958 by USGS.

Tin Creek: stream, flows NE $13 \mathrm{mi}$. to Shishmaref Inlet, $10 \mathrm{mi}$. $\mathrm{S}$ of Shishmaref, KotzebueKobuk Low.; $66^{\circ} 07^{\prime} \mathrm{N}, 166^{\circ} 04^{\prime} \mathrm{W}$; (map 112).

Prospectors' name reported in 1908 by Knopf (1908, fig. 2), USGS.

Tin Creek: stream, in York Mts., flows SW 3.5 mi. to Lost River $27 \mathrm{mi}$. NW of Teller, Seward Penin. High.; $65^{\circ} 27^{\prime} \mathrm{N}, 167^{\circ} 11^{\prime} \mathrm{W}$; (map 111).

Prospectors' name reported in 1903 by Collier (1904, pl. 2), USGS. Named for the occurrence of tin ore in the area.

Tindestak: locality, see Gantegastaki.

Tindir Creek: stream, heads in Canada, flows NW across Alaska-Canada boundary $22 \mathrm{mi}$. to Nation River, $19 \mathrm{mi}$. NE of that stream's junc. with Yukon River and $45 \mathrm{mi}$. N of Eagle, Porcupine Plat.; $65^{\circ} 25^{\prime} 30^{\prime \prime} \mathrm{N}, 141^{\circ}$ 23'00' W; BGN 1912; (map 103). 
Named in 1910 by IBC survey and reported by Thomas Riggs, of the survey, to be an Indian word meaning "moose."

Tine Lake: lake, $0.4 \mathrm{mi}$. long, on Kenai Penin., W of Snowshoe Lake, $33 \mathrm{mi}$. NE of Kenai, Cook Inlet Low.; $60^{\circ} 46^{\prime} 10^{\prime \prime} \mathrm{N}, 150^{\circ} 25^{\prime} 00^{\prime \prime}$ W; (map 62).

Named about 1963 by officials of Kenai National Moose Range, for administrative purposes.

Tingberg Island: island, $0.2 \mathrm{mi}$. long, $\mathrm{W}$ of Nakat Bay, off NW coast of Kauaganut I., Coast Mts.; $54^{\circ} 45^{\prime} 30^{\prime \prime} \mathrm{N}, 130^{\circ} 44^{\prime} 30^{\prime \prime} \mathrm{W}$; $B G N$ 1937; (map 2).

Named in 1936 by USC\&GS for C. E. Tingberg, a member of the crew of the U.S.S. Hassler, which made the first surveys in this area for USC\&GS in 1883.

Tingmeachsiovik: stream, see Inigok Creek.

Tingmeachsiovik River: stream, distributary of Fish Creek, flows NE $10 \mathrm{mi}$. to Harrison Bay, W of Colville River Delta, Arctic Plain; $70^{\circ}$ $25^{\prime} \mathrm{N}, 151^{\circ} 22^{\prime} \mathrm{W}$; (map 149).

Eskimo name reported in 1951 by USC\&GS.

Tingmerkpuk Mountain: mountain, 3,787 ft., in De Long Mts., $30 \mathrm{mi}$. ENE of Mount Kelly, Brooks Ra.; 68 $33^{\prime} 45^{\prime \prime} \mathrm{N}, 162^{\circ} 28^{\prime} 00^{\prime \prime} \mathrm{W}$; (map 130).

Named by USGS in 1926 . See Tingmerkpuk River.

Tingmerkpuk River: stream, in De Long Mts.. flows NE $27.5 \mathrm{mi}$. to Kokolik River, $\mathrm{E}$ of Tingmerkpuk Mtn., $8 \mathrm{mi}$. E of Poko Mtn. and $44.5 \mathrm{mi}$. NE of Mount Kelly, Brooks Ra.; $68^{\circ} 47^{\prime} 30^{\prime \prime} \mathrm{N}, 162^{\circ} 04^{\prime} 30^{\prime \prime} \mathrm{W}$; (map 130).

Eskimo name for the American Golden Eagle (Aquila chrysaetos canadensis), shown on a 1926 fieldsheet by Gerald FitzGerald, USGS. The Eskimo name means "largest bird [tingmiakpak]."

Tingook Ridge: ridge, see Tinguk Ridge.

Tingo Shugarum: locality, see Pingoshugarun. Tingowaiak Island: island, see Boulder Shoals.

Tinguk Ridge: ridge, $600 \mathrm{ft}$., extends $4.5 \mathrm{mi}$. along $\mathrm{E}$ bank of Mapsorak Creek, $18 \mathrm{mi}$. SE of Cape Thompson, Arctic Slope; $68^{\circ} 07^{\prime} \mathrm{N}$, $165^{\circ} 17^{\prime}$ W; BGN 1963; (map 129). Var. Tingook Ridge.

Eskimo name meaning "liver [tinguq]" reported in 1950 by USC\&GS as "Ting-ook."

Tin Gulch: ravine, extends SW $0.7 \mathrm{mi}$. to Buck Creek, in Mint River basin, $2 \mathrm{mi}$. ESE of Potato Mtn. and $17 \mathrm{mi}$. NE of Cape Prince of Wales, Seward Penin. High.; 65 ${ }^{\circ} 28^{\prime} 30^{\prime \prime}$ N, $167^{\circ} 30^{\prime} 30^{\prime \prime} \mathrm{W}$; (map 111).

Prospectors' name reported in 1918 by Steidtmann and Cathcart (1922, fig. 14), USGS.

Tinhorn Gulch: ravine, extends NE $1.5 \mathrm{mi}$. to Greenhorn Gulch, $39 \mathrm{mi}$. SW of Circle, Yukon-Tanana High.; $65^{\circ} 26^{\prime} 50^{\prime \prime} \mathrm{N}, 145^{\circ} 04^{\prime}$ $10^{\prime \prime} \mathrm{W}$; (map 104).

Named by prospectors; reported in 1896 by Spurr (1898, pl. 50), USGS.

Tinjik Lake: lake, $0.9 \mathrm{mi}$. long, $1 \mathrm{mi}$. SW of Below Tree Lake and $14 \mathrm{mi}$. NE of Arctic
Village, Brooks Ra.; $68^{\circ} 19^{\prime} \mathrm{N}, 145^{\circ} 19^{\prime} \mathrm{W}$; (map 136).

Kutchin Indian name obtained at Arctic Village in 1956 by T. E. Taylor, USGS.

Tinjikvun Lake: lake, $0.6 \mathrm{mi}$. across, $6 \mathrm{mi}$. NW of Venetie and $40 \mathrm{mi}$. SW of Christian, Yukon Flats.; 67 $06^{\prime} \mathrm{N}, 146^{\circ} 32^{\prime} \mathrm{W}$; (map 122).

Kutcha-kutchin Indian name obtained in. 1956 by T. E. Taylor, USGS.

Tin Kettle Creek: stream, flows NE $2.5 \mathrm{mi}$. to Franklin Creek, $48 \mathrm{mi}$. SW of Eagle, YukonTanana High.; $64^{\circ} 10^{\prime} \mathrm{N}, 141^{\circ} 48^{\prime} \mathrm{W}$; (map 102).

Named by prospectors and reported in 1903 by Prindle (1905, pl. 16), USGS.

Tinnas Creek: stream, see Tenas Creek.

Tinplate Hill: hill, 3,440 ft., between Skolai Creek and Nizina Glacier, $24 \mathrm{mi}$. NE of McCarthy, Wrangell Mts.; $61^{\circ} 40^{\prime} 00^{\prime \prime} \mathrm{N}, 142^{\circ} 24^{\prime}$ 30" W; (map 67).

Local name obtained by USGS and published on maps since 1954 .

Tiny Island: island, $0.8 \mathrm{mi}$. long, between Devils Cove and Kukak Bay, on E coast of Alaska Penin., in Katmai National Monument, 30 mi. NE of Mount Katmai, Aleutian Ra.; $58^{\circ}$ $20^{\prime} 15^{\prime \prime} \mathrm{N}, 154^{\circ} 10^{\prime} 00^{\prime \prime} \mathrm{W}$; (map 42).

Local descriptive name; reported in 1951 by USGS.

Tiny Island: island, $2 \mathrm{mi}$. long, in Dease Inlet, one of Kikiktak Is., $32 \mathrm{mi}$. SE of Barrow, Arctic Plain; $71^{\circ} 00^{\prime} 30^{\prime \prime} \mathrm{N}, 155^{\circ} 36^{\prime} 00^{\prime \prime} \mathrm{W}$; (map 153).

The origin of the name is unknown, but it appears to have been first used on Brit. Adm. charts compiled between 1843 and 1855 .

Tiochpit Mountain: mountain, see Tiokpit Mountain.

Tiokpit Mountain: mountain, 2,000 ft., $3 \mathrm{mi}$. N of junc. of Paiyun Creek and Kanektok River and $72 \mathrm{mi}$. NE of Goodnews, Kilbuck-Kuskokwim Mts.; $59^{\circ} 56^{\prime} \mathrm{N}, 160^{\circ} 22^{\prime} \mathrm{W}$; (map 53). Var. Tiochpit Mountain.

Eskimo name published by J. E. Spurr and W. S. Post (in Spurr, 1900, map 10), USGS.

Tip Creek: stream, flows NE $9 \mathrm{mi}$. to Flint Creek, $18 \mathrm{mi}$. NE of Long, Nowitna Low. ; $64^{\circ} 29^{\prime} \mathrm{N}$, $154^{\circ} 55^{\prime} \mathrm{W}$; (map 98).

Prospectors' name reported in 1912 by Eakin (in Brooks and others, 1913, pl. 10), USGS.

Tiplighak Bay: bay, see Tiflighak Bay.

Tipooktulearuk River: stream, flows S $19 \mathrm{mi}$. to Inglutalik River, $23 \mathrm{mi}$. SE of Haycock, Nulato Hills; $65^{\circ} 00^{\prime} \mathrm{N}, 160^{\circ} 33^{\prime} \mathrm{W}$; (map 109).

Eskimo name reported by the U.S. Army Corps of Engineers in 1949.

Tipping Point: point of land, W tip of Perry I., of $\mathrm{E}$ side of Perry Passage, 22 mi ESE of Whittier, Chugach Mts.; $60^{\circ} 43^{\prime} 30^{\prime \prime} \mathrm{N}$, $148^{\circ} 01^{\prime} 05^{\prime \prime} \mathrm{W}$; (map 63$)$.

Local name reported in 1952 by USGS.

Tired Mountain: mountain, $2,575 \mathrm{ft}$., on Annette I., $5 \mathrm{mi}$. NE of Metlakatla, Alex. Arch.; $55^{\circ} 10^{\prime} 08^{\prime \prime} \mathrm{N}, 131^{\circ} 28^{\prime} 00^{\prime \prime} \mathrm{W}$; (map 3).

Named in 1883 by Lt. Comdr. H. E. Nichols, USN.
Tired Pup Creek: stream, heads at Tired Pup Glacier terminus, flows SE $14 \mathrm{mi}$. to Stony River $21 \mathrm{mi}$. NE of junc. of Necons River, 62 mi. N of Lake Clark, Alaska Ra.; 61 ${ }^{\circ} 17^{\prime} \mathrm{N}$, $153^{\circ} 47^{\prime} \mathrm{W}$; (map 71).

Name shown on a 1907 manuscript map probably done by a prospector.

Tired Pup Glacier: glacier, extends NW $5.5 \mathrm{mi}$. at head of Tired Pup Creek, $4.5 \mathrm{mi}$. SW of Mount Mausolus and $75 \mathrm{mi}$. N of Lake Clark, Alaska Ra.; $61^{\circ} 30^{\prime} \mathrm{N}, 153^{\circ} 56^{\prime} \mathrm{W}$; (map 71).

Named in 1956 by Orth.

Tishdogatumina Lake: lake, $1.8 \mathrm{mi}$. long, $1 \mathrm{mi}$. $W$ of Echoing Lake and $20 \mathrm{mi}$. NW of Stevens Village, Yukon Flats; $66^{\circ} 17^{\prime} \mathrm{N}$, $149^{\circ} 23^{\prime} \mathrm{W}$; (map 118).

Kutchin Indian name obtained in 1956 by T. E. Taylor, USGS.

Tishou River: stream, see Tisuk River.

Tiskeet Lake: lake, in Koyukuk River flats, 26 mi. SW of Roundabout Min., Koyukuk Low; $65^{\circ} 26^{\prime} \mathrm{N}, 157^{\circ} 25^{\prime} \mathrm{W}$; (map 108).

Koyukan Indian name reported by USGS, in 1955.

Tisku River: stream, see Tsirku River.

Tissook River: stream, see Tisuk River.

Tisuk River: stream, flows W $22 \mathrm{mi}$. to Bering Sea, $11 \mathrm{mi}$. SE of Cape Douglas and 40 mi. NW of Nome, Seward Penin. High.; $64^{\circ} 53^{\prime} \mathrm{N}, 166^{\circ} 24^{\prime} \mathrm{W}$; (map 94). Var. Tishou River, Tissook River.

Eskimo name reported in 1900 as "Tisuk" by E. C. Barnard (in Brooks, 1901, pl. 17), USGS.

Titaluk River: stream, heads at $69^{\circ} 23^{\prime} \mathrm{N}$, $157^{\circ} 11^{\prime} \mathrm{W}$, flows NE $180 \mathrm{mi}$. to Ikpikpuk River, Arctic Plain; $69^{\circ} 57^{\prime} \mathrm{N}, 154^{\circ} 44^{\prime} \mathrm{W}$; $B G N$ 1925; (map 142). Var. Teetaluk River, Teiteluk River.

Named in 1924 by USGS; derived from the Eskimo name of a fish caught by Ens. W. $L$. Howard in June 1886. "Caught our first fish; native name Tee-tal-uk, scientific name, Lota marculosa" (Stoney, 1900, p. 74).

Titarlilik Lake: lake, see Etivlik Lake.

Titcliff Island: island, $0.5 \mathrm{mi}$. long, in Wide Bay, $\mathbf{N}$ of Cape Kayakliut, on $\mathbf{S}$ coast of Alaska Penin., $43 \mathrm{mi}$. SE of Ugashik, Aleutian Ra.; $57^{\circ} 19^{\prime} 45^{\prime \prime} \mathrm{N}, 156^{\circ} 20^{\prime} 10^{\prime \prime} \mathrm{W}$; (map 36).

Named in 1923 by USC\&GS and published in the 1925 supplement to the 1916 Coast Pilot (p. 157).

Tithe Creek: stream, flows $S 10 \mathrm{mi}$. to Kanik River, $38 \mathrm{mi}$. W of Dillingham, Kilbuck-Kuskokwim Mts; $58^{\circ} 59^{\prime} 30^{\prime \prime} \mathrm{N}, 159^{\circ} 31^{\prime} 30^{\prime \prime} \mathrm{W}$; (map 40).

Local name reported in 1951 by USGS.

Titley Creek: stream, flows SE to Pargon River, $15 \mathrm{mi}$. E of Council, Seward Penin. High.; (map 110).

Prospectors' name recorded on the 1900 "Map of Nome Peninsula" by J. M. Davidson and B. D. Blakeslee. This stream has not been positively identified.

Titna River: stream, heads on Sischu Mtn., flows W $80 \mathrm{mi}$. to Nowitna River, $31 \mathrm{mi}$. SE of Monzonite Hills, Kilbuck-Kuskokwim Mts.; 
$64^{\circ} 22^{\prime} \mathrm{N}, 153^{\circ} 38^{\prime} \mathrm{W}$; (map 98).

Local name reported in 1915 by $H$. $M$. Eakin (in Brooks and others, 1916, pl. 10), USGS.

Titnuk Creek: stream, flows N $45 \mathrm{mi}$. to Holitna River, $25 \mathrm{mi}$. S of Sleetmute, Stony River Low.; $61^{\circ} 21^{\prime} \mathrm{N}, 157^{\circ} 03^{\prime} \mathrm{W}$ : BGN 1948; (map 72).

Eskimo name reported in 1945 by USGS.

Tittmann, Mount: peak, 9,400 ft., at head of Tittmann Glacier, $56 \mathrm{mi}$. SE of McCarthy, St. Elias Mts.: $B G N 1917 ; 61^{\circ} 07^{\prime} \mathrm{N}, 141^{\circ}$ $13^{\prime} \mathrm{W}$; (map 67).

Sce Tittmann Glacier.

Tittmann Glacier: glacier, heads on Mount Tittmann and trends $7 \mathrm{mi}$. SE to Anderson Glacier, $3 \mathrm{mi}$. W of Alaska-Canada boundary and 65 mi. SE of McCarthy, St. Elias Mts.; $B G N$ $1917 ; 61^{\circ} 07^{\prime} \mathrm{N}, 141^{\circ} 05^{\prime} \mathrm{W}$; (map 67).

Named for Dr. Otto Hilgard Tittman, 1850-1938, former International Boundary Commissioner for the U.S.

Titukilsk: locality, see Nikishka No. 3.

Titus Creek: stream, heads on Titus Mtn., flows SE $20 \mathrm{mi}$. to Koness River, $26 \mathrm{mi}$. SE of Arctic Village, Brooks Ra.; $68^{\circ} 01^{\prime} 45^{\prime \prime} \mathrm{N}$,

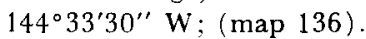

Local name reported in 1956 by $R$. C. Foley, USGS.

Titus Island: island, $0.4 \mathrm{mi}$. long, in Halthmund Lake, $11 \mathrm{mi}$. W of Northway, Alaska Ra.; $62^{\circ} 58^{\prime} \mathrm{N}, 142^{\circ} 19^{\prime} \mathrm{W}$; (map 84).

Locai name reported in 1962 by USGS, so named because for years it has been claimed by the Titus clan of Indians as its trapping grounds.

Titus Lakes: lakes, group, extends $2.5 \mathrm{mi}$. SE of Titus Paul Hill, W of Kalutna River, 25 mi. SE of Tok, Yukon-Tanana High.; $63^{\circ}$ $05^{\prime} 30^{\prime \prime} \mathrm{N}, 142^{\circ} 21^{\prime} 00^{\prime \prime} \mathrm{W}$; (map 85).

Local name published by USGS in 1965. The lakes are considered the fishing grounds of the Titus clan of Indians.

Titus Mountain: peak, 5,307 ft., at head of Titus Creek, $17 \mathrm{mi}$. NE of Arctic Village, Brooks Ra.; $68^{\circ} 26^{\prime} 30^{\prime \prime} \mathrm{N}, 144^{\circ} 56^{\prime} 30^{\prime \prime} \mathrm{W}$; (map 136).

Local name shown on a 1926 field sheet by Gerald FitzGerald, USGS.

Titus Paul Hill: hill, 2,113 ft., $8.3 \mathrm{mi}$. $E$ of Tetlin Lake, $23 \mathrm{mi}$. SE of Tok, Alaska Ra.: $63^{\circ} 07^{\prime} \mathrm{N}, 142^{\circ} 24^{\prime} \mathrm{W}$; (map 85$)$.

Local name reported by USGS in 1963. Probably named for one of the Titus Indian chiefs.

Tiunok: village, sec Tyonek.

Tiurpa Island: island, $0.5 \mathrm{mi}$. long, in Necker Is., on $W$ coast of Baranof I., Alex. Arch.; $56^{\circ} 48^{\prime} 50^{\prime \prime} \mathrm{N}, 135^{\circ} 25^{\prime} 00^{\prime \prime} \mathrm{W}$; (map 5) Var. Ostrov Tyurpa.

Named in 1809 by the Russian navigator, Ivan Vasiliev the first; published by Lt. Sarichev (1826, map 19), IRN, as "O[strov] Tyurpa," or "Tyurpa Island."

Tivehvun Lake: lake, $2 \mathrm{mi}$. long, $3 \mathrm{mi}$. $\mathrm{N}$ of Shovun Lake and $19 \mathrm{mi}$. NW of Fort Yukon, Yukon Flats; $66^{\circ} 50^{\prime} \mathrm{N}, 145^{\circ} 22^{\prime} \mathrm{W}$; (map 119).
Kutchin Indian name obtained in 1956 by T. E. Taylor, USGS.

Tivlarak Bay: bight, see Dovelawik Bay.

Tivyagak Creek: stream, flows NW $8 \mathrm{mi}$. to South Fork Goodnews River, $10 \mathrm{mi}$. E of Goodnews, Kilbuck-Kuskokwim Mts.; $59^{\circ}$ $08^{\prime} 45^{\prime \prime} \mathrm{N}, 161^{\circ} 18^{\prime} 30^{\prime \prime} \mathrm{W}$; (map 53).

Eskimo name reported in 1954 by USGS.

Tiyaktalik Mountain: mountain, $1,840 \mathrm{ft}$., in Igichuk Hills $13 \mathrm{mi}$, NE of Cape Krusenstern, Kotzebue-Kobuk Low.; $67^{\circ} 14^{\prime} 30^{\prime \prime} \mathrm{N}, 163^{\circ}$ 19'30" W; (map 128).

Eskimo name meaning "place where the weasel lives" according to USC\&GS in 1950. Tizhgelede: locality, see Tigshelde.

Tizhgelede: village, see Shageluk.

Tiznik: bay, see Chignik Bay.

Tkhalka, Ostrov: island, see Hinchinbrook Island.

Tkhalkhak: stream, see Stony River.

Tklik: locality, on right bank of Yukon River, $26 \mathrm{mi}$. below Andreafsky, near mouth of Azacharum Slough, Yukon-Kuskokwim Delta; $62^{\circ} 14^{\prime} \mathrm{N}, 163^{\circ} 51^{\prime} \mathrm{W} ;$ (map 77). Var. Ta-clik, T'Click.

Former Eskimo village or camp recorded as "Ta-clik," on "Edwards' Track Chart of the Yukon," dated 1899.

Tkok: point of land and village, see Hope, Point and Point Hope.

Tlachkahíniku: stream, see Porcupine Creek.

T Lake: lake, $1.3 \mathrm{mi}$. long, $1 \mathrm{mi}$. SE of Long Lake and $19 \mathrm{mi}$. W of Glennallen, Copper River Basin ; $62^{\circ} 11^{\prime} \mathrm{N}, 146^{\circ} 07^{\prime} \mathrm{W}$; (map 83). Local name published in 1952 by USGS.

T Lake: lake, $1.1 \mathrm{mi}$. long, $\mathrm{N}$ of Billy Creek, $38 \mathrm{mi}$. NW of Tanacross, Yukon-Tanana High.; $63^{\circ} 48^{\prime} \mathrm{N}, 143^{\circ} 53^{\prime} \mathrm{W}$; ( $\operatorname{map} 85$ ).

Local name published by USGS in 1950 . Named because the lake's outline is in the form of a $T$.

Tlakinikut, Point: point of land, see Craven, Point.

Tlanak: locality, "in the Sitka country."

Former Tlingit village or camp published in 1909 by J. R. Swanton, BAE, (Hodge 1910, p. 762).

Tlatek: locality, on right bank of Yukon River, $35 \mathrm{mi}$. above Andreafsky, Yukon-Kuskokwim Delta: $62^{\circ} 00^{\prime} \mathrm{N}, 162^{\circ} 30^{\prime} \mathrm{W}$ : (map 74). Var. Tlatekamat, Tlatekamute.

Former Eskimo village or camp recorded in 1869 as "Tlatekamute" by Capt. Raymond (1871, p. 25).

Tlatekamat: locality, see Tlatek.

Tlatekamute: locality, see Talate.

Tlatekamute: settlement, see Takshak.

Tlatl Hills: range, NE spur of Kaiyuh Mts., extends NE $40 \mathrm{mi}$, between Mud and Little Mud Rivers, $45 \mathrm{mi}$. S of Galena and $50 \mathrm{mi}$. SW of Nulato, Kilbuck-Kuskokwim Mts.; $64^{\circ} 00^{\prime} \mathrm{N}, 157^{\circ} 30^{\prime} \mathrm{W}$; (map 90$)$.

Indian name reported in 1954 by USGS.

Tlatskokot: locality, see Camp Creek.

Tlatsqeqatna: stream, see Ground Surface Slough.

Tlechegn Lake: lake, $1 \mathrm{mi}$. long, E of Kalutna River, between Fish Camp and Tsilchin Lakes,
26 mi. SE of 'Tok, Alaska Ra.; $63^{\circ} 09^{\prime} 30^{\prime \prime} \mathrm{N}$, $142^{\circ} 13^{\prime} 30^{\prime \prime} \mathrm{W}$ : (map 85$)$.

Indian name published by USGS in 1965 . Tlechopcity: water passage, see Tongass Port. Tleekakeela River: stream, see Tlikakila River. Tleekh: island, see Kruzof Island.

Tlegan, Reka: stream, see Tlegan River.

Tlegan River: river, southernmost of five rivers on delta of Alsek River, flows $S$ into Gulf of Alaska, $50 \mathrm{mi}$. SE of Yakutat, Malaspina Coastal Plain; $59^{\circ} 07^{\circ} \mathrm{N}, 138^{\circ} 30^{\prime} \mathrm{W}$; (map 46). Var. Reka Tlegan.

Tlingit Indian name reported by Capt. Tebenkov (1852, map 7), IRN, as "R[eka] Tlegan", or "Tlegan River." This name is not shown on recent maps.

Tlégogitno: village, see Shageluk.

Tlegokokhkakat: locality, see Tleket.

Tlegon: locality, on Innoko River $\mathrm{E}$ of junc. of its North Fork, Kilbuck-Kuskokwim Mts.; $63^{\circ} 48^{\prime} \mathrm{N}, 156^{\circ} 30^{\prime} \mathrm{W}$; (map 90).

Former Indian village reported in 1838 by F. Kolmakov, and $1842-44$ by Lt. L. A. Zagoskin, IRN.

Tlégoshitno: village, see Shageluk.

Tlegozhitno: village, see Shageluk.

Tlegu Beach: beach, $\mathrm{N}$ of Tanani at head of Chilkoot Inlet, $14 \mathrm{mi}$. S of Skagway, Coast Mts. ; $59^{\circ} 16^{\prime} 25^{\prime \prime} \mathrm{N}, 135^{\circ} 26^{\prime} 30^{\prime \prime} \mathrm{W}$; (map 45).

Tlingit Indian name published in 1923 on IBC Sheet 9 (1951 atlas).

Tlehini River: stream, see Klehini River.

Tlehonsiti: water passage, see Tongass Port.

Tleket: locality, on Innoko River, between the junctions of its North Fork and Iditarod River, Innoko Low.; (map 90). Var. Kkholikakat, Tlegokokhkakat, Tlek-et.

In 1842-44 Lt. L. A. Zagoskin reported three Indian villages or camps in this area. They were named Kkholikakat, Tlegokokhkakat, and Tlek-et.

Tlekunuwu Point: point of land, see Lehunua Point.

Tlevach Strait: water passage, see Tlevak Strait. Tlevak, Proliv:water passage, see Tlevak Strait. Tlevak: village, see Klawock.

Tlevakan Bay: water passage, see Tlevak Strait. Tlevakh Inlet: water passage, see Klawak Inlet. Tlevak Inlet: water passage, see Klawak Inlet. Tlevakkhan, Zaliv: water passage, see Klawak Inlet.

Tlevakkhyn Bay: z'ater passage, sec Klawak Inlet.

Tlevak Narrows: water passage, $0.5 \mathrm{mi}$. long, between Dall and Prince of Wales Is., in $\mathbf{N}$ entrance to Tlevak Strait, Alex. Arch.; $55^{\circ}$ $16^{\prime} \mathrm{N}, 133^{\circ} 07^{\prime} \mathrm{W}$; BGN 1934; (map 4). Var. The Skookum Chuck.

Name published in 1902 by USGS. USC\&GS reported in 1932 that this feature is locally known as "The Skookum Chuck." See Salt Chuck, village.

Tlevak Strait: water passage, extends SE $28 \mathrm{mi}$. from Meares Passage to Cordova Bay, between Dall and Sukkwan Is., Alex. Arch.: $55^{\circ} 02^{\prime} \mathrm{N}, 132^{\circ} 58^{\prime} \mathrm{W}$; BGN 1939; (maps 1 and 4). Var. Proliv Tlevaak, Tlevach Strait, Tlevak Straits, Tlevakan Bay. 
"The name Tlevaak Strait appears to be due to [Capt. M.D.] Tebenkov [IRN], and may have its origin in the same root as the name of Klahuak [Klawock] settlement and Tlevakhan Gulf [Klawak Inlet] farther north" (USC\&GS, 1883, p. 69). The name was published in 1852 as "Proliv Tlevaak," i.e. "Tlevaak Strait," by the Russian Hydrog. Dept. on Chart 1493.

Tlevak Straits: water passage, see Tlevak Strait. Tlewak: village, sec Klawock.

Tliagenadëden: locality, see Parks.

Tliagenalëden: locality, see Parks.

Tliakinikut, Point: point of land, see Craven, Point.

Tlialil: locality, on left bank of Yukon River near mouth of Patsy Slough, $3.5 \mathrm{mi}$. NE of Nulato, Koyukuk Low.; $64^{\circ} 45^{\prime} \mathrm{N}, 158^{\circ} 00^{\prime}$ W; (map 97). Var. Tlialil-kakat, Tljalilkachat.

Former Indian village or camp reported in 1842-44 as "Tlialil-kakat" by Lt. L. A. Zagoskin. In the 1880 Census Petroff (1884, p. 37) recorded a population of 27 in 3 houses. Tlialil-kakat: locality, see Tlialil.

Tliankhini, Point: point of land, see Craven, Point.

Tlickearrik: locality', see Klikitarik.

Tlicketawik: locality, sec Klikitarik.

Tlieshitna River: stream, see Tazlina River.

Tlikakila River: stream, flows SW $50 \mathrm{mi}$. from its head at Summit Lake to Little Lake Clark, $45 \mathrm{mi}$. NE of Nondalton, Aleutian Ra.; $60^{\circ}$. $23^{\prime} 30^{\prime \prime} \mathrm{N}, 153^{\circ} 48^{\prime} 30^{\prime \prime} \mathrm{W}$; BGN 1910; (map 61). Var. Klikakillah Creek, Big River, Bulshi River, Chickaclachno River, Tleekakeela River.

Tanaina Indian name reported as "Tleekakeela" in 1902 by W. H. Osgood, USDA.

Tlikakila River: stream, heads at glacier terminus, flows NW $15 \mathrm{mi}$. to Two Lakes, $88 \mathrm{mi}$. W of Tyonek, Alaska Ra.; $61^{\circ} 08^{\prime} 30^{\prime \prime} \mathrm{N}$, $153^{\circ} 44^{\prime} 50^{\prime \prime}$ W ; (map 71). Var. Big River, Bulshi River, Chicakaclachno, Klikakillah, Tleckakeela.

Tanaina Indian name reported in 1902 by W. H. Osgood, USDA, as "Tleckakeela."

Tlingit Peak: mountain, 3,274 ft., in Glacier Bay National Monument, $1.6 \mathrm{mi}$. E of mouth of Tyndall Cove on Geikic Inlet and $48 \mathrm{mi}$. NW of Hoonah, St. Elias Mts.; $58^{\circ} 37^{\prime} 00^{\prime \prime} \mathrm{N}$, $136^{\circ} 20^{\prime} 20^{\prime \prime} \mathrm{W}$; (map 10).

Name reported in 1951 by USGS; named "for the Tlingit Indians."

Tlingit Point: point of land, at mouth of Muir Inlet, in Glacier Bay National Monument, 52 mi. NW of Hoonah, St. Elias Mts.; $58^{\circ} 45^{\prime} 20^{\prime \prime}$ N, $136^{\circ} 10^{\prime} 30^{\prime \prime} \mathrm{W}$; BCN 1937; (map 10). Var. Thlingit Point.

Named Thlingit Point in 1936 by W. S. Cooper (1937, p. 62 and pl. 1) for the Tlingit Indians who lived in this area.

Tlis-kon, Mount: mountain, see Kliskon, Mount. Tlistec: locality, "in the north part of the Tlingit territory, *** definite locality unknown." Var. L!îstí.
Former Tlingit village or camp reported as L'istí by J. R. Swanton, BAE (Hodge, 1910, p. 765).

Tlitlna: stream, sec Herb Creek.

Tljalilkachat: locality, see Tlialil.

Tlocogn Lake: lake, $1 \mathrm{mi}$. long, on $\mathrm{S}$ bank of Tanana River, $26 \mathrm{mi}$. SE of Tok, Alaska Ra.; $63^{\circ} 09^{\prime} \mathrm{N}, 142^{\circ} 13^{\prime} \mathrm{W}$; (map 85).

Indian name published by USGS in 1964 .

Tlozhavun Lake: lake, $1 \mathrm{mi}$. long, $6 \mathrm{mi}$. SW of Twelvemile Lake and $17 \mathrm{mi}$. SW of Fort Yukon, Yukon Flats, $66^{\circ} 24^{\prime} 20^{\prime \prime} \mathrm{N}, 145^{\circ} 44^{\prime}$ $00^{\prime \prime} \mathrm{W}$; (map 119).

Kutchin Indian name obtained in 1956 by T. E. Taylor, USGS.

Tluhashaiyikan: locality, "in the Sitka country." Var. L !uxâ'caiyîk-ān.

Former Tlingit village reported as " $L$ ! $u x \hat{a}^{\prime}$ caiytk-ān, town straight opposite Mt. Edgecombe" by J. R. Swanton, BAE (Hodge, 1910, p. 766).

Tlukatsukot: lake, see Skinny Fish Lake.

Tluna Icefall: icefall, of $800 \mathrm{ft}$., in Mount McKinley National Park, extends N $0.8 \mathrm{mi}$. between Peters Basin and Peters Glacier, $6 \mathrm{mi}$. NW of summit of Mount McKinley, Alaska Ra.; $63^{\circ} 08^{\prime} \mathrm{N}, 151^{\circ} 07^{\prime} \mathrm{W}$; (map 88).

Name reported about 1952 by USGS.

Tlushashakian: locality, at or near Cape Spenccr, St. Elias Mts.; $58^{\circ} 13^{\prime} \mathrm{N}, 136^{\circ} 39^{\prime} \mathrm{W}$; (map 10). Var. Klughuggue.

Former native village reported as " $L$ ! $u c \bar{a}$ " cak! $i-\bar{a} n$, town on top of a sand hill" by J. R.

Swanton, BAE (Hodge 1910, p. 766).

Tlutlertaut: locality, see The Forks.

Tlyakhini, Mys: point of land, see Craven, Point.

Tlyakhinikut, Mys: point of land, see Craven, Point.

Tmaktogmiut: locality, on $\mathbf{E}$ shore of Norton Sound, $E$ of Besboro I., Nulato Hills; (map 96).

Eskimo village or camp published in 1861 by P. Tikhmeniev of the Russian American Company. The name does not appear on any other available map.

T Mountain: mountain, see T, Mount.

Toadstools, The: islands, in Iniskin Bay, $21 \mathrm{mi}$. $\mathrm{N}$ of Augustine I., Aleutian Ra.; $59^{\circ} 20^{\prime} 00^{\prime \prime}$ N, 153 24'30' W; BGN 1916; (map 51).

Named by USG\&GS in 1914 .

Toatut: locality, sce Espenberg.

Toaulevik Point: point of land, see Toawlevic Point.

Toawlevic Point: point of land, on Seward Penin., extends into Kotzebue Sound, $7 \mathrm{mi}$. NW of Deering, Kotzebue-Kobuk Low.; $66^{\circ} 06^{\prime} \mathrm{N}, 162^{\circ} 57^{\prime} \mathrm{W}$; (map 113). Var. Gullhead Point, Toaulevik Point.

Eskimo name reported in 1950 by USGS. Tobacco Hill : hill, see Loud Hill.

Tobatokh Creek: stream, flows NE and SE 12 mi. to Melozitna River, $2 \mathrm{mi}$. $\mathrm{N}$ of Norseman Lake and $51 \mathrm{mi}$. NW of Tanana, KokrinesHodzana High.; $65^{\circ} 49^{\prime} 30^{\prime \prime} \mathrm{N}, 152^{\circ} 56^{\prime} 00^{\prime \prime}$ W; (map 106).

Koyukan Indian name obtained in 1956 at Hughes by Orth.
Tobin Creek: stream, flows WSW $7 \mathrm{mi}$., to Chandalar Lake, $1.5 \mathrm{mi}$. $\mathrm{N}$ of Chandalar, Brooks Ra.; 67 $31^{\prime} \mathrm{N}, 148^{\circ} 29^{\prime}$ W; (map 123).

Named for August L. Tobin, who prospected in the area from 1898 to 1919: reported by A. G. Maddren (in Brooks and others, 1910, pl. 7), USGS.

Tobin Creek: stream, flows SE $5 \mathrm{mi}$. to Wild River, $5 \mathrm{mi}$. S of Tobin Mtn. and $36 \mathrm{mi}$. NW of Wiseman, Brooks Ra.; 67 $34^{\prime} 20^{\prime \prime} \mathrm{N}$, $151^{\circ} 28^{\prime} 00^{\prime \prime} \mathrm{W}$; BGN 1932; (map 124).

Named for August Tobin, a prospector in the early 1900's; reported by Robert Marshall in 1932.

Tobin Mountain: mountain, 4,460 ft., $6 \mathrm{mi}$. NNE of Sirr Mtn. and $40 \mathrm{mi}$. NW of Wise-

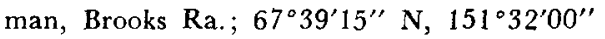
W; BGN 1932; (map 124).

See Tobin Creek.

Tobin Pass: pass, 3,200 ft., between drainage basins of Big Creek and North Fork Chandalar River, $6 \mathrm{mi}$. E of Chandalar, Brooks Ra.; $67^{\circ} 30^{\prime} \mathrm{N}, 148^{\circ} 17^{\prime} \mathrm{W}$; (map 123).

Locally named for August L. Tobin, who was a prospector in this area from 1898 to 1919.

Tobit Greek: stream, flows S $0.6 \mathrm{mi}$. to Ogotoruk Creek, $\mathrm{N}$ of Mitik Creek, $6.5 \mathrm{mi}$. SE of Cape Thompson, Arctic Slope; $68^{\circ} 06^{\prime} 50^{\prime \prime} \mathrm{N}, 165^{\circ}$ 44'20" W; BGN 1963; (map 129).

Name reported in 1962 by personnel of Project Chariot.

Toboggan Glacier: glacier, trends N $2.3 \mathrm{mi}$. to its terminus at head of a stream which drains into Harriman Fiord, $56 \mathrm{mi}$. SE of Anchorage, Chugach Mts.; $61^{\circ} 02^{\prime} 20^{\prime \prime} \mathrm{N}, 148^{\circ} 16^{\prime} 45^{\prime \prime} \mathrm{W}$; (map 69).

Named in 1899 by members of the Harriman Alaska Expedition.

Tobona: locality, on $\mathrm{N}$ shore of Cook Inlet at North Foreland, 2 mi. S of Tyonek, Cook Inlet Low.; $61^{\circ} 02^{\prime} 40^{\prime \prime}$ N. $151^{\circ} 11^{\prime} 15^{\prime \prime} \mathrm{W}$; BGN 1961; (map 70). Var. Moquawkie, Tyonek Town.

Name of a former Tanaina Indian village, supposedly meaning "people of the beach," reported by USGS in 1958.

Tobuk Creek: stream, flows S $28 \mathrm{mi}$. through Iniakuk Lake to Malamute Fork Alatna River, Brooks Ra.; $67^{\circ} 04^{\prime} \mathrm{N}, 153^{\circ} 10^{\prime} \mathrm{W}$; $B G N$ 1932; (map 125).

Named by Robert Marshall in 1931 for "Old Tobuk," a Kobuk Eskimo then living at Alatna.

Toby Creek: stream, heads at glacier terminus, flows NW $3.3 \mathrm{mi}$. to Chitistone River, $3.1 \mathrm{mi}$. $\mathrm{NE}$ of junc. with Glacier Crcek, $11 \mathrm{mi}$. NE of McCarthy, Wrangell Mts.; $61^{\circ} 29^{\prime} \mathrm{N}, 142^{\circ}$ $18^{\prime} \mathrm{W}$; (map 67).

Local name reported in 1907 by D. C. Witherspoon, USGS. Name may have been derived from "tebay" which Lt. Allen (1887, p. 54), USA, says is an Indian word for "a variety of sheep."

Toby Creek: stream, in Nutzotin Mts., flows NW $2.7 \mathrm{mi}$. to Chathenda Creek, $4.2 \mathrm{mi}$. $\mathrm{N}$ of 
Beaver Lake, Alaska Ra.; $62^{\circ} 06^{\prime} 10^{\prime \prime} \mathrm{N}, 141^{\circ}{ }^{-}$ 46'15" W; (map 84).

Local name reported by USGS in 1960 .

Tochatno, Reka: stream, see Takotna River.

Tochilnoi: point of land, see Tachilni, Cape.

Tochotno: locality, on Kuskokwim River. Former Indian village reported in 1842-44 by Lt. L. A. Zagoskin, quoted in the 1880 Census with a population of 9 , by Petroff (1884, p. 37).

Tochotno, Reka: stream, see Takotna River.

Tochtlik: locality, see Toklik.

Toclat River: stream, see Kantishna River.

Toclat River: stream, see Toklat River.

Todatonten, Lake: lake, $3.5 \mathrm{mi}$. long, $29 \mathrm{mi}$. SW of Allakaket, Kokrines-Hodzana High. $66^{\circ} 09^{\prime} \mathrm{N}, 152^{\circ} 56^{\prime} \mathrm{W} ;$ BGN 1960; (map 117 ) Var. Lake Mentanontle, Lake Mentanontli, Mentanontlekakat Lake, Mentantlekakat Lake, Tatatontly Lake, Todatonten Lake.

Koyukan Indian name reported in 1885 by Lt. Allen (1887, p. 96), USA, as "Tatatontly Lake." His map however, showed "Mentanontlekakat Lake," obviously a cartographer's error, for he writes "The outlet of this lake has the euphoneous name of 'Mentanontlekakat.' The ending '-kakat' means 'mouth of." "The present spelling of the name was reported by Orth in 1956.

Todd: settlement, pop. 5, on Chichagof I., 9 mi. W of Chatham Strait and $27 \mathrm{mi}$. NW of Baranof, Alex. Arch.; $57^{\circ} 27^{\prime} 40^{\prime \prime} \mathrm{N}, 135^{\circ} 02^{\prime}$ $30^{\prime \prime} \mathrm{W}$; (map 9).

Name of a former cannery; published by USC\&GS in the 1943 Alaska Coast Pilot (p. 378).

Todd Creek: stream, flows N $5.5 \mathrm{mi}$. to Charley River $14 \mathrm{mi}$. SW of that stream's junc. with Yukon River, Yukon-Tanana High.; $65^{\circ} 08^{\prime}$ N, $142^{\circ} 57^{\prime} \mathrm{W}$; (map 103).

Prospectors' name from an unpublished map by E. J. Chamberlain, dated 1902.

Toe Point: point of land, at S tip of Harbor I., $35 \mathrm{mi}$. SW of Seward, Chugach Mts.; $59^{\circ}$ $38^{\prime} 31^{\prime \prime} \mathrm{N}, 149^{\circ} 39^{\prime} 50^{\prime \prime} \mathrm{W}$; BGN 1930; (map 49).

So named by the 1912 USC\&GS field party, "because of its shape."

Tofty: locality, summer pop. 6, on $\mathbf{E}$ bank of Sullivan Creek, $7 \mathrm{mi}$. SW of Roughtop Mtn. and $35 \mathrm{mi}$. ESE of Tanana, Yukon-Tanana High.; $65^{\circ} 05^{\prime} 35^{\prime \prime} \mathrm{N}, 150^{\circ} 53^{\prime} 00^{\prime \prime} \mathrm{W}$; (map 106).

Mining camp developed as a supply point for the Sullivan Creek workings about 1908. A post office was established in 1908; discontinued in 1943 (Ricks, 1965, p. 65). Named for A. F. Tofty who discovered gold in the area, and is reported to have taken out 376 ozs. in 6 weeks. He died in British Guiana in 1923.

Tofty Gulch: stream, flows SE $1.1 \mathrm{mi}$. to Sullivan Creek, $0.9 \mathrm{mi}$. SW of Tofty and $35 \mathrm{mi}$. ESE of Tanana, Yukon-Tanana High.; $65^{\circ} 05^{\prime} 00^{\prime \prime}$ $N$, 150 $53^{\prime} 40^{\prime \prime} \mathrm{W}$; (map 106).

Named for A. F. Tof ty who discovered gold here in 1909; reported in 1931 by J. B. Mertie, USGS. See Tofty, locality.
Togaik Bay: bay, see Togiak Bay.

Togiagamiut: village, see Togiak.

Togiagamut: village, see Togiak.

Togiagamute: village, see Togiak.

Togiak: village, pop. 220, at head of Togiak Bay, $2 \mathrm{mi}$. W of mouth of Tagiak River and $43 \mathrm{mi}$. E of Goodnews, Kilbuck-Kuskokwim Mts.; $59^{\circ} 04^{\prime} \mathrm{N}, 160^{\circ} 24^{\prime} \mathrm{W}$; (map 53). Var. Nasauguluk, Owens, Selo Tugiak, Selo Tugiatak, Tagiak, Togiagamiut, Togiagamut, Togiagamute, Togiakamut, Togiak Village. Eskimo village name reported as "S[elo] Tugiatak," or "Tugiak Village," by Lt. Sarichev (1826, map 3); and as "S[elo] Tugiak" by Capt. Tebenkov (1852, map 4), IRN. In 1880 Petroff (1881, p. 48) recorded two villages, "Togiagamute," population 276 (94 in 1890) and "Togiak Station," population 28 (14 in 1890), both located, on his map, $\mathbf{E}$ of the mouth of the river about $7 \mathrm{mi}$. apart. The southernmost "Togiak Station" has been called "Owens," named, according to Frank Waskey, local trader and prospector, for Johnny Owens who operated this important trading post. "Togiak Village" was published in the 1947 Coast Pilot (p. 530). The population was 71 in 1945 and 108 in 1950.

Togiakamut: village, see Togiak.

Togiak Bay: bay, extends SW $18 \mathrm{mi}$. from Togiak River to Hagemeister I. and E $25 \mathrm{mi}$. from Tongue Point to mouth. of Neguthlik River, Kilbuck-Kuskokwim Mts.; 58 $51^{\prime}$ N, $160^{\circ} 30^{\prime} \mathrm{W}$; (map 39). Var. Togaik Bay, Towogiak Bay, Zaliv Tugiak, Zaliv Tugiyak.

Eskimo name reported in 1849 as "Zaliv Tugiak," meaning "Tugiak Bay," by Capt. Tebenkov (1852, map 4), IRN. It was called "Togiak Bay" by Ivan Petroff in 1880 Census.

Togiak Lake: lake, extends SW $13 \mathrm{mi}$. from mouth of Izavieknik River, $75 \mathrm{mi}$. NE of Goodnews, Kilbuck-Kuskokwim Mts.; 59 $32^{\prime}$ N, $159^{\circ} 42^{\prime}$ W; (map 53). Var. Kagan Lake, Ozero Tugiak.

Eskimo name reported as "Oz[ero] Tugiak" meaning "Lake Tugiak" by Lt. Sarichev, (1826, map 3), IRN.

Togiakpak: locality, on Tagayarak River at mouth of Jew River, $8 \mathrm{mi}$. SW of Helmick Point and $48 \mathrm{mi}$. SW of Bethel, YukonKuskokwim Delta; $60^{\circ} 16^{\prime} \mathrm{N}, 162^{\circ} 41^{\prime} \mathrm{W}$; (map 58).

Eskimo name reported in 1949 by USC\&GS.

Togiak River: stream, heads at Togiak Lake, flows SW $48 \mathrm{mi}$. to Togiak Bay, $2 \mathrm{mi}$. E of Togiak and 45 mi. E of Goodnews, KilbuckKuskokwim Mts.; $59^{\circ} 03^{\prime} \mathrm{N}, 160^{\circ} 21^{\prime} \mathrm{W}$; (map 53). Var. Reka Tugiyak, Tugiak River.

Eskimo name reported as "R[eka] Tugiyak," or "Tugiak River," by Capt. Tebenkov (1852, map 3), IRN. It was called "Togiak River" by Ivan Petroff in the 1880 Census.

Togiak Village: village, see Togiak.

Togiaratsorik: locality, on left bank of Kuskokwim River near its mouth, Yukon-Kusko- kwim Delta; 60 $33^{\prime} \mathrm{N}, 162^{\circ} 12^{\prime} \mathrm{W}$; (map 58). Var. Taghiaratzoriamute, Togiarhazoriamute.

Former Eskimo village or camp recorded as "Taghiaratzoriamute" on the 1880 Census map by Ivan Petroff.

Togiarhazoriamute: locality, see Togiaratsorik. Toglik Mountain: mountain, 1,361 ft., $2 \mathrm{mi}$. NE of Dome Mtn. and $9 \mathrm{mi}$. SE of Goodnews, Kilbuck-Kuskokwim Mts.; $59^{\circ} 05^{\prime} 30^{\prime \prime} \mathrm{N}$, $161^{\circ} 21^{\prime} 00^{\prime \prime} \mathrm{W}$; (map 53 ).

Eskimo name reported in 1954 by USGS. Togoyuk Creek: stream, flows NW $9 \mathrm{mi}$. to Killik River, $\mathbf{N}$ of Mayukuit Mtn., Brooks Ra.; $68^{\circ} 14^{\prime} \mathrm{N}, 154^{\circ} 06^{\prime} \mathrm{W}$; (map 133).

Eskimo name reported in 1956 by T. E. Taylor, USGS.

Togrorurak: hill, see Sakrorak Mountain.

Tohitkah Mountain: mountain, 5,750 ft., 5.5 mi. $\mathrm{N}$ of junc. of Kelsall and Chilkat Rivers, $28 \mathrm{mi}$. NW of Skagway, St. Elias Mts.; $59^{\circ}$ $36^{\prime} 35^{\prime \prime} \mathrm{N}, 136^{\circ} 03^{\prime} 10^{\prime \prime} \mathrm{W}$; (map 45).

Tlingit Indian name given by E. C. Robertson, geologist; published in 1952 by USGS.

Tohnokalong: locality, on right bank of Yukon River, $30 \mathrm{mi}$. ENE of Ruby, Nowitna Low.; $64^{\circ} 57^{\prime} \mathrm{N}, 154^{\circ} 26^{\prime} \mathrm{W}$; (map 98).

Former Indian village name published by Hodge (1910, p. 771), BAE.

Tohwun-nukakat: stream, see Birch Creek.

Toik Hill: mountain, 1,298 ft., $6.5 \mathrm{mi}$. SE of Klikitarik and $36 \mathrm{mi}$. SW of Unalakeet, Nulato Hills, $63^{\circ} 25^{\prime} 30^{\prime \prime} \mathrm{N}, 161^{\circ} 18^{\prime} 00^{\prime \prime} \mathrm{W}$; (map 91). Var. Tok Hill.

Eskimo name reported in 1898 by USC\&GS

Tok: locality, on Koyukuk I. at junc. of Koyukuk and Yukon Rivers, Koyukuk Low.; $64^{\circ} 54^{\prime}$ N, $157^{\circ} 35^{\prime}$ W; (map 97). Var. Tokhakate, Tok-kakat, Tok-khakat.

Former Indian village or camp reported as "Tokhakate," population 6 in 1844 by Lt. L. A. Zagoskin.

Tok: village, pop. 129 , at junc. of Alaska and Glenn Highways, $5 \mathrm{mi}$. SW of junc. of Tok and Tanana Rivers and $12 \mathrm{mi}$. SE of Tanacross, Alaska Ra.; $63^{\circ} 20^{\prime} \mathrm{N}, 142^{\circ} 59^{\prime} \mathrm{W}$; (map 85). Var. Tok Junction.

Tok, which took its name from the nearby stream, developed since the building of the Alaska and Glenn Highways in the 1940's. The U.S. Customs and Immigration office is located here.

Tokaina Creek: stream, flows NNW $9 \mathrm{mi}$. to Tazlina Lake, $56 \mathrm{mi}$. N of Valdez, Chugach Mts.; $61^{\circ} 55^{\prime} 00^{\prime \prime} \mathrm{N}, 146^{\circ} 24^{\prime} 50^{\prime \prime} \mathrm{W}$; (map 68).

Name shown on a manuscript map by USGS dated 1917.

Tokai River: stream, see Tok River.

Tokatjikh Creek: stream, flows SE $13 \mathrm{mi}$. to Melozitna River, $4 \mathrm{mi}$. S of Tokatjikh Hill, $39 \mathrm{mi}$. NNE of Birches, Kokrines--Hodzana High.; $65^{\circ} 39^{\prime} 35^{\prime \prime} \mathrm{N}, 153^{\circ} 02^{\prime} 30^{\prime \prime} \mathrm{W}$; (map 107).

Koyukan Indian name obtained at Huslia in 1956 by Orth. 
Tokatjikh Hill: hill, 1,488 ft., E of Tokatjikh Creek and $N$ of Melozitna River, $43 \mathrm{mi}$. NNE of Birches, Kokrines-Hodzana High.; $65^{\circ} 43^{\prime}$ $15^{\prime \prime} \mathrm{N}, 153^{\circ} 03^{\prime} 00^{\prime \prime} \mathrm{W}$; (map 107).

Koyukan Indian name obtained at Huslia in 1956 by Orth.

Tokchouk: locality, see Tuksuk.

Tokchouk Channel: water passage, see Tukchuk Channel.

Tokeatl's Village: locality, former Indian summer camp reported in the 1880 Census with a population of 26 , by Petroff $(1884$, p. 32$)$.

Tokeen: locality, see Old Tokeen.

Tokeen: village, on $\mathrm{W}$ coast of $\mathrm{El}$ Capitan $\mathrm{I}$., $33 \mathrm{mi}$. NW of Craig, Alex. Arch.; 55 $56^{\prime} 15^{\prime \prime}$ N, $133^{\circ} 19^{\prime} 30^{\prime \prime} \mathrm{W}$; (map 4). Var. New Tokeen.

This settlement was probably established by the former residents of Old Tokeen, 7 miles to the northwest, when the marble quarry there was abandoned in the late 1930's. It has a store, an ice and cold-storage plant, and a floating shrimp cannery (U.S. Goast and Geodetic Survey, 1962, p. 97). The name "New Tokeen" was recorded in 1949 by USGS.

Tokeen Bay: bay, $3 \mathrm{mi}$. across, on $\mathbf{S}$ coast of Kosciusko I., Alex. Arch.; 56 $00^{\circ} \mathrm{N}, 133^{\circ} 25^{\prime}$ $\mathrm{W}$; $(\operatorname{map} 6)$.

Indian name published by USC\&GS in 1925 Coast Pilot (p. 163). See Tokeen.

Tokeen Cove: bay, $0.6 \mathrm{mi}$. across, on NW coast

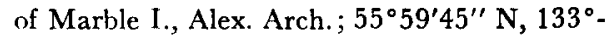
$28^{\prime} 30^{\prime \prime} \mathrm{W}$; (map 4).

Local name published in 1964 on USC\&GS Chart 8171.

Tokeen Peak: mountain, 2,352 ft., between Davidson Inlet and Tokeen Bay, on SE coast of Kosciusko I., Alex. Arch.; 56 $02^{\prime} 45^{\prime \prime} \mathrm{N}$, $133^{\circ} 25^{\prime} 45^{\prime \prime} \mathrm{W}$; (map 6).

Indian name published in 1943 by USC\&GS. See Tokeen.

Tok Glacier: glacier, trends SE $3 \mathrm{mi}$. to its terminus at head of Tok River, $38 \mathrm{mi}$. SW of Tok, Alaska Ra.; $63^{\circ} 08^{\prime} \mathrm{N}, 144^{\circ} 09^{\prime} \mathrm{W}$; (map 86).

Name reported in 1952 by USGS.

Tokhakate: locality, see Tok.

Tokhakklanten Lake: lake, sce Tokhaklanten, Lake.

Tokhaklanten, Lake: lake, $2.5 \mathrm{mi}$. long, $16 \mathrm{mi}$. NW of Hughes, Hogatza High.; 66 $6^{\circ} 12^{\prime} \mathrm{N}$, $154^{\circ} 42^{\prime} \mathrm{W}$; (map 116). Var. Tokhakklanten Lakc.

Indian name recorded at Hughes in 1956 by Orth.

Tok-Hehe Creek: stream, see Tokhini Creek.

Tok-Hene: locality, sec Old Tokeen.

Tok-Hene Creek: stream, see Tokhini Creek.

Tok Hill: mountain, see Toik Hill.

'Tokhin: locality, see Old Tokeen.

Tokhini : locality, see Old Tokeen.

Tokichitna Glacier: glacier, sec Tokositna Glacier.

Tokichitna River: stream, see Tokositna River.

Tokini Creek: stream, flows E $1.8 \mathrm{mi}$. to El Capitan Passage, on NE coast of Kosciusko I., Alex. Arch.; $56^{\circ} 07^{\prime} 30^{\prime \prime} \mathrm{N}, 133^{\circ} 17^{\prime} 30^{\prime \prime} \mathrm{W}$; (map 6). Var. Tok-Hehe Creek, Tok-Hene Creek.

Tlingit Indian name "adopted by the fisheries" and reported in 1897 by Lt. Comdr. J. F. Moser, USN, as "Tok-Hehe Creek" and in 1901 as "Tok-Hene Creek." This name is from the words "Tok" and "Hin" meaning "Tok River." See Tokeen.

Tokio River: stream, sec Station Creek.

Tokio River: stream, see Tok River.

Tokisha Mountains: ridge, see Tokosha Mountains.

Tok Junction: village, see Tok.

Tok-kakat : locality, see Tok.

Tok-khakat: locality, see Tok.

Toklat: locality, in Mount McKinley National Park, on $\mathrm{W}$ bank of Toklat River at Denali Highway, $10 \mathrm{mi}$. NE of Eielson Visitor Center, Alaska Ra.; $63^{\circ} 31^{\prime} 10^{\prime \prime} \mathrm{N}, 150^{\circ} 02^{\prime} 45^{\prime \prime} \mathrm{W}$; (map 88).

Published in 1932 by ARC.

Toklat: locality, on left bank of Kantishna River near junc. of Toklat River, Tanana Low.; $64^{\circ} 28^{\prime} \mathrm{N}, 150^{\circ} 20^{\prime} \mathrm{W}$; (map 99).

Former settlement and river landing which, named for the Toklat River, had a population of 44 in 1930.

Toklat River: stream, flows NW $85 \mathrm{mi}$. to Kantishna River $50 \mathrm{mi}$. E of the Bitzshtini Mts., Minto Flats; $64^{\circ} 27^{\prime} 15^{\prime \prime} \mathrm{N}, 150^{\circ} 18^{\prime} 45^{\prime \prime}$ W; (map 99). Var. Toclat River, Tutlut River.

Tanana Indian name reported as "Toclat River" in 1885 by Lt. H. T. Allen, USA, with the translation, "dish water" (1887, p. 85). Lt. Allen applied the name to the stream presently known as Kantishna River and the name "Toklat" is relegated to a major tributary of the Kantishna. This is probably the same name spelled "Tutlut" by Ivan Petroff in 1880.

Toklat River: stream, see Sushana River.

Toklik: locality, on $N$ bank of Yukon River 16 mi. SW of Russian Mission, Yukon-Kuskokwim Delta; 61 $37^{\prime} 15^{\prime \prime} \mathrm{N}, 161^{\circ} 41^{\prime} 50^{\prime \prime} \mathrm{W}$; (map 73). Var. Bennetts, Tochtlik, Toklikmute.

Eskimo name shown on a 1916 field sheet by R. H. Sargent, USGS. Sargent shows three cabins here, but present maps show one. Hrdlička (1943, p. 234) refers to it as "a small live village," called "Tochtlik," in 1929.

Toklikmutc: locality, see Toklik.

Tokomarik Mountain: mountain, 1,131 ft., 12 mi. E of Cape Newenham and $30 \mathrm{mi}$. W of Hagemeister I., Kilbuck-Kuskokwim Mts.; $58^{\circ} 38^{\prime} 30^{\prime \prime} \mathrm{N}, 161^{\circ} 51^{\prime} 15^{\prime \prime} \mathrm{W}$; (map 39).

Eskimo name published in 1948 by USGS Tokopna River: stream, see Takotna River.

Tokosha Mountains: ridge, 6,000 ft., extends NE-SW $8 \mathrm{mi}$. between Ruth and Tokositna Glaciers, $26 \mathrm{mi}$. NW of Talkeetna, Alaska Ra.; $62^{\circ} 42^{\prime} \mathrm{N}, 150^{\circ} 37^{\prime} \mathrm{W}$; BGN 1962; (map 81). Var. Tokisha Mountains.

Tanaina Indian name meaning "treeless mountains (or treeless area)," given in 1906 by the Cook-Parker Expedition "after the Tokositna River" (Browne, 1913, p. 54, 66). Tokoshitna River: stream, see Tokositna River. Tokositna Glacier: glacier, heads E of Mount Hunter and trends SE $23 \mathrm{mi}$. to its terminus at head of Tokositna River, $32 \mathrm{mi}$. NW of Talkeetna, Alaska Ra.; $62^{\circ} 40^{\prime} \mathrm{N}, 150^{\circ} 47^{\prime}$ W; BGN 1962; (map 81). Var. Tokichitna Glacier.

Named after the river by the Cook-Parker Expedition in 1906.

Tokositna River: stream, heads at Tokositna Glacier, flows SE and NE $41 \mathrm{mi}$. to Chulitna River, $25 \mathrm{mi}$. NW of Talkeetna, Cook Inlet Low.; $62^{\circ} 40^{\prime} 45^{\prime \prime} \mathrm{N}, 150^{\circ} 17^{\prime} 00^{\prime \prime} \mathrm{W}$; $B G N$ 1962; (map 81). Var. Tokichitna River, Tokoshitna River.

Tanaina Indian name meaning "stream from treeless area;" reported to A. H. Brooks in 1902 by prospector George Aberhardt.

Tokotna: village, see Takotna.

Tok River: stream, heads at glacier terminus, flows NE $60 \mathrm{mi}$. to Tanana River, $5 \mathrm{mi}$. NE of Tok, Alaska Ra.; $63^{\circ} 22^{\prime} \mathrm{N}, 142^{\circ} 50^{\prime} \mathrm{W}$; $B G N$ 1936; (map 85). Var. Takai River, Tokai River, Tokio River.

Indian name reported in 1885 as "Tokai River" by Lt. Allen (1887, p. 78), USA. "Tok River" was reported in 1901 by Brooks (1900a, p. 451), USGS.

Tokshook: locality, see Tuksuk.

Tokshook Channel: water passage, see Tuksuk Channel.

Toksook Bay: village, pop. 160, on Nelson I., $6.5 \mathrm{mi}$. SE of Tanunak, Yukon-Kuskokwim Delta; $60^{\circ} 31^{\prime} 45^{\prime \prime} \mathrm{N}, 165^{\circ} 06^{\prime} 00^{\prime \prime} \mathrm{W}$; $B G N$ 1965; (map 57).

Eskimo village established in 1964 when most of the population of Nightmute moved to this new location.

Toksook River: stream, heads in Kaluyut Mts., flows SW $35 \mathrm{mi}$. to Kangirlvar Bay, $110 \mathrm{mi}$. SW of Bethel, on Nelson Island, Yukon-Kuskokwim Delta; $60^{\circ} 30^{\prime} \mathrm{N}, 1^{\circ} 5^{\circ} 00 \mathrm{~W}$; (map 58). Var. Tuksuk River, Tooksook River. Eskimo name reported in 1949 by USC\&GS.

Tokun, Lake: lake, $1.5 \mathrm{mi}$. long, $16 \mathrm{mi}$. NE of Katalla, Chugach Mts.; $60^{\circ} 24^{\prime} \mathrm{N}, 144^{\circ} 18^{\prime}$ W; (map 64).

Indian name reported in 1903 by G. C. Martin, USGS.

Tokun Creek: stream, flows N $1.5 \mathrm{mi}$. to Lake Tokun, 16 mi. NE of Katalla, Chugach Mts.; $60^{\circ} 24^{\prime} \mathrm{N}, 144^{\circ} 17^{\prime} \mathrm{W}$; (map 64).

Indian name reported in 1903 by G. C. Martin, USGS.

Tokun Ridge: ridge, $1,900 \mathrm{ft}$., extends $3.5 \mathrm{mi}$, along $\mathrm{E}$ side of Lake Tokun, $18 \mathrm{mi}$. NE of Katalla, Chugach Mts.; $60^{\circ} 24^{\prime} \mathrm{N}, 144^{\circ} 15^{\prime}$ W; (map 64).

Local name reported on a GLO plat of the Bering River Coal Field in 1915. Name derived from nearby Tokun Lake and Tokun Creek.

Tokusatatkuaten Lake: lake, see Tokusatatquaten Lake. 
Tokusatatquaten Lake: lake, $1.3 \mathrm{mi}$. across, 4 mi. E of Sithylemenkat Lake and $56 \mathrm{mi}$. SE of Bettles, Brooks Ra.; $66^{\circ} 07^{\prime} \mathrm{N}, 151^{\circ} 11^{\prime} \mathrm{W}$; (map 117). Var. Tokusatatkuaten Lake.

Koyukan Indian name obtained in 1956 at Allakaket by Orth as "Tokusatatkuaten;" published as above.

Tolageak: locality, sitc of Eskimo village, on Kasegaluk Lagoon, at $\mathrm{S}$ point of entrance to Utukok River, $24 \mathrm{mi}$. SW of Icy Cape, Arctic Plain; $70^{\circ} 02^{\prime} \mathrm{N}, 162^{\circ} 27^{\prime} \mathrm{W}$; (map 146).

Smith and Mertie (1930, p. 103), USGS, noted that "there are a great number of abandoned sod huts and igloos that mark the site of what was once a native village of considerable size." The name was reported in 1965 to Orth to mean "landing place."

To-lah-gah: mountain, see McKinley, Mount.

Tolaktovut Point: point of land, extends $\mathrm{N}$ into Harrison Bay from the Colville River Delta, Arctic Plain: $70^{\circ} 27^{\prime} 50^{\prime \prime} \mathrm{N}, 150^{\circ} 54^{\prime} 20^{\prime \prime} \mathrm{W}$; (map 149)

Eskimo name referring to "a place where boats are landed," reported in 1951 by USC\&GS.

Tolavana: rifllage, see Tolovana.

Tolch Rock: hill, $0.5 \mathrm{mi}$. W of $\mathbf{S}$ end of Mendenhall Lake and $10 \mathrm{mi}$. NW of Juneau, Coast Mts.; $58^{\circ} 25^{\prime} \mathrm{N}, 134^{\circ} 36^{\prime} \mathrm{W}$; (map 11).

Local name published by USGS in 1962.

Toledo Harbor: bay, $0.2 \mathrm{mi}$. across, $8.5 \mathrm{mi}$. $\mathrm{N}$ of Port Alexander, on $\mathbf{S}$ coast of Baranof I., Alex. Arch.; $56^{\circ} 22^{\prime} 25^{\prime \prime} \mathrm{N}, 134^{\circ} 38^{\prime} 00^{\prime \prime} \mathrm{W}$; (map 5).

Local name used by fishermen; published in 1925 by USC\&GS

Tolishden Slough: stream, flows NE $10 \mathrm{mi}$. to Koyukuk River, $7 \mathrm{mi}$. SW of Roundabout Mtn., Koyukuk Low.; $65^{\circ} 27^{\prime} \mathrm{N}, 156^{\circ} 39^{\prime} \mathrm{W}$; (map 108).

Koyukan Indian name reported by USGS in 1955.

Tollison Lake: lake, see Question Lake.

Tolookuk Creek: stream, see Kahgeatak Creek. Tolookuk Creek: stream, see Tulugak Creek.

Tolovana: village, pop. 13, on right bank of Tanana River, near mouth of Tolovana River, $64 \mathrm{mi}$. W of Fairbanks, Tanana Low.; $64^{\circ} 51^{\prime}$ $15^{\prime \prime} \mathrm{N}, 149^{\circ} 49^{\prime} 25^{\prime \prime} \mathrm{W}$; Var. Tolavana, Tolvano, Hootana.

Named "Tolavana" by the U.S. Army Signal Corps in 1903. A postmaster was appointed the same year and the post office was tentatively called Hootana, but when the post office was finally established the following year, it was given the name "Tolovana," for the stream. The post office was discontinued in 1957 (Ricks, 1965, p. 66).

Tolovana Hot Springs: springs, $\mathrm{W}$ of Tolovana River, $20 \mathrm{mi}$. SW of Livengood, YukonTanana High.; $65^{\circ} 16^{\prime} \mathrm{N}, 1^{\circ} 8^{\circ} 52^{\prime} \mathrm{W}$; (map 105). Var. Hot Spring, Hot Springs.

Local name derived from Tolovana River; Published in 1906 by USGS.

Tolovana Hot Springs Dome: mountain, 2,386 ft., $\mathrm{N}$ of Tolovana Hot Springs, $20 \mathrm{mi}$. SW of Livengood, Yukon-Tanana High.; $65^{\circ} 17^{\prime} \mathrm{N}$, $148^{\circ} 54^{\prime}$ W; BGN 1962; (map 105). Var. Hot Springs Dome.

Originally named Hot Springs Dome about 1906 by prospectors for the nearby hot springs. However, the present name was suggested to differentiate the mountain from another Hot Springs Dome.

Tolovana River: stream, heads at junc. of Livengood and Olive Creeks, flows SW $117 \mathrm{mi}$. to Tanana River, $64 \mathrm{mi}$. W. of Fairbanks, Tanana Low.; 64 $51^{\prime} \mathrm{N}, 149^{\circ} 50^{\prime} \mathrm{W}$; (map 100). Var. Nilkoka River, Tolovania River.

A Tanana Indian name reported in 1902 by A. H. Brooks and D. L. Reaburn, USGS. The stream had been given the Indian name "Nilkoka" by W. J. Peters and A. H. Brooks in 1898.

Tolovana River: stream, see Chatanika River. Tolovania River: stream, see Tolovana River.

Tolovano: village, see Tolovana.

Toloviksak River: watercourse, see Talbiksok River.

Tolsona Creek: stream, heads in lake, flows SE $30 \mathrm{mi}$. to Tazlina River, $15 \mathrm{mi}$. W of Glennallen, Copper River Basin; $62^{\circ} 04^{\prime}$ N, $146^{\circ} 00^{\prime}$ W; (map 83). Var. Tolsona River.

Indian name reported by USGS (Brooks and others, 1915, p. 124).

Tolsona Lake: lake, $1.3 \mathrm{mi}$. long, $\mathrm{N}$ of Glenn Highway, $17 \mathrm{mi}$. W of Glennallen, Conper River Basin; $62^{\circ} 07^{\prime} \mathrm{N}, 146^{\circ} 03^{\prime} \mathrm{W}$; (map 83).

Local name published in 1951 by USGS. Tolsona River: stream, see Tolsona Creek.

Tolson Creek: stream, flows NW $12 \mathrm{mi}$. to Sanona Creek, $13 \mathrm{mi}$. SE of junc. of Oshetna and Susitna Rivers, Talkeetna Mts.; $62^{\circ} 28^{\prime}$ $15^{\prime \prime} \mathrm{N}, 147^{\circ} 12^{\prime} 20^{\prime \prime} \mathrm{W}$; (map 82).

Local name reported in 1951 by USGS.

Tolson Mountain: mountain, see Totson Mountain.

Tolstie: point of land, see Tolstoi Point.

Tolstoi: locality, on E bank of Tolstoi Creek N of its junc. with Mastodon Creek and $23 \mathrm{mi}$. NW of Ophir, Kilbuck-Kuskokwim Mts.; $63^{\circ}$ $21^{\prime} 10^{\prime \prime} \mathrm{N}, 157^{\circ} 04^{\prime} 10^{\prime \prime} \mathrm{W}$; (map 90). Var. Olsons Roadhouse, Tolstoy.

Boat landing and supply camp for the Mastodon Creek diggings established about 1916. It had a post office in 1917 and 1918. It is now abandoned.

Tolstoi: point of land, see Chiniak, Cape.

Tolstoi, Cape: point of land, on E entrance of Pavlof Bay, near SW end of Alaska Penin., Aleutian Ra.; 55 $22^{\prime} \mathrm{N}, 161^{\circ} 30^{\prime} \mathrm{W}$; (map 28). Var. Broad Cape.

Shown as "M[ys] Tolstoi," or "broad cape," on Russian Hydrog. Dept. Chart 1379 (1847) ; reported as "Cape Tolstoi" in 1929 by USGS.

Tolstoi, Cape: point of land, see Burunof, Cape. Tolstoi, Cape: promontory, see Kovurof Point. Tolstoi Bay: locality, site of a fishing station on E coast of Prince of Wales I., in Thorne Bay; $55^{\circ} 41^{\prime} 30^{\prime \prime} \mathrm{N}, 132^{\circ} 33^{\prime} 00^{\prime \prime} \mathrm{W}$; (map 4).

The name of this former fishing station was first published in the 11 th Census (1893, p.
$30)$; derived from Tolstoi Point. See Tolstoi Point.

Tolstoi Bay: estuary, extends S $4 \mathrm{mi}$. off Clarence Strait, on E coast of Prince of Wales I., at head of Kasaan Penin., Alex. Arch.; 55 $40^{\prime}$ N, $132^{\circ} 26^{\prime} \mathbf{W}$; (map 4).

Descriptive Russian name meaning "broad," given in 1882 by Lt. Comdr. H. E. Nichols, ÜSN.

Tolstoi Cape: point of land, see Tolstoi Point. Tolstoi Creek: stream, heads in Beaver Mts. at $62^{\circ} 57^{\prime} \mathrm{N}, 157^{\circ} 01^{\prime} \mathrm{W}$, flows $\mathrm{N} 75 \mathrm{mi}$. to Dishna River $11 \mathrm{mi}$. S of its junc. with Innoko River, $32 \mathrm{mi}$. NW of Ophir and $61 \mathrm{mi}$. NW of McGrath, Innoko Low.; $63^{\circ} 27^{\prime} \mathrm{N}, 157^{\circ} 16^{\prime}$ W; (map 90). Var. Tolstoi River.

Prospectors' name obtained in 1908 by Maddren (1910, pl. 1), USGS.

Tolstoi Island: island, $500 \mathrm{ft}$., long, in Clarence Strait, on E coast of Prince of Wales I., 1.5 mi. NE of Thorne Head, Alex. Arch.; $55^{\circ} 41^{\prime}$ $45^{\prime \prime} \mathrm{N}, 132^{\circ} 25^{\prime} 40^{\prime \prime} \mathrm{W}$; (map 4). Bay.

Descriptive Russian name. See Tolstoi

Tolstoi Mountain: mountain, 1,910 ft., near head of Kasaan Penin., on E coast of Prince of Wales I., Alex. Arch.; 55 $38^{\prime} 45^{\prime \prime} \mathrm{N}$, $132^{\circ} 23^{\prime} 00^{\prime \prime} \mathrm{W}$; (map 4).

Named in 1914 by A. H. Brooks, USGS. See Tolstoi Point.

Tolstoi Peak: mountain, 1,700 ft, near E entrance of Pavlof Bay, near SW end of Alaska Penin., Aleutian Ra.; 55 $22^{\prime} 20^{\prime \prime}$ N, $161^{\circ} 28^{\prime}$ $00^{\prime \prime} \mathrm{W}$; (map 28).

Local name reported in 1929 by USGS.

Tolstoi Point: point of land, between Clarence Strait and Tolstoi Bay, on $\mathrm{E}$ coast of Prince of Wales I., Alex. Arch.; 55 $40^{\prime} 10^{\prime \prime} \mathrm{N}$, $132^{\circ} 23^{\prime} 10^{\prime \prime} \mathrm{W}$; (map 4). Var. Broad Point, Mys Tolstyy.

Name published in 1853 as " $\mathrm{M}$ [ys] Tolstyy," meaning "broad point," on Russian Hydrog. Dept. Chart 1493; published as "Broad Point" in the 1883 Coast Pilot (p. 87).

Tolstoi Point: point of land, on $\mathrm{E}$ tip of St. George I., in Pribilof Is.; $56^{\circ} 35^{\prime} 40^{\prime \prime}$ N, $169^{\circ} 28^{\prime} 00^{\prime \prime} \mathrm{W}$; (map 38). Var. Kagalogh, Mys Vostochnoy, Vostochnoi.

Descriptive Russian name, reported in 1903 by G. R. Putnam, USC\&GS, from the Russian "tolstoy" meaning "thick" (p 1013-15). Putnam claimed (in Baker, 1906, p. 631): "The native name is 'Kagalogh' * * " which probably comes from the Aleut word "Kagaluk," meaning "stern of a baidarka," according to R. H. Geoghegan. This feature was called by Capt. Tebenkov (1852, map 21) "M[ys] Vostochnoy," meaning "Eastern Cape."

Tolstoi Point: point of land, on SW coast of St. Paul I., in Pribilof Is.; $57^{\circ} 08^{\prime} 15^{\prime \prime} \mathrm{N}, 170^{\circ}$ $17^{\prime} 30^{\prime \prime} \mathrm{W}$; (map 38).

Descriptive Russian name, published by Elliott (1881, St. Paul map) and derived from the Russian "tolstoy," meaning "broad."

Tolstoi Point: point of land, between Seal and Tonki Bays, $36 \mathrm{mi}$. NE of Afognak, on NE 
coast of Afognak I., N of Kodiak I.; $58^{\circ} 23^{\prime}$ $45^{\prime \prime} \mathrm{N}, 152^{\circ} 07^{\prime} 30^{\prime \prime} \mathrm{W}$; (map 43). Var. Tolstie, Tolstoi Cape.

Transliteration of the descriptive name "M[ys] Tolstyy," meaning "broad point" published by the Russian American Company in 1849 .

Tolstoi Point: point of land, on Norton Sound, $18 \mathrm{mi}$. SW of Unalakleet, Nulato Hills; $63^{\circ}$. $37^{\circ} 30^{\prime \prime} \mathrm{N}, 161^{\circ} 00^{\prime} 50^{\prime \prime} \mathrm{W}$; (map 91).

Russian name reported in $1842-44$ by Lt. L. A. Zagoskin, IRN, as "Mys Tolstoy."

Tolstoi Point: point of land, see Broad Point

Tolstoi River: stream, see Tolstoi Creek.

Tolstoi Rookery: rookery, on N shore of Tolstoi Point, on SW coast of St. Paul I., in Pribilo Is. ; $57^{\circ} 08^{\prime} 15^{\prime \prime} \mathrm{N}, 170^{\circ} 17^{\prime} 30^{\prime \prime} \mathrm{W}$; (map 38).

Local name of a seal rookery with $3,000 \mathrm{ft}$. of sea-margin, reported by Elliott (1881, p. 53--54)

Tolstoi Sands: beach, $0.5 \mathrm{mi}$. long, on E shore of English Bay, on SW coast of St. Paul I., in Pribilof Is.; $57^{\circ} 08^{\prime} 40^{\prime \prime} \mathrm{N}, 170^{\circ} 17^{\prime} 00^{\prime \prime} \mathrm{W}$; (map 38).

Local name reported in 1965 by USBF.

Tolstoy: locality, see Tolstoi.

Tolstoy, Mys: point of land, see Burunof, Cape Tolstoy, Mys: point of land, see Nome, Cape. Tolstoy Point: point of land, see Broad Point. Tolstyy, Mys: point of land, see Nome, Cape. Tolstyy, Mys: point of land, see Tolstoi Point. Tolugakruak: stream, see Carbon Creek.

Tolukak Creek: stream, see Kahgeatak Creek. Tolukak Creek: stream, see Tulugak Creek.

Toluksagamut: village, see Tuluksak.

Tomasagnu River: stream, flows $\mathrm{W}$ into Dease Inlet, Arctic Plain; (map 148).

Name shown in 1855 on British Admiralty Chart 593, but not definitely located.

Tomato Creek: stream, flows NE $8 \mathrm{mi}$. to Mosquito Creek, $55 \mathrm{mi}$. SW of Eagle, YukonTanana High.; $64^{\circ} 08^{\prime} \mathrm{N}, 142^{\circ} 10^{\prime} \mathrm{W}$; (map 102).

Named by prospectors and shown on a 1902 manuscript map by C. A. Woodruff, Fort Cudahy, Canada. This stream is not identified on present-day maps.

Tombstone Bay: bay, $0.8 \mathrm{mi}$. across, along $\mathrm{W}$ bank of Portland Canal, $1.5 \mathrm{mi}$. S of Turn Point, Coast Mts.; $55^{\circ} 24^{\prime} 30^{\prime \prime} \mathrm{N}, 130^{\circ} 03^{\prime} 00^{\prime \prime}$ W; (map 3).

Named in 1868 by Staff Comdr. David Pender, RN.

Tombstone Rocks: rocks, on W coast of Kodiak I., $15 \mathrm{mi}$. NW of Ayakulik and $20 \mathrm{mi}$. SW of Karluk; $57^{\circ} 21^{\prime} 12^{\prime \prime} \mathrm{N}, 154^{\circ} 49^{\prime} 00^{\prime \prime} \mathrm{W}$; $B G N$ 1931; (map 35).

Named by USC\&GS in 1919 "because of the resemblance to tombstones."

Tom Cook Slough: stream, flows SW $25 \mathrm{mi}$. to Huslia River, $24 \mathrm{mi}$. NW of Roundabout Mtn., Koyukuk Low.; 65⒌ $3^{\prime}$ N, $156^{\circ} 37^{\prime}$ W ; (map 108).

Local name obtained at Huslia by USGS in 1954 or 1955.

Tom Creek: stream, flows SE $8.5 \mathrm{mi}$. to Bradfield Canal, $12 \mathrm{mi}$. E of its mouth at Ernest Sound, Coast Mts. ; $56^{\circ} 12^{\prime} 40^{\prime \prime} \mathrm{N}, 131^{\circ} 40^{\prime} 45^{\prime \prime}$
W; BGN 1923; (map 7). Var. Grant Creek.

Named in 1923 by USFS for an Indian who used to live at the mouth of the stream. The stream had previously been called "Grant Creek" for William D. Grant, president of the Wrangell Pulp and Paper Company.

Tom Creek: stream, between Wapoo Creek and Innoko River, flows W $9.5 \mathrm{mi}$. to Crescent Creek $1 \mathrm{mi}$. E of its junc. with Wapoo Creek, $45 \mathrm{mi}$. NW of Ophir and $73 \mathrm{mi}$. NW of Mc-

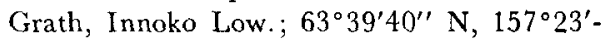
20" W; (map 90).

Prospectors' name reported in 1913 by H. M. Eakin, USGS.

Tom Creek: stream, flows SW 2 mi. to Gilmore Creek, $3 \mathrm{mi}$. W of Gilmore Dome, $13 \mathrm{mi}$. NE of Fairbanks, Yukon-Tanana High.; 64 ${ }^{\circ} 59^{\prime}$ $\mathrm{N}, 147^{\circ} 27^{\prime} \mathrm{W}$; (map 100).

Apparently, named locally for Tom Gilmore, Felix Pedro's partner; reported in 1903 by T. G. Gerdine (in Prindle, 1905, pl. 16), USGS.

Tomgass: water passage, see Tongass Port.

Tomgass Harbor: $b a y$, see Tamgas Harbor.

Tomgaz Gavan: bay, see Tamgas Harbor.

Tom Gray Creek: stream, heads E of Wolf Creek Mtn., flows SW 12 mi. to Nageethluk River, $29 \mathrm{mi}$. N of Russian Mission, YukonKuskokwim Delta; $62^{\circ} 12^{\prime} 25^{\prime \prime} \mathrm{N}, 161^{\circ} 29^{\prime} 00^{\prime \prime}$ W; (map 78).

Local name reported in 1949 by USC\&GS.

Tom Killae Creek: stream, flows $\mathrm{N} 10 \mathrm{mi}$. to South Fork Hoholitna River, $32 \mathrm{mi}$. WSW of Whitefish Lake and $70 \mathrm{mi}$. NW of Nondalton, Lime Hills; $60^{\circ} 49^{\prime} \mathrm{N}, 155^{\circ} 54^{\prime} \mathrm{W}$; (map 61).

Local name reported in 1950 by USC\&GS.

Tom Lake: lake, $0.3 \mathrm{mi}$. across, $\mathrm{E}$ of Tom Creek, $12 \mathrm{mi}$. NE of mouth of Bradfield Canal at Ernest Sound, Coast Mts. ; 56 $15^{\circ} 30^{\prime \prime} \mathrm{N}, 131^{\circ}$. $42^{\prime} 30^{\prime \prime} \mathrm{W}$; ( $\left.\operatorname{map} 7\right)$.

Local name derived from Tom Creek and published in 1955 on USGS map.

Tom Lake: lake, see Brooks, Lake.

Tommy Creek: stream, flows $\mathrm{W} 12 \mathrm{mi}$. to Iliamna Lake, $15 \mathrm{mi}$. SE of Iliamna, Aleutian Ra.; $59^{\circ} 37^{\prime}$ N, $154^{\circ} 35^{\prime}$ W; (map 51).

Local name published by USGS in 1954.

Tommy Creek: stream, flows W $5.5 \mathrm{mi}$. to Lake Clark, $25 \mathrm{mi}$. NE of Nondalton, Aleutian Ra.; $60^{\circ} 09^{\prime} \mathrm{N}, 154^{\circ} 14^{\prime} \mathrm{W}$; (map 61).

Local name reported in 1954 by USGS.

Tommy Glacier: glacier, $1 \mathrm{mi}$. long, just $\mathrm{S}$ of Crescent Glacier, $30 \mathrm{mi}$. NE of Whittier, Chugach Mts. ; $60^{\circ} 59^{\prime} 15^{\prime \prime} \mathrm{N}, 147^{\circ} 53^{\prime} 00^{\prime \prime} \mathrm{W}$; $B G N$ 1910; (map 63).

Local name reported in 1908 by Grant and Higgins (1910, pls. 1, 2), USGS.

Tommy Island: island, $0.3 \mathrm{mi}$. long, in Lake Clark, $7 \mathrm{mi}$. S of Kijik Mtn. and $27 \mathrm{mi}$. NE of Nondalton, Aleutian Ra.; $60^{\circ} 14^{\prime} 45^{\prime \prime} \mathrm{N}$, $154^{\circ} 14^{\prime} 30^{\prime \prime} \mathrm{W}$; (map 61$)$.

Local name reported in 1954 by USGS.

Tommy Lake: lake, $1.5 \mathrm{mi}$. long, $41 \mathrm{mi}$. SE of Chalkyitsik, Porcupine Plat.; $66^{\circ} 18^{\prime} \mathrm{N}, 142^{\circ}$ 32' W ; (map 120)

Local name obtained in 1956 by T. E. Taylor and R. C. Foley, USGS.
Tommy Point: point of land, on SE shore of Iliamna Lake, $1 \mathrm{mi}$. WNW of Leon Bay and $15 \mathrm{mi}$. SE of Iliamna, Aleutian Ra.; $59^{\circ}$. $35^{\prime} 30^{\prime \prime} \mathrm{N}, 154^{\circ} 39^{\prime} 00^{\prime \prime} \mathrm{W}$; (map 51).

Local name published by USGS in 1954.

Tommys Pup: stream, flows SE $1 \mathrm{mi}$. to Deadwood Creek, $8 \mathrm{mi}$. W of Circle Hot Springs and $34 \mathrm{mi}$. SW of Circle, Yukon-Tanana High.; $65^{\circ} 28^{\prime} 15^{\prime \prime} \mathrm{N}, 144^{\circ} 55^{\prime} 30^{\prime \prime} \mathrm{W}$; (map 104).

Prospectors' name reported in 1954 or 1955 by USGS topographers.

Tomname Lagoon: lagoon, $5.5 \mathrm{mi}$. long, $0.5 \mathrm{mi}$. $\mathrm{W}$ of Tomname Point, $\mathrm{N}$ coast of St. Lawrence I.; $63^{\circ} 21^{\prime} \mathrm{N}, 169^{\circ} 30^{\prime} \mathrm{W}$; BGN 1951; (map 93). Var. Tamnik Lagoon.

Eskimo name reported in 1949 by Maj. H. B. Allen, USAF.

Tomname Mountain: hill, $889 \mathrm{ft}, 21 \mathrm{mi}$. W of Northeast Cape, St. Lawrence I.; $63^{\circ} 20^{\prime} \mathrm{N}$, $169^{\circ} 22^{\prime}$ W; BGN 1951; (map 93). Var. Mary Mountain, Mount Mary, Mount Sooghmeghat, Sooghmeghat Mountain.

Eskimo name reported in 1949 by Maj. H. B. Allen, USAF.

Tomname Point: point of land, at Sooghmeghat $22 \mathrm{mi}$. W of Northeast Cape; $\mathrm{N}$ coast of St. Lawrence I.; $63^{\circ} 21^{\prime} \mathrm{N}, 169^{\circ} 24^{\prime} \mathrm{W}$; (map 93). Var. Cape Tam-nik, Tamnik Point.

Eskimo name reported in 1932 by O. W. Geist, Univ. of Alaska.

Tom Paine Creek: stream, flows $N 6.5 \mathrm{mi}$. to Liberty Creek, $14 \mathrm{mi}$. SE of Chicken and 58 mi. NE of Tok, Yukon-Tanana High.; $63^{\circ}$. $55^{\prime} 00^{\prime \prime} \mathrm{N}, 141^{\circ} 37^{\prime} 35^{\prime \prime} \mathrm{W}$; (map 85).

Local name published by USGS in 1950. Toms Greek: stream, heads in lake, flows NW $3.5 \mathrm{mi}$. to Bear Creek, $45 \mathrm{mi}$. N of Tyonek, Cook Inlet Low.; $61^{\circ} 43^{\prime} \mathrm{N}, 150^{\circ} 58^{\prime} \mathrm{W}$; (map 70)

Local name reported in 1954 by USGS.

Tom's Ranch: locality, on Security Bay, on $\mathbf{N}$ coast of Kuiu I., Alex Arch.; 56 $52^{\prime} \mathrm{N}, 134^{\circ}$ $20^{\prime}$ W; (map 5). Var. Tonis Ranch.

Former Indian village or camp destroyed in 1869 by Commander R. W. Meade, USN; published by USC\&GS in the 1880's.

Tom Thumb Cove: cove, see Corvie Bay.

Tom White, Mount: mountain, 10,630 ft., 15 mi. NE of Carbon Mtn. and $72 \mathrm{mi}$. NE of Cordova, Chugach Mts.; 60 $39^{\circ} 45^{\prime \prime} \mathrm{N}, 143^{\circ}$. 38'50" W; BGN 1950; (map 65).

Named for Tom White, "pioneer of southeastern Alaska."

Tonawanda Creek: stream, flows $\mathrm{S} 3 \mathrm{mi}$. to Baker Creek, $7 \mathrm{mi}$. SE of Roughtop Mtn. and $42 \mathrm{mi}$. ESE of Tanana, Yukon-Tanana High.; $65^{\circ} 06^{\prime} 00^{\prime \prime} \mathrm{N}, 150^{\circ} 38^{\prime} 38^{\prime \prime} \mathrm{W}$; (map 106).

Prospectors' name reported in 1963 by Bond Taber, USGS.

Tonclanukna Creek: stream, heads at Swift Fork Kuskokwim River, flows SW $22 \mathrm{mi}$. to Slow Fork Kuskokwim River, 40 mi. NE of Medfra, Kuskokwim Low.; $63^{\circ} 18^{\prime} \mathrm{N}, 1^{\circ} 3^{\circ} 35^{\prime} \mathrm{W}$; (map 89).

Indian name obtained in 1958 by T. E Taylor, USGS.

Tondustek: locality, see Gantegastaki. 
Tongas: locality, sce Tongass.

Tongas: water passage, sce Tongass Port.

Tongass: locality, on $\mathrm{E}$ coast of Tongass $\mathrm{I}$., Coast Mts.; $54^{\circ} 46^{\prime} 30^{\prime \prime}$ N, $130^{\circ} 14^{\prime} 30^{\prime \prime}$; (map 2). Var. Fort Tomgas, Fort Tongas, TAngā'sh, Tongas, Tont-a-quans, Tungāss, Tungāss-kon, Tungrass.

Former Tlingit Indian village or camp named for the island. In June 1868 a military post, called "Fort Tongass" was established, and maintained here until September 1870. Population recorded as 273 in 1880 and 255 in 1890.

Tongass, Port: water passage, $1.5 \mathrm{mi}$. long, extends $N$ between Tongass $I$. and mainland, Coast Mts.; $54^{\circ} 46^{\prime} 30^{\prime \prime} \mathrm{N}, 130^{\circ} 43^{\prime} 45^{\prime \prime} \mathrm{W}$; (map 2). Var. Tlechopcity, Tlehonsiti, Tomgass, Tongas.

Lt. Comdr. H. E. Nichols, USN, reported, in the 1891 Coast Pilot (p. 79), "Port Tongass is a small harbor, ***." The Russians who used this harbor called it "Tlehonsiti" (Baker, 1906, p. 632).

Tongass Island: island, $0.8 \mathrm{mi}$. long, $\mathrm{W}$ of Port Tongass, in Nakat Bay, NE Dixon Entrance, Coast Mts.; $54^{\circ} 46^{\prime} 30^{\prime \prime}$ N, $130^{\circ} 14^{\prime} 30^{\prime \prime} \mathrm{W}$; (map 2). Var. Kut-tuk-wah Island, Tongas Island.

Local name published in the 1891 Coast Pilot (p. 79). The Indian name "Kut-tukwah" was published in 1869 by USC\&GS.

Tongass Narrows: water passage, $14 \mathrm{mi}$. long, connects $W$ end of Behm Canal with Revil lagigedo Channel, between Gravina and Revillagigedo Is., SE end is divided by Pennock I. into its East and West Channels, Alex. Arch.; $55^{\circ} 22^{\prime} \mathrm{N}, 131^{\circ} 43^{\prime} \mathrm{W} ;$ BGN 1937; (map 3).

Named by local pilots about 1878-80; published in 1885 by USC\&GS.

Tongass National Forest: in SE Alaska, extends SE from White Pass, on Alaska-Canada boundary, and Glacier Bay National Monument along the Coast Mts. to Dixon Entrance, including most of the mainland and off-shore archipelagos.

The Tongass National Forest, the largest national forest in the United States, was created by Presidential Proclamation on September 10, 1907.

Tongass Passage: water passage, $4 \mathrm{mi}$. long, extends SE from Sitklan Passage to Dixon Entrance, E of Sitklan I., Coast Mts.; 54 $45^{\prime} 50^{\prime \prime}$ $\mathrm{N}, 130^{\circ} 39^{\prime} 30^{\prime \prime} \mathrm{W} ; B G N$ 1954; (map 2).

Local name published in the 1891 Corast Pilot (p. 80).

Tungass Passage: water passage, sec Sitklan Passage.

Tongass Point: point of land, see Katakwa Point. Tongass Reef: reef, in Nakat Bay, extends NW $0.3 \mathrm{mi}$. from Port Tongass, $0.5 \mathrm{mi}$. N of Tongass I., Coast Mts.; $54^{\circ} 47^{\prime} \mathrm{N}, 130^{\circ} 44^{\prime} \mathrm{W}$; (map 2)

Named by Lt. Comdr. H. E. Nichols, USN, and published in the 1891 Coast Pilot (p. 79).

Tongue Glacier: glacier, trends NW $2.5 \mathrm{mi}$. to its terminus at Left Fork West Glacier
Creek, $52 \mathrm{mi}$. NE of Nondalton, Aleutian Ra.; $60^{\circ} 05^{\prime} \mathrm{N}, 153^{\circ} 19^{\prime} \mathrm{W}$; (map 61).

Descriptive name reported in 1958 by USGS.

Tongue Point: spit, between Hagemeister Strait and Togiak Bay, $23 \mathrm{mi}$. SW of Togiak, Kilbuck-Kuskokwim Mts. ; $58^{\circ} 49^{\prime} \mathrm{N}, 160^{\circ} 50^{\prime} \mathrm{W}$; (map 39).

So named in 1890 by USBF "because it is long and narrow--like a tongue."

Tongue Point: point of land, in Valdez Arm, at $S$ entrance to Jack Bay, $15 \mathrm{mi}$. WSW of Valdez, Chugach Mts.; $61^{\circ} 02^{\prime} 10^{\prime \prime} \mathrm{N}, 146^{\circ} 39^{\prime} 45^{\prime \prime} \mathrm{W}$; (map 68).

Named in 1898 by Capt. W. R. Abercrombie, USA.

Tonina Island: island, $0.3 \mathrm{mi}$. across, $\mathbf{N}$ Maurelle Is., Alex. Arch.; $55^{\circ} 41^{\prime} 30^{\prime \prime} \mathrm{N}, 133^{\circ} 36^{\prime} 15^{\prime \prime} \mathrm{W}$; BGN 1925; (map 4).

Spanish name meaning "fresh tunny (blue fin tuna);" given in 1924 by USC\&GS, "because the fish is mentioned by [Francisco Antonio] Maurelle in his journal." [Author's Note: I have been unable to locate such a reference.]

Tonis Ranch: locality, see Tom's Ranch.

Tonitleagmund Lake: lake, $0.9 \mathrm{mi}$. long, $\mathrm{S}$ of Tetlin Lake, $22 \mathrm{mi}$. SSE of Tok, Alaska Ra.; $63^{\circ} 03^{\prime} \mathrm{N}, 142^{\circ} 42^{\prime} \mathrm{W}$; (map 85).

Indian name published by USGS in 1964

Tonka: locality, $6 \mathrm{mi}$. S of Petersburg, on SE coast of Kupreanof I., Alex. Arch.; 56 $46^{\circ} 30^{\prime \prime}$ $\mathrm{N}, 132^{\circ} 57^{\prime} 30^{\prime \prime} \mathrm{W}$; (map 6).

This is the site of an abandoned cannery, established in 1901 (U.S. Coast and Geodetic Survey, 1901, addenda facing p. 9). It obtained a post office in 1902 which was discontinued in 1905 (Ricks, 1965, p. 66).

Tonkey, Point: point of land, see Narrow Point. Tonkeye: point of land, see Narrow Cape.

Tonki, Mys: spit, see Unga Spit.

Tonki Bay: bay, $4 \mathrm{mi}$. across, $35 \mathrm{mi}$. NE of Afognak, on $\mathrm{E}$ coast of Afognak $\mathrm{I}$, $\mathrm{N}$ of Kodiak I.; $58^{\circ} 20^{\prime} \mathrm{N}, 152^{\circ} 04^{\prime} \mathrm{W}$; BGN 1910 ; (map 43).

Russian name meaning "thin" derived from Tonki Cape, given by USC\&GS in 1910.

Tonki Cape: point of land, on $\mathrm{E}$ coast of Afognak I., 37 mi. NE of Afognak, $\mathrm{N}$ of Kodiak I.; $58^{\circ} 21^{\prime} \mathrm{N}, 151^{\circ} 59^{\prime} \mathrm{W}$; BGN 1910; (map 43). Var. Tonkie Capc.

Transliteration by USC\&GS in 1868 of the descriptive name "M[ys] Tonkiy," meaning "thin cape," published by the Russian American Company in 1849.

Tonki Cape Peninsula: peninsula, $10 \mathrm{mi}$. long, on E coast of Afognak I., $30 \mathrm{mi}$. NE of Afognak, Kodiak I.; $58^{\circ} 15^{\prime} \mathrm{N}, 152^{\circ} 00^{\prime} \mathrm{W}$; (map 43 ).

Local name reported in 1952 by USGS; derived from Tonki Cape.

Tonkie: point of land, see Narrow Cape.

Tonkie Cape: point of land, see Tonki Cape

Tonkie Mees: point of land, see Tonki Point.

Tonkina: stream, see Gulkana River.

Tonki Point: point of land, on SE coast of St. Paul I., in Pribilof Is.; $57^{\circ} 08^{\prime} 50^{\prime \prime} \mathrm{N}, 170^{\circ}$ $12^{\prime} 40^{\prime \prime} \mathrm{W}$; (map 38). Var. Narrow Point,
Rocky Point, Stony Point, Tonkie Mees

Name published by Elliott (1881, St. Paul notes) as "Tonkie Mees" from the Russian "M[ys] Tonkiy" meaning "thin (or slender) cape."

Tonki Point: point of land, see Narrow Point. Tonki Point: point of land, see Thin Point.

Tonkiy, Mys: point of land, see Narrow Cape.

Tonkiy, Mys: point of land, see Narrow Point.

Tonkoi, Cap: point of land, see Bay Point.

Tonkoi, Mys: point of land, see Thin Point.

Tonkoi Point: point of land, see Bay Point.

Tonkoy, Cape: point of land, see Thin Point.

Tonnie Creek: stream, on Iniskin Penin., flows E $1.5 \mathrm{mi}$. to Fitz Creek, $4 \mathrm{mi}$. S. of Chinitna Bay, Aleutian Ra.; 59 $45^{\prime} 40^{\prime \prime}$ N, $153^{\circ} 13^{\prime} 15^{\prime \prime}$ W; BGN 1947; (map 51 ).

Local name reported in 1947 by USGS. It was named for a rock unit along the creek named in 1938 by oil company geologists.

Tonnie Creek: stream, see Right Branch Trail Creek.

Tonnie Creek: stream, see Trail Creek.

Tonnie Peak: peak, 2,500 ft., on Iniskin Penin., 3 mi. S of head of Chinitna Bay, Aleutian Ra.; $59^{\circ} 46^{\prime} 00^{\prime \prime} \mathrm{N}, 153^{\circ} 16^{\prime} 00^{\prime \prime} \mathrm{W}$; (map 51).

Local name reported in 1922 by USGS.

Tonoek Bay: bay, see Tonowek Bay.

Tonok: locality, at mouth of Eldorado Creek on Norton Sound, $1 \mathrm{mi}$. W of Bluff and $19 \mathrm{mi}$. E of Solomon, Seward Penin. High.; 64 $34^{\prime}$ $\mathrm{N}, 163^{\circ} 48^{\prime} \mathrm{W}$; (map 95)

Site of a mining camp; reported about 1940 by USC\&GS and published on Chart 9380 .

Tonowek Bay: bay, extends NE $3 \mathrm{mi}$, off Gulf of Esquibel, between Prince of Wales and Heceta Is., Alex. Arch.; 55 $44^{\prime} \mathrm{N}, 133^{\circ} 24^{\prime} \mathrm{W}$; (map 4). Var. Bukhta Tonoyek, Tonoek Bay, Tonoyek Bay.

Probably an Indian name; published in 1853 on Russian Hydrog. Dept. Chart 1493 as "Bukh[ta] Tonoyek," or "Tonoyek Bay."

Tonowek Creek: stream, heads in Jay Lake, flows SE $1.7 \mathrm{mi}$. to Tonowek Bay, SE coast of Heceta I., Alex. Arch.; $55^{\circ} 45^{\prime} 40^{\prime \prime}$ N, $133^{\circ}$. 22'10" W; (map 4).

Local name recorded in 1951 by USGS. See Tonowek Bay.

Tonowek Narrows: water passage, extends NE $2 \mathrm{mi}$. from Tonowek Bay to Karheen Passage, between Heceta and Prince of Wales Is., Alex. Arch.; 55 $45^{\prime} 30^{\prime \prime} \mathrm{N}, 133^{\circ} 20^{\prime} 00^{\prime \prime} \mathrm{W}$; $B G N$ 1914; (map 4). Var. Little Skookum Chuck.

Name reported in 1914 by USC\&GS. This feature is known locally as "Little Skookum Chuck" (U.S. Coast and Geodetic Survey, 1925 , p. 251 ; 1962, p. 93). See Salt Chuck, village.

Tonowek Ridge: cliff, elev. 1,000 ft., SE coast of Heceta I., Alex. Arch.; $55^{\circ} 44^{\prime} 45^{\prime \prime}$ N, $133^{\circ}$. 24'15" W; (map 4).

Local name recorded in 1951 by USGS. See Tonowek Bay.

Tonoyek, Bukhta: bay, see Tonowek Bay.

Tonoyek Bay: bay, see Tonowek Bay.

Tonsina: locality, on Richardson Highway, 0.5 mi. S of Tonsina River and $52 \mathrm{mi}$. NE of Valdez, Chugach Mts.; $61^{\circ} 39^{\prime} 20^{\prime \prime} \mathrm{N}, 145^{\circ} 10^{\prime}$ 
$30^{\prime \prime} \mathrm{W}$; (map 68). Var. Tonsina Lodge, Tonsina Roadhouse.

A telegraph station was established here in 1902 by the U.S. Army Signal Corps. A post office was cstablished in 1903 and was discontinued in 1916. It was reestablished in 1930 and was discontinued in 1933.

Tonsina Bay: bay, 1.5 mi. wide, on Kenai Penin., on $W$ short of Nuka Passage, $30 \mathrm{mi}$. SE of Seldovia, Chugach Mts.; $59^{\circ} 18^{\prime} \mathrm{N}, 150^{\circ} 54^{\prime}$ W; (map 50).

Local name reported by USGS in 1951.

Tonsina Creek: stream, on Kenai Penin., flows NE $5 \mathrm{mi}$. to $W$ side of Resurrection Bay, 3.5 mi. S of Seward, Chugach Mts.; $60^{\circ} 02^{\prime} 59^{\prime \prime} \mathrm{N}$, $149^{\circ} 26^{\prime} 15^{\prime \prime} \mathrm{W}$; (map 63). Var. Archer.

Local name published by D. H. Sleem on his map of Central Alaska dated 1910.

Tonsina Glacier: glacier, heads at $61^{\circ} 17^{\prime} 45^{\prime \prime} \mathrm{N}$, $145^{\circ} 58^{\prime} 30^{\prime \prime} \mathrm{W}$, trends $\mathrm{E} 11 \mathrm{mi}$. to its terminus (1951) at head of Tonsina River, $25 \mathrm{mi}$. NE of Valdez, Chugach Mts.; $61^{\circ} 19^{\prime} 45^{\prime \prime} \mathrm{N}, 145^{\circ}$ $40^{\prime} 00^{\prime \prime}$ W; BGN 1932; (map 68).

Name published in 1933 by USGS.

Tonsina Lake: lake, trends N-S $6 \mathrm{mi}$. on Tonsina River, $8 \mathrm{mi}$. NNE of Tonsina Glacier and 37 mi. NE of Valdez, Chugach Mts.; $61^{\circ} 31^{\prime}$ $45^{\prime \prime} \mathrm{N}, 145^{\circ} 29^{\prime} 45^{\prime \prime} \mathrm{W}$; (map 68).

Indian name, derived from the stream name, reported in 1900 by F. C. Schrader.

Tonsina Lodge: locality, see Tonsina.

Tonsina Point: point of land, on Kenai Penin., on NW side of Resurrection Bay, $3.5 \mathrm{mi}$. S of Seward, Chugach Mts. ; $60^{\circ} 03^{\prime} \mathrm{N}, 149^{\circ} 26^{\prime}$ W; (map 63).

Name published on recent USGS maps; derived from nearby Tonsina Creek.

Tonsina Roadhouse: locality, sec Tonsina.

Tonsol Lake: lake, $0.7 \mathrm{mi}$. long, SW of Fish Lake $2 \mathrm{mi}$. $E$ of Tetlin Lake and $21 \mathrm{mi}$. SE of Tok, Alaska $\mathrm{Ra} . ; 63^{\circ} 02^{\prime} \mathrm{N}, 142^{\circ} 39^{\prime} \mathrm{W}$; (map 85).

Local name published by. USGS in 1965.

Tont-a-quans: locality, see Tongass.

Tontethaimund Lake: lake, $2.5 \mathrm{mi}$. long, $1.8 \mathrm{mi}$. $\mathrm{N}$ of Northway, Alaska Ra.; 62 $59^{\prime} \mathrm{N}$, $141^{\circ} 52^{\prime} \mathrm{W}$; BGN 1962; (map 84). Var. Birch Lakes.

Indian name reported by USGS in 1955.

Tony Creek: stream, flows W $1 \mathrm{mi}$. to Venetia Creek, between Colly and Victoria Creeks, 21 mi. NW of Solomon, Seward Penin. High.; $64^{\circ} 50^{\prime} \mathrm{N}, 164^{\circ} 46^{\prime} \mathrm{W}$; (map 95).

Prospectors' name reported on a map of Cape Nome gold fields by David Fox, Jr., dated 1901

Tony Lake: lake, $2.5 \mathrm{mi}$. long, $9.5 \mathrm{mi}$. NE of Beaver, Yukon Flats; $66^{\circ} 28^{\prime} \mathrm{N}, 147^{\circ} 07^{\prime} \mathrm{W}$; (map 118)

Local name obtained in 1956 by USGS.

Tony Slough: stream, an anabranch of Yukon River, flows NW $4.5 \mathrm{mi}$., $7 \mathrm{mi}$. NE of Beaver, Yukon Flats; $66^{\circ} 25^{\prime} 30^{\prime \prime} \mathrm{N}, 147^{\circ} 12^{\prime} 00^{\prime \prime} \mathrm{W}$; (map 118)

Local name obtained in 1956 by USGS.

Tonzona River: stream, heads in Alaska Ra., at Mystic Pass, flows NE $15 \mathrm{mi}$., then NW $60 \mathrm{mi}$., to join Slow Fork to form East Fork
Kuskokwim River, $30 \mathrm{mi}$. E of Medfra, Kuskokwim Low.; 63 ${ }^{\circ} 11^{\prime} 30^{\prime \prime} \mathrm{N}, 153^{\circ} 45^{\prime} 30^{\prime \prime}$ W; BGN 1964; (map 89). Var. East Fork Kuskokwim River, Ghedotlothna, Swift Fork.

The Indian name "Tonzona" was applied in 1899 to the stream now called "Little Tonzona River" by Lt. J. S. Herron, USA. A. H. Brooks, USGS, traveling nearer the foot of the Alaska Range in 1902 mistakenly applied Herron's name "Tonzona" to this stream. The greater publication of Brooks' application of the name established its present usage.

Tonzona River: stream, see Little Tonzona River.

Too-clok: locality, see Tutlut.

Toogamak: bight, see Unimak Bight.

Toogedach: island, see Tugidak Island.

Toogidach: island, see Tugidak Island.

Tooguk Lagoon: lagoon, see Tugak Lagoon.

Toohidack: island, see Tugidak Island.

Tooie Creek: stream, in Chigmit Mts., flows SE $6 \mathrm{mi}$. to Silver Salmon Creek, $1 \mathrm{mi}$. N of Chinitna Bay, Aleutian Ra.; $59^{\circ} 52^{\prime} 30^{\prime \prime} \mathrm{N}$, $153^{\circ} 13^{\prime} 30^{\prime \prime} \mathrm{W}$; BGN 1962; (map 51).

Local name reported in 1951 by USGS.

Tooinichook Mountains: mountains, see Tahinichok Mountains.

Tookhlagamute: locality, see Tuklak.

Tookinghak: mountain, see Tukingak Mountain.

Took-key-auk Mountain: mountain, see Tukingak Mountain.

Tookozetna Bay: estuary, see Tuxedni Bay.

Tookrook River: water passage, see Tukrok River.

Tooksook: locality, see Tuksuk.

Tooksook Bay: bay, see Kangirlvar Bay.

Tooksook Channel: water passage, see Tuksuk Channel.

Tooksook River: stream, sec Toksook River.

Toolavia: point of land, see Christie Point.

Tooleekskoi: locality, see Tulik.

Toolemina: locality, see Boat Extreme.

Toolemina: barrier island, see Tulimanik Island.

Toolik Lake: lake, see Tulilik Lake.

Toolik River: stream, heads in lake at $68^{\circ} 36^{\prime} 30^{\prime \prime}$ $\mathrm{N}, 149^{\circ} 16^{\prime} 30^{\prime \prime} \mathrm{W}$, flows $\mathrm{N} 120 \mathrm{mi}$. to Kuparuk River, 35 mi. SW of Gwydyr Bay, Arctic Plain; 69 $56^{\prime} \mathrm{N}, 149^{\circ} 30^{\circ} \mathrm{W}$; (map 140).

Eskimo name for common loon (Gavia immer) and yellow-billed loon (Gavia adamsi); of ten spelled "tudlik" or "tulik"; given about 1951 by USGS geologists.

Toolilik Lake : lake, see Tulilik Lake

Toolooguk Creek: stream, see Tulugak Creek.

Toolooka-anahamute: locality, see Tuluka.

Too-look-sook River: stream, see Tutuksuk River.

Tooloolak Koogowranga: stream, see Tulukak Creek.

Tooloorak: cliffs, see Tulurak.

Tooloouk River: locality, see Tuluuk.

Toolukaanahamute: locality, see Tuluka.

Toome Creek: stream, see Tumi Creek.

Too Much Gold Creek: stream, flows NW $1 \mathrm{mi}$. to Fish Creek, 20 mi. NE of Fairbanks, YukonTanana High.; $65^{\circ} 01^{\prime} 45^{\prime \prime} \mathrm{N}, 147^{\circ} 09^{\prime} 10^{\prime \prime} \mathrm{W}$; (map 105).
Named by prospectors; published in 1908 by USGS.

Too Much Gold Creek: stream, flows SE $1 \mathrm{mi}$. to Fairbanks Creek, 20 mi. NE of Fairbanks, Yukon-Tanana High.; $65^{\circ} 04^{\prime} \mathrm{N}, 147^{\circ} 18^{\prime} \mathrm{W}$; (map 105).

Named by prospectors; published in 1908 by USGS.

Toongak River: stream, see Tungak Creek.

Toonuk Mountain: hill, see Tungnak Hill.

Toosigpahk Creek: stream, see Tasikpak Creek.

Toosigpahk Lagoon: lagoon, see Tasikpak Lagoon.

Tooth Cove: cove, $0.9 \mathrm{mi}$. long, on $\mathrm{W}$ coast of Aialik Penin., $4 \mathrm{mi}$. $\mathrm{N}$ of Three Hole Bay, 23 mi. SW of Seward, Chugach Mts.; 59 $49^{\prime} \mathrm{N}$, $149^{\circ} 40^{\prime} \mathrm{W}$; (map 49).

Descriptive name published in 1915 by USGS.

Tooth Lake: lake, $0.7 \mathrm{mi}$. long, $\mathrm{N}$ of Chitina River, $1.4 \mathrm{mi}$. NW of Skull Lake and $26 \mathrm{mi}$. SW of McCarthy, Copper River Basin ; 61 ${ }^{\circ} 23^{\prime}$ $30^{\prime \prime} \mathrm{N}, 143^{\circ} 41^{\prime} 00^{\prime \prime} \mathrm{W}$; (map 67).

So named by USGS in 1951 because the shoreline traces the outline of a tooth.

Tooth Mountain: mountain, 1,000 ft., $7 \mathrm{mi}$. E of Carter Bay and $12 \mathrm{mi}$. NW of Goodnews, Kilbuck-Kuskokwim Mts. ; $59^{\circ} 16^{\prime} \mathrm{N}, 161^{\circ} 45^{\prime}$ W; (map 53).

Descriptive name given in 1913 by USC\&GS "because it has a sharp tooth-like pinnacle on the northern edge of the summit." The name was published in 1915 on Chart 9103.

Tpotooksook River: stream, see Tutuksuk River. Topagaruk River: stream, see Topagoruk River. Topagoruk River: stream, heads at $69^{\circ} 40^{\prime} \mathrm{N}$, $156^{\circ} 41^{\prime} \mathrm{W}$, flows $\mathrm{N} 160 \mathrm{mi}$, to Admiralty Bay, Arctic Plain; $70^{\circ} 50^{\prime} \mathrm{N}, 1^{\circ} 5^{\circ} 54^{\prime} \mathrm{W}$; (map 148). Var. Kagavik River, Topagaruk River.

This Eskimo name first appears on a field sheet by J. E. Whitaker, USGS, in 1923. Orth recorded the name as "Tupikrorak" at Barrow in 1965, and was told it refers in meaning to "place for tent."

Topanica: locality, see Topanika.

Topanika: locality, on E shore of Norton Sound, $22 \mathrm{mi}$. SE of Cape Denbigh, Nulato Hills; $64^{\circ} 21^{\prime} \mathrm{N}, 160^{\circ} 57^{\prime} \mathrm{W}$; (map 96). Var. Tapkhamikhuagmut, Tapkhamikkhuag-myut, Taupanica, Topanica, To-pan-i-kwa, Tulpanika, Tulpanikha, Tuphamikva, Tuphamikwa, Tup-hanikwa.

Former Eskimo village or camp published as "Tapkhamikhuagmut" by Lt. Zagoskin (1847, v. 1, p. 72). Recorded in 1869 as "Topánika" by W. H. Dall $(1870$, p. 20$)$; listed in the 1880 Census as "Tup-hamikva," population 10 , by Ivan Petroff.

To-pan-i-kwa: locality, see Topanika.

Topcock : locality, see Topkok.

Topcock, Cape: point of land, see Topkok Head.

Topcock Creek: stream, see Topkok River.

Topeka Glacier: glacier, in Glacier Bay National Monument, trends S $2 \mathrm{mi}$. to its 1961 terminus $2 \mathrm{mi}$. NE of head of Toyatte Glacier, $82 \mathrm{mi}$. NW of Hoonah, St. Elias Mts.; 58 $56^{\prime}$ $15^{\prime \prime} \mathrm{N}, 137^{\circ} 05^{\prime} 00^{\prime \prime} \mathrm{W}$; (map 10). 
Named in 1936 by W. O. Field, Jr., and W. S. Cooper for the SS Topeka.

Topkak, Cape: point of land, see Topkok Head. Topkok: locality, at mouth of Topkok River, $\mathbf{N}$ shore of Norton Sound, $15 \mathrm{mi}$. E. of Solomon, Seward Penin High.; $64^{\circ} 34^{\prime} \mathrm{N}, 163^{\circ} 57^{\prime} \mathrm{W}$; (map 95). Var. Tap-hok, Topcock, Tupka-ak.

Former Eskimo village reported in the 1880 Census as "Tup-ka-ak," population 15. The 1890 Census listed "Tap-hok" but gave no population. A mining camp appears to have been set up here in about 1900 and tho 1908 "Map of Seward Peninsula" by Arthur Gibson shows a "Topkok Roadhouse" at this site.

Topkok: locality, see Tapkhakg-miut.

Topkok, Cape: point of land, see Topkok Head.

Topkok Head: point of land, on N coast of Norton Sound, $14 \mathrm{mi}$. E of Solomon, Seward Penin. High.; 64 $34^{\circ} 3^{\prime} \mathrm{N}, 163^{\circ} 58^{\prime \prime} \mathrm{W}$; (map 95). Var. Cape Topcock, Cape Topkak, Cape Topkok, Mys Utes, Mys Utesistyy.

Local name reported in 1900 by Barnard (in Brooks, 1901, pl. 17), USGS. USG\&GS published "Cape Topkok" in 1900. The name is derived from the village reported as "Tupka-ak" by Petroff in the 10th Census in 1880. This appears to be the feature reported in $1842-44$ as "M[ys] Utesistyy," meaning "cliffy cape," by Lt. L. A. Zagoskin, IRN, and shown as "M[ys] Utes" by Capt. Tebenkov (1852, map 2), IRN.

Topkok River: stream, flows SE $5 \mathrm{mi}$. to Norton Sound at Topkok, $15 \mathrm{mi}$. E of Solomon,

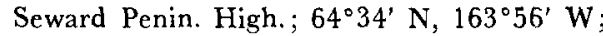
(map 95). Var. Topcock Creek.

Eskimo name reported in 1900 by E. C. Barnard (in Brooks, 1901, pl. 17), USGS. Reported as "Topcock Creek" in 1899 by Schrader and Brooks (1900, map 3), USGS.

Top Lake: lake, 2,500 ft. long, drains into Eightmile Creck, $51 \mathrm{mi}$. NW of Tyonek, Alaska Ra.; $61^{\circ} 48^{\prime} 10^{\prime \prime} \mathrm{N}, 151^{\circ} 18^{\prime} 15^{\prime \prime} \mathrm{W}$; (map 70).

Local descriptive name reported in 1954 by USGS.

Topless Peak: peak, 4,100 ft., $0.8 \mathrm{mi} . \mathrm{N}$ of Vesper Peak and $6 \mathrm{mi}$. NE of Juneau, Coast Mts.; $58^{\circ} 23^{\prime} 00^{\prime \prime} \mathrm{N}, 134^{\circ} 21^{\prime} 45^{\prime \prime} \mathrm{W}$; (map 11).

Local descriptive name reported by $D$. A. Brew and A. B. Ford, USGS, in 1965.

Top Mountain: mountain, see Pop Mountain.

Topnotch Creek: stream, flows S $2 \mathrm{mi}$. to Kasson Creek which flows to Solomon River, $9 \mathrm{mi}$. NE of Solomon, Seward Penin. High.; $64^{\circ} 41^{\prime}$ N, $164^{\circ} 24^{\prime} \mathrm{W}$; (map 95).

Prospectors' name reported on a map of Cape Nome gold fields by David Fox, Jr., dated 1901.

Topographers Peak: peak, 3,015 ft., on Alaska Penin., in Katmai National Monument, 14 mi. SW of Mount Katmai, Aleutian Ra.; $58^{\circ}$ $05^{\prime} 15^{\prime \prime} \mathrm{N}, 155^{\circ} 09^{\prime} 30^{\prime \prime} \mathrm{W}$; BGN 1924; (map 42).

Named by R. F. Griggs, for Paul R. Hagelbarger, topographer on the 1919 National Geographic Society Katmai Expedition.

Topor, Mys: point of land, see Hatchet Point.
Toporkof: island, see Puffin Island.

Toporkof Bay: bay, see Puffin Bay.

Toporkoff Bay: bay, see Puffin Bay.

Toporkof Point: point of land, see Puffin Point.

Toporkov, Ostrov: island, see Puffin Island.

Toporkova Bukhta: bay, see Puffin Bay.

Toporkov Bay: bay, see Puffin Bay.

Toporkov Point: point of land, see Puffin Point. Toporkovy, Mys: point of land, see Puffin Point.

Topsy Creek: stream, in Glacier Bay National Monument, flows SW $5 \mathrm{mi}$. to Gulf of Alaska, $2.4 \mathrm{mi}$. S of mouth of Steelhead Creek and $81 \mathrm{mi}$. NW of Hoonah, St. Elias Mts.; 58 $33^{\prime}$ $30^{\prime \prime} \mathrm{N}, 137^{\circ} 29^{\prime} 45^{\prime \prime} \mathrm{W}$; BGN 1959; (map 10). Var. Steelhead Creek, North Branch Steelhead Creek.

Local name reported by J. B. Mertie (in Smith and others, 1933, fig. 4), USGS. It was published as "Steelhead Creek" by members of the Harvard-Dartmouth Expedition, 1933-34, (Washburn and Goldthwait, 1936, map).

Toqakvik: locality, see Chrome.

Toral: locality, see Taral.

Torbert, Mount: mountain, 11,413 ft., in Tordrillo Mts., $49 \mathrm{mi}$. NW of Tyonek, Alaska Ra.; $61^{\circ} 24^{\prime} 35^{\prime \prime} \mathrm{N}, 152^{\circ} 24^{\prime} 35^{\prime \prime} \mathrm{W}$; $B G N$ 1964; (map 70).

Name reported by S. R. Capps and R. H. Sargent (in Smith and others, 1929, pl. 3), USGS. Named for John B. Torbert, USGS cartographer, who died in 1929.

Torch Bay: bay, $3 \mathrm{mi}$. long, in Glacier Bay National Monument, on Gulf of Alaska, $2 \mathrm{mi}$. $\mathrm{SE}$ of Dixon Harbor and $52 \mathrm{mi}$. NW of Hoonah, St. Elias Mts.; $58^{\circ} 18^{\prime} 30^{\prime \prime} \mathrm{N}, 136^{\circ}$ $48^{\prime} 30^{\prime \prime} \mathrm{W}$; (map 10).

Named by USC\&GS in 1926; published in 1929.

Tordrillo Mountains: mountains, 8,000-11,000 $\mathrm{ft}$., in group $50 \mathrm{mi}$. long and $40 \mathrm{mi}$. wide, at SW end of Alaska Ra.; bounded on $\mathrm{N}$ and W by Skwentna River, on S by Chakachatna River, and on $E$ by lowlands of Susitna River; $61^{\circ} 30^{\prime} \mathrm{N}, 152^{\circ} 15^{\prime} \mathrm{W}$; (map 70). Var. Tordrillo Range.

Named in 1898 by J. E. Spurr, USGS; probably a form of an Indian name.

Tordrillo Range: mountains, see Tordrillo Mountains.

Torment Creek: stream, heads in Ray Mts., flows NE 19 mi. to Kanuti Kilolitna River, $50 \mathrm{mi}$. NW of Rampart and $62 \mathrm{mi}$. NE of Tanana, Kokrines-Hodzana High.; 65 $59^{\prime}$ N, $151^{\circ} 14^{\prime} \mathrm{W}$; (map 106).

Local name reported in 1956 by Orth; so named because of the "tormenting course of the creek and the mosquitoes."

Torno Cape: point of land, see Black Cape.

Torok Creek: stream, flows NE $15 \mathrm{mi}$. to Chandler River, $3 \mathrm{mi}$. S of Tukto Bluff and $41 \mathrm{mi}$. NW of Anaktuvuk Pass, Arctic Slope; $68^{\circ}$ $41^{\circ} 15^{\prime \prime} \mathrm{N}, 152^{\circ} 17^{\prime} 30^{\prime \prime} \mathrm{W}$; BGN 1949; (map $134)$.

Eskimo name given in 1948 by J. S. Detterman, USGS, for the camp dog.

Torongwalk: mountain, see Towak Mountain.
Torpedo Lake: lake, $0.5 \mathrm{mi}$. long, drains $\mathrm{W}$ to Kenai River $3 \mathrm{mi}$. W of Skilak Lake, $24 \mathrm{mi}$. $\mathrm{SE}$ of Kenai, Cook Inlet Low.; 60 $28^{\prime} 40^{\prime \prime}$ $\mathrm{N}, 150^{\circ} 34^{\prime} 35^{\prime \prime} \mathrm{W}$; (map 62).

Local name reported in 1951 by USGS. Torrance Creek: stream, see Mina Creek.

Torrent Inlet: bay, 2 mi. across, off Peard Bay, $E$ of Nalimiut Point, $10 \mathrm{mi}$. SE of Point Franklin, Arctic Plain; $70^{\circ} 49^{\prime} \mathrm{N}, 158^{\circ} 24^{\prime}$ W; (map 147).

Named by English naval officers about 1850.

Torres, Ensenada de: bay, see Saint Nicholas, Port.

Torsar Island: island, $0.5 \mathrm{mi}$. across, $2 \mathrm{mi} \mathrm{NW}$ of Goddard, in Necker Is., on W coast of Baranof I., Alex. Arch.; 56 51'00' N, $135^{\circ} 25^{\prime} 30^{\prime \prime}$ W; (map 5). Var. Ostrov Torsar.

Named in 1809 by the Russian navigator, Ivan Vasiliev the first; published by Lt. Sarichev (1826, map 19), IRN, as "O[strov] Torsar," or "Torsar Island."

Tortella: locality, near mouth of Nenana River, probably at or near present village of Nenana, Tanana Low.; $64^{\circ} 34^{\prime} \mathrm{N}, 149^{\circ} 05^{\prime} \mathrm{W}$; (map 100). Var. Tortilli.

Former Tanana Indian village reported in 1902 by A. H. Brooks, USGS. A map by Lt. Gibbs, USA, dated 1902, shows a village spelled "Tortilli" on the north side of the Tanana River.

Tortilli: locality, see Tortella.

Tosechargut: stream, see Tozitna River.

Tosekargut: stream, see Tozitna River.

Totakdagrich Cachegen Lake: lake, $0.4 \mathrm{mi}$. long, $1 \mathrm{mi}$. S of Ninemile $\mathrm{I}$. and $10 \mathrm{mi}$. NE of Ruby, Nowitna Low.; $64^{\circ} 49^{\prime} \mathrm{N}, 155^{\circ} 11^{\prime} \mathrm{W}$; (map 98).

Local name reported about 1952 by USGS.

Totascholëden: locality, see Dementi.

Totascholjöden: locality, see Dementi.

Totaskholëden: locality, see Dementi.

Totatlanika River: stream, heads at junc. of All Gold and Dexter Creeks, flows $N 63 \mathrm{mi}$. to Tanana River, $10 \mathrm{mi}$. E of Nenana, Tanana Low.; 64⒊ $34^{\prime} 10^{\prime \prime} \mathrm{N}, 148^{\circ} 46^{\prime} 30^{\prime \prime} \mathrm{W}$; (map 100). Var. Bradley River.

Tanana Indian name meaning "Totatla Creek" adopted and used by miners and reported in 1906 by L. M. Prindle (in Brooks and others, 1907, pl. 4), USGS. This may have been the stream named "Bradley River" by Lt. Allen ( 1887 , pl. 1), USA, in 1885 although it was more likely to have been the present-day Wood River.

Totchaket Slough: stream, flows $\mathrm{N} 7 \mathrm{mi}$. to Tanana River, $7 \mathrm{mi}$. S of Minto and $44 \mathrm{mi}$. W of Fairbanks, Tanana Low.: $64^{\circ} 47^{\prime} \mathrm{N}$, $149^{\circ} 12^{\prime} \mathrm{W}$; (map 100).

Indian name published in the 1950's.

Totchikala: locality, on Unalaska I., Aleutian Is.; $53^{\circ} 35^{\prime} \mathrm{N}, 166^{\circ} 55^{\prime} \mathrm{W}$; (map 23). Var. Totzikala.

Former Aleut village or camp published by Rev. Coxe (1787, p. 161).

Totek Hills: mountains, $1,370 \mathrm{ft}$., $32 \mathrm{mi}$. SW of Nenana, Tanana Low.; $64^{\circ} 17^{\prime} \mathrm{N}, 149^{\circ} 54^{\prime} \mathrm{W}$; (map 100). 
Tanana Indian name published by USGS on recent maps.

Totem Bay: bay, extends $4 \mathrm{mi}$. S to Sumner Strait, on $\mathrm{S}$ coast of Kupreanof I., Alex. Arch.; $56^{\circ} 28^{\prime} \mathrm{N}, 133^{\circ} 23^{\prime} \mathrm{W}$; (map 6).

Named in 1886 by USC\&GS "on account of the detached pillars of rock on its western shore, which resemble the Indian totem poles."

Totem Bight: bight, $0.7 \mathrm{mi}$. wide, on $\mathrm{W}$ coast of Revillagigedo I., on $\mathrm{E}$ shore of Tongass Narrows, 5 mi. NW of Ketchikan, Alex. Arch.; $55^{\circ} 25^{\prime} 30^{\prime \prime} \mathrm{N}, 131^{\circ} 47^{\prime} 00 \mathrm{~W}$; (map 3).

Local name recorded in 1954 by USGS. Totem Lodge: suburb, see Mud Bay.

Totem Point: point of land, on a small island at $W$ point of entrance to Totem Bay, on $S$ coast of Kupreanof I., Alex. Arch.; $56^{\circ}$ $27^{\prime} 10^{\prime \prime} \mathrm{N}, 133^{\circ} 26^{\prime} 00^{\prime \prime} \mathrm{W}$; (map 6).

Local name recorded in 1949 by USGS.

Totem Rock: rock, in Kanaga Bay, on SE coast of Kanaga I., Aleutian Is., $51^{\circ} 42^{\prime} 30^{\prime \prime} \mathrm{N}, 177^{\circ}$ $11^{\prime 3} 3$ ' W; (map 17).

Name published in 1957 on an AMS map. Totem Village: suburb, see Mud Bay.

Toti Island: island, $0.5 \mathrm{mi}$. long, between Bucareli and Trocadero Bays, on $W$ coast of Prince of Wales I., Alex. Arch.; 55 $24^{\prime} 45^{\prime \prime} \mathrm{N}, 133^{\circ}$ 07'25" W; BGN 1922; (map 4). Var. Isla Toti, Isla Toty, Robber Island.

Spanish name given in $1775-79$ by Juan de la Bodega y Quadra and Francisco Antonio Maurelle as "Isla Toti," meaning "robber island." The translation of this name was used by USC\&GS but was discontinued in 1922 because of confusion with Ladrones Islands. See Ladrones Islands.

Totoilon Mountains: mountains, at head of Yentna drainage basin, Alaska Ra.; 62 $00^{\prime}$ N, $153^{\circ} 00^{\prime} \mathrm{W}$; (map 81). Var. To-toy-lon Mountains.

Tanaina Indian name obtained in 1899 by Lt. J. S. Herron, USA, who spelled it "To-toylon."

Totondu River: stream, see Tatonduk River.

Tototlindu: stream, see Mission Creek.

To-toy-lon Mountains: mountains, see Totoilon Mountains.

Totsahdmund Lake: lake, see Steve Lake.

Totschunda Creek: stream, heads in Mentasta Mts., flows SE 12 mi. to Nabesna River, 7.5 mi. NE of Devils Mtn., Alaska Ra.; $62^{\circ} 27^{\prime}$ $\mathrm{N}, 142^{\circ} 42^{\prime} \mathrm{W}$; (map 84).

Indian name reported in 1902 by F. C. Schrader, USGS. According to Moffit (1941, p. 137), USGS, the name is "derived from Indian words meaning 'red stone' and is appropriate, as the rocks of this appearance are readily traced from the north side of the Totschunda Creek Valley to Suslota Creek."

Totsenbet: stream, see Wild River.

Totsenbetna: stream, see Wild River.

Totsenbet River: stream, see John River.

Totshotno: stream, see Takotna River.

Totson Mountain: mountain, 2,714 ft., in Kaiyuh Mts.; 23 mi. SW of Galena and 31 mi. SE of Nulato, Kilbuck-Kuskokwim Mts.; $64^{\circ} 27^{\prime}$ N, $157^{\circ} 18^{\prime}$ W; (map 97). Var. Monte Takaïaka, Tolson Mountain.
Indian name reported in 1927 by USC\&GS. This may be the same as "M[onte] Takaiaka," on Lt. L. A. Zagoskin's 1850 map.

Toty, Isla: island, see Toti Island.

Totzikala: locality, see Totchikala.

Totzunbetna: stream, see Wild River.

Totzunbitna: stream, see Wild River.

Touchit Cove: estuary, extends E $0.6 \mathrm{mi}$. near mouth of Shoe Inlet, on NW coast of Long I., Alex. Arch.; $54^{\circ} 55^{\prime} 30^{\prime \prime} \mathrm{N}, 132^{\circ} 48^{\prime} 00^{\prime \prime} \mathrm{W}$; $B G N$ 1929; (map 1).

Name published on a 1923 manuscript map by USFS.

Tougamak: bight, see Unimak Bight.

Toughimik Island: island, see Little Koniuji Island.

Tough. Luck Creek: stream, flows S $1 \mathrm{mi}$. to Chatanika River, $1.9 \mathrm{mi}$. upstream from the mouth of Sourdough Creek and $49 \mathrm{mi}$. NE of Yukon-Tanana High.; 65 $17^{\prime} 50^{\prime \prime} \mathrm{N}, 146^{\circ}$. $25^{\prime} 45^{\prime \prime} \mathrm{W}$; (map 104).

Prospectors' name reported in 1954 or 1955 by USGS topographers.

Tougidak: island, see Tugidak Island.

Tougidok: island, see Tugidak Island.

Toukatl Creek: stream, see Ulukuk River.

Toulak, Mount: mountain, see Tulik Volcano.

Toulakságamut: village, see Tuluksak.

Toulikskoi: mountain, see Tulik Volcano.

Touliouliaga: point of land, see Lazaref, Cape.

Tounak: island, see Chernabura Island.

Toungovlik: island, see Tungulik.

Tours, Île de: island, see Pinnacle Island.

Toussaint Island: island, $1.5 \mathrm{mi}$. across, in Yukon River, $2 \mathrm{mi}$. SE of Fort Yukon, Yukon Flats; $66^{\circ} 32^{\prime} \mathrm{N}, 145^{\circ} 15^{\prime} \mathrm{W}$; (máp 119).

Local name obtained in 1956 by USGS.

Towahmina Lake: lake, $1 \mathrm{mi}$. long, $36 \mathrm{mi}$. NE of Medfra, Kuskokwim Low.; $63^{\circ} 20^{\prime} \mathrm{N}, 153^{\circ}$ 41' W; (map 89).

Indian name obtained in 1958 by T. E. Taylor, USGS.

Towak Creek: stream, on $\mathrm{N}$ slope of Towak Mtn., flows N 3.4 mi. to Scammon Bay, 7.5 mi. E of Cape Romanzof, Yukon-Kuskokwim Delta ; 61 ${ }^{\circ} 49^{\prime} 30^{\prime \prime} \mathrm{N}, 1^{\circ} 5^{\circ} 52^{\prime} 15^{\prime \prime} \mathrm{W}$; (map 75). Var. Towak River.

Eskimo name reported by AMS in 1952.

Towak Mountain: mountain, 2,342 ft., on Cape Romanzof, in Askinuk Mts., between Kokechik and Scammon Bays, Yukon-Kuskokwim Delta: $61^{\circ} 47^{\circ} \mathrm{N}, 165^{\circ} 57^{\prime} \mathrm{W}$ : (map 75). Var. Tro-wak, Torongwalk.

Eskimo name reported by USC\&GS in 1949. Towak River: stream, see Towak Creek.

Towayat's Village: locality, on Etolin I., Alex. Arch.: $56^{\circ} 06^{\prime} \mathrm{N}, 132^{\circ} 21^{\prime}$ W: (map 6). Var. Toyā't's Village.

Former summer camp of a Tlingit Indian chief, Toyä't, listed in the 1880 Census, with a population of 82 , by Petroff (1884, p. 32).

Tower Bluff Rapids: rapids, in Tanana River, at base of Tower Bluffs, $17 \mathrm{mi}$. NW of Tanacross, Yukon-Tanana High.; $63^{\circ} 32^{\prime} 30^{\prime \prime} \mathrm{N}$, $143^{\circ} 47^{\prime} 00^{\prime \prime} \mathrm{W}$; (map 85).

Named in 1885 by Lt. Allen (1887, p. 81 ), USA.
Tower Bluffs: bluffs, elev. $3,210 \mathrm{ft}$, on $\mathrm{E}$ bank of Tanana River, extend N $6.5 \mathrm{mi}$. from junc. of Robertson and Tanana Rivers, $15 \mathrm{mi}$. NW of Tanacross, Yukon-Tanana High.: $63^{\circ} 31^{\prime}$ $\mathrm{N}, 143^{\circ} 45^{\prime} \mathrm{W}$; (map 85).

Named in 1885 by Lt. Allen (1887, p. 81), USA.

Tower Point: point of land, on SW coast of Unalaska I., Aleutian Is.; $53^{\circ} 23^{\prime} 05^{\prime \prime} \mathrm{N}, 167^{\circ}$ 13'00" W; BGN 1939; (map 23 ).

So named by USC\&GS in 1939 because "the nearness of this point to Buttress Point forms two most conspicuous landmarks in the vicinity."

Towers, The: ridge, see Mendenhall Towers.

Towers Arm: bay, $4 \mathrm{mi}$. long, at head of Duncan Canal, on Kupreanof I., Alex. Arch.; $56^{\circ} 48^{\prime}$ N, $133^{\circ} 19^{\prime} \mathrm{W}$; BGN 1966; (map 6). Var. Towers Bay.

Local name reported in 1933 by USC\&GS; "given for a prospector who carried on extensive mining operations in this vicinity for several years."

Towers Bay: bay, see Towers Arm.

Towers Lake: lake, $1 \mathrm{mi}$. long, $4.5 \mathrm{mi}$. NW of Towers Arm and $20 \mathrm{mi}$. W of Petersburg, on Kupreanof I., Alex. Arch.; 56 52'15" N, $133^{\circ}$. $28^{\prime} 30^{\prime \prime} \mathrm{W}$; (map 6).

Local name recorded in 1948 by USGS.

Towhead Mountain: mountain, 4,856 ft., on E bank of Tana River $12 \mathrm{mi}$. SE of its junc. with Chitina River and $27 \mathrm{mi}$. SE of McCarthy, St. Elias Mts. ; $61^{\circ} 03^{\prime} \mathrm{N}, 142^{\circ} 40^{\prime} \mathrm{W}$; (map 67).

Named in 1900 by F. C. Schrader (Mendenhall and Schrader, 1903, pl. 3), USGS.

Town Lake: lake, $0.3 \mathrm{mi}$. across, $\mathrm{S}$ of Chitina and $66 \mathrm{mi}$. NE of Valdez, Chugach Mts.; $61^{\circ}$ $30^{\prime} 50^{\prime \prime} \mathrm{N}, 144^{\circ} 26^{\prime} 10^{\prime \prime} \mathrm{W}$; (map 68).

Local name published in the 1950's by USGS.

Townsend Peak: mountain, 5,700 ft., $1.7 \mathrm{mi} . \mathrm{E}$ of Mount Mahlo and $17 \mathrm{mi}$. N of Valdez, Chugach Mts.; $61^{\circ} 21^{\prime} 20^{\prime \prime} \mathrm{N}, 146^{\circ} 13^{\prime} 20^{\prime \prime} \mathrm{W} ; B G N$ 1960; (map 68). Var. Rice Peak, Summit Peak.

Named by L. E. Nielsen in 1960 for "Dr. Leroy S. Townsend *** physician at Copper Center during the winter of 1898-99 * * * wrote a report on scurvy in the Abercrombie report ***."

Townshend, Point : point of land, see Brightman, Point.

Towogiak Bay: bay, see Togiak Bay.

Towrockeeleegowrak: locality, see Turakiligorak.

Towshecargut: stream, see Tozitna River.

Toyatte Glacier: glacier, in Glacier Bay National Monument, trends SE $3 \mathrm{mi}$. to Johns Hopkins Inlet $5.5 \mathrm{mi}$. NE of Johns Hopkins Glacier, $80 \mathrm{mi}$. NW of Hoonah, St. Elias Mts. : 58 $53^{\prime} 45^{\prime \prime} \mathrm{N}, 137^{\circ} 03^{\prime} 45^{\prime \prime} \mathrm{W}$; BGN 1937; (map 10).

Named by Muir (1915, p. 204) for Toyatte. a chief of the Stickeen Indians, who accompanied him in 1879 and who was killed while attempting to quell a riot between the Taku 
and Stickeen Indians, described by Muir in "Travels in Alaska."

Toy Harbor: cove, $0.1 \mathrm{mi}$. across, on SE shore of Necker Bay, on Baranof I., Alex. Arch.; $56^{\circ} 43^{\prime} 10^{\prime \prime} \mathrm{N}, 135^{\circ} 04^{\prime} 40^{\prime \prime} \mathrm{W}$; BGN 1926; (map 5).

Named in 1924 by USC\&GS; published in 1925 Coast Pilot (p. 284).

Toyonak: locality, on W shore of Cook Inlet near mouth of McArthur River, Cook Inlet Low.; $60^{\circ} 54^{\prime} \mathrm{N}, 151^{\circ} 42^{\prime} \mathrm{W}$; (map 62).

Former Eskimo village or camp published in Polk's Gazetteer, 1916.

Toyoniek: settlement, see Old Tyonek.

Toyonok: settlement, see Old Tyonek.

Toyonok: village, see Tyonek.

Toyons Bay: bay, see Redoubt Bay.

Toza Island: island, $0.3 \mathrm{mi}$. long, Maurelle Is., Alex. Arch.; $55^{\circ} 37^{\prime} 15^{\prime \prime} \mathrm{N}, 133^{\circ} 39^{\prime} 30^{\prime \prime} \mathrm{W}$; (map 4).

Spanish name meaning "log (bulky piece of wood) " recorded in 1951 by USGS.

Tozer Creek: stream, flows SW $8 \mathrm{mi}$. to Don River which flows to Breving Lagoon, $18 \mathrm{mi}$. NW of Teller, Seward Penin. High.; $65^{\circ} 26^{\prime} \mathrm{N}$, $166^{\circ} 48^{\prime} \mathrm{W}$; (map 111).

Prospectors' name shown on the 1900 "Map of Nome Peninsula" by J. M. Davidson and B. D. Blakeslee.

Tozhgelede: locality, see Tigshelde.

Tozi, Mount: peak, 5,519 ft., highest point in Ray Mts., $25 \mathrm{mi}$. NW of Rampart and $48 \mathrm{mi}$. NE of Tanana, Kokrines-Hodzana High,; $65^{\circ}$ $41^{\prime} 30^{\prime \prime} \mathrm{N}, 150^{\circ} 57^{\prime} 00^{\prime \prime} \mathrm{W}$; (map 106).

Local name reported in 1956 by Orth; named for the Tozitna River.

Tozikakat: locality, on $\mathrm{N}$ bank of Yukon River at mouth of Tozitna River, Kokrines-Hodzana High.; $65^{\circ} 09^{\prime} \mathrm{N}, 152^{\circ} 24^{\prime} \mathrm{W}$; (map 106).

Former Indian village or camp recorded in the 1880 Census by Ivan Petroff (Hodge, 1910, p. 797).

Tozikakat: stream, see Tozitna River.

Tozimoran Creek: stream, flows E $13 \mathrm{mi}$. to Tozitna River, $17 \mathrm{mi}$. NW of Tanana, Kokrines-Hodzana High.; $65^{\circ} 21^{\prime} 00^{\prime \prime} \mathrm{N}, 152^{\circ} 30^{\prime}$ $00^{\prime \prime} \mathrm{W}$; (map 106).

Prospectors' name reported by USGS about 1940 , but probably in use many years before. Name derived from Moran Dome and Tozitna River.

Tozi River: stream, see Tozitna River.

Tozitna Island: island, $2 \mathrm{mi}$. long, in Yukon River at mouth of Tozitna River, $10 \mathrm{mi}$. WSW of Tanana, Nowitna Low.; $65^{\circ} 07^{\prime} 30^{\prime \prime} \mathrm{N}, 152^{\circ}$. $26^{\prime} 00^{\prime \prime} \mathrm{W}$; (map 106). Var. Zona Island.

Local name reported in 1952 by USGS.

Tozitna River: stream, heads in Ray Mts., flows $\mathrm{W}$ and $\mathrm{S}$, between the Ray and Rampart Mts., $83 \mathrm{mi}$. to Yukon River, $10 \mathrm{mi}$. WSW of Tanana, Kokrines-Hodzana High.; $65^{\circ} 08^{\prime} 15^{\prime \prime}$ N, $152^{\circ} 25^{\prime} 00^{\prime \prime} \mathrm{W}$; BGN 1907; (map 106). Var, Tosechargut, Tosekargut, Towshecargut, Tozi River, Tozikakat.

Indian name, "Tozi River," reported by personnel of the Western Union Telegraph Expedition of 1867 as "Towshecargut." In 1869 Raymond (1871, p. 23), U.S. Engineers, wrote it "Tosekargut," and Dall (1870, p. 282) spelled it "Tosikakat," or "mouth of the Tozi."

Tozitna Slough: channel, Yukon River, flows W 2 mi. N of Tozitna I., $10 \mathrm{mi}$. WSW of Tanana, Nowitna Low.; $65^{\circ} 07^{\prime} 30^{\prime \prime} \mathrm{N}, 152^{\circ}$. $26^{\prime} 00^{\prime \prime} \mathrm{W}$; (map 106).

Local name reported in 1952 by USGS.

T Peak: mountain, see T, Mount.

Trace Creek: stream, see Montana Creek.

Track Rock: rock, $0.3 \mathrm{mi}$. across, $\mathbf{N}$ of Tongass $\mathrm{I}$, in Nakat Bay, Coast Mts.; $54^{\circ} 46^{\prime} 50^{\prime \prime} \mathrm{N}$, $130^{\circ} 44^{\prime} 28^{\prime \prime} \mathrm{W}$; (map 2).

Named by Lt. Comdr. H. E. Nichols, USN, in 1883 .

Tractor Creek: stream, flows $3.7 \mathrm{mi} . \mathrm{S}$ to Nizina River $\mathbf{W}$ of its junc. with Kennicott River, 7 mi. SW of McCarthy, Wrangell Mts.; $B G N$ 1966; 61 $21^{\circ} 00^{\prime \prime} \mathrm{N}, 143^{\circ} 06^{\prime} 40^{\prime \prime} \mathrm{W}$; (map 67).

Local name for the stream in which "Sam Snyder got his caterpillar tractor stuck"; reported in 1965 by L. A. Yehle, USGS.

Tractor Lake: lake, $4 \mathrm{mi}$. long, $25 \mathrm{mi}$. S of Barrow, Arctic Plain; $70^{\circ} 55^{\prime} 45^{\prime \prime}$ N. $157^{\circ} 11^{\prime}$ 15" W; (map 147).

Local name reported in 1956 by USGS.

Tracy Arm: estuary, a fiord, heads in South Sawyer Glacier, trends SW $28 \mathrm{mi}$. to Holkham Bay, $42 \mathrm{mi}$. SE of Juneau, Coast Mts.; $57^{\circ} 46^{\prime}$ $54^{\prime \prime} \mathrm{N}, 133^{\circ} 37^{\prime} 42^{\prime \prime} \mathrm{W}$; BGN 1964; (map 8).

Named in 1889 by Lt. Comdr. H. B. Mansfield, USN, for B. F. Tracy, 1830-1915, Secretary of the Navy under Benjamin Harrison, 1889-93. He was a lawyer and U.S. District Attorney in New York. During the Civil War he served in the Union forces, achieving the rank of Brigadier General.

Trader Mountain: mountain, 2,641 ft., $9 \mathrm{mi}$. W of Pavlof Bay, Bristol Bay Low.; 55 $33^{\prime} \mathrm{N}$, $161^{\circ} 55^{\prime} \mathrm{W}$; (map 28).

Local name reported in 1929 by USGS. Possibly named for Traders Cove, an anchorage on the eastern side of Isanotski Strait.

Traders Bay: bight, see Trading Bay.

Traders Cove: bay, $1 \mathrm{mi}$. across, part of Driftwood Bay, on S coast of Umnak I., Aleutian Is. ; $52^{\circ} 57^{\prime} 30^{\prime \prime} \mathrm{N}, 168^{\circ} 42^{\prime} 15^{\prime \prime} \mathrm{W}$; BGN 1940 ; (map 21).

Local name given in 1939 by USC\&GS because "an early Russian trading vessel anchored in Driftwood Bay."

Traders Cove: cove, $1 \mathrm{mi}$. across, on $\mathbf{S}$ coast of Amukta I., Alcutian Is.; $52^{\circ} 27^{\prime} 30^{\prime \prime} \mathrm{N}, 171^{\circ}$. $17^{\prime} 10^{\prime \prime} \mathrm{W}$; (map 20).

Name published in 1951 on a USGS map. Traders Cove: cove, $0.7 \mathrm{mi}$. across, in Bechevin Bay, Aleutian Ra.; $54^{\circ} 54^{\prime} \mathrm{N}, 163^{\circ} 19^{\prime} \mathrm{W}$; (map 25).

Local name, published in 1882 by USC\&GS. Traders Head: point of land, on $\mathrm{E}$ side of Bechevin Bay, SW end of Alaska Penin., Aleutian Ra.; 54 $56^{\prime}$ N, $163^{\circ} 19^{\prime}$ W ; (map 25).

Named by USC\&GS in 1926: derived from Trader: Cove.

Traders Island: island, about $2 \mathrm{mi}$. across, in $\mathrm{E}$ end of Peril Strait, $\mathbf{N}$ of Catherinc I., $23 \mathrm{mi}$.
N. of Baranof, Alex. Arch.; $57^{\circ} 26^{\prime}$ N, $134^{\circ} 53^{\prime}$ W; $(\operatorname{map} 9)$.

The name "Traitors Island" was given by Lt. Comdr. R. W. Meade, USN, in 1869, to the largest island in a group of islands located here. It was spelled erroneously by USC\&GS as "Traders Island" which is the name of another island about $2 \mathrm{mi}$. in extent (USC\&GS, 1883 , p. 167\%). No island of this size now exists in this group. Either Meade mistook several of the islands as one island or else the island has been broken up to form the Traders Islands of present charts. The original name "Traitors Islands" is no longer used.

Traders Island: island, see Koyukuk Island.

Traders Islands: islands, extend $1.3 \mathrm{mi} . \mathrm{N}$ of Catherine I., in E end of Peril Strait, $23 \mathrm{mi}$. N of Baranof, Alex. Arch.; 57 $26^{\prime}$ N, 134 ${ }^{\circ} 53^{\prime} \mathrm{W}$; (map 9). Var. Traitors Islands.

The largest of this group of islands was called "Traitor Island" by Comdr. R. W. Meade, USN, in 1869; this name was published on Hydrog. Chart 225. USC\&GS erroneously published the name as "Traders" for both the largest island and the group.

Traders Mountain: mountain, $1,845 \mathrm{ft}$, on Traders Head, on $\mathbf{E}$ shore of Bechevin Bay, Aleutian Ra.; $54^{\circ} 55^{\prime} 55^{\prime \prime} \mathrm{N}, 163^{\circ} 19^{\prime} 00^{\prime \prime} \mathrm{W}$; (map 25).

Name taken from Traders Cove and published in 1927 by USC\&GS.

Trading Bay: bight, extends NE $25 \mathrm{mi}$. on W shore of Cook Inlet, from West Foreland to Granite Point, $23 \mathrm{mi}$. NW of Kenai, Cook Inlet Low.; $60^{\circ} 55^{\prime} \mathrm{N}, 151^{\circ} 35^{\prime} \mathrm{W}$; (map 62). Var. Traders Bay.

Named in August 1786 by Capt. Portlock (1789, p. 119) who anchored here and traded with the Indians.

Trail: locality, see Crown Point.

Trail Creek: stream, flows NW $5 \mathrm{mi}$. to Butte Creek, $28 \mathrm{mi}$. N of Goodnews, KilbuckKuskokwim Mts.; $59^{\circ} 29^{\prime} 45^{\prime \prime} \mathrm{N}, 161^{\circ} 30^{\prime} 00^{\prime \prime}$ W; (map 53).

Probably a prospectors' name reported by A. G. Maddren (in Brooks, 1915, p. 358), USGS.

Trail Creek: stream, flows S $22 \mathrm{mi}$. to Izavieknik River, $90 \mathrm{mi}$. NE of Goodnews, KilbuckKuskokwim Mts.; $59^{\circ} 48^{\prime} \mathrm{N}, 1^{\circ} 9^{\circ} 33^{\prime} \mathrm{W}$; (map 53).

Local name published in 1951 by USGS. Trail Creek: stream, in Chigmit Mts., at head of Iniskin Penin., formed by its Right and Wrong Branches, flows NE $1 \mathrm{mi}$. to Chinitna Bay, Aleutian Ra.; $59^{\circ} 48^{\prime} 45^{\prime \prime} \mathrm{N}, 153^{\circ} 16^{\prime} 00^{\prime \prime}$ W; BGN 1962 ; (map 51). Var. Low Creek, Tonnic Creek.

Local name reported in 1958 by USGS.

Trail Creek: stream, heads at Trail Glacier on Kenai Penin., flows SW 22 mi. to Kenai Lake, $20 \mathrm{mi}$. N of Seward, Chugach Mts.; $60^{\circ} 24^{\prime} 40^{\prime \prime} \mathrm{N}, 149^{\circ} 22^{\prime} 30^{\prime \prime} \mathrm{W}$; BGN 1966; (map 63). Var. North Fork Trail Creek, Trail River.

Local name reported in 1898 by Mendenhall (1900, map 6), USGS. 
Trail Creek: stream, flows SE $7.7 \mathrm{mi}$. to Alexander Creek, $3 \mathrm{mi}$. W of Susitna, and $33 \mathrm{mi}$. $\mathrm{NW}$ of Anchorage, Cook Inlet Low.; 61 ${ }^{\circ}$ $32^{\prime} 40^{\prime \prime} \mathrm{N}, 150^{\circ} 36^{\prime} 50^{\prime \prime} \mathrm{W}$; (map 70).

Local name reported in 1935 by USGS.

Trail Creek: stream, flows NW $4.5 \mathrm{mi}$. from Kuskulana Pass to Kuskulana River, $30 \mathrm{mi}$. NW of McCarthy, Wrangell Mts.; 61 ${ }^{\circ} 35^{\prime} \mathrm{N}$, $143^{\circ} 44^{\prime} \mathrm{W}$; ( $\operatorname{map} 67$ ).

Local name reported in 1900 by $T$. G. Gerdine, USGS.

Trail Creek: stream, heads in a lake, flows SW 8.6 mi., through Trail Lake, to East Fork Matanuska River, $60 \mathrm{mi}$. NW of Valdez, Copper River Basin, 61 ${ }^{\circ} 49^{\prime} 10^{\prime \prime} \mathrm{N}, 147^{\circ} 23^{\prime} 30^{\prime \prime}$ W ; (map 69).

Local name reported in 1951 by USGS.

Trail Creek: stream, flows SE $13 \mathrm{mi}$. to Iditarod River, $7.3 \mathrm{mi}$. W of Flat and $53 \mathrm{mi}$. NE of Holy Cross, Kilbuck-Kuskokwim Mts.; 62 ${ }^{\circ}$ -

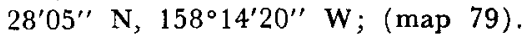

Prospectors' name published in 1921 by USGS.

Trail Creek: stream, in Mentasta Mts., flows S $10 \mathrm{mi}$. to Jack Creek, E of Jack Lake, $12 \mathrm{mi}$. NW of Devils Mtn., Alaska Ra.; 62 $31^{\prime} \mathrm{N}$, $143^{\circ} 14^{\prime}$ W; BGN 1939; (map 84).

Local name reported by USGS in 1939.

Trail Creek: stream, flows SW $12 \mathrm{mi}$. to Little Tok River, $25 \mathrm{mi}$. S of Tok, Alaska Ra; $62^{\circ}$ $59^{\prime} \mathrm{N}, 143^{\circ} 20^{\prime} \mathrm{W}$; BGN 1936; (map 84).

Local name given because the route from Mentasta Pass to Tetling village follows this stream.

Trail Creek: stream, distributary of Kouwegok Slough, flows SE $2 \mathrm{mi}$. to Unalakleet River, $1 \mathrm{mi}$. E. of Unalakleet, Nulato Hills; $63^{\circ}$ $52^{\prime} 30^{\prime \prime} \mathrm{N}, 160^{\circ} 44^{\prime} 45^{\prime \prime} \mathrm{W}$; (map 91).

Local name reported in 1952 by USC\&GS.

Trail Creek: stream, flows W $2 \mathrm{mi}$. to Dome Creek, $25 \mathrm{mi}$. S of Eagle, Yukon-Tanana High.; $64^{\circ} 25^{\prime} \mathrm{N}, 141^{\circ} 06^{\prime} \mathrm{W}$; (map 102).

Named by prospectors and shown on an 1898 manuscript map by E. E. Ball, prospector. Probably so named because the win. ter trail from Liberty to Dome Creek passed through this area. This stream is not shown on present-day maps.

Trail Creek: stream, flows NE $16 \mathrm{mi}$. to Sulatna River, $5 \mathrm{mi}$. NW of Monzonite Hills, Nowitna Low.; 64 $26^{\prime} \mathrm{N}, 154^{\circ} 47^{\prime} \mathrm{W}$; (map 98).

Prospectors' name reported in 1911 by $A$. G. Maddren (in Brooks and others, 1912, p. 294-296), USGS.

Trail Creek: stream, in Bendeleben Mts., flows E $2.7 \mathrm{mi}$. to Caribou Creek which flows to Tubutulik River, $38 \mathrm{mi}$. SE of Imuruk Lake, Scward Penin. High.; $65^{\circ} 07^{\prime} \mathrm{N}, 162^{\circ} 27^{\prime} \mathrm{W}$; (map 110).

Prospectors' name published on the 1908 "Map of Seward Peninsula" by Arthur Gibson.

Trail Creek: stream, flows SW $5 \mathrm{mi}$. to Boulder Creek, $27 \mathrm{mi}$. E. of Tanana, Yukon-Tanana High.; $65^{\circ} 08^{\prime} 30^{\prime \prime} \mathrm{N}, 151^{\circ} 10^{\prime} 00^{\prime \prime} \mathrm{W}$; (map 106).

Local name reported in 1952 by USGS.
Trail Creek: stream, flows NE $15 \mathrm{mi}$. to Beaver Creek, $40 \mathrm{mi}$. NE of Fairbanks, YukonTanana High.; $65^{\circ} 23^{\prime} \mathrm{N}, 147^{\circ} 20^{\prime} \mathrm{W}$; (map 105).

Named by prospectors; published in 1906 by USGS.

Trail Creek: stream, flows SE to Garfield Creek which flows to Kuzitrin River, $2 \mathrm{mi}$. S. of Baldy Mtn. and $38 \mathrm{mi}$. W of Imuruk Lake, Seward Penin. High.; 653 $31^{\prime} 30^{\prime \prime}$ N, 164 $34^{\circ}$ $00^{\prime \prime} \mathrm{W}$; (map 110$)$.

Prospectors' name shown on a map of Cape Nome gold fields by David Fox, Jr., dated 1901.

Trail Creek: stream, flows SW $2.8 \mathrm{mi}$. to Cottonwood Creek which flows to Goodhope River, $15 \mathrm{mi}$. NW of Imuruk Lake, Seward Penin. High.; $65^{\circ} 47^{\prime} \mathrm{N}, 163^{\circ} 25^{\prime} \mathrm{W}$; BGN 1952; (map 110).

Prospectors' name reported in 1901 by USGS (Collier, 1902, pl. 12).

Trail Creek: stream, flows NE $17 \mathrm{mi}$. to West Fork North Fork Chandalar River, $21 \mathrm{mi}$. SSW of Chandalar, Brooks Ra.; $67^{\circ} 12^{\prime} 00^{\prime \prime} \mathrm{N}$, $148^{\circ} 36^{\prime} 20^{\prime \prime} \mathrm{W}$; (map 123).

Prospectors' name obtained in 1909 by A. G. Maddren (in Brooks and others, 1910, pl. 7), USGS.

Trail Creek: stream, flows SE $2.5 \mathrm{mi}$. to Ogotoruk Creek, $6.7 \mathrm{mi}$. E of Cape Thompson, Arctic Slope; $68^{\circ} 08^{\prime} 15^{\prime \prime} \mathrm{N}, 165^{\circ} 43^{\prime} 20^{\prime \prime} \mathrm{W}$; BGN 1963; (map 129).

Named about 1962 by personnel of Project Chariot.

Trail Creek: stream, heads $\mathrm{E}$ of Nucleus Mtn. in De Long Mts., flows SW $44 \mathrm{mi}$. to Kugururok River, $11 \mathrm{mi}$. SW of Misheguk Mtn., Brooks Ra.; $68^{\circ} 09^{\prime} \mathrm{N}, 161^{\circ} 28^{\prime} \mathrm{W}$; BGN I926; (map 131).

Local name reported in 1925 by Gerald FitzGerald, USGS, named by the Eskimos in the vicinity.

Trail Creek: stream, at $\mathrm{E}$ end of Brooks Ra., flows NE $5.5 \mathrm{mi}$. across Alaska-Canada boundary to Joe Creek in Yukon, Canada; $68^{\circ} 55^{\prime} 30^{\prime \prime} \mathrm{N}, 140^{\circ} 56^{\prime} 30^{\prime \prime} \mathrm{W}$; (map 137).

Local name reported in 1956 by USGS.

Trail Creek: stream, see Geohenda Creek.

Trail Glacier: glacier, heads $4 \mathrm{mi}$. SW of head of Spencer Glacier, trends NW $6 \mathrm{mi}$. to its terminus at hcad of Trail Creek, $36 \mathrm{mi}$. NE of Seward, Chugach Mts.; $60^{\circ} 35^{\prime} 15^{\prime \prime} \mathrm{N}, 149^{\circ}$ 01'15" W; (map 63).

Local name reported in 1912 by Grant and Higgins (1913, pl. 1), USGS. Name derived from Trail Creek which drains the glacier.

Trail Lake: locality, see Crown Point.

Trail Lake: lake, $0.4 \mathrm{mi}$. long, on Kenai Penin. $\mathrm{N}$ of Tustumena Lake, $18 \mathrm{mi}$. S of Kenai, Cook Inlet Low.; $60^{\circ} 18^{\prime} 45^{\prime \prime} \mathrm{N}, 151^{\circ} 04^{\prime} 40^{\prime \prime}$ W: (map 62).

Named about 1963 by officials of Kenai National Moose Range, for administrative purposes.

Trail Lake: lake, $0.7 \mathrm{mi}$. long, E of Lower Sucker Creek, $40 \mathrm{mi}$. NE of Tyonek, Cook In- let Low.; $61^{\circ} 37^{\prime} 25^{\prime \prime} \mathrm{N}, 150^{\circ} 45^{\prime} 30^{\prime \prime} \mathrm{W}$; (map 70).

Local descriptive name reported in 1954 by USGS.

Trail Lake: lake, $1 \mathrm{mi}$. long, in course of Trail Creek, $60 \mathrm{mi}$. NW of Valdez, Copper River Basin; 61 $50^{\prime} 45^{\prime \prime} \mathrm{N}, 147^{\circ} 19^{\prime} 30^{\prime \prime} \mathrm{W}$; BGN 1960; (map 69).

So named in 1956 by USGS because "the lake drains out through Trail Creek."

Trail Lake: lake, see Upper Trail Lake.

Trail Ridge: ridge, $475 \mathrm{ft}$., extends NW $10 \mathrm{mi}$. from Susitna River, between Yentna River and Alexander Creek, $35 \mathrm{mi} \mathrm{NW}$ of Anchorage, Cook Inlet Low; $61^{\circ} 37^{\prime} \mathrm{N}, 150^{\circ} 37^{\prime} \mathrm{W}$; (map 70).

Local descriptive name reported in 1958 by USGS.

Trail River: stream, on N part of Chichagof I., flows NW $7 \mathrm{mi}$. to head of Idaho Inlet, 22 mi. W of Hoonah, Alex. Arch.; 58 $03^{\prime} 55^{\prime \prime}$ $N, 136^{\circ} 06^{\prime} 20^{\prime \prime} \mathrm{W}$; BGN 1960; (map 10).

So named by USGS in 1955 "because the stream affords a natural trail between Idaho Inlet and Tenakee Inlet."

Trail River: stream, see Trail Creek.

Trail Station: locality, see Crown Point.

Train Creek: stream, flows NW $17 \mathrm{mi}$. to Telaquana River, $75 \mathrm{mi}$. NE of Nondalton, Alaska Ra.; $60^{\circ} 52^{\prime} \mathrm{N}, 154^{\circ} 03^{\prime} \mathrm{W}$; BGN 1931; (map 61).

Local name reported in 1929 by S. R. Capps and Gerald FitzGerald, USGS.

Traitors Cove: estuary, extends NE $8 \mathrm{mi}$. off Behm Canal, on $W$ coast of Revillagigedo I., Alex. Arch.; 55 $42^{\prime} \mathrm{N}, 1^{\circ} 31^{\circ} 39^{\prime} \mathrm{W}$; (map 3). Var. Bukhta Tretr (izmyny).

Named by Capt. Vancouver, RN, "August 12, 1793, on account of trouble there with the Indians" (Wagner, 1937, p. 419); this name was transliterated and published in 1853 as "Bukhta Tretr (izmyny)" on Russian Hydrog. Dept. Chart 1495.

Traitors Greek: stream, heads in lake, on Revillagigedo I., flows NW $6.3 \mathrm{mi}$. to Traitors Cove, Alex. Arch.; $55^{\circ} 44^{\prime} 10^{\prime \prime} \mathrm{N}, 1^{\circ} 31^{\circ} 30^{\prime} 50^{\prime \prime} \mathrm{W}$; BGN 1962; (map 3).

Local name reported in 1961 by USFS.

Traitors Islands: islands, see Traders Islands.

Traleika: mountain, see McKinley, Mount.

Tralcika: mountain range, in Alaska Ra. near Mount McKinley.

For this undefined range, J. E. Spurr, USGS, suggested the Indian word "Traleyka," meaning "high mountains."

Traleika Col: pass, 9,900 ft., in Mount McKinley National Park near head of Traleika Glacier, $7 \mathrm{mi}$. E of Mount McKinley, Alaska Ra.; $62^{\circ} 04^{\prime} \mathrm{N}, 150^{\circ} 46^{\prime} \mathrm{W}$; (map 88).

Named by Bradford Washburn about 1945 . See Traleika Glacier.

Traleika Glacier: glacier, in Mount McKinley National Park, trends N $12 \mathrm{mi}$. to Muldrow Glacier, 10 mi.' NE of Mount McKinley, Alaska Ra.; $63^{\circ} 13^{\prime} \mathrm{N}, 150^{\circ} 42^{\prime} \mathrm{W} ; B G N$ 1947; (map 88).

Named by Bradford Washburn about 1945; derived from the Susitna [Tanaina] Indian 
name for Mount McKinley reported to mean "great one" or "the high one."

Traleika Icefall: icefall, of $2,500 \mathrm{ft}$., in Mount McKinley National Park, extends NNE 0.8 mi. at head of West Fork Traleika Glacier, 4 mi. E of Mount McKinley, Alaska Ra.; $63^{\circ} 05^{\prime} 30^{\prime \prime} \mathrm{N}, 150^{\circ} 52^{\prime} 30^{\prime \prime} \mathrm{W}$; (map 88).

Climbers' name published on recent maps. Traleyka: mountain, see McKinley, Mount.

Tramp Point: point of land, on E coast of Revillagigedo I, S of Sargent Bay, Alex. Arch.; $55^{\circ} 31^{\prime} 30^{\prime \prime} \mathrm{N}, 130^{\circ} 58^{\prime} 50^{\prime \prime} \mathrm{W}$; (map 3)

Arbitrary name given in 1891 by USC\&GS. Tramway: locality, see Tramway Bar.

Tramway Bar: locality, on Middle Fork Koyukuk River, opposite mouth of Chapman Creek and $24 \mathrm{mi}$. SW of Wiseman, Brooks Ra.; $67^{\circ} 05^{\prime}$ $\mathrm{N}, 150^{\circ} 30^{\prime} \mathrm{W}$; (map 124). Var. Tramway. Shown as "Tramway" in 1899 by T. G. Gerdine, USGS, on a fieldsheet Of it, Marshall $(1956$, , 84) wrote, "The major scenic feature along the Middle Fork *** is the canyor *** called Tramway Bar, where gold ir paying quantities was first discovered *** ir 1893 . It is probable that a mining tramway la small dumpcart running on ar overhead cablel existed here during the early gold-mining operations."

Tranquil Point: point of land, on $\mathrm{W}$ coast of Frince of Wales $1 ., 7 \mathrm{mi}$. SW of Craig, Alex.

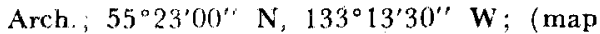
4). Var Mys del Sosiyego, Punta del Sosiego, Hunta Sosiego

Translation of the narne: "Punta del Sosiego," ox "point of tranquility," given in 17751779 by Dor Juan de la Bodega y Quadra and Francisco Antonio Maurelle.

Tracidee Greek: stream. see Charley River.

Trap Bay: bay, 1 mi. across, along SE shore of Terraker Inlet along $\mathrm{E}$ coast of Chichagof I., $8 \mathrm{mi}$ SE of Tenakee Springs, Alex, Arch.; $57^{\circ} 45^{\prime} \mathrm{N}, 135^{\circ} 01^{\prime} \mathrm{W} ; B C N$ 1930, (map 9) Local name reported in 1928 by USFS.

Trap Creek: stream, flows SW $0.5 \mathrm{mi}$ to Fast Fork Solomon River near its head, $15 \mathrm{mi}$. NE of Solomon, Seward Penin. High.; 64 ${ }^{\circ} 42^{\prime}$ N, $164^{\circ} 04^{\prime} \mathrm{W},(\operatorname{map} 95)$.

Prospectors name reported on a 1902 prospectors' manuscript map.

Trap House Hills: hills, on SW shore of Nelson Lagoon, $28 \mathrm{mu}$. W of settlement of Port Mol. ler, Bristol Bay Low ; 55 $57^{\prime} 30^{\prime \prime} \mathrm{N}, 161^{\circ} 18^{\prime}$ $30 \% \mathrm{~W}$; (map 28 )

Local name shown or a 1963 USC\&GS chart.

Trap Lake: lake, $1,500 \mathrm{ft}$. long, on Revillagigedo Island, near mouth of Carroll Inlet, $3.5 \mathrm{mi}$. NE of Carroll Point, Alex Arch.: 55'19'35" N, $131^{\circ} 24^{\prime} 00^{\prime \prime}$ W, BGN 1923; (map 3$)$ Named in 1923 by USFS.

Trap lake: lake, $1 \mathrm{~mm}$ long, $1 \mathrm{mi}$ s of Tsina Glacier and 13 mi NE of Valde, Chugach Mts. $61^{\circ} 14^{\prime} 20^{\prime \prime} \mathrm{N}, 1^{\circ} 5^{\circ} 55^{\prime}\left(10^{\prime \prime}\right.$ W $B G N$ 1965 ; (map 68)

So named in 196 in $^{\text {by }}$ A. S. Post, USGS, "because the lake lies it a valley trapped between two glaciers"

Trap Lake Glacier: glacter, see Tsina Glacier.
Trapper Creek: stream, heads in lake, flows S $34 \mathrm{mi}$. through Trapper Lake to Kroto Creek, $13 \mathrm{mi}$. NW of Willow and $46 \mathrm{mi}$. NW of Anchorage, Cook Inlet Low.; $61^{\circ} 51^{\prime} \mathrm{N}, 150^{\circ} 22^{\prime}$ $\mathrm{W}$; (map 70).

Local name reported in 1954 by USGS

Trapper Creek: stream, flows SW $2.3 \mathrm{mi}$. to Crooked Greek $5 \mathrm{mi}$. NW of its junc. with Kuskokwim River, $5 \mathrm{mi}$. NW of Village of Crooked Creek, Kilbuck-Kuskokwim Mts.; $61^{\circ} 55^{\prime} 45^{\prime \prime} \mathrm{N}, 158^{\circ} 11^{\prime} 40^{\prime \prime}$ W; BGN 1945; (map 72)

Local name reported in 1944 by USGS.

Trapper Joe Lake: lake, $0.7 \mathrm{mi}$. long, on Kenai Penin., drains $\mathbf{N}$ to Chickaloon River, $20 \mathrm{mi}$ SW of Hope and $40 \mathrm{mi}$. NE of Kenai, Cook Inlet Low.; $60^{\circ} 46^{\prime} \mathrm{N}, 150^{\circ} 05^{\prime} \mathrm{W}$; (map 62). Local name reported in 1958 by USGS

Trapper Lake: lake, $4.8 \mathrm{mi}$. long, in course of Trapper Creek, W of Susitna River, $53 \mathrm{mi}$. NW of Anchorage, Cook Inlet Low.; $62^{\circ} 00^{\prime}$ $00^{\prime \prime} \mathrm{N}, 150^{\circ} 14^{\prime} 30^{\prime \prime} \mathrm{W}$; (map 70).

Local name reported in 1954 by USGS.

Trappers Cove: cove, $0.2 \mathrm{mi}$ across, on $\mathrm{SW}$ shore of Bay of Is., Aleutian Is.; $51^{\circ} 46^{\prime} 35^{\prime \prime} \mathrm{N}, 176^{\circ}$ 49'00" W; BCN 1936; (map 17).

Named by members of the U.S. Navy Aleutian Island Survey Expedition in 1933.

Trap Point: point of land, on S bank of Chickamin River, at Behm Canal, Coast Mts.; 55 $47^{\prime} \mathrm{N}, 130^{\circ} 58^{\prime} \mathrm{W}$; (map 3 ).

Name published in 1891 by USC\&GS

Trap Point: point of land, on W shore of Moser Bay, 41 mi. S of Karluk, on SW ccrast of Kodiak I. ; $57^{\circ} 00^{\prime} 10^{\prime \prime} \mathrm{N}, 154^{\circ} 09^{\prime} 00^{\prime \prime} \mathrm{W}$; (map 35)

Local name published in 1943 by USC\&GS

Trap Point: point of land, on $\mathrm{W}$ coast of Chichagof I., NW point of entrance to Ford Arm of Slocum Arm, $8 \mathrm{mi}$. SE of Chichagof, Alex. Arch.; $57^{\circ} 33^{\prime} 15^{\prime \prime} \mathrm{N}, 136^{\circ} 00^{\prime} 40^{\prime \prime} \mathrm{W}$; (map 9)

Name published in 1928 by USC\&GS on Chart 8280

Trasera Island: isiand, $0.2 \mathrm{mi}$. across, central Maurelle Is., Alex. Arch.; $55^{\circ} 38^{\prime}\left(15^{\prime \prime} \mathrm{N}, 133^{\circ}\right.$ $36^{\prime} 25^{\prime \prime} \mathrm{W}$; (map 4)

Spanish name meaning "back (posterior part) :" recorded in 1951 by USGS.

Trava Point: point of land, in Kuliliak Bay, on $S$ roast of Unalaska 1 . Aleutian Is ; $53^{\circ} 26^{\prime} 15^{\prime \prime}$ N, $167^{\circ} 01^{\prime} 50^{\prime \prime} \mathrm{W} ; B G N$ 1939; (map 23)

Russian name meaning "grass" given by USC\&GS in 1937 because of the tall grass which covers this point

Travasey Crcek : stream, see Traverse Creek.

Travelair Creek: stream, flows NW $20 \mathrm{mi}$ to Oolamnagavik River, $19 \mathrm{mi}$ N of Kurupa Lake, Brooks Ra: $68^{\circ} 39^{\prime} \mathrm{N}$, 154.28' W $B G N 1960$ : (map 133 ).

So named about 1950 by USGS geologists during exploration of the Naval Petroleum Reserve No 4 because "a Travelair [plare] rrashed and burned near the creek."

Traver Creek: stream, heads at Guerin Clacter terminus and flows $8 \mathrm{mi}$. $\mathrm{N}$ to White River, $65 \mathrm{mi}$. NE of McCarthy, St Elias Mts: $61^{\circ}$. $44^{\prime} \mathrm{N}, 142^{\circ}\left(04^{\circ} \mathrm{W}\right.$ : (map 67).
Local name reported in 1908 by S. R. Capps (Moffit and Knopf, 1910, pl. 1), USGS.

Travers Creek: stream, on Kenai Penin., flows SW $2 \mathrm{mi}$. to $\mathrm{N}$ entrance of Kachemak Bay $11 \mathrm{mi}$. NW of Homer, Cook Inlet Low.; $59^{\circ}$. $43^{\prime} 40^{\prime \prime} \mathrm{N}, 151^{\circ} 49^{\prime} 30^{\prime \prime} \mathrm{W}$; (map 50).

Name reported by R. W. Stone (1904, pl. 13), USGS.

Traverse Creek: stream, flows SSW $4.4 \mathrm{mi}$. to Harrison Greek, $9 \mathrm{mi}$. SSW of Circle Hot Springs and $38 \mathrm{mi}$. SW of Circle, YukonTanana High.; $65^{\circ} 22^{\prime} \mathrm{N}, 144^{\circ} 49^{\prime} \mathrm{W}$; BGN 1959; (map 104). Var. Portage Creek, Travasey Creek.

In 1908 USGS reported this stream as Travasey Creck (Covert and Ellsworth, 1909, pl. 4); however, the present name came into local usage and was published by Mertie (1937b, pl. 1), USGS

Traverse Peak: mountain, 2,838 ft., at head of Ungalik River, $57 \mathrm{mi}$. SE of Haycock, Nulato Hills; $65^{\circ} 10^{\prime} \mathrm{N}, 159^{\circ} 12 \mathrm{~W}$; BGN 1910; (map 109) Var. Divide Peak.

Named in 1909 by A. H. Brooks, USGS

Traversie: area, in S Anchorage, $2 \mathrm{mi}$. SE of City Hall, Cook Inlet Low, $61^{\circ} 11^{\prime} 40^{\prime \prime} \mathrm{N}$, $149^{\circ} 51^{\prime} 20^{\prime \prime} \mathrm{W}$; (map 69).

Residential district in city of Anchorage reported in 1954 by office of city engineer of Anchorage.

Treadwell: village, pop. 13 (1940), on NE coast of Douglas I., on Gastineau Channel, $1.2 \mathrm{mi}$. $\mathrm{SE}$ of Douglas and $3 \mathrm{mi}$. SE of Juneau, Coast Mts.; $58^{\circ} 16^{\prime} \mathrm{N}, 134^{\circ} 22^{\prime} \mathrm{W}$; (map 11)

Named for John Treadwell, 1842-1927, one of the early miners in the Juneau area He arrived in Juncau in 1881 and mined in the Gold Creek area. Later the same year he organized the Treadwell Gold Mining Co. In 1889 he sold his interests and left Alaska. Treadwell was a company town founded in 1881, incorporated in 1901, and disincorporated in 1912. The town had a pop. of 1,222 in 1910. After the mines flooded in 1917, the pop. fell to 325 in 1920 and continued to decline as mining operations gradually stopped (DeArmond, 1957, p. 44-45)

Treadwell Ditch: ditch, on $\mathrm{E}$. part of Douglas I., extends from Fish Creck NW and S along hase of mountains 15 mi. to Bullion Creek, 5 mi. SE of Juneau, Coast Mts. ; $58^{\circ} 14^{\prime} 20^{\prime \prime} \mathrm{N}$, $134^{\circ} 20^{\prime} 45^{\prime \prime} \mathrm{W}$; (map 11).

Named for the Treadwell Gold Mining Company which, between $1882-90$, built the ditch to deliver water to the mines for power purposes. It is now in poor repair (DeArmond, 157 , p. 45 )

Treadwell Glory Hole: locality, on NE coast of Douglas I, $0.4 \mathrm{mi}$. NW of Treadwell and 2.7 mi. SE of Juneau, Coast Mts.; $58^{\circ} 16^{\prime} 00^{\prime \prime} \mathrm{N}$, $134^{\circ} 22^{\prime} 45^{\prime \prime} \mathrm{W}^{\prime}$, (map, 11) Var. Glory Hole

Named for the Trradwell Gold Mining Co. which carried on open-pit mining in this area from 1881 to 1917 which resulted in an enormous hole now partly filled with water (DeArnond, 195\%, p. 44)

Treasure Creek: stream, anabranch of Kahiltna River, flows SF $9.5 \mathrm{mi}, 27 \mathrm{mi}$. SW of Tal. 
keetna, Alaska Ra.; 62 $13^{\prime} 30^{\prime \prime} \mathrm{N}, 150^{\circ} 55^{\prime}-$ 35" W; (map 81).

Prospectors' name reported in 1906 by R. W. Porter, USGS.

Treasure Creek: stream, heads E of Chelatna Lake, flows SE $14 \mathrm{mi}$. to Kahiltna River, 33 mi. W of Talkeetna, Alaska Ra.; 62 $21^{\prime} 35^{\prime \prime}$ $\mathrm{N}, 151^{\circ} 11^{\prime} 10^{\prime \prime} \mathrm{W}$; (map 81 )

Prospectors' name reported in 1906 by R. W. Porter, USGS.

Treasure Creek: stream, flows NE $4.2 \mathrm{mi}$. to Vault Creek, 13 mi. N of Fairbanks, YukonTanana High.; $65^{\circ} 01^{\prime} 50^{\prime \prime} \mathrm{N}, 147^{\circ} 42^{\prime} 45^{\prime \prime} \mathrm{W}$; (map 105).

Named by prospectors; reported in 1903 by T. G. Gerdine (Prindle, 1905, pl. 13), USGS. Treasury Hill: mountain, 1,800 ft., $4 \mathrm{mi}$. $\mathrm{N}$ of Auke Bay, near head of Lake Creek and 14 mi. NW of Juneau, Coast Mts.; $58^{\circ} 26^{\prime} 20^{\prime \prime}$ $\mathrm{N}, 134^{\circ} 41^{\prime} 00^{\prime \prime} \mathrm{W}$; (map 11).

Named by miners V. C. Spaulding and Charles Wyley in 1908 (Knopf, 1912, p. 56).

Treat Island: island, $16 \mathrm{mi}$. long, formed by Koyukuk River and Cutoff Slough, $30 \mathrm{mi}$. NE of Roundabout Mtn., Koyukuk Low.; $65^{\circ} 55^{\prime} \mathrm{N}, 156^{\circ} 08^{\prime} \mathrm{W}$; (map 107 and 108). Var. Treats Island.

A letter written by Lt. H. T. Allen, USA, Jan. 3, 1894, states that this island was named in 1885 "In honor of Lt. Charles G. Treat, U.S.A., my classmate and special friend." It is shown as Treats Island by Allen (1887, map).

Treats Island: island, see Treat Island.

Treble Mountain: mountain, 4,500 ft., "near the head of Portland Canal," near Hyder; (map $3)$.

Descriptive name given in 1868 by Staff Comdr. David Pender, RN.

Tre Brata: rocks, sec Three Brothers.

Tree Island: island, $0.1 \mathrm{mi}$. across, at mouth of Gambier Bay, off Admiralty I., 1 mi NW of Church Point and $60 \mathrm{mi}$. NE of Sitka, Alex. Arch.; $57^{\circ} 27^{\prime} 40^{\prime \prime} \mathrm{N}, 133^{\circ} 55^{\prime} 20^{\prime \prime} \mathrm{W}$ (map 8).

Name published by USC\&GS in the 1925 Coast Pilot (p. 225) because "Tree Island appears as a clump of tress ***:"

Tree Lake: lake, $0.4 \mathrm{mi}$. long, on Kenai Penin. $6 \mathrm{mi}$. NW of Sterling and $11 \mathrm{mi}$. E of Kenai,

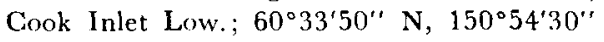
$\mathrm{W}$; (map 62).

Named about 1963 by officials of Kenai National Moose Range, for administrative purposes.

Treeless Island: island, $450 \mathrm{ft}$. across, in Marmot Bay, 0.5 mi. E of Whale I., $\mathrm{N}$ of Kodiak I., $57^{\circ} 59^{\prime} 12^{\prime \prime} \mathrm{N}, 152^{\circ} 42^{\prime} 20^{\prime \prime} \mathrm{W}$; (map 34). Var. Nizmennic Kamennic, Ostrov Nizmennyy Kamennyy.

Described by Sub-Lt. Mikhail Murashev, IRN, in 1839 or 1840 as "Os[trov] Nizmennyy Kamennyy," meaning "Low Rocky Island." The descriptive name "Treeless" was given to this island in 1900 by Lt. Comdr. J. F. Moser, USN, of the USBF steamer Albatross.

Tree Mountain: mountain, 3,374 ft., in Glacier Bay National Monument, $5 \mathrm{mi}$. E of Adams
Inlet and $64 \mathrm{mi}$. NW of Juneau, St. Elias Mts.; $58^{\circ} 51^{\prime} 50^{\prime \prime} \mathrm{N}, 135^{\circ} 49^{\prime} 10^{\prime \prime} \mathrm{W}$; (map 11).

Named by John Muir in 1892. The name was published by Reid (1892, p. 22), USGS.

Tree Point: point of land, $0.2 \mathrm{mi}$. long, extends SW from $\mathbf{E}$ shore of Revillagigedo Channel, Coast Mts.; $54^{\circ} 48^{\prime} 15^{\prime \prime} \mathrm{N}, 130^{\circ} 55^{\prime} 45^{\prime \prime} \mathrm{W}$; (map 2).

This point was reserved for lighthouse purposes and named by Executive Order, Janu. ary 4,1901 .

Tree Point: point of land, on W shore of Karluk Lake, $21 \mathrm{mi}$. SE of Karluk, Kodiak I.; 57 . $21^{\prime} 10^{\prime \prime} \mathrm{N}, 154^{\circ} 03^{\prime} 05^{\prime \prime} \mathrm{W}$; (map 35).

Local descriptive name reported in 1952 by USGS.

Trekhamena: lake, see Snohomish, Lake.

Trekh Kekurnie: point of land, sce Three Pillar Point.

Trekh Kekurnyy, Mys: point of land, see Three Pillar Point.

Trekh Svyatiteley, Gavan: cove, see Three Saints Harbor.

Trembley Creek: stream, flows SE $5.5 \mathrm{mi}$. to Kuyuktuvuk Creek, $1.5 \mathrm{mi}$. NW of junc. of Kuyuktuvuk Creek with Dietrich River and $48 \mathrm{mi}$. NW of Chandalar, Brooks Ra.; $67^{\circ}$. $51^{\prime} 15^{\prime \prime} \mathrm{N}, 149^{\circ} 53^{\prime} 30^{\prime \prime} \mathrm{W}$; (map 123). Var. Sheep Creek.

Name reported in 1901 by W. J. Peters, USGS (Schrader, 1904, pl. 2).

Tremel Island: island, on left bank of Yukon River, W of Brant I. and $13 \mathrm{mi}$. E of Birches, Nowitna Low.; $65^{\circ} 09^{\prime} \mathrm{N}, 153^{\circ} 09^{\prime} \mathrm{W}$; (map 107).

Riverboat pilots' name shown on a 1940 "Navigation Chart of the Tanana-Yukon Rivers" published by the Department of the Interior.

Trena Lake: lake, $0.4 \mathrm{mi}$. long, on Kenai Penin., $0.7 \mathrm{mi}$. N of Seldovia, Chugach Mts.; $59^{\circ}$ $27^{\prime} 15^{\prime \prime} \mathrm{N}, 151^{\circ} 42^{\prime} 20^{\prime \prime} \mathrm{W}$; (map 50).

Local name reported by USGS in 1951.

Tretr (izmyny), Bukhta: estuary, see Traitors Cove.

Treville, Punta de: point of land, see Whitshed, Point.

Trial Creek: stream, on $\mathrm{E}$ coast of Alaska Penin., flows E $7.2 \mathrm{mi}$. to Puale Bay, $44 \mathrm{mi}$. NW of Karluk, Alcutian Ra.; $57^{\circ} 42^{\prime} 20^{\prime \prime} \mathrm{N}$. $153^{\circ} 37^{\prime} 45^{\prime \prime} \mathrm{W}$; (map 35$)$.

Local name published in 1943 by USC\&GS.

Triangle Island: island, $0.1 \mathrm{mi}$. across, at $\mathrm{N}$ cnd of Queen Inlet, on Glacier Bay, in Glacier Bay National Monument, $1.7 \mathrm{mi}$. S of terminus of Carroll Glacier and $71 \mathrm{mi}$. NW of Hoonah, St. Elias Mts.; $58^{\circ} 57^{\prime} 25^{\prime \prime} \mathrm{N}, 136^{\circ}$ $31^{\prime} 50^{\prime \prime} \mathrm{W}$ : (map 10). Var. Triangle Islet. So named in 1892 by Reid (1896, pl. 8j) "because of the shape of the island."

Triangle Island: island, $1.2 \mathrm{mi}$. across, in Iliamna Lake, $4 \mathrm{mi}$. W of Flat I. and $16 \mathrm{mi}$. E of Iliamna, Aleutian Ra.; $59^{\circ} 43^{\prime} \mathrm{N}, 154^{\circ} 28^{\prime}$ W; $(\operatorname{map} 51)$

Local descriptive name for this generally triangular island. The name was published by USGS in 1954 .
Triangle Island: island, $0.2 \mathrm{mi}$. long, $2.2 \mathrm{mi}$. $\mathrm{NE}$ of Dunulimjingia Point and $15 \mathrm{mi}$. SE of Cape Etolin, off NE coast of Nunivak I.; $60^{\circ}$ $21^{\prime} 00^{\prime \prime}$ N, $165^{\circ} 45^{\prime} 20^{\prime \prime} \mathrm{W}$; (map 57).

Name reported about 1908 by USC\&GS.

Triangle Islet: island, see Triangle Island.

Triangle Lake: lake, $1.5 \mathrm{mi}$. long, $8 \mathrm{mi}$. $\mathrm{S}$ of Harlequin Lake and $33 \mathrm{mi}$. SE of Yakutat, Malaspina Coastal Plain; $59^{\circ} 17^{\prime} 38^{\prime \prime} \mathrm{N}, 138^{\circ}$ $56^{\prime} 20^{\prime \prime} \mathrm{W}$; BGN 1966; (map 46).

Local descriptive name reported in 1966 by USFS.

Triangle Lake: lake, $500 \mathrm{ft}$. across, $1.2 \mathrm{mi}$. S of Sixmile Lake and $4.5 \mathrm{mi}$. NE of Anchorage, Cook Inlet Low.; $61^{\circ} 16^{\prime} 18^{\prime \prime} \mathrm{N}, 149^{\circ} 48^{\prime} 35^{\prime \prime}$ W; (map 69).

Descriptive name reported in 1952 by USGS.

Triangle Lake: lake, 1,000 ft. across, in Matanuska Valley, $4 \mathrm{mi}$. SW of Palmer, Cook Inlet Low.; 61 $33^{\prime} 25^{\prime \prime} \mathrm{N}, 149^{\circ} 12^{\prime \prime} 25^{\prime \prime} \mathrm{W}$; (map 69).

Descriptive name reported in 1951 by USGS.

Triangle Peak: peak, 3,505 ft., W of Cook Inlet, $4.5 \mathrm{mi}$. SW of Slope Mtn. and $64 \mathrm{mi}$. SW of Kenai, Aleutian Ra.; 60001'40" N, $152^{\circ}$ $45^{\prime} 00^{\prime \prime} \mathrm{W}$; (map 62).

Local descriptive name; published in 1912 by USC\&GS.

Tri Brata, Kamen: rocks, see Three Brothers.

Tributary Creek: stream, on Kenai Penin., flows NE 2 mi. to Pass Creek, $12 \mathrm{mi}$. SW of Sunrise,

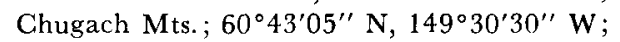
(map 63).

Local name reported about 1914 by B. L. Johnson (in Martin and others, 1915, pl. 2), USGS.

Tributary Creek: stream, flows NW $5 \mathrm{mi}$. to East Fork Toklat River, 35 mi. SW of Healy, Alaska Ra.; $63^{\circ} 36^{\prime} 30^{\prime \prime} \mathrm{N}, 149^{\circ} 53^{\prime} 00^{\prime \prime} \mathrm{W}$; (map 87).

Local descriptive name reported by USGS in 1954.

Tributary Creek: stream, flows $2.8 \mathrm{mi}$. to Big Hurrah Creek, $9 \mathrm{mi}$. NE of Solomon, Seward Penin. High.; 64 $39^{\circ} \mathrm{N}, 164^{\circ} 13^{\prime} \mathrm{W}$ : (map 95).

Prospectors' name reported on a 1902 prospcctors' manuscript map.

Tributary Creek: stream, flows E $7 \mathrm{mi}$., $\mathrm{N}$ of Slatepile Mtn., to Ernie Creek, $43 \mathrm{mi}$. NW of Wiseman, Brooks Ra.; $67^{\circ} 58^{\prime} 45^{\prime \prime} \mathrm{N}, 150^{\circ} 50^{\prime}-$ $00^{\prime \prime} \mathrm{W}$; (map 124).

Name reported in 1939 by Marshall (1956, map).

Tricouni Peak: peak, 5,505 ft., at junc. of West Branch and Taku Glaciers, $3 \mathrm{mi}$. NE of The Snow Towers and $26 \mathrm{mi}$. N of Juneau, Coast Mts.: $58^{\circ} 40^{\prime} 15^{\prime \prime} \mathrm{N}, 134^{\circ} 29^{\prime} 15^{\prime \prime} \mathrm{W}$ : (map) 11).

Name proposed by members of the Juncall Icefield Research Project and published by USGS in 1960.

Trident, Mount: volcano, 6,790 ft., threc pcaks, between Katmai Pass and Mount Katmai, in Katmai National Monument, Alaska Penin.; Aleutian Ra.; $58^{\circ} 14^{\prime} \mathrm{N}, 155^{\circ} 05^{\prime} \mathrm{W}: B G N$ 
1966; (map 42). Var. The Trident, Trident Volcano.

Descriptive name given as Trident by R. F. Griggs, National Geographic Society, in 1916, because of its three peaks.

Trident, The: zolcano, see Trident, Mount.

Trident Bay: bay, $1 \mathrm{mi}$. across, on SE coast of Akun I., Krenitzin Is., Aleutian 1s. ; $54^{\circ} 08^{\prime} 30^{\prime \prime}$ $\mathrm{N}, 165^{\circ} 32^{\prime} 30^{\prime \prime} \mathrm{W}$; (map 24)

Named in 1901 by J. J. Gilhert, USG\&GS.

Trident Glacier: glacier, three arms, heads on Mount Shand, trends $\mathrm{N} 18 \mathrm{mi}$. to its terminus at head of Delta Creek, $13 \mathrm{mi}$. NE of Mount Hayes, Alaska Ra.; 63⒋ $45^{\prime} 15^{\prime \prime} \mathrm{N}, 146^{\circ} 25^{\prime} 00^{\prime \prime}$ W; BGN 1949; (map 86).

Named in 1941 by Bradford Washburn "because of its three prongs.".

Trident Volcano: volcano, see Trident, Mount.

Trigger Lake: lake, $0.7 \mathrm{mi}$. long, on Kenai Penin. $\mathrm{N}$ of Bedlam Lake, $42 \mathrm{mi}$. NE of Kenai, Cook Inlet Low.; $60^{\circ} 56^{\prime} 30^{\prime \prime} \mathrm{N}, 150^{\circ} 21^{\prime} 00^{\prime} \mathrm{W}$; (map 62)

Named about 1963 by officials of Kenai National Moose Range, for administrative purposes.

Trilby Creek: stream, flows SW $1.6 \mathrm{mi}$. to Big Hurrah Creek, $8 \mathrm{mi}$. NE of Solomon, Seward Penin. High.; $64^{\circ} 39^{\prime} \mathrm{N}, 164^{\circ} 16^{\prime} \mathrm{W}$; (map 95). Var. Right Branch Big Hurrah Creek. Prospectors' name reported in 1899 by Schrader and Brooks (1900, map 3), USGS.

Trilby Creek: stream, in Bendeleben Mts., flows SW 2 mi. to Paragon River near its head, 11 mi. NE of Mount Bendeleben, Seward Penin. High.; $65^{\circ} 14^{\prime} \mathrm{N}, 163^{\circ} 45^{\prime} \mathrm{W}$; (map 110).

Prospectors' name reported on a map of Cape Nome gold fields by David Fox, Jr., dated 1901.

Trilby Creek: stream, flows SE to Magnolia Creek which flows to Igloo Creek, in American River basin, $14 \mathrm{mi}$. SW of Kougarok Mtn. and $33 \mathrm{mi}$. NE of Teller, Seward Penin. High.; $65^{\circ} 30^{\prime} \mathrm{N}, 165^{\circ} 22^{\prime} \mathrm{W}$; (map 111).

Prospectors' name reported on a map of Cape Nome goldfields by David Fox, Jr., dated 1901.

Trilby Creek: stream, flows NW $4 \mathrm{mi}$. to Windy Creek which flows to Budd Creek, in American River basin, $11 \mathrm{mi}$. SW of Kougarok Mtn. and $33 \mathrm{mi}$. NE of Teller, Seward Penin. High.; $65^{\circ} 34^{\prime} \mathrm{N}, 165^{\circ} 28^{\prime} \mathrm{W}$; (map 111). Var. Ohio Creek.

Prospectors' name reported in 1901 by T. G. Gerdine (in Collier, 1902, pl. 12), USGS.

Trilby Creek: stream, flows SE $4 \mathrm{mi}$. to Middle Fork Chandalar River, $14 \mathrm{mi}$. ESE of Chandalar, Brooks Ra.; $67^{\circ} 24^{\prime} \mathrm{N}, 148^{\circ} 02^{\prime} \mathrm{W}$; (map 123).

Prospectors' name obtained in 1909 by A. G. Maddren (in Brooks and others, 1910, pl. 7), USGS.

Trilby Creek: stream, see East Fork Solomon River.

Trilby Creek: stream, sec Grizzly Creek.

Trilby Gulch: ravine, trends W $1 \mathrm{mi}$. to Hungry Creek which flows to Oregon Creek, a tributary to Cripple River, $15 \mathrm{mi}$. NW of Nome,
Seward Penin. High.; $64^{\circ} 40^{\prime} 20^{\prime \prime} \mathrm{N}, 65^{\circ} 42^{\prime}-$ $00^{\prime \prime} \mathrm{W}$; (map 94).

Prospectors' name shown on the 1904 map of Cape Nome Precinct by Arthur Gibson.

Trimble Glacier: glacier, in Tordrillo Mts., formed by the junc. of its North and South Branches, trends NE $4 \mathrm{mi}$. to its terminus at head of Trimble River, $56 \mathrm{mi}$. NW of Tyonek, Alaska Ra.; $61^{\circ} 44^{\prime} 45^{\prime \prime} \mathrm{N}, 152^{\circ} 03^{\prime}$ 00" W; BGN 1963; (map 70). Var. Hayes Glacier.

Named by USGS in 1961 for Kelley W. Trimble, 1885-1955, USGS topographer, who did the first topographic survey in this area.

Trimble River: stream, heads at terminus of Trimble Glacier in Tordrillo Mts., flows $\mathrm{N} 7$ mi. to Hayes River, $62 \mathrm{mi}$. NW of Tyonek, Alaska Ra.; $61^{\circ} 50^{\prime} 20^{\prime \prime} \mathrm{N}, 152^{\circ} 05^{\prime} 00^{\prime \prime} \mathrm{W}$; BGN 1963; (map 70).

Name proposed in 1958 by USGS for Kelly W. Trimble, 1885-1955, USGS topographer, who did the first topographic survey in this area in 1926.

Trim Island: island, $0.2 \mathrm{mi}$. wide, in Karheen Passage, betwen Heceta and Tuxekan Is., Alex. Arch.; $55^{\circ} 47^{\prime} 30^{\prime \prime} \mathrm{N}, 133^{\circ} 17^{\prime} 30^{\prime \prime} \mathrm{W}$; (map 4).

Name published in 1923 by USC\&GS.

Trimokish Hills: range, 4,000 ft., extends N 18 $\mathrm{mi}$. between headwaters of Middle and Windy Forks Kuskokwim River, $68 \mathrm{mi}$. SE of McGrath, Alaska Ra.; $62^{\circ} 15^{\prime} \mathrm{N}, 154^{\circ} 10^{\prime} \mathrm{W}$; (map 80).

Local name obtained in 1958 by USGS.

Trims Creek: stream, flows SW $3 \mathrm{mi}$. to Delta River, crossing Richardson Highway $28 \mathrm{mi}$. NW of Paxson, Alaska Ra.; $63^{\circ} 25^{\prime} 25^{\prime \prime} \mathrm{N}$, $145^{\circ} 46^{\prime} 05^{\prime \prime} \mathrm{W}$; (map 86).

Name reported in 1952 by USGS.

Trinachak: locality, "in the Nushagak district," Bristol Bay Low.; (map 40). Var. Trinachamiut.

Former Eskimo village recorded as "Trinachamiut," population 20 , in the 1890 Census (1893, p. 164).

Trinachamiut: locality, see Trinachak.

Trinidad, Cabo de: point of land, see Trinity, Cape.

Trinidad, Cape: point of land, see Trinity, Cape. Trinidad, Islas de: islands, see Trinity Islands. Trinidad Island: islands, see Trinity Islands.

Trinity, Cape: point of land, on $\mathrm{SW}$ coast of Kodiak I., at $\mathbf{S}$ tip of Aliulik Penin., Kodiak I. ; $56^{\circ} 44^{\prime} 50^{\prime \prime} \mathrm{N}, 154^{\circ} 08^{\prime} 30^{\prime \prime} \mathrm{W}$; (map 32). Var. Aliulik, Aliutik, Cape South, Cape Trinidad, Iuzhnoi, Mys Yuzhnoy, Trinidad, Utchno.

Name derived from Trinity Islands, given by Capt. Cook (1785, v. 2, p. 407-08), RN, in 1778. He wrote "the Westernmost [sic] part of the continent now in sight, being a low point facing Trinity Island, and which we called Cape Trinity ***." This feature was called "M[ys] Yuzhnoy," (South Cape), by Capt. Tebenkov (1852, map 22); USC\&GS gave "Aliulik" as the native name for this feature in 1934.
Trinity Creek: stream, flows NW $1.5 \mathrm{mi}$. to Sinuk River, $22 \mathrm{mi}$. NW of Nome, Seward Penin. High.; $64^{\circ} 46^{\prime} \mathrm{N}, 165^{\circ} 48^{\prime} \mathrm{W}$; (map 94).

Prospectors' name reported in 1900 by E. C. Barnard (in Brooks, 1901, pl. 17), USGS.

Trinity Creek: stream, flows NE $2.2 \mathrm{mi}$. to Washington Creek which flows to Kougarok Creek, $9 \mathrm{mi}$. SW of Midnight Mtn. and 50 mi NW of Imuruk Lake, Seward Penin. High.; $65^{\circ} 44^{\prime} \mathrm{N}, 164^{\circ} 54^{\prime} \mathrm{W}$; (map 110 ).

Prospectors' name reported in 1906 by $\mathrm{A}$. H. Brooks (in Collier and others, 1908, pl. 9), USGS.

Trinity Creek: stream, flows SW 2 mi. to Kobuk River, $13 \mathrm{mi}$. E of Shungnak, Kotzebue-Kobuk Low.; 66 $54^{\prime} \mathrm{N}, 156^{\circ} 41^{\prime} \mathrm{W}$; (map 115).

Prospectors' name reported by USGS after 1940.

Trinity Creek: stream, in Baird Mts., flows SW $4 \mathrm{mi}$. to Kobuk River, $13 \mathrm{mi}$. ENE of Kiana, Brooks Ra.; $67^{\circ} 00^{\prime} 20^{\prime \prime} \mathrm{N}, 159^{\circ} 58^{\prime} 00^{\prime \prime}$ W; (map 127).

Name used by prospectors; reported in 1910 by P. S. Smith (in Brooks and others, 1911, pl. 13), USGS.

Trinity Island: islands, see Trinity Islands.

Trinity Islands: islands, extend $1 \mathrm{mi}$. NW off Long I., in Sanak Is. ; $54^{\circ} 26^{\prime} \mathrm{N}, 162^{\circ} 52^{\prime} \mathrm{W}$; (map 25).

Name reported by Ferdinand Westdahl, USC\&GS, commander of the Coast Survey steamer $M c A r t h u r$, who made surveys in this area in 1901 .

Trinity Islands: islands, off SW coast of Kodiak I., include Sitkinak and Tugidak Is.; 56 $33^{\prime}$ $\mathrm{N}, 154^{\circ} 20^{\prime} \mathrm{W}$; (map 32). Var. Islas de Trinidad, Kightak Sichtunak, Siktunak Island, Trinidad Island, Trinity Island.

Name published as "Trinity Island" by Capt. Cook (1785, v. 2, p. 407), RN. These islands were called "Trinidad Island" by Galiano (1802, map 3) and "Kightak Sichtunak," (Sichtunak Island), by Sauer (1802, p. 174). The Russian Hydrog. Dept. published the name as "O[strovy] Troitsy," (Trin. ity Islands) in 1847 on Chart 1378; this name was also published by USC\&GS in 1868 .

Trinity Lakes: lakes, extend N-S $3.5 \mathrm{mi}$., $36 \mathrm{mi}$. NW of Tyonek, Cook Inlet Low.; $61^{\circ} 36^{\prime} 25^{\prime \prime}$ $\mathrm{N}, 151^{\circ} 26^{\prime} 30^{\prime \prime} \mathrm{W}$; (map 70).

Local descriptive name reported in 1954 by USGS.

Trinity Point: point of land, on NE coast of Kenai Penin., on $\mathbf{S}$ side of Passage Canal, $5 \mathrm{mi}$. NE of Whittier, Chugach Mts.; $60^{\circ}$. $48^{\prime} 25^{\prime \prime} \mathrm{N}, 148^{\circ} 33^{\prime} 20^{\prime \prime} \mathrm{W}$; (map 63).

Named in 1914 by USC\&GS; published in 1916.

Trip Cove: cove, $0.5 \mathrm{mi}$. across, on $\mathrm{N}$ coast of Spruce I. NE of Kodiak I.; 57 $57^{\prime} 30^{\prime \prime} \mathrm{N}$, $152^{\circ} 27^{\prime} 30^{\prime \prime} \mathrm{W}$; (map 34).

Local name published in 1943 by USC\&GS.

Triple Creek: stream, flows E $1.7 \mathrm{mi}$. to Minook Creek, $12 \mathrm{mi}$. S of Rampart, Yukon-Tanana High.; $65^{\circ} 19^{\prime} 50^{\prime \prime} \mathrm{N}, 150^{\circ} 08^{\prime} 20^{\prime \prime} \mathrm{W}$; (map 106). 
Prospectors' name reported in 1931 by $\mathrm{J}$. B. Mertie, USGS

Triple Creek: stream, see Iron Creek.

Triple Divide Peak: mountain, 2,250 ft., at head of Middle Yoke Creek, on central Great Sitkin I., Aleutian Is.; $52^{\circ} 02^{\prime} 30 \mathrm{~N}, 176^{\circ} 05^{\prime} 30^{\prime \prime} \mathrm{W}$; (map 17)

Descriptive name published by USGS (in Simons and Mathewson, 1955, p. 29)

Triple Lakes: lakes, extend NW-SE $1.5 \mathrm{mi}$, $1 \mathrm{mi}$. W of Yanert and $13 \mathrm{mi}$. S of Healy, Alaska Ra.; $63^{\circ} 40^{\prime} \mathrm{N}, 148^{\circ} 52^{\prime} \mathrm{W}$; (map 87).

Local descriptive name reported in 1950 by USGS.

Triplet Islands: islands, the largest $0.3 \mathrm{mi}$. long, in Portlock Harbor on W. coast of Chichagof I., $6.5 \mathrm{mi}$. NW of Chichagof, Alex. Arch.; $57^{\circ} 43^{\prime} 35^{\prime \prime} \mathrm{N}, 136^{\circ} 13^{\prime} 35^{\prime \prime} \mathrm{W}$; (map 9).

Descriptive name published in 1928 by USC\&GS on Chart 8258.

Triplet Rocks: rocks, group of three, at $\mathrm{S}$ tip of Akutan I., Aleutian Is.; $54^{\circ} 02^{\prime} 30^{\prime \prime} \mathrm{N}, 166^{\circ}$ $03^{\prime} 00^{\prime \prime} \mathrm{W}$; (map 23).

Descriptive name given by J. J. Gilbert, commander of the Coast Survey steamer Pathfinder during 1900-01.

Triplet Rocks: rocks, in Tlevak Strait, extend $1,300 \mathrm{ft}$., near head of Cordova Bay, $0.3 \mathrm{mi}$. $\mathrm{SE}$ of Jackson I., Alex. Arch.; 54 $58^{\prime} 30^{\prime \prime} \mathrm{N}$, $132^{\circ} 42^{\prime} 10^{\prime \prime} \mathrm{W}$; (map 1 ).

Local descriptive name reported in 1951 by USGS.

Triplets, The: islands, $0.3 \mathrm{mi}$. long, at $\mathrm{SE}$ end of Kashevarof I., on NE coast of Prince of Wales I., Alex. Arch.; $56^{\circ} 03^{\prime} 30^{\prime \prime} \mathrm{N}, 132^{\circ}$ $50^{\prime} 00^{\prime \prime} \mathrm{W}$; (map 6).

Navigator's descriptive name published in 1907 by USC\&GS.

Triplets, The: islands, extend $1.2 \mathrm{mi}$., in Marmot Bay $1.5 \mathrm{mi}$. N of Spruce I., NE of Kodiak I. $57^{\circ} 59^{\prime} 15^{\prime \prime} \mathrm{N}, 152^{\circ} 28^{\prime} 30^{\prime \prime} \mathrm{W} ; B G N$ 1909; (map 34). Var. Ostrova Kameniste, Rocky Islands, Rocky Islets.

Named "Os[trova] Kameniste" by Sub-Lt. Mikhail Murashev in 1839 or 1840 and published on Russian Hydrog. Dept. Chart 1425. Baker (1906, p. 532) published "Rocky Islands," a translation of Murashev's name. Because of duplication the name was changed to "The Triplets" by USC\&GS in 1909.

Tripod Creek: stream, see Nuka River.

Tripod Hill: mountain, 1,255 ft., on SE shore of Orca Inlet, $1 \mathrm{mi}$. NE of Cordova, Chugach Mts. ; $60^{\circ} 33^{\prime} 20^{\prime \prime} \mathrm{N}, 145^{\circ} 44^{\prime} 00^{\prime \prime} \mathrm{W}$; (map 64).

Local name published in 1951 by USGS.

Tripple Creek: stream, flows SE $2.8 \mathrm{mi}$. to Nome River, $6 \mathrm{mi}$. NE of Nome, Seward Penin. High.; 64'31' N, $165^{\circ} 13^{\prime} \mathrm{W}$; (map 94). Var. Extra Dry Creek.

Prospectors' name reported on a map by S. E. King dated 1900

Tripple Creek: stream, see Iron Creek.

Tripyramid, Mount: mountain, 11,600 ft., in Mount McKinley National Park, consists of East, Central, and West Pyramid Peaks, $12 \mathrm{mi}$. NE of Mount McKinley, Alaska Ra.; $63^{\circ} 09^{\prime}$ $30^{\prime \prime} \mathrm{N}, 150^{\circ} 41^{\prime} 30^{\prime \prime} \mathrm{W}$; (map 88).
Named in 1945 by Bradford Washburn; name suggested by Mount Tripyramid in the Sandwich Range of New Hampshire.

Trista, Isla : rock, sec Seal Rocks.

Triste Island: island, $150 \mathrm{ft}$. long, in Port Real Marina, on NE coast of Baker I., NE of Triste Point, Alex. Arch.; 55 $25^{\prime} 15^{\prime \prime} \mathrm{N}, 133^{\circ} 29^{\prime} 45^{\prime \prime}$ W; (map 4). Var. Ostrov Triste, Isla Triste, Ysla Triste.

Spanish name given in 1775-79 by Don Juan de la Bodega y Quadra and Francisco Antonio Maurelle as "Isla Triste," meaning "Sorrowful Island."

Triste Point: point of land, $1.3 \mathrm{mi}$. W of Santa Rita I., on NE coast of Baker I., Alex. Arch.; $55^{\circ} 25^{\prime} 15^{\prime \prime} \mathrm{N}, 133^{\circ} 30^{\prime} 00^{\prime \prime} \mathrm{W}$; BGN 1923; (map 4)

Spanish word meaning "sorrowful" given in 1923 by USC\&GS ; derived from Triste Island.

Tritt Greek: stream, heads in Seagull Lake, flows SW through Seagull Lake, $27 \mathrm{mi}$. to East Fork Chandalar River, $1 \mathrm{mi}$. E of Arctic Village, Brooks Ra.; $68^{\circ} 08^{\prime} \mathrm{N}, 145^{\circ} 30^{\prime} \mathrm{W}$; (map 136).

Locally named for Albert Tritt; reported in 1926 by J. B. Mertie (in Smith, P. S., and others, 1929, pl. 1), USGS.

Triumvirate Glacier: glacier, in Tordrillo Mts. formed by junc, of three glaciers, trends SW $14 \mathrm{mi}$. to its terminus (1958), $4 \mathrm{mi}$. W of Beluga Lake and $32 \mathrm{mi}$. NW of Tyonek, Alaska Ra.; $61^{\circ} 25^{\prime} \mathrm{N}, 151^{\circ} 46^{\prime} \mathrm{W}$; BGN 1930; (map $70)$

Named by S. R. Capps and R. H. Sargent (in Smith and others, 1929, pl. 3), USGS, "because this glacier is composed of the joining of three large glaciers."

Trocadero Bay: bay, extends SE $11 \mathrm{mi}$., off Bucareli Bay, on W coast of Prince of Wales I., Alex. Arch.; $55^{\circ} 24^{\prime} \mathrm{N}, 133^{\circ} 08^{\prime} \mathrm{W}$; (map 4). Var. Caños del Trocadero, Frocadero Bay, Big Harbor.

Named "Caños del Trocadero" on June 1, 1779, by Francisco Antonio Maurelle. "Trocadero was the name of a fort in the Bay of Cadiz. Adopted by Capt. George Vancouver, RN, under the same name, except that he spelled it with an F" (Wagner, 1937, p. 420).

Trogshak: locality, on $\mathrm{E}$ bank of Kwimlilthla Slough, $9.5 \mathrm{mi}$. SE of Kwiguk, Yukon-Kuskokwim Delta ; 62 $39^{\prime} \mathrm{N}, 164^{\circ} 18^{\prime} \mathrm{W}$; (map 77).

Eskimo camp or village, now abandoned, reported in 1899 by G. R. Putnam, USC\&GS, who wrote it "Trogshagamiut," "Trogshak people."

Troller Islands: islands, at entrance to Tebenkof Bay, on $W$ coast of Kuiu I., Alex. Arch.; $56^{\circ} 28^{\prime} 00^{\prime \prime} \mathrm{N}, 134^{\circ} 12^{\prime} 20^{\prime \prime} \mathrm{W}$; BGN 1929; (map 5).

So named in 1928 by USC\&GS because "a channel running north and south through this group is used by trollers as anchorage."

Troller Point: point of land, at $\mathrm{N}$ end of Troller Is., at entrance to Tebenkof Bay, on Kuiu I., Alex. Arch.; $56^{\circ} 28^{\prime} 45^{\prime \prime} \mathrm{N}, 134^{\circ} 13^{\prime}$ 00" W; BGN 1929; (map 5).

Named in 1928 by USC\&GS.
Trollers Cove: cove, extends S $1 \mathrm{mi}$. off Kasaan Bay, on E coast of Prince of Wales I., $1.8 \mathrm{mi}$. $S$ of Patterson I., Alex. Arch.; $55^{\circ} 22^{\prime} 15^{\prime \prime} \mathrm{N}$, $132^{\circ} 12^{\prime} 00^{\prime \prime} \mathrm{W}$; $B G N$ 1923; (map 4).

So named in 1923 by USC\&GS because this cove is a "favorite Haven for Fishermen from Twentyfathom Bank in Clarence Strait."

Trollers Creek: stream, flows N $1.4 \mathrm{mi}$. to Knudson Cove, $\mathrm{E}$ of Survey Point, on $\mathrm{W}$ coast of Revillagigedo I., Alex. Arch.; 55 $28^{\prime} 15^{\prime \prime} \mathrm{N}$, $131^{\circ} 47^{\prime} 50^{\prime \prime}$ W; BGN 1937; (map 3).

Local name reported in 1936 by USFS

Trollup, Point: point of land, on E bank of Behm Canal, $N$ point of entrance to Smeaton Bay, Coast Mts.; 55 $18^{\prime} 50^{\prime \prime} \mathrm{N}, 130^{\circ} 52^{\prime} 15^{\prime \prime} \mathrm{W}$; (map 3)

Named by Capt. Vancouver, RN, in 1793 "no doubt after Sir Henry Trollope, RN, who served during the American war" (Wagner, 1937, p. 420).

Trophy Lake: lake, $0.2 \mathrm{mi}$. across, on Kenai Penin., $13 \mathrm{mi}$. S of Caribou I. in Tustumena Lake and $35 \mathrm{mi}$. S of Kenai, Cook Inlet Low.; $60^{\circ} 03^{\prime} 25^{\prime \prime} \mathrm{N}, 151^{\circ} 04^{\prime} 45^{\prime \prime} \mathrm{W}$; (map 62).

Named about 1963 by officials of Kenai National Moose Range, for administrative purposes.

Tropical Ridge: ridge, elev. 1,040 ft., $1.5 \mathrm{mi}$ long, between Conquer Point and Kiska Harbor, central Kiska I., Aleutian Is.; 51 ${ }^{\circ} 59^{\prime} 30^{\prime \prime}$ N, $177^{\circ} 30^{\prime} 30^{\prime \prime} \mathrm{E}$; (map 14).

One of many arbitrary names applied to features on Kiska I. by USAAF for tactical purposes during World War II.

Trouble Creek: stream, flows NW $11 \mathrm{mi}$. to Chandler River, $20 \mathrm{mi}$. SE of Umiat, Arctic Slope; $69^{\circ} 08^{\prime} \mathrm{N}, 151^{\circ} 40^{\prime} \mathrm{W}$; BGN 1960; (map 141).

So named by USGS geologists during $\mathrm{ex}$ ploration of Naval Petroleum Reserve No. 4 between 1945-53, "because our field party had difficulty crossing this stream with weasels [tracked vehicles]. Several tracks and springs were broken."

Trouble Island: island, $0.2 \mathrm{mi}$. long, at $\mathrm{S}$ end of Keku Strait, between Kupreanof and Kuiu Is., Alex. Arch.; 56 $27^{\prime} 50^{\prime \prime} \mathrm{N}, 133^{\circ} 41^{\prime} 00^{\prime \prime} \mathrm{W}$; (map 6).

Named by USC\&GS for charting purposes; published in 1932 Coast Pilot (p. 256).

Troublesome Creek: stream, on Kenai Penin., flows W $2 \mathrm{mi}$. to Travers Creek, $11 \mathrm{mi}$. NW of Homer, Cook Inlet Low.; $59^{\circ} 43^{\prime} 45^{\prime \prime} \mathrm{N}$, $151^{\circ} 49^{\prime} 00^{\prime \prime} \mathrm{W}$; (map 50).

Local name reported and published by USGS in the 1950's.

Troublesome Creek: stream, heads at glacier W of Upper Lake George, flows E $2.2 \mathrm{mi}$. to Lake Fork Knik River, 28 mi. SE of Palmer, Chugach Mts.; $61^{\circ} 16^{\prime} 40^{\prime \prime} \mathrm{N}, 148^{\circ} 36^{\prime} 35^{\prime \prime} \mathrm{W}$; (map 69).

Local name reported in 1960 by USGS

Troublesome Greek: stream, heads in lake, flows SW $14 \mathrm{mi}$. to Chulitna River, $21 \mathrm{mi}$. NW of Talkeetna, Cook Inlet Low.; $62^{\circ} 37^{\prime} 30^{\prime \prime} \mathrm{N}$, $150^{\circ} 14^{\prime} 30^{\prime \prime} \mathrm{W}$; (map 81).

Prospectors' name published in 1940 by USGS. 
Troublesome Creek: stream, heads at $65^{\circ} 17^{\prime} \mathrm{N}$, $149^{\circ} 45^{\prime} \mathrm{W}$, flows $\mathrm{N} 40 \mathrm{mi}$. to Hess Creek, 80 mi. NW of Fairbanks, Yukon-Tanana High.; $65^{\circ} 43^{\prime} \mathrm{N}, 149^{\circ} 28^{\prime} \mathrm{W}$; (map 105).

Named by prospectors, according to a report in 1902 by Lt. Hjalmar Erickson, USA; published by USGS (Prindle, 1905, pl. 16).

Trout Creek: stream, flows $\mathrm{S}$ to Ishut Creek which flows to Anikovik River, about $14 \mathrm{mi}$. $\mathrm{E}$ of Cape Prince of Wales, Seward Penin. High.; (map 111).

Prospectors' name reported on a precinct map of Seward Peninsula gold fields by Monroe and Hutchins, corrected up to June 1903 by Arthur Gibson. This feature cannot be precisely identified on current maps.

Trout Creek: stream, flows NW $3.5 \mathrm{mi}$. to McHenry Inlet, on SW coast of Etolin I., Alex. Arch.; $56^{\circ} 02^{\prime} 00^{\prime \prime} \mathrm{N}, 132^{\circ} 22^{\prime} 40^{\prime \prime} \mathrm{W}$; (map 6).

Local name "given by the fisheries"; reported in 1900 by Lt. Comdr. J. F. Moser, USN.

Trout Creek: stream, flows W $7 \mathrm{mi}$. to Sumner Strait, on W coast of Kosciusko I., Alex. Arch.; $56^{\circ} 03^{\prime} \cdot \mathrm{N}, 133^{\circ} 42^{\prime} \mathrm{W}$; (map 6).

Local name recorded in 1949 by USGS.

Trout Creek: stream, flows S $2.5 \mathrm{mi}$. to Stillwater Creek, $22 \mathrm{mi}$. NE of Katalla, Ghugach Mts.; $60^{\circ} 24^{\prime} \mathrm{N}, 144^{\circ} 02^{\prime} \mathrm{W}$; (map 64).

Local name reported in 1903 by G. C. Martin, USGS.

Trout Creek: stream, heads in Peters Hills, flows NW $1.9 \mathrm{mi}$. to Cache Creek, $30 \mathrm{mi}$. NW of Talkeetna, Alaska Ra.; $62^{\circ} 29^{\prime} 45^{\prime \prime} \mathrm{N}, 150^{\circ}$. $27^{\prime} 50^{\prime \prime} \mathrm{W}$; (map 81).

Prospectors' name reported in 1911 by Capps (1913, fig. 5) , USGS.

Trout Creek: stream, flows E $1 \mathrm{mi}$. to valley of Nome River, $15 \mathrm{mi}$. N of Nome, Seward Penin. High.; $64^{\circ} 43^{\prime} \mathrm{N}, 165^{\circ} 19^{\prime} \mathrm{W}$; (map 94).

Prospectors' name published on the 1900 "Map of Nome Peninsula" by J. M. Davidson and $\mathrm{B}$. D. Blakeslee.

Trout Creek: stream, flows NE $3.2 \mathrm{mi}$. to Bear River which flows to Niukluk River, $26 \mathrm{mi}$. NE of Solomon, Seward Penin. High.; $64^{\circ} 50^{\prime}$ $N, 163^{\circ} 51^{\prime} \mathrm{W}$; (map 95).

Prospectors' name reported in 1900 by $\mathrm{E}$. C. Barnard (in Brooks, 1901, pl. 17), USGS.

Trout Creek: stream, flows NW $11 \mathrm{mi}$. to Yukon River, $27 \mathrm{mi}$. NNW of Eagle, Yukon-Tanana High.; $65^{\circ} 07^{\prime} 20^{\prime \prime} \mathrm{N}, 141^{\circ} 39^{\prime} 50^{\prime \prime} \mathrm{W}$; (map 103 ).

Prospectors' name from an unpublished map by E. J. Chamberlain, dated 1902 .

Trout Creek: stream, flows E $3 \mathrm{mi}$. to Granite Creek, $14 \mathrm{mi}$. S of Rampart, Yukon-Tanana High.; $65^{\circ} 18^{\prime} 10^{\prime \prime}$ N, $150^{\circ} 09^{\prime} 30^{\prime \prime} \mathrm{W}$; (map 106).

Prospectors' namc reported in 1931 by $\mathrm{J}$. B. Mertie, USGS.

Trout Creek: stream, on $\mathrm{E}$ shore of Arctic Lagoon, flows W $21 \mathrm{mi}$. to Kugrupaga Inlet, $26 \mathrm{mi}$. SW of Shishmaref, Kotzebue-Kobuk Low. $66^{\circ} 01^{\prime} \mathrm{N}, 166^{\circ} 47^{\prime} \mathrm{W}$; (map 112).
Prospectors' name reported in 1901 by A. J. Collier, USGS.

Trout Creek: stream, flows E $6 \mathrm{mi}$. and joins Slate Creek to form Pitka Fork $53 \mathrm{mi}$. NW of Beaver, Kokrines-Hodzana High.; $66^{\circ} 58^{\prime} 20^{\prime \prime}$ $\mathrm{N}, 148^{\circ} 33^{\prime} 30^{\prime \prime} \mathrm{W}$; (map 118).

Local name obtained in 1956 by USGS.

Trout Creek: stream, see Majority Creek.

Trout Hill: hill, $895 \mathrm{ft}$., on Annette I., E of Port

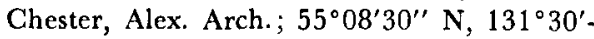
$30^{\prime \prime} \mathrm{W}$; (map 3 ).

Named in 1883 by Lt. Comdr. H. E. Nichols, USN.

Trout Lagoon: lagoon, $0.3 \mathrm{mi}$. across, W of Kiska Harbor on east-central Kiska I., Aleutian Is. $51^{\circ} 58^{\prime} 25^{\prime \prime} \mathrm{N}, 177^{\circ} 32^{\prime} 00^{\prime \prime} \mathrm{E} ; \mathrm{BGN} 1937$; (map 14).

Local name reported in 1905 by USC\&GS

Trout Lake: lake, on Annette I., drains $\mathrm{W}$ into Port Chester, Alex. Arch.; $55^{\circ} 68^{\prime} 50^{\prime \prime} \mathrm{N}, 131^{\circ}$ $30^{\prime} 15^{\prime \prime} \mathrm{W}$; BGN 1923; (map 3). Var. Upper Trout Lakes.

Named Upper Trout Lakes in 1896 by USC\&GS ; changed to Trout Lake in 1923.

Trout Lake: lake, $0.3 \mathrm{mi}$. long, in course of Pat Creck, $8.5 \mathrm{mi}$. S of Wrangell, on NW coast of Wrangell I., Alex. Arch.: $56^{\circ} 21^{\prime} \mathrm{N}, 132^{\circ}$. $20^{\prime} \mathrm{W}$; (map 6).

Named in 1886 by Lt. Comdr. A. S. Snow, USN; published in 1887 on USC\&GS Chart 706.

Trout Lake: lake, $1.7 \mathrm{mi}$. long, on Kenai Penin., $1.5 \mathrm{mi}$. SW of Juneau Lake and $28 \mathrm{mi}$. SW of Hope, Chugach Mts.; $60^{\circ} 33^{\prime} 30^{\prime \prime}$ N, 149 $54^{\prime}$ $30^{\prime \prime} \mathrm{W}$; (map 63).

Local name reported in 1951 by USGS.

Trout Lake: lake, $1 \mathrm{mi}$. long, on Kenai Penin., SW of Gavia Lake, $24 \mathrm{mi}$. NE of Kenai, Cook Inlet Low.; $60^{\circ} 41^{\prime} \mathrm{N}, 150^{\circ} 37^{\prime} \mathrm{W}$; (map 62).

Named about 1963 by officials of Kenai National Moose Range, for administrative purposes.

Trout Lake: lake, $2.8 \mathrm{mi}$. long, in course of Hungry Creek, $4.5 \mathrm{mi}$. NE of Tundra Lake and $61 \mathrm{mi}$. SE of Sleetmute, Lime Hills; $61^{\circ}$ $17^{\prime} \mathrm{N}, 155^{\circ} 32^{\prime} \mathrm{W}$ (map 71).

Prospectors' name published in 1951 by USGS.

Trout Lake: lake, 1,200 ft. long, in course of Limestone Creek $2.8 \mathrm{mi}$. N of its junc. with Middle Fork Chistochina River, $28 \mathrm{mi}$. NE

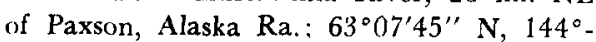
$38^{\prime} 30^{\prime \prime} \mathrm{W}$; (map 86$)$.

Prospectors' name reported in 1902 by T. G. Gerdine, USGS.

Troutman Lake: lake, $2.5 \mathrm{mi}$. long, $0.5 \mathrm{mi}$. S of Gambell, NW end of St. Lawrence $I$.; $63^{\circ}$ $46^{\prime} \mathrm{N}, 171^{\circ} 43^{\prime} \mathrm{W}$; BGN 1951; (map 93). Var. Navvook Lake, Nayrak Lake, Ninghak, Niyghak Lake.

Named in the 1930's by O. W. Geist, Univ. of Alaska, for S. P. Troutman, a government teacher on the island

Tro-wak: mountain, see Towak Mountain

Troy, Mount: mountain, 3,005 ft., on Douglas I., $3 \mathrm{mi}$. SW of Douglas and $3.5 \mathrm{mi}$. SW of Juneau, Coast Mts.; $58^{\circ} 16^{\prime} 00^{\prime \prime} \mathrm{N}, 134^{\circ} 28^{\prime}$ 30" W : BGN 1952; (map 11).
Named by the USFS in 1950 for John Weir Troy, 1868--1942, former Alaskan governor and newspaperman. $\mathrm{He}_{\mathrm{e}}$ was born and brought up in the State of Washington, and then entered the newspaper business. In 1897, he went to Alaska to cover the gold rush. In 1899 he became editor and publisher of the Skagway Daily Alaskan and in 1913 he went to Juneau as editor of the Daily Alaska Empire. In 1919 he became Collector of Customs for Alaska. He served as Governor from 1933-39.

Troy Creek: stream, flows $\mathrm{S}$ to Ishut Creek which flows to Anikovik River, about $14 \mathrm{mi}$. E of Cape Prince of Wales, Seward Penin. High.; (map 111 ).

Prospectors' name shown on the 1900 "Map of Nome Peninsula" by J. M. Davidson and B. D. Blakeslee. This feature cannot be precisely identified on current maps.

Truax Range: hills, trend N-S, SE of Mount Kachauik and about $10 \mathrm{mi}$. NE of Golovin, Seward Penin. High.; (map 95).

Local name published by Schrader (1900c, p. 16), USGS. The feature was not identified on subsequent maps.

Trubitsina, Cape: point of land, see Edgecumbe, Cape.

Trubitsina, Mys: point of land, see Edgecumbe, Cape.

Trubitsina Cape: point of land, see Trubitsin Point.

Trubitsin Point: point of land, $0.5 \mathrm{mi}$. E of Capc Edgecumbe, on S tip of Kruzof I., Alex. Arch.; $56^{\circ} 59^{\prime} 40^{\prime \prime} \mathrm{N}, 135^{\circ} 50^{\prime} 10^{\prime \prime} \mathrm{W} ; B G N$ 1926; (map 5). Var. Trubitsina Cape.

Named in 1926 by USC\&GS for Grigori Trubitsin, who was a boatswain who served under Capt. A. I. Chirikov, IRN, in 1741. Alexander Baranov applied this name to Cape Edgecumbe in the 1790's.

Trubitsin Point: point of land, see Edgecumbe, Cape.

True Summit: peak, 4,500 ft., on Olds Mountain, $2.7 \mathrm{mi}$. N of Clark Peak and $5 \mathrm{mi}$. NE of Juneau, Coast Mts.; $58^{\circ} 20^{\prime} 20^{\prime \prime} \mathrm{N}, 134^{\circ} 17^{\prime} 25^{\prime \prime}$ W; (map 11).

Local name reported by $U$. A. Brew and A. B. Ford, USGS, in 1965.

Trumpeter Lake: lake, $0.4 \mathrm{mi}$, across, on coursc of Ratz Creek, NE part of Prince of Wales I., Alex. Arch.; $55^{\circ} 53^{\prime} \mathrm{N}, 132^{\circ} 38^{\prime}$ W; $B G N$ 1962; (map 4).

Local name given "because of the use [by] trumpcter swans for wintering area"; reported in 1961 by USFS.

Trumpeter Lake: lake, $0.4 \mathrm{mi}$. across, on Kenai Penin. S of Brood Lake, $28 \mathrm{mi}$. $\mathbf{E}$ of Kenai. Cook Inlet Low.: $60^{\circ} 33^{\prime} 45^{\prime \prime} \mathrm{N}, 150^{\circ} 25^{\prime} 45^{\prime \prime}$ $\mathrm{W}$; (map 62)

Named about 1963 by officials of Kenai National Moose Range, for the Trumpeter Swan (Olor buccinator) which breeds in southern Alaska.

Trunk Island: island, $1 \mathrm{mi}$. long, in Behm Canal, off Helm Point, off $\mathbf{E}$ coast of Cleveland Penin., Alex. Arch.; 55 $36^{\prime} \mathrm{N}, 131^{\circ} 53^{\prime}$ W; (map 3). 
Named in 1886 by USC\&GS.

Trunk Point: point of land, on E coast of Tanaga I., Aleutian Is.; $51^{\circ} 46^{\prime} 10^{\prime \prime} \mathrm{N}, 177^{\circ} 46^{\prime} 45^{\prime \prime} \mathrm{W}$; (map 17).

Name published by USC\&GS in the 1944 Aleutian Coast Pilot (p. 118).

Truth River: stream, flows NE $3 \mathrm{mi}$. to Throat River 4 mi. S of Selawik, Kotzebue-Kobuk Low.; $66^{\circ} 33^{\prime} \mathrm{N}, 159^{\circ} 59^{\prime} \mathrm{W}$; (map 114).

Local name reported by the U.S. Army Corps of Engineers in 1955.

Truuli Peak: peak, 6,612 ft., in Kenai Mts. on Kenai Penin., $19 \mathrm{mi}$. NE of head of Kachemak Bay, Chugach Mts. ; $59^{\circ} 54^{\prime} 50^{\prime \prime}$ N, $150^{\circ} 25^{\prime} 55^{\prime \prime}$ W; BGN 1966; (map 50).

So named in 1966 by the Mountaineering Club of Alaska to preserve the native name for the Kenai Mountains. According to Baker (1906, p. 359), USGS, Constantin "Grewingk, 1849 , deriving his information from Wosnesenski, 1842, gives the native name of these mountains as Trüüli, also written Truuli."

Tsa Cove: cove, $1,600 \mathrm{ft}$. across, along $\mathrm{S}$ coast of Revillagigedo I., NE of Bull I., near head of George Inlet, Alex. Arch.; $55^{\circ} 30^{\prime} \mathrm{N}, 131^{\circ}$. $28^{\prime} \mathrm{W}$; (map 3).

Arbitrary name given in 1891 by USC\&GS. Tsadaha Canyon: canyon, see Tsadaka Canyon. Tsadaka Canyon: canyon, 2 mi. long, near mouth of Moose Creek, $6 \mathrm{mi}$. NE of Palmer, Cook Inlet Low.; $61^{\circ} 41^{\prime} \mathrm{N}, 149^{\circ} 04^{\prime} \mathrm{W}$; BGN 1966; (map 69). Var. Tsadaha Canyon.

Tanaina Indian name meaning "moose," re. ported in 1898 by Capt. Glenn (Glenn and Abercrombie, 1899, p. 52), USA.

Tsadaka Creek: stream, see Moose Creek.

Tsaina: stream, see Tiekel River.

Tsaina: stream, see Tsina River.

Tsalk: bay, see Marmot Bay.

Tsammana: locality, $\mathrm{S}$ of Lincoln Bight, on NW coast of St. Paul I., in Pribilof Is. ; $57^{\circ} 12^{\prime} 20^{\prime \prime}$ N, $170^{\circ} 22^{\prime} 40^{\prime \prime} \mathrm{W}$; (map 38). Var. Tsammanah.

Probably an Aleut name which appeared on a map by Elliott (1881, St. Paul map) as "Tsammanah." USBF reports in 1965 that the name is still used.

Tsammanah: locality, see Tsammana.

Tsantikihin: locality, on Gold Creek near Juneau, Coast Mts.; 58 $18^{\prime} \mathrm{N}, 134^{\circ} 24^{\prime} \mathrm{W}$; (map 11). Var. Tsantîk !îhin, Tsenta-ka-hini.

Former Tlingit village name published in 1909 as "Tsantîk! ihin," meaning "small flounder creek" [Gold Creek], by J. R. Swanton, BAE (Hodge 1910, p. 822)

Tsaritsa Rock: rock, in Galankin Is., off W coast of Baranof I., 2 mi. S of Sitka, Alex. Arch.; $57^{\circ} 01^{\prime} 18^{\prime \prime} \mathrm{N}, 135^{\circ} 19^{\prime} 25^{\prime \prime} \mathrm{W}$; (map 9).

Named by the Russians for one of their vessels, which struck the rock (U.S. Coast and Geodetic Survey, 1883, p. 143).

Tsatasronick: stream, see Herron River.

Tsatasronik: stream, see Herron River.

T'satsúmi: locality, see Techek.

Tsayagtulek Creek: stream, flows NW $3 \mathrm{mi}$. to Kancktok River, $70 \mathrm{mi}$. NE of Goodnews, Kilbuck-Kuskokwim Mts. ; $59^{\circ} 54^{\prime} \mathrm{N}, 160^{\circ} 21^{\prime} \mathrm{W}$; (map 53).
Eskimo name reported in 1954 by USGS,

Tsbantotloden Lake: lake, $1 \mathrm{mi}$. across, $1 \mathrm{mi}$. N of Duck Lake and $64 \mathrm{mi}$. SE of Shungnak, Koyukuk Low.; $65^{\circ} 03^{\prime} \mathrm{N}, 156^{\circ} 15^{\prime} \mathrm{W}$; (map 115).

Koyukan Indian name reported in 1952 by USGS.

Tschagevanachtuli: stream, see Swift River.

Tschaljchuk: stream, see Stony River.

Tschallono: stream, see Selatna River.

Tschaltschuk: stream, see Stony River.

Tschaltshuck: stream, see Stony River.

Tschantotalich: stream, see Shantatalik Creek.

Tschechina: island, see Great Sitkin Island.

Tschechina Island: island, see Great Sitkin Island.

Tschechovla: island, see Chugul Island.

Tschechovla Island: island, see Segula Island.

Tschechovle Island: island, see Segula Island.

Tscherikow: island, see Chirikof Island.

Tscherikow's Island: island, see Chirikof Island.

Tschernowskoje: village, see Chernofski.

Tschibocki Island: island, see Saint Lawrence Island.

Tschigmit Mountains: mountain range, see Alaska Range.

Tschijschi: bay, sec Marmot Bay.

Tschilkathin: stream, see Chilkat River.

Tschilkat Islands: islands, see Chilkat Islands.

Tschilkat See: lake, see Chilkat Lake.

Tschilkūt: locality, see Chilkoot.

Tschilkūt See: lake, see Chilkoot Lake.

Tschillkat Inlet: estuary, see Chilkoot Inlet.

Tschiniklik: mountain, see Chiniklik, Mount.

Tschinkitâné, Baie de: bay, "this probably is Norfolk Sound (Sitka Sound)," Alex. Arch.

Tlingit Indian name recorded by Marchand expedition in 1787. See Wagner (1937, p. $363)$.

Tschirikoff : island, see Chirikof Island.

Tschirikow: point of land, see Ommaney, Cape.

Tschirikow Bay: water passage, see Chatham Strait.

Tschitschagoff Harbor: bay, sec Chichago Harbor.

Tschitschitnak: stream, see Chichitnok River Tschokfach tolígamut: village, see Chakwaktolik.

Tschugatschik, Bai: bay, see Kachemak Bay.

Tschugatsk Halbinsel: peninsula, see Kenai Peninsula.

Tschuh-nek-kutsch-kleh-eek: mountain, see Chunekukleik Mountain

Tschuiou River: stream, see Douglas River.

Tschuiow River: stream, see Douglas River.

Tschuktschen-See: sea, sec Chukchi Sea

Tsedolalindin Lake: lake, $6 \mathrm{mi}$. $\mathrm{N}$ of Roundabout Mtn., Koyukuk Low. : $65^{\circ} 38^{\prime}$ N, $156^{\circ}$. 34' W; (map 108).

Koyukan Indian name obtained at Huslia by USGS in 1955 .

Tsee-na: stream, see Tsina River.

Tseétoht: stream, see Ray River.

Tsek-nuk-sank-y: locality, see Sikanasankian.

Tseldatna: stream, see Soldotna Creek.

Tsemalukmená: lake, see Sprucefish Lake.

Tsenta-ka-hini: locality, see Tsantikihin.

Tseplitel Teplyye Klyuchi : locality, see Goddard.

Tsetchina Island: island, see Great Sitkin Island.
Tsetseka: stream, see Unalakleet River.

Tshachaling-Atachtoli Lake: lake, $1 \mathrm{mi}$. long, $\mathrm{W}$ of Nenevok Lake and $78 \mathrm{mi}$. NE of Goodnews, Kilbuck-Kuskokwim Mts.; $59^{\circ} 47^{\prime} \mathrm{N}, 159^{\circ}$ 53' W; (map 53).

Eskimo name shown on an 1898 fieldsheet by W. S. Post, USGS.

Tshakhtol, Guba: bay, see Shaktoolik Bay.

Tshaktog-myut: village, see Shaktoolik.

Tshayagagamut: locality, on right bank o? Togiak River, $1 \mathrm{mi}$. above mouth of Tshayagaguk River and $66 \mathrm{mi}$. NE of Goodnews, Kilbuck-Kuskokwim Mts.; $59^{\circ} 27^{\prime}$ N, $159^{\circ} 48^{\prime}$ W; (map 53).

Eskimo name of a camp shown with two structures labelled "caches" on a fieldsheet by W. S. Post, USGS. The name means "Tshayagak people." The place is no longer occupied.

Tshayagaguk River: stream, flows $5 \mathrm{mi}$. SE to Togiak River, $7 \mathrm{mi}$. S of Togiak Lake and 66 mi. NE of Goodnews, Kilbuck-Kuskokwim Mts.; $59^{\circ} 26^{\prime} \mathrm{N}, 159^{\circ} 50^{\prime} \mathrm{W}$; (map 53).

Eskimo name shown on a 1898 fieldsheet by W. S. Post; USGS.

Tshernov, Cape: point of land, see Chernofski Point.

Tshugulla: island, see Chugul Island.

Tsī'choān: locality, see Shakan.

Tsilchin Lake: lake, $1.8 \mathrm{mi}$. long, between Kalutna and Tanana River, $15 \mathrm{mi}$. NW of Northway Junction, Alaska Ra.; $63^{\circ} 07^{\prime} \mathrm{N}$, $142^{\circ} 12^{\prime} \mathrm{W}$; (map 85).

Indian name published by USGS in 1964 .

Tsilkat Inlet: estuary, see Chilkat Inlet.

T'silkat Islands: islands, see Chilkat Islands.

Tsilkat River: stream, see Chilkat River.

Tsina: locality, see Tsina Station.

Tsina Glacier: glacier, heads $4.2 \mathrm{mi}$. NW of Girls Mtn., trends SE and NE, $6.2 \mathrm{mi}$. to its terminus (1953), $0.5 \mathrm{mi}$. W of Tsina River and $19 \mathrm{mi}$. NE of Valdez, Chugach Mts.; $61^{\circ}$. $15^{\prime} 30^{\prime \prime} \mathrm{N}, 145^{\circ} 48^{\prime} 30^{\prime \prime} \mathrm{W}$; BGN 1964; (map 68.) Var. Trap Lake Glacier.

Named in 1963 by USGS.

Tsina River: stream, heads in glacier, flows $\mathrm{E}$ $24 \mathrm{mi}$. to Tiekel River, $0.7 \mathrm{mi}$. SE of mouth of Stuart Creek and $34 \mathrm{mi}$. NE of Valdez, Chugach Mts.; $61^{\circ} 16^{\prime} \mathrm{N}, 145^{\circ} 16^{\prime} \mathrm{W}$; (map 68). Var. China River, Tsaina, Tsee-na.

Ahtena Indian name meaning "bent (crooked) river [tsa' $i$-na]" spelled "Tsaina" by F. C. Schrader, USGS, in 1898 and as "China" by Capt. W. R. Abercrombie, USA, the same year. See Tiekel River.

Tsina Station: locality, along Tsina River, $2 \mathrm{mi}$. NE of Ptarmigan and $25 \mathrm{mi}$. NE of Valdez, Chugach Mts.; $61^{\circ} 11^{\prime} 45^{\prime \prime} \mathrm{N}, 145^{\circ} 33^{\prime} 30^{\prime \prime} \mathrm{W}$ : (map 68). Var. Tsina, Saina.

A telegraph station was established here in 1902 by the U.S. Army, Signal Corps. It was officially called "Saina."

Tsingigkalik Lake: lake, $1 \mathrm{mi}$. wide, $2 \mathrm{mi}$. $\mathrm{E}$ of Kwinhagak and $45 \mathrm{mi}$. NW of Goodnews, Yukon-Kuskokwim Delta ; 59 $45^{\prime} \mathrm{N}, 161^{\circ} 50^{\prime}$ W; (map 53).

Eskimo name published in 1951 by USGS. 
Tsirku Glacier: glacier, heads in British Columbia at $59^{\circ} 17^{\prime} \mathrm{N}, 136^{\circ} 47^{\prime} \mathrm{W}$, trends E $10 \mathrm{mi}$. to its 1954 terminus, $1 \mathrm{mi}$. $W$ of head of Tsirku River and $41 \mathrm{mi}$. SW of Skagway, St. Elias Mts.; $59^{\circ} 18^{\prime} 00^{\prime \prime} \mathrm{N}, 136^{\circ} 26^{\prime} 30^{\prime \prime}$ BGN 1954; (map 45).

Tlingit Indian name given by United States and Canada, published in 1923 on IBC Sheet 9 (1951 atlas).

Tsirku River: stream, heads in glacier on $\mathrm{N}$ slope of Takhinsha Mts., flows NE $25 \mathrm{mi}$. to Chilkat River at Klukwan, $21 \mathrm{mi}$. SW of Skagway, St. Elias Mts. ; 59 $23^{\prime} 20^{\prime \prime} \mathrm{N}, 135^{\circ} 52^{\prime} 00^{\prime \prime} \mathrm{W}$; BGN 1921; (map 45). Var. Big Salmon River, Salmon River, Tisku River, Zirku River.

Tlingit Indian name reported as "Zirku" by Aurel and Arthur Krause (1883, map). The Indian name meaning "big salmon" is spelled "Tsirku" in the 1883 Coast Pilot (p. 198). It was called "Tisku River" by surveyors in 1899, and "Salmon River" by Brooks (1900b, pl. 49), USGS. According to E. C. Robertson, USGS, the local residents speak of it as the Big Salmon River.

Tsisi Creek: stream, flows NE $22 \mathrm{mi}$. to Kosina Creek $6.5 \mathrm{mi}$. S of its junc. with Susitna River and $65 \mathrm{mi}$. SE of Cantwell, Talkeetna Mts.; $62^{\circ} 42^{\prime} \mathrm{N}, 148^{\circ} 00^{\prime} \mathrm{W}$; (map 82 ).

Indian name reported in 1951 by USGS

Tsi-u: stream, see Tsivat River.

Tsiu River: stream, heads in lake at $1950 \mathrm{Ber}$ ing Glacier terminus, flows $\mathrm{S} 8 \mathrm{mi}$. to Tsivat River, Alaska, $24 \mathrm{mi}$. E of Cape Yakataga, Malaspina Coastal Plain; $60^{\circ} 04^{\prime} \mathrm{N}, 143^{\circ} 08^{\prime}$ W; (map 65)

Indian name reported in 1904 by G. C. Martin, USGS; originally applied to the Tsivat River; both names may be derived from the same source.

Tsivat River: stream, heads at terminus of Bering Glacier, flows E and SW $16 \mathrm{mi}$. to Gulf of Alaska, 9 mi. W of mouth of Kaliakh River and $97 \mathrm{mi}$. SE of Cordova, Malaspina Coastal Plain; $60^{\circ} 04^{\prime} 30^{\prime \prime} \mathrm{N}, 143^{\circ} 04^{\prime} 30^{\prime \prime} \mathrm{W}$; (map 65 ). Var. Tsi-u.

Indian name transcribed into Russian by Capt. Tebenkov (1852, map 7), IRN, as "R[eka] Tsivot," or "Tsivor River." G. G. Martin, USGS, recorded the name in 1904 as "Tsi-u."

Tsiyeehvun Lake: lake, $1 \mathrm{mi}$. long, oxbow of Black River, $32 \mathrm{mi}$. NE of Fort Yukon, Yukon Flats; $66^{\circ} 39^{\prime} 10^{\prime \prime} \mathrm{N}, 144^{\circ} 08^{\prime} 30^{\prime \prime} \mathrm{W}$; (map 119).

Kutchin Indian name obtained in 1956 by T. E. Taylor, USGS.

Tsl-Kaht River: stream, see Chilkat River.

Tsogliakten: locality, see Zogliakten.

Tsoglyakhten: locality, see Zogliakten.

Tsoktui Hill: hill, $600 \mathrm{ft}$., $\mathrm{S}$ of Black River and $0.3 \mathrm{mi}$. W of Chalkyitsik, Yukon Flats; $66^{\circ} 39^{\prime}$ $\mathrm{N}, 143^{\circ} 45^{\prime} \mathrm{W}$; (map 120$)$.

Kutchin Indian name obtained in 1944 by USGS.

Tsolmund Lake: lake, $1.6 \mathrm{mi}$. long, W of Chisana River, $9.6 \mathrm{mi}$. SE of Northway, Alaska Ra.; $62^{\circ} 50^{\prime} \mathrm{N}, 141^{\circ} 44^{\prime} \mathrm{W}$; (map 84). Var. Big Lake.
Indian name reported by USGS in 1955. Tsonagoliakten: locality, see Zonagoliakten. Tsonagolyakhten: locality, see Zonagoliakten. Tsonogokhlyakhten: locality, see Zonagoliakten Tsukhwarat Bay: estuary, see Iookswarat Bay. Tsukli Island: island, see Montague Island. Tsukon: locality, on W bank of Marten Creek, $24 \mathrm{mi}$. NW of Fort Yukon, Yukon Flats; $66^{\circ}$. $50^{\prime} 35^{\prime \prime} \mathrm{N}, 145^{\circ} 48^{\prime} 00^{\prime \prime} \mathrm{W}$; (map 119).

Kutchin Indian name obtained in 1956 by T. E. Taylor, USGS.

Tsurotlurna Slough: stream, flows NE $14 \mathrm{mi}$. to Khotol River, $23 \mathrm{mi}$. SE of Nulato, Koyukuk Low.; $64^{\circ} 24^{\prime} \mathrm{N}, 158^{\circ} 16^{\prime} \mathrm{W}$; (map 97).

Indian name reported in 1935 by Frederica de Laguna, BAE.

Tsusena Butte: mountain, $4,312 \mathrm{ft}$., on $\mathrm{E}$ bank of Tsusena Creek $7 \mathrm{mi}$. $\mathrm{N}$ of its junc. with Susitna River and $35 \mathrm{mi}$. SE of Cantwell, Talkeetna Mts.; $62^{\circ} 55^{\prime} 30^{\prime \prime} \mathrm{N}, 148^{\circ} 31^{\prime} 30^{\prime \prime} \mathrm{W}$; (map 82).

Indian name published in 1917 on a USGS manuscript map.

Tsusena Creek: stream, flows S $28 \mathrm{mi}$. to Susitna River, $41 \mathrm{mi}$. SE of Cantwell, Talkeetna Mts.; $62^{\circ} 49^{\prime} 25^{\prime \prime} \mathrm{N}, 148^{\circ} 36^{\prime} 40^{\prime \prime} \mathrm{W}$; (map 82).

Indian name reported in 1951 by USGS

Tsyooktuihvun Lake: lake, $1.5 \mathrm{mi}$. long, $29 \mathrm{mi}$. $\mathrm{W}$ of Christian and $24 \mathrm{mi}$. N of Venetie, Brooks Ra.; $67^{\circ} 22^{\prime} \mathrm{N}, 146^{\circ} 18^{\prime} \mathrm{W}$; (map 122).

Kutcha-kutchin Indian name obtained in 1956 by T. E. Taylor, USGS

Ttachegno, Reka: stream, see North Fork Innoko River.

Ttakhtog-myut: village, see Shaktoolik.

Ttalitui : locality, see Dementi.

Ttallily: locality, see Dementi.

Ttallity: locality, see Dementi.

Ttatity: locality, see Dementi.

Ttieguzhek: locality, see Tuchiak.

Ttiekigakg: point of land, and village, see Hope, Point, and Point Hope.

Ttikigakg: point of land and village, sec Hope, Point, and Point Hope.

Ttunaiskysch : estuary, see Cook Inlet.

Ttutago: locality, see Tutago.

Ttutaho: locality, see Tutago.

Tuak Peak: mountain, see Tugak Peak.

Tuapaktushak Creek: stream, heads in lake, flows $\mathrm{N} 5 \mathrm{mi}$. to Chukchi Sea, $21 \mathrm{mi}$. E of Point Franklin, Arctic Plain; $70^{\circ} 54^{\prime} 30^{\prime \prime} \mathrm{N}$, $157^{\circ} 38^{\prime} 30 \mathrm{~W}$; (map 147). Var. Tuapaktushuk Creek.

Eskimo name reported in 1950 by USC\&GS

Tuapaktushuk Creek : stream, see Tuapaktushak Creek.

Tubkooch Point: point of land, see Theodore Point.

Tubukhtuligmut: locality, see Tubutulik.

Tubuktuligmiut: locality, see Tubutulik.

Tubuktulik: locality, see Tubutulik.

Tubuktulik River: stream, see Tubutulik River.

Tubungaluk Creek: stream, flows SE $15 \mathrm{mi}$. to Kuskokwim River, 6.5 mi. NE of Bethel, Yukon-Kuskokwim Delta; $60^{\circ} 51^{\prime} \mathrm{N}, 161^{\circ} 36^{\prime} \mathrm{W}$; (map 59). Var. Tubungaluk River.

Eskimo name reported in 1951 by USC\&GS.
Tubungaluk River: stream, see Tubungaluk Creek.

Tubutulik: locality, on Kwimiuk Inlet, on $\mathrm{N}$ shore of Norton Bay near mouth of Tubutulik River, Seward Penin. High.; $64^{\circ} 45^{\prime} \mathrm{N}, 161^{\circ}$. $34^{\prime}$ W; (map 96). Var. Tebooktolic, Tubukhtuligmut, Tubuktuligmiut, Tubuktulik.

Former large Eskimo village reported in 1842-44 as "Tubukhtuligmut" by Lt. Zagoskin $(1847$, p. 73 ).

Tubutulik River: stream, flows SE $25 \mathrm{mi}$, to Kwiniuk Inlet at NW end of Norton Bay, 25 mi. SW of Koyuk, Seward Penin. High.; $64^{\circ}$ $45^{\prime} \mathrm{N}, 161^{\circ} 54^{\prime} \mathrm{W}$; (map 96). Var. Tubuktulik River, Tebooktolic River.

Eskimo name reported as "Tubuktulik" in 1849 by Capt. M. D. Tebenkov, IRN.

Tu-ca-omina: lake, see Snohomish, Lake.

Tuchan Tan: promontory, see East Foreland.

Tuchiak: locality, on left bank of Kawanak Pass, $15 \mathrm{mi}$. NE of Kwiguk, Yukon-Kuskokwim Delta; 62 $55^{\prime} 30^{\prime \prime} \mathrm{N}, 164^{\circ} 12^{\prime} 00^{\prime \prime} \mathrm{W}$; (map 77). Var. Ttieguzhek.

Eskimo summer camp reported in 1948 by USC\&GS. This may be the "Ttieguzhek" Eskimo village or camp reported in 1832 by the creole Glazunof and which name Lt. Zagoskin, IRN, published in 1848 .

Tuchidock: island, see Tugidak Islard.

Tuchidok: island, see Tugidak Island.

Tuck Creek: stream, in Mentasta Mts., flows E $17 \mathrm{mi}$, to Tetlin River, $27 \mathrm{mi} \mathrm{SW}$ of Northway, Alaska Ra. ; $62^{\circ} 50^{\prime} \mathrm{N}, 142^{\circ} 45^{\prime} \mathrm{W}$; (map 84). Var. Tuck River.

Named in 1902 by D. C. Witherspoon, USGS ; derived from the nickname of a member of his survey party.

Tucker River: stream, see Coleen River.

Tuckers: locality, on W bank of Tuckers Slough $2.3 \mathrm{mi} . \mathrm{N}$ of its junc. with Yukon River and $17 \mathrm{mi}$. NE of Russian Mission, Nulato Hills; $61^{\circ} 57^{\prime} 40^{\prime \prime} \mathrm{N}, 160^{\circ} 55^{\prime} 50^{\prime \prime} \mathrm{W}$; (map 73). Var. Hitts.

Named for the Tucker family and shown on maps since 1942; the place consists of one or two cabins.

Tuckers Crossing: crossing, in Yukon River 8 mi. NE of Russian Mission, Yukon-Kuskokwim Delta ; $61^{\circ} 53^{\prime} \mathrm{N}, 160^{\circ} 13^{\prime} \mathrm{W}$; (map 73).

Riverboat pilots' name for a navigational crossing in the river, shown on a 1922 manuscript chart of the Yukon River.

Tuckers Fish Camp: fish camp, on $\mathrm{N}$ bank of Yukon River, between Baldhead and Dogfish Mts., $14 \mathrm{mi}$. NE of Russian Mission, Nulato Hills; $61^{\circ} 55^{\prime} \mathrm{N}, 161^{\circ} 00^{\prime} \mathrm{W}$; (map 73).

Local name shown on a 1916 field sheet by R. H. Sargent, USGS.

Tuckers Slough: watercourse, anabranch of Yukon River, flows SW $14 \mathrm{mi}$., $1.5 \mathrm{mi}$. N of Pearl I. and $15 \mathrm{mi}$. NE of Russian Mission, Yukon-Kuskokwim Delta ; $61^{\circ} 56^{\prime} \mathrm{N}, 160^{\circ} 58^{\prime}$ W; (map 73).

Local name shown on a 1916 fieldsheet by R. H. Sargent, USGS; named for the local Tucker family.

Tuckfield: locality, site of a whaling station, on gravel bar between Chukchi Sea and mouth of 
Kukpuk River, $11 \mathrm{mi}$. NE of village of Point Hope, Arctic Slope ; $68^{\circ} 25^{\prime} 10^{\prime \prime} \mathrm{N}, 166^{\circ} 24^{\prime} 05^{\prime \prime}$ W; (map 129). Var. Tuckfields.

The local name Tuckfields was reported in 1903 by A. J. Collier, USGS. It was probably named after "Little Joe" Tuckfield, a whaler who served with Capt. Dexter on Grampus (Stockton, 1890, p. 183).

Tuckfields: locality, see Tuckfield.

Tuck River: stream, see Tuck Creek.

Tueenichook Mountains; mountains, see Tahinichok Mountains.

Tuentna River: stream, see Nixon Fork.

Tuesday Creek: stream, flows W to Anikovik River, about $15 \mathrm{mi}$. SE of Cape Prince of Wales, Seward Penin. High.; (map 111).

Prospectors' name shown on the 1900 "Map of Nome Peninsula" by J. M. Davidson and B. D. Blakeslee. This feature cannot be precisely identified on current maps.

Tuft Rock: rock, in San Christoval Channel, 0.7 mi. W of Rosary I., Alex. Arch.; 55 $34^{\prime} 35^{\prime \prime} \mathrm{N}$, $133^{\circ} 19^{\prime} 20^{\prime \prime} \mathrm{W}$; (map 4).

Name published by USC\&GS in the 1917 Alaska Coast Pilot (p. 109).

Tugak Lagoon: lagoon, $0.7 \mathrm{mi}$. long, on Chukchi Sea coast, $16 \mathrm{mi}$. NW of Kivalina, KotzebueKobuk Low.; $67^{\circ} 54^{\prime} \mathrm{N}, 164^{\circ} 59^{\prime \prime} \mathrm{W}$; $B G N$ 1963; (map 128). Var. Tooguk Lagoon.

Eskimo name meaning "walrus ivory," according to USC\&GS in 1950.

Tugak Peak: mountain, 8,500 ft., in Romanzof Mts., 2 mi. S of Mount Michelson, Brooks Ra.; $69^{\circ} 17^{\prime} \mathrm{N}, 144^{\circ} 16^{\prime} \mathrm{W}$; BGN 1965; (map 139). Var. Mount Murie, Tuak Peak.

Eskimo name [Tuak] reported to mean "walrus tusk" by G. G. Barnes, USGS. Originally approved by BGN as Mount Murie, November 1964, but rescinded April 1965 at the request of Mrs. Murie. Her late husband, Olaus Murie, leading proponent in establishing the Arctic Wilderness Range, disapproved applying personal names to physical features.

Tugamak: bight, see Unimak Bight.

Tugamak Range: mountain range, $7.5 \mathrm{mi}$. long, on NW coast of Unimak I., Aleutian Is.; $54^{\circ} 51^{\prime} \mathrm{N}, 164^{\circ} 27^{\prime} \mathrm{W}$; BGN 1942; (map 24).

Aleut name for Unimak Bay; given by USC\&GS in 1940 "because visible from Unimak Bay * * *."

Tugedak: island, see Tugidak Island.

Tug-ga-rag-a-wick: stream, see Koyukuk River.

Tug Gulch: ravine, trends S $0.7 \mathrm{mi}$. to Lillian Greek, $9 \mathrm{mi}$. NE of Nome, Seward Penin. High.; $64^{\circ} 37^{\prime} \mathrm{N}, 165^{\circ} 14^{\prime} \mathrm{W}$; (map 94).

Prospectors' name reported in 1904 by $T$. G. Gerdine, USGS.

Tugiak, Ozero: lake, see Togiak Lake.

Tugiak, Zaliv: bay, see Togiak Bay.

Tugiak River: stream, see Togiak River.

Tugidak Island: island, $18 \mathrm{mi}$. Jong, in Trinity Is., Kodiak I.; $56^{\circ} 30^{\prime} \mathrm{N}, 154^{\circ} 40^{\prime} \mathrm{W}$; (map 32). Var. Toogedach, Toogidach, Toohidack, Tougidak, Tougidok, Tuchidock, Tuchidok, Tugedak, Tugijak.

Transliteration of the Aleut name published by Sarichev (1852, map 3) as "Os[trov] Tugi- dak." According to R. H. Geoghegan, the word means "moon" or "mouth."

Tugidak Passage: water passage, between Tugidak and Sitkanik Is., in Trinity Is., Kodiak I. ; $56^{\circ} 33^{\prime} \mathrm{N}, 154^{\circ} 22^{\prime} \mathrm{W}$; BGN 1935; (map 32). Var. Tugidak Slue.

Name derived from Tugidak Island and given by USC\&GS in 1934. This feature was reported in 1906 as "Tugidak Slue" by W. C. Hodgkins, USC\&GS.

Tugidak Slue: water passage, see Tugidak Passage.

Tugijak: island, see Tugidak Island.

Tugiyak, Reka: stream, see Togiak River.

Tugiyak, Zaliv: bay, see Togiak Bay.

Tugnnuk Greek: stream, see Oligavik Creek.

Tug'una'raro'logh': point of land, see Sea Lion Point.

Tug'una'raro'logh-koverushka': hill, see South Sealion Hill.

Tuinichuk Mountains: mountains, see Tahinichok Mountains.

Tu-i-u'nak: village, see Tyonek.

Tu-i-u'nuk: village, see Tyonek.

Tukachak: locality, on right bank of Yukon River, $13 \mathrm{mi}$. below Andreafsky, Yukon-Kuskokwim Delta; $62^{\circ} 06^{\prime} \mathrm{N}, 163^{\circ} 08^{\prime} \mathrm{W}$; (map 77). Var. Tukamiut.

Former Eskimo village or camp reported in 1899 by G. R. Putnam, USC\&GS.

Tukallah Lake: lake, $1 \mathrm{mi}$. long, in course of Threemile Creek, $4.5 \mathrm{mi}$. N of Tyonek, Cook Inlet Low.; $61^{\circ} 08^{\prime} 40^{\prime \prime} \mathrm{N}, 151^{\circ} 07^{\prime} 30^{\prime \prime} \mathrm{W}$; (map 70).

Tanaina Indian name reported in 1958 by USGS.

Tukamiut: locality, see Tukachak.

Tukgahgo Mountain: mountain, 4,675 ft., in Takshanuk Mts., $3.5 \mathrm{mi}$. SW of Chilkoot and $16 \mathrm{mi}$. SW of Skagway, Coast Mts.; $59^{\circ} 18^{\prime} \mathrm{N}$, $135^{\circ} 38^{\prime} \mathrm{W}$; (map 45).

Indian name given by E. C. Robertson, geologist ; published in 1952 by USGS.

Tukhlak: locality, see Tuklak.

Tukikapak: locality, see Tukukapak.

Tukingak Mountain: mountain, 1,080 ft., in Mulgrave Hills, $20 \mathrm{mi}$. SE of Kivalina, Arctic Slope; $67^{\circ} 37^{\prime} \mathrm{N}, 163^{\circ} 51^{\prime} \mathrm{W}$; (map 128). Var. Tookinghak, Took-key-auk Mountain, Tuukingaaq.

Eskimo name meaning "to brace oneself" reported in 1950 by USC\&GS.

Tukingarok Creek: stream, heads in Lisburne Hills, flows SE 6 mi. to Ipewik River $8 \mathrm{mi}$. NE of its junc. with Kukpuk River. Arctic Slope; $68^{\circ} 25^{\prime} 30^{\prime \prime}$ N, $165^{\circ} 30^{\prime} 00^{\prime \prime}$ W; (map 129). Var. Tukingnuwa.

Eskimo name reported in 1960 as "Tukingnuwa" by D. C. Foote, Project Chariot.

Tukingnuwa: stream, see Tukingarok Creek.

Tukkeragerum: locality, on coast of Beaufort Sea, W of Barter I. ; (map 152).

This Eskimo name appears on John Simpson's 1853 native map. The name appears to be applied to a stream and is shown as, "Tukke-ra-ge-run 5 th sleep do."

Tuklak: locality, on right bank of Kukokwim River, between Kwigalok and Uknavik, below
Yukon-Kuskokwim Portage; $61^{\circ} 29^{\prime} \mathrm{N}, 160^{\circ}$ 27' W; (map 73). Var. Tookhlagamute, Tukhlak.

Former Indian Village or camp recorded in 1879 as "Tookhlagamute," population 92 , by E. W. Nelson, U.S. Signal Service, and reported by Ivan Petroff in the 1880 Census.

Tuklomarak Lake: lake, $4 \mathrm{mi}$. across, $9 \mathrm{mi}$. SW of Selawik, Kotzebue-Kobuk, Low.; $66^{\circ} 27^{\prime}$ N, $160^{\circ} 05^{\prime} \mathrm{W}$; (map 114).

Eskimo name obtained by U.S. Army Corps of Engineers in 1955.

Tuklon Igloos: locality, see Tuklung.

Tuklukyet: locality, see Grant Creek.

Tuklukyet: locality, see Nuklukyet.

Tuklung: locality, on W bank of Tuklung River, on Nushagak Penin., $31 \mathrm{mi}$. SW of Dillingham, Bristol Bay Low.; 58 $49^{\prime} 35^{\prime \prime}$ N, $159^{\circ}$. $14^{\prime} 25^{\prime \prime} \mathrm{W}$; (map 40). Var. Tuklon Igloos.

Eskimo village, reported by USC\&GS in 1948 to be abandoned. It may be used as a camp because it had a population of 30 in 1950.

Tuklung River: stream, flows SE $24 \mathrm{mi}$. to Igushik River, $28 \mathrm{mi}$. SW of Dillingham, Bristol Bay Low.; $58^{\circ} 50^{\prime} \mathrm{N}, 159^{\circ} 07^{\prime} \mathrm{W}$; (map 40).

Eskimo name reported in 1952 by USGS.

Tukmakna Creek: stream, heads on Anthracite Ridge, flows SW $2.5 \mathrm{mi}$. to Mudflow Creek, between Kutzkatna and Purinton Creeks, 36 mi. NE of Palmer, Talkeetna Mts. ; $61^{\circ} 49^{\prime} 10^{\prime \prime}$ N, $148^{\circ} 07^{\prime} 00^{\prime \prime} \mathrm{W}$; BGN 1932; (map 69).

Reported in 1932 by a USGS field party.

Tukomina, Lake: lake, see Snohomish, Lake.

Tukomina, Lake: lake, see North Snohomish Lake.

Tukpahlearik Creek: stream, in Baird Mts., flows SW $17 \mathrm{mi}$. to Omar River $22 \mathrm{mi}$. NE of its junc. with Squirrel River, $32 \mathrm{mi}$. N of Kiana, Brooks Ra.; $67^{\circ} 26^{\prime} \mathrm{N}, 160^{\circ} 36^{\prime} \mathrm{W}$; (map 127).

Eskimo name obtained in 1955 by U.S. Army Corps of Engineers.

Tukrok River: water passage, $7.3 \mathrm{mi}$. long, between Krusenstern Lagoon and KotzebueKobuk Low.; 67 $04^{\prime} \mathrm{N}, 163^{\circ} 18^{\prime} \mathrm{W}$; (map 128). Var. Ahneeyahm Koonga, Tookrook River, Tukrok River, Tukruk River.

Eskimo name meaning "inlet (entrance)" according to USC\&GS in 1950.

Tukruk River: water passage, see Tukrok River. Tuk-sed-ni Bay: estuary, see Tuxedni Bay.

Tukshik: lake, see Tikchik Lake.

Tuk-shik-ha-mut: locality, see Tikchik.

Tukshik River: stream, see Tikchik River.

Tuksuk: locality, on Seward Penin. at mouth of Tuksuk Channel, $10 \mathrm{mi}$. E of Teller, Seward Penin. High; $65^{\circ} 14^{\prime} \mathrm{N}, 166^{\circ} 03^{\prime} \mathrm{W}$; (map 111). Var. Klaxermette, Takchuk, Takso, Taksomut, Taksomute, Taksumut, Tokchouk, Tokshook, Tooksook.

Former Eskimo village or camp reported in 1827 as "Tokshook" by Capt. Beechey (1831, p. 541 ).

Tuksuk Channel: water passage, extends NWSE 9 mi. between Imuruk Basin and Grantley Harbor, $10 \mathrm{mi}$. E of Teller, Seward Penin. 
Higb. $65^{\circ} 14^{\circ} \mathrm{N}, 166^{\circ} 02^{\prime} \mathrm{W}$; (map 111). Var Takrtuk Channel, Tokchouk Channel, Tokstwok Channel. Tooksook Channel.

In 1827 Capt. Beechey (1831, p. 541), RN, described the leature as, "strait, called Tokshook by the natives." Reported as "Tuksuk" and mapped in 1900 by E. C. Barnard (in Brooks. 1901, pl 12), USGS. "Tuksuk" is Eskimo, said to mean "channel" or "long."

Tuksuk River: stream, see 'Toksook River.

Tuktu Bluff: bluff, E of Junc. of Chandler and Kiruktagiak Rivers, $11 \mathrm{mi}$. W of Gunsight Mtn. and $44 \mathrm{mi}$. NW of Anaktuvuk Pass, Arctic Slope; $68^{\circ} 44^{\prime} \mathrm{N}, 152^{\circ} 18^{\prime} \mathrm{W} ; B G N$ 1949: (map 134)

Eskimo name used by USGS geologists during the exploration of Naval Petroleum Reserve: No 4 name given in 1944 . "Tuktu" is an Eskimo word for caribou.

Tukukapak: locality, on E bank of Akularak Pass, $11 \mathrm{mi}$ SE of Kwiguk. Yukon-Kuskokwim Delta, 6.2 $36^{\prime} 35^{\prime \prime} \mathrm{N}, 164^{\circ} 21^{\prime} 30^{\prime \prime} \mathrm{W}$; (map 77. Vat Tukikapak.

According, to a 1950 USC\&GS field report, this is a striall Eskimo settlement of three families The name was originally obtained in 1899 by G. R. Putnam, USC\&GS.

Tukusitnu Bay estuary, see Tuxedni Bay.

Tukuto Creek: stream, heads in Howard Hills, flows NE $25 \mathrm{mi}$. to Etivluk River, $20 \mathrm{mi}$. NE of Howard Pass, Brooks Ra.; 68 $31^{\prime} \mathrm{N}, 156^{\circ}$ $31^{\prime}$ W; BCN 1926; (map 132).

This Eskimo name appears on a fieldsheet by Gerald FitzGerald, USGS, in 1925. It may be the Fiskimo name for "fog" [taktuktoq] which frequently occurs on the north slope of Brooks Range, or it may be a form of "taqtu" meaning "kidney".

Tukuto Lake: lake, 2 mi. long, in Brooks Ra., 20 mi. $\mathrm{N}$ of Howard Pass; $68^{\circ} 30^{\prime} \mathrm{N}, 157^{\circ} 02^{\prime} \mathrm{W}$; (map 132). Var. Nioktun Lake.

Named by USGS for nearby Tukuto Creek in 1951 Orth reports the present-day Eskimo name as "Nioqtun" meaning "drill" or "bit." This is the same name as Nigtun Lake in Howard Pass.

Tukuzit, Zaliv: estuary, see Tuxedni Bay.

Tukuzit Bay: estuary, see Tuxedni Bay.

Tula, Punta de: point of land, see Fula, Point.

Tulageak Point: point of land, on $\mathrm{S}$ shore of Elson Lagoon, $24 \mathrm{mi}$. SE of Barrow, Arctic Plain, $71^{\circ} 11^{\prime} 45^{\prime \prime} \mathrm{N}, 155^{\circ} 44^{\prime} 10^{\prime \prime} \mathrm{W}$; (map 153 i.

Eskimo name "Tulakgeak" which means "landing place" and was first recorded at Barrow by USC\&GS in 1951.

Tulatdlukhna: stream, see Green Water Creek.

Tulebagh Lake: lake, $2.4 \mathrm{mi}$. long, $2 \mathrm{mi}$. $\mathrm{N}$ of Tanjoga Lake and $26 \mathrm{mi}$. NE of Stevens Village, Yukon Flats; $66^{\circ} 20^{\prime} \mathrm{N}, 148^{\circ} 36^{\prime} \mathrm{W}$; (map 118).

Kutchin Indian name obtained in 1956 by T. E. Taylor, USGS

Tulik. locality, on $\mathrm{E}$ coast of Umnak I. near Tulik Volcano, Aleutian Is.; $53^{\circ} 19^{\prime} \mathrm{N}, 168^{\circ}$. $00^{\prime}$ W ; (map 22). Var. Tooleekskoi, Tulikskoi. Tulinskoe.
Former Eskimo village or camp reported in 1834 as "Tulinskoe," population 26, by Father Veniaminov (1840, v. 2, p. 202).

Tulik, Mount: mountain, sec Tulik Volcano

Tulik Lake: lake, see Tulilik Lake.

Tulik River: stream, on E coast of Umnak I., flows SE to Umnak Pass, SW of Fort Glenn, Aleutian Is.; $53^{\circ} 21^{\prime} 10^{\prime \prime} \mathrm{N}, 167^{\circ} 55^{\prime} 30^{\prime \prime} \mathrm{W}$; (map 23).

Aleut name [tuluq] reported in 1942 by U.S. Army Corps of Engineers and published by USGS (Byers, 1959, pl. 41). The name means "crack or fissure" (Geoghegan, 1944, p. 121)

Tulikskaya, Sopka: mountain, see Tulik Volcano.

Tulikskoi: locality, see Tulik.

Tulikskoi: mountain, see Tulik Volocano.

Tulik Volcano: mountain, 4,111 ft., on Umnak I. $3 \mathrm{mi}$. SE of Okmok Caldera, Aleutian Is.; $53^{\circ} 21^{\prime} 30^{\prime \prime}$ N, $168^{\circ} 03^{\prime} 15^{\prime \prime}$ W; (map 22). Var. Mount Toulak, Mount Tulik, Sopka Tulikskaya, Toulikskoi, Tulikskoi.

Aleut name published as "Toulikskoi," by Capt. Lutke (1836, p. 298), and as "So[pka] Tulikskaya," or "Tulik Volcano," by Capt. Tebenkov (1852, map 25), IRN. The name is probably from the Aleut word "tuliq," which according to R. H. Geohegan means "crack" or "fissure."

Tulilik, Lake: lake, $0.3 \mathrm{mi}$. long, $2.1 \mathrm{mi}$. $\mathrm{S}$ of junc. of Easter Creek and Killik River, Brooks Ra.; $68^{\circ} 07^{\prime} \mathrm{N}, 154^{\circ} 08^{\prime} \mathrm{W}$; (map 133).

Eskimo name reported in 1956 by T. E. Taylor, USGS.

Tulilik Lake: lake, $1 \mathrm{mi}$. across, on Chukchi Sea coast, $6 \mathrm{mi}$. NE of Cape Krusenstern, Kotzebue-Kobuk Low. ; $67^{\circ} 13^{\prime} \mathrm{N}$; $163^{\circ} 40^{\prime} \mathrm{W}$; (map 128). Var. Toolik Lake, Toolilik Lake, Tulik Lake.

Eskimo name meaning "king loon," reported by USC\&GS in 1950. Probably refers to the Yellow-billed 'Loon (Gavia adamsi), normally written "tulik" or "tutlik."

Tulimanak: locality, see Boat Extreme.

Tulimanak Island: barrier island, see Tulimanik Island.

Tulimanik Island: barrier island, $1 \mathrm{mi}$. long, between Fatigue Bay and Beaufort Sea, $43 \mathrm{mi}$. ESE of Barrow, Arctic Plain; $71^{\circ} 07^{\prime} 30^{\prime \prime} \mathrm{N}$, $154^{\circ} 56^{\prime} 00^{\prime \prime} \mathrm{W}$; (map 153). Var. Toolemina, Tulimanak Island, Tullimanik Island.

Eskimo name "Toolemina [tulimanak]," meaning "whale rib" was shown on Comdr. Maguire's map (Great Britain, 1854, map facing p. 186), located at the southeast end of Fatigue Bay; other maps have shown the name on nearby islands.

Tulinskoe: locality, see Tulik.

Tulioumnint: peninsula, see Castle Point.

Tuliumnit, Mys: peninsula, see Castle Cape.

Tuliumnit Point: peninsula, sce Castle Cape.

Tuliumnit Point: promontory, on $\mathrm{E}$ shore of Alaska Penin., NE tip of Castle Cape, SE entrance to Chignik Bay, $12 \mathrm{mi}$. SE of Chignik, Aleutian Ra.; $56^{\circ} 14^{\prime} \mathrm{N}, 158^{\circ} 07^{\prime} \mathrm{W}$; (map 30). Var. Castle Cape, Castle Point, Mys Tuliumnit, Point Tutiumnik.

Native name shown in 1847 as "M[ys] Tuliumnit," meaning "Tuliumnit Point," on Russian Hydrog. Dept. Chart 1379; reported about 1899 by Lt. Comdr. J. F. Moser, USN, of the USBF steamer Albatross, as "Tuliumnit Point or Castle Cape." Its many pinnacles and buttresses suggest the name "Castle."

Tuliviksak: stream, see Tatlawiksuk River.

Tullimanik Island: barrier island, see Tulimanik Island.

Tullimanirk: locality, see Boat Extreme.

Tulpanika: locality, see Topanika.

Tulpanikha: locality, see Topanika.

Tulsona Creek: stream, flows S $28 \mathrm{mi}$. to Copper River, $13 \mathrm{mi}$. SE of Chistochina, Copper River Basin; 62 $24^{\prime} \mathrm{N}, 145^{\circ} 04^{\prime} \mathrm{W}$; (map 83). Var. Talsona Creek.

Indian name called "Talsona" by the U.S Army Signal Corps and published as "Tulsona" by Mendenhall (in Mendenhall and Schrader, 1903, p. 14), USGS.

Tulugak, Lake: lake, 2 mi. long, in Noatak River Valley, $\mathrm{N}$ of Noatak Canyon, $42 \mathrm{mi}$. NE of Noatak, Brooks Ra.; $67^{\circ} 58^{\prime} \mathrm{N}, 161^{\circ} 43^{\prime} \mathrm{W}$; (map 127). Var. Neeksigalik Lake.

Eskimo name meaning "raven," obtained in 1956 at Noatak by Orth.

Tulugak Creek: stream, flows NW $5 \mathrm{mi}$. N of Tulugak Lake to Anaktuvuk opposite Makaktuk Lake, $13 \mathrm{mi}$. NE of Anaktuvuk Pass, Brooks Ra.; $68^{\circ} 17^{\prime} 45^{\prime \prime}$ N, $151^{\circ} 29^{\prime} 00^{\prime \prime} \mathrm{W}$; (map 134).

Eskimo name, meaning "raven," reported by Rausch (1951, p. 150).

Tulugak Creek: stream, flows $\mathrm{N} 6 \mathrm{mi}$. to Chukchi Sea, $1 \mathrm{mi}$. S of Cape Beaufort and $55 \mathrm{mi}$. SW of Point Lay, Arctic Plain; 69 $09^{\circ} 15^{\prime \prime} \mathrm{N}$, $163^{\circ} 52^{\prime} 30^{\prime \prime} \mathrm{W}$; (map 145). Var. Tolookuk Creek, Toolooguk Creek, Tolukak Creek.

Eskimo name reported as Toolookok by USC\&GS in 1949, meaning "two ravens." USGS published the present spelling, a name meaning "raven."

Tulugak Lake: lake, $0.8 \mathrm{mi}$. long, $1 \mathrm{mi}$. SE of junc. of Tulugak Creek with Anaktuvuk River, 12 mi. NE of Anaktuvuk Pass, Brooks Ra.; $68^{\circ} 17^{\prime} \mathrm{N}, 151^{\circ} 28^{\prime} \mathrm{W}$; (map 134).

Eskimo name, meaning "raven," reported by Rausch (195.1, p. 150).

Tuluga River: stream, formed by its East and West Forks, flows $45 \mathrm{mi}$. NE to Anaktuvuk River, $29 \mathrm{mi}$. SW of Umiat, Arctic Slope; $69^{\circ} 15^{\prime} \mathrm{N}, 151^{\circ} 01^{\prime} \mathrm{W}$; BGN 1949; (map 141).

Eskimo name meaning "raven [tulugak]" reported in 1901 by Peters and Schrader (1904, pl. 2), USGS. This refers to the northern raven, Corvus corax principalis ( $\mathrm{I}$. N. Gabrielson and F. C. Lincoln, 1959, p. 616).

Tuluka: locality, on right bank of Kuskokwim River near Aniak; $61^{\circ} 36^{\prime} \mathrm{N}, 159^{\circ} 25^{\prime} \mathrm{W}$; (map 73). Var, Toolukaanahamute, Toolooka-anahamute, Tulukaenagamyut, Tulukagnagamiut. 
Former Eskimo village or camp reported in 1842-44 by Lt. L. A. Zagoskin, IRN, and published in 1861 by P. Tikhmeniev as "Tulukaenagamyut." Petroff, in the 1880 Census, shows "Toolooka-anahamute" and "Toolukaanahamute" with a population of 59 . The 1890 Census lists "Tulukagnagamiut" with 17 inhabitants. The name may mean "raven people."

Tulukaenagamyut: locality, see Tuluka.

Tulukagnagamiut: locality, see Tuluka.

Tulukak Creek: stream, flows SE $8 \mathrm{mi}$. to Kivalina River, $18 \mathrm{mi}$. NE of Kivalina, KotzebueKobuk Low.; 67 $58^{\prime} \mathrm{N}, 164^{\circ} 14^{\prime} \mathrm{W}$; (map 128). Var. Tooloolak Koogowranga, Tulukak Kuugauzanga.

Eskimo name meaning "two ravens" reported in 1966 by E. S. Burch.

Tulukak Kuugauzanga: stream, see Tulukak Creek.

Tulukságmiut: village, see Tuluksak.

Tuluksak: village, pop. 137, on S bank of Tuluksak River, $48 \mathrm{mi}$. SE of Russian Mission, Yukon-Kuskokwim Delta; $61^{\circ} 06^{\prime} \mathrm{N}, 160^{\circ} 58^{\prime}$ W; (map 73). Var. Iulukiak, Toluksagamut, Toulakságamut, Tuluksagmiut, Tulusksak, Tul'yagmyut.

Eskimo name meaning "raven [?]" published by Tikhmeniev in 1861 as "Tul'yagmyut," presumably from information obtained by $L$. A. Zagoskin, IRN, in 1842-44. In the 1880 Census Ivan Petroff lists the name as "Tuluksak," population 150.

Tuluksak River: stream, heads at $61^{\circ} 11^{\prime} \mathrm{N}$ $159^{\circ} 55^{\prime} \mathrm{W}$, and flows $\mathrm{S}$ and $\mathrm{NW} 90 \mathrm{mi}$. to Kuskokwim River S of Tuluksak, $48 \mathrm{mi}$. SE of Russian Mission, Yukon-Kuskokwim Delta; $61^{\circ} 06^{\prime} \mathrm{N}, 160^{\circ} 58^{\prime} \mathrm{W}$; (map 73). Var. Tulusksak River.

Local name reported by A. G. Maddren, USGS, in 1908; derived from the name of a village located at the stream's mouth.

Tulurak: cliffs, at junc. of Tulukak Creek and Kivalina River, $18 \mathrm{mi}$. NE of Kivalina, Kotzebue-Kobuk Low. ; $67^{\circ} 58^{\prime} \mathrm{N}, 164^{\circ} 14^{\prime} \mathrm{W}$; (map 128). Var. 'Tooloorak, Tuluraq.

Eskimo name meaning "raven" reported in 1966 by E. S. Burch.

Tuluraq : cliffs, see Tulurak.

Tu-lu-shu-lit-na: stream, see Talachulitna River.

Tulusksak: village, see Tuluksak.

Tulusksak River: stream, see Tuluksak River.

Tuluuk: locality, on S bank of Yukon River, near mouth of Etivluk River, Arctic Slope; $68^{\circ} 59^{\prime} \mathrm{N}, 156^{\circ} 00^{\prime} \mathrm{W}$; (map 133). Var. Tooloouk River.

Former Eskimo village of 10 houses and 70 inhabitants, visited in 1886 by Lt. Stoney (1900, p. 68), and recorded as "Tooloouk."

Tuluvak Bluffs: bluffs, elev. $600 \mathrm{ft}$., between Chandler River and Outpost Creek, $20 \mathrm{mi}$. SE of Umiat, Arctic Slope; $69^{\circ} 10^{\prime} \mathrm{N}, 151^{\circ} 30^{\prime}$ W; BGN 1949; (map 141).

Eskimo name meaning "raven [tulugak]," reported in 1956 by T. E. Taylor, USGS.

Tul'yagmyut: village, see Tuluksak.

Tumak of Lake: lake, $1.4 \mathrm{mi}$. long, $11 \mathrm{mi}$. NW of village of Port Alexander, on S coast of Bar- anof I., Alex. Arch.; $56^{\circ} 22^{\prime} 00^{\prime \prime} \mathrm{N}, 1^{\circ} 4^{\circ} 51^{\prime}$ $30^{\prime \prime} \mathrm{W}$; BGN 1933; (map 5 ).

Named in 1933 by USFS "for a Russian who was killed in the massacre of the first Sitka settlement" in 1802.

Tuman Head: promontory, elev. 200-300 ft., includes North and South Tuman Points, on W coast of Semisopochnoi I., Aleutian Is.; $51^{\circ} 58^{\prime} 30^{\prime \prime} \mathrm{N}, 179^{\circ} 28^{\prime} 30^{\prime \prime} \mathrm{E}$; (map 15).

Name published on a 1943 U.S. Army Corps of Engineers map.

Tumannoi; island, see Chirikof Island.

Tumannoi, Ostrova: islands, see Hazy Islands. Tumannoi Island: island, see Poa Island.

Tumannoi Islands: islands, see Semidi Islands.

Tuman Point: point of land, on $\mathrm{W}$ coast of Semisopochnoi I., Aleutian Is.; $51^{\circ} 58^{\prime} 55^{\prime \prime}$ N, $179^{\circ} 28^{\prime} 05^{\prime \prime}$ E; BGN 1937; (map 15). Var. North Tuman Point.

Transliteration of the Russian word "tuman" meaning "fog." The name was reported by personnel of the U.S.S. Oglala in 1935. The point was shown as part of Tuman Head on a 1943 U.S. Army Corps of Engineers map.

Tumble Creek: stream, heads at glacier terminus $\mathrm{E}$ of Copper Glacier, flows E $10 \mathrm{mi}$. to Jacksina Creek $4.5 \mathrm{mi}$. NE of Jacksina Glacier terminus, Wrangell $\mathrm{Mts} . ; 62^{\circ} 11^{\prime} \mathrm{N}, 143^{\circ} 21^{\prime}$ W; (map 84).

Named in 1902 by F. C. Schrader, USGS, because of its "torrential gradient and roughness."

Tumi Creek: stream, flows SW $1 \mathrm{mi}$. to Chukchi Sea, W of Telavirak Hills, $7.5 \mathrm{mi}$. SE of Cape Thompson, Arctic Slope; $68^{\circ} 05^{\prime} 45^{\prime \prime} \mathrm{N}, 1^{\circ}$. 43'20" W; BGN 1963; (map 129). Var. Toome Creek, Tumit Creek.

Eskimo name meaning "trail [foot print]" reported in 1962 by personnel of Project Chariot.

Tumit Creek: stream, flows E $2 \mathrm{mi}$. to Grand Central River, $30 \mathrm{mi}$. NE of Nome, Seward Penin. High.; $64^{\circ} 56^{\prime} \mathrm{N}, 165^{\circ} 10^{\prime} \mathrm{W}$; (map 94). Var. Thumit Creek.

Eskimo name meaning "trail" reported in 1912 by R. H. Sargent, USGS.

Tumit Creek: stream, in De Long Mts., flows SE $25 \mathrm{mi}$. to Nimiuktuk River, $30 \mathrm{mi}$. E of Misheguk Mtn., Brooks Ra.; $68^{\circ} 13^{\prime}$ N, $159^{\circ} 55^{\prime}$ W; (map 131).

Eskimo name, obtained at Noatak by Orth in 1956, meaning "trails."

Tumit Creek: stream, sec Tumi Creek.

Tummy: lake, see Twin Glacier Lake.

Tum Point: point of land, $\mathrm{S}$ point of entrance to Hunter Bay, on SW coast of Prince of Wales I., Alex. Arch.; $54^{\circ} 52^{\prime} 40^{\prime \prime} \mathrm{N}, 132^{\circ} 21^{\prime} 40^{\prime \prime} \mathrm{W}$; (map 1).

Name published in 1951 by USGS.

Tum Tum, Mount: mountain, 1,960 ft., on S coast at SW end of Unalaska I., Aleutian Is.; $53^{\circ} 15^{\prime} 50^{\prime \prime} \mathrm{N}, 167^{\circ} 38^{\prime} 05^{\prime \prime} \mathrm{W}$; (map 23).

Name reported in 1942 by U.S. Army Corps of Engineers and published in 1951 on a USGS map.

Tunagak: locality, "in the Kuskokwim district." Var. Tunaghamiut.

Former Eskimo village or camp recorded as
"Tunaghamiut," population 71, in the 1890 Census (1893, p. 1964).

Tunaghamiut: locality, see Tunagak.

Tunak Hill: hill, see Tungnak Hill.

Tunalik River: stream, heads in lake, flows NW $29 \mathrm{mi}$. to Avak Inlet, $10 \mathrm{mi}$. S of Icy Cape, Arctic Plain; $70^{\circ} 11^{\prime} \mathrm{N}, 161^{\circ} 44^{\prime} \mathrm{W}$; (map 146).

Eskimo name recorded at Wainwright in 1956 by Orth; means "the one behind," referring to its position behind Sikolik Lake.

Tunalkten Hot Spring: spring, S of Tunalkten Lake, in Koyukuk River valley, $12 \mathrm{mi}$. NE of Hughes, Kokrines-Hodzana High.; 66 ${ }^{\circ} 12^{\prime} \mathrm{N}$, $154^{\circ} 01^{\prime} \mathrm{W}$; (map 116).

Indian name, reported to mean "hot spring," recorded at Hughes in 1956 by Orth.

Tunalkten Lake: lake, $0.5 \mathrm{mi}$. long, in Koyukuk River valley, $12 \mathrm{mi}$. NE of Hughes, KokrinesHodzana High.; $66^{\circ} 12^{\prime} \mathrm{N}, 154^{\circ} 01^{\prime} \mathrm{W}$; (map 116).

Indian name recorded at Hughes in 1956 by Orth; named for Tunalkten Hot Spring.

Tundra: locality, on $\mathrm{N}$ shore, or near Takslesluk Lake, Yukon-Kuskokwim Delta; 61 ${ }^{\circ} 08^{\prime} \mathrm{N}$, 162 $49^{\prime}$ W; BGN 1937; (map 74).

Former Eskimo village or camp recorded on a 1923 map, locality has not been definitely identified.

Tundra Creek: stream, flows SW $5 \mathrm{mi}$. to Smalls River, $10 \mathrm{mi}$. SW of Goodnews, KilbuckKuskokwim Mts.; $59^{\circ} 00^{\prime} 25^{\prime \prime} \mathrm{N}, 161^{\circ} 44^{\prime} 30^{\prime \prime}$ W; BGN 1938; (map 53).

Local name reported in 1933 by USGS. "So named because it flows through tundra consisting of dwarf shrubs and herbs with mosses and lichens, which covers much of this region."

Tundra Creek: stream, flows W $6 \mathrm{mi}$. from a lake to Kanayut River, $4 \mathrm{mi}$. $\mathrm{E}$ of Kanayut Bluff and $45 \mathrm{mi}$. NE of Anaktuvuk Pass, Arctic Slope; $68^{\circ} 43^{\prime} \mathrm{N}, 150^{\circ} 59^{\prime} \mathrm{W} ; B G N$ 1960; (map 134).

Named in 1945 by R. E. Fellows, USGS, while doing geological investigation.

Tundra Hill: mountain, see Riot Hill.

Tundra Lake: lake, $0.6 \mathrm{mi}$. long, on Kenai Penin., $1.5 \mathrm{mi}$. W of McLain Lake and 31 mi. NE of Kenai, Cook Inlet Low. ; $60^{\circ} 51^{\prime} 45^{\prime \prime}$ N, $150^{\circ} 38^{\prime} 30^{\prime \prime} \mathrm{W}$; (map 62).

Named about 1963 by officials of Kenai National Moose Range, for administrative purposes.

Tundra Lake: lake, $4.5 \mathrm{mi}$. long, at head of Stink River, $56 \mathrm{mi}$. SE of Sleetmute, Lime Hills; $61^{\circ} 13^{\prime} 30^{\prime \prime} \mathrm{N}, 155^{\circ} 43^{\prime} 40^{\prime \prime} \mathrm{W}$; (map 71).

Prospectors' name published in 1951 by USGS.

Tundra Point: point of land, sec Survey Point. Tundra River: stream, sec Johnson River.

Tundra River: stream, see Pikmiktalik River.

Tunehean Creek: stream, flows W $10 \mathrm{mi}$. to Keku Strait, on SW coast of Kupreanof I., $17 \mathrm{mi}$. $\mathrm{N}$ of Point Baker, Alex. Arch.; $56^{\circ}$ $36^{\prime} 00^{\prime \prime} \mathrm{N}, 133^{\circ} 38^{\prime} 30^{\prime \prime} \mathrm{W}$; (map 6).

Indian name published by USC\&GS in 1932 Coast Pilot (p. 256). 
Tungaich Point: point of land, extends $\mathrm{N}$ into Kasegaluk Lagoon, $15 \mathrm{mi}$. NE of Point Lay, Arctic Plain; 69 $54^{\prime} \mathrm{N}, 162^{\circ} 37^{\prime} \mathrm{W}$; (map 145). Var. Tungaitch Point.

Eskimo name reported by USC\&GS in 1949, which is supposed to mean "devil's profile" referring to the appearance of the lagoon bank.

Tunga Inlet: water passage, extends $0.8 \mathrm{mi}$., between El Capitan Passage and Salt Water Lagoon, $W$ coast of Prince of Wales I., Alex. Arch.; $55^{\circ} 58^{\prime} 20^{\prime \prime} \mathrm{N}, 133^{\circ} 15^{\prime} 00^{\prime \prime} \mathrm{W}$; BGN 1932; (map 4). Var. Salt Water Lagoon, Tunga Lagoon.

Haida Indian name from the word "tanga," meaning "sea" or "salt," given in 1932 by USC\&GS. The name "Salt Water Lagoon" was published for this feature in 1925 Coast Pilot (p. 155).

Tungaitch Point: point of land, see Tungaich Point.

Tungak Creek: stream, flows W $15 \mathrm{mi}$. to Kuskokwak Channel Kuskokwim Bay, $5 \mathrm{mi}$. NW of Quinnagak, Yukon-Kuskokwim Delta; 5959' $\mathrm{N}, 162^{\circ} 09^{\prime} \mathrm{W}$; (map 54).

Eskimo name obtained in 1938 by the ARC.

Tungak Creek: stream, flows W $20 \mathrm{mi}$. to Kasegaluk Lagoon, $13 \mathrm{mi}$. NE of Point Lay, Arctic Plain; $69^{\circ} 54^{\prime} \mathrm{N}, 162^{\circ} 39^{\prime} \mathrm{W}$; (map 145). Var. Toongak River, Tungak River.

Eskimo name reported by Orth in 1956, referring to "spirit" or "devil," and probably is related in derivation to nearby Tungaich Point. USC\&GS reported the name Kugaghaurak in 1949, meaning "easy to ford stream."

Tungak Island: island, see Barter Island.

Tungak River: stream, see Tungak Creek.

Tunga Lagoon: water passage, see Tunga Inlet.

Tungaluk Slough: stream, flows E $6.5 \mathrm{mi}$. to Aphrewn River, $5 \mathrm{mi}$. $\mathrm{N}$ of Hazen Bay, $\mathrm{Yu}$ kon-Kuskokwim Delta ; $61^{\circ} 14^{\prime} \mathrm{N}, 1^{\circ} 5^{\circ} 20^{\prime} \mathrm{W}$; (map 75).

Eskimo name obtained at Hooper Bay by USC\&GS in 1951.

Tungāss: locality, see Tongass.

Tungāss-kon: locality, see Tongass.

Tungent Point: point of land, see Tangent Point.

Tungnak Creek: stream, heads in Lisburne Hills, flows E $23 \mathrm{mi}$. to Nilik River, $28 \mathrm{mi}$. E of Cape Dyer, Arctic Slope; $68^{\circ} 37^{\prime} 30^{\prime \prime} \mathrm{N}, 165^{\circ} 07^{\prime} 45^{\prime \prime}$ W; (map 129).

Eskimo name reported in 1956 by Orth; derived from 'Tungnak Hill.

Tungnak Creek: stream, see Oligavik Creek.

Tungnak Hill: hill, $510 \mathrm{ft}$., $3.5 \mathrm{mi}$. SW of junc. of Tungnak Creek and Nilik River, $25 \mathrm{mi}$. E of Cape Dyer, Arctic Slope; 68 $36^{\prime} 15^{\prime \prime} \mathrm{N}$, $165^{\circ} 15^{\prime} 30^{\prime \prime} \mathrm{W}$; (map 129). Var. Toonuk Mountain, Tunak Hill.

Eskimo name meaning "resembles back fat [as on a caribou]" reported in 1956 by Orth.

Tungnaq Creek: stream, see Oligavik Creek.

Tungpuk River: stream, heads at $61^{\circ} 49^{\prime} \mathrm{N}$ $164^{\circ} 52^{\prime} \mathrm{W}$, flows NW $25 \mathrm{mi}$. to Kun River, $10 \mathrm{mi}$. E of village of Scammon Bay, YukonKuskokwim Delta ; $61^{\circ} 52^{\prime} 20^{\prime \prime}$ N, $165^{\circ} 17^{\prime} 30^{\prime \prime}$ W; (map 75).
Eskimo name reported by USC\&GS in 1949

Tungrass: locality, see Tongass.

Tungsten Gulch: ravine, extends NW $0.5 \mathrm{mi}$. to First Chance Creek, $9 \mathrm{mi}$. NE of Fairbanks, Yukon-Tanana High.; 64 $57^{\circ} 15^{\prime \prime}$ N, $147^{\circ} 32^{\prime}$ $50^{\prime \prime} \mathrm{W}$; (map 100).

Local name derived from Tungsten Hill; reported in 1916 by J. B. Mertie, Jr. (in Brooks and others, 1918, p. 423), USGS.

Tungsten Hill: mountain, 1,900 ft., $1.5 \mathrm{mi}$. SW of Gilmore Dome, Yukon-Tanana High.; $64^{\circ} 57^{\prime} 30^{\prime \prime} \mathrm{N}, 147^{\circ} 30^{\prime} 40^{\prime \prime} \mathrm{W}$; (map 100).

Local name reported in 1916 by J. B. Mertie, Jr. (in Brooks and others, 1918, p. 423), USGS.

Tungulara Mountain: mountain, 1,581 ft., on W coast of Alitak Bay, at $\mathbf{S}$ end of Kodiak I.; $56^{\circ} 59^{\prime} 05^{\prime \prime} \mathrm{N}, 154^{\circ} 11^{\prime} 20^{\prime \prime} \mathrm{W}$; BGN 1934; (map 32). Var. Blacktop Mountain.

Native name, "synonymous with Blacktop * * *," given in 1934 by USC\&GS.

Tungulik : island, in Shumagin Is., Aleutian Ra. $55^{\circ} \mathrm{N}, 160^{\circ} \mathrm{W}$; (map 27). Var. Toungovlik, Tunulik, Tunulyak.

Aleut name published by Lutke (1836, p. 267) as "Toungovlik," and by Father Veniaminov (1840, v. 1, p. 255) as "Tunulik" and "Tunulyak" (p. 266). According to R. H Geoghegan, Father Veniaminov took the name from the Aleut "tunggaq" meaning "hard, solid, or firm." The exact location of this island is not known.

Tuniak, Cape: point of land, see Chiniak, Cape. Tuniak Bay: bay, see Chiniak Bay.

Tuniakhpuk: locality, see Tuniakpuk.

Tuniak Point: point of land, 'see Chiniak, Cape Tuniakpuk: locality, on left bank of Togiak River, $2 \mathrm{mi}$. W of Kashiagamiut and $54 \mathrm{mi}$. NE of Goodnews, Kilbuck-Kuskokwim Mts. $59^{\circ} 22^{\prime} \mathrm{N}, 160^{\circ} 09^{\prime} \mathrm{W}$; (map 53). Var. Tuniapak, Tuniakhpuk, Tunniakhpuk, Tunniakhput.

Former Eskimo village reported by Ivan Petroff in the 1880 Census as "Tuniakhpuk" and "Tunniakhpuk", meaning "big Tuniak." The population in 1880 was 137 .

Tunilkhanten, Lake: lake, $0.5 \mathrm{mi}$. across, $2 \mathrm{mi}$. $\mathrm{N}$ of Lake Tokhaklanten and $18 \mathrm{mi}$. NW of Hughes, Hogatza High.; $66^{\circ} 14^{\prime} \mathrm{N}, 154^{\circ} 42^{\prime}$ W; (map 116).

Indian name reported to mean "clear water lake," recorded at Hughes in 1956 by Orth.

Tunis Mountain: ridge, 4,790 ft., extends NW 6 mi. from Post River, between South Fork Kuskokwim River and Tin Creek, $76 \mathrm{mi}$. SE of McGrath, Alaska Ra.; $62^{\circ} 24^{\prime} \mathrm{N}, 153^{\circ} 34^{\prime} \mathrm{W}$; (map 80).

Named in 1898 by W. S. Post, USGS; "in keeping with the rest of our [Post's and J. E. Spurr's] exotic names."

Tunkaleshna Creek: stream, flows SW $18 \mathrm{mi}$. to Stony River $3 \mathrm{mi}$. $\mathrm{N}$ of its junc. with Telaquana River, $60 \mathrm{mi}$. N of Lake Clark, Alaska Ra.; $61^{\circ} 07^{\prime} \mathrm{N}, 154^{\circ} 26^{\prime} \mathrm{W}$; (map 71).

Indian name published in 1951 by USGS. Tunnel: locality, mile 51.0 on The Alaska RR., $3 \mathrm{mi}$. S of Placer River Valley, $22 \mathrm{mi}$. SE of
Sunrise, Chugach Mts.; $60^{\circ} 40^{\prime} 00^{\prime \prime} \mathrm{N}, 149^{\circ}-$ $02^{\prime} 30^{\prime \prime} \mathrm{W}$; (map 63). Var. Tunnel Siding, Tunnel Station.

Local name for a station on The Alaska RR. reported in 1909 as Tunnel Siding by Grant and Higgins (1913, pl. 1), USGS. The Alaska RR. guides of 1922 list the station as "Tunnel." A post office was established here in 1930, but was discontinued in 1931. Recent maps indicate a site with three or four buildings. The name of the station was derived from the two RR. tunnels in the vicinity.

Tunnel Creek: stream, flows SE $1.3 \mathrm{mi}$. to EIdorado Creek which flows to Candle Creek, $0.4 \mathrm{mi}$. NE of Mosquito Creek and $33 \mathrm{mi}$. $\mathrm{NE}$ of Imuruk Lake, Seward Penin. High.; $65^{\circ} 44^{\prime} \mathrm{N}, 162^{\circ} 04^{\prime} \mathrm{W}$; (map 110).

Local name reported in 1950 by USGS.

Tunnel Station: locality, see Tunnel.

Tunniakhpuk: locality, see Tuniakpuk.

Tunniakhput: locality, see Tuniakpuk.

Tŭn-nū-ē-rǔn-pak: watercourse, see Tunurokpak Channel.

Tunnuuraq: stream, see Tunurak Slough.

Tunravik: locality, on right bank of Nushagak River $1 \mathrm{mi}$. NE of junc. of Tunravik Creek, $57 \mathrm{mi}$. NE of Dillingham, Bristol Bay Low.; $59^{\circ} 31^{\prime} \mathrm{N}, 157^{\circ} 15^{\prime} \mathrm{W}$; BGN 1931; (map 52). Var. Tunravk.

Eskimo village or camp name obtained in 1930 from F. H. Waskey and Beverley Polley, local inhabitants, by Gerald FitzGerald, USGS; published by Mertic (1938b, pl. 1) USGS.

Tunravik Creek: stream, flows SE $10 \mathrm{mi}$. to Nushagak River, $14 \mathrm{mi}$. NE of Ekwok and 56 mi. NE of Dillingham, Bristol Bay Low.; $59^{\circ} 30^{\prime} \mathrm{N}, 157^{\circ} 17^{\prime} \mathrm{W}$; BGN 1931; (map 52).

Eskimo name obtained in 1931 from F. $H$. Waskey and Beverley Polley, local inhabitants, by Gerald FitzGerald, USGS.

Tunravk: locality, see Tunravik.

Tuntaluliag: village, see Tuntutuliak.

Tuntatuliag: village, see Tuntutuliak.

Tuntatuliak: village, see Tuntutuliak.

Tuntatuling: village, see Tuntutuliak.

Tuntunguak Mountain: mountain, 2,000 ft., 4 mi. $\mathrm{N}$ of Goodnews Lake and $48 \mathrm{mi}$. NE of Goodnews, Kilbuck-Kuskokwim Mts.; 59 $32^{\prime}$ $\mathrm{N}, 160^{\circ} 35^{\prime} \mathrm{W}$; $(\operatorname{map} 53)$.

Eskimo name reported to mean "deer-like", obtained about 1951 by D. H. Hoare, USGS from Rev. C. B. Michael, missionary at Quinhagak.

Tuntut Mountains: mountain range, extends SSW 220 mi. from Kuskokwim River to Togiak Bay on $\mathrm{N}$ side of Bristol Bay, KilbuckKuskokwim Mts.; $60^{\circ} \mathrm{N}, 160^{\circ} \mathrm{W}$.

Shown by Ivan Petroff in the 1880 Census; applied to what is now the Ahklun Mountains, Kilbuck Mountains, and lower end of the Kuskokwim Mountains.

Tuntutuli: locality, on Wolf Creek Mountain, bounded by Stuyahok, Nageethluk, Atchuelinguk, and Bonasila Rivers, Nulato Hills; $62^{\circ} 20^{\prime}$ $\mathrm{N}, 161^{\circ} 20^{\prime} \mathrm{W}$; (map 78). Var. Dondadulik. 
Eskimo name meaning "abounding with caribou" reported in 1949 by USC\&GS.

Tuntutuliak: village, pop. 144, $3 \mathrm{mi}$. NW of junc. of Kinak River with Kuskokwim River, $45 \mathrm{mi}$. SW of Bethel, Yukon-Kuskokwim Delta; 6022' N, $162^{\circ} 38^{\prime}$ W; BGN 1963; (map 58). Var. Tuntaluliag, Tuntatuliag, Tuntatuliak, Tuntatuling, Tuntutuliag.

Eskimo village listed in the 1950 Census with a population of 68 . The name is reported to mean "many caribou (reindeer)."

Tunugarat Hill: hill, 1,610 ft., on right bank of Colville River, between Kuakat Ridge and Lost Temper Creek, Arctic Slope; 68 $52^{\prime} \mathrm{N}$, $157^{\circ} 28^{\prime} \mathrm{W}$; (map 132).

Eskimo name meaning "to turn aside" or "to turn away," reported by T. E. Taylor, USGS, in 1956.

Tunuigak Slough: water course, $2.5 \mathrm{mi}$. long, in Yukon Delta, $5 \mathrm{mi}$. SW of Kwiguk, YukonKuskokwim Delta; 62 $42^{\prime} \mathrm{N}, 164^{\circ} 35^{\prime} \mathrm{W}$; (map 77).

Eskimo name obtained in 1948 by USC\&GS.

Tunuing River: stream, heads in lake, $W$ of Nichols Spit, on Nushagak Penin., flows NW $30 \mathrm{mi}$. to Igushik River, $25 \mathrm{mi}$. SW of Dillingham, Bristol Bay Low.; $58^{\circ} 49^{\prime}$ N, $159^{\circ} 02^{\prime}$ W ; (map 40).

Local name reported in 1952 by USGS.

Tunukuchiak Creek: stream, flows N $17 \mathrm{mi}$. to Noatak River, $26 \mathrm{mi}$. SE of Howard Pass, Brooks Ra.; $67^{\circ} 52^{\prime} \mathrm{N}, 156^{\circ} 30^{\prime} \mathrm{W}$; (map 126).

Eskimo name reported to mean "to go (or sneak) behind," obtained at Noatak by Orth in 1956.

Tunulik: island, see Tungulik.

Tunulik River: stream, flows SW $13 \mathrm{mi}$. to Goodnews Bay, $1.5 \mathrm{mi}$. NW of Goodnews, Kilbuck-Kuskokwim Mts.; $59^{\circ} 08^{\prime} 00^{\prime \prime} \mathrm{N}, 161^{\circ}$ $37^{\prime} 30^{\prime \prime} \mathrm{W}$; (map 53).

Eskimo name reported in 1919 by G. L. Harrington (in Brooks, 1921, pl. 7), USGS, who reported that it means "one that has the back [?]."

Tunulyak: island, see Tungulik.

Tununa: village, see Tanunak.

Tunurak Slough: stream, channel of Kobuk River, $2.5 \mathrm{mi}$. Iong, near Ambler, KotzebueKobuk Low.; $67^{\circ} 04^{\prime} \mathrm{N}, 157^{\circ} 54^{\prime} \mathrm{W}$; (map 126). Var. Tunnuuraq.

Eskimo name reported as "Tunnuuraq" by Wilfried Zibell in 1965.

Tunurokpak Channel: watercourse, anabranch of Yukon River, flows N $21 \mathrm{mi}$., $28 \mathrm{mi}$. SE of Kwiguk, Yukon-Kuskokwim Delta ; $62^{\circ} 27^{\prime} 30^{\prime \prime}$ N, $163^{\circ} 55^{\prime} 00^{\prime \prime}$ W; (map 77). Var. Tŭnnū-ē-rŭn-pak.

Eskimo name obtained in 1899 by G. R. Putnam, USC\&GS, who suggested that it may mean "big slough."

Tunusiktok Lake: lake, $3.5 \mathrm{mi}$. long, $22 \mathrm{mi}$. SE of Point Lay, Arctic Plain; 69 $34^{\prime} \mathrm{N}, 162^{\circ} 14^{\prime}$ W; (map 145).

Eskimo name obtained at Point Lay by Orth in 1956, meaning "it lies behind."

Tunutuk Creek: stream, heads on $\mathrm{W}$ side of Little Kobuk Sand Dune, flows $N 8 \mathrm{mi}$. to
Kobuk River, Brooks Ra.; $67^{\circ} 07^{\prime}$ N, $158^{\circ} 22^{\prime}$ W; (map 126).

Eskimo name obtained by Mendenhall (1902, pl. 5), USGS, in 1901.

Tuomi: settlement, on NE shore of Tuomi Lake, $4.7 \mathrm{mi}$. NE of Anchorage, Cook Inlet Low.; $61^{\circ} 16^{\prime} 32^{\prime \prime} \mathrm{N}, 149^{\circ} 49^{\prime} 10^{\prime \prime} \mathrm{W}$; (map 69).

Local name reported in 1942 by AMS. Recent USGS maps indicate a site of five or six buildings. See Tuomi Lake.

Tuomi Lake: lake, $800 \mathrm{ft}$. across, $1.4 \mathrm{mi}$. S of Sixmile Lake and $4.4 \mathrm{mi}$. NE of Anchorage, Cook Inlet Low.; $61^{\circ} 16^{\prime} 32^{\prime \prime} \mathrm{N}, 1^{\circ} 9^{\circ} 49^{\prime} 16^{\prime \prime}$ W; (map 69).

Local name reported in 1942 by AMS named for Onni Tuomi, a Finnish family who homesteaded here in the 1920's. The name "tuomi" means "chokecherry.".

Tup-hamikva: locality, see Topanika.

Tup-hamikwa: locality, see Topanika.

Tup-hanikwa: locality, see Topanika.

Tupichalik: lake, see Desperation Lake.

Tupichalik Creek: stream, heads in a lake, flows NW $9 \mathrm{mi}$. to Desperation Lake, $47 \mathrm{mi}$. WNW of Howard Pass, Brooks Ra. ; 68 $19^{\circ} 30^{\prime \prime}$ N, 158 $42^{\prime} 00^{\prime \prime} \mathrm{W}$; (map 132).

Named by Orth in 1958; a translation of the Eskimo name for Desperation Lake. "Tupichalik" means "new tent."

Tupikchak Creek: stream, heads on Tupikchak Mtn., flows NE 17 mi. to Utukok River, Arctic Slope; $68^{\circ} 57^{\prime} \mathrm{N}, 161^{\circ} 13^{\prime} \mathrm{W}$; (map 131).

Named by USGS geologists in 1950 for the mountain.

Tupikchak Greek: stream, flows W $22 \mathrm{mi}$. to Kukpowruk River, $10 \mathrm{mi}$. $\mathrm{N}$ of Poko and Igloo Mts., $40 \mathrm{mi}$. NNW of Mount Kelly, Arctic Slope; 68 $59^{\prime} \mathrm{N}, 162^{\circ} 54^{\prime} \mathrm{W}$; (map 130).

Eskimo name meaning "new house (tent)" reported in 1926 by P. S. Smith, USGS.

Tupikchak Mountain: mountain, 2,950 ft., 45 mi. NNW of Misheguk Mtn., Arctic Slope; $68^{\circ} 51^{\prime} \mathrm{N}, 161^{\circ} 45^{\prime} \mathrm{W}$; (map 131)

Eskimo name reported by $P$. S. Smith, USGS, in 1926, meaning "new tent." Smith's notes refer to the Tupikchak Hills on the west side of the Kokolik River.

Tupik Creek: stream, heads at glacier on Mount Igikpak, flows NW $8 \mathrm{mi}$. to Noatak River, Brooks Ra.; $67^{\circ} 32^{\prime} \mathrm{N}, 155^{\circ} 08^{\prime} \mathrm{W}$; (map 125).

Eskimo name meaning "tent," recorded in Kobuk by Orth, USGS, in 1956.

Tupik Creek: stream, in De Long Mts., flows ESE $7 \mathrm{mi}$. to join Kogruk Creek to form the Utukok River, Brooks Ra.; $68^{\circ} 34^{\prime} \mathrm{N}, 161^{\circ} 06^{\prime}$ W; BGN 1961; (map 131).

Named by USGS geologists in 1950 "for Tupik Mtn. on the north side of this stream." Tupik Mountain: mountain, 3,900 ft., in De Long Mts., 23 mi. N of Misheguk Mtn., Brooks Ra. ; 6834' N, 161'11' W; BGN 1961; (map 131).

Named by USGS geologists in 1950. It is an 'Eskimo word meaning 'tent', which the mountain resembles."

Tup-ka-ak: locality, see Topkok.
Tupkak Bar: spit, on $\mathbf{E}$ side of entrance to Wainwright Inlet, $3 \mathrm{mi}$. SW of Wainwright, Arctic Plain; $70^{\circ} 35^{\prime} 40^{\prime \prime} \mathrm{N}, 160^{\circ} 06^{\prime} 30^{\prime \prime} \mathrm{W}$; (map 146).

Eskimo name published in 1955 by AMS. The Eskimo word "tapqaq" means "sand spit."

Tup-kug-ameuts: locality, see Taapkuk.

Tupoy, Mys: point of land, see Blunt Point.

Tupuknuk Slough: stream, anabranch of Kuskokwim River, flows SW $15 \mathrm{mi}$. to Napaiskak Slough, $5 \mathrm{mi}$. S of Bethel, Yukon-Kuskokwim Delta; $60^{\circ} 42^{\prime} 40^{\prime \prime} \mathrm{N}, 161^{\circ} 44^{\prime} 30^{\prime \prime} \mathrm{W}$; (map 59). GS.

Eskimo name reported in 1951 by USG\& GS.

Tuqdjkan: locality, see Tuxekan.

Turaaqiligauzaq: locality, see Turakiligorak.

Turakiligorak: locality, $9 \mathrm{mi}$. NE of Kivalina, Kotzebue-Kobuk Low.; $67^{\circ} 49^{\prime} \mathrm{N}, 164^{\circ} 17^{\prime} \mathrm{W}$; (map 128). Var. Towrockeeleegowrak, Turaaqiligauzaq.

Eskimo name meaning "little tobacco [wild plants] making place" reported in 1966 by E. S. Burch.

Turbid Greek: stream, flows SE $18 \mathrm{mi}$. across Beaufort Basin to Kukpowruk River, $6 \mathrm{mi}$. $\mathrm{N}$ of Raven Basin, $31 \mathrm{mi}$. ENE of Mount Kelly, Arctic Slope; $68^{\circ} 53^{\prime} \mathrm{N}, 1^{\circ} 3^{\circ} 08^{\prime} \mathrm{W}$; (map 130).

Probably so named in 1949 by Chapman or Sable $(1960$, p. 55), USGS, "because of its exceptionally yellow muddy water."

Turbot, Point: point of land, $\mathrm{N}$ point of entrance to Takatz Bay, on $\mathbf{E}$ coast of Baranof I., 5 mi. N of Baranof, Alex. Arch.; 5 $7^{\circ} 09^{\prime} 45^{\prime \prime} \mathrm{N}$, $134^{\circ} 48^{\prime} 00^{\prime \prime} \mathrm{W}$; (map 9).

Named in 1895 by Lt. Comdr. E. K. Moore, USN; published in 1899 by USC\&GS on Chart 8050.

Turf Point: point of land, southernmost point of Seguam I., Aleutian Is.; $52^{\circ} 15^{\prime} \mathrm{N}, 172^{\circ} 32^{\prime}$ W; (map 19).

Descriptive name given by a special U.S. Navy survey party, because of its grass-covered slopes; published by USC\&GS in 1944 Aleutian Coast Pilot (p. 86).

Turk Creek: stream, flows NW $2.5 \mathrm{mi}$. to Cherry Creek, $53 \mathrm{mi}$. S of Eagle, Yukon-Tanana High.; $64^{\circ} 05^{\prime} \mathrm{N}, 141^{\circ} 09^{\prime} \mathrm{W}$; (map 102).

Named by prospectors and shown on an 1898 manuscript map by E. F. Ball, prospector.

Turkey Cove: cove, $0.4 \mathrm{mi}$. across, $1.25 \mathrm{mi}$. W of Gertrude Cove, on Vega Bay, $\mathbf{S}$ coast of Kiska I., Aleutian Is., $51^{\circ} 55^{\prime} 50^{\prime \prime} \mathrm{N}, 177^{\circ} 24^{\prime}$ $20^{\prime \prime} \mathrm{E}$; (map 14).

One of the "bird names" arbitrarily applied to features on Kiska I. in 1943 by USAAF for tactical purposes during World War II.

Turmath Creek: stream, flows S $2 \mathrm{mi}$. to Sand Bay, Great Sitkin I., Alcutian Is.; 51 $59^{\prime} 50^{\prime \prime}$ $\mathrm{N}, 176^{\circ} 07^{\prime} 47^{\prime \prime} \mathrm{W}$; (map 17).

Name published in 1951 on a USGS map. Turnabout Island: island, $1 \mathrm{mi}$. long, E-W in Frederick Sound, $4 \mathrm{mi}$. NW of Pinta Point and $52 \mathrm{mi}$. E of Sitka; Alex. Arch.; 57 $07^{\prime} 30^{\prime \prime}$ 
N, $133^{\circ} 58^{\prime} 40^{\prime \prime}$ W; (map 8). Var. Ostrov Povorotnyy, Povorotny Island.

This is an 1882 translation by USC\&GS of "Ostrov Povorotnyy," the name published in 1848 on Russian Hydrog. Dept. Chart 1396.

Turnabout Island: island, see Povorotni Island.

Turnabout Point: point of land, see Povorotni Point.

Turnagain: $R R$. station, mile 106.2, on The Alaska RR,, $6.3 \mathrm{mi}$. S of Anchorage, Cook Inlet Low.; $61^{\circ} 07^{\prime} 41^{\prime \prime} \mathrm{N}, 149^{\circ} 52^{\prime} 00^{\prime \prime} \mathrm{W}$; $B G N$ 1945; (map 69). Var. Edes, Finnegan, Turnagin.

Railroad station established about 1940.

Turnagain Arm: estuary, trends NW $48 \mathrm{mi}$. from mouth of Placer River to head of Cook Inlet, SW of Anchorage, Cook Inlet Low.; $61^{\circ} 06^{\prime}$ N, $150^{\circ} 12^{\prime} \mathrm{W}$; (map 63). Var. Resurrection Bay, River Turnagain, Turnagain Bay, Zaliv Vozvratseniya.

So named "River Turnagain" by Capt. Cook (1785, v. 2, p. 395-396), RN, on June 1,1778 , because he was unable to proceed any further inland and had to turn around here. He made various observations and concluded, "These circumstances convinced me, that no passage [from the Pacific to the Atlantic Ocean] was to be expected by this side river, any more than by the main branch." The name was adopted by Capt. Vancouver, RN, in 1794 as "Turnagain Arm." The name "Zaliv Vozvratseniya" meaning "Return Bay" was published for this feature by Capt. Tebenkov (1852, map 5), IRN.

Turnagain Bay: estuary, see Turnagain Arm.

Turnagain Heights: area, in SW part of Anchorage, Cook Inlet Low.; $61^{\circ} 11^{\prime} 54^{\prime \prime} \mathrm{N}$, $149^{\circ} 56^{\prime} 40^{\prime \prime} \mathrm{W}$; (map 69).

Local name reported in 1952 by USGS.

Turnagain Island: island, see Fire Island.

Turnagin: locality, see Turnagain.

Turnagin: railroad station, see Turnagain.

Turnaround Creek: stream, flows NW $13 \mathrm{mi}$. to Melozitna River, $48 \mathrm{mi}$. W of Birches, Kokrines-Hodzana High.; $65^{\circ} 04^{\prime} 00^{\prime \prime} \mathrm{N}, 155^{\circ}$ $11^{\prime 2} 25^{\prime \prime} \mathrm{W}$; ( $\left.\operatorname{map} 97\right)$.

So named in 1956 by Orth because his airplane pilot had to turn around here on two occasions because of bad weather.

Turn Cape: point of land, see Course Point.

Turner, Cape: point of land, see Chichagof Point.

Turner, Mount: mountain, 8,500 ft., in Glacier Bay National Monument, on Alaska-Canada boundary, $4.3 \mathrm{mi}$. SW. of Mount Porde and $90 \mathrm{mi}$. NW of Hoonah, St. Elias Mts.; $59^{\circ}-$ $00^{\prime} 00^{\prime \prime} \mathrm{N}, 137^{\circ} 16^{\prime} 50^{\prime \prime} \mathrm{W}$; BGN 1922; (map $10)$.

Named by USC\&GS for George Turner, 1850-1932, who was Boundary Commissioner in 1903. He was U.S. Senator from Washington, 1887-1903, and a member of the International Joint Commission, United States and Canada, 1913-14. The name was published on USC\&GS Chart 8000 in 1908.
Turner, Point: point of land, on $\mathrm{S}$ tip of Khantaak I., in Monti Bay, $1.9 \mathrm{mi}$. NW of Yakutat, Malaspina Coastal Plain; 59 33'. $30^{\prime \prime} \mathrm{N}, 139^{\circ} 46^{\prime} 50^{\prime \prime} \mathrm{W}$; (map 46). Var. Mys Povorotnyy, Point Turni, Turning Point.

Named by Capt. George Dixon, RN, in 1789 for James Turner, the mate of his ship, Queen Charlotte. It was called "M[ys] Turney," meaning "Point Turni," by Capt. Tebenkov, IRN, (1852, map 7); it was mistranslated from the English on the 1847 Russian Hydrog. Dept. Chart 1378 as "M[ys] Povorotnyy," meaning "Cape Turning" or "Turning Point" (U.S. Coast and Geodetic Survey, 1883, p. 207).

Turner Bay: cove, $1.3 \mathrm{mi}$. long, at $\mathrm{SW}$ end of Chulitna Bay, $15 \mathrm{mi}$. NE of Nondalton, Alaska Ra.; $60^{\circ} 11^{\prime} \mathrm{N}, 154^{\circ} 33^{\prime} \mathrm{W}$; (map 61).

Local name reported in 1954 by USGS.

Turner Cape: point of land, see Chichagof Point.

Turner Creek: stream, flows W $1 \mathrm{mi}$. from Turner Lake to Taku Inlet, $16 \mathrm{mi}$. E of Juneau, Coast Mts. ; $58^{\circ} 19^{\prime} 10^{\prime \prime} \mathrm{N}, 133^{\circ} 59^{\prime} 10^{\prime \prime}$ W; BGN 1931; (map 12)

Name derived from Turner Lake in 1931 by USFS.

Turner Creek: stream, flows SE $11 \mathrm{mi}$. to Noxapaga River, $1 \mathrm{mi}$. N of Noxapaga and $30 \mathrm{mi}$. SW of Imuruk Lake, Seward Penin. High.; $65^{\circ} 29^{\prime} \mathrm{N}, 164^{\circ} 15^{\prime} \mathrm{W} ; B G N$ 1952; (map 110).

Prospectors' name reported in 1900 by Brooks (1901, pl. 11), USGS.

Turner Glacier: glacier, heads on Mount Cook, trends $20 \mathrm{mi}$. SE to its 1951 terminus on Disenchantment Bay, 32 mi. NE of Yakutat, St. Elias Mts.; $60^{\circ} 01^{\prime} \mathrm{N}, 139^{\circ} 05^{\prime} \mathrm{W}$; $B G N$ 1900; (map 66). Var. Dalton Glacier, Duffield Glacier, Sumner Glacier.

This feature was named "Dalton Glacier" by Russell (1891, p. 98), "in honor of John Dalton, a miner and frontiersman." Dalton was subsequently accused of murder and Russell made a request to BGN in 1894 to change the name to honor John Henry Turner, USC\&GS, who spent three years in Alaska making surveys. Before BGN acted in 1900 , USC\&GS used the name "Duffield Glacier" on its charts in honor of William Ward Duffield, USC\&GS.

Turner Island: island, $3 \mathrm{mi}$. long, between Big Koniuji and Nagai Is., in Shumagin Is., Aleutian Ra.; $55^{\circ} 02^{\prime} \mathrm{N}, 159^{\circ} 49^{\prime} \mathrm{W}$; (map 27). Var. Stiernfeld Island.

Named by USC\&GS first as Stiernfeld Island in 1887 and then as Turner Island in 1891.

Turner Island: island, see Bendel Island.

Turner Lake: lake, $9 \mathrm{mi}$. long, trends $\mathrm{NE}$ from $58^{\circ} 17^{\prime} \mathrm{N}, 133^{\circ} 48^{\prime} \mathrm{W}$, to Turner Creek, $1 \mathrm{mi}$. $\mathrm{E}$ of Taku Inlet and $16 \mathrm{mi}$. E of Juneau, Coast Mts. ; $58^{\circ} 18^{\prime} 40^{\prime \prime} \mathrm{N}, 133^{\circ} 57^{\prime} 30^{\prime \prime} \mathrm{W}$; (map 12).

Local name published in 1890 by USC\&GS.

Turner Lake: lake, $0.7 \mathrm{mi}$. long, $1.5 \mathrm{mi}$. E of Ellamar Mtn. and $40 \mathrm{mi}$. NW of Cordova, Chugach Mts.; $60^{\circ} 54^{\prime} 30^{\prime \prime} \mathrm{N}, 146^{\circ} 37^{\prime} 30^{\prime \prime} \mathrm{W}$; (map 64).
Local name reported in 1912 by R. H. Sargent and C. E. Giffin (in Capps and Johnson, 1915, pl. 1), USGS.

Turner River: stream, flows $12 \mathrm{mi}$. NW to Demarcation Bay, $4 \mathrm{mi}$. SW of Demarcation Point, Arctic Plain; $69^{\circ} 39^{\prime} \mathrm{N}, 141^{\circ} 23^{\prime} \mathrm{W}$; $B G N$ 1912; (map 138). Var. Akootchook Creek, Akutsok Creek.

This name was originally applied to the Kongakut River in 1894 by Frederick Funston, USA, and honors John Henry Turner, USC\&GS, who made a sled trip from the Porcupine River to the Arctic Ocean in 1890. The name has since been relegated to this smaller stream because of confusion as to which stream Funston had named (Leffingwell, 1919, p. 91-92).

Turner River: stream, see Kongakut River.

Turni, Point: point of land, see Turner Point. Turning Island: island, $300 \mathrm{ft}$. across, in Middle Channel, in Sitka Sound, S of Sitka, Alex. Arch.; $57^{\circ} 02^{\prime} 40^{\prime \prime} \mathrm{N}, 135^{\circ} 20^{\prime} 05^{\prime \prime} \mathrm{W}$; (map 9). Var. Ostrov Povorotni, Turning Islet.

This is an 1882 translation by USC\&GS of the name "Ostrov Povorotni" given by the Russians about 1850.

Turning Islet: island, see Turning Island.

Turning Point: point of land, see Turner Point.

Turn Island: island, $400 \mathrm{ft}$. long, in Cordova Bay, near entrance to Klakas Inlet, on SW coast of Prince of Wales I., Alex. Arch.; 54 ${ }^{\circ}$ $52^{\prime} 10^{\prime \prime} \mathrm{N}, 132^{\circ} 23^{\prime} 30^{\prime \prime} \mathrm{W}$; (map 1).

Name published in 1899 by USC\&GS.

Turn Island: island, see Amik Island.

Turn Islands: island, $0.2 \mathrm{mi}$. long, in Zimovia Strait $1.5 \mathrm{mi}$. E of Anita Bay, between Wrangell and Etolin Is., Alex. Arch.; $56^{\circ} 14^{\prime} 20^{\prime \prime}$ W, 132 20'10" W; BGN 1923; (map 6).

Named in 1923 by USC\&GS.

Turn Mountain: mountain, 2,867 ft., on N part of Kupreanof I., 3 mi. SE of Pinta Point and $58 \mathrm{mi}$. E of Sitka; Alex. Arch.; 57 $03^{\prime} 55^{\prime \prime} \mathrm{N}$, $133^{\circ} 50^{\prime} 55^{\prime \prime} \mathrm{W}$; (map 8).

Local name reported in 1955 by USGS.

Turn Point: point of land, $\mathrm{N}$ tip of Dall I., Alex. Arch.; $55^{\circ} 15^{\prime} 55^{\prime \prime} \mathrm{N}, 133^{\circ} 07^{\prime} 55^{\prime \prime} \mathrm{W}$; (map 4).

Local name published by Dall (U.S. Coast and Geodetic Survey, 1883, p. 69).

Turn Point: point of land, $\mathrm{W}$ tip of Tuxekan

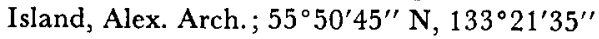
W; (map 4).

Named in 1903 or 1904 by E. F. Dickins, USC\&GS, who wrote "named by our party, has no local name."

Turn Point: point of land, on $\mathrm{W}$ bank of Portland Canal, $5.6 \mathrm{mi}$. N of Breezy Point, Coast Mts.; $55^{\circ} 26^{\prime} 10^{\prime \prime} \mathrm{N}, 130^{\circ} 03^{\prime} 00^{\prime \prime} \mathrm{W}$; (map 3 ).

Named in 1868 by Staff Comdr. David Pender, RN.

Turn Point: point of land, NW tip of Mitkof I. in Wrangell Narrows, $1 \mathrm{mi}$. W of Petersburg, Alex. Arch.; $56^{\circ} 59^{\prime} 05^{\prime \prime} \mathrm{N}, 132^{\circ} 58^{\prime} 50^{\prime \prime} \mathrm{W}$; (map 6). Var. Cone Point.

Named in 1881 by Lt. Comdr. H. E. Nichols, USN ; called "Cone Point" in 1869 by Comdr. R. W. Meade, USN. 
Turn Point: point of land, at $\mathrm{W}$ end of Kootznahoo Inlet, on $\mathrm{W}$ coast of Admiralty I., $0.3 \mathrm{mi}$. N of Angoon, Alex. Arch.; 57 $30^{\prime} 25^{\prime \prime}$ $\mathrm{N}, 134^{\circ} 34^{\prime} 40^{\prime \prime} \mathrm{W}$; (map 9).

Named in 1869 by Comdr. R. W. Meade, USN; published on Hydrographic Chart 225. Boats turn at this point when going from Chatham Inlet to Stillwater Anchorage.

Turn Rock: rock, between Goat Mouth Inlet and Tlevak Strait on $\mathbf{S}$ coast of Goat I., Alex. Arch.; 55 $10^{\prime} 02^{\prime \prime} \mathrm{N}, 132^{\circ} 54^{\prime} 50^{\prime \prime} \mathrm{W}$; (map 4).

Name published in 1905 by USC\&GS.

Turquoise Lake: lake, $5 \mathrm{mi}$. long, at head of Mulchatna River, $60 \mathrm{mi}$. NE of Nondalton, Alaska Ra.; $60^{\circ} 47^{\prime} \mathrm{N}, 152^{\circ} 57^{\prime} \mathrm{W}$; (map 61). Local descriptive name; reported by Capps (1935, pl. 2), USGS.

Turret Point: point of land, on S coast of Adak I., Aleutian Is. ; $51^{\circ} 36^{\prime} 45^{\prime \prime} \mathrm{N}, 176^{\circ} 48^{\prime} 15^{\prime \prime} \mathrm{W}$; BGN 1936; (map 17).

Name given by Lt. William Gibson, USN, commander of the schooner Fenimore Cooper, during the North Pacific Exploring Expedition in 1855.

Turtle Hill: hill, 3,104 ft., in Mount McKinley National Park, $\mathrm{S}$ of McKinley Bar, $7.5 \mathrm{mi}$. SE of Wonder Lake, Alaska Ra.; $63^{\circ} 23^{\prime} \mathrm{N}, 150^{\circ}$ 41' W ; (map 88).

Local name reported in 1954 by USGS.

Turtle Island: island, $0.7 \mathrm{mi}$. across, central Maurelle Is., Alex. Arch.; 55 $39^{\prime}$ N, $133^{\circ} 37^{\prime}$ W; BGN 1917; (map 4).

Descriptive name given in 1917 by USC\&GS because "The charted outline resembles a turtle."

Turtle Island: island, $1.3 \mathrm{mi}$. long, in Yukon River, 21 mi. NW of Holy Cross, Nulato Hills; $62^{\circ} 28^{\prime} 15^{\prime \prime} \mathrm{N}, 160^{\circ} 06^{\prime} 30^{\prime \prime} \mathrm{W}$; (map 78).

Riverboat pilots' name shown on a 1940 "Navigation Chart of the Tanana-Yukon Rivers" published by the U.S. Dept. of the Interior.

Turtle Reef: reef, in Cook Inlet at $\mathrm{S}$ entrance of Iliamna Bay, $18 \mathrm{mi}$. N of Augustine I., Aleutian Ra.; $59^{\circ} 36^{\prime} 40^{\prime \prime} \mathrm{N}, 153^{\circ} 33^{\prime} 00^{\prime \prime} \mathrm{W}$; $B G N 1916$; (map 51$)$.

Named by USC\&GS in 1907.

Tuscarora Rock: rock, N of Unalaska in Unalaska Bay, NE coast of Unalaska I., Aleutian Is.; $53^{\circ} 52^{\prime} 45^{\prime \prime} \mathrm{N}, 166^{\circ} 32^{\prime} 00^{\prime \prime} \mathrm{W}$; (map 23).

Local name published in 1900 by USC\&GS.

Tuseraru: lake, see Nuwuk Lake.

Tushaday Lake: lake, see Tushadg Lake.

Tushadg Lake: lake, $1.2 \mathrm{mi}$. long, $3 \mathrm{mi}$. SE of Northway, Alaska Ra.; $62^{\circ} 56^{\prime} \mathrm{N}, 141^{\circ} 50^{\prime}$ W; (map 84). Var. Tushaday Lake.

Local name reported by USGS in 1960 .

Tushtena Pass: pass, 4,800 ft., between Tok and Robertson Rivers, $19 \mathrm{mi}$. SW of Tanacross, Alaska Ra. ; $63^{\circ} 17^{\prime} \mathrm{N}, 143^{\circ} 57^{\prime} \mathrm{W}$; BGN 1936; (map 85)

Indian name reported by USGS in 1936 Tusich, Cape: point of land, see Tusik, Cape.

Tusigpak Creek: stream, see Tasikpak Creek.

Tusik, Cape: point of land, on S central Kanaga I., Aleutian Is.; $51^{\circ} 41^{\prime} 05^{\prime \prime} \mathrm{N}, 177^{\circ} 16^{\prime} 00^{\prime \prime} \mathrm{W}$; $B G N$ 1936; (map 17). Var. Gape Tusich, Mys Tusikh.
Aleut name published by Capt. Tebenkov (1852, map 28), IRN, as "M[ys] Tusikh," or "Cape Tusikh."

Tusikh, Mys: point of land, see Tusik, Cape.

Tusikpak Lagoon: lagoon, see Tasikpak Lagoon.

Tusikpak Lake: lake, 2 mi. long, on Chukchi Sea coast, $18 \mathrm{mi}$. NE of Point Hope, Arctic Slope; $68^{\circ} 28^{\prime} \mathrm{N}, 166^{\circ} 12^{\prime} \mathrm{W}$; (map 129).

Eskimo name meaning "big lagoon [lake]" published in 1964 by USGS.

Tusikpok Creek: stream, see Tasikpak Creek.

Tusikpok Lagoon: lagoon, see Tasikpak Lagoon.

Tusikvoak, Lake: lake, $8 \mathrm{mi}$. long, $17 \mathrm{mi}$. SE of Barrow, Arctic Plain; $71^{\circ} 04^{\prime} 40^{\prime \prime} \mathrm{N}, 156^{\circ}$ 06'30" W; (map 153). Var. Sikukik Lake, Teseeruq Lake.

Eskimo name "tasikruak," recorded at Barrow by T. E. Taylor, USGS, in 1956 which means "old lagoon."

Tusk, The: mountain, 5,730 ft., in Another River basin, $6.5 \mathrm{mi}$. SW of Kenibuna Lake and $69 \mathrm{mi}$. W of Tyonek, Alaska Ra.; $61^{\circ} 08^{\prime} 30^{\prime \prime}$ $\mathrm{N}, 153^{\circ} 10^{\prime} 10^{\prime \prime} \mathrm{W}$; (map 71).

So named in 1928 by S. R. Capps and Gerald FitzGerald, USGS, because of "the tusk-like appearance of the glaciated granite pinnacle."

Tusk, The: peak, 6,680 ft., in Berners Bay Peaks, $4.5 \mathrm{mi}$. W of Echo Mtn. and $24 \mathrm{mi}$. $\mathrm{N}$ of Juneau, Coast Mts.; 58 $43^{\prime} 08^{\prime \prime}$ N., $134^{\circ} 30^{\prime}$ 15" W; BGN 1965; (map 11). Var. Black Tusk, Tusk Tower.

Descriptive name given by members of the Juneau Iceficld Research Project in 1964.

Tusk Tower: peak, see Tusk, The.

Tusoluksuk: stream, see Tatlawiksuk River.

Tusta Creek: stream, flows SE $0.5 \mathrm{mi}$. into Salt Lake $20 \mathrm{mi}$. NW of Juneau, Coast Mts. ; $58^{\circ}$ $29^{\prime} 45^{\prime \prime} \mathrm{N}, 134^{\circ} 47^{\prime} 00^{\prime \prime} \mathrm{W}$; (map 11).

Local name reported by $R$. N. DeArmond (1957, p. 38)

Tustumena Glacier: glacier, on Kenai Penin., trends NW $16 \mathrm{mi}$. from Harding Icefield to its 1951 terminus at head of Glacier Creek, $42 \mathrm{mi}$. SE of Kenai, Chugach Mts.; $60^{\circ} 03^{\prime} 30^{\prime \prime} \mathrm{N}$, $150^{\circ} 34^{\prime} 00^{\prime \prime} \mathrm{W}$; (map 62).

Local name reported about 1911 by USGS (Martin and others, 1915, pl. 2).

Tustumena Lake: lake, $24 \mathrm{mi}$. long, on Kenai Peninsula, $20 \mathrm{mi}$. SE of Kenai, Cook Inlet Low.; $60^{\circ} 10^{\prime} \mathrm{N}, 150^{\circ} 50^{\prime} \mathrm{W}$; (map 62). Var. Ozero Chustylena, Skilakh Lake, Tustumena See.

Tanaina Indian name reported in 1840 by the Russian scientist I. G. Wosnesenski; published in 1847 as "Oz[ero] Chustylena," meaning "Chustylena Lake," on Russian Hydrog. Dept. Chart 1378. Skilak and Tustumena Lakes were shown on Ivan Petroff's 1880 map as one lake to which he applied the name "Skilakh Lake."

Tustumena See: lake, see Tustumena Lake.

Tutago: locality, on left bank of Yukon River opposite mouth of Bear Creek, Innoko Low.; $63^{\circ} 30^{\prime} \mathrm{N}, 1^{\circ} 29^{\circ} 21^{\prime} \mathrm{W}$; (map 91). Var. Tchouchago, Ttutago, Ttutaho, Tuttago, Yakutskalitnik, Yakutzkelignik, Yakutsklitnik.
Former Indian village recorded in 1848 as "Tuttago" by Lt. L. A. Zagoskin, IRN; published as "Tchouchago" on his 1850 map. Whymper (1869 p. 264) published the name "Yakutzkelignik."

Tutagvak Bay: bay, see Wainwright Inlet,

Tutak Creek: stream, heads on Kikmiksot Mtn. in Mulgrave Hills, flows NW $24 \mathrm{mi}$. to Wulik River, $25 \mathrm{mi}$. NE of Kivalina, Arctic Slope; 67 $52^{\prime} 30^{\prime \prime} \mathrm{N}, 163^{\circ} 41^{\prime} 00^{\prime \prime} \mathrm{W}$; (map 128).Var. Seevoochaek, Seevooram Koonga.

Eskimo name meaning "labret" obtained at Kivalina by Orth in 1956 . In 1960, D. C. Foote reported that the stream is called "Seevoochaek" derived from a bluff by the same name.

Tutakoke River: stream, flows W $13 \mathrm{mi}$. to Angyoyaravak Bay, Yukon-Kuskokwim Delta; $61^{\circ} 15^{\prime} \mathrm{N}, 165^{\circ} 37^{\prime} \mathrm{W}$; (map 75).

Eskimo name reported by USC\&GS in 1951 . Tutiumnik: peninsula, see Castle Cape.

Tutiumnik, Point: promontory, see Tuliumnit Point.

Tutkaimund Lake: lake, $1 \mathrm{mi}$. long, $7 \mathrm{mi}$. E of Tetlin Lake and $20 \mathrm{mi}$. W of Northway Junction, Alaska Ra.; $63^{\circ} 05^{\prime} \mathrm{N}, 142^{\circ} 26^{\prime} \mathrm{W}$; (map 85).

Indian name published by USGS in 1964 .

Tutkiya: locality, on $\mathbf{W}$ side of Colville River Delta, Arctic Plain; $70^{\circ} 25^{\prime} \mathrm{N}, 151^{\circ} 10^{\prime} \mathrm{W}$; (map 149).

Eskimo name appearing on Maguire's map (Great Britain, 1854, facing p. 186). It may refer to a camping place.

Tutlut: locality, at junc. of Kantishna and Yukon Rivers, Minto Flats; $64^{\circ} 45^{\prime} \mathrm{N}, 149^{\circ}$. $59^{\prime} \mathrm{W}$; (map 100). Var. Too-clok.

Former Indian village or camp recorded in the 1880 Census by Petroff (1884 map); published as "Too-clock band" by Lt. Schwatka (1885, p. 95), USA.

Tutlut River: stream, see Nenana River.

Tutlut River: stream, Toklat River.

Tutna Lake: lake, $2.5 \mathrm{mi}$. across, $2 \mathrm{mi}$. W of Mesa Mtn., and $30 \mathrm{mi}$. NW of Nondalton, Alaska Ra.; $60^{\circ} 21^{\prime} \mathrm{N}, 155^{\circ} 21^{\prime} \mathrm{W}$; (map 61). Var. Summit Lake, Dootny Lake, Davna Lake, Duvna Lake.

Tanaina Indian name reported in 1914 by P. S. Smith and R. H. Sargent, USGS. According to Lt. L. A. Zagoskin, IRN, in 1842-44, Tutna was the name of an Indian tribe along the Kuskokwim from Kolmak of to the Holitna River.

Tutolivik: locality, on Wainwright Inlet, $4.5 \mathrm{mi}$. SE of Wainwright, Arctic Plain; $70^{\circ} 35^{\prime} 52^{\prime \prime} \mathrm{N}$, $159^{\circ} 52^{\prime} 29^{\prime \prime}$ W; (map 146).

Eskimo name reported in 1955 by AMS.

Tutsógemut: locality, see Techek.

Tuttago: locality, see Tutago.

Tuttle Creek: stream, flows SW $15 \mathrm{mi}$. to Kugrupaga River, $11 \mathrm{mi}$. W of Ear Mtn. and 44 mi. NW of Teller, Seward Penin. High.; $65^{\circ} 53^{\prime} \mathrm{N}, 166^{\circ} 37^{\prime} \mathrm{W}$; (map 111).

Prospectors' name reported in 1901 by T. G. Gerdine (in Collier, 1902, pl. 12), USGS.

Tutua Wing River: stream, see Kuk River. 
Tutuksuk River: stream, heads in Baird Mts., flows $\mathrm{S} 45 \mathrm{mi}$. to Kobuk River $2 \mathrm{mi}$. NE of its junc. with Salmon River, $36 \mathrm{mi}$. NE of Kiana, Brooks Ra.; $67^{\circ} 10^{\prime} 30^{\prime \prime} \mathrm{N}, 159^{\circ} 22^{\prime} 00^{\prime \prime}$ W; BGN 1912; (map 127). Var. Labret River, Too-look-sook River, Tootooksook River.

In 1885, Lt. Stoney (1900, map), USN, gave the name for this stream as "Labret or Too-look-sook River." W. C. Mendenhall, USGS, in 1901 wrote the name "Tootooksook" and says it means "caribou pelt."

Tutusirok, Lake: lake, $1 \mathrm{mi}$. long, $5 \mathrm{mi}$. NE of confluence of Noatak and Nimiuktuk Rivers, Brooks Ra.; $68^{\circ} 10^{\prime} \mathrm{N}, 159^{\circ} 51^{\prime} \mathrm{W}$; (map 131).

Eskimo name meaning "he meets a caribou," obtained at Noatak by Orth in 1956 .

Tututalak Mountain: mountain, 4,474 ft., in Maiyumerak Mts. of the Baird Mts., on W bank of Akikukchiak Creek, $49 \mathrm{mi}$. NE of Noatak, Brooks Ra.; $67^{\circ} 46^{\prime} \mathrm{N}, 161^{\circ} 10^{\prime} \mathrm{W}$; (map 127).

Eskimo name meaning "caught a caribou," obtained in 1956 at Noatak by Orth.

Tuukingaaq: mountain, see Tukingak Mountain.

Tuvak, Lake: lake, $4 \mathrm{mi}$. long, $15 \mathrm{mi}$. SE of Point Franklin, Arctic Plain; $70^{\circ} 42^{\prime} 10^{\prime \prime} \mathrm{N}$, $158^{\circ} 24^{\prime} 30^{\prime \prime} \mathrm{W}$; (map 147).

Eskimo name meaning "old (stranded) icecake"; reported in 1956 by Orth.

Tuviarok: locality, see Nushagak.

Tuxeau: locality, see Tuxekan.

Tuxecan: locality, see Tuxekan.

Tuxedni Bay: estuary, extends SE $14 \mathrm{mi}$. from mouth of Tuxedni River to Cook Inlet, at Chisik I., $52 \mathrm{mi}$. SW of Kenai, Aleutian Ra.; 60'$12^{\prime} \mathrm{N}, 152^{\circ} 34^{\prime} \mathrm{W}$; BGN 1926; (map 62). Var. Snug Harbor, Tookozetna Bay, Tuksed-ni Bay, Tukusitnu Bay, Tukuzit Bay, Tuxedni Harbor, Zaliv Tukuzit.

Native name published as " $Z$ [aliv] Tukuzit," or "Tukuzit Bay," by Capt. Tebenkov (1852, map 5). W. H. Dall, USC\&GS, reported the name as "Tuk-sed-ni" in the late 1800 's.

Tuxedni Channel: water passage, extends SE 6 mi., from Tuxedni Bay to Cook Inlet, $W$ of Chisik I., $55 \mathrm{mi}$. SW of Kenai, Aleutian Ra.; $60^{\circ} 08^{\prime} \mathrm{N}, 152^{\circ} 37^{\prime} \mathrm{W}$; (map 62).

Local name published in 1943 by USC\&GS; derived from Tuxedni Bay.

Tuxedni Glacier: glacier, trends N $16 \mathrm{mi}$. from Llianma Volcano to its terminus $2.5 \mathrm{mi}$. $\mathrm{S}$ of the Tuxedni River, $65 \mathrm{mi}$. NE of Nondalton, Aleutian Ra.; $60^{\circ} 15^{\prime} 30^{\prime \prime} \mathrm{N}, 153^{\circ} 02^{\prime} 00^{\prime \prime} \mathrm{W}$; (map 61).

Local name reported in 1958 by USGS; derived from Tuxedni River.

Tuxedni Harbor: estuary, see Tuxedni Bay

Tuxedni River: stream, heads at glacier terminus, flows E $19 \mathrm{mi}$. to Tuxedni Bay, $60 \mathrm{mi}$. SW of Kenai, Aleutian Ra.; $60^{\circ} 15^{\prime} \mathrm{N}, 152^{\circ} 55^{\prime}$ W; (map 62).

Local name rejorted in 1958 by USGS; derived from Tuxedni Bay.
Tuxekan: locality, at $\mathbf{N}$ entrance to Tuxekan Narrows, W coast of Prince of Wales I., Alex Arch.; $55^{\circ} 53^{\prime} 20^{\prime \prime} \mathrm{N}, 133^{\circ} 14^{\prime} 30^{\prime \prime} \mathrm{W}$; BGN 1954; (map 4). Var. Taqdjikan, Tuxeau, Tuxecan, Tuxican, Tuqdjkan.

Name of a former Tlingit Indian village published in 1895 as "Tuxeau" and in 1899 as "Tuxecan" by USC\&GS. Hodge (1910, p. 858), BAE, says "Tuxican. An old Tlingit town belonging to the Henya *** Formerly it was the chief Henya town, but the Henya have now moved to Klawak."

Tuxekan Island: island, $10 \mathrm{mi}$. long, between Heceta and Prince of Wales Is., Alex. Arch.; $55^{\circ} 51^{\prime} \mathrm{N}, 133^{\circ} 17^{\prime} \mathrm{W}$; (map 4).

Named in 1904 by E. F. Dickins, USC\&GS, "after the Indian Village * * *,"

Tuxekan Narrows: water passage, 2 mi. long, $\mathrm{N}$ end of Tuxekan Passage, between Prince of Wales and Tuxekan Is., Alex. Arch.; $55^{\circ} 52^{\prime} 30^{\prime \prime} \mathrm{N}, 133^{\circ} 14^{\prime} 00^{\prime \prime} \mathrm{W}$; (map 4).

Name published in 1943 by USC\&GS.

Tuxekan Passage: water passage, $7 \mathrm{mi}$. long and $2 \mathrm{mi}$. wide, between Prince of Wales and Tuxekan Is., Alex. Arch.; $55^{\circ} 50^{\prime} \mathrm{N}, 133^{\circ} 12^{\prime}$ W; (map 4).

Named in 1904 by E. F. Dickins, USC\&GS, "after the Indian Village situated on that passage."

Tuxican: locality, see Tuxekan.

Tuxsuk River: stream, see Dooksook River.

Tuyugiak: locality, see Togiak.

Tvativak Bay: cove, extends $\mathrm{N} 1 \mathrm{mi}$., off Bristol Bay, on $W$ coast of Nushagak Penin., $E$ of Kulukak Bay, $40 \mathrm{mi}$. SW of Dillingham, Kilbuck-Kuskokwim Mts. ; $58^{\circ} 50^{\prime}$ N, $159^{\circ} 33^{\prime}$ W; (map 40).

Eskimo name reported in 1952 by USGS. Tvikan, Mount: mountain: see Ivekan Mountain.

Tvishak River: stream, see Ivishak River.

Twelve Fathom Strait: water passage, between Simeonof and Little Koniuji Is., in Shumagin Is., Aleutian Ra.; $54^{\circ} 57^{\prime} \mathrm{N}, 159^{\circ} 22^{\prime} \mathrm{W}$; (map 26). Var. Twelve Fathom Straits, 12 Fathom Strait.

Named by fishermen for its depth; surveyed in 1872 by W. H. Dall, USC\&GS.

Twelve Fathom Straits: water passage, see Twelve Fathom Strait.

Twelvemile Arm Kasaan Bay: estuary, extends SW $15 \mathrm{mi}$. off Kasaan Bay, on Prince of Wales I.; Alex. Arch.; 55 $32^{\prime} \mathrm{N}, 132^{\circ} 31^{\prime} \mathrm{W}$; (map 4). Var. Eighteen-mile Arm.

Named in 1886 by Lt. Comdr. R. Clover, USN. This feature was called Eighteen-mile Arm in 1883 Coast Pilot (p. 86)

Twelvemile Cache: locality, see Twelvemile House.

Twelvemile Canyon: canyon, $12 \mathrm{mi}$. long, near mouth of North Fork Bremner River, $8 \mathrm{mi}$ SW of Hanagita Peak and $69 \mathrm{mi}$. NE of Cordova, Chugach Mts.; $60^{\circ} 58^{\prime} 40^{\prime \prime} \mathrm{N}, 143^{\circ} 54^{\prime}$ $00^{\prime \prime}$ W; (map 65). Var. Twelve Mile Canyon.

Local name reported by H. F. Moffit (1914, pl. 1), USGS.

Twelve Mile Creek: stream, see Excelsior Creek.
Twelvemile Creek: stream, on Prince of Wales Is., flows $\mathrm{N} 6 \mathrm{mi}$. to head of Twelvemile Arm Kasaan Bay, Alex. Arch.; $55^{\circ} 21^{\prime} \mathrm{N}, 133^{\circ} 44^{\prime}$ W; (map 4).

Name published in 1920 by USC\&GS.

Twelvemile Creek: stream, flows N $6 \mathrm{mi}$. to Frederick Sound, $12 \mathrm{mi}$. NW of Petersburg, on NE coast of Lindenberg Penin., Kupreanof I., Alex. Arch.; $56^{\circ} 58^{\prime} 40^{\prime \prime} \mathrm{N}, 133^{\circ} 04^{\prime} 00^{\prime \prime} \mathrm{W}$; (map 6).

Local name recorded in 1951 by USGS.

Twelvemile Creek: stream, heads in small glacier on $\mathrm{S}$ slope of Granite Ridge, flows $\mathrm{N}$ then $\mathrm{S}$, $8 \mathrm{mi}$. to Granite Creek, $1.5 \mathrm{mi}$. E of Barkley Lake and $110 \mathrm{mi}$. E of Cordova, St. Elias Mts.; $60^{\circ} 43^{\prime} 00^{\prime \prime} \mathrm{N}, 141^{\circ} 30^{\prime} 45^{\prime \prime} \mathrm{W}$; (map 65).

Local name reported by F. H. Moffit (1918, pl. 6), USGS.

Twelvemile Creek: stream, heads at lake, flows E $12 \mathrm{mi}$. to Gulkana River $3.2 \mathrm{mi}$. SW of Paxson Lake, Alaska Ra.; $62^{\circ} 49^{\prime} \mathrm{N}, 145^{\circ} 40^{\prime}$ W; (map 83).

Local name reported by USGS in 1950.

Twelvemile Creek: stream, flows S $5 \mathrm{mi}$. to Walker Fork, $51 \mathrm{mi}$. S of Eagle, YukonTanana High.; $64^{\circ} 04^{\prime} 30^{\prime \prime} \mathrm{N}, 141^{\circ} 20^{\prime} 00^{\prime \prime} \mathrm{W}$; (map 102).

Named by prospectors and reported in 1898 by E. C. Barnard, USGS. So named because the stream is 12 miles up Walker Fork.

Twelvemile Creek: stream, flows E $8 \mathrm{mi}$. to Birch Greek, $56 \mathrm{mi}$. SW of Circle, Yukon-Tanana High.; $65^{\circ} 23^{\prime} 30^{\prime \prime} \mathrm{N}, 145^{\circ} 43^{\prime} 00^{\prime \prime} \mathrm{W}$; (map 104).

So named by prospectors probably because its mouth is about $12 \mathrm{mi}$. west of Mastodon Dome. Some of the early gold discoveries of the Birch Creek region were made there in 1893 (Spurr, 1898, p. 347). The name was reported in 1903 by Gerdine (in Prindle, 1905, pl. 13), USGS.

Twelvemile Creek: stream, flows E $4.5 \mathrm{mi}$. to Middle Fork Koyukuk River, $2 \mathrm{mi}$. NW of Cathedral Mtn. and $17 \mathrm{mi}$. S of Wiseman, Brooks Ra.; $67^{\circ} 11^{\prime} \mathrm{N}, 150^{\circ} 20^{\prime} \mathrm{W}$; (map 124).

Local name reported on a map of the Koyukuk River dated 1899 made by G. H. Wonson, master of the steamer Dorothy.

Twelvemile Creek: stream, flows SW $10 \mathrm{mi}$. to Noatak River, $35 \mathrm{mi}$. SW of Survey Pass, Brooks Ra.; $67^{\circ} 35^{\prime} \mathrm{N}, 155^{\circ} 13^{\prime} \mathrm{W}$; (map 125).

Named used by prospectors, reported by P. S. Smith (1913), USGS

Twelvemile Creek: stream, see Angayu Creek. Twelvemile Fishing Camp: locality, on $\mathrm{N}$ end of Huggins I., opposite mouth of Batza River and $32 \mathrm{mi}$. NNE of Hochandochtla Mtn., Kokrines-Hodzana High.; $65^{\circ} 56^{\prime} 50^{\prime \prime} \mathrm{N}, 154^{\circ}$ $26^{\prime} 00^{\prime \prime} \mathrm{W}$; (map 107).

Local name obtained in 1954 by USGS topographers.

Twelvemile House: locality, on Birch Creek, 12 mi. SW of Circle, Yukon-Tanana High.; $65^{\circ}$ $42^{\prime} \mathrm{N}, 144^{\circ} 23^{\prime} \mathrm{W}$; (map 104). Var. Twelvemile Cache. 
Local name for a former mining camp originally reported to be "Twelvemile Cache" by J. E. Spurr, USGS, in 1896 . However, when a roadhouse developed there, local usage adopted the present form reported in 1903 by T. G. Gerdine (in Prindle, 1905, pl. 13), USGS.

Twelvemile Island: island, $1.5 \mathrm{mi}$. long, in Yukon River, 9 mi. ENE of Tanana, KokrinesHodzana High.; $65^{\circ} 12^{\prime} \mathrm{N}, 151^{\circ} 47^{\prime} \mathrm{W}$; (map 106).

Riverboat pilots' name shown on a Yukon River track chart manuscript dated 1906.

Twelvemile Island: island, $0.7 \mathrm{mi}$. long, in Yukon River, $11 \mathrm{mi}$. W of Rampart, Kokrines-Hodzana High.; $65^{\circ} 29^{\prime} 30^{\prime \prime} \mathrm{N}, 150^{\circ} 33^{\prime} 00^{\prime \prime} \mathrm{W}$; (map 106).

Local name reported in 1956 by Orth; so named because it was considered to be 12 miles downstream from Rampart.

Twelvemile Island: island, $3.4 \mathrm{mi}$. long, in the Yukon River, $12 \mathrm{mi}$. SE of Fort Yukon, Yukon Flats; $66^{\circ} 26^{\prime} 30^{\prime \prime} \mathrm{N}, 145^{\circ} 05^{\prime} 00^{\prime \prime} \mathrm{W}$; (map 119). Var. Seventeenmile Island.

Local name reported by USGS in 1956; so named because the island is 12 miles upstream from Fort Yukon; the island was shown on Edwards' Track Chart of the Yukon in 1899 as "Seventeenmile Island."

Twelvemile Lake: lake, $0.6 \mathrm{mi}$. long, $0.7 \mathrm{mi}$. $\mathrm{S}$ of junc. of Peters and Willow Creeks, $23 \mathrm{mi}$. NW of Palmer, Talkeetna Mts. ; $61^{\circ} 46^{\prime} 20^{\prime \prime}$ $\mathrm{N}, 149^{\circ} 43^{\prime} 00^{\prime \prime} \mathrm{W}$; (map 69).

Local name reported on a 1961 Alaska Highway Division planning map.

Twelvemile Lake: lake, $1.4 \mathrm{mi}$. across, $4.5 \mathrm{mi}$. NW of Lake George, and $34 \mathrm{mi}$. SE of Delta Junction, Tanana Low.; $63^{\circ} 51^{\prime} 40^{\prime \prime} \mathrm{N}, 144^{\circ}$ $40^{\prime} 45^{\prime \prime} \mathrm{W}$; (map 86).

Name reported in 1952 by USGS.

Twelvemile Lake: lake, 1 mi. long, on $\mathrm{S}$ bank of Yukon River, $0.5 \mathrm{mi}$. S of Twelvemile I. and $9 \mathrm{mi}$. ENE of Tanana, Yukon-Tanana High.; $65^{\circ} 11^{\prime} 30^{\prime \prime} \mathrm{N}, 151^{\circ} 48^{\prime} 00^{\prime \prime} \mathrm{W}$; (map 106).

Local name reported in 1954 by $R$. E. Isto, USGS; so named because of its relationship to Twelvemile I.

Twelvemile Lake: lake, $2 \mathrm{mi}$. long, $11 \mathrm{mi}$. SW of Fort Yukon, Yukon Flats; $66^{\circ} 27^{\prime} \mathrm{N}, 145^{\circ}$. 32' W; (map 119).

Local name obtained in 1956 by USGS; so called because the lake is about 12 miles from Fort Yukon by way of the winter trail.

Twelvemile Lake: lake, $1 \mathrm{mi}$. long, $9 \mathrm{mi}$. NE of Beaver, Yukon Flats; $66^{\circ} 28^{\prime} \mathrm{N}, 147^{\circ} 12^{\prime} \mathrm{W}$; (map. 118).

Local name obtained in 1956 by USGS; name derived from the distance to Beaver via a year-round trail.

Twelvemile Lakes: lakes, see Chicago Lakes.

Twelvemile Mountain: mountain, 3,190 ft., 6 mi. W of Cathedral Mtn. and $20 \mathrm{mi}$. S of Wiseman, Brooks Ra.; $67^{\circ} 09^{\prime} 15^{\prime \prime} \mathrm{N}, 150^{\circ}$ 27'00" W; BGN 1932; (map 124).

Local name reported in 1932 by Robert Marshall who wrote "in general use since 1898 , because the mountain and nearby creek stand about 12 mi. from Bettles."
Twelvemile Slough: watercourse, in distributary system of Yukon River, heads at Paimiut Slough and flows W $15 \mathrm{mi}$. to Yukon River $28 \mathrm{mi}$. NE of Russian Mission, Yukon-Kuskokwim Delta; $61^{\circ} 56^{\prime} 30^{\prime \prime} \mathrm{N}, 160^{\circ} 30^{\prime} 30^{\prime \prime} \mathrm{W}$; (map 73). Var. Reindeer Slough.

Local name shown on a manuscript chart of the Yukon River dated 1922; probably so named because the slough was thought to be twelve miles long.

Twelvemile Summit: pass, $3,000 \mathrm{ft}$., $10 \mathrm{mi}$. SW of Pinnell Mtn. and $62 \mathrm{mi}$. SW of Circle, along the Steese Highway, Yukon-Tanana High.; $65^{\circ} 24^{\prime} \mathrm{N}, 145^{\circ} 58^{\prime} \mathrm{W}$; (map 104).

This pass is on the divide between the Tanana and Yukon River drainage areas. It was named early by prospectors because of its distance from a group of mining claims on Birch Creek (Henning, 1965, p. 206). The name was published in 1952 by USGS.

Twenty Fathom Bank: shoal, extends NE $2 \mathrm{mi}$. from $\mathrm{E}$ coast of Prince of Wales I., $4.5 \mathrm{mi}$. SE of Patterson I., Alex. Arch.; $55^{\circ} 20^{\prime} 30^{\prime \prime} \mathrm{N}$, $132^{\circ} 07^{\prime} 00^{\prime \prime} \mathrm{W}$; (map 4).

Descriptive name given in 1895 by USC\&GS.

Twentyfive Mile Creek: stream, flows W $4.5 \mathrm{mi}$. to Salcha River, $30 \mathrm{mi}$. NW of Big Delta, Yukon-Tanana High.; $64^{\circ} 32^{\prime} \mathrm{N}, 146^{\circ} 17^{\prime} \mathrm{W}$; (map 101).

Local name published in 1951 by USGS. So named because its mouth is approximately 25 miles upstream from the junc. of the Salcha and Tanana Rivers.

Twentyfive Mile Lake: lake, 1,300 ft. across, 3 mi. NE of Kroto Lake and $18 \mathrm{mi}$. NW of Talkeetna, Alaska Ra.; $62^{\circ} 28^{\prime} 45^{\prime \prime} \mathrm{N}, 150^{\circ}$ $35^{\prime} 10^{\prime \prime} \mathrm{W}$; (map 81)

Local descriptive name reported in 1958 by USGS.

Twenty-five Pup: stream, flows NW $1 \mathrm{mi}$. to Deadwood Creek, $11 \mathrm{mi}$. SSW of Central and $37 \mathrm{mi}$. SW of Circle, Yukon-Tanana High.; $65^{\circ} 26^{\prime} 10^{\prime \prime} \mathrm{N}, 144^{\circ} 58^{\prime} 00^{\prime \prime} \mathrm{W}$; (map 104).

Named by prospectors and reported in 1952 by W. S. West and J. J. Matzko, USGS.

Twentyfour Mile Creek: stream, flows NE $16 \mathrm{mi}$. to Hadweenzic River, $25 \mathrm{mi}$. NE of Beaver; Yukon Flats; $66^{\circ} 41^{\prime} 30^{\prime \prime} \mathrm{N}, 147^{\circ} 04^{\prime} 00^{\prime \prime} \mathrm{W}$; (map 118).

Local name obtained in 1956 by USGS; name derived from the distance to Beaver via a year-round trail.

Twentyfour Mile Slough: stream, anabranch of Tanana River, flows NE $3 \mathrm{mi}$., $21 \mathrm{mi}$. $\mathrm{N}$ of Nenana, Tanana Low.; $64^{\circ} 51^{\prime} \mathrm{N}, 1^{\circ} 9^{\circ} 07^{\prime} \mathrm{W}$; (map 100).

So named because the mouth of the slough is 24 miles from Nenana, following the meanders of the Tanana River. Name published on recent USGS maps.

Twentymile Creek: stream, flows S $12 \mathrm{mi}$. to Kroto Creek, $18 \mathrm{mi}$. SW of Talkeetna, Cook Inlet Low.; $62^{\circ} 15^{\prime} 05^{\prime \prime} \mathrm{N}, 150^{\circ} 39^{\prime} 10^{\prime \prime} \mathrm{W}$; (map 81).

Local descriptive name reported in 1958 by USGS.
Twentymile Creek: stream, flows SE $19 \mathrm{mi}$. to Yukon River, $12 \mathrm{mi}$. NE of Rampart, KokrinesHodzana High.; $65^{\circ} 38^{\prime} 20^{\prime \prime}$ N, . $149^{\circ} 55^{\prime} 50^{\prime \prime}$ W; (map 105).

So named by prospectors "because the mouth of the stream is twenty miles upstream along the Yukon River from Rampart." The name is shown in 1902 on a map by Lt. Hjalmer Erickson, USA, and W. Yanert.

Twentymile Glacier: glacier, in $\mathrm{SE}$ end of Chugach Mts., trends SW $9 \mathrm{mi}$. to head of Glacier River, $12 \mathrm{mi}$. NW of Whittier, Chugach Mts.; $60^{\circ} 56^{\prime} \mathrm{N}, 148^{\circ} 48^{\prime} \mathrm{W}$; (map 63).

Local name reported on recent USGS maps; derived from nearby Twentymile River.

Twentymile Lake: lake, $1.5 \mathrm{mi}$. long, $1.2 \mathrm{mi}$. W of Christian River and $18 \mathrm{mi}$. NW of Fort Yukon, Yukon Flats; $66^{\circ} 48^{\prime} 30^{\prime \prime} \mathrm{N}, 145^{\circ} 34^{\prime}$. $00^{\prime \prime} \mathrm{W}$; (map 119).

Local name obtained in 1956 by USGS; so called because the lake is approximately 20 miles from Fort Yukon by way of the winter trail.

Twentymile River: stream, heads in W end of Chugach Mts., flows SW $17 \mathrm{mi}$. to head of Turnagain Arm, $16 \mathrm{mi}$. SE of Sunrise, Chugach Mts.; $60^{\circ} 50^{\prime \prime} 45^{\prime \prime} \mathrm{N}, 148^{\circ} 59^{\prime} 30^{\prime \prime} \mathrm{W}$; (map $63)$. Var. Twenty Mile River, 20 Mile River.

Local name reported in 1898 by Capt. Glenn (Glenn and Abercrombie, 1899, map), USA.

Twentymile River Station: locality, on The Alaska Railroad on E end of Turnagain Arm, $15 \mathrm{mi}$. SE of Sunrise, Chugach Mts.; $60^{\circ} 50^{\prime}$ $15^{\prime \prime} \mathrm{N}, 148^{\circ} 58^{\prime} 45^{\prime \prime} \mathrm{W}$; (map 63).

This railroad station or stop was reported by Grant and Higgins (1913, pl. 1), USGS ; it has since been abandoned.

Twentymile Slough: stream, anabranch of Yentna River, flows SE $13.6 \mathrm{mi}$., $50 \mathrm{mi}$. NW of Anchorage, Cook Inlet Low.; 61 $41^{\circ} 40^{\prime \prime} \mathrm{N}$, $150^{\circ} 47^{\prime} 15^{\prime \prime} \mathrm{W}$; (map 70).

Local name reported in 1954 by USGS.

Twentynine Mile Ridge: ridge, trends NE-SW $10 \mathrm{mi}$. between Thirtytwo Mile and Twentyfour Mile Creeks, $20 \mathrm{mi}$. $N$ of Beaver, Kokrines-Hodzana High.; $66^{\circ} 40^{\prime} \mathrm{N}, 147^{\circ} 26^{\prime} \mathrm{W}$; (map 118).

Local name published in 1951 by USGS; "so named because the ridge is approximately 29 miles up the Hadweenzic River from the Yukon River."

Twentyseven Mile Glacier: glacier, heads $2 \mathrm{mi}$. S of Girls Mtn., trends SE $1.2 \mathrm{mi}$. to its terminus, $1.5 \mathrm{mi}$. NW of Thompson Pass and 17 mi. E of Valdez, Chugach Mts.; $61^{\circ} 08^{\prime} 45^{\prime \prime}$ $\mathrm{N}, 145^{\circ} 45^{\prime} 15^{\prime \prime} \mathrm{W}$; BGN 1965; (map 68).

Named in 1960 by H. W. Coulter, USGS, "because the glacier is about twentyseven miles up the Richardson Highway from Valdez."

Twentysixmile Creek: stream, on $\mathrm{E}$ bank of Yukon River, about $17 \mathrm{mi}$. SE of Circle, Porcupine Plat.; $65^{\circ} 35^{\prime} \mathrm{N}, 143^{\circ} 55^{\prime} \mathrm{W}$; (map 103).

Name published in 1925 by ARC; this feature has not been positively identified.

Twenty-six Pup: stream, flows NW $2 \mathrm{mi}$. to Deadwood Creek, $6.8 \mathrm{mi}$. W of Circle Hot 
Springs and $30 \mathrm{mi}$. SW of Circle, YukonTanana High.; $65^{\circ} 29^{\prime} 40^{\prime \prime} \mathrm{N}, 144^{\circ} 52^{\prime} 10^{\prime \prime} \mathrm{W}$; (map 104).

Prospectors' name reported in 1954 or 1955 by USGS topographers.

Twentythree Mile Slough: stream, anabranch flows NW $8 \mathrm{mi}$. to Tanana River, $23 \mathrm{mi}$. SE of Fairbanks, 'Tanana Low.; $64^{\circ} 41^{\prime} \mathrm{N}, 147^{\circ} 16^{\prime}$ W; (map 100).

So called because it is 23 miles southeast of Fairbanks; published on recent maps.

Twentytwo Gulch: ravine, in Kantishna Hills, extends $\mathrm{N} 1.5 \mathrm{mi}$. to Glacier Creek, $5.5 \mathrm{mi}$. N

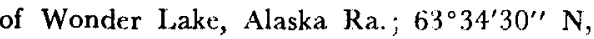
15053'00" W; BCN 1932; (map 38).

Prospectors' name referring to "Claim No. 22"; reported in 1932 by F. G. Wells and S. C. Kain, USGS.

Twentytwo Mile Slough: stream, anabranch of Yukon River, flows NW $4.3 \mathrm{mi}, 44 \mathrm{mi}$. SE of Fort Yukon, Yukon Flats; $66^{\circ} 03^{\prime} 30^{\prime \prime} \mathrm{N}$, $144^{\circ} 17^{\prime} 40^{\prime \prime} \mathrm{W} ;(\operatorname{map} 119)$

Local name obtained in 1956 by USCS; so called because it is 32 miles downstream from Circle.

Twentytwo Mile Village: locality, on an island in Yukon River, $46 \mathrm{mi}$. SE of Fort Yukon, Yukon Flats; $66^{\circ} 02^{\prime} 20^{\prime \prime} \mathrm{N}, 144^{\circ} 16^{\prime}\left(00^{\prime \prime} \mathrm{W}\right.$ (map 119).

Local name of a camp derived from Twentytwo Mile Slough; name obtained in 1956 by USGS.

Twenty-two Pup: stream, flows E $1.4 \mathrm{mi}$, to Deadwood Creek, $6.9 \mathrm{mi}$. W of Circle Hot Springs and $33 \mathrm{mi}$. SW of Circle, YukonTanana High.; $65^{\circ} 29^{\prime} 30^{\prime \prime} \mathrm{N}, 144^{\circ} 53^{\prime} 00^{\prime \prime} \mathrm{W}$; (map 104).

Prospectors' name reported in 1954 or 1955 by USGS topographers.

Twilight Creek: stream, flows NE $1.5 \mathrm{mi}$. to Trail Creek, $10 \mathrm{mi}$. E of Long and $26 \mathrm{mi}$. SE of Ruby, Kilbuck-Kuskokwim Mts. ; 64 $23^{\circ} 50^{\prime \prime}$ $\mathrm{N}, 155^{\circ} 10^{\prime} 15^{\prime \prime} \mathrm{W}$; (map 98$)$.

Prospectors' name reported in 1913 by Eakin (1914, pl. 3), USGS. The stream's identity is in doubt.

Twilight Creek: stream, in Ray Mts., W of Mount Tozi, flows SE $9.5 \mathrm{mi}$. to Tozitna River, $44 \mathrm{mi}$. NE of Tanana, Kokrines-Hodzana High.; $65^{\circ} 35^{\prime} 30^{\prime \prime} \mathrm{N}, 150^{\circ} 56^{\prime} 30^{\prime \prime} \mathrm{W}$; (map 106).

So named in 1956 by Orth, because, from the ridge above, the deep stream valley appeared to be in twilight, owing to the low sun.

Twin Bay: bay, see Driftwood Bay.

Twin Bay: bay, see Skan Bay.

Twin Bays: bay, $0.6 \mathrm{mi}$. across, on SE coast of Tanaga I., Aleutian Is.; $51^{\circ} 52^{\prime} 10^{\prime \prime} \mathrm{N}, 177^{\circ}$ 53'30' W; (map 17).

Descriptive name published in 1951 on a USGS map.

Twin Bluffs: bluffs, on $\mathrm{E}$ side of Nanushuk River, $8 \mathrm{mi}$. NE of Rooftop Ridge and $64 \mathrm{mi}$. NE of Anaktuvuk Pass, Arctic Slope; $69^{\circ} 00^{\prime}$ N, 150 45' W; (map 134).

Descriptive name given by USGS geologists during the exploration of Naval Petroleum Reserve No. 4 ; name given in 1944
Twin Butte Mountain: buttes, see Twin Buttes.

Twin Buttes: mountain, 1,982 ft., $28 \mathrm{mi}$. $\mathrm{S}$ of Flat and $33 \mathrm{mi}$. NW of Sleetmute, KilbuckKuskokwim Mts. ; $62^{\circ} 03^{\prime} \mathrm{N}, 157^{\circ} 52^{\prime} \mathrm{W}$; (map 79).

Local name reported in 1933 by J. B. Mertie, USGS.

Twin Buttes: buttes, 1,368 ft., extend NE-SW $2.4 \mathrm{mi}$., $8 \mathrm{mi}$. NW of Poorman and $44 \mathrm{mi}$. SW of Ruby, Kilbuck-Kuskokwim Mts. ; $64^{\circ} 08^{\prime} \mathrm{N}$, $155^{\circ} 48^{\prime}$ W; (map 98). Var. 'Twin Butte Mountain.

Prospectors' name reported in 1911 by A. (9. Maddren (in Brooks and others, 1912, p 294... 296), USGS.

Twin Buttes: mountain, $3,025 \mathrm{ft} ., 30 \mathrm{mi}$. NW of Chena Hot Springs and $35 \mathrm{mi}$. NE of Farr. banks, Yukon. Tanana High, $65^{\prime \prime} 10^{\prime} \mathrm{N}, 146^{\circ}$ $58^{\prime}$ W; (map 104).

Descriptive name given by prospectors; reported in 1903 by 13SGS (Prindle, 1905, pl. 13 ).

Twincairn Cone: hill, $1,8 \% 8 \mathrm{ft} ., 2 \mathrm{mi}$. NW of Asses Ears $M$ tn and $12 \mathrm{mi}$. NW of Imuruk liake, Seward Penin. High. $65^{\circ} 47^{\prime} N, 163^{\circ} 19^{\prime}$ W; BGN 1952; (map 110)

Reported in 1950) by D. M. Hopkins, USGS, so named because at "the summit of the cone there are two large cairns built by Eskimos before white men entered the country. The carns are a conspicuous landmark from four miles away in any direction."

Twin Calderas: craters, two, $0.2 \mathrm{mi}$. across, 1 mi $N$ of $W$ end of Kuzitrin Lake and $12 \mathrm{mi}$. $\mathrm{S}$ of Imuruk Lake, Seward Penin. High., $65^{\circ}$ $25^{\prime} \mathrm{N}, 163^{\prime \prime} 16^{\prime} \mathrm{W}$; BGN 1952; (map 110).

Reported in 1950 by D. M. Hopkins, USGS; descriptive name applied by a USGS field party about 1948

Twin Creek: stream, formed by Big and Little Boulder Creeks, flows E $3.5 \mathrm{mj}$ to Mills Creek, $44 \mathrm{mi}$. W of 'Talkeetna, Alaska Ra.; $62^{\circ} 20^{\prime} 05^{\prime \prime}$ N, $151^{\circ} 28^{\prime} 00^{\prime \prime} \mathrm{W}$; $(\operatorname{map} 81)$.

Prospectors' name reported in 1906 by R. W. Porter, USGS.

Twin Creek: stream, flows S $3 \mathrm{mi}$. to Fortymile River, $37 \mathrm{mi}$. S of Eagle, Yukon-Tanana High.; $64^{\circ} 01^{\prime} \mathrm{N}, 141^{\circ} 16^{\prime} \mathrm{W}$; (map 102).

Prospectors' name obtained in 1898 by $\mathrm{E}$. C. Barnard, USGS.

Twin Creek: stream, flows SW $2.5 \mathrm{mi}$. to Pedro Creek, $13 \mathrm{mi}$. NE of Fairbanks, YukonTanana High.; $65^{\prime \prime} 00^{\prime} 47^{\prime \prime} \mathrm{N}, 147^{\circ} 28^{\prime} 30^{\prime \prime} \mathrm{W}$; (map 105).

Named by prospectors, reported in 1903 by T. G. Gerdine, (Prindle, 1905, pl. 13), USGS.

Twin Creek: stream, flows E $4.5 \mathrm{mi}$. to Tatalina River, $34 \mathrm{mi}$, NW of Fairbanks, YukonTanana High.; $65^{\circ} 12^{\prime} 45^{\prime \prime} \mathrm{N}, 148^{\circ} 28^{\prime} 50^{\prime \prime} \mathrm{W}$; (map 105).

Local name published by USGS in the 1950 's.

Twin Creek: styeam, sep Davidson Creek.

Twin Dewey Peaks: peaks, highest 5,645 ft. 0.4 mi. apart, $1.8 \mathrm{mi}$. E of Reid Falls and $3 \mathrm{mi}$. $\mathrm{NE}$ of Skagway, Coast Mts.; $59^{\circ} 28^{\prime} 15^{\prime \prime} \mathrm{N}$, $135^{\circ} 13^{\prime} 50^{\prime \prime} \mathrm{W}$; (map 45).
Local name obtained by USGS field personnel and published on Federal maps. since 1950.

Twin Falls Creek: stream, heads in 3 lakes, flows S 3 mi. to head of Sawmill Bay, $18 \mathrm{mi}$. SW of Valdez, Chugach Mts.; 61 $04^{\prime} 15^{\prime \prime} \mathrm{N}$, $146^{\circ} 47^{\prime} 10^{\prime \prime} \mathrm{W}$; (map 68).

Local name reported in 1911 by USGS

Twin Glacier: glacier, in Glacier Bay National Monument, heads $0.6 \mathrm{mi}$. S of Mount Merriam, trends E $1.2 \mathrm{mi}, 64 \mathrm{mi}$. NW of Hoonah, St. Elias Mts.; $58^{\circ} 53^{\prime} 35^{\prime \prime} \mathrm{N}, 136^{\circ} 23^{\prime} 50^{\prime \prime} \mathrm{W}$; (map 10). Var. Twin Glaciers.

Descriptive name given in 1890 by Reid $(1896, p .427)$. At that time there were two glaciers bere. Since then, one has disappeared and the larger has retredted northward lwin Glacier Camp: locality, ate Taku Lodge rwin Glacier Lake: iake, $34 \mathrm{~mm}$. across, at is terminus of West Twin Glacier, $0.4 \mathrm{mi}$ of Taku River and 25 mi. NE of luneau, coast Mts., 58 "31'4." N, $1333^{\circ} 53^{\prime} 000^{\prime \prime}$ w BGN 1929; (map 12) Var. Tummy Twin Lake.

Descriptive name given on 1929 by USPFS and shown as twin Lake in 1923 un IBC Sheets (1951 Atlas).

Twin Glacier Peak: mountain peak, 4,596 ft., 3 mi. $\mathrm{N}$ of 'Twin Glaciex' Lake, between East 'Twin Glacier and West Twin Glacier, $27 \mathrm{mi}$. $\mathrm{NE}$ of Juneau, Coast Mts.; $58^{\circ} 36^{\prime} 10^{\prime \prime} \mathrm{N}$, $133^{\circ} 56^{\prime 2} 20^{\prime \prime} \mathrm{W}$; BGN 1940; (map 12).

Descriptive name slerived from Twin Glacier Lake; published in 1960 on a UJSGS inap.

Twin Glaciers: glacier, see East 'Twin Glacier. Twin Glaciers: glacier, see Harvard Glacier. Twin Glaciers: glaczer, see Twin Glacier. Twin Glaciers: glacier, see West Twin Glacier Twin Glaciers: glacier, see Yale Glacier.

Twin Hills: mountains, $5,690 \mathrm{ft} ., 14 \mathrm{mi}$. $\mathrm{sW}$ of Lone Butte and $74 \mathrm{mi}$. W of Gulkana, Talkeetna Mts.; $62^{\circ} 23^{\prime} \mathrm{N}, 147^{\circ} 39^{\prime} \mathrm{W}$; (map 82)

Local descriptive name reported in 1931 by USGS.

Twin Island: island, $0.3 \mathrm{mi}$. across, $4.5 \mathrm{mi} . \mathrm{S}$ of Chichagof along $W$ coast of Chichagof $I_{\text {, }}$ Alex. Arch.; 57 $36^{\prime} 00^{\prime \prime} \mathrm{N}, 1^{\circ} 36^{\circ} 05^{\prime} 40^{\prime \prime} \mathrm{W}$; BGN 1908; (map 9).

Named in 1908 by USC\&GS and published in 1909 on Chart 8280

Twin Island Creek: stream, flows NW $10 \mathrm{mi}$. to Iditarod River, $23 \mathrm{mi}$. N of Flat and 51 mi. E of Holkachuck, Kilbuck-Kuskokwim Mts.; $62^{\circ} 46^{\prime} 50^{\prime \prime}$ N, $157^{\circ} 56^{\prime} 40^{\prime \prime} \mathrm{W}$; (map 79).

Local name obtained in 1952 by USGS topographers.

Twin Island Lake: lake, $1.7 \mathrm{mi}$. long, $4.5 \mathrm{mi}$. $\mathrm{N}$ of Neck Lake, on Prince of Wales 1., Alex Arch.; $56^{\circ} 09^{\prime} 45^{\prime \prime}$ N, $133^{\circ} 13^{\prime} 00^{\prime \prime} \mathrm{W}$, (map 6).

Local descriptive name reported in 1949 by USGS.

Twin Island Lake: lake, $1.2 \mathrm{mi}$. long, in Elmendorf Moraine, $7 \mathrm{mi}$. NW of Anchorage, Cook Inlet Low ; $61^{\circ} 19^{\prime} 00^{\prime \prime} \mathrm{N}, 150^{\circ} 00^{\prime} 45^{\prime \prime} \mathrm{W}$; $(\operatorname{map} 70)$

Local descriptive name reported in 1958 by USGS. 
Twin Island Lake: lake, $3 \mathrm{mi}$. long, $30 \mathrm{mi}$. SW of Fort Yukon, Yukon Flats; $66^{\circ} 12^{\prime} \mathrm{N}, 145^{\circ}$ 48' W; (map 119).

Local name obtained in 1956 by USGS; named for the two islands in the lake.

Twin Islands: islands, two, larger of which is 0.2 mi. long, in Revillagigedo Channel at its junc. with Behm Canal and Felice Strait, $1.8 \mathrm{mi}$. N of Mary I., Alex. Arch.; 55 $08^{\prime}$ N, $131^{\circ} 28^{\prime}$ W; (map 3). Var. The Sisters.

Named in 1880 by W. E. George, a local pilot; called "The Sisters" on USC\&GS Chart 710 published in 1885 .

Twin Islands: islands, two, Favorita and Princesa Is., Maurelle Is., Alex. Arch.; 55 $39^{\prime} 30^{\prime \prime} \mathrm{N}$, $133^{\circ} 40^{\prime} 30^{\prime \prime} \mathrm{W}$; (map 4). Var. Swift Islands. Descriptive name given in 1917 by USC\&GS.

Twin Islands: islands, two, extend $0.2 \mathrm{mi}$., in El Capitan Passage, between El Capitan and Orr Is., Alex. Arch. ; 55 $55^{\prime} 00^{\prime \prime} \mathrm{N}, 133^{\circ} 21^{\prime} 25^{\prime \prime} \mathrm{W}$; (map 4).

Local descripitive name published in the 1925 Coast Pilot (p. 154).

Twin Islands: islands, on $\mathrm{W}$ shore of Dora Passage, $1 \mathrm{mi}$. E of Harris Penin., $36 \mathrm{mi}$. SW of Seward, Chugach Mts.; $59^{\circ} 40^{\prime}$ N, $149^{\circ} 43^{\prime}$ W; BGN 1911; (map 49).

Descriptive name given in 1909 by U. S. Grant, USGS.

Twin Islands: islands, see Sister Islands.

Twin Islet: rocks, between Holiday and Near Is., $0.7 \mathrm{mi}$. $\mathrm{E}$ of Kodiak, Kodiak I. ; $57^{\circ} 47^{\prime} 15^{\prime \prime}$ N, $152^{\circ} 23^{\prime} 05^{\prime \prime}$ W; (map 34). Var. Dvoinoi, Ostrova Dvoynoy.

Translation by Baker (1906, p. 644) of the name "Os[trova] Dvoynoy" published by Sarichev (1826, map 16). This feature is not named on current sources.

Twin Lake: lake, see Twin Glacier Lake.

Twin Lake Creek: stream, heads in a lake, flows SE $2 \mathrm{mi}$. to Greyling Creek, $3 \mathrm{mi}$. W of Tonsina Lake and $36 \mathrm{mi}$. NE of Valdez, Chugach Mts.; 61 $31^{\circ} 40^{\prime \prime} \mathrm{N}, 145^{\circ} 35^{\prime} 40^{\prime \prime} \mathrm{W}$; (map 68).

Local name published in the 1950 's by USGS.

Twin Lakes: lakes, two, each 1,300 ft. long, on Attu I., $3 \mathrm{mi}$. SW of Attu Mtn., Aleutian Is.; $52^{\circ} 52^{\prime} 30^{\prime \prime}$ N., $172^{\circ} 51^{\prime} 45^{\prime \prime}$ E ; (map 13).

Named by the U.S. Army during World War II ; published in 1948 by AMS.

Twin Lakes: lakes, $0.5 \mathrm{mi}$. long, on Narrow Cape, on $\mathrm{E}$ coast of Kodiak I.; $57^{\circ} 25^{\prime} 40^{\prime \prime} \mathrm{N}$. $152^{\circ} 20^{\prime} 40^{\prime \prime} \mathrm{W}$; (map 34$)$.

Local descriptive name reported in 1951 by USGS.

Twin Lakes: lakes, each $0.8 \mathrm{mi}$. long, on Kenai Penin., in Kenai Mts., W of Skilak Glacier, 43 mi. SE of Kenai, Chugach Mts.; $60^{\circ} 16^{\prime} 45^{\prime \prime}$ N, $150^{\circ} 09^{\prime} 30^{\prime \prime} \mathrm{W}$; (map 62).

Local descriptive name; reported in 1958 by USGS.

Twin Lakes: lakes, $12 \mathrm{mi}$. long, at head of Chilikadrotna River, $55 \mathrm{mi}$. NE of Nondalton, Alaska Ra.; 60³8' N, $153^{\circ} 55^{\prime}$ W ; (map 61).

Descriptive name reported by Capps (1935, pl. 2), USGS.
Twin Lakes: two lakes, one $2 \mathrm{mi}$. long, other 1.4 mi. long, NW of Heavenly Ridge and $59 \mathrm{mi}$. NW of Valdez, Copper River Basin; 61 '56'$30^{\prime \prime} \mathrm{N}, 146^{\circ} 48^{\prime} 00^{\prime \prime} \mathrm{W}$, (map 68).

Local name published in the 1950's by USGS.

Twin Lakes: lakes, at head of Moose Creek, 16 mi. NW of Glennallen, Copper River Basin; $62^{\circ} 13^{\prime} \mathrm{N}, 145^{\circ} 56^{\prime} \mathrm{W}$; (map 83).

Local name reported in 1898 by Capt. Glenn (in Glenn and Abercrombie, 1899, p. 63), USA.

Twin Lakes: lakes, $\mathrm{N}$ of Jack Lake, $13 \mathrm{mi}$. NW of Nabesna, Wrangell Mts.; 62 $32^{\prime} \mathrm{N}$, $143^{\circ} 16^{\prime} \mathrm{W}$; (map 84).

Local name reported in 1960 by USGS.

Twin Lakes: lakes, each $900 \mathrm{ft}$. long, $9 \mathrm{mi}$. SE of Dickey Lake, $23 \mathrm{mi}$. SW of Paxson, Alaska Ra. ; $62^{\circ} 48^{\prime} \mathrm{N}, 146^{\circ} 01^{\prime} \mathrm{W}$; (map 83).

Local name reported by USGS in 1951 .

Twin Lakes: lakes, two, largest $0.4 \mathrm{mi}$. across between Elk Creek and Nome River, $7 \mathrm{mi}$. $\mathrm{NE}$ of Nome, Seward Penin. High.; $64^{\circ} 35^{\prime} \mathrm{N}$, $165^{\circ} 15^{\prime} \mathrm{W}$; (map 94).

Local name reported on the 1903 Campion Mining and Trading. Co. map by George $M$. Ashford.

Twin Lakes: lakes, at head of Twin Lakes Creek, $2 \mathrm{mi}$. NW of Stevens Village, Yukon Flats $66^{\circ} 02^{\prime} 20^{\prime \prime} \mathrm{N}, 149^{\circ} 08^{\prime} 20^{\prime} \mathrm{W}$; (map 118).

Local descriptive name obtained in 1956 by USGS.

Twin Lakes: lake, $2.3 \mathrm{mi}$. long, $12 \mathrm{mi}$. S of Beaver, Yukon Flats; $66^{\circ} 11^{\prime} 15^{\prime \prime} \mathrm{N}, 147^{\circ} 30^{\prime}$ $00 " \mathrm{~W}$; (map 118).

Descriptive name obtained in 1956 by USGS; so called because the north and south halves of the lake are almost cut off by a peninsula.

Twin Lakes: lakes, between Pat and Meadow Creeks, $20 \mathrm{mi}$. NE of Stevens Village, Yukon Flats; $66^{\circ} 14^{\prime} \mathrm{N}, 148^{\circ} 39^{\prime} \mathrm{W}$; (map 118).

Local descriptive name obtained in 1956 by USGS.

Twin Lakes: lakes, two lakes, each $1 \mathrm{mi}$. long, in Hogatza Flats, $21 \mathrm{mi}$. NW of Hughes, Hogatza High.; $66^{\circ} 19^{\prime} 30^{\prime \prime} \mathrm{N}, 154^{\circ} 36^{\prime} 00^{\prime \prime} \mathrm{W}$; (map 116)

Local descriptive name; recorded at Hughes in 1956 by Orth.

Twin Lakes: lakes, 1.5 and $3.5 \mathrm{mi}$. long, respectively, at $\mathrm{N}$ end of South Fork Flats, $15 \mathrm{mi}$. W of Chandalar, Brooks Ra.; $67^{\circ} 30^{\prime} \mathrm{N}, 149^{\circ}$ 04' W; (map 123).

Local name reported in 1956 by T. E. Taylor, USGS.

Twin Lakes Creek: stream, ftows $\mathrm{S} 1 \mathrm{mi}$. to Yukon River, $1 \mathrm{mi}$. NW of Stevens Village, Yukon Flats; $66^{\circ} 01^{\prime} 15^{\prime \prime} \mathrm{N}, 1^{\circ} 9^{\circ} 07^{\prime} 30^{\prime \prime} \mathrm{W}$; (map 118).

Local descriptive name obtained in 1956 by USGS.

Twinlava Point: point of land, on SW coast of Umnak I., Aleutian Is.; $53^{\circ} 10^{\prime} 45^{\prime \prime} \mathrm{N}, 168^{\circ}$ 46'00" W; BGN 1940; (map 22). Var. Lavanak Point.
Named in 1939 by USC\&GS. This point was called "Lavanak," a coined name, in 1938 by a USC\&GS field party.

Twin Mountain: hill, $627 \mathrm{ft}$, , $22 \mathrm{mi}$. NE of Cape Mendenhall, near E coast of Nunivak I.; $60^{\circ}$ $02^{\prime} \mathrm{N}, 165^{\circ} 43^{\prime} \mathrm{W}$; (map 57). Var. Twin Mountains.

This is a breached volcanic crater which gives the appearance of two mountains. Name reported in 1912 by USC\&GS.

Twin Mountain: mountain, 2,630 ft., $2.5 \mathrm{mi}$. E of $S$ entrance of Tuxekan Passage, $W$ coast of Prince of Wales I., Alex. Arch.; $55^{\circ} 46^{\prime} \mathrm{N}$, $133^{\circ} 10^{\prime} \mathrm{W}$; (map 4).

Descriptive name given in 1903 or 1904 by E. F. Dickins, USCi\&GS, who wrotc "named by our party, has no local name."

Twin Mountain: mountain, 2,195 ft., $9 \mathrm{mi}$. N of Tooth Mtn. and $20 \mathrm{mi}$. N of Goodnews, Kilbuck-Kuskokwim Mts.; $59^{\circ} 23^{\prime} \mathrm{N}, 161^{\circ} 42^{\prime}$ W; (map 53).

Descriptive name given in 1914 by USC\&GS "because it has two peaks of similar elevation, Northeast Twin and Southwest Twin."

Twin Mountain: mountain, 3,595 ft., in Kuskokwim Mts., near head of Innoko River, $9 \mathrm{mi}$. $E$ of Ophir and $24 \mathrm{mi}$. NW of McGrath, Kilbuck-Kuskokwim Mts.; $63^{\circ} 09^{\prime} \mathrm{N}, 156^{\circ} 14^{\prime} \mathrm{W}$; (map 90). Var. Twin Peaks.

Prospectors' name obtained in 1908 by Maddren (1910, pl. 1), USGS.

Twin Mountain: mountain, $1,140 \mathrm{ft}$., $W$ of Snake River, $11 \mathrm{mi}$. NW of Nome, Seward Penin. High., $64^{\circ} 40^{\prime} \mathrm{N}, 165^{\circ} 28^{\prime} \mathrm{W}$; (map 94).

Prospectors' name reported in 1904 by $\mathrm{T}$. G. Gerdine, USGS.

Twin Mountain: mountain, 5,784 ft, $25 \mathrm{mi}$. SW of junc. of Charley and Yukon Rivers, YukonTanana High.; $65^{\circ} 06^{\prime} \mathrm{N}, 143^{\circ} 28^{\prime} \mathrm{W}$; (map 103).

Prospectors' name reported in 1905 by $D$. C. Witherspoon, USGS. Probably so named because the mountain appears to have two peaks when seen from the north.

Twin Mountain: hill, see Ingri Butte.

Twin Mountain: hills, see Mulik Hills.

Twin Mountain Creek: stream, flows S $2 \mathrm{mi}$. to Canyon Creek which flows to Imuruk Basin, $17 \mathrm{mi}$. SE of Teller, Seward Penin. High.; $65^{\circ}$ $03^{\prime} \mathrm{N}, 166^{\circ} 05^{\prime} \mathrm{W}$; (map 111).

Prospectors' name reported on a map of Cape Nome goldfields by David Fox, Jr., dated 1901.

Twin Mountains: hill, see Twin Mountain.

Twin Mountains Creek: stream, heads W of Twin Mtn., flows SW 2 mi. to Boulder Creek. $11 \mathrm{mi}$. NW of Nome, Seward Penin. High. $64^{\circ} 39^{\prime} \mathrm{N}, 165^{\circ} 31^{\prime} \mathrm{W}$; (map 94).

Prospectors' name reported in 1900 by $E$ C. Barnard (in Brooks, 1901, pl. 17), USGS

Twin Peaks: mountain, 2,500 ft., two summits. at head of Waterfall Bay on W coast of Dall $I$., Alex. Arch.; 54 $56^{\circ} 25^{\prime \prime} \mathrm{N}, 133^{\circ} 02^{\prime} 00^{\prime \prime} \mathrm{W}$ : (map 1)

Local descriptive name published by USC\&GS in 1943. 
Twin Peaks: mountain, 3,090 ft., on Revillagigedo I., near mouth of George Inlet, $5 \mathrm{mi}$. $\mathrm{NE}$ of Ketchikan, Alex. Arch.; $55^{\circ} 22^{\prime} 10^{\prime \prime} \mathrm{N}$, $131^{\circ} 30^{\prime} 15^{\prime \prime} \mathrm{W}$; (map 3).

Local named reported in 1954 by USGS.

Twin Peaks: mountain, 1,494 ft., includes North and South Peaks, on W shore of Alitak Bay at $S$ end of Kodiak I.; $56^{\circ} 54^{\prime} 15^{\prime \prime} N$, $154^{\circ} 13^{\prime} 30^{\prime \prime}$ W; (map 32).

Descriptive name reported in 1900 by Lt. Comdr. J. F. Moser, USN.

Twin Peaks: mountains, $7,087 \mathrm{ft}$, $20 \mathrm{mi}$. ENE of Petersburg, Coast Mts. ; $56^{\circ} 56^{\prime} 40^{\prime \prime} \mathrm{N}, 132^{\circ}$ 25'45" W; (map 6).

Descriptive name given for charting purposes in 1943 by USC\&GS.

Twin Peaks: mountain, 1,478 ft, $5 \mathrm{mi}$. $\mathrm{N}$ of Narrow Cape, on $\mathbf{E}$ coast of Kodiak I. ; $57^{\circ}$ $30^{\prime} 20^{\prime \prime} \mathrm{N}, 152^{\circ} 09^{\prime} 30^{\prime \prime} \mathrm{W}$; (map 34$)$.

Local descriptive name reported in 1949 by USGS.

Twin Peaks: mountain, see Twin Mountain.

Twin Point: point of land, on NW coast of Kruzof I., 24 mi. NW of Sitka, Alex. Arch.; $57^{\circ} 16^{\prime} \mathrm{N}, 135^{\circ} 51^{\prime} \mathrm{W}$; (map 9).

Descriptive name given in 1897 by Lt. Comdr. E. K. Moore, USN. This is the more northern of two similar points.

Twin Point: point of land, on $\mathbf{E}$ coast of Glass Penin. on Admiralty I., 6 mi. N of Washburn Peak and $38 \mathrm{mi}$. SE of Juneau, Alex. Arch.; $57^{\circ} 54^{\prime} 45^{\prime \prime} \mathrm{N}, 133^{\circ} 59^{\prime} 30^{\prime \prime} \mathrm{W}$; (map 8).

Descriptive name given in 1889 by Lt. Comdr. H. B. Mansfield, USN; published in 1892 by USC\&GS.

Twin Rift: mountain, 3,502 ft., on Cleveland Penin., E of Lake McDonald, Alex. Arch.; $55^{\circ} 59^{\prime} \mathrm{N}, 131^{\circ} 48^{\prime} \mathrm{W}$; (map 3$)$.

Name published in 1910 by USC\&GS.

Twin Rocks: rocks, $0.7 \mathrm{mi}$. ESE of Harpoon Point on SE coast of Kiska I., Aleutian Is. $51^{\circ} 55^{\prime} 17^{\prime \prime} \mathrm{N}, 177^{\circ} 37^{\prime} 15^{\prime \prime}$ E; BGN 1937; (map 14).

Local name reported in 1906 by USC\&GS

Twin Rocks: rocks, awash at high tide, in St. Nicholas Channel, between Lulu and Noyes Is., Alex. Arch.; $55^{\circ} 28^{\prime} 30^{\prime \prime} \mathrm{N}, 133^{\circ} 36^{\prime} 30^{\prime \prime}$ W; $(\operatorname{map} 4)$.

Local descriptive name published in the 1925 Coast Pilot (p. 181).

Twin Rocks: rocks, $7 \mathrm{mi}$. SE of Mummy I., 10 mi. SW of Cordova, Chugach Mts. ; $60^{\circ} 27^{\prime} \mathrm{N}$, $145^{\circ} 57^{\prime} \mathrm{W}$; (map 64).

Descriptive name published in 1943 by USC\&GS.

Twins: islands, three, $10 \mathrm{mi}$. E of Nagai I., in Shumagin Is., Aleutian Ra.; $54^{\circ} 57^{\prime} 30^{\prime \prime} \mathrm{N}$, $159^{\circ} 52^{\prime} 00^{\prime \prime} \mathrm{W}$; (map 26).

Local name reported in 1872 by W. $\mathrm{H}$ Dall, USC\&GS.

Twins: rocks, see Hanin Rocks.

Twins, The: islands, $1 \mathrm{mi}$. across, in Galankin Is., $1.2 \mathrm{mi}$. S of Sitka, on $\mathrm{W}$ coast of Baranof 1., Alex. Arch.; $57^{\circ} 02^{\prime} 30^{\prime \prime} \mathrm{N}, 135^{\circ} 18^{\prime} 45^{\prime \prime} \mathrm{W}$; (map 9). Var. Dvoini Bratev, Entrance Island.

USC\&GS derived the name "Twins" about 1882 from translation of part of "Dvoini
Bratev," meaning "twin brothers"; published by Lt. Sarichev (1826, map 19), IRN; given in 1809 by the navigator Ivan Vasiliev the first.

Twins, The: islands, in Stephens Passage, $3 \mathrm{mi}$. W of Hobart Bay and $73 \mathrm{mi}$. NE of Sitka, Coast Mts.; $57^{\circ} 25^{\prime} 30^{\prime \prime} \mathrm{N}, 133^{\circ} 32^{\prime} 15^{\prime \prime} \mathrm{W}$; (map 8).

Descriptive name given in 1869 by Comdr. R. W. Meade, (USC\&GS, 1883, p. 129), USN. Twins, The: islands, on S edge of Walrus Is., $3 \mathrm{mi}$. SW of Crooked I. and $20 \mathrm{mi}$. E of Hagemeister I., Kilbuck-Kuskokwim Mts.; $58^{\circ} 35^{\prime} 30^{\prime \prime} \mathrm{N}, 160^{\circ} 18^{\prime} 30^{\prime \prime} \mathrm{W}$; (map 39).

These two islands were collectively named in 1890 by officers of the USBF steamer Albatross.

Twins, The: mountains, two, 3,200 ft., on $\mathrm{S}$ side of Alaska Penin., $7.5 \mathrm{mi}$. NW of Cape Kunmik, Aleutian Ra.; $56^{\circ} 52^{\prime}$ N, $157^{\circ} 16^{\prime} \mathrm{W}$; (map 31).

Named by prospectors; reported in 1923 by R. H. Sargent, USGS, and published in 1924 on a USGS map.

Twin Sisters: ridge, 2,000 ft., extends SW $5 \mathrm{mi}$. from junc. of Goldrun Creek and Pitka Fork, $45 \mathrm{mi}$. NW of Beaver, Kokrines-Hodzana High.; $66^{\circ} 48^{\prime} \mathrm{N}, 148^{\circ} 39^{\prime} \mathrm{W}$; (map 118).

Local descriptive name obtained in 1956 by USGS.

Twin Sisters Peak: mountain, 5,750 ft., $3 \mathrm{mi}$. $\mathbf{S}$ of junc. of Styx River and South Fork Kuskokwim River, $87 \mathrm{mi}$. NW of Tyonek, Alaska Ra.; $61^{\circ} 52^{\prime} 20^{\prime \prime} \mathrm{N}, 153^{\circ} 10^{\prime} 00^{\prime \prime} \mathrm{W}$; (map 71).

Local name reported in 1958 by USGS.

Twin Slough: stream, flows NW $12 \mathrm{mi}$. to Yukon River, NE of Ham I., 23 mi. NE of Ruby, Nowitna Low.; $64^{\circ} 54^{\prime} \mathrm{N}, 154^{\circ} 49^{\prime} \mathrm{W}$; (map 98 ).

Riverboat pilots' name shown on 1940 "Navigation Chart, Tanana Yukon-Rivers" of the River Boat Service, U.S. Dept. of Interior.

Twin Summit Ridge: ridge, with two peaks, 3,780 and $3,700 \mathrm{ft}$. high, extends $2 \mathrm{mi}$. NE from Gold Pass to Carlson Creek, $6 \mathrm{mi}$. E of Juneau, Coast Mts. ; $58^{\circ} 19^{\prime} \mathrm{N}, 134^{\circ} 15^{\prime} \mathrm{W}$; (map 11).

Local descriptive name reported by $D$. A. Brew and A. B. Ford, USGS, in 1965.

Twist Creek: stream, flows SE $1 \mathrm{mi}$. to Fitz Creek, at Iniskin, $28 \mathrm{mi}$. NE of Augustine I., Aleutian Ra.; $59^{\circ} 44^{\prime} 40^{\prime \prime} \mathrm{N}, 153^{\circ} 14^{\prime} 25^{\prime \prime} \mathrm{W}$; BGN 1962; (map 51).

Local name published by USGS in 1958.

Twistem Creek: stream, heads in De Long Mts., flows NE $4 \mathrm{mi}$. to Kiligwa River, $20 \mathrm{mi}$. $\mathrm{N}$ of Feniak Lake, Brooks Ra.; $68^{\circ} 33^{\prime} \mathrm{N}, 158^{\circ} 30^{\prime}$ W; BGN 1960; (map 132).

Named in 1950 by I. L. Tailleur, USCS, "for a game of chance played while resting on this stream."

Twister Creek: stream, heads in a lake, flows SW $2.5 \mathrm{mi}$. to Susitna River, $0.5 \mathrm{mi}$. S of Talkeetna, Cook Inlet Low.; $62^{\circ} 18^{\prime} 50^{\prime \prime} \mathrm{N}, 150^{\circ}$. $06^{\prime} 30^{\prime \prime} \mathrm{W}$; (map 81$)$.
Descriptive name given by surveyors and shown on a RR. location blueprint map compiled in 1915.

Twitter Creek: stream, on Kenai Penin., flows W $8 \mathrm{mi}$. to Anchor River, $6 \mathrm{mi}$. NW of Homer, Cook Inlet Low.; $59^{\circ} 43^{\prime} \mathrm{N}, 151^{\circ} 38^{\prime} \mathrm{W}$ (map $50)$.

Local name reported and published by USGS in the 1950's.

Two, Lake: lake, $2,000 \mathrm{ft}$. long, $\mathrm{SW}$ of Lake Four, $8 \mathrm{mi}$. S of Talkeetna, Cook Inlet Low.; $62^{\circ} 12^{\prime} 30^{\prime \prime} \mathrm{N}, 150^{\circ} 03^{\prime} 30^{\prime \prime} \mathrm{W}$ (map 81).

Local descriptive name reported in 1958 by USGS.

Two Arm Bay: bay, 3 mi. wide, on SE coast of Kenai Penin., $50 \mathrm{mi}$. E of Homer, Chugach Mts.; $59^{\circ} 36^{\prime} \mathrm{N}, 150^{\circ} 03^{\prime} \mathrm{W}$; (map 50).

Descriptive name reported by Grant and Higgins (1910, pl. 3), USGS, in 1909.

Two-bit Creek: stream, flows $\mathrm{S} 1 \mathrm{mi}$. to Half Dollar Creek, $2.5 \mathrm{mi}$. S of Ketchem Dome and $34 \mathrm{mi}$. SW of Circle, Yukon-Tanana High.; $65^{\circ} 25^{\prime} 30^{\prime \prime} \mathrm{N}, 144^{\circ} 47^{\prime} 00^{\prime \prime} \mathrm{W}$; (map 104). Var. Two Bit Gulch.

Named by prospectors and reported in 1910 by C. E. Ellsworth and G. L. Parker (in Brooks and others, 1911, p. 164), USGS, as "Two Bit Gulch."

Two-bit Gulch: ravine, trends $\mathrm{E}$ to Kougarok River, S of Course Gold Creek, $16 \mathrm{mi}$. SW of Midnight Mtn., Seward Penin. High.; $65^{\circ} 34^{\prime}$ $\mathrm{N}, 164^{\circ} 44^{\prime} \mathrm{W}$; (map 111).

Local name reported in 1907 by Henshaw and Covert (1908, p. 95), USGS. This feature cannot be precisely located on current maps.

Two Bit Gulch: stream, see Two-bit Creek.

Two By Four Creek: stream, in Nutzotin Mts., flows W $5 \mathrm{mi}$. to Sheep Creek $3.5 \mathrm{mi}$. SE of its junc. with Chisana River, Alaska Ra.; $62^{\circ} 14^{\prime} 30^{\prime \prime} \mathrm{N}, 141^{\circ} 45^{\prime} 00^{\prime \prime} \mathrm{W}$; (map 84).

Local name reported by USGS in 1960.

Twocone Point: point of land, $2 \mathrm{mi}$. NE of Cape Kuliuk, on NW coast of Kodiak I.; $57^{\circ} 50^{\prime} 00^{\prime \prime}$ $\mathrm{N}, 153^{\circ} 53^{\prime} 30^{\prime \prime} \mathrm{W} ; B G N$ 1930; (map 34).

Descriptive name given by USC\&GS in 1930 , "because of two prominent cones bac: of the point $* * *$.

Twocrack Island: island, $0.3 \mathrm{mi}$. across, $\mathrm{N}$ end of Maurelle Is., Alex. Arch.; 55 $42^{\prime} \mathrm{N}, 133^{\circ}$. 37' W; BGN 1908; (map 4).

Local descriptive name reported in 1907 by E. F. Dickins, USC\&GS.

Twoday Mountain: mountain, 4,460 ft., $11 \mathrm{mi}$. $\mathrm{S}$ of Wild Lake and $40 \mathrm{mi}$. W of Wiseman, Brooks Ra.; $67^{\circ} 18^{\prime} 15^{\prime \prime} \mathrm{N}, 151^{\circ} 35^{\prime} 00^{\prime \prime} \mathrm{W}$; BGN 1932; (map 124).

Local name in use since 1904; reported by Robert Marshall in 1932.

Two Echo Cliffs: cliffs, with two summits, 5,095 ft. and 5,000 ft., 1.7 mi. NW of Nugget Mtn. and $10 \mathrm{mi}$. $\mathrm{N}$ of Juneau, Coast Mts.; $58^{\circ} 26^{\prime}$. $45^{\prime \prime} \mathrm{N}, 134^{\circ} 23^{\prime} 30^{\prime \prime} \mathrm{W}$; (map 11)

Local name reported in 1965 by D. A. Brew and A. B. Ford, USGS.

Two Girl Lagoon: lagoon, see Aghnaghak Lagoon. 
Two Headed Cape: island, see Twoheaded Island.

Twoheaded Island: island, $3 \mathrm{mi}$. long, $7 \mathrm{mi}$. NE of Kaguyak, on coast of Kodiak I.; $56^{\circ} 54^{\prime} \mathrm{N}$, $153^{\circ} 35^{\prime}$ W; (map 33). Var. Double Headed Point, Nazikach Island, Nasikan Island, Nazikak Island, Nazikak Point, Two Headed Cape, Two-headed Point.

Descriptive name; first reported by Capt. Cook (1785, v. 2, p. 406), RN, as Twoheaded Point. It seems that he was not able to tell that this feature was not a part of the mainland as he said, "The North East extreme was lost in a haze, but the point to the South West, whose elevated summit terminated in two round hills, on that account was called two-headed Point * * *." The generic, island, was first used by Lt. Sarichev (1826, map 17), IRN, who published the native name as "Os[trov] Nasiktakh," i.e. "Nasiktakh I."

Two-headed Point: island, see Twoheaded Island.

Two Island Lake: lake, $0.7 \mathrm{mi}$. long, on Kenai Penin., $1.7 \mathrm{mi}$. $\mathrm{N}$ of Barabara Lake and 21 mi. W of Hope, Cook Inlet Low.; $60^{\circ} 53^{\prime} \mathrm{N}$, $150^{\circ} 16^{\prime} \mathrm{W}$; (map 62).

Local descriptive name; reported in 1958 by USGS.

Two Lakes: lake, $4.8 \mathrm{mi}$. long, in course of Necons River, $50 \mathrm{mi}$. $\mathrm{N}$ of Lake Clark and $87 \mathrm{mi}$. W of Tyonek, Alaska Ra.; $61^{\circ} 07^{\prime} 30^{\prime \prime}$ N, 153 $47^{\prime} 45^{\prime \prime}$ W; BGN 1930; (map 71$)$.

Descriptive name reported in 1928 , by $S$. R. Capps and Gerald FitzGerald, USGS, "as applied by prospectors and trappers who occasionally come to live in a cabin on the north side of these lakes."

Twomile Creek: stream, on S slope of Watson Peak, flows $1 \mathrm{mi}$. $\mathrm{S}$ to Gulf of Alaska, $1.2 \mathrm{mi}$. $\mathrm{E}$ of Cape Yakataga and $99 \mathrm{mi}$. NW of Yakutat, St. Elias Mts. ; $60^{\circ} 03^{\prime} 45^{\prime \prime} \mathrm{N}, 142^{\circ} 21^{\prime} 30^{\prime \prime}$ W; BGN 1945; (map 65).

Local descriptive name reported in 1945 by USGS; named because "the creek is two miles east of Cape Yakataga."

Twomile Creek: stream, flows NE $8 \mathrm{mi}$. to Innoko River, parallel to Fourmile Creek, 39 mi. N of Ophir and $55 \mathrm{mi}$. NW of McGrath, Innoko Low.; $63^{\circ} 41^{\prime} 45^{\prime \prime} \mathrm{N}, 156^{\circ} 22^{\prime} 40^{\prime \prime} \mathrm{W}$; (map 90).

Prospectors' name reported in 1913 by H. M. Eakin, USGS.

Twomile Island: island, $1.3 \mathrm{mi}$. across, largest of Rabbit Is., in Iliamna Lake, $6 \mathrm{mi}$. ESE of Iliamna, Aleutian Ra.; $59^{\circ} 44^{\prime} \mathrm{N}, 154^{\circ} 44^{\prime} \mathrm{W}$; (map 51).

Local name published in 1954 by USGS.

Twomile Lake: lake, $0.6 \mathrm{mi}$. across, $15 \mathrm{mi}$. SE of Minto, Tanana Low.; $64^{\circ} 44^{\prime} \mathrm{N}, 148^{\circ} 52^{\prime}$ W; (map 100).

Probably so named because the lake is approximately $2 \mathrm{mi}$. southwest of Dunbar, a station on The Alaska RR. The name appears on recent maps.

Two Moon Bay: bay, $2 \mathrm{mi}$. wide, on $\mathrm{S}$ shore of Port Fidalgo, $32 \mathrm{mi}$. NW of Cordova,
Chugach Mts.; $60^{\circ} 46^{\prime} \mathrm{N}, 146^{\circ} 34^{\prime} \mathrm{W} ; B G N$ 1910; (map 64). Var. Bowie Bay.

Local name reported in 1905 by U. S. Grant, USGS. The bay was originally called "Bowie Bay" in 1901 by H. P. Ritter, USC\&GS, for a member of his party, William Bowie.

Two Plate Creek: stream, heads at glacier and flows SE $2.8 \mathrm{mi}$. to Maclaren River, 0.7 mi. S of Maclaren Glacier terminus, $25 \mathrm{mi}$. SE of Mount Hayes, Alaska Ra.; 631 $16^{\prime} 20^{\prime \prime}$ $\mathrm{N}, 146^{\circ} 30^{\prime} 30^{\prime \prime} \mathrm{W}$; (map 86).

Name reported in 1952 by USGS.

Twoprong Mountain: mountain, 6,000 ft., 5 miles $\mathrm{N}$ of $\mathrm{Mt}$. Doonerak and $40 \mathrm{mi}$. $\mathrm{N}$ of Wiseman, Brooks Ra.; 67 $58^{\prime} 30^{\prime \prime}$ N, 150 $37^{\prime}$. 30" W; BGN 1932 ; (map 124).

Named in 1930 by Marshall (1956, p. 50) who wrote "Directly across Nakshakluk Creek rose the paired pinnacle of Twoprong mountain, each prong jutting straight up into the sky."

Two Spot Mountains: mountain, 1,223 ft., on W bank of Paradise Creek, $30 \mathrm{mi}$. NW of Holy Cross, Nulato Hills, $62^{\circ} 21^{\prime} \mathrm{N}, 160^{\circ} 39^{\prime}$ W; $(\operatorname{map} 78)$.

Named in 1916 by R. H. Sargent (in Harrington, 1918, pl. 1), USGS ; name suggested by "two patches of snow on its slopes."

Two Tree Island: island, $200 \mathrm{ft}$. long, $\mathrm{N}$ of Vank I., Alex. Arch.; $56^{\circ} 29^{\prime} 40^{\prime \prime}$ N, $132^{\circ} 38^{\prime}$ $00^{\prime \prime} \mathrm{W} ;(\operatorname{map} 6)$. Var. Two-tree Islet.

Descriptive made given in 1869 by Comdr. R. W. Meade, USN.

Two-tree Islet: island, see Two Tree Island.

Two White Men Creek: stream, see Middle Fork Fortymile River

Tya Inlet: estuary, see Taiya Inlet.

Tyee: locality, on Murder Cove, on $\mathrm{S}$ tip of Admiralty I., Alex. Arch.; $57^{\circ} 02^{\prime} 30^{\prime \prime} \mathrm{N}$, $134^{\circ} 3230^{\prime \prime} \mathrm{W}$; (map 9).

This is the former location of a cannery and fishing station. A post office by this name was established in 1907 and discontinued in 1953 (Ricks, 1965). In 1962 the facilities were in ruins.

Tyee, Mount: mountain, 4,716 ft., $3 \mathrm{mi}$. SE of head of Bradfield Canal, Coast Mts.; 56 $12^{\prime}$ $20^{\prime \prime} \mathrm{N}, 131^{\circ} 26^{\prime} 10^{\prime \prime} \mathrm{W}$; (map 7).

Named in 1886 by Lt. Comdr. A. S. Snow, USN. Baker (1906, p. 645) wrote, "Native word, meaning 'chief' or 'head man'."

Tyee Creek: stream, heads in Tyee Lake, flows NW 1 mi. to Hidden Creek, $S$ of mouth of Bradfield River at head of Bradfield Canal, Coast Mts.; $56^{\circ} 12^{\prime} 50^{\prime \prime} \mathrm{N}, 131^{\circ} 31^{\prime} 20^{\prime \prime} \mathrm{W}$ (map 7).

Local name derived from Mount Tyee; reported in 1923 by USFS.

Tyee Lake: lake, $2 \mathrm{mi}$. long, $2 \mathrm{mi}$. $\mathrm{S}$ of head of Bradfield Canal, Coast Mts.; $56^{\circ} 11^{\prime} 30^{\prime \prime} \mathrm{N}$, $131^{\circ} 28^{\prime} 30^{\prime \prime} \mathrm{W}$; (map 7$)$.

Local name derived from Mount Tyee; reported in 1923 by USFS.

Tyeen Glacier: glacier, in Glacier Bay National Monument, trends SE $1.5 \mathrm{mi}$. to its $1961 \mathrm{ter}$ minus, $1.8 \mathrm{mi}$. NW of Johns Hopkins Inlet and $2.4 \mathrm{mi}$. W of terminus of Toyatte Gla- cier, $80 \mathrm{mi}$. NW of Hoonah, St. Elias Mts.; $58^{\circ} 53^{\prime} \mathrm{N}, 137^{\circ} 08^{\prime} \mathrm{W}$; BGN 1937; (map 10).

Named in 1936 by W. O. Field and W. S. Cooper (in Cooper, 1937, fig. 17 and p. 62) for Tyeen, a Stickeen Indian, who was captain of John Muir's boat on his journey up "Sum Dum" or Holkham Bay in 1880 (Muir, 1915, p. 208-233).

Tyndall Cove: estuary, $2.6 \mathrm{mi}$. long in Glacier Bay National Monument, extends NW to Geikie Inlet, $50 \mathrm{mi}$. NW of Hoonah, St. Elias Mts.; $58^{\circ} 37^{\prime} 30^{\prime \prime} \mathrm{N}, 136^{\circ} 23^{\prime} 30^{\prime \prime} \mathrm{W}$; (map 10).

Local name reported in 1951 by USGS.

Tyndall Glacier: glacier, heads $5 \mathrm{mi}$. S of The Hump, trends SW $16 \mathrm{mi}$. to head of Icy Bay, $65 \mathrm{mi}$. NW of Yakutat, Chugach Mts.; $60^{\circ}$ $03^{\prime} 30^{\prime \prime} \mathrm{N}, 141^{\circ} 18^{\prime} 00^{\prime \prime} \mathrm{W}$; (map 65).

Named by members of the New York Times Expedition of 1886 for John Tyndall, 1820 93, British physicist and natural philosopher. In his early life he was a member of The Irish Ordinance Survey and English Survey. $\mathrm{He}$ received his $\mathrm{Ph}$. D. at the Univ. of Marburg in 1851 and in 1854 he was appointed professor of physics at the Royal Institution of London. $\mathrm{He}$ made frequent trips to Switzerland to study glaciers and glacial phenomena, especially the cause of the flow of glacier ice.

Tyone Creek: stream, flows SW $5 \mathrm{mi}$. to Keno Creek, $32 \mathrm{mi}$. NE of Goodnews, KilbuckKuskokwim Mts.; $59^{\circ} 33^{\prime} \mathrm{N}, 161^{\circ} 20^{\prime} \mathrm{W}$; (map 53).

Name published by G. L. Harrington (in Brooks and others, 1921, pl. 7), USGS.

Tyone Creek: stream, heads at $62^{\circ} 14^{\prime} \mathrm{N}$, $147^{\circ} 29^{\prime} \mathrm{W}$, flows NE $56 \mathrm{mi}$. to Tyone River, $60 \mathrm{mi}$. NW of Gulkana, Copper River Basin; $62^{\circ} 39^{\prime} 25^{\prime \prime} \mathrm{N}, 147^{\circ} 02^{\prime} 10^{\prime \prime} \mathrm{W}$; (map 82).

Local name reported in 1906 by Sidney Paige and Adolph Knopf (in Brooks and others, 1907, pI. 118), USGS. The name is an "Alaska jargon word for "chief'."

Tyonek: village, pop. 187, on NW shore of Cook Inlet, $43 \mathrm{mi}$. SW of Anchorage, Cook Inlet Low.; 61 ${ }^{\circ} 04^{\prime} 00^{\prime} \mathrm{N}, 151^{\circ} 08^{\prime} 20^{\prime \prime} \mathrm{W}$; (map 70). Var. Beluga, Moquawkie, Tiunok, Toyonok, Tu-i-u'nak, Tu-i-u'nŭk, Tyonick, Toyonok, Tyoonok, Tyunok.

Tanaina Indian village reported in 1880 as "Toyonok" by Ivan Petroff as consisting of "2 whites, 6 creoles, and 109 natives." This Indian name means "little chief" and the Eskimo name "Tu-j-u'nŭk" reportedly means "marsh people" (Hodge, 1907, p. 860). A post office named "Tyoonok" was established in 1896; renamed Tyonok in 1905, Beluga in 1909, Moquawkie in 1915, and Tyonek in 1933 (Ricks, 1965, p. 67). In 1890, the village had a population of $115 ; 50$ in 1920 136 in 1939; and 132 in 1950.

Tyonek Creek: stream, flows SE $15 \mathrm{mi}$. to Cook Inlet at North Foreland, 2 mi. SW of Tyonek, Cook Inlet Low.; 61 $02^{\prime} 30^{\prime \prime} \mathrm{N}, 151^{\circ} 11^{\prime} 30^{\prime \prime}$ W; BGN 1916; (map 70).

Local name reported in 1958 by USGS 
Tyonek Station: settlement, see Old Tyonek.

Tyonek Town: locality, see Tobona.

Tyone Lake: lake, $5.5 \mathrm{mi}$, long, $\mathrm{N}$ of Susitna Lake, at head of Tyone River, $43 \mathrm{mi}$. NW of Gulkana, Copper River Basin; $62^{\circ} 30^{\prime} \mathrm{N}, 146^{\circ}$ 45' W; (map 83).

Local name reported by F. $H$. Moffit (in Brooks and others, 1915 , p. 6), USGS.

Tyone River: stream, heads at Tyone Lake, flows NW $30 \mathrm{mi}$. to Susitna River, $7 \mathrm{mi}$. NE of Oshetna River and $68 \mathrm{mi}$. NW of Gulkana, Copper River Basin; 62 $42^{\prime} 20^{\prime \prime}$ N, 147 $12^{\prime}$ 45" W; (map 82). Var. Tyrone River.

Local name reported in 1906 by Sidney Paige and Adolph Knopf (in Brooks and others, 1907, p. 118), USGS. The name is an "Alaska jargon word for 'chief"."

Tyone Village: locality, on $\mathrm{N}$ shore of Tyone Lake, $46 \mathrm{mi}$. NW of Gulkana, Copper River Basin; $62^{\circ} 31^{\prime} \mathrm{N}, 146^{\circ} 43^{\prime} \mathrm{W}$; (map 83).

Local name reported in 1952 by USGS.

Tyonick: village, see Tyonek.

Tyonok: village, see Tyonek.

Tyons Bay: bay, see Redoubt Bay.

Tyoonok: village, see Tyonek.

Typhoon Peak: peak, 7,600 ft., in Storm Range, $1.5 \mathrm{mi}$. SE of Mount Ogilvie and $38 \mathrm{mi}$. N of Juneau, Coast Mts. ; 58 $50^{\prime} 47^{\prime} \mathrm{N}, 134^{\circ} 13^{\prime} 40^{\prime \prime}$ W; BGN 1965; (map 11).

Named in 1964 by members of the Juneau Icéfield Research Program.

Tyrena Creek: stream, flows NE 2 mi. to. Trout Creek, $3.4 \mathrm{mi}$. S of that stream's junc, with Yukon River and $25 \mathrm{mi}$. NW of Eagle, YukonTanana High.; $65^{\circ} 04^{\prime} 30^{\prime \prime} \mathrm{N}, 141^{\circ} 42^{\prime} 40^{\prime \prime} \mathrm{W}$; (map 103).

Prospectors' name from an unpublished map by E. J. Chamberlain, dated 1902.

Tyrone River: stream, see Tyone River.

Tyunok: village, see Tyonek.

Tyurpa, Ostrov: Island, see Tiurpa Island.

Tyya: locality, see Dyea.

Tyya Inlet: estuary, see Taiya Inlet.

Tzaharagamute: locality, see Tzahavak.

Tzahavagamut: locality, see Tzahavak.

Tzahavagamute: locality, see Tzahavak.

Tzahavak: locality, on $\mathbf{S}$ shore of Chagvan Bay, $20 \mathrm{mi}$. S of Goodnews Bay, Kilbuck-Kuskokwim Mts.; $58^{\circ} 45^{\prime} \mathrm{N}, 161^{\circ} 45^{\prime} \mathrm{W}$; (map 39). Var. Tzaharagamute, Tzahavagamut, Tzahavagamute.

Former Eskimo village or camp reported as "Tzahavagamute," population 48 , by Petroff (1881, p. 53).

Tzeldatnu: stream, see Soldotna Creek.

Tzuse Shoal: shoal, $0.4 \mathrm{mi}$. long, at $\mathrm{S}$ entrance to Yakutat Roads, $\mathrm{N}$ of Monti Bay and 1.4 mi. NW of Yakutat, Malaspina Coastal Plain; $59^{\circ} 33^{\prime} 40^{\prime \prime}$ N, $139^{\circ} 45^{\prime} 55^{\prime \prime}$ W; (map 46). Var. Southeast Shoal.

Local name published in 1959 by the USGS. It is called Southeast Shoal in the USC\&GS 1947 Alaska Coast Pilot (p. 79).

\section{U}

Ualik: locality, near head of Nushagak Penin., on $W$ shore of Kulukak Bay, $43 \mathrm{mi}$. W of village of Clarks Point, Kilbuck-Kuskokwim
Mts.; $58^{\circ} 55^{\prime} \mathrm{N}, 159^{\circ} 45^{\prime} \mathrm{W}$; (map 40). Var. Ooailik, Ooalligamut, Ooallikh.

Former Eskimo village or camp reported in 1880 as "Ooallikh," population 68, by Petroff (1884, p. 17).

Ualik Lake: lake, $8 \mathrm{mi}$. long, near head of Nushagak Penin., source of Kanik River, 35 mi. WNW of village of Clarks Point, KilbuckKuskokwim Mts.; $59^{\circ} 03^{\prime}$ N, $159^{\circ} 29^{\prime}$ W; (map 53). Var. Kulukak Lake, Kulyukak, Lake Ualik, Oallek Lake.

Eskimo name "Oallek" obtained in 1898 from Rev. Wood [cnna], missionary; published by Spurr (1900, map 10), USGS. Recorded as "Oz[ero] Kulyukak" by Capt. Tebenkov (1852, map 4), IRN.

Ubezhisheha, Ostrov: island, see Refuge Island. Ubezhitsha: island, see Refuge Island.

Ubi, Isla: island, see Ubi Island.

Ubi, Ysla: island, see Ubi Island.

Ubiennaya, Gavan: bay, see Massacre Bay.

Ubiennoi Bay: bay, see Temnac Bay.

Ubiennoi Bay: bay, see Massacre Bay.

Ubiennykh, Gavan: bay, sec Massacre Bay.

Ubi Island: island, $700 \mathrm{ft}$. long, in Bucareli Bay, on NW coast of Suemez I., W of Point Remedios, Alex. Arch.; 55 $19^{\prime} 40^{\prime \prime} \mathrm{N}, 133^{\circ} 26^{\prime} 25^{\prime \prime}$ W; (map 4). Var. Isla Obi, Isla Ubi, Ysla Ubi.

Spanish name given in 1775-79 by Don Juan de la Bodega y Quadra and Francisco Antonio Maurelle as "Isla Ubi," or "Ubi Island."

Ubiyenna Bay: bay, see Massacre Bay.

Ubiyenna Harbor: bay, see Massacre Bay.

Ubiyennaya, Gavan: bay, see Massacre Bay.

Ubiyennykh, Gavan: bay, see Massacre Bay.

Ublutuoch River: stream, heads in lake at $69^{\circ} 58^{\prime}$ $\mathrm{N}, 152^{\circ} 01^{\prime} \mathrm{W}$, flows $\mathrm{NE}$ and NW $55 \mathrm{mi}$. to Fish Creek, $5 \mathrm{mi}$. $S$ of Harrison Bay, Arctic Plain; $70^{\circ} 19^{\prime} 15^{\prime \prime} \mathrm{N}, 151^{\circ} 21^{\prime} 10^{\prime \prime} \mathrm{W}$; (map 149).

Eskimo name reported in 1951 by USC\&GS and reported to mean "fat fish."

Uchagmjut: locality, see Uchak.

Uchak: locality, "on right bank of Kuskokwim River." Var. Uchagmjut, Ugokhamiut.

Former Eskimo village or camp recorded as "Uchagmjut" by Holmberg (1855, map); and as "Ugokhamiut" in the 1890 Census (1893, p. 164).

Uchitak: locality, on SE shore of Norton Sound near Tolstoi Point, Nulato Hills; $63^{\circ} 37^{\prime} \mathrm{N}$, $161^{\circ} 00^{\prime}$ W; (map 91). Var. OutchitakMioute.

Former Eskimo village or camp published in 1850 as "Outchitak-Mioute" on Lt. L. A. Zagoskin's map. (Hodge 1910 p. 862).

Uchtumuch Bay: bay, see Temnac Bay.

Uchugrak Hills: hills, 1,863 ft., extend N-S 4 mi., $\mathbf{N}$ of Noatak River, $4 \mathrm{mi}$. W of Poktovik $\mathrm{Mts}$, and $18 \mathrm{mi}$. SW of Misheguk Mtn., Brooks Ra.; 68 $04^{\prime} \mathrm{N}, 161^{\circ} 35^{\prime} \mathrm{W}$; (map 131). Var. Chugruk Hills.

Descriptive Eskimo name meaning "old vulva," reported by USGS in 1956.

Ucomude: locality, on $\mathrm{N}$ shore of Kiliuda Bay, on SE coast of Kodiak Island; (map 34).
Aleut name reported in 1805 by Lisianski (1814, map facing p. 169). This name probably means "akom bay." Location unknown. Udagak Bay: cove, $0.6 \mathrm{mi}$. across, $2 \mathrm{mi}$. $\mathrm{SW}$ of Sedanka, at $\mathrm{E}$ end of Unalaska I., Aleutian Is.; $53^{\circ} 44^{\prime} 15^{\prime \prime} \mathrm{N}, 166^{\circ} 19^{\prime} 20^{\prime \prime} \mathrm{W}$; (map 23). Var. Ilmudichtchit, Ilmudikhchit.

Name derived from Udagak Strait and given by J. J. Gilbert, USC\&GS, commander of the Coast Survey Steamer Pathfinder during 1900-01. The name "Ilmudikhchit" was reported for this feature in 1790 by Lt. G. A. Sarichev, IRN.

Udagakh Strait: water passage, see Udagak Strait.

Udagak Strait: water passage, between Unalaska and Sedanka Is., Aleutian Is.; $53^{\circ} 44^{\prime} 20^{\prime \prime}$ N, $166^{\circ} 17^{\prime} 30^{\prime \prime} \mathrm{W}$; (map 23). Var. Idagak Strait, Oudagakh Strait, Spirkin Strait, Udagakh Strait.

Aleut name published by Lt. Sarichev (1826, map 14), IRN, as "Proliv Udagakh," or "Udagakh Strait." It was later called "Oudagakh" by Capt. Lutke (1836, p. 284), IRN, and then "Proliv Spirkin," or "Spirkin Strait," by Capt. Tebenkov (1852, map 26), IRN. According to R. H. Geoghegan, the name may have been taken from the Aleut word "idakuk" which means "leaves, passes away, emanates from."

Udak, Cape: point of land, on S coast of Umnak I., Aleutian Is. : $52^{\circ} 55^{\prime} \mathrm{N}, 168^{\circ} 46^{\prime} \mathrm{W}$; (map 21). Var. Mys Udakh.

Aleut name published by Capt. Tebenkov (1852, map 25), IRN, as "M[ys] Udakh," or "Cape Udakh," probably from the Aleut "udaq" which, according to R. H. Geoghegan, means "dried fish."

Udakh, Mys: point of land, see Udak, Cape.

Udakhta Harbor: anchorage, see Dutch Harbor.

Udamak Cove: cove, $0.6 \mathrm{mi}$. across, in Anderson Bay, part of Makushin Bay on $W$ coast of Unalaska I., Aleutian Is.; $53^{\circ} 38^{\prime} 20^{\prime \prime} \mathrm{N}$, $166^{\circ} 48^{\prime} 00^{\prime \prime} \mathrm{W}$; (map 23).

Aleut name reported in 1802 by Lt. G. A Sarichev, IRN, as "Udamak."

Udamat Bay: bay, $1.1 \mathrm{mi}$. across, in Beaver Inlet N central coast of Sedanka I., Aleutian Is. $53^{\circ} 48^{\prime} 30^{\prime \prime} \mathrm{N}, 166^{\circ} 13^{\prime} 30^{\prime \prime} \mathrm{W}$; (map 23). Var. Gull Bay.

Aleut name reported by Lt. Sarichev ( 1826 , map 14), IRN, as "Zal[iv] Udamat," or "Udamat Bay." This feature was called Gull Bay by USBF in 1888 .

Udrivik, Lake: lake, $1.8 \mathrm{mi}$. across, in Killik River valley, $19 \mathrm{mi}$. NE of Kurupa Lake, Brooks Ra.; $68^{\circ} 30^{\prime}$ N, $154^{\circ} 00^{\prime} \mathrm{W}$; (map 133). Var. Blank Lake.

Eskimo name reported in 1956 by T. E. Taylor, USGS. A 1924 fieldsheet by Gerald FitzGerald, USGS, shows "Blank Lake," a name probably given for Walter R. Blankenship, the expedition's camp hand.

Ufigag Creek: stream, see Ukfigag Creek.

Ugadachan Creek: stream, flows $\mathbf{S}$ into Ugadaga Bay on $\mathrm{N}$ side of Beaver Inlet, on Unalaska I., Aleutian Is.; $53^{\circ} 49^{\prime} 30^{\prime \prime} \mathrm{N}, 166^{\circ} 25^{\prime} 00^{\prime \prime}$ W; (map 23). 
Name derived from Ugadagan Bay (Ugadaga Bay) and reported by von Langsdorff (1813-14, v. 2, p. 29). It is not named on modern maps.

Ugagak: village, see Ugashik.

Ugagak River: stream, see Ugashik River.

Ugagik: village, see Egegik.

Ugagik River: stream, see Egegik River.

Ugaguk: village, see Egegik.

Ugaguk River: stream, see Egegik River.

Ugaguk River: stream, see Ugashik River.

Ugaiak: point of land, see Ugyak, Cape.

Ugainshak Island, island, see Ugaiushak Island.

Ugaiuscha Island: island, see Ugaiushak Island.

Ugaiuschak Island: island, see Ugaiushak Island.

Ugaiushak Island: island, $2 \mathrm{mi}$. long, $7 \mathrm{mi}$. S of Cape Kuyuyukak and $13 \mathrm{mi}$. E of Cape Kunmik, Aleutian Ra.; $56^{\circ} 47^{\prime} \mathrm{N}, 156^{\circ} 51^{\prime}$ W; (map 31). Var. Ile Agaiouchack, [Ostrov] Ugaiutak, Ugaiuscha Island, Ugaiuschak Island, Ugaiutak Island, Ugainshak Island, Ugajutchak Island, Ugaluschak Island.

Eskimo name published in 1827 as "I[le] Agaiouchack" by Adm. A. J. von Krusenstern (1827, map 20), IRN.

Ugaiutak, Ostrov: island, see Ugaiushak Island. Ugaiutak Island: island, see Ugaiushak Island. U-gai-yak, Cape: point of land, see Ugyak, Cape.

Ugajutchak Island: island, see Ugaiushak Island.

Ugak Bay: bay, extends NW $21 \mathrm{mi}$., off Gulf of Alaska, on E coast of Kodiak I.; $57^{\circ} 25^{\prime}$ N, $152^{\circ} 35^{\prime}$ W ; (map 34). Var. Dgak Bay, Igak Bay, Igakskie, Igatskai, Ihack Bay, Irak Bay, Oohack, Puerto de Roxas, Zaliv Igatskoy.

Native name given in 1805 by Lisianski (1814, p. 173) as "Bay of Ihack." Published as "Za[liv] Igatskoy," or "Igat Bay," by Sarichev (1826, map 3). Name possibly comes from the Aleut "qugaq" which, according to R. H. Geoghegan means "evil spirit." Wagner (1937, p. 492) says "According to Baker's dictionary [p. 646] *** Puerto de Roxas * * was a Spanish name for Ugak Bay * ** but I have never discovered it on any Spanish map in that locality."

Ugak Island: island, $3 \mathrm{mi}$. long, in Gulf of Alaska, at mouth of Ugak Bay, on E coast of Kodiak I. ; 57 $23^{\prime}$ N, $152^{\circ} 17^{\prime}$ W ; (map 34). Var. Dgak Island, Oohack Island.

Native name derived from Ugak Bay and published as "Oohäck island" by Lisianski (1814, p. 142). See Ugak Bay.

Ugak Island: island, $0.1 \mathrm{mi}$. across, in Chiniak Bay, $\mathrm{N}$ of Cape Chiniak, on $\mathrm{E}$ coast of Kodiak I.; $57^{\circ} 37^{\prime} 55^{\prime \prime} \mathrm{N}, 152^{\circ} 09^{\prime} 30^{\prime \prime} \mathrm{W}$; (map 34).

Native name reported by von Langsdorff (1814, p. 56).

Ugaklik River: stream, flows NW $35 \mathrm{mi}$. to Eek River, $47 \mathrm{mi}$. S of Bethel, Yukon-Kuskokwim Delta; 6007'30" N, 161 '38'15" W; (map 59).

Eskimo name reported in 1951 by USC\&GS.

Ugalak Creek: stream, flows NW $3.2 \mathrm{mi}$. around Guard Hill to Ogotoruk Creek, $9 \mathrm{mi}$. E of
Cape Thompson, Arctic Slope; 68 $09^{\prime} \mathrm{N}$, $165^{\circ} 38^{\prime}$ W; BGN 1963; (map 129). Var. Oogahluk Creek.

Eskimo name reported in 1962 by personnel of Project Chariot as "Oogahluk."

Ugalek Bay: bay, on coast of Sedanka I., off NE coast of Unalaska I., Aleutian Is.; (map 23).

Aleut name called "Zal[iv] Ugalek," or "Ugalek Bay," by Lt. Sarichev (1826, map 14), IRN, and published by Baker (1906, p. 647). The name does not appear on modern maps.

Ugalgal Island: island, see Egg Island.

Ugalgan Island: island, see Egg Island.

Ugalohan Island: island, see Egg Island.

Ugaluschak Island: island, see Ugaiushak Island.

Ugamak Bay: bay, 2 mi. across, on SE coast of Ugamak 1., Krenitzin Is., Aleutian Is.; $54^{\circ} 12^{\prime} 30^{\prime \prime} \mathrm{N}, 164^{\circ} 47^{\prime} 30^{\prime \prime} \mathrm{W}$; (map 24).

Named in 1901 for Ugamak Island by J. J. Gilbert, USC\&GS.

Ugamak Island: island, $5.2 \mathrm{mi}$. long, $36 \mathrm{mi}$. $\mathrm{E}$ of Akutan, easternmost of Krenitzin Is., Fox Is., Aleutian Is.; $54^{\circ} 12^{\prime} 30^{\prime \prime} \mathrm{N}, 164^{\circ} 50^{\prime} 00^{\prime \prime} \mathrm{W}$; (map 24). Var. Ooagalga, Ugamok Island, Ugomok Island, Ukamak Island.

Aleut name transcribed by Father Veniaminov $(1840$, v. 1, p. 202) as "O[strov] Ugamak," which, according to R. H. Geoghegan, may mean "ceremony island."

Ugamakskie: water passage, see Ugamak Strait.

Ugamak Strait: water passage, $3 \mathrm{mi}$. wide, between Ugamak and Kaligagan Is., in Krenitzin Is., Aleutian Is.; $54^{\circ} 11^{\prime} \mathrm{N}, 164^{\circ} 52^{\prime} \mathrm{W}$; (map 24). Var. Ugamakskie.

Aleut name transcribed by Father Veniaminov (1840, v. 1, p. 16) as "Ugamakskey," and probably is derived from the name of the island.

Ugamok: island, see Chirikof Island.

Ugamok Island: island, see Ugamak Island.

Uganik: locality, on $\mathrm{W}$ shore of Northeast Arm Uganik Bay, on N coast of Kodiak I.; $57^{\circ} 46^{\prime}$ N, $153^{\circ} 24^{\prime} \mathrm{W}$; (map 34). Var. Oohanick, Ooganak, Uganuk.

Eskimo village reported as "Oohanick" in 1805 by Lisianski (1814, map facing p. 169). The Tenth Census in 1880 lists "Ooganok," population 73 while the Eleventh Census in 1890 lists "Uganak," population 31.

Uganik, Cape: point of land, at NW tip of Uganik I., $\mathrm{N}$ coast of Kodiak I.; $57^{\circ} 58^{\prime} \mathrm{N}$, $153^{\circ} 30^{\prime}$ W; (map 34). Var. East Point, Mys Uganik.

Name derived from Uganik Island and published as "M[ys] Uganik," or "Cape Uganik," by Capt. Tebenkov (1852, map 23). Called East Point in 1897 by Lt. Comdr. J. F. Moser, USN, of USBF steamer Albatross.

Uganik Bay: bay, extends SE $11 \mathrm{mi}$, off Shelikof Strait, on N coast of Kodiak I.; $57^{\circ} 50^{\prime} \mathrm{N}$, $153^{\circ} 32^{\prime}$ W ; (map 34). Var. Ooganak Bay, Ooganok, Uganuk Bay.

Name derived from Uganik Island and published as "Ooganak Bay" by Petroff (1881, p. 29 ) in the 10 th Census in 1880.
Uganik Island: island, $16 \mathrm{mi}$. long, between Uganik and Vickoda Bays, on $\mathbf{N}$ coast of Kodiak I.; 57 $53^{\prime} \mathrm{N}, 153^{\circ} 20^{\prime} \mathrm{W}$; BGN 1931; (map 34). Var. Oohanick Island, Uganuk Island.

Native name reported in 1805 by Lisianski (1814, p. 169) as "Oohanick Island." Baker (1906, p. 647) wrote a transliteration of the Russian "O[strov] Uganik," or "Uganik Island," published by Capt. Tebenkov (1852, map 23). The USC\&GS erroneously transliterated Capt. Tebenkov's spelling as "Uganuk" and USBF did the same in 1888.

Uganik Lake: lake, $3.5 \mathrm{mi}$. long, in course of Uganik River, SE of East Arm Uganik Bay, on $\mathrm{N}$ coast of Kodiak I.; $57^{\circ} 40^{\prime} \mathrm{N}, 153^{\circ} 20^{\prime} \mathrm{W}$; (map 34).

Name derived from Uganik Island and published in 1952 by USGS.

Uganik Passage: water passage, $20 \mathrm{mi}$. long, between Uganik Bay and Uganik I., N coast of Kodiak I.; $57^{\circ} 51^{\prime} \mathrm{N}, 153^{\circ} 25^{\prime} \mathrm{W}$; BGN 1909; (map 34).

Name derived from Uganik Island and given in 1909 by Capt. W. C. Hodgkins, USC\&GS.

Uganik River: stream, heads in lake, flows NW through Uganik Lake $24 \mathrm{mi}$. to East Arm Uganik Bay, on N coast of Kodiak I.; $57^{\circ} 41^{\prime}$. $30^{\prime \prime} \mathrm{N}, 153^{\circ} 25^{\prime} 45^{\prime \prime} \mathrm{W}$; (map 34).

Name derived from Uganik Island and published in 1952 by USGS.

Uganuk: locality, see Uganik.

Uganuk Bay: bay, see Uganik Bay.

Uganuk Island: island, see Uganik Island.

Uganuk Spit: spit, see Packers Spit.

Ugashek, Ozero: lake, see Becharof Lake.

Ugashik: village, pop. 36 , on NW coast of Alaska Penin., on $\mathrm{E}$ bank of Ugashik River, $9 \mathrm{mi}$. from its mouth, Bristol Bay Low.; 57 $30^{\prime} 45^{\prime \prime}$ N, 157 $23^{\prime} 45^{\prime \prime} \mathbf{W}$; (map 36). Var. Igagik, Oogahik, Oogashik, Ugagak, Ungashik.

Eskimo village listed by Ivan Petroff in the 1880 Census as "Oogashik," population 177; 154 in 1890; 84 in 1930; 55 in 1939; and 48 in 1950 . The Ugashik post office was maintained here intermittently from 1932 to 1963 (Ricks, 1965, p. 67).

Ugashik, Mount: mountain, 2,230 ft., between Crooked and Ugashik Creeks, on Alaska Penin., 41 mi. NE of Ugashik, Aleutian Ra.; $57^{\circ} 37^{\prime} \mathrm{N}, 156^{\circ} 19^{\prime} \mathrm{W}$; (map 36).

Name reported in 1902 by J. L. McPherson of Iliamna; published by G. C. Martin (1921, pl. 10), USGS.

Ugashik Bay: estuary, extends NW $9 \mathrm{mi}$. to Bristol Bay, on $\mathrm{N}$ coast of Alaska Penin., at mouth of Ugashik River, 6 mi. W of Ugashik, Bristol Bay Low.; $57^{\circ} 35^{\prime} \mathrm{N}, 157^{\circ} 42^{\prime} \mathrm{W}$; (map 36).

Local name published in 1909 by USC\&GS; derived from Ugashik River.

Ugashik Creek: stream, flows NW $18 \mathrm{mi}$. to Upper Ugashik Lake, on Alaska Penin., 35 mi. NE of Ugashik, Aleutian Ra.; $57^{\circ} 42^{\prime} 40^{\prime \prime}$ N, $156^{\circ} 34^{\prime} 05^{\prime \prime} \mathrm{W}$; (map 36).

Eskimo name reported in 1902 by J. L. McPherson of Iliamna. 
Ugashik Lakes: lake, see Lower Ugashik Lake. Ugashilk River: stream, heads in Upper Ugashik Lake and flows $W$, through Lower Ugashik Lake, $43 \mathrm{mi}$. to Ugashik Bay, on NW coast of Alaska Penin., $9 \mathrm{mi}$. SW of Ugashik, Bristol Bay Low.; $57^{\circ} 30^{\prime} \mathrm{N}, 157^{\circ} 37^{\prime} \mathrm{W}$; (map 36). Var. Egegik River, Igakik River, Oogahik, Oogashak, Oogashik, Ougatchik Riviere, Reka Sulima, Reka Ugazhak, Riviere Soulima, Ugagak River, Ugaguk River, Ugatschik River, Ugazhik River.

Eskimo name transcribed in French as "Ougatchik Riviere," in 1828 by Capt. Lutke (1836, p. 259), IRN. At the same time Capt. M. N. Staniukovich of the corvette Moller, called it "Soulima" in his journal, and for many years there was considerable confusion concerning the name of the stream or streams. According to Grewingk (1850, p. 129) there were two streams. The present spelling was given by W. H. Dall in 1868 .

Ugat, Cape: point of land, $6.5 \mathrm{mi}$. NE of Cape Kuliuk, on NW coast of Kodiak I.; $57^{\circ} 52^{\prime} 20^{\prime \prime}$ $\mathrm{N}, 153^{\circ} 50^{\prime} 40^{\prime} \mathrm{W}$; (map 34). Var. Mys Ugat, Ugat Point.

Transliteration by USC\&GS in 1868 of the native name published in Russian as " $M$ [ys] Ugat," "Cape Ugat," by Capt. Tebenkov (1852, map 22)

Ugatschik River: stream, see Ugashik River.

Ugavigamiut: locality, see Uknavik.

Ugavik: locality, see Uknavik.

Ugazhak, Reka: stream, see Ugashik River.

Ugazhik River: stream, see Ugashik River.

Ugchirnak Mountain: hill, $948 \mathrm{ft}$., on NW coast of Nelson I., $8 \mathrm{mi}$. NE of Cape Vancouver, Yukon-Kuskokwim Delta; $60^{\circ} 37^{\prime} \mathrm{N}, 165^{\circ} 14^{\prime}$ W; (map 57).

Eskimo name meaning "it goes on top" obtained at Tanunak in 1951 by USC\&GS.

Ughkooleekuk Cove: cove, in Koomlangeelkuk Bay, $4.6 \mathrm{mi}$. SW of Savoonga, $\mathrm{N}$ coast of St. Lawrence I.; $63^{\circ} 40^{\prime} \mathrm{N}, 170^{\circ} 37^{\prime} \mathrm{W}$; $B G N$ 1951; (map 93). Var. Ughkulikak Cove.

Eskimo name recommended by the Savoonga village and reported in 1949 by Maj. H. B. Allen, USAF.

Ughkulikak Cove: cove, see Ughkooleekuk Cove. Ugiagik: village, see Egegik.

Ugiagwik, Lake: lake, see Becharof Lake.

Ugiak: point of land, see Ugyak, Cape.

Ugiatok: locality, on Agattu I., Aleutian Is.; $52^{\circ} 25^{\prime} \mathrm{N}, 173^{\circ} 35^{\prime} \mathrm{E}$; (map 13 ).

Former Aleut village or camp (Hodge, 1910 , p. 863), BAE.

Ugidakh, Kamen: island, see Ugidak Island.

Ugidakh Island: island, see Ugidak Island.

Ugidak Island: island, $0.1 \mathrm{mi}$. across, borders Tanaga Pass, $3.5 \mathrm{mi}$. E of Skagul I., Aleutian Is.; $51^{\circ} 35^{\prime} 00^{\prime \prime} \mathrm{N}, 178^{\circ} 30^{\prime} 30^{\prime \prime} \mathrm{W}$; (map 16). Var. Kamen Ugidakh, Ugidakh Island.

Aleut name published by Capt. Tebenkov (1852, map 28), IRN, as "K[amen] Ugidakh," or "Ugidakh Rock," and shown on an 1855 U.S. Navy Hydrog. Chart as Ugidakh Island.

Ugiu-ug: village, see Biorka.

Uglaamie: town, see Barrow.

Uglivia: locality, see Uglovaia.
Uglovaia: locality, on right bank of Yukon River, at or near Marshall, Yukon-Kuskokwim Delta ; $61^{\circ} 53^{\prime} \mathrm{N}, 162^{\circ} 05^{\prime} \mathrm{W}$; (map 74). Var. Ooglovia, Ouglovaia, Sabotnisky, Uglivia.

Russianized Eskimo name reported in 1879 as "Ouglovaia" by E. W. Nelson, U.S. Signal Service. Listed in 1880 as "Ooglovia," Eskimo village, population 102, by Ivan Petroff. Ugnasik: village, see Unga.

Ugnuravik River: stream, flows N $35 \mathrm{mi}$. to Simpson Lagoon, $14 \mathrm{mi}$. W of Beechey Point, Arctic Plain; $70^{\circ} 29^{\prime} 30^{\prime \prime} \mathrm{N}, 1^{\circ} 49^{\circ} 46^{\prime} 30^{\prime \prime} \mathrm{W}$; (map 150).

Eskimo name referring to the "place where ducks are driven and killed"; reported by USC\&GS in 1951

Ugokhamiut: locality, see Uchak.

Ugolnoi: island, see Ukolnoi Island.

Ugolnoy, Mys: point of land, see Coal Point.

Ugolnoy, Ostrov: island, see Charcoal Island

Ugolnoy, Zaliv: bay, see Coal Bay.

Ugomok Island: island, see Ugamak Island.

Ugovik: locality, see Uknavik.

Ugroorak: bluff, see Ugrurak Bluff.

Ugrurak Bluff: bluff, on shore of Chuckchi Sea, $15 \mathrm{mi}$. N of Cape Krusenstern, KotzebueKobuk Low.; $67^{\circ} 18^{\prime}$ N, $163^{\circ} 48^{\prime}$ W; (map 128). Var. Ogrooruk, Ookwroorat Bluff, Ugroorak, Ugzuuzaq.

Eskimo name meaning "little piece of blubber" reported in 1950 by USC\&GS.

Ugtikun: locality, on Agattu I., Aleutian Is.; $52^{\circ} 25^{\prime} \mathrm{N}, 173^{\circ} 35^{\prime} \mathrm{E}$; (map 13 ).

Former Aleut village or camp (Hodge, 1910 , p. 863), BAE.

Ugtumuk: locality, on Agattu I., Aleutian Is. $52^{\circ} 25^{\prime} \mathrm{N}, 173^{\circ} 35^{\prime} \mathrm{E}$; (map 13 ).

Former Aleut village or camp (Hodge, 1910 , p. 863), BAE.

Uguiúg: locality, see Beaver.

Ugujuk: village, see Uyak.

Uguligik Island: island, see Aguligik Island.

Ugushtu, Ostrov: island, see Crooked Island.

Ugutchtu Island: island, see Ushagat Island.

Uguyug: locality, see Beaver.

Uguyug: village, see Biorka.

Ugyak, Cape: point of land, between Kaflia and Kukak Bays, on $\mathbf{E}$ coast of Alaska Penin., in Katmai National Monument, $32 \mathrm{mi}$. E of Mount Katmai, Aleutian Ra.; 58 $16^{\prime} 45^{\prime \prime}$ $\mathrm{N}, 154^{\circ} 06^{\prime} 00^{\prime \prime} \mathrm{W}$; (map 42). Var. Cape U-gai-yak, Cap Ighiack, Ilak, Mys Igiak, Ugaiak, Ugiak.

Native name published in French as " $\mathrm{C}$ [ap] Ighiack" by von Krusenstern (1827, map 17); published in 1847 in Russian as "M[ys] Igisk" on Russian Hydrog. Dept. Chart 1378. Locally called Cape "U-gai-yak" according to W. H. Dall, USC\&GS; published as "Cape Ugyak" in 1888 by USBF.

Ugzuuzaq: bluff, see Ugrurak Bluff.

Uhaiak: locality, on Hepburn Penin. on $\mathbf{S}$ coast of Kodiak I., $57^{\circ} 00^{\prime} \mathrm{N}, 153^{\circ} 55^{\prime} \mathrm{W}$; (map 33). Var. Oohaiack

Former Eskimo village or camp recorded in 1804 as "Oohaiack" by Capt. Lisianski (1814, map facing p. 169), IRN.
Uhaiak Peninsula: peninsula, see Hepburn Peninsula.

Uhaskek: locality, between Gull and Dangerous Capes, on SE coast of Kodiak I.; $57^{\circ} 24^{\prime} \mathrm{N}$, $152^{\circ} 38^{\prime} \mathrm{W}$; (map 43). Var. Oohaskeck.

Former Eskimo village or camp recorded in 1804 as "Oohaskeck" by Capt. Lisianski (1814, map facing p. 169), IRN.

Uhler Creek: stream, flows W $9 \mathrm{mi}$. to South Fork Fortymile River, $45 \mathrm{mi}$. SW of Eagle, Yukon-Tanana High.; 64. $12^{\prime} 20^{\prime \prime} \mathrm{N}, 141^{\circ}$ $05^{\prime} 00^{\prime \prime}$ W; (map 102). Var. Yuler Creek.

Named by prospectors and reported in 1896 by Spurr (1898, pl. 44), USGS.

Uhvak: hills, see Awak Hills.

Uhvowm Koonga: stream, see Auvom Creek.

Uiak Bay: bay, see Uyak Bay.

Ui-lu-gu-lum-gui-guok: stream, see Kokwok River.

Uinakhtagewik: locality, see Uinuk.

Uinaklagovik: locality, see Uinuk.

Uindkhem, Mys: point of land, see Windham, Point.

Uinuk: locality, on $\mathrm{N}$ shore of Norton Sound, at mouth of Nome River, $4 \mathrm{mi}$. SE of Nome, Seward Penin. High.; $64^{\circ} 29^{\prime}$ N, $165^{\circ} 18^{\prime} \mathrm{W}$; (map 94). Var. Oo-innakhtagowik, Ooinukhlagowik, Ooinuklagowik, Ooinuktagowik, Uinakhtagewik.

Former Eskimo village reported in 1880 by Ivan Petroff as "Oo-innakhtagowik", population 10, in the 10th Census.

Uivak: promontory, see Lisburne, Cape.

Uivaksak Creek: stream, heads in De Long Mts., flows SW $15 \mathrm{mi}$. through Desperation Lake to Anisak River, Brooks Ra., 68 ${ }^{\circ} 18^{\prime} \mathrm{N}, 158^{\circ} 58^{\prime}$ W; BGN 1960; (map 132). Var. Fry Creek.

Eskimo name meaning "like a cape, for going around," reported by USGS in 1956.

Uivaq: promontory, see Lisburne, Cape.

Uivfak: promontory, see Lisburne, Cape.

Ujah Islet: island, see Uyak Island.

Ujakushatsch: volcano, see Redoubt Volcano.

Ujut Bay: bay, see Izhut Bay.

Ujut Bay: bay, see King Cove.

Ukagamut: locality, see Nunaikak.

Ukak: locality, on NW coast of Nelson Island, $27 \mathrm{mi}$. NE of Cape Vancouver, YukonKuskokwim Delta; $60^{\circ} 44^{\prime} \mathrm{N}, 164^{\circ} 56^{\prime} \mathrm{W}$; (map 58). Var. Ookagamiut, Ookagamute, Ookak, Ukogamute.

Former Eskimo village, abandoned before 1945 , now used as a summer camp; reported as "Ookagamiut," by E. W. Nelson, U.S. Signal Service, who visited the village in December 1878. Ivan Petroff, in the 1880 Census, recorded "Ookagamute," population $25 ; 15$ in 1939. Some maps have erroneously located this village on the Ningaluk River. See Unakak.

Ukak: locality, see Nunaikak.

Ukak: locality, see Savonoski.

Ukak: locality, see Unakak.

Ukak: lake, see Kukaklik Lake.

Ukak River: stream, heads in lake, flows N 12 mi. to Iliuk Arm Naknek Lake, on Alaska Penin., in Katmai National Monument, 23 
mi. NW of Mount Katmai, Aleutian Ra.; $58^{\circ} 31^{\prime} 50^{\prime \prime} \mathrm{N}, 155^{\circ} 20^{\prime} 30^{\prime \prime} \mathrm{W}$; BGN 1924; (map 42).

Native name published in 1917 by R. F. Griggs, National Geographic Society. Griggs camped near the site of a village named "Ukak" and called his camp and the river by that name.

Ukalikchik: locality, on W bank of Ukalikchik River near its junc. with Kashunuk River, 28 mi. E of village of Hooper Bay, YukonKuskokwim Delta ; $61^{\circ} 26^{\prime} 30^{\prime \prime} \mathrm{N}, 165^{\circ} 16^{\prime} 25^{\prime \prime}$ W; (map 75).

Eskimo name reported by USC\&GS in 1951 .

Ukalikchik River: stream, flows SE $20 \mathrm{mi}$. to Kashunuk River $28 \mathrm{mi}$. E of village of Hooper Bay, Yukon-Kuskokwim Delta; $61^{\circ} 26^{\prime} \mathrm{N}$, $165^{\circ} 16^{\prime} \mathrm{W}$; (map 75$)$.

Eskimo name reported by USC\&GS in 1951. Ukamak Island: island, see Ugamak Island.

Ukamok: island, see Chirikof Island.

Ukashik: locality, on Agattu I., Aleutian Is.; $52^{\circ} 25^{\prime} \mathrm{N}, 173^{\circ} 35^{\prime} \mathrm{E}$; (map 13).

Former Aleut village or camp (Hodge, 1910, p. 864), BAE.

Ukawatne: stream, see Ukawutni Creek.

Ukawutni Creek: stream, flows SW $15 \mathrm{mi}$. to Victor Slough in the Yukon River, $0.4 \mathrm{mi}$. $\mathrm{N}$ of Mickey I. and $32 \mathrm{mi}$. NE of Ruby, Kokrines-Hodzana High.; $64^{\circ} 56^{\prime} 20^{\prime \prime} \mathrm{N}, 154^{\circ}$ 30'25" W; (map 98). Var. Ukawatne.

Native name reported in 1869 by W. H. Dall (1870, p. 282), USC\&GS, as Ukawatne and Ukawutni.

Ukayukhpalyk Island: island, see Kiukpalik Island.

Ukazatel, Ostrov: island, see Guide Island.

Ukerukuvik River: stream, see Okerokovik River.

Ukfigag Creek: stream, flows NW $4 \mathrm{mi}$. to Goodnews Bay, $3.5 \mathrm{mi}$. $\mathrm{S}$ of Goodnews, KilbuckKuskokwim Mts. ; $59^{\circ} 04^{\prime} \mathrm{N}, 161^{\circ} 36^{\prime} \mathrm{W}$; (map 53). Var. Ufigag Creek.

Eskimo name reported to mean "little trees" obtained at Goodnews about 1951 by J. M. Hoare, USGS.

Ukhagmiut: locality, see Oknagamut.

Ukhapatit: rocks, see Youghapotit Rocks.

Ukhvigchagvag: locality, on Holitna River, Stony River Low.; $61^{\circ} 30^{\prime} \mathrm{N}, 157^{\circ} 00^{\prime} \mathrm{W}$; (map 72). Var. Ukvigchagvag-myut.

Former Eskimo village or camp recorded in 1842-44 as "Ukvigchagvag-myut" by Lt. L. A. Zagoskin (1847, p. 75), IRN.

Ukinik Creek: stream, see Ukinyak Creek.

Ukinyak Greek: stream, heads in Lisburne Hills, flows $S$ and $W 11 \mathrm{mi}$. to Chukchi Sea, $6 \mathrm{mi}$. $\mathrm{N}$ of Cape Dyer, Arctic Slope; $68^{\circ} 44^{\prime} 10^{\prime \prime} \mathrm{N}$, $166^{\circ} 11^{\prime} 55^{\prime \prime} \mathrm{W}$; (map 129). Var. Ukinik Creek, Ukinyaq Creek, Ukinyuk Creek.

Eskimo name reported in 1956 by Orth to mean "cut"; so called "because the stream cuts into the mountains."

Ukinyaq Creek: stream, see Ukinyak Creek. Ukinyuk Creek: stream, see Ukinyak Creek.

Ukivak: locality, see Ukivok.

Ukivok: village, pop. 30 , on King I., in Bering Sea $W$ of Seward Penin., $43 \mathrm{mi}$. $\mathrm{S}$ of Cape
Prince of Wales, $64^{\circ} 58^{\prime} \mathrm{N}, 168^{\circ} 04^{\prime} \mathrm{W}$; (map 111). Var. King Island, Ookevok, Ookivok. Oukivak, Oukevok, Oukwak, Ovkévok, Ukivak, Ukivuk, Ukiwuk.

Eskimo village reported by Dall (1877, p. $15)$; this was also the Eskimo name for King Island. Recorded in the 1880 Census as "Ookivok" by Petroff (1884, map). The 1890 Census (1893, p. 145) reported "The only Alaskan people residing in cliff dwellings * * * enlarged from the cavernous fissures that exist on the island," population 200. Balcom (1965, p. 32) wrote, "Most of the inhabitants moved to Nome and other places to find employment, as King Island is inaccessible part of the year because of its location and weather."

Ukivok Island: island, see King Island.

Ukivuk: locality, see Ukivok.

Ukiwuk: locality, see Ukivok.

Ukiwuk Island: island, see King Island.

Utklik Dunes: sand dunes, see Ooklik Dunes.

UkmaggrukMountain: mountain, see Angmakrok Mountain.

Uknadak: locality, see Uknodok.

Uknadak Island: island, see Hog Island.

Uknavik: locality, on right bank of Kuskokwim River, between Lower Kalskag and Tuklak, 40 mi. SE of Russian Mission, Yukon-Kuskokwim Delta; $61^{\circ} 25^{\prime} \mathrm{N}, 160^{\circ} 37^{\prime} \mathrm{W}$; (map 73). Var. Gavimamut, Odgavigamut, Odgovigamut, Ogavik, Ogalvick, Ogalvik, Ogilvik, Okavigamut, Okhnagamiut, Okavígamut, Oogavigmute, Oogovigamute, Oogovik, Oogowigamute, Ougavik, Ugavik, Ugavigamiut, Ugovik. Although it is difficult to correlate names of the Eskimo villages along the Kuskokwim River on the early small-scale maps, this place appears to have been the same as the "Oogovigamute," population 206, listed in Petroff's 1880 Census. It is probable that E. W. Nelson, U.S. Signal Service, obtained the name for Petroff in January 1879. The 1890 Census listed "Ugavigamiut," population 57. W. S. Post, USGS, on his 1898 fieldsheet recorded "Oknavigamut" with a note "from Kilbuck" (Rev. J. H. Kilbuck, Moravian missionary); he also showed a Moravian Mission school located there.. The mission, called "Ougavik," was established about 1893 (Schwalbe, 1951, p. 46) and abandoned about 1906 (p. 94), because of a declining population caused "by a shifting river bed." In his diary in 1930, Hrdlička (1943, p. 317) wrote, "Oogovik, a place abandoned some years ago. A large fine site * * twenty hollows from igloos." See Akahamut and Nak.

Uknodok: locality, on Hog I. in Unalaska Bay, on $\mathbf{N}$ coast of Unalaska I., Aleutian Is.; $53^{\circ}$ $54^{\prime} \mathrm{N}, 166^{\circ} 34^{\prime} \mathrm{W}$; (map 23). Var. Ouknadok, Uknadak, Ukunadok.

Former Aleut village or camp published as "Ukunadok" by Rev. Coxe (1787, p. 167). Reported as "Uknadak" by Father Veniaminov $(1840$, v. 1, p. 188), who wrote that the village was the site of a dispute between the Unalaskans and the Aleuts from Unimak in which the latter were exterminated.
Uknodok, Ostrov: island, see Hog Island.

Ukodlint: locality, on Golovnin Bay, on N shore of Norton Sound, Seward Penin. High.; $64^{\circ}$ $27^{\prime} \mathrm{N}, 163^{\circ} 00^{\prime} \mathrm{W}$; (map 95).

Former Eskimo village or camp reported in the 1890 Census (1893, p. 162).

Ukogamute: locality, see Ukak.

Ukolnoi Island: island, $7.5 \mathrm{mi}$. long, $4 \mathrm{mi}$. NE of Dolgoi I., one of Pavlof Is., Aleutian Ra.; $55^{\circ} 13^{\prime} \mathrm{N}, 161^{\circ} 38^{\prime} \mathrm{W}$; (map 28). Var. Kitagutak, Ugolnoi, Youkolny.

Name reported as "O[strov] Youkolny," meaning "stone coal" by Capt. Lutke (1836, p. 271), IRN. Shown as "Ukolnoi Island" on 1882 USC\&GS chart. The Aleut name is "Kitagutak," according to Father Veniaminov (1840, v. 1, p. 252).

Ukolnoi Rocks: rocks, between Ukolnoi and Wosnesenski Is., $12 \mathrm{mi}$. NE of Dolgoi I., Aleutian Ra.; 55 $14^{\prime} 30^{\prime \prime} \mathrm{N}, 161^{\circ} 27^{\prime} 30^{\prime \prime} \mathrm{W}$; (map 28).

Probably named for Ukolnoi Island; shown on a 1964 USC\&GS chart.

Ukpik Slough : stream, see Ikpik Slough.

Ukpiksuk: locality, $3 \mathrm{mi}$. $\mathrm{N}$ of Kivalina, Kotzebue-Kobuk Low.; $67^{\circ} 46^{\prime} \mathrm{N}, 164^{\circ} 32^{\prime} \mathrm{W}$; (map 128). Var. Ookpicksook, Uqpiqsuq. Eskimo name meaning "there are willows" reported in 1966 by E. S. Burch.

Ukshivik: locality, on Barling Bay, on SE coast of Kodiak I., $57^{\circ} 11^{\prime} \mathrm{N}, 153^{\circ} 22^{\prime} \mathrm{W}$; (map 34). Var. Ukshivikag-miut, Ukshivikak, Ukshivkag-miut.

Former Eskimo village or camp published as "Ukshivikag-miut" on the Russian American Company's 1849 map. Baker (1906, p. 649) wrote, "Ukshi'vik means a winter village from Ukshuk (winter), and vik, the locative termination."

Ukshivikag-miut: locality, see Ukshivik.

Ukshivikak: locality, see Ukshivik.

Ukshivkag-miut: locality, see Ukshivik.

Uksukalik: locality, along left bank of Black River, $10 \mathrm{mi}$. ESE of Black, Yukon-Kuskokwim Delta; $62^{\circ} 20^{\prime} \mathrm{N}, 165^{\circ} 12^{\prime} \mathrm{W}$; (map 76).

Reported about 1946 by USGS.

Uksukfak River: stream, see Kinia River.

Ukuk: locality, on Nelson I., Yukon-Kuskokwim Delta ; $60^{\circ} 30^{\prime} \mathrm{N}, 165^{\circ} 00^{\prime} \mathrm{W}$; (map 57).

Former Eskimo village or camp reported in the 1890 Census (1893, p. 111).

Ukuksik: locality, see Amungna.

Ukunadok: locality, see Uknodok.

Ukushe Island: island, see Akusha Island.

Ukvigchagvag-myut: locality, see Ukhvigchagvag.

Ukvikhtulig-mut: locality, see Opiktulik.

Ukvikhtulig-myut: locality, see Opiktulik.

Ukviktulik: locality, see Opiktulik.

Ulach Island: island, see Ulak Island.

Ulaga Island: island, see Carlisle Island.

Ulahula River: river, see Hulahula.

Ulakaia Hill: hill, $946 \mathrm{ft} ., 2 \mathrm{mi}$. S of St. George, highest point on St. George $I$., in Pribilof Is. ; $56^{\circ} 34^{\prime} 40^{\prime \prime} \mathrm{N}, 169^{\circ} 34^{\prime} 45^{\prime \prime} \mathrm{W}$; (map 38). Var. Ahlucheyak Hill, Ahluckeyak Hill, Alu- 
keyak Hill, Oolakaiya Hill, Ulakiya.

Aleut name shown as "Ahlucheyak" and "Ahluckeyak" by Elliott (1881, p. 18), meaning "rough back-bone"; as "Oolakaiya" by Joseph Stanley-Brown in 1891; and as " $\mathrm{Ul}^{\prime}$. akiya'" by Putnam (1903, p. 1016), USC\& GS, meaning "high house," because "the old native houses had rounded roofs similar to the shape of this hill." These three names appear to be different spellings of the same Aleut name.

Ulakakogavik: village, see Utukakarvik.

U Lake: lake, $1 \mathrm{mi}$. long, $1 \mathrm{mi}$. S of Swan Lake and $8 \mathrm{mi}$. NE of Arctic Village, Brooks Ra.; $68^{\circ} 13^{\prime} 30^{\prime \prime} \mathrm{N}, 145^{\circ} 23^{\prime} 30^{\prime \prime} \mathrm{W}$; (map 136).

Local descriptive name obtained in 1956 by USGS.

Ulakh Island: island, see Ulak Island.

Ulakhta Harbor: anchorage, see Dutch Harbor.

Ulak Island: island, $6.5 \mathrm{mi}$. long, Delarof Is., Aleutian Is.; $51^{\circ} 22^{\prime} \mathrm{N}, 178^{\circ} 57^{\prime} \mathrm{W}$; (map 16). Var. Illak Island, Ioulakh Island, Ulach Island, Ulakh Island, Youlak Island.

Name published by Lt. Sarichev (1826, map 3), IRN, as "Illak" apparently from the Aleut name "Ulak" or "Ulaq" meaning "house" or "everybody's house." The adopted name was published on a USC\&GS chart.

Ulak Island: island, elev. $688 \mathrm{ft}$., $1 \mathrm{mi}$. long, 3 mi. E of Great Sitkin I., Andreanof Is., Aleutian Is.; $52^{\circ} 02^{\prime} 40^{\prime \prime} \mathrm{N}, 175^{\circ} 54^{\prime} 00^{\prime \prime} \mathrm{W}$; BGN 1890; (map 18). Var. Ulakh Island, Uliadak Island, Ulyadak, Ostrov, Ulyadakh, Ostrov.

Aleut name published as "Ulak Ile," or "Ulak Island," by Capt. Lutke (1836, p. 323), IRN, and is apparently of the same derivation as "O[strov] Ulyadak," or "Ulyadak Island," shown on Russian Hydrog. Dept. Chart 1400 in 1848. The Aleut name "Ulaq" means "house."

Ulakiya: hill, see Ulakaia Hill.

Ulak Pass: water passage, $4 \mathrm{mi}$. wide, between Ulak and Amatignak Is., Delarof Is., Aleutian Is. ; $51^{\circ} 18^{\prime} 30^{\prime \prime} \mathrm{N}, 179^{\circ} 03^{\prime} 00^{\prime \prime} \mathrm{W}$; (map 16).

Name published by USC\&GS in 1954 Coast Pilot (p. 459).

Ulakta Head: point of land, $\mathrm{N}$ tip of Amaknak I. in Unalaska Bay, Aleutian Is.; 53 $55^{\prime} 35^{\prime \prime}$ $\mathrm{N}, 166^{\circ} 30^{\prime} 45^{\prime \prime} \mathrm{W}$; (map 23). Var. North Head, Ulakhta Head.

Aleut name reported by George Davidson, USC\&GS, in 1869. Baker (1906, p. 649), wrote "a name derived from Udakta (now Dutch) harbor, the change from Udakta to Ulakta being apparently accidental."

Ulamashak Mountain: hill, see Oolamushak Hill.

Ulanach, Cape: point of land, see Chlanak. Cape.

Ulaneak Creek: stream, heads on NW slope of Blind Pass Mtn., flows SW $20 \mathrm{mi}$. to Ambler River, Brooks Ra.; $67^{\circ} 24^{\prime} \mathrm{N}, 156^{\circ} 51^{\prime} \mathrm{W}$; (map 126).

Eskimo name reported to generally mean "wrong route" or "blind pass," obtained at Shungnak and Kobuk by Orth in 1956.
Ularakartha Point: point of land, at Great East Rookery, NW of Tolstoi Point, on NE coast of St. George I., in Pribilof Is.; $56^{\circ} 36^{\prime} \mathrm{N}, 169^{\circ}$. $29^{\prime} \mathrm{W}$; (map 38 ).

This Aleut name meaning "point opposite house," was reported as "Ul'arakartha'" by Putnam (1903, p. 1016), USC\&GS.

Ulezara: locality, on Chukchi Sea coast near Cape Krusenstern, Kotzebue-Kobuk Low.; $67^{\circ} \mathrm{N}, 163^{\circ} \mathrm{W}$; (map 128). Var. Ulezaramiut.

Former Eskimo village or camp recorded as "Ulezaramiut" in the 1890 Census (1893, p. 162).

Ulezaramiut: locality, see Ulezara.

Uliadak Island: island, see Ulak Island.

Uliaga Island: island, $2 \mathrm{mi}$. across, northernmost of Islands of Four Mountains, Aleutian Is.; $53^{\circ} 04^{\prime} 00^{\prime \prime} \mathrm{N}, 169^{\circ} 05^{\prime} 30^{\prime \prime} \mathrm{W}$; (map 22). Var. Kagalgin Island, Kigalga Island, Kigalgin Island, Ostrov Chegulak, Ostrov Ullyaga.

Aleut name reported in 1894 by the U.S. Navy Hydrog. Office. The island was recorded in 1847 as "O[strov] Chegulak," or "Chegulak Island," on Russian Hydrog. Dept. Chart 1379, and "O[strov] Ullyaga," or "Ullyaga Island," by Capt. Tebenkov (1852, map 25, dated 1849), IRN.

Uliaga Island: island, see Carlisle Island.

Uliagant Island: island, see Carlisle Island.

Uliaga Pass: water passage, between Kagamil and Uliaga Is., Aleutian Is.; $53^{\circ} 02^{\prime} 30^{\prime \prime} \mathrm{N}$, $169^{\circ} 45^{\prime} 00^{\prime \prime} \mathrm{W}$; (map 22).

Name derived from Uliaga I.; published in 1944 Aleutian Coast Pilot (p. 72).

Ulinnoi Island: island, see Ulinoi Island.

Ulinnoy, Ostrov: island, see Ulinoi Island.

Ulinoi Island: island, $0.2 \mathrm{mi}$. long, in Redoubt Bay, $9 \mathrm{mi}$. SW of Sitka, on W coast of Baranof I., Alex. Arch.; 56 $56^{\prime} 00^{\prime \prime}$ N, $135^{\circ} 23^{\prime} 40^{\prime \prime} \mathrm{W}$; (map 5). Var. Ostrov Ulinnoy, Ulinnoi Island.

Named in 1809 by the Russian navigator, Ivan Vasiliev the first; published by Lt. Sarichev (1826, map 19), IRN, as "O[strov] Ulinnoy," or "Ulinnoy Island."

Ulitka, Cape: point of land, NW tip of Noyes I., Alex. Arch.; $55^{\circ} 33^{\prime} 45^{\prime \prime} \mathrm{N}, 133^{\circ} 43^{\prime} 35^{\prime \prime} \mathrm{W}$; $B G N$ 1923; (map 4). Var. Snail Cape.

Russian word meaning "snail," given in 1923 by USC\&GS.

Ulitka Bay: $b a y, 0.8 \mathrm{mi}$. wide, NW coast of

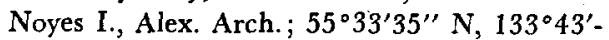
$00^{\prime \prime}$ W; BGN 1923; (map 4).

Named in 1923 by USC\&GS; derived from Cape Ulitka. See Ulitka, Cape.

Ulliaga Island: island, see Carlisle Island.

Ulliagin Island: island, see Carlisle Island.

Ulloa Canal: water passage, see Ulloa Channel.

Ulloa Channel: water passage, extends SE 10 mi,, off Bucareli Bay, between Prince of Wales and Suemez Is., Alex. Arch.; 55 $19^{\prime}$ N, $133^{\circ} 17^{\prime}$ W; $B G N$ 1908; (map 4). Var. Canal Ysla de Ulloa, Ulloa Canal.

This feature was named "Canal Ysla de Ulloa," meaning "Canal of Ulloa Island," by the Spanish about 1792, possibly for Francisco de Ulloa, a Spanish explorer; shortened to
Ulloa Channel in 1907 by E. F. Dickins, USC\&GS. "Ulloa canal appears to have derived its name from being supposed to communicate with Cordova Bay, the land north of Cordova Bay being styled Isla Ulloa [Ulloa Island] in Galiano's Atlas [1802, map 3]"' (U.S. Coast and Geodetic Survey, 1883, p. 97).

Ulloa Island: island, $0.7 \mathrm{mi}$. long, in Ulloa Channel, $0.5 \mathrm{mi}$. N of Dall I., Alex. Arch.; 55 ${ }^{\circ} 17^{\prime}$ N, $133^{\circ} 09^{\prime} \mathrm{W}$; BGN 1908; (map 4).

Named in 1907 by E. F. Dickins, USC\&GS. Ullyaga, Ostrov: island, see Carlisle Island. Ullyaga, Ostrov: island, see Uliaga Island. Ullyagin, Ostrov: island, see Carlisle Island. Ullyagin Island: island, see Herbert Island. Ul 'malyanok, M[ys]: point of land, see IImalianuk, Cape.

Ulnik: bay, see Marmot Bay.

Ulokagmiut: locality, see Ulokak.

Ulokak: locality, in Kuskokwim district, probably near mouth of Holokuk River, KilbukKuskokwim Mts.; $61^{\circ} 33^{\prime} \mathrm{N}, 158^{\circ} 36^{\prime} \mathrm{W}$; (map 72). Var. Ulokagmiut.

Former Eskimo village or camp recorded as "Ulokagmiut" in the 1890 Census (1893, p. 164). See Holokuk River.

Ulokak River: stream, see Holokuk River.

Ulokat Hills: hills, $1,000 \mathrm{ft}$., extend $2.5 \mathrm{mi} . \mathrm{N}$ of Black River, at S end of Kuzilvak Mts., 31 mi. E of Scammon Bay, Yukon-Kuskokwim Delta; 61 $57^{\circ} \mathrm{N}, 164^{\circ} 38^{\prime} \mathrm{W}$; (map 74).

Eskimo name meaning "slate" or "slate knife [Ulo]," reported by G. R. Putnam, USC\&GS, in 1899.

Ulo Mountain: mountain, see Oolah Mountain.

Ulo Pass: pass, see Oolah Pass.

Ulo Valley: valley, see Oolah Valley.

Ultramarine Glacier: glacier, on E side of Kenai Penin., heads in Sargent Icefield, trends NE $4 \mathrm{mi}$. to its terminus, $1 \mathrm{mi}$. SW of head of Blue Fiord, $14 \mathrm{mi}$. NW of Chenega, Chugach Mts.; $60^{\circ} 25^{\prime} 30^{\prime \prime} \mathrm{N}, 148^{\circ} 18^{\prime} 00^{\prime \prime} \mathrm{W} ; B G N$ 1910; (map 63)

So named in 1908 by Grant (Grant and Higgins, 1913, p. 45), USGS, "because of the clear blue color of the ice near its end ***."

Ulukak: locality, see Ulukuk.

Ulukluk Creek: stream, flows NE $19 \mathrm{mi}$. to the Buckland River, $49 \mathrm{mi}$. NE of Haycock, Nulato Hills; $65^{\circ} 45^{\prime} \mathrm{N}, 160^{\circ} 05^{\prime} \mathrm{W}$; (map 109).

Eskimo name reported in 1949 by the U.S. Army Corps of Engineers.

Uluksian Creek: stream, flows SW $15 \mathrm{mi}$. to Noatak River $15 \mathrm{mi}$. SW of its junc. with Nimiuktuk River, Brooks Ra.; $67^{\circ} 55^{\prime} 05^{\prime \prime} \mathrm{N}$, $160^{\circ} 12^{\prime} 15^{\prime \prime} \mathrm{W}$; (map 127).

Eskimo name meaning "[going the] wrong way," obtained in 1956 at Noatak by Orth.

Uluksrak Bluff: bluff, elev. $700 \mathrm{ft}$., on $\mathrm{W}$ bank of Colville River $3 \mathrm{mi}$. $\mathrm{N}$ of its junc. with Chandler River, Arctic Slope; $69^{\circ} 30^{\prime} \mathrm{N}, 151^{\circ}$ 30' W; (map 141). 
Eskimo name meaning "material for ulus [semi-circular knife]," reported in 1956 by T. E. Taylor, USGS.

Ulukuk: locality, on Unalakleet River 20 or 30 mi. E of Norton Sound, Nulato Hills ; $63^{\circ} 55^{\prime}$ N, $160^{\circ} 15^{\prime}$. W ; (map 91). Var. Alookuk, Alukuk, Ulukak, Zlukak.

Former Eskimo village or camp reported in 1842-44 by Lt. L. A. Zagoskin, IRN.

Ulukuk Hills: hills, near the Unalakleet River, 30 or $40 \mathrm{mi}$. E of Norton Sound, Nulato Hills, near $63^{\circ} 55^{\prime} \mathrm{N}, 160^{\circ} 15^{\prime} \mathrm{W}$; (map 91).

Eskimo name reported in 1866 by $\mathrm{W}$. $\mathrm{H}$. Dall.

Ulukuk River: stream, tributary to Unalakleet River, 30 or $40 \mathrm{mi}$. E of Norton Sound, Nulato Hills, near $63^{\circ} 55^{\prime} \mathrm{N}, 160^{\circ} 15^{\prime} \mathrm{W}$; (map 91). Var. Kychchogljuk River, Reka Kuikhoglyuk, Ryka Toukatl ili Tstsytsekatoyna, Toukatl Creek, Zyzek-twina River.

Eskimo name reported in 1866 by $W$. $H$. Dall. The name "Ryka Toulatl ili Tstsytsekatoyna," meaning "Toukatl or Little Tstsytsek River," was reported in 1842-1844 by Lt. L. A. Zagoskin, IRN.

Uluruk Point: promontory, on SW coast of Nelson I., $4 \mathrm{mi}$. SE of Cape Vancouver, YukonKuskokwim Delta; $60^{\circ} 30^{\prime} \mathrm{N}, 165^{\circ} 22^{\prime} \mathrm{W}$; (map 57).

Eskimo name meaning "old knife (ulu)" obtained in 1951 by USC\&GS. Another source gives the meaning as "tongue."

Ulva Cove: cove, $0.4 \mathrm{mi}$. across, $\mathrm{N}$ of $\mathrm{Knob}$ Point on $\mathrm{E}$ coast of Amatignak 1., Delarof Is., Aleutian Is.; $51^{\circ} 15^{\prime} 40^{\prime \prime} \mathrm{N}, 179^{\circ} 04^{\prime} 00^{\prime \prime} \mathrm{W}$; (map 16).

Local name published on 1954 USGS map. Ulyadak, Ostrov: island, see Ulak Island. Ulyadakh, Ostrov: island, see Ulak Island. Ulyaga, Ostrov: island, see Carlisle Island Ulyaga Island: island, see Herbert Island. Ulyagan, Ostrov: island, see Carlisle Island. Umaatchak Peak: hill, see Umarachek Peak.

Umagachiak Hill: mountain, see Umagatsiak Hill.

Umagachyiam, Kugoranga: stream, see Umagatsiak Creek.

Umagatsiak Creek: stream, flows SW $4 \mathrm{mi}$. to Chukchi Sea, $20 \mathrm{mi}$. SE of Kivalina, Kotzebue-Kobuk Low.; 67 $32^{\prime} \mathrm{N}, 164^{\circ} 01^{\prime} \mathrm{W}$. Var. Oomagahchyam Koogowranga, Umagachyiam Kugoranga.

Eskimo name reported by E. S. Burch, in 1966 , to mean "new heart."

Umagatsiak Hill: mountain, $6 \mathrm{mi}$. N of Imik Lagoon and $21 \mathrm{mi}$. SE of Kivalina, Arctic Slope; $67^{\circ} 34^{\prime} \mathrm{N}, 163^{\circ} 36^{\prime} \mathrm{W}$. Var. Oomagahchyak, Ummagaatsiaq, Umagachiak Hill.

Eskimo name reported by E. S. Burch, in 1966.

Umagatsaiak Mountain: mountain, 1,045 ft., 2 mi. SE Kisemaraktuk Mtn. and $17 \mathrm{mi}$. N of Kifalina, Arctic Slope; $67^{\circ} 58^{\prime} \mathrm{N}, 164^{\circ} 34^{\prime} \mathrm{W}$; (map 128). Var. Oomagahchyak, Ummagaatsiaq.

Eskimo name meaning "new heart" according to E.S. Burch in 1966.
Umagvirak: locality, patch of willows, along Omikviorok River, $12 \mathrm{mi}$. SE of Kivalina, Kotzebue-Kobuk Low.; $67^{\circ} 40^{\prime} \mathrm{N}, 164^{\circ} 08^{\prime} \mathrm{W}$; (map 128). Var. Oomagveerak.

Eskimo name meaning "place where there is willows" reported in 1966 by E. S. Burch. Umahachek Creek: stream, heads in Tahinichok Mts. at SW end of Mulgrave Hills, flows SW $4.5 \mathrm{mi}$. to Chukchi Sea, $19 \mathrm{mi}$. SE of Kivalina, Kotzebue-Kobuk Low.; $67^{\circ} 32^{\prime} \mathrm{N}, 164^{\circ} 00^{\prime} \mathrm{W}$; (map 128). Var. Oommahahtchek Creek.

Eskimo name meaning "heart," according to USC\&GS in 1950.

Umak, Cape: point of land, on SW coast of Umak I., Aleutian Is.; $51^{\circ} 51^{\prime} 40^{\prime \prime} \mathrm{N}, 176^{\circ} 03^{\prime}$ $00^{\prime \prime} \mathrm{W}$; BGN 1936; (map 17).

Name derived from Umak Island, and given by members of the U.S. Navy Aleutian Island Survey Expedition in 1934.

Umakalookta: stream, see Black River.

Umak Bight: cove, $0.6 \mathrm{mi}$. across, Umak I., Aleutian Is.; $51^{\circ} 53^{\prime} 45^{\prime \prime} \mathrm{N}, 176^{\circ} 00^{\prime} 00^{\prime \prime} \mathrm{W}$; BGN 1936; (map 17).

Name derived from Umak Island, and given by members of the U.S. Navy Aleutian Island Survey Expedition in 1934.

Umakh Island: island, see Umak Island.

Umak Island: island, $6.5 \mathrm{mi}$. long, one of Andreanof Is., Aleutian Is.; $51^{\circ} 53^{\prime} \mathrm{N}, 176^{\circ}$ 02' W; BGN 1890; (map 17). Var. Oumakh Island, Umakh Island, Yumakh Island.

Aleut name published by Capt. Tebenkov (1852, map 28), IRN, as "O[strov] Umakh," or "Umakh Island."

Umak Pass: water passage, between Umak and Little Tanaga Is., Aleutian Is.; $51^{\circ} 51^{\prime} 30^{\prime \prime} \mathrm{N}$, $176^{\circ} 03^{\prime} 00^{\prime \prime} \mathrm{W}$; BGN 1936; (map 17).

Name derived from Umak Island, and given by members of the U.S. Navy Aleutian Island Survey Expedition in 1934.

Umalik: stream, see Omilak Creek.

Umanangula Bluffs: cliff, extends $1.3 \mathrm{mi}$. along $\mathrm{S}$ coast of St. George I., in Pribilof Is.; $56^{\circ}$ $32^{\prime} 10^{\prime \prime} \mathrm{N}, 169^{\circ} 36^{\prime} 00^{\prime \prime} \mathrm{W}$; (map 38).

Aleut name reported by Putnam (1903, p. 1016), USC\&GS, as "Uman'angul'a," meaning "cannot be seen"; so named "because they are not visible from the village ***."

Umanangula Lake: lake, $0.1 \mathrm{mi}$. across, near $\mathrm{S}$ coast of St. George I., in Pribilof Is.; $56^{\circ}$ $32^{\prime} 35^{\prime \prime} \mathrm{N}, 169^{\circ} 37^{\prime} 00^{\prime \prime} \mathrm{W}$; (map 38).

Aleut name listed by Putnam (1903, p. 1016), USC\&GS, as "Uman'angu'lan-an'yi," meaning "lake near Umanangula."

Umarachek Creek: stream, flows SW $7 \mathrm{mi}$. to Okpiksugruk Creek, $13 \mathrm{mi}$. NW of Kivalina Arctic Slope; $67^{\circ} 52^{\prime} 10^{\prime \prime} \mathrm{N}, 164^{\circ} 50^{\prime} 55^{\prime \prime} \mathrm{W}$; $B G N$ 1963; (map 128). Var. Oakpisoorook River, Oomarachek Creek, Umarachiak Creek.

Eskimo name meaning "heart," according to USG\&GS in 1950.

Umarachek Peak: hill, $500 \mathrm{ft}$., on $\mathrm{N}$ bank of Asikpak River, 12 mi. 'NW of Kivalina, Arctic Slope; $67^{\circ} 53^{\prime} \mathrm{N}, 164^{\circ} 47^{\prime} \mathrm{W}$; (map 128). Var. Umaatchak Peak.

Eskimo name meaning "heart," according to USC\&GS in 1950.
Umarachiak Creek: stream, see Umarachek Creek.

Umbrella Glacier: glacier, on Iliamna Volcano, in Chigmit Mts., trends SW $6 \mathrm{mi}$. to its 1958 terminus at head of Right Fork West Glacier Creek, Aleutian Ra.; 59 $58^{\prime} \mathrm{N}, 153^{\circ} 14^{\prime} \mathrm{W}$; (map 51).

Named in 1924 by R. H. Sargent, USGS, "because of an overhang-like an umbrella."

Umbrella Reef: reef, $0.1 \mathrm{mi}$. across, in Gulf of Alaska, E of mouth of Lawrence Creek, 14 mi. SE of Cape Yakataga, Chugach Mts.; $60^{\circ} 01^{\prime} 25^{\prime \prime} \mathrm{N}, 142^{\circ} 02^{\prime} 50^{\prime \prime} \mathrm{W}$; (map 65).

Name reported by Moffit (1914, pl. 1), USGS.

Umeyalak Point: point of land, see Emekyalok Point.

Umga Island: island, $0.4 \mathrm{mi}$. long, between Sanak I. and Alaska Penin., $14 \mathrm{mi}$. SW of Deer I., Aleutian Ra.; $54^{\circ} 48^{\prime} 10^{\prime \prime}$ N, $162^{\circ} 43^{\prime}$ $20^{\prime \prime} \mathrm{W}$; (map 25).

Aleut name reported in 1847 as "O[strov] Umga," or "Umga Island," by the Russian Hydrog. Dept. on Chart 1379.

Umiak Bend: bend, on Wulik River, $8 \mathrm{mi}$. NW of Kivalina, Kotzebue-Kobuk Low.; $67^{\circ} 47^{\prime}$ N, $164^{\circ} 17^{\prime}$ W; (map 128). Var. Oomeyak.

Eskimo name referring to an incident here when a skin boat (umiak) was destroyed by rough water; reported in 1966 by $\mathbf{E}$. S. Burch.

Umiak Mountain: mountain, see Igloo Mountain.

Umiat: village, pop. 5 , on $\mathrm{N}$ bank of Colville River, $75 \mathrm{mi}$. S of Harrison Bay, Arctic Slope; $69^{\circ} 22^{\prime} \mathrm{N}, 152^{\circ} 08^{\prime} \mathrm{W}$; (map 141).

Eskimo name meaning "boats," a name applied to the locality because the river boats were cached there. The name was borrowed from the Eskimo when an emergency airfield was established there, and in 1945 the place became a supply and operation base for oil exploration in Naval Petroleum Reserve No. 4. The place is still maintained as a major airfield between Barrow and Fairbanks.

Umiat Lake: lake, $1 \mathrm{mi}$. long, on $\mathrm{N}$ bank of Colville River, $1 \mathrm{mi}$. NE of Umiat, Arctic Slope; $69^{\circ} 23^{\prime} 05^{\prime \prime} \mathrm{N}, 152^{\circ} 06^{\prime} 00^{\prime \prime} \mathrm{W}$; (map 141).

Named about 1945 by USGS geologists of the Naval Petroleum Reserve No. 4.

Umiat Mountain: hill, $843 \mathrm{ft}$., on $\mathrm{N}$ bank of Colville River, $2.5 \mathrm{mi}$. NE of Umiat, Arctic Slope; $69^{\circ} 23^{\prime} 30^{\prime \prime} \mathrm{N}, 152^{\circ} 00^{\prime} 00^{\prime \prime} \mathrm{W} ; B G N$ 1949; (map 141).

Named about 1945 by USGS geologists of the Naval Petroleum Reserve No. 4.

Umiukrak Hill: hill, see Sentinel Hill.

Umiurak Hill: hill, see Sentinel Hill.

Umivrak Hill: hill, see Sentinel Hill.

Umkumiut: locality, on Nelson I., on Kangirlvar Bay, $9 \mathrm{mi}$. SE of Cape Vancouver, YukonKuskokwim Delta; $60^{\circ} 30^{\prime} \mathrm{N}, 165^{\circ} 12^{\prime} \mathrm{W}$; (map 57). Var. Umkumute, Umkumut.

This is an Eskimo summer camp or village that had a population of 99 in 1950.

Umkumut: locality, see Umkumiut.

Umkumute: locality, see Umkumiut.

Umla Island: island, $0.7 \mathrm{mi}$. long, between Sanak 
and Caton Is., one of Sanak Is., Aleutian Ra. $54^{\circ} 20^{\prime} 55^{\prime \prime} \mathrm{N}, 162^{\circ} 27^{\prime} 45^{\prime \prime} \mathrm{W}$; (map 25).

Aleut name reported by Ferdinand Westdahl, USC\&GS, commander of the Coast Survey steamer McArthur, who made surveys in this area in 1901.

Ummagaatsiaq: mountain, see Umagatsiak Hill. Ummagaatsiaq: mountain, see Umagatsaiak Mountain.

Umnak: village, pop. 20 , on Umnak I., $3 \mathrm{mi}$. $\mathrm{N}$ of Nikolski, Aleutian Is.; $53^{\circ} 16^{\prime} \mathrm{N}, 168^{\circ} 13$ W; (map 22).

Aleut village listed in 1960 census.

Umnak: village, see Nikolski.

Umnak Island: island, $70 \mathrm{mi}$. long, one of Fox Is., Aleutian Is.; $53^{\circ} 15^{\prime} \mathrm{N}, 168^{\circ} 20^{\prime} \mathrm{W} ; B G N$ 1890; (map 22). Var. Amnak Island, Amnuk Island, Isla de Omanaca, Oomanak Island, Oomnak Island, Oumnakh Island, Oumnak Island, Umyak Island.

Aleut name reported in 1768 by Capt. Lt. Krenitzin and Lt. Levashev (Coxe, 1787, map p. 205), IRN. This island was called "Oomanak" by Capt. Cook (1785, v. 2, p. 504), RN, and "Umnak" by Father Veniaminov $(1840$, v. 1, p. 139). There is an old Aleut legend, as told by Ted Bank (1956, p. 227-228), that when the first Aleuts came to the islands there were no trees, as now, except on this island. There was one tree, with no branches or leaves, so tall that it disappeared in the clouds. The tree was twisted, and to the Aleuts it looked like the seaweed that they used to make fish lines; therefore, they called the island "Umnaqs" meaning "fish line." Visions told the people that the tree stood for the $A$ leut way of life, and if it were destroyed, the Aleut race would disappear forever. When the Russians came to the island, they cut down the tree to make a house for themselves, but they all died soon after. The Aleuts were afraid and built a house around the stump of the tree to protect it. Bank reports that this house is still there.

Umnak Lake: lake, $1.3 \mathrm{mi}$. long, in SW part of Umnak I., Aleutian Is.; $52^{\circ} 56^{\prime} 00^{\prime \prime} \mathrm{N}, 168^{\circ}$. 51'40" W; BGN 1940; (map 21).

So named in 1938 by USC\&GS, "because it is the largest lake on Umnak Island."

Umnak Pass: water passage, between Umnak and Unalaska Is., Aleutian Is.; $53^{\circ} 22^{\prime} \mathrm{N}$, $167^{\circ} 50^{\prime} \mathrm{W}$; (map 23). Var. Umnakskoy.

Aleut name published as "Pr[oliv] Umnakskoy," or "Umnak Strait," by Capt. Tebenkov (1852, map 25), IRN.

Umnakskoy: water passage, see Umnak Pass.

Umnokalukta: locality, on Black River, near its junc. with Kobuk River, Kotzebue-Kobuk Low.; $66^{\circ} 55^{\prime} \mathrm{N}, 157^{\circ} 30^{\prime} \mathrm{W}$; (map 115).

Former Eskimo fishing village reported in 1885 as "Um-nok-a-luk-ta" by Lt. J. C. Cantwell (in Healy, 1887, p. 28), USRCS. See Black River.

Um-nok-a-luk-ta: stream, see Black River.

Um-ok-a-look-tok: stream, see Black River.

Umshaliuk Cape: point of land, see Sedanka Point.

Umyak Island: island, see Umnak Island.
Una, Lake: lake, $800 \mathrm{ft}$. long, on $\mathrm{W}$ coast of Woody I., $2.2 \mathrm{mi}$. SE of Kodiak, Kodiak I.; $57^{\circ} 46^{\prime} 25^{\prime \prime} \mathrm{N}, 152^{\circ} 21^{\prime} 00^{\prime \prime} \mathrm{W}$; (map 34).

Local name published in 1943 by USC\&GS. Unagtuligmut: locality, see Ungalik.

Unaguig Inlet: estuary, see Unakwik Inlet.

Unaguik Inlet: estuary, see Unakwik Inlet.

Unakagak: locality, see Unakak.

Unakagmut: locality, see Unakak.

Unakak: locality, on Ningaluk River near Hazen Bay, $32 \mathrm{mi}$. NE of Cape Vancouver, YukonKuskokwim Delta; 60 54' N, 164.48' W; (map 58). Var. Oonakagamute, Ukak, Unakagak, Unakagmut.

Former Eskimo village listed as "Oonakagamute," population 20, in the 1880 Census by Petroff $(1884$, p. 11$)$; probably obtained by W. H. Nelson, U.S. Signal Service, who visited the village in December 1878.

Unakerair River: stream, see Unakserak River.

Unakserak River: stream, heads at Kutuk Pass, flows $25 \mathrm{mi}$. SW to Alatna River, $21 \mathrm{mi}$. S of Survey Pass, Brooks Ra.; $67^{\circ} 33^{\prime} \mathrm{N}, 154^{\circ} 08^{\prime}$ W; BCN 1912; (map 125). Var. Unakerair River.

Eskimo name reported by P: S. Smith (1913), USGS.

Unaktolik: locality, see Ungalik.

Unaktolik River: stream, see Ungalik River.

Unakwik Bay: estuary, see Unakwik Inlet.

Unakwik Inlet: estuary, on S coast of Alaska, trends S $19 \mathrm{mi}$. from terminus of Meares Glacier to Prince William Sound, $38 \mathrm{mi}$. NE of Whittier, Chugach Mts.; $60^{\circ} 53^{\prime} 00^{\prime \prime} \mathrm{N}$, $147^{\circ} 33^{\prime} 15^{\prime \prime} \mathrm{W}$; (map 63). Var. Unaquick Bay, Unaguig Inlet, Unaguik Inlet.

Eskimo name reported in 1898 as "Unaguig Inlet" by Capt. Glenn (in Glenn and Abercrombie, 1899, p. 24), USA. Its present spelling was given by Grant and Higgins (1910, pl. 2), USGS.

Unakwik Peak: mountain, $3,229 \mathrm{ft}$., near head of Lafayette Glacier, $50 \mathrm{mi}$. SW of Valdez, Chugach Mts.; $61^{\circ} 00^{\prime} 45^{\prime \prime} \mathrm{N}, 147^{\circ} 44^{\prime} 30^{\prime \prime} \mathrm{W}$; BGN 1964; (map 69). Var. Unawik Point.

Eskimo name reported in 1908 by Grant and Higgins (1910, pl. 2), USGS.

Unakwik Point: point of land, at $\mathrm{E}$ side of entrance to Unakwik Inlet, $42 \mathrm{mi}$. NE of Whittier, Ghugach Mts.; $60^{\circ} 53^{\prime} 40^{\prime \prime} \mathrm{N}, 147^{\circ} 31^{\prime} 00^{\prime \prime}$ W; (map 63).

Eskimo name published on recent USGS maps; derived from nearby Unakwik Inlet.

Unalachleet: village, see Unalakleet.

Unalachleet River: stream, see Unalakleet River.

Unalakhlit: village, see Unalakleet.

Unalakleet: village, pop. 574, on Norton Sound, $\mathrm{N}$ of mouth of Unalakleet River, Nulato Hills; $63^{\circ} 52^{\prime} 25^{\prime \prime} \mathrm{N}, 160^{\circ} 47^{\prime} 00^{\prime \prime} \mathrm{W}$; BGN 1919; (map 91). Var. Oonalakleet, Oonalaklik, Ounalakleet, Ounalaklik, Unalachleet, Unalakhlit, Unalaklik, Unalaklit.

Eskimo name spelled "Ounalaklik" by Lt. L. A. Zagoskin, IRN, on an 1850 map. Ivan Petroff lists "Oonalakleet," population 100, in the 1880 Census, population 175 in 1890; 247 in $1910 ; 285$ in $1920 ; 261$ in $1930 ; 329$ in
1939; and 469 in 1950. Because it is the terminus of a long used winter route from Anvik on the Yukon, the inhabitants are a mixed race of Eskimo and Indian. The Unalakleet post office was established in 1901 (Ricks, 1865, p. 68).

Unalakleet River: stream, heads in Kaltag Mts. at $64^{\circ} 20^{\prime} \mathrm{N}, 159^{\circ} 16^{\prime} \mathrm{W}$, flows SW $90 \mathrm{mi}$. to Norton Sound $\mathrm{S}$ of Unalakleet, Nulato Hills; $63^{\circ} 52^{\prime} 10^{\prime \prime} \mathrm{N}, 160^{\circ} 47^{\prime} 15^{\prime \prime} \mathrm{W}$; BGN 1919; (map 91). Var. Oonalakleet River, Ounalaklik River, Reka Unalaklit, Tsetseka, Unalachleet River, Unalaklik River.

Eskimo name recorded in 1842-44 as "R[eka] Unalaklik" by Lt. L. A. Zagoskin, IRN; spelled "Unalaklit" in 1852 on Russian Hydrog. Dept. Chart 1455, which also gives the Indian name as "Tsetseka."

Unalaklik: village, see Unalakleet.

Unalaklit: village, see Unalakleet.

Unalaklit, Reka: stream, see Unalakleet River. Unalaklik River: stream, see Unalakleet River. Unalashka: island, see Unalaska Island.

Unalashka Bay: bay, see Unalaska Bay.

Unalaska: village, pop. 218, on S shore of Una. laska Bay, Unalaska I., Aleutian Is. ; 5352'$30^{\prime \prime} \mathrm{N}, 166^{\circ} 32^{\prime} 00^{\prime \prime} \mathrm{W}$; BGN 1934; (map 23). Var. Gavanskoe, Gavanskoi, Iljljuljuk, Illiuliuk, Illyulyuk, Iloolook, Oonalaska, Ounalaska.

Aleut village reported as "Illyulyuk" by Lt. Sarichev (1826, map 14), IRN, on a map dated 1792. R. H. Geoghegan considers the name to be derived from the Aleut word "ilulaq," meaning "dwelling together harmonious[ly]." The village developed into the commercial center of the Aleutians in the 19 th century and the name "Unalaska" derived from the island, became popular usage. The village population was 196 in $1831 ; 406$ in $1880 ; 317$ in $1890 ; 281$ in $1910 ; 299$ in $1920 ; 226$ in $1930 ; 298$ in 1939 ; and 173 in 1950. The Ounalaska post office was established in 1888; name changed to Unalaska in 1898.

Unalaska Bay: bay, $7 \mathrm{mi}$. across, on NE coast of Unalaska I., Aleutian Is.; $53^{\circ} 58^{\prime} \mathrm{N}, 166^{\circ} 30^{\prime}$ W; BGN 1905; (map 23). Var. Baie de Illiuliuk, Baie du Capitaine, Captains Bay, Captains Harbor, Kapitanskaya Gavan, Unalashka Bay.

Named by George Davidson, USC\&GS, in 1867. William H. Dall, USC\&GS, called it Captain's Bay in 1875, but the USBF reverted to "Unalaska Bay" in 1888. This feature was published by Lt. Sarichev (1826, map 14, dated 1792), IRN, as "Kapitanskaya Gavan," or "Captains Harbor," in honor of Lt. Michael Levashev, IRN, who spent the winter of 1768-69 in what is now known as Captains Bay, an arm of Unalaska Bay.

Unalaska Harbor: harbor, see Iliuliuk Harbor. Unalaska Harbor: bay, see Iliuliuk Bay.

Unalaska Island: island, $20 \mathrm{mi}$. long, one of Fox Is., Aleutian Is.; $53^{\circ} 35^{\prime} \mathrm{N}, 166^{\circ} 50^{\prime} \mathrm{W}$; $B G N$ 1905; (map 23). Var, Aavn Alaska, Agunalaksha, Auan Alaska, Nagounalaska, Nagunalaska, Oonalashka, Ounalachka, Unalashka. 
This island, largest of the eastern Aleutians, was first discovered by the Russians in about 1760. They called it both "Unalashka" and "Agunalashka" (Coxe, 1787, chap. 8-10). The Aleut name was published by Lt. Sarichev (1826, map 14, dated 1792), IRN, as "Ostrov Unalashka," or "Unalashka Island," which Baker (1906, p. 652) says is "a contraction of the true name "Nagounalaska' * * *:" Father Veniaminov (1840, v. 1, p. 158), who lived on the island for ten years, wrote that the Aleuts called it "Na-uan Alakhskha," meaning "this here Alakhskha." According to R. H. Geoghegan, the name comes from the word "unanak" which is the name the Fox Islanders use to designate themselves.

Unalaska Lake: lake, $0.5 \mathrm{mi}$. long, $\mathrm{S}$ of Iliuluk Bay, in Unalaska Bay, on NE coast of Unalaska I., Aleutian Is.; $53^{\circ} 52^{\prime} 05^{\prime \prime} \mathrm{N}, 166^{\circ} 31^{\prime}$ 25" W; (map 23).

Named for Unalaska Island and published in 1951 on a USGS map.

Unalga: locality, on Malga Bay, on NW coast of Unalga I., Aleutian Is.; $53^{\circ} 59^{\prime} \mathrm{N}, 166^{\circ} 10^{\prime}$ W; (map 23). Var. Oonalga, Oonalgenskoi, Unalginskoe.

Former Eskimo village recorded as "Unalginskoe" by Father Veniaminov (1840, v. 2, p. 203). Listed in the 1880 census as "Oonalga." The population in 1880 was 23 .

Unalga Bight: cove, $0.7 \mathrm{mi}$. across, Bay of Is., Adak I., Aleutian Is.; $51^{\circ} 47^{\prime} 10^{\prime \prime} \mathrm{N}, 176^{\circ} 48^{\prime}$ $00^{\prime \prime} \mathrm{W}$; (map 17).

Named by members of the U.S. Navy Aleutian Island Survey Expedition in 1933 "for the U.S.S. Unalga, or for one of the other Alaskan features after which the ship was named."

Unalga Cove: bay, see Malga Bay.

Unalga Island: island, $1.5 \mathrm{mi}$. across, one of Delarof Is., Aleutian Is. ; $51^{\circ} 34^{\prime} 40^{\prime \prime}$ N, $179^{\circ}$ $03^{\prime} 00^{\prime \prime} \mathrm{W}$; (map 16). Var. Ostrov Unalga, Ostrov Zapadnyy Unalga.

Name of Aleut origin; published in 1848 on Russian Hydrog. Chart 1400, as "O[strov] Zapadnyy Unalga," or "western Unalga island," to distinguish it from the Unalga Island between Akutan and Unalaska Islands; published by Capt. Tebenkov (1852, map 28), IRN, as "O[strov] Unalga."

Unalga Island: island, $4.5 \mathrm{mi}$. long, one of Fox Is. between Akutan and Unalaska Is., Aleutian Is.; $53^{\circ} 58^{\prime} 30^{\prime \prime} \mathrm{N}, 166^{\circ} 08^{\prime} 30^{\prime \prime} \mathrm{W}$; (map 23). Var. Oonella Island, Ostrov Oonalgi, Ounalga Isle.

Aleut name reported by Rev. Coxe (1787, p. 209), who took it from the 1768-69 logs of Capt. Lt. P. K. Krenitzin and Lt. M. Levashev. Published as "O[strov] Unalga," or "Unalga Island," by Lt. Sarichev (1826, map 14, dated 1792), IRN; reported as "Oonella Island" by Capt. Cook (1778, v. 2, p. 425), RN; as "Ostrov Oonalgi" by Commodore Billings (1792, p. 232), IRN; and as "Ounalga Isle" by Capt. Lutke (1836, p. 288), IRN.
Unalga Pass: water passage, between Unalga and Unalaska Is., Aleutian Is.; $53^{\circ} 58^{\prime} \mathrm{N}, 166^{\circ}$ 14' W; (map 23). Var. Canal de Camacho, Ounalga Pass.

Aleut name derived from Unalga I. and reported by Capt. Lutke (1836, p. 283), IRN, as "Detroit d'Ounalga," or "Ounalga Strait." This feature was also published by Father Veniaminov (1840, v. 1, p. 19) as "P[roliv] Unalginskiy," or "Unalga Strait." It was called "Canal de Camacho" by Martinez about July 22, 1788, in honor of one of his pilots (Wagner, 1937, p. 437).

Unalginskoe: locality, see Unalga.

Unalischachwak, Cape: point of land, see Unalishagvak, Cape.

Unalishagvak, Cape: point of land, on $\mathbf{E}$ coast of Alaska Penin., E of Jute Bay, $47 \mathrm{mi}$. W of Karluk, Aleutian Ra.; $57^{\circ} 32^{\prime} 45^{\prime \prime} \mathrm{N}, 155^{\circ}$. $43^{\prime} 40^{\prime \prime}$ W; (map 35). Var. Cape Unalischachwak, Cape Unalishakhvak, Cape Una. lishogvak.

Native name published by Capt. Tebenkov (1852, map 22), IRN, as "M[ys] Unalishagvak," or "Cape Unalishagvak."

Unalishakhvak, Cape: point of land, see Unalishagvak, Cape.

Unalishogvak, Cape: point of land, see Unalishagvak, Cape.

Unaluk River: stream, flows SW $16 \mathrm{mi}$. to Kinegnak River, $1 \mathrm{mi}$. E of Kinegnak and $24 \mathrm{mi}$. NE of Cape Newenham, KilbuckKuskokwim Mts.; $58^{\circ} 50^{\prime} \mathrm{N}, 161^{\circ} 38^{\prime} \mathrm{W} ; \mathrm{BGN}$ 1938; (map 39).

Eskimo name reported in 1938 by J. B. Mertie and Gerald FitzGerald, USGS.

Unana, Mount: mountain, 5,490 ft., $4 \mathrm{mi}$. NE of Shelter Cove on Russell Fiord and $23 \mathrm{mi}$. NE of Yakutat, St. Elias Mts.; $59^{\circ} 45^{\prime} 35^{\prime \prime} \mathrm{N}, 139^{\circ}$. $13^{\prime} 05^{\prime \prime} \mathrm{W}$; (map 46).

Name reported by Russell (1892, p. 88), USGS.

Unangashik: locality, near Strogonof Point, SW entrance to Port Heiden, Bristol Bay Low.; $56^{\circ} 50^{\prime} \mathrm{N}, 158^{\circ} 57^{\prime} \mathrm{W}$; (map 30). Var. Oonangashik, Oonongashik.

Former Eskimo village listed as "Oonangashik" and "Oonongashik" in the 1880 Census with a population of $37 ; 190$ in 1890 .

Unanimous Creek: stream, heads on Eureka Dome, flows SE $1.2 \mathrm{mi}$. to Eureka Creek, 20 mi. S of Rampart, Yukon-Tanana High. $65^{\circ} 12^{\prime} 15^{\prime \prime} \mathrm{N}, 150^{\circ} 12^{\prime} 30^{\prime \prime} \mathrm{W}$; (map 106).

Prospectors' name reported in 1931 by J. B. Mertie, USGS

Unaquick Bay: estuary, see Unakwik Inlet.

Unaska Island: island, see Yunaska Island.

Unastal Island: island, see Guide Island.

Unatkuyuk Island: island, see Wosnesenski Island.

Unatlotly: bluff, on N bank of Koyukuk River, $1 \mathrm{mi}$. SW of Allakaket, Hogatza High.; $66^{\circ}$ $34^{\prime} \mathrm{N}, 152^{\circ} 41^{\prime} \mathrm{W}$; (map 117). Var. Nishthla-tot-li, Unutlatly.

Koyukan Indian name obtained in 1885 by Lt. Allen (1887, p. 98), USA. The area on top of the bluff was a trading place of the Eskimos and Indians. Archdeacon Stuck
(1917, p. 340) gave the name as "Nish-thlatot-li."

Unatlotly Creek: stream, heads in lake and flows SE $10 \mathrm{mi}$. to Koyukuk River, $2 \mathrm{mi}$. SW of Allakaket, Hogatza High.; $66^{\circ} 33^{\prime} \mathrm{N}, 152^{\circ}$ 42' W; (map 117).

Name reported in 1885 by Lt. Allen (1887, p. 99), USA.

Unatolik: locality, see Ungalik.

Unavikhshak, Ostrov: island, see Unavikshak Island.

Unavikshak Island: island, $2 \mathrm{mi}$. long, $\mathrm{S}$ of Alaska Penin., 4 mi. E of Cape Kumliun and 27 mi. SW of Cape Kunmik, Aleutian Ra.; $56^{\circ}$. $30^{\prime} \mathrm{N}, 157^{\circ} 43^{\prime} \mathrm{W}$; (map 31). Var. Ile Ouna-nigh-mack, Ostrov Unavikhshak.

Eskimo name published as "I[le] Ounanighmack" by von Krusenstern (1827, map 20), IRN, and as "O[strov] Unavikhshak" by the Russian Hydrog. Dept. (1847, Chart 1379).

Unawik Point: mountain, see Unakwik Peak.

Uncle Sam Creek: stream, flows SW $8 \mathrm{mi}$. to McCoy Creek, $28 \mathrm{mi}$. NW of Big Delta, Yukon-Tanana High.; $64^{\circ} 29^{\prime} \mathrm{N}, 146^{\circ} 21^{\prime} \mathrm{W}$; (map 101).

Prospectors' name; reported in 1910 by USGS (Capps, 1912, pl. 1).

Uncle Sam Creek: stream, flows S $3.7 \mathrm{mi}$. to Pine Creek, $5 \mathrm{mi}$. NE of Solomon, Seward Penin. High.; $64^{\circ} 36^{\prime} \mathrm{N}, 164^{\circ} 18^{\prime} \mathrm{W}$; (map 95).

Prospectors' name shown on Arthur Gibson's "Map of Nome Precinct" dated 1904.

Uncle Sam Creek: stream, flows E $13 \mathrm{mi}$. to Tolovana River, $35 \mathrm{mi}$. SE of Rampart, Tanana Low.; $65^{\circ} 09^{\prime} 30^{\prime \prime} \mathrm{N}, 149^{\circ} 19^{\prime} 30^{\prime \prime} \mathrm{W}$; (map 105).

Named by prospectors; published in 1906 by USGS.

Uncle Sam Creek: stream, see Sam Patch Creck.

Uncle Sam Mountain: mountain, 1,297 ft., $7 \mathrm{mi}$. NE of Solomon, Seward Penin. High.; 64 $37^{\prime}$ $\mathrm{N}, 164^{\circ} 16^{\prime} \mathrm{W}$; (map 95).

Local name reported in 1905 by T. G. Gerdine, USGS.

Uncompahgre Creek: stream, flows $\mathrm{N} 4 \mathrm{mi}$. to Charley River $12 \mathrm{mi}$. S of that stream's junc. with Yukon River, Yukon-Tanana High.; $65^{\circ}$. $09^{\prime} \mathrm{N}, 142^{\circ} 53^{\prime} \mathrm{W}$; (map 103).

Probably named by prospectors from the mining area of southwestern Colorado, where this Ute Indian name was common; from an unpublished map by E. J. Chamberlain, dated 1902.

Under Cloud Mountain: peak, 4,005 ft., $4.5 \mathrm{mi}$. NW of Arctic Village, Brooks Ra.; $68^{\circ} 11^{\prime}$. N, $145^{\circ} 36^{\prime} \mathrm{W}$; (map 136).

Translation of a Kutchin Indian name reported in 1956 by T. E. Taylor, USGS.

Underhill Creek: stream, flows W $10 \mathrm{mi}$. to Stony River $15 \mathrm{mi}$. NW of its junc. with Telaguana River, $65 \mathrm{mi}$. NW of Lake Clark, Lime Hills; $61^{\circ} 14^{\prime} \mathrm{N}, 154^{\circ} 44^{\prime} \mathrm{W}$; (map 71 ).

Prospectors' name published in 1951 by USGS.

Unga: village, pop. 43, on Delarof Harbor, on SE coast of Unga I., in Shumagin Is., Aleu- 
tian Ra.; $55^{\circ} 11^{\prime} 00^{\prime \prime} \mathrm{N}, 160^{\circ} 30^{\prime} 10^{\prime \prime} \mathrm{W}$; (map 28). Var. Delarof, Delarov, Delarovskoi, Oongenskoi, Ounga, Ougnagok, Ugnasik.

Aleut village reported as "Ougnagok" by F. P. Lutke in 1836. According to Petroff (1884, p. 35) Father Ioann Veniaminov called it "Delarov" in 1833. See Delarof Harbor. The population was 116 in $1833 ; 185$ in $1880 ; 159$ in $1890 ; 108$ in $1910 ; 313$ in $1920 ; 150$ in $1930 ; 152$ in 1939 ; and 107 in 1950. The "Ounga" post office, established in 1888, changed its name to Unga in 1894; discontinued in 1958 (Ricks, 1965, p. 49, 68).

Unga Cape: point of land, SE tip of Unga I., in Shumagin Is., Aleutian Ra.; $55^{\circ} 08^{\prime} 10^{\prime \prime} \mathrm{N}$, $160^{\circ} 31^{\prime} 30^{\prime \prime} \mathrm{W}$; (map 28). Var. Cape Unga.

Named in 1888 by USBF; published in 1916 Coast Pilot (p. 180).

Unga Creek: stream, heads on $\mathrm{N}$ slope of Tulik Volcano, flows SE $4.5 \mathrm{mi}$. to the Pacific Ocean, on NE coast of Umnak I., Aleutian Is.; $53^{\circ} 20^{\prime} 10^{\prime \prime} \mathrm{N}, 167^{\circ} 58^{\prime} 40^{\prime \prime} \mathrm{W}$; (map 23).

Name published by USGS (Byers, 1959, pl. 41). This name may have been derived from an Aleut word and arbitrarily "clipped" for convenience. See Geoghegan (1944, p. 123).

Unga Harbor: cove, see Delarof Harbor.

Unga Island: island, $15 \mathrm{mi}$. long, largest and most important of Shumagin Is., Aleutian Ra.; $55^{\circ} 15^{\prime} \mathrm{N}, 160^{\circ} 40^{\prime} \mathrm{W}$; (map 28). Var. Ostrov Unga, Ounga Island.

Aleut name reported as "Ounga" in 1827 by Adm. A. J. von Krusenstern, IRN; in 1840 Veniaminov (v. 1, p. 254), gave the name "O[strov] Unga."

Unga Islands: islands, see Shumagin Islands.

Ungalak Mountain: mountain, 1,553 ft., N of Bend Mtn., $10 \mathrm{mi}$. SW of Russian Mission, Yukon-Kuskokwim Delta; $61^{\circ} 41^{\prime} 30^{\prime \prime} \mathrm{N}$, $161^{\circ} 33^{\prime} 15^{\prime \prime} \mathrm{W}$; (map 73).

Eskimo name reported by USC\&GS in 1948.

Ungalambingoi: dunes, see Oongalambingoi Dunes.

Ungalik: locality, on SE shore of Norton Bay near mouth of Ungalik River, Nulato Hills; $64^{\circ} 33^{\prime}$ N, 160 53' W; (map 96). Var. Oonakhtolik, Ounag-touli, Unagtuligmut, Unaktolik, Unatolik, Ungaliktalik, Ungawaktolik, Unoctolik, Unoktolik.

Former Eskimo village reported in 1842-44 as "Ounag-touli" and "Unagtuligmut," by Lt. L. A. Zagoskin, IRN. In the 1880 Census, Ivan Petroff listed "Oonakhtolik," population 15. The name is now applied to a placer mine several miles upstream.

Ungalik River: stream, heads on Traverse Peak, flows SW $90 \mathrm{mi}$. to Norton Bay at Ungalik, Nulato Hills; $64^{\circ} 34^{\prime} \mathrm{N}, 160^{\circ} 55^{\prime} \mathrm{W}$; (map 96). Var. Oungaklitalik River, Unaktolik River, Ungaliktalik River, Unoktolik River.

Eskimo name given in 1880 by Ivan Petroff as "Oungaklitalik R." See Ungalik.

Ungaliktalik: locality, see Ungalik.

Ungaliktalik River: stream, see Ungalik River. Ungalikthluk: locality, on left bank of Ungalikthluk River, $12 \mathrm{mi}$. SE of Togiak, Kilbuck-
Kuskokwim Mts.; $58^{\circ} 56^{\prime}$ N, $160^{\circ} 08^{\prime}$ W; (map 39).

Eskimo name reported in 1948 by USC\&GS. Ivan Petroff showed a village symbol in this area on an 1881 map, but he failed to give a name.

Ungalikthluk River: stream, heads at $59^{\circ} 15^{\prime} \mathrm{N}$ $159^{\circ} 45^{\prime} \mathrm{W}$, flows SW $40 \mathrm{mi}$. to Togiak Bay E of Rocky Point, 13 mi. SE of Togiak, KilbuckKuskokwim Mts.; 58 $54^{\prime} \mathrm{N}, 160^{\circ} 10^{\prime} \mathrm{W}$; (map 39). Var. Kukayachagak River, Nukayachagak Creek, Nukayachagak River.

Eskimo name obtained about 1948 by USGS from Frank Waskey, local trader and prospector.

Ungalikthluk River: stream, see Negukthlik River.

Ungalukthluk River: stream, see Negukthlik River.

Ungalukuk River: stream, see Negukthlik River. Unga Reef: reef, in Popof Strait, in Shumagin Is., Aleutian Ra.; $55^{\circ} 20^{\prime} 20^{\prime \prime} \mathrm{N}, 160^{\circ} 31^{\prime} 25^{\prime \prime}$ W; (map 28).

Named in 1872 by W. H. Dall.

Ungashik: village, see Ugashik.

Unga Spit: spit, $\mathbf{N}$ tip of Unga I, in Shumagin Is., Aleutian Ra.; $55^{\circ} 24^{\prime} 30^{\prime \prime} \mathrm{N}, 160^{\circ} 43^{\prime} 30^{\prime \prime}$ W; (map 28). Var. Narrow Cape, Mys Tonki.

Local name published by USC\&GS in 1926 Coast Pilot (p. 199). Called "M[ys] Tonki," or "narrow cape," on Russian Hydrog. Dept. Chart 1379 (1847) and listed as Narrow Cape by Baker (1906, p. 454), USGS. Recent maps show the point to be fairly wide. Unga Strait: water passage, between Unga I. and $S$ part of Alaska Penin, Aleutian Ra.; $55^{\circ} 25^{\prime}$ $\mathrm{N}, 160^{\circ} 30^{\prime} \mathrm{W}$; (map 28).

Named in 1872 by W. H. Dall.

Ungayak Hill: hill, see Oongayuk Hill.

Ungay Bay: bay, see Alimuda Bay.

Ungaymilud Bay: bay, see Alimuda Bay.

Ungayukaukurnik: mountains, see Parents Mountains.

Ungeeleganjiak: stream, see Reed River.

Ungeeletargeeak: stream, see Reed River.

Ungluayagat Mountain: mountain, 1,400 ft., E of Goodnews Lake, $45 \mathrm{mi}$. NE of Goodnews, Kilbuck-Kuskokwim Mts.; $59^{\circ} 28^{\prime} \mathrm{N}, 160^{\circ} 30^{\prime}$ W; (map 53).

Eskimo name reported to mean "little nest" referring to nests of the eagles located on the mountain. This name was obtained at Goodnews about 1951 by J. M. Hoare, USGS.

Ungulak: hill, see Ungulungwak Hill.

Ungulukthluk River: stream, see Negukthlik River.

Ungulungwak Hill: hill, $377 \mathrm{ft} ., 35 \mathrm{mi} . \mathrm{S}$ of Kwiguk, Yukon-Kuskokwim Delta; $62^{\circ} 17^{\prime} \mathrm{N}$, $164^{\circ} 14^{\prime} \mathrm{W}$; (map 77). Var. Ungulak.

Eskimo name obtained in 1899 by G. R. Putnam, USCi\&GS

Unguriak Camp: locality, Eskimo camp, on Ongoveyuk Lagoon, $29 \mathrm{mi}$. SE of Savoonga, St. Lawrence I.; $63^{\circ} 27^{\prime} \mathrm{N}, 169^{\circ} 47^{\prime} \mathrm{W}$; (map 93). Var. Franks Camp, Oongooriak Camp, Oongooviak Camp, Sepilla Camp.
Eskimo name reported in 1932 by $O$. W. Geist, Univ. of Alaska, as "Oongooviak."

Ungwaktolik: locality, see Ungalik.

Ungyat: point of land, see Vngyat Point.

Unietkhalen: bay, see Uniktali Bay.

Unigun: islands, see Four Mountains, Islands of.

Uniktalia: bay, see Uniktali Bay.

Uniktali Bay: bay, $0.7 \mathrm{mi}$. across, part of Beaver Inlet, $\mathbf{E}$ coast of Unalska I., Aleutian Is.; $53^{\circ} 47^{\prime} 15^{\prime \prime}$ N, $166^{\circ} 30^{\prime} 00^{\prime \prime}$ W; (map 23). Var. Mountain Bay, Uniktalia, Unietkhalen.

Aleut name called "Zal[iv] Unytkhalen," or "Unytkhalen Bay," by Lt. Sarichev (1826, map 14), IRN. This name possibly comes from the Aleut word "unaxtak" which, according to R. H. Geoghegan, means "broken." This bay was called "Mountain Bay" by USBF in 1888 .

Unilak: locality, see Omilak.

Unimak: locality, at SW end of Unimak I., Aleutian Is.; $54^{\circ} 28^{\prime} \mathrm{N}, 164^{\circ} 40^{\prime} \mathrm{W}$; (map 24).

Village reported in the 1940 Census with a population of 88 .

Unimak Bay: bight, see Unimak Bight.

Unimak Bight: bight, extends $15 \mathrm{mi}$. from Cape Lutke to Cape Rukavitsie, on S coast of Unimak I., Aleutian Is.; $54^{\circ} 35^{\prime} \mathrm{N}, 164^{\circ} 10^{\prime} \mathrm{W}$; $B G N$ 1965; (map 24). Var. Toogamak, Tougamak, Tugamak, Unimak Bay.

Named about 1885 by USC\&GS for Unimak Island. Its Aleut name was recorded by Father Veniaminov (1840, v. 1, p. 211) as "Tyramak" ["Tugamak"].

Unimak Cove: bay, $0.7 \mathrm{mi}$. across, on $\mathrm{N}$ central coast of Sanak I., Aleutian Ra.; 54 $27^{\prime} 30^{\prime \prime}$ $\mathrm{N}, 162^{\circ} 39^{\prime} 30^{\prime \prime} \mathrm{W}$; (map 25).

Name derived from Unimak Island; reported by Ferdinand Westdahl, USC\&GS, commander of the Coast Survey steamer McArthur, who made surveys in this area in 1901.

Unimak Island: island, $67 \mathrm{mi}$. long and $22 \mathrm{mi}$. wide, in Fox Is., Aleutian Is.; $54^{\circ} 45^{\prime} \mathrm{N}$, $165^{\circ} 00^{\prime} \mathrm{W}$; BGN 1890; (map 24). Var. Don Jose de Flores, Ile de Ounimak, Isla San Gonzalo, Oonemak Island, Oonimak Island.

Aleut name recorded by Capt. Cook (1785, v. 2, p. 426), RN, July 2, 1778; it is called by the people of these parts "Oonemak, * * *," Estéban José Martínez called the island "Don Jose de Flores" in 1788; and López de Haro called it "Isla San Gonzalo" on July 16,1788 , probably derived from his Christian name (Wagner, 1937, p. 500).

Unimak Pass: zeater passage, $13 \mathrm{mi}$. wide, between Unimak I. and Krenitzin Is., Aleutian Is.; $54^{\circ} 20^{\prime} \mathrm{N}, 164^{\circ} 50^{\prime} \mathrm{W}$; BGN 1890; (map 24). Var. Ounimak Detroit, Proliv Unimakskiy.

Capt. Lutke (1836, p. 304-5), IRN, reports this name as "Ounimak detroit" [strait] probably for convenience after the island name. Capt. Tebenkov (1852, map 26), IRN, shows "Proliv Unimakskiy" meaning "Unimak Strait." Unimak Pass is one of the 
principal ship passages through the Aleutian Islands.

Unimakskiy, Proliv: water passage, see Unimak Pass.

Union: locality, see Union City.

Union Bay: bay, near mouth of Ernest Sound, on NW coast of Cleveland Penin, $42 \mathrm{mi}$. NE of Craig, Alex. Arch.; $55^{\circ} 46^{\prime} \mathrm{N}, 132^{\circ} 13^{\prime} \mathrm{W}$; (map 4).

Name appears prior to 1880 on unpublished charts (Baker, 1906, p. 653).

Union City: locality, site of prospectors' camp at junc. of Koyukuk River and its South Fork, $20 \mathrm{mi}$. E of Allakaket, Kanuti Flats; $66^{\circ} 35^{\prime} \mathrm{N}$, $151^{\circ} 56^{\prime} \mathrm{W}$; (map 117). Var. Union.

Name reported in 1899 by G. H. Wonson, Master of the steamer Dorothy, on his manuscript map of the Koyukuk River. One of several temporary camps established by prcspectors caught on the river during the winter of 1898-99.

Union City: locality, see New Boston.

Union Creek: stream, flows W $1.7 \mathrm{mi}$. to Kvichak River, $1 \mathrm{mi}$. S of Levelock and $58 \mathrm{mi}$. $\mathrm{E}$ of Dillingham, Bristol Bay Low.; 59 $05^{\prime} 45^{\prime \prime} \mathrm{N}$, $156^{\circ} 50^{\prime} 30^{\prime \prime} \mathrm{W}$; (map 52).

Local name published in 1952 by USGS.

Union Creek: stream, flows $\mathrm{N} 1 \mathrm{mi}$. to Teddys Fork, $10 \mathrm{mi}$. SW of Eagle, Yukon-Tanana High.; 64 $41^{\prime} \mathrm{N}, 141^{\circ} 22^{\prime} \mathrm{W}$; (map 102).

Prospectors' name shown on an 1898 manuscript map by C. A. Woodruff of Fort Cudahy, Canada.

Union Creek: stream, flows WSW $2 \mathrm{mi}$. to Bonanza River, $17 \mathrm{mi}$. NW of Solomon, Seward Penin. High.; $64^{\circ} 45^{\prime} 40^{\prime \prime} \mathrm{N}, 164^{\circ} 45^{\prime} 30^{\prime \prime} \mathrm{W}$; (map 95)

Prospectors' name reported on the 1900 "Map of Nome Peninsula" by J. M. Davidson and B. D. Blakeslee.

Union Creek: stream, flows NW $8 \mathrm{mi}$. to Troublesome Creek, $17 \mathrm{mi}$. E of Rampart, Yukon-Tanana High.; $65^{\circ} 30^{\prime} \mathrm{N}, 149^{\circ} 33^{\prime} \mathrm{W}$; (map 105).

Named by prospectors; reported in 1908 by USGS (Covert and Ellsworth, 1909, pl. 5).

Union Creek: ravine, see Union Gulch.

Union Gulch: ravine, trends SW $0.7 \mathrm{mi}$. to Buster Creek, 9 mi. NE of Nome, Seward Penin. High.; $64^{\circ} 36^{\prime} \mathrm{N}, 165^{\circ} 13^{\prime} \mathrm{W}$; (map 94).

Prospectors' name reported in 1904 by T. G. Gerdine, USGS.

Union Gulch: ravine, trends NW $1.3 \mathrm{mi}$. to Fourth of July Creek $7 \mathrm{mi}$. WSW of that stream's junc. with Yukon River and $33 \mathrm{mi}$. NW of Eagle, Yukon-Tanana High.; $65^{\circ} 07^{\prime}$ $45^{\prime \prime} \mathrm{N}, 141^{\circ} 59^{\prime} 50^{\prime \prime} \mathrm{W}$; (map 103). Var. Union Creek.

"Union Creek" was reported in 1938 by Mertie (1942, p. 250), USGS.

Union Point: point of land, $\mathrm{W}$ tip of Cleveland Penin., between Union Bay and Vixen Inlet, Alex. Arch.; $55^{\circ} 48^{\prime} 10^{\prime \prime} \mathrm{N}, 132^{\circ} 11^{\prime} 05^{\prime \prime} \mathrm{W}$; (map 4).

Named by local fishermen and reported in 1904 by H. C. Fassett, USBF.

Unishka, Ostrov: island, see Unishka Island.
Unishka Island: island, $0.3 \mathrm{mi}$. long, $5 \mathrm{mi}$. $\mathrm{N}$ of Goddard, on W coast of Baranof I., Alex. Arch.; $56^{\circ} 54^{\prime} 30^{\prime \prime} \mathrm{N}, 134^{\circ} 22^{\prime} 30^{\prime \prime} \mathrm{W}$; (map 5). Var. Ostrov Unishka.

Named in 1809 by the Russian navigator, Ivan Vasiliev the first; published by Lt. Sarichev (1826, map 19), IRN, as "O[strov] Unishka," or "Unishka Island."

University of Alaska Range: mountain range, see University Range.

University Peak: peak, 15,030 ft., at $\mathrm{E}$ end of University Range, $4 \mathrm{mi}$. SW of Mount Bona and $38 \mathrm{mi}$. SE of McGarthy, St. Elias Mts.; BGN 1953; $61^{\circ} 20^{\prime} \mathrm{N}, 141^{\circ} 48^{\prime} \mathrm{W}$; (map 67). Var. Peak A.

Named in 1952 by Terris Moore, then President of the Univ. of Alaska, who wrote: "I herewith claim by virtue of prior discovery to name two peaks about five and ten miles west-southwest of Mount Bona. I informed regents of the University of my intention to name one of these peaks University Peak for the University of Alaska."

University Range: mountain range, elev. 7,000 to $15,000 \mathrm{ft}$., trends $20 \mathrm{mi}$. SE from Chitistone River to University Peak, $38 \mathrm{mi}$ : $\mathrm{E}$ of McCarthy, St. Elias Mts. ; BGN 1966; $61^{\circ} 20^{\prime}$ $\mathrm{N}, 141^{\circ} 47^{\prime} \mathrm{W}$ (SE end) $61^{\circ} 29^{\prime} \mathrm{N}, 142^{\circ} 18^{\prime}$ W (NW end); (map 67). Var. University of Alaska Range.

Named in 1965 by Terris Moore, former President of the Univ. of Alaska, for the Univ. of Alaska.

Unknown Glacier: glacier, heads near AlaskaCanada Boundary Peak 94 about $58^{\circ} 47^{\prime} \mathrm{N}$, $134^{\circ} 05^{\prime} \mathrm{W}$; trends $\mathrm{SE}$ about $3.5 \mathrm{mi}$. to Hades Highway, $33 \mathrm{mi}$. NNE of Juneau, Coast Mts.; $58^{\circ} 42^{\prime} 30^{\prime \prime} \mathrm{N}, 133^{\circ} 56^{\prime} 30^{\prime \prime} \mathrm{W}$; (map 12).

Local name reported in 1960 by USGS.

Unlucky Island: island, $900 \mathrm{ft}$. long, between Doyle and Trocadero Bays, on $\mathrm{W}$ coast of Prince of Wales I., Alex. Arch.; 5, $5^{\circ} 24^{\prime} 00^{\prime \prime}$ N, $133^{\circ} 03^{\prime} 15^{\prime \prime} \mathrm{W}$; (map 4). Var. Isla Desgraciada, La Desgraciada.

Translation of the name "Isla Desgraciada" given in $1775-79$ by Don Juan de la Bodega y Quadra and Francisco Antonio Maurelle.

Unmanokuk Creek: stream, flows NW $5 \mathrm{mi}$. to Kobuk River, 25 mi. NW of Selawik, Hogatza High.; $66^{\circ} 55^{\prime} \mathrm{N}, 160^{\circ} 27^{\prime} \mathrm{W}$; (map 114).

Eskimo name obtained in 1955 by U.S. Army Corps of Engineers.

Un-nah-tak: locality, see Unnatak.

Unnamed Peak: peak, see Centurian Peak.

Unnatak: locality, on $\mathrm{N}$ bank of Kobuk River near mouth of Ambler River, Brooks Ra.; $67^{\circ} 06^{\prime} \mathrm{N}, 157^{\circ} 48^{\prime} \mathrm{W}$; (map 126). Var. Un-nah-tak.

Former Eskimo village or camp reported in 1885 as "Un-nah-tak," by Lt. J. C. Cantwell, USRCS (Baker, 1906, p. 654).

Uno Basin: basin, 1 mi. across, near head of Uno Creek, $1.4 \mathrm{mi}$. NE of Shoup Bay and $9.8 \mathrm{mi}$. $\mathrm{N}$ of Valdez, Chugach Mts.; 61 ${ }^{\circ} 14^{\prime} 15^{\prime \prime} \mathrm{N}$, $146^{\circ} 32^{\prime} 30^{\prime \prime} \mathrm{W}$; (map 68).

Local name reported in 1909 by U. S. Grant and D. F. Higgins, USGS.
Uno Creek: stream, flows SW $2.5 \mathrm{mi}$. to head of Shoup Bay, and $11 \mathrm{mi}$. NW of Valdez, Chugach Mts.; $61^{\circ} 08^{\prime} 40^{\prime \prime} \mathrm{N}, 146^{\circ} 35^{\prime} 15^{\prime \prime} \mathrm{W}$; (map 68).

Local name reported in 1909 by U. S. Grant and D. F. Higgins, USGS.

Unoctolik: locality, see Ungalik.

Unoktolik: locality, see Ungalik.

Unoktolik River: stream, see Ungalik River.

Unowhokkuik Creek: stream, flows $S 5 \mathrm{mi}$. to Hardluck Bay, $46 \mathrm{mi}$. N of Dillingham, Kilbuck-Kuskokwim Mts.; $59^{\circ} 42^{\prime} \mathrm{N}, 158^{\circ} 48^{\prime} \mathrm{W}$; (map 52).

Eskimo name recorded as "U-now-hok-kuik" on a 1910 manuscript map by H. C. Fassett, USBF.

Unroojithok Lake: lake, $0.5 \mathrm{mi}$. across, $3 \mathrm{mi}$. N of Kimiksthek Hill, $40 \mathrm{mi}$. NW of Cape Mendenhall, Nunivak I., $60^{\circ} 09^{\prime} \mathrm{N}, 167^{\circ} 04^{\prime} \mathrm{W}$; (map 57). Var. Unruchithak Lake.

Eskimo name reported to mean "stomach" in 1949 by USC\&GS.

Unruchithak Lake: lake, see Unroojithok Lake. Un-suz-ee: mountain, see Haystack Mountain.

Unsuzi Mountain: mountain, see Haystack Mountain.

Unuk: locality, see Uinuk.

Unukpay: promontory, see Thompson, Cape.

Unukpay Cliff: cliff, see Imnakpak Cliff.

Unuk River: stream, heads in Canada, on E side of Mount Stoeckl, flows SW $28 \mathrm{mi}$. to head of Burroughs Bay, Coast Mts.; $56^{\circ} 05^{\prime} \mathrm{N}, 131^{\circ} 05^{\prime}$ W; (map 7). Var. Junock River, Junuk River.

Indian name reported by USC\&GS between 1880 and 1900. M. W. Gorman (in Baker, 1906 , p. 654) says "The correct name of this river is 'Junuk' or 'Junock'."

Unuqpay: promontory, see Thompson, Cape.

Unutlatly: bluff, see Unatlotly.

Upapak Cape: point of land, see Upapak Point. Upapak Point: point of land, $10.5 \mathrm{mi}$. S of Gambell, W coast of St. Lawrence I.; 63 $38^{\prime} 30^{\prime \prime}$ $\mathrm{N}, 171^{\circ} 47^{\prime} 00^{\prime \prime} \mathrm{W}$; BGN 1951; (map 93). Var. Apapok Cape, Cape Apapak, Upapak Cape.

Eskimo name meaning "potlach" [apapak], reported in 1932 by $O$. W. Geist, Univ. of Alaska.

Uphoon Mouth: stream mouth, see Apoon Mouth.

Uphoon Pass: stream, see Apoon Pass.

Upiktalik: locality, see Opiktulik.

Upkuarok Creek: stream, on Seward Penin., flows NW 19 mi. to Arctic Lagoon on Chukchi Sca, $48 \mathrm{mi}$. NW of Teller, Kotzebue-Kobuk Low.; $65^{\circ} 55^{\prime} \mathrm{N}, 166^{\circ} 57^{\prime} \mathrm{W}$; (map 111).

Prospectors' name published in 1956 by USGS.

Upland Creek: stream, see Shepard Creek.

Upnuck Lake: lake, see Upnuk Lake.

Upnuk Lake: lake, $10 \mathrm{mi}$. long, among Tikchik Lakes, $5 \mathrm{mi}$. $\mathrm{N}$ of Chikuminuk Lake and 112 mi. SW of Sleetmute, Kilbuck-Kuskokwim Mts. ; $60^{\circ} 22^{\prime} \mathrm{N}, 158^{\circ} 47^{\prime} \mathrm{W}$; BGN 1932; (map 60). Var. Upnuck Lake, Uppnuk Lake.

Eskimo name reported in 1915 by USBF

Up-nut: stream, see Anikovik River. 
Upper Arm Cabin Cove: cove, $0.3 \mathrm{mi}$. across, part of Cabin Cove, on $\mathrm{E}$ coast of Kagalaska I., Aleutian Is.; $51^{\circ} 50^{\prime} 00^{\prime \prime} \mathrm{N}, 176^{\circ} 18^{\prime} 45^{\prime \prime} \mathrm{W}$; $B G N$ 1936; (map 17). Var. North Arm Cabin Cove.

Descriptive name given in 1934 by members of the U.S. Navy Aleutian Island Survey Expedition.

Upper Basin: valley, $1.2 \mathrm{mi}$. long, along upper course of Nugget Creek, $3 \mathrm{mi}$. E of Mendenhall Lake and $9 \mathrm{mi}$. $\mathrm{N}$ of Juneau, Coast Mts.; $58^{\circ} 26^{\prime} \mathrm{N}, 134^{\circ} 26^{\prime} \mathrm{W}$; (map 11).

Name published in 1962 by USGS.

Upper Boulder Creek: stream, flows NW $6 \mathrm{mi}$. to Salcha River $11 \mathrm{mi}$. E of that stream's junc. with its North Fork and $46 \mathrm{mi}$. NE of Big Delta, Yukon-Tanana High.; $64^{\circ} 40^{\prime} \mathrm{N}, 144^{\circ}$ 57' W; (map 101).

Local name reported in 1958 by USGS.

Upper Brentwood Lake: lake, $1.5 \mathrm{mi}$. long, one of Brentwood Lakes, $2.5 \mathrm{mi}$. W of Patterson Bay, on SE Baranof I., Alex. Arch.; 56 ${ }^{\circ}$ $37^{\prime} \mathrm{N}, 134^{\circ} 45^{\prime} \mathrm{W}$; (map 5$)$.

Local name reported in 1933 by USFS.

Upper Camp Creek: stream, see Camp Creek.

Upper Canyon: canyon, of Moose Creek, extends E $5 \mathrm{mi}$. from junc. of Eureka Creek, $1.3 \mathrm{mi}$. $\mathrm{N}$ of Wonder Lake, Alaska Ra.; 63 $31^{\circ} \mathrm{N}$, $150^{\circ} 53^{\prime} \mathrm{W}$; (map 88).

Local name reported in 1954 by USGS.

Upper Carmen River: stream, flows NW $5.5 \mathrm{mi}$. to Carmen Lake, $8.5 \mathrm{mi}$. NW of Whittier, Chugach Mts.; $60^{\circ} 53^{\prime} 35^{\prime \prime} \mathrm{N}, 148^{\circ} 45^{\prime} 50^{\prime \prime} \mathrm{W}$; (map 63).

Local name reported in 1951 by USGS.

Upper Checats Lake: lake, $3.6 \mathrm{mi}$. long, $3 \mathrm{mi}$. E af Behm Canal between Punchbowl and Winstanley Lakes, Coast Mts. ; $55^{\circ} 28^{\prime} 30^{\prime \prime} \mathrm{N}$, $130^{\circ} 47^{\prime} 15^{\prime \prime}$ W ; (map 3). Var. Checats Lake.

Tlingit Indian name recorded in 1955 by USGS; reported as "Checats Lake" in 1897 by Lt. Comdr. J. F. Moser, USN.

Upper Chignik Lake: lake, see Black Lake.

Upper Chuligmiut: locality, see Chulik.

Upper Cohoe Lake: lake, $0.7 \mathrm{mi}$. long, one of Cohoe Lakes, on $W$ coast of Kenai Penin., $15 \mathrm{mi}$. SW of Kenai, Cook Inlet Low.; $60^{\circ} 20^{\prime}$ $00^{\prime \prime} \mathrm{N}, 151^{\circ} 19^{\prime} 35^{\prime \prime} \mathrm{W}$; BGN 1966; (map 62).

D. F. Smith, Anchorage, proposed this name in 1965 to differentiate the Cohoe Lakes.

Upper Copper Lake: lake, $2.5 \mathrm{mi}$. long, $1 \mathrm{mi}$. SW of Meadow Lake and $30 \mathrm{mi}$. NW of Augustine I., Aleutian Ra.; $59^{\circ} 35^{\prime} 45^{\prime \prime} \mathrm{N}, 154^{\circ} 07^{\prime} 30^{\prime \prime}$ W; (map 51).

Name published in 1954 by USGS.

Upper Dewey Lake: lake, $0.4 \mathrm{mi}$. long, $1.4 \mathrm{mi}$. $\mathrm{E}$ of Lower Dewey Lake and $2 \mathrm{mi}$. SE of Skagway, Coast Mts.; $59^{\circ} 26^{\prime} 30^{\prime \prime} \mathrm{N}, 135^{\circ} 18^{\prime} 45^{\prime \prime}$ W; $(\operatorname{map} 45)$.

Local name obtained by USGS field personnel and published on Federal maps since 1950.

Upper Doame Lake: lake, $1 \mathrm{mi}$. long, in Deception Hills, $2.4 \mathrm{mi}$. SE of Lower Doame Lake and $64 \mathrm{mi}$. SE of Yakutat, St. Elias Mts: $59^{\circ} 06^{\prime} 25^{\prime \prime} \mathrm{N}, 138^{\circ} 08^{\prime} 20^{\prime \prime} \mathrm{W}$; (map 46).

Local name published in 1959 by USGS
Upper Fire Lake: lake, $0.5 \mathrm{mi}$. long, one of the Fire Lakes, along Glenn Highway, $15 \mathrm{mi}$. NE of Anchorage, Cook Inlet Low.; 61 $21^{\prime} \mathrm{N}$, $149^{\circ} 32^{\prime} \mathrm{W}$; (map 69).

Local name reported in 1960 by USGS.

Upper Fish Lake: lake, $1.3 \mathrm{mi}$. long, at head of Fish Creek, 3.5 mi. NE of Paxson, Alaska Ra.; $63^{\circ} 04^{\prime} \mathrm{N}, 145^{\circ} 23^{\prime} \mathrm{W}$; (map 86).

Name reported in 1952 by USGS.

Upper Fish River Basin: basin, see McCarthys Marsh.

Upper Fork Twelvemile Creek: stream, flows SW $4 \mathrm{mi}$. to Twelvemile Creek, $3 \mathrm{mi}$. NW of Twelvemile Mtn. and $18 \mathrm{mi}$. SW of Wiseman, Brooks Ra.; $67^{\circ} 12^{\prime} 00^{\prime \prime} \mathrm{N}, 150^{\circ} 30^{\prime} 00^{\prime \prime} \mathrm{W}$; (map 124).

Local name reported in 1956 by T. E. Taylor, USGS.

Upper Halfway Lake: lake, $1.3 \mathrm{mi}$. long, $1.5 \mathrm{mi}$. SW of Lower Halfway Lake and $24 \mathrm{mi}$. SE of Beaver, Yukon-Tanana High.; $66^{\circ} 04^{\prime} \mathrm{N}$, $147^{\circ} 00^{\prime} \mathrm{W}$; (map 119).

Local descriptive name obtained in 1956 by USGS.

Upper Jean Lake: lake, $0.6 \mathrm{mi}$. long, on Kenai Penin., at head of Jean Creek, $37 \mathrm{mi}$. E of Kenai, Chugach Mts.; $60^{\circ} 31^{\prime} 45^{\prime \prime} \mathrm{N}, 150^{\circ}$. $12^{\prime} 30^{\prime \prime} \mathrm{W}$; (map 62).

So named about 1963 by officials of Kenai National Moose Range, because it is the largest of several lakes above Jean Lake.

Upper Kaltag: village, see Kaltag.

Upper Ketchikan Lake: lake, $1.7 \mathrm{mi}$. long, in course of Ketchikan Creek, $2.4 \mathrm{mi}$. N of Ketchikan, Revillagigedo I., Alex. Arch.; 55 23'$30^{\prime \prime}$ N, 131 '37'30" W; BGN 1966; (map 3). Var. Ketchikan Lake, Ketchikan Lakes, Ketchikan Lake Number Two.

Local name reported in 1911 as "Ketchikan Lake" by USFS.

Upper Killey Lake: lake, $0.3 \mathrm{mi}$. long, on Kenai Penin., $5 \mathrm{mi}$. NE of Killey Glacier terminus and $40 \mathrm{mi}$. SE of Kenai, Chugach Mts.; $60^{\circ}$ $12^{\prime} 45^{\prime \prime} \mathrm{N}, 150^{\circ} 18^{\prime} 50^{\prime \prime} \mathrm{W}$; (map 62).

Named for the Killey River about 1963 by officials of Kenai National Moose Range, for administrative purposes.

Upper Kobuk Canyon: canyon, along Kobuk River, $10 \mathrm{mi}$. N of Norutak Lake, Brooks Ra.; $66^{\circ} 58^{\prime}, \mathrm{N}, 154^{\circ} 22^{\prime} \mathrm{W}$; (map 116).

Name published in 1956 by USGS. Lt. J. C. Cantwell, USRCS, refers to it as a gorge (Healy, 1887, p. 34).

Upper Lake: lake, $0.1 \mathrm{mi}$. across, on NE coast of St. George I., in Pribilof Is.; $56^{\circ} 35^{\prime} 55^{\prime \prime} \mathrm{N}$, $169^{\circ} 32^{\prime} 05^{\prime \prime}$ W; (map 38). Var. Kos'eraan'ag.

This is a translation of an Aleut name listed by Putnam (1903, p. 1015), USC\&GS, as "Kos'era-an'ag," and so called because the lake "is above the marshy hollow back of the village [St. George], where there was formerly a lake."

Upper Lake: lake, see Black Lake.

Upper Lake George: lake, $8 \mathrm{mi}$. long, near terminus of Lake George Glacier, $40 \mathrm{mi}$. E of Anchorage, Chugach Mts.; $61^{\circ} 13^{\prime} 30^{\prime \prime} \mathrm{N}$, $148^{\circ} 38^{\prime} 15^{\prime \prime} \mathrm{W}$ : (map 69).
Descriptive name reported in 1951 by K. H. Stone (1963, p. 33).

Upper Mahoney Lake: lake, $0.7 \mathrm{mi}$. long, on Revillagigedo I., $0.5 \mathrm{mi}$. W of George Inlet, $1 \mathrm{mi}$. SW of Mahoney Lake, Alex. Arch.; $55^{\circ} 24^{\prime} 40^{\prime \prime} \mathrm{N}, 131^{\circ} 33^{\prime} 30^{\prime \prime} \mathrm{W}$; (map 3).

Local name reported in 1954 by USGS.

Upper Malina Lake: lake, $1.4 \mathrm{mi}$. long, $15 \mathrm{mi}$. NW of Afognak, on W coast of Afognak I.; $58^{\circ} 09^{\prime} 30^{\prime \prime} \mathrm{N}, 153^{\circ} 05^{\prime} 00^{\prime \prime} \mathrm{W}$; (map 43).

Name derived from Malina Bay; published in 1952 by USGS.

Upper Marten Lake: lake, $1 \mathrm{mi}$. long, at head of Marten Creek, $4.5 \mathrm{mi}$. N of Bradfield Canal, Coast Mts.; $56^{\circ} 17^{\prime} 30^{\prime \prime} \mathrm{N}, 131^{\circ} 50^{\prime} 00^{\prime \prime}$ W; (map 7). Var. Marten Upper Lake.

Local name reported in 1955 by USGS.

Upper Mouth Birch Creek: stream, distributary, flows NW $35 \mathrm{mi}$. from Birch Creek to Yukon River, $25 \mathrm{mi}$. SW of Fort Yukon, Yukon Flats; $66^{\circ} 31^{\prime} 20^{\prime \prime} \mathrm{N}, 146^{\circ} 09^{\prime} 00^{\prime \prime} \mathrm{W}$; (map 119).

Local name published in 1951 by USGS. Upper Mouth Porcupine River: stream, distributary of Porcupine River, flows $\mathrm{S} 2 \mathrm{mi}$. to Yukon River, $1 \mathrm{mi}$. NW of Fort Yukon, Yukon Flats; $66^{\circ} 34^{\prime} 30^{\prime \prime} \mathrm{N}, 145^{\circ} 19^{\prime} 00^{\prime \prime} \mathrm{W}$; (map 119).

Local name obtained in 1956 by USGS.

Upper Nickeyville: area, in city limits of Ketchikan, on Revillagigedo I., Alex. Arch.; $55^{\circ} 21^{\prime}$ $15^{\prime \prime} \mathrm{N}, 131^{\circ} 41^{\prime} 15^{\prime \prime} \mathrm{W}$; (map 3).

Named for an early settler, Nickey [cnna], but the once prominent name is "used very little today."

Upper Niklaremut Creek: stream, flows S $1.5 \mathrm{mi}$. to Yukon River, $3 \mathrm{mi}$. NW of Ruby, KokrinesHodzana High.; $64^{\circ} 44^{\prime} 45^{\prime \prime} \mathrm{N}, 1^{\circ} 5^{\circ} 32^{\prime} 40^{\prime \prime}$ W; (map 98). Var. Necklaremont River.

Riverboat pilots' name shown on 1940 "Navigation Chart, Tanana-Yukon Rivers" of the River Boat Service, U.S. Dept. of Interior.

Upper Ohmer Lake: lake, on Kenai Penin., 0.5 mi. long, $0.5 \mathrm{mi}$. E of Lower Ohmer Lake, $34 \mathrm{mi}$. E of Kenai, Cook Inlet Low.; $60^{\circ} 27^{\prime}$ $20^{\prime \prime} \mathrm{N}, 150^{\circ} 17^{\prime} 30^{\prime \prime} \mathrm{W}$; BGN 1966; (map 62).

Named about 1963 by officials of Kenai National Moose Range for the late Earl N. Ohmer, former chairman of the Territorial Game Commission.

Upper Paradise Lake: lake, $1.5 \mathrm{mi}$. long, at NE end of Paradise Lakes, $22 \mathrm{mi}$. NE of Seward, Chugach Mts.; $60^{\circ} 22^{\prime} \mathrm{N}, 149^{\circ} 01^{\prime} \mathrm{W}$; (map 63).

Local name reported in 1951 by USGS.

Upper Passage: water passage, in Prince William Sound, $3.5 \mathrm{mi}$. long, between Eleanor and Ingot Is., $24 \mathrm{mi}$. NE of Chenega, Chugach Mts.; $60^{\circ} 32^{\prime} \mathrm{N}, 147^{\circ} 37^{\prime} \mathrm{W}$; BGN 1908; (map 63). Var. Eleanor Passage.

Local descriptive name reported in 1908 by USC\&GS.

Upper Quartz Creek: stream, see Slate Creek.

Upper Ramparts: canyon, extends $11 \mathrm{mi}$. along Porcupine River, $8 \mathrm{mi}$. $\mathrm{N}$ of Old Rampart and $33 \mathrm{mi}$. NE of Coleen Mtn., Porcupine Plat.; $67^{\circ} 19^{\prime} \mathrm{N}, 141^{\circ} 30^{\prime} \mathrm{W}$; (map 121).

Name reported in 1895 by USC\&GS. 
Upper Rock Creek: stream, flows NE $8 \mathrm{mi}$. to Rock Creek, $13 \mathrm{mi}$. NNE of Porcupine Dome and $39 \mathrm{mi}$. SW of Circle, Yukon-Tanana High.; $65^{\circ} 42^{\prime} \mathrm{N}, 145^{\circ} 22^{\prime} \mathrm{W}$; (map 104).

Prospectors' name reported in 1954 or 1955 by USGS topographers.

Upper Russian Lake: lake, on Kenai Penin., 3 mi. SW of Cooper Mtn. and $22 \mathrm{mi}$. NW of Seward, Chugach Mts.; $60^{\circ} 20^{\prime} 30^{\prime \prime}$ N, $149^{\circ}$ $52^{\prime} 30^{\prime \prime} \mathrm{W}$; (map 63). Var. Russian Lake.

Local name published by USGS (Martin and others, 1915, pl. 2).

Upper Silver Bow Basin: valley, see Lurvey Basin.

Upper Silvis Lake: lake, $1 \mathrm{mi}$. long, on Revil-

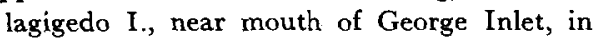
course of Beaver Falls Creek, Alex. Arch.; $55^{\circ} 22^{\prime} 40^{\prime \prime} \mathrm{N}, 131^{\circ} 31^{\prime} 45^{\prime \prime} \mathrm{W}$; (map 3). Var. Silvis Lakes.

Local name reported in 1954 by USGS.

Upper Skolai Lake: lake, W of Russell Glacier, at head of Skolai Creek, $33 \mathrm{mi}$. NE of McCarthy, Wrangell Mts.'; $61^{\circ} 38^{\prime} \mathrm{N}, 141^{\circ} 59^{\prime} \mathrm{W}$; $(\operatorname{map} 67)$.

Local name reported in 1914 by C. E. Giffin, USGS.

Upper Slate Creek: locality, on S bank of Slate Creek $1.5 \mathrm{mi}$. E of its junc. with Chistochina River and $23 \mathrm{mi}$. NE of Paxson, Alaska Ra.; $63^{\circ} 10^{\prime} 00^{\prime \prime} \mathrm{N}, 144^{\circ} 49^{\prime} 15^{\prime \prime} \mathrm{W}$; (map 86).

Name reported in 1952 by USGS

Upper Sucker Creek: stream, heads in lake, flows NE 9 mi. to Sucker Lake, $41 \mathrm{mi}$. NE of Tyonek, Cook Inlet Low.; 61 $39^{\prime} 15^{\prime \prime}$ N, 150 $54^{\prime} 25^{\prime \prime}$ W; (map 70).

Local name reported in 1954 by USGC.

Upper Sweetheart Lake: lake, $1.5 \mathrm{mi}$. long, on Sweetheart Creek, $1 \mathrm{mi}$. E of Lower Sweetheart Lake and $40 \mathrm{mi}$. ESE of Juneau, Coast Mts.; $57^{\circ} 59^{\prime} 45^{\prime \prime} \mathrm{N}, 133^{\circ} 30^{\prime} 15^{\prime \prime} \mathrm{W}$; (map 8).

Local name reported in 1955 by USGS.

Upper Taku Neve: glacier, see Matthes Glacier.

Upper Talarik Creek: stream, flows $S 25 \mathrm{mi}$. to Iliamna Lake, $15 \mathrm{mi}$. SW of Iliamna, Bristol

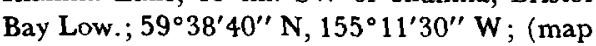
51). Var. Talarik Creek.

Name published as "Talarik Creek" by G. C. Martin and F. J. Katz (1912, pl. 1), USGS. Local usage added the adjective "Upper" to differentiate it from Lower Talarik Creek to the west.

Upper Tangle Lake: lake, $0.3 \mathrm{mi}$. long, $\mathrm{N}$ of Tangle Lakes, between Gulkana and MacLaren Rivers, $18 \mathrm{mi}$. W of Paxson, Alaska Ra.; $63^{\circ} 00^{\prime} \mathrm{N}, 146^{\circ} 05^{\prime} \mathrm{W}$; (map 83).

Local name reported in 1956 by USGS.

Upper Tazimina Lake: lake, $8.5 \mathrm{mi}$. long in course of Tazimina River, $20 \mathrm{mi}$. NE of Nondalton, Aleutian Ra.; $60^{\circ} 03^{\prime} \mathrm{N}, 154^{\circ} 06^{\prime}$ W; (map 61).

Local name reported in 1909 by USGS; derived from the Tazimina River which runs through both Upper and Lower Tazimina Lakes.

Upper Telida Lake: lake, $2.5 \mathrm{mi}$. NE of Lower Telida Lake and $54 \mathrm{mi}$. NE of Medfra, Kuskokwim Low.; $63^{\circ} 26^{\prime} \mathrm{N}, 153^{\circ} 09^{\prime} \mathrm{W}$; (map 89).
Local name derived from the village name; reported in 1958 by USGS.

Upper Togiak Lake: lake, $5 \mathrm{mi}$. long, in Izavieknik River, $7 \mathrm{mi}$. NE of Togiak Lake and $90 \mathrm{mi}$. NE of Goodnews, KilbuckKuskokwim Mts. ; $59^{\circ} 50^{\prime} \mathrm{N}, 159^{\circ} 30^{\prime} \mathrm{W}$; (map 53 ).

Local name published in 1951 by USGS.

Upper Trail Lake: lake, $5.8 \mathrm{mi}$. long, on Kenai Penin. in course of Trail Creek, $\mathrm{N}$ of Lower Trail Lake, $24 \mathrm{mi}$. N of Seward, Chugach Mts.; $60^{\circ} 30^{\prime} \mathrm{N}, 149^{\circ} 22^{\prime} \mathrm{W}$; BGN 1966; (map 63). Var. Trail Lake

Local descriptive name reported in 1915 by USGS.

Upper Trout Lakes: lake, see Trout Lake.

Upper Ugashik Lake: lake, $17 \mathrm{mi}$. long at head of Ugashik River $S$ of Becharof Lake, on Alaska Penin., $22 \mathrm{mi}$. NE of Ugashik, Aleutian Ra.; $57^{\circ} 41^{\prime} \mathrm{N}, 156^{\circ} 39^{\prime} \mathrm{W}$; (map 36).

Local name reported as "Ugashik Lakes" for both Upper and Lower Ugashik Lakes in 1903 by G. C. Martin (1905, pl. 6), USGS. Upper Ugashik Lake is shown separately on a USGS map published in 1956.

Upper Willow Creek: stream, flows SW $2.5 \mathrm{mi}$. to Willow Creek SE of Bullion Mtn., $14 \mathrm{mi}$. NW of Palmer, Talkeetna Mts.; $61^{\circ} 45^{\prime} 40^{\prime \prime} \mathrm{N}$, $149^{\circ} 21^{\prime} 25^{\prime \prime} \mathrm{W}$; (map 69).

Local name reported in 1942 by AMS

Upper Wolf Lake: lake, $1.3 \mathrm{mi}$. long, on Revillagigedo I., SE of Moser Bay, Alex. Arch.; 55'32' N, 131 ${ }^{\circ} 36^{\prime} \mathrm{W}$; BGN 1962; (map 3). Var. Wolf Lake.

Local name reported in 1961 by USFS.

Uppnuk Lake: lake, see Upnuk Lake.

Uprayt, Mys: point of land, see Upright, Cape.

Upright, Cape: point of land, $13 \mathrm{mi}$. E of Sugarloaf Mtn., on SE tip of St. Matthew I.; $60^{\circ} 19^{\prime}$ N, $172^{\circ} 15^{\prime}$ W; (map 56). Var. Cape Mountain Peak, Cape Otviesnoi, Cape Peak, Cape Perpendiculaire, Cape Upwright, Mys Otvysnoy, Mys Pik, Mys Uprayt.

Named by Capt. Cook (1785, p. 438), on July 29, 1778, who wrote "It was the South East extremity, and formed a perpendicular cliff of considerable height; on which account it was called Point Upright * * *." Cook later referred to it as "Cape Upright" (p 491). The name was transliterated on Russian Hydrog. Dept. Chart 1427 (1849) as "M[ys] Uprayt," and translated by Capt. Tebenkov (1852, map 20) to "M[ys] Otvysnoy." G. A. Sarichev calls it "Mys Pik," i.e., "Cape Peak" in 1826.

Uprugalet Mountain: mountain, 2,350 ft., at head of East Fork Andreafsky River, $26 \mathrm{mi}$. SE of Saint Michael, Nulato Hills; $63^{\circ} 08^{\prime} \mathrm{N}$, $161^{\circ} 36^{\prime} \mathrm{W}$; ( $\operatorname{map} 91$ ).

Eskimo name reported in 1949 by USC\&GS

Upshur, Mount: mountain, 6,701 ft., on AlaskaCanada boundary, $20 \mathrm{mi}$. NW of Hyder, Coast Mts.; $56^{\circ} 07^{\prime} 45^{\prime \prime} \mathrm{N}, 130^{\circ} 21^{\prime} 00^{\prime \prime} \mathrm{W}$; $B G N$ 1924; $(\operatorname{map} 7)$.

Named in 1924 for Abel Parker Upshur, 1790-1844, American statesman.

Upwright, Cape: point of land, see Upright, Cape.
Uqpiqsugzum Kunga: stream, see Okpiksugruk Creek.

Uqpiqsugzuq: locality, see Ukpiksugruk.

Uqpiqsuq: locality, see Ukpiksuk.

Uquksiq: locality, see Amungna.

Uranatina River: stream, flows E $13 \mathrm{mi}$. to Copper River, $3.3 \mathrm{mi}$. NW of Spirit Mtn. and $54 \mathrm{mi}$. NE of Valdez, Chugach Mts.; 61 $21^{\prime}$ $15^{\prime \prime} \mathrm{N}, 144^{\circ} 42^{\prime} 10^{\prime \prime} \mathrm{W}$; (map 68). Var. Teikell River, Téikhell River, Tiekell River.

Indian name reported in 1898 by Capt. W. R. Abercrombie, USA. It is the "Tiekhell River" reported in 1885 by Lt. H. T. Allen, USA.

Urey, Point: point of land, between Islas Bay and $S$ end of Lisianski Strait, on $W$ coast of Chichagof I., $17 \mathrm{mi}$. NW of Chichagof, Alex. Arch.; $57^{\circ} 49^{\prime} 15^{\prime \prime} \mathrm{N}, 136^{\circ} 25^{\prime} 00^{\prime \prime} \mathrm{W}$; (map 9).

Named in 1879 by W. H. Dall, USC\&GS; published in the 1883 Alaska Coast Pilot (p. 184). It was named for Capt. Urey Theodorovich Lisianski, IRN, Russian navigator who explored these waters in 1804 and 1805. The name "Urey" is sometimes spelled "Iuri" from the Russian "Yuriy," meaning "George."

Urey Rocks: rocks, off W coast of Chichagof I., at $\mathrm{S}$ end of Lisianski Strait, $17 \mathrm{mi}$. NW of Chichagof, Alex. Arch.; 57 $49^{\prime} 15^{\prime \prime} \mathrm{N}, 136^{\circ}$ $26^{\prime} 20^{\prime \prime} \mathrm{W}$; ( $\left.\operatorname{map} 9\right)$.

Named in 1925 by USC\&GS; published in the 1925 Coast Pilot (p. 324). The name was derived from nearby Urey Point.

Urielof Island: island, see Urilof Island.

Urili, Kamen: rocks, see Shag Rocks.

Urilia Bay: bay, $8 \mathrm{mi}$. across, on $\mathrm{N}$ coast of $\mathrm{Un}$ mak I., Aleutian Is.; $54^{\circ} 55^{\prime} \mathrm{N}, 164^{\circ} 18^{\prime} \mathrm{W}$; $B G N$ 1904; (map 24). Var. Bukhta Urilya, Shaw Bay.

Russian name published by Capt. Tebenkov (1852, map 26) as Bukh[ta] Urilya meaning "Shag (Cormorant) Bay." This feature was called Shaw Bay in 1888 by USBF.

Urilie Rocks: rocks, see Shag Rocks.

Urili Island: island, see Shag Island.

Urili Rocks: rocks, see Shag Rocks.

Urilof Island: island, $0.2 \mathrm{mi}$. long, $5 \mathrm{mi}$. SW of Goddard, in Necker Is., on W coast of Baranof I., Alex. Arch.; $56^{\circ} 47^{\prime} 15^{\prime \prime} \mathrm{N}, 135^{\circ} 28^{\prime} 05^{\prime \prime} \mathrm{W}$; (map 5). Var. Ostrov Urilov, Urielof Island.

Named in 1809 by the Russian navigator, Ivan Vasiliev the first; published by Lt. Sarichev (1826, map 19), IRN, as "O[strov] Urilov," or "Urilov Island."

Urilov, Ostrov: island, see Urilof Island

Urilya, Bukhta: bay, see Urilia Bay.

Ursua Channel: water passage, $7 \mathrm{mi}$. long, connects Bucareli and San Alberto Bays, S of San Fernando I., Alex. Arch.; $55^{\circ} 27^{\prime} \mathrm{N}, 133^{\circ} 20^{\prime}$ W; BGN 1923; (map 4).

Named in 1923 by USC\&GS "for El Bailio Frey Don Antonio Maria Bucareli y Ursua [1717-99] the most popular and successful Viceroy of New Spain [Mexico]."

Ursus Cove: bay, 6 mi. across, enters Kamishak Bay on SE coast of Alaska Peninsula, $14 \mathrm{mi}$. NW of Augustine I., Aleutian Ra.; $59^{\circ} 32^{\prime} \mathrm{N}$, 
$153^{\circ} 40^{\prime}$ W; BGN 1906; (map 51). Var. Bear Cove.

According to G. C. Martin, USGS, the local name for this feature in 1904 was Bear Cove. However, owing to the multiplicity of "bear" names throughout Alaska, BGN renamed the bay using the Latin word for bear.

Ursus Head: promontory, 1,400 ft., on $\mathrm{N}$ side of entrance to Ursus Cove, Kamishak Bay, 11 mi. NW of Augustine I., Aleutian Ra.; $59^{\circ} 33^{\prime}$ 15" N, 153 35'20" W; BGN 1916; (map 51). Var. Bear Head.

Named by USC\&GS in 1913.

Ursus Lake: lake, $1.2 \mathrm{mi}$. long, on Kenai Penin. $0.8 \mathrm{mi}$. N of Coyote Lake and $32 \mathrm{mi}$. NE of Kenai, Cook Inlet Low.; $60^{\circ} 46^{\prime} \mathrm{N}, 150^{\circ} 27^{\prime}$ w; (map 62).

Named about 1963 by officials of Kenai National Moose Range, for administrative purposes.

Ursus Peak: peak, 4,850 ft., in Endicott $\mathrm{Mts}$., $13.5 \mathrm{mi}$. NNE of Sillyasheen Mtn., Brooks Ra.; $67^{\circ} 57^{\prime} 00^{\prime \prime} \mathrm{N}, 152^{\circ} 32^{\prime} 00^{\prime \prime} \mathrm{W}$; $B G N$ 1966; (map 124).

So named in 1966 by Mr. and Mrs. Gilbert F. Staender because they observed numerous grizzlies on this peak.

Urumangnak River: stream, on Nelson I., flows SE $16 \mathrm{mi}$. to Kolavinarak River, $88 \mathrm{mi}$. SW of Bethel, Yukon-Kuskokwim Delta; $60^{\circ} 34^{\prime}$ $50^{\prime \prime} \mathrm{N}, 164^{\circ} 22^{\prime} 45^{\prime \prime}$ W; (map 58). Var. Awomanak River.

Eskimo name meaning "very warm" reported in 1949 by USC\&GS.

Usak: locality, along shore of Chukchi Sea, 4 mi. SE of Kivalina, Kotzebue-Kobuk Low.; $67^{\circ} 42^{\prime} \mathrm{N}, 164^{\circ} 25^{\prime} \mathrm{W}$; (map 128). Var. Oosak.

Eskimo name reported in 1966 by E. S. Burch.

U.S. Camp: locality, at mouth of U.S. Creek 45 mi. NE of Fairbanks, Yukon-Tanana High.; $65^{\circ} 16^{\prime} \mathrm{N}, 146^{\circ} 44^{\prime} \mathrm{W}$; (map 104).

Name of a road camp along Steese Highway; derived from U.S. Creek and published in 1954 by USGS.

Uschugat Island: island, see Ushagat Island.

U.S. Creek: stream, flows $S 3 \mathrm{mi}$. to Chatanika River, $25 \mathrm{mi}$. NW of Chena Hot Springs and $45 \mathrm{mi}$. NE of Fairbanks, Yukon-Tanana High.; $65^{\circ} 15^{\prime} 50^{\prime \prime} \mathrm{N}, 146^{\circ} 44^{\prime} 00^{\prime \prime} \mathrm{W}$; (map 104).

Prospectors' name reported in 1954 or 1955 by USGS topographers.

U-S Creek: stream, flows SW $2.5 \mathrm{mi}$. to American Creek, $2.7 \mathrm{mi}$. E of Fish Lake and $26 \mathrm{mi}$. ESE of Tanana, Yukon-Tanana High.; $65^{\circ} 04^{\prime}$ $20^{\prime \prime} \mathrm{N}, 151^{\circ} 13^{\prime} 00^{\prime \prime} \mathrm{W}$; (map 106).

Local name reported in 1952 by USGS.

Useless Cove: estuary, extends SW $1 \mathrm{mi}$. to SE shore of Long Bay, $53 \mathrm{mi}$. NE of Whittier. Chugach Mts.; $60^{\circ} 56^{\prime} 20^{\prime \prime} \mathrm{N}, 147^{\circ} 11^{\prime} 45^{\prime \prime} \mathrm{W}$; (map 63).

Local name reported in 1951 by USGS.

Userdie Point: point of land, see Zeal Point.

Userdiye, Mys: point of land, see Zeal Point.

U.S. Gulch: ravine, trends $\mathrm{N} 1 \mathrm{mi}$. to Uhler Creek, $45 \mathrm{mi}$. SW of Eagle, Yukon-Tanana High.; $65^{\circ} 12^{\prime} \mathrm{N}, 141^{\circ} 40^{\prime} \mathrm{W}$; (map 102).
Named by prospectors and shown on an 1898 manuscript map by E. F. Ball, prospector. This ravine is not identified on present-day maps.

Ushagat Island: island, $8 \mathrm{mi}$. long, in Gulf of Alaska, westernmost of Barren Is., between Nord and Sud Is., $68 \mathrm{mi}$. NE of Afognak, Chugach Mts.; $58^{\circ} 55^{\prime} 30^{\prime \prime} \mathrm{N}, 152^{\circ} 15^{\prime} 00^{\prime \prime} \mathrm{W}$; (map 43). Var. Ugutchtu Island, Uschugat Island, Ushugat Island.

Aleut [?] name published by Capt. Tebenkov (1852, map 5), IRN, as "O[strov] Ushagat," or "Unshagat Island," and as "O[strov] Ugushtu," or "Ugushtu Island" (map 22). The feature was called Ushugat Island by USC\&GS in 1868 .

Usher Rock: rock, in Western Channel, Sitka Sound, 2 mi. W of Sitka, Alex. Arch.; 57 $03^{\prime}$ $15^{\prime \prime} \mathrm{N}, 135^{\circ} 23^{\prime} 55^{\prime \prime} \mathrm{W}$; (map 9).

Named in 1879 by the U.S. Navy for Lt. Nathaniel R. Usher, USN, then on duty at Sitka. The name was published by USC\&GS in the 1883 Coast Pilot (p. 140).

Ushk Bay: bay, $4 \mathrm{mi}$. long and $1 \mathrm{mi}$. wide, 4 $\mathrm{mi}$. S of Hoonah Sound, $20 \mathrm{mi}$. SE of Chichagof, Alex. Arch.; $57^{\circ} 34^{\prime} \mathrm{N}, 135^{\circ} 35^{\prime} \mathrm{W}$; (map 9).

Name reported in 1895 by Lt. Comdr. E. K. Moore, USN; published in 1899 by USC\&GS on Chart 8050.

Ushki Hills: hills, see Nichols Hills.

Ushk Point: point of land, on Chichagof I., N point of entrance to Ushk Bay, $4 \mathrm{mi}$. S of Hoonah Sound, $20 \mathrm{mi}$. SE of Chichagof, Alex. Arch.; 57 $34^{\prime} 15^{\prime \prime} \mathrm{N}, 1^{\circ} 35^{\circ} 34^{\prime} 45^{\prime \prime} \mathrm{W}$; (map 9).

Named in 1895 by Lt. Comdr. E. K. Moore, USN; published in 1900 by USC\&GS on Chart 8282.

Ushugat Island: island, see Ushagat Island. Usibelli: settlement, pop. 30, on right bank of Healy Creek $6 \mathrm{mi}$. E of Healy, Alaska Ra.; $63^{\circ} 51^{\prime} 30^{\prime \prime} \mathrm{N}, 148^{\circ} 46^{\prime} 45^{\prime \prime} \mathrm{W}$; (map 87).

Named for Emil Usibelli who opened a coal mine in the area about 1940 .

Usibelli Peak: peak, 6,129 ft., $1.4 \mathrm{mi}$. W of Mount Lathrop and $15 \mathrm{mi}$. ENE of Healy, Alaska Ra.; $63^{\circ} 54^{\prime} 20^{\prime \prime} \mathrm{N}, 148^{\circ} 28^{\prime} 30^{\prime \prime} \mathrm{W}$; $B G N 1965$; (map 87).

Named in 1965 by USGS for Emile Usibelli, 1892-1964, former operator of a local coal mine.

Usinka : village, see Uzinki.

Usinka Narrows: water passage, see Narrow Strait.

Uski Island: island, $0.3 \mathrm{mi}$. long, in St. Paul Harbor W of Near I., $0.6 \mathrm{mi}$. SW of Kodiak, Kodiak I. ; $57^{\circ} 46^{\prime} 50^{\prime \prime} \mathrm{N}, 152^{\circ} 24^{\prime} 35^{\prime \prime} \mathrm{W}$; (map 34). Var. Ostrov Uskoy, Uskoi Island.

Aleut name published as "Os[trov] Uskoy," or "Uskoy Island," by Lt. Sarichev (1826, map 16), IRN; Father Veniaminov (1846, p. 65) suggested that this name may be from "usgiq," meaning "willow."

Uskoi Island: island, see Uski Island.

Uskoy, Ostrov: island, see Uski Island.

Usof Bay: bay, $1.5 \mathrm{mi}$. across, $\mathrm{S}$ coast of Unalaska I., Aleutian Is.; $53^{\circ} 30^{\prime} \mathrm{N}, 166^{\circ} 45^{\prime} \mathrm{W}$;
BGN 1904; (map 23). Var. Usova, Whalebone Bay.

Russian name published by Capt. Tebenkov (1852 map 26), IRN, as "Z[aliv] Usova" meaning "Usof's Bay." It was called Whalebone Bay in 1888 by USBF.

Usova: bay, see Usof Bay.

Ustay: stream, see Tanis River.

Ustay Lake: lake, $1.4 \mathrm{mi}$. across, at $1961 \mathrm{ter}$ minus of Rodman Glacier, head of Ustay River, $2 \mathrm{mi}$. SE of Akwe Lake and $41 \mathrm{mi}$. SE of Yakutat, St. Elias Mts.; $59^{\circ} 17^{\prime} 30^{\prime \prime}$ N, $138^{\circ}$ 42'30' W; BGN 1962; (map 46).

Local name derived from Ustay River.

Us-tay River: stream, see Ustay River.

Ustay River: stream, heads at Ustay Lake and flows $\mathrm{S}$ and NW to Akwe River, $37 \mathrm{mi}$. SE of Yakutat, Malaspina Coastal Plain; 59 $14^{\prime} 00^{\prime \prime}$ N, $138^{\circ} 49^{\prime} 40^{\prime \prime} \mathrm{W}$; BGN 1962; (map 46). Var. Akwe River, Tanis River, Us-tay River.

Tlingit Indian name reported as "Us-tay" by Lt. Comdr. Moser (1901, p. 387 and pl. $43)$, USN. The name seems to have been applied to both the Akwe and Tanis Rivers of Capt. Tebenkov (1852, map 7), IRN. The name has been restricted to its present application since 1926.

Ustay River: stream, see Akwe River.

Ustia Point: point of land, $17 \mathrm{mi}$. W of Afognak, $W$ point of entrance to Onion Bay, SW coast of Raspberry I., N of Kodiak I.; $58^{\circ} 02^{\prime} 45^{\prime \prime}$ N, $153^{\circ} 15^{\prime} 00^{\prime \prime} \mathrm{W}$; BGN 1909; (map 43). Var. Entrance Cape.

Russian descriptive name meaning "mouth (of a river)" given by Sub-Lt. Mikhail Murashev, IRN, in 1839 or 1840 and published by the Russian Hydrog. Dept. in 1849 on Chart 1425. The Russian American Company applied this name in 1849 to Malina Point, 4 miles SW of this point.

Ustia rieki : point of land, see Rivermouth Point. Ustiugof Shoal: shoal, $15 \mathrm{mi}$. long, in Bristol Bay, $10 \mathrm{mi}$. SE of Cape Constantine on Nushagak Penin. and $48 \mathrm{mi}$. S of Dillingham, Bristol Bay Low. ; $58^{\circ} 17^{\prime} \mathrm{N}, 158^{\circ} 41^{\prime} \mathrm{W}$; (map 40). Var. Banka Ustiugova.

Named by Capt. Tebenkov (1852, map 4), IRN, as "Banka Ustiugova" for a Mr. Ustiugof [cnna], whose surveys of this area in 1818 were praised by Capt. Tebenkov.

Ustiugova, Banka: shoal, see Ustiugof Shoal.

Ustya, Cape: point of land, see Malina Point.

Usukteo River: stream, see Usuktuk River.

Usuktuk River: stream, heads at $69^{\circ} 40^{\prime} \mathrm{N}$, $156^{\circ} 41^{\prime} \mathrm{W}$, flows $\mathrm{NE}$ and $\mathrm{NW} 135 \mathrm{mi}$. to Meade River, $3 \mathrm{mi}$. N of village of Meade River, Arctic Plain; $70^{\circ} 31^{\prime} 10^{\prime \prime} \mathrm{N}, 157^{\circ} 23^{\prime}$ $00^{\prime \prime}$ W; BGN 1949; (map 147). Var. Esuktak River, Esukteo River, Esuktu River, Esuktuk River, Suktu River, Usukteo River, Usuktu River, Usuuktu River.

Lt. Ray (1885, p. 27), USA, wrote on March 29, 1883, "a large stream called Usuuktu comes in from the eastward with a channel about forty yards wide and high, bold banks." Lt. Ray spells it "Esuktu" on his map. It has been reported that this Eskimo name refers in meaning to a penis. 
Usuktu River: stream, see Usuktuk River. Usuuktu River: stream, see Usuktuk River.

Utah Creek: stream, flows $\mathrm{S}$ to Pacific Ocean, $0.5 \mathrm{mi}$. NE of Kettle Cape, on $\mathbf{E}$ coast of Umnak I., Aleutian Is.; $53^{\circ} 17^{\prime} 15^{\prime \prime} \mathrm{N}$, $168^{\circ} 06^{\prime} 10^{\prime \prime} \mathrm{W}$; (map 22).

Name published by Byers (1959, pl. 41), USGS.

Utah Creek: stream, flows E $3 \mathrm{mi}$. to Mission Creek, $11 \mathrm{mi}$. W of Eagle, Yukon-Tanana High.; 64 $44^{\prime} 25^{\prime \prime} \mathrm{N}, 141^{\circ} 34^{\prime} 00^{\prime \prime} \mathrm{W}$; (map 102).

Prospectors' name obtained in 1898 by $\mathbf{E}$. C. Barnard, USGS

Utah Creek: stream, heads on Roughtop Mtn., flows SE $9.5 \mathrm{mi}$. to Baker Creek, $44 \mathrm{mi}$. ESE of Tanana, Yukon-Tanana High.; $65^{\circ} 05^{\prime} 30^{\prime \prime}$ N, 150 $34^{\prime} 40^{\prime \prime} \mathrm{W}$; (map 106).

Prospectors' name reported in 1931 by $\mathrm{J}$. B. Mertie, USGS.

Utakaht Slough: watercourse, in Yukon Delta, $4.8 \mathrm{mi}$. long, $3 \mathrm{mi}$. E of Kwiguk, YukonKuskokwim DeIta; $62^{\circ} 45^{\prime} \mathrm{N}, 164^{\circ} 23^{\prime} \mathrm{W}$; (map 77).

Eskimo name obtained in 1899 by G. R. Putnam, USG\&GS. Published in 1899 on Chart 9372.

Utalug, Cape: point of land, SE tip of Atka I., Aleutian Is.; $52^{\circ} 06^{\prime} 00^{\prime \prime} \mathrm{N}, 174^{\circ} 05^{\prime} 50^{\prime \prime} \mathrm{W}$ : (map 18).

Name published as "M[ys] Utalug," or Utalug," by Capt. Tebenkov (1852, map 27), IRN, possibly from the Aleut word "Utaq," meaning "thumb," since Cape Utalug promontory resembles a thumb.

Utchno: point of land, see Trinity, Cape.

Utes, Cape: point of land, on $\mathrm{S}$ shore of Nazan Bay, on E coast of Atka I., Aleutian Is.; 52 ${ }^{\circ}$ $10^{\prime} 15^{\prime \prime} \mathrm{N}, 174^{\circ} 08^{\prime} 15^{\prime \prime} \mathrm{W}$; (map 18).

Russian name, meaning "cliff" or "escarpment," published as "M[ys] Utes," or "Cape Utes," by Capt. Tebenkov (1852, map 27), IRN.

Utes, Mys: point of land, see Topkok Head.

Utesistoi Island: shoal, $0.3 \mathrm{mi}$. long, in Kalsin Bay, near Isthmus Cove, on $\mathrm{E}$ coast of Kodiak I.; 57 $37^{\prime} 30^{\prime \prime} \mathrm{N}, 152^{\circ} 22^{\prime} 00^{\prime \prime} \mathrm{W}$; BGN 1941; (map 34). Var. Ostrov Utesistoy, Rocky Island.

Transliteration of the name "Os[trov] Utesistoy" published by Sarichev (1826, map 16). Baker (1906, p. 531) published "Rocky Island," the translation of Sarichev's name. Because of duplications the name was changed to its present form in 1940 by USC\&GS.

Utesistoi Island: island, see Zaimka Island.

Utesistoy, Ostrov: island, see Zaimka Island.

Utesistoy, Ostrov: shoal, see Utesistoi Island.

Utesistyy, Mys: point of land, see Topkok Head.

Utesof: point of land, see Cliff Point.

Utesov, Mys: point of land, see Cliff Point.

Utica: locality, on left bank of Inmachuk River, 1 mi. NE of settlement of Fink Creek and 21 mi. NNE of Imuruk Lake, Seward Penin. High.; $65^{\circ} 55^{\prime} \mathrm{N}, 162^{\circ} 59^{\prime} \mathrm{W}$; (map 110).

Site of landing strip reported about 1950 by USGS.
Utica Creek: stream, flows SW $1 \mathrm{mi}$. to Ophir Creek, $8 \mathrm{mi}$. $\mathrm{N}$ of Council and $42 \mathrm{mi}$. SW of Imuruk Lake, Seward Penin. High.; $65^{\circ}$ $01^{\prime} \mathrm{N}, 163^{\circ} 39^{\prime} \mathrm{W}$; (map 110$)$.

Prospectors' name published on the 1908 "Map of Seward Peninsula" by Arthur Gibson. Utichey, Ostrov: island, see Calming Island.

Utichey, Ostrov: island, see Rocky Isiet.

Utichi Island : island, see Calming Island.

Utkeagvik: town, see Barrow.

Utkeakhvik: town, see Barrow.

Utkeavic: town, see Barrow.

Utkiavi: town, see Barrow.

Utkiavik: locality, $25 \mathrm{mi}$. NE of Point Hope, Arctic Slope; near $68^{\circ} 30^{\prime} \mathrm{N}, 166^{\circ} 15^{\prime} \mathrm{W}$; (map 129).

Archeological site reported in 1932 by H. B. Collins (Giddings, 1964, p. 38)

Utkiaving : town, see Barrow.

Utkiawiñ : town, see Barrow.

Utkok Valley: valley, see Utukok River Valley.

Utkusikrak Hill: hill, $525 \mathrm{ft}$., on Chukchi Sea coast, $E$ of Tasikpak Lagoon, $20 \mathrm{mi}$. NW of Kivalina, Arctic Slope; 67 $56^{\prime} 30^{\prime \prime}$ N, $165^{\circ}$ 02'30" W; BGN 1963; (map 128). Var. Oatcoosekruk Mountain, Otkusekrak Mountain.

Eskimo name meaning "material for making a cooking pot"; reported in 1950 by USC\&GS. Utmak: point of land, see Kettle Cape.

Utnathlokik Creek: stream, flows SW $10 \mathrm{mi}$. to Mulchatna River, $75 \mathrm{mi}$. NE of Dillinghım, Bristol Bay Low.; $59^{\circ} 45^{\prime}$ N, 156 $58^{\prime} \mathrm{W}$; (map 52).

Eskimo name shown on a 1910 manuscript map by H. C. Fassett, USBF, as "Ut-na-thlokik."

Utokak: villages, see Utukok villages.

Utopia: locality, airplane landing field and installation, between Utopia Creek and Indian River, $60 \mathrm{mi}$. N of Birches, Kokrines-Hodzana High.; $65^{\circ} 59^{\prime} 40^{\prime \prime} \mathrm{N}, 153^{\circ} 41^{\prime} 30^{\prime \prime} \mathrm{W}$; (map 107).

Local name obtained in 1954 by USGS topographers.

Utopia Creek: stream, flows E $4.5 \mathrm{mi}$., S of mining community of Utopia, to Indian River, $60 \mathrm{mi}$. N of Birches, Kokrines-Hodzana High.; 65 $59^{\prime} 40^{\prime \prime} \mathrm{N}, 153^{\circ} 39^{\prime} 50^{\prime \prime} \mathrm{W}$; (map 107).

Local name obtained in 1954 by USGS topographers.

Utoqaq: locality, see Otokkok.

Utoqaq : villages, see Utukok villages.

Utta Rock: rock, see Hattie Rock.

Utuka : locality, see Otokkok.

Utukakarvik: village, on W bank of Black River, $27 \mathrm{mi}$. E of Scammon Bay, Yukon-Kuskokwim Delta; $61^{\circ} 57^{\prime} 40^{\prime \prime} \mathrm{N}, 164^{\circ} 45^{\prime} 00^{\prime \prime} \mathrm{W}$; (map 74). Var. Oolakukkogavik, Ulakakogavik.

This Eskimo name is probably better rendered "Ulakakogavik" and generally means "place where slate [for making Ulas] is found." The name was reported by USC\&GS in 1948 as "Oolakukkogavik."

Utukakg: villages, see Utukok villages.

Utukak River: stream, see Utukok River.

Utukok: locality, see Otokkok.
Utukok Cape: point of land, see Icy Cape.

Utukok Pass: water passage, in barrier bar between Chukchi Sea and Kasegaluk Lagoon S of 'Solivik I., $23 \mathrm{mi}$. SW of Icy Cape, Arctic Plain; $70^{\circ} 05^{\prime} \mathrm{N}, 162^{\circ} 31^{\prime} \mathrm{W}$; (map 146).

Name reported in 1949 by USC\&GS.

Utukok River: stream, formed in De Long Mts. by junc. of Kogruk and Tupik Creeks, at $68^{\circ}$ $34^{\prime} \mathrm{N}, 161^{\circ} 06^{\prime} \mathrm{W}$, flows NW $225 \mathrm{mi}$. to Kasegaluk Lagoon, $20 \mathrm{mi}$. SW of Icy Cape, Arctic Plain; $70^{\circ} 03^{\prime} \mathrm{N}, 162^{\circ} 21^{\prime} \mathrm{W}^{\prime}$; (map 146). Var. Ootokok River, Otookok River, Otokok River, Utoqaq River, Utukak River.

"Utoqaq" is the Eskimo name for "Icy Cape" and means "old" or "ancient." The name of the river appears to have been first mentioned by Lt. Zagoskin (1847, p. 74), IRN, when he referred to the Utukak-myut, or Utukak people, "on river of same name." Zagoskin received this information from Kashevarov whose Creole guide, Utuktak, drew a map of the coast south of Point Barrow in 1838. The name was published in 1899 by USC\&GS as "Ootokok River."

Utukok River Basin: valley, see Utukok River Valley.

Utukok River Valley: valley, along Utukok River, on N slope of Brooks Ra., $80 \mathrm{mi}$. S of Wainwright, Arctic Slope; (map 144). Var. Utukok River Basin, Utkok Valley.

Named in 1923 by W. T. Foran, USGS, after the Utukok River.

Utukok villages: "Utoqaq" is an Eskimo word meaning "old" or "ancient," and as a name was applied to Icy Cape and the present Utukok River. The name was also applied todtie Eskimo living on the river and in the vickity of Icy Cape near the stream's mouth. The Utukok people were first mentioned, as such, by Lt. Zagoskin (1847, p. 74), IRN, as the "Utukak-myut," or "Utukak people." Zagoskin received his information from Kashevarov whose Creole guide named "Utuktat" drew a map of the coast $S$ of Barrow in 1838. The villages where many of these "Ututok" people lived in 1880 were referred to as "Otok-kok" in in the 10th U.S. Census, and late 19th century maps show at least two villages with this name. One was located at the mouth of the Utukok River and the other at or near Icy Cape. Russian Hydrog. Dept. Chart 1495, dated 1854, shows the name "sel[enie] Kayakishvigmyut," or "Kayakishvig people's village," in the Icy Cape area. Var. Kaiakishvigmiut, Kayakishvigmyut, Ootookok, Otokkok, Otokok, Otookok, Otukah, Utokak, Utoqaq, Utukakg.

Uviuvok Island: island, see King Island.

Uwik Slough: watercourse, in Yukon Delta, flows N 15 mi. from Okshokwewhik Pass to Norton Sound, $37 \mathrm{mi}$. N of Kwiguk, Yukon-Kuskokwim Delta ; $63^{\circ} 15^{\prime} \mathrm{N}, 164^{\circ} 09^{\prime} \mathrm{W}$; (map 92). Var. Oowik.

Eskimo name reported in 1899 as "Oowik" by G. R. Putnam, USC\&GS.

Uwuk: promontory, see Lisburne, Cape.

Uyak: village, pop. 10, on W shore of Uyak Bay $S$ of Harvester I., on NW coast of Kodiak I.; 
$57^{\circ} 38^{\prime} 20^{\prime \prime} \mathrm{N}, 154^{\circ} 00^{\prime} 00^{\prime \prime} \mathrm{W}$; (map 34). Var. Bobrowskoje, Ooiak, Ooiatsk, Ugujuk.

Eskimo village reported in 1805 as "Ooiatsk" by Capt. Lisianski (1814, map facing p. 169). Listed in the 10th Census as "Ooiak," population 76, by Petroff (1884, p. 29); and in the 11 th Census as "Uyak," population less than 20 (1893, p. 79). A post office, established in 1900, was discontinued in 1937 (Ricks, 1965, p. 68).

Uyak: village, see Larsen Bay.

Uyak, Cape: point of land, $6.5 \mathrm{mi}$. NE of Karluk, on W coast of Kodiak I.; $57^{\circ} 38^{\prime} 20^{\prime \prime} \mathrm{N}, 154^{\circ}$ $20^{\prime} 50^{\prime \prime} \mathrm{W}$; (map 35$)$. Var. Sevenmile Point, West Point.

Aleut name published by Capt. Tebenkov (1852, map 22), IRN, as "M[ys] Uyak," or "Cape Uyak." This feature was called "West Point" by Capt. Lisianski (1814, map, p. 169), IRN, and Baker (1906, p. 656) reports "Locally called 'Sevenmile point' * * *."

Uyak Anchorage: water passage, at mouth of Uyak Bay between Harvester I. and NW coast of Kodiak I.; $57^{\circ} 39^{\prime} \mathrm{N}, 154^{\circ} 00^{\prime} \mathrm{W}$; (map 35).

Aleut name derived from Cape Uyak; reported in 1897.

Uyak Bay: bay, extends SSE $40 \mathrm{mi}$. off Shelikof Strait, on NW coast of Kodiak I.; $57^{\circ} 48^{\prime} \mathrm{N}$, $154^{\circ} 04^{\prime}$ W; (map 34). Var. Bay of Oohiack, Ooiak Bay, Ooyak Bay, Uiak Bay, Zaliv Uyak.

Native name recorded in 1805 as Bay of Oohiack by Lisianski (1814, map facing p. 169). The name was given as "Zaliv Uyak," or "Uyak Bay," by Capt. Tebenkov (1852, map 9) and "Ooyak Bay" by Petroff (1881, p. 29) in the 10th Census in 1880.

Uyak Island: island, $0.15 \mathrm{mi}$. across, in center of Nazan Bay, on E coast of Atka I., Aleutian Is. ; $52^{\circ} 12^{\prime} 20^{\prime \prime} \mathrm{N}, 174^{\circ} 09^{\prime} 02^{\prime \prime} \mathrm{W}$; (map 18). Var. Ujah Islet.

Aleut name, published as "O[strov] Uyak," or "Uyak Island," by Capt. Tebenkov (1852, map 27), IRN.

Uyakturok Creek: stream, heads in Lisburne Hills, flows E $19 \mathrm{mi}$. to Nilik River $4 \mathrm{mi}$. N of its junc. with Ipewik River, $28 \mathrm{mi}$. SE of Cape Dyer, Arctic Slope; 68 $32^{\prime} 30^{\prime \prime} \mathrm{N}, 165^{\circ}$ $09^{\prime} 00^{\prime \prime}$ W; (map 129). Var. Yarukturuk Creek.

Eskimo name reported in 1960 by D. C. Foote, of Project Chariot, to mean "rough rocks."

Uyaraaqsiiwik: hill, see Uyaraksivik Hill.

Uyaraksivik Hill: hill, $268 \mathrm{ft}$., on right bank of Kivalina River $14 \mathrm{mi}$. NE of Kivalina, Arctic Slope; $67^{\circ} 53^{\prime} \mathrm{N}, 164^{\circ} 14^{\prime} \mathrm{W}$; (map 128). Var. Ooyarockseevick, Uyaraaqsiiwik.

Eskimo name meaning "place where things are buried under stones"; so called because the Eskimo reportedly once buried here for safe keeping, under moss and stones, the caribou they killed; reported in 1966 by $\mathrm{E}$. S. Burch.

Uyon Lakes: lakes, two, $2.3 \mathrm{mi}$. and $3.5 \mathrm{mi}$. long, drain NW to Noatak River $12 \mathrm{mi}$. SW of its junc. with Nimiuktuk River, $68 \mathrm{mi}$. $\mathrm{N}$ of
Kiana, Brooks Ra.; $67^{\circ} 51^{\prime} \mathrm{N}, 160^{\circ} 13^{\prime} \mathrm{W}$; (map 127).

Eskimo name obtained in 1955 by U.S. Army Corps of Engineers.

Uyut Bay: bay, see Izhut Bay.

Uzavigiak River: stream, see Osviak River.

Uzenkiy, Proliv: water passage, see Narrow Strait.

Uzenkoi Strait: water passage, see Narrow Strait.

Uzenkoy, Proliv: water passage, see Narrow Strait.

Uzinkee: village, see Ouzinkie.

Uzinki : village, see Ouzinkie.

Uzinkie: village, see Ouzinkie.

Uzinki Point: point of land, W tip of Spruce I., at $\mathrm{N}$ entrance to Narrow Strait, NE of Kodiak I.; $57^{\circ} 55^{\prime} \mathrm{N}, 152^{\circ} 31^{\prime} \mathrm{W}$; BGN 1909; (map 34). Var. Elovoi, Mys Yelovoy, Spruce Cape, Spruce Point, Yelovoi.

Transliteration of the Russian "Uzenkiy," from "uzkiy," meaning "narrow." Named "M[ys] Yelovoy" by Sub-Lt. Mikhail Murashev in 1839 or 1840 and published in 1849 on Russian Hydrog. Dept. Chart 1425. Baker (1906, p. 594) published "Spruce Cape," the translation of Murashev's name. Because of duplication and its appropriate descriptive qualities, the present name was given by USC\&GS in 1909.

Uzinkoy Prolivchik: water passage, see Narrow Strait.

Uzkostey, Mys: point of laxd, see Uzkosti Point. Uzkosti Point: point of land, on SW coast of Whale I., $18 \mathrm{mi}$. NW of Kodiak, $\mathrm{N}$ coast of Kodiak I.; $57^{\circ} 55^{\prime} 40^{\prime \prime} \mathrm{N}, 152^{\circ} 48^{\prime} 50^{\prime \prime} \mathrm{W}$; BGN 1957; (map 34). Var. Mys Uzkostey, Narrow Point, Narrows Point.

Transliteration of the name "M[ys] Uzkostey," meaning "narrow cape," given by Sub-Lt. Mikhail Murashev in 1839 or 1840 and published in 1849 on Russian Hydrog. Dept. Chart 1425.

\section{V}

Vacahanyande Mountain: mountain, 1,445 ft., $\mathrm{N}$ of Salmon Village, $33 \mathrm{mi}$. $\mathrm{E}$ of Chalkyitsik, Porcupine Plat.; $66^{\circ} 35^{\prime} \mathrm{N}, 142^{\circ} 33^{\prime} \mathrm{W}$; (map 120).

Tranjik-kutchin Indian name; obtained in 1956 by T. E. Taylor, USGS.

Vachon Island: island, $3 \mathrm{mi}$. long, in Tanana River, at mouth of Cosna River, $33 \mathrm{mi}$. NE of Bitzshtini Mts., Nowitna Low.; 64 $52^{\prime} \mathrm{N}$, $151^{\circ} 20^{\prime} \mathrm{W}$; (map 99).

Riverboat pilots' name published on a 1940 "Navigation Chart of the Tanana-Yukon Rivers" by the U.S. Dept. of Interior.

Vadine Greek: stream, flows NW $4 \mathrm{mi}$. to Kokomo Creek, $27 \mathrm{mi}$. NE of Fairbanks, Yukon-Tanana High.; $65^{\circ} 10^{\prime} 45^{\prime \prime} \mathrm{N}, 147^{\circ}$ $12^{\prime} 00^{\prime \prime} \mathrm{W}$; (map 105).

Local name published by USGS in the 1950 's.

Vagitchitchate: locality, near mouth of Innoko River, at or near Railroad City, Innoko Low. $62^{\circ} 11^{\prime} \mathrm{N}, 1^{\circ} 9^{\circ} 39^{\prime} \mathrm{W}$; (map 78). Var. Kushichagat, Vashichagat.
Former Indian village or camp published on Lt. L. A. Zagoskin's 1850 map (Hodge, 1910, p. 879).

Vagt Lake: lake, $0.5 \mathrm{mi}$. long, $0.2 \mathrm{mi}$. E of Lower Trail Lake, $24 \mathrm{mi}$. NE of Seward, Chugach Mts.; 60²7' N, $149^{\circ} 21^{\prime} \mathrm{W}$; (map 63).

Local name reported in 1951 by USGS.

Vakeekalik Creek: stream, flows NW $3 \mathrm{mi}$. to Etolin Strait, $10 \mathrm{mi}$. SE of Cape Etolin, on NE coast of Nunivak I.; $60^{\circ} 18^{\prime} 45^{\prime \prime} \mathrm{N}, 166^{\circ}$ $00^{\prime} 00^{\prime \prime} \mathrm{W}$; ( $\left.\operatorname{map} 57\right)$.

Eskimo name reported in 1937 by USAAF. Valdes, Puerto de: estuary, see Valdez, Port.

Valdes Narrows: water passage, see Valdez Narrows.

Valdez: town, pop. 555, on E end of Port Valdez, $45 \mathrm{mi}$. NW of Cordova and $115 \mathrm{mi}$. $E$ of Anchorage, Chugach Mts.; $61^{\circ} 07^{\prime} \mathrm{N}, 146^{\circ} 16^{\prime}$ W; (map 68). Var. Copper City.

Town established in 1898 as a debarkation point, with an excellent ice-free harbor, for men seeking a route to the Klondike gold region. It was originally called "Copper City" but name was changed when the Valdez post office was established in 1899 . Valdez soon became the supply center of its own gold mining region. The town is located on the distributary delta of Valdez Glacier, and was severely damaged during the 1964 Good Friday earthquake. Plans are being made to move the town to more stable ground three miles northwest. The population of Valdez was 810 in 1910; 466 in 1920; 442 in 1930; 529 in 1939; and 554 in 1950.

Valdez, Port: estuary, $13 \mathrm{mi}$. long, trends E-W from $3 \mathrm{mi}$. NE of Valdez Arm to its head at Valdez, Chugach Mts.; $61^{\circ} 05^{\prime} \mathrm{N}, 146^{\circ} 39^{\prime} \mathrm{W}$; $B G N$ 1913; (map 68). Var. Puerto de Valdes.

Named on June 16,1790, by Don Salvador Fidalgo for the celebrated Spanish naval officer Antonio Valdés y Basan. Having been adopred by Capt. Vancouver, the name came into local use (Wagner, 1937, p. 420).

Valdez, Port: water passage, see Valdez Arm.

Valdez Arm: water passage, $15 \mathrm{mi}$. long, connects Prince William Sound and Port Valdez, $12 \mathrm{mi}$. W of Valdez, Chugach Mts.; $60^{\circ} 53^{\prime} \mathrm{N}$, $146^{\circ} 54^{\prime}$ W; BGN 1913; (map 64). Var. Port Valdez, Valdez Bay.

Named about 1910 by USC\&GS.

Valdez Bay: water passage, see Valdez Arm.

Valdez Camp: locality, $2.4 \mathrm{mi}$. N of West Peak and $6 \mathrm{mi}$. NE of Valdez, Chugach Mts.; $61^{\circ}$ $11^{\prime} 40^{\prime \prime} \mathrm{N}, 146^{\circ} 12^{\prime} 15^{\prime \prime} \mathrm{W}$; (map 68).

This was the name of a mining camp reported in 1911 by USGS.

Valdez Creek: locality, see Denali.

Valdez Creek: stream, flows SW $14 \mathrm{mi}$. to Susitna River, $66 \mathrm{mi}$. SE of Healy, Alaska Ra.; $63^{\circ} 10^{\prime} \mathrm{N}, 147^{\circ} 30^{\prime} \mathrm{W}$; (map 87).

Local name reported in 1908 by F. H. Moffit (in Brooks and others, 1909, p. 159), USGS.

Valdez Glacier: glacier, heads $0.7 \mathrm{mi}$. S of Mount Cashman, trends SE $22 \mathrm{mi}$. to its terminus, $2 \mathrm{mi}$. SE of West Peak and $4 \mathrm{mi}$. NE of Val- 
dez, Chugach Mts.; $61^{\circ} 08^{\prime} 45^{\prime \prime} \mathrm{N}, 146^{\circ} 09^{\prime} 30^{\prime \prime}$ W; (map 68).

Named in 1898 by Capt. W. R. Abercrombie, USA.

Valdez Narrows: water passage, trends SW $2 \mathrm{mi}$. from Port Valdez to Valdez Arm, $14 \mathrm{mi}$. SW of Valdez, Chugach Mts.; $61^{\circ} 03^{\prime} 15^{\prime \prime} \mathrm{N}, 146^{\circ} 40^{\prime}$ $30^{\prime \prime} \mathrm{W}$; (map 68). Var. Stanton Narrows, Valdes Narrows.

Named "Valdes Narrows" in 1898 by Capt. W. R. Abercrombie, USA. He also called the passage "Stanton Narrows."

Valdez Summit: pass, highest point on trail over Valdez Glacier; Chugach Mts.; $61^{\circ} 20^{\prime} \mathrm{N}$, $146^{\circ} 20^{\prime}$ W; BGN 1904; (map 68). Var. Valdes Summit.

"So called by the 3,000 (more or less) prospectors who used it in 1898" (Baker, 1906, p. 657).

Vale, Mys: point of land, see Whaley, Point.

Valerie Glacier: glacier, heads at $60^{\circ} 11^{\prime} \mathrm{N}$, $139^{\circ} 45^{\prime} \mathrm{W}$, trends SE $14 \mathrm{mi}$. to Hubbard Glacier, 2 mi. NE of head of Disenchantment Bay and $29 \mathrm{mi}$. NE of Yakutat, St. Elias Mts. ; $60^{\circ} 04^{\prime} \mathrm{N}, 139^{\circ} 25^{\prime} \mathrm{W}$; BGN 1960; (map 66).

Named aiter Miss Valerie F. Wood, 19331951 , who served as an assistant to the scientific part of Project Snow Cornice of the Arctic Institute of North America. She was killed in an airplane crash about July 27, 1951, with her mother (see Mount Foresta), somewhere in the vicinity of this glacier. The name was proposed by the Arctic Institute of North America.

Valhalla, Mount: mountain, 12,135 ft., $2.5 \mathrm{mi}$. $\mathrm{SE}$ of Mount Willard Gibbs and $36 \mathrm{mi}$. NW of Valdez, Chugach Mts. ; $61^{\circ} 27^{\prime} 35^{\prime \prime} \mathrm{N}, 147^{\circ}$ 04'40' W; BGN 1965; (map 69).

Named in 1957 by L. E. Nielsen because the peak is "a fitting throne of the gods." Nielsen was a member of the first ascent party on July $1,1957$.

Vallenar Bay: estuary, extends SE $2 \mathrm{mi}$., off Clarence Strait, on NW coast of Gravina I., Alex. Arch.; $55^{\circ} 23^{\prime} 30^{\prime \prime} \mathrm{N}, 131^{\circ} 51^{\prime} 30^{\prime \prime} \mathrm{W}$; (map 3).

Named in 1883 by Lt. Comdr. H. E. Nichols, USN. See Vallenar Point.

Vallenar Creek: stream, flows NW $4 \mathrm{mi}$. to Vallenar Bay, on Gravina I., Alex. Arch.; $55^{\circ} 22^{\prime} 35^{\prime \prime} \mathrm{N}, 131^{\circ} 49^{\prime} 40^{\prime \prime} \mathrm{W}$; BGN 1962; (map 3).

Local name reported in 1961 by USFS.

Vallenar Point: point of land, N tip of Gravina I., Alex. Arch.; $55^{\circ} 25^{\prime} 35^{\prime \prime} \mathrm{N}, 131^{\circ} 51^{\prime} 00^{\prime \prime}$ W; (map 3).

Named by Capt. Vancouver, RN, "August 13, 1793, no doubt after his friend Ambrosio O'Higgins de Vallenar, Viceroy of Chile" (Wagner, 1937, p. 420) ; O'Higgins, of Ballenagh, Ireland, naturalized in Chile, became a national hero.

Vallenar Rock: rock, between Clarence Strait and Tongass Narrows, $0.6 \mathrm{mi}$. NW of Vallenar Point, Gravina I., Alex. Arch.; 55 $25^{\prime} 50^{\prime \prime}$ N, $131^{\circ} 51^{\prime} 46^{\prime \prime} \mathrm{W}$; BGN 1966; (map 3). Var. Vallenar Rocks.
Named in 1885 by Lt. Comdr. H. E. Nichols, USN.

Vallenar Rocks: rock, see Vallenar Rock.

Valley Greek: stream, flows S $5.2 \mathrm{mi}$. to Bonanza Creek, $5 \mathrm{mi}$. SW of Monzonite Hills, Nowitna

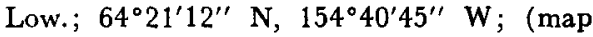
98).

Local name reported about 1952 by USGS

Valpa Creek: stream, flows NE $3 \mathrm{mi}$. to Canyon Creek which flows to Imuruk Basin, $33 \mathrm{mi}$. NW of Nome, Seward Penin. High.; 64. $56^{\prime} \mathrm{N}$, $165^{\circ} 54^{\prime} \mathrm{W}$; (map 94).

Prospectors' name published on the 1908 "Map of Seward Peninsula" by Arthur Gibson Valpol, Mys: point of land, see Walpole, Point. Valve Creek: stream, heads on Serpentine Ridge, flows NW $1.7 \mathrm{mi}$. to Boulder Creek, $23 \mathrm{mi}$. ESE of Tanana, Yukon-Tanana High.; $65^{\circ} 07^{\prime} 50^{\prime \prime}$ $\mathrm{N}, 151^{\circ} 16^{\prime} 50^{\prime \prime} \mathrm{W}$; (map 106).

Local name reported in 1952 by USGS.

Van Auke Bay: cove, see Admiralty Cove.

Van Cleve Glacier: glacier, trends $W$ to its terminus $1 \mathrm{mi}$. E of Van Cleve Lake, $35 \mathrm{mi}$. NE of Katalla, Chugach Mts. ; $60^{\circ} 42^{\prime} \mathrm{N}, 144^{\circ} 17^{\prime}$ W; (map 64).

Named in 1910 by Lawrence Martin, USGS, for J. R. Van Cleve, general manager of the Copper River and Northwestern Railroad.

Van Cleve Lake: lake, $4 \mathrm{mi}$. long, $7 \mathrm{mi}$. $\mathrm{E}$ of Miles Lake and $35 \mathrm{mi}$. NE of Katalla, Chugach Mts.; $60^{\circ} 42^{\prime} \mathrm{N}, 144^{\circ} 22^{\prime} \mathrm{W}$; (map 64).

Named for nearby Van Cleve Glacier and published in 1959 by USGS.

Vancouver, Cape: promontory, on $\mathrm{W}$ tip of Nelson I., $125 \mathrm{mi}$. SW of Bethel, YukonKuskokwim Delta; $60^{\circ} 33^{\prime} \mathrm{N}, 165^{\circ} 25^{\prime} \mathrm{W}$; BGN 1944; (map 57).

Discovered in 1821 by A. K. Etolin and named by him for Capt. George Vancouver, RN, 1757-98.

Vancouver, Mount: mountain, 15,700 ft., on Alaska-Canada boundary, $26 \mathrm{mi}$. E of Mount Augusta and $55 \mathrm{mi}$. $\mathbf{N}$ of Yakutat, St. Elias Mts.; $60^{\circ} 20^{\prime} \mathrm{N}, 139^{\circ} 41^{\prime} \mathrm{W}$; (map 66.). Var. Boundary Peak 181

Named by W. H. Dall, USC\&GS, in 1874, for Capt. George Vancouver, RN, 1757-98, British navigator who explored the SE coast of Alaska in 1792-94. The name was first published in the 1881 USC\&GS Coast Pilot (p. 211). It was first climbed July 5, 1949 (Farquhar, 1959, p. 232).

Vancouver Island: island, $0.1 \mathrm{mi}$. long, off $\mathrm{S}$ tip of Duke I., Alex. Arch.; 54.51'15" N, $131^{\circ}$ 20'15" W; (map 2)

Name published in 1885 by USG\&GS; named for Capt. George Vancouver, RN, who, "in command of the sloop of war Discovery *** made a surveying and exploring voyage from England to Northwest America and around the world from 1790 to 1795." The published account of this voyage was used extensively in the preparation of this dictionary.

Vandeput, Point: point of land, extends S $3 \mathrm{mi}$. into Frederick Sound, $90 \mathrm{mi}$. E of Sitka; Coast Mts.; $57^{\circ} 01^{\prime} 15^{\prime \prime} \mathrm{N}, 133^{\circ} 00^{\prime} 00^{\prime \prime} \mathrm{W}$; (map 8). Var. Mys Vendipot.
Named by Capt. George Vancouver, RN, in 1794 for Adm. George Vandeput, RN, who died in 1800 . It was reached by Lt. Joseph Whidbey, RN, on Aug. 16, 1794, and marked the end of one of his trips of exploration (Wagner, 1937, p. 420)

Vanderbilt Hill: locality, on E shore of Gastineau Channel, $1 \mathrm{mi}$. SE of mouth of Lemon Creek and $3 \mathrm{mi}$. NW of Juneau, Coast Mts. ; 58 $20^{\prime}$ $40^{\prime \prime} \mathrm{N}, 132^{\circ} 29^{\prime} 30^{\prime \prime} \mathrm{W}$; (map 11).

Apparently named for John W. Vanderbilt who lived in the vicinity between 1906-07, as watchman for one of the mining properties on Lemon Creek (DeArmond, 1957, p. 46).

Vanderbilt Point: point of land, on E bank of Chilkat River, $3 \mathrm{mi}$. W of the summit of Tukgahgo Mtn. and $18 \mathrm{mi}$. SW of Skagway, St. Elias Mts.; 59 $18^{\prime} 30^{\prime \prime} \mathrm{N}, 135^{\circ} 43^{\prime} 10^{\prime \prime} \mathrm{W}$; (map 45). Var. Povorotni.

Named in 1880 by the U.S. Navy for Capt. J. M. Vanderbilt, captain of the trading steamer Favorite; the name was published by USC\&GS in the 1883 Coast Pilot (p. 198 and pl. 1819). It is apparently equivalent to the Russian name Povorotni.

Vanderbilt Reef: reef, at junc. of Favorite Channel and Lynn Canal, $3.6 \mathrm{mi}$. NE of Little I. and $30 \mathrm{mi}$. NW of Juneau, Coast Mts.; $58^{\circ} 35^{\prime} 30^{\prime \prime} \mathrm{N}, 135^{\circ} 01^{\prime} 00^{\prime \prime} \mathrm{W}$; (map 11).

Named in 1880 by Capt. L. A. Beardslee, USN, for the man who discovered the reef, Capt. J. M. Vanderbilt of the Northwest Trading Co. Capt. Vanderbilt came to Alaska about 1875 and became captain of the company's steamer Favorite, which did surveying work for the U.S. Navy. He died in 1890 (DeArmond, 1957, p. 30). The name was published by USC\&GS in 1883 Coast Pilot (p. 194).

Vanderlann Peak: mountain, 1,810 ft., $1.1 \mathrm{mi}$. $\mathrm{N}$ of Lake Nicholas, eastern Attu I., Aleutian Is.; $52^{\circ} 53^{\prime} 39^{\prime \prime} \mathrm{N}, 173^{\circ} 14^{\prime} 30^{\prime \prime} \mathrm{E}$; (map 13).

Name shown on an AMS map published in 1948 , and given by the U.S. Army during World War II. The name is not used today.

Van Hatten Creek: stream, flows NE $15 \mathrm{mi}$. to Black River, $33 \mathrm{mi}$. NNE of junc. of Kandik and Yukon Rivers, Porcupine Plat.; $65^{\circ} 48^{\prime}$ N, $142^{\circ} 02^{\prime} \mathrm{W}$; (map 103).

Local name published in 1956 by USGS. Van Horn Ridge: ridge, in Glacier Bay National Monument, extends SW $3 \mathrm{mi}$., $1 \mathrm{mi}$. W of Red Mtn. and $40 \mathrm{mi}$. SW of Skagway, St. Elias Mts.; $59^{\circ} 02^{\prime} \mathrm{N}, 136^{\circ} 03^{\prime} \mathrm{W}$; (map 45).

Named by American Geographical Society in 1947 for F. R. Van Horn, 1872-1933, American geologist who visited Muir Inlet in 1913. Van Horn was born in Ohio and was a graduate of Rutgers Univ. He taught geology and minerology at Rutgers Univ. and at the Case School of Applied Science. He was Director of the Cleveland Museum of Natural History, 1920-33. He was the author of numerous scientific papers mostly dealing with minerology.

Vankagina River: stream, see Vankahini River. Vankahini River: stream, one of five rivers on delta of Alsek River, flows $S$ into Gulf of 
Alaska, $50 \mathrm{mi}$. SE of Yakutat, Malaspina Coastal Plain; $59^{\circ} 07^{\prime} \mathrm{N}, 138^{\circ} 30^{\prime} \mathrm{W}$; (map 46). Var. Vankagina River.

Tlingit Indian name reported by Capt. Tebenkov (1852, map 7), IRN, as "R[eka] Vankagina," or "Vankagina River." Name is not shown on recent maps.

Vank Island: island, $3.5 \mathrm{mi}$. long, $8 \mathrm{mi}$. W of Wrangell, Alex. Arch.; 56 $28^{\prime} \mathrm{N}, 132^{\circ} 36^{\prime} \mathrm{W}$; (map 6). Var. Ostrov Vank.

Published in 1848 on Russian Hydrog. Dept. Chart 1396 as "O[strov] Vank," or "Vank Island."

Van Milligan Creek: stream, flows NE $1.5 \mathrm{mi}$. to Fish Creek, $58 \mathrm{mi}$. SW of Eagle, YukonTanana High.; $64^{\circ} 19^{\prime} 15^{\prime \prime} \mathrm{N}, 142^{\circ} 44^{\prime} 00^{\prime \prime} \mathrm{W}$; (map 102)

Prospectors' name shown on an 1898 manuscript map by C. A. Woodruff, Fort Cudahy, Canada.

Vanover: area, in NE part of Anchorage, between Glenn Highway and Lawrence, Cook Inlet Low.; $61^{\circ} 13^{\prime} 12^{\prime \prime} \mathrm{N}, 149^{\circ} 48^{\prime} 15^{\prime \prime} \mathrm{W}$; (map 69).

Local name reported in 1954 by the city engineer of Anchorage.

Van Sant Cove: bight, $0.5 \mathrm{mi}$. across, off Davidson Inlet, on SE coast of Kosciusko I., $40 \mathrm{mi}$ NW of Craig, Alex. Arch.; 55 $59^{\prime}$ N, $133^{\circ} 32^{\prime}$ W; (map 4).

Named in 1904 by E. F. Dickins, USC\&GS "after the Superintendent of the Holbrook Fishery."

Vantage Peak: peak, 5,585 ft., $0.5 \mathrm{mi}$. N of Icy Basin, $3.8 \mathrm{mi}$. SE of Exploration Peak and $26 \mathrm{mi}$. NE of Juneau, Coast Mts.; $58^{\circ} 39^{\prime} 20^{\prime \prime}$ N, 134 $09^{\prime} 50^{\prime \prime} \mathrm{W}$; (map 11).

Name proposed by members of the Juneau Icefield Research Program and published in 1960 by USGS.

Vantage Rock: rock, at mouth of Seal Bay, 35 mi. NE of Afognak, on NE coast of Afognak I. ; $58^{\circ} 23^{\prime} 48^{\prime \prime} \mathrm{N}, 152^{\circ} 10^{\prime} 30^{\prime \prime} \mathrm{W} ; B G N$ 1934; (map 43).

This descriptive name published by USC\&GS in 1932 "because of its [the island's] prominence."

Vanticlese Creek: stream, heads at Old John Lake, flows SE $23 \mathrm{mi}$. to Koness River $42 \mathrm{mi}$. NE of Christian, Brooks Ra.; $67^{\circ} 53^{\prime} \mathrm{N}, 144^{\circ}$. 23' W; (map 122).

Kutcha-kutchin Indian name obtained in 1956 by $T$. E. Taylor, USGS.

Van Wagenen, Mount: mountain, 7,038 ft., on Alaska-Canada boundary, $5.2 \mathrm{mi}$. NW of Chilkoot Pass and $20 \mathrm{mi}$. N of Skagway, Coast Mts.; $59^{\circ} 44^{\prime} 15^{\prime \prime} \mathrm{N}, 135^{\circ} 21^{\prime} 30^{\prime \prime} \mathrm{W}$; BGN 1954: (map 45).

Named in 1927 by the United States and Canada for James H. Van Wagenen, 18811935, civil engineer and IBC Commissioner. Van Wagenen was born in Iowa and was educated in Illinois and Missouri. He was topographic engineer with USGS in 1909. In 1915 he was appointed chief engineer of the U.S. section of the IBC; he was appointed Commissioner in 1929.
Variegated Glacicr: glacier, heads $0.5 \mathrm{mi}$. W of Mount Jette, trends W $12 \mathrm{mi}$. to its $1961 \mathrm{ter}$ minus, $1.5 \mathrm{mi}$. E of mouth of Russell Fiord and $34 \mathrm{mi}$. NE of Yakutat, St. Elias Mts.; $60^{\circ} 00^{\prime}$ $00^{\prime \prime} \mathrm{N}, 139^{\circ} 22^{\prime} 30^{\prime \prime} \mathrm{W}$; (map 46).

Descriptive name given by Tarr and Martin (1906, p. 147), USGS, "because of its varicolored moraines."

Vashichagat: locality, see Vagitchitchate.

Vasileva, Banka: rock, see Vasilief Rock.

Vasileva, Mel: rock, see Vasilief Rock.

Vasileva, Podvodnaya Banka: shoal, see Vasilief Bank.

Vasileva Rock: rock, see Vasilief Rock

Vasilevka: shoal, see Vasilief Bank.

Vasilief Bank: shoal, $1.5 \mathrm{mi}$. long, at $\mathrm{N}$ entrance to Redoubt Bay, $7 \mathrm{mi}$. SW of Sitka, Alex. Arch.; $56^{\circ} 57^{\prime} 15^{\prime \prime} \mathrm{N}, 135^{\circ} 26^{\prime} 00^{\prime \prime} \mathrm{W}$; (map 5). Var. Podvodnaya Banka Vasileva, Vasilevka.

Named "Podrodnaya banka Vasileva," meaning "Vasilev's submerged bank," in 1809 by the Russians; published by Lt. Sarichev (1826, map 19), IRN. It was probably named for the navigator Ivan Vasiliev the first, IRN, who made surveys in this vicinity in 1809.

Vasilief Bay: bay, $1 \mathrm{mi}$. across, on $\mathrm{SE}$ coast of Atka I., Aleutian Is.; $52^{\circ} 06^{\prime} 20^{\prime \prime} \mathrm{N}, 174^{\circ}-$ $22^{\prime} 00^{\prime \prime}$ W; (map 18).

Named for the pilot, Ens. Vasiliev, IRN, and published as "Bukh[ta] Vasilieva," or "Vasiliev Bay," by Capt. Lutke (1836, p. 317), IRN. Vasili means "Basil" or "William."

Vasilief Point: promontory, see Corwin, Cape. Vasilief Reef: reef, see Williams Reef.

Vasilief Rock: rock, on W coast of Baranof I., $1.3 \mathrm{mi}$. S of Biorka I. and $19 \mathrm{mi}$. SW of Sitka, Alex. Arch.; $56^{\circ} 49^{\prime} 00^{\prime \prime} \mathrm{N}, 1^{\circ} 5^{\circ} 32^{\prime} 30^{\prime \prime} \mathrm{W}$; (map 5). Var. Mel Vasileva, Vasileva Rock. Named "Mel Vasileva," meaning "Vasilev's Shoal," in 1809 by the Russians. See Vasilief Bank.

Vasilief Rock: rock, in Chiniak Bay, $1 \mathrm{mi}$. S of Woody I. and $4 \mathrm{mi}$. SE of Kodiak, Kodiak I.; $57^{\circ} 45^{\prime} 05^{\prime \prime}$ N, $152^{\circ} 19^{\prime} 35^{\prime \prime}$ W; (map 34). Var. Banka Vasileva.

Name published as "Banka Vasileva" meaning "Vasiliev Bank" by Sarichev (1826, map 16) and given its present form by USC\&GS in 1907.

Vassar Glacier: glacier, trends SE $4.3 \mathrm{mi}$. to College Fiord, $2 \mathrm{mi}$. W of College Point and $52 \mathrm{mi}$. W of Valdez, Chugach Mts.; $61^{\circ}$. $12^{\prime} \mathrm{N}, 147^{\circ} 47^{\prime} \mathrm{W}$; (map 69).

Named by members of the Harriman Alaska Expedition in 1899 for Vassar College, Poughkeepsie, N.Y.

Vassar Heights: ridge, see Chicken Ridge.

Vasyleva, Podvodnaya banka: reef, see Williams Reef.

Vatney Gulch: ravine, see Shaft Gully.

Vaughan Lewis Glacier: glacier, heads $2.5 \mathrm{mi}$. W of Mount Moore, trerds NW $3 \mathrm{mi}$. to Gilkey Glacier, $2.5 \mathrm{mi}$. W of Bizzard Peak and $37 \mathrm{mi}$. N of Juneau, Coast Mts.; $58^{\circ} 49^{\prime} 45^{\prime \prime}$ N, 134⒈'25' W; BGN 1962; (map 11).
Named in 1962 by members of the Juneau Icefield Research Program for W. Vaughan Lewis, English geomorphologist and worldrenowned expert on glaciers.

Vault: locality, on right bank of Vault Creek, $0.5 \mathrm{mi}$. $\mathrm{E}$ of Treasure Creek and $12 \mathrm{mi}$. $\mathrm{N}$ of Fairbanks, Yukon-Tanana High.; $65^{\circ} 02^{\prime} \mathrm{N}$, $147^{\circ} 42^{\prime} \mathrm{W}$; (map 105).

Name of a former mining camp published in 1907 by USGS. A post office was established here in 1908 and discontinued in 1909 (Ricks, 1965, p. 69).

Vault Creek: stream, flows NW $7 \mathrm{mi}$. to Chatanika River, $15 \mathrm{mi}$. N of Fairbanks, YukonTanana High.; $65^{\circ} 04^{\prime} 15^{\prime \prime} \mathrm{N}, 147^{\circ} 45^{\prime} 40^{\prime \prime} \mathrm{W}$; (map 105). Var. Moose Creek.

Local name originally reported in 1903 as Moose Creek by USGS; however, a manuscript map by C. W. Joynt dated 1905 shows it as Vault Creek.

Vavilofskaia Gavan: bay, see Baralof Bay. Vcevidofski: mountain, see Vsevidof, Mount.

Veahna Creek: stream, flows NW $20 \mathrm{mi}$. to Kuskokwim River $7.7 \mathrm{mi}$. NE of its junc. with Holokuk River, $6 \mathrm{mi}$. NE of Little Mountain Village, Kilbuck-Kuskokwim Mts. ; $61^{\circ} 35^{\prime} 45^{\prime \prime}$ $\mathrm{N}, 158^{\circ} 24^{\prime} 00^{\prime \prime} \mathrm{W}$; BGN 1948; (map 72).

Native name said to mean "I don't know river"; reported in 1945 by USGS.

Vecélovskoi, Cape: point of land, see Cheerful, Cape.

Vedzh, Ostrov: islands, see Wedge Islands.

Vega Bay: bight, $7.5 \mathrm{mi}$. across, faces $\mathrm{SE}$ to Pacific Ocean, on southern Kiska I., Aleutian Is.; $51^{\circ} 53^{\prime} 00^{\prime \prime} \mathrm{N}, 177^{\circ} 00^{\prime} 24^{\prime \prime} \mathrm{E}$; BGN 1937; (map 14).

Named for the U.S.S. Vega, a supply ship for the U.S. Navy Exploring Expedition of 1935.

Vega Point: point of land, S tip of Kiska I., Aleutian Is.; $51^{\circ} 50^{\prime} \mathrm{N}, 177^{\circ} 19^{\prime} \mathrm{E} ; B G N$ 1937; (map 14).

Named for the U.S.S. Vega, supply ship for the U.S. Navy Exploring Expedition of 1935.

Vegas Islands: islands, $1 \mathrm{mi}$. long, at NE end of Sealed Passage, $\mathrm{N}$ of Duke I., Alex. Arch.; $54^{\circ} 58^{\prime} 00^{\prime \prime} \mathrm{N}, 131^{\circ} 28^{\prime} 00^{\prime \prime} \mathrm{W}$; (map 2).

Named in 1883 by Lt. Comdr. H. E. Nichols, USN.

Veh-tenjerlow: lakes, see Vetenjerlo Lakes.

Vein Mountain: mountain, 2,375 ft., on Althorp Penin., on Chichagof I., $1.4 \mathrm{mi}$. $\mathrm{E}$ of Column Point and $35 \mathrm{mi}$. $\mathrm{W}$ of Hoonah, Alex. Arch.; $58^{\circ} 07^{\prime} 10^{\prime \prime} \mathrm{N}, 136^{\circ} 24^{\prime} 20^{\prime \prime} \mathrm{W}$; (map 10).

Local name published by USGS in the 1950's.

Vein Point: point of land, $S$ tip of island in Ogden Passage, off $\mathbf{W}$ coast of Chichagof I., $3.2 \mathrm{mi}$. SW of Chichagof, Alex. Arch.; 57 $37^{\prime}$ $30^{\prime \prime} \mathrm{N}, 136^{\circ} 08^{\prime} 45^{\prime \prime} \mathrm{W}$; (map 9).

Name published in 1928 by USC\&GS on Chart 8280 .

Veleska Lake: lake, $0.9 \mathrm{mi}$. long, at foot of Tunis Mtn., $4.7 \mathrm{mi}$. W of junc. of South Fork Kuskokwim and Post Rivers and $75 \mathrm{mi}$. SE of McGrath, Alaska Ra.; 62 $24^{\prime} 30^{\prime \prime} \mathrm{N}$, $153^{\circ} 36^{\prime} 40^{\prime \prime}$ W; (map 80).

Local name obtained in 1958 by USGS. 
Velvet Creek: stream, flows S $4 \mathrm{mi}$. to Barnum Creek, $13 \mathrm{mi}$. NE of Goodnews, KilbuckKuskokwim Mts.; $59^{\circ} 18^{\prime}$ N, $161^{\circ} 26^{\prime}$ W; (map 53).

Local name reported in 1954 by USGS. Vendipot, Mys: point of land, see Vandeput, Point.

Venetia Creek: stream, flows SW $7 \mathrm{mi}$. to Eldorado River, $23 \mathrm{mi}$. NW of Solomon, Seward Penin. High.; $64^{\circ} 47^{\prime} \mathrm{N}, 164^{\circ} 58^{\prime} \mathrm{W}$; (map 95).

Prospectors' name reported in 1900 by E. C. Barnard (in Brooks, 1901, pl. 17), USGS.

Venetic: village, pop. 107, $41 \mathrm{mi}$. SW of Christian, Yukon Flats; $67^{\circ} 01^{\prime} \mathrm{N}, 146^{\circ} 25^{\prime} \mathrm{W}$; (map 122).

Kutcha-kutchin Indian village. Post office established in 1938 (Ricks, 1965, p. 69).

Venetie Lake: lake, $2.4 \mathrm{mi}$. long, $3 \mathrm{mi}$. N of Venetie and $40 \mathrm{mi}$. SW of Christian, Yukon Flats; $67^{\circ} 03^{\prime} \mathrm{N}, 146^{\circ} 21^{\prime} \mathrm{W}$; (map 122).

Local name reported in 1956 by T. E. Taylor, USGS.

Venetie Landing: locality, on $\mathrm{N}$ bank of Yukon River, $20 \mathrm{mi}$. NW of Fort Yukon, Yukon Flats; $66^{\circ} 36^{\prime} 40^{\prime \prime} \mathrm{N}, 145^{\circ} 59^{\prime} 40^{\prime \prime} \mathrm{W}$; (map 119).

Local name obtained in 1956 by USGS; named for the Venetie Indian Reservation on which the landing is located.

Veniaminof, Mount: volcano, 8,225 ft., on Aleutian Penin., Aleutian Ra.; 56 ${ }^{\circ} 12^{\prime} \mathrm{N}$, $159^{\circ} 24^{\prime}$ W. Var. Veniaminof Crater, Veniaminof Volcano, Vulkan Wenjaminow.

Constantin Grewingk in 1849 wrote "We have named this point on our maps 'Vukan Wenjaminow.'" Named in honor of Father Ioann [Ivan Popov] Veniaminov, 1797-1879, Russian Orthodox missionary priest, Bishop of Russian America, and Metropolitan of Moscow, whose writings on Aleut language and ethnology are still standard references. The name "Veniaminof Crater" is shown on a 1927 USGS map, presumably intended to apply only to the volcano's crater.

Veniaminof Crater: volcano, see Veniaminof, Mount.

Veniaminof Volcano: volcano, see Veniaminof, Mount.

Venisa Point: point of land, in Glacier Bay National Monument, $0.8 \mathrm{mi}$. E of Sugarloaf I. and $53 \mathrm{mi}$. NW of Hoonah, St. Elias Mts.; $58^{\circ} 18^{\prime} 40^{\prime \prime} \mathrm{N}, 136^{\circ} 50^{\prime} 20^{\prime \prime} \mathrm{W}$; BGN 1930; (map 10). Var. Garnet Point.

So named Garnet 'Point by USC\&GS in 1926 , because the rocky face of the point is studded with small particles resembling garnets. The name was changed in 1929 to the Russian word for garnet (venisa) "in order to eliminate duplication."

Venizali: locality, see Vinasale.

Vent Mountain: crater, see Aniakchak Crater.

Vent Mountain: mountain, 3,200 ft., on Alaska Penin., on S slope of Aniakchak Crater, $19 \mathrm{mi}$. $\mathrm{SE}$ of Port Heiden Airfield, Aleutian Ra.; $56^{\circ} 53^{\prime} \mathrm{N}, 158^{\circ} 09^{\prime} \mathrm{W}$; (map 30 ).

Descriptive name given in 1923 by $R$. $H$. Sargent, USGS.
Ventosa Island: island, see Kochu Island.

Ventura, La: island, "in the northeast part of San Alberto Bay, Bucareli Bay," Alex. Arch.; (map 4). Var. Bentura Island, Isla de Bentura.

Spanish name referring to a "woman innkeeper" given by the 1779 Arteaga expedition (Wagner, 1937, p. 522).

Ventura Creek: stream, flows W $0.5 \mathrm{mi}$. to Alma Creek, $18 \mathrm{mi}$. NE of Solomon, Seward Penin. High.; $64^{\circ} 48^{\prime} \mathrm{N}, 164^{\circ} 10^{\prime} \mathrm{W}$; (map 95).

Prospectors' name reported on a 1902 prospector's manuscript map.

Venturi Lake: lake, $1 \mathrm{mi}$. across, $3 \mathrm{mi}$. SW of Seven Sisters and $31 \mathrm{mi}$. W of Augustine I., Aleutian Ra.; $59^{\circ} 23^{\prime} \mathrm{N}, 154^{\circ} 17^{\prime} \mathrm{W}$; (map 51).

Local name published in 1954 by USGS.

Vera Bay: bight, $1.1 \mathrm{mi}$. across, on $\mathrm{N}$ coast of Long I. ; 6 mi. E of Kodiak, Kodiak I.; 57 $47^{\circ}$ $10^{\prime \prime} \mathrm{N}, 152^{\circ} 14^{\prime} 00^{\prime \prime} \mathrm{W}$; (map 34).

Local name reported in 1949 by USGS.

Verdant Creek: stream, flows $\mathrm{N} 24 \mathrm{mi}$. to Okpikruak River $11 \mathrm{mi}$. $\mathrm{S}$ of its junc. with Okokmilaga River, Brooks Ra.; $68^{\circ} 35^{\prime} \mathrm{N}$, $153^{\circ} 29^{\prime} \mathrm{W}$; (map 133).

So named in 1949 by W. W. Patton, USGS, during exploration of Naval Petroleum Reserve No. 4, because "during the summer months the broad valley through which this creek flows supports a thick cover of green tundra vegetation."

Verdant Island: island, in Aialik Bay, $0.3 \mathrm{mi}$. SE of Harris Penin. and $32 \mathrm{mi}$. SW of Seward, Chugach Mts.; 59 $43^{\prime} \mathrm{N}, 149^{\circ} 44^{\prime} \mathrm{W}$; (map 49).

Local name reported in the early 1950's by USC\&GS

Verdant Island: island, $0.3 \mathrm{mi}$. across, at mouth of Icy Bay, off E coast of Kenai Penin., $4 \mathrm{mi}$. SW of Chenega, Chugach Mts.; $60^{\circ} 16^{\prime} \mathrm{N}$, $148^{\circ} 11^{\prime} \mathrm{W}$; BGN 1934; (map 63).

So named by a USC\&GS field party in 1933 , "because it is heavily wooded and has a green appearance."

Verde, Isla: island, see Verde Island.

Verde, Ostrov: point of land, see Verde Point.

Verde, Point: point of land, see Verde Point.

Verde, Punta: point of land, see Verde Point.

Verde, Ysla: island, see Verde Island.

Verde Island: island, $0.5 \mathrm{mi}$. long, in Port Refugio, off E coast of Suemez I., $15 \mathrm{mi}$. SW of Craig, Alex. Arch.; $55^{\circ} 17^{\prime} \mathrm{N}, 133^{\circ} 19^{\prime} \mathrm{W}$; (map 4). Var. Isla Verde, Ysla Verde.

Spanish name given in $1775-79$ by Don Juan de la Bodega y Quadra and Francisco Antonio Maurelle as "Isla Verde," meaning "Green Island."

Verde Point: point of land, $\mathrm{N}$ point of entrance to Port Refugio, on E coast of Suemez I., Alex. Arch.; $55^{\circ} 18^{\prime} 30^{\prime \prime} \mathrm{N}, 133^{\circ} 17^{\prime} 45^{\prime \prime} \mathrm{W}$; (map 4). Var. Ostrov Verde, Punta Verde, Point Verde.

Spanish name given in $1775-79$ by Don Juan de la Bodega y Quadra and Francisco Antonio Maurelle as "Punta Verde," meaning "Green Point."
Verdure Point: point of land, on $\mathrm{W}$ bank of Portland Canal, $0.7 \mathrm{mi}$. S of Davis River, Coast Mts.; $55^{\circ} 45^{\prime} \mathrm{N}, 130^{\circ} 10^{\prime} \mathrm{W}$; (map 3).

Descriptive name given in 1868 by Staff Comdr. David Pender, RN.

Verkhui, Ozero: lake, see Beaver Lake.

Vermont Creek: stream, flows $3 \mathrm{mi}$. S to Pacific Ocean, $2.6 \mathrm{mi}$. NE of Kettle Cape, on $\mathrm{E}$ coast of Umnak I., Aleutian Is.; $53^{\circ} 18^{\prime} \mathrm{N}, 168^{\circ} 14^{\prime}$ W; (map 22).

Name published by Byers (1959, pl. 41), USGS.

Vermont Creek: stream, flows E $2 \mathrm{mi}$. from Vermont Dome to Hammond River, $7 \mathrm{mi}$. $\mathrm{N}$ of Wiseman, Brooks Ra.; $67^{\circ} 31^{\prime} \mathrm{N}, 150^{\circ} 06^{\prime} \mathrm{W}$; (map 124).

Local name taken from Vermont Dome; reported by Robert Marshall about 1930 .

Vermont Dome: mountain, 4,560 ft., $9 \mathrm{mi}$. $\mathrm{N}$ of Wiseman, Brooks Ra.; 67 $31^{\prime} 30^{\prime \prime} \mathrm{N}, 150^{\circ} 13^{\prime}$ 00" W; BGN 1932; (map 124).

Local name in general use since 1901; reported by Robert Marshall in 1932.

Vermont Pass: pass, between heads of Nolan and Right Fork Vermont Creeks $2 \mathrm{mi}$. SW of Vermont Dome and $7 \mathrm{mi}$. N of Wiseman, Brooks Ra.; $67^{\circ} 30^{\prime} \mathrm{N}, 150^{\circ} 12^{\prime} \mathrm{W}$; (map 124).

Local name taken from Vermont Dome; reported by Robert Marshall about 1930.

Vermouth Brook: stream, see Minor Creek.

Veronica, Lake: lake, see Lieuy Lake.

Verstovaia, Mount: mountain, see Verstovia, Mount.

Verstovaia Peak: mountain, see Verstovia, Mount.

Verstova Mountain: mountain, see Verstovia, Mount.

Verstovaya, Gora: mountain, see Verstovia, Mount.

Verstovia, Mount: mountain, 3,300 ft., $2.5 \mathrm{mi}$. $\mathrm{E}$ of Sitka, on $\mathrm{W}$ coast of Baranof $\mathrm{I}$., Alex. Arch.; $57^{\circ} 03^{\prime} 30^{\prime \prime} \mathrm{N}, 135^{\circ} 16^{\prime} 00^{\prime \prime} \mathrm{W}$; BGN 1897; (map 9). Var. Gora Verstovaya, Mount Verstovaia, Verstova Mountain, Verstovaia Peak, Werstberg Mountain.

Russian name meaning "verst [Russian unit of distance equal to $0.6629 \mathrm{mi}$.]" given in 1809 by the navigator Ivan Vasiliev the first; published by L.t. Sarichev (1826, map 19), IRN, as "Gora Verstovaya."

Verstovia, Mount: mountain, see Arrowhead Peak.

Vert Island: island, $0.1 \mathrm{mi}$. long, $0.2 \mathrm{mi}$. SW of Scott I. and $19 \mathrm{mi}$. N of Augustine I., Aleutian Ra.; $59^{\circ} 38^{\prime} \mathrm{N}, 153^{\circ} 26^{\prime} \mathrm{W}$; BGN 1916; (map 11).

So named in 1913 by USC\&GS because of the green color of the island.

Very Inlet: estuary, extends S $4 \mathrm{mi}$. NE from Foggy Bay along Revillagigedo Channel, Coast Mts.; $54^{\circ} 58^{\prime} 45^{\prime \prime} \mathrm{N}, 130^{\circ} 55^{\prime} 30^{\prime \prime} \mathrm{W}$; (map 2).

Local name reported by $H$. C. Fassett, USBF, in 1904.

Veselofski: locality, see Cheerful.

Veselofski, Cape: point of land, see Cheerful, Cape.

Veselovskiy, Mys: point of land, sec Cheerful, Cape. 
Vesoki: island, see High Island.

Vesolia Mista: locality, just NE of Big Lake, on NE coast of St. Paul I., in Pribilof Is.; $57^{\circ}$ $13^{\prime} 30^{\prime \prime} \mathrm{N}, 170^{\circ} 08^{\prime} 30^{\prime \prime} \mathrm{W}$; (map 38).

Russian name reported by Elliott $(1881, \mathrm{p}$. 20) meaning "jolly place"; the site of one of the first settlements on St. Paul I. "where much carousing was indulged in."

Vesper Peak: peak, 4,505 ft., E of Ptarmigan Glacier, $1.3 \mathrm{mi}$. NW of Observation Peak and $5 \mathrm{mi}$. NE of Juneau, Coast Mts.; $58^{\circ} 22^{\prime} 15^{\prime \prime}$ N, $134^{\circ} 21^{\prime} 45^{\prime \prime} \mathrm{W}$; (map 11).

Local name published in 1962 by USGS.

Vesta, Mount: mountain, 2,095 ft., $0.6 \mathrm{mi}$. S of Rose Inlet, on W coast of Dall I., Alex. Arch.; $54^{\circ} 56^{\prime} \mathrm{N}, 132^{\circ} 58^{\prime} \mathrm{W}$; (map 1).

Name derived from Vesta Bay; published in 1951 by USGS.

Vesta Bay: estuary, extends W $1.4 \mathrm{mi}$. off Kaigani Strait, on $\mathrm{E}$ coast of Dall I., Alex. Arch.; $54^{\circ} 56^{\prime} 15^{\prime \prime} \mathrm{N}, 132^{\circ} 54^{\prime} 00^{\prime \prime} \mathrm{W}$; $B G N$ 1908; (map 1).

Local name recorded in 1907 by Capt. E. F. Dickins, USC\&GS.

Vesta Point: point of land, $\mathrm{N}$ point of entrance to Vesta Bay, on $\mathrm{E}$ coast of Dall I., Alex. Arch.; $54^{\circ} 56^{\prime} 20^{\prime \prime} \mathrm{N}, 132^{\circ} 54^{\prime} 20^{\prime \prime} \mathrm{W}$; BGN 1928; (map 1).

So named in 1927 by Capt. R. S. Patton, USC\&GS, "because of its proximity to Vesta Bay and also because the triangulation station Vesta is on this point."

Vesuvius Valley: valley, extends $2.5 \mathrm{mi}$. N of Copper Mountain, $38 \mathrm{mi}$. NW of Cordova, Chugach Mts.; 60 $54^{\prime} \mathrm{N}, 146^{\circ} 35^{\prime} \mathrm{W}$; (map 64).

Local name reported by Capps and Johnson (1915, pl. 1), USGS. The valley derived its name from a mining claim in the area.

Veta, Mount: mountain, 5,825 ft., $15 \mathrm{mi}$. NW of Kechumstuk Mtn. and $68 \mathrm{mi}$. SW of Eagle, Yukon-Tanana High.; $64^{\circ} 12^{\prime} \mathrm{N}, 143^{\circ} 00^{\prime} \mathrm{W}$; (map 102).

Named by prospectors and shown on a manuscript map compiled in 1905 by Maj. William A. Glassford, USA.

Veta Bay: bay, 3 mi. wide, on $\mathrm{W}$ coast of Baker I., $21 \mathrm{mi}$. SW of Craig, Alex. Arch.; 55 $21^{\prime} \mathrm{N}$, $133^{\circ} 39^{\prime}$ W ; BGN 1923; (map 4).

Spanish word meaning "a vein (or stripe of mineral)," given in 1923 by USC\&GS, because "it is bordered by bluffs of veined or striped rock."

Veta Creek: stream, flows SE $6 \mathrm{mi}$. to Kechumstuk Creek, $68 \mathrm{mi}$. SW of Eagle, YukonTanana High.; $64^{\circ} 08^{\prime} 30^{\prime \prime} \mathrm{N}, 142^{\circ} 54^{\prime} 40^{\prime \prime} \mathrm{W}$; (map 102).

Local name derived from Mount Veta; published in 1956 by USGS.

Veta Point: point of land, on $\mathrm{W}$ coast of Baker I., $\mathrm{N}$ point of entrance to Veta Bay, Alex.

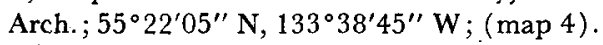
Bay.

Named in 1923 by USC\&GS. See Veta

Vetenjerlo Lakes: lakes, between Kokacho and Marten Creeks, $35 \mathrm{mi}$. NW of Fort Yukon, Yukon Flats; $66^{\circ} 59^{\prime} \mathrm{N}, 145^{\circ} 56^{\prime} \mathrm{W}$; (map 119). Var. Veh-tenjerlow.
Kutchin Indian name obtained in 1956 by T. E. Taylor, USGS.

Vettatrin Lake: lake, $1 \mathrm{mi}$. long, $5 \mathrm{mi}$. NW of Tetsyeh Mtr. and $28 \mathrm{mi}$. NE of Arctic Village, Brooks Ra.; $68^{\circ} 30^{\prime} \mathrm{N}, 1^{\circ} 04^{\prime} \mathrm{W}$; (map 136).

Kutchin Indian name obtained at Arctic Village in 1956 by T. E. Taylor, USGS.

Vettekwi Lake: lake, $3 \mathrm{mi}$. long, $2.5 \mathrm{mi}$. NE of Arctic Village, Brooks Ra.; $68^{\circ} 09^{\prime} \mathrm{N}, 145^{\circ} 25^{\prime}$ W; (map 136).

Kutchin Indian name obtained at Arctic Village in 1956 by T. E. Taylor, USGS.

Vexation Point: point of land, easternmost point of Woody I., in Wrangell Narrows, off coast of Lindenberg Penin., Kupreanof I., $11 \mathrm{mi}$. S of Petersburg, Alex. Arch.; $56^{\circ} 39^{\prime} 15^{\prime \prime} \mathrm{N}$, $132^{\circ} 55^{\prime} 40^{\prime \prime} \mathrm{W}$; (map 6).

Named in 1869 by Comdr. R. W. Meade, USN, for charting purposes; "in memory of the annoyance experienced at this point in taking the Saginaw through Wrangell strait." Viapan Lake: lake, $0.9 \mathrm{mi}$. long, on NW shore of Cook Inlet, $4 \mathrm{mi}$. NE of Tyonek, Cook Inlet Low.; $61^{\circ} 08^{\prime} 00^{\prime \prime} \mathrm{N}, 151^{\circ} 06^{\prime} 20^{\prime \prime} \mathrm{W}$; $(\operatorname{map} 70)$.

Local name reported in 1958 by USGS.

Vichnefski Rock: rock, in Sumner Strait, off NW coast of Zarembo I., Alex. Arch.; 56 $26^{\prime} 15^{\prime \prime}$ $\mathrm{N}, 133^{\circ} 01^{\prime} 00^{\prime \prime} \mathrm{W}$; (map 6).

This feature was probably named in the middle 1800 's by the Russians.

Vickery Creek: stream, see Victor Creek.

Vicory Creek: stream, see Victor Creek.

Vi Creek: stream, flows SSE $8 \mathrm{mi}$. to Middle Fork Koyukuk River, $1.2 \mathrm{mi}$. N of mouth of Gold Creek and $36 \mathrm{mi}$. W of Chandalar, Brooks Ra.; 67 $32^{\prime} \mathrm{N}, 1^{\circ} 49^{\circ} 52^{\prime} \mathrm{W}$; (map 123). Var. Adams Creek.

Local name reported in 1956 by T. E. Taylor, USGS.

Victari Creek: stream, see Victoria Greek.

Victor Creek: stream, heads at terminus of Mother Goose Glacier, flows W $5 \mathrm{mi}$. to E shore of Kenai Lake, $17 \mathrm{mi}$. N of Seward, Chugach Mts.; $60^{\circ} 21^{\prime} 45^{\prime \prime} \mathrm{N}, 149^{\circ} 21^{\prime} 15^{\prime \prime} \mathrm{W}$; BGN 1912; (map 63). Var. Victory Creek, Vicory Creek, Vickery Creek.

Local name published in 1910 by D. H. Sleem on a map of Central Alaska.

Victor Gulch: ravine, extends N $1.2 \mathrm{mi}$. to left bank of Innoko River, $1.2 \mathrm{mi}$. SE of Ophir and $30 \mathrm{mi}$. NW of McGrath, Kilbuck-Kuskokwim Mts.; $63^{\circ} 08^{\prime} \mathrm{N}, 156^{\circ} 29^{\prime} \mathrm{W}$; (map 90).

Prospectors' name reported in 1912 by $A$. G. Maddren and H. M. Eakin, USGS.

Victor Gulch: ravine, at head of Nugget Creek, extends $2.5 \mathrm{mi}$. NW from Poss Mtn., $35 \mathrm{mi}$. W of Chandalar, Brooks Ra.; $68^{\circ} 28^{\prime} \mathrm{N}, 149^{\circ}$ 52' W; (map 123).

Local name reported in 1956 by T. E. Taylor, USGS.

Victoria Creek: stream, flows N $15 \mathrm{mi}$. to Kuskokwim River, $6.3 \mathrm{mi}$. SW of Little Mountain Village and $27 \mathrm{mi}$. E of Aniak, KilbuckKuskokwim Mts.; $61^{\circ} 31^{\prime} 50^{\prime \prime} \mathrm{N}, 158^{\circ} 44^{\prime} 20^{\prime \prime}$ W; BGN 1948; (map 72).

Local name given when the steamboat Vic- toria was frozen in at the stream's mouth one winter; reported in 1945 by USGS.

Victoria Creek: stream, flows SW $3 \mathrm{mi}$. to Coal Creek which flows to Solomon River, $14 \mathrm{mi}$. NE of Solomon, Seward Penin. High.; 64 $4^{\circ} 5^{\prime}$ N, $164^{\circ} 14^{\prime} \mathrm{W}$; (map 95).

Prospectors' name reported in 1900 by E. C. Barnard (in Brooks, 1901, pl. 17), USGS. Victoria Creek: stream, flows S $1 \mathrm{mi}$. to Venetia Creek, $21 \mathrm{mi}$. NW of Solomon, Seward Penin. High.; $64^{\circ} 49^{\prime} \mathrm{N}, 164^{\circ} 48^{\prime} \mathrm{W}$; (map 95). Var. Victari Creek.

Prospectors' name shown as "Victari" on a map by David Fox, Jr., dated 1901.

Victoria Creek: stream, flows SW $2 \mathrm{mi}$., joins Johnson Creek to form Smallwood Creek, 13 mi. NE of Fairbanks, Yukon-Tanana High.; $64^{\circ} 57^{\prime} 25^{\prime \prime} \mathrm{N}, 147^{\circ} 21^{\prime} 00^{\prime \prime} \mathrm{W}$; (map 100).

Local name published in 1908 by USGS.

Victoria Creek: stream, flows NE $37 \mathrm{mi}$. to Beaver Creek, $75 \mathrm{mi}$. W of Circle, YukonTanana High.; $65^{\circ} 48^{\prime} 25^{\prime \prime} \mathrm{N}, 146^{\circ} 39^{\prime} 00^{\prime \prime} \mathrm{W}$; (map 104). Var. Golden Creek.

Named by prospectors and reported in 1902 by Lt. Hjalmar Erickson, USA. Named for the riverboat Victoria.

Victoria Creek: stream, flows $\mathrm{N}$ to McKinley Creek which flows to Boulder Creek, about 25 mi. NW of Nome, Seward Penin. High.; (map 94).

Prospectors' name reported on the 1900 "Map of Nome Peninsula" by J. M. Davidson and B. D. Blakeslee; this feature has not been positively identified.

Victoria Creek: stream, see Lone Creek.

Victoria Mountain: mountain, 4,588 ft., $50 \mathrm{mi}$. ENE of Livengood and $80 \mathrm{mi}$. W of Circle, Yukon-Tanana High.; $65^{\circ} 47^{\prime} \mathrm{N}, 146^{\circ} 56^{\prime} \mathrm{W}$; (map 104).

Name derived by prospectors from Victoria Creek and published in 1951 by USGS.

Victor Island: island, $1.5 \mathrm{mi}$, across, formed by Victor Slough and Yukon River, $12 \mathrm{mi}$. SW of Beaver, Yukon Flats; $66^{\circ} 14^{\prime} 30^{\prime \prime} \mathrm{N}, 147^{\circ}$. $46^{\prime} 00^{\prime \prime} \mathrm{W}$; (map 118).

Locally named for a "sourdough" who had a cabin on the island, as shown on William Yanert's 1916 manuscript map (in Stuck, 1917, map facing p. 122).

Victor Lake: lake, $0.8 \mathrm{mi}$. long, $0.2 \mathrm{mi}$. $\mathrm{SE}$ of Olaf Lake and $19 \mathrm{mi}$. SE of Beaver, Yukon Flats; $66^{\circ} 12^{\prime} 00^{\prime \prime} \mathrm{N}, 146^{\circ} 50^{\prime} 20^{\prime \prime} \mathrm{W}$; (map 119).

Local name obtained in 1956 by USGS.

Victor Slough: channel, in Yukon River, flows SW $2.6 \mathrm{mi}$. around $\mathrm{N}$ side of Mickey I., 30 mi. NE of Ruby, Nowitna Low.; 64 $56^{\prime} \mathrm{N}$, 154 ${ }^{\circ} 33^{\prime} \mathrm{W}$; (map 98).

Riverboat pilots' name shown on 1940 "Navigation Chart, Tanana-Yukon Rivers" of the River Boat Service, U.S. Dept. of Interior. Victor Slough: stream, anabranch of Yukon River, $2 \mathrm{mi}$. long, $\mathbf{N}$ of Victor $\mathbf{I}$. and $13 \mathrm{mi}$. SW of Beaver, Yukon Flats; $66^{\circ} 15^{\prime} 30^{\prime \prime} \mathrm{N}$, $147^{\circ} 47^{\prime} 45^{\prime \prime} \mathrm{W}$; (map 181).

Local name derived from Victor Island; reported in 1956 by T. E. Taylor, USGS.

Victory Greek: stream, see Victor Creek. 
Viekhoda: point of land, see Outlet Cape.

Viekoda Bay: bay, extends SE $18 \mathrm{mi}$., off Shelikof Strait, on N coast of Kodiak I.; 57 55' N, $153^{\circ} 15^{\prime} \mathrm{W}$; BGN 1909; (map 34).

Russian name meaning "outlet" given in 1909 by USC\&GS. The name was derived from "M[ys] Vykhoda," or "Outlet Cape," given by Sub-Lt. Mikhail Murashev in 1839 or 1840 for the eastern point of entrance to this bay, and was published in 1849 on Russian Hydrog. Dept. Chart 1425.

Viesokaia: volcano, see Redoubt Volcano.

Viesokie Kamen: rock, see Pillar Rock.

Viesoki Island: island, $750 \mathrm{ft}$. long, in mouth of Middle Bay, 6 mi. S of Kodiak, Kodiak I.; $57^{\circ} 42^{\prime} 15^{\prime \prime} \mathrm{N}, 152^{\circ} 26^{\prime} 15^{\prime \prime} \mathrm{W}$; $B G N$ 1941; (map 34). Var. Ostrov Vysokoy, Visokoi Rock.

Transliteration by USC\&GS in 1910 of the name "Os[trov] Vysokoy," meaning "High Island"; published by Sarichev (1826, map 16), IRN.

Viesokoi : island, see High Island.

Viesokoi Rock: rock, $0.1 \mathrm{mi}$. across, $1.8 \mathrm{mi}$. NW of Goddard, on W coast of Baranof I., Alex. Arch.; $56^{\circ} 52^{\prime} 10^{\prime \prime} \mathrm{N}, 135^{\circ} 25^{\prime} 00^{\prime \prime} \mathrm{W}$; (map 5). Var. High Rock, High Rock Islet, Ostrov Vysokoy Kamen.

Named in 1809 by the Russian navigator, Ivan Vasiliev the first; published by Lt. Sarichev (1826, map 19), IRN, as "O[strov] Vysokoy Kamen," meaning "high rock island."

Vieth Ridge: ridge, $2 \mathrm{mi}$. long, $\mathrm{E}$ of Ballentine Creek, on northern Attu I., Aleutian Is.; $53^{\circ} 57^{\prime} 30^{\prime \prime} \mathrm{N}, 173^{\circ} 04^{\prime} 00^{\prime \prime} \mathbf{E}$; (map 13).

Named by the U.S. Army during its occupation of the island during World War II; name shown on an AMS map published in 1948.

View Cove: estuary, extends NW 5 mi. off Baldy Bay, on E coast of Dall I., Alex. Arch.; $55^{\circ} 03^{\prime}$ $\mathrm{N}, 132^{\circ} 59^{\prime} \mathrm{W}$; (map 4$)$.

Named in 1881 by Lt. Comdr. H. E. Nichols, USN.

Vigor Creek: stream, flows SW $3 \mathrm{mi}$. to Tolovana River, $14 \mathrm{mi}$. SW of Livengood, YukonTanana High.; $65^{\circ} 20^{\prime} \mathrm{N}, 148^{\circ} 41^{\prime} \mathrm{W}$; (map 105).

Local name published by USGS in the 1950's.

Viking Rock: rock, on W shore of Redfish Bay, $9.9 \mathrm{mi}$. NW of village of Port Alexander, on $S$ coast of Baranof I., Alex. Arch.; 56 $16^{\circ} 05^{\prime \prime}$ $\mathrm{N}, 134^{\circ} 52^{\prime} 20^{\prime \prime} \mathrm{W}$; (map 5).

Named in 1897 by Lt. Comdr. J. F. Moser, USN, commander of USBF steamer Albatross.

Village Cove: cove, $0.4 \mathrm{mi}$. across, $\mathrm{N}$ of St. Paul, on $\mathrm{S}$ coast of St. Paul I., in Pribilof Is.; $57^{\circ} 07^{\prime} 40^{\prime \prime} \mathrm{N}, 170^{\circ} 16^{\prime} 40^{\prime \prime} \mathrm{W}$; (map 38).

Local name recorded about 1900 by USC\&GS.

Village Cove: cove, see Zolotoi Bay.

Village Creek: stream, on $S$ coast of Alaska Penin., flows E $4 \mathrm{mi}$. to a lagoon at head of Aniakchak Bay, $16 \mathrm{mi}$. SW of Cape Kunmik, Aleutian Ra.; $56^{\circ} 43^{\prime} \mathrm{N}, 157^{\circ} 35^{\prime} \mathrm{W}$; (map 31 ).

Local name reported in 1951 by USGS.
Village Creek: stream, flows NE $7.7 \mathrm{mi}$. to Kuskokwim River 0.6 mi. S of its junc, with Crooked Creek, $34 \mathrm{mi}$. NW of Sleetmute, Kilbuck-Kuskokwim Mts.; $61^{\circ} 51^{\prime} 40^{\prime \prime} \mathrm{N}$ $158^{\circ} 07^{\prime} 40^{\prime \prime}$ W; $B G N$ 1944; (map 72).

So named because the mouth of the stream is by the village of Crooked Creek; reported in 1944 by USGS.

Village Creek: stream, flows NW $4 \mathrm{mi}$. to Bering Strait at Wales, on Cape Prince of Wales, $55 \mathrm{mi}$. NW of Teller, Seward Penin. High.; $65^{\circ} 36^{\prime} \mathrm{N}, 168^{\circ} 05^{\prime} \mathrm{W}$; (map 111). Var. Mission Creek.

Prospectors' name reported in 1907 by Knopf (1908, pl. 1), USGS.

Village Creek: stream, on Seward Penin., flows N $6 \mathrm{mi}$. to Lopp Lagoon, $8 \mathrm{mi}$. NE of Cape Prince of Wales and $52 \mathrm{mi}$. NW of Teller, Kotzebue-Kobuk Low.; $65^{\circ} 40^{\prime} \mathrm{N}, 167^{\circ} 52^{\prime} \mathrm{W}$; (map 111)

Prospectors' name reported on the 1908 "Map of Seward Peninsula" by Arthur Gibson.

Village Ekouk: village, see Ekuk.

Village Island: island, $0.2 \mathrm{mi}$. long, in Cat Passage, $0.4 \mathrm{mi}$. SW of Cat I., Alex. Arch.; $55^{\circ}$ $00^{\prime} 40^{\prime \prime} \mathrm{N}, 131^{\circ} 17^{\prime} 00^{\prime \prime} \mathrm{W}$; (map 3).

Named in 1883 by Lt. Comdr. H. E. Nichols, USN; so called because he "found an Indian village here containing 15 houses."

Village Islands: islands, $0.6 \mathrm{mi}$. long, in Zimovia Strait, between Wrangell and Etolin Is., 20 mi. S of Wrangell, Alex. Arch.; $56^{\circ} 12^{\prime} 30^{\prime \prime} \mathrm{N}$, $132^{\circ} 17^{\prime} 30^{\prime \prime} \mathrm{W}$; (map 6). Var. Village Islets.

So named in 1896 by Lt. Comdr. A. S. Snow, USN, because they are opposite a deserted Indian village.

Village Islands: islands, group extends $1.7 \mathrm{mi}$. in Uganik Bay, $1.6 \mathrm{mi}$. NW of Rock Point, on $\mathrm{N}$ coast of Kodiak I.; $57^{\circ} 47^{\prime} 15^{\prime \prime} \mathrm{N}, 153^{\circ} 32^{\prime}$ $30^{\prime \prime} \mathrm{W}$; (map 34).

Named in 1897 by Lt. Comdr. J. F. Moser, USN, of the USBF steamer Albatross.

Village Islets: islands, see Village Islands.

Village Katmay: locality, see Katmai.

Village Point: point of land, at Metlakatla, on W coast of Annette I., Alex. Arch.; $55^{\circ} 08^{\prime} 00^{\prime \prime}$ $\mathrm{N}, 131^{\circ} 34^{\prime} 30^{\prime \prime} \mathrm{W}$; (map 3 ).

Named in 1883 by Lt. Comdr. H. E. Nichols, USN; so called "because of an Indian village here."

Village Point: point of land, $\mathrm{N}$ point of entrance to Chaik Bay, on $W$ coast of Admiralty I., 11 mi. S of Angoon, Alex. Arch.; $57^{\circ} 20^{\prime} 30^{\prime \prime} \mathrm{N}$, $134^{\circ} 34^{\prime} 20^{\prime \prime} \mathrm{W}$; (map 9).

Named in 1869 by Comdr. R. W. Meade, USN, and published on Hydrog. Chart 225. So named because a mile to the east was a very populous Tlingit Indian village named Letushkwin sometimes called Old Kootznahoo or Khudsnu (USC\&GS, 1883, p. 175).

Village Point: point of land, see Cabin Point. Village Reef: reef, in Hot Springs Bay, off $\mathrm{E}$ coast of Tanaga I., Aleutian Is.; $51^{\circ} 47^{\prime} 00^{\prime \prime}$ $\mathrm{N}, 177^{\circ} 47^{\prime} 45^{\prime \prime} \mathrm{W}$; (map 17)

Name published by USC\&GS in 1956 on Chart 9145.
Village Reefs: reefs, $1 \mathrm{mi}$. long, $1 \mathrm{mi}$. E of Afognak, off S coast of Afognak I.; $58^{\circ} 00^{\prime} 30^{\prime \prime}$ $\mathrm{N}, 152^{\circ} 45^{\prime} 00^{\prime \prime} \mathrm{W}$; (map 43$)$.

Local name reported in 1900 by Lt. Comdr. J. F. Moser, USN, commander of the USBF steamer Albatross.

Village Rock: rock, in Jinhi Bay, NE coast of Tuxekan I., Alex. Arch.; 55 $53^{\prime} 20^{\prime \prime} \mathrm{N}$, $133^{\circ} 15^{\prime} 15^{\prime \prime} \mathrm{W}$; (map 4).

Local name published in 1964 by USC\&GS.

Village Rock: rock, along $W$ coast of Admiralty I., at $\mathrm{W}$ end of Kootznahoo Inlet, $0.1 \mathrm{mi}$. N of Angoon, Alex. Arch.; $57^{\circ} 30^{\prime} 20^{\prime \prime} \mathrm{N}$, $134^{\circ} 34^{\prime} 50^{\prime \prime} \mathrm{W}$; (map 9).

Named by Comdr. R. W. Meade, USN, and published in 1869 on Hydrographic Chart 225. So named because the village of Angoon is just to the $S$.

Village Shoal: shoal, $0.5 \mathrm{mi}$. across, at mouth of Port Mulgrave, on Khantaak I., $2 \mathrm{mi}$. NW of Yakutat, Malaspina Coastal Plain ; 59 $34^{\prime} 10^{\prime \prime}$ $\mathrm{N}, 139^{\circ} 46^{\prime} 30^{\prime \prime} \mathrm{W}$; (map 46).

Named by Lt. Giles B. Harber, USN, in 1892. Name published by USC\&GS in 1904 on Chart 8455.

Village Slough: estuary, see Esatkuat.

Village Spit: spit, on Alaska Penin. SW of village of Port Moller, on W shore of Herendeen Bay, Bristol Bay Low.; $55^{\circ} 48^{\prime} 15^{\prime \prime} \mathrm{N}, 160^{\circ} 54^{\prime} 00^{\prime \prime}$ W; (map 28).

Local name published by USC\&GS in 1963.

Villaluenga, Point: point of land, in Glacier Bay National Monument, $\mathrm{N}$ shore of Cross Sound, $0.6 \mathrm{mi}$. W of Cape Spencer and $46 \mathrm{mi}$. NW of Hoonah, St. Elias Mts.; $58^{\circ} 12^{\prime} 45^{\prime \prime} \mathrm{N}, 136^{\circ}$ $40^{\prime} 45^{\prime \prime} \mathrm{W}$; BGN 1930; (map 10).

Named by Duflot de Mofras in his "Exploration du Territoire de l'Oregon, 1830-42," for an unidentified point on Cape Spencer. A sharp point drawn in this area on his chart resembles this point more than any of the others. The name is probably a surname.

Villaluenga, Punta de: point of land, see Cape Spencer.

Villard, Mount: mountain, $4,990 \mathrm{ft}$., $5 \mathrm{mi}$. $\mathrm{N}$ of mouth of Katzehin River, on Chilkoot Inlet, $13 \mathrm{mi}$. S of Skagway, Coast Mts.; $59^{\circ} 16^{\prime} 15^{\prime \prime}$ N, $135^{\circ} 18^{\prime} 10^{\prime \prime} \mathrm{W}$; (map 45).

Probably named by W. H. Dall, USC\&GS, in 1883 for Henry Villard, 1835-1900, American journalist and financier. The name was published in the 1883 Coast Pilot (p. 199). Henry Villard was born in Germany and came to the United States in 1853. He was a newspaper reporter and reported the LincolnDouglas debates. He was also a Givil War correspondent.

Villard Glacier: glacier, on N side of Mt. Villard, trends NE $2 \mathrm{mi}$. to its 1964 terminus, $12 \mathrm{mi}$. $\mathrm{S}$ of Skagway, Coast Mts.; $59^{\circ} 17^{\prime} 30^{\prime \prime} \mathrm{N}, 135^{\circ}$ $15^{\prime} 30^{\prime \prime} \mathrm{W}$; (map 45).

Named by W. H. Dall, USC\&GS, for Henry Villard, and published in the 1883 Alaska Coast Pilot (pl. 1819).

Vinasahle: locality, see Vinasale.

Vinasahle Mountain: mountain, see Vinasale Mountain. 
Vinasale: locality, on left bank of Kuskokwim River, $20 \mathrm{mi}$. S of McGrath, KilbuckKuskokwim Mts.; $62^{\circ} 40^{\prime} 30^{\prime \prime} \mathrm{N}, 155^{\circ} 44^{\prime} 30^{\prime \prime}$ W; (map 80). Var. Gorod Vinisali, Venizali, Vinasahle, Vinisahle.

Ingalik Indian village and later a trading post reported in $1842-44$ by Lt. L. A. Zagoskin, IRN, as "G[orod] Vinisali." W. S. Post and J. E. Spurr, USGS, who visited the place August 1, 1898, found it deserted, and Post recorded "Vinasahle" on his fieldsheet. It is reported to have been abandoned about 1935 (Hosley, 1961, p. 112). The population in 1890 was 140

Vinasale Mountain: mountain, 1,683 ft., on E bank of Kuskokwim River, $18 \mathrm{mi}$. S of McGrath, Kilbuck-Kuskokwim Mts.; $62^{\circ} 42^{\prime} \mathrm{N}$, $155^{\circ} 42^{\prime}$ W ; (map 80). Var. Sopka Vinisali, Vinasahle Mountain.

This is probably an Ingalik Indian name recorded in $1842-44$ by Lt. L. A. Zagoskin, IRN, as "Sopka Vinisali." See Vinasale.

Vincennes, Mount: mountain, 1,942 ft., on W Adak I., Aleutian Is.; $51^{\circ} 46^{\prime} 05^{\prime \prime} \mathrm{N}, 176^{\circ} 46^{\prime}$ 30" W; BGN 1936; (map 17).

Named by the U.S. Navy Hydrog. Office for the U.S.S. Vincennes. See Vincennes Point.

Vincennes Point: point of land, on $\mathbf{S}$ shore of Expedition Harbor, Bay of Is., Adak I., Aleutian Is.; $51^{\circ} 47^{\prime} 18^{\prime \prime} \mathrm{N}, 176^{\circ} 44^{\prime} 50^{\prime \prime} \mathrm{W}$; $B G N$ 1936; (map 17). Var. Middle Point.

Named by the U.S. Navy Hydrog. Office in 1936 for the U.S.S. Vincennes, flagship of the North Pacific Exploring Expedition in 1855 (in A. B. Cole, 1947, p. 5 ).

Vindent, Point: point, on SE coast of Klokachef I., SW of Chichagof I., $20 \mathrm{mi}$. SE of Chichagof, Alex. Arch.; $57^{\circ} 24^{\prime} \mathrm{N}, 135^{\circ} 52^{\prime} \mathrm{W}$; $B G N 1930$; (map 9).

Name reported in 1930 by USC\&GS.

Vincent Island: island, see Hogan Island.

Vincent Island: island, see Klokachef Island.

Vincent Reef: reef, SW of Chichagof I., off SE Coast of Klokachef I., $20 \mathrm{mi}$. SE of Chichagof, Alex. Arch.; $57^{\circ} 24^{\prime} \mathrm{N}, 135^{\circ} 52^{\prime} \mathrm{W}$; $B G N$ 1930; (map 9).

Named in 1930 by USC\&GS "for Vincent Point from which the reef extends."

Vincents Camp: locality, on right bank of Koyukuk River, $14 \mathrm{mi}$. W of Roundabout Mtn., Koyukuk Low.; $65^{\circ} 33^{\prime}$ N, $157^{\circ} 02^{\prime} \mathrm{W}$; (map 108).

Local name obtained at Huslia by USGS in 1954 or 1955.

Vinegar Creek: stream, flows SW $1.4 \mathrm{mi}$. to East Fork Solomon River, $11 \mathrm{mi}$. NE of Solomon, Seward Penin. High.; $64^{\circ} 42^{\prime} \mathrm{N}, 164^{\circ} 17^{\prime} \mathrm{W}$; (map 95).

Prospectors' name reported on a 1902 prospector's manuscript map.

Vinisahle: locality, see Vinasale.

Vinkhem, Ostrov: island, see Wingham Island. Viola Creek: stream, see Violet Creek.

Violet Creek: stream, flows SW $1 \mathrm{mi}$. to Hazel Creek, $7 \mathrm{mi}$. NE of Nome, Seward Penin. High.; $64^{\circ} 33^{\prime} \mathrm{N}, 165^{\circ} 13^{\prime} \mathrm{W}$; (map 94). Var. Viola Creek.
Prospectors' name shown on the 1902 "Map of the Nome and Snake River Country" by J. M. Davidson.

Virgin Bay: cove, $0.6 \mathrm{mi}$. wide, on $\mathrm{E}$ shore of Tatlitlek Narrows, $40 \mathrm{mi}$. NW of Cordova, Chugach Mts.; 60 $53^{\prime} 30^{\prime \prime} \mathrm{N}, 146^{\circ} 42^{\prime} 30^{\prime \prime}$ W; (map 64). Var. Gladhaugh Bay.

Local name reported by Capps and Johnson (1915, pl. 1), USGS. The Bay has also been called "Gladhaugh Bay" for M. O. Gladhaugh who, with C. Peterson, staked mining claims here in 1897.

Virgin Creek: stream, flows W $3.5 \mathrm{mi}$. to Glacier Creek, $1 \mathrm{mi}$. NE of Girdwood and $35 \mathrm{mi}$. SE of Anchorage, Chugach Mts.; 60 $57^{\circ} 05^{\prime \prime} \mathrm{N}$, $149^{\circ} 08^{\prime} 30^{\prime \prime} \mathrm{W}$; (map 63).

Local miners' name reported in 1899 by Lt. Herron (1901, map facing p. 11), USA.

Virgin Creek: stream, see Virginia Creek.

Virginia Butte: hill, 1,796 ft., $2 \mathrm{mi}$. E of Cloud Lake and $4.5 \mathrm{mi}$. $\mathrm{N}$ of Imuruk Lake, Seward Penin. High.; $65^{\circ} 43^{\prime} \mathrm{N}, 163^{\circ} 09^{\prime} \mathrm{W}$; $B G N$ 1952; (map 110).

Reported in 1950 by D. M. Hopkins, USGS; "named for the home State of one of the members of the Geological Survey Field party in 1948."

Virginia Greek: stream, flows S to Garfield Creek which flows to Kuzitrin River, about 22 mi. NW of Mount Bendeleben and $37 \mathrm{mi}$. SW of Imuruk Lake, Seward Penin. High.; (map 110). Var. Virgin Creek.

Prospectors' name reported in 1901 by T. G. Gerdine (in Collier, 1902, pl. 12), USGS. This feature cannot be identified on current maps.

Virginia Creek: stream, flows S $0.6 \mathrm{mi}$. to Skowl Arm Kasaan Bay, on $E$ coast of Prince of Wales I., Alex. Arch.; 55 $25^{\prime} 50^{\prime \prime}$ N, $132^{\circ} 2^{\prime 2}$ $50^{\prime \prime} \mathrm{W}$; (map 4).

Local name recorded in 1949 by USGS.

Virginia Creek: stream, flows NW $7 \mathrm{mi}$. to Wood River, 35 mi. E of Healy, Alaska Ra.; 63 $53^{\circ}$ $15^{\prime \prime} \mathrm{N}, 147^{\circ} 50^{\prime} 10^{\prime \prime} \mathrm{W}$; (map 87).

Prospectors' name shown on a 1910 fieldsheet by J. W. Bagley, USGS; published by Capps (1912, pl. 1), USGS.

Virginia Creek: stream, flows SE $0.6 \mathrm{mi}$. to Shovel Creek, $11 \mathrm{mi}$. N of Solomon, Seward Penin. High.; $64^{\circ} 42^{\prime} 50^{\prime \prime} \mathrm{N}, 164^{\circ} 26^{\prime} 15^{\prime \prime} \mathrm{W}$; (map 95)

Prospectors' name reported on a 1902 prospectors' manuscript.

Virginia Creek: stream, flows SW $2.3 \mathrm{mi}$. to join Russel Creek to form Goldbottom Creek which flows to Niukluk River, $10 \mathrm{mi}$. NW of Council and $43 \mathrm{mi}$. SW of Imuruk Lake, Seward Penin. High.; $65^{\circ} 01^{\prime} \mathrm{N}, 163^{\circ} 50^{\prime} \mathrm{W}$; (map 110).

Prospectors' name published on 1908 "Map of Seward Peninsula" by Arthur Gibson.

Virginia Creek: stream, flows $\mathrm{N} 4 \mathrm{mi}$. to Igloo Creek which flows to American River, $34 \mathrm{mi}$. NE of Teller, Seward Penin. High.; $65^{\circ} 28^{\prime}$ N, $165^{\circ} 18^{\prime} \mathrm{W}$; (map 111).

Prospectors' name reported in 1900 by Messrs. Kemp and David Fox (in Brooks, 1901, pl. 11).
Virginia Creek: stream, on Seward Penin., flows NE $5.3 \mathrm{mi}$. to Kirk Creek, $19 \mathrm{mi}$. SE of Deering, Kotzebue-Kobuk Low.; $66^{\circ} 00^{\prime} \mathrm{N}, 162^{\circ}$ 04' W; (map 113).

Prospectors' name reported in 1908 by F. F. Henshaw (in Brooks and others, 1909, fig. 21), USGS.

Virginia Gulch: ravine, trends N.W. $1.3 \mathrm{mi}$. to White Creek, $17 \mathrm{mi}$. SE of McCarthy, St. Elias Mts.; $61^{\circ} 16^{\prime} \mathrm{N}, 142^{\circ} 32^{\prime} \mathrm{W}$; (map 67).

Named by prospectors; reported by George M. Esterly of Valdez on his 1902 map of the Nizina Mining District; and used by USGS (Mendenhall and Schrader, 1903, fig 5).

Virginia Lake: lake, $2 \mathrm{mi}$. long, $8 \mathrm{mi}$. $\mathrm{E}$ of Wrangell, Coast Mts.; $56^{\circ} 28^{\prime} 45^{\prime \prime} \mathrm{N}, 132^{\circ} 10^{\prime}$ $00^{\prime \prime}$ W; BGN 1966; (map 6). Var. Lake Virginia, Mill Lake.

Named in 1914 by E. L. Jones, USBF, for his wife Virginia Brent Fox Jones; "Mill Lake" was reported as a local name for this feature in 1905 by F. E. Wright and C. W. Wright (1908, fig. 22), USGS.

Virginia Lake: lake, $0.8 \mathrm{mi}$. long, on $\mathrm{W}$ bank of Nabesna River, at mouth of Jacksina Creek, $4 \mathrm{mi}$. E of Nabesna, Wrangell Mts.; $62^{\circ} 21^{\prime} \mathrm{N}$, $142^{\circ} 54^{\prime} \mathrm{W}$; (map 84).

Local name reported in 1960 by USGS.

Virginia Peak: mountain, 3,760 ft., $\mathrm{N}$ of Anita Bay, on NE coast of Etolin I., Alex. Arch.; $56^{\circ} 13^{\prime} 30^{\prime \prime} \mathrm{N}, 132^{\circ} 26^{\prime} 30^{\prime \prime} \mathrm{W}$; (map 6).

Named in 1886 by Lt. Comdr. A. S. Snow, USN.

Virgo Mountain: mountain, 1,400 ft., $15 \mathrm{mi}$. SE of Susie Mtn. and $14 \mathrm{mi}$. NW of Hagemeister I., Kilbuck-Kuskokwim Mts. ; $58^{\circ} 51^{\prime} \mathrm{N}, 161^{\circ}$ $16^{\prime} \mathrm{W}$; (map 39).

Local name published in 1951 by USGS.

Virublennoi Island: island, $0.1 \mathrm{mi}$. across, connected to Japonski I., in Sitka Sound, $1.5 \mathrm{mi}$. SW of Sitka, Alex. Arch.; 57 $02^{\circ} 44^{\prime \prime} \mathrm{N}, 135^{\circ}$ $22^{\prime} 30^{\prime \prime}$ W ; (map 9). Var. Ostrov Vyrublenney.

Russian name meaning "cut out" given in 1809 by the navigator Ivan Vasiliev the first; published by Lt. Sarichev (1826, map 19), IRN, as "O[strov] Vyrublennoy."

Visokoi : island, see High Island.

Visokoi Rock: island, see Viesoki Island.

Vista Creek: stream, flows NW $1 \mathrm{mi}$. to Nugget Creek, $1.8 \mathrm{mi}$. E of 1962 terminus of Mendenhall Glacier and $8.5 \mathrm{mi}$. NW of Juneau, Coast Mts.; $58^{\circ} 25^{\prime} 15^{\prime \prime} \mathrm{N}, 134^{\circ} 29^{\prime} 00^{\prime \prime} \mathrm{W}$; (map 11).

Local name published in 1962 by USGS. Vitskari Island: island, $0.1 \mathrm{mi}$. across, in Sitka Sound, $8.5 \mathrm{mi}$. SW of Sitka, on W coast of Baranof I., Alex. Arch.; 57 $00^{\prime} 00^{\prime \prime}$ N, $135^{\circ}$. $32^{\prime} 30^{\prime \prime} \mathrm{W}$; (map 5). Var. Middle Islands, Ostrov Vitskary.

Named in 1809 by the Russian navigator, Ivan Vasiliev the first; published by Lt. Sarichev (1826, map 19), IRN, as "O[strov] Vitskary," or "Vitskary Island." "According to George Kostrometinoff, United States court interpreter at Sitka, this means "Capt. Witz's chastisement" (Baker, 1906, p. 661). In 
1804 this feature was called "Middle Islands" by Capt. U. T. Lisianski, IRN.

Vitskari Rocks: rocks, N of Vitskari I., in Sitka Sound, $8.5 \mathrm{mi}$. SW of Sitka, Alex. Arch.; $57^{\circ} 00^{\prime} 25^{\prime \prime} \mathrm{N}, 135^{\circ} 33^{\prime} 00^{\prime \prime} \mathrm{W}$; (map 9). Var. Kamen Vitskary, Middle Rocks.

Named "Vitskary" in 1809 by the Russian navigator, Ivan Vasiliev the first. See Vitskari Island.

Vitskary, Kamen: rocks, see Vistskari Rocks. Vitskary, Ostrov: island, see Vitskari Island. Vivghaanok, Mount: hill, see Kookoolik Hill.

Vivid Lake: lake, $0.8 \mathrm{mi}$. long, in Glacier Bay National Monument, 2 mi. W of Black Cap Mtn., and $62 \mathrm{mi}$. NW of Hoonah, St. Elias Mts.; $58^{\circ} 50^{\prime} 30^{\prime \prime} \mathrm{N}, 136^{\circ} 27^{\prime} 20^{\prime \prime} \mathrm{W}$; $B G N$ 1962; (map 10).

So named by NPS in 1962, "because its vivid blue-green color is in striking contrast to the color of the other lakes in the area."

Vixen Bay: estuary, extends S $3 \mathrm{mi}$. off Boca de Quadra, $3 \mathrm{mi}$. W of Mink Bay, Coast Mts.; $55^{\circ} 04^{\prime} 30^{\prime \prime} \mathrm{N}, 130^{\circ} 47^{\prime} 50^{\prime \prime} \mathrm{W}$; (map 3).

One of many arbitrary names applied to features in this area in 1891 by USC\&GS.

Vixen Harbor: bay, 1.2 mi. wide, near mouth of Vixen Inlet, on W coast of Cleveland Penin., $45 \mathrm{mi}$. NE of Craig, Alex. Arch.; 55 $48^{\prime} 15^{\prime \prime}$ N, $132^{\circ} 09^{\prime} 15^{\prime \prime} \mathrm{W}$; (map 4).

Name derived from Vixen Inlet; published in 1924 by USC\&GS.

Vixen Inlet: estuary, $5.5 \mathrm{mi}$. long, $\mathrm{W}$ coast of Cleveland Penin., Alex. Arch.; $55^{\circ} 50^{\prime} \mathrm{N}$, $132^{\circ} 07^{\prime} \mathrm{W}$; (map 4).

Named in 1886 by Lt. Comdr. A. S. Snow, USN, after the USC\&GS steam launch Vixen.

Vixen Islands: islands, $0.5 \mathrm{mi}$. across, in Hoonah Sound, off $S$ coast of Chichagof I., $20 \mathrm{mi}$. E of Chichagof, Alex. Arch.; $57^{\circ} 37^{\prime} \cdot \mathrm{N}, 135^{\circ} 35^{\prime}$ W; (map 9).

Named in 1895 by Lt. Comdr. E. K. Moore, USN, "for the USC\&GS launch Vixen." The name was published in 1900 by USC\&GS on Chart 8282.

Vixen Lake: lake, $1 \mathrm{mi}$. long, on Kenai Penin. $\mathrm{E}$ of Coyote Lake, $31 \mathrm{mi}$. NE of Kenai, Cook Inlet Low.; $60^{\circ} 44^{\prime} 00^{\prime \prime} \mathrm{N}, 150^{\circ} 25^{\prime} 30^{\prime \prime} \mathrm{W}$; (map 62).

Named about 1963 by officials of Kenai National Moose Range, for administrative purposes.

Vixen Point: point of land, $\mathrm{N}$ point of entrance to Vixen Inlet, $\mathrm{W}$ coast of Cleveland Penin., Alex. Arch.; $55^{\circ} 50^{\prime} 45^{\prime \prime} \mathrm{N}, 132^{\circ} 05^{\prime} 30^{\prime \prime} \mathrm{W}$; (map 4).

Named by local fishermen and reported in 1904 by H. C. Fassett, USBF.

Vkhoda, Mys: point of land, see South Point.

V Lake: lake, $0.9 \mathrm{mi}$. long, S of Grayling Lake, $44 \mathrm{mi}$. WNW of Glennallen, Copper River Basin; 62 $2^{\circ} 16^{\prime} 45^{\prime \prime} \mathrm{N}, 146^{\circ} 52^{\prime} 00^{\prime \prime} \mathrm{W}$; (map 83).

Local name reported in 1959 by USGS. Vnechni Rock: rock, see Outer Rock.

Vngyat Cape: point of land, see Vngyat Point.

Vngyat Point: point of land, $18 \mathrm{mi}$. S of Gambell, W coast of St. Lawrence I.; 63 $32^{\prime} \mathbf{N}$, $171^{\circ} 50^{\prime}$ W; BGN 1951; (map 93). Var. Cape Lhookoovik, Lhookoovik Cape, Lhookoovik Point, Lookoovik Cape, Tikighapak Cape, Ungyat, Vngyat Cape, West Cape.

Eskimo name meaning "boats" [ungyat]; so named, according to Orth in 1965, because rocks on the point look like boats from a distance. The "V" spelling, recommended in 1949 by Maj. H. B. Allen, USAF, appears to be an error.

Vnutrennie: point of land, see Inner Point.

Vnutrenniy, Mys: point of land, see Inner Point. Vnutrenniy Gorbun, Kamyen: rock, see Inner Humpback Rock.

Vnyshniy, Kamen: rock, see Outer Rock.

Vodapoini Point: point of land, on $\mathrm{N}$ shore of Deer Passage, at E entrance to Cold Bay, 16 mi. SE of village of Cold Bay, on SW end of Alaska Penin., Aleutian Ra.; 55 $02^{\prime} 10^{\prime \prime} \mathrm{N}$, $162^{\circ} 24^{\prime} 30^{\prime \prime} \mathrm{W}$; (map 29). Var. Cold Cape, Vodopoini Point.

Name published in the 1916 Coast Pilot (p. $186)$; derived from the Russian "Vodopoynyy" meaning "watering place."

Vodopad River: stream, flows W $10 \mathrm{mi}$. through Green Lake to Silver Bay, $9 \mathrm{mi}$. SE of Sitka, on W coast of Baranof I., Alex. Arch.; 56 $59^{\prime}$ $10^{\prime \prime} \mathrm{N}, 135^{\circ} 07^{\prime} 10^{\prime \prime} \mathrm{W}$; (map 5).

Descriptive Russian name meaning "waterfall" given in 1898 by USC\&GS. This adjective is applied to individual falls on early Russian charts.

Vodopoini Point: point of land, see Vodapoini Point.

Voevodskago Island: island, see Woewodski Island.

Vogel Lake: lake, $0.9 \mathrm{mi}$. long, on Kenai Penin., at head of Miller Creek, $3.5 \mathrm{mi}$. SW of Point Possession and $25 \mathrm{mi}$. SW of Anchorage, Cook Inlet Low.; $60^{\circ} 59^{\prime} 30^{\prime \prime} \mathrm{N}, 150^{\circ} 25^{\prime} 30^{\prime \prime} \mathrm{W}$; (map 62).

Local name reported in 1958 by USGS.

Volcan de Miranda: mountain, see Iliamna Volcano.

Volcano Bay: bay, 2 mi. across, $W$ coast of Unalaska I., 2 mi. SE of Cape Kovrizhka, Aleutian Is.; $53^{\circ} 48^{\prime} 45^{\prime \prime} \mathrm{N}, 167^{\circ} 06^{\prime} 30^{\prime \prime} \mathrm{W}$; (map 23). Named in 1888 by USBF.

Volcano Bay: bay, $3 \mathrm{mi}$. across, $28 \mathrm{mi}$. E of village of Cold Bay, at SW end of Alaska Penin., Aleutian Ra.; $55^{\circ} 13^{\prime} \mathrm{N}, 162^{\circ} 00^{\prime} \mathrm{W}$; (map 28, 29).

Name reported by W. H. Dall, USC\&GS, in 1880 , "because of its proximity to Pavlof Volcano."

Volcano Creek: stream, flows W $13 \mathrm{mi}$. to Mother Goose Lake, on Alaska Penin., $23 \mathrm{mi}$. SE of Ugashik, Aleutian Ra.; $57^{\circ} 13^{\prime} \mathrm{N}, 157^{\circ}$ 16' W; (map 36).

Descriptive name given in 1923 by $R$. H. Sargent, USGS, because the river heads on the volcano, Mount Chiginagak.

Volcano Creek: stream, flows $\mathrm{N} 4.5 \mathrm{mi}$. to Clums Fork Birch Creek, $63 \mathrm{mi}$. SW of Circle, YukonTanana High.; $65^{\circ} 08^{\prime} 30^{\prime \prime} \mathrm{N}, 145^{\circ} 29^{\prime} 00^{\prime \prime} \mathrm{W}$; (map 104).

Named by prospectors; reported in 1911 by USGS (Prindle, 1913, pl. 1).
Volcano Greek: stream, heads on $\mathrm{N}$ side of Kavaksurak Mtn., flows E $9 \mathrm{mi}$. to Etivluk River, $12 \mathrm{mi}$. NNE of Howard Pass, Brooks Ra.; $68^{\circ} 22^{\prime} 30^{\prime \prime} \mathrm{N}, 156^{\circ} 42^{\prime} 00^{\prime \prime} \mathrm{W}$; (map 132).

Named in 1966 by geologists of BP Exploration Company, Alaska, Inc., "for the volcanic rock, well exposed in cliffs along the creek course."

Volcanoes, The: hills, see Ingakslugwat Hills.

Volcan Point: point of land, see Vulcan. Point. Volchie Island: barrier beach, see Walrus Island.

Volga Island: island, $200 \mathrm{ft}$. long, in Middle Channel, Sitka Sound, $0.8 \mathrm{mi}$. S of Sitka, Alex.

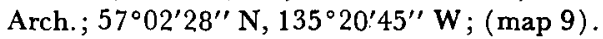
Var. Ostrov Volga.

Russian name published by Capt. Tebenkov (1852, map 38) as "O[strov] Volga," mean. ing "Volga Island," presumably for the great river in Russia.

Volkmar Lake: lake, $1.7 \mathrm{mi}$. long, $20 \mathrm{mi}$. E of Big Delta, Yukon-Tanana High.; $64^{\circ} 07^{\prime} \mathrm{N}$, $145^{\circ} 11^{\prime} \mathrm{W}$; (map 101). Var. Magoffin Lake. Named in 1887 by Lt. H. T. Allen, USA.

Volkmar River: stream, heads at $64^{\circ} 09^{\prime} \mathrm{N}$, $144^{\circ} 12^{\prime} \mathrm{W}$, flows SW $33 \mathrm{mi}$. to Tanana River, $23 \mathrm{mi}$. SE of Big Delta, Yukon-Tanana High.; $64^{\circ} 04^{\prime}$ N, $145^{\circ} 08^{\prime}$ W; '(map 101). Var. Goodpaster River.

Originally named Goodpaster River in 1885 by Lt. H. T. Allen, USA, "in honor of the Goodpaster family in Kentucky." The stream now known as Goodpaster River he named Volkmar River for Col. William Volkmar, USA (Allen, 1887, pl. 3). Later, the names were transposed by explorers and Volkmar River was reported in 1903 by USGS at its present location (Prindle, 1913a, pl. 16).

Volkmar River: stream, see Goodpaster River.

Volunteer Creek: stream, flows SE $2.2 \mathrm{mi}$. to Bonanza River, $10 \mathrm{mi}$. NW of Solomon, Seward Penin. High.; $64^{\circ} 37^{\prime} \mathrm{N}, 164^{\circ} 44^{\prime} \mathrm{W}$; (map 95).

Prospectors' name shown on Arthur Gibson's "Map of Cape Nome Precinct" dated 1904.

Von Frank Creek: stream, flows SW $9 \mathrm{mi}$. to Nixon Fork, $24 \mathrm{mi}$. NE of Medfra, KilbuckKuskokwim Mts.; $63^{\circ} 26^{\prime} \mathrm{N}, 154^{\circ} 28^{\prime} \mathrm{W}$; (map 89).

Local name reported in 1910 by A. G. Maddren (in Brooks and others, 1911, pl. 14), USGS.

Von Frank Mountain: mountain, 4,508 ft., 32 mi. NE of Medfra, Kilbuck-Kuskokwim Mts.; $63^{\circ} 33^{\prime} \mathrm{N}, 154^{\circ} 20^{\prime} \mathrm{W}$; (map 89).

Local name obtained in 1924 by J. S. Brown (in Smith, P. S., and others, 1926, pl. 5), USGS.

Voorhees Isles: islands, see Lively Islands.

Vork, Mys: point of land, see Cape York.

Voroney, Ostrov: island, see Crow Island.

Voronkoffski Island: island, see Woronkofski Island.

Voronkovskiy, Ostrov: island, see Woronkofski Island.

Voronkowski Island: island, see Woronkofski Island. 
Vorontsova, Mys: point of land, see Woronzof, Point.

Vorota Island: island, $0.4 \mathrm{mi}$. long, $3.5 \mathrm{mi}$. S of Chichagof, between Elbow Passage and Smooth Channel, on W coast of Chichagof I., Alex. Arch.; $57^{\circ} 36^{\prime} 40^{\prime \prime} \mathrm{N}, 136^{\circ} 06^{\prime} 15^{\prime \prime} \mathrm{W}$; BGN 1922; ( $\operatorname{map} 9$ ).

Russian word meaning "gates" given in 1922 by USC\&GS.

Vorsehung, Cap der: point of land, see Providence, Cape.

Vorzui Mountain: mountain, 4,200 ft., $3 \mathrm{mi}$. S of Signal Mtn. and $12 \mathrm{mi}$. NE of Arctic Village, Brooks Ra.; $68^{\circ} 11^{\prime} \mathrm{N}, 145^{\circ} 06^{\prime} \mathrm{W}$; (map 136).

Kutchin Indian name obtained at Arctic Village in 1956 by T. E. Taylor, USGS.

Voskresenskaia Bay: estuary, see Resurrection Bay.

Voskresenskaya Gavan: estuary, see Resurrection Bay.

Voskresenskaya Guba: estuary, sce Resurrection Bay.

Vosnesenski Island: island, see Wosnesenski Island.

Voss Creek: stream, flows NE $2 \mathrm{mi}$. to South Fork Fortymile River, $50 \mathrm{mi}$. SW of Eagle, Yukon-Tanana High.; $64^{\circ} 07^{\prime} 10^{\prime \prime} \mathrm{N}, 141^{\circ} 46^{\prime}$ $20^{\prime \prime} \mathrm{W}$; (map 102).

Prospectors' name obtained in 1898 by $\mathrm{E}$. C. Barnard, USGS.

Voss Creek: stream, see Justice Creek.

Vossnessenski Island: island, see Wosnesenski Island.

Vossnessensky Island: island, see Wosnesenski Island.

Vostochni: point of land, see Orient Point.

Vostochni, Cape: point of land, see Chirikof Point.

Vostochnie: locality, on NE tip of St. Paul I., in Pribilof Is.; $57^{\circ} 14^{\prime} 30^{\prime \prime} \mathrm{N}, 170^{\circ} 06^{\prime} 30^{\prime \prime} \mathrm{W}$; (map 38). Var. Novastoshnah.

Russian name meaning "east," published by USC\&GS in 1898. Elliott (1881, St. Paul notes) reported the local name "Novastoshnah," meaning "of recent growth," so called because "this locality in pioneer days was an island to itself ***." This name is derived from the Russian word "novyy" meaning "new."

Vostochnie: point of land, see East Cape.

Vostochnie Point: point of land, see Northeast Point.

Vostochnie Rookery: rookery, on Northeast Point, on NE coast of St. Paul I., in Pribilof Is.; $57^{\circ} 15^{\prime} \mathrm{N}, 170^{\circ} 06^{\prime} \mathrm{W}$; (map 38). Var. North East Rookery, Novastoshnah Rookery. According to Elliott (1881, p. 56-57) this is the largest seal rookery on St. Paul I. with $15,840 \mathrm{ft}$. of sea-margin. See Vostochnie.

Vostochnoi: point of land, see Tolstoi Point.

Vostochnoy, Mys: point of land, see Chirikof Point.

Vostochnoy, Mys: point of land, see Tolstoi Point.

Vostochnyy, Farvater: water passage, see Eastern Channel.
Vostochnyy, Mys: point of land, see East Foreland.

Vostochnyy, Mys: point of land, see East Cape. Vostochnyy, Mys: point of land, see Northeast Point.

Vostochnyy, Mys: point of land, see Orient Point.

Vostoi Forland, Mys: promontory, see East Foreland.

Vovodskago, Gavan: bight, see Woewodski Harbor.

Voyevodskago, Ostrova: island, see Woewodski Island.

Voznesensky Island: island, see Wosnesenski Island.

Vozoychenski Island: island, see Wosnesenski Island.

Vozvratseniya, Zaliv: estuary, see Turnagain Arm.

Vrangel, Gavan : $b a y$, see Wrangell, Port.

Vrangeli, Gavan: estuary, see Wrangell, Port.

Vrangeli, Zaliv: bay, see Wrangell, Port.

Vrangelya, Mys: point of land, see Wrangell, Cape.

Vrangelya, Ostrov: island, see Wrangell Island.

Vrangelya, Proliv: water passage, see Wrangell Narrows.

Vreeland Creek: stream, flows NE $30 \mathrm{mi}$. to Kuskokwim River, $0.9 \mathrm{mi}$. NW of Sleetmute, Kilbuck-Kuskokwim Mts.; $61^{\circ} 42^{\prime} 50^{\prime \prime} \mathrm{N}$, $157^{\circ} 11^{\prime} 15^{\prime \prime} \mathrm{W}$; BGN 1948; (map 72)

Named for Mary Vreeland, native trapper who lived near mouth of stream; reported in 1945 by USGS.

Vsevidof, Mount: mountain, 7,050 ft., on Umnak I., $6 \mathrm{mi}$. W of Mount Recheshnoi, Aleutian Is. ; $53^{\circ} 07^{\prime} 45^{\prime \prime} \mathrm{N}, 168^{\circ} 40^{\prime} 45^{\prime \prime} \mathrm{W}$; BGN 1947; (map 22). Var. Mount Recheshnoi, Mount Sewidowsky, Swewidow, Vcevidofski, Vsevidof Volcano, Wsewidow.

Name derived from Vsevidof Island and reported in 1830 by Father Ioann Veniaminov. Vsevidof, Mount: mountain, see Recheshnoi, Mount.

Vsevidof Island: island, $1.5 \mathrm{mi}$. across, $4 \mathrm{mi} . \mathrm{S}$ of Amos Bay, on S coast of Umnak I., Aleutian Is.; $52^{\circ} 59^{\prime} \mathrm{N}, 168^{\circ} 28^{\prime} \mathrm{W}$; (map 21). Var. Ostrova Vsevidova, Ostrovki Sevidovskaia, Sevidovskie Ostrovki, Sevidow Island, Vsevidof Islets, Vsevidow Island.

Published by Father Veniaminov (1840, v. 1, p. 155) as "Sevidovskie Ostrovki," or "Sevidovskie Island," and by Capt. Tebenkov (1852, map 25), IRN, as "O[stro]va Vsevidova," or "Vsevidova Island." Baker (1906, p. 662) suggested that this feature may have been named for "Andrei Vsevidof, a Russian fur trader, who was in the Aleutian Islands in 1747."

Vsevidof Islets: island, see Vsevidof Island.

Vsevidof Volcano: mountain, see Vsevidof, Mount.

Vsevidova, Ostrova: island, see Vsevidof Island.

Vsevidow Island: island, see Vsevidof Island.

Vtoryee Porogi: rapids, see Southern Rapids.

Vuikhtuligmute: locality, see Vuikhtulik.

Vuikhtulik: locality, on $\mathrm{N}$ shore of Aleknagik Lake, $30 \mathrm{mi}$. NNW of Dillingham, Kilbuck-
Kuskokwim Mts.; $59^{\circ} 25^{\prime} \mathrm{N}, 1^{\circ} 58^{\circ} 54^{\prime}$ W; (map 52). Var. Vuikhtuligmute.

Former Eskimo village or camp recorded in 1880 as "Vuikhtuligmute," population 51 , by Petroff (1881, p. 50).

Vukhduli: locality, on right bank of Wood River, $13 \mathrm{mi}$. $\mathrm{N}$ of Dillingham, Bristol Bay Low.; $59^{\circ} 14^{\prime} \mathrm{N}, 158^{\circ} 33^{\prime} \mathrm{W}$; (map 52).

Eskimo village or camp recorded as "Vukh. du-li" on a 1910 manuscript map by H. C. Fassett, USBF.

Vukpalik Creek: stream, flows SW $25 \mathrm{mi}$. to Nushagak River, $85 \mathrm{mi}$. W of Lake Clark and $112 \mathrm{mi}$. S of Sleetmute, Kilbuck-Kuskokwim Mts.; $60^{\circ} 11^{\prime} \mathrm{N}, 157^{\circ} 15^{\prime} \mathrm{W} ; B G N$ 1932; $(\operatorname{map} 60)$.

Eskimo name reported in 1931 by Gerald FitzGerald, USGS.

Vulcan Cove : bay, see Sarana Bay.

Vulcan Creek: stream, flows SE $5.6 \mathrm{mi}$. to Tubutulik River, $22 \mathrm{mi}$. NE of Elim and 73 mi. NE of Solomon, Seward Penin. High.; $64^{\circ} 55^{\prime} \mathrm{N}, 162^{\circ} 09^{\prime} \mathrm{W}$; (map 95).

Local name reported in 1900 by W. J. Peters (in Mendenhall, 1901, pl. 20), USGS.

Vulcan Point: point of land, $2.7 \mathrm{mi}$. W of Kiska Volcano, on NW coast of Kiska I., Aleutian Is.; $52^{\circ} 06^{\prime} 10^{\prime \prime} \mathrm{N}, 177^{\circ} 32^{\prime} 35^{\prime \prime} \mathrm{E}$; BGN 1937; (map 14). Var. Volcan Point.

Named for its proximity to Kiska Volcano.

Vulcan Point: point of land, on $\mathrm{S}$ coast of Akutan I., in Krenitzin Is., Fox Is., Aleutian Is. ; $54^{\circ} 04^{\prime} 35^{\prime \prime} \mathrm{N}, 165^{\circ} 49^{\prime} 00^{\prime \prime} \mathrm{W}$; (map 24).

Named in 1888 by USBF. The name is derived from adjacent Aarana Bay, which was originally called "Vulcan Cove" by USBF .

Vundik Lake: lake, $5 \mathrm{mi}$. long, $33 \mathrm{mi}$. NW of Coleen Mtn., Yukon Flats; $67^{\circ} 22^{\prime} \mathrm{N}, 143^{\circ} 48^{\prime}$ W; (map 121).

Kutcha-kutchin Indian name reported in 1956 to mean "big lake [vandjik]" by T. E. Taylor, USGS.

Vunicth Lakes: lakes, see Vunikth Lakes.

Vunikth Lakes: lakes, $2 \mathrm{mi}$. W of Vehtenjerlo Lakes and $39 \mathrm{mi}$. NW of Fort Yukon, Yukon Flats; $66^{\circ} 59^{\prime} \mathrm{N}, 146^{\circ} 08^{\prime} \mathrm{W}$; (map 119). Var. Vunicth Lakes.

Kutchin Indian name obtained in 1956 by T. E. Taylor, USGS.

Vunittsieh Lakes: lakes, $\mathrm{E}$ of Ackerman Lake, draining into Chekhechunnjik Creek, $29 \mathrm{mi}$. $\mathrm{E}$ of Chandalar, Brooks Ra.; 67 $32^{\prime} 30^{\prime \prime} \mathrm{N}$, $147^{\circ} 24^{\prime} 00^{\prime \prime} \mathrm{W}$; (map 123).

Kutchin Indian name obtained in 1956 by T. E. Trylor, USGS. The "vun" (or "van") means lake.

Vunle Lakes: lakes, $12 \mathrm{mi}$. S of Chalkyitsik, Yukon Flats; $66^{\circ} 28^{\prime} \mathrm{N}, 143^{\circ} 42^{\prime} \mathrm{W}$; (map 120).

Tranjik-kutchin Indian name; obtained in 1956 by T. E. Taylor, USGS

Vunlui Lake: lake, $0.5 \mathrm{mi}$. long, $17 \mathrm{mi}$. NW of Bearman Lake and $44 \mathrm{mi}$. NW of Fort Yukon, Yukon Flats; $66^{\circ} 51^{\prime} 30^{\prime \prime} \mathrm{N}, 1^{\circ} 46^{\circ} 41^{\prime} 30^{\prime \prime} \mathrm{W}$; (map 119).

Kutchin Indian name obtained in 1956 by T. E. Taylor, USGS. 
Vunvekottlui Lake: lake, $1.5 \mathrm{mi}$. long, in Dempsey Creek, $23 \mathrm{mi}$. W of Midnight Hill, Porcupine Plat.; $66^{\circ} 06^{\prime} \mathrm{N}, 141^{\circ} 54^{\prime} \mathrm{W}$; (map 120).

Tranjik-kutchin Indian name; obtained in 1956 by T. E. Taylor, USGS.

Vunzik Lake: lake, $1 \mathrm{mi}$. long, $17 \mathrm{mi}$. NW of Bearman Lake and $42 \mathrm{mi}$. NW of Fort Yukon, Yukon Flats; $66^{\circ} 48^{\prime} \mathrm{N}, 146^{\circ} 39^{\prime} \mathrm{W}$; (map 119).

Kutchin Indian name obtained in 1956 by T. E. Taylor, USGS.

Vykhoda, Mys: point of land, see Outlet Cape.

Vykhodnoy, Mys: point of land, see Outlet Cape.

Vyrublennoy, Ostrov: island, see Virublennoi Island.

Vysokoi Island: island, see Cliff Island.

Vysokoy, Ostrov: island, see Cliff Island.

Vysokoy, Ostrov: island, see Viesoki Island.

Vysokoy Kamen, Ostrov: rock, see Viesokoi Rock.

Vysylovskoe: locality, see Cheerful.

\section{W}

Wabash Creek: stream, flows NW $17 \mathrm{mi}$. to Nixon Fork $21 \mathrm{mi}$. NW of Medfra, KilbuckKuskokwim Mts. ; $63^{\circ} 15^{\prime} \mathrm{N}, 155^{\circ} 18^{\prime} \mathrm{W}$; (map 89).

Local name reported in 1958 by USGS.

Wabash Creek: stream, flows NW $10 \mathrm{mi}$. to Kiwalik Lagoon, $57 \mathrm{mi}$. NW of Haycock, Seward Penin. High.; $65^{\circ} 59^{\prime} \mathrm{N}, 161^{\circ} 46^{\prime} \mathrm{W}$; (map 109).

Local name reported in 1908 by USGS (Brooks and others, 1909, fig. 21).

Wachsmuth, Mount: mountain, 4,921 ft., E of Shainin Lake, $23 \mathrm{mi}$. NE of Anaktuvuk Pass, Brooks Ra.; $68^{\circ} 20^{\prime} \mathrm{N}, 151^{\circ} 00^{\prime} \mathrm{W}$; BGN 1960 ; (map 134).

Named by USGS geologists in 1951 for Charles Wachsmuth, 1829-96, American geologist and paleontologist.

Wachusett Cove: cove, $0.4 \mathrm{mi}$. across, at mouth of Freshwater Bay, on $\mathbf{E}$ coast of Chichagof I., $8.5 \mathrm{mi}$. NE of Tenakee Springs, Alex. Arch.; $57^{\circ} 50^{\prime} \mathrm{N}, 135^{\circ} 00^{\prime} \mathrm{W}$; (map 9).

Named in 1881 by the U.S. Navy for the U.S.S. Wachusett, commanded by Comdr. Henry Glass, USN, used in surveying the cove that year. The name was published by USC\&GS in the 1883 Alaska Coast Pilot (p. $180)$.

Wachusett Inlet: estuary, in Glacier Bay National Monument, heads in Plateau Glacier, trends E $4 \mathrm{mi}$. to Muir Inlet, $1.6 \mathrm{mi}$. NW of Point McLeod and $63 \mathrm{mi}$. NW of Hoonah, St. Elias Mts.; $58^{\circ} 56^{\prime} 30^{\prime \prime} \mathrm{N}, 136^{\circ} 08^{\prime} 00^{\prime \prime} \mathrm{W}$; $B G N$ 1948; (map 10). Var. Cushing Inlet, Wisconsin Inlet.

Named for the U.S.S. Wachusett which entered Glacier Bay in 1881. The inlet has been formed since 1907 by the recession of Plateau and Muir Glaciers. It was named "Cushing Inlet" for Cushing Glacier by USC\&GS and published on Chart 8306 in 1942. It was called "Wisconsin Inlet" by members of the Glacier Bay Expedition of 1941 (Field. 1947, map), because John Muir,
R. S. Tarr, Lawrence Martin, and F. T Thwaites, geologic investigators in this area, were connected with the Univ. of Wisconsin. Wachusett Point: point of land, see Rowlee Point.

Wacker: village, see Ward Cove.

Wacker City: village, see Ward Cove.

Wadding Cove: estuary, extends N $1.8 \mathrm{mi}$. off Behm Canal, on $\mathrm{E}$ coast of Cleveland Penin., Alex. Arch.; 55 $37^{\prime} \mathrm{N}, 131^{\circ} 53^{\prime} \mathrm{W}$; (map 3).

Local navigators' name obtained in 1904 by H. C. Fassett, USBF.

Wade, Mount: mountain, 7,960 ft., on AlaskaCanada boundary, $2.4 \mathrm{mi}$. SE of Mount Duff and $41 \mathrm{mi}$. NE of Yakutat, St. Elias Mts.; $59^{\circ} 49^{\prime} \mathrm{N}, 138^{\circ} 40^{\prime} \mathrm{W} ; B G N$ 1923; (map 46). Var. Boundary Peak 173.

Named by IBC in 1923 for Frederick Coate Wade, 1860-1924, who was junior councilor before the Alaska Tribunal in 1903. He was born in Ontario and attended Toronto Univ. $\mathrm{He}$ was employed as an editorial writer before being called to the bar in 1886 . In 1887 he represented the U.S. Department of Justice concerning a claim for the surrender of Sitting Bull after the Custer Massacre. He was active in the public affairs of Canada and was the author of several books.

Wade Creek: stream, flows SW $9 \mathrm{mi}$. to Walker Fork, $52 \mathrm{mi}$. SW of Eagle, Yukon-Tanana High.; 64ㅇ․ $04^{\prime} 30^{\prime \prime} \mathrm{N}, 141^{\circ} 37^{\prime} 15^{\prime \prime} \mathrm{W}$; (map 102). Var. Jack Wade Creek.

Reported in 1898 by E. C. Barnard, USGS. Named for Jack Wade, a prospector, who discovered gold on this stream about 1895 (Prindle, 1905, p. 40).

Wade Creek: stream, see Burnt River.

Wadell Lake: lake, $0.5 \mathrm{mi}$. long, $4 \mathrm{mi}$. W of Harriet Point and $39 \mathrm{mi}$. SW of Kenai, Aleutian Ra.; $60^{\circ} 24^{\prime} 30^{\prime \prime} \mathrm{N}, 152^{\circ} 21^{\prime} 15^{\prime \prime} \mathrm{W}$; (map 62).

Local name reported in 1958 by USGS.

Wadleigh Creek: stream, see Waydelich Creek.

Wadleigh Island: island, $5.5 \mathrm{mi}$. long, between Klawak Inlet and San Alberto Bay, Alex. Arch.; $55^{\circ} 34^{\prime} N, 133^{\circ} 09^{\prime} \mathrm{W}$; (map 4).

Name published in 1943 by USC\&GS; derived from Wadleigh Rock.

Wadleigh Rock: rock, in San Alberto Bay, $\mathrm{S}$ of Alberto Is., $4 \mathrm{mi}$. $\mathrm{N}$ of Craig, of Klawock, Alex. Arch.; $55^{\circ} 31^{\prime} 45^{\prime \prime} \mathrm{N}, 133^{\circ} 10^{\prime} 25^{\prime \prime} \mathrm{W}$; $B G N$ 1908; (map 4).

Local name recorded in 1907 by E. F. Dickins, USC\&GS, as "name of person or vessel lost on it."

Wadzis: island, see Biorka Island.

Wager Creek: stream, heads in De Long Mts., flows $\mathrm{N} 9 \mathrm{mi}$. to Drenchwater Creek, $18 \mathrm{mi}$. N of Desperation Lake, Brooks Ra.; 68 $35^{\prime} \mathrm{N}$, $158^{\circ} 35^{\prime} \mathrm{W}$; $B G N$ 1960; (map 132).

Named in 1951 by B. H. Kent, USGS, for a camp incident.

Wagner Gulch: ravine, extends NW $0.7 \mathrm{mi}$., at head of Mills Creek, $46 \mathrm{mi}$. W of Talkeetna, Alaska Ra.; $62^{\circ} 21^{\prime} 25^{\prime \prime} \mathrm{N}, 151^{\circ} 32^{\prime} 00^{\prime \prime} \mathrm{W}$; (map 81)

Prospectors' name reported in 1911 by Capps (1913, fig. 7), USGS.
Wagner Lake: lake, see Tetlin Lake.

Wagon Box Creek: stream, flows $\mathrm{N} 4.8 \mathrm{mi}$. to Norton Sound, $24 \mathrm{mi}$. E of Saint Michael, Nulato Hills; $63^{\circ} 29^{\prime} \mathrm{N}, 161^{\circ} 15^{\prime} \mathrm{W}$; (map 91).

Local name reported in 1952 by USG\&GS. Wagon Wheel Creek: stream, heads in Bendeleben Mts., flows SW $8 \mathrm{mi}$ to Fish River, $28 \mathrm{mi}$. S of Imuruk Lake, Seward Penin. High.; $65^{\circ} 10^{\prime} \mathrm{N}, 163^{\circ} 07^{\prime} \mathrm{W}$; (map 110).

Prospectors' name published on the 1908 "Map of Seward Peninsula" by Arthur Gibson. Wahmus Creek: stream, see Wattamuse Creek. Wahoo Lake: lake, $1 \mathrm{mi}$. long, $\mathrm{W}$ of and draining into Echooka River, $16 \mathrm{mi}$. SW of Mount Salisbury and $67 \mathrm{mi}$. SW of Mount Michelson, Brooks Ra.; $69^{\circ} 04^{\prime} 20^{\prime \prime} \mathrm{N}, 146^{\circ} 55^{\prime} 30^{\prime \prime} \mathrm{W}$; $B G N$ 1960; (map 139).

Named by W. P. Brosgé, USGS, in 1952 for the Wahoo limestone formation.

Wahpoo Creek: stream, flows SW $3.7 \mathrm{mi}$. to Wilson Creek $3.3 \mathrm{mi}$. E of Marshall, Nulato Hills; $61^{\circ} 53^{\prime} \mathrm{N}, 161^{\circ} 59^{\prime} \mathrm{W}$; (map 73).

Prospectors' name reported in 1916 by Harrington (1918, map), USGS.

Wainwright: village, pop. 253, on Ghukchi Sea coast $\mathrm{N}$ of Wainwright Inlet, $47 \mathrm{mi}$. NE of Icy Cape, Arctic Plain; $70^{\circ} 38^{\prime} 15^{\prime \prime} \mathrm{N}$, $160^{\circ} 01^{\prime} 45^{\prime \prime} \mathrm{W}$; (map 146). Var. Olgonik, Wainwright Inlet.

Name derived from that of the lagoon. This area has been conducive to settlement for centuries. Several villages have existed on the land between Wainwright Inlet and the sea, the most recent one being Wainwright, the major village between Barrow and Point Hope. A post office was established here in 1916.

Wainwright Inlet: bay, $6 \mathrm{mi}$. across, at mouth of Kuk River, $\mathrm{S}$ of Wainwright, Arctic Plain; $70^{\circ} 36^{\prime} \mathrm{N}, 160^{\circ} 00^{\prime} \mathrm{W}$; BGN 1925; (map 146). Var. Olrona, Tutagvak Bay, Wainwright Lagoon.

Named by Capt. F. W. Beechey, RN, for Lt. John Wainwright, RN, astronomical observer and officer on his ship, the H.M.S. Blossom. Surgeon John Simpson's native map of 1853 shows the Eskimo name "Olrona" and P. Tikhmeniev's 1861 map shows " $\mathrm{Zal}[\mathrm{iv}]$ Tutagvak," which may mean "big labret."

Wainwright Inlet: village, see Wainwright.

Wainwright Lagoon: bay, see Wainwright Inlet.

Wait Creek: stream, flows SE $6.6 \mathrm{mi}$. to Jacksina Creek $8.5 \mathrm{mi}$. SW of its junc. with Nabesna River, Wrangell Mts.; $62^{\circ} 18^{\prime} \mathrm{N}$, $143^{\circ} 06^{\prime}$ W; (map 84). Var. Waite Creek.

Named in 1902 by F. C. Schrader, USGS, because for a week he was delayed here by bad weather.

Waite Creek: stream, see Wait Creek.

Wakefield Lakes: lakes, on Baranof I., includes Deep and Long Lakes, $27 \mathrm{mi}$. SE of Sitka, Alex. Arch.; 56 $52^{\prime}$ N, $134^{\circ} 44^{\prime}$ W ; (map 5).

Local name recorded in 1951 by USGS.

Wakeup Creek: stream, flows $1.7 \mathrm{mi}$. SE, then SW, to California Creek, $3 \mathrm{mi}$. SW of Big Lake and $26 \mathrm{mi}$. W of Chandalar, Brooks Ra.; $67^{\circ} 28^{\prime} 30^{\prime \prime} \mathrm{N}, 149^{\circ} 29^{\prime} 00^{\prime \prime} \mathrm{W}$; (map 123). 
This name was applied to a neighboring stream, as reported in 1923 by J. B. Mertie, Jr. (in Brooks and others, 1925, pl. 6), USGS. The present name application was first published by USGS on a 1956 map.

Waklarok: locality, site of an Eskimo village, on $\mathrm{S}$ shore of Kwemeluk Pass, $17 \mathrm{mi}$. NE of Black, Yukon-Kuskokwim Delta; 62 $32^{\prime} 15^{\prime \prime} \mathrm{N}, 165^{\circ}$ $00^{\prime} 20^{\prime \prime} \mathrm{W}$; (map 76). Var. Waklarokamiut.

Eskimo name obtained by G. R. Putnam, USC\&GS, in 1899, as "Waklarokamiut," or "people of Waklarok."

Waklarokamiut: locality, see Waklarok.

Waklarok Slough: stream, on left bank of Kwemeluk Pass near its mouth at Waklarok, Yukon-Kuskokwim Delta; $62^{\circ} 32^{\prime} \mathrm{N}, 165^{\circ} 00^{\prime}$ W; (map 76).

Eskimo name obtained by G. R. Putnam, USC\&GS, in 1899.

Walakpaat: estuary, see Walakpa Bay.

Walakpa: locality, on Chukchi Sea coast, at Walakpa Bay, $11 \mathrm{mi}$. SW of Barrow, Arctic Plain; (map 153). Var. Walapai, Walakpan, Walakpat, Walakpra, Wallikipi, Wolikpot.

Eskimo name, Walakpak, reported to mean "big village" (see Walakpa Bay). This locality has been a campsite for generations because of its relation to a good coastal inlet. William Smyth reported that in August 1826 a village of nine tents was located one-half mile from the mouth of the inlet (Beechey, 1831, p. 312, 315).

Walakpa Bay: estuary, extends $6 \mathrm{mi}$. E from Chukchi Sea, $11 \mathrm{mi}$. SW of Barrow, Arctic Plain; $71^{\circ} 08^{\prime} 25^{\prime \prime} \mathrm{N}, 157^{\circ} 02^{\prime} 45^{\prime \prime} \mathrm{W}$; -(map 153). Var. Refuge Inlet, Walapai, Walakpaat, Walakpan.

In 1853 Comdr. Rochfort Maguire, RN, recorded the Eskimo name as "Walakpan" (Great Britain, 1854, map facing p. 186). Lt. P. H. Ray (1885, p. 55), USA, recorded the name "Walakpa" for the sixth camp site below Nuwuk. Sgt. John Murdoch, USA, of Ray's party spelled the name "Walapai." The Eskimo of today pronounce the name "Walakpak" and say it refers in meaning to a "big village." Beechey (1831, p. 313316), RN, named the estuary "Refuge Inlet" after the barge sent to explore the coast to Point Barrow was trapped there by ice from August 25 to 28, 182.6. Will Rogers and Wiley Post were killed in a plane crash there August 15, 1935 (Brower, 1942, p. 295-301).

Walakpan: locality, see Walakpa.

Walakpan: estuary, see Walakpa Bay.

Walakpa River: stream, flows N $6 \mathrm{mi}$. to Walakpa Bay, $13 \mathrm{mi}$. SW of Barrow, Arctic Plain; $71^{\circ} 07^{\prime} 45^{\prime \prime} \mathrm{N}, 157^{\circ} 02^{\prime} 15^{\prime \prime} \mathrm{W}$; (map 153).

Eskimo name. See Walakpa Bay and Walakpa.

Walakpat: locality, see Walakpa.

Walakpra: locality, see Walakpa.

Walapai : locality, see Walakpa.

Walapai : estuary, see Walakpa Bay.

Walby Creek: stream, flows $\mathrm{N} 1 \mathrm{mi}$. to Wade Creek at Jack Wade, $46 \mathrm{mi}$. SW of Eagle,
Yukon-Tanana High.; $64^{\circ} 09^{\prime} 00^{\prime \prime} \mathrm{N}, 141^{\circ} 27^{\prime}$ $30^{\prime \prime} \mathrm{W}$; (map 102).

Local name published in 1956 by USGS.

Walden Point: point of land, between Annette Bay and Nichols Passage, on N coast of Annette I., Alex. Arch.; 55 $16^{\prime} 30^{\prime \prime} \mathrm{N}, 131^{\circ} 35^{\prime}$ $15^{\prime \prime} \mathrm{W}$; (map 3).

Local navigators' name obtained in 1904 by H. C. Fassett, USBF.

Walden Rocks: rocks, extend $0.5 \mathrm{mi}$, in Nichols Passage, $0.6 \mathrm{mi}$. W of Walden Point, on Annette I., Alex. Arch.; $55^{\circ} 16^{\prime} 15^{\prime \prime} \mathrm{N}, 131^{\circ} 36^{\prime}$ $20^{\prime \prime} \mathrm{W}$; (map 3). Var. Race Reef.

Named by Lt. Comdr. H. E. Nichols, USN, in 1883 ; "Race Reef" was published as a local name for this feature in 1883 Coast Pilot (p. 79).

Waldren Fork: stream, see Little Waldren Fork. Waldron Creek: stream, flows W $14 \mathrm{mi}$. to Yukon River, $40 \mathrm{mi}$. NE of Rampart, Yukon-Tanana High.; 65 $52^{\prime} \mathrm{N}, 149^{\circ} 19^{\prime} \mathrm{W}$; (map 105).

Named by prospectors; reported by $\mathrm{Lt}$. Erickson, USA, in 1902. Name was published by USGS (Prindle, 1905, pl. 16).

Wales: village, pop. 128 , at mouth of Village Creek, on coast of Cape Prince of Wales, at $\mathrm{W}$ end of Seward Penin., Kotzebue-Kobuk Low.; $65^{\circ} 37^{\prime} \mathrm{N}, 168^{\circ} 05^{\prime} \mathrm{W}$; BGN 1944; (map 111). Var. Eidannoo, Kingaghee, King-a-khi, Kingegan, Kingegan Mission, Kingeghee, Kingigamute.

In 1827 Capt. Beechey (1831, p. 540), RN, wrote: "The natives have a village upon the low land near the cape called Eidannoo, and a nother inland named King-aghe * * ." Beechey later noted (1831, p. 543): "These were some of the most clearly and well dressed people we had seen anywhere on the coast. Their residence was at King-a-ghee, a place which, judging from the respectability of parties from that place, whom we had seen elsewhere, must be important among the Esquimaux villages upon the coast." Capt. E. E. Smith, USRCS, reported the village as "Kingigamute" with a population of 400 Eskimo in the 10th Census in 1880 . The 1890 Census listed 488 persons. In 1890 the American Missionary Association of the Congregational Church established a mission here (Brooks, 1901, p. 23), and in 1894 a U.S. Government reindeer station was organized. The post office of Wales was established in 1902 and continues in operation today. The population in 1910 was 337 ; in 1920,136 ; in 1930 , 170 ; in 1939,193 ; and in $1950,141$.

Walhalla Slough: stream, $8 \mathrm{mi}$. long, distributary of Copper River, $20 \mathrm{mi}$. SE of Cordova, Malaspina Coastal Plain; $60^{\circ} 21^{\prime} \mathrm{N}, 145^{\circ} 22^{\prime} \mathrm{W}$; (map 64).

Local name published in 1951 by USGS. Walik Creek: stream, flows N $8 \mathrm{mi}$. to Peard Bay, 9 mi. SE of Point Franklin, Arctic Plain; $70^{\circ} 47^{\prime} 50^{\prime \prime} \mathrm{N}, 158^{\circ} 33^{\prime} 35^{\prime \prime} \mathrm{W}$; (map 147).

Eskimo name reported in 1950 by USC\&GS.

Walkaround Creek: stream, flows $\mathrm{S} 10 \mathrm{mi}$. to Hunt Fork, $6.5 \mathrm{mi}$. NE of Sillyasheen Mtn. and $73 \mathrm{mi}$. NW of Wiseman, Brooks Ra.; $67^{\circ} 51^{\prime} \mathrm{N}, 152^{\circ} 37^{\prime} \mathrm{W} ; B G N$ 1932; (map 124).

Named in 1931 by Marshall (1956, p. 105) as a result of his party's lighthearted approach to the difficulties they encountered in trying to cross this storm-flooded stream. His companion remarked, "There's one safe rule in traveling this north country in summer. If you can't get across them, you can always walk around them.' So as we headed upstream once more, we christened this stream Walkaround Creek."

Walker, Lake: lake, see Naknek Lake.

Walker Channel: water passage, $4 \mathrm{mi}$. long, along SE coast of Beauchamp I., $10 \mathrm{mi}$. SE of Goddard, on SW coast of Baranof I., Alex. Arch.; $56^{\circ} 42^{\prime} \mathrm{N}, 135^{\circ} 13^{\prime} \mathrm{W}$; (map 5).

Local name used by fishermen; published in 1929 by USC\&GS.

Walker Cove: estuary, on mainland, extends NE 8.5 mi., off Behm Canal, Coast Mts.; 55 $43^{\prime}$ $\mathrm{N}, 130^{\circ} 54^{\prime} \mathrm{W}$; (map 3 ).

This feature was "examined by Joseph Whidbey, August 25, 1793 and named by him or [Capt. George] Vancouver [RN] after the surgeon of the Chatham William Walker"; (Wagner, 1937, p. 421).

Walker Creek: stream, at $N$ end of Cleveland Penin., heads in a lake, flows $\mathrm{S} 4.5 \mathrm{mi}$. to Lake McDonald, Alex. Arch.; 55 $39^{\prime} \mathrm{N}, 1^{\circ} 1^{\circ} 50^{\prime}$ W; (map 3$)$.

Local name reported in 1952 by USGS.

Walker Creek: stream, on mainland, flows W 2.6 mi. to Walker Cove off Behm Canal, $8 \mathrm{mi}$. E of Ledge Point, Coast Mts.; $55^{\circ} 45^{\prime} 10^{\prime \prime} \mathrm{N}$, $130^{\circ} 42^{\prime} 00^{\prime \prime} \mathrm{W}$; BGN 1923; (map 3).

Named in 1923 by USFS.

Walker Creek: stream, on N end of Kenai Penin., flows NW $6 \mathrm{mi}$. to Sixmile Creek, $2 \mathrm{mi}$. S of Sunrise and $30 \mathrm{mi}$. SE of Anchorage, Chugach Mts.; $60^{\circ} 51^{\prime} 15^{\prime \prime} \mathrm{N}, 149^{\circ} 25^{\prime} 00^{\prime \prime} \mathrm{W}$; (map 63).

Local prospectors' name; reported about 1914 by B. L. Johnson (in Martin and others, 1915 , pl. 2), USGS.

Walker Creek: stream, flows N $6.6 \mathrm{mi}$. to Sanona Creek, $22 \mathrm{mi}$. $\mathrm{S}$ of junc. of Oshetna and Susitna Rivers, Talkeetna Mts. ; 62 $19^{\prime} 30^{\prime \prime} \mathrm{N}$, $147^{\circ} 19^{\prime} 00^{\prime \prime} \mathrm{W}$; (map 82).

Local name reported in 1951 by USGS.

Walker Creek: stream, flows NW $7 \mathrm{mi}$. to Nenana River, $38 \mathrm{mi}$. S of Nenana, Alaska Ra.; $64^{\circ} 01^{\prime} \mathrm{N}, 149^{\circ} 07^{\prime} \mathrm{W}$; (map 100).

Local name published in 1915 on GLO [BLM] survey plat.

Walker Creek: stream, flows NW 2 mi. to Eagle Creek which flows to Right Fork Bluestone River, $13 \mathrm{mi}$. S of Teller, Seward Penin. High.; $65^{\circ} 05^{\prime} \mathrm{N}, 166^{\circ} 25^{\prime} \mathrm{W}$; (map 111).

Prospectors' name reported on the 1908 "Map of Seward Peninsula" by Arthur Gibson.

Walker Dome: mountain, 3,942 ft., $7 \mathrm{mi}$. W of Jumbo Dome and $8 \mathrm{mi}$. N of Healy, Alaska Ra.; $63^{\circ} 57^{\prime} 45^{\prime \prime} \mathrm{N}, 148^{\circ} 53^{\prime} 30^{\prime \prime} \mathrm{W}$; (map 87). Local name reported in 1950 by USGS.

Walker Fork: stream, flows W $7.5 \mathrm{mi}$. to South Fork Fortymile River, $52 \mathrm{mi}$. SW of Eagle, Yukon-Tanana High.; $64^{\circ} 06^{\prime} \mathrm{N}, 141^{\circ} 46^{\prime} \mathrm{W}$; 
(map 102). Var. Walker Fork South Fork, Walker's Fork, Walkers Fork.

Named by prospectors and reported in 1896 by Spurr (1898, pl. 46), USGS. In 1889 "the headwaters of Walker Fork were staked out in claims" (p. 116).

Walker Fork South Fork: stream, see Walker Fork.

Walker Island: island, $1,800 \mathrm{ft}$. long, NE of Ham I., between Felice Strait and Revillagigedo Channel, Alex. Arch.; 55 $11^{\prime} 15^{\prime \prime} \mathrm{N}, 131^{\circ}$ $19^{\prime} 45^{\prime \prime} \mathrm{W}$; (map 3). Var. Lewis Island.

Named about 1880 by local navigators; reported by USC\&GS.

Walker Island: island, see Lewis Island.

Walker Lake: lake, on mainland, $3.5 \mathrm{mi}$. E of Walker Cove, drains $\mathrm{SW}$ to Rudyerd Bay, Coast Mts.; $55^{\circ} 45^{\prime} \mathrm{N}, 130^{\circ} 35^{\prime} \mathrm{W}, B G N$ 1962; (map 3)

Local name reported in 1961 by USFS.

Walker Lake: lake, $1 \mathrm{mi}$. long, on a branch of Little Salmon River, $3.8 \mathrm{mi}$. SE of Porcupine and $29 \mathrm{mi}$. SW of Skagway, St. Elias Mts.; $59^{\circ} 23^{\prime} 30^{\prime \prime} \mathrm{N}, 136^{\circ} 08^{\prime} 30^{\prime \prime} \mathrm{W}$; (map 45).

Local name obtained by USGS field personnel and published on Federal maps since 1950.

Walker Point: point of land, $\mathrm{E}$ point of entrance to Murder Cove, on S coast of Admiralty I., $1 \mathrm{mi}$. S of Tyee, Alex Arch.; $57^{\circ} 01^{\prime} 30^{\prime \prime} \mathrm{N}$, $134^{\circ} 32^{\prime} 35^{\prime \prime} \mathrm{W}$; (map 9).

Name published by USC\&GS in the 1925 Coast Pilot (p. 219).

Walkers Fork: settlement, see Boundary. Walker's Fork: stream, see Walker Fork.

Walker Slough: stream, $7 \mathrm{mi}$. long, anabranch of Yukon River, $\mathrm{E}$ of Holy Cross, Innoko Low.; $62^{\circ} 09^{\prime} \mathrm{N}, 159^{\circ} 46^{\prime} \mathrm{W}$; (map 78).

Local name reported in 1916 by G. L. Harrington and R. H. Sargent (in Harrington, 1918, pl. 1), USGS.

Walker Station Island: island, see Station Island.

Wall, The: ridge, trends $\mathrm{N}-\mathrm{S} 2.5 \mathrm{mi}$., at head of Taku Glacier, $2.3 \mathrm{mi}$. W of Centurian Peak and $30 \mathrm{mi}$. N of Juneau, Coast Mts. $58^{\circ} 45^{\prime} \mathrm{N}, 134^{\circ} 20^{\prime} \mathrm{W}$; (map 11).

Descriptive name published in 1960 by USGS.

Wallace Lake: lake, see Clear Lake.

Wallace Reef: reef, off $\mathbf{S}$ coast of Annette I., in Felice Strait, Alex. Arch.; $55^{\circ} 00^{\prime} 20^{\prime \prime} \mathrm{N}, 131^{\circ}$. 24'20" W; (map 3).

Named in 1893 by Lt. G. B. Harber, USN.

Wallace Rock: rock, in Cordova Bay, $3.6 \mathrm{mi}$. SE of Shipwreck Point, on SW coast of Prince of Wales I., Alex. Arch.; $54^{\circ} 51^{\prime} \mathrm{N}, 132^{\circ} 27^{\prime}$ W; (map 1).

Named in 1899 by USC\&GS.

Walla Walla: locality, on Norton Bay, $8 \mathrm{mi}$. SW of Elim and $59 \mathrm{mi}$. E of Solomon, Seward Penin. High.; 64 ${ }^{\circ} 33^{\prime} \mathrm{N}, 162^{\circ} 28^{\prime} \mathrm{W}$; (map $95)$. Var. Walla Walla Roadhouse.

Local name reported in 1909 by Smith and Eakin $(1911, \mathrm{pl} .1)$, USGS. Site of a roadhouse on the winter trail to Nome.

Walla Walla Creek: stream, flows S $6 \mathrm{mi}$. around W side of Mount Kwiniuk to Norton Bay, 8 mi. SW of Elim, Seward Penin. High.; $64^{\circ}$ $33^{\prime} \mathrm{N}, 162^{\circ} 28^{\prime} \mathrm{W}$; BGN 1910; (map 95).

Local name reported in 1909 by Smith and Eakin (1911, pl. 1), USGS.

Walla Walla Roadhouse: locality, see Walla Walla.

Wall Bay: bay, $1.2 \mathrm{mi}$. across, on $\mathrm{N}$ coast of Atka I., Aleutian Is.; $52^{\circ} 06^{\prime} 30^{\prime \prime} \mathrm{N}, 174^{\circ} 53^{\prime} 10^{\prime \prime}$ W; (map 18).

Name published on a 1943 USC\&GS chart. Wallcutt Mountain: mountain, 5,593 ft., at headwaters of Bear and Mission Creeks, 23 mi. SW of Eagle, Yukon-Tanana High.; $64^{\circ}$ $39^{\prime} \mathrm{N}, 141^{\circ} 40^{\prime} \mathrm{W}$; (map 102). Var. Wolcot Mountain.

Local name shown on an 1899 fieldsheet by W. J. Peters, USGS. The name was spelled "Wolcot" on a 1905 manuscript map by Maj. W. A. Glassferd, U.S. Army Signal Corps.

Wallick Creek: stream, flows SE 6 mi. to Caribou Creek $2.5 \mathrm{mi}$. W of that stream's junc. with Hogatza River, $37 \mathrm{mi}$. WNW of Hughes, Hogatza High.; $66^{\circ} 10^{\prime} \mathrm{N}, 155^{\circ} 32^{\prime} \mathrm{W}$; (map 116).

Local name applied about 1955 ; reported to be the family name of an Indian worker who helped in the mining development; recorded in 1956 by Orth.

Wallikipi: locality, see Walakpa.

Walling Gulch: ravine, trends S $0.5 \mathrm{mi}$. to Norton Sound, between Silverbow and Eldorado Creeks, $18 \mathrm{mi}$. E of Solomon, Seward Penin. High.; $64^{\circ} 39^{\prime} \mathrm{N}, 163^{\circ} 50^{\prime} \mathrm{W}$; (map 95).

Prospectors' name shown on Arthur Gibson's "Map of Cape Nome Precinct" dated 1904. This feature cannot be precisely located on current maps.

Wall of China: ridge, 4,300 ft., extends NW 3 mi. between Little Nelchina River and White Hill, $16 \mathrm{mi}$. N of Tahneta Pass, Talkeetna Mts. ; $62^{\circ} 07^{\prime} \mathrm{N}, 147^{\circ} 25^{\prime} \mathrm{W}$; BGN 1960; (map 82 ).

Descriptive local name reported in 1956 to USGS by C. F. Fields. "A whitish ledge or outcrop band of steeply-dipping limestone winds across the hilltops."

Wall Street Creek: stream, flows NW $4 \mathrm{mi}$. to South Fork Fortymile River, $54 \mathrm{mi}$. SW of Eagle, Yukon-Tanana High.; $64^{\circ} 03^{\prime} 30^{\prime \prime} \mathrm{N}$, $141^{\circ} 45^{\prime} 50^{\prime \prime} \mathrm{W}$; (map 102).

Named by prospectors "for the famous street in New York City"; reported in 1898 by E. C. Barnard, USGS.

Wally Creek: stream, in Rampart Mts., flows SE $1.7 \mathrm{mi}$. to Morelock Creek $2 \mathrm{mi}$. $\mathrm{N}$ of that stream's junc. with Yukon River, 24 mi. ENE of Tanana, Kokrines-Hodzana High.; $65^{\circ} 17^{\prime}$. $30^{\prime \prime} \mathrm{N}, 151^{\circ} 18^{\prime} 00^{\prime \prime} \mathrm{W}$; (map 106).

Prospectors' name reported by USGS about 1940.

Walnut Creek: stream, flows SW 2 mi. to Fairbanks Creek, $21 \mathrm{mi}$. NE of Fairbanks, YukonTanana High.; $65^{\circ} 04^{\prime} 45^{\prime \prime} \mathrm{N}, 147^{\circ} 11^{\prime} 30^{\prime \prime} \mathrm{W}$; (map 105).

Named by prospectors; reported in 1903 by T. G. Gerdine (Prindle, 1905, pl. 13), USGS.
Walpole, Point: point of land, on $\mathrm{W}$ end of an island, in Stephens Passage at $S$ entrance to Port Houghton, $2 \mathrm{mi}$. $\mathrm{N}$ of Fort Point and 71 mi. E of Sitka, Coast Mts. ; $57^{\circ} 18^{\prime} 15^{\prime \prime} \mathrm{N}$, $133^{\circ} 31^{\prime} 10^{\prime \prime} \mathrm{W}$; (map 8). Var. Mys Valpol.

Named by Capt. George Vancouver, RN, in 1794 after its discovery by Lt. Joseph Whidbey on August 4, 1794, for George Walpole, Earl of Oxford, England (Wagner, 1937, p. 421). This name was published in 1848 as "Mys Valpol," or "Valpol Cape," by the Russian Hydrog. Dept. on Chart 1396.

Walrus Bight: bight, $0.3 \mathrm{mi}$. across, between Northeast and Sea Lion Points, on NE coast of St. Paul I., in Pribilof Is.; $57^{\circ} 14^{\prime} 30^{\prime \prime} \mathrm{N}$, $170^{\circ} 05^{\prime} 50^{\prime \prime} \mathrm{W}$; (map 38 ).

Named in 1897 by W. W. Duffield, USC\&GS.

Walrus Island: barrier beach, $22 \mathrm{mi}$. long, one of Kudobin Is., $9 \mathrm{mi}$. W of village of Port Moller, Bristol Bay Low.; 56 $01^{\prime} 40^{\prime \prime} \mathrm{N}$, $160^{\circ} 50^{\prime} 00^{\prime \prime} \mathrm{W}$; (map 28). Var. Volchie Island.

Named in 1882 by W. H. Dall, USC\&GS. Capt. Lutke (1836) referred to the island as "Volchie," meaning "wolf"; name now applied to the eastern tip of this feature.

Walrus Island: island, $0.4 \mathrm{mi}$. long, $9 \mathrm{mi}$. E of St. Paul I., in Pribilof Is.; $57^{\circ} 11^{\prime} \mathrm{N}, 169^{\circ} 56^{\prime}$ W; (map 38). Var. Morjovi, Morserovia, Morsezovia, Morzhovoi, Ostrov Morzhovoy.

Translation from the Russian "O[strov] Morzhovoy" meaning "Walrus Island," published by Lt. Sarichev (1826, map 3).

Walrus Island: island, see Amak Island.

Walrus Island: island, see Round Island.

Walrus Islands: islands, extend SE $30 \mathrm{mi}$, in Bristol Bay, include High I., Crooked I., Black Rock I., and Round I., $15 \mathrm{mi}$. E of Hagemeister I., Kilbuck-Kuskokwim Mts.; $58^{\circ}$ $43^{\prime} \mathrm{N}, 160^{\circ} 15^{\prime} \mathrm{W}$; (map 39).

The Russian name "Morzh," meaning "walrus," was applied to an island by Lt. Sarichev (1826, map 3), IRN, which Capt. Tebenkov (1852, map 4), IRN, identified with the Round Island of Capt. Cook (1785, v. 2, p. 431 ), RN. Tebenkov applied the name "Ostrova Morzhovyya," or "Walrus Islands," to the whole group of islands east of Hagemeister Island.

Walrus Peak: peak, see North Walrus Peak.

Walrus Peak: peak, see South Walrus Peak.

Walrus Peak South: peak, see South Walrus Peak.

Walrus Point: point of land, see Lug Point.

Walrussia: state, see Alaska.

Walsh Creek: stream, flows NW $0.9 \mathrm{mi}$. to Ward Cove, on SW coast of Revillagigedo I., Alex. Arch.; 55 $23^{\prime} 45^{\prime \prime} \mathrm{N}, 131^{\circ} 43^{\prime} 40^{\prime \prime} \mathrm{W}$; BGN 1933; (map 3). Var. Watering-place Creek.

Named in 1933 by USFS "for the founders of the first salmon packing company in the vicinity."

Walsh Glacier: glacier, heads in Canada at about $60^{\circ} 55^{\prime} \mathrm{N}, 140^{\circ} 40^{\prime} \mathrm{W}$, trends $\mathrm{W} 48 \mathrm{mi}$. to Logan Glacier, $10 \mathrm{mi}$. SW of Mount George and $107 \mathrm{mi}$. NW of Yakutat, St. Elias Mts.; $60^{\circ} 55^{\prime} \mathrm{N}, 141^{\circ} 12^{\prime} \mathrm{W}$; BGN 1917; (map 65). 
Named in 1900 by J. F. McArthur for Maj. J. M. Walsh, Royal Northwest Mounted Police. Published in 1916 by the IBC on Sheet No. 36.

Walter, Port: bay, $0.5 \mathrm{mi}$. across, $9.5 \mathrm{mi}$. $\mathrm{N}$ of the village of Port Alexander, on $S$ coast of Baranof I., Alex. Arch.; 56 $23^{\prime} 30^{\prime \prime}$ N, $134^{\circ}$ $38^{\prime} 30^{\prime \prime} \mathrm{W}$; (map 5$)$.

Named for charting purposes; name published in 1901 by USC\&GS.

Walter Island: island, $0.5 \mathrm{mi}$. long, in Port Houghton, $1 \mathrm{mi}$. NW of Sandbcrn Canal and $83 \mathrm{mi}$. E of Sitka, Coast Mts.; $57^{\circ} 18^{\prime} 30^{\prime \prime} \mathrm{N}$, $133^{\circ} 17^{\prime} 15^{\prime \prime} \mathrm{W}$; (map 8).

Named in 1882 by Lt. Comdr. H. E. Nichols, USN; name published by USC\&GS in the 1883 Coast Pilot (p. 128).

Walter Island Arm: estuary, see Sandborn Canal.

Walton Creek: stream, flows SE to Kigezruk Creek, about $12 \mathrm{mi}$. SE of Cape Prince of Wales, Seward Penin, High.; (map 111).

Prospectors' name shown on the 1900 "Map of Nome Peninsula" by J. M. Davidson and B. D. Blakeslee. This feature cannot be precisely identified on current maps.

Wanda Island: island, $0.2 \mathrm{mi}$. long, between Sanak and Caton Is., one of Sanak Is., Aleutian Ra.; $54^{\circ} 24^{\prime} 40^{\prime \prime} \mathrm{N}, 162^{\circ} 31^{\prime} 30^{\prime \prime} \mathrm{W}$; (map 25).

Name reported by Ferdinand Westdahl, USC\&GS, commander of the Coast Survey' steamer McArthur, who made surveys in this area in 1901.

Wanda Island: island, off left bank of Yukon River, across from Falcon Cliffs and about 11 mi. SW of Nulato, Koyukuk Low.; $64^{\circ} 32^{\prime} \mathrm{N}$, $158^{\circ} 16^{\prime} \mathrm{W}$; (map 97).

Riverboat pilots' name shown on a 1940 "Navigation Chart of the Tanana-Yukon Rivers" published by U.S. Dept. of Interior. Wanita Creek: stream, see Flat Creek.

Wanmayee Creek: stream, flows SE $4 \mathrm{mi}$. to Boxer River, $5 \mathrm{mi}$. NW of Southwest Cape, St. Lawrence I.; $63^{\circ} 21^{\prime} \mathrm{N}, 171^{\circ} 34^{\prime} \mathrm{W} ; B G N$ 1951; (map 93). Var. Wanmayee River, Wanmeyi Creek.

Eskimo name reported in 1949 by Maj. H. B. Allen, USAF.

Wanmayee River: stream, see Wanmayee Creek. Wanmeyi Creek: stream, see Wanmayee Creek. Wapoo Creek: stream, flows SW $45 \mathrm{mi}$. to Innoko River $6.4 \mathrm{mi}$. NW of its junc. with Dishna River, $46 \mathrm{mi}$. NW of Ophir and 74 mi. NW of McGrath, Innoko Low.; 63 ${ }^{\circ} 39^{\prime} 30^{\prime \prime}$ N, 157 $27^{\prime} 00^{\prime \prime} \mathrm{W}$; (map 90).

Prospectors' name reported in 1913 by $\mathrm{H}$. M. Eakin, USGS.

Wapoo Hills: range, $700 \mathrm{ft}$., between Galatea and Wapoo Creeks, extends NE $20 \mathrm{mi}$. from Innoko River, $48 \mathrm{mi}$. NW of Ophir and 65 mi. S of Galena; Kilbuck-Kuskokwim Mts.; $63^{\circ} 47^{\prime} \mathrm{N}, 157^{\circ} 15^{\prime} \mathrm{W}$; (map 90).

Local name reported in 1964 by Arthur Gervais, USGS.

Warbler Lake: lake, $0.7 \mathrm{mi}$. long, on Kenai Penin. E of Mull Lake, $42 \mathrm{mi}$. NE of Kenai,
Cook Inlet Low.; $60^{\circ} 54^{\prime} 50^{\prime \prime} \mathrm{N}, 150^{\circ} 17^{\prime} 00^{\prime \prime}$ W; (map 62).

Named about 1963 by officials of Kenai National Moose Range, probably for the Orangecrowned Warbler (Vermivora celata celata), which migrates from the south Atlantic states to northwestern Alaska (Pearson, 1944, pt. 3 , p. 120).

Warburton Island: island, $400 \mathrm{ft}$. long, in Nichols Passage, $2 \mathrm{mi}$. W of Metlakatla, Alex. Arch.; $55^{\circ} 08^{\prime} \mathrm{N}, 131^{\circ} 38^{\prime} \mathrm{W}$; (map 3 ).

Named in 1883 by Lt. Comdr. H. E. Nichols, USN.

Ward Cove: village, pop. 69 , on $\mathrm{N}$ shore of Ward Cove at SW end of Revillagigedo I., $4.5 \mathrm{mi}$. NW of Ketchikan, Alex. Arch.; 55 $24^{\prime} 30^{\prime \prime}$ N, 131 43'30" W; BGN 1966; (map 3). Var. Wards Cove, Wacker, Wacker City.

This village is an extension of the settlement area of Ketchikan northwest along the highway. A saltery was established here in 1883-84 by W. W. Waud. Eugene Wacker was first postmaster of the Wacker post office established 1920. The post office name was changed to Wards Cove in 1951 and then to Ward Cove in 1954 (Ricks, 1965, p. 69-70). The village population was 57 in 1930 .

Ward Cove: estuary, extends NE $1.5 \mathrm{mi}$. off Tongass Narrows, on the SW coast of Revillagigedo I., Alex. Arch.; 55 $23^{\prime} 30^{\prime \prime} \mathrm{N}, 131^{\circ}$. $44^{\prime} 30^{\prime \prime}$ W; (map 3). Var. Wards Cove.

Named in the 1880's by USC\&GS for one of the officers of the U.S.S. Patterson, the first Coast Survey ship to enter Alaska waters in 1884.

Ward Creek: stream, heads in a lake, flows SW through Ingram, Connell, and Ward Lakes, $7.5 \mathrm{mi}$. to Ward Cove, on SW coast of Revillagigedo I., Alex. Arch.; $55^{\circ} 24^{\prime} 30^{\prime \prime}$ N, $131^{\circ}$. 42'55" W; (map 3).

Local name recorded in 1954 by USGS.

Ward Creek: stream, flows W $14 \mathrm{mi}$. to Chatham Strait, on W coast of Admiralty I., $25 \mathrm{mi}$. N of Angoon, Alex. Arch. ; 57 $52^{\prime}$ N, $134^{\circ} 43^{\prime}$ W; (map 9).

Named in 1920 by J. P. Williams, USFS. The name "so far as known has no local significance."

Warde, Point: point of land, $\mathrm{S}$ point of entrance to Bradfield Canal, $30 \mathrm{mi}$. SE of Wrangell. Alex. Arch.; $56^{\circ} 10^{\prime} 30^{\prime \prime} \mathrm{N}, 131^{\circ} 58^{\prime} 00^{\prime \prime} \mathrm{W}$; $(\operatorname{map} 7)$.

Named in 1793 by Capt. George Vancouver, RN.

Ward Lake: lake, in course of Ward Creek, 0.7 mi. NE of Ward Cove, on SW coast of Revillagigedo I., Alex. Arch.; 55 $24^{\prime} 45^{\prime \prime}$ N, $131^{\circ}$ $42^{\prime} 00^{\prime \prime} \mathrm{W}$; (map 3$)$.

Local name recorded in 1954 by USGS.

Ward Mountain: mountain, 2,670 ft., W of Juno Mtn. and $2 \mathrm{mi}$. SE of Ward Cove, on Revillagigedo I., Alex. Arch.; 55 $23^{\prime} 18^{\prime \prime}$ N, $131^{\circ} 40^{\prime} 45^{\prime \prime} \mathrm{W}$; (map 3).

Named in 1883 by Lt. Comdr. H. E. Nichols, USN.

Wards Cove: village, see Ward Cove.

Wards Cove: estuary, see Ward Cove.
Warehouse Bluff: promontory, 2 mi. long, rises $30 \mathrm{ft}$. above shore of Kuskokwim Bay, S of Warehouse Creek, $4 \mathrm{mi}$. N of Quinhagak, Yukon Kuskokwim Delta; $59^{\circ} 56^{\prime} \mathrm{N}, 162^{\circ} 06^{\prime}$ W; (map 54).

Local name reported by USC\&GS in the 1914 Annual Report (p. 63); derived from a mission warehouse near Shiniak village.

Warehouse Channel Kuskokwim Bay: channel, extends S $25 \mathrm{mi}$. from mouth of Warehouse Creek to point $16 \mathrm{mi}$. NW of mouth of Jacksmith Creek, $19 \mathrm{mi}$. NW of Carter Bay, YukonKuskokwim Delta; $59^{\circ} 36^{\prime} \mathrm{N}, 162^{\circ} 12^{\prime} \mathrm{W}$; (map 54).

Local name reported by USC\&GS in the 1914 Annual Report (p. 63); derived from a mission warehouse near Shiniak village.

Warehouse Creek: stream, flows W $10 \mathrm{mi}$. to Kuskokwim Bay, $3 \mathrm{mi}$. N of Quinhagak, Yukon-Kuskokwim Delta ; $59^{\circ} 56^{\prime} \mathrm{N}, 162^{\circ} 06^{\prime} \mathrm{W}$; (map 54)

Local name published in 1915 by USC\&GS; derived from the mission warehouse near Shiniak village.

Waring Mountains: mountain range, $1,800 \mathrm{ft}$., trends E $65 \mathrm{mi}$. from Hotham Peak, S of Kobuk River valley, Brooks Ra.; $66^{\circ} 50^{\prime} \mathrm{N}$, $159^{\circ} 45^{\prime} \mathrm{W}$; (maps 114,115).

Named in 1886 by Lt. Stoney (1900, map), USN, possibly for Howard Scott Waring, USN.

Warm Chuck Inlet: estuary, on SE coast of Heceta I., trending SE $5 \mathrm{mi}$. to Gulf of Esquibel, $20 \mathrm{mi}$. NW of Craig, Alex. Arch.; 55 $45^{\prime} \mathrm{N}, 133^{\circ} 29^{\prime} \mathrm{W}$; (map 4).

Named in 1914 by USC\&GS. See Salt Chuck, village.

Warm Creek: stream, flows SW $8.2 \mathrm{mi}$. to Goldbottom Creek which flows to Niukluk River, $32 \mathrm{mi}$. NE of Solomon, Seward Penin. High.; $64^{\circ} 57^{\prime} \mathrm{N}, 163^{\circ} 55^{\prime} \mathrm{W}$; (map 95). Var. Anderson Creek.

Prospectors' name published in January 1900 by Schrader (1900c, p. 16), USGS. This appears to be the stream shown as "Anderson" on the 1900 "Map of Nome Peninsula" by J. M. Davidson and B. D. Blakeslee. They applied the name "Warm" to a stream to the north.

Warm Pass Valley: valley, 2 mi. long on Skagway River, $0.6 \mathrm{mi}$. N of Laughton Glacier and 10 ni. NE of Skagway, Coast Mts.; 59 32'$35^{\prime \prime} \mathrm{N}, 135^{\circ} 04^{\prime} 00^{\prime \prime} \mathrm{W}$; (map 45).

Local name obtained by USGS field personnel and published on Federal maps since 1950.

Warm Spring Bay: bay, $1 \mathrm{mi}$. across, on $\mathrm{E}$ coast of Baranof I., at Baranof, Alex. Arch.; 57 05' N, 134 $47^{\prime}$ W; (map 9).

Named in 1895 by Lt. Comdr. E. K. Moore, USN; published in 1899 by USC\&GS on Chart 8050 . So named because "at the head of the bay is a waterfall *** and near the waterfall there are several warm mineral springs." (U.S. Coast and Geodetic Survey, 1943, p. 332)

Warm Springs: springs, on E coast of Baranof I., at head of Warm Spring Bay, $20 \mathrm{mi}$. E. of 
Sitka, Alex. Arch.; 57 $05^{\prime} 10^{\prime \prime} \mathrm{N}, 134^{\circ} 50^{\prime} 20^{\prime \prime}$ W; (map 9).

Local descriptive name reported in 1951 by USGS.

Warm Springs Slough: stream, see Ketili River. Warnecke Creek: stream, see McKelvie Creek.

Warner Bay: bay, on Alaska Penin., trends S 4 mi. W of Ship Mtn. to Pacific Ocean, $11 \mathrm{mi}$. $\mathrm{S}$ of Chignik, Aleutian Ra.; $56^{\circ} 08^{\prime} \mathrm{N}, 158^{\circ}$ 24' W; (map 30). Var. Prospect Bay.

Called Prospect Bay by USGS (in P. S. Smith and others, 1929, pl. 6) because of a copper prospect nearby. "Warner or Prospect Bay" is given by USC\&GS in 1916 Coast Pilot (p. 160), whereas Warner Bay is shown on a 1928 USC\&GS chart.

Warner Creek: stream, heads in Kuskokwim Mts., flows SW $20 \mathrm{mi}$. to Innoko River, 2.8 $\mathrm{mi}$. NW of Ophir and $34 \mathrm{mi}$. NW of McGrath, Kilbuck-Kuskokwim Mts.; 6310' N, $156^{\circ} 36^{\prime} \mathrm{W}$; (map 90). Var. Warren Creek.

Prospectors' name reported in 1912 by H. M. Eakin, USGS; the stream was called Warren Creek in 1910 by A. G. Maddren, USGS.

Warner Creek: stream, flows NW $2.5 \mathrm{mi}$., joins Grace Creek to form Wade Creek, $45 \mathrm{mi}$. SW of Eagle, Yukon-Tanana High.; 64 $4^{\circ} 10^{\prime} 00^{\prime \prime} \mathrm{N}$, $141^{\circ} 24^{\prime} 30^{\prime \prime} \mathrm{W}$; (map 102).

Local name published in 1956 by USGS.

Warren: locality, along Seward Penin. RR., on Banner Creek which flows to Nome River, $10 \mathrm{mi}$. NE of Nome, Seward Penin. High.; $64^{\circ} 39^{\prime} \mathrm{N}, 165^{\circ} 19^{\prime} \mathrm{W}$; (map 95). Var. Banner Creek.

Site of a railroad station established in 1905 (Cole, 1953, p. 14). The mining camp located here was known as "Banner Creek."

Warren, Point: point of land, at $\mathrm{W}$ end of barrier beach on $\mathbf{N}$ shore of Norton Sound, 1 mi. SW of Solomon, Seward Penin. High.; $64^{\circ} 33^{\prime} \mathrm{N}, 164^{\circ} 25^{\prime} \mathrm{W}$; (map 95).

Local name reported on a 1903-04 Council City and Solomon River Railroad map.

Warren Channel: water passage, $3 \mathrm{mi}$. long, between Kosciusko and Warren Is., Alex. Arch.; $55^{\circ} 55^{\prime} \mathrm{N}, 133^{\circ} 50^{\prime} \mathrm{W}$; (map 4).

Named in 1904 by E. F. Dickins, USC\&GS, "after the Island."

Warren Cove: bay, $1 \mathrm{mi}$. long, SW coast of Warren I., Alex. Arch.; 55 $52^{\prime} 30^{\prime \prime} \mathrm{N}, 133^{\circ}$ $50^{\prime} 30^{\prime \prime} \mathrm{W}$; (map 4).

Named in 1904 by E. F. Dickins, USC\&GS, "after the Island on which it is situated."

Warren Creek: stream, flows NW $8.5 \mathrm{mi}$. to Mascot Creek, $80 \mathrm{mi}$. W of Circle, YukonTanana High.; $65^{\circ} 43^{\prime} \mathrm{N}, 146^{\circ} 53^{\prime} \mathrm{W}$; (map 104).

Named by prospectors; published in 1906 by USGS.

Warren Creek: stream, flows SE $1 \mathrm{mi}$. to Cosmos Creek, $7 \mathrm{mi}$. N of Shungnak, Brooks Ra.; $66^{\circ} 59^{\prime} 20^{\prime \prime} \mathrm{N}, 157^{\circ} 09^{\prime} 45^{\prime \prime} \mathrm{W}$; (map 115).

Prospectors' name reported after 1940 by USGS.

Warren Creek: stream, see Warner Creek.

Warren Island: island, $6.5 \mathrm{mi}$. long in Iphigenia Bay, $42 \mathrm{mi}$. NW of Craig, Alex. Arch.; 55 53'
N, 133 $53^{\prime}$ W; (map 4). Var. Warren's Island, Warrens Island.

Discovered on September 11, 1793, by Joseph Whidbey and named "Warren's Island" by Capt. George Vancouver, RN, for Sir John Borlase Warren.

Warren Peak: mountain, 2,329 ft., highest point on Warren 1., Alex. Arch.; $55^{\circ} 54^{\prime} 50^{\prime \prime} \mathrm{N}$, $133^{\circ} 53^{\prime} 15^{\prime \prime} \mathrm{W}$; (map 4).

Named in 1886 by Lt. Comdr. A. S. Snow, USN.

Warrens Island: island, see Warren Island.

Warrick Peak: peak, 7,590 ft., in Nutzotin Mts., E. of junc. of Chavolda Creek and Chisana River, $10 \mathrm{mi}$. N of Euchre Mtn., Alaska Ra.; $62^{\circ} 11^{\prime} 05^{\prime \prime} \mathrm{N}, 142^{\circ} 01^{\prime} 30^{\prime \prime} \mathrm{W}$; (map 84).

Local named reported in 1960 by USGS. Warsham Bay: bay, see Kisselen Bay.

Wart Island: island, see Sundstrom Island.

Warton: town, see Palmer.

Wart Point: point of land, $\mathrm{S}$ point of entrance to Manzanita Bay, on $\mathrm{E}$ coast of Revillagigedo I., Alex. Arch.; 55 $35^{\prime} 20^{\prime \prime} \mathrm{N}, 130^{\circ} 56^{\prime} 30^{\prime \prime} \mathrm{W}$; (map 3).

Arbitrary name given in 1891 by USC\&GS.

Washbowl Basin: valley, $0.4 \mathrm{mi}$. long, $1 \mathrm{mi}$. W of mouth of Canyon Slough and $5 \mathrm{mi}$. SE of Valdez, Chugach Mts. ; $61^{\circ} 03^{\prime} 45^{\prime \prime} \mathrm{N}, 146^{\circ} 08^{\prime}$ $45^{\prime \prime} \mathrm{W}$; (map 68).

Local name published in 1950 by USGS.

Washburn: locality, 2 mi. SW of Birch Lake, on left bank of Tanana River, $28 \mathrm{mi}$. NW of Big Delta, Tanana Low.; $64^{\circ} 18^{\prime} \mathrm{N}, 146^{\circ} 44^{\prime} \mathrm{W}$; (map 101).

Site of a stage station reported in 1908 by J. W. Bagley, USGS. A post office was established here in 1907, but discontinued in 1913 (Ricks, 1965, p. 70). It does not appear on recent maps.

Washburn: village, see Big Delta.

Washburn Peak: mountain, 1,760 ft., $2.7 \mathrm{mi}$. SW of Attu, Attu I., Aleutian Is.; 52 $54^{\prime} 50^{\prime \prime}$ $\mathrm{N}, 173^{\circ} 11^{\prime} 30^{\prime \prime} \mathrm{E}$; (map 13).

Name shown on an AMS map published in 1948, and given by the U.S. Army during World War II. The name is not used today. Washburn Peak: peak, 3,316 ft., NW of Wheeler Peak on Glass Penin., Admiralty I., $36 \mathrm{mi}$. SE of Juneau, Alex. Arch.; 57 $49^{\prime} 50^{\prime \prime} \mathrm{N}, 133^{\circ}$. 58'30' W; BGN 1934; (map 8).

Named in 1887 by Lt. Comdr. C. M. Thomas, USN, probably for Cadwallader Colden Washburn, 1818-1882, a major general in the Union Army in the Civil War, U.S. Representative from Wisconsin, 1867-71, and Governor of Wisconsin, 1872-74.

Washburn Slough: slough, flows $1.5 \mathrm{mi}$. to Yukon River at Devils Elbow, $1 \mathrm{mi}$. NW of Roundabout Mtn. and $23 \mathrm{mi}$. SW of Russian Mission, Yukon-Kuskokwim Delta; 61 $31^{\circ} \mathrm{N}$, $161^{\circ} 55^{\prime} \mathrm{W}$; (map 73).

Riverboat pilots' name shown on a 1922 manuscript chart of the Yukon River; probably named for the riverboat Washburn that was sunk here in 1918.

Washdown Point: point, on SE tip of Koyukuk I., in Yukon River, $19 \mathrm{mi}$. NE of Nulato, Koyukuk Low.; $64^{\circ} 52^{\prime} \mathrm{N}, 157^{\circ} 32^{\prime}$ (map 97).
Local name reported in 1954 by USGS.

Washe Creek: stream, flows NE $6 \mathrm{mi}$. to Cross Creek, $6 \mathrm{mi}$. N of Euchre Mtn., Wrangell Mts. ; $62^{\circ} 08^{\prime} \mathrm{N}, 142^{\circ} 12^{\prime} \mathrm{W}$; (map 84).

Local name reported in 1960 by USGS.

Washington Bay: bay, $0.2 \mathrm{mi}$. across, on NW coast of Kuiu I., Alex. Arch.; $56^{\circ} 43^{\prime} 00^{\prime \prime}$ N, $134^{\circ} 23^{\prime} 20^{\prime \prime} \mathrm{W}$; (map 5).

Local name used by fishermen; published in 1899 by USC\&GS.

Washington Creek: stream, flows SW $15 \mathrm{mi}$. to Nixon River, 16 mi. NW of Medfra, KilbuckKuskokwim Mts.; $63^{\circ} 15^{\prime} \mathrm{N}, 1^{\circ} 5^{\circ} 14^{\prime} \mathrm{W}$; (map 89)

Local name reported in 1910 by A. G. Maddren (in Brooks and others, 1911, pl. 14), USGS.

Washington Creek: stream, flows SW $1 \mathrm{mi}$. to Nome River, $0.1 \mathrm{mi}$. W of Stevens Gulch and 6 mi. NE of Nome, Seward Penin. High.; $64^{\circ} 31^{\prime} \mathrm{N}, 165^{\circ} 12^{\prime} \mathrm{W}$; (map 94).

Prospectors' name reported on the 1903 Campion Mining and Trading Co. map by George M. Ashford.

Washington Creek: stream, flows SW $2.4 \mathrm{mi}$. to Flambeau River, $16 \mathrm{mi}$. NE of Nome, Seward Penin. High.; $64^{\circ} 42^{\prime}, 165^{\circ} 05^{\prime} \mathrm{W}$; (map 94).

Prospectors' name reported on a map by S. E. King dated 1900.

Washington Creek: stream, flows SW $7 \mathrm{mi}$. to Sinuk River, $21 \mathrm{mi}$. NW of Nome, Seward Penin. High.; 64 $44^{\circ} \mathrm{N}, 165^{\circ} 56^{\prime} \mathrm{W}$; (map 94).

Prospectors' name reported in 1900 by E. C. Barnard (in Brooks, 1901, pl. 17), USGS.

Washington Creek: stream, heads on Bean Ridge, flows SE $5 \mathrm{mi}$. to Hot Springs Slough, $3 \mathrm{mi}$. $E$ of village of Manley Hot Springs and $46 \mathrm{mi}$. ESE of Tanana, Yukon-Tanana High.; $65^{\circ} 00^{\prime} 15^{\prime \prime} \mathrm{N}, 150^{\circ} 31^{\prime} 00^{\prime \prime} \mathrm{W}$; (map 106).

Local name reported in 1952 by USGS.

Washington Creek: stream, flows SW $50 \mathrm{mi}$. to Tatalina River, $40 \mathrm{mi}$. NW of Fairbanks, Yukon-Tanana High.; $65^{\circ} 04^{\prime} \mathrm{N}, 149^{\circ} 03^{\prime} \mathrm{W}$; (map 105). Var. Benikakat River.

Named by prospectors; reported in 1908 by USGS (Covert and Ellsworth, 1909, pl. 2). The Indian name, Benikakat, appeared on a railroad map in 1911.

Washington Creek: stream, flows NW $28 \mathrm{mi}$. to Yukon River $14 \mathrm{mi}$. E of junc. of Charley River, Yukon-Tanana High.; $65^{\circ} 19^{\prime} 15^{\prime \prime} \mathrm{N}$, $142^{\circ} 18^{\prime} 10^{\prime \prime}$ W; (map 103). Var. Tendashundu River.

Prospectors' name from an unpublished map by E. J. Chamberlain, dated 1902. Lt. Schwatka (1885, sheet 8), USA, used the Indian name "Tendashundu."

Washington Creek: stream, flows E $12 \mathrm{mi}$. to join Macklin Creek to form Kougarok River, $8 \mathrm{mi}$. SW of Midnight Mtn. and $49 \mathrm{mi}$. WNW of Imuruk Lake, Seward Penin. High.; $65^{\circ} 44^{\prime}$ N, $164^{\circ} 51^{\prime} \mathrm{W}$; (map 110). Var. Left Fork Kougarok River.

Prospectors' name reported in 1906 by A. H. Brooks (in Collier and others, 1908, pl. 9), USGS. 
Washington Creek: stream, flows NW $2 \mathrm{mi}$. to Inmachuk River, 23 mi. NE of Imuruk Lake, Seward Penin. High.; $65^{\circ} 52^{\prime} \mathrm{N}, 162^{\circ} 58^{\prime} \mathrm{W}$; (map 110)

Prospectors' name reported in 1903 by D. C. Witherspoon (in Moffit, 1905, pl. 2), USGS.

Washington Creek: stream, flows SE to Lone Mountain Creek which flows to American River, about $35 \mathrm{mi}$. NE of Teller, Seward Penin. High.; (map 111).

Prospectors' name shown on a 1901 map of Cape Nome gold fields by David Fox, Jr. This feature cannot be precisely identified on current maps.

Washington Creek: stream, see Little Washington Creek.

Washington Glacier: glacier, see Barry Glacier.

Washington Monument Rock: rock, in Revil-

lagigedo Channel, SW of entrance to Boca de Quadra, Coast Mts. ; $55^{\circ} 04^{\prime} 30^{\prime \prime} \mathrm{N}, 1^{\circ} 01^{\circ}$ $05^{\prime \prime} \mathrm{W}$; (map 3$)$.

Discovered and named in the 1920's by USC\&GS while conducting underwater sweeping operations in coastal waters for the purpose of charting navigational hazards. This feature was named because of its resemblance to the Washington Monument in Washington, D.C., and "reached within 17 feet of the surface in general depths of 650 feet" (Wraight and Roberts, 1957, p. 33-34).

Washington Peak: peak, 4,065 ft., $3 \mathrm{mi}$. E of Sandborn Canal and $88 \mathrm{mi}$. E of Sitka, Coast Mts.; $57^{\circ} 15^{\prime} 50^{\prime \prime} \mathrm{N}, 133^{\circ} 09^{\prime} 20^{\prime \prime} \mathrm{W}$; (map 8). Named in 1895 by USC\&GS.

Wash Reef: rocks, $1.5 \mathrm{mi}$. NE of Cape Sasmik, Tanaga I., Aleutian Is. ; $51^{\circ} 37^{\prime} 53^{\prime \prime} \mathrm{N}, 177^{\circ}$ 54'15" W; (map 17).

Name published by USC\&GS in 1957 on Chart 9146.

Wasilieff Reef: reef, see Williams Reef.

Wasilla: village, pop. 112, in Matanuska Valley, mi. 159.8 on The Alaska RR., between Lucile and Wasilla Lakes, $11 \mathrm{mi}$. SW of Palmer, Cook Inlet Low.; 61 $34^{\prime} 55^{\prime \prime} \mathrm{N}, 1^{\circ} 9^{\circ} 26^{\prime} 15^{\prime \prime}$ W; BGN 1917; (map 69). Var. Wassila.

Name of station on The Alaska Railroad that came into being about 1916. A post office was established here in 1917 (Ricks, 1965, p. 70). The village derived its name from nearby Wasilla Creek.

Wasilla Creek: stream, flows SW $22 \mathrm{mi}$. in Matanuska Valley to Palmer Slough, $11 \mathrm{mi}$. $\mathrm{SW}$ of Palmer, Cook Inlet Low.; $61^{\circ} 31^{\prime} \mathrm{N}$, $149^{\circ} 23^{\prime} \mathrm{W}$; (map 69). Var. Wassila Creek, Wassilla Creek.

Name used by local miners; reported in 1906 as "Wassilla Creek" by T. G. Gerdine and R. H. Sargent, USGS. Reportedly named for "Wassilla, a chief of the Knik Indians." The name "Wassila" is apparently derived from the Russian surname, "Vasiliev," meaning "Basil."

Wasilla Lake: lake, 2 mi. long, in Matanuska Valley, E of Wasilla, $8.5 \mathrm{mi}$. SW of Palmer, Cook Inlet Low.; 61 $35^{\prime} 15^{\prime \prime} \mathrm{N}, 149^{\circ} 23^{\prime} 45^{\prime \prime}$ W; (map 69).

Named about 1917 by the builders of The
Alaska Railroad; name derived from nearby Wasilla Greek.

Waskanareska Bay: cove, $0.6 \mathrm{mi}$. across, on SW coast of Afognak I., $6.7 \mathrm{mi}$. NW of Afognak, Kodiak I.; $58^{\circ} 01^{\prime} 30^{\prime \prime} \mathrm{N}, 152^{\circ} 57^{\prime} 00^{\prime \prime} \mathrm{W}$; (map 43).

Local name reported in 1952 by USGS.

Waskey, Mount: mountain, 5,026 ft., $12 \mathrm{mi}$. NE of Togiak Lake and $85 \mathrm{mi}$. NE of Goodnews, Kilbuck-Kuskokwim Mts. : $59^{\circ} 46^{\prime} \mathrm{N}, 159^{\circ} 15^{\prime}$ W; BGN 1931; (map 53).

Named by local inhabitants for Frank $H$. Waskey, the first delegate to Congress from the Territory of Alaska. He was a local trader and prospector and travelled much of the region. He collected information over a period of more than 30 years about local names from natives, prospectors, and airplane pilots. This name was reported in 1931 by USGS.

Wasp Cove: cove, extends SW $0.5 \mathrm{mi}$. off Behm Canal, on SE coast of Revillagigedo I., Alex. Arch.; $55^{\circ} 25^{\prime} 45^{\prime \prime} \mathrm{N}, 130^{\circ} 58^{\prime} 45^{\prime \prime} \mathrm{W}$; BGN 1928; (map 3).

Local name reported in 1928 by USFS; derived from Wasp Point.

Wasp Point: point of land, on SE coast of Revillagigedo I., between Princess Bay and Short Pass, Alex. Arch.; $55^{\circ} 22^{\prime} 45^{\prime \prime} \mathrm{N}, 130^{\circ} 59^{\prime} 25^{\prime \prime}$ W; (map 3).

Named in 1891 by USC\&GS.

Wasp Point: point of land, $\mathrm{S}$ tip of Quail I. in Yukon River, Innoko Low.; $63^{\circ} 53^{\prime} \mathrm{N}, 159^{\circ} 08^{\prime}$ W; (map 91).

Riverboat pilots' name shown on a 1940 "Navigation Chart of the Tanana-Yukon Rivers" published by the U.S. Dept. of Interior.

Wassila: village, see Wasilla.

Wassila Creek: stream, see Wasilla Creek.

Wassilla Creek: stream, see Wasilla Creek.

Wassillas Lake: lake, see Lucile Lake.

Wasta Creek: stream, heads in lake, flows E 4 mi. to Spacious Bay, on NE coast of Cleveland Penin., Alex. Arch.; 55 $51^{\prime} 25^{\prime \prime}$ N, $131^{\circ}$. $55^{\prime} 00^{\prime \prime} \mathrm{W}$; (map 3).

Local name published in 1943 by USC\&GS.

Watana, Mount: mountain, $6,255 \mathrm{ft}$., $24 \mathrm{mi}$. NW junc. of Oshetna and Susitna Rivers, Talkeetna Mts. ; $62^{\circ} 43^{\prime} 30^{\prime \prime} \mathrm{N}, 148^{\circ} 07^{\prime} 00^{\prime \prime} \mathrm{W}$; (map 82).

Local name recorded in 1952 by USGS.

Watana Creek: stream, flows SW $24 \mathrm{mi}$. to Sustina River, $31 \mathrm{mi}$. NW of mouth of Oshetna River and $45 \mathrm{mi}$. SE of Cantwell, Talkeetna Mts.; $62^{\circ} 49^{\prime} 50^{\prime \prime} \mathrm{N}, 148^{\circ} 15^{\prime} 30^{\prime \prime} \mathrm{W}$; (map 82).

Indian name reported by Ellsworth and Davenport (1915b, pl. 5), USGS.

Watana Lake: lake, $1.6 \mathrm{mi}$. long, $\mathrm{E}$ of Mount Watana, $12 \mathrm{mi}$. NW of junc. of Oshetna and Susitna Rivers, Talkeetna Mts.; $62^{\circ} 43^{\prime} 45^{\prime \prime}$ $\mathrm{N}, 148^{\circ} 02^{\prime} 45^{\prime \prime} \mathrm{W}$; (map 82).

Local name recorded in 1952 by USGS.

Watch Point: point of land, on E shore of Seldovia Bay, within the limits of village of Seldovia, Chugach Mts.; $59^{\circ} 26^{\prime} 45^{\prime \prime} \mathrm{N}, 151^{\circ}$ 43'00' W; BGN 1908; (map 50). Var. Lookout Point.
Name reported by USC\&GS in 1908. It was locally called Lookout Point, but because of duplication, the name was changed to a suitable synonym.

Waterboot Creek: stream, flows NW $10 \mathrm{mi}$. to Atsaksovluk Creek $5 \mathrm{mi}$. SE of its junc. with Aniak River, $83 \mathrm{mi}$. SW of Sleetmute, Kilbuck-Kuskokwim Mts.; $60^{\circ} 54^{\prime} \mathrm{N}, 159^{\circ} 00^{\prime}$ W; $B G N 1948$; (map 60).

Local name reported in 1945 by USGS; the name refers to "an incident in connection with prospectors boating on this stream."

Waterboot Creek: stream, see Atsaksovluk Creek.

Water Creek: stream, flows S $28 \mathrm{mi}$. to Junjik River, $18 \mathrm{mi}$. NW of Arctic Village, Brooks Ra.; $68^{\circ} 23^{\prime} \mathrm{N}, 145^{\circ} 41^{\prime} \mathrm{W}$; (map 136).

Translation of Kutchin Indian name reported in 1956 by T. E. Taylor, USGS.

Water Creek Mountain: peak, 4,920 ft., $7 \mathrm{mi}$. $\mathrm{N}$ of junc. of Water Creek and Junjik River and $25 \mathrm{mi}$. $\mathrm{N}$ of Arctic Village, Brooks Ra.; $68^{\circ} 29^{\prime} \mathrm{N}, 145^{\circ} 38^{\prime} \mathrm{W}$; (map 136).

Local name reported in 1956 by $R$. C. Foley, USGS.

Waterfall: locality, a cannery, on $W$ coast of Prince of Wales I., $13 \mathrm{mi}$. SW of Craig, Alex. Arch.; 55 $17^{\prime} 50^{\prime \prime} \mathrm{N}, 133^{\circ} 14^{\prime} 30^{\prime \prime} \mathrm{W}$; (map 4).

Name published by H. M. Eakin (in Brooks and others, 1915, pl. 5), USGS. "Waterfall *** has a cannery and store at which some fishermen's supplies, gasoline, and fuel oil can be obtained *** cannery wharf ***. Waterfall has radio communication during the canning season" (U.S. Coast and Geodetic Survey, 1962, p. 83).

Waterfall Bay: estuary, extends $\mathrm{E} 4 \mathrm{mi}$. on W coast of Dall I., Alex. Arch.; $54^{\circ} 56^{\prime} \mathrm{N}, 133^{\circ}$. $09^{\prime} \mathrm{W}$; (map 1$)$.

Name published by USC\&GS in 1914.

Waterfall Cove: cove, $0.4 \mathrm{mi}$. across, on $\mathrm{NE}$ coast of Baranof I., $7 \mathrm{mi}$. N of Baranof, Alex. Arch.; $57^{\circ} 11^{\prime} 45^{\prime \prime} \mathrm{N}, 134^{\circ} 50^{\prime} 00^{\prime \prime} \mathrm{W}$; (map 9).

Local name reported in 1951 by USGS.

Waterfall Cove: cove, $0.6 \mathrm{mi}$. across, along $\mathrm{W}$ coast of Chichagof I., on $\mathbf{E}$ side of Slocum Arm, $11 \mathrm{mi}$. SE of Chichagof, Alex. Arch.; $57^{\circ} 31^{\prime} \mathrm{N}, 135^{\circ} 55^{\prime} \mathrm{W}$; BGN 1908; (map 9).

Named in 1908 by E. F. Dickins, USC\&GS, for "the waterfall located on the outlet of Waterfall Lake." The name was published in the 1908 Coast Pilot (p. 172).

Waterfall Creek: stream, flows S $8 \mathrm{mi}$. to Meshik River, on Alaska Penin., $11 \mathrm{mi}$. S of Vent Mtn. in Aniakchak Crater, Bristol Bay Low. $56^{\circ} 43^{\prime} \mathrm{N}, 158^{\circ} 08^{\prime} \mathrm{W}$; (map 30).

Descriptive name reported in 1923 by $R$. H. Sargent, USGS.

Waterfall Creek: stream, flows $S 10 \mathrm{mi}$. to Susitna River, $65 \mathrm{mi}$. SE of Cantwell, Alaska Ra.; 62 $57^{\prime} 50^{\prime \prime} \mathrm{N}, 147^{\circ} 12^{\prime} 05^{\prime \prime} \mathrm{W}$; (map 82).

Local descriptive name reported in 1931 by USGS.

Waterfall Creek: stream, heads at AlaskaCanada boundary, flows NW $16 \mathrm{mi}$. to $\mathrm{Na}$ tion River $15 \mathrm{mi}$. NNE of that stream's junc. with Yukon River and $41 \mathrm{mi}$. N of Eagle, 
Porcupine Plat.; $65^{\circ} 22^{\prime} 30^{\prime \prime} \mathrm{N}, 141^{\circ} 26^{\prime} 30^{\prime \prime} \mathrm{W}$ (map 103).

Descriptive name reported in 1930 by $\mathrm{J}$. B. Mertie, Jr., USGS

Waterfall Creek: stream, see North Fork Snake River.

Waterfall Head: point of land, see Cascade Point.

Waterfall Lake: lake, $0.9 \mathrm{mi}$. long, on $\mathrm{W}$ coast of Dall I., 1 mi. $\mathbf{N}$ of Waterfall Bay, Alex. Arch.; $54^{\circ} 58^{\prime} 20^{\prime \prime} \mathrm{N}, 133^{\circ} 06^{\prime} 00^{\prime \prime} \mathrm{W}$; $B G N$ 1935; (map 1).

Named in 1935 by USGS.

Waterfall Lake: lake, $0.3 \mathrm{mi}$. across, on W coast of Chichagof I., $12 \mathrm{mi}$. SE of Chichagof, Alex. Arch.; $57^{\circ} 32^{\prime} \mathrm{N}, 1^{\circ} 5^{\circ} 52^{\prime} \mathrm{W} ; B G N$ 1923; (map 9).

Named in 1923 by USFS for the waterfall located on the stream that drains the lake.

Waterfall Lake: lake, $0.8 \mathrm{mi}$. long, $14 \mathrm{mi}$. $\mathrm{N}$ of Chalkyitsik, Yukon Flats; $66^{\circ} 45^{\prime}$ N, $143^{\circ}$ $49^{\prime} \mathrm{W}$; (map 120).

Local descriptive name; reported in 1956 by R. C. Foley, USGS.

Waterfall Peak: peak, 3,400 ft., $1.5 \mathrm{mi}$. W of Swanlake and $103 \mathrm{mi}$. E of Sitka, Coast Mts.; $57^{\circ} 01^{\prime} 30^{\prime \prime} \mathrm{N}, 132^{\circ} 46^{\prime} 30^{\prime \prime} \mathrm{W}$; (map 8).

Named in 1887 by Lt. Comdr. C. M. Thomas, USN; name published in 1888 by USC\&GS. So named because of the falls along Cascade Creek south of the mountain. Waterfall Peak: mountain, see Porter Peak.

Waterfall Point: point of land, between Clark and Orzinski Bays, on $\mathrm{W}$ shore of Stepovak Bay, near SW end of Alaska Penin., Aleutian Ra.; 55 $43^{\prime} 20^{\prime \prime} \mathrm{N}, 160^{\circ} 01^{\prime} 20^{\prime \prime} \mathrm{W}$; (map 28).

Descriptive name published by USC\&GS in 1916 Coast Pilot (p. 164); so named because of "a conspicuous waterfall at the southern tip."

Waterfalls, Bay of: bay, $5 \mathrm{mi}$. across on SW coast of Adak I., Aleutian Is.; $51^{\circ} 38^{\prime} \mathrm{N}$, $176^{\circ} 52^{\prime} \mathrm{W}$; BGN 1936; (map 17).

Name given by Lt. William Gibson, USN, commander of the schooner Fenimore Cooper, during the North Pacific Exploring Expedition in 1855 .

Waterfowl Lake: lake, $0.7 \mathrm{mi}$. long, on Kenai Penin. W of Canoe Lake, $22 \mathrm{mi}$. NE of Kenai, Cook Inlet Low.; $60^{\circ} 43^{\prime} 10^{\prime \prime} \mathrm{N}, 150^{\circ} 42^{\prime} 45^{\prime \prime}$ W; (map 62).

Named about 1963 by officials of Kenai National Moose Range, for administrative purposes.

Watering-place Creek: stream, see Walsh Creek.

Water Lake: lake, 1,200 ft. long, on $\mathrm{E}$ coast of Prince of Wales I., $\mathrm{N}$ of Thorne Bay, Alex. Arch.; 55 $41^{\prime} 30^{\prime \prime} \mathrm{N}, 132^{\circ} 30^{\prime} 55^{\prime \prime} \mathrm{W} ; B G N$ 1962; (map 4).

Local name reported in 1961 by USFS.

Waterman Canyon: canyon, $0.5 \mathrm{mi}$. long, on Kenai Penin., $1 \mathrm{mi}$. N of Kachemak Bay and $6 \mathrm{mi}$. NE of Homer, Cook Inlet Low.; $59^{\circ} 41^{\prime} 30^{\prime \prime} \mathrm{N}, 151^{\circ} 24^{\prime} 15^{\prime \prime} \mathrm{W}$; (map 50).

Local name reported and published by USGS in 1950.

Watermelon Lake: lake, $1 \mathrm{mi}$. across, $11 \mathrm{mi}$. NF of head of Ikpikpuk River, Arctic Plain; $69^{\circ} 28^{\prime} \mathrm{N}, 154^{\circ} 22^{\prime} \mathrm{W} ; B G N$ 1960; (map 142).

So named by geologists in the 1940 's "because a supply airplane which landed here brought a rare treat-a watermelon."

Watermouse Creek: stream, see Wattamuse Creek.

Waters, Mount: mountain, 5,237 ft., at head of Nelson Glacier, $14 \mathrm{mi}$. E of Wrangell, Coast Mts.; $56^{\circ} 31^{\prime} 30^{\prime \prime} \mathrm{N}, 132^{\circ} 01^{\prime} 30^{\prime \prime} \mathrm{W}$; BGN 1944; (map 6).

Named in 1944 by USGS

Waters, Point: point of land, on $E$ shore of Port Bainbridge, $14 \mathrm{mi}$. SW of Chenega, and 40 mi. E of Seward, Chugach Mts.; $60^{\circ} 07^{\prime} 00^{\prime \prime}$ N, $148^{\circ} 18^{\prime} 15^{\prime \prime} \mathrm{W}$; (map 63).

Named about May 28, 1794, by Joseph Whidbey, of Capt. George Vancouver's party, while exploring Port Bainbridge (Wagner, 1937, p. 421).

Waterson Gulch: ravine, trends W $0.5 \mathrm{mi}$. to Gracier Greek, about $8 \mathrm{mi}$. N of Nome, Seward Penin. High. (map 94).

Prospectors' name published on the 1900 "Map of Nome Peninsula" by J. M. Davidson and B. D. Blakeslee. This feature cannot be precisely identified on recent maps.

Watkins Point: point of land, on $\mathrm{W}$ coast of Cleveland Penin., at $\mathrm{S}$ entrance to Seward Passage, Alex. Arch.; $55^{\circ} 58^{\prime} \mathrm{N}, 132^{\circ} 02^{\prime} \mathrm{W}$ (map 4).

Named by local fishermen and reported in 1904 by H. C. Fassett, USBF.

Watson, Mount: mountain, $12,516 \mathrm{ft}$., $2 \mathrm{mi}$. W of Alaska-Canada boundary, $6.5 \mathrm{mi}$. $\mathrm{S}$ of Mount Lodge, and $84 \mathrm{mi}$. SW of Skagway, St. Elias Mts.; $59^{\circ} 00^{\prime} 30^{\prime \prime} \mathrm{N}, 137^{\circ} 33^{\prime} 15^{\prime \prime} \mathrm{W}$; $B G N$ 1924; ( $\operatorname{map} 45$ ).

Named in 1924 for David Thompson Watson, 1844-1916, lawyer, who was U.S Counsel of the Alaska Boundary Tribunal in 1903. Watson was born in Pennsylvania and received his law degree from Harvard Univ. The name was published in 1928 on IBC Sheet 12 (1951 atlas).

Watson Creek: stream, heads in Robinson Mts. and flows $4 \mathrm{mi}$. SW to the Gulf of Alaska $1.8 \mathrm{mi}$. W of Claybluff Point and $71 \mathrm{mi}$. NW of Yakutat, Malaspina Coastal Plain $59^{\circ} 57^{\prime} 50^{\prime \prime} \mathrm{N}, 141^{\circ} 38^{\prime} 05^{\prime \prime} \mathrm{W}$; (map 47).

Local name published in 1948 by USGS. Watson Creek: stream, flows NW $1.3 \mathrm{mi}$. to Birch Creek which flows to Big Four Creek, $21 \mathrm{mi}$. NE of Solomon, Seward Penin. High.; $64^{\circ} 49^{\prime}$ N, $164^{\circ} 09^{\prime} \mathrm{W}$; (map 95).

Prospectors' name reported on a 1902 prospectors' manuscript map.

Watson Fork: stream, flows SW $4 \mathrm{mi}$. to Fish Creek, $55 \mathrm{mi}$. SW of Eagle, Yukon-Tanana High.; $64^{\circ} 18^{\prime} 30^{\prime \prime} \mathrm{N}, 142^{\circ} 43^{\prime} 00^{\prime \prime} \mathrm{W}$; (map 102).

Prospectors' name shown on an 1898 manuscript map by C. A. Woodruff, Fort Cudahy, Canada.

Watson Glacier: glacier, trends S $4 \mathrm{mi}$. to Yakataga Glacier, $11 \mathrm{mi}$. NE of Cape Yakataga and $95 \mathrm{mi}$. NW of Yakutat, Chugach Mts.; $60^{\circ} 09^{\prime} 30^{\prime \prime} \mathrm{N}, 142^{\circ} 10^{\prime} 45^{\prime \prime} \mathrm{W} ; B G N \quad 1946$; (map 65)

Named in 1945 by USGS for Ben Watson who "has contributed to knowledge of the Territory as a collector for the Smithsonian Institution and other natural history museums."

Watson Lake: lake, $0.5 \mathrm{mi}$. long, one of the Seven Lakes, on Kenai Penin., in course of East Fork Moose River, $29 \mathrm{mi}$. SE of Kenai, Cook Inlet Low.; $60^{\circ} 32^{\prime} 15^{\prime \prime} \mathrm{N}, 150^{\circ} 28^{\prime} 00^{\prime \prime}$ W; (map 62).

Named about 1963 by officials of Kenai National Moose Range, for administrative purposes.

Watson Peak: peak, 2,258 ft., $2.8 \mathrm{mi}$. NE of Cape Yakataga and $99 \mathrm{mi}$. NW of Yakutat, St. Elias Mts.; $60^{\circ} 05^{\prime} 00^{\prime \prime} \mathrm{N}, 142^{\circ} 22^{\prime} 30^{\prime \prime} \mathrm{W}$; (map 65).

Local name published in 1951 by USGS.

Watson Point: point of land, on NW coast of Baranof I., $1.4 \mathrm{mi}$. NW of Sitka, Alex. Arch.; $57^{\circ} 04^{\prime} 00^{\prime \prime} \mathrm{N}, 135^{\circ} 21^{\prime} 50^{\prime \prime} \mathrm{W}$; (map 9).

Local name reported in 1951 by USGS.

Wattamuse Creek: stream, flows SE $3 \mathrm{mi}$, to Cascade Creek, 20 mi. NE of Goodnews, KilbuckKuskokwim Mts. ; $59^{\circ} 20^{\prime} \mathrm{N}, 161^{\circ} 15^{\prime} \mathrm{W}$; (map 53). Var. Nakahkpuk, Wahmus Creek, Watermouse Creek.

Eskimo name reported as "Wahmus" or folk etymologized into "Watermouse Creek" according to G. C. Martin (1919, p. 40), USGS. In 1919 G. L. Harrington, USGS, reported that the name is a corruption of "Bartimeus," the baptismal name of an Eskimo for whom the stream was named. $\mathrm{He}$ also reported that the Eskimos called it "Nakahkpuk," said to mean "stream between mountains." Gold was found on this creek in 1917 by an Eskimo herding reindeer in the vicinity. This discovery resulted in the Discovery group of productive placer mines located along the creek (Brooks and others, 1921, p. 225).

Waverly Island: island, see Tangik Island.

Waw, Mount: mountain, 7,910 ft., in Romanzof $\mathrm{Mts}, 4 \mathrm{mi}$. NE of Mt. Hubley and $14 \mathrm{mi}$. NE of Mt. Michelson, Brooks Ra.; $69^{\circ} 20^{\prime} \mathrm{N}$, $143^{\circ} 43^{\prime}$ W ; (map 138)

Named about 1957 by personnel participating in the International Geophysical Year glaciological work in the Romanzof Mountains.

Waxell Ridge: ridge, elev. 4,000-10,000 ft., extends from head of Steller Glacier E $26 \mathrm{mi}$ to Bering Glacier, $90 \mathrm{mi}$. E of Cordova, Chutach Mts. and St. Elias Mts.; $60^{\circ} 32^{\prime} \mathrm{N}, 143^{\circ}$ 04' W; (map 65). Var. Swen Waxell Ridge, Waxel Ridge.

Named in 1913 by A. G. Maddren, USGS, for Lt. Sven Waxell (Waxel), sailing master under Vitus Bering on the Alaskan discovery voyage in 1741; upon Bering's death, Waxell succeeded to command.

Waxel Ridge: ridge, see Waxell Ridge.

Wayanda Ledge: reef, in Sergius Narrows, at W end of Peril Strait, off NW coast of Baranof I., Alex. Arch.; $57^{\circ} 24^{\prime} 23^{\prime \prime} \mathrm{N}, 135^{\circ} 37^{\prime} 22^{\prime \prime} \mathrm{W}$; 
$B G N$ 1897; (map 9). Var. Eureka Ledge, Wayanda Rock, Wyanda Ledge.

Named by USC\&GS ; published as "Wayanda Rock" in the 1883 Coast Pilot (p. 161). The ledge was named for the Revenue Cutter Wayanda which once struck it. It has also been called "Eureka Ledge" for the steamer Eureka which struck it in 1883 . The latter name was published on Chart 8259.

Wayanda Rock: reef, see Wayanda Ledge.

Wayanda Rock: rock, see California Rock.

Waydelich Creek: stream, flows $2 \mathrm{mi}$. SE to Auke Bay at Spaulding Point, $10 \mathrm{mi}$. NW of Juneau, Coast Mts.; $58^{\circ} 23^{\prime} 00^{\prime \prime} \mathrm{N}, 134^{\circ} 39^{\prime} 15^{\prime \prime} \mathrm{W}$; $B G N$ 1964; (map 11). Var. Wadleigh Creek.

Named for John W. Waydelich, 18371914 , one of the first white settlers in the Auke Bay area. After graduating from Yale University, he went to Montana and then to Alaska. In 1881 he moved to Juneau, and in 1892 claimed a homestead on Auke Bay along the creek which now bears his name. (DeArmond, 1957, p. 46-47).

Way Point: point of land, on W coast of Dall I., in Hook Arm Sea Otter Harbor, Alex. Arch.; $55^{\circ} 07^{\prime} 40^{\prime \prime} \mathrm{N}, 133^{\circ} 09^{\prime} 00^{\prime \prime} \mathrm{W}$; (map 4).

Name published in 1924 by USC\&GS.

Weare: locality, see Tanana.

Weare Dike: locality, on a slough $\mathbf{N}$ of Yukon River, $6 \mathrm{mi}$. $\mathrm{E}$ of Blade I. and $19 \mathrm{mi}$. SW of Russian Mission, Yukon-Kuskokwim Delta; $61^{\circ} 37^{\prime} 20^{\prime \prime}$ N, $161^{\circ} 46^{\prime} 00^{\prime \prime}$ W; (map 73). Var. Weare Dyke.

Site of a dike shown on a 1916 USGS map; name derived from "the Portus B. Weare [that] was the first steamboat of the N.A.T. and $T$. Company, built in 1892 . She was named for Portus B. Weare, of Chicago, one of the organizers of the company" (Curtain, 1938 , p. 280). "During the winter of 189899 the Weare * * * wintered about fifteen miles below Russian Mission, where she was stuck in the open river, near the bank. A breakwater was built in front of her at a cost of five thousand dollars, and she was saved from the ice jams in the spring. The breakwater must have stood, for on U.S. [Geological] Survey Maps made *** in 1916 the place is marked, and named 'Weare Dyke" " (p. 283).

Weare Dyke: locality, see Weare Dike.

Weary River: stream, flows SE $40 \mathrm{mi}$. to Snake River, $13 \mathrm{mi}$. SW of Dillingham, Bristol Bay Low.; 58 $58^{\prime} \mathrm{N}, 158^{\circ} 49^{\prime} \mathrm{W}$; BGN 1937; (map 40).

So named in 1952 by USGS "because of the sluggishness of the stream and the time consumed in traversing its very winding course."

Weasel Cove: estuary, extends N $1.3 \mathrm{mi}$., off Boca de Quadra, $0.5 \mathrm{mi}$. W of Badger Bay, Coast Mts.; $55^{\circ} 08^{\prime} 30^{\prime \prime} \mathrm{N}, 130^{\circ} 49^{\prime} 45^{\prime \prime} \mathrm{W}$ (map 3)

One of many arbitrary names applied to features in this area in 1891 by USC\&GS.

Weasel Cove: cove, extends $\mathrm{S} 1 \mathrm{mi}$, at head of Spiridon Bay, on NW coast of Kodiak I.; $57^{\circ} 36^{\prime} 00^{\prime \prime} \mathrm{N}, 153^{\circ} 36^{\prime} 45^{\prime \prime} \mathrm{W} ; B G N$ 1931; (map 34).

Descriptive name given by USC\&GS in 1929 , "because of numerous weasels seen on the beach in the cove."

Weasel Creek: stream, flows $\mathrm{N} 12 \mathrm{mi}$. to Tom Killae Creek, $30 \mathrm{mi}$. SW of Whitefish Lake and $60 \mathrm{mi}$. NW of Nondalton, Lime Hills; $60^{\circ} 42^{\prime} 30^{\prime \prime} \mathrm{N}, 155^{\circ} 46^{\prime} 50^{\prime \prime} \mathrm{W}$; (map 61).

Local name reported in 1950 by USC\&GS.

Weasel Creek: stream, flows $W$ and NE $12 \mathrm{mi}$. to Maybe Creek, $\mathbf{E}$ of Kimikpak Ridge and 20 mi. SE of head of Ikpikpuk River, Arctic Slope; 69 $14^{\prime} \mathrm{N}, 153^{\circ} 56^{\prime} \mathrm{W}$; BGN 1949; (map 142).

Named by the geologists on the Naval Petroleum Reserve No. 4 exploration for the tracked vehicle called a Weasel, which was used extensively for tundra exploration.

Weasel Lake: lake, $0.7 \mathrm{mi}$. long, on Kenai Penin., $1.4 \mathrm{mi}$. W of Rock Lake and $21 \mathrm{mi}$. NE of Kenai, Cook Inlet Low.; $60^{\circ} 39^{\prime} 40^{\prime \prime} \mathrm{N}, 150^{\circ}$. $41^{\prime} 45^{\prime \prime} \mathrm{W}$; (map 62).

Named about 1963 by officials of the Kenai National Moose Range, for administrative purposes.

Weasel Mountain: mountain, 2,410 ft., on Alaska Penin., forms SE end of a 6-mi. promontory between Hook and Chignik Bays, $17 \mathrm{mi}$. NE of Chignik, Aleutian Ra.; $56^{\circ} 29^{\prime} \mathrm{N}, 158^{\circ} 08^{\prime}$ W; (map 30).

Name reported in 1923 by R. H. Sargent, USGS ; published in 1927 by USGS.

Weasel Point, ridge, near S end of Lake Peters, Franklin Mts., Brooks Ra.; (map 139).

Name published by Bee and Hall (1956, p. 295).

Webber Creek: stream, flows NE $17 \mathrm{mi}$. to Yukon River, $32 \mathrm{mi}$. SSE of Circle, Yukon-Tanana High.; $65^{\circ} 24^{\prime} 30^{\prime \prime} \mathrm{N}, 143^{\circ} 33^{\prime} 00^{\prime \prime} \mathrm{W}$; (map 103).

Prospectors' name recorded in 1902 by Lt. Hjalmar Erickson, USA, and William Yanert.

Weber Creek: stream, on Kenai Penin., flows NW $2 \mathrm{mi}$. to Canyon Creek, $12 \mathrm{mi}$. S of Sunrise and $27 \mathrm{mi}$. W of Whittier, Chugach Mts.; $60^{\circ} 42^{\prime} 50^{\prime \prime} \mathrm{N}, 149^{\circ} 27^{\prime} 25^{\prime \prime} \mathrm{W}$; (map 63).

Local prospectors' name reported about 1914 by B. L. Johnson (in Martin and others, 1915, pl. 2), USGS.

Weber Point: point of land, see Beacon Point. Webories Creek: stream, flows SE $3 \mathrm{mi}$. to Melozimoran Creek, $3.5 \mathrm{mi}$. $\mathrm{N}$ of Moran Dome and $30 \mathrm{mi}$. NW of Tanana, Kokrines-Hodzana High.; $65^{\circ} 25^{\prime} 30^{\prime \prime} \mathrm{N}, 152^{\circ} 55^{\prime} 00^{\prime \prime} \mathrm{W}$; $B G N$ 1960; (map 106).

Named in 1955 by R. M. Chapman, USGS, for Martin Webories, who died in 1946, "who prospected in the Grant-Tozimoran Greeks for a number of years. He had a cabin on this stream ***."

Webster Lake: lake, $0.3 \mathrm{mi}$. across, on NE coast of St. Paul I., in Pribilof Is.; $57^{\circ} 14^{\prime} 10^{\prime \prime} \mathrm{N}$, $170^{\circ} 06^{\prime} 40^{\prime \prime} \mathrm{W}$; (map 38).

Name reported by W. W. Duffield, USC\& GS, in 1897; probably named for the owner of a nearby house, labeled "Webster's House" on Elliott's map of St. Paul (1881).
Webster Peak: mountain peak, 3,500 ft, $1 \mathrm{mi}$. NW of Everett Peak, 3 mi. NW of Point Styleman, on Stephens Passage, $27 \mathrm{mi}$. SE of Juneau, Coast Mts.; $58^{\circ} 00^{\prime} 45^{\prime \prime} \mathrm{N}, 133^{\circ} 55^{\prime} 50^{\prime \prime}$ W; (map 12).

Local name reported in 1951 by USGS.

Webster Point: point of land, on SW coast of Prince of Wales I., $4 \mathrm{mi}$. E of Jackson I., Alex. Arch.; 54 $58^{\prime} 15^{\prime \prime} \mathrm{N}, 132^{\circ} 36^{\prime} 45^{\prime \prime} \mathrm{W}$; (map 1).

Local name recorded in 1905 by E. F. Dickins, USC\&GS.

Webuk: locality, see Wevok.

Webuk Konikto: promontory, see Thompson, Cape.

Webuk Unasiksuk: promontory, see Lisburne, Cape.

Wedge, Cape: point of land, on $\mathrm{N}$ tip of Nagai I., in Shumagin Is., Aleutian Ra.; $55^{\circ} 17^{\prime} \mathrm{N}$, $159^{\circ} 53^{\prime} \mathrm{W}$; (map 27). Var. Wedge Cape. Named by W. H. Dall, USC\&GS, in 1872.

Wedge Cape: point of land, in Bay of Waterfalls, on SW coast of Adak I., Aleutian Is.; $51^{\circ}$ $38^{\prime} 30^{\prime \prime} \mathrm{N}, 176^{\circ} 49^{\prime} 50^{\prime \prime} \mathrm{W}$; BGN 1936; (map 17).

Named by U.S. Navy in 1893 , and published by the U.S. Navy Hydrog. Office in 1895.

Wedge Glacier: glacier, trends NW $1 \mathrm{mi}$. to its terminus, $1.5 \mathrm{mi}$. $\mathrm{E}$ of head of Harriman Fiord, $18 \mathrm{mi}$. NE of Whittier, Chugach Mts.; $60^{\circ} 58^{\prime} 00^{\prime \prime} \mathrm{N}, 148^{\circ} 23^{\prime} 45^{\prime \prime} \mathrm{W}$; (map 63).

Descriptive name given in 1899 by the members of the Harriman Alaska Expedition; probably named because the glacier trends down a progressively narrowing valley.

Wedge Island: islands, see Wedge Islands.

Wedge Islands: islands, off-shore group, extends $1.3 \mathrm{mi}$. in Clarence Strait, $2 \mathrm{mi}$. N of Adams Point, on SE coast of Prince of Wales I., Alex. Arch.; $55^{\circ} 08^{\prime} 45^{\prime \prime} \mathrm{N}, 131^{\circ} 57^{\prime} 45^{\prime \prime} \mathrm{W}$; (map 3). Var. Ostrov Vedzh, Wedge Island.

The largest of these islands was named "Wedge Island" in 1793 by Capt. George Vancouver, RN, because of its shape (Wagner, 1937, p. 421).

Wedge Mountain: mountain, 3,400 ft., on Chichagof I., $2.3 \mathrm{mi}$. NE of Pelican, Alex. Arch.; 57 $59^{\prime} 22^{\prime \prime} \mathrm{N}, 136^{\circ} 11^{\prime} 50^{\prime \prime} \mathrm{W}$; $B G N$ 1960; (map 9).

Descriptive name given in 1955 by $D$. L. Rossman, USGS, because "the mountain has a wedge shape."

Wedge Peak: peak, 10,239 ft., in Mount McKinley National Park, $17 \mathrm{mi}$. SSW of EieIson Visitor Center and $18 \mathrm{mi}$. ENE of Mount McKinley, Alaska Ra.; $63^{\circ} 12^{\prime} 15^{\prime \prime} \mathrm{N}, 150^{\circ}$ $30^{\prime} 40^{\prime \prime} \mathrm{W}$; (map 88).

Descriptive name given in 1945 by the U.S. Army Air Force Cold Weather test party.

Wedge Point: point of land, on SW coast of Adak I., Aleutian Is., $51^{\circ} 42^{\prime} 00^{\prime \prime} \mathrm{N}, 176^{\circ} 55^{\prime}$ 45" W; BGN 1936; (map 17).

Name given by Lt: William Gibson, USN, commander of the schooner Fenimore Cooper, 
during the North Pacific Exploring Expedition in 1855.

Wedge Point: point of land, between Aspid and Alimuda Bays, on SW coast of Unalaska I., Aleutian Is., $53^{\circ} 26^{\prime} 55^{\prime \prime} \mathrm{N}, 167^{\circ} 23^{\prime} 35^{\prime \prime} \mathrm{W}$; $B G N$ 1938; (map 23).

Descriptive name given in 1937 by USC\&GS.

Wedge Point: point of land, on NW coast of Woronkofski I., Alex. Arch.; 56 $25^{\prime} 15^{\prime \prime} \mathrm{N}$, $132^{\circ} 32^{\prime} 00^{\prime \prime} \mathrm{W}$; (map 6).

Descriptive name obtained from local navigators; reported in 1904 by H. C. Fassett, USBF.

Wedge Point: point of land, see Ram Point.

Wedgewood Creek: stream, flows SW $6 \mathrm{mi}$. to Rock Creek, $13 \mathrm{mi}$. NNE of Porcupine Dome, and $38 \mathrm{mi}$. SW of Circle, Yukon-Tanana High.; $65^{\circ} 41^{\prime} 15^{\prime \prime} \mathrm{N}, 1^{\circ} 25^{\circ} 20^{\prime} 00^{\prime \prime} \mathrm{W}$; (map 104).

Prospectors' name reported in 1954 or 1955 by USGS topographers.

Weed Bight: bight, between Shoal Point and Round Head, on NE coast of Kanaga I., Aleutian Is.; $51^{\circ} 53^{\prime} \mathrm{N}, 177^{\circ} 04^{\prime} \mathrm{W}$; (map 17).

Name published in 1957 on an AMS map.

Weed Lake: lake, $0.3 \mathrm{mi}$. long, on Kenai Penin. SW of Dabbler Lake, $18 \mathrm{mi}$. NE of Kenai, Cook Inlet Low.; $60^{\circ} 41^{\prime} 30^{\prime \prime} \mathrm{N}, 150^{\circ} 46^{\prime} 30^{\prime \prime}$ W; (map 62).

Named about 1963 by officials of Kenai National Moose Range for administrative purposes.

Weedy Shoals: reefs, on E shore of Zachary Bay, Unga I., in Shumagin Is., Aleutian Ra.; $55^{\circ}$ $22^{\prime} 20^{\prime \prime} \mathrm{N}, 160^{\circ} 36^{\prime} 00^{\prime \prime} \mathrm{W}$; (map 28).

Named in 1872 by W. H. Dall.

Weelung Creek: stream, flows W 3 mi. to Kuskokwim Bay, 55 mi. NW of Goodnews, YukonKuskokwim Delta ; $59^{\circ} 50^{\prime} \mathrm{N}, 162^{\circ} 03^{\prime} \mathrm{W}$; (map 54).

Name reported in 1951 by USGS.

Weeping Wall: cliff, on NW coast of Umnak I., Aleutian Is.; $53^{\circ} 28^{\prime} \mathrm{N}, 168^{\circ} 15^{\prime} \mathrm{W} ; B G N$ 1942; (map 22).

Descriptive name given in 1939 by USC\&GS "because several cracks in the rocks emit a series of waterfalls during and immediately after the rainy season."

Weigle, Point: point of land, between Little and Davison Bays, on W coast of Chichagof I., 11 mi. NW of Chichagof, Alex. Arch.; 5 $7^{\circ} 46^{\prime} 40^{\prime \prime}$ $\mathrm{N}, 136^{\circ} 18^{\prime} 20^{\prime \prime} \mathrm{W}$; (map 9).

Named by the USC\&GS for W. G. Weigle, U.S. Forest Supervisor at Ketchikan. The name was published in 1919 on Chart 8250.

Weinie Lake: lake, 2,000 ft. long, in Matanuska Valley, $12 \mathrm{mi}$. SW of Palmer, Cook Inlet Low.; $61^{\circ} 31^{\prime} 40^{\prime \prime} \mathrm{N}, 149^{\circ} 26^{\prime} 45^{\prime \prime} \mathrm{W}$; (map 69).

Local name reported in 1942 by USGS.

Weir Island: island, $2.1 \mathrm{mi}$. long, in Yukon River, $56 \mathrm{mi}$. SSW of Nulato, Innoko Low.; $63^{\circ}$ $58^{\prime} 30^{\prime \prime} \mathrm{N}, 158^{\circ} 54^{\prime} 00^{\prime \prime} \mathrm{W}$; (map 90).

Riverboat pilots' name shown on 1940 "Navigation Chart of the Tanana-Yukon Rivers" by Dept. of Interior.

Weir Island: island, $3.3 \mathrm{mi}$. long, in Yukon River, $\mathbf{S}$ of Flora $\mathrm{I}$. and $2 \mathrm{mi}$. $\mathrm{E}$ of Birches,
Nowitna Low.; $65^{\circ} 07^{\prime} 30^{\prime \prime} \mathrm{N}, 153^{\circ} 27^{\prime} 00^{\prime \prime} \mathrm{W}$; (map 107).

Riverboat pilots' name shown on a 1940 "Navigation Chart of the Tanana-Yukon Rivers" published by the Department of the Interior.

Weir Slough: slough, anabranch of Yukon River, flows W 4 mi., S of Weir I. and $2 \mathrm{mi}$. E of Birches, Nowitna Low.; $65^{\circ} 08^{\prime} \mathrm{N}, 153^{\circ} 30^{\prime}$ W; (map 107).

Riverboat pilots' name shown on a 1940 "Navigation Chart of the Tanana-Yukon Rivers" published by the Department of the Interior.

Welcome, Lake: lake, $1.6 \mathrm{mi}$. long, on $\mathrm{W}$ coast of Dall I., $1.2 \mathrm{mi}$. E of Welcome Point, Alex. Arch.; $54^{\circ} 59^{\prime} \mathrm{N}, 133^{\circ} 07^{\prime} \mathrm{W}$; BGN 1935; (map 1).

Named in 1935 by USGS.

Welcome, Point: point of land, on $\mathrm{S}$ coast of Bird I., in Shumagin Is., Aleutian Ra. ; $54^{\circ} 48^{\prime}$ $\mathrm{N}, 159^{\circ} 47^{\prime} \mathrm{W}$; (map 26).

Named published in 1882 by USC\&GS

Welcome Bay: bay, $0.2 \mathrm{mi}$. across, on $\mathrm{N}$ coast of Tigalda I., Aleutian Is.; $54^{\circ} 05^{\prime} 45^{\prime \prime}$ N., $165^{\circ}$ $01^{\prime} 30^{\prime \prime}$ W.; (map 24).

Name published in 1965 by USC\&GS.

Welcome Cove: estuary, extends NE $0.6 \mathrm{mi}$., on W coast of Dall I., W of Lake Welcome, Alex. Arch.; $54^{\circ} 58^{\prime} 30^{\prime \prime} \mathrm{N}, 133^{\circ} 09^{\prime} 45^{\prime \prime} \mathrm{W}$; (map 1).

Name published by USC\&GS in the 1925 Coast Pilot (p. 168).

Welcome Creek: stream, flows NW $15 \mathrm{mi}$. from a glacier to Kanayut River, $9 \mathrm{mi}$. $\mathrm{S}$ of Table Top and $31 \mathrm{mi}$. NE of Anaktuvuk Yass, Brooks Ra.; $68^{\circ} 29^{\prime} \mathrm{N}, 150^{\circ} 58^{\prime} \mathrm{W}$; (map 134).

Named by USGS geologists during the exploration of Naval Petroleum Reserve No. 4; name given in 1944

Welcome Point: point of land, between Camp and Welcome Coves, on W coast of Dall I., Alex. Arch.; 54 $53^{\circ} 55^{\prime \prime} \mathrm{N}, 133^{\circ} 10^{\prime} 15^{\prime \prime} \mathrm{W}$; $B G N$ 1928; (map 1).

Named in 1927 by USC\&GS "because of its proximity to Welcome Cove."

Welker, Mount: mountain, 5,155 ft., AlaskaCanada boundary, $6 \mathrm{mi}$. $\mathrm{N}$ of Hyder, Coast Mts.; $56^{\circ} 00^{\prime} 30^{\prime \prime} \mathrm{N}, 130^{\circ} 00^{\prime} 05^{\prime \prime} \mathrm{W} ; B G N$ 1923; (map 7).

Named in 1923 by USC\&GS for Capt. Philip A. Welker, USC\&GS, an IBC surveyor from 1893 to 1895 and "who, in 1895, astronomically determined the southern land origin of the Alaska Lisiere boundary, at a point about 2 miles east of this peak * * ."

Well Creek: stream, flows SE $1.5 \mathrm{mi}$. to Bowser Creek, $0.5 \mathrm{mi}$. N of Oil Bay and $22 \mathrm{mi}$. N of Augustine I., Aleutian Ra.; $59^{\circ} 40^{\prime} 30^{\prime \prime} \mathrm{N}$, $153^{\circ} 19^{\prime} 00^{\prime \prime} \mathrm{W}$; BGN 1962; (map 51)

So named locally because it flows through an area where wells were drilled for oil.

Weller, Mount: mountain, 4,744 ft., in Sadlerochit Mts., $4 \mathrm{mi}$. NW of Sunset Pass and 27 mi. NW of Mount Michelson, Brooks Ra.; $69^{\circ} 38^{\prime} \mathrm{N}, 144^{\circ} 53^{\prime} \mathrm{W}$; BGN 1961; (map 139). Var. Weller Peak.
Named by Leffingwell (1919, p. 100), USGS, for Stuart Weller, 1870-1927, American geologist and paleontologist.

Wellesley Glacier: glacier, trends E $4 \mathrm{mi}$. to a lagoon, on $W$ bank of College Fiord, $3.7 \mathrm{mi}$. SW of College Point and $54 \mathrm{mi}$. W of Valdez, Chugach Mts.; $61^{\circ} 11^{\prime} \mathrm{N}, 147^{\circ} 52^{\prime} \mathrm{W}$; (map 69).

Named in 1899 by members of the Harriman Alaska Expedition of Wellesley College, Wellesley, Mass.

Wellesley Lakes: lakes, group, extend $3 \mathrm{mi}$., in Nutzotin Mts., $\mathrm{N}$ of Wellesley Mtn., $13 \mathrm{mi}$. SW of point where Alaska Highway crosses Alaska-Canada boundary, Alaska Ra.; $62^{\circ} 28^{\prime}$ N, $141^{\circ} 18^{\prime} \mathrm{W}$; (map 84).

Named in 1891 by C. W. Hayes, USGS, for Wellesley College.

Wellesley Mountain: mountain, 4,966 ft., between Snag Creek and Chisana River, $16 \mathrm{mi}$. SW of point where Alaska Highway crosses Alaska-Canada boundary, Alaska Ra.; $62^{\circ} 11^{\prime}$ $\mathrm{N}, 141^{\circ} 17^{\prime} \mathrm{W}$; (map 84).

Named in 1898 by W. J. Peters and A. H. Brooks, USGS, for Wellesley College.

Wells: locality, on E shore of Chilkat River, 1.8 mi. NW of Klukwan and $22 \mathrm{mi}$. W of Skagway, Coast Mts.; $59^{\circ} 25^{\prime} 00^{\prime \prime} \mathrm{N}, 135^{\circ} 55^{\prime} 45^{\prime \prime}$ W; $(\operatorname{map} 45)$.

Local name reported by Wright (1904, pl. 2 and p. 11) USGS. A mining office was established here in 1900, and in 1903 it was a post for the Northwest Mounted Police on what was then the provisional boundary between the United States and Canada.

Wells, Port: estuary, extends S $14 \mathrm{mi}$. from S end of College Fiord to Wells Passage, $16 \mathrm{mi}$. E of Whittier, Chugach Mts.; $60^{\circ} 48^{\prime} \mathrm{N}, 148^{\circ} 14^{\prime}$ W; (map 63).

Named in 1794 by Capt. Vancouver (Wag. ner, 1937, p. 421), RN, "perhaps for Edward Wells, mathematician and geographer."

Wells Bay: estuary, extends S. $9.5 \mathrm{mi}$. to Prince William Sound, $44 \mathrm{mi}$. NE of Whittier, Chugach Mts.; $60^{\circ} 53^{\prime} 30^{\prime \prime} \mathrm{N}, 147^{\circ} 28^{\prime} 30^{\prime \prime} \mathrm{W}$; (map 63).

Local name reported in 1908 by U. S. Grant and D. F. Higgins (in Brooks and others, 1909, pl. 4), USGS. Name probably derived from nearby Port Wells.

Wells Greek: stream, flows SW $18 \mathrm{mi}$. to Nenana River, $38 \mathrm{mi}$. SE of Healy, Alaska Ra.; $63^{\circ}$. $23^{\prime} 30^{\prime \prime} \mathrm{N}, 148^{\circ} 22^{\prime} 30^{\prime \prime} \mathrm{W}$; (map 87).

Local name reported in 1913 by J. W. Bagley, USGS.

Wells Creek: stream, flows SE $5.5 \mathrm{mi}$. to Tozimoran Creek $6 \mathrm{mi}$. NW of that stream's junc. with Tozitna River, $23 \mathrm{mi}$. NW of Tanana. Kokrines-Hodzana high.; $65^{\circ} 24^{\prime} 00^{\prime \prime} \mathrm{N}, 152^{\circ}$ $39^{\prime} 30^{\prime \prime} \mathrm{W}$; (map 106).

Prospectors' name reported in 1956 by R. M. Chapman, USGS.

Wells Mountain: ridge, 5,500 ft., extends NE $13 \mathrm{mi}$. between Iron Creek and Talkeetna River, $24 \mathrm{mi}$. NE of Talkeetna, Talkeetna Mts.; $62^{\circ} 26^{\prime} \mathrm{N}, 149^{\circ} 12^{\prime} \mathrm{W}$; (map 82).

Local name recorded in 1950 by USGS. 
Wells Passage: water passage, extends E $16 \mathrm{mi}$. from $S$ end of Port Wells to Prince William Sound, on S side of Esther I., $24 \mathrm{mi}$. E of Whittier, Chugach Mts.; $60^{\circ} 46^{\prime} \mathrm{N}, 148^{\circ} 04^{\prime}$ W; BGN 1914; (map 63).

Local name reported in 1914 by USC\&GS; so named because it leads to Port Wells.

Wenjaminow, Vulkan: volcano, see Veniaminof, Mount.

Wenrich Island: island, $1.1 \mathrm{mi}$. long, in Tanana River, across from mouth of Chena River, 6 mi. SW of Fairbanks, Tanana Low.; $64^{\circ} 47^{\prime}$ $15^{\prime \prime} \mathrm{N}, 147^{\circ} 55^{\prime} 00^{\prime \prime} \mathrm{W}$; (map 100).

Local name reported in 1950 by USGS topographers.

Werick Island: island, $0.5 \mathrm{mi}$. long, SW of Hotspur I., in Sealed Passage, Alex. Arch.; 54\% $57^{\prime} 45^{\prime \prime} \mathrm{N}, 131^{\circ} 31^{\prime} 00^{\prime \prime} \mathrm{W}$; (map 2).

Named by USC\&GS in 1886 .

Wernicke Glacier: glacier, trends W $20 \mathrm{mi}$. to its terminus at Wernicke River, $45 \mathrm{mi}$. N of Katalla, Chugach Mts.; $60^{\circ} 49^{\prime} 15^{\prime \prime} \mathrm{N}, 144^{\circ}$ $18^{\prime} 30^{\prime \prime} \mathrm{W}$; (map 64).

Name published in 1959 by USGS.

Wernicke River: stream, flows W $8 \mathrm{mi}$. to the Copper River, $45 \mathrm{mi}$. N of Katalla, Chugach Mts.; $60^{\circ} 15^{\prime} \mathrm{N}, 144^{\circ} 30^{\prime} \mathrm{W}$; (map 64).

Named by Lawrence Martin in 1910, for L. Wernicke "one of the engineers building the Copper River and Northwestern Railway."

Werstberg Mountain: mountain, see Verstovia, Mount.

Weshrinarin Creek: stream, flows NE $8 \mathrm{mi}$. to Yukon River $9 \mathrm{mi}$. E of its junc. with Charley River, Yukon-Tanana High.; $65^{\circ} 20^{\prime} \mathrm{N}, 142^{\circ}$ $28^{\prime}$ W ; (map 103).

Prospectors' name from a map by E. F. Ball dated 1898. The name appears to be of Indian origin.

Wesley Creek: stream, flows $\mathrm{S} 9 \mathrm{mi}$. to Kobuk River, 2 mi. E of Shungnak, Kotzebue-Kobuk Low.; $66^{\circ} 54^{\prime} \mathrm{N}, 157^{\circ} 03^{\prime} \mathrm{W}$; (map 115).

Local name reported in 1910 by P. S. Smith and H. M. Eakin, USGS.

Wesley Creek: stream, see Seattle Creek.

Wesley Falls Creek: stream, flows NW $2 \mathrm{mi}$. to Rude River, $10 \mathrm{mi}$. NE of Cordova, Chugach Mts. ; $60^{\circ} 40^{\prime} 30^{\prime \prime} \mathrm{N}, 145^{\circ} 35^{\prime} 20^{\prime \prime} \mathrm{W}$; (map 64).

Local name reported in 1913 by $B$. $L$. Johnson (in Brooks and others, 1914, pl. 7), USGS.

Wesselow: volcano, see Makushin Volcano.

Wessels Reef: reef, in Gulf of Alaska, 22 mi. N of Middleton I., Malaspina Coastal Plain; $59^{\circ} 47^{\prime} \mathrm{N}, 146^{\circ} 12^{\prime} \mathrm{W}$; (map 48).

Named by USC\&GS for John Wessels, master of the schooner Kodiak, who discovered the reef on October 25,1881 .

West Amatuli Island: island, $3 \mathrm{mi}$. long, one of the Barren Is., in Gulf of Alaska, between East Amatuli I. and Ushagat I., $70 \mathrm{mi}$. NE of Afognak, Chugach Mts.; $58^{\circ} 56^{\prime} \mathrm{N}, 152^{\circ} 03^{\prime}$ W; (map 43). Var. Amatuli Island.

Name given by USGS in 1908 in contradistinction to East Amatuli Island. This island is one of the "Islas de Langara" [Barren Islands] named in 1779 by Don Juan de la Bo- dega y Quadra and Francisco Antonio Maurelle for Juan de Langara. See East Amatuli Island.

West Anchor Cove: bay, $2.5 \mathrm{mi}$. across, on Ikatan Penin. on SE coast of Unimak I., Aleutian Is.; $54^{\circ} 41^{\prime} \mathrm{N}, 163^{\circ} 11^{\prime} \mathrm{W}$; (map 25).

Descriptive name given in 1888 by USBF. West Arm: bay, see Deep Cove.

West Arm: bay, see Taroka Arm.

West Arm Bay of Isles: estuary, on $\mathrm{E}$ coast of Knight I., trends E 2 mi. to head of Bay of Isles, $14 \mathrm{mi}$. NE of Chenega and $44 \mathrm{mi}$. SE of Whittier, Chugach Mts.; $60^{\circ} 23^{\prime} 15^{\prime \prime} \mathrm{N}, 147^{\circ}$ 42'30' W; BGN 1917; (map 63). Var. North Arm.

Descriptive name published in 1917 by USC\&GS

West Arm Chilkoot Inlet: estuary, see Lutak Inlet.

West Arm Cholmondeley Sound: estuary, extends W $7.5 \mathrm{mi}$, at head of Cholmondeley Sound, on SE coast of Prince of Wales I., Alex. Arch.; $55^{\circ} 15^{\prime} \mathrm{N}, 132^{\circ} 17^{\prime} \mathrm{W}$; $B G N$ 1961; (map 4).

Local name reported in 1901 by $\mathrm{A}$. $\mathrm{H}$. Brooks, USGS.

West Arm Holtz Bay: bay, on Attu I., extends W 1.5 mi from Center Point in Holtz Bay, Aleutian Is.; $52^{\circ} 55^{\prime} 50^{\prime \prime} \mathrm{N}, 173^{\circ} 09^{\prime} 00^{\prime \prime} \mathrm{E}$; (map 13).

Descriptive name published in 1947 Alaska Coast Pilot (pt. 2, p. 492).

West Arm Kendrick Bay: estuary, extends NW $2.5 \mathrm{mi}$. off Kendrick Bay, on SE coast of Prince of Wales I., Alex. Arch.; 54 $53^{\prime} 30^{\prime \prime}$ $\mathrm{N}, 132^{\circ} 03^{\prime} 15^{\prime \prime} \mathrm{W}$; (map 1$)$.

Local name reported by $H$. C. Fassett, USBF, in 1904

West Arm Mirror Harbor: bay, $0.1 \mathrm{mi}$. across, between Bertha Bay and Mirror Harbor, on W coast of Chichagof I., $12 \mathrm{mi}$. NW of Chichagof, Alex. Arch.; $57^{\circ} 47^{\prime} 40^{\prime \prime} \mathrm{N}, 136^{\circ}$ 19'30" W; (map 9).

Descriptive name published by USC\&GS in the 1925 Coast Pilot (p. 322).

West Arm Moira Sound: estuary, extends W 3 mi., off Moira Sound, on SE coast of Prince of Wales I., Alex. Arch.; $55^{\circ} 00^{\prime}$ N, $132^{\circ} 11^{\prime}$ W; (map 1).

Descriptive local name recorded in 1904 by H. C. Fassett, USBF.

West Arm Nakwasina Passage: water passage, see Nakwasina Passage.

West Arm Nevidiskov Bay: bay, $0.8 \mathrm{mi}$. across, on $\mathbf{S}$ coast of Attu I., NW part of Nevidiskov Bay, Aleutian Is.; $52^{\circ} 47^{\prime} 30^{\prime \prime} \mathrm{N}, 172^{\circ} 49^{\prime} 30^{\prime \prime}$ E; (map 13).

Descriptive name referred to as the "West Arm" in 1946 supplement to 1944 Aleutian Coast Pilot.

West Arm Nuka Bay: estuary, 2 mi. wide, on SE coast of Kenai Penin., $42 \mathrm{mi}$. E of Seldovia, Chugach Mts.; $59^{\circ} 28^{\prime} \mathrm{N}, 150^{\circ} 33^{\prime} \mathrm{W}$; $B G N$ 1929: (map 50).

Local descriptive name reported in 1927 by USC\&GS.

West Arm Perenosa Bay: bay, see Big Waterfall Bay.
West Arm Port Dick: bay, $1.2 \mathrm{mi}$. wide, on S shore of Kenai Penin., $25 \mathrm{mi}$. SE of Seldovia, Chugach Mts.; $59^{\circ} 15^{\prime} 45^{\prime \prime} \mathrm{N}, 151^{\circ} 05^{\prime} 45^{\prime \prime} \mathrm{W}$; (map 50).

Local descriptive name reported in 1912 by USC\&GS on Coast Chart 8554.

West Arm Solomon River: stream, distributary of Solomon River, flows S $2 \mathrm{mi}$. from Solomon River at Solomon to a lagoon at Norton Sound, Seward Penin. High.; $64^{\circ} 28^{\prime} \mathrm{N}, 164^{\circ}$. $26^{\prime} \mathrm{W}$; (map 95).

Local name reported in 1903 or 1904 on a location map of Council City \& Solomon River Railroad.

West Bay: cove, $0.7 \mathrm{mi}$. wide, on $\mathrm{N}$ coast of Bligh Island, $42 \mathrm{mi}$. NW of Cordova, Chugach Mts.; $60^{\circ} 54^{\prime} \mathrm{N}, 146^{\circ} 47^{\prime} \mathrm{W}$; BGN 1913; (map 64). Var. Busby Bay.

Local name used by boat captains reported in 1903 by H. P. Ritter, USC\&GS.

West Bay: bay, see Three Arm Bay.

West Beach: beach, $0.7 \mathrm{mi}$. long, on NE coast of Attu I. at head of West Arm Holtz Bay, Aleutian Is.; $52^{\circ} 55^{\prime} 40^{\prime \prime} \mathrm{N}, 1^{\prime} 73^{\circ} 07^{\prime} 40^{\prime \prime} \mathrm{E}$; (map 13).

Descriptive name given by U.S. Army during World War II; published in 1948 by AMS.

West Beaver Lake: lake, $0.8 \mathrm{mi}$. long, one of the Beaver Lakes, $25 \mathrm{mi}$. N of Anchorage, Cook Inlet Low.; $61^{\circ} 35^{\prime} 10^{\prime \prime} \mathrm{N}, 149^{\circ} 50^{\prime} 30^{\prime \prime}$ W; (map 69).

Local name reported in 1950 by USGS.

West Bee Rock: rock, one of Bee Rocks in Clarence Strait, $4 \mathrm{mi}$. SW of Duke I., Alex.

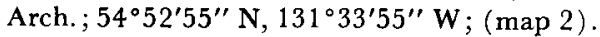

Local name published in 1943 by USC\&GS.

West Bight: cove, see Mailboat Cove.

West Branch: stream, see Tamarack Creek.

West Branch Eklutna Glacier: glacier, trends NE $4 \mathrm{mi}$. to Eklutna Glacier, $30 \mathrm{mi}$. $\mathrm{E}$ of Anchorage, Chugach Mts.; 61 ${ }^{\circ} 15^{\prime} 05^{\prime \prime} \mathrm{N}, 148^{\circ}$ 59'30" W; BGN 1964; (map 69).

Local name reported in 1964 by USGS.

West Branch Sherrette Creek: stream, flows NE $9 \mathrm{mi}$. to Sherrette Creek, $17 \mathrm{mi}$. SE of Mount Bendeleben and $56 \mathrm{mi}$. SW of Imuruk Lake, Seward Penin. High.; $65^{\circ} 01^{\prime} \mathrm{N}, 164^{\circ} 32^{\prime} \mathrm{W}$; (map 110). Var. Sherrett Creek.

Local name published in 1956 by USGS. Shown as "Sherrett" on a 1901 map of Cape Nome gold fields by David Fox, Jr.

West Branch Simeon Creek: stream, see Featherly Creek.

West Branch Taku Glacier: glacier, trends NE $6.5 \mathrm{mi}$. to Taku Glacier, $3 \mathrm{mi}$. $\mathrm{E}$ of Tricouni Peak and $26 \mathrm{mi}$. N of Juneau, Coast Mts.; $58^{\circ} 41^{\prime} \mathrm{N}, 134^{\circ} 25^{\prime} \mathrm{W}$; BGN 1965; (map 11). Var. Northwest Branch Taku Glacier.

Named in 1964 by members of the Juneau Icefield Research Project.

Westbrook Glacier: glacier, trends N $1.3 \mathrm{mi}$. to its terminus at head of Big Creek, $5 \mathrm{mi}$. SW of Mount Shasta and $14 \mathrm{mi}$. W of Valdez, Chugach Mts.; $61^{\circ} 07^{\prime} 45^{\prime \prime} \mathrm{N}, 146^{\circ} 41^{\prime} 10^{\prime \prime} \mathrm{W}$; (map 68).

Local name reported in 1911 by USGS.

West Brother: island, see West Brother Island. 
West Brother Island: island, $2 \mathrm{mi}$. long, in The Brothers Is., $59 \mathrm{mi}$. E of Sitka, Alex. Arch.; $57^{\circ} 17^{\prime} 30^{\prime \prime} \mathrm{N}, 133^{\circ} 51^{\prime} 15^{\prime \prime}$ W; (map 8). Var. West Brother.

Descriptive name published in 1940 by USGS.

West Buttons: mountain, E of South Fork Flats, $11 \mathrm{mi}$. W of East Buttons and $31 \mathrm{mi}$. SW of Chandalar, Brooks Ra.; $67^{\circ} 15^{\prime} \mathrm{N}, 149^{\circ} 26^{\prime} \mathrm{W}$; (map 123).

Local name reported in 1956 by T. E. Taylor, USGS.

West Buttress: ridge, elev. 12,000-18,000 ft., in Mount McKinley National Park, extends W $2.7 \mathrm{mi}$. from Denali Pass, on Mount McKinley, Alaska Ra.; $63^{\circ} 05^{\prime} \mathrm{N}, 151^{\circ} 04^{\prime} \mathrm{W}$; (map 88).

Descriptive name reported in 1910 by F. A. Cook.

West Canning River: stream, distributary of Canning River, heads at $69^{\circ} 56^{\prime} 30^{\prime \prime} \mathrm{N}, 146^{\circ}$ $19^{\prime} 00^{\prime \prime} \mathrm{W}$, and flows NE $18 \mathrm{mi}$. to Lion Bay, Arctic Plain; $70^{\circ} 09^{\prime} 10^{\prime \prime} \mathrm{N}, 145^{\circ} 56^{\prime} 10^{\prime \prime} \mathrm{W}$; (map 151)

This may be the stream Franklin (1828) shows as Sir T. Staines R. on his map.

West Cape: point of land, on W coast of Deer I., at SW end of Aleutian Ra.; $54^{\circ} 55^{\prime} 40^{\prime \prime} \mathrm{N}$, $162^{\circ} 25^{\prime} 00^{\prime \prime} \mathrm{W}$; (map 25).

Descriptive name given in 1888 by USBF. West Cape: point of land, see Bunnell Cape. West Cape: point of land, see Tatik Point. West Cape: point of land, see Vngyat Point. West Cape: point of land, see Zapadni Point. West Cape Lazaref: point of land, see Aksit, Cape.

West Channel: channel, $13 \mathrm{mi}$. long, in Nushagak Bay, W of Big Shoals, $20 \mathrm{mi}$. SW of Dillingham, Bristol Bay Low.; $58^{\circ} 36^{\prime} \mathrm{N}, 158^{\circ} 30^{\prime} \mathrm{W}$; (map 40).

Name reported in 1950 by USC\&GS; location and navigability of these channels changes from year to year.

West Channel: water passage, along $\mathrm{W}$ shore of Pybus Bay, at SE end of Admiralty I., $25 \mathrm{mi}$. $\mathrm{SE}$ of Angoon, Alex. Arch.; $57^{\circ} 18^{\prime} \mathrm{N}, 134^{\circ} 06^{\prime}$ W; (map 9).

Descriptive name published by USC\&GS in the 1932 Coast Pilot (p. 290).

West Channel Hayward Strait: water passage, between Hayward Strait and Krestof Sound, $11 \mathrm{mi}$. NW of Sitka, Alex. Arch.; $57^{\circ} 09^{\prime} 10^{\prime \prime}$ $\mathrm{N}, 135^{\circ} 34^{\prime} 00^{\prime \prime} \mathrm{W}$; (map 9).

Descriptive name published in 1900 by USC\&GS on Chart 8281.

West Channel Island: island, $0.7 \mathrm{mi}$. long, in Wide Bay, NE of Terrace I., on SE coast of Alaska Penin, $45 \mathrm{mi}$. SE of Ugashik, Aleutian Ra.; 57 $23^{\prime} 20^{\prime \prime} \mathrm{N}, 156^{\circ} 14^{\prime} 30^{\prime \prime} \mathrm{W}$; (map 36). Descriptive name given in 1923 by USC\&GS

West Channel Kuskokwim Bay: channel, extends S $24 \mathrm{mi}$. from mouth of Kuskokwim River to point $20 \mathrm{mi}$. W of Kwinhagak, $30 \mathrm{mi}$. NW of Carter Bay, Yukon-Kuskokwim Delta; $59^{\circ} 40^{\prime}$ $\mathrm{N}, 162^{\circ} 30^{\prime} \mathrm{W} ;(\operatorname{map} 54)$.

Descriptive name given in 1913 by USC\&GS
West Channel Massacre Bay: water passage, western entrance to Massacre Bay, on SE coast of Attu I., Aleutian Is.; 52 $49^{\prime} 00^{\prime \prime} \mathrm{N}$, $172^{\circ} 12^{\prime} 15^{\prime \prime} \mathrm{E}$; (map 13).

Descriptive name listed in 1944 Aleutian Coast Pilot.

West Chunu Point: point of land, on SW coast of Kanaga I., Aleutian Is. ; $51^{\circ} 39^{\prime} 50^{\prime \prime} \mathrm{N}, 177^{\circ}$ 40'00" W; (map 17)

Descriptive name published in 1951 on a USGS map.

West Clem Creek: stream, flows SW $4.3 \mathrm{mi}$. to Duck Creek, $52 \mathrm{mi}$. NW of Haycock, Seward Penin. High.; $65^{\circ} 57^{\prime} \mathrm{N}, 161^{\circ} 30^{\prime} \mathrm{W}$; (map 109).

Local name published on maps after 1950.

West Cove: cove, $0.8 \mathrm{mi}$. across, just $\mathrm{N}$ of Sitkin Point, on the $W$ coast of Little Sitkin I., Aleutian Is.; $51^{\circ} 57^{\prime} 30^{\prime \prime} \mathrm{N}, 178^{\circ} 27^{\prime} 30^{\prime \prime} \mathrm{E}$; (map 15). Var. West-northwest Cove.

Reported by Snyder (1959, pl. 23), USGS.

West Cove: cove, $0.6 \mathrm{mi}$. across, on $\mathrm{W}$ coast of Agattu I., Aleutian Is. ; $52^{\circ} 26^{\prime} 10^{\prime \prime} \mathrm{N}, 172^{\circ}$ $24^{\prime} 30^{\prime \prime}$ E; (map 13)

Listed in 1944 Aleutian Coast Pilot.

West Cove: cove, $1 \mathrm{mi}$. across, on $\mathrm{W}$ shore of Stepovak Bay, near SW end of Alaska Penin., Aleutian Ra.; $55^{\circ} 38^{\prime} 30^{\prime \prime} \mathrm{N}, 160^{\circ} 16^{\prime} 00^{\prime \prime} \mathrm{W}$; (map 28)

Named by Harriman Alaska Expedition (1904, v. 4, p. 75).

West Crawfish Inlet: $b a y, 0.5 \mathrm{mi}$. across and $8 \mathrm{mi}$. long, $5 \mathrm{mi}$. SE of Goddard, on W coast of Baranof I., Alex. Arch.; $56^{\circ} 47^{\prime} \mathrm{N}, 135^{\circ} 15^{\prime}$ W; (map 5).

Local name used by fishermen; published in 1929 by USC\&GS.

West Creek: stream, flows SE $5 \mathrm{mi}$. to mouth of Main Creek, at Amber Bay, on S shore of Alaska Penin., $11.5 \mathrm{mi}$. NW of Cape Kunmik, Aleutian Ra.; $56^{\circ} 51^{\prime} \mathrm{N}, 157^{\circ} 28^{\prime} \mathrm{W}$; (map 31).

Local descriptive name reported in 1951 by USGS

West Creek: stream, flows SE $2.8 \mathrm{mi}$. to Shovel Creek, $8 \mathrm{mi}$. N of Solomon, Seward Penin. High.; $64^{\circ} 40^{\prime} \mathrm{N}, 164^{\circ} 25^{\prime} \mathrm{W}$; (map 95).

Prospectors' name reported in 1900 by E. C. Barnard (in Brooks, 1901, pl. 1.7), USGS.

West Creek: stream, flows E $1.7 \mathrm{mi}$. to Inmachuk River, $23 \mathrm{mi}$. NE of Imuruk Lake, Seward Penin. High.; $65^{\circ} 52^{\prime} \mathrm{N}, 162^{\circ} 58^{\prime} \mathrm{W}$; (map 110).

Prospectors' name reported in 1901 by D. L. Reaburn (in Mendenhall, 1902, pl. 4a), USGS.

West Creek: stream, see Esch Creek.

Westdahl Cove: cove, $1 \mathrm{mi}$. wide, on $\mathrm{W}$ coast of Nuka I., $34 \mathrm{mi}$. SE of Seldovia, Chugach Mts.; $59^{\circ} 19^{\prime} 30^{\prime \prime} \mathrm{N}, 150^{\circ} 46^{\prime} 00^{\prime \prime} \mathrm{W}$; $B G N$ 1931; (map 50)

Named by a USC\&GS field party "for the launch Westdahl used in making surveys in this area."

Westdahl Peak: mountain, 5,118 ft., on SW Unimak I., $13 \mathrm{mi}$. W of Cape Lutke, Aleutian Is.; $54^{\circ} 31^{\prime} \mathrm{N}, 164^{\circ} 39^{\prime} \mathrm{W}$.; (map 24).

Named in 1902 by O. H. Tittmann,
USC\&GS, for Ferdinand Westdahl, USC\&GS who determined its geographic position in 1901

Westdahl Point: point of laind, in Glacier Bay National Monument, $4 \mathrm{mi}$. $\mathrm{N}$ of Wachusett Inlet, on Muir Inlet, $66 \mathrm{mi}$. NW of Hoonah, St. Elias Mts. ; $58^{\circ} 58^{\prime} 45^{\prime \prime} \mathrm{N}, 136^{\circ} 08^{\prime} 30^{\prime \prime} \mathrm{W}$; (map 10)

Named by members of the Glacier Bay Expedition of 1941 (Field, 1947, pl. 1) for the USC\&GS vessel Westdahl, which was engaged in charting Muir Inlet in 1939 and 1940. The most northerly soundings in the bay were made off this point.

Westdahl Reef: rock, see Westdahl Rock.

Westdahl Rock: rock, $9 \mathrm{mi}$. SE of Cape Pankof, Unimak I., and $9 \mathrm{mi}$. $\mathrm{N}$ of Point Petrof, Sanak I., Aleutian Ra.; 54 $37^{\prime} 30^{\prime \prime}$ N $162^{\circ} 50^{\prime} 15^{\prime \prime} \mathrm{W}$; BGN 1965; (map 25). Var. Gilbert Reef, McArthur Reef, New Shoal, Westdahl Reef.

Named "Westdahl Reef" by USC\&GS in 1925 for Ferdinand Westdahl, USC\&GS, commander of the Coast Survey steamer $\mathrm{Mc}$ Arthur, who made surveys in the area in 1901. This feature was discovered by W. E. Parker, USC\&GS, commander of the steamer Patterson, during a survey of the area in 1911 . West End Creek: stream, heads on Sheep Mtn., flows W $1.7 \mathrm{mi}$. to Caribou Creek, $49 \mathrm{mi}$. NE of Palmer, Talkeetna Mts.; 61 $48^{\prime} 30^{\prime \prime} \mathrm{N}$, $147^{\circ} 41^{\prime} 30^{\prime \prime} \mathrm{W}$; BGN 1960; (map 69).

Named in 1956 by USGS because "it is located at the west end of Sheep Mountain."

Westerly Island: island, $0.2 \mathrm{mi}$. long, in Ernest Sound, $1.6 \mathrm{mi}$. S of Brownson I. and $48 \mathrm{mi}$. $\mathrm{NE}$ of Craig, Alex. Arch.; 55 $54^{\prime} 10^{\prime \prime} \mathrm{N}$, $132^{\circ} 09^{\prime} 15^{\prime \prime} \mathrm{W}$; (map 4).

Local descriptive name published in 1923 by USC\&GS.

Western Anchorage: water passage, in NW part of Sitka Harbor, $1 \mathrm{mi}$. NW of Sitka, Alex. Arch.; $57^{\circ} 03^{\prime} 30^{\prime \prime} \mathrm{N}, 135^{\circ} 21^{\prime} 40^{\prime \prime} \mathrm{W}$; (map 9).

Local name reported by Baker (1906, p 670), USGS

Western Channel: water passage, in Sitka Sound, extends $\mathrm{N}$ toward Western Anchorage, Sitka Harbor, $2 \mathrm{mi}$. W of Sitka, Alex. Arch. $57^{\circ} 03^{\prime} 00^{\prime \prime} \mathrm{N}, 135^{\circ} 23^{\prime} 30^{\prime \prime} \mathrm{W}$; (map 9). Var. Farvater Zapadnyy.

An 1882 translation by USC\&GS of name "Farv[ater] Zapadnyy" published by Capt. Tebenkov (1852, map 38).

Western Inlet: bay, $0.3 \mathrm{mi}$. across, on NW coast of Shuyak I., $46 \mathrm{mi}$. N of Kodiak 1 . $58^{\circ} 35^{\prime} 30^{\prime \prime} \mathrm{N}, 152^{\circ} 37^{\prime} 30^{\prime \prime} \mathrm{W}$; (map 43).

Name published by USC\&GS in 1927 on Chart 8555.

Western Point: point of land, W tip of Kanaga I., Aleutian Is.; $51^{\circ} 42^{\prime} 30^{\prime \prime} \mathrm{N}, 177^{\circ} 42^{\prime} 00^{\prime \prime} \mathrm{W}$; (map 17)

Name published by USC\&GS in the 1947 Coast Pilot (pt. 2, p. 469).

Western Sitkin Island: island, see Little Sitkin Island.

Western Unalga Island: island, see Unalga Island. 
West Finger Lake: lake, one of the Finger Lakes, on Kenai Penin., 13 mi. NE of Kenai, Cook Inlet Low.; $60^{\circ} 39^{\prime} \mathrm{N}, 150^{\circ} 54^{\prime} \mathrm{W}$; (map 62).

Named about 1963 by officials of Kenai National Moose Range, for administrative purposes.

West Flank Island: island, off SE coast of Esther I., at SE end of Esther Passage, $26 \mathrm{mi}$. NE of Whittier, Chugach Mts. ; $60^{\circ} 48^{\prime} 50^{\prime \prime} \mathrm{N}, 147^{\circ}$ 54'15' W; (map 63).

Local name reported in 1952 by USGS.

West Foreland: point of land, on W shore of Cook Inlet, between Redoubt and Trading Bays, $20 \mathrm{mi}$. NW of Kenai, Cook Inlet Low.; $60^{\circ} 43^{\prime} 00^{\prime \prime} \mathrm{N}, 151^{\circ} 42^{\prime} 30^{\prime \prime} \mathrm{W}$; (map 62). Var. Mys Zapadnyy ili Kystotank, West Forland.

Named by Capt. George Vancouver, RN, on April 18, 1794 (Wagner, 1937, p. 421). The name "M[ys] Zapadnyy ili Kystotank," meaning "West or Kystotank Cape," was published in 1847 for this feature on Russian Hydrog. Dept. Chart 1378.

West Forest Lake: lake, $0.7 \mathrm{mi}$. Iong, on Kenai Penin. W of East Forest Lake, $9 \mathrm{mi}$. $\mathrm{N}$ of Sterling and $15 \mathrm{mi}$. NE of Kenai, Cook Inlet Low. ; $60^{\circ} 40^{\prime} \mathrm{N}, 150^{\circ} 50^{\prime} \mathrm{W}$; (map 62). Var. Forest Lake.

Named about 1963 by officials of Kenai National Moose Range, for administrative purposes.

West Fork: locality, on right bank of West Fork Tolovana River, $6 \mathrm{mi}$. SW of Livengood, Yukon-Tanana High.; $65^{\circ} 27^{\prime}$ N. $148^{\circ} 39^{\prime}$ W; (map 105).

This place, being at the head of navigation for small boats on the Tolovana River, was established in 1915 as a small supply point for the Livengood camp. In 1916 it contained a sawmill, roadhouse, and some warehouses (Brooks and others, 1918, p. 229).

West Fork: stream, see Big River.

West Fork Ahtell Creek: stream, flows SE $6 \mathrm{mi}$. to Ahtell Creek, $8 \mathrm{mi}$. NW of Slana, Alaska Ra.; $62^{\circ} 49^{\prime} \mathrm{N}, 144^{\circ} 04^{\prime} \mathrm{W}$; (map 83 ).

Local name reported in 1954 by USGS.

West Fork Arolic Creek: stream, see Faro Creek.

West Fork Blue River: stream, flows S $1.5 \mathrm{mi}$. from Canada near boundary monument 46 to left bank of Blue River, $3 \mathrm{mi}$. NW of Blue Lake, Coast Mts.; $56^{\circ} 22^{\prime} 30^{\prime \prime} \mathrm{N}, 130^{\circ} 58^{\prime} 15^{\prime \prime}$ W; $(\operatorname{map} 7)$.

Local name reported in 1955 by USGS.

West Fork Buck Creek: stream, heads on Potato Mtn. and flows NE $1 \mathrm{mi}$. to Buck Creek, in Mint River basin, $17 \mathrm{mi}$. NE of Cape Prince of Wales, Seward Penin. High.; 65 $5^{\circ} 39^{\prime} 30^{\prime \prime}$ N, 167 $31^{\prime} 45^{\prime \prime} \mathrm{W}$; (map 111)

Prospectors' name reported in 1918 by Steidtmann and Cathcart (1922, fig. 14), USGS.

West Fork Buckland River: stream, flows NW 41 mi. to Buckland River, $45 \mathrm{mi}$. NE of Haycock, Seward Penin. High.; $65^{\circ} 49^{\prime} \mathrm{N}, 160^{\circ} 40^{\prime}$ W: (map 109).

Local name reported in 1908 by USGS (Brooks and others, 1909, fig. 21).
West Fork Chandalar River: stream, flows E 24 mi. to North Fork Chandalar River $5 \mathrm{mi}$. W of that stream's junc. with Middle Fork Chandalair River and $21 \mathrm{mi}$. S of Chandalar, Brooks Ra.; $67^{\circ} 11^{\prime} 20^{\prime \prime} \mathrm{N}, 148^{\circ} 30^{\prime} 30^{\prime \prime} \mathrm{W}$; $B G N$ 1912; (map 123). Var. Granite Creek.

Local name reported in 1912 by $\mathrm{A}$. $\mathrm{H}$. Brooks, USGS. T. G. Gerdine, USGS, shows the name "Granite Greek" on an 1899 fieldsheet.

West Fork Chandalar River : stream, see Crooked Creek.

West Fork Chandalar River: stream, see Granite Creek.

West Fork Chena River: stream, flows SW 16 mi., joins North Fork Chena River to form Chena River, 48 mi. NE of Fairbanks, YukonTanana High.; $65^{\circ} 03^{\prime} 12^{\prime \prime} \mathrm{N}, 146^{\circ} 11^{\prime} 00^{\prime \prime} \mathrm{W}$; $B G N 1965$; (map 104).

Named by prospectors; reported in 1903 by USGS (Prindle, 1905; pl. 13). The early maps included Frozenfoot Creek as part of Wiest Fork

West Fork Chena River: stream, see Frozenfoot Creek.

West Fork Chena River: stream, see North Fork Chena River.

West Fork Chignik River: stream, heads on Mount Veniaminof on Alaska Penin., flows NE $24 \mathrm{mi}$. to Chignik River, $4 \mathrm{mi}$. N of Chignik Lake, Aleutian Ra.; $56^{\circ} 23^{\prime} \mathrm{N}$, $158^{\circ} 56^{\prime}$ W; (map 30).

Name reported in 1923 by $R$. H. Sargent, USGS; published in 1927 by USGS.

West Fork Chilkat River: stream, see Kelsall River.

West Fork Chistochina River: stream, heads at glacier between Gakona and Chistochina Glaciers, flows SE $5.8 \mathrm{mi}$. to Chistochina River, $18 \mathrm{mi}$. NE of Paxson, Alaska Ra.; $63^{\circ} 07^{\prime} 10^{\prime \prime} \mathrm{N}, 144^{\circ} 56^{\prime} 45^{\prime \prime} \mathrm{W}$; (map 86).

Local name reported in 1900 by T. G. Gerdine (in Mendenhall and Schrader, 1903, pl. 9), USGS

West Fork Chukowan River: stream, see Enatalik Creek.

West Fork Chulitna River: stream, heads at West Fork Glacier, flows SE $30 \mathrm{mi}$. to Chulitna River, $60 \mathrm{mi}$. SW of Healy, Alaska Ra.; $63^{\circ}$ $03^{\prime} 15^{\prime \prime} \mathrm{N}, 149^{\circ} 36^{\prime} 00^{\prime \prime} \mathrm{W}$; (map 87).

Local name reported in 1913 by J. W. Bagley, USGS.

West Fork Coal Creek: stream, heads NE of Strandline Lake, flows SE $12 \mathrm{mi}$. to Coal Creek, $33 \mathrm{mi}$. NW of Tyonek, Cook Inlet Low.; $61^{\circ} 28^{\prime} 50^{\prime \prime} \mathrm{N}, 151^{\circ} 37^{\prime} 55^{\prime \prime} \mathrm{W}$; (map $70)$.

Local name reported in 1958 by USGS.

West Fork Dall River: stream, flows E $25 \mathrm{mi}$ to Dall River, $30 \mathrm{mi}$. NW of Stevens Village, Kokrines-Hodzana High.; $66^{\circ} 20^{\prime} \mathrm{N}, 149^{\circ} 48^{\prime}$ W; (map 118).

Local name obtained in 1956 by USGS

West Fork Dennison Fork: stream, flows NE 53 mi. from Sixtymile Butte to Dennison Fork, $49 \mathrm{mi}$. NE of Tok, Yukon-Tanana High.; $63^{\circ} 54^{\prime} \mathrm{N}, 142^{\circ} 03^{\prime} \mathrm{W}$; (map 85).
Local name reported by D. C. Witherspoon, USGS, in 1907.

West Fork Espenberg River: stream, on Seward Penin., flows NW then NE $15 \mathrm{mi}$. to Espenberg River, $48 \mathrm{mi}$. NW of Deering, KotzebueKobuk Low.; $66^{\circ} 30^{\prime} \mathrm{N}, 164^{\circ} 06^{\prime} \mathrm{W}$; (map 113).

Local name reported in 1950 by USGS.

West Fork Fish Creek: stream, distributary of Fish Creek, flows SW $2.5 \mathrm{mi}$, to Susitna River, $23 \mathrm{mi}$. NW of Anchorage, Cook Inlet Low.; $61^{\circ} 25^{\prime} 15^{\prime \prime} \mathrm{N}, 150^{\circ} 27^{\prime} 45^{\prime \prime} \mathrm{W}$; (map 70).

Local name reported in 1958 by USGS.

West Fork Flat Creek: stream, flows NE $10 \mathrm{mi}$., joins East Fork Flat Creek to form Flat Creek, $25 \mathrm{mi}$. SE of Beaver, Yukon-Tanana High.; $66^{\circ} 04^{\prime} 10^{\prime \prime} \mathrm{N}, 146^{\circ} 51^{\prime} 40^{\prime \prime} \mathrm{W}$; (map 119).

Local name obtained in 1956 by USGS.

West Fork Glacier: glacier, trends $7.9 \mathrm{mi}$. SE to its terminus at head of West Fork Nizina River, $8 \mathrm{mi}$. NE of McCarthy, Wrangell Mts.; $61^{\circ} 36^{\prime} \mathrm{N}, 142^{\circ} 40^{\prime} \mathrm{W}$; (map 67).

Local name reported in 1902 by USGS (Mendenhall and Schrader, 1903, pl. 9).

West Fork Glacier: glacier, trends E $11 \mathrm{mi}$. from Anderson Pass to its terminus at head of West Fork Chulitna River, $24 \mathrm{mi}$. SE of head of McKinley River, Alaska Ra.; $63^{\circ} 16^{\prime} \mathrm{N}$, $149^{\circ} 55^{\prime} \mathrm{W}$; $B G N$ 1947; (map 87).

Local name reported by Woodbury Abbey, U.S. Army Corps of Engineers, on the blueprint of his 1921 Mount McKinley National Park survey.

West Fork Glacier: glacier, trends SW $20 \mathrm{mi}$. to its 1956 terminus at headwaters of West Fork Susitna River, $55 \mathrm{mi}$. SE of Healy, Alaska Ra.; 63⒉ $4^{\prime} \mathrm{N}, 147^{\circ} 32^{\prime} \mathrm{W}$; (map 87).

Local name reported in 1913 by J. W. Bagley (in Moffit, 1915, fig. 2), USGS.

West Fork Glen Creek: stream, flows SE $1.2 \mathrm{mi}$. from Glacier Peak, joins East Fork to form Glen Creek, $11 \mathrm{mi}$. NE of Wonder Lake, Alaska Ra.; $63^{\circ} 33^{\prime} 20^{\prime \prime} \mathrm{N}, 150^{\circ} 44^{\prime} 25^{\prime \prime} \mathrm{W}$; (map 88).

Prospectors' name reported in 1905 by L. M. Prindle, USGS

West Fork Granite Creek: stream, flows NE 3.5 mi. to Granite Creek $5.5 \mathrm{mi}$. SW of its junc. with Slana River, $31 \mathrm{mi}$. NE of Chistochina, Alaska Ra.; $62^{\circ} 56^{\prime} \mathrm{N}, 144^{\circ} 10^{\prime} \mathrm{W}$; (map 83).

Local name reported in 1954 by USGS.

West Fork Grubstake Creek: stream, flows N 1 mi. to Grubstake Creek, $14 \mathrm{mi}$. NW of Palmer, Talkeetna Mts.; $61^{\circ} 44^{\prime} 55^{\prime \prime}$ N, $149^{\circ} 25^{\prime} 05^{\prime \prime}$ W; (map 69)

Local name reported in 1950 by USGS.

West Fork Gulkana River: stream, flows SE 43 mi. from a lake to Gulkana River, $5 \mathrm{mi}$. NW of Sourdough and $32 \mathrm{mi}$. $\mathrm{N}$ of Glennallen, Copper River Basin: $62^{\circ} 35^{\prime} \mathrm{N}, 145^{\circ} 38^{\prime} \mathrm{W}$ : (map 83).

Local name shown on a 1910 field sheet by D. C. Witherspoon, USGS.

West Fork Henshaw Creek: stream, heads in lake, in Alatna Hills, flows SE 24 mi., joins East Fork to form Henshaw Creek, $14 \mathrm{mi}$. NE of Allakaket, Hogatza High.; $66^{\circ} 43^{\prime} \mathrm{N}, 152^{\circ}$ 20' W; (map 117). 
Local name reported in 1956 by T. E. Taylor, USGS.

West Fork Iligluruk Creek: stream, see Spike Creek.

West Fork Indian Creek: stream, flows NE 3.4 mi. to Indian Creek, $89 \mathrm{mi}$. SW of Talkeetna, Alaska Ra.; $62^{\circ} 08^{\prime} 55^{\prime \prime} \mathrm{N}, 152^{\circ} 50^{\prime} 00^{\prime \prime} \mathrm{W}$; (map 81).

Local name reported in 1958 by USGS.

West Fork Jackson Creek: stream, see OK Creek.

West Fork Katete River: stream, heads at $56^{\circ} 26^{\prime} 50^{\prime \prime} \mathrm{N}, 131^{\circ} 44^{\prime} 10^{\prime \prime} \mathrm{W}$; flows N $13 \mathrm{mi}$. into Canada near boundary monument 60, Coast Mts. ; $56^{\circ} 40^{\prime} \mathrm{N}, 131^{\circ} 45^{\prime} \mathrm{W}$; (map 7).

Local name reported in 1955 by USGS.

West Fork Kiligwa River: stream, see Jubilee Creek.

West Fork Koyukuk River: stream, see Tinayguk River.

West Fork Kuskokwim River: stream, see Big River.

West Fork Kustatan River: stream, distributary of Bachatna Creek, flows SE $6 \mathrm{mi}$. to Kusta$\tan$ River, $28 \mathrm{mi}$. NW of Kenai, Cook Inlet Low.; $60^{\circ} 47^{\prime} \mathrm{N}, 151^{\circ} 54^{\prime} \mathrm{W}$; (map 62).

Local name reported in 1958 by USGS.

West Fork Kuyukutuk River: stream, flows E 4 mi. to its junc. with South Fork to form Kuyukutuk River, $13 \mathrm{mi}$. NW of Russian Mission, Nulato Hills; $61^{\circ} 52^{\prime} \mathrm{N}, 161^{\circ} 41^{\prime} \mathrm{W}$; (map 73).

Prospectors' name reported in 1916 by Harrington (1918, map), USGS.

West Fork Ladue River: stream, see Ladue River.

West Fork Libby River: stream, flows SE $13 \mathrm{mi}$. to Libby River, $10 \mathrm{mi}$. SW of Mount Bendeleben and $49 \mathrm{mi}$. SW of Imuruk Lake, Seward Penin. High.; $65^{\circ} 04^{\prime} \mathrm{N}, 164^{\circ} 16^{\prime} \mathrm{W}$; (map 110).

Prospectors' name reported on a map of Cape Nome gold fields by David Fox, Jr., dated 1901.

West Fork Little Delta River: stream, flows NW $29 \mathrm{mi}$., joins East Fork to form Little Delta River, $25 \mathrm{mi}$. NW of Mount Hayes, Alaska Ra.; $63^{\circ} 57^{\prime} 40^{\prime \prime} \mathrm{N}, 146^{\circ} 55^{\prime} 20^{\prime \prime} \mathrm{W}$; (map 86). Name reported in 1910 by D. C. Witherspoon, USGS.

West Fork Little Mud River: stream, heads on E slope of Magitchlie Ra., flows SE $35 \mathrm{mi}$. to Little Mud River, $53 \mathrm{mi}$. S of Nulato and 74 mi. NW of Ophír, Kilbuck-Kuskokwim Mts.; $63^{\circ} 57^{\prime} \mathrm{N}, 158^{\circ} 06^{\prime} \mathrm{W}$; (map 90).

Local name obtained from Joseph Ferris in 1954 by R. E. Isto, USGS.

West Fork Maclaren River: stream, heads at glacier terminus in Clearwater Mts., flows SE $14 \mathrm{mi}$. to Maclaren River, $3 \mathrm{mi}$. N of Denali Highway, 32 mi. S of Mount Hayes, Alaska Ra.; 630.9 $45^{\prime \prime} \mathrm{N}, 146^{\circ} 33^{\prime} 15^{\prime \prime} \mathrm{W}$; (map 86).

Local name reported on 1910 fieldsheet by C. E. Giffin, USGS.

West Fork Middle River: stream, see West Middle River.

West Fork Moose Creek: stream, flows SE 5.8 mi. to Moose Creek, $10.5 \mathrm{mi}$. W of Talkeetna,
Cook Inlet Low.; $62^{\circ} 19^{\prime} 00^{\prime \prime} \mathrm{N}, 150^{\circ} 26^{\prime} 30^{\prime \prime}$ W; (map 81).

Local name reported in 1958 by USGS.

West Fork Moose River: stream, on Kenai Penin., flows SE $8.5 \mathrm{mi}$. to Moose River, 21 mi. $\mathrm{E}$ of Kenai, Cook Inlet Low.; $60^{\circ} 35^{\prime} \mathrm{N}$, $150^{\circ} 40^{\prime} \mathrm{W}$; (map 62$)$.

Local name reported in 1958 by USGS.

West Fork Nixon Fork: stream, flows SE $24 \mathrm{mi}$. to Nixon Fork, $23 \mathrm{mi}$. NW of Medfra, Kilbuck-Kuskokwim Mts.; $63^{\circ} 15^{\prime} \mathrm{N}, 155^{\circ} 22^{\prime}$ W; (map 89). Var. Middle Fork Nixon Fork, Tuentna River.

Local name published in 1921 by USGS.

West Fork Nizina River: stream, heads at terminus of West Fork Glacier and flows $7.2 \mathrm{mi}$. $\mathrm{SE}$ to Nizina River, $18 \mathrm{mi}$. NE of McCarthy, Wrangell Mts.; $61^{\circ} 36^{\prime} \mathrm{N}, 142^{\circ} 34^{\prime} \mathrm{W}$; (map 67).

Local name reported in 1922 by F. H. Moffit (in Smith and others, 1930, p. 144), USGS.

West Fork North Fork Innoko River: stream, flows NE and S $40 \mathrm{mi}$. to North Fork Innoko River, $56 \mathrm{mi}$. SE of Galena and $58 \mathrm{mi}$. N of Ophir, Kilbuck-Kuskokwim Mts.; 635' $156^{\circ} 18^{\prime} \mathrm{W}$; (map 90).

Local name obtained from Joseph Ferris in 1954 by R. E. Isto, USGS.

West Fork Oakpisoorook River: stream, see Okpiksugruk Creek.

West Fork Rainy Creek: stream, flows SE 5.3 mi., joins North Fork to form Rainy Creek, $22 \mathrm{mi}$. NW of Paxson, Alaska Ra.; 63⒈ $7^{\prime} 30^{\prime \prime}$ N, $145^{\circ} 53^{\prime} 35^{\prime \prime} \mathrm{W}$; (map 86$)$.

Local name reported in 1910 by C. E. Giffin, USGS.

West Fork Robertson River: stream, heads at glacier N of Mount Kimball, and flows NE $20 \mathrm{mi}$. to Robertson River, $36 \mathrm{mi}$. NW of Tok, Alaska Ra.; $63^{\circ} 27^{\prime} \mathrm{N}, 144^{\circ} 07^{\prime} \mathrm{W}$; (map 86).

Name reported in 1952 by USGS.

West Fork Ruth Glacier: glacier, heads S of Mt. McKinley National Park and trends E $7.5 \mathrm{mi}$., joining Northwest Fork at Ruth Amphitheater, $9 \mathrm{mi}$. SE of Denali Pass, Alaska Ra.; $62^{\circ}$. $59^{\prime} 30^{\prime \prime} \mathrm{N}, 150^{\circ} 49^{\prime} 30^{\prime \prime} \mathrm{W}$; (map 81).

Mountain climbers' name published in the late 1940's.

West Fork Shavivoik River: stream, see Shaviovik River.

West Fork Shellman Creek: stream, flows SE $7.5 \mathrm{mi}$. to Shellman Creek, $57 \mathrm{mi}$. NE of Medfra, Kilbuck-Kuskokwim Mts.; $63^{\circ} 41^{\prime} \mathrm{N}$, $153^{\circ} 26^{\prime} \mathrm{W}$; (map 89).

Local name reported in 1958 by USGS.

West Fork Situk River: stream, heads $0.1 \mathrm{mi}$. S of Lake Redfield, flows S 6 mi. to Situk River, $4.2 \mathrm{mi} \mathrm{SE}$ of Redfield Cove and $8.5 \mathrm{mi}$. NE of Yakutat, Malaspina Coastal Plain; 59 $30^{\prime}$ $00^{\prime \prime} \mathrm{N}, 139^{\circ} 29^{\prime} 20^{\prime \prime} \mathrm{W}$; (map 46).

Local name published in 1959 by USGS.

West Fork South Fork Goodpaster River: stream, flows SW $13 \mathrm{mi}$. to South Fork Goodpaster River $38 \mathrm{mi}$. E of Big Delta, Yukon-Tanana High.; $64^{\circ} 12^{\prime} 40^{\prime \prime} \mathrm{N}, 144^{\circ} 35^{\prime} 50^{\prime \prime} \mathrm{W}$; (map 101).

Local name reported in 1955 by USGS.
West Fork Susitna River: stream, heads at terminus of West Fork Glacier, flows SE 15 mi. to Susitna River, $65 \mathrm{mi}$. SE of Healy, Alaska Ra.; $63^{\circ} 13^{\prime} \mathrm{N}, 147^{\circ} 29^{\prime} \mathrm{W}$; (map 87).

Local name reported in 1910 by D. C. Witherspoon (in Moffit, 1912, pl. 1), USGS.

West Fork Texas Creek: stream, heads at Texas Lake, flows E $6.5 \mathrm{mi}$. to join North Fork to form Texas Creek, $5 \mathrm{mi}$. S of Mount Bayard and Alaska-Canada boundary, Coast Mts.; $56^{\circ} 03^{\prime} 10^{\prime \prime} \mathrm{N}, 130^{\circ} 05^{\prime} 30^{\prime \prime} \mathrm{W}$; (map 7).

Descriptive name published by A. F. Buddington (in Brooks and others, 1925, p. 85), USGS.

West Fork The Forks: stream, flows S $27 \mathrm{mi}$. to join the East Fork to form The Forks, $15 \mathrm{mi}$. $\mathrm{N}$ of Stevens Village, Yukon Flats; $66^{\circ} 13^{\prime} \mathrm{N}$, $149^{\circ} 05^{\prime} \mathrm{W}$; (map 118).

Local name obtained in 1956 by USGS.

West Fork Tolovana River: stream, heads at junc. of Goose and Starvation Creeks, flows NE $25 \mathrm{mi}$. to Tolovana River, $6 \mathrm{mi}$. SW of Livengood, Yukon Tanana High.; $65^{\circ} 27^{\prime} \mathrm{N}$, $148^{\circ} 39^{\prime} \mathrm{W}$; (map 105).

Local name published in 1907 by USGS. West Fork Tozitna River: stream, see Dagislakhna Creek.

West Fork Trail Creek: stream, flows ESE $3 \mathrm{mi}$. to Trail Creek $1 \mathrm{mi}$. $\mathrm{N}$ of that stream's junc. with Boulder Creek, $27 \mathrm{mi}$. E of Tanana, Yukon-Tanana High.; $65^{\circ} 09^{\prime} 30^{\prime \prime} \mathrm{N}, 151^{\circ} 09^{\prime}$ 00" W; (map 106).

Local name reported in 1952 by USGS.

West Fork Traleika Glacier: glacier, trends NE and E $3.5 \mathrm{mi}$. from Traleika Icefall to Traleika Glacier, $4 \mathrm{mi}$. E of Mount McKinley, Alaska Ra.; $63^{\circ} 07^{\prime} \mathrm{N}, 150^{\circ} 50^{\prime} \mathrm{W}$; (map 88).

Mountain climbers' name published in 1954 by USGS.

West Fork Tuluga River: stream, flows N $15 \mathrm{mi}$. to join East Fork to form Tuluga River, 14 mi. NE of Gunsight Mtn. and $53 \mathrm{mi}$. N of Anaktuvuk Pass, Arctic Slope; $68^{\circ} 54^{\prime} \mathrm{N}$, $151^{\circ} 34^{\prime} \mathrm{W}$; (map 134).

Name reported in 1950 by USGS.

West Fork Twentytwo Gulch: ravine, in Kantishna Hills, extends NE $1 \mathrm{mi}$. from Wickersham Dome to Twentytwo Gulch, $5 \mathrm{mi}$. N of Wonder Lake, Alaska Ra.; $63^{\circ} 34^{\prime} 10^{\prime \prime} \mathrm{N}$, $150^{\circ} 53^{\prime} 10^{\prime \prime} \mathrm{W}$; (map 88).

Local name reported in 1954 by USGS.

West Fork Twin Creek: stream, heads at $57^{\circ} 34^{\prime} 15^{\prime \prime} \mathrm{N}, 152^{\circ} 20^{\prime} 00^{\prime \prime} \mathrm{W}$, flows NE $7 \mathrm{mi}$. to join East Fork Twin Creek at Chiniak Bay, $14 \mathrm{mi}$. SE of Kodiak, Kodiak I. ; $57^{\circ} 37^{\prime} 10^{\prime \prime} \mathrm{N}$, $152^{\circ} 15^{\prime} 30^{\prime \prime} \mathrm{W}$; (map 34).

Local name reported in 1966 by the Alaska State: Geographic Board.

West Fork Windy Creek: stream, flows SE 8 mi. to Windy Creek, $30 \mathrm{mi}$. S of Healy, Alaska Ra.; $63^{\circ} 26^{\prime} 30^{\prime \prime} \mathrm{N}, 149^{\circ} 04^{\prime} 00^{\prime \prime} \mathrm{W}$; (map 87).

Local name shown on a 1916 fieldsheet by C. E. Giffin, USGS.

West Fork Wolf Creek: stream, flows N $13 \mathrm{mi}$. to Wolf Creek, $3 \mathrm{mi}$. SE of that stream's mouth and $31 \mathrm{mi}$. NW of Birches, KokrinesHodzana High, ; $65^{\circ} 28^{\prime} 00^{\prime \prime} \mathrm{N}, 154^{\circ} 06^{\prime} 40^{\prime \prime} \mathrm{W}$; (map 107). 
Local name obtained in 1954 by USGS topographers.

West Fork Yentna River: stream, heads $4 \mathrm{mi}$. W of Mystic Pass, flows SE $45 \mathrm{mi}$., joins East Fork to form Yentna River, $53 \mathrm{mi}$. W of Talkeetna, Alaska Ra.; $62^{\circ} 26^{\prime} 50^{\prime \prime} \mathrm{N}, 151^{\circ} 46^{\prime}$ $30^{\prime \prime} \mathrm{W}$; (map 81).

Name reported in 1906 by R. W. Porter, USGS.

West Fork Young Creek: stream, flows S $3.3 \mathrm{mi}$. to Young Creek, $17 \mathrm{mi}$. NE of Palmer, Talkeetna Mts.; $61^{\circ} 45^{\prime} 30^{\prime \prime} \mathrm{N}, 148^{\circ} 48^{\prime} 10^{\prime \prime} \mathrm{W}$; (map 69).

Local name reported in 1915 by GLO[BLM].

West Forland: point of land, see West Foreland.

West Francis Rock: rock, off N coast of Baranof I. in Sergius Narrows, in Peril Strait, $26 \mathrm{mi}$. NW of Sitka, Alex. Arch.; $57^{\circ} 24^{\prime} 20^{\prime \prime} \mathrm{N}, 135^{\circ}$ 38'05" W; (map 9).

Named in 1884 by Comdr. J. B. Coghlan, USN, for pilot E. H. Francis, who was the first person to make soundings on the rock (U.S. Coast and Geodetic Survey, 1891, p. 187).

West Gable Cannery: locality, see Port Nellie Juan.

Westgate: area, subdivision now within corporate limits of City of Fairbanks, on S bank of Chena River, Tanana Low. ; 64 $50^{\prime} 15^{\prime \prime} \mathrm{N}, 147^{\circ} 47^{\prime}$. 25" W; (map 100).

Name probably derived from its being at the west end of the city adjacent to the airport.

West Georgia: coast, region between Point Barrow and Cape Lisburne, Arctic Plain; (map 147).

Name shown on Capt. F. W. Beechey's chart of Point Rodney to Point Barrow, 182627.

West Glacier: glacier, extends NE $11 \mathrm{mi}$. from Mount Sanford to its 1957 terminus near Copper River, $5.5 \mathrm{mi}$. N of Copper Glacier terminus, Wrangell Mts.; $62^{\circ} 15^{\prime} \mathrm{N}, 144^{\circ} 00^{\prime}$ W; (map 84).

Local name reported in 1951 by USGS.

West Glacier Creek: stream, in Chigmit Mts., formed by its Left and Right Forks, flows SE 6 mi. to Chinitna Bay, Aleutian Ra.; 59 51'$45^{\prime \prime} \mathrm{N}, 153^{\circ} 12^{\prime} 10^{\prime \prime} \mathrm{W}$; BGN 1906; (map 51).

Local name reported in 1904 by G. C. Martin, USGS.

West Gland Lake: lake, $100 \mathrm{yd}$. across, $0.8 \mathrm{mi}$. NW of Bukhti Point, Kiska I., Aleutian Is.; $51^{\circ} 55^{\prime} 20^{\prime \prime} \mathrm{N}, 177^{\circ} 27^{\prime} 30^{\prime \prime}$ E.; (map 14).

An arbitrary name beginning with " $W$ " to correspond to "W" grid used by the U.S. Army for tactical purposes during World War II; published on a 1953 AMS map.

West Gulkana Glacier: glacier, trends S 2 mi. to its terminus, $16 \mathrm{mi}$. $\mathrm{N}$ of Paxson, Alaska Ra.; $63^{\circ} 15^{\prime} 30^{\prime \prime} \mathrm{N}, 145^{\circ} 29^{\prime} 25^{\prime \prime} \mathrm{W}$; $B G N$ 1959; (map 86).

Named in 1958 by the American Geographical Society.

West Gulkana Glacier: glacier, see Gulkana Glacier.
West Head: point of land, NW entrance point to Popof Strait, on NE coast of Unga I., in Shumagin Is., Aleutian Ra.; $55^{\circ} 22^{\prime} 45^{\prime \prime} \mathrm{N}$, $160^{\circ} 31^{\prime} 30^{\prime \prime} \mathrm{W}$; ( $\operatorname{map} 28$ ).

Named in 1872 by W. H. Dall, USC\&GS.

West Head: promontory, see Alaid Head.

West Hill: hill, $293 \mathrm{ft}$., on Stuart I., $19 \mathrm{mi}$. NW of St. Michael, Yukon-Kuskokwim Delta; $63^{\circ} 35^{\prime} 30^{\prime \prime} \mathrm{N}, 162^{\circ} 36^{\prime} 30^{\prime \prime} \mathrm{W}$; (map 92).

Named in 1898 by USC\&GS.

West Island: island, $2.5 \mathrm{mi}$. long, one of Kashevarof Is., in Kashevarof Passage, off $\mathrm{N}$ coast of Prince of Wales I., Alex. Arch.; 56 ${ }^{\circ}$ $10^{\prime} \mathrm{N}, 133^{\circ} 00^{\prime} \mathrm{W}$; (map 6).

Descriptive name given in 1886 by Lt. Comdr. A. S. Snow, USN, because it is the westernmost of central group of Kashevarof Islands.

West Juneau: area, of Juneau on Douglas I., on W shore of Gastineau Channel, $1.8 \mathrm{mi}$. NW of Douglas, Coast Mts. ; $58^{\circ} 17^{\prime} 45^{\prime \prime} \mathrm{N}, 134^{\circ}$ $26^{\prime} 00^{\prime \prime} \mathrm{W}$; (map 11).

Name published in 1948 by USGS.

West Kiska Lake: lagoon, $1.7 \mathrm{mi}$. long, separated from Bamboo Bay on Bering Sea by a barrier beach on NW Kiska I., Aleutian Is. ; $52^{\circ} 04^{\prime}$ $00^{\prime \prime} \mathrm{N}, 177^{\circ} 32^{\prime} 00^{\prime \prime} \mathrm{E}$; (map 14).

Name shown on 1943 USAAF map.

West Konetz: point of land, see Dalnoi Point.

West Lake: lake, see West Lili Lake.

West Landing: beach, on $S$ shore of Village Cove at St. Paul, on S coast of St. Paul I., in Pribilof Is.; $57^{\circ} 07^{\prime} 30^{\prime \prime} \mathrm{N}, 170^{\circ} 16^{\prime} 40^{\prime \prime} \mathrm{W}$; (map 38).

Local name reported in 1965 by USBF.

West Lili Lake: lake, $800 \mathrm{ft}$. long, on Kenai Penin. $W$ of Lili Lake, $8.5 \mathrm{mi}$. N of Sterling and $15 \mathrm{mi}$. E of Kenai, Cook Inlet Low.; $60^{\circ} 39^{\prime} 30^{\prime \prime}$ N, $150^{\circ} 49^{\prime} 30^{\prime \prime}$ W; (map 62). Var. West Lake.

Named about 1963 by officials of Kenai National Moose Range, for administrative purposes.

West Massacre Valley: valley, on Attu I. extends SW $4.3 \mathrm{mi}$. from Jarmin Pass to Massacre Bay, Aleutian Is.; $52^{\circ} 51^{\prime} \mathrm{N}, 173^{\circ} 12^{\prime} \mathrm{E}$; (map 13).

Descriptive name derived from Massacre Bay by U.S. Army during World War II; published in 1948 by AMS.

West Middle River: stream, distributary, flows N 15 mi. from Nenana River to Tanana River, $4 \mathrm{mi}$. NW of Nenana, Tanana Low. ; 64 $37^{\circ} 25^{\prime \prime}$ N, $149^{\circ} 08^{\prime} 00^{\prime \prime} \mathrm{W}$; BGN 1952; (map 100). Var. West Fork Middle River.

Local name published by USGS (Capps, 1940, pl. 3).

West Mill Rock: rock, $400 \mathrm{ft}$. long, in Kaigani Strait, $0.3 \mathrm{mi}$. $\mathrm{S}$ of $\mathrm{Keg}$ Point, on $\mathrm{E}$ coast

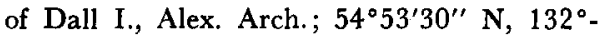
$50^{\prime} 55^{\prime \prime} \mathrm{W}$; (map 1 ).

Named by Lt. Comdr. H. E. Nichols, USN, in 1881 .

West Mountain: mountain, see Bebauch Mountain.

West Mountains: mountains, see Weston Mountains.
West Nagai Strait: water passage, between Nagai and Andronica Is., in Shumagin Is., Aleutian Ra.; $55^{\circ} 16^{\prime} \mathrm{N}, 160^{\circ} 00^{\prime} \mathrm{W}$; (map 28).

Named in 1874 by W. H. Dall, USC\&GS.

West-northwest Bight: bight, $1 \mathrm{mi}$. across, on NW coast of Semisopochnoi I., Aleutian Is.; $51^{\circ} 59^{\prime} 05^{\prime \prime} \mathrm{N}, 179^{\circ} 30^{\prime} 40^{\prime \prime} \mathrm{E}$; (map 15).

Name published on a 1943 U.S. Army Corps of Engineers map.

West-northwest Cove: cove, see West Cove.

West-northwest Point: point of land, on NW coast of Semisopochnoi I., Aleutian Is.; $51^{\circ}$. $59^{\prime} 35^{\prime \prime} \mathrm{N}, 179^{\circ} 31^{\prime} 20^{\prime \prime} \mathrm{E}$; (map 15).

Name published on a 1943 U.S. Army Corps of Engineers map.

West Nunatak Glacier: glacier, heads at $59^{\circ} 37^{\prime}$ $\mathrm{N}, 138^{\circ} 39^{\prime} \mathrm{W}$, trends NW $16 \mathrm{mi}$. to its 1961 terminus $1 \mathrm{mi}$. S of Nunatak Fiord, $32 \mathrm{mi}$. NE of Yakutat, St. Elias Mts.; BGN 1965; (map 46). Var. Nunatuk Glacier.

Named by USGS in 1961. Originally this glacier was part of Nunatak Glacier, named in 1891 by Russell (1892, p. 86), because it then appeared to be a single glacier with a nunatak, or rock island, projecting through the ice near its terminus. Since then the glacier has retreated seven miles, completely uncovering the nunatak. The glacier now consists of two arms. The arm to the southwest is West Nunatak Glacier, the other arm is East Nunatak Glacier.

Weston Mountains: mountains, $1,850 \mathrm{ft}$., on southeastern Attu I., Aleutian Is.; 52 ${ }^{\circ} 49^{\prime} \mathrm{N}$, $173^{\circ} 08^{\prime} \mathrm{E}$; (map 13). Var. West Mountains.

Name published in 1948 as "Weston Mountains" and in 1959 as "West Mountains" by AMS.

Westover Creek: stream, flows SW $6 \mathrm{mi}$. and joins Bear Creek to form Rock Creek, $36 \mathrm{mi}$. SW of Circle, Yukon-Tanana High.; 65 $40^{\prime}$ $15^{\prime \prime} \mathrm{N}, 145^{\circ} 17^{\prime} 00^{\prime \prime} \mathrm{W}$; (map 104).

Prospectors' name reported in 1954 or 1955 by USGS topographers.

West Patuk Creek: stream, heads at glacier in Franklin Mts., flows NE $9.5 \mathrm{mi}$. to Hulahula River, $11 \mathrm{mi}$. SW of Mount Michelson, Brooks Ra.; $69^{\circ} 11^{\prime} \mathrm{N}, 144^{\circ} 35^{\prime} \mathrm{W}$; (map 139).

Eskimo name reported in 1956 by USGS. West Peak: peak, 1,960 ft., on NE coast of Attu $\mathrm{I}$, at $\mathrm{N}$ end of Fishhook Ridge, Aleutian Is.; 52 $55^{\prime} 42^{\prime \prime} \mathrm{N}, 173^{\circ} 12^{\prime} 15^{\prime \prime} \mathrm{E}$; (map 13).

Descriptive name given in July 1855 by Lt. William Gibson, USN.

West Peak: peak, 3,620 ft., $3 \mathrm{mi}$. ESE of Thane and $7 \mathrm{mi}$. SE of Juneau, Coast Mts.; 58 $8^{\circ} 5^{\prime}$ $10^{\prime \prime} \mathrm{N}, 134^{\circ} 15^{\prime} 10^{\prime \prime} \mathrm{W}$; (map 11).

Local name reported in 1917 by $D$. C. Witherspoon, USGS.

West Peak: peak, 5,200 ft., $2 \mathrm{mi}$. NW of terminus of Valdez Glacier, and $3.5 \mathrm{mi}$. NE of Valdez, Chugach Mts.; $61^{\circ} 09^{\prime} 40^{\prime \prime} \mathrm{N}, 146^{\circ} 12^{\prime} 50^{\prime \prime} \mathrm{W}$; (map 68).

Named in 1898 by Capt. W. R. Abercrombie, USA.

West Peak: peak, 2,329 ft., on Ear Mtn., 0.5 mi. SW of Ears Peak and $46 \mathrm{mi}$. N of Teller, Seward Penin. High.; $65^{\circ} 55^{\prime} 20^{\prime \prime}$ N, $166^{\circ} 14^{\prime}$ - 
$30^{\prime \prime}$ W ; (map 111). Var. South Summit Ear Mountain.

Descriptive name given in 1945 by a USGS field party.

West Peak: mountain, see Ancon Peak.

West Petersburg: village, pop. 26, on $\mathrm{E}$ coast of Lindenberg Penin., Kupreanof I., separated from Petersburg by Wrangell Narrows, Alex. Arch.; $56^{\circ} 48^{\prime} 10^{\prime \prime} \mathrm{N}, 132^{\circ} 58^{\prime} 15^{\prime \prime} \mathrm{W}$; (map 6).

This is a residential area probably inhabited by those employed in the operation of a nearby sawmill on Bayou Point.

West Point: mountain, 5,865 ft., $68 \mathrm{mi}$. NE of Big Delta, Yukon-Tanana High.; 64. $57^{\prime} \mathrm{N}$, $144^{\circ} 42^{\prime} \mathrm{W}$; (map 101).

Local name reported in 1904 by $D$. C. Witherspoon (in Prindle, 1913a, pl. 1), USGS.

West Point: point of land, SW entrance to Chernofski Harbor, SW coast of Unalaska I., Aleutian Is.; $53^{\circ} 24^{\prime} 30^{\prime \prime} \mathrm{N}, 167^{\circ} 34^{\prime} 55^{\prime \prime} \mathrm{W}$; (map 23).

Descriptive name given in 1888 by USBF.

West Point: point of land, W entrance to Chichagof Bay, on W shore of Stepovak Bay, near SW end of Alaska Penin., Aleutian Ra.; $55^{\circ} 39^{\prime} \mathrm{N}, 160^{\circ} 15^{\prime} \mathrm{W}$; (map 28).

Named in 1899 by Harriman Alaska Expedition (1904, v. 4, p. 75).

West Point: point of land, on W coast of Chirikof I., $100 \mathrm{mi}$. SW of Kodiak I.; $55^{\circ} 49^{\prime} \mathrm{N}, 155^{\circ}$ $44^{\prime} \mathrm{W}$; (map 32$)$.

Descriptive name given in 1874 by $\mathrm{W} . \mathrm{H}$. Dall, USC\&GS

West Point: point of land, on $\mathrm{N}$ coast of Kupreanof I., at mouth of Portage Bay, 77 mi. SE of Sitka, Alex. Arch.; $57^{\circ} 00^{\prime} 30^{\prime \prime} \mathrm{N}$, $133^{\circ} 19^{\prime} 40^{\prime \prime} \mathrm{W}$; (map 8).

Descriptive name given in 1882 by Lt. Comdr. H. E. Nichols, USN; name published in 1889 by USC\&GS.

West Point: point of land, on $\mathrm{W}$ shore of Uganik Bay, on $\mathrm{N}$ coast of Kodiak I.; $57^{\circ} 50^{\prime} 00^{\prime \prime} \mathrm{N}$, $153^{\circ} 34^{\prime} 20^{\prime \prime} \mathrm{W}$; (map 34).

Descriptive name given in 1897 by Lt. Comdr. J. F. Moser, USN, of the USBF steamer Albatross.

West Point: point of land, on Chichagof I., at mouth of Pavlof Harbor, on SW shore of Freshwater Bay, $8 \mathrm{mi}$. NE of Tenakee Springs, Alex. Arch.; $57^{\circ} 51^{\prime} 00^{\prime \prime} \mathrm{N}, 135^{\circ} 01^{\prime} 45^{\prime \prime} \mathrm{W}$; (map 9).

Descriptive name given by Comdr. R. W. Meade, USN; published in 1869 on Hydrog. Chart 225. Name not shown on recent maps.

West Point: point of land, on right bank of Kuskokwim River, $4 \mathrm{mi}$. NW of Eek I. and 48 mi. SW of Bethel, Yukon-Kuskokwim Delta; $60^{\circ} 12^{\prime} \mathrm{N}, 162^{\circ} 27^{\prime} \mathrm{W}$; (map 58).

Descriptive name published in 1915 by USC\&GS on Chart 9104.

West Point: point of land, SW point of Fire I., in Cook Inlet, $14 \mathrm{mi}$. SW of Anchorage, Cook Inlet Low.; $61^{\circ} 07^{\prime} 35^{\prime \prime} \mathrm{N}, 150^{\circ} 17^{\prime} 00^{\prime \prime} \mathrm{W}$; BGN 1916; (map 70).

Local name reported in 1898 by Capt. Glenn and Capt. Abercrombie (1899, map), USA.

West Point: point of land, on S coast of Seward Penin., 6 mi. E of mouth of Sinuk River and
$20 \mathrm{mi}$. W of Nome, Seward Penin. High.; $64^{\circ} 34^{\prime} \mathrm{N}, 166^{\circ} 03^{\prime} \mathrm{W}$; (map 94).

Local descriptive name published by Schrader and Brooks (1900, map 3), USGS.

West Point: point of land, see Uyak, Cape.

West Portage Creek: stream, see Portage Creek. West Pyramid Peak: peak, 11,720 ft., in Mount McKinley National Park, on Mount Tripyramid, $11 \mathrm{mi}$. NE of Mount McKinley, Alaska Ra.; $63^{\circ} 08^{\prime} 45^{\prime \prime} \mathrm{N}, 150^{\circ} 42^{\prime} 30^{\prime \prime} \mathrm{W}$; $B G N 1948$; (map 88)

Named in 1948 by Bradford Washburn.

West Rock: rock, $500 \mathrm{ft}$. across, in Clarence Strait, $6 \mathrm{mi}$. SW of Cape Northumberland at $\mathrm{S}$ end of Duke I., Alex. Arch.; 54 $48^{\prime} 45^{\prime \prime}$ $\mathrm{N}, 131^{\circ} 30^{\prime} 00^{\prime \prime} \mathrm{W}$; (map 2).

Named in 1883 by Lt. Comdr. H. E. Nichols, USN, in 1883.

West Rock: rock, in Sumner Strait, $0.5 \mathrm{mi}$. W of village of Point Baker, on $\mathrm{N}$ coast of Prince of Wales I., Alex. Arch.; $56^{\circ} 21^{\prime} 15^{\prime \prime} \mathrm{N}, 133^{\circ}$ $38^{\prime} 00^{\prime \prime} \mathrm{W}$; (map 6).

Local descriptive name reported in 1949 by USGS.

West San Lorenzo Island: island, $1 \mathrm{mi}$. long, one of San Lorenzo Is., in Gulf of Esqibel, $2.5 \mathrm{mi}$. $\mathrm{N}$ of Noyes I., Alex. Arch.; $55^{\circ} 35^{\prime} \mathrm{N}, 133^{\circ}$ $37^{\prime}$ W; BGN 1917; (map 4). Var. Hydra Island.

Named in 1916 by USC\&GS. See San Lorenzo Islands.

West Sentinel Island: island, $650 \mathrm{ft}$. long, in McKenzie Inlet, off $\mathbf{E}$ coast of Prince of Wales I., S of Skowl Arm Kasaan Bay, Alex. Arch.; $55^{\circ} 23^{\prime} 30^{\prime \prime} \mathrm{N}, 132^{\circ} 22^{\prime} 30^{\prime \prime} \mathrm{W}$; (map 4).

Local descriptive name obtained in 1905 by E. F. Dickins, USC\&GS.

West-southwest Bight: bight, $1.5 \mathrm{mi}$. across, on $\mathrm{W}$ coast of Semisopochnoi I., Aleutian Is. ; $51^{\circ}$ $57^{\prime} 00^{\prime \prime} \mathrm{N}, 179^{\circ} 28^{\prime} 30^{\prime \prime} \mathrm{E}$; (map 15).

Name published on a 1943 U.S. Army Corps of Engineers map.

West-Southwest Cape: point of land, see Sarichef Cape.

West-southwest Head: point of land, on W coast of Semisopochnoi I., Aleutian Is.; 51 $56^{\prime} 00^{\prime \prime}$ N, $179^{\circ} 28^{\prime} 05^{\prime \prime} \mathbf{E}$; (map 15).

Name published on a 1943 U.S. Army Corps of Engineers map.

Wests Peak: peak, 4,800 ft., $5 \mathrm{mi}$. W of Cranberry Peak and $45 \mathrm{mi}$. N of Valdez, Chugach Mts.; $61^{\circ} 45^{\prime} 25^{\prime \prime} \mathrm{N}, 146^{\circ} 05^{\prime} 30^{\prime \prime} \mathrm{W}$; (map 68).

Named in 1898 by Lt. P. G. Lowe, USA, of Capt. W. R. Abercrombie's party.

West Spit: point of land, on $\mathrm{E}$ coast of Whitney I., $0.5 \mathrm{mi}$. NW of village of Cape Fanshaw and $77 \mathrm{mi}$. E of Sitka, Coast Mts.; $57^{\circ} 13^{\prime} 10^{\prime \prime}$ N, $133^{\circ} 30^{\prime} 45^{\prime \prime} \mathrm{W}$; (map 8).

Descriptive name given by Lt. Comdr. H. E. Nichols, USN; published by USC\&GS in the 1891 Coast Pilot (p. 145).

West Steller Valley: valley, $2.5 \mathrm{mi}$. long, in course of Steller River, on $\mathbf{N}$ coast Attu I., Aleutian Is.; $52^{\circ} 58^{\prime} 50^{\prime \prime} \mathrm{N}, 172^{\circ} 54^{\prime} 25^{\prime \prime} \mathrm{E}$; (map 13)
Descriptive name derived from Steller Cove by U.S. Army during World War II; published in 1948 by AMS.

West Summit: peak, 4,400 ft., on Olds Mtn., 0.4 mi. SW of True Summit and $5 \mathrm{mi}$. NE of Juneau, Coast Mts. ; $58^{\circ} 20^{\prime} 15^{\prime \prime} \mathrm{N}, 134^{\circ} 18^{\prime} 00^{\prime \prime}$ W; (map 11).

Local descriptive name reported in 1965 by D. A. Brew and A. B. Ford, USGS.

West Thetis Island: barrier island, see Thetis Island.

West Tributary Muir Glacier: glacier, see Morse Glacier.

West Twin Bay: estuary, on Perry I., trends NW $3 \mathrm{mi}$. to Wells Passage, $22 \mathrm{mi}$. E of Whittier, Chugach Mts.; $60^{\circ} 44^{\prime} 10^{\prime \prime} \mathrm{N}, 147^{\circ} 59^{\prime} 15^{\prime \prime} \mathrm{W}$; (map 63).

So named in 1914 "because it is the western one of the two bays" and published in 1915 by USC\&GS.

West Twin Glacier: glacier, heads in Hades Highway, trends SSE $5 \mathrm{mi}$. to Twin Glacier Lake, $7.5 \mathrm{mi}$. W of Kluchman Mtn., Coast Mts.; $58^{\circ} 33^{\prime} 25^{\prime \prime} \mathrm{N}, 133^{\circ} 56^{\prime} 10^{\prime \prime} \mathrm{W}$; $B G N$ 1966; (map 12). Var. Twin Glacier, Twin Glaciers.

Named relative to East Twin Glacier; published by Lawrence (1950, p. 195).

West Twin Lake: lake, $2.7 \mathrm{mi}$. long, $4 \mathrm{mi}$. W of East Twin Lake and $35 \mathrm{mi}$. E of Bitzshtini Mts., Tanana Low.; $64^{\circ} 27^{\prime} \mathrm{N}, 150^{\circ} 50^{\prime} \mathrm{W}$; (map 99).

Local descriptive name reported in 1952 by USGS.

West Twin Lake: lake, $1.1 \mathrm{mi}$. long, on Chukchi Sea coast, $6 \mathrm{mi}$. SE of Barrow, Arctic Plain; $71^{\circ} 16^{\prime} 30^{\prime \prime} \mathrm{N}, 156^{\circ} 29^{\prime} 30^{\prime \prime} \mathrm{W}$; (map 153).

Descriptive name used for scientific purposes (Carson and Hussey, 1962).

West Twin Peak: peak, 5,401 ft., $2.5 \mathrm{mi}$. N of Eklutna Lake and $11 \mathrm{mi}$. SW of Palmer, Chugach Mts.; $61^{\circ} 26^{\prime} 30^{\prime \prime} \mathrm{N}, 1^{\circ} 49^{\circ} 09^{\prime} 30^{\prime \prime} \mathrm{W}$; (map 69).

Local name reported in 1960 by USGS. Westway Bight: bight, between Shoal and Naga Points, on NE coast of Kanaga I., Aleutian Is.; $51^{\prime} 49^{\prime} 30^{\prime \prime} \mathrm{N}, 177^{\circ} 07^{\prime} 30^{\prime \prime} \mathrm{W}$; (map 17).

Name published in 1957 on an AMS map. West Yahtse River: stream, see Yahtse River. Wetbutt Creek: stream, heads $\mathrm{W}$ of terminus of Kahiltna Glacier and flows SE $13 \mathrm{mi}$. to Kahiltna River, $35 \mathrm{mi}$. W of Talkeetna, Alaska Ra.; $62^{\circ} 30^{\prime} 45^{\prime \prime} \mathrm{N}, 151^{\circ} 20^{\prime} 05^{\prime \prime} \mathrm{W}$; (map 81).

Mountain climbers' name published in the late 1940's.

Wet Gulch: ravine, extends SE 3 mi. from Willow Creek, W of Bald Mountain Ridge, $17 \mathrm{mi}$. NW of Palmer, Talkeetna Mts.; 61 $45^{\prime} 40^{\prime \prime} \mathrm{N}$, $149^{\circ} 29^{\prime} 05^{\prime \prime} \mathrm{W}$; (map 69).

Local name reported in 1906 by Sidney Paige and Adolph Knopf (in Brooks and others, 1907, p. 118), USGS.

Wet Gulch: ravine, trends NW $0.3 \mathrm{mi}$. to Left Fork Dexter Creek, $5.5 \mathrm{mi}$. NE of Nome, Seward Penin. High.; $64^{\circ} 35^{\prime} \mathrm{N}, 165^{\circ} 20^{\prime} \mathrm{W}$; (map 94).

Prospectors' name reported in 1904 by T. G. Gerdine, USGS. 
Wet Gulch: ravine, trends W $0.4 \mathrm{mi}$. to Hobson Creek, $18 \mathrm{mi}$. NE of Nome, Seward Penin. High.; $64^{\circ} 46^{\prime} \mathrm{N}, 165^{\circ} 16^{\prime} \mathrm{W}$; (map 94). Prospectors' name shown on the 1902 "Map of the Nome and Snake River Country" by J. M. Davidson.

Wevok: locality, on Chukchi Sea coast, $3 \mathrm{mi}$. E of Cape Lisburne and $41 \mathrm{mi}$. NE of Point Hope, Arctic Slope ; $68^{\circ} 52^{\prime} 25^{\prime \prime} N, 166^{\circ} 05^{\prime} 10^{\prime \prime}$ W; (map 129). Var. Webuk, Wevuk.

Former Eskimo village name derived from the Eskimo name of Cape Lisburne and published in 1890 by USC\&GS.

Wevok: promontory, see Lisburne, Cape.

Wevuk: locality, see Wevok.

Wevuk: promontory, see Lisburne, Cape.

We-wa-le-ah: point of land, see Simpson, Cape. Whacksback Mountain: hill, see Coffee Dome. Whakatna Creek: stream, flows $6 \mathrm{mi}$. to Yukon River, $29 \mathrm{mi}$. NE of Nulato, Koyukuk Low.; $64^{\circ} 49^{\prime} 30^{\prime \prime} \mathrm{N}, 156^{\circ} 57^{\prime} 00^{\prime \prime} \mathrm{W}$; (map 97).

Koyukan Indian name shown on a 1905 manuscript navigation chart of the Yukon River.

Whaleback, The: rock, elev. $22 \mathrm{ft}$., $0.1 \mathrm{mi}$. across, between Nagai and Andronica Is., in Shumagin Is., Aleutian Ra.; $55^{\circ} 16^{\prime} 50^{\prime \prime} \mathrm{N}, 160^{\circ} 04^{\prime} 50^{\prime \prime}$ W; (map 28).

Local descriptive name published in 1953 by USGS.

Whale Bay: bay, $1.5 \mathrm{mi}$. across, on Caton I., Sanak Is., Aleutian Ra.; $54^{\circ} 24^{\prime} \mathrm{N}, 162^{\circ} 23^{\prime}$ W; (map 25).

Name reported by Ferdinand Westdahl, USC\&GS, commander of the Coast Survey steamer McArthur, who made surveys in this area in 1901.

Whale Bay: bay, $2.5 \mathrm{mi}$. across, on SW coast of Baranof I., Alex. Arch.; 56 $35^{\prime} \mathrm{N}, 135^{\circ} 05^{\prime}$ W; (map 5). Var. Kay-e-ghlen, Keetovaia Bay, Kitovaya Bukhta, Port Banks, Port Guibert.

Name published by USC\&GS in the 1883 Coast Pilot (p. 133) ; derived from "Kitovaya Bukhta"; published in 1850 by the Russian American Company.

Whale Bay: bay, on E coast of Kenai Penin., extends NE $4 \mathrm{mi}$. to Knight Island Passage, $4 \mathrm{mi}$. SW of Chenega and $45 \mathrm{mi}$. E of Seward, Chugach Mts.; $60^{\circ} 14^{\prime} 30^{\prime \prime} \mathrm{N}, 148^{\circ} 09^{\prime} 30^{\prime \prime} \mathrm{W}$; (map 63).

Local name reported in 1905 by U. S. Grant, USGS.

Whalebone Bay: bay, see Usof Bay.

Whalebone Cape: point of land, $\mathrm{S}$ coast of Unalaska I., Aleutian Is.; $53^{\circ} 30^{\prime} \mathrm{N}, 166^{\circ} 40^{\prime} \mathrm{W}$; $B G N 1904$; (map 23).

So named in 1888 by USBF because of the great amount of whalebone found there.

Whalebone Island: island, see Whale Island.

Whale Creek: stream, flows $3 \mathrm{mi}$. SW to Gulf of Alaska, $3 \mathrm{mi}$. NW of mouth of Steelhead Creek, $83 \mathrm{mi}$. NW of Hoonah, Malaspina Coastal Plain; 58 $35^{\prime} 00^{\prime \prime} \mathrm{N}, 137^{\circ} 33^{\prime} 25^{\prime \prime} \mathrm{W}$; (map 10).

Name published by members of the Harvard-Dartmouth Expedition, 1933-34 (Washburn and Goldthwait, 1936 map).
Whale Head: cliff, $400 \mathrm{ft}$., on $\mathrm{SW}$ coast of Whale Head I., $35 \mathrm{mi}$. NW of Craig, Alex. Arch.; $55^{\circ} 51^{\prime} 15^{\prime \prime} \mathrm{N}, 133^{\circ} 41^{\prime} 00^{\prime \prime} \mathrm{W}$; (map 4)

Descriptive name derived from Whale $\mathrm{Head}$ Island; published in 1906 by USC\&GS.

Whale Head Island: island, $1.3 \mathrm{mi}$. long, at mouth of Davidson Inlet, Alex. Arch.; $55^{\circ}$ $51^{\prime} 40^{\prime \prime} \mathrm{N}, 133^{\circ} 41^{\prime} 00^{\prime \prime} \mathrm{W}$; (map 4).

Named in 1903 or 1904 by E. F. Dickins, USC\&GS, who wrote "named by our party, has no local name."

Whale Island: island, $0.3 \mathrm{mi}$. across, in Galankin Is., Sitka Sound, $1.5 \mathrm{mi}$. $\mathrm{S}$ of Sitka, Alex. Arch.; $57^{\circ} 01^{\prime} 30^{\prime \prime} \mathrm{N}, 135^{\circ} 20^{\prime} 30^{\prime \prime} \mathrm{W}$; (map 9). Var. Kitovi Island, Ostrov Kitovey, Quitoway Island, Whalebone Island.

This is an 1882 translation by USC\&GS of the name given in 1809 by the Russian navigator Ivan Vasiliev the first; reported by Lt. Sarichev (1826, map 19), IRN, as "O[strov] Kitovey."

Whale Island: island, $5 \mathrm{mi}$. across, between Kupreanof Strait and Marmot Bay, $\mathrm{N}$ of Kodiak I.; $57^{\circ} 57^{\prime} \mathrm{N}, 152^{\circ} 47^{\prime} \mathrm{W}$; BGN 1905; (map 34). Var. Govorushechie Island, Ketoy Island, Kittiwake Island, Kitoi Island, Ostrov Govorushechiy ili Kitoy.

Called "Os[trov] Govorushechiy ili Kitoy," meaning "Kittiwake [red-legged seagull, Rissa brevirostris], or Whale Island," by Sub-Lt. Mikhail Murashev in 1839 or 1840 and published in 1849 on Russian Hydrog. Dept. Chart 1425. The name "Whale Island" was reported to be the local name for this feature in 1897 by Lt. Comdr. J. F. Moser, USN, of the USBF steamer Albatross.

Whale Island: island, $0.3 \mathrm{mi}$. long, off $\mathrm{S}$ coast of Alaska, $0.5 \mathrm{mi}$. S of Cape Martin, $2.7 \mathrm{mi}$. SW of Katalla, Malaspina Coastal Plain; $60^{\circ}$ $10^{\prime} 30 \mathrm{~N}, 144^{\circ} 35^{\prime} 00^{\prime \prime} \mathrm{W}$; (map 64)

Local name reported in 1905 by G. C. Martin (in Brooks and others, pl. 16), USGS.

Whale Island: island, $0.5 \mathrm{mi}$. long, on Norton Sound, $0.6 \mathrm{mi}$. N of St. Michael, Yukon-Kuskokwim Delta; 63⒉ $9^{\prime} 35^{\prime \prime} \mathrm{N}, 162^{\circ} 00^{\prime} 30^{\prime \prime} \mathrm{W}$; (map 92)

Local descriptive name obtained in 1898 by USC\&GS ; published on Chart 9370 .

Whale Island: barrier island, on Beaufort Sea coast, one of Plover Is., Arctic Plain; (map 153).

Probably named by a British naval officer prior to 1855. The island can not now be identified.

Whale Mountain: mountain, 5,930 ft., on $\mathrm{E}$ bank of Kongakut River, $30 \mathrm{mi}$. S of Demarcation Point, Brooks Ra.; $69^{\circ} 15^{\prime} \mathrm{N}, 141^{\circ} 30^{\prime}$ W; (map 138).

Descriptive name shown on a 1912 (?) fieldsheet by $\mathbf{E}$. de $\mathbf{K}$. Leffingwell.

Whalen Bay: estuary, $0.8 \mathrm{mi}$. wide, at $\mathrm{E}$ end of Port Fidalgo, $25 \mathrm{mi}$. NW of Cordova, Chugach Mts.; $60^{\circ} 49^{\prime} \mathrm{N}, 146^{\circ} 16^{\prime} \mathrm{W}$; (map 64).

Named for a local miner and reported in 1908 by U. S. Grant (in Brooks and others, 1909, pl. 4), USGS.
Whale Passage: water passage, $10 \mathrm{mi}$, long, between Thorne and Prince of Wales Is., Alex. Arch.; 56 $04^{\prime} \mathrm{N}, 133^{\circ} 05^{\prime} \mathrm{W}$; (map 6).

Named in 1886 by Lt. Comdr. A. S. Snow, USN; name published in 1887 on USC\&GS Chart 706.

Whale Passage: water passage, extends NW 4.5 mi. from Kizhuyak Bay to Kupreanof Strait, between Whale and Kodiak Is.; $57^{\circ} 56^{\prime} \mathrm{N}$, $152^{\circ} 50^{\prime} \mathrm{W}$; (map 34). Var. Little Raspberry Strait, Proliv Maloy Malinovoy, Sievernoi.

Name derived from Whale Island and given in 1897 by Lt. Comdr. J. F. Moser, USN, of the USBF Albatross. Called "Pr[oliv] Maloy Malinovoy," meaning "Little Raspberry Strait," by Sub-Lt. Mikhail Murashev in 1839 or 1840 and published in 1849 on Russian Hydrog. Dept. Chart 1425. Baker (1906, p. 671) erroneously wrote, "Called 'Sievernoi' (northern) by Murashef."

Whale Point: point of land, $\mathrm{E}$ point of entrance to Mutt Cove, $\mathrm{S}$ coast of Kiska I., Aleutian Is.; $51^{\circ} 55^{\prime} 45^{\prime \prime} \mathrm{N}, 177^{\circ} 30^{\prime} 40^{\prime \prime} \mathrm{E}$; (map 14).

This is one of the animal names arbitrarily applied to features in this area in 1943 by USAAF for tactical purposes during World War II.

Whale Point: point of land, on Caton I., Sanak Is., Aleutian Ra.; $54^{\circ} 24^{\prime} 15^{\prime \prime} \mathrm{N}, 162^{\circ} 24^{\prime} 00^{\prime \prime}$ W; (map 25).

Name reported by Ferdinand Westdahl, USC\&GS, commander of the Coast Survey steamer McArthur, who made surveys in this area in 1901.

Whale Point: point of land, $\mathrm{E}$ tip of Smeaton I., in Behm Canal, Coast Mts.; $55^{\circ} 20^{\prime} 30^{\prime \prime} \mathrm{N}$, $130^{\circ} 55^{\prime} 40^{\prime \prime} \mathrm{W}$; (map 3).

Local name published in 1891 by USC\&GS.

Whale Point: point of land, on $\mathrm{S}$ coast of St. Paul I., in Pribilof Is.; $57^{\circ} 07^{\prime} 30^{\prime \prime} \mathrm{N}, 170^{\circ} 15^{\prime}$ $20^{\prime \prime}$ W; (map 38). Var. Ketavie Point, Kitovi Point.

This is a translation of the Russian name "Mys Kitovyy," which means "whale cape," reported by Elliott (1881, St. Paul notes) as "Ketavie (of a whale) because a large right whale was stranded here in 1849."

Whale Rock: rock, $400 \mathrm{ft}$. long, in Revillagigedo Channel, $2 \mathrm{mi}$. S of Mary I., Alex. Arch.; $55^{\circ} 01^{\prime} \mathrm{N}_{1} 131^{\circ} 11^{\prime} \mathrm{W}$; (map 3).

Named by local pilots about 1880 ; published in 1885 by USC\&GS.

Whale Rock: rock, at mouth of Davidson Inlet, $0.5 \mathrm{mi}$. SW of Whale Head Island, Alex. Arch.; $55^{\circ} 50^{\prime} 40^{\prime \prime} \mathrm{N}, 133^{\circ} 41^{\prime} 25^{\prime \prime} \mathrm{W}$; (map 4).

Named in 1904 by E. F. Dickins, USC\&GS. "The rock looks like a whale at low tide." Whalers Creek: stream, on Alaska Penin., flows E $3 \mathrm{mi}$. to Chignik Lagoon, $9 \mathrm{mi}$. W of Chignik, Aleutian Ra.; $56^{\circ} 18^{\prime} \mathrm{N}, 158^{\circ} 37^{\prime} \mathrm{W}$; (map 30).

Local name reported in 1904 by R. W. Stone (in Brooks and others, 1905, p. 165), USGS.

Whaletail Cove: cove, $22 \mathrm{mi}$. SE of Wrangell, extends E $1 \mathrm{mi}$. to Zimovia Strait, $2.5 \mathrm{mi}$. E 
of Olive Cove, on $\mathbf{E}$ coast of Etolin I., Alex. Arch.; $56^{\circ} 11^{\prime} 10^{\prime \prime} \mathrm{N}, 132^{\circ} 15^{\prime} 00^{\prime \prime} \mathrm{W}$; BGN 1923; (map 6).

Descriptive name given in 1923 by USC\&GS "because of its shape."

Waletail Point: point of land, at entrance to Whitetail Cove, in Zimovia Strait, on E coast of Etolin I., $21 \mathrm{mi}$. SE of Wrangell, Alex. Arch.; $56^{\circ} 11^{\prime} 30^{\prime \prime} \mathrm{N}, 132^{\circ} 09^{\prime} 15^{\prime \prime} \mathrm{W}$; (map 6).

Descriptive name given for charting purposes by USC\&GS in 1925 Coast Pilot (p. 121).

Whaley, Point: point of land, $\mathrm{N}$ tip of Revillagigedo I., Alex. Arch.; 55 58'20' N, $131^{\circ}$ $15^{\prime} 45^{\prime \prime} \mathrm{W}$; (map 3). Var. Cape Whaley, Mys Vale.

Named August 11, 1793, by Capt. Vancouver, RN (Wagner, 1937, p. 421).

Wharf Point: point of land, on NE coast of Seguam I., Aleutian Is.; $52^{\circ} 22^{\prime} \mathrm{N}, 172^{\circ} 20^{\prime}$ W; (map 19).

Descriptive named given by a special U.S. Navy survey party because the point resembles a wharf or pier from a distance; published by USC\&GS in 1944 Aleutian Coast Pilot (p. 85).

Wheat Cove: cove, $0.3 \mathrm{mi}$. across, $1.5 \mathrm{mi}$. $\mathrm{S}$ of Witchcraft Point, on NW coast of Kiska I., Aleutian Is., $52^{\circ} 02^{\prime} \mathrm{N}, 177^{\circ} 30^{\prime} \mathrm{E}$; (map 14).

This is one of the plant names arbitrarily applied to features on Kiska Island in 1943 by USAAF for tactical purposes during World War II.

Wheat Lake: lake, $0.8 \mathrm{mi}$. long, $4.5 \mathrm{mi}$. $\mathrm{E}$ of junc. of Nizina and Chitina Rivers, $8.5 \mathrm{mi}$. SW of McCarthy, Wrangell Mts.; BGN 1966; $61^{\circ} 20^{\prime} 20^{\prime \prime} \mathrm{N}, 143^{\circ} 05^{\prime} 45^{\prime \prime} \mathrm{W}$; (map 67).

Named in 1965 by L. A. Yehle, USGS, for publication and geologic description purposes.

Wheel Creek: stream, flows SE $0.6 \mathrm{mi}$. to Penny River, $12 \mathrm{mi}$. NW of Nome, Seward Penin. High; $64^{\circ} 39^{\prime} \mathrm{N}, 165^{\circ} 38^{\prime} \mathrm{W}$; (map 94). Var. Wheel Gulch.

Prospectors' name reported as "Wheel Gulch" on Arthur Gibson's "Map of Cape Nome Precinct" dated 1904.

Wheeler Creek: stream, near NW coast of Admiralty I., flows NNW $9 \mathrm{mi}$. to Game Cove on Chatham Strait, $22 \mathrm{mi}$. SW of Juneau, Alex. Arch.; $58^{\circ} 03^{\prime} 30^{\prime \prime} \mathrm{N}, 134^{\circ} 47^{\prime} 30^{\prime \prime} \mathrm{W}$; $B G N$ 1929; (map 11).

Named for Frank Wheeler, an early settler along the creek. Name reported in 1928 by USFS.

Wheeler Creek: stream, flows NE $10 \mathrm{mi}$. to Munson Creek, $52 \mathrm{mi}$. N of Big Delta, YukonTanana High.; $64^{\circ} 54^{\prime} 30^{\prime \prime}$ N, $145^{\circ} 59^{\prime} 00^{\prime \prime} \mathrm{W}$; (map 101).

Local name reported in 1910 by USGS (Capps, 1912, pl. 1).

Wheeler Creek: stream, flows S $24 \mathrm{mi}$. to Dakli River, 56 mi. SE of Shungnak, Hogatza High.; $66^{\circ} 10^{\prime} \mathrm{N}, 156^{\circ} 18^{\prime} \mathrm{W}$; (map 115 ).

Local name reported by USGS in 1952.

Wheeler Peak: peak, 2,731 ft., on Glass Penin. on Admiralty I., 2 mi. SW of Point Glass and $38 \mathrm{mi}$. SE of Juneau, Alex. Arch.; 57 $47^{\prime} 30^{\prime \prime} \mathrm{N}, 133^{\circ} 56^{\prime} 30^{\prime \prime} \mathrm{W}$; BGN 1934; (map 8).

Named in 1887 by Lt. Gomdr. C. M. Thomas, USN, probably for Lt. George M. Wheeler, who made extensive surveys of the United States west of the 100 th meridian.

Wheel Gulch: stream, see Wheel Creek.

Whelan Creek: stream, flows NE $2.5 \mathrm{mi}$. to Coffee Creek in Kougarok River basin, $47 \mathrm{mi}$. SW of Imuruk Lake, Seward Penin. High.; $65^{\circ} 18^{\prime} \mathrm{N}, 164^{\circ} 38^{\prime} \mathrm{W}$; (map 110).

Prospectors' name reported on the 1908 "Map of Seward Peninsula" by Arthur Gibson.

Whidbey, Point: point of land, on Lynn Canal, $\mathrm{E}$ entrance to St. James Bay, $1.4 \mathrm{mi}$. NE of St. James Point and $32 \mathrm{mi}$. NW of Juneau, St. Elias Mts.; $58^{\circ} 34^{\prime} 40^{\prime \prime}$ N., $135^{\circ} 08^{\prime} 10^{\prime \prime} \mathrm{W}$; (map 11). Var. Point Grant, Whidby Point.

Named by George Davidson, USC\&GS, for Joseph Whidbey, RN, one of Capt. George Vancouver's principal assistants during his explorations in 1792-95 and Master of the H.M.S. Discovery. The name "Point Whidbey" was published by USC\&GS in 1883 Coast Pilot (p. 195). In 1889 Comdr. R. W. Meade, USN, called it "Point Grant."

Whidbey Bay: bay, $4.7 \mathrm{mi}$. across, between Capes Fairfield and Mansfield, on Kenai Penin., 22 mi. SE of Seward, Chugach Mts.; $59^{\circ} 56^{\prime} \mathrm{N}$, $148^{\circ} 56^{\prime}$ W; $B G N 1910$; (map 49).

Named in 1908 by U. S. Grant, USGS, "after Vancouver's Lieut, 'Joseph Whidbey."

Whidbey Passage: water passage, $9 \mathrm{mi}$. long, along the $W$ shore of Glacier Bay, in Glacier Bay National Monument, E of Fingers Bay, $40 \mathrm{mi}$. NW of Hoonah, St. Elias Mts.; $58^{\circ} 37^{\prime}$ $\mathrm{N}, 136^{\circ} 12^{\prime} \mathrm{W} ; B G N$ 1942; (map 10).

Named by USC\&GS in 1942 for Joseph Whidbey, Master of the Discovery and one of Capt. George Vancouver's principal assistants, who landed at the mouth of Glacier Bay in 1794.

Whihshet, Point: point of land, see Whitshed, Point.

Whip Island: island, $0.2 \mathrm{mi}$. long, one of seven in SW entrance to Lash Bay, off SW coast of Tanaga I., Aleutian Is.; $51^{\circ} 39^{\prime} 50^{\prime \prime} \mathrm{N}$, $178^{\circ} 03^{\prime} 00^{\prime \prime} \mathrm{W}$; (map 16).

Local name published on a 1954 USGS map.

Whipple, Mount: mountain, 5,745 ft., on AlaskaCanada boundary, $10 \mathrm{mi}$. SE of Stikine River, Coast Mts.; $56^{\circ} 36^{\prime} 45^{\prime \prime} \mathrm{N}, 131^{\circ} 34^{\prime} 45^{\prime \prime} \mathrm{W}$; (map 7). Var. Mount Wipple.

Named "by Hunter in $1877 * * *$ * (Baker, 1906, p. 671)

Whipple Creek: stream, on Revillagigedo I., flows W $4 \mathrm{mi}$. to Tongass Narrows, $1.9 \mathrm{mi}$. SE of Point Higgins, Alex. Arch.; 55 $26^{\prime} 15^{\prime \prime} \mathrm{N}$, $131^{\circ} 48^{\prime} 00^{\prime \prime}$ W; BGN 1933; (map 3). Var. Falls Creek.

Local name reported in 1933 by USFS named "for an early settler who had a fish trap near the mouth of the creek."

Whirl Point: point of land, $\mathbf{E}$ coast of Unimak I., in Isanotski Strait, Aleutian Is.; 54 $49^{\prime} 30^{\prime \prime}$.
N, $163^{\circ} 22^{\prime} 30^{\prime \prime} \mathrm{W}$; (map 25).

Name published by USC\&GS in the 1926 Coast Pilot (p. 216). It was so named because the tidal currents swirl violently about it. Whirlpool Creek: stream, flows SW $10 \mathrm{mi}$. to head of Nixon Fork, $24 \mathrm{mi}$. NE of Medfra, Kilbuck-Kuskokwim Mts.; $63^{\circ} 26^{\prime} \mathrm{N}, 154^{\circ} 28^{\prime}$ W ; (map 89)

Local name reported in 1910 by A. G. Maddren (in Brooks and others, 1911, pl. 14), USGS.

Whirlpool Island: island, $4.6 \mathrm{mi}$. long, between Whirlpool Slough and Yukon River, $8 \mathrm{mi}$. SW of Beaver, Yukon Flats; $66^{\circ} 17^{\prime} \mathrm{N}, 147^{\circ} 38^{\prime} \mathrm{W}$; (map 118).

Locally named for the whirlpool on the west side of the island at the mouth of Whirlpool Slough; reported in 1956 by T. E. Tay. lor, USGS.

Whirlpool Point: point of land, extends $\mathrm{S}$ between Winter Bay and Hessa Narrows, on SW coast of Prince of Wales I., Alex. Arch.; 54 $4^{\circ}$ $46^{\prime} 50^{\prime \prime} \mathrm{N}, 132^{\circ} 18^{\prime} 20^{\prime \prime} \mathrm{W}$; (map 1):

Local descriptive name reported in 1948 by USGS.

Whirlpool Point: point of land, on $\mathrm{N}$ central coast of Sitkinak I., in Trinity Is., Kodiak I.; $56^{\circ} 37^{\prime} 00^{\prime \prime} \mathrm{N}, 154^{\circ} 05^{\prime} 30^{\prime \prime}$ W; BGN 1934; (map 32).

Descriptive name given in 1934 by USC\&GS "because of the dangerous whirlpools extending NE from the point."

Whirlpool Rock: rock, $0.5 \mathrm{mi}$. NW of Careful Point, off $\mathrm{W}$ coast of Adak I., Aleutian Is. $51^{\circ} 50^{\prime} 00^{\prime \prime} \mathrm{N}, 176^{\circ} 52^{\prime} 35^{\prime \prime} \mathrm{W}$; (map 17).

Name published by USC\&GS in the 1944 Aleutian Coast Pilot (p. 111).

Whirlpool Slough: stream, anabranch of Yukon River, flows W $4.5 \mathrm{mi}$., $9 \mathrm{mi}$. SW of Beaver, Yukon Flats; $66^{\circ} 17^{\prime} \mathrm{N}, 147^{\circ} 40^{\prime} \mathrm{W}$; (map 118).

Local name shown on a 1916 manuscript map by William Yanert (Stuck, 1917, p. 122). The channel was named for the whirlpool at its mouth.

Whirlwind Creek: stream, flows SW $10 \mathrm{mi}$. to Nixon Fork Takotna River $5 \mathrm{mi}$. NE of mouth of Cottonwood Creek and $24 \mathrm{mi}$. NE of Medfra, Kilbuck-Kuskokwim Mts.; $63^{\circ} 26^{\prime} \mathrm{N}$, $154^{\circ} 28^{\prime} \mathrm{W}$; (map 89).

Local name obtained in 1924 by J. S. Brown (in P. S. Smith and others, 1926, pl.5), USGS Whirlwind Ridge: ridge, extends NE-SW 2.3 mi., 34 mi. NE of Medfra, Kilbuck-Kusko-

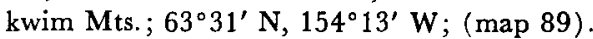

Local name obtained in 1924 by J. S. Brown (in Smith, P. S., and others 1926, pl. 5), USGS.

Whisker Point: point of land, between Tlevak Strait and South Pass, on SE coast of Goat I., Alex. Arch.; $55^{\circ} 10^{\prime} 10^{\prime \prime} \mathrm{N}, 132^{\circ} 53^{\prime} 30^{\prime \prime} \mathrm{W}$; (map 4)

Local name published in 1965 by USC\&GS.

Whiskers Creek: stream, flows $S 11.5 \mathrm{mi}$. to Susitna River, $4 \mathrm{mi}$. N of Talkeetna, Cook Inlet Low.; $62^{\circ} 22^{\prime} 40^{\prime \prime} \mathrm{N}, 150^{\circ} 10^{\prime} 10^{\prime \prime} \mathrm{W}$; (map 81).

Local name reported in 1958 by USGS. 
Whiskey Cove: cove, $0.3 \mathrm{mi}$. wide, on NW coast of Hawkins I., $12 \mathrm{mi}$. W of Cordova, Chugach Mts.; $60^{\circ} 32^{\prime} \mathrm{N}, 146^{\circ} 06^{\prime} \mathrm{W}$; (map 64).

Name published in 1950 by USGS.

Whiskey Creek: locality, on right bank of Yukon River, at mouth of Whiskey Creek and $52 \mathrm{mi}$ $E$ of Nulato, Kokrines-Hodzana High.; $64^{\circ} 41^{\prime}$ N, $156^{\circ} 21^{\prime} \mathrm{W}$; (map 97).

Local name reported in 1954 by USGS.

Whiskey Creek: stream, flows S $2.3 \mathrm{mi}$. to Edgar Creek $11.2 \mathrm{mi}$. E of Marshall, Nulato Hills; 61 ${ }^{\circ} 53^{\prime} 08^{\prime \prime} \mathrm{N}, 161^{\circ} 44^{\prime} 30^{\prime \prime} \mathrm{W}$; (map 73). Var. Whisky Creek.

Prospectors' name reported in 1916 by Harrington (1918, map), USGS.

Whiskey Creek: stream, flows SE $1.8 \mathrm{mi}$. to Yukon River, $52 \mathrm{mi}$. E of Nulato, KokrinesHodzana High.; $64^{\circ} 41^{\prime} \mathrm{N}, 156^{\circ} 21^{\prime} \mathrm{W}$; (map 97).

Riverboat pilots' name shown on a 1940 "Navigation Chart of the Tanana-Yukon Rivers" published by U.S. Dept. of Interior. Whiskey Creek: stream, flows NE $3 \mathrm{mi}$. to Casadepaga River $15 \mathrm{mi}$. NE of Solomon, Seward Penin. High.; $64^{\circ} 47^{\prime} \mathrm{N}, 164^{\circ} 35^{\prime} \mathrm{W}$; (map 95).

Prospectors' name reported on a map of Cape Nome gold fields by David Fox, Jr., dated 1901.

Whiskey Creek: stream, see Moose Creek.

Whiskey Gulch: ravine, $0.3 \mathrm{mi}$. long, on W coast of Kenai Penin., 4 mi. NNE of Anchor Point and $16 \mathrm{mi}$. NW of Homer, Cook Inlet Low.; $59^{\circ} 50^{\prime} \mathrm{N}, 151^{\circ} 49^{\prime} \mathrm{W}$; (map 50).

Local name reported and published by USGS in 1950.

Whiskey Gulch: ravine, trends NE $0.5 \mathrm{mi}$. to Little Eldorado Creek, $16 \mathrm{mi}$. NE of Fairbanks, Yukon-Tanana High.; $65^{\circ} 03^{\prime} 55^{\prime \prime} \mathrm{N}$, $147^{\circ} 32^{\prime} 20^{\prime \prime} \mathrm{W}$; (map 105).

Named by prospectors and published in 1908 by USGS.

Whiskey Hill Glacier: glacier, trends $5 \mathrm{mi}$. S from Chisana Pass to Rohn Glacier, $10 \mathrm{mi}$. $\mathrm{NE}$ of Regal Mtn. and $30 \mathrm{mi}$. NE of McCarthy, Wrangell Mts.; $61^{\circ} 50^{\prime} \mathrm{N}, 142^{\circ} 35^{\prime} \mathrm{W}$; (map 67).

Local name published by USGS in 1954.

Whiskey Island: island, $2.5 \mathrm{mi}$. long, adjacent to Hot Slough, in Tanana River, $24 \mathrm{mi}$. SW of Fairbanks, Tanana Low.; 64.39'15" N, $148^{\circ} 22^{\prime} 00^{\prime \prime} \mathrm{W}$; (map 100).

Local name reported in 1950 by USGS topographers.

Whiskey Jack Slough: channel, of Yukon River, flows NW $2.5 \mathrm{mi}$. N of Little Joker I., $17 \mathrm{mi}$. $\mathrm{W}$ of Tanana, Nowitna Low.; $65^{\circ} 10^{\prime} \mathrm{N}$, $152^{\circ} 40^{\prime} \mathrm{W}$; (map 106)

Local name reported in 1952 by USGS. Probably named for the Alaska Jay, Whiskey Jack, or Camp Robber (Perisoreus canadensis fumifrons).

Whiskey Lake: lake, $1 \mathrm{mi}$. long, in course of Hewitt Creek, $63 \mathrm{mi}$. NW of Tyonek, Alaska Ra.; $61^{\circ} 59^{\prime} 30^{\prime \prime} \mathrm{N}, 151^{\circ} 24^{\prime} 00^{\prime \prime} \mathrm{W}$; (map 70).

Local name reported in 1954 by USGS.

Whiskey Pass: water passage, $1 \mathrm{mi}$. long, between Butterworth and Woewodski Is., $19 \mathrm{mi}$. SW of Petersburg, on $\mathrm{S}$ coast of Kupreanof I., Alex. Arch.; $56^{\circ} 32^{\prime} 30^{\prime \prime} \mathrm{N}, 133^{\circ} 03^{\prime} 30^{\prime \prime} \mathrm{W}$ (map 6).

Local fishermen's name reported in 1947 by USC\&GS.

Whiskey Slough: stream, anabranch of Talkeetna River, flows S $1.2 \mathrm{mi}$., $3.5 \mathrm{mi}$. NE of Talkeetna, Cook Inlet Low.; $62^{\circ} 21^{\prime} \mathrm{N}, 150^{\circ} 01^{\prime}$ W; (map 81).

Local name reported in 1958 by USGS.

Whisky Cove: cove, $1,100 \mathrm{ft}$. across, on $\mathrm{N}$ coast of Pennock I., $0.8 \mathrm{mi}$. SE of Ketchikan, Alex. Arch.; $55^{\circ} 19^{\prime} 45^{\prime \prime} \mathrm{N}, 131^{\circ} 37^{\prime} 55^{\prime \prime} \mathrm{W}$; (map 3).

Local name reported in 1954 by USGS.

Whisky Creek: stream, see Whiskey Creek.

Whisper Lake: lake, $0.7 \mathrm{mi}$. long, on Kenai Penin. Sof Sterling Highway, $5 \mathrm{mi}$. W of Sterling and $13 \mathrm{mi}$. E of Kenai, Cook Inlet Low.; $60^{\circ} 31^{\prime} \mathrm{N}, 150^{\circ} 54^{\prime} \mathrm{W}$; $B G N$ 1948; (map 62).

Named in 1948 by local homesteaders.

Whistler Creek: stream, flows SW $4 \mathrm{mi}$. to Caribou Creek, $19 \mathrm{mi}$. NW of Tahneta Pass, Talkeetna Mts.; $62^{\circ} 01^{\prime} 05^{\prime \prime} \mathrm{N}, 147^{\circ} 50^{\prime} 35^{\prime \prime} \mathrm{W}$; $B G N$ 1960; (map 82).

Named in 1956 by USGS; it "is a common nickname of the marmot" which inhabit the area.

Whistler Creek: stream, heads in Dutch Hills, flows SW $4 \mathrm{mi}$. to Granite Creek, $36 \mathrm{mi}$. NW of Talkeetna, Alaska Ra.; $62^{\circ} 30^{\prime} 35^{\prime \prime} \mathrm{N}, 151^{\circ}$ $09^{\prime} 45^{\prime \prime} \mathrm{W}$; (map 81).

Local name reported in 1958 by USGS.

Whistler Creek: stream, heads at glacier, flows S $3.5 \mathrm{mi}$. to Alder Creek $10 \mathrm{mi}$. NW of its junc. with Tokositna River, $35 \mathrm{mi}$. NW of Talkeetna, Alaska Ra.; $62^{\circ} 47^{\prime} 40^{\prime \prime}$ N, $150^{\circ}$ 30'10' W: (map 81).

Prospectors' name published in 1940 by USGS.

Whistler Creek: stream, flows SW $3.8 \mathrm{mi}$. to Delta River, crossing Richardson Highway $32 \mathrm{mi}$. NW of Paxson, Alaska Ra.; 63 ${ }^{\circ} 8^{\prime} 05^{\prime \prime}$ N, $145^{\circ} 51^{\prime} 00^{\prime \prime} \mathrm{W}$; (map 86).

Name reported in 1952 by USGS.

Whistler Creek: stream, heads at glacier and flows N $4 \mathrm{mi}$. to East Fork Delta River, $11 \mathrm{mi}$. NW of Mount Hayes, Alaska Ra.; $63^{\circ} 46^{\prime} 25^{\prime \prime}$ N, $146^{\circ} 49^{\prime} 40^{\prime \prime} \mathrm{W}$; (map 86)

Name reported in 1952 by USGS

Whistler Creek: stream, heads at glacier in Franklin Mts., flows NE $11 \mathrm{mi}$. to Lake Schrader, $19 \mathrm{mi}$. NW of Mount Michelson, Brooks Ra.; $69^{\circ} 22^{\prime} \mathrm{N}, 145^{\circ} 03^{\prime} \mathrm{W} ; B G N 1960$; (map 139). Var. Snake Creek.

Named by Bee and Hall (1956, p. 295) in August 1952, for the whistlelike call of the hoary marmot (Marmota caligata broweri). Whistler Creek: stream, see Pirate Creek.

Whistle Ridge: ridge, $4,700 \mathrm{ft}$., extends $\mathrm{E} 6.5 \mathrm{mi}$. from headwaters of Rock Creek, $25 \mathrm{mi}$. W of Paxson, Alaska Ra.; $63^{\circ} 05^{\prime}$ N, $146^{\circ} 20^{\prime} \mathrm{W}$; (map 86).

So named in 1955 by Reuben Kachadoorian, USGS, "because of the abundance of whistling marmots" in the area.
Whistlewing Bay: lagoon, $1.3 \mathrm{mi}$. long, on $\mathrm{N}$ shore of Iliamna Lake, $7 \mathrm{mi}$. E of Iliamna, Aleutian Ra.; $59^{\circ} 45^{\prime} 45^{\prime \prime} \mathrm{N}, 154^{\circ} 44^{\prime} 30^{\prime \prime} \mathrm{W}$; (map 51).

Local name reported in 1954 by USGS.

Whistling Gulch: ravine, trends $\mathrm{SW} 1 \mathrm{mi}$. to Hidden Creek, $8 \mathrm{mi}$. N of Medfra, Kilbuck-

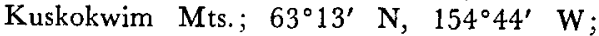
(map 89)

Local name reported in 1958 by USGS.

White, Point: point of land, W coast of Duke I., Alex. Arch.; 54 $56^{\prime} 00^{\prime \prime} \mathrm{N}, 131^{\circ} 29^{\prime} 30^{\prime \prime} \mathrm{W}$; (map 2)

Local name reported in 1955 by USGS.

White, Point: point of land, on NW coast of Kupreanof I., between Frederick Sound and Keku Strait, $40 \mathrm{mi}$. SE of Angoon, Alex. Arch.; $57^{\circ} 00^{\prime} 15^{\prime \prime} \mathrm{N}, 134^{\circ} 00^{\prime} 30^{\prime \prime} \mathrm{W}$; (map 9).

Apparently a local descriptive name published by USC\&GS in the 1891 Coast Pilot (p. 140).

White Bluff: bluff, elev. $80 \mathrm{ft} ., 7 \mathrm{mi}$. S of Point Baker, on NW coast of Prince of Wales $\mathrm{I}$., Alex. Arch.; $56^{\circ} 15^{\prime} 20^{\prime \prime} \mathrm{N}, 133^{\circ} 37^{\prime} 45^{\prime \prime} \mathrm{W}$; (map 6).

Local descriptive name recorded in 1964 by USC\&GS.

White Bluff: cliff, elev. $480 \mathrm{ft}$., on W shore of Zachary Bay, Unga I., in Shumagin Is., Aleutian Ra.; $55^{\circ} 22^{\prime} 00^{\prime \prime} \mathrm{N}, 160^{\circ} 39^{\prime} 00^{\prime \prime} \mathrm{W}$; (map 28)

Local name published on a 1917 USC\&GS chart.

White Cap Mountain: mountain, 3,299 ft., in Glacier Bay National Monument, $2.6 \mathrm{mi}$. NE of mouth of Dundas River and $37 \mathrm{mi}$. NW of Hoonah, St. Elias Mts.; $58^{\circ} 24^{\prime} 30^{\prime \prime} \mathrm{N}, 136^{\circ}$ 15'40" W; BGN 1960; (map 10).

Descriptive name given by USGS in 1956 "because the top of the mountain is capped by massive white limestone."

White Channel Creek: stream, flows NE $4.7 \mathrm{mi}$. to Trail Creek, $10 \mathrm{mi}$. $\mathbf{E}$ of Long and $26 \mathrm{mi}$. SE of Ruby, Nowitna Low.; $64^{\circ} 24^{\prime} \mathrm{N}, 155^{\circ}$ 09' W; (map 98).

Prospectors' name reported in 1913 by Eakin (1914, pl. 3), USGS.

White Cliff: cliff, $700 \mathrm{ft}$., SW Heceta I., Alex. Arch.; $55^{\circ} 44^{\prime} 00^{\prime \prime} \mathrm{N}, 133^{\circ} 38^{\prime} 25^{\prime \prime} \mathrm{W}$; $B G N$ 1908; (map 4).

Local navigators' name recorded by $\mathbf{L t}$. Comdr. H. E. Nichols (U.S. Coast and Geodetic Survey, 1891, p. 122), USN.

White Cliff: cliff, elev. $300 \mathrm{ft}$., on SW coast of White Cliff I., in Davidson Inlet, $33 \mathrm{mi}$. NW

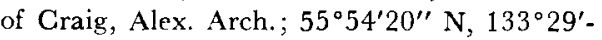
30" W; (map 4).

Descriptive name published in 1923 by USC\&GS.

White Cliff: cliff, on $\mathrm{E}$ coast of Baranof I., 1.5 mi. $\mathrm{N}$ of Takatz Bay and $20 \mathrm{mi}$. E of Sitka, Alex. Arch.; 57 $11^{\prime} \mathrm{N}, 134^{\circ} 49^{\prime} \mathrm{W}$; (map 9).

Local descriptive name reported in 1951 by USGS.

White Cliff Island: island, $1 \mathrm{mi}$. across, $\mathrm{E}$ part of Davidson Inlet, Alex. Arch.; 55 59 $39^{\prime} 30^{\prime \prime} \mathrm{N}$, $133^{\circ} 29^{\prime} 00^{\prime \prime} \mathrm{W}$; (map 4). 
Descriptive name given in 1903 or 1904 by E. F. Dickins, USC\&GS, who wrote "named by our party, has no local name."

White Cliff Passage: water passage, $0.5 \mathrm{mi}$. long, between Orr and White Cliff Is., E part of Davidson Inlet, Alex. Arch.; 55 $54^{\prime} 45^{\prime \prime} \mathrm{N}$, $133^{\circ} 28^{\prime} 30^{\prime \prime} \mathrm{W}$; (map 4).

Local descriptive name published in 1964 by USC\&GS.

White Cliff Point: point of land, S tip of Moser I., in Hoonah Sound, $18 \mathrm{~m}$. E of Chichagof, Alex. Arch.; $57^{\circ} 38^{\prime} 30^{\prime \prime} \mathrm{N}, 135^{\circ} 37^{\prime} 10^{\prime \prime} \mathrm{W}$; (map 9).

Descriptive name given in 1895 by $L t$. Comdr. E. K. Moore, USN.

White Cliffs: cliffs, southern cliffs of Kokrines Hills, on right bank of Yukon River, $19 \mathrm{mi}$. NE of Ruby, Kokrines-Hodzana High.; $64^{\circ}$ $54^{\prime} \mathrm{N}, 154^{\circ} 58^{\prime} \mathrm{W}$; (map 98).

Local name reported about 1952 by USGS.

White Crag Island: island, $0.1 \mathrm{mi}$. across, in Takanis Bay, on SW coast of Yakobi I., 24 mi. NW of Chichagof, Alex. Arch.; 57 $54^{\prime} 20^{\prime \prime}$ N, $136^{\circ} 32^{\prime} 35^{\prime \prime}$ W; BGN 1929; (map 9).

Descriptive name given in 1928 by USC\&GS. The island "is bare and has a conspicuous white top, which forms a prominent landmark."

White Creek: stream, on Kenai Penin., flows NE $3.5 \mathrm{mi}$. to Resurrection Creek, $11 \mathrm{mi}$. SW of Hope, and $35 \mathrm{mi}$. W of Whittier, Chugach Mts. ; $60^{\circ} 45^{\prime} 10^{\prime \prime} \mathrm{N}, 149^{\circ} 42^{\prime} 10^{\prime \prime} \mathrm{W}$; (map 63).

Local prospectors' name reported in 1904 by Moffit (1906, pl. 2), USGS.

White Creek: stream, flows $5 \mathrm{mi}$. NW and joins Rex Creek to form Chititu Creek, $15 \mathrm{mi}$. SE of McCarthy, St. Elias Mts.; $61^{\circ} 17^{\prime} 35^{\prime \prime} \mathrm{N}$, $142^{\circ} 34^{\prime} 40^{\prime \prime}$ W ; (map 67). Var. White Gulch. Local name reported in 1908 by D. C. Witherspoon (in Moffit and Capps, 1911, pl. 2), USGS. Reported in 1902 as "White Gulch" by G. M. Esterly, of Valdez (Mendenhall and Schrader, 1903, fig. 5).

White Creek: stream, flows $6 \mathrm{mi}$. SW to Tok River $16 \mathrm{mi}$. NW of junc. of Little Tok River, $26 \mathrm{mi}$. SW of Tok, Alaska Ra.; $63^{\circ} 12^{\prime} \mathrm{N}$, $143^{\circ} 47^{\prime} \mathrm{W}$; BGN 1936; (map 85).

Local name reported in 1936 by USGS.

White Creek: stream, flows NW $5 \mathrm{mi}$. to Valdez Creek, $65 \mathrm{mi}$. SE of Healy, Alaska Ra.; $63^{\circ}$ $12^{\prime} 15^{\prime \prime} \mathrm{N}, 147^{\circ} 19^{\prime} 30^{\prime \prime} \mathrm{W}$; (map 87).

Prospectors' name shown on a 1910 fieldsheet by D. C. Witherspoon, and published by Moffit (1912, pl. 1), USGS.

White Creek: stream, heads at glacier terminus, in Mount McKinley National Park, flows NW $30 \mathrm{mi}$. to Foraker River, $35 \mathrm{mi}$. SSE of village of Lake Minchumina, Tanana Low.; 63 ${ }^{\circ} 7^{\prime}$ $00^{\prime \prime} \mathrm{N}, 151^{\circ} 52^{\prime} 10^{\prime \prime} \mathrm{W}$; (map 88).

Local name reported in 1925 by S. R. Capps, USGS.

White Creek: stream, flows SW $10 \mathrm{mi}$. to South Fork Goodpaster River, $23 \mathrm{mi}$. E of Big Delta, Yukon-Tanana High.; $64^{\circ} 12^{\prime} \mathrm{N}, 145^{\circ} 05^{\prime} \mathrm{W}$; (map 101).

Local name reported in 1908 by J. W. Bagley, USGS.
White Eye: settlement, on right bank of Yukon River, $46 \mathrm{mi}$. SW of Fort Yukon, Yukon Flats; $66^{\circ} 28^{\prime} \mathrm{N}, 146^{\circ} 54^{\prime} \mathrm{W}$; (map 119). Var. White Eye Camp, White Eyes Camp.

Indian settlement named by prospectors about 1898 for the chief; name published on an 1898 manuscript map by E. F. Ball, prospector, as "White Eye's Camp." The 1940 Census gave a population of 15 .

White Eye Camp: settlement, see White Eye. White Eyes Camp: settlement, see White Eye.

Whiteface Mountain: mountain, 6,000 ft., $5 \mathrm{mi}$. SW of Harvey Mtn. and $28 \mathrm{mi}$. N of Wiseman, Brooks Ra.; $67^{\circ} 48^{\prime} 15^{\prime \prime} \mathrm{N}, 150^{\circ} 23^{\prime} 00^{\prime \prime} \mathrm{W}$; BGN 1932; (map 124).

So named about 1930 by Robert Marshall, "because of its resemblance to a peak of the same name in the Adirondacks."

White Falls: waterfall, on S shore of Expedition Harbor, Bay of Is., Adak I., Aleutian Is. $51^{\circ} 47^{\prime} 05^{\prime \prime} \mathrm{N}, 175^{\circ} 46^{\prime} 05^{\prime \prime} \mathrm{W}$; (map 17).

Descriptive name published by USC\&GS in 1960 on Chart 9120

Whitefish Lake: locality, $1 \mathrm{mi}$. W of Whitefish Lake and $65 \mathrm{mi}$. $\mathrm{N}$ of Nondalton, Lime Hills; $60^{\circ} 56^{\prime} 30^{\prime \prime} \mathrm{N}, 155^{\circ} 01^{\prime} 30^{\prime \prime} \mathrm{W}$; BGN 1966; (map 61). Var. Hungry.

Local name reported in April 1966 by the postmaster at Stony River. Recent USGS maps indicate only a cabin at this site.

White Fish Lake: lake, $5 \mathrm{mi}$. SE of junc. of Kaiyuh Slough and Wounded Cub Creek, 17 mi. SE of Nulato, Koyukuk Low.; $64^{\circ} 29^{\prime} \mathrm{N}$, $158^{\circ} 02^{\prime} \mathrm{W}$; (map 97). Var. Tasezekot.

Appears to be a translation of an Indian name; reported in 1935 by Frederica de Laguna, BAE.

White Fish Lake: lake, on Seward Penin., 2 mi. across, $60 \mathrm{mi}$. NW of Deering, KotzebueKobuk Low.; $66^{\circ} 23^{\prime} \mathrm{N}, 164^{\circ} 45^{\prime} \mathrm{W}$; (map 113).

Local name reported in 1950 by USGS.

White Fish Lake: lake, see Fish Lake.

Whitefish Lake: lake, at head of Hoholitna River, $65 \mathrm{mi}$. N of Nondalton, Lime Hills; $60^{\circ} 57^{\prime}-$ $30^{\prime \prime} \mathrm{N}, 154^{\circ} 52^{\prime} 30^{\prime \prime} \mathrm{W}$; (map 61). Var. White Fish Lake.

Local name reported on a 1912 blueprint of the Alaska Short Line Railway.

Whitefish Lake: lake, $7.5 \mathrm{mi}$. across, $18 \mathrm{mi}$. SW of Aniak, Yukon-Kuskokwim Delta ; 61 '22' $\mathrm{N}, 160^{\circ} 01^{\prime} \mathrm{W}$; (map 73$)$.

Local name shown on a 1914 fieldsheet by A. G. Maddren, USGS.

Whitefish Lake: lake, $4 \mathrm{mi}$. $\mathrm{N}$ of Old Cutoff Trading Post and $19 \mathrm{mi}$. NE of Roundabout Mtn., Koyukuk Low.; $65^{\circ} 47^{\prime} \mathrm{N}, 156^{\circ} 15^{\prime} \mathrm{W}$; (map 108).

Local name obtained at Huslia by USGS in 1954 or 1955.

Whitefish Lake: lake, $1 \mathrm{mi}$. across, $42 \mathrm{mi}$. NW of Midnight Hill, Porcupine Plat.; 66 $6^{\circ} 15^{\prime} 30^{\prime \prime}$ N, $142^{\circ} 29^{\prime} 00^{\prime \prime} \mathrm{W}$; (map 120).

Local name obtained in 1956 by T. E. Taylor and R. C. Foley, USGS.

White Fox Lake: lake, $0.6 \mathrm{mi}$. long, $\mathrm{E}$ of Long Lake, $21 \mathrm{mi}$. SW of Beaver, Yukon Flats; $66^{\circ} 16^{\prime} 40^{\prime \prime} \mathrm{N}, 148^{\circ} 07^{\prime} 00^{\prime \prime} \mathrm{W}$; (map 118).
Probably named by William Yanert who showed it on a 1916 manuscript map of the Yukon Flats (Stuck, 1917, map facing p. 122).

White Glacier: glacier, in Glacier Bay National Monument, trends W $3 \mathrm{mi}$. to its 1961 terminus, $0.7 \mathrm{mi}$. SW of Mount Case and $66 \mathrm{mi}$. $\mathrm{NW}$ of Juneau, St. Elias Mts.; $58^{\circ} 48^{\prime} 40^{\prime \prime}$ N, $135^{\circ} 58^{\prime} 55^{\prime \prime} \mathrm{W}$; (map 11).

Descriptive name given in 1890 by Reid (1892, p. 33), USGS.

White Gulch: stream, see White Creek.

White Gull Island: island, $0.1 \mathrm{mi}$. across, in Iliamna Bay, $19 \mathrm{mi}$. N of Augustine I., Aleutian Ra.; $59^{\circ} 37^{\prime} \mathrm{N}, 153^{\circ} 34^{\prime} \mathrm{W}$; BGN 1916; (map 51).

Local name published in 1907 on USC\&GS Chart 8665.

White Hill: hill, 4,610 ft., between Little Nelchina River and Tyone Creek, $17 \mathrm{mi}$. $\mathrm{N}$ of Tahneta Pass, Talkeetna Mts. ; $62^{\circ} 08^{\prime} \mathrm{N}, 147^{\circ}$ 23' W; BGN 1960; (map 82).

Descriptive name given by USGS in 1956 because it is a conspicious whitish hill of limestone.

White Hills: ridge, extends SW $25 \mathrm{mi}$. from Toolik River, $15 \mathrm{mi}$. W of junc. of Ivishak and Sagavanirktok Rivers, Arctic Plain; $69^{\circ}$ $34^{\prime} \mathrm{N}, 149^{\circ} 27^{\prime} \mathrm{W}$; BGN 1949; (map 140).

Local name reported in 1949 by USGS.

Whitehorse Creek: stream, flows NE $3 \mathrm{mi}$. to Grouse Creek which flows to Mint River, 41 mi. NW of Teller, Seward Penin. High.; $65^{\circ} 40^{\prime} \mathrm{N}, 167^{\circ} 24^{\prime} \mathrm{W}$; (map 111). Var. White Horse Creek.

Prospectors' name reported on the 1908 "Map of Seward Peninsula" by Arthur Gibson.

White Island: island, see Error Island.

White Lake: lake, $0.2 \mathrm{mi}$. long, on $\mathrm{W}$ bank of Knik Arm Cook Inlet, $0.6 \mathrm{mi}$. W of Knik and $17 \mathrm{mi}$. NE of Anchorage, Cook Inlet Low.; $61^{\circ} 27^{\prime} 30^{\prime \prime} \mathrm{N}, 1^{\circ} 49^{\circ} 43^{\prime} 45^{\prime \prime} \mathrm{W}$; (map 69).

Local name reported in 1942 by AMS.

White Lake: lake, $1 \mathrm{mi}$. long, $16 \mathrm{mi}$. S of Christian and $13 \mathrm{mi}$. SE of Flooded Lake, Yukon Flats; $67^{\circ} 08^{\prime} \mathrm{N}, 145^{\circ} 06^{\prime} \mathrm{W}$; (map 122).

Local name reported in 1956 by T. E. Taylor, USGS.

White Lake: lake, $1 \mathrm{mi}$. across, $\mathrm{W}$ of Chandler River, $28 \mathrm{mi}$. WNW of Anaktuvuk Pass, Brooks Ra.; $68^{\circ} 20^{\prime} 30^{\prime \prime} \mathrm{N}, 152^{\circ} 35^{\prime} 00^{\prime \prime} \mathrm{W}$; (map 134).

Named in 1944 by USGS geologists during the exploration of Naval Petroleum Reserve No. 4, because "higher altitude preserves ice later."

White Mans Point: point of land, see Muir Point.

White Mountain: village, pop. 151, on left bank of Fish River, $15 \mathrm{mi}$. NW of Golovin and 33 mi. NE of Solomon, Seward Penin. High.; $64^{\circ} 41^{\prime} \mathrm{N}, 163^{\circ} 24^{\prime} \mathrm{W}$; (map 95).

Established in 1899 when C. D. Lane put up a large warehouse as headquarters for the supplies he intended to use on his numerous gold claims in the Council district 
(North American Transportation and Trading Company, 1900, p. 25). The name was derived from the mountain on its north side. Colby $(1939$, p. 363$)$ referred to this as a fishing village with a population of 205. A post office was established in 1932 and continues today (Ricks, 1965, p. 70-71). The population was 198 in $1920 ; 205$ in $1930 ; 199$ in $1939 ; 129$ in 1950 ; and 151 in 1960 , of whom 119 were Eskimo. See Ekathliomute.

White Mountain: mountain, 2,121 ft., on Dall I., W of View Cove, Alex. Arch.; $55^{\circ} 04^{\prime} 40^{\prime \prime}$ N, $133^{\circ} 06^{\prime} 30^{\prime \prime} \mathrm{W}$; (map 4).

Descriptive name published in 1924 by USC\&GS.

White Mountain: mountain, $\mathrm{N}$ of Nabesna, 5 mi. NW of junc. of Jacksina Creek and Nabesna River, Wrangell Mts.; $62^{\circ} 23 \mathrm{~N}, 143^{\circ}$ 02' W; BGN 1939; (map 84).

Local name reported in 1960 by USGS; so named because of massive white limestone outcrops on its east slope.

White Mountain : peak, see Snowy Peak.

White Mountain Creek: stream, flows $\mathrm{N} 17 \mathrm{mi}$. to Johns Creek, $45 \mathrm{mi}$. NE of Medfra, KilbuckKuskokwim Mts. ; $63^{\circ} 41^{\prime} \mathrm{N}, 154^{\circ} 11^{\prime} \mathrm{W}$; (map 89).

Local name reported in 1954 by USGS.

White Mountain Creek: stream, flows SW $18 \mathrm{mi}$. to Porcupine River, $14 \mathrm{mi}$. WSW of Canalaska Mtn. and $38 \mathrm{mi}$. ENE of Coleen Mtn., Brooks Ra.; $67^{\circ} 19^{\prime} \mathrm{N}, 141^{\circ} 32^{\prime} \mathrm{W}$; (map 121).

Name reported by $M$. G. White (1952, fig. 1), USGS, in 1948.

White Mountains: mountains, 5,000 ft., trend ENE $70 \mathrm{mi}$., bounded on the SW and NW by Beaver Creek and on the NE by Preacher Creek, $60 \mathrm{mi}$. W of Circle, Yukon-Tanana High.; $65^{\circ} 24^{\prime} \mathrm{N}, 147^{\circ} 30^{\prime} \mathrm{W}$ [SW end], $65^{\circ} 49^{\prime}$ $\mathrm{N}, 145^{\circ} 33^{\prime} \mathrm{W}$ [NE end]; (map 104).

Descriptive name given by prospectors; reported in 1903 by Prindle (1905, p. 74), USGS. So named because they are composed of white limestone (Brooks and others, 1906, p. 130).

Whiteout Glacier: glacier, $11 \mathrm{mi}$. long, heads at $61^{\circ} 06^{\prime} 45^{\prime \prime} \mathrm{N}, 148^{\circ} 55^{\prime} 30^{\prime \prime} \mathrm{W}$, trends $\mathrm{N}$ for 4 $\mathrm{mi}$., then $\mathrm{E}$, to Upper Lake George, $39 \mathrm{mi}$. $\mathrm{E}$ of Anchorage, Chugach Mts.; $61^{\circ} 10^{\prime} 30^{\prime \prime} \mathrm{N}$, 148 $43^{\prime} 20^{\prime \prime}$ W; [1957] BGN 1966; (map 69).

Named in 1963 by the Mountaineering Club of Alaska for nearby Whiteout Peak.

Whiteout Peak: mountain, 7,135 ft., $7.5 \mathrm{mi}$. SW of Upper Lake George and $33 \mathrm{mi}$. E of Anchorage, Chugach Mts.; $61^{\circ} 07^{\prime} 45^{\prime \prime} \mathrm{N}, 148^{\circ}$ 54'15" W; BGN 1964; (map 69).

Descriptive name given in 1963 by members of the Mountaineering Club of Alaska pertaining to the "usual weather conditions experienced by climbers in this area." A whiteout is an "opaque diffusion of sky and snow."

White Pass: RR. station, on The White Pass and Yukon RR., on Alaska-Canada boundary, 12 mi. NW of Skagway, Coast Mts.; 59 $37^{\prime} \mathrm{N}$, $135^{\circ} 08^{\prime} \mathrm{W}$; (map 45$)$.

Local name reported in 1925 by IBC.
White Pass: pass, 2,900 ft., on Alaska-Canada boundary, $4 \mathrm{mi}$. NE of Mount Cleveland and 13 mi NE of Skagway, Coast Mts.; $59^{\circ} 37^{\prime} 30^{\prime \prime}$ N, $135^{\circ} 08^{\prime} 05^{\prime \prime}$ W; BGN 1954; (map 45). Var. Shasheki, Skagway Pass.

Named by William Ogilvie, Dominion Land Surveyor, in 1887 for Thomas White, Canadian Minister of the Interior. This pass is probably the same as Shasheki, a Tlingit Indian name reported by W. H. Dall, USC\&GS, and published in the 1883 Coast Pilot (p. 200). This pass was on one of the principal routes to the Yukon taken by the prospectors during the Klondike Gold Rush 1897-1900. Although the White Pass route was less direct than the favorite, but steeper Chilkoot Pass route, it was used by more prospectors during the winter months.

White Pass Fork: stream, heads in Summit Lake and flows $4 \mathrm{mi}$. $\mathrm{S}$ to Skagway River, $9 \mathrm{mi}$. $\mathrm{NE}$ of Skagway, Coast Mts., $59^{\circ} 34^{\prime} 05^{\prime \prime} \mathrm{N}$, $135^{\circ} 09^{\prime} 50^{\prime \prime} \mathrm{W}$; (map 45).

Local name obtained by USGS personnel and published on Federal maps since 1950.

White Point: point of land, W entrance point to Bechevin Bay, $\mathrm{N}$ coast of Atka I., Aleutian Is. ; $52^{\circ} 03^{\prime} 20^{\prime \prime} \mathrm{N}, 175^{\circ} 07^{\prime} 00^{\prime \prime} \mathrm{W}$; (map 18).

Descriptive name applied "because of light gray bluffs." Published by the USC\&GS in the 1944 Aleutian Coast Pilot (p. 99).

White Point: point of land, on NW coast of $\mathrm{El}$ Capitan I., $25 \mathrm{mi}$. N of Craig, Alex. Arch.; $55^{\circ} 56^{\prime} 45^{\prime \prime} \mathrm{N}, 133^{\circ} 20^{\prime} 25^{\prime \prime} \mathrm{W}$; (map 4).

Local name published in 1925 Coast Pilot (p. 155).

White Princess: peak, 9,800 ft., near head of Gerstle Glacier, $27 \mathrm{mi}$. N of Paxson, Alaska Ra. ; $63^{\circ} 25^{\prime} 15^{\prime \prime} \mathrm{N}, 145^{\circ} 25^{\prime} 20^{\prime \prime} \mathrm{W}$; (map 86). Name reported in 1952 by USGS.

White Reef: rocks, extend 1,500 ft., in Revillagigedo Channel, near mouth of Boca de Quadra, Coast Mts.; $55^{\circ} 04^{\prime} \mathrm{N}, 131^{\circ} 02^{\prime} \mathrm{W}$; (map 3).

Descriptive name given in 1883 by Lt. Comdr. H. E. Nichols, USN.

White River: stream, on Revillagigedo I., flows NE $8 \mathrm{mi}$. to George Inlet, SW of Bull I., Alex. Arch.; 55 $28^{\prime} \mathrm{N}, 131^{\circ} 32^{\prime} \mathrm{W}$; (map 3).

Local navigators' name obtained in 1904 by H. C. Fassett, USBF.

White River: stream, heads in lake NW of Kapho Mts., flows SE $8 \mathrm{mi}$. to join Bradfield River at head of Bradfield Canal, Coast Mts. ; 56 ${ }^{\circ} 14^{\prime}$ $\mathrm{N}, 131^{\circ} 30^{\circ} \mathrm{W}$; (map 7).

Local name reported in 1923 by USFS.

White River: stream, heads at White River Glacier terminus, flows $W$ and $S 5.6 \mathrm{mi}$. to Gulf of Alaska, $7 \mathrm{mi}$. SE of Cape Yakataga, Chugach Mts.; $60^{\circ} 02^{\prime} 50^{\prime \prime} \mathrm{N}, 142^{\circ} 13^{\prime} 15^{\prime \prime} \mathrm{W}$; (map 65).

Named in 1897 by oil prospectors; reported in 1903 by G. C. Martin, USGS.

White River: stream, about $200 \mathrm{mi}$. long, heads in Alaska at terminus of Russell Glacier, flows NE into Canada to Yukon River, Wrangell Mts.; $63^{\circ} 10^{\prime} \mathrm{N}, 139^{\circ} 32^{\prime} \mathrm{W}$; BGN 1953; (map 67).
Discovered in 1850 by Robert Campbell of Hudson's Bay Company and so named by him on account of its color. Lt. Schwatka (1885b, p. 39), USA, wrote of this stream: "its waters seemingly liquid mud, from whence it probably derives its name. It is called by the "Sticks" the Yukokon Heenah (Yu-ko-kon) or Yukokon River, and by the Chilkats another name, meaning Sand River, from the immense number of sand bars and banks which they say exists along its course."

White River: stream, flows NE $10 \mathrm{mi}$. to Imuruk Basin, $19 \mathrm{mi}$. SE of Teller, Seward Penin. High.; $65^{\circ} 05^{\prime} \mathrm{N}, 165^{\circ} 51^{\prime} \mathrm{W}$; (map 111).

Prospectors' name reported on the 1908 "Map of Seward Peninsula" by Arthur Gibson. White River Glacier: glacier, heads at Guyot Glacier, $2 \mathrm{mi}$. N of Munday Peak, trends SW and $W 5 \mathrm{mi}$. to its 1950 terminus in lake at head of White River, $11 \mathrm{mi}$. $\mathbf{E}$ of Cape Yakataga, Chugach Mts.; $60^{\circ} 04^{\prime} 15^{\prime \prime} \mathrm{N}, 142^{\circ} 07^{\prime}$ $00^{\prime \prime} \mathrm{W}$; (map 65).

Name published by F. H. Moffit (1914, pl. 1), USGS.

White Rock: rock, $120 \mathrm{ft}$. high, in Clarence Strait, 1.3 mi. S of Duke I., Alex. Arch.; 54$50^{\prime} 15^{\prime \prime} \mathrm{N}, 131^{\circ} 22^{\prime} 00^{\prime \prime} \mathrm{W}$; (map 2).

Named in 1886 by $R$. Clover, USN.

White Rock: rock, in Sumner Strait, between Zarembo and Kupreanof Is., Alex. Arch.; 56 ${ }^{\circ}$ $28^{\prime} 30^{\prime \prime} \mathrm{N}, 133^{\circ} 01^{\prime} 45^{\prime \prime} \mathrm{W}$; (map 6).

Descriptive name given in 1886 by Lt. Comdr. A. S. Snow, USN, because of its "very white" color.

White Rock: rock, at mouth of Kempff Bay, in Alitak Bay, at S end of Kodiak I.; $56^{\circ} 54^{\prime} 08^{\prime \prime}$ $\mathrm{N}, 154^{\circ} 10^{\prime} 55^{\prime \prime} \mathrm{W}$; (map 32$)$.

Descriptive name published in 1943 by USC\&GS.

White Rock: rock, off Point of Turbot, $\mathrm{N}$ of Takatz Bay, along $\mathrm{E}$ coast of Baranof I., 5 mi. N of Baranof, Alex. Arch.; 57 $09^{\prime} 50^{\prime \prime} \mathrm{N}$, $134^{\circ} 47^{\prime} 55^{\prime \prime} \mathrm{W}$; ( $\operatorname{map} 9$ ).

Descriptive name published by USC\&GS in the 1943 Coast Pilot (p. 342). So named because it is "a prominent, light-colored rock."

White Rock: rock, in Chatham Strait, $4.5 \mathrm{mi}$. NE of Chatham, off SE coast of Chichagof I., Alex. Arch.; 57 $32^{\prime} 45^{\prime \prime}$ N, 134 $50^{\prime} 55^{\prime \prime} \mathrm{W}$; (map 9). Var. Kamen Byloy.

An 1882 translation by USC\&GS of descriptive name "Kamen Byloy" given in 1849 by Capt. Tebenkov (1852, map 8).

White Rock: rocks, see Bieli Rocks.

White Rock. rock, see Hattie Rock.

Whiterock Island: island, $0.5 \mathrm{mi}$. long, at mouth of Moira Sound, along SE coast of Prince of Wales I., Alex. Arch.; 55 03'20' N, 131 ${ }^{\circ} 59^{\prime}$ $35^{\prime \prime}$ W; (map 3). Var. White Rock Island.

Local name published in the 1925 Coast Pilot (p. 75).

White Rocks: rocks, extend $700 \mathrm{ft}$., between Brownson Bay and Dixon Entrance, on $S$ coast of Prince of Wales I., Alex. Arch.; 54 ${ }^{\circ}$ $43^{\prime} \mathrm{N}, 132^{\circ} 14^{\prime} \mathrm{W}$; (map 1$)$.

Local name reported in 1948 by USGS.

White Sand Creek: stream, flows SE $5.8 \mathrm{mi}$. to Tyrone Creek, $22 \mathrm{mi}$. NE of Tahneta Pass, 
Talkeetna Mts. ; $62^{\circ} 11^{\prime} 35^{\prime \prime}$ N, $147^{\circ} 11^{\prime} 00^{\prime \prime} \mathrm{W}$; BGN 1960; (map 82).

Named in 1956 by USGS "for the bluffs of white sand located along this stream." Whiteshed: village, see Whitshed.

White Sisters: islands, $0.2 \mathrm{mi}$. across, along W coast of Chichagof I., $6.2 \mathrm{mi}$. WSW of Chichagof, Alex. Arch.; $57^{\circ} 38^{\prime} \mathrm{N}, 136^{\circ} 15^{\prime} \mathrm{W}$; BGN 1908; (map 9).

Descriptive name given in 1908 by USC\&GS. So named because "they consist of two large white rocks close together."

White Snow Mountain: mountain, 2,497 ft., 20 mi. NW of Outlook Point and $29 \mathrm{mi}$. NE of Christian, Brooks Ra. ; $67^{\circ} 34^{\prime} \mathrm{N}, 144^{\circ} 16^{\prime} \mathrm{W}$; (map 122).

Local name reported in 1956 by T. E. Taylor, USGS.

Whites Point: point of land, see Shoals Point. Whites Roadhouse: locality, on right bank of Tanana River, 8 mi. SE of Fairbanks, Tanana Low.; $64^{\circ} 45^{\prime} \mathrm{N}, 147^{\circ} 30^{\prime} \mathrm{W}$; (map 100).

Name of a roadhouse along the FairbanksValdez Trail, probably named for the original owner. The name was published in 1912 by USGS.

Whitestone Cove: cove, $0.2 \mathrm{mi}$. across, in Neva Strait on NW coast of Baranof I., $15 \mathrm{mi}$. NW of Sitka, Alex. Arch.; 57 $14^{\prime} 50^{\prime \prime} \mathrm{N}, 135^{\circ} 33^{\prime}$ $40^{\prime \prime} \mathrm{W}$; (map 9).

Name published in 1900 by USC\&GS on Chart 8281; probably named for Whitestone Narrows just to the west.

Whitestone Creek: stream, flows N $1 \mathrm{mi}$. to Alder Creek, in Bluestone River basin, $15 \mathrm{mi}$. SE of Teller, Seward Penin. High.; $65^{\circ} 04^{\prime} \mathrm{N}$, $166^{\circ} 10^{\prime} \mathrm{W}$; (map 111).

Prospectors' name reported on a map of Cape Nome goldfields by David Fox, Jr., dated 1901.

Whitestone Harbor: cove, $1 \mathrm{mi}$. across, on Icy Straits, on $\mathrm{N}$ coast of Chichagof I., $4 \mathrm{mi}$. WNW of Point Augusta and $29 \mathrm{mi}$. SW of Juneau, Alex. Arch.; $58^{\circ} 04^{\prime} \mathrm{N}, 135^{\circ} 04^{\prime} \mathrm{W}$; $B G N$ 1929; (map 11).

Local name reported in 1928 by USFS.

Whitestone Islet: rock, see Whitestone Rock.

Whitestone Narrows: water passage, in Neva Strait, on NW coast of Baranof I., $16 \mathrm{mi}$. NW of Sitka, Alex. Arch.; 57 $14^{\prime} 50^{\prime \prime}$ N, $135^{\circ} 33^{\prime}$. 45" W; (map 9).

Named in 1869 by Comdr. R. W. Meade, USN; published by USC\&GS in the 1883 Coast Pilot (p. 156).

Whitestone Point: point of land, on SE shore of Neva Strait, at Whitestone Narrows, on NW coast of Baranof 1., $16 \mathrm{mi}$. NW of Sitka, Alex. Arch.; 57 $14^{\prime} 45^{\prime \prime} \mathrm{N}, 1^{\circ} 5^{\circ} 33^{\prime} 30^{\prime \prime} \mathrm{W}$; (map 9).

Name published by W. H. Dall, USC\&GS, in the 1883 Coast Pilot (p. 156). The name probably was derived from nearby Whitestone Narrows.

Whitestone Rock: rock, in Neva Strait on NW coast of Baranof I., $16 \mathrm{mi}$. NW of Sitka, Alex. Arch.; 57 $14^{\prime} 50^{\prime \prime}$ N, $135^{\circ} 33^{\prime} 45^{\prime \prime}$ W ; (map 9). Var. Whitestone Islet.

Local name given about 1880 and published by USC\&GS in the 1883 Coast Pilot (p. 156). The name is probably derived from Whitestone Narrows where the rock is located.

Whitestripe Lake: lake, $0.5 \mathrm{mi}$. across, $5 \mathrm{mi}$. NNE of Chichagof, on W coast of Chichagof I., Alex. Arch.; $57^{\circ} 44^{\prime} 20^{\prime \prime} \mathrm{N}, 136^{\circ} 04^{\prime} 20^{\prime \prime} \mathrm{W}$; $B G N$ 1939; (map 9).

Descriptive name given in 1939 by local inhabitants. The lake is called "Whitestripe" because it is underlaid by the same band of white marble which gives Whitestripe Mountain its name.

Whitestripe Mountain: mountain, $2,877 \mathrm{ft} ., 4.5$ mi. NE of Chichagof, on $W$ coast of Chichag of I., Alex. Arch.; $57^{\circ} 43^{\prime} 30^{\prime \prime} \mathrm{N}, 136^{\circ} 03^{\prime} 00^{\prime \prime} \mathrm{W}$; $B G N$ 1939; (map 9).

Named in 1939 by local inhabitants. So named because of a conspicuous band of white marble which crosses the mountain.

White Sulphur Springs: springs, on N shore of Bertha Bay, on W coast of Chichagof I., 13 mi. NW of Chichagof, Alex. Arch.; $57^{\circ} 48^{\prime} 25^{\prime \prime}$ N, $136^{\circ} 20^{\prime} 45^{\prime \prime} \mathrm{W} ; B G N$ 1917; (map 9). Var. Hooniah Hot Springs, Hooniah Sound Hot Springs, Hooniah Warm Springs.

Named in 1916 by "Surveyor Crowthers of Juneau." The name is derived from the white color of the sulphur deposits. "Prior to 1916 the springs were used only by a few natives who ventured north from Sitka on hunting and trapping expeditions. No improvements were made to the springs, the natives merely using the shallow natural pools in the ledges." The springs were origirally called "Hooniah Hot Springs" by USC\&GS on Chart 8050 in 1902, and "Hooniah Warm Springs" in the 1908 Coast Pilot (p. 168). The name was changed to "White Sulphur Springs" in 1917 to avoid confusion with Tenakee Hot Springs.

White Thunder Ridge: ridge, $4 \mathrm{mi}$. long, trends SE from Muir Glacier to $W$ shore of Muir Inlet, $44 \mathrm{mi}$. SW of Skagway, St. Elias Mts.; $59^{\circ} 02^{\prime} 00^{\prime \prime} \mathrm{N}, 136^{\circ} 11^{\prime} 30^{\prime \prime} \mathrm{W}$; (map 45).

Named by Douglas Brown, American Geographical Society, who established a photographic station on the summit in 1946. Named from the noise produced by the discharging front of the glaciers. The name was published by the American Geographical Society (Field, 1947, pl. 1)

Whitewater Bay: bay, $1.5 \mathrm{mi}$. across, on SW coast of Admiralty I., $16 \mathrm{mi}$. S of Angoon, Alex. Arch.; $57^{\circ} 15^{\prime} \mathrm{N}, 134^{\circ} 37^{\prime} \mathrm{W}$; (map 9). Var. Lower Khudsnu Lower Kootznahoo Bay, Lower Koutsnow Bay.

Descriptive name given in 1869 by Comdr. R. W. Meade, USN, and published by USC\&GS in the 1883 Coast Pilot (p. 174).

Whitewater Creek: stream, flows SW $6 \mathrm{mi}$. to Kiknik Creek, $7 \mathrm{mi}$. SW of Taylor Mts. and $63 \mathrm{mi}$. S of Sleetmute, Kilbuck-Kuskokwim Mts. ; $60^{\circ} 50^{\prime} \mathrm{N}, 157^{\circ} 30^{\prime} \mathrm{W} ; B G N$ 1948; (map $60)$.

Local descriptive name reported in 1945 by USGS.

Whitewing Valley: valley, extends NE-SW 7 mi. in Horn Mts. $34 \mathrm{mi}$. NE of Aniak, Kil-
buck-Kuskokwim Mts.; $61^{\circ} 42^{\prime} \mathrm{N}, 158^{\circ} 30^{\prime} \mathrm{W}$; $B G N$ 1945; (map 72).

So named in 1944 by USGS because of "the unusual abundance of whitewing ptarmigan in this valley."

Whitham Lake: lake, $0.7 \mathrm{mi}$. long, $1.2 \mathrm{mi}$. W of junc. of Fish and Jacksina Creeks and $2.6 \mathrm{mi}$. SE of Nabesna, Wrangell Mts.; $62^{\circ} 20^{\prime} 00^{\prime \prime} \mathrm{N}$, $142^{\circ} 57^{\prime} 30^{\prime \prime} \mathrm{W}$; (map 84).

Local name reported in 1960 by USGS.

Whiting Falls: waterfall, on a tributary to Copper River, $55 \mathrm{mi}$. NW of Cordova, Chugach Mts.; $60^{\circ} 59^{\prime} 30^{\prime \prime} \mathrm{N}, 144^{\circ} 50^{\prime} 20^{\prime \prime} \mathrm{W}$; (map 64).

Name published in 1950 by USGS.

Whiting Harbor: bay, $0.4 \mathrm{mi}$. across, formed by islands tied to Japonski I., $1 \mathrm{mi}$. W of Sitka, Alex. Arch.; $57^{\circ} 03^{\prime} \mathrm{N}, 135^{\circ} 22^{\prime} \mathrm{W}$; (map 9).

Named in 1880 by the U.S. Navy presumably for Commodore William D. Whiting, USN; published in 1883 Coast Pilot (p. 142).

Whiting Point: point of land, on Whiting River, $3 \mathrm{mi}$. NE of Port Snettisham and $35 \mathrm{mi}$. SE of Juneau, Coast Mts.; $58^{\circ} 01^{\prime} 05^{\prime \prime} \mathrm{N}, 133^{\circ}$ $38^{\prime 2} 5^{\prime \prime} \mathrm{W}$; (map 8).

Named in 1888 by Lt. Comdr. C. M. Thomas, USN, for Assistant-Surgeon Robert Whiting, USN, a member of his party.

Whiting River: stream, heads in British Columbia $58^{\circ} 20^{\prime} \mathrm{N}, 132^{\circ} 30^{\prime} \mathrm{W}$, flows SW, across Alaska-Canada boundary, $50 \mathrm{mi}$. to Gilbert Bay, $33 \mathrm{mi}$. SE of Juneau, Coast Mts.; $57^{\circ}$ $59^{\prime} 30^{\prime \prime} \mathrm{N}, 133^{\circ} 42^{\prime} 30^{\prime \prime} \mathrm{W}$; BGN 1954; (map 8).

Named in 1888 by Lt. Comdr. C. M Thomas, USN, for assistant surgeon Robert Whiting, USN, a member of his surveying party. The name was published by USC\&GS in the 1891 Coast Pilot (p. 149).

Whitman Creek: stream, on Revillagigedo I., heads in a lake, flows SE through Whitman Lake $4 \mathrm{mi}$. to mouth of George Inlet, Alex. Arch.; 55 $19^{\prime} 45^{\prime \prime} \mathrm{N}, 131^{\circ} 30^{\prime} 40^{\prime \prime} \mathrm{W} ; B G N$ 1966; (map 3). Var. Case Creek.

Local name reported in 1966 by USFS.

Whitman Lake: lake, $1.1 \mathrm{mi}$. long, on Revillagigedo $1 ., \mathrm{W}$ of mouth of George Inlet, in course of Whitman Creek, Alex. Arch.; $55^{\circ}$ $20^{\prime} 10^{\prime \prime} \mathrm{N}, 131^{\circ} 32^{\prime} 45^{\prime \prime} \mathrm{W}$; (map 3 ).

Local name published in 1917 by USG\&GS. Whitney: suburb, part of Elmendorf Air Force Base, mi. 119.1 on The Alaska RR. $4.3 \mathrm{mi}$. NE of Anchorage, Cook Inlet Low. ; 61 ${ }^{\circ} 15^{\prime} 15^{\prime \prime}$ $\mathrm{N}, 149^{\circ} 46^{\prime} 30^{\prime \prime} \mathrm{W}$; (map 69).

Name of a station on The Alaska RR. first published in the 1918 Railway Guide Index.

Whitney Island: island, 3 mi. long, between Fanshaw Bay and Cleveland Passage, $3 \mathrm{mi}$. NE of Cape Fanshaw and $70 \mathrm{mi}$. E of Sitka, Coast Mts.; $57^{\circ} 13^{\prime} 30^{\prime \prime} \mathrm{N}, 133^{\circ} 31^{\prime} 30^{\prime \prime} \mathrm{W}$; (map 8).

Named in 1887 by Lt. Comdr. C. M. Thomas, USN, for William Collins Whitney, 1841-1904, lawyer and Secretary of Navy under President Grover Cleveland, 1885-89. Name published by USC\&GS in the 1891 Coast Pilot (p. 145).

Whitshed: village, pop. 10 (summer pop. 60), on peninsula $8 \mathrm{mi}$. SW of Cordova, Chugach 
Mts. ; 60²8' N, $145^{\circ} 57^{\prime}$ W; (map 64). Var. Port Whiteshed, Port Whitshed, Whiteshed.

Local name published in 1951 by USGS on a map indicating a probable cannery with two or three buildings. Name derived from nearby Point Whitshed.

Whitshed, Point: point of land, at SW end of Heney Ra., $8 \mathrm{mi}$. SW of Cordova, Chugach Mts.; $60^{\circ} 27^{\prime} \mathrm{N}, 145^{\circ} .53^{\prime} \mathrm{W}$; (map 64). Var. Cape Whitshed, Point Whihshet, Point Whitshet, Point Witshed, Puenta de Orevilla, Punta de Treville.

Named by Capt. George Vancouver, RN, for Capt. Whitshed, RN, after the point of land was examined by James Johnstone on June 25 , 1794 (Wagner, 1937, p. 421). It was called "Punta de Treville" by Don Ignacio Arteaga in 1779 for Louis René Madeleine le Vasson de Latouche Treville, French admiral who died in 1804 (Wagner, 1937, p. 520).

Whitshet, Point: point of land, see Whitshed Point.

Whitsol Lake: lake, $0.8 \mathrm{mi}$. long, $\mathrm{N}$ of Kroto Slough, $35 \mathrm{mi}$. NW of Anchorage, Cook Inlet Low.; $61^{\circ} 40^{\prime} 10^{\prime \prime} \mathrm{N}, 150^{\circ} 25^{\prime} 20^{\prime \prime} \mathrm{W}$; (map $70)$.

Local name reported in 1958 by USGS.

Whitsunday, Cape: point of land, see Pillar Cape.

Whitsunday Bay: bay, see Izhut Bay.

Whitsuntide: point of land, see Izhut, Cape.

Whitsuntide Bay: bay, see Marmot Bay.

Whitsuntide Bay: water passage, see Shelikhof Strait.

Whittier: village, pop. 809, on NE end of Kenai Penin., at head of Passage Cana', $28 \mathrm{mi}$. SE of Sunrise and $50 \mathrm{mi}$. SE of Anchorage, Chugach Mts. ; $60^{\circ} 46^{\prime} 30^{\prime \prime} \mathrm{N}, 148^{\circ} 41^{\prime} 00^{\prime \prime} \mathrm{W}$; (map 63).

Port and RR. terminus established during World War II. The name derived from nearby Whittier Glacier was reported in 1943 by USGS. The population in 1950 was 629 . A post office was established here in 1946 and discontinued in 1961 (Ricks, 1965, p. 71).

Whittier Creek: stream, heads at terminus or Whittier Glacier, flows NW $2 \mathrm{mi}$. to Passage Canal at Whittier, Chugach Mts.; $60^{\circ} 41^{\prime} 35^{\prime \prime}$ $\mathrm{N}, 148^{\circ} 41^{\prime} 35^{\prime \prime} \mathrm{W}$; (map 63).

Local name reported in 1951 by USGS.

Whittier Glacier: glacier, on NE end of Kenai Penin., trends NE $4 \mathrm{mi}$. to its terminus, $1 \mathrm{mi}$. S of Whittier, Chugach Mts.; $60^{\circ} 40^{\prime} 30^{\prime \prime} \mathrm{N}$, $148^{\circ} 40^{\prime} 30^{\prime \prime}$ W; (map 63). Var. Portage Glacier.

Named and published in 1915 by USC\&GS for the American poet John Greenleaf Whittier, 1807-92.

Whittren Creek: stream, flows NE $1 \mathrm{mi}$. to Gold Run which flows to Bluestone River, $14 \mathrm{mi}$. SE of Teller, Seward Penin. High.; 65 $04^{\circ} 45^{\prime \prime} \mathrm{N}$, $166^{\circ} 12^{\prime} 20^{\prime \prime} \mathrm{W}$; (map 111).

Prospectors' name reported on the 1908 "Map of Seward Peninsula" by Arthur Gibson.

Whontleya: locality, along right bank of Yukon River, extends $10 \mathrm{mi}$. from Bishop Rock to mouth of Koyukuk River, $20 \mathrm{mi}$. NE of Nulato,

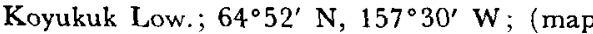
97).
Indian fishing ground reported in 1952 by USGS.

Why Creek: stream, see Query Creek.

Why Lake: lake, $1.5 \mathrm{mi}$. long, $2 \mathrm{mi}$. SE of Big Creek and $29 \mathrm{mi}$. SE of Beaver, Yukon-Tanana High.; $66^{\circ} 02^{\prime} 50^{\prime \prime} \mathrm{N}, 146^{\circ} 39^{\prime} 00^{\prime \prime} \mathrm{W}$; (map 119).

Local descriptive name obtained in 1956 by USGS.

Whymper Creek: stream, flows NE $8 \mathrm{mi}$. to Lynx Creek, $20 \mathrm{mi}$. NE of Rampart, Yukon-Tanana High.; 65 $37^{\circ} 30^{\prime \prime}$ N, $149^{\circ} 36^{\prime} 00^{\prime \prime}$ W ; (map 105).

Name originally applied to Hess Creek in 1866-67 by Capt. Frank Ketchum, leader of the Western Union Telegraph Company Expedition, for Frederick Whymper, English artist with the party. However, when gold was discovered in the area by Mike Hess in 1892, the larger stream came to be known as Hess Creek.

Whymper Creek: stream, see Hess Creek.

Whymper River: stream, see Hess Creek.

Wibel: locality, on Kenai Penin., $6 \mathrm{mi}$. NNE of Lower Summit Lake and $10 \mathrm{mi}$. S. of Sunrise, Chugach Mts.; $60^{\circ} 44^{\prime} 50^{\prime \prime} \mathrm{N}, 149^{\circ} 27^{\prime} 00^{\prime \prime}$ W; (map 63). Var. Wibel's.

Former mining camp reported in 1915 by USGS as "Wibel's." Recent USGS maps indicate a site of six buildings.

Wibel's: locality, see Wibel.

Wick, Mount: mountain, 1,476 ft., $7 \mathrm{mi}$. E of Mount Mordaunt and $39 \mathrm{mi}$. NE of Solomon, Seward Penin. High.; $64^{\circ} 55^{\prime} \mathrm{N}, 163^{\circ} 28^{\prime} \mathrm{W}$; (map 95).

Local name reported on the 1908 "Map of Seward Peninsula" by Arthur Gibson.

Wickersham, Mount: mountain, 7,415 ft., W of Matanuska Glacier, $47 \mathrm{mi}$. NE of Palmer, Chugach Mts.; $61^{\circ} 42^{\prime} 30^{\prime \prime} \mathrm{N}, 147^{\circ} 42^{\prime} 00^{\prime \prime} \mathrm{W}$; BGN 1960; (map 69)

Named in 1960 by E. L. Bartlett, U.S. Senator from Alaska and F. A. Seaton, Secretary of the Interior, for James Wickersham, 1857-1939, attorney, District Judge of the Third Judicial Division of Alaska, and Territorial Delegate to Congress. He was the leader of the first and unsuccessful attempt to climb Mount McKinley in 1903.

Wickersham Creek: stream, flows $S 7 \mathrm{mi}$. to Butte Creek, $68 \mathrm{mi}$. SE of Healy, Talkeetna Mts.; $63^{\circ} 04^{\prime} \mathrm{N}, 147^{\circ} 39^{\prime} \mathrm{W}$; (map 87).

Locally named for James Wickersham; reported in 1913 by J. W. Bagley (in Brooks and others, 1914, pl. 12), USGS.

Wickersham Creek: stream, flows S 3 mi. to Gold Creek, $48 \mathrm{mi}$. N of Big Delta, Yukon-Tanana High.; $64^{\circ} 49^{\prime} 35^{\prime \prime} \mathrm{N}, 145^{\circ} 36^{\prime} 00^{\prime \prime} \mathrm{W}$; (map 101).

Named by prospectors and reported in 1905 by D. C. Witherspoon (in Prindle, 1913a, pl. 1), USGS.

Wickersham Creek: stream, flows NE $20 \mathrm{mi}$. to Beaver Creek, 37 mi. N of Fairbanks, YukonTanana High.; $65^{\circ} 22^{\prime} 30^{\prime \prime} \mathrm{N}, 147^{\circ} 44^{\prime} 45^{\prime \prime} \mathrm{W}$; (map 105)
Named by prospectors for James Wickersham, 1857-1939, district judge; published in 1906 by USGS.

Wickersham Dome: mountain, 3,207 ft., $27 \mathrm{mi}$. NW of Fairbanks, Yukon-Tanana High.; $65^{\circ} 13^{\prime} \mathrm{N}, 148^{\circ} 04^{\prime} \mathrm{W}$; (map 105).

Name derived from Wickersham Creek that heads on the southeast slope of the mountain. The name is published in recent USGS maps. Wickersham Dome: peak, 3,858 ft., on $\mathrm{E}$ bank of Moose Creek, at $S$ end of Kantishna Hills, $4 \mathrm{mi}, \mathrm{N}$ of Wonder Lake, Alaska Ra.; $63^{\circ} 33^{\prime} 15^{\prime \prime} \mathrm{N}, 150^{\circ} 55^{\prime} 15^{\prime \prime} \mathrm{W}$; (map 88).

Named in 1932 by USGS for James Wickersham, 1857-1939. See Wickersham, Mount. Wickersham Wall: cliff, elev. $16,500 \mathrm{ft}$., in Mount McKinley National Park, W face of Mount McKinley, rises $9,000 \mathrm{ft}$. above Peters Basin, $7.7 \mathrm{mi}$. NW of summit of Mount McKinley, Alaska Ra.; $63^{\circ} 07^{\prime} \mathrm{N}, 151^{\circ} 03^{\prime} \mathrm{W}$; (map 88).

Named by Bradford Washburn about 1945 for James Wickersham, 1857-1939. "Judge Wickersham made the first attempt to climb McKinley by this wall in June 1903." See Wickersham, Mount.

Wide Bay: bay, $0.7 \mathrm{mi}$. across, on NE side of Unalaska Bay on NE coast of Unalaska I., Aleutian Is.; $53^{\circ} 57^{\prime} \mathrm{N}, 166^{\circ} 37^{\prime} \mathrm{W}$; (map 23).

This name was published in 1944 Aleutian Coast Pilot (p. 39).

Wide Bay: bay, $15 \mathrm{mi}$. across, between Capes Igvak and Kayakliut, on $\mathbf{S}$ coast of Alaska Penin., 40 mi. SE of Ugashik, Aleutian Ra.; $57^{\circ} 22^{\prime} \mathrm{N}, 156^{\circ} 11^{\prime} \mathrm{W}$; BGN 1923; (map 36). Var. Baie Khallikvit, Baie Kiialiakvit, Kialagvik Bay, Kialagvit, Kialakvit, Kialyakvit.

Local descriptive name reported by USC\& GS in 1921. The Eskimo name for this feature was published as "Kialakvit" by the Russian Hydrog. Dept. in 1848 on Chart 1379.

Widgeon Creek: stream, flows NW $7.4 \mathrm{mi}$. to Bonanza Creek, $9 \mathrm{mi}$. SE of Flat, KilbuckKuskokwim Mts.; 62 $12^{\prime} 50^{\prime \prime} \mathrm{N}, 157^{\circ} 54^{\prime} 30^{\prime \prime}$ W; (map 79).

Prospectors' name reported in 1933 by J. B. Mertie, USGS.

Widgeon Lake: lake, $1 \mathrm{mi}$. long, $2 \mathrm{mi}$. NE of Philacte Bay and $90 \mathrm{mi}$. W of Bethel, YukonKuskokwim Delta; $60^{\circ} 53^{\prime}$ N, $164^{\circ} 24^{\prime} \mathrm{W}$; (map 58).

Name used by personnel of Clarence Rhode National Wildlife Refuge; reported in 1965.

Widgeon Lake: lake, $0.5 \mathrm{mi}$. long, in Teocalli Mts.; 2 mi. W of Rainy Pass Lake and $95 \mathrm{mi}$. $\mathrm{SE}$ of McGrath, Alaska Ra., $62^{\circ} 12^{\prime} 15^{\prime \prime} \mathrm{N}$ $153^{\circ} 09^{\prime} 00^{\prime \prime} \mathrm{W}$; (map 80).

Local name reported in 1958 by USGS; named for the float and wheel airplane "that once landed here."

Wiehl Mountain: mountain, 5,600 ft., $4.5 \mathrm{mi}$. NW of junc. of Mathews and Bettles Rivers and $30 \mathrm{mi}$. WNW of Chandalar, Brooks, Ra.; $67^{\circ} 37^{\prime} 00^{\prime \prime} \mathrm{N}, 149^{\circ} 35.30^{\prime \prime} \mathrm{W}$; (map 123).

Name reported about 1930 by Robert Marshall (1956, map).

Wiener Lake: lake, 2,100 ft. long, on Glenn Highway $34 \mathrm{mi}$. NE of Palmer, Talkeetna 
Mts. ; $61^{\circ} 48^{\prime} 40^{\prime \prime} \mathrm{N}, 148^{\circ} 10^{\prime} 00^{\prime \prime} \mathrm{W}$; (map 69). Local name reported in 1948 by USGS.

Wien Lake: lake, $4.5 \mathrm{mi}$. long, $22 \mathrm{mi}$. SE of Bitzshtini Mts., Kilbuck-Kuskokwim Mts.; $64^{\circ} 21^{\prime} \mathrm{N}, 151^{\circ} 18^{\prime} \mathrm{W}$; (map 99).

Locally named for "Sig or Noel Wien who once landed here with a float plane"; reported in 1952 by USGS.

Wien Mountain: mountain, 6,000 ft., $2 \mathrm{mi}$. NE of Mount Doonerak and $37 \mathrm{mi}$. NW of Wiseman, Brooks Ra.; $67^{\circ} 55^{\prime} \mathrm{N}, 150^{\circ} 32^{\prime} \mathrm{W}$; $B G N$ 1932; (map 124).

Named about 1930 by Robert Marshall "after Noel Wien, first aviator to land in the Koyukuk and to fly over this peak."

Wigand Creek: stream, heads in Wyoming Hills, in Mount McKinley National Park, flows $\mathbf{N}$ $17 \mathrm{mi}$, to Toklat River $\mathrm{W}$ of junc. of its East Fork, Alaska Ra.; $63^{\circ} 54^{\prime} \mathrm{N}, 150^{\circ} 09^{\prime} \mathrm{W}$; (map 88).

Name shown on a 1922 blueprint map of "Mount McKinley National Park" by Woodbury Abbey, U.S. Army Corps of Engineers.

Wiggle Creek: stream, heads in lake, flows S 9 mi. to Talkeetna River, $1.4 \mathrm{mi}$. N of Talkeetna, Cook Inlet Low.; 62²0'45" N, 150 $06^{\prime}$ $30^{\prime \prime} \mathrm{W}$; (map 81).

Name published in 1918 on a plat by GLO (BLM).

Wiggly Creek: stream, on Alaska Penin., meandering WNW $7 \mathrm{mi}$. to Upper Cinder River, 26 mi. NW of Cape Kunmik, Aleutian Ra.; $56^{\circ}$ $59^{\prime} \mathrm{N}, 157^{\circ} 46^{\prime} \mathrm{W}$; (map 31 ).

So named in 1923 by R. H. Sargent, USGS, "because of its [wiggly] meanders."

Wigwam Creek: stream, flows E $3 \mathrm{mi}$. to Columbia Creek, 5.6 mi. NE of Fairbanks, Yukon-

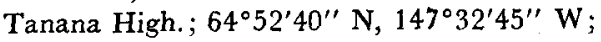
(map 100).

Local name reported in 1907 by C. G. Covert, USGS.

Wiki Peak: mountain, 7,655 ft., $5 \mathrm{mi}$. N of Ptarmigan Lake and $67 \mathrm{mi}$. NE of McCarthy, Alaska Ra.; $61^{\circ} 56^{\prime} 15^{\prime \prime} \mathrm{N}, 141^{\circ} 12^{\prime} 30^{\prime \prime} \mathrm{W}$; (map 67).

Local name published by USGS in 1954 .

Wilber Creek: stream, flows NE $7 \mathrm{mi}$. to Tolovana River, $7 \mathrm{mi}$. SE of Livengood, YukonTanana High.; $65^{\circ} 27^{\prime} 45^{\prime \prime} \mathrm{N}, 148^{\circ} 20^{\prime} 45^{\prime \prime} \mathrm{W}$; (map 105). Var. Wilbur Creek.

Local name reported in 1915 as Wilbur Creek by USGS (Brooks and others, 1916, pl. $9)$. Local usage has changed the spelling to "Wilber."

Wilbur, Mount: mountain, 10,820 ft., in Fairweather Ra., Glacier Bay National Monument, $1 \mathrm{mi}$. W of Mount Orville and 80 mi. NW of Hoonah, St. Elias Mts.; $58^{\circ}$ $44^{\prime} 25^{\prime \prime} \mathrm{N}, 137^{\circ} 19^{\prime} 00^{\prime \prime} \mathrm{W}$; BGN 1962; (map 10).

Name proposed to NPS by Senator Ernest Gruening in 1961 to honor Wilbur Wright, 1867-1912, who with his brother Orville, designed the first successful airplane. When published, this name was misapplied to a mountain $4.5 \mathrm{mi}$. to the southeast.

Wilbur Creek: stream, see Wilber Creek.
Wilburs Place: locality, on right bank of Yukon River, 6.5 mi. NW of Pitkas Point and $47 \mathrm{mi}$. NW of Marshall, Yukon-Kuskokwim Delta; $62^{\circ} 04^{\prime} 55^{\prime \prime} \mathrm{N}, 163^{\circ} 28^{\prime} 00^{\prime \prime} \mathrm{W}$; (map 77).

Eskimo name obtained in 1952 by U.S. Army Corps of Engineers.

Wilby Island: island, $0.5 \mathrm{mi}$. long, at $\mathrm{S}$ entrance to Port Chalmers, off $W$ coast of Montague I., $30 \mathrm{mi}$. E of Chenega, Chugach Mts.; $60^{\circ} 14^{\prime} 30^{\prime \prime} \mathrm{N}, 147^{\circ} 13^{\prime} 20^{\prime \prime} \mathrm{W}$; (map 63).

Named in 1787 by Capt. Portlock (1789, p. 215), possibly for William Wilbye, assistant trader on Capt. Portlock's voyage.

Wildcat Cove: bay, $1.5 \mathrm{mi}$. wide, on $\mathrm{E}$ coast of Ragged I., in Pye Is.; $48 \mathrm{mi}$. E. of Seldovia, Chugach Mts.; $59^{\circ} 25^{\prime} \mathrm{N}, 150^{\circ} 22^{\prime} \mathrm{W}$; BGN 1929; (map 50).

Named in 1927 by USC\&GS for the motor launch Wildcat, which was used in making the survey in this locality in 1927.

Wildcat Creek: stream, flows $\mathrm{N} 1.5 \mathrm{mi}$. to Treasure Creek, $12 \mathrm{mi}$. N of Fairbanks, Yukon-Tanana High.; $65^{\circ} 01^{\prime} 10^{\prime \prime} \mathrm{N}, 147^{\circ} 43^{\prime}$ $25^{\prime \prime} \mathrm{W}$; (map 105).

Named by prospectors; published in 1908 by USGS.

Wildcat Pass: water passage, $0.3 \mathrm{mi}$. wide, between Ragged I. and Rabbit I., in Pye Is., $47 \mathrm{mi}$. E of Seldovia, Chugach Mts.; $59^{\circ} 23^{\prime}$ $00^{\prime \prime} \mathrm{N}, 150^{\circ} 23^{\prime} 30^{\prime \prime} \mathrm{W}$; BGN 1929; (map 50).

Named in 1929 by USC\&GS for the motor launch Wildcat, used during a survey in this vicinity in 1927.

Wild Creek: stream, heads in lake, flows S 8.5 $\mathrm{mi}$. to Ugak Bay, on $\mathbf{E}$ coast of Kodiak I., $57^{\circ} 30^{\prime} 15^{\prime \prime} \mathrm{N}, 152^{\circ} 53^{\prime} 40^{\prime \prime} \mathrm{W}$; BGN 1933; (map 34).

Local name reported in 1933 by Gerald FitzGerald, USGS.

Wild Creek : stream, see Wild River.

Wild Creek: stream, see Rainy Creek.

Wilderness Lake: lake, $0.7 \mathrm{mi}$. across, on Kenai Penin. NW of King Lake, $36 \mathrm{mi}$. NE of Kenai, Cook Inlet Low.; $60^{\circ} 49^{\prime} 30^{\prime \prime} \mathrm{N}, 150^{\circ} 22^{\prime} 00^{\prime \prime}$ W; (map 62).

Named about 1963 by officials of Kenai National Moose Range, for administrative purposes.

Wild Goose Creek: stream, flows NW $1 \mathrm{mi}$. to Port Clarence, $7 \mathrm{mi}$. SW of Teller, Seward Penin. High.; $65^{\circ} 10^{\prime} \mathrm{N}, 166^{\circ} 28^{\prime} \mathrm{W}$; (map 111).

Prospectors' name reported on the 1908 "Map of Seward Peninsula" by Arthur Gibson.

Wild Goose Creek: stream, see Goose Creek. Wildhorse Creek: stream, flows $\mathrm{E} 3 \mathrm{mi}$. to left bank of Resurrection Creek, $1.5 \mathrm{mi}$. S of Hope, Chugach Mts.; $60^{\circ} 53^{\prime} 45^{\prime \prime} \mathrm{N}, 149^{\circ} 38^{\prime} 15^{\prime \prime} \mathrm{W}$; (map 63).

Name published on 1952 USGS map.

Wildhorse Creek: stream, flows $S \dot{E} 6.5 \mathrm{mi}$. to Bear Creek $1 \mathrm{mi}$. E of its junc. with Tokositna River and $33 \mathrm{mi}$. NW of Talkeetna, Alaska Ra.; $62^{\circ} 39^{\prime} 35^{\prime \prime} \mathrm{N}, 150^{\circ} 50^{\prime} 50^{\prime \prime} \mathrm{W}$; (map 81).

Prospectors' name reported in 1906 by R. W. Porter, USGS.
Wildhorse Creek: stream, heads near $\mathbf{E}$ end of Sevenmile Lake, flows E $11 \mathrm{mi}$. to Delta River, $17 \mathrm{mi}$. NW of Paxson, Alaska Ra.; $63^{\circ} 10^{\prime} 50^{\prime \prime} \mathrm{N}, 145^{\circ} 56^{\prime} 15^{\prime \prime} \mathrm{W}$; (map 86).

Name shown on 1910 fieldsheet by C. E. Giffin, USGS.

Wild Lake: lake, 0.5 mi. long, on Kenai Penin., $1 \mathrm{mi}$. N of Gene Lake and $35 \mathrm{mi}$. NE of Kenai, Cook Inlet Low.; $60^{\circ} 51^{\prime} 50^{\prime \prime} \mathrm{N}, 150^{\circ} 28^{\prime} 30^{\prime \prime}$ W; (map 62).

Named about 1963 by officials of Kenai National Moose Range, for administrative purposes.

Wild Lake: lake, $6 \mathrm{mi}$. long, in course of Wild River, $40 \mathrm{mi}$. W of Wiseman, Kanuti Flats; $67^{\circ} 30^{\prime} \mathrm{N}, 151^{\circ} 35^{\prime} \mathrm{W}$; BGN 1932; (map 124).

Local name reported in 1932 by Robert Marshall.

Wild Rice Lake: lake, $0.1 \mathrm{mi}$. across, on $\mathrm{W}$ coast of Chichagof I., N of Bertha Bay, $13.5 \mathrm{mi}$. NW of Chichagof, Alex. Arch.; $57^{\circ} 48^{\prime} 25^{\prime \prime} \mathrm{N}, 136^{\circ}$ $21^{\prime} 00^{\prime \prime} \mathrm{W}$; (map 9).

Local name published in 1928 by USC\&GS. Wild River: stream, heads in lake, flows $S 60$ mi. from Tobin Mtn. through Wild Lake to Koyukuk River, $6 \mathrm{mi}$. NE of Bettles, Kanuti Flats; $66^{\circ} 56^{\prime} 30^{\prime \prime} \mathrm{N}, 151^{\circ} 30^{\prime} 00^{\prime \prime} \mathrm{W}$; $B G N$ 1906; (map 117). Var. Hokatena, Hokotena River, Totsenbet, Totsenbetna, Totzunbetna, Totzunbitna, Wild Creek.

This name, reported in 1899 by F. C. Schrader, USGS, appears to be a translation of Koyukan Indian name often spelled "Totsenbetna." In 1885, Lt. Allen (1887, p. 99), USA, obtained the Indian name, which he spelled "Totzunbitna." Wild River was the scene of a gold stampede in 1913-15 (Marshall, 1956, p. 117).

Wiley Creek: stream, heads at glacier terminus and flows NW $4.5 \mathrm{mi}$. to White River at Russell Glacier, $42 \mathrm{mi}$. NE of McCarthy, St. Elias Mts. ; $61^{\circ} 04^{\prime} \mathrm{N}, 141^{\circ} 37^{\prime} \mathrm{W}$; (map 67).

Local name reported in 1914 by C. E. Giffin (in Capps, 1916, pl. 1), USGS.

Wilhelmina Creek: stream, flows NE to Eagle Creek, $73 \mathrm{mi}$. E of Bethel, Kilbuck-Kuskokwim Mts. ; $60^{\circ} 53^{\prime} \mathrm{N}, 159^{\circ} 38^{\prime} \mathrm{W}$; (map 59).

Prospectors' name reported in 1914 by A. G. Maddren (in Brooks, 1915, pl. 11), USGS.

Wilkes Peak: mountain, 3,201 ft., in Wilkes Range, $19 \mathrm{mi}$. SE of Petersburg, Coast Mts.; $56^{\circ} 43^{\prime} 45^{\prime \prime} \mathrm{N}, 132^{\circ} 28^{\prime} 30^{\prime \prime} \mathrm{W}$; (map 6).

Named in 1887 by Lt. Comdr. C. M. Thomas, USN, for Rear Adm. Charles Wilkes, USN.

Wilkes Range: mountain range, extends SE 6 mi. from Wilkes Peak, at mouth of Stikine River, $20 \mathrm{mi}$. SE of Petersburg, Coast Mts.; $56^{\circ} 43^{\prime}$ $\mathrm{N}, 132^{\circ} 26^{\prime} \mathrm{W}$; (map 6).

Named in 1887 by Lt. Comdr. C. M. Thomas, USN, for Rear Adm. Charles Wilkes, USN.

Wilkins Creek: stream, flows NW $5.4 \mathrm{mi}$. to Maston Creek which flows to Crosby Creek, in Kugrupaga River basin, $6 \mathrm{mi}$. SW of Ear Mtn. and $40 \mathrm{mi}$. N of Teller, Seward Penin. High.; $65^{\circ} 50^{\prime} \mathrm{N}, 166^{\circ} 20^{\prime} \mathrm{W}$; (map 111 ). 
Prospectors' name reported in 1901 by T. G. Gerdine (in Collier, 1902, pl. 12), USGS Wilkins Creek: stream, flows NW to Big Hurrah Creek near its head, about $9 \mathrm{mi}$. NE of Solomon, Seward Penin. High.; (map 95).

Prospectors' name reported on a prospector's manuscript map dated 1902. This stream cannot be precisely located on current maps.

Willard Inlet: estuary, on mainland, extends $\mathrm{N}$ $14 \mathrm{mi}$. off, Fillmore Inlet, Coast Mts. ; $54^{\circ} 48^{\prime}$ $\mathrm{N}, 130^{\circ} 38^{\prime} \mathrm{W}$; (map 2$)$.

Named in 1891 by USC\&GS.

Willard Island: island, $4 \mathrm{mi}$. long, in Blackstone Bay, $2 \mathrm{mi}$. NE of terminus of Blackstone Glacier, 4 mi. SE of Whittier, Chugach Mts.; $60^{\circ} 42^{\prime} \mathrm{N}, 148^{\circ} 38^{\prime} \mathrm{W}$; (map 63).

Named in 1909 by U. S. Grant and published by USGS (Grant and Higgins, 1910-11, p. 402).

William, Port: bay, $0.2 \mathrm{mi}$. across, on $\mathrm{S}$ coast of Shuyak I., $40 \mathrm{mi}$. N of Kodiak I. ; $58^{\circ} 29^{\prime} 20^{\prime \prime}$ $\mathrm{N}, 152^{\circ} 35^{\prime} 00^{\prime \prime} \mathrm{W}$; (map 43).

Local name published by USC\&GS in the 1920's.

William Cove: cove, $0.7 \mathrm{mi}$. across, faces NW to Little Sitkin Pass, between Northwest Head and Finger Point, on NW coast of Little Sitkin I., Aleutian Is.; $51^{\circ} 58^{\prime} 45^{\prime \prime} \mathrm{N}, 178^{\circ}$ 27'30" E; (map 15). Var. Northwest Cove.

Reported by Snyder (1959, pl. 23), USGS.

William Creek: stream, flows E $6 \mathrm{mi}$. to Notch Creek, $10 \mathrm{mi}$. N of Euchre Mtn., Wrangell Mts.; $62^{\circ} 12^{\prime} \mathrm{N}, 142^{\circ} 21^{\prime} \mathrm{W}$; (map 84).

Local name reported in 1959 by USGS.

William Henry Bay: bay, $1 \mathrm{mi}$. long, on W shore of Lynn Canal, $2 \mathrm{mi}$. NW of Danger Point and $41 \mathrm{mi}$. NW of Juneau, St. Elias Mts.; $58^{\circ} 43^{\prime} 30^{\prime \prime} \mathrm{N}, 135^{\circ} 13^{\prime} 30^{\prime \prime} \mathrm{W}$; (map 11).

Name obtained in 1869 by Comdr. Richard W. Meade, USN, from the Hudson Bay traders. The name was published in 1883 Coast Pilot (p. 195).

Williams, Lake: lake, $1,000 \mathrm{ft}$. across, on SE coast of Prince of Wales I., between Paul Lake and Port Johnson, E of John Creek, Alex. Arch.; $55^{\circ} 08^{\prime} 40^{\prime \prime} \mathrm{N}, 132^{\circ} 02^{\prime} 40^{\prime \prime} \mathrm{W}$; (map 4).

Local name reported in 1901 by Lt. Comdr. J. F. Moser, USN, of the USBF steamer Albatross.

Williams, Mount: mountain, 7,500 ft., $6 \mathrm{mi}$. NW of Miles Lake and $40 \mathrm{mi}$. NW of Katalla, Chugach Mts.; $60^{\circ} 43^{\prime} \mathrm{N}, 144^{\circ} 54^{\prime} \mathrm{W}$; BGN 1930; $(\operatorname{map} 64)$.

Named in 1910 by Lawrence Martin for Alfred Williams, assistant engineer of the Copper River and Northwestern Railroad at that time.

Williams, Point: point of $l$ and, see Craven, Point.

Williams Cove: cove, $1 \mathrm{mi}$. across, on $\mathrm{W}$ shore of Tracy Arm, $4 \mathrm{mi}$. $\mathrm{N}$ of Holkham Bay, 39 mi. SW of Juneau, Coast Mts.; $54^{\circ} 51^{\prime} 15^{\prime \prime} \mathrm{N}$, $133^{\circ} 37^{\prime} 00^{\prime \prime} \mathrm{W}$; BGN 1964; (map 8).

Named by Maxine Williams for her husband, Valta F. Williams, 1907-62, who guided hunters in this area and who organized the first Guides Association of Southeast Alaska.
He lived in Alaska for almost 30 years and was an outdoorsman, hunter, fisherman, and guide.

Williams Creek: stream, distributary of Tanis River, fows SE $8 \mathrm{mi}$. to Alsek River, $0.8 \mathrm{mi}$. $\mathrm{N}$ of Dry Bay and $48 \mathrm{mi}$. SE of Yakutat, Malaspina Coastal Plain; 59 $10^{\prime} 20^{\prime \prime} \mathrm{N}, 138^{\circ}$ $34^{\prime} 40^{\prime \prime}$ W; BGN 1962; (map 46). Var. Gines Creek.

Feature named for deceased pioneer resident; name used locally for over 40 years.

Williams Creek: stream, flows E $3 \mathrm{mi}$. to Iliamna Bay, $24 \mathrm{mi}$. NW of Augustine I., Aleutian Ra.; $59^{\circ} 41^{\prime} \mathrm{N}, 153^{\circ} 38^{\prime} \mathrm{W}$; (map 51).

Local name published in 1958 by USGS. Williams Creek: stream, flows NE $4 \mathrm{mi}$. to Salcha River, $24 \mathrm{mi}$. W of Twin Mtn. and 52 mi. S of Circle, Yukon-Tanana High.; $65^{\circ}$ $05^{\prime} \mathrm{N}, 144^{\circ} 08^{\prime} \mathrm{W}$; (map 104).

Prospectors' name reported in 1954 or 1955 by USGS topographers.

Williams Creek: stream, see Lucky Dog Creek. Williams Glacier: glacier, trends NW $1.2 \mathrm{mi}$, $4.5 \mathrm{mi}$. E of College Point and $50 \mathrm{mi}$. W of Valdez, Chugach Mts.; $61^{\circ} 04^{\prime} \mathrm{N}, 147^{\circ} 47^{\prime} \mathrm{W}$; $B G N$ 1910; (map 69).

Name reported in 1908 by Grant and Higgins (1910, pl. 2), USGS. Named for Williams College, Williamstown, Mass., founded in 1785.

Williams Hill: mountain, 1,140 ft., $2.6 \mathrm{mi}$. N of Chichagof, on $W$ coast of Chichagof I., Alex. Arch.; $57^{\circ} 42^{\prime} 10^{\prime \prime} \mathrm{N}, 136^{\circ} 06^{\prime} 30^{\prime \prime} \mathrm{W}$; $B G N$ 1939; (map 9).

Named in 1939 by local inhabitants for D. J. Williams who died about 1935 . Williams was manager of operations for the Hirst Chichagof Mine, and brought the mine into production.

Williams Island: island, see Grassy Island.

Williams Lake: lake, $0.2 \mathrm{mi}$. long, $0.5 \mathrm{mi}$. S of Addison Creek at its mouth, on Holtz Bay, Attu I., Aleutian Is.; $52^{\circ} 55^{\prime} 00^{\prime \prime} \mathrm{N}, 173^{\circ} 08^{\prime}$ 15" E; (map 13).

Name shown on an AMS map published in 1948 , and given by the U.S. Army during World War II. The name is not used today. Williams Lake: lake, $0.9 \mathrm{mi}$. long, $6.1 \mathrm{mi}$. $\mathrm{N}$ of village of Lake Minchumina, Tanana Low.; $63^{\circ} 58^{\prime} 30^{\prime \prime} \mathrm{N}, 152^{\circ} 20^{\prime} 00^{\prime \prime} \mathrm{W}$; (map 88).

Local name reported in 1954 by USGS.

William Smith River: stream, see Smith River. Williams Mountain: mountain, 3,336 ft., trends NW-SE $2 \mathrm{mi}$., E of Stephens Passage, 2.5 mi. NE of Butler Peak and $15 \mathrm{mi} \mathrm{SE}$ of Juneau, Coast Mts.; $58^{\circ} 09^{\prime} 35^{\prime \prime}$ N, 134 $04^{\circ}$ $55^{\prime \prime} \mathrm{W}$ [NW end]; $58^{\circ} 08^{\prime} 16^{\prime \prime} \mathrm{N}, 134^{\circ} 00^{\prime} 35^{\prime \prime}$ W [SE end]; BGN 1966; (map 11). Var. Williams Peak.

Named in 1966 by USFS for Jason P. Williams, 1878-1954, who spent many years engaged in forest research in the area.

Williams Peak: mountain, see Williams Mountain.

Williamsport: locality, in Chigmit Mts., on W shore of Iliamna Bay, at mouth of Williams Creek, Aleutian Ra.; 59 $41^{\prime} \mathrm{N}, 1^{\circ} 3^{\circ} 38^{\prime} \mathrm{W}$; (map 51)
Local name reported in 1957 by USGS.

Williams Reef: reef, extends $0.4 \mathrm{mi}$. in Gulf of Alaska, $4 \mathrm{mi}$. NE of Long I., NE of Kodiak I.; $57^{\circ} 49^{\prime} 55^{\prime \prime} \mathrm{N}, 152^{\circ} 10^{\prime} 15^{\prime \prime} \mathrm{W}$; BGN 1907; (map 34). Var. Podvodnaya banka Vasyleva, Vasilief Reef, Wasilieff Reef.

Local name given by USC\&GS in 1907. Identified as "Podvodnaya banka Vasyleva", meaning "the submerged Vasiliev bank", and published by Lt. Sarichev (1826, map 16).

Williams Slough: stream, flows NW $7.5 \mathrm{mi}$. to Tanana River, $3 \mathrm{mi}$. E of Harper Bend, and $35 \mathrm{mi}$. NE of Bitzshtini Mits., Nowitna Low.; $64^{\circ} 56^{\prime} \mathrm{N}, 151^{\circ} 31^{\prime} \mathrm{W}$; (map 99).

Riverboat pilots' name published on a 1940 "Navigation Chart of the Tanana-Yukon Rivers" by the U.S. Dept. of Interior.

Willibert, Mount: mountain, 6,782 ft., on AlaskaCanada boundary, $29 \mathrm{mi}$. NW of Hyder, Coast Mts.; $56^{\circ} 14^{\prime} 40^{\prime \prime} \mathrm{N}, 130^{\circ} 28^{\prime} 00^{\prime \prime} \mathrm{W}$; $B G N$ 1927; (map 7).

Named in 1927 for Willibert Simpson, Canadian IBC surveyor.

Willie Petes: locality, on Graveyard Point, $4 \mathrm{mi}$. $\mathrm{S}$ of Bethel, Yukon-Kuskokwim Delta; $60^{\circ}$ $44^{\prime} 30^{\prime \prime} \mathrm{N}, 161^{\circ} 44^{\prime} 00^{\prime \prime} \mathrm{W}$; (map 59).

Eskimo camp reported in 1951 by USC\&GS. Willis Creek: stream, flows SW $3.7 \mathrm{mi}$. to Kuskokwim River, $5.4 \mathrm{mi}$. NW of Red Devil and 11 mi. NW of Sleetmute, Kilbuck-Kuskokwim Mts. ; $61^{\circ} 48^{\prime} 45^{\prime \prime} \mathrm{N}, 157^{\circ} 26^{\prime} 00^{\prime \prime} \mathrm{W}$; (map 72).

Local name obtained in 1952 by USGS. Willis Creek: stream, flows SW $3 \mathrm{mi}$. to Feather River, $32 \mathrm{mi}$. NW of Nome, Seward Penin. High.; $64^{\circ} 50^{\prime} \mathrm{N}, 166^{\circ} 10^{\prime} \mathrm{W}$; (map 94).

Prospectors' name reported in 1900 by E. C. Barnard (in Brooks, 1901, pl. 17), USGS. Williwaw, Mount: mountain, 5,445 ft., near head of Ship Creek, $14 \mathrm{mi}$. SE of Anchorage, Chugach Mts.; $61^{\circ} 06^{\prime} 15^{\prime \prime} \mathrm{N}, 1^{\circ} 49^{\circ} 30^{\prime} 45^{\prime \prime} \mathrm{W}$; $B G N$ 1964; (map 69).

Named in 1963 by the Mountaineering Club of Alaska because "in May 1892 an infantry company from nearby Fort Richardson was caught in a williwaw on the near slopes of this mountain. Three soldiers died of exhaustion before they were rescued."

Williwaw Cove: cove, $0.9 \mathrm{mi}$. across, $\mathrm{W}$ of Patterson Point, Little Sitkin I., Aleutian Is.; $51^{\circ} 59^{\prime} 10^{\prime \prime} \mathrm{N}, 178^{\circ} 29^{\prime} 30^{\prime \prime} \mathrm{E}$; (map 15).

Descriptive name given by personnel by the U.S.S. Oglala in 1935, "for a dangerous, downslope, gusty wind, common on Little Sitkin and other Aleutian Islands."

Williwaw Pass: pass, $550 \mathrm{ft}$, $0.7 \mathrm{mi}$. SE of Lief Cove on west-central Kiska I., Aleutian Is.; $51^{\circ} 55^{\prime} 40^{\prime \prime} \mathrm{N}, 177^{\circ} 20^{\prime} 30^{\prime \prime} \mathrm{E}$; (map 14).

One of many arbitrary names applied to features on Kiska I. by USAAF for tactical purposes during World War II.

Williwaw Point: point of land, in Kuliliak Bay, on $\mathrm{S}$ coast of Unalaska I., Aleutian Is.; $53^{\circ}$ $28^{\prime} 00^{\prime \prime} \mathrm{N}, 167^{\circ} 01^{\prime} 35^{\prime \prime} \mathrm{W}$; BGN 1939; (map 23). Var. Sand Point.

Descriptive name given by USC\&GS in 1931 because of "the violent gusts of wind called williwaws which come up suddenly and then calm down." 
Willoughby Cove: cove, $1 \mathrm{mi}$. across, on SE coast of Lemesurier I., in South Passage, $3 \mathrm{mi}$. $\mathrm{S}$ of Lemesurier Light and $25 \mathrm{mi}$. NW of Hoonah, St. Elias Mts. ; $58^{\circ} 16^{\prime} 20^{\prime \prime} \mathrm{N}, 136^{\circ} 03^{\prime} 15^{\prime \prime}$ W; (map 10)

Named by G. C. Hanus, USN, in 1880 for Richard S. Willoughby, "an Alaskan pioneer." The name was published by USC\&GS in the 1883 Alaska Coast Pilot (p. 190). Willoughby came to Alaska about 1860 and is mentioned in Alexander Badlam's "Wonders of Alaska," (1890, p. 127-131), in which Badlam describes "Willoughby's Mirage" on Muir Glacier.

Willoughby Island: island, $3.8 \mathrm{mi}$. long, in Glacier Bay, in Glacier Bay National Monument, $1.6 \mathrm{mi}$. $\mathbf{E}$ of Finders Bay and $40 \mathrm{mi}$. NW of Hoonah, St. Elias Mts. ; $58^{\circ} 35^{\prime} \mathrm{N}, 136^{\circ} 07^{\prime}$ W; (map 10).

Named by U.S. Navy in 1880 for Richard G. Willoughby, "an Alaskan pioneer" (USC\&GS, 1883, p. 189).

Willow: village, pop. $78, \mathrm{mi} .185 .7$ on The Alaska RR., $37 \mathrm{mi}$. N of Anchorage, Cook Inlet Low.; $61^{\circ} 44^{\prime} 45^{\prime \prime} \mathrm{N}, 150^{\circ} 02^{\prime} 30^{\prime \prime} \mathrm{W}$; $B G N$ 1965; (map 70). Var. Willow Creek, Willow Station.

Name of a village along The Alaska Railroad that had its start when gold was discovered in the area about 1897 . The name appears on an Alaska Railroad Commission map dated 1923. A post office was established here in 1948 (Ricks, 1965, p. 71).

Willow Bay: locality, on $\mathrm{N}$ coast of Seward Penin., on shore of Willow Bay, $10 \mathrm{mi}$. E of Deering, Kotzebue-Kobuk Low.; (map 113).

Name of a former landing published in a 1921 Alaska Steamship Company folder. Recent maps show a site with ruins.

Willow Bay: bay, $5 \mathrm{mi}$. across, on NE coast of Seward Penin., $10 \mathrm{mi}$. E of Deering, KotzebueKobuk Low.; $66^{\circ} 05^{\prime} \mathrm{N}, 162^{\circ} 21^{\prime} \mathrm{W}$; (map 113 ).

Local name reported in 1955 by the U.S. Army Corps of Engineers; derived from Willow Creek.

Willow Creek: locality, $3.5 \mathrm{mi}$. E of junc. of Willow Creek and Iditarod River, $6.3 \mathrm{mi}$. SW of Flat, Kilbuck-Kuskokwim Mts.; $62^{\circ} 22^{\prime} \mathrm{N}$, $158^{\circ} 04^{\prime} \mathrm{W}$; (map 79$)$.

Mining camp established in 1908 ; name reported in 1910 by A. G. Maddren, USGS.

Willow Creek: settlement, camp for the Willow Creek Mine, on W bank of Willow Creek, 7.5 SE of Marshall, Nulato Hills; $61^{\circ} 48^{\prime} 30^{\prime \prime} \mathrm{N}$, $161^{\circ} 54^{\prime} 30^{\prime \prime} \mathrm{W}$; (map 73).

This camp was established about 1916 when extensive mining operations began on the stream "Willow Creek."

Willow Creek: village, see Willow.

Willow Creek: stream, $2.5 \mathrm{mi}$. long, flows NE to Fork Creek, 14.5 NW of Heart Lake, $71 \mathrm{mi}$. SE of Bethel, Kilbuck-Kuskokwim Mts.; $60^{\circ}$ $14^{\prime} \mathrm{N}, 160^{\circ} 01^{\prime} \mathrm{W}$; (map 59).

Local name reported in 1955 by J. M. Hoare, USGS.

Willow Creek: stream, on Kenai Penin., flows NW $1.5 \mathrm{mi}$. to Resurrection Creek, $7 \mathrm{mi}$. S of
Hope and $33 \mathrm{mi}$. W of Whittier, Chugach Mts. ; $60^{\circ} 48^{\prime} 50^{\prime \prime} \mathrm{N}, 149^{\circ} 38^{\prime} 45^{\prime \prime} \mathrm{W}$; (map 63). Local prospectors' name reported in 1904 by Moffit (1906, pl. 2), USGS.

Willow Creek: stream, flows $\mathrm{N} 3 \mathrm{mi}$. to Nerelna Creek, 68 mi. NE of Valdez, Chugach Mts.; $61^{\circ} 24^{\prime} 45^{\prime \prime} \mathrm{N}, 144^{\circ} 17^{\prime} 25^{\prime \prime} \mathrm{W}$; (map 68).

Local name published by USGS (Moffit, 1914, pl. 1).

Willow Creek: stream, flows SE $2 \mathrm{mi}$. to Kotsina River, $2.4 \mathrm{mi}$. W of Hubbard Peak and 76 mi. NE of Valdez, Wrangell Mts.; 61 ${ }^{\circ} 42^{\prime} 10^{\prime \prime}$ N, $144^{\circ} 18^{\prime} 15^{\prime \prime} \mathrm{W}$; (map 68 ).

Local name reported in 1907 by USGS.

Willow Creek: stream, heads on N slope of Stuck Mtn., flows SE $10 \mathrm{mi}$. to Tonsina River, $8 \mathrm{mi}$. NE of Tonsina and $59 \mathrm{mi}$. NE of Valdez, Chugach Mts. ; $61^{\circ} 42^{\prime} 35^{\prime \prime} \mathrm{N}, 144^{\circ} 56^{\prime} 50^{\prime \prime} \mathrm{W}$; (map 68).

Local name published in 1950 by USGS.

Willow Creek: stream, flows SW $3.5 \mathrm{mi}$. to Spruce Creek $8.4 \mathrm{mi}$. SE of Marshall, Nulato Hills; $61^{\circ} 46^{\prime} 55^{\prime \prime} \mathrm{N}, 161^{\circ} 55^{\prime} 30^{\prime \prime} \mathrm{W}$; (map 73).

Prospectors' name reported in 1916 by Harrington (1918, map), USGS.

Willow Creek: stream, heads on Bald Mountain Ridge, flows W $34 \mathrm{mi}$. to Susitna River, $5 \mathrm{mi}$. NW of Willow and $40 \mathrm{mi}$. NW of Anchorage, Cook Inlet Low.; $61^{\circ} 47^{\prime} 00^{\prime \prime} \mathrm{N}, 150^{\circ} 09^{\prime} 40^{\prime \prime}$ W; (map 70). Var. Andrew River.

Local name reported in 1906 by T. G. Gerdine and R. H. Sargent, USGS. This may be the same stream that Lt. H. G. Learnard, USA, of Capt. E. F. Glenn's party gave as the Andrew River, in 1898.

Willow Creek: stream, in Nutzotin Mts., flows NE $6 \mathrm{mi}$. to Beaver Creek, $2.6 \mathrm{mi}$. SE to Beaver Lake, Alaska Ra.; 62 ${ }^{\circ} 01^{\prime} \mathrm{N}, 141^{\circ} 43^{\prime} \mathrm{W}$ (map 84).

Local name reported by Capps (1916, pl 1), USGS.

Willow Creek: stream, heads in Horn Mts., flows NE $3 \mathrm{mi}$. to Crooked Creek, $12 \mathrm{mi}$. NE of Tahneta Pass and $63 \mathrm{mi}$. SW of Gulkana, Talkeetna Mts.; $62^{\circ} 02^{\prime} 50^{\prime \prime} \mathrm{N}, 147^{\circ} 14^{\prime} 00^{\prime \prime} \mathrm{W}$; (map 82).

Local name published by Theodore Chapin (in Brooks and others, 1915, fig. 3), USGS.

Willow Creek: stream, flows W $7 \mathrm{mi}$. to George River, $28 \mathrm{mi}$. SE of Flat, Kilbuck-Kuskokwim Mts. ; $62^{\circ} 21^{\prime} \mathrm{N}, 157^{\circ} 12^{\prime} \mathrm{W}$; (map 79).

Local name obtained in 1952 by USGS topographers.

Willow Creek: stream, flows SW and NW $6.9 \mathrm{mi}$ to Iditarod River, $\mathrm{E}$ of Swinging Dome, 8.4 mi. SW of Flat and 52 mi. NE of Holy Cross, Kilbuck-Kuskokwim Mts. ; $62^{\circ} 21^{\prime} 40^{\prime \prime}$ N, $158^{\circ}$ $10^{\prime} 50^{\prime \prime} \mathrm{W}$; (map 79).

Prospectors' name obtained in 1913 by Eakin (1914, pl. 1), USGS.

Willow Creek: stream, heads in Dutch Hills, flows SE $3 \mathrm{mi}$. to Cottonwood Creek $0.4 \mathrm{mi}$. $\mathrm{N}$ of its junc. with Peters Creek, and $27 \mathrm{mi}$. NW of Talkeetna, Alaska Ra.; $62^{\circ} 32^{\prime} 50^{\prime \prime} \mathrm{N}$, $150^{\circ} 49^{\prime} 10^{\prime \prime} \mathrm{W}$; (map 81).

Prospectors' name reported in 1906 by $R$. W. Porter, USGS.
Willow Creek: stream, flows SE $5.3 \mathrm{mi}$. to Moore Creek, $30 \mathrm{mi}$. NE of Flat and $54 \mathrm{mi}$. SW of McGrath, Kilbuck-Kuskokwim, Mts. ; $62^{\circ} 36^{\prime}$ $00^{\prime \prime} \mathrm{N}, 157^{\circ} 07^{\prime} 40^{\prime \prime} \mathrm{W}$; (map 79).

Prospectors' name reported in 1912 by $\mathrm{H}$. M. Eakin, USGS

Willow Creek: stream, flows SE $8 \mathrm{mi}$. to Beaver Creek $8.4 \mathrm{mi}$. W of its junc. with Anvik River, $28 \mathrm{mi}$. NW of Anvik, Nulato Hills; $62^{\circ} 52^{\prime} 30^{\prime \prime}$ $\mathrm{N}$; $160^{\circ} 58^{\prime} 30^{\prime \prime} \mathrm{W}$; (map 78).

Local name obtained in 1952 by USGS.

Willow Creek: stream, flows SW $1.7 \mathrm{mi}$. to Chisna River $3.5 \mathrm{mi}$. NE of its junc. with Chistochina River, $23 \mathrm{mi}$. NE of Paxson, Alaska Ra.; $63^{\circ} 05^{\prime} 30^{\prime \prime} \mathrm{N}, 144^{\circ} 47^{\prime} 05^{\prime \prime} \mathrm{W}$; (map 86). Var. Red Mountain Creek.

Prospectors' name reported in 1903 by W. C. Mendenhall, USGS.

Willow Creek: stream, flows S $0.4 \mathrm{mi}$. to Valdez Creek, $67 \mathrm{mi}$. SE of Healy, Alaska Ra.; $63^{\circ}$ $10^{\prime} 45^{\prime \prime} \mathrm{N}, 147^{\circ} 28^{\prime} 20^{\prime \prime} \mathrm{W}$; (map 87).

Local name reported in 1908 by Moffit (in Brooks, 1909, fig. 16), USGS.

Willow Creek: stream, heads in Mount McKinley National Park, flows N $3.7 \mathrm{mi}$, to Moose Creek, $1.3 \mathrm{mi}$. NNW of Wonder Lake, Alaska Ra.; $63^{\circ} 31^{\prime} 15^{\prime \prime} \mathrm{N}, 150^{\circ} 56^{\prime} 25^{\prime \prime} \mathrm{W}$; (map 88).

Prospectors' name shown on a 1905 manuscript map of "Kantishna Gold Fields" by A. Friedrich, prospector.

Willow Creek: stream, flows S $2.5 \mathrm{mi}$. to North Fork Moose Creek, $2 \mathrm{mi}$. ENE of Wonder Lake, Alaska Ra.; $63^{\circ} 32^{\prime} 00^{\prime \prime}$ N, $150^{\circ} 39^{\prime} 25^{\prime \prime}$ W; BGN 1932; (map 88).

Prospectors' name reported in 1905 by L. M. Prindle, USGS.

Willow Creek: stream, flows SW $7 \mathrm{mi}$. to Gold Greek, $58 \mathrm{mi}$. SW of Eagle, Yukon-Tanana High.; $64^{\circ} 10^{\prime} 30^{\prime \prime} \mathrm{N}, 142^{\circ} 27^{\prime} 40^{\prime \prime} \mathrm{W}$; (map 102).

Named by prospectors and shown on an 1898 manuscript map by C. A. Woodruff, Fort Cudahy, Canada.

Willow Creek: stream, flows SW $2.3 \mathrm{mi}$. to Basin Creek, $3.4 \mathrm{mi}$. W of Long and $24 \mathrm{mi}$. SW of Ruby, Kilbuck-Kuskokwim Mts. ; $64^{\circ} 24^{\prime} \mathrm{N}$, 155³7' W; BGN 1936; (map 98).

Prospectors' name published by Mertie and Harrington (1924, p. 94), USGS.

Willow Creek: stream, anabranch, heads at Camp Creek, flows SW $2.8 \mathrm{mi}$. to Khotol River, $19 \mathrm{mi}$. SE of Nulato, Koyukuk Low.; $64^{\circ}$ $28^{\prime} \mathrm{N}, 157^{\circ} 50^{\prime} \mathrm{W}$; (map 97). Var. Yuquaqilokhna.

Appears to be a translation of an Indian name; reported in 1935 by Frederica de Laguna, BAE.

Willow Creek: stream, flows SW $3 \mathrm{mi}$. to Ungalik River, 4.2 mi. NW of Christmas Mtn., Nulato Hills; $64^{\circ} 35^{\prime} \mathrm{N}, 160^{\circ} 41^{\prime} \mathrm{W}$; (map 96).

Local name published in 1943 by USC\&GS.

Willow Creek: stream, flows SE $3.5 \mathrm{mi}$. to Penny River, 9 mi. NW of Nome, Seward Penin. High.; $64^{\circ} 35^{\prime} \mathrm{N}, 165^{\circ} 40^{\prime} \mathrm{W}$; (map 94). Var. Biggs Creek. 
Prospectors' name reported in 1899 by D. C. Witherspoon (in Schrader and Brooks, 1900, map 2), USGS. The 1900 "Map of Nome Peninsula" by J. M. Davidson and B. D. Blakeslee shows "Biggs" along the upper half of this stream.

Willow Creek: stream, flows E $2.3 \mathrm{mi}$. to Osborn Creek, $11 \mathrm{mi}$. NE of Nome, Seward Penin. High.; 64 $36^{\circ} \mathrm{N}, 165^{\circ} 08^{\prime} \mathrm{W}$; (map 94).

Prospectors' name reported in 1900 by E. C. Barnard (in Brooks, 1901, pl. 17), USGS. Willow Creek: stream, flows NW $26 \mathrm{mi}$. to Sevenmile Slough, $20 \mathrm{mi}$. SW of Fairbanks, Tanana Low.; $64^{\circ} 40^{\prime} \mathrm{N}, 148^{\circ} 14^{\prime} \mathrm{W}$; (map 100).

Local name shown on a manuscript railroad location map dated 1914

Willow Creek: stream, flows SW $2.5 \mathrm{mi}$. to Cripple River, $17 \mathrm{mi}$. NW of Nome, Seward Penin. High.; $64^{\circ} 40^{\prime} \mathrm{N}, 165^{\circ} 48^{\prime} \mathrm{W}$; (map 94).

Prospectors' name reported on a 1901 map of Cape Nome gold fields by David Fox, Jr.

Willow Creek: stream, flows SE $1.2 \mathrm{mi}$. to Nome River Valley, $15 \mathrm{mi}$. N of Nome, Seward Penin. High.; $64^{\circ} 43^{\prime} \mathrm{N}, 165^{\circ} 19^{\prime} \mathrm{W}$; (map 94).

Prospectors' name reported on a map by S. E. King dated 1900.

Willow Creek: stream, flows E $2 \mathrm{mi}$. to Solomon River, $12 \mathrm{mi}$. NE of Solomon, Seward Penin. High.; 64 $43^{\prime} 30^{\prime \prime} \mathrm{N}, 164^{\circ} 19^{\prime} 00^{\prime \prime} \mathrm{W}$; (map 95).

Prospectors' name reported on a 1902 prospectors' manuscript map.

Willow Creek: stream, flows NE $3.3 \mathrm{mi}$. to Casadepaga River, $14 \mathrm{mi}$. N of Solomon, Seward Penin. High.; 64 $46^{\circ} \mathrm{N}, 164^{\circ} 31^{\prime} \mathrm{W}$; (map 95)

Prospectors' name reported in 1900 by E. C. Barnard (in Brooks, 1901, pl. 17), USGS.

Willow Creek: stream, flows SE $1.5 \mathrm{mi}$. to Ester Creek, $11 \mathrm{mi}$. W of Fairbanks, Yukon-Tanana High.; 64 $50^{\prime} 55^{\prime \prime} \mathrm{N}, 148^{\circ} 04^{\prime} 45^{\prime \prime} \mathrm{W}$; (map 100).

Local name reported in 1908 by $\mathrm{A}$. $\mathrm{H}$. Brooks, USGS.

Willow Creek: stream, flows W $3.5 \mathrm{mi}$. to Eldorado River near its head, $25 \mathrm{mi}$. NW of Solomon, Seward Penin. High.; 64 $51^{\prime} \mathrm{N}$, $164^{\circ} 58^{\prime} \mathrm{W}$; (map 95)

Prospectors' name reported on a map of Cape Nome gold fields by David Fox, Jr., dated 1901

Willow Creek: stream, flows N $2.5 \mathrm{mi}$. to Pilgrim River, $28 \mathrm{mi}$. NW of Solomon, Seward Penin.

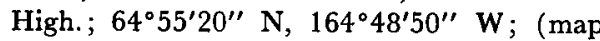
95).

Prospectors' name reported on a map of Cape Nome gold fields by David Fox, Jr., dated 1901 .

Willow Creek: stream, flows N $0.8 \mathrm{mi}$. to Cleary Creek, $17 \mathrm{mi}$. NE of Fairbanks, YukonTanana High.; $65^{\circ} 04^{\prime} \mathrm{N}, 147^{\circ} 27^{\prime} \mathrm{W}$; (map 105).

Named by prospectors; published in 1908 by USGS.

Willow Creek: stream, flows NW $4 \mathrm{mi}$. to Salcha River, $17 \mathrm{mi}$. W of Twin Mtn; and
$52 \mathrm{mi}$. S of Circle, Yukon-Tanana High.; $65^{\circ} 05^{\prime} \mathrm{N}, 144^{\circ} 02^{\prime} \mathrm{W}$; (map 104).

Prospectors' name reported in 1954 or 1955 by USGS topographers.

Willow Creek: stream, flows SW $5 \mathrm{mi}$. to Chatanika River, 16 mi. N of Fairbanks, YukonTanana High.; $65^{\circ} 05^{\prime} 05^{\prime \prime} \mathrm{N}, 147^{\circ} 45^{\prime} 40^{\prime \prime} \mathrm{W}$; (map 105).

Named by prospectors; published in 1908 by USGS.

Willow Creek: stream, flows NE $13 \mathrm{mi}$. to Koyuk River, $8 \mathrm{mi}$. SW of Haycock, Seward Penin. High.; $65^{\circ} 08^{\prime} \mathrm{N}, 161^{\circ} 22^{\prime} \mathrm{W}$; (map 109).

Prospectors' name reported in 1909 by P. S. Smith, USGS

Willow Creek: stream, flows SW $5 \mathrm{mi}$. to Port Clarence, $5 \mathrm{mi}$. SW of Teller, Seward Penin. High.; $65^{\circ} 12^{\prime} \mathrm{N}, 166^{\circ} 28^{\prime} \mathrm{W}$; (map 111).

Local name reported in 1900 by E. C. Barnard (in Brooks, 1901, pl. 17), USGS.

Willow Creek: stream, flows S $3 \mathrm{mi}$. to Birch Creek, $6 \mathrm{mi}$. S of Pinnell Mtn. and $54 \mathrm{mi}$. SW of Circle, Yukon-Tanana High.; $65^{\circ} 24^{\prime} 20^{\prime \prime}$ N, $145^{\circ} 40^{\prime} 00^{\prime \prime} \mathrm{W}$; (map 104).

Prospectors' name reported in 1952 by USGS topographers.

Willow Creek: stream, flows NE $6.5 \mathrm{mi}$. to Troublesome Creek, $16 \mathrm{mi}$. E of Rampart, Yukon-Tanana High.; $65^{\circ} 29^{\prime} 20^{\prime \prime} \mathrm{N}$, $149^{\circ} 38^{\prime} 25^{\prime \prime} \mathrm{W}$; (map 105).

Named by prospectors; reported in 1902 by Lt. H. Erickson, USA.

Willow Creek: stream, flows NW 2 mi. to Tozer Creek which flows to Don River, $3.8 \mathrm{mi}$. NW of Black Mtn. and $22 \mathrm{mi}$. NW of Teller, Seward Penin. High.; $65^{\circ} 31^{\prime} \mathrm{N}, 166^{\circ} 47^{\prime} \mathrm{W}$; (Map 111).

Prospectors' name reported in 1918 by Steidtmann and Cathcart (1922, pl. 12), USGS.

Willow Creek: stream, flows NE $3 \mathrm{mi}$. to South Fork Hess Creek, $9 \mathrm{mi}$. NE of Livengood, Yukon-Tanana High.; $65^{\circ} 38^{\prime} \mathrm{N}, 148^{\circ} 26^{\prime} \mathrm{W}$; (map 105).

Named by prospectors; reported in 1915 by Brooks (Brooks and others, 1916, pl. 9), USGS.

Willow Creek: stream, flows NE $14 \mathrm{mi}$. to Rock Creek, $14 \mathrm{mi}$. NNE of Porcupine Dome and $40 \mathrm{mi}$. SW of Circle, Yukon-Tanana High. $65^{\circ} 43^{\prime} \mathrm{N}, 145^{\circ} 24^{\prime} \mathrm{W}$; (map 104).

Named by prospectors and reported in 1904 by D. C. Witherspoon, USGS.

Willow Creek: stream, flows NW $1 \mathrm{mi}$. to Macklin Creek near its junc. with Kougarok River, $8 \mathrm{mi}$. SW of Midnight Mtn. and $49 \mathrm{mi}$. NW of Imuruk Lake, Seward Penin. High.; $65^{\circ} 44^{\prime} \mathrm{N}, 164^{\circ} 51^{\prime} \mathrm{W}$; (map 110).

Prospectors' name reported on the 1908 "Map of Seward Peninsula" by Arthur Gibson. Willow Creek: stream, flows NW $17 \mathrm{mi}$. to Beaver Creek, $44 \mathrm{mi}$. NE of Livengood, Yukon-Tanana High.; $65^{\circ} 45^{\prime} 30^{\prime \prime} \mathrm{N}, 147^{\circ}$. $10^{\prime} 00^{\prime \prime} \mathrm{W}$; (map 105).

Named by prospectors; and published in 1906 by USGS.

Willow Creek: stream, flows SE $2 \mathrm{mi}$. to Candle Creek, $9 \mathrm{mi}$. SW of Candle and $34 \mathrm{mi}$. NE of
Imuruk Lake, Seward Penin. High.; $65^{\circ} 48^{\prime}$ N, $162^{\circ} 05^{\prime} \mathrm{W}$; $(\operatorname{map} 110)$.

Prospectors' name reported in 1903 by D. C. Witherspoon (in Moffit, 1905, pl. 2) USGS.

Willow Creek: stream, flows SW $5 \mathrm{mi}$. to Koyukuk River, $2.5 \mathrm{mi}$. N of Fry I. and 20 mi. NNW of Hochandochtla Mtn., KokrinesHodzana High.; $65^{\circ} 49^{\prime} 20^{\prime \prime} \mathrm{N}, 155^{\circ} 00^{\prime} 30^{\prime \prime}$ W; (map 107).

Local name obtained in 1954 by USGS topographers.

Willow Creek: stream, flows SE $2.2 \mathrm{mi}$. to Burnt River which flows to Kugruk River, $21 \mathrm{mi}$. NE of Imuruk Lake, Seward Penin. High.; 65 ${ }^{\circ} 52^{\prime}$ $\mathrm{N}, 162^{\circ} 48^{\prime} \mathrm{W}$; (map 110).

Prospectors' name reported in 1908 by F. F. Henshaw (in Brooks and others, 1909, fig. 21), USGS

Willow Creek: stream, flows S $2.5 \mathrm{mi}$, to Crosby Creek which flows to Kugrupaga River, $4 \mathrm{mi}$. $\mathrm{S}$ of Ear Mtn. and $42 \mathrm{mi}$. N of Teller, Seward Penin. High.; $65^{\circ} 52^{\prime} \mathrm{N}, 166^{\circ} 16^{\prime} \mathrm{W}$; (map 111).

Prospectors' name reported in 1901 by T. G, Gerdine (in Collier, 1902, pl. 12), USGS.

Willow Creek: stream, on Seward Penin., flows NE $7.6 \mathrm{mi}$. to Willow Bay, $10 \mathrm{mi}$. SE of Deering, Kotzebue-Kobuk Low.; $66^{\circ} 02^{\prime} \mathrm{N}, 162^{\circ} 21^{\prime}$ W; (map 113).

Prospectors' name reported in 1908 by F. F. Henshaw (in Brooks and others, 1909, fig. 21), USGS.

Willow Creek: stream, flows W $7 \mathrm{mi}$. to Robert Creek, E of Horace Mtn., $18.5 \mathrm{mi}$. NW of Chandalar, Brooks Ra.; $67^{\circ} 40^{\prime} \mathrm{N}, 1^{\circ} 49^{\circ} 03^{\prime} \mathrm{W}$; (map 123). Var. Sheep Creek.

Local name reported in 1956 by T. E. Taylor, USGS

Willow Creek: stream, flows N $5.5 \mathrm{mi}$. to Clear River, W of Foggytop Mtn., $24 \mathrm{mi}$. NW of Wiseman, Brooks Ra.; $67^{\circ} 40^{\prime} 30^{\prime \prime} \mathrm{N}, 150^{\circ} 42^{\prime}$ $00^{\prime \prime} \mathrm{W}$; (map 124).

Local descriptive name obtained in 1956 by USGS topographers.

Willow Creek: stream, flows $5 \mathrm{mi}$. NW to Anaktuvuk River, $11 \mathrm{mi}$. $\mathrm{N}$ of Table Top and $48 \mathrm{mi}$. NE of Anaktuvuk Pass, Arctic Slope; $68^{\circ} 47^{\prime} \mathrm{N}, 151^{\circ} 06^{\prime} \mathrm{W}$; (map 134).

Named by USGS geologists about 1950 . Schrader, USGS, originally applied the name to the Kanayut River in 1901.

Willow Creek: stream, flows SW to Kougarok River, N of Arctic Creek, about $12 \mathrm{mi}$. SW of Midnight Mtn. and $46 \mathrm{mi}$. W of Imuruk Lake, Seward Penin. High.; (map 110).

Prospectors' name reported on a precinct map of Seward Peninsula by Monroe and Hutchins. This stream cannot be precisely located on current maps.

Willow Creek: stream, flows NW $1 \mathrm{mi}$. to Solomon River between Quartz and Moran Creeks, about $6 \mathrm{mi}$. NE of Solomon, Seward Penin. High.; (map 95).

Prospectors' name reported on prospector's manuscript map dated 1902. This stream cannot be precisely located on current maps. 
Willow Creek: stream, flows NE to West Creek which flows to Shovel Creek, E of Branch Creek, $8 \mathrm{mi}$. NNW of Solomon, Seward Penin. High.; (map 95).

Prospectors' name reported on a prospector's manuscript map dated 1902. This stream cannot be precisely located on current maps.

Willow Creek : stream, see Kanayut River.

Willow Creek: stream, see Little Willow Creek. Willow Creek: stream, see Lower Willow Creek. Willow Creek: stream, see Rock Creek.

Willow Creek Ridge: ridge, see Rooftop Ridge. Willow Gulch: ravine, trends SW $0.7 \mathrm{mi}$. to Casadepaga River, $2.7 \mathrm{mi}$. SW of Casadepaga and $15 \mathrm{mi}$. NE of Solomon, Seward Penin. High.; $64^{\circ} 47^{\prime} \mathrm{N}, 164^{\circ} 26^{\prime} \mathrm{W}$; (map 95).

Prospectors' name reported in 1907 by USGS geologists (Smith, P. S., 1910, pl. 4).

Willow House: locality, on right bank of Christian River, $35 \mathrm{mi}$. N of Christian, Brooks Ra.; $67^{\circ} 53^{\prime} \mathrm{N}, 145^{\circ} 17^{\prime} \mathrm{W}$; (map 122).

Local name reported in 1956 by T. E. Taylor, USGS.

Willow Island: island, $0.8 \mathrm{mi}$. across, in Yukon River, $\mathbf{S}$ of Blade I. and $22 \mathrm{mi}$. S of Marshall, Yukon-Kuskokwim Delta ; $61^{\circ} 34^{\prime} \mathrm{N}, 161^{\circ} 59^{\prime}$ W; (map 73).

Riverboat pilots' name shown on a 1916 field sheet by R. H. Sargent, USGS.

Willow Island: islands, see Willow Islands.

Willow Islands: islands, $0.4 \mathrm{mi}$. across, at mouth of Unuk River and head of Burroughs Bay, Coast Mts.; $56^{\circ} 04^{\prime} 20^{\prime \prime} \mathrm{N}, 131^{\circ} 05^{\prime} 00^{\prime \prime} \mathrm{W}$; (map 7). Var. Willow Island.

Named in 1889 by USC\&GS. This name was applied to one of the islands by Baker (1906, p. 676).

Willow Lake: lake, $0.4 \mathrm{mi}$. long, on Kenai Penin. $0.4 \mathrm{mi}$. S. of Kayak Lake, $27 \mathrm{mi}$. NE of Kenai, Cook Inlet Low.; $60^{\circ} 44^{\prime} 25^{\prime \prime} \mathrm{N}, 150^{\circ} 35^{\prime} 00^{\prime \prime}$ W; (map 62).

Named about 1963 by officials of Kenai National Moose Range for administrative purposes.

Willow Lake: lake, $0.9 \mathrm{mi}$. long, $\mathrm{W}$ of Willow, $36 \mathrm{mi}$. $\mathrm{N}$ of Anchorage, Cook Inlet Low.; $61^{\circ} 44^{\prime} 40^{\prime \prime} \mathrm{N}, 150^{\circ} 03^{\prime} 30^{\prime \prime} \mathrm{W}$; (map 70).

Local name reported in 1958 by USGS.

Willow Lake: lake, $1.7 \mathrm{mi}$. long, $1 \mathrm{mi}$. NE of Willow Mtn. and $58 \mathrm{mi}$. NE of Valdez, Chugach Mts.; $61^{\circ} 47^{\prime} \mathrm{N}, 145^{\circ} 10 \mathrm{~W} ; B G N$ 1932; (map 68).

Local named reported in 1932 by C. F. Feuchsel, USGS.

Willow Lake: lake, $0.7 \mathrm{mi}$. long, W of Alaska Highway, $19 \mathrm{mi}$. SE of Tok, Alaska Ra; $63^{\circ} 14^{\prime} \mathrm{N}, 142^{\circ} 23^{\prime} \mathrm{W}$; (map 85).

Local name published in 1964 by USGS.

Willow Lake: lake, $0.9 \mathrm{mi}$. long, $1.6 \mathrm{mi}$. S of Beaver Creek and $19 \mathrm{mi}$. SE of Beaver, Yukon Flats; $66^{\circ} 12^{\prime} \mathrm{N}, 146^{\circ} 49^{\prime} \mathrm{W}$; (map 119).

Local descriptive name obtained in 1956 by USGS

Willow Lake: lake, $0.7 \mathrm{mi}$. long, $13 \mathrm{mi}$. NE of Chalkyitsik, Yukon Flats; $66^{\circ} 50^{\prime} \mathrm{N}, 143^{\circ} 34^{\prime}$ W; (map 120)

Local name obtained in 1956 by $T$. E. Taylor and R. C. Foley, USGS.
Willow Mountain: mountain, 3,300 ft., $3.2 \mathrm{mi}$. SE of Stuck Mtn. and $57 \mathrm{mi}$. NE of Valdez, Chugach Mts. ; $61^{\circ} 46^{\prime} 20^{\prime \prime} \mathrm{N}, 145^{\circ} 12^{\prime} 10^{\prime \prime} \mathrm{W}$; (map 68).

Local name published in 1950 by USGS. Willow Mountain: mountain, $2,033 \mathrm{ft}$., between Lake and Yenlo Creeks, $34 \mathrm{mi}$. SW of Talkeetna, Alaska Ra.; $62^{\circ} 12^{\prime} 45^{\prime \prime} \mathrm{N}, 151^{\circ} 08^{\prime} 45^{\prime \prime}$ W; (map 81).

Local name reported in 1906 by $R$. W. Porter, USGS.

Willow Point: point of land, on $\mathrm{N}$ end of island in Yukon River, $27 \mathrm{mi}$. SW of Fort Yukon, Yukon Flats; $66^{\circ} 32^{\prime} 00^{\prime \prime} \mathrm{N}, 146^{\circ} 14^{\prime} 30^{\prime \prime} \mathrm{W}$; (map 119).

Local descriptive name obtained in 1956 by USGS.

Willow Point: point of land, see Talnik Point.

Willows, Valley of the: valley, extending $3 \mathrm{mi}$., near head of Ikpikpuk River, Arctic Slope; $69^{\circ} 26^{\prime}$ N., $154^{\circ} 48^{\prime}$ W.; (map 142).

This originated as a locality name used by geologists on the Naval Petroleum Reserve No. 4 exploration in the 1940's. It is near here that Ens. W. L. Howard noted "at this place the last green brush was seen ten to twelve feet high" (Stoney, 1900, p. 72).

Willow Station: village, see Willow.

Willson Creek: stream, see Wilson Creek.

Wilson, Mount: mountain, 7,390 ft., in Tongass National Forest, $4 \mathrm{mi}$. SE of Mount John Jay, Coast Mts.; $56^{\circ} 05^{\prime} 47^{\prime \prime} \mathrm{N}, 130^{\circ} 21^{\prime} 45^{\prime \prime} \mathrm{W}$; BGN 1960; (map 7).

Named by R. E. Isto,' USGS, for Roland M. Wilson, 1891-1959, USGS topographic engineer who mapped this area in 1924.

Wilson, Point: point of land, at $\mathrm{S}$ point of entrance to Wilson Cove, on $S$ coast of Admiralty I., $9 \mathrm{mi}$. NE of Baranof, Alex. Arch.; $57^{\circ} 08^{\prime}$. 05" N, 134 $38^{\circ} 00^{\prime \prime} \mathrm{W}$; (map 9).

Name published in 1899 by USC\&GS on Chart 8050.

Wilson Arm: estuary, heads at Wilson River, extends SW $6.3 \mathrm{mi}$., joins Bakewell Arm to form Smeaton Bay, Coast Mts.; $55^{\circ} 19^{\prime} \mathrm{N}$, $130^{\circ} 42^{\prime} \mathrm{W}$; (map 3 ).

Local navigators' name obtained in 1904 by H. C. Fassett, USBF.

Wilson Bay: cove, $0.1 \mathrm{mi}$. across, on $\mathrm{NW}$ coast of Latouche I., $19 \mathrm{mi}$. SE of Chenega, Chugach Mts.; $60^{\circ} 02^{\prime} 20^{\prime \prime} \mathrm{N}, 147^{\circ} 54^{\prime} 50^{\prime \prime} \mathrm{W}$ : (map 63).

Named for a "local miner"; reported in 1908 by U. S. Grant and D. F. Higgins (in Brooks and others, 1909, pl. 4), USGS.

Wilson Creek: stream, on Kenai Penin., flows W $2 \mathrm{mi}$. to Canyon Creek near Saxton, $13 \mathrm{mi}$. S of Sunrise and $27 \mathrm{mi}$. SW of Whittier, Chugach Mts.; $60^{\circ} 42^{\prime} 05^{\prime \prime} \mathrm{N}, 149^{\circ} 27^{\prime} 35^{\prime \prime} \mathrm{W}$; (map 63).

Local prospectors' name reported about 1914 by B. L. Johnson (in Martin and others, 1915, pl. 2), USGS.

Wilson Creek: stream, heads near Disappointment Mine, flows W. $8 \mathrm{mi}$. to Wilson Creek Slough, $1.3 \mathrm{mi}$. S of Marshall, Yukon-Kuskokwim Delta; $61^{\circ} 51^{\prime} 50^{\prime \prime} \mathrm{N}, 162^{\circ} 03^{\prime} 20^{\prime \prime} \mathrm{W}$ (map 74).
Miners' name published by Harrington (1918, p. 56), USGS. Named for Woodrow Wilson, 1856-1924, 28th President of the United States, 1913-1921 (Stuck, 1917, p. 197). See Marshall Village.

Wilson Creek: stream, flows NW $2.5 \mathrm{mi}$. to Mastodon Creek, $18 \mathrm{mi}$. NW of Ophir and $47 \mathrm{mi}$. NW of McGrath, Kilbuck-Kuskokwim Mts.; $63^{\circ} 20^{\prime} 50^{\prime \prime} \mathrm{N}, 156^{\circ} 51^{\prime} 40^{\prime \prime} \mathrm{W}$; (map 90).

Prospectors' name obtained in 1933 by J. B. Mertie, Jr. (in Smith, P. S., 1936, pl. 4), USGS.

Wilson Creek: stream, flows NE $2.5 \mathrm{mi}$. to Eva Creek, $37 \mathrm{mi}$. SE of Nenana, Alaska Ra.; $64^{\circ}$ $03^{\prime} \mathrm{N}, 148^{\circ} 49^{\prime} \mathrm{W}$; (map 100)

Local name reported in 1916 by G. C. Martin, USGS.

Wilson Creek: stream, flows NE $3 \mathrm{mi}$. to Mosquito Fork, $55 \mathrm{mi}$. SW of Eagle, YukonTanana High.; $64^{\circ} 04^{\prime} \mathrm{N}, 141^{\circ} 59^{\prime} \mathrm{W}$; (map 102).

Prospectors' name shown on a 1902 manuscript map by E. J. Chamberlain, U.S. Deputy Surveyor.

Wilson Creek: stream, flows NE $6 \mathrm{mi}$. to North Fork Fortymile River, $42 \mathrm{mi}$. SW of Eagle, Yukon-Tanana High.; $64^{\circ} 16^{\prime} 20^{\prime \prime} \mathrm{N}, 141^{\circ}$ 54'10" W; (map 102).

Prospectors' name obtained in 1898 by E. C. Barnard, USGS

Wilson Creek: stream, flows SE $2.5 \mathrm{mi}$. to Lower Willow Creek which flows to Casadepaga River, $18 \mathrm{mi}$. N of Solomon; $64^{\circ} 48^{\prime} \mathrm{N}, 164^{\circ} 28^{\prime}$ W; (map 95). Var. Willson Creek.

Prospectors' name reported in 1900 by E. C. Barnard (in Brooks, 1901, pl. 17), USGS

Wilson Creek: stream, N of Switchback Mtn., flows SE $7 \mathrm{mi}$., joins Golden Creek to form Illinois Creek, $17 \mathrm{mi}$. NE of Birches, KokrinesHodzana High.; $65^{\circ} 17^{\prime} 10^{\prime \prime} \mathrm{N}, 153^{\circ} 07^{\prime} 00^{\prime \prime} \mathrm{W}$; (map 107)

Prospectors' name reported by USGS in the 1940 's, but probably was used much earlier.

Wilson Creek: stream, flows NW $10 \mathrm{mi}$. to Kiwalik River, $19 \mathrm{mi}$. NW of Haycock, Seward Penin. High.; $65^{\circ} 26^{\prime} \mathrm{N}, 161^{\circ} 32^{\prime} \mathrm{W}$; (map 109).

Local name reported in 1917 by G. L Harrington, USGS.

Wilson Creek: stream, flows W $2.5 \mathrm{mi}$. to American River, $28 \mathrm{mi}$. NE of Teller, Seward Penin High.; $65^{\circ} 33^{\prime} \mathrm{N}, 165^{\circ} 40^{\prime} \mathrm{W}$; (map 111).

Prospectors' name reported on a map of Cape Nome goldfields by David Fox, Jr., dated 1901.

Wilson Creek: stream, flows SE $3 \mathrm{mi}$. to South Fork Hess Creek, $10 \mathrm{mi}$. NE of Livengood, Yukon-Tanana High.; $65^{\circ} 38^{\prime} 40^{\prime \prime} \mathrm{N}, 148^{\circ}$. $24^{\prime} 30^{\prime \prime} \mathrm{W}$; (map 105).

Named by prospectors; reported in 1916 by J. B. Mertie, (in Brooks and others, 1918, pl. 13), USGS.

Wilson Creek: stream, flows S $6.5 \mathrm{mi}$. from Rosie Creek Pass to South Fork Koyukuk River, 24 mi. S of Wiseman, Brooks Ra.; 67 $07^{\circ} 50^{\prime \prime} \mathrm{N}$, $150^{\circ} 10^{\prime} 00^{\prime \prime} \mathrm{W}$; (map 124). 
Local name shown on an 1899 fieldsheet by T. G. Gerdine, USGS.

Wilson Creek: stream, see Alameda Creek. Wilsun Creek: stream, see Chavolda Creek. Wilson Creek: stream, see Deer Creek.

Wilson Creek Slough: stream, channel of Yukon

River, extends $8 \mathrm{mi}$. between Ingrihak and Marshall, E of Arbor I., Yukon-Kuskokwim Delta; $61^{\circ} 49^{\prime} \mathrm{N}, 162^{\circ} 03^{\prime} \mathrm{W}$; (map 74).

Local name published in 1962 by USGS.

Wilson Gulch: ravine, trends W $0.8 \mathrm{mi}$. to Cache Creek, $30 \mathrm{mi}$. NW of Talkeetna, Alaska Ra.; $62^{\circ} 29^{\prime} 20^{\prime \prime} \mathrm{N}, 150^{\circ} 59^{\prime} 20^{\prime \prime} \mathrm{W}$; (map 81).

Local name reported in 1958 by USGS.

Wilson Islands: islands, $0.4 \mathrm{mi}$. long, off $\mathrm{SE}$ coast of Mitkof I., $10 \mathrm{mi}$. NW of Wrangell, Alex. Arch.; $56^{\circ} 33^{\prime} \mathrm{N}, 132^{\circ} 36 \mathrm{~W}$; (map 6).

Named in 1887 by Lt. Comdr. G. M. Thomas, USN, for charting purposes; name published in 1888 on USC\&GS Chart 705.

Wilson Lake: lake, $5 \mathrm{mi}$. long, on mainland, drained by Wilson River into Wilson Arm, Coast Mts.; $55^{\circ} 31^{\prime} \mathrm{N}, 130^{\circ} 33^{\prime} \mathrm{W}$; (map 3).

Local name reported in 1955 by USGS.

Wilson Lake: lake, $2 \mathrm{mi}$. across, cutoff meander on $\mathrm{E}$ bank of Kuskokwim River, $12 \mathrm{mi}$. SW of McGrath, Kuskokwim Low.; $62^{\circ} 46^{\prime} 30^{\prime \prime} \mathrm{N}$, $155^{\circ} 40^{\prime} 30^{\prime \prime} \mathrm{W}$; (map 80).

Local name obtained in 1954 by USGS.

Wilson River: stream, heads in Adam Mts., flows SW $25 \mathrm{mi}$. through Wilson Lake to Wilson Arm, Coast Mts.; $55^{\circ} 23^{\prime} 45^{\prime \prime} \mathrm{N}, 130^{\circ} 36^{\prime} 28^{\prime \prime}$ W; (map 3).

Local name reported in 1955 by USGS.

Wilson River: stream, heads on $\mathrm{W}$ shore of Snowy Lake, flows NW $1.5 \mathrm{mi}$. through Lake Hayden to Wilson Bay, on Latouche I., 18 $\mathrm{mi}$. SE of Chenega, Chugach Mts.; $60^{\circ} 02^{\prime} 20^{\prime \prime}$ $\mathrm{N}, 147^{\circ} 54^{\prime} 33^{\prime \prime} \mathrm{W}$; (map 63).

Name published on 1951 USGS map; derived from Wilson Bay.

Wilsons: locality, on $\mathbf{E}$ bank of Kuskokwim River, $0.6 \mathrm{mi}$. $\mathrm{N}$ of Wilson Lakes and $11 \mathrm{mi}$. SW of McGrath, Kuskokwim Low.; 62 $47^{\circ} 45^{\prime \prime}$ N, 155 $42^{\prime} 15^{\prime \prime} \mathrm{W}$; (map 80).

Name shown on a 1923 ARC map.

Wimbledon, Point: point of land, on $\mathrm{N}$ shore of North Inian Pass, in Glacier Bay National Monument, $3 \mathrm{mi}$. SW of Dundas Bay, $36 \mathrm{mi}$. NW of Hoonah, St. Elias Mts.; $58^{\circ} 18^{\prime} 00^{\prime \prime} \mathrm{N}$, $136^{\circ} 22^{\prime} 30^{\prime \prime} \mathrm{W}$; (map 10). Var. Point Winbledon.

Named by Capt. George Vancouver, RN, in 1794 for Wimbledon, one of the seats of the Spencer family in England (Wagner, 1937 , p. 422). Some charts erroneously call it "Winbledon." Wimbledon is a suburb of London and is now the headquarters of tennis in England.

Winbledon, Point: point of land, see Wimbledon, Point.

Windbound Bay: bay, $0.8 \mathrm{mi}$. across, on W shore of Stepovak Bay, near SW end of Alaska Penin., Aleutian Ra.; $55^{\circ} 40^{\prime} \mathrm{N}, 160^{\circ} 10^{\prime} \mathrm{W}$; (map 28).

Local name published by USC\&GS in 1916 Coast Pilot (p. 165).
Wind Creek: stream, on Alaska Penin., flows S $3 \mathrm{mi}$. to Rainbow Creek, $7 \mathrm{mi}$. SE of Vent Mtn. in Aniakchak Crater, Aleutian Ra.; $56^{\circ} 47^{\prime} \mathrm{N}, 158^{\circ} 05^{\prime} \mathrm{W}$; (map 30 ).

Name reported in 1923 by R. H. Sargent, USGS; published in 1927 by USGS.

Wind Creek: stream, flows SE $6 \mathrm{mi}$. to Kinegnak River, $4 \mathrm{mi}$. SE of Susie Mtn. and $30 \mathrm{mi}$. NE of Cape Newenham, Kilbuck-Kuskokwim Mts. ; $58^{\circ} 56^{\prime} \mathrm{N}, 161^{\circ} 32^{\prime} \mathrm{W}$; BGN 1938; (map 39).

Local name reported in 1938 by J. B. Mertie, Jr., and Gerald FitzGerald, USGS.

Windfall Creek: stream, flows NW $4.5 \mathrm{mi}$. to Herbert River, 2 mi. SW of terminus of Herbert Glacier and $20 \mathrm{mi}$. NW of Juneau, Coast Mts.; $58^{\circ} 30^{\prime} 55^{\prime \prime} \mathrm{N}, 134^{\circ} 44^{\prime} 30^{\prime \prime} \mathrm{W}$; (map 11).

Prospectors' name found in mining records of 1891. "Windfall" was a name frequently used by early miners for creeks in this part of the country (DeArmond, 1957, p. 48).

Windfall Creek: stream, see Pirate Creek.

Windfall Harbor: bay, $2 \mathrm{mi}$. across, on $\mathrm{W}$ side of Seymour Canal, on $\mathbf{E}$ coast of Admiralty I., $28 \mathrm{mi}$ NNE of Angoon, Alex. Arch.; 57 52' N, $134^{\circ} 17^{\prime} \mathrm{W}$; (map 9).

Named in 1889 by Lt. Comdr. H. B. Mansfield, USN; published by USC\&GS in the 1891 Coast Pilot (p. 145).

Windfall Harbor: estuary, extends SW 2 mi. off Clarence Strait, near head of Kasaan Penin., on $\mathrm{E}$ coast of Prince of Wales I., Alex. Arch.; $55^{\circ} 36^{\prime} \mathrm{N}, 132^{\circ} 20^{\prime} \mathrm{W}$; (map 4).

Named by local fishermen and reported in 1904 by H. C. Fassett, USBF.

Windfall Island: island, $1 \mathrm{mi}$. long, in mouth of Windfall Harbor, on coast of Admiralty I., $29 \mathrm{mi}$. NNE of Angoon, Alex. Arch.; 57 53'$30^{\prime \prime} \mathrm{N}, 134^{\circ} 15^{\prime} 30^{\prime \prime} \mathrm{W}$; (map 9).

Named in 1889 by Lt. Comdr. H. B. Mansfield, USN; published by USC\&GS in the 1891 Coast Pilot (p. 145).

Windfall Islands: islands, $1.5 \mathrm{mi}$. long, at $\mathrm{S}$ point of entrance to Tebenkof Bay, on $W$ coast of Kuiu I., Alex. Arch.; $56^{\circ} 27^{\prime} 30^{\prime \prime} \mathrm{N}, 134^{\circ} 14^{\prime}$ $00^{\prime \prime} \mathrm{W} ; B G N$ 1929; (map 5).

Local name reported in 1928 by USC\&GS. Windfall Lake: lake, $0.8 \mathrm{mi}$. long, on Windfall Creek, $2 \mathrm{mi}$. $\mathrm{S}$ of terminus of Herbert Glacier and $18 \mathrm{mi}$. NW of Juneau, Coast Mts.; $58^{\circ}$ $30^{\prime} 40^{\prime \prime} \mathrm{N}, 134^{\circ} 44^{\prime} 00^{\prime \prime} \mathrm{W}$; (map 11).

Name derived from Windfall Creek, which drains it, and first mentioned in mining records in 1894 (DeArmond, 1957, p. 47-48).

Windfall Mountain: mountain, 2,581 ft., on E bank of Yukon River, $20 \mathrm{mi}$. N of Eagle, Porcupine Plat.; $65^{\circ} 02^{\prime} 40^{\prime \prime} \mathrm{N}, 141^{\circ} 16^{\prime} 10^{\prime \prime}$ W; (map 103).

So named in 1930 by J. B. Mertie, Jr., USGS, because of the heavy fall of burned trees found on its slopes.

Windham: locality, pop. 20 (1940), at head of Windham Bay, $4 \mathrm{mi}$. E of The Narrows and $63 \mathrm{mi}$. SE of Juneau, Coast Mts. ; 57 $35^{\prime} 50^{\prime \prime}$ $\mathrm{N}, 133^{\circ} 20^{\prime} 45^{\prime \prime} \mathrm{W}$; (map 8 ).

Site of a gold-mining camp built about 1900 , when mining operations along Spruce
Creek were expanded. Here a post office was maintained from 1903 to 1956 (Ricks, 1965, p. 71).

Windham, Point: point of land, on $\mathrm{E}$ shore of Stephens Passage, at mouth of Windham Bay, $4 \mathrm{mi}$. N of Sunset I. and $60 \mathrm{mi}$. SSE of Juneau, Coast Mts.; $57^{\circ} 33^{\prime} 40^{\prime \prime} \mathrm{N}, 133^{\circ} 34^{\prime} 00^{\prime \prime}$ W; (map 8). Var. Mys Uindkhem.

Named by Capt. George Vancouver, RN, after its discovery by Lt. Joseph Whidbey on Aug. 13, 1794, probably for William Windham, 1750-1810, English statesman (Wagner, 1937, p. 422). Windham served as English Secretary of War 1792-1801, and Secretary of State for War and Colonies, 1806-07. This name was published in 1848 as "Mys Uindkhem," that is, "Uindkhem Cape," by the Russian Hydrog. Dept. on Chart 1396.

Windham Bay: estuary, extends SW $8 \mathrm{mi}$. from Windham to Stephens Passage, $14 \mathrm{mi}$. S of Holkham Bay and $61 \mathrm{mi}$. SE of Juneau, Coast Mts.; 57 $33^{\prime} 30^{\prime \prime} \mathrm{N}, 1^{\circ} 33^{\circ} 31^{\prime} 30^{\prime \prime} \mathrm{W}$; (map 8).

Name derived from Point Windham by W. H. Dall, USC\&GS, published in the 1883 Coast Pilot (p. 129).

Winding Creek: stream, flows NW $12 \mathrm{mi}$. to Bering Sea, $2 \mathrm{mi}$. S of Oksenof Point, on NW coast of Unimak I., Aleutian Is.; 54 $51^{\prime} \mathrm{N}$, $164^{\circ} 33^{\prime} \mathrm{W}$; BGN 1942; (map 24). Var. Snake River.

This stream was originally called Snake River by the 1939 USC\&GS field party because "*** this river is very crooked." The name, however, was changed the following year to Winding Creek, thought to be more appropriate "*** since the stream is small to be called a river and the name snake might be thought to indicate the presence of many reptiles in it."

Winding Creek: stream, flows SW $1.5 \mathrm{mi}$., from Glenn Highway to Matanuska River, $37 \mathrm{mi}$. NE of Palmer, Talkeetna Mts.; $61^{\circ} 46^{\prime} 50^{\prime \prime} \mathrm{N}$, $148^{\circ} 03^{\prime} 30^{\prime \prime} \mathrm{W}$; (map 69).

Descriptive name reported on 1913 USGS manuscript map.

Windmill Lake: lake, $1 \mathrm{mi}$. long, in swamp, 26 mi. NE of Ruby, Nowitna Low.; 64. $49^{\prime} \mathrm{N}$, $154^{\circ} 34^{\prime} \mathrm{W}$; (map 98).

Local name obtained in 1956 by Orth.

Windom Glacier: glacier, see Norris Glacier.

Wind Point: point of land, on $\mathrm{W}$ shore of Thomas Bay, $2 \mathrm{mi}$. NW of Ruth I. and $96 \mathrm{mi}$. E of Sitka, Coast Mts. ; $57^{\circ} 02^{\prime} 45^{\prime \prime} \mathrm{N}, 132^{\circ} 51^{\prime}$. $50^{\prime \prime} \mathrm{W}$; (map 8).

Named in 1887 by Lt. Comdr. C. M. Thomas, USN; name published in 1888 by USC\&GS.

Wind River: stream, heads at Lake Kulik, flows SE $2 \mathrm{mi}$. to Mikchalk Lake, $53 \mathrm{mi}$. NW of Dillingham, Kilbuck-Kuskokwim Mts.; 59 ${ }^{\circ} 45^{\prime}$ N, $158^{\circ} 53^{\prime} \mathrm{W}$; BGN 1931; (map 52). Var. Gui-guok-lok.

Local name obtained in 1930 from $F$. H. Waskey and Beverley Polley, local inhabitants, by Gerald FitzGerald, USGS. The Eskimo name "Gui-guok-lok" was recorded on a 1910 manuscript map by H. C. Fassett, USBF. 
Wind River: stream, heads at $68^{\circ} 34^{\prime} \mathrm{N}, 147^{\circ} 18^{\prime}$ W, flows SE $80 \mathrm{mi}$. to East Fork Chandalar River $39 \mathrm{mi}$. NW of Christian, Brooks Ra.; $67^{\circ} 47^{\prime} \mathrm{N}, 146^{\circ} 09^{\prime} \mathrm{W}$; (map 122).

Local name reported in 1927 by J. B. Mertie, USGS.

Windy: locality, at junc. of Bain Creek with Nenana River, $28 \mathrm{mi}$. S of Healy, mi. 326.7 on Alaska RR., Alaska Ra.; $63^{\circ} 28^{\prime} \mathrm{N}, 148^{\circ} 49^{\prime}$ W; (map 87). Var. Bain Creek, Windy Creek.

Name of a railroad station reported by The Alaska RR. on its 1922 timetable.

Windy Arm: locality, at $S$ end of valley between Twelvemile and Cathedral Mts., on Middle Fork Koyukuk River, $2.5 \mathrm{mi}$. N of mouth of Chapman Greek and $21 \mathrm{mi}$. S of Wiseman, Brooks Ra.; $67^{\circ} 07^{\prime} 30^{\prime \prime} \mathrm{N}, 150^{\circ} 26^{\prime}$ $00^{\prime \prime} \mathrm{W}$; (map 124).

Local name reported in 1930 by Marshall (1956, p. 81).

Windy Bay: bay, 2 mi. long, $\mathrm{W}$ coast of Coronation I., $55 \mathrm{mi}$. NW of Craig, Alex. Arch.; $55^{\circ} 52^{\prime} \mathrm{N}, 134^{\circ} 20^{\prime} \mathrm{W}$; (map 4).

Descriptive name published in 1916 by USC\&GS.

Windy Bay: bay, $1.5 \mathrm{mi}$. wide, on $\mathrm{S}$ coast of Kenai Penin., Ghugach Mts.; 59 $13^{\prime} 30^{\prime \prime} \mathrm{N}$, $151^{\circ} 27^{\prime} 30^{\prime \prime} \mathrm{W}$; (map 50).

Local'name reported in 1909 by U. S. Grant and D. F. Higgins (in Brooks and others, 1910, pl. 3), USGS.

Windy Bay: estuary, on S shore of Alaska Penin., trends SE $4 \mathrm{mi}$. to Kuiukta Buy, $16 \mathrm{mi}$. SW of Chignik, Aleutian Ra.; $56^{\circ} 06^{\prime} \mathrm{N}, 158^{\circ} 39^{\prime}$ $\mathrm{W}$; (map 30$)$.

Local name published by USC\&GS in 1916 Coast Pilot (p. 161). So named "because of the strong winds and 'williwaws' encountered there."

Windy Bay: estuary, $1 \mathrm{mi}$. wide, on NW coast of Hawkins I., $9 \mathrm{mi}$. W of Cordova, Chugach Mts.; $60^{\circ} 34^{\prime} \mathrm{N}, 145^{\circ} 58^{\prime} \mathrm{W}$; (map 64).

Named in 1900 by H. P. Ritter, USC\&GS.

Windy Bend: bend, of Yukon River, $\mathrm{W}$ of Long Point, $9 \mathrm{mi}$. NE of Stevens Village, Yukon Flats; $66^{\circ} 05^{\prime} \mathrm{N}, 148^{\circ} 49^{\prime} \mathrm{W}$; (map 118 ).

Local descriptive name obtained in 1956 by USGS.

Windy Camp: locality, $0.7 \mathrm{mi}$. W of junc. of Banner Creek and Nome River, $9 \mathrm{mi}$. NNE of Nome, Seward Penin. High.; 64 $38^{\prime} \mathrm{N}$, $165^{\circ} 19^{\prime} \mathrm{W}$; (map 94).

Site of a mining camp shown on the 1902 "Map of Nome and Snake River Country" by J. M. Davidson.

Windy Channel: water passage, see Windy Passage.

Windy Corner: pass, $13,150 \mathrm{ft}$., at $\mathbf{S}$ end of Wickersham Wall, on W slope of Mount McKinley, Alaska Ra.; $63^{\circ} 04^{\prime} \mathrm{N}, 151^{\circ} 06^{\prime} \mathrm{W}$; (map 88).

Mountain climbers' name published in 1954 by USGS.

Windy Cove: bay, $1.1 \mathrm{mi}$. across, on $\mathrm{N}$ shore of Cape Romanzof, Yukon-Kuskokwim Delta; $61^{\circ} 49^{\prime} \mathrm{N}, 166^{\circ} 04^{\prime} \mathrm{W}$; (map 75).
Named by G. R. Putnam, USC\&GS, in 1899, "because of its exposed position."

Windy Cove: bight, $2 \mathrm{mi}$. wide, along $\mathrm{S}$ shore of Imuruk Basin, $25 \mathrm{mi}$. SE of Teller, Seward Penin. High.; $65^{\circ} 04^{\prime} \mathrm{N}, 165^{\circ} 42^{\prime} \mathrm{W}$; (map 111). Var. Graphite Bay.

Local name reported about 1940 by USC\&GS and published on Chart 9380. Shown as "Graphite Bay" by S. H. Cathcart (in Brooks and others, 1922, fig. 16), USGS.

Windy Cove: estuary, extends $\mathrm{N} 1.7 \mathrm{mi}$. to Coco Harbor on E coast of Dall I., $32 \mathrm{mi}$. S of Craig, Alex. Arch.; $55^{\circ} 02^{\prime} 15^{\prime \prime} \mathrm{N}, 133^{\circ} 01^{\prime} 10^{\prime \prime}$ W; (map 4).

Local name published in 1932 Coast Pilot (p. 192).

Windy Creek: locality, see Windy.

Windy Creek: stream, flows $\mathrm{N}$ to River Lethe at Three Forks, on Alaska Penin., in Katmai National Monument, $16 \mathrm{mi}$. NW of Mount Katmai, Aleutian Ra.; $58^{\circ} 22^{\prime} 25^{\prime \prime} \mathrm{N}, 155^{\circ} 20^{\prime} 05^{\prime \prime}$ W; (map 42).

Descriptive name given in 1919 by $R . F$. Griggs, National Geographic Society.

Windy Creek: stream, flows W $2 \mathrm{mi}$. to Windy Bay, on Hawkins I., $7 \mathrm{mi}$. W of Cordova, Chugach Mts.; $60^{\circ} 33^{\prime} 30^{\prime \prime} \mathrm{N}, 145^{\circ} 55^{\prime} 30^{\prime \prime} \mathrm{W}$; (map 64).

Name published in 1950 by USGS; derived from Windy Bay to which the stream flows.

Windy Creek: stream, heads in Peters Hills, flows W 4 mi. to Cache Creek $31 \mathrm{mi}$. NW of Talkeetna, Alaska Ra.; $62^{\circ} 27^{\prime} 25^{\prime \prime} \mathrm{N}, 151^{\circ} 01^{\prime} 50^{\prime \prime}$ W; (map 81).

Prospectors' name reported in 1906 by R. W. Porter, USGS.

Windy Creek: stream, heads in Beaver Mts., flows W $24 \mathrm{mi}$. to Dishna River, $35 \mathrm{mi}$. NE of Flat, Kilbuck-Kuskokwim Mts.; $62^{\circ} 54^{\prime} 25^{\prime \prime}$ $\mathrm{N}, 157^{\circ} 31^{\prime} 00^{\prime \prime} \mathrm{W}$; (map 79).

Local name obtained in 1952 by USGS topographers.

Windy Creek: stream, flows W $15 \mathrm{mi}$. to Susitna River, $70 \mathrm{mi}$. SE of Healy, Alaska Ra.; 63․ $07^{\prime} \mathrm{N}, 147^{\circ} 31^{\prime} \mathrm{W}$; (map 87).

Local name reported in 1910 by F. H. Moffit, USGS.

Windy Creek: stream, flows SE $12 \mathrm{mi}$. to Jack River, $32 \mathrm{mi}$. S of Healy, Alaska Ra.; $3^{\circ}{ }^{\circ} 5^{\prime}$ $45^{\prime \prime} \mathrm{N}, 148^{\circ} 52^{\prime} 30^{\prime \prime} \mathrm{W}$; (map 87).

Local name obtained in 1913 by J. W. Bagley, and published by Moffit (1915, pl. 1), USGS.

Windy Creek: stream, flows N $15 \mathrm{mi}$. to Julius Creek, $20 \mathrm{mi}$. S of Nenana, Tanana Low.; $64^{\circ} 17^{\prime} \mathrm{N}, 149^{\circ} 03^{\prime} \mathrm{W}$; (map 100). Var. Chicken Creek.

Local name reported in 1916 by G. C. Martin (in Brooks and others, 1918, pl. 17), USGS.

Windy Creek: stream, flows NW $4 \mathrm{mi}$. to Tanana River, $7 \mathrm{mi}$. E of Nenana, Tanana Low.; $64^{\circ}$ $34^{\prime} \mathrm{N}, 148^{\circ} 51^{\prime} \mathrm{W}$; (map 100$)$.

Local descriptive name published in 1916 on a GLO [BLM] survey plat.

Windy Creek: stream, flows NW $1 \mathrm{mi}$. to Fox River between Hugh Rowe and Sunrise Creeks, 21 mi. NE of Solomon, Seward Penin.
High.; $64^{\circ} 44^{\prime} 45^{\prime \prime} \mathrm{N}, 163^{\circ} 52^{\prime} 05^{\prime \prime} \mathrm{W}$; (map 95).

Prospectors' name reported on a map of Cape Nome gold fields by David Fox, Jr., dated 1901.

Windy Creek: stream, flows S $2 \mathrm{mi}$. to Stewart River, $21 \mathrm{mi}$. N of Nome, Seward Penin. High.; $64^{\circ} 48^{\prime} \mathrm{N}, 165^{\circ} 27^{\prime} \mathrm{W}$; (map 94).

Prospectors' name reported in 1904 by T. G. Gerdine, USGS.

Windy Creek: stream, flows $\mathrm{S} 7 \mathrm{mi}$. to Sinuk River, $26 \mathrm{mi}$. N of Nome, Seward Penin. High.; 64 $4^{\circ} 53^{\prime} \mathrm{N}, 165^{\circ} 27^{\prime} \mathrm{W}$; (map 94).

Prospectors' name reported in 1900 by E. C. Barnard (in Brooks, 1901, pl. 17), USGS.

Windy Creek: stream, flows SE $1.8 \mathrm{mi}$. to O'Connor Creek, $8.5 \mathrm{mi}$. NW of Fairbanks, YukonTanana High.; $64^{\circ} 56^{\prime} 15^{\prime \prime} \mathrm{N}, 147^{\circ} 53^{\prime} 30^{\prime \prime} \mathrm{W}$; (map 100).

Local name published in 1908 by USGS.

Windy Creek: stream, flows NE $0.5 \mathrm{mi}$. to Bullion Creek $1 \mathrm{mi}$. W of its junc. with Pargon River, $13 \mathrm{mi}$. NE of Council and $24 \mathrm{mi}$. SE of Mount Bendeleben, Seward Penin. High.; $65^{\circ} 02^{\prime} \mathrm{N}, 163^{\circ} 21^{\prime} \mathrm{W}$; (map 110$)$.

Prospectors' name reported on a map of Cape Nome gold fields by David Fox, Jr., dated 1901.

Windy Creek: stream, flows NE $3 \mathrm{mi}$. to Right Fork Bluestone River, $11 \mathrm{mi}$. SE of Teller, Seward Penin. High.; $65^{\circ} 06^{\prime} \mathrm{N}, 166^{\circ} 20^{\prime} \mathrm{W}$; (map 111).

Local name reported in 1900 by E. C. Barnard (in Brooks, 1901, pl. 17), USGS.

Windy Creek: stream, heads in Bendeleben Mts., flows SW $10 \mathrm{mi}$. to Telephone Creek which flows to Fish River, $33 \mathrm{mi}$. SE of Imuruk Lake, Seward Penin. High.; $65^{\circ} 07^{\prime} \mathrm{N}, 162^{\circ} 54^{\prime} \mathrm{W}$; (map 110).

Prospectors' name published on the 1908 "Map of Seward Peninsula" by Arthur Gibson.

Windy Creek: stream, flows E $2 \mathrm{mi}$. to Lynx Creek S of Lynx Dome, $25 \mathrm{mi}$. WNW of Tanana, Kokrines-Hodzana High.; $65^{\circ} 15^{\prime} \mathrm{N}$, $152^{\circ} 56^{\prime} \mathrm{W}$; (map 106).

Prospectors' name reported in 1956 by $R$. M. Chapman, USGS.

Windy Creek: stream, in Rampart Mts., heads on Senatis Mtn., flows S $4 \mathrm{mi}$. to Yukon River, $25 \mathrm{mi}$. ENE of Tanana, Kokrines-Hodzana High.; $65^{\circ} 16^{\prime} 00^{\prime \prime} \mathrm{N}, 151^{\circ} 14^{\prime} 30^{\prime \prime} \mathrm{W}$; (map 106).

Named in 1905 by ARC surveyors.

Windy Creek: stream, flows E $9 \mathrm{mi}$. to Kougarok River $15 \mathrm{mi}$. NW of its junc. with Kuzitrin River and $45 \mathrm{mi}$. SW of Imuruk Lake, Seward Penin. High.; $65^{\circ} 28^{\prime} \mathrm{N}, 164^{\circ} 42^{\prime} \mathrm{W}$; (map 110).

Prospectors' name reported in 1900 by Brooks (1901, pl. 11), USGS.

Windy Creek: stream, flows NW $7 \mathrm{mi}$. to Budd Creek which flows to American River, $10 \mathrm{mi}$. SW of Kougarok Mtn. and $34 \mathrm{mi}$. NE of Teller, Seward Penin. High.; $65^{\circ} 36^{\prime} \mathrm{N}, 16^{\circ} 32^{\prime} \mathrm{W}$; $B G N$ 1957; (map 111). Var. Million Creek. Prospectors' name reported in 1901 by $\mathrm{T}$. G. Gerdine (in Collier, 1902, pl. 12), USGS. 
Windy Creek: stream, flows NW to Candle Creek, about $14 \mathrm{mi}$. SW of Candle and $30 \mathrm{mi}$. NE of Imuruk Lake, Seward Penin. High.; (map 110).

Prospectors' name reported on a precinct map of Seward Peninsula by Monroe and Hutchins; corrected to June 1903 by Arthur Gibson. This stream cannot be precisely located on current maps.

Windy Fork Middle Fork Kuskokwim River: stream, heads at glacier at $62^{\circ} 00^{\prime} \mathrm{N}, 153^{\circ} 58^{\prime}$ W, flows NW 70 mi. to Middle Fork Kuskokwim River $19 \mathrm{mi}$. SE of its junc, with Kuskokwim River and $34 \mathrm{mi}$. SE of McGrath, Kuskokwim Low.; $62^{\circ} 45^{\prime} 40^{\prime \prime} \mathrm{N}, 154^{\circ} 37^{\prime} 50^{\prime \prime}$ W; (map 80).

Local name reported in 1940 by USGS.

Windy Gap: pass, $1,900 \mathrm{ft}$., trends NW $0.5 \mathrm{mi}$. from Fossil Creek; $5 \mathrm{mi}$. NW of Cache Mtn., $32 \mathrm{mi}$. E of Livengood, Yukon-Tanana High. $65^{\circ} 34^{\prime} 30^{\prime \prime} \mathrm{N}, 14^{\circ} 27^{\prime} 10^{\prime \prime} \mathrm{W}$; (map 105).

Local name published by USGS in the 1950 's.

Windy Lake: lake, $0.4 \mathrm{mi}$. long, on Kenai Penin. $4 \mathrm{mi}$. W of Devils Bay in Tustumena Lake and $40 \mathrm{mi}$. SE of Kenai, Cook Inlet Low.; $60^{\circ}$ $02^{\prime} 45^{\prime \prime} \mathrm{N}, 150^{\circ} 48^{\prime} 30^{\prime \prime} \mathrm{W}$; (map 62).

Named about 1963 by officials of Kenai National Moose Range, for administrative purposes.

Windy Lake: lake, $0.7 \mathrm{mi}$. long, in Mentasta Mts., SE of Devils Mtn., Alaska Ra.; $62^{\circ} 25^{\prime}$ $\mathrm{N}, 142^{\circ} 54^{\prime} \mathrm{W}$; (map 84).

Local name reported in 1960 by USGS.

Windy Lake: lake, $1.5 \mathrm{mi}$. long, $19 \mathrm{mi}$. S of Cape Sabine, $68 \mathrm{mi}$. E of Point Hope, Arctic Slope; $68^{\circ} 39^{\prime} 50^{\prime \prime} \mathrm{N}, 164^{\circ} 16^{\prime} 30^{\prime \prime} \mathrm{W}$; $B G N$ 1965; (map 130).

Named in 1965 by geologists of the B. P. Exploration Co. Inc.

Windy Pass: pass, see Middle Pass.

Windy Passage: water passage, $2 \mathrm{mi}$. S of Goddard, between Gornoi $I_{\text {. and }} \mathrm{W}$ coast of Baranof I., Alex. Arch.; $56^{\circ} 48^{\prime} \mathrm{N}, 135^{\circ} 21^{\prime}$ W; (map 5). Var. Audrey Passage, Dorothy Narrows, Windy Channel.

Descriptive name given for charting purposes by USC\&GS as "Windy Channel" in the 1925 Coast Pilot (p. 287) and in 1929 as "Windy Passage."

Windy Peak: mountain, 1,765 ft., on W coast of Coronation I. N of Windy Bay, $56 \mathrm{mi}$. NW of Craig, Alex. Arch.; $55^{\circ} 53^{\prime} 10^{\prime \prime} \mathrm{N}, 134^{\circ} 19^{\prime} 15^{\prime \prime}$ W; BGN 1925; (map 4).

Descriptive name derived from Windy Bay and given in 1925 by USC\&GS.

Windy Point: point of land, on SE coast of Prince of Wales I., $4.8 \mathrm{mi}$. SE of Chasina Point, Alex. Arch.; $55^{\circ} 13^{\prime} 00^{\prime \prime} \mathrm{N}, 131^{\circ} 58^{\prime} 45^{\prime \prime}$ W; (map 3).

Local name published in 1923 by USC\&GS

Windy Point: point of land, on S coast of Alaska, extending $W$ into Softuk Lagoon, $5 \mathrm{mi}$. NW of Katalla, Malaspina Coastal Plain; 60 $13^{\prime} 30^{\prime \prime} \mathrm{N}, 144^{\circ} 40^{\prime} 00^{\prime \prime} \mathrm{W}$; (map 64).

Local descriptive name published in 1950 by USGS.
Windy Point: point of land, on $\mathrm{N}$ coast of Kenai Penin., $\mathrm{S}$ shore of Turnagain Arm, $5.5 \mathrm{mi}$. NW of Sunrise, Chugach Mts.; $60^{\circ} 56^{\prime} 15^{\prime \prime} \mathrm{N}, 149^{\circ}$ 34'00" W; (map 63).

Name published in 1943 by USC\&GS.

Windy River: stream, on Kenai Penin., flows N $3 \mathrm{mi}$. then $\mathrm{S} 2.5 \mathrm{mi}$. to Rocky River, $11 \mathrm{mi}$. SE of Seldovia, Chugach Mts.; $59^{\circ} 23^{\prime} \mathrm{N}$, $151^{\circ} 25^{\prime} \mathrm{W}$; (map 50 ).

Local name reported by A. C. Gill (in Martin and others, 1920, pl. 1), USGS.

Windy River: stream, see Rocky River.

Winers Lake: lake, $0.8 \mathrm{mi}$. long, in headwaters of Slate Creek, $12 \mathrm{mi}$. S of Poss Mtn. and 38 mi. SW of Chandalar Brooks Ra.; $67^{\circ} 15^{\prime} \mathrm{N}$, $149^{\circ} 47^{\prime} \mathrm{W}$; (map 123 ;

Local name reported in 1956 by $T$. E. Taylor, USGS.

Winfield Creek: stream, flows NW to Port Clarence, about 9 mi. SW of Teller, Seward Penin. High.; (map 111).

Prospectors' name reported on the 1908 "Map of Seward Peninsula" by Arthur Gibson. This stream cannot be identified on current maps.

Winfred Island: island, $0.3 \mathrm{mi}$. across, in Porcupine Is., on W coast of Chichagof I., $14 \mathrm{mi}$. NW of Chichagof, Alex. Arch.; 57 $48^{\prime} \mathrm{N}$, $136^{\circ} 23^{\prime} \mathrm{W}$; (map 9).

Name published in 1928 by USC\&GS on Chart 8258.

Wingham Island: island, $4 \mathrm{mi}$. long, at mouth of Controller Bay and $11 \mathrm{mi}$. of SE of Katalla, Malaspina Coastal Plain; $60^{\circ} 01^{\prime} \mathrm{N}, 144^{\circ} 23^{\prime}$ W; (map 64). Var. Isla Dudosa, Little Kayak Island, Mitchells Island, Ostrov Shiganik, Ostrov Vinkhem.

Named on June 13, 1794, by Peter Puget, RN, a member of Vancouver's expedition (Wagner, 1937, p. 422). It was called "Mitchells Island" in 1788 by Capt. John Meares, RN. The Eskimo name for this island, published by Capt. Tebenkov (1852, map 6) was "Os[trov] Shiganik," or "Shiganik Island." It was called "Isla Dudosa" July 16, 1791, by Capt. Alessandro Malaspina "which he thought might be connected to Kayak Island and hence a peninsula" (Wagner, 1937, p. 449).

Winnebago Creek: stream, see Winston Creek.

Winneham Creek : stream, see Winston Creek.

Winner Creek: stream, flows W $6.5 \mathrm{mi}$. to Glacier Creek, $14 \mathrm{mi}$. NE of Sunrise and 20 mi. NW of Whittier, Chugach Mts.; 60 $59^{\prime}$ $40^{\prime \prime} \mathrm{N}, 149^{\circ} 04^{\prime} 30^{\prime \prime} \mathrm{W}$; (map 63).

Local name published in 1898 by Mendenhall (1900, p. 279), USGS.

Winnic Creek: stream, flows E $7 \mathrm{mi}$. to North Fork Koyukuk River, 3.5 mi. NE of Florence Lake and $23.5 \mathrm{mi}$. SW of Wiseman, Brooks Ra.; $67^{\circ} 11^{\prime} 45^{\prime \prime} \mathrm{N}, 150^{\circ} 48^{\prime} 15^{\prime \prime} \mathrm{W}$; (map 124).

Lccal name shown on an 1899 fieldsheet by T. G. Gerdine, USGS.

Winning Cove: cove, $0.2 \mathrm{mi}$. across, along $\mathrm{E}$ shore of Glass Penin., on $\mathbf{E}$ coast of Admiralty I., $30 \mathrm{mi}$. NE of Angoon, Alex. Arch.; $57^{\circ}$ $51^{\prime} 50^{\prime \prime} \mathrm{N}, 134^{\circ} 06^{\prime} 30^{\prime \prime} \mathrm{W}$; (map 9).
Local name reported in 1928 by H. E. Smith, USFS.

Winona Creek: stream, flows SW $2.8 \mathrm{mi}$. to Skookum Creek in Noxapaga River basin, 32 mi. SW of Imuruk Lake, Seward Penin. High.; $65^{\circ} 33^{\prime} \mathrm{N}, 164^{\circ} 17^{\prime} \mathrm{W}$; BGN 1952; (map 110).

Prospectors' name reported in 1901 by T. G. Gerdine (in Collier, 1902, pl. 12), USGS.

Winslow, Cape: point of land, see Wislow Cape. Winslow, Point: point of land, E point of entrance to Mary Island Anchorage, on $\mathrm{N}$ coast of Mary I., Alex. Arch.; $55^{\circ} 06^{\prime} 30^{\prime \prime} \mathrm{N}, 131^{\circ}$. $11^{\prime} 25^{\prime \prime} \mathrm{W}$; (map 3).

This name was originally applied about 1880 to Giant Point by local pilots; transferred in 1883 to above location by USC\&GS. Winslow Island: island, see Wislow Island. Winslow Point: point of land, see Giant Point. Winstanley Creek: stream, flows NW through Winstanley Lakes $8 \mathrm{mi}$. to Shoalwater Pass, on $\mathrm{E}$ shore of Behm Canal, Coast Mts.; $55^{\circ}$ $24^{\prime} 28^{\prime \prime}$ N, 130 52'55" W; (map 3).

Local name reported in 1955 by USGS.

Winstanley Island: island, $4.3 \mathrm{mi}$. long, in Behm Canal, 2 mi. NE of Smeaton I., Coast Mts.; $55^{\circ} 26^{\prime} \mathrm{N}, 130^{\circ} 59^{\prime} \mathrm{W}$; (map 3 ).

Named in 1879 by W. H. Dall, USC\&GS, for the English engineer who built the first Eddystone Lighthouse near Plymouth, England in 1696-1699, and who lost his life there in 1703; published in the 1883 Coast Pilot (p. 72).

Winstanley Lakes: lakes, two, extend $3.5 \mathrm{mi}$. in course of Winstanley Creek, $1.5 \mathrm{mi}$. E of Behm Canal, Coast Mts.; $55^{\circ} 26^{\prime} \mathrm{N}, 130^{\circ} 50^{\prime} \mathrm{W}$; (map 3)

Local name recorded in 1955 by USGS.

Winston Creek: stream, flows NE $1 \mathrm{mi}$. to Solomon River, $11 \mathrm{mi}$. NE of Solomon, Seward Penin. High.; $64^{\circ} 42^{\prime} \mathrm{N}, 164^{\circ} 18^{\prime} \mathrm{W}$; (map 95). Var. Winnebago Creek, Winneham Creek.

Prospectors' name published in 1956 by USGS. The name "Winnebago" was shown on a prospectors' manuscript map dated 1902; it was reported in 1905 as applying to this stream by T. G. Gerdine, USGS.

Winter Anchorage: bay, see Gibson Cove.

Winter Bay: bay, $1.8 \mathrm{mi}$. across, on SW coast of Prince of Wales I., $\mathrm{N}$ of Hessa I., Alex. Arch.; $54^{\circ} 46^{\prime} 00^{\prime \prime} \mathrm{N}, 132^{\circ} 20^{\prime} 50^{\prime \prime}$; (map 1).

Local name reported in 1948 by USGS.

Winter Cove: cove, see Dark Cove.

Winter Creek: stream, flows NW $3 \mathrm{mi}$. to Bonanza Creek, $41 \mathrm{mi}$. SE of Nenana, Alaska Ra.; $64^{\circ} 01^{\prime} \mathrm{N}, 148^{\circ} 41^{\prime} \mathrm{W}$; (map 100).

Local name reported by USGS (Capps, 1912, pl. 1).

Winter Creek: stream, flows NW $0.4 \mathrm{mi}$. to Bluestone River, $13 \mathrm{mi}$. SE of Telle», Seward Penin. High.; $65^{\circ} 06^{\prime} \mathrm{N}, 166^{\circ} 12^{\prime} \mathrm{W}$; (map 111).

Prospectors' name reported on the 1908 "Map of Seward Peninsula" by Arthur Gibson. 
Winter Creek: stream, flows SW $12 \mathrm{mi}$. to Kaviruk River, $37 \mathrm{mi}$. NE of Teller, Seward Penin. High.; $65^{\circ} 19^{\prime} \mathrm{N}, 165^{\circ} 06^{\prime} \mathrm{W}$; (map 111).

Prospector's name reported in 1901 by $T$. G. Gerdine (in Collier, 1902, pl. 12), USGS.

Winter Creek: stream, flows W $2.3 \mathrm{mi}$. to Tolovana River, $9 \mathrm{mi}$. SW of Livengood, YukonTanana High.; $65^{\circ} 24^{\prime} 30^{\prime \prime} \cdot \mathrm{N}, 148^{\circ} 38^{\prime} 00^{\prime \prime} \mathrm{W}$; (map 105).

Local name published by USGS in the 1950 's.

Winter Harbor: bay, $0.3 \mathrm{mi}$. wide, near $\mathrm{S}$ entrance to Tuxekan Passage, $W$ coast of Prince of Wales 1., Alex. Arch:; 55 46 $15^{\prime \prime} \mathrm{N}$, $133^{\circ} 13^{\prime} 45^{\prime \prime} \mathrm{W}$; (map 4).

Local name published in 1964 by USC\&GS. Winter Harbor: bay, see Gibson Cove.

Winter Island: island, $900 \mathrm{ft}$. long, at head of Afognak Bay, $4.5 \mathrm{mi}$. NNW of Afognak, Kodiak I., $58^{\circ} 04^{\prime} 25^{\prime \prime} \mathrm{N}, 152^{\circ} 47^{\prime} 00^{\prime \prime} \mathrm{W}$; (map 43 ).

Name reported in $\mathbf{i} 900$ by Lt. Comdr. J. F. Moser, USN, who made surveys and investigations in this area while commander of the USBF steamer Albatross from 1897 to 1901.

Winter Lake: lake, $0.6 \mathrm{mi}$. long, on Attu I., in course of Diehm Creek, Aleutian Is.; 52 $56^{\prime}$ $00^{\prime \prime} \mathrm{N}, 173^{\circ} 00^{\prime} 15^{\prime \prime} \mathrm{E}$; (map 13$)$.

Named by U.S. Army during World War II ; map published in 1948 by AMS.

Winthrop Point: bend, on left bank of Koyukuk River, $36 \mathrm{mi}$. NW of Hochandochtla Mtn., Kokrines-Hodzana High.; $66^{\circ} 00^{\prime} \mathrm{N}, 155^{\circ} 30^{\prime}$ W; (map 107)

Named in 1899 by F. C. Schrader, USGS.

Wipple, Mount: mountain, see Whipple, Mount. Wisconsin Inlet: estuary', see Wachusett Inlet.

Wiseman: village, pop. 12, on Middle Fork Koyukuk River, at junc. of Wiseman Creek, Brooks Ra. ; $67^{\circ} 25^{\prime} \mathrm{N}, 150^{\circ} 06^{\prime} \mathrm{W}$; (map 124). Var. Nolan, Wrights.

In response to increased activity in mining on Nolan and Wiseman Creeks in 1911, the local population began to abandon Coldfoot, 10 miles to the south. Supplies were brought up the Middle Fork Koyukuk River to the site of "Wright's old roadhouse, named for B. E. Wright, keeper, at the mouth of Wiseman Creek" where a new town developed. It was first called "Wrights," after the roadhouse, then "Nolan," after the nearby gold-bearing creek, and finally "Wiseman," after the stream (Marshall, 1933, p. 42). A post office was established here in 1909 called "Nolan." The post office name was changed in 1923 to "Wiseman"; it was discontinued in 1956 (Ricks, 1965, p. 71).

Wiseman Creek: stream, flows E 12 mi. to Middle Fork Koyukuk River at Wiseman, Brooks Ra.; $67^{\circ} 24^{\prime} 30^{\prime \prime} \mathrm{N}, 150^{\circ} 06^{\prime} 00^{\prime \prime} \mathrm{W}$; (map 124).

Local name shown on an 1899 fieldsheet by T. G. Gerdine, USGS.

Wishbone Hill: mountain, 2,333 ft., E of Moose Creek, $10 \mathrm{mi}$. NE of Palmer, Cook Inlet Low.; $61^{\circ} 44^{\prime} 10^{\prime \prime} \mathrm{N}, 148^{\circ} 57^{\prime} 00^{\prime \prime} \mathrm{W}$; (map 69).
Local name reported in 1910 by G. G. Martin (in Brooks and others, 1911, pl. 8), USGS. So named because of its shape.

Wishbone Lake: lake, $0.6 \mathrm{mi}$. long, $9 \mathrm{mi}$. NE of Palmer at head of Buffalo Creek, Cook Inlet Low.; $61^{\circ} 43^{\prime} 40^{\prime \prime} \mathrm{N}, 149^{\circ} 01^{\prime} 00^{\prime \prime} \mathrm{W}$; (map $69)$.

Local name reported in 1915 by USGS; name derived from nearby Wishbone Hill.

Wislow Cape: point of land, on $\mathrm{N}$ coast of Unalaska I., Aleutian Is.; 54 $50^{\prime} 00^{\prime \prime} \mathrm{N}, 166^{\circ}$ $44^{\prime} 45^{\prime \prime}$ W; BGN 1962; (map 46). Var. Cape Winslow.

Named in 1888 by USBF. It may be a possible error for "Winslow."

Wislow Island: island, $0.1 \mathrm{mi}$. long, in Reese Bay, $N$ coast of Unalaska I., Aleutian Is.; $54^{\circ} 00^{\prime} 25^{\prime \prime} \mathrm{N}, 166^{\circ} 43^{\prime} 03^{\prime \prime}$ W; BGN 1962. Var. Winslow Island.

Named in 1888 by USBF. It may be a possible error of "Winslow."

Witchcraft Point: point of land, $2 \mathrm{mi}$. SW of West Kiska Lake, on NW coast of Kiska I., Aleutian Is.; $52^{\circ} 03^{\prime} 10^{\prime \prime} \mathrm{N}, 177^{\circ} 30^{\prime} 00^{\prime \prime} \mathrm{E}$; $B G N 1937$; (map 14).

Named in 1936 by the U.S. Navy Hydrog. Office.

Witches Cauldron: valley, heads near Devils Thumb on Alaska-Canada boundary, extends NW $10 \mathrm{mi}$. to Baird Glacier, $105 \mathrm{mi}$. E of Sitka, Coast Mts.; $57^{\circ} 10^{\prime} \mathrm{N}, 132^{\circ} 34^{\prime} \mathrm{W}$; $B G N$ 1966; (map 8).

Descriptive name given in 1965 by $A$. S. Post, USGS, who wrote "The confused moraines on the glaciers, the lack of surface drainage and the steep, gloomy canyon walls all heighten the feeling of foreboding. It is a sinister unworldly place."

Witherspoon, Mount: mountain, $12,012 \mathrm{ft}$., in Dora Keen Ra., at head of Columbia Glacier, $36 \mathrm{mi}$. NW of Valdez, Ghugach Mts.; $61^{\circ}$. $23^{\prime} 45^{\prime \prime} \mathrm{N}, 147^{\circ} 11^{\prime} 55^{\prime \prime} \mathrm{W}$; BGN 1928; (map $69)$.

Named in 1928 by USGS for David C. Witherspoon, USGS topographer, "who at the time of his retirement in 1921 had mapped a greater area of Alaska than any other man."

Witnesses, The: islands, in San Alberto Bay, 5 mi. W of Klawock and $7 \mathrm{mi}$. NW of Craig, Alex. Arch.; 55 $33^{\prime} 10^{\prime \prime} \mathrm{N}, 133^{\circ} 13^{\prime} 30^{\prime \prime} \mathrm{W}$; (map 4). Var. Los Testigos.

Translation of the name "Los Testigos" given in 1775-79 by Don Juan de la Bodega y Quadra and Francisco Antonio Maurelle.

Witness Rocks: rocks, in San Alberto Bay, NW of The Witnesses, $6 \mathrm{mi}$. NW of Craig, Alex. Arch.: $55^{\circ} 33^{\prime} 25^{\prime \prime} \mathrm{N}, 133^{\circ} 15^{\prime} 15^{\prime \prime} \mathrm{W}$; (map 4).

Local name published in 1914 by USC\&GS. Witshed, Point: point of land, see Whitshed, Point.

Wloyukuk River: stream, see Holokuk River.

Wnderika Mountain: mountain, see Abercrombie Mountain.

Wodehouse Point: point of land, see Woodhouse, Point.

Woewodski Harbor: bight, $1.3 \mathrm{mi}$. across, on SE coast of Admiralty I, between Liesnoi I. and Deepwater Point, Alex. Arch.; $57^{\circ} 10^{\prime} \mathrm{N}$, $134^{\circ} 14^{\prime} \mathrm{W}$; (map 9). Var. Gavan Vovodskago, Woewodsky Harbor.

Named in 1838 by Capt. Lt. D. F. Zarembo for Stepan Vasilivich Woewodski, Director of the Russian American Colonies from 1854 to 1859; published in 1848 as "Gavan Vovodskago" meaning "Woewodski Harbor" on Russian Hydrog. Dept. Chart 1396.

Woewodski Island: island, $5 \mathrm{mi}$. long, between Duncan Canal and Wrangell Narrows, $15 \mathrm{mi}$. $S$ of Petersburg, Alex. Arch.; $56^{\circ} 34^{\prime}$ N, $133^{\circ}$ $00^{\prime} \mathrm{W}$; (map 6). Var. Medviezhi, Ostrova, Voevodskago Island, Voyevodskago, Ostrova, Woewodsky Island, Bear Island.

Published in 1848 on Russian Hydrog. Dept. Chart 1396 as "O[strov]a Voyevodskago." Named for Capt. Lt. Stepan Vasilivich Woewodski, chief director of the Russian American Colonies, 1854-59. In 1838 G. Lindenberg called part of the island "Medvezhiy," meaning "of the bear."

Woewodski Lake: lake, see Harvey Lake.

Woewodsky Harbor: bight, see Woewodski Harbor.

Woewodsky Island: island, see Woewodski Island.

Wohlschlag Slough: stream, see Central Marsh Slough

Wolasatux: village, on left bank of Yukon River, 7 mi. S of Nulato, Nulato Hills; $B G N$ 1932; (map 97). Var. Wolasaluk, Wolsatux. Reported as "Wolsatux" in 1885 by Lt. $H$. T. Allen, USA. Wolasátux was a young man who escaped massacre at Nulato in 1851.

Wolcot Mountain: mountain, see Sheep Mountain.

Wolcot Mountain: mountain, see Wallcutt Mountain.

Wolcott Mountain: mountain, see Sheep Mountain.

Wolcott Reef: reef, $11 \mathrm{mi}$. NE of Karluk, on W coast of Kodiak I. ; $57^{\circ} 40^{\prime} 15^{\prime \prime}$ N, $154^{\circ} 11^{\prime} 45^{\prime \prime}$ W; (map 35)

Local name published in 1943 by USC\&GS.

Woleek River: stream, see Wulik River.

Wolf Creek: locality, on Wolf Creek, $24 \mathrm{mi}$. NE of Fairbanks, Yukon-Tanana High.; $65^{\circ} 04^{\prime}$ $\mathrm{N}, 147^{\circ} 21^{\prime} \mathrm{W}$; (map 105).

Local name of a temporary mining camp; published in 1916 in Polk's Gazetteer.

Wolf Creek: stream, on Alaska Penin., flows NW $6 \mathrm{mi}$. to Meshik River, $13 \mathrm{mi}$. S of Vent Mtn. in Aniakchak Crater, Bristol Bay Low.; $56^{\circ} 41^{\prime} \mathrm{N}, 158^{\circ} 12^{\prime} \mathrm{W}$; (map 30).

Name reported in 1923 by R. H. Sargent, USGS; published in 1927 by USGS.

Wolf Creek: stream, in Glacier Bay National Monument, flows NW $4 \mathrm{mi}$. to tidal flat on Spokane Cove, Glacier Bay, $21 \mathrm{mi}$. NW of Gustavus, St. Elias Mts.; $58^{\circ} 42^{\prime} 17^{\prime \prime} \mathrm{N}, 135^{\circ}$. 57'06" W; BGN 1963; (map 11).

Local name reported in 1961 by NPS.

Wolf Creek: stream, on Kenai Penin. flows SE $3.5 \mathrm{mi}$. to Resurrection Creek, $7.5 \mathrm{mi}$. $\mathrm{S}$ of Hope and $32 \mathrm{mi}$. W of Whittier, Chugach Mts. ; $60^{\circ} 48^{\prime} 15^{\prime \prime} \mathrm{N}, 149^{\circ} 39^{\prime} 00^{\prime \prime}$ W ; (map $63)$. 
Local prospectors' name reported in 1904 by Moffit (1906, pl. 2), USGS.

Wolf Creek: stream, heads on Wolf Creek Mtn., flows $\mathrm{S} 7 \mathrm{mi}$. to Tom Gray Creek $3.5 \mathrm{mi}$. NE of its junc, with Nageethluk River, $32 \mathrm{mi}$. N of Russian Mission, Yukon-Kuskokwim Delta. ; $62^{\circ} 14^{\prime} 45^{\prime \prime} \mathrm{N}, 161^{\circ} 25^{\prime} 00^{\prime \prime} \mathrm{W}$; (map 78).

Local name obtained in 1952 by USGS.

Wolf Creek: stream, heads in Dutch Hills, flows SE $2 \mathrm{mi}$. to Ramsdyke Creek, $30 \mathrm{mi}$. NW of Talkeetna, Alaska Ra.; $62^{\circ} 36^{\prime} 38^{\prime \prime} \mathrm{N}, 150^{\circ}$ $48^{\prime} 30^{\prime \prime} \mathrm{W}$; (map 81).

Prospectors' name reported in 1906 by $R$. W. Porter, USGS.

Wolf Creek: stream, flows N $18 \mathrm{mi}$. to Herron River, $27 \mathrm{mi}$. S of village of Lake Minchumina, Tanana Low.; $63^{\circ} 28^{\prime} 15^{\prime \prime} \mathrm{N}, 152^{\circ} 20^{\prime}$ $30^{\prime \prime} \mathrm{W}$; (map 88).

Local name reported in 1954 by USGS.

Wolf Creek: stream, flows E $18 \mathrm{mi}$. to Mosquito Fork, $37 \mathrm{mi}$. N of Tok, Yukon-Tanana High.; $63^{\circ} 50^{\prime} 50^{\prime \prime} \mathrm{N}, 142^{\circ} 58^{\prime} 45^{\prime \prime} \mathrm{W}$; (map 85).

Local name reported in 1907 by D. C. Witherspoon, USGS

Wolf Creek: stream, flows NE $10 \mathrm{mi}$. to Mission Creek, $3.5 \mathrm{mi}$. NW of Eagle, Yukon-Tanana High. ; $64^{\circ} 49^{\prime} \mathrm{N}, 141^{\circ} 19^{\prime} \mathrm{W}$; (map 102).

Named by prospectors and reported in 1896 by Spurr (1898, pl. 48), USGS.

Wolf Creek: stream, flows NW $4.5 \mathrm{mi}$. to East Fork Chena River, 13 mi. ESE of Far Mtn. and $65 \mathrm{mi}$. SW of Circle, Yukon-Tanana High.; $65^{\circ} 02^{\prime} 45^{\prime \prime} \mathrm{N}, 145^{\circ} 20^{\prime} 05^{\prime \prime} \mathrm{W}$; (map 104).

Prospectors' name reported in 1954 or 1955 by USGS topographers.

Wolf Creek: stream, flows NW $2 \mathrm{mi}$. to Cleary Creek, $19 \mathrm{mi}$. NE of Fairbanks, YukonTanana High.; $65^{\circ} 05^{\prime} 15^{\prime \prime}$ N, $147^{\circ} 25^{\prime} 00^{\prime \prime}$ W ; (map 105).

Named by prospectors; reported in 1903 by T. G. Gerdine (Prindle, 1905, pl. 13), USGS.

Wolf Creek: stream, flows N $12 \mathrm{mi}$. to Birch Creek, $45 \mathrm{mi}$. SW of Circle, Yukon-Tanana High.; $65^{\circ} 18^{\prime} 20^{\prime \prime} \mathrm{N}, 145^{\circ} 02^{\prime} 00^{\prime \prime} \mathrm{W}$; (map 104).

Named by prospectors and reported in 1905 by D. C. Witherspoon (in Prindle, 1906, pl. 1), USGS.

Wolf Creek: stream, heads on Wolf Mtn., flows NW $14 \mathrm{mi}$. to Melozitna River, $30 \mathrm{mi}$. NW of Birches, Kokrines-Hodzana High.; $65^{\circ}$ $29^{\prime} 35^{\prime \prime} \mathrm{N}, 154^{\circ} 09^{\prime} 45^{\prime \prime} \mathrm{W}$; (map 107).

Local name obtained in 1954 by USGS topographers

Wolf Creek: stream, flows SW $4.5 \mathrm{mi}$. to Moose Creek, $12 \mathrm{mi}$. NE of Livengood, YukonTanana High.; $65^{\circ} 40^{\prime} \mathrm{N}, 148^{\circ} 17^{\prime} \mathrm{W}$; (map 105).

Named by prospectors; reported in 1916 by J. B. Mertie (in Brooks and others, 1918, pl. 13), USGS.

Wolf Creek: stream, flows SW $3 \mathrm{mi}$. to SE end of Big Lake $21 \mathrm{mi}$. W of Chandalar, Brooks Ra.; 67 $29^{\prime} 00^{\prime \prime}$ N, $149^{\circ} 18^{\prime} 30^{\prime \prime}$ W; (map 123).
Local name reported in 1956 by T. E. Taylor, USGS.

Wolf Creek: stream, flows SW $6.5 \mathrm{mi}$. from a lake to Tinayguk River, $7 \mathrm{mi}$. NNE of Tobin Mtn. and $48 \mathrm{mi}$. NW of Wiseman, Brooks Ra.; $67^{\circ} 44^{\prime} 30^{\prime \prime} \mathrm{N}, 151^{\circ} 26^{\prime} 30^{\prime \prime} \mathrm{W}$; BGN 1932; (map 124).

Local name reported by Robert Marshall in 1932.

Wolf Creek: stream, flows $\mathrm{N} 2.5 \mathrm{mi}$. to Kukpuk River $S$ of its junc. with Kakpeyak River, 16 mi. NE of Cape Thompson, Arctic Slope; $68^{\circ} 14^{\prime} 35^{\prime \prime} \mathrm{N}, 165^{\circ} 24^{\prime} 40^{\prime \prime} \mathrm{W}$; BGN 1963; (map 129).

Named in 1960 by Project Chariot personnel.

Wolf Creek: stream, heads at $69^{\circ} 21^{\prime} \mathrm{N}, 153^{\circ} 22^{\prime}$ $\mathrm{W}$, flows NW $75 \mathrm{mi}$. and joins Key Creek to form Price River, $35 \mathrm{mi}$. NE of head of Ikpikpuk River, Arctic Plain; 69 $44^{\prime} 30^{\prime \prime} \mathrm{N}, 153^{\circ}$ $49^{\prime} 30^{\prime \prime} \mathrm{W}$; BGN 1960; (map 142).

Name proposed in 1951 by USGS for use in geologic mapping; named for the numerous wolves seen in this area.

Wolf Creek Mountain: mountain, 2,455 ft., 37 mi. $\mathrm{N}$ of Russian Mission and $51 \mathrm{mi}$. $\mathrm{W}$ of Holy Cross, Nulato Hills; $62^{\circ} 20^{\prime} \mathrm{N}, 161^{\circ} 21^{\prime}$ $\mathrm{W} ;(\operatorname{map} 78)$.

Local name obtained in 1952 by USGS.

Wolfe Lake: lake, see Wolf Lake.

Wolf Island: island, see Kritskoi Island.

Wolf Island: islands, see Kudobin Islands.

Wolf Lake: lake, $0.8 \mathrm{mi}$. long, on Prince of Wales I., $2 \mathrm{mi}$. $W$ of entrance to Twelvemile Arm and $22 \mathrm{mi}$. NE of Craig, Alex. Arch.; 55 $32^{\prime}$ $\mathrm{N}, 132^{\circ} 36^{\prime} \mathrm{W}$; BGN 1960; (map 4).

Named in 1956 by C. L. Sainsbury, USGS, because of "the large number of wolves that live near the lake and prey upon the beaver in the numerous small ponds near Wolf Lake."

Wolf Lake: lake, $0.7 \mathrm{mi}$. long, on Kenai Penin. NNE of the Finger Lakes $13 \mathrm{mi}$. NE of Kenai, Cook Inlet Low.; $60^{\circ} 40^{\prime} 00^{\prime \prime} \mathrm{N}, 150^{\circ} 54^{\prime} 50^{\prime \prime}$ W; (map 62)

Named about 1963 by officials of Kenai National Moose Range, for administrative purposes.

Wolf Lake: lake, $0.6 \mathrm{mi}$. long, in Matanuska Valley, $6 \mathrm{mi}$. NW of Palmer, Cook Inlet Low.; $61^{\circ} 38^{\prime} 40^{\prime \prime}$ N, $149^{\circ} 16^{\prime} 35^{\prime \prime}$ W; (map 69). Var. Wolfe Lake.

Local name reported in 1942 as Wolfe Lake by AMS

Wolf Lake: lake, $2.6 \mathrm{mi}$. long, $\mathrm{N}$ of Tanana River, $7 \mathrm{mi}$. NE of Tanacross, Yukon-Tanana High.; $63^{\circ} 27^{\prime} \mathrm{N}, 143^{\circ} 10^{\prime} \mathrm{W}$; (map 85).

Local name published by USGS in 1950

Wolf Lake: lake, see Upper Wolf Lake.

Wolf Lakes: lakes, extend N-S $1.5 \mathrm{mi}$, , between Beluga and Little Susitna Mts., $38 \mathrm{mi}$. N of Tyonek, Alaska Ra.; $61^{\circ} 38^{\prime} 15^{\prime \prime} \mathrm{N}, 151^{\circ} 05^{\prime}$ $00^{\prime \prime} \mathrm{W}$; (map 70).

Local name reported in 1954 by USGS.

Wolf Mountain: mountain, 1,565 ft., in Kuskokwim Mts., $2.5 \mathrm{mi}$. NE of Sugarloaf Mtn., 38 mi. E of Flat, Kilbuck-Kuskokwim Mts, ; $62^{\circ}$ $33^{\prime} 15^{\prime \prime} \mathrm{N}, 156^{\circ} 49^{\prime} 30^{\prime \prime} \mathrm{W}$; (map 79).
Local name obtained in 1952 by USGS topographers.

Wolf Mountain: mountain, 4,978 ft., in Korines Hills between headwaters of Wolf and Hot Springs Creeks, $19 \mathrm{mi}$. NW of Birches, Kokrines-Hodzana High.; $65^{\circ} 19^{\prime} \mathrm{N}, 154^{\circ} 04^{\prime} \mathrm{W}$; (map 107).

Local name obtained in 1954 by USGS topographers.

Wolf Point: point of land, on $\mathrm{N}$ coast of Kiska I., Aleutian Is.; $52^{\circ} 07^{\prime} 25^{\prime \prime} \mathrm{N}, 177^{\circ} 33^{\prime} 40^{\prime \prime}$ E; (map 14). Var. Blackbird Point.

Shown on recent maps of Kiska Island; variant shown on a 1943 USAAF map.

Wolf Point: point of land, $\mathrm{E}$ tip of Walrus I., Kudobin Is., $8.5 \mathrm{mi}$. NW of village of Port Moller, Bristol Bay Low.; 56 $01^{\prime} 30^{\prime \prime} \mathrm{N}$, $160^{\circ} 49^{\prime} 00^{\prime \prime} \mathrm{W}$; (map 28).

Translation of the Russian word "volchie" by W. H. Dall, USC\&GS, in 1882; Capt. F. P. Lutke applied the name "Volchie" to the entire island in 1836.

Wolf Point: point of land, in Glacier Bay National Monument on W shore of Muir Inlet, $43 \mathrm{mi}$. SW of Skagway, St. Elias Mts. ; $59^{\circ} 00^{\prime}$ $15^{\prime \prime} \mathrm{N}, 136^{\circ} 09^{\prime} 10^{\prime \prime} \mathrm{W}$; (map 45).

So named by the American Geographical Society (Field, 1947, pl. 1) "because of wolf tracks seen there in 1941."

Wolf Point: promontory, on $\mathrm{N}$ bank of Knik River, 16 mi. SE of Palmer, Chugach Mts.; $61^{\circ} 28^{\prime} 45^{\prime \prime} \mathrm{N}, 148^{\circ} 41^{\prime} 30^{\prime \prime} \mathrm{W}$; (map 69).

Local name reported in 1960 by USGS.

Wolf Pup: ravine, trends NW $2 \mathrm{mi}$. to Middle Fork Koyukuk River, 1 mi. S of mouth of Gold Creek and $36 \mathrm{mi}$. W of Chandalar, Brooks Ra.; $67^{\circ} 30^{\prime}$ N, $149^{\circ} 52^{\prime}$ W; (map 123).

Local name reported in 1956 by T. E. Taylor, USGS.

Wolf Rock: rock, $750 \mathrm{ft}$. long, in Pacific Ocean, 13 mi. W of Dall I., Alex. Arch.; $55^{\circ} 01^{\prime} 15^{\prime \prime}$ N, 133 29'15" W; (map 4). Var. Flat Island, Forrester's Island, Isla Algives, Isla Rasa.

Named in 1794 by Capt. George Vancouver, RN. In 1774-1779, the Spaniards called the island "Isla Rasa" meaning "flat island;" and in 1788, Capt. John Meares called it "Forrester's Island." It was called "Isla Algives" by Don Juan de la Bodega y Quadra about August 1, 1779.

Wolikpot: locality, see Walakpa.

Wolik River: stream, see Wulik River.

Wolk Harbor: bay, $1.8 \mathrm{mi}$. long, on $\mathrm{S}$ coast of Dall I., Alex. Arch.; 54 $40^{\prime} 45^{\prime \prime}$ N, $132^{\circ}$ $47^{\prime} 15^{\prime \prime}$ W; (map 1). Var. Polk Harbour.

Local name published in USC\&GS in 1911.

Wolk Point: point of land, $\mathrm{S}$ point of entrance to Wolk Harbor, on S coast of Dall I., Alex. Arch.; 54 $40^{\prime} 20^{\prime \prime} \mathrm{N}, 132^{\circ} 46^{\prime} 35^{\prime \prime} \mathrm{W}$; $B G N$ 1929; (map 1).

Name derived from Wolk Harbor; given by Capt. R. S. Patton, USC\&GS, in 1928.

Wolley, Cape: point of land, see Woolley, Cape. Wolverine Creek: stream, $1.5 \mathrm{mi}$. long, on NE coast of Cleveland Penin., drains Lake Mc- 
Donald into Yes Bay, Alex. Arch.; 55 $55^{\prime} 00^{\prime \prime}$ N, $131^{\circ} 47^{\prime} 30^{\prime \prime} \mathrm{W}$; (map 3$)$.

Local name reported by USGS in 1952.

Wolverine Creek: stream, on $\mathbf{S}$ shore of Alaska Penin., flows NE $3 \mathrm{mi}$, to a lagoon, at head of Aniakchak Bay, $15 \mathrm{mi}$. SW of Cape Kunmik; Aleutian Ra.; $56^{\circ} 42^{\prime} \mathrm{N}, 157^{\circ} 34^{\prime} \mathrm{W}$; (map 31).

Local name reported in 1951 by USGS.

Wolverine Creek: stream, on $\mathrm{N}$ end of Kenai Penin., flows NW $4.5 \mathrm{mi}$. to Ingram Creek, $12 \mathrm{mi}$. SE of Sunrise and $16 \mathrm{mi}$. W of Whittier, Chugach Mts. ; $60^{\circ} 49^{\prime} 20^{\prime \prime} \mathrm{N}, 149^{\circ} 07^{\prime} 15^{\prime \prime}$ $\mathrm{W} ;(\operatorname{map} 63)$.

Local prospectors' name reported in 1904 by Moffit (1906, pl. 2), USGS.

Wolverine Creek: stream, heads on Little Mount Susitna, flows NE $15 \mathrm{mi}$. to Lower Sucker Creek, $39 \mathrm{mi}$. NE of Tyonek, Cook Inlet Low.; $61^{\circ} 36^{\prime} 40^{\prime \prime} \mathrm{N}, 150^{\circ} 45^{\prime} 01^{\prime \prime} \mathrm{W}$; (map $70)$.

Local name reported in 1935 by USGS.

Wolverine Creek: stream, heads at glacier, flows NW $16 \mathrm{mi}$. to Matanuska River, $4.8 \mathrm{mi}$. NE of Palmer, Cook Inlet Low.; $61^{\circ} 40^{\prime} \mathrm{N}$, $149^{\circ} 03^{\prime} \mathrm{W}$; (map 69).

Name reported by GLO (BLM) on a 1915 land plat.

Wolverine Creek: stream, in Teocalli Mts., heads SE of Knox Peak, flows SW $3.7 \mathrm{mi}$. to South Fork Kuskokwim River $9 \mathrm{mi}$. $\mathrm{S}$ of junc. of Tatina River, $91 \mathrm{mi}$. SE of McGrath, Alaska Ra.; $62^{\circ} 10^{\prime} \mathrm{N}, 153^{\circ} 22^{\prime} \mathrm{W}$; (map 80).

Local name reported in 1931 by USGS.

Wolverine Creek: stream, flows SE $3.1 \mathrm{mi}$. to Camp Creek, $49 \mathrm{mi}$. W of Talkeetna, Alaska Ra.; 62 $25^{\prime} 38^{\prime \prime} \mathrm{N}, 151^{\circ} 36^{\prime} 40^{\prime \prime} \mathrm{W}$; (map 81).

Prospectors' name reported in 1906 by $R$. W. Porter, USGS.

Wolverine Greek: stream, flows S and W $3.2 \mathrm{mi}$., from Mount Eielson to Crystal Creek, E of Muldrow Glacier, $4.5 \mathrm{mi}$. SSW of Eielson Visitor Center, Alaska Ra.; $63^{\circ} 22^{\prime} 15^{\prime \prime} 150^{\circ} 22^{\prime}$ $00^{\prime \prime}$ W; BGN 1932; (map 88).

So named by USGS in 1931 because "many wolverines were observed on this creek during the past summer."

Wolverine Creek: stream, flows SE $8 \mathrm{mi}$. to North Fork Kuskokwim River, 32 mi. NE of Medfra, Kilbuck-Kuskokwim Mts. ; $63^{\circ} 22^{\prime} \mathrm{N}, 153^{\circ} 51^{\prime}$ W; (map 89).

Local name reported in 1958 by USGS.

Wolverine Creek: stream, flows W 3 mi. to Tibbs Creek $6 \mathrm{mi}$. S of that stream's junc. with Goodpaster River and $50 \mathrm{mi}$. ENE of Big Delta, Yukon-Tanana High.; $64^{\circ} 23^{\prime} \mathrm{N}, 144^{\circ}$ $16^{\prime} \mathrm{W}$; (map 101).

Local name published in 1956 by USGS.

Wolverine Creek: stream, flows SE $2.8 \mathrm{mi}$. to right bank of Ottertail Creek, $8 \mathrm{mi}$. SE of Chena Hot Springs and $60 \mathrm{mi}$. N of Big Delta, Yukon-Tanana High.; $64^{\circ} 59^{\prime} 10^{\prime \prime} \mathrm{N}, 145^{\circ} 50^{\prime}$ 00" W; (map 101).

Prospectors' name reported in 1913 by USGS as the name of the stream now known as Demar Creek.

Wolverine Creek: stream, flows SW $6.5 \mathrm{mi}$. to North Fork Baker Creek, $6 \mathrm{mi}$. E of Rough- top Mtn. and $25 \mathrm{mi}$. SW of Rampart, YukonTanana High.; $65^{\circ} 11^{\prime} 00^{\prime \prime} \mathrm{N}, 150^{\circ} 35^{\prime} 30^{\prime \prime} \mathrm{W}$; (map 106).

Prospectors' name reported in 1911 by $\mathbf{H}$. M. Eakin, USGS.

Wolverine Creek: stream, flows NE $16.5 \mathrm{mi}$. S of Crag Peak to John River, $9.5 \mathrm{mi}$. SE of junc. of Hunt Fork and John River and 59 mi. W of Wiseman, Brooks Ra.; $67^{\circ} 37^{\prime} \mathrm{N}$, 15216' W; BGN 1932; (map 124). Var. Wolverine River.

Name reported in 1930 by Robert Marshall. Wolverine Creek: stream, flows $\mathrm{N} 10 \mathrm{mi}$. from Hatbox Mesa to Ayiyak River, $57 \mathrm{mi}$. NW of Anaktuvuk Pass, Brooks Ra.; 68 ${ }^{\circ} 55^{\prime} \mathrm{N}$, $152^{\circ} 26^{\prime} \mathrm{W}$; (map 134).

Named by USGS geologists during the exploration of Navel Petroleum Reserve No. 4; name given in 1944.

Wolverine Creek: stream, see Demar Creek.

Wolverine Falls: falls, on $\mathrm{S}$ tributary $3 \mathrm{mi}$. SE of its junc. with Savonoski River, on Alaska Penin., in Katmai National Monument, $21 \mathrm{mi}$. NE of Mount Katmai, Aleutian Ra.; 58 $32^{\prime}$ $50^{\prime \prime} \mathrm{N}, 154^{\circ} 43^{\prime} 10^{\prime \prime} \mathrm{W}$; (map 42).

Local name reported in 1951 by USGS.

Wolverine Fork: stream, flows SE $7 \mathrm{mi}$. to Chuitna River, $20 \mathrm{mi}$. NW of Tyonek, Alaska Ra. ; $61^{\circ} 12^{\prime} 00^{\prime \prime} \mathrm{N}, 151^{\circ} 39^{\prime} 30^{\prime \prime} \mathrm{W}$; BGN 1964; (map 70).

Named in 1963 by USGS.

Wolverine Gulch: ravine, trends $\mathrm{N} 1.5 \mathrm{mi}$. to Canoe Bay, $11 \mathrm{mi}$. E of Pavlof Bay, near SW end of Alaska Penin., Aleutian Ra.; 55 $31^{\prime} 40^{\prime \prime}$ N, 161 $09^{\prime} 30^{\prime \prime} \mathrm{W}$; (map 28).

Local name reported in 1929 by USGS.

Wolverine Lake: lake, $0.3 \mathrm{mi}$. long, on Kenai Penin. in Kenai Mts., $4 \mathrm{mi}$. $\mathrm{E}$ of Tustumena Lake and $32 \mathrm{mi}$. SE of Kenai, Chugach Mts.; $60^{\circ} 12^{\prime} \mathrm{N}, 150^{\circ} 38^{\prime} \mathrm{W}$; (map 62).

Named about 1963 by officials of Kenai National Moose Range, for administrative purposes.

Wolverine Lake: lake, $0.8 \mathrm{mi}$. long, $6 \mathrm{mi}$. NE of Palmer, Cook Inlet Low.; $61^{\circ} 39^{\prime} 45^{\prime \prime} \mathrm{N}, 148^{\circ}$ $58^{\prime} 00^{\prime \prime} \mathrm{W}$; ( $\operatorname{map} 69$ ).

Local name reported in 1942 by AMS.

Wolverine Lake: lake, $0.3 \mathrm{mi}$. across, $15 \mathrm{mi}$. NE of Chalkyitsik, Yukon Flats; $66^{\circ} 50^{\prime} \mathrm{N}, 143^{\circ}$ $29^{\prime} \mathrm{W}$; (map 120).

Local name obtained in 1956 by T. E. Taylor and R. C. Foley, USGS.

Wolverine Mountain: mountain, 4,653 ft., 3.7 mi. E of Paxson, Alaska Ra.; 63 ${ }^{\circ} 01^{\prime} 25^{\prime \prime} \mathrm{N}$, $145^{\circ} 22^{\prime} 40^{\prime \prime} \mathrm{W}$; (map 86).

Name reported in 1952 by USGS.

Wolverine Mountain: mountain, 4,580 ft., 14 mi. SE of Rampart, Yukon-Tanana High.; $65^{\circ} 20^{\prime} \mathrm{N}, 149^{\circ} 53^{\prime} \mathrm{W}$; (map 105).

Named by prospectors and reported in 1902 by A. H. Brooks, USGS.

Wolverine Peak: mountain, 4,455 ft., between North and South Forks Campbell Creek, 10 mi. SE of Anchorage, Chugach Mts.; $61^{\circ} 08^{\prime}$ 05" N, 149 36'45" W; BGN 1964; (map 69)

Named in 1963 by members of the Mountaineering Club of Alaska because "wolverine tracks were seen near its summit on an early M.C.A. ascent in winter."

Wolverine River: stream, see Wolverine: Creek

Woman Lake: lake, $0.2 \mathrm{mi}$. long, $0.8 \mathrm{mi}$. NE of junc. of Montana Creek and Susitna River, $14 \mathrm{mi}$. S of Talkeetna, Cook Inlet Low.; $62^{\circ}$ $05^{\prime} 50^{\prime \prime} \mathrm{N}, 150^{\circ} 03^{\prime} 20^{\prime \prime} \mathrm{W}$; (map 81).

Local name reported in 1958 by USGS.

Womans Bay: bay, see Womens Bay.

Womens Bay: bay, extends SW $5 \mathrm{mi}$. off Chiniak Bay, $5 \mathrm{mi}$. SW of Kodiak, Kodiak I.; $57^{\circ} 43^{\prime} \mathrm{N}, 152^{\circ} 31^{\prime} \mathrm{W}$; BGN 1939; (map 34). Var. Babia Bay, Babya Bay, English Bay, Guba Babya, Womans Bay.

Translation by Baker (1906, p. 679) of the name "Guba Babya," published by Sarichev (1826, map 16). In 1938 USG\&GS published the name "English Bay."

Womens Bay: bay, see Shakmanof Cove.

Wonder Bay: bay, $2 \mathrm{mi}$. across, on NW coast of Shuyak I., $48 \mathrm{mi}$. N of Kodiak I.; $58^{\circ} 36^{\prime} 40^{\prime \prime}$ $\mathrm{N}, 152^{\circ} 36^{\prime} 00^{\prime \prime} \mathrm{W}$; (map 43).

Name published by USC\&GS in 1927 on Chart 8555.

Wonder Creek: stream, flows SW $0.5 \mathrm{mi}$. to Center Creek $2 \mathrm{mi}$. N of Nome, Seward Penin. High.; $64^{\circ} 32^{\prime} 10^{\prime \prime} \mathrm{N}, 165^{\circ} 23^{\prime} 50^{\prime \prime} \mathrm{W}$; (map 94).

Prospectors' name published on the 1900 "Map of Nome Peninsula" by J. M. Davidson and B. D. Blakeslee.

Wonder Creek: stream, flows SE $1.5 \mathrm{mi}$. to Livengood Creek, $3 \mathrm{mi}$. NE of Livengood, YukonTanana High.; $65^{\circ} 33^{\prime} \mathrm{N}, 148^{\circ} 26^{\prime} \mathrm{W}$; (map 105).

Named by prospectors; reported in 1915 by Brooks (in Brooks and others, 1916, pl. 9), USGS.

Wonder Creek: stream, flows W $1 \mathrm{mi}$. to California Creek, $15 \mathrm{mi}$. NE of Shungnak, Brooks Ra.; $66^{\circ} 57^{\prime} 40^{\prime \prime}$ N, $156^{\circ} 37^{\prime} 00^{\prime \prime}$ W ; (map 115).

Prospectors' name reported after 1940 by USGS.

Wonder Creek: stream, see Center Creek.

Wonder Gulch: ravine, in Dutch Hills, trends NE $0.8 \mathrm{mi}$. to Ramsdyke Creek, $30 \mathrm{mi}$. NW of Talkeetna, Alaska Ra.; $62^{\circ} 36^{\prime} 45^{\prime \prime} \mathrm{N}, 150^{\circ} 48^{\prime}$ $30 " \mathrm{~W}$; (map 81).

Prospectors' name reported in the 1930's by USGS.

Wonder Gulch: ravine, trends S $1 \mathrm{mi}$. to Coffee Creek, in Kougarok River basin, $49 \mathrm{mi}$. SW of Imuruk Lake, Seward Penin. High.; $65^{\circ} 19^{\prime}$ $\mathrm{N}, 164^{\circ} 44^{\prime} \mathrm{W}$; (map 110 ).

Prospectors' name reported on the 1908 "Map of Seward Peninsula" by Arthur Gibson.

Wonder Lake: lake, $0.9 \mathrm{mi}$. long, on Kenai Penin., $0.8 \mathrm{mi}$. SE of Pepper Lake, $35 \mathrm{mi}$. NE of Kenai, Cook Inlet Low.; 60 $49^{\prime} 15^{\prime \prime}$ $\mathrm{N}, 150^{\circ} 24^{\prime} 30^{\prime \prime} \mathrm{W}$; (map 62).

Named about 1963 by officials of Kenai National Moose Range, for administrative purposes.

Wonder Lake: lake, $2.7 \mathrm{mi}$. long, in Mount McKinley National Park, $27 \mathrm{mi}$. NNE of Mount McKinley, Alaska Ra.; $63^{\circ} 28^{\prime} 30^{\prime \prime} \mathrm{N}, 150^{\circ}$ 52'30' W ; BGN 1932; (map 88). 
Local name shown on a 1916 fieldsheet by C.' E. Giffin, USGS.

Wonder Park: suburb, $\mathrm{E}$ of Anchorage and $\mathrm{S}$ of Glenn Highway, Cook Inlet Low.; 61 ${ }^{\circ} 13^{\prime} 24^{\prime \prime}$ $\mathrm{N}, 149^{\circ} 47^{\prime} 00^{\prime \prime} \mathrm{W}$; (map 69$)$.

Local name reported in 1954 by the city engineer of Anchorage.

Wood, Mount: mountain, 2,836 ft., in Glacier Bay National Monument, $1.7 \mathrm{mi}$. E of Wood Lake and $47 \mathrm{mi}$. NW of Hoonah, St. Elias Mts.; $58^{\circ} 32^{\prime} 45^{\prime \prime} \mathrm{N}, 136^{\circ} 26^{\prime} 20^{\prime \prime} \mathrm{W}$; (map $10)$.

Local name reported in 1951 by USGS.

Woodard Canyon: ravine, $0.3 \mathrm{mi}$. long, on Kenai Penin., $0.5 \mathrm{mi}$. N of Homer, Cook Inlet Low.; $59^{\circ} 39^{\prime} 30^{\prime \prime} \mathrm{N}, 151^{\circ} 33^{\prime} 15^{\prime \prime} \mathrm{W}$; (map 50).

Local name reported and published in 1950 by USGS.

Woodcamp Creek: stream, flows SE $13 \mathrm{mi}$. to Yukon River, $30 \mathrm{mi}$. NE of Rampart, Kokrines-Hodzana High.; $65^{\circ} 52^{\prime} 30^{\prime \prime} \mathrm{N}, 149^{\circ} 41^{\prime}$. $45^{\prime \prime} \mathrm{W}$; (map 105).

Local name published by USGS in the 1950 's.

Wood Canyon: canyon, extends $7 \mathrm{mi}$. along Copper River, $1 \mathrm{mi}$. S of Taral and $62 \mathrm{mi}$. $\mathrm{NE}$ of Valdez, Chugach Mts.; $61^{\circ} 25^{\prime} \mathrm{N}$, $144^{\circ} 28^{\prime} \mathrm{W}$; (map 68).

Named "Woods Cañon" in 1885 by Lt. H. T. Allen, USA, for Col. H. Clay Wood, USA.

Woodchopper: locality, on Woodchopper Creek at junc. of Deep Creek, $33 \mathrm{mi}$. ESE of Tanana, Yukon-Tanana High.; $65^{\circ} 03^{\prime \prime} \mathrm{N}, 151^{\circ} 00^{\prime} \mathrm{W}$; (map 106).

This was a former mining camp established about 1907.

Woodchopper Creek: locality, on Woodchopper Creek at mouth of Iron Creek, $19 \mathrm{mi}$. W of junc. of Charley and Yukon Rivers, Tanana. Yukon High.; $65^{\circ} 17^{\prime} 40^{\prime \prime} \mathrm{N}, 143^{\circ} 24^{\prime} 30^{\prime \prime} \mathrm{W}$; (map 103).

Mining camp shown on maps after 1940

Woodchopper Creek: stream, heads on Serpentine Ridge, flows SSE $8.5 \mathrm{mi}$. to Pattersen Creek, $33 \mathrm{mi}$. SE of Tanana, Yukon-Tanana High.; $65^{\circ} 01^{\prime} 20^{\prime \prime} \mathrm{N}, 151^{\circ} 02^{\prime} 00^{\prime \prime} \mathrm{W}$; (map 106).

Prospectors' name reported in 1906 by USGS (Prindle, 1908, p. 5).

Woodchopper Creek: stream, heads at $65^{\circ} 11^{\prime}$ $\mathrm{N}, 143^{\circ} 46^{\prime} \mathrm{W}$, flows $\mathrm{NE} 20 \mathrm{mi}$. to Yukon River $16 \mathrm{mi}$. NW of its junc. with Charley River, Yukon-Tanana High.; $6^{\circ} 21^{\prime} 20^{\prime \prime} \mathrm{N}$, $143^{\circ} 19^{\prime} 10^{\prime \prime} \mathrm{W}$; (map 103).

Local name found on a manuscript map by E. F. Ball dated 1898 and on a fieldsheet prepared by A. J. Collier, USGS, in 1902. The name may allude to woodchopping on the banks of this stream to furnish fuel for river steamboats.

Woodchopper Creek: stream, heads on Bismark Mtn., flows SW $6 \mathrm{mi}$. to Garland Creek, 11 mi. NW of Shungnak, Brooks Ra.; $67^{\circ} 00^{\prime} \mathrm{N}$, $157^{\circ} 24^{\prime} \mathrm{W}$; (map 126).

Local name given about 1901 "due to a woodyard located at the mouth" of Garland Creek which furnished fuel for the riverboats.
Woodchopper Island: island, see Melozi Island.

Woodchopper Roadhouse: locality, abandoned roadhouse on left bank of Yukon River, $1 \mathrm{mi}$. $E$ of mouth of Woodchopper Creek, YukonTanana High.; $65^{\circ} 21^{\prime} 30^{\prime \prime} \mathrm{N}, 143^{\circ} 18^{\prime} 00^{\prime \prime} \mathrm{W}$; map 103). Var. Woodchopper.

Locality at the site of Woodchopper, a mining camp, which was established about 1910 ; reported by L. M. Prindle and J. B. Mertie, Jr. (in Brooks and others, 1912, pl. 10), USGS.

Woodchopper's Island: island, in Mitchell Bay, on W coast of Admiralty I., $5 \mathrm{mi}$. $\mathrm{E}$ of Angoon, Alex. Arch.; 57 $32^{\prime} \mathrm{N}, 134^{\circ} 21^{\prime} \mathrm{W}$; (map 9).

Named in 1869 by Comdr. R. W. Meade, USN; published in 1881 on Hydrog. Chart 882. Comdr. Meade indicates a probable island in this area, but recent maps show a peninsula instead of an island. The name does not appear on recent maps.

Woodchuck Gulch: ravine, trends W $0.5 \mathrm{mi}$. to Buster Creek, $10 \mathrm{mi}$. NE of Nome, Seward Penin. High.; $64^{\circ} 37^{\prime} \mathrm{N}, 165^{\circ} 12^{\prime} \mathrm{W}$; (map 94). Var. Goodluck Gulch.

Prospectors' name published in 1956 by USGS. Shown as "Goodluck Gulch" on Arthur Gibson's "Map of Cape Nome Precinct" dated 1904

Woodcock, Point: point of land, on NW coast of Montague I., $10 \mathrm{mi}$. NE of Cape Cleare, 60 mi. SE of Seward, Chugach Mts. ; $59^{\circ} 54^{\prime} 15^{\prime \prime}$ N, $147^{\circ} 48^{\prime} 40^{\prime \prime}$ W; (map 49).

Named by Capt. Nathaniel Portlock (1789, p. 7), about April 24, 1787, for Joseph Woodcock, an apprentice aboard the King George, who was frequently sent ashore among the Indians as a hostage. Name shown only on his chart (Wagner, 1937, p. 524)

Wood Cove: cove, $1,500 \mathrm{ft}$. across, on $\mathrm{E}$ coast of Forrester I., Alex. Arch.; 54 $48^{\prime} 30^{\prime \prime} \cdot \mathrm{N}$, $133^{\circ} 31^{\prime} 00^{\prime \prime} \mathrm{W}$; (map 1$)$.

Local name published by USC\&GS in 1943.

Wood Creek: stream, flows SW $2.5 \mathrm{mi}$. to Mineral Creek, $0.1 \mathrm{mi}$. N of McIntosh and $5.4 \mathrm{mi}$. NW of Valdez, Chugach Mts. ; $61^{\circ} 11^{\prime}$ $10^{\prime \prime} \mathrm{N}, 146^{\circ} 20^{\prime} 20^{\prime \prime} \mathrm{W}$; (map 68).

Prospectors' name reported in 1911 by USGS. There was an Olsen and Wood Mine on the stream.

Wood Creek: stream, heads in Horn Mts., flows $\mathrm{S} 1.6 \mathrm{mi}$. to Alfred Creek, $58 \mathrm{mi}$. NE of Palmer, Talkeetna Mts.; $61^{\circ} 57^{\prime} \mathrm{N}, 147^{\circ} 30^{\prime}$ W; (map 69).

Local name reported in 1952 by USGS.

Wood Creek: stream, flows NW $10 \mathrm{mi}$. to South Fork Sulatna River, $13 \mathrm{mi}$. E of Sulatna Crossing and $22 \mathrm{mi}$. SW of Monzonite Hills, Kilbuck-Kuskokwim Mts.; $64^{\circ} 09^{\prime} 45^{\prime \prime} \mathrm{N}, 155^{\circ}$ 02'48" W ; (map 98).

Local name reported about 1952 by USGS. Wood Creek: stream, see Wood River.

Wooded Island: island, $0.8 \mathrm{mi}$. long, in Marmot Bay, NW of Spruce I., NE of Kodiak I.; $57^{\circ} 57^{\prime} 30^{\prime \prime}$ N, $152^{\circ} 29^{\prime} 30^{\prime \prime} \mathrm{W}$; (map 34). Var. Liesistoi, Ostrov Lysistoy.

Translation of the descriptive name "O[strov] Lysistoy," given to this island by Sub-Lt. Mikhail Murashev in 1839 or 1840 and published in 1849 on Russian Hydrog. Dept. Chart 1425.

Wooded Island: island, see Makhnati Island.

Wooded Island: island, see Woody Island.

Wooded Islands: islands, $1 \mathrm{mi}$. SE of Montague I., in Gulf of Alaska, $75 \mathrm{mi}$. SE of Seward, Chugach Mts.; $59^{\circ} 52^{\prime} \mathrm{N}, 147^{\circ} 23^{\prime} \mathrm{W}$; (map 49).

These islands were described by Capt. George Vancouver, RN, in 1794 and apparently named in 1869 by USC\&GS.

Wooden Canoe Lake: lake, $0.5 \mathrm{mi}$. across, $7 \mathrm{mi}$. SE of Minto, Tanana Low.; $64^{\circ} 51^{\prime} 45^{\prime \prime} \mathrm{N}$, $148^{\circ} 58^{\prime} 30^{\prime \prime}-\mathrm{W}$; (map 100)

Local name reported in 1950 by USGS topographers.

Wooden Island: island, $0.2 \mathrm{mi}$. across, $\mathrm{S}$ of Cape Ommaney, $6 \mathrm{mi}$. S of Port Alexander, Alex. Arch.; $56^{\circ} 09^{\prime} 40^{\prime \prime} \mathrm{N}, 134^{\circ} 39^{\prime} 30^{\prime} \mathrm{W}$; (map 5).

Var. Woodens Rock.

Named by Capt. George Vancouver, RN, who called it "Woodens Rock" on August 24, 1794, "to commemorate Isaac Wooden [a member of his party], who fell overboard and was drowned near this island" (Wagner, 1937, p. 422).

Woodens Rock: island, see Wooden Islands.

Wooden Wheel Cove: cove, $0.6 \mathrm{mi}$. long, in Port Protection, $1.5 \mathrm{mi}$. S of village of Point Baker, on $\mathbf{N}$ coast of Prince of Wales I., Alex. Arch.; $56^{\circ} 19^{\prime} 45^{\prime \prime} \mathrm{N}, 133^{\circ} 36^{\prime} 30^{\prime \prime} \mathrm{W}$; (map 6).

Local name recorded in 1949 by USGS.

Woodhouse, Point: point of land, on $\mathrm{S}$ coast of Biorka I., $18 \mathrm{mi}$. SW of Sitka, Alex. Arch.; $56^{\circ} 50^{\prime} 05^{\prime \prime} \mathrm{N}, 135^{\circ} 32^{\prime} 15^{\prime \prime} \mathrm{W}$; (map 5). Var. Wodehouse Point.

Named by Capt. George Vancouver, RN, on July 30, 1794 (Wagner, 1937, p. 422). Vancouver gave this name to high land west of Crawfish Inlet, 14 miles southeastward. The name was reapplied to the present location by Russian naval officers in the early 1800 's (Sarichev, 1826, map 19)

Wood Island: island, see Woody Island.

Wood Islands: islands, among Maurelle Is., 26 mi. NW of Craig, Alex. Arch.; $55^{\circ} 40^{\prime} \mathrm{N}, 133^{\circ}$. 43' W; (map 4). Var. Gardiner Islands.

Local descriptive name published in 1915 by USC\&GS.

Wood Lake: lake, $1.6 \mathrm{mi}$. long, in Glacier Bay National Monument, $0.5 \mathrm{mi}$. $\mathrm{S}$ of head of Geikie Inlet and $48 \mathrm{mi}$. NW of Hoonah, St. Elias Mts.; $58^{\circ} 34^{\prime} 45^{\prime \prime} \mathrm{N}, 136^{\circ} 28^{\prime} 50^{\prime \prime} \mathrm{W}$; (map 10).

Local name published by USGS in the 1950 's.

Woodland Creek: stream, see Woodland Echo Creek.

Woodland Echo Creek: stream, flows E $7 \mathrm{mi}$. from Woodland Echo Pass to North Fork Chandalar River, $7.5 \mathrm{mi}$. SW of Chandalar, Brooks Ra.; $67^{\circ} 27^{\prime} \mathrm{N}, 148^{\circ} 46^{\prime} \mathrm{W}$; (map 123). Var. Woodland Creek.

Name reported in 1909 as "Woodland Creek" by A. G. Maddren (in Brooks and others, 1910, pl. 7), USGS. 
Woodland Echo Pass: pass, $7 \mathrm{mi}$. NE of O'Keefe Hills and $13 \mathrm{mi}$. WSW of Chandalar, Brooks Ra. ; $67^{\circ} 26^{\prime} 30^{\prime \prime} \mathrm{N}, 149^{\circ} 00^{\prime} 00^{\prime \prime} \mathrm{W}$; (map 123). Local name reported in 1956 by T. E. Taylor, USGS.

Woodman Creek: stream, flows E to Big Four Creek, between Birch and Surprise Creeks, about $20 \mathrm{mi}$. NE of Solomon, Seward Penin. High.; (map 95).

Prospectors' name reported on the 1900 "Map of Nome Peninsula" by J. M. Davidson and B. D. Blakeslee. This stream cannot be precisely located on current maps.

Woodpecker Cove: cove, extends SW $0.5 \mathrm{mi}$. to Sumner Strait, on $\mathbf{S}$ coast of Mitkof I., Alex. Arch.; $56^{\circ} 30^{\prime} 00^{\prime \prime} \mathrm{N}, 132^{\circ} 49^{\prime} 15^{\prime \prime} \mathrm{W}$; BGN 1917; (map 6).

Local name reported in 1916 by USC\&GS. Woodpecker Lake: lake, $0.7 \mathrm{mi}$. long, on Kenai Penin. N of Eagle Lake, $9 \mathrm{mi}$. NE of Kenai, Cook Inlet Low.; $60^{\circ} 37^{\prime} 15^{\prime \prime} \mathrm{N}, 151^{\circ} 00^{\prime} 00^{\prime \prime}$ W; (map 62).

Named about 1963 by officials of Kenai National Moose Range, probably for the Alaska Three-toed Woodpecker (Picoides americanus fasciatus), "Far into the north $* * *$ it becomes the commonest of Woodpeckers" (Pearson, 1944, pt. 2, p. 144).

Wood Point: point of land, NW tip of Point Agassiz Penin., $13 \mathrm{mi}$. N of Petersburg, Coast Mts. ; $56^{\circ} 59^{\prime} 45^{\prime \prime} N, 132^{\circ} 56^{\prime} 57^{\prime \prime} \mathrm{W}$; (map 6). Local name published by USC\&GS in 1925 Coast Pilot (p. 211).

Wood Point: point of land, on S shore of Norton Sound, $10 \mathrm{mi}$. E of St. Michael Bay and $40 \mathrm{mi}$. SW of Unalakleet, Nulato Hills; $63^{\circ} 28^{\prime} \mathrm{N}$, $161^{\circ} 40^{\prime} \mathrm{W}$; (map 91).

Local name reported in 1903 by Dr. C. D. Lind of Unalakleet (Jackson, 1904, p. 55).

Wood River: locality, on Tanana River near mouth of Wood River, $15 \mathrm{mi}$. E of Nenana, Tanana Low.; 64. $35^{\prime} \mathrm{N}, 1^{\circ} 8^{\circ} 38^{\prime} \mathrm{W}$; (map 100). Var. Wood River Landing.

Name of site of a trading post, riverboat woodyard, and landing; published in Polk's Gazetteer in 1916.

Wood River: village, pop. 15, at junc. of Wood and Nushagak Rivers, $2 \mathrm{mi}$. NE of Dillingham, Bristol Bay Low.; 59 $04^{\prime} \mathrm{N}, 158^{\circ} 26^{\prime}$ W; (map 52). Var. Ah-lek-nüg-uk, Wood River Cannery.

Located on site of Eskimo village of "Ahlek-nüg-uk," which was recorded on a 1910 manuscript map by H. C. Fassett, USBF.

Wood River: stream, heads in Aleknagik Lake and flows SSE $20 \mathrm{mi}$. to Nushagak River just NE of Dillingham, Bristol Bay Low.; 59 $03^{\circ}$ $\mathrm{N}, 158^{\circ} 25^{\prime} \mathrm{W}$; (map 52). Var. Ahleknuguk River, Aleknagik River, Aliagnagik River, Alyagnagik River, Reka Aleknagek.

Local name published by USBF in 1890 . Lt. Sarichev (1826, map 3), IRN, calls the stream "Alyagnagik" and Capt. Tebenkov (1852, map 2), IRN, shows "Aleknagek," both obviously referring to the same Eskimo name.

Wood River: stream, heads at glacier in Alaska Ra. at $63^{\circ} 42^{\prime} \mathrm{N}, 147^{\circ} 32^{\prime} \mathrm{W}$, flows NW 115 $\mathrm{mi}$. into Tanana River, $14 \mathrm{mi}$. E of Nenana,

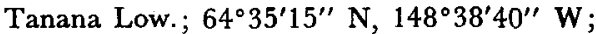
(map 100). Var. Bradley River.

Local name reported in 1906 by L. M. Prindle (in Brooks and others, 1907, pl. 4), USGS. Probably so called because a riverboat woodyard was located near the stream's mouth. This is probably the same feature Lt. Allen (1887, pl. 1), USA, named Bradley River in 1885.

Wood River: stream, flows NW $26 \mathrm{mi}$. to Black River, $50 \mathrm{mi}$. NE of junc. of Charley and Yukon Rivers, Porcupine Plat.; 65 $57^{\circ} \mathrm{N}$, $142^{\circ} 02^{\prime} \mathrm{W}$; (map 103). Var. Wood Creek.

Local name published in 1951 as "Wood Creek," and in 1956 as "Wood River" by USGS.

Wood River Buttes: mountains, $1,051 \mathrm{ft}$., $4 \mathrm{mi}$. long, between Wood River and Crooked Creek, 28 mi. S of Fairbanks, Tanana Low.; $64^{\circ} 28^{\prime} \mathrm{N}, 148^{\circ} 08^{\prime} \mathrm{W}$; (map 100).

Local name derived from Wood River; reported in 1910 by USGS (Capps, 1912, pl. 1).

Wood River Cannery: village, see Wood River. Wood River Lakes: lakes, four, extend S $45 \mathrm{mi}$. from Lake Kulik to Lake Aleknagik, $S$ of Tikchik Lakes, $18 \mathrm{mi}$. $\mathrm{N}$ of Dillingham, Kilbuck-Kuskokwim Mts. ; $59^{\circ} 30^{\prime}$ N, $159^{\circ} 00^{\prime} \mathrm{W}$; (map 52)

Reported about 1930 by Gerald Fitzgerald (in Mertie, 1938b, p. 14), USGS. The four lakes are drained by the Wood River.

Wood River Landing: locality, see Wood River. Wood River Mountains: mountains, 2,000-3,500 $\mathrm{ft}$., in group $100 \mathrm{mi}$. long and $30 \mathrm{mi}$. wide, extend NNE from Bristol Bay to Chikuminuk Lake, bounded on $\mathrm{W}$ by Togiak River, Kilbuck-Kuskokwim Mts.; $60^{\circ} 13^{\prime} \mathrm{N}, 159^{\circ} 00^{\prime} \mathrm{W}$ [N end], $58^{\circ} 50^{\prime} \mathrm{N}, 159^{\circ} 50^{\prime} \mathrm{W}$ [S end]; (map 53). Var. Tikchik Mountains.

Local name reported in 1939 by USC\&GS. Mertie (1938b, p. 14), USGS, referred to these mountains when he wrote "here designated the Tikchik Mountains."

Woodrow: locality, on Kenai Penin., W of Bear Lake, mi. 6.9 on The Alaska RR., 6 mi. NE of Seward, Chugach Mts.; $60^{\circ} 01^{\prime} 30^{\prime \prime} \mathrm{N}, 149^{\circ}$. 22'30" W; (map 63). Var. Bear Creek.

Listed as a flag stop in the 1918 RR. guide of The Alaska RR. Recent USGS maps indicate a site with three or four buildings.

Woodrow: city, see Anchorage.

Woodrow, Port: city, see Anchorage.

Woodrow Creek: stream, see Ship Creek.

Woods Creek: stream, flows SE $2.5 \mathrm{mi}$. to Mendeltna Creek S of Glenn Highway, $31 \mathrm{mi}$. W of Glennallen, Copper River Basin; $62^{\circ}$ $02^{\prime} \mathrm{N}, 146^{\circ} 29^{\prime} \mathrm{W}$; (map 83).

Local name published by ARG in 1924 .

Woods Creek: stream, flows NE $15 \mathrm{mi}$. to Yukon River, $2.5 \mathrm{mi}$. $\mathrm{N}$ of Blackburn I. and $50 \mathrm{mi}$. SE of Unalakleet, Nulato Hills; $63^{\circ} 27^{\prime} 20^{\prime \prime} \mathrm{N}$, $159^{\circ} 28^{\prime} 00^{\prime \prime} \mathrm{W}$; ( $\left.\operatorname{map} 91\right)$

Local name reported in 1949 by USC\&GS

Woods Creek: stream, flows $\mathrm{N} 2 \mathrm{mi}$. to join Camp Creek to form Canyon Creek, $48 \mathrm{mi}$. S of Eagle, Yukon-Tanana High.; 64 $06^{\prime} 45^{\prime \prime} \mathrm{N}$, $141^{\circ} 06^{\prime} 45^{\prime \prime} \mathrm{W}$; (map 102). Var. J. Woods Creek.

Named by prospectors and reported in 1898 by E. C. Barnard, USGS. Probably named for a prospector J. Woods (cnna) in that it is shown as J. Woods Creek on a 1902 manuscript map by C. A. Woodruff.

Woods Glacier: glacier, see Carroll Glacier.

Woods Lake: lake, 0.6 mi. long, on Kenai Penin., $0.5 \mathrm{mi}$. SW of Gene Lake and $33 \mathrm{mi}$. NE of Kenai, Cook Inlet Low.; $60^{\circ} 48^{\prime} 20^{\prime \prime} \mathrm{N}, 150^{\circ}$ $29^{\prime} 00^{\prime \prime} \mathrm{W}$; (map 62).

Named about 1963 by officials of Kenai National Moose Range, for administrative purposes.

Wood Spit: spit, on S shore of Holkham Bay at entrance to Endicott Arm, $3 \mathrm{mi}$. E of Point Astley and $50 \mathrm{mi}$. SE of Juneau, Coast Mts.; $57^{\circ} 43^{\prime} 30^{\prime \prime} \mathrm{N}, 133^{\circ} 34^{\prime} 30^{\prime \prime} \mathrm{W}$; (map 8).

Name applied in 1889 by Lt. Comdr. H. B. Mansfield, USN, "because it was wooded;" published by USC\&GS in the 1891 Coast Pilot (p. 147).

Wood Spur: settlement, pop. 30, along The Alaska RR. near Nenana, Tanana Low.; (map 69).

Village or RR. siding on The Alaska RR. reported by Rand McNally (1966, p. 63).

Woods Willow Creek: stream, flows NE $3.3 \mathrm{mi}$. to Bonanza Creek, which flows to Casadepaga River, 28 mi. NE of Solomon, Seward Penin. High.; $64^{\circ} 57^{\prime} \mathrm{N}, 164^{\circ} 12^{\prime} \mathrm{W}$; (map 95).

Prospectors' name published in 1956 by USGS.

Woodworth Glacier: glacier, heads $10 \mathrm{mi}$. W of Cordova Peak, trends NE $10 \mathrm{mi}$. to its terminus (1953) at Tasnuna River, $5 \mathrm{mi}$. E of terminus of Tasnuna Glacier, and $34 \mathrm{mi}$. SE of Valdez, Chugach Mts.; $61^{\circ} 02^{\prime} 00^{\prime \prime} \mathrm{N}, 145^{\circ}$ $15^{\prime} 30^{\prime \prime} \mathrm{W}$; (map 68).

Named in 1898 by F. C. Schrader, for Jay Backus Woodworth, 1865-1925, geologist, Harvard University.

Woodyard Creek: stream, flows NE $24 \mathrm{mi}$. to Koyukuk River, $47 \mathrm{mi}$. SW of Roundabout Mt., Koyukuk Low.; $65^{\circ} 02^{\prime} \mathrm{N}, 157^{\circ} 39^{\prime} \mathrm{W}$; (map 108).

Local name obtained at Koyukuk by Orth in 1956. The name probably originated during the period of steamboat river transportation when a woodyard for the boats was located at the stream's mouth.

Woody Inlet: lagoon, see Tachinisok Inlet.

Woody Island: island, $0.2 \mathrm{mi}$. long, in Wrangell Narrows, E coast of Lindenberg Penin., Kupreanof I., $11 \mathrm{mi}$. S of Petersburg, Alex. Arch.; $56^{\circ} 39^{\prime} 10^{\prime \prime} \mathrm{N}, 132^{\circ} 56^{\prime} 00^{\prime \prime} \mathrm{W}$; (map 6). Var. Liesnoi Island, Ostrov Lysnoy.

This is a translation about 1880 by USC\&GS of the name "Ostrov Lysnoy," which was given in 1838 by G. Lindenberg.

Woody Island: island, $2.7 \mathrm{mi}$. long, in Chiniak Bay, $2.6 \mathrm{mi}$. E of Kodiak, Kodiak I.; $57^{\circ} 47^{\prime}$ $\mathrm{N}, 152^{\circ} 20^{\prime} \mathrm{W}$; (map 34). Var. Liesnoi Island, Otrov Lysnoy, Wooded Island, Wood Island.

Translation of the descriptive name "Os[trov] Lysnoy given in 1804 by Lisianski 
(1814, p. 169). Ameigh and Chaffin (1962, p. 51) stated "it is believed that the Russians were using it [Woody Island] as an agricultural colony as early as $1792 *$ * *." They also noted that the Russian American Ice Co. [Kodiak Ice Co. after 1867] imported horses [the first in Alaska] to Woody Island and built a road [the first in Alaska] around the island. "Boat building flourished both at Kodiak and Woody Island during the late 1800 's" (p. 50). In 1894 the U.S. Post Office Department established the "Wood Island" Post Office, but it was discontinued in 1895.

Woody Island Channel: water passage, $5 \mathrm{mi}$. long, between Woody and Kodiak Is., $1.5 \mathrm{mi}$. E of Kodiak, $57^{\circ} 47^{\prime} \mathrm{N}, 152^{\circ} 22^{\prime} \mathrm{W}$; (map 34). Name derived from Woody Island and published in 1949 by USGS.

Woody Islet: island, see Liesnoi Island.

Woody Point: point of land, $\mathbf{N}$ point of entrance to Whitewater Bay, on $W$ coast of Admiralty I., $15 \mathrm{mi}$. NE of Baranof, Alex Arch.; 57 $16^{\prime} 20^{\prime \prime} \mathrm{N}, 134^{\circ} 36^{\prime} 45^{\prime \prime} \mathrm{W}$; (map 9).

Descriptive name given in 1869 by Comdr. R. W. Meade, USN, published by USC\&GS in the 1883 Coast Pilot (p. 174) with this note: "In SE Alaska all points are woody, and about one-third of them have been named so, to the great confusion of hydrographers."

Wooleek: stream, see Wulik River.

Woolley, Cape: point of land, on Bering Sea, 37 mi NW of Nome, Seward Penin, High.; $64^{\circ} 48^{\prime} \mathrm{N}, 166^{\circ} 28^{\prime} \mathrm{W}$; (map 94). Var. Cape Wolley, Cape Wooly.

Named in 1826 by Capt. Beechey (1831, map facing p. 328), RN.

Woolly Harbor: lagoon, see Kitchen, The.

Wooly, Cape: point of land, see Woolley Cape. Wooly Head: promontory, elev. 1,200 ft., on W coast of Nagai I., in Shumagin Is., Aleutian Ra.; $55^{\circ} 06^{\prime} 30^{\prime \prime} \mathrm{N}, 160^{\circ} 11^{\prime} 00^{\prime \prime} \mathrm{W}$; (map 28).

So named by fishermen prior to 1871 because of the violent gusts of wind called "woolies" experienced there; published by USC\&GS on an 1882 coast chart. This term is considered to be derived from a Patagonian word for "gust of wind" or may be descriptive of the "white foam formed on the water from wind."

Wordie, Mount: mountain, 4,950 ft., in Glacier Bay National Monument, $5 \mathrm{mi}$. NW of Mount Merriam and $81 \mathrm{mi}$. NW of Hoonah, St. Elias Mts. ; $58^{\circ} 26^{\prime} 25^{\prime \prime} \mathrm{N}, 136^{\circ} 28^{\prime} 15^{\prime \prime} \mathrm{W}$; (map 10).

Named by members of the Glacier Bay Expedition of 1941 (Field, 1947, map) for James Mann Wordie, a British glacier geologist and polar explorer, who visited Muir Glacier in 1913. He was a geologist on the Shackleton Antarctic Expedition, 1914-17, and on several expeditions to Greenland.

Woronkofski, Mount: mountain, 3,240 ft., on central Woronkofski I., $6.5 \mathrm{mi}$. SW of Wrangell, Alex. Arch.; 56 $23^{\prime} 20^{\prime \prime}$ N, $132^{\circ}$ 29'15" W; BGN 1917; (map 6). Var. Ancon Peak.

Named by USC\&GS in 1916; it was called "Ancon Peak" by Lt. Comdr. A. S. Snow,
USN, in 1886 for the steamship Ancon. See Woronkofski Island and Ancon Peak.

Woronkofski Island: island, $7 \mathrm{mi}$. long, between Stikine and Zimovia Straits, $5 \mathrm{mi}$. SW of Wrangell, Alex. Arch.; $56^{\circ} 23^{\prime} \mathrm{N}$, $132^{\circ} 30^{\prime} \mathrm{W}$; (map 6). Var. Ostrov Voronkovskiy, Voronkoffski Island, Voronkowski Island.

Published in 1848 on Russian Hydrog. Dept. Chart 1396 as "O[strov] Voronkovskiy." Named for Lt. Woronkovski, IRN, who explored the southern shore of the Alaska Peninsula in 1836.

Woronkofski Point: point of land, northernmost point on Woronkofski I., Alex. Arch.; 56 ${ }^{\circ}$ $26^{\prime} 20^{\prime \prime} \mathrm{N}, 132^{\circ} 28^{\prime} 40^{\prime \prime} \mathrm{W}$; (map 6).

Named in 1879 by W. H. Dall, USC\&GS. Woronzo, Point: point of land, see Woronzof, Point.

Woronzof, Point: point of land, on $\mathrm{S}$ coast of Knik Arm, $4 \mathrm{mi}$. W of Anchorage, Cook Inlet Low. ; $61^{\circ} 12^{\prime} 15^{\prime \prime} \mathrm{N}, 150^{\circ} 01^{\prime} 00^{\prime \prime} \mathrm{W}$; (map 70). Var. Mys Vorontsova, Point Woronzo, Point Woronzow.

Named by Lt. Joseph Whidbey, RN, a member of Capt. George Vancouver's expedition, on May 4, 1794, "after the Russian ambassador at St. James [the English court]" (Wagner, 1937, p. 422).

Woronzow, Point: point of land, see Woronzof Point.

Worsham Bay: bay, see Kisselen Bay.

Worship Cove: cove, $1 \mathrm{mi}$. across, on northwestern Kiska I., Aleutian Is.; $52^{\circ} 06^{\prime} 45^{\prime \prime} \mathrm{N}$, $177^{\circ} 33^{\prime} 20^{\prime \prime} \mathrm{E}$; (map 14).

An arbitrary name beginning with " $W$ " to correspond to "W" grid used by the U.S. Army for tactical purposes during World War II; published on a 1953 AMS map.

Worthington Glacier: glacier, heads $2 \mathrm{mi}$. SW of Girls Mtn., trends E $3.8 \mathrm{mi}$. to its terminus, $3 \mathrm{mi}$. SW of Ptarmigan and $20 \mathrm{mi}$. NE of Valdez, Chugach Mts.; $61^{\circ} 10^{\prime} 10^{\prime \prime} \mathrm{N}, 145^{\circ}$ $42^{\prime} 30^{\prime \prime} \mathrm{W}$; (map 68).

Local name reported in 1900 by F. C. Schrader, USGS.

Worthmans: locality, see Wortmanns.

Wortmann Creek: stream Wortmanns Creek.

Wortmann Glacier: glacier, see Wortmanns Glacier.

Wortmanns: locality, on Richardson Highway $1.5 \mathrm{mi}$. NE of mouth of Bear Creek and 15 mi. E of Valdez, Chugach Mts.; $61^{\circ} 06^{\prime} 35^{\prime \prime} \mathrm{N}$, $145^{\circ} 49^{\prime} 15^{\prime \prime}$ W; (map 68). Var. Worthmans, Wortmann's Road House, Wortmanns, Wortmans.

Former roadhouse and mining camp reported 1908 by Moffit and Maddren (1909, pl. 1), USGS.

Wortmanns Creek: stream, heads at terminus (1953) of Wortmanns Glacier and flows NW $6.5 \mathrm{mi}$. to Lowe River, $0.5 \mathrm{mi}$. SE of Wortmanns and $16 \mathrm{mi}$. E of Valdez, Chugach Mts.; $61^{\circ} 06^{\prime} 15^{\prime \prime} \mathrm{N}, 145^{\circ} 48^{\prime} 15^{\prime \prime} \mathrm{W}$; BGN 1964; (map 68). Var. Wortmann Creek.

Named in 1963 by A. S. Post "for the village of Wortmann."
Wortmanns Glacier: glacier, heads $8 \mathrm{mi}$. E of Meteorite Mtn. and trends $\mathrm{N} 3.3 \mathrm{mi}$ to its terminus (1953) at head of Wortmanns Creek, $6 \mathrm{mi}$. SE of Wortmanns and $18 \mathrm{mi}$. SE of Valdez, Chugach Mts.; $61^{\circ} 01^{\prime} 30^{\prime \prime} \mathrm{N}, 145^{\circ}-$ $44^{\prime} 55^{\prime \prime}$ W; BGN 1964; (map 68). Var. Wortmann Glacier.

Named in 1963 by A. S. Post "for the village of Wortmann."

Wortmann's Road House: locality, see Wortmanns.

Wortmans: locality, see Wortmanns.

Wosnesenski Glacier: glacier, heads in Kenai Mts. and trends to its terminus at an unnamed stream $18 \mathrm{mi}$. SE of Homer, Chugach Mts.; $59^{\circ} 30^{\prime} 30^{\prime \prime} \mathrm{N}$; $151^{\circ} 03^{\prime} 00^{\prime \prime} \mathrm{W}$; (map 50).

Named by Dall (1870, p. 339), for I. G. Wosnesenski, Russian Academy of Sciences, who made collections and observations in this region about 1840 .

Wosnesenski Island: island, $4.5 \mathrm{mi}$. across, $10 \mathrm{mi}$ NE of Dolgoi I., one of Paulof Is., Aleutian Ra.; 55 $11^{\prime} \mathrm{N}, 161^{\circ} 22^{\prime} \mathrm{W}$; BGN 1901; (map 28). Var. Ostrov Peregrebnoy, Peregrebny Island, Unatkuyuk Island, Vosnesenski Island, Vossnessensky Island, Vossnessenski Island, Voznesensky Island, Vozoychenski Island, Wosnesensky Island, Wossnessensky Island.

In 1868 the name Wossnessenski Island was shown on USC\&GS charts, undoubtedly named in honor of Ilia (Elia) G. Wosnesenski who in 1842-44 explored western Alaska for the St. Petersburg Academy of Sciences. This island was formerly named " $\mathrm{O}$ [strov] Peregrebnoy" by Father Ioann Veniaminov (1840, v. 1, p. 252), which is the Russian form of the Aleut name "Unatkuyuk" meaning "crested" or "serrated." Capt. F. P. Lutke, IRN, in 1836 reported it as "[Ile] Peregrebny."

Wosnesensky Island: island, see Wosnesenski Island.

Wossnessensky Island: island, see Wosnesenski Island.

Wounded Cub Creek: stream, flows SE $10 \mathrm{mi}$. to Mink Creek, $13 \mathrm{mi}$. S of Nulato, Koyukuk Low.; $64^{\circ} 32^{\prime} \mathrm{N}, 158^{\circ} 20^{\prime} \mathrm{W}$; (map 97). Var. Nitdlqaitaldatdlna.

Appears to be a translation of an Indian name; reported in 1935 by Frederica de Laguna, BAE.

Wrangel: town, see Wrangell.

Wrangel, Baie; bay, see Wrangell, Port.

Wrangel, Cape: point of land, see Wrangell, Cape.

Wrangel, Mount: mountain, see Wrangell, Mount.

Wrangel Bay: bay, see Wrangell, Port.

Wrangell: town, pop. 1,315 , on $\mathrm{N}$ coast of Wrangell I., Alex. Arch.; $56^{\circ} 28^{\prime} 00^{\prime \prime} \mathrm{N}, 132^{\circ}$ $22^{\prime} 40^{\prime \prime}$ W; BGN 1944; (map 6). Var. Fort Wrangell, Fort Stikine, Redoubt Saint Dionysius, Redut Svataya Dioniciya, Wrangel, Wrangle.

Wrangell began as a stockade built by the Russians occupying the island in 1834 "to prevent encroachment by the Hudson's Bay Company traders" (Bridgwater and Sherwood, 1950 , p. 2,175). It was called "Red[ut] 
Sv[ataya] Dioniciya," meaning "Redoubt [fort] Saint Dionysius," by the Russian Hydrog. Dept. on Chart 1396 published in 1848. In 1839 the Russians leased part of Southeast Alaska to the British who changed the name to "Fort Stikine." When the United States purchased Alaska in 1867 a military post, called Fort Wrangell, was established here; it was abandoned in 1877. Fort Wrangel post office was established in 1869; changed to Wrangell in 1902 (Ricks, 1965, p. 21, 72). Because of its location Wrangell became an important supply point for fur traders and miners beginning with the Stikine gold rush in 1861 (Alaska Sportsman, 1962, no. 12, p. $30)$. The population in 1890 was $316 ; 1000$ (est.) in 1938; 948 in 1945 ; and 1162 in 1950. Wrangell's economy today is dominated by the fishing and lumbering industries, maintaining three canneries and two large lumber mills.

Wrangell, Cape: point of land, on W tip of Attu I., westernmost point of Aleutian Is.; 52 ${ }^{\circ} 55^{\prime}$ $30^{\prime \prime} \mathrm{N}, 172^{\circ} 28^{\prime} 00^{\prime \prime} \mathrm{E}$; (map 13). Var. Cape Wrangel, Mys Vrangelya.

Named for Baron von Wrangell by Capt. Lutke (1836, p. 328), IRN. The name was published by the Russians as "Mys Vrangelya," or "Cape Wrangell," in 1848 on Russian Hydrog. Dept. Chart 1400.

Wrangell, Mount: mountain, 14,163 ft., $15 \mathrm{mi}$. $\mathrm{S}$ of Mount Sanford, Wrangell Mts.; $62^{\circ} 00^{\prime}$ N, $144^{\circ} 00^{\prime} \mathrm{W}$; (map 83). Var. Chechitno Peak, Mount Wrangel, Mount Wrangle, Tillman Mountain.

Named by the Russians for Baron von Wrangell; reported in 1885 by Lt. Allen (1887, p. 57), USA, however it appears that he named this same mountain "Tillman" for Samuel Escue Tillman, professor at United States Military Academy at West Point.

Wrangell, Port: estuary, extends NW $6.5 \mathrm{mi}$. from Cape Providence, on E coast of Alaska Penin., 35 mi. NE of Sutwik I., Aleutian Ra.; $57^{\circ} 01^{\prime} \mathrm{N}, 156^{\circ} 31^{\prime} \mathrm{W}$; (map 36). Var. Baie Wrangel, Gavan Vrangeli.

Surveyed in 1831 by Ens. Vasiliev and named for Adm. Baron Ferdinand Petrovich von Wrangell, 1794-1870, IRN, Director of Russian American Colonies. The name was published in 1835 as "B[aie] Wrangel" by Adm. A. J. von Krusenstern, IRN.

Wrangell, Port: harbor, see Wrangell Harbor.

Wrangell Bay: locality, see Kuiukuk.

Wrangell Bay: bay, see Wrangell, Port.

Wrangell Cove: bay, $1.5 \mathrm{mi}$. across on W coast of Attu I., W of Etienne Head, Aleutian Is.; $52^{\circ} 55^{\prime} \mathrm{N}, 172^{\circ} 30^{\prime} \mathrm{E}$; (map 13). Var. Kapsco Bay.

Named derived from Cape Wrangell and published in 1946 supplement to 1944 Aleutian Coast Pilot (p. 19). The name "Kapsco Bay" was shown on a manuscript map by $L$. $M$. Turner in the 1880's.

Wrangell Crater: peak, 13,951 ft., volcanic cone on Mount Wrangell $3 \mathrm{mi}$. $\mathrm{N}$ of head of Cheshnina Glacier, $9 \mathrm{mi}$. $\mathrm{N}$ of its terminus (1959) and $93 \mathrm{mi}$. NE of Valdez, Wrangell
Mts.; $61^{\circ} 59^{\prime} 30^{\prime \prime} \mathrm{N}, 144^{\circ} 04^{\prime} 20^{\prime \prime} \mathrm{W}$; (map 68). Var. Mount Wrangell Crater.

Name published in 1931 by USGS.

Wrangell Harbor: harbor, $0.3 \mathrm{mi}$. across, at Wrangell, on $\mathrm{N}$ coast of Wrangell I., Alex. Arch.; $56^{\circ} 28^{\prime} \mathrm{N}, 132^{\circ} 23^{\prime} \mathrm{W}$; (map 6). Var. Etholine Harbor, Etolin Harbor, Gavan Etolina, Port Wrangell, Wrangell Harbor.

This feature was originally called "Etolin Harbor," for Capt. Adolph Karlovich Etolin, Director of the Russian American Colonies from 1841 to 1845 ; named by Capt. Lt. D. F. Zarembo, who surveyed it in 1834 . It was called "Port Wrangell" by Lt. Comdr. H. E. Nichols, USN, in 1882.

Wrangell Island: island, trends NW-SE $30 \mathrm{mi}$., separated from Etolin $I$. on $W$ by Zimovia Strait, $14 \mathrm{mi}$. E of Zarembo I., Alex. Arch.; $56^{\circ} 16^{\prime} \mathrm{N}, 132^{\circ} 12^{\prime} \mathrm{W}$; (map 6). Var. Ostrov Kackhanna, Ostrov Vrangelya.

This name was published in 1848 as "Os[trov] Vrangelya" on Russian Hydrog. Dept. Chart 1396; named for Adm. Baron Ferdinand Petrovich von Wrangell. According to Capt. Tebenkov (1852, map 8), IRN, the Indian name was "O[trov] Kackhanna," or "Kachkhanna Island."

Wrangell Island: island, $0.4 \mathrm{mi}$. long, in Necker Is., E of Biorka I., $16 \mathrm{mi}$. SW of Sitka, Alex. Arch.; 56 $51^{\prime} 05^{\prime \prime} \mathrm{N}, 135^{\circ} 29^{\prime} 30^{\prime \prime} \mathrm{W}$; (map 5). Var. Big Wrangell Island, Kach-Khanna, Ostrov Bolshoy Vrangel, Wrangle Island.

Named in early 1800's by Russians for Adm. Baron Ferdinand Petrovich von Wrangell, IRN; published by Lt. Sarichev (1826, map 19), IRN, as "O[strov]' Bol[shoy] Vrangel," meaning "Big Wrangell Island." Capt. Tebenkov (1852, map 38), IRN, published the Indian name "Kach-Khanna" for this island.

Wrangell Mountains: mountain range, $100 \mathrm{mi}$. long and $60 \mathrm{mi}$. wide, bounded on $\mathrm{W}$ by Copper River; on NE by Jack Creek, Copper Creek, Notch Creek, and Geohenda Creek; on SE by head of White River, Skolai Pass, Chitistone River; and on $\mathrm{S}$ by Chitina and Nizina Rivers; $61^{\circ} 45^{\prime} \mathrm{N}, 141^{\circ} 50^{\prime} \mathrm{W}$ [E end], $62^{\circ} 05^{\prime}$ $\mathrm{N}, 144^{\circ} 50^{\prime} \mathrm{W}$ [W end] (map 67).

So called in 1901 by F. C. Schrader, USGS ; presumably for Mount Wrangell, which was thought at that time to be the highest peak in the range.

Wrangell Narrows: water passage, extends S 24 mi. from Frederick Sound to Sumner Strait, separates Mitkof I. from Kupreanof and Woewodski Is., Alex. Arch.; 56 $31^{\prime} \mathrm{N}$, $132^{\circ} 55^{\prime}$ W; BGN 1917; (map 6). Var. Proliv Vrangelya, Wrangell Strait.

This feature was named "Proliv Vrangelya," or "Wrangell Strait," in 1838 by G. Lindenberg for Adm. Baron Ferdinand Petrovich von Wrangell; name published in 1850 on Russian Hydrog. Dept. Chart 1441. The name "Wrangell Narrows" was originally applied to the central part of Wrangell Strait where it is most constricted.

Wrangell North Flat: tidal flat, see North Flat.
Wrangell Peak: mountain, $3,747 \mathrm{ft}, 5 \mathrm{mi}$. NE of Wrangell, Coast Mts.; $56^{\circ} 32^{\prime} 30^{\prime \prime} \mathrm{N}$, $132^{\circ} 19^{\prime} 10^{\prime \prime} \mathrm{W}$; (map 6). Var. Wrangel Peak.

Named in 1887 by USC\&GS. See Wrangell.

Wrangell Range: mountain range, $1,000-1,600$ $\mathrm{ft}$., on W end of Attu I., extends ENE $12 \mathrm{mi}$. from Cape Wrangell, Aleutian Is.; $52^{\circ} 57^{\prime}$ N, $172^{\circ} 38^{\prime} \mathrm{E}$; (map 13).

Name derived from Cape Wrangell; published in 1948 by AMS.

Wrangell South Flat: tidal flat, see South Flat. Wrangell Strait: water passage, see Wrangell Narrows.

Wrangel Peak: mountain, see Wrangell Peak. Wrangel: town, see Wrangell.

Wrangle Mount: mountain, see Wrangell, Mount.

Wrangle Island: island, see Wrangell Island. Wrench Creek: stream, heads in De Long Mts., flows SSE $30 \mathrm{mi}$. to Kelly River, $40 \mathrm{mi}$. SE of Mount Kelly, Brooks Ra.; 68 ${ }^{\circ} 05^{\prime} \mathrm{N}$, $162^{\circ} 19^{\prime}$ W; BGN 1966; (map 130). Var. Katak Creek.

So named in 1965 by the B. P. Exploration Co. "because the creek is being eroded along the line of a strong transcurrent (wrench) fault." The Eskimo name for this stream is Katak, meaning "fallow."

Wrench Lake: lake, $64 \mathrm{mi}$. NE of Haycock, Nulato Hills; $65^{\circ} 43^{\prime} \mathrm{N}, 159^{\circ} 20^{\prime} \mathrm{W}$; (map 109).

Local name published on maps after 1950.

Wren Lake: lake, $0.5 \mathrm{mi}$. long, on Kenai Penin. W of King Lake, $36 \mathrm{mi}$. NE of Kenai, Cook Inlet Low,; $60^{\circ} 48^{\prime} 30^{\prime \prime} \mathrm{N}, 150^{\circ} 22^{\prime} 30^{\prime \prime} \mathrm{W}$; (map 62).

Named about 1963 by officials of Kenai National Moose Range, probably for the Western Winter Wren (Nunnus hiemalis pacificus), which breeds on the south coast of Alaska (Pearson, 1944, pt. 3, p. 195).

Wren Point: point of land, see Nemo Point.

Wright, Mount: peak, ESE of Ketchikan in the Coast Mts. ; (map 3 ).

Probably named for the brothers Charles Will Wright and Fred Eugene Wright, USGS geologists, who worked in southeast Alaska in the early 1900's and contributed to the nomenclature of the area in their reports. This feature has not been precisely located on maps. Wright, Mount: mountain, 5,139 ft., $1 \mathrm{mi}$. N of Dirt Glacier, Glacier Bay National Monument, $52 \mathrm{mi}$. NW of Hoonah, St. Elias Mts.; $58^{\circ} 47^{\prime} 55^{\prime \prime} \mathrm{N}, 136^{\circ} 01^{\prime} 30^{\prime \prime} \mathrm{W}$; (map 10).

Named in 1891 by Reid (1892, p. 30), USGS, for George Frederick Wright, 18381921, pastor and glacial geologist. Most of his life was spent as a theologian and Congregational minister. $\mathrm{He}$ was professor at the Oberlin Theological Seminary from 1881 to 1907 . He was the author of many geological publications, including "The Ice Age in North America." Wright spent some time in the Glacier Bay area in 1886. There is another Mount Wright $43 \mathrm{mi}$. W of this feature. 
Wright, Mount: mountain, 4,275 ft., $15 \mathrm{mi}$. W of Mount Healy, Alaska Ra.; $63^{\circ} 44^{\prime} 45^{\prime \prime} \mathrm{N}$, 149 30'00" W; BGN 1947; (map 87).

Named in 1943 by NPS for George $M$. Wright, 1904-1936, founder of the Wildlife Division of the National Park Service in 1929. He was the first to discover a surfbird nest in Mount McKinley National Park.

Wright Creek: stream, on SW coast of Prince oi Wales I., flows SW $1.5 \mathrm{mi}$. to Hetta Inlet, SE of Copper Harbor, Alex. Arch.; 55 ${ }^{\circ} 11^{\prime} 50^{\prime \prime}$ N, $132^{\circ} 36^{\prime} 35^{\prime \prime} \mathrm{W}$; (map 4).

Name reported in 1908 by C. W. Wright (in Brooks and others, 1909, pl. 3), USGS.

Wright Glacier: glacier, heads in British Columbia at $58^{\circ} 22^{\prime} \mathrm{N}, 133^{\circ} 22^{\prime} \mathrm{W}$, trends NW 16 mi. to Wright River, $31 \mathrm{mi}$. E of Juneau, Coast Mts.; $58^{\circ} 29^{\prime} 45^{\prime \prime} \mathrm{N}, 133^{\circ} 39^{\prime} 15^{\prime \prime} \mathrm{W}$; $B G N$ 1953; (map 12).

Named in 1891 by C. W. Hayes, USGS, for George Frederick Wright, 1838-1921, professor at Oberlin Theological Seminary from 1881-1907.

Wright Island: island, see Aston Island.

Wright Peaks: mountain peaks, $3.2 \mathrm{mi}$. NE of terminus of Wright Glacier and $35 \mathrm{mi}$. E of Juneau, Coast Mts.; $58^{\circ} 31^{\prime} 15^{\prime \prime} \mathrm{N}, 133^{\circ} 33^{\prime}$ $45^{\prime \prime} \mathrm{W}$; (map 12).

Name derived from Wright Glacier; published in 1923 on IBC sheet 8 (1951 Atlas).

Wright Point: point of land, on $E$ shore between Admiralty Bay and Dease Inlet, $37 \mathrm{mi}$. SE of Barrow, Arctic Plain; $70^{\circ} 56^{\prime} 40^{\prime \prime} \mathrm{N}, 155^{\circ} 30^{\prime}$. $30^{\prime \prime} \mathrm{W}$; (map 148). Var. Point Wright.

Name first appears on Comdr. Maguire's map (Great Britain, 1854, facing p. 186) as Pt. Wright, but published on the Brit. Adm. Chart 593 with the generic last.

Wright River: stream, heads at terminus of Wright Glacier, Hows NW 4 mi. to Taku River, $29 \mathrm{mi}$. NE of Juneau, Coast Mts.; $58^{\circ} 31^{\prime}$ 45" N, 133 44'15" W; BGN 1932; (map 12).

Local name derived from Wright Glacier; reported in 1932 by B. D. Stewart, USGS.

Wrights: village, see Wiseman.

Wrong Branch Trail Creek: stream, in Chigmit Mts., at head of Iniskin Penin., flows NE 2.5 mi., joins Right Branch to form Trail Creek, $0.7 \mathrm{mi}$. S of Chinitna Bay, Aleutian Ra.; $59^{\circ}$ $47^{\prime} 45^{\prime \prime} \mathrm{N}, 153^{\circ} 16^{\prime} 40^{\prime \prime} \mathrm{W}$; BGN 1962; (map 51).

Local name reported in 1951 by USGS.

Wrong Creek: stream, distributary of Kashunuk River, flows S $20 \mathrm{mi}$. to Nungatak River, $2 \mathrm{mi}$. N of Nuigalak Lake, Yukon-Kuskokwim Delta ; 61 $35^{\prime} 15^{\prime \prime} \mathrm{N}, 164^{\circ} 35^{\prime} 20^{\prime \prime} \mathrm{W}$; (map 74).

Local name reported by Orth in 1965 .

Wrongtail Creek: stream, flows NE and E 20 mi. to Dagislakhna Creek $4 \mathrm{mi}$. NW of that stream's junc. with Tozitna River, $28 \mathrm{mi}$. NNW of Tanana, Kokrines-Hodzana High.; $65^{\circ} 34^{\prime} 00^{\prime \prime} \mathrm{N}, 152^{\circ} 17^{\prime} 30^{\prime \prime} \mathrm{W}$; (map 106).

Local name reported in 1956 by Orth.

Wsewidow: mountain, see Vsevidof, Mount W. Smith's River: stream, see Smith River. Wukuklook Creek: stream, flows SE $7 \mathrm{mi}$. to Iyoukeen Cove on E coast of Chichagof I., 14 mi. NE of Tenakee Springs, Alex. Arch.; $57^{\circ} 55^{\prime} 20^{\prime \prime} \mathrm{N}, 134^{\circ} 56^{\prime} 15^{\prime \prime} \mathrm{W}$; (map 9).

Local name derived from a Tlingit Indian word, "wa-kak-luk," meaning "stream by cliff" or "cliff ;" reported in 1958 by USGS.

Wulik Peaks: mountain peaks, trend NE-SW 17 mi., in De Long Mts., 18 mi. S of Mount Kelly, $47 \mathrm{mi}$. N of Noatak, Brooks Ra.; $68^{\circ} 15^{\prime} \mathrm{N}$, $163^{\circ} 16^{\prime} \mathrm{W}$ [NE end] $68^{\circ} 08^{\prime} \mathrm{N}, 163^{\circ} 54^{\prime} \mathrm{W}$. [SW end]; BGN 1965; (map 130).

Named for the nearby Wulik River, which is an Eskimo name. Named in 1965 by geologists of the B.P. Exploration Cio., Inc.

Wulik River: stream, heads in the De Long Mts. $5 \mathrm{mi}$. N of Sheep Mtn., at $68^{\circ} 23^{\prime} \mathrm{N}, 162^{\circ} 54^{\prime}$ $\mathrm{W}$ and flows SW $80 \mathrm{mi}$. to Kivalina Lagoon, $E$ of Kivalina, and $42 \mathrm{mi}$. NW of Noatak, Kotzebue-Kobuk Low.; $67^{\circ} 44^{\prime} \mathrm{N}, 164^{\circ} 31^{\prime} \mathrm{W}$; (map 128). Var. Woleek River, Wooleek River, Wolik River.

Eskimo name reported by Lt. G. M. Stoney, USN, in 1886, as "Woleek."

Wyanda Ledge: reef, see Wayanda Ledge.

Wyanda Rock: rock, see California Rock.

Wye Creek: stream, flows W $0.8 \mathrm{mi}$. to Dahl Creek $9 \mathrm{mi}$. NE of Shungnak, Brooks Ra.; $66^{\circ} 08^{\prime} \mathrm{N}, 156^{\circ} 51^{\prime} \mathrm{W}$; (map 115).

Local name reported in 1943 by $R$. $R$. Coats, USGS.

Wyoming Creek: stream, flows NW $2 \mathrm{mi}$. to Creston Creek, $5.5 \mathrm{mi}$. N of Cripple Creek Mts. and $52 \mathrm{mi}$. NW of Medfra, KilbuckKuskokwim Mts.; $63^{\circ} 36^{\prime} \mathrm{N}, 1^{\circ} 5^{\circ} 57^{\prime} \mathrm{W}$; (map 89).

Local name reported in 1954 by USGS.

Wyoming Hills: mountains, 5,800 ft., extend NE $7.2 \mathrm{mi}$. from Toklat River to East Fork Toklat River, $8.5 \mathrm{mi}$. SW of Healy, Alaska Ra.; $63^{\circ}$ $39^{\prime} \mathrm{N}, 149^{\circ} 58^{\prime} \mathrm{W}$; (map 87).

Local name published by USGS in 1954 . Wyvill Reef: reef, off $\mathrm{W}$ coast of Baranof $\mathrm{I}$, in Neva Strait, $1 \mathrm{mi}$. S of Saint John Baptist Bay, Alex. Arch.; $57^{\circ} 16^{\prime} 24^{\prime \prime} \mathrm{N}_{0} 135^{\circ} 35^{\prime} 18^{\prime \prime}$ W; (map 9).

Probably locally named; reported in 1897 by Lt. Comdr. E. K. Moore, USN, and published in 1900 on USC\&GS Chart 8281.

\section{$\mathbf{x}$}

Xask Creek : stream, see Haska Creek.

Xatacyan Lagoon: lagoon, $0.2 \mathrm{mi}$. long, $0.6 \mathrm{mi}$. NW of Unalaska, in Unalaska Bay on NE coast of Unalaska I., Aleutian Is.; $53^{\circ} 52^{\prime} 58^{\prime \prime}$ $\mathrm{N}, 166^{\circ} 33^{\prime} 00^{\prime \prime} \mathrm{W}$; (map 23).

Name published by USC\&GS in 1965 on Chart 9008.

X Creek: stream, flows NE $0.7 \mathrm{mi}$. to Bering Sea on northern Kiska. 1., Aleutian Is. ; $52^{\circ} 07^{\prime} 05^{\prime \prime}$ $\mathrm{N}, 177^{\circ} 39^{\prime} 00^{\prime \prime} \mathrm{E}$; (map 14).

An arbitrary name beginning with " $X$ " to sorrespond to " $X$ " grid used by the U.S. Army for tactical purposes during World War II; published on a 1953 AMS map.

X-Ray Creek: stream, flows E $1.1 \mathrm{mi}$. to Bering Sea, on N coast of Kiska I., Aleutian Is.; $52^{\circ}$ 06'03" N, 177'39'42" E; (map 14).

An arbitrary name beginning with " $X$ " to correspond to " $\mathrm{X}$ " grid used by the U.S. Army for tactical purposes during World War II; published on a 1953 AMS map.

X-Ray Ridge: ridge, $1 \mathrm{mi}$. long, between X-Ray Greek and $\mathrm{X}$-Wave Creek, on $\mathrm{N}$ coast of Kiska I., Aleutian Is.; $52^{\circ} 06^{\prime} 00^{\prime \prime} \mathrm{N}, 177^{\circ}$ $38^{\prime} 15^{\prime \prime} \mathrm{E}$; (map 14).

An arbitrary name beginning with " $X$ " to correspond to " $\mathrm{X}$ " grid used by the U.S. Army for tactical purposes during World War II; published on a 1953 AMS map.

X-Wave Creek: stream, flows E 1.2 mi. to Bering Sea, on $\mathbf{N}$ coast of Kiska I., Aleutian Is., $52^{\circ} 06^{\prime} 07^{\prime \prime} \mathrm{N}, 177^{\circ} 39^{\prime} 45^{\prime \prime} \mathrm{E}$; (map 14).

An arbitrary name beginning with " $X$ " to correspond to " $X$ " grid used by the U.S. Army for tactical purposes during. World War II; published on a 1953 AMS map.

\section{$\mathbf{Y}$}

Yaachnoy, Ostrov: island, see Deranof Island.

Yaas Bay: estuary, see Yes Bay.

Yabloshny, Ostrov: island, see Middle Island. Yachérgamut: locality, see Yacherk.

Yacherk: locality, $30 \mathrm{mi}$. W of Dillingham, on left bank of Igushik River, 2 mi. E of Amanka Lake, Kilbuck-Kuskokwim Mts.; 59 $03^{\prime} \mathrm{N}$, $159^{\circ} 13^{\prime} \mathrm{W}$; (map 53). Var. Yachérgamut, Yatshergamut.

Former Eskimo village or camp shown on a 1898 field sheet as "Yatshergamut," meaning "Yatsherk people" by W. S. Post, USGS. Yachnoi: island, see Deranof Island.

Yachnoy Island: island, see Hunt Island.

Yachtshilagamiut: locality, see Yakchilak.

Yachzikatna River: stream, see Iditarod River.

Yacko Creek: stream, flows N $12 \mathrm{mi}$., joins Joe Creek to form Sanona Creek, $22 \mathrm{mi}$. S of junc. of Oshetna and Susitna Rivers and $65 \mathrm{mi}$. W of Gulkana, Talkeetna Mts.; 62 $19^{\prime} 30^{\prime \prime} \mathrm{N}$, $147^{\circ} 22^{\prime} 00^{\prime \prime} \mathrm{W}$; (map 82).

Indian name reported by $F$. $H$. Moffit (in Brooks and others, 1915, fig. 3), USGS.

Yacootat Bay: bay, see Yakutat Bay.

Yadno River: stream, see Yentna River.

Yaga Glacier: glacier, heads $2 \mathrm{mi}$. SW of Yaga Peak, trends $2 \mathrm{mi}$. SW to Yakataga Glacier, $4.1 \mathrm{mi}$. NW of Mount Eberly and $92 \mathrm{mi}$. NW of Yakutat, Chugach Mts.; $60^{\circ} 10^{\prime} \mathrm{N}, 142^{\circ} 04^{\prime}$ W; BGN 1945; (map 65).

Local name derived from Yaga Peak.

Yagak, Cape: point of land, see Yakak, Cape.

Yaganuda Cove: cove, $1.5 \mathrm{mi}$. across, between Dalnoi and Rush Points, on SW coast of St. George I., in Pribilof Is.; $56^{\circ} 36^{\prime} \mathrm{N}, 169^{\circ} 46^{\prime}$ $\mathrm{W}$; (map 38).

Aleut name reported in 1897 by Putnam (1903, p. 1016), USC\&GS, as 'Yag'an-uda', meaning "wooded bay *** so called because there is drift-wood on the beach."

Yaga Peak: peak, 8,440 ft., in Robinson Mts., W of Guyot Glacier, at head of Yaga Glacier, 19 mi. NE of Cape Yakataga, Chugach Mts.; $60^{\circ} 12^{\prime} 20^{\prime \prime} \mathrm{N}, 141^{\circ} 57^{\prime} 35^{\prime \prime} \mathrm{W}$; BGN 1945; (map 65) .

Name reported in 1913 by USGS; published by Martin (1921, pl. 6).

Yagekhtalyk: bay, see Alitak Bay.

Yagektaliek: bay, see Alitak Bay. 
Yaghmelngak Mountain: hill, $594 \mathrm{ft} ., 15 \mathrm{mi} . \mathrm{N}$ of Southwest Cape, St. Lawrence I.; 63 $31^{\prime}$ $\mathrm{N}, 171^{\circ} 26^{\prime} \mathrm{W}$; BGN 1951; (map 93). Var. Olugooseenuk Mountain.

Eskimo name meaning "the lowest one." according to Orth in 1965. The name was reported in 1949 by Maj. H. B. Allen, USAF.

Yaghmelugak Mountain: mountain, see Olngooseenuk Mountain.

Yahku Cove: cove, $0.5 \mathrm{mi}$. long, on SE coast of Tuxekan I., $23 \mathrm{mi}$. N of Craig, Alex. Arch.; $55^{\circ} 47^{\prime} 30^{\prime \prime} \mathrm{N}, 133^{\circ} 14^{\prime} 15^{\prime \prime} \mathrm{W}$; (map 4).

Indian name published in 1964 by USC\&GS.

Yahtse Glacier: glacier, heads on Barkley Ridge, at Mount Miller, trends SE $40 \mathrm{mi}$. to its 1963 terminus at Icy Bay, Chugach Mts.; $60^{\circ} 08^{\prime}$ N, 141 $24^{\prime}$ W; BGN 1964; (map 65).

Name proposed in 1963 by A. S. Post, USGS, because the relatively recent retreat of Guyot Glacier formed another branch on the IW side of the Guyot Hills. The name is derived from the Yahtse River, which may have once flowed into Icy Bay in this area.

Yahtse River: stream, heads at terminus of Malaspina Glacier and flows SW $10 \mathrm{mi}$. to Gulf of Alaska, $5 \mathrm{mi}$. E of Point Riou and $63 \mathrm{mi}$. W of Yakutat, Malaspina Coastal Plain; 59 $51^{\prime}$ $45^{\prime \prime} \mathrm{N}, 141^{\circ} 24^{\prime} 00^{\prime \prime} \mathrm{W}$; BGN 1965; (map 47). Var. East Yahtse River, Jones River, West Yahtse River, Yahtse-Tah, Yatseha Hini.

According to William Williams (1889, p. 392), "Yahtse" is "the name by which the Jones River is known to the Indians." $H$. W. Topham reported the name in 1889 as Yahtse-Tah. In 1886 Lt. F. Schwatka, USA, named it the Jones River after the proprietor of the New York Times.

Yahtse-tah-shah: mountain, see Saint Elias, Mount.

Yaichnia Islets: island, sec Guibert Islets.

Yaichni Island: island, see Guillemot Island.

Yaichnoy, Mys: point of land, see Egg Point.

Yaichnyy, Mys: point of land, see Egg Point

Yaichnyy, Ostrov: island, see Egg Island.

Yaichnyya, Ostrova: islands, see Guibert Islets.

Yaignoy, Ostrov: island, see Egg Island.

Yaitchni, Mys: point of land, see Egg Point.

Yaitchny Islets: islands, see Guibert.

Yakaio, Cape: point of land, see Yakataga, Cape.

Yakak, Cape: point of land, SW tip of Adak I., Aleutian Is.; $51^{\circ} 35^{\prime} 40^{\prime \prime} \mathrm{N}, 176^{\circ} 56^{\prime} 00^{\prime \prime} \mathrm{W}$ $B G N$ 1936; (map 17). Var. Cape Jachach, Gape Yagak, Mys Yakhakh.

Aleut name published by the Russians as "M[ys] Yakhakh," or "Cape Yakhakh" (in Tebenkov, 1852, map p. 28). This point was reported by Father Ioann Veniaminov as "Yagak," which he translated as "firewood" or "driftwood." This word may come from the Aleut word "Yagaqadaq" which, according to R. H. Geoghegan, means "firewood" or "firgrove."

Yakak Peninsula: peninsula, $10 \mathrm{mi}$. long, SW part of Adak I., Aleutian Is.; $51^{\circ} 40^{\prime} \mathrm{N}, 176^{\circ}$. 55' W; (map 17).

Name published by USGS (in Fraser and Snyder, 1959, pl. 52).
Yakatag: village, see Cape Yakataga.

Yakatag, Cape: point of land, see Yakataga, Cape.

Yakataga: village, see Cape Yakataga.

Yakataga, Cape: point of land, on Gulf of Alaska, $2.4 \mathrm{mi}$. SW of Watson Peak and $100 \mathrm{mi}$. NW of Yukutat, St. Elias Mts.; $60^{\circ} 03^{\prime} 40^{\prime \prime} \mathrm{N}$, $142^{\circ} 26^{\prime} 00^{\prime \prime} \mathrm{W}$; BGN 1908; (map 65). Var. Cape Iaktag, Cape Yakaio, Cape Yakatag, Yokataga Reef.

Tlingit Indian name published by Capt. Tebenkov (1852, map 7), IRN, as "M[ys] Yaktaga" on an 1849 map.

Yakataga Glacier: glacier, heads at $\mathrm{E}$ end of Dahlgren Ridge, in Robinson Mts., trends SW $15 \mathrm{mi}$. to its 1950 terminus at head of $\mathrm{Ya}$ kataga River, Chugach Mts.; $60^{\circ} 07^{\prime} 30^{\prime \prime} \mathrm{N}$, $142^{\circ} 16^{\prime} 00^{\prime \prime} \mathrm{W}$; BGN 1945; (map 65).

Name reported by A. C. Maddren (in Brooks and others, 1914, pl. 4), USGS.

Yakataga Reef: point of land, see Yakataga, Cape.

Yakataga Ridge: ridge, in Robinson Mts., extends $W$ from Guyot Glacier $10 \mathrm{mi}$. to 1950 terminus of Yakataga Glacier, $92 \mathrm{mi}$. NW of Yakutat, Chugach Mts.; $60^{\circ} 06^{\prime} 50^{\prime \prime} \mathrm{N}, 142^{\circ}$ $10^{\prime} 00^{\prime \prime} \mathrm{W}$; BGN 1945; (map 65).

Local name derived from Yakataga Glacier.

Yakataga River: stream, heads at Yakataga Glacier terminus, flows SW $10 \mathrm{mi}$., in two major channels: North Channel to Duktoth River 2 mi. above its mouth; South Channel to Gulf of Alaska 2 mi. W of Cape Yakataga, Chugach Mts.; $60^{\circ} 06^{\prime} 00^{\prime \prime} \mathrm{N}, 142^{\circ} 31^{\prime} 00^{\prime \prime} \mathrm{W}$ (N mouth) ; $60^{\circ} 04^{\prime} 30^{\prime \prime} \mathrm{N}, 142^{\circ} 28^{\prime} 30^{\prime \prime} \mathrm{W}$ (S mouth); BGN 1945; (map 65). Var. Yaktag River.

Local name reported in 1903 as "Yaktag" by G. C. Martin, USGS; spelling changed to agree with Cape Yakataga.

Yakataga River: stream, see North Channel Yakataga River.

Yakataga River: stream, see South Channel Yakataga River.

Yakchilak: locality, on Helmick Point, $43 \mathrm{mi}$. SW of Bethel, Yukon-Kuskokwim Delta, $60^{\circ} 18^{\prime} \mathrm{N}, 162^{\circ} 27^{\prime} \mathrm{W}$; (map 58). Var. Yachtshilagamiut, Yukhtokialgamute.

Former Eskimo village reported in 1878 by E. W. Nelson, L.S. Signal Service, who gave its name as "Yukhtokialgamute." W. S. Post and J. E. Spurr, USGS, spelled the name "Yachtshilagamut," which they obtained in 1898 from J. H. Kilbuck, Moravian missionary.

Yak'da't Hlahayik: village, see Yakutat.

Yakiao, Cape: point of land, see Yakataga, Cape.

Yakitat: village, see Yakutat.

Yaklak, Mys: point of land, see Aklek, Cape.

Yaklek: point of land, see Aklek, Cape.

Yakobi Island: island, $19 \mathrm{mi}$. long, trends N-S, off NW coast of Chichagof I., Alex. Arch.; $57^{\circ} 56^{\prime} \mathrm{N}, 136^{\circ} 27^{\prime} \mathrm{W}$; (map 9). Var. Jacob Island, Jacobieff Island, Jakobi Island, Ostrov Yakobiya.

Named in 1804 by Capt. U. T. Lisianski, IRN, probably for General Ivan Yakobi, "afterward the head of the Colonial Direction (U.S. Goast and Geodetic Survey, 1883, p. 184)."

Yakobi Island: island, see Chichagof Island.

Yakobi Peak: mountain, 2,444 ft., on $\mathrm{S}$ central Yakobi I., off W coast of Chichagof I., $22 \mathrm{mi}$. $\mathrm{NW}$ of Chichagof, $57^{\circ} 55^{\prime} \mathrm{N}, 136^{\circ} 27^{\prime} \mathrm{W}$; (map 9).

Name published in 1929 by USG\&GS on Chart 8260; probably named for Yakobi Island.

Yakobi Rock: rock, off NW coast of Yakobi I., $0.4 \mathrm{mi}$. W of Bingham Cove, $41 \mathrm{mi}$. W of Hoonah, Alex. Arch.; 58 $05^{\prime} 10^{\prime \prime}$ N, $136^{\circ} 33^{\prime}-$ $40^{\prime \prime} \mathrm{W}$; (map 10).

Named in 1901 by J. F. Pratt, USC\&GS for Yakobi Island; published on Chart 8304 in 1904.

Yakobiya, Ostrov: island, see Yakobi Island.

Yakorni Point: point of land, see Anchorage Point.

Yakorniy, Mys: point of land, see Anchorage Point.

Yaktag, Cape: point of land, see Yakataga, Cape.

Yaktaga, Cape: point of land, see Yakataga, Cape.

Yaktag River: stream, see Yakataga River.

Yakudat: village, see Yakutat.

Yakutania Point: point of land, in Taiya Inlet, $0.5 \mathrm{mi}$. SW of Skagway, Coast Mts. ; $59^{\circ} 27^{\prime}$. $10^{\prime \prime} \mathrm{N}, 135^{\circ} 20^{\prime} 00^{\prime \prime} \mathrm{W}$; (map 45).

Tlingit Indian name "Yakutan-ya," reported to mean "canoe-landing"; published in 1923 on IBC Sheet 9 (1951 atlas).

Yakutanya Creek: stream, see Kasidaya Creek. Yakutat: village, pop. 230, on $\mathrm{W}$ end of Monti Bay, $210 \mathrm{mi}$. NW of Juneau, Malaspina Coastal Plain; $59^{\circ} 33^{\prime}$ N. $139^{\circ} 44^{\prime}$ W; $B G N$ 1944; (map 46). Var. Yak'da't Hlahayik, Yakitat, Yakudat.

Tlingit Indian village; the principal winter village of the Yakutats, a subtribe of the Tlingits, reported by Ivan Petroff in the 1880 Census. Its population was 500 in 1880,300 in 1890,271 in 1910,165 in 1920,265 in 1930, 292 in 1939, and 298 in 1950. The Yakitat post office was established in 1892 and discontinued in 1895 . It was reestablished as "Yakutat" in 1901 (Ricks, 1965, p. 72).

Yakutat Bay: bay, $18 \mathrm{mi}$. across, extends SW from Disenchantment Bay to Gulf of Alaska, Malaspina Coastal Plain; $59^{\circ} 40^{\prime} \mathrm{N}, 140^{\circ} 00^{\prime}$ W; BGN 1944; (map 46). Var. Admiralty Bay, Almirantazgo, Amirante Bay, Bahia Admiralty, Baie de Monti, Bay of Yakutat, Behring Bay, Bering Bay, Jacootat Bay, Yacootat Bay.

Tlingit Indian name reported as "Jacootat" and "Yacootat" by Lisianski in 1805. It was named "Baie de Monti" by La Perouse, who visited it in 1786, for one of his officers. In the same year Capt. Nathaniel Portlock named it "Admiralty Bay." The Spaniards called it "Almirantazgo." Bering's name (Bering Bay) has been applied to the feature on the assumption that he visited it in 1741 . As a result 
of usage the native name "Yakutat" has been adopted.

Yakutat Colony: locality, see Glory of Russia.

Yakutat Foreland: area, between Dangerous River and Yakutat Bay, and St. Elias Mts. and Gulf of Alaska, Malaspina Coastal Plain; $59^{\circ} 32^{\prime} \mathrm{N}, 139^{\circ} 24^{\prime} \mathrm{W}$; (map 46).

Name reported by Tarr and Martin (1906, map), USGS.

Yakutat Glacier: glacier, heads at $59^{\circ} 32^{\prime} \mathrm{N}$, $138^{\circ} 38^{\prime} \mathrm{W}$, trends $11 \mathrm{mi}$. SW to its 1961 terminus on Harlequin Lake, $29 \mathrm{mi}$. $\mathrm{E}$ of Yakutat, St. Elias Mts.; $59^{\circ} 28^{\prime} \mathrm{N}, 138^{\circ} 54^{\prime}$ W; (map 46).

This name, derived from Yakutat Bay, was published in 1895 by USC\&GS on Chart 8000.

Yakutat Roads: water passage, 2 mi. long, trends NE between Monti Bay and Johnstone Passage, $1 \mathrm{mi}$. NW of Yakutat, Malaspina Coastal Plain; $59^{\circ} 33^{\prime} 30^{\prime \prime} \mathrm{N}, 139^{\circ} 46^{\prime} 00^{\prime \prime} \mathrm{W}$; (map 46).

Named by Lt. Giles B. Harber, USN, in 1892 probably for Yakutat Bay. Name published in 1901 by USC\&GS on Chart 8455.

Yakutskalitnik: locality, see Tutago.

Yakutsklitnik: locality, see Tutago.

Yakutzkelignik: locality, see Tutago.

Yalchikatna River: stream, see Iditarod River. Yalchikatno River: stream, see Iditarod River.

Yale Arm College Fiord: estuary, extends NE 3.4 mi. between College Fiord and Yale Glacier, $50 \mathrm{mi}$. W of Valdez, Chugach Mts.; 61 ${ }^{\circ} 12^{\prime}$ $\mathrm{N}, 147^{\circ} 46^{\prime} \mathrm{W}$; (map 69). Var. East Arm Yale Fiord.

Named in 1910 by Lawrence Martin (in Tarr and Martin, 1914, map 7).

Yale Creek: stream, flows S $5 \mathrm{mi}$. to Igloo Creek which flows to American River, $34 \mathrm{mi}$. NE of Teller, Seward Penin. High.; $65^{\circ} 28^{\prime} \mathrm{N}$, $165^{\circ} 18^{\prime} \mathrm{W}$; (map 111).

Prospectors' name reported in 1900 by Messrs. Kemp and David Fox (in Brooks, 1901, pl. 11).

Yale Glacier: glacier, heads between Mount Cardozo and Mount Einstein, trends SW 20 mi. to Yale Arm College Fiord, $47 \mathrm{mi}$. W of Valdez, Chugach Mts.; $61^{\circ} 12^{\prime} \mathrm{N}, 147^{\circ} 42^{\prime} \mathrm{W}$; (map 69). Var. Twin Glaciers.

Named by members of the Harriman Alaska Expedition in 1899 for Yale University, New Haven, Conn. Harvard and Yale Glaciers were called "Twin Glaciers" in 1898 by Capt. E. F. Glenn, USA.

Yalik: locality, on SE coast of Kenai Penin. on shore of Yalik Bay, $38 \mathrm{mi}$. E of Seldovia, Chugach Mts.; $59^{\circ} 27^{\prime} \mathrm{N}, 150^{\circ} 36^{\prime} \mathrm{W}$; (map 50).

Former Indian village reported in the 1880 Census, with a population of 32 , by Ivan Petroff (1884, p. 29).

Yalik Bay: bay, 1 mi. wide, at SW entrance to West Arm Nuka Bay, $40 \mathrm{mi}$. E of Seldovia, Chugach Mts.; $59^{\circ} 28^{\prime} \mathrm{N}, 150^{\circ} 35^{\prime} \mathrm{W}$; BGN 1929; (map 50). Var. Cabin Bay.

Named by U. S. Grant, USGS, in 1911, for an old settlement there (Grant and Higgins, 1913, pl. 2).
Yalik Glacier: glacier, heads at $59^{\circ} 34^{\prime} 30^{\prime \prime} \mathrm{N}$, $150^{\circ} 47^{\prime} 00^{\prime \prime} \mathrm{W}$, in Kenai Mts., trends S $9 \mathrm{mi}$. to its terminus $1.7 \mathrm{mi}$. N of Nuka Passage, Chugach Mts.; $59^{\circ} 27^{\prime} 15^{\prime \prime} \mathrm{N}, 150^{\circ} 43^{\prime} 00^{\prime \prime} \mathrm{W}$; $B G N$ 1911; (map 50). Var. Avis Glacier.

Named by U. S. Grant, USGS, in 1911, for an abandoned Indian settlement on the shore of Yalik Bay.

Yalik Point: point of land, on NW shore of Nuka Bay, $40 \mathrm{mi}$. E of Seldovia, Chugach Mts.; $59^{\circ} 27^{\prime} \mathrm{N}, 150^{\circ} 35^{\prime} \mathrm{W}$; BGN 1929; (map 50).

So named by USC\&GS in 1929 because of its proximity to Yalik Bay.

Yamani Cove: bay, $0.2 \mathrm{mi}$. across, formed by Yamani Islets, at $\mathrm{N}$ point of entrance to Necker Bay, on SW coast of Baranof I., Alex. Arch.; $56^{\circ} 40^{\prime} 20^{\prime \prime} \mathrm{N}, 135^{\circ} 10^{\prime} 30^{\prime \prime} \mathrm{W}$; $B G N$ 1926; (map 5).

Russian name from "yamistyy" meaning "full of holes" given in 1925 by USC\&GS because of "the islands which plug the bay."

Yamani Islets: islands, $0.8 \mathrm{mi}$. across, at $\mathrm{N}$ point of entrance to Necker Bay, on SW coast of Baranof I., Alex. Arch.; 56 $40^{\prime} 15^{\prime \prime}$ N, $135^{\circ}$ $11^{\prime} 00^{\prime \prime}$ W; (map 5). Var. Ostrova Yamanyi.

In 1850 this feature was named "O[stro]va Yamanyi," meaning "islands of holes [or pits]," by the Russian American Company.

Yamanyi, Ostrova: islands, see Yamani Islets. Yanaliuk, Cape: point of land, on $\mathrm{S}$ coast of Unalaska I., Aleutian Is.; $53^{\circ} 32^{\prime} 20^{\prime \prime} \mathrm{N}, 166^{\circ}$ 35'30" W; BGN 1938 (map 23). Var. Bog Cape, Cape Alexander, Cape Yanalyun, Ianaliun.

Aleut name published as "M[ys] Yanalyun," or "Cape Yanalyun," by Capt. Tebenkov (1852, map 26), IRN. According to R. H. Geoghegan, this is possibly derived from the Aleut word "yunalgakuk," meaning "it is cut through." This point was called "Bog Cape" by USBF in 1888 . It was also called "Alexander" by USC\&GS in 1900.

Yanalyun, Cape: point of land, see Yanaliuk Cape.

Yancarnie Bay: estuary, see Yantarni Bay.

Yanert: locality, mile 343.7 on The Alaska RR., $13 \mathrm{mi}$. S of Healy, Alaska Ra.; $63^{\circ} 39^{\prime} 40^{\prime \prime} \mathrm{N}$, $148^{\circ} 50^{\prime} 15^{\prime \prime} \mathrm{W}$; (map 87).

Name of a railroad stop reported by The Alaska RR. on its 1922 timetable.

Yanert Fork: stream, heads at Yanert Glacicr and flows NW $31 \mathrm{mi}$. to Nenana River, $14 \mathrm{mi}$. SE of Healy, Alaska Ra.; $63^{\circ} 41^{\prime} \mathrm{N}, 148^{\circ} 46^{\prime}$ W; (map 87).

Named for Sergeant William Yanert, USA, a member of the 1898 expedition under the command of Capt. Edwin F. Glenn, USA. Reported in 1910 by J. W. Bagley and D. C. Witherspoon (in Moffit, F. H., 1915, pl. 1), USGS.

Yanert Glacier: glacier, heads at $63^{\circ} 38^{\prime} \mathrm{N}$, $147^{\circ} 18^{\prime} \mathrm{W}$, and trends $\mathrm{W} 19 \mathrm{mi}$. to head of Yanert Fork, $40 \mathrm{mi}$. SE of Healy, Alaska Ra.; $63^{\circ} 35^{\prime} 45^{\prime \prime} \mathrm{N}, 147^{\circ} 52^{\prime} 45^{\prime \prime} \mathrm{W}$; (map 87).

Named for Sergeant William Yanert, USA. See Yancrt Fork.

Yankee Basin: valley, $0.6 \mathrm{mi}$. long, at head of South Fork Cowee Creek, $2.4 \mathrm{mi}$. NW of terminus of Eagle Glacier and $24 \mathrm{mi}$. NW of Juneau, Coast Mts.; 58 $35^{\prime} \mathrm{N}, 134^{\circ} 49^{\prime} \mathrm{W}$; (map 11).

Name given by miners about 1903; published by C. W. Wright (in Spencer, 1906, p. 131); USGS.

Yankee Cove: cove, $0.2 \mathrm{mi}$. across, on $\mathrm{E}$ shore of Favorite Channel, $1.2 \mathrm{mi}$. NE of North I. and $26 \mathrm{mi}$. NW of Juneau, Coast Mts.; 58 ${ }^{\circ}$. $35^{\prime} 20^{\prime \prime} \mathrm{N}, 134^{\circ} 54^{\prime} 05^{\prime \prime} \mathrm{W}$; (map 11).

Local name published by C. W. Wright (in Spencer, 1906, p. 132 and pl. 37), USGS. In 1906 a 2-mile plank road ran from the beach at the head of the cove to a mining stamp mill. Yankee Creek: stream, flows NE $13 \mathrm{mi}$. to Innoko River, $8 \mathrm{mi}$. SE of Ophir and $25 \mathrm{mi}$. NW of McGrath, Kilbuck-Kuskokwim Mts.; $63^{\circ} 04^{\prime} \mathrm{N}, 156^{\circ} 20^{\prime} \mathrm{W}$; (map 90).

Prospectors' name obtained in 1908 by Maddren (1910, pl. 1), USGS.

Yankee Creek: stream, flows $\mathrm{N} 2 \mathrm{mi}$. to Porcupine Creek, $2 \mathrm{mi}$. NNE of Porcupine Dome and $45 \mathrm{mi}$. SW of Gircle, Yukon-Tanana High.; $65^{\circ} 33^{\prime} \mathrm{N}, 145^{\circ} 30^{\prime} \mathrm{W}$; (map 104).

Named by prospectors and reported in 1931 by Mertie (1937b, pl. 1), USGS.

Yankee Creek: stream, flows W $3.5 \mathrm{mi}$., $\mathrm{N}$ of Snowshoe Pass to Glacier River, $1 \mathrm{mi}$. S of mouth of Washington Creek and $10 \mathrm{mi}$. NW of Wiseman, Brooks Ra.; 67 $30^{\prime} \mathrm{N}, 150^{\circ} 25^{\prime} \mathrm{W}$; (map 124).

Local name reported in 1938 by Marshall (1956, p. 139).

Yankee Point: point of land, on W bank of Portland Canal, $2.3 \mathrm{mi}$. NE of Glacier Point, Coast Mts.; $55^{\circ} 50^{\prime} 40^{\prime \prime} \mathrm{N}, 130^{\circ} 04^{\prime} 25^{\prime \prime} \mathrm{W}$; (map 3).

Name published in 1897 by USC\&GS.

Yankee Ridge: ridge, elev. 1,800-2,600 ft., extends $8 \mathrm{mi}$. on $\mathrm{S}$ bank of Old Crow River, SW of Ammerman Mtn., $3 \mathrm{mi}$. W of Alaska-Canada boundary and $59 \mathrm{mi}$. E of Table Mtn., Porcupine Plat.; $68^{\circ} 18^{\prime} \mathrm{N}, 141^{\circ} 15^{\prime} \mathrm{W}$; (map 137).

Local name reported in 1956 by USGS.

Yankee River: stream, heads in York Mts., flows to Lopp Lagoon, $43 \mathrm{mi}$. NW of Teller, Seward Penin. High.; $65^{\circ} 43^{\prime} \mathrm{N}, 167^{\circ} 22^{\prime} \mathrm{W}$; (map 111).

Prospectors' name reported in 1900 by Brooks (1901, pl. 13), USGS.

Yankee Slough: stream, flows SW $5.5 \mathrm{mi}$. to St. Joe Creek $1 \mathrm{mi}$. $\mathrm{N}$ of its junc. with Yukon River, $55 \mathrm{mi}$. SE of Unalakleet, Innoko Low.; $63^{\circ} 14^{\prime} 45^{\prime \prime} \mathrm{N}, 159^{\circ} 41^{\prime} 00^{\prime \prime} \mathrm{W}$; (map 91 ).

Local name reported in 1949 by USC\&GS

Yanovski, Mount: mountain, 3,492 ft., $8 \mathrm{mi}$. NE of Whale Bay, on S central Baranof I., Alex. Arch.; $56^{\circ} 38^{\prime} 30^{\prime \prime} \mathrm{N}, 134^{\circ} 48^{\prime} 30^{\prime \prime} \mathrm{W}$; $B G N$ 1935; (map 5).

Named in 1935 by USFS "for Semeon Ivanovich Yanovski, Governor of Russian America from October 24, 1818, to September $15,1820 . "$

Yantar, Reka: stream, see Amber Creek.

Yantarni Bay: estuary, $4 \mathrm{mi}$. long, on $\mathrm{S}$ coast of Alaska Penin., NE of Cape Kunmik, Aleutian Ra.; $56^{\circ} 48^{\prime} \mathrm{N}, 157^{\circ} 07^{\prime} \mathrm{W}$; (map 31$)$. 
Var. Baie d'Ambre Jaoune, Yancarnie Bay, Yantarnie Bay, Zaliv Yantarniy.

So named by the Russians because of the reported occurrence of "yantar," or "amber," here; published in French as "Baie d'Ambre Jaoune" by von Krusenstern (1827, map 20), IRN, and as "Z[aliv] Yantarniy" by the Russian Hydrog. Dept. Chart 1379 in 1847.

Yantarni Creek: stream, on Alaska Penin., flows SE $8 \mathrm{mi}$. to head of Yantarni Bay, $6.5 \mathrm{mi}$. N of Cape Kunmik, Aleutian Ra.; 56 $52^{\prime} \mathrm{N}$, $157^{\circ} 11^{\prime} \mathrm{W}$; (map 31$)$.

Local name reported in 1951 by USGS. Yantarnie Bay: estuary, see Yantarni Bay. Yantarniy, Zaliv: bay, see Amber Bay. Yantarniy, Zaliv: estuary, see Yantarni Bay Yantnu River: stream, see Yentna River. Yaponskoi Island: island, see Japonski Island. Yaponskoy, Ostrov: island, see Japonski Island. Yar'am-anatu'ulug: point of land, at $\mathrm{W}$ end of Great East Rookery, on NE coast of St. George I., in Pribilof Is.; $56^{\circ} 36^{\prime} 20^{\prime \prime} \mathrm{N}, 169^{\circ} 29^{\prime} 35^{\prime \prime}$ W; (map 38).

Aleut name reported by Putnam (1903, p. 1016), USC\&GS, meaning "narrow point."

Yarboro Inlet: estuary, see Yarborough Inlet.

Yarborough Inlet: estuary, of $\mathrm{W}$ channel of Sagavanirtok River, near $E$ entrance to Prudhoe Bay, $24 \mathrm{mi}$. SE of Beechey Point, Arctic Plain; (map 150). Var. Yarboro Inlet.

So named by Franklin (1828, p. 159), RN Aug. 16, 1826. Leffingwell (1919, p. 89) writes, "no inlet exists, unless it is the western mouth of the river." Marcus Baker (1906, p. 685) spells it Yarboro.

Yarger Lake: lake, $1.4 \mathrm{mi}$. long, between Alaska Highway and Chisana River, $5.5 \mathrm{mi}$. SE of Northway Junction, Alaska Ra.; 62 $58^{\prime} \mathrm{N}$, $141^{\circ} 39^{\prime} \mathrm{W}$; (map 84).

Local name reported in 1954 by USGS.

Yarrow Creek: stream, flows NE $1.1 \mathrm{mi}$. to Eldorado Creek which flows to Noxapaga River, $26 \mathrm{mi}$. NW of Imuruk Lake, Seward Penin High.; $65^{\circ} 42 \mathrm{~N}, 164^{\circ} 08^{\prime} \mathrm{W}$; (map 110).

Prospectors' name reported on the 1908 "Map of Seward Peninsula" by Arthur Gibson. Yarukturuk Creek : stream, see Uyakturok Creek. Yas Bay: estuary, see Yes Bay.

Yasha Island: island, $0.2 \mathrm{mi}$. across, in Chatham Strait, $5 \mathrm{mi}$. S of Admiralty I. and $30 \mathrm{mi}$. SE of Sitka, Alex. Arch.; 56 $58^{\prime} 00^{\prime \prime}$ N, 134 $33^{\circ}$ $30^{\prime \prime} \mathrm{W}$; (map 5).

Russian name, diminutive of "Yakov" and equivalent to the English "Jacob"; probably first applied to this island in 1809 by Ivan Vasiliev the first.

Yasni Island: island, see Andronica Island.

Yasuda Mountain: mountain, 5,200 ft., $4 \mathrm{mi}$. W of Nichenthraw Mtn. and $20 \mathrm{mi}$. N of Arctic Village, Brooks Ra.; $68^{\circ} 25^{\prime} \mathrm{N}, 145^{\circ} 32^{\prime} \mathrm{W}$; (map 136).

Locally named for Frank Yasuda who came to Alaska about 1900 ; reported in 1926 by J. B. Mertie, Jr. (in Smith, P. S., and others, 1929, pl. 1), USGS.

Yath-ta-gotna River: stream, see Iditarod River. Yatseha Hini: stream, see Yahtse River.
Yatshergamut: locality, see Yacherk.

Yatuk Creek: stream, on $\mathrm{W}$ coast of Prince of Wales I., flows S $4 \mathrm{mi}$. to Naukati Bay, 30 mi. N of Craig, Alex. Arch.; 55 53'25" N, $133^{\circ} 09^{\prime} 20^{\prime \prime} \mathrm{W}$; (map 4$)$.

Indian name recorded in 1949 by USGS.

Yayik Peninsula: peninsula, see Chilkat Peninsula.

Yealthanuk Mountain: mountain, see Surgeon Mountain.

Yealthkaklatselahini: stream, see Little Boulder Creek.

Yearling Lake: lake, $0.5 \mathrm{mi}$. long, on Kenai Penin. NE of Camp Island Lake, $20 \mathrm{mi}$. NE of Kenai, Cook Inlet Low.; $60^{\circ} 38^{\prime} 15^{\prime \prime} \mathrm{N}$, $150^{\circ} 41^{\prime} 00^{\prime \prime} \mathrm{W}$; ( $\left.\operatorname{map} 62\right)$.

Named about 1963 by officials of Kenai National Moose Range, for administrative purposes.

Yeatman, Mount: mountain, 5,670 ft., at head of Irene Glacier, $5.4 \mathrm{mi}$. W of Mount Carmack and $8 \mathrm{mi}$. NW of Skagway, Coast Mts.; $59^{\circ}$. $33^{\prime} 30^{\prime \prime} \mathrm{N}, 135^{\circ} 24^{\prime} 15^{\prime \prime} \mathrm{W}$; ( $\left.\operatorname{map} 45\right)$.

Named in 1898 by J. A. Flemer, USC\&GS. Yedokyevskiye, Ostrova: islands, see Semidi Islands.

Yeek Sha Mountain: mountain, 2,320 ft., on Admiralty I., 2 mi. S of Pleasant Bay, on $E$ shore of Seymour Bay, $49 \mathrm{mi}$. S of Juneau, Alex. Arch.; $57^{\circ} 36^{\prime} 30^{\prime \prime} \mathrm{N}, 1^{\circ} 3^{\circ} 59^{\prime} 45^{\prime \prime} \mathrm{W}$; (map 8)

Tlingit Indian name reported in 1951 by USGS.

Yehldagahl Creek: stream, see Yeldagalga Creek.

Yehring Creek: stream, heads in glacier, flows $\mathrm{S} 8 \mathrm{mi}$. to Taku River, $5 \mathrm{mi}$. SW of Canyon I. and $27 \mathrm{mi}$. NE of Juneau, Coast Mts.; 58 $30^{\prime}$ $00^{\prime \prime} \mathrm{N}, 133^{\circ} 48^{\prime} 10^{\prime \prime} \mathrm{W} ;$ BGN 1932; (map 12).

Local name reported in 1932 by B. D. Stewart, USGS, named for Oscar Yehring, a settler who resided in the vicinity of the mouth of this stream.

Yekgolm Ekgalit-tch, Ostrova: islands, see Eckholms, The.

Yekuk: village, see Ekuk.

Yekuk: village, see Ekwok.

Yelchthini: stream, see Kelsall River.

Yeldagalga Creek: stream, heads $1 \mathrm{mi}$. NW of Sinclair Mtn., flows $4 \mathrm{mi}$. W to Chilkoot Inlet, $3.2 \mathrm{mi}$. ENE of Seduction Point and $25 \mathrm{mi}$. S of Skagway, Coast Mts.; $59^{\circ} 06^{\prime} 05^{\prime \prime} \mathrm{N}, 135^{\circ}$ $13^{\prime} 20^{\prime \prime}$ W; (map 45). Var. Yehldagahl Creek.

Tlingit Indian name published in 1923 on IBC Sheet 9 (1951 atlas).

Yellow Bear Mountain: mountain, 3,050 ft., of central Admiralty I., $6 \mathrm{mi}$. S of Hasselborg Lake and $14 \mathrm{mi}$. NE of Angoon, Alex. Arch.; $57^{\circ} 34^{\prime} 10^{\prime \prime} \mathrm{N}, 134^{\circ} 13^{\prime} 30^{\prime \prime} \mathrm{W}$; BGN 1928; (map 9).

Named in 1925 by H. J. Coolidge "after a bear I got there whose hair was almost all a light sandy yellow color."

Yellow Bluff Creek: stream, on Alaska Penin., flows N 17 mi. to Port Heiden, $15 \mathrm{mi}$. S of Port Heiden Airfield, Bristol Bay Low.; $56^{\circ} 46^{\prime} \mathrm{N}$, $158^{\circ} 44^{\prime} \mathrm{W}$; (map 30$)$.
Descriptive name reported in 1923 by R. H. Sargent, USGS.

Yellow Cliffs: cliffs, on E coast of Knight I., 2 $\mathrm{mi}$. SE of Iron Mtn. and $16 \mathrm{mi}$. NE of Chenega, Chugach Mts.; $60^{\circ} 20^{\prime} 30^{\prime \prime} \mathrm{N}, 147^{\circ}$. $38^{\prime} 20^{\prime \prime} \mathrm{W}$; (map 63).

Descriptive name published in 1930 by USC\&GS.

Yellow Creek: stream, flows SE $12 \mathrm{mi}$, to Kvichak River, $60 \mathrm{mi}$. NE of Dillingham, Bristol Bay Low.; $59^{\circ} 11^{\prime} \mathrm{N}, 156^{\circ} 46^{\prime} \mathrm{W}$; (map 52).

Local name reported in 1952 by USGS.

Yellow Creek: stream, in Kantishna Hills, flows $\mathrm{N} 1.4 \mathrm{mi}$. to Glacier Creek, $5.5 \mathrm{mi}$. NNE of Wonder Lake, Alaska Ra.; $63^{\circ} 34^{\prime} 10^{\prime \prime} \mathrm{N}, 150^{\circ}$ $50^{\prime} 05^{\prime \prime} \mathrm{W}$; BGN 1932; (map 88).

Local name shown on a 1916 fieldsheet by C. E. Giffin, USGS.

Yellow Creek: stream, flows W $1.8 \mathrm{mi}$. to Lynx Creek, $1.5 \mathrm{mi}$. W of Lynx Dome and $26 \mathrm{mi}$. WNW of Tanana, Kokrines-Hodzana High.; $65^{\circ} 16^{\prime} 00^{\prime \prime} \mathrm{N}, 152^{\circ} 56^{\prime} 30^{\prime \prime} \mathrm{W}$; (map 106).

Prospectors' name reported in 1956 by R. M. Chapman, USGS.

Yellow Creek: stream, flows NW $4 \mathrm{mi}$. to Beaver Creek, $80 \mathrm{mi}$. W of Circle, Yukon-Tanana High.; $65^{\circ} 46^{\prime} 10^{\prime \prime} \mathrm{N}, 146^{\circ} 45^{\prime} 10^{\prime \prime} \mathrm{W}$; (map 104).

Named by prospectors and published in 1906 by USGS.

Yellow Hill: hill, $540 \mathrm{ft}$., on SW coast of Annette I., $1.7 \mathrm{mi}$. S of Metlakatla, Alex. Arch.; $55^{\circ} 06^{\prime} 10^{\prime \prime} \mathrm{N}, 131^{\circ} 34^{\prime} 29^{\prime \prime} \mathrm{W}$; (map 3).

Descriptive name given in 1883 by Lt. Comdr. H. E. Nichols, USN.

Yellow Island: island, $0.3 \mathrm{mi}$. long, off $\mathrm{S}$ coast of Kupreanof I., Alex. Arch.; $56^{\circ} 25^{\prime} 45^{\prime \prime} \mathrm{N}$, $133^{\circ} 32^{\prime} 45^{\prime \prime} \mathrm{W}$; ( $\operatorname{map} 6$ ).

Local name recorded in 1949 by USGS.

Yellow Jacket Creek: stream, flows S $3 \mathrm{mi}$. to East Fork Matanuska River $55 \mathrm{mi}$. NE of Palmer, Copper River Basin; 61 ${ }^{\circ} 47^{\prime} 35^{\prime \prime} \mathrm{N}$, $147^{\circ} 30^{\prime} 05^{\prime \prime} \mathrm{W}$; BGN 1952; (map 69). Var. Iron Creek.

Local name reported by C. F. Fuechsel, USGS, in 1950. So named because the rocks along the side of the stream are "bright yellow, red, and white."

Yellowjacket Creek: stream, flows NE $13 \mathrm{mi}$. to Talkeetna River, $15 \mathrm{mi}$. N of Talkeetna Glacier and $51 \mathrm{mi}$. E of Talkeetna, Talkeetna Mts. ; $62^{\circ} 24^{\prime} 20^{\prime \prime} \mathrm{N}, 148^{\circ} 31^{\prime} 50^{\prime \prime} \mathrm{W}$; (map 82).

Local name recorded in 1906 by T. G. Gerdine and R. H. Sargent, USGS.

Yellow Point: point of land, on NE shore of Tamgas Harbor, Annette I., Alex. Arch.; $55^{\circ}$.

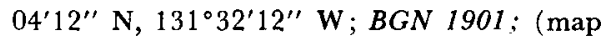
3). Var. Signal Point.

This point was probably named in 1883 by Lt. Comdr. H. E. Nichols, USN; called "Signal Point" by USC\&GS in 1886.

Yellow Point: point of land, in Peril Strait, on Baranof I., $0.7 \mathrm{mi}$. N of Middle Point and 28 mi. NW of Sitka, Alex. Arch.; $57^{\circ} 26^{\prime} 50^{\prime \prime} \mathrm{N}$, $135^{\circ} 33^{\prime} 00^{\prime \prime}$ W; (map 9). Var. Mys Zheltyy, Zholti Point. 
An 1882 translation by USC\&GS of name published in 1848 on Russian Hydrog. Dept. Chart 1397 as "M[ys] Zheltyy."

Yellow Pup: stream, flows NE $1 \mathrm{mi}$. to Pearl Creek, $15 \mathrm{mi}$. NE of Fairbanks, YukonTanana High.; $64^{\circ} 59^{\prime} 20^{\prime \prime} \mathrm{N}, 147^{\circ} 17^{\prime} 40^{\prime \prime} \mathrm{W}$; $B G N$ 1933; (map 100). Var. Pearl Creek, Yellow Pup Creek.

Local name reported in 1913 by $\mathrm{T}$. Chapin (in Brooks and others, 1914, fig. 5), USGS.

Yellow River: stream, flows SW $60 \mathrm{mi}$. to Anvik River, $57 \mathrm{mi}$. NW of Holy Cross, Nulato Hills; $62^{\circ} 55^{\prime} \mathrm{N}, 160^{\circ} 41^{\prime} \mathrm{W}$; (map 78).

Prospectors' descriptive name reported in 1916 by G. L. Harrington (in Brooks and others, 1918, pl. 16), USGS.

Yellow River: stream, flows to the central section of Kuskokwim River.

During the winter of 1900-01, a typical dogsled stampede to the Kuskokwim Valley was made by a large number of men from Nome. The movement was based on rumors of the discovery of placer gold on a stream designated as the Yellow River, but the location of this stream has never been determined. The stampede was called the "Yellow River stampede" or the "Pete McDonald stampede" (Brooks and others, 1915, p. 299).

Yellow Rock: rock, on NE coast of Baranof $I$. in Kelp Bay, NE of Crow I., $15 \mathrm{mi}$. $\mathrm{N}$ of Baranof, Alex. Arch.; $57^{\circ} 18^{\prime} 15^{\prime \prime}$ N, $134^{\circ}$. $54^{\prime} 00^{\prime \prime}$ W; (map 9).

Descriptive name given in 1895 by Lt. Comdr. E. K. Moore, USN.

Yellow Rocks: islands, $0.3 \mathrm{mi}$. long, $\mathrm{NE}$ of Dixon Entrance, $6.5 \mathrm{mi}$. S of Duke I., Alex. Arch.; $54^{\circ} 47^{\prime} 30^{\prime \prime} \mathrm{N}, 131^{\circ} 13^{\prime} 45^{\prime \prime} \mathrm{W}$; (map 2).

Descriptive name given in 1883 by Lt. Comdr. H. E. Nichols, USN.

Yellowstone Creek: stream, flows NW $4.4 \mathrm{mi}$. to Willow Creek, 0.1 mi. E of Port Clarence and $5 \mathrm{mi}$. SW of Teller, Seward Penin. High.; $65^{\circ} 12^{\prime} \mathrm{N}, 166^{\circ} 28^{\prime} \mathrm{W}$; (map 111).

Local name reported in 1900 by $E$. C. Barnard (in Brooks, 1901, pl. 17), USGS.

Yellow Water Creek: stream, flows S $8.2 \mathrm{mi}$. to Scottie Creek, $21 \mathrm{mi}$. $\mathrm{N}$ of Point where Alaska Highway crosses Alaska-Canada boundary, Alaska Ra.; $62^{\circ} 54^{\prime} 50^{\prime \prime} \mathrm{N}, 141^{\circ}$. $00^{\prime} 10^{\prime \prime}$ W ; BGN 1912; (map 84).

Name reported in 1912 by Thomas Riggs, IBC, "because of the water's yellow appearance."

Yellow Water Creek: stream, see Swamp Creek.

Yellowy Island: island, see Spruce Island.

Yelnu Islets: islands, group extends $0.2 \mathrm{mi}$., in Pearse Canal, $0.9 \mathrm{mi}$. S of Hidden Inlet, Coast Mts.; $54^{\circ} 56^{\prime} \mathrm{N}, 130^{\circ} 20^{\prime} \mathrm{W} ; B G N$ 1937; (map 2). Var. Swirl Islands, Yentnoo Islets.

Local name recorded in 1936 by USC\&GS. Yelovoi: locality, on SW coast of Spruce I. in Narrow Strait, $7.5 \mathrm{mi}$. N of Kodiak, Kodiak I. ; $57^{\circ} 54^{\prime} \mathrm{N}, 152^{\circ} 24^{\prime} \mathrm{W}$; (map 34).

Russian name for a former Eskimo village or camp, reported in the 1880 Census, with a population of 78 , by Petroff $(1884$, p. 28$)$.

Yelovoi: point of land, see Uzinki Point.
Yelovoi, Ostrov: island, see Spruce Island. Yelovoi Island: island, see Spruce Island. Yelovoy, Ostrov: island, see Elovoi Island.

Yelovoy, Mys: point of land, see Uzinki Point. Yelovoy, Proliv: water passage, see Narrow Strait.

Yelovoy Vneshney, Mys: point of land, see Spruce Cape.

Yelowoi Island: island, see Elovoi Island.

Yelowy Island: island, see Spruce Island.

Yelper Cove: cove, on Hinchinbrook I., at NW entrance to Hawkins Islarid Cutoff, $22 \mathrm{mi}$. SW of Cordova, Chugach Mts.; $60^{\circ} 28^{\prime} \mathrm{N}$, $146^{\circ} 23^{\prime} \mathrm{W}$; (map 64).

Name published in 1950 by USGS

Yeltakaska Creek: stream, see Little Boulder Creek.

Yempalizda, Mys de la: point of land, see Palisade Point.

Yendestaka: locality, see Gantegastaki.

Yende'staq!e: locality, see Gantegastaki.

Yenituk Creek: stream, flows SE $7 \mathrm{mi}$. to John River $9 \mathrm{mi}$. NE of Cairn Mtn. and $67 \mathrm{mi}$. NW of Wiseman, Brooks Ra.; 67 $57^{\prime} 00^{\prime \prime} \mathrm{N}$, $152^{\circ} 13^{\prime} 00^{\prime \prime} \mathrm{W}$; BGN 1932; (map 124).

Eskimo name reported about 1930 by Marshall (1956, p. 107) who wrote, "near the mouth of a minor western tributary, Yenituck (white face) Creek ***. Its name refers to the appearance of the hills in which the stream rises."

Yenlo, Mount: mountain, 3,961 ft., in Yenlo Hills, 39 mi. SW of Talkeetna, Alaska Ra.; $62^{\circ} 09^{\prime} \mathrm{N}, 151^{\circ} 16^{\prime} \mathrm{W}$; (map 81$)$.

Named in 1898 by J. E. Spurr and W. S. Post, USGS.

Yenlo Greek: stream, heads in lake W of Willow Mtn., flows SE $15.5 \mathrm{mi}$. to Lake Creek, $33 \mathrm{mi}$. $\mathrm{SE}$ of Talkeetna, Cook Inlet Low.; $62^{\circ} 03^{\prime} 45^{\prime \prime}$ $\mathrm{N}, 150^{\circ} 59^{\prime} 20^{\prime \prime} \mathrm{W}$; (map 81 ).

Prospectors' name reported in 1906 by R. W. Purter, USGS.

Yenlo Hills: ridge, extends N-S $10 \mathrm{mi}$., $37 \mathrm{mi}$. SW of Talkeetna, Alaska Ra.; $62^{\circ} 08^{\prime} \mathrm{N}$, $151^{\circ} 16^{\prime} \mathrm{W}$; $(\operatorname{map} 81)$.

Local name reported in 1911 by $S . R$. Capps (in Brooks and others, 1912, pl. 9), USGS

Yentna Glacier: glacier, heads in Mount McKinley National Park, trends SW $20 \mathrm{mi}$. to its terminus at East Fork Yentna River, $60 \mathrm{mi}$. NW of Talkeetna, Alaska Ra.; $62^{\circ} 35^{\prime} 30^{\prime \prime} \mathrm{N}$, $151^{\circ} 53^{\prime} 30^{\prime \prime} \mathrm{W}$; (map 81).

Name published by Cook (1908, p. 157).

Yentna River: stream, formed by its East and West Forks at $62^{\circ} 16^{\prime} 50^{\prime \prime} \mathrm{N}, 151^{\circ} 43^{\prime} 10^{\prime \prime} \mathrm{W}$, flows SE $75 \mathrm{mi}$. to Susitna River, $30 \mathrm{mi}$. NW of Anchorage, Cook Inlet Low.; 61 $33^{\prime} 45^{\prime \prime}$ N, $150^{\circ} 28^{\prime} 30^{\prime \prime} \mathrm{W}$; (map 70). Var. Johnson River, Katcheldat River, Yadno River, Yantnu River, Yetna River.

Tanaina Indian name reported by Spurr (1900, p. 46), USGS. "Sometimes called Johnson River after the first white man to ascend it."

Yentnoo Islets: islands, see Yelnu Islets.

Yeri Pass: pass, see Yori Pass.
Yermak Lake: lake, $1.1 \mathrm{mi}$. long, $2.5 \mathrm{mi}$. S of Gut Bay, on SE coast of Baranof I., Alex. Arch.; 56 $41^{\prime} 45^{\prime \prime} \mathrm{N}, 134^{\circ} 39^{\prime} 30^{\prime \prime} \mathrm{W}$; BGN 1935; (map 5).

Named in 1935 by USFS "for a ship in fleet brought to Sitka by Baranof in 1804 when he re-established the post after an absence of two years." See Baranof Island.

Yerrick Creek: stream, heads on Mount Neuberger and flows $\mathrm{N}$ to Tanana River, $6.5 \mathrm{mi}$. W of Tanacross, Alaska Ra.; 63 $24^{\prime} \mathrm{N}$, $143^{\circ} 33^{\prime} \mathrm{W}$; (map 85).

Local name published by USGS in 1951. Yes: locality, seg Yes Bay.

Yes Bay: locality, on NE coast of Cleveland Penin., 3 mi. N of Spacious Bay, Alex. Arch.; $55^{\circ} 55^{\prime}$ N, $131^{\circ} 48^{\prime}$ W; BGN 1899; (map 3). $V$ ar. Yess Bay, Yes, McDonald.

This is the site of an abandoned cannery which was established in 1886 . Published as "Yess Bay * * * about 30 Chinese usually empoyed here, with a dozen white men, and a large number of native [Indian] men and women" (11th Census in 1890, 1893, p. 23).

Yes Bay: estuary, extends NW $6 \mathrm{mi}$. off Behm Canal, on NE coast of Cleveland Penin., Alex. Arch.; 55 $53^{\prime} \mathrm{N}, 131^{\circ} 44^{\prime} \mathrm{W}$; BGN 1899; (map 3). Var. McDonald Bay, Yaas Bay, Yas Bay, Yess Bay.

Name published as "Yess Bay" in the 11 th Census in 1890 (1893, p. 23); derived from the Tlingit Indian word "yas" meaning "mussel." This feature was called "McDonald Bay" in 1879 by W. H. Dall, USC\&GS.

Yess Bay: locality, see Yes Bay.

Yess Bay: estuary, see Yes Bay.

Yestrelya, Zaliv de la: estuary, see Estrella Port. Yetna Creek: stream, flows E $10 \mathrm{mi}$. to Copper River, $0.3 \mathrm{mi}$. $\mathrm{N}$ of Copper Center and $66 \mathrm{mi}$. $\mathrm{NE}$ of Valdez, Copper River Basin; 61 '57'30' $\mathrm{N}, 145^{\circ} 17^{\prime} 30^{\prime \prime} \mathrm{W}$; (map 68).

Local name published in 1950 by USGS.

Yetna River: stream, formed by confluence of Big and Little Yetna Rivers, flows NE $60 \mathrm{mi}$. to Iditarod River, $43 \mathrm{mi}$. NE of Holikachuck and $55 \mathrm{mi}$. W of Ophir, Innoko Low.; $63^{\circ} 10^{\prime} 45^{\prime \prime} \mathrm{N}, 158^{\circ} 16^{\prime} 00^{\prime \prime} \mathrm{W}$; (map 90).

Local name obtained in 1954 by R. E. Isto, USGS.

Yetna River: stream, see Yentna River.

Yevvashichey, Zaliv: bay, see Marmot Bay.

Y'hindastachy: locality, see Gantegastaki.

Yindastuki: locality, see Gantegastaki.

Yindastuki Indian Reservation: locality, see Gantegastaki.

Yistletaw: locality, on right bank of Yukon River, 23 mi. NE of Nulato, Koyukuk Low.; $64^{\circ} 49^{\prime}$ $\mathrm{N}, 157^{\circ} 22^{\prime} \mathrm{W}$; (map 97).

Indian fish camp reported in 1952 by USGS Yklyk: mountain, see Barometer Mountain.

Y Lake: lake, $1.3 \mathrm{mi}$. long, $5 \mathrm{mi}$. W of Deep Lake, $33 \mathrm{mi}$. NW of Glennallen, Copper River Basin; $62^{\circ} 29^{\prime} \mathrm{N}, 146^{\circ} 13^{\prime} \mathrm{W}$; (map 83).

Local name reported in 1951 by USGS

Yllota Slough: stream, anabranch of Yukon River at Fort Yukon, flows NW $2.3 \mathrm{mi}$., Yukon Flats; $66^{\circ} 33^{\prime} 30^{\prime \prime} \mathrm{N}, 145^{\circ} 14^{\prime} 40^{\prime \prime} \mathrm{W}$; (map 119). 
Local name obtained in 1956 by USGS.

Ynveeghik River: stream, flows NW $7 \mathrm{mi}$. to lagoon, 2 mi. SW of Tikukha Point, $\mathrm{N}$ coast of St. Lawrence I.; $63^{\circ} 34^{\prime} \mathrm{N}, 170^{\circ} 57^{\prime} \mathrm{W}$; $B G N$ 1951; (map 93). Var. Anvik River, Ingresik, River.

Eskimo name more correctly rendered "Ingresik," meaning "rising slope." The entry spelling was reported in 1949 by Maj. H. B. Allen, USAF.

Yoder Lake: lake, $0.6 \mathrm{mi}$. long, $0.9 \mathrm{mi}$. NNW of Blackfish Lake, $21 \mathrm{mi}$ SSW of village of Lake Minchumina, Tanana Low.; 63 $37^{\prime} 45^{\prime \prime} \mathrm{N}$, $152^{\circ} 41^{\prime} 30^{\prime \prime} \mathrm{W}$; (map 88).

Local name obtained in 1958 from Fabian Carey and "Val" Blackburn by USGS.

Yohn Lake: lake, $0.6 \mathrm{mi}$. long, W of Little Susitna River, $19 \mathrm{mi}$. NW of Anchorage, Cook Inlet Low.; $61^{\circ} 28^{\prime} 10^{\prime \prime} \mathrm{N}, 150^{\circ} 10^{\prime} 30^{\prime \prime} \mathrm{W}$; $(\operatorname{map} 70)$.

Local name reported in 1958 by USGS.

Yokakek: locality, on right bank of Yukon River, $56 \mathrm{mi}$. E of Nulato, Koyukuk Low.; $64^{\circ} 43^{\prime} \mathrm{N}$, $156^{\circ} 13^{\prime} \mathrm{W}$; (map 97)

Koyukan Indian camp shown on a 1905 manuscript navigation chart of the Yukon River.

Yokeak Creek: stream, see Big Boulder Creek.

Yoke Bay: bay, $3 \mathrm{mi}$. across, on SE coast of Great Sitkin I., Aleutian Is.; $52^{\circ} 00^{\prime} 30^{\prime \prime} \mathrm{N}, 176^{\circ} 00^{\prime}$ $00^{\prime \prime} \mathrm{W} ;$ BGN 19.36; (map 17).

So named by members of the U.S. Navy Aleutian Island Survey Expedition in 1934, because "its shape suggests the letter $Y$. Yoke is the name for the letter $Y$ when sent by signal."

Yoke Mountain: mountain, 2,539 ft., with 2 peaks called North Yoke and South Yoke Mts., 4 mi. E of Jacksmith Bay and $28 \mathrm{mi}$. N of Goodnews, Kilbuck-Kuskokwim Mts.; $59^{\circ}$. $30^{\prime} \mathrm{N}, 161^{\circ} 38^{\prime} \mathrm{W}$; (map 53$)$.

Named "North Yoke" and "South Yoke" in 1914 by USC\&GS.

Yoke Pass: water passage, between Great Sitkin I. and Igitkin Bank, Aleutian Is.; 51 $59^{\prime} 00^{\prime \prime}$ N, $176^{\circ} 00^{\prime} 50^{\prime \prime} \mathrm{W}$; BGN 1936; (map 17).

Name derived from Yoke Bay, and given by members of the U.S. Navy Aleutian Island Survey Expedition in 1934.

Yokneda Lakes: lakes, group, $2 \mathrm{mi}$. across, 4.7 mi. S of Chistochina and $37 \mathrm{mi}$. NE of Glennallen, Copper River Basin; $62^{\circ} 29^{\prime} \mathrm{N}, 144^{\circ}$ 42' W; (map 83).

Indian name reported in 1949 by USGS.

Yokontah Slough: watercourse, see Yokontoh Slough.

Yokontoh Slough: watercourse, $5 \mathrm{mi}$. long, anabranch of Yukon River, SE of Blackburn I. and $54 \mathrm{mi}$. SE of Unalakleet, Innoko Low.; $63^{\circ} 21^{\prime} 35^{\prime \prime} \mathrm{N}, 159^{\circ} 28^{\prime} 10^{\prime \prime} \mathrm{W}$; BGN 1960; (map 91). Var. Papa Willic Creek, Yokontah Slough, Yukontoh Slough.

Indian name reported in 1935 by Frederica de Laguna, BAE.

Yokuchargut Crcek: stream, see Hess Creek.

Yondestuk: locality, see Gantegastaki.

Yori Pass: pass, 3,700 ft, near head of Contact Creek, on Alaska Penin., in Katmai National
Monument, $25 \mathrm{mi}$. NW of Mount Katmai, Aleutian Ra.; $58^{\circ} 20^{\prime} 15^{\prime \prime} \mathrm{N}, 155^{\circ} 38^{\prime} 45^{\prime \prime} \mathrm{W}$; (map 42). Var. Yeri Pass.

Named by R. F. Griggs for Charles Yori, his assistant on the 1919 National Geographic Society Katmai Expedition.

York: locality, on Bering Sea coast, at mouth of Anikovik River, $14 \mathrm{mi}$. SW of Cape Prince of Wales and $41 \mathrm{mi}$. NW of Teller, Seward Penin. High.; $65^{\circ} 30^{\prime} \mathrm{N}, 167^{\circ} 41^{\prime} \mathrm{W}$; (map 111).

Site of a mining camp established in 1899. Brooks (1901, p. 69), USGS, noted: "In the spring of 1900 York promised to be a place of importance, but in the early fall its population had been reduced to about twenty or thirty." Upon Brooks' return to the States, he widely disseminated the announcement that stream tin had been found in the vicinity of York (Steidtmann and Cathcart, 1922, p. 13-14). The camp probably had a resurgence of people for "In the latter part of the season [1901], a great many prospectors searched the York region for tin" (Collier, 1904, p. 11). A post office was established here in 1900 and was discontinued in 1902 (Ricks, 1965, p. 72). By 1907 York was described as "a small collection of cabins and tents" (Collier and others, 1908, p. 59).

York, Cape: point of land, about $6 \mathrm{mi}$. SW of York Mts., on Bering Sea, $35 \mathrm{mi}$. NW of Teller, Seward Penin. High.; $65^{\circ} 25^{\prime}$ N, $167^{\circ}$. $28^{\prime} \mathrm{W}$; (map 111). Var. Mys Iork, Mys Vork.

Named in 1827 by Capt. Beechey (1831, p. 541), RN, "in honor of his late Royal Highness," the Duke of York of England.

York Creek: stream, $4 \mathrm{mi}$. long, flows $\mathrm{W}$ to Glacier Bay E of S tip of South Marble I., in Glacier Bay National Monument, St. Elias Mts.; $58^{\circ} 38^{\prime} 25^{\prime \prime} \mathrm{N}, 135^{\circ} 55^{\prime} 00^{\prime \prime} \mathrm{W}$; $B G N$ 1948; (map 11). Var. York River.

Named in 1948 for William York, a camp helper for a time with H. F. Reid's expedition in 1892.

York Creek: stream, heads in York Mts., flows NE $18 \mathrm{mi}$. to Pinguk River which flows to Arctic Lagoon, $40 \mathrm{mi}$. NW of Teller, Seward Penin. High.; $65^{\circ} 46^{\prime} \mathrm{N}, 167^{\circ} 02^{\prime} \mathrm{W}$; (map 111).

Prospectors' name reported in 1903 by Collier (1904, pl. 2), USGS.

York River: stream, see York Creek.

York Mountains: mountains, in group, $18 \mathrm{mi}$. long and $10 \mathrm{mi}$. wide, on $\mathrm{S}$ coast Seward Penin., $20 \mathrm{mi}$. SE of Cape Prince of Wales and $25 \mathrm{mi}$. NW of Teller, Seward Penin. High.; $65^{\circ} 30^{\prime} \mathrm{N}, 167^{\circ} 15^{\prime} \mathrm{W}$; (map 111).

Local name reported in 1900 by Brooks (1901, pl. 3), USGS.

Youcon: stream, see Yukon River.

You Creek: stream, heads at $\mathrm{E}$ end of Brooks Ra.; flows SE $7 \mathrm{mi}$. across Alaska-Canada boundary to Firth River in Yukon, Canada; $68^{\circ} 40^{\prime} 30^{\prime \prime} \mathrm{N}, 140^{\circ} 55^{\prime} 00^{\prime \prime} \mathrm{W}$; (map 137).

Local name reported in 1956 by USGS

Youghapotit Rocks: rocks, $14 \mathrm{mi}$. SE of Siknik Cape, $14 \mathrm{mi}$. NW of Southeast Cape, off St.
Lawrence I.; $63^{\circ} 04^{\prime} \mathrm{N}, 169^{\circ} 57^{\prime} \mathrm{W} ; B G N$ 1951; (map 93). Var. Ukhapatit.

Eskimo name more correctly rendered "Ukhapatit"; réported in 1949 by Maj. H. B. Allen, USAF.

Youkolny: island, see Ukolnoi Island.

Youlak Island: island, see Ulak Island.

Younaska Island: island, see Yunaska Island.

Young, Mount: mountain, 5,700 ft., on boundary of Glacier Bay National Monument, in Chilkat Range, $4.3 \mathrm{mi}$. NE of Endicott Lake and $57 \mathrm{mi}$. NW of Juneau, St. Elias Mts.; $58^{\circ} 51^{\prime} 45^{\prime \prime} \mathrm{N}, 135^{\circ} 34^{\prime} 35^{\prime \prime} \mathrm{W}$; (map 11).

Named in 1892 by Harry F. Reid, USGS, for Rev. S. Hall Young, who accompanied John Muir to Glacier Bay in 1879-80 (Reid, 1892, p. 30).

Young, Point: point of land, in Stephens Passsage, on N. coast of Admiralty I., $0.5 \mathrm{mi} \mathrm{NE}$ of Admiralty Cove and $9 \mathrm{mi}$. SW of Juneau, Alex. Arch.; $58^{\circ} 11^{\prime} 45^{\prime \prime} \mathrm{N}, 134^{\circ} 33^{\prime} 30^{\prime \prime} \mathrm{W}$; (map 11).

Discovered by Joseph Whidbey, RN, and named in 1794 by Capt. George Vancouver, RN, for Adm. Sir George Young, RN (Wagner, 1937, p. 422).

Young Bay: bay, $5 \mathrm{mi}$. across, on $\mathrm{N}$ coast of Admiralty I., W of Point Young, $12 \mathrm{mi} \mathrm{SW}$ of Juneau, Coast Mts. ; $58^{\circ} 10^{\prime} \mathrm{N}, 134^{\circ} 40^{\prime} \mathrm{W}$; (map 11).

Apparently named by W. H. Dall, USC\&GS, and published in 1883 Coast Pilot (p. 172). The name probably derived from Point Young which was named by Capt. George Vancouver, RN, in 1794.

Young Beach: beach, on N coast of Admiralty I., $0.2 \mathrm{mi}$. SW of Point Young and $9 \mathrm{mi}$. SW of Juneau, Alex. Arch.; 58 $11^{\prime} 30^{\prime \prime} \mathrm{N}$, $134^{\circ} 34^{\prime} 15^{\prime \prime} \mathrm{W}$; (map 11).

Local name published in 1951 by USGS.

Young Creek: stream, heads at glacier terminus and flows $28 \mathrm{mi}$. NW to Nizina River, $3 \mathrm{mi}$. SE of McCarthy, St. Elias Mts.; 61 ${ }^{\circ} 22^{\prime} \mathrm{N}$, $142^{\circ} 37^{\prime} \mathrm{W}$; (map 67).

Named in 1901 by T. G. Gerdine (Moffit, 1914, pl. 1), USGS, for Robert Young, a member of his party.

Young Creek: stream, flows S $9 \mathrm{mi}$. to Kings River, $16 \mathrm{mi}$. NE of Palmer, Chugach Mts.; $61^{\circ} 44^{\prime} 55^{\prime \prime} \mathrm{N}, 1^{\circ} 48^{\circ} 42^{\prime} 25^{\prime \prime}$ W; (map 69). Var. Little Kings Creek, Youngs Creek.

Named by Capt. E. F. Glenn, USA, in 1898, after Cpl. Young [cnna], a member of his party.

Young Creek: stream, flows $4.5 \mathrm{mi}$. SE to Rock Lakc, $5 \mathrm{mi}$. $\mathrm{N}$ of Pingpong $\mathrm{Mtn}$. and $59 \mathrm{mi}$. $\mathrm{NE}$ of McCarty, Alaska Ra.; $61^{\circ} 48^{\prime} 20^{\prime \prime} \mathrm{N}$, $141^{\circ} 19^{\prime} 00^{\prime \prime} \mathrm{W}$; ( $\operatorname{map} 67$ ).

Local name obtained by USGS and published on maps since 1954.

Young Creek: stream, flows N $5 \mathrm{mi}$. to Wood River $33 \mathrm{mi}$. SE of Healy, Alaska Ra.; $63^{\circ} 45^{\prime} \mathrm{N}, 147^{\circ} 53^{\prime} \mathrm{W}$; (map 87).

Local name reported in 1910 by J. W. Bagley (in Capps, 1912, pl. 2), USGS.

Younger Creek: stream, heads in Canada, flows W $3 \mathrm{mi}$. to Poker Creek, $52 \mathrm{mi}$. S of Eagle, 
Yukon-Tanana High.; $64^{\circ} 03^{\prime} \mathrm{N}, 141^{\circ} 02^{\prime} \mathrm{W}$; (map 102).

Named by prospectors; reported in 1896 by Spurr (1898, pl. 46), USGS.

Young Glacier: glacier, see Dawes Glacier.

Young Goose Creek: stream, flows NE $4 \mathrm{mi}$. to West Fork Buckland River, $41 \mathrm{mi}$. NE of Haycock, Seward Penin. High. ; $65^{\circ} 45^{\prime}$ N, $160^{\circ} 35^{\prime}$ W; (map 109).

Local name published on maps after 1950.

Young Hill: mountain, 2,360 ft., $1.4 \mathrm{mi}$. SE of Winter Lake, Attu I., Aleutian Is. ; $52^{\circ} 55^{\prime} 23^{\prime \prime}$ $N, 173^{\circ} 02^{\prime} 05^{\prime \prime} \mathrm{E}$; (map 13).

Named by the U.S. Army during its occupation of the island during World War II ; name shown on an AMS map published in 1948.

Young Island: island, $2 \mathrm{mi}$. across, in Beardslee Is., in Glacier Bay, Glacier Bay National Monument, $0.2 \mathrm{mi}$. NW of Lester I., and 57 mi. WNW of Juneau, St. Elias Mts.; $58^{\circ} 28^{\prime}$ $30^{\prime \prime} \mathrm{N}, 135^{\circ} 58^{\prime} 30^{\prime \prime} \mathrm{W} . \quad B G N$ 1948; (map 11).

Named in 1938 by a USC\&GS field party for Rev. S. Hall Young, who accompanied John Muir to Glacier Bay in 1879-80.

Young Island: island, bounded by Huntington Slough and Koyukuk River, $21 \mathrm{mi}$. NE of Roundabout Mtn., Koyukuk Low.; $65^{\circ} 49^{\prime} \mathrm{N}$, $156^{\circ} 17^{\prime} \mathrm{W}$; (map 108). Var. Dall Island, Dolls Island.

"River boat name" reported in 1900 by Lt. B. H. Camden, USRCS. This may be the same island Lt. H. T. Allen, USA, in 1885 called "Dall Island" for W. H. Dall, USC\&GS.

Young Lake: lake, $6 \mathrm{mi}$. long, on Admiralty Creek, $4 \mathrm{mi}$. SE of Admiralty Cove and 12 mi. SSW of Juneau, Alex. Arch.; $58^{\circ} 08^{\prime} 00^{\prime \prime}$ $\mathrm{N}, 134^{\circ} 29^{\prime} 30^{\prime \prime} \mathrm{W}$; (map 11).

Local name published in 1946 by USFS.

Young Rock: rock, $7.5 \mathrm{mi}$. S of Wrangell, off N coast of Etolin I., Alex. Arch.; $56^{\circ} 21^{\prime} 30^{\prime \prime} \mathrm{N}$, $132^{\circ} 23^{\prime} 10^{\prime \prime} \mathrm{W}$; (map 6).

Named in 1882 by USC\&GS for Rev. Samuel Hall Young who discovered this rock the same year.

Youngs Creek: stream, see Young Creek.

Youngs Island: island, $3.9 \mathrm{mi}$. long, between Yukon River and Pike Slough, $4 \mathrm{mi}$. SW of Birches, Nowitna Low. ; $65^{\circ} 05^{\prime} \mathrm{N}, 153^{\circ} 41^{\prime} \mathrm{W}$; (map 107).

Riverboat pilots' name shown on a 1940 "Navigation Chart of the Tanana-Yukon Rivers" published by the Department of the Interior.

Youngstown: locality, site of settlement, on E bank of Yentna River, at Youngstown Bend, $50 \mathrm{mi}$. SW of Talkeetna, Alaska Ra.; $62^{\circ} 13^{\prime}$ $50^{\prime \prime} \mathrm{N}, 151^{\circ} 39^{\prime} 00^{\prime \prime} \mathrm{W}$; (map 81).

Name reported in 1906 by R. W. Porter, USGS.

Youngstown Bend: bend, in Yentna River 10 mi. SW of Collinsville and $50 \mathrm{mi}$. SW of Talkeetna, Alaska Ra.; $62^{\circ} \uparrow 3^{\prime} 45^{\prime \prime} \mathrm{N}, 151^{\circ} 38^{\prime} 30^{\prime \prime}$ W; (map 81).

Local name reported in 1958 by USGS.

Youp-nut: stream, see Anikovik River.
Your Creek: stream, flows SE $46 \mathrm{mi}$. to Middle Fork Chandalar River, $14 \mathrm{mi}$. E of Bend Mtn and $28 \mathrm{mi}$. NE of Chandalar, Brooks Ra. $67^{\circ} 47^{\prime} \mathrm{N}, 147^{\circ} 46^{\prime} \mathrm{W}$; (map 123).

Prospectors' name obtained in 1909 by A G. Maddren (in Brooks and others, 1910, pl. 7), USGS.

Youth Creek: stream, flows SE $12 \mathrm{mi}$. to Lake Aleknagik, $34 \mathrm{mi}$. NW of Dillingham, Kilbuck-Kuskokwim Mts.; $59^{\circ} 26^{\prime} \mathrm{N}, 159^{\circ} 01^{\prime} \mathrm{W}$; BGN 1931; (map 53).

Local name given by Frank Waskey, local trader and prospector; reported in 1931 by Gerald FitzGerald, USGS.

Youunglik River: stream, see Yuonglik River.

Ysleta: island, sce Isleta.

Yslotillos, Punta de los: point of land, see Isleta, Point.

Yubae Wan: bay, see Temnac Bay.

Yucon: stream, see Yukon River.

Yugnak Rocks: rocks, see Yugnat Rocks.

Yugnat Rocks: rocks, group, extends $1 \mathrm{mi}$. in Shelikof Strait, $1.5 \mathrm{mi}$. E of Kukak Point, on $S$ coast of Alaska Penin., in Katmai National Monument, $34 \mathrm{mi}$. NE of Mount Katmai, Aleutian Ra.; $58^{\circ} 20^{\prime} 50^{\prime \prime} \mathrm{N}, 154^{\circ} 02^{\prime} 30^{\prime \prime} \mathrm{W}$; (map 42). Var. Kamen Yugnat, Yugnak Rocks.

Native name reported in 1831 by Ens. Vasiliev and published in 1847 as "K[amen] Yugnat" on Russian Hydrog. Dept. Chart 1378.

Yugok Lake: lake, $0.4 \mathrm{mi}$. long, on Kenai Penin. between Chick and Paddle Lakes, $30 \mathrm{mi}$. NE of Kenai, Cook Inlet Low.; $60^{\circ} 45^{\prime} 40^{\prime \prime} \mathrm{N}, 150^{\circ}$. $30^{\prime} 45^{\prime \prime} \mathrm{W}$; (map 62).

Named about 1963 by officials of Kenai National Moose Range, for administrative purposes.

Yug Point: point of land, on S tip of Little Kiska I., Aleutian Is.; $51^{\circ} 56^{\prime} 40^{\prime \prime} \mathrm{N}, 177^{\circ} 39^{\prime} 10^{\prime \prime} \mathrm{E}$; $B G N$ 1937; (map 14). Var. South Cape.

Russian word "Yug," meaning "south," given in 1933 by the Hydrog. Office of the U.S. Navy. It was reported in 1905 as "South Cape" by USC\&GS.

Yukagamut: locality, see Akahamut.

Yukagamut: locality, see Nunaikak.

Yukagamute: locality, see Nunaikak.

Yukamak: island, see Chirikof Island.

Yuka Mountain: mountain, see Yuki Mountain. Yukamut: locality, see Akahamut.

Yukaniluk Creek: stream, heads in a lake and flows W $17 \mathrm{mi}$. to Little Bogus Creek, $7 \mathrm{mi}$. NE of Tuluksak and $48 \mathrm{mi}$. SE of Russian Mission, Yukon-Kuskokwim Delta ; $61^{\circ} 10^{\prime} \mathrm{N}$, $160^{\circ} 47^{\prime} \mathrm{W}$; (map 73 ).

Local name reported by USC\&GS in 1948. Yukhtokialgamute: locality, see Yakchilak. Yukie Island: island, see Yuki Island.

Yuki Island: island, in Yukon River, $60 \mathrm{mi}$. E of Nulato, Kilbuck-Kuskokwim Mts.; 64 $43^{\prime} \mathrm{N}$, $156^{\circ} 04^{\prime} \mathrm{W}$; (map 97). Var. Yukie Island.

Riverboat pilots' name shown on a 1940 "Navigation Chart of the Tanana-Yukon Rivers" published by U.S. Dept. of Interior.

Yuki Mountain: mountain, 2,149 ft., $23 \mathrm{mi}$. SW of Ruby, Kilbuck-Kuskokwim Mts.; $64^{\circ} 28^{\prime}$ N, $155^{\circ} 53^{\prime} \mathrm{W}$; (map 98). Var. Yuka Mountain, Yuko Mountain.

Name reported as "Yuko Mountain" in 1921 by USGS; named for the nearby stream. Yuki River: stream, flows NE $85 \mathrm{mi}$. to Yukon River, $59 \mathrm{mi}$. E of Nulato, Kilbuck-Kuskokwim Mts.; $64^{\circ} 43^{\prime} \mathrm{N}, 156^{\circ} 07^{\prime} \mathrm{W}$; (map 97).

Local name reported in 1954 by USGS. Yukkhana, Reka: stream, see Kwikpak Pass. Yukla, Mount: mountain, 7,535 ft., $7.5 \mathrm{mi}$. NE of Moraine Pass and $26 \mathrm{mi}$. E of Anchorage, Chugach Mts.; $61^{\circ} 11^{\prime} 30^{\prime \prime} \mathrm{N}, 1^{\circ} 9^{\circ} 06^{\prime} 30^{\prime \prime} \mathrm{W}$; BGN 1964; (map 69).

Named in 1963 by members of the Mountaineering Club of Alaska; derived from Tanaina Indian name "Yuklahina" meaning "eagle river." "This mountain is the highest in the Eagle River drainage * * *."

Yukla Creek: stream, see Eagle River.

Yuklahina River: stream, see Eagle River.

Yuklahitna River: stream, see Eagle River.

Yukochakat Creek: stream, see Hess Creek.

Yukokakat: stream, see Soonkakat River.

Yuko Mountain: mountain, see Yuki Mountain.

Yukon Bar: ridge, elev. 2,600 ft., extends E 2 mi. from junc. of Hunter and Miller Creeks, 4 mi. SE of Rampart, Yukon-Tanana High.; $65^{\circ} 29^{\prime} \mathrm{N}, 150^{\circ} 02^{\prime} \mathrm{W}$; (map 106).

Prospectors' name shown on a manuscript map dated 1906; reported in 1956 by Orth.

Yukon Creek: stream, flows NW $34 \mathrm{mi}$. to Khotol River, $23 \mathrm{mi}$. S of Nulato, Koyukuk Low.; 64 $24^{\prime} \mathrm{N}, 158^{\circ} 15^{\prime} \mathrm{W}$; (map 97).

Local name reported in 1935 by Frederica de Laguna, BAE.

Yukon Flats: $f$ lat, $180 \mathrm{mi}$. long, and $70 \mathrm{mi}$. wide, along Yukon River and lower course of Porcupine River, extends $60 \mathrm{mi}$. E and $120 \mathrm{mi}$. $\mathrm{W}$ from Fort Yukon; $66^{\circ} 30^{\prime} \mathrm{N}, 146^{\circ} 00^{\prime} \mathrm{W}$.

Descriptive name long, applied to this feature.

Yukon Fork: stream, flows NW $10 \mathrm{mi}$. to South Fork Birch Creek, $42 \mathrm{mi}$. S of Circle, YukonTanana High.; $63^{\circ} 14^{\prime} 30^{\prime \prime} \mathrm{N}, 144^{\circ} 18^{\prime} 40^{\prime \prime} \mathrm{W}$; (map 104). Var. East Fork of Birch Creek, South Fork of Birch Creek.

According to D. C. Witherspoon, USGS, this stream was locally called South Fork or East Fork Birch Creek in 1904. Its present name is Yukon Fork, reported in 1955 by USGS.

Yukon Harbor: cove, $0.7 \mathrm{mi}$. across, on SE coast of Big Koniuji I., in Shumagin Is., Aleutian Ra.; $55^{\circ} 04^{\prime} 20^{\prime \prime}$ N, $159^{\circ} 30^{\prime} 30^{\prime \prime} \mathrm{W}$; (map 27).

Named by W. H. Dall, USC\&GS, in 1874, for the USC\&GS schooner Yukon.

Yukon Hill: mountain, 1,200 ft., $35 \mathrm{mi}$. N of Goodnews, Kilbuck-Kuskokwim Mts.; 59 $35^{\prime}$ N, $161^{\circ} 38^{\prime} \mathrm{W}$; (map 53).

Named in 1914 by USC\&GS for its surveying vessel Yukon; published in 1915 on Chart 9103.

Yukon Hills : mountains, see Kokrines Hills.

Yukon Island: island, $1.5 \mathrm{mi}$. long, on SE edge of Kachemak Bay, on Kenai Penin. $9 \mathrm{mi}$. S of Homer, Chugach Mts.; 59 $31^{\prime} 30^{\prime \prime} \mathrm{N}, 151^{\circ}$ $29^{\prime} 30^{\prime \prime} \mathrm{W}$; (map 50). 
Named by W. H. Dall, in 1880, for the USC\&GS schooner Yukon.

Yukon-Kuskokwim Portage: portage, $30 \mathrm{mi}$. long, extends generally from Portage Slough on Yukon River up Talbiksok River, across Kulik Lake, down Johnson River and Crooked and Mud Creeks to Kuskokwim River, YukonKuskokwim Delta ; $61^{\circ} 35^{\prime} \mathrm{N}, 160^{\circ} 45^{\prime} \mathrm{W}$; (map 73).

This is the closest the Yukon and Kuskokwim Rivers approach each other. This almost all-water portage between the two great rivers has been used since prehistoric times. Probably the first known white man to use this portage was the Russian, Glazunov, in 1834. Trail cabins were located at various distances along the portage. The airplane has reduced its importance in recent years. R. H. Sargent, USGS, made the first detailed map of the portage in 1919.

Yukon Reef: reef, $1 \mathrm{mi}$. long, on $\mathrm{NW}$ coast of Sanak I., Aleutian Ra.; 54 $30^{\prime} \mathrm{N}, 162^{\circ} 51^{\prime} \mathrm{W}$; $B G N$ 1940; (map 25). Var. McLoughlin Rocks, McLoughlins Rocks.

Local name reported by USC\&GS in 1939 "since the SS Yukon of the Pacific Alaska Navigation Company was lost there June 23, 1913. The residents of Sanak *** sometimes refer to Yukon reef as McLoughlins Rocks * * *." Samuel Applegate, reported the name "McLoughlin Rocks" in 1900. See Point Petrof.

Yukon River: stream, about $1,500 \mathrm{mi}$. long, heads in Marsh Lake in Yukon, Canada, flows NW into Alaska to Fort Yukon, then SW to Bering Sea at Norton Sound; $62^{\circ} 32^{\prime} \mathrm{N}, 163^{\circ}$ 54' W; BGN 1950; Var. Jukchana, Juna, Kuikpak, Kvichpak, Kvikhpakh, Kwichpak, Kwikpak, Lewes River, Lewis River, Nigato, Youcon, Yucon.

This, the principal river in Alaska, presently has an Indian name first obtained by Hudson's Bay Company traders who explored the upper river, establishing Fort Yukon in 1847. The Russians explored the lower river in the 1830's establishing the post at Nulato in 1841. The Eskimo, who occupied the lower Yukon, including its delta, descriptively called it "Kuikpak" meaning "big river." The Indian name "Yukon" probably means the same thing. Lt. $H$. T. Allen recorded in 1885 another Indian name, "Nigato" ("Niga" is said to mean "river"), and Constantin Grewingk recorded the names "Juna" and "Jukchana." All of these names were variously spelled. The prescnt form of the name was adopted by Canada and the United States in the 1890's.

Yukon-Tanana Highlands: mountains, see Tanana Hills.

Yukon-Tanana Upland: mountains, see Tanana Hills.

Yukontoh Slough: watercourse, see Yokontoh Slough.

Yukuk Bay: bay, $0.6 \mathrm{mi}$. across, $8 \mathrm{mi}$. NW of Afognak, on SW coast of Afognak I., $N$ of Kodiak I.; $58^{\circ} 02^{\prime} 10^{\prime \prime} \mathrm{N}, 152^{\circ} 58^{\prime} 30^{\prime \prime} \mathrm{W}$; (map 43). Var. Iukuk Bay.
Transliteration of the Aleut name reported by Sub-Lt. Mikhail Murashev, IRN, in 1839 or 1840 and published by the Russian Hydrog. Dept. in 1849, on Chart 1425 as "Zaliv Yukuk." This name may be from the word "Uxcuq," which means "puffin" according to R. H. Geoghegan.

Yukutat Settlement: locality, see Glory of Russia.

Yukutzcharkat Creek: stream, see Hess Creek.

Yukwonilnuk: stream, see Julian Creek.

Yukwonilnuk River: stream, see George River. Yukwonilnuk River: stream, see Jungjuk Creek. Yukwonilnuk River: stream, see Owhat River. Yuler Creek: stream, see Uhler Creek.

Yumakh Island: island, see Umak Island.

Yunaka: stream, see Koyukuk River.

Yunakh, Ostrov: island, see Kanu Island.

Yunakh Island: island, see Kanu Island.

Yunaska Island: island, $14 \mathrm{mi}$. long, one of Islands of Four Mts.; Aleutian Is.; $52^{\circ} 38^{\prime} \mathrm{N}$, $170^{\circ} 40^{\prime} \mathrm{W}$; BGN 1890; (map 20). Var. Junaska Island, Unaska Island, Younaska Island, Yunaska, Ostrov.

Aleut name published by Lt. Sarichev (1826, map 3) as "Os[trov] Yunaska," or "Yunaska Island."

Yunnaka: stream, see Koyukuk River.

Yuonglik River: stream, flows SE $12 \mathrm{mi}$. to Golovnin Lagoon, $7 \mathrm{mi}$. N of Golovin and 40 mi. NE of Solomon, Seward Penin. High.; $64^{\circ} 39^{\prime} \mathrm{N}, 163^{\circ} 07^{\prime} \mathrm{W}$; (map 95). Var. Eureka Creek, Youunglik River.

Eskimo name reported in 1900 as "Youunglik River" and published in 1902 on USC\&GS Chart 9380. "Eureka Creek" was reported in 1909 by Smith and Eakin (1911, pl. 1), USGS.

Yuquaqilokhna: stream, see Willow Creek.

Yuthagotna River: stream, see Iditarod River.

Yutokh Hill: hill, 1,105 ft., on S shore of Lake Minchumina, Tanana Low.; $63^{\circ} 52^{\prime} 40^{\prime \prime} \mathrm{N}$, $152^{\circ} 11^{\prime} 20^{\prime \prime} \mathrm{W}$; (map 88).

Tanana Indian name reported in 1954 by USGS.

Yuzhni Point: point 0 , land, on $\mathrm{S}$ coast of Whale I., $N$ of Kodiak I.; $57^{\circ} 55^{\prime} 15^{\prime \prime} N$ N, 152 $46^{\prime} 30^{\prime \prime}$ W; (map 34). Var. Mys Yuzhnyy.

Transliteration of the descriptive name "M[ys] Yuzhnyy," meaning "south cape," given to this point by Sub-Lt. Mikhail Murashev in 1839 or 1840 and published in 1849 on Russian Hydrog. Dept. Chart 1425.

Yuzhniy, Ostrov: rock, see South Island.

Yuzhnoy, Mys: point of land, see Trinity, Cape.

Yuzhnyy, Mys: point of land, see Cascade Point.

Yuzhnyy, Mys: point of land, see South Point.

Yuzhnyy, Mys: point of land, see Yuzhni Point.

\section{$\mathbf{Z}$}

Zachar Bay: $b a y$, extends SE $8.5 \mathrm{mi}$. off Uyak Bay, on NW coast of Kodiak I.; $57^{\circ} 35^{\prime} \mathrm{N}$, $153^{\circ} 50^{\prime}$ W ; BGN 1910; (map 34).

Name reported in 1910 by USC\&GS.

Zachary Bay: bay, $2 \mathrm{mi}$. across, on $\mathrm{N}$ coast of Unga I., in Shumagin Is., Aleutian Ra.; $55^{\circ}$ $22^{\prime} \mathrm{N}, 160^{\circ} 38^{\prime} \mathrm{W}$; (map 28). Var. Coal
Harbor, Sacharowskaja, Zakharefskaia, Zakhareffskaia.

Named "Zakharovskaia anse," or "Zakharof Bay," by Capt. Lutke (1836, p. 267) "for a Russian named Zakharef," according to W. H. Dall. Published as "Zachary Bay" in 1872 by USC\&GS. Shown as "Coal Harbor" on 1890 USBF chart.

Zaikof Bay: bay, at NE end of Montague I., trends NE $6.7 \mathrm{mi}$. to W side of Hinchinbrook Entrance, at $\mathrm{S}$ end of Prince William Sound, $40 \mathrm{mi}$. ENE of Chenega, Chugach Mts.; $60^{\circ}$ $19^{\prime} \mathrm{N}, 146^{\circ} 58^{\prime} \mathrm{W}$; (map 63). Var. Zaikoff Bay, Zaliv Zaykova.

Name published by Capt. Tebenkov (1852, map 6), IRN, presumably after Stepan Kosmovich Zaikof, who was chief of the trading post St. Nicholas (Kenai) in the 18 th century. Zaikoff Bay: bay, see Zaikof Bay.

Zaikof Point: point of land, on NE tip of Montague I., $45 \mathrm{mi}$. SW of Cordova, Chugach Mts.; $60^{\circ} 19^{\prime} \mathrm{N}, 146^{\circ} 55^{\prime} \mathrm{W}$; (map 64). Var. Punta de Puente.

So named in 1868 by George Davidson, USC\&GS. Name derived from nearby Zaikof Bay. This is probably the "Punta de Puente," meaning "point of the bridge" in Spanish, given by Don Ignacio Arteaga about August 1, 1779 (Wagner, 1937, p. 487).

Zaimka Island: island, $0.4 \mathrm{mi}$. long, in mouth of Womens Bay, 5 mi. SW of Kodiak, Kodiak I.; $57^{\circ} 43^{\prime} 50^{\prime \prime} \mathrm{N}, 152^{\circ} 27^{\prime} 50^{\prime \prime} \mathrm{W} ;$ BGN 1941; (map 34). Var: Cilff Islet, High Island, Ostrov Utesistoy, Utesistoi Island.

Local Russian name meaning "meadow" reported by USC\&GS in 1940. Called "Os[trov] Utesistoy" meaning "Rocky Island" by Sarichev (1826, map 16). Baker (1906, p. 187) translated this name as "Cliff Island" which USC\&GS misapplied to this island in 1910. This error was corrected in 1940 by USC\&GS. See Cliff Island.

Zaimka Ridge: ridge, $200 \mathrm{ft}$., $1.5 \mathrm{mi}$. long, on $\mathrm{E}$ shore of Womens Bay, $7 \mathrm{mi}$. SW of Kodiak, Kodiak I.; $57^{\circ} 42^{\prime} 30^{\prime \prime} \mathrm{N}, 152^{\circ} 30^{\prime} 00^{\prime \prime} \mathrm{W}$; (map 34).

Name derived from Zaimka Island and published in 1943 by USC\&GS.

Zakatlatan: locality, see Louden.

Zakhareffskaia: $b a y$, see Zachary Bay.

Zakharova, Zaliv: bay, see Stepovak Bay.

Zakrishka Island: island, see Krishka Island.

Zakritoi Basin : bay, see Kritoi Basin.

Zakritoi Bay: bay, see Banks, Port.

Zakritoy, Zaliv: bay, see Banks, Port.

Zaliva, Mys: point of land, see Bay Point.

Zaliva Point: point of land, on $\mathbf{S}$ coast of Great Sitkin I., Aleutian Is.; $51^{\circ} 58^{\prime} 45^{\prime \prime}$ N, 176 04'$50^{\prime \prime} \mathrm{W} ;$ BGN 1936; (map 17).

Russian name meaning "bay," given by members of the U.S. Navy Aleutian Island Survey Expedition in 1934.

Zaliva Point: point of land, see Bay Point.

Zaliva Point: point of land, see Bukhti Point.

Zaliva Point: point of land, see Hatchet Point.

Zane Hills: mountains, $4,053 \mathrm{ft}$., $8 \mathrm{mi}$. wide, extend NW-SE $50 \mathrm{mi}$. from near Zane Pass to Koyukuk River, $50 \mathrm{mi}$. SE of Shungnak, 
Hogatza High.; $66^{\circ} 15^{\prime} \mathrm{N}, 156^{\circ} 00^{\prime} \mathrm{W}$; (map 116).

Named in 1910 by P. S. Smith (1913, p. 24), USGS, for Ens. A. V. Zane, USN, a member of Lt. G. M. Stoney's expedition, who made a side trip from Fort Cosmos, on the Kobuk, to Nulato, on the Yukon, and back, in the winter of 1885-86. He traveled alongside these mountains on his trip.

Zane Pass: pass, 1,200 ft., at $\mathrm{N}$ end of Zane Hills, 33 mi. SE of Shungnak, Hogatza High.; $66^{\circ} 30^{\prime} \mathrm{N}, 156^{\circ} 30^{\prime} \mathrm{W}$; (map 115).

Named in 1886 by Lt. Stoney (1900, map and p. 57-65), USN, for Ens. A. V. Zane, USN, a member of Stoney's expedition.

Zanett, Mount: peak, see Zanetti, Mount.

Zanetti, Mount: peak, 13,000 ft., $4 \mathrm{mi}$. NW of Mount Wrangell, Wrangell Mts.; $62^{\circ} 02^{\prime} \mathrm{N}$, $144^{\circ} 06^{\prime} \mathrm{W}$; (map 83). Var. Mount Zanett. Local name reported by Mendenhall. (1903, p. 399), USGS.

Zapad Head: point of land, on NW coast of Segula I., Aleutian Is.; $52^{\circ} 02^{\prime} 30^{\prime \prime} \mathrm{N}, 178^{\circ} 05^{\prime}$ 20" E; BGN 1937; (map 15).

From the Russian word for "west." This name was reported by personnel of the U.S.S. Oglala, and published on a 1935 chart of the U.S. Navy Hydrog. Office.

Zapadni Bay: bay, $3 \mathrm{mi}$. across, on SW coast of St. George I., in Pribilof Is.; $56^{\circ} 34^{\prime}$ N, $169^{\circ}$. $41^{\prime}$ W; (map 38). Var. Southwest Bay.

Russian name from the word "zapad," meaning "west," reported by Putnam (1903, p. 1016), USC\&GS. According to Elliott (1881, p. 19), the Russians imported Aleuts of other islands, for their fur seal industry, and about 1787 a village was established at Zapadni Bay.

Zapadnie Numaden-algaralogray: rookery, see Zapadni Rookery.

Zapadnie Point: point of land, see Southwest Point.

Zapadnie Point: point of land, see Zapadni Point.

Zapadnie Rookery: rookery, see Zapadni Rookery.

Zapadni Point: point of land, on SW coast of St. Paul I., in Pribilof Is.; $57^{\circ} 08^{\prime} 45^{\prime \prime} \mathrm{N}$, $170^{\circ} 20^{\prime} 40^{\prime \prime} \mathrm{W}$; (map 38). Var. South Point, Zapadnie Point.

Russian name from the word "zapad" meaning "west," reported by Elliott (1881, St. Paul map) in 1874 as "Zapadnie." USC\&GS called this feature "South Point."

Zapadni Point: point of land, on NW coast of Spruce I., NE of Kodiak I.; 57 $57^{\prime} 20^{\prime \prime} \mathrm{N}$, $152^{\circ} 28^{\prime} 40^{\prime \prime} \mathrm{W}$; (map 34). Var. Mys Zapadniy, West Cape.

Transliteration of "M[ys] Zapadniy" a name given by Sub-Lt. Mikhail Murashev in 1839 or 1840, and published in 1849 on Russian Hydrog. Dept. Chart 1425. Baker (1906, p. 668) published "West Cape," the translation of Murashev's name. Because of duplication the name was changed to its present form by USC\&GS in 1909.

Zapadni Reef Rookery: rookery, see Zapadni Rookery.
Zapadni Rookery: rookery, on Zapadni Bay on SW coast of St. George I., in Pribilof Is.; $56^{\circ} 34^{\prime} 00^{\prime \prime}$ N, $169^{\circ} 39^{\prime} 35^{\prime \prime}$ W; (map 38). Var. Zapadnie Numaden-algaralogray.

Russian name reported by Elliott (1881, St. George map), derived from the Russian word "zapad" meaning "west."

Zapadni Rookery: rookery, on Zapadni Point, on W shore of English Bay, St. Paul I., in Pribilof Is.; $57^{\circ} 08^{\prime} 50^{\prime \prime} \mathrm{N}, 170^{\circ} 20^{\prime} 00^{\prime \prime} \mathrm{W}$; (map 38). Var. Zapadnie Rookery, Zapadni Reef Rookery.

Local Russian name reported by Elliott (1881, St. Paul map) in 1874 as "Zapadnie." Rookery name was derived from Zapadni Point.

Zapadniy, Mys: point of land, see Zapadni Point. Zapadnyy, Farvater: water passage, see Western Channel.

Zapadnyy, Mys: point of land, see Southwest Point.

Zapadnyy, Mys: point of land, see West Foreland.

Zaremba Island: island, see Zarembo.

Zarembo, Ostrov: island, see Zarembo Island.

Zarembo Island: island, $15 \mathrm{mi}$. across, between Kupreanof and Etolin Is., Alex. Arch.; 56 ${ }^{\circ}$ $20^{\circ} \mathrm{N}, 132^{\circ} 50^{\prime} \mathrm{W}$; (map 6). Var. Duke of York Island, Ostrov Zarembo, Zaremba Island.

Published in 1848 on Russian Hydrog. Dept. Chart 1396 as "Os[trov] Zarembo." Named for Capt. Lt. Dionysius Fedorovich Zarembo who made surveys in this vicinity in 1834 and 1838. Capt. George Vancouver, RN, called it "Duke of York Island" in 1793.

Zatchlitschak Island: island, see Sitkalidak Island.

Zatschra Island: island, see Hydra Island.

Zaykova, Zaliv: bay, see Zaikof Bay.

Zdluiat: locality, on E shore of Knik Arm Cook Inlet, Cook Inlet Low.; (map 69).

Former Tanaina Indian village listed by Ivan Petroff in the 1880 Census with a population of 16.

Zdorovya, Mys: point of land, see Heald Point. Zeal Point: point of land, between Neva Strait and Saint John Baptist Bay, on NW coast of Baranof I., 19 mi. NW of Sitka, Alex. Arch.; $57^{\circ} 17^{\prime} 30^{\prime \prime} \mathrm{N}, 135^{\circ} 36^{\prime} 00^{\prime \prime} \mathrm{W}$; (map 9). Var. Mys Userdiye, Ouserdie Point, Userdie Point.

This is a translation by USC\&GS about 1882 of the name given by the Russian pilot Ens. Vasiliev; published in 1848 on Russian Hydrog. Dept. Chart 1397 as "M[ys] Userdiye."

Zeaman Gulch: ravine, trends $\mathrm{N} 0.5 \mathrm{mi}$. to Osborn Creek, $7.5 \mathrm{mi}$. NE of Nome, Seward Penin. High.; 64 $32^{\circ} 45^{\prime \prime} \mathrm{N}, 165^{\circ} 09^{\prime} 50^{\prime \prime} \mathrm{W}$; (map 94).

Prospectors' name reported in 1904 by T. G. Gerdine, USGS.

Zeikhell: stream, see Tiekel River.

Zelenoi, Mys : point of land, see Green Point.

Zelenoi Point: point of land, see Green Point.

Zelenoi Rocks: rocks, see Green Rocks.

Zelenoy, Mys : point of land, see December Point. Zelenyy, Mys: point of land, see December Point.
Zelenyy, Mys: point of land, see Green Point. Zeloni Point: point of land, see December Point. Zelonoi Point: point of land, see Green Point. Zelony Point: point of land, see Green Point. Zeman Creek: stream, flows NW to Banner Greek which flows to Belt Greek, about $3 \mathrm{mi}$. $\mathrm{N}$ of Mount Bendeleben, Seward Penin. High.; (map 110).

Prospectors' name shown on a map of Cape Nome gold fields by David Fox, Jr., dated 1901. This stream cannot be precisely located on current maps.

Zenobia Rock: rock, in Sitka Sound, $3.8 \mathrm{mi}$. SW of Sitka, Alax. Arch.; 57 $00^{\prime} 15^{\prime \prime}$ N, 135 $23^{\prime}$ $18^{\prime \prime}$ W; (map 9).

Named by Russians for the ship Zenobia "which struck upon it in 1855" (Baker, 1906, p. 689).

Zephyr Creek: stream, flows SE $2 \mathrm{mi}$. to Hope Creek, $71 \mathrm{mi}$. SW of Circle, Yukon-Tanana High.; $65^{\circ} 24^{\prime} 20^{\prime \prime} \mathrm{N}, 146^{\circ} 19^{\prime} 10^{\prime \prime} \mathrm{W}$; (map 104).

Named by prospectors; published by USGS (Prindle, 1908, pl. 4).

Zeto Point: point of land, on NE coast of Adak I., Aleutian Is. ; $51^{\circ} 54^{\prime} 35^{\prime \prime} \mathrm{N}, 176^{\circ} 33^{\prime} 25^{\prime \prime} \mathrm{W}$; $B G N 1936$; (map 17).

Named by members of the U.S. Navy Aleutian Island Survey Expedition in 1934, for the survey signal Zeto, located on this point.

Zfiatitz: cove, see Three Saints Harbor.

Zharof, Ostrov: island, see Egg Island.

Zhekiski, Point : point of land, see Shekesti, Point.

Zheltyy, Mys : point of land, see Yellow Point.

Zhila, Mys: point of land, see Blunt Point.

Zhila, Mys: point of land, see Head Point.

Zhilo Cove: cove, $0.4 \mathrm{mi}$. across, at head of Islas Bay, $16 \mathrm{mi}$. NW of Chichagof, on W coast of Chichagof I., Alex. Arch.; 57 $50^{\prime} 15^{\prime \prime}$ $\mathrm{N}, 136^{\circ} 22^{\prime} 20^{\prime \prime} \mathrm{W}$; (map 9).

Russian word from "zhilishche" meaning "house", given in 1928 by USC\&GS.

Zholti Point: point of land, see Yellow Point.

Zhuravlina, Guba: estuary, see Crane Gove.

Zhuravlina Cove: estuary, see Crane Cove.

Ziatitz: locality, see Nunamiut.

Ziatitz: cove, see Three Saints Harbor.

Ziegler Cove: cove, at $\mathrm{N}$ entrance to Pigot Bay, on SW side of Port Wells, $14 \mathrm{mi}$. NE of Whittier, Chugach Mts.; $60^{\circ} 50^{\prime} \mathrm{N}, 148^{\circ} 19^{\prime}$ W; (map 63).

Local named reported in 1954 by USC\&GS

Zimmerman Creek: stream, flows SE $7 \mathrm{mi}$. to Iditarod River, $7 \mathrm{mi}$. NW of Flat, KilbuckKuskokwim Mts.; $62^{\circ} 31^{\prime} 30^{\prime \prime} \mathrm{N}, 158^{\circ} 10^{\prime} 15^{\prime \prime}$ W; (map 79).

Prospectors' name obtained in 1952 by USGS topographers.

Zimmerman Creek: stream, flows SE $8 \mathrm{mi}$. from Thazzik Mtn. to East Fork Chandalar River, $40 \mathrm{mi}$. SE of Chandalar, Brooks Ra.; $67^{\circ} 09^{\prime}-$ $40^{\prime \prime} \mathrm{N}, 147^{\circ} 17^{\prime} 00^{\prime \prime} \mathrm{W}$; (map 123).

Prospectors' name obtained in 1909 by $\mathrm{A}$. G. Maddren (in Brooks and others, 1910, pl. 7), USGS.

Zimovia Islets: islands, $22 \mathrm{mi}$. SE of Wrangell, $0.7 \mathrm{mi}$. long, in Zimovia Strait between 
Wrangell and Etolin Is., Alex. Arch.; 56 $11^{\prime}$ $10^{\prime \prime} \mathrm{N}, 132^{\circ} 12^{\prime} 30^{\prime \prime} \mathrm{W}$; BCN 1937; (map 6). Named in 1937 by USFS.

Zimovia Point: point of land, on $\mathrm{N}$ bank of Chilkat River, $1 \mathrm{mi}$. W of Dok Point and 17 mi. SW of Skagway, Coast Mts.; $59^{\circ} 15^{\prime} 55^{\prime \prime}$ N, $135^{\circ} 37^{\prime} 55^{\prime \prime}$ W; (map 45). Var. Spuhn Point.

Named "M[ys] Zimovia" meaning "winter point" by the Russian Hydrog. Dept. in 1848 on Chart 1396. It appears to be identical with Spuhn Point, named in 1880 by the U.S. Navy. Both names were published by USC\&GS in the 1883 Coast Pilot, p. 198.

Zimovia Strait: water passage, extends SE 30 mi. from Sumner Strait to Ernest Sound, separates Wrangell I. from Etolin and Woronkofski Is., Alex. Arch.; $56^{\circ} 13^{\prime} \mathrm{N}, 132^{\circ} 20^{\prime} \mathrm{W}$; (map 6). Var. Proliv Zimovya.

Published in 1853 on Russian Hydrog. Dept. Chart 1493 as "Proliv Zimovya" meaning "winter strait."

Zimovya, Proliv: water passage, see Zimovia Strait.

Zingaramute: locality, see Siniogamute.

Zipper Creek: stream, heads in Brassiere Hills, flows $1 \mathrm{mi}$. $\mathrm{S}$ to head of Taku Inlet, $0.5 \mathrm{mi}$. NE of 1962 terminus of Taku Glacier and 19 mi. NE of Juneau, Coast Mts.; $58^{\circ} 56^{\prime} 50^{\prime \prime} \mathrm{N}$, $134^{\circ} 01^{\prime} 15^{\prime \prime}: \mathrm{W}$; (map 11).

Local name reported in 1965 by $D$. A. Brew and A. B. Ford, USGS.

Zip Rock: rock, in Glacier Bay National Monument, off $\mathrm{N}$ shore of Cross Sound, $0.5 \mathrm{mi}$. SW of mouth of Dicks Arm, 45 mi. NW of Hoonah, St. Elias Mts.; $58^{\circ} 12^{\prime} 20^{\prime \prime} \mathrm{N}, 136^{\circ} 39^{\prime} 40^{\prime \prime} \mathrm{W}$; $B G N$ 1930; (map 10)

Named by USC\&GS in 1929 for the triangulation point $\mathrm{Zip}$ on the rock. The rock is useful as a landmark for entering the harbor.

Zirku River: stream, see Tsirku River.

Ziskokadlo: ridge, $25 \mathrm{mi}$. long, trends $\mathrm{NW}$ from head of Chilkoot Inlet, $10 \mathrm{mi}$. W of Skagway, St. Elias Mts.; $59^{\circ} 25^{\prime} \mathrm{N}, 135^{\circ} 35^{\prime} \mathrm{W}$; (map 45)

Probably a Tlingit Indian name given by Aurel and Authur Krause (1883, map).

Zitziana River: stream, flows NE $63 \mathrm{mi}$. to Tanana River, $55 \mathrm{mi}$. NE of the Bitzshini Mts., Nowitna Low.; $64^{\circ} 58^{\prime} \mathrm{N}, 150^{\circ} 30^{\prime} \mathrm{W}$; (map 99). Var. Lorentz River, Lorenz River, Nushakantna River.
Tanana Indian name reported in 1909 by C. E. Giffin and R. B. Oliver (in Eakin, 1918, pl. 1), USGS. Lt. Allen (1887, map) in 1885 reported the stream's name as "Lorenz River" and in 1898 Capt. E. F. Glenn reported "Lorentz River." In the 1880 census Ivan Petrof reported the stream as "Nushakantna River."

Zlukak: locality, see Ulukuk.

Zogliakten: locality, on left bank of Koyukuk River, between Khotylkakat and Zonagoliakten, about $42 \mathrm{mi}$. SW of Huslia, Koyukuk Low.; $65^{\circ} 23^{\prime} \mathrm{N}, 157^{\circ} 36^{\prime} \mathrm{W}$; (map 108). Var. Tsogliakhten, Tsogliakten, Tsoglyakhten, Zogljachten.

Former Koyukuk Indian village or camp reported in 1844 , with a population of 7 , by Lt. L. A. Zagoskin, IRN.

Zogljachten: locality, see Zogliakten.

Zolotoi Bay: cove, $0.5 \mathrm{mi}$. across, S of settlement of St. Paul, on S coast of St. Paul I., in Pribilof Is.; $57^{\circ} 07^{\prime} 00^{\prime \prime} \mathrm{N}, 170^{\circ} 17^{\prime} 00^{\prime \prime} \mathrm{W}$; (map 38). Var. Village Cove, Zoltoi Bay.

Russian word "zolotoy" meaning "golden," reported in 1874 by Elliott (1881, St. Paul notes) as "Zoltoi."

Zolotoi Sands: beach, $0.1 \mathrm{mi}$. long, $\mathrm{S}$ of St. Paul, on S coast of St. Paul I., in Pribilof Is.; $57^{\circ} 07^{\prime} 00^{\prime \prime} \mathrm{N}, 170^{\circ} 16^{\prime} 20^{\prime \prime} \mathrm{W}$; (map 38). Var. Zoltoi Sands.

Russian word "zolotoy" meaning "golden," reported as "Zoltoi" by Elliott (1881, St. Paul notes).

Zoltoi Bay: cove, see Zolotoi Bay.

Zoltoi Sands: beach, see Zolotoi Sands.

Zonagogliakten: locality, see Zonagoliakten.

Zonagoliakten: locality, on left bank of Koyukuk River, between Zogliakten and Kakhlyakblyakakat, about $45 \mathrm{mi}$. SW of Huslia, Koyukuk Low.; $65^{\circ} 20^{\prime}$ N, $157^{\circ} 38^{\prime}$ W ; (map 108).Var. Tsonagoliakten, Tsonagolyakhten, Tsonogokhlyakhten, Zonagogliakten, Zonogchljachten.

Former Koyukan Indian village or cámp reported in 1844 with a population of 11 , by Lt. L. A. Zagoskin, IRN.

Zona Island: island, see Tozitna Island.

Zone Greek: stream, flows NE $2 \mathrm{mi}$. to an unnamed stream in Sunshine Valley, $40 \mathrm{mi}$. NW of Dillingham, Kilbuck-Kuskokwim Mts. $59^{\circ} 30^{\prime} \mathrm{N}, 159^{\circ} 06^{\prime} \mathrm{W}$; (map 53 )

Local name published in 1951 by USGS.

Zone Creek: stream, flows S and SW $3 \mathrm{mi}$. to Spruce Creek, W of Slope Creek and $7.2 \mathrm{mi}$.
$\mathrm{SE}$ of Marshall, Nulato Hills; $61^{\circ} 47^{\prime} 10^{\prime \prime} \mathrm{N}$, $161^{\circ} 58^{\prime} 50^{\prime \prime} \mathrm{W}$; (map 73).

Prospectors' name reported by Harrington (1918, map), USGS, in 1916.

Zonogchljachten: locality, see Zonagoliakten.

Zotschomnia Islands: islands, see Noisy Islands.

Zouboff: islands, see Pribilof Islands.

Zoubov: islands, see Pribilof Islands.

Zowoputchek, Mys: point of land, see Gull, Cape.

Zuboff Rock: rock, see Zubof Rock.

Zubof Rock: rock, in The Basin, Kelp Bay, SW of Crow I., on NW coast of Baranof I., Alex. Arch.; $57^{\circ} 17^{\prime} 30^{\prime \prime} \mathrm{N}, 134^{\circ} 55^{\prime} 50^{\prime \prime} \mathrm{W}$; (map 9). Var. Zuboff Rock.

Name reported in 1895 by Lt. Comdr. J. F. Moser, USN, as "Zuboff," which is a Russian surname.

Zumik Islands: islands, see Semidi Islands.

Zutchwik Island: island, see Sutwik Island.

Zwinge Valley: valley, on Attu I., extends E 1.4 mi. to West Massacre Valley S of Black Mtn., Aleutian Is.; $52^{\circ} 52^{\prime} 40^{\prime \prime} \mathrm{N}, 173^{\circ} 09^{\prime} 15^{\prime \prime} \mathrm{E}$ (map 13).

Named by U.S. Army during World War II ; published in 1948 by AMS.

Zyzek-twina River: stream, see Ulukuk River. 12 Fathom Strait: water passage, see Twelve Fathom Strait

196 Mile Creek: stream, flows SW $9 \mathrm{mi}$. to Susitna River $10 \mathrm{mi}$. NW of Willow and 47 mi. $N$ of Anchorage, Cook Inlet Low.; $61^{\circ} 53^{\prime} 45^{\prime \prime} \mathrm{N}, 150^{\circ} 06^{\prime} 00^{\prime \prime} \mathrm{W}$; (map 70).

Name published in 1954 by USGS; "so named because it is 196 miles from Seward to where The Alaska Railroad crosses the stream.

1971/2 Mile Creek: stream, flows SW $6.4 \mathrm{mi}$. to 196 Mile Creek, $47 \mathrm{mi}$. N of Anchorage, Cook Inlet Low.; $61^{\circ} 53^{\prime} 50^{\prime \prime} \mathrm{N}, 150^{\circ} 04^{\prime} 30^{\prime \prime} \mathrm{W}$; (map 70).

Name published by USGS in 1954; "so named because it is 1971/2 miles from Seward to where the Alaska Railroad crosses this stream."

1848 Hill: mountain, $1,848 \mathrm{ft},, 1 \mathrm{mi}$. W of Andrew Lagoon on $\mathrm{N}$ coast of Adak I., Aleutian Is.; $51^{\circ} 56^{\prime} 10^{\prime \prime} \mathrm{N}, 176^{\circ} 41^{\prime} 45^{\prime \prime} \mathrm{W}$; (map 17).

Name published by USGS (Coats, 1956, p. 59); "Place name not shown on standard maps but used for convenience in this report." 8900, Peak: mountain, see Aylesworth, Mount. 


\section{SELECTED BIBLIOGRAPHY}

Abercrombie, W. R., 1900, Copper River Exploring Expedition, 1899; Washington, U.S Govt. Printing Office, 169 p.; issued also as S. Doc. 306, U.S. 56th Cong., 1st sess.

Abruzzi, Duke of the, 1900: see Filippi, Filippo de.

Alaska Call, 1959a, Bethel on the Kuskokwim River: v. 1, no. 3, p. 5-6.

1959b, Nushagak area in Bristol Bay: v. 1 , no. 3 , p. $9-19$.

Alaska Coast Pilot: see U.S. Coast and Gcodetic Survey.

Alaska Highway Guidebook, 1965. See Henning, 1965.

Alaska Railroad Commission, 1913, Railway routes in Alaska: U.S. 62d Cong., 3d sess., Doc. 1346,172 p.

Alaska Sportsman, published monthly: Juneau, Alaska-Northwest Publishing Co.

Alekseev, A. I., 1966, Joseph Billings: Royal Geog. Soc., [London] Geog. Jour., v. 132, pt. 2, p. 233-238.

Aleutian Coast Pilot, 1944: see U.S. Coast and Geodetic Survey.

Allen, H. T., 1887, Report of an expedition to the Copper, Tanana, and Koyukuk Rivers in the Territory of Alaska in the year 1885: see U.S. Army, Department of the Columbia, 1887.

Ameigh, G. C., Jr., and Chaffin, Y. M., 1962, Alaska's Kodiak Island, a camera report of life at Kodiak, Alaska: Kodiak, G. C. Ameigh, Jr., 163 p., 200 photos.

Andrews, C. L., 1916, Alaska under the Russians, Baranof the builder:' Pacific Northwest Quart., v. 7 (July), p. 202-216.

1938, The story of Alaska: Caldwell, Idaho, The Claxton Printers, Ltd., 303 p.

Atwood, W. W., 1911, Geology and mineral resources of parts of the Alaska Peninsula: U.S. Geol. Survey Bull. 467, 137 p.

Badlam, Alexander, 1890, The wonders of Alaska: San Francisco, The Bancroft Co., $148 \mathrm{p}$.

Bailey, M. B., 1949, Old Harbor: Alaska Sportsman, v. 15, no. 4, p. 6-11.

Baker, Marcus, 1900, Alaskan geographic names: U.S. Geol. Survey 21st Ann. Rept., pt. 2, p. 487-509.

- 1901, Geographic dictionary of Alaska: U.S. Geol. Survey Bull. 187, 446 p.

1906, Geographic dictionary of Alaska [2d ed.]: U.S. Geol. Survey Bull. 299, 690 p. (Prepared by James McCormick.)

Balch, T. W., 1903, The Alaska frontier: Philadelphia, Allen, Lane and Scott, 198 p.

Balcom, M. G., 1965, Ghost towns of Alaska: Chicago, Adams Press, $80 \mathrm{p}$
Bancroft, H. H., 1886, History of Alaska, 1730 1885, in The Works: San Francisco, A. L. Bancroft and Co., v. 33, 775 p.

Bank, Ted, 1956, Birthplace of the winds: New York, Thomas Y. Crowell Co., 274 p.

Barnes, F. F., 1943, Geology of the Portage Pass area, Alaska: U.S. Geol. Survey Bull. 926-D, p. 211-235.

Barnes, F. F., and Cobb, E. H., 1959, Geology and coal resources of the Homer district, Kenai coal field, Alaska: U.S. Geol. Survey Bull. 1058-F, p. 217-260.

Barnes, F. F., and Payne, T. G., 1956, The Wishbone Hill district, Matanuska coal field, Alaska: U.S. Geol. Survey Bull. 1016, 88 p.

Barnes, F. F., and Sokol, Daniel, 1959, Geology and coal resources of the Little Susitna district, Matanuska coal field, Alaska: U.S. Geol. Survey Bull. 1058-D, p. 121-138.

Barnes, F. F., Wahrhaftig, Clyde, Hickcox, C. A., Freedman, Jacob, Cobb, E. H., and Hopkins, D. M., 1951, Coal investigations in south-central Alaska, 1944-46: U.S. Geol. Survey Bull. 963-E, p. 137-208.

Barth, T. F. W., 1956, Geology and petrology of the Pribilof Islands, Alaska: U.S. Geol. Survey Bull. 1028-F, p. 101-160.

Bauer, L. A., 1902, U.S. magnetic declination tables and isogonic charts for 1902 and principal facts relating to the earth's magnetism: U.S. Coast and Geodetic Survey: Washington: Washington, U.S. Govt. Printing Office, $405 \mathrm{p}$.

Bayou, Katherine, 1946, First up the Susitna: Alaska Sportsman, v. 12, no. 11, p. 10.

__ 1957, The Crow Creek miners: Alaska Sportsman, v. 13, no. 1, p. 14.

Bean, T. H., 1891, Report on the Salmon and Salmon Rivers of Alaska, with notes on the conditions, methods, and needs of the Salmon fisheries: U.S. Fish Comm. Bull., v. 9, p. 165208.

Beardslee, L. A., 1882, Reports of Captain L. A. Beardslee, U.S. Navy, relative to affairs in Alaska, and the operations of the U.S.S. Jamestown, under his command while in the waters of that territory: Washington, $198 \mathrm{p}$.; issued as S. Ex. Doc. 71, U.S. 47 th Cong., 1 st sess.

Becker, G. F., 1898, Reconnaissance of the gold fields of southern Alaska, with some notes on general geology: U.S. Geol. Survey 18th Ann. Rept., pt. 3, p. 1-86.

Bee, J. W., and Hall, E. R., 1956, Mammals of northern Alaska on the Arctic slope: Kansas Univ. Mus. Nat. History, Misc. Pub. 8, 309 p. Beechey, F. W., 1831, Narrative of a voyage to the Pacific and Beering's Strait [sic], to coop- erate with the polar expeditions; performed in His Majesty's ship Blossom, under the command of Capt. F. W. Beechey *** in the years $1825,26,27,28$ : London, $H$. Colburn and R. Bentley, v. 1, p. 1-392; v. 2, p. $393-$ 742.

Berg, H. C., and Hinckley, D. W., 1963, Reconnaissance geology of northern Baranof Island, Alaska: U.S. Geol. Survey Bull. 1141-O, $24 \mathrm{p}$.

Berg, L. S., 1919, Izvestiya o Beringom Prolive i ego beregakh do Beringa i Kuka [Information concerning Bering Strait and its coastal areas]: Zapiski Gidrografiya, [v.] 2.

Billings, Joseph, 1802: see Sauer, 1802.

Birket-Smith, Kaj, and Laguna, Frederica de, 1938, The Eyak Indians of the Copper River delta, Alaska: Copenhaven, Levin \& Munksgaard, E. Munksgaard, 591 p.

Blackwelder, Eliot, 1907, Glacial features of the Alaskan coast between Yakutat Bay and the Alsek River: Jour. Geol., v. 15, p. 415-433.

Boas, Franz, 1911, Handbook of American Indian languages, pt. 1: Bur. Am. Ethnology Bull. 40,1069 p.

Bowsher, A. L., and Dutro, J. T., Jr., 1957, The Paleozoic section in the Shainin Lake area, central Brooks Range, Alaska: U.S. Geol. Survey Prof. Paper 303-A, p. 1-39.

Bressler, C. T., 1950, Garnet deposits near Wrangell, southeastern Alaska: U.S. Geol. Survey Bull. 963-C, p. 81-93.

Bridgwater, William, and Sherwood, E. J., eds., 1950, Columbia Encyclopedia [2d ed.]: Morningside Heights, N.Y., Columbia University Press, 2203 p.

Brooks, A. H., 1900a, A reconnaissance in the White and Tanana River basins, Alaska, in 1898: U.S. Geol. Survey 20th Ann. Rept., pt. 7, p. 425-494.

1900b, A reconnaissance from Pyramid Harbor to Eagle City, Alaska, including a description of the copper deposits of the upper White and Tanana Rivers: U.S. Geol. Survey 21st Ann. Rept., pt. 2, p. 331-391.

1901, Reconnaissances in the Cape Nome and Norton Bay regions, Alaska, in 1900: A reconnaissance of the Cape Nome and adjacent gold fields of Seward Peninsula, Alaska, in 1900 , with A reconnaissance in the Norton Bay region, Alaska, in 1900, by W. C. Mendenhall: U.S. Geol. Survey Spec. Pub., 222 p.

1902a, The coal resources of Alaska; U.S. Geol. Survey 22d Ann. Rept., pt. 3, p. 515-571.

1902b, Preliminary report on the Ketchikan mining district, Alaska, with an introductory sketch of the geology of southeastern 
Alaska: U.S. Geol. Survey Prof. Paper 1, $120 \mathrm{p}$.

Brooks, A. H., 1906, The geography and geology of Alaska, a summary of existing knowledge, with A section on climate, by Cleveland Abbe, $\mathrm{Jr}$, and a topographic map and description thereof, by R. U. Goode: U.S. Geol. Survey Prof. Paper 45, $327 \mathrm{p}$.

- 1911, The Mount McKinley region, Alaska, with descriptions of the igneous rocks and of the Bonnifield and Kantishna districts, by L. M. Prindle: U.S. Geol. Survey Prof. Paper 70, $234 \mathrm{p}$.

1916a, Antimony deposits of Alaska: U.S. Geol. Survey Bull. 649, 67 p.

$1916 \mathrm{~b}$, The physiographic provinces of Alaska: Washington Acad. Sci. Jour., v. 6, p. 252-253.

1953, Blazing Alaska's trails: Caldwell, Idaho, The Caxton Printers, Ltd., pub. jointly by Alaska Univ, and Arctic Inst. North America, $528 \mathrm{p}$.

Brooks, A. H., and others, 1905, Report on progress of investigations of mineral resources of Alaska in 1904: U.S. Geol. Survey Bull. 259, $185 \mathrm{p}$.

1906, Report on progress of investigations of mineral resources of Alaska in 1905: U.S. Geol. Survey Bull. 284, 157 p.

1907 , Report of progress of investigations of mineral resources of Alaska in 1906: U.S. Geol. Survey Bull. 314, 226 p.

1908, Mineral resources of Alaska, report on progress of investigations in 1907: U.S. Geol. Survey Bull. 345, 285 p.

1909, Mineral resources of Alaska, report on progress of investigations in 1908: U.S. Geol. Survey Bull. 379, 401 p.

1910, Mineral resources of Alaska, report on progress of investigations in 1909: U.S. Geol. Survey Bull. 442, 418 p.

1911, Mineral resources of Alaska, report of progress of investigations in 1910: U.S. Geol. Survey Bull. 480, 319 p.

1912, Mineral resources of Alaska, report on progress of investigations in 1911: U.S. Geol. Survey Bull. 520, 344 p.

1913, Mineral resources of Alaska, report on progress of investigations in 1912: U.S. Geol. Survey Bull. 542, 303 p.

1914, Mineral resources of Alaska, report on progress of investigations in 1913: U.S. Geol. Survey Bull. 592, 407 p.

1915, Mineral resources of Alaska, report on progress of investigations in 1914: U.S. Geol. Survey Bull. 622, 373 p.

1916, Mineral resources of Alaska, report on progress of investigations in 1915 : U.S. Geol. Survey Bull. 642, 266 p.

1918, Mineral resources of Alaska, re port on progress of investigations in 1916: U.S. Geol. Survey Bull. 662, 458 p.

1921, Mineral resources of Alaska, re. port on progress of investigations in 1919: U.S. Geol. Survey Bull. 714, 244 p.

1922, Mineral resources of Alaska, re. port on progress of investigations in 1920: U.S. Geol. Survey Bull. 722, $261 \mathrm{p}$.
Brooks, A. H., and others, 1923, Mineral resources of Alaska, report on progress of investigations in 1921: U.S. Geol. Survey Bull. $739,165 \mathrm{p}$.

1924, Mineral resources of Alaska, report on progress of investigations in 1922: U.S. Geol, Survey Bull. 755, 218 p.

1925, Mineral resources of Alaska, report on progress of investigations in 1923: U.S. Geol. Survey Bull. 773, 263 p.

Brower, C. D., 1942, Fifty years below zero: New York, Dodd, Mead and Co., 310 p.

Browne, Belmore, 1913, The conquest of Mt McKinley: Boston, Houghton Mifflin Co., $381 \mathrm{p}$.

Bruce, M. W., 1895, Alaska; its history and resources, goldfields, routes, and scenery: Seattle, Wash., Lowman and Hanford Co., 128 p.

Buddington, A. F., 1929, Geology of Hyder and vicinity, southeastern Alaska, with a reconnaissance of Chickamin River: U.S. Geol. Survey Bull. 807, 124 p.

Buddington, A. F., and Chapin, Theodore, 1929, Geology and mineral deposits of southeastern Alaska: U.S. Geol. Survey Bull. 800, 398 p. Burchard, E. F., 1920, Marble resources of southeastern Alaska, with a section on the geography and geology, by Theodore Chapin: U.S. Geol. Survey Bull. 682, 118 p.

Bureau of Education: Introduction of reindeer into Alaska: see Jackson, 1893-98, 1900-6, 1908.

Burroughs, John, Muir, John, and Grinnell, G. B., 1902, Narrative, glaciers, natives: Harriman Alaska Exped., v. 1, 183 p.

Byers, F. M., Jr., 1957, Tungsten deposits in the Fairbanks district, Alaska: U.S. Geol. Survey Bull. 1024-I, p. 179-216.

1959, Geology of Umnak and Bogoslof Islands, Aleutian Islands, Alaska: U.S. Geol Survey Bull. 1028-L, p. 267-369 [1960].

Byers, F. M., Jr., and Sainsbury, C. L., 1956, Tungsten deposits of the Hyder district, Alaska: U.S. Geol. Survey Bull. 1024-F, p. $123-140$ [1957].

Cady, W. M., Wallace, R. E., Hoare, J. M., and Webber, E. J., 1955, The central Kuskokwim region, Alaska: U.S. Geol. Survey Prof. Paper 268, 132 p.

Cairnes, D. D., 1914, The Yukon-Alaska international boundary, between Porcupine and Yukon Rivers: Canada Geol. Survey Mem. $67,161 \mathrm{p}$.

Callahan, J. E., and Wayland, R. G., 1965 Geologic reconnaissance of the West Creek damsite near Skagway, Alaska: U.S. Geol. Survey Bull. 1211-A, 13 p.

Cantwell, J. C., 1902, Report of the operations of the U.S. revenue-steamer Nunivak on the Yukon River station, Alaska, 1899-1901: U.S. Revenue-Cutter Service, 325 p.; issued also as Treasury Dept. Doc. 2276 and S. Doc. 155 , U.S. 58th Cong., 2d sess.

Capps, S. R., 1912, The Bonnifield region, Alaska: U.S. Geol. Survey Bull. 501, 64 p.

1913, The Yentna district, Alaska: U.S. Geol. Survey Bull. 534, 75 p.

1915, The Willow Creek district, Alaska: U.S. Geol. Survey Bull. 607, 86 p.
Capps, S. R., 1916, The Chisana-White River district, Alaska: U.S. Geol. Survey Bull. 630, $130 \mathrm{p}$.

1919, The Kantishna region, Alaska: U.S. Geol. Survey Bull. 687, 118 p.

1927, Geology of the upper Matanuska Valley, Alaska: U.S. Geol. Survey Bull. 791, $92 \mathrm{p}$.

1932, Glaciation in Alaska: U.S. Geol. Survey Prof. Paper 170-A, p. 1-8.

- 1933, Mineral investigations in the Alaska Railroad belt, 1931 : U.S. Geol. Survey Bull. 844-B, p. 119-135.

1934, Notes on the geology of the Alaska Peninsula and Aleutian Islands: U.S. Geol. Survey Bull. 857-D, p. 141-153.

1935, The southern Alaska Range: U.S. Geol. Survey Bull. 862, 101 p.

1937a, Kodiak and adjacent islands:

U.S. Geol. Survey Bull. 880-C, p. 111-184.

$1937 \mathrm{~b}$, Kodiak and vicinity: U.S. Geol.

Survey Bull. 868-B, p. 93-134.

1940, Geology of the Alaska Railroad region: U.S. Geol. Survey Bull. 907, 201 p.

Capps, S. R., and Johnson, B. L., 1915, The Ellamar district, Alaska: U.S. Geol. Survey Bull. 605, 125 p.

Capps, S. R., and Tuck, Ralph, 1935, The Willow Creek-Kashwitna district, Alaska: U.S. Geol. Survey Bull. 864-B, p. 95-113.

Carlson, S. W., and Soroka, Very Rev. Leonid, 1954, Faith of our fathers, the Eastern Orthodox religion, [3d ed., revised]: Minneapolis, Minn., Olympic Press, 176 p. [1962].

Carroll, J. A., 1957, The first ten years in Alaska: memoirs of a Fort Yukon trapper, 1911 1912: New York, Exposition Press, 120 p.

Carson, C. E., and Hussey, K. M., 1962, The oriented lakes of Arctic Alaska: Jour. Geology, v. 70, no. 4, p. 417-439.

Cederstrom, D. J., 1963, Ground-water resources of the Fairbanks area, Alaska: U.S. Geol. Survey Water-Supply Paper 1590, $84 \mathrm{p}$.

Census of Alaska, 1880, Tenth census of the United States: see Petroff, 1884.

1890 , Eleventh census of the United States: see U.S. Bureau of the Census, 1893. Chapin, Theodore, 1918, The Nelchina-Susitna region, Alaska: U.S. Geol. Survey Bull. 668, $67 \mathrm{p}$.

1919, The structure and stratigraphy of Gravina and Revillagigedo Islands, Alaska: U.S. Geol. Survey Prof. Paper 120-D, p. 83100 .

1920, Geography and geology of southeastern Alaska: see Burchard, 1920.

Chapman, R. M., Detterman, R. L., and Mangus, M. D., 1964, Geology of the Killik-Etivluk Rivers region, Alaska: U.S. Geol. Survey Prof. Paper 303-F, p. 325-407.

Chapman, R. M., and Sable, E. G., 1960, Geology of the Utukok-Corwin region, northwestern Alaska: U.S. Geol. Survey Prof. Paper 303-C, p. 47-167 [1961].

Chevigny, Hector, 1965, Russian America, the great Alaskan venture 1741-1867: New York, The Viking Press, $270 \mathrm{p}$.

Coast Pilot: see U.S. Coast and Geodetic Survey. 
Coats, R. R., 1950, Volcanic activity in the Aleutian arc: U.S. Geol. Survey Bull. 974-B, p. $35-49$.

1953, Geology of Buldir Island, Aleutian Islands, Alaska: U.S. Geol. Survey Bull. 989-A, p. 1-26.

1956a, Geology of northern Adak Island, Alaska: U.S. Geol. Survey Bull. 1028-C, p 45-67.

- 1956b, Geology of northern Kanaga Island, Alaska: U.S. Geol. Survey Bull. 1028-D, p. 69-81.

1956c, Reconnaissance geology of some western Aleutian Islands, Alaska: U.S. Geol. Survey Bull. 1028-E, p. 83-100.

1959a, Geologic reconnaissance of Gareloi Island, Aleutian Islands, Alaska: U.S Geol. Survey Bull. 1028-J, p. 249-256.

1959b, Geologic reconnaissance of Semisopochnoi Island, western Aleutian Islands, Alaska: U.S. Geol. Survey Bull. 1028-O, p. $477-519$ [1960].

Coats, R. R., Nelson, W. H., Lewis, R. Q., and Powers, H. A., 1961, Geologic reconnaissance of Kiska Island, Aleutian Islands, Alaska: U.S. Geol. Survey Bull. 1028-R, p. 563-581.

Colby, Merle, 1939, A guide to Alaska, last American frontier: New York, The MacMillan Co., 427 p.

Cole, A. B., 1947, Yankee surveyors in the Shogun's Seas, records of the United States surveying expedition to the north Pacific Ocean, 1853-1856: Princeton, N.J., Princeton Univ. Press, $161 \mathrm{p}$.

Gole, C. O., 1953, Gold rush railroad: Alaska Sportsman, v. 19 , no. 10 , p. 12 .

Collier, A. J., 1902, A reconnaissance of the northwestern portion of Seward Peninsula, Alaska: U.S. Geol. Survey Prof. Paper 2, 70 p. 1903, The coal resources of the Yukon, Alaska: U.S. Geol. Survey Bull. 218, 71 p.

- 1904, The tin deposits of the York region, Alaska: U.S. Gcol. Survey Bull. 229, $61 \mathrm{p}$.

1906, Geology and coal resources of the Cape Lisburne region, Alaska: U.S. Geol. Survey Bull. 278, 54 p.

Collier, A. J., Hess, F. L. Smith, P. S., and Brooks, A. H., 1908, The gold placers of parts of Seward Peninsula, Alaska, including the Nome, Council, Kougarok, Port Clarence, and Goodhope precincts: U.S. Geol. Survey Bull. $328,343 \mathrm{p}$

Collins, H. B., 1928, The Eskimo of western Alaska, in Explorations and field-work of the Smithsonian Institution in 1927: Smithsonian Inst. Pub. 2957, p. 149-156

Collins, H. B., Clark, A. H., and Walker, E. H., 1945, The Aleutian Islands-their pcople and natural history: Smithsonian Inst. War Background Studies, no. 21 , pub. 3775,131 p.

Collinson, Richard, 1855, Account of the proceedings of H.M.S. Enterprise from Bering Strait to Cambridge Bay: Royal Geog. Soc. Jour., v. 25, p. 194-206.

Condon, W. H., 1961, Geology of the Craig quadrangle, Alaska: U.S. Geol. Survey Bull. 1108-B, p. B1-B43 [1962].
Cook, F. A., 1908, To the top of the continent: New York, Doubleday Page \& Co., 321 p.

Cook, James, 1785, A voyage to the Pacific Ocean. Undertaken, by the command of His Majesty, for making discoveries in the Northern Hemisphere ***. In the years 1776, $1777,1778,1779$, \& 1780 [2d ed.]: London: G. Nicol, $3 \mathrm{v}$. and atlas in folio. (v. 1 and 2 by Cook, v. 3 by James King).

Cooper, W. S., 1931, A third expedition to Glacier Bay, Alaska: Ecology, v. 12 (Jan.), p. 61-95.

- 1937, The problem of Glacier Bay, Alaska-a study of glacier variations: Geog. Rev., v. 27 (Jan.), p. 37-62.

Covert, C. C., and Ellsworth, C. E., 1909, Watersupply investigations in the Yukon-Tanana region, Alaska, 1907 and 1908 (Fairbanks, Circle, and Rampart districts): U.S. Geol. Survey Water-Supply Paper 228, 108 p.

Coxe, William, 1787, Account of the Russian discoveries between Asia and America [3d ed.]: London, $\mathrm{T}$. Cadell, $454 \mathrm{p}$.

Currier, F. B., 1966, All you need to do is run up that mountain [Marathon Mountain]: Alaska Sportsman, v. 32, no. 9, p. 10-13.

Curtin, W. R., 1938, Yukon voyages; unofficial log of the steamer Yukoner: Caldwell, Idaho, The Caxton Printers, Ltd., 299 p.

Cushing, H. P., 1891, Notes on the Muir Glacier region, Alaska, and its geology: Am. Geol., v. 8 (Oct.), p. 207-230.

1892 , Notes on the geology of the vicinity of Muir Glacier: Nat. Geog. Mag., v. 4, p. $56-62$.

Dall, W. H., 1870, Alaska and its resources: Boston, Lee \& Shepard, 627 p.

1877, Tribes of the extreme Northwest, in Contributions to North American ethnology: U.S. Geog. and Geol. Survey of the Rocky Mtn. Region, v. 1, pt. 1, p. 1-156. 1896a, Geographical notes in Alaska: Am. Geog. Soc. Jour. [Bull.], v. 28, p. 1-20. $1896 \mathrm{~b}$, Report on coal and lignite of Alaska: U.S. Geol. Survey 17th Ann. Report., pt. 1, p. 793-908.

Dall, W. H., and Baker, Marcus, 1879, Partial list of charts and maps relating to Alaska and the adjacent regions: U.S. Coast and Geod. Survey, Pacific Coast Pilot, 2d ser., app. 1, p. 163-375.

Dall, W. H., Keelcr, Charles, Fernow, B. E. Gannett, Henry, Brewer, W. H., Merriam, C. H., Grinnell, G. B., and Washburn, M. L., 1902, History, geography resources: Harriman Alaska Exped., v. 2, p. 185-393.

Dall, W. H., and others, 1898, The Yukon Territory: London, Downey \& Co., Ltd., 438 p. Davidson, George, 1869, Coast Pilot of Alaska, first part, from southern boundary to Cook's Inlet: U.S. Coast and Geodetic Survey, 246 p. 1902, Copper River of Alaska: Geog. Soc. Pacific, Trans. and Proc., ser. 2, v. 2, p. $45-50$.

1903, The Alaska boundary: San Francisco, Alaska Packers Assoc., 235 p.

Davies, F. C., 1965, On the Valdez Trail: Alaska Sportsman, v. 31 , no. 6 , p. 22-24.
DeArmond, R. E., 1962, And so it was namedGirdwood: Alaska Sportsman, v. 28, no. 6, p. 40-41.

DeArmond, R. N., 1957, Some names around Juneau: Sitka, Alaska, Sitka Printing Co., $48 \mathrm{p}$.

Dease, P. W., and Simpson, Thomas, 1843: see Simpson, 1843, for an account of their work.

Detterman, R. L., Bickel, R. S., and Gryc, George, 1963, Geology of the Chandler River region, Alaska: U.S. Geol. Survey Prof. Paper 303-E, p. 223-324.

Dixon, George, 1739, A voyage around the world; but more particularly to the northwest coast of America; performed in 1785, 1786,1787 , and 1788 in the King George and Queen Charlotte, Captains Portlock and Dixon: London, G. Goulding, 360 p.

Drewes, Harald, Fraser, G. D., Snyder, G. L., and Barnett, H. F., Jr., 1961, Geology of Unalaska Island and adjacent insular shelf, Aleutian Islands, Alaska: U.S. Geol. Survey Bull. 1028-S, p. 583-676 [1962].

Dufresne, Frank, 1946, Alaska's animals and fishes: New York, A. S. Barnes and Co., 297 p.

Eakin, H. M., 1913, A geologic reconnaissance of a part of the Rampart quadrangle, Alaska: U.S. Geol. Survey Bull. 535, 38 p.

_ 1914, The Iditarod-Ruby region, Alaska: U.S. Geol. Survey Bull. 578, 45 p.

1916, The Yukon-Koyukuk region, Alaska: U.S. Geol. Survey Bull. 631, 88 p. 1918, The Cosna-Nowitna region, Alaska: U.S. Geol. Survey Bull. 667, $54 \mathrm{p}$. 1919, The Porcupine gold placer district, Alaska: U.S. Geol. Survey Bull. 699, 29 p.

Eckhart, R. A., 1953, Gypsiferous deposits on Sheep Mountain, Alaska: U.S. Geol. Survey Bull. 989-C, p. 39-61.

Eckhart, R. A., and Plafker, George, 1959, Haydite raw material in the Kings River, Sutton, and Lawing arcas, Alaska: U.S. Geol. Survey Bull. 1039-C, p. 33-65.

Eicher, G. J., 1943, Shortcut North: Alaska Life, v. 6, no. 1, p. 7-10.

Eldridge, G. H., 1900, A reconnaissance in the Susitna basin and adjacent territory, Alaska, in 1898: U.S. Geol. Survey 20th Ann. Rept., pt. 7, p. 1-29.

Elliott, H. W., 1881, A monograph of the Pribylov Group, or the Seal-Islands of Alaska: Washington, U.S. Govt. Printing Office, sec. 9, mon. A; reprinted with additions, 1882, A monograph of the Seal-Islands of Alaska: U.S. Comm. of Fish and Fisheries Spec. Bull., $176 \mathrm{p}$.

1886, Our Arctic province, Alaska and the Seal Islands: New York, Charles Scribner's Sons, $473 \mathrm{p}$.

Ellsworth, C. E., and Davenport, R. W., 1915a, A water-power reconnaissance in south-central Alaska, with a section on southeastern Alaska, by J. C. Hoyt: U.S. Geol. Survey WaterSupply Paper 372, 173 p.

-1915b, Surface water supply of the Yukon-Tanana region, Alaska: U.S. Geol. Survey Water-Supply Paper 342, 343 p. 
Emerson, B. K., Gilbert, G. K., Palache, Charles, Dall, W. H., Ulrich, E. O., and Knowlton, F. H., 1904, Geology and paleontology: Harriman Alaska Exped., v. 4, 173 p.

Emmons, S. F., and Hayes, C. W., 1903, Contributions to economic geology, 1902: U.S. Geol. Survey Bull. 213, 283 p.

-1904, Contributions to economic geology, 1903: U.S. Geol. Survey Bull. 225, $382 \mathrm{p}$

Farquhar, F. P., 1959, Naming Alaska's mountains; with some accounts of their first ascent Am. Alpine Jour., v. 11, p. 211-232.

Fernald, A. T., 1960, Geomorphology of the upper Kuskokwim region, Alaska: U.S. Geol. Survey Bull. 1071-G, p. 191-279.

1964, Surficial geology of the central Kobuk River valley, northwestern Alaska: U.S. Geol. Survey Bull. 1181-K, 31 p.

Field, W. O., Jr., 1937, Observations on Alaska coastal glaciers in 1935: Geog. Rev., v. 27 (Jan.), p. 63-81.

1947, The glacier recession in Muir Inlet, Glacier Bay, Alaska: Geog. Rev., v. 37, no. 3, p. 369-399.

Filippi, Filippo de, 1900, The ascent of Mount St. Elias by H.R.H. Prince Luigi Amedeo di Savoia, Duke of the Abruzzi; narrated by Filippo de Filippi; illustrated by Vittorio Sella and translated by Signora Linda Villari with the author's supervision: New York, Frederick A. Stokes Co., 241 p.

FitzGerald, Gerald, 1944, Reconnaissance of Porcupine Valley, Alaska: U.S. Geol. Survey Bull. 933-D, p. 219-243.

1951, Surveying and mapping in Alaska: U.S. Geol. Survey Girc. 101, 24 p.

Flint, G. M., Jr., and Cobb, E. H., 1953, Gypsum deposits near Iyoukeen Gove, Chichag of Island, southeastern Alaska: U.S. Geol. Survey Bull. 989-B, p. 27-37.

Franklin, John, 1828, Narrative of a second expedition to the shores of the polar sea, in the years 1825,1826 , and $1827 * * *$; including an account of the progress of a detachment to the eastward, by John Richardson: London, J. Murray, 320 p.; repub. 1829 in Philadelphia, Carey, Lea, and Carey, $318 \mathrm{p}$

Fraser, G. D., and Barnett, H. F., 1959, Geology of the Delarof and westernmost Andreanof Islands, Aleutian Islands, Alaska: U.S. Geol. Survey Bull. 1028-I, p. 211-248.

Fraser, G. D., and Snyder, G. L., 1959, Geology of southern Adak Island and Kagalaska Island, Alaska: U.S. 'Geol. Survey Bull. 1028-M, p. 371-408.

Gabrielson, I. N., and Lincoln, F. C., 1959, Birds of Alaska: Harrisburg, Pa., The Stackpole Co., and Washington, D.C., Wildlife Management Inst., $911 \mathrm{p}$.

Galiano, D. A., 1802, Relación del viage hecho por las goletas Sutil y Mexicana en el año de 1792, para reconocer el estrecho de Fuca; con una introdución en que se da noticia de las expediciones executadas anteriormente par los Españoles en busca del paso del noroeste de la América. De orden del rey. [Narrative of the trip made by the ships Sutil and Mexi- cana in the year 1792 to survey the Strait of Fuca, with an introduction which gives information of the expeditions made previously by the Spanish looking for the northwest passage of America. By order of the King]: Madrid, imprenta real, $185 \mathrm{p}$. and atlas.

Gault, H. R., and Fellows, R. E., 1953, Zinccopper deposit at Tracy Arm, Petersburg district, Alaska: U.S. Geol. Survey Bull. 998-A, p. 1-13.

Gault, H. R., Rossman, D. L., Flint, G. M., Jr., and Ray, R. G., 1953, Some zinc-lead deposits of the Wrangell district, Alaska: U.S. Geol. Survey Bull. 998-B, p. 15-58.

Geist, O. W., 1936, Archaeological excavations at Kukulik, St. Lawrence Island, Alaska: Univ. Alaska Misc. Pubs., 391 p.

Geoghegan, R. H., 1944, The Aleut language, the elements of Aleut grammar with a dictionary in two parts containing basic vocabularies of Aleut and English: Washington, U.S. Dept Interior, 169 p.; ed. by Fredericka I. Martin.

Gibson, William, and Nichols, Haven, 1953, Configuration of the Aleutian Ridge, Rat Islands-Semisopochnoi Island to west of Buldir Island: Geol. Soc. Am. Bull., v. 64, no. 10 , p. $1173-1187$.

Giddings, J. L., 1964, The archeology of Cape Denbigh: Providence, R.I., Brown Univ. Press, $331 \mathrm{p}$.

Gilbert, G. K., 1904, Glaciers and glaciation: Harriman Alaska Exped., v. 3, 231 p.

Gill, A. C., 1922, Chromite of Kenai Peninsula, Alaska: U.S. Geol. Survey Bull. 742, 52 p.

Glenn, E. F., and Abercrombie, W. R., 1899, Reports of explorations in the Territory of Alaska, made under the direction of the Secretary of War by Captain Edwin F. Glenn and Captain W. R. Abercrombie: U.S. Adjutant General's Office, Mil. Inf. Div., pub. 25 (War Dept. doc. 102), 464 p.

Golder, F. A., 1914, Russian expansion on the Pacific, 1641-1850: Cleveland, The Arthur H. Clark Co., 368 p.

1922, Bering's voyages; an account of the efforts of the Russians to determine the relation of Asia and America: Am. Geog. Soc. Research Ser. 1, v. 1, 371 p.

1925 , Bering's voyages; an account of the efforts of the Russians to determine the relation of Asia and America: Am. Geog. Soc. Research Ser. 2, v. 2, 290 p.

Golovin, P. N., 1862, Obzor russkikh kolonii v Siev. Amerikiye [Survey of the Russian colonies in North America]: St. Petersburg, in Morskoi Sbornik, v. 1, no. 1, p. 19-192; English translation in Congressional Papers, U.S. House Ex. Doc. 177, U.S. 40th Cong., 2d sess., p. 109-112.

Gordon, G. B., 1917, In the Alaskan wilderness: Philadelphia, The John C. Winston Co., 247 p. Gorman, M. W., 1903, The Lake Illiamna region, Alaska: Pacific Monthly, v. 9 (May), p. 299-304.

Grant, U. S., and Higgins, D. F., 1910, Reconnaissance of the geology and mineral resources of Prince William Sound, Alaska: U.S. Geol. Survey Bull. 443, $89 \mathrm{p}$.
Grant, U. S., and Higgins, D. F., 1910-11, Glaciers of Prince William Sound and the southern part of the Kenai Peninsula, Alaska: Am. Geog. Soc. Bull., v. 42, p. 721-738; v. 43, p. 321-338, 401-417, 721-737.

1913, Coastal glaciers of Prince William Sound and Kenai Peninsula, Alaska: U.S. Geol. Survey Bull. 526, 75 p.

Grantz, Arthur, 1956, Magnetite deposits at Tuxedni Bay, Alaska: U.S. Geol. Survey Bull. 1024-D, p. 95-106.

- 1964, Stratigraphic reconnaissance of the Matanuska Formation in the Matanuska Valley, Alaska: U.S. Geol. Survey Bull. 1181-I, 33 p.

Grantz, Arthur, Plafker, George, and Kachadoorian, Reuben, 1964, Alaska's Good Friday earthquake, March 27, 1964, a preliminary geologic evaluation: U.S. Geol. Survey Circ. $491,35 \mathrm{p}$.

Great Britain, 1852, Report of the committee appointed by the Lords Commissioners of the Admiralty to inquire into and report on the recent Arctic expeditions in search of Sir John Franklin, together with the minutes of evidence taken before the committee and papers connected with the subject: London, George Edward Eyre and William Spottiswoode, 199 p.

1854, Papers relative to the recent Arctic expeditions in search of Sir John Franklin and the crews of H.M.S. Erebus and Terror: London, George Edward Eyre and William Spottiswoode, 225 p. (includes a "Chart of part of the coast of North America shewing the journeys of Comr. Maguire, H.M.S. Plover * * *.")

1855 , Further papers relative to the recent Arctic expeditions in search of Sir John Franklin and the crews of H.M.S. Erebus and Terror: London, George Edward Eyre and William Spottiswoode, $958 \mathrm{p}$.

Grewingk, Constantin, 1850, Beitrag zur Kenntniss der orographischen und geognostischen Beschaffenheit der Nord-West Kuste Amerikas, mit den anliegenden Inseln [Contribution to the knowledge of the orography and geography of the northwest coast of America and neighboring islands]: Russisch-Kaiserlichen Mineralogischen Gesell. zu St. Petersburg Verh. fur $1848-49$, p. 76-424; reprinted in St. Petersburg Gedruckt bey K. Kray, 351 p.

Griggs, R. F., 1922, The Valley of Ten Thousand Smokes: Washington, Nat. Geog. Soc., $340 \mathrm{p}$.

Grinnell, Joseph, 1909, Birds and mammals of the 1907 Alexander expedition to southeastern Alaska, in Univ. of California Pub. in Zool.: Berkeley, Calif., The University Press, v. 5, no. $2,264 \mathrm{p}$.

Gruening, Ernest, 1954, The State of Alaska: New York, Random House, $606 \mathrm{p}$.

Guild, P. W., 1942, Chromite deposits of Kenai Peninsula, Alaska: U.S. Geol. Survey Bull. 931-G, p. 139-175.

Guild, P. W., and Balsley, J. R., Jr., 1942, Chromite deposits of Red Bluff Bay and vicin- 
ity, Baranof Island, Alaska: U.S. Geol. Survey Bull. 936-G, p. 171-187.

Gunther, Erna, 1956: see Krause, 1885.

Hallock, Charles, 1898, Two hundred miles up the Kuskokwim: Nat. Geog. Mag., v. 9 (Feb.), p. 85-92.

Hand, B. F., 1905, The Cook Inlet country: Alaska's Mag., v. 1 (May), p. 147-150.

Harriman Alaska Expedition, 1902-05, Harriman Alaska expedition of 1899: New York, Doubleday, Page, and Co., v. 1-5, 8-13, ed. by C. H. Merriam; (repub. 1910-14 by Smithsonian Inst. as Harriman Alaska Ser. of Smithsonian Inst.; v. 14 pub. 1914) by Smithsonian Inst.

Harrington, G. L., 1918, The Anvik-Andreafski region, Alaska (including the Marshall district) : U.S. Geol. Survey Bull. 683, 70 p.

Hayes, C. W., 1892, An expedition through the Yukon district: Nat. Geog. Mag., v. 4 (May 15), p. 118-162.

- 1898, Copper River as a route to the Yukon basin: Am. Geog. Soc. Jour. [Bull.], v. 30, p. 127-134.

Healy, M. A., 1887, Report of the cruise of the revenue marine steamer Corwin in the Arctic Ocean in the year 1885: U.S. Revenue-Cutter Service, 102 p.; issued also as H. Ex. Doc. 153, U.S. 49th Cong., 1st sess. (includes repts. by J. C. Cantwell, S. B. McLenegan, and C. H. Townsend).

- 1889, Report of the cruise of the revenue marine steamer Corzein in the Arctic Ocean in the year 1884: U.S. Revenue-Cutter Service, 128 p.; issued also as H. Misc. Doc. 602, U.S. 50th Cong., 1st sess. (includes repts. by J. C. Cantwell and S. B. McLenegan).

Henning, Bob, 1965, The Milepost, Alaska Highway Guidebook [17th revised ed.]: Juneau, Alaska Northwest Pub. Co., 224 p.

Henshaw, F. F., and Covert, C. C., 1908, Water-supply investigations in Alaska, 190607 (Nome and Kougarok regions, Seward Peninsula; Fairbanks district, Yukon-Tanana region): U.S. Geol. Survey Water-Supply Paper 218, 156 p.

Henshaw, F. F., and Parker, G. L., 1913, Surface water supply of Seward Peninsula, Alaska, with a sketch of the geography and geology, by P. S. Smith, and a description of methods of placer mining, by A. H. Brooks: U.S. Geol. Survey Water-Supply Paper 314, 317 p.

Herron, J. S., 1901, Explorations in Alaska, 1899, for an all-American overland route from Cook Inlet, Pacific Ocean, to the Yukon: U.S. Adjutant General's Office, Military Information Div., pub. 31, 77 p. (War Dept. doc. no. 138); issued also as S. Doc. 689, U.S. 60th Cong., $2 \mathrm{~d}$ sess.

Hick, George, 1954, Pioneer prospector: Alaska Univ., 32 p. [ed. by C. E. Bunnell].

Hill, J. M., 1933, Lode deposits of the Fairbanks district, Alaska: U.S. Geol. Survey Bull. 849-B, p. 29-163.

Hinz, Rev. John, 1944, Grammar and vocabulary of the Eskimo language as spoken by the Kuskokwim and southwest coast Eskimos of Alaska: Bethlehem, Pa., The Soc. for Prop- agating the Gospel, the Moravian Church, $199 \mathrm{p}$.

Hodge, F. W., ed., 1907, Handbook of American Indians, north of Mexico: Bur. Am. Ethnology Bull. 30, pt. 1, 972 p.

1910, Handbook of American Indians, north of Mexico: Bur. Am. Ethnology Bull. 30 , pt. 2, 1221 p.

Holmberg, H. J., 1855, Ethnographische Skizzen über die Volker des russischen Amerika: Helsingfors, Gedruckt bei H. C. Friis, 2 v.

Holmes, G. W., 1965, Geologic reconnaissance along the Alaska Highway, Delta River to Tok Junction, Alaska: U.S. Geol. Survey. Bull. 1181- H, 19 p.

Holmes, G. W., and Lewis, C. R., 1965, Quaternary geology of the Mount Chamberlin area, Brooks Range, Alaska: U.S. Geol. Survey Bull. 1201-B, 32 p.

Hooper, C. L., 1881, Report of the cruise of the U.S. Revenue-Steamer Corwin in the Arctic Ocean, 1880: U.S. Revenue-Cutter Service, $71 \mathrm{p}$.; issued as Treasury Dept. Doc. 118.

Hopkins, D. M., 1963, Geology of the Imuruk Lake area, Seward Peninsula, Alaska: U.S. Geol. Survey Bull. 1141-C, 101 p. [1964].

Hopkins, D. M., Karlstrom, T. N. V., and others, 1955, Permafrost and ground water in Alaska: U.S. Geol. Survey Prof. Paper 264-F, p. 113146

Hopkins, D. M., and Sigafoos, R. S., 1951, Frost action and vegetation patterns on Seward Peninsula, Alaska: U.S. Geol. Survey Bull. 974-C, p. 51-101.

Hosley, E. H., 1961, The McGrath Ingalik: Anthropol. Papers Alaska Univ., v. 9, no. 2, p. $93-113$.

Houston, J. R., Bates, R. G., Velikanje, R. S., and Wedow, Helmuth, Jr., 1958, Reconnaissance for radioactive deposits in southeastern Alaska, 1952: U.S. Geol. Survey Bull. 1058-A, p. 1-31.

Hoyt, J. C., 1915, A water-power reconnaissance in southeastern Alaska: see Ellsworth and Davenport, 1915a.

Hoyt, J. C., and Henshaw, F. F., 1907, Water supply of Nome region, Seward Peninsula, Alaska, 1906: U.S. Geol. Survey WaterSupply Paper 196, $52 \mathrm{p}$.

Hrdlička, Aleš, 1930, Anthropological survey in Alaska: Bur. Am. Ethnology 46th Ann. Rept. p. $19-374$.

- 1933, The Eskimos of the Kuskokwim: Am. Jour. of Phys. Anthropology, v. 18, no. 1, p. $93-135$.

1943, Alaska Diary 1926-1931: Lancaster, Pa., The Jaques Cattell Press, 414 p.

- 1945, The Aleutian and Commander Islands and their inhabitants: Philadelphia, The Wistar Inst. Anatomy and Biology, $630 \mathrm{p}$. Hughes, John, 1948, The Yukon on the Yukon: Alaska Sportsman, v. 14, no. 12, p. 12.

Hull, Thomas, 1853, Barrow Point to Port Moore: British Adm. Chart 2164; engraved by J. C. Walker [1854].

Hulley, C. C., 1953, Alaska, 1741-1953: Portland, Oreg., Binfords \& Mort, $406 \mathrm{p}$.
Hyatt, Alpheus, and Smith, J. P., 1905, The Triassic cephalopod genera of America: U.S. Geol. Survey Prof. Paper 40, 394 p.

International Boundary Commission, 1918a, Atlas of the international boundary between the United States and Canada, Arctic Ocean to Mount St. Elias: U.S. Dept. State, 38 sheets (sheets 1-32, pub. 1914; sheets 33-38, 1918).

$1918 \mathrm{~b}$, Joint report upon the survey and demarcation on the international boundary between the United States and Canada along the 141st meridian from the Arctic Ocean to Mount St. Elias: U.S. Dept. State, 305 p.

- 1951, Joint maps of international boundary between United States and Canada, from Cape Munzon to Mount St. Elias: U.S. Dept. State, 13 sheets (sheets 1, 2 pub. earlier, no date; sheets $3-5$, pub. 1927 ; sheets $6-10$, 1923 ; sheets $11-13,1928$ ).

1952 , Joint report upon the survey and demarcation of the boundary between Canada and the United States from Tongass Passage to Mount St. Elias: U.S. Dept. State, 365 p.

International Polar Expedition, 1885, Report of the International Polar Expedition to Point Barrow, Alaska, in response to the resolution of the House of Representatives of December 11, 1848: U.S. Signal Office, Arctic ser. publications, no. 1, 695 p.; issued also as H. Ex. Doc. 44 , U.S. 48th Cong., 2d sess.

Irving, Lawrence, 1954, Biological reconnaissance along the Ahlasuruk River east of Howard Pass, Brooks Range, Alaska, with notes on the Avifauna: Jour. Washington Acad. Sci., v. 44, no. 7, p. 201-211.

Isto, R. E., 1958, Alaska geographical names: Geol. Soc. Am. Bull., v. 69, no. 12, pt. 2, p. 1754-1755.

Jackson, Sheldon, 1880, Alaska, and missions on the north Pacific coast: New York, Dodd, Mead, \& Co., 327 p.

- 1893, Introduction of reindeer into Alaska [1891-92]: U.S. Bur. [Office] Education; issued also as S. Misc. Doc. 22, U.S. 52d Cong., 2d sess.

1894, Report on introduction of domestic reindeer into Alaska, 1893: U.S. Bur. [Office] Education; issued also as S. Ex. Doc. 70 , U.S. 53d Cong., 2d sess.

1895, Report on introduction of domestic rcindeer into Alaska, 1894: U.S. Bur. [Office] Education; issued as S. Ex. Doc. 92, U.S. 53d Cong., 3d sess.

1896, Report on introduction of domestir reindeer into Alaska, 1895: U.S. Bur. [Office] Education; issued also as S. Doc. 111, U.S. 54 th Cong., 1st sess.

1897, Report on introduction of domestic reindeer into Alaska, 1895: U.S. Bur. [Office] Education; issued also as $S$. Doc. 49, U.S. 54th Cong., 2d sess.

1898a, Report on introduction of domestic reindeer into Alaska, 1897: U.S. Bur. [Office] Education [1898]; issued as S. Doc. 30, U.S. 55th Cong., 2d sess.

1898b, Report on introduction of domestic reindeer into Alaska, 1898: U.S. Bur. [Of- 
fice] Education; issued also as S. Doc. 34, U.S. 55th Cong., 3d sess.

Jackson, Sheldon, 1900, Ninth annual report on introduction of domestic reindeer into Alaska, 1899: U.S. Bur. [Office] Education; issued also as S. Doc. 245, U.S. 56th Cong., 1st sess.

1901, Tenth annual report on introduction of domestic reindeer into Alaska, 1900: U.S. Bur. [Office] Education; issued also as $\mathbf{S}$. Doc. 206, U.S. 56th Cong., 2d sess.

1902 , Eleventh annual report on introduction of domestic reindeer into Alaska, 1901 : U.S. Bur. [Office] Education; issued as S. Doc. 98, U.S. 57th Cong., 1st sess.

1903 , Twelfth annual report on introduction of domestic reindeer into Alaska, 1902: U.S. Bur. [Office] Education; issued also as S. Doc. 70, U.S. 57 th Cong., $2 \mathrm{~d}$ sess.

1904 , Thirteenth annual report on introduction of domestic reindeer into Alaska, 1903: U.S. Bur. [Office] Education; issued as S. Doc. 210 , U.S. 58th Cong., $2 \mathrm{~d}$ sess.

- 1905, Fourteenth annual report on introduction of domestic reindeer into Alaska, 1904: U.S. Bur. [Office] Education; issued also as S. Doc. 61 , U.S. 58th Cong., 3d sess.

1906, Fifteenth annual report on introduction of domestic reindeer into Alaska, 1905: U.S. Bur. [Office] Education; issued also as S. Doc. 499, U.S. 59th Cong., 1st sess.

1908 , Sixteenth annual report on introduction of domestic reindeer into Alaska, 1906: U.S. Bur. [Office] Education; issued also as S. Doc. 501, U.S. 60th Cong., 1st sess.

Jenness, Diamond, 1928, Comparative vocabulary of the western Eskimo dialects, in part A, Eskimo language and technology, of volume 5, Report of the Canadian Arctic Expedition 1913-18: Ottawa, F. A. Acland, 134 p.

1944, Grammatical notes on some western Eskimo dialects, in part B, Eskimo language, of Report of the Canadian Arctic Expedition 1913-18: Ottawa, Edmond Cloutier, $34 \mathrm{p}$.

Jochelson, Waldemar, 1925, Archaeological investigations in the Aleutian Islands: Carnegie Inst. Washington, Pub. 367, 145 p.

Johnson, F. A., 1961, Waterpower resources of the Bradley River basin, Kenai Peninsula, Alaska: U.S. Geol. Survey Water-Supply Paper 1610- $\dot{\mathrm{A}}, 25$ p.

1962, Waterpower resources near Petersburg and Juneau, southeastern Alaska: U.S. Geol. Survey Water-Supply Paper 1529, 102 p.

Johnson, H. A., and Stanton, K. L., 1955, Matanuska Valley memoir: Palmer, Alaska Agr., Expt. Sta. Bull. 21, 31 p.

Jones, L. F., 1914, A study of the Thlingets [sic] of Alaska: New York, Chicago, Fleming $\mathrm{H}$. Revell Co., 261 p.

Jones, Strachan, 1867, The Kutchin Tribes, in George Gibbs, Notes on the Tinneh or Chippewyan Indians: Smithsonian Inst. Ann. Rept. 1866 , p. $320-327$.

Karistrom, T. N. V., 1964, Quaternary geology of the Kenai Lowland and glacial history of the Cook Inlet region, Alaska: U.S. Geol. Survey Prof. Paper 443, 69 p.
Keele, Joseph, 1910, A reconnaissance across the Mackenzie Mountains on the Pelly, Ross, and Gravel Rivers, Yukon and North West Territories: Ottawa, Govt. Printing Bureau, $54 \mathrm{p}$.

Keithahn, E. L., 1962, Chirikof, the foggy island: Alaska Sportsman, April, v. 28, no. 4, p. 16 .

Keller, A. S., Morris, R. H., and Detterman, R. L., 1961, Geology of the Shaviovik and Sagavanirktok Rivers region, Alaska: U.S. Geol. Survey Prof. Paper 303-D, p. 169-222.

Keller, A. S., and Reiser, H. N., 1959, Geology of the Mount Katmai area, Alaska: U.S. Geol. Survey Bull. 1058-G, p. 260-297.

Kennedy, G. C., 1953, Geology and mineral deposits of Jumbo basin, southeastern Alaska: U.S. Geol. Survey Prof. Paper 251, 46 p.

Kennedy, G. C., and Waldron, H. H., 1955, Geology of Pavlof Volcano and vicinity, Alaska: U.S. Geol. Survey Bull. 1028-A, p. 1-19 [1956].

Kennedy, G. C., and Walton, M. S., Jr., 1946, Nickel investigations in southeastern Alaska: U.S. Geol. Survey Bull. 947-C, p. 39-64.

Killeen, P. L., and Ordway, R. J., 1955, Radioactivity investigations at Ear Mountain, Seward Peninsula, Alaska: U.S. Geol. Survey Bull. 1024-C, p. 59-94.

Kindle, E. M., 1908, Geologic reconnaissance of the Porcupine Valley, Alaska: Geol. Soc. Am. Bull., v. 19 (Oct.), p. 315-338.

King, Joe, 1909, The Tanana Valley: AlaskaYukon Mag., v. 7 (Jan.), p. 251-258.

Kingston, Jack, and Miller, J. D., 1945, Nickelcopper prospect near Spirit Mountain, Copper River region, Alaska: U.S. Geol. Survey Bull. 943-C, p. 49-57.

Kitchener, L. D., 1954, Flag over the North: Seattle, Wash., Superior Pub. Co., 349 p.

Klotz, O. J., 1899, Notes on glaciers of southeastern Alaska and adjoining territory: Geog. Jour., v. 14 (Nov.), p. 523-534.

Knopf, Adolph, 1908, Geology of the Seward Peninsula tin deposits, Alaska: U.S. Geol. Survey Bull. 358, 71 p.

1911, Geology of the Berners Bay region, Alaska: U.S. Geol. Survey Bull. 446, 58 p.

1912a, The Eagle River region, southeastern Alaska: U.S. Geol. Survey Bull. 502, $61 \mathrm{p}$.

1912b, The Sitka mining district: U.S Geol. Survey Bull. 504, 32 p.

Kotzebue, Otto von, 1821, A voyage of discovery, into the South Sea and Bering's Straits, for the purpose of exploring a north-east passage; translated from the German by H. E. Lloyd: London, Longman, Hurst, Rees, Orme, and Brown, 3 v.

Krause, Arthur, and Krause, Aurel, 1883, Das Chilcat-Gebiet in Alaska [The Chilkat territory in Alaska]: Zeitschr., Gesell. Erdkunde Berlin, p. 344-368.

Krause, Aurel, 1885, Die Tlinkit-Indianer [The Tlingit Indians]: Jena; English translation by Erna Gunther, 1956, Seattle, Wash., Univ. Washington Press for Am. Ethnological Soc., $328 \mathrm{p}$.
Krusenstern, A. J. von, 1827, Atlas de l'ocean Pacifique: St. Petersburg.

Laguna, Frederica de, 1934, The archaeology of Cook Inlet, Alaska: Philadelphia, Univ. of Pennsylvania Press, 263 p.

_ 1947, The pre-history of northern North America as seen from the Yukon: Soc. for Am. Archeology, Mem., v. 12, no. 3, pt. 2, 360 p. - 1960, The story of a Tlingit Community: a problem in the relationship between archeological, ethnology, and historical methods: Bur. Am. Ethnology Bull. 172, 254 p.

Laguna, Frederica de, Riddell, F. A., McGeein, D. F., Lane, K. S., and Freed, J. A., 1964, Archeology of the Yakutat Bay area, Alaska: Bur. Am. Ethnology Bull. 192, 226 p.

Langsdorff, G. H. von, 1813-14, Voyages and travels in various parts of the world during the years 1803-07: London, H. Colburn, 2 v.

La Perouse, J. F. G., 1799, Voyage round the world in the years 1785-1788: London, G. G. and J. Robinson, $2 \mathrm{v}$. and atlas folio; originally published in 1797, Paris, Imp. de la Republique, $4 \mathrm{v}$, and atlas folio.

Latham, R. G., 1846, On the ethnography of Russian America: Edinburgh New Philos. Jour., v. 40 (Jan.), p. 35-44.

- 1848, On the ethnography of Russian America: Ethnological Soc. London Jour., $\mathbf{v}$. 1, p. 182-191.

Lathram, E. H., Pomeroy, J. S., Berg, H. C., and Loney, R. A., 1965, Reconnaissance geolog; of Admiralty Island, Alaska: U.S. Geol. Survey Bull. 1181-R, 48 p.

Lawrence, D. B., 1950, Glacier fluctuation for six centuries in southeastern Alaska and its relation to solar activity: Geog. Rev., April, v. 40, p. 191-223.

Leffingwell, E. de K., 1919, The Canning River region, northern Alaska: U.S. Geol. Survey Prof. Paper 109, 251 p.

Lewis, R. Q., Nelson, W. H., and Powers, H. A., 1960, Geology of Rat Island, Aleutian Islands, Alaska: U.S. Geol. Survey Bull. 1028-Q, p. 555-562.

Libbey, William, 1886, Some of the geographical features of southeastern Alaska: Am. Geog. Soc. Jour. [Bull.], v. 18, p. 279-300.

Lisianski, U. T., 1814, A voyage round the world in the years $1803-05$, performed by order of His Imperial Majesty Alexander the First, emperor of Russia, in the ship Neva: London, printed for J. Booth, 388 p.; originally pub. in Russian by F. Drekhsler, 1812, St. Petersburg, 2 v., 581 p.

Loney, R. A., 1964, Stratigraphy and petrography of the Pybus-Gambier area, Admiralty Island, Alaska: U.S. Geol. Survey Bull. 1178. 103 p. [1965].

Loney, R. A., Condon, W. H., and Dutro, J. T., Jr., 1963, Geology of the Freshwater Bay area, Chichagof Island, Alaska: U.S. Geol. Survey Bull. 1108-C, 54 p.

Lutke, F. P., 1836, Voyage autour du monde, executé par ordre de Sa Majesté l'empereur Nicolas $1^{\text {er }}$, sur la corvette le Séniavine, dans les années 1826-1829 [Voyage around the world, executed by order of His Majesty 
Emperor Nicholas I, in the sloop of war Séviavine, in the years 1826-1829]: St. Petersburg, C. Hintze; earlier editions published in Paris and St. Petersburg.

MacDonald, Rose M. E., 1921, An analytical subject bibliography of the publications of the Bureau of Fisheries 1871-1920: Rept. U.S. Commissioner Fisheries 1920, app. 5, 306 p.

MacKevett, E. M., Jr., 1963, Geology and ore deposits of the Bokan Mountain uraniumthorium area, southeastern Alaska: U.S. Geol. Survey Bull. 1154, 125 p. [1964].

MacKevett, E. M., Jr., and Blake, M. C., Jr., 1963, Geology of the North Bradfield River iron prospect, southeastern Alaska: U.S. Geol. Survey Bull. 1108-D, 21 p.

1964, Geology of the Sumdum copperzinc prospect, southeastern Alaska: U.S. Geol. Survey Bull. 1108-E, $31 \mathrm{p}$.

Maclear, J. P., 1898, Sailing directions for Bering Sea and Alaska: London, printed for the hydrog. office, Admiralty, by Eyre and Spottiswoode, $352 \mathrm{p}$.

McPherson, J. L., 1907, Reconnaissance and survey for a land route from Fairbanks to Council City, Alaska. S. Doc. 214, U.S. 59th Cong., 29 p.

Maddren, A. G., 1910, The Innoko gold-placer district, Alaska, with accounts of the central Kuskokwim Valley and the Ruby Creek and Gold Hill placers: U.S. Geol. Survey Bull. 410, 87 p.

1913, The Koyukuk-Chandalar region, Alaska: U.S. Geol. Survey Bull. 532, 119 p.

Maguire, Rochfort, 1853: see Hull, 1853. 1854: see Great Britain, 1854.

Marshall, Robert, 1933, Arctic village: New York, Smith and R. Haas, 399 p.

1934, Reconnaissance of the northern Koyukuk Valley, Alaska: U.S. Geol. Survey Bull. 844-E, p. 247-264.

1956, Arctic wilderness: Berkeley, Calif., Univ. California Press, 171 p.

Martin, G. C., 1905, The petroleum fields of the Pacific coast of Alaska, with an account of the Bering River coal deposits: U.S. Geol. Survey Bull. 250, 64 p.

1906, A reconnaissance of the Matanuska coal field, Alaska, in 1905: U.S. Geol. Survey Bull. 289, 36 p.

- 1908, Geology and mineral resources of the Controller Bay region, Alaska: U.S. Geol. Survey Bull. 335, 141 p.

1913, The recent eruption of Katmai volcano in Alaska; an account of one of the most tremendous volcanic explosions known in history: Nat. Geog. Mag., v. 24, p. 131-181.

1919, The Nenana coal field, Alaska:

U.S. Geol. Survey Bull. 664, 54 p.

1921, Preliminary report on petroleum in Alaska: U.S. Geol. Survey Bull. 719, 83 p.

- 1926, The Mesozoic stratigraphy of Alaska: U.S. Geol. Survey Bull. 776, 493 p. Martin, G. C., Johnson, B. L., and Grant, U.S., 1915, Geology and mineral resources of Kenai Peninsula, Alaska: U.S. Geol. Survey Bull. 587,243 p.
Martin, G. C., and Katz, F. J., 1912a, Geology and coal fields of the lower Matanuska Valley, Alaska: U.S. Geol. Survey Bull. 500, 98 p. $1912 \mathrm{~b}$, A geologic reconnaissance of the Iliamna region, Alaska: U.S. Geol. Survey Bull. 485, 138 p.

Martin, G. C., and others, 1919, Mineral resources of Alaska, report on progress of investigations in 1917: U.S. Geol. Survey Bull. 692, $400 \mathrm{p}$.

- 1920, Mineral resources of Alaska, report on progress of investigations in 1918: U.S. Geol. Survey Bull. 712, 198 p.

Meares, John, 1790, Voyages made in the years 1788-1789 from China to the northwest coast of America: London, J. Walter, 372 p.; 2d ed. pub. 1791, 2 v.

Mendenhall, W. C., 1900, A reconnaissance from Resurrection Bay to the Tanana River, Alaska, in 1898: U.S. Geol. Survey 20th Ann. Rept., pt. 7, 265-340.

-1901, A reconnaissance in the Norton Bay region, Alaska, in 1900: see Brooks, 1901. - 1902, Reconnaissance from Fort Hamlin to Kotzebue Sound, Alaska, by way of Dall, Kanuti, Allen, and Kowak Rivers: U.S. Geol. Survey Prof. Paper 10, $68 \mathrm{p}$.

- 1903, The Wrangle Mountains, Alaska: Nat. Geog. Mag., v. 14 , no. 11 , p. 395-407.

1905, Geology of the central Ciopper River region, Alaska: U.S. Geol. Survey Prof. Paper 41, 133 p.

Mendenhall, W. C., and Schrader, F. C., 1903, The mineral resources of the Mount Wrangell district, Alaska: U.S. Geol. Survey Prof. Paper $15,71 \mathrm{p}$.

Merriam, G. \& C., Co., 1964, Webster's Geographical Dictionary [revised ed.]: Springfield, Mass., G. \& C. Merriam Co., 1,293 p.

Mertie, J. B., Jr., 1930, Geology of the EagleCircle district, Alaska: U.S. Geol. Survey Bull. 816, 168 p.

1931, A geologic reconnaissance of the Dennison Fork district, Alaska: U.S. Geol. Survey Bull. 827, 44 p.

1934, Mineral deposits of the Rampart and Hot Springs districts, Alaska: U.S. Geol. Survey Bull. 844-D, p. 163-224.

- 1936, Mineral deposits of the RubyKuskokwim region: U.S. Geol. Survey Bull. 864-C, p. 115-255.

1937a, The Kaiyuh Hills: U.S. Geol

Survey Bull. 868-D, p. 145-178.

- 1937b, The Yukon-Tanana region Alaska: U.S. Geol. Survey Bull. 872, 276 p.

1938a, Gold placers of the Fortymile, Eagle, and Gircle districts, Alaska: U.S. Geol. Survey Bull. 897-C, p. 133-261.

1938b, The Nushagak district, Alaska: U.S. Geol. Survey Bull. 903, 96 p.

-1939, Platinum deposits of the Goodnews Bay district, Alaska: U.S. Geol. Survey Bull. 910-B, p. 115-145 [1940].

- 1940, The Goodnews platinum deposits, Alaska: U.S. Geol. Survey Bull. 918, 97 p.

1942, Tertiary deposits of the EagleCircle district, Alaska: U.S. Geol. Survey Bull. 917-D, p. 213-264.
Mertie, J. B., Jr., and Harrington, G. L., 1924, The Ruby-Kuskokwim region, Alaska: U.S. Geol. Survey Bull. 754, 129 p.

Mikkelsen, Ejnar, 1909, Conquering the Arctic ice: Philadelphia, George W. Jacobs \& Co.; London, W. Heinemann, $470 \mathrm{p}$.

Milepost, The, 1965: see Henning, 1965.

Miller, D. J., 1946, Copper deposits of the Nizina district, Alaska, with an introduction by $\mathbf{F} . \mathbf{H}$. Moffit: U.S. Geol. Survey Bull. 947-F, p. 93120.

1960, Giant waves in Lituya Bay, Alaska: U.S. Geol. Survey Prof. Paper 354-C, p. 51-86.

Miller, D. J., Payne, T. G., and Gryc, George, 1959 , Geology of possible petroleum provinces in Alaska, with an annotated bibliography by E. H. Cobb: U.S. Geol. Survey Bull. 1094, $131 \mathrm{p}$.

Miller, J. C., 1962a, Geology of waterpower sites on Crater Lake, Long Lake, and Speel River near Juneau, Alaska: U.S. Geol. Survey Bull. 1031-D, p. 71-101.

- 1962b, Geology of waterpower sites on Scenery, Cascade, and Delta Creeks, near Petersburg, Alaska: U.S. Geol. Survey Bull. 1031-E, p. 103-125.

Miller, R. D., and Dobrovolny, Ernest, 1959, Surficial geology of Anchorage and vicinity, Alaska: U.S. Geol. Survey Bull. 1093, 128 p. [1960].

Moffit, F. H., 1905, The Fairhaven gold placers, Seward Peninsula, Alaska: U.S. Geol. Survey Bull. 247, 85 p.

1906, Mineral resources of Kenai Peninsula, Alaska: Gold fields of the Turnagain Arm region; and Coal fields of the Kachemak Bay region, by R. W. Stone; Geol. Survey Bull. 277,80 p.

- 1912, Headwater regions of Gulkana and Susitna Rivers, Alaska, with accounts of the Valdez Creek and Chistochina placer districts: U.S. Geol. Survey Bull. 498, 82 p.

_ 1913, Geology of the Nome and Grand Central quadrangles, Alaska: U.S. Geol. Survey BuIl. 533, $140 \mathrm{p}$.

1914, Geology of the Hanagita-Bremner region, Alaska: U.S. Geol. Survey Bull. 576, $56 \mathrm{p}$.

1915, The Broad Pass region, Alaska, with sections on Quaternary deposits, igneous rocks, and glaciation, by J. E. Pogue: U.S. Geol. Survey Bull. 608, 80 p.

1918, The upper Chitina Valley, Alaska:

U.S. Geol. Survey Bull. 675, 82 p.

1927, The Iniskin-Chinitna Peninsula and Snug Harbor district, Alaska: U.S. Geol. Survey Bull. 789, $71 \mathrm{p}$.

1935, Geology of the Tonsina district, Alaska: U.S. Geol. Survey Bull. 866, 38 p.

1936, Upper Copper and Tanana Rivers: U.S. Geol. Survey Bull. 868-C, p. 135143.

- 1937, Recent mineral developments in the Copper River region: U.S. Geol. Survey Bull. 880-B, p. 97-109.

1938a, The Suslota Pass district, upper Copper River region, Alaska: U.S. Geol. Survey Bull. 844-C, p. 137-162. 
Moffit, F. H., 1938b, Geology of the Chitina Valley and adjacent area, Alaska: U.S. Geol. Survey Bull. 894, $137 \mathrm{p}$.

$1938 \mathrm{c}$, Geology of the Slana-Tok district, Alaska: U.S. Geol. Survey Bull. 904, 54 p.

1941, Geology of the upper Tetling Riv. er district, Alaska: U.S. Geol. Survey Bull. 917-B, p. 115-157.

1942, Geology of the Gerstle River district, Alaska, with a report on the Black Rapids Glacier: U.S. Geol. Survey Bull. 926-B, p. $107-160$.

1943, Geology of the Nutzotin Mountains, Alaska, with a section on the Igneous rocks, by R. G. Wayland; Gold deposits near Nabesna, by R. G. Wayland: U.S. Geol. Survey Bull. 933-B, p. 103-199.

1944, Mining in the northern Copper River region, Alaska: U.S. Geol. Survey Bull. 943-B, p. 25-47.

1954a, Geology of the eastern part of the Alaska Range and adjacent area: U.S Geol. Survey Bull. 989-D, p. 65-218.

1954b, Geology of the Prince William Sound region, Alaska: U.S. Geol. Survey Bull. 989-E, p. 225-310.

Moffit, F. H., and Capps, S. R., 1911, Geology and mineral resources of the Nizina district, Alaska: U.S. Geol. Survey Bull. 448, 111 p.

Moffit, F. H., and Fellows, R. E., 1950, Copper deposits of the Prince William Sound district, Alaska: U.S. Geol. Survey Bull. 963-B, p. 4780.

Moffit, F. H., and Knopf, Adolph, 1910, Mineral resources of the Nabesna-White River district, Alaska, with a section on the Quaternary, by S. R. Capps: U.S. Geol. Survey Bull. $417,64 \mathrm{p}$.

Moffit, F. H., and Maddren, A. G., 1909, Mineral resources of the Kotsina-Chitina region, Alaska: U.S. Geol. Survey Bull. 374, 103 p.

Moffit, F. H., and Mertie, J. B., Jr., 1923, The Kotsina-Kuskulana district, Alaska: U.S Geol. Survey Bull. 745, 149 p.

Moffit, F. H., and others, 1927, Mineral resources of Alaska, report on progress of investigations in 1925: U.S. Geol. Survey Bull. 792, 122 p

Moser, J. F., 1899a, The Salmon and Salmon fisheries of Alaska. Report of the operations of the U.S. Fish Commission steamer Albatross for the year ending June 30,1898: U.S. Fish Comm. Bull., v. 18, p. 1-178.

$1899 \mathrm{~b}$, Alaska, hydrographic notes and sailing directions relating to portions of Alaska from Dixon Entrance to Yakutat Bay, including reconnaissance surveys of Cordova Bay, Bucarelli Bay, and Red Fish Bay, 1897: U.S. Coast and Geod. Survey Bull. 37, p. 113-118. 1899c, Alaska, hydrographic notes, sailing directions, and charts of surveys relating to the vicinity of Prince William Sound, Cook Inlet, Kodiak Island, and route from Unalaska to Chignik, through Unimak Pass and inside the islands, 1897: U.S. Coast and Geod. Survey Bull. 38, p. 121-142.

1902, Alaska Salmon investigations in 1900 and 1901 : U.S. Fish Comm. Bull. 21, p. 173-398.
Moxham, R. M., and Eckhart, R. A., 1956, Marl deposits in the Knik Arm area, Alaska: U.S. Geol. Survey Bull. 1039-A, p. 1-23.

Moxham, R. M., Eckhart, R. A., and Cobb, E. H., 1959, Geology and cement raw materials of the Windy Creek area, Alaska: U.S. Geol. Survey Bull. 1039-D, p. 67-100 [1960].

Mueller, R. J., 1964, A short illustrated topical dictionary of western Kutchin: Fairbanks, Summer Inst. Linguistics, $52 \mathrm{p}$.

Muir, John, 1915, Travels in Alaska : Boston and New York, Houghton Mifflin Co., 236 p

1917, The cruise of the Corwin, journal of the Arctic expedition of 1881 in search of De Long and the Jeannette: Boston and New York, Houghton Mifflin Co., 272 p.

Murdoch, John, 1890, On Eskimo geographic names ending in Miut: Nat. Geog. Mag., v. 9 (April), p. 90.

1892, Ethnological results of the Point Barrow expedition: Bur. Am. Ethnology 9th Ann. Rept., 1887-88, 441 p.

Naish, Constance, and Story, Gillian, 1963, English-Tlingit Dictionary-Nouns: Fairbanks, Summer Inst. of Linguistics, $81 \mathrm{p}$.

Neilson, W. A., ed., 1957, Webster's new international dictionary of the English language [2d ed., unabridged]: Springfield, Mass., G. \& G. Merriam Co.

Nelson, E. W., 1882, A sledge journey in the delta of Yukon, northern Alaska: Royal Geog. Soc. Proc., New Ser., v. 4 (Nov.), p. 660-670.

1899, The Eskimo about Bering Strait: Bur. Am. Ethnology 18th Ann. Rept., pt. 1, p. $3-518$.

Nelson, W. H., 1959, Geology of Segula, Davidof, and Khvostof Islands, Alaska: U.S. Geol. Survey Bull. 1028-K, p. 257-266.

Nielsen, L. E., 1957, Preliminary study on the regime and movement of the Taku Glacier, Alaska: Geol. Soc. Am. Bull., v. 68, no. 2, p. 171-180.

1963, A glaciological reconnaissance of the Columbia Glacier, Alaska: Arctic, v. 16, no. 2, p. 134-142.

North American Transportation and Trading Company, 1900, Alaska and the gold fields of Nome, Golovin Bay, Forty Mile, the Klondike and other districts: Chicago and Seattle, North Am. Transp. and Trading Co., 136 p.

Ogilvie, William, 1897, Lectures on the Klondike mining district: Victoria, British Columbia, Richard Wolfenden, Printer to the Queen's Most Excellent Majesty, $14 \mathrm{p}$.

1913, Early days on the Yukon and the story of its gold finds: London, John Lane; New York, The John Lane Co., 306 p.

Okun, S. B., 1951, The Russian American Company: Cambridge, Mass., Harvard Univ. Press, 311 p.; ed. by B. D. Grekov, translated by Carl Ginsburg.

Osgood, Cornelius, 1936a, Contributions to the Ethnography of the Kutchin: Yale Univ. Pubs. Anthropology, no. 14, $188 \mathrm{p}$.

$1936 \mathrm{~b}$, The distribution of the Northern Athapaskan Indian: Yale Univ. Pubs. Anthropology, no. 7,23 p.
Osgood, Cornelius, 1937, The Ethnography of the Tanaina: Yale Univ. Pubs. Anthropology, no. $16,229 \mathrm{p}$

Osgood, W. H., 1900, Results of a biological reconnaissance of the Yukon River region: U.S. Bur. Biol. Survey, North Am. Fauna 19, $100 \mathrm{p}$.

1901, Natural history of the Queen Charlotte Islands, British Columbia, and natural history of the Cook Inlet region, Alaska: U.S. Bur. Biol. Survey, North Am. Fauna 21, 87 p.

1904a, A biological reconnaissance of the base of the Alaska Peninsula: U.S. Bur. Biol. Survey, North Am. Fauna 24, 86 p.

- 1904b, Lake Clark, a little known Alaskan lake: Natl. Geog. Mag., v. 15, p. 326331.

1909, Biological investigations in Alaska and Yukon Territory; [pt.] 1, East Central Alaska; [pt.] 2, The Ogilvie Range, Yukon; [pt.] 3, The Macmillan River, Yukon: U.S. Bur. Biol. Survey, North Am. Fauna 30, 96 p.

Osgood, W. H., Preble, E. A., and Parker, G. H., 1915, The fur-seals and other life of the Pribilof Islands, Alaska, in 1914: U.S. Fish Comm. Bull., v. 34, p. 1-72.

Oswalt, W. H., 1960, Eskimos and Indians of western Alaska, 1861-1868-extracts from the diary of Father Illarion: Anthropol. Papers of Alaska Univ., v. 8, no. 2, p. 100-118.

1963, Napaskiak, an Alaskan Eskimo community: Tucson, Ariz., Univ. Arizona Press, $163 \mathrm{p}$

Paige, Sidney, Foran, W. T., and Gilluly, James, 1925, A reconnaissance of the Point Barrow region, Alaska: U.S. Geol. Survey Bull. 772 , $33 \mathrm{p}$.

Paige, Sidney, and Knopf, Adolph, 1907, Geologic reconnaissance in the Matanuska and Talkeetna basins, Alaska: U.S. Geol. Survey Bull. 327, 71 p.

Park, C. F., Jr., 1933, The Girdwood district, Alaska: U.S. Geol. Survey Bull. 849-G, p. 381-424.

Patton, W. W., Jr., and Tailleur, I. L., 1964 Geology of the Killik-Itkillik region, Alaska: U.S. Geol. Survey Prof. Paper 303-G, p. 409500

Pearson, Grant, 1948, Little Johnnie of Kantishna: Alaska Sportsman, v. 14, no. 7, p. 6-9.

Pearson, T. G., 1944, Birds of America: Garden City, N.Y., Garden City Publishing Co., Inc. pt. 1, 272 p.; pt. 2, 271 p.; pt. 3, 289 p.

Pecora, W. T., 1942, Nickel-copper deposits on the west coast of Chichagof Island, Alaska: U.S. Geol. Survey Bull. 936-I, p. 221-243.

Pedersen, Elsa, 1949, Seldovia: Alaska Sportsman, v. 15 , no. 7 , p. 6

Petroff, Ivan, 1881, Letter from the Secretary of the Interior transmitting a preliminary report upon the population, industry and resources of Alaska: U.S. 46th Cong., 3d sess. doc. $40,86 \mathrm{p}$

- 1884, Report on the population, industries, and resources of Alaska: U.S. Census Office, Census Report, 10th Census, v. 8, 189 p.; issued also as H. Misc. Doc. 42 , pt. 8 , U.S. 47 th Cong., 2d sess. 
Petroff, Ivan, 1891a, Alaska, in Report on the internal commerce of the U.S. for the year 1890: U.S. Bur. Statistics (Treasury Dept.), app., p. 3-46.

- 1891b, Geographical and ethnological notes on Alaska: Geog. Soc. of Pacific Trans. and Proc., ser. 1, v. 2, no. 2, p. 1-15.

Plafker, George, 1955, Geologic investigations of proposed power sites at Cooper, Grant, Ptarmigan, and Crescent Lakes, Alaska: U.S. Geol. Survey Bull. 1031-A, p. 1-23.

1956, Occurrence of diatomaceous earth near Kenai, Alaska: U.S. Geol. Survey Bull. 1039-B, p. 25-31.

1962, Geologic investigations of proposed powersites at Sheep Creek, Carlson Creek, and Turner Lake, Alaska: U.S. Geol. Survey Bull. 1031-F, p. 127-148.

Polk, R. L., and Company, 1915-16, Polk's * * Alaska-Yukon gazetteer and business directory: Seattle, Wash., 1035 p. [1915].

_ 1917-18, Polk's * * * Alaska-Yukon gazetteer and business directory: Seattle, Wash., 1063 p. [1917].

Portlock, Nathaniel, 1789, A voyage round the world; but more particularly to the northwest coast of America: performed in 1785, 1786,1787 , and 1788, in the King George and Queen Charlotte, Captains Portlock and - Dixon: London, J. Stockdale and G. Goulding, $384 \mathrm{p}$.

Pough, R. H., 1946, Audubon bird guide: Garden City, New York, Doubleday \& Co., Inc., $312 \mathrm{p}$.

Powell, A. M., 1910, Trailing and camping in Alaska; New York, Wessels and Bissel, 379 p

Powvers, H. A., Coats, R. R., and Nelson, W. H., 1960, Geology and submarine physiography of Amchitka Island, Alaska: U.S. Geol. Survey Bull. 1028-P, p. 521-554.

Priestley, W. E., 1909a, The Kuskokwim RiverAlaska's neglected highway: Alaska-Yukon Mag., v. 8 (July), p. 275-282.

$1909 \mathrm{~b}$, The Susitna-Alaska's land of promisc: Alaska-Yukon Mag., v. 8 (Aug.), p. $407-418$.

1910, Down the Tanana River on a raft: Alaska-Yukon Mag., v. 9 (April), p. 281-289.

Prince, B. L., 1964, The Alaska Railroad: Anchorage, Ken Wray's Print Shop, 1092 p., 2 pts. in $1 \mathrm{v}$.

Prindle, L. M., 1905, The gold placers of the Fortymile, Birch Creek, and Fairbanks regions, Alaska: U.S. Geol. Survey Bull. 251, 89 p.

1906, The Yukon Tanana region, Alaska: Description of Circle quadrangle: U.S. Geol. Survey Bull. 295, 27 p.

1908, The Fairbanks and Rampart quadrangles, Yukon-Tanana region, Alaska, with a section on the Rampart placers, by F. L. Hess, and a paper on the water supply of the Fairbanks region, by C. C. Covert: U.S. Geol. Survey Bull. 337, 102 p.

_ 1909, The Fortymile quadrangle, Yukon-Tanana region, Alaska: U.S. Geol. Survey Bull. $375,52 \mathrm{p}$.

1913a, A geologic reconnaissance of the Fairbanks quadrangle, Alaska, with a de- tailed description of the Fairbanks district, by L. M. Prindle and F. J. Katz, and an account of lode mining near Fairbanks, by P. S. Smith: U.S. Geol. Survey Bull. 525, 220 p.

Prindle, L. M., 1913b, A geologic reconnaissance of the Circle quadrangle, Alaska: U.S. Geol. Survey Bull. 538, $82 \mathrm{p}$.

Prindle, L. M., and Hess, F. L., 1906, The Rampart gold placer region, Alaska: U.S. Geol. Survey Bull. 280, $54 \mathrm{p}$.

Prindle, L. M., and Katz, F. J., 1913, A detailed description of the Fairbanks district: See Prindle, 1913a, p. 59-152.

Putnam, G. R., 1903, Geographic names in Alaska: U.S. Coast and Geod. Survey Ann. Rept., p. 1011-1016.

Rainey, F. G., 1939, Archaeology in central Alaska: Am. Mus. Nat. History, New York, Anthropol. Papers, v. 36, pt. 4, p. 351-405.

Rand McNally, 1966, Commercial Atlas and Marketing Guide [97th ed.]: Chicago, New York, San Francisco, Rand McNally \& Co., $524 \mathrm{p}$.

Rathbun, Richard, 1894, Summary of the fishery investigations conducted in the north Pacific Ocean and Bering Sea from July 1, 1888, to July 1,1892 , by the U.S. Fish Commission steamer Albatross: U.S. Fish Comm. Bull., v. 13, p. 127-201.

Raup, H. M., and Denny, C. S., 1950, Photo interpretation of the terrain along the southern part of the Alaska Highway: U.S. Geol. Survey Bull. 963-D, p. 95-135 [1951].

Rausch, R. L., 1951, Notes on the Nunamiut Eskimo and mammals of the Anaktuvuk region, Brooks Range, Alaska: Arctic, v. 4, p. $147-195$.

Ray, J. C., 1933, The Willow Creek gold-lode district, Alaska: U.S. Geol. Survey Bull. 849-C, p. 165-229.

Ray, P. H., 1885, Narrative, in International Polar Expedition, 1885: p. 19-34; reprinted in 1900 with slight changes, U.S. Cong., Sen. Comm. Mil. Affairs.

Ray, R. G., 1954, Geology and ore deposits of the Willow Creek mining district, Alaska: U.S. Geol. Survey Bull. 1004, 86 p.

Raymond, C. W., 1871, Report of a reconnaissance of the Yukon River, Alaska Territory: Washington, U.S. Govt. Printing Office, 113 p.; issued also as S. Ex. Doc. 12, U.S. 42d Cong., 1st sess.; pt. 1 reprinted, 1900, in U.S. Cong., Sen. Comm. on Military Affairs. - 1873, The Yukon River region, Alaska: Am. Geog. Soc. Jour. [Bull.], v. 3, p. 158-192. Reed, J. C., Jr., 1961, Geology of the Mount McKinley quadrangle, Alaska: U.S. Geol. Survey Bull. 1108-A, 36 p.

Reed, J. C., Sr., 1933, The Mount Eielson district, Alaska: U.S. Geol. Survey Bull. 849-D, p. 231-287 [1934].

1942, Nickel-copper deposit at Funter Bay, Admiralty Island, Alaska: U.S. Geol. Survey Bull. 936-O, p. 349-361.

1958, Exploration of Naval Petroleum Reserve No. 4 and adjacent areas, northern Alaska, 1944-53, part 1, History of the ex- ploration: U.S. Geol. Survey Prof. Paper 301, $192 \mathrm{p}$.

Reed, J. C., Sr., and Coats, R. R., 1942, Geology and ore deposits of the Chichagof mining district, Alaska: U.S. Geol. Survey Bull. 929, $148 \mathrm{p}$.

Reed, J. C., Sr., and Dorr, J. V. N., 2d, 1942, Nickel deposits of Bohemia Basin and vicinity, Yakobi Island, Alaska: U.S. Geol. Survey Bull. 931-F, p. 105-138.

Reed, J. C., Sr., and Gates, G. O., 1942, Nickelcopper deposits at Snipe Bay, Baranof Island, Alaska: U.S. Geol. Survey Bull. 936-M, p. 321-330.

Reid, H. F., 1892, Studies of Muir Glacier, Alaska: Nat. Geog. Mag., v. 4 (Mar.), p. 19-84.

- 1896, Glacier Bay and its glaciers: U.S. Geol. Survey 16th Ann. Rept., pt. 1, p. 415461.

Remington, C. H. ("Copper River Joe"), 1939, A golden cross(?) on trails from the Valdez Glacier: Los Angeles, White-Thompson. $200 \mathrm{p}$.

Richards, R. W., and Waring, G. A., 1933, Progress of surveys in the Anthracite Ridge district: U.S. Geol. Survey Bull. 849-A, p. 1-27.

Rickard, T. A., 1909, Through the Yukon and Alaska: San Francisco, Mining and Scientific Press, $392 \mathrm{p}$.

Ricks, M. B., 1965, Directory of Alaska postoffices and postmasters, 1867-1963: Ketchikan, Alaska, Tongass Pub. Co., 72 p.

Robinson, G. D., and Twenhofel, W. S., 1953, Some lead-zinc and zinc-copper deposits of the Ketchikan and Wales districts, Alaska: U.S. Geol. Survey Bull. 998-C, p. 59-84.

Robinson, G. D., Wedow, Helmuth, Jr., and Lyons, J. B., 1955, Radioactivity investigations in the Cache Creek area, Yentna dis. trict, Alaska: U.S. Geol. Survey Bull. 1024-A, p. 1-23.

Roguszka, D. D., 1964, Cordova, four strikes but not out: Alaska Sportsman, v. 30 , no. 3, p. 8 11.

Rohn, Oscar, 1900, A reconnaissance of the Chitina River and the Skolai Mountains, Alaska: U.S. Geol. Survey 21 st Ann. Rept., pt. 2, p. 393-440.

Ross, C. P., 1933a, Mineral deposits near the West Fork of the Chulitna River, Alaska: U.S. Geol. Survey Bull. 849-E, p. 289-333.

$1933 \mathrm{~b}$, The Valdez Creek mining district, Alaska: U.S. Geol. Survey Bull. 849--H, p. $425-468$.

Rossman, D. L., 1959a, Geology and ore deposits in the Reid Inlet area, Glacier Bay, Alaska: U.S. Geol. Survey Bull. 1058-B, p. 33-59.

1959b, Geology and ore deposits of northwestern Chichagof Island, Alaska: U.S Geol. Survey Bull. 1058-E, p. 139-216 [1960]. 1963, Geology of the eastern part of the Mount Fairweather quadrangle, Glacier Bay, Alaska: U.S. Geol. Survey Bull. 1121-K, $57 \mathrm{p}$.

Russell, I. C., 1891, An expedition to Mount St. Elias, Alaska: Nat. Geog. Mag., v. 3, p. 53204. 
Russell, I. C., 1892, Second expedition to Mount St. Elias in 1891: U.S. Geol. Survey 13th Ann. Rept., pt. 2, p. 1-91.

1895, A journey up the Yukon River: Am. Geog. Soc. Jour. [Bull.], v. 27, no. 2, p. 143-160.

Sainsbury, C. L., 1957, Some pegmatite deposits in southeastern Alaska: U.S. Geol. Survey Bull. 1024-G, p. 141-161.

1961, Geology of part of the Craig C-2 quadrangle and adjoining areas, Prince of Wales Island, southeastern Alaska: U.S. Geol. Survey Bull. 1058-H, p. 299-362.

___ 1964, Geology of Lost River mine area, Alaska: U.S. Geol. Survey Bull. 1129, 80 p.

Sainsbury, C. L., and Mackevett, E. M., Jr., 1965, Quicksilver deposits of southwestern Alaska: U.S. Geol. Survey Bull. 1187, 89 p.

Sarichev, G. A., 1826, Atlas Svernoy chasti Vostochnago Okeana, sostavlen v chertezhnoy Gosudarstvennago Admiraltezhkago Departamenta, s Novg yshikh opisey i kart, 1826, Pod Rukovodstvom Viche-Admirala i Gidrografa Sarycheva [Atlas of the northern part of the Pacific Ccean, compiled in sheets by the Imperial Navy Department from the latest reports and maps, 1826, under the direction of Vice-Admiral and Hydrographer Sarychev]: St. Petersburg, 33 sheets.

Sather, A. J., 1947, Shame and fortune: Alaska Sportsman, v. 13, no. 11, p. 12.

Sauer, Martin, 1802, An account of a geographical and astronomical expedition to the northern parts of Russia, for ascertaining the degrees of latitude and longitude of the mouth of the river Kovima; of the whole coast of the Tshutski, to East Cape; and of the islands in the Eastern ocean, stretching to the American coast. Performed *** by Commodore Joseph Billings in the years 1785-94: London, T. Gadell, jun. \& W. Davies, 332 p.

Schmidke, Clifford, 1949, The Devil's Thumb: Alaska Sportsman, v. 15, no. 9, p. 10.

Schmitter, Ferdinand, 1910, Upper Yukon native customs and folk-lore: Smithsonian Inst. Misc. Colln., v. 56, no. 4, 30 p.

Schrader, F. C., 1900a, A reconnaissance of a part of Prince William Sound and the Copper River district, Alaska, in 1898: U.S. Geol. Survey 20th Ann. Rept., pt. 7, p. 341-423.

$1900 \mathrm{~b}$, Preliminary report on a reconnaissance along the Chandlar and Koyukuk Rivers, Alaska, in 1899: U.S. Geol. Survey 21 st Ann. Rept., pt. 2, p. 441-486.

1900c, The Cape Nome gold district: Nat. Geog. Mag., v. 11, no. 1, p. 15-23.

1904, A reconnaissance in northern Alaska across the Rocky Mountains, along Koyukuk, John, Anaktuvuk, and Colville rivers and the Arctic coast to Cape Lisburne, in 1901: U.S. Geol. Survey Prof. Paper 20, $139 \mathrm{p}$.

Schrader, F. C., and Brooks, A. H., 1900, Preliminary report on the Cape Nome gold region, Alaska: U.S. Geol. Survey Spec. Pub., 56 p.

Schrader, F. C., and Spencer, A. C., 1901, The geology and mineral resources of a portion of the Copper River district, Alaska: U.S. Geol. Survey Spec. Pub., 94 p.

Schwalbe, A. B., 1951, Dayspring on the Kuskokwim; the story of Moravian Missions in Alaska: Bethlehem, Pa., Moravian Press, $264 \mathrm{p}$.

Science, v. 3, June 6, p. 677-682; June 13, Schwatka, Frederick, 1884, The middle Yukon: p. 706-711.

1885a, Along Alaska's great river: New York, Cassell \& Co., Ltd., 360 p.

1885b: see U.S. Army, Department of the Columbia, 1885.

1891, A summer in Alaska--enlarged version of author's 1885, Along Alaska's great river: Philadelphia, J. Y. Huber Co., 481 p.; repub., 1893, St. Louis, Mo., J. W. Henry Co.

Seitz, J. F., 1959, Geology of Geikie Inlet area, Glacier Bay, Alaska: U.S. Geol. Survey Bull. 1058-C, p. 61-120.

Seltzer, L. E., ed., 1952, The Columbia Lippincott gazetteer of the world: Morningside Heights, New York, Columbia University Press, 2,148 p.

Seton-Karr, H. W., 1887, Shores and alps of Alaska: London, S. Low, Marston, Searle, and Rivington, $248 \mathrm{p}$.

Sharples, A. W., 1938, Alaska Wild Flowers: Stanford Univ., Calif., Stanford Univ. Press, $156 \mathrm{p}$.

Shenitz, H. A., 1961, Baranov, empire builder: Alaska Sportsman, July, v. 27, no. 7, p. 11

Sherwood, M. B., 1965, Exploration of Alaska, 1865-1900: New Haven and London, Yale Univ. Press, 192 p.

Simons, F. S., and Mathewson, D. E., 1955 , Geology of Great Sitkin Island, Alaska: U.S. Geol. Survey Bull. 1028-B, p. 21-43 [1956].

Simpson, John, 1855, Observations upon the western Esquimaux, with native map: British Blue Books, v. 35, p. 917-942.

Simpson, Sir George, 1847, Narrative of a journey round the world, during the years 1841 and 1842: London, H. Colburn, 2 v.; reprinted as An overland journey around the world, during the years 1841 and 1842: Philadelphia, Lea \& Blanchard, 2 pts. in $1 \mathrm{v}$

Simpson, Thomas, 1843, Narrative of the discoveries on the north coast of America; ef fected by the officers of the Hudson's Bay Company during the years 1836-39: London, R. Bentley, 419 p.

Sims, V. C., 1965, But his name wasn't Manley: Alaska Sportsman, May, v. 31, no. 5, p. 14.

Smith, P. S., 1910, Geology and mineral resources of the Solomon and Casadepaga quadrangles, Seward Peninsula, Alaska: U.S. Geol. Survey Bull. 433, 234 p.

1913, The Noatak-Kobuk region, Alaska: U.S. Geol. Survey Bull. 536, 160 p. 1917, The Lake Clark-central Kuskokwim region, Alaska: U.S. Geol. Survey Bull. $655,162 \mathrm{p}$

1933, Mineral industry of Alaska in 1931 and Administrative report: U.S. Geol. Survey Bull. 844-A, 117 p.

1934a, Mineral industry of Alaska in 1932: U.S. Geol. Survey Bull. 857-A, p. 1-91.
Smith, P. S., 1934b, Mineral industry of Alaska in 1933: U.S. Geol. Survey Bull. 864-A, p. 1-94. 1936, Mineral industry of Alaska in

1934 : U.S. Geol. Survey Bull. 868-A, p. 1-91. 1937. Mineral industry of Alaska in 1935: U.S. Geol. Survey Bull. 880-A, p. 1-95. 1938, Mineral industry of Alaska in 1936: U.S. Geol. Survey Bull. 897-A, p. 1107.

1939a, Areal geology of Alaska: U.S. Geol. Survey, Prof. Paper 192, 100 p. $1939 \mathrm{~b}$, Mineral industry of Alaska in 1937: U.S. Geol. Survey Bull. 910-A, p. 1113 .

1939c, Mineral industry of Alaska in 1938: U.S. Geol. Survey Bull. 917-A, p. 1113.

1941a, Fineness of gold from Alaska placers: U.S. Geol. Survey Bull. 910-C, p. $147-272$.

1941b, Mineral industry of Alaska in 1939: U.S. Geol. Survey Bull. 926-A, p. 1106.

1942, Mineral industry of Alaska in 1940: U.S. Geol. Survey Bull. 933-A, p. 1102.

1944, Mineral industry of Alaska in 1941 and 1942: U.S. Geol. Survey Bull. 943-A, p. $1-23$.

Smith, P. S., and Eakin, H. M., 1911, A geologic reconnaissance in southeastern Seward Peninsula and the Norton Bay-Nulato region, Alaska: U.S. Geol. Survey Bull. 449, 146 p.

Smith, P. S., and Mertie, J. B., Jr., 1930, Geology and mineral resources of northwestern Alaska: U.S. Geol. Survey Bull. 815, 351 p.

Smith, P. S., Mertie, J. B., Jr., and Foran, W. T., 1926, Summary of recent surveys in northern Alaska: U.S. Geol. Survey Bull. 783-E, p. 151166.

Smith, P. S., and others, 1926, Mineral resources of Alaska, report on progress of investigations in 1924: U.S. Geol. Survey Bull. 783, 168 p.

1929, Mineral resources of Alaska, re. port on progress of investigations in 1926: U.S. Geol. Survey Bull. 797, 227 p

1930a, Mineral resources of Alaska, report on progress of investigations in 1927: U.S. Geol. Survey Bull. 810, 172 p.

1930b, Mincral resources of Alaska, report on progress of investigations in 1928: U.S. Geol. Survey Bull. 813, 166 p.

1932, Mincral resources of Alaska, report on progress of investigations in 1929 : U.S. Geol. Survey Bull. 824, 181 p.

1933, Mineral resources of Alaska, report on progress of investigations in 1930: U.S. Geol. Survey Bull. 836, 443 p.

Smith, W. R., 1925, Aniakchak Crater, Alaska Peninsula: U.S. Geol. Survey Prof. Paper 132-J, p. 139-149.

Sniffen, M. K., and Carrington, T. S., 1914, The Indians of the Yukon and Tanana Valleys, Alaska: Philadelphia, Indian Rights Assoc. Pub., 2d ser., no. 98, 35 p.

Snyder, G. L., 1957, Ocean floor structures, northeastern Rat Islands, Alaska: U.S. Geol. Survey Bull. 1028-G, p. 161-167 [1958]. 
Snyder, G. L., 1959, Geology of Little Sitkin Island, Alaska: U.S. Geol. Survey Bull. 1028H, p. 169-210.

Soward, K. S., 1961, Geologic investigations of proposed powersites at Baranof and Carbon Lakes, Baranof Island, Alaska: U.S. Geol. Survey Bull. 1031-B, p. 25-46 [1962].

- 1962, Geology of waterpower sites on the Bradley River, Kenai Peninsula, Alaska: U.S. Geol. Survey Bull. 1031-C, p. 47-70.

Spencer, A. C., 1906, The Juneau goldbelt, Alaska; and A reconnaissance of Admiralty Island, Alaska, by C. W. Wright: U.S. Geol. Survey Bull. 287, 161 p.

Spencer, R. F., 1959, The northern Alaskan Eskimo; a study in ecology and society: Bur. Am. Ethnology Bull. 71, 490 p.

Spetzman, L. A., 1959, Vegetation of the Arctic Slope of Alaska: U.S. Geol. Survey Prof. Paper 302-B, p. 19-58.

Spurr, J. E., 1898, Geology of the Yukon gold district, Alaska: U.S. Geol. Survey 18th Ann. Rept., pt. 3, p. 87-392.

- 1900, A reconnaissance in southwestern C.laska in 1898: U.S. Geol. Survey 20th Ann. Rept., pt. 7, p. 31-264.

Stearns, N. D., Stearns, H. T., and Waring, G. A., 1937, Thermal springs in the United States: U.S. Geol. Survey Water-Supply Paper 679-B, p. 59-206.

Stefansson, Karl, and Moxham, R. M., 1946, Copper bullion claims, Rua Cove, Knight Island, Alaska: U.S. Geol. Survey Bull. 947-E, p. 85-92.

Steidtmann, Edward, and Cathcart, S. H., 1922, Geology of the York tin deposits, Alaska: U.S. Geol. Survey Bull. 733, 130 p.

Stejer, F. A., 1956, Pyrite deposits at Horseshoe Bay, Latouche Island, Alaska: U.S. Geol. Survey Bull. 1024-E, p. 107-122.

Stewart, G. R., 1956, The name Alaska: Names, v. 4, no. 4, p. 193-260.

Stockton, C. H., 1890, The Arctic cruise of the U.S.S. Thetis in the summer and autumn of 1889: Nat. Geog. Mag., v. 2, no. 3, p. 171198.

Stone, K. H., 1963, The annual emptying of Lake George, Alaska: Arctic, v. 16, no, 1 , p. 26-40.

Stone, R. W., 1906, Coal fields of the Kachemak Bay region: see Moffit, 1906.

Stoney, G. M., 1900, Naval explorations in Alaska ; an account of two naval expeditions to northern Alaska, with official maps of the country explored: Annapolis, Md., U.S. Naval Inst., $105 \mathrm{p}$.

Stuck, Hudson, 1914a, The ascent of Denali: New York, C. Scribner's Sons, 188 p.

$1914 b$, Ten thousand miles with a dog sled; a narrative of winter travel in interior Alaska: New York, C. Scribner's Sons, 420 p. 1917, Voyages on the Yukon and its tributaries: New York, G. Scribner's Sons, $397 \mathrm{p}$.

- 1920, A winter circuit of our Arctic coast; a narrative of a journey with dog-sleds around the entire Arctic coast of Alaska: New York, Charles Scribner's Sons, 347 p.
Swanton, J. R., 1908, Social conditions, beliefs, and linguistic relationships of the Tlingit Indians: Bur. Am. Ethnology 26th Ann. Rept., $480 \mathrm{p}$.

1910, Handbook of American Indians, north of Mexico; Bur. Am. Ethnology Bull. 30 , pt. 2, 1,221 p.

- 1952, The Indian tribes of North America: Bur. of Am. Ethnology Bull. 145, 726 p.; issued also as H. Doc. 383 , U.S. 81 st Cong., $2 d$ sess.

Tanner, Z. L., 1891, The fishing grounds of Bristol Bay, Alaska-a preliminary report upon the investigations of the U.S. Fish Commission steamer Albatross during the summer of 1890: U.S. Fish Comm. Bull., v. 9, p. 279-288.

Tanner, Z. L., and others, 1890, Explorations of the fishing grounds of Alaska, Washington Territory, and Oregon, during 1888 , by the U.S. Fish Commission steamer Albatross: U.S. Fish Comm. Bull., v. 8, p. 1-95.

Tarr, R. S., 1909, The Yakutat Bay region, Alaska; [pt. 1] Physiography and glacial geology, by R. S. Tarr, and [pt. 2] Areal geology, by R. S. Tarr and B. S. Butler: U.S. Geol. Survey Prof. Paper 64, $183 \mathrm{p}$

Tarr, R. S., and Butler, B. S., 1909, The Yakutat Bay region, Alaska-Areal geology: see Tarr, R. S., 1909.

Tarr, R. S., and Martin, Lawrence, 1906 Glaciers and glaciation of Yakutat Bay, Alaska: Am. Geog. Soc. Bull., v. 38 , no. 3, p. $145-167$.

1912, The earthquakes at Yakutat Bay, Alaska, in September, 1899: U.S. Geol. Survey Prof. Paper 69, 135 p.

1914, Alaska glacier studies of the National Geographic Society in the Yakutat Bay, Prince William Sound, and lower Copper River regions: Washington, Nat. Geog. Soc., $498 \mathrm{p}$.

Tebenkov, M. D., 1852, Atlas sieu-zapadaykh beregov Ameriki * * * [Atlas of the N.W. shores of America from Bering Strait to Cape Corrientes and the Aleutian Islands, together with some places on the N.E. shore of Asia]: St. Petersburg, 39 maps.

Thibert, Arthur, 1958, English-Eskimo, EskimoEnglish Dictionary [revised ed.]: Ottawa, Ottawa Univ., Research Center for Amerindian Anthropology, $173 \mathrm{p}$.

Tikhmeniev, P., 1861-63, Istoricheskoe obozrenie obrazovaniia Rossiisko-Amerikanskoi Kopanii i dieistvii eia do nastoiashchnago vremeni [Historical review of the organization of the Russian-American Company and its operations down to the present time]: St. Petersburg, E. Veimar, v. 1, 1861 ; v. 2, 1863.

Tolmie, W. F., and Dawson, G. M., 1884, Comparative vocabularies of the Indian tribes of British Columbia: Montreal, Dawson Brothers, $127 \mathrm{p}$

Tompkins, S. R., 1945, Alaska, Promyshlennik and Sourdough: Norman, Univ. Oklahoma Press, $350 \mathrm{p}$.

Tompkins, S. R., and Moorhead, M. L., 1949, Russia's approach to America: British Columbia Hist. Quart.; Pt. 1, from Russian sources,
1741-1761, v. 13, no. 2, p. 53-67; Pt. 2, from Spanish sources, $1761-1775$, v. 13, nos. 3-4, p. 231-255.

Topham, H. W., 1889, An expedition to Mount St. Elias: Alpine Jour., v. 14, p. 345-371.

Trainer, F. W., 1960, Geology and ground-water resources of the Matanuska Valley agricultural area, Alaska: U.S. Geol. Survey WaterSupply Paper 1494, 116 p.

1961, Eolian deposits of the Matanuska Valley agricultural area, Alaska: U.S. Geol. Survey Bull. 1121-C, 35 p.

Tuck, Ralph, 1933, The Moose Pass-Hope district, Kenai Peninsula, Alaska: U.S. Geol. Survey Bull. 849-I, p. 469-530.

1934, The Curry district, Alaska: U.S. Geol. Survey Bull. 857-C, p. 99-140.

1937, The Eska Creek coal deposits, Matanuska Valley: U.S. Geol. Survey Bull. 880-D, p. 185-214.

1938, The Valdez. Creek mining district in 1936: U.S. Geol. Survey Bull. 897-B, p. 109-131.

Twenhofel, W. S., Reed, J. C., and Gates, G. O., 1949, Some mineral investigations in southeastern Alaska: U.S. Geol. Survey Bull. 963-A, p. 1-45.

Twenhofel, W. S., Robinson, G. D., and Gault, H. R., 1946, Molybdenite investigations in southeastern Alaska: U.S. Geol. Survey Bull. 947-B, p. 7-38.

U.S. Adjutant-General's Office, Military Information Division, 1899, Reports of explorations in the Territory of Alaska: see Glenn, E. F., and Abercrombie, W. R., 1899.

1901, Explorations in Alaska, 1899, for an all-American overland route from Cook Inlet, Pacific Ocean, to the Yukon: see Herron, 1901.

U.S. Army Corps of Engineers, 1956, Southwestern Alaska; letter from the Secretary of the Army: Washington, U.S. Govt. Printing Office, 89 p. [1957]; H. Doc. 390, U.S. 84th Cong., 2d sess.

U.S. Army Department of the Columbia, 1885, Report of a military reconnaissance in Alaska, made in 1883, by Frederick Schwatka: Washington, U.S. Govt. Printing Office, 121 p.; issued also as S. Ex. Doc. 2, U.S. 48th Cong., $2 \mathrm{~d}$ sess.; reprinted in 1900 with slight changes, U.S. Cong., Sen. Comm. Mil. Affairs.

- 1887, Report of an expedition to the Copper, Tanana, and Koyukuk Rivers, in the Territory of Alaska, in the year $1885 * * *$ under the direction of General Nelson A. Miles, commanding the Department of the Columbia, by Lt. Henry T. Allen: Washington, U.S. Govt. Printing Office, 1.72 p.; issued also as S. Ex. Doc. 125, U.S. 49th Cong., 2d sess.

U.S. Bureau of the Census, 1884, Tenth census of Alaska: see Petroff, 1884.

1893, Report of Population and resources of Alaska at the 11 th census: Washington, U.S. Govt. Printing Office, 282 p.; issued as H. Misc. Doc. 340, pt. 7, U.S. 52d Cong., 1st sess. 
U.S. Bureau of Education: Introduction of reindeer into Alaska: see Jackson, 1893-98, 1900 6, 1908.

U.S. Coast and Geodetic Survey, published annually, Annual Report of the Superintendent: Washington, U.S. Govt. Printing Office.

- published annually, Supplements to U.S. Coast Pilots.

- 1869, Alaska Coast Pilot: see Davidson, 1869 .

1883, Pacific Coast Pilot, Alaska, part 1, Coast from Dixon Entrance to Yakutat Bay with the inland passage: Washington, U.S. Govt. Printing Office.

1891, Pacific Coast Pilot, Alaska, part 1, Dixon Entrance to Yakutat Bay with inland passage from Strait of Fuca to Dixon Entrance [3d ed.]: Washington, U.S. Govt. Printing Office.

1899, Alaska Coast Pilot notes on the Fox Islands passes, Unalaska Bay, Bering Sea, and Arctic Ocean as far as Point Barrow: [revised by Lt. D. H. Jarvis, USRCS]; Bull. 40.

1901, Pacific Coast Pilot, Alaska, part 1, Dixon Entrance to Yakutat Bay with inland passage from Juan de Fuca Strait to Dixon Entrance [4th ed.]: Washington, U.S. Govt. Printing Office.

_ 1908a, U.S. Coast Pilot, Alaska, part 1, Dixon Entrance to Yakutat Bay with inland passage from Juan de Fuca Strait to Dixon Entrance [5th ed.]: Washington, U.S. Govt. Printing Office.

1908b, Alaska Coast Pilot notes from Yakutat Bay to Cook Inlet: Washington, U.S. Govt. Printing Office.

1908c, Coast Pilot notes on Bering Sea and Arctic Ocean: Washington, U.S. Govt. Printing Office [1909] (replaces Bull. 40).

1910, Coast Pilot notes from Yakutat Bay to Cook Inlet and Shelikof Strait [2d ed.]: Washington, U.S. Govt. Printing Office.

- 1916, U.S. Coast Pilot, Alaska, part 2, Yakutat Bay to Arctic Ocean [1st ed.]: Washington, U.S. Govt. Printing Office.

1917, U.S. Coast Pilot, Alaska, part 1, Dixon Entrance to Yakutat Bay [6th ed.]: Washington, U.S. Govt. Printing Office.

1925, U.S. Coast Pilot, Alaska, part 1, Dixon Entrance to Yakutat Bay [7th ed.]: Washington, U.S. Govt. Printing Office.

1926, U.S. Coast Pilot, Alaska, part 2, Yakutat Bay to Arctic Ocean [2d ed.]: Washington, Govt. Printing Office.

1931, U.S. Coast Pilot, Alaska, part 2, Yakutat Bay to Arctic Ocean [3d ed.]: Washington, U.S. Govt. Printing Office.

1932, U.S. Goast Pilot, Alaska, part 1, Dixon Entrance to Yakutat Bay [8th ed.]: Washington, U.S. Govt. Printing Office.

- 1938, U.S. Coast Pilot, Alaska, part 2, Yakutat Bay to Arctic Ocean [4th ed.]: Washington, U.S. Govt. Printing Office.

1943a, U.S. Coast Pilot, Alaska, part 1, Dixon Entrance to Yakutat Bay [3d ed.]: Washington, U.S. Govt. Printing Office.
U.S. Coast and Geodetic Survey, 1943b, Geographic names in the coastal areas of Alaska: Washington, U.S. Dept. Commerce, 133 p. 1944, U.S. Coast Pilot, Alaska, Aleutian Islands [1st ed.]: Washington, U.S. Govt. Printing Office.

1947, U.S. Coast Pilot, Alaska, part 2, Yakutat Bay to Arctic Ocean [5th ed.]: Washington, U.S. Govt. Printing Office.

1952, U.S. Coast Pilot, southeast Alaska, Dixon Entrance to Yakutat Bay [10th ed.]: Washington, U.S. Govt. Printing Office.

1954, U.S. Coast Pilot 9, Alaska, Cape Spencer to Arctic Ocean [6th ed.]: Washington, U.S. Govt. Printing Office [1955].

1962, U.S. Coast Pilot 8, Pacific Coast, Alaska, Dixon Entrance to Cape Spencer [11 th ed.]: Washington, U.S. Govt. Printing Office.

1964, U.S. Coast Pilot 9, Pacific and Arctic Coasts, Alaska, Cape Spencer to Beaufort Sea [7th ed.]: Washington, U.S. Govt. Printing Office.

U.S. Congress, Senate Committee on Military Affairs, 1900, Compilation of narratives on explorations in Alaska: Senate Rept. 1023, U.S. 56th Cong., 1st sess., 856 p. (Contains a collection of narratives pub. from 1869 to 1899 ; includes reports by C. F. Raymond, O. O. Howard, Ivan Petroff, Frederick Schwatka, P. H. Ray, W. R. Abercnombie, H. T. Allen, W. P. Richardson, E. H. Wells, and E. F. Glenn.)

U.S. Fish and Wildlife Service, 1955, Fishery publication index, 1920-54: Circular 36, $254 \mathrm{p}$.

U.S. Geological Survey, 1898, Eighteenth annual report, pt. 3: Washington, U.S. Govt. Printing Office, $861 \mathrm{p}$.

1899, Maps and descriptions of routes of exploration in Alaska in 1898, with general information concerning the Territory: U.S. Geol. Survey Spec. Pub., 138 p.

1900a, Twentieth annual report, pt. 7: Washington, U.S. Govt. Printing Office, $494 \mathrm{p}$.

1900b, Twenty-first annual report, pt. 2: Washington, U.S. Govt. Printing Office, p. 331-509.

U.S. Revenue-Cutter Service, 1883, Cruise of the revenue steamer Corwin in Alaska and the NW Arctic Ocean in 1881. Notes and memoranda: Washington, U.S. Govt. Printing Office, 120 p.; issued as Treasury Dept. Doc. 429; H. Ex. Doc. 105, U.S. 47th Cong., 2d sess.; and S. Ex. Doc. 204, U.S. 48th Cong., 1 st sess. (Contains reports by I. C. Rosse, John Muir, E. W. Nelson, and T. H. Bean.)

1899, Report of the cruise of the U.S. revenue cutter Bear and the overland expedition for the relief of the whalers in the Arctic Ocean, from November 27, 1897, to September 13, 1898: Washington, U.S. Govt Printing Office, 144 p.; issued as Treasury Dept. Doc. 2101, and H. Doc. 511, U.S. 56th Cong., 2d sess.

_-_. see also Cantwell, 1902 ; Healy, 1887, 1889; and Hooper, 1881.
Van Alstine, R. E., and Black, R. F., 1946, Copper deposits of the Kotsina-Kuskulana district, Alaska, with an introduction by F. H. Moffit: U.S. Geol. Survey Bull. 947-G, p. 121-141.

Vancouver, George, 1798, 1801, A voyage of discovery to the North Pacific Ocean, and round the world; London, printed for G. G. and J. Robinson, 3 v.; reprinted 1801, London, for J. Stockdale, 6 v.

Veniaminov, Ioann, 1840, Zapiski ob ostrovakh Unalashkinskago otdiyela [Notes on the islands of the Unalaska district]: St. Petersburg, Imp. Acad. Sci., 3 v. in 2.

1846, Opyt grammatiki Aleutskolisjevskago iazyka [Essay toward a grammar and dictionary of the Aleutian-Fox language]: St. Petersburg, Imp. Acad. Sci., 120 p.; translated into English by R. H. Geoghegan, 1906, Fairbanks, Alaska, 160 p. (typewritten).

Wagner, H. R., 1937, The Cartography of the northwest coast of America to the year 1800: Berkeley, Calif., Univ. California Press, 2 v., $543 \mathrm{p}$.

Wahrhaftig, Clyde, 1951, Geology and coal deposits of the western part of the Nenana coal Field, Alaska: U.S. Geol. Survey Bull. 963-E, p. 169-186.

1958, Quaternary geology of the Nenana River valley and adjacent parts of the Alaska Range: U.S. Geol. Survey Prof. Paper 293, p. $1-70$.

P. 1965, Physiographic divisions of Alaska: U.S. Geol. Survey Prof. Paper 482, 52 p.

Wahrhaftig, Clyde, and Hickcox, C. A., 1955, Geology and coal deposits, Jarvis Greek coal field, Alaska: U.S. Geol. Survey Bull. 989-G, p. 353-367.

Wahrhaftig, Clyde, Hickcox, C. A., and Freedman, Jacob, 1951, Coal deposits on Healy and Lignite Greeks, Nenana coal fields, Alaska: U.S. Geol. Survey Bull. 963-E, p. 141-165.

Waldron, H. H., 1961, Geologic reconnaissance of Frosty Peak volcano and vicinity, Alaska: U.S. Geol. Survey Bull. 1028-T, p. 677-708.

Waring, G. A., 1917, Mineral springs of Alaska, with a chapter on the chemical character of some surface waters of Alaska, by R. B. Dole and A. A. Chambers: U.S. Geol. Survey Water-Supply Paper 418, 118 p.

1934, Core drilling for coal in the Moose Greek area, Alaska: U.S. Geol. Survey Bull. 857-E, p. 155-173.

1936, Geology of the Anthracite Ridge coal district, Alaska: U.S. Geol. Survey Bull. $860,57 \mathrm{p}$.

Warner, L. A., Goddard, E. N., and others, 1961, Iron and copper deposits of Kasaan Peninsula, Prince of Wales Island, southeastern Alaska: U.S. Geol. Survey Bull. 1090, 136 p.

Washburn, Bradford: see Washburn, H. B.

Washburn, H. B., 1942, The ascent of Mount Hayes: Am. Alpine Jour., v. 4, no. 3, p. 323334.

Washburn, H. B., and Goldthwaite, Richard Parker, 1936, Map of Lituya Bay and Mount Crillon District: Geog. Jour., v. 87, no. 6, facing p. 576 . 
